4

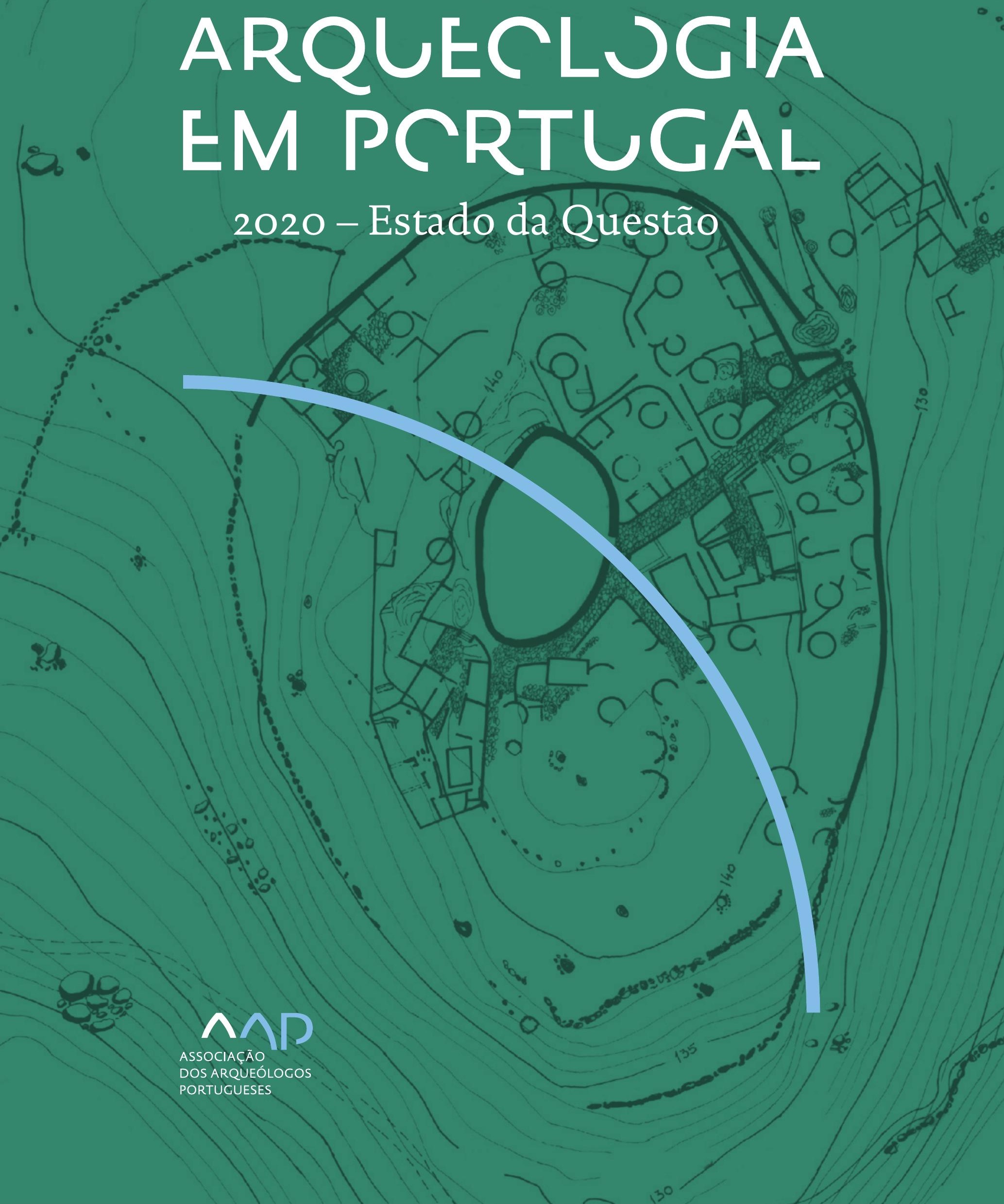





\section{ARQUECLUGIA EM PCRTUGAL 2020 - Estado da Questão}

Textos 
Coordenação editorial: José Morais Arnaud, César Neves e Andrea Martins Design gráfico: Flatland Design

AAP - ISBN: 978-972-9451-89-8

CITCEM - ISBN: 978-989-8970-25-1

Associação dos Arqueólogos Portugueses e CITCEM

Lisboa, 2020

O conteúdo dos artigos é da inteira responsabilidade dos autores. Sendo assim a Associação dos Arqueólogos Portugueses declina qualquer responsabilidade por eventuais equívocos ou questões de ordem ética e legal.

Desenho de capa:

Planta do castro de Monte Mozinho (Museu Municipal de Penafiel).

\section{$\hat{\wedge} \mathrm{P}$}

DOS ARQUEÓLOGOS PORTUGUESES

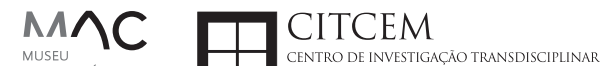
MUSEU
ARQUELLÓGICO
DO CARMO
U.PORTO

FLUP FACULDADE DE LETRAS
UNIVERSIDADE DO PORTO

Apoio

EC para a Ciência 


\section{Índice}

15 Prefácio

José Morais Arnaud

\section{Historiografia e Teoria}

17 Território, comunidade, memória e emoção: a contribuição da história da arqueologia (algumas primeiras e breves reflexões)

Ana Cristina Martins

25 Como descolonizar a arqueologia portuguesa?

Rui Gomes Coelho

41 Arqueologia e Modernidade: uma revisitação pessoal e breve de alguns aspetos da obra homónima de Julian Thomas de 2004

Vítor Oliveira Jorge

57 Dados para a História das Mulheres na Arqueologia portuguesa, dos finais do século XIX aos inícios do século XX: números, nomes e tabelas

Filipa Dimas / Mariana Diniz

73 Retractos da arqueologia portuguesa na imprensa: (in)visibilidades no feminino

Catarina Costeira / Elsa Luís

85 Arqueologia e Arqueólogos no Norte de Portugal Jacinta Bugalhão

101 Vieira Guimarães (1864-1939) e a arqueologia em Tomar: uma abordagem sobre o território e as gentes

João Amendoeira Peixoto / Ana Cristina Martins

115 Os memoráveis? A arqueologia algarvia na imprensa nacional e regional na presente centúria (2001-2019): características, visões do(s) passado(s) e a arqueologia

enquanto marca

Frederico Agosto / João Silva

129 A Evolução da Arqueologia Urbana e a Valorização Patrimonial no Barlavento Algarvio: Os casos de Portimão e Silves

Artur Mateus / Diogo Varandas / Rafael Boavida

\section{Gestão, Valorização e Salvaguarda do Património}

145 O Caderno Reivindicativo e as condições de trabalho em Arqueologia Miguel Rocha / Liliana Matias Carvalho / Regis Barbosa / Mauro Correia / Sara Simões / Jacinta Bugalhão / Sara Brito / Liliana Veríssimo Carvalho / Richard Peace / Pedro Peça / Cézer Santos

155 Os Estudos de Impacte Patrimonial como elemento para uma estratégia sustentável de minimização de impactes no âmbito de reconversões agrícolas Tiago do Pereiro

165 Salvaguarda de Património arqueológico em operações florestais: gestão e sensibilização Filipa Bragança / Gertrudes Zambujo / Sandra Lourenço / Belém Paiva / Carlos Banha / Frederico Tatá Regala / Helena Moura / Jacinta Bugalhão / João Marques / José Correia / Pedro Faria / Samuel Melro

179 Os valores do Património: uma investigação sobre os Sítios Pré-históricos de Arte Rupestre do Vale do Rio Côa e de Siega Verde José Paulo Francisco 
189 Conjugando recursos arqueológicos e naturais para potenciar as visitas ao Geoparque Litoral de Viana do Castelo (Noroeste de Portugal)

Hugo A. Sampaio / Ana M.S. Bettencourt / Susana Marinho / Ricardo Carvalhido

203 Áreas de Potencial Arqueológico na Região do Médio Tejo: Modelo Espacial Preditivo Rita Ferreira Anastácio / Ana Filipa Martins / Luiz Oosterbeek

223 Património Arqueológico e Gestão Territorial: O contributo da Arqueologia para a revisão do PDM de Avis

Ana Cristina Ribeiro

237 A coleção arqueológica do extinto Museu Municipal do Porto - Origens, Percursos e Estudos

Sónia Couto

251 Valpaços - uma nova carta arqueológica

Pedro Pereira / Maria de Fátima Casares Machado

263 Arqueologia na Cidade de Peniche

Adriano Constantino / Luís Rendeiro

273 Arqueologia Urbana: a cidade de Lagos como caso de Estudo Cátia Neto

285 Estratégias de promoção do património cultural subaquático nos Açores. O caso da ilha do Faial

José Luís Neto / José Bettencourt / Luís Borges / Pedro Parreira

297 Carta Arqueológica da Cidade Velha: Uma primeira abordagem

Jaylson Monteiro / Nireide Tavares / Sara da Veiga / Claudino Ramos / Edson Brito /

Carlos Carvalho / Francisco Moreira / Adalberto Tavares

311 Antropologia Virtual: novas metodologias para a análise morfológica e funcional Ricardo Miguel Godinho / Célia Gonçalves

\section{Didáctica da Arqueologia}

327 Como os projetos de Arqueologia podem contribuir para uma comunidade culturalmente mais consciente Alexandra Figueiredo / Claúdio Monteiro / Adolfo Silveira / Ricardo Lopes

337 Educação Patrimonial - Um cidadão esclarecido é um cidadão ativo! Ana Paula Almeida

351 A aproximação da Arqueologia à sala de aula: um caso de estudo no $3^{\circ}$ ciclo do Ensino Básico Luís Serrão Gil

363 Arqueologia 3.o - Pensar e comunicar a Arqueologia para um futuro sustentável Mónica Rolo

377 “Conversa de Arqueólogos" - Divulgar a Arqueologia em tempos de Pandemia Diogo Teixeira Dias

389 Escola Profissional de Arqueologia: desafios e oportunidades Susana Nunes / Dulcineia Pinto / Júlia Silva / Ana Mascarenhas

399 Os Museus de Arqueologia e os Jovens: a oferta educativa para o público adolescente Beatriz Correia Barata / Leonor Medeiros

411 O museu universitário como mediador entre a ciência e a sociedade: o exemplo da secção de arqueologia no Museu de História Natural e da Ciência da Universidade do Porto (MHNC-UP)

Rita Gaspar 
421 Museu de Lanifícios: Real Fábrica de Panos. Atividades no âmbito da Arqueologia Beatriz Correia Barata / Rita Salvado

427 Arqueologia Pública e o caso da localidade da Mata (Torres Novas) Cláudia Manso / Ana Rita Ferreira / Cristiana Ferreira / Vanessa Cardoso Antunes

431 Do sítio arqueológico ao museu: um percurso (também) didático Lídia Fernandes

447 Estão todos convidados para a Festa! E para dançar também... O projecto do Serviço Educativo do Museu Arqueológico do Carmo na $5^{\underline{a}}$ Edição da Festa da Arqueologia Rita Pires dos Santos

459 O “Clã de Carenque”, um projeto didático de arqueologia Eduardo Gonzalez Rocha

469 Mediação cultural: peixe que puxa carroça nas Ruínas Romanas de Troia Inês Vaz Pinto / Ana Patrícia Magalhães / Patrícia Brum / Filipa Santos

481 Didática Arqueológica, experiências do Projeto Mértola Vila Museu Maria de Fátima Palma / Clara Rodrigues / Susana Gómez / Lígia Rafael

\section{Arte Rupestre}

497 Os inventários de arte rupestre em Portugal Mila Simões de Abreu

513 O projeto FIRST-ART - conservação, documentação e gestão das primeiras manifestações de arte rupestre no Sudoeste da Península Ibérica: as grutas do Escoural e Maltravieso Sara Garcês / Hipólito Collado / José Julio García Arranz / Luiz Oosterbeek / António Carlos Silva / Pierluigi Rosina / Hugo Gomes / Anabela Borralheiro Pereira / George Nash / Esmeralda Gomes / Nelson Almeida / Carlos Carpetudo

523 Trabalhos de documentação de arte paleolítica realizados no âmbito do projeto PalæoCôa André Tomás Santos / António Fernando Barbosa / Luís Luís / Marcelo Silvestre / Thierry Aubry

537 Imagens fantasmagóricas, silhuetas elusivas: as figuras humanas na arte do Paleolítico Superior da região do Côa Mário Reis

$55^{1}$ Os motivos zoomórficos representados nas placas de tear de Vila Nova de São Pedro (Azambuja, Portugal) Andrea Martins / César Neves / José M. Arnaud / Mariana Diniz

571 Arte Rupestre do Monte de Góios (Lanhelas, Caminha). Síntese dos resultados dos trabalhos efectuados em 2007-2009 Mário Varela Gomes

599 Gravuras rupestres de barquiformes no Monte de S. Romão, Guimarães, Noroeste de Portugal Daniela Cardoso

613 Círculos segmentados gravados na Bacia do Rio Lima (Noroeste de Portugal): contributos para o seu estudo Diogo Marinho / Ana M.S. Bettencourt / Hugo Aluai Sampaio

631 Equídeos gravados no curso inferior do Rio Mouro, Monção (NW Portugal). Análise preliminar Coutinho, L.M. / Bettencourt, A.M.S / Sampaio, Hugo A.S

645 Paletas na Arte Rupestre do Noroeste de Portugal. Inventário preliminar Bruna Sousa Afonso / Ana M. S. Bettencourt / Hugo A. Sampaio 


\section{Pré-História}

661 O projeto Miño/Minho: balanço de quatro anos de trabalhos arqueológicos Sérgio Monteiro-Rodrigues / João Pedro Cunha-Ribeiro / Eduardo Méndez-Quintas / Carlos Ferreira / Pedro Xavier / José Meireles / Alberto Gomes / Manuel Santonja / Alfredo Pérez-González

677 A ocupação paleolítica da margem esquerda do Baixo Minho: a indústria lítica do sítio de Pedreiras 2 (Monção, Portugal) e a sua integração no contexto regional Carlos Ferreira / João Pedro Cunha-Ribeiro / Sérgio Monteiro-Rodrigues / Eduardo Méndez-Quintas / Pedro Xavier / José Meireles / Alberto Gomes / Manuel Santonja / Alfredo Pérez-González

693 O sítio acheulense do Plistocénico médio da Gruta da Aroeira Joan Daura / Montserrat Sanz / Filipa Rodrigues / Pedro Souto / João Zilhão

703 As sociedades neandertais no Barlavento algarvio: modelos preditivos com recurso aos SIG

Daniela Maio

715 A utilização de quartzo durante o Paleolítico Superior no território dos vales dos rios Vouga e Côa

Cristina Gameiro / Thierry Aubry / Bárbara Costa / Sérgio Gomes / Luís Luís / Carmen Manzano / André Tomás Santos

733 Uma perspetiva diacrónica da ocupação do concheiro do Cabeço da Amoreira (Muge, Portugal) a partir da tecnologia lítica Joana Belmiro / João Cascalheira / Célia Gonçalves

745 Novos dados sobre a Pré-história Antiga no concelho de Palmela. A intervenção arqueológica no sítio do Poceirão I

Michelle Teixeira Santos

757 Problemas em torno de Datas Absolutas Pré-Históricas no Norte do Alentejo Jorge de Oliveira

771 Povoamento pré-histórico nas áreas montanhosas do NO de Portugal: o Abrigo 1 de Vale de Cerdeira Pedro Xavier / José Meireles / Carlos Alves

783 Apreciação do povoamento do Neolítico Inicial na Baixa Bacia do Douro. A Lavra I (Serra da Aboboreira) como caso de estudo Maria de Jesus Sanches

797 O Processo de Neolitização na Plataforma do Mondego: os dados do Sector C do Outeiro dos Castelos de Beijós (Carregal do Sal)

João Carlos de Senna-Martinez / José Manuel Quintã Ventura / Andreia Carvalho / Cíntia Maurício

823 Novos trabalhos na Lapa da Bugalheira (Almonda, Torres Novas) Filipa Rodrigues / Pedro Souto / Artur Ferreira / Alexandre Varanda / Luís Gomes / Helena Gomes / João Zilhão

837 A pedra polida e afeiçoada do sítio do Neolítico médio da Moita do Ourives (Benavente, Portugal)

César Neves

857 Casal do Outeiro (Encarnação, Mafra): novos contributos para o conhecimento do povoamento do Neolítico final na Península de Lisboa.

Cátia Delicado / Carlos Maneira e Costa / Marta Miranda / Ana Catarina Sousa

873 Stresse infantil, morbilidade e mortalidade no sítio arqueológico do Neolítico Final/ Calcolítico ( $4^{\circ}$ e $3^{\circ}$ milénio a.C.) do Monte do Carrascal 2 (Ferreira do Alentejo, Beja) Liliana Matias de Carvalho / Sofia N. Wasterlain 
885 Come together: O Conjunto Megalítico das Motas (Monção, Viana do Castelo) e as expressões Campaniformes do Alto Minho Ana Catarina Basílio / Rui Ramos

899 Trabalhos arqueológicos no sítio Calcolítico da Pedreira do Poio Carla Magalhães / João Muralha / Mário Reis / António Batarda Fernandes

913 O sítio arqueológico de Castanheiro do Vento. Da arquitectura do sítio à arquitectura de um território João Muralha Cardoso

925 Estudo zooarqueológico das faunas do Calcolítico final de Vila Nova de São Pedro (Azambuja, Portugal): Campanhas de 2017 e 2018 Cleia Detry / Ana Catarina Francisco / Mariana Diniz / Andrea Martins / César Neves / José Morais Arnaud

943 As faunas depositadas no Museu Arqueológico do Carmo provenientes de Vila Nova de São Pedro (Azambuja): as campanhas de 1937 a 1967 Ana Catarina Francisco / Cleia Detry / César Neves / Andrea Martins / Mariana Diniz / José Morais Arnaud

959 Análise funcional de material lítico em sílex do castro de Vila Nova de S. Pedro (Azambuja, Portugal): uma primeira abordagem Rafael Lima

971 O recinto da Folha do Ouro 1 (Serpa) no contexto dos recintos de fossos calcolíticos alentejanos

António Carlos Valera / Tiago do Pereiro / Pedro Valério / António M. Monge Soares

\section{Proto-História}

987 Produção de sal marinho na Idade do Bronze do noroeste Português. Alguns dados para uma reflexão

Ana M. S. Bettencourt / Sara Luz / Nuno Oliveira / Pedro P. Simões / Maria Isabel C. Alves / Emílio Abad-Vidal

1001 A estátua-menir do Pedrão ou de São Bartolomeu do Mar (Esposende, noroeste de Portugal) no contexto arqueológico da fachada costeira de entre os rios Neiva e Cávado Ana M. S. Bettencourt / Manuel Santos-Estévez / Pedro Pimenta Simões / Luís Gonçalves

1015 O Castro do Muro (Vandoma/Baltar, Paredes) - notas para uma biografia de ocupação da Idade do Bronze à Idade Média

Maria Antónia D. Silva / Ana M. S. Bettencourt / António Manuel S. P. Silva / Natália Félix

1031 Do Bronze Final à Idade Média - continuidades e hiatos na ocupação de Povoados em Oliveira de Azeméis João Tiago Tavares / Adriaan de Man

1041 As faunas do final da Idade do Bronze no Sul de Portugal: leituras desde o Outeiro do Circo (Beja)

Nelson J. Almeida / Íris Dias / Cleia Detry / Eduardo Porfírio / Miguel Serra

1055 A Espada do Monte das Oliveiras (Serpa) - uma arma do Bronze Pleno do Sudoeste Rui M. G. Monge Soares / Pedro Valério / Mariana Nabais / António M. Monge Soares

1065 São Julião da Branca (Albergaria-a-Velha) - Investigação e valorização de um povoado do Bronze Final

António Manuel S. P. Silva / Paulo A. P. Lemos / Sara Almeida e Silva / Edite Martins de Sá

1083 Do castro de S. João ao Mosteiro de Santa Clara: notícia de uma intervenção arqueológica, em Vila do Conde Rui Pinheiro 
1095 O castro de Ovil (Espinho), um quarto de século de investigação - resultados e questões em aberto

Jorge Fernando Salvador / António Manuel S. P. Silva

1111 O Castro de Salreu (Estarreja), um povoado proto-histórico no litoral do Entre Douro e Vouga

Sara Almeida e Silva / António Manuel S. P. Silva / Paulo A. P. Lemos / Edite Martins de Sá

1127 Castro de Nossa Senhora das Necessidades (Sernancelhe): uma primeira análise artefactual Telma Susana O. Ribeiro

${ }_{1141}$ A cividade de Bagunte. O estado atual da investigação Pedro Brochado de Almeida

1153 Zoomorfos na cerâmica da Idade do Ferro no NW Peninsular: inventário, cronologias e significado Nuno Oliveira / Cristina Seoane

1163 Vasos gregos em Portugal: diferentes maneiras de contar a história do intercâmbio cultural na Idade do Ferro

Daniela Ferreira

1175 Os exotica da necrópole da Idade do Ferro do Olival do Senhor dos Mártires (Alcácer do Sal) no seu contexto regional

Francisco B. Gomes

\section{Antiguidade Clássica e Tardia}

1191 O uso de madeira como combustível no sítio da Quinta de Crestelos (Baixo Sabor): da Idade do Ferro à Romanização Filipe Vaz / João Tereso / Sérgio Simões Pereira / José Sastre / Javier Larrazabal Galarza / Susana Cosme / José António Pereira / Israel Espi

1207 Cultivos de Época Romana no Baixo Sabor: continuidade em tempos de mudança? João Pedro Tereso / Sérgio Simões Pereira / Filipe Santos / Luís Seabra / Filipe Vaz

1221 A casa romana na Hispânia: aplicação dos modelos itálicos nas províncias ibéricas Fernanda Magalhães / Diego Machado / Manuela Martins

1235 As pinturas murais romanas da Rua General Sousa Machado, n. ${ }^{5}$ 1, Chaves José Carvalho

1243 Trás do Castelo (Vale de Mir, Pegarinhos, Alijó) - Uma exploração agrícola romana do Douro

Tony Silvino / Pedro Pereira

1255 A sequência de ocupação no quadrante sudeste de Bracara Augusta: as transformações de uma unidade doméstica Lara Fernandes / Manuela Martins

1263 Os Mosaicos com decoração geométrica e geométrico-vegetalista dos sítios arqueológicos da área do Conuentus Bracaraugustanus. Novas abordagens quanto à conservação, restauro, decoração e datação Maria de Fátima Abraços / Licínia Wrench

1277 “Casa Romana” do Castro de São Domingos (Cristelos, Lousada): Escavação, Estudo e Musealização Paulo André de P. Lemos

1291 A arqueobotânica no Castro de Guifões (Matosinhos, Noroeste de Portugal): O primeiro estudo carpológico

Luís Seabra / Andreia Arezes / Catarina Magalhães / José Varela / João Pedro Tereso 
1305 Um Horreum Augustano na Foz do Douro (Monte do Castelo de Gaia, Vila Nova de Gaia) Rui Ramos

1311 Ponderais romanos na Lusitânia: padrões, formas, materiais e contextos de utilização Diego Barrios Rodríguez

1323 Um almofariz centro-itálico na foz do Mondego

Marco Penajoia

1335 Estruturas romanas de Carnide - Lisboa Luísa Batalha / Mário Monteiro / Guilherme Cardoso

1347 O contexto funerário do sector da "necrópole NO" da Rua das Portas de S. Antão (Lisboa): o espaço, os artefactos, os indivíduos e a sua interconectividade na interpretação do passado Sílvia Loja, José Carlos Quaresma, Nelson Cabaço, Marina Lourenço, Sílvia Casimiro, Rodrigo Banha da Silva, Francisca Alves-Cardoso

${ }_{1361}$ Povoamento em época Romana na Amadora - resultados de um projeto pluridisciplinar Gisela Encarnação / Vanessa Dias

1371 A Arquitectura Residencial em Mirobriga (Santiago do Cacém): contributo a partir de um estudo de caso Filipe Sousa / Catarina Felício

${ }_{1385}$ O fim do ciclo. Saneamento e gestão de resíduos nos edifícios termais de Mirobriga (Santiago do Cacém)

Catarina Felício / Filipe Sousa

1399 Balsa, Topografia e Urbanismo de uma Cidade Portuária Vítor Silva Dias / João Pedro Bernardes / Celso Candeias / Cristina Tété Garcia

1413 No Largo das Mouras Velhas em Faro (2017): novas evidências da necrópole norte de Ossonoba e da sua ocupação medieval Ricardo Costeira da Silva / Paulo Botelho / Fernando Santos / Liliana Nunes

1429 Instrumentos de pesca recuperados numa fábrica de salga em Ossonoba (Faro) Inês Rasteiro / Ricardo Costeira da Silva / Paulo Botelho

1439 A Necrópole Romana do Eirô, Duas Igrejas (Penafiel): intervenção arqueológica de 2016 Laura Sousa / Teresa Soeiro

1457 Ritual, descarte ou afetividade? A presença de Canis lupus familiaris na Necrópole Noroeste de Olisipo (Lisboa)

Beatriz Calapez Santos / Sofia Simões Pereira / Rodrigo Banha da Silva / Sílvia Casimiro / Cleia Detry / Francisca Alves Cardoso

1467 Dinâmicas económicas em Bracara na Antiguidade Tardia Diego Machado / Manuela Martins / Fernanda Magalhães / Natália Botica

1479 Cerâmicas e Vidros da Antiguidade Tardia do Edifício sob a Igreja do Bom Jesus (Vila Nova de Gaia) Joaquim Filipe Ramos

1493 Novos contributos para a topografia histórica de Mértola no período romano e na Antiguidade Tardia Virgílio Lopes

\section{8. Época Medieval}

1511 Cerâmicas islâmicas no Garb setentrional "português": algumas evidências e incógnitas Constança dos Santos / Helena Catarino / Susana Gómez / Maria José Gonçalves / Isabel Inácio / Gonçalo Lopes / Jacinta Bugalhão / Sandra Cavaco / Jaquelina Covaneiro / Isabel Cristina Fernandes / Ana Sofia Gomes 
1525 Contributo para o conhecimento da cosmética islâmica, em Silves, durante a Idade Média Rosa Varela Gomes

1537 Yábura e o seu território - uma análise histórico-arqueológica de Évora entre os séculos VIII-XII José Rui Santos

1547 A encosta sul do Castelo de Palmela - resultados preliminares da escavação arqueológica Luís Filipe Pereira / Michelle Teixeira Santos

1559 A igreja de São Lourenço (Mouraria, Lisboa): um conjunto de silos e de cerâmica medieval islâmica

Andreia Filipa Moreira Rodrigues

1571 O registo material de movimentações populacionais no Médio Tejo, durante os séculos XII-XIII. Dois casos de "sunken featured buildings", nos concelhos de Cartaxo e Torres Novas Marco Liberato / Helena Santos / Nuno Santos

1585 O nordeste transmontano nos alvores da Idade média. Notas para reflexão Ana Maria da Costa Oliveira

1601 Sepulturas escavadas na rocha do Norte de Portugal e do Vale do Douro: primeiros resultados do Projecto SER-NPVD

Mário Jorge Barroca / César Guedes / Andreia Arezes / Ana Maria Oliveira

1619 "Portucalem Castrum Novum" entre o Mediterrâneo e o Atlântico: o estudo dos materiais cerâmicos alto-medievais do arqueossítio da rua de D. Hugo, nํ. 5 (Porto) João Luís Veloso

1627 A Alta Idade Média na fronteira de Lafões: notas preliminares sobre a Arqueologia no Concelho de Vouzela

Manuel Luís Real / Catarina Tente

1641 Um conjunto cerâmico medieval fora de portas: um breve testemunho aveirense Susana Temudo

${ }_{1651}$ Os Lóios do Porto: uma perspetiva integrada no panorama funerário da Baixa Idade Média à Época Moderna em meios urbanos em Portugal

Ana Lema Seabra

1659 O Caminho Português Interior de Santiago como eixo viário na Idade Média Pedro Azevedo

1665 Morfologia Urbana: Um exercício em torno do Castelo de Ourém André Donas-Botto / Jaqueline Pereira

1677 Intervenção arqueológica na Rua Marquês de Pombal/Largo do Espírito Santo (Bucelas, Loures)

Florbela Estêvão / Nathalie Antunes-Ferreira / Dário Ramos Neves / Inês Lisboa

1691 O Cemitério Medieval do Poço do Borratém e a espacialidade funerária na cidade de Lisboa Inês Belém / Vanessa Filipe / Vasco Noronha Vieira / Sónia Ferro / Rodrigo Banha da Silva

1705 Um Espaço Funerário Conventual do séc. XV em Lisboa: o caso do Convento de São Domingos da Cidade Sérgio Pedroso / Sílvia Casimiro / Rodrigo Banha da Silva / Francisca Alves Cardoso

\section{9. Época Moderna e Contemporânea}

1721 Arqueologia Moderna em Portugal: algumas reflexões críticas em torno da quantificação de conjuntos cerâmicos e suas inferências históricas e antropológicas Rodrigo Banha da Silva / André Bargão / Sara da Cruz Ferreira

1733 Faianças de dois contextos entre os finais do século XVI e XVIII do Palácio dos Condes de Penafiel, Lisboa

Martim Lopes / Tomás Mesquita 
1747 Um perfil de consumo do século XVIII na foz do Tejo: O caso do Mercado da Ribeira, Lisboa Sara da Cruz Ferreira / Rodrigo Banha da Silva / André Bargão

1761 Os Cachimbos dos Séculos XVII e XVIII do Palácio Mesquitela e Convento dos Inglesinhos (Lisboa)

Inês Simão / Marina Pinto / João Pimenta / Sara da Cruz Ferreira / André Bargão / Rodrigo Banha da Silva

1775 "Tomar os fumos da erua que chamão em Portugal erua sancta». Estudo de Cachimbos provenientes da Rua do Terreiro do Trigo, Lisboa

Miguel Martins de Sousa / José Pedro Henriques / Vanessa Galiza Filipe

1787 Cachimbos de Barro Caulínitico da Sé da Cidade Velha (República de Cabo Verde)

Rodrigo Banha da Silva / João Pimenta / Clementino Amaro

1801 Algumas considerações sobre espólio não cerâmico recuperado no Largo de Jesus (Lisboa) Carlos Boavida

1815 Adereços de vidro, dos séculos XVI-XVIII, procedentes do antigo Convento de Santana de Lisboa (anéis, braceletes e contas)

Joana Gonçalves / Rosa Varela Gomes / Mário Varela Gomes

1837 Da ostentação, luxo e poder à simplicidade do uso quotidiano: arqueologia e simbologia de joias e adornos da Idade Moderna Portuguesa Jéssica Iglésias

1849 Os amuletos em Portugal - dos objetos às superstições: o coral vermelho Alexandra Vieira

1865 Cerâmicas de Vila Franca de Xira nos séculos XV e XVI Eva Pires

1879 «Não passa por teu o que me pertence». Marcas de individualização associadas a faianças do Convento de Nossa Senhora de Aracoeli, Alcácer do Sal Catarina Parreira / Íris Fragoso / Miguel Martins de Sousa

1891 Cerâmica de Leiria: alguns focos de produção

Jaqueline Pereira / André Donas-Botto

1901 Os Fornos na Rua da Biquinha, em Óbidos Hugo Silva / Filipe Oliveira

1909 A casa de Pêro Fernandes, contador dos contos de D. Manuel I: o sítio arqueológico da Silha do Alferes, Seixal (século XVI) Mariana Nunes Ferreira

1921 O Alto da Vigia (Sintra) e a vigilância e defesa da costa Alexandre Gonçalves / Sandra Santos

1937 O contexto da torre sineira da Igreja de Santa Maria de Loures Paulo Calaveira / Martim Lopes

1949 A Necrópole do Hospital Militar do Castelo de São Jorge e as práticas funerárias na Lisboa de Época Moderna Susana Henriques / Liliana Matias de Carvalho / Ana Amarante / Sofia N. Wasterlain

1963 SAND - Sarilhos Grandes Entre dois Mundos: o adro da Igreja e a Paleobiologia dos ossos humanos recuperados

Paula Alves Pereira / Roger Lee Jesus / Bruno M. Magalhães

1975 Expansão urbana da vila de Cascais no século XVII e XVIII: a intervenção arqueológica na Rua da Vitória no 15 a 17

Tiago Pereira / Vanessa Filipe

1987 Novos dados para o conhecimento do Urbanismo de Faro em época Moderna Ana Rosa 
1995 Um exemplo de Arqueologia Urbana em Alcoutim: o Antigo Edifício dos CTT Marco Fernandes / Marta Dias / Alexandra Gradim / Virgílio Lopes / Susana Gómez Martínez

2007 Palácio dos Ferrazes (Rua das Flores/Rua da Vitória, Porto): a cocheira de Domingos Oliveira Maia

Francisco Raimundo

2021 As muitas vidas de um edifício urbano: História, Arqueologia e Antropologia no antigo Recreatório Paroquial de Penafiel Helena Bernardo / Jorge Sampaio / Marta Borges

2035 O convento de Nossa Senhora da Esperança de Ponta Delgada: o contributo da arqueologia para o conhecimento de um monumento identitário João Gonçalves Araújo / N’Zinga Oliveira

2047 Arqueologia na ilha do Corvo... em busca da capela de Nossa Senhora do Rosário Tânia Manuel Casimiro / José Luís Neto / Luís Borges / Pedro Parreira

2059 Perdidos à vista da Costa. Trabalhos arqueológicos subaquáticos na Barra do Tejo Jorge Freire / José Bettencourt / Augusto Salgado

2071 Arqueologia marítima em Cabo Verde: enquadramento e primeiros resultados do projecto CONCHA

José Bettencourt / Adilson Dias / Carlos Lima / Christelle Chouzenoux / Cristóvão Fonseca / Dúnia Pereira / Gonçalo Lopes / Inês Coelho / Jaylson Monteiro / José Lima / Maria Eugénia Alves / Patrícia Carvalho / Tiago Silva

2085 Trabalhos arqueológicos na Cidade Velha (Ribeira Grande de Santiago, Cabo Verde): reflexões sobre um projecto de investigação e divulgação patrimonial André Teixeira / Jaylson Monteiro / Mariana Mateus / Nireide Tavares / Cristovão Fonseca / Gonçalo C. Lopes / Joana Bento Torres / Dúnia Pereira / André Bargão / Aurélie Mayer / Bruno Zélie / Carlos Lima / Christelle Chouzenoux / Inês Henriques / Inês Pinto Coelho / José Lima / Patrícia Carvalho / Tiago Silva

2103 A antiga fortificação de Quelba / Khor Kalba (E.A.U.). Resultados de quatro campanhas de escavações, problemáticas e perspectivas futuras Rui Carita / Rosa Varela Gomes / Mário Varela Gomes / Kamyar Kamyad

2123 Colónias para homens novos: arqueologia da colonização agrária fascista no noroeste ibérico Xurxo Ayán Vila / José Mạ . Señorán Martín 


\section{Prefácio}

O volume que agora se publica constitui um instrumento indispensável para quem pretenda acompanhar os trabalhos do III Congresso de Arqueologia da Associação dos Arqueólogos Portugueses (III CAAP), que decorrerá nos próximos dias 18, 19, 20 e 21 de Novembro de 2020, em Lisboa e no Porto, sendo ainda completado com uma visita ao Castro de Monte Mozinho e ao Museu de Penafiel, no dia 22 de Novembro, em que se comemora o $157^{\circ}$ aniversário da Associação dos Arqueólogos Portugueses (AAP), a convite da Câmara Municipal de Penafiel, a quem se agradece na pessoa do seu Presidente, Dr. Antonino de Sousa.

Tendo os dois anteriores congressos organizados pela AAP decorrido em Lisboa, com o apoio da Biblioteca Nacional, e das Faculdade de Letras da Universidade de Lisboa, e da Faculdade de Ciências Sociais e Humanas da Universidade Nova de Lisboa, e com a participação de arqueólogos provenientes de todo o país, a Direcção da AAP decidiu continuar esta colaboração com o meio académico nacional, promovendo uma certa descentralização, tendo lançado um desafio a todas as universidades públicas do país com ensino de Arqueologia para acolherem e participarem na organização do III CAAP.

Esse desafio foi prontamente aceite pela Faculdade de Letras da Universidade do Porto e pelo CITCEM - Centro de Investigação Transdisciplinar "Cultura Espaço e Memória”, a quem agradecemos na pessoa dos Professores Doutores Fernanda Ribeiro - Directora da Faculdade de Letras, Amélia Polónia - Coordenadora Científica do CITCEM e Mário Barroca - Professor Catedrático de Arqueologia e Sub-Director da Faculdade de Letras da Universidade do Porto.

O III CAAP foi de início programado para ocorrer de forma presencial, como os dois anteriores. Porém, devido à pandemia do novo Corona vírus (Covid-19), que entretanto assumiu proporções muito grandes, acabou por se decidir que o encontro científico seria realizado, em parte, de forma presencial - limitada às sessões de abertura e encerramento, com um número limitado de participantes - sendo as sessões de trabalho realizadas em modo de videoconferência, a partir de salas disponibilizadas para o efeito na AAP e na Faculdade de Letras da Universidade do Porto, ou do local escolhido por cada um dos comunicantes. Com esta solução, procura-se possibilitar um contacto e um debate de ideias e troca de conhecimentos tão próximo quanto possível entre os vários participantes, sem colocar em risco a sua segurança sanitária, cumprindo as normas recomendadas pelas autoridades nacionais e mundiais de saúde pública. A visita programada ao Castro de Monte Mozinho e ao Museu de Penafiel decorrerá com número limitado de inscrições, cumprindo todas as normas de segurança.

Apesar de toda a instabilidade que o país e o mundo têm vivido durante o ano de 2020, a resposta da comunidade arqueológica ao desafio deste Congresso foi, uma vez mais, excelente, tendo mesmo ultrapassado ligeiramente a adesão aos eventos anteriores. Com efeito, participarão cerca de 350 arqueólogos e foram entregues, dentro dos prazos e aceites, 112 comunicações e 46 posters, o que perfaz um total de 158 apresentações, agrupadas pelas seguintes áreas temáticas: 1. Historiografia e Teoria; 2. Gestão, Valori- 
zação e Salvaguarda do Património; 3. Didáctica da Arqueologia; 4. Arte Rupestre; 5. Pré-História; 6. Proto-História; 7. Antiguidade Clássica e Tardia; 8. Época Medieval; 9. Época Moderna e Contemporânea.

No total, os textos entregues perfazem cerca de 2.20o páginas de trabalho científico, com estudos de âmbitos temáticos e envolvendo quadros crono-culturais muito díspares, num retrato actualizado da investigação arqueológica realizada por diversos arqueólogos que, independentemente da sua nacionalidade, trabalham no território actualmente português ou sobre contextos relacionados com a presença portuguesa no Mundo.

Devido ao elevado custo dos suportes digitais individuais, e às conhecidas restrições orçamentais resultantes da pandemia em curso, ao contrário das anteriores edições, disponibilizadas em DVD e em cartão-pen, os estudos apresentados no III CAAP serão disponibilizadas a todos os inscritos e, a toda a comunidade arqueológica, nos sites da AAP e da FLUL - CITCEM através dos seguintes endereços: http://museuarqueologicodocarmo.pt/actas_III_congresso.htmle https://doi.org/10.21747/978-989-897025-1/arq. A disponibilização imediata de todos os artigos enquadra-se nos pressupostos da Ciência Aberta e Ciência Cidadã, possibilitando um acesso ilimitado a tod@s fazendo com que a partilha do conhecimento seja verdadeiramente efectiva.

A realização em tempo útil deste Congresso, nas condições particularmente difíceis do confinamento que nos foi imposto, só foi possível graças ao cumprimento rigoroso das normas e prazos para entrega dos textos, e sobretudo ao empenho, dedicação e profissionalismo dos nossos consócios Andrea Martins e César Neves, da Comissão Científica e Executiva do III CAAP, assim como do designer Paulo Freitas, a quem manifestamos aqui o nosso profundo agradecimento.

A concluir, resta-nos desejar que o III Congresso da Associação dos Arqueólogos Portugueses decorra da melhor maneira possível mostrando, mais uma vez, a vitalidade, a qualidade científica e a resiliência da comunidade arqueológica portuguesa.

José Morais Arnaud

(Presidente da Direcção da Associação dos Arqueólogos Portugueses) 
(

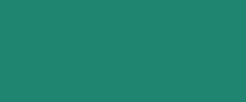

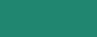

$=$

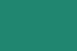

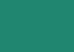

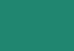

\section{Historiografia e Teoria \\ e Teoria \\ a}

1

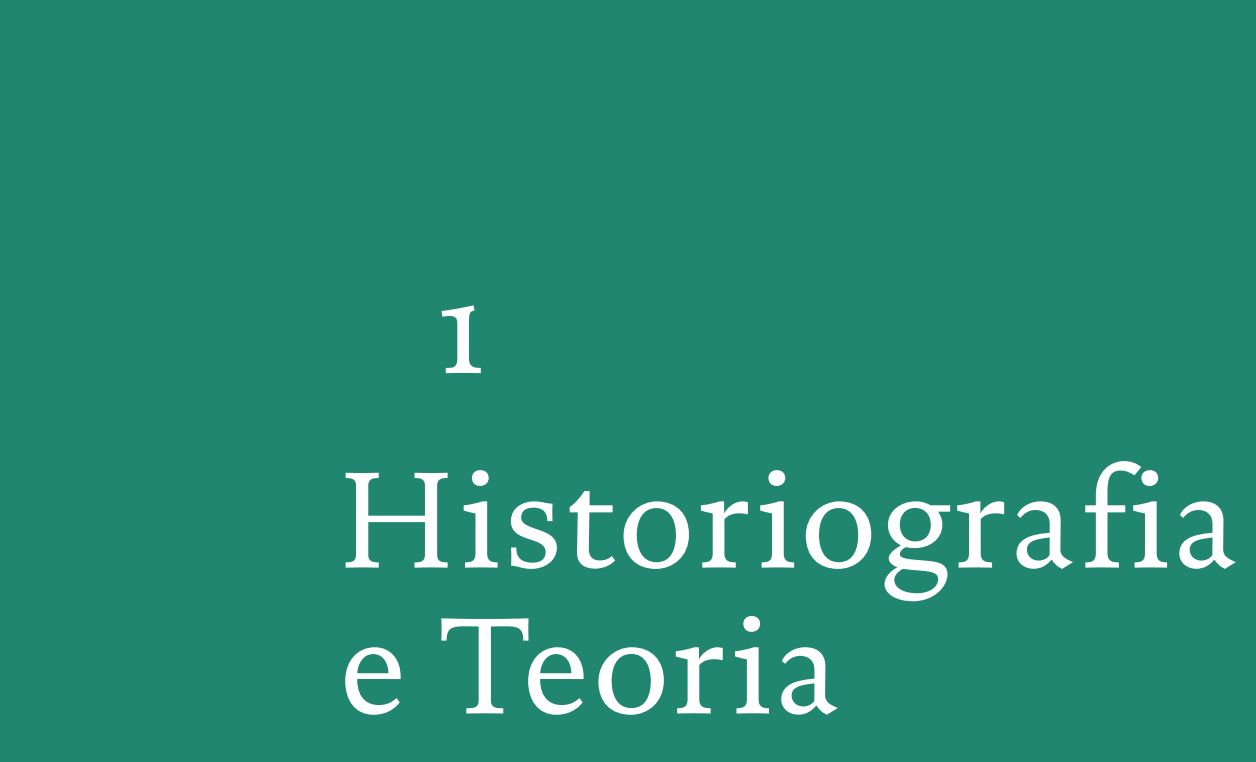




\title{
TERRITÓRIO, COMUNIDADE, MEMÓRIA E EMOÇÃO: A CONTRIBUIÇÃO DA HISTÓRIA DA ARQUEOLOGIA (ALGUMAS PRIMEIRAS E BREVES REFLEXÕES)
}

\author{
Ana Cristina Martins ${ }^{1}$
}

\begin{abstract}
"Not only are landscapes inevitably physically shaped or altered by human cultural practices - and in that sense 'cultural', but they are also 'cultural' in the sense that the way they are conceived and understood dictates how they are managed and used"
\end{abstract}

(Smith, 2006: 78)

\section{RESUMO}

Contribuindo para a composição de discursos escritos e iconográficos de índole identitária, a arqueologia tem desempenhado um papel, por vezes, determinante no desenvolvimento de comunidades locais. Capacidade que deveria ser aprofundada por ajudar a desconstruir mitos e a recuperar memórias, favorecendo, assim, a proximidade e o entrosamento entre território, cidadão, comunidade, produção de conhecimento científico e patrimonial e desenvolvimento sustentável de diferentes populações e geografias. Trata-se, porém, de um envolvimento que exige um esforço crescente e contínuo de cidadania, mormente por parte de quem, em contexto universitário e ciente das implicações da prática de uma exigente 'ciência cidadã', deve incentivar o gizamento e a concretização de projetos inovadores destinados a cumprir alguns dos 'Objetivos de Desenvolvimento Sustentável da Agenda 2030' e a própria 'Agenda 2030'. Propomos, por conseguinte, debater, a partir de um caso concreto da região eborense, em que medida a própria história da arqueologia, enquanto disciplina universitária, pode - e deve, no nosso entender -, concorrer para a intersecção entre arqueologia, território, comunidade, memória e desenvolvimento local, ultrapassando o mero - porém, necessário -, domínio conceptual. Palavras-chave: Arqueologia, Território: Comunidade, Memória e Emoção, História da Arqueologia.

\begin{abstract}
Contributing to the composition of written and iconographic discourses of an identity nature, archaeology has sometimes played a determining role in the development of local communities. This capacity should be deepened by helping to deconstruct myths and recover memories, thus favouring the proximity and harmony between territory, citizen, community, production of scientific and heritage knowledge and sustainable development of different populations and geographies. However, it is an involvement that requires a growing and continuous effort of citizenship, especially by those who, in a university context and aware of the implications of the practice of a demanding 'citizen science', should encourage the development and implementation of innovative projects aimed at meeting some of the 'Millennium Development Goals' and the 'Agenda 2030' itself. We therefore propose to debate, based on a specific case of the Évora region, to what extent the history of archaeology itself, as a university discipline, can - and should, in our opinion - contribute to the intersection between archaeology, territory, community, memory and local development, going beyond the mere - but necessary - conceptual domain.
\end{abstract}

Keywords: Archaeology, Territory: Community, Memory and Emotion, History of Archaeology.

1. IHC - polo da Universidade de Évora | Uniarq - Centro de Arqueologia da Universidade de Lisboa; acmartins@uevora.pt 


\section{CONTEXTO INICIAL}

\section{Is (still) history of archaeology useful?}

É com esta pergunta que os organizadores do simpósio da comissão de história da arqueologia da UISPP - Union Internationale des Sciences Préhistoriques et Protohistoriques (Roma, 10-11 de outubro, 2020) decidem suscitar a reflexão de quem nele participa ${ }^{2}$. Pergunta algo inusitada, dirão muitos, sobretudo quantos se dedicam aos estudos históricos, independentemente das suas especialidades. Transposto, porém, o limiar da surpresa inicial, reconhece-se a importância desta questão ao mesmo tempo provocadora e desafiante. Um desafio apenas possível porque a história da arqueologia terá alcançado já a sua maioridade. Situação que, (quase) inevitavelmente, implica a perda de uma certa inocência e a aquisição de responsabilidade acrescida perante o objeto estudado, o mundo académico e a generalidade do público. Uma (certa) inocência verificada, por exemplo, com o reconhecimento da utilização da arqueologia e da própria história da arqueologia por diversos agentes e com propósitos distintos. Utilização que, em última análise, tem, de algum modo, garantido a afirmação e o desenvolvimento da própria história da arqueologia.

Por outro lado, não esqueçamos que há muito que a história da ciência ocupa o seu lugar no contexto académico, como parte integrante do conhecimento de atores, espaços e projetos que concorrem para a asserção e evolução de teorias e práticas de cada disciplina científica. Evidência que tem atribuído maior lógica à existência - no caso que importa aqui realçar -, da história da arqueologia no quadro geral das disciplinas académicas, enquanto lhe tem conferido um sentido de maior comprometimento nesse mesmo âmbito e perante os diferentes públicos com os quais se relaciona.

Questões que, no conjunto, não serão de somenos relevância face à relação algo ambivalente como a história da arqueologia tem vindo a ser olhada em diferentes contextos de produção e divulgação de conhecimento arqueológico. Uma duplicidade que pode suscitar dúvidas sobre a viabilidade da história da arqueologia, nomeadamente entre arqueólogos que possam estar-lhe mais alheados, independen-

2. Programa consultável em https://www.efrome.it/la-recherche/agenda-et-manifestations/actualite/is-still-history-of-archaeology-useful.html temente das razões, transcorridas que se encontram as décadas de maior fulgor historiográfico na sequência da redescoberta de arquivos, datas celebrativas, protagonistas e conexão entre arqueologia e agendas ideológicas e políticas.

Convocados, por conseguinte, a refletir em conjunto sobre o futuro desta especialidade, foram vários os contributos apresentados no encontro de Roma (vide supra), fruto, na sua maioria, de experiências individuais colhidas no terreno.

\section{A HISTÓRIA DA ARQUEOLOGIA E A(S) SUA(S) UTILIDADE(S): EIS A (NÃO) QUESTÃO?}

Demonstrar a essencialidade de uma especialidade, qualquer que ela seja, poderá parecer algo complexo. A história da arqueologia não é exceção. Desde logo porque, à semelhança de outras histórias da ciência, o passado desta disciplina académica poderá parecer, aos menos avisados, não contribuir significativamente para o seu presente e futuro. Neste sentido, a pergunta deveria ter sido colocada de outra forma, assaz contundente: "será que a história da arqueologia tem utilidade?» ou, então, «deverá a história da arqueologia ser útil»? Mas, útil para quem e para o quê? Quem se dedica ao escrutínio dos percursos da arqueologia até aos nossos dias dirá que sim, que é útil e deverá ser útil. Sim, porque o arqueólogo e a arqueologia na atualidade são produtos cumulativos do pensamento e ação de quem os precede; sim, porque permite conhecer esse pensamento e essa ação para melhor compreender o presente; sim, porque contribui para recuperar e (re) construir memórias; sim, simplesmente porque lhes interessa, do ponto de vista da ciência fundamental, escavar arquivos e coleções em demanda de nomes, episódios e projetos descurados ou intercisos que valerá a pena revisitar por razões distintas.

Outros, todavia, poderão relevar tais justificativas, considerando que a história da arqueologia pouco acrescentará a projetos concebidos e levados a efeito nos nossos dias. Para estes, importará (quase) somente localizar, identificar, analisar, interpretar, preservar e divulgar materialidades corroboradores e/ou reveladoras de quotidianos mais ou menos longínquos. Mas será que a história da arqueologia não poderá ir além de datas e atos comemorativos, e de contribuir para a elaboração de histórias institucionais e biografias científicas? Poderá a história da arqueologia 
concorrer para a recuperação de "invisibilidades" refletidas na atualidade? Terá a história da arqueologia capacidade para aprofundar as ligações mantidas entre ciência, atores, espaços, ideologias, políticas e projetos de investigação, de modo a que fenómenos registados nos nossos dias sejam melhor entendidos? Poderá e deverá a história da arqueologia concorrer para a fixação e aumento do bem-estar das comunidades e desenvolvimento dos seus respetivos territórios?

Não só pode e tem essa capacidade, como - acrescentamos -, deve aplicá-la, sendo mais proativa na observação de vínculos entre o passado e o presente com vista a melhorar este último e perspetivar ações futuras, potenciando, também assim, um melhor entendimento de linhas prioritárias de investigação. Fazê-lo, todavia, significará comprometer e/ou reiterar socialmente a produção historiográfica. Um compromisso que aduzirá maior sentido aos estudos realizados e projetados, justificando, ainda mais, aquela que se pretenderá seja a lógica existencial desta especialidade. Situação que nos deveria instar a aprofundar, em permanência, os nossos objetivos enquanto investigadores e indivíduos inseridos numa sociedade cada vez mais complexa. Também por isso, a questão da "utilidade" da história da arqueologia deveria (talvez) ser colocada a todos os campos de estudo, em especial aos de aplicação aparentemente menos óbvia, imediata e prática. Ainda assim, poderemos perguntar em que medida um conhecimento produzido será inútil. ${ }^{3}$

Parece-nos, por conseguinte, que interrogar se a história da arqueologia é útil significará questionar a relação íntima e natural entre epistemologia, trabalho prático e competências académicas de qualquer exercício científico. Por outro lado, demandar se a história da arqueologia ainda é útil parece sugerir que o foi e corre o risco de deixar de o ser. Mas, se assim fosse, quais as razões subjacentes a essa circunstância?

Se observarmos os anos mais recentes da história da historiografia da arqueologia, talvez obtenhamos uma pista sobre este quesito. Com efeito, haverá alguns indícios que apontam para um certo esmorecimento generalizado do mundo académico com rela-

\footnotetext{
3. Tratar-se-á, ainda assim, de uma questão interessante por nos relembrar, de algum modo, a Querela entre Antigos e Modernos dos séculos XVII e XVIII, e a discussão sobrevinda em meados de Novecentos sobre ciência "fundamental" / "pura"/ "básica" vs. ciência "prática", ainda no rescaldo da II Guerra Mundial.
}

ção à história da arqueologia, especialmente entre a maioria dos jovens estudantes, tanto em Portugal, como noutros países.

O que justificará este afastamento? A ausência de futuro exclusivo na área? $\mathrm{O}$ intenso trabalho diário enquanto arqueólogos de campo e de gabinete que inviabiliza um olhar mais atento sobre questões historiográficas? A autonomização universitária da arqueologia em relação à história? Ou será, antes, o facto de não divisarem, por completo, o papel da história da arqueologia na execução de projetos de investigação que suscite uma maior aproximação entre ciência, território e comunidades, num exercício de 'ciência cidadã' incentivada por agências nacionais e internacionais de financiamento científico? Para os historiadores, designadamente da arqueologia, a importância do estudo do passado é uma não dúvida. Mas, como demonstrar aos não historiadores, aos não cultores das humanidades e das sociabilidades, a importância, na atualidade, da investigação do pretérito? Mais do que isso, como explicar aos diferentes públicos a relevância desse mesmo passado?

A solução parece residir na ligação entre produção de conhecimento científico, comunidades locais e seus territórios. Nada, porém, que seja propriamente uma novidade para os arqueólogos, para mencionarmos apenas a disciplina que aqui nos traz, pois nunca houve, nem podia haver, arqueologia (totalmente) descontextualizada do território e das suas comunidades. Trata-se de uma ligação presente no passado, como se conclui relendo histórias da arqueologia sob alguns regimes políticos e agendas pessoais, coletivas, públicas ou privadas (Díaz-Andreu, 2007).

Não obstante, mesmo que de modo pouco ou nada ciente, este vínculo tem sido hierárquico e alógeno. Organizam-se, é certo, dias abertos, visitas, palestras, conferências e exposições que suscitam a curiosidade e o interesse das gentes locais. Muito pouco, porém, parece envolver diretamente as comunidades e os territórios desde o primeiro momento, ou seja, desde que pré-germina a ideia conducente à investigação no terreno. Não obstante, temos assistido em Portugal, nos últimos anos, a projetos revestidos desta preocupação e que assumem um caráter exemplar ${ }^{4}$. Projetos que predizem

4. Exemplos: 'RIBACUDANA - associação de fronteira para o desenvolvimento comunitário' e 'Vila Nova de São Pedro - VNSP 3000 '. 
um futuro próximo bastante promissor neste âmbito. Um futuro que desejamos venha a ser preenchido com programas de "ciência cidadã" apreendidos na sua essência e não em resultado de critérios de avaliação fixados por organismos responsáveis pelo de financiamento científico.

Independentemente destas breves considerações, pensamos que os projetos nas áreas das ciências humanas e sociais podem correr o risco de serem entendidos como prescindíveis ao não incluírem a componente societal.

Além das suas reais motivações, poder-se-á afirmar que parte significativa dos jovens estudantes e académicos procuram, cada vez mais, uma ligação profunda e consistente entre arqueologia e sociedade, entre conhecimento arqueológico e desenvolvimento social sustentável.

Dito isto, talvez seja o momento de questionar em que medida esta procura decorre de uma necessidade e de uma ética intrínsecas e não de uma tendência observada em temas de investigação que têm vindo a ser maioritariamente financiados. Com efeito, ainda que não reconhecida pela totalidade dos intervenientes, parece existir uma certa (se não total) distorção neste processo que tem instado à inclusão (por vezes) forçada de propósitos societais nas candidaturas, considerando, por exemplo, os "Objetivos de Desenvolvimento do Milénio" (ODM) definidos pela Organização das Nações Unidas.

Mas, por mais vicioso que pareça, têm sido alcançados alguns desideratos traçados por projetos colocados a concurso. Desde logo, ao reconhecer-se o papel de instituições, como associações, academias, universidades e museus, no desenvolvimento da arqueologia. Depois e sobretudo, ao convocar populações locais a esses mesmos projetos para que possam acrescentar, quantas vezes de forma entusiástica, dados fundamentais à concretização dos mesmos. Uma concretização que acaba por fazer aumentar a própria autoestima das comunidades assim envolvidas (Babo, Guerra e Quintela, 2007; Carvalho, 2017). Será este o caso de projetos que lançam mão da recolha de memórias orais, à luz das quais se conhecem pormenores necessários a um melhor entendimento de processos de investigação transatos e de toda uma série de dinâmicas interpessoais e interinstitucionais que lhes eram inerentes. Projetos que, sendo inclusivos, promovem a investigação histórica multidisciplinar local e regional. Projetos que visam a compreensão e a divulgação da importância da arqueologia no desenvolvimento sustentável local através da organização de museus de sítio, de exposições temporárias, de merchandising próprio, da recuperação e novos estudos de sítios, indivíduos e instituições. Projetos que motivam e permitem cruzar e relacionar municípios em busca de uma história comum traduzida em encontros científicos, exposições, visitas, atividades escolares e de outra natureza. Projetos que, sendo de história da arqueologia ou que a incluem, podem e devem concorrer para a materialização de alguns ODM, a exemplo do destinado a "promover a igualdade entre os sexos e capacitar as mulheres".

Neste sentido, a história da arqueologia permite descobrir nomes e obras esquecidas; publicar ou republicar obras; recuperar e reanalisar projetos, mormente de contexto museológico. Além disso, a história da arqueologia pode e deve contextualizar e esclarecer o momento e o modo como, por exemplo, as mulheres foram ingressando na arqueologia, escrutinando papéis desempenhados, realizações, obstáculos e frustrações. Uma análise aplicável a outros atores da arqueologia que, por razões certamente muito diferentes, foram mantidos na sombra até se tornarem invisíveis.

Entretanto, a já decenária 'arqueologia pública' tem conquistado terreno apreciável neste século XXI, nomeadamente pelo muito que carreia na revelação de excertos importantes do passado que foram sendo olvidados ou truncados por motivos vários ${ }^{5}$. Em simultâneo, a arqueologia pública tem abarcado conceitos aparentemente tão díspares e ao mesmo tempo complementares, quanto os de arqueologia comunitária $^{6}$ e colaborativa (Tully, 2007); feminista e de género7 (Díaz-Andreu e Sorensen, 1998; Martins, 2016); pós-colonial; indígena; etnográfica; estudos patrimoniais. Em suma, estaremos perante uma arqueologia que, tendo sido (quase) sempre pública, assume agora um crescente perfil ativista na medida em que o arqueólogo se encontra mais cien-

\footnotetext{
5. Importância plasmada, por exemplo, na revista quadrimestral Public Archaeology, editada pelo arqueólogo inglês Tim Schadia-Hall desde 2000 e publicada pela Maney Publishing.

6. Relevância traduzida no Journal of Community Archaeo$\log y$ \& Heritage, publicado pela Taylor $\mathbb{\&}$ Francis.

7. No âmbito das quais têm sido acrescentados temas como os do assédio e da violência sexual em contexto de ensino e de produção de conhecimento arqueológico.
} 
te do seu papel na sociedade, contribuindo para dar voz a quem não a tem, a perdeu ou não a recuperou ${ }^{8}$. Assim se franqueia, em definitivo, a era da arqueologia prática ao serem criados projetos de investigação com a participação de comunidades, com as suas emoções e os seus afetos, e com os quais também se modelam identidades e narrativas (escritas e iconográficas) (Peralta e Anico, 1006; Alatalo, 2015; Bodicce, 2018). Aspetos que têm sido atendidos pela história da arqueologia e que deveriam ser mais considerados, especialmente para conceber atividades fomentadoras da proximidade entre território, cidadãos, comunidades, produção científica e desenvolvimento sustentável. Porque as realidades de âmbito local, regional, nacional e transnacional são diversas, as necessidades múltiplas e as possibilidades emergem, quantas vezes, da sua intersecção, numa sociedade em permanente mutação.

\section{3. ÉVORA E O SEU TEMPO ROMANO. O TEMPLO ROMANO DE ÉVORA}

Mas, e quanto à arqueologia, em concreto, em Évora ou na região eborense?

O templo romano é, sem dúvida, um dos elementos centrais da imagem de Évora, tal como outros monumentos são apresentados como representações de demais localidades, regiões ou países. Assim sucede, como se um território e as suas comunidades sejam identificados/identificáveis por uma imagem, neste caso monumental. Como se um monumento contenha em si todas as variabilidades de um mesmo território e suas gentes. Trata-se, porém, de um método, de um recurso e de uma estratégia que não é de hoje nem de agora: o de associar território, comu-

\footnotetext{
8. Casos, em Portugal, dos projetos 'Trabalhadores forçados portugueses no III Reich, 1939-1945. Memória, responsabilidade, futuro"; a recolha de memórias, sobretudo orais, promovida pelo Museu Nacional da Resistência e da Liberdade; a realização, em Lisboa, do '1. ․ Encontro Memória para Todos. História, Memória e Comunidade(s)’ onde foram apresentados resultados preliminares dos projetos arqueológicos "Adegas da Memória" e "Arquivos de Memória", este último pertencente ao Parque e Museu do Côa. Exemplos que advêm, em certa medida, de uma linha de investigação que tem preponderado além-fronteiras, mormente com o incentivo da UNESCO (por exemplo, no combate ao antissemitismo), inclusive para resgate de memórias relacionadas, direta e indiretamente, com a II Guerra Mundial, resultando em encontros científicos, exposições temporárias e edições monográficas.
}

nidades e cultura material, conferindo-lhes a coesão essencial à construção e manutenção de unidade ou da ideia de unidade, mormente nacional.

Estamos, também por isto, perante uma imagem (= templo romano) que tem sido construída ao longo dos tempos, sobretudo desde a eclosão do turismo cultural no país e inerente composição de itinerários de visitas enquadrados por uma imagética e um modo de estar romântico. Uma imagem enraizada entre meados de Oitocentos, com a aplicação da teoria do restauro estilístico violletiano à sua estrutura, e inícios de Novecentos, ao ser incluído no segundo decreto de classificação de monumentos nacionais, datado de 1907 (Martins, 2005). Antes, porém, já o templo é referido em exemplares - principalmente espanhóis -, de literatura de viagem, assim como em artigos de periódicos, enquanto é objeto de registo fotográfico (Martins, 2003; Rodrigues, 2007). O fato de ser o único exemplar desta tipologia arquitetónica clássica existente numa cidade portuguesa, a relativa curta distância da fronteira espanhola, suscita desde cedo a curiosidade e o interesse de intelectuais locais e de forasteiros ilustrados, sejam eles portugueses ou estrangeiros (Salas Álvarez, 2019). Um testemunho do poder da Roma imperial que distingue a urbe eborense das demais existentes no território, enquanto revela a sua importância neste contexto clássico. Mais do que isso, demonstra a presença continuada de comunidade(s) na sua geografia acolhedora de arquiteturas e gramáticas decorativas representativas de vários contextos históricos que a têm marcado ao longo dos tempos.

A centralidade, por um lado, do templo na malha urbana, e a perda da sua função primeva, por outro, ditam-lhe outras sortes, como sucede um pouco por toda a Europa anteriormente ocupada pela águia imperial romana. Assim se compreende que seja aproveitado, por exemplo, como açougue, o último destino que lhe é conhecido. Nada que nos deva surpreender, nomeadamente quando a história do património se encontra preenchida de testemunhos similares de ocupações e reocupações; adaptações e readaptações dos mesmos espaços a novas funcionalidades. Fenómeno que, na verdade, se perde na noite dos tempos e sobrevive até aos nossos dias.

Enquanto isto, o templo romano de Évora surge como (quase) sinónimo da cidade e sua história, assim como da própria região eborense. Torna-se uma verdadeira imagem de marca da urbe e seu entorno, encontrando-se em capas de edições que lhes 
são dedicadas. Neste contexto, o templo romano poderá ser entendido como elemento "falante" ao significar a cidade de Évora. Um signo significante que acaba por ser de tal forma apropriado no seu significado trans-memorial e trans-contextual (Serrão 2001 e 2008) que surge em quase todos os suportes: postais, selos, medalhas, emblemática (heráldica, vexilologia, ex-librística), cartazes da mais variada natureza e objetivos, incluindo culturais e desportivos, e capas editoriais, mormente turísticas. Mas o templo é fruído também de outro modo, a saber, como cenário de espetáculos.

São, no entanto, utilizações que nos dizem ainda muito pouco acerca do sentir e da relação entre templo, território e comunidade(s). Pelo menos, da maior parte de comunidade(s) residentes ao longo do tempo na cidade e na geografia imediatamente envolvente. Até porque os suportes acima enunciados contendo a imagem do templo, sendo visíveis e circulando, são desfrutados por um estrato reduzido de gente mais esclarecida. Mas quando o templo serve de pano de fundo a campanhas publicitárias e eleitorais; quando é associado a espaços comerciais e, sobretudo, quando é elemento recorrente em diversas tipologias de peças comercializáveis (= merchandising), então estaremos perante a interiorização mais generalizada da sua importância. Mas será um reconhecimento do templo enquanto parte intrínseca do território e suas gentes ou do seu valor turístico, porquanto distintivo, e, por conseguinte, comercial, donde económico?

De que modo as comunidades locais entendem e interpretam o templo romano? O que conhecem dele? Sentem-no como seu? Fruem-no quotidianamente? Em que circunstâncias? De que modo? Com que propósito(s)? O templo será verdadeiramente central na vida eborense e dos eborenses? De que forma? Encontrar-se-á nos momentos-chave das suas vidas ou são outros espaços e monumentos a ocupar preferentemente essas memórias e a fixá-las como se de mnemónicas se tratassem? Tem o monumento suscitado maior empenho local em (re) descobrir a herança clássica do território, aumentando a procura de conhecimentos na área? Serão os estudos realizados no templo e sobre o templo do conhecimento geral das comunidades? Estará ele contemplado em atividades de diferentes níveis de ensino e de formação ao longo da vida? Será ele inserido em ações destinadas a diversas faixas etárias e pertenças sociais? Existirá entendimento local quanto à sua importância no desenvolvimento sustentável da cidade e da região? As comunidades locais promovem a sua salvaguarda? Terá ele o mesmo significado para todas as comunidades deste mesmo território? Identificam-se com o monumento? Trata-se de um amplo conjunto de interrogações necessárias para compreendermos a dinâmica estabelecida ao longo dos tempos entre templo, território e comunidades locais e regionais, num primeiro plano, e nacionais e internacionais, num segundo. Uma análise que nos remete para outras dimensões historiográficas a serem contempladas pela história $\mathrm{da}$ arqueologia que tem, pode e deve ter aqui um papel nuclear, firmando pontes e (re)construindo aços dinâmicos entre o passado e o presente, sempre numa perspetiva de futuro.

O papel da memória e o das emoções configuram algumas destas dimensões. Sobretudo o desempenhado pelas emoções. Emoções que, por dependerem de normas sociais vigentes em cada momento, são historicamente variáveis e mutáveis nos seus mais variados contextos. Por isso, também, as emoções e as suas expressões configuram construções históricas ao mesmo tempo que moldam a própria história. Mas porque são aparentemente menos visíveis, há que procurá-las, identificá-las e compreendê-las, nomeadamente do ponto de vista da história da arqueologia.

Propomos, por conseguinte, construir um projeto que nos permita conhecer o monumento no seu território e na interação com as comunidades. Um projeto que possibilite avaliar a perceção que as comunidades vão estabelecendo sobre o monumento e o valor simbólico que carreia, desde uma perspetiva cultural, antropológica e sociológica. Análise que deverá ser focada no período que decorre entre finais de Setecentos e a atualidade, considerando as fontes primárias e secundárias disponíveis que acreditamos serem suficientes para mapear memórias e emoções. Será este mapeamento, esta paisagem e geografia de afetos, a revelar o modo diferenciado como o monumento tem sido observado, interpretado, acolhido, vivenciado, fixado, reproduzido e divulgado. Por outras palavras, as fontes - incluindo as orais -, demonstrarão a variabilidade de perceção do templo de acordo com as pertenças sociais, económicas, culturais e científicas de cada elemento ativo, individual e coletivo, público e privado, deste processo de trans-memória e trans-contextualidade verificável ao nível da micro-história e da cripto- 
-história deste monumento (Serrão 2001 e 2008). Para alcançar tal desiderato haverá, também, que produzir questionários e realizar entrevistas. Tarefas a serem executadas por uma equipa multidisciplinar e, desejavelmente, transfronteiriça, que analisará os resultados assim obtidos. Mais do que isso, será necessário agregar representantes de instituições relacionadas, direta e indiretamente, com as vivências produzidas sobre o monumento e a propósito do monumento. Somente assim obteremos uma imagem alargada da relação gerada entre comunidades, território e templo romano. Somente assim se compreenderá como as comunidades se integram nos seus processos de estudo, preservação e divulgação, e a ligação emocional e intelectual que com ele estabelecem (Smith, 2006). Fenómeno que queremos estender para lá das fronteiras eborenses, alentejanas e portuguesas, aferindo utilizações, memórias e emoções registadas por estrangeiros, mormente espanhóis, sobre o monumento, enquanto procuraremos cotejar este conjunto de sentires com outros produzidos aquando da observação de testemunhos congéneres, como o de Mérida.

Mais do que isto, pretendemos saber em que medida, a partir desta análise, existe uma 'comunidade patrimonial'9 em Évora, para lá, evidentemente, do contributo fundamental e sempre presente de instituições como a do já centenário Grupo Pro-Évora (1919). Em caso afirmativo, aspiramos capturar o papel deste monumento em estratégias formais e informais de intercâmbio, mormente, educativo, cultural e científico; de socialização do património e do património enquanto ativo socializador e socializante; inclusão social; regeneração urbana; coesão comunitária; educação patrimonial e para o património; no estabelecer de pontes entre diferentes agentes culturais e científicos eborenses, locais e não locais, permanentes ou temporários; de relação entre monumento e turismo cultural (Gill, 2007); no desenvolvimento económico do território; na firmação de (i)lógicas identitárias; de (re)afirmações ideológicas e políticas (Torrico, 2006).

Uma 'comunidade patrimonial' que deve ser incluída e entrosada no processo de identificação, inter-

\footnotetext{
9. Definida pela Convenção de Faro do Conselho da Europa (2005) enquanto "composta por pessoas que valorizam determinados aspetos do património cultural que desejam, através da iniciativa pública, manter e transmitir às gerações futuras.".
}

pretação, salvaguarda e valorização do monumento. Porque são as pessoas que fazem os lugares, neste caso o monumento, porque a elas se devem as memórias, as vivências e as emoções que o mesmo tem potenciado ao longo dos tempos. Reminiscências experienciadas de modo diverso, tanto individual quanto coletivamente, dependendo das histórias de vida de cada protagonista deste complexo e (quase) interminável processo.

Também aqui a história da arqueologia pode e deve dar o seu contributo, ampliando e aprofundando excertos de um percurso enriquecido pelos variados contextos históricos que tem atravessado. Porque são esses pedaços de uma história única que humanizam o monumento, o integram no intricado xadrez emotivo de quem com ele convive, dele vive e através dele perpetua memórias intergeracionais.

\section{ALGUMAS REFLEXÕES FINAIS}

Por conseguinte, à pergunta inicial Is (still) history of archaeology useful?, respondemos "evidente que é (ainda) útil!”.

A história da arqueologia é útil quando trata da história das instituições, investigadores, cidadãos, territórios e agendas, direta e indiretamente ligados à arqueologia, aos seus métodos, teorias e práticas. A história da arqueologia é útil quando estuda antigas escavações e coleções - incluindo de museus -, para reavaliar resultados e conclusões à luz de conhecimentos, necessidades e objetivos atuais. A história da arqueologia éútil quando envolve diferentes especialistas para identificar estudos, reexaminar, recontextualizar, e divulgar, por exemplo, restos mortais humanos e testemunhos de cultura material recolhidos em antigas colónias. A história da arqueologia é útil quando contempla registos de memória oral nas suas investigações para localizar e compreender melhor locais e artefactos decorrentes de episódios contemporâneos englobados nos conceitos de "Arqueologia de Conflito", "Arqueologia Pós-conflito" e "Dark Heritage". A história da arqueologia é útil quando responde de forma inclusiva a premências e anseios quotidianos de investigadores e comunidades locais. Ela é ainda útil quando revela indivíduos, instituições, teorias, métodos e práticas, sucessos e fracassos, promoções e omissões.

A história da arqueologia continuará a ser útil enquanto revelar e valorizar o património local - material e imaterial; móvel e imóvel -, essencial à au- 
toestima de comunidades inseridas em territórios específicos, contribuindo, também assim, para o desenvolvimento do turismo cultural e arqueológico de diferentes localidades e regiões.

A história da arqueologia continuará a ser útil enquanto houver quem pretenda tornar-se historiador da arqueologia e nela entrevir potencial para gizar projetos de arqueologia, mais do que pública, comunitária, destinados a cumprir, colaborativamente, alguns dos ODM, reforçando a relação entre 'arqueologia prática', teoria arqueológica, gestão patrimonial e aquelas que serão as preocupações realçadas em cada contexto por distintos representantes civis, governamentais e comunitários. Nunca, porém, esquecendo que à academia caberá parte substantiva da teorização dos assuntos analisados.

\section{Lisboa, Primavera-Verão de 2020}

\section{AGRADECIMENTOS}

Os primeiros agradecimentos são devidos à Associação dos Arqueólogos Portugueses (AAP), à qual dedico já 25 anos do meu percurso científico. Depois, à equipa que tem organizado os congressos da AAP. Por fim, mas não menos importante, aos responsáveis por esta edição num contexto pandémico que marcará para sempre as nossas vidas e a existência da própria AAP.

\section{BIBLIOGRAFIA}

AlAtAlO, Malla (2015) - Reading Pictures, Constructing Narratives - A Study upon Pictorial Narrativity and a Narrative Analysis of Work Photography. Pro Gradu Thesis. University of Lapland, Faculty of Art, and Design. 82 pp.

BABO, Elisa, GUERRA, Paula e QUINTELA, Pedro (2007) - Estruturas museológicas, desenvolvimento, envolvimento e participação local: uma aproximação a alguns casos portugueses. In Atas das IX Jornadas do Departamento de Sociologia da Universidade de Évora - Transpondo Fronteiras, 15 pp. [https://sigarra.up.pt/faup/pt/pub_geral.pub_ view?pi_pub_base_id=75086].

BELTRÁN, José, FABIÃO, Carlos e MORA, Bartolomé, eds. (2019) - La Historia de la Arqueologia Hispano-Portuguesa a Debate. SPAL Monografías Arqueología, XXX. Universidade de Sevilha, Universidade de Málaga, UNIARQ / Universidade de Lisboa.

BODICCE, Rob (2018) - The history of emotions. Manchester: Manchester University Press.

CARVALHO, Diana Alexandra Simões (2017) - Ensaio sobre a relação entre as comunidades locais e o seu património cultural - a comunidade de Castro Laboreiro como estudo de caso. [disponível em http://www.cta.ipt.pt/download/ OIPDownload/ideario_JULHO_2.pdf]

DIAZ-ANDREU, Margarita (2007) - A World History of Nineteenth-Century Archaeology: Nationalism, Colonialism, and the Past. Oxford: Oxford University Press.

DIAZ-ANDREU, Margarita and SØRENSEN, Marie-Louise S., eds. (1998) - Excavating Women: A History of Women in European Archaeology. London: Routledge.

GILL, Alison (2007) - Turismo, Comunidades e Gestão de Crescimento. In Compêndio de Turismo. Lisboa: Instituto Piaget, pp. 631-646.

MARTINS, Ana Cristina (2016) - Pioneiras da Arqueologia em Portugal: "another brick" against "the wall" of indifference. Maria de Lourdes Costa Arthur (1924-2003). Clepsydra. Revista de Estudios del Género y Teoría Feminista, 15, pp. 77-10o.

MARTINS, Ana Cristina (2005) - A Associação dos Arqueólogos Portugueses na senda da salvaguarda patrimonial. 100 anos de (trans)formação (1863-1963). [texto policopiado]. Tese de doutoramento em História apresentado à Universidade de Lisboa.

MARTINS, Ana Cristina (2003) - Possidónio da Silva (18061896) e o resgate da memória. Um percurso na arqueologia de Oitocentos. Lisboa: Associação dos Arqueólogos Portugueses.

PERALTA, Elsa e ANICO, Marta (2006) - Patrimónios e identidades: ficções contemporâneas. Oeiras: Celta Editora.

RODRIGUES, Paulo S. (2007) - O passado é uma cidade ideal: um olhar sobre a patrimonização de Évora, Revista de História da Arte, 4, pp. 270-296.

SALAS ÁLVAREZ, Jesús de la A. (2019) - El interés de la Ilustración española por las antigüidades portuguesas. El caso de Évora. In BELTRÁN, José, FABIÃO, Carlos e MORA, Bartolomé, eds. - La Historia de la Arqueologia Hispano-Portuguesa a Debate. SPAL Monografías Arqueología, XXX. Universidade de Sevilha, Universidade de Málaga, UNIARQ / Universidade de Lisboa, pp. 27-56.

SERRÃO, Vítor (2001) - A cripto-história de Arte. Lisboa: Livros Horizonte.

SERRÃO, Vítor (2008) - A trans-memória das imagens. Estudos iconológicos de pintura portuguesa (sécs. XVI-XVIII). Lisboa: Edições Cosmos.

SMITH, Laurajane (2006) - Heritage as a Cultural Process. In Uses of heritage. London: Routledge.

TORRICO, Juan Agudo (2006) - Patrimónios e discursos identitários. In Patrimónios e Identidades: Ficções Contemporâneas. Oeiras: Celta Editora, pp. 21-34.

TULLY, Gemma (2007) - Community archaeology: general methods and standards of practice. Public Archaeology, 6: 3, pp. 155-187. 


\title{
COMO DESCOLONIZAR A ARQUEOLOGIA PORTUGUESA?
}

\author{
Rui Gomes Coelho'
}

\begin{abstract}
RESUMO
Enquanto disciplina, a arqueologia é um produto da modernidade ocidental e de relações de colonialidade contemporâneas. Neste texto discuto brevemente a arqueologia no contexto da descolonização do saber e da sociedade. De seguida, exponho quatro problemas centrais com que devemos lidar, seguidos de propostas de discussão ou exemplos de experiências descolonizadoras. O projeto descolonial está longe de ser uma mera abstração. Pelo contrário, é uma oportunidade para imaginarmos um mundo com justiça social.

Palavras-chave: Colonialidade, Descolonização, Ativismo, Epistemicídio.
\end{abstract}

\begin{abstract}
As a discipline, archaeology is the product of western modernity and contemporary relations of coloniality. In this text, I briefly discuss archaeology regarding the decolonization of knowledge and society. After that I will expose four key issues that need to be dealt with, followed by ideas for discussion or examples of decolonizing experiences. The decolonial project is far from being just an abstraction. On the contrary, it is an opportunity for us to imagine a world with social justice.
\end{abstract}

Keywords: Coloniality, Decolonization, Activism, Epistemicide.

\section{INTRODUÇÃO}

Desde pelo menos a década de 1980 que a virada pós-colonial tem influenciado a arqueologia e as suas disciplinas irmãs, nomeadamente a antropologia e a história. No caso concreto da arqueologia, essa virada relaciona-se com a crítica da disciplina enquanto produto e instrumento da modernidade europeia, e do seu envolvimento nos projetos imperial e do estado-nação. Essa crítica é hoje necessária perante os legados coloniais que teimam em persistir nas nossas sociedades.

Enquanto prática disciplinar, a arqueologia apareceu no século XIX como um projeto das elites burguesas destinado a estabelecer uma narrativa explicativa do estado-nação. Com a emergência dos regimes liberais, a legitimidade do poder deixou de residir em deus e na relação entre deus e o soberano para passar a estabelecer-se a partir do povo, organizado num estado-nação. Coube às novas elites definir essa comunidade e quais eram os limites espaciais e tem- porais do estado-nação. Como podemos imaginar, a comunidade do estado-nação foi compartimentada e hierarquizada de modo a consolidar a posição social de uma determinada burguesia urbana que tentava controlar tanto o poder económico como o poder político (Cf. Anderson, 1983; Hobsbawm \& Ranger, 1983).

A arqueologia, enquanto campo do saber focado no estudo das origens da humanidade, foi instrumental na definição da profundidade temporal do estado-nação. Por outro lado, a disciplina também serviu para desenhar fronteiras físicas e sociais entre as elites urbanas ilustradas e o resto da comunidade nacional, cujo dever era trabalhar e servir. De acordo com a visão linear da história que promoviam, as elites eram a vanguarda do progresso e a chave para a transformação do estado-nação numa comunidade moderna. A larga maioria da população partilhava muito pouco com as elites: comportava-se e falava de maneira diferente, produzia conhecimento de forma distinta, e tinha prioridades económicas e

1. Department of Archaeology, Durham University; UNIARQ - Centro de Arqueologia da Universidade de Lisboa; rui.g.coelho@ durham.ac.uk 
políticas diversas. Esta maioria foi definida como tradicional, isto é, foi-lhe atribuída uma maior ligação ao passado e à terra. Dependendo do contexto, o caráter tradicional das comunidades equivaleu à ideia de primitivismo ou atraso. Disciplinas como a etnologia e a arqueologia serviram para classificar e documentar as tradições que davam corpo ao estado-nação. A maioria das pessoas passou a ser um sujeito de estudo, produtoras de informação para ser analisada e tornada inteligível nos termos das elites, isto é, através da ciência (Cf. Leal, 20oo; Thomas, 2004). Na fase final deste processo extrativo, o conhecimento retornaria às comunidades de origem, mas com forma e conteúdo definidos à maneira das elites.

As comunidades ditas tradicionais possuíam os seus próprios modelos de produção de conhecimento, que podiam ou não cruzar-se com a ciência. Porém, estes modelos foram sendo gradualmente marginalizados a favor de um modelo comum e estandardizado, disseminado pelo ensino oficial (Cf. Anderson, 1983). Os modos locais de fazer e transmitir a história passaram a ser entendidos como superstições ou tradições, de onde poderia ocasionalmente extrair-se alguma verdade científica pelo filtro do estudioso autorizado. Deste processo de subalternização emerge um paradoxo: as comunidades rurais estão presas ao passado e ligadas à terra, mas não lhes é reconhecido o conhecimento da sua própria história. Ao arqueólogo cabiam então as tarefas de contar essa história, de proteger os vestígios materiais dos seus guardiões tradicionais e de envolver as comunidades numa nova relação com o passado. É assim que se estabelecem os museus arqueológicos de caráter nacional e regional a partir do final do século XIX, ou que se escolhem e restauram os monumentos que importam (Cf. Gomes, 2011, pp. 495-496).

Desta forma, podemos assumir que a arqueologia é intrinsecamente colonial no sentido em que depende de práticas de extração e acumulação, assim como da validação de uma determinada narrativa hegemónica sobre o passado. Para Aníbal Quijano (2007), estas práticas marcaram as divisões sociais centrais do mundo moderno, particularmente as que têm uma fundamentação racial, étnica e nacional. As relações de poder que subjazem ao projeto colonial ocidental não se circunscreveram aos territórios de colonização e conquista das Américas ou de África. Pelo contrário, elas espelham e articulam- -se com a emergência do próprio estado-nação e continuam a alimentar o modo como produzimos conhecimento e o tornamos inteligível (Cf. Scott, 2008). É por isso que devemos fazer uma distinção entre colonialismo e colonialidade. Enquanto o colonialismo clássico terminou com o fim dos impérios e as independências formais das antigas colónias, as relações de desigualdade geradas no seio do colonialismo continuam presentes (Grosfoguel, 2007; Quijano, 2007). A descolonização que faz falta à arqueologia portuguesa é uma resposta à colonialidade presente na forma como se pensa, pratica e comunica arqueologia.

Os efeitos mais perniciosos da colonialidade da arqueologia correspondem ao que Boaventura de Sousa Santos (2014) chamou de epistemicídio. Através da universalização de modelos de produção de conhecimento característicos da modernidade ocidental, o mundo foi perdendo diversidade na experiência humana e sujeito a relações de desigualdade. Essas relações estruturam as grandes divisões de poder e recursos que testemunhamos hoje entre o norte e o sul globais. De qualquer modo, é preciso termos em conta que as desigualdades globais que condicionam a existência da humanidade têm configurações muito específicas e locais. Os arqueólogos, por exemplo, operam em algumas dessas configurações no exercício diário da profissão, nas relações interpessoais e com as comunidades com quem trabalham.

A relação de desigualdade entre os arqueólogos e as comunidades raramente foi questionada, e permanece ainda hoje como o modelo predominante na forma como os arqueólogos interagem com o público em Portugal. Os modos locais de produção e transmissão da história quase desapareceram, e os arqueólogos são os únicos agentes autorizados na produção de conhecimento sobre o passado através dos vestígios materiais. A desintegração dos saberes locais e as barreiras sociais resultaram na desconexão que muita gente sente em relação ao conhecimento arqueológico.

O movimento descolonial tem ido mais além das críticas pós-coloniais, embora nelas se fundamente. Os seus proponentes defendem que no contexto atual de aceleração do neoliberalismo, não basta analisar e expor a colonialidade do projeto da modernidade universalista e dos seus modos de produção de conhecimento. Pelo contrário, a arqueologia modernista corresponde a um modelo de estar e conhecer o mundo que é destrutivo e que deve des- 
montado (Cf. Grofoguel, 2007; Quijano, 2007; Santos, 2014). Nesse sentido, a descolonização da arqueologia implica tanto a identificação das relações de poder que a tornam colonial, como o abandono das práticas de extração e acumulação que continuam a servir para sancionar desigualdades sociais. Finalmente, a descolonização requere a transformação radical da disciplina.

Ramón Grofoguel propôs que a virada descolonial deve consistir em três elementos centrais. Primeiro, na construção de um modo de produção de conhecimento fundamentado num cânone mais vasto que $o$ ocidental. Segundo, num diálogo crítico entre vários projetos epistemológicos, éticos e políticos na direção de um mundo "pluriversal". Finalmente, na consideração de perspetivas do sul global que se pensem desde e com corpos e espaços subalternizados (Grofoguel, 2007, p. 212). Nada disto é fácil. O projeto descolonial, através do qual confrontamos séculos de dominação, exploração e injustiça social, requere muita determinação e dedicação pessoais. Estas qualidades são próprias de muitos entre nós que nos comprometemos politicamente na vida, independentemente da forma como encaramos as relações entre política e arqueologia. Porém, somos confrontados quotidianamente com desigualdades sociais, que se revelam tanto no interior da disciplina como através da prática arqueológica. A revelação das injustiças sociais não nos pode deixar indiferentes e por isso o projeto descolonial é um programa através do qual podemos articular a nossa ação enquanto arqueólogos e enquanto cidadãos (Cf. Coelho, 2O2O).

Assim, a questão que intitula este texto poderia ser formulada de outra maneira: de que forma podemos imaginar a arqueologia num mundo mais justo?

A dificuldade em imaginarmos uma disciplina diferente, descolonizada, tem suscitado muitas questões sobre o significado do conceito de descolonização e os seus efeitos práticos. Este capítulo é o resultado de muitas conversas que fui tendo em torno deste tema com alunos, colegas e membros das comunidades com quem trabalho. Por isso, o texto está organizado em torno de quatro questões e problemas centrais no debate sobre a descolonização da arqueologia. Em cada uma dessas questões procurei expor o problema no contexto português, suas possíveis soluções, e algumas das experiências de caráter descolonizador já feitas em Portugal e no estado espanhol.

\section{AS RELAÇÕES ENTRE ARQUEÓLOGOS \\ E AS COMUNIDADES LIGADAS AOS SÍTIOS \\ E COLEÇÕES EM QUE TRABALHAM É DESIGUAL E EXTRACTIVISTA. COMO TRABALHAR COME PARA AS PESSOAS?}

Numa sociedade justa e democrática, descolonizada, as comunidades devem poder definir as suas próprias narrativas e ter controlo sobre os traços materiais que as sustentam. Enquanto arqueólogos empenhados na descolonização da disciplina, devemos deixar de considerar as comunidades como sujeitos a partir dos quais se extrai informação para produzirmos conhecimento científico. Pelo contrário, devemos reconhecer o papel que historicamente desempenhámos na criação de desigualdades, e promover um modo de produção de conhecimento que esteja ao serviço das comunidades. Ou seja, devemos deixar de trabalhar sobre as comunidades, e passar a trabalhar com e para as comunidades (Cf. Atalay, 2010; Atalay, Clauss, McGuire \& Welch, 2014). Trata-se de uma viragem radical que requere que nos impliquemos primeiramente num processo de reconhecimento e escuta, e só depois na definição de questões e metodologias científicas.

A legislação que regula os trabalhos arqueológicos em Portugal passou a requerer, desde 2014, a realização de iniciativas de educação patrimonial. No regulamento lê-se que "estas, para além de decorrerem de uma responsabilidade do arqueólogo, devem constituir uma oportunidade de aproximação da disciplina científica aos cidadãos" ${ }^{2}$. Este regulamento corresponde ao aprofundamento da sensibilidade patrimonialista liberal na qual as comunidades são sujeitos passivos, recetores da "educação" que lhes é fornecida por arqueólogos cientes da sua “responsabilidade”. É inquestionável que este regulamento encorajou a divulgação das atividades arqueológicas junto do cidadão comum, e estimulou o aparecimento de alguns projetos com uma forte componente de arqueologia pública. Porém, o regulamento aprofunda uma atitude que persiste desde o século XIX entre os arqueólogos, que se auto-validam como os únicos agentes na produção de conhecimento sobre o passado independentemente de o transmitirem ou não às comunidades (Cf. Valera, 2008).

Em Portugal ensaiaram-se modelos alternativos de

2. Decreto-lei n.o 164/2014 de 4 de Novembro. 
produção de conhecimento arqueológico centrados na emancipação da sociedade, e na sua transformação radical. No contexto revolucionário de 19741975 e nos anos que se seguiram, alguns grupos de arqueólogos procuraram mobilizar a disciplina para transformar a comunidade. Essas tentativas essencialmente baseavam-se na ideia de que a exposição e divulgação de uma narrativa materialista histórica sobre o passado poderia encorajar as pessoas a intervir na sociedade do presente. Por outro lado, pensou-se também que a passagem de uma arqueologia elitista para uma arqueologia ao serviço do povo poderia ser um veículo de desenvolvimento económico e, desde modo, um instrumento de emancipação (Coelho, no prelo).

Em anos mais recentes têm sido feitos projetos com uma forte componente de arqueologia pública. De um modo geral, esses projetos correspondem à sociabilização do conhecimento produzido por arqueólogos junto de comunidades mais ou menos alargadas. Em alguns casos, os arqueólogos assumem que os seus projetos podem ser veículos para valorizar o envolvimento das comunidades nos sítios arqueológicos. Esta nova atitude marca uma viragem na atitude patrimonialista liberal na medida em que prevê uma função afetiva na produção de conhecimento arqueológico, e não apenas económica ou social. Esta componente afetiva pode viabilizar o auto-empoderamento das comunidades através da sua própria consciencialização enquanto agentes da produção de património (Cf. Porfírio, 2015; Diniz, Neves, Martins, Carvalho \& Arnaud, 2018; Torres, 2009).

Porém, a arqueologia continua a fazer-se fundamentalmente sobre pessoas. Uma arqueologia descolonial deve ser feita com e para as pessoas, estimulando relações em que as comunidades deixem de ser sujeitos de investigação e passem a ser agentes (Cf. Atalay, 2010). Uma arqueologia descolonial pode ser um instrumento que sirva para dar visibilidade a relações históricas de desigualdade que se perpetuam no presente, nomeadamente a relação entre as cidades e o mundo rural, ou ainda entre as elites e as comunidades rurais que foram sendo desempossadas das suas terras, modos de subsistência e de produção de conhecimento. Esta transformação não é fácil porque confronta toda a tradição modernista e liberal em que os arqueólogos são os únicos agentes autorizados na produção de conhecimento. Porém, podemos beneficiar de experiências anteriores em que arqueólogos procuraram de algum modo confrontar relações injustas.

Os projetos de investigação arqueológica iniciam-se com a identificação de um problema científico e a necessidade de o resolver. A primeira coisa que devemos fazer é perguntar: de que modo o problema e o projeto poderão afetar as comunidades junto das quais iremos trabalhar? De que modo poderão as comunidades beneficiar deste projeto? O que é que as pessoas querem?

É possível que nunca apareçam respostas diretas para estas questões. As próprias comunidades estranharão tais questões, dado que raramente os arqueólogos lhes terão perguntado alguma coisa nestes termos. Porém, são questões que devemos fazer a nós próprios. Desde logo, as questões implicam-nos num processo de escuta que reconhece a existência de uma comunidade que dá sentido ao sítio ou coleção arqueológica. Esse reconhecimento precede o desenho das questões e metodologias científicas. É possível que no diálogo estabelecido com as partes interessadas se redefinam questões e métodos, tendo em vista a resposta às perguntas centrais que devem nortear um projeto descolonial.

O projeto arqueológico Castro de San Lourenzo na paróquia de Cereixa, província galega de Lugo, exemplifica vários dos aspetos que caraterizam um projeto descolonial: a crítica ao modelo extractivista na produção de conhecimento, o desenho dos objetivos do projeto a partir das expetativas existentes na comunidade, e a sociabilização do projeto nos termos da própria comunidade (Ayán Vila, no prelo). O projeto teve início em 2016 e desde então tem implicado a escavação de um castro de origens romanas e a sua ermida medieval de São Lourenço, assim como a casa de Repil, uma construção camponesa do início do século XX que serviu de abrigo a guerrilheiros anti-franquistas depois da guerra civil espanhola (1936-1939). O projeto é dirigido pelo arqueólogo Xurxo Ayán Vila, filho da terra, com o apoio do município, da administração provincial e sobretudo da Fundação Abanca. $\mathrm{O}$ apoio da fundação é mediado por outra pessoa de origens locais, antigo imigrante. Desde o início, os objetivos consistiram na valorização do património da paróquia de Cereixa como instrumento para a desaceleração do abandono do mundo rural que se verifica desde os anos de 196o. As origens do projeto são afetivas, na medida em que resultam da inquietação dos filhos da terra que observam o seu definhamento 
social e económico e decidem atuar com os instrumentos disponíveis. A arqueologia é um deles.

$\mathrm{O}$ projeto fundamenta-se num processo informal de consulta permanente com a comunidade, através do qual se identificaram os sítios mais importantes da paróquia: o castro e a casa de Repil. O interesse comunitário pelo projeto permitiu a viabilização e continuidade dos trabalhos arqueológicos. Por sua vez, a arqueologia ancorou um programa mais vasto de revalorização da memória local que inclui a recriação de uma procissão em honra de São Lourenço que havia desaparecido no princípio do século XX e a comemoração da resistência antifascista no pós-guerra. Assim, a escavação da ermida e da casa guerrilheira serviram de catalisadores para reinventar narrativas que até então enquadravam aquela porção do mundo rural galego. Ao contrário de um mundo destinado a desaparecer, obsoleto e conservador, a comunidade de Cereixa reclamou o controlo da narrativa que se faz sobre si própria. Enquanto o castro e a romaria anual garantem a profundidade temporal da própria paróquia, a casa de Repil funciona como ponto de orientação no universo de expetativas políticas que a comunidade projeta no futuro ${ }^{3}$.

\section{OS MUSEUS ARQUEOLÓGICOS CONTÊM COLEÇÕES QUE FORAM OBTIDAS ATRA- VÉS DE RELAÇÕES DE DESIGUALDADE ESTABELECIDAS TANTO EM PORTUGAL COMO NAS ANTIGAS COLÓNIAS. COMO LIDAR COM ESSAS COLEÇÕES?}

Os museus foram instituições centrais na definição e disseminação de narrativas hegemónicas sobre o estado-nação (Peralta, 2017). Os arqueólogos empenharam-se em estabelecer os contornos físicos dessas instituições, casas em que os objetos deveriam ser cuidadosamente organizados e exibidos de forma a conformar uma narrativa sobre as origens e emergência da comunidade nacional (Cf. Gomes, 2011, pp. 504-506). Invariavelmente, essa narrativa fixou-se numa sucessão linear e progressiva de "culturas" identificáveis pelos seus traços materiais e que gradualmente se foram aproximando do estado-nação atual, tanto em forma como em conteúdo. Embora as visitas dos museus sejam normalmente feitas a partir das salas que se referem aos contextos

3. O projeto Castro de San Lourenzo pode ser acompanhado através de http://sanlourenzo.net mais antigos, o objetivo do museu arqueológico típico é o de convencer o visitante que chega à sala final de que todas as outras salas eram representações coerentes de um passado inevitável.

Homens como José Leite de Vasconcelos apressaram-se a resgatar os traços do passado do seio de comunidades que, de um modo ou de outro, até aí lhes haviam dado sentido. Foi assim que se estabeleceu a prática oficialmente sancionada de recolher material arqueológico no que é hoje o Museu Nacional de Arqueologia, por exemplo, em nome da sua proteção e disponibilização à comunidade científica. Claro que isso significou que as comunidades que tinham até aí acolhido o material deixaram de lhe ter acesso direto, mas no estado-nação moderno elas são simplesmente recetoras e não produtoras de conhecimento. Para o fundador do MNA, os grupos não-letrados pertenciam todos ao mesmo contínuo "selvagem" que aguardava as luzes da civilização, independentemente da parte do mundo em que se encontravam (Cf. Diniz, 2008). A relação de desigualdade entre os arqueólogos e as comunidades na produção de conhecimento sobre o passado emergiu no século XIX, mas continua a ser largamente inquestionada. Quando olhamos para os primórdios da arqueologia, é fácil pensarmos que homens como Vasconcelos foram pioneiros e cruzados do saber. Nessa perspetiva, se não tivessem sido eles, o nosso património ter-se-ia perdido para sempre ou estaria abandonado, exposto a riscos de destruição. Na verdade, as comunidades locais sempre deram sentido aos objetos e sítios arqueológicos, enquadrando-os nas suas próprias temporalidades.

Durante muito tempo, era comum que arqueólogos documentassem lendas e tradições associadas aos sítios onde trabalhavam. Essas ditas lendas eram os traços de uma determinada visão do mundo que configurava a interpretação de coisas que os arqueólogos passaram a analisar com um olhar moderno. Em muitos lugares há evidências dessas interpretações, que se materializavam por exemplo na curadoria de determinados artefactos antigos em lugares públicos ou na sua preservação intencional na esfera privada. À semelhança de práticas semelhantes por toda a Europa, a preservação de epígrafes romanas ou esculturas medievais em fachadas de edifícios modernos é uma evidência deste processo. Em sociedades largamente iletradas, a curadoria destes objetos funcionava como um método mnemónico para o recontar de histórias. Narrativas sobre san- 
tos, mouras encantadas, entre outras, documentam temporalidades alternativas que foram dissipadas ou ocultadas pela emergência da modernidade e com a ajuda dos próprios arqueólogos (Cf. Hamilakis, 2011).

Sabemos que nem sempre as comunidades locais concordaram com a remoção de coleções arqueológicas dos locais onde foram encontradas ou visibilizadas. Existem várias histórias que chegaram até nós e que exemplificam tensões entre arqueólogos e comunidades em torno do destino a dar às coleções (veja-se por exemplo Silva, 2004, pp. 44-45).

Em contextos coloniais, o modelo de arqueologia extractivista praticado na Europa implicou-se de forma muito mais evidente. Nas colónias, a desigualdade das relações entre arqueólogos e comunidades confundia-se com a própria desigualdade política e social imposta pela relação colonial: os arqueólogos eram sempre ou quase sempre de origem europeia, formados em Portugal e praticantes de um modo de produção de conhecimento especificamente eurocêntrico.

Desde o início dos impérios modernos que os europeus constituíram coleções de objetos provenientes dos espaços coloniais. Porém, a partir do século XIX instituíram-se práticas de coleção sistemática a coberto de missões científicas ou da ação intencional de agentes coloniais que recolhiam objetos e os enviavam para instituições científicas. Em alguns casos constituíram-se coleções no domínio privado que acabaram depois por ser doadas a instituições. Tal como noutras paragens, os arqueólogos implicados em projetos coloniais procuraram conferir profundidade histórica aos territórios em que trabalhavam e estabelecer-lhe limites físicos. O trabalho científico foi também uma forma de efetivar a posse desses territórios nas mãos de autoridades europeias (Cf. Conde, Martins \& Senna-Martínez, 2015; Martins, 2015). Conhecer era uma forma de dominar, e a arqueologia também aí jogou o seu papel. Pouco antes da revolução de 1974, com as lutas de libertação a progredirem em África, o reitor dos Estudos Gerais de Moçambique defendia ainda a "ocupação técnico-científica do Mundo Português” (Simão, 1966, p. 288). Todas estas atividades geraram traços materiais sob a forma de coleções e documentação, que continua presente em território português e nas instalações de museus e arquivos portugueses.

A questão que se coloca é: como podemos fazer para mitigar, e até reparar as relações de desigualdade que foram sendo geradas através da aquisição e gestão de coleções arqueológicas?

Em primeiro lugar devemos reconhecer que a aquisição e gestão de muitas coleções arqueológicas foram feitas em circunstâncias inaceitáveis numa sociedade democrática. Não podemos mudar o passado, mas podemos entender de que modo os eventos do passado continuam a reproduzir ou a potenciar relações de desigualdade no presente.

O segundo passo deve ser a inventariação das coleções arqueológicas obtidas em relações desiguais ou coercivas. Não é possível gerir coleções sem as conhecer. Nesse sentido, ao inventário deve seguir-se um programa de estudo de coleções que permita conhecer as circunstâncias da sua aquisição e os efeitos que a remoção da coleção teve nas comunidades de origem.

Uma vez concluídos os inventários e os estudos, as instituições detentoras das coleções devem poder formar uma ideia mais clara sobre as circunstâncias da aquisição, e formular uma estratégia de reparação das relações de desigualdade que a aquisição da coleção viabilizou. Com a divulgação pública desta informação, é possível que comunidades ou instituições nas regiões de origem das coleções decidam contatar os detentores das coleções para solicitar um processo de restituição das coleções. Esta atitude implica que aceitemos colocar-nos uma posição de vulnerabilidade, abdicando da razão que preside à posse de bens arqueológicos. Em muitos casos, é possível que não exista qualquer documentação oficial que comprove a origem das coleções. Ainda assim, devemos saber escutar e procurar encontrar uma solução que seja coerente com as ideias democráticas da nossa sociedade (Cf. Macamo, 2017). Independentemente de existirem pedidos de restituição, as instituições podem e devem sempre promover uma recontextualização das coleções à luz de uma atitude descolonial.

Muitos se perguntarão se existem nas instituições portuguesas objetos que foram obtidos em relações desiguais, em que se duvide do consenso sobre a transação. Também se levantam questões sobre quem poderá ter a iniciativa para descolonizar os museus e as coleções, ou de que modo isso poderá ser feito. Estas três interrogações são legítimas e merecem a nossa reflexão.

As instituições portuguesas estão cheias de coleções obtidas em relações desiguais, particularmente em antigos territórios coloniais. Durante a dita- 
dura, o estado português organizou várias missões científicas em África e na Ásia que tiveram por objetivo conhecer as populações coloniais. Essas missões faziam parte de um programa de mapeamento social e económico das colónias de modo a potenciar a sua transformação em recursos. No caso das missões antropológicas e arqueológicas, os objetivos do estado passaram pelo escrutínio das comunidades para melhor as controlar, mas também pela extração de informação que poderia beneficiar a administração colonial na economia dos saberes. Assim, do mesmo modo que companhias mineiras ou agrícolas exploravam a força de trabalho para enriquecer grandes empresas coloniais, as missões científicas exploravam os produtores de conhecimento locais para extrair informação e circulá-la nos locais em que essa informação granjeava prestígio, assim como benefícios académicos e culturais. Estas missões materializaram-se em abundantes coleções, na sua maioria em museus e arquivos estatais em Portugal. Dado o contexto em que essas coleções foram constituídas, não é difícil imaginarmos que os objetos foram obtidos sob pressão direta ou indireta junto de comunidades que tinham pouca margem de manobra para negociar. Ainda que possam existir recibos de compra e relatórios detalhados que documentem o processo de obtenção de coleções, a verdade é que as populações sob domínio colonial estavam constrangidas, especialmente a partir do início das guerras de libertação (Cf. Figueiredo, no prelo).

Quando se discute o tema da descolonização dos museus, é comum pensar-se que as coleções em causa são maioritariamente constituídas por objetos etnográficos. Na verdade, conhecem-se coleções arqueológicas provenientes de missões científicas em espaços coloniais. Na ausência de uma inventariação exaustiva de museus e arquivos portugueses no que toca a este tema, podemos focar-nos no Museu Nacional de Arqueologia (MNA) e no antigo Instituto de Investigação Científica e Tropical (IICT).

O MNA foi na sua fundação um museu etnológico imperial, tendo acolhido objetos provenientes de espaços coloniais. A grande maioria desses objetos foram depois transferidos para o Museu Nacional de Etnologia, aberto em 1976. De qualquer modo, no seu arquivo conservam-se pequenas coleções provenientes de um sítio arqueológico em Angola, de outro em Moçambique, e de dois na Guiné-Bissau. Existem ainda vários artefactos líticos africanos, mas cuja proveniência específica se desconhece. Todas estas coleções, num total de 68 objetos, resultaram de ofertas ao $\mathrm{MNA}^{4}$.

As coleções que pertenceram ao IICT, e que hoje estão à guarda da Universidade de Lisboa, são mais significativas. O Instituto surgiu em 1936 quando vários organismos técnicos focados no império foram agregados na Junta das Missões Geográficas e de Investigações do Ultramar. Depois de várias transformações, foi extinto em 2015 e as suas funções integradas na universidade. As coleções foram recolhidas pela Missão Antropobiológica de Angola (1948-1955), pela Missão Antropológica e Etnológica da Guiné (1946-1947), pela Missão Antropológica de Moçambique (1936-1956) e pela Missão Antropológica de Timor (1953-1963). São constituídas sobretudo por líticos, mas também cerâmicas e material osteológico (Coelho, Pinto \& Casanova, 2014, p. 9). A maioria do espólio é proveniente de Angola, que está representada por 341 sítios arqueológicos e 170.174 objetos. Seguem-se Moçambique (96 sítios e 9.613 artefactos), Timor (20 sítios e 1.895 artefactos) e Guiné-Bissau (um sítio de onde provêm 1951 objetos). Este espólio corresponde a um total de 183.633 objetos obtidos no decurso de cerca de três décadas. Esta contabilização é limitada às coleções conservadas na Universidade de Lisboa, e é possível que corresponda apenas a uma pequena parte do espólio obtido em territórios coloniais que se encontra hoje em Portugal.

Inventários públicos como os do MNA e do IICT são um instrumento essencial na gestão de coleções, sobretudo para fins de estudo e conservação. Os inventários devem também ser uma ferramenta de trabalho na avaliação do comprometimento ético dos profissionais do património cultural na desconstrução dos modos coloniais de pensar o passado. É certo que a natureza dos museus é colonial, mas a extensão da colonialidade é pouco palpável. Os inventários permitem-nos quantificar e concretizar aquilo que de outro modo seria uma abstração. Os arquivos são práticas de poder, mas também locais onde o poder acontece (Mbembe, 2002). No quadro da arqueologia descolonial, im-

4. Cf. inventário de sítios arqueológicos representados no MNA, disponível em http://www.museunacionalarqueologia.gov.pt/wp-content/uploads/CODIGOS-30-o12020.pdf. Agradeço informações adicionais de António Carvalho e Luísa Guerreiro, Julho de 2020. 
porta que invertamos o poder estabelecido nos arquivos e depósitos arqueológicos em que se foram acumulando os frutos das relações de desigualdade. A questão que se coloca de seguida é: o que fazer com estas coleções?

As coleções podem ser geridas através da restituição ou da recontextualização. A existência de inventários detalhados como os do MNA e do IICT permite-nos entender as circunstâncias em que as coleções foram constituídas, e também entender a extensão das mesmas ou o seu estado de conservação. Estas informações são cruciais para que os responsáveis por essas coleções possam responder a possíveis demandas de restituição ou de outra natureza. Apesar da atualidade internacional deste tema, não existem ainda pedidos formais de restituição de coleções de arqueologia obtidas em relações de desigualdade. Porém, é possível que exista memória dessas coleções nas comunidades que as socializaram antes do seu destino final e que um dia essas comunidades manifestem interesse em reavê-las formalmente. Independentemente da possibilidade, as instituições que possuem coleções desta natureza devem ser as primeiras a encarar e questionar as circunstâncias coloniais com que elas passaram à sua tutela. Devem fazê-lo por dever ético em relação às comunidades, mas também por coerência para com os princípios democráticos da nossa sociedade.

Uma forma de lidarmos com estas coleções será a recontextualização. A recontextualização passa por um questionamento da forma como as coleções têm sido descritas e expostas publicamente. Os museus e exposições de arqueologia raramente apresentam o processo da aquisição dos objetos que expõem, e mais raramente ainda promovem o estudo crítico dessas circunstâncias. Por outro lado, poucas vezes se questiona a exibição pública de objetos e até restos humanos que haviam sido ocultados intencionalmente pelas comunidades que os socializaram. As múmias Chancay que se encontram expostas no Museu Arqueológico do Carmo (MAC), em Lisboa, foram recentemente alvo de uma tentativa de recontextualização numa perspetiva descolonial. As duas múmias expostas no museu são os restos mortais de duas pessoas que viveram no noroeste do Peru no século XVI. As múmias resultaram de rituais funerários e foram recolhidas no século XIX, possivelmente com o propósito de serem vendidas a colecionadores. Foram então compradas pelo administrador colonial e diplomata português Januário
Correia de Almeida em 1878-1879, que mais tarde se tornou presidente da Associação dos Arqueólogos Portugueses (AAP) e as ofereceu ao museu (Cardoso, 2012-2013).

Procurando questionar o museu enquanto espaço institucional que gera e veicula desigualdades, os artistas Filipa Cordeiro e Rui Mourão revisitaram as múmias. Com o projeto O Tempo das Huacas, ofereceram uma revisão crítica da forma como as múmias estão expostas, enquadrando-as nas origens coloniais do colecionismo moderno. Simultaneamente, fizeram uma performance com o objetivo de devolver agência aos indivíduos perante a atitude colonial dos visitantes e arqueólogos, que objetificam os restos humanos para lhes extrair informação ou pelo gozo voyeurístico. A performance e o trabalho crítico foram registados em vídeo, sendo disponibilizados em linha com um guia alternativo do museu. Nenhuma componente destas intervenções foi autorizada pela AAP, que gere o museu ${ }^{5}$.

O caso do MAC é particularmente importante na nossa discussão porque retira o peso da responsabilidade do trabalho descolonizador das comunidades que socializaram as múmias, e desloca-o para o próprio museu e para aqueles que beneficiam da relação colonial. Não existem hoje comunidades que se auto-identifiquem como Chancay, e nunca foi feito nenhum pedido de restituição das múmias. No entanto, o trabalho de Filipa Cordeiro e Rui Mourão lembra-nos que a exposição não consentida e voyeurística de restos humanos não se coadunam com os princípios de respeito mútuo que defendemos na nossa própria sociedade. Neste caso, a atitude descolonial não corresponde necessariamente a uma reação a outros, mas sim a um processo de auto-reconhecimento na sociedade que beneficiou de relações coloniais. A questão das múmias do MAC e da exposição de restos humanos levanta um problema mais específico, que é o da manipulação de restos humanos em trabalhos arqueológicos.

5. Cf. O Tempo das Huacas, disponível em https://sites. google.com/view/otempodashuacas 


\section{ARQUEÓLOGOS E ANTROPÓLOGOS BIOLÓGICOS ESCAVAM, ANALISAM E EXPÕEM RESTOS HUMANOS OBTIDOS SEM CONSENTIMENTO INDIVIDUAL, OU DAS COMUNIDADES DE ORIGEM. COMO LIDAR DE FORMA ÉTICA COM RESTOS HUMANOS?}

A escavação de necrópoles é uma das atividades arqueológicas que mais atenção recebe nas comunidades, que frequentemente convidam os antropólogos a explicar-lhes as origens e fins das ossadas que vão encontrando. Não é por acaso que isto acontece. A morte é um evento estruturante na experiência humana e encontra-se materializado de múltiplas formas no quotidiano individual ou na paisagem que socializamos. As comunidades sempre manipularam restos humanos, tanto em contextos rituais como profanos. No entanto, a visibilidade de restos humanos e a banalização da sua manipulação é um fenómeno da modernidade ocidental que se deve grandemente à emergência de práticas científicas a partir do século XIX. À semelhança do que aconteceu com seus congéneres europeus, os antropólogos portugueses obtiveram restos humanos em espaços colonizados que se encontram hoje em instituições de todo o país (Cf. Roque, 2006; 2014). E quanto ao que acontece no interior de Portugal? Para a maioria das pessoas de hoje, o encontro frequente com restos humanos é mediado pela arqueologia. A expansão dos centros urbanos e das infraestruturas em Portugal, a partir da década de 1970, esteve por detrás da emergência da arqueologia preventiva e de emergência. Uma das consequências deste processo foi a multiplicação de escavações de necrópoles, a acumulação de restos humanos em depósitos, e um crescente envolvimento do estado na sua gestão (Cf. Umbelino \& Santos, 2011).

No Endovélico, inventário de sítios e trabalhos arqueológicos, estão listados 20 cemitérios e 1857 necrópoles de vários períodos históricos. Antropólogos biológicos são responsáveis pela inventariação e análise de restos humanos, cujas informações são depois vertidas em relatórios que se entregam aos organismos do estado responsáveis pela arqueologia. Os restos propriamente ditos são arquivados como quaisquer outros vestígios arqueológicos. Nunca se contabilizaram os trabalhos arqueológicos em necrópoles que resultaram em publicações científicas, para além dos relatórios. Porém, podemos supor que uma porção significativa dos trabalhos inventariados no Endovélico nunca foram publicados. Das 1857 necrópoles identificadas, apenas 1109 foram alvo de algum tipo de publicação, incluindo simples notas em noticiários arqueológicos ${ }^{6}$. Em alguns casos, restos humanos são expostos em museus para ilustrar narrativas históricas ou antropológicas.

Estas circunstâncias são problemáticas por dois motivos. Primeiro, pressupõem a separação radical entre a sociedade atual e os indivíduos cujos restos são identificados em trabalhos arqueológicos. Esta objetificação de seres humanos confronta a intencionalidade das comunidades em que eles viveram e que ritualizaram a sua morte, assim como a relação íntima que as comunidades atuais têm com os seus mortos. Nenhuma pessoa encarou a sepultura com a expetativa de ser extraída, analisada, embalada em sacos de plástico ou exposta. A falta de consentimento, individual ou coletivo, para a manipulação de restos humanos é uma situação que nos deve fazer refletir enquanto cidadãos de uma sociedade baseada em relações de respeito mútuo. É certo que não podemos aplicar valores atuais às comunidades do passado. Porém, produzimos conhecimento sobre essas comunidades no presente e de acordo com o quadro ético do presente.

Este questionamento leva-nos ao segundo problema. A exumação de restos humanos dos locais em que foram ritualmente deixados é legalmente justificada pela necessidade de os preservar em nome do conhecimento científico. Na prática, esses restos são removidos do contexto em que foram ou são sociabilizados por por força de uma abstração. Adicionalmente, o seu estudo científico é frequentemente limitado pelas circunstâncias em que decorrem os projetos nos quais são encontrados. Deste modo, ainda que possamos aceitar o benefício coletivo que os estudos antropológicos podem trazer à sociedade como um todo, a verdade é que esses benefícios não são efetivamente concretizados.

Como podemos então lidar com esses restos de uma forma que humanize os indivíduos e comunidades em causa, e que seja coerente com os princípios éticos da nossa sociedade para com os mortos? A resposta a esta questão não passa pela paragem de todos os trabalhos em necrópoles, mas sim com um

6. A base de dados Endovélico é da responsabilidade do Ministério da Cultura e pode ser consultada em https:// arqueologia.patrimoniocultural.pt 
maior comprometimento com a sua dimensão ética. Podemos, para isso, inspirar-nos nas discussões que já decorrem um pouco por toda a Europa (Cf. Mays, 2005; Pearson, Schadla-Hall \& Moshenska, 2011).

Desde logo, devem evitar-se trabalhos desta natureza quando necrópoles e restos humanos não estão efetivamente em risco de destruição. Perante a impossibilidade de obter consentimento, devem ser respeitadas as últimas escolhas dos envolvidos. No entanto, não faltarão necrópoles a quem trabalha na arqueologia preventiva. É ocioso pensarmos que no contexto atual podemos mudar a legislação para que não se autorizem obras que tenham impactos negativos em necrópoles.

Podemos ainda assim fazer duas coisas. Primeiro, insistirmos para que os restos humanos exumados sejam efetivamente analisados, garantindo as condições apropriadas aos estudos antropológicos. Depois, devemos considerar a re-dignificação dos indivíduos cujos restos humanos foram exumados. Isto pode fazer-se através de uma nova inumação, particularmente nos casos em que se reconheça a ritualidade envolvida, ou através da remoção de restos humanos que se encontram nas galerias dos museus. No contexto atual, em que se discute o reenterramento de material arqueológico por falta de espaço nos depósitos, é imperioso que se discuta um fim digno para restos mortais. Por outro lado, não há nenhuma razão legítima para a exposição pública de restos humanos quando esta pode ser perfeitamente substituída por narrativas escritas ou faladas, ou através de representações gráficas. Restos humanos expostos em museus podem e devem ser retirados da exposição pública para depósitos onde sejam respeitosamente acondicionados.

Apesar das coleções provenientes de antigas colónias que se guardam hoje em Portugal, é certo que os restos humanos não são centrais na descolonização da arqueologia em território português do mesmo modo que em países como os EUA. Nesses territórios, os arqueólogos foram agentes colonizadores através da espoliação sistemática de espaços sagrados e sepulturas indígenas entre os séculos XIX e boa parte do século XX. Através de legislação recente e depois de uma longa discussão nos meios académicos e profissionais, os arqueólogos norte-americanos têm vindo a reconhecer o seu papel na criação de desigualdades e injustiças. Nesse contexto, estão a promover a restituição de coleções e restos humanos às suas comunidades de origem (Colwell, 2017).
Em Portugal, a descolonização funcionará de maneira diferente. Devemos ter em conta a autoridade que as práticas científicas exerceram e continuam a exercer junto das comunidades, que as desautoriza de qualquer envolvimento em processos de consulta. Porém, quando os arqueólogos se abrem à consulta, podem obter posições diferentes. No contexto de projetos de arqueologia comunitária em Ávila e em Cereixa, no estado espanhol, as comunidades locais têm manifestado abertamente o seu incómodo com a remoção de restos humanos por arqueólogos, inclusivamente de uma necrópole medieval. No caso de Cereixa, existem propostas no seio da comunidade para o reenterramento ou, pelo menos, para que se mande dizer missa em memória dos defuntos7. É possível que em Portugal se revele uma atitude semelhante se soubermos escutar.

\section{DE UM MODO GERAL, A COMPOSIÇÃO SOCIAL DA COMUNIDADE ARQUEOLÓ- GICA É MUITO HOMOGÉNEA E NÃO CORRESPONDE À DIVERSIDADE DA SOCIEDADE PORTUGUESA. COMO TORNAR A ARQUEOLOGIA MAIS DIVERSA E INCLUSIVA?}

A composição social da comunidade arqueológica é determinante na forma como se constroem narrativas sobre o passado, e como estas dão sentido ao presente. O passado é sempre definido a partir do presente e das expetativas de quem pensa sobre ele (Cf. Olivier, 2008). Deste modo, é inevitável que as origens sociais dos arqueólogos determinem as questões, e até $\mathrm{o}$ acesso aos meios que lhes permitem construir uma narrativa sobre o passado. Se pensarmos que a descolonização da disciplina passa pelo questionamento das relações de poder desiguais legitimadas por leituras do passado, então é crucial que a comunidade arqueológica se diversifique.

Durante a maior parte da sua história, a comunidade arqueológica portuguesa estava dominada por homens de classe alta, em muitos casos residentes nos grandes núcleos urbanos. Esses homens pertenciam

\footnotetext{
7. Cf. "La ética la arqueología", uma conversa entre Juan Pablo López e Xurxo Ayán Vila na Cadena Ser, Novembro de 2019, disponível em https://cadenaser.com/emisora/ 2019/11/21/ser_avila/1574333305_23238o.html. Agradeço as informações adicionais de Xurxo Ayán Vila, Novembro de 2019 .
} 
invariavelmente à elite que sustentava o poder político vigente e tinham ocupações profissionais muito variadas. Esta realidade começou a mudar com a Revolução de 1974, que proporcionou uma democratização gradual da esfera pública e dos contextos sociais em que se pratica arqueologia (Bugalhão, 2017). Em 2017, Jacinta Bugalhão apresentou o mais alargado retrato social da arqueologia já feito em Portugal. No decénio de 1900-1909 os arqueólogos ativos eram 33. Esse número só cresceu significativamente a partir de 1970-1979, aumentando para 371 arqueólogos. Esse número subiu para 1385 em 2000-2009, decrescendo para 1313 em 2017. A década de 1970 também foi marcada pela entrada de um grande número de mulheres na comunidade, tornando-se maioritárias em 2000-2009. A percentagem de estrangeiros tem-se mantido relativamente estável em torno dos $10 \%$ desde cerca de 1920 , ocasionalmente ultrapassando esse número. A média etária dos arqueólogos foi baixando ao longo do tempo, até ter atingido o mínimo de 31 anos em 2000-2009. Ao mesmo tempo, o número de arqueólogos com mestrado ou doutoramento aumentou (Bugalhão, 2017). Todavia, estes dados revelaram pouco sobre a diversidade social da arqueologia.

Em Maio de 2020 elaborei um questionário voltado para este aspeto, complementando assim o trabalho anteriormente feito ${ }^{8}$. Responderam 190 trabalhadores de arqueologia, uma amostra que corresponde a 14.5\% dos 1313 arqueólogos ativos reportados em 2017. São dados limitados mas que ainda assim nos inspiram várias reflexões.

Nesta amostra, os trabalhadores de arqueologia estrangeiros correspondem a $5.3 \%$ da comunidade, um número que está muito perto da percentagem de estrangeiros em Portugal $(4.7 \%)^{9}$. Porém, a diversidade étnico-racial é extraordinariamente bai$\mathrm{xa}, \mathrm{com}$ apenas um afro-descendente (0.5\%) e seis pessoas a identificarem-se como de "origem mista" (3.6\%). As autoridades portuguesas não permitem a inclusão deste tipo de dados nos censos, impossibi-

8. Inquérito inspirado por uma análise sociológica sobre origens sociais de estudantes universitários, elaborada por Machado, Costa, Mautitti, Martins, Casanova \& Almeida, 2003.

9. Dados da base PORDATA, da Fundação Francisco Manuel dos Santos. Disponível em https://www.pordata.pt/ Europa/População+estrangeira+em+percentagem+da+po pulação+residente-1624 litando qualquer tipo de comparação com o resto da população. Todavia, podemos dizer com segurança que a sociedade portuguesa é mais diversa do que estes números podem sugerir. Mais reduzida que a diversidade étnico-racial é a diversidade de género, com apenas uma pessoa a identificar-se como não binária (0.5\%). A comunidade é mais diversa em termos de classe, confirmando-se que já vão longe os tempos em que os arqueólogos pertenciam a uma elite muito restrita. São $54.7 \%$ os trabalhadores que praticam arqueologia por conta de outrem, enquanto $30.5 \%$ o fazem por conta própria. É provável que uma parte significativa destes corresponda aos chamados "falsos recibos verdes", indicadores de permanente instabilidade laboral.

Apesar desta crescente diversidade, a identificação da classe dos trabalhadores de arqueologia é mais complexa. Como em qualquer grupo social, existem muitos fatores objetivos e subjetivos que dão forma à experiência de classe: a vida familiar, a educação e até as regiões de origem. Deste modo, procurei entender quais eram as origens sociais dos membros da comunidade arqueológica. Analisando as ocupações dos pais, verificámos que $32.2 \%$ são operários, artífices e trabalhadores não qualificados. No caso das mães, estas categorias ocupam $20.5 \%$. Entre as mulheres, $19.2 \%$ são trabalhadoras do cuidado em contexto familiar, independentemente da classe social. No que toca à formação académica dos pais, tivemos apenas 151 respostas. Ficámos a saber que apenas $26.5 \%$ dos pais e $27.8 \%$ das mães frequentaram o ensino superior, enquanto $47.68 \%$ dos respondentes declararam não ter nenhum familiar que tenha frequentado o ensino superior em gerações anteriores à sua.

Isto significa que na comunidade arqueológica existem muitas pessoas com origens economicamente modestas, provenientes de famílias com experiências de vida que raramente se confundiram com a educação formal universitária. Esta diversidade potencia a construção de narrativas alternativas sobre o passado. Porém, isto significa também que é através das universidades que a maioria dos trabalhadores de arqueologia conhecem e produzem narrativas. $\mathrm{O}$ acesso à comunidade arqueológica é essencialmente enquadrado pelo ensino universitário, cujos docentes têm origens significativamente diferentes da maioria dos trabalhadores de arqueologia. Assim, da amostra de 13 professores respondentes, apenas $23.07 \%$ têm pais operários ou trabalhadores 
não qualificados, e 15.38\% das mães nas mesmas circunstâncias. $23.07 \%$ das mães eram trabalhadoras do cuidado. $30.76 \%$ dos pais e mães frequentaram o ensino superior.

Apesar da pequena amostra, suspeitamos que o contexto social de origem dos docentes universitários lhes proporcionou estabilidade material, apoio educativo e social que foram tendencialmente diferentes das da maioria da comunidade arqueológica. As diferenças sociais podem ter um impacto importante na construção de narrativas sobre o passado, ainda que não seja diretamente mensurável. As salas de aula são espaços de reprodução social em que existe uma desigualdade de poder inerente entre professores e alunos. O contraste entre as origens de uns e outros nas universidades portuguesas poderá dificultar a diversificação de narrativas. Como podemos então tornar a arqueologia socialmente mais diversa?

A falta de diversidade social é um problema comum a muitas comunidades de práticas em Portugal e está longe de ser um exclusivo da arqueologia. Em países como os EUA e o Brasil, políticas de ação afirmativa têm sido importantes na diversificação de setores mais fechados, através da criação de sistemas de quotas para grupos pouco representados em universidades e outras organizações. Todavia, as circunstâncias institucionais em Portugal desencorajam a criação de quotas que considerem desigualdades sociais, e em particular as que se fundamentam em questões étnico-raciais (Cf. Marcelino, 2019).

Ainda assim, a comunidade arqueológica pode chamar a si a responsabilidade de contribuir para a minimização dessas desigualdades através dos meios ao seu dispor. As salas de aula universitárias podem ser um território de encorajamento para o reconhecimento das desigualdades na disciplina, para o desenvolvimento de projetos que sirvam para as questionar e contribuir para a auto-confiança dos alunos. O movimento associativo, por outro lado, pode abrir as portas à diversidade e ser também funcionar como um instrumento de superação dessas desigualdades. Diversificar os júris de prémios de arqueologia, tornando-os mais representativos da diversidade social e qualificações académicas já existentes na comunidade arqueológica, poderá ser um instrumento poderoso no encorajamento de narrativas alternativas. Através das suas atividades especializadas, as associações profissionais, sindicais e de defesa do património têm a possibilida- de de apontar problemas e propor soluções para a transformação social da arqueologia. As empresas podem melhorar as condições de trabalho e os salários dos trabalhadores, desconstruindo o contínuo extractivista que afeta tanto o processo de construção do conhecimento sobre o passado como o trabalho daqueles que o produzem. Por seu lado, os investigadores podem elaborar agendas de pesquisa que visibilizem histórias e grupos historicamente marginalizados, propondo narrativas alternativas que sirvam para questionar as desigualdades que estão por detrás de processos de marginalização no passado e no presente.

Em 2018, fui co-responsável pelo projeto Cambedo 1946: Arqueologia da Resistência da Raia Galego-Portuguesa (Coelho \& Ayán Vila, 2019). Este projeto centrou-se nos eventos de 19 e 20 de Dezembro de 1946 na aldeia transmontana de Cambedo, Chaves. Por esses dias, a aldeia tinha acolhido um grupo de guerrilheiros galegos anti-franquistas que ali normalmente se resguardavam da repressão do outro lado da fronteira. Cambedo havia sido um lugar de passo para refugiados de guerra e exilados políticos, que durante a Guerra Civil espanhola procuraram um porto seguro e recebiam o apoio das comunidades locais. Em Dezembro de 1946, as autoridades portuguesas e espanholas decidiram por cobro a estas práticas de hospitalidade. Cercaram Cambedo, perseguiram os guerrilheiros, e o exército português chegou a bombardear a população civil. O projeto incluiu a prospeção de traços materiais dos eventos, a escavação de um refúgio usado por guerrilheiros e de uma das casas destruídas no bombardeamento. Durante todos os trabalhos, promovemos também várias ações de arqueologia pública, incluindo duas sessões de discussão muito participadas em Cambedo e na sede de freguesia, Vilarelho da Raia ${ }^{10}$.

Este projeto consistiu numa experiência descolonizadora a vários níveis. Em primeiro lugar, a equipa foi propositadamente constituída para que nela estivessem representados colegas de várias nacionalidades, com origens sociais distintas, que pudessem oferecer leituras do passado que não estivessem enformadas de nacionalismo metodológico. Em segundo lugar, procurámos trabalhar com a comunidade de Cambedo enquanto agentes da sua própria história, não como informantes nem guardiães do

10. Mais informações sobre o projeto Cambedo 1946 em https://www.facebook.com/cambedo1946/ 
"património". Por tratarmos de eventos recentes, a participação da comunidade no trabalho interpretativo e na sua socialização foi bastante fluida. Finalmente, procurámos alternativas às questões histórico-culturalistas que geralmente dominam a pesquisa arqueológica, isto é, que se focam as origens e na reconstituição cultural dos grupos humanos do passado. Entendemos a arqueologia como uma disciplina que deve centrar-se no presente. Deste modo, os temas que escolhemos devem responder a problemas do presente: a consolidação das ditaduras ibéricas e suas consequências, o exercício de terror de estado experimentado em espaços coloniais e seus legados no Portugal contemporâneo, ou a selagem fronteiriça própria do projeto do estado-nação moderno.

Esta atitude descolonizadora serviu para nos centrarmos na experiência de 1946 como um contexto em que se confrontaram a modernidade imposta pelos estados, e a modernidade alternativa construída a partir de baixo. Esta alternativa materializou-se numa ética de hospitalidade para com os exilados e guerrilheiros que atravessavam a fronteira, e que decidimos invocar no contexto da atual crise humanitária global.

\section{CONCLUSÃO}

A definição da arqueologia enquanto campo de produção do conhecimento foi concomitante à emergência do estado-nação, do racismo científico e do colonialismo moderno. Esta equação tornou os arqueólogos em agentes muito particulares do que Boaventura de Sousa Santos (2014) chamou de epistemicídio, isto é, a obliteração de formas vernaculares de construção do passado e a sua substituição por um entendimento linear e teleológico da história. Deste modo, a forma como pensamos o passado e o mediamos no presente resulta de uma configuração específica que gera e reproduz desigualdades étnicas, raciais, de classe, entre outras. Ainda que os impérios coloniais já tenham formalmente acabado, as relações de poder que se geraram a partir do colonialismo moderno continuam a moldar o modo como produzimos conhecimento e nos relacionamos uns com os outros (Grosfoguel, 2007; Quijano, 2007). É por isso que devemos considerar a descolonização da arqueologia.

Neste capítulo expus brevemente vários problemas que afetam a arqueologia portuguesa, cuja comu- nidade de práticas se sustenta em relações de colonialidade: as relações desiguais entre arqueólogos e comunidades, a gestão de coleções museológicas e de restos humanos obtidas em relações não consensuais e, finalmente, as contradições da diversidade social na comunidade arqueológica. Enquanto refleti sobre estes problemas, perguntei-me de que forma poderíamos imaginar a arqueologia num mundo mais justo. É trabalhoso imaginarmos uma disciplina diferente, descolonizada. Apesar das dificuldades e até da hostilidade que o projeto descolonial enfrenta, há boas razões para pensarmos que pode ter efeitos práticos. Foi por isso que apontei para as discussões possíveis e para as experiências já existentes. Voltemos agora às escavações, museus, laboratórios e salas de aula. Há muito para fazer.

\section{BIBLIOGRAFIA}

ANDERSON, Benedict (1983) - Imagined Communities: Reflections on the Origin and Spread of Nationalism. Londres: Verso.

ATALAY, Sonya (2010) - Community-Based Archaeology: Research with, by, and for Indigenous and Local Communities. Berkeley: University of California Press.

ATALAY, Sonya; CLAUSS, Lee R.; MCGUIRE, Randall H.; WELCH, John R., eds. (2014) - Transforming Archaeology: Activist Practices and Prospects.

AYÁN VILA, Xurxo (no prelo) - Myth, science and community: The archaeological project of San Lourenzo hillfort (Galicia, Spain). Journal of Community Archaeology $\&$ Heritage.

BUGALHÃO, Jacinta (2017) - Arqueólogos Portugueses. In ARNAUD, José M.; MARTINS, Andrea, eds. - Arqueologia em Portugal. 2017 - Estado da Questão. Lisboa: Associação dos Arqueólogos Portugueses. pp. 19-31.

CARDOSO, João L. (2012-2013) - O Conde de São Januário, presidente da Associação dos Arqueólogos Portugueses (1896-1901). Arqueologia \& História. Lisboa.64-65. pp.31-44.

COELHO, Rui G. (no prelo) - Portugal é uma máquina. In ALONSO GONZÁLEZ, Pablo - O Antipatrimónio: Fetichismo do Passado e Dominação do Presente. Lisboa: Imprensa de Ciências Sociais.

COELHO, Rui G. (2020) - The Politics of Interpretation in Historical Archaeology. In ORSER, Charles E.; ZARANKIN, Andrés; FUNARI, Pedro; LAWRENCE, Susan; SYMONDS, James, eds. - The Routledge Handbook of Global Historical Archaeology. Londres: Routledge.

COELHO, Rui G.; AYÁN VILA, Xurxo (2019) - Cambedo, 1946: Carta sobre o achamento de Portugal. Vestígios. 13:2. pp. $61-87$. 
COELHO, Ana G.; PINTO, Inês; CASANOVA, Maria da C. (2014) - A coleção arqueológica do IICT no novo milénio. Antrope. Tomar. 1. pp. 7-23.

COLWELL, Chip (2017) - Plundered Skulls and Stolen Spirits: Inside the Fight to Reclaim Native America's Culture. Chicago: University of Chicago Press.

CONDE, Patrícia; MARTINS, Ana C.; SENNA-MARTÍNEZ, João C. (2015) - Arqueologia em contexto colonial. Moçambique e Angola: entre a indiferença e a internacionalização. In MALAQUIAS, I.; ANDRADE, A.; BONIFÁCIO, V.; MALONEK, H., eds. - Perspetivas sobre Construir Ciência-Construir o Mundo. Aveiro: Universidade de Aveiro. pp. 301-310.

DINIZ, Mariana (2008) - José Leite de Vasconcelos entre o Folklore e a Ciência (ou a Ambiguidade de uma Agenda). O Arqueólogo Português. Lisboa. 26. pp. 127-144.

DINIZ, Mariana; NEVES, César; MARTINS, Andrea; CARVALHO, Daniel; ARNAUD, José M. (2018) - Papéis, funções e disfunções do património arqueológico: o caso do povoado calcolítico de Vila Nova de São Pedro. Arqueologia \& História. Lisboa. 68. pp. 169-180.

FIGUEIREDO, João (no prelo) - Diamond desire - Probing the epistemological entanglements of geology and ethnography at Diamang (Angola). South African Historical Journal.

GOMES, Sérgio (2011) - O passado, a identidade e as teias do governo: Estudos sobre os entrelaçamentos das práticas de produção do conhecimento arqueológico e de construção da identidade nacional salazarista. Dissertação de doutoramento. Porto: Universidade do Porto.

GROFOGUEL, Ramón (2007) - The epistemic decolonial turn: Beyond political-economy paradigms. Cultural Studies. 21:1-2. pp. 211-223.

HOBSBAWM, Eric; RANGER, Terence, eds. (1983) - The Invention of Tradition. Cambridge: Cambridge University Press.

HAMILAKIS, Yannis (2011) - Indigenous archaeologies in Ottoman Greece. In BAHRANI, Zainab; ÇELIK, Zeynep; ELDEM, Edhem, eds. - Scramble for the Past: The Story of Archaeology in the Ottoman Empire. Istambul: Salt. pp. 49-59.

LEAL, João (200o) - Etnografias Portuguesas (1870-1970). Cultura Popular eIdentidade Nacional. Lisboa: Dom Quixote.

MACAMO, Elísio (2017) - Portugal pode pedir desculpas? Quantas vezes forem necessárias. Público, 11 de Outubro. Disponível em https://www.publico.pt/2017/10/11/sociedade/opiniao/quantas-vezes-forem-necessarias-178 7481

MACHADO, Fernando L.; COSTA, António F. da; MAURITTI, R.; MARTINS, S. da C.; CASANOVA, José L.; ALMEIDA, J. F. de (2003) - Classes sociais e estudantes universitários: Origens, oportunidades e orientações. Revista Crítica de Ciências Sociais. 66. pp.45-8o.
MARCELINO, Catarina (2019) - Relatório sobre Racismo, Xenofobia e Discriminação Étnico-racial em Portugal. Lisboa: Assembleia da República. Disponível em https:// tinyurl.com/yzvbyeyj

MARTINS, Ana C. (2015) - Arqueologia portuguesa em solo africano durante o Estado Novo: (alguns) atores, espaços e projetos - o caso de Moçambique. Africana Studia. 24. pp. 129-143.

MAYS, Simon (2005) - Guidance for Best Practice for the Treatment of Human Remains. Advisory Panel on the Archaeology of Burials in England.

MBEMBE, Achille (2002) - The Power of the Archive and its Limits. In HAMILTON, Carolyn; HARRIS, Verne; TAYLOR, Jane; PICKOVER, Michele; REID, Graeme; SALEH, Razia, eds. - Refiguring the Archive. Dordrecht: Kluwer Academic Publishers. pp. 19-26.

OLIVIER, Laurent (2008) - Le Sombre Abîme du Temps. Paris: Éditions du Seuil.

PEARSON, Mike P.; SCHADLA-HALL, T.; MOSHENSKA, Gabe (2011) - Resolving the Human Remains Crisis in British Archaeology. Papers of the Institute of Archaeology. Londres. 21. pp. 5-9.

PERALTA, Elsa (2017) - Lisboa e a Memória do Império: Património, Museus e Espaço Público. Lisboa: Le Monde Diplomatique, Outro Modo.

PORFÍRIO, Eduardo (2015) - Experiências de divulgação da arqueologia: O caso do projeto Outeiro do Circo (Beja, Baixo Alentejo, Portugal). Antrope. Tomar. 2. pp. 31-53.

QUIJANO, Aníbal (2007) - Coloniality and Modernity/ Rationality. Cultural Studies. 21:2-3, pp. 168-178.

ROQUE, Ricardo (2006) - A Antropologia Colonial Portuguesa (c. 1911-1950). In CURTO, Diogo R., ed. - Estudos de Sociologia da Leitura em Portugal no Séc. XX. Lisboa: Fundação Calouste Gulbenkian. pp. 789-822.

ROQUE, Ricardo (2014) - Race and the Mobility of Humans as Things. Science, Technology and Human Values. 39:4. pp. 6o6-616.

SANTOS, Boaventura de S. (2014) - Epistemologies of the South: Justice Against Epistemicide. Londres: Routledge.

SILVA, António C. (2004) - A arqueologia e a Reforma Agrária. In MURTEIRA, António, ed. - Uma Revolução na Revolução: Reforma Agrária no Sul de Portugal. Porto: Campo das Letras. pp. 39-52.

SIMÃO, João V. (1966) - O Incentivo à Investigação Científica. In Celebrar o Passado. Construir o Futuro. Ciclo de conferências promovido pela Comissão Executiva do $40^{\circ}$ aniversário da Revolução Nacional. Vol. 1. Lisboa: Panorama. pp. 273-288.

SCOTT, James (1998) - Seeing Like a State: How Certain Schemes to Improve the Human Condition Have Failed. New Haven: Yale University Press. 
THOMAS, Julian (2004) - Archaeology and Modernity. Londres: Routledge.

TORRES, Cláudio (2009) - Memória Comunitária e Espaço Cultural. Xelb. Silves. 9. pp. 13-18.

UMBELINO, Cláudia; SANTOS, Ana L. (2011) - Portugal. In MARQUEZ-GRANT, Nicholas; FIBIGER, L., eds. (2011) - The Routledge Handbook of Archaeological Human Remains and Legislation. Londres: Routledge.

VALERA, António C. (2008) - A divulgação do conhecimento em arqueologia: Reflexões em torno de fundamentos e experiências. Praxis Archaeologica. 3. pp. 9-23. 


\title{
ARQUEOLOGIA E MODERNIDADE: UMA REVISITAÇÃO PESSOAL E BREVE DE ALGUNS ASPETOS DA OBRA HOMÓNIMA DE JULIAN THOMAS DE 2004
}

\author{
Vítor Oliveira Jorge ${ }^{\mathrm{I}}$
}

\begin{abstract}
“O problema (...) é que o pensamento moderno depende tão fortemente de fundamentos e origens, e contudo, em última análise, as origens dos povos e organizações contemporâneos parecem ser inacessíveis. Essa é uma das razões pelas quais a arqueologia tem sido tão importante para a modernidade e, no entanto, sempre falha em alcançar o que se espera dela: trazer o passado à sua presença total.”
\end{abstract}

(Thomas, 2004, p. 233)

“(...) o objeto que a arqueologia estuda - o passado - está ausente, e a disciplina busca continuamente um certo grau de certeza que é difícil de atingir."

(idem, ibidem, p. 247)

RESUMO

Em 2004, Julian Thomas (Universidade de Manchester), publicou uma obra importante: "Archaeology and Modernity", na qual procurou mostrar que a arqueologia é uma ciência, uma disciplina e uma atividade que só poderiam ter surgido na nossa Modernidade, isto é, no período que se abriu com o século XVII europeu. Passados 16 anos, pode fazer-se um balanço e certamente propor alguns tópicos novos, ainda não abordados naquele livro, quer por opção do autor, quer pelo próprio desenvolvimento dos nossos conhecimentos. Esta comunicação pretende ser um pequeno contributo nesse sentido, muito embora assumindo um carácter pessoal e muito parcelar. Se em 2004 as conclusões e propostas finais do livro deviam ser discutidas, o tempo entretanto decorrido mudou obviamente o quadro das questões.

Palavras-chave: Modernidade, Arqueologia, Filosofia, Pensamento crítico.

\section{ABSTRACT}

In 2004, Julian Thomas (University of Manchester), published an important work: "Archaeology and Modernity" in which he sought to show that archeology is a science, a discipline and an activity that could only have appeared in our Modernity, that is, in the period that opened with the European seventeenth century. After 16 years, we can take stock of it and certainly propose some new topics, not yet covered in that book, either at the option of the author, or because of the development of our knowledge. This paper intends to be a short contribution in that sense, although assuming its personal and very partial nature. If in 2004 the book's final conclusions and proposals should be discussed, the time that has elapsed since then has obviously changed the picture of the issues.

Keywords: Modernity, Archaeology, Philosophy, Critical thought. 
Acentuando que só com a Modernidade (fenómeno e período da história ocidental que tendeu a alastrar a todo o mundo, adquirindo facetas muito diversificadas; houve, claro, muitas formas de "modernização") a arqueologia teria sido possível, o autor do livro que me serve de base de raciocínio refere como essa Modernidade é toda ela feita de contradições e paradoxos.

Algumas ideias centrais que caracterizam esse período da história ocidental - a admitir que pode ser considerado assim - são expostas logo nas páginas 2 e 3 (sem preocupação de hierarquizar os tópicos): capitalismo (num momento de grande desenvolvimento, e certamente a característica que envolve todas as outras...); aparecimento dos estados-nação; industrialização; desenvolvimento de comunicações e transportes; mercantilismo; controlo da violência pelo Estado; vigilância, fiscalização; luta política permanente; ampliação do modo de vida urbano; agitação, turbulência, mudança contínuas; declínio da tradição, nomeadamente das crenças religiosas; insatisfação, inquietação; permanente crítica da própria modernidade por si mesma; crises frequentes sem aparente resolução; fragmentação social, individualismo; legislação estatal para assegurar códigos laicos de conduta moral e manter a ordem; vontade de planeamento e de previsão do futuro; tendência para as "grandes narrativas" com a sua componente utópica, etc.

De facto, uma valorização do imanente em relação ao transcendente, de uma realidade material e "presente" em oposição à autoridade espiritual do "passado", por um lado, e uma acentuação do "novo" (palavra quase mágica) relativamente ao antigo, tradicional, caduco, são, por assim dizer, tópicos quase obsessivos da Modernidade. A quem ingenuamente surpreendesse que a arqueologia (à letra, ciência das coisas antigas) pudesse precisamente ocorrer nesta altura (e só nela), Thomas volta a lembrar por exemplo, na página 53 , que “(...) a arqueologia é também caracteristicamente moderna porque afirma que se pode criar conhecimento novo a partir de coisas materiais." E, na página seguinte, acrescenta: “(...) a arqueologia usa coisas materiais para abordar aspectos do passado que não são referidos em nenhum texto escrito." Por vezes, em todo o livro, aparece também a expressão "cul- tura material”2 ou, mesmo, o conceito mais genérico de "materialidade(s)".

"Coisas materiais" são portanto, neste contexto, realidades que contrastam com documentos escritos, e que pertencem ao que o autor também designa "mundo material" (cf., por ex., p. 13). Esse mundo de conhecimentos potenciais, por oposição nomeadamente ao dos livros, tinha sido trazido à tona tipicamente pelo empirismo de um Bacon, representante, entre muitos outros, da "nova ciência" que a Modernidade fez emergir, sobretudo a partir do século XVII. Como é sabido, o racionalismo ocidental, no seu sentido genérico, pode ser tipificado, nas suas duas facetas, pelo mesmo Bacon, do lado da observação e valorização da realidade direta, e, do ângulo mais propriamente abstrato, por Descartes, consagrando sobretudo um pensamento de cariz matemático. Muito influenciado por Martin Heidegger ${ }^{3}$, Thomas irá ao longo do livro sempre criticar a dicotomia cartesiana mente-corpo, o que é coerente para quem não valorize a linha que, por Platão e Descartes, culmina em Hegel ("a substância é sujeito"), e que considera Descartes como o criador do sujeito moderno, sem o qual teria sido impossível Kant e de um modo geral todo o chamado "idealismo alemão" e, claro, mais perto de nós,

\footnotetext{
2. Conceito que, mais recentemente, o autor reviu, considerando-o "uma contradição nos termos", com o que estou inteiramente de acordo (conversa pessoal).

3. Heidegger foi um dos maiores pensadores do século XX, apesar de ter aderido à ideologia nazi, como se tem vindo a comprovar cada vez mais. Mas isso nem por sombras elimina a sua importância filosófica. J. Thomas, na sua obra de 2004, justifica a esta luz (filosófica) a sua opção (fascínio pela obra heideggeriana), o que aliás se não tornaria necessário. Por exemplo, Žižek (que fez a sua tese sobre Heidegger em Liubliana), aborda o pensamento filosófico do autor alemão muitas vezes, nomeadamente em O Sujeito Incómodo (The Ticklish Subject, 1999). Na introdução ao seu tratado sobre Hegel, Menos Que Nada. Hegel e a Sombra do Materialismo Dialético (tenho várias edições, cito a francesa, p. 18) Žižek cartografa sinteticamente o campo filosófico-ideológico atual em 4 posições, designando a $4^{\underline{a}}$ como "pensamento da finitude transcendental (que culmina com Heidegger)." E Žižek acrescenta (ib.): A tese deste livro ["Menos Que Nada..."] é dupla: (1) há uma posição que escapa a estas quatro posições, a saber a de um desfasamento ou de uma ruptura pré-transcendental, a que Freud chama a pulsão; (2) esta dimensão constitui o próprio núcleo da subjetividade moderna."
} 
a obra crucial de um "anti-filósofo", o psicanalista Jacques Lacan. ${ }^{4}$

A realidade material é pois um dos conceitos a debater aqui, bem como um outro que, percorrendo todo o livro, aparece logo na primeira frase que abre o mesmo: "A arqueologia investiga o passado por meio de coisas materiais.” (p. 1); refiro-me, claro, à noção de passado, naturalmente por oposição à de presente. É importante este aspecto, porque logo na mesma abertura da obra, Thomas concebe passado e presente em articulação relacional, referindo que não se trata apenas, em arqueologia, de reconstruir "como as coisas foram", mas de “(...) estabelecer uma relação entre o passado e o presente.” (ib.). Essa relação (noção inspirada em Gadamer) impõe-nos uma compreensão de como ambos, passado e presente, estão em diálogo, através de uma distância produtiva que nos permite continuamente "(...) apreender mais, tanto acerca dos mundos passados como de nós próprios." (ib.). Assim, pois, tentar dar um significado ao "passado" é o mesmo movimento de tentar compreender o nosso "presente": uma atitude dialógica e não uma posição positivista, dominada pelo desejo de reconstituir, ou reconstruir, essa entidade inefável por excelência que seria "o passado".

Por que razão este livro foi importante quando apareceu, nos princípios deste século, e ainda hoje nos convida à releitura e reflexão? Porque nesta síntese um arqueólogo, especialista do que em Portugal chamaríamos a Pré-história recente, claramente mostra como é fundamental, para cada um de nós, subir um degrau (no sentido da abstração, da teoria, do pensamento transdisciplinar) e tentar compreender, desde aí, por que é que a arqueologia passou a existir e quais as suas ligações multidireccionais com todo esse mundo que designamos Modernidade. Ou seja, tentar ver de um modo mais global por que motivo nos dedicamos a esta atividade, que condições a tornaram possível e mesmo atraente, para nós, para o público, para as instituições que a ensinam e promovem.

4. Numa época confusa como aquela em que vivemos, no dealbar da terceira década do século XXI, estou convencido que esta via é a mais produtiva para um pensamento progressista e lúcido, afastado das tendências pós-modernas e relativistas, e em particular de um fantasma que assola alguma arqueologia atual, a dos chamados "novos materialismos", mesmo na sua dimensão mais consistente, a da "ontologia orientada para os objetos."
Esta atitude teórico-filosófico-histórica não era nova em 2004 na trajetória de Thomas: perpassa toda a sua obra, e nomeadamente já antes, em 1996, ele nos tinha oferecido um livro tipicamente "heideggeriano", "Time, Culture and Identity”, que subtitulou: "an interpretive archaeology" (uma arqueologia interpretativa, "corrente" que se insere nas arqueologias pós-processuais), e no qual abordava claramente alguns dos temas que aqui desenvolve. Como todo o investigador de qualidade, arguto e atento ao seu presente, Julian Thomas sempre tem mesclado produtivamente teoria e prática arqueológica, num balancear constante; assim a visão que nos dá do Neolítico das chamadas Ilhas Britânicas é extremamente rica e susceptível de inspirar, mesmo, a arqueologia continental. Esta atitude não é tão frequente quanto seria para desejar.

Mas voltemos ao livro, não para esgotar a sua rica extensão de questões (comentá-las daria outro livro...), mas para apenas aflorar alguns tópicos. O próprio autor, no prefácio (p. xi) apresenta-o como dividido em três partes: uma primeira, abarcando os dois capítulos iniciais, e correspondendo a uma exposição geral da interligação da arqueologia com a Modernidade; uma segunda, em que em sucessivos capítulos são abordadas questões de epistemologia, depois de processos históricos e naturais, da importância do estado-nação em toda esta problemática, do humanismo e da sua atenção à esfera individual, das relações entre profundidade e superfície, da mente, cognição, perceção e conhecimento, e finalmente do problema da matéria e materialidade. O livro remata com uma conclusão em que são apresentadas sugestôes no sentido de uma "arqueologia contra-moderna”, ou seja, procurando contribuir para a superação do estado da arqueologia na Modernidade. Embora estando de acordo com grande parte do que aí se afirma, julgo que esse capítulo final seria decerto aquele que o próprio autor hoje gostaria eventualmente de reescrever, havendo ali "pano para mangas", quer no sentido de um profícuo debate em torno do que lá está, quer em torno do que lá (do meu ponto de vista, é claro) não está.

Interrogação primordial: que é “o passado", que significa "trazer o passado ao presente", que significa o "lamento" (tão frequente entre nós, arqueólogos, que por vezes parecemos ser os autores de um "saber infeliz consigo mesmo") de que o passado, supostamente o "objeto" da arqueologia, "se ausentou" ? 
O passado é uma representação, uma representação de uma das modalidades do tempo linear humano (não falo do tempo da física, assunto em que não sou competente), que evidentemente não é possível concretizar, e muito menos totalizar. Por isso, trata-se de um produto da nossa imaginação, de uma certa forma, mesmo, do nosso "delírio", se quisermos. Tal como as outras duas figuras fantasmáticas daquele tempo humano linear, o presente e o futuro. Como tal, não pode ser objecto de qualquer "ciência", de qualquer conhecimento que deseje reger-se por normas compartidas por uma comunidade de estudiosos, para atingir um objetivo por todos reconhecido como o mais certo, ou provável, em cada momento.

Que significaria, por exemplo, "presentificar" um qualquer "presente” que já decorreu? Quais as suas balizas? A que escala se daria essa presentificação? No caso concreto da arqueologia, seria podermos emergir, como numa espécie de filme, sonho ou pesadelo, numa realidade qualquer anterior à nossa, quais etnólogos de outro tempo, inserirmo-nos nessa realidade e nela sobreviver, para podermos dar conta das estruturas sociais e económicas, das representações, dos ditos e interditos desse espaço-tempo?... Mas quais os seus limites, qual a forma de diálogo que poderíamos estabelecer com essa realidade fantasmática que se ausentou? É óbvio que o que digo é do domínio do impossível, ou da realidade virtual, ou de uma manifestação de alteração da minha consciência no sentido do total descolamento da realidade (para não dizer da demência). Não, o objeto da arqueologia não pode ser o passado, nem podemos estabelecer genericamente $o$ nosso método como uma dialogia entre duas representações ilusórias, o presente e o passado. Pois obviamente não há nada de mais diáfano e indefinível do que o presente.

Tudo o que de facto temos, individual e colectivamente, e sobre que se debruça a arqueologia, são ruínas ou vestígios, a descoberto, meio enterrados ou submersos, ou completamente invisíveis. Com isso nos confrontamos, sobre isso nos debruçamos, segundo regras e leis, com uma metodologia já firmada, procurando recolher o máximo de informação possível sobre algo, estendido num espaço, o qual perdeu sentido para a vida moderna, não tem hoje função. Ora o poder moderno não deixa nada de fora, é global, e nenhuma caracterização desse poder pode jamais esquecer que ele é exercido, sobre- tudo a partir dos anos 70 do século XX, no quadro de um capitalismo neoliberal e de uma sociedade de consumo hedonista que é hoje, para falar depressa, o novo "ópio do povo". Todos estamos nela, todos fomos absorvidos por ela.

A essa massa imensa, dispersa, desigual, tantas vezes abandonada, das ruínas ou vestígios de vidas anteriores, não chamaria de modo algum "registo arqueológico" (tradução do inglês "archaeological record"), porque um registo se conota em geral com uma autoria e com uma intencionalidade definida ou definível, mas antes e apenas realidade arqueológica. A realidade arqueológica está aí, e é o nosso foco de trabalho por excelência. Essa intervenção "reanima" um local em princípio abandonado, pois é uma tarefa de equipa, no qual se confrontam discursos e propostas, metodologias, etc. Claro que a sua caracterização como sítio arqueológico digno de intervenção implica todo um trabalho prévio, pleno de condicionalismos de toda a espécie, e um trabalho ulterior, nomeadamente de gabinete, laboratório, museu, também sujeito a muitas condicionantes, como bem sabemos.

Que procuramos com toda essa atividade? Parto aqui da experiência paradigmática de um caso particular de arqueologia terrestre em ambiente rural, porque a arqueologia em geral defronta-se com uma amplitude muito grande, diversificada, de situações. E assumo-a como uma investigação (o que já vai sendo raro...), a única que merece o nome de ciência. Procuramos transformar as características de um local, sobre o qual vamos exercendo uma ação de decapagem ("escavação"), num conjunto de modelos, trabalháveis fora desse local, a duas ou mais dimensões. Como todos os sítios arqueológicos são contentores de unidades mais pequenas de informação, estas são registadas e, sempre que possível, sob a forma de amostras, transportadas para local de estudo. Estes artefactos (ou ecofactos) mais pequenos, exumados do artefacto maior que é o próprio local, são desse modo descontextualizados. Ficamos assim progressivamente com um sítio mais ou menos transformado pela nossa ação, e com um arquivo de dados potencialmente imenso. Só ambos, articulados, fazem sentido. O local é mudo e os registos são sempre esqueléticos, pobres, em relação a uma experiência subjetiva, irrepetível, que é a de uma escavação em curso. Todos temos a experiência da desilusão de voltar a um local que escavámos e depois foi restaurado e "musealizado": quase todos os problemas 
encontrados foram elididos no produto final visível, visitável, onde às vezes, para nosso espanto, encontramos "guias" a explicar coisas às pessoas, fascinadas com as estórias, coisas essas que nada, ou pouco, têm a ver com o que se passou connosco ali. Sim, há uma cumplicidade afetiva e intelectual dos arqueólogos com os sítios que abordaram, que corresponderam a uma parte mais ou menos longa das suas vidas, e que por vezes já não reconhecem, passada a tecnologia dos restauradores e "museógrafos", em geral empresas que saltam de tarefa para tarefa. Para o arqueólogo um sítio arqueológico não é um local de tarefas: é um nó de vivências, intransmissível.

Que temporalidades encontramos na realidade arqueológica enquanto temos a felicidade de a estudar? Temporalidades locais, parciais, indícios de um antes e um depois, que na maior parte dos casos são difíceis de conectar entre si. Mais do que evidências, realidades facilmente explicáveis, deparamo-nos com aporias, com irresolúveis, isto é, com realidades físicas, materiais, que não são passíveis de interpretação numa dada fase da história dos trabalhos no local. Essas áreas, ou micro-áreas, devem ser assim acauteladas, protegidas, com paragem da intervenção, para um depois. Como um livro de que não percebêssemos uma passagem, mas nem por isso deixamos de continuar a ler, esperando um efeito de compreensão retroativa e contextual, mais à frente. As realidades arqueológicas, e em particular as muitas que a uma primeira abordagem nos aparecem como incompreensíveis, podem resultar da ação humana, eventualmente de dinâmicas naturais, mas, na maior parte dos casos, resultam de um imbricação - como toda a realidade arqueológica - entre o humano (intencional ou não) e o natural. Seria muito importante que, em vez de nos seus relatórios os arqueólogos reportarem apenas o que foi entendido, como se todas as peças de um eventual puzzle entroncassem umas nas outras, aplicando uma temporalidade linear à própria lógica hesitante e dialéctica do seu trabalho de campo, expusessem documentalmente as tais aporias, dúvidas, impasses, porque elas seriam cruciais para outros (ou eles próprios) mais tarde poderem prosseguir a pesquisa. Para esta ter de facto um cariz científico, quer dizer, ser tanto quanto possível recuperável por outrem. Muito antes de servir para contar estórias, ou a história do sítio, da região, e para reconstituir seja o que for, etc., a atividade descrita reporta-se à incidência da atenção sobre um local, incidência que idealmen- te não teria condicionalismos apertados de tempo (como qualquer outra pesquisa científica) nem de conclusões precipitadas por imposição exterior, alheia à dinâmica interna da pesquisa.

Onde está o "passado" em tudo isto?... mais uma vez, não tem sentido imediato tal fantasma, embora a experiência repetida de um local, por uma equipa, durante anos, essa sim, crie uma história, uma tradição mesmo, uma afinidade e uma afetividade (positiva ou negativa) entre as pessoas envolvidas, como já referi. A arqueologia é isto: um trabalho de equipa visando em última análise dar sentido(s) a um local desafetado pela Modernidade. ${ }^{5}$ Se algum passado existe, é esse: a história da pesquisa e as etapas por que foi passando e as questões e hipóteses que foi desenvolvendo, e que tentam explicar a biografia do local, podendo apontar, evidentemente, para um âmbito mais alargado em termos de problemática. Porque é importante confrontar o público não com explicações domésticas, todas prontas, sobre um suposto "passado", mas com problemas, perguntas, questões, sobre o diálogo que se foi estabelecendo ali entre suspeitas e certezas, entre hipóteses e confirmações, e... entre perguntas que não chegaram a ter resposta. É extremamente importante, crucial mesmo, saber conviver com a dúvida, a incerteza, a perda, em suma, com o caracter não-Todo da realidade, e portanto também com a contingência do nosso pensamento, que é parte dessa realidade.

Vejamos agora: coisas materiais, mundo material, cultura material, materialidade(s), que é isso?... Em última análise, o conceito de matéria e de materialismo reporta-nos para uma velha dualidade, a da substância (conceito que Thomas usa nalguns momentos do livro) e do sujeito. Ambos os conceitos são muito complexos nas suas diversas aceções, que atravessam toda a história da filosofia. Substância seria aquilo que persiste, que subjaz ao

\footnotetext{
5. Como esta tem horror ao vazio, e visa o ordenamento do território, a arqueologia insere-se aí, nesses "buracos" do "desenvolvimentismo", em locais de paragem, onde depois ou ao mesmo tempo dos arqueólogos vêm (pelo menos idealmente) os restauradores e toda uma bateria de curiosos e jornalistas, fazer a mediação do local para os visitantes. Entretanto, os arqueólogos e outros cientistas com quem trabalham terão produzido uma vasta quantidade de publicações, e deverão, por uma questão ética, apresentar as suas conclusões numa brochura ou qualquer outro suporte que torne inteligível para outros o que ali se passou desde que se iniciaram os trabalhos.
} 
que muda, ao que aparece; sujeito, reportar-se-ia à entidade pensante, ao ser humano precário que, perante a substância, procura dar dela uma explicação, compreendê-la. O filósofo esloveno Mladen Dolar, numa explicação notável pela sua clareza ${ }^{6}$, diz-nos que muitas realidades foram candidatas à ideia de substância; uma delas foi o materialismo. "Matéria”, pois, valorizada como o que é essencial, por oposição a ideia ou espírito; materialismo contra idealismo. Claro que isto é uma simplificação enorme. Dolar é um hegeliano nosso contemporâneo, como muitos outros, aliás, uma vez que Hegel foi o grande denegado da filosofia ocidental, começando porém, nos últimos tempos, o que é animador, a ter uma importância cada vez maior. Para Hegel, matéria era uma abstração pura, ao mesmo título de espírito: produtos do pensamento, realidades que nunca ninguém viu. Nesse sentido, valorizar a matéria como conceito-chave do nosso pensamento é uma simplificação irrisória. E Hegel, que não apreciava aforismos, tem também aquela célebre frase que já atrás invoquei, "a substância é sujeito", o que vem na mesma linha, mas praticamente é o conceito-chave de toda a arquitetura fabulosa da sua filosofia dialética. $\mathrm{Na}$ verdade, quando penso em algo exterior a mim, quer o verbalize ou não, eu, como sujeito, estou já a entrar num "movimento" de mediação; ou seja, se considero que algo é substância, elemento supostamente último e universal, estou já a sair do modo da substancialidade, da lógica da conectividade. A substância é sujeito na medida em que é mediatizada pelo sujeito, e portanto mesmo a ideia de materialismo é imaterial. A matéria é uma ideia, um produto do pensamento. E daí que possamos também afirmar que o absoluto é sujeito, porque absoluto não é algo de transcendente e inacessível, de numenal, como na filosofia de Kant (que tem sido a base de quase todo o pensamento ocidental, o qual lamentavelmente retrogradou em relação a Hegel $^{7}$, mas representa uma realidade histórica, um conhecimento em que efetivamente é superada, no

6. Ver o vídeo, com bloco notas à mão: https://youtu.be/ UBlOABhRglo (acedido em julho 2020).

7. O próprio Marx, o incontornável Marx, não entendeu totalmente Hegel, do qual partiu, deixando-nos uma obra notável sobre o capitalismo, a alienação, a ideologia, mas abrindo caminho a uma visão teleológica da história (o proletariado como portador providencial do futuro redentor da exploração) que, como se verificou, não acertou. momento concreto (e apenas só nesse, porque nem a história nem o espírito jamais param) em que se efetiva, a dicotomia entre pensamento e realidade. Voltando agora à minha circunstância concreta de arqueólogo: quando me debruço, com outro(a)s, sobre um sítio arqueológico, não me interessa nada estar a gastar tempo com especulações sobre a sua "materialidade" ou não. O que se nos coloca evidentemente são questões práticas e metodológicas (que obviamente são também teóricas) de como melhor abordar em conjunto uma realidade que, como em toda a ciência, é opaca, consistindo o nosso trabalho em procurar desfazer essa opacidade numa multidão de outras opacidades menores (os "dados", os registos), esperando torná-los compreensíveis (ou pelo menos não tão opacos) através dos métodos aplicados, métodos esses validados pelas normas em vigor em arqueologia, que podemos e devemos sempre ampliar/corrigir criticamente e aplicar a cada caso com precisão e disciplina de grupo, dentro de um diálogo democrático. Estou de acordo nesse aspeto com Julian Thomas quando defende um trabalho colegial (p. 247 da obra em referência) $)^{8}$ na direção das escavações. Foi aliás o que sempre praticámos, desde 1998, no sítio pré-histórico de Castanheiro do Vento, concelho de Vila Nova de Foz Côa. A exigência científica dessa colegialidade, repartindo responsabilidades e motivando pessoas em diálogo e confrontação, é evidentemente muito maior (e muito mais justa) do que a de uma direção unipessoal, em que em última análise é um diretor clarividente que decide do caminho a seguir.

Se sou arqueólogo, se identifico com outro(a)s um sítio como fazendo parte da realidade arqueológica, se estamos autorizados pela autoridade pública a aí intervir, estamos a fazê-lo em nome de toda a comunidade científica e não só: a ética é aqui absolutamente essencial. Estamos a servir de mediadores entre uma realidade única, que vamos inexoravelmente alterar, e todos os outro(a)s, não apenas em nome de uma racionalidade abstrata, mas de algo de

8. Cito Thomas, p. 247: “Talvez em algumas circunstâncias a posição de diretor do sítio seja realmente supérflua e até limite a riqueza do que pode ser dito sobre o sítio. Pode não ser totalmente irreal imaginar um projeto de campo executado como coletivo, ou no qual pessoas diferentes se revezem na direção de diferentes fases da investigação." E acrescento: claro que isto pressupõe uma arqueologia de alto nível de qualidade em todos os aspetos, incluindo uma ética da lealdade e do rigor compartilhado. 
muito concreto, irrepetível, em termos de memória de interesse universal (construída hoje, agora, bem entendido). Quando um geólogo recolhe as suas observações e amostras neste e naquele local, claro que ele trabalha adentro de uma ciência diferente, com as suas complexidades, subtilezas, e regras próprias, exigindo muita experiência, esforço e saber; mas ele atua - pelo menos muitas vezes - sobre realidades repetíveis, no todo ou em parte. Nós, como arqueólogos, operamos sempre sobre entidades singulares, e todo o nosso esforço consiste em tentar passar da sua universalidade abstrata (estéril) para a sua universalidade concreta (viva, rica, porque iluminando facetas da realidade que podem ser novas e mesmo, até, únicas). O arqueólogo é o cientista do espaço que mais tempo demora numa determinada parcela do território, a qual tem a obrigação de compreender em si, e na sua conectividade com outros sítios vizinhos e toda a paisagem em geral. Porque jamais os seres humanos se circunscreveram aos meros espaços que a Modernidade nos deixou para atuar como arqueólogos.

Quem, por exemplo, entrou alguma vez na gruta de Lascaux (na original) percebe intuitivamente do que estou a falar, quando refiro que a arqueologia é uma experiência simultaneamente racional e emocional (retroalimentando-se uma à outra): sei que é um caso extremo, porque essa experiência nos marca para toda a vida, mas serve para exprimir a experiência arqueológica no seu limite e no seu fascínio. Quando saímos da gruta de Lascaux, onde só podemos permanecer uns 20 minutos e entrar com um técnico ${ }^{9}$ não nos perguntamos se acabamos de passar por uma realidade material ou espiritual. Percebemos sim, intuitivamente, que o que acabamos de ver nos prova, de forma impressiva, que os autores daquelas obras (melhor dizendo, de todo aquele espaço interior) eram já, no Paleolítico superior, pessoas como nós, extremamente complexas. Eis um exemplo de como a substância (uma realidade que desejaríamos que permanecesse para sempre, intacta, incólume ao tempo) é também sujeito. Ao olhá-la, com os olhos do ocidental do século XX, ao mergulhar no interior daquela cavidade, eu entro num mundo que era opaco na sua excecionalidade para um homem medieval, mesmo que ele tivesse por casualidade ali penetrado.

9. Pelo menos era assim em finais de 1996, quando fui autorizado a visitá-la.
Ou seja, há uma progressão do espírito humano, uma historicidade radical do mesmo: o que é para mim uma absoluta obra de arte, cujo sentido original (se é que o houve, em termos de "mistério" desvendado e explicado pelos seus autores - temos de nos lembrar da célebre elocução de Hegel de que os mistérios dos antigos egípcios eram também mistérios para eles mesmos) me escapa e acaba até por ser o menos importante, o que é que ele - esse sentido ou sentidos - seria para outras pessoas, de outros tempos/culturas: decerto algo de muito diferente do que me pode parecer, e algo que pode ter servido de base a narrativas muito diversas até ser selado no tempo até à sua descoberta casual.

É pois um absurdo estarmos a preocupar-nos com o facto de uma "coisa" ser material ou não. Há milhões de crucifixos, pois que a cena da crucificação é por assim dizer a mais importante, emblemática, tremendamente simbólica, da nossa cultura ocidental cristã. ${ }^{10}$ Mas um crucifixo, mesmo que todo partido e reduzido a pedaços, é uma entidade material, espiritual, ambas ao mesmo tempo, ou o que queiramos chamar-lhe, sejamos crentes ou não?... um crucifixo, ou fragmento do mesmo, toca-nos, afeta-nos, porque é um elemento da nossa cultura. Ora é com a mesma disposição de espírito que temos de abordar um sítio arqueológico: ali, em algum ou alguns momentos do tempo, estiveram pessoas, seres humanos, os quais, em tudo o que fizeram, não procediam como um animal ou uma árvore, mas antes tinham autoconsciência e portanto um inconsciente (mesmo que, com toda a probabilidade, não estivessem conscientes disso - nós, europeus, levámos milénios até aparecer Freud!! E ainda há muita gente culta que não percebeu a sua importância...). Tinham intencionalidade, sabiam que iam morrer (qualquer que fosse a representação que disso construíam) e também comunicavam uns com os outros, tinham segredos e malícia, copulavam e reproduziam-se não como animais, mas através desse "mais" (dessa fantasia que transforma a cópula "obscena" em ato cultural) que é essencial à reprodução humana, etc., etc. Nós sabemos que as suas vidas, a sua opacidade, permanecerá para

10. A pergunta que Cristo formula ao Pai na cruz é lancinante, terrível: “pai, por que me abandonaste?”. Sintetiza a nossa cultura. A religião cristã é a única em que dá origem a um verdadeiro ateísmo, porque na cruz, quem morre, é o próprio Deus, indissolúvel do filho. 
sempre na nossa interrogação: mas, nós como eles, somos seres sociais, que precisamos do Outro para nos constituirmos, somos seres da fala, da linguagem, e, como tal, somos seres da castração (tenhamos ou não consciência disso), no sentido que a psicanálise freudiano-lacaniana a caracterizou. Ou seja, viemos ao mundo indefesos, só crescemos e nos tornamos adultos dentro de uma comunidade, e portanto estamos imersos num universo simbólico e não apenas imaginário, somos falados pela linguagem materna, ou seja, mesmo quando exprimimos o que sentimos ser mais íntimo, estamos a falar a linguagem do Outro que aprendemos, exprimimo-nos pois a partir de uma "extimidade", isto é, de algo que Lacan conceptualizou ${ }^{11}$ e que rompe a dualidade exterior-interior; a nossa mais pretensa "intimidade" é um Outro para cada um de nós... quer tenhamos ou não consciência disso, lembro mais uma vez.

Portanto, sem que haja qualquer sentido em considerar a existência de uma "natureza humana", atemporal e supra-histórica, sabemos, quando nos acercamos de um sítio arqueológico, que ele é diferente de um outro local qualquer, que temos de o abordar com uma prevenção teórica e metodológica que tomba dentro da problemática das "ciências do espírito" ou da "cultura". Sabemos também que, ao contrário das outras espécies em geral, o ser humano é suscetível de se comportar de forma ambígua, polissémica, manhosa, calculada, isto é, cheia de sentidos e de subentendidos, e por consequência a realidade arqueológica igualmente tem de ser diversificada e com um tipo de complexidade próprio, que nos impede de projetar nela a nossa "filosofia espontânea”. E, muito menos, um funcionalismo chão do nosso senso comum. Todavia, essa ingenuidade permanece em alguns colegas, como sabemos, e temos de ter todo o cuidado na utilização de conclusões que eles tendem a apresentar como certas, precisamente quando se trata de questões mais desafiantes do nosso senso comum atual.

Como refere Julian Thomas no seu livro, estudar a modernidade (e a emergência da arqueologia científica que ela exigiu e possibilitou) põe-nos desde logo de sobreaviso sobre aquilo que somos ou julgamos ser, e portanto, dada a variabilidade humana, ficamos logo cientes daquilo que outros não pode-

11. V. por exemplo, Estimacy, de Jacques-Alain Miller, in https://www.lacan.com/symptom/extimity.html riam, em princípio, ser ou fazer. "Modernos" não eram com certeza; mesmo nós, segundo alguns, nunca o chegámos a ser (Latour ${ }^{12}$ ).

É preciso abordar a realidade arqueológica com distância, com sentido crítico e a "suspeita" que ela gera, mas ao mesmo tempo com a empatia de estarmos sempre dentro do campo das ciências sociais e humanas, e não no das ciências naturais, por mais que recorramos à colaboração aberta com os nossos colegas dessas áreas; todos temos muito a aprender uns com os outros, porque cada modo de conhecimento pode tornar-se um campo fechado, senão mesmo uma fortaleza bem defendida, com uma linguagem técnica idiossincrática e tudo, se não percebermos que ao menos o conhecimento não deveria, não deve, ser propriedade privada de ninguém.

Este é um ponto capital, que distingue as arqueologias ditas pós-processuais das processuais: a realidade arqueológica ("archaeological record"), com que nos confrontamos hoje, não se pode encarar como uma realidade natural, produto de fatores que agem ou agiram na "natureza", porque sobre ela sabemos, mesmo sendo apenas constituída por elementos "materiais", que é prenhe de sentidos "meaning(s)", palavra importante que aparece com frequência em Thomas e autores afins - especificamente humanos. Esses sentidos são-nos desconhecidos, é verdade, no seu aspeto específico; mas podemos sempre ter presente, pelo menos em termos de probabilidade, aquilo que não são, que nunca podiam ter significado para qualquer ser humano. É aqui que se instala uma espécie de "diálogo mudo" entre nós e o que encontramos. O conhecimento humano procede muito por descarte de teorias ou procedimentos que deixaram de ser úteis à nossa visão ou procedimento atuais; e também pode levantar hipóteses interpretativas mais ou menos verosímeis. Não podemos provar como cientificamente certa a hipótese a, b ou c; mas, apenas o formulá-la é uma forma de enriquecimento intelectual e de conhecimento, com base na experiência de observação direta. E podemos rejeitar como muito improváveis ou mesmo impossíveis (erradas) as hipóteses, digamos, $x, y$, ou z. Dou um exemplo: quando, em contexto fechado, selado intencionalmente, encontro um conjunto de fragmentos de vasos cerâmicos que não colam uns aos outros, que são relativamen-

12. Latour, Bruno (2007) - Nous N’Avons Jamais Été Modernes, Paris: La Découverte. 
te diferentes na pasta, cor, etc., e que têm fraturas muito antigas, isto é, que não só foram depositados nesse contexto já partidos, mas pertencem a recipientes diferentes, tenho de concluir, como muito provável, que essa foi uma deposição intencional de realidades parciais, que pelo facto de serem colocadas junto umas das outras, e "escondidas", significavam qualquer coisa de especial. Posso mesmo ir mais longe, quando esta mesma realidade, ou outras análogas (deposições fechadas de vários objetos já sem qualquer utilidade), se repete no mesmo sítio arqueológico: as pessoas que, numa certa altura, ou numa certa época geral datável, atuaram naquele local, atribuíam importância simbólica (no sentido vulgar de simbolismo) à junção num espaço diminuto e escondido de pedaços de objetos sem qualquer funcionalidade. Com conhecimento de outros sítios arqueológicos do mesmo tipo/época, e até da mesma região, e de informação de natureza etnológica oriunda de diversíssimos contextos, eu poderia escrever todo um livro só sobre as possíveis interpretações de tais deposições simbólicas escondidas. Mas refreio-me nessa solução fácil, e posso perguntar, no âmbito do local em estudo - penso por exemplo em Castanheiro do Vento (Horta do Douro, Vila Nova de Foz Côa $)^{13}$ e no sítio em parte análogo de Castelo Velho de Freixo de Numão na mesma zona ${ }^{14}$, a $11 \mathrm{~km}$ de distância em linha reta se tal sistema de deposições não existiria em todo o sítio, a diferentes escalas. De facto, durante as escavações daquele primeiro local (C. Vento), que já duram há mais de 20 anos, todo um conjunto de objetos "anómalos" (pela forma, aspeto, ou localização) foram encontrados, em diferentes posições. Não sendo este o local próprio, dou apenas dois exemplos, entre muitos. As principais estruturas que ali se encontram correspondem a embasamentos pétreos (de xisto, aglutinados por argila) de muros de terra; nesses embasamentos, ou no que deles resta, foram encontrados, no caso de um dos muretes, quantidades enormes de pequenos fragmentos de quartzo, de dimensão e forma repetitivas, cuja cor

13. Escavações atualmente dirigidas pelo autor, por João Muralha Cardoso, Ana Margarida Vale, e Sérgio Alexandre Gomes, mas por cuja direção já passaram outros arqueólogos, como Leonor Sousa Pereira, Gonçalo Leite Velho, Bárbara Carvalho.

14. Escavações dirigidas por Susana Soares Lopes, da FLUP, já concluídas há muito, e iniciadas em 1989. branca contrastava, no momento da sua exposição pelos trabalhos, com o alaranjado-acastanhado característico da argila local, ou a cor mais escura dos xistos e grauvaques. Esses elementos, brilhantes ao sol, não seriam visíveis após a construção terminada, nem tinham qualquer propósito funcional; estavam ali a sinalizar qualquer coisa, eram elementos simbólicos. ${ }^{15}$ Um outro aspeto, entre centenas, que nos chamou necessariamente a atenção, foi a deposição na vertical, ao longo de certos embasamentos, e próximo destes, de pedaços talhados de paredes de vasos cerâmicos de certa dimensão (como se fossem placas mais ou menos planas, e onde portanto a curvatura da pança não seria muito acentuada); usando uma expressão corrente, não serviam ali para nada; eram mais uma deposição simbólica.

Mas tudo isto só surpreende um espírito ingénuo, se pensarmos que, em todas as épocas e em muitas culturas, o maior esforço dos seres humanos que realizaram construções providas de certa durabilidade, se descontarmos as militares, se concentrou em "obras" que não tinham um qualquer préstimo, que não fosse precisamente simbólico, e hoje constituem grande parte do património histórico-cultural que queremos preservar e admirar. E porquê? Neste aspeto podemos arriscar uma afirmação geral. O ser humano - mau grado as ideias "continuistas", que negam a "exceção humana", e são de atroz simplismo - é totalmente diferente das outras espécies, uma vez que é dotado de autoconsciência e portanto também de inconsciente, sendo que a realidade lhe aparece como algo de inquietantemente estranho ("Unheimliche" na expressão de Freud ${ }^{16}$, que o inglês traduz por "uncanny"). Essa "estranheza" está ligada a todo o comportamento simbólico (no sentido corrente e não lacaniano da palavra) e, de um modo geral, ao imenso esforço (de conceptualização mas também de transformação e marcação física do espaço-tempo, frequentemente através da construção de locais ou outros espaços relacionados com

15. Uma vez, uma aluna chamou-me a atenção para uma área que estava a escavar e onde lhe aparecia, no mesmo nível e lado a lado, numa área restrita, uma certa quantidade de elementos de xisto, todos de cor e textura diferentes, acrescentando inteligentemente: "professor, está aqui todo um manual de geologia”. Descontando o exagero do seu entusiasmo, ela tinha razão: todo o sítio é um agregado de elementos ali depositados intencionalmente.

16. Cf., por exemplo https://pt.wikipedia.org/wiki/O_ inquietante (acedido em julho 2020). 
cultos religiosos) que todo o ser humano, desde pelo menos o que na Europa designamos Paleolítico superior, parece ter feito para dar um sentido ("meaning") ao mundo e à sua existência. Esse aspeto é fulcral, traduzindo-se em inúmeros sinais, desde o enterramento e culto dos defuntos, até às manifestações da chamada "arte rupestre", e, de um modo geral, à necessidade, por parte dos grupos ou comunidades, de demarcarem "culturalmente" o "natural”, desde o corpo (apondo-lhe transformações e signos de todo o tipo) até ao território, construindo aquilo que nós, com os olhos de hoje (os únicos, obviamente, com que podemos tentar compreender o Outro) podemos chamar "paisagens simbólicas", pontuadas por construções mais ou menos perenes, que sempre procuraram dar um sentido humano ao espaço. Sem entrar em detalhes, tudo se passa como se o ser humano, dotado da linguagem, ser da fala (que sempre "falha" na totalidade do que supostamente quereria dizer, comunicar; e portanto o ser humano é também um ser "falhado", barrado, como nos ensina a psicanálise lacaniana), não pudesse suportar a vacuidade de sentido com que o espaço e o tempo lhe aparecem na sua aparente continuidade, na sua estranha alteridade, precisando de os cindir, de os marcar, de os dividir com pontos de referência. Transforma assim os espaços naturais, através de uma variedade infinita de dispositivos e de formas, naquilo que poderíamos designar, com os olhos de hoje, "paisagens culturais, humanizadas", ou seja, ambientes dotados de significação, em que as comunidades se refletem e, ao mesmo tempo, se sentem por sua vez refletidas, na medida em que assim também se constituem identidades coletivas e memórias, povoadas de narrativas, efabulações, cenários de inúmeras vivências e inculcação de laços sociais, etc. Inculcações essas que se produziriam, desde logo, no momento da construção de tais dispositivos, sobretudo daqueles que requereriam imenso trabalho coletivo (como é o caso do já citado Castanheiro do Vento, na nossa linguagem atual uma "colina monumentalizada"), certa disciplina e concertação entre todos os executantes da "obra", incluindo os encarregados de a manter e de, eventualmente, lhe produzirem transformações.

Num texto recente, intitulado "A Arqueologia na encruzilhada dos saberes contemporâneos: uma perspetiva” (v. bibliografia) tentei resumidamente sintetizar, com base em diversos autores não arqueólogos, a minha visão atual da disciplina como um todo. Porque, tal como também o livro de Julian Thomas nos mostra, só de fora da arqueologia (como de qualquer outro saber) se pode ter dela uma visão distanciada e crítica, relacionada com o conjunto do saber contemporâneo. Claro que a inter e a transdisciplinaridade só se conseguem a partir de um certo amadurecimento interno de cada disciplina; e por isso a luta da minha geração, pelo menos em Portugal, foi a independentização da arqueologia como disciplina e prática adultas, tanto ao nível da investigação, como do seu ensino, como da sua administração pública, central e local. Dada a tradicional vinculação à história, era crucial separar as duas disciplinas, no sentido de impedir que a arqueologia continuasse a ser "ciência auxiliar" de qualquer outra. Isso foi um passo em frente, como já tinha sido, muito antes, a desvinculação da arqueologia em relação à arquitetura: lembremo-nos por exemplo de que a centenária Associação dos Arqueólogos Portugueses se começou por designar "Real Associação dos Arquitetos Civis e Arqueólogos Portugueses.” Este ponto é importante, porque tem a ver com o estatuto da realidade arqueológica, a que muitos continuam a chamar "registo arqueológico", e que Julian Thomas comenta em vários pontos do seu livro, nomeadamente a pp. 210 e seguintes, quando se refere às posições de Childe e de Binford. Trata-se de saber se as "coisas materiais" com que a arqueologia se confronta têm "sentido" ("meaning"), isto é, podem ser interpretadas como resultado de ações pretéritas: para Childe, só depois de passaram pelo crivo da classificação e tipologia; para Binford, tais realidades só poderão eventualmente ter sentido depois de filtradas por todos os modernos processos de estudo das ciências naturais a elas aplicáveis. Ora, a forma de encarar a arqueologia não é independente da área específica de estudo de cada autor: Childe foi um pré-historiador histórico-cultural que entroncou essa visão com uma forma de evolucionismo e de marxismo; Binford estudou sobretudo caçadores-recolectores, e pertence a um mundo académico norte-americano onde arqueologia e antropologia (incluindo a "física") se imbricam, e está muito influenciado pelo "espírito" das ciências naturais. Um arqueólogo da época romana, da Idade Média, da época moderna ou contemporânea, mais ou menos provido de documentos escritos, tem de ter uma perspetiva completamente diferente, histórica, do arqueólogo da pré-história que, por não ter tais documentos (e, muitas vezes, a "ilusão de sa- 
ber” que eles conferem...) se vê confrontado apenas com a mudez da "matéria" bruta, para acentuarmos o contraste. "Bruta" não será de facto a palavra mais adequada, porque numerosos estudos antropológicos nos advertem para uma série de aspetos que nunca podemos aplicar a sociedades pré-modernas. Inúmeras observações apontam para ontologias de povos contemporâneos estudados pela antropologia em que de modo algum as rochas, os sedimentos, os elementos vegetais, a água, etc., não eram apenas encarados como elementos materiais ou "matérias-primas", isto é, como matéria mais ou menos inerte que o ser humano usava nas suas obras, conferindo-lhes "sentido". Humanidade e natureza não estão separadas uma da outra como no naturalismo racionalista europeu que começa a emergir no século XVI; antes, o ser humano está imerso num mundo de que faz parte intrínseca, mundo esse povoado de sentidos que ele tem por si mesmo, e que não lhe são conferidos, ou impostos, pelo ser humano. Isto não quer dizer que possamos aplicar à pré-história uma ontologista animista como Philippe Descola caracterizou na Amazónia, ou uma cosmologia totemista como ocorria na Austrália antes de ser invadida por europeus, ou mesmo uma visão analogista do mundo, muito espalhada, incluindo no próprio Ocidente, antes do racionalismo moderno (Descola, 2005). Mas pelo menos significa descentrar a nossa cultura moderna de ocidentais relativamente a outras possibilidades ontológicas, mostrando como o modo de interpretar em pré-história tem de ter regras muito flexíveis, muito diversificadas, e proceder com uma prudência que frequentemente perdemos de vista. Nós, arqueólogos, e em particular estudiosos da pré-história como aquele que escreve, não podemos apenas circunscrever-nos a toda a tecnologia hoje ao nosso dispor; temos, para além dela, de estar atentos ao debate cultural e científico contemporâneo ${ }^{17}$, antropológico, sociológico, etc. - filosófico em última análise - para não cairmos na pobre rotina de, acrescentando novidades e descobertas, por vezes sensacionais, nos movermos sempre dentro da mesma redoma, na nossa zona de conforto doméstico. Porque assim repetimos, no essencial, ba-

17. Veja-se, por exemplo, o excelente e esclarecedor debate entre dois "gigantes" da antropologia atual, Tim Ingold (numa linha vitalista, mas original) e Philippe Descola (numa linha estruturalista, como continuador do grande Lévi-Strauss): Être au Monde..., 2014 (v. bibliografia). nalidades discursivas, "déjà vus" interpretativos, confrangedoras redações que até podem ter ressonância poética, mas nada acrescentam de um ponto de vista realmente crítico, racional, científico em suma. É claro que tanto Gordon Childe, como Leroi-Gourhan, como Claude Lévi-Strauss, como Jean Guilaine, como Lewis Binford, como Ian Hodder, como Michael Shanks, entre muitos outros, nos ajudaram sempre a ver "paisagens conceptuais” novas, e por vezes muito poderosas. Nunca estarão esgotados, como o próprio Julian Thomas, que sempre nos traz, precisamente, inspiradores pensamentos, incitações para refletirmos. Mas as novas gerações, aos ombros desses gigantes, terão agora de construir arquiteturas disciplinares próprias, adaptadas a cada submundo da arqueologia, e não confundindo abertura com importação acrítica de ideias que, parecendo fascinantes, ou virem ao encontro dos nossos problemas interpretativos - penso, por exemplo, nos "novos materialismos", que começam a fascinar alguns jovens - ainda mais nos afastam deles. Não advogo assim uma teoria geral para a arqueologia, pois creio que isso não tem sentido, nem acontece noutras ciências. Há, quando muito, e na época atual de tantas incertezas, teorias "regionais" mais ou menos úteis para este ou aquele domínio, as quais deverão estar constantemente sujeitas à crítica e ao debate informado. Claro que nada disto acontecerá se o ensino universitário continuar a degradar-se e, paralelamente, se a arqueologia for abandonada como disciplina menor, sem meios para a pesquisa de fundo, e apenas útil para "reconstituir" certos sítios como pontos de interesse turístico, num quadro de crise geral societária. Quer dizer, no modelo de sociedade em que nos encontramos nunca poderemos ir muito longe; apenas, e com algumas exceções, continuar a realizar trabalhos pontuais para fazer "prova de vida"; por isso, quem possa ainda alertar para este estado de coisas tem absoluta obrigação ética de o fazer.

Voltando ao livro de Julian Thomas que nos serve de "rampa" para debater algumas ideias sobre arqueologia, não há dúvida de que é uma obra excelente. Os dois primeiros capítulos são sínteses bem conseguidas para caracterizar a emergência da Modernidade (cap. 1) e o papel da arqueologia nascente nas tensões que a modernidade gerou (cap. 2). Tenho o meu exemplar todo sublinhado a várias cores, numa óbvia estratigrafia de leituras e de entusiasmos; gostaria porém de comentar sucintamente alguns pon- 
tos. Na pág. 1, diz-se que o passado nunca se revela inteiramente a nós; pelo que atrás referi, penso que essa afirmação era escusada; na pág. 4, parece sugerir-se que remotas "escavações" ainda não eram arqueologia, mas se dirigiam a realidades arqueológicas; no meu entender, não, não era assim, as realidades arqueológicas foram criadas pela arqueologia, na Modernidade como Thomas tão bem explica, e não pré-existiram, em embrião, a essa nossa época; na pág. 15, relativamente aos gabinetes de antiguidades como teatros de memória (uma boa caracterização) diz-se serem alheios ao atual museu...bem, o museu é uma realidade que explodiu em tantas direções e se liga com tantas outras coisas, incluindo a encenação de memórias, que não sei se se pode ser tão afirmativo assim... Nas págs. 47,48 e 50 parece escamotear-se a evidência de que tanto a $\mathrm{I}^{\mathrm{a}}$ como a $2^{\underline{a}}$ guerras mundiais foram afrontamentos de escala inaudita entre potências capitalistas, na luta pela supremacia de oligarquias, que não recuaram perante nada, e nisso estou de acordo com Bauman, citado pelo próprio Julian Thomas (p. 49), segundo o qual que o nazismo (bem como aliás todos os fascismos, o italiano, o espanhol, o português, e por aí adiante...) foram produtos típicos da Modernidade (aos quais aliás poderíamos juntar o próprio estalinismo, e por aí fora....). ${ }^{18} \mathrm{~A}$ Modernidade trouxe-nos aquilo que Arendt designou "banalidade do mal". ${ }^{19}$

O cap. 3 do livro tem um título que entendo menos bem: "A tirania do método". Logicamente, trata-se de descrever metodologias em relação às quais o autor, influenciado por Heidegger (v. p. 59, por ex.), tem uma posição de discordância, com a qual basicamente estou de acordo, embora eu não assuma o anti-cartesianismo que Thomas partilha; Descartes

18. Aliás, a realidade globalizada que hoje vivemos, na sua extrema violência e desumanidade trágicas, não se pode entender fora da estratégia capitalista neoliberal, que todos os países e todas as esferas de ação contaminou: a busca de lucro sobrepôs-se a qualquer racionalidade e a qualquer moralidade, que chegam a assumir formas extremas, verdadeiramente circenses (chefes de estado eleitos que se comportam como palhaços; mafias que tomaram conta da realidade de bastantes países), desbragadas, sem entraves, numa manifestação agonística de que o sistema do lucro é total, assumida e orgulhosamente obsceno. Encena-se em público, sem vergonha. É um circo, sim, mas mortífero.

19. V. por exemplo sobre o assunto a tese de Diniz, Nádia Souki (2008) - Hannah Arendt e a Banalidade do Mal, Minas Gerais: Universidade Federal de Minas Gerais. foi crucial no seu tempo, e é óbvio que temos de recolher o que de útil nos deixou, situando-o num momento particularmente frutuoso da história do pensamento. Claro que a realidade arqueológica não nos aparece sob a forma de uma qualquer "materialidade" a que teríamos depois de conferir "sentido". Qualquer elemento da realidade, da "substância" que o sujeito vê, nomeia, e pretende entender, está desde logo mediada por esse mesmo sujeito e por toda a "bagagem" que traz consigo. Esse conceito de mediação (hegeliana) é fundamental, para entendermos dialeticamente a nossa relação dialética com o Outro, incluindo tudo, nomeadamente as chamadas "coisas materiais". Em arqueologia, naturalmente, tal mediação é metodologicamente orienta$\mathrm{da}$, como em qualquer trabalho científico, segundo os métodos e os pré-conceitos de cada época/escola. E portanto a "distinção absoluta entre objeto e sujeito" de que fala Thomas na p.77 não é limitativa, se em vez de a tomarmos rigidamente, introduzirmos a mediação subjetiva que está sempre presente (e é produto em arqueologia de uma "negociação" de equipa) entre nós e a realidade. Porque obviamente no trabalho de campo, por exemplo, sendo uma tarefa coletiva, nada do que aí ocorre deixa de passar por esta triangulação: o que lá está no terreno, os métodos consensualizados pela equipa dirigente, e a subjetividade desta e de cada um dos seus membros. Claro que a orientação dos trabalhos e as conclusões que dele resultam implicam sempre, em cada momento, esta dialética; nós estamos sempre a fazer escolhas, nomeadamente entre estratégias a seguir, e por isso o mesmo sítio, se idealmente fosse passível de ser estudado por duas equipas diferentes, forneceria com certeza realidades (mais ou menos) diferentes. Se a realidade em geral não é totalizável, se ela é não-Toda, a nossa posição de investigadores também o é, por mais esforços que devamos fazer no sentido de reduzirmos aqueles elementos de subjetividade que prejudiquem o entendimento de colegas, presentes ou futuros. É a isto que chamamos objetividade: não a revelação/resolução "matemática" de fórmulas indiscutíveis dentro da sua lógica específica (as quais têm o seu lugar próprio), mas uma disposição e prática de rigor sempre em afinação, e onde a intuição, a perspicácia, toda a bagagem cultural de uma equipa, enfim, entram em linha de conta decisiva. Por isso uma escavação é também performativa, um evento único, levado a cabo por pessoas concretas, dotadas de meios concretos, 
e não uma experimentação laboratorial quando esta é totalmente sujeita a um algoritmo mais rígido. E isto aplica-se a todo o "processo arqueológico", desde o princípio ao fim de um projeto: sempre obra de sujeitos concretos, procurando, porque investidos de uma responsabilidade pública, ser o mais rigorosos possível perante uma realidade que vão alterando à medida que a observam, e que portanto, longe de ser uma realidade estática ou morta, é sempre dinâmica e mediada pela atividade intencional e até afetiva (na medida em que nela ressoam necessariamente afetos; nós não somos robôs) dos que com ela se confrontam.

Os capítulos 4, 5 e 6 do livro são também excelentes. Claro que, como escreve o autor na pág. 144, “(...) nós nunca podemos entrar na vida mental de uma pessoa do passado (...)", mesmo que seja o Homem do Gelo encontrado congelado nos Alpes. Nós, cada um de nós, não podemos nunca "entrar" na vida mental do Outro, presente ou pretérito; e por isso é que o Outro, sendo para nós essencial (nenhum sujeito se constitui sozinho, como também evidentemente refere Thomas) é ao mesmo tempo um "eterno enigma"; mas, como a psicanálise lacaniana nos ensina, ele é também um enigma para si mesmo. ${ }^{20} \mathrm{Na}$ pág. seguinte, Thomas refere que "as arqueologias do indivíduo não nos dão uma teoria do sujeito (...)"; ora, claro, não dão nem podiam dar partindo dos pressupostos simplistas de que partem. Esta consideração também se aplica ao exposto na pág. seguinte (147). Não é preciso lembrar que o problema do sujeito - central na Modernidade, pelo menos desde, precisamente, Descartes - é um problema antiquíssimo da filosofia...e para a discussão do qual os contributos da psicanálise lacaniana, no âmbito filosófico, são incontornáveis: basta ver a complexidade imensa da filosofia žižekiana (entre muitas) a esse respeito ${ }^{21}$, a qual desde 1989 se vem impondo mundialmente; pode a arqueologia passar ao lado dela e de tantas outras que com ela dialogam ou se confrontam? Claro que não.

Quanto ao cap.7, tão interessante, é pena que se quede em Freud, que não vá um pouco além das perspe-

20. V. por exemplo o meu capítulo contendo um resumido comentário do grafo do desejo, de Lacan, em: https://ler. letras.up.pt/uploads/ficheiros/18125.pdf

21. Cf. por exemplo o livro recente de Žižek, Slavoj (2019), Sex and the Failed Absolute, Londres: Bloomsbury Academic. tivas que este grande autor há um século nos deixou. De facto, neste capítulo consagrado à relações entre profundidades e superfícies que têm constituído uma das preocupações do pensamento moderno, Julian Thomas aborda o paralelismo das noções de Freud como fundador da psicanálise com aquelas em que também se baseia a arqueologia, nomeadamente no que toca à importância, real ou metafórica, dada à dicotomia superfície-profundidade que, segundo ele, preside a ambas as disciplinas (bem como, repito, a muitas outras áreas do saber filhas da Modernidade). Seria na profundidade do solo, do que se não vê à vista desarmada antes da escavação, como na "profundidade da psique", que se não revela senão em sonhos, atos falhados, lapsos de linguagem, etc., que tanto Freud como os autores seus contemporâneos, nomeadamente os arqueólogos, veriam a "verdade" da realidade, que se mostra de forma enganadora à superfície. Esta dialética profundidade-superfície, típica da Modernidade, é aqui acentuada de justa forma por Julian Thomas. Posteriormente, em artigo intitulado "Sigmund Freud's archaeological metaphor and archaeology's self-understanding" (ver bibliografia), o autor aprofunda e desenvolve os pontos de ligação entre as duas disciplinas no momento do nascimento da psicanálise e no de maturação da arqueologia, que podemos situar convencionalmente a partir do início do século XX. E escreve (p. 62) que “A arqueologia e a psicanálise têm uma longa história em comum e (...) isso é também uma plataforma para futuros desenvolvimentos que se podem revelar enriquecedores para nós todos. Assim como as mais recentes formas de psicanálise podem ser úteis à arqueologia, pode dar-se o caso de que um entendimento transformado da arqueologia e suas práticas possa ajudar a psicanálise a reavaliar as sua própria história." ${ }^{22}$ No fim deste capítulo, Thomas faz uma

\footnotetext{
22. Assim, o autor toca aqui num ponto que me vem interessando muito desde 2006, altura em que, por via de ter "descoberto" Slavoj Žižek, fui de novo recuperar uma antiga curiosidade (vinda dos tempos estruturalistas) por Jacques Lacan, autor que tenho andado a estudar. De facto, como Julian Thomas sabe, a psicanálise, longe de ter parado em Freud, o seu criador, teve imensas repercussões e desenvolvimentos, sendo indispensável para compreender, por exemplo, o pensamento francês de todo o século XX e, em geral, o pensamento contemporâneo. Ora, na linha de raciocínio de Thomas, ou seja, de que a arqueologia não existe numa ilha, mas o seu aparecimento e desenvolvimento se liga intimamente a todo o pensamento moderno e contem-
} 
importante advertência, ao escrever (p. 17o) que uma “(...) visão essencialista do passado poderia ser comparada com a visão pós-cartesiana da mente, bem escondida no interior da pessoa. Do mesmo modo, é inútil imaginar que o passado é uma substância que está oculta em sítios obscuros aguardando ser posta à luz. Os vestígios do passado estão todos à nossa volta, e nós habitamos o passado em importantes sentidos." Não poderia estar mais de acordo; aliás, a própria psicanálise lacaniana, que esteve sempre em reformulação constante, de acordo com a evolução teórica e a prática crítica do autor (uma articulação dinâmica teoria/prática que também encontramos em arqueologia, como em múltiplos saberes), "desmedicamentalizou" muito Freud e alterou as suas tópicas. Por exemplo, a noção de inconsciente de Freud foi profundamente reformulada, mantida como uma simples "ficção útil", bastando atentar em dois célebres aforismos de Lacan, mil vezes repetidos por ele e outros, em milhares de escritos, para se ver como a questão, que não posso desenvolver aqui, foi totalmente alterada e complexificada: "o inconsciente está estruturado como uma linguagem" e "o inconsciente é o discurso do outro". A obra de Lacan aponta para um universo de sentido completamente diferente do de Freud ${ }^{23}$, mas muito útil - para não

porâneo, penso que se pode prolongar utilmente o contributo de Thomas no sentido de mostrar que não só a arqueologia contemporânea, mas toda a cultura dos nossos dias não pode passar sem os desenvolvimentos da psicanálise, e em particular sobre o ensino de Lacan e seus seguidores. Não se trata de incensar Lacan, tanto mais que a sua obra esteve sempre em renovação... Lacan pensava, provavelmente com razão, que a sua grande descoberta teria sido o "objecto pequeno a" (o objecto causa do desejo)... ora bem, esse último Lacan - com a importância dada ao Real no conjunto do seu nó borromeano, Real esse de que o pequeno a (a com letra pequena, de autre em francês, por referência a Autre, o grande Outro) é um resto, mas um resto crucial esse último Lacan, dizia, é indispensável para se compreender o nosso presente e, claro, também a nossa arqueologia, que evidentemente lida com o aqui e o agora em que nos encontramos imersos.

23. Apesar dele ter sempre dito aos que o ouviam, "sejam freudianos, e não lacanianos”, e sempre ter considerado a sua obra como um retorno a Freud (para a desviar dos imensos desvirtuamentos que sofreu, gravíssimos, particularmente no meio anglo-saxónico e especialmente norte-americano, em que a psicanálise foi totalmente subvertida no pior sentido, o de um reforço da psicologia do ego), esse retorno, essa repetição se quisermos, fez de Lacan um dos maiores pensadores originais do século XX. A melhor continuidade que se pode dar a um "inspirador" é tomar como obrigação repensá-lo, transformá-lo, atualizá-lo. dizer indispensável - à compreensão do humano e portanto da arqueologia também (v. por exemplo Chieza, 2007 ${ }^{24}$ ).

Não me sobra praticamente espaço para comentar devidamente os capítulos 8 (Mente, Perceção e Conhecimento), 9 (Materialidades) e 10 (Para uma Arqueologia Contra-moderna), mas creio que o que deixei dito ou sugerido antes talvez colmate em parte essa lacuna. Apenas posso dizer que, apesar de tudo, e do que conheço, estou muito mais do lado de Heidegger (o inspirador filosófico de J. Thomas) do que da filosofia da mente e do cognitivismo, muito mais do lado da teorização que sobre a experiência humana vem desenvolvendo um antropólogo como Tim Ingold do que da vertente "cognitiva" da arqueologia processual pela qual enveredaram autores como Colin Renfrew ou Steven Mithen (este último chegou a escrever um livro intitulado The Prehistory of the Mind, em 1996, Londres: Thames and Hudson), etc. Mas também me afastei, desde que tive tempo para estudar mais, de certo relativismo pós-moderno que afeta muita da arqueologia pós-processual. A arqueologia vive uma crise que acompanha a crise social neoliberal, e que a leva a ser atraída por novas ideias emergentes, como as de DeLanda, Graham Harman, e que atingem possivelmente o seu cúmulo com Jane Bennett e a sua noção de "matéria vibrante". Não, situo-me antes na linha da "escola de Liubliana" (Žižek, Mladen Dolar, Alenka Zupančič) e muitos outros autores que trabalham nesta linha, e estou convencido de que é por vezes nas épocas de maior crise e transformação social (como foi a da transição do século XVIII para o XIX, à qual devemos um Kant e todos os restantes que culminaram num dos mais notáveis autores do espírito humano, Hegel). É a Hegel que temos de voltar, penso eu (e estou bem acompanhado...), tomando em consideração no nosso domínio das ciências sociais e humanas, a que a arqueologia pertence, colegas de grande vulto, quer na antropologia (como Tim Ingold) quer na arqueologia (como Julian Thomas), e partir de um diálogo crítico e informado com esses autores, que me merecem respeito e confiança, mesmo na discordância, para construir novas filosofias (ou teorias, como se quiser) da arqueologia pré-histórica.

Ao seguir este caminho, tudo o que desejo é firmá-lo

24. Um livro que integralmente traduzi para a língua portuguesa (tradução inédita). 
bem, através de estudo continuado, para poder um dia, se a vida me deixar tempo e ânimo, escrever algo que possa ombrear com o esforço daqueles meus amigos e mestres. No entretanto, aconselho todos os meus colegas portugueses a lerem e relerem "Archaeology and Modernity", que aqui me serviu de pretexto de pensamento, e que é ainda, como todas as obras inteligentes, um livro inspirador.

Loures, julho de 2020

\section{BIBLIOGRAFIA}

CHIEZA, Lorenzo (2007) - Subjectivity and Otherness: a Philosophical Reading of Lacan, Cambridge-Massachusetts: MIT Press.

DESCOLA, Philippe (2005) - Par-Delà Nature et Culture, Paris: Gallimard.

DESCOLA, Philippe; INGOLD, Tim; LUSSAULT, Michel (2014)-Être au Monde: Quelle Expérience Commune?, Lyon: Presses Universitaires de Lyon.

FOUCAULT, Michel (2005) - As Palavras e as Coisas. Uma Arqueologia das Ciências Humanas, Lisboa: Ed. 70.

FOUCAULT, Michel (2005) - A Arqueologia do Saber, Coimbra: Almedina.

FOUCAULT, Michel (2005) - Naissance de la Clinique, Paris: Presses Universitaires de France.

JAMESON, Fredric (1991) - Postmodernism or, The Cultural Logic of Late Capitalism, London: Verso.

INGOLD, Tim (2015) - Estar Vivo: Ensaios sobre Movimento, Conhecimento e Descrição, Petrópolis: Editora Vozes.

LACAN, Jacques (2014) - Séminaire - XI - Les Quatre Concepts Fondamentaux de la Psychanalyse, Paris: Les Éditions du Seuil.

JORGE, Vítor Oliveira (2020) - Como se Faz um "Eu". Retornando sucintamente ao problema da constituição do sujeito e da subjetividade, in Jorge, Vítor Oliveira, coord. Modos de Fazer/Ways of Making [ebook], Porto: CITCEM, pp. 267-283.

JORGE, Vítor Oliveira (2020) - A Arqueologia na encruzilhada dos saberes contemporâneos: uma perspetiva, Conferência de encerramento do TAG ibérico 2020, organizado pela UNIARQ/FLUP e pela AAP, fevereiro 2020, Lisboa [inédito, consultável: https://www.academia.edu/ 43533673/A_Arqueologia_na_encruzilhada_dos_saberes_ contemporâneos_uma_perspetiva]

THOMAS, Julian (1996) - Time, Culture and Identity, Londres: Routledge.
THOMAS, Julian (2004) - Archaeology and Modernity, Londres: Routledge.

THOMAS, Julian (2004) - Archaeology's place in Modernity, in MODERNISM/modernity, vol. 11, number one, pp. $17-34$.

THOMAS, Julian (2009) - Sigmund Freud's Archaeological metaphor and archaeology's self-understanding, in Holtorf, Cornelius; Piccini, Angela, eds. - Contemporary Archaeologies: Excavating Now, Londres, Peter Lang, pp. 33-45.

ŽIŽEK, Slavoj (2009) - O Sujeito Incómodo. O Centro Ausente da Ontologia Política, Lisboa: Relógio d’ Água.

ŽIŽEK, Slavoj (2015) - Moins Que Rien: Hegel et l'Ombre du Matérialisme Dialectique, Paris: Fayard. 


\title{
DADOS PARA A HISTÓRIA DAS MULHERES NA ARQUEOLOGIA PORTUGUESA, DOS FINAIS DO SÉCULO XIX AOS INÍCIOS DO SÉC XXI (NÚMEROS, NOMES E TABELAS)
}

\author{
Filipa Dimas ${ }^{1}$, Mariana Diniz ${ }^{2}$
}

\begin{abstract}
RESUMO
O presente artigo foca a presença das mulheres no meio arqueológico português, a partir de uma análise bibliométrica realizada a partir de duas revistas da especialidade - O Arqueólogo Português e Trabalhos de Antropologia e Etnologia - e da recolha, no Endovélico, de informação relativa à direcção, por mulheres, de escavações arqueológicas. Os resultados em ambas as revistas revelam uma presença minoritária de mulheres como expectável. Observa- se uma trajectória que se inicia abaixo do 1\%, nas primeiras décadas do século XX, para atingir valores quase paritários na segunda década do século XXI. Também os dados do Endovélico demonstram o aparecimento e crescimento efectivo da presença de mulheres, na segunda metade do séc. XX, num percurso, por vezes mais abrupto que gradual, condicionado por um conjunto de factores políticos, sociais e ideológicos. Palavras-chave: Mulheres na Arqueologia, História da Arqueologia em Portugal, O Arqueólogo Português, Trabalhos de Antropologia e Etnologia, Endovélico.
\end{abstract}

\begin{abstract}
The present article focuses on the presence of women in the field of Portuguese archaeology. Based on a bibliometric analysis of two archaeology magazines - O Arqueólogo Português and Trabalhos de Antropologia e Etnologia - as well as data gathering from Endovélico, regarding archaeological excavations directed by women. Both magazines reveal a minority presence. In which it can be seen a number that starts below $1 \%$, in the first decades of the $2 \mathrm{O}^{\text {th }}$ century, to reach almost even numbers in the second decade of the $21^{\text {st }}$ century. In addition, collection of data from Endovélico demonstrates the effective growth of women in the second half of the $2 \mathrm{O}^{\text {th }}$ century. In a path, sometimes more abrupt than gradual, due to a set of political, social, and ideological factors. Keywords: Women in Archaeology, History of Archaeology in Portugal, O Arqueólogo Português, Trabalhos de Antropologia e Etnologia, Endovélico.
\end{abstract}

\section{INTRODUÇÃO/BREVE HISTÓRIA DO TEMA}

O presente artigo foca a presença das mulheres no meio arqueológico português, a partir de uma análise bibliométrica realizada a duas publicações periódicas de grande longevidade que podem reflectir o seu trajecto, nesta ciência, ao longo do século XX e nas primeiras décadas do séc. XXI. Esta temática, com impacto tardio em Portugal, tem, no entanto, despertado um interesse crescente quer como fenómeno social amplo, quer ao nível da biografia científica de figuras particulares. Este artigo reúne dados para essa História das Mulheres, na Arqueologia,

\footnotetext{
1. Mestranda em Arqueologia da Faculdade de Ciências Sociais e Humanas, Universidade Nova de Lisboa (NOVA-FCSH); filipadimaso4@gmail.com
}

2. UNIARQ - Faculdade de Letras da Universidade de Lisboa. Associação dos Arqueólogos Portugueses. 
uma história ainda em construção. O tópico Mulheres em Arqueologia, no Passado ou no Presente, no duplo papel de actrizes e autoras da História, é como acontece com a presença feminina em Ciência, um fenómeno que, apesar de antecedentes mais remotos, surge na segunda metade do século XX, fundamentalmente a partir da década de 70 , na sequência de uma nova onda de feminismo e do aumento do número de mulheres na Universidade (Maffía, 2006). Em Arqueologia, será apenas nos anos 80 que a Arqueologia do Género, através de três personagens fundamentais - Margaret Conkey, Janet Spector e Joan Gero (Díaz-Andreu, 2014) - abre este debate, numa Ciência ainda predominantemente masculina e sexista (Wylie, 1997). Desde então, assiste-se a uma multiplicação efectiva de trabalhos sobre a matéria. Para além da realização de conferências e congressos sobre o tema (Díaz-Andreu, 2014), destacam-se obras como as de Cheryl Claasen, relativa ao panorama norte-americano (Claasen, 1994), e mais tarde, já no XXI, uma monografia dedicada às pioneiras da Arqueologia, mais uma vez no mundo ocidental (Cohen \& Joukowsky, 20o6). Em Portugal, as questões de Género são, muito tardiamente, abordadas quando analisado o cenário internacional. Só, na segunda metade da década de 9o, é publicado o primeiro artigo acerca das mulheres, na Arqueologia portuguesa, por Vítor Oliveira Jorge e Susana Oliveira Jorge, que identificam quatro etapas fundamentais nesta História (Jorge \& Jorge, 1996), à qual, hoje, têm que se somar os papeis das gerações Millenials e Geração Z.

Nas duas primeiras décadas do século XXI, é crescente o número de publicações sobre o papel das mulheres na Arqueologia Portuguesa, que como previsível, é tratado fundamentalmente, mas não exclusivamente, por autoras (Thébaud, 1996; Diniz, 2006; Maffía, 2006; Gomes, 2015), mas menos frequentes são os textos que abordam o papel das mulheres nas sociedades passadas (Diniz, 2006). A primeira periodização proposta em 1996 (Jorge \& Jorge 1996), é actualizada (Bugalhão, 2017) e são apresentadas as primeiras análises quantitativas e explorados os trajetos de figuras pioneiras - ainda excepcionais ao longo dos anos 50 e 60 , entre as quais se destacam Maria de Lourdes Costa Arthur, Irisalva Moita (Bugalhão, 2013, 2017; Martins 2016; Bastos \& Almeida 2019), a muito breve carreira arqueológica da medievalista Virgínia Rau (Melo \& Cardoso, 2014; Fernandes, 2017), ou a acção de uma estrangeira como Vera Leisner (Boaventura, 2017). Ao mesmo tempo, e para além das personagens, o quadro social da prática da Arqueologia, no Portugal contemporâneo é fonte de interesse crescente. No relatório DISCO "Discovering the Archaeologists of Europe", em 2014, as questões de Género são abordadas e quantificadas, numa comunidade constituída por $53 \%$ de indivíduos do sexo feminino (Costa et al., 2014), e, acompanhando uma tendência, Género e questões laborais passarão a fazer parte das agendas da política arqueológica (Simões et al., 2018).

Que, em Arqueologia, como em qualquer outra área de actividade, o papel das mulheres é, ao longo do século $\mathrm{XX}$, crescente, mais que uma premissa de trabalho é um pré-conceito. Dessa intervenção crescente não existem dúvidas. No entanto, para além de uma percepção social, mais ou menos generalizada e mais ou menos interiorizada, considera-se decisiva a reunião de dados que quantitativamente documentem essa História. E esse é o fundamental objectivo deste trabalho.

\section{MATERIAIS E METODOLOGIA DE ANÁLISE}

Tendo como objectivo central identificar e datar a crescente presença de mulheres na Arqueologia portuguesa, ao longo do século XX e primeiras décadas do século XXI, foi realizada uma análise bibliométrica a duas publicações periódicas fundamentais no panorama português: O Arqueólogo Português (OAP), editado pelo Museu Nacional de Arqueologia (MNA - Lisboa), e os Trabalhos de Antropologia e Etnologia editados pela Sociedade Portuguesa Antropologia e Etnologia (SPAE-Porto).

$\mathrm{Na}$ análise bibliométrica foram tidos em consideração, para cada volume analisado, os seguintes parâmetros: o número total de ocorrências de autores masculinos e femininos, contabilizados apenas uma vez, independentemente do número de artigos que assinem e da ordem em que surjam na assinatura do artigo, e a autoria dos artigos, Artigos $\mathrm{H}$ - primeiro, e único, autor homem, Artigos M - primeira, e única, autora mulher; Artigos $\mathrm{H}+\mathrm{H}-$ dois, ou mais, autores homens; $\mathrm{H}+\mathrm{M}$ e $\mathrm{M}+\mathrm{H}$ - artigos em parceria; $\mathrm{M}+\mathrm{M}-$ duas, ou mais, autoras, mulheres.

Para além desta análise foi ainda realizado um levantamento exaustivo da direcção de escavações arqueológicas conduzidas por mulheres, a partir do inventário do património arqueológico nacional - 
Endovélico (Direção-Geral do Património Cultural / DGPC). Para contextualização dos dados obtidos recorreu-se também à PORDATA.

\subsection{O Arqueólogo Português (MNA)}

A revista $O$ Arqueólogo Português (OAP), fundada em 1895, por José Leite de Vasconcelos, como órgão do, hoje, Museu Nacional de Arqueologia foi, como um dos mais antigos periódicos em continuidade no domínio da Arqueologia em Portugal, uma escolha óbvia para averiguar o género dos/as principais protagonistas, ou signatários/as, do conhecimento arqueológico produzido em Portugal.

A recolha foi realizada através da consulta da totalidade dos volumes, no site da DGPC, na secção do O Arqueólogo Português e da consulta online dos últimos volumes, através do catálogo da Biblioteca de Arqueologia e da Biblioteca do Museu Nacional de Arqueologia.

Foram utilizados os seguintes descritores, nesta recolha; Ano/ Série/Volume/N․o de ocorrências de Autores/N ․o ocorrências de Autoras/ N.․ artigos escritos por homens/ N.. Artigos escritos por mulheres/N.. artigos em parcerias exclusivamente masculinas/ N ․o. artigos em parcerias exclusivamente femininas/ №. artigos assinados por equipas mistas. Foram ainda levantados os nomes e os temas de estudo da totalidade dos signatários, dados que não serão discutidos no presente trabalho.

Os dados foram organizados, em folhas Excel, consoante as séries, Série 1 (1895-1938), Série 2 (19511964), Série 3 (1967-1977), Série 4 (1983-2008) e Série 5 (2011-2017), considerando-se como Ano do volume aquele que figura na capa, independentemente do ano efectivo de lançamento da obra.

\subsection{Trabalhos de Antropologia e Etnologia (SPAE)} A revista Trabalhos de Antropologia e Etnologia (TAE), fundada em 1919, por António Mendes Corrêa e por Joaquim Santos, ligada à Faculdade de Ciências da Universidade do Porto e ao Instituto de Antropologia (hoje Sociedade Portuguesa de Antropologia e Etnologia), foi o segundo periódico selecionado para esta análise. A sua antiguidade e longevidade, a edição na cidade do Porto torna-a mais apta a reflectir outro país arqueológico mais distante da capital, justificando a sua escolha, para esta análise que se pretende de âmbito nacional.

A recolha foi realizada através da consulta da totalidade dos volumes publicados, (1919-2019), dispo- níveis no site oficial dos Trabalhos de Antropologia e Etnologia, bem como, através do catálogo online da Biblioteca de Arqueologia. Os dados relativos ao $1^{\circ}$ Congresso de Arqueologia Peninsular foram retirados do catálogo online da Biblioteca de Arqueologia e do Dialnet e dividido em dois, sendo um ainda relativo às Actas do $1^{\circ}$ Congresso de Arqueologia Peninsular e outro apresentando o Dossier Côa.

A metodologia utilizada para os Trabalhos de Antropologia e Etnologia foi semelhante à utilizada na revista anterior, todavia, a recolha de dados foi feita por volume e fascículos. Ao contrário d'OAP, esta revista não está organizada por Séries, pelo que os dados são apresentados na sua globalidade. Desta forma, foram analisados, entre 1919 e 2019, a totalidade dos volumes já publicados, excetuando o volume 45, que não consta da base de dados oficial da revista. Foram ainda levantados os nomes e os temas de estudo da totalidade dos signatários, dados que também não serão discutidos no presente trabalho.

\subsection{Base de dados do património arqueológico/ Endovélico (DGPC)}

$\mathrm{Na}$ base de dados do património arqueológico português Endovélico (DGPC), acessível através do Portal do Arqueólogo foram procuradas na Categoria Trabalhos exclusivamente as direcções de escavações arqueológicas realizadas por mulheres, excluindo-se desta análise, por limitação do tempo, todas as outras categorias de trabalhos em que estas possam estar envolvidas, tais como: Acompanhamento; Conservação e Restauro; Estudo de Espólio; Fiscalização; Levantamento; Outros; Prospeção; Prospeção Geofísica; Relocalização/Identificação; Salvamento; Sondagem; Valorização; Verificação de achado. Nesta primeira recolha, os descritores utilizados foram: Nome/Categoria/Ano/Sítio Arqueológico/Período/Responsáveis/Co-responsáveis/ Pessoas (Relação) ${ }^{3}$, e os dados recolhidos, de forma manual, inseridos em ficheiro Excel, relativos ao período compreendido entre 1940 e 2018.

Uma segunda recolha, mais abrangente foi realizada a partir do Endovélico, para a década 2010-2019, sendo para este intervalo recolhidos todos os dados relativos a direcções de escavações realizadas por homens, por mulheres ou por equipas mistas. Esta

\footnotetext{
3. Um outro aspecto relevante, mas não abordado aqui são as co-direcções assumidas por marido e mulher ou casais não formalizados.
} 
recolha pretende dar continuidade à análise já feita até 2014, por Jacinta Bugalhão (Bugalhão 2017), ao mesmo tempo que procura dados mais finos para justificar a quebra acentuada da direcção de escavações por mulheres, registada entre 2010 e 2019.

\section{RESULTADOS}

\subsection{O Arqueológo Português - Resultados}

Para analisar a presença das mulheres na revista O Arqueólogo Português, foram recolhidos dados da $\mathrm{I}^{\mathrm{a}} \mathrm{à} 5^{\mathrm{a}}$ Série, relativos à totalidade dos volumes já publicados, entre 1895 e 2017. No total destes 122 anos, as assinaturas femininas correspondem a cerca de $21 \%$ do conjunto. Este valor médio, muito baixo, esconde, no entanto, um trajecto, de ritmo desigual, e cuja história aqui se pretende reconstituir (Tabela 1).

$1^{a}$ Série (1895-1938)

A $1^{2}$ Série tem início em 1895 e fim em 1938, e revela números esperados para a época. Em 30 volumes, apenas se regista a presença de 3 signatárias, comparativamente ao número elevado de assinaturas masculinas -463 ocorrências, que deram origem a 1213 dos artigos, número totalitário face aos três textos de autoria feminina (Tabela 1, Figura 1).

Numa revista fundada em 1895, apenas em 1919, surge a primeira assinatura feminina, Carolina Michaëlis de Vasconcelos, escreve sobre literatura, entre 1923 e 1924 e Robélia Pires de Sousa Lobo escreve sobre Augusto de Sousa Lobo. Apenas no volume relativo ao ano de 1938, mas lançado efectivamente em 1956, reaparece um texto de autoria feminina, o primeiro de temática arqueológica, de Rosa Capeans, sobre o mundo Romano.

40 anos depois do primeiro volume lançado, O Arqueólogo Português regista a presença também de uma arqueóloga portuguesa...

\section{2를 Série (1951-1964)}

A segunda série corresponde ao período entre $1951 \mathrm{e}$ 1964, em que foram publicados um total de 5 volumes, correspondendo a 47 ocorrências onomásticas. No total, registam-se 32 nomes masculinos e 15 nomes femininos (Tabela 1).

Relativamente à serie anterior, o peso das assinaturas femininas escala de forma notável para os cerca de $32 \%$, revelando um peso, precoce e de alguma forma inconsequente, de mulheres-autoras (tabela 1). De apenas três nomes de mulheres, na longíssima
$\mathrm{I}^{\underline{\mathrm{a}}}$ série registam-se agora 15 , num intervalo curto de cerca de 13 anos. Rosa Capeans, volta a estar presente, no volume de 1956, mas outros nomes surgem como o de Irisalva Moita, em 1951, num trabalho sobre mundo Romano e em 1956, sobre Pré-História, e mais tarde, em 1964, Margarida Ribeiro e Maria Cristina Moreira de Sá de Dougedroit, sobre epigrafia. Uma outra mulher, estrangeira, Vera Leisner assinará, com o marido, textos sobre Megalitismo, a partir dos anos 50.

No entanto, a análise dos valores relativos às autorias revela um outro panorama. A importância das mulheres é indiscutivelmente crescente, fazem já parte efectiva de grupos de trabalho, no terreno e no gabinete, mas como primeiras assinantes o seu peso é ainda diminuto e apenas $19 \%$ dos artigos tem uma mulher como primeira, e única, autora. Ao mesmo tempo, surgem parcerias científicas, mistas, com cerca de $7,5 \%$ dos casos, seguido das autorias conjuntas femininas, que representam cerca de $4 \%$ das assinaturas (Tabela 1, Figura 1).

$3^{\underline{a}}$ Série (1967-1977)

A $3^{\text {a }}$ série é publicada entre 1967 e 1977, e conta com 9 volumes. Tal como a anterior, esta série é curta, tendo a duração de cerca de 10 anos. Contabilizaram-se, mas excluíram-se desta análise, as notícias, textos muito breves de carácter informativo, cujo grande número, sem autoria, podia diluir o significado efectivo das assinaturas masculinas e femininas (Tabela 1). Num total de 159 autorias, o total de autorias femininas é de 36 assinaturas. Esta quebra face aos valores da $2^{2}$ Série, corresponde, no entanto a dois momentos distintos na História das mulheres, na Arqueologia portuguesa, como é visível quando se desdobram os valores obtidos para esta $3^{\underline{a}}$ Série (Tabela 1A). Nos volumes relativos a 1967-1972, a presença discreta das mulheres ronda apenas os $19 \%$. No entanto, no volume relativo aos anos de 1974-77, correspondendo ao apogeu do processo revolucionário em curso que se segue à Revolução de Abril de 74, o peso das assinaturas femininas aumenta para $37 \%$, invertendo a tendência, e projectando as mulheres como personagens decisivas na Arqueologia nacional. No total, o número de artigos com primeira, e única, autora mulher, sobe para 35, significando também aqui um crescimento substantivo da presença feminina, num momento em que a renovação social e também da comunidade arqueológica portuguesa 
integra uma componente expressiva de mulheres (Tabela 1A, figura 1).

Agora, ao lado da etnóloga Margarida Ribeiro, vinda ainda da $2^{\underline{a}}$ Série, outros nomes, alguns que serão decisivos na década de 8o, surgem pela primeira vez: Maria Adelaide Garcia Pereira, Maria Luísa Abreu Nunes, Maria Amélia Horta Pereira, Maria da Graça Amaral da Costa, Seomara da Veiga Ferreira, Maria Manuela Alves Dias, Maria Cristina Santos, Maria João Coutinho, Isilda Pires Martins, Susana Oliveira Jorge, Joaquina Soares, Ana Ramos Pereira. E a presença já tradicional do Instituto Arqueológico Alemão, em Lisboa, é assumida por Philine Kalb.

\section{4 $4^{\mathrm{a}}$ Série (1983-2008)}

Entre 1983 e 2008, são publicados 26 volumes que correspondem à $4^{\underline{a}}$ Série da revista, num total de 350 artigos. Num crescimento esperado, ainda que minoritárias, as autoras atingem os $35 \%$ do conjunto e a percentagem de artigos assinados por mulheres, como primeira, e única, autora mantém-se nos $25 \%$ do total (Tabela 1, figura 1). O lugar das mulheres é óbvio, mas minoritário. Ao longo desta longa série quase centena e meia de autoras, de forma muito desigual de volume para volume, reflectem de forma tímida as mudanças cruciais que Portugal atravessa e a comunidade arqueológica em particular com destaque para a profissionalização da Arqueologia. A presença de mulheres é muito visível nos diferentes cenários - academia, trabalhos de campo, congressos - mas a essa percepção corresponde uma (decepcionante?) percentagem de $35 \%$. Os artigos assinados por autores masculinos e femininos são dominantes na área das parcerias refletindo a natureza mista da maior parte das equipas de investigação, em Arqueologia (Tabela 1, figura 1).

\section{$5^{\text {a Série (2011-2017) }}$}

O número de autoras atinge os $45 \%$ do conjunto. Uma presença quase paritária de assinaturas masculinas e femininas é registada pela primeira vez, num contexto social em que são constantes as iniciativas para a igualdade de Género, assumida, mas ainda não alcançada. No entanto, e mais uma vez, este crescimento do número de mulheres-autoras n'OAP não se reflecte linearmente na percentagem de artigos. Quando analisados os textos escritos, dominam aqueles de autor -homem, a solo ou em equipa - em $46 \%$ dos casos - contra $29 \%$ de artigos de autoria feminina exclusiva - a solo ou em equi- pa, registando-se ainda em constante crescimento, o peso dos artigos de equipas mistas - 19\% (tabela 1, figura 1).

O gráfico da figura 2, ilustra e sustenta a proposição de partida, a do crescente, ainda que sujeito a quedas, papel das mulheres no período em análise. N'OAP depois de duas décadas de exclusividade masculina, as primeiras mulheres-autoras fazem a sua, pontual, aparição. Depois de uma longíssima $1^{\underline{a}}$ Série, três autoras em 43 anos, nos anos 50/6o, detecta-se um crescimento brusco no número de mulheres, reflexo de uma modernidade prematura e de alguma forma inconsequente. Será apenas depois da Revolução de 1974 que, de forma definitiva, a presença feminina não deixa de crescer para hoje, ainda sem atingir a paridade, rondar os $45 \%$ (Tabela 1 ).

\subsection{Trabalhos de Antropologia e Etnologia}

Em 100 anos, a percentagem de mulheres que publicaram na revista atinge os $23,8 \%$, enquanto que os homens correspondem aos 75, 9 \% restantes. Em termos de assinaturas, é expectável que esta percentagem reflita o número das autorias, uma vez que, tal como acontece com os artigos de autor único-homem-74, 6\% do total, por regra, as mulheres escrevem a solo - cerca de 9,6. Relativamente às parcerias, dominam as constituídas por signatários do sexo masculino. Todavia, artigos co-assinados entre homens e mulheres não ficam muito atrás com cerca de $4,4 \%$, mas as parcerias femininas acabam por ser inferiores ao número de artigos sem autor, com o,8\% (Tabela 2).

Em 1922, surge a primeira mulher a assinar um artigo, Amélia Bacelar, na área da Antropologia Física e Paleontologia, neste caso, em conjunto com um homem - segundo autor, e seu marido, Fernando Frade Viegas da Costa (Saldanha, 2014), inaugurando-se uma longíssima tradição, em Ciência, de parcerias de investigação e escrita, entre marido e mulher que podem - como neste caso - ou não, conservar o seu apelido de nascimento.

A presença das mulheres é ao longo de seis décadas muito escassa, e até à década de 8o, as mulheres-autoras não atingem os 10\% do conjunto (Tabela 2). Dedicam-se sobretudo às Ciências Sociais, nomeadamente às áreas da Antropologia e Demografia. O primeiro texto de natureza especificamente arqueológico, assinado no feminino, surge em 1963, da autoria de Maria Fernandes da Soledad de Castro, 
dedicado à metalurgia. Em 1969, uma estrangeira, Denise Ferembach assina um artigo dedicado à Pré-História e à Antropologia Física.

Os valores alteram-se apenas na década de oitenta quando as mulheres começam a ganhar destaque na revista, ultrapassando a barreira dos $20 \%$ das autorias (Tabela 2). No campo da Arqueologia, nomes que serão constantes nas décadas seguintes como Manuela Martins, Susana Oliveira Jorge e Salete Ponte, Raquel Vilaça, Maria de Jesus Sanches, Anabela Gomes Lebre, fazem parte de uma Nova Arqueologia portuguesa que também se define por um outro peso das personagens femininas. A dimensão internacional da Arqueologia portuguesa está também representada, Blanca García e An Lentacker assinam textos sobre temática portuguesas.

Nos anos noventa, mais especificamente a partir de 1993, nos volumes relativos à publicação das Actas do I Congresso de Arqueologia Peninsular (CAP), decorrido na Faculdade de Letras do Porto, em Outubro de 1993, as assinaturas de mulheres, de onde constam nomes - que representam diferentes gerações - como Ana Cristina Araújo, Carla Stockler Nunes, Maria de Jesus Sanches, Susana Oliveira Jorge, Eugénia Cunha, Ana Maria Silva, Teresa Alves Araújo, Carmo Marrafa, Ana Luísa Santos, Ana Isabel Santoa, Manuela Martins, Manuela Delgado, Salete da Ponte, An Lentacker, Mariana Diniz, Ana M. S. Bettencourt, Helena Catarino, Maria Isabel M. Ribeiro, Isabel Figueiral, Joaquina Soares, Ana Margarida Arruda, Jacinta Bugalhão, Raquel Vilaça, e que, pela primeira vez, atingem cerca de um terço do conjunto. Se é certo que os 33,3\% de nomes femininos constantes destas actas, refletem a composição, à data, da comunidade arqueológica ibérica e não especificamente da comunidade portuguesa, dada a natureza do I CAP, os valores dos últimos anos da década - 1996-1999, atingindo os 40\% de assinaturas femininas nos TAE, demonstra bem como outro patamar quantitativo foi efectivamente alcançado pela revista (Tabela 2, tabela 2A). O crescimento da década de 9o, consolida-se na primeira década do séc. XXI, onde, no entanto não se detectam sinais de uma paridade maior. O lugar das mulheres parece estabilizar em torno dos $33 \%$ e só na $2^{\underline{a}}$ década do séc. XXI, se vai para além dos $40 \%$ de autoras (Tabela 2).

Quanto à percentagem de artigos assinados por mulheres, a solo ou em parceria com outras mulheres, os números são sempre menos generosos e só na se- gunda década do séc.XXI, os artigos de autoras - cerca de $42 \%$ - se aproxima da percentagem de nomes femininos na revista - cerca de $44 \%$ (Tabela 2, figura 3 , figura 4). Ao longo das décadas anteriores, e ainda que os nomes de mulheres se fossem tornando progressivamente mais comuns a partir dos anos 8o, é muito baixa a percentagem de artigos de mulheres a solo ou em parceria. Esta discrepância de valores reflecte a especificidade do trajecto feminino em Ciência, que dá origem a um menor número de artigos do que os produzidos por autores-homens e os números, irrisórios, de parcerias femininas.

O gráfico da figura 4, ilustra e sustenta a proposição de partida, a do crescente papel das mulheres no período em análise. Neste caso particular, os números revelaram que a presença significativa de mulheres é inesperadamente tardia, fenómeno próprio das últimas duas décadas do séc.XX, quando se detecta uma subida abrupta dos valores que, com alguma estagnação na viragem do milénio, voltam a disparar, na segunda década do séc. XXI.

Realizando uma leitura de conjunto em ambas as revistas, como ilustram os gráficos das figs. 5 e 6 , são idênticos os pontos de partida, entre os finais do séc. XIX e as primeiras décadas do séc. XX, as mulheres são menos que pontuais nas páginas das duas publicações, e são idênticos os pontos de chegada numa, quase, paridade, as mulheres ultrapassam os $40 \%$ das autorias de artigos científicos, na segunda década do séc. XXI.

Os trajectos não são, no entanto, paralelos. Nitidamente, n'OAP (Tabela 1, Figura 5), sinais da modernidade dos meados do séc. XX fazem-se sentir - provavelmente de forma prematura e por isso os números voltam a cair até à Revolução de Abril - mas na revista do Porto, o panorama não regista alterações até aos finais da década de 70 (Figura 5, figura 6). No Portugal democrático, e num trajecto talvez mais lento que o esperado, a presença de mulheres é crescente, mas - surpreendentemente minoritária, estabilizada em torno dos $30 \%$. Um outro patamar atinge-se só na segunda década do século $\mathrm{XXI}$, e quando para muitos as questões da igualdade de género parecem já anacrónicas, a presença de mulheres ronda os $45 \%$.

\subsection{Base de dados - Endovélico}

Como referido anteriormente a recolha da base de dados do Património Cultural, Endovélico centrou-se na categoria Escavação dirigida por mulheres, 
no período compreendido entre 1940 - surge, em 1943, o primeiro nome de uma mulher - ainda que estrangeira - associada à direcção de trabalhos de campo - Vera Leisner.

Como expectável, este é também um trajecto ascendente. Os nomes de mulheres surgem pontuais na década de 40, a sua visibilidade parece, nestes domínios, menor ainda que no campo das publicações científicas e o crescimento precoce, mas não sustentado, dos anos 50 visível n'OAP, também aqui se verifica. Até quase aos finais do século XX, numa comunidade arqueológica de pequena dimensão, muito estreitamente ligada às Universidades, o número de mulheres é reduzido também. Nos anos 80 - regista-se o primeiro, e imenso, salto que se repete, antecedendo, o momento da profissionalização da classe arqueológica, nos cenários da arqueologia de contrato, dominante na primeira década do século XXI, onde as leis do mercado parecem pouco sexistas. De uma actividade marcadamente masculina, a escavação torna-se também um domínio de acção feminina (figura 7).

Uma análise conjunta dos dois gráficos (Figura 7 e 8) permite, no entanto, uma leitura mais nítida do real - se na década de 8o, o número de mulheres dispara, é de registar que elas são esmagadoramente co-responsáveis ou pessoa-relação, e apenas em pouco mais de $20 \%$ dos casos assumem a direcção plena dos trabalhos. Este quadro não sofre alterações significativas, até aos inícios do século XXI - quando o número de direcções femininas quase iguala o das co-direcções. É neste período que o relatório DISCO (Costa et al., 2014), define a comunidade arqueológica como essencialmente paritária, classificação que parece justificar-se também atendendo aos números verificados nas publicações científicas. No entanto, esta tendência de crescimento das mulheres no terreno parece inverter-se subitamente e os valores da última década em análise-2010-2018 - merecem uma análise mais detalhada. A queda muito significativa no número de trabalhos dirigidos por mulheres (Figura 7), justificou uma recolha mais abrangente da informação disponível no Endovélico para este período (Tabela 3) procurando identificar as causas desta inversão de tendência e a sua relação com as oscilações do mercado de trabalho. Admitindo-se como provável que alguns números hoje constantes do Endovélico possam ainda vir a ser alterados, os anos de 2010-2018, correspondem a um primeiro momento de crescimento-2010-2011, a uma quebra, quase para metade dos trabalhos de escavação 2012-2014, uma retoma ligeira em 2015, e números novamente em queda nos anos de 20162019. Ao longo de todo este período, as direcções femininas são sempre minoritárias - atingindo os valores máximos de 31\% em 2011, e de 35\%, em 2015 - num cenário em que dominam as direcções masculinas ou, como fenómeno de peso crescente, as equipas mistas (Figura 9).

\section{DISCUSSÃO. PARA A HISTÓRIA DAS MULHERES NA ARQUEOLOGIA, EM PORTUGAL: AS ETAPAS DE UMA PERIO- DIZAÇÃO DE CRONOLOGIA VARIÁVEL}

A partir dos dados recolhidos foi construída uma proposta de periodização (Tabela 3) para a História das Mulheres na Arqueologia Portuguesa, utilizando marcos quantitativos próprios desse percurso como limites para cada uma das quatro fases fundamentais que se identificaram: Alone in the woods, A Place in the Sun, Minority Report e Bonnie and Clyde. Estas etapas reflectem uma história das mulheres que é, nas duas revistas, muito semelhante - da invisibilidade, quase, total a uma, quase total, paridade - mas não sincrónica. Nascidas ambas as revistas, num ambiente ferozmente positivista, que é com grande probabilidade um dos momentos de mais total exclusão das mulheres dos diferentes cenários da vida pública, O Arqueólogo Português apresenta, nas primeiras décadas de existência, o ambiente próprio da Ciência masculina onde, como num clube inglês, as mulheres não entram. Numa revista fundada em 1895, a primeira mulher assina em 1921.

A primeira das quatro etapas - Alone in the woods - refere precisamente a solidão destas figuras femininas que ficam sempre aquém dos $10 \%$ do conjunto de autores, n’OAP até aos finais da 1ํérie, em 1938, e nos TAE, até ao final dos anos 70 .

Uma segunda etapa-A Place in the Sun-abre-se com

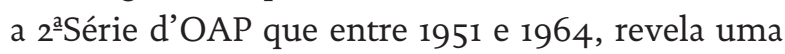
inesperada modernidade, num Portugal que ideologicamente não se renova na Europa do pós-guerra, e que permanecerá orgulhosamente só, mas onde os números reflectem - pelo menos na cidade de Lisboa - uma mudança efectiva de comportamentos e onde as mulheres-autoras, algumas antigas estudantes da Faculdade de Letras de Lisboa como Maria de Lurdes Costa Arthur ou Irisalva Moita, representarão cerca 
de $30 \%$ das assinaturas. Este protagonismo nítido, mas fácil de interromper numa comunidade de pequenas dimensões, foi n'OAP fugaz. Na revista do Porto, esta segunda fase é tardia e só na década de 80 , a percentagem de assinaturas femininas atinge os $30 \%$ do conjunto. Podem ser várias as explicações - a criação tardia da Faculdade de Letras do Porto, que só acontece em 1961, tornará mais tardia a criação, ou importação, de massa crítica, neste caso feminina, e um ambiente tradicionalmente mais conservador podem justificar as diferentes cronologias da Etapa 2, nas duas revistas.

A Etapa 3 - Minority Report - corresponde ao momento em que se detectem mais de $30 \%$ de assinaturas de mulheres, entre os autores. Esta fase corresponde n'OAP a uma muito tímida primavera marcelista, dos finais de 60/inícios da década de 70, e aos $38 \%$ de autorias femininas no volume relativo aos anos revolucionários de 1974-1977. Prolonga-se esta $3^{\circ}$ etapa n'OAP - inesperadamente - pelo longuíssimo intervalo da $4^{a}$ Série - que se estende de 1983 a 2008. Ao longo deste período de 25 anos, a sociedade portuguesa transforma-se de forma profunda. A Europeização crescente, iniciada com a adesão à CEE, em 1986, a criação de licenciaturas em Arqueologia em diferentes Universidades nacionais, a profissionalização da Arqueologia iniciada nos finais dos anos 9o, e que dá origem a um crescimento brutal da comunidade arqueológica não alteram, no entanto, estes valores. Nos TAE, serão as Actas do $1^{\circ}$ Congresso de Arqueologia Peninsular, que entre 1993 e 1995, trazem a revista para este outro patamar, onde as autorias femininas, ainda que ibéricas, ultrapassam os $38 \%$. Para muitos esta Etapa 3 parecia corresponder já a uma fase de "plena igualdade" entre sexos, num Portugal do século XXI, mas os números efectivos apontam noutro sentido, diferente do que pode ser a sua percepção social. O lugar das mulheres é agora óbvio, mas, duradouramente, minoritário.

A Etapa 4-Bonnie and Clyde, numa alusão a uma parceria célebre e verdadeiramente igualitária, atinge-se em ambas as publicações, apenas na segunda década do séc. XXI, numa demonstração clara da lentidão dos processos de mudança social. No entanto, uma percentagem de assinaturas femininas superior a 40\% não representa, agora, o atingir de um estádio de perfeição social que podia justificar o fim da História, primeiro no sentido judaico, depois marxista e por fim de F. Fukuyama. Na população portuguesa, as mulheres são mais numerosas do que os homens - correspondendo de acordo com a PORDATA, a cerca de $53 \%$ da população, pelo que numa comunidade cientifica natural - seria expectável encontrar igual proporção de autoras.

Relativamente aos dados do Endovélico, o trajecto é idêntico, mas mais uma vez não necessariamente sincrónico, com o identificado nas publicações periódicas. As direcções de trabalhos - a faceta mais claramente autoritária e masculina da actividade não são significativas antes da década de 80 e, se na escrita de textos, a autoria feminina é visível, desde os anos 50, na revista de Lisboa, as escavações permanecem como um baluarte de acção masculina.

A partir dos anos 80 e até aos finais da década seguinte, em direcção de escavações conectadas fundamentalmente com projectos de investigação, as mulheres assumem um peso crescente, mas será entre 2000-2009, acompanhando a explosão da comunidade arqueológica portuguesa que decorre da aplicação do Tratado de Malta, pelo Instituto Português de Arqueologia, que a direcção de escavações, maioritariamente realizadas no âmbito de trabalhos de Arqueologia contratual, se torna, pela acção do Mercado sem preferências de Género, uma actividade paritária.

Surpreendente, ou não, é a impressionante queda do número de mulheres a dirigir escavações, na década seguinte - entre 2012 e 2019.

A crise financeira internacional, que deflagra em 2008 e cujas mais graves consequências se farão sentir em Portugal entre 2011-2014, pode ser a mais óbvia explicação para este resultado.

No entanto, uma vez que aqui não se avalia o número de intervenções acontecidas e a sua oscilação ao longo do tempo, mas apenas o género daqueles que dirigem os trabalhos, parece claro que, como em tantos outros sectores, o emprego feminino é mais penalizado do que o masculino, nos momentos de crise económica.

Desde 2014, a retoma económica, dará origem a outro tipo de trabalhos que não a escavação e esta categoria já não é um indicador eficaz do peso do trabalho feminino, em Arqueologia. Nos últimos anos, categorias como as da Sondagem e do Acompanhamento parecem constituir o fundamental da actividade arqueológica, a analisar num outro contexto. 


\section{CONSIDERAÇÕES FINAIS}

A premissa da paridade, ou mais exactamente de um ligeiro predomínio do número de mulheres nos diferentes cenários, de que parte este texto, assume-se como como atitude fundamental, não como vingança tardia, mas como reflexo expectável de uma população natural onde as mulheres são ligeiramente maioritárias.

Os números recolhidos não deixam dúvidas quanto ao longo trajecto percorrido e não deixam também dúvidas sobre como, hoje, no Ocidente, as mulheres beneficiam, em todas as áreas, de uma longa, e internacional, batalha que construiu o Presente. Batalhas necessárias, porque os tempos, esses não mudam por eles próprios...

\section{BIBLIOGRAFIA}

BASTOS, Margarida Almeida; ALMEIDA, Rita Fragoso de (2019) - Irisalva Moita. Um percurso fotobiográfico. (J. S. Monteiro, Ed.) Lisboa: Museu de Lisboa - EGEAC, E. M. (Primeira).

BOAVENTURA, Rui (2017) - Vera.Leisner@Portugal.pt. Ophiussa, Revista do Centro de Arqueologia da Universidade de Lisboa. 1, pp. 131-142.

BUGALHÃO, Jacinta (2013) - As Mulheres na Arqueologia Portuguesa. In ARNAUD, José Morais, MARTINS, Andrea \& NEVES, César, eds. - Arqueologia em Portugal-15o anos Lisboa: Associação dos Arqueólogos Portugueses, pp. 19-23.

BUGALHÃO, Jacinta (2017) - O Papel da Mulher na Arqueologia Portuguesa. Ophiussa, Revista do Centro de Arqueologia da Universidade de Lisboa. 1, pp. 123-130.

CLAASEN, Cheryl (1994) - Women in Archaeology. (C. Claasen, Ed.) Philadelphia: University of Pennsylvania Press (First).

COHEN, Getzel M.; JOUKOWSKY, Martha Sharp (2006) - Breaking Ground. (G. M. Cohen and M. S. Joukowsky, Eds.) Ann Arbor: The University of Miching Press. (2009 ${ }^{\text {th }}$ edition).

COSTA, Cláudia; DUARTE, Cidália; TERESO, João; LAGO, Miguel; VIEGAS, Catarina; GRILO, Carolina; RAPOSO, Jorge; DINIZ, Mariana; LIMA, Alexandra (2014) - Discovering the Archaeologists of Portugal 2012-14. Associação Profissional de Arqueólogos.

DÍAZ-ANDREU, Margarita (2014) - Historia del estudio del género en Arqueología. SAGVNTVM - Papeles del Laboratorio de Arqueología de Valencia. Extra 15: Desmutant Lara Croft. Drones, Arqueología i Universitat, pp. 25-32.

DINIZ, Mariana (2006) - Para a história das mulheres na Pré-história: em torno de alguns atributos do discurso. Promontoria. 4, pp. 37-51.
FERNANDES, Hermenegildo (2017) - Virgínia Rau: Algumas variações sobre um cosmopolitismo. Faces de Eva. Estudos sobre a Mulher. 37, pp. 23-39.

GOMES, Francisco (2015) - Género, identidade e poder: para uma leitura crítica das relações de género em Arqueologia. Conimbriga. 54, pp. 27-44.

JORGE, Susana Oliveira; JORGE, Vítor Oliveira (1996) Women in Portuguese Archaeology. Trabalhos de Antropologia e Etnologia. 36, pp. 159-167.

MAFFÍA, Diana (2006) - El Vínculo Crítico entre Género y Ciencia. Clepsydra: Revista de Estudios de Género y Teoría Feminista. 5, pp. 37-57.

MARTINS, Ana (2016) - Pioneiras da Arqueologia em Portugal: «another brick» against "the wall» of indifference. Maria de Lourdes Costa Arthur (1924-2003). Clepsydra: Revista de Estudios de Género y Teoría Feminista. 15, pp.77-100.

MELO, Ana Ávila de; CARDOSO, João Luís (2014) - Virgínia Rau. Uma Medievalista na Pré-História. Estudos arqueológicos de oeiras. 21, pp. 511-546.

PORDATA - Estatísticas, gráficos e indicadores de Municípios, Portugal e Europa.

SALDANHA, Ana Rita Borba (2014) - Práticas, redes e produções científicas dos naturalistas do Museu Bocage na Europa entre guerras (1914-1945). O património documental do Arquivo MUHNAC_UL. Relatório de Estágio. Mestrado em Gestão e Valorização do Património Histórico e Cultural. Escola de Ciências Sociais. Departamento de História. Universidade de Évora.

SIMÕES, Sara; BRITO, Sara; CARVALHO, Liliana; BUGALHÃO, Jacinta; MOREIRA, Andreia (2018) - Questões de Género em Contexto Laboral em Arqueologia: breves notas. Al-madan. Adenda electrónica. 22:2, pp.111-113.

THÉBAUD, Françoise (1996) - Explorations of Gender. In DUBY, Georges, PERROT, Michelle \& THÉBAUD, Françoise, eds. - V. A History of Women. Toward a Cultural Identity in the Twentieth Century Cambridge, Massachusetts; London, England: The Belknap Press of Harvard University Press, pp. 1-13 (First)

WYLIE, Alison (1997) - The Engendering of Archaeology Refiguring Feminist Science Studies. Osiris. 12, pp. 8o-99. 
Artigos n' O Arqueólogo Português (1895-2017)

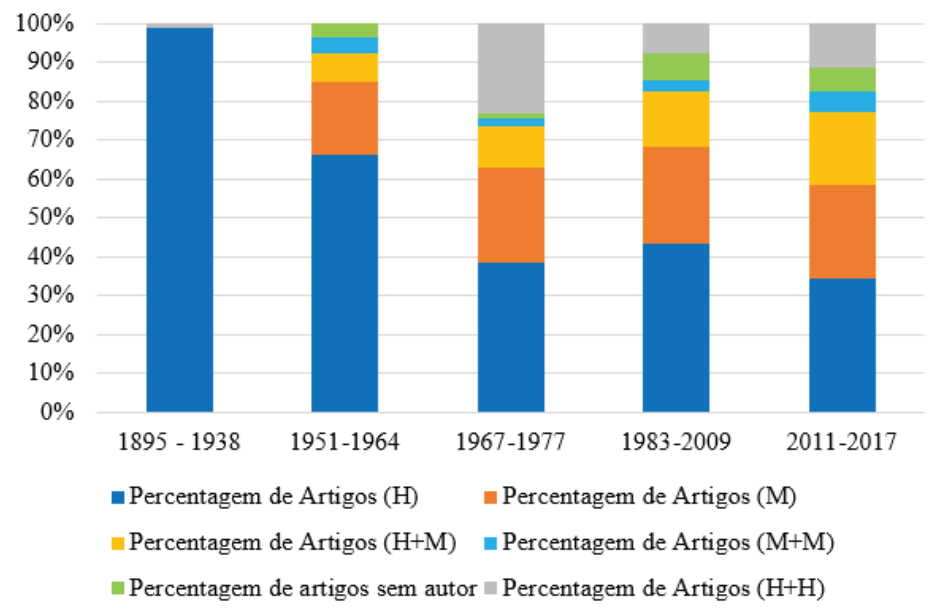

Figura 1 - Artigos n' O Arqueólogo Português - Género dos Autores.

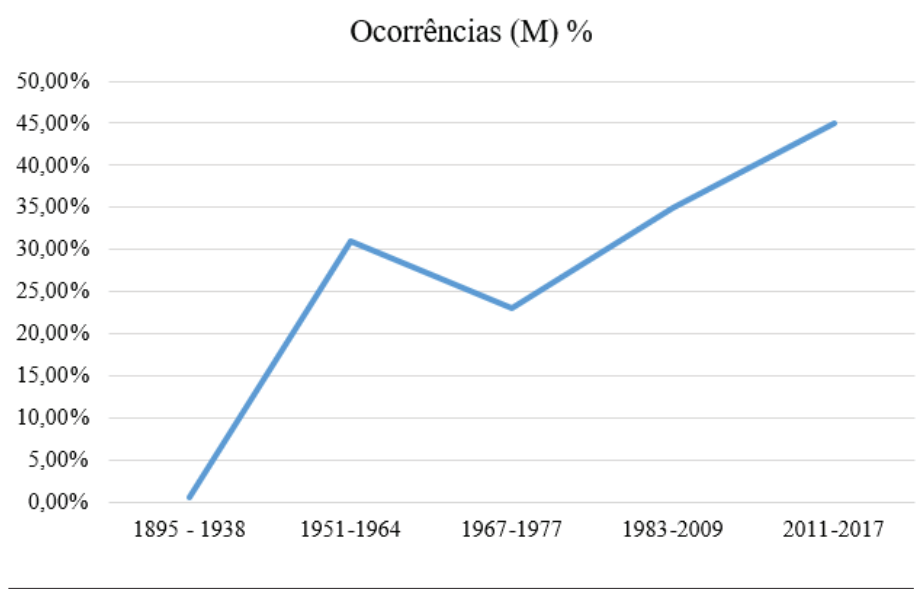

Figura 2 - Autoras n’Arqueólogo Português (1895-2017).

Artigos nos TAE (1919-2019) - género dos autores

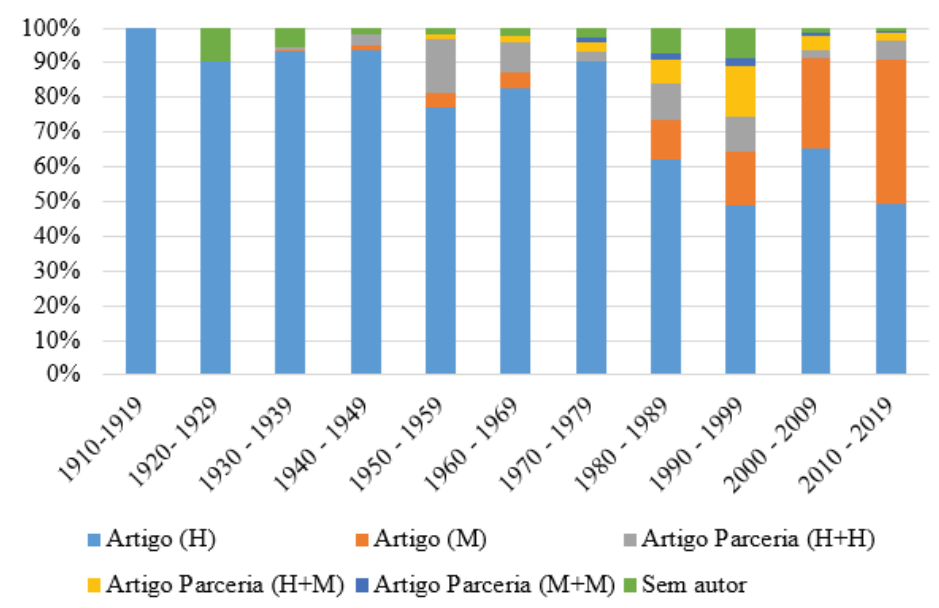

Figura 3 - Artigos nos Trabalhos de Antropologia e Etnologia (1919-2019) - Género dos Autores (1919-2019) - Género dos Autores. 


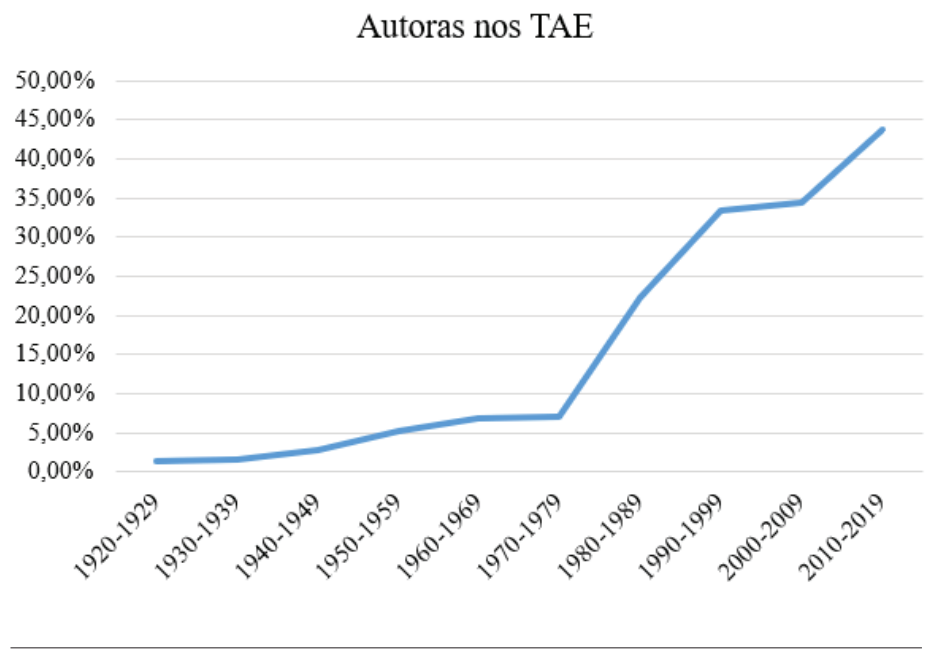

Figura 4 - Autoras nos Trabalhos de Antropologia e Etnologia (1919-2019).

Assinaturas masculinas e femininas - OAP $1^{\mathrm{a}}-5^{\mathrm{a}}$ Série (em percentagem)

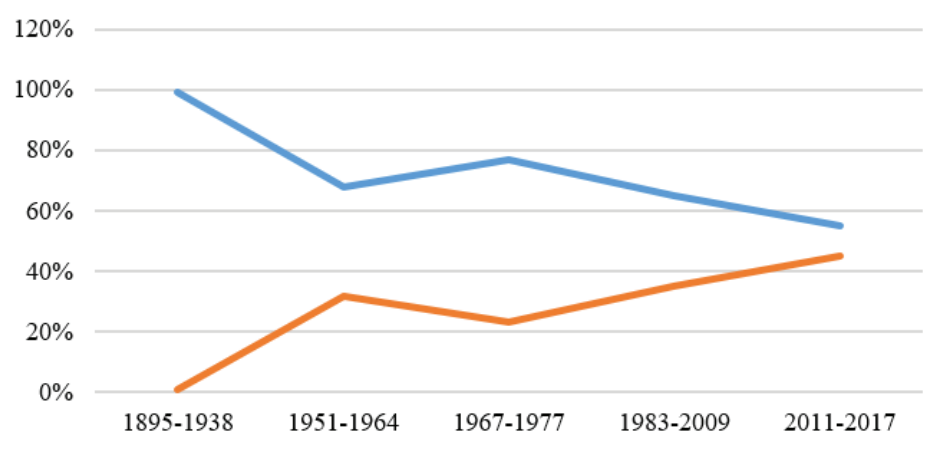

Figura 5 - Assinaturas masculinas e femininas n' O Arqueólogo Português (1895-2017).

Assinaturas masculinas e femininas - TAE 1919-2019

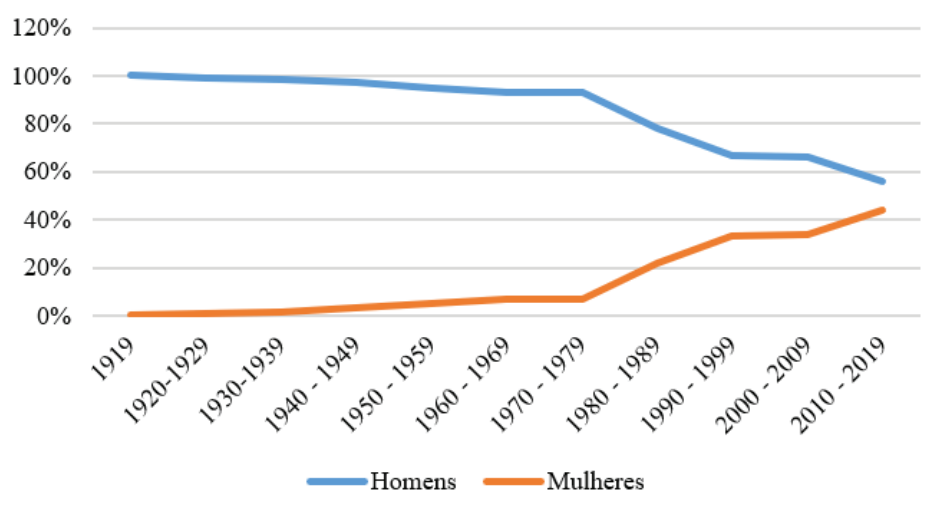

Figura 6 - Assinaturas masculinas e femininas nos Trabalhos de Antropologia e Etnologia (1919-2019). 
Escavações com direcção/co-direccão/pessoa relação de mulheres - Portal do Arqueólogo (1940-2018)

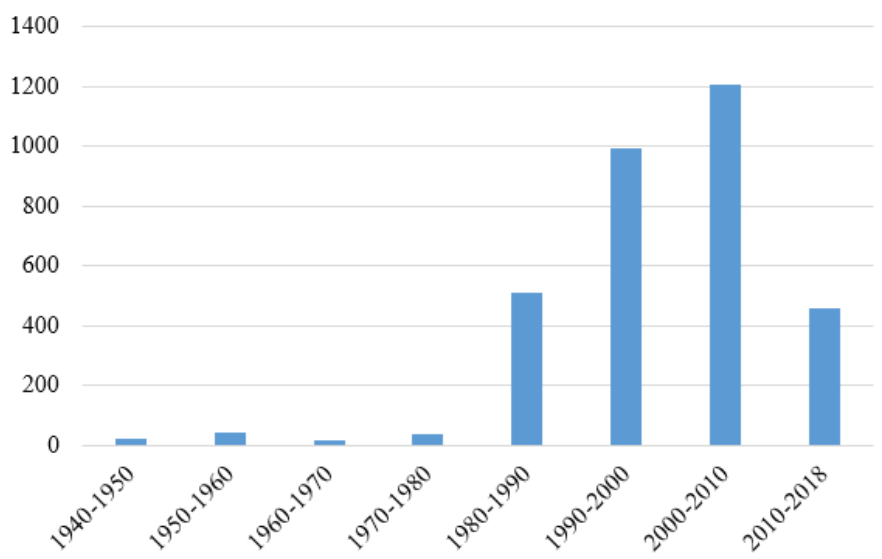

Figura 7 - Escavações com direcção / co-direcção / pessoas relação de mulheres Portal do Arqueólogo (1940-2018).

Mulheres em categorias de direcção - Portal do Arqueólogo (1940-2018)

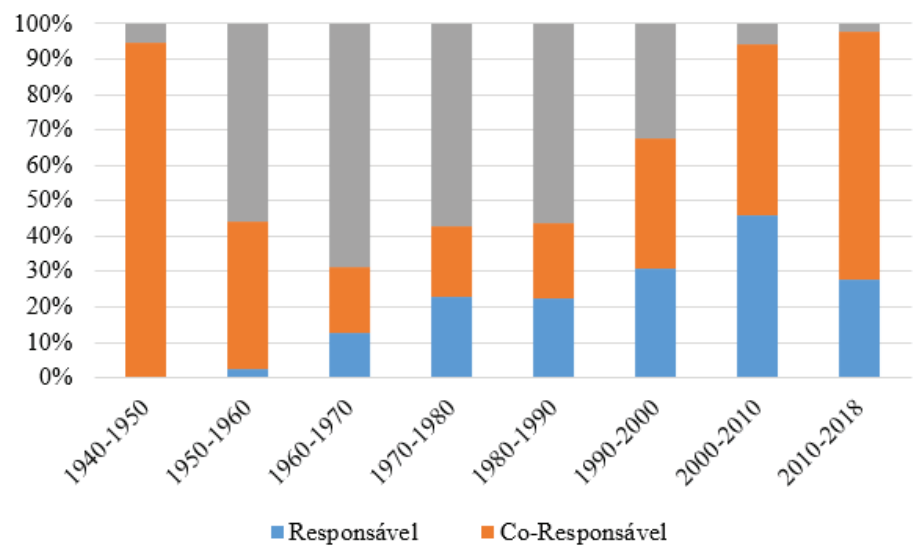

Figura 8 - Mulheres em categorias de direcção - Portal do Arqueólogo (1940-2018).

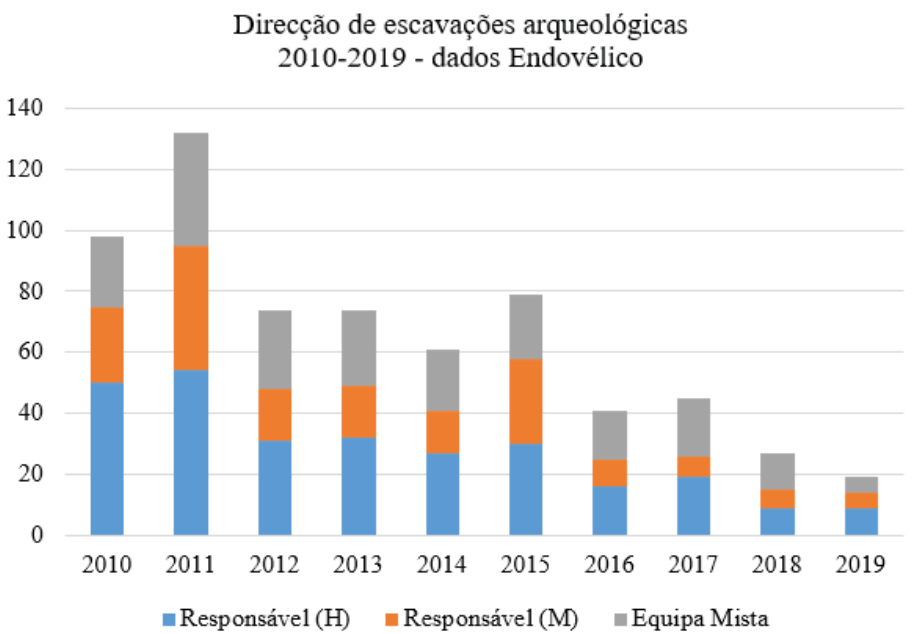

Figura 9 - Direcção de Escavações arqueológicas - 2010-2019 (Endovélico). 


\begin{tabular}{|c|c|c|c|c|c|c|c|c|c|c|c|c|}
\hline Anos & Série & $\begin{array}{c}\text { № de } \\
\text { Volumes }\end{array}$ & $\begin{array}{c}\text { Ocorrências } \\
\text { (H) }\end{array}$ & $\begin{array}{l}\text { Ocorrências } \\
\text { (M) }\end{array}$ & $\begin{array}{l}\text { Total de } \\
\text { Autores }\end{array}$ & $\begin{array}{l}\text { Artigo } \\
\text { (H) }\end{array}$ & $\begin{array}{l}\text { Artigo } \\
\text { (M) }\end{array}$ & $\begin{array}{c}\text { Artigo } \\
\text { Parceria } \\
(\mathrm{H}+\mathrm{H})\end{array}$ & $\begin{array}{c}\text { Artigo } \\
\text { Parceria } \\
(\mathrm{H}+\mathrm{M} \\
\mathrm{M}+\mathrm{H})\end{array}$ & $\begin{array}{c}\text { Artigo } \\
\text { Parceria } \\
(\mathrm{M}+\mathrm{M})\end{array}$ & $\begin{array}{l}\text { Sem } \\
\text { autor }\end{array}$ & $\begin{array}{c}\text { Total } \\
\text { de } \\
\text { artigos }\end{array}$ \\
\hline \multirow{2}{*}{$\begin{array}{c}1895^{-} \\
1938\end{array}$} & \multirow{2}{*}{1} & \multirow{2}{*}{30} & 463 & 3 & 466 & 1213 & 3 & 14 & $\mathrm{O}$ & $\mathrm{O}$ & o & 1232 \\
\hline & & & $99,4 \%$ & $0,6 \%$ & $100 \%$ & $98,5 \%$ & $0,5 \%$ & $1 \%$ & O\% & O\% & o\% & $100 \%$ \\
\hline \multirow{2}{*}{$\begin{array}{l}1951- \\
1964\end{array}$} & \multirow{2}{*}{2} & \multirow{2}{*}{5} & 32 & 15 & 47 & 35 & 10 & $\mathrm{O}$ & 4 & 2 & 2 & 53 \\
\hline & & & $68,1 \%$ & $31,9 \%$ & $100 \%$ & $66,0 \%$ & $18,9 \%$ & $0,0 \%$ & $7,5 \%$ & $3,8 \%$ & $3,8 \%$ & $100,0 \%$ \\
\hline \multirow{2}{*}{$\begin{array}{l}1967- \\
1977\end{array}$} & \multirow{2}{*}{3} & \multirow{2}{*}{9} & 123 & 36 & 159 & 55 & 35 & 33 & 15 & 3 & 2 & 143 \\
\hline & & & $77 \%$ & $23 \%$ & $100 \%$ & $39 \%$ & $25 \%$ & $23 \%$ & $11 \%$ & $2 \%$ & $1,3 \%$ & $100 \%$ \\
\hline \multirow{2}{*}{$\begin{array}{l}1983- \\
2009\end{array}$} & \multirow{2}{*}{4} & \multirow{2}{*}{26} & 277 & 147 & 424 & 151 & 88 & 27 & 50 & 10 & 24 & 350 \\
\hline & & & $65 \%$ & $35 \%$ & $100 \%$ & $43,1 \%$ & $25,1 \%$ & $7,7 \%$ & $14,3 \%$ & $2,9 \%$ & $6,9 \%$ & $100 \%$ \\
\hline \multirow{2}{*}{$\begin{array}{l}2011- \\
2017\end{array}$} & \multirow{2}{*}{5} & \multirow{2}{*}{7} & 72 & 60 & 132 & 27 & 19 & 9 & 15 & 4 & 5 & 79 \\
\hline & & & $55 \%$ & $45 \%$ & $100 \%$ & $34 \%$ & $24 \%$ & $12 \%$ & $19 \%$ & $5 \%$ & $6 \%$ & $100 \%$ \\
\hline Total & - & 77 & 967 & 261 & 1228 & 1481 & 155 & 83 & 84 & 19 & 33 & 1855 \\
\hline
\end{tabular}

Tabela 1 - O Arqueólogo Português - 1aa à $5^{\underline{a}}$ Série (1895-2017) - Valores de Género.

\begin{tabular}{|c|c|c|c|c|c|}
\hline Anos & Série & № de Volumes & Ocorrências $(\mathrm{H})$ & Ocorrências (M) & Total de Ocorrências \\
\hline \multirow{2}{*}{$1967-1972$} & \multirow{2}{*}{3} & \multirow{2}{*}{4} & 91 & 21 & 112 \\
\hline & & & $81 \%$ & $19 \%$ & $100 \%$ \\
\hline \multirow{2}{*}{ 1974-1977 } & \multirow{2}{*}{3} & \multirow{2}{*}{3} & 25 & 15 & 40 \\
\hline & & & $63 \%$ & $37 \%$ & $100 \%$ \\
\hline
\end{tabular}

Tabela 1A - O Arqueólogo Português - $3^{\underline{a}}$ Série - Valores de Género 


\begin{tabular}{|c|c|c|c|c|c|c|c|c|c|c|c|}
\hline Anos & $\begin{array}{l}\text { Volumes; } \\
\text { fascículos }\end{array}$ & $\begin{array}{l}\text { Ocorrências } \\
(\mathrm{H})\end{array}$ & $\begin{array}{l}\text { Ocorrências } \\
\text { (M) }\end{array}$ & $\begin{array}{l}\text { Total de } \\
\text { Autores }\end{array}$ & $\begin{array}{l}\text { Artigo } \\
(\mathrm{H})\end{array}$ & $\begin{array}{c}\text { Artigo } \\
(\mathrm{M})\end{array}$ & $\begin{array}{l}\text { Artigo } \\
\text { Parceria } \\
(\mathrm{H}+\mathrm{H})\end{array}$ & $\begin{array}{c}\text { Artigo } \\
\text { Parceria } \\
(\mathrm{H}+\mathrm{M})\end{array}$ & $\begin{array}{c}\text { Artigo } \\
\text { Parceria } \\
(\mathrm{M}+\mathrm{M})\end{array}$ & $\begin{array}{l}\text { Sem } \\
\text { autor }\end{array}$ & $\begin{array}{l}\text { Total de } \\
\text { artigos }\end{array}$ \\
\hline \multirow{2}{*}{$1910-1919$} & & 1 & o & 1 & 1 & o & o & o & o & o & 1 \\
\hline & & $100 \%$ & ०\% & 1 & $100 \%$ & ०\% & o\% & ०\% & ०\% & ०\% & $100 \%$ \\
\hline \multirow{2}{*}{$1920-1929$} & \multirow{2}{*}{$1 ; 4$} & 72 & 1 & 73 & 209 & o & o & 1 & o & 22 & 232 \\
\hline & & $98,6 \%$ & $1,4 \%$ & $100,0 \%$ & $90 \%$ & ०\% & ०\% & $0.5 \%$ & ०\% & $9,4 \%$ & $100 \%$ \\
\hline \multirow{2}{*}{ 1930-1939 } & \multirow{2}{*}{$4 ; 9$} & 133 & 2 & 135 & $55^{8}$ & 2 & 5 & o & o & 34 & 599 \\
\hline & & $98,5 \%$ & $1,5 \%$ & $100,0 \%$ & $93,1 \%$ & $0,2 \%$ & $0,8 \%$ & ०\% & ०\% & $5,6 \%$ & $100 \%$ \\
\hline \multirow{2}{*}{$1940-1949$} & \multirow{2}{*}{$9 ; 12$} & 69 & 2 & 71 & 161 & 2 & 6 & o & o & 3 & 172 \\
\hline & & $97,1 \%$ & $2,9 \%$ & $100,0 \%$ & $93,6 \%$ & $1,1 \%$ & $3,4 \%$ & ०\% & ०\% & $1,7 \%$ & $100 \%$ \\
\hline \multirow{2}{*}{ 1950-1959 } & \multirow{2}{*}{$12 ; 17$} & 91 & 5 & 96 & 74 & 4 & 15 & 1 & o & 2 & 96 \\
\hline & & $94,7 \%$ & $5,3 \%$ & $100,0 \%$ & $77 \%$ & $4,1 \%$ & $15,6 \%$ & $1 \%$ & ०\% & $2 \%$ & $100 \%$ \\
\hline \multirow{2}{*}{$1960-1969$} & \multirow{2}{*}{$18 ; 21$} & 69 & 5 & 74 & 77 & 4 & 8 & 2 & o & 2 & 93 \\
\hline & & $93,2 \%$ & $6,8 \%$ & $100,0 \%$ & $82,7 \%$ & $4,3 \%$ & $8,6 \%$ & 2.1 & o\% & 2.1 & $100 \%$ \\
\hline \multirow{2}{*}{$1970-1979$} & \multirow{2}{*}{$22 ; 23$} & 40 & 3 & 43 & 66 & o & 2 & 2 & 1 & 2 & 73 \\
\hline & & $93 \%$ & $7 \%$ & $100,0 \%$ & $90,4 \%$ & ०\% & $2,7 \%$ & $2,7 \%$ & $1,3 \%$ & $2,7 \%$ & $100 \%$ \\
\hline \multirow{2}{*}{$1980-1989$} & \multirow{2}{*}{$23 ; 29$} & 133 & 38 & 171 & 119 & 22 & 20 & 13 & 4 & 14 & 192 \\
\hline & & $77,7 \%$ & $22,3 \%$ & $100,0 \%$ & $61,9 \%$ & $11,4 \%$ & $10,4 \%$ & $6,7 \%$ & $2 \%$ & $7,2 \%$ & $100 \%$ \\
\hline \multirow{2}{*}{ 1990-1999 } & \multirow{2}{*}{$30 ; 39$} & 386 & 193 & 585 & 230 & 75 & 46 & 69 & 11 & 42 & 473 \\
\hline & & $66,6 \%$ & $33,3 \%$ & $100,0 \%$ & $48,6 \%$ & $15,8 \%$ & $9,7 \%$ & $14,5 \%$ & $2,3 \%$ & $8,8 \%$ & $100 \%$ \\
\hline \multirow{2}{*}{ 2000-2009 } & \multirow{2}{*}{$40 ; 49$} & 126 & 66 & 192 & 138 & 55 & 5 & 9 & 2 & 3 & 212 \\
\hline & & $65,6 \%$ & $34,4 \%$ & $100,0 \%$ & $65 \%$ & 25,9 & $2,3 \%$ & $4,2 \%$ & $0,9 \%$ & $1,4 \%$ & $100 \%$ \\
\hline \multirow{2}{*}{$2010-2019$} & \multirow{2}{*}{$50 ; 59$} & 77 & 60 & 137 & 65 & 55 & 7 & 3 & 1 & 1 & 132 \\
\hline & & $56,2 \%$ & $43,8 \%$ & $100,0 \%$ & $49,2 \%$ & $41,6 \%$ & $5,3 \%$ & $2,2 \%$ & $0,7 \%$ & $0,7 \%$ & $100 \%$ \\
\hline \multirow{2}{*}{ Total } & \multirow{2}{*}{59} & 1197 & 375 & 1578 & 1698 & 219 & 114 & 100 & 19 & 125 & 2275 \\
\hline & & $76,1 \%$ & $23,9 \%$ & $100,0 \%$ & $74,6 \%$ & $9,6 \%$ & $5 \%$ & $4,3 \%$ & $0,8 \%$ & $5,4 \%$ & $100 \%$ \\
\hline
\end{tabular}

Tabela 2 - Levantamento de Trabalhos de Antropologia e Etnologia por década. Valores de Género.

\begin{tabular}{|c|c|c|c|c|c|}
\hline Décadas & Homens (Autores) & $\%$ & Mulheres (Autoras) & $\%$ & Total \\
\hline $1990-1992$ & 25 & $84 \%$ & 6 & $16 \%$ & $100 \%$ \\
\hline $\begin{array}{c}1993-1995 \\
\text { (Actas do I CAP) }\end{array}$ & 288 & $67 \%$ & 138 & $33 \%$ & $100 \%$ \\
\hline $1996-1999$ & 73 & $60 \%$ & 49 & $40 \%$ & $100 \%$ \\
\hline Total & 386 & $66,6 \%$ & 193 & $33,4 \%$ & $100 \%$ \\
\hline
\end{tabular}

Tabela 2A - Trabalhos de Antropologia e Etnologia na década de noventa. Valores de Género. 


\begin{tabular}{|c|c|c|c|c|c|c|}
\hline \multicolumn{7}{|c|}{ Etapas da História das Mulheres na Arqueologia Portuguesa } \\
\hline & \multicolumn{3}{|c|}{ OAP } & \multicolumn{3}{|c|}{ TAE } \\
\hline & Periodização & $\sigma^{7}$ & $\mathbf{9}$ & Periodização & $\sigma^{7}$ & 9 \\
\hline \multirow{3}{*}{1 - ALONE IN THE WOODS } & \multirow{3}{*}{$\begin{array}{c}1^{\underline{\underline{a}}} \text { Série } \\
1895-1938\end{array}$} & \multirow{3}{*}{463} & \multirow{3}{*}{3} & $1919-1930$ & 93 & 1 \\
\hline & & & & $1931-1969$ & 342 & 14 \\
\hline & & & & $1971-1979$ & 40 & 3 \\
\hline \multirow[t]{2}{*}{ 2-A PLACE IN THE SUN } & $\begin{array}{c}2^{\text {a }} \text { Série } \\
1951-1964\end{array}$ & 32 & 15 & \multirow[b]{2}{*}{$1980-1992$} & \multirow{2}{*}{178} & \multirow{2}{*}{51} \\
\hline & $\begin{array}{c}3^{\underline{a} \text { Série }} \\
1967 \text { - até } 1970\end{array}$ & 53 & 10 & & & \\
\hline \multirow{2}{*}{$\begin{array}{c}3 \text { - MINORITY REPORT } \\
\leq 40 \%\end{array}$} & $\begin{array}{c}3^{\underline{a}} \text { Série } \\
1971-1977\end{array}$ & 62 & 26 & $\begin{array}{c}\text { 1993-1995 } \\
1^{\circ} \text { Congresso de } \\
\text { Arqueologia Peninsular }\end{array}$ & 238 & 145 \\
\hline & $\begin{array}{c}4^{\underline{a} \text { Série }} \\
1983-2008\end{array}$ & 277 & 147 & $1996-2003$ & 141 & 76 \\
\hline $\begin{array}{c}4 \text { - BONNIE AND CLYDE } \\
\geq 40 \%\end{array}$ & $\begin{array}{l}5^{\underline{a} \text { Série }} \\
\text { 2011-2017 }\end{array}$ & 72 & 60 & 2011-2019 & 71 & 53 \\
\hline
\end{tabular}

Tabela 3 - Etapas da História das Mulheres na Arqueologia Portuguesa. 


\title{
RETRACTOS DA ARQUEOLOGIA PORTUGUESA NA IMPRENSA: (IN)VISIBILIDADES NO FEMININO
}

\author{
Catarina Costeira ${ }^{1}$, Elsa Luís ${ }^{2}$
}

\begin{abstract}
RESUMO
Partindo da presença da arqueologia portuguesa nos meios de comunicação social, com especial destaque para a imprensa escrita digital dos últimos dez anos, discute-se a visibilidade feminina dentro da profissão e como esta é transmitida para a sociedade.

Considerando as fontes citadas nas notícias de arqueologia como representativas da distribuição de mulheres em diferentes sectores da actividade arqueológica e os respectivos cargos que ocupam, é surpreendente a disparidade encontrada entre fontes masculinas e femininas, especialmente numa altura em que teremos atingido a paridade de género nos profissionais de arqueologia no activo. Esta maior invisibilidade feminina contribui para a manutenção de preconceitos de género e limita os exemplos que passamos para as novas gerações.

Palavras-chave: Arqueologia de género, Arqueologia no feminino, Meios de Comunicação, Estratégias de Comunicação.
\end{abstract}

\begin{abstract}
In this paper, we address the visibility of women in Portuguese archaeology and how that image is perceived by the society, through the lens of the digital written press of the last ten years.

Considering sources found in archeology news as a representation of the distribution of women in different areas of archaeological activity, and their respective positions, we've noticed a surprising disparity found in male and female sources, especially at a time when we have reached gender parity in active archeology professionals. This female invisibility contributes to the maintenance of gender prejudices and limits the examples that we pass on to the new generations.
\end{abstract}

Keywords: Gender Archaeology, Women in Archaeology, Media, Communication Strategies.

\begin{abstract}
"A diferença de critério com que se encara, no nosso país, o trabalho profissional feminino, em relação ao lar, conforme as diversas classes, marca um aspecto muito importante da vida da mulher, da sua própria mentalidade e também da mentalidade do homem, assim como das normas que predominam na sociedade"
\end{abstract}

Maria Lamas, Mulheres do meu País, 1948

\section{INTRODUÇÃO}

A consolidação da arqueologia enquanto disciplina científica autónoma em Portugal remonta à segunda metade do século XIX, acompanhando, ainda que com um ritmo próprio, as principais tendências da arqueologia europeia e mundial (Diniz e Gonçalves, 1993-1994; Fabião, 1999). Apesar desta longevidade e de um evidente crescimento e dinamismo nas últimas décadas, a história da arqueologia portuguesa é um tema pouco abordado, centrando-se sobretudo nos alvores da disciplina e nos arqueólogos

\footnotetext{
1. Centro de Arqueologia da Universidade de Lisboa Uniarq / Núcleo de Arqueologia da Câmara Municipal de Sintra; catarinacosteira@gmail.com
}

2. Centro de Arqueologia da Universidade de Lisboa Uniarq / NewsMuseum; elsavluis@gmail.com 
pioneiros, muitas vezes apresentados como figuras tutelares. Esta falta de reflexão sobre as condições e circunstâncias da produção de conhecimento arqueológico e dos seus autores ao longo do tempo torna mais difícil a construção da memória e consciência profissional e científica por parte dos arqueólogos portugueses.

Apesar de alguns trabalhos mais recentes terem como intento a caracterização e quantificação dos arqueólogos e trabalhos de arqueologia em Portugal (Costa et al., 2014; Bugalhão, 2011; 2013; 2017; Simões, et al., 2018), os dados disponíveis necessitam de um maior aprofundamento. É igualmente essencial estudar a imagem dos arqueólogos na comunidade, como forma de alterar muitos dos estereótipos relacionados com esta atividade e os seus profissionais, sobretudo os que são veiculados pelos meios de comunicação.

$\mathrm{Na}$ atualidade, os meios de comunicação, pelo seu universalismo, rapidez e versatilidade, têm um papel fundamental no acesso de todos os cidadãos à informação, independentemente da sua localização geográfica, dos seus graus académicos, do seu enquadramento social ou económico. O poder e credibilidade dos meios de comunicação tornam-nos agentes essenciais na definição de identidades e na percepção da realidade (Souza, 2014; Savietto; 2015, Martins, 2015). Consideramos que conhecer e refletir sobre a forma como os media abordam a arqueologia portuguesa e os seus profissionais é importante para potenciar o retorno social desta atividade, contribuindo para a sua aproximação à comunidade. Começámos por estudar a presença da arqueologia portuguesa nos meios de comunicação social através da análise da imprensa escrita digital. No decorrer desta investigação deparamo-nos com uma grande diversidade de problemáticas, selecionando para o presente trabalho a diferença na representatividade entre arqueólogos e arqueólogas nos meios de comunicação.

Tal como muitos estudos têm vindo a demonstrar (Cerqueira, 2008; Mota-Ribeiro e Pinto-Coelho, 2005; Magalhães e Alvarez, 2014, Souza, 2014; Martins, 2013; Martins, 2015; Savietto, 2015; Sabbati et al., 2018), a representação do género feminino nos meios de comunicação portugueses é ainda muito desigual e estereotipada, apesar do longo caminho de emancipação feminina que tem sido desbravado desde o início do século XX, acentuado a partir da Revolução de 1974. Com efeito, a imagem da mulher veiculada pela comunicação social não reflete na plenitude o seu papel cada vez mais presente e interventivo a nível profissional, científico, político e social. No caso concreto da arqueologia portuguesa, em que se atingiu a paridade de género em termos profissionais (Bugalhão, 2017 b), é surpreendente o silêncio dos meios de comunicação em torno de arqueólogas com percursos cientificamente relevantes e a desproporção entre fontes masculinas identificadas e fontes femininas anónimas ou ausentes. De facto, o crescimento de arqueólogas em Portugal, a partir sobretudo da década de 1970, não foi acompanhado de uma mudança de paradigma nos modos de fazer e pensar a arqueologia, mantendo-se uma disciplina dominada por temas e comportamentos androcêntricos. As abordagens integradas na designada Arqueologia de Género, tal como muitas outras correntes pós-processualistas, têm-se desenvolvido de forma tímida em Portugal (Diniz, 2006), situação que, apesar de tudo, parece estar a mudar nas primeiras décadas do século XXI, com o aumento de iniciativas (colóquios, seminários, artigos e inquéritos) que promovem a reflexão sobre a presença e o papel da mulher na prática arqueológica e a crítica a um Passado demasiado masculino, em que as mulheres ou não têm lugar ou desempenham sempre o papel secundário (Boaventura, 2011; Bugalhão, 2013; Gomes, 2011 e 2015; Vale, 2015 e Martins, 2016).

Com este trabalho esperamos contribuir para a reflexão sobre a sub-representação das arqueólogas nos meios de comunicação portugueses na atualidade e para a necessidade de consolidar o conhecimento sobre o papel destas profissionais ao longo da história da disciplina e desta forma aproximar a imagem que a comunidade constrói da arqueologia e dos seus profissionais da atualidade.

\section{A ARQUEOLOGIA PORTUGUESA NA IMPRENSA ESCRITA DIGITAL, CONTEXTO E METODOLOGIA}

Recentemente realizámos um estudo preliminar sobre a presença da arqueologia portuguesa nos meios de comunicação social, tomando como caso de estudo a imprensa escrita digital (Luís e Costeira, no prelo).

O objectivo geral desse trabalho foi o de avaliar a quantidade e qualidade de notícias sobre arqueologia portuguesa tendo como base a imprensa escrita digital ao longo de dez anos de publicações, entre 
2009-2019. Foram, neste contexto, consultados jornais nacionais generalistas de grande divulgação, como o Expresso, Público, Observador, Correio da Manhã, Sol, Jornal I, Jornal de Notícias e Diário de Notícias, recorrendo aos motores de busca online de cada jornale/ou utilizando filtros com palavras-chave relacionadas com a actividade arqueológica nas suas variadas valências, como escavações arqueológicas, projectos de investigação, sítios e materiais arqueológicos, museus de arqueologia, e também condições laborais e legislação sobre arqueologia. Nesta análise, não foram considerados artigos de opinião. As notícias recuperadas deverão constituir uma parte da totalidade de notícias produzidas no período enunciado, na medida em que não existe uma obrigatoriedade em manter um arquivo online, nem único nem de cada jornal, em canal aberto para o público geral, nem se verifica uma uniformização das notícias que ainda se mantêm online; deparámo-nos, por exemplo, com casos em que apenas se conserva o título e a data da notícia. Os próprios sites dos jornais portugueses não dispõem de um sistema de pesquisa avançada e limitam o número de resultados por cada pesquisa e/ou por cada palavra-chave, sendo necessário realizar várias pesquisas, com diferentes palavras-chave, para se obter a maior quantidade possível de resultados. Um outro constrangimento prende-se com o acesso restrito em vários destes jornais online, que, procurando maximizar a sua receita, limitam a quantidade de notícias de acesso livre, estando apenas disponível o título e o lead. Estas notícias de acesso reservado foram consideradas, ficando, no entanto, condicionado o total preenchimento dos campos de análise. Ainda equacionámos adquirir o acesso a um ou mais jornais online, porém, para percebermos qual é, realmente, a informação que pode chegar a todos os cidadãos, de forma mais universal e sem restrições financeiras, optámos por utilizar os recursos que estão disponíveis online de forma gratuita. Acreditamos que a contratualização de um serviço de clipping poderia colmatar estas lacunas, mas, atendendo à natureza preliminar destes estudos e aos elevados custos que estes serviços acarretam, optámos por realizar a pesquisa manualmente.

Apesar de todos estes constrangimentos metodológicos, consideramos que o conjunto de notícias recuperado deverá constitui uma eficaz amostragem e que nos permite extrair considerações importantes sobre a imagem da disciplina e dos seus agentes.
Entre as várias observações e conclusões a que esse estudo inicial nos permitiu chegar, destacamos as mais relevantes para um melhor enquadramento do papel da mulher na arqueologia portuguesa, visto através dos meios de comunicação social. Assim, verificámos que os jornais que mais publicam notícias de arqueologia são o Público e o Diário de Notícias e, tendencialmente, apresentam notícias mais completas e desenvolvidas (Gráfico 1). Ao longo do período analisado verificou-se uma tendência crescente de publicação de notícias com temáticas arqueológicas, com pico centrado nos anos de 2017 e 2018, o que coincide com um crescimento generalizado de trabalhos arqueológicos e do número de arqueólogos em actividade (Bugalhão, 2017b). Neste particular, é notório também o crescimento da arqueologia empresarial preventiva, que trouxe novas fontes de financiamento privadas à actividade arqueológica, permitindo a entrada e manutenção de novos profissionais. Por outro lado, este aumento de notícias traduz também a existência de transformações dentro da própria comunidade arqueológica, especialmente nas universidades, centros de investigação e empresas de arqueologia, que vão aumentando a sua preocupação com a comunicação da sua actividade ao grande público e criando rúbricas de comunicação e divulgação dentro dos seus próprios projectos, até para tentar garantir os mesmos níveis de financiamento após a crise financeira de 20082011 (a título de exemplo vide Pereira, 2020).

Os temas mais procurados (Gráficos 2 e 3), ou seja, com maior quantidade de notícias, são os das Descobertas Arqueológicas, Museus de Arqueologia e Projectos de Investigação, alimentando a curiosidade natural do público por estes temas, incluindo o fascínio e deslumbramento pela descoberta, pela novidade, pelo "tesouro enterrado", bem como a divulgação de resultados da investigação e novidades relacionadas com exposições em museus de arqueologia. No caso concreto dos museus de arqueologia, regista-se uma quantidade significativa de notícias relacionadas com questões de gestão e administração que denotam uma preferência pelo enquadramento político deste assunto. Evidenciam-se os casos do Museu Nacional de Arqueologia, com 64 notícias, nas quais se destaca o debate sobre a sua possível transferência para outro edifício em Lisboa e as notícias relacionadas com a nomeação do director; e o do Museu e Parque do Côa, com 122 notícias, sobressaindo os temas da direcção e gestão da fundação e do museu. 
Os temas relacionados com questões sociais e laborais da profissão, como as condições de trabalho, as instituições da tutela e algumas notícias sobre arqueólogos, surgem em menor quantidade, podendo a sua maior visibilidade estar associada à criação do sindicato de arqueologia, STARQ, que ocorreu dentro do período considerado (Mesquita e Simões, 2014).

É frequente o recurso a declarações de diversificadas fontes nas notícias de arqueologia, nomeadamente pedidas a representantes de instituições públicas como a Direção Geral do Património Cultural (DGPC), as Direções Regionais de Cultura (DRC), o Ministério da Cultura e as Câmaras Municipais; das Universidades e Centros de Investigação; dos Museus de Arqueologia, com especial destaque para o Museu Nacional de Arqueologia; e também de profissionais em nome individual, empresas de arqueologia, profissionais das arqueociências, e ainda de instituições profissionais como o Sindicato de Arqueologia ou a Associação de Arqueólogos Portugueses. Neste tema concreto, chamou-nos a atenção o facto de termos registado uma diferença muito significativa entre fontes masculinas e fontes femininas, sobretudo numa altura em que já teremos atingido a igualdade de género na profissão (Bugalhão, 2017 a; Simões et al., 2018), surgindo a necessidade de compreendermos as razões subjacentes. É neste encadeamento que surgiu a motivação para este trabalho, sobretudo no contexto actual, ainda inspirado pelo movimento internacional $\mathrm{Me}$ Too, em que se debatem muitas questões relacionadas com o género, como a igualdade no trabalho, no vencimento, no acesso aos cargos de decisão e de direcção, nas questões de família e parentalidade, entre outras. Procuramos, neste pequeno ensaio, analisar de que forma é que a arqueóloga (ou outra profissional relacionada com a arqueologia) se encontra representada nos meios de comunicação social, qual é a imagem que é transmitida, e que exemplos estamos a construir para as gerações futuras. Não se trata apenas de analisar os números da representatividade, ainda que, por si, revelem muito, mas também de questionar qual a imagem do arqueólogo da actualidade e como a mulher se enquadra nessa imagem.

Para este fim, partimos da base de dados de notícias que recolhemos anteriormente, com o mesmo intervalo de tempo, 2009-2019, e concentrámo-nos nos descritores que melhor nos poderiam ajudar a reflectir sobre estas temáticas, como a quantidade de notícias e sua evolução no tempo, os temas mais representados, e, sobretudo, as fontes utilizadas nas notícias, o relevo que é dado aos profissionais da área e qual o seu género. Destacámos as notícias que atribuíam relevância ao arqueólogo/a, quer de forma biográfica, quer pela sua actividade laboral e/ou científica, e ainda as que nos revelam em que contextos encontramos mulheres referidas nas notícias, qual o seu cargo e qual o destaque que lhes é atribuído, sempre em comparação com o que é dado aos elementos do sexo masculino.

\section{MULHERES COMO FONTES NAS NOTÍCIAS DE ARQUEOLOGIA}

Partindo de uma amostra de 1279 notícias, a sua grande maioria refere ou cita uma ou mais fontes que complementam a informação disponibilizada e conferem maior credibilidade à própria notícia, sendo relevante referir que apenas 128 entradas não mencionam fontes.

Dentro das fontes mencionadas, e retiradas as que apenas indicam a instituição consultada, destacamos as que nos permitem aferir qual o género, quer pelo nome, quer pelo pronome utilizado: 528 homens e 221 mulheres, perfazendo, como o gráfico abaixo indica, $70 \%$ e 30\%, respectivamente (Gráfico 4).

Em várias notícias são referidos arqueólogos e arqueólogas como parte de projectos de investigação ou outro tipo de trabalhos arqueológicos, aos quais não são pedidas declarações, pelo que não foram considerados para esta estatística de fontes.

Se olharmos para a presença de fontes femininas em comparação com a evolução do volume de notícias nos dez anos considerados (Gráfico 5), verificamos que não parece haver um acompanhamento das fontes femininas ao aumento de notícias. Esta situação poderá ser justificada pela forte presença de profissionais masculinos ligados à arqueologia em cargos de responsabilidade/decisão, aliada ao mais recente crescimento de mulheres no sector. Contudo, também pode refletir a secundarização das vozes femininas nos meios de comunicação, mantendo a esfera pública no domínio masculino. Com efeito, os meios de comunicação portugueses continuam a privilegiar o especialista/cientista homem como fonte de informação segura, mantendo as figuras femininas num plano secundário, o que obviamente vai contribuir para manter a desigualdade de representa- 
ções de género na sociedade. Estas representações são tão enraizadas que as mulheres não têm consciência desta desigualdade, considerando que têm a mesma oportunidade de se expressar nos meios de comunicação, o que não é acompanhado pelos dados quantitativos (Lobo e Cabecinhas, 2013; Martins, 2013; Savietto, 2015; Sabbati et al., 2018). Esta sub-representação feminina nos meios de comunicação está associada às lógicas de mediação, à permanência de perspetivas masculinas apresentadas como neutras (Martins, 2013) e à falta de consciência feminina desta barreira invisível de falta de expressão, devido à interiorização, desde a infância, "(...) de um conjunto de atitudes que tende (...) a manter uma postura submissa por parte das mulheres nas diversas esferas sociais" (Viegas e Faria, 2001).

Este silêncio das vozes femininas nos meios de comunicação é acompanhado pelo silêncio na própria academia, com a manutenção de discursos explicitamente androcêntricos sobre o Passado e a falta de uma reflexão escrita sobre estas temáticas (Vale, 2015).

Estes exemplos, a que se podiam associar muitos outros, evidenciam a insuficiente democratização da esfera privada e quotidiana em Portugal (Gomes, 2011; Martins, 2013), com a consequente manutenção de muitos dos valores patriarcais e masculinos, perpetuando-se a figura cimeira e, por vezes, exclusiva do pai - "chefe de família", em muita da documentação oficial basilar dos indivíduos e nas cerimónias e tomadas de decisão das mais diversas instituições do país. Os cenários de poder e a História, mesmo da Revolução e da Democracia, são palcos maioritariamente masculinos, em que faltam e se esquecem as personagens femininas.

\section{O ARQUEÓlOGO E A ARQUEÓlOGA COMO TEMA DE NOTÍCIA}

Os meios de comunicação social são, indiscutivelmente, guardadores de memórias, uma parte do nosso arquivo social, cultural, económico, político, entre tantos outros. Não só nos informam da actualidade, como recuperam acontecimentos, reorganizam a informação e têm a capacidade de, como agora muito se fala, contar histórias e estórias. Esta capacidade de trazer para a visibilidade e discussão públicas uma enorme diversidade de assuntos e temas é fundamental para a construção da nossa percepção do real e da forma como nos relacionamos
(Gonçalves, 2004/05; Martins, 2013). Estes meios de comunicação têm ainda o poder de construir (e destruir) a imagem que cada um de nós tem sobre um indivíduo ou uma classe profissional, e destacar e homenagear percursos profissionais ou contributos para determinadas áreas da sociedade. Neste sentido, a periodicidade com que temas de arqueologia são abordados e a forma como os arqueólogos são retratados nos meios de comunicação serão fundamentais para a construção da imagem pública da disciplina e da classe profissional e para o seu reconhecimento social.

Contabilizamos o número de notícias que se centram na figura do arqueólogo, que destacam a pessoa pelo seu percurso profissional e por ter ganhado visibilidade nacional e/ou internacional. Das 27 notícias que têm como tema principal o arqueólogo, apenas três se referem a mulheres, números que demonstram bem a diferença mediática entre os géneros: “Arqueóloga Maria Antónia Amaral é a nova directora do castelo de São Jorge" (Expresso, 19 Junho 2019); "Uma egiptóloga portuguesa a ensinar em Harvard? Sim, éa Inês" (Público, 27 de Maio de 2018); "Nas antas do Alentejo já se falou alemão" (Público, 20 de Agosto de 2015). De destacar que temos uma notícia de 2015 que refere um casal de arqueólogos, Georg e Vera Leisner, sublinhando como era uma mulher excepcional, por estar em pé de igualdade com o marido; e duas notícias já bem recentes, 2018 e 2019, uma que destaca um cargo político e outra uma investigadora com sucesso internacional.

As notícias de cariz biográfico, que incluem arqueólogos de diferentes gerações, e os obituários que analisamos referem-se exclusivamente a homens. O mérito profissional e pessoal dos arqueólogos referidos nestas notícias, como por exemplo Cláudio Torres, João Zilhão, António Martinho Baptista, ou Albano Belino é inegável, contudo, se pensarmos na quantidade e diversidade de arqueólogas, que desde os anos 60 se têm destacado a nível nacional e internacional (vide Bugalhão, 2013, com vários nomes citados), este vazio torna-se mais difícil de explicar, consistindo numa opção dos jornalistas e das redações e não a ausência real de arqueólogas. De facto, a notabilidade profissional e a liderança feminina são ainda vistas pela sociedade como algo estranho, raro e mesmo inapropriado, independentemente da posição política, o que é potenciado por esta invisibilidade nos meios de comunicação.

A ausência de biografias de arqueólogas nos meios 
de comunicação é uma forma subtil de as manter na sombra, tornando mais difícil às profissionais mais novas encontrarem referências no feminino e ampliarem as suas expetativas e ambições. As assimetrias de género no plano da memória histórica consistem num significativo entrave ao empoderamento feminino, porque condicionam as expetativas profissionais e pessoais, perpetuando papéis sociais anacrónicos.

\section{REPRESENTAÇÃO DAS MULHERES EM DIFERENTES CONTEXTOS}

Se observarmos o Gráfico 6, verificamos que o enquadramento profissional mais frequente das arqueólogas citadas como fontes é a categoria designada por "arqueólogas", que inclui profissionais independentes e profissionais em que, estando associadas a instituições, nomeadamente empresas, essa relação não é referida; e a categoria das "universidades”, em que se inclui professoras e investigadoras. Estes dados reflectem o grande crescimento das mulheres no ensino superior e no mercado de trabalho. De facto, a percentagem de mulheres nas licenciaturas, mestrados e doutoramentos em arqueologia, entre 2009 e 2019, situa-se entre os $53 \%$ e os $56 \%$ (Costa et al., 2014; Bugalhão, 2017 a e 2017 b; Diniz, 2019), tendo uma tendência de crescimento, em sintonia com as médias nacionais e europeias (Lazar et al., 2014), o que demonstra a igualdade no acesso aos vários níveis de ensino graduado e pós-graduado. No entanto, se procurarmos a presença feminina em cargos de liderança nas universidades e nos centros de investigação, o seu destaque já não é tão evidente. Não deixa de ser significativa a desproporção entre as fontes masculinas, 149 entradas, e femininas, 57 entradas, nas notícias relacionadas com a investigação científica e universidades. Com efeito, para o número de mulheres nos cursos pós-graduados e como bolseiras de investigação, a representação de arqueólogas - investigadoras parece-nos muito diminuta. O número expressivo de "arqueólogas" como fontes de informação ajusta-se ao crescimento feminino no mercado de trabalho, e é evidente sobretudo no número de direcções científicas (Bugalhão, 2017 a). Consideramos que estes dados devem ser detalhados no futuro, procurando-se determinar não só o número de direcções, mas o de arqueólogas que exercem a profissão mesmo que não dirijam trabalhos e assim aferir qual é o real peso das direcções femininas. Por outro lado, seria igualmente interessante perceber que tipo de trabalhos arqueológicos são normalmente dirigidos por mulheres, qual a sua duração, dimensão das equipas e localização geográfica e assim tentar compreender se as arqueólogas têm mais constrangimentos nas deslocações e / ou nos horários.

Se relacionarmos a percentagem de "arqueólogas" (32\%) com a percentagem de "arqueólogas associadas a empresas" (5\%) a desproporção é muito significativa, o que parece reflectir a grande quantidade de profissionais independentes (precários) e a fraca representação feminina nas lideranças das empresas de arqueologia de média e grande dimensão. Em termos globais, estes dados aproximam-se dos registados para a globalidade do sector empresarial português (Rodrigues, 2017; CCIG, 2017), demonstrando a desigualdade no acesso aos mais altos cargos das hierarquias organizacionais privadas, com consequente desperdício de talento e especialização.

No que se refere à presença de mulheres em instituições públicas da administração local (câmaras municipais) e central (tutela), os dados apresentados são reduzidos em termos gerais. No entanto, a desproporção de género não nos parece tão significativa, pelo menos numa primeira observação, já que encontramos várias mulheres em cargos relacionados com a cultura e o património, como pelouros de vereadores municipais ou o próprio ministério da cultura. Porém, numa análise mais cuidada no que diz respeito às notícias cujo tema são as instituições de tutela, encontramos uma diferença substantiva no recurso a fontes masculinas e femininas, contabilizando estas últimas metade das primeiras ( 27 masculinas e 13 femininas).

Como vários investigadores têm chamado a atenção (Martins, 2013, 2015; Almeida, 2016), a presença de mulheres na política portuguesa é ainda diminuta, situação que tem vindo a mudar lentamente, sobretudo no que se refere aos cargos mais destacados do país. Em termos de pastas ministeriais, a saúde, a educação e a cultura são as que apresentam maior presença feminina, o que pode ajudar a explicar a sensação de menor desigualdade de género nas autarquias e na tutela. Contudo, a total ausência de mulheres em áreas como as obras públicas ou a economia, acabam por manter a invisibilidade em muitos dos cenários e decisões relevantes para a arqueologia. Os cargos de liderança dos museus e associações profissionais são tendencialmente desempenha- 
dos por homens, quer nas instituições centenárias, como o Museu Nacional de Arqueologia ou a Associação dos Arqueólogos Portugueses, quer nas instituições fundadas mais recentemente, como o Campo Arqueológico de Mértola, o Museu e Parque do Côa ou mesmo o Sindicato dos Trabalhadores de Arqueologia. Neste particular, as fontes acabam por corroborar esta situação, com um contraste de 96 fontes masculinas com 30 fontes femininas.

Esta falta de representação feminina nos principais cargos de liderança, mesmo de instituições constituídas em democracia, ajuda a explicar a menor visibilidade mediática das arqueólogas (Martins, 2013) e está sobretudo associada a elementos culturais (preconceitos, atitudes discriminatórias na divisão dos papéis por géneros), muito resistentes à mudança, uma vez que o número e a qualificação das mulheres em arqueologia, tal como em muitas outras áreas científicas e técnicas, são cada vez mais significativas e diferenciadas.

\section{A IMAGEM DO PROFISSIONAL DE ARQUEOLOGIA ATRAVÉS DOS MEDIA}

A imagem que a comunidade portuguesa tem do arqueólogo é muito influenciada pelos meios de comunicação, cinema e literatura. No imaginário português e europeu, o arqueólogo é um homem, branco, europeu, culto, despistado, vestido de forma pouco convencional, solitário e economicamente desafogado, coincidindo ainda com a imagem romântica do explorador/descobridor do final do século XIX, inícios do século XX (Ibáñez Alfonso, 2015). Esta imagem, evidente em muitas das descrições de investigadores - arqueólogos, realizadas pelos meios de comunicação, está associada à valorização da escavação/descoberta enquanto tema principal da actividade arqueológica. Esta situação conduz à invisibilidade e desvalorização de outras actividades e funções do arqueólogo, como o trabalho de laboratório, pesquisa bibliográfica e produção escrita de relatórios, artigos, livros e teses, as etapas de investigação menos financiadas em qualquer contexto laboral português, o que contribui para a falsa ideia de que se o arqueólogo não está no campo não está a fazer nada. Recentemente, com a progressiva visibilidade das descobertas realizadas em contexto urbano, começa a verificar-se, ainda que de forma ténue, alguma mudança na descrição do arqueólogo, evidenciando os diferentes contextos de trabalho e as diferentes tarefas que realiza: "As botas de borracha antes cobertas de lama e os capacetes poeirentos já foram arrumados num canto longe da vista, mas o trabalho dos arqueólogos está longe de chegar ao fim. Agora é em laboratório, entre caixas e tabuleiros repletos de cacos, que se procura escrever mais um capítulo da história da cidade." (Caco a caco, os vestígios romanos da Praça D. Luís I vão ganhando forma, Público, 21 de Abril de 2013).

Outro dos grandes problemas consiste na invisibilidade do trabalho em equipa, herdeira da figura do arqueólogo dos finais do século XIX, quando as relações de trabalho eram muito desiguais e apenas o arqueólogo tinha formação e destaque. Contudo, com a profissionalização da arqueologia e a democratização da sociedade, esta ideia não só é falsa como é arriscada, uma vez que perpetua preconceitos, contribuindo para a precarização e desregulação da actividade. $\mathrm{O}$ arqueólogo deve ser considerado como um elemento de uma equipa, com funções específicas de acordo com a sua formação e contexto laboral; os trabalhos e projectos arqueológicos devem assentar em equipas e não em individualidades.

No imaginário da comunidade, a arqueologia ainda é uma actividade tipicamente masculina, pelas suas características: ao ar livre, em contexto de obra, em territórios distantes, exigindo força, etc. A figura da arqueóloga, em sentido oposto, é vista com algum desconforto, como uma certa transgressão à norma social estabelecida e não como uma actividade profissional, especializada, quotidiana, desenvolvida por uma mãe de família. Veja-se, título de exemplo, como o trabalho da arqueóloga é descrito numa das notícias que consultámos: "Entramos num espaço pequeno onde duas arqueólogas sorridentes andam à volta com esqueletos, montando puzzles complexos e guardando as peças em saquinhos de plástico" ("Cláudio Torres e Mértola", Público, 21 de Abril de 2012). Mas talvez mais significativo seja o próximo exemplo em que, dentro da mesma notícia, se opta por duas descrições bem distintas entre dois arqueólogos, um homem e uma mulher: "Em Reguengos de Monsaraz, António Valera dissolve o calor com a paixão pela arqueologia e à falta de vento responde com o entusiasmo de novas descobertas (...) Se António aparecesse num filme a situação não causava tanta estranheza. Com a barba desalinhada, o pólo e as calças de ganga manchados de terra, exerce a profissão há 27 anos. Ao longo do tempo, muitas descobertas especiais ficaram na sua memória, como a do Verão 
do ano passado (...) Lucy Evangelista, arqueóloga da ERA (...) Sorridente, fala com entusiasmo sobre a povoação. Alta, com sardas e olhos claros, não faz lembrar os arqueólogos dos filmes, habitualmente cobertos de terra." "“Quando 1500 anos de história se contam debaixo dos pés", Público, 9 de Agosto de 2012). O arqueólogo ainda é descrito de forma romantizada, remetendo para uma actividade mais relacionada com as nossas fantasias do que uma ciência e um trabalho técnico especializado.

Esta imagem do trabalho do arqueólogo e do arqueólogo em si, transmitida pela comunicação social, instituições em que a sociedade confia, perpetua muitos dos estereótipos de género e do papel da mulher na sociedade, não esquecendo que "una difusión deficiente (...) puede provocar peores consecuencias que el proprio desconocimiento, ya que el publico pocas veces se cuestiona la veracidad de lo que ve (...), y esas representaciones erróneas, estereotipadas, llegan a influir firmemente en la construcción de la futura percepción popular del ejercicio profesional." (Ibáñez Alfonso, 2015, p. 329).

Existe ainda um longo caminho a percorrer para uma verdadeira igualdade de género no trabalho em arqueologia, e uma parte desse mesmo caminho passa pela divulgação e discussão dos tópicos que aqui apenas aflorámos, e de muitos outros, que contribuam para termos uma mais informada compreensão destes mecanismos, conscientes ou inconscientes, de perpetuação de preconceitos e limitações profissionais impostos às mulheres da profissão, e também para a criação de soluções e alternativas. Uma destas será, assim pensamos, a de divulgar mais o papel das mulheres na arqueologia desde os alvores da disciplina, porque, apesar das dificuldades, sacrifícios e do reduzido número, a sua história merece ser conhecida, potencializando o poder do exemplo. Por outro lado, é necessária uma maior aproximação à comunidade e uma maior clareza na apresentação dos diferentes contextos e ferramentas de trabalho que o arqueólogo utiliza, de maneira a que a profissão se torne mais conhecida e socialmente mais relevante. Uma comunicação da arqueologia que inclua a sua riqueza e diversidade de profissionais, tipos e contextos de trabalho contribuirá, certamente, para a construção de uma imagem mais real e inclusiva desta profissão, mas, simultaneamente, não fará perder o fascínio e a paixão que nos continua sempre a motivar.

\section{BIBLIOGRAFIA}

Recursos digitais, consultados em Janeiro 2020:

www.cmjornal.pt

www.dn.pt

www.expresso.pt

www.ionline.pt

www.jn.pt

www.observador.pt

www.publico.pt

www.sol.sapo.pt

ALMEIDA, M. (2016) - Mulheres na política portuguesa. Em: FERREIRA, E.; VENTURA, I; REGO, L.; TAVARES, M.; ALMEIDA, M.A. (eds). Percursos Feministas: Desafiar os tempos. Universidade Feminista / UMAR., pp. 164-174.

BOAVENTURA, R. (2011) - Bodies in motion. In LILLIOS, K. (ed.) - Comparative archaeologies: The American Southwest $(A D 900-1600)$ and the Iberian Peninsula (30oo 150o BC). Oxford, pp. 209-220.

BUGALHÃO, J. (2011) - Os desafios da Arqueologia portuguesa nas últimas décadas. Arqueologia e História, Lisboa, 6o-61, pp. 19-43.

BUGALHÃO, J. (2013) - As mulheres na arqueologia portuguesa. In ARNAUD, J.; MARTINS, A.; NEVES, C. (coord.) - A arqueologia em Portugal -15o anos. Lisboa, pp. 19-23.

BUGALHÃO, J. (2017a) - O papel da mulher na arqueologia portuguesa. Ophiussa. Lisboa, 1, pp. 123-130.

BUGALHÃO, J. (2017b) - Arqueólogos Portugueses. In ARNAUD, J.; MARTINS, A.; (coord.) - A arqueologia em Portugal-2017 Estado da Questão. Lisboa, pp. 19-32.

CERQUEIRA, C. (2008) - A imprensa e a perspectiva de género. Quando elas são notícia no Dia Internacional da Mulher. Observatorio (OBS) Journal, 5, pp. 139-164.

COMISSÃO PARA A CIDADANIA E IGUALDADE DE GÉNERO (2017) - Poder e tomada de decisão política. Mulheres e homens nos órgãos executivos do poder local.

COMISSÃO PARA A CIDADANIA E IGUALDADE DE GÉNERO (2017) - Poder e tomada de decisão nas empresas: mulheres e homens.

COMISSÃO PARA A CIDADANIA E IGUALDADE DE GÉNERO (2017) - Igualdade de género em Portugal - Boletim estatístico.

COSTA, C., DUARTE, C., TERESO, J., VIEGAS, C., LAGO, M., GRILO, C., RAPOSO, J., DINIZ, M., LIMA, A. (2014) Discovering the Archaeologists of Portugal 2012-14, Associação Profissional de Arqueólogos. Lisboa.

DINIZ, M. (2006) - Para a História das Mulheres na Pré-história: em torno de alguns atributos do discurso. Promontoria, 4, p. 37-51.

DINIZ, M. (2019) - Archaeology PhDs at Portuguese Universities: A Brief Overview of the Last Decade (2010-2018). E-Journal of Portuguese History, 17:2. 
DINIZ, M.; GONÇALVES, V. S. (1993-1994) - Na 2. ํㅡ metade do século XIX: luzes e sombras sobre a institucionalização da arqueologia em Portugal. O Arqueólogo Português, Lisboa, série IV, 11/12, pp. 175-187.

FABIÃO, C. (1999) - Um século de arqueologia em Portugal -I. Al-madan. Almada, série 2, 8, pp. 104-126.

GOMES, F. (2011) - Arqueologia e Género(s): de strange bedfellows a um paradigma de leitura crítica do Passado. Sapiens: História, Património e Arqueologia, 5, pp. 6-30.

GOMES, F. (2015) - Género, identidade e poder: para uma crítica das relações de género em arqueologia. Conímbriga. Coimbra, LIV, pp. 27-44.

GOMES, S. (2011) - O Passado, a identidade e as teias do governo. Estudos sobre os entrelaçamentos das práticas de produção do conhecimento arqueológico e de construção da identidade nacional salazarista. Tese de doutoramento apresentada à Faculdade de Letras da Universidade do Porto.

GONÇALVES, T. (2004/05) - A abordagem do enquadramento nos estudos do jornalismo. Caleidoscópio, 5/6, 157-167.

IBÁÑEZ ALFONSO, M. (2015) - De la realidad al mito. La representación del arqueólogo desde la cultura ilustrada a la cultura de masas. ROMULA. Sevilla, 14, p. 293-331.

LAZAR, I.; KOMPARE, T.; LONDEN, H. (2014) - The Archaeologist of the Future is Likely to be a Woman: Age and Gender Patterns in European Archaeology. Archaeologies: Journal of the World Archaeological Congress, 10, pp. 257-28o.

LOBO, P.; CABECINHAS, R. (2013) - Perspectivas de género no acesso ao espaço público mediatizado: reflectindo sobre os conteúdos noticiosos do telejornal. Estudos em Comunicação, 13, pp. 195236.

LUÍS, E.; COSTEIRA, C. (no prelo) - A arqueologia portuguesa nos meios de comunicação. Comunicação apresentada na sessão 19: No todo es lo que parece: Repensando la educación pública y la divulgación en la Arqueología y en la gestión del Patrimonio de la Península Ibérica. TAG Ibérico, Lisboa, $202 \mathrm{O}$.

MAGALHÃES, S.; ALVAREZ, T. (2014) - Mulheres e Media. Associação Portuguesa de Estudos sobre as Mulheres.

MARTINS, A. (2016) - Pioneiras da arqueologia em Portugal: "Another Brick" against "The Wall" of indifference. María de Lourdes Costa Arthur (1924-2003). Revista Clepsydra, 15, p. 77-100.

MARTINS, C. (2013) - Mulheres, política e visibilidade mediática. As lideranças de Maria de Lourdes Pintasilgo e Manuela Ferreira Leite. Tese de doutoramento apresentada à Faculdade de Ciências Sociais e Humanas da Universidade Nova de Lisboa.

MARTINS, C. (2015) - Mulheres, Liderança Política e Media. Alêtheia Editores
MESQUITA, A.; SIMÕES, S. (2014) - Os trabalhadores de arqueologia portuguesa já têm um sindicato. Al-madan online, Almada, 2ª série, 19, pp. 197-198.

MOTA-RIBEIRO, S.; PINTO-COELHO, Z. (2005) - Imagens de mulheres na imprensa portuguesa. In Actas do IV Congresso da SOPCOM - Repensar os Media: Novos Contextos da Comunicação e da Informação. 20-21 Outubro, Universidade de Aveiro.

PEREIRA, A. (2020) - Análise de Benchmarking e esboço de plano de comunicação estratégico para a Uniarq (Centro de Arqueologia da Universidade de Lisboa). Projecto apresentado na Pós-graduação em gestão e políticas de ciência e tecnologia.

RODRIGUES, M. (2017) - A representatividade das mulheres na liderança de topo. Tese de mestrado apresentada à Faculdade de Economia da Universidade do Porto.

SABBATI, G.; PRPIC, M.; SHREEVES, R. (2018) - Gender equality in the EU's digital and media sectors. European Parliamentary Research Service.

SAVIETTO, D. (2015) - Mulheres e mídia global: uma análise internacional da perspectiva das mulheres sobre suas representações midiáticas. Dissertação de mestrado apresentada à Faculdade de Letras da Universidade de Coimbra.

SIMÕES, S.; BRITO, S.; CARVALHO, L.; BUGALHÃO, J.; MOREIRA, A. (2018) - Questões de género em contexto laboral em arqueologia. Breves notas. Al-madan on-line. Almada, II série (22), tomo 2, pp. 109-111.

SOUZA, J. (2014) - A invisibilidade das mulheres nos media: quando a representação de género define o sexo da notícia. Revista Media e Jornalismo - Da Cidade do México à Aldeia Transnacional. 25, (14-2), pp. 91-103.

VALE, A. (2015) - A mulher e a Pré-história. Alguns apontamentos para questionar a tradição e a tradução da mulher mãe e mulher - deusa na arqueologia pré-histórica. Conímbriga. Coimbra, LIV, pp. 5-25.

VIEGAS, J. M. L.; FARIA, S. (2001) - As Mulheres na Política. Lisboa, Celta. 


\section{Jornais com notícias de Arqueologia}

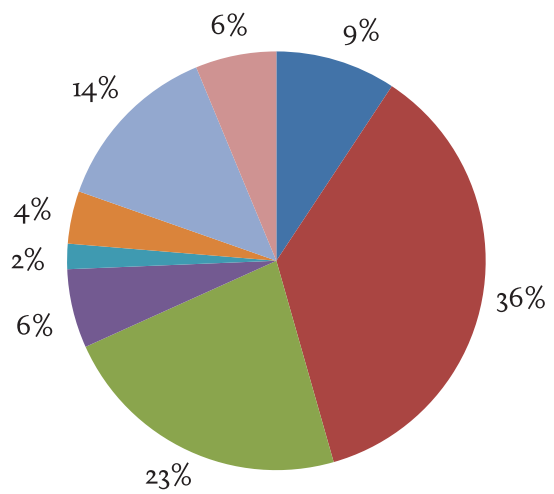
Expresso
- Público
Diário de Notícias
- Jornal de Notícias
- Jornal I
- Sol
- Correio da Manhã
- Observador

Gráfico 1 - Distribuição das notícias de arqueologia pelos jornais generalistas nacionais.

\section{Tema Principal das Notícias}

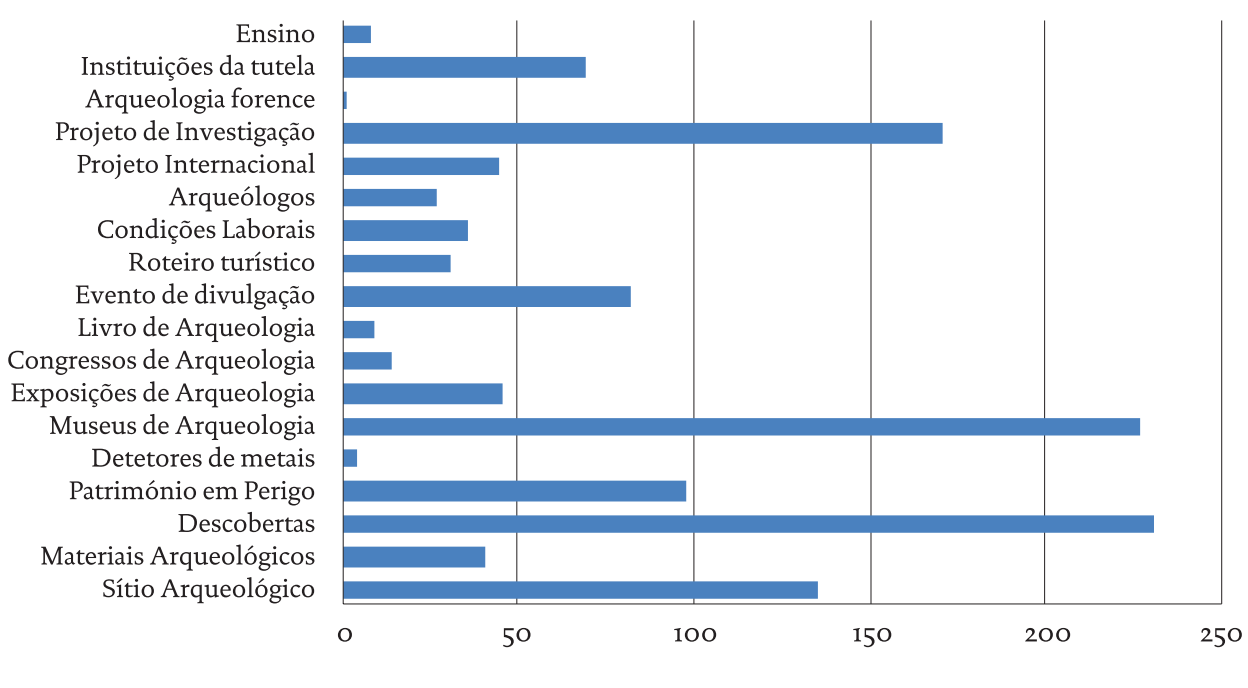

Gráfico 2 - Temas principais das notícias sobre arqueologia.

\section{Dossiers Temáticos}

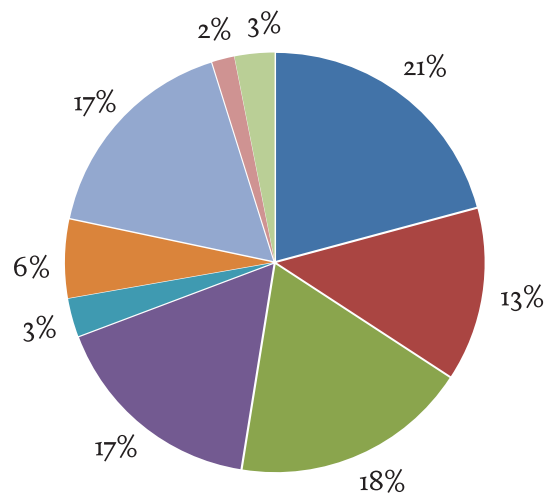
- Arte Rupestre
- Arqueologia Subaquática
- Arqueologia preventiva
- Projecto de Valorização
- Classificação
- Esqueletos
- Escavação
Açores
№ de visitantes

Gráfico 3 - Principais dossiers temáticos das notícias sobre arqueologia. 


\section{Género das Fontes}

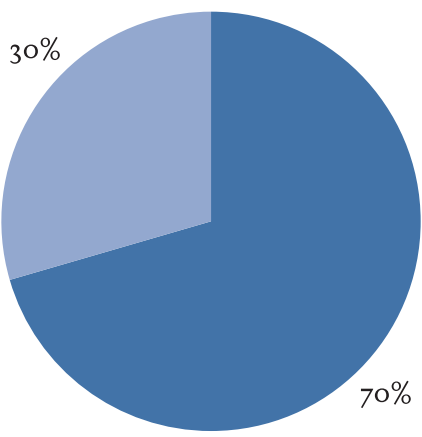

Masculinas

Femininas

Gráfico 4 - Relação entre fontes masculinas e fontes femininas das notícias sobre arqueologia.

\section{Evolução do volume de notícias}

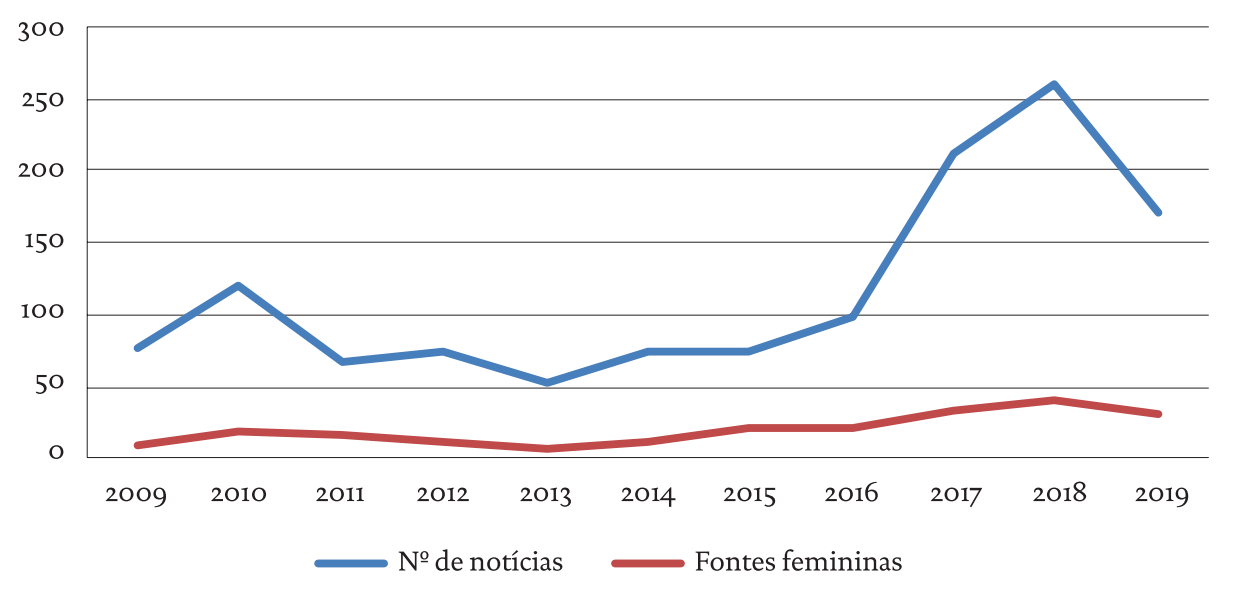

Gráfico 5 - Evolução do número de notícias publicadas sobre arqueologia e do recurso a fontes femininas entre 2009 e 2019 .

\section{Enquadramento profissional das fontes femininas}

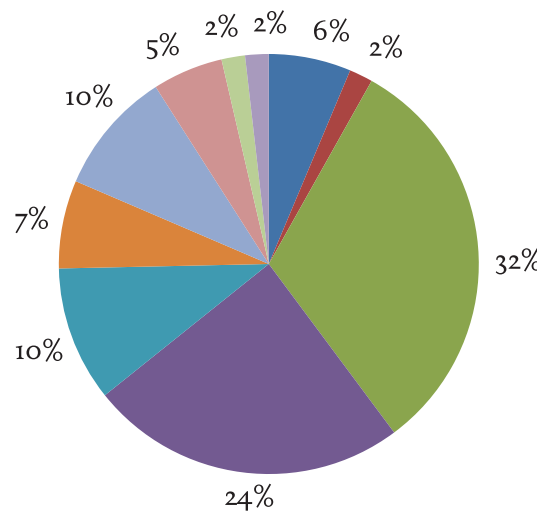

- C.M,

- Instituições

- Arqueólogas

- Universidade

- Tutela

- Antropólogas

- Museus

Empresas

- Sindicato

- Outros

Gráfico 6 - Enquadramento profissional das fontes femininas nas notícias de arqueologia. 


\title{
ARQUEOLOGIA E ARQUEÓLOGOS NO NORTE DE PORTUGAL
}

\author{
Jacinta Bugalhão'
}

\begin{abstract}
RESUMO
Este trabalho pretende apresentar dados quantitativos sobre a Arqueologia no Norte de Portugal entre 1970 e início do século XX. São analisados o ensino da Arqueologia, os arqueólogos, as instituições com actividade em Arqueologia e a actividade arqueológica, procurando identificar convergências e divergências, relativamente ao todo nacional. São abordados os estabelecimentos de ensino superior da região e a sua oferta formativa. São apresentadas as distribuições por sexo, idade, habilitação, forma de exercício da actividade, tipo de vínculo laboral e enquadramento institucional dos arqueólogos naturais da região Norte. Sobre a actividade arqueológica são abordadas a categoria (investigação, valorização, preventiva e de emergência), tipologia e enquadramento institucional e também a Arqueologia urbana e a desenvolvida em meio subaquático ou húmido.

Palavras-chave: Arqueologia portuguesa, História da Arqueologia, Região Norte, Actividade arqueológica, Profissão de arqueólogo.
\end{abstract}

\begin{abstract}
This paper intends to present quantitative data on Archeology in the North of Portugal between 1970 and the beginning of the $2 \mathrm{O}^{\text {th }}$ century. Archeology teaching, archaeologists, institutions with labour in Archeology and archaeological activity are analyzed, seeking to identify convergences and divergences, in relation to the national reality. Higher education establishments in the region and their training offer are covered. The distributions by sex, age, qualification, form of exercise of the activity, type of employment relationship and institutional framework of northern archaeologists are presented. On the archaeological activity, the category (research, valorisation, preventive and emergency), typology and institutional framework and also urban archeology and the one developed in underwater or humid environments are addressed.

Keywords: Portuguese archeology, History of Archeology, North region, Archaeological activity, Profession of archaeologist.
\end{abstract}

\section{1. ÂMBITO}

Neste trabalho apresentam-se os dados relativos à região Norte recolhidos no âmbito do projeto de doutoramento (em fase de conclusão) desenvolvido pela signatária desde 2012, na Faculdade de Letras da Universidade de Lisboa (com a UNIARQ e a DGPC como entidades de acolhimento), sob orientação de Carlos Fabião, subordinado ao tema "A Arqueologia em Portugal, entre o final do século XX e o início do século XXI". A sua principal fonte de informa- ção é o Endovélico, sistema de informação e gestão arqueológica, gerido pela DGPC.

No presente trabalho considera-se a região Norte conforme ela está definida no Decreto-Lei n.. 68/2008 de 14 de Abril que delimita as unidades territoriais para efeitos de organização territorial e estatística (NUTS) ${ }^{2}$ (Figura 1). O período em estudo corresponde aos 45 anos compreendidos entre 1970 e 2014, e foi decomposto em quinquénios, para análise evolutiva.

$\mathrm{Na}$ análise de dados quantitativos, os valores apre-

1. DGPC; UNIARQ/Faculdade de Letras da Universidade de Lisboa; Centro de Estudos de Arqueologia, Artes e Ciências do Património; jacintabugalhao@gmail.com

2. A região Norte inclui as sub-regiões Minho-Lima, Cávado, Ave, Grande Porto, Tâmega, Entre Douro e Vouga, Douro e Alto Trás-os-Montes, compreendendo 86 conselhos. A delimitação das NUTS vem sofrendo actualizações, em 2009, 2013 e 2015, mas a configuração da região (NUTS II) Norte mantém-se inalterada. 
sentados referem-se aos que foi possível apurar nos universos em análise (arqueólogos, instituições, trabalhos arqueológicos, projectos, etc).

\section{ENSINO SUPERIOR DA ARQUEOLOGIA NO NORTE DE PORTUGAL}

O ensino da Arqueologia nas universidades portuguesas começou disperso em disciplinas clássicas como filologia, história de arte antiga, epigrafia, numismática. No final do século XIX, com o desenvolvimento dos estudos pré-históricos, alguns conteúdos arqueológicos foram marcando presença no ensino das ciências naturais, nomeadamente na área científica da Geologia. A partir de 1911, Mendes Correia ensinou Antropologia na Faculdade de Ciências da Universidade do Porto, na qual chegou a catedrático (Fabião, 1999, p. 120). O mesmo arqueólogo ensinou a Arqueologia na Faculdade de Letras da Universidade do Porto (Fabião, 2011, p. 170), entre 1919 e 1922 (Centeno, Soeiro e Sanches, 2013, p. 33). Nos anos 50 do século XX, D. Domingos de Pinho Brandão ensinou Arqueologia no Seminário Maior do Porto (Centeno, Soeiro e Sanches, 2013, p. 36). Na reforma das leis orgânicas das Faculdades de Letras de 1957 é considerada a licenciatura em História (que integrava as disciplinas de Pré-História e de Arqueologia) e instituído o doutoramento em Arqueologia. Em 1961, após a restauração da Faculdade de Letras do Porto (Centeno, Soeiro e Sanches, 2013, p. 35) são aí disponibilizados os cursos de licenciatura em História e de doutoramento em Arqueologia (Centeno, Soeiro e Sanches, 2013, p. 36). A partir de 1968, as disciplinas de Pré-História e Arqueologia ficam sob a responsabilidade de Carlos Alberto Ferreira de Almeida (Centeno, Soeiro e Sanches, 2013, p. 38).

A seguir ao 25 de Abril, em 1975, operaram-se reformas dos cursos de História, comtemplando a criação da "pré-especialização" em Arqueologia, nas três universidades clássicas (Arnaud, 2013, p. 77; Centeno, Soeiro e Sanches, 2013, p. 38), assumindo, por vezes, configuração mais especializada, como foi o caso "pré-especialização" em Pré-História ministrada na Faculdade de Letras do Porto. Nos últimos anos da década de 70 do século XX, a Universidade de Braga cria áreas de investigação em Arqueologia (Lemos, 1987, p. 8). Na Faculdade de Letras da Universidade do Porto, onde leccionavam Arqueologia seis docentes (Centeno, Soeiro e Sanches, 2013, p. 38), são reforçados os conteúdos relativos à Pré-
-História e, em 1978, é criada a variante História de Arte e Arqueologia (Jorge, 2003, p. 1454; Centeno, Soeiro e Sanches, 2013, p. 43).

Em 1980 começa a funcionar a variante Arqueologia da licenciatura em História na Faculdade de Letras do Porto (Jorge e Marques, 1992, p. 36; Jorge, 2003, p. 1454; Centeno, Soeiro e Sanches, 2013, p. 43) e, mais tarde, em 1998, na Universidade do Minho (Meireles, 2006, p. 117). A partir de 1990 a Escola Profissional de Arqueologia do Freixo, Marco de Canaveses oferece formação profissional de nível secundário em Arqueologia (Dias, 1998, p. 38). A Faculdade de Letras da Universidade do Porto teve um papel muito relevante no processo de autonomização do ensino universitário da Arqueologia. Após a já referida variante, criou, em 1989, o primeiro curso de Mestrado em Arqueologia a funcionar em Portugal (Jorge e Marques, 1992, p. 36; Jorge, 2003, p. 1454; Centeno, Soeiro e Sanches, 2013, p. 43). Em 1996, foi criado na mesma faculdade o Mestrado em Arqueologia Pré-Histórica.

$\mathrm{Na}$ Universidade do Minho, o ensino na Arqueologia iniciou-se no âmbito da licenciatura em História e Ciências Sociais (Jorge e Marques, 1992, p. 36). Refiram-se ainda os estabelecimentos de ensino superior com investigadores e áreas de investigação em Arqueologia, na Universidade de Trás-os-Montes e Alto Douro e na Universidade Portucalense Infante D. Henrique (Jorge e Marques, 1992, p. 36). $\mathrm{Na}$ Faculdade de Letras da Universidade do Porto, é finalmente instituída a primeira licenciatura em Arqueologia em 1999 (Jorge, 2003, p. 1454; Soeiro, 2006, p. 118) e também o curso de Doutoramento em Arqueologia (Centeno, Soeiro e Sanches, 2013, p. 44). Na Universidade do Minho, é criada em 2003 a Licenciatura em Arqueologia e o doutoramento em Arqueologia.

Entretanto, decorre o processo de Bolonha em Portugal (Raposo, 2006). Na Faculdade de Letras da Universidade do Porto, em 2007, são adaptados os cursos de mestrado e doutoramento (2.. e $3 .^{\circ}$ ciclo) em Arqueologia. Na Universidade do Minho, sucedem-se entre 2007 e 2012 adaptações e alterações do mestrado em Arqueologia. A Universidade de Trás-os-Montes e Alto Douro cria, em 2007, o doutoramento em Quaternário Materiais e Culturas e, em 2005, em colaboração com o Instituto Politécnico de Tomar, o mestrado em Arqueologia Pré-Histórica e Arte Rupestre. Ao nível dos estabelecimentos privados, registaram-se os mestrados em 
de Arqueologia, na Universidade Fernando Pessoa, em 2007 e na Universidade Portucalense Infante D. Henrique, em 2009.

Em estudo anterior, foram analisados os dados quantitativos e evolutivos disponíveis para a obtenção de grau académico superior - licenciaturas, mestrados e doutoramento - na área científica da Arqueologia (Bugalhão, 2016; Bugalhão, 2017, p. 126-128), em Portugal, entre 1970 e $2014^{3}$.

Em Portugal, entre 1978 e 2014, terão concluído licenciatura/1.. ciclo de Bolonha na área científica da Arqueologia cerca de 2.500 alunos ${ }^{4}$ (Bugalhão, 2016), dos quais cerca de $34 \%$ diplomaram-se em estabelecimentos de ensino da região Norte $(70 \%$ na Faculdade de Letras do Porto e $30 \%$ na Universidade do Minho).

Relativamente ao mestrado/2..$^{\circ}$ ciclo de Bolonha, entre 1983 e 2014, registaram-se 724 graduados (em Arqueologia, e outras áreas científicas como a História, Antropologia, Arqueologia, Geologia, Geografia, Física, Química, Sistemas de Informação e Informática, Filosofia, Literatura, Arquitectura e Artes, Conservação e Restauro, Museologia, Património, Cultura e Turismo) com dissertação sobre temática arqueológica (Bugalhão, 2016). Na região Norte foram obtidos 242 graus de mestrado/2.. ciclo de Bolonha, entre 1993 e 2014 (33\% do total). Destes, $57 \%$ foram obtidos na Faculdade de Letras da universidade do Porto, $22 \%$ na Universidade do Minho, $17 \%$ na Universidade de Trás-os-Montes e Alto Douro (por vezes em parceria com o Instituto Politécnico de Tomar) e $4 \%$ em outros estabele-

3. Relativamente às licenciaturas, recorreu-se aos dados estatísticos da DGEEC (disponíveis apenas desde 1993), relativos aos graus obtidos em estabelecimentos de ensino superior portugueses. Relativamente aos mestrados e doutoramentos, consideraram-se considerados todos os diplomados em Arqueologia (ou outras áreas científicas mas com dissertação na temática arqueológica), entre 1970 e 2014, em estabelecimentos de ensino superior portugueses e estrangeiros, que incidiram sobre contextos arqueológicos portugueses (incluindo Arqueologia das antigas colónias portuguesas, na perspectiva da História da Arqueologia e contextos arqueológicos portugueses fora do território português) ou sem delimitação geográfica específica.

4. Estima-se em cerca de 50 o número de licenciados em História, com "pré-especialização" em Arqueologia a nível nacional. Entre 1985 e 1992, estimam-se em 250 os licenciados em História, variante Arqueologia. A partir dos dados disponibilizados pela DGEEC sabe-se que, entre $1993 \mathrm{e}$ 2014, se registam 1.956 licenciados em Arqueologia. cimentos de ensino superior (como a Faculdade de Ciências da Universidade do Porto, a Universidade Católica do Porto, a Universidade Fernando Pessoa e a Universidade Portucalense).

Quanto ao grau de doutoramento/3. ${ }^{\circ}$ ciclo de Bolonha, entre 1974 e 2014, registaram-se 195 diplomados (em Arqueologia, nas outras áreas científicas já referidas para mestrado/2.. ciclo) com dissertação sobre temática arqueológica, em estabelecimentos de ensino superior portugueses e estrangeiros (incidindo sobre contextos arqueológicos portugueses) (Bugalhão, 2016), dos quais, 24\% foram obtidos em universidades da região. Distribuem-se entre a Faculdade de Letras da Universidade do Porto (50\%), Universidade do Minho (35\%) e a Universidade de Trás-os-Montes e Alto Douro (15\%).

Em termos evolutivos, analisados os graus conferidos pelos estabelecimentos de ensino superior da região Norte pode observar-se uma tendência crescente no número de licenciados, interrompida apenas no último quinquénio (provavelmente devido à diminuição do número de alunos no ensino superior em consequência da crise económica e financeira), idêntica à verificada a nível nacional (Gráfico 1). Nos mestrados regista-se um primeiro momento de crescimento no quinquénio de 1995-1999, relacionado com a criação do mestrado de Arqueologia na Faculdade de Letras do Porto, seguido de dez anos de alguma estabilização (quando no resto do país este valor se mantém crescente) e dos últimos dez anos em estudo de forte aumento do número de diplomados (Gráfico 1). O número de doutorados na região é bastante modesto até 2004, revelando forte crescimentos nos dez anos seguintes, numa evolução semelhante ao todo nacional (Jorge, 1986, p. 2; Jorge e Marques, 1992, p. 36; Jorge e Jorge, 1996, p. 165; Lemos, 2003, p. 49; Silva, 2003, p. 68; Lemos, 2007, p. 107; Bugalhão, 2017, p. 23; 30) (Gráfico 1). $\mathrm{O}$ ensino superior da Arqueologia na região Norte iniciou-se no início do século XX na Universidade do Porto, onde em 1957, foi instituído o grau de doutor em Arqueologia e História de Arte. Entre meados dos anos 70 e os anos 9o, verificou-se uma tendência de especialização no ensino superior da Arqueologia e o número de estabelecimentos de ensino superior envolvido neste aumenta e dispersa-se mais no território. A partir de 1995, aumenta o número de mestrados e de 2005, de doutoramentos, numa tendência muito acentuada pela implementação do modelo de Bolonha no ensino superior por- 
tuguês e pela alteração do regime jurídico de enquadramento da actividade arqueológica. A evolução da formação superior em Arqueologia na região Norte contribuiu para a alteração muito significativa do nível habilitacional dos arqueólogos em Portugal, que evoluiu da quase ausência ou indistinção, para uma realidade de elevada, cumulativa e especializada qualificação académica e científica.

\section{ARQUEÓLOGOS DO NORTE DO PAÍS}

Os dados aqui apresentados foram recolhidos no referido projecto de doutoramento, no qual se identificaram 2.080 arqueólogos com actividade em Portugal entre 1970 e 2014, dos quais 1.837 com nacionalidade portuguesa. Os valores apurados revelaram que neste período trabalharam em Portugal 309 arqueólogos naturais da região Norte (das mais populosas e urbanizadas do país), ou seja $26 \%$ do total de arqueólogos com nacionalidade portuguesa (Bugalhão, 2017, p. 23; 28-29). É importante sublinhar que os dados aqui tratados se referem à região de naturalidade dos arqueólogos e não à região de actividade dos arqueólogos.

A naturalidade dos arqueólogos foi confrontada com os valores globais de naturalidade da população nascida em Portugal ${ }^{5}$. A comparação destes valores, e com as cautelas que se impõem devidas à natureza muito diferente dos dados, permite propor que os arqueólogos naturais da região Norte ( $28 \%$ do total de portugueses se excluídos os nascidos fora do país) representam um peso relativo consideravelmente inferior ao da população nascida naquela região, $40 \%$ ). Foi também analisada a evolução do peso relativo dos arqueólogos em actividade entre 1970 e 2014 nascidos na região Norte, concluindo-se que estes ganham peso relativo ao longo do período em estudo, representando inicialmente $19 \%$ do total e, no último quinquénio, $26 \%$ do total (Gráfico 2). $\mathrm{Na}$ distribuição por sexo dos arqueólogos nascidos na região Norte, registam-se $63 \%$ de homens e $37 \%$ de mulheres. Aliás, a região Norte, regista a única espe-

5. Utilizaram-se como referência os dados disponibilizados pela PORDATA/INE (estatísticas de Nados-Vivos) relativos à taxa bruta de natalidade no país (portugueses nascidos fora do país não são considerados) em 1981 (inclui todos os nascimentos e não apenas os de nacionais portugueses), sendo estes comparados com os valores dos arqueólogos nascidos entre 1980 e 1989, em actividade em Portugal entre 1970 e 2014. cificidade regional divergente da situação de paridade verificada a nível nacional (Bugalhão, 2017, p. 22), revelando uma sub-representação do sexo feminino. Refira-se ainda que entre os arqueólogos portugueses do sexo masculino em actividade em Portugal no período em estudo, $30 \%$ nasceram no Norte; do sexo feminino, apenas $21 \%$ nasceram nesta região.

Quando analisada a evolução quinquenal da distribuição por naturalidade de homens e mulheres, verifica-se que entre os naturais da região Norte há sempre mais homens que mulheres, embora a diferença se vá atenuando (Gráfico 3). Entre os naturais do Norte do país, no período em estudo, a profissão de arqueólogo não alcançou (ainda) a paridade de género, já alcançada a nível nacional (Bugalhão, no prelo).

A análise evolutiva da estrutura etária dos arqueólogos nascidos no Norte do país foi efectuada através do apuramento da sua média etária ${ }^{6}$ em cada quinquénio. À semelhança do que ocorre a nível nacional (Bugalhão, 2017, p. 23 e 29), este valor revela um rejuvenescimento progressivo dos arqueólogos nascidos na região, em actividade entre 1970 e 2009, seguida de uma ligeira subida da média etária no último quinquénio em análise. Comparativamente com a realidade nacional, até 1984 os arqueólogos nascidos no Norte são tendencialmente mais velhos; entre 1985 e 2004, revelam média etária idêntica à nacional; e entre 2005 e 2014, são mais jovens (Gráfico 4 ).

Foram também analisadas as habilitações académicas dos arqueólogos com naturalidade nortenha, apurando-se que $98 \%$ possuem licenciatura/1..${ }^{\circ}$ ciclo de Bolonha, $39 \%$ possuem mestrado/2.. ciclo, $9 \%$ possuem doutoramento/ $3 .$. ciclo e $2 \%$ possuem outras habilitações "não secundárias"7 (valor particularmente elevado). Comparativamente à realidade nacional, os nortenhos registam um valor relativo superior de mestres/2. ${ }^{\circ}$ ciclo (eventual-

6. A média etária dos arqueólogos em actividade no quinquénio foi calculada a partir da idade de cada arqueólogo completada no terceiro ano do mesmo.

7. Na categoria "outras habilitações académicas não secundárias” integraram-se as qualificações académicas subsequentes ao ensino secundário, não obtidas em estabelecimento de ensino superior. Enquadram-se nesta categoria os estudos religiosos, militares e do chamado "magistério primário", outros cursos conferentes de grau académico "médio" ou ainda curso de ensino informal (por exemplo o curso de conservador de museu). 
mente relacionado com a criação e funcionamento do primeiro mestrado em Arqueologia em Portugal, na Faculdade de Letras do Porto, no final dos anos 8 o do século $\mathrm{XX}$ ) e um valor relativo inferior de doutorados $/ 3$. ․ ciclo de Bolonha. Ao contrário do que se passa noutras regiões (Bugalhão, 2017, p. 23), não se regista nenhum arqueólogo natural da região Norte, que tenha permanecido sem habilitação académica superior durante todo o período em estudo. À semelhança do ocorrido a nível nacional, os arqueólogos nascidos na região Norte tornam-se progressivamente mais qualificados ao longo do período em estudo (Gráfico 5).

Relativamente à forma de exercício da actividade, $13 \%$ dos arqueólogos nascidos na região Norte foram arqueólogos amadores (especialmente nos primeiros quinze anos em estudo), tratando-se, na sua maioria, de professores do ensino básico e secundário, profissionais de museus e bibliotecas e membros do clero. Os arqueólogos profissionais representam $90 \%$ do total e para estes foi analisado o tipo de vínculo, relação ou situação laboral. Entre os arqueólogos profissionais naturais da região Norte, $66 \%$ foram trabalhadores independentes, $33 \%$ trabalhadores dependentes, 10\% empresários e 5\% bolseiros/investigadores (note-se que um arqueólogo regista frequentemente no seu currículo vários tipos de vínculo, relação ou situação laboral). Comparativamente com os valores nacionais (Bugalhão, 2017, p. 24-25 e 31), entre os naturais do Norte regista-se uma incidência superior de trabalho independente e de empresários; e uma incidência inferior de trabalho dependente e de bolseiros/investigadores. Até aos anos 80 do século XX, os arqueólogos em actividade em Portugal eram trabalhadores dependentes ou amadores. Na evolução quinquenal (apenas a partir de 1990, quando esta distinção se justifica), observa-se naturalmente um crescimento do trabalho independente (que surge com valores assinaláveis de forma precoce nesta região), mas também o surgimento e consolidação dos empresários, bem como dos bolseiros/investigadores (Gráfico 6). $\mathrm{O}$ enquadramento institucional do trabalho dos arqueólogos em Portugal caracteriza-se por uma forte instabilidade, volatilidade e versatilidade. Sublinha-se por isso que um arqueólogo, no período em estudo e em cada quinquénio, pode trabalhar apenas para ou numa instituição ou para ou em várias. Salienta-se também que o trabalho de arqueólogos enquadrado por empresas de arqueologia, outro tipo de empresas ou sem enquadramento institucional se implanta e consolida apenas a partir dos anos 90 do século XX. Entre os arqueólogos nascidos na região Norte, $65 \%$ trabalharam sem qualquer enquadramento institucional, 59\% trabalharam em empresas de arqueologia, 30\% na administração pública local, $27 \%$ em universidades ou unidade de investigação portuguesas, $18 \%$ em outro tipo de empresas, 12\% na administração pública central, 10\% em associação, e um número residual (1) trabalhou para universidade ou unidade de investigação estrangeira (Gráfico 7). Comparativamente com a realidade nacional, os arqueólogos nascidos no Norte têm o seu trabalho mais frequentemente enquadrado pela administração pública local, por universidades ou unidade de investigação portuguesas e por empresas, de arqueologia e outras. Pelo contrário, os arqueólogos nascidos no Norte têm o seu trabalho mais raramente enquadrado pela administração pública central, associações e universidades ou unidades de investigação estrangeiras. Os arqueólogos nortenhos trabalham mais frequentemente sem qualquer enquadramento institucional, situação fortemente relacionada com o trabalho em regime liberal ou independente.

\section{INSTITUIÇÕES COM ACTIVIDADE EM ARQUEOLOGIA DO NORTE DO PAÍS}

Foram analisadas as instituições com actividade em Arqueologia entre 1970 e 2014, sedeadas na região Norte de Portugal, tendo-se contabilizado um total de 200 entidades ( $22 \%$ do total nacional), entre as quais se incluem 42 museus de Arqueologia ou com colecções de Arqueologia ( $27 \%$ do total nacional). Estas instituições enquadram o trabalho dos arqueólogos mas desempenham também outras importantes funções (frequentemente em acumulação), como a museológica, a gestão de espólios e colecções arqueológicas, a tutelar, o apoio à investigação, a representação académica, profissional e sindical, a edição científica, etc. Foi analisada a distribuição por tipo das instituições com actividade em Arqueologia sedeadas na região Norte. O grupo maioritário é constituído por organismos da administração pública local ${ }^{8}$ (39\%), seguindo-se as asso-

8. A categoria “Administração Pública Local” integra maioritariamente municípios, mas também outro tipo de organismos autárquicos. 
ciações (20\%), as empresas fora do sector arqueológico $^{9}(14 \%)$, as empresas de arqueologia (13\%), as universidades e unidades de investigação portuguesas (6\%), a administração pública central (5\%) e, por fim, os outros tipos de instituição ${ }^{10}(3 \%)$ (Gráfico 8). Os organismos da administração pública local são as instituições com actividade em Arqueologia mais numerosas na região Norte, realidade possivelmente potenciada pela a elevada concentração de municípios nesta região ( $31 \%$ dos localizados no território continental). Entre 1980 e a actualidade, os municípios intensificaram determinantemente a sua actividade nas várias frentes e tarefas, consolidando-se como as principais instituições da Arqueologia nacional (Jorge, 1986, p. 2; Lemos, 1987, p. 10; Real, 1993, p. 25-26; Almeida, 2007a, p. 132). As associações são o segundo tipo de instituição mais representado, espelhando a sua importância na Arqueologia da região. Entre 2000 e 2014, as empresas de arqueologia são principais entidades enquadrantes da actividade arqueológica (Lago, 2003, p. 103; Bugalhão, 2011, p. 27) e principais as entidades de enquadramento do trabalho de arqueólogos (principalmente dos mais jovens), como contratantes e/ou empregadoras (Almeida, 2007, p. 130; Bugalhão, 2011, p. 35-36; Bugalhão, 2017, p. 25). No Norte, encontra-se sedeado um número razoável de universidades ou unidades de investigação, ao contrário do que sucede nas regiões mais periféricas, menos desenvolvidas e menos povoadas do país.

Relativamente à evolução temporal, verifica-se uma tendência de crescimento linear ao longo de todo o período em análise, mais intensa entre 1995 e 2004, relacionada com a progressiva estruturação, organização e institucionalização da Arqueologia nacional. Até aos anos 80 do século XX, a actividade arqueológica desenvolve-se de forma amadora ou proto-profissional, baseada frequentemente na ini-

\footnotetext{
9. Na categoria "Empresa-Outras" consideraram-se as empresas não sendo exclusivamente prestadoras de serviços de arqueologia contratam e enquadram actividade arqueológica, nomeadamente, empresas com actividade na avaliação de impacte ambiental, empreiteiros, promotores imobiliários, empresas gestoras de redes de infra-estruturas básicas, etc, e também as editoras de bibliografia arqueológica (o que contribui para a sua elevada representação quantitativa).

10. Na categoria "Outros" foram incluídos os tipos com uma presença muito residual no universo em análise, por exemplo, escolas de ensino básico e secundário, fundações e organismos eclesiásticos.
}

ciativa individual e sem suporte institucional. Nesta fase, menos institucionalizada, verifica-se uma intervenção mais intensa de organismos públicos e associações. Numa segunda fase, mais institucionalizada, assumem prevalência as entidades privadas (Gráfico 9).

\section{ACTIVIDADE ARQUEOLÓGICA NA REGIÃO NORTE}

Os trabalhos arqueológicos realizados na região Norte de Portugal entre 1970 e 2014 correspondem a $32 \%$ dos realizados em Portugal continental. Em termos absolutos, o número de trabalhos arqueológicos desenvolvidos no Norte demonstra uma tendência de crescimento entre 1970 e 2009, seguida de uma retracção no quinquénio de 2010-2014. $\mathrm{Na}$ evolução quinquenal, a região Norte representa entre 1o e $42 \%$ do total nacional. Entre 1975 e 1989 , a maioria dos trabalhos arqueológico decorrem no Norte (entre 27 e $42 \%$ ), situação que se repete entre 2000 e 2004 (26\%). Os projectos de enquadramento da actividade arqueológica realizado no Norte representam $29 \%$ do total nacional. Em termos evolutivos e em correspondência com o verificado para os trabalhos arqueológicos, observa-se que a região Norte regista o número mais elevado de projectos entre 1975 e 1984 (30 e $38 \%$ do total) e entre 1995 e 2014 (entre 28 e 30\%) (Gráfico 10).

No que se refere à categoria ${ }^{11}$ dos trabalhos arqueológicos, na região Norte decorreu a maioria dos trabalhos de investigação e preventivos realizados em Portugal no período em estudo. Na perspectiva evolutiva, regista-se duas fases distintas. Até 1999, a maioria dos trabalhos arqueológicos enquadram-se na categoria A - Investigação. A partir de 2000 e de forma progressivamente mais intensa, a maioria dos trabalhos arqueológicos enquadram-se na categoria C - Preventiva (Gráfico 11).

A Arqueologia de investigação (categoria A) desenvolvida na região Norte representa $27 \%$ do total. Procurou-se caracterizar o objecto dos projectos de investigação, nomeadamente, o (ou os) período

\footnotetext{
11. Conforme o n. ${ }^{1} 1$ do artigo $3 .{ }^{\circ}$ do Regulamento de Trabalhos Arqueológicos (Decreto-Lei n.ํㅜㄹo/99 de 15 de Julho) e o artigo 3. - do Regulamento de Trabalhos Arqueológicos (Decreto-Lei n.. ${ }^{\circ}$ 164/2014 de 4 de novembro).
} 
cronológico $^{12}$ sobre o qual incidem. A investigação em contextos proto-históricos é especialmente relevante no Norte e pré-história recente alcança representação relativa significativa (Gráfico 12).

Os trabalhos de valorização (categoria B) no Norte do país representam $29 \%$ dos realizados a nível nacional. Registam tendência crescente até 2009 e, comparativamente com o todo nacional, assumem maior preponderância entre 1975 e 1984 e entre 2005 e 2009 (Gráfico 11). Em 2016, 26\% dos sítios arqueológicos valorizados situavam-se na região Norte (Raposo, 2016, p. 72-73).

Os trabalhos arqueológicos preventivos (categoria C) realizados no Norte representam $25 \%$ do total nacional, incluindo: trabalhos realizados no âmbito de processos de licenciamento e obras (56\%); trabalhos realizados no âmbito de processos de avaliação de impacte ambiental (39\%); trabalhos realizados no âmbito de projectos de carta arqueológica e ordenamento e gestão do território (3\%); e trabalhos realizados no âmbito de projectos de intervenção e/ ou valorização de Património arquitectónico (3\%). Os trabalhos de emergência (categoria D) realizados na região Norte representam 20\% do total nacional e atingiram representação quantitativa máxima nos anos 80 do século XX (Gráfico 11).

Relativamente ao tipo de trabalho, as intervenções desenvolvidas na região Norte, distribuem-se por 46\% de escavações, $30 \%$ de acompanhamentos, $20 \%$ de prospecções, $3 \%$ de intervenções de conservação e restauro e $2 \%$ de levantamentos (registo), em proporção semelhante à observada a nível nacional.

$\mathrm{O}$ enquadramento institucional da actividade arqueológica na região regista é garantido por empresas de arqueologia (47\%), administração pública local (14\%), universidades e unidades de investigação (13\%), associações (7\%), administração pública central (4\%) e outros tipos de empresa (2\%). Os trabalhos arqueológicos sem entidade enquadrante representam $13 \%$ do total. As empresas de arqueologia surgem no final dos anos 9o do século XX, consolidam a sua presença até 2009 e registam ligeira quebra no último quinquénio. Situação idêntica ocorre

12. Consideraram-se os blocos cronológicos: Pré-História Antiga (Paleolítico, Mesolítico/Epipaleolítico), Pré-História Recente (Neolítico e Calcolítico), Proto-História (Idade do Bronze e Idade do Ferro), Romano, Medieval, Moderno, Contemporâneo e Diacrónico (centrados em problemáticas de evolução de longa duração cronológica e cultural). outro tipo de empresas e com as intervenções sem enquadramento institucional, igualmente associadas à arqueologia comercial. A Arqueologia municipal também regista tendência semelhante embora em volume mais reduzido. $\mathrm{O}$ volume de actividade arqueológica enquadrada pelas universidades e unidades de investigação portuguesas revela tendência estável, bem como a enquadrada pela administração pública central que registou nos anos 90 do século XX a sua fase mais dinâmica (Gráfico 13).

Os trabalhos arqueológicos realizados em meio urbano na região Norte representam $27 \%$ do total nacional, sendo a região com maior número de intervenções entre 2000 e 2004. A nível regional a actividade arqueológica urbana representa $38 \%$ do total (Bugalhão, 2018a, p. 34) e apresenta tendência de crescimento no período em estudo. Reconhecem-se duas fases: entre 1970 e 1994, a actividade decorre essencialmente em meio rural; entre 1995 e 2014, a actividade em meio urbano ganha preponderância crescendo chegando a suplantar a realizada em meio rural no último quinquénio (Gráfico 14). Em termos quantitativos destacam-se pelo elevado número de intervenções arqueológicas realizadas, as cidades do Porto, Braga, Chaves, Viana do Castelo, Penafiel, Vila Nova de Gaia e Guimarães (Bugalhão, 2018a, p. 34). Uma avaliação ainda preliminar revela que os trabalhos arqueológicos desenvolvidos em meio subaquático e/ou húmido ma região Norte representam $23 \%$ do total (Bugalhão, 2018b, p. 46).

$O$ financiamento da actividade arqueológica em Portugal durante o período em estudo ocorre principalmente sob dois formatos, o directo e o contratualizado. O primeiro refere-se à forma de financiamento tradicional: (i) no âmbito das instituições (públicas ou privadas) que se dedicam à actividade arqueológica com recursos próprios; (ii) ou através da atribuição de subsídios, bolsas e outro tipo de pacotes financeiros para a custear (sem transacção de natureza comercial envolvida). O segundo formato refere-se à arqueologia comercial (arqueologia contratual ou arqueologia sob contrato) na qual o financiamento decorre de um contrato de natureza comercial, podendo ocorrer em contexto empresarial ou liberal. Trata-se de financiamento indirecto, pois provém de fontes não destinadas directamente à Arqueologia, constituindo uma parcela de orçamentos de estudos, planos, projectos e obras no âmbito dos quais são impostos trabalhos arqueológicos preventivos, ao abrigo da aplicação do princí- 
pio do poluidor-pagador adaptado à gestão do património arqueológico (artigo 6. da Convenção de Malta e n.. 3 do artigo 79.. da Lei n.. $107 / 2001$, Lei Base do Património Cultural). Na região Norte, entre 1970 e 2014, o financiamento directo representa cerca de $36 \%$ e o financiamento indirecto no âmbito da arqueologia comercial representa cerca de $64 \%$, valores alinhados com os relativos ao todo nacional.

\section{ARQUEOLOGIA E ARQUEÓLOGOS NO NORTE DE PORTUGAL}

A região Norte do país desempenhou um papel muito relevante no ensino da Arqueologia em Portugal, quer ao nível técnico, através da Escola Profissional de Arqueologia do Freixo, quer, principalmente, a nível superior, através da Faculdade de Letras da Universidade do Porto. Esta faculdade desempenhou um papel pioneiro com a criação das licenciaturas em História, variante Arqueologia (1990) e em Arqueologia (1999) e do mestrado em Arqueologia (1989). No período em estudo, a Faculdade de Letras da Universidade do Porto é o estabelecimento de ensino superior português com maior número de diplomados em mestrado/2.. ciclo de Bolonha e doutoramento/ $3 .{ }^{\circ}$ ciclo de Bolonha. Também a Universidade do Minho regista um desempenho relevante nesta matéria, nomeadamente no que se refere aos estudos académicos sobre Arqueologia em meio urbano.

Entre os naturais da região Norte do país verifica-se, aparentemente, uma apetência pela Arqueologia ligeiramente inferior à registada a nível nacional. $\mathrm{O}$ número de mulheres arqueólogas nascidas no Norte é também proporcionalmente inferior. Contudo, estas duas realidades têm vindo a atenuar-se. No início do período em estudo, os arqueólogos nortenhos eram tendencialmente mais velhos, mas em 2014 eram já, em média, mais jovens, comparativamente com os valores nacionais. Ao longo das últimas décadas, os arqueólogos nortenhos são progressivamente mais qualificados; o número de titulares de mestrado é proporcionalmente elevado, mas são proporcionalmente menos frequentes os titulares de doutoramento. $\mathrm{O}$ amadorismo foi progressivamente abandonado entre os arqueólogos nascidos no Norte. Entre os profissionais, regista-se uma incidência superior de trabalho independente e de empresários; e uma incidência inferior de trabalho dependente e de bolseiros/investigadores. Neste grupo registam- -se também valores elevados de trabalho sem qualquer enquadramento institucional, mas um número muito elevado de arqueólogos trabalha em empresas de arqueologia e em municípios.

No Norte encontra-se sedeado um número significativo de instituições com actividade em Arqueologia, destacando-se os municípios, as empresas de arqueologia e as universidades e unidades de investigação. Entre 1970 e 2014, a actividade arqueológica portuguesa desenvolve-se de forma equilibrada em todas as regiões de Portugal continental, registando um forte crescimento (Bugalhão, 2011, p. 27), tanto em meio rural e subaquático, como, principalmente em meio urbano (Bugalhão, 2018a). A região Norte regista valores significativos nos projectos e trabalhos de investigação, especialmente sobre contextos proto-históricos e da pré-história recente. As intervenções de valorização e musealização de sítios arqueológicos é também especialmente relevante na região. Os trabalhos preventivos assumiram progressivamente prevalência quantitativa, nomeadamente no âmbito de processos de licenciamento e obras e de avaliação de impacte ambiental. As intervenções de emergência atingiram valores significativos nos anos 80 do século $\mathrm{XX}$. $\mathrm{O}$ enquadramento institucional desta actividade é bastante diversificado, destacando-se as empresas de arqueologia, a administração pública local e as universidades e unidades de investigação.

\section{BIBLIOGRAFIA}

ALMEIDA, Maria José (2007) - Inquérito Nacional à Actividade Arqueológica: uma segunda leitura sobre a actividade arqueológica nas autarquias portuguesas. Praxis Arqueológica - Revista Electrónica de Teoria, Metodologia e Política da Arqueologia. Porto. 2, pp. 129-169.

ARNAUD, José Morais, ed. (2013) - Memória e intervenção. 150 Anos da Associação dos Arqueólogos Portugueses. Lisboa: Associação dos Arqueólogos Portugueses, 110 p.

BUGALHÃO, Jacinta (2011) - Os desafios da Arqueologia portuguesa nas últimas décadas. Arqueologia e História. Lisboa, 6o-61, pp. 19-43.

BUGALHÃO, Jacinta (2016) - Arqueologia, Universidades e Ensino em números e em gráficos. Documento não publicado preparado no âmbito da Sessão "Arqueologia - Universidades e Ensino, em números e em gráficos”, organizada pela Secção de Arqueologia da Associação dos Arqueólogos Portugueses, em Lisboa, a 9 de Abril de 2016. Disponível em: https://www.academia.edu/37215410/Arqueologia_Universidades_e_Ensino_em_n\%C3\%BAmeros_e_em_gr\% 3 \%Arficos (acedido em 13 de Novembro de 2018). 
BUGALHÃO, Jacinta (2017) - Arqueólogos Portugueses. In ARNAUD, José Morais; MARTINS, Andrea, eds. - Arqueologia em Portugal / 2017 - Estado da Questão. Lisboa: Associação dos Arqueólogos Portugueses, pp. 19-31.

BUGALHÃO, Jacinta (2018a) - Arqueologia urbana, em Portugal, hoje. Revista Património. Lisboa. 5 (2017-2018), pp. 30-39.

BUGALHÃO, Jacinta (2018b) - A actividade arqueológica subaquática no quadro da Arqueologia Portuguesa. CulturAçores - Revista de Cultura. Angra do Heroísmo. 8 (Janeiro-Junho, 2018), pp.44-47.

BUGALHÃO, Jacinta (no prelo) - Gender divergence and convergence in Portuguese Archaeology. Actas do AGE Workshop 2017. Gender and Change in Archaeology, Lisboa, 19 e 20 de Outubro de 2017. Instituto de História Contemporânea, Grupo Ciência: Estudos de História Filosofia e Cultura Científica (Universidade de Évora), Faculdade de Ciências Sociais e Humanas da Universidade Nova de Lisboa, Secção de Arqueologia da Sociedade de Geografia de Lisboa e AGE, Archaeology and Gender in Europe. Archeaopress.

CENTENO, Rui; SOEIRO, Teresa; SANCHES, Maria de Jesus (2013) - Caminhos e encruzilhadas. O ensino e a investigação em Arqueologia na Faculdade de Letras da U.P. Revista da Faculdade de Letras. Ciências e Técnicas do Património (Homenagem a Armando Coelho Ferreira da Silva). Porto. XIII, pp. 31-48.

DIAS, Lino Tavares (1998) - A Escola Profissional de Arqueologia enquanto instituição de suporte para a investigação arqueológica. In SILVA, Maria Isabel; MAIA, Maria Isaura dos Santos; SOUSA, Maria José Carvalho e; PINTO, Paulo Costa, eds. (1998) - Encontros Cem anos de Arqueologia "O Archeólogo Português". Vila do Conde: Associação de Protecção do Património Arqueológico de Vila do Conde, pp. 37-40.

FABIÃO, Carlos (1999) - Um século de Arqueologia em Portugal - I. Al-Madan. Almada. II Série, 8, pp. 104-126.

FABIÃO, Carlos (2011) - Uma História da Arqueologia Portuguesa. Das origens à descoberta da Arte do Côa. Lisboa: Clube do Coleccionador dos Correios/CTT Correios de Portugal, $192 \mathrm{p}$.

JORGE, Susana Oliveira (2003) - A Faculdade de Letras da Universidade do Porto e a Pré-História do Norte de Portugal: notas para a história da investigação dos últimos vinte e cinco anos. In Os Reinos Ibéricos na Idade Média: livro de homenagem ao Professor Doutor Humberto Carlos Baquero Moreno, Porto: Universidade do Porto/Faculdade de Letras, vol. 3, pp. 1453-1482.

JORGE, Susana Oliveira; JORGE, Vítor Oliveira (1996) Women in Portuguese archaeology. Trabalhos de Antropologia e Etnologia. Porto. XXXVI, pp. 159-167.

JORGE, Vítor Oliveira (1986) - Sobre a importância de se organizar a arqueologia portuguesa por meio de projectos e de se definir uma hierarquia de competências de quem neles intervém. Arqueologia. Porto. 13 (Junho de 1986), pp. 2-5.

JORGE, Vítor Oliveira; MARQUES, Teresa (1992) - A Arqueologia nas Universidades. Al-Madan. Almada. II Série, 1, pp. 36-38.

LAGO, Miguel (2003) - Profissão: arqueólogo (na transição do milénio). In CARNEIRO, Sérgio, ed. - Nos 10 Anos da APA. Que Futuro para a Arqueologia Profissional? Porto: Associação Profissional de Arqueólogos, pp. 95-108.

LEMOS, Francisco Sande (1987) - As três idades da arqueologia portuguesa. Forum. Braga. 2, pp. 5-11.

LEMOS, Francisco Sande (2003) - Arqueologia em Portugal em tempo de crise. In CARNEIRO, Sérgio, ed. - Nos 10 Anos da APA. Que Futuro para a Arqueologia Profissional? Porto: Associação Profissional de Arqueólogos, pp. 49-55.

LEMOS, Francisco Sande (2007) - Memórias do Tempo recente... Al-Madan. Almada. II Série, 15, pp. 106-109.

MEIRELES, José (2006) - A Arqueologia na Universidade do Minho. Al-Madan. Almada. II Série, 14 (Dezembro de 2006), pp. 116-117.

PORDATA - Pordata, Base de Dados de Portugal Contemporâneo. Fundação Francisco Manuel dos Santos. Disponível em: http://www.pordata.pt/.

RAPOSO, Jorge (2006) - Bolonha e o Ensino da Arqueologia e de Áreas de Conhecimento Afins. Al-Madan. Almada. II Série, 14 (Dezembro de 2006), pp. 102-110.

RAPOSO, Jorge (2016) - Sítios Arqueológicos Portugueses Revisitados: 500 arqueossítios ou conjuntos em condições de fruição pública responsável. Al-Madan. Almada. II Série, 20 (Janeiro de 2016), pp. 70-196.

REAL, Fernando C. S. (1995) - A Arqueologia Portuguesa em mapas e números. In JORGE, Vítor Oliveira, ed. $-1 .{ }^{\circ}$ Congresso de Arqueologia Peninsular. Actas, VIII (Trabalhos de Arqueologia e Etnologia, XXXV: 4). Porto: Sociedade Portuguesa de Antropologia e Etnologia, pp. 19-40.

SILVA, António Manuel (2003) - A APA, a razão e sentido de uma associação profissional. In CARNEIRO, Sérgio, ed. - Nos 10 Anos da APA. Que Futuro para a Arqueologia Profissional? Porto: Associação Profissional de Arqueólogos, pp. 67-76.

SOEIRO, Teresa (2006) - Licenciatura em Arqueologia na Universidade do Porto: adequação ao "Processo de Bolonha”. Al-Madan. Almada. II Série, 14 (Dezembro de 2006), pp. 118-119. 


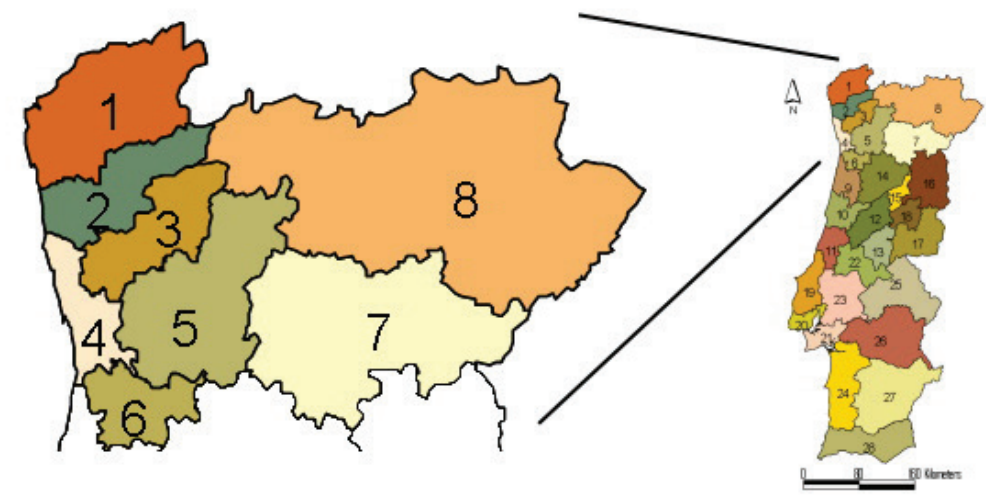

Figura 1

Diplomados em Arqueologia em estabelecimentos de ensino superior da região Norte por quinquénio 1975 - 2014

(valores estimados a tracejado)

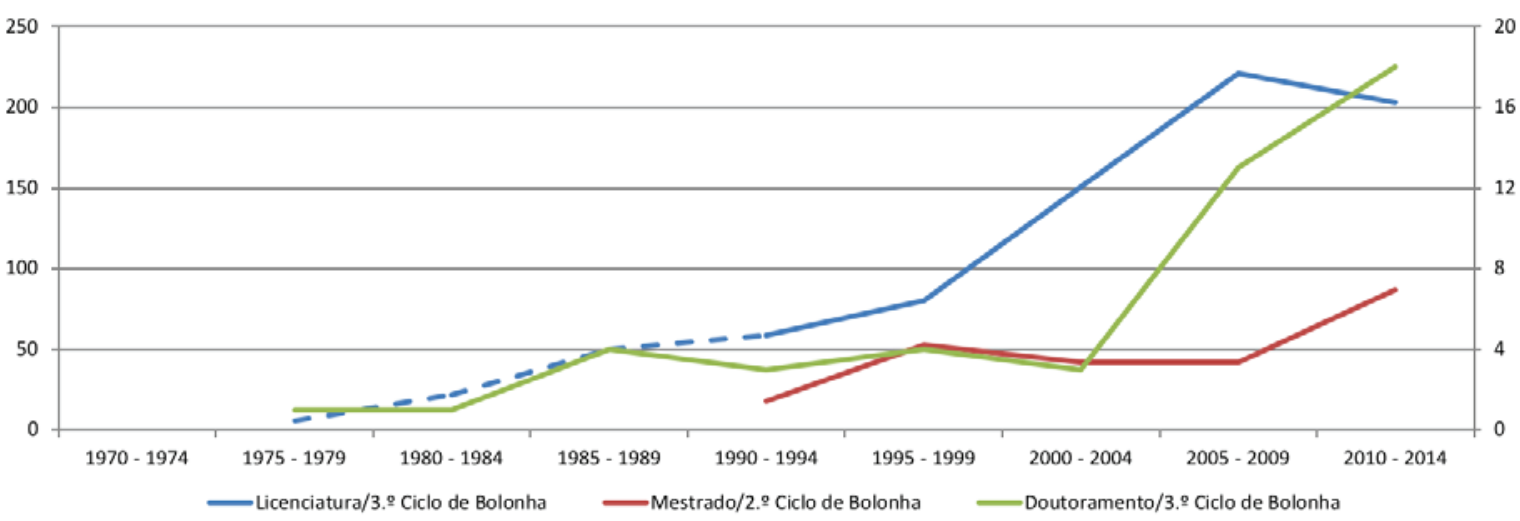

Gráfico 1

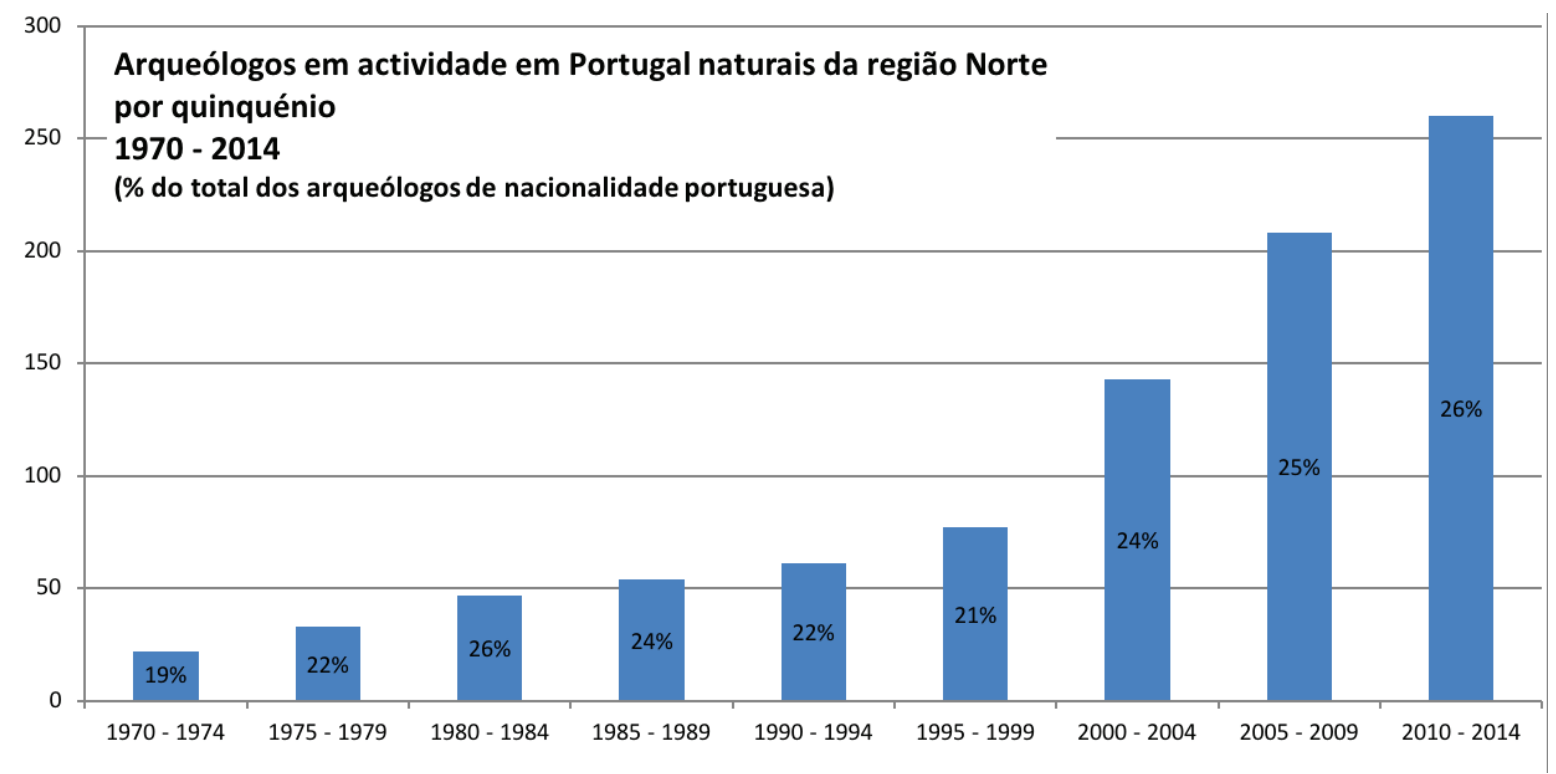

Gráfico 2 
Arqueólogos em actividade em Portugal naturais da região Norte

1970 - 2014

Sexo por quinquénio

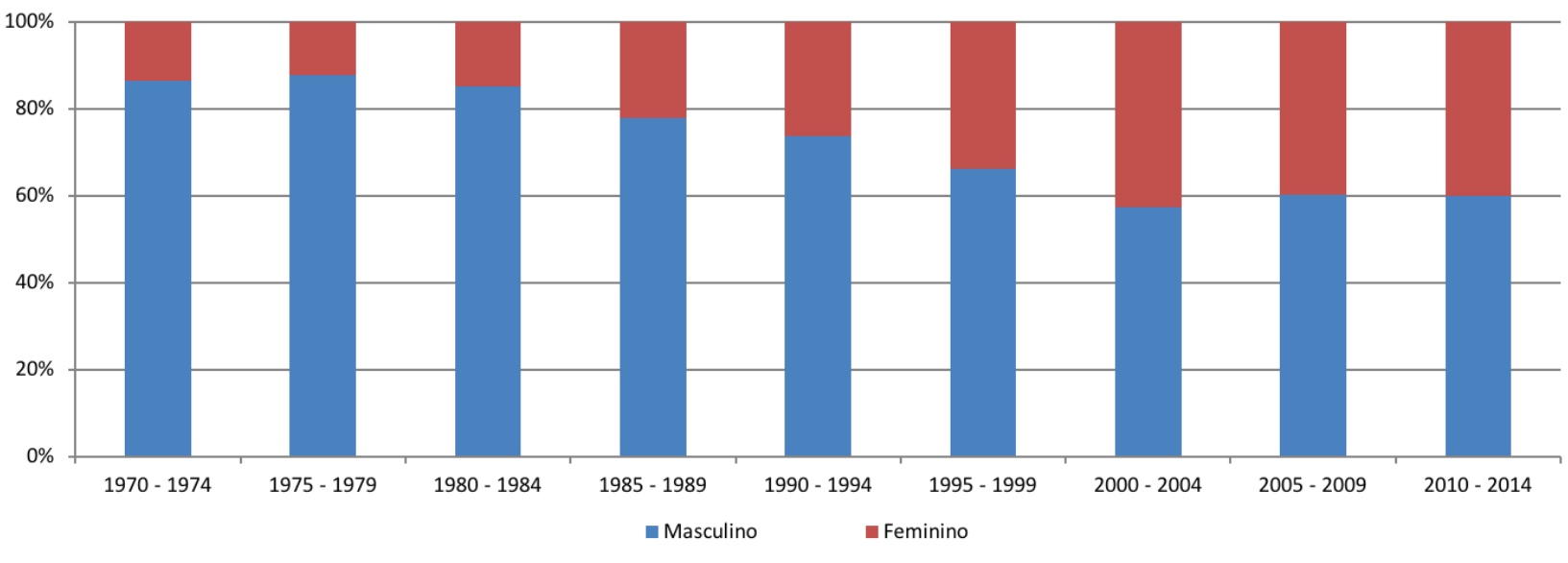

Gráfico 3

Arqueólogos em actividade em Portugal naturais da região Norte

1970 - 2014

Média etária por quinquénio

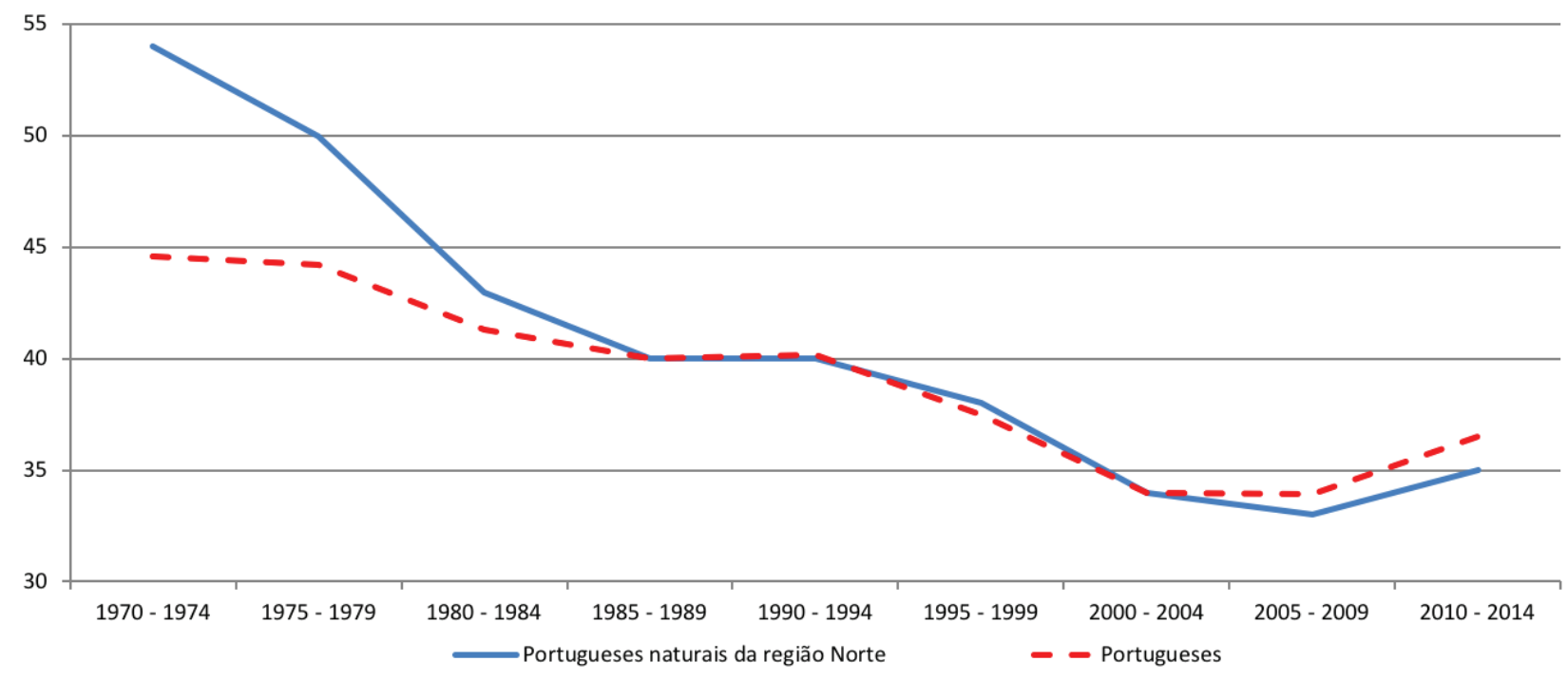

Gráfico 4 
Arqueólogos em actividade em Portugal naturais da região Norte

1970 - 2014

Habilitação académica no quinquénio

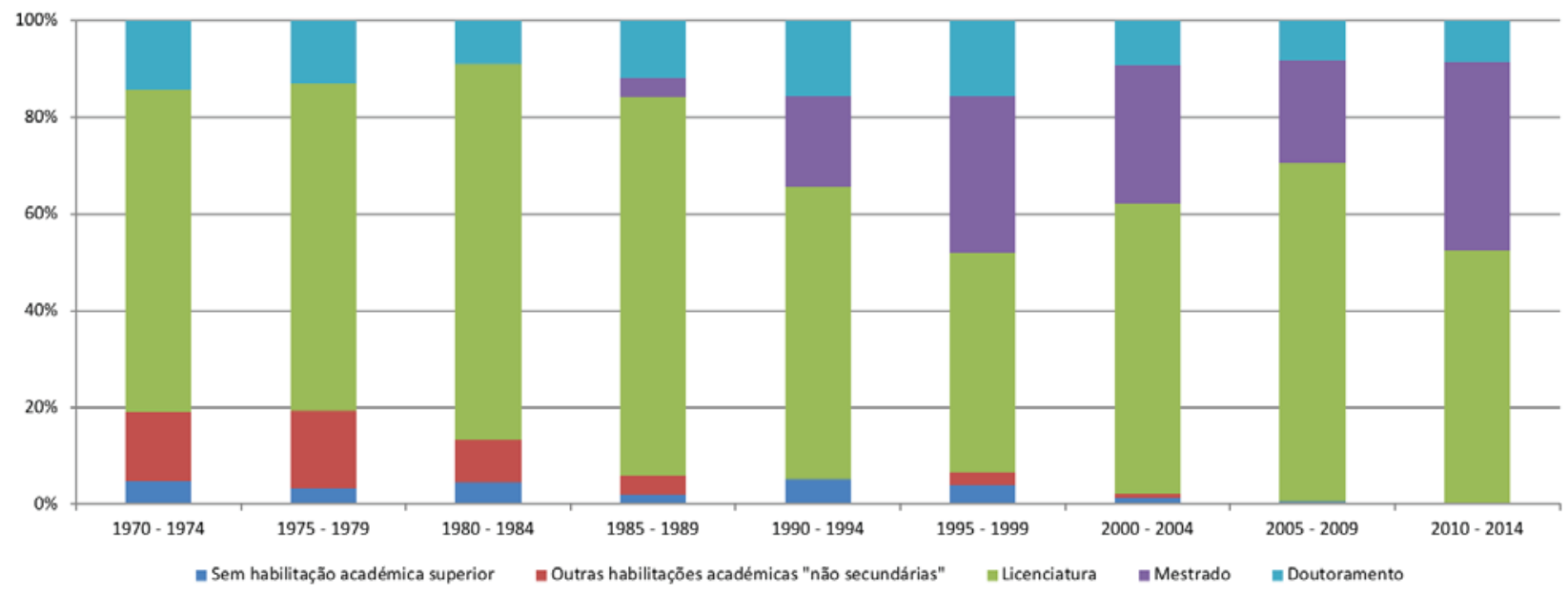

Gráfico 5

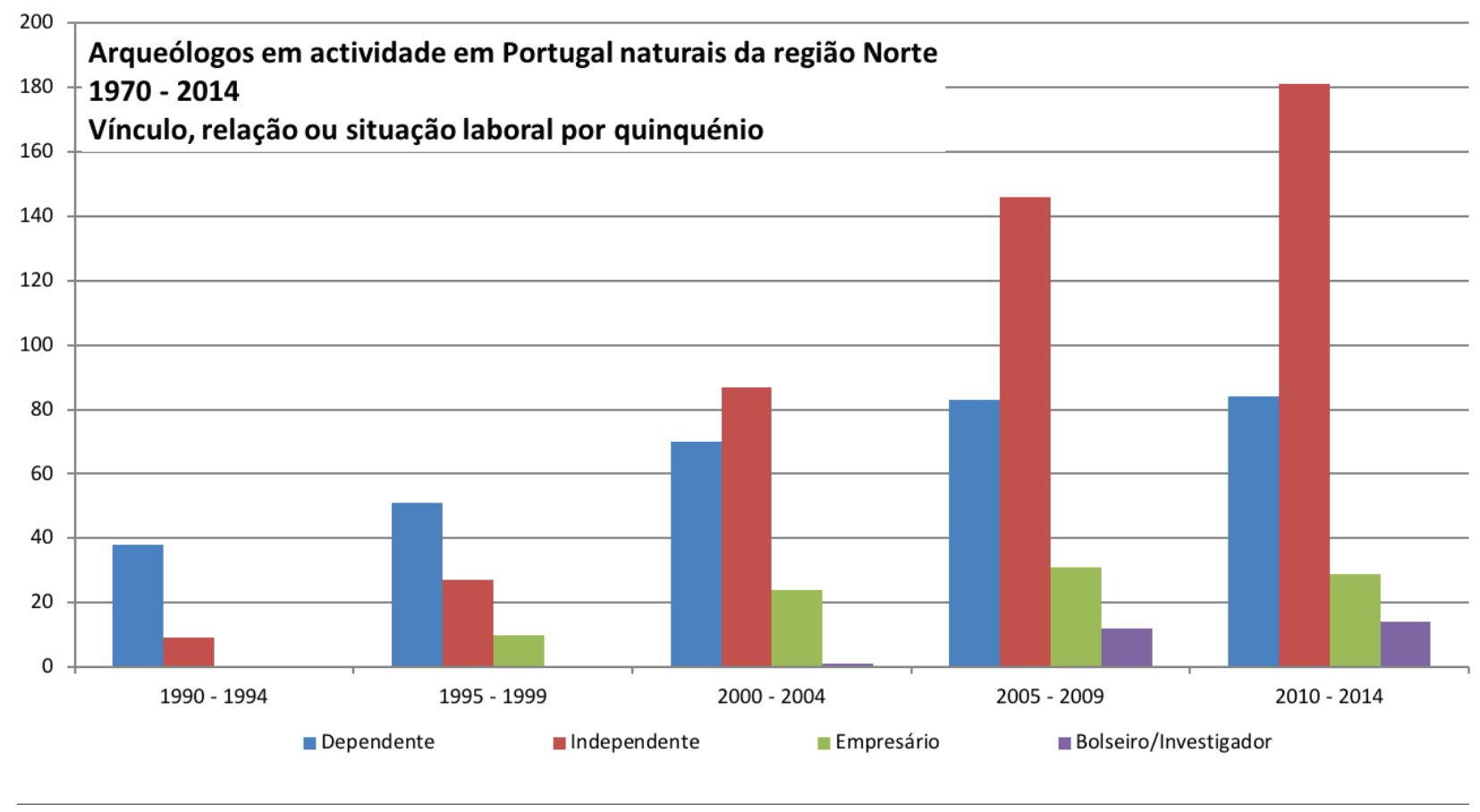

Gráfico 6 


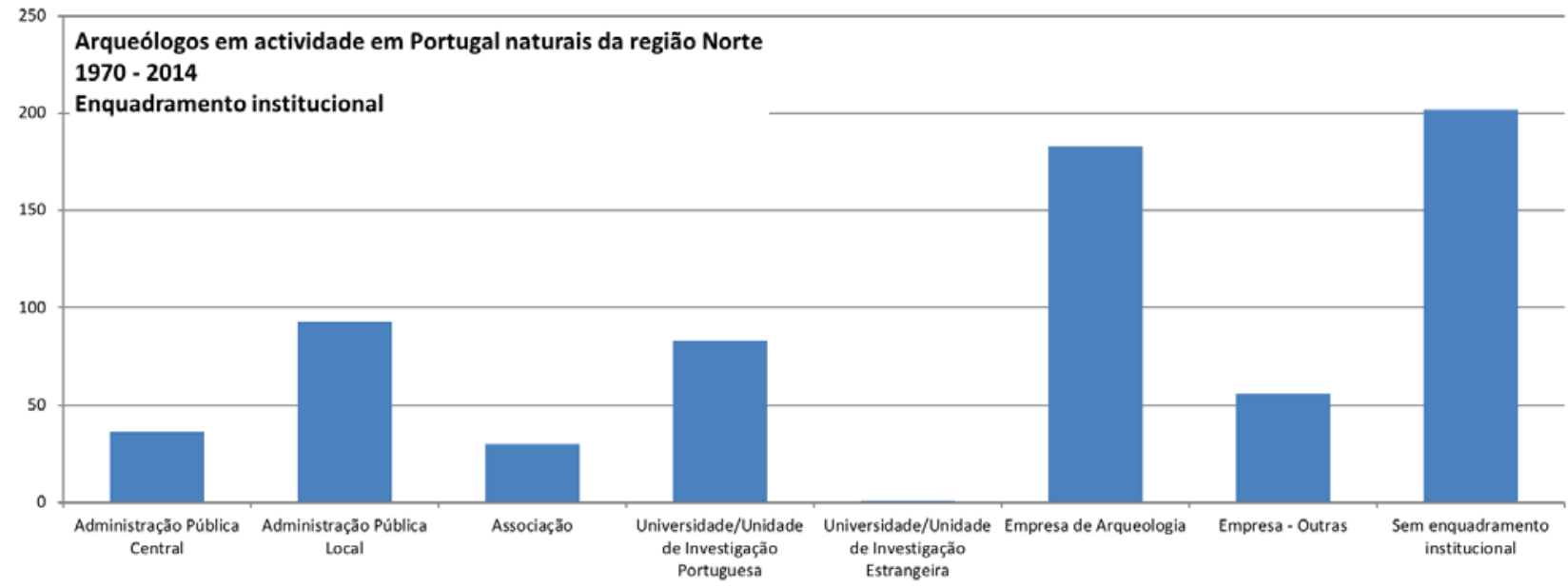

Gráfico 7

Instituições com actividade em Arqueologia sedeadas na região Norte

1970 - 2014

Tipo

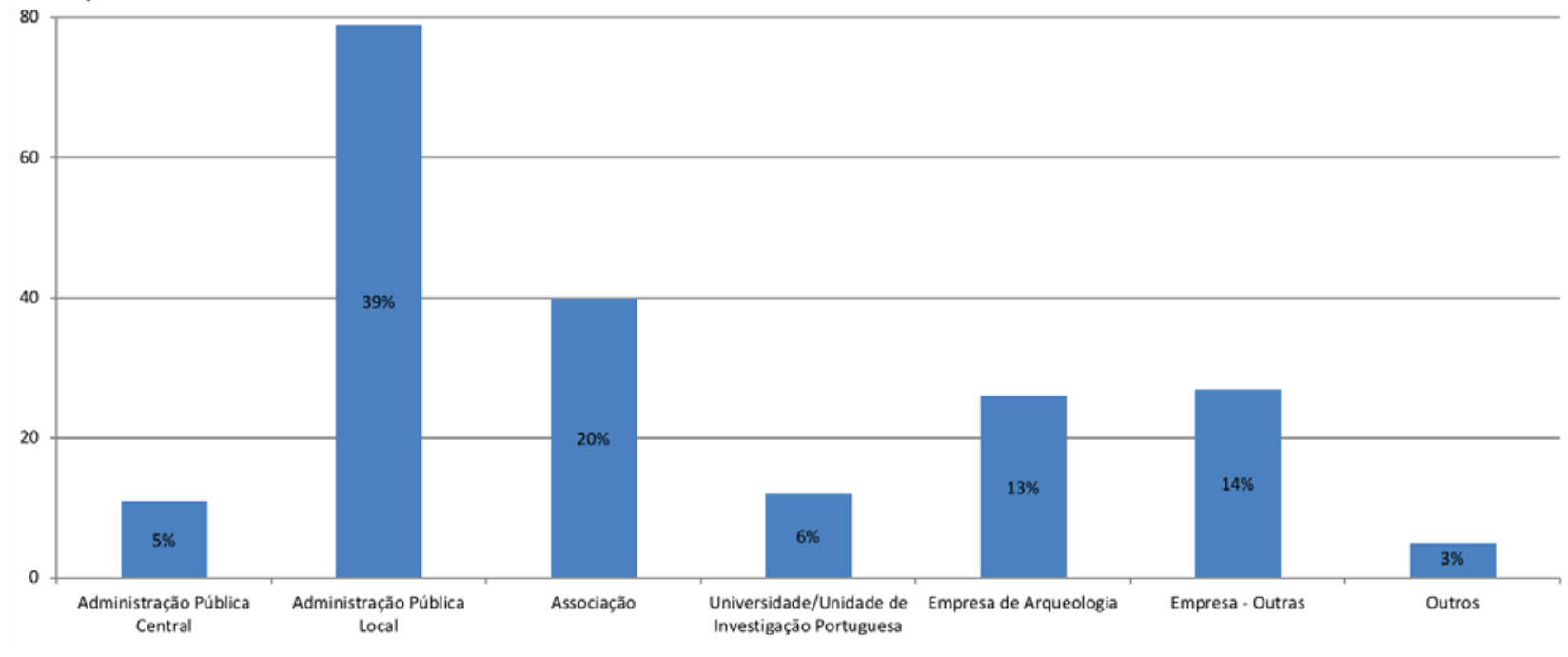

Gráfico 8 


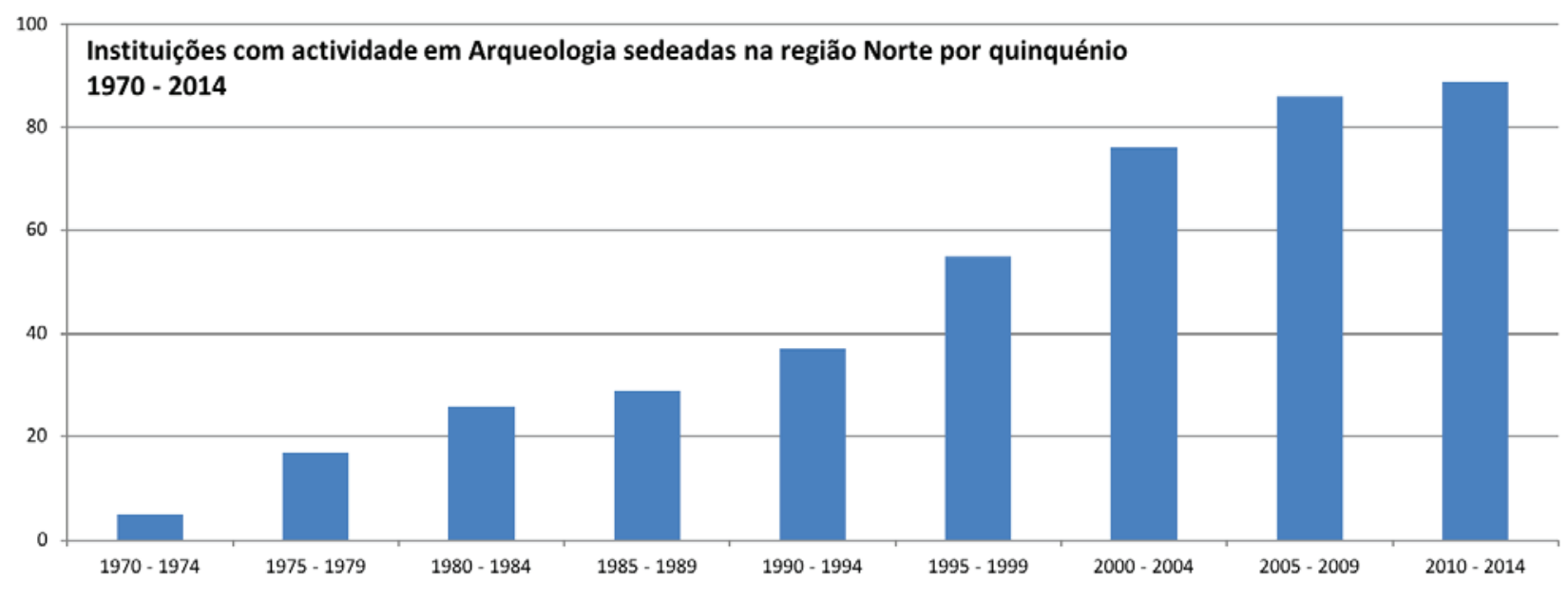

Gráfico 9

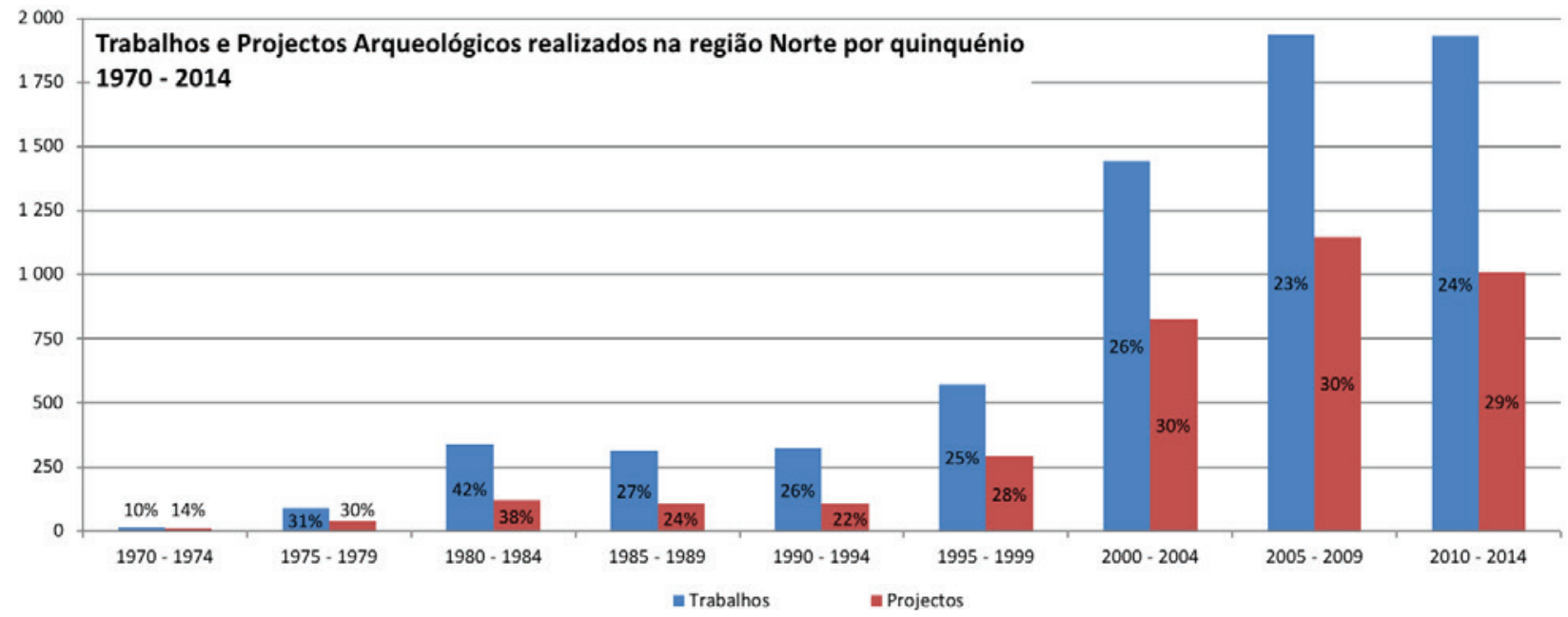

Gráfico 10 


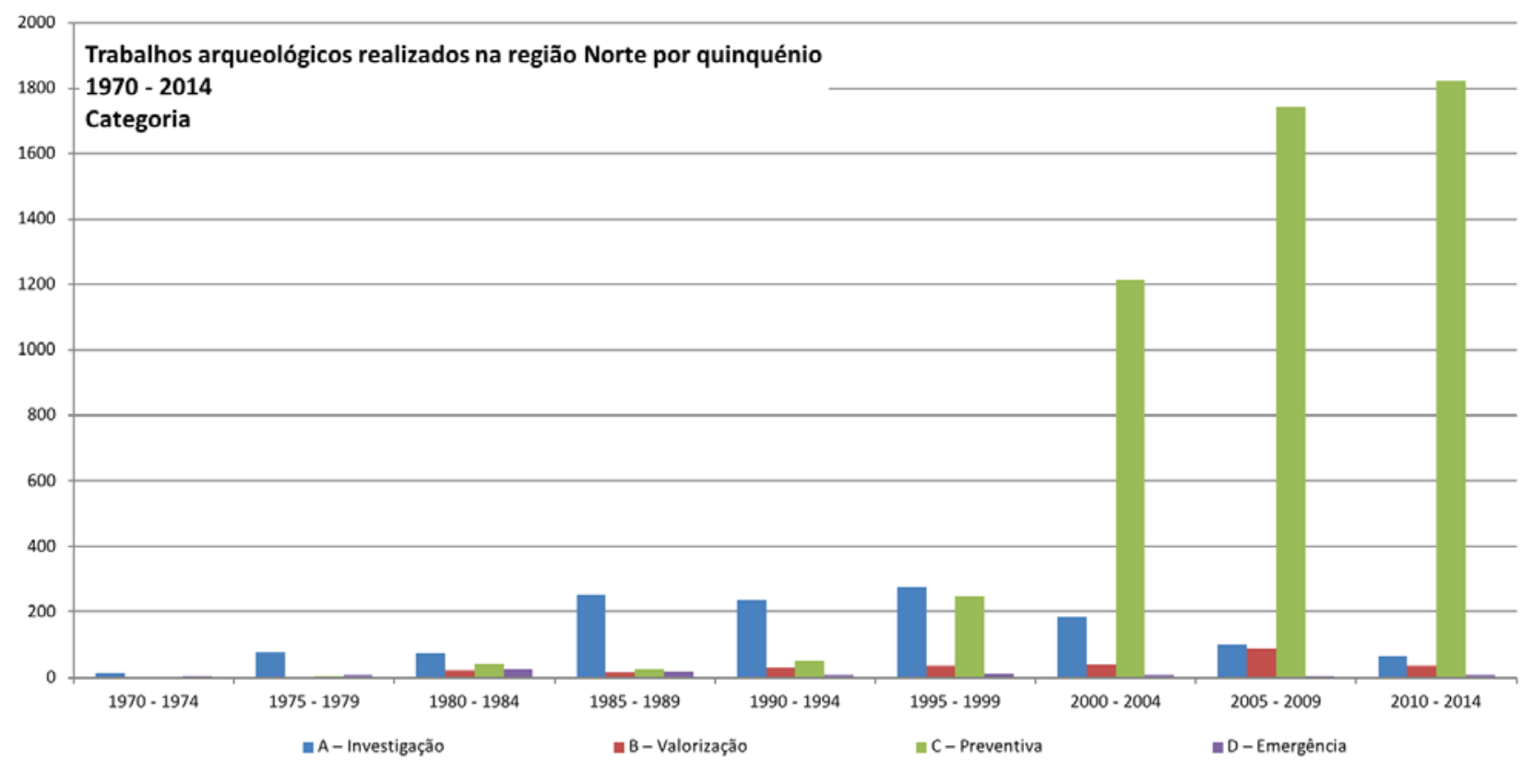

Gráfico 11

Projectos de Investigação desenvolvidos na região Norte

1970 - 2014

Período histórico

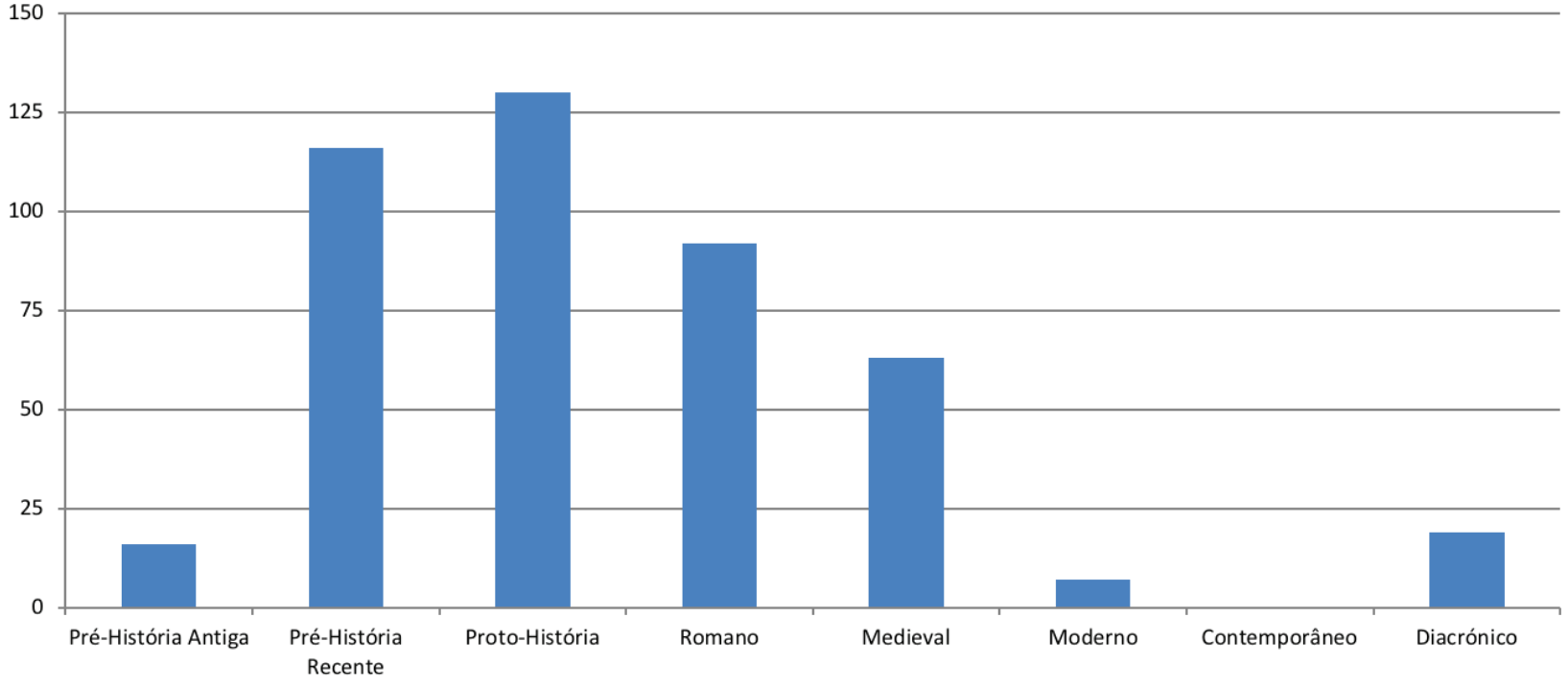

Gráfico 12 


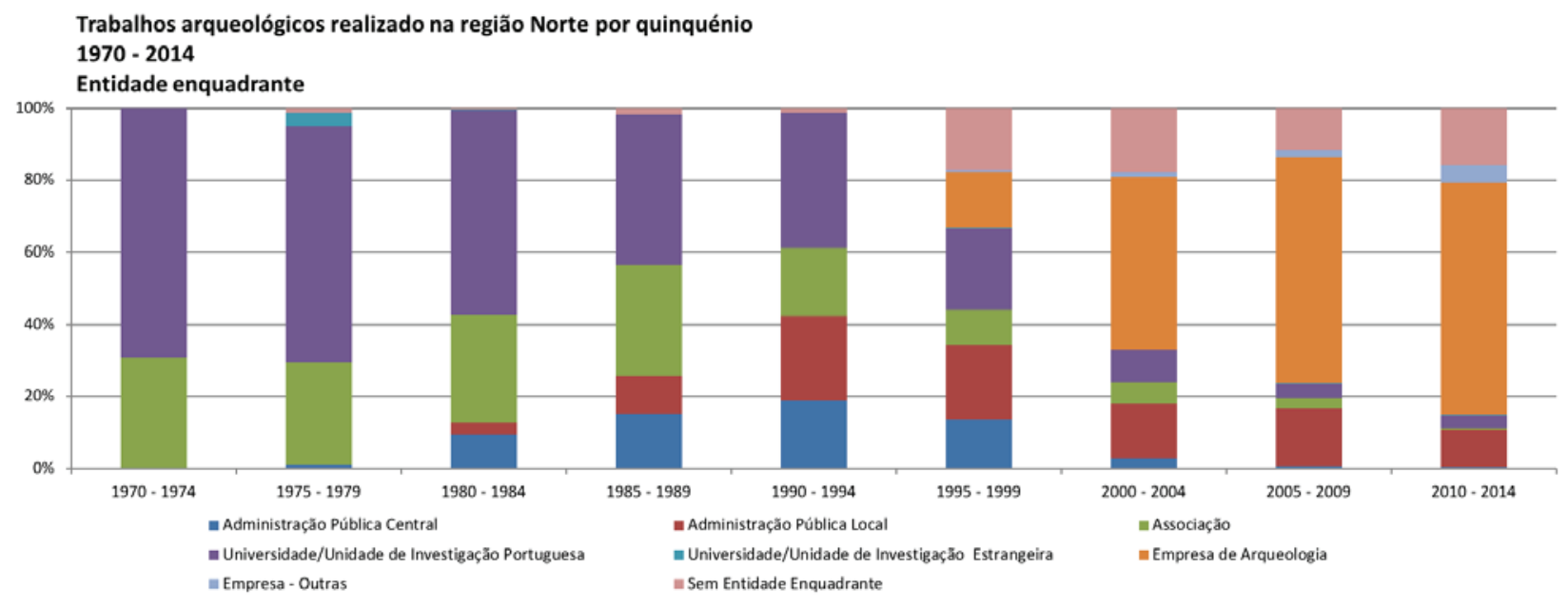

Gráfico 13

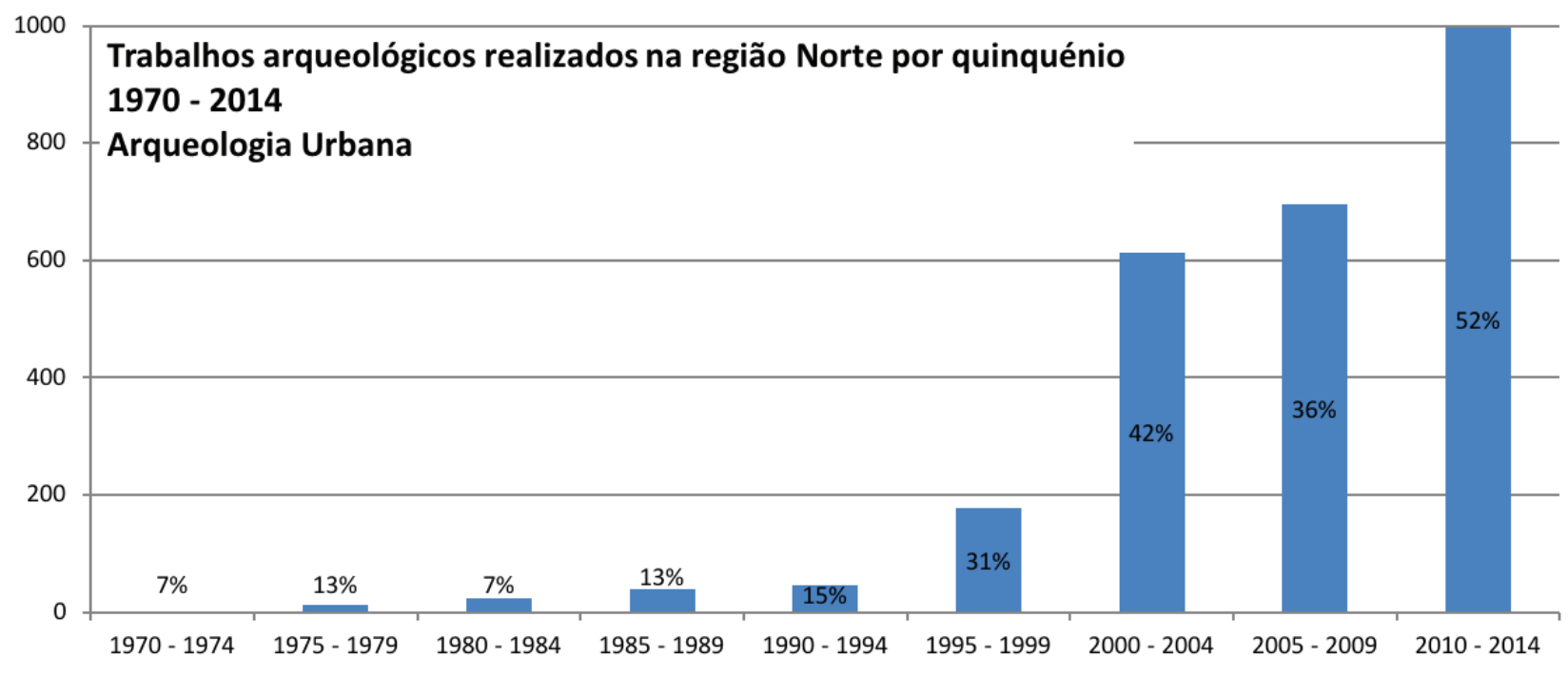

Gráfico 14 


\title{
VIEIRA GUIMARÃES (1864-1939) E A ARQUEOLOGIA EM TOMAR: UMA ABORDAGEM SOBRE O TERRITÓRIO E AS GENTES
}

\author{
João Amendoeira Peixoto' ${ }^{1}$, Ana Cristina Martins ${ }^{2}$
}

\begin{abstract}
RESUMO
Nascido em Tomar em 1864, formado em medicina pela Escola Médico Cirúrgica de Lisboa, José Vieira Guimarães falece em Lisboa em 1939. Durante a sua vida desempenhou várias ações para a valorização do património cultural da terra onde nasceu, participa em projetos arqueológicos e publicações, assim como, contacta com estudiosos como o arqueólogo José Leite de Vasconcelos.

José Vieira Guimarães envolve-se em associações e academias, é sócio da Associação dos Arqueólogos Portugueses, participa em escavações, investiga, publica artigos e livros, participa em congressos, firma a hipótese, de Seilium romana se situar em Tomar.

Apresentamos conteúdo inédito sobre a participação num congresso em 1923, assim como, consideramos que comete uma falha, em nossa opinião, a prova potencial do seu trabalho.

Palavras-chave: José Vieira Guimarães, Tomar, Arqueologia, Seilium, Território.
\end{abstract}

\begin{abstract}
Born in Tomar in 1864, graduated in medicine from Escola Médico Cirúrgica de Lisboa, José Vieira Guimarães died in Lisbon in 1939. During his life performed several actions to enhance cultural heritage from Tomar. He had participated in archaeological projects, publications and contacted with scholars like the archaeologist José Leite de Vasconcelos.

José Vieira Guimarães was involved in associations and academies, was a member of Association of Portuguese Archaeologists, had participated in excavations, investigated, published articles and books, participated in congresses, confirmed the hypothesis of Seilium romana being located in Tomar.

We present unprecedented content about his participation in a congress in 1923, as well as, we consider that he had fault with the potential proof of his work.

Keywords: José Vieira Guimarães, Tomar, Archaeology, Seilium, Territory.
\end{abstract}

\section{ENQUADRAMENTO INTRODUTÓRIO}

A comunicação "Vieira Guimarães (1864-1939) e a Arqueologia em Tomar: uma abordagem sobre o território e as gentes" presente no III Congresso da Associação dos Arqueólogos Portugueses, que decorre de 19 a 22 de novembro de 2020, inclui conteúdo incorporado no trabalho de doutoramento em História e Filosofia da Ciência da Universidade de Évora, coordenação da Prof. Doutora Maria de Fátima Nunes, intitulado: Medicina e Património Cultural em Tomar - o caso de José Vieira da Silva Guimarães, e orientação da Prof. Doutora Ana Cristina Martins.

\section{ARQUEOLOGIA E PATRIMÓNIO CULTURAL EM TOMAR}

Sobre a arqueologia em Tomar, é necessário relembrar o século XIX em que o conhecimento da Antiguidade Clássica é cultivado pelas Academias e Socieda-

\footnotetext{
1. Universidade de Évora; joaoalveı@gmail.com

2. Universidade de Évora; acmartins@uevora.pt
} 
des eruditas, sendo de dar destaque à Associação dos Arquitetos Civis Portugueses, fundada em 1863 por Joaquim Possidónio da Silva (1806-1896) ${ }^{3}$, que tinha em Tomar como sócio correspondente Pedro de Roure Pietra (1815-1874)4, elemento que realizou escavações na região (Peixoto, 2020). Esta associação é designada, a partir de 1871, através da agregação da componente arqueológica, por Real Associação dos Arquitetos Civis e Arqueólogos Portugueses (RAACAP) (Martins, 2013; Martins, 2015; Martins, 2016).

De Pedro de Roure Pietra, das várias intervenções arqueológicas que executa, é de assinalar a descoberta de cipos romanos em 1857 , confirmação da presença romana em terras nabantinas, tendo Joaquim Possidónio da Silva publicado um artigo sobre $\mathrm{Na}$ bância em 1881, onde relembra o seu correspondente, no Boletim da Real Associação dos Architectos Civis e Archeologos Portuguezes, e refere a descoberta da cidade romana Nabância em Portugal, neste caso concreto em Marmelais5. (Silva, 1881) É, no entanto, de assinalar que Nabância é mencionada e identificada na região de Tomar por outros autores de séculos anteriores a esta publicação. ${ }^{6}$

Tendo em consideração que os principais centros de conhecimento estavam localizados em Lisboa,

3. Joaquim Possidónio Narciso da Silva (1806-1896), fidalgo e arquiteto da Casa Real, fundador da Associação dos Arquitetos Civis Portugueses em 1863. (Martins, 2013)

4. Pedro de Roure Schiappa Pietra (1815-1874), administrador de fábricas, agrónomo, político, sócio correspondente n.o 68, junho de1864, da Associação dos Arquitetos Civis Portugueses. (Peixoto, 2020)

5. Possidónio da Silva localiza a sua descoberta em "Marmelaio" no lugar de Marmelais, que pode ser subdivido atualmente em Marmelais de Baixo e Marmelais de Cima, localizando-o a dois $\mathrm{km}$ de Tomar e a um $\mathrm{km}$ da margem esquerda do rio Nabão, situado na antiga freguesia de Santa Maria dos Olivais, hoje União de Freguesias de Tomar. (Silva, 1895). Sobre este assunto, a Direção Geral do Património Cultural atribui outra designação às "ruínas de Nabância", a de "Vila romana de Cardais", dado tratar-se do sítio de Cardais em Marmelais de baixo.(DGPC, 2020) De acordo com Ana Cristina Martins (2003), este tema foi bastante debatido pelo Concelho Superior de Monumentos, no que toca ao valor histórico e arqueológico do sítio ponderando-se a hipótese de desclassificação. (Martins, 2003)

6. Vide, a título de exemplo, a obra "História da Vida e Martyrio da Gloriosa Virgem Santa Eria, Freira da Ordem Patriarcha Sam Bento, natural de Nabancia, que hoje he a notavel Villa de Thomar em o Reyno de Portugal" publicado em 1618 e da autoria do Freire Isidoro da Barreira.
Coimbra e Porto, por motivos de recursos humanos e materiais, a dimensão do património cultural de Tomar, através da sua história, monumentos e ruínas, levaram alguns eruditos a realizar intervenções na região, surgindo Vieira Guimarães nesta contenda. (Martins, 2016)

José Vieira da Silva Guimarães (1864-1939), natural de Tomar e formado em Medicina na Escola Médico Cirúrgica de Lisboa, realiza todo um percurso de vida centrado na valorização da terra de onde é natural, tendo participado em diversas associações, academias e sociedades, publicado obras literárias, recebido o grau de Comendador da Ordem de Cristo em 1903, é eleito deputado da nação e torna-se professor de História e Geografia no Liceu Camões em Lisboa desde 1905, ocupando o cargo de diretor da Sociedade Propaganda de Portugal em 1914, entre mais, torna-se sócio correspondente da RAACAP em 1905. (Peixoto, 2019) (Figura 1)

Sobre José Vieira Guimarães há dois assuntos de relevância na história da Arqueologia em Tomar. O primeiro acontece em 1895 , ainda como estudante de medicina, em que participa numa investigação na igreja de Santa Maria dos Olivais; sobre o segundo assunto, na década de vinte do século XX, em que publica a obra THOMAR S.ta IRIA (1927) sobre as origens romanas de Tomar, teoriza a localização de Seilium na região nabantina, sendo necessário realçar que o envolvimento de José Vieira Guimarães na Arqueologia em Tomar, entre estes dois momentos, surge como permanente tal como teremos a oportunidade de verificar. (Guimarães, 1927)

\section{AS COMEMORAÇÕES DO CENTENÁRIO DE D. GUALDIM PAIS}

A relevância da história local é constantemente elevada na segunda metade do século XIX pela população tomarense com enfoque através da imprensa e comemorações.

José Vieira da Silva Guimarães idealiza em 1895 a criação de um centenário dedicado a D. Gualdim Pais, quarto mestre da Ordem dos Templários, fundador do castelo e vila de Tomar, que incorpora uma série de festejos onde os monumentos, história local e indústria nabantina são colocados em destaque através dos mais diversos meios de divulgação tal como a imprensa local e nacional, assim como, de uma exposição agrícola e industrial concelhia sobre a qual, o estudante de medicina, publica o Catálogo 
da Exposição Industrial-Agrícola de Thomar. Esta será a primeira publicação de José Vieira Guimarães, nela discorre sobre as origens de Tomar, remontando a epochas romanas, acharemos a origem da famosa Nabancia, relembrando que é na região onde se situam estas ruínas que D. Gualdim Pais escolhe a edificação do castelo. (Guimarães, 1895, p. 3)

Na edição do semanário local A Verdade, № ${ }^{\circ} 81$ de 14 de abril de 1895, meses antes das comemorações dedicadas ao fundador de Tomar, é publicada a notícia "Última Hora", onde revela que Manuel Henrique Pinto e José Vieira da Silva Guimarães, após investigações, descobrem a campa e repectivo epitaphio de D. Gualdim Paes, os quaes ha muito se consideravam perdidos ou anniquillado. (Magalhães, 1895 , p. 3) (Figura 2).

Esta descoberta envolveu escavações na Igreja de Santa Maria dos Olivais ${ }^{7}$ em Tomar, sendo que os elementos sepulcrais do mestre templário se encontravam desaparecidos tal como nos revela Pedro de Roure Pietra numa publicação na Gazeta de Portugal em $1863^{8}$, onde confirma o facto quando se refere às obras mandadas erguer na igreja durante os reinados de D. Manuel I e de D. João III: os mestres haviam barbaramente (...) sepultados os ossos em uma das capellas laterais, que então foram abertas, collocando uma inscripção na parede, que o padre Carvalho diz ter visto, mas que ainda até hoje não foi possivel descobrir. (Costa, 1712; Pietra, 1863, p.1)

A lápide parietal do túmulo de D. Gualdim Pais, encontra-se hoje exposta na Igreja de Santa Maria dos Olivais em Tomar, no entanto, sobre a campa, tal como é noticiado, ou sepulcro deste cavaleiro templá-

7. Templo de origens beneditinas, reconstruído no século XII pelos templários, também denominado de Igreja de Santa Maria do Olival, está localizado na antiga freguesia de Santa Maria dos Olivais em Tomar, hoje pertencente à União das Freguesias de Tomar, entre a Avenida D. Maria II e a Rua Aquiles da Mota Lima.

8. Através de uma carta de Pedro de Roure Pietra presente na correspondência de Possidónio da Silva, foi possível localizar junto da Biblioteca Nacional de Portugal of folhetim da autoria de Pedro Pietra presente na Gazeta de Portugal (Pietra, 1863), que inclui a informação sobre o desaparecimento da inscrição dedicada ao mestre templário D. Gualdim Pais. Segundo Pietra (1963), a fonte da existência desta inscrição é o Tomo III da Corografia portugueza e descripçam topografica do famoso Reyno de Portugal do padre António Carvalho da Costa; informação que se confirma consultando a obra na página 156: (...) em cuja parede se pozo epitáfio de D. Gualdim (...). (Costa, 1712) rio, é presentemente desconhecida a sua existência. Necessário ressalvar que a edição seguinte do jornal A Verdade, a № 782 de 21 de abril, refere igualmente o envolvimento de José da Silva Magalhães na descoberta, arquitecto e irmão do editor deste jornal, António da Silva Magalhães (1834-1897) ${ }^{9}$ : esquecemos de dizer, já no número passado, que o Sr. José da Silva Magalhães tem sido um excellente cooperador nas investigações a que os nossos amigos Pinto e o Guimarães tem precedido em Sta. Maria dos Olivaes. (Magalhães, 1895a, p. 2)

Nesta edição é mencionado também o conteúdo da inscrição descoberta na igreja de Santa Maria do Olival em Tomar:

Dissemos no número passado que se tinha encontrado o glorioso epithaphio do glorioso fundador da nossa formosa cidade. Devido, como também dissemos, às investigações dos nossos amigos Manuel H. Pinto e Vieira Guimarães, e que se tinha alcançado aquele bom resultado $^{\text {10 }}$ (Magalhães, 1895a, p. 2)

9. António da Silva Magalhães (1834-1897), fotógrafo, editor, fundador e proprietário da Typografia Photographia Tomarense, onde se imprimiu o primeiro jornal local A Emancipação, ao qual se seguiu o jornal A Verdade por si criado do qual é diretor e proprietário, dedicou-se igualmente ao colecionismo, teatro, política e arqueologia. É próximo de José Vieira Guimarães, tendo este lhe dedicado alguns dos seus trabalhos escritos. (Ventura, 2014)

10. Por considerarmos de utilidade para este artigo, transcrevemos a restante informação desta notícia: (...) Pois tratando-se agora de levar a efeito a celebração do $7^{\circ}$ centenário do seu passamento, vinha lançar imensa luz sobre este notável acontecimento e coroar a obra benemérita a que aquelles nossos amigos se têm devotado. A inscrição é a mesma que estava no grande túmulo onde admiram por longos séculos os venerados restos de tão illustre guerreiro. São prova disso a forma da cruz dos Templários que se acha no principio do epithaphio, a era de Cézar, que só no reinado de D. João I começou a ser substituida pela de Christo. E os escriptores antigos que merecem credito pelo escriptos everassidade com que escreveram as suas chronicas. Diz ele em latim: Oblit frater Gualdinus magister militum templo portugalie era milesima ducentosi (...) tertia, tertio Ibidus octobris. Hic castrum Tomaris cum multis aliis populauit. requiescat in pace. Amen. A tradução deve ser: Faleceu o irmão Gualdim mestre dos cavaleiros do Templo em Portugal ao 13 d'outubro de 1195. Este, com muitos outros cavalleiros povoou o castello de Thomar. Descanse em Paz. Amen.

Por aqui se vê pois que a morte de Gualdim Pais, esse Templário illustre a quem Portugal tanto deve pela ações homérias de valor e lealdade e pelo seu alto tato politico, foi a 13 de outubro de 1195 
Surge neste jornal outra informação relevante, sobre uma nova descoberta na Igreja de Santa Maria dos Olivais, refere-se à sua data de fundação:

Mais um preciso indicio se descobriu um dia d'esta semana e se chega a esclarecer melhor, talvez venha em auxílio d'aquelles que depois de longos estudos, se incliname a dizer que tudo que hoje ainda se vê do principal em SMaria é (?) de Gualdim Paes. Na porta principal em duas pedras veem se algumas letras, indicando que grande inscrição alli tivesse existido. Do que resta só há a palavras Era e mais 2 XIII que parece indicar o anno da fundação d'aquelle templo. Pois, se se chegar a recompôr aquella era, sômos levados a crer que será a de 1213, nos quaes tirando 38 annos de avança da era de Cezar, temos o anno de 1175, anno em que Gualdim Paes era vivo (Magalhães, 1895a, p. 2)

Com base na bibliografia consultada e na informação disponibilizada pela Direção Geral do Património Cultural, não há indícios desta data e da fundação templária da Igreja de Santa Maria dos Olivais, remetendo para o século XII: A primitiva igreja terá sido edificada no século XII, por iniciativa de D. Gualdim Pais, mestre da Ordem do Templo, para cemitério dos freires. (...). Em visita ao local, por observação direta, foi possível identificar, na porta principal, a inscrição mencionada. (Direção Geral do Património Cultural, 2020)

Manuel Henrique Pinto (1853-1912), noticiado como participante nesta descoberta na companhia de José Vieira Guimarães, trata-se do pintor naturalista, elemento do Grupo O Leão e próximo de José Malhoa (1855-1933), ambos pintores do primeiro naturalismo português, que em 1895 cumpria funções como diretor da Escola de Desenho Industrial Jácome Ratton em Tomar desde 1888, ano em que ocupa o lugar do seu falecido amigo Cipriano Martins (1841-1888), outro elemento do Grupo O Leão. (Museu Centro de Artes Figueiró dos Vinhos, 2020)

Neste mesmo ano é publicada a obra Inscripções Portuguezas (1895) da autoria de Luciano Cordeiro (1844-19oo), historiador e geógrafo português, onde o epitáfio está incluído na obra, tendo o autor feito referência ao centenário valorizando a,

feliz ideia de tomar por tema o nome e a memória do valente Templario portuguez Galdino Paes, tão deploravelmente esquecido tambem, e de quem póde dizer-se que foi, alem de fundador de Thomar, um dos mais intrepidos e persistentes cooperadores da fundação de Portugal (Cordeiro, 1895, p. 46) (Figura 3).

Luciano Cordeiro menciona nesta obra a sua amizade com o pintor Manuel Henrique Pinto, assim como, uma ligação profissional ao revelar que o mesmo o tem auxiliado na recolha de calcos de inscrições portuguesas. O geógrafo confirma igualmente a presença de mais dois amigos presentes na investigação de Santa Maria dos Olivais, que de acordo com a informação já apresentada correspondem a José Vieira Guimarães e a José da Silva Magalhães, que resultou na descoberta do epitáfio de D. Gualdim Pais, tal como nos revela:

Sob aquella idéa se reanimou o empenho do meu amigo e distincto director-professor da Escola Industrial d'aquella cidade, sr. Manuel Henrique Pinto, de encontrar a jazida dos restos do glorioso Templario. Aproveito a occasião para dizer, com reconhecimento, que o sr. Pinto tem sido o meu mais dedicado e caloroso auxiliar n'esta colheita de calcos de inscripções portuguezas ${ }^{11}$ (Cordeiro, 1895, p. 46)

O Diario Illustrado de Lisboa, edição de 13 de outubro de 1895, № 8:104, assinala igualmente o centenário, dedicando uma crónica à vida de D. Gualdim Pais onde já revela a existência da inscrição recentemente descoberta, assim como, inclui duas ilustrações dedicadas à ocasião e notícia alguns acontecimentos sobre este centenário. (Silva, 1895) (Figura 4).

11. Por considerarmos de utilidade para este artigo, transcrevemos a restante informação sobre este assunto: (...) Honra lhe seja, que n'isso não é a mim, mas á Historia e ao paiz, que presta um bello serviço.

Obtendo licença para sondar as paredes d'aquella interessantissima e vetusta igreja de Santa Maria do Olival ou dos Olivaes, que por si dava assumpto para uma soberba monographia sobre a historia da architectura nacional, o sr. Pinto, com dois amigos egualmente interessados n'esta pesquiza, começou-a e teve a fortuna de, ás primeiras tentativas, encontrar a pedra (naturalmente um dos lados do sarcophago), em que está, nitida e graciosamente cavada a inscripção de que tirou e me enviou o magnifico calco, em poucos minutos reproduzido pelo lapis primoroso e firme de Casanova. Como se vê, a inscripção não offerece hesitações ou duvidas de leitura ou de contemporaneidade, esta ultima perfeitamente flagrante, para quem conhece a epigraphia tumular do tempo, com as suas cruzes espalmadas (pattées) iniciaes, com as maiusculas oscillando entre o romano e o gothico, com o seu pautado, até com a sua redacção dos velhos obituarios e livros de calendas, monasticos. (Cordeiro, 1895, p. 46) 
Esta descoberta permitiu aumentar a curiosidade sobre estas comemorações, comprovável pela adesão nacional, onde hotéis e habitações da região de Tomar, foram amplamente preenchidos de forasteiros, tal como reporta a imprensa local, durante os dias 13, 14 e 15 de outubro de 1895 .

\section{SEILIUM ROMANA EM TOMAR}

Em 1895, José Leite de Vasconcelos ${ }^{12}$ publica no Archeologo Portugues o artigo Antiguidades romanas de Thomar, onde cita o jornal A Verdade, $\mathrm{n}^{\circ} 703$ de 15 de outubro de 1893, do editor António da Silva Magalhães; artigo sobre vestígios da importante cidade de Nabancia, que testemunha o aparecimento de uma cabeça de estátua romana, assim como, de moedas romanas, incluindo de uma em particular que a imprensa local faz surgir a palavra NABAENTVUM, considerando-se, assim, provar a existência de Nabância em Tomar. (Magalhães, 1893; Vasconcelos, 1895) (Figura 5).

Relativamente ao assunto Nabância, o arqueólogo José Leite de Vasconcelos demonstra a seguinte posição: Á cêrca do nome Nabancia dado, quer as ruínas romanas exploradas pelo benemerito archeologo, o SR. Possidonio da Silva, e que existem perto de Tomar, - as quais visitei em 1890 na amável companhia do Sr. Antonio da Silva Magalhães, a quem se refere a notícia antecedente, quer as outras ruínas situadas em local diverso faço por em quanto algumas reservas. (Vasconcelos, 1895, p. 14)

Para além de demonstrar as suas reservas sobre a existência de uma povoação romana que se denominaria Nabância, questiona igualmente a moeda romana que aparentava fazer surgir a palavra NABAENTVUM. José Leite de Vasconcelos refere que se tomou a palavra "CASCANTVM" pela anterior, referindo-se, assim, ao município de Cascanto (...) que ficava na Hispania Citerior (...) muito longe

\footnotetext{
12. José Leite de Vasconcelos Pereira (1858-1941), formado em Ciencias Naturais em 1881 e em Medicina na Escola Médico Cirúrgica do Porto em 1886, desenvolve como tese "A Evolução da Linguagem”, já com sinais de duas paixões: a arqueologia e a filologia. Trabalhou na Biblioteca Nacional 23 anos, formou-se em Filologia em Paris, fundou o Museu Etnográfico Português, atual Museu Nacional de Arqueologia, tendo desenvolvido várias atividades e investigações neste campo. (Mariotto, 2020)
}

do município nabantino. No entanto, o arqueológo assinala várias descobertas que provam a presença romana na região, inclusive na Torre de Menagem do Castelo de Tomar, considerando que os vestígios romanos se estendem numa área bastante dilatada. (Vasconcelos, 1895, p. 14)

Desta forma, José Leite de Vasconcelos, em 1895, questiona a opinião local e a de Joaquim Possidónio da Silva sobre a real existência de uma povoação romana de nome Nabância, mostrando igualmente uma diferente leitura da moeda de cobre, que serviria de prova física, dando-lhe uma diferente origem.

Noutra publicação de José Leite de Vasconcelos no Archeologo Português de 1914, o assunto Nabância é novamente abordado, sendo que, desta vez, se refere à publicação de uma carta que o arqueólogo escreveu ao Presidente do Conselho dos Monumentos Nacionais sobre a sua ida a Tomar no sentido de examinar as ruínas romanas. (Vasconcelos, 1914, p. 146)

Nesta carta, José Leite Vasconcelos refere que se dirigiu para o local das ruínas na companhia do meu colega e amigo Dr. Vieira Guimarães, que, sabendo da visita, quis dar-me o gosto de andar comigo. A visita é realizada ao sítio Cardais, onde descreve os achados e local, que recorda ter sido crismado por Possidónio da Silva como Nabância, assim como, desenha objetos que encontrou guardados no local "numa casa moderna".

José Leite de Vasconcelos contesta a localização de Nabância em Cardais concebida por Possidónio da Silva, explicando igualmente que este fundador do Museu do Carmo, desconheceria o mais antigo livro que nos fala de Nabancia (...) o Breviarium de Braga (...) aí se conta o martírio de Santa Iria (...) tinham o governo de Nabância (qui principabantur apud NABANTIAM); lenda que acontece na região de Tomar e que localiza os antigos mosteiros beneditinos onde hoje se situam o Convento de Santa Iria e a Igreja de Santa Maria dos Olivais. (Vasconcelos, 1914, p. 148; Arquivo Nacional Torre do Tombo, 202O; Convento de Cristo, 202O)

De acordo com José Leite de Vasconcelos, se há um local para situar Nabância, esta se situaria na margem esquerda do rio, à entrada de Tomar para quem vai de Coimbra", ou seja, em Santa Maria dos Olivais, revelando que segundo o Sr. Vieira Guimarães, alicerces de casas, tijolos queimados (lares), cima- 
lhas, fragmentos de estátuas, etc. são frequentes de encontrar nessa localização. ${ }^{13}$

Esta informação permite-nos perceber que José Vieira Guimarães acompanha os achados arqueológicos da região, considerando que é sócio correspondente da RAACAP desde 1905 e representante em Tomar do concelho dos monumentos desde 1902, no entanto, não sendo permitido afirmar que participa diretamente nas escavações arqueológicas relacionadas com achados romanos, com base nas informações apresentadas por Leite de Vasconcelos sobre Nabância e no envolvimento de José Vieira Guimarães nas pesquisas de 1895 e ligação de proximidade com a família Silva Magalhães, permite deduzir a sua participação nas pesquisas arqueológicas.

José Leite de Vasconcelos, antes de concluir esta sua carta, informa sobre duas pedras de certo mérito que foram indicadas pelo Dr. Vieira Guimarães. A primeira é romana e encontra-se na base da Torre de Menagem do castelo de Tomar, descoberta em 1912 quando a torre se desentulhou, tendo inscrito: ao Génio do município; ou seja; GENIO MVNICIPI. (Vasconcelos, 1914)

Segundo o arqueólogo, este facto prova que a antiga povoação de Tomar de que provém Tomar pertenceria à classe dos municípios; quanto à segunda inscrição é de origem medieval. José Leite de Vasconcelos conclui a carta publicada, sobre a importância da conservação das estruturas romanas, questionando o trabalho de Joaquim Possidónio da Silva. ${ }^{14}$

Sobre este mesmo tema, José Vieira Guimarães publica em 1927 a obra Thomar Sta. Iria, onde questiona a localização da povoação de Sellium, assinalada por Ptolomeu e incluída do Itinerário antonino, sendo a designação gráfica atual Seilium ${ }^{15}$. Nesta mesma

13. Santa Maria dos Olivais, é uma antiga freguesia extinta em 2012-2013, com cerca de 17, $23^{\mathrm{Km} 2}$ de área, no concelho de Tomar, que inclui nela a Igreja de Santa Maria do Olival (C.M.T., 2020). As escavações arqueológicas na região, no que toca à época romana, demonstram vários vestígios, incluindo o Forum descoberto atrás do Quartel dos Bombeiros e diversos edifícios habitacionais como os descobertos na Alameda 1ํㅡe Março em Tomar. (Batata, 1997)

14. De acordo com Jorge Custódio (2008), o assunto Nabância é um dos processos mais antigos do serviço de monumentos de Portugal, que irá culminar com o seu abandono declarado e fim do mito de Nabância.

15. De acordo com Salete da Ponte (1994), nas fontes históricas antigas como o Itinerário de Antonino a grafia do termo Sellium é deturpada, considerando que o termo Seiliense obra, para além de relembrar os dois cipos romanos descobertos por Pedro de Roure Pietra e que localiza no Museu do Carmo, lembra que os escritores têm feito situar Sellium em Seice, hoje humilde aldeia, num estreito vale de Ourém, sem que para isso apresentem sólida razão, a não ser a semelhança das duas palavras começarem por S ou por C conforme a ortografia de cada um, ou em Seixo, povoação cujo nome se encontra muitas vezes, como diz Hubner, mas não refere. (Guimarães, 1927, p. 6)

José Vieira Guimarães contradiz este raciocínio, com base em estudos de Onomatologia, referindo que Sellium não poderia formar Seice pelo facto desta palavra derivar da latina Salix que com o sufixo airus, na nossa língua, deu a palavra salgueiro que originou também Saúz, Seice, donde o nome de Seiça, ressalvando que o lugar apresenta abundância de água e exemplares daquela árvore incluindo uma de maior corpulência.

O médico nabantino sustenta que Antonino e Ptolomeu são os únicos escritores que anunciam a existência de Sellium, sendo que Ptolomeu, grego do século II, na sua Geografia enumera Sellium como uma das povoações importantes da Lusitânia, enquanto que o Itinerário antonino, do tempo de Júlio César e revisto nos séculos III e IV, localiza a povoação de Sellium a 32 milhas de Scalabis e a 44 de Aeminium. Considerando Scalabis Santarém e Aeminium Coimbra, José Vieira Guimarães traçou as distâncias em relação a Tomar. Em comparação com os dados do Itinerário, para com Coimbra há um erro de 164 metros; e entre Santarém e Tomar encontra uma diferença de 108 metros. Valores que José Vieira Guimarães considera irrelevantes e demonstrativos de que Sellium se situa em Tomar. (Guimarães, 1927, pp.7-10)

Indo ao encontro de uma das fontes de José Vieira Guimarães, na obra Noticias archeologicas de Portugal de Emílio Hubner de 1871, a ligação entre Sellium e a povoação de Seixo é apresentada de forma bastante duvidosa pelo autor, tal como o demonstra em virtude de uma remota semelhança de palavras, sendo de destacar que este parágrafo surge entre outros dois referentes à região de Tomar, sem que este assunto lhes seja associado, o que cria a possibilidade deste trabalho ter contribuído bastante para o

referido em inscrições funerárias permite chegar ao consenso de "Sellium = Seilium". (Ponte, 1994) José Vieira Guimarães, depara-se com esta situação a que denomina de "paradoxo”. (Guimarães, 1927) 
pensamento de José Vieira Guimarães. Outra possível fonte, da autoria de João Maria Baptista e publicada em 1876, apresenta esta mesma leitura, no entanto, demonstra a proximidade entre a povoação de Seixo e Tomar, tal como apresenta: Em Seixo ou Ceice próximo de Thomar collocam alguns a cidade Sellium só pela semelhança remota das palavras e por ser Sellium a immediata a Thomar no Itinerario. (Guimarães, 1927)

José Vieira Guimarães comete, em nossa opinião, um erro na sua obra, que lhe valeria a comprovação da sua teoria, da localização de Sellium em Tomar, quando menciona o conteúdo de uma estela romana presente em Lorvão referente a um jovem seiliense, onde surge o paradoxo de não se escrever selliense. Sobre este assunto, o autor refere: Esta pedra procede de Lorvão, povoação próxima da antiga Aeminium, e a 44 milhas de Sellium, o que dá a máxima probabilidade a que este seiliense, tivesse sido natural de Sellium e não de Seilense, povoação galega, conhecida por uma inscrição que vem no Corpus II, $2562 .{ }^{16}$ (Guimarães, 1927, p. 8)

Esta informação abordada por José Vieira Guimarães parece estar relacionada com um artigo de José Leite Vasconcelos publicado em 1914, Inscrição romana de Lorvão, onde menciona que o,

epíteto pátrio Seiliensis traz-nos à mente o adjectivo geográfico Seilensis de uma inscrição galega do Corpus, II, 2562, e o nome Sellium, que nesta forma figura no Itenerário de Antonino (...) é bastante provável que Seiliensis não se refira a uma terceira povoação, e se relacione antes com Sellium do que com o galego Seilensis (Vasconcelos, 1914b, p. 366).

José Leite de Vasconceles acrescenta, que segundo este raciocínio, é errónea a forma Sellium, que deve substituir-se por Seilium, defendendo que a origem desta situação poderá estar nos antigos manuscritos, onde a letra "I" foi tomada por uma "L". (Vasconcelos, 1914a)

Na realidade, o conteúdo desta inscrição galega presente no Corpus II, 2562, que é ignorada no seu conteúdo escrito por José Leite de Vasconcelos e poste-

16. Esta citação presente na página 8 da obra Thomar Sta. Iria (1927), demonstra o "paradoxo" de José Vieira Guimarães, em o habitante de Sellium não se designar de selliense, assim como, desconhecer o conteúdo da inscrição galega, que resolveria esta sua questão. (Guimarães, 1927) riormente por José Vieira Guimarães, é dedicada a um indivíduo romano, cujo nome surge igualmente numa segunda estela presente na Torre de Menagem do castelo de Tomar, contendo ambas as dedicatórias o nome da sua mãe Sabinula. De assinalar a presença, na mesma torre, de uma terceira inscrição relacionada com este elemento feminino.

A inscrição galega datada de II d.C., foi localizada numa praia ${ }^{17}$ perto de Finisterra por volta de 1750, tendo servido como base de altar de uma igreja em Queiruga até 1822, data em que foi mandada retirar por não se considerar correto o seu uso religioso, no entanto, mantém-se exposta numa parede lateral do mesmo espaço religioso. (Bayón, 1997; Património Galego, 2012) (Figura 6).

A leitura da inscrição:

C(aius) ATTIVS ATTIANVS RVFINVS SEILIENSIS

ANN(orum) XXII H(ic) S(utis) E(st)

RVFVS PATER ET SABINVLA MATER FECE

(Caio Attio Attiano Rufino seiliense aqui morreu com a idade de 22 anos Pai Rufino e mãe Sabinula mandaram erguer)

Sobre as estelas presentes na Torre de Menagem em Tomar, os seus respetivos conteúdos comprovam a ligação à inscrição anterior: (Batata et al., 1983)

RVFVS ET SABINVLA/VXOR/SIBI
Rufus e Sabinula sua mulher
(fez este monumento em memória do seu marido)
G [aio]ATTIO/ATTIA/NO RVFINO/SABINVLA/
MATER P[osuit]

A Gaio Attio Attiano Rufino sua mãe fez (este monumento) $)^{18}$

17. De acordo com a história local galega, a estela é descoberta por pescadores no areal da praia, após uma tempestade marítima que revoltou o areal, tal como nos documenta Bayón (1997): Sucedió que un fortísimo temporal removió la masa arenosa de la playa y la dejó al descubierto. Las Gentes marineras, por el pretigio de su aparicón milagrosa, considerandola algo sagrado, le dieron cobijo en el templo parroquial, ocupando el ara del altar Mayor. (Bayón, 1997) O local deste acontecimento é a praia de Seiras em Porto do Son, Galiza. (Património Galego, 2012)

18. Os autores do catálogo da exposição de 1983, nomeiam Gaio em vez de Caio, da mesma forma como José Vieira Guimarães o faz na obra Thomar Sta. Iria (1927), quando se refere a esta mesma estela presente na Torre de Menagem 
A inscrição dedicada a Rufus por Sabinula, sua mulher, é datada de I d.C. - II d.C., encontra-se na verga da janela do $1^{\circ}$ andar do lado sul da Torre de Menagem, enquanto que a dedicada a Caio, com a mesma datação, situa-se na pardeira de uma janela do $1^{\circ}$ andar do lado sul da Torre de Menagem.

Na obra Thomar Sta. Iria (1927) de José Vieira Guimarães, as inscrições tomarenses apresentadas neste artigo, referentes a Sabinula, estão documentadas, no entanto, acontece a pouco provável situação, desconhecida pelo médico nabantino, de o indivíduo por si referenciado pela inscrição galega, que identifica, localizando-a no Corpus II, 2562, corresponder ao mesmo que se encontra mencionado noutra inscrição presente na Torre de Menagem em Tomar, filho de Sabinula. Os nomes dos pais de $R u$ fino comprovam esta ligação, o que na realidade a ser percecionada por José Vieira Guimarães, consideramos que teria sido a sua prova fulcral para complementar a teoria sobre Sellium. ${ }^{19}$

em Tomar. No nosso entender esta leitura é introduzida em erro, pois se se observar a fotografia 11 do catálogo da exposição, o primeiro nome encontra-se superiormente encoberto por outra estrutura da Torre de Menagem, induzindo parecer a letra “G”. Este facto é comprovável através da leitura da inscrição de Queiruga, onde é evidente tratar-se de um “C”, cuja letra em pedra calcária é semelhante à estela de Tomar. Temos desta forma, Caio em vez de Gaio. (Guimarães, 1927; Batata et al., 1983)

19. No século XII, os templários utilizaram as ruínas das antigas civilizações romana e bárbara da região de Tomar, para erguer o castelo e convento. O Catálogo Tomar na arte antiga (1983), apresenta um espólio em imagem de achados nabantinos, onde as duas inscrições funerárias dedicadas por Sabinula surgem em fotografia 9, 10 e 11. (Batata et al., 1983) Segundo os autores, as estelas terão sido encontradas na margem esquerda do rio Nabão. De acordo com estudos galegos (1959), a lápide de Queiruga e de Tomar referem-se ao mesmo indivíduo, sendo que se trata de um cenotáfio, sustentando Salete da Ponte (1994), de que este seiliense "falecera em terras da Galiza". (Castillo \& D 'Ors, 1959; Centro de Estudios Historicos, 1959; Ponte, 1994, p.138) O coautor deste artigo João Amendoeira Peixoto, apresenta uma nova possibilidade sobre este assunto, em crónica publicada no Jornal Cidade de Tomar de 14 de fevereiro de 2020 , considera a existência de uma quarta inscrição descoberta em Deva (Chester, Inglaterra), referente a um elemento da Legio Valeria XX Vitrix, Caius Attius Rufinus, contemporânea às anteriores, que pode corresponder ao seiliense de 22 anos, sugerindo que a estela galega é mandada erguer pela família simbolicamente perto de Finisterra, local terrestre mais a ocidente, tratando-se igualmente de um cenotáfio. (Peixoto, 2020a)
A localização de Seilium em Tomar é hoje aceite pela comunidade científica, no entanto, foi contestada por alguns historiógrafos durante décadas, tais como Amorim Rosa (1900-1976), que na obra História de Tomar (1965), composta por dois volumes, enobrece a visão da existência de uma Nabância romana em Tomar, sem mencionar Seilium, referindo-se a José Vieira Guimarães da seguinte forma: $E$ isto escreveu Vieira Guimarães, que sempre quis negar, por razões que não vêm para o caso, a existência, evidente, de Nabância. (Rosa, 1965, p. 20)

Por outro lado, esta mesma obra dá-nos uma prova escrita do envolvimento de José Vieira Guimarães em projetos arqueológicos em Tomar, quando se refere à descoberta de estruturas de edifícios, moedas romanas de vários imperadores, tijolos, vasos e outros instrumentos, na zona da Cerrada de João do Couto e envolvente, por diversos indivíduos em várias décadas de achados arqueológicos: Conjugando o que o major Figueiredo encontrou na sanja $G$ com as cornijas encontradas por Possidónio da Silva e Dr. Vieira Guimarães, e os pedaços de fustes que falava o Dr. Sousa. (Rosa, 1965, p. 21)

De acordo com o site de Arqueologia do Património Cultural, na descrição da última escavação de 2008/2009, surgem achados da época romana nos trabalhos arqueológicos desenvolvidos junto à Igreja de Santa Maria dos Olivais em Tomar:

Os trabalhos arqueológicos desenvolvidos nas proximidades da Igreja de Santa Maria do Olival (Tomar-Santarém) integraram-se no projeto de minimização de impactos - II Fase da empreitada de construção dos arranjos exteriores no Flecheiro, proposto pela Tomar Polis. A intervenção arqueológica recaiu na área da necrópole medieval e moderna de Santa Maria do Olival. Permitiu identificar ainda estruturas habitacionais $e$ alguns fornos cerâmicos de cronologia romana, que parecem enquadrar-se na área extramuros da cidade romana de Sellium. (Portal do Arqueólogo, 202Oa)

Complementando a informação da presença de fornos cerâmicos romanos sob a necrópole medieval, torna-se complementar referir um artigo publicado pela Universidade de Letras da Universidade de Coimbra em 2002, intitulado Marcas de oficina em tijolos romanos de Seilium, onde os autores identificam marcas de oficina com as letras RPS em material encontrado na região de Tomar, Cardais e no Cerrado do Couto, datado de I d.C.. (Fernandes \& Ferreira, 2002) 
Os investigadores referem que a menção da $\mathrm{R}(\mathrm{es})$ $\mathrm{P}$ (ublica) é habitualmente representada pelas siglas R. P.; considerando a localização do tijolo, propuseram a seguinte interpretação: $\mathrm{R}(\mathrm{es}) \mathrm{P}$ (ublica) S(eiliensis) A República Seiliense.

Neste artigo, publicado em 2002, os autores desconhecem a existência de fornos de cerâmica em Seilium, considerando apenas o conhecimento de um forno extramuros:

A possibilidade de ambas as marcas serem oriundas da área de Cardais e não de Seilium, tendo em conta a ausência de registo de proveniência, não afecta a interpretação das siglas e do seu significado, já que, na época romana, era habitual (e desejável) a localização das instalações de fabrico de cerâmica de construção fora da cidade e nas proximidades dos barreiros. (Fernandes \& Ferreira, 2002, p. 261)

No entanto, tal como já tivemos a oportunidade de demonstrar, os achados arqueológicos que se sucederam nos anos seguintes revelam a existência de fornos cerâmicos junto à Igreja de Santa Maria dos Olivais em Tomar, achados que complementam o raciocínio da investigação anterior. (Fernandes \& Ferreira, 2002)

Desta forma, as investigações mais recentes consolidam o trabalho de José Vieira Guimarães, que na obra THOMAR Sta. Iria (1927), situa Sellium romana em Tomar, assim como, relembra a lenda de Santa Iria através dos vários autores, a padroeira de Tomar que tinha como tio o abade Sélio, cuja grafia se aproxima de Sellium. Outra aproximação presente na mesma obra, refere-se a um documento de 1317, transcrito por Pedro Alvares Seco da Ordem de Cristo, com a seguinte informação: na dita çidade oouvera moesteiros dosffrades negrados de queffora obade don selho tyo de Santa Eyrea e que soyam chamar a santa Maria de Thomar santa Maria de selho. (Guimarães, 1927, p.107).

José Vieira Guimarães recorda igualmente uma descoberta na década de 80 do século XIX, realizada pelo proprietário José Pereira Prista enquanto fazia a plantação da vinha, perto do antigo ribeiro das Canas em Tomar e junto à estrada que segue para a Serra, que foi convidado a visitar onde encontra,

vasta área coberta de ruínas de construcções, mais ou menos salientes, vários lares, tijolos grandes e pequenos, candeias de barro, mós de moinhos de mão, algumas moedas romanas e principalmente muitas e grandes pedras, tendo um dos topos moldados, indicativos de terem servido em alta cornija (Guimarães, 1927, p. 50).

Sobre este mesmo tema, encontrámos aquele que é um achado inédito e de interesse para este artigo, tratando-se de um capítulo da autoria de José Vieira Guimarães com cerca de dez páginas, intitulado A "Sellium" dos romanos é hoje representada por Thomar e a via militar de "Scalabis" a "Aeminium" passava ali, extraído de um boletim da "Asociación Española para el Progreso de las Ciencias", referente à sessão de 27 de junho de 1923 que aconteceu em Salamanca. (Guimarães, 1924)

O segundo congresso misto, organizado pela Associação Portuguesa para o Progresso da Ciência e pela Associação Espanhola para o Progresso das Ciências, realiza-se em Salamanca entre os dias 24 e 29 de junho de 1923, e é presidido na sessão de abertura pelo rei de Espanha D. Afonso XIII (1886-1941), tendo particularmente várias intervenções nacionais no terceiro tomo, onde intervém o médico nabantino. (Guimarães, 1924; Morais, 2007)

$\mathrm{Na}$ intervenção do dia 27 de junho, José Vieira Guimarães apresenta-se como Médico, professor do Liceu Camões, sócio da Real Academia de História de Madrid e da Academia das Sciencias de Lisboa, etc., etc., inicia por justificar Não falo castelhano e tenho pena, elogiando Salamanca, a Roma la chica tal como menciona, dando lugar a memórias de visita às ruas, monumentos e encantos, abordando a história da terra, até que na mudança de discurso cita Garcia de Resende: Non pude mais escrever,/ Por nã teer mais descoberto.; apresenta: a minha comunicação, é: A Sellium dos romanos é hoje representada por Thomar e a via militar de Scalabis a Aeminium passava ali. (Guimarães, 1924, p.63)

José Vieira Guimarães identifica a presença romana em Tomar, categoriza Nabância como lenda, explica e localiza Seilium em Tomar:

Ptolomeu que sob o nome de Sellium a nomeia em sua Geografia, e o Itenerario Antonino que lhe assigna-la a situação. Assigna-lha entre Scalabis e Aeminium, na única via que ligava a provincia da Lusitania á Tarraconense. Diz ele que Sellium ficava a 32 milhas de Scalabis e a 44 de Aeminium. A sêr Scalabis Santarem e Aeminium Coimbra, como assente está serem pontos d'aquela via, basta a eles nos referirmos e termos portanto de vêr a correspondência de Sellium com essas ci- 
dades, para assim podermos identifica-la. De Thomar a Coimbra contavam-se 13 leguas, e sendo uma maiores e outra menores, podemos dár a cada uma, como media geral, 5 kilometros, o que nos dá para as 13 leguas, 65 kilometros ou 65: ooo metros, os quais divididos por 1481 metros que são atribuídos a cada milha, temos 44 milhas e mais uns 164 metros. Diferença mínima a que não se ligará importância e por este lado devemos aceitar a concordância de Sellium com Thomar. Agora vejamos a distancia de Scalabis a Sellium. D'aquela a esta eram 32 milhas que á razão dos 1481 metros, são 47:392 metros que diferenção 108 metros dos 47:50o das 9, 1/2 léguas que distanciam Santarem de Tomar. Tambem pouca diferença é a de 108 metros que encontramos. (Guimarães, 1924, pp. 63-64)

Da mesma forma, como viria a apresentar na obra Thomar Sta. Iria (1927), o autor menciona Ceice e os estudos de Onomatologia que comprovam que Sellium não originou palavra Ceice, no entanto, o artigo de Salamanca menciona o nome dos cientistas envolvidos: a Sr $r^{\underline{a}}$. D. Carolina Micaelis de Vasconcelos e o Srọ. Dr. José Joaquim Nunes. (Guimarães, 1924, p. 64)

No Congresso de Salamanca, José Vieira Guimarães refere igualmente a presença de inscrições romanas no castelo de Tomar, provenientes da povoação, assim como, menciona a via romana de Scalabis a Aeminium, que Hubner não aceitou n'essa direção, que passaria por Sellium. Apresenta sobre este assunto, a correspondência por carta que realiza com o Dr. Feio de Carvalho, onde demonstra a sua visão sobre a via militar romana de Sellium (Thomar) a Aeminium (Coimbra), questionando se se lembrava de encontrar pedaços de calçada romana "em sítios que foram cortados pela estrada n.. 51 , assim como, se considerava que estas calçadas tinha sido construídas segundo os princípios que os romanos empregavam. Em resposta a José Vieira Guimarães, o Dr. Feio de Carvalho esclarece ter vislumbrado pequenos troços de calçada em Espinhal, assim como, entre os lugares da Venda das Figueiras e Tojeira, por onde passa a E. N. 51; entre mais informação, José Vieira Guimarães considera a ajuda deste ilustre engenheiro bastante útil, pois considera como prova da existência da estrada que passava em Sellium na direção de Aeminium. (Guimarães, 1924, pp. 68-71)

\section{CONCLUSÃO}

De um modo geral, poder-se-á afirmar que os trabalhos de investigação desenvolvidos por José Vieira da Silva Guimarães foram de importância para o estudo da Arqueologia em Tomar e de utilidade para investigações futuras.

Com este artigo conseguimos percorrer décadas de estudos arqueológicos em Tomar, onde surgem nomes como Joaquim Possidónio da Silva e José Leite de Vasconcelos, onde é entendível a divergência de opinião deste último arqueólogo no que toca ao assunto da existência e localização de Nabância na região. José Vieira da Silva Guimarães assiste a décadas de achados em Tomar e à evolução arqueológica, manifesta ser um seguidor de José Leite de Vasconcelos, questionando a existência de Nabância e erguendo uma nova visão, participa nas sociedades e associações que erguem a ciência.

Nesta contenda, é de assinalar a mudança de opinião de José Vieira Guimarães no que toca ao assunto relacionado com a presença romana em Tomar, considerando que no catálogo publicado em 1895 identifica Nabância romana na região, seguindo a linha de pensamento de Joaquim Possidónio da Silva e as publicações de António da Silva Magalhães, assim como, dos redatores do jornal A Verdade. Após a nova visão apresentada por José Leite de Vasconcelos em 1914, onde este coloca em causa a localização de Nabância defendida por Possidónio da Silva, José Vieira Guimarães questiona inclusive sobre a sua existência e aprofunda conhecimentos acerca do tema da lenda de Santa Iria. A presença do arqueólogo José Leite de Vasconcelos parece ser decisiva para o desencadear de acontecimentos que culminam na publicação da obra Thomar Sta. Iria em 1927.

A participação de José Vieira Guimarães em congressos é uma constante ao longo da sua vida, sendo que este artigo desvenda a participação deste nabantino em mais um, o congresso misto de Salamanca em 1923, onde defende a sua visão de localizar Seilium em Tomar, onde passaria a via romana entre Scalabis a Aeminium.

A descoberta do capítulo da intervenção de José Vieira Guimarães numa livraria de Madrid, permite perceber que a defesa desta visão acontece quatro anos antes da publicação da obra Thomar Sta. Iria, minuciosamente preparada, mas, no entanto, contestada. Sendo que consideramos, que a principal prova ficou por mostrar pelo médico nabantino, 
quando ignorou o conteúdo de uma estela encontrada na Galiza de um seiliense, que levou à localização de uma imaginária Seilensis no local galego, quando na realidade a inscrição revela o mesmo indivíduo que é mencionado numa outra estela romana presente na Torre de Menagem do Castelo de Tomar, tratando-se de um natural de terras nabantinas. Esta descoberta, em nossa análise, seria a prova que faltava a José Vieira Guimarães para sustentar com maior solidez a sua teoria.

Este artigo tem na sua base as gentes e o território que contam parte dos acontecimentos da Arqueologia em Tomar, onde José Vieira da Silva Guimarães é um elemento de relevo em prol da evolução do conhecimento científico. Desta forma, consideramos que através da pessoa que é este nabantino, em muito contribuímos para o estudo da Arqueologia em Tomar, com conteúdo que enriquece o entendimento da temática Nabância, assim como, na construção de conhecimento sobre o estudo de Seilium.

\section{FONTES}

Arquivo Nacional Torre do Tombo (2020) - Convento de Santa Iria de Tomar. Acedido em 12 de julho de 2020, em: https://digitarq.arquivos.pt/details?id=1379990

Direção Geral do Património Cultural (2020) - Acedido em 12 de julho de 2020, em: http://www.patrimoniocultural. gov.pt/en/patrimonio/patrimonio-imovel/pesquisa-do-patrimonio/classificado-ou-em-vias-de-classificacao/ geral/view/70607

\section{BIBLIOGRAFIA}

BATATA, C.; MOREIRA, B.; PONTE, S.; SILVA, V. (1983) Catálogo Tomar na arte antiga: exposição 1 a 20 de Março de 1983 integrado nas comemorações do Dia da Cidade. Tomar: Câmara Municipal de Tomar.

BATATA, Carlos (1997) - As origens de Tomar: a carta arqueológica do concelho. Tomar: Centro de Estudos e Protecção do Património da Região de Tomar.

C.M.T. - Câmara Municipal de Tomar (2020) - União das Freguesias de Tomar. Acedido em 12 de julho de 2020, em: http://www.cm-tomar.pt/index.php/pt/juntas-freguesia?start=10\#santa-maria-dos-olivais

CARVALHO, António; RAPOSO, Luís (2015) - José Leite de Vasconcelos: peregrino do saber. Lisboa: Museu Nacional de Arqueologia/Imprensa Nacional-Casa da Moeda.

CASTILLO, A; D’Ors, A. (1959) - Inscripciones romana de Galicia. Cuadernos de Estudios Gallegos 14. Corunha: Instituto Padre Sarmiento de Estudios Gallegos.
CENTRO DE ESTUDIOS HISTÓRICOS (1959) - Emérita. Madrid: Centro Estudios Históricos.

CORDEIRO, Luciano (1895) - Inscripções Portuguezas. Lisboa: Imprensa Nacional.

COSTA, António Carvalho da (1712) - Corografia portuguesa, e descripçam topografica do famoso reyno de Portugal: Tomo III. Lisboa: Oficina Real Deslandesiana.

Convento de Cristo (2020) - Igreja de Santa Maria do Olival. Acedido em 12 de julho de 2020, em: http://www.conventocristo.gov.pt/pt/index.php?s=white\&pid=237\&iden tificador=ct161_pt

CUSTÓDIO, Jorge (2008) - Renascença Artística e Práticas de Conservação e Restauro Arquitetónico em Portugal, durante a $1^{\underline{a}}$ República. Volume 1 . Tese de doutoramento apresentadas à Universidade de Évora.

Direção Geral do Património Cultural (2020) - Igreja de Santa Maria do Olival, compreendendo os túmulos, designadamente odeD.Diogo Pinheiro, 1.․․ bispo do Funchal. Acedido em 11 de julho de 2020, em: http://www.patrimoniocultural. gov.pt/pt/patrimonio/patrimonio-imovel/pesquisa-do-patrimonio/classificado-ou-em-vias-de-classificacao/ geral/view/70610

FERNANDES, Luís da Silva; FERREIRA, Rui (2002) - Marcas de oficina em tijolos romanos de Seilium. Conimbriga. Coimbra. 41, 257-267.

GARCÍA BAYÓN, Carlos (1997) - Piedras ilustres de la Barbanza, Muros y Xallas. Galiza: Editorial Diputación Provincial.

GUIMARÃES, José Vieira da Silva (1895) - Catálogo da Exposição Industrial-Agrícola de Thomar. Lisboa: Imprensa Lucas.

GUIMARÃES, José Vieira (1924) - A “Sellium” dos romanos é hoje representada por thomar e a via militar de "Scalabis" a "Aeminium" passava ali. Boletín de la "Asociación Española para el Progreso de las Ciencias". Madrid. Congresso de Salamanca, sessão de 27 de junho de 1923. Tomo VIII, pp. 61-71.

GUIMARÃES, José Vieira da Silva (1927) - Thomar Sta. Iria. Lisboa: Livraria Coelho.

MAGALHÃES, António da Silva (1893, 15 de outubro) Ruinas da Nabancia. A Verdade, pp. 2-3.

MAGALHÃES, António da Silva (1895, 14 de abril) - Última hora. A Verdade, p. 3.

MAGALHÃES, António da Silva (1895a, 21 de abril) - Centenário de Gualdim Paes. A Verdade, p. 2.

MARTINS, Ana Cristina (2003) - Possidónio da Siva (18o61896) e o elogio da memória. Um percurso na arqueologia de Oitocentos. Lisboa: AAP. 
MARTINS, Ana Cristina (2012-2013) - Entre a metamorfose e a adaptação de associação dos arquitectos civis portugueses a real associação dos arquitectos civis e arqueólogos portugueses (1863-1896). Arqueologia e História. Lisboa. Vol. 64-65: 15-29.

MARTINS, Ana Cristina (2015) - A Associação dos Arqueólogos Portugueses na senda da salvaguarda patrimonial. 100 anos de transformação (1863-1963). 2 vols. [Texto policopiado]. Tese de Doutoramento em História (História da Arte) apresentada à Universidade de Lisboa.

MARTINS, Ana Cristina (2016) - Francisco Tavares Proença Júnior (1883-1916) e arqueologia em Castelo Branco na viragem para o século XX: textos, contextos e (des)venturas. II Congresso Internacional de Arqueologia da Região de Castelo Branco. Castelo Branco. pp. 25-6o.

MARTINS, Ana Cristina (2017) - A Real Associação dos Arquitectos Civis e Arqueólogos Portugueses e o Museu Arqueológico do Carmo: alguns percursos internacionais (abordagem preliminar). Boletim da Academia Internacional da Cultura Portuguesa. Lisboa. pp. 99-131.

MARIOTTO, Elisabeta (2020) - José Leite de Vasconcelos. Acedido em 12 de julho de 2020, em: http://cvc.instituto-camoes.pt/seculo-xix/jose-leite-de-vasconcelos.html\#. XwtvGyhKiUk

MORAIS, Marta (2007) - A primeira década dos congressos luso-espanhóis para o progresso das ciências. Aveiro: Universidade de Aveiro.

Museu Centro de Artes Figueiró dos Vinhos (2020) - Biografia de Manuel Henrique Pinto. Acedido em 11 de julho de 2020, em: https://www.mcafigueirodosvinhos.pt/ index.php/2013-04-08-14-35-07/os-nossos-artistas/8-noticias/47-biografia-de-manuel-henrique-pinto

Património Galego (2012) - Lauda Romana de Queiruga. Acedido em 12 de julho de 2020, em: http://patrimoniogalego.net/index.php/23441/2012/o8/lauda-romana-dequeiruga/

PEIXOTO, João Amendoeira (2019) - Vieira Guimarães e o Património Cultural de Tomar: primeira abordagem. Tomar: Gualdim Edições.

PEIXOTO, João Amendoeira (2020) - Thomar Pietra: segredo de pedra. Tomar: Gualdim Edições.

PEIXOTO, João Amendoeira (2O2Oa, 14 de fevereiro) - Sabinula e o seu filho Caius. Jornal Cidade de Tomar, p. 30.

PIETRA, Pedro de Roure (1863, 28 de fevereiro) - Gualdim Paes. Gazeta de Portugal, p. 1.

Portal do Arqueólogo (2020). Tomar/Sellium - Cerrado de João do Couto. [Consult. 22 de novembro de 2019] Disponível em: http://arqueologia.patrimoniocultural.pt/index.php?sid $=$ sitios\&subsid $=54066$
Portal do Arqueólogo (2020a) - Escavação 2008/2009. [Consult. 22 de novembro de 2019] Disponível em: https:// arqueologia.patrimoniocultural.pt/index.php?sid=trabalho s\&subsid=3170224

PONTE, Salete da (1994) - J.L. Vasconcelos e os percursos por Tomar antiga. O Arqueólogo Português, Série IV. 11-12: 135-141.

SILVA, Pedro Corrêa da (1895, 13 de outubro) - D. Gualdim Paes. Diario Illustrado, p. 1.

SILVA, Joaquim Possidónio da (1881) - Descobrimento da Cidade Romana «Nabancia» em Portugal. Boletim da Real Associação dos Architectos Civis e Archeologos Portuguezes. Lisboa. Tomo III. 10: 152-154.

VASCONCELOS, José Leite (1895) - Antiguidades romanas de Tomar. O Archeologo Português. 1: 13-15.

VASCONCELOS, José Leite (1914) - Antiguidades de Tomar. O Archeologo Português. 19: 146-151.

VASCONCELOS, José Leite (1914a) - Inscrição romana de Lorvão. O Archeologo Português. 19: 365-366.

VENTURA, António (2004) - António da Silva Magalhães Photographo de Thomar. Tomar: Câmara Municipal de Tomar. 


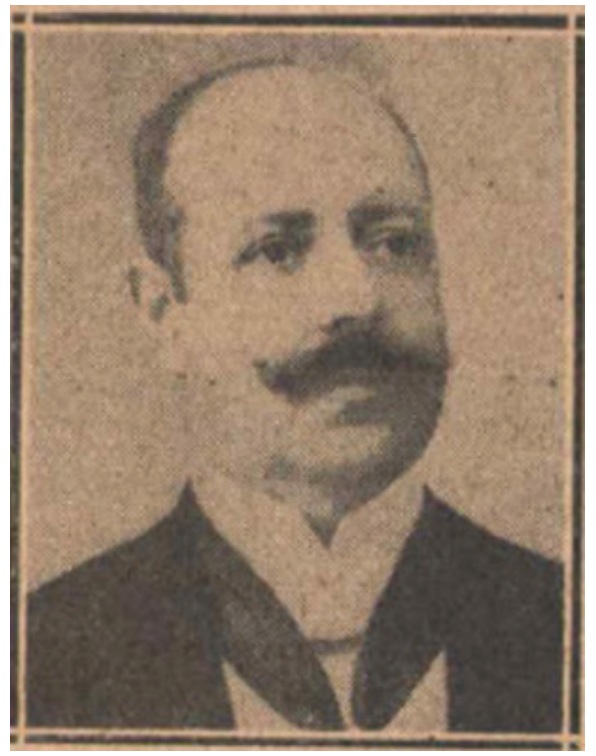

Figura 1 - José Vieira da Silva Guimarães.

\section{A' altima bora}

1) - prequizas n que procederam ta eggresju do Sunita Mario dus Olivace, un nossos minizos on kl's. Munoel Hientique Pinto o Juné Vieiri da Silva Guimurane, foit encontrerta a cuthina e resprectivo opitnphio do D. Gualditic Pnon, os qunes bu nututo se connidorhram perdidos ou nnutiquillados.

No proximo numiero nos roferirombs tom mais vingar a obto sosumpto.

Figura 2 - Notícia do jornal A Verdade, edição №781. (Magalhães, 1895).

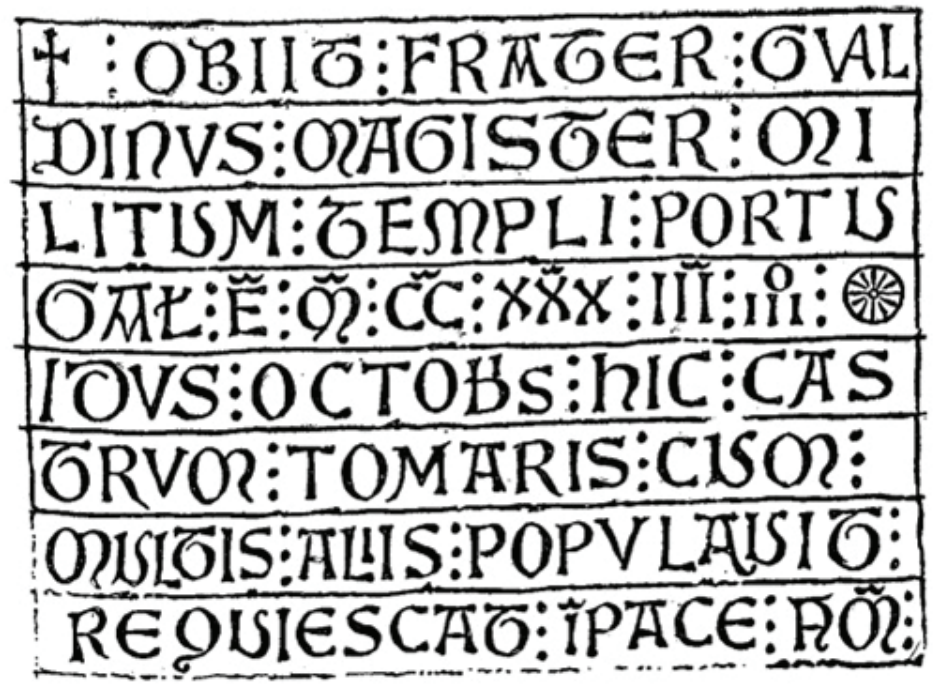

Figura 3 - Ilustração presente na obra de Luciano Cordeiro (1895), com possibilidade de ser da autoria de Manuel Henrique Pinto (Cordeiro, 1895, p. 46). 

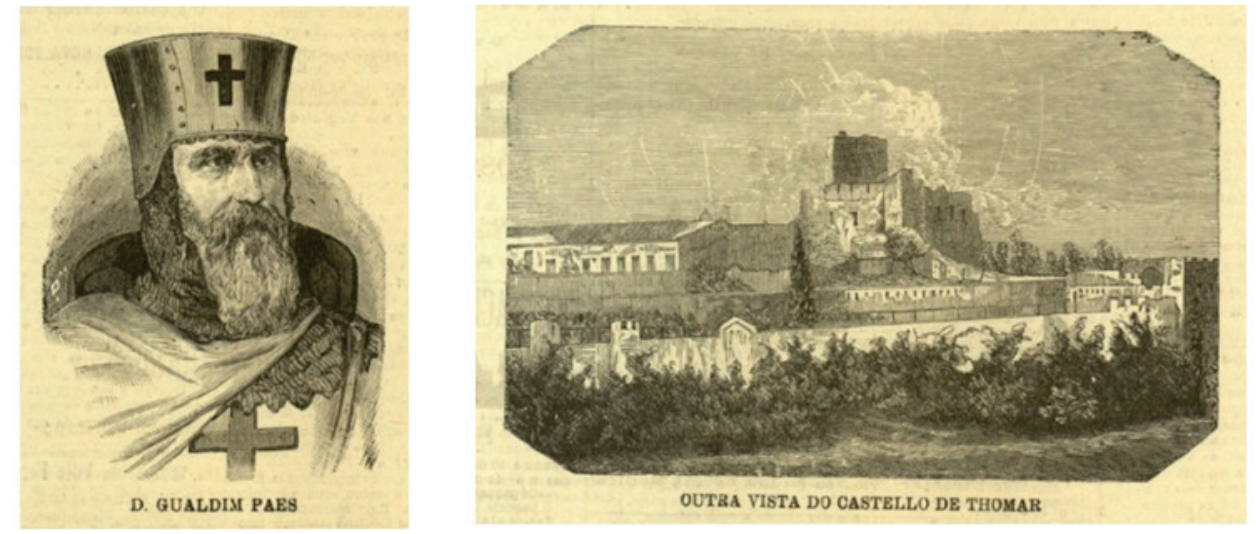

Figura 4 - Ilustrações do Diario Illustrado (Silva, 1895).

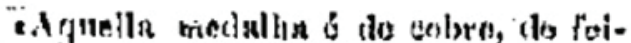

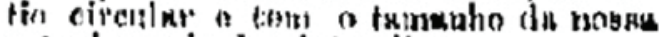
aofinal mortia de vinte rós:

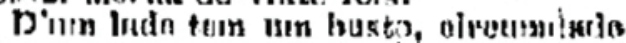

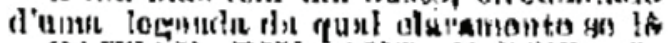

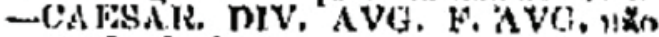

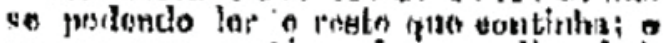
to revorso, contern a insegem d'uen losl,

tendo. is sun parte ouperior a palavtu MVNI(JIP. a ma interior... BAEN'VAI, reconhecondo-se por uns pequenissionos

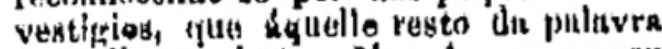
yrecudian so lettris N. e $A_{\text {, }}$ que no rou

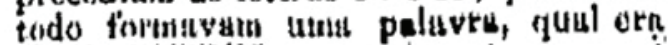
NABALN'IVM,

$-$

Figura 5 - Extrato do jornal A Verdade, no 703 de 15 de outubro, que comprova a leitura, por parte da imprensa local, da palavra "NABAENTVM".

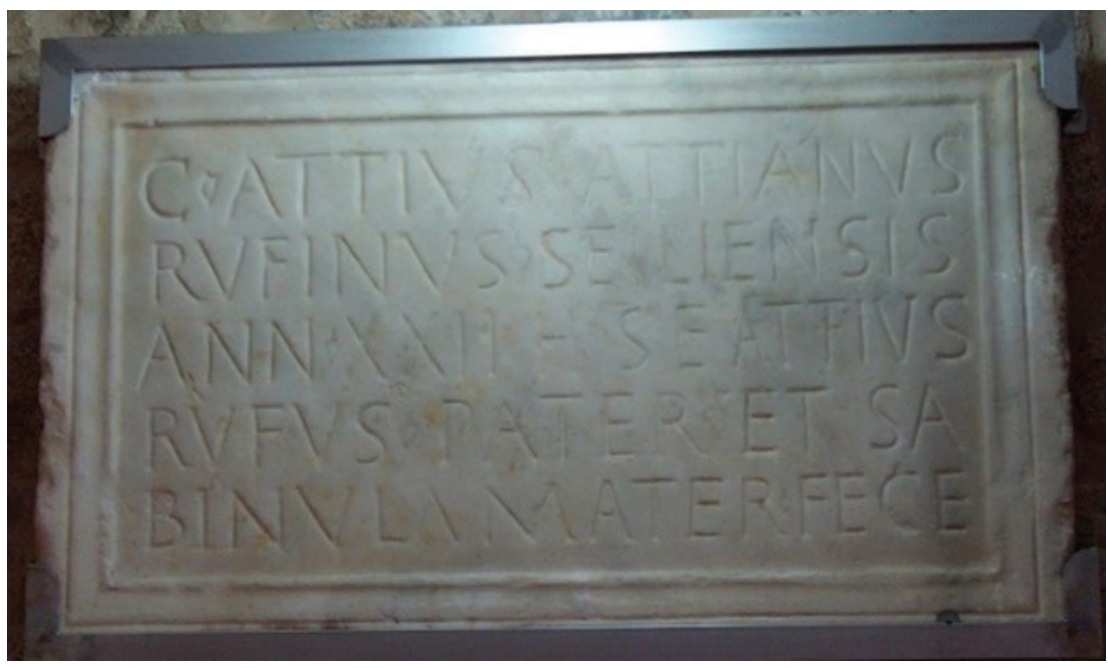

Figura 6 - Estela romana em Queiruga, Galiza. (Património Galego, 2020) 


\title{
OS MEMORÁVEIS? A ARQUEOLOGIA ALGARVIA NA IMPRENSA NACIONAL E REGIONAL NA PRESENTE CENTÚRIA (2001-2019): CARACTERÍSTICAS, VISÕES DO(S) PASSADO(S) E A ARQUEOLOGIA ENQUANTO MARCA
}

Frederico Agosto ${ }^{1}$, João Silva ${ }^{2}$

\begin{abstract}
RESUMO
O presente artigo ocupar-se-á da forma como os jornais - enquanto veículo de informação privilegiada com o grande público - apresentam o passado, a arqueologia e o arqueólogo. Para tal, proceder-se-á dialecticamente a um estudo comparativo entre a imprensa nacional e a imprensa regional, de forma a abarcar as diferentes realidades editoriais existentes e evidenciar os mecanismos de ambas aquando da escolha do que publicar. Por fim, e respeitando o questionário de base, far-se-á uma reflexão sobre os estereótipos relacionados com a arqueologia e a sua praxis, juntamente com a visão de passado que vinculam.

Palavras-chave: Imprensa Nacional, Imprensa Regional, Arqueologia Algarvia, Arqueologia Pública, Comodificação.
\end{abstract}

ABSTRACT

This article will deal with how newspapers - seen here as a main vehicle of information with the general public - present the past, archaeology and the archaeologist. To this end, a comparative study will dialectically be carried out between national and the regional presses, in order to encompass the different type of presses at play but as well to discriminate between the different mechanisms of both when it comes to choosing what to publish. Finally, a synthesis/concluding chapter will be dedicated to reflections on the existing stereotypes related to archaeology per se, its practice, and a critique of how the past is conveyed in the press.

Keywords: National Press, Regional Press, Algarvian Archaeology, Public Archaeology, Commodification.

«De que vitória falas, disse eu então

da que faz um escravo do teu irmão?

ou duma outra que rebenta

como um rio de fúria no peito feito tormenta

quando não há nada a perder no que se tenta?»

José Mário Branco

- Cantiga da velha mãe e dos seus dois filhos

À perenidade da sua memória

\section{INTRODUÇÃO}

A crer nos postulados construtivistas, com que as linhas do presente artigo se tecem, o conhecimento constrói-se com base nas convenções científicas e, forçosamente, com base na agnição que se possua sobre uma determinada realidade. Posto isto, e tendo em conta que os media são a principal via de acesso por parte do grande público às realidades arqueológicas, são eles que delimitam à partida as bases do que pode ser cognoscível. É o seu papel metonímico,

1. Mestrando em Arqueologia na Faculdade de Letras da Universidade de Lisboa; fosagosto@gmail.com

2. Mestrando em Arqueologia na Faculdade de Letras da Universidade de Lisboa; jodavid.ms@gmail.com 
à semelhança do já elegantemente argumentado por Shanks e Tilley (1988, p. 13) para o caso dos museus, que os torna de suma importância: as realidades que se escolhem são as únicas tornadas passíveis de ser percepcionadas e, assim, as únicas existentes - qual ilusão transcendental Kantiana (Luhmann, 2000, p. 4; vide Ribeiro, 2001, p. 82).

Tem este artigo o objectivo de compreender qual o espaço que a arqueologia portuguesa, utilizando a arqueologia algarvia como metonímia - realidade bem circunscrita geograficamente e numa zona economicamente rica e mormente assente no turismo - se perfila na imprensa nacional e regional na presente centúria, juntamente com os estereótipos relacionados com a arqueologia, a sua prática e a visão do passado vinculada por estas. Procurar-se-á também compreender quais são os conteúdos expostos ao grande público juntamente com as razões que o justificam em ambas as imprensas. Conforme crê um dos signatários (FA), a impossibilidade de se arribar a um ponto definitivo, total e final no processo de criação de conhecimento implica forçosamente que todas as "reflexões finais» aqui ensaiadas sejam sim, em verdade, mais a síntese (na sua acepção dialéctica) entre os vários elementos que servem de base para reflexões futuras do que uma qualquer conclusão que se procure definitiva.

É de matizar que a análise terá um forte pendor externalista. Não se descurará por completo, porém, algum internalismo, devido às razões já expressas por O. Moro Abadía (2009, p. 21).

\section{METODOLOGIA}

Devido à natureza dissímil da imprensa nacional e regional (vide Correia, 1998, p. 5 para uma listagem de vários elementos que diferenciam a regional), os apartados que se seguem desenvolvem-se sob o signo dialéctico, estabelecendo-se e definindo-se os elementos em confronto para, posteriormente, se dissertar sobre a síntese produzida, coadjuvada da devida interpretação.

De forma a perscrutar o objecto de análise em apreço, tomou-se como base para a imprensa nacional os seguintes jornais: Público, Expresso, Sol, Diário de Notícias, Jornal de Notícias, Observador e Correio da Manhã. O carácter fragmentário da imprensa regional, que pode só se focar a uma escala concelhia, motivou a adopção do grande jornal regional do sul português e do Algarve em particular: o Sul Informação.
O ciberespaço, segundo o ensaio sobre teoria dos media protagonizado por Wolfgang Ernst (2013, p. 138), corresponde ao momento de democratização do arquivo, pelo desmantelamento das hierarquias do espaço, chegando a um público mais generalizado e, assim, configurando-se como um melhor veículo para o estudo do objecto de análise proposto e como um melhor meio para poder responder ao questionário prévio. Destarte, a pesquisa baseou-se nas respectivas plataformas digitais dos jornais sobre notícias relacionadas com a arqueologia do Algarve.

A análise incidirá sobre cinco prismas em concreto. i) A modalidade consiste em indicar se a notícia se endereça directamente à arqueologia, ou se esta é somente trazida à colação numa outra discussão (indirecta). Permite avaliar o peso que é dado à arqueologia na discussão de grandes temáticas que sejam transversais e de manifesta relevância nos dias actuais (e.g. como se lida com o património relacionado com a escravatura).ii) A data de publicação das notícias poderá permitir entrever se existe não só alguma concentração editorial como atestar uma putativa sazonalidade nesta. Está intimamente ligada, por isso, tanto com as variáveis da modalidade como com a da natureza dos trabalhos. iii) Porventura das questões mais importantes a que se quer contribuir neste artigo está relacionada sobre a escolha dos períodos cronológicos que perfilam nos jornais nacionais e regionais. Se os jornais são poderosos dispositivos metonímicos, a exclusão de certas temporalidades pode proscrever ao oblívio certas cronologias. Perceber a razão desta exclusão é, assim, de assaz importância. iv) Através das lentes da geografia, sistematizando a espacialidade das notícias, poder-se-á compreender se existe alguma relação entre o maior poderio económico de um concelho em concreto com uma maior (ou menor) representação nas várias imprensas. v) Por fim, importa conhecer a natureza dos trabalhos arqueológicos e o seu respectivo enquadramento legal. Assim, um discurso sobre os actores, sejam eles de instituições públicas (e.g. universidades) ou oriundos da iniciativa privada (i.e. empresas), pode ser tecido.

Por fim, os dados aqui empregues foram recolhidos numa perspectiva fenomenológica, ou seja, procedendo ao trabalho mecânico de transpor para a base de dados a informação que somente constava na notícia, não se tendo "digerido a realidade» (Lyotard, 1992, p. 7) nem acrescentado informações ou cruzando com outras notícias. 


\section{RESULTADOS}

\subsection{Modalidades}

No que é atinente às modalidades, é possível concluir que na imprensa nacional a arqueologia é quase só exclusivamente mobilizada para a sua discussão directa (93,8\%) (Tabela 1).

O panorama inverte-se na imprensa regional, onde a arqueologia apresenta-se somente $68,8 \%$ de forma directa e 31,2\% indirectamente (Tabela 2).

A evidente clivagem entre as duas imprensas poderá, em parte, encontrar justificação na própria índole dos jornais: se uma tem um engajamento mais declarado com a população local, com a qual tem uma relação muito mais forte (e.g. vide Correia, 1998, p. 5; Ghizzoni, 2013, p. 136), a outra tem na obtenção de lucro uma das suas silabas tónicas (e.g. vide Pereira, 2004, p. 9; Ribeiro, 2001, p. 81). Embora não se recuse por completo que as redacções dos vários jornais nacionais não possam ter nos seus princípios um salutar espírito de missão, é inegável, até pela sua própria natureza, que uma das funções dos jornais regionais é informar em maior detalhe as populações locais sobre a sua região. Este elemento está também intimamente ligado com a sua relação com as elites locais e possíveis relações clientelares (Correia, 1998, p. 5; Pascoal, 2008, p. 11). Outra das diferenças a ter em consideração cinge-se com a parca experiência dos jornalistas da imprensa regional, os quais, possuindo "baixos níveis de capital escolar» (Pascoal, 2008, p. 6), acabam por dar azo a uma manifesta disparidade em toda a chaîne opératoire da elaboração da notícia (vide Pascoal, 2008, p. 10). A diferença na formação é, deste modo, incontornável. Ainda assim, não se nota nos jornais nacionais uma preocupação tão manifesta em mobilizar a arqueologia (e seguramente a algarvia) para a reflexão colectiva de problemáticas na ordem do dia.

Muito antes pelo contrário, é de salientar que quando esta aparece indirectamente na imprensa nacional, o que é muito raro $(6,3 \%)$, esta vem comodificada, reduzindo-a a simples produto económico: não parece haver espaço para a discussão do património arqueológico em outras grandes discussões (no sentido anglo-saxónico da expressão) enquanto um potencial educativo e de sensibilização para todos que no Algarve estudam, trabalham ou se veraneiem. Tal parece contrastar com algumas notícias evidenciadas nos jornais regionais que ligam a arqueologia, com os seus respectivos contextos, a uma declarada preocupação de arqueologia pública. A arqueologia é assim posta ao serviço de conteúdos que procuram a pedagogia, não se limitando a uma simples exposição descritiva contextual. Esta tendência é mais frequente na imprensa regional do que na imprensa nacional.

\subsection{As datas de publicação}

Os meses de maior incidências jornalística sobre a arqueologia do Algarve concentram-se, claramente, durantes os meses estivais e sobre o que imediatamente os antecede (Maio) (Tabela 3). Os demais, isoladamente, são quase epifenómenos.

Estando em relativo contraste com a imprensa nacional, denota-se que os meses de menor actividade jornalística sobre a arqueologia resumem-se ao período entre Outubro e Fevereiro - abarcando parte do Outono e o Inverno (Tabela 4).

Sem grandes surpresas, os meses mais intensos nesta matéria são os relativos ao Verão. Tal se justifica por serem os meses que, em primeiro lugar, proporcionam as condições climatéricas ideais à realização de trabalhos arqueológicos de campo e, num segundo plano, por se configurarem como os meses de interrupção lectiva, permitindo o deslocamento das equipas de directores e voluntários ao campo.

Esta proposta é acalentada e confirmada porquanto a maioria dos trabalhos arqueológicos desenvolvidos em plagas algarvias têm a indelével marca d'água das universidades e dos trabalhos de investigação (50\% em ambas as imprensas - vide apartado 3.5.).

Os outros meses, que se destacam pela negativa, são ocupados por notícias referentes a alguns trabalhos de Tipo C e B.

A maior duração no tempo das notícias relacionadas com a arqueologia por parte dos jornais regionais justifica-se por serem entidades com um olhar mais atento ao local e ao que nele se passa, contrastando, evidentemente, com a impressa nacional.

\subsection{Concelho}

Somente os concelhos de Loulé (20\%), Tavira (16,3\%) e Vila Real de Santo António (15\%) se apresentam expressivamente (Tabela 5). Os restantes não detêm especial relevância que mereça menções adicionais. Demarcando-se do evidenciado nos jornais nacionais, o olhar atento dos aparatos jornalísticos $d a$ região, pela região e para a região resultou numa multiplicidade de concelhos a poderem ser considerados estatisticamente significativos (Tabela 6). 
Loulé (19,8\%), Portimão (15,2\%), Faro (10,3\%), Silves $(13,3 \%)$, Vila do Bispo (11,4\%) e, em menor grau, Tavira (7,6\%) são os concelhos em destaque.

Embora entidades concelhias como Loulé, Tavira e Vila Real de Santo António tenham uma maior exposição mediática na imprensa nacional, o que se materializa no supra exposto, deve ser mencionado que a quase totalidade deles é relativa a um pequeno conjunto de sítios/acontecimentos. Tavira, com a cidade romana de Balsa e a exposição do Museu Nacional de Arqueologia da arqueologia do concelho; Loulé com a recente exposição, também no Museu Nacional de Arqueologia e também sobre o património arqueológico do seu território; e Vila Real de Santo António que, com as escavações em Cacela Velha, encerram a quase totalidade de notícias sobre os respectivos concelhos.

O papel recentemente desempenhado pela Câmara Municipal de Loulé enquanto promotora da actividade arqueológica, financiando trabalhos dentro do concelho e apoiando colóquios sobre trabalhos realizados nas suas fronteiras, como o realizado no dia 22 de Novembro de 2019 sobre os trinta anos da edição da tese de doutoramento de Victor Gonçalves - «Megalitismo e Metalurgia no Alto Algarve Oriente: uma aproximação integrada» (1989), em muito contribuem para um maior enlevo até a nível nacional deste concelho. Resulta natural que este se perfile como o mais bem representado nas várias redacções.

Salienta-se a quase ausência de Portimão nos jornais nacionais $(1,3 \%)$, contrastando com a sua presença mais expressiva na realidade regional $(15,2 \%)$. O móbil de tal situação, por estranho que possa parecer à primeira vista, queda-se justificada por uma só razão: são em boa parte relativas quer ao povoado de Alcalar como às suas necrópoles do $3^{\circ}$ milénio a.n.e. Como já referido, a imprensa regional tem uma maior relação com a população local, funcionando a nacional mais como um empresa privada que, através da notícia e da produção de mais-valia, visa o lucro. Destarte, a escolha do que noticiar coaduna-se intimamente com a escolha de qual o material mais passível de ser comodificado. Mesmo que se aborde esta questão num outro apartado com mais detalhe (vide apartado 3.4.), relegando-se para lá um maior detalhe argumentativo, é seguro dizer que a pré-história é muito menos vendável que um outro período histórico mais presente no imaginário geral.

Sendo os trabalhos de investigação positivamente relacionáveis com as notícias produzidas, não é de surpreender que nos concelhos onde estes são não-existentes/pouco expressivos exista, de facto, menos matéria noticiada.

Verifica-se também a grande concentração de notícias na região litoral. Tal pode dever-se a, pelo menos, três ordens de razão: i) a presença humana mais intensa, actualmente, no litoral do que noutras áreas. ii) Às dificuldades acrescidas inerentes à logística na prospecção e escavação, tanto pelo acidentado terreno como pelas vias de comunicação mais parcas em uma das zonas mais isoladas de todo o Algarve (i.e. Serra), como o elegantemente exposto por Victor Gonçalves (1989, pp. 87-8 e 9o) demonstra. E, por fim, iii) sendo o litoral a região mais rica das três, e a que mais pressão turística tem, é clarividente que seja esta a que tenha mais verba para o financiamento de escavações de investigação como as que mais interesse tenham na actividade arqueológica, tendo em vista a sua rentabilização económica enquanto atractivo turístico, ou seja, na sua potencial comodificação.

\subsection{Cronologia}

Regista-se um domínio absoluto dos períodos históricos face aos pré-históricos e proto-históricos (Tabela 7). As notícias relacionas com o mundo romano $(38,8 \%)$ são as dominantes, seguindo-se as do período medieval islâmico isoladamente $(17,9 \%)$ e em junção com o medieval cristão (13,4\%).

Entrevendo-se uma realidade mais diluída, a imprensa regional encontra em três grandes períodos com dimensões estatísticas análogas as suas linhas mestras: Calcolítico (17,5\%), Romano (17,5\%) e Medieval Islâmico $(16,3 \%)$ (Tabela 8$)$.

Se uma das principais funções do jornal é vender, como o é na imprensa nacional, a escolha da cronologia dos sítios noticiados não é, de longe, inocente. O mundo histórico, na qual a antiguidade clássica figura por excelência, seja pelo cânone de que serviu durante séculos ou, por sua vez, pelo impacto cultural que o mesmo teve até aos dias de hoje, configura-se como uma realidade muito melhor conhecida do público em geral do que a anterior à presença romana. Os próprios jornalistas, não tendo particular formação ou sensibilidade na área da pré-história, não conseguem nela reconhecer o seu potencial enquanto bem económico. Os jornais, através da pré-história, não conseguem estabelecer tão facilmente comunicação entre a redacção e o pú- 
blico, ou seja, não se arriba a um contexto de significado comum (Luhmann, 200o, p. 15).

Como já argumentado, os jornais, à semelhança dos museus, são activos construtores da realidade para quem os lê. A escolha do período romano, manifestamente presente em qualquer das imprensas, para além das razões já acima expostas, prende-se também com a construção de uma identidade nacional cuja fundação é a romano-cristã. Bastará relembrar que a ideia de associação entre a nação portuguesa (na sua acepção enquanto povo) à Lusitânia não é, de longe, uma ideia recente ou em desuso em contexto popular.

Por outro lado, e isto é inescapável, existe um maior número de trabalhos de investigação que versam quer sobre o mundo romano (e.g. Monte Molião) quer sobre as realidades islâmicas (e.g. Cacela Velha e Silves), o que condiciona, à partida, as notícias que daqui brotarem.

Explica-se uma maior presença da pré-história na imprensa regional devido ao já argumentado no subcapítulo anterior: o menor potencial de comodificação de contextos pré-históricas, como Alcalar, reflectindo assim o peso distinto que este tem na imprensa nacional e nos seus congéneres regionais.

Com o advento das teorias pós-coloniais (Said, 2003 [1978]), a ideia do Oriente enquanto entidade "that is based on the Orient's special place in European Western experience" (Said, 2003, p. 1) foi tornada cognoscível. Ainda assim, e embora largos sejam os passos que já foram dados desde os finais da década de 70 , ainda primam em plataformas com uma tremenda exposição construções do mundo islâmico enquanto algo exótico e distante. O arquétipo islâmico vendido é metonímico de um Oriente orientalizado pelo Ocidente, que nada é mais, para o comum do europeu que o consume, do que "one of its deepest and most recurring images of the Othern (Said, 2003, p. 1).

Procurando ilustrar o exposto, atente-se à pequena peça jornalística, da autoria de Idálio Revez e Joana Bourgard (2014), intitulada de «Descoberto complexo balnear islâmico único em Portugal». Nela, para além da total comodificação do património arqueológico ao serviço do turismo estival, é possível auditar, tanto no início como no final, acompanhado de um cenário que foca e particulariza vários elementos de um complexo balnear no extremo ocidente da Europa, a «Güldür Gül», uma canção sufi, otomana e cantada em turco!
Posto isto, é também possível defender um certo orientalismo nos processos de comodificação do património islâmico em Portugal.

\subsection{Natureza dos trabalhos}

Os trabalhos de Tipo A abrangem mais do que a maioria das notícias (55,2\%\%). Salvante os de Tipo B, que estão em segundo lugar com $29,3 \%$, os demais são de pouca significância estatística (Tabela 9). Não obstante o elevado número de intervenções de Tipo C, e algumas de Tipo D, estas apresentam-se sub-representadas na imprensa nacional.

À semelhança do evidenciado nos jornais nacionais, destaca-se em primeiro plano os trabalhos de investigação, com 49,4\%, seguido dos atinentes à valorização e musealização, com 30,6\% (Tabela 10). É de notar a acrescida importância dos trabalhos Tipo C neste tipo de imprensa.

Resultando claro o peso dos trabalhos de investigação no que acaba por ser a sua expressão editorial tanto nas plagas algarvias como em âmbito nacional, queda-se como (aparentemente) estranha a ausência dos trabalhos de Tipo C, de longe os mais frequentes dos trabalhos de campo. Tal poderá ser explicado pelo carácter pouco visível, muito fragmentado e de difícil reconhecimento das realidades arqueológicas produzidas pela arqueologia preventiva.

Também nos trabalhos de investigação, que são quase sempre financiados por entidades locais e públicas (i.e. câmaras municipais), são os próprios organismos camarários os que muitas das vezes entram em contacto com as redacções de jornais, trazendo jornalistas aos sítios e, assim, aumentando a visibilidade dos projectos a serem empreendidos.

A maior assiduidade das notícias analisadas nos media regionais que têm como enquadramento legal os trabalhos de Tipo C queda-se justificada, uma vez mais, numa maior importância dada à dimensão de serviço público e dever informativo às populações locais.

As notícias relativas à musealização de bens arqueológicos exumados de contextos algarvios na imprensa nacional estão quase exclusivamente relacionadas com o Museu Nacional de Arqueologia, em Lisboa. Nos jornais regionais, onde a atenção é, naturalmente, voltada às realidades algarvias, tal não se sucede. Contudo, há que questionar se a sub-representação presente na imprensa nacional não se poderá relacionar com uma visão centralizadora - afim da evidenciada há longos anos na administração pública na- 
cional. Da mesma forma como os principais órgãos de gestão têm em Lisboa a sua residência, também a grande maioria das sedes das redacções se situam na capital, criando uma visão geograficamente unívoca.

\section{REFLEXÕES FINAIS, OU DA COMODIFI- CAÇÃO DE UM ESTEREÓTIPO}

\begin{abstract}
"AL JIZAH, EGYPT - A team of British and Egyptian archaeologists made a stunning discovery Monday, unearthing several intact specimens of "skeleton people" - skinless, organless humans who populated the Nile delta region an estimated 6,ooo years ago.» "Archaeological Dig uncovers Ancient Race of Skeleton People» - Notícia do "The Onion» de 8/12/99, com o humor que lhe é próprio.
\end{abstract}

A presença da arqueologia algarvia nos jornais possui características distintas consoante a imprensa em questão, reflectindo acima de tudo a natureza dissimilante entre ambas as redacções. A nacional precipita-se naturalmente para uma maior comodificação da arqueologia, por ter um interesse acrescido na obtenção de lucro através da extracção de mais-valia na produção de notícias e peças jornalísticas (e.g. vide Ribeiro, 2001, p. 81). A regional, por sua vez, por ter uma relação mais próxima e forte às comunidades locais e por se dedicar a uma região em concreto, juntamente com formações de base distintas, dá espaço a notícias não tão facilmente tornadas simples produto económico. O tratamento muito diferenciado dado à pré-história e uma maior abrangência regional na imprensa regional são disso justo exemplo (Tabela 5, 6, 7 e 8).

A sobre-representação do litoral algarvio face às demais regiões queda-se justificada pela sua maior capacidade económica, podendo financiar trabalhos de campo de investigação nos seus territórios - de longe os mais patentes nos jornais (tabela 9 e 10).

Não sendo o jornalismo uma ilha isolada do mundo que o rodeia, nela ainda se reflecte todo um conjunto de visões sobre o passado e o Outro que em muito trespassam o âmbito dos jornais, como um certo orientalismo atesta. Infelizmente, os jornais não mobilizam a arqueologia e os seus contributos para discutir de forma crítica temáticas fracturantes, como, por exemplo, o que fazer com restos humanos de contextos da escravatura africana.

Uma vez feita a reflexão sobre as razões que motivam a escolha de temas arqueológicos para entrin- cheirarem nos jornais e como ela é feita, importa perceber qual é a imagem que é transmitida para o grande público sobre a arqueologia. Importa compreender quais os trâmites em que a arqueologia passa para ser tornada em peça jornalística rentável. Importa, por isso, perceber a Arqueologia enquanto Marca (Holtorf, 2016), com as subsequentes implicações na percepção do(s) passado(s) e da própria actividade arqueológica.

Perpassam essencialmente dois grandes estereótipos da arqueologia e da sua prática: o tema $\mathrm{R}$ (o mais frequente), definido pela arqueologia enquanto fonte de revelações sensacionais (Holtorf, 2016, p. 84); e, este já em menor grau, o tema $\mathrm{D}$, onde o arqueólogo é apresentado como se tratasse de um detective em funções (Holtorf, 2016, pp. 75-6).

Ambos os estereótipos não são, aliás, mutualmente exclusivos, muito antes pelo contrário (Holtorf, 2016, p. 85).

Também se verifica a existência de notícias onde é outorgado aos achados o papel unilateral da produção de conhecimento. A arqueologia queda-se destarte na simples audição de um artefacto "falante". Estes são assim a grande fonte para os tempos pretéritos. Neste ensejo o arqueólogo torna-se somente mero trabalhador mecânico e perfeitamente alienado do seu trabalho para extrair da terra a História, não tendo particular questionário científico a responder nem participando no processo interpretativo - que espaço tem sequer o arqueólogo na interpretação de uma materialidade tão (aparentemente) clarividente? É neste pêndulo entre o essencialismo e o antiquarismo em que os artefactos, enquanto testemunho metonímico de um Passado único, são $O$ Passado. Esta philos artefactualista perpetua uma visão acrítica do passado e poda o que podia ser uma frondosa árvore de complexidade, reduzindo os tempos pretéritos a simples engenho de consumo fácil a um vasto público - qual fast-food cultural. A História arqueológica passa a ser cognoscível através do vaso per se, votando ao oblívio tanto a sociedade que o produziu como as contradições internas desta. Os jornais comungam assim de uma visão de uma arqueologia enquadrada numa narrativa aventuresca - quiçá militar - onde os nossos Indiana Jones, após intensos prélios, podem mostrar ao mundo os espólios das suas conquistas: os materiais arqueológicos (Holtorf, 2016, p. 65).

A arqueologia aparece também intimamente associada ao enigma, servindo desta forma como mais 
um mecanismo de comodificação. Conforme já observado por Holtfort (2016, p. 9o), a arqueologia pode em parte ser comparada a filmes de terror ou aos $X$-Files, não pela melosa voz da Scully ou o cinismo do Mulder, mas sim porque ambos lidam com o desconhecido e o mistério, assim se aparentando ao grande público.

Conquanto seja evidente a comodificação que a arqueologia é alvo, esta não se opera em todas as suas dimensões. Tomando por base a partição de Moshenska (2009, pp. 46-7) e adaptando-a à realidade em discussão, a arqueologia é comodificada principalmente em duas dimensões nos jornais: através da imagética que produz (tipo 5) e do material arqueológico (tipo 1). A natureza interligada de ambos reforça o foco fetichista do artefacto dado pelos jornais. Mais do que propriamente um apanágio ou uma inovação da imprensa portuguesa, há que levantar a possibilidade desta forma de apresentar e representar o passado corresponder à sedimentação discursiva perpetuada por revistas internacionais de impacto global, como a National Geographic. De facto, são várias as parecenças verificadas na análise do presente objecto de estudo e as descritas por Joan Gero e Dolores Root (1990) para esta revista, como a visão de um passado resumido ao artefacto (p. 28 e 34) e o leitmotiv do explorador/aventura (p. 27). Não se verificou, contudo, a importante crítica androcêntrica que as autoras fazem à NatGeo em qualquer das imprensas. Este facto pode dever-se, em parte, à relativa paridade de género em quem assina as notícias relacionadas com a arqueologia.

No que é atinente à relação entre a arqueologia e a divulgação jornalística: mesmo que o arqueólogo seja um narrador por excelência, havendo no contacto com o público um lado demarcadamente performativo (Fagan, 2002, p. 254), este é proscrito a mero apontamento, a um detalhe não relevante na notícia. A sua palavra é somente utilizada como o enunciar das "pistas» sobre as realidades em apreço - qual detective em trabalho. Se Alfred Kidder (1949) tivesse de rescrever os dois tipos de arqueólogos que postulou no imaginário popular, sendo estes o "hairy-chested" e o "hairy-chinned», e à luz do já exposto, teria de incluir um terceiro tipo: o mudo. Todavia, a referenciação da palavra do arqueólogo nas notícias - citando-o directamente - não pode ser descartada como também sendo um mecanismo de salvaguarda das redacções que assim evitam a construção de uma imagem pública de jornal=verdade, com a sua consequente validade apriorística a evitar (Luhmann, 2000, p. 5).

A forma como a arqueologia e a sua materialidade é encarada na imprensa, muito mais do que corresponder a um intento de transmitir informação, encontra expressão numa condição de entretenimento (se entendida como uma quasi-heterotopia - vide Luhmann, 200o, pp. 51-52) - um entretenimento sofisticado de consumo rápido. Deveras, a comodificação da cultura ao serviço dos interesses económicos resulta tendencialmente na castração do pensamento reflexivo, onde "Thought becomes short-winded, confines itself to apprehending isolated facts. Intellectual connections are rejected as an inconvenient and useless exertion.» (Horkheimer e Adorno, 2002, p. 163; sem negrito no original).

\subsection{E concluindo um trabalho em eterno devir...} Por fim, considera-se que a inexistência de uma sólida organização interna dentro da comunidade arqueológica, dotando-nos de força e coesão, não permite à classe ter a expressividade e o peso desejáveis na sociedade civil. Enquanto tal não for ultrapassado, dificilmente poderá sistematicamente o arqueólogo ter uma palavra a dizer sobre a (re)construção do(s) passado(s) nos media.

A prática de redacção em jornais sobre matéria arqueológica em muito pode ser majorada qualitativamente se for o próprio arqueólogo a escrever. Mais do que um despautério utópico, é de salientar o conjunto de notícias no Sul Informação, assinadas por Cristina Tété Garcia e Maria João Valente, intituladas «Crónicas de uma escavação arqueológican. Aqui, para além haver um claro cunho pedagógico bem conseguido (i.e. sem entrar em paternalismos desnecessários), são explicados não só os processos de escavação arqueológica como o que foi intervencionado. E é apresentada uma visão humana sobre o extraído dos arquivos pétreos da História, ficando patente que quem habitou o espaço foram pessoas e não meros artefactos (aparentemente) desirmanados.

Só a sistemática integração de arqueólogos nas trincheiras jornalísticas pode alterar decisivamente o paradigma vigente. Tal pode ter consequências muito positivas não só para a percepção do público do arqueólogo e do seu métier como tornar a exposição de tempos pretéritos numa salubre prática reflexiva, anulando os sensacionalismos (que é, aliás, parte do ponto 2 do código deontológico dos jornalistas) e desvelando o que de tão humano há nas copiosas 
materialidades que escavamos. É esse mesmo lado humano que falta. E se a arqueologia que se deseja em plena centúria de XXI é uma onde exista intensa relação com o público, retribuindo às comunidades locais e nacionais o fruto do labor arqueológico, urge a reflexão sobre as formas como a arqueologia é consumida e transmitida (Moshenska, 2009, p. 47). E rapidamente.

Que a todos sirva de estímulo para as mais salutares reflexões futuras.

Vale

\author{
Primeira versão de Outono de 2019, \\ revisto e ampliado na Primavera e terminado \\ nos primeiros dias estivais de 2020 , \\ Península de Lisboa
}

\section{AGRADECIMENTOS}

Há que agradecer à Prof. Miguel Calado e ao Philipp Teuchmann pela revisão do texto, pelos preciosos comentários e pelas salubres discussões (na acepção anglo-saxónica do termo) queacrescentaram insofismávelvalorao presente artigo. Agradeço também à Prof. a Ana Margarida Arruda pelos perspicazes comentários a uma primeira versão do texto, ainda em contexto académico livre de pandemias, assim como o desafio de avançar com a publicação. O produto final é, evidentemente, da exclusiva responsabilidade dos autores.

\section{BIBLIOGRAFIA}

CORREIA, João (1998) - Jornalismo regional e cidadania. Biblioteca On-line de Ciências da Comunicação. pp. 1-6.

ERNST, Wolfgang (2013) - Digital memory and the archive. 1st. ed. Minneapolis: University of Minnesota Press.

Fagan, Brian (2002) - Epilogue. In LITTLE, Barbara, eds. Public Benefits of Archaeology. Gainesville: University Press of Florida. pp. 253-6o.

GERO, Joan; ROOT, Dolores (1990) - Public Presentations and Private Concerns: Archaeology in the Pages of National Geographic. In GATHERCOLE, Peter; LOWENTHAL, David, eds. - The Politics of the Past. London: Unwin Himan. pp. 532-548.

GHIZZONI, Manuela (2013) - Jornalismo Regional como Mediador Social: Uma Análise de Conteúdo. Revista Vernáculo. 32, pp. 136-166.

GONÇALVES, Victor Santos (1989) - Megalitismo e metalurgia no Alto Algarve Oriental: uma aproximação integrada. Lisboa: Instituto Nacional de Investigação Científica.
HOLTORF, Cornelius (2016) - Archaeology Is a Brand! The meaning of archeology in contemporary popular culture. London and New York: Routledge.

HORKHEIMER, Max; ADORNO, Theodor (2002) - Dialectic of Enlightenment: Philosophical Fragments. Standford: Stanford University Press.

LUHMANN, Niklas (200o) - The Reality of the Mass Media. Standford: Stanford University Press.

LYOTARD, Jean François (1992) - La phenomenologie. $11^{\text {th }}$. ed. Paris: Presses Universitaires de France.

MORO ABADÍA, Oscar (2009) - The History of Archaeology as Seen Through the Externalism-Internalism Debate: Historical Development and Current Challenges. Bulletin of the History of Archaeology. 19. 2, pp.13-26.

MOSHENSKA, Gabriel (2009) - What is Public Archaeology? Present Pasts. 1, pp. 46-48.

PASCOAL, Isabel (2008) - Os jornalistas da imprensa regional e os condicionalismos ao exercício da profissão. In III Congresso Português de Sociologia: Práticas e Processos da Mudança Social. pp. 1-13.

PEREIRA, Fábio (2004) - Da responsabilidade social ao jornalismo de mercado: o jornalismo como profissão. Biblioteca On-line de Ciências da Comunicação. pp. 1-15.

REVEZ, Idálio; BOURDARD, Joana (2014) - Descoberto complexo balnear islâmico único em Portugal. Público. https://www.publico.pt/2014/o1/23/video/complexo-balnear-islamico-unico-em-portugal-2014012O-184030

RIBEIRO, Jorge (2001) - Sempre Alerta: condições e contradições do trabalho jornalístico. São Paulo: Olho d'Água.

SAID, Edward (2003) - Orientalism: Western Conceptions of the Orient. $5^{\text {th }}$. ed. London: Penguin Books.

SHANKS, Michael; TILLEY, Christopher (1988) - Social Theory and Archaeology. Albuquerque: University of New Mexico Press. 
Modalidade - Imp. Nacional

\begin{tabular}{ll|l|l|l|l} 
& & Frequência & Percentagem & Percentagem válida & $\begin{array}{l}\text { Percentagem } \\
\text { acumulativa }\end{array}$ \\
\hline \multirow{2}{*}{ Válido } & Directa & 75 & 93,8 & 93,8 & 93,8 \\
\cline { 2 - 6 } & Indirecta & 5 & 6,3 & 6,3 & 100,0 \\
\cline { 2 - 6 } & Total & 80 & 100,0 & 100,0 & \\
\hline
\end{tabular}

Tabela 1 - Tabela descritiva das modalidades das notícias publicadas na imprensa nacional (valores arredondados à décima).

\begin{tabular}{|c|c|c|c|c|c|}
\hline & & Frequência & Percentagem & $\begin{array}{l}\text { Percentagem } \\
\text { válida }\end{array}$ & $\begin{array}{l}\text { Percentagem } \\
\text { acumulativa }\end{array}$ \\
\hline \multirow[t]{3}{*}{ Válido } & Directa & 181 & 68,8 & 68,8 & 68,8 \\
\hline & Indirecta & 82 & 31,2 & 31,2 & 100,0 \\
\hline & Total & 263 & 100,0 & 100,0 & \\
\hline
\end{tabular}

Tabela 2 - Tabela descritiva das modalidades das notícias publicadas na imprensa nacional (valores arredondados à décima).

\section{Mês - Imp. Nacional}

\begin{tabular}{|c|c|c|c|c|c|}
\hline & & Frequência & Percentagem & $\begin{array}{l}\text { Percentagem } \\
\text { válida }\end{array}$ & $\begin{array}{l}\text { Percentagem } \\
\text { acumulativa }\end{array}$ \\
\hline \multirow[t]{12}{*}{ Válido } & Janeiro & 6 & 7,5 & 7,5 & 7,5 \\
\hline & Fevereiro & 4 & 5,0 & 5,0 & 12,5 \\
\hline & Março & 1 & 1,3 & 1,3 & 13,8 \\
\hline & Abril & 7 & 8,8 & 8,8 & 22,6 \\
\hline & Maio & 10 & 12,5 & 12,5 & 35,1 \\
\hline & Junho & 12 & 15,0 & 15,0 & 50,1 \\
\hline & Julho & 16 & 20,0 & 20,0 & 70,1 \\
\hline & Agosto & 10 & 12,5 & 12,5 & 82,6 \\
\hline & Setembro & 11 & 13,8 & 13,8 & 96,4 \\
\hline & Outubro & 1 & 1,3 & 1,3 & 97,7 \\
\hline & Dezembro & 2 & 2,5 & 2,5 & 100 \\
\hline & Total & 80 & 100,0 & 100,0 & \\
\hline
\end{tabular}

Tabela 3 - Tabela descritiva da data de publicação das notícias da imprensa nacional distribuída por meses (valores arredondados à décima). 


\section{Mês - Imp. Regional}

\begin{tabular}{|c|c|c|c|c|c|}
\hline & & Frequência & Percentagem & $\begin{array}{l}\text { Percentagem } \\
\text { válida }\end{array}$ & $\begin{array}{l}\text { Percentagem } \\
\text { acumulativa }\end{array}$ \\
\hline \multirow[t]{13}{*}{ Válido } & Janeiro & 10 & 3,8 & 3,8 & 3,8 \\
\hline & Fevereiro & 19 & 7,2 & 7,2 & 11,0 \\
\hline & Março & 26 & 9,9 & 9,9 & 20,9 \\
\hline & Abril & 29 & 11,0 & 11,0 & 31,9 \\
\hline & Maio & 27 & 10,3 & 10,3 & 42,2 \\
\hline & Junho & 22 & 8,4 & 8,4 & 50,6 \\
\hline & Julho & 34 & 12,9 & 12,9 & 63,5 \\
\hline & Agosto & 29 & 11,0 & 11,0 & 74,5 \\
\hline & Setembro & 26 & 9,9 & 9,9 & 84,4 \\
\hline & Outubro & 18 & 6,8 & 6,8 & 91,2 \\
\hline & Novembro & 19 & 7,2 & 7,2 & 98,4 \\
\hline & Dezembro & 4 & 1,5 & 1,5 & 100 \\
\hline & Total & 263 & 100,0 & 100,0 & \\
\hline
\end{tabular}

Tabela 4 - Tabela descritiva da data de publicação das notícias da imprensa regional distribuída por meses (valores arredondados à décima).

\section{Concelho-Imp. Nacional}

\begin{tabular}{|c|c|c|c|c|c|}
\hline & & Frequência & Percentagem & $\begin{array}{l}\text { Percentagem } \\
\text { válida }\end{array}$ & $\begin{array}{l}\text { Percentagem } \\
\text { acumulativa }\end{array}$ \\
\hline \multirow[t]{18}{*}{ Válido } & & 6 & 7,5 & 7,5 & 7,5 \\
\hline & Albufeira & 2 & 2,5 & 2,5 & 10,0 \\
\hline & Alcoutim & 1 & 1,3 & 1,3 & 11,3 \\
\hline & Aljezur & 3 & 3,8 & 3,8 & 15,0 \\
\hline & Castro Marim & 1 & 1,3 & 1,3 & 16,3 \\
\hline & Faro & 4 & 5,0 & 5,0 & 21,3 \\
\hline & Lagoa & 2 & 2,5 & 2,5 & 23,8 \\
\hline & Lagoa (e Viana do Castelo) & 1 & 1,3 & 1,3 & 25,0 \\
\hline & Lagos & 5 & 6,3 & 6,3 & 31,3 \\
\hline & Loulé & 16 & 20,0 & 20,0 & 51,2 \\
\hline & Monchique & 1 & 1,3 & 1,3 & 52,5 \\
\hline & Portimão & 1 & 1,3 & 1,3 & 53,8 \\
\hline & Sagres & 2 & 2,5 & 2,5 & 56,3 \\
\hline & Silves & 2 & 2,5 & 2,5 & 58,8 \\
\hline & Tavira & 13 & 16,3 & 16,3 & 75,0 \\
\hline & Vila do Bispo & 8 & 10,0 & 10,0 & 85,0 \\
\hline & Vila Real de Santo António & 12 & 15,0 & 15,0 & 100,0 \\
\hline & Total & 80 & 100,0 & 100,0 & \\
\hline
\end{tabular}

Tabela 5 - Tabela descritiva da geografia das notícias da imprensa nacional distribuída por concelhos (valores arredondados à décima). 


\begin{tabular}{|c|c|c|c|c|c|}
\hline & & Frequência & Percentagem & $\begin{array}{l}\text { Percentagem } \\
\text { válida }\end{array}$ & $\begin{array}{l}\text { Percentagem } \\
\text { acumulativa }\end{array}$ \\
\hline \multirow[t]{24}{*}{ Válido } & . & 1 & 4 & 4 & ,4 \\
\hline & Albufeira & 7 & 2,7 & 2,7 & 3,0 \\
\hline & Alcoutim & 2 & 8 & 8 & 3,8 \\
\hline & Aljezur & 4 & 1,5 & 1,5 & 5,3 \\
\hline & Castro Marim & 1 &, 4 &, 4 & 5,7 \\
\hline & Faro & 27 & 10,3 & 10,3 & 16,0 \\
\hline & Lagoa & 2 & 8 & 8 & 16,7 \\
\hline & Lagoa e São Brás de Alportel & 1 & 4 & 4 & 17,1 \\
\hline & Lagos & 14 & 5,3 & 5,3 & 22,4 \\
\hline & Lagos e Portimão & 1 & 4 &, 4 & 22,8 \\
\hline & Loulé & 52 & 19,8 & 19,8 & 42,6 \\
\hline & Loulé (e Almodôvar) & 1 &, 4 &, 4 & 43,0 \\
\hline & Monchique & 4 & 1,5 & 1,5 & 44,5 \\
\hline & Olhão & 1 &, 4 &, 4 & 44,9 \\
\hline & Portimão & 40 & 15,2 & 15,2 & 60,1 \\
\hline & Portimão e Loulé & 1 & ,4 &, 4 & 60,5 \\
\hline & $\begin{array}{l}\text { Portimão, Lagoa, Silves } \\
\text { e Monchique }\end{array}$ & 2 & 8 & ,8 & 61,2 \\
\hline & São Brás de Alportel & 4 & 1,5 & 1,5 & 62,7 \\
\hline & Silves & 35 & 13,3 & 13,3 & 76,0 \\
\hline & Tavira & 20 & 7,6 & 7,6 & 83,7 \\
\hline & Vários & 4 & 1,5 & 1,5 & 85,2 \\
\hline & Vila do Bispo & 30 & 11,4 & 11,4 & 96,6 \\
\hline & Vila Real de Santo António & 9 & 3,4 & 3,4 & 100,0 \\
\hline & Total & 263 & 100,0 & 100,0 & \\
\hline
\end{tabular}

Tabela 6 - Tabela descritiva da geografia das notícias da imprensa regional distribuída por concelhos (valores arredondados à décima). 


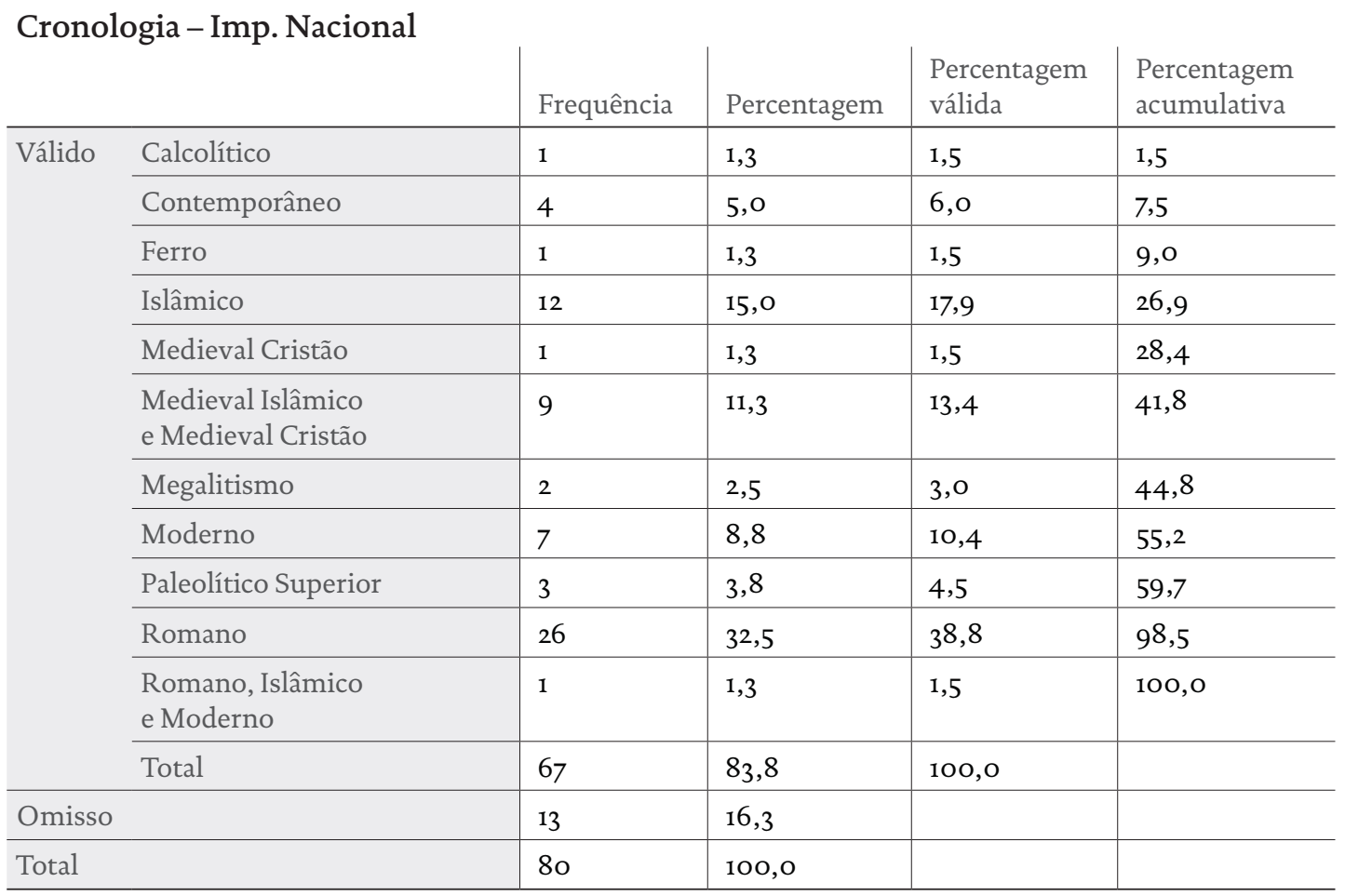

Tabela 7-Tabela descritiva das cronologias mencionadas das notícias publicadas na imprensa nacional (valores arredondados à décima).

\begin{tabular}{|c|c|c|c|c|c|}
\hline \multicolumn{6}{|c|}{ Cronologia - Imp. Regional } \\
\hline & & Frequência & Percentagem & válida & acumulativa \\
\hline \multirow[t]{16}{*}{ Válido } & Calcolítico & 14 & 5,3 & 17,5 & 17,5 \\
\hline & $\begin{array}{l}\text { Calcolítico, Romano, } \\
\text { Medieval }\end{array}$ & 1 & 4 & 1,3 & 18,8 \\
\hline & Contemporâneo & 2 & ,8 & 2,5 & 21,3 \\
\hline & Idade do Bronze, Islâmico & 2 & ,8 & 2,5 & 23,8 \\
\hline & Idade do Ferro, Romano & 7 & 2,7 & 8,8 & 32,5 \\
\hline & Islâmico & 13 & 4,9 & 16,3 & 48,8 \\
\hline & Islâmico e Medieval Cristão & 8 & 3,0 & 10,0 & 58,8 \\
\hline & Moderno & 5 & 1,9 & 6,3 & 65,0 \\
\hline & Moderno e Contemporâneo & 1 & 4 & 1,3 & 66,3 \\
\hline & Paleolítico & 7 & 2,7 & 8,8 & 75,0 \\
\hline & Romano & 14 & 5,3 & 17,5 & 92,5 \\
\hline & Romano até Contemporâneo & 2 & 8 & 2,5 & 95,0 \\
\hline & Romano, Moderno & 2 & ,8 & 2,5 & 97,5 \\
\hline & $\begin{array}{l}\text { Romano, Moderno, } \\
\text { Contemporâneo }\end{array}$ & 1 & 4 & 1,3 & 98,8 \\
\hline & Tardo-Medieval & 1 & 4 & 1,3 & 100,0 \\
\hline & Total & 80 & 30,4 & 100,0 & \\
\hline Omisso & & 183 & 69,6 & & \\
\hline Total & & 263 & 100,0 & & \\
\hline
\end{tabular}

Tabela 8 - Tabela descritiva das cronologias mencionadas das notícias publicadas na imprensa regional (valores arredondados à décima). 
Natureza dos trabalhos - Imp. Nacional

\begin{tabular}{ll|l|l|l|l} 
& & & & & \\
& & Frequência & Percentagem & $\begin{array}{l}\text { Percentagem } \\
\text { válida }\end{array}$ & $\begin{array}{l}\text { Percentagem } \\
\text { acumulativa }\end{array}$ \\
\hline Válido & Tipo A & 32 & 40,0 & 55,2 & 55,2 \\
\cline { 2 - 6 } & Tipo B & 17 & 21,3 & 29,3 & 84,5 \\
\cline { 2 - 6 } & Tipo C & 8 & 10,0 & 13,8 & 98,3 \\
\cline { 2 - 6 } & Tipo D & 1 & 1,3 & 1,7 & 100,0 \\
\hline & Total & 58 & 72,5 & 100,0 & \\
\hline Omisso & 22 & 27,5 & & \\
\hline Total & 80 & 100,0 & &
\end{tabular}

Tabela 9- Tabela descritiva da natureza legal dos trabalhos arqueológicos mencionados nas notícias publicadas na imprensa nacional (valores arredondados à décima).

\begin{tabular}{|c|c|c|c|c|c|}
\hline & & Frequência & Percentagem & $\begin{array}{l}\text { Percentagem } \\
\text { válida }\end{array}$ & $\begin{array}{l}\text { Percentagem } \\
\text { acumulativa }\end{array}$ \\
\hline \multirow[t]{4}{*}{ Válido } & Tipo A & 42 & 16,0 & 49,4 & 49,4 \\
\hline & Tipo B & 26 & 9,9 & 30,6 & 80,0 \\
\hline & Tipo C & 17 & 6,5 & 20,0 & 100,0 \\
\hline & Total & 85 & 32,3 & 100,0 & \\
\hline Omisso & & 178 & 67,7 & & \\
\hline Total & & 263 & 100,0 & & \\
\hline
\end{tabular}

Tabela 10 - Tabela descritiva da natureza legal dos trabalhos arqueológicos mencionados nas notícias publicadas na imprensa regional (valores arredondados à décima). 


\title{
A EVOLUÇÃO DA ARQUEOLOGIA URBANA E A VALORIZAÇÃO PATRIMONIAL NO BARLAVENTO ALGARVIO: OS CASOS DE PORTIMÃO E SILVES
}

\author{
Artur Mateus ${ }^{1}$, Diogo Varandas ${ }^{2}$, Rafael Boavida ${ }^{3}$
}

\begin{abstract}
RESUMO
Com este artigo, pretende-se realizar uma breve síntese sobre o panorama e evolução da arqueologia urbana nos concelhos de Portimão e Silves. O objetivo principal será entender a evolução da identificação, valorização e divulgação dos sítios arqueológicos gerados por esta prática, e a forma como se enquadram no quotidiano das cidades abordadas neste estudo. Deste modo, recorreu-se à base de dados do "Portal do Arqueólogo", Planos Diretores Municipais (PDM), documentos de divulgação patrimonial regionais e nacionais e a notícias municipais e nacionais. A necessidade de uma arqueologia urbana tornou-se fundamental e imperativa no final do século passado, devido à sua relevância na reconstrução identitária e histórica dos respetivos concelhos. Igualmente, analisar-se-á o impacto dos trabalhos urbanos no desenvolvimento turístico-cultural local. Palavras-chave: Arqueologia Urbana, Arqueologia Pública, Turismo Cultural, Portimão, Silves.
\end{abstract}

\begin{abstract}
With this article, we pretend to address the situation and evolution of the Urban Archaeology of the municipalities of Portimão and Silves in brief and generic terms. We will focus on understanding the basic evolution of the background in which the identification, protection and divulgation of archaeological sites was done, and how these connect to everyday city life. For this, we searched the "Portal do Arqueólogo" database, the urban master legislations (PDM's), as well as the local-national press. The urge for a strong Urban Archaeology has been visible since the end of the last century, due to its importance for the reconstruction of local histories and identities. The impact of this in the development of local tourism was sought.

Keywords: Urban Archaeology, Public Archaeology, Cultural Tourism, Portimão, Silves.
\end{abstract}

\section{INTRODUÇÃO}

A arqueologia urbana tornou-se fulcral nas últimas décadas por um conjunto de circunstâncias, a começar com a verificação de que a própria arqueologia, enquanto ciência, granjeou já a partir da década de 90 com a polémica que ultrapassou fronteiras das gravuras rupestres do Côa. As obras construtivas no Alqueva, na mesma década, não só se afirmaram para a rutura do estigma de que o passado humano e os seus vestígios constituem um impedimento para a concretização de grandes obras, mas também demarcaram o papel do arqueólogo no seio de uma área que ultrapassa o âmbito académico. Este passa, então, a integrar uma parte fulcral para a recolha de conhecimento histórico, arqueológico e etnográfico, funcionando ainda como um intermédio entre a comunidade e a divulgação do conhecimento científico. A legislação é adaptada não apenas para a preservação e salvaguarda do património, mas também para o fomento da produção de conhecimento sobre as histórias, gestos e identidades locais, na evolução

\footnotetext{
1. Mestrando de Arqueologia da Faculdade de Letras da Universidade de Lisboa; artur.q.mateus@gmail.com

2. Mestrando de Arqueologia da Faculdade de Letras da Universidade de Lisboa; dvarandas@campus.ul.pt

3. Mestrando de Arqueologia da Faculdade de Letras da Universidade de Lisboa; rafaelboavida@campus.ul.pt
} 
da malha territorial e urbana de uma dada região ou comunidade. Portanto, a criação desta nova legislação criou um boom nacional (e internacional) relativamente aos trabalhos arqueológicos em contextos urbanos e, como veremos adiante, os casos de Portimão e Silves (Figura 1) não se encontram de todo alienados desta nova realidade.

O presente trabalho foi estruturado em três pontos: Um primeiro, onde se procurou enquadrar o surgimento e atuação da arqueologia urbana nos concelhos de Silves e Portimão, no âmbito da história da investigação arqueológica e da proteção patrimonial do Algarve; Um segundo ponto, onde se dá a conhecer os modos em que se tem vindo a efectuar os trabalhos arqueológicos nestes dois ambientes citadinos, geralmente associados às áreas de preservação histórica dos centros, quer sejam estes realizados por entidades públicas ou privadas; Como último ponto, abordaremos o panorama da componente de divulgação e valorização turístico-cultural que se fomentou nestes concelhos.

\section{BREVE HISTÓRIA DOS TRABALHOS ARQUEOLÓGICOS DE CARIZ URBANO}

Quando observamos o panorama da história dos trabalhos arqueológicos nestes dois concelhos, podemos estabelecer uma evolução essencialmente caracterizada por três etapas. Uma primeira, que diz respeito aos trabalhos pioneiros de Estácio da Veiga, na segunda metade do século XIX, com o seu projeto dos volumes "Antiguidades Monumentaes do Algarve", que ainda hoje marcam toda uma fase da arqueologia do Algarve. No que concerne aos concelhos de Portimão e Silves, são inúmeras as observações, levantamentos e trabalhos levados a cabo pelo mesmo, sendo de mencionar as suas intervenções no Castelo de Silves, na Cisterna dos Cães (Gonçalves, 2007: p. 423), como também na icónica jazida de Alcalar (Portimão) (Soares, Pereira \& Freitas, 2007). Após os trabalhos do mesmo, assistimos a um marasmo arqueológico (Figura 2), onde poucos trabalhos são realizados com o intuito e abrangência científica semelhante aos de Estácio da Veiga e, desta forma, não vocacionados num objetivo de compilação, quase que enciclopédica como era o estilo de antigamente. No entanto, há que salientar os esforços da DGEMN em recuperar o Castelo de Silves durante as décadas de 30 e 40 (Correia, 2011: p. 373-374). Podemos afirmar que estas intervenções correspondem às ideologias políticas implementadas pelo Estado Novo, onde a história e as "velhas pedras" (Correia, 2011: p. 324) combinam-se para legitimar um passado nacional, comum a todos os portugueses, credibilizando, assim, o presente (Correia, 2011: p. 245). Paralelamente à ação da DGEMN, é de salientar os percursos pelo Barlavento algarvio, e em particular por Portimão, de algumas figuras como José Formosinho e Abel Viana, que mantinham ainda viva a atividade arqueológica. O primeiro desejava, inclusive, a criação de um museu regional sediado em Lagos, pressionando até a DGEMN, com o objetivo de expor os vestígios presentes nestes concelhos, projeto este coevo com a ideologia estatal da época (Bernardes, 2019: p. 106).

Entretanto, nos anos 6o, surgem as primeiras discussões teóricas sobre a proteção e preservação do património urbano (Valente, 2012: pp. 180-182). Nesta década, temos a destacar o trabalho liderado pelo Arquiteto Cabeça Padrão - Estudos de Prospecção, Preservação e Recuperação de Elementos Urbanísticos e Arquitectónicos Notáveis, em Áreas Urbanas e Marginais Viárias, na Região do Algarve. É um trabalho composto por um conjunto de 49 volumes, que engloba as cidades de Portimão (vol. 19) e Silves (vol. 34) (Ribeiro \& alii, 2016: pp. 335, 342; Valente, 2012: p. 184).

Podemos salientar o ponto de viragem que se assume a partir da década de 70 a nível nacional, que se reflete, igualmente, nestes concelhos. Existe uma maior consciencialização do espaço urbano como um local histórico e identitário. Desta forma, a arqueologia também conhece um novo vigor, entrando assim numa "segunda etapa" (Bernardes, 2010). Merecem destaque os trabalhos iniciais de Mário e Rosa Varela Gomes, ainda acompanhados por Caetano de Mello Beirão. Na cidade de Silves, incidiram-se no Poço-Cisterna Almóada e no Pátio a ele anexado, como também na Alcáçova de Silves (Gonçalves, 2007: p. 423-426).

O panorama da pressão urbana crescia, visível em todo o território algarvio e, particularmente, em Portimão (vide Leonardo, 2011: p. 33). Simultaneamente, os trabalhos continuavam sem uma legislação que obrigasse uma proteção do património arqueológico. Somente com o contexto da Convenção de Malta, em 1992, e a criação de bases para a elaboração das leis de defesa do património arqueológico a nível europeu, é que o cenário dos trabalhos de arqueologia urbana passaram a atuar num novo paradigma, diga- 
mos, numa terceira etapa da Arqueologia nestes concelhos (Figura 2). Deste modo, a nível nacional, cria-se o IPPAR, no mesmo ano. Em 1993, é criado em Silves, e noutros pontos do país, o Gabinete Técnico Local (G.T.L.) que elabora o Plano de Pormenor / Salvaguarda do Centro Histórico de Silves. No entanto, as ações levadas a cabo por este Gabinete não surtiram efeito, como se verifica pela ausência das medidas propostas no Plano de Pormenor, no futuro Plano Diretor Municipal (PDM), redigido em 1995 (Valente, 2012: p. 188).

Já em 1997, o Instituto Português de Arqueologia (IPA) (ex-IPPAR) conduz diversos trabalhos em Portimão, entre 1999-2002 (cuja ação contava com uma extensão e equipa na cidade de Silves), no que toca ao levantamento e relocalização de sítios/ocorrências arqueológicas. No concelho de Silves, os trabalhos arqueológicos e sítios identificados, através de trabalhos de acompanhamentos, sondagens, levantamentos, escavações, aumentam com relativa significância na própria cidade de Silves e no território da freguesia de São Bartolomeu de Messines (Gonçalves, 2007: p. 426). Nesta altura, em Portimão, é de referir também o relevante trabalho de levantamento arqueológico desempenhado por Isabel Soares (2001), atualmente chefe de divisão de $\mathrm{Mu}$ seus, Património e Arquivo Histórico do Município de Portimão (DMPAH). No entanto, a componente arqueológica, incorporada na Câmara Municipal de Silves, apenas surgiu em 2002. Nos anos prévios ao Gabinete de Arqueologia, Conservação e Restauro, existia a designada "Oficina de Restauro", estabelecida no final dos anos 8o, que apoiava pontualmente algumas intervenções arqueológicas (Gonçalves e Rodrigues, 2011: p. 544).

\section{A ARQUEOLOGIA URBANA DE PORTIMÃO E SILVES}

Como já foi aqui abordado, os trabalhos enquadrados nestas segunda e terceira etapas, refletem os pensamentos contemporâneos do espaço citadino como um lugar de memórias, esse que deve ser preservado e estimado. Saliente-se a recomendação da UNESCO, promulgada a dez de novembro de 2011, precisamente referente à proteção da integridade $\mathrm{e}$ "espírito" dos centros históricos urbanos enquanto espaços de memória que devem ser preservados: “[...] as alterações descontroladas da densidade e do crescimento urbano podem colocar em risco o espíri- to do lugar, a integridade do tecido urbano e a identidade das comunidades. Algumas áreas históricas urbanas estão a perder a sua funcionalidade, o seu papel tradicional e a sua população." (UNESCO, 2011, ponto 17-trad. Cabral).

Os dois centros urbanos de que falamos podem integrar-se na esfera deste panorama, onde ambos são alvos de várias intervenções arqueológicas, tanto em casos de construções de novas infraestruturas ou no âmbito de uma recuperação e revalorização de antigos edifícios, tal como é o caso do Teatro Mascarenhas Gregório (Silves) e do próprio Museu de Portimão.

No que toca às ações dos municípios, a Câmara Municipal de Silves, através do seu Gabinete de Arqueologia, realiza alguns trabalhos de intervenção arqueológica. Devido ao número reduzido de profissionais e ao seu território extenso de atuação, com grande potencial arqueológico, o Gabinete foca-se nos trabalhos de emergência ou de pequena envergadura, sendo que os grandes trabalhos interventivos ficam ao encargo de equipas externas a este Gabinete (Gonçalves \& Rodrigues, 2011: p. 549), como por exemplo os trabalhos realizados no âmbito do Programa POLIS e outros, como o Teatro Mascarenhas Gregório ("ERA - Arqueologia”) (Encarnação \& Gonçalves, 2013: p. 261; Websites: "ERA Arqueologia” - era-arqueologia.pt; Portal do Arqueólogo arqueologia.patrimoniocultural.pt.; Fontes consultadas em dezembro de 2019). No caso do concelho de Portimão, é de mencionar a ação da Câmara Municipal, liderada pela equipa do Museu do município, no que toca aos trabalhos de acompanhamento e minimização de impactes no âmbito da construção civil. Disto, são exemplos os relatórios efetuados face a três dos Planos de Pormenor outorgados pela Câmara (do Barranco Rodrigo - 2007; da Quinta do Malheiro - 2017; e da Horta do Palácio - 2010), tal como os levantamentos arqueológicos e patrimoniais associados ao projeto de reabilitação do Centro Histórico de Portimão (ARU, 2014).

De todo o modo, o vértice empresarial da ação da arqueologia urbana no concelho é de mencionar, sendo Portimão mais um exemplo onde as empresas de arqueologia encontram-se em constante atuação, alguns dos quais exercendo trabalhos de envergadura considerável. Veja-se, a título de exemplo, as intervenções no antigo "edifício Mabor" levadas a cabo pela empresa "AES Arqueologia”, entre outros trabalhos de acompanhamento e reabilitação. Este 
cenário de acompanhamentos no centro histórico anda em par com a atuação empresarial fora dos centros citadinos, como os trabalhos de conservação e restauro tanto na villa Romana da Abicada, como também num dos monumentos de Alcalar, realizados pela empresa "ERA Arqueologia", aos quais se adicionam os vários acompanhamentos arqueológicos associados ao projeto da montagem da linha de alta tensão Portimão-Tunes, desempenhados pela mesma empresa.

Em paralelo com esta cidade, temos a destacar a importância que a arqueologia constitui para o desenvolvimento do espaço urbano de Silves. Há que salientar os trabalhos arqueológicos decorrentes na Rua da Cruz, a propósito da edificação da nova biblioteca municipal (Gonçalves, 2008: p. 4-5), no Hospital Velho de Silves, no Salão Paroquial de Silves e o próprio Museu Municipal de Arqueologia de Silves (Gomes, 2006: p. 29; Portal do Arqueólogo arqueologia.patrimoniocultural.pt: Fonte consultada em dezembro de 2019).

Também neste quadro, o Programa POLIS apresenta-se como o elemento mais claro de um espaço em constante evolução e renovação urbanística, na qual os trabalhos arqueológicos destas empresas privadas quase que ditam o ritmo dessas transformações. Segundo os dados recolhidos no Portal do Arqueólogo, estes trabalhos constituem $26,74 \%$ dos sítios identificados nesta cidade. São, na sua essência, trabalhos de prevenção, com o objetivo de minimizar impactes sobre o património arqueológico, aliado ao objetivo (externo ao âmbito arqueológico) de revitalizar e requalificar os vários espaços intervencionados. Como casos exemplares, entre tantos outros, destacamos aqui os trabalhos decorrentes no próprio Castelo de Silves, entre 2003 e 2007, com vista a musealização do espaço, projeto liderado por Rosa Varela Gomes; na rua da Sé entre 2004 e 2006 e, no mesmo local, entre 2017 e 2019, onde se pôs a descoberto vários vestígios osteológicos num fosso islâmico, possivelmente ligado à conquista de Silves, a barbacã e, ainda, evidências do que poderia ser a antiga mesquita de Xilb. Estes últimos foram trabalhos de acompanhamento arqueológico ao encargo da “Archeo'Estudos, Lda." (Pires, 2019); e, no Largo José Correia Lobo, entre 2004 e 2006, onde se identificou uma necrópole de cronologia islâmica. Por outro lado, uma decisão polémica no âmbito dos trabalhos do Programa POLIS, é descrita no jornal "Público" e noticiada como: "Túmulo Islâmico deixado sob conduta de esgotos"
(Revez, 2006). O título, por si só, é bastante sugestivo. Segundo esta, descobriu-se na rua 25 de Abril um túmulo de um murabit, em outras palavras, de um homem santo da comunidade islâmica. É uma notícia que, por várias razões, revela as dificuldades de se realizar Arqueologia Urbana. De um lado, temos de ter em conta a proteção do património e como se deve proceder de forma a que esse não seja afetado. Do outro, temos o lado burocrático e financeiro, que escapa às propostas e intenções dos arqueólogos. É uma Arqueologia que tende a estar condicionada a pressões externas, que colocam entraves à realização de um trabalho dinâmico e vocacionado tanto para o debate científico como para a divulgação cultural local e turística (Lopes, 2018).

Se nos debruçarmos sobre a figura 5 , não causa surpresa serem as próprias capitais municipais de Portimão e Silves, aquelas cujas ocorrências arqueológicas mais se atribuem a um âmbito urbano, dada a sua maior área edificada. Por outro lado, note-se a densidade de ocorrências arqueológicas identificadas nas freguesias comparativamente mais rurais, em particular as freguesias de São Bartolomeu de Messines (Silves) e da Mexilhoeira-Grande (Portimão), onde a arqueologia urbana é praticamente residual. No entanto, para este primeiro local, temos de mencionar o trabalho realizado por Jorge Estevão Correia (2005 apud. Gonçalves, 2007: p. 427), que identifica 65 novos sítios nesta freguesia. É de referir o caso da freguesia de Alvor (Portimão), tendo o espaço urbano desta uma origem histórica em função da sua posição geográfica, pesqueira, na entrada da ria de Alvor, cujos vestígios antigos têm sido objeto de intervenções em meio urbano, havendo aliás uma proposta de criação de uma carta de Sensibilidade Arqueológica (vide Pereira, 2018: p. 105, 109-110).

Torna-se interessante cruzar este panorama com o da figura 6 , no sentido em que se atendermos ao número de projetos de arqueologia nos dois concelhos (e porventura trabalhos associados a estes), contabilizados no "Portal do Arqueólogo", a quantidade dos mesmos que incidiram em zonas urbanas é muito considerável na quantificação total - correspondendo precisamente ao cenário de crescente pressão urbanística e à necessidade de se proceder aos acompanhamentos de salvaguarda patrimonial aquando das obras. 


\section{A IMPORTÂNCIA DESTES TRABALHOS PARA A CULTURA LOCAL E VISIBILIDADE TURÍSTICA}

Os casos de Silves e Portimão afiguram-se assim como elementos singulares da arqueologia urbana. Os trabalhos, e consecutiva valorização patrimonial, permitem conferir uma oferta cultural a um amplo espectro demográfico, que acompanha os desenvolvimentos arqueológicos citadinos. A importância destes trabalhos, observada nos anteriores capítulos, é significativa ao ponto de se afirmar como um elemento para a própria evolução e construção da cidade, através dos respetivos PDMs. Como tal, trata-se de um assunto público, que necessita de ser difundido e valorizado pelas populações locais. Repare-se, fora do âmbito geográfico deste artigo, mas exemplificativo, a importância entre Lagos e a sua suposta fundação com o nome de Laccobriga, que se perpetuou no quotidiano da cidade e incentivou à designação de um habitante de Lagos como um Laccobrigense. Tal situação aplica-se, também, aos contextos de Portimão e Silves. A importância do ambiente e identidade de Silves, como cidade medieval islâmica e cristã, permanece valorizada nos dias de hoje através de diversas entidades institucionais e culturais, como as ações do Museu Municipal de Arqueologia de Silves e a famosa feira medieval da cidade (Valente, 2012).

A análise dos sítios arqueológicos de ambos os concelhos enquadra-se, desta forma, nas estratégias desenvolvidas pelos núcleos museológicos locais. Uma rápida observação do panorama cronológico referente aos sítios arqueológicos presentes no Portal do Arqueólogo revela que, no caso de Silves, a maioria das intervenções e identificação de sítios arqueológicos abrangem contextos de cronologia Islâmica e Medieval. Um esforço para a valorização de outras cronologias está patente na estratégia de divulgação cultural municipal. A criação de um percurso denominado como "o roteiro dos menires" enaltece o passado pré-histórico, mas também inclui outros sítios de cronologia medieval. Um olhar mais cuidadoso pela musealização e divulgação patrimonial coloca, novamente, o passado islâmico e medieval cristão em destaque, através da conservação do poço-cisterna almóada no Museu Municipal de Arqueologia.

Não obstante, a herança e identidade de uma cidade não é apenas atribuída a uma cronologia. $\mathrm{O}$ caso de Portimão reflete um outro tipo de valorização, através da toponímia associada às ruas. É o caso da rua do Menir onde, nas imediações, podemos encontrar os dois menires de Vale de França (um deles atualmente denominado por Menir dos Três Bicos). No entanto, a localização destes não nos remete para o seu "espírito contextual" pré-histórico, pelo mesmo facto de se localizarem num espaço agora citadino. A importância destes marcos territoriais, certamente, influenciaram o pensamento e tradição das populações, que perpetuaram a memória destes monumentos na própria cidade. O contexto enquadra-se com a grande importância do complexo de Alcalar, localizado dentro deste concelho, na Praia de Mexilhoeira. Apesar de Portimão ser por tradição uma cidade pesqueira e marítima, cuja valorização do património moderno e contemporâneo citadino é enaltecido, a cidade não esquece a sua história mais antiga. Contudo, é preciso destacar que a importância dada a Alcalar não é partilhada por todos os períodos históricos. Note-se o caso da villa Romana da Abicada que, apesar da sua classificação como Monumento Nacional, permanece num estado de conservação e exposição bastante precário, pelo menos desde o ano de 2013, segundo a notícia do jornal "Sul Informação" (Rodrigues, 2013).

Esta discrepância entre períodos cronológicos pouco ou nada condiz com a dispersão temporal dos sítios arqueológicos identificados nas respetivas freguesias. O gráfico apresentado (fig. 7) demonstra a variabilidade de cronologias de todas as freguesias do Concelho de Silves, que englobam um total de 308 sítios com entrada na base de dados do Portal do Arqueólogo. Esta análise, contudo, teve os seus problemas devido à estruturação da base de dados e das características próprias dos sítios arqueológicos. A presença de contextos com uma ampla diacronia cronológica inflacionaram, de forma moderada, o total de sítios contabilizados, pois uma estação arqueológica que possuí dois períodos distintos (por exemplo medieval e romano), foi contabilizada como duas entradas. Não obstante, os dados são interessantes, dado o panorama que este estudo aferiu. O caso da freguesia de Silves é marcado por uma maioria de sítios de cronologia Medieval/Islâmica $(46,67 \%)$, que se alinham com a divulgação e tipo de política, ou estratégia, de valorização cultural. Muito deriva, como já referido, do forte desenvolvimento da arqueologia urbana na cidade e no programa POLIS que a abrangeu. Destacam-se, igualmente, 
as baixas percentagens de todos os outros períodos cronológicos, com a exceção dos sítios associados a uma cronologia Moderna/Contemporânea, que, não obstante, partilham uma maioria de entradas no Portal do Arqueólogo com os sítios aferidos de cronologia Medieval/Islâmica.

A realidade fora da freguesia de Silves, como já referido no capítulo 3, caracteriza-se por uma maior ruralidade e menor incidência de arqueologia em âmbito urbano. A maioria destas demonstram uma relativa dispersão entre as diversas cronologias, com a exceção da freguesia de Algoz e Tunes. Contudo, o peso dos sítios medievos continua a ser impactante neste contexto, constituindo-se como a principal realidade trabalhada e explorada de um ponto visto científico e de arqueologia pública no concelho de Silves.

O caso de Portimão é particularmente curioso. Note-se que, nos principais websites de divulgação patrimonial e cultural, há uma expressiva atenção dada aos sítios e monumentos de período Contemporâneo/Moderno. Contudo, o Portal do Arqueólogo demonstra que estes sítios e período histórico não são, em nenhuma freguesia, maioritários. A predominância está em sítios de cronologia romana, que dominam em todas as regiões do concelho (tendo o contexto da evolução da identificação de sítios romanos - vide Bernardes, 2010). Refira-se que, no caso da Mexilhoeira Grande (fig. 8), é visível uma maioria atribuível ao período da Pré-História recente, porém, o problema que já foi mencionado no caso de Silves repete-se. Efetivamente, as entradas no Portal do Arqueólogo em torno do núcleo megalítico de Alcalar são extensas, o que inflaciona de forma substancial as percentagens obtidas. Se estas referências fossem retiradas, a cronologia romana estaria, novamente, em maioria. A conclusão passível a retirar, é que a prática de conservação e valorização arqueológica em Portimão, não parece seguir a restante realidade arqueológica que caracteriza o concelho, pois como já mencionámos, a villa Romana da Abicada, ilustrativa do fenómeno das villae do Algarve, permanece num estado precário, pouco valorativo, no quadro da divulgação cultural e turística municipal, contrastando em grande medida com as condições visíveis, por exemplo, de Alcalar.

No âmbito da valorização do património arqueológico do concelho de Portimão, é de destacar, desde logo, a ação central do Museu do Município. É de notar a importância dada ao contexto dos vestígios da Pré-História recente, expressada com maior evi- dência no centro de interpretação de Alcalar (onde o próprio museu realiza visitas e atividades). Esta harmonia entre os espaços museológicos é, igualmente, de salientar, dada a possibilidade de obter um bilhete único de visita a ambos os espaços, o que demonstra uma sincronia municipal saudável em relação à divulgação patrimonial/cultural. Embora tenhamos referido uma certa apatia perante contextos de cronologia romana, o potencial de valorização de período contemporâneo/moderno é, claramente, aproveitado, dado que os antigos edifícios associados ao cariz costeiro e pesqueiro de Portimão são alvo de trabalhos de restauração e conservação, no qual o próprio Museu Municipal de Portimão é o melhor exemplo. O reaproveitamento de uma antiga unidade fabril de conservas de peixe no ano de 2008 , como um espaço museológico moderno, permite, assim, perpetuar a memória e tradição da cidade, mas, também, expor toda a história do concelho num espaço, historicamente, importante. Destaque-se, igualmente, a importância dada a este contexto, com a realização de diversas exposições temporárias, cujo foco centra-se nas tradicionais atividades portuárias da cidade (Mateus, 2018: p. 11-12), mas que nunca esquece a sua exposição permanente, cronologicamente abrangente e central num contexto municipal.

A oferta municipal, plasmada nos roteiros culturais e patrimoniais dos websites das respetivas câmaras, não diverge do panorama apresentado anteriormente. Veja-se a predominância de sítios de cronologia Contemporânea e Moderna, que pode ser explicada por estarmos a lidar com dados de todo o concelho e não restritos às freguesias. A frequente menção a espaços religiosos, como as igrejas matrizes, é o principal factor desta dispersão. Não obstante, se observarmos a figura 9, as conclusões que podemos retirar são que a tradição medieval e islâmica de Silves possui um peso significativo, comparativamente aos restantes. Note-se, porém, uma maior variabilidade da oferta patrimonial, particularmente, nos campos da Pré-História Recente e do período Romano, característica análoga com as anteriores propostas. Portimão, contudo, é caracterizado por um predomínio claro de sítios/monumentos de período Contemporâneo e Moderno, que se relaciona com a herança e aposta na valorização destes períodos em concreto.

O panorama nacional pouco ou nada diverge dos roteiros nacionais, como se observa na figura 10. O caso de Silves é particularmente confuso neste 
contexto, dado que a referência a espaços de cronologia Romana subitamente desaparece e é substituída por sítios de cronologia Proto-Histórica. A Pré-História Recente é representada por uma percentagem semelhante, que acompanha a tendência dos sítios de cronologia Medieval e Moderna/Contemporânea. A problemática já apresentada no contexto regional, reflete-se da mesma forma no nacional. Portimão, novamente, segue o padrão que já estabelecemos ao longo do trabalho, marcado por uma grande importância dos sítios Contemporâneos e Modernos. A cronologia romana e pré-histórica recente está apenas representada pelos sítios da villa romana da Abicada e o complexo megalítico de Alcalar.

\section{CONCLUSÃO}

Os casos de Portimão e Silves são, assim, relacionáveis e quase únicos no contexto do Barlavento Algarvio. A prática de uma arqueologia urbana apenas pode ser comparada com um outro município, o de Lagos. Esta tríade, tendo em conta os dados disponibilizados pelo Portal do Arqueólogo e levantamentos estatísticos do Algarve (PROTALG), é caracterizada pelo maior número de sítios arqueológicos por concelho, assim como pela maior percentagem de uma prática arqueológica urbana. São, igualmente, os concelhos com maior variabilidade de sítios arqueológicos preservados e reabilitados, tanto em âmbito urbano (caso do Castelo de Silves), como em âmbito rural (caso do complexo megalítico de Alcalar). Esta realidade é coeva com o investimento e interesse municipal em desenvolver e apoiar a prática arqueológica pública.

À medida que a legislação portuguesa foi-se alterando, a própria arqueologia urbana dos dois concelhos conheceu um boom. A presença de uma filial do IPA na cidade de Silves contribuiu para este aumento da prática arqueológica, assim como os vários trabalhos de Rosa Varela Gomes no Castelo de Silves e no Poço-Cisterna Almóada que, juntamente com a contribuição científica e os atos de divulgação cultural (resultantes desses trabalhos), relembram a necessidade cultural da existência de uma Arqueologia Urbana para preservar o passado histórico, potenciando também o crescimento turístico da cidade. Também, com o advento do Programa POLIS na cidade, as ações de empresas privadas de arqueologia fazem aumentar esta potencialidade divulgativa e protecionista do património aí presente, existindo em Silves quatro Monumentos Nacionais na própria cidade. No caso de Portimão, o papel da equipa do museu municipal, juntamente com as empresas de arqueologia tem vindo a caracterizar o esforço de preservação das várias ocorrências e sítios do meio urbano, para os quais o museu, e o grupo de amigos do mesmo (GAMP), assume-se como um elo para a consciencialização do Património local. A reabilitação arqueológica dos centros históricos em ambos os concelhos torna-se fundamental nas dinâmicas de valorização de cada cidade, assumindo-se como reflexo imediato do carácter geográfico e histórico, diferente, de cada uma. Onde em Silves o período medieval e islâmico em torno de uma paisagem histórica ligada ao castelo é importante, a tradição etnográfica portuária de Portimão, aliada a uma forte valorização no cenário pré-histórico é contrastante. Os dados do Portal do Arqueólogo afiguram-se como essenciais para uma análise e estudo em torno das temáticas aqui discutidas. A sua criação e desenvolvimento é algo essencial para o estado de arqueologia portuguesa, que permite uma maior harmonia e facilidade no desenvolvimento de estudos arqueológicos. Não obstante, é dotado de problemas e alguns aspetos técnicos, que necessitam de ser discutidos. Esta observação não procura denegrir a plataforma, pelo contrário, procura valorizar e aperfeiçoar a mesma. Veja-se que ao longo da realização deste estudo enfrentamos, consistentemente, o mesmo problema. O caso de Alcalar é, talvez, o mais sugestivo e fácil de debater, dada a sua personalidade de núcleo ou complexo. Porém, não é esta imagem que o Portal apresenta, visto que todos os seus elementos são identificados como um sítio arqueológico, que apenas inflaciona e condiciona uma análise estatística como a nossa.

A sugestão que apresentamos é categorizar e agrupar estes sítios. Em vez de lidarmos com um sítio de Alcalar 1, 2, 3 e assim sucessivamente, acreditamos que fosse mais simples e eficiente ajustar a plataforma de forma a criar um grupo designado como Alcalar, que dentro deste teria todos os seus elementos individualizados e de fácil acesso. Se por um lado auxilia a produção de análises estatísticas, por outro facilita o acesso e navegação da plataforma, dada a maior simplicidade do website. Outro problema, talvez mais discutível e de mais complicada resolução, é relativo à identificação de sítios arqueológicos através de achados dispersos ou elementos singulares. $\mathrm{O}$ caso das âncoras, frequentes no contexto algar- 
vio, e imediata associação a um sítio arqueológico, é exagerado e talvez enganador. O problema poderia ser resolvido com a criação de um outro filtro, que permita uma distinção entre sítios arqueológicos e potenciais sítios arqueológicos. Novamente, sugerimos esta proposta como uma alternativa mais agregadora e com o intuito de simplificar a plataforma e a procura na mesma.

\section{BIBLIOGRAFIA}

BERNARDES, J. P. (2010) - A Investigação Arqueológica do Período Romano no Algarve: Balanço e perspectivas de investigação. In XELB, (Actas do $7^{\circ}$ Encontro de Arqueologia do Algarve), Silves : Câmara Municipal de Silves, ํํำ, pp. 385-398.

BERNARDES, J. P. (2019) - José Formosinho e a arqueologia da primeira metade do século XX no barlavento algarvio. In FORTES, J. B.; FABIÃO, C. \& SERRANO, B. M. (eds.) La Historia de la Arqueología Hispano-Portuguesa a Debate: Historiografia, coleccionismo, investigación y gestión arqueológicos en España y Portugal. SPAL Monografía Arqueología, XXX, pp. 105-119.

BICHO, Nuno; ROCHA; Leonor; BERNARDES, João P.; OLIVEIRA, Luís; LUÍs, Carlos \& BICHO, Cidália F. (2001) - A Situação Actual da Arqueologia e do Património Arqueológico no Algarve. Comissão de Coordenação da Região do Algarve.

CORREIA, Luís Miguel M. V. (2011) - Castelos em Portugal: retrato do seu perfil arquitectónico (1509-1949). $2^{\underline{a}}$ edição, Coimbra: Imprensa da Universidade de Coimbra.

ENCARNAÇÃO, J. \& GONÇALVES, M. (2013) - Cilpes/ Cilpis/Xilb/Silves? Para uma discussão antiga, um novo contributo. A inscrição de Silves evocativa do templo de Neptuno. In Espacio, Tiempo y Forma, Serie II, $\mathrm{H}^{\mathrm{a}}$ Antigua, t. 26 , pp. $255^{-276}$.

GOMES, Rosa Varela (2006) - Silves (Xelb): Uma Cidade do Gharb al-Andalus. O Núcleo Urbano. Trabalhos de Arqueologia, no 44, Lisboa: Instituto Português de Arqueologia.

GONÇALVES, Maria José (2007) - Arqueologia no Concelho de Silves. O Contributo Pioneiro de Estácio da Veiga. In XELB (Actas do $4^{\circ}$ Encontro de Arqueologia do Algarve), Silves: Câmara Municipal de Silves, n.ํำ , pp. 421-434.

GONÇALVES, Maria José (2008) - Silves islâmica: a muralha do arrabalde oriental e a dinâmica de ocupação do espaço adjacente. Dissertação de tese de Mestrado, em Teoria e Métodos da Arqueologia, Faculdade de Ciências Humanas e Sociais, Universidade do Algarve.

GONÇALVES, Maria José \& RODRIGUES, António Medeiros (2011) - Silves: balanço e perspectivas da actividade arqueológica municipal. In Actas do Encontro Arqueologia e Autarquias (Cascais, Setembro de 2008), Câmara Municipal de Cascais, pp. 543-566.
LEONARDO, Filipe (2011) - Desenvolvimento Urbano de Portimão: A importância da Muralha Quatrocentista para a malha urbana da Cidade (Dissertação de Mestrado em Arquitectura). Instituto Superior Manuel Teixeira Gomes.

LOPES, M. Conceição (2018) - Arqueologia na cidade em construção. In BERNARDES, J. P.; ETCHVARNE, C.; LOPES, M. C. \& COSTA, C. (eds.) Arqueologia Urbana em Centros Históricos. Universidade do Algarve, pp. 322-334.

MATEUS, A. R. S. (2018) - Museu Municipal de Portimão: instituição cultural ao serviço da comunidade. Relatório de Estágio. Mestrado em Gestão e Valorização do Património Histórico e Cultural, Escola de Ciências Sociais - Universidade de Évora, Departamento de História.

PIRES, B. F. (2019, 17 de Junho) - Achado inédito em Silves testemunha a violência da Reconquista Cristã. [Versão eletrónica]. Barlavento (Disponível em consulta online: 26/12/2019).

REVEZ, Idálio (2006, 12 de Maio) - Túmulo Islâmico deixado sob conduta de esgotos [Versão eletrónica]. Público (Disponível em consulta online: 27/12/2019).

RIBEIRO, Fernando; VALVERDE, Isabel; COSTA, Miguel \& AGUIAR, José (2016) - Prospeção e Defesa da Paisagem Urbana do Algarve (1965-70): A Arquitetura Tradicional e a Preservação do Património Urbano na Proposta da DGSU. In Actas do $1^{\circ}$ Colóquio Internacional Arquitetura Popular, Município de Arcos de Valdevez, pp. 335-351.

RODRIGUES, E. (2013, 23 de Abril) - Villa Romana da Abicada não está abandonada.mas parece [Versão eletrónica]. Sulinformação (Disponível em consulta online: 27/12/2019).

SOARES, Isabel (2001) - Concelho de Portimão Levantamento do Património Móvel e Imóvel de Interesse Relevante para o Estudo da História Local. Portimão.

SOARES, I; PEREIRA, A. \& FREITAS, V. (2007) - Percursos de Estácio da Veiga no Município de Portimão. In XELB (Actas do $4^{-}$Encontro de Arqueologia do Algarve), Silves: Câmara Municipal de Silves, n. ${ }^{\circ}$ 7, pp. 435-442.

VALENTE, Teresa (2012) - O “centro histórico" de Silves: limites e abordagens. In Promontoria, Universidade do Algarve, FCHS, nํ10, pp. 179-192.

\section{*outros documentos:}

Plano Regional de Ordenamento do Território do Algarve (PROTALG), Volume II - Caracterização e Diagnóstico, Anexo R-Património Cultural. Comissão de Coordenação e Desenvolvimento Regional do Algarve, Fevereiro de 2004.

ARU - Área de Reabilitação Urbana - Centro Histórico de Portimão (2014) Câmara Municipal de Portimão - Divisão de Regeneração Urbana.

ORU - Operação de Reabilitação Urbana de Silves. Divisão de Ordenamento e Gestão Urbanística / Ordenamento do Território. Câmara Municipal de Silves (12 de Abril de 2017). 
Plano de Pormenor - Quinta do Malheiro, Portimão; Componente Património Cultural. Março de 2017. C. M. Portimão. Efectuado pelo Museu de Portimão (Vera Freitas).

Plano de Pormenor: Estruturação Urbanística da Horta do Palácio, Portimão - Componente Património Cultural (Histórico-Arqueológico). C. M. Portimão. Setembro de 2010, efectuado pelo Museu de Portimão (Vera Freitas).

Plano de Pormenor do Barraco Rodrigo. Capítulo 8: Património Arquitectónico e Arqueológico. C. M. Portimão. Efectuado por Vera Freitas, do Museu Municipal de Portimão, Dezembro de 2007.

Plano Diretor Municipal de Portimão (2010) - Diário da Re-

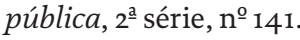

Plano Diretor Municipal de Silves (1995) - Diário da República, I série-B, $\mathrm{n}^{\circ} 279$.

Roteiro Turístico Nacional do Algarve - www.visitalgarve. $\mathrm{pt} / \mathrm{pt} / \mathrm{menu} / 35 /$ concelhos.aspx [Consultado:06/o1/2020].

RoteiroTurísticodePortimão-https://www.cm-portimao. pt/ [Consultado: 06/o1/2020].

RoteiroTurístico deSilves-https://www.cm-silves.pt/pt/ Default.aspx [Consultado: 06/o1/2020].

\section{WEBGRAFIA}

Website do Portal do Arqueólogo. Disponível em https:// www.arqueologia.patrimoniocultural.pt

Website da Câmara Municipal de Portimão. Disponível em https://www.cm-portimao.pt/

Website da Câmara Municipal de Silves. Disponível em https://www.cm-silves.pt/

Website do Museu de Portimão. Disponível em https:// www.museudeportimao.pt/
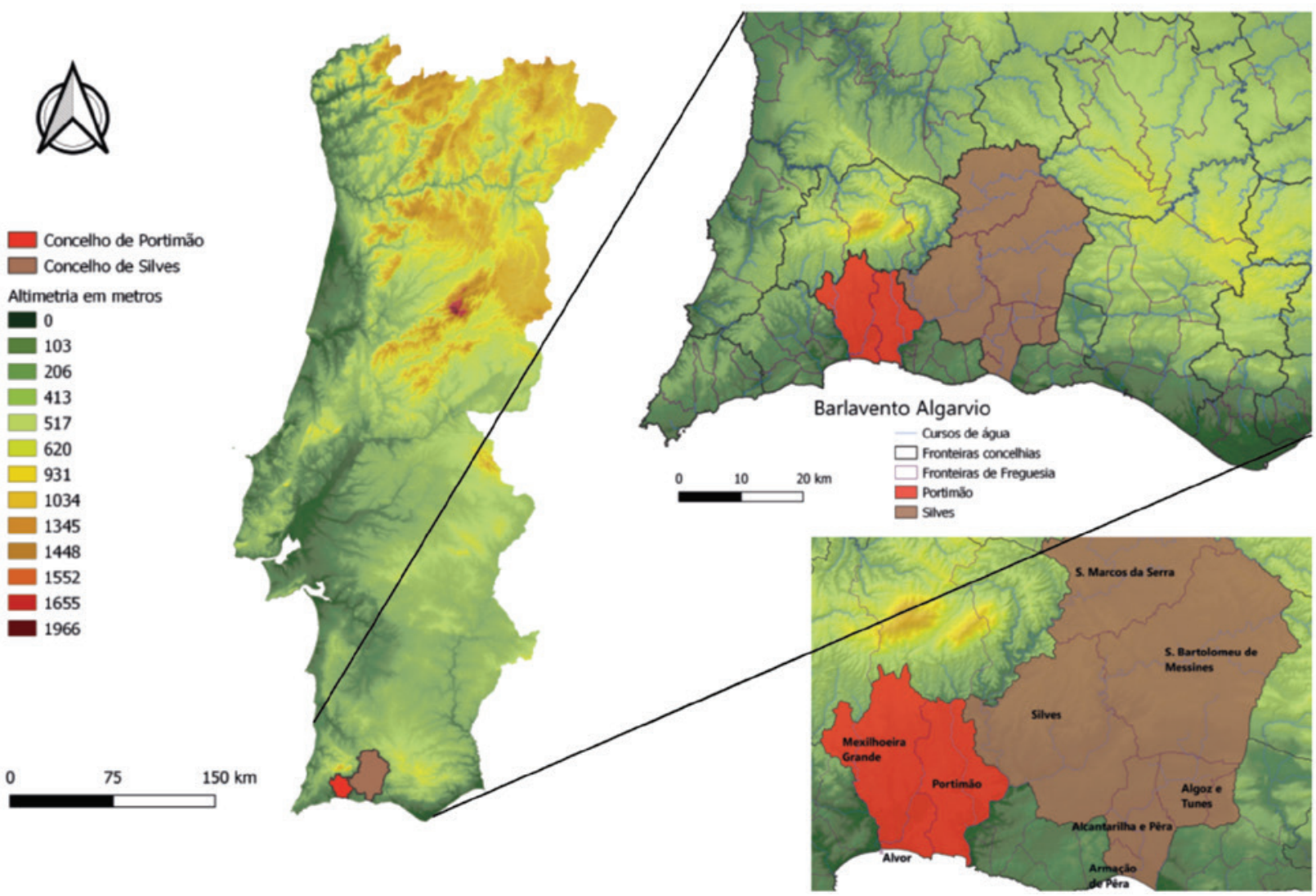

Figura 1 - Mapa da localização dos concelhos de Portimão e Silves. 


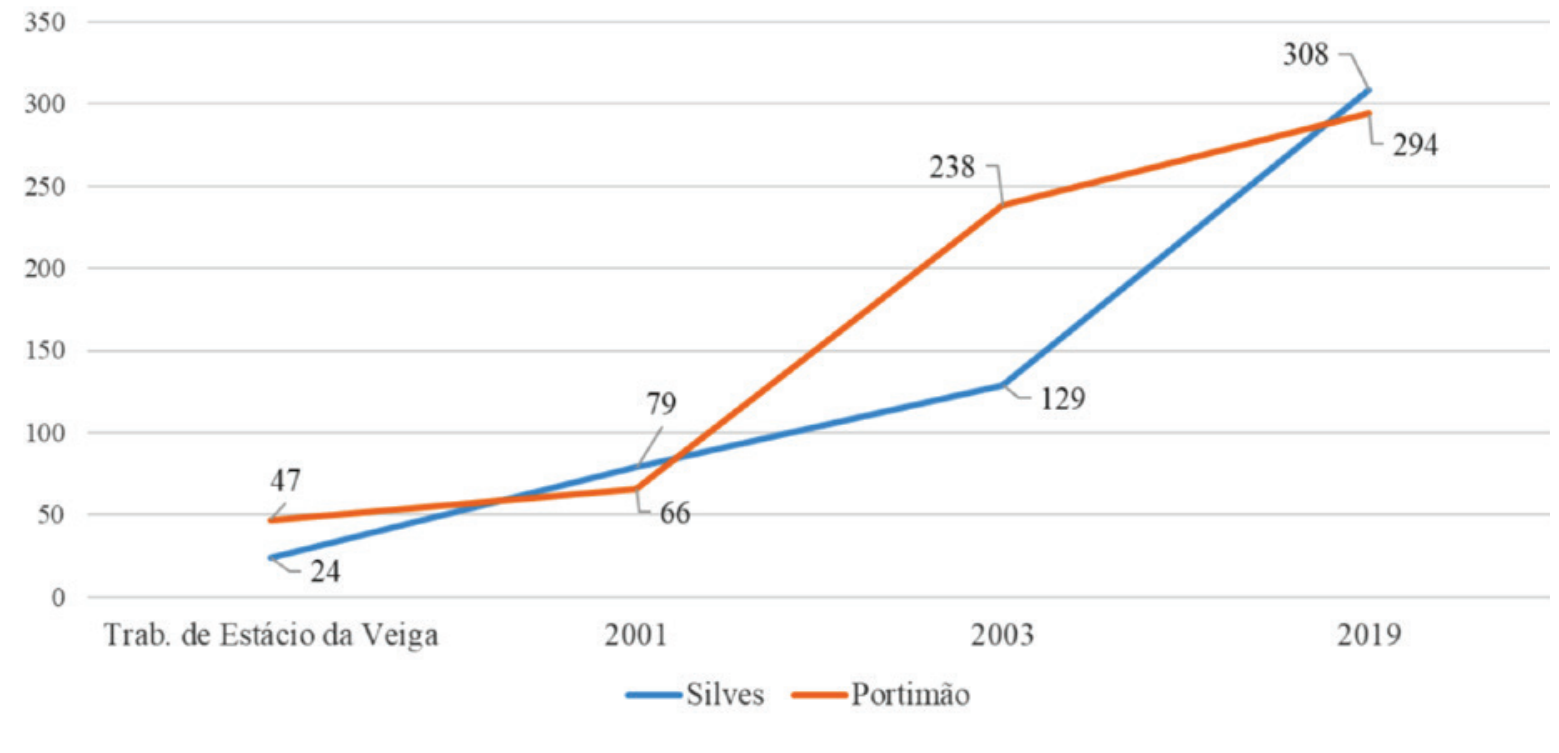

Figura 2 - Gráfico da evolução do número de sítios e achados arqueológicos dos concelhos de Portimão e Silves (Fontes e dados consultados: Bicho $\mathbb{Z}^{3}$ alii., 2001; PROTALG, Vol. II, Anexo R, 2004; Soares, Pereira e Freitas, 2007; Portal do Arqueólogo - Dados consultados em dezembro de 2019).

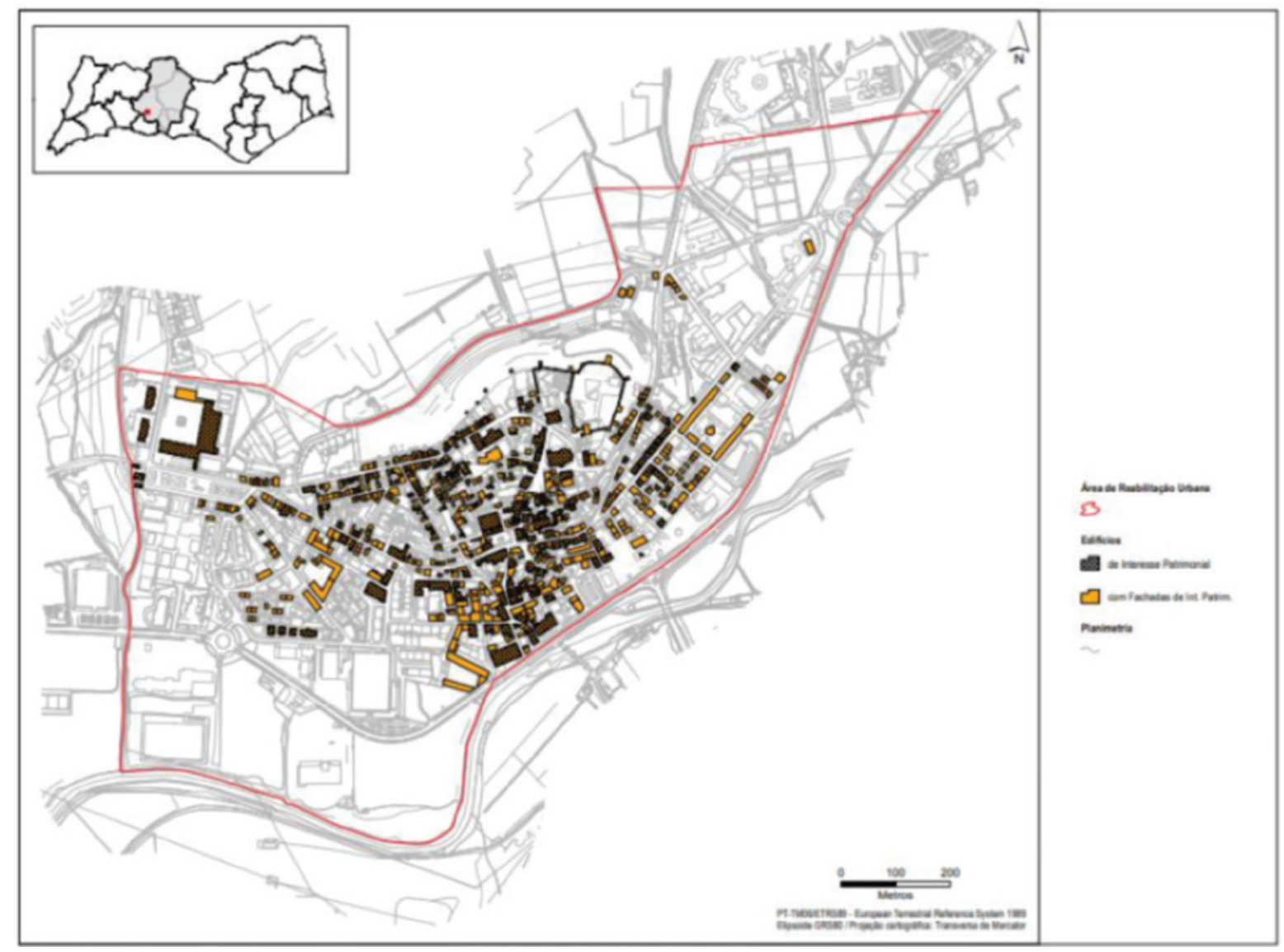

Figura 3 - Planta da Área Urbana com os espaços e edifícios de interesse Patrimonial. Retirado de: cm-silves.pt (Operação de Reabilitação Urbana, 12 de abril de 2107). 


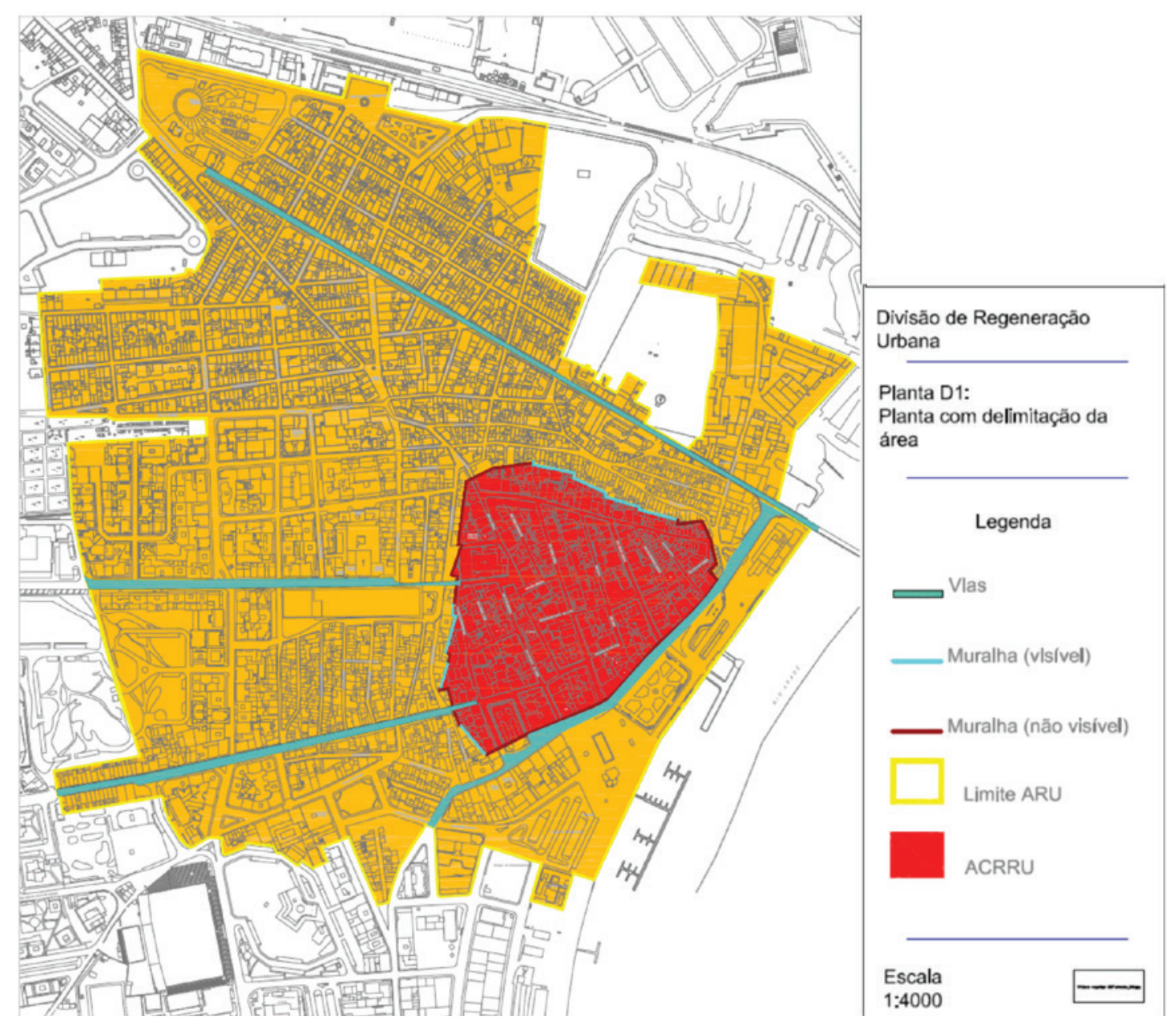

Figura 4 - Planta com a Delimitação da Área do Centro Histórico. Retirado do Plano da Área de Reabilitação Urbana de Portimão (website da câmara municipal de Portimão - cm-portimao.pt: anexos ARU).

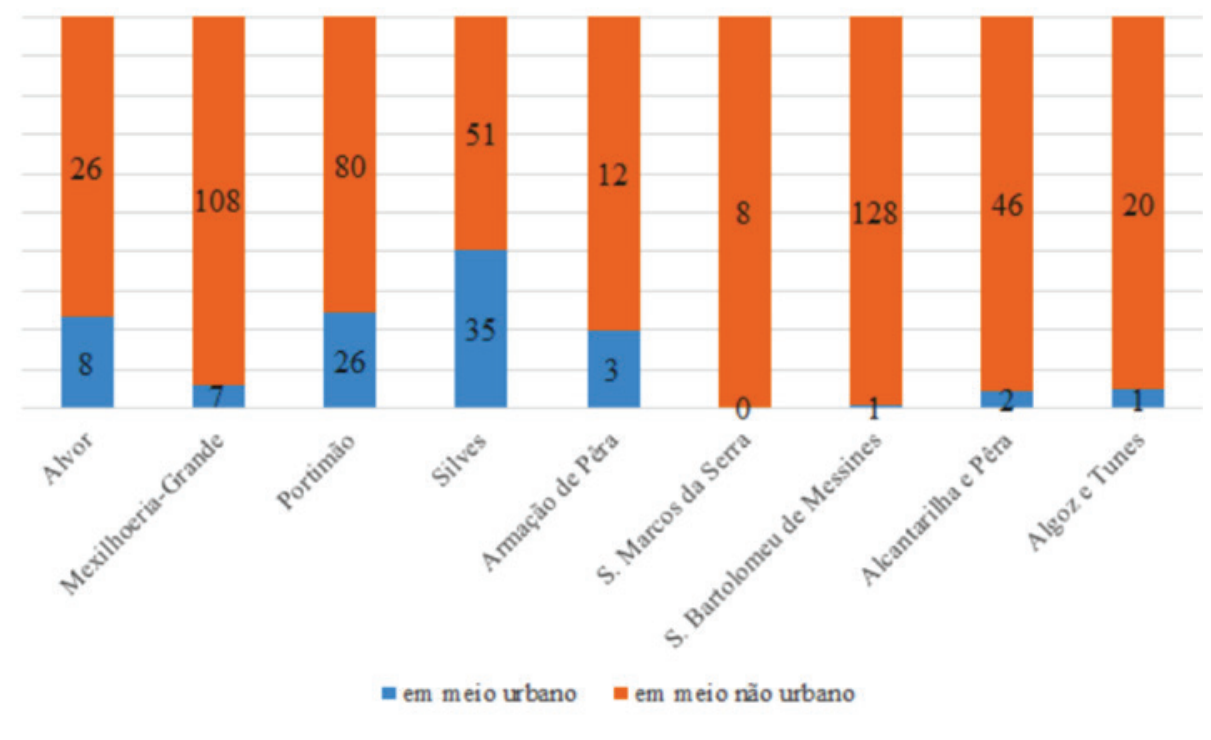

Figura 5- Gráfico do número de "sítios" e "ocorrências" arqueológicas nas freguesias dos concelhos de Portimão e Silves segundo a sua inserção, ou não, em meio urbano (Dados consultados no Portal do Arqueólogo em dezembro de 2019). 


\section{Portimão}

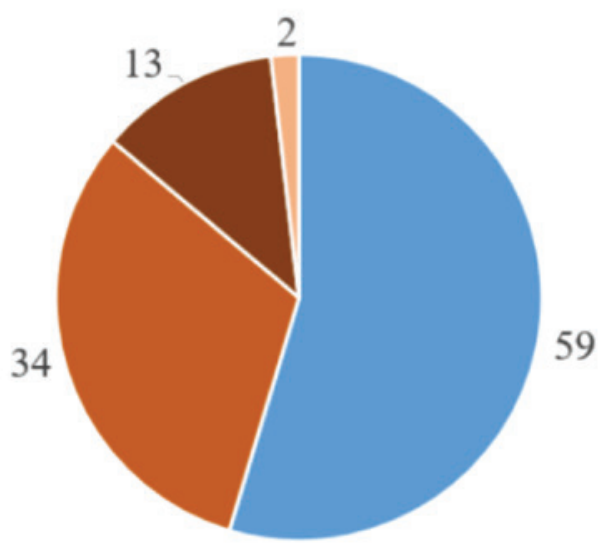

= Prevenção - meio Urb. Investigação - meio Urb.

- Prevenção - meio não Urb. - Investigação - meio não Urb.

" Valorização - meio não Urb.

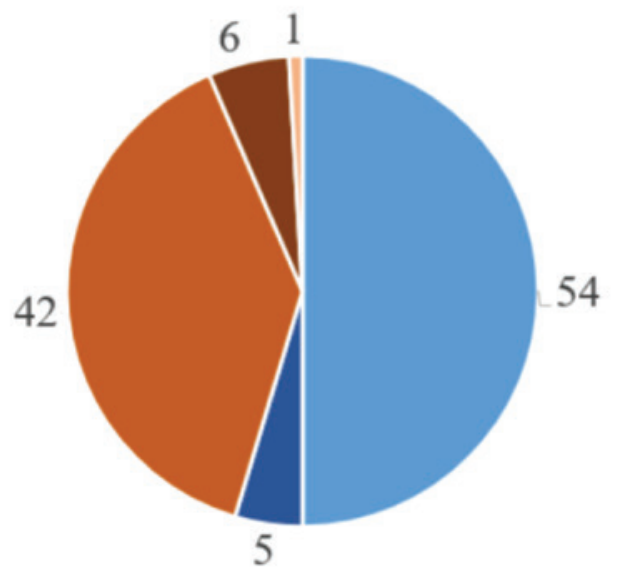

54

Figura 6 - Gráfico do número de projetos (e seus tipos) identificados no Portal do Arqueólogo nos concelhos de Portimão e Silves e a sua inserção em meio urbano ou em meio não urbano (Dados consultados no Portal do Arqueólogo em dezembro de 2019).

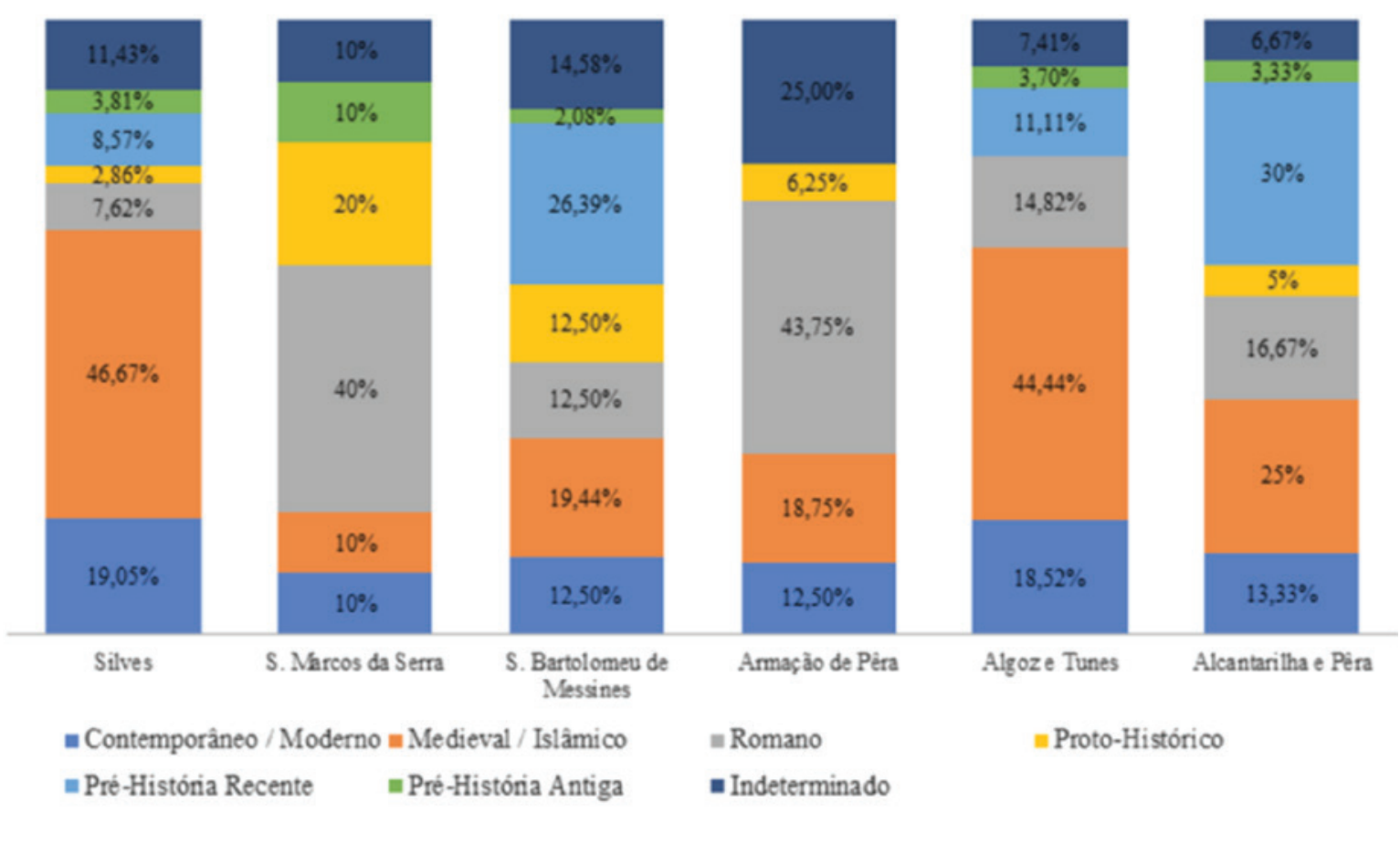

Figura 7 - Gráfico com a Percentagem dos sítios consoante as suas cronologias, no concelho de Silves. Dados Retirados do Portal do Arqueólogo. 


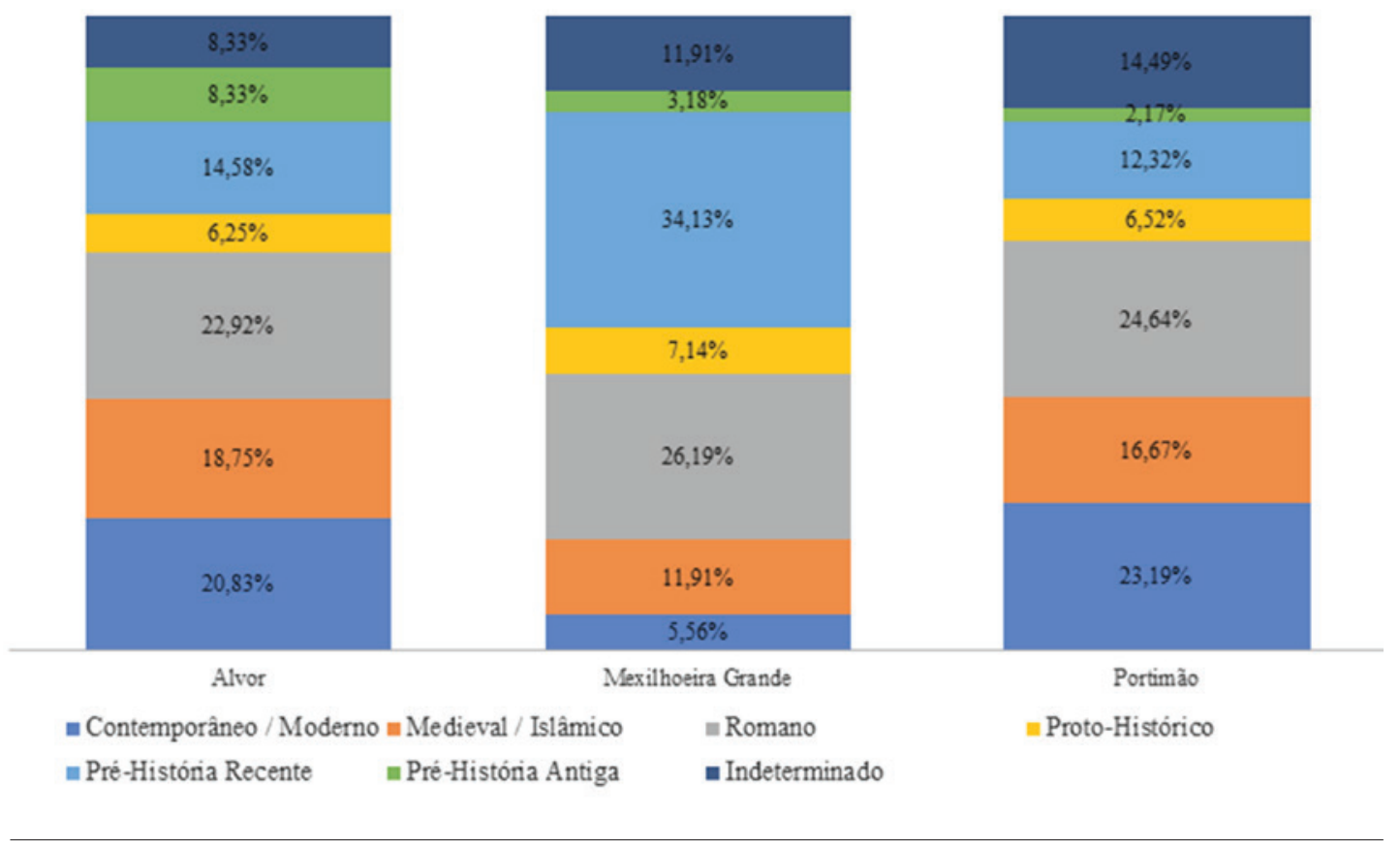

Figura 8 - Gráfico com a Percentagem dos sítios consoante as suas cronologias, no concelho de Portimão. Dados Retirados do Portal do Arqueólogo.
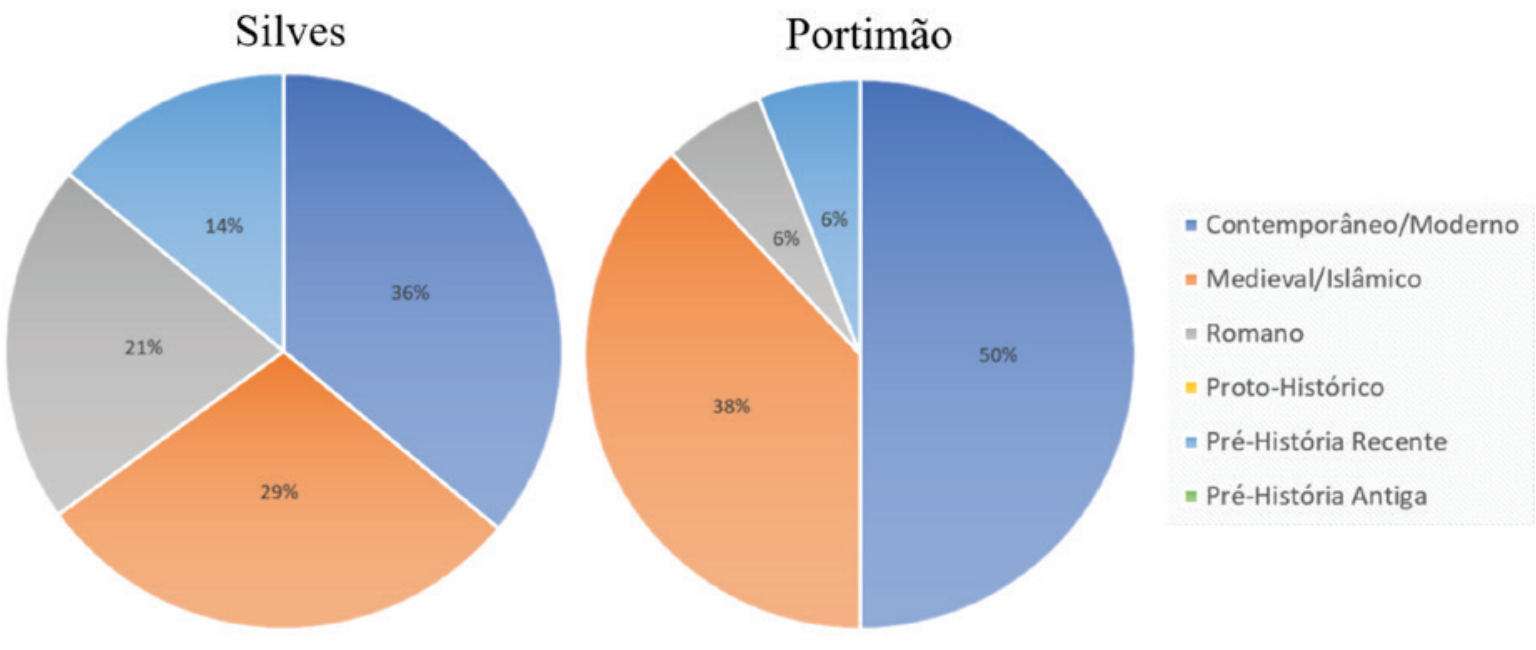

Figura 9 - Gráficos referentes à distribuição da cronologia dos sítios arqueológicos presentes nos roteiros turísticos de Portimão e Silves. Dados Retirados dos websites municipais (cm-silves.pt e cm-portimao.pt). 

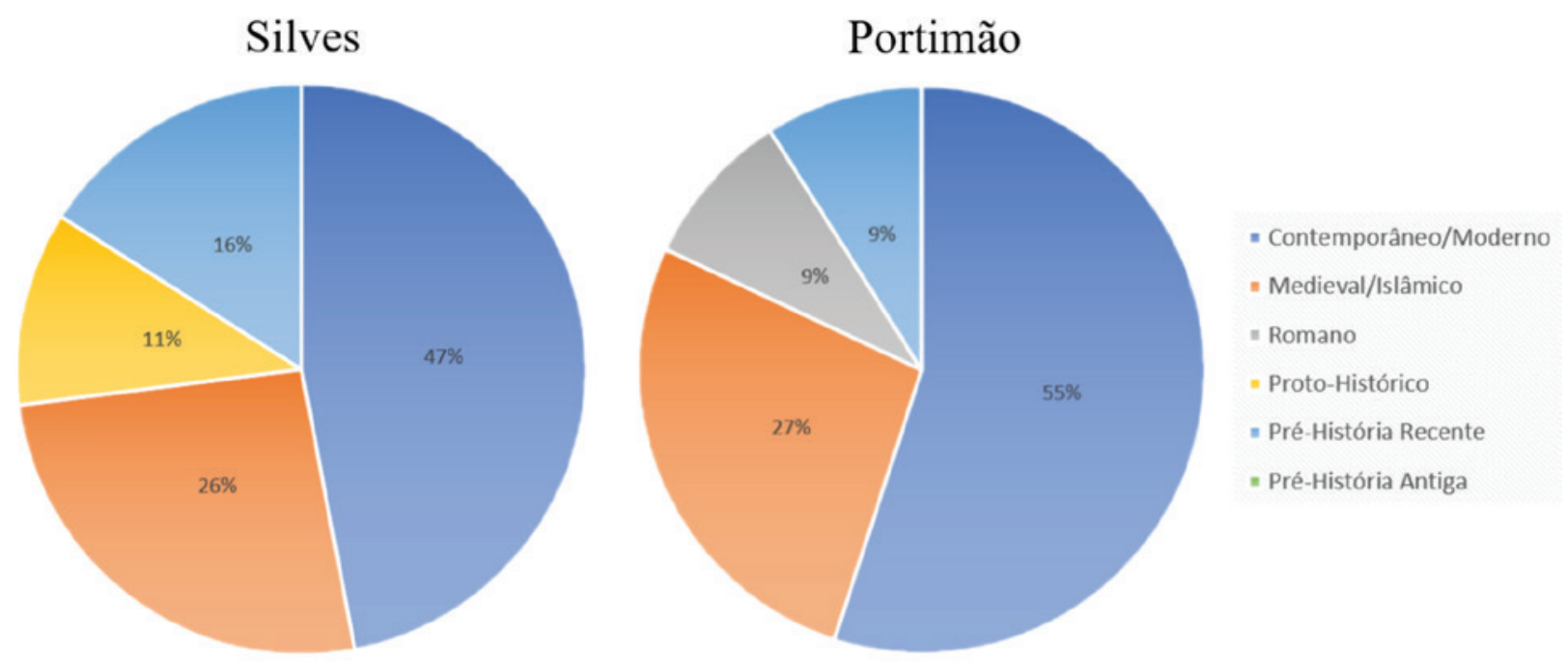

Figura 10 - Gráficos referentes à distribuição da cronologia dos sítios arqueológicos presentes nos roteiros turísticos de Portimão e Silves. Dados Retirados do website de turismo nacional (www.visitaalgarve.pt/pt/menu/35/concelhos.aspx). 
2

Gestão, Valorização

e Salvaguarda

do Património 


\title{
O CADERNO REIVINDICATIVO E AS CONDIÇÕES DE TRABALHO EM ARQUEOLOGIA
}

Miguel Rocha ${ }^{1}$, Liliana Matias Carvalho² ${ }^{2}$, Regis Barbosa ${ }^{3}$, Mauro Correia ${ }^{4}$, Sara Simões ${ }^{5}$, Jacinta Bugalhão ${ }^{6}$, Sara Brito ${ }^{7}$, Liliana Veríssimo Carvalho ${ }^{8}$, Richard Peace ${ }^{9}$, Pedro Peça $^{10}$, Cézer Santos ${ }^{11}$

\begin{abstract}
RESUMO
Ser profissional de Arqueologia em Portugal significa, para a grande maioria, trabalhar sob um regime de precariedade e desregulação laboral, em condições pouco dignas e injustas. Neste sentido, a elaboração de um Caderno Reivindicativo para o trabalho em Arqueologia, como proposta concreta de discussão e de mobilização para a transformação e melhoria das condições de trabalho, constitui um eixo fundamental e prioritário da ação do STARQ - Sindicato dos Trabalhadores de Arqueologia. Por outro lado, ao apelar à discussão e participação das reivindicações formuladas, o STARQ procura ampliar o esclarecimento dos trabalhadores, criando entre eles um maior e mais forte sentido de organização e unidade, essenciais na conquista e garantia dos seus direitos. Palavras-chave: Setor laboral da Arqueologia, Atividade Sindical, Contratação Coletiva, Direito do Trabalho.
\end{abstract}

\begin{abstract}
Being an archaeology professional in Portugal means, for the vast majority, working under job insecurity and labour law deregulation, in unworthy and unfair working conditions. In this sense, the elaboration of a Caderno Reivindicativo (a list of demands) for work in Archaeology is a concrete proposal for discussion and mobilization towards change and improvement of working conditions. Therefore, it is a fundamental and urgent line of action for STARQ - The Portuguese archaeologists' union. By inviting others to discuss the announced claims, STARQ seeks to expand the understanding of workers' rights, creating among them a greater sense of organization and unity, essential to the achievement and warranty of their rights.

Keywords: Archeological setor, Workers rights, Union movement, Collective Labour Agreement, Labour Law.
\end{abstract}

\footnotetext{
1. STARQ; 1sd1514@gmail.com

2.STARQ; liliana_m_carvalho@yahoo.com.br

3.STARQ; regisbarbosa81@gmail.com

4.STARQ; maurocorreia_arq@outlook.pt

5.STARQ; saratsimoes@yahoo.com

6.STARQ; jacintabugalhao@gmail.com

7. STARQ; sarazenite@gmail.com

8. STARQ; verissimo.liliana@gmail.com

9. STARQ; richard.a.peace@gmail.com

10.STARQ; pedropeca@gmail.com

11.STARQ; cezer.santos@gmail.com
} 


\section{A PROFISSIONALIZAÇÃO DA ARQUEO- LOGIA EM PORTUGAL OU COMO PERCORRER O CAMINHO DAS PEDRAS}

O conceito de arqueólogo e, consequentemente de Arqueologia, em Portugal sofreu significativa evolução no decorrer do século XX (Bugalhão, 2017, p. 19). Evoluindo de uma espécie de hobby (amador), muitas vezes não remunerado, entrando paulatinamente no ordenamento jurídico português, até à atual situação onde a atividade é reconhecida como profissão, só acessível através de habilitação académica superior, e como disciplina científica devidamente enquadrada e regulamentada. Através do Decreto-Lei 164/2014 de 4 de Novembro (Regulamento de Trabalhos Arqueológicos), consideram-se aptas a dirigir trabalhos arqueológicos as pessoas academicamente habilitadas em Arqueologia, com prática profissional comprovada, especificando as condições da habilitação académica e a duração da experiência curricular.

Assim, a Arqueologia em Portugal, tal como noutras partes do mundo, passou por todas as fases de consolidação do pensamento arqueológico referidas por Renfrew e Bahn (1991), nomeadamente o amadorismo/coleccionismo, a academia, surgindo posteriormente a Arqueologia comercial. Podemos, conscientemente, falar de um amadurecimento da disciplina tal como da profissão.

Para além da evolução da profissão de arqueólogo, mais estudada, se recuarmos a 1893, data da abertura do Museu Etnográfico Português, pela mão de Leite de Vasconcelos, encontramos os primeiros trabalhadores em Arqueologia, a que se juntam os do quadro dos Serviços Geológicos (Bicho, 2006). No entanto, tendemos a esquecer os trabalhadores que hoje chamaríamos de "indiferenciados", que acompanharam as escavações promovidas desde Henri Breuil a Georges Zbyszewski, entre outros. Esses trabalhadores, usualmente locais e próximos dos sítios arqueológicos, tanto geográfica como emocionalmente, são veículos informais de informações arqueológicas. Com muita frequência, as suas memórias foram essenciais para reconstruir as intervenções arqueológicas daqueles que inscreveram o seu nome na disciplina ${ }^{12}$. Nos dias de hoje, estes trabalhadores seriam profissionais de Arqueologia e

12. Considerem-se os casos dos trabalhos arqueológicos promovidos por Manuel Heleno, Abel Viana e António Dias de Deus (Rolo, 2018; Wolfram, 2011). a sua vida, ganhando ao dia e provavelmente apenas durante uma parte do ano, não seria totalmente distante dos seus companheiros atuais.

O caminho para a profissionalização decorreu da consciencialização crescente sobre a importância do Património Cultural. A perspetiva de intervenção e regulamentação da salvaguarda e emergência arqueológica esteve subjacente à criação dos Serviços Regionais de Arqueologia em 1980 (Silva, 1995). Como refere o autor, "de um lado tínhamos toda uma nova geração de arqueólogos, recém saídos das Faculdades e fortemente motivados pela perspectiva de defesa do património, fenómenos que nos anos imediatos à Revolução do 25 de Abril conheceu efectiva expressão pública. Do outro, tínhamos vastas parcelas do território nacional que, face à retoma económica que se sucedeu à crise revolucionária, começavam a sofrer impactes significativos sobre o respectivo subsolo" (Silva, 1995, p. 98). Nesta fase inicial, a Arqueologia de salvaguarda era essencialmente assegurada pelos técnicos da administração central ou, mais raramente, local. No entanto, houve um crescimento do número de intervenções, fruto de um processo de que fizeram parte o extraordinário aumento da pressão de obras públicas sobre o território rural e os centros históricos (nos anos 90 do século XX), o processo de salvaguarda das gravuras do Côa (1994-1995), a criação do Instituto Português de Arqueologia (IPA) e a consequente ratificação da Convenção de Malta, em 1997.

Neste contexto surgiram as primeiras empresas de Arqueologia. Ainda no final dos anos 1990 tinha-se iniciado a construção da barragem do Alqueva, até hoje o maior projeto de Arqueologia preventiva em Portugal, que contribuiu para a consolidação da profissão de arqueólogo, do papel das empresas e da função fiscalizadora da administração central, já com o IPA. Nos primeiros anos das obras da barragem, empresas de Arqueologia recém-formadas trabalhavam lado a lado com equipas de investigação. Como refere António Carlos Silva "ainda que involuntariamente, o Projecto Arqueológico de Alqueva acabaria por contribuir de forma decisiva (...) para o florescimento da Arqueologia empresarial que se verificou em Portugal na transição do século" (2014, p. 21). Toda esta mudança na dinâmica do trabalho de Arqueologia não foi acompanhada da devida reflexão por parte de entidades públicas competentes, associações representativas e dos próprios trabalhadores, remetidos para um sistema laboral baseado 
na precariedade, ao qual a maioria só conseguia fugir abandonando a profissão.

Em pleno contexto da crise das dívidas soberanas, em 2012, um grupo de mais de 100 trabalhadores de Arqueologia achou ter chegado a um limite de desproteção laboral e de falta de perspetivas sobre as suas vidas futuras, assim avançaram com a criação do Sindicato dos Trabalhadores de Arqueologia (STARQ) (Mesquita \& Simões, 2014). Em 2020, o STARQ alcançou já uma representatividade muito significativa (superior a 10\% do universo global dos trabalhadores em Arqueologia), embora ainda com assimetrias regionais que se pretendem atenuar através da intensificação e disseminação do trabalho sindical. Considera-se por isso ser o momento para enfrentar os problemas estruturais da nossa realidade laboral, ou seja, identificar ruturas (com base num diagnóstico rigoroso) e promover soluções baseadas na lei e sustentáveis no tempo. O Caderno Reivindicativo é um instrumento e um referencial para o desenvolvimento do trabalho do sindicato nos próximos anos, quer junto das entidades públicas competentes, quer, principalmente, junto das entidades patronais privadas, nomeadamente as empresas de Arqueologia.

\section{DA PERTINÊNCIA E NECESSIDADE}

O trabalho em Arqueologia caracteriza-se pela sua desregulação: fragilidade dos vínculos laborais, precaridade, falta de condições de higiene, saúde e segurança e dificuldades acrescidas do trabalhador deslocado. O problema-base centra-se no regime laboral. As empresas que desenvolvem atividade no setor da Arqueologia e do Património suprem as suas necessidades de recursos humanos, essencialmente, através da aquisição de serviços e não, como deveriam, pela assinatura de contratos laborais. Ainda que as necessidades de postos de trabalho sejam permanentes, frequentemente as empresas preferem ocupá-los com trabalhadores em regime de prestação de serviços. A situação precária em que centenas de trabalhadores de Arqueologia se encontram, nomeadamente pela utilização abusiva e ilegal do recibo verde é assim uma realidade constante dos nossos dias, proporcionando condições de trabalho pouco dignas e injustas. Por outro lado, os valores praticados nos contratos de trabalho não se adequam à formação, responsabilidade e experiência pedida aos trabalhadores assalariados.
Os dados disponíveis apontam para que $75 \%$ dos profissionais exerce a profissão sob vínculos laborais precários, disfarçados de profissionais liberais (vulgo trabalhador independente/recibos verdes), ou com vínculos dependentes a prazo ou por tempo determinado (Bugalhão, 2017, p. 25). No que concerne aos rendimentos, em 2012, o rendimento médio anual de um arqueólogo em Portugal era $43 \%$ do rendimento médio dos técnicos superiores (APA, 2014, p. 76). A título de exemplo, o projeto DISCO 2014 constatou que cerca de metade dos arqueólogos não eram remunerados pelo tempo de trabalho despendido na elaboração de relatórios técnicos (APA, 2014, p. 87).

Assim, a experiência permite-nos facilmente constatar, infelizmente, que nem sempre a legislação existente e a sua aplicação respondem a estes problemas, observando-se, aliás, vazios legais. Nesse âmbito, a ação reivindicativa não só é o primeiro passo, como é um dos eixos prioritários do trabalho sindical. O Caderno Reivindicativo do STARQ procura regular o trabalho em Arqueologia, que se pretende abrangente e consensual entre os trabalhadores (através de um processo de discussão alargado) e de mobilização para a transformação e melhoria das condições laborais. As reivindicações propostas estão abertas à discussão e participação (segundo um calendário a divulgar) ampliando, também, o esclarecimento dos trabalhadores e o seu sentido de união.

\section{FUNÇÃO E OBJETIVOS}

No ordenamento jurídico português (Constituição, Código do Trabalho e demais legislação), a regulamentação coletiva de trabalho é o principal instrumento de regulação das relações laborais, competindo especialmente ao Estado a promoção da contratação coletiva, para que esta abranja o maior número possível de trabalhadores e empregadores. Assim, os contratos de trabalho devem ser preferencialmente regidos pela regulamentação coletiva de trabalho.

A Constituição da República Portuguesa (art.․5 56..) estabelece que o direito de negociação coletiva dos trabalhadores é exercido exclusivamente pelas associações sindicais. Nesse sentido, a partir de um adequado diagnóstico da situação pré-existente, o STARQ decidiu elaborar uma proposta de Caderno Reivindicativo. Este é um instrumento de promoção e defesa dos direitos dos trabalhadores, que visa a 
melhoria dos salários e a obtenção de direitos, com base nos princípios de igualdade e solidariedade, assim como a melhoria das condições de saúde, higiene e segurança no trabalho, sempre tendo em conta as especificidades do trabalho em Arqueologia.

O intuito fundamental do Caderno Reivindicativo é a resolução dos problemas individuais e coletivos dos trabalhadores, através da fixação de condições de trabalho que respeitem os seus direitos, com base em objetivos reivindicativos que reflitam as suas necessidades, com o propósito final de instituir um regime de trabalho mais favorável e equitativo, que contrarie a precariedade vigente.

A partir deste Caderno, a elaboração dos instrumentos de regulamentação coletiva de trabalho, e demais acordos, decorre de forma essencialmente negocial entre as partes, os sindicatos e os empregadores, de acordo com a Lei, em respeito pelo princípio da boa-fé. O Caderno Reivindicativo pode ainda ser visto como uma base justa para um contrato de trabalho em Arqueologia.

\section{PROBLEMÁTICAS LABORAIS ASSOCIA- DAS À ARQUEOLOGIA EMPRESARIAL}

As empresas de Arqueologia e Património não podem continuar a basear a sua atividade na prestação de serviços, na obtenção de lucro através do trabalho mal pago e pouco reconhecido de profissionais altamente qualificados. A situação precária em que centenas de trabalhadores se encontram, nomeadamente pela utilização abusiva e, muitas vezes ilegal, do recibo verde, é a prática comum, proporcionando condições de trabalho e de vida pouco dignas e injustas (STARQ, 2020a,b). Neste contexto, o preceito-base das reivindicações só pode ser este: o desempenho de funções permanentes deve dar lugar a vínculo efetivo, com os direitos legais daí decorrentes, que promovam a dignidade do trabalhador, a boa conciliação do trabalho com a vida familiar e pessoal, a expectativa de uma carreira profissional realizada e de consolidação crescente das suas condições económicas e sociais. Daí decorre a necessidade de se promover, entre outras medidas, a regularização dos vínculos precários. Como instrumento de combate à precariedade também é essencial a proposição de salários dignos, regulados e equitativos para todos os trabalhadores.

\section{REIVINDICAÇÕES FUNDAMENTAIS}

A primeira e principal reivindicação do Caderno refere-se à regularização dos vínculos precários, num justo equilíbrio entre o valor de recursos consignados às despesas de pessoal e às respeitantes a prestações de serviços. Neste âmbito o STARQ propõe: (i) adequação dos mapas de pessoal às necessidades das empresas; (ii) celebração de contratos por tempo indeterminado (efetivo ou sem termo) com os trabalhadores que desempenhem funções há dois ou mais anos ou que preencham necessidades permanentes; (iii) regularização dos vínculos precários e cessação do recurso ilegal a falsos recibos verdes, estágios, bolsas e trabalho de estudantes que asseguram tarefas que correspondem a necessidades permanentes; (iv) início de um processo negocial de regulamentação coletiva do trabalho a nível setorial ou empresarial, visando a vinculação e regularização dos trabalhadores precários, através do estabelecimento de objetivos calendarizados, com base no volume de trabalho de cada entidade.

Além do combate à precariedade é fundamental o reconhecimento da evolução profissional dos trabalhadores, configurada numa proposta de carreira que assegure conteúdos funcionais bem definidos e regras de progressão profissional claras, procurando a fixação de níveis salariais base para cada uma das categorias profissionais propostas. Neste sentido, o STARQ propõe o estabelecimento de níveis salariais base para cinco carreiras ${ }^{13}$ : Operário de Arqueologia, Técnico de Arqueologia, Arqueólogo Auxiliar, Arqueólogo Diretor e Arqueólogo Especialista. A progressão na carreira deverá ocorrer com base na antiguidade, no valor de $4 \%$ ao ano sobre o salário base da categoria.

Para a regulação do trabalho em Arqueologia é também fundamental o estabelecimento de garantias mínimas aos trabalhadores deslocados, determinando-se as necessárias obrigações da entidade patronal. O STARQ defende que: (i) a entidade patronal deve assumir diretamente, ou sob reembolso, o pagamento das despesas de deslocação; (ii) em alternativa, há lugar ao pagamento de todas as despesas de transporte e de ajudas de custo individuais (em valor a fixar); (iii) considerando a sazonalidade e a diferença de custo de vida entre as várias regiões

13. A mesma estrutura é aplicável a profissionais de outras áreas científicas que trabalhem no setor da Arqueologia. 
do país, quando este valor se revele insuficiente para cobrir a totalidade destes custos, deve ser garantido o pagamento integral e direto das despesas de alojamento e alimentação; no caso excecional de utilização de viatura própria, reclama-se o pagamento adicional de um subsídio de transporte por $\mathrm{Km}$, que cubra as despesas de combustível, e desgaste da viatura, bem como o pagamento de portagens, estacionamento, limpeza e lavagens e seguro automóvel para viagens (veículo, ocupante e terceiros).

Outro dos aspetos a regular é a duração das jornadas de trabalho e horário laboral. As formas de organização do trabalho em Arqueologia potenciam a flexibilidade e a autonomia, assim como a responsabilidade do trabalhador no desenvolvimento da sua prestação laboral. O acesso fácil à Internet transformou a atividade laboral, constituindo um meio de comunicação muito frequente e cada vez mais utilizado nas relações entre empregadores e trabalhadores. A facilidade de comunicação tem implicado, em várias situações, o trabalho fora do horário para a realização de tarefas de organização e partilha do registo arqueológico, bem como para a elaboração de documentos técnicos. As novas formas de comunicação apresentam características que desequilibram, potencialmente, a relação entre o tempo de vida profissional e o tempo de vida privada e familiar. Nesta perspetiva, salienta-se a necessidade de garantir certos direitos fundamentais, principalmente o direito à desconexão, ou seja, ao descanso, ao repouso e à integridade física e mental dos trabalhadores, bem como o necessário estabelecimento de limites ao controlo eletrónico do empregador. A este respeito o STARQ propõe: (i) um período normal de trabalho não superior a trinta e cinco horas em cada semana, nem a sete horas diárias; (ii) o direito a um intervalo para refeição ou descanso não inferior a uma nem superior a duas horas, não podendo os trabalhadores prestar mais de cinco horas seguidas de trabalho; (iii) o direito a uma pausa de 15 minutos em cada um dos períodos de trabalho diário (manhã e tarde), que conte para todos os efeitos como tempo de trabalho efetivo; (iv) o direito a dois dias de descanso semanal, gozados, em regra, em dias completos e sucessivos, ao sábado e ao domingo; (v) o direito à desconexão, ou seja, o direito a não atender chamadas, ler e/ou escrever mensagens de correio eletrónico, ler e/ou responder a mensagens de telemóvel ou a conversações em redes sociais, que estejam relacionadas com trabalho, fora do seu horário de trabalho; (vi) integração no horário de trabalho do tempo das deslocações para locais de trabalho a mais de $25 \mathrm{~km}$ de distância do posto de trabalho habitual; (vii) garantia de 24 horas de trabalho anuais remunerado para a realização de ações de divulgação científica, procurando responder ao exigido no Regulamento dos Trabalhos Arqueológicos.

O período normal de trabalho deve ser respeitado. Tudo o que está para lá do mesmo constitui-se como prestação de trabalho extraordinário, que, por isso mesmo, deve conferir a justa recompensa pelo esforço pessoal e familiar que acarreta. Neste sentido é necessário uma motivadora compensação do trabalho suplementar, bem como o pagamento do subsídio de turno, nos casos em que se justifiquem. Sobre trabalho extraordinário o STARQ propõe: (i) o pagamento do trabalho suplementar pelo valor da retribuição horária com acréscimo de $75 \%$ na primeira hora ou fração e $100 \%$ por hora ou fração subsequente, em dia útil e de $100 \%$ por cada hora ou fração, em dia de descanso semanal, obrigatório, complementar, ou feriado; (ii) a compensação do trabalho por turnos, caso se verifique, através de um subsídio de turno, a 50\% da respetiva remuneração base mensal, para o trabalho prestado em regime de três turnos e de laboração contínua com folga rotativa e a $35 \%$ da respetiva remuneração base mensal, para o trabalho prestado em regime de dois turnos e de laboração contínua com folga rotativa; (iii) o trabalho prestado entre as $20 \mathrm{~h}$ de um e as $8 \mathrm{~h}$ do dia seguinte seja considerado trabalho noturno, remunerado com um acréscimo de $50 \%$ da sua retribuição, por cada hora ou fração; (iv) obrigatoriedade de dispensa de trabalho noturno a partir dos 50 anos (desde que requerido).

A dificuldade de conciliação do trabalho com a vida familiar e pessoal, característica do trabalho em Arqueologia, é agravada pela precariedade e falta de regulação da atividade, com consequências nefastas na vida social, económica e pessoal dos profissionais. Por exemplo, nos índices sintéticos de fecundidade dos profissionais em Arqueologia, que se situava nos 0,5 por mulher e nos 0,7 nos homens, com uma média de o,6 que representa pouco mais de metade da média nacional que, em 2013, era de 1,03 (APA, 2014, p. 43-45), sendo apontados como os principais fatores para estes baixos índices os baixos rendimentos e a natureza do próprio trabalho (APA, 2014, p. 44).

É imperativo ter consciência desta realidade e pro- 
mover a sua correção, atenuando as disfunções verificadas. Com a existência a priori de direitos definidos, a dificuldade de mediação entre a esfera laboral e a pessoal e familiar será mais fácil. Assim, na elaboração do horário de trabalho, o STARQ considera que a entidade patronal deve ter em consideração as exigências de proteção da segurança e saúde do trabalhador, facilitando a conciliação da sua atividade profissional com a vida familiar e o acesso à educação (frequência de curso escolar ou académico) e à formação técnica ou profissional. A este propósito o STARQ propõe: (i) dispensa de progenitores com filhos menores, com deficiência ou doença crónica da prestação do trabalho noturno ou por turnos, através de requerimento para o efeito; (ii) organização de horários e formas de trabalho compatíveis para trabalhadores com filhos menores com deficiência ou doença crónica, idosos ou outros familiares que careçam de apoio; (iii) garantia de transporte para os trabalhadores na deslocação para o domicílio em condições de segurança, sempre que pratique um horário que não seja compatível com os transportes locais; (iv) o direito à prestação de assistência inadiável e imprescindível em caso de doença ou acidente de cônjuge ou pessoa que viva em união de facto ou economia comum com o trabalhador, parente ou afim em linha reta ou $2^{\circ}$ grau da linha colateral (em faltas justificadas).

A valorização profissional é um pilar incontornável da promoção da competência, eficácia e eficiência dos trabalhadores. A formação profissional, em particular, é um instrumento essencial para assegurar a transmissão, a análise e a concretização dos conhecimentos e da prática. $\mathrm{O}$ acesso à formação profissional (contínua) ao longo da vida é um dos direitos base do Código do Trabalho (Lei n.․ㄱ 7/2009, art. ${ }^{\circ} 130^{\circ}, 131^{\circ}, 132^{\circ}, 133^{\circ}$ e $134^{\circ}$, Diário da República n. ${ }^{\circ}$ 30/2009, Série I de 2009-02-12), contribui para a melhoria das competências dos trabalhadores e, consequentemente, para o aumento da qualidade do trabalho desenvolvido.

No atual panorama laboral a formação profissional contínua, em particular após a conclusão da licenciatura, é comum nos profissionais de Arqueologia, mas é realizada, sobretudo às expensas dos próprios (consequência da precariedade e falta de investimentos das entidades empregadoras) com os constrangimentos daí decorrentes. Em 2014 o cenário apresentado, não muito diferente do atual, revela que "a maioria dos arqueólogos inquiridos $(74,5 \%)$ afirmaram que fizeram ações de formação após a licenciatura, mas apenas $53,3 \%$ as mantém ao longo da sua atividade profissional (...); uma percentagem significativa $(21,8 \%)$ responde que nunca faz formação profissional contínua” (Disco, 2014, p. 52), o que constitui violação das obrigações das entidades empregadoras (Disco, 2014, p. 53-54). Neste âmbito, o STARQ propõe: (i) acesso à formação profissional de todos os trabalhadores, nomeadamente às 40 horas anuais, enquadrada em horário laboral; a formação profissional deve propiciar a formação contínua, técnica e científica dos trabalhadores, a aquisição de conhecimentos, designadamente na área das novas tecnologias, e da segurança, saúde e higiene no trabalho, bem como a introdução a novos mecanismos nas formas de trabalho; a elaboração de planos anuais de formação, discutidos e negociados com os trabalhadores, e as suas organizações representativas, que promovam a valorização das respetivas carreiras e desempenhos profissionais.

De igual modo, são necessárias condições mínimas de trabalho, que permitam exercer a profissão com dignidade e autonomia. É urgente providenciar boas condições de exercício profissional, nomeadamente no que diz respeito à segurança, saúde e higiene no trabalho e prevenção de doenças profissionais, garantindo-se a conformidade com os requisitos de segurança e de saúde aplicáveis. Refira-se a obrigatoriedade de cumprimento da legislação em vigor (Lei n.․102/2009, de 1o de Setembro) em matéria de prevenção da segurança, saúde e higiene no trabalho no que se refere à informação aos trabalhadores sobre as normas legais, convencionadas e regulamentadas correspondentes. Sobre segurança, saúde e higiene no trabalho o STARQ propõe: (i) identificar e prevenir os riscos previsíveis nas atividades desenvolvidas (inclusive antes da entrada das equipas de Arqueologia), por forma a eliminar ou reduzir a exposição a agentes de risco e aumentar os níveis de proteção; (ii) promover a formação e integrar os conhecimentos dos riscos para a segurança e saúde do trabalhador nos planos anuais de formação profissional; (iii) priorizar medidas de proteção coletiva e individual, adequadas aos equipamentos e materiais; (iv) promover a colaboração de todos os trabalhadores na realização e manutenção das melhores condições possíveis de segurança, higiene e saúde; (v) manter ou garantir instalações, equipamentos e locais de trabalho em condições de higiene e segurança, conforme as disposições legais em vigor, 
para que os trabalhadores se encontrem protegidos contra riscos de acidentes e doenças profissionais, garantindo a fiscalização das mesmas condições em cada local de trabalho, incluindo os trabalhos de Arqueologia prévios ao início das obras; (vi) sem prejuízo da existência de um refeitório geral, disponibilização aos trabalhadores de um local condigno, arejado e asseado, com mesas e cadeiras suficientes e equipado com os eletrodomésticos que sejam necessários à conservação e ao aquecimento de refeições ligeiras; (vii) garantia de locais de trabalho com os requisitos necessários e indispensáveis, incluindo a existência de vestiários, lavabos e balneários para uso dos trabalhadores, com condições de higiene e segurança; (viii) nos termos do Decreto-Lei n.. 53A/98 de 11 de Março, atribuição de um suplemento de risco, penosidade ou insalubridade, sempre que as condições de trabalho assim o exijam, nomeadamente em trabalhos arqueológicos em ambiente insalubres ou por fatores externos ou naturais que possam resultar em danos físicos ou psicológicos ao trabalhador; (ix) sempre que se verificarem temperaturas ambientais, medidas pelas entidades oficiais, mínimas abaixo de $5^{\circ} \mathrm{C}$ e máximas acima de $35^{\circ} \mathrm{C}$, o trabalhador ao ar livre deverá receber um subsídio de risco. Em alternativa poder-se-á optar pela redução ou adaptação do horário laboral, de modo a ajustar-se às melhores condições térmicas, sem prejuízo do trabalhador.

A maternidade e a paternidade constituem valores sociais incontestáveis. Nesse sentido, os trabalhadores têm direito à proteção da sociedade e do Estado no exercício da maternidade e paternidade. De forma a consagrar este entendimento, que infelizmente nem sempre se repercute nas relações laborais em Arqueologia (Simões et al., 2018, p. 112), até pelas características do regime laboral existente, o STARQ defende:

i. Licença em situação de risco clínico durante a gravidez, nos termos do art. ${ }^{\circ} 37$ da Lei n. ${ }^{\circ}$ 7/2009 (Código do Trabalho);

ii. Licença por interrupção de gravidez, nos termos do art.․․ 38 da Lei n.. $7 / 2009$ (Código do Trabalho);

iii. Licença parental exclusiva da mãe trabalhadora de até 30 dias antes do parto e obrigatória de seis semanas a seguir ao parto;

iv. Licença parental inicial de 120,150 ou 180 dias consecutivos a mãe e pai trabalhadores, cujo gozo podem partilhar após o parto, no respei- tante aos 150 ou 180 dias, sem prejuízo de outros direitos da mãe, completando a entidade patronal o subsídio parental inicial atribuído pela Segurança Social, de forma a garantir à mãe e pai trabalhadores o recebimento de $100 \%$ do seu vencimento base mensal. O gozo da licença pode ser usufruído em simultâneo pelos progenitores entre os 150 e os 180 dias e é acrescida em 30 dias, no caso de cada um dos progenitores gozar, em exclusivo, um período de 30 dias consecutivos, ou dois períodos de 15 dias consecutivos, após o período de gozo obrigatório pela mãe, referido no número anterior;

v. No caso de nascimentos múltiplos, o período de licença previsto no número anterior é acrescido de 30 dias por cada gémeo além do primeiro;

vi. Em caso de internamento hospitalar da criança ou do progenitor que estiver a gozar a licença parental inicial ou durante o período após o parto, o período de licença suspende-se, a pedido do progenitor, pelo tempo de duração do internamento;

vii. Licença parental exclusiva e obrigatória do pai de 20 dias úteis, seguidos ou interpolados, a seguir ao nascimento do filho, dez dos quais gozados de modo consecutivo imediatamente a seguir a este. Após o gozo desta licença, o pai tem ainda direito a 10 dias úteis de licença, seguidos ou interpolados, desde que gozados com a licença parental inicial da mãe. No caso de nascimentos múltiplos, à licença prevista acrescem dois dias por cada gémeo além do primeiro. A retribuição desta licença, na parte não subsidiada pela Segurança Social, será suportada pela entidade patronal;

viii. Licença por adoção, nos termos do art. ${ }^{\circ} 44 \mathrm{da}$ Lei n.. 7/2009 (Código do Trabalho);

ix. Licença parental complementar em qualquer das modalidades, nos termos do art. .51 da Lei n. ${ }^{\circ}$ 7/2009 (Código do Trabalho);

x. Dispensa da prestação de trabalho por parte de trabalhadora grávida, puérpera ou lactante, por motivo de proteção da sua segurança e saúde, nos termos do art. ${ }^{\circ} 62$ da Lei n. ${ }^{\circ}$ 7/2009 (Código do Trabalho);

xi. Dispensa para consultas pré-natais e de preparação para o parto da trabalhadora grávida e pai, pelo tempo e número de vezes necessários, 
devendo as mesmas consultas serem, sempre que possível, fora do horário de trabalho;

xii. Dispensa para avaliação para adopção, nos termos do art. ${ }^{\circ} 4$ da Lei n. ${ }^{\circ}$ 7/2009 (Código do Trabalho);

xiii. Dispensa diária para amamentação ou aleitação da mãe, durante o tempo que durar a amamentação, gozada em dois períodos distintos, com a duração de uma hora cada e de acordo com o interesse da criança, salvo se outro regime mais favorável for acordado com a empresa. Sendo que, no caso de não haver amamentação, desde que ambos os progenitores exerçam atividade profissional, qualquer deles ou ambos, consoante decisão conjunta, têm direito a dispensa para aleitação, até o filho perfazer um ano. No caso de nascimentos múltiplos, a dispensa referida é acrescida de mais 30 minutos por cada gémeo além do primeiro;

xiv. Direito a faltar ao trabalho para assistência, inadiável e imprescindível, a filho menor, a filho com deficiência ou com doença crónica, em caso de doença ou acidente, até 30 dias por ano ou durante todo o período de eventual hospitalização, completando a entidade patronal o subsídio atribuído pela Segurança Social, de forma a garantir à mãe e pai trabalhadores o recebimento de $100 \%$ do seu vencimento base mensal;

xv. Faltas para assistência a neto, nos termos do art. ${ }^{\circ} 50$ da Lei n. ${ }^{\circ}$ 7/2009 (Código do Trabalho);

xvi. Licença para assistência a filho, nos termos do art. ${ }^{\circ} 2$ da Lei n.. 7/2009 (Código do Trabalho);

xvii. Licença para assistência a filho com deficiência ou doença crónica, nos termos do art. ${ }^{\circ} 53$ da Lei n. ${ }^{\circ}$ 7/2009 (Código do Trabalho);

xviii. Horário flexível ${ }^{14}$ ou trabalho a tempo parcial $^{15}$ de trabalhador com responsabilidades

\footnotetext{
14. Entende-se por horário flexível aquele em que o trabalhador pode escolher, dentro de certos limites, nomeadamente o de estar enquadrado dentro do horário de funcionamento da empresa ou serviço, as horas de início e termo do período normal de trabalho diário.

15. O período normal de trabalho a tempo parcial corresponde a metade do praticado a tempo completo numa situação comparável e, conforme o pedido do trabalhador, é prestado diariamente, de manhã ou de tarde, ou em três dias por semana.
}

familiares (com filho menor de 12 anos ou, independentemente da idade, filho com deficiência ou doença crónica que com ele viva em comunhão de mesa e habitação);

xix. Dispensa de prestação de trabalho em regime de adaptabilidade, nos termos do art. $.58 \mathrm{da}$ Lei n. ${ }^{\circ}$ 7/2009 (Código do Trabalho);

xx. Dispensa de prestação de trabalho suplementar da trabalhadora grávida, lactante e o/a trabalhador/a com filho menor;

xxi. Dispensa de prestação de trabalho no período noturno ou por turnos da trabalhadora grávida, lactante e o/a trabalhador/a com filho menor;

xxii. Direito da trabalhadora grávida, puérpera ou lactante a especiais condições de segurança e saúde nos locais de trabalho, de modo a evitar a exposição a riscos para a sua segurança e saúde. Sem prejuízo de outras obrigações previstas em legislação especial, em atividade susceptível de apresentar um risco específico de exposição a agentes, processos ou condições de trabalho, a entidade patronal deve proceder à avaliação da natureza, grau e duração da exposição de trabalhadora grávida, puérpera ou lactante, de modo a determinar qualquer risco para a sua segurança e saúde e as repercussões sobre a gravidez ou a amamentação, bem como as medidas a tomar;

xxiii. O despedimento de trabalhadora grávida, puérpera ou lactante ou de trabalhador no gozo de licença parental carece de parecer prévio da entidade competente na área da igualdade de oportunidades entre homens e mulheres (CITE), presumindo-se feito sem justa causa o despedimento por facto imputável a trabalhador que se encontre em qualquer das situações referidas.

\section{CONCLUSÕES}

O caminho a percorrer na negociação do Contrato Coletivo é longo e muito exigente. Depois de concluída a primeira versão do Caderno Reivindicativo, será apresentado a todos os associados do STARQ, para efeitos de debate e recolha de contributos, processo que será seguidamente alargado a toda a comunidade arqueológica. Finalizado o Caderno Reivindicativo e, com base neste, o STARQ iniciará um período de negociação com as empresas e entidades 
patronais. Nessa fase, os trabalhadores serão chamados a desempenhar um papel ativo e crítico na discussão, defesa e negociação dos seus direitos, bem como na reflexão sobre a forma como está estruturada a atividade em Arqueologia. Este momento exigirá uma atitude solidária e coletiva, na procura de relações profissionais justas, equitativas, democráticas e igualitárias.

\section{BIBLIOGRAFIA}

APA (2014) - DISCO. Discovering the Archaeologists of Portugal 2012-14. Associação Profissional de Arqueólogos, 149 p. Disponível em: https://www.discovering-archaeologists. eu/national_reports/2014/PT\%20DISCO\%202014\%2O Portugal\%2onational\%2oreport\%2oportuguese.pdf (acedido em 18 de maio de 2018).

BICHO, Nuno Ferreira (2006) - Manual de Arqueologia Pré-Histórica. Edições 7o, p. 53.

BUGALHÃO, Jacinta (2017) - O papel da mulher na arqueologia portuguesa. Ophiussa.Lisboa, 1, pp. 123-13o. Disponível em: http://ophiussa.letras.ulisboa.pt/article/TmcgPQ\# (acedido em em 18 de maio de 2018).

BUGALHÃO, Jacinta (2017) - Arqueólogos Portugueses. In ARNAUD, José Morais; MARTINS, Andrea, eds. - ArqueologiaemPortugal/2017-Estadoda Questão.Lisboa: Associação dos Arqueólogos Portugueses, pp. 19-31. Disponível em: http://museuarqueologicodocarmo.pt/publicacoes/outras_publicacoes/II_congresso_aap_actas.pdf (acedido em 18 de maio de 2018).

MESQUITA, Ana; SIMÕES, Sara (2014) - Os Trabalhadores de Arqueologia Portugueses já têm um Sindicato. Al-madan online. Almada. II Série, 19 (1), pp. 197-198. Disponível em: https://issuu.com/almadan/docs/al_madanonline19_1 (acedido em 18 de maio de 2018).

RENFREW, Colin; BAHN, Paul (1991) - Archaeology. Theories, Methods and Practice. Londres: Thames and Hudson, $543 \mathrm{p}$.

ROLO, Ana Mónica da Silva (2018) - O mundo funerário romano no Noroeste Alentejano (Portugal): o contributo das intervenções de Abel Viana e António Dias de Deus. Tese de doutoramento em Arqueologia apresentada à Faculdade de Letras da Universidade de Lisboa. Disponível em: https:// repositorio.ul.pt/bitstream/10451/37249/1/ulfl257354_ td_Vol\%2oI.pdf (acedido em Junho de 220).

SILVA, António Carlos (1995) - Arqueologia Preventiva e de Salvaguarda: a ponta do iceberg. Al-madan. Almada. II Série, 4, pp. 97-10o.

SIMÕES, Sara; BRITO, Sara; CARVALHO, Liliana; BUGALHÃO, Jacinta; MOREIRA, Andreia (2018) - Questões de Género em Contexto Laboral em Arqueologia: breves notas. Al-madan online. Almada. II Série, 22 (2), pp. 111-113.
Disponível em: https://issuu.com/almadan/docs/al-madanonline22_2 (acedido em 18 de maio de 2018).

COMISSÃO IGUALDADE MULHERES E HOMENS (2018) - Caracterização e dados sobre as desigualdades das mulheres no trabalho (discriminação salarial, precariedade, conciliação, maternidade/paternidade, assédio, doenças profissionais). CGTP. Disponível em http://www.cgtp.pt/ images/images/2018/o3/mulheresnotrabalho.pdf (acedido em 18 de maio de 2018).

STARQ, 2020a - Pandemia COVID-19. Impacto laboral em Arqueologia. Resultados de inquérito submetido à comunidade de trabalhadores de arqueologia (entre 21 e 31 de Março de 2020). STARQ. Disponível em: http://starq.info/ wp_direc/wp-content/uploads/2020/o4/COVID-Inqu\% $\mathrm{C}_{3} \%$ Agrito-Relat\% $\mathrm{C}_{3} \%$ B 3 rio.pdf (acedido em 25 de Junho de 2020).

STARQ, 2020b - Pandemia COVID-19. Impacto laboral em Arqueologia. Resultados de inquérito submetido à comunidade de trabalhadores de arqueologia (entre 8 e 25 de Maio de 2020). STARQ. Disponível em: http://starq.info/ wp_direc/wp-content/uploads/2020/o7/COVID_Inqu\% $\mathrm{C}_{3} \%$ Agrito-2_-Relat\% $\mathrm{C}_{3} \%$ B3rio_final.pdf (acedido em 9 de Julho de 2020).

WOLFRAM, Mélanie (2011) - Uma síntese sobre a cristianização do mundo rural no sul da Lusitania: arqueologia-arquitectura-epigrafia. Tese de doutoramento em Arqueologia apresentada à Faculdade de Letras da Universidade de Lisboa. Disponível em: https://repositorio.ul.pt/bitstream/10451/5678/3/ullsdo62156_td_tese.pdf(acedido em Junho de 2020). 


\title{
OS ESTUDOS DE IMPACTE PATRIMONIAL COMO ELEMENTO PARA UMA ESTRATÉGIA SUSTENTÁVEL DE MINIMIZAÇÃO DE IMPACTES NO ÂMBITO DE RECONVERSÕES AGRÍCOLAS
}

\author{
Tiago do Pereiro ${ }^{1}$
}

\begin{abstract}
RESUMO
As transformações na paisagem do interior alentejano, resultantes da ampliação das áreas de regadio ocorrida nos últimos anos, atinge hoje enormes proporções. No âmbito das reconversões agrícolas destas áreas, cabe aos promotores cumprirem a legislação aplicável ao património arqueológico. Dado que os projectos de âmbito agrícola não estão abrangidos pelos processos de AIA, os territórios que lhes estão afectos não têm sido objecto de qualquer tipo de estudos prévios no que respeita às questões do âmbito do património em geral e da arqueologia em particular. O objectivo deste texto é o de divulgar uma metodologia assente na realização de Estudos de Impacte Patrimonial, explanando as suas especificidades e as estratégias aplicadas na interação entre as partes envolvidas.

Palavras-chave: Estudo de Impacte Patrimonial, Reconversão Agrícola.
\end{abstract}

\begin{abstract}
The changes in the landscape of the Alentejo countryside, resulting from the expansion of irrigated areas that occurred in recent years, today reach enormous proportions. In the context of agricultural reconversions in these areas, it is up to the promoters to comply with the legislation applicable to the archaeological heritage. Given that agricultural projects are not covered by EIA processes, the territories that have been assigned to them have not been the subject of any kind of preliminary studies with regard to issues of heritage in general and archeology in particular. The purpose of this text is to disseminate a methodology based on the performance of Heritage Impact Studies, explaining its specificities and the strategies applied in the interaction between the subjects involved.
\end{abstract}

Keywords: Heritage Impact Studies, Agricultural Conversion.

\section{INTRODUÇÃO}

Quando há 20 anos foram fechadas as comportas do que viria a ser o grande lago do Alqueva, não existiu um planeamento crítico de obrigações e medidas de salvaguarda a implementar relativamente ao que de óbvio iria suceder ao património arqueológico enquadrado nas áreas de desenvolvimento de novos projectos agrícolas, assentes em regadio. Se, por um lado, o plano de minimizações de impactes decorrentes da construção do amplo sistema de rega implementado pela EDIA, a partir da Barragem do Alqueva, contribuiu de forma muito expressiva para os processos de conhecimento sobre o passado das ocupações humanas do actual território alentejano, por outro, esqueceu por completo que os vastíssimos territórios a serem regados e reconvertidos para novas culturas agrícolas seriam esquecidos e que não mereceriam quaisquer condicionantes decorrentes da sua intersecção com o património arqueológico. Assim, durante muito anos, foi-se assistindo nas fases de projecto e de implementação das obras do

1. ERA Arqueologia; tiagopereiro@era-arqueologia.pt 
sistema de Alqueva a uma proliferação de trabalhos arqueológicos, desde os estudos e trabalhos prévios sobre património, inseridos em Estudos de Impacte Ambiental (EIA), aos acompanhamentos de obras e às escavações arqueológicas enquadradas em processos de minimização de impactes. Paralelamente, em relação às afectações ou destruições ocorridas e denunciadas em relação ao património arqueológico inserido nos territórios agrícolas alimentados pelo sistema de Alqueva, foi-se assistindo, durante esses mesmos anos, a uma quase generalizada falta de atenção dos profissionais de arqueologia para tal problema e a uma total incúria ou incapacidade de agir nos diferentes momentos dos processos por parte dos organismos do Estado responsáveis pelo património arqueológico. Esta contradição, verdadeiramente escandalosa, entre o que se passava nos espaços das obras do sistema de Alqueva e o que ocorria nos terrenos agrícolas por ele regados, revelou um Alentejo a duas velocidades, chegando-se ao ponto de, em certos casos, no mesmo sítio arqueológico ocorrerem, em simultâneo, escavações arqueológicas devidamente orientadas por instrumentos de gestão territorial e destruições associadas ao evoluir de trabalhos agrícolas em espaços sem quaisquer condicionantes específicas. Este estado de coisas expôs os paradoxos ou a total ausência de lógica nas políticas de preservação e sustentabilidade futura do património arqueológico alentejano (Figura 1).

Apesar de se assistir a uma proliferação de extensas zonas de reconversões agrícolas um pouco por todo o pais, assumindo o caso alentejano como objecto do presente texto, é evidente que crescentes preocupações que a nossa sociedade tem vindo lentamente a demonstrar relativamente à ponderada gestão do património colectivo, nomeadamente arqueológico, ainda não mereceu do Estado, no que respeita a grandes empreendimentos agrícolas, uma definição concreta, clara e inequívoca de mecanismos de gestão territorial que lhe fossem aplicáveis. É, precisamente aqui, que os Estudos de Impacte Patrimonial (EIP) podem ser uma excelente ferramenta de gestão de processos e de Avaliação de Impacte Patrimonial (AIP), conforme a ERA Arqueologia o tem vindo a testar.

\section{OBRIGAÇÕES LEGAIS}

Como Portugal não tem qualquer tradição na realização de Estudos de Impacte Patrimonial (EIP), no caso de empreendimentos agrícolas com incidência em valores patrimoniais ou arqueológicos relativamente aos quais existem condicionantes legais limitadas, cabe aos seus promotores cumprirem a legislação vigente, nomeadamente a Lei de Bases do Património Cultural (Lei no 107/2001) e os Planos Directores Municipais (PDM).

No primeiro caso, decorrente da aplicação da Lei do Património, salientam-se dois aspectos de condicionamento genérico de quaisquer intervenções que incidam sobre bens arqueológicos: por um lado, a identificação de quaisquer testemunhos arqueológicos implica que da mesma seja dada informação à administração do património cultural ou à autoridade policial (Capítulo II, Art $^{\circ}$ 78, ponto 2); por outro lado, cabe à administração do património cultural determinar condicionantes à prossecução de obras de maneira a ser garantida a conservação total ou parcial de estruturas arqueológicas descobertas no decurso das mesmas (Capítulo II, Art $^{\circ}$ 79, ponto 2), cabendo aos promotores todos os custos inerentes às operações de arqueologia preventiva $e$ de salvamento tornadas necessárias pela realização dos seus projectos (Capítulo II, Arto ${ }^{\circ}$ 79, pontos $3 \mathrm{e}$ 4). Naturalmente, no caso de bens arqueológicos classificados, o regime definido pela Lei do Património (Capítulo II) é claro e concreto, estabelecendo as formas de condicionamento à concretização de projectos e obras em sítios e respectivas áreas anexas.

No segundo caso, resultante da aplicação de diferentes PDM's, podem ocorrer condicionalismos à aprovação ou implementação de projectos. Tais situações, ainda não generalizadas a todos os municípios alentejanos e muito menos ao todo nacional, resultam de inventários de sítios arqueológicos e de normativos de medidas cautelares aplicáveis em caso de eventual afectação por projectos. Infelizmente, nos casos em que estes inventários ocorrem, é por demais evidente que se tratam de listagens muito incompletas face ao expectável património arqueológico que permanece por identificar e consequentemente por inventariar. Acresce a este facto a deficiente cartografia dos sítios cadastrados, normalmente associados a pontos em mapas, sendo extremamente raros os casos em que os sítios arqueológicos surgem representados sob a forma de polígonos delimitadores das respectivas áreas. $\mathrm{Ou}$ seja, a maioria dos sítios arqueológicos alentejanos e portugueses não estão minimamente protegidos pelos PDM's em vigor. 
A agravar a situação vigente, tem perdurado em Portugal o desenquadramento dos projectos de âmbito agrícola dos instrumentos legais de Avaliação de Impacte Ambiental (AIA), daí decorrendo que os territórios sujeitos à sua implementação não têm sido objecto de qualquer tipo de estudos prévios visando a sua inventariação, caracterização, definição de medidas de salvaguarda ou de minimização de impactes.

Resumindo e já que os postulados acima referidos no que respeita à Lei de Bases do Património Cultural não têm efectivamente sido aplicados por manifesta incapacidade da administração do património, no caso deste tipo de processos as ferramentas de condicionamento legal à implementação de empreendimentos agrícolas em áreas de potencial arqueológico têm-se restringido a alguns PDM's ou à eventual denúncia pública de destruições que se têm sucedido sob o olhar mais ou menos atento ou empenhado de profissionais de arqueologia ou de membros das comunidades locais.

Perante um estado das coisas em que à expansão da rede de rega de Alqueva se tem associado uma revolução no uso dos solos agrícolas de vastas áreas do Alentejo com reconfigurações da sua topografia ou revolvimentos significativos das suas camadas superficiais, em certos casos até cerca de $1.5 \mathrm{~m}$ de profundidade, a tutela da arqueologia (DGPC - Direcção Geral do Património Cultural) e a administração do património cultural regional (Direcção Regional de Cultura) têm procurado prosseguir a uma estratégia de actuação em várias frentes.

Assim, e antes de mais tem-se procurado incrementar os níveis de articulação com municípios, desenvolvendo ou consolidando os inventários de sítios e normas inclusas em PDM's que assegurem possibilidades de condicionamento a projectos; paralelamente, tem-se assistido a uma insistência em acções de informação e de sensibilização de agricultores para as questões de âmbito legal respeitantes à salvaguarda do património arqueológico; complementarmente, procura-se prosseguir uma articulação, seguramente complexa, com o Ministério da Agricultura, por forma a criar novas condições de conciliação entre processos de licenciamento agrícola e respectivos condicionamentos arqueológicos. Neste âmbito, destaque-se os avanços ocorridos com a inclusão de novos procedimentos relacionados com o licenciamento de determinados projectos financiados por fundos comunitários (Norma Transitória 15/2018-PDR 202O), infelizmente apenas aplicáveis a sítios classificados ou inventariados. Por fim, nomeadamente em casos ocorridos no Alentejo, parece evidente que a administração do património cultural tem procurado, de forma claramente desarticulada entre os seus órgãos centrais e regionais, que o não cumprimento da legislação seja devidamente averiguado e punido, tendo-se incrementado as queixas apresentadas nos tribunais.

Ou seja, os sítios classificados e inventariados parecem estar, lenta mas progressivamente, a ser protegidos através de condicionantes legais, continuando as vastíssimas áreas de potencial arqueológico desconhecido, e por inventariar, a ser abandonadas e sujeitas a descontrolados processos de afectação ou destruição. E não tenhamos dúvidas que o património arqueológico catalogado no Alentejo é seguramente uma ínfima parte da totalidade efectivamente presente no subsolo.

\section{ESTUDOS DE IMPACTE PATRIMONIAL (EIP) COMO FERRAMENTAS DE GESTÃO TERRITORIAL}

Genericamente, os projectos de âmbito agrícola não estão sujeitos a procedimentos de Avaliação de Impacte Ambiental (AIA). Tais processos apenas ocorrem em casos específicos e abrangendo enormes áreas, sendo que na prática é possível e recorrente assistir à segmentação de projectos por forma a evitar tais procedimentos potencialmente constrangedores à sua concretização.

Neste contexto, criador de todas as condições para o prosseguimento da delapidação do património arqueológico alentejano, a ERA Arqueologia tem vindo a defender e a concretizar EIP assentes em metodologias de Avaliação de Impacte Patrimonial (AIP). Tais estudos, não tipificados na lei portuguesa, têm vindo a ser aprovados pela tutela do património arqueológico (DGPC), assumindo-se a sua concretização inédita como fundamental para o trilhar de um novo caminho que, estrategicamente, possa assegurar uma efectiva gestão global dos recursos arqueológicos inseridos em territórios agrícolas.

Numa perspectiva muito abrangente, este tipo de estudos incidindo em áreas de desenvolvimento de projectos agrícolas permite contribuir decisivamente para uma definição de:

- verdadeiros quadros de referência do património arqueológico inserido nas áreas de trabalho, incluindo os elementos desconhecidos e acres- 
centados aos inventários (nacional e locais) que assim se vão enriquecendo;

- regras aplicáveis em termos de avaliação do património existente nas áreas em análise;

- regras de avaliação de impactes estimados e de sistemas de ponderação de medidas preventivas e de minimização a considerar em casos de potencial afectação;

- um quadro de dados passíveis de facilitar e agilizar as decisões por parte da tutela do património;

- um modelo capaz de reduzir os riscos para os diferentes intervenientes, assegurando a salvaguarda do património e reduzindo os potenciais conflitos entre diferentes actores destes processos, nomeadamente decorrentes de destruições patrimoniais.

A sua concretização assenta na legislação em vigor para o património arqueológico (Lei 107/2001 - Lei de Bases do Património Cultural; Decreto-Lei no 164/2014 de 4 de Novembro - Regulamento dos Trabalhos Arqueológicos; Circular IGESPAR ro de Setembro de 2004 - Termos de referência para o descritor Património Arqueológico em estudos de impacte ambiental).

A sua definição assenta, em termos de pressupostos teóricos, no "Guidence on Heritage Impact Assessments for Cultural World Heritage Properties" (ICOMOS, 2011) e no "Standards and guidance for archaeological field evaluation" (CIFA, 2014), procurando-se, através da sua realização, garantir aos promotores de projectos agrícolas a atempada identificação dos bens patrimoniais presentes nas suas áreas de implementação, de maneira a tornar possível a sua avaliação e salvaguarda, quer efectiva quer pelo seu registo.

Os EIP, tal como são encarados pela ERA Arqueologia, têm como objectivo assegurar uma correcta gestão dos projectos agrícolas, nomeadamente em termos dos impactes que possam ter no património arqueológico e edificado presente nas áreas de trabalho, procurando-se sempre:

- a partir da sua implementação garantir o total cumprimento das obrigações legais relativamente à inventariação e protecção do património inserido em áreas a afectar pelo empreendimento agrícola;

- assegurar todas as condições necessárias à consistente salvaguarda do investimento na implementação do projecto agrícola, no estrito respeito pelo património cultural inserido nas propriedades.

Nesse sentido, na sua execução são devidamente considerados os seguintes objectivos específicos:

- realização de um inventário patrimonial das áreas de trabalho;

- caracterização e avaliação patrimonial de cada um dos elementos de património imóvel identificados (arqueológicos e edificados), incluindo os já conhecidos e previamente inventariados, bem como outros a identificar através de prospecções de terreno, análise de cartografia, fotografia aérea/imagens de satélite e prospecção geofísica;

- definição do grau de afectação de cada um dos elementos patrimoniais pelas acções de implementação dos projectos agrícolas;

- definição de medidas de salvaguarda e de minimização de impactes sobre o património, decorrentes da implementação do projecto agrícola;

- definição de recomendações de boas práticas agrícolas em áreas de existência de elementos patrimoniais arqueológicos ou edificados.

\section{METODOLOGIA}

Face aos objectivos definidos pelo processo de AIP, pretende-se que a realização de um EIP assente num conjunto de trabalhos de campo e de gabinete concretizados de forma faseada, por forma a fornecer às entidades tutelares e aos promotores dos projectos todos os dados que permitam assumir as mais adequadas decisões, salvaguardar os bens patrimoniais e assegurar a ponderada implementação dos projectos agrícolas.

A primeira fase dos EIP realizados pela ERA consiste no contacto entre as partes envolvidas, nomeadamente a nossa equipa técnica responsável pelo estudo, o promotor, a tutela do património e os serviços municipais competentes.

A segunda fase implica a pesquisa prévia sobre a área de trabalho e a definição de uma situação de referência criada a partir da compilação e inventariação de dados existentes para a área em estudo, através da recolha da bibliografia geral e específica, bem como da consulta das bases de dados informáticas existentes na DGPC e DRCA e outras disponíveis:

- Memória descritiva do projecto a implementar;

- Base de Dados do Endovélico;

- Atlas do Património Classificado e em Vias de 
Classificação;

- Planta de Ordenamento dos diferentes PDM;

- Estudos de Impacte Ambiental e Relatórios de Trabalhos Arqueológicos;

- Bibliografia especifica (Artigos, Noticias, Teses, etc.).

Paralelamente, é realizada uma sistematização de dados relativos à paisagem das áreas de trabalho, incluindo geologia, topografia, toponímia e análise de fotografia aérea, sempre numa perspectiva de, a partir de modelos de ocupação territorial relativos a diferentes períodos histórico-culturais, antecipar eventuais ocorrências a confirmar no terreno e criar um modelo sequêncial relativo à evolução da ocupação e uso das paisagens. Depois de recolhidos e tratados, estes dados são inseridos num sistema de informação geográfica (SIG) que serve de base para os trabalhos de campo de arqueologia, tornando-se também uma base de informações para uma adequada gestão agrícola por parte dos promotores dos projectos.

A terceira fase consiste na prospecção direccionada para a relocalização dos sítios previamente inventariados durante a fase de pesquisa prévia; paralelamente, e numa perspectiva de prospecção sistemática são percorridas todas as áreas de trabalhos, de maneira a assegurar o seu consistente varrimento, passível de assegurar uma exaustiva recolha de dados. Os sítios identificados (áreas de dispersão de materiais arqueológicos ou de implantação de estruturas) durante o trabalho de campo são registados numa ficha de Inventário e georreferenciados de modo a criar pontos e polígonos para serem inseridos na layer de arqueologia do projecto global da reconversão agrícola.

A quarta e última fase destes trabalhos consiste na elaboração de um relatório técnico referente aos trabalhos arqueológicos realizados, que serve de suporte à layer de arqueologia. Neste relatório é feita a análise e avaliação sumária das ocorrências patrimoniais identificadas, seguida da sua hierarquização, de acordo com a sua importância científica e patrimonial. O relatório inclui também a definição da situação de referência com o inventário de todos os sítios identificados, a avaliação de impactes estimados sobre os diferentes elementos patrimoniais decorrentes da implementação do projecto agrícola, e propostas, quando aplicável, inerentes às medidas de salvaguarda e de minimização.

No relatório final deve constar ainda um conjun- to de recomendações de boas práticas agrícolas em áreas de existência de elementos patrimoniais arqueológicos ou edificados que assegurem uma sustentável compatibilização futura da sua salvaguarda com o necessário uso dos solos por parte das entidades da área agrícola (Figura 2).

\section{CASO DE ESTUDO: EIP DA HERDADE DOS CUNQUEIROS}

O EIP realizado na Herdade dos Cunqueiros (Évora) teve origem numa solicitação de reunião de esclarecimentos por parte do promotor à tutela do património, no sentido de aferir previamente da necessidade de trabalhos de minimização dos sítios arqueológicos que constavam na base de dados do Endovélico, uma vez que não existiam sítios registados na carta de condicionantes do Plano Director Municipal de Évora.

$\mathrm{Na}$ sequência dessa reunião, a DRCAlent concluiu que seria importante proceder a uma prospecção sistemática da área total do projecto (cerca de 20oha) antes de se iniciarem os trabalhos de reconversão agrícola. No sentido de serem implementadas boas práticas no que diz respeito à gestão de valores $\mathrm{Pa}$ trimoniais e/ou Arqueológicos existentes na área a afectar, o promotor solicitou a realização de um EIP, que veio a merecer aprovação por parte da tutela do património.

Os trabalhos começaram com a pesquisa prévia de base de dados e bibliografia. Na análise dos relatórios de trabalhos anteriores, foram tidos em conta aspectos essenciais a serem truncados com a avaliação a realizar. São eles, o tipo de contexto, a que profundidade da superfície se encontram, e em que estado de preservação estavam aquando da intervenção. Todos os dados foram tratados de forma a serem inseridos numa base de dados em SIG, resultando desta informação uma nota técnica prévia que foi fornecida ao promotor com todos os dados disponíveis. Este documento inicial tem a vantagem de aproximar o promotor/cliente dos aspectos mais técnicos da arqueologia, prevenir para a legislação em vigor, e também de alertar para os condicionalismos que podem resultar da avaliação patrimonial e de impactes estimados a ser elaborada durante as prospecções. De seguida, a totalidade da Herdade foi prospectada sistematicamente durante cerca de 1 semana por uma equipa de três arqueólogos. Ao fim do dia a base de dados em SIG era atualizada e realizado 
um ponto de situação com o promotor. No decorrer destes trabalhos foram relocalizadas sete ocorrências e identificados oito novos sítios. As principais medidas de minimização elencadas neste projecto tiveram em conta uma análise de avaliação do impacte estimado das várias componentes do projecto (ripagens a determinada profundidade, abertura de valas para o sistema de rega, etc.), relativamente ao tipo de sítio e respectivo valor patrimonial considerado. Entre estas, foi proposto que em sítios de maior potencial/valor patrimonial se procedesse a uma campanha de prospecção geofísica.

As imagens recolhidas da prospecção geofísica e inseridas na base de dados de informação geográfica tiveram impacto na definição de áreas precisas de contextos arqueológicos, permitindo a sua correcta delimitação física no terreno, na identificação de antigas condutas de rega, que viriam a ser aproveitadas no novo projecto e, por fim, na construção de um maior conhecimento dos próprios sítios. Relativamente aos elementos etnográficos, que correspondem a uma memória importante do património local e integram um património paisagístico intemporal, propôs-se que os mesmos fossem preservados e integrados no projecto, algo que se viria a verificar com o "amanho" de algumas destas estruturas da cultura popular.

Estes trabalhos permitiram que o projectista do sistema de rega a implantar, ainda em fase de projecto, tivesse uma camada denominada "Arqueologia" e implantasse as condutas do sistema de rega, de forma a não intercetarem os sítios e/ou manchas de materiais identificadas e delimitadas, tanto no terreno como em cartografia.

Ainda assim, e para os casos em que ainda existiam dúvidas relativamente à extensão e presença de contextos arqueológicos, foi proposto e realizado o acompanhamento arqueológico da abertura das valas do sistema de rega em zonas próximas de sítios arqueológicos e em áreas que, devido à sua composição morfológica, sugeriam a presença de ocupações antrópicas. Nestes trabalhos finais não foram identificados contextos.

O património arqueológico e etnográfico, relevante, ficou delimitado e preservado no campo com barrotes de $10 \mathrm{em}$ 1om, permitindo o seu acesso futuro por parte de investigadores (Figura 3 ).

\section{CONCLUSÃO}

Com o advento da agricultura, os territórios, nomeadamente aqueles em que os solos são propícios à prática agrícola, foram sendo transformados pelas comunidades humanas que os exploravam. Estas transformações primitivas teriam um impacte reduzido na paisagem, contudo, com a revolução industrial, e a entrada em cena da máquina a vapor na agricultura, a preparação dos solos foi elevada a uma outra dimensão. No caso do interior alentejano, as transformações mais evidentes da paisagem encontram o seu inicio nas denominadas "campanhas do trigo" em pleno século XX, tendo impactes irreversíveis na morfologia da paisagem. Ainda assim, a extensão do alcance desta "modera" paisagem alentejana, tinha os seus limites bem definidos: solos de boa qualidade. No presente recente, esses limites, já não são definidos pela qualidade dos solos mas sim pelos blocos de rega que fornecem água da albufeira de Alqueva, uma vez que também as culturas agrícolas com maior expressão em termos de crescimento da ocupação do território passaram a ser a oliveira, o amendoal e a vinha (Figura 4).

O impacte na paisagem associado a estas novas culturas ditas de regadio ou "em sebe", tem o seu início com o processo de terraformação (termo utilizado para definir a fase inicial da reconversão agrícola), assentando em grandes movimentações de solo, tanto em extensão como em profundidade. No caso de existirem ocorrências patrimoniais, nomeadamente sítios arqueológicos, torna-se evidente que se não forem respeitadas as condicionantes legais de protecção do património, quando existem, o dano que estruturas, contextos e depósitos arqueológicos estão sujeitos é enorme. Nestes casos, o cadastro inicial e prévio dos terrenos, no que á componente patrimonial diz respeito, é essencial para um equilíbrio entre o desenvolvimento do projecto e a responsabilidade legal e social que devemos ter pelo caminho trilhado pelas comunidades que nos antecedem. É nesse sentido que os Estudos de Impacte Patrimonial são uma mais valia, uma vez que permitem acompanhar um projecto num determinado território, desde a sua fase inicial, precavendo que tais impactes negativos possam ocorrer.

Até ao momento, e desde 2018, a ERA já realizou cerca de 55 EIP abrangendo a totalidade do interior alentejano, para diferentes promotores, tendo alcançado resultados promissores na passagem da men- 
sagem da necessidade da aplicação deste conceito: "Prevenir antes de afectar".

Por fim, refere-se da necessidade de adaptação de conceitos por ambas as partes, devendo o estado central ter uma acção mais informativa e formativa.

\section{BIBLIOGRAFIA}

CIFA, (2014) - Standards and guidance for archaeological field evaluation". https://www.archaeologists.net/sites/ default/files/CIfAS\&GFieldevaluation_1.pdf

ICOMOS, (2011) - Guidence on Heritage Impact Assessments for Cultural World Heritage Properties. https:// www.icomos.org/world_heritage/HIA_20110201.pdf

PEREIRO, Tiago (2018) - Relatório Final dos Trabalhos Arqueológicos (EIP) Herdade dos Cunqueiros, São Manços, Évora. ERA-Arqueologia S.A.
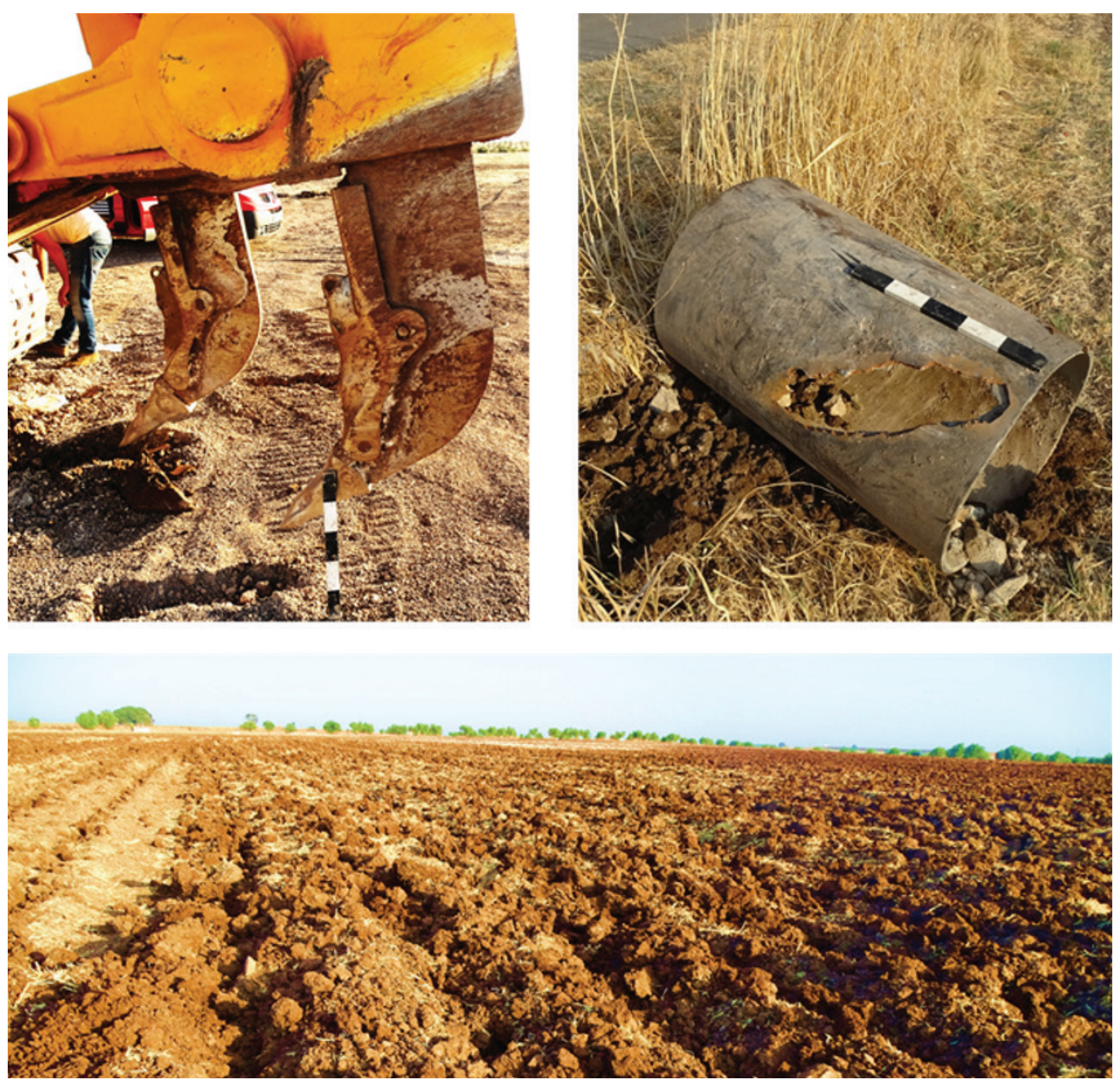

Figura 1 - No canto superior esquerdo o tipo de máquina utilizada para remobilizar os solos (escala de $50 \mathrm{~cm}$ ). Do lado direito pormenor de impacte produzido em conduta de ferro forjado localizada a im de profundidade. Em baixo aspecto de um terreno lavrado. 

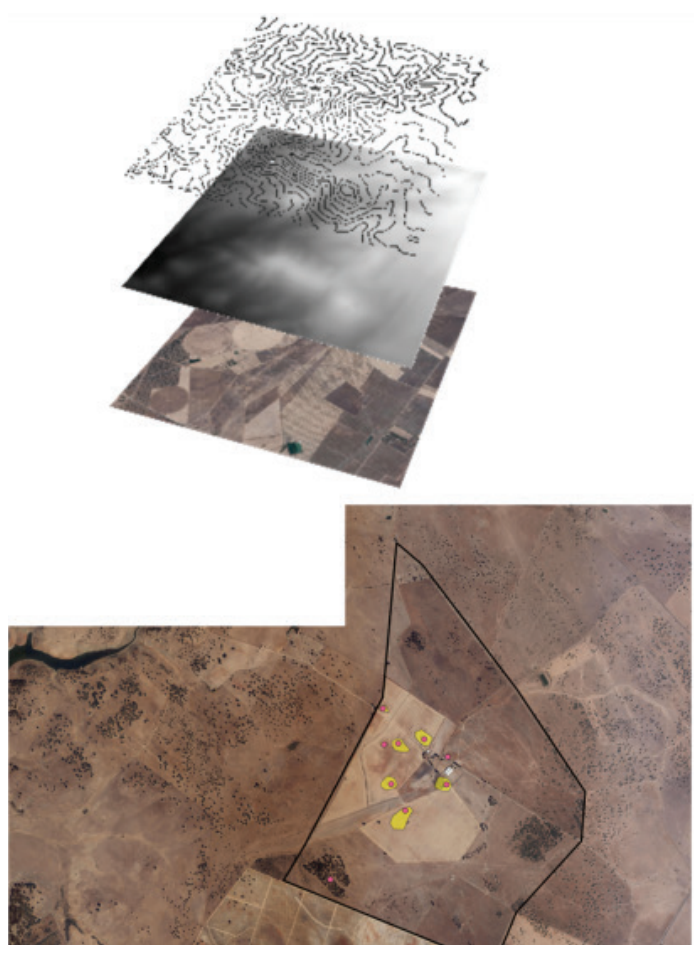
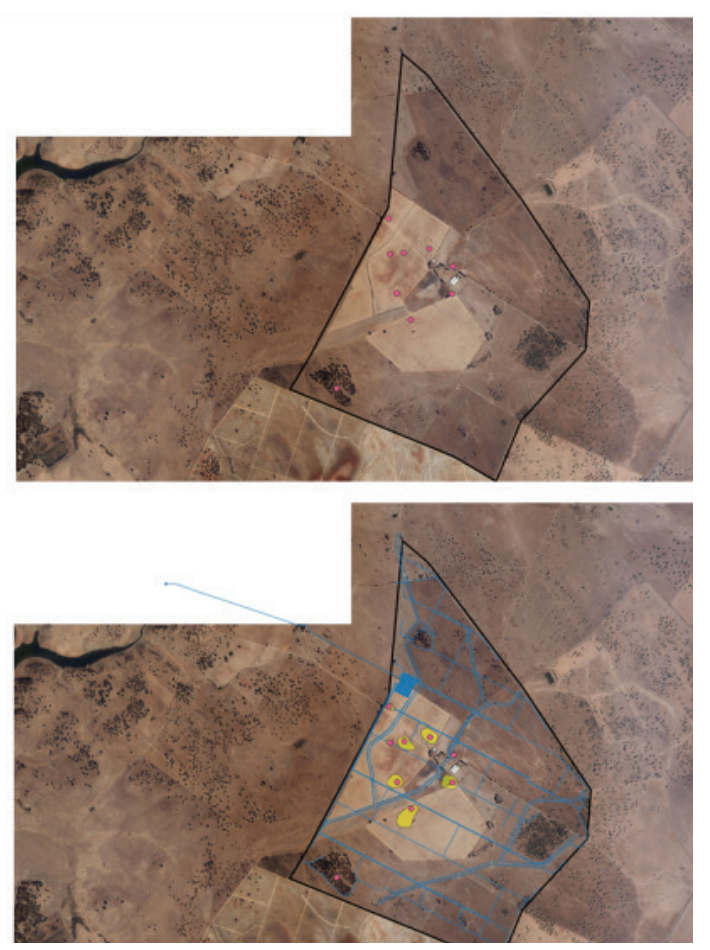

Figura 2 - Diferentes camadas do processo de integração de informação em ambiente SIG.
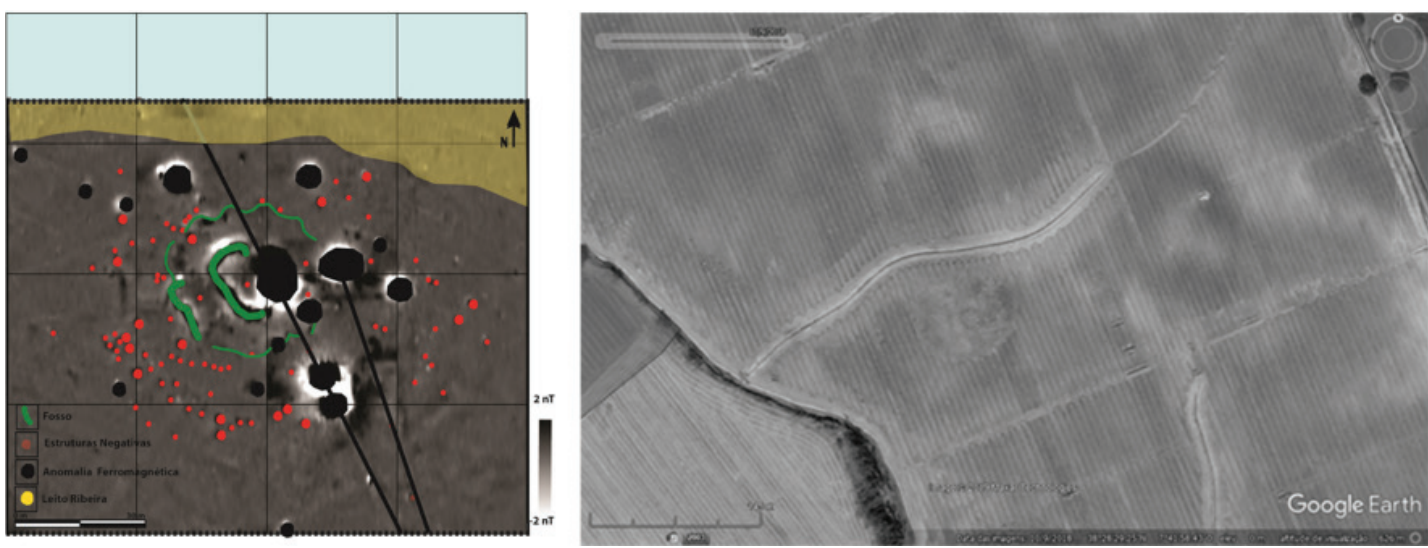

Figura 3 - Prospecção geofísica realizada no sítio Horta do Albardão 3 e respectiva zona de protecção em imagem de satélite. 


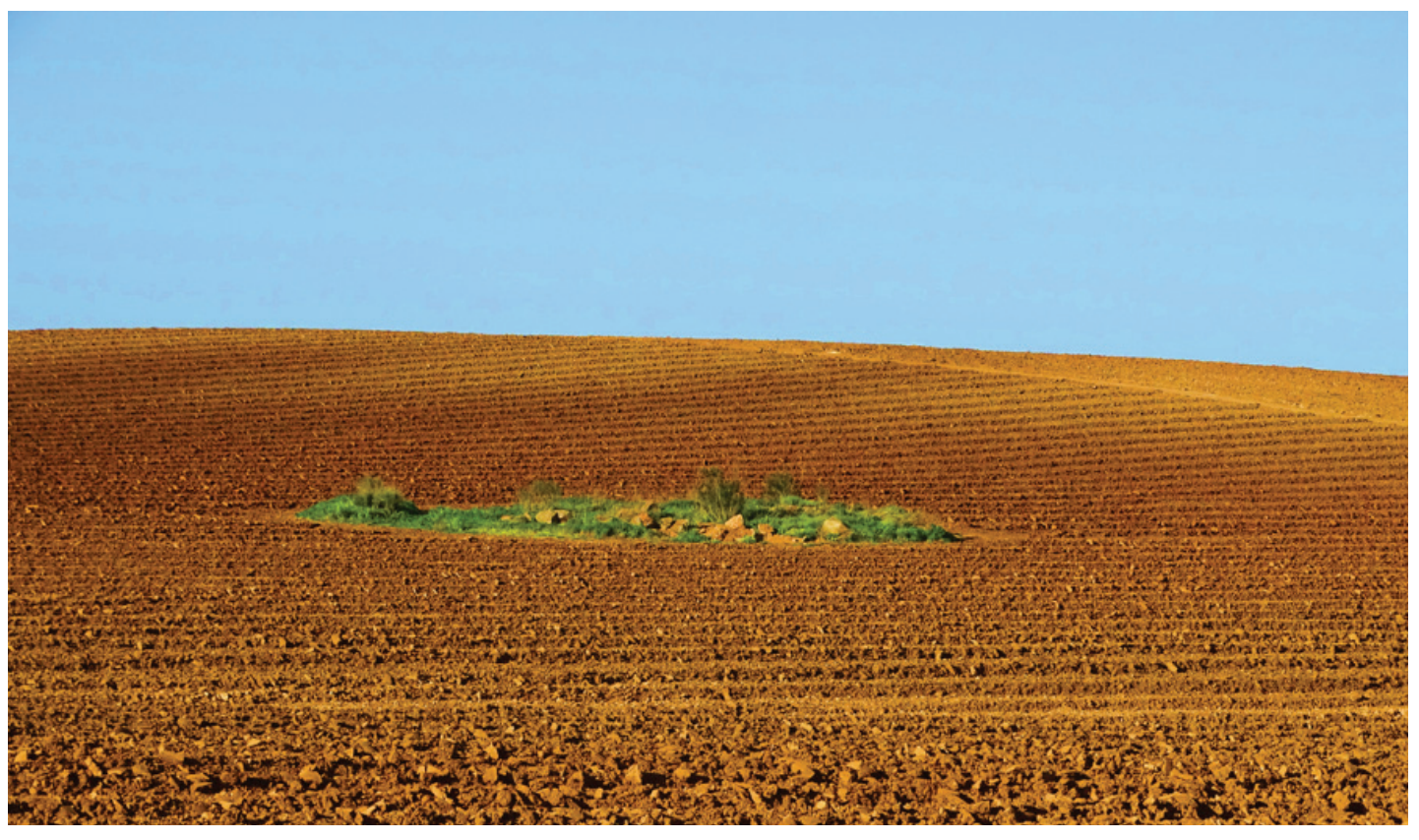

Figura 4 - Vista geral de um sítio arqueológico delimitado com área de protecção na sequência de um EIP. 


\section{SALVAGUARDA DE PATRIMÓNIO ARQUEOLÓGICO EM OPERAÇÕES FLORESTAIS: GESTÃO E SENSIBILIZAÇÃO}

Filipa Bragança ${ }^{1}$, Gertrudes Zambujo ${ }^{2}$, Sandra Lourenço ${ }^{3}$, Belém Paiva ${ }^{4}$, Carlos Banha ${ }^{5}$, Frederico Tatá Regala ${ }^{6}$, Helena Moura $^{7}$, Jacinta Bugalhão ${ }^{8}$, João Marques ${ }^{9}$, José Correia $^{10}$, Pedro Faria ${ }^{11}$, Samuel Melro ${ }^{12}$

RESUMO

A atividade florestal regista uma elevada dinâmica em Portugal, sobretudo desde os incêndios de 2017 e com os novos Programas Regionais de Ordenamento Florestal. Neste contexto, a Direção-Geral do Património Cultural e as Direções Regionais de Cultura constituíram um Grupo de Trabalho para a definição de procedimentos no âmbito da salvaguarda do Património arqueológico em projetos florestais e agricultura intensiva. No âmbito florestal foi elaborado um conjunto de orientações relativas à salvaguarda do Património arqueológico, preparam-se ações de sensibilização, destinadas à administração local, proprietários e gestores florestais. As iniciativas procuraram a introdução de boas práticas de salvaguarda patrimonial, o estímulo de uma relação sustentável entre o homem, o seu território e o Património Arqueológico, recurso finito e não renovável. Palavras-chave: Salvaguarda do Património arqueológico, Projetos florestais, Ordenamento florestal, Gestão do território, Sensibilização patrimonial.

\section{ABSTRACT}

The forestation and reforestation activity registers a high dynamics in national territory, very implemented in the aftermath of the great fires that occurred between June and October 2017 and with the revision of the Regional Forest Management Programmes. In this context, the Directorate-General for Cultural Heritage (DGPC) and the Regional Directorates for Culture formed a Task Force (TF) for the definition of procedures and regulations in the context of safeguarding of archaeological heritage in forestry and intensive agriculture projects. Within the scope of forestry projects, the TF produced a set of guidelines relating the safeguarding of the archaeological heritage, to be implemented in multi-annual plantations with impacting techniques of soil mobilization (namely: removal of stones, heavy mechanical scarification, subsoiling, ground levelling, mega ridges-furrows, and terracing, among others). Another of the TF activity area is related with the preparation of awareness raising actions, both for stakeholders in local administration, with obligations in territory management, and for those with interests associated with forestry, which includes owners, investors and forest managers.

Thus, it is intended to advertise the initiatives that have been developed in order to introduce and promote good practices related with the safeguarding of the cultural heritage in forestry operations, in order to stimulate a sustainable relationship between man and his territory, namely, with the Archaeological Heritage, a finite and non-renewable resource.

Keywords: Archaeological heritage rescue, forestry projects, forest management, territory management, heritage education.

\footnotetext{
1.DGPC; fbraganca@dgpc.pt

2. DGPC; gzambujo@dgpc.pt

3. DGPC; slourenco@dgpc.pt

4.DRC Norte; bpaiva@culturanorte.gov.pt

5.DRC Centro; cbanha@drcc.gov.pt

6. DRC Algarve; ftata@cultalg.gov.pt

7. DRC Centro; hmoura@drcc.gov.pt
}

\author{
8. DGPC; jbugalhao@dgpc.pt \\ 9. DGPC; jmarque@dgpc.pt \\ 10.DGPC; jcorreia@dgpc.pt
}

11.DRC Norte; pfaria@culturanorte.gov.pt

12. DRC Alentejo; samuel.melro@cultura-alentejo.gov.pt 


\section{INTRODUÇÃO}

Em Junho de 2017 foi constituído o Grupo de Trabalho de Salvaguarda de Património Arqueológico em Operações Agrícolas e Florestais (GT), composto por elementos da Direção Geral do Património Cultural (DGPC), da Direção Regional de Cultura do Norte (DRC Norte), da Direção Regional de Cultura do Centro (DRC Centro), da Direção Regional de Cultura do Alentejo (DRC Alentejo) e da Direção Regional de Cultura do Algarve (DRC Algarve), com $o$ intuito de encontrar soluções, que atendessem às especificidades regionais. Pretendia-se garantir a proteção deste Património em projetos agrícolas e florestais, procurando travar, deste modo, destruições por falta de um planeamento adequado, através da criação de procedimentos técnicos, com critérios homogéneos, estabelecidos a montante destas operações com elevado impacte ao nível do solo. Desde essa data o GT tem reunido regularmente, tendo produzido a seguinte documentação:

i. Circular: Termos de Referência para procedimentos técnicos salvaguarda do Património Arqueológico no âmbito de projetos florestais

ii. Brochura: Procedimentos para a Salvaguarda do Património Arqueológico em Operações Agrícolas

iii. Guia: Os Projetos Agrícolas e a Salvaguarda de Património Arqueológico

iv. Brochura: Procedimentos para a Salvaguarda do Património Arqueológico em Operações Florestais

v. Guia: Os Projetos Florestais e a Salvaguarda de Património arqueológico

\section{HISTORIAL E ENQUADRAMENTO LEGAL}

A atividade florestal foi há muito identificada como crítica para a conservação do Património arqueológico. Nas últimas quatro décadas registaram-se em Portugal diversos episódios de destruição de sítios arqueológicos na sequência de trabalhos florestais que, como tantas outras emergências, despoletaram intervenções de salvamento com vista à recuperação da informação arqueológica associada aos sítios afetados. Refiram-se a título de exemplo, os trabalhos arqueológicos realizados em 1981 e 1982, na Fonte do Sapo (CNS ${ }^{13}$ 1199), Mogadouro, pela

13. CNS - Acrónimo correspondente ao Código Nacional de Sítio Arqueológico
Unidade de Arqueologia da Universidade do Minho; em 1986 e 1978, em São Martinho da Gândara/Castro de Recarei (CNS 6704), Oliveira de Azeméis, por José Augusto Teixeira Maia Marques; em 1987, na Base Aérea de Beja I (CNS 1527), em Beja, pelo IPPC; em 1989, no povoado da Charneca da Salavessa (CNS 6812), Nisa, pela Associação de Estudos do Alto Tejo; ou em 199o, no Castelo Velho de Degebe (CNS 1091), Reguengos de Monsaraz, pelo IPPC, entre muitos outros (Caninas e Henriques, 1995).

Este panorama registou forte agravamento no final da década de 8o, com a expansão da florestação intensiva de vastas áreas do país, nomeadamente monocultura do eucalipto no âmbito do crescimento da indústria de pasta de papel (Alves, Pereira e Silva, 2007, p. 20). O crescimento do eucaliptal levantou sérios problemas de natureza ambiental, motivando um movimento de contestação das associações de defesa do ambiente, no qual a proteção do Património Cultural esteve essencialmente omissa (Caninas e Henriques, 2008). Mas, de facto, este tipo de explorações florestais comportava uma intervenção mecanizada e com recurso a meios muito pesados, potenciando em muito o seu carácter destrutivo para os vestígios arqueológicos. Esta realidade provocou a multiplicação das situações de afetação patrimonial, bem como o aumento da amplitude e intensidade do impacte destrutivo (Caninas e Henriques, 1995; Henriques, Caninas e Chambino, 2008), gerando uma corrente de reflexão na comunidade arqueológica, na procura de soluções no âmbito da arqueologia preventiva que permitissem a adequada proteção deste Património (Arnaud, 1991, p. 13-14; Caninas e Henriques, 2008). Em 27 de Fevereiro de 1989, o Conselho Consultivo do IPPC emitiu uma moção em que expressava preocupação com estas reiteradas destruições e apelava à articulação entre as áreas governativas da Cultura, do Ambiente e da Agricultura com vista à resolução do problema (Figura 1).

Neste contexto, em 1989, o então IPPC promoveu protocolos de colaboração com as três maiores empresas de florestação, com vista ao enquadramento das intervenções arqueológicas preventivas no âmbito da sua atividade. Foram criadas equipas técnicas de Arqueologia que procediam à prospeção prévia das áreas a florestar, à delimitação das áreas de proteção dos locais com interesse arqueológico, à realização de sondagens nos sítios arqueológicos loca- 
lizados nas áreas a florestar e ao acompanhamento dos trabalhos de florestação (Arnaud, Almeida e Bugalhão, 1991; Arnaud, Muralha e Estorninho, 1991; Arnaud, Ramos e Martins, 1991). Estes protocolos vigoraram com eficácia relativa (AEAT, 1994) até 1997, quando o Estado passou a assumir um papel normativo e fiscalizador, deixando de garantir a execução direta dos trabalhos arqueológicos.

Por outro lado, ao longo do tempo foi-se consolidando a necessidade de aprofundamento do conhecimento da Carta Arqueológica de todo o território nacional, como única forma de salvaguardar os vestígios arqueológicos ameaçados pelo avanço da floresta (Henriques, Caninas e Chambino, 2008). Contudo, a verdade é que estes procedimentos nunca foram completamente eficazes, continuando a verificar-se situações de destruição (embora menos frequentes devido à diminuição dos projetos de novas florestações). Assim, nos últimos vinte anos, a salvaguarda patrimonial no âmbito de projetos florestais (em conjunto com a agricultura intensiva) mantém-se uma preocupação, pois embora os procedimentos de arqueologia preventiva sejam já muito abrangentes e eficazes, esta atividade continua a representar um impacto considerável na paisagem e no subsolo com graves afetações do Património, sem que se assegure a sua preservação no quadro geral do licenciamento, financiamento e regulação destas atividades (Caninas, Henriques e Gouveia, 2008). Desta realidade têm feito eco, os arqueólogos que nos diversos organismos da administração pública com competência sobre o Património Cultural acompanham a atividade arqueológica e exercem a sua fiscalização, através de inúmeras iniciativas, contactos institucionais, propostas de atuação e salvaguarda, denúncias e, principalmente, reflexão crítica sobre os diversos e complexos aspetos desta problemática.

$\mathrm{O}$ enquadramento dos trabalhos arqueológicos preventivos no âmbito da atividade florestal decorre, por norma, em contexto de gestão municipal do território, de Avaliação de Impacte Ambiental (AIA) e de Ordenamento e Gestão do Território. A partir do final dos anos 90 do século XX, em Portugal, foram progressivamente adotados (a nível legislativo, regulamentar e de boas práticas) procedimentos de arqueologia preventiva, preconizados na Convenção Europeia para a Proteção do Património Arqueológico (revista), aprovada pelo Conselho da Europa, em La Valetta, Malta, em 16 de Janeiro de
1992 e ratificada pelo Estado Português, em 1997 (Resolução da Assembleia da República n.ำ 71/97 de 12 de Dezembro).

Estes princípios foram plasmados na Lei n.․ 107/ 2001, de 8 de setembro, (que estabelece as Bases da Política e do Regime de Proteção e Valorização do Património Cultural), pelo que desde então, a salvaguarda do Património arqueológico no âmbito de projetos/explorações florestais perdeu especificidade, sendo englobada na generalidade dos "empreendimentos públicos ou privados que envolvam significativa transformação da topografia ou paisagem" (n. 94 do Artigo 79.․ da referida Lei), em grande parte baseada na aplicação dos princípios da conservação pelo registo científico e financiada ao abrigo do princípio do poluidor-pagador.

Contudo, e volvidas várias décadas de experiência, conclui-se que a salvaguarda do Património arqueológico no âmbito de projetos/explorações florestais revela ainda fragilidades significativas que se consubstanciam na perda de informação e de bens arqueológicos. Quando detetável a atuação pautou-se casuisticamente por medidas provisórias de salvaguarda perante o risco de destruição e perda dos valores arqueológicos ou, na maior parte das situações, pelo estabelecimento de medidas de minimização a posteriori sobre danos já verificados. Estas fragilidades resultam do licenciamento e das limitações existentes no enquadramento previsto no regime jurídico da AIA (Decreto-Lei n.․ำ151-B/2013 de 31 de outubro, com as alterações sucessivas, e republicado pelo Decreto-Lei n.ำ 152-B/2017 de 11 de dezembro). De acordo com este regime jurídico (Anexo 2, Ponto 1), são apenas sujeitos a procedimento de AIA projetos de florestação e reflorestação, desde que impliquem a substituição de espécies preexistentes, em áreas isoladas ou contínuas, com espécies de rápido crescimento e desflorestação destinada à conversão para outro tipo de utilização das terras:

i. Nos casos gerais: em projetos de florestação/ reflorestação com uma área $\geq 350$ ha, ou $\geq 140$ ha, se, em conjunto com povoamentos preexistentes das mesmas espécies, distando entre si menos de $1 \mathrm{~km}$, der origem a uma área florestada superior a $350 \mathrm{ha}$; em projetos de desflorestação $\geq 50$ ha; 
ii. Nas áreas sensíveis ${ }^{14}$ : em projetos de florestação/reflorestação com uma área $\geq 70$ ha, ou $\geq$ $3 \mathrm{o} \mathrm{ha}$, se, em conjunto com povoamentos preexistentes das mesmas espécies, distando entre si menos de $1 \mathrm{~km}$, der origem a uma área florestada superior a $70 \mathrm{ha}$; em projetos de desflorestação $\geq 10$ ha.

Por outro lado, no âmbito dos Instrumentos de Gestão Territorial (IGT), o estabelecimento de medidas de salvaguarda patrimonial não tem revelado uma verdadeira eficácia e alcance. Às operações florestais subjaz um conjunto de instrumentos de gestão territorial com distintos níveis de planeamento: a nível regional ou supramunicipal, os Planos Regionais de Ordenamento Florestal (PROF) que se articulam com outros instrumentos de planeamento territorial; a nível local, os Planos de Gestão Florestal (PGF) que por sua vez consagram os Planos de Utilização de Baldios (PUB). A existência de um PGF e dos Planos de Defesa da Floresta (PDF) vincula todos os proprietários e produtores florestais abrangidos pela área territorial das Zonas de Intervenção Florestal (ZIF), áreas florestais contínuas geridas por uma única entidade. Por fim a nível operacional, em continuidade dos PDF existem os Planos Específicos de Intervenção Florestal (PEIF) (zonas de risco de incêndio, pragas e doenças, etc.). Apesar da emissão parcial, pelo que claramente insuficiente, de pareceres da administração do Património Cultural sobre estes IGT e PGF, tais contributos não vieram a resultar em igual número de trabalhos arqueológicos preventivos. O mesmo se pode dizer quanto à interação com o Regime Jurídico das Ações de Arborização e Rearborização (RJAAR), através da plataforma RJAAR - SIICNF, gerido pelo ICNF, mecanismo associado às ações sujeitas a autorização e a comunicação prévia. Nesse âmbito tem-se verificado no território nacional de forma desfasada

14. "Áreas sensíveis»: i) Áreas protegidas, classificadas ao abrigo do Decreto-Lei n.․ 142/2008, de 24 de julho; ii) Sítios da Rede Natura 200o, zonas especiais de conservação e zonas de proteção especial, classificadas nos termos do Decreto-Lei n.. $140 / 99$, de 24 de abril, no âmbito das Diretivas n.os 79/409/CEE, do Conselho, de 2 de abril de 1979, relativa à conservação das aves selvagens, e 92/43/CEE, do Conselho, de 21 de maio de 1992, relativa à preservação dos habitats naturais e da fauna e da flora selvagens; iii) Zonas de proteção dos bens imóveis classificados ou em vias de classificação, definidas nos termos da Lei n. ${ }^{\circ}$ 107/2001, de 8 de setembro (alínea a) do artigo 2.. B/2017 de 11 de dezembro. e não sistemática a participação dos organismos da administração pública com competência sobre o Património Cultural quando solicitado a "consultas e pareceres". Em suma, apesar dos trabalhos florestais serem alvo de uma série de instrumentos e mecanismos que visam a implementação de medidas de salvaguarda patrimonial, sejam no articulado dos PROF ou dos PGF, seja nos pareceres solicitados pelo RJAAR, não se considera que estejam a ser devidamente atendidos os procedimentos e a aplicação dos princípios da arqueologia preventiva.

\section{PROPOSTA DE TERMOS DE REFERÊNCIA PARA PROCEDIMENTOS TÉCNICOS DE SALVAGUARDA DO PATRIMÓNIO ARQUEOLÓGICO NO ÂMBITO DE PROJETOS/EXPLORAÇÕES FLORESTAIS}

Tendo por base a experiência de décadas da Administração do Património Cultural na sua vertente arqueológica, e constatando-se a necessidade, perante a crescente expansão do número de projetos florestais sem enquadramento no previsto no regime jurídico de AIA, verificou-se ser útil proceder à elaboração de um normativo que preconize procedimentos mais eficazes. Assim, foi elaborado pelo GT o documento Termos de Referência para procedimentos técnicos de salvaguarda do Património arqueológico no âmbito de projetos/explorações florestais (concluído em final de 2018), que aguarda homologação superior por parte da DGPC. O documento tem como principais objetivos: (i) definição e implementação de procedimentos que abranjam a totalidade dos projetos/explorações florestais, permitindo a adequada salvaguarda do Património arqueológico e da informação técnica e científica a este inerente, de acordo com a legislação em vigor; (ii) definição e implementação de procedimentos que promovam a uniformização de critérios técnicos e científicos e de atuação por parte dos organismos da administração pública com competência sobre o Património Cultural. Pretende-se igualmente que sirva de orientação para a emissão de pareceres para a salvaguarda do Património arqueológico, nomeadamente em sede de RJAAR. Os procedimentos técnicos previstos no documento aplicam-se, independentemente dos procedimentos de salvaguarda arqueológica decorrentes da legislação e regulamentação específica relativa a licenciamento, autorização e informação prévia de operações florestais. 
$\mathrm{Na}$ estratégia preconizada, nas propriedades (ou parcelas) com uma área inferior a 100 ha e nas quais não tenham sido identificados até ao momento vestígios patrimoniais não é imposta qualquer condicionante. Realça-se ainda que, caso sejam encontrados quaisquer testemunhos arqueológicos no âmbito das atividades florestais, os proprietários/ promotores ficam obrigados a dar conhecimento do achado no prazo de quarenta e oito horas à administração do Património Cultural competente (DGPCe DRC) ou à autoridade policial (Artigo 78. da Lei n.․ 107/2001, de 8 de setembro), a fim de que sejam implementadas as medidas de salvaguarda adequadas nos termos da Lei.

Para as propriedades (ou parcelas) com uma área igual ou superior a 100 ha, preconiza-se a realização de prospeção sistemática prévia. Em função dos seus resultados deverá propor-se para aprovação da DGPC/ DRC, a metodologia e as medidas de minimização a aplicar, como acompanhamento arqueológico, sondagem, escavação arqueológica ou outros, assim como a estratégia de salvaguarda a implementar.

Independentemente da sua dimensão, nas propriedades (ou parcelas) em cujo perímetro se conservem vestígios arqueológicos e/ou que registem sítios arqueológicos localizados a uma distância inferior a $500 \mathrm{~m}$ do seu limite exterior, deverão ser promovidos trabalhos de prospeção sistemática prévia e, em função dos seus resultados, determinadas ulteriores medidas de salvaguarda. Neste caso, os proprietários/promotores deverão promover também acompanhamento, sondagem ou escavação de caraterização dos sítios já inventariados, bem como de outros que venham a ser identificados no decurso dos trabalhos arqueológicos, de forma a evitar qualquer impacte sobre estes. Em função dos resultados poderão ainda ser propostas e aprovadas pela DGPC/DRC outras medidas de salvaguarda que se considerem necessárias, como por exemplo a delimitação cartográfica e, preferencialmente, a manutenção de um sistema de demarcação física no terreno dos sítios já inventariados, bem como de outros que venham a ser identificados no decurso dos trabalhos arqueológicos, de forma a assegurar a sua proteção. $\mathrm{O}$ sistema de demarcação física dos sítios, a ser aprovado pelos organismos da administração pública com competência sobre o Património Cultural, pode decorrer do ordenamento florestal, servindo como zona de descontinuidade ou de faixa de gestão combustível. Deverá ser construído em estrutura durável que se mantenha durante toda a fase de exploração. A limpeza de vegetação, manutenção e gestão das áreas demarcadas são igualmente da responsabilidade do proprietário/promotor.

Note-se que a definição da estratégia de salvaguarda a adoptar deverá ter em consideração, não apenas os critérios de extensão e de existência ou não de sítios arqueológicos previamente inventariados, mas também o tipo e potencial destrutivo das ações florestais previstas em cada projeto/exploração. Os trabalhos arqueológicos a desenvolver deverão ser precedidos do estabelecimento da situação de referência relativa a cada projeto/exploração e deverão incidir não apenas nas áreas florestais, mas sobre todas as áreas a afetar no âmbito do projeto/ exploração (estruturas de apoio à atividade florestal, de drenagem ou rega, acessos viários, aceiros, etc.). Nos termos da Lei n. ${ }^{\circ}$ 107/2001 de 8 de setembro, a proposta prevê ainda a possibilidade de os proprietários/promotores de projetos/explorações florestais promoverem, total ou parcialmente, a expensas suas, os trabalhos arqueológicos de cuja conclusão possa resultar a cessação das limitações impostas ao uso do terreno.

\section{INCÊNDIOS}

4.1. Trabalhos arqueológicos realizados na sequência de incêndios florestais em Portugal

Os incêndios florestais são uma realidade endémica em Portugal, mas com significativo agravamento, mercê do progressivo despovoamento do território interior e do abandono gradual das atividades económicas que asseguram a gestão da biomassa vegetal, como a agricultura, o pastoreio e a floresta tradicional (Conselho Nacional de Reflorestação, 2005). Assim, aos riscos patrimoniais da atividade florestal juntam-se os riscos decorrentes dos incêndios florestais, de intensidade e amplitude progressivamente maiores nos últimos vinte anos (Caninas e Henriques, 2008). Como resposta aos grandes incêndios de 2003, foram desencadeadas diversas iniciativas de emergência, com vista à caracterização de danos e recuperação de informação arqueológica (Real, 2003; Delgado, Oosterbeek e Cruz, 2006; Caninas, Henriques e Gouveia, 2008). Situação idêntica se verificou em 2005, embora em menor escala e, principalmente em 2017, quando os incêndios florestais alcançaram dimensão de calamidade pública à escala nacional, com 150 concelhos abrangidos, 
cerca 600 ooo ha ardidos e cerca de 1500 sítios arqueológicos potencialmente impactados.

Em 2017, a DGPC preconizou uma estratégia de âmbito nacional que permitisse mitigar os diversos impactes em causa: danos diretos e indiretos (decorrentes dos processos erosivos subsequentes) do fogo sobre estruturas e contextos estratigráficos (Garcês e Oosterbeek, 2017; Bragança, Zambujo e Lourenço, 2018 e 2019; Real et alii, 2019); impactes dos trabalhos de recuperação (limpeza, ordenamento e reflorestação; corte e arrasto de madeira queimada; construção ou melhoramento de infraestruturas florestais, reconstrução de habitações e outras infraestruturas ardidas etc); reposição ou criação de faixas de servidão pública para proteção de eixos viários e ferroviários, habitações, aglomerados urbanos, instalações industriais e agropecuárias, linhas elétricas e de telecomunicações, ou outras. Nos organismos dependentes do Ministério da Cultura foram desenvolvidas diversas ações com vista à implementação desta estratégia.

\subsection{Gestão da informação SIG}

No decurso da devastação provocada pelos incêndios florestais de 2017 a DGPC procurou criar uma metodologia de diagnóstico para estimar e posteriormente aferir o Património arqueológico potencialmente afetado. Nesse sentido foi efetuado o cruzamento entre as áreas ardidas, obtidas através de imagem satélite e disponibilizadas em formato geográfico digita $1^{15}$ no site do ICNF (em conformidade com o disposto no n. ${ }^{\circ} 5$ do art. ${ }^{\circ}$ 2.. do Decreto-Lei n. ${ }^{0} 124 / 2006$, de 28 de junho, na redação dada pelo Decreto-Lei n. ${ }^{-17} / 2009$, de 14 de janeiro), e a informação geográfica digital ${ }^{16}$ dos sítios arqueológicos georreferenciados da DGPC.

Importa referir que, de acordo com o ICNF, a cobertura das áreas ardidas à data não era exaustiva, uma vez que não incluía as áreas inferiores a 1oha, estando prevista a retificação destes dados através do trabalho de campo desenvolvido quer pela GNR, quer pela Proteção Civil. Face a esta informação, foi assumido que a confrontação obtida tinha carácter provisório, acarretando uma margem de erro na avaliação efetuada, e agravando potencialmente o número de sítios afetados pelos incêndios.

15. No caso, em formato ESRI shapefile

16. Idem
4.3. Proposta de estratégia global de resposta aos incêndios (proposta pelo GT - 2017)

A catástrofe nacional provocada pelos incêndios de 2017 mobilizou toda a comunidade nacional para a intervenção necessária à reconstrução de vidas, bens e modos de subsistência. Face a este cenário excecional e conscientes dos impactes diretos infligidos nos sítios arqueológicos pelos incêndios e pelo seu necessário combate, bem como pelos impactes subsequentes - como sejam, por exemplo, a exposição excessiva dos contextos arqueológicos a processos erosivos potenciados na época de chuvas devido ao desaparecimento do coberto vegetal, os trabalhos de limpeza e de ordenamento das florestas, a construção e melhoramentos de várias infraestruturas associadas à exploração florestal e a outros equipamentos, as ações de reflorestação e florestação -, tornou-se premente diagnosticar, avaliar e definir medidas de salvaguarda (Figura 2).

Tendo em conta a grande extensão e a elevada dispersão de território abrangido, estes trabalhos, acarretavam elevados riscos para o Património arqueológico. Neste caso, a responsabilidade da salvaguarda arqueológica recairia sobre as entidades públicas que implementaram esta medida e, principalmente, sobre organismos da administração pública com competência sobre o Património Cultural. Dada a dimensão do território afetado, propôs-se superiormente que a estratégia de trabalho fosse efetuada com a colaboração de uma rede alargada de arqueólogos e instituições. Contudo, superiormente houve o entendimento de serem os próprios serviços da administração central e regional do Património Cultural a fazerem o levantamento da situação do Património arqueológico afetado pelos incêndios. Apesar do mérito do trabalho desenvolvido há que assumir que este ficou muito aquém do que seria técnica e patrimonialmente desejável, muito devido à falta recursos humanos das entidades competentes envolvidas. Assim sendo, os resultados apurados em grande parte do território nacional não espelham a amplitude dos impactes dos incêndios de 2017 sobre o Património arqueológico.

\subsection{Ações de âmbito regional}

a) Ação desenvolvida no âmbito dos incêndios de 2017 na Região de Lisboa e Vale do Tejo

Nos trabalhos de levantamento realizados na área de Lisboa e Vale do Tejo, área de atuação da DGPC (Bragança, Zambujo e Lourenço, 2018) foi excluí- 
do o concelho de Mação uma vez que este foi alvo de trabalhos de prospeção efetuados pelo Instituto Terra e Memória - Centro de Estudos Superiores de Mação (Garcês e Oosterbeek, 2017). O trabalho desenvolvido pela DGPC teve como principais objetivos: diagnosticar e avaliar os impactes diretos e indiretos dos incêndios; descrever o estado atual dos sítios, o seu estado de conservação e os danos causados pelos incêndios; identificar potenciais riscos no âmbito dos trabalhos de limpeza, ordenamento e reflorestação; detetar novos sítios nas áreas ardidas, assim como propor medidas de salvaguarda. Metodologicamente com base no trabalho de cruzamento de dados efetuado a nível nacional, procedeu-se ao seguinte: elaboração de cartografia com a inclusão das áreas ardidas e implantação dos sítios arqueológicos tendo por base as CMP, criação de uma ficha tipo de monitorização dos sítios, consulta das cartas arqueológicas dos municípios afetados (Batata, 1997; Batata e Arsénio, 2006; Pereira, 2006; Silva, Batista e Gaspar, 2009) e contacto com os arqueólogos das autarquias e investigadores com projetos nas áreas afetadas.

Os resultados destes trabalhos (ver Quadro 1) permitiram cindir os impactes em impactes por ação direta dos incêndios e impactes expectáveis. Os impactes resultantes da ação direta dos incêndios identificados no terreno foram, o estalamento observado na sepultura escavada na rocha da Fonte Seca (CNS 24813); as estruturas queimadas no povoado proto-histórico do Maxial (CNS 13142), nos casais de época moderna da Ribeira de Vale do Castro (CNS 37647) e no núcleo de povoamento de Vale Carvalho (CNS 25199), e, os resultantes das ações de corte e remoção de árvores, nomeadamente a fratura de um marco da Ordem de Cristo da Senhora da Orada IV (CNS 24853) (Figura 3).

Os impactes expectáveis, transversais a todos os sítios observados, surgiriam quando ocorressem os trabalhos de corte, limpeza do terreno e reflorestação e são uma consequência direta dos incêndios, colocando em risco de destruição o Património arqueológico. De igual modo, os sítios arqueológicos desprotegidos da sua cobertura vegetal ficarão expostos e vulneráveis aos agentes climáticos, nomeadamente à erosão por ação da chuva e do vento, acelerando o seu processo de deterioração, mesmo após a fase de combate ao fogo.

Atendendo à escassez dos recursos humanos e técnicos da administração central, apenas foi possível realizar este trabalho dado o número reduzido de sítios conhecidos potencialmente afetados nesta região, não tendo permitido a realização de trabalhos de prospeção sistemática das áreas ardidas o que iria, necessariamente, levar à identificação de novos sítios arqueológicos. Para os sítios em que se verificou terem sido afetados ou estarem em risco de afetação foi proposto um conjunto de medidas de minimização, incluindo levantamento topográfico, sondagens arqueológicas e acompanhamento dos trabalhos associados à reflorestação. (Quadro 1)

Como foi referido, no concelho de Mação o levantamento foi realizado por Sara Garcês e Luiz Oosterbeek (Garcês e Oosterbeek, 2017). Inicialmente estimaram-se 29 sítios afetados pelos incêndios, impacte apenas confirmado em 11, encontrando-se ainda 2 sítios arqueológicos em fase de avaliação, aquando da elaboração do relatório. Neste concelho os sítios que mais sofreram com os efeitos negativos dos incêndios foram os de arte rupestre (em que as superfícies/suportes nos quais foram feitas as representações se encontravam cobertos de fuligem) e os povoados fortificados (em que as pedras que constituem as estruturas se apresentavam fraturadas devido às altas temperaturas a que foram expostas durante o incêndio). É também importante referir que em sítios recentemente intervencionados, como o Castelo Velho da Zimbreira (CNS 2779) e o Castelo Velho do Caratão (CNS 2762), a área das sondagens arqueológicas ardeu, bem como a manta geotêxtil que as cobria. Nos sítios integrados em percursos de visitação (caso das gravuras do Vale do Ocreza) as estruturas de apoio aos visitantes (painéis explicativos, pontes de madeira, etc.) arderam e alguns caminhos ficaram obstruídos devido à queda de árvores. Todos estes sítios foram alvo de propostas de medidas de minimização destes impactes.

\section{b) Ação desenvolvida no âmbito dos incêndios de 2017 na Região Centro}

Dos trabalhos de levantamento realizados na região Centro houve intervenção direta dos técnicos da DRC nos trabalhos de reconhecimento realizados pelos municípios de Mangualde, Tondela, Oliveira de Frades e Vouzela. No caso de Vouzela os trabalhos foram enquadrados no âmbito de um projeto de investigação existente à data, Lafões: Estudo do Património Histórico Arqueológico de Vouzela, da responsabilidade do investigador Manuel Luís Real, tendo-se constatado efeitos dos incêndios 
sobre os sítios arqueológicos e sobre as infraestruturas de apoio à sua visita. Este trabalho orientou-se também para a identificação de novos sítios arqueológicos, sendo que as excepcionais condições de visibilidade do território logo após os incêndios permitiram identificar sítios inéditos, desde túmulos Pré e Proto-históricos (passando de 44 ocorrências identificadas para 77 após os trabalhos), sítios de ocupação Proto-Histórica em locais abertos, 81 troços de calçadas de diferentes cronologias, bem como caminhos vicinais e estruturas agrárias tradicionais. $\mathrm{Na}$ sequência das realidades identificadas foi proposta a adoção de medidas de salvaguarda como a “... sinalização de sítios, contactos com os proprietários, acompanhamento e fiscalização de trabalhos silvícolas, definição de áreas de não reflorestação, $e$ acções de divulgação e sensibilização junto das populações locais e em gabinete (inventário sistemático de ocorrências e definição de áreas de proteção georreferenciadas)" (Real et alii, 2019).

Realizaram-se igualmente trabalhos de levantamento das áreas ardidas por iniciativa de arqueólogos dos municípios de Arganil, Guarda, Penela e Figueira da Foz. Em Arganil o reconhecimento permitiu a deteção de jazidas não inventariadas. $\mathrm{Na}$ Guarda, a equipa de arqueologia da Câmara Municipal, coordenada por Vitor Pereira, procedeu ao levantamento, tendo identificado 23 sítios arqueológicos afetados, destacando-se o povoado fortificado Castro do Jarmelo (CNS 266), classificado como Imóvel de Interesse Público ${ }^{17}$. No Fundão, em visita efetuada por técnicos do Museu Arqueológico Municipal José Monteiro e da DRC Centro ao Cabeço da Argemela (CNS 14759) em fevereiro de 2018, no âmbito da instrução do processo de classificação do sítio, foi possível verificar a afetação do povoado fortificado e área envolvente, incluindo a provável afetação dos sítios arqueológicos da Serra do Gomes: Serra do Gomes (CNS 26861) e Serra do Gomes I (CNS 26863), considerando que esta tinha sido visivelmente percorrida pela vaga de incêndios de 2017. Em Penela confirmou-se que os incêndios não atingiram os sítios arqueológicos identificados como potencialmente afetados. Na Figueira da Foz efetuou-se a sobreposição de cartografia das áreas ardidas e das plantas de Ordenamento e Condicio-

17. "Castro do Jarmelo, com a sua linha exterior de muralhas”, classificado como Imóvel de Interesse Público (IIP) pelo Decreto nº.39 175, DG, I Série, nº 77, de 17-04-1953. nantes do PDM, tendo-se deduzido não haver perigo evidente para os elementos do Património Cultural conhecidos.

\section{c) Ação desenvolvida no âmbito dos incêndios de 2017 na Região Norte}

$\mathrm{Na}$ região Norte foram estabelecidos contactos com as autarquias e, quando possível, com os arqueólogos/serviços municipais de arqueologia no sentido de procurar reunir informação pertinente e atualizada tendo por base a listagem geral de sítios arqueológicos passíveis de terem sofrido afetação pelos incêndios ocorridos, elaborada pelo GT. Face aos constrangimentos existentes, não foram efetuados trabalhos sistemáticos de verificação no terreno por parte dos técnicos da DRCN ou de equipas de arqueologia contratadas para o efeito.

Ainda assim, foi possível sistematizar a informação remetida por diversos municípios. Segundo informação da Câmara Municipal de Paços de Ferreira não houve afetação de nenhum dos três sítios inicialmente elencados: Citânia de Sanfins (CNS 6); Eiriz (CNS 2855) e Salgueiros (CNS 3757). Em Vila Flor não foi afetado o único sítio elencado como passível de tal: Santo Estevão (CNS 18083). No concelho de Bragança nenhum dos dois sítios inicialmente elencados: Torre do Castro (CNS 5037) e Castrilhão (CNS 5038), foi afetado. Em Celorico de Basto não houve afetação de qualquer um dos sítios inicialmente identificados: Senhora da Guia (CNS 22667); Vale (CNS 3775); Tapada da Montanha (CNS 20229); Serra Branca (CNS 21529); Carvalhais (CNS 21531); Sobreira I (CNS 21563) e Monte do Corgo (CNS 21552). Em Cabeceiras de Basto não houve igualmente afetação de nenhum dos seis sítios inicialmente identificados: Ladariu (CNS 3391); Monte de Ladário (CNS 3745); Ponte Antiga de Cavez (CNS 2819); Chacim (CNS 2329); Outeiro dos Moiros/Cividade de Chacim (CNS 25) e Rio Douro (CNS 5155). No concelho de Guimarães não foi afetado o sítio inicialmente elencado como passível de afetação: Castro de São Bartolomeu (CNS 14308). Em Penafiel não foi afetado nenhum dos dois sítios inicialmente identificados como passíveis de tal: Vale dos Mortos (CNS 3833) e Boelhe (CNS 4233). No concelho da Trofa nenhum dos dois sítios inicialmente listados: Trofa Velha 4/ Peça Má 1 (CNS 3977) e Lanteneu i (CNS 26261), foi afetado. Em Santo Tirso não houve qualquer afetação de sítios arqueológicos, nomeadamente do sítio Redundo 
(CNS 3033), inicialmente elencado como passível de ter sofrido afetação. Em Macedo de Cavaleiros, dos 13 sítios inicialmente listados, apenas foi possível apurar informação relativa aos sítios de Real Filatório de Chacim (CNS 11375) e Ponte do Bairrinho (CNS 17244), verificando-se que não foram afetados. Em Carrazeda de Ansiães nenhum dos três sítios inicialmente elencados: São Pedro (CNS 16688); Anta da Samorinha (CNS 16940) e Senhora da Graça (CNS 2569) terá sido afetado. No concelho de Ribeira de Pena, dos sete sítios inicialmente identificados: Regado do Salgueiro Gordo III (CNS 23196); Carvoeira (CNS 25591); Franguinha Negra III (CNS 23189); Seixinhos (CNS 7360); Ponte de Louredo (CNS 2481); Calhau dos Cantinhos/ Fonte Santa (CNS 19391) e Fonte de Prata/ Latas da Pinha (CNS 19388), apenas foi recolhida informação relativa à Ponte de Lourede (CNS 2481), constatando-se que não foi afetada. Em Monção, onde dos quatro sítios inicialmente identificados como passíveis de ter sofrido afetação: Costa do Mendoiro (CNS 18033); Nossa Senhora da Assunção / Nossa Senhora da Ascensão (CNS 2556); Barbeita/ Ponte do Mouro (CNS 4793) e Santa Tecla (CNS 2484), apenas o sítio de Santa Tecla (CNS 2484), terá sido efetivamente afetado. Relativamente ao concelho de Vila Nova de Foz Côa apurou-se que não foram afetados os núcleos de gravuras rupestres do Parque Arqueológico do Vale do Côa ${ }^{18}$. Em relação aos concelhos de Póvoa de Varzim, Santo Tirso e Vila do Conde, onde ocorreram incêndios menores, foi ainda apurado não ter havido afetação de Património arqueológico. Ao que foi possível constatar, não houve sítios classificados afetados pela vaga de incêndios.

\section{d) Ação desenvolvida no âmbito dos incêndios de 2017 na Região do Alentejo}

$\mathrm{Na}$ região do Alentejo, da listagem inicial de sítios arqueológicos potencialmente afetados pelos incêndios florestais de 2017, apenas foi confirmada no terreno a situação do Monte da Boiça 1/Anta da Pata do Cavalo (CNS 8oog), que, apesar de se localizar

18. "Conjunto dos Sítios Arqueológicos no Vale do Rio Côa", classificado como Monumento Nacional (MN) e inscrito na lista do Património Mundial da UNESCO em dezembro de 1998 - Decreto n.ำ 32/97, DR, I Série-B, n. ${ }^{\circ}$ 150,

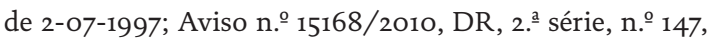
de 30-07-2010; Anúncio n.. 13471/2012, DR, 2. ․ㅗ́rie, n.ำ

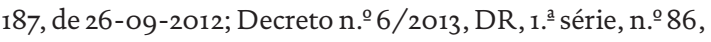
de 6-05-2013. nas imediações de uma área ardida, não chegou a ser afetado pelos incêndios.

\section{e) Ação desenvolvida no âmbito dos incêndios de 2017 na Região do Algarve}

Nesta região não foram efetuados quaisquer trabalhos, visto que no ano de 2017 os incêndios no Algarve tiveram uma expressão pontual e em áreas muito reduzidas, não tendo havido conhecimento de terem sido afetados sítios arqueológicos. Este padrão manteve-se em 2018, ano em que ocorreu apenas uma verificação de impactes provocados pelos incêndios, no Cerro do Castelo de Alferce (CNS 1283), efetuado pelo arqueólogo da autarquia de Monchique.

\section{DIVULGAÇÃO E SENSIBILIZAÇÃO - BROCHURA E GUIA; AÇÕES DE SENSIBILI- ZAÇÃO PROPOSTAS PARA 2020 E OUTRAS}

A par das iniciativas acima descritas, e por se considerar que é urgente aproximar o discurso arqueológico do público em geral, não estando de outra forma garantida a sua salvaguarda, o GT procurou desenvolver documentação de sensibilização a disponibilizar às entidades com responsabilidade direta nos programas de florestação e reflorestação (ICNF, autarquias, gestores florestais, entidades de certificação florestal e proprietários), alertando-as para a necessidade de serem adotadas medidas de salvaguarda do Património arqueológico.

Foram produzidos dois documentos: um díptico relativo aos, "Procedimentos para a Salvaguarda do Património arqueológico em Operações Florestais" e um manual em formato digital designado de "Guia - Procedimentos para a Salvaguarda do Património arqueológico em Operações Florestais". Ambos os documentos procuram responder, de forma simples e sintética às mais básicas dúvidas e questões que poderão surgir ao nível da salvaguarda do Património arqueológico no decurso de operações florestais. Assim, procuram esclarecer, numa linguagem acessível, o que é o Património arqueológico, quais são os organismos da administração pública com competência sobre este Património, de que proteção legal goza este Património, quais os impactes que as operações florestais poderão ter sobre os sítios e ocorrências patrimoniais, como é que é possível saber se existe Património arqueológico numa unidade florestal, o que fazer caso exista Património, ou caso os vestígios surjam no decurso 
de uma operação florestal e quais os impactes que os incêndios florestais e as ações preventivas e pós-incêndio poderão ter sobre este tipo de Património (Figura 4).

Está ainda prevista a realização de ações de sensibilização, de carácter regional, desde já, junto das Comunidades Intermunicipais de Lisboa e Vale do Tejo, que se pretendem alargar ao restante território nacional, com o intuito de estabelecer sinergias com as câmaras municipais, alertando o nível local para as questões da salvaguarda do Património arqueológico no âmbito dos licenciamentos e apreciação de projetos de âmbito florestal.

Numa primeira fase, estas ações de sensibilização terão em vista o envolvimento dos gabinetes florestais e de arqueologia municipais na salvaguarda do Património arqueológico. Posteriormente procurar-se-á proceder à sensibilização de proprietários e gestores florestais e entidades de certificação florestal (da norma FSC de Gestão Florestal para Portugal e PEFC - Norma Portuguesa 4406 de Sistemas de Gestão Florestal Sustentável). O conteúdo destas ações procura fazer o historial da relação da floresta com o Património Cultural ao longo das últimas décadas, enquadrar legalmente a salvaguarda do Património com os instrumentos de ordenamento, administração e gestão da floresta, e, ainda, apresentar procedimentos para uma eficaz preservação do Património arqueológico em projetos florestais, harmonizando a gestão da floresta com a proteção do Património Cultural.

\section{BALANÇO E PERSPETIVAS}

Nas últimas décadas, tem havido um esforço por parte dos organismos da administração pública com competência sobre o Património Cultural para, por um lado notificar as entidades de Gestão Florestal/ proprietários sobre a existência de sítios arqueológicos nas suas propriedades, e da obrigatoriedade da salvaguarda dos mesmos, e, por outro, sensibilizar os gestores florestais/proprietários para a obrigatoriedade do recurso a mão-de-obra especializada em arqueologia para executar o trabalho de levantamento, análise, avaliação e proposta de medidas de salvaguarda do Património Cultural existente nas propriedades.

Lamentavelmente apesar do esforço que tem vindo a ser feito, quer pela DGPC, quer pelas DRC, para já, estas ações têm produzido poucos resulta- dos concretos, facto que é facilmente mensurável através do baixo número de pedidos de autorização submetidos para a realização de trabalhos arqueológicos no âmbito de arborizações e rearborizações, verificando-se mesmo uma resistência das entidades com responsabilidade na gestão da floresta em implementar as medidas de salvaguarda determinadas pelos organismos da administração pública com competência sobre o Património Cultural.

Torna-se por isso urgente ultrapassar este impasse ou mesmo ausência de diálogo entre a fileira florestal e a administração do Património Cultural, tendo em vista a sua salvaguarda. É disso exemplo a incontornável necessidade de reconversão da floresta nacional dotando-a de maior resiliência aos incêndios, que conduziu ao desenvolvimento no Programa Nacional da Política do Ordenamento do Território e do Programa de Transformação da Paisagem (publicado nas Resoluções do Conselho de Ministros n.. 48/2020 e n.. 49/2020, Diário da República n.․․ 121/2O2O, Série I, de 24 de junho), que prevê a criação de 20 Programas de Reordenamento e Gestão da Paisagem, que correspondem a cerca de $20 \%$ da área florestal do país, centrada sobretudo no Norte e Centro de Portugal e nas Serras de São Mamede, Caldeirão e Monchique. A seleção destas áreas, feita pelo ICNF em colaboração com a Direção-Geral do Território (DGT), teve em conta a perigosidade de incêndio, considerando-as áreas de "risco alto e muito alto". A prioridade do programa é clara, sendo a adesão dos proprietários de carácter obrigatório, celebrada por um contrato a 20 anos, e estando, os que não queiram aderir, compelidos a arrendar os terrenos ao Estado de modo a não impedir a implantação do programa. O programa prevê a reestruturação do espaço florestal com a criação de descontinuidades florestais, estando prevista a substituição de áreas de eucalipto por outras espécies mais resilientes aos incêndios. A implementação destas medidas, que terão claramente grande impacte no subsolo, requererá uma articulação sem par entre os organismos da administração pública com competência sobre o Património Cultural e a autoridade da floresta nacional de forma a garantir a compatibilização da implementação dos programas previstos, com a salvaguarda do Património arqueológico e assegurar a obrigatoriedade dos trabalhos arqueológicos necessários na execução destes programas. As prioridades definidas e reiteradas nestas disposições legais não poderão vir a ser implementadas com a manutenção 
da atual incapacidade de dar cumprimento à legislação que salvaguarda o Património arqueológico, requerendo das entidades envolvidas uma alteração do modus operandi, o que impõe o estabelecimento de sinergias interinstitucionais e políticas até ao presente incipientes. A persistência dos problemas descritos na salvaguarda do Património arqueológico no âmbito da atividade florestal demonstra que as respostas dos organismos da administração pública com competência sobre o Património Cultural e das tutelas políticas não têm sido eficazes. A DGPC e as DRC têm de conferir a esta problemática a prioridade que merece, sendo mais assertivas e eficazes na definição e implementação de medidas corretivas. A resolução dos problemas referidos passará por um trabalho transversal entre o Ministério da Cultura e a área governativa do ambiente e das florestas e com a administração pública local que permita ultrapassar os fortes obstáculos já plenamente diagnosticados.

\section{BIBLIOGRAFIA}

ALVES, António Monteiro; PEREIRA, João Santos; SILVA, João M. Neves (2007) - A introdução e expansão do eucalipto em Portugal. In ALVES, António Monteiro; PEREIRA, João Santos; SILVA, João M. Neves, eds. - O Eucaliptal em Portugal: Impactes Ambientais e Investigação Científica. Lisboa: Isapress Editora, pp. 13-24.

ARNAUD, José Morais (1991) - Palavras de abertura do Secretário-Geral das Jornadas. In Actas das IV Jornadas Arqueológicas. Lisboa: Associação dos Arqueólogos Portugueses, pp. 13-14.

ARNAUD, José Morais (1994) - A Componente Arqueológica no Processo de AIA em Portugal. In Avaliação de Impacte Ambiental, Conceitos, Procedimentos e Aplicações, Lisboa: Centro de Estudos de Planeamento e Gestão do Ambiente, pp. $252-263$.

ARNAUD, José Morais; ALMEIDA, Pedro Freire; BUGALHÃO, Jacinta (1991) - Intervenções Arqueológicas nas áreas a florestar pela Soporcel. In Actas das IV Jornadas Arqueológicas da Associação dos Arqueólogos Portugueses. Lisboa: Associação dos Arqueólogos Portugueses, pp. 75-82.

ARNAUD, José Morais; MURALHA, João; ESTORNINHO, Alexandra (1991) - Intervenções Arqueológicas nas áreas a florestar pela Celbi. In Actas das IV Jornadas Arqueológicas da Associação dos Arqueólogos Portugueses. Lisboa: Associação dos Arqueólogos Portugueses, pp. 69-74.

ARNAUD, José Morais; RAMOS, Carlos Alberto; MARTINS, Artur Gonçalves (1991) - Prospecção arqueológica na Herdade do Gavião. In Actas das IV Jornadas Arqueológicas da Associação dos Arqueólogos Portugueses. Lisboa: Associação dos Arqueólogos Portugueses, pp. 83-86.
AEAT (1994) - A destruição do Património Arqueológico no território português. O testemunho da Associação de Estudos do alto Tejo. Jornal do Fundão. Fundão. 8 de abril, pp. 18-19.

BATATA, Carlos (1997) - As Origens de Tomar. Carta Arqueológica do Concelho. Coimbra: Centro de Estudos e Protecção do Património da Região de Tomar, 359 p.

BATATA, Carlos; ARSÉNIO, Paulo (2006) - Carta Arqueológica do Concelho de Ferreira do Zêzere. Ferreira do Zêzere: Câmara Municipal Ferreira do Zêzere/Ozecarus, 147 p.

BRAGANÇA, Filipa; ZAMBUJO, Gertrudes; LOURENÇO, Sandra (2018) - Relatório dos Trabalhos de Monitorização dos Sítios Arqueológicos afectados pelos incêndios de 2017 na Região de Lisboa e Vale do Tejo. Arquivo da Arqueologia Portuguesa, DGPC (documento policopiado).

BRAGANÇA, Filipa; ZAMBUJO, Gertrudes; LOURENÇO, Sandra (2019) - Balanço dos Incêndios 2017: região de Lisboa e Vale do Tejo. In ROCHA, Leonor; BRANCO, Gertrudes; SANTOS, Ivo, eds. - Salvaguarda Arqueológica. Archaeological Safeguard (Scientia Antiquitatis, 1). Évora, pp.477-489. Disponível em: http://www.scientiaantiquitatis.uevora.pt /index.php/SA/issue/view/26/V3_Ni (acedido em maio de 2020).

CANINAS, João; HENRIQUES, Francisco (1995) - Exemplos da destruição do arqueológico no sul da beira interior. Al-madan. Almada. II série, 4, pp. 115-118.

CANINAS, João; HENRIQUES, Francisco, GOUVEIA, Jorge (2008) - Contributos para uma caracterização do impacte dos fogos florestais de 2003 sobre o património arqueológico e o património construído no distrito de Castelo Branco. AÇAFA On Line, 1. Disponível em: http://www.altotejo. org/acafa/docs/Arquivo/Impactes_no_Patrimonio_dos_ Fogos_de_2003.pdf (acedido em março de 2017).

CANINAS, João; HENRIQUES, Francisco; SALVADO, Pedro; CHAMBINO, Mário (2019) - Carta Arqueológica da Comunidade Intermunicipal da Beira Baixa 106 anos depois de Francisco Tavares de Proença Júnior. Scientia Antiquitatis. Évora. 2. pp. 5-48. Disponível em: http://www.scientiaantiquitatis.uevora.pt/index.php/SA/issue/view/30 (acedido em junho de 2020).

CANINAS, João; HENRIQUES, Francisco (2008) - O Património arqueológico e o sector florestal. In Actas das I Jornadas de Belmonte. Belmonte: Câmara Municipal de Belmonte, pp. 285-309.

CONSELHO NACIONAL DE REFLORESTAÇÃO (2005) - Orientações estratégicas para a recuperação das áreas ardidas em 2003 e 2004. Lisboa. 30 de junho de 2005. Ministério da Agricultura, do Desenvolvimento Rural e das Pescas, Secretaria de Estado do Desenvolvimento Rural e das Florestas (documento policopiado). Disponível em: http:// www2.icnf.pt/portal/florestas/dfci/relat/raa/resource/ doc/CNR-OER-Docfinal.pdf (acedido em maio de 2020). 
CRUZ, Ana; OOSTERBEEK, Luiz; DELGADO, Cidália (2006) - Incêndios 2003, estratégias e resultados. In Arkeos: perspectivas em diálogo, 16. Tomar: CEIPHAR, pp. 77-88.

HENRIQUES, Francisco; CANINAS, João; CHAMBINO, Mário (2008) - Carta Arqueológica de Vila Velha de Ródão. Uma leitura actualizada dos dados da Pré-História Recente. In BUENO-RAMIREZ, Primitiva; BARROSO-BERMEJO, Rosa; BALBÍN-BERHMANN, Rodrigo de, eds. - Graphical Markers and Megalith Builders in the International Tagus, Iberian Peninsula (BAR International Series, 1765) Oxford: Archeopress, pp. 79-88.

PEREIRA, Jaqueline (2006) - Carta arqueológica do concelho de Ourém. Ourém: Câmara Municipal de Ourém, 221 p.

PEREIRA, Vitor; RAMOS, Tiago (2016) - Levantamento arqueológico no concelho da Guarda. Relatório 2015. Guarda: Câmara Municipal da Guarda. Arquivo da Arqueologia Portuguesa, DGPC (documento policopiado).

RAMOS, Tiago (2014) - O castro do Jarmelo em época medieval: o contributo da arqueologia para o seu estudo. Dissertação de mestrado apresentada à FCSH da UNL. Disponível em: https://run.unl.pt/bitstream/10362/13754/1/tese. pdf (acedido em junho de 2020).

GARCÊS, Sara; OOSTERBEEK, Luiz (2017) - Intervenção de Emergência. Relatório de Impacto dos Incêndios de 2017 nos Sítios Arqueológicos do Município de Mação. Mação: Instituto Terra e Memória. Arquivo da Arqueologia Portuguesa, DGPC (documento policopiado).
REAL, Fernando (2003) - Os Incêndios de 2003 e a Arqueologia na Política de Ordenamento Florestal. Al-madan. Almada. II série, 12, pp. 202-2O3.

REAL, Manuel Luís; CARVALHO, António Faustino; TENTE, Catarina; BRANCO, Daniel de Melo; PEREIRA, Luís André; CARVAlHO, Pedro Sobral de; RAMOS, Tiago (2019) - Estratégias de Recuperação e Salvaguarda do Património Histórico-Arqueológico de Vouzela (Viseu, Portugal) após os incêndios florestais de outubro de 2017. In ROCHA, Leonor; BRANCO, Gertrudes; SANTOS, Ivo, eds. - Salvaguarda Arqueológica. Archaeological Safeguard (Scientia Antiquitatis, 1). Évora, pp.461-476. Disponível em: http://www.scientiaantiquitatis.uevora.pt/index.php/ $\mathrm{SA} /$ issue/view/26/V3_Ni (acedido em maio de 2020).

SILVA, J. Candeias; BATISTA, Álvaro; GASPAR, Filomena (2009) - Carta Arqueológica do Concelho de Abrantes. Abrantes: Câmara Municipal de Abrantes. Disponível em: http://cm-abrantes.pt/images/documentos/cultura-e-patrimonio/patrimonio/carta-arqueologica/carta.html (acedido em fevereiro de 2018).

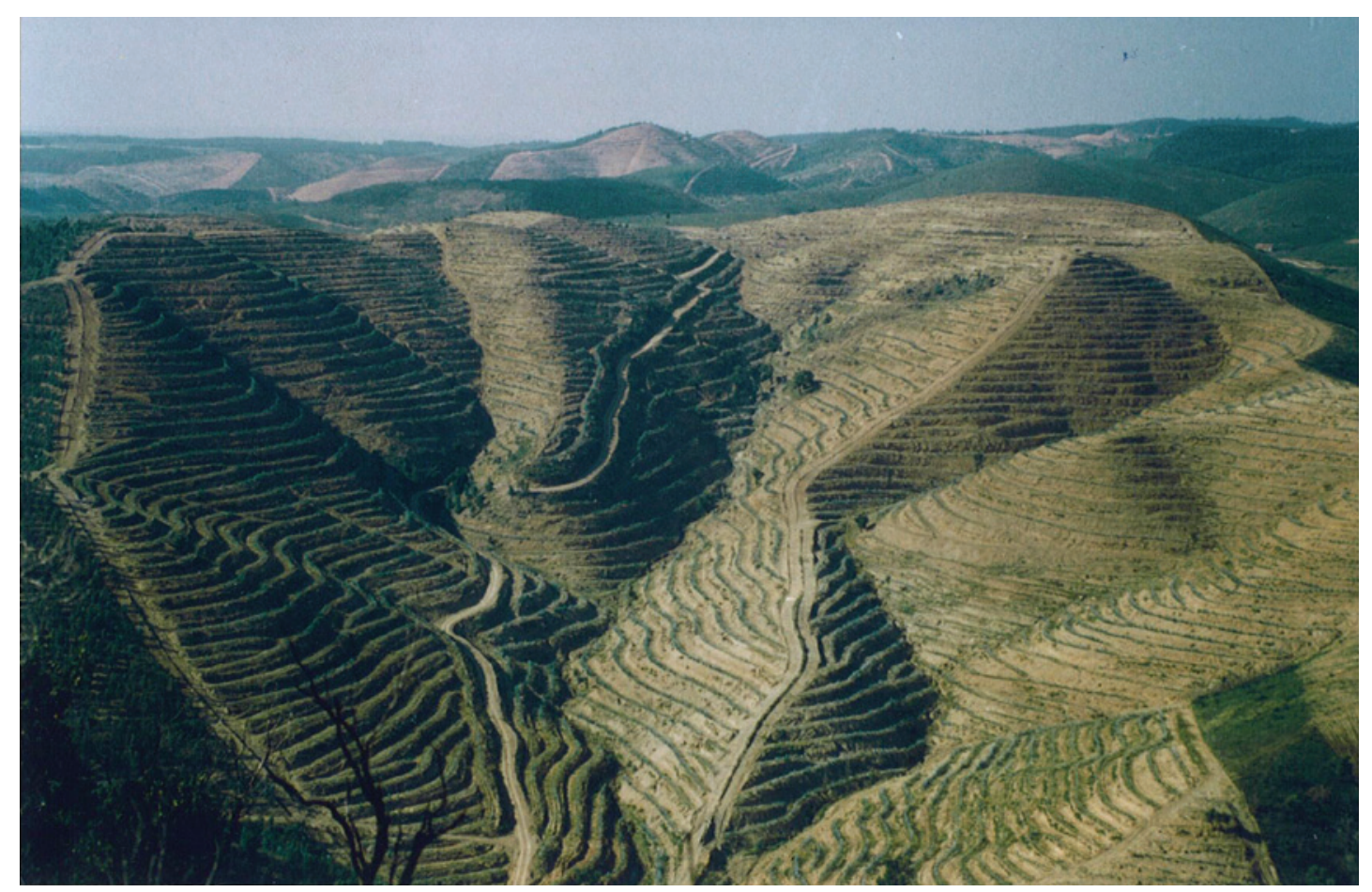

Figura 1 - Plantação de eucaliptos em socalco na serra algarvia, no início da década de 9 o do século XX - DGPC. 

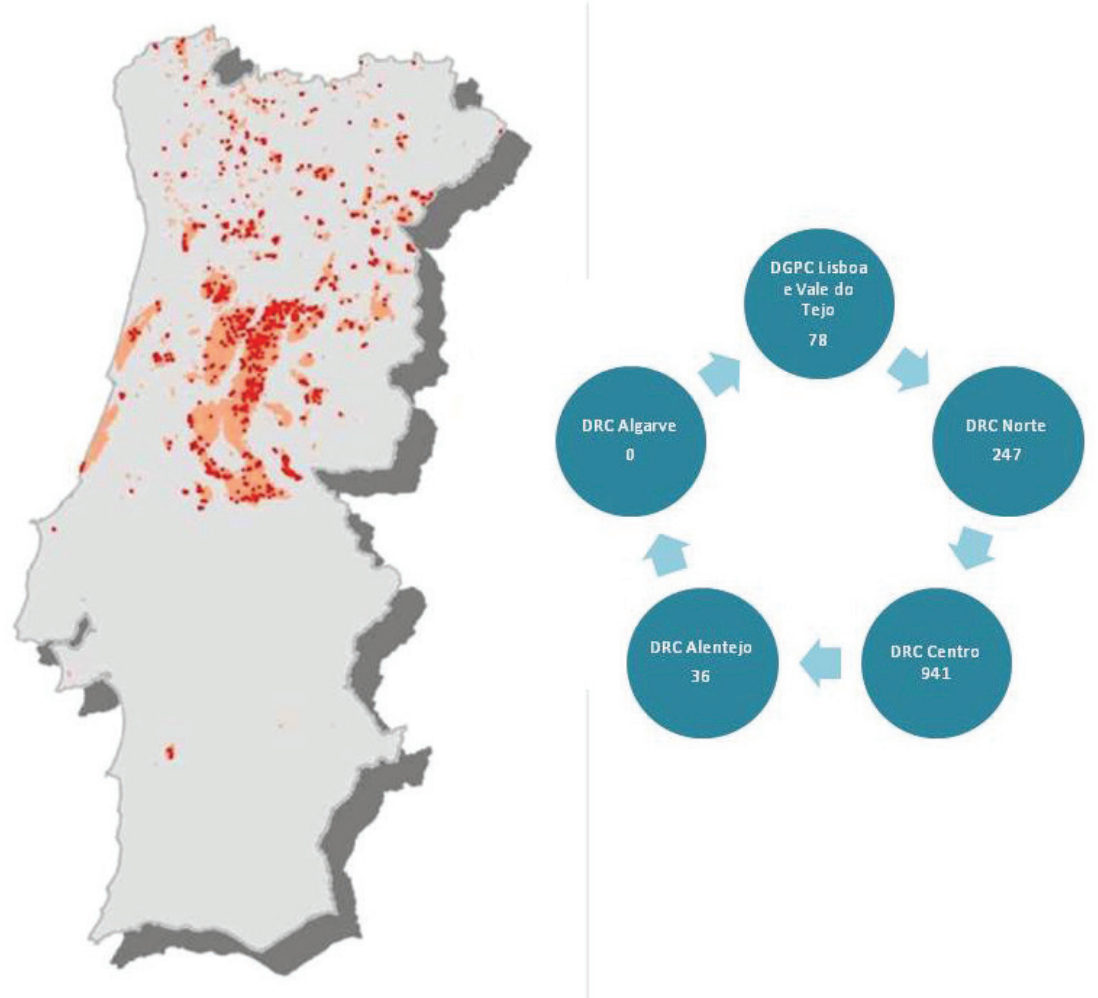

Figura 2 - Projeção das áreas ardidas em Portugal Continental em 2017 que abrangeu 150 concelhos, cerca 600.000 ha ardidos, com a indicação do número de sítios potencialmente afetados por região.

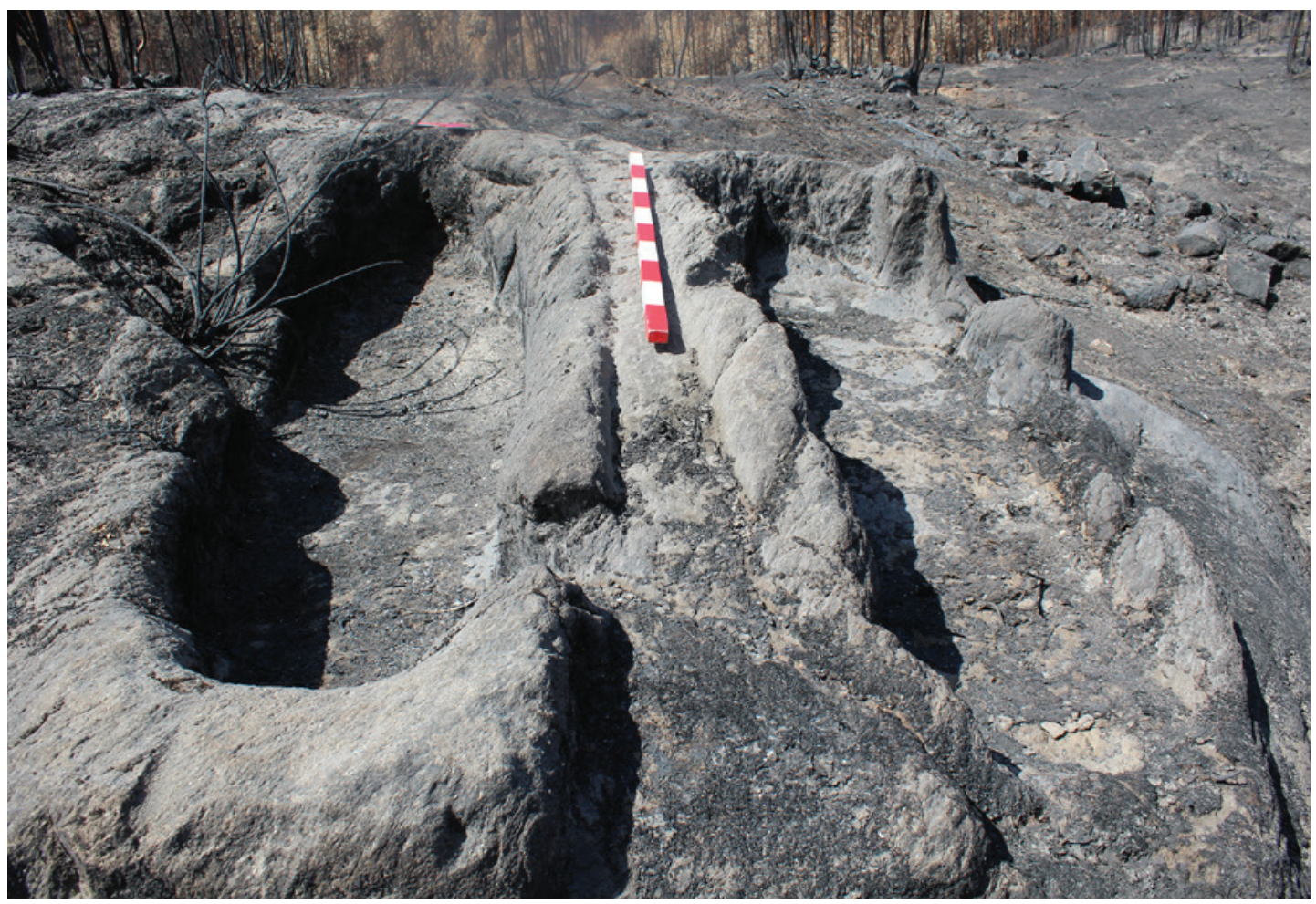

Figura 3 - Impacte provocado pelos incêndios de 2017 nas sepulturas escavadas na rocha da Fonte Seca (CNS 24813) - DGPC. 
O que é Património Arqueológico? Património Arqueologico integra todos os vestigos matonais cu; a preservaça o estrido perminem traçar a historia da humanicade e da sua relaçáo com o ambiente. Estes vestigios sáo muito variacos abrangen estruturas tacimente identificáveis no lerreno, sinais a superticie que percuram na memoria da populaçalo, ou indiclos diticeris de identiticar a um oinar nao trenaco, con manchas de materiais ou aleerą̧̄̄es no

O Patrimonio Arqueologico - recurso cultural finito e năo rencvável - goza de un regine especial de proteçáo legal. Atendend a diversidace e especificidade dest Património, a legislaçáa portuguesa defin que qualquer trabalho arqueologico tem de ser obrigatoriamente realizado por arqueclogo devidamente autorizado pelo Estado o segundo metodologias próprias.

Qual a consequência desta proteção legal?

Onde existam, ou se presuma existirem, vestigios arqueológicos em risco de afetaçắ. - Estado poderá determinar a necessidace do execuçăo de trabahos arqueológicos para salvaguardar esse Património, desce logo attavés do princípio da conservaçăo pelo registo cientifico.

Se durarte qualquer operaçâo florestal identificar vestigios arqueológicos, e obrigado a dar conhecimento do achado a administraçáo do património cultura! competente (DCPC ou DRC) ou à autoridade policial, no prazo de quarenta e oito horas A destruiçąo de Património Arqueológico é um crime punivel por lei (Artigo $1033^{\circ}$ da Lef n? 107/2001 de 8 de setembro. Lei de Bases do Parrimónio Cultura).

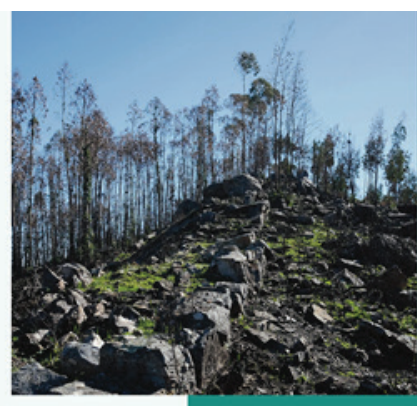

As operações florestais com potencial impacte na mobilização de solos podem resultar na destruição ou séria ameaça ao Património Arqueológico.

Que impacte têm estas operaçōes sobre o Património Arqueológico? As operacbas florestas com potencial impacie na mobilzaçeo de solos (tais como a reacacicho de desmateçes, preparaçà de terrenos. arborizaçes ejou rearbonzaços, abertura de crvachos, sumbas e aceiros, eic), apresentan um grau de intrusáo no suosolo que pode resutar na destruiçăo ou seria ameaça a. Patrimonio Arqueologico. Dosto modo, caso a sua operaçāo flloresta envolva a transiomaçăo do terreno onde se localizern vestiglos arquaclogicos, ilica obrigado a promovor o custoar os oorngatorios trabalihces. arqueologicos preventivos ou de salvamento. Após a realizaçăo des trabalhos arqueologicos, e conforme os resultados cblidos, as entidades de Tutela do Património Arqueológico poderão renogar as condicionantes arqueologicas, ibertando o seu terreno para se poder realzar a cperacão florestal, ou determinar a necessidace de mas trabahos arquoologgicos.

Uma avaliaçăo previa dos eventuais impactes das operaçbes fllorestais sobre 0 Património Arqueológico, que garanta a Zonas de Intervençäo Florestol e nas med do Plano de Gestão Florestal, será mais vantajosa e menos onerosa para si co que ume atuaçăo posterior, dacorrents da dastruiçāo de vestigos e da consequente imposição de medisas de minimizaçăo de danos e demàs consequéncies logais

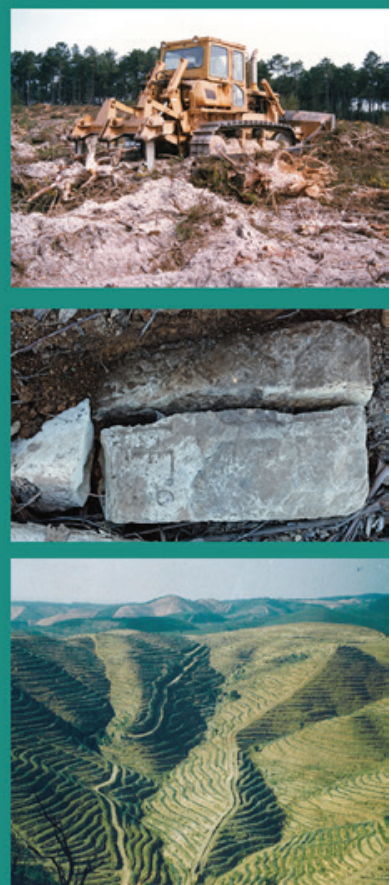

Figura 4 - Interior do díptico, referente à Salvaguarda de Património Arqueológico em Operações Florestais, produzido pelo grupo de trabalho-DGPC.

\begin{tabular}{|c|c|c|c|c|c|c|c|c|c|}
\hline \multirow[t]{2}{*}{ Concelhos } & \multirow[t]{2}{*}{$\begin{array}{l}\text { Levantamento } \\
\text { Inicial }{ }^{1)}\end{array}$} & \multicolumn{2}{|c|}{$\begin{array}{l}\text { Sítios Potencialmente } \\
\text { em Risco }\end{array}$} & \multirow[t]{2}{*}{$\begin{array}{l}\text { Novos } \\
\text { Sítios }\end{array}$} & \multicolumn{2}{|c|}{$\begin{array}{l}\text { Localização } \\
\text { no Terreno }\end{array}$} & \multicolumn{3}{|c|}{$\begin{array}{l}\text { Grau de afetação } \\
\text { e área ardida }\end{array}$} \\
\hline & & Relocalizados & $\begin{array}{l}\text { Não } \\
\text { Relocalizados }\end{array}$ & & $\begin{array}{l}\text { Área } \\
\text { Ardida }\end{array}$ & $\begin{array}{l}\text { Área Não } \\
\text { Ardida }\end{array}$ & Total & Parcial & $\begin{array}{l}\text { Não } \\
\text { Afetado }\end{array}$ \\
\hline Óbidos & 8 & 8 & - & - & 8 & - & 7 & - & 1 \\
\hline Tomar & 4 & 1 & 3 & 1? & 1 & 1 & 1 & - & - \\
\hline Ourém & 4 & 2 & 2 & - & 2 & - & 2 & - & - \\
\hline Abrantes & 14 & 14 & - & - & 10 & 4 & 10 & - & - \\
\hline $\begin{array}{l}\text { Ferreira } \\
\text { do Zêzere }\end{array}$ & 22 & 9 & 13 & 1 & 6 & 4 & 4 & 2 & - \\
\hline Alcobaça & 3 & 3 & 1 & - & 3 & - & 2 & - & 1 \\
\hline $\begin{array}{l}\text { Caldas } \\
\text { da Rainha }\end{array}$ & 1 & 1 & - & - & 1 & - & - & 1 & - \\
\hline Total & 56 & 38 & 19 & 2 & 31 & 9 & 26 & 3 & 2 \\
\hline
\end{tabular}

Quadro 1 - Síntese dos dados apurados pelos trabalhos de campo desenvolvidos pela DGPC, com referência aos sítios abrangidos num perímetro de $50 \mathrm{~m}$ em torno das áreas ardidas apresentadas pelo ICNF. 


\title{
OS VALORES DO PATRIMÓNIO: UMA INVESTIGAÇÃO SOBRE OS SÍTIOS PRÉ-HISTÓRICOS DE ARTE RUPESTRE DO VALE DO RIO CÔA E DE SIEGA VERDE
}

\author{
José Paulo Francisco
}

\begin{abstract}
RESUMO
Apresentação do projecto de investigação de doutoramento Os Valores do Património: uma investigação sobre os sítios pré-históricos de arte rupestre do Vale do Rio Côa e de Siega Verde, em curso na Faculdade de Geografia e História da Universidade de Barcelona, sob a orientação da Professora Margarita Díaz-Andreu. Sintetizam-se as perguntas de investigação e os objectivos gerais e específicos, à luz das convenções e recomendações da Unesco para os sítios integrados na Lista do Património Mundial. A arte rupestre do Vale do Côa foi incluída nessa lista em 1998, tendo a área sido alargada às manifestações artísticas de Siega Verde em 2010. Palavras-chave: Arte rupestre, Metodologia, Vale do Côa, Património, Legislação do património.
\end{abstract}

\begin{abstract}
Presentation of the $\mathrm{PhD}$ research project Heritage values: research into Pre-historic rock art sites of the Côa River Valley and Siega Verde, to be developed at the Geography and History Faculty of the University of Barcelona, under supervisionof ProfessorMargaritaDíaz-Andreu. The author summarises the research questions and general and specific objectives under the scope of Unesco conventions and recommendations for World Heritage sites. The rock art of the Côa Valley has been part of that list since 2007, whereas the artistic manifestations of Siega Verde were considered an integral part of the same area from 2010.
\end{abstract} Keywords: Rock art, Methodology, Côa Valley, Heritage, Legislation on heritage.

\section{INTRODUÇÃO}

Porque conservamos o património e para quem? Esta é a pergunta que esta tese de doutoramento pretende responder no contexto dos Sítios Pré-históricos de Arte Rupestre do Vale do Rio Côa e de Siega Verde. O interesse, da identificação e avaliação dos valores patrimoniais que levaremos a cabo nesta tese de doutoramento, reside na compreensão dos Sítios de Arte Rupestre do Vale do Rio Côa e de Siega Verde como fenómeno social e na hipótese de construção de uma proposta de plano de gestão destes bens patrimoniais com base nos valores identificados, que valorize o papel das Comunidades, conforme os objectivos estratégicos da Convenção do Património Mundial, "The "fifth C" for "Communities" (o quinto "C", significando este C Comunidade e sendo os outros quatro: Credibilidade; Conservação; Capacidade e Comunicação (Albert, 2012); (UNESCO, 2007: 193).

\section{OBJECTIVO GERAL, ESPECÍFICOS E PERGUNTAS DE INVESTIGAÇÃO}

O objectivo geral desta investigação é analisar o valor social dos Sítios Pré-históricos de Arte Rupestre do Vale do Rio Côa e de Siega Verde. Gerar conhecimento sobre o que significaram e geraram, em termos sociais desde a sua descoberta até à actualidade e contrastar o modelo de gestão actual destes sítios, com o estabelecido, nas Orientações Técnicas para a Aplicação da Convenção do Património Mundial, no respeitante à participação social.

1. Arqueólogo, membro do Grup d’Arqueologia Pública i Patrimoni Universitat de Barcelona: http://www.gapp.cat/ Facultat de Filosofia i de Geografía e Història, Carrer Montalegre 6, o8oo1, Barcelona; josepaulofrancisco32@gmail.com 


\subsection{Objectivos específicos}

Os objectivos específicos são:

1. Identificar e analisar os valores patrimoniais actuais dos Sítios Pré-históricos de Arte Rupestre do Vale do Rio Côa e de Siega Verde.

2. Analisar se existiram mudanças nos valores do património ao longo do último século.

3. Estudar como os valores patrimoniais são per- cebidos pelos diferentes actores.

a) Pelos responsáveis pelas políticas públicas.

b).Pelas comunidades locais.

c)Por outros grupos.

4. Realizar um estudo da importância da tipologia de valores identificados no âmbito dos diversos grupos, com especial ênfase no valor social.

5. Ver como as novas directivas da UNESCO para fomentar a participação social estão a ser percebidas e implementadas: pelos gestores e pelas comunidades.

6. Perceber quais são os elementos relacionados com os valores do património que deveriam constar num Plano de Gestão dos Sítios Pré-históricos de Arte Rupestre do Vale do Rio Côa e de Siega Verde.

\subsection{Perguntas de investigação}

Os objectivos mencionados, têm como desiderato, responder às seguintes perguntas de investigação:

1. O que significaram e significam os Sítios Préhistóricos de Arte Rupestre do Vale do Rio Côa e de Siega Verde, em termos sociais, desde a sua descoberta até à actualidade?

2. Qual o impacto social ao nível local da sua inscrição na Lista do Património Mundial?

3. Em que âmbitos as comunidades locais participam na gestão deste bem cultural transfronteiriço?

4. São os valores do património identificados considerados na gestão dos sítios?

5. Quais são os valores do património, que deveriam constar num Plano de Gestão dos Sítios Pré-históricos de Arte Rupestre do Vale do Rio Côa e de Siega Verde?

\subsection{Importância deste trabalho}

A importância deste trabalho de investigação, reside na necessidade de aplicação do conceito de valores do património nos estudos do património arqueológico, uma prática interdisciplinar e transdisciplinar que pretende caracterizar os processos históricos e sociais gerados em torno dos bens patrimoniais. A prática actual da gestão do património, considera a gestão baseada nos valores como um dos enfoques mais importantes da gestão do património arqueológico (Austrália ICOMOS, 2000; Johnston et al., 2006; Aplin, 2002; Doumas, 2013; de la Torre, 2013). A identificação e avaliação dos valores patrimoniais dos sítios arqueológicos deste caso de estudo (Pearson \& Sullivan, 1995: 126; Lung et al., 2007) contribuirá para uma proposta de Plano de Gestão, tendo por base o pressuposto de que a marginalização de alguns valores e a supremacia de outros pode diminuir o significado de um lugar (Mason, 1999). Na actualidade a gestão dos sítios classificados como Património Mundial pela UNESCO, exige a identificação e avaliação dos valores atribuídos a estes sítios pelas diferentes partes interessadas (Carter \& Bramley, 2002; Feilden \& Jokileht, 1993; Mydland \& Grahn, 2012). Face a inexistência de um Plano de Gestão dos Sítios Pré-Históricos de Arte Rupestre do Vale do Rio Côa e de Siega Verde, a identificação e avaliação dos seus valores patrimoniais pode contribuir para a elaboração desse plano.

\section{CONTEXTO DA INVESTIGAÇÃO}

A importância que a sociedade atribui ao património cultural tem vindo a alterar-se, ao seu valor identitário, acresce hoje o valor social e económico enquanto recurso territorial gerador de fortes contributos para as economias locais e regionais, nomeadamente, no contexto do turismo patrimonial. No entanto são ainda escassos os estudos de impacto social e económico aplicados ao património cultural que o comprovem, inexistentes para o nosso caso de estudo. Esta investigação em Arqueologia Pública, visa obter uma visão da percepção e valor social destes elementos do património arqueológico, classificados como Património Mundial pela UNESCO. Medir o retorno sociocultural e económico do investimento realizado nas acções de investigação, conservação e patrimonialização, o impacto social e económico do seu estatuto de Património Mundial e do turismo patrimonial nas comunidades locais e analisar a sustentabilidade das práticas de gestão com base nos valores identificados.

A identificação e avaliação dos valores patrimoniais dos Sítios Pré-Históricos de Arte Rupestre do Vale do Rio Côa e de Siega Verde e o impacto das actividades arqueológicas sobre os cidadãos, permi- 
tirá estudar o próprio valor social da arqueologia. O papel do arqueólogo na atribuição de valores do património, pode ser encontrado no conteúdo dos códigos de conduta das associações profissionais de arqueologia, que emergiram no contexto da gestão de património a partir dos anos 6o (para uma visão geral, ver, por exemplo, Aitchison, 2007; Meskell \& Pels, 2005; Lynott \& Wylie, 2000). Em todos esses códigos, os arqueólogos são considerados "os principais conselheiros sobre os valores do património" (Okamura, 2010: 58).

\subsection{Os valores do património}

No início do século XX, o conceito de valor tornou-se cada vez mais importante no campo da conservação, Alois Riegl (1903) na sua obra O Culto Moderno dos Monumentos, investigou o papel dos diferentes valores no contexto da conservação, descreve diferentes tipos de valor que servem para orientar a ação para as intervenções de conservação. Riegl defende a existência de um afastamento entre o autor e o espectador das diferentes épocas “... o sentido e a importância dos monumentos não cabem às próprias obras em virtude da sua determinação originária, mas somos nós, modernos, quem lhos atribui" (Riegl, 2013; 14). Enquanto Ruskin e Viollet-le-Duc, enfatizam uma abordagem específica para a conservação baseada na importância da idade e integridade, respectivamente, Riegl teoriza a conservação sistematicamente com base na ideia de valor.

A prevalência de um determinado tipo de valor serve, para explicar por que certas intervenções são preferidas em detrimento de outras (Herrmann, 2015: 115). Na primeira metade da década de 1980, Tainter e Lucas (Tainter \& Lucas, 1983) e Lipe (Lipe, 1984) abordaram a questão da importância da investigação sobre a gestão de recursos culturais, destacaram a ideia de qualidade em relação à "significância" e "valor e significado", ou seja, a noção de valor como guia para a selecção (Herrmann, 2015: 117-118).

O termo "valores patrimoniais" refere-se aos significados e valores que os indivíduos e grupos de pessoas concedem ao património (Díaz-Andreu, 2016 $\mathrm{a}$; b; 2017). Os valores patrimoniais podem ser definidos como um conjunto de características ou qualidades objectos e locais culturais, e práticas culturais intangíveis percebidas como positivas por certos indivíduos ou grupos (Díaz-Andreu, no prelo). Os valores do património não são fixos, mas criados culturalmente (Díaz-Andreu, no prelo), existem vários tipos de valor, histórico, estético, natural, antropológico, simbólico, social e económico entre outros, sendo de relevar a importância atribuída nas últimas quatro décadas ao valor social "um apego colectivo a um lugar que incorpora significados e valores que são importantes para uma comunidade ou comunidades" (Jones, 2017: 22).

Para uma avaliação dos valores dos sítios arqueológicos e patrimoniais, precisamos considerar a relevância dos valores artísticos, históricos e sociais que estes sítios geram, tal realização requer o envolvimento das partes interessadas como bens compartilhados que são e não vistos como bens públicos ou de mercado (Klamer, 2014: 59). Os estudos de impacto económico servem para avaliar os valores financeiros gerados por um museu, um sítio arqueológico, avaliam o retorno económico das actividades económicas geradas (Klamer, 2014: 61). Os valores culturais de um sítio arqueológico compreendem os seus aspectos artísticos, históricos, estéticos, valores espirituais, valores sociais e dizem respeito à sociedade em geral, os valores pessoais são os valores que um sítio arqueológico e patrimonial pode ter para uma pessoa, os valores podem variar entre os stakeholders, as crianças tendem a ter interesses que pode ser bastante diferente dos adultos (Klamer, 2014: 64-65).

No período de 1998 até 2005, o Getty Conservation Institute (GCI) desenvolveu uma investigação denominada "Research on the Values of Heritage", dedicada aos valores do património, visava estabelecer vínculos entre as abordagens culturais e económicas de valorização do património. Desta investigação resultou a publicação de um conjunto de publicações de referência, Economics and Heritage Conservation:A Meeting Organized by the Getty Conservation Institute (Mason, 1999), resultante de um encontro ocorrido em Dezembro de 1998, em Los Angeles, e publicado em 1999: Values and Heritage Conservation:Research Report (Avrami, Mason, \& de la Torre, 2000), no ano 2000 e Assessing the Values of Cultural Heritage: Research Repor (de la Torre, 2002), em 2002. Um dos pontos a relevar do encontro de 1998, seria a preocupação com a crescente valoração do património em termos do valor económico, em detrimento de outras abordagens de avaliação e a constatação de que os métodos utilizados seriam insuficientes para identificar os vários valores do património. Outra conclusão relevante deste encontro foi a compreensão da noção essen- 
cialmente pública e colectiva do património, desta forma, percebe-se ainda mais a necessidade de melhor compreendermos os processos sociais envolv dos na valorização do património, com o objectivo de estender os múltiplos valores atribuídos ao património cultural, nomeadamente aos valores patrimoniais dos sítios arqueológicos.

No entanto o termo "valor" poderia ser substituído pelo termo "significância" (Austrália, ICOMOS: 2000). A Significância, segundo Mason (Mason, 2002), é "construída e modelada pelo tempo, lugar e pessoas envolvidas na sua articulação" indica a importância geral de um sítio, determinada através da análise da totalidade dos valores que lhe são atribuídos, reflecte o grau de importância do lugar (Mason \& Avrami, 2002), pode ser vista como uma definição mais ampla do que os valores do património (Mason, 2002) correspondentes às diferentes partes interessadas (Doumas, 2013; de la Torre, 2013). Mason e Avrami (2002:16-17) sugerem sete grupos de valores na avaliação de significância: valor histórico e artístico; valor social e cívico; valor espiritual ou religioso; valor simbólico ou de identidade; valor científico; valor natural; valor económico.

Outra questão importante em relação à compreensão dos valores patrimoniais é a origem conceptual dos valores, os valores são intrínsecos, isto é, objectivos e corporificados no objecto patrimonial; ou só existem em relação a outra coisa, são extrínsecos, isto é, subjectivos e atribuído pelas pessoas. Estas duas perspectivas estão ligadas às ideias de valor universal e representativo. Com o crescente reconhecimento da diversidade cultural, o conceito de valor patrimonial foi além do intrínseco e universal e foi reconhecida a natureza extrínseca e relativa dos valores, relevando o papel central das pessoas e comunidades na definição do património e dos seus valores.

$\mathrm{O}$ valor é assim determinado pela cognição e pelo contexto, é relacional, esta perspectiva construtivista foi confirmada na investigação do Getty Conservation Institute na segunda metade da década de 1990 (Herrmann, 2015: 119-122). Na maior parte dos casos, os valores patrimoniais não são intrínsecos, mas sim subjectivos, ligados ao contexto, não é apenas o especialista que identifica os valores do património, mas as várias partes interessadas envolvidas e que se interessam pelo património, as comunidades locais. Desta forma o "valor universal excepcional" dos sítios inscritos na Lista do Património Mundial da UNESCO deve ser gerido por forma a considerar os valores do lugar para as comunidades locais. Os valores do património nãos são um conceito imutável (Taylor, 2004) são uma construção cultural e social (Darvill, 1995; Mason, 2006; Hall, 1997; Heras et al., 2013).

A tipologia dos valores do património tem sido objecto de debate nos últimos anos (Matarasso, 1997; Williams, 1997; Sandell, 1998; Persson, 2000; Sheppard, 2000; Evans, 2001; Parker, 2002; Frey, 1997; Russell \& Winkworth, 2001; de la Torre, 2013; Mason \& Avrami, 2002; English Heritage, 2006). Existem diferentes tipos de valores patrimoniais, a mais antiga classificação sistemática conhecida no campo da conservação foi feita por Aloise Riegl em 1903 na sua obra "O Culto Moderno dos Monumentos" (Riegl, 2013), um estudo tipológico sobre os valores artísticos e históricos da arte e arquitectura. A tipologia de Riegl incluía o: valor artístico, valor histórico, valor de antiguidade, valor comemorativo e valor actual, discute a diferença entre valores memoriais e actuais. Recentemente outras tipologias foram criadas (Labadi, 2007, 2013; Mason, 2008; Battaini-Dragoni, 2005).

Outra classificação realizada por Lipe (Lipe,1984) identifica o valor económico, estético, associativo e simbólico, baseada na ideia de contexto (no âmbito da investigação encomendada pelo Getty Institute, a ideia de contexto foi reforçada), distingue quatro contextos de valor e os seus tipos associados: o potencial económico é expresso em valor económico; a tradição estilística, psicologia humana e outros factores influenciam os padrões estéticos, sendo, o valor estético e o conhecimento tradicional, que se manifestam, por exemplo, em documentos históricos, tradições orais e mitologia, que determinam o valor associativo ou simbólico. A Carta de Veneza, considera o valor histórico, arqueológico e valor estético enquanto a Convenção do Património Mundial os valores: histórico, artístico, científico, estético, etnológico ou antropológico, e além desses considera ainda o valor social (Herrmann, 2015: 124-125). Os valores desempenham um papel central nos estudos do património, desde da década de setenta do século XX. Desde esse momento, assistimos a uma crescente importância da avaliação e gestão dos diversos valores do património, com o interesse pós-moderno na construção social do património, o foco vais mais além dos valores intrínsecos e a natureza "extrínseca "dos valores do património tem sido considerada, ou seja, o entendimento de que os 
valores são construídos por indivíduos e grupos de pessoas (Herrmann, 2015: 116-117). Várias tipologias de valores têm sido propostas, mas, no entanto, as classificações são subjectivas e dependentes das perspectivas dos especialistas ou do contexto da investigação.

Os relatórios sobre valor e economia do património cultural organizados pelo Getty Conservation Institute, no âmbito da investigação "Research on the Values of Heritage" acrescentam que o termo valor é entendido e utilizado para nos referirmos às "qualidades e características vistas nas coisas" e varia amplamente do valor estético ou simbólico ao económico (Herrmann, 2015: 116-117). Distinguem os conceitos de valor e significado, sendo que o "significado cultural", é entendido como um termo abrangente para o conjunto de valores atribuídos a um sítio. Em termos práticos conduziram a uma (re)teorização do conceito de conservação dos monumentos e sítios, de um mero foco no aspecto material das intervenções para a gestão de valores patrimoniais.

\subsection{Natureza do valor de património}

O valor é assim determinado pela cognição e pelo contexto, é relacional, esta perspectiva construtivista foi confirmada na investigação do Getty Conservation Institute (Herrmann, 2015: 119-122). Na maior parte dos casos, os valores patrimoniais não são intrínsecos, mas sim subjectivos, ligados ao contexto, não é apenas o especialista que identifica os valores do património, mas as várias partes interessadas envolvidas e que se interessam pelo património, as comunidades locais. Desta forma o valor universal dos sítios inscritos na Lista do Património Mundial da UNESCO deve ser gerido por forma a considerar os valores do lugar para as comunidades locais. Os valores do património nãos são um conceito imutável (Taylor, 2004) são uma construção cultural e social (Darvill, 1995; Mason, 2006; Hall, 1997; Heras et al., 2013).

\subsection{Valor social do património}

O valor social do património é um conceito complexo (Pearson \& Sullivan, 1995: 155), tem sido utilizado de diversas maneiras: identidade da comunidade; apego ao lugar; valor simbólico; associações espirituais; capital social; lazer; e educação (Jones \& Leech, 2015: 6, Jones, $2016 \&$ 2017). A terminologia inclui além do "valor social" conceitos sobrepostos como "valor comunitário" (Pearson \& Sullivan, 1995), "valor comunal" (English Heritage, 2008), "valor da comunidade patrimonial" (Conselho da Europa, 2005 \& 2009) e "significado social" (Bryne et al., 2003) usados para designar aspectos do que é descrito como valor social. A tipologia de valores patrimoniais considerados pelos especialistas ao longo dos últimos dois séculos, mostra a consideração inicial dos valores históricos e estéticos, a inclusão nos finais do século XIX do valor natural e antropológico e a importância atribuída ao valor histórico, a par do artístico e valor de antiguidade.

As Cartas Internacionais produzidas no século XX privilegiaram os valores históricos, científicos e estéticos, juntamente com a ênfase no tecido histórico (por exemplo, Carta de Atenas, 1931; Carta de Veneza, 1964). Só na segunda metade do século XX desde a reunião do ICOMOS realizada em Burra no ano de 1979 (ICOMOS Australia,1979), assistimos à assunção do valor social do património e à necessidade de avaliação do significado do lugar, ou seja, à análise dos valores do lugar além do seu valor de uso. A Carta para a Conservação dos Locais de Importância Cultural, Carta de Burra - The Australia ICOMOS Guidelines for the Conservation of Places of Cultural Significance de 1979 (cuja última atualização foi realizada em 2013), foi adoptada pelo ICOMOS-Austrália neste momento e posteriormente revista em 1981, 1988, 1999 e 2013. Colocou a avaliação do "significado cultural" no centro do processo de conservação com base no seguinte pressuposto: "lugares de significado cultural enriquecem a vida das pessoas, muitas vezes proporcionando um profundo e inspirador senso de conexão com a comunidade e a paisagem e com as experiências vividas" (ICOMOS Austrália, 1979: 1). O valor social é definido nas Directrizes da Carta de Burra como "as qualidades pelas quais um lugar se tornou um foco espiritual, político, nacional ou outro sentimento cultural", é assim colocado em pé de igualdade, pelo menos em teoria, com o valor histórico, estético, cultural e científico (ICOMOS Austrália, 2013). Este documento apresenta a noção de significado cultural, onde se encontram valores como os históricos, estéticos, científicos e sociais.

\section{METODOLOGIAS DE INVESTIGAÇÃO}

Nesta investigação aplicaremos a metodologia antropológica ou etnográfica aplicada à arqueologia. As abordagens desde as etnografias arqueológicas 
oferecem informações importantes sobre a multivocalidade e os discursos gerados sobre os sítios arqueológicos e para a tomada de decisões na gestão de património (Castañeda \& Matthews, 2008; Geurds, 2007; Hamilakis \& Anagnostopoulis, 2009; van der Linde, 2012). A etnografia arqueológica pode ser definida como um espaço transdisciplinar e transcultural que permite a interacção entre os investigadores e diversos públicos (Hamilakis \& Anagnostopoulis, 2009). Constitui um método reflexivo para investigar o que a arqueologia faz na sociedade (Smith, 2004: 1), tem as suas origens nas arqueologias pós-processuais interpretativas dos anos 80 e 90 do século XX e na ideia de que as interpretações do passado são socialmente construídas, multivocais e politicamente influenciadas (van der Linde, 2012: 25). $\mathrm{Na}$ última década surgiram estudos que aplicaram o método etnográfico em arqueologia numa perspectiva histórica (Castañeda \& Matthews, 2008; Edgeworth, 2006; Hamilakis \&Anagnostopoulis, 2009; Hollowell \& Nicholas, 2008; Pyburn, 2008; 2009). Numa categorização entre as intersecções da etnografia e arqueologia, Castañeda (2008), fez uma distinção entre "etnoarqueologia" e "etnografias da arqueologia”. Na qual define a etnoarqueologia como o uso pelos arqueólogos de métodos etnográficos, destinados a produzir conhecimento que contribua para entender o passado como uma realidade material que é epistemologicamente mas não ontologicamente, separada do presente (Castañeda, 2008: 28). Outra das intersecções entre a arqueologia e etnografia é definida como "etnografias da arqueologia”, cujo método aplica a etnografia e a antropologia sociocultural para compreender o funcionamento político, histórico e discursivo da arqueologia nos contextos sociais contemporâneos (van der Linde, 2012: 25).

A maioria das etnografias de projectos arqueológicos focaliza-se no entorno dos sítios arqueológicos (Bartu, 200o; Castañeda, 2008: 37; Chiang, 2012; El-Haj, 2001; Meskell, 2005, "interface social" (Long, 2003) onde a multiplicidade de interpretações possibilita o desenvolvimento de etnografias arqueológicas através de métodos como a observação participante (Castañeda, 2008: 37). Os pontos fortes da etnografia arqueológica, são a sua reflexividade crítica, natureza holística, o seu carácter multitemporal e não presentista, envolvimento sensorial com o mundo, compromisso político e a sua concepção como prática colectiva, que transcende as fronteiras entre o investigador e os seus diversos públicos (van der Linde, 2012: 25).

A etnografia arqueológica não é simplesmente uma prática emergente de reaproximação da arqueologia social e da antropologia social, é um espaço interdisciplinar, transcultural, que ao nível da metodologia e da prática, envolve investigações multicêntricas, etnográficas e etno-históricas, como entrevistas formais, informais e observação participante (Hamilakis \& Anagnostopoulos, 2009: 67). Mais do que a reintrodução da etnografia em projectos arqueológicos, é um espaço transdisciplinar e transcultural de relacionamento, diálogo e crítica, entre investigadores e outros actores sociais centrado nos vestígios do passado (Hamilakis \& Anagnostopoulos, 2009: 67). A etnografia arqueológica pode incluir também as etnografias da prática arqueológica e dos arqueólogos, especialmente as maneiras pelas quais os conhecimentos arqueológicos são produzidos e as práticas arqueológicas são realizadas (Edgeworth, 2006). As etnografias arqueológicas perturbam as ontologias arqueológicas convencionais e os modos de pensar e da prática disciplinar (Hamilakis \& Anagnostopoulos, 2009: 71).

A observação participante desta investigação, consistirá no registo das dinâmicas dos grupos de interesse, obtidas pela observação e compreensão das relações entre as comunidades locais e os sítios arqueológicos. A par da observação participante, realizarei entrevistas semiestruturadas individuais e em grupo, gravadas por meios audiovisuais, por forma a capturar e transmitir a multivocalidade dessas duas paisagens patrimoniais, um documentário, um arquivo audiovisual e uma série de clips de filme das entrevistas com o objectivo de apresentar e divulgar os valores patrimoniais atribuídos aos sítios arqueológicos pelas comunidades locais.

A estratégia metodológica REAP a utilizar (cf. Low, 2002) envolve, um enfoque interpretativo e pretende produzir uma descrição das várias considerações acerca do fenómeno social em investigação. Esta estratégia pretende determinar os valores culturais e sociais atribuídos a estes sítios arqueológicos pelas comunidades locais. As metodologias supramencionadas, serão complementadas pela avaliação dos valores económicos a realizar nesta investigação com recurso às metodologias propostas por Klamer (Klamer, 2004). Nomeadamente o estudo de impacto do valor económico adicionado pelo processo de investigação, conservação e patrimonialização, 
gerado pelo retorno económico do investimento realizado no processo de estudo, conservação e valorização dos Sítios Pré-historicos de Arte Rupestre do Vale do Côa e de Siega Verde nos diversos sectores da economia. Estes projectos de arqueologia pública, serão investigados na relação dos diversos agentes, contextos e processos sociais, através da etnografia como componentes do processo e dinâmica da investigação arqueológica, base para processos interactivos entre arqueólogos, partes interessadas, público e intercâmbio transcultural de interpretações, reivindicações e significados do passado (Castañeda, 2008: 54).

\section{BIBLIOGRAFIA}

ALBERT, Marie-Theres (2012) - Perspectives of World Heritage: towards future-oriented strategies with the five 'Cs'. In ALBERT, Marie-Theres et al., eds. - Community Development through World Heritage. Paris: UNESCO World Heritage Centre, (World Heritage papers, 31), pp. 32-38.

APLIN, G. (2002) - Heritage identification:Conservation and management. Oxford: Oxford University Press.

AUSTRALIA ICOMOS (1979) - The Burra Charter. Disponível em: https://australia.icomos.org/publications/charters / [Acedido em 15 de Julho 2020].

AUSTRALIA ICOMOS (1988) - Guidelines to the BurraCharter: procedures for undertaking studies and reports. Disponível em: https://australia.icomos.org/wp-content/ uploads/Guidelines-to-the-Burra-Charter_-Procedures. pdf[Acedido em 15 Julho 2020].

AUSTRALIA ICOMOS (200o) - The Burra Charter: The Australia ICOMOS Charter for Places of Cultural Significance 1999, with associated guidelines and code on the ethics of co-existence in conserving significant places. Australia ICOMOS Inc. Available at: http://australia.icomos.org/wp-content/uploads/BURRA_CHARTER.pdf. [Acedido em 15 Julho 2020].

AUSTRALIA ICOMOS (2013) - Practice Note: Understanding and assessing cultural significance. Disponível online: https://australia.icomos.org/wp-content/uploads/ Practice-Note_Understanding-and-assessing-culturalsignificance.pdf [Acedido em 15 Julho 2020].

AVRAMI, E.; de la Torre, M; Mason, R., eds. (200o) - The Values and Benefits of Cultural Heritage Conservation: Research Report. Los Angeles: CA: Getty Conservation Institute.

BATTAINI-DRAGONI, G., ed. (2005) - Guidance on Heritage Assessment. Strasbour: Council of Europe.

BARTU, A. (200o) - Where is Catalhöyülk? Multiple sites in the construction of an archaeological site. In: HODDER, I. ed. - Towards a reflexive method in archaeology. The example at Catalhöyük. Cambridge and London: McDonald Institute for Archaeological Research and British Institute of Archaeology at Ankara, pp. 1010-109.

BYRNE, Denis, BRAYSHAW, H., IRELAND, T. (2003) Social Significance: A Discussion Paper. Second edition. Hurstville: New South Wales National Parks and Wildlife Service.

CASTAÑEDA, Q. E., MATTHEWS, C., eds. (2008) Ethnographic Archaeologies: Reflections on Stakeholders and Archaeological Practices. Lanham: MD: Altamira Press.

CASTAÑEDA, Q. E. (2008) - The 'ethnographic turn' in archaeology: research positioning and reflexivity in ethnographic archaeologies, In CASTAÑEDA, Q.; MATTEWS, C., eds. - Ethnographic Archaeologies: Reflections on Stakeholders and Archaeological Practices, Lanham MD: AltaMira Press, pp. 25-61.

CARTER, R. W.; BRAMLEY, R. (2002) - Defining Heritage Values and Significance for Improved Resource Management: An Application to Australian Tourism. International Journal of Heritage Studies 8:3, pp. 175-199.

CHIANG, M. (2012) - Memory Contested, Locality Transformed. Representing Japanese Colonial 'Heritage'. Archaeological Studies Leiden University 26, Leiden: Leiden University Press.

CONSELHO DA EUROPA (2005) - Convenção Quadro do Conselho da Europa Relativa ao Valor do Património Cultural para a Sociedade, Resolução da Assembleia da República n.ำ47/2008 de 12 de Setembro, Diário da República, 1.a série, $177,6640-6652$.

DARVILL, T. C. (1995) - Value systems in archaeology, In COOPER, M. A.; FIRTH, A. Firth; CARMAN, J.; WEATLEY, eds. - A Managing Archaeology, Routledge: London, pp. 40-50.

DE LA TORRE, M. (2002) - Assessing the Values of Cultural Heritage: Research Report. Los Angeles: The Getty Conservation Institute.

DE LA TORRE, M. (2013) - Values and Heritage Conservation. Heritage $\&$ Society 6:2, pp. 155-166.

DÍAZ-ANDREU, M. (2016a) - Arqueología, comunidad y valor social: un reto para el património arqueológico del siglo XX?. In DÍAZ-ANDREU, M; PASTOR PÉREZ, A; RUIZ, A., eds. - Arqueología y Comunidad. El valor social del patrimonio arqueológico en el siglo XX. Madrid: JAS Arqueología S.L.U, pp. 69-89.

DÍAZ ANDREU, M. (2016b) - Social values and local communities in World Heritage: a dream too far?' European Journal of Post-Classical Archaeologies [special section: M. Díaz-Andreu (ed.) World Heritage \& the Public], 6, pp. 193-212.

DÍAZ ANDREU, M. (2017) - Introduction: Heritage Values and the Public. Journal of Community Archaeology $\&$ Heritage 4.1, pp. 2-6. 
DÍAZ-ANDREU, M. (no prelo) - From Aesthetics to Economics. A History of Heritage Values.

DOUMAS, C. G. (2013) - Managing the Archaeological Heritage: The Case of Akrotiri, Thera (Santorini). Conservation and Management of Archaeological Sites 15:1, pp. 109-120.

EDGEWORTH, M. (2006) - Ethnographies of archaeological practice: cultural encounters, material transformations. Lanham MD: Altamira Press.

EL-HAJ, Nadia Abu (2001) - Facts on the Ground: Archaeological Practice and Territorial Self-Fashioning in Israeli Society. Chicago: University of Chicago Press.

ENGLISH HERITAGE (2006) - Conservation Principles for the Sustainable Management of the Historic Environment. First Stage Consultation. London: English Heritage.

ENGLISH HERITAGE (2008) - Conservation Principles. London: English Heritage.

GEURDS, Alexander (2007) - Grounding the Past: The Praxis Participatory Arcaheology in the Mixtexa Alta, Oaxaca, Mexico: Leiden: CNWS Publications.

HALL, C. M.; MACARTHUR, S. (1998) - Integrating Stakeholders into Heritage Management, Involving the Community, In Integrated Heritage Management: Principles and Practices, pp. 41-85. London: The Stationery Office.

HAMILAKIS, Y.; ANAGNOSTOPOULOS, A. (2009) Archaeological Ethnographies. Public Archaeology 8.2-3. Cambridge: Maney Publishing.

HERAS, C. V.; WIJFFELS, A.; CARDOSO, F.; VANDESANDE, A. SANTANA, M.; ORSHOVENVAN, J.; BALENVAN, K (2013) - A Value-Based Monitoring System to Support Heritage Conservation Planning. Journal of Cultural Heritage Management and Sustainable Development 3:2, pp. 130-147.

HALL, S. (1997) - Representation: Cultural Representations and Signifying Practices. London: Sage Publications.

HERAS, V.C.; WIJFFELS, A.; CARDOSO, F.; VANDESANDE, A.; SANTANA, M.; ORSHOVEN, J.; STEENBERGHEN, T.; VAN BALENS, K. (2013) - A value-based monitoring system to support heritage conservation planning. Journal of Cultural Heritage Management and Sustainable Development, 3: 2, pp. 130-147.

HERRMANN, JUDITH (2015) - Tracing change in World Cultural Heritage: the recognition of intangible heritage, Ph.D. Thesis, Faculté de l'aménagement, Université de Montréal, disponível online: https://papyrus.bib.umontreal.ca/xmlui/bitstream/handle/1866/14112/Herrmann Judith_2015These.pdf?sequence=2 (Acedido a 15 de Julho 2020).

HOLLOWELL, J.; NICHOLAS, G. (2008) - A Critical Assessment of Ethnography in Archaeology.In CASTAÑEDA, Q.; MATTEWS, C. eds. - Ethnographic archaeologies: reflections on stakeholders and archaeological practices, Lanham MD: AltaMira Press, pp.63-94.

HOLLOWELL, J.; NICHOLAS, G. (2009) - Using Ethnographic Methods to Articulate Community-Based Conceptions of Cultural Heritage Management. Public Archaeology, 8:2-3, pp. 141-16o.

JONES, S.; LEECH, S (2015) - Valuing the historic environment: A critical review of existing approaches to social value. London: Arts and Humanities Research Council.

JONES, S. (2017) - Wrestling with the Social Value of Heritage: Problems, Dilemmas and Opportunities, Journal of Community Archaeology \& Heritage, 4:1, pp. 23-37.

JOHNSTON, C.; CAIRNES, L.; EYLES, K.; JOHNSTON, C. (2006) - An Integrated Approach to Environment and Heritage Issues. Prepared for the Australian State of the Environment Committee. Canberra: Department of Environment and Heritage.

KLAMER, A. (2014) - The Values of Archaeological and Heritage Sites, Public Archaeology, 13:1 pp. 59-70.

LABADI, Sophia (2007) - Representations of the Nation and Cultural Diversity in Discourses on World Heritage. Journal of Social Archaeology, 7:2, pp. 147-170.

LABADI, Sophia (2013) - UNESCO, cultural heritage, and outstanding universal value: Value-based analyses of the World Heritage and Intangible Cultural Heritage Conventions. Lanham: Alta Mira Press.

LIPE, W. (1984) - Value and Meaning in Cultural Resources. In CLEERE, Henry, ed. - Approaches to the Archaeological Heritage. A Comparative Study of World Cultural Resource Management Systems. Cambridge: Cambridge University Press, pp. 1-11.

LONG, N. (2003) - An actor-oriented approach to development intervention'. In CRUZ, D.A., ed. - Rural life improvement in Asia. Report of an APO Seminar on Rural Life Improvement for Community Development held in Japan. Tokyo: Asian Productivity Organization.

LOW, S. M. (2002) - Anthropological-ethnographic methods for the assessment of cultural values in heritage conservation'. In DE LA TORRE, M., ed. - Assessing the values of cultural heritage, Los Angeles: Getty Conservation Institute, pp. 31-49.

LUNG, D. P. Y.; DISTEFANO, L.; LEE, H. Y.; WONG, D. T. Y. (2007) - Interpreting the Significance of Heritage sites. In ENGLEHART, R., ed. - Englehardt Asia Conserved: Lessons Learned from the UNESCO Asia-Pacific Heritage Awards for Cultural Heritage Conservation (200O-2004), Bangkok: UNESCO, pp. 21-27.

MARSHALL, Y., (2002) - What is community archaeology? World Archaeology 34:2, pp. 211-219.

MASON, R. (1999) - Economics and Heritage Conservation: Concepts Values and Agendas for Research: A Meeting 
Organized by the Getty Conservation Institute Economics and Heritage Conservation. Los Angeles: J. Paul Getty Trust, pp. 2-18.

MASON, R.; AVRAMI, E. (2002) - Heritage values and challenges of conservation planning', In TEUTONICO J.M.; PALUMBO, G. eds. - Management Planning for Archaeological Sites: An International Workshop. Los Angeles: The Getty Conservation Institute, pp. 13-26.

MASON, R. (2002a) - Assessing Values in Conservation Planning: Methodological Issues and Choices. Assessing the Values of Cultural Heritage. Los Angeles: The Getty Conservation Institute.

MASON, R. (2002b) - Assessing values in conservation planning. In DE LA TORRE, M. ed. - Assessing the Values of Cultural Heritage, Los Angeles: The Getty Conservation Institute, pp. 5-30.

MASON, R. (2006) - Theoretical and Practical Arguments for Values-Centered Preservation". CRM: The Journal of Heritage Stewardship 3: 2, pp 21-48.

MASON, R. (2008a) - Assessing Values in Conservation Planning. In FAIRCLOUGH, G.; HARRISON, R.; JAMESOSN, J.H.; SCHOFIELD, J., eds. - The Heritage Reader. New York: Routledge, pp. 99-124.

MASON, R. (2008b) - Be interested and beware: Joining economic valuation and heritage conservation. International Journal of Heritage Studies, 14: 4, pp. 303-318.

MATARASSO, F. (1997) - Use or Ornament? The Social Impact of Participation in the Arts. Comedia, Bournes Green, Stroud.

MYDLAND, L.; GRAHN, W. (2012) - Identifying Heritage Values in Local Communities'. International Journal of Heritage Studies 18:6, pp. 564-587.

MILLS, J.; BONNER, A.; FRANCIS, K. (2006) - The development of constructivist grounded theory'. International Journal of Qualitative Methods 5:1, pp 1-10.

MESKELL, L.; PELS, P. eds. (2005) - Embedding Ethics. Oxford: Berg.

MESKELL, L. (2007) - Falling walls and mending fences. Archaeological ethnograph in the Limpopo'. Journal of Social Archaeology 33 :2, pp, 383-40o.

OKAMURA, K. (2010) - A consideration of heritage values in contemporary society'. In SMITH, G. S.; MESSENGER, P. M.; SODERLAND, H. A., eds - Heritage Values in Contemporary Society. New York: Routledge.

PARKER, S. (2002) - Neighbourhood Renewal and Social Inclusion: The Role of Museums, Libraries and Archives. London: Museums, Libraries and Archives Council.

PEARSON, M.; SULLIVAN, S. (1995) - Looking after Heritage Places: the Basics of Heritage Planning for Managers, Landowners and Administrators. Carlton, Victoria: Melbourne University Press.
PERSON, P. E. (200o) - Community Impact of Science Centers: Is There Any? Curator'. The Museum Journal 43:1, pp. 9-17.

POULIOS, I. (2010) - Moving Beyond a 'Values-Based Approach' to Heritage Conservation'. Conservation and Management of Archaeological Sites 12:2, pp. 170-185.

PYBURN, K.A. (2009) - Practising Archaeology-As if it Really Matters. Public Archaeology: Archaeological Ethnographies 8, pp. 161-175.

PYBURN, K.A (2008) - Archaeology as Activism. The Pageantry of Archaeology. In MATTEWS, C.; CASTANESA, Q. eds. - The Public Meanings of the Archaeological. Walnut Creek: Altamira Press.

RIEGL, Alois (2013) - O Culto Modeno dos Monumentos de Alois Riegl. Lisboa: Edições 70.

RUSSELL, R.; WINKWORT, K. (2001) - Significance: A Guide to Assessing the Significance of Cultural Heritage $\mathrm{Ob}$ jects and Collections. Canberra. Heritage Collections Council.

SANDELL. R. (1988) - Museums as Agents of Social Inclusion'. Museum Management and Curatorship 17:4, pp. 63-74.

SHEPPARD, B. (200o) - Do Museums Make a difference? Evaluating Programs for Social Change'. Curator 43:1, pp. 63-74.

Slayter, R.O. (1983) - The Origin and Evolution of the World Heritage Convention. Ambio 12 3:4, pp. 138-140.

SMITH, Laurajane (2004) - Archaeological theory and the politics of cultural heritage. London. New York: Routledge.

SORENSEN, S.M.L.; CARMAN, J. (2009) - Heritage Studies: Methods and Approaches. London; New York: Routledge.

TAINTER, Joseph A.; LUCAS, G. John (1983) - Epistemology and the significance concept. American Antiquity 48:4, pp. 707-719.

TAYLOR, K. (2004) - Cultural Heritage Management: A Possible Role for Charters and Principles in Asia. International Journal of Heritage Studies 10:5, pp. 417-433.

TEUTONICO, J.; PALUMBO, G. (2002) - Management planning for archaeological sites: an international workshop organized by the Getty Conservation. Los Angeles: The Getty Conservation Institute.

TRUSCOTT, M.; YOUNG, D. (2000) - Revising the Burra Charter. Conservation and Management of Archaeological Sites 4:2, pp. 101-116.

UNESCO WHC. (2007) - Thirty-first session Christchurch, New Zealand. Disponível online em: https://whc. unesco.org/archive/2007/whco7-31com-24e.pdf [Accesso 15 de Julho 2020].

UNESCO (2017) - Orientações Técnicas para a Aplicação da Convenção do Património Mundial. Disponível on line 
em: http://whc.unesco.org/en/guidelines/ [Acedido em 15 Julho 2020].

VAN DER LINDE, S.J. (2012) - Digging holes abroad. An ethnography of Dutch Archaeological Research Projects Abroad. Leiden: Leiden University Press.

WATERTON, E.; SMITH, L.; CAMPBELL, G. (2006) - The utility of discourse analysis to heritage studies: The Burra Charter and social inclusion. International Journal of Heritage Studies 12:4, pp. 339-355. 


\title{
CONJUGANDO RECURSOS ARQUEOLÓGICOS E NATURAIS PARA POTENCIAR AS VISITAS AO GEOPARQUE LITORAL DE VIANA DO CASTELO (NOROESTE DE PORTUGAL)
}

\author{
Hugo A. Sampaio ${ }^{1,2}$, Ana M.S. Bettencourt ${ }^{1}$, Susana Marinho ${ }^{3}$, Ricardo Carvalhido 4
}

\begin{abstract}
RESUMO
O Geoparque Litoral de Viana do Castelo ocupa $320 \mathrm{~km}^{2}$ do NW português. Inclui áreas costeiras e montanhosas e contextos socioculturais e territoriais distintos e um conjunto único e diverso de sítios arqueológicos. O presente trabalho pretende mostrar como alguns desses sítios detêm potencial lúdico e educativo, por si só ou quando articulados com os restantes recursos geológicos.

Sublinham-se e propõem-se certas ações para a valorização do património arqueológico localizado no interior e limites do Geoparque, evidenciando o que já foi feito para conhecer e proteger este importante (mas frágil) conjunto de vestígios do passado.

Palavras-chave: Património cultural, Património natural, Valorização de sítios arqueológicos, Turismo
\end{abstract} arqueológico em rede.

\begin{abstract}
The Coastal Geopark of Viana do Castelo occupies $320 \mathrm{~km} 2$ of the Portuguese NW. It includes coastal and mountainous areas and distinct sociocultural and territorial contexts, and a unique and diverse set of archaeological sites. The present work intends to show how some of these sites have leisure and educational potential on their own, or when articulated with other geological resources. Some actions are highlighted and proposed for the valorisation of the archaeological heritage located inside the limits of the Geopark, evidencing what has already been done to know and protect this important (but fragile) set of past traces. Keywords: Cultural heritage, Natural heritage, Valorisation of archaeological sites, Archaeological networking tourism.
\end{abstract}

\section{INTRODUÇÃO}

O património é o legado do passado que corresponde a tudo o que é criado pela Natureza ou que resulta da agência humana e que se multiplica em diversas manifestações, como o património natural e cultural (Barranha, 2016, pp. 27-30). Numa perspetiva racional, este último resulta de um processo cultural (Waterton \& Smith, 2009, pp. 1012) que espelha o uso presente do passado e a forma como as sociedades o valorizam, seja ele tangível ou intangível (Timothy \& Tahan, 2020, p. 5). A sua heterogeneidade inclui o património arqueológico, caraterizado como parcial, frágil e não renová-

\footnotetext{
1. Laboratório de Paisagens Património e Território (Lab2PT) | Departamento de História do Instituto de Ciências Sociais da Universidade do Minho; hugoaluai@gmail.com; bettencourt.ana@gmail.com.

2. Centro de Investigação em Turismo, Inovação e Desenvolvimento (CITur) | Escola Superior de Hotelaria e Turismo do Instituto Politécnico do Cávado e do Ave.

3. Escola Superior de Hotelaria e Turismo do Instituto Politécnico do Cávado e do Ave; susmarinho@gmail.com.

4. Câmara Municipal de Viana do Castelo | Diretor do Geoparque Litoral de Viana do Castelo; carvalhido@cm-viana-castelo.pt
} 
vel (ICOMOS, 1990, p. 20), caracterizado pela sua fragmentação e pouca visibilidade (Solsona Monzonis \& Rico Cánovas, 2014, p. 38). Esta condição levanta sérios desafios à sua valorização, cabendo à Arqueologia a construção de significados e de discursos interpretativos perceptíveis pelo público em geral (Hodder \& Hutson, 2003, p. 221). Além da sua natureza complexa, deve referir-se a falta de investimento (humano e financeiro) e de interesse político na sua recuperação. Como tal, a sua especificidade faz com que, muitas vezes, seja desconsiderado enquanto recurso turístico (Yamamoto \& Nieto Hernández, 2013, p. 78). Algumas estratégias, contudo, têm tentado contrariar esta situação, como os Projetos ArcheoMed 5 , ARCHEOMEDSITES $^{6}$ ou NÒSTOI 7 , por exemplo, ou as linhas de orientação propostas pela própria UNESCO (2001), quando defende que "heritage in all its forms must be preserved, enhanced and handed on to future generations as a record of human experience and aspirations". O próprio World Heritage Committee e o Programa World Heritage and Sustainable Tourism $^{8}$ visam promover a maximização do usufruto turístico do Património Mundial, nunca descurando da sua salvaguarda (WHC, 2020). É em relação a este aspecto que começa o verdadeiro desafio: como podem os arqueólogos, técnicos de património e stakeholders utilizar este registo parcial e altamente secionado do passado como atrativo turístico? Como pode a sua interpretação tornar-se perceptível e ser transmitida como mensagem, ao público em geral?

Em muitos casos, os turistas sentem-se impelidos a visitar vestígios arqueológicos pelo interesse no passado, pela originalidade, pela observação na primeira pessoa e pela curiosidade e busca de uma experiência diferente (Walker, 2005, p. 6o-61).

Se é certo que o perfil do turista arqueológico possa corresponder ao visitante de média idade ou mais velho, bem educado, com formação académica, que permanece mais tempo nos destinos que visita e que gasta mais dinheiro (Timothy, 2011, pp. 27-30), não é menos verdade que há franjas de turistas mais

\footnotetext{
5. http://www.archeomedproject.eu/archeomed-project.

6. https://www.archeomedsites.beniculturali.it/project/ presentation/.

7. https://www.nostoi.xyz.

8. https://whc.unesco.org/en/tourism/.
}

novos igualmente interessados, ainda que com menos poder de compra, pelo que explorar novas formas de valorizar o património cultural é uma ação fulcral para conseguir uma atividade turística mais sustentável e que vai de encontro aos princípios definidos pela World Tourism Organization ${ }^{9}$ (UNWTO, 2020). Assim, e de acordo com os diferentes tipos de património, devem implementar-se diferentes estratégias. Estas deverão considerar os recursos disponíveis de uma determinada região, cidade ou país sem, contudo, menosprezar princípios básicos de sustentabilidade ambiental, social e económica (UNESCO, 2006).

Por seu turno, o Turismo Cultural, onde se insere o arqueológico, enquanto atividade económica tem, também, a capacidade de ligar as populações locais ao seu património (Thomas, 2017, p. 14) e de fomentar a identidade cultural (Mateus, 2003, p. 21), em especial nos contextos em que estão envolvidas minorias ou comunidades de menor expressão. Tal advém da capacidade que o património cultural tem de servir de ponte com a ancestralidade, com $\mathrm{o}(\mathrm{s})$ sentido(s) de lugar e as origens identitárias (Davidson \& Brandon, 2012, pp. 606-607). Sendo verdade que nem todo o património arqueológico é passível de ser valorizado turisticamente, a UNESCO (2006) destaca a viabilidade do uso do património para fins turísticos embora tendo em conta o necessário e equilibrado "casamento" entre sustentabilidade, cultura e turismo. Mas tornar o património arqueológico visitável é, também, abrir portas a fenómenos menos positivos, tais como: o vandalismo dos sítios; a produção de lixo ou o desgaste resultante do excesso de visitantes (Timothy, 2011, pp. 158-163). Vários países que apostaram intensamente no turismo arqueológico, como o Peru (Machu Picchu), a Jordânia (Petra), o Reino Unido (Stonehenge) ou o Egito (pirâmides de Gizé), por exemplo, vêm-se constantemente desafiados pela tarefa de combater os excessos "consumistas" dos produtos arqueológicos (Timothy \& Tahan, 2020, p. 16). Com o objetivo de controlar estas desvantagens, Enseñat-Soberanis et alii (2019, pp. 347-351) destacam três estratégias possíveis nos casos sensíveis: (a) estratégias restritivas, através do controlo do número de visitantes, proibindo acessos a determinados espaços ou lugares, a fotografias ou à manipulação de património; (b) estratégias redistri-

9. https://www.unwto.org/sustainable-development. 
butivas, baseadas na criação de números restritos de visitantes para determinadas áreas e com horas de visita marcada, o que pode acontecer de forma recorrente ou ser aplicado em horas de ponta; (c) estratégias interpretativas, com especial ênfase na demonstração e no ensino do valor que o património tem, persuadindo os visitantes a alterar os seus comportamentos negativos para com o mesmo. Se proibir não se mostra justo e reencaminhar para outras atrações nem sempre é exequível, crê-se que a estratégia pela via da educação poderá ser, definitivamente, uma opção, em especial apostando na formação da população mais nova, dos gestores, dos decisores, dos profissionais de Turismo e dos visitantes do futuro.

Na maioria do Noroeste de Portugal, o conjunto de sítios arqueológicos, sendo de grande interesse científico, tem especificidades que implicam que a sua valorização patrimonial e turística se faça em articulação com outros recursos e com estratégias interpretativas. Estas especificidades relacionam-se com o seu estado de conservação, a falta de conhecimento da sua importância por parte da população local e dos decisores políticos e, também, as suas características intrínsecas, por vezes pouco espetaculares para poderem servir de produto âncora por si só. Tal é o caso do património arqueológico que se encontra no Geoparque Litoral de Viana do Castelo (GLVC). Deste modo, o objectivo deste trabalho é procurar estratégias para interligar o património arqueológico com outros recursos naturais e culturais existentes neste território.

\section{O GEOPARQUE LITORAL DE VIANA DO CASTELO}

Um Geoparque é uma área com um território bem definido que integra em si um património geológico de relevância, a diferentes escalas. No conjunto, reúne um conjunto significativo de geossítios cuja importância para a compreensão e conhecimento da história geológica pode ser local, regional, nacional ou internacional. À luz dos pressupostos Gobal Geopark Network"10 "Geoparks are single, unified geographical areas where sites and landscapes of international geological significance are managed with a holistic concept of protection, education and sustainable development (...) [which] uses its geo-

10. http://www.globalgeopark.org/aboutGGN/6398.htm. logical heritage, in connection with all other aspects of the area's natural and cultural heritage, to enhance awareness and understanding of key issues (...) [giving] local people a sense of pride in their region and strengthen their identification with the area" (GGN, 2020). Como tal, estão associados a uma estratégia de desenvolvimento sustentável que inclui a integração de aspetos culturais e naturais de diferentes âmbitos, como o património cultural (incluindo o arqueológico, histórico, gastronómico, artesanal ou imaterial) e os recursos ecológicos.

O Geoparque Litoral de Viana do Castelo (GLVC), aspirante à Global Geopark Network, alberga fisicamente todo o concelho de Viana do Castelo (Noroeste de Portugal). Totalizando uma área de $320 \mathrm{~km}^{2}$, as suas características geomorfológicas permitem aceder a diferentes geossítios. Assim, do contacto entre o oceano Atlântico, o estuário do rio Lima e a Serra de Arga, decorre uma riqueza ecológica e cultural de inegável valor turístico (Carvalhido, Ribeiro \& Cunha, 2017, p. 27) (Figura 1).

No total, o GLVC integra um conjunto de monumentos naturais classificados e de valências naturais e culturais de valor histórico-cultural. Estes mostram-se propícios à prática de caminhadas, ciclismo e hipismo, interligando diversos sítios de interesse científico e cultural entre si (Carvalhido, 2016, p. 2). Entre estas valências figura um grupo diversificado de vestígios arqueológicos pertencentes a diferentes períodos cronológico-culturais, desde a Pré-história à contemporaneidade que, associados ao conhecimento histórico, são determinantes para a compreensão do passado e da história local e para desenhar o quadro socioeconómico da região, ao longo do tempo.

\subsection{Recursos naturais e recursos arqueológicos}

No total, O GLVC integra 13 geossítios classificados de importância local, regional, nacional e internacional (Carvalhido, Ribeiro \& Cunha, 2017, p. 27). Entre estes, especial destaque para aqueles cuja articulação com vestígios arqueológicos é passível de ajudar na sua valorização.

O geossítio de Canto Marinho, na freguesia de Carreço, inclui cerca de 713 pias salineiras escavadas em rochas de micaxisto do período Ordovícico (Costa et alii, 2012, p.104) dispersas por 24 hectares (Figura 2). Situação idêntica em termos arqueológicos, ocorre no geossítio da Ribeira de Anha, em Darque (Carvalhido, 2016, p. 31, Bettencourt et alii, 2020, 
no prelo). O Alcantilado de Montedor, a norte de Canto Marinho e também em Carreço, importa pela geomorfologia, tectónica e alterações da plataforma costeira (Carvalhido, Ribeiro \& Cunha, 2017, p. 27) e integra as gravuras rupestres de Fornelos, cujo valor e particularidade de narrativa interpretativa-se mostra de inegável valor (Bettencourt et alii, 2017). O geossítio das Ínsuas do Lima valoriza o "importante couto salineiro de Portuzelo-Meadela" (Carvalhido, 2016, p. 27) e o das Cristas Quartzíticas do Campo Mineiro de Folgadoiro-Verdes tem uma ampla relação com a mineração (Alves, 2014, p. 1415; Carvalhido, Pereira, Cunha, 2017, p. 28).

Em termos de infraestruturas de apoio, o GLVC conta com um passadiço em madeira ao longo da costa atlântica que permite a visita de diferentes geossítios. A sua existência é crucial, pois favorece a visitação daqueles sítios e permite sensibilizar, envolver e aproximar as populações locais, e o público em geral, do património existente e promover o conhecimento geológico e cultural. Vinca-se, assim, a estreita relação entre o GLVC e estratégias sustentáveis onde a congregação dos seus recursos ecológicos e histórico-culturais se torna uma excelente ferramenta para o desenvolvimento da economia regional, enfatizando a prática do Geoturismo, do Turismo Natureza, do Turismo Cultural ou Histórico, não esquecendo a promoção da Gastronomia, dos Vinhos, do Artesanato e de muitas outras tradições e costumes locais.

A área do GLVC compreende um total de 156 sítios arqueológicos cartografados ${ }^{11}$, dos quais 43 se inserem na Pré-história, 39 na Idade do Ferro, 31 na época romana e 46 na Idade Média (CMVC, 2020). Apesar do trabalho já realizado, o número de sítios arqueológicos conhecidos, desde 2014, é manifestamente maior e mais diversificado em termos cronológicos, podendo ser contabilizado na ordem dos milhares (Bettencourt \& Abad-Vidal, 2014; Santos, 2013, 2014; Bettencourt \& Santos-Estévez, 2018; Bettencourt, 2019; Costa et alii, 2019; Oliveira, 2019; Oliveira \& Bettencourt, 2020; Bettencourt et alii, 2020, no prelo), o que potencia a sua importância científica e estratégica em termos turísticos. Tendo presente a estreita relação com a Geologia, este texto centra-se em três recursos arqueológicos passíveis de conjugação,

11. http://www.cm-viana-castelo.pt/pt/roteiro-arqueologico. nomeadamente: os associados à produção de sal; os associados à extração mineira de estanho, ouro e volfrâmio; e os relacionados com a arte rupestre, aos quais se dará maior destaque.

\subsubsection{Os recursos associados à produção de sal}

Além das já mencionadas pias salineiras de Canto Marinho (Costa et alii, 2012, 2019, p. 104) (Figura 2), destacam-se os inúmeros núcleos deste tipo de ocorrências desde, pelo menos, a foz da Ribeira de Anha, em Darque, até Afife, com especial destaque para os núcleos existentes entre Fornelos e o Forte de Paçô e os das mais diversas praias da freguesia de Afife (Bettencourt et alii, 202O; Bettencourt et alii, no prelo). Se bem que tradicionalmente classificadas como da Idade do Ferro (Almeida, 2005, p. 148; Costa et alii, 2012, p. 96, 2019), novos dados possibilitaram recuar esta atividade, no litoral de Viana do Castelo, para a Idade do Bronze, cerca de 1000 anos antes do que se pensava (Bettencourt et alii, 2020; Bettencourt et alii, no prelo; Oliveira \& Bettencourt, 2020).

Se as pias salineiras cortadas na rocha puderam ser reutilizadas na Idade do ferro e durante a época romana e medieval, a metodologia de extração de sal complexificou-se. Vestígios desta atividade, datáveis destes períodos, existem também no litoral do Geoparque, entre as freguesias de Areosa e Afife ${ }^{12}$, embora ainda não devidamente estudados. A produção de sal permaneceu no estuário do Lima até aos séculos XVIII e XIX (Fernandes, 1994) existindo, ainda, vestígios dessa atividade nas freguesias da Meadela, Santa Marta de Portuzelo e Darque, perfeitamente enquadráveis no âmbito do geossítio das Ínsuas do Lima (Carvalhido, 2016, p. 27).

Contribuindo para a sua preservação e em associação a esta atividade deveria ser valorizado o importante antigo complexo de seca do Bacalhau, no Cais Novo, junto à atual rua da Seca, na freguesia de Darque (Figura 3). O seu estado de ruina, se valorizado e musealizado, poderia articular-se com o antigo Navio-Hospital que acompanhava a frota da pesca do bacalhau à Terra Nova (Fundação Gil Eannes, 2007) - o atual Navio-Museu Gil Eanes, atracado junto à Doca Comercial de Viana do Castelo, produto turístico já existente no seio do Geoparque. A importância desta atividade ancestral na

12. Conforme comunicação pessoal do Engenheiro Horácio Faria, da Câmara Municipal de Viana do Castelo. 
região poderia ainda relacionar-se, em formato de Centro Interpretativo, com as oscilações da linha da costa e a atual transgressão marinha.

\subsubsection{Os recursos associados à extração mineira de estanho, ouro e volfrâmio}

Segundo a Carta Geológica de Portugal, folha 5-A, à escala 1:50 ooo (Teixeira, Medeiros \& Coelho, 1972, p. 34-35), a área do Geoparque é rica em cassiterite, ouro e volfrâmio. A cassiterite era abundante, em especial nas freguesias de Cardielos, Nogueira e Vilar de Murtede, bem como nas aluviões do estuário do Lima (Alves, 1996). Estas caraterísticas tornaram esta área predileta para as primeiras populações mineiras, em especial os metalurgistas da Pré-história, cuja necessidade de estanho levou à procura e coleta daquele recurso ainda durante $\mathrm{o} 2^{\circ}$ milénio a.C., isto é, na Idade do Bronze Médio, comprovadas pelas descobertas do machado de bronze de Bandeira, na freguesia de Santa maria Maior (Fernandes et alli, 2011) e do Folgadoiro, na freguesia de Santa Maria Maior (Fernandes et alli, 2011) e no Folgadoiro, na freguesia de Vilar de Murteda, este último em contexto de limpeza de escombreiras de mineração (Zbyszewski \& Ferreira, 1955, p. 50, fig. 2). Do Bronze Final há a registar os depósitos de Cobidalto, na freguesia da Areosa (Bettencourt et alli, 2014) e o de Pereiras Pequenas, na freguesia de Vila de Punhe (Manteiga Brea, Bettencourt, Comendador Rey, 2014), um dos maiores do Noroeste de Portugal. A mineração durante o Bronze Final e a Idade do Ferro atesta-se, por exemplo, nos Castros de Santo António, em Afife (Oliveira \& Bettencourt, 2020) e no Castro de Terronha, em Cardielos (Oliveira, 2019), respetivamente, e a romana na freguesia de Vila Mou (Moreira, 1981, pp. 405-407; Brochado, 2004, p. 38) e no Alto da Bouça da Breia, Folgadoura (Alves, 2014, p. 607). A última grande etapa da mineração foi a do estanho e do volfrâmio, em especial no período entre as duas Grandes Guerras (Nunes, 2010, pp. 10o, 112, 375, 397-398). A serra d'Arga, onde a concentração das explorações é maior, totaliza 21 concessões mineiras de estanho ocorridas em especial a partir das décadas de 30 e 40 do século XX (Lima, 2006, p. 257). No século XX é de destacar o complexo mineiro do Folgadoiro, com inúmeras cortas e minas em poço/galeria, bem como as importantes cortas de extração de volfrâmio, ainda visíveis a céu aberto, nas áreas de Montaria, Vilar de Murteda, Amonde ou Lanheses (Lima, 2006, pp. $84-85,103,203,206,243,245,250,253,255$, $257,259,280,288,466,558,604)$.

A valorização destes recursos com a criação de itinerários mineiros seria uma forma de associar, com sucesso e grande interesse científico e didático, um bom número de recursos geológicos e arqueológicos, desde a Pré-história à Arqueologia Industrial.

\subsubsection{A arte rupestre}

A arte rupestre, pela superfície em que é gravada, está intrinsecamente relacionada com a forma e as características litológicas do afloramento (Bettencourt et alii, 2017, p. 168). O estudo, ainda que preliminar, da arte rupestre das serras de Santa Luzia (Cardoso, 1897; Viana, 1960; Lanhas, 1969; Baptista \& Magalhães, 1985; Baptista, 1986; Alves, 1989; Santos, 2013, 2014; Bettencourt et alii, 2017; Santos-Estévez \& Bettencourt, 2017; Santos-Estévez et alii, 2017; Moreira, 2018; Bettencourt, 2019) e de Perre (Paço, 1942; Loureiro, 2006; Silva, 2008; 2014a, 2014b; Bettencourt, 2013, Bettencourt \& Santos-Estévez, 2018), assim como do Monte do Santinho/Monte de Roques (Magalhães, 2016, pp. 41-43) tem revelado o grande número, diversidade e importância deste recurso arqueológico no território do GLVC. No Corpus Virtual de Arte Rupestre do Noroeste-CVARN (www.cvarn. org), portal de difusão da arte rupestre do Noroeste disponibilizado em linha da responsabilidade de Bettencourt e Abad-Vidal (2014) e realizado no âmbito de um projeto de investigação, desenvolvido entre 2010 e 2014 (Bettencourt, Abad-Vidal \& Rodrigues, 2017), foi possível criar 45 entradas de arte rupestre pertencentes ao concelho de Viana do Castelo, distribuídos por 10 freguesias (Afife, Amonde, Areosa, Cardielos, Carreço, Freixieiro de Soutelo, Nogueira, Outeiro, Perre e Santa Maria Maior $)^{13}$. A estas há que juntar as gravuras rupestres inventariadas após esse período, que correspondem a mais 21, algumas delas inéditas (total de 9) e que se distribuem, igualmente, na margem esquerda do rio $\mathrm{Lima}^{14}$.

13. Algumas entradas correspondem a sítios já destruídos e, em dois casos, a observação noturna posterior, com luz artificial, demonstrou não se tratarem se gravados rupestres (Fornelos 2 e Pedra do Sol).

14. Disponíveis na base de dados que alimenta o CVARN mas ainda não disponibilizadas online. 
Se é verdade que o valor turístico de alguns destes sítios gravados é mínimo, há, contudo, alguns de extrema espetacularidade que interessa destacar e dar a conhecer de forma mais abrangente. Referimo-nos, por exemplo, a Lajedo 1, em Amonde (Bettencourt, Sá, Amorim, 2014) (Figura 4); Cais, em Freixieiro do Soutelo (Bettencourt, 2014a); conjunto da Ereira (inédito) e da Matança (Bettencourt, Silva, Simões, 2014), em Afife; Calvo 1, Fornelos (Bettencourt \& Simões, 2014a); Fraga/Laje do Bica (Baptista \& Magalhães, 1995; Bettencourt, 2009, p. 137-138, 155, 162), Moinhos do Marinheiro (inédita) e o conjunto da Sinadora, em Carreço (Bettencourt \& Amorim, 2014a, 2014b, 2014C, 2014d, 2014e, 2014f, 2014g) (Figura 5); Escampadinhos (Bettencourt et alii, 2014) (Figura 6) e Cabeço da Boucinha 1 (Bettencourt, 2014b), na Areosa; conjunto da Breia (com destaque para as Breias 1, 4, 5, 6 e 12), em Cardielos (Bettencourt, 2013; Bettencourt \& Santos-Estévez, 2018) (Figura 7) e Penedo da Moura 1 e 2, em Nogueira (Paço, 1942; Loureiro, 2006) (Figura 8).

Estes 11 sítios que correspondem, grosso modo, a 26 afloramentos gravados, foram selecionados por diversos motivos, a saber: número de motivos e sua visibilidade; diversidade de motivos; diversidade cronológica; diversidade de discursos interpretativos; aspectos litológicos e características da geoforma onde se gravaram; contexto físico; acessibilidades; bom estado de conservação e diversidade geográfica, possibilitando o acesso a vários discursos associados a estas materialidades e a várias áreas do Geoparque. Se Fornelos, Fraga do Bica, Moinhos do Marinheiro e o conjunto da Sinadora possibilitam a sua articulação com paisagens e geossítios litorais, Ereira, Matança, Calvo 1 e Escampadinhos inserem o visitante em pontos altos da serra de Santa Luzia, com particularidades geológicas distintas e com possibilidade da sua articulação com o Planalto Granítico das Chãs de Santa Luzia.

As gravuras de Lajedo 1 apresentam a especificidade de terem sido efetuadas num afloramentos de filito distribuído em bancadas (Bettencourt, Sá \& Amorim, 2014). Já as gravuras de Nogueira e Breia, localizadas na vertente nascente da serra de Perre e sobranceiras ao geossítio das Cristas Quartzíticas do Campo Mineiro de Folgadoiro-Verdes, disfrutam de contextos paisagísticos de grande interesse, por vezes com observação privilegiada para a serra de Arga ou para o vale do Lima (Figuras 4 e 8).
De salientar que a seleção destes sítios, gravados desde o Neolítico à Idade Média ou Moderna, isto é, desde os finais do 5\%/inícios do $4^{\circ}$ milénios AC até ao século XVI, teve em conta o facto de proporcionarem o conhecimento de diferentes formas de interação das comunidades do passado com o espaço em que se inseriram, materializando, igualmente, universos ideológicos distintos e proporcionando ao visitante experiências (na primeira pessoa) únicas da sacralidade do território ao longo do tempo (Figura 9).

Deve destacar-se que alguns destes sítios gravados já tinham sido considerados significativos para integrarem uma rota de arte rupestre da bacia do Lima, como é o caso de Penedo da Moura 1 e 2 (Nogueira), de Breia 1 e 2 (Cardielos), do Cabeço da Boucinha 1 e dos Escampadinhos (Areosa) (Sá, 2015, pp. 142-148).

Estes sítios apresentam algumas particularidades que condicionam a sua visibilidade a determinadas horas do dia, motivo pelo qual a sua valorização deve ser pensada de forma cuidada para não defraudar o visitante. Tal implica o desenvolvimento de diversas tarefas. Desde logo, e dada a natureza particular que facilmente afeta a observação destas gravuras, será imperativo produzir conteúdos de apoio gráfico e visual que permitam aos visitantes vislumbrar as gravuras. Não é de descartar, neste cenário, o recurso a materiais tridimensionais via fotogrametria, quer disponibilizados através de aplicações de telemóvel quer de modo a que possam chegar, numa perspetiva inclusiva, a pessoas com deficiências visuais ou motoras. Não menos importante, será a consecução de um centro interpretativo.

Bom exemplo de práticas sustentáveis futuras aplicadas ao registo arqueológico, é a implementação de fotogrametria para criar modelos $3 \mathrm{D}$ virtuais. O detalhe atingido por estes modelos, ainda que carentes de alguns pormenores (como, por exemplo, o facto de não detetarem as técnicas de gravação aplicadas aquando da execução das gravuras), mostra-se uma ferramenta de grande importância e de uso diversificado. Neste cenário, estes materiais não só servem a divulgação deste património em diferentes contextos, como se podem mostrar um efetivo e importante apoio a visitas-guiadas. Na verdade, o caráter diferenciador da visita-guiada a este tipo de recurso assenta, precisamente, na hora a que o mesmo é visitado. Como tal, é pertinente vincar que as melhores horas do 
dia para o fazer correspondem ao nascer e ao por do sol, com especial enfâse para as visitas noturnas, cuja experiência se mostra única. Contudo, tal implica uma concepção integrada, preocupada e válida ao nível das boas práticas, a par da necessidade, por parte dos guias, do acesso a conhecimentos especializados que permitam engrandecer a experiência dos visitantes. Isto obriga ao acesso a descrições concertadas entre arqueólogos e geólogos, destacando as particularidades litológicas de interesse para um público mais exigente.

\section{CONSIDERAÇÕES FINAIS}

Tendo como ponto de partida a seleção de recursos arqueológicos passíveis de se articularem com recursos naturais para, dessa forma, incrementar a oferta de produtos turísticos no território do GLVC, este trabalho demonstra que estes existem e que constituem uma mais valia que urge dinamizar. Embora outras combinações possam ser possíveis, os recursos arqueológicos escolhidos para demonstrar a sua possibilidade de articulação com a geologia incidiram em três áreas: a produção de sal, a exploração mineira de estanho, ouro e volfrâmio e a arte rupestre.

Se para a produção de sal há já alguns itinerários que combinam recursos naturais e arqueológicos (conforme são exemplo os geossítios de Canto Marinho e da Ínsuas do Lima), para a exploração mineira poderá ser ponderada a articulação entre as cortas desativadas das minas do Folgadoiro e as gravuras rupestres da Breia, do Penedo da Moura 1 e 2 e do Lajedo 1. Quanto à arte rupestre há apenas um afloramento gravado valorizado no âmbito de um geossítio - o de Fornelos. Ainda assim, a sua placa informativa apresenta-se manifestamente incompleta em termos do diálogo passível de estabelecer entreosmotivosgravadoseageoforma (Bettencourt et alii, 2017), além de estar mal localizada. Também se deve destacar que no seio deste geossítio há o conjunto de gravuras rupestres da Sinadora, passível, igualmente, de destaque, quer pela sua diversidade geomorfológica em relação a Fornelos quer pela gramática estilística que apresenta e pelos diferentes universos ideológicos que materializa.

Para tentar inverter esta situação, há algumas ações que poderão produzir certos resultados, muitas das quais estão já a ser implementadas como parte de iniciativas planeadas. São exemplo a percep- ção, por parte da gestão do GLVC, da necessidade de criar discursos concertados; a criação de alguns modelos tridimensionais fotogramétricos a partir de fotografia digital, tanto para sítios naturais como arqueológicos, que possam, depois, ser canalizados para conteúdos interpretativos; o desenvolvimento de novo projetos de investigação relacionados com a arte rupestre da região, em diálogo com a arqueoastronomia, proporcionando novos discursos interpretativos; o estudo relativo às percepções que os habitantes locais e a generalidade da população vianense tem sobre o recurso arte rupestre, através da implementação de um questionário posteriormente tratado com recurso a Statistical Package for the Social Sciences (SPSS); a realização de visitas guiadas aos locais e aproximação aos stakeholders para promover o conhecimento e vincar a importância local deste património; a criação do Núcleo Museológico do Património Mineiro de Arga e Lima, uma porta do GLVC dedicada à mineração que vem valorizar a herança cultural local. Conscientes que a educação patrimonial é um longo caminho a trilhar, a população mais nova, os gestores, os decisores políticos, os profissionais de turismo e os visitantes do futuro devem estar informados. Mas o processo de consolidação educativo tem, obrigatoriamente, que acontecer a diferentes escalas. É indispensável que as comunidades locais saibam o que têm e lhe atribuam valor identitário. Só dessa forma é possível passar para outros níveis de projeção, sejam eles regionais, nacionais ou internacionais. Este é o primeiro passo para assegurar etapas futuras de valorização dentro de uma lógica de sustentabilidade social, económica e ambiental. Não deverão ser alheias, a esta realidade, políticas concertadas entre diferentes atores locais, cabendo o envolvimento entre associações, residentes e empresários do sector turístico sob a mediação inteligente do executivo municipal.

\section{APOIOS}

Trabalho realizado no âmbito da Dissertação de Mestrado em Turismo, Inovação e Desenvolvimento subordinada ao tema A arte rupestre como potenciadora de novas experiências culturais no âmbito do Geoparque Litoral de Viana do Castelo (Noroeste de Portugal), em curso na Escola Superior de Gestão e Tecnologia do Instituto Politécnico de Viana do Castelo, e do projeto Rota de Arte Rupestre do 
Noroeste Português: um projeto de Turismo Cultural, coordenado por Ana M.S. Bettencourt.

\section{BIBLIOGRAFIA}

ALMEIDA, Carlos A.B. (2005) - A exploração do sal na costa portuguesa a Norte do Rio Ave: da Antiguidade Clássica à Baixa Idade Média. In AMORIM, Inês, ed. - Seminário Internacional sobre o Sal Português. Porto: Instituto de História Moderna, pp. 139-170.

ALVES, António M.C. (1996) - Causas e processos da dinâmica sedimentary na evolução actual do litoral do Alto Minho. Braga: Universidade do Minho (Doutoramento).

ALVES, Lourenço (1989) - A Comenda de Santa Maria de Carreço (monografia). carreço: Junta de Freguesia de Carreço.

ALVES, Raquel C. (2014) - Contribuição para um sistema de gestão integrada de sítios mineiros do NW de Portugal. Braga: Universidade do Minho (Tese de Doutoramento).

BAPTISTA, Ivone (1986) - Arte Rupestre de Carreço. Boletim Cultural Alto Minho. Viana do Castelo. 3, pp. 116 -128.

BAPTISTA, Ivone; Magalhães, Carmo (1985) - Arte rupestre de Carreço, Centro de Estudos Regionais. Boletim Cultural Alto Minho. Viana do Castelo. 2, pp. 92-102.

BARRANHA, Helena (2016) - Património cultural: conceitos e critérios fundamentais. Lisboa: IST Press/ICOMOS Portugal.

BETTENCOURT, Ana M.S. (20og) - Entre os montes e as águas: ensaio sobre a percepção dos limites na pré-história da faixa costeira entre o Minho e o Lima (NW português). In BETTENCOURT, Ana M.S.; ALVES, Lara B., eds. - Dos montes, das pedras e das águas: formas de interacção com o espaço natural da pré-história à actualidade. Braga: CITCEM, pp. 131-162.

BETTENCOURT, Ana M.S. (2013) - Gravuras rupestres da Breia, Cardielos, Viana do Castelo. In BETTENCOURT Ana M.S., ed. - A Pré-História do Noroeste Português. Braga/Tomar: CEIPHAR/CITCEM, pp. 207-215.

BETTENCOURT, Ana M.S. (2014a) - Cais. In Bettencourt, Ana M.S.; Abad-Vidal, Emilio, eds. - CVARN-Corpus Virtual de Arte Rupestre do Noroeste Português (www.cvarn.org).

BETTENCOURT, Ana M.S. (2014b) - Cabeço da Boucinha 1. In Ana M.S. Bettencourt, Emilio Abad-Vidal, eds. -CVARN-Corpus Virtual de Arte Rupestre do Noroeste Português (www.cvarn.org).

BETTENCOURT, Ana M.S. (2019) - Equídeos nos Montes do Noroeste português. Narrativas míticas gravadas nas rochas. In PEREIRA, Andreia, ed. - O garrano: contributos da investigação histórico-arqueológica, antropológica e equestre para a sua valorização. Viana do Castelo: Município de Viana do Castelo, pp. 135-148.
BETTENCOURT, Ana M.S.; AMORIM, Maria João (2014) - Sinadora I In BETTENCOURT, Ana M.S.; ABAD-VIDAL, Emílio, eds. - CVARN-Corpus Virtual de Arte Rupestre do Noroeste Português (www.cvarn.org).

BETTENCOURT, Ana M.S.; AMORIM, Maria João (2014c) - Sinadora 2. In BETTENCOURT, Ana M.S.; ABAD-VIDAL, Emilio, eds. - CVARN-Corpus Virtual de Arte Rupestre do Noroeste Português (www.cvarn.org).

BETTENCOURT, Ana M.S.; AMORIM, Maria João (2014d) - Sinadora 3. In BETTENCOURT, Ana M.S.; ABAD-VIDAL, Emilio, eds. - CVARN-Corpus Virtual de Arte Rupestre do Noroeste Português (www.cvarn.org).

BETTENCOURT, Ana M.S.; AMORIM, Maria João (2014e) - Sinadora 4 In BETTENCOURT, Ana M.S.; ABAD-VIDAL, Emílio, eds. - CVARN-Corpus Virtual de Arte Rupestre do Noroeste Português (www.cvarn.org).

BETTENCOURT, A.M.S.; AMORIM, Maria J. (2014f ) Sinadora 5. In BETTENCOURT, Ana M.S.; ABAD-VIDAL, Emílio, eds. - CVARN-Corpus Virtual de Arte Rupestre do Noroeste Português (www.cvarn.org).

BETTENCOURT, A.M.S., AMORIM, Maria J. (2014g) Sinadora 6. In BETTENCOURT, Ana M.S.; ABAD-VIDAL, Emílio, eds. - CVARN-Corpus Virtual de Arte Rupestre do Noroeste Português (www.cvarn.org).

BETTENCOURT, Ana M.S.; ABAD-VIDAL, Emílio (2014) - Corpus Virtual de Arte Rupestre do Noroeste Português CVARN (www.cvarn.org).

BETTENCOURT, A.M.S.; SIMÕES, Pedro P. (2014) - Calvo 1. In Bettencourt, Ana M.S.; Abad-Vidal, Emílio, eds. CVARN-Corpus Virtual de Arte Rupestre do Noroeste Português (www.cvarn.org).

BETTENCOURT, A.M.S.; SANTOS-ESTÉVEZ, Manuel (2018) - A geografia mágica do Monte de São Silvestre, em Viana do Castelo, através da arte rupestre. Braga: Lab2PT.

BETTENCOURT, Ana M.S.; SÁ, Edite; AMORIM, Diana (2014) - Lajedo 1. In Bettencourt, Ana M.S.; Abad-Vidal, Emílio, eds. - CVARN-Corpus Virtual de Arte Rupestre do Noroeste Português (www.cvarn.org).

BETTENCOURT, Ana M.S.; SILVA, Isabel S.; SIMÕES, Pedro P. (2014) - Matança/Suvidade. In Bettencourt, Ana M.S.; Abad-Vidal, Emílio, eds. - CVARN-Corpus Virtual de Arte Rupestre do Noroeste Português (www.cvarn.org).

BETTENCOURT, Ana M.S.; ABAD-VIDAL, Emilio; RODRIGUES, Alda (2017) - CVARN - Rock Art Virtual Corpus of North-Western Portugal. A multimedia tool to investigate and describe Post-Palaeolithic rock art. In BETTENCOURT, A.M.S., SANTOS-ESTÉVEZ, M.; SAMPAIO, Hugo A.; CARDOSO, Daniela, eds.-Recorded Places, Experienced Places. The Holocene rock art of the Iberian Atlantic north-west. British Archaeological Reports - International Series, 2878. Oxford: BAR Publishing, pp. 19-26. 
BETTENCOURT, A.M.S.; COMENDADOR REY, Beatriz; SIMÕES, Pedro P.; ALVES, Maria I.C. (2014) - O depósito de machados do Bronze Final de Cobidalto, Areosa (Viana do Castelo). Novos dados para a sua contextualização e interpretação. In BETTENCOURT, Ana M.S., COMENDADOR REY, Beatriz; SAMPAIO, Hugo; SÁ, Edite, eds. - Corpos e Metais na Fachada Atlântica da Ibéria. Do Neolítico à Idade do Bronze. Braga: APEQ, CITCEM, pp. 131-142.

BETTENCOURT, Ana M.S.; AMORIM, Maria João; MENDES, Sílvia; NOGUEIRA, Cristina; SIMÕES, Pedro P. (2014) - Escampadinhos. In Ana M.S. Bettencourt; Emilio Abad-Vidal, eds. - CVARN-Corpus Virtual de Arte Rupestre do Noroeste Português (www.cvarn.org).

BETTENCOURT, A.M.S.; LUZ, Sara; SIMÕES, Pedro P.; ALVES, Maria I.C.; ABAD-VIDAL, Emilio (no prelo) Bronze Age sea salt production in Northwest Iberian Peninsula. In MARCIGNY, Cyril; MORDANT Claude, eds. - Bronze 2019: 20 ans de recherches, Dijon: Suppléments au Bulletin de l'APRAB.

BETTENCOURT, Ana M.S.; LUZ, Sara; OLIVEIRA, Nuno; SIMÕES, Pedro P.; ALVES, Maria Isabel C.; ABAD-VIDAL, Emilio (2020) - Produção de sal marinho na Idade do Bronze do Noroeste português. Alguns dados para uma reflexão. In Actas do III Congresso da Associação de Arqueólogos Portuguese, Porto: Faculdade de Letras da Universidade do Porto.

BROCHADO, Cláudio (2004) - Povoamento Tardo-romano e Altimedieval na bacia terminal do rio Lima (séculos IV-XI). Porto: Faculdade de Letras da Universidade do Porto (Tese de Mestrado).

CARDOSO, Fonseca (1897) - Penedo com insculturas, nos arredores de Viana do Castelo. O Archeologo Português. Lisboa. 3, pp. 170-172.

CARVALHIDO, Ricardo (2014) - Processo de classificação dos 5 monumentos naturais locais de Viana do Castelo: Anexo II - Memória Descritiva. Viana do Castelo: Câmara Municipal de Viana do Castelo.

CARVAlHIDO, Ricardo; PEREIRA, D.; CUNHA, Pedro (2017) - Geossítios do Geoparque Litoral de Viana do Castelo. Atas do $8^{\circ}$ Congresso Nacional de Geomorfologia: Geomorfologia 2017. Porto: APGeom, pp. 27-29.

COSTA, Miguel; MACHADO, Jorge; LOPES, Hugo; ALMEIDA, Tiago (2012) - Pias salineiras da praia do Canto Marinho. Inventário Arqueológico. Cadernos Vianenses. Viana do Castelo. 46, pp. 95-111.

COSTA, Miguel; ALMEIDA, Tiago; MACHADO, Jorge (2019) - A exploração de sal na Proto-História. O exemplo de Viana do Castelo, comunicação apresentada nos Encontros monográficos co património Cultural in situ. A prudoción de sal en época romana no sur de Galicia e Norte de Portugal, A Guarda, March 29th, 2019. Disponível em https:// www.youtube.com/watch?v=leDyyodniAM [consultado em: $1 / 4 / 2020]$.
DAVIDSON, James M.; BRANDON, Jamie C. (2012) Descenent community partenering, the politics of time, and the logistics of reality: Tales from North American, African diáspora, archaeology. In SKEATES, Robin; MCDAVID, Carol \& CARMAN, John, eds. - The Oxford Handbook of Public Archaeology. Oxford: Oxford University Press, pp. 605-628.

ENSEÑAT-SOBERANIS, Fernando; FRAUSTO-MARTÍNEZ, Oscar; GÁNDARA-VÀSQUEZ, Manuel (2019) A visitor flow management process for touristified archaeological sites. Journal of Heritage Tourism. London. 14:4, pp. 340-357.

FERNANDES, Almeida (1994) - Meadela Histórica. Paróquia de Santa Cristina da Meadela. Viana do Castelo: Ed. autor.

FERNANDES, João O.; BETTENCOURT, Ana M.S.; COMENDADOR REY, Beatriz; ALVES, Maria I.C. (2011) - O depósito metálico da Bandeira, Viana do Castelo (Norte de Portugal) no contexto dos depósitos metálicos do Bronze Médio do curso inferior da bacia do rio Lima. Estudos do Quaternário. Porto.7, pp. 33-39.

FUNDAÇÃO GIL EANNES (2007) - História do Navio. Disponível em https://www.fundacaogileannes.pt/engine.php? cat $=10 \&$ sheet $=3$ [consultado em: $13 / 7 / 2020]$.

GLOBAL GEOPARK NETWORK (2020) - What is a UNESCO Global Geopark? Disponível em http://www. globalgeopark.org/aboutGGN/6398.htm [consultado em: 10/6/2020].

HODDER, Ian; HUTSON, Scott (2003) - Reading the past: current approaches to interpretation in Archaeology ( $3^{\underline{a}}$ ed.). Cambridge: Cambridge University Press.

ICOMOS 1990 - Charter for the Protection and Management of the Archaeological Heritage, International Committee on Archaeological Heritage Management Information, 3, pp. 20-24.

LANHAS, Fernando (1969) - As Gravuras Rupestres de Montedor. Revista de Etnografia. Porto. 13(2), pp. 367-386.

LIMA, Maria F.D. (2006) - Caracterização e estratégias de valorização sustentável de ocorrências geológicas com importância patrimonial. Braga: Universidade do Minho (Tese de Doutoramento).

LOUREIRO, Luís F. (2006) - O santuário rupestre do Penedo da Moura (Nogueira, Viana do Castelo. Almadan Online. Almada. 14: pp.11-16.

MAGALHÃES, Marisa C. (2016) - O Calcolítico e a Idade do Bronze na bacia do rio Neiva, NW de Portugal. Braga: Universidade do Minho (Tese de Mestrado).

MANTEIGA BREA, Alexandre; BETTENCOURT, Ana M.S.; COMENDADOR REY, Beatriz (2014) - El depósito de Pereiras Pequenas en Vila de Punhe, Viana do Castelo (Norte de Portugal). Una revisión del contexto deposicional. Gallaecia. Santiago de Compostela. 33, pp. 121-136. 
MATEUS, J. (2003) - Arqueologia ambiental sob a tutela da Cultura - uma experiência com 20 anos, um desafio para a nossa arqueologia. In MATEUS, José E.; MORENO-GARCíA, Marta; FARIA, António M., eds. - Paleoecologia humana e arqueociências um programa multidisciplinar para a arqueologia sob a tutela da cultura. Lisboa: Instituto Português de Arqueologia (IPA), Ministério da Cultura, pp. 21-32.

MOREIRA, José (2018) - Podomorfos na Fachada Ocidental do Noroeste de Portugal, entre os Rios Douro e Minho. Braga: Universidade do Minho (Tese de Mestrado).

MOREIRA, Manuel A.F. (1981) - As Arrugiae da Época Romana no Vale de Rio Tinto. Actas do I Colóquio Galaico Minhoto, Ponte de Lima (vol. II). Ponte de Lima. Instituto Cultural Galaico-Minhoto, pp. 395-423.

NUNES, J.P.A. (2010) - O Estado Novo e o Volfrâmio (19331947). Coimbra: Imprensa da Universidade de Coimbra.

OLIVEIRA, Nuno (2019) - The Iron Age settlement of Terronha (Viana do Castelo, Northwestern Portugal): ananlysis of ceramic and lithic materials in context. Heritage. Basel. 1:2, pp. 65-71.

OLIVEIRA, Nuno; BETTENCOURT, Ana M.S. (2020) - O povoado de Santo António (Afife, Viana do Castelo), na Idade do Bronze Final. Antrope. Tomar. 13 (no prelo).

PAÇO, Afonso do (1942) - Gravuras rupestres de Outeiro e Carreço (Viana do Castelo). O Instituto. Coimbra. 1oo, pp. 271-274.

SÁ, Sofia (2015) - Turismo Arqueológico: um Projeto de Valorização da Arte Rupestre do Vale do Lima. Braga: Universidade do Minho (Tese de Mestrado).

SANTOS, Ana C. (2013) - Gravuras rupestres da Laje da Churra. In BETTENCOURT, Ana M.S., ed. - A Pré-História do Noroeste Português (volume 2). Braga/Tomar: CEIPHAR/CITCEM, pp. 196-20o.

SANTOS, Ana C. (2014) - A Lage da Churra (Carreço, Viana

do Castelo). Estudo Monográfico de um Lugar Gravado. Braga: Universidade do Minho (Tese de Mestrado).

SANTOS-ESTÉVEZ, Manuel; BETTENCOURT, Ana M.S. (2017) - O conjunto de gravuras rupestres de Santo Adrião (Caminha, Portugal). Embarcações, armas, cavalos e ex-votos. In ARNAUD, José M.; MARTINS, Andrea, eds. Arqueologia em Portugal 2017-Estado da Questão. Lisboa: Associação de Arqueólogos Portugueses, pp. 1055-1070.

SANTOS-ESTÉVEZ, Manuel; BETTENCOURT, Ana M.S.; SAMPAIO, Hugo A.; CARDOSO, Daniela; BROCHADO, Cláudio; FERREIRA, Gonçalo (2017) - Shape and meaning. Engraved weapons as materialisations of the Calcolithic/ Early Bronze Age cosmogony. In BETTENCOURT, Ana M.S.; SANTOS-ESTÉVEZ, Manuel; SAMPAIO, Hugo A.; CARDOSO, Daniela, eds. - Recorded Places, Experienced Places. The Holocene Rock Art of the Iberia Atlantic Northwest, Oxford: BAR Publishing, pp. 151-165.
SILVA, António (2008)-Vivre au-delà du fleuve de l'oubli; portrait de la communauté villageoise du Castro do Vieito au moment de l'intégration du NO de la péninsule ibérique dans l'orbis Romanum: estuaire du Rio Lima, NO du Portugal, Coimbra: Universidade de Coimbra (Tese de Doutoramento).

SILVA, António (2014a) - Piotinha 1. In A.M.S. Bettencourt; E. Abad-Vidal (eds.) CVARN-Corpus Virtual de Arte Rupestre do Noroeste Português.

SILVA, António (2014b) - Piotinha 2. In A.M.S. Bettencourt; E. Abad-Vidal (eds.) CVARN-Corpus Virtual de Arte Rupestre do Noroeste Português (www.cvarn.org).

SOLSONA MONZONÍS, Javier; RICO CÁNOVAS, Elisa (2014) - Patrimonio arqueológico in situ: desarrollo y turismo. In Vives-Ferrándiz Sánchez, Jaime; Ferrer García, Carlos, ed. - El pasado en su lugar: patrimonio arqueológico, desarrollo y turismo. Valência: Museo de Prehistória de Valência, pp. 29-62.

TEIXEIRA, Carlos; MEDEIROS, Artur C.; COELHO, António V.P. (1972) - Carta geológica de Portugal na escala de 1/50 ooo: notícia explicativa da folha 5-A, Viana do Castelo. Lisboa: Serviços Geológicos do Exército.

THOMAS, Suzie (2017) - Community Archaeology. In Moshenska, Gabrie, ed. - Key Concepts in Public Archaeology. London: University College London Press.

TIMOTHY, Dallen J. (2011) - Cultural Heritage and Tourism: An Introduction. Bristol: Channel View Publications.

TIMOTHY, Dallen J.; Tahan, Lina G. (2020) - Archaeology and Tourism. Consuming, Managing and Protecting the Human Past. In TIMOTHY, Dallen J.; TAHAN, Lina G., eds. - Archaeology and Tourism: Touring the Past. Bristol: Channel View Publications, pp. 10-44.

UNESCO (2001) - Universal Declaration on Cultural Diversity. United Nations Educational, Scientific and Cultural Organization Disponível em: http://portal.unesco.org/ en/ev.php-URL_ID=13179\&URL_DO=DO_TOPIC\&URL_ $\mathrm{SECTION=201.html} \mathrm{[consultado} \mathrm{em} \mathrm{4/6/2020].}$

UNESCO (2006) - Tourism, Culture and Sustainable Development. Paris: UNESCO.

UNWTO (2020) - Sustainable tourism development guidelines. United Nations World Tourism Organization. Disponível em: https://www.unwto.org/sustainable-development. [consultado a $11 / 6 / 2020]$.

VIANA, Abel (1960) - Insculturas Rupestres do Alto Minho (Lanhelas e Carreço, Viana do Castelo Portugal). Boletim de la Comisión de Monumentos Históricos y Artísticos de Orense. Ourense. 22(1-4), pp. 209-321.

WALKER, Cameron (2005) - Archaeological Tourism: looking for answers along Mexico's Maya Reviera. National Association for the Practice of Anthropology Bulletin. Washington, D.C. 23:(1), pp. 60-76. 
WATERTON, Emma;-SMITH, Laurajane (2009) - There is no such thing as heritage. In WATERTON, Emma; SMITH, Laurajane, eds. - Taking Archaeology Out of Heritage. Newcastle-upon-Tyre: Cambridge Scholars, pp. 10-27.

WHC (2020) - Sustainable Tourism. UNESCO World Heritage and Sustainable Tourism Programme. World Heritage Committee. Disponível em: https://whc.unesco.org/en/ tourism/ [consultado em 10/6/2020].

YAMAMOTO, Yoko Sugiura; NIETO HERNÁNDEZ, Rubén (2013) - Una reflexión sobre la preservación del patrimonio arqueológico: el caso de los sitios de escala menor en el Estado de México. Anales de Antropología. Ciudad de México. 48:2, pp.75-95.
ZBYSZWESKI, Georges; FERREIRA, Octávio V. (1955) - Sur un plaque anthropomorphe en cuivre dans la mine d'étain de "Folgadoura". Comunicações dos Serviços Geológicos de Portugal, 36, pp. 49-5o.

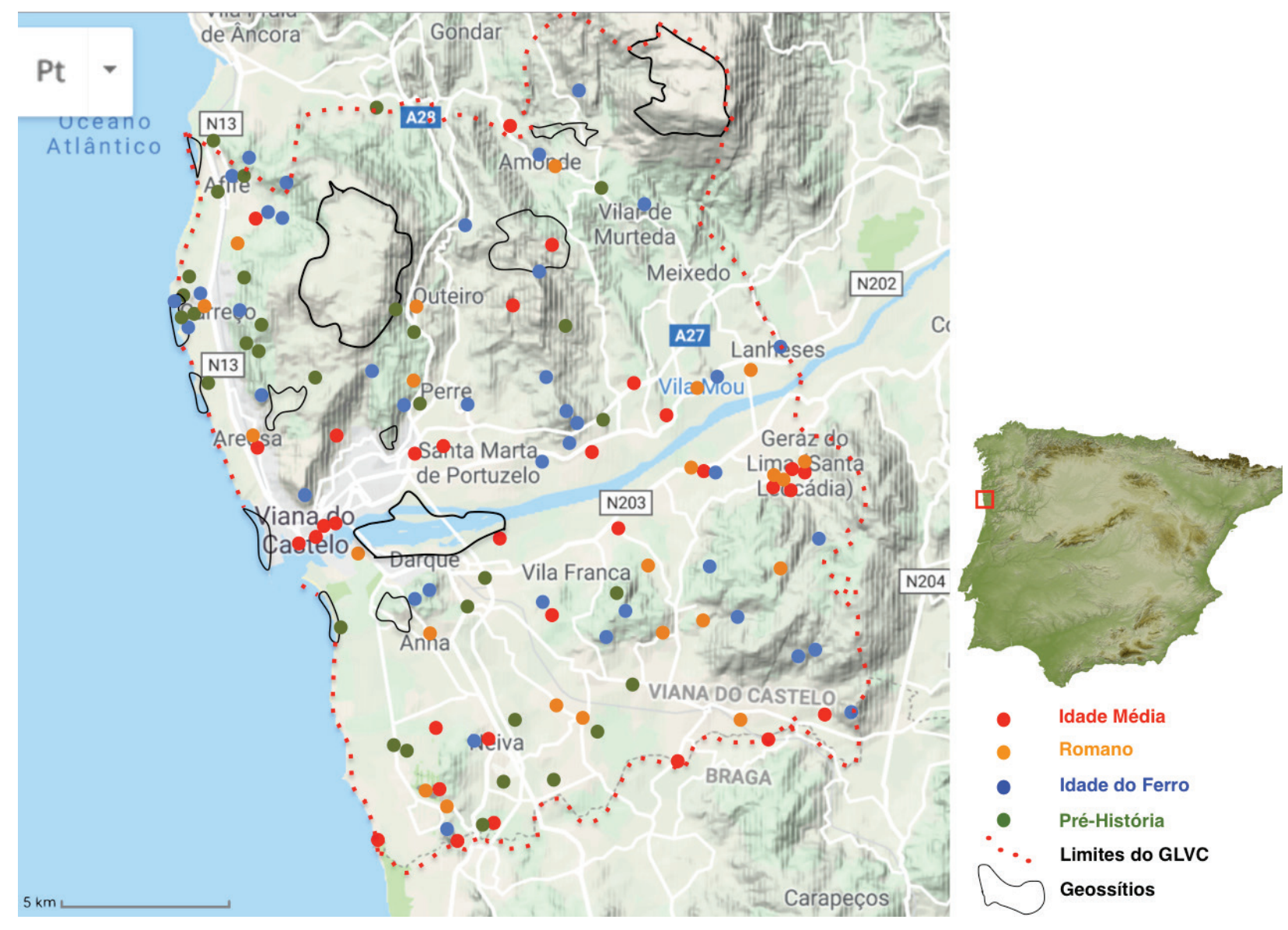

Figura 1 - Mapa de sítios arqueológicos com limites e geossítios do GLVC classificados; Fonte: adaptado de http://www.cmviana-castelo.pt/pt/roteiro-arqueologico sobre base do Google Maps. 

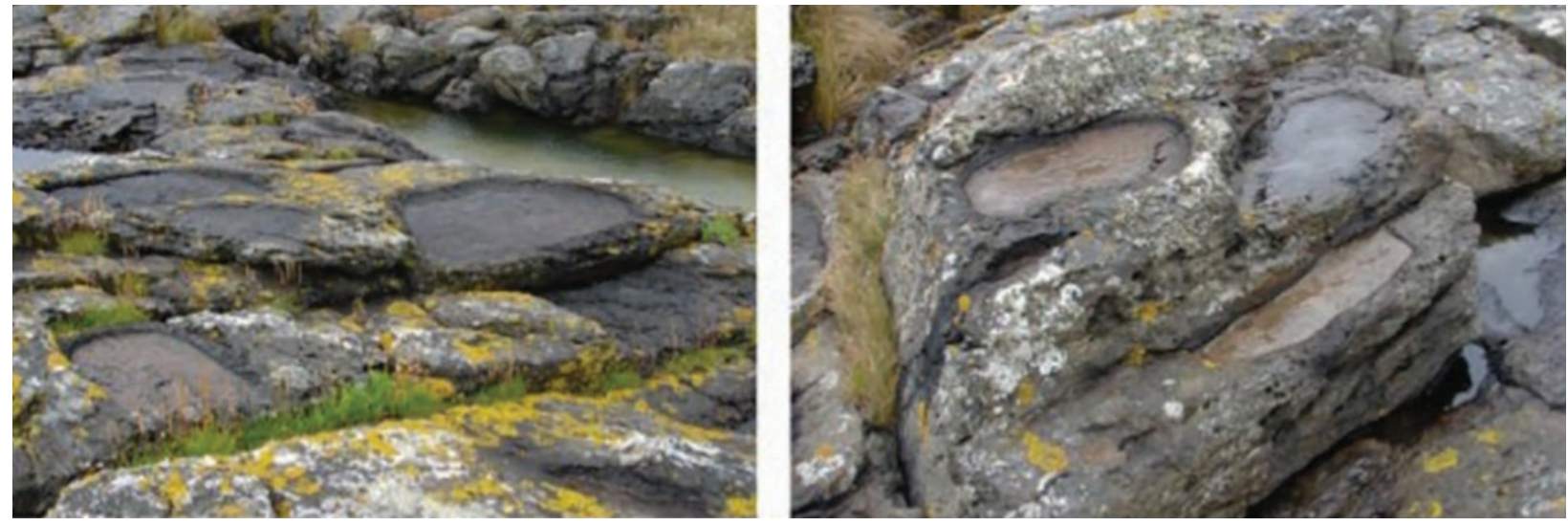

Figura 2 - Alguns exemplares das pias salineiras, de origem antrópica, que integram o sítio de Canto Marinho.
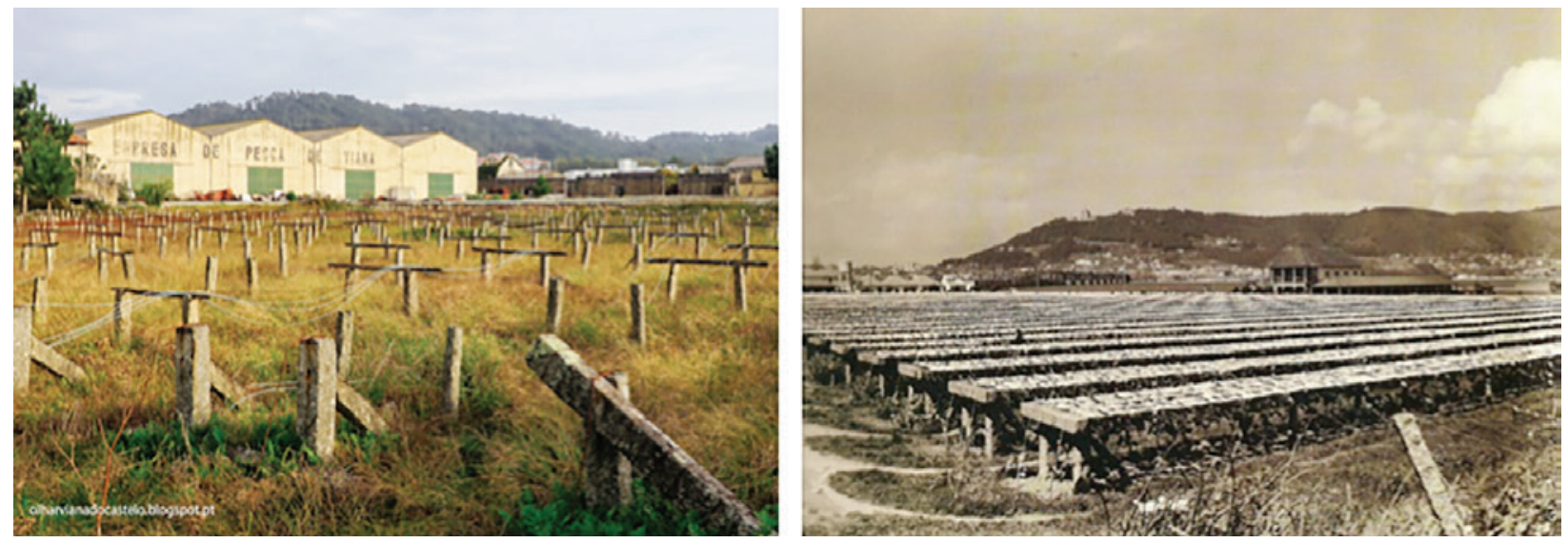

Figura 3 - Complexo de seca do bacalhau do Cais Novo, Darque, Viana do Castelo (à esquerda) e fotografia da atividade aí realizada durante o século XX; Fonte: https://bloguedominho.blogs.sapo.pt/1554662.html.

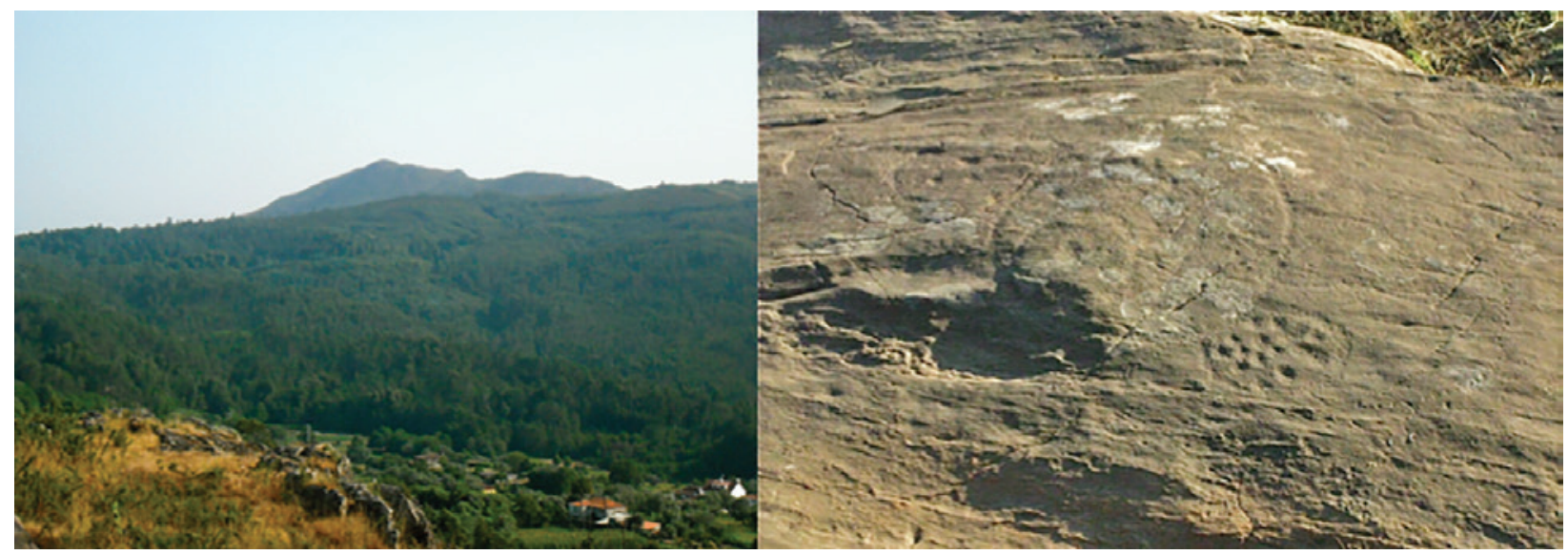

Figura 4 - Lajedo 1 com vista para o topo da Serra de Santa Luzia; Fonte: A.M.S. Bettencourt e Bettencourt, Sá \& Amorim, 2014, p. 2, Fig. 1. 


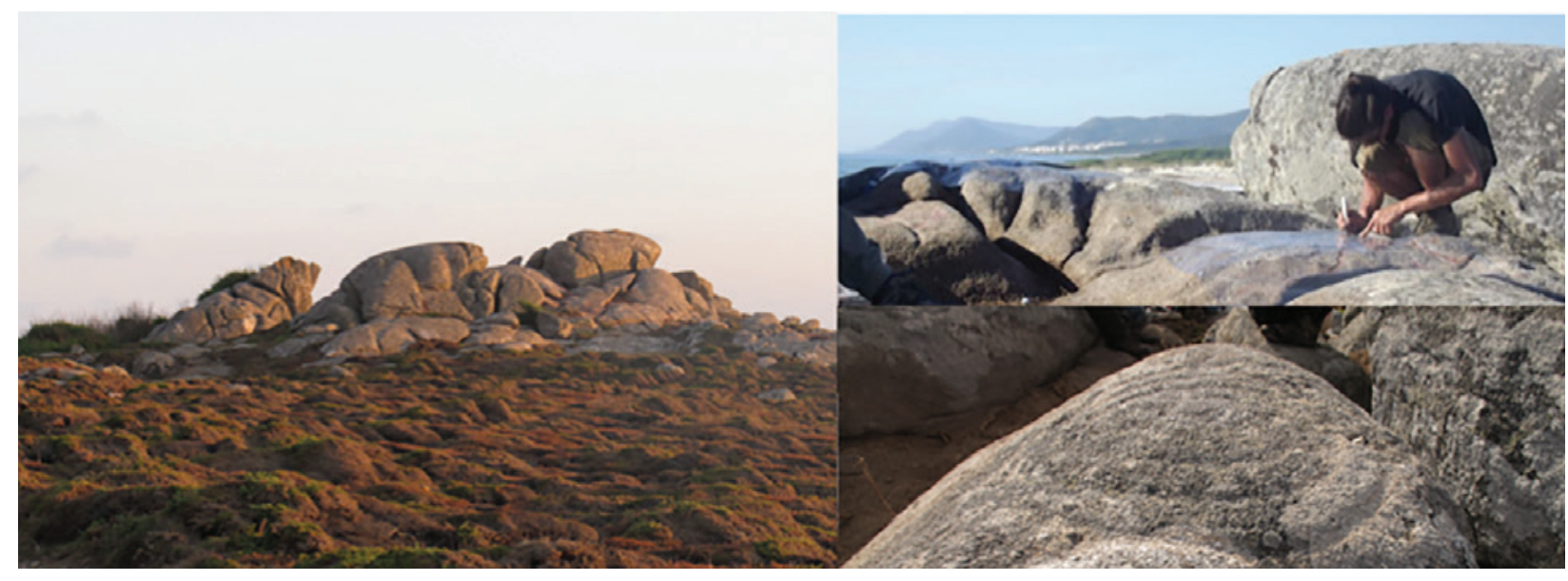

Figura 5 - Afloramentos da Sinadora (esquerda) e pormenor das suas gravuras e da vista obtida a partir do-local; Fonte: A.M. S. Bettencourt.
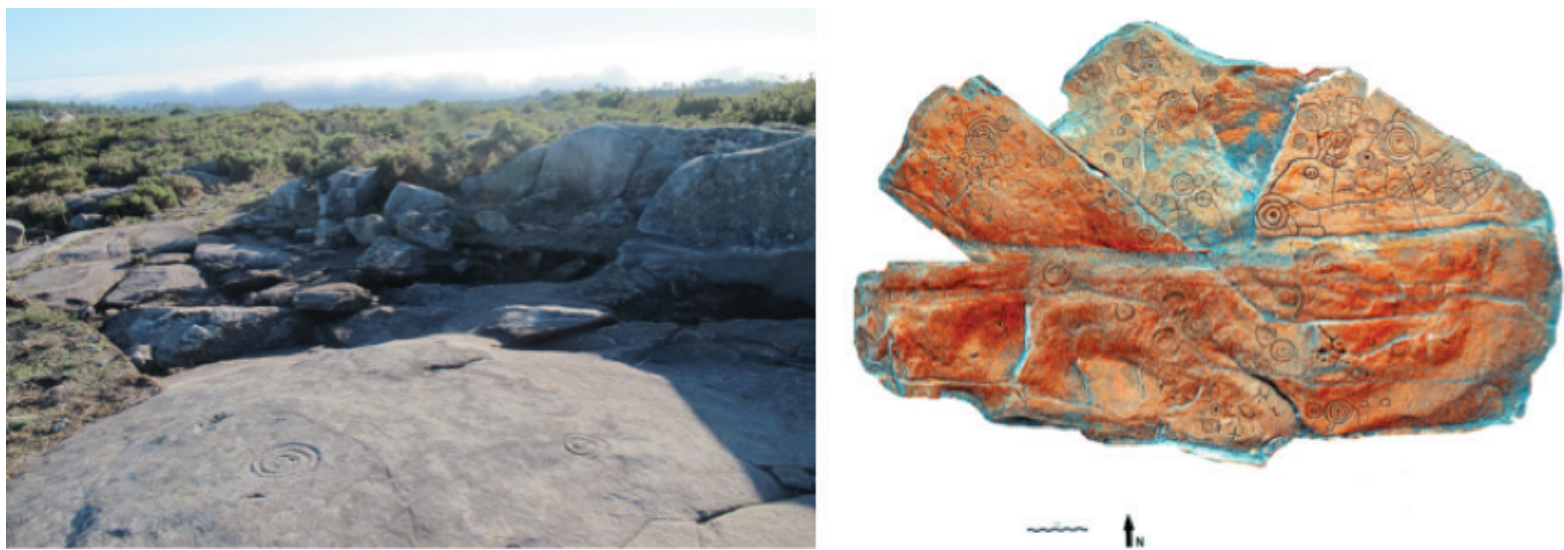

tw

Figura 6 - Afloramentos dos Escampadinhos (esquerda) (fonte: A.M.S. Bettencourt) e fotogrametria da Breia 1 (direita); Fonte: adaptado de Bettencourt \& Santos-Estévez, 2018, p. 34, Fig. 8.

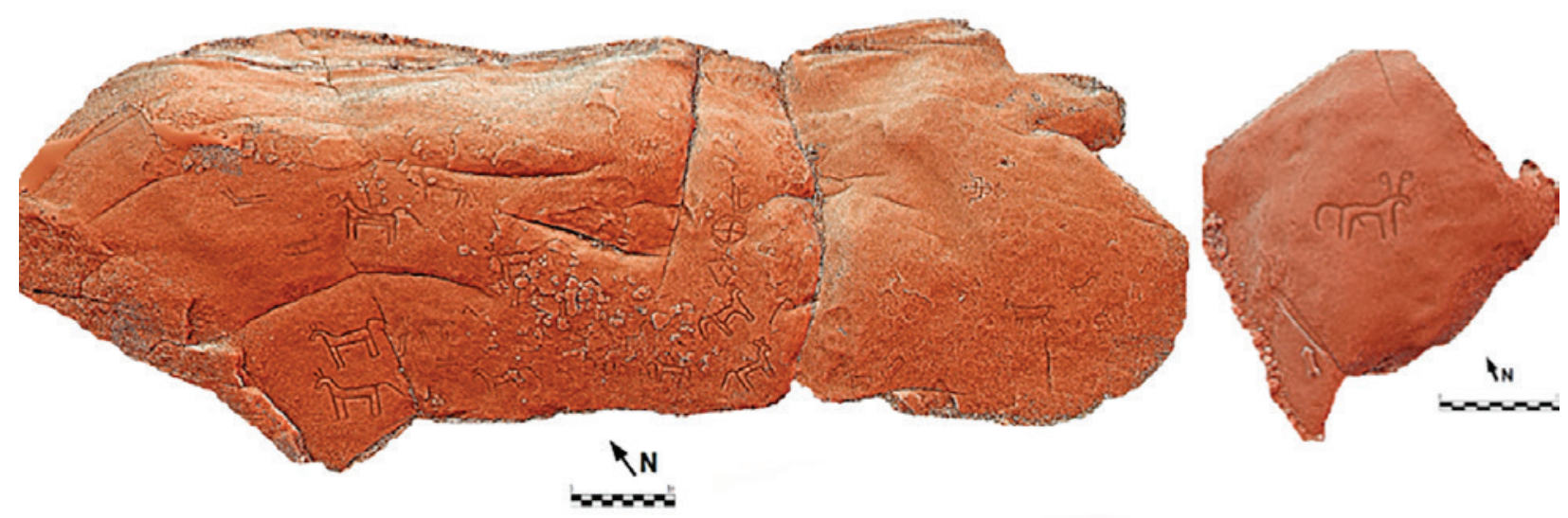

Figura 7 - Breia 5 (esquerda) e Breia 6 (direita); Fonte: Bettencourt \& Santos-Estévez, 2018, p. 59, Fig. 26, p. 62 , Fig. 28. 


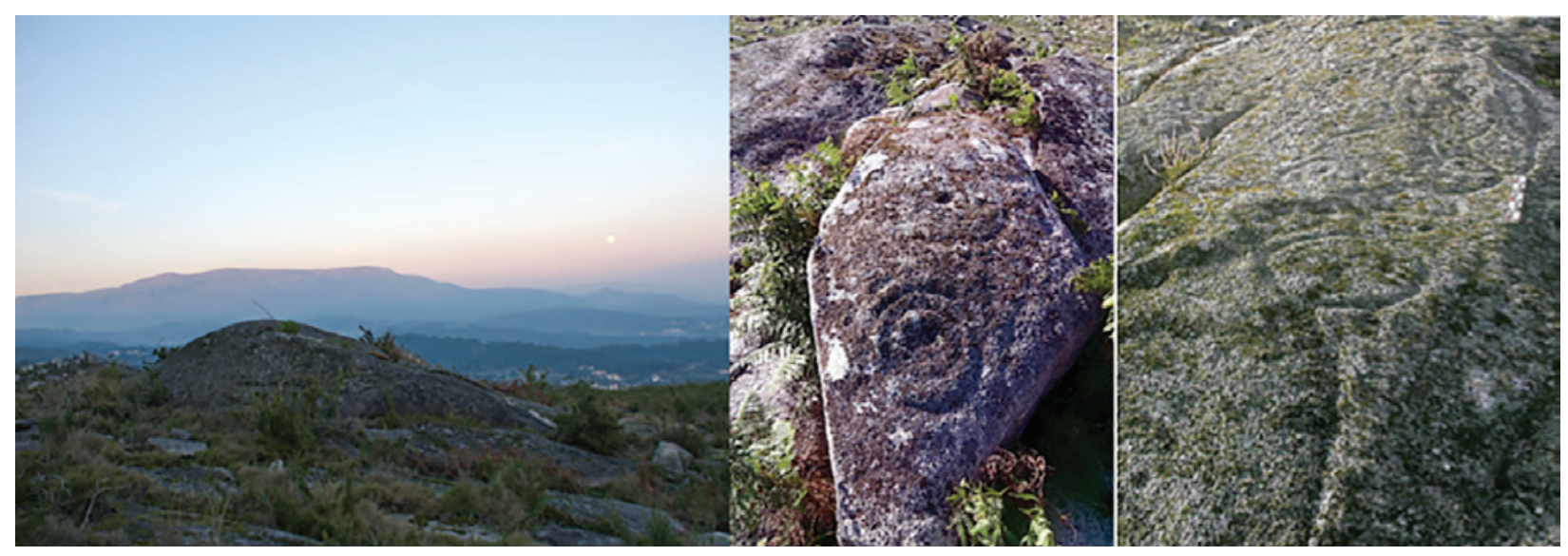

Figura 8 - Sítios de arte rupestre de Penedo da Moura 1 e 2 e vista para a serra de Arga; Fonte: A.M.S. Bettencourt.

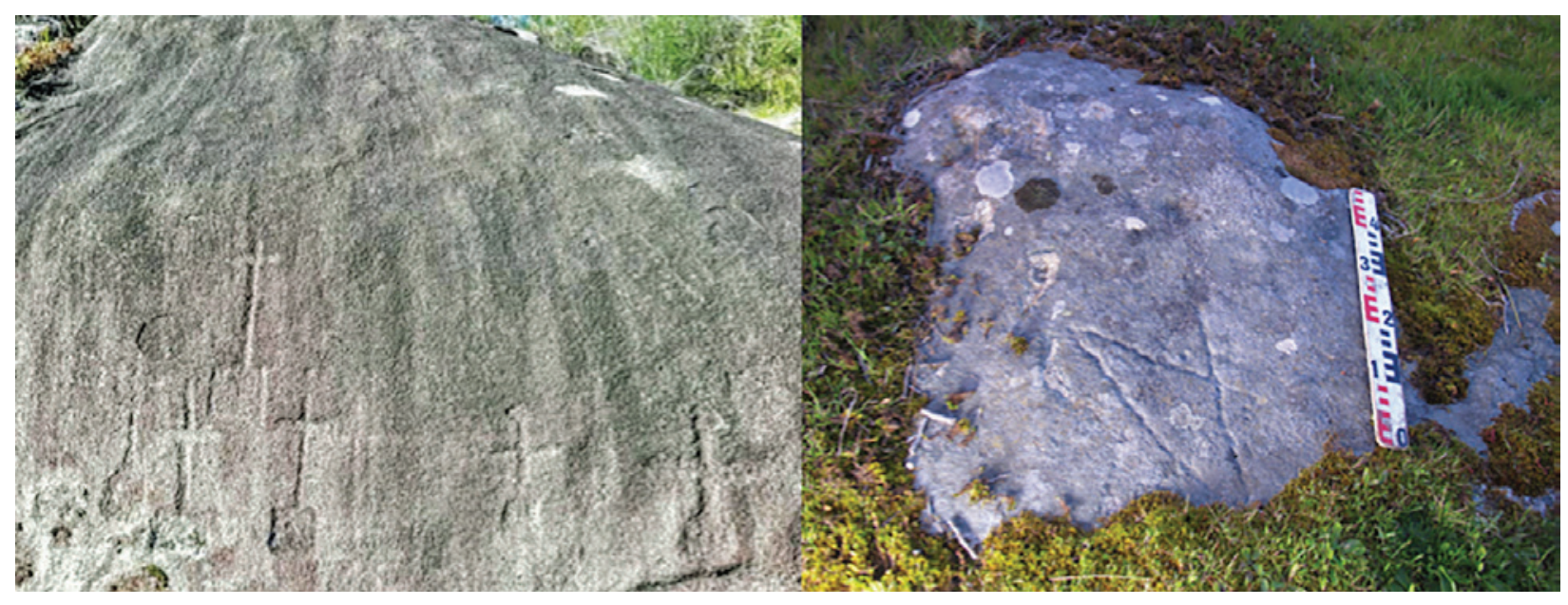

Figura 9- Gravuras de iconografia cristã: Breia 12 com cruzes latinas e gregas, algumas com bases quadrangulares e circulares, figurando cruzeiros (esquerda), e pentagrama dos Moinhos do Marinheiro (direita); Fonte: fonte figura da esquerda: José Alvarez Alonso; fonte figura da direita: A.M.S. Bettencourt. 


\title{
ÁREAS DE POTENCIAL ARQUEOLÓGICO NA REGIÃO DO MÉDIO TEJO: MODELO ESPACIAL PREDITIVO
}

\author{
Rita Ferreira Anastácio ${ }^{1}$, Ana Filipa Martins ${ }^{2}$, Luiz Oosterbeek ${ }^{3}$
}

\begin{abstract}
RESUMO
Este artigo apresenta os resultados da construção de um Modelo Espacial Preditivo Arqueológico baseado na análise de um conjunto de variáveis.

O objetivo principal deste estudo para a Região do Médio Tejo é a identificação de áreas de potencial arqueológico para prospeção arqueológica, ou seja, áreas que apresentam uma maior probabilidade de ocorrência de novos sítios, através da aplicação de modelos espaciais preditivos, partindo de uma base de dados geográfica de sítios arqueológicos compilada e atualizada nas suas cronologias várias, e modelada através de Sistemas de Informação Geográfica, no quadro do projeto de investigação MTAS, apoiado pela FCT.

Assim, através de uma metodologia essencialmente estatística, descritiva e univariada e utilizando dois métodos - o método da adição binária e o método dos pesos - foram obtidas as áreas com potencialidade de prospeção de novos sítios arqueológicos, para a região do Médio Tejo.

Palavras-chave: Modelo Espacial Preditivo, Sítios Arqueológicos, Sistemas de Informação Geográfica, Áreas de Potencial Arqueológico.
\end{abstract}

\begin{abstract}
This article presents the results of the construction of an Archaeological Predictive Spatial Model based on the analysis of a set of variables.

The main objective of this study is to identify areas of archaeological potential for archaeological exploration, for the Médio Tejo Region. This areas are more likely to occur in new sites, through the application of predictive spatial models, starting from a base of geographic data from archaeological sites compiled and updated in their various chronologies, and modeled through Geographic Information Systems, within the framework of the MTAS research project, supported by FCT.

Thus, through an essentially statistical, descriptive and univariate methodology and using two methods - the method of binary addition and the method of weights - the areas with potential for prospecting new archaeological sites were obtained for the Médio Tejo Region.

Keywords: Predictive Spatial Model, Archaeological Sites, Geographic Information Systems, Areas of Archaeological Potential.
\end{abstract}

\section{INTRODUÇÃO}

A distribuição dos vestígios arqueológicos no espaço não é aleatória. Está inerente a um padrão influenciado por vários fatores, tais como: o comportamento das comunidades humanas do passado, os processos naturais e ambientais, e a ação humana na paisagem. De um modo geral, parte-se do princípio de que o comportamento humano no passado produz padrões na cultura material e na paisagem, que embora possam ser alterados por processos naturais e pela contínua ação antrópica, encontram-se ainda hoje em dia representados na paisagem (Warren et al., 200o).

\footnotetext{
1. Instituto Politécnico de Tomar, Centro de Geociências da Universidade de Coimbra; rfanastacio@ipt.pt.

2. Instituto Politécnico de Tomar.

3. Instituto Politécnico de Tomar, Centro de Geociências da Universidade de Coimbra.
} 
O desenvolvimento de modelos preditivos é uma das mais frequentes aplicações em Sistemas de Informação Geográfica, no âmbito da investigação arqueológica (Wheatley et al., 2002, Kvamme, 2006), baseando-se em três pressupostos principais: (1) a escolha do local influenciada por elementos ambientais, naturais e físicos favoráveis à fixação humana, criando um padrão espacial específico; (2) as condições do passado que condicionaram a fixação humana encontrarem-se, direta ou indiretamente, representadas na paisagem atual; (3) os sítios que se localizam numa mesma área de características ambientais (físicas e naturais) análogas têm tendência a depender de igual forma do meio envolvente (Warren et al., 2000; Bona, 2000).

A previsão é a componente central da análise espacial e o objetivo da modelação preditiva é gerar um modelo espacial que tenha implicações preditivas para observações futuras. Em contextos arqueológicos, significa que o objetivo é construir uma hipótese sobre a localização de vestígios arqueológicos que possa ser usada para prever a localização de locais que ainda não foram observados (Wheatley et al., 2002). O desenvolvimento dos modelos preditivos na Arqueologia, tem vindo a permitir dotar os arqueólogos com informações sobre a potencial distribuição dos sítios arqueológicos, possibilitando otimizar o trabalho de campo, gestão de recursos culturais e tomada de decisões sobre a preservação, contribuindo para uma gestão do território mais eficaz. Os métodos mais comuns utilizados são o método da intersecção e o método dos pesos. O primeiro método assenta sobre o princípio que todas as variáveis independentes contribuem de forma igual para a determinação do potencial de localização de um sítio arqueológico; enquanto que o segundo método considera que cada variável independente contribui com pesos diferentes sobre o potencial de localização de um sítio arqueológico. O peso de cada variável independente no modelo estima-se através da sua relação estatística com a localização de sítios arqueológicos conhecidos (Bona, 2000; Ebert, 200o).

\section{ENQUADRAMENTO GEOGRÁFICO DO MÉDIO TEJO}

A região do Médio Tejo, com cerca de 3.344,o km², localiza-se na região Centro de Portugal, abrangendo os concelhos de Abrantes, Alcanena, Constância, Entroncamento, Ferreira do Zêzere, Mação,
Ourém, Sardoal, Sertã, Tomar, Torres Novas, Vila de Rei e Vila Nova da Barquinha. Em 2008 foi constituída a Comunidade Intermunicipal do Médio Tejo (CIMT) com o intuito de promover o desenvolvimento equilibrado e sustentável do seu território de intervenção, com base no planeamento estratégico regional e o apoio às autarquias dos concelhos que a constituem (Figura 1).

Esta região caracteriza-se por classes de altimetria que vão até pouco mais de $1000 \mathrm{~m}$ e de uma forma geral as altitudes predominantes situam-se entre os $50 \mathrm{~m}$ e os $400 \mathrm{~m}$. A sudoeste, nos concelhos de Alcanena, Ourém de Torres Novas e a nordeste, no concelho da Sertã são onde se encontram as altitudes mais elevadas, acima dos $1000 \mathrm{~m}$, correspondendo ao maciço calcário estremenho (serras de Aire e Candeeiros). Os Concelhos de Ferreira do Zêzere, Mação e Vila de Rei apresentam situações pontuais de altitudes entre 400 e $600 \mathrm{om}$. A sul encontra-se as áreas aplanadas correspondentes à bacia aluvionar do rio Tejo abrangendo os concelhos Abrantes, Constância, Tomar, Torres Novas e Vila Nova da Barquinha, com altitudes baixas que não ultrapassam os 50 metros.

Esta região apresenta uma extensa rede hidrográfica e está incluída praticamente na sua totalidade na Região Hidrográfica do Tejo, nomeadamente na margem direita do rio Tejo, onde são afluentes do Tejo Superior as sub-bacias dos rios Ocreza e Zêzere (que por sua vez tem como afluente o Rio Nabão), e do Tejo Inferior Alviela e Almonda.

\section{METODOLOGIA}

Um modelo preditivo pode ser considerado como um exemplo de modelação empírica, em que se parte do estudo da relação existente entre os fatores (ou variáveis) utilizados na análise, baseado nos conjuntos de valores conhecidos para cada um deles, procura estimar o comportamento das relações entre esses mesmos fatores no restante espaço da área. O modelo preditivo é constituído por 3 componentes: os dados ou informação pré-conhecida; o processo ou método de extrapolação e o resultado (Ebert, 200o; p. 3; Hatzinikolaou, 2006).

No caso da aplicação à investigação arqueológica, estes modelos partem da análise de características de implantação de sítios arqueológicos e, estabelecendo uma relação entre essas características, tenta estimar de que forma influenciaram a localização de cada sí- 
tio. Porque essa localização depende da relação com as características do local, pode-se definir de forma genérica uma função que traduz essa relação.

(1)Considerando que corresponde à localização de sítios arqueológicos e que está dependente da sua relação com múltiplas variáveis que condicionam a localização. Diz-se que a primeira é uma variável dependente e as restantes são variáveis independentes. Estas podem ser de natureza ambiental, como a altimetria e suas derivadas declives e orientação das encostas, os tipos de solo ou a proximidade de recursos hídricos; ou de ordem cultural/social, nomeadamente a localização de exploração mineiras ou a distância entre povoados (Ebert, 200o).

$\mathrm{O}$ processo de relacionar as características de implantação por forma a determinar a potencial existência de novos sítios pode ser alcançado de formas distintas, como o demonstra a inúmera bibliografia existente sobre a utilização de modelos preditivos em Arqueologia: assentando maioritariamente sobre métodos quantitativos de tratamento dos dados, abrangem técnica tão distintas como a regressão linear ou redes neuronais ou, ainda, a utilização de fuzzy logic (Hatzinikolaou, 2006). Os métodos mais comuns (Bona, 200o; Ebert, 200o) são:

- Método da interseção: este método baseia-se na sobreposição binária das variáveis independentes e assenta no princípio de que todas as variáveis contribuem de forma igual para determinação do potencial de localização de um sítio arqueológico, para cada ponto da área em estudo.

- Método dos pesos: ao contrário do anterior, este método assume que cada característica contribui de forma distinta e com pesos diferentes sobre o potencial de localização de um sítio arqueológico. O peso de cada variável independente no modelo estima-se através da sua relação estatística com a localização de sítios arqueológicos conhecidos. Por permitir que as características tenham impactos distintos na determinação do resultado final do modelo, pode-se considerar este método mais realista que $o$ anterior.

Para a construção a base de dados geográfica de apoio à modelação em SIG consideraram-se as seguintes variáveis: como variável dependente a informação sobre sítios arqueológicos, que inclui a sua localização, designação, tipologia e cronologia; como variáveis independentes as seguintes variáveis com características que poderão ter influenciado a fixação do homem nesta região (Kvamme, 2006; Ebert, 2000; Warren et al., 2000; Wheatley et al., 2002; Lock et al., 2006):

- Declive: por razões de fácil implantação de povoados bem como de atividades agrícolas, supõe-se que o declive dos terrenos poderá ter tido impacto na localização dos sítios arqueológicos.

- Distância a recursos hídricos: os recursos hídricos são de principal importância à fixação do homem. No presente estudo optou-se por incluir as linhas de água de maior expressão na região.

- Orientação de encostas: um fator geográfico que poderá ter influenciado a localização de sítios arqueológicos, nomeadamente em relação a proteção de ventos dominantes e maior exposição solar.

- Ocupação de solo: se os tipos de solo influenciam diretamente atividades como a exploração de recursos naturais, nomeadamente a agricultura, a atual ocupação do solo pode indiciar a propensão dos solos a essas mesmas atividades com base na sua utilização atual.

\section{DESENVOLVIMENTO DO MODELO PREDITIVO}

Com o intuito de simplificar a descrição do processo de desenvolvimento do modelo, optou-se por definir três etapas: a primeira etapa estruturar os dados; a segunda etapa classificar as variáveis independentes e finalmente, a terceira etapa proceder ao teste estatístico para identificar o nível de relação entre as variáveis independentes e a variável dependente.

\subsection{Preparação dos dados}

O primeiro passo modelo é a compilação e compatibilização dos dados que provêm de diferentes fontes, a partir do suporte inicial em formato tabular. A base de dados de partida é constituída por 614 sítios arqueológicos para a Região do Médio Tejo e inclui a sua designação, localização, tipologia e cronologia. Com base na sua localização (coordenadas) foi produzido o tema geográfico, recorrendo ao software ArcGis/ArcMap ESRI ${ }^{\circledR}$ usando a funcionalidade Create Feature Class From XY Table, que permite obter a representação geográfica dos dados baseada em coordenadas constantes em campos numéricos. Posteriormente, com o objetivo de testar o modelo, foram 
criados dois subconjuntos: 1) Sítios de modelo (composto por 491 sítios, cerca de 80\% dos sítios arqueológicos da base de dados), e 2) Sítios de teste (composto por 193 sítios, cerca de $20 \%$ dos sítios arqueológicos da base de dados).

Nesta fase procedeu-se à criação de temas geográficos derivados da Altimetria 1:2500o da cartografia militar, que permitiu construir o Modelo Digital de Terreno (MDT), designadamente o tema de declives e orientação das encostas (Figura 2).

Para preparar os dados geográficos relativo à variável recursos hídricos, foi determinada a distância a utilizar no modelo, usando um algoritmo baseado em custos associados ao percurso, tendo em conta o declive: o Cost Distance, que entra em linha de conta com eventuais obstáculos ou tão simplesmente com a dificuldade que se apresenta a um caminhante quando subindo ou descendo uma encosta comparado com o mesmo percurso num terreno plano (Figura 3).

Na maioria dos casos, o custo associado a este tipo de percursos em modelos de Arqueologia utiliza o declive como superfície de custo (Wheatley et al., 2002).

\subsection{Etapa 2 - Classificação das variáveis inde- pendentes}

Para proceder ao tratamento estatístico das variáveis independentes e testar a sua relação com a variável dependente, efetuou-se previamente a sua reclassificação (Figura 4).

O processo de reclassificação obedeceu a um conjunto de princípios em função de cada uma das variáveis que foram sobrepostos com os sítios arqueológicos do modelo:

1 - Agregação das categorias de ocupação do solo em sete classes simplificadas de ocupação do solo Corine Land Cover CLC20o6 (Anastácio, R. pp.113, 2016) de acordo com a Tabela 1.

O resultado da sua aplicabilidade deu origem a uma carta de ocupação do solo (Figura 5).

1 - Para a carta de declive e para o cálculo da distância aos rios foram geradas classes baseadas na distribuição estatística de cada variável (Santos, 2006). Para proceder a esta divisão foram utilizadas as funcionalidades de reclassificação que tem em consideração o desvio-padrão dessa distribuição: 1 Std Dev para o declive (Figura 6) e I/2 Std Dev para a distância aos rios (Figura 7).

1 - Para a orientação das encostas, como se trata de uma variável contínua cíclica $\left(\mathrm{o}^{\circ}-360^{\circ}\right)$, utilizaram-se os pontos cardeais e colaterais para a sua classificação: plano, N, NE, E, SE, S, SO, O, NO (Figura 8). Antes de proceder à análise estatística das variáveis, houve que transformar os diversos temas geográficos em formato vetorial para o formato raster, por forma a uniformizar a informação e proceder à análise espacial.

Por fim, procedeu-se ao cálculo estatístico da relação entre cada variável independente e a variável dependente, utilizando a funcionalidade Zonal Statistics as Table (Figura 9).

A informação recolhida tratou-se do número de células do raster de sítios arqueológicos ("sitios_Raster") que se encontravam dentro de cada classe das variáveis independentes (ocupação do solo, declive, orientação das encostas e distância a rios) eidentificar de que forma cada classe das variáveis independentes influencia a distribuição da variável dependente.

\subsection{Etapa 3-Teste às variáveis independentes}

$\mathrm{O}$ teste às variáveis independentes permite validar o pressuposto de que cada variável tem uma relação de não-aleatoriedade com a variável dependente, ou seja, que o facto de um sítio arqueológico se encontrar num determinado tipo de solo ou a uma curta distância de um rio não é casual. Caso este teste não consiga provar essa não-aleatoriedade, tal significa que a relação que está a ser testada é fraca, podendo-se considerar que a variável independente não teve influência na localização de sítios arqueológicos, pelo que deve ser excluída do modelo. No presente caso de estudo optou-se pela utilização do teste de Kolmogorov-Smirnov-largamente demonstrado em contextos semelhantes ao que se pretende criar (Kvamme, 2006; Ebert, 2000; Wheatley et al., 2002). O teste parte de duas hipóteses (Ebert, 200o):

$\mathrm{H}_{\mathrm{o}}$ - a distribuição da variável dependente é aleatória face à variável independente com que está a ser testada (também denominada hipótese nula).

$\mathrm{H}_{1}$ - a distribuição da variável dependente não é aleatória face à variável independente com que está a ser testada.

E compara a distribuição cumulativa de cada uma das variáveis. Caso a sua semelhança - designada $D_{\text {máx }}$ - seja inferior a um valor teórico $D_{\text {Ks }}$, então deve-se aceitar a hipótese $\mathrm{H}_{\mathrm{o}}$ e descartar a variável independente do modelo por se considerar que 
esta não teve influência na distribuição da variável dependente. Caso о valor $\mathrm{D}_{\text {кs }}$ seja excedido, rejeita-se $\mathrm{H}_{\mathrm{o}}$, aceitando-se como verdadeira a hipótese $\mathrm{H}_{1}$ e inclui-se a respetiva variável independente no modelo.

Para um nível de significância de o,05 a fórmula para o cálculo do valor teórico é, sendo n o número de sítios $(\mathrm{n}=491)$. Na Tabela 2 apresenta-se o resultado do teste para cada uma das variáveis.

Por comparação com o valor DKS, que para esse caso de estudo é de 0,061 para um nível de significância de 0,05 , deverão ser todas as variáveis independentes consideradas para a criação do modelo preditivo. É agora possível reescrever a equação (I) utilizando as variáveis independentes relevantes identificadas:

(2)

\section{Método 1 - Método da Sobreposição Binária}

No método da sobreposição binária, ou sobreposição booleana, os critérios são adaptados à lógica binária (o/1), em termos de aptidão, combináveis sequencialmente, através de operadores como a interseção e a união. Ou seja, consiste em reclassificar cada uma das variáveis em mapas temáticos binários (formato raster), e a cada célula atribuir um valor de o ou 1, em função da presença ou ausência de uma das características de localização dos sítios ( $\mathrm{o}=$ ausência, $1=$ presença). Asáreas que apresentam menos locais do que o esperado são classificadas com o e as áreas onde ocorrem locais ou mais do que o esperado com 1. Realizando esta operação para todas as variáveis, o modelo final é obtido adicionando os vários mapas binários. As células com maior agregação representam os pontos do mapa com maior probabilidade. A fórmula de criação de um modelo deste tipo pode-se apresentar da seguinte forma:

(3) Embora o modelo criado seja bastante prático a sua grande desvantagem é a inexistência de ponderação das variáveis. Desta forma, partindo da premissa que os fatores ambientais que influenciaram a localização dos sítios não tiveram o mesmo grau de importância, o passo seguinte foi calcular o peso de cada variável independente a ser incluída no modelo preditivo arqueológico. Ou seja, a cada mapa temático foi atribuído um peso diferente, uma vez que os fatores que influenciaram a localização dos sítios não possuem o mesmo grau de importância, não podendo consequentemente serem tratados igualitariamente.

\section{Método 2 - Método dos Pesos}

Este método utiliza uma função baseada no peso das variáveis, ou seja, parte do pressuposto que cada variável teve uma influência distinta na localização dos sítios arqueológicos.

O peso das variáveis independentes foi determinado com base na proporcionalidade da área em que a variável determinou a existência, ou seja, a área das classes em que o número de sítios observados não é nulo (Tabela 3).

(4)

\section{RESULTADOS}

Como todo o processo de cálculo se encontra assente em temas geográficos em formato raster, ao serem aplicadas as fórmulas apresentadas anteriormente ((3) e (4)) determina-se um valor específico para cada célula do modelo, usando a ferramenta Raster Calculator. Para cada célula da área de estudo obtém-se assim um valor que indica o maior ou menor potencial de existência de um sítio arqueológico nesse local.

Na Figura 10 apresenta-se o resultado do método da sobreposição binária para o total dos sítios arqueológicos em estudo, aplicando a equação (3).

Na Figura 11 apresenta-se o resultado do método dos pesos para o total dos sítios arqueológicos em estudo, aplicando a equação (4).

\subsection{Teste ao método 2}

Um modelo, qualquer que seja a realidade que ele procure representar e a forma como tenha sido construído, tem que ser testado antes de sobre ele ser depositado um nível de confiança suficiente que justifique e apoie a sua utilização (Kvamme, 2006). Havendo múltiplas formas de produzir esse teste, aquela que mais segurança garante é a utilização de um subconjunto de dados reais que tenha sido produzido aleatoriamente e omitido do universo na construção do modelo. Conforme anteriormente referido, foi inicialmente retirado um subconjunto ao universo de sítios arqueológicos utilizados que serviu para testar a capacidade de predição do modelo (Figura 12).

Para testar o método 2 (método de pesos), o mapa produzido foi reclassificado em três classes (limitadas por $50 \%, 80 \%$ e $100 \%$ do potencial de existência de sítios arqueológicos) após o que se determinaram as estatísticas do conjunto de sítios de 
teste para cada uma dessas áreas, usando mais uma vez a funcionalidade Zonal Statistics as Table (Tabela 4) e (Figura 13), de acordo com (Santos, 2006). O modelo identifica que cerca de dois terços da área ocupada por sítios submetidos ao teste numa região de potencial inferior a $50 \%$, sendo que os restantes um terço se encontra em áreas com um potencial superior a $50 \%$. Estes resultados podem dever-se a múltiplos fatores, que se podem englobar em duas classes, nomeadamente:

-Fatores de ordem interpretativa: na proximidade de recursos hídricos não é suficiente considerar-se a existência e proximidade de rios na modelação sem considerar a qualidade da sua água, sendo que esta poderá influenciar drasticamente os resultados do modelo (Wescott et al., 2000).

- Fatores de ordem técnica: o estudo apresentado não inclui certamente todos os critérios que levaram à fixação humana. Se os fatores ambientais são passíveis de estarem representados na cartografia utilizada, outras há de ordem social ou cultural que dificilmente serão recriáveis num modelo deste tipo, caso deles não exista relato histórico ou evidência arqueológica que os comprove. O tema de distância a recursos hídricos recriado neste estudo considera o declive como sendo o fator de custo na distância ponderada. No entanto, apesar desta ser uma simplificação comum neste tipo de modelos aplicados à Arqueologia, ela não tem em conta o tipo de terreno ou de coberto vegetal que atravessa no trajeto - considerando o mesmo declive, solos arenosos serão mais "difíceis" de atravessar do que terrenos de solo compacto, ou zonas de pastagem com mato rasteiro ou mesmo territórios atravessados por caminhos já existentes (Wheatley et al., 2002).

Estas considerações não devem, no entanto, ser consideradas limitativas, mas incentivadoras na continuidade do estudo agora desenvolvido. Como qualquer outro estudo em sistemas de informação geográfica, também um modelo preditivo deve ser constituído por um conjunto de iterações que validam, refinam e consolidam o sistema que está a ser implementado. Um modelo deverá ser visto como um processo evolutivo e interativo, em que novos dados poderão ser integrados em qualquer altura para otimizar e consolidar os resultados (Bona, 2000).

\section{CONSIDERAÇÕES FINAIS}

Pelo carácter geográfico-espacial dos dados com que lida, a Arqueologia, à semelhança do que outras ciências ou disciplinas vêm fazendo há já algumas décadas em Portugal, só poderá beneficiar da utilização de SIG. Este benefício manifestar-se-á não apenas na vertente de investigação arqueológica, mas igualmente na administração e planeamento de território e proteção de vestígios arqueológicos no terreno.

A utilização de um modelo preditivo só por si, isento de pensamento interpretativo e análise crítica, pode conduzir a erros, não devendo ser considerado mais que um meio de alcançar os fins a que a investigação arqueológica se propõe. O resultado de um modelo preditivo, utilizado sem critério, poderá conduzir à não execução de estudos ou investigação mais aprofundadas em zonas identificadas como de reduzida propensão à existência de sítios arqueológicos. Mais que o resultado de um modelo preditivo é a sua interpretação segundo o eixo arqueológico que pode traduzir a utilização destes meios em informação útil para o investigador. Conforme visível nos mapas resultantes do modelo criado, o nível baixo de potencialidade não invalida a existência de sítios arqueológicos, pelo que qualquer atividade que possa interferir com o subsolo não deverá ser menos cuidada nas medidas de prevenção e estudos de impacte a efetuar.

A aplicação de modelos preditivos assenta sobre condições que poderão ser julgadas falíveis. Nomeadamente, a investigação centra-se sobre os fatores ambientais que levaram à fixação do homem num ponto em particular da paisagem. Ignora assim que sistemas mais alargados se geram num território, nomeadamente que o povoado ou acampamento poderá constituir apenas um componente num sistema complexos, e que a relação entre vários povoados poderá ter levado, mais que qualquer fator externo, a uma nova fixação. Igualmente a qualidade dos dados poderá influenciar determinantemente os resultados de um modelo preditivo. No entanto, atendendo às considerações anteriormente abordadas, o modelo preditivo pode e deve constituir-se como mais uma ferramenta na investigação arqueológica, nomeadamente quando este considera a integração e exploração da paisagem pelo Homem no passado. De igual forma, quando administrando e gerindo os espaços e territórios 
de hoje, poderá o modelo preditivo ser utilizado como ferramenta auxiliar na interpretação do potencial cultural desses mesmos territórios. Um conhecimento da potencialidade da existência de sítios arqueológicos poderá minimizar a realização de atividades que possam interferir de forma irremediável com vestígios existentes no subsolo ou, quando tal não é possível, recomendar uma maior atenção e cuidados na realização de estudos que antecedam essas atividades.

\section{BIBLIOGRAFIA}

ANASTÁCIO, Rita (2016) - Da Gestão Do Património Cultural À Gestão Do Território Com Recurso A Tecnologias De Informação Geográfica: Contributos Metodológicos: Caso De Estudo - Região Do Médio Tejo. Tese de doutoramento em Quaternário Materiais e Culturas. Universidade de Trás-os-Montes e Alto Douro. Vila Real. (Documento policopiado).

BONA, Luke D. (200o) - Protecting Cultural Resources through Forest Management Planning in Ontario Using Archaeological Predictive Modeling. Practical Applications of GIS for Archaeologists - A Predictive Modeling Toolkit. Westcott, K. L.; Brandom J.. London: Taylor \& Francis.

EBERT, J. I. (2000) - The State of the Art in "Inductive" Predictive Modeling: Seven Big Mistakes (and Lots of Smaller Ones). Practical Applications of GIS for Archaeologists - A Predictive Modeling Toolkit. Westcott, L. K., Brandom J.. London: Taylor \& Francis.

HATZINIKOLAOU, Eugenia (2006) - Quantitative Methods in Archaeological Prediction: From Binary to Fuzzy Logic. GIS and Archaeological Site Location Modeling. Mehrer, M. W.; Westcott, K. L.. London New York: Taylor \& Francis.

LOCK, G.; HARRIS T. (2006) - Enhancing Predictive Archaelogical Modeling: Integrating Location, Landscape, and Culture. GIS and Archaeological Site Location Modeling. Mehrer, M. W.; Westcott, K. L.. London New York: Taylor \& Francis.

KVAMME, K. L. (2006) - There and Back Again: Revisiting Archaeological Locational Modeling. GIS and Archaeological Site Location Modeling. Mehrer, M. W.; Westcott, K. L.. London New York: Taylor \& Francis.

SANTOS, Pedro (2006) - Aplicações de Sistemas de Informação Geográfica em Arqueologia. Dissertação de mestrado. Instituto Superior de Estatística e Gestão de Informação da Universidade Nova de Lisboa.

WARREN R.; ASCHD. L. (200o) - A Predictive Model of Archaeological Site Location in the Eastern Prairie Peninsula. Practical Applications of GIS for Archaeologists - A Predictive Modeling Toolkit. Westcott, L. K., Brandom J.. London: Taylor \& Francis.
WESCOTT, K.; KUIPER, J. (200o) - Using a GIS to Model Prehistoric Site Distributions in the Upper Chesapeake Bay. Practical Applications of GIS for Archaeologists - A Predictive Modeling Toolkit. Westcott, L. K., Brandom J.. London: Taylor \& Francis.

WHEATLEY, David; GILLINGS Mark (2002) - Spatial tecnology and archaeology - The Archaeological Applications of GIS. London and New York: Taylor \& Francis. 

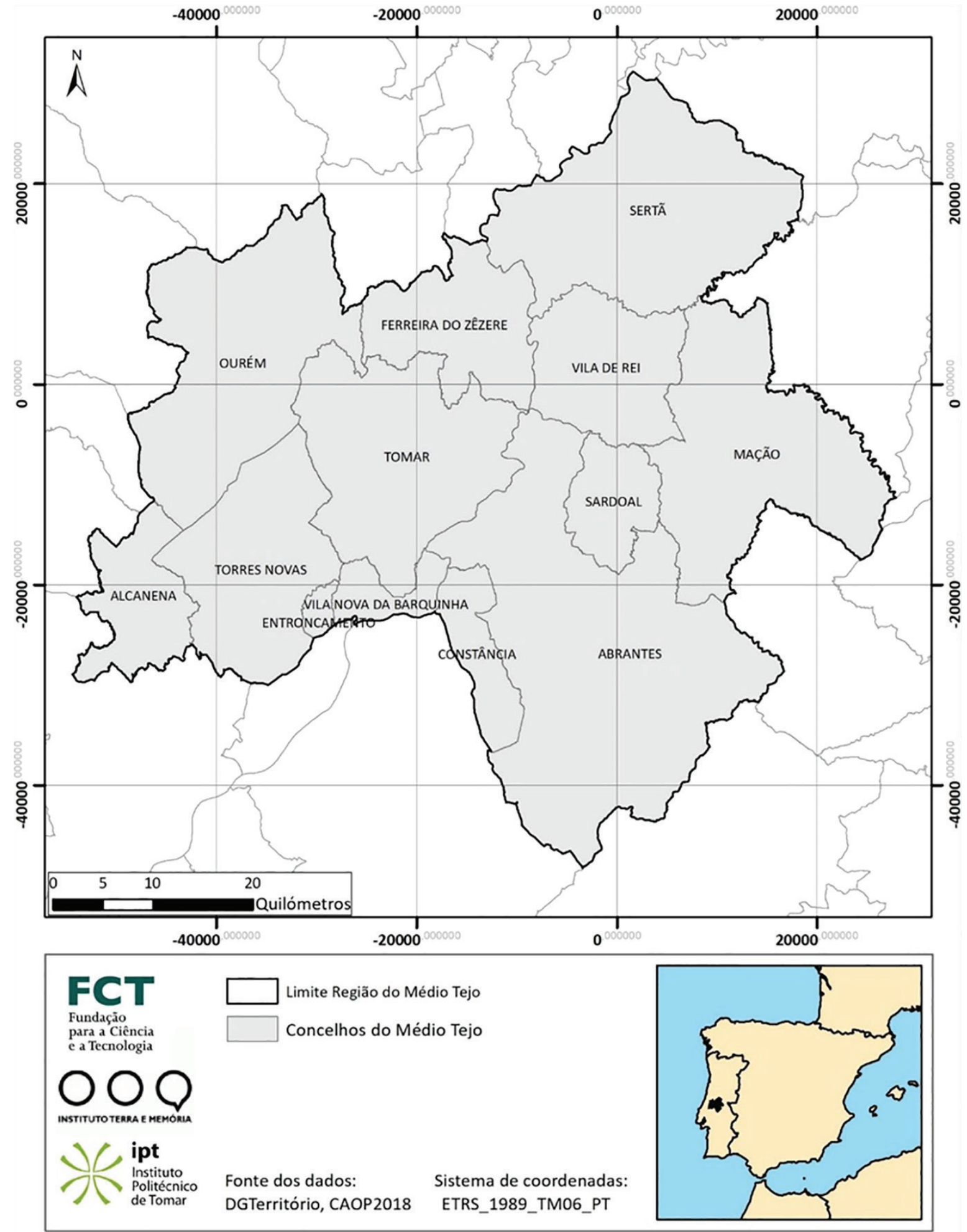

Figura 1 - Região do Médio Tejo: divisão administrativa. 


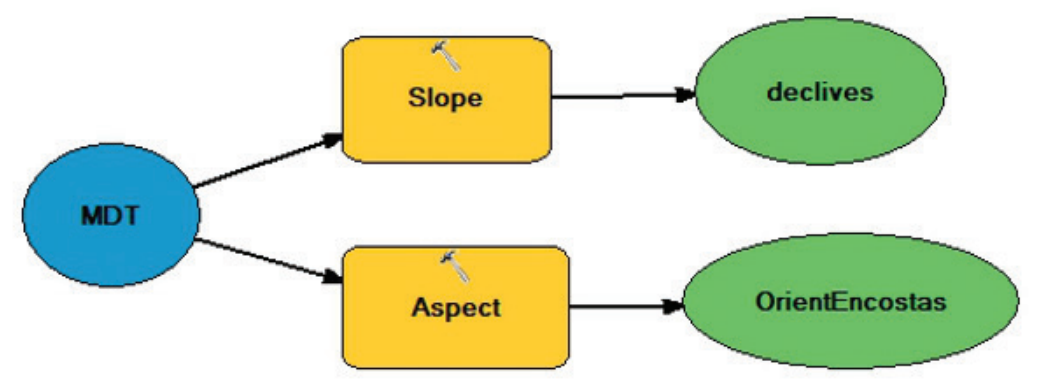

Figura 2 - Fluxograma funcional de obtenção da cartografia derivada do MDT.

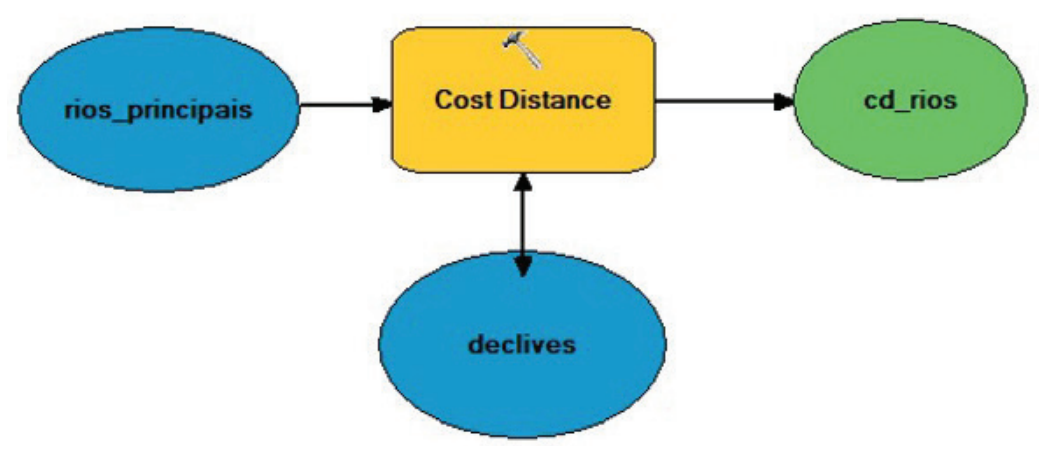

Figura 3 - Fluxograma funcional de cálculo da distância aos rios.

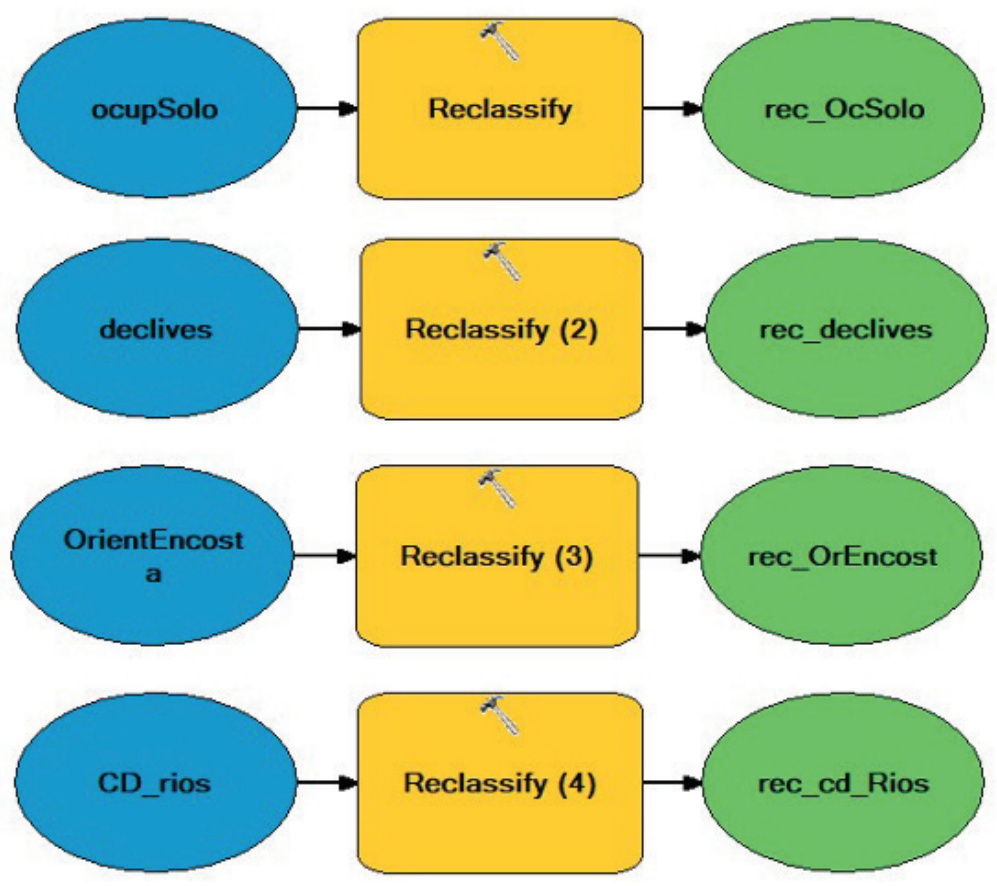

Figura 4 - Fluxograma funcional de reclassificação das variáveis independentes. 


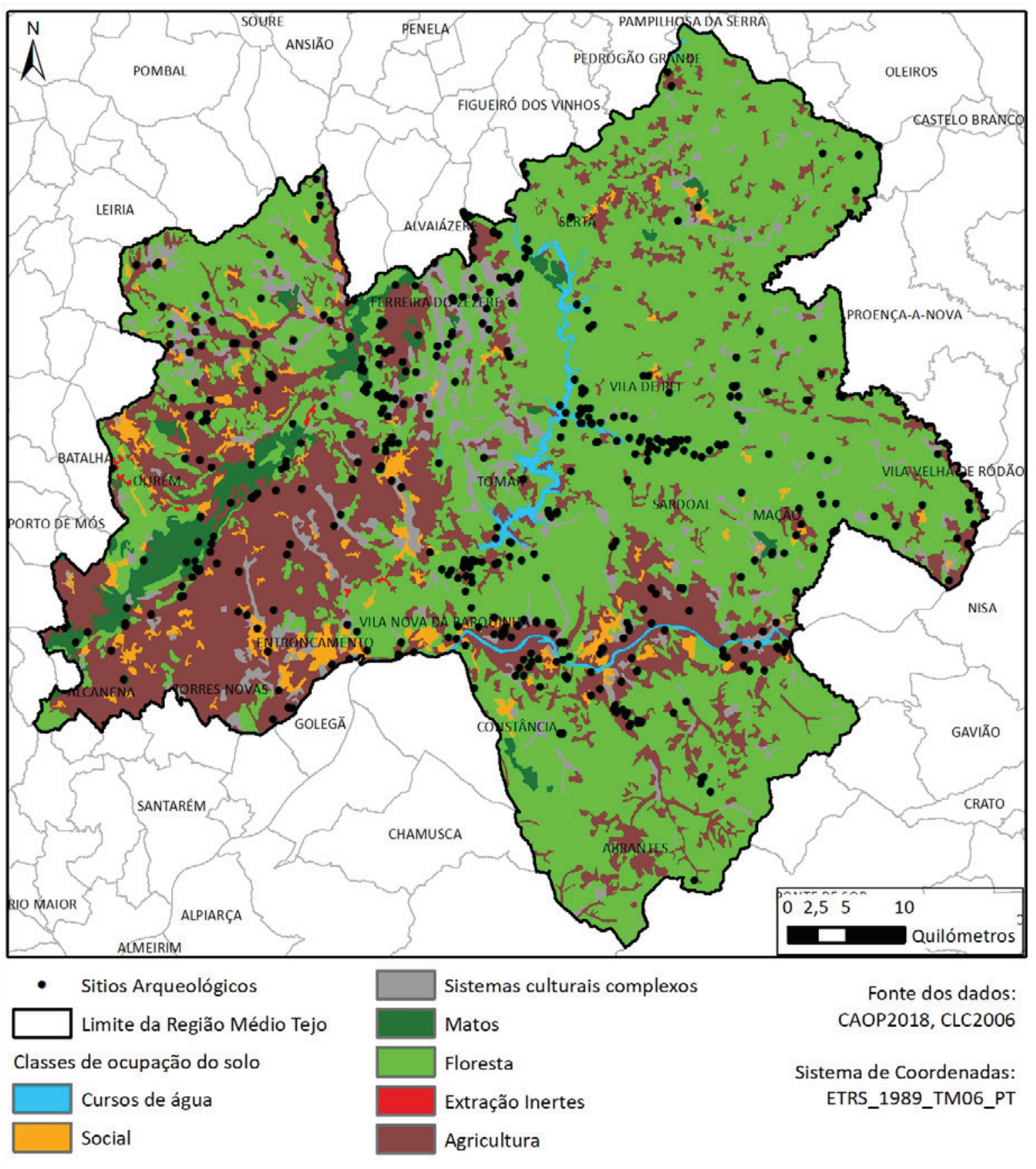

Figura 5-Carta de ocupação do solo. 


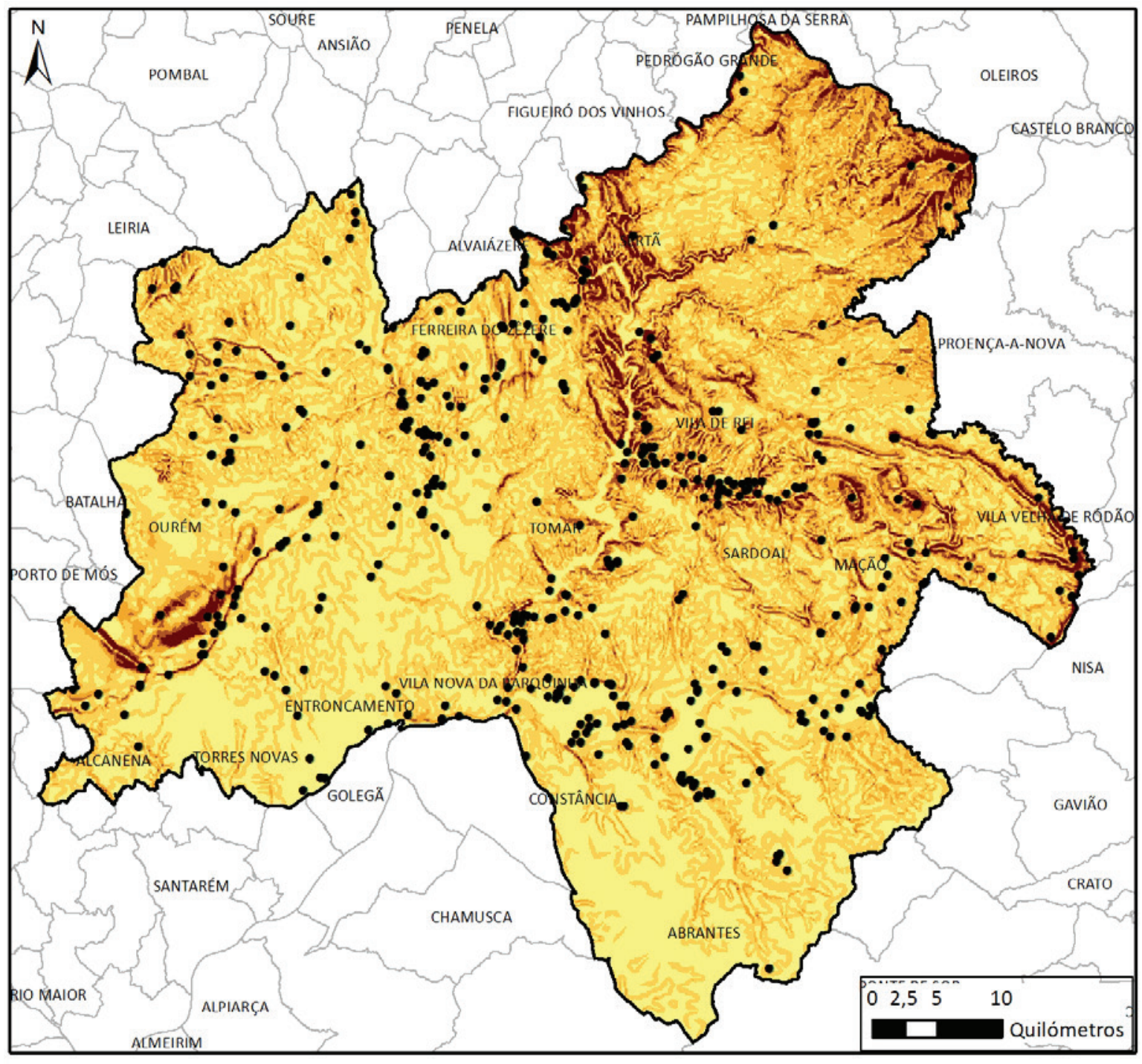

- Sitios Arqueológicos Limite da Região Médio Tejo
Classes de declive

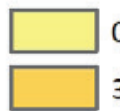

$0-3 \%$

$3 \%-11 \%$

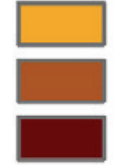

$11 \%-19 \%$

$19 \%-27 \%$

$27 \%-80 \%$
Fonte dos dados: CAOP2018

Sistema de Coordenadas: ETRS_1989_TM06_PT

Figura 6 - Carta de Declives. 


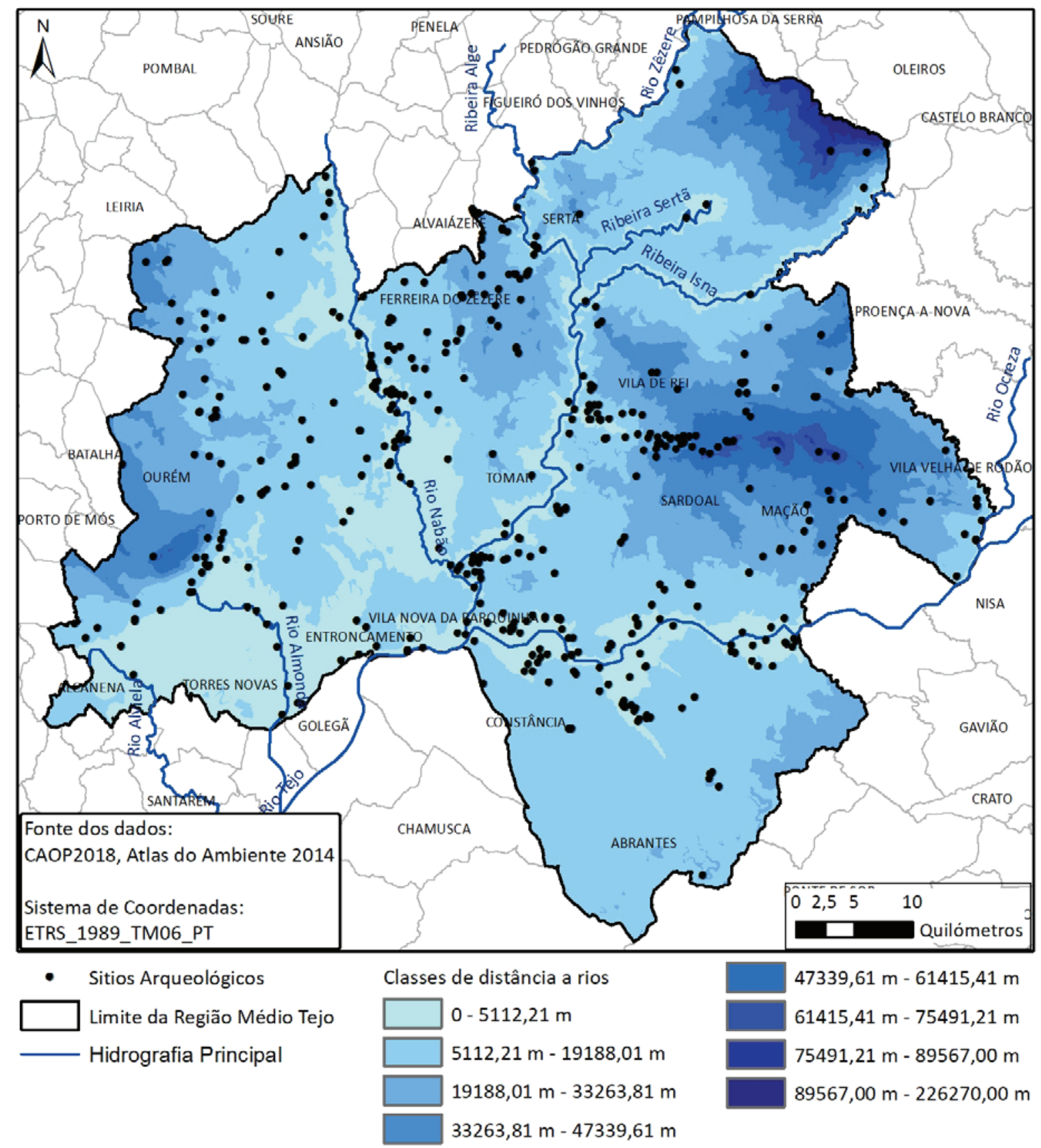

Figura 7-Hidrografia e distância a rios baseada em custos. 


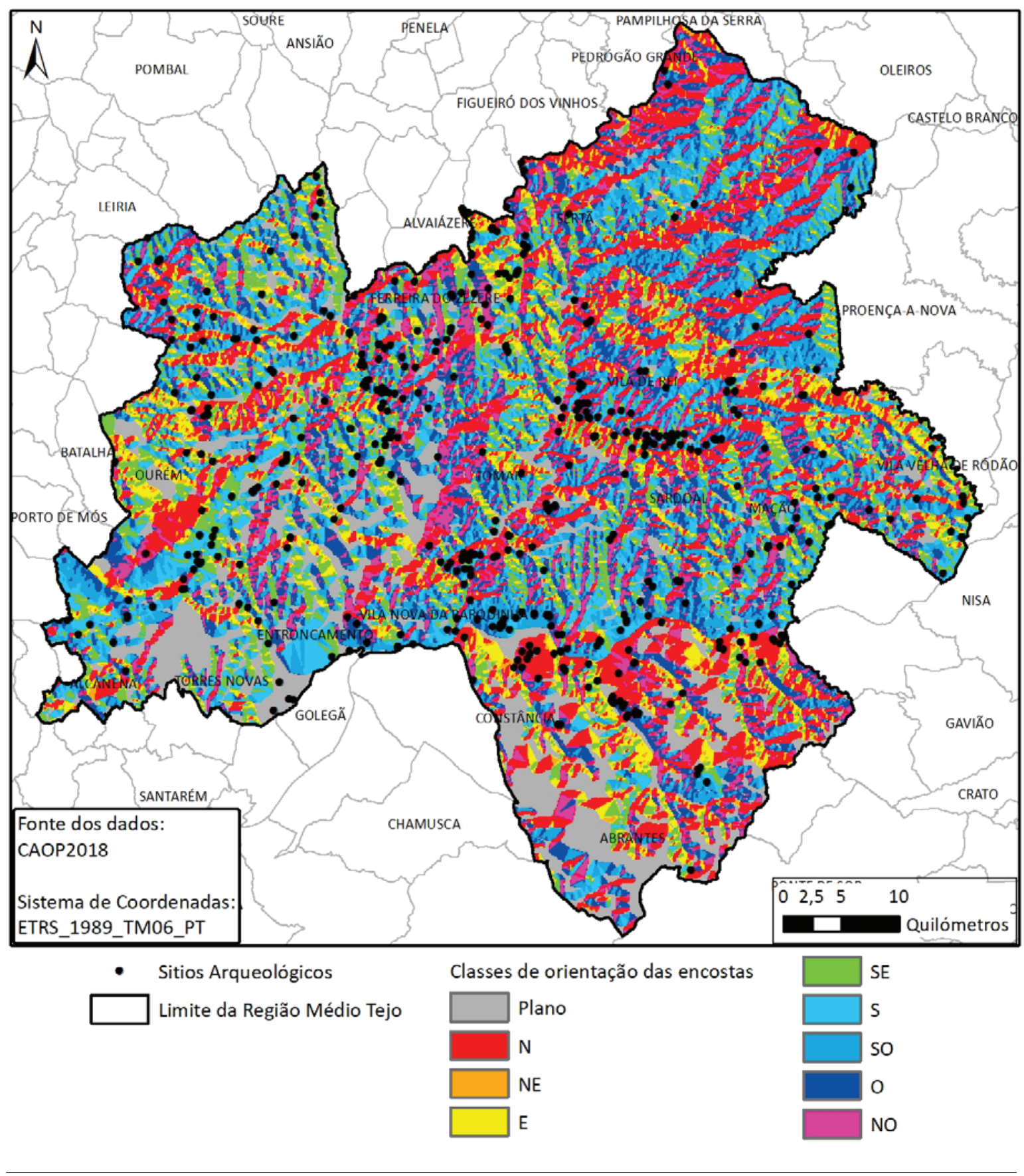

Figura 8 - Carta de orientação das encostas. 


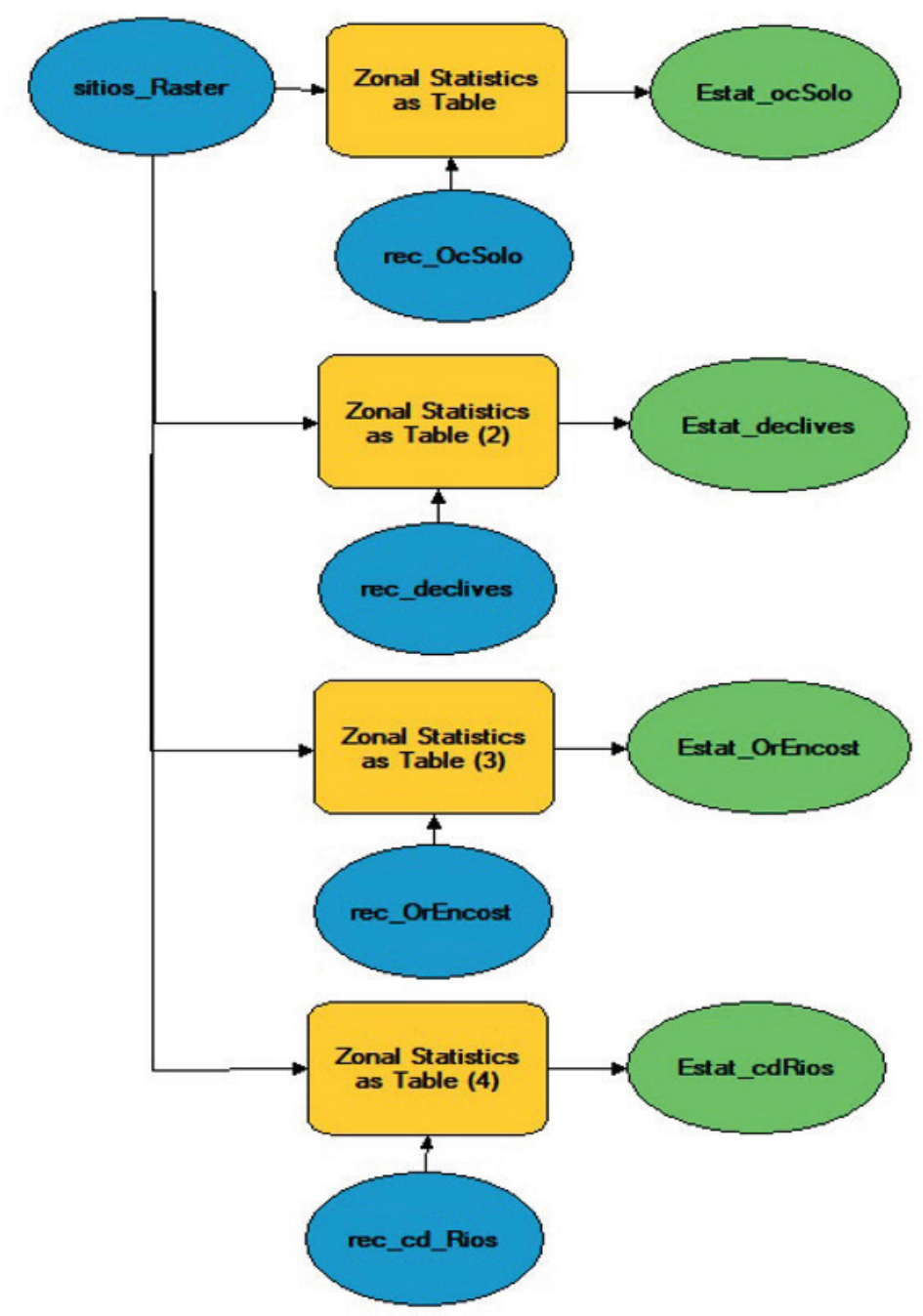

Figura 9 - Fluxograma funcional de obtenção de estatísticas. 


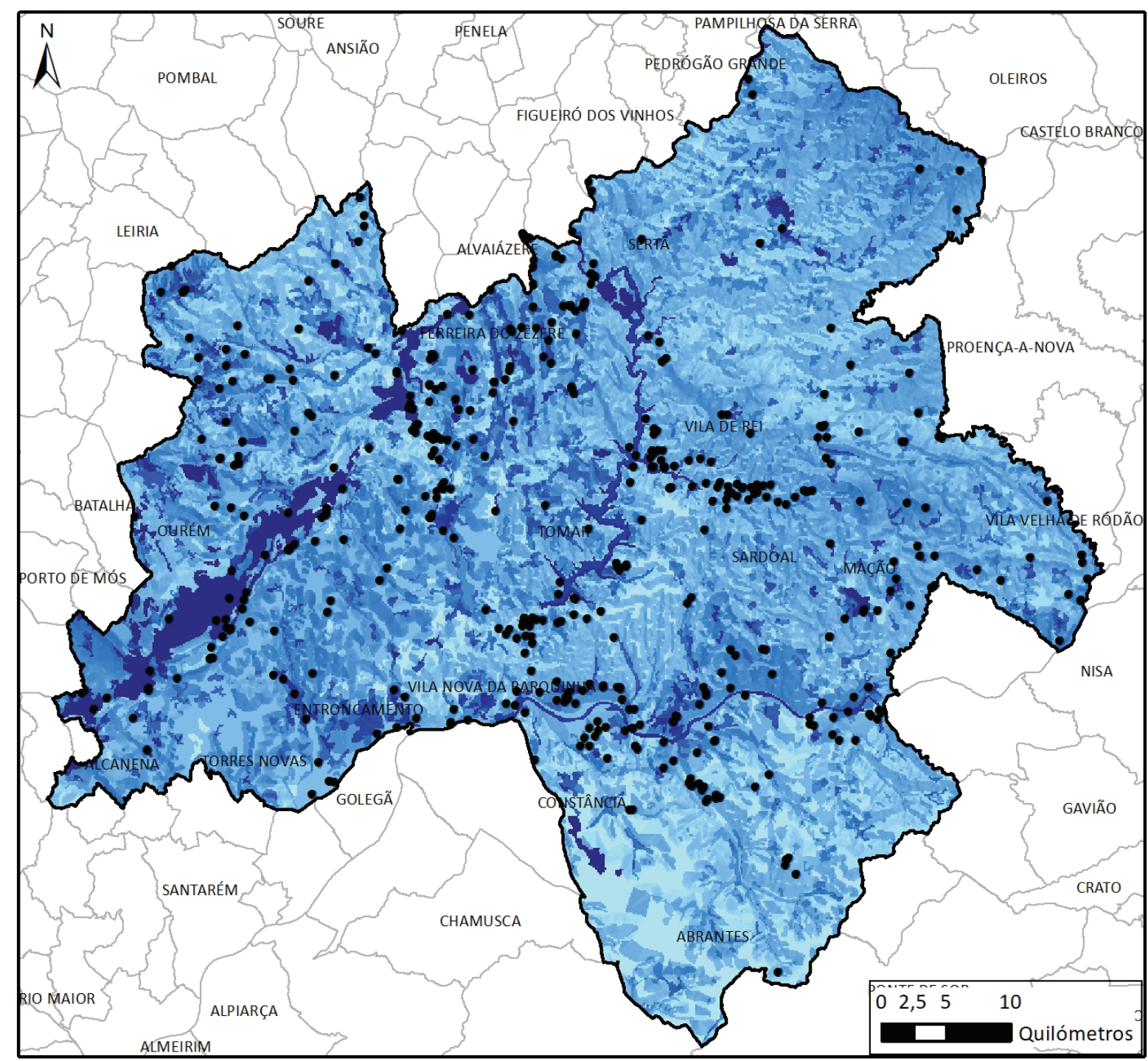

- Sitios Arqueológicos

Potencial (Método de Pesos)

Limite da Região Médio Tejo

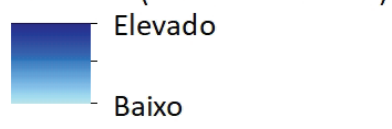

Fonte dos dados: CAOP2018

Sistema de Coordenadas: ETRS_1989_TM06_PT

Figura 10 - Áreas potenciais de existência de sítios arqueológicos, utilizando o método da sobreposição binária. 


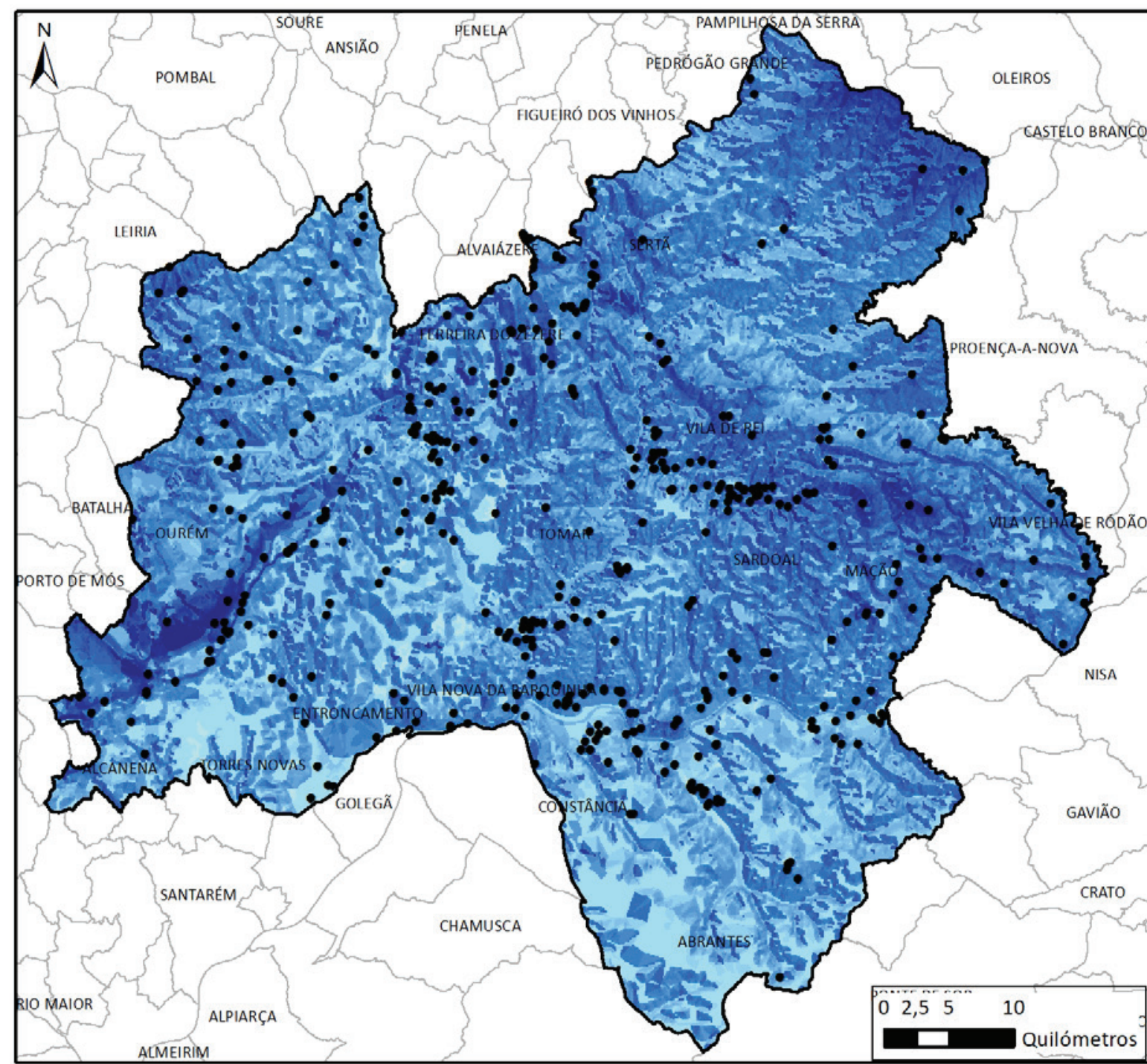

- Sitios Arqueológicos
$\square$ Limite da Região Médio Tejo

Potencial (Método da sobreposição binária)

Elevado

Baixo
Fonte dos dados: CAOP2018

Sistema de Coordenadas: ETRS_1989_TM06_PT

Figura 11 - Potencialidade de existência de sítios arqueológicos, utilizando o método de pesos. 


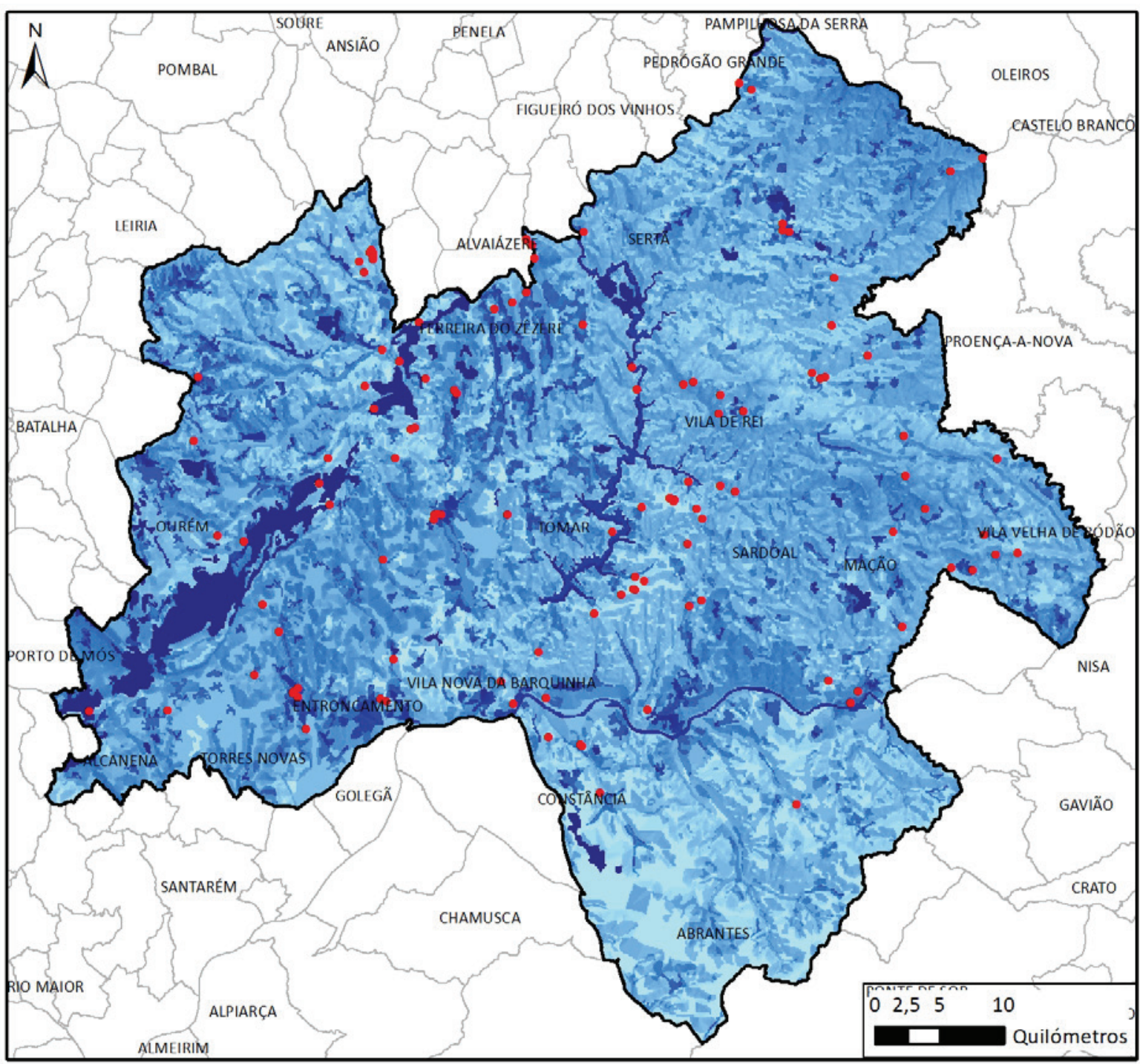

- Sitios Teste

Potencial (Método de Pesos) Elevado

Fonte dos dados: CAOP2018

Baixo

Figura 12 - Sítios de teste sobre modelo obtido através do método dos pesos. 


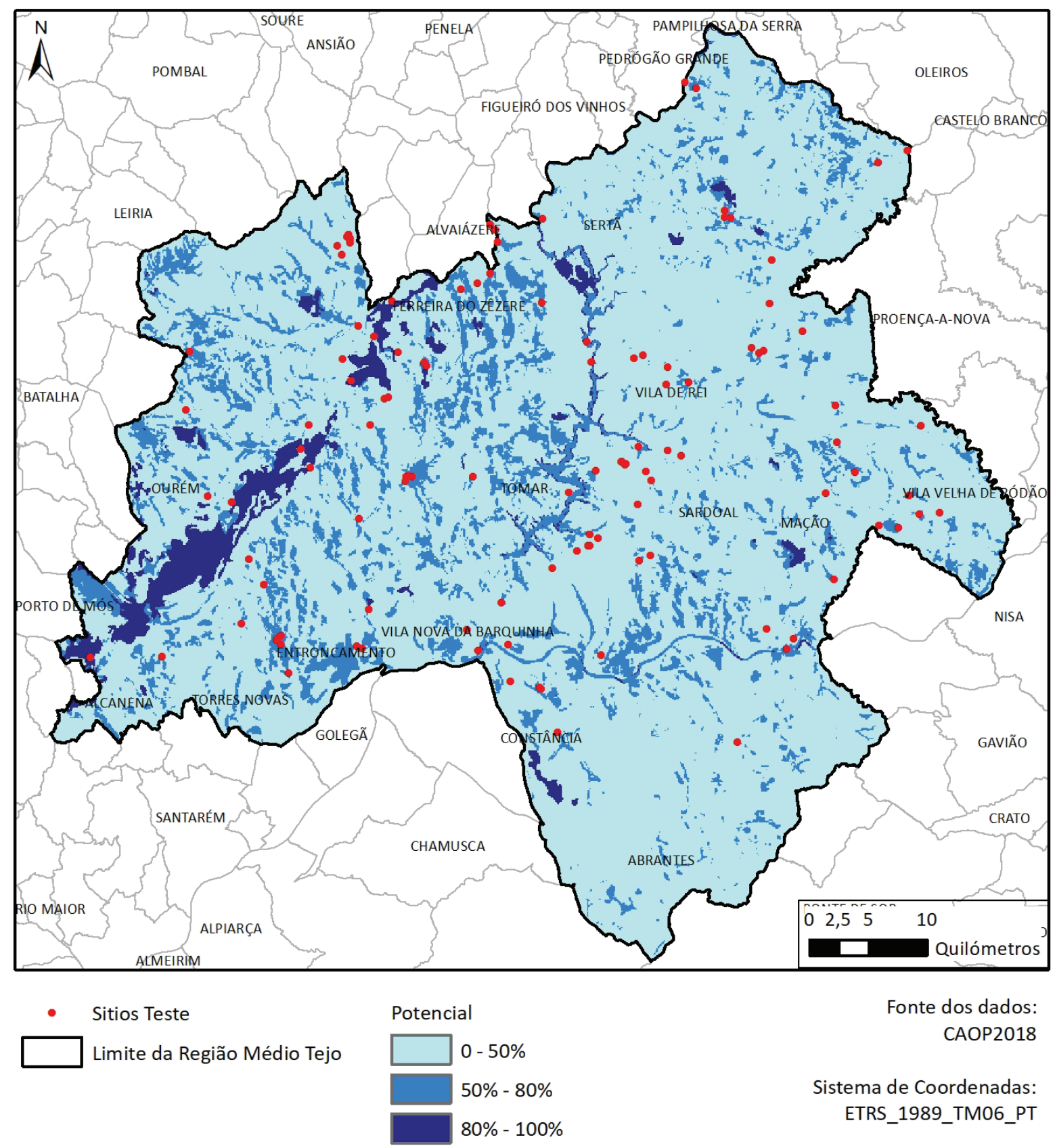

Figura 13 - Sítios de teste sobre classes de potencial modelo obtido através do método dos pesos. 


\begin{tabular}{|c|c|}
\hline Classe & Categoria CLC20o6 \\
\hline \multirow{6}{*}{ Social } & Aeroportos e aeródromos \\
\hline & Equipamentos desportivos, culturais e de lazer e zonas históricas \\
\hline & Indústria, comércio e equipamentos gerais \\
\hline & Redes viárias e ferroviárias e espaços associados \\
\hline & Tecido urbano contínuo \\
\hline & Tecido urbano descontínuo \\
\hline \multirow{7}{*}{ Agricultura } & Agricultura com espaços naturais e seminaturais \\
\hline & Culturas temporárias de sequeiro \\
\hline & Culturas temporárias de regadio \\
\hline & Culturas temporárias e/ou pastagens associadas a culturas permanentes \\
\hline & Olivais \\
\hline & Pomares \\
\hline & Vinhas \\
\hline \multirow{5}{*}{ Floresta } & Florestas de folhosas \\
\hline & Florestas de resinosas \\
\hline & Florestas mistas \\
\hline & Florestas abertas, cortes e novas plantações \\
\hline & Sistemas agroflorestais \\
\hline Sistemas Culturais complexos & Sistemas culturais e parcelares complexos \\
\hline Matos & Vegetação esclerofila \\
\hline \multirow{2}{*}{ Cursos de Água } & Cursos de água \\
\hline & Planos de água \\
\hline \multirow{2}{*}{ Extração de Inertes } & Áreas de extração de inertes \\
\hline & Áreas de deposição de resíduos \\
\hline
\end{tabular}

Tabela 1 - Classificação das classes de ocupação do solo.

\begin{tabular}{|c|c|}
\hline Variável Independente & Dmáx \\
\hline Declives & 0,148 \\
\hline Orientação de encostas & 0,141 \\
\hline Distância a rios & 0,200 \\
\hline Ocupação do solo & 0,084 \\
\hline
\end{tabular}

Tabela 2 - Valores de $\mathrm{D}_{\text {máx }}$ para cada variável independente. 


\begin{tabular}{|c|c|c|}
\hline Variáveis Independentes & Área $\left(\mathrm{m}^{2}\right)$ & Pesos \\
\hline Declives & 885034 & 0,111 \\
\hline Orientação de encostas & 885034 & 0,111 \\
\hline Distância a rios & 5346064 & 0,671 \\
\hline Ocupação do solo & 846056 & 0,106 \\
\hline Total & 7962188 & \\
\hline
\end{tabular}

Tabela 3 - Pesos das variáveis independentes.

\begin{tabular}{|c|c|c|}
\hline Potencial (\%) & Sítios & Frequência \\
\hline $0-50$ & 90 & $73,17 \%$ \\
\hline $50-80$ & 27 & $21,95 \%$ \\
\hline $80-100$ & 6 & $4,88 \%$ \\
\hline Total & 123 & $100,00 \%$ \\
\hline
\end{tabular}

Tabela 4 - Resultado do teste ao modelo obtido através do método de pesos. 


\title{
PATRIMÓNIO ARQUEOLÓGICO E GESTÃO TERRITORIAL: O CONTRIBUTO DA ARQUEOLOGIA PARA A REVISÃO DO PDM DE AVIS
}

\author{
Ana Cristina Ribeiro ${ }^{1}$
}

\begin{abstract}
RESUMO
O diagnóstico actual da Arqueologia no concelho de Avis reflecte um conhecimento profundo e sistemático do território, das suas particularidades e da diversidade de expressões que traduzem a ocupação humana nesta região, preconizando a necessidade premente de se efectivar a revisão do Plano Director Municipal.

Apresenta-se uma síntese do contributo do Centro de Arqueologia de Avis para o estudo e a salvaguarda do património arqueológico, abordando as opções estratégicas e os procedimentos considerados fundamentais para uma intervenção municipal face aos novos desafios que se colocam na gestão desses valores patrimoniais e na sua afirmação nas dinâmicas locais, que passa pela inserção nas políticas e nos instrumentos de gestão e ordenamento do território e nas estratégias de desenvolvimento local.
\end{abstract}

Palavras-chave: Território, Património arqueológico, Gestão integrada, Salvaguarda, Revisão do PDM.

\begin{abstract}
The current diagnosis of Archaeology in the municipality of Avis reflects a deep and systematic knowledge of the territory, its particularities and the diversity of expressions that translate the human occupation in this region, advocating the urgent need to revise the Municipal Master Plan.

A summary of the contribution of the Avis Archaeology Centre to the study and safeguarding of archaeological heritage is presented, addressing the strategic options and procedures considered fundamental for a municipal intervention in the face of the new challenges in the management of these heritage values and their affirmation in local dynamics, which includes insertion in the politics and instruments of management and planning of the territory and in local development strategies.
\end{abstract}

Keywords: Territory, Archaeological heritage, Integrated management, Safeguarding, Review of the PDM.

\section{INTRODUÇÃO}

As autarquias, enquanto promotoras da actividade arqueológica, têm um papel determinante na salvaguarda, estudo e valorização do património arqueológico local. Contudo, a expressão desse contributo é condicionada pela sensibilidade e vontade do poder local, determinando o reconhecimento da Arquelogia e assim das estruturas, das equipas, dos recursos e dos meios disponíveis para o desenvolvimento de trabalhos arqueológicos, assim como da concretização de medidas de salvaguarda e valorização.

Apesar de deter um nível de intervenção privilegiado enquanto agentes locais, acedendo de forma directa ao património arqueológico e estabelecendo, simultaneamente, uma relação próxima com a comunidade, o facto é que a arqueologia nem sempre é uma prioridade das autarquias, uma vez que o património arqueológico continua a ser encarado como um obstáculo que condiciona o desenvolvimento local. Consequentemente, um dos maiores desafios que se impõe à arqueologia municipal é consciencializar para a importância da salvaguarda dos valores patrimoniais, demonstrando que, quando devidamente geridos, podem contribuir para o desenvolvimento local, pelo que é fundamental definir e

1. Centro de Arqueologia de Avis; ana.ribeiro@cm-avis.pt 
implementar mecanismos adequados de avaliação e intervenção preventivas.

Por conseguinte, a existência de valores arqueológicos associados a um território implica uma responsabilidade acrescida ao nível da gestão municipal, que se efectiva na implementação de um conjunto de meios e instrumentos que promovem o estudo, a salvaguarda e a valorização desse património.

Embora o panorama, em diversos casos, não se afigure o mais favorável, o facto é que a arqueologia municipal tem vindo a adquirir uma expressão significativa que se manifesta em diversos exemplos.

A criação de estruturas orgânicas com atribuições relacionadas com a prática arqueológica, desenvolvida por arqueólogos em regime de continuidade e com relações laborais estáveis, e a crescente valorização do património arqueológico enquanto recurso local, têm contribuído para o crescimento e consolidação da arqueologia municipal.

Desta forma, são criadas as condições base para uma intervenção activa da arqueologia no planeamento e gestão do património arqueológico no âmbito dos instrumentos de gestão territorial que, consequentemente, irá refletir-se na criação de medidas de protecção e salvaguarda adequadas às realidades arqueológicas.

É neste contexto que se integra o caso de Avis, onde, a partir dos trabalhos desenvolvidos nos últimos anos, se definiu uma nova visão para o território e para o património arqueológico que assenta, não só na revisão de registos precedentes e na identificação de um número considerável de novos sítios, mas também no reconhecimento de novos focos de ameaça à integridade dos locais de interesse arqueológico e na necessidade de se implementarem estratégias revistas e actualizadas de protecção, gestão e valorização destes bens, em articulação com os demais recursos e factores territoriais.

Torna-se cada vez mais evidente a necessidade de conciliar, adequar e definir medidas de preservação e valorização desses valores que, por sua vez, induzem ao registo e estudo, criando-se uma base de trabalho que, para além do reforço e manutenção da identidade local, contribuem para a criação e renovação de uma oferta vocacionada para a dinamização cultural e turística, com repercussões nos planos sociais e, sobretudo, económico.

\section{INSTRUMENTOS DE GESTÃO TERRITO- RIAL E PATRIMÓNIO ARQUEOLÓGICO EM AVIS: UM BREVE ENQUADRAMENTO}

O reconhecimento da importância dos valores patrimoniais reflecte-se, em Avis, na elaboração, no início da década de 8 o do século XX, de estratégias de identificação e avaliação do património cultural local, com vista à constituição de um inventário e à definição de acções de valorização.

Ao nível do património arqueológico, este trabalho reúne a bibliografia para o concelho de Avis e identifica os locais de interesse arqueológico, delineando propostas de intervenção futura com vista à sua valorização.

Este levantamento terá favorecido e facilitado, numa fase posterior, a integração do património arqueológico nos instrumentos de gestão do território (IGT) e a definição de normas regulamentares de protecção. O Plano de Urbanização de Avis (PU), publicado em 1994, é omisso relativamente ao património arqueológico, mas revela já alguma preocupação com os valores patrimoniais do núcleo urbano histórico de Avis. Para isso evoca o património edificado classificado, assinalando ainda valores edificados não classificados, mas de reconhecido valor patrimonial, para o qual são definidas normas específicas.

O Plano Director Municipal de Avis (PDM), de 1995, estabelece os condicionamentos decorrentes do regime de protecção do património, com a identificação do património edificado e arqueológico classificado existente no concelho. O regulamento abrange ainda os sítios arqueológicos incluídos na planta de condicionantes, correspondentes, à data da publicação, a 62 locais.

O património arqueológico figura igualmente nos Planos de Ordenamento das Albufeiras de Maranhão e de Montargil (POA), de 1999 e 2002. O POA de Maranhão é mais rigoroso na sua regulamentação, considerando, para efeitos de aplicação das normas de salvaguarda, o património arqueológico no plano de água, em meio submerso ou submersível, e na área envolvente, correspondente a uma faixa de $500 \mathrm{~m}$, prevendo medidas que visam a sua protecção e salvaguarda, aplicáveis aos sítios assinalados na planta de síntese ou aos que possam ser identificados posteriormente.

Em 2008 é publicado o Plano de Pormenor de Salvaguarda e Valorização do Centro Histórico de Avis (PPSVCHA), que implementa medidas que assegu- 
ram a salvaguarda dos valores arqueológico e fomentam a arqueologia de carácter preventivo na zona antiga da vila, acautelando-se que a eficácia das acções preventivas ultrapassa o acompanhamento de obras, permitindo, assim, uma maior participação da arqueologia na gestão e no planeamento urbanísticos.

Desta forma, procurou-se garantir a aplicação de medidas preventivas materializadas no âmbito de licenciamento de obras, na participação/consulta em fase prévia de projectos, e no acompanhamento arqueológico de obras, que constitui ainda a forma mais frequente de intervenção.

Após a conclusão do estudo que esteve na origem do PPSVCHA, desenvolvido entre 2002 e 2004, promoveu-se uma abordagem alargada ao concelho, com resultados que reclamam uma actualização urgente das normas de salvaguarda do património arqueológico local e a sua respectiva inserção nos IGT de Avis. (Quadro 1)

\section{UM DIAGNÓSTICO DO PATRIMÓNIO ARQUEOLÓGICO LOCAL}

A partir de 2005 fomenta-se uma estratégia continuada de levantamento e diagnóstico do património arqueológico local.

Nesse sentido, e de forma a criar uma visão global e integrada dos testemunhos de ocupação no concelho, foi iniciada a Carta Arqueológica de Avis (Ribeiro, 2008, p. 1-12).

Os dados reunidos anteriormente eram claramente insatisfatórios, atendendo à dimensão do território e às suas características naturais, deixando antever lacunas na identificação de sítios e levantando inúmeras questões relativas à ocupação humana, que careciam de uma abordagem mais aprofundada.

A Carta Arqueológica de Avis pretendia assim rever a informação já conhecida e definir estratégias que possibilitassem a identificação de novos sítios, actualizando o inventário e promovendo o estudo e a valorização do património arqueológico local.

A informação reunida veio contribuir para uma gestão integrada destes valores no território e, desta forma, para a participação nas dinâmicas de desenvolvimento local.

A visão fraccionada e incompleta que existia no início do projecto foi-se atenuando à medida que os trabalhos se desenvolviam.

A identificação de um conjunto significativo de sítios e monumentos arqueológicos inéditos demonstrou que a realidade era bem mais variada e multifacetada do que a que se conhecia no início da Carta Arqueológica, cujo quadro de referência, reunido no PDM, incluía 62 locais de interesse arqueológico. No final da Carta Arqueológica de Avis, o inventário incluía 205 sítios registados. (Gráficos 1 e 2)

Actualmente, o inventário de sítios aqueológicos reúne 335 ocorrências para o concelho, resultantes de trabalhos mais recentes associados ao projecto “Territórios e espaços de morte na pré-história recente-TEMPH” (idem, 2018a p.73-94; idem, 2018b, p. 83-10o).

Dos dados reunidos, 65 correspondem a sítios relocalizados, referenciados em trabalhos precedentes, sendo os restantes 269 locais inéditos. (Gráfico 3 ) Neste processo de incremento da actividade arqueológica em Avis, a acção preventiva assumiu um papel igualmente importante. Com o objectivo de minimizar o impacto decorrente da realização de obras em locais ou imóveis com sensibilidade arqueológica, procurou-se envolver a arqueologia, com o devido enquadramento no PPSVCHA, nas intervenções em áreas de reconhecido ou potencial valor patrimonial. Para além dos resultados obtidos, que têm permitido alargar o conhecimento sobre a ocupação da zona antiga de Avis, a intervenção da arqueologia tem vindo a afirmar-se, ainda que com alguns constrangimentos, no âmbito do licenciamento de obras públicas e particulares, na fiscalização, na participação na revisão dos instrumentos de gestão territorial e na consulta na fase de elaboração de projectos.

Consciente das competências das autarquias em matéria de património, e num contexto favorável à actividade arqueológica em Avis (idem, 2011, 567588), foi criado, em 2011 o Centro de Arqueologia de Avis (CAA), serviço municipal que tem procurado despoletar mecanismos actualizados e revistos de avaliação e intervenção preventivas aplicados ao património arqueológico, assegurando a sua identificação, inventário, estudo, salvaguarda e divulgação (idem, 2012, p. 191-193).

No âmbito da sua actuação, o CAA tem, ao nível do planeamento e do ordenamento do território, um papel fundamental no reconhecimento do potencial património arqueológico existente no concelho e na promoção do seu estudo e enquadramento territorial, fomentando meios de gestão que procuram assegurar a sua protecção e salvaguarda em articulação com o território.

A organização da informação resultante dos diver- 
sos trabalhos assume, neste contexto, particular relevo. A realização do Inventário Geral de Património Arqueológico de Avis (IGPAA) e o respectivo sistema de informação geográfica constituem um importante contributo para a gestão e valorização do património arqueológico local.

O IGPAA tem por base a ficha de sítio arqueológico, onde se reúnem os critérios descritivos fundamentais para a caracterização individualizada dos sítios. Associados a cada uma das fichas estão outros ficheiros com informação complementar.

As fichas de sítio estão correlacionadas com a cartografia SIG, desenvolvida com base nas folhas das Cartas Militares de Portugal, à escala 1:25 000. Perspectivando-se o melhoramento da base georreferenciada com a integração de cartografia actualizada, assim como de novos elementos de análise, será possível, em breve, tornar mais eficaz a leitura global do território.

Com esta base de trabalho tem sido possível proceder à sistematização dos locais de interesse arqueológico, aspecto preponderante na gestão integrada do território e nas dinâmicas culturais e turísticas. (Quadro 2)

\section{CONTRIBUTO DA ARQUEOLOGIA NA REVISÃO DO PDM DE AVIS}

Com a revisão de dados e a identificação de novos testemunhos de ocupação do território verificou-se, a partir de 2005, um aumento considerável dos valores arqueológicos inventariados, que se devem, em grande medida, à Carta Arqueológica de Avis e, posteriormente, ao projecto TEMPH.

Mas, se por um lado se verificou um acréscimo de sítios de interesse arqueológico, por outro lado identificaram-se novos factores que ameaçam a sua integridade, decorrentes do ritmo acelerado das transformações da paisagem e do território, verificado há mais de uma década, na sequência da implementação da produção agrícola em regime intensivo.

Perante o actual quadro de referência do património arqueológico de Avis, importa pois reflectir e, consequentemente, agir preventivamente no que diz respeito às medidas de salvaguarda a aplicar, em particular no que se refere aos locais que não se encontram integrados no PDM ou que não estão classificados, em vias de classificação ou em área de servidão administrativa de proteção a bens culturais imóveis. Neste âmbito, a inventariação dos valores patrimo- niais decorrente dos trabalhos realizados assume especial relevo, para o processo de revisão do PDM, uma vez que fornece uma visão global sobre as realidades e o potencial arqueológico do concelho, identifica aptidões e avalia possíveis interferências. O inventário constitui, por isso, a base para o desenvolvimento de acções que promovam a sua salvaguarda, gestão e valorização em coerência com os restantes recursos territoriais.

Em 2019, e no âmbito do Relatório do Estado do Ordenamento do Território (REOT), onde se definiu o enquadramento estratégico que fundamentará a necessidade de revisão do PDM de Avis, o CAA realizou um diagnóstico síntese do património arqueológico do concelho integrado no IGPAA, e estabeleceu as linhas orientadoras de medidas de salvaguarda do património arqueológico adequadas, sublinhando a necessidade de se regulamentar a avaliação e $\mathrm{a}$ intervenção preventivas.

Os trabalhos desenvolvidos permitiram definir categorias patrimoniais e actualizar a sua distribuição geográfica, associada a dois contextos diferenciados, correspondentes aos núcleos urbanos e ao meio rural. Com esta distinção procurou-se qualificar, de forma adequada às respectivas particularidades, as opções estratégicas e os procedimentos metodológicos e técnicos a adoptar na implementação de medidas de salvaguarda.

Esta orientação permitirá também gerir, de forma mais eficaz, o desenvolvimento dos sectores económicos predominantes em cada um desses contextos, em harmonia com o património arqueológico existente, garantindo a minimização de impactos sobre a informação que confere identidade a este território. Para os núcleos urbanos, encontram-se regulamentadas, através do PPSVCHA, normas de protecção do património arqueológico aplicáveis ao Centro Histórico de Avis.

No entanto, e considerando a antiguidade de ocupação da maioria dos restantes núcleos urbanos do concelho, entende-se pertinente a definição de zonamentos que correspondam a diferentes áreas de protecção com as respectivas normas de salvaguarda. No que se refere ao património arqueológico em meio rural, contexto onde se verifica um claro predomínio de sítios arqueológicos, foram identificados diferentes níveis de valor patrimonial.

Assim, e com base no reconhecimento da existência de diversas realidades, considera-se que, ao nível do património arqueológico neste contexto, deverá 
ser assegurada, no âmbito da revisão do PDM, a valoração dos locais de interesse arqueológico, à qual deverão corresponder diferentes graus de proteção e normas de salvaguarda.

Esta categorização será definida com base no tipo de sítio e terá em consideração a avaliação patrimonial, realizada no decurso dos trabalhos promovidos pelo CAA e cujos critérios se encontram assinalados na ficha de sítio. Deste modo, será possível definir zonas de protecção para os sítios, determinar medidas preventivas de acordo com o potencial arqueológico associada ao tipo de sítio e identificar condições de intervenção.

A aplicação de medidas preventivas deverá ser igualmente acautelada para o património arqueológico submerso ou submersível, associado aos planos de água das albufeiras de Maranhão e Montargil, anteriormente preconizadas com os respectivos POA, assim como para os achados arqueológicos ocasionais, evitando a destruição ou a dispersão de testemunhos arqueológicos.

Considerando a actividade continuada desenvolvida pelo CAA, é expectável a identificação de novas realidades, assim como a revisão de dados. Por conseguinte, e tendo em consideração a necessidade de se acautelar uma permanente actualização do inventário do património local, deverá ser contemplada a integração de novos sítios arqueológicos, sujeitando-se à regulamentação dos planos em vigor.

A nova redacção do PDM deverá, por isso, contemplar a aplicação das medidas de salvaguarda do património arqueológico aos sítios que venham a ser identificados após a sua publicação.

Com a consolidação de um serviço municipal como o CAA, tem sido garantido, de forma sistemática, o estudo, a salvaguarda e a valorização do património arqueológico local.

Os projectos de investigação têm assegurado o estudo continuado do território, com a permanente revisão e actualização da informação face à descoberta de novas realidades.

A acção preventiva, aplicada sobretudo à área abrangida pelo PPSVCHA, assim como a participação nos processos de licenciamento, no âmbito do enquadramento no PDM ou PPSCHA, têm determinando, embora de forma não constante, uma avaliação arqueológica dos impactos das operações urbanísticas, agrícolas e florestais.

Não menos importantes são as componentes de valorização e divulgação, pois é através destas acções que se promove uma consciencialização para a importância da preservação dos valores patrimoniais. Por essa razão, o CAA tem desenvolvido diversas iniciativas que asseguram um contacto permanente com a comunidade e com um público diversificado. Ainda neste âmbito, foi implementado, em 2016, o Plano de Gestão e Valorização de Sítios e Monumentos Arqueológicos (Ribeiro, 2017, p33-42), ferramenta essencial para a definição de estratégias de intervenção que visam a conservação e divulgação do património arqueológico.

Pelo trabalho desenvolvido, o contributo do CAA na gestão do património local e nas opções estratégicas para o desenvolvimento do concelho, é determinante para a manutenção dos factores distintivos e genuínos que conferem a este território singularidade, os quais, se devidamente valorizados, poderão contribuir significativamente para o turismo cultural e dinamismo socioeconómico local.

O CAA tem assegurado o diagnóstico permanente do património arqueológico do concelho, reconhecendo o seu potencial, a natureza e o grau das ameaças, assim como tem avaliado e definido as medidas que deverão ser adoptadas para contribuir para a preservação dos bens patrimoniais.

Porém, e no contexto actual, é cada vez mais expressiva a alteração, profunda e acelerada, da paisagem agrícola com a expansão das produções em regime intensivo nesta região, que tendem a descaracterizar este território, e em particular em Avis, onde a disponibilidade de recursos hídricos associados à albufeira de Maranhão, tem favorecido o crescimento desregulado deste modo de produção.

No sentido de minimizar os impactos negativos associados a esta prática crescente, a revisão do PDM constitui uma excelente oportunidade para se definirem medidas actualizadas e adaptadas a esta nova realidade, conferindo à autarquia, de acordo com as suas competências, um papel activo e interventivo na gestão dos recursos locais.

Por essa razão, mais do que normas e condicionantes de protecção, é necessário fazer verter no regulamento do PDM, ainda que previstos na lei geral, códigos de conduta adaptados às realidades locais, na relação actividade humana versus património e o recíproco.

O CAA reúne o conhecimento e dispõe das condições essenciais para contribuir, de forma decisiva, para a elaboração do estudo de caracterização territorial integrado na revisão do PDM de Avis, crian- 
do simultaneamente as condições para uma maior participação nas estratégias municipais relacionadas com o planeamento e ordenamento territoriais. Só através de uma articulação activa e constante com os restantes serviços municipais intervenientes nestas matérias será possível implementar, com a eficácia desejável, um conjunto de normas, procedimento e rotinas que assegurem a salvaguarda de uma herança comum, sendo expectável que os sucessivos executivos encarem esta valência e competência.

\section{BIBLIOGRAFIA}

ANASTÁCIO, Rita Ferreira; OOSTERBEEK, Luís e ROSINA, Pierluigi (2015) - Gestão integrada do território e do património: a importância dos sistemas de informação geográfica. Sémata, Ciências Sociais e Humana, vol. 27, pp. 187-197.

MARTINS, Ana Margarida Nunes (2011) - A salvaguarda do património cultural no ordenamento territorial. O caso específico do património arqueológico. Instituto de Ciências Jurídico-Políticas, Faculdade de Direito de Lisboa.

MIRANDA, Eduardo $\mathbb{E}$ alii (2011) - Instrumento para o planeamento e gestão do património: o caso de Évora. Actas do Encontro Arqueologia e Autarquias, Câmara Municipal de Cascais, pp. 13-39.

PEREIRA, Angelina Rosa Mateus (2018) - A salvaguarda do património arqueológico nos instrumentos de gestão territorial e regulamentos municipais do Algarve: dois casos de estudo. Faculdade de Letras da Universidade de Lisboa.

RIBEIRO, Ana Cristina (2018b) - O Complexo do Pedrogão no contexto das primeiras sociedades camponesas: breves notas sobre o povoamento neolítico no concelho de Avis. Revista de História e Economia. São Paulo/Lisboa, volume 21, pp. 83-10o.

RIBEIRO, Ana Cristina (2018a) - Território e espaços de morte na Pré-História Recente. Contributo para uma nova leitura do povoamento megalítico no concelho de Avis. Actas do VIII Encontro de Arqueologia do Sudoeste Peninsular. Serpa e Aroche. Câmara Municipal de Serpa, pp. 73-94.

RIBEIRO, Ana Cristina (2017) - Plano de Gestão e Valorização de Sítios e Monumentos Arqueológicos: um contributo para a salvaguarda do património megalítico de Avis. Al-madan Online, n. ${ }^{2}$, tomo 2, pp. 33-42.

RIBEIRO, Ana (2012) - Centro de Arqueologia de Avis: um novo impulso no estudo e na preservação do património arqueológico do Concelho. Al-madan Online, n. ${ }^{1}$ 17, tomo 1 , p. 191-193.

RIBEIRO, Ana Cristina (2011) - (Re)descobrir Avis. Contributo para o estudo e valorização do património arqueológico do concelho. Actas do Encontro Arqueologia e Autarquias. Câmara Municipal de Cascais, p. 567-588.
RIBEIRO, Ana Cristina (2008) - Uma primeira leitura da Carta Arqueológica de Avis. Al-madan Online, n.ำ 16, VII, p. 1-12. 


\begin{tabular}{lll}
\hline Ano & Medida & Descrição \\
\hline 1994 & Regulamentação & Plano de Urbanização \\
\hline 1995 & Regulamentação & Plano Director Municipal \\
\hline 1999 & Regulamentação & Plano de Ordenamento da Albufeira de Maranhão \\
\hline 2002 & Regulamentação & Plano de Ordenamento da Albufeira de Montargil \\
\hline 2008 & Regulamentação & $\begin{array}{l}\text { Plano de Pormenor de Salvaguarda e Valorização do Centro } \\
\text { Histórico de Avis }\end{array}$ \\
\hline
\end{tabular}

Quadro 1 - IGT de Avis com abrangência ao património arqueológico.

\begin{tabular}{|c|c|c|}
\hline Ano & Medida & Designação \\
\hline $2005-2009$ & Investigação & Carta Arqueológica de Avis \\
\hline 2006-2010 & Investigação & Intervenção Arqueológica no sítio da Ladeira, Ervedal ( $1^{\underline{a}}$ fase) \\
\hline $2010 / 2014$ & Investigação & Carta Arqueológica de Avis ( $2 .^{\cdot}$ fase) \\
\hline $2014 / 2018$ & Investigação & $\begin{array}{l}\text { Território e espaços de morte na pré-história recente. } \\
\text { Contributo para o estudo do povoamento megalítico } \\
\text { no concelho de Avis (1. 믈 })\end{array}$ \\
\hline $\begin{array}{l}2012 / \\
\text { em curso }\end{array}$ & $\begin{array}{l}\text { Acção preventiva / } \\
\text { Investigação }\end{array}$ & $\begin{array}{l}\text { Intervenção arqueológica no Mosteiro de São Bento de Avis } \\
\text { - Conservação da Ala Poente do Claustro Velho e Espaços } \\
\text { Adjacentes }\end{array}$ \\
\hline Desde 2004 & $\begin{array}{l}\text { Avaliação } \\
\text { arqueológica }\end{array}$ & $\begin{array}{l}\text { Emissão de pareceres no âmbito do licenciamento de operações } \\
\text { urbanísticas e de enquadramento de actividade agrícola } \\
\text { e florestal }\end{array}$ \\
\hline Desde 2004 & Acção preventiva & $\begin{array}{l}\text { Intervenções diversas de carácter preventivo, com particular } \\
\text { incidência no Centro Histórico de Avis }\end{array}$ \\
\hline $2016 / 2019$ & Gestão e Valorização & $\begin{array}{l}\text { Plano de gestão e valorização de sítios e monumentos } \\
\text { arqueológicos_Património Megalítico (1. ㅁa fase) }\end{array}$ \\
\hline Em curso & $\begin{array}{l}\text { Inventário, gestão } \\
\text { e planeamento }\end{array}$ & $\begin{array}{l}\text { Reestruturação do Inventário geral do património arqueológico } \\
\text { de Avis (IGPAA) }\end{array}$ \\
\hline Em curso & $\begin{array}{l}\text { Inventário, gestão } \\
\text { e planeamento }\end{array}$ & Actualização da base SIG do IGPAA \\
\hline Em curso & $\begin{array}{l}\text { Inventário, gestão } \\
\text { e planeamento }\end{array}$ & Revisão do PDM de Avis \\
\hline Em curso & Investigação & $\begin{array}{l}\text { Território e espaços de morte na pré-história recente. } \\
\text { Contributo para o estudo do povoamento megalítico } \\
\text { no concelho de Avis ( } 2 .{ }^{.} \text {fase) }\end{array}$ \\
\hline
\end{tabular}

Quadro 2 - Principais acções desenvolvidas ao nível da gestão do património arqueológico em Avis. 


\section{Gráfico 1}

Registo de sítios arqueológicos

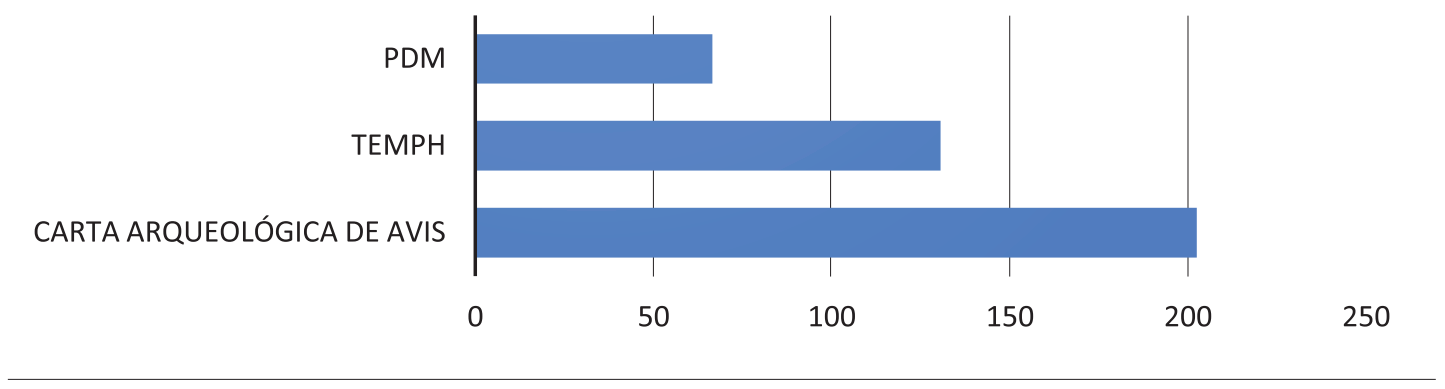

Gráfico 1 - Registo de sítios arqueológicos.

Gráfico 2

Registo de sítios arqueológicos

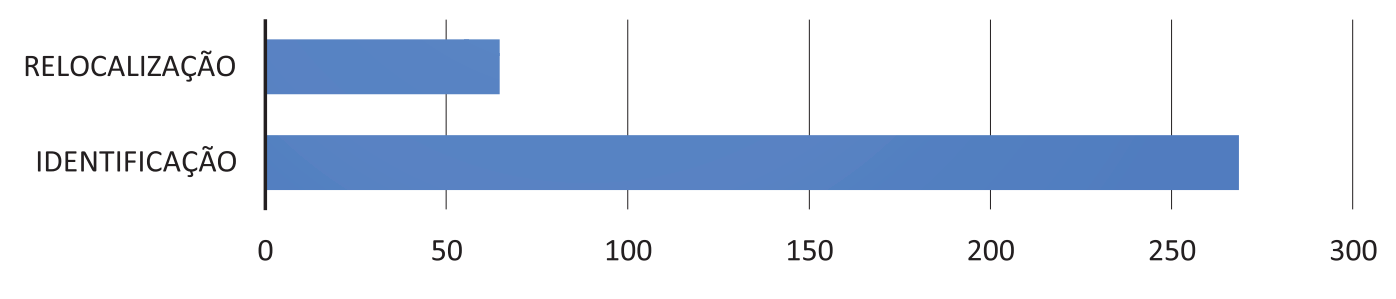

Gráfico 2 - Registo de sítios arqueológicos.

Gráfico 3

Distribuição dos sítios por freguesia

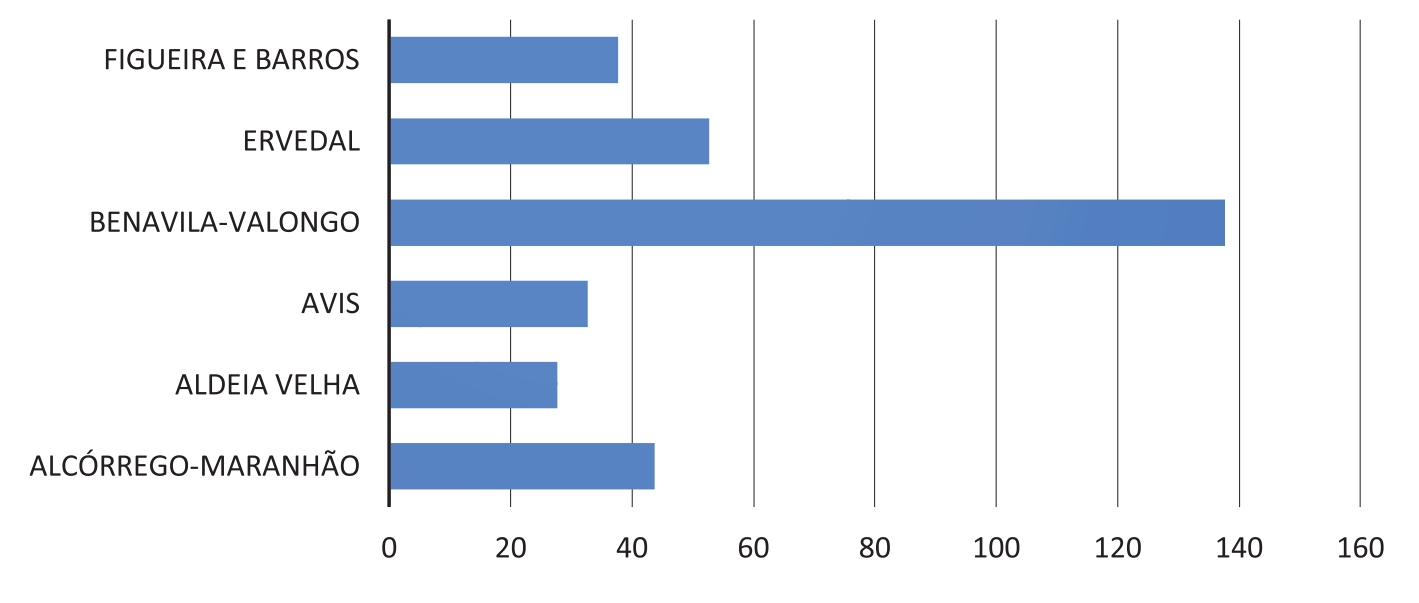

Gráfico 3 - Distribuição dos sítios por freguesia. 


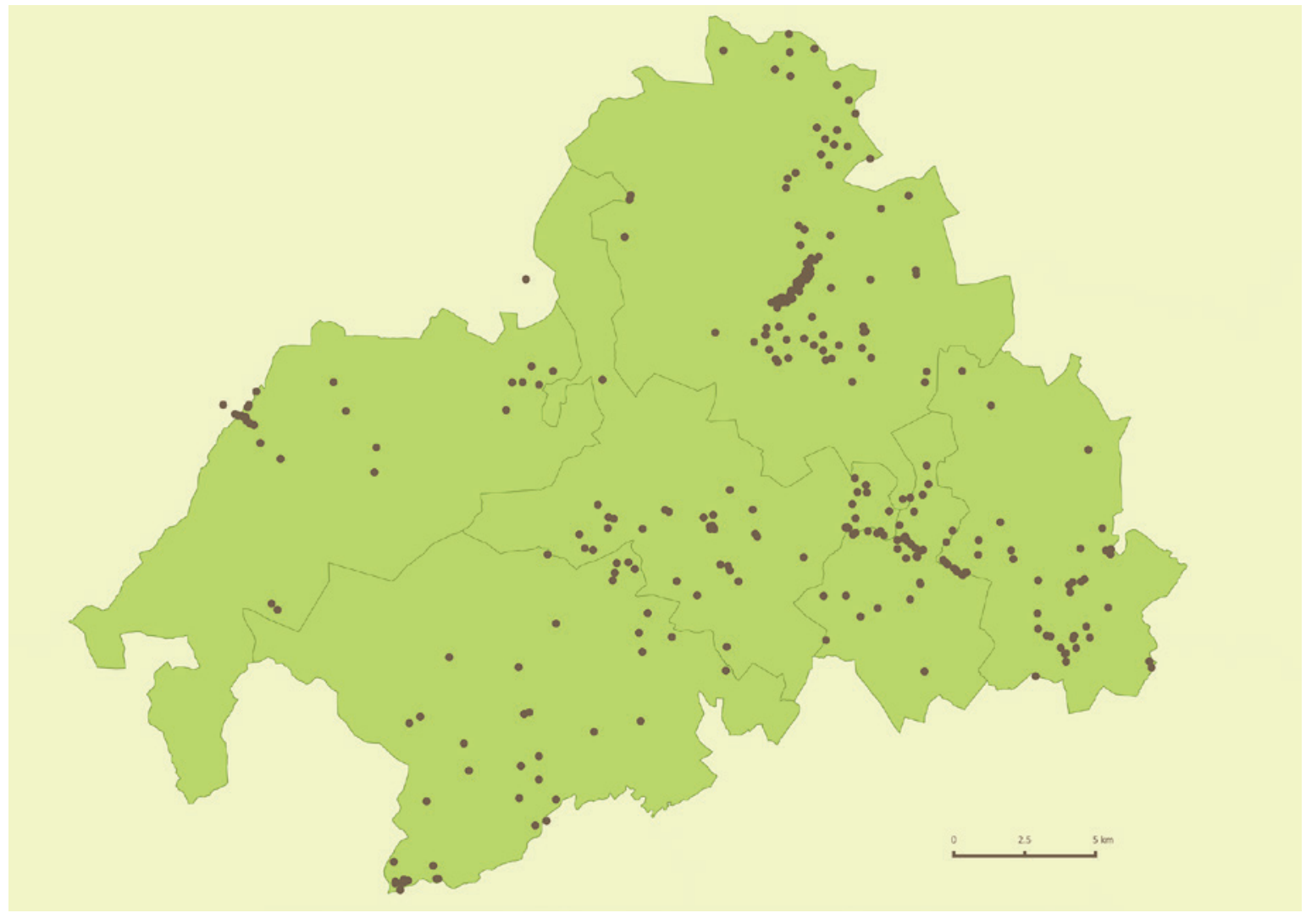

Figura 1 - Mapa síntese dos sítios integrados no Inventário Geral de Património Arqueológico de Avis.

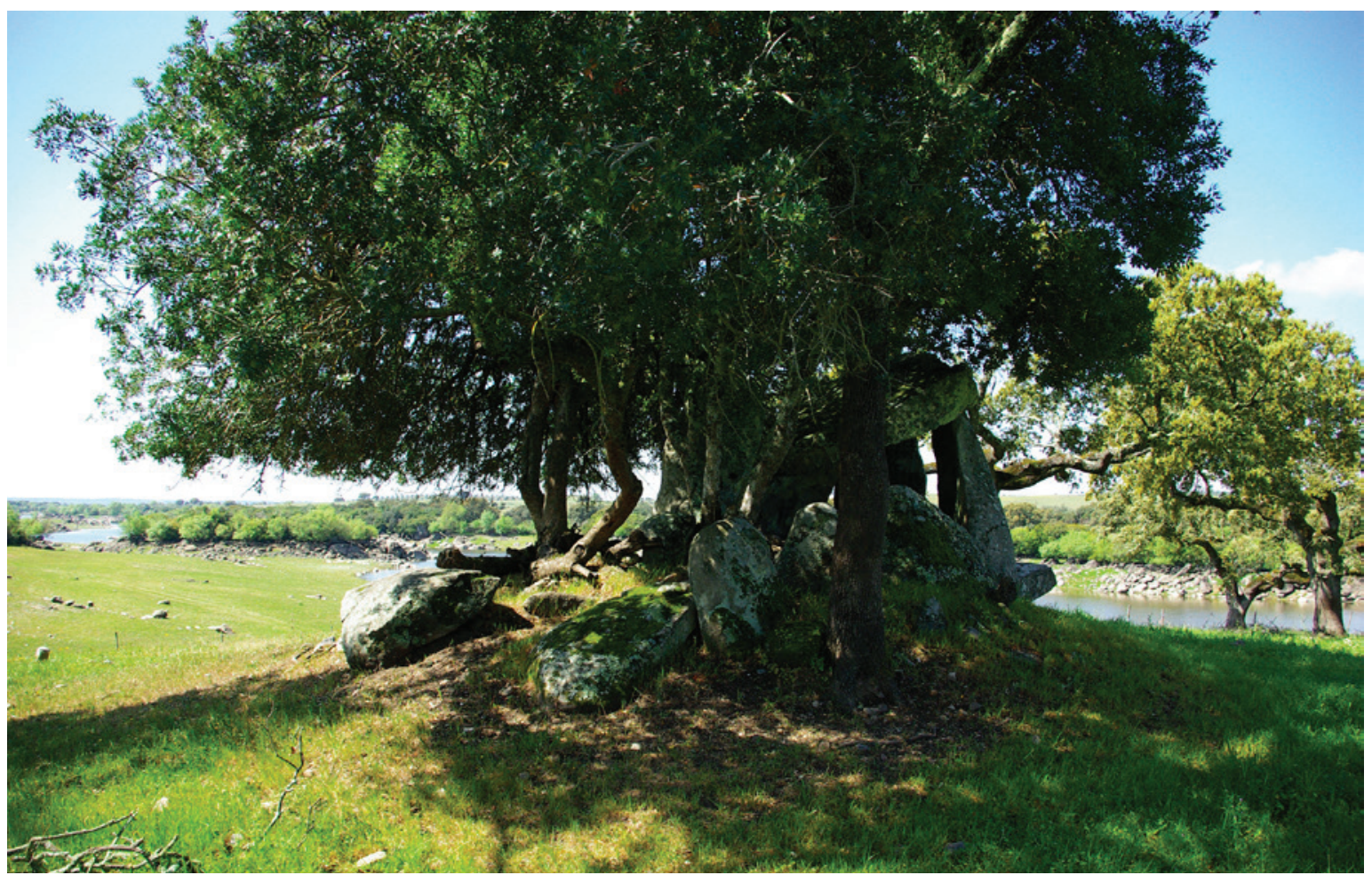

Figura 2 - Anta da Cumeada. 


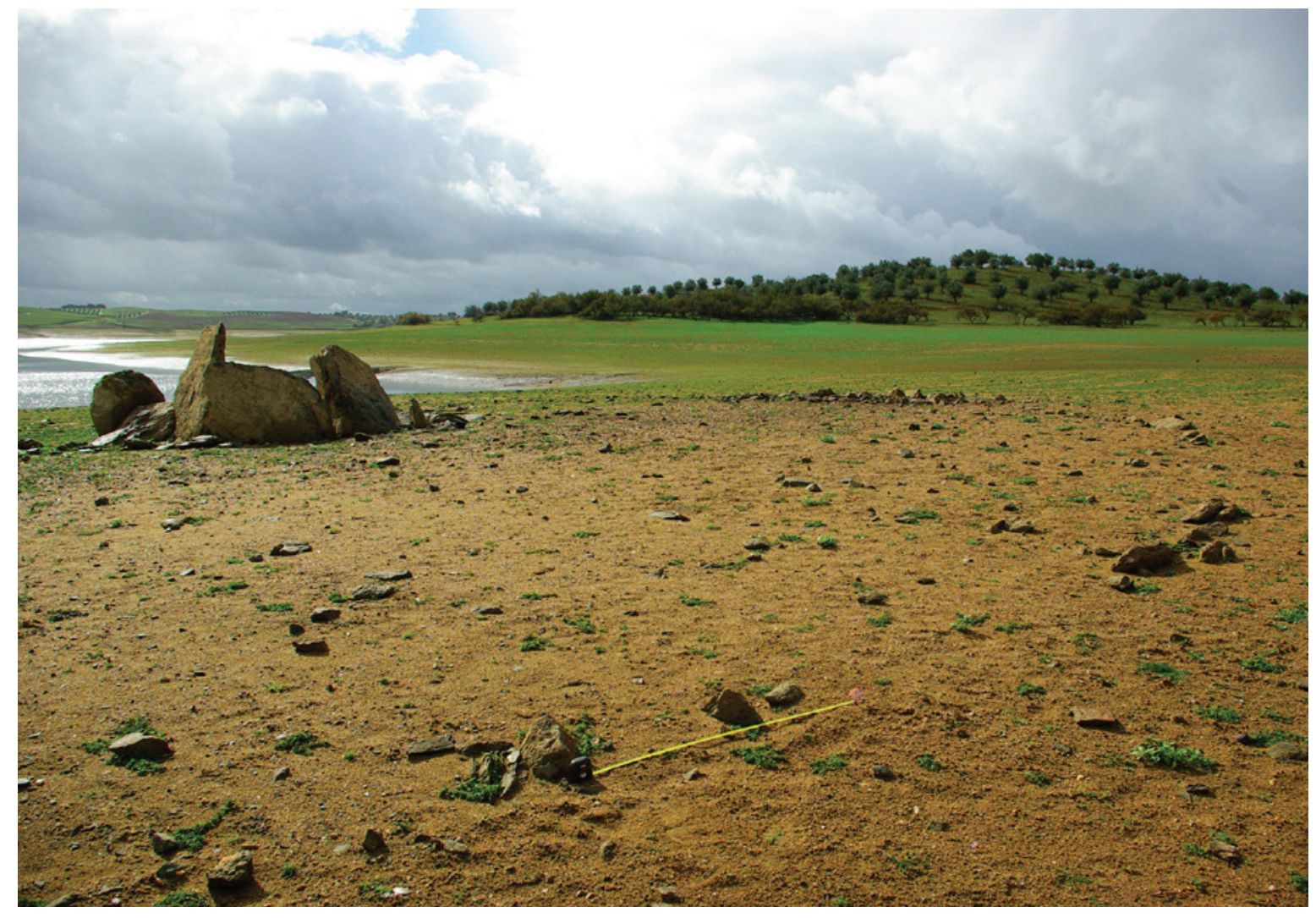

Figura 3 - Anta Rui Vaz 3.

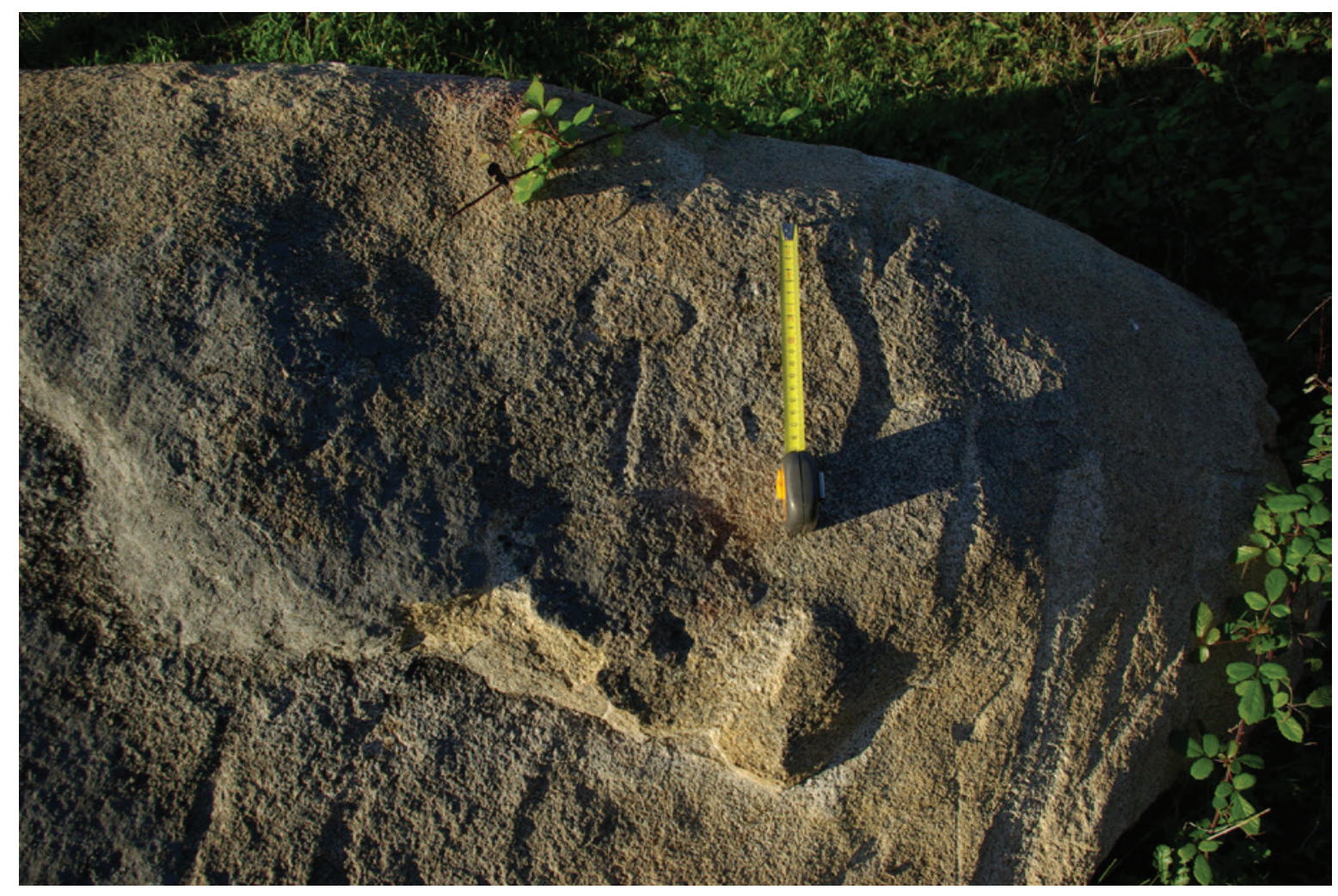

Figura 4 - Pormenor de monólito associado à Anta da Coutada. 


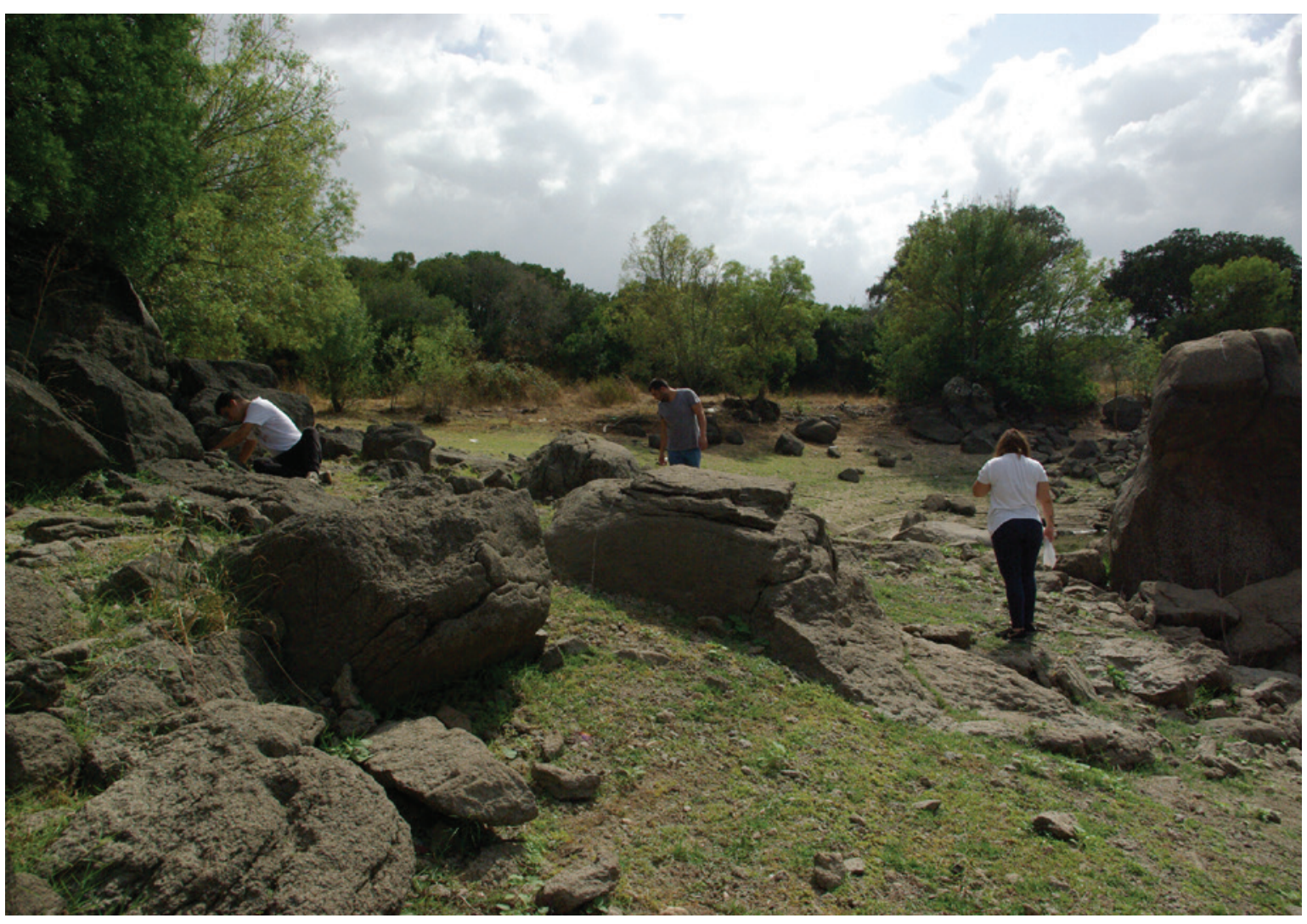

Figura 5- Trabalhos de prospecção no Complexo do Pedrogão. 


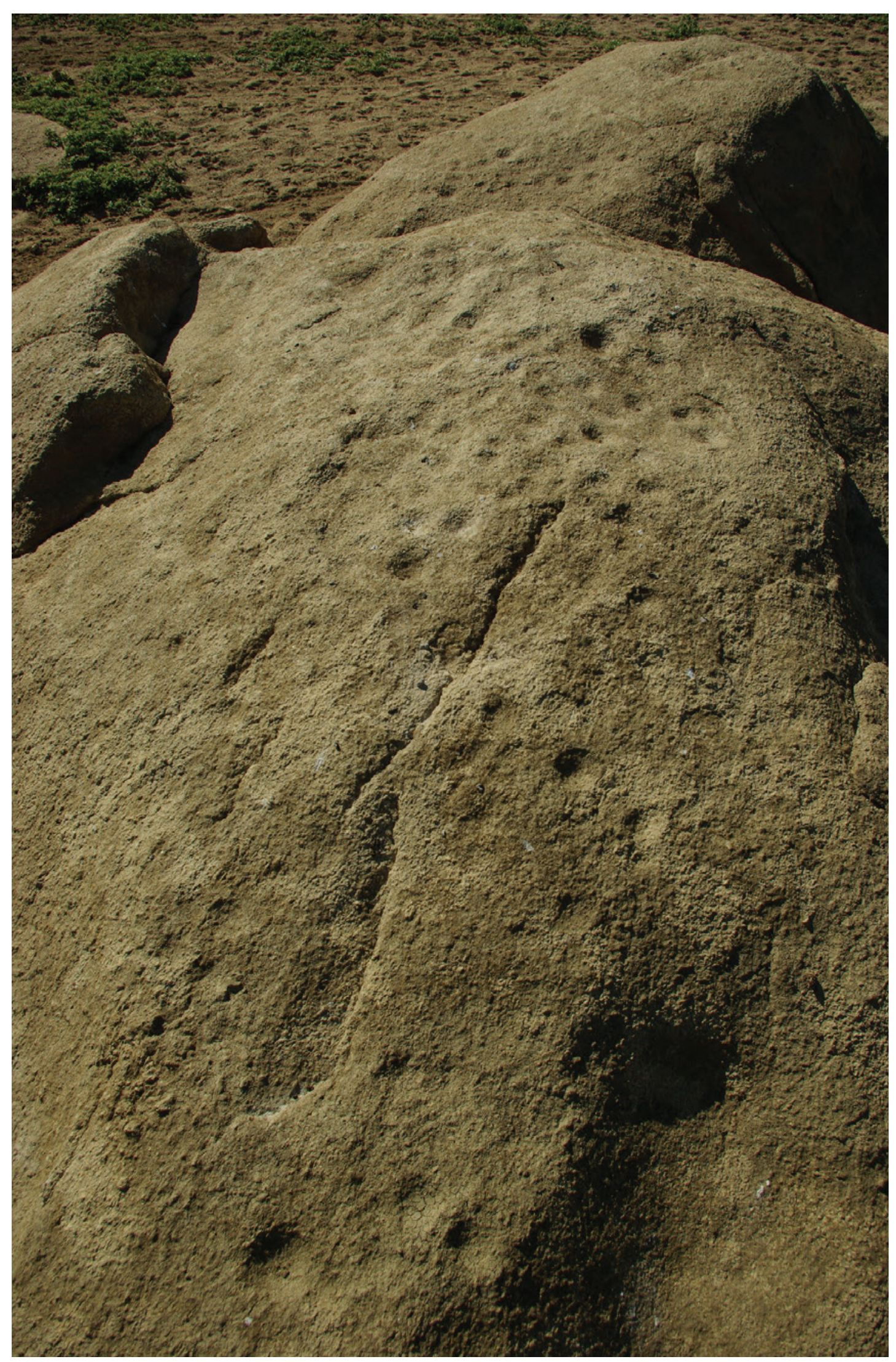

Figura 6 - Painel gravado. Horta das Rosas 7. 


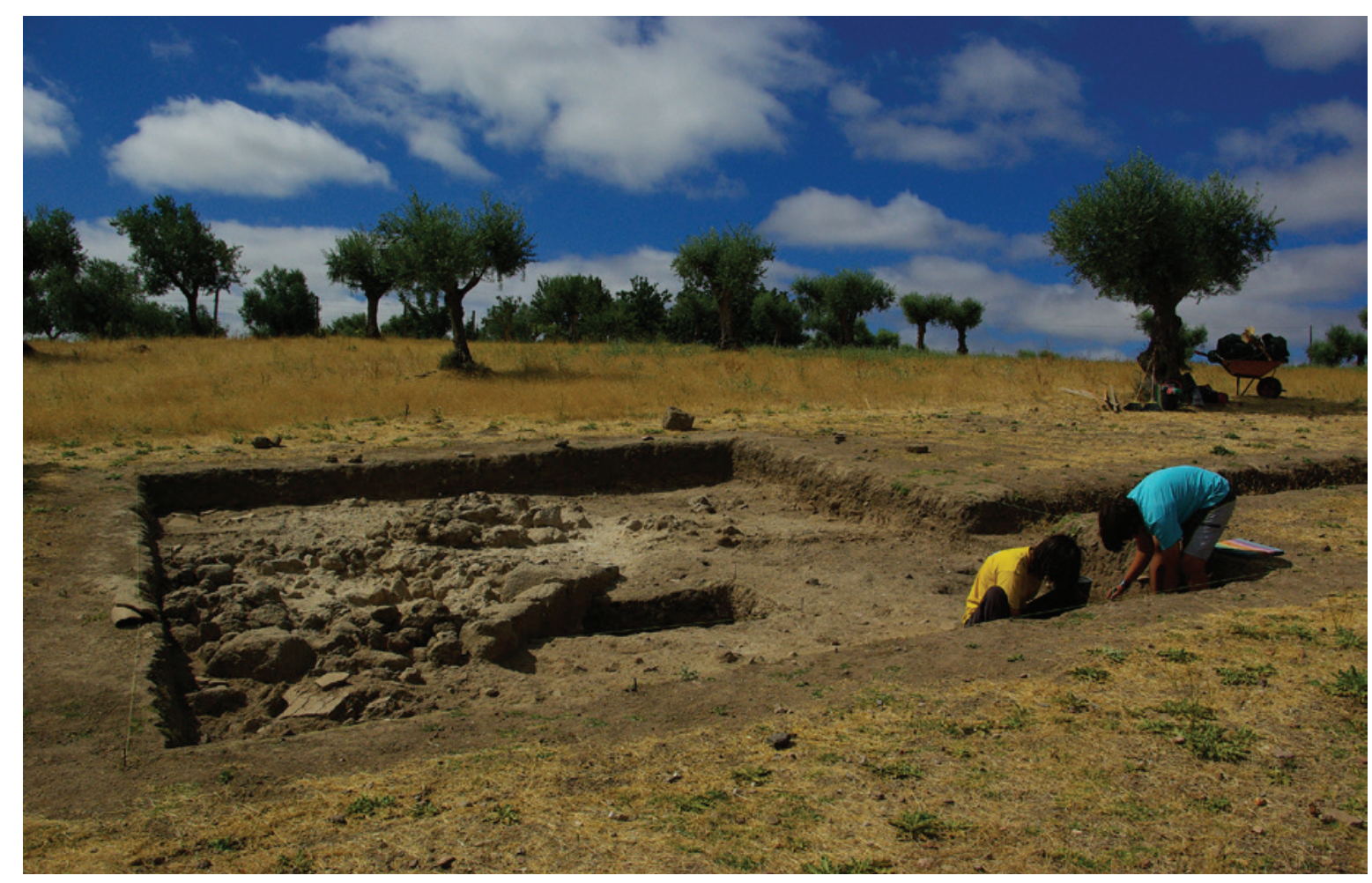

Figura 7 - Trabalhos de escavação no sítio da Ladeira.

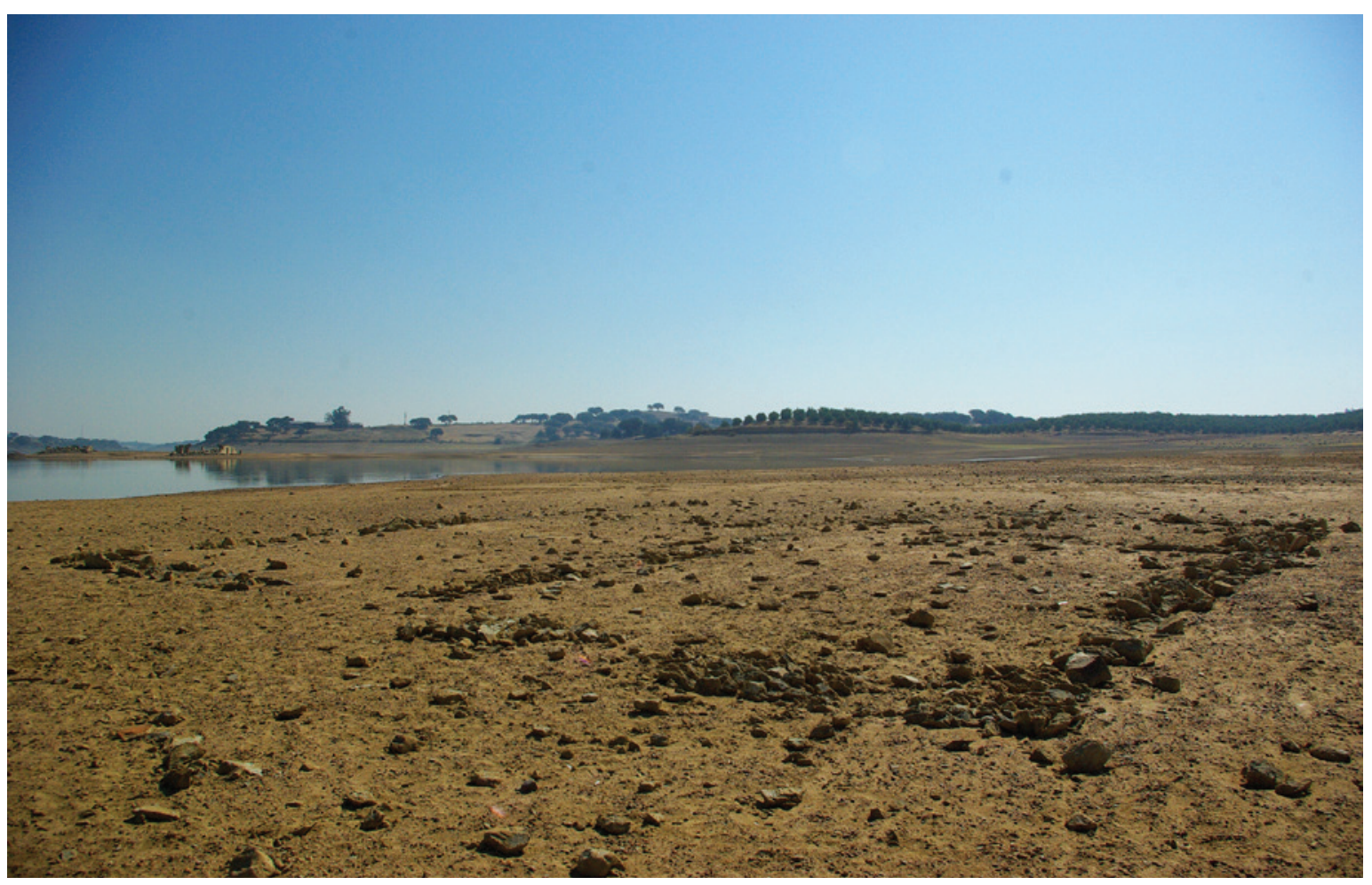

Figura 8 - Estruturas de período romano. Carapeta 3. 


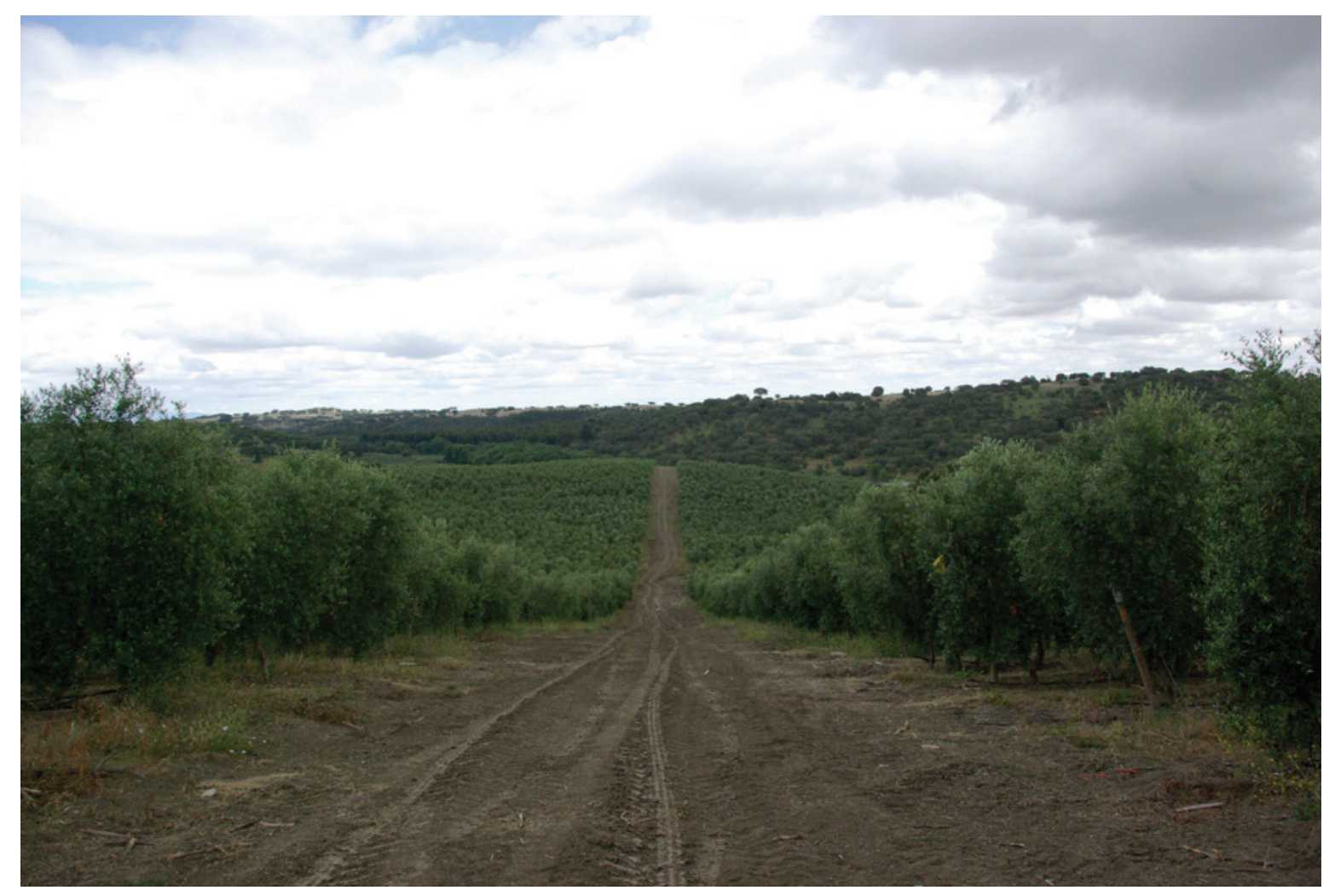

Figura 9 - Vista geral sobre sítio de período romano (Terrujo 1) afectado por olival intensivo.

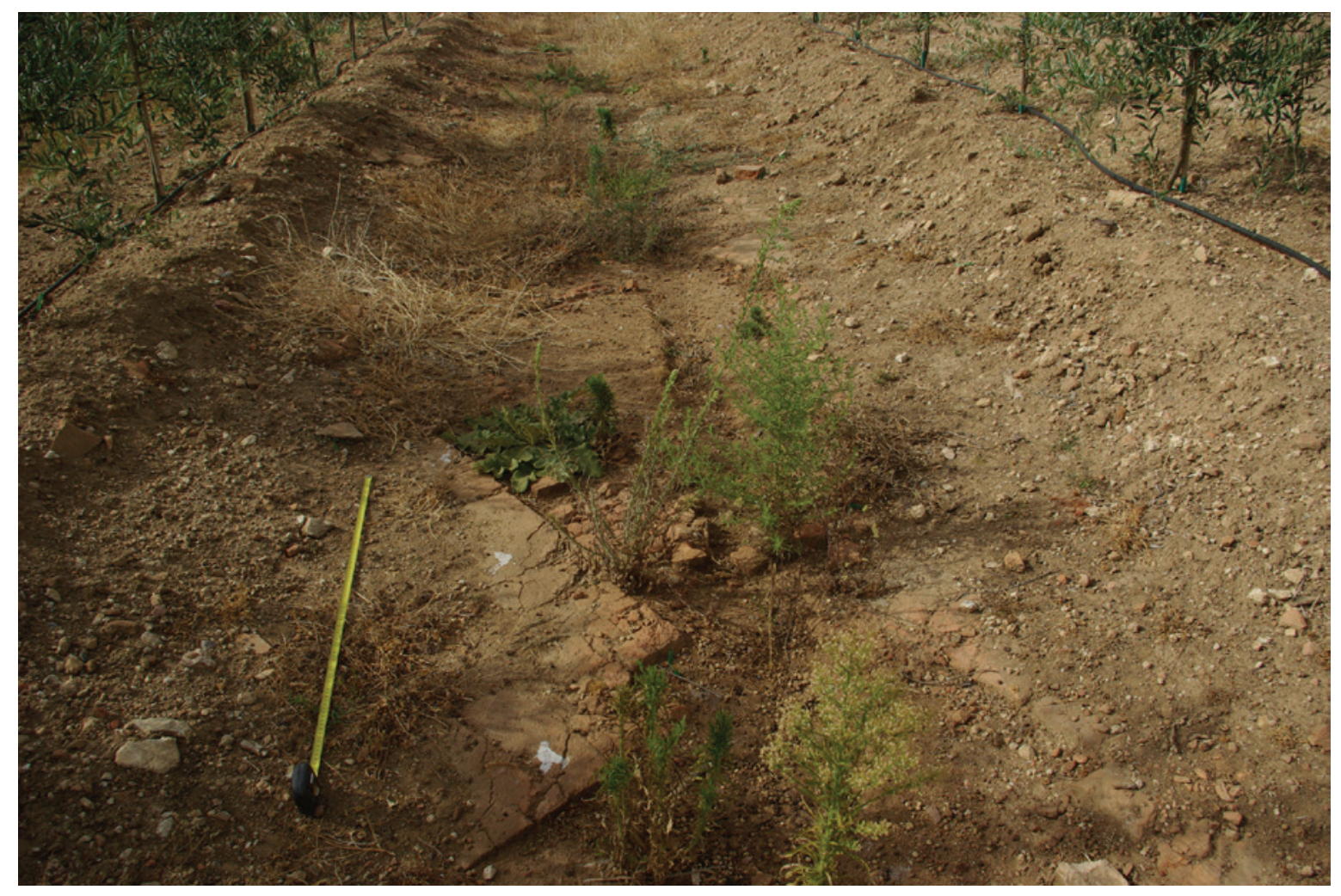

Figura 1o - Afectação de estruturas na villa Entre Águas I na sequência da plantação de olival intensivo. 


\title{
A COLEÇÃO ARQUEOLÓGICA DO EXTINTO MUSEU MUNICIPAL DO PORTO - ORIGENS, PERCURSOS E ESTUDOS
}

\author{
Sónia Couto ${ }^{1}$
}

\begin{abstract}
RESUMO
O artigo aqui apresentado tem como propósito dar a conhecer a coleção arqueológica do extinto Museu Municipal do Porto, contextualizando-a na história deste museu e como foi constituída, colocando em evidência o importante papel de Rocha Peixoto neste processo.

O percurso desta coleção foi complexo e caracterizado por sucessivas transições entre museus e outros espaços não museológicos, deparando-se com condições adversas no que respeita à conservação, estudo e inventariação da mesma, até chegar ao seu depósito legal que é o Museu Nacional Soares dos Reis. Após a saída da maioria da coleção arqueológica deste museu, a sua dispersão prosseguiu, desconhecendo-se onde se encontram depositados vários objectos até aos dias de hoje.

Palavras-chave: Museu Municipal do Porto, Arqueologia, Rocha Peixoto, Museu Nacional Soares dos Reis, Museu de Etnografia, História do Douro Litoral.
\end{abstract}

\begin{abstract}
The article presented here aims to make known the archaeological collection of the extinct Municipal Museum of Porto, contextualizing it in the history of this museum and how it was constituted, highlighting the important role of Rocha Peixoto in this process.

The route of this collection was complex and characterized by successive transitions between museums and other non-museological spaces, facing adverse conditions regarding to its conservation, study and inventory, until reaching its legal deposit, which is the Museu Nacional Soares dos Kings. After the majority of the archaeological collection left this museum, its dispersion continued, it is unknown where several objects are deposited until today.

Keywords: Museu Municipal do Porto, Archeology, Rocha Peixoto, Museu Nacional Soares dos Reis, Museu de Etnografia, História do Douro Litoral.
\end{abstract}

\section{ORIGEM E HISTÓRIA DO MUSEU MUNICIPAL DO PORTO E DA SUA COLEÇÃO ARQUEOLÓGICA}

O Museu Municipal do Porto foi o primeiro museu municipal do país, tendo a sua coleção inicial como base o fundo do Museu Allen (constituído em 1836), que após o seu encerramento pela morte do seu fundador João Allen em 1848, foi colocado a leilão em hasta pública, tendo sido adquirido em 1850 pela Câmara Municipal do Porto.

Da coleção Allen fazia parte um vasto espólio que ia desde pintura, escultura, história natural, mineralogia, geologia, malacologia, etnografia, arqueo- logia, artes decorativas, curiosidades industriais, paramentaria religiosa, numismática, etc. Ele como grande coleccionador e admirador das civilizações clássicas, adquiriu nas suas várias viagens diversas peças arqueológicas, sobretudo oriundas de Roma e Pompeia. À data da aquisição do acervo do Museu Allen pela autarquia do Porto, constava da seção de arqueologia uma pequena colecção egípcia (composta por 8 peças entre estatuetas, amuletos e um escaravelho); uma colecção de vasos gregos (composta por 15 peças), uma colecção de 10 lucernas itálicas, uma estatueta em terracota, um sarcófago romano e ainda alguns fragmentos de mosaico e olarias romanas (Santos, 2005, pp. 99-105) .

1. Arqueóloga/Investigadora independente; sonia.couto@gmail.com 
Com a aquisição do acervo do Museu Allen e devido à falta de instalações para o novo museu, a Câmara Municipal do Porto decide alugar à família Allen as instalações onde o seu museu estava instalado na Rua da Restauração (Figura 1) e é assim aberto no mesmo espaço o Museu Municipal do Porto, inaugurado a 11 de Abril de 1852.

Inicialmente teve a designação de Novo Museu Portuense, conforme consta no Regulamento Interno do Museu datado de 1853. O museu esteve fechado durante um período para obras de reabilitação, reabrindo ao público a 30 de Janeiro de 1853 . A partir de 1858 passou a designar-se Museu Municipal do Porto. A sua direção foi assumida por Eduardo Augusto Allen, um dos filhos do fundador do Museu Allen, que esteve em funções entre 1852 e 1899 (Santos, 2005, pp. 100-101).

Em meados de 1860, a sociedade portuense vai dar início a debates e polémicas na imprensa escrita sobre as funções e a missão de um museu municipal, obrigando a Câmara a apresentar uma posição pública em relação ao seu museu. Apesar de todos estes problemas este continuava a ter sucesso, apresentando um elevado número de visitantes.

O surgimento da Sociedade Carlos Ribeiro no Porto em 1887, composta por personalidades como Ricardo Severo, Rocha Peixoto, Fonseca Cardoso entre outros, em muito veio fomentar estas críticas ao museu, sobretudo por Rocha Peixoto que nomeou uma comissão promovida por esta sociedade, da qual ele também fazia parte, para estudar e reorganizar o Museu Municipal do Porto (MMP) e a sua instalação em edifício próprio.

As más condições de conservação do edifício da Rua da Restauração, aliado às lacunas relativamente à acomodação dos quadros, a iluminação deficiente, entre outros problemas, conduziu a que o museu encerrasse por algum tempo para obras de beneficiação (Almeida, 2006-2007 pp. 47-50).

É precisamente neste período que Rocha Peixoto assume a direção deste Museu, onde esteve entre 1900 e 1909. Com a sua entrada introduziu-se uma nova dinâmica museológica, tendo contribuído substancialmente para o enriquecimento da coleção do Museu, com particular destaque para a coleção arqueológica, quer por doações, aquisições e até mesmo pela troca de objetos entre museus municipais, prática comum na época. Foi aliás da sua responsabilidade o estímulo ao intercâmbio científico e à prática das boas relações entre os museus nacionais.
Nos livros de registos de doações e compras de espólio para o museu, constam várias aquisições realizadas por Rocha Peixoto. Para isso muito contribuiu o facto de ele acompanhar de perto a investigação arqueológica da época, sobretudo em sítios arqueológicos do norte do país, o que lhe permitiu enriquecer o acervo do museu. Do espólio incorporado por ele, destacam-se lápides epigráficas, cerâmicas, moedas, machados de bronze, etc. Na região do grande Porto são vários os sítios arqueológicos onde Rocha Peixoto escavou e recolheu espólio para o MMP, como por exemplo no castro de Laúndos e na villae romana de Vila Mendo na Póvoa de Varzim, de onde proveio uma valiosa coleção de joias proto-históricas que figuram ainda hoje na sala de exposição permanente de ourivesaria do MNSR (Rocha Peixoto, 1908, p.4); o Castro de Guifões em Matosinhos, de onde vieram um sarcófago medieval, uma lucerna, uma urna incineradora em vidro romano, cerâmicas e mós, elementos que constam actualmente das seções de Lapidária e vidros do Museu Nacional Soares dos Reis (MNSR). Os vidros romanos já foram aliás estudados por Jorge e Adília Alarcão (Alarcão, 1964, pp. 73-79).

São vários os investigadores que neste período realizavam escavações arqueológicas e ofereciam o espólio aos museus, o MMP também não fugiu à regra, aparecendo ofertas de nomes conhecidos da nossa arqueologia como José Fortes, José de Pinho, Ricardo Severo, José Leite Vasconcelos e o próprio Rocha Peixoto (Figura 2 e 3 ).

Foi ainda da autoria de Rocha Peixoto em 1902, o Guia do Museu Municipal do Porto, com o inventário das coleções que este museu possuía, estando o mesmo dividido pelas seções de Arqueologia, Etnografia, Arte Industrial, Pintura, Escultura, Cerâmica, Numismática Nacional e Estrangeira (Peixoto, 1902, pp.7-24).

Apesar das várias tentativas de Rocha Peixoto no sentido de obter um espaço novo adequado à dimensão das coleções do museu, este acabaria por encerrar as instalações na Rua da Restauração a 21 de Julho de 1905, transferindo-se para a dependência da Biblioteca Pública Municipal do Porto, localizada em São Lázaro no edifício do extinto Convento de Santo António da cidade, onde já funcionava também o Museu Portuense e a Escola de Belas Artes do Porto. Nas novas instalações e face às circunstâncias do espaço, Rocha Peixoto cria a seção de Lapidária, aproveitando o claustro do convento para aí expor a 
coleção de peças em pedra como capitéis, estátuas, sarcófagos, restos arquitetónicos, escudos de armas, estelas etc. Rocha Peixoto enriqueceu ainda o património artístico do museu, sobretudo com os objetos, que por depósito legal no museu, vieram dos extintos conventos do Porto e Vila do Conde, tais como painéis de azulejos que podemos ver expostos até aos dias de hoje neste edifício.

Entre 1905 e 1906 Rocha Peixoto levou a cabo várias iniciativas no sentido de valorizar Museu, enviando fotografias das diversas colecções para vários museus do país, e distribuiu uma comunicação aos beneméritos da arqueologia, relatando o estado do museu e apelando à cooperação, tendo mesmo conseguido mobilizar o ilustre Prof. Schulten para uma visita ao Porto em 1906, na companhia de Mendes Correia, José Fortes e Ricardo Severo, que se debruçaram atentamente a visitar a colecção de arqueologia, dando particular destaque à famosa Pedra dos Namorados. (Almeida, 2008, pp. 110-113)

Com a morte de Rocha Peixoto em 1909, o museu entra num processo de estagnação e ruína, sabendo-se que em 1912 o MMP se encontrava encerrado, estando apenas exposta ao público a seção lapidar instalada nos claustros do mosteiro. Em 1913 o museu reabre e a sua direção passa a ser a mesma da Biblioteca Pública Municipal do Porto. José Pereira de Sampaio Bruno passa a exercer o lugar de conservador do museu até 1914, data do seu falecimento, sendo desta forma substituído por João Grave, que também viria a falecer em 1919. É neste ano que numa sessão da Comissão Administrativa da Câmara Municipal do Porto, o seu presidente Dr. Armando Marques Guedes apoiou a remodelação do Museu Municipal, sob a proposta de A. J. Paiva Manso, tornando este estabelecimento autónomo da Biblioteca Pública Municipal. Assim, quem acaba por assumir a direção do MMP é Júlio Brandão, cargo que irá exercer até 1939, ano em que se aposentou (Couto, 2011, pp. 32-33).

O cargo de conservador do museu é assumido por Pedro Vitorino de 1922 até 1933, passando a partir deste ano e até 1938 a exercer o cargo de vice-diretor. A sua ida para o museu no entanto não foi suficiente para resolver os problemas com que este se deparava, mesmo tendo feito tentativas de seguir as matrizes definidas anteriormente por Rocha Peixoto.

A sua ação em prol do museu era bem evidente, tanto que Pedro Vitorino fez parte em 1929 do grupo fundador dos Amigos do Museu Municipal do
Porto, cujos objetivos eram sobretudo o enriquecimento das coleções e a promoção da investigação, exposições, conferências e publicações na defesa do património da cidade do Porto, em colaboração com outros museus. Porém, a inexistência de condições para o progresso do museu levou à sua estagnação e consequente abandono, mantendo-se inalterado até Novembro de 1938 quando foi extinto.

\section{O FIM DO MUSEU MUNICIPAL DO PORTO E A INCORPORAÇÃO DO SEU ACERVO NO MUSEU NACIONAL SOARES DOS REIS}

Com a nomeação do Museu Soares dos Reis a museu nacional e a aquisição de um novo espaço para a sua instalação, o Palácio dos Carrancas, é ordenado através do decreto-lei no 27:878 de 21 de Julho de 1937 que todo o espólio do Museu Municipal do Porto fosse incorporado a título de depósito no Museu Nacional Soares dos Reis, precedido de inventário e identificação.

O Museu Municipal do Porto tinha apenas uma série de inventariações fragmentárias de algumas coleções, nomeadamente um inventário parcial datado de 1920, como nos dá conta o Relatório que o Museu Municipal do Porto apresentou ao presidente da C.M. Porto Dr. Mendes Corrêa em 1939, no qual é referido ainda que o museu possuía inúmeras obras de arte por inventariar que se encontravam dispersas em arrecadações do museu e nas águas furtadas do edifício da Câmara Municipal do Porto da altura. (Almeida, 2008, pp. 129-130)

A desorganização em que se encontrava o MMP, foi aliás denunciada e contestada por parte de Pedro Vitorino na sua obra "Brandão o coveiro do Museu Municipal do Porto", publicada em 1939, após a realização deste inventário, colocando em causa a direção do museu por parte de Júlio Brandão e tecendo duras críticas ao mau estado em que as coleções se encontravam, afirmando mesmo que muitas delas estavam ocultas em armários. Referiu ainda as medidas tomadas por ele sobretudo no que respeita ao regresso de objetos e coleções que se encontravam nos depósitos da C. M. Porto, em locais em risco de ruína, afirmando também que foi da sua iniciativa a criação de etiquetas e de livros de registo dos objetos que se encontravam no museu. Por este motivo, foi necessário realizar um exaustivo inventário de todo o seu acervo, que pela sua dimensão e a escassez de recursos humanos foi demorado, tendo sido 
desenvolvido entre 1938/1940. Este trabalho de inventariação foi materializado em 20 volumes divididos por várias secções desde pintura, escultura, desenho, gravura, fotografia, etnografia, numismática, arqueologia e lapidária, ourivesaria, cerâmica, cristais e vidros, objectos arqueológicos, etc. (Vitorino, 1939, pp. 5-10).

O processo de transferência de todo o espólio do MMP para o Museu Nacional Soares dos Reis decorreu entre 13 de Junho de 1940 e 5 de Abril de 1941, sendo que a coleção arqueológica só foi incorporada em 1941. O Museu Nacional Soares dos Reis abriu provisoriamente as suas portas ao público no Palácio dos Carrancas a 4 Julho 1940 com uma exposição de obras de Soares dos Reis, apesar da sua inauguração oficial ter ocorrido apenas em 1942.

Apesar de se tratar de um museu direcionado para a arte, este acabaria por assumir um carácter misto, passando a integrar uma sala de arqueologia (Figura 4) como nos dá conta o catálogo/guia do MNSR datado de 1952, que faz referência aos objetos expostos nesta sala e nos jardins arqueológicos, entre eles o famoso sarcófago romano da coleção do João Allen/ MMP. (1952², pp.5-19)

\section{A COLEÇÃO ARQUEOLÓGICA DO MMP}

Este acervo quando transitou para o MNSR manteve a mesma organização que possuía no extinto MMP, por esse motivo encontramos objetos arqueológicos dispersos por várias secções. Por exemplo na seção de Ourivesaria encontra-se um conjunto de jóias proto-históricas em ouro (um colar, um par de aros, um par de brincos, dois pares de arrecadas) e ainda o escaravelho em ouro egípcio; na secção de Vidros existem frascos e uma urna cinerária em vidro romano, na secção de Lapidária composta por vários elementos como aras e estelas romanas, sarcófagos, mós, pedras com inscrições, brasões e vários elementos arquitetónicos provenientes de conventos e mosteiros extintos, constam um total de 139 peças no inventário do MMP. A seção de Numismática possui coleções de moedas de cronologias variadas, que na sua maioria transitaram para o Gabinete de Numismática da C.M. Porto.

Da seção de objectos arqueológicos do inventário do MMP realizado entre 1938-1940, constam cerca de 271 itens relativos a materiais arqueológicos variados, sendo que alguns estão agrupados por lotes, caixotes, sacos com vários objetos, tornado ainda mais difícil perceber com precisão o número exacto de objetos. Esta seção é composta predominantemente por materiais cerâmicos de cronologias da idade do ferro e romanização, sobretudo utensílios em cerâmica, alguns exemplares de sigilattas e uma candela. Pode-se ainda encontrar fragmentos de ânforas, mosaicos romanos, azulejos, uma ossada humana, pesos de tear e cossoiros, pesos de rede, machados e outros objetos líticos da pré-história, materiais em bronze como machados, uma fíbula, um bracelete, um amuleto, uma ponta de lança. Fazem ainda parte desta seção de arqueologia uma colecção de vasos gregos; um conjunto de estatuetas egípcias, um conjunto de lucernas itálicas e ainda uma enigmática estatueta em terracota, todos estes da colecção Allen.

A maioria dos materiais é proveniente de estações arqueológicas do Norte do país, como por exemplo Castro de São Félix, Villa de S. Martin Vaz e Estela na Póvoa de Varzim, estudadas por José Fortes (1905-19o8, pp. 604-618); Necrópole do Bairral em Baião estudada por Ricardo Severo (1906, pp. 417-430); Necrópole de Vila Verde, Necrópole da Lomba, Necrópole de Laboriz, Necrópole de Ataúdes e Necrópole de Vilarinho todas localizadas em Amarante e estudadas por Helena Portela (1998, pp.); o Castro da Agra de S. Brás em Frazão, Paços de Ferreira estudada por Manuel Vieira Dinis (1976, pp. 217-222); o Castro de Guifões, Matosinhos; Ponte de Lima; Trofa; Barcelos; Valongo; Póvoa de Lanhoso; Valença, Viana do Castelo; Melgaço, Bragança. Aparecem no entanto materiais de outras regiões do país como o Castro de Ossela em Oliveira de Azeméis onde Rocha Peixoto também realizou escavações, de Santarém, Evoramonte, Castelo de Vide, Alentejo, Salvaterra de Magos e também de Pontevedra e Mérida em Espanha.

Quando se iniciou esta investigação no âmbito da minha dissertação de mestrado desenvolvida entre 2009 e 2011, encontrava-se na secção de Diversos das reservas do Museu Nacional Soares dos Reis um conjunto de peças arqueológicas pertencentes ao Museu Municipal do Porto entre elas a coleção egípcia estudada por Luis Manuel Araújo (1995, pp. 7-20), a de vasos gregos estudada por Rui Morais e Maria Helena Rocha-Pereira (2008, pp. 1-72) e de lucernas itálicas também estudadas por Rui Morais (2008-2009, pp. 65-79) e ainda 23 objetos arqueológicos de cronologias, materiais e tipologias diferentes, que se encontravam por estudar. Estes últimos, na maioria não possuía número de inventário do 
MMP, alguns apresentavam etiquetas coladas com a sua proveniência e quem ofereceu, outros tinham escrito directamente no objecto a tinta uma numeração que se assumiu ser o número de inventário do MMP e nos restantes não existia qualquer informação. Como tal foi necessário realizar um exercício de cruzamento de informação, nomeadamente com o inventário realizado entre 1938/1940, o Guia do MMP de 1902 e documentação como livros de registo de entrada de espólio existentes no arquivo do MMP. Apenas para oito deles conseguiu-se informação precisa de que eram provenientes do MMP e fazer corresponder com o número de inventário: um machado de pedra, um machado pedra polido; um peso de tear (Figura 7); uma Ampulla de duas asas simétricas; um amuleto Figas Phallus (Figura 6), um bracelete aberto e um corpo de fíbula todos em bronze e ainda uma estatueta celtibérica em terracota. Dos restantes objectos, alguns deles não possuem número de inventário, apresentando apenas etiquetas com indicação do sítio de proveniência e/ou quem ofereceu, colocando-se a hipótese de pertencerem ao MMP, visto serem oriundos de escavações arqueológicas realizadas no inicio do século XX, outros não têm qualquer informação. Este lote é composto por: uma lâmina de sílex (Figura 5); um prato, uma bilha, um copo e um jarro de cerâmica romana, um fragmento de machado polido sob seixo; um núcleo de seixo em quartzito; um machado polido em anfibolito; uma enxó em silimanite; um jarro trilobado romano; um copo cerâmica romana; um prato cerâmica romana; uma bilha de cerâmica romana; uma estatueta em bronze. Foi ainda contemplado neste estudo um conjunto de cinco objetos arqueológicos que fazem parte da coleção do Museu Nacional Soares dos Reis, que aqui foram incorporados nos dos finais da década de 40 do século XX, sendo eles: um púcaro e uma tigela de cerâmica romana; uma estatueta de Marte, um cabo de Pátera e um machado de talão todos em bronze e ainda uma ânfora localizada na seção de cerâmica posteriormente à entrega da minha dissertação de mestrado, por esse motivo foi apenas estudada posteriormente e incluída na exposição realizada em 2012 neste museu. Estas incorporações no MNSR não são surpreendentes ocorrerem visto que após o encerramento do MMP não existia outro museu no Porto para acolher este tipo de espólio.

\section{PROCESSO DE TRANSIÇÃO DA COLEÇÃOMARQUEOLÓGICA DO MUSEU NACIONAL SOARES DOS REIS PARA O MUSEU DE ETNOGRAFIA E HISTÓRIA DO DOURO LITORAL}

O processo de dispersão deste espólio não ficaria por aqui, pois sendo o Museu Nacional Soares dos Reis um museu de arte e com a abertura em 1945 do Museu de Etnografia e História do Douro Litoral, foi autorizado em 1955 por despacho da presidência da C. M. Porto datado de 03-09-1955, através do ofício $2532 / 55$, que se transferisse o espólio da secção de arqueologia provenientes do Museu Municipal do Porto para o Museu de Etnografia e História do Douro Litoral, desde que das mesmas ficasse a constar que pertenciam ao património municipal. Da lista de materiais que transitaram constavam todos os objetos da seção de arqueologia do inventário do MMP, com exceção das 3 coleções de Allen, respetivamente a de vasos gregos, a egípcia, a de lucernas e ainda uma estatueta celtibérica em terracota. Permaneceram também no MNSR vários materiais em bronze como um amuleto Figas Phallus, um bracelete aberto e um corpo de fíbula, bem como todos os objetos arqueológicos das seções de Ourivesaria, Lapidária e Vidros. Foram ainda para o Museu de Etnografia e História do Douro Litoral da secção de Lapidária, subsecção de Avulsos: 1 caixote com seixos marítimos; um caixote com fragmentos de ânforas e cântaros; 13 caixotes com fragmentos cerâmicos; um caixote com uma ossada humana; um pacote com azulejos e 11 peças de mosaicos.

Neste processo de transferência, coloca-se a hipótese de alguns dos objetos terem ficado no MNSR por razões que se desconhece, nomeadamente alguns dos referidos anteriormente estudados na minha dissertação de mestrado que faziam parte do inventário do MMP.

O Museu de Etnografia e História do Douro Litoral como refere Maria do Rosário Pestana manteve-se em funcionamento entre 1945 e 1959. "Entre 1948 e 1957 (datas disponíveis nos livros de tombo), o Museu mais que duplicou o seu fundo, em parte devido a depósitos ou transferências de outras instituições: Instituto de Antropologia da Universidade do Porto, Museu Nacional Soares dos Reis, Câmara Municipal do Porto, comissões venatórias regionais do Centro e do Norte, etc."(Pestana, 2009, p.6). 
Em 1959 com a extinção das autarquias provinciais, o museu foi reformulado, passando a designar-se $\mathrm{Mu}$ seu de Etnologia do Porto e dirigido por Fernando de Castro Pires de Lima. Depois de 1970, as instalações do Museu começaram a degradar-se com repercussões nas condições de conservação das coleções.

Existem referências sobre o estado de degradação em que o Museu de Etnografia e História do Douro Litoral se encontrava já na década de 6o, como nos dá conta Joaquim Neves dos Santos sobre o mau estado de conservação de um mosaico romano proveniente de Lavra que ali se encontrava com reflexos particularmente negativos nas condições de conservação das suas colecções (1963, pp. 11-13).

Fernando Lanhas assume a sua direção entre 1973 e 1993. Em 1989, o museu passa a ser tutelado do IPPC e em 1991 pelo IPM, vindo a ser encerrado ao público em 1992, após um incêndio que sofreu que conduziu a um avançado estado de ruína do imóvel (Pestana, 2009, p. 11).

Pode-se afirmar que a transferência da coleção arqueológica do MMP para o Museu de Etnografia e História do Douro Litoral, deu início a um processo de desmembramento desta coleção, que se irá prolongar até 2013.

\section{O ENCERRAMENTO DO MUSEU DE ETNOLOGIA DO PORTO E O INÍCIO DO PROCESSO DE DISPERSÃO DA COLEÇÃO ARQUEOLÓGICA DO MUSEU MUNICIPAL DO PORTO}

Na sequência do seu encerramento, o IPM toma medidas no sentido de salvaguardar o espólio do museu. Assim, numa primeira fase ordena o depósito das suas coleções em diversos museus com vista à sua proteção, numa segunda fase foram efetuadas com a colaboração da DGEMN, obras nas coberturas e na fachada do Palácio, tendo sido realizado ainda numa terceira fase um processo de sistematização do seu inventário (Pestana, 2209, p. 11).

É desta forma que se dá continuidade à dispersão do espólio arqueológico do Museu Municipal do Porto, pois até hoje apesar das várias tentativas levadas a cabo por várias pessoas e entidades, nunca foi facultada uma lista com a indicação dos objetos do MMP que saíram do Museu de Etnologia e em que museus ou locais foram depositados.

Do que se conseguiu apurar, sabe-se que quase todo o espólio pertencente ao Museu de Etnologia, foi depositado em vários museus, entre eles o Museu D. Diogo de Sousa, Museu dos Biscainhos, Museu da Nazaré, Museu Municipal de Penafiel, Museu Municipal Póvoa de Varzim, entre outros e uma parte foi enviada para o quartel de São Braz no Porto, cujo edifício também se encontrava em mau estado, tendo o telhado entretanto desabado em cima de parte das coleções que ali se encontram. Até ao momento sabe-se que este edifício se encontra encerrado e sem acesso.

No palacete de S. João Novo ficou ainda a biblioteca, o arquivo, uma parte da coleção de museografia e também alguns caixotes com espólio, visto não se ter decidido para onde iriam. Desde este período (anos 9o do século XX) até 2012, o estado de degradação do palacete foi aumentando de forma drástica. (Soares, 2016, pp. 149-155)

A investigação do percurso que a coleção arqueo-lógica do Museu Municipal do Porto tomou desde que foi incorporada no Museu Nacional Soares dos Reis, iniciou-se como já se referiu anteriormente através da dissertação de mestrado desenvolvida entre 2009-2011.

A investigação desenvolvida revestiu-se de várias condicionantes, por um lado a impossibilidade ter acesso ao Museu de Etnologia por estar encerrado, por outro não possuir informação relativa ao espólio que lá existia e em que museus tinha sido depositado após o seu encerramento.

Ao tentar perceber esta coleção e o seu percurso, através da consulta dos escassos documentos com informações concretas sobre a mesma e o cruzamento dessas mesmas fontes, conduziram a uma série de dúvidas, pois rapidamente se pode perceber a inexistência de inventários completos e rigorosos, pautados por incorreções que induziram em erro algumas das suposições assumidas neste trabalho.

Apenas em 2012 quando é decidido pela tutela a retirada do espólio que ainda restava no palacete onde estava instalado o Museu de Etnologia do Porto, processo no qual é delegado ao MNSR a responsabilidade da recolha do espólio que pertencia ao Museu Municipal do Porto que ainda lá existisse, é que se constata que uma parte do espólio arqueológico que tinha sido para ali transferido em 1957 vindo do MNSR ainda lá se encontrava e em muito mau estado de conservação.

Nesta campanha de resgate do espólio realizada em 2012, são trazidos para o MNSR um total de 44 objetos cerâmicos de cronologia na sua maioria romana, 
40 dos quais faziam parte do Inventário do Museu Municipal do Porto (Figuras 8 e 10).

Na sequência da vinda deste espólio, foi-me endereçado o convite pelo MNSR para continuar o estudo desta coleção, tentando recuperar assim o acervo arqueológico do Museu Municipal do Porto e realizar uma inventariação do mesmo, de forma a se tentar localizar o paradeiro dos materiais em falta.

Em 2013 são ainda recuperados cerca de 35 objetos que ainda se encontravam perdidos nas instalações do Museu de Etnologia, estes na sua maioria composto por materiais líticos e em bronze (Figura 9). Pelas escassas indicações de numeração de inventário, percebe-se que a maioria deles também pertence ao MMP.

Todos estess objectos resgatados em 2012 e 2013 foram alvo de todo um processo de limpeza profunda, consolidação e algum restauro pelo Museu D. Diogo de Sousa em Braga, dado o estado avançado de degradação em que se encontravam, consequência do seu abandono durante décadas nesse espaço.

Mais uma vez por razões desconhecidas, percebe-se que a coleção arqueológica do Museu Municipal do Porto tinha voltado a ser desmembrada, ficando alguns objetos ali perdidos e outros incorporados em museus tais como o D. Diogo de Sousa, como nos dão conta os diversos trabalhos de investigação realizados, nos quais fazem referência a espólio do MMP que se encontra depositado presentemente no Museu D. Diogo de Sousa. Alguns desses estudos contemplam por exemplo um conjunto de cerca de 20 machados em bronze de várias regiões do norte de Portugal (Bottaini,.Giardino, C. \& Paternoster, 2012, pp.19-34); um conjunto de 17 peças cerâmicas romanas das necrópoles da Lomba e Laboriz localizadas em Amarante, estudadas por Helena Portela (1998, pp. 12-97).

Com base nestes trabalhos, começa-se a perceber que uma parte significativa do espólio arqueológico do MMP poderia estar depositado no Museu D. Diogo de Sousa e após alguns contatos, no início de 2015 foi cedida amavelmente pela $\mathrm{Dr}^{\mathrm{a}}$ Isabel Silva, directora daquele museu, uma lista do espólio arqueológico que possuíam vindo do Museu de Etnologia do Porto, entre ele o pertencente ao MMP. Esta lista permite perceber que este espólio foi sendo depositado no Museu D. Diogo de Sousa nos anos de 1993, 1999, 2010 e 2011. Também permitiu verificar que algum do espólio do Museu de Etnologia foi incorporado noutros museus que consta da lista, nomeadamente no Museu Municipal da Póvoa de Varzim, fazendo crer que poderá incluir materiais do MMP.

Com estes novos dados, ainda que com algumas lacunas pois a lista apresenta números de inventário repetidos e outros que se pensam estar errados, foi possível não só localizar grande parte do espólio arqueológico do MMP, visto que até então apenas se conhecia o que estava em depósito no MNSR e o resgatado entre 2012-2013 das instalações do Museu de Etnologia, como também ter uma perceção do que ainda está por localizar.

\section{CONCLUSÃO}

Até ao momento desconhece-se o paradeiro de vários objectos da colecção arqueológica do Museu Municipal do Porto, não se sabendo se foram incorporados/depositados noutros museus além dos já conhecidos (MNSR e MDDS), ou se estão nas instalações do Quartel de S. Brás, para onde foi muito do espólio que estava no Museu de Etnologia do Porto. Pretende-se por isso com este artigo, não só dar conhecimento da existência deste importante acervo que se tem dispersado por circunstâncias adversas, mas também constituir uma chamada de atenção para as políticas patrimoniais e museológicas portuguesas que continuam a cair em erros recorrentes, contribuindo para que se perca no tempo e espaço coleções como esta.

Ainda que aparentemente estas coleções não sejam vistas como importantes, constituem elementos materiais que relatam e autenticam a história da museologia e arqueologia portuguesa. Neste caso concreto, fazem parte materiais arqueológicos recolhidos num período em a arqueologia portuguesa dava os seus primeiros passos e que se revelam importantes elementos para a compreensão da ocupação humana no nosso território ao longo dos tempos.

Prova disso são os vários estudos já desenvolvidos por diferentes investigadores que envolvem muitos dos objetos desta coleção arqueológica, cujos resultados foram materializados em publicações, catálogos, comunicações e exposições.

Por esse motivo torna-se necessária a divulgação deste espólio para que mais investigadores tenham conhecimento da sua existência e para que mais estudos sobre os mesmos venham a ser desenvolvidos. 


\section{BIBLIOGRAFIA}

ALARCÃO, Jorge de; ALCÃO, Adília Moutinho (1964) Vidros Romanos no Museu Soares dos Reis. Museu. Porto. Série 2. №8, pp.73-79.

ALMEIDA, António Manuel Passos (2008) - Museu Municipal do Porto: das origens à sua extinção. Porto. Dissertação de Mestrado em Museologia, apresentada à Faculdade de Letras da Universidade do Porto. Policopiado.

ALMEIDA, António Manuel Passos (2006-2007) - Contributos ao Estudo da Museologia Portuense no Século XIX. O Museu do Colecionador João Allen e o Museu Municipal do Porto, Revista da Faculdade de Letras Ciências e Técnicas do Património. Porto. I Série. vol. V-VI, pp. 31-55.

ARAÚJO, Luís Manuel de (1995) - A colecção Egípcia do Museu Nacional de Soares dos Reis. Museu. Porto. Círculo Dr. José de Figueiredo. IV série. nº 3, pp. 7-20.

BOTTAINI, Carlo E., GIARDINO, Claudio \& PATERNOSTER, Giovanni (2012) - Estudo de um conjunto de machados metálicos do norte de Portugal. Câmara Municipal de Oeiras. Estudos arqueológicos de Oeiras. 19, 2, pp. 19-34.

COUTO, Sónia Alexandra de Castro (2011) - Objectos da colecção arqueológica do Museu Nacional Soares dos Reis. Dissertação de Mestrado em História e Património apresentada à Faculdade de Letras da Universidade do Porto. Policopiado.

DINIS, Manuel Vieira (1976) - O Castro de S.Brás (Frazão) Paços de Ferreira. Guimarães. 86, Jan-Dez, pp. 217-222.

FORTES, José (1905-1908) - Thesouro de Viatodos. Da idade do Bronze. Portugalia. 2 (1-4), pp. 110-111.

FORTES, José (1899-1908) - A necrópole dolménica de Salles. Portugália s/n. Porto., pp. 666-686.

MACHADO, Ana Paula; MORAIS, Rui; ROCHA-PEREIRA, Maria Helena (2008) - Vasos gregos. Porto. IMC/MNSR.

MORAIS, Rui (2008-2009) - A colecção de lucernas do Museu Nacional de Soares dos Reis. Museu. IV série.17, pp. 65-79.

Museu Nacional Soares dos Reis (1952) - Catálogo-Guia do Museu Nacional Soares dos Reis: secção Lapidar. Porto. $2^{\underline{a}}$ edição.

PEIXOTO, Rocha (1902) - Guia do Museu Municipal do Porto. Porto. Typographia Central.

PEIXOTO, Rocha (1908) - Notícia acerca das explorações archeologicas da Cividade de Terroso e do Castro de Laúndos no concelho da Póvoa de Varzim (1906-1907 Portugália. Tomo II. 4, pp. 677-68o.

PESTANA, Maria Rosário Correia Pereira (2009) - O Museu de Etnografia e História do Douro Litoral: etnografia e museologia na construção do Douro Litoral, Trabalhos de Antropologia e Etnologia. 49, 1-4, pp. 79-92.
PORTELA, Maria Helena (1998) - Necrópoles Romanas do concelho de Amarante, Dissertação de Mestrado apresentada à Faculdade de Letras da Universidade do Porto.

ROCHA-PEREIRA, Maria Helena da, MORAIS, Rui e MACHADO, Ana Paula (2008) - Vasos Gregos. Colecção de João Allen. Porto: IMC.

SEVERO, Ricardo (1906) - Necrópoles lusitano-romanas de inumação: cemitério do Bairral. Portugália. Tomo II. Fasc. 3, pp. 417-430.

SANTOS, Joaquim Neves (1963) - Temas Regionais de Arqueologia e Etnografia II: Um Mosaico Romano de Lavra, Matosinhos, Edição do Autor.

SANTOS, Paula M. M. L. (2005) - Um coleccionador do Porto romântico: João Allen (1781-1848). Lisboa. Edição de autor com o apoio da FCT e IPM.

SOARES, Catarina (2016) - A Casa de S. João Novo e o Museu de Etnografia e História da Província do Douro-Litoral (1710-2016): estudo histórico-integrado, problemas e reflexões para a sua salvaguarda. Porto. Dissertação de Mestrado em História da Arte Portuguesa, apresentada à Faculdade de Letras da Universidade do Porto. Policopiado.

VITORINO, Pedro (1939) - Brandão o coveiro do Museu Municipal do Porto. Porto: Marânaus. 


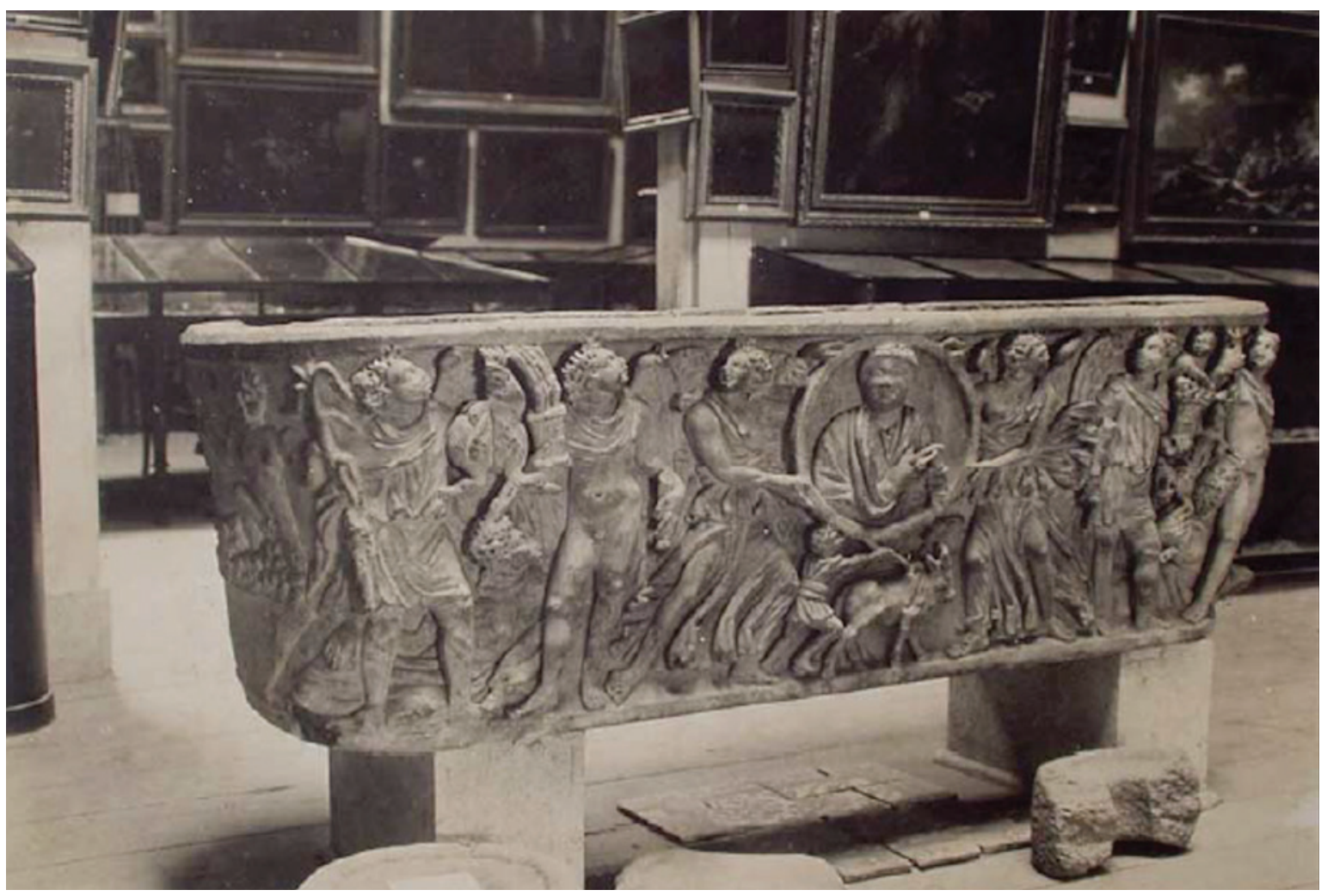

Figura 1 - Sarcófago romano, Museu Municipal do Porto, Rua da Restauração 1902 (fotografia retirada de Almeida, 2008, p.209).

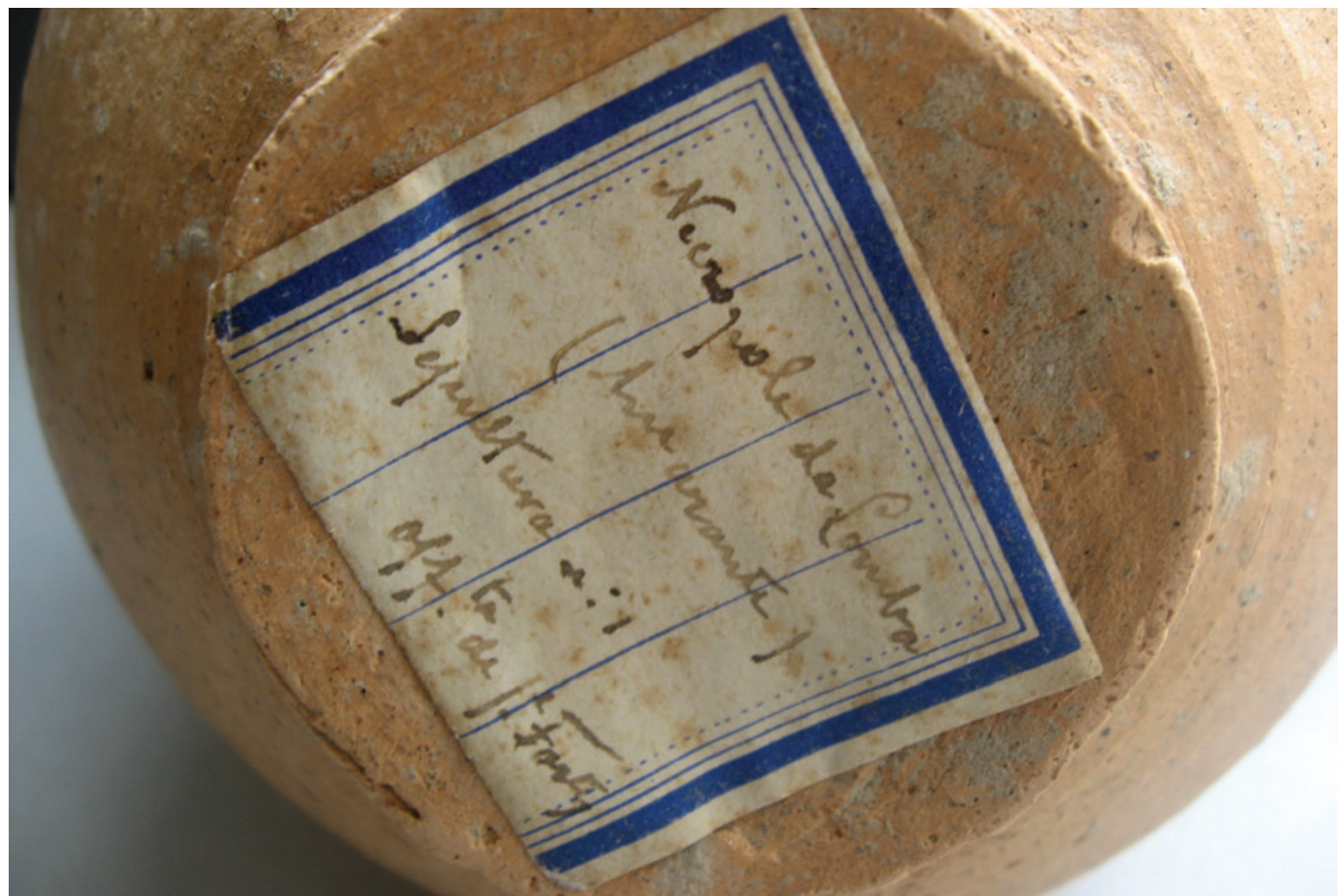

Figura 2 - Vasilha cerâmica proveniente da necrópole da Lomba, Amarante oferecida por José Fortes ao MMP (Fotografia de Ana Paula Machado, MNSR). 


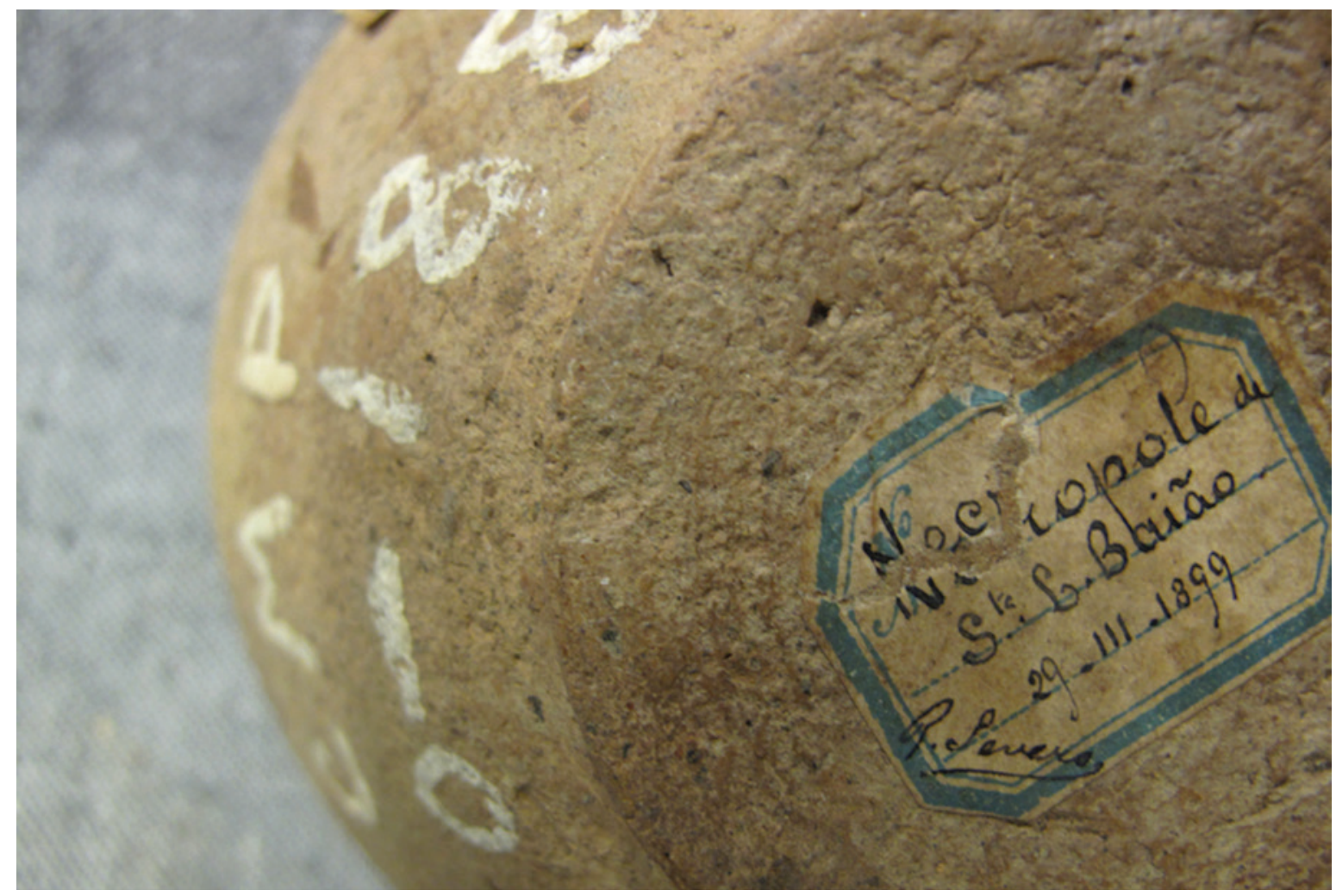

Figura 3 - Vasilha cerâmica proveniente da necrópole de Santa Leocádia, Baião, oferecida por Ricardo Severo ao MMP (Fotografia de Ana Paula Machado, MNSR)

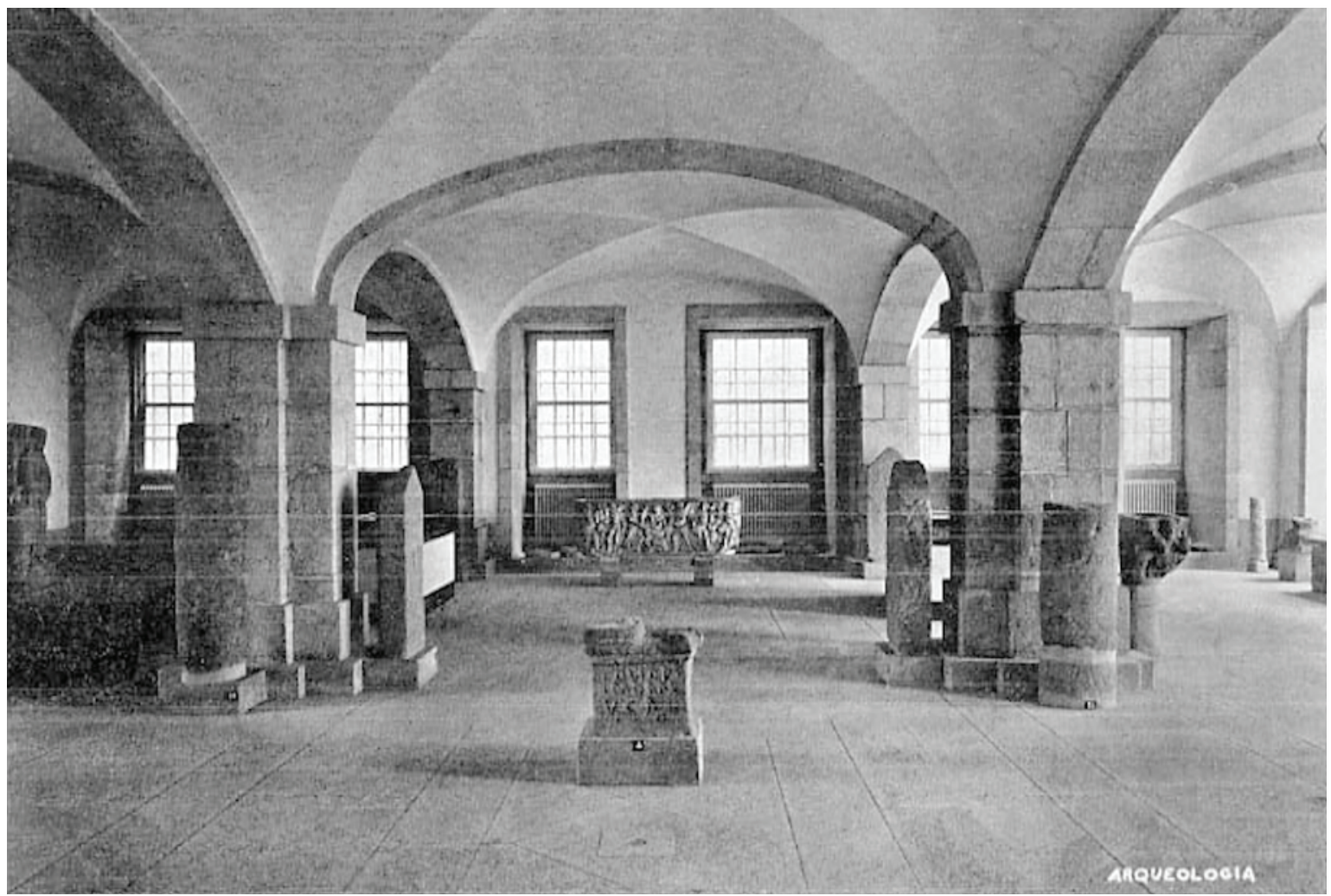

Figura 4 - Sala de Arqueologia do Museu Nacional Soares dos Reis (Fotografia cedida pelo Museu Nacional Soares dos Reis). 


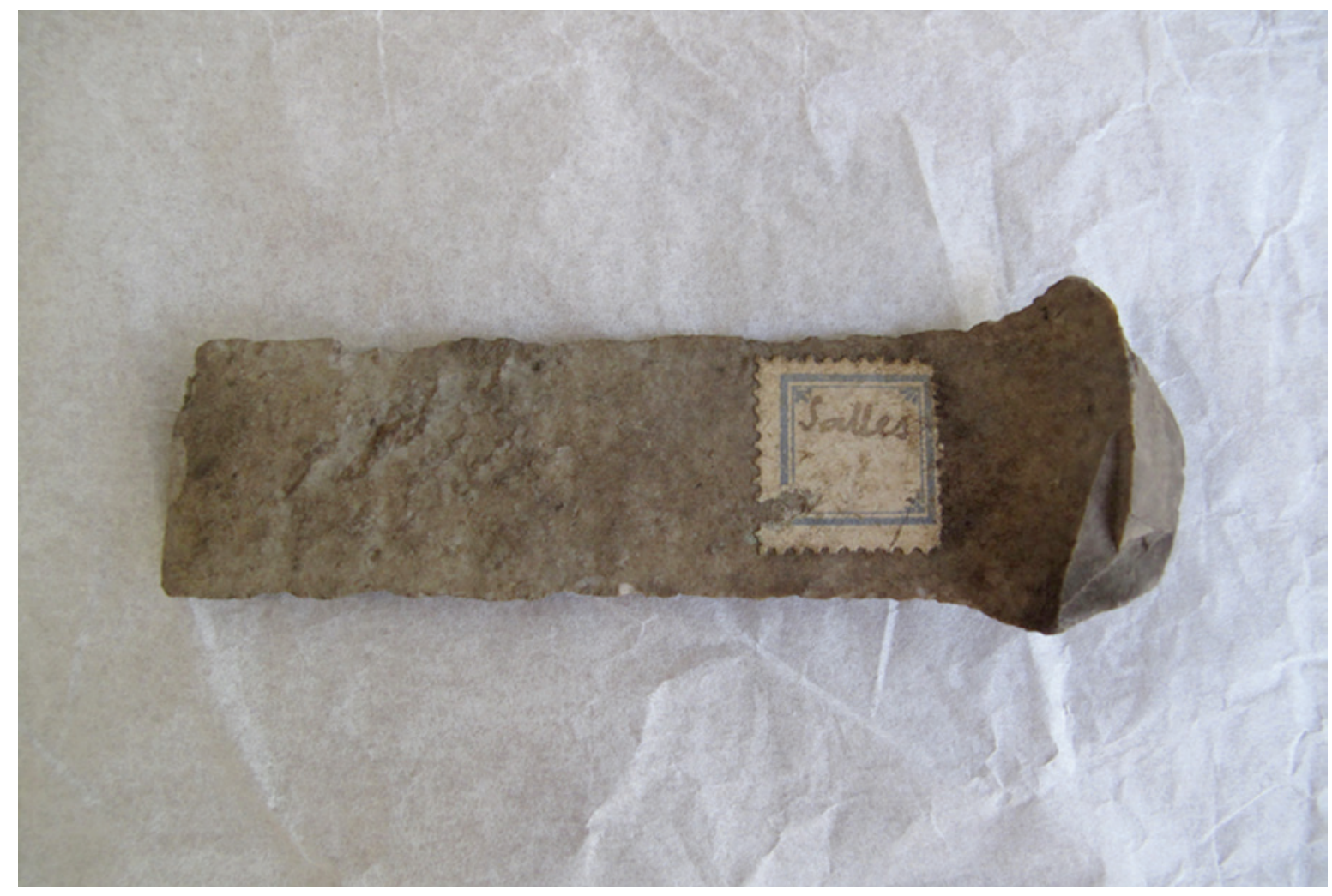

Figura 5 - Lâmina de Sílex proveniente da Necrópole de Sales, Montalegre (Fotografia de Sónia Couto).

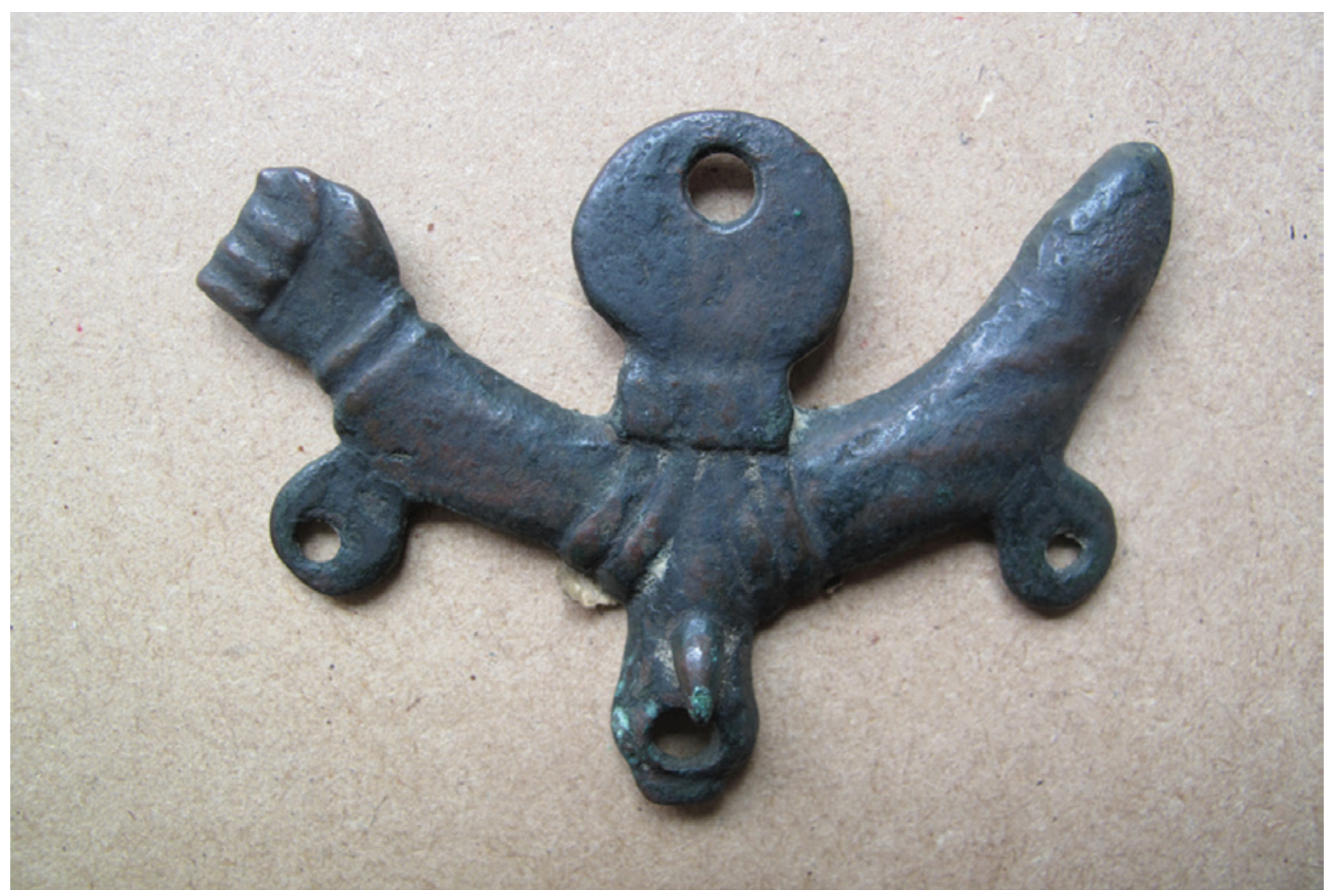

Figura 6 - Amuleto Figas Phallus proveniente de Pompeia (Fotografia de Sónia Couto). 


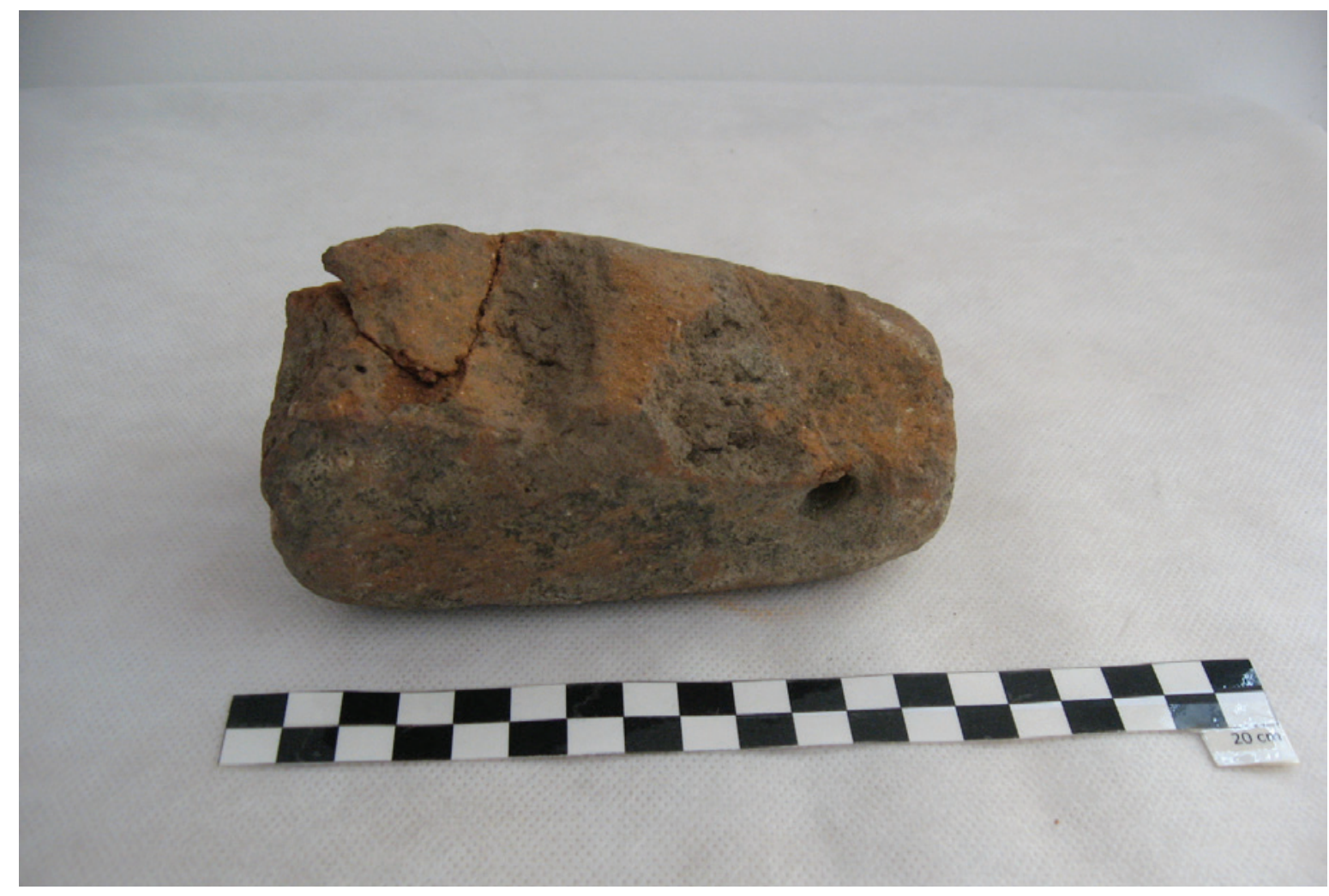

Figura 7 - Peso de tear proveniente do Castro de Ossela, Oliveira de Azeméis, (Fotografia de Sónia Couto).

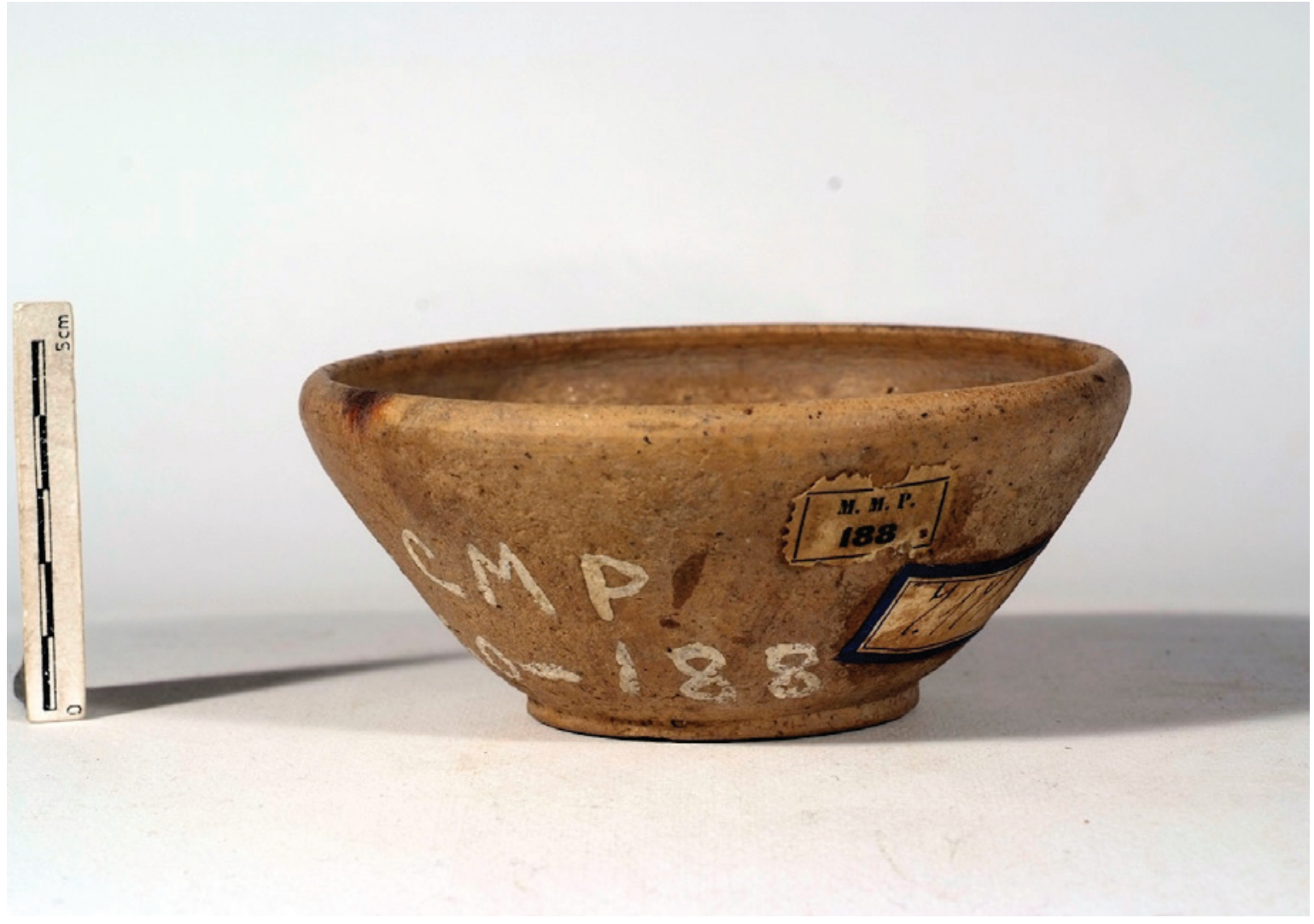

Figura 8 - Tigela em cerâmica proveniente da Necrópole do Bairral, Santa Leocádia, Baião (Fotografia de Ana Paula Machado, MNSR). 


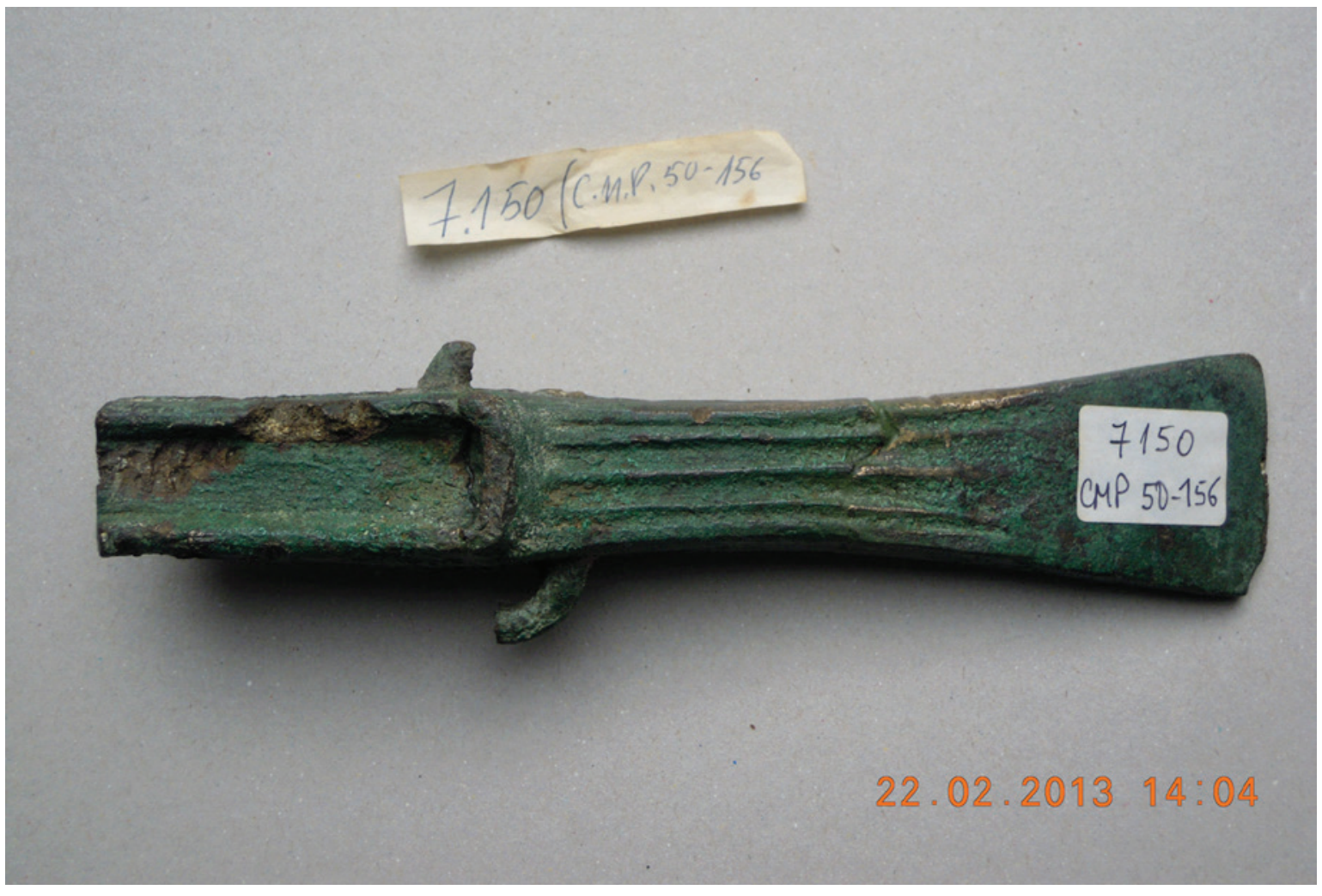

Figura 9- Machado de bronze proveniente de Viatodos, Famalicão (Fotografia de Ana Paula Machado, MNSR).

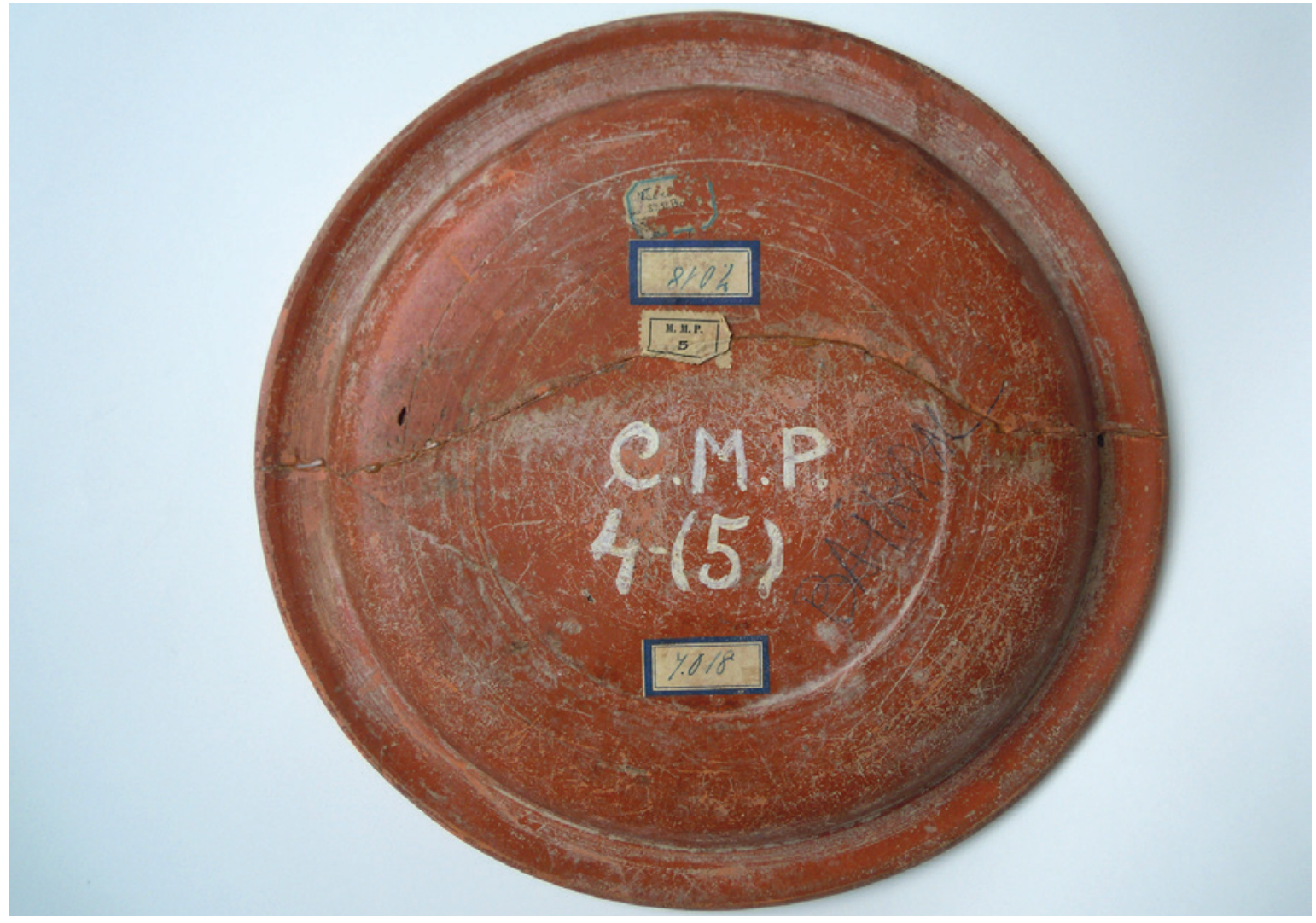

Figura 10 - Prato em sigillata proveniente da Necrópole do Bairral, Santa Leocádia, Baião (Fotografia de Ana Paula Machado, MNSR). 


\title{
VALPAÇOS - UMA NOVA CARTA ARQUEOLÓGICA
}

\author{
Pedro Pereira ${ }^{1}$, Maria de Fátima Casares Machado ${ }^{2}$
}

\begin{abstract}
RESUMO
Valpaços é recente no panorama administrativo português. O despovoamento do antigo concelho de Monforte de Rio Livre levou à reformulação da estrutura administrativa do território entre a serra da Padrela e o Rabaçal, entre Chaves e Mirandela, com a extinção do concelho de Carrazedo de Montenegro e a apropriação de territórios de concelhos vizinhos.

Desde a agregação, num só território, das terras frias e quentes, de uma multiplicidade de realidades geológicas, de fauna e flora, mas também arqueológicas. Em 200o, foi realizada uma carta arqueológica para o território de Valpaços. No entanto, o presente trabalho tem como objectivo primário operacionalizar os mecanismos de preservação do património do concelho, promovendo a sensibilização para um legado frágil.

O trabalho que tem vindo a ser realizado pelo município de Valpaços tem como objectivo não só identificar novos sítios, mas também re-localizar e proteger o património arqueológico conhecido.

Palavras-chave: Valpaços, Carta Arqueológica.
\end{abstract}

\begin{abstract}
Valpaços is a very recent administrative division in portuguese history. The abandonment that Monforte de Rio Livre suffered made it necessary to create a new administrative area, between the Padrela Hills and the Rabaçal, in between Chaves and Mirandela, extinguishing Carrazedo de Montenegro and incorportating adjoining territories.

Ever since the agregation, in a single territory, of the so called "terras frias" and "terras quentes, of multiple geological, faunistic and floral realities, but also by archaeological challenges. The current research has the main objective to update the heritage protection mechanisms of the territory, while promoting its fragility. The work being carried out by the Valpaços city hall is centered not only on identifying new sites, but also protecting known ones.
\end{abstract}

Keywords: Valpaços, Archaeological Chart.

\section{VALPAÇOS, UM TERRITÓRIO MULTI-FACETADO}

A primeira questão que devemos colocar é a de porquê de uma nova carta arqueológica para Valpaços? Adérito de Freitas, que tem estudado o território de Valpaços nas últimas quatro décadas, publicou uma primeira súmula deste conhecimento adquirido em 2001, na Carta Arqueológica do Concelho de Valpaços. Todavia, o autor é o primeiro a declarar que não teve a oportunidade de estudar a fundo a larga maioria dos sítios e materiais. Paralelamente, ao longo das duas décadas subsequentes, novos estudos têm vindo a ser realizados sobre o território, tanto de Valpaços (FREITAS, 2001; 2010 e 2011) como dos concelhos limítrofes, permitindo uma melhor perceção sobre a evolução da ocupação humana desta zona (CARVALHO et allii, 2017).

O património arqueológico em Portugal, a sua divulgação e, sobretudo, a sua proteção, tem recebido atenção por parte das estruturas da tutela mas também outros órgãos públicos e privados. Com a ascensão do turismo, o património arqueológico, em conjunto com outros elementos, ganha uma nova dimensão. Ao mesmo tempo, tratando-se de um património extremamente frágil, a divulgação

1. CITCEM; pedro.abrunhosa.pereira@gmail.com.

2. Câmara Municipal de Valpaços; fatimaxado@gmail.com. 
e promoção do património arqueológico entre a população local faz com que a mesma se aproprie dele, vendo-o como uma mais valia para a sua região e protegendo-o.

O espaço que abrange nos nossos dias o concelho de Valpaços é fruto de uma criação administrativa relativamente recente. Parcialmente dentro de espaços geológicos e climáticos extremamente distintos, Valpaços possui uma variedade pouco usual de condições geográficas, aumentando a riqueza actual do património arqueológico presente no território (Figura 1).

Território multifacetado, a Ocidente, Valpaços é geologicamente marcado pelos xistos, pertence a uma realidade climática designada como Terra Fria, com uma maior pluviosidade e uma temperatura média anual relativamente baixa. A Oriente, o território é pontihado pelo granito. Com a aproximação do leito do Rabaçal, o clima torna-se mais próximo do concelho vizinho de Mirandela, da Terra Quente, com menor pluviosidade ao longo do ano e temperaturas mais altas durante o Verão, ainda que com um Inverno rigoroso. Este mosaico de realidades climáticas e geológicas é bem visível quando atravessamos o concelho, sobretudo através das práticas agrícolas, adaptadas a cada zona. Paralelamente, ao longo dos tempos, o ser humano tem preferido determinados território para se estabelecer, seja durante a Pré-História, em que zonas de altitude média mais baixa no concelho são de maior predileção, próximas de cursos de água, seja durante a Romanização, com uma adaptação aos novos paradigmas da realidade administrativa e viária vigente.

Quando abordamos um território é necessário com-preender também que muitos dos sítios escolhidos pelo Homem como habitat têm uma longa ou longas ocupações, podendo ter existido rupturas nas mesmas. Em muitos casos, os povoados proto-históricos possuiam já uma ocupação humana anterior à Idade do Ferro. Muitos são romanizados, outros, são abandonados. Existem ainda casos em que se verifica uma ocupação durante a Idade do Ferro e novamente uma ocupação durante momentos, sobretudo iniciais, da Idade Média. Em muitos casos, a população local poderia ter ainda a consciência da existência de uma estrutura defensiva, ainda que abandonada durante o período romano, que poderia servir de abrigo.

\section{O TERRITÓRIO DE VALPAÇOS ANTES DE SER VALPAÇOS}

A Pré-História é o período que menos conhecemos quando falamos sobre a História de Valpaços. Embora vários investigadores se tenham debruçado sobre o tema no território (entre outros podemos citar aqui os trabalhos de Maria de Jesus Sanches e Joana Ribeiro (SANCHES 1994 e 1997 e RIBEIRO, 2007.), os vestígios são extremamente ténues se excluirmos os monumentos funerários, de cronologia relativamente recente dentro do paradigma da Pré-História, e a arte rupestre. São praticamente desconhecidos núcleos de habitat humano, com a exlusão do Outeiro do Homem, em Argeriz, identificado por Adérito de Freitas. Ao longo das prospecções realizadas no decurso do presente trabalho, foi identificado um outro possível núcleo de ocupação, no vale do Rabaçal, onde no decurso de trabalhos agrícolas foram recolhidos machados em anfibolitor ${ }^{3}$.

Paralelamente, a falta de intervenções no terreno, sondagens ou escavações, fazem com que as datações dos sítios pré-históricos de Valpaços sejam apenas relativas e passíveis de re-interpretações (Figura 2).

Nos últimos anos foram publicados vários trabalhos centrados na questão da arte rupestre presente em Valpaços (FREITAS, 2011; SANCHES 1994 e 1997; RIBEIRO, 2007 e 2017). Tal como referimos anteriormente, as representações artísticas datáveis da Pré-História concentram-se nas zonas mais a Sul, tradicionalmente mais temperadas, do concelho. São, na sua larga maioria gravuras, com representações simples de covinhas, podomorfos e serpentiformes. No entanto, estes tipos de representações são também conhecidas mais a Norte, no sítio da Saínça, em Tinhela, ou no conjunto de gravuras do Castro de Nossa Senhora da Ribeira, em Lampaça, Bouçoais (RIBEIRO, 2007), mas também em pequenos núcleos, como sucede com os vários conjuntos

\footnotetext{
3. Localizadas em terrenos próximos da aldeia abandonada do Cachão, o proprietário do terreno e fiel depositário dos materiais permitiu-nos registá-los. Em visita à zona, muito alterada por trabalhos agrícolas durante o século XX, é também possível observar a existência de uma série de abrigos, embora sem traços visíveis de ocupação. Foi ainda nesta zona que foi registado um grande painel com gravuras de tipo "covinha" no decurso de um Estudo de Impacto Ambiental (NETO e CHAVES, 2011). Infelizmente, as coordenadas do sítio estão incorretas e não foi possível detetar o local exato do painel.
} 
conhecidos em povoados fortificados, como no Castro de Vilanova e no Castro de Santa Valha (FREITAS, 2011). As representações figurativas e pinturas são mais escassas, embora sejam conhecidos no concelho alguns exemplos, mais uma vez concentrados na zona Sul do mesmo. Ao mesmo tempo, a leitura destes conjuntos deve tomar em conta as zonas de ribeiras e rios onde as mesmas se encontram, formando conjuntos que decorrem de Valpaços até Mirandela e Murça, sobretudo na zona da Serra de Passos (RIBEIRO, 2017 in CARVALHO et allii, 2017.).

A Idade do Ferro, ou Proto-história, é também um momento complexo a decifrar, embora neste caso tenham sido realizadas intervenções mais extensas no terreno, que permitiram ter alguns dados que permitem a leitura de alguns elementos sobre o período. No entanto, de entre os 27 povoados tradicionalmente identificados como proto-históricos no território de Valpaços, muitos não possuem material de superfície nem estruturas passíveis de os identificar como tais, muitas vezes sendo visíveis apenas materiais de cronologia romana, como tegulae e imbrex. Paralelamente, muitos destes sítios possuem ocupações anteriores, como aparenta ser o caso do Castro de Santa Valha que possui uma série de gravuras rupestres datáveis de momentos anteriores à Idade do Ferro (FREITAS, 2011). Ao mesmo tempo, muitos destes povoados aparentam sofrer momentos de re-ocupação, tal como sucede noutros casos no Noroeste peninsular, sobretudo durante a Alta Idade Média (Figura 3).

A ocupação da proto-história em Valpaços aparenta pautar-se sobretudo com os povoados fortificados. No entanto, mesmo no caso deste tipo de estrutura, são lisíveis alguns aspectos interessantes no território. No caso do sítio das Fragas da Cerca, por exemplo, é notória a presença de enormes conheiras no sopé das estruturas defensivas, próximas do ribeiro que bordeja a face Oeste do povoado, o que, associada à intervenção do Serviço Nacional de Minas na zona há algumas décadas (CASTRO e CORDEIRO, 1963), poderá indicar uma vocação de mineração presente na zona.

Um estudo de visualizações entre os vários povoados fortificados permitiu ainda definir, ao nível visual, que os mesmos poderão constituír partes de grupos, existindo certamente contactos próximos entre eles. Para além dos povoados fortificados com elementos patentes de uma realidade histórica da Proto-História, existem poucos outros achados que po- derão ser associados, com algum grau de certeza, a este período. Dois deles consistiram em achados fortuítos, de tesouros. O primeiro, bastante conhecido, é o chamado tesouro de Lebução, no qual estão integradas uma série de jóias datáveis da Idade do Ferro. O segundo, menos conhecido, consiste num torque, em exposição no Museu de Numismática de Vila Real, descoberto nos arredores de Rendufe. Para além destes conjuntos, algumas gravuras rupestres, sobretudo quando inseridas nas áreas de castros, poderão ser datáveis da Idade do Ferro: é o caso dos blocos do Castro de Ribas, um dos quais com um elemento circular e motivos radiais e outro com um motivo em espiral, infelizmente em paradeiro desconhecido actualmente. Neste caso específico, tal como outros investigadores propuseram (FREITAS, 2001), poderá tratar-se de uma re-utilização de elementos arquitectónicos. Paralelamente, são conhecidos casos em que as muralhas recebiam grafitos, como sucede no Castro de Yecla de Yeltes, em Castilla y León, Espanha.

Finalmente, a ocupação datável da Idade do Ferro no concelho é notória, sobretudo através da grande quantidade de povoados fortificados que sobreviveram. No entanto, se a prospecção arqueológica permite elacções sobre alguns pontos, comparando através de paralelos conhecidos noutros territórios, serão necessárias sondagens, sobretudo nos castros, para se poder ter uma melhor compreensão de como se desenvolveram e como se procede à transição com o período romano e medieval.

O período Romano é de leitura mais simples sobre o território de Valpaços, ainda que com constrangimentos similares aos patentes nos restantes períodos. Os materiais visíveis em prospeção são menos passíveis a interpretações e as estruturas são, normalmente, mais estandardizadas. Um dos elementos fulcrais que nos permite ler o território de Valpaços no período romano é a rede viária. $O$ facto de uma série de estruturas viárias romanas terem sobrevivido, em maior ou menor escala, permitiu a identificação de uma série de novos sítios ao longo dos seus percursos. Paralelamente, conseguimos, conjugando estudos anteriores sobre as redes viárias (BARRADAS, 1956, FREITAS, 2001 e TEIXEIRA, 1996), e a localização de sítios com ocupação humana no concelho, compreender como é que o território actual do mesmo estaria organizado no período romano.

A maior parte dos sítios comprovadamente romanos no concelho de Valpaços consistem em manchas de 
materiais, de maior ou menor dimensão, localizadas sobretudo em zonas próximas das redes viárias, e em povoados indígenas que foram romanizados. Existem três eixos viários com alguma monumentalidade que atravessam Valpaços: o iter XVII, descrito no Itinerário de Antonino, a via que parte de Aquae Flaviae ao Douro, passando por Três Minas, a via que ligava Formil a Três Minas e, numa menor escala, a via entre a actual povoação de Friões e Aquae Flaviae. No decurso da prospecção realizada ao longo destas vias, foi possível identificar uma série de derivações às mesmas e, em alguns casos, como sucedeu com Milagres II, sítios inéditos. Com a atualização do estado de conhecimentos sobre os eixos viários do concelho, é possível ter uma melhor leitura sobre o território de Valpaços, tanto no período romano como imediatamente antes e depois do mesmo. Alguns dos eixos viários de período clássico continuação a ter alguma importância até aos nossos dias, como é o caso de grande parte do iter XVII durante a sua passagem pela povoação de Sá, coberto hoje em dia com um piso de alcatrão.

Os elementos associados ao mundo dos mortos, como as aras e depósitos votivos, são também notórias no território de Valpaços, sobretudo tendo em conta que a sua concentração normalmente se dá próxima de eixos viários. Dividem-se em três conjuntos principais: um a Norte, acompanhando a via entre Formil e Três Minas, na zona de Lebução; um segundo, mais próximo da fronteira com Chaves, na mesma via; e um terceiro, entre a via Formil e Três Minas e a via que parte de Aquae Flaviae ao Douro, muito possivelmente uma via secundária que foi substituída pela construção da estrada M541.

Relativamente ao habitat, existem 14 povoados fortificados que possuem indícios de superfície de romanização, embora não seja possível delinear um quadro mais completo sem intervenções no terreno. Paralelamente, existem 39 manchas de superfície com materiais de cronologia romana, estando uma dezena dos mesmos em zonas próximas de castros romanizados. Existem também referências de achados isolados, como sucedeu com o conjunto de materiais descoberto em Valpaços e em depósito no Museu Abade de Baçal, em Bragança. Embora muito possivelmente estas peças possam provir de uma necrópole, a falta de dados sobre o contexto em que as mesmas foram descoberta impede uma interpretação mais cuidada (Figura 4).

Com o dealbar do período romano e a estrutura ad- ministrativa existente, o território conhecido hoje com Valpaços sofrerá uma série de alterações. A chegada de povos bárbaros ao território por volta de 409 da nossa Era será pouco linear. Idácio, o então bispo de Aquae Flaviae, narra-nos um panorama de fome, guerra, desolação e violência. No entanto, devemos diferenciar o colapso das estruturas, administrativas e sociais e a sua substituição por uma nova ordem, em oposto ao mundo latino em que Idácio vivia.

As lutas de poder entre os vários povos bárbaros terminam com a estabilidade concedida pela criação do Reino Suevo, em 429. Este último terminará cerca de século e meio mais tarde, com a unificação, em 585 , com o Reino Visigodo. As invasões muçulmanas de 711 irão criar um novo momento de instabilidade, ampliado com a reconquista cristã. Será apenas durante o reinado de Ordonho I, entre 850 e 866, que o processo de reconquista, repovoamento e re-organização dos territórios será mais efetivo. Pouco após este reinado, Chaves é conquistada, em 872. O espaço é dividido entre territoria, elementos territoriais decalcados da organização diocesana, e civitates, territórios que são dominados por um nobre. O período conturbado da Alta Idade Média deixará marcas no território e nas suas povoações, de tal forma em que, quando Fernando Magno procedia à concessão de forais nas zonas mais montanhosas do Norte, aparenta existir uma certa uniformidade relativamente ao roubo: estritamente proibido dentro das comunidades, mas permitido legalmente entre elas, sendo que o rei ficaria com um quinto do mesmo (TENTE, 2017 in CARVALHO et allii, 2017). Finalmente, a divisão provincial eclesiástica segue, de forma próxima, a divisão administrativa de Dioclesiano, no século IV, estando Valpaços sob a alçada da Dioceses de Braga, tal como atestas vários marcos no concelho (PEREIRA e MACHADO, 202O).

A materialidade da Alta Idade Média é mais complexa, sobretudo tendo em conta que temos um vazio de documentação para o território importante. Paralelamente, a construção não oficial e não eclesiástica na Idade Média dá primazia aos materiais perecíveis, como madeira e outros materiais vegetais. $\mathrm{O}$ mesmo se pode dizer de grande parte dos elementos do dia a dia, desde os instrumentos ao vestuário, fazendo com que muitos dados da vivências das populações deste território sejam extremamente difíceis de abordar. O primeiro documento conhecido para este período refere-se a uma doação (PARENTE, 2013: 69), em 109o, de um terreno em Rio Torto. Outros 
documentos deste género são conhecidos para o território. No entanto, os primeiros forais régios e outros documentos para o actual território datam já do período da nacionalidade $2^{4}$, tal como a maior parte da documentação mais antiga conhecida para o território em questão.

No entanto, sobreviveram alguns dados do período medieval de Valpaços. Um dos mais notórios são as sepulturas escavadas na rocha. De um total de 16 sepulturas deste género conhecidas no concelho, a maioria encontra-se nas zonas de eixos viários, tanto do iter XVII como da via medieval entre Murça e Vale de Telhas. Relativamente ao património religioso, podemos ainda referir a existência de alguns elementos, em igrejas recentes, que poderão ter sido re-aproveitados durante re-construções, de edifícios religiosos mais antigos, tal como sucede com a Igreja de Lampaça, onde são re-utilizados elementos romanos mas também medievais no edifício de construção recente.

Finalmente, no século XIII, em 1258, as inquirições de Afonso III (PARENTE, 2013: 535 a 537), referem 22 povoações no território actual de Valpaços, existindo todas ainda hoje em dia (Figura 5).

\section{UM PATRIMÓNIO MULTI-SECULAR MAS POUCO DISCUTIDO: OS LAGARES ESCAVADOS NA ROCHA}

Um pouco por toda a bacia mediterrânica, desde o Próximo Oriente (FRANKEL, 1998) até ao estreito de Gibraltar, são conhecidas estruturas escavadas na rocha, de morfologias muito distintas, associadas à produção de vinho (e, em muitos casos, de outros produtos, como mel, azeite, perfumes, etc).

Desde cedo que as estruturas de lagares escavados na rocha começam a ser estudadas no contexto peninsular e durante o último século, vários investigadores têm-se debruçado sobre o tema, em maior ou menos extensão $3^{5}$. Todavia, a dificuldade em datar e estudar as suas morfologias, a sua localização se en-

\footnotetext{
4. Aqui podemos citar o caso da doação de Argeriz, por Afonso Henriques, ao Mosteiro de Salzedas, em 1152 (FREITAS, 2001 e PARENTE; 2013).

5. Carlos Alberto Brochado de Almeida, António do Nascimento Sá Coixão, Catarina Tente, Adérito de Freitas, Yolanda de Peña Cervantes ou Alberto Reboreda são apenas alguns de uma longa lista de investigadores que trabalham ou trabalharam esta questão.
}

contrar muitas vezes em zonas de difícil acesso e este ser um tema difícil faz com que muitas vezes seja desanimador trabalhar este tema. Paralelamente, o facto de os lagares escavados na rocha levantarem, ainda hoje, tantas questões fazem com que este seja um tema extremamente interessante.

Um dos pontos mais importantes em análise são as razões que levaram à construção dos lagares escavados na rocha. Uma estrutura de tipo lagar necessita de uma zona de prensagem, ou calcatorium, e uma zona de recolha, ou lacus. No entanto, muitas estruturas possuem apenas uma zona de prensagem, sendo o resultado da mesma recolhido numa zona inferior, com uma peça móvel (Figura 6).

Analisando os lagares dispersos pelo território de Valpaços, encontramos um total de 120 estruturas, com um total de oito tipologias funcionais. Entre os indivíduos conhecidos, a maior parte concentra-se em zonas isoladas ainda hoje, sendo as teorias que nos parecem mais coerentes para a construção destes lagares a de que as estruturas serviriam para produzir vinho próximas de vinhas com acessos mais complexos, permitindo transportar o líquido diretamente para a sua zona de estágio, e, eventualmente, a fuga a taxas e dízimas a pagar pela produção de vinho, sobretudo a partir da Idade Média. Embora as duas teorias sejam concomitantes, elas poderão explicar a localização isolada das estruturas (Figura 7). Uma outra questão interessante é a do quando é que as estruturas são utilizadas. Embora ainda não tenha sido possível estabelecer um paralelo directo com Valpaços, sabemos que noutros territórios os lagares escavados na rocha são utilizados até há muito pouco tempo (PEREIRA, 2017). A sua longa diacronia funcional dificulta a resposta à questão. No entanto, em alguns casos, como sucede com a estrutura das Trigueiriças, Santa Valha, a grande quantidade de material romano na zona aponta para, pelo menos, um início funcional no período romano, ainda que apenas em algumas das estruturas. Ao mesmo tempo, uma leitura da localização destas estruturas, discriminadas em tipologias, em cartografia, faz com que seja percetível uma possível utilização e discriminação de territórios a partir de sítios arqueológicos conhecidos da prospeção.

No caso do sítio da Muradelha, em Fiães, por exemplo, a concentração de lagares de tipologia semelhante, sobretudo na zona a Sul do sítio, com uma ocupação eminentemente romana, poderá indicar a localização de vinhas nessa zona, exploradas pelo 
mesmo proprietário ou conjunto de proprietários. Neste caso, existem cinco lagares escavados na rocha, quatro de tipo $\mathrm{A}_{1}$, um de tipo $\mathrm{A}_{5}$ e um de tipo $\mathrm{B}$, todos num raio de 800 metros. Ao mesmo tempo, no caso dos lagares do Vale da Fenda e da Ribeira da Lança, existem sete lagares de tipo Ar e três de tipo B1, todos num raio inferior a 800 metros, em vários vales, a partir de uma mancha de material de cronologia romana previamente desconhecida (PEREIRA e MACHADO, 2020), sendo que em três dos lagares foi identificado material de superfície de cronologia romana.

Ao longo do trabalho de relocalização e prospecção que foi realizado em Valpaços, foi possível, tendo em conta que foi analisado o território como um todo, compreender melhor tanto a organização das estruturas de lagares tal como encetar uma possível datação relativa dos mesmos.

\section{VALPAÇOS E A SUA CARTA ARQUEOLÓGICA}

Tal como observamos anteriormente, a produção de uma carta arqueológica é essencial para a organização das dinâmicas territoriais e administrativas de um município. Seja a partir da questão da proteção do património arqueológico, seja através de uma melhor estruturação do Plano Diretor Municipal, um elemento deste género permite ainda uma melhor leitura do território em questão ao longo uma cronologia ampla.

Ao longo da preparação desta carta arqueológica foi necessário contactar, para além das populações locais e juntas de freguesias, uma série de museus e cidadãos externos ao concelho, depositários de materiais arqueológicos provenientes de Valpaços. Foram ainda consultadas centenas de referências bibliográficas referentes ao concelho e ao território em questão.

O trabalho foi dividido em duas fases principais: a prospeção direccionada, sobretudo nos sítios que eram já conhecidos através da bibliografia e da base de dados do Endovélico; e a prospeção intensiva, realizada pontualmente em zonas com um maior potencial (Figura 8).

Foram inventariados um total de 344 sítios arqueológicos, desde a Pré-História à Idade Média, tendo sido propostas as classificações de onze sítios ou conjuntos mais emblemáticos ao município. Ao longo do trabalho foram confirmadas as ocorrências patrimoniais no território, o seu estado de conservação e dispersão, se consistissem em manchas de superfície, e foram realizados registos, tanto fotográficos como ortofotográficos, de estruturas e elementos que, devido a diversos fatores, poderiam estar em risco.

No final do trabalho será realizada uma apresentação pública de resultados e será produzida uma exposição itinerante sobre a carta arqueológica, ambas previstas para o final do ano corrente, e, durante os meses seguintes à elaboração deste artigo, serão realizadas sondagens de controlo em alguns sítios do concelho, de forma a tentar obter sequências estratigráficas seguras,, nomeadamente no Santuário de Argeriz e no Castro de Santa Valha (Figura 9).

Finalmente, o trabalho de uma carta arqueológica nunca pode ser considerado terminado. Novos sítios irão certamente aparecer no decurso dos próximos anos ou meses. Poderão ser iniciados projetos de investigação que abranjam o território de Valpaços e que, certamente, trarão surpresas e novidades para a história do concelho e do território em que se insere.

\section{BIBLIOGRAFIA}

ALARCÃO, Jorge de (1988) - Roman Portugal. Vol. I. Warminster: Aris \& Phillips.

ALVES, Francisco Manuel (1938) - Memórias arqueológico-históricas do distrito de Bragança: arqueologia, etnografia e arte. Porto: Emp. Guedes, Vol. 10.

BARRADAS, Lereno Antunes (1956) - Vias romanas das regiões de Chaves e Bragança.In: Revista de Guimarães. Guimarães. 66: 12, p.159-240.

BARROCA, Mário (1987) - Necrópoles e Sepulturas Medievais de Entre-Douro e Minho (séculos Va XV). Policopiado.

BURGESS, Richard (1993) - The Chronicle of Hydatius and the Consularia Constantinopolitana. Oxford: Clarendon Press.

CARVALHO, Pedro, GOMES, Luís Filipe Coutinho e MARQUES, João Nuno (coord.) (2017) - Estudo histórico e etnológico do vale do Tua (Concelhos de Alijó, Carrazeda de Ansiães, Mirandela, Murça e Vila Flor), EDP/Edições Afrontamento.

CASTRO, Luís de Albuquerque e CORDEIRO, L. (1963) Um "fornax "lusoromano. In Estudos, Notas e Trabalhos do Serviço do Fomento Mineiro. Lisboa. 16: 12, pp. 117-128.

FONTE, João e CARDOSO, Ismael (2005) - O Castelo de Monforte de Rio Livre. In Al-madan. IIa Série. № 13 .

FONTE, João e COSTA-GARCIA, José Manuel (2016) - Alto da Cerca (Valpaços, Portugal): Um assentamento militar ro- 
mano na Serra da Padrela e sua relação com o distrito mineiro de Tresminas. Estudos do Quaternário.№ 14, pp. 39-56.

FRANKEL, Rafael (1998) - Wine and Oil Production in Antiquity in Israel and Other Mediterranean Countries. Jsot/ Asor Monographs, $\mathrm{n}^{\circ} 10$.

FREITAS, Adérito Medeiros de (2001) - Carta Arqueológica de Valpaços. Valpaços: Câmara Municipal de Valpaços.

FREITAS, Adérito Medeiros de (2010) - Lagares cavados nas rochas. Valpaços: Câmara Municipal de Valpaços.

FREITAS, Adérito Medeiros de (2011) - Corpus dos Petróglifos de Valpaços. Valpaços: Câmara Municipal de Valpaços.

JORGE, Vitor Oliveira (1983-1984) - Megalitismo no Norte de Portugal. Um novo balanço. Portugália. Nova Série. Vol.. Porto; Faculdade de Letras da Universidade do Porto

LEMOS, Francisco Sande (1993) - Povoamento Romano de Trás-os-Montes Oriental. Braga: Universidade do Minho, 6 Vols. Policopiado.

LOPO, Joaquim de Castro (1954) - O Concelho de Valpaços. Lourenço Marques: Edição do Autor.

NETO, Albertino Chan Rodrigues e CHAVES, Carlos Alberto Roque Neto (2011) - Relatório sobre o Descritor Património Arqueológico, Arquitetónico e Etnológico do Estudo de Impacte Ambiental dos Aproveitamentos Hidroeléctricos dos rios Calvo e Rabaçal (Mirandela e Valpaços). Policopiado.

PARENTE, João (2013) - Idade Média no Distrito de Vila Real - Documentos desde o ano 569 ao ano 1278. Tomo I. Âncora editores.

PEÑA CERVANTES, Yolanda (2019) - Los lagares rupestres de la Península Ibérica: sistemas de estrujado y problemática cronológica. In ArkeoGazte: Revista de arqueología Arkelogia aldizkaria, №. 9 (Ejemplar dedicado a: Arqueología y trabajo), pp. 83-99.

PEREIRA, Luís e LOPES, Alexandra Justo (2007) - Relocalização, identificação e inspecção de sítios pela Extensão do IPA - Macedo de Cavaleiros.

PEREIRA, Pedro (2017) - O Vinho na Lusitânia. CITCEM/ Afrontamento.

PEREIRA, Pedro, VANZELLER, José e NEVES, Joana (2003) - Levantamento e análise das gravuras de Nossa Senhora da Ribeira, Lebução. Trabalho apresentado na cadeira de Trabalhos Práticos de Arqueologia II. FLUP (policopiado).

PEREIRA, Pedro e MACHADO, Maria de Fátima (2020) Carta Arqueológica de Valpaços. Inédito.

RIBEIRO, Joana (2007) - Entre a Gravura e a Escultura: A Estação Rupestre de Lampaça no contexto da arte de ar livre da região. Trabalho apresentado na cadeira de Seminário de Projecto. FLUP. (policopiado).

RODRÍGUEZ COLMENERO, António, AIRES, Firmino e ALCORTA, Enrique (1997) - Aqvae Flaviae I. Fontes Epi- gráficas da Gallaecia Meridional Interior. Chaves: Câmara Municipal de Chaves.

SANCHES, Maria de Jesus (1994) - Megalitismo na bacia de Mirandela. In Actas do Seminário "O Megalitismo no Centro de Portugal». Viseu: Centro de Estudos Préhistóricos da Beira Alta, (Estudos PréHistóricos, 2), pp. 249-284.

SANCHES, Maria de Jesus (1997) - Pré-História recente de Trás-os-Montes e Alto Douro. O abrigo do Buraco da Pala (Mirandela) no contexto regional). In Textos. Porto: Sociedade Portuguesa de Antropologia e Etnologia, (Textos, 1), 2 Vols.

SILVA, Armando Coelho Ferreira da (1986) - A Cultura Castreja no Noroeste de Portugal. Paços de Ferreira: Museu Arqueológico da Citânia de Sanfins e Câmara Municipal de Paços de Ferreira.

SILVA, Pedro Miguel Reis (2016) - Povoamento Proto-Histórico do alto Tâmega: as mudanças do I milénio a.C. e a resistência do substrato indígena. Porto: Faculdade de Letras da Universidade do Porto (policopiado).

TEIXEIRA, Ricardo Jorge Coelho Marques Abrantes (1996) - De Aquae Flaviae a Chaves. Povoamento e organização do território entre a Antiguidade e a Idade Média. Porto: Faculdade de Letras da Universidade do Porto (policopiado).

TEIXEIRA, Ricardo Pinheiro (2015) - A Evolução do Povoado e Castelo de Monforte de Rio Livre na Idade Média. Porto: Faculdade de Letras da Universidade do Porto.

VIEIRA, Alexandra (2015) - Contributo para o estudo dos vestígios arqueológicos - do VI ao I milénio a.C.. Paisagens e memórias na bacia hidrográfica do Douro. Tese apresentada à Faculdade de Letras da Universidade do Porto para obtenção de grau de Doutor em Arqueologia. Policopiada. 


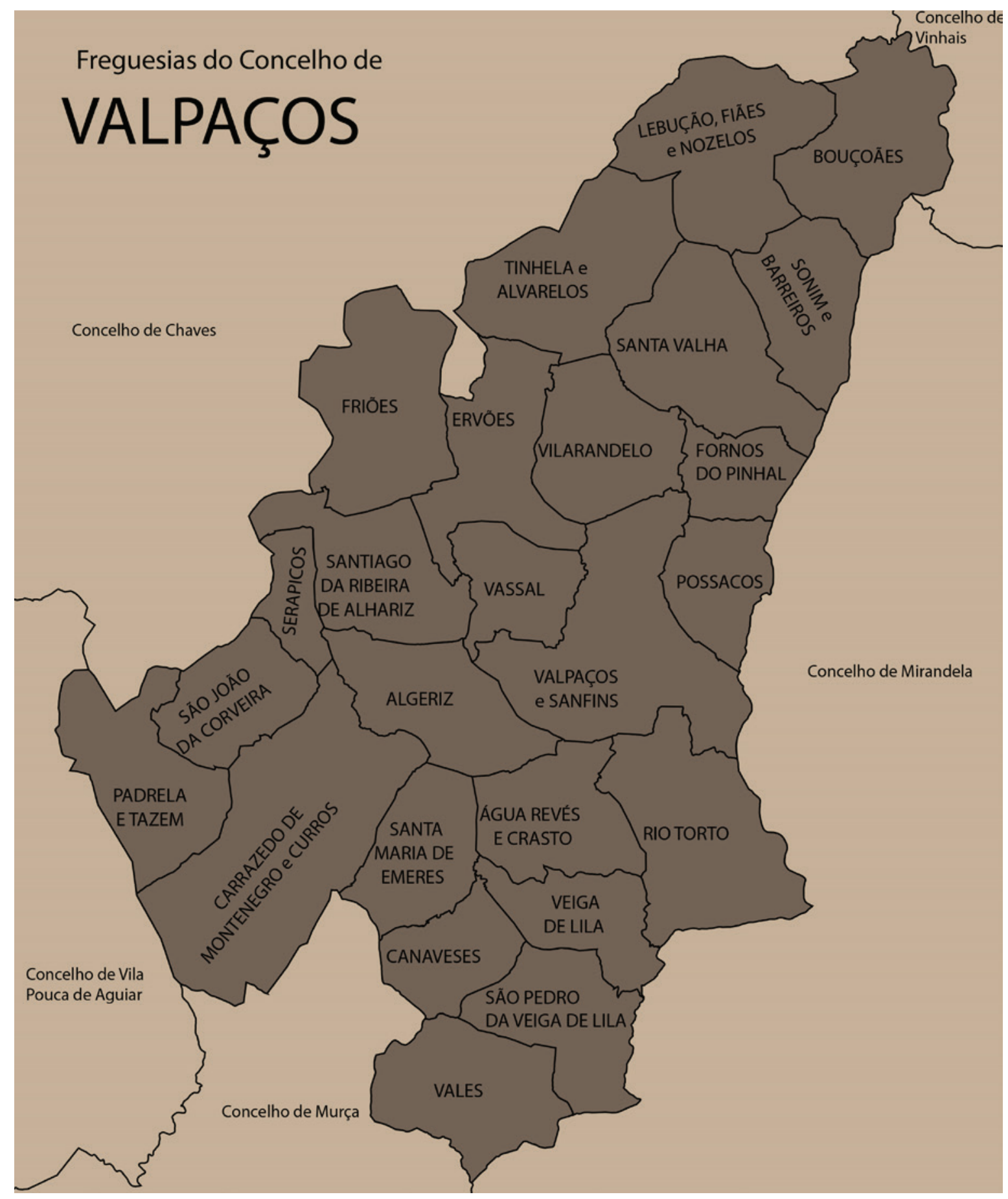

Figura 1 - Mapa do Concelho de Valpaços.(adaptado pelos autores a partir do mapa da Direcção-Geral do Território, Carta Administrativa Oficial de Portugal (CAOP), versão 2013). 


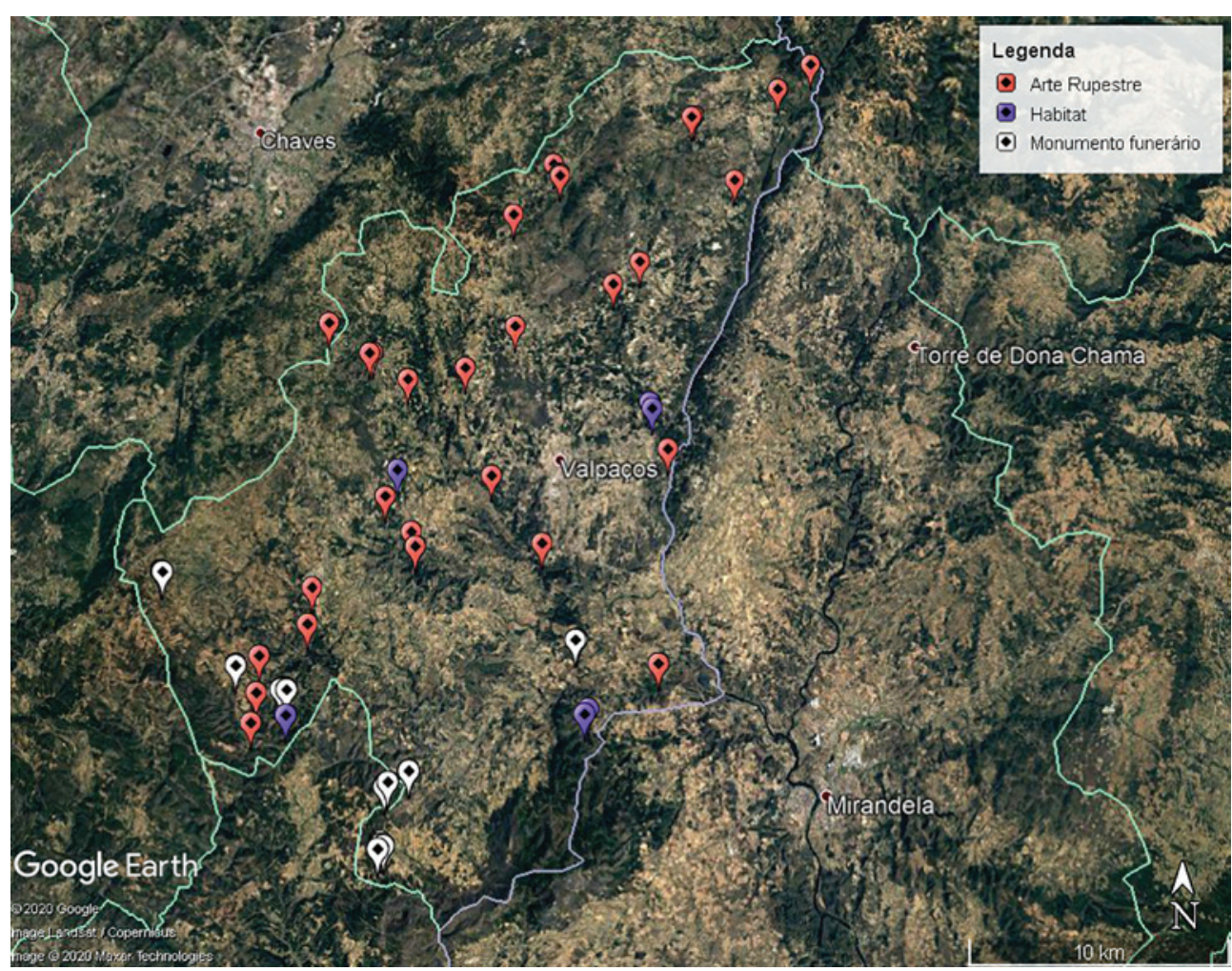

Figura 2-Mapa com a localização dos vários tipos de sítios com ocupação durante a Pré-História no Concelho de Valpaços.

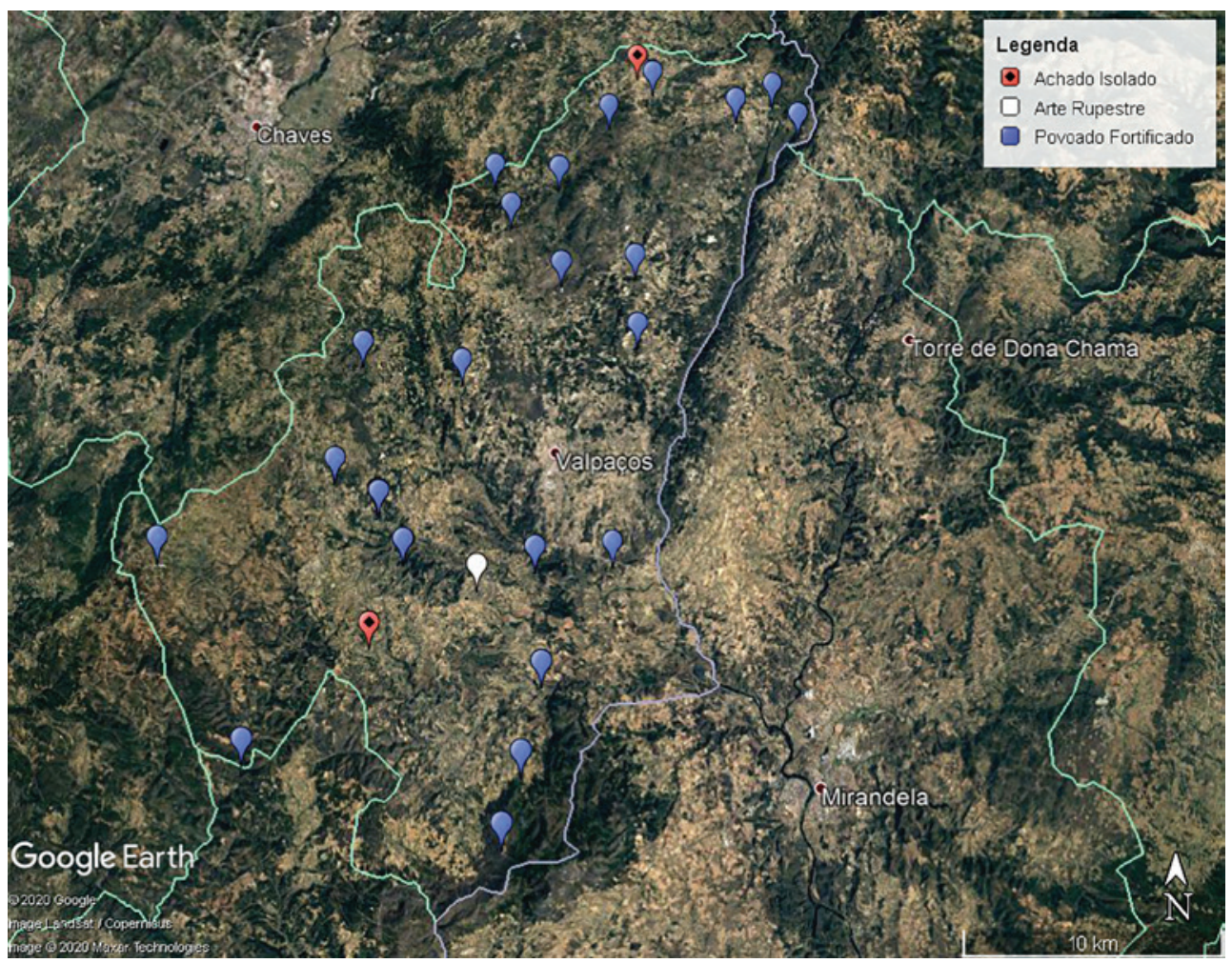

Figura 3 - Mapa com a localização dos vários tipos de sítios com ocupação durante a Proto-História no Concelho de Valpaços. 


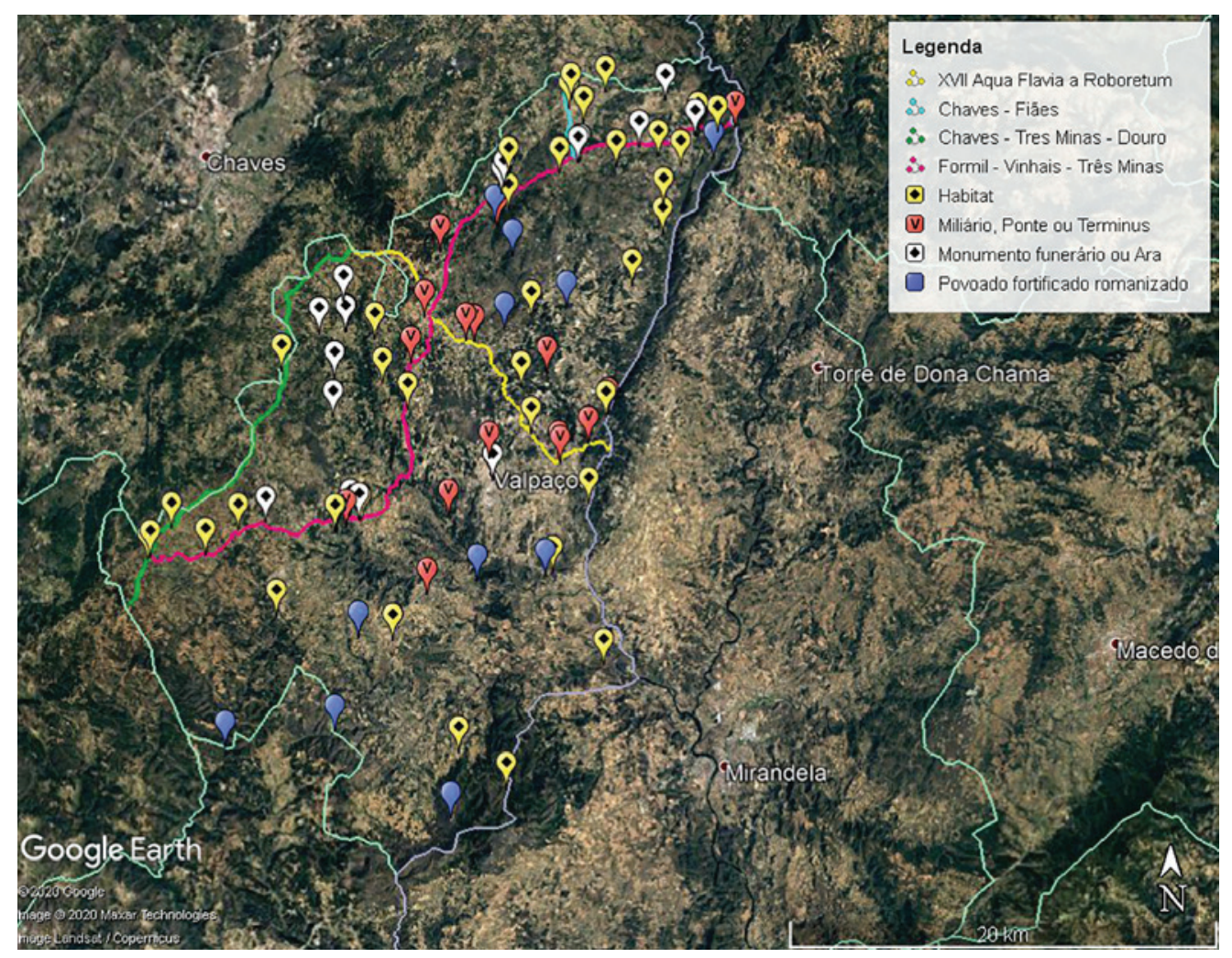

Figura 4-Mapa com a localização dos vários tipos de sítios com ocupação durante o período romano e vias conhecidas no Concelho de Valpaços.

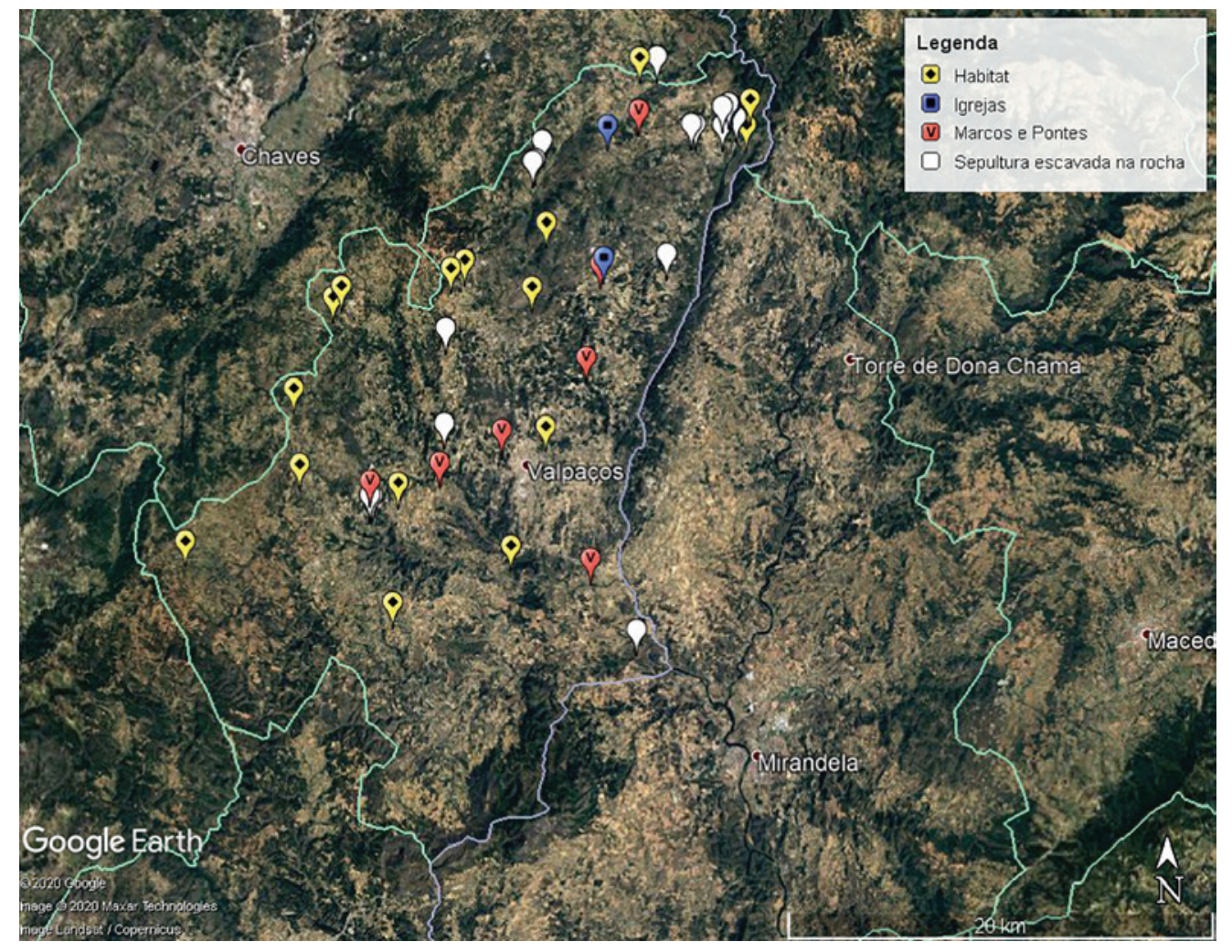

Figura 5-Mapa com a localização dos vários tipos de sítios com ocupação durante o período medieval e no Concelho de Valpaços. 


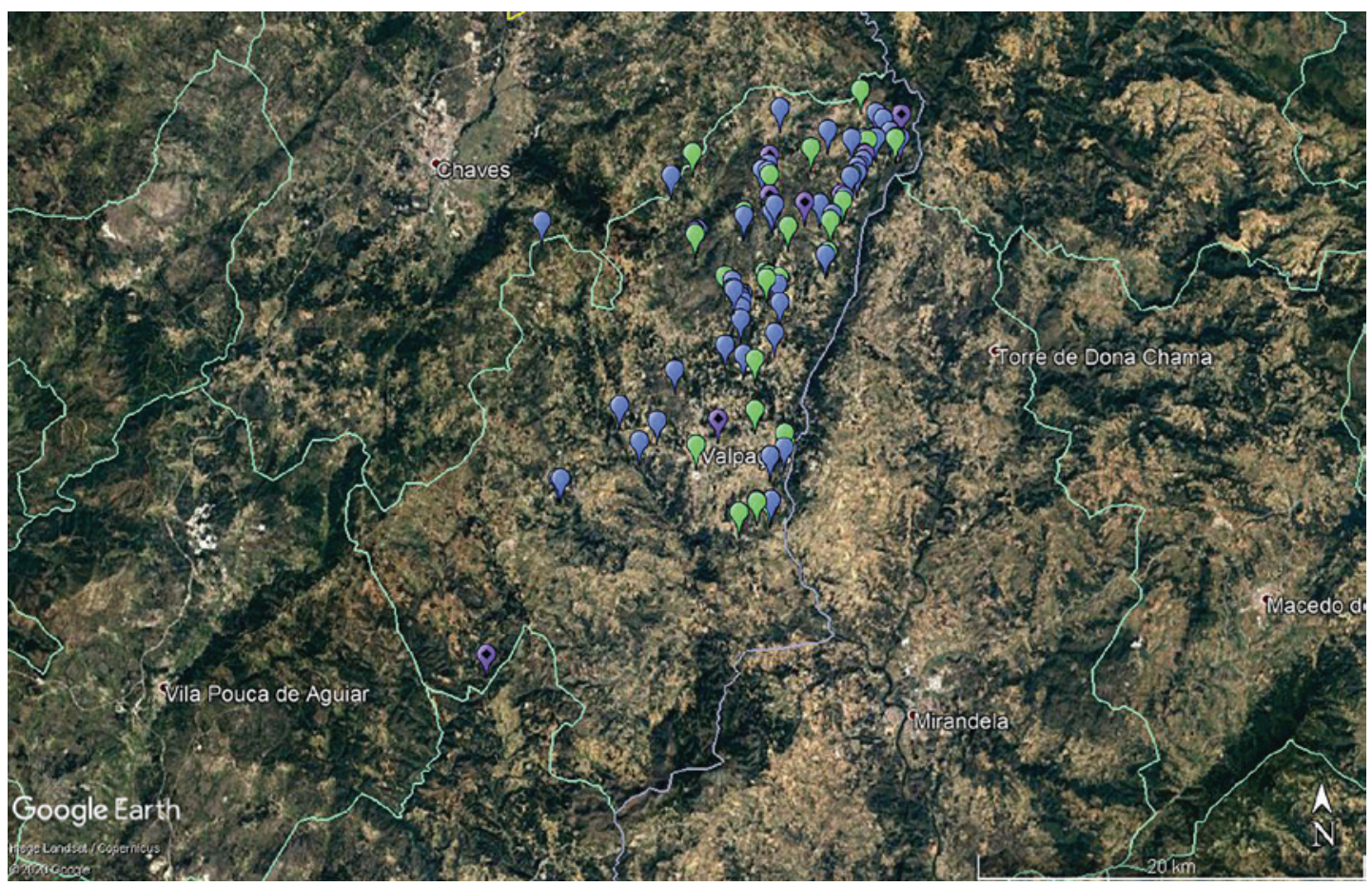

Figura 6 - Dispersão e localização dos lagares escavados na rocha no concelho de Valpaços.

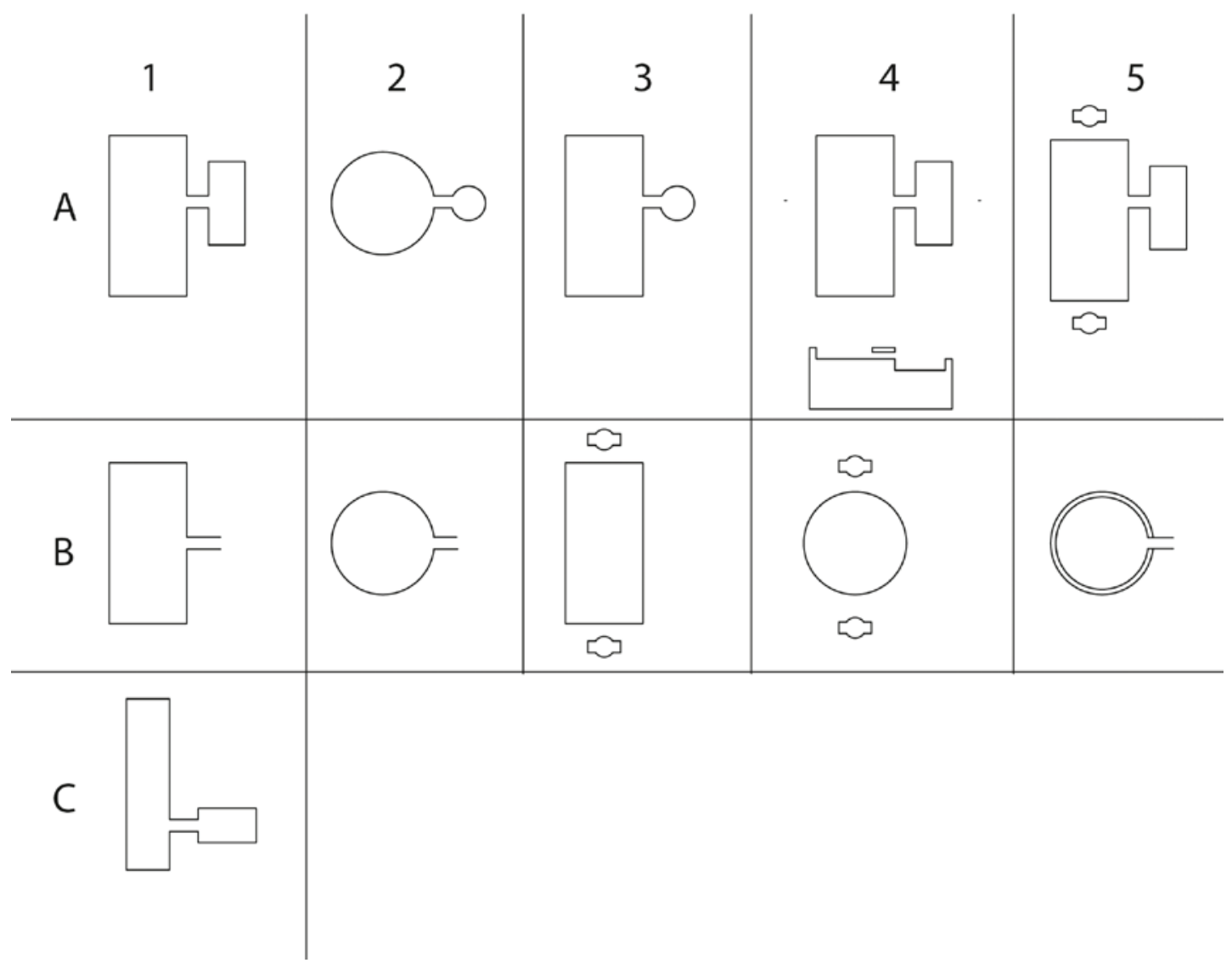

Figura 7 - Tipologias de plantas utilizadas para os lagares rupestres em Valpaços. 


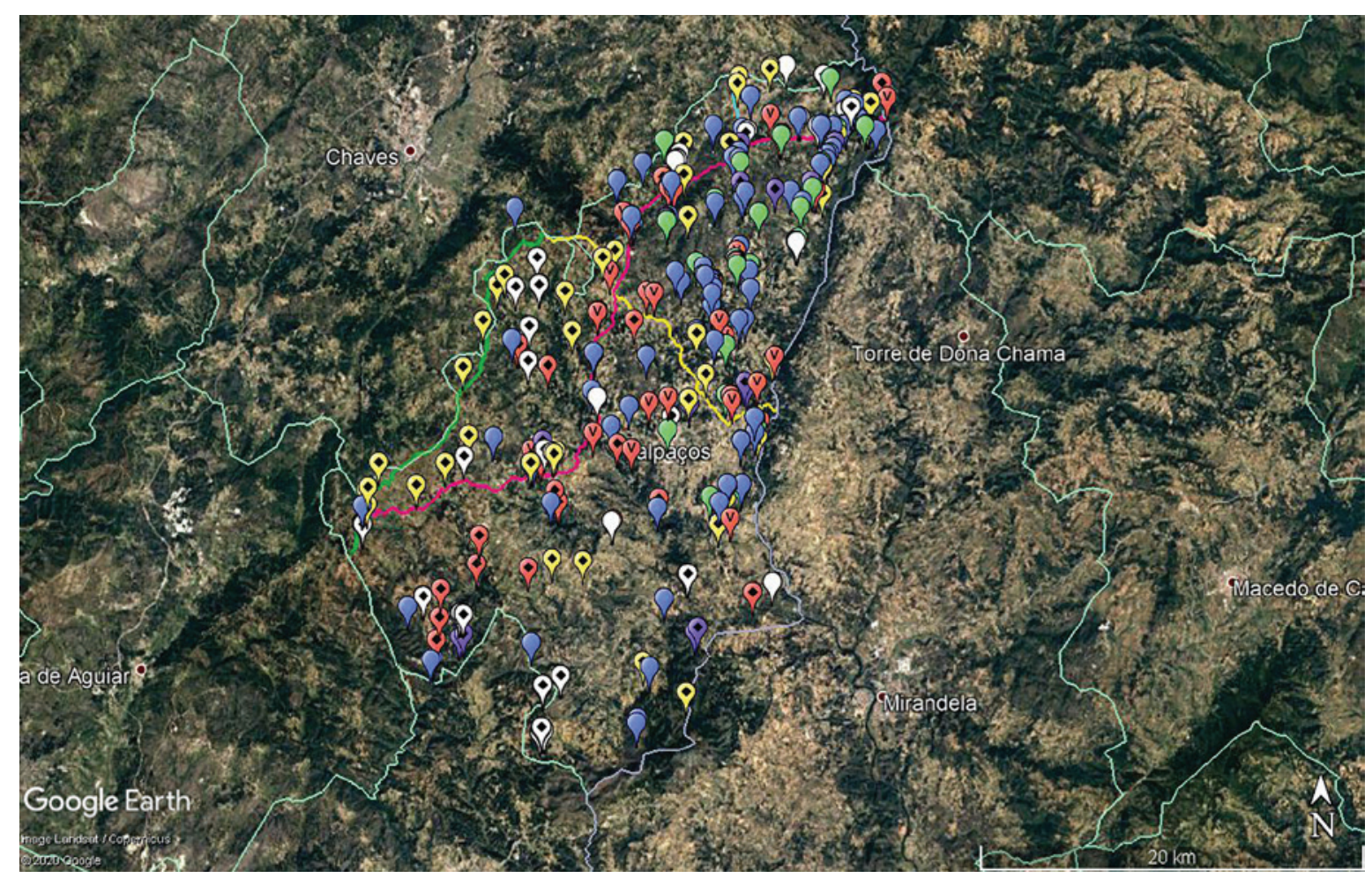

Figura 8 - Ortofotomapa com a localização de todos os sítios arqueológicos conhecidos no concelho de Valpaços.

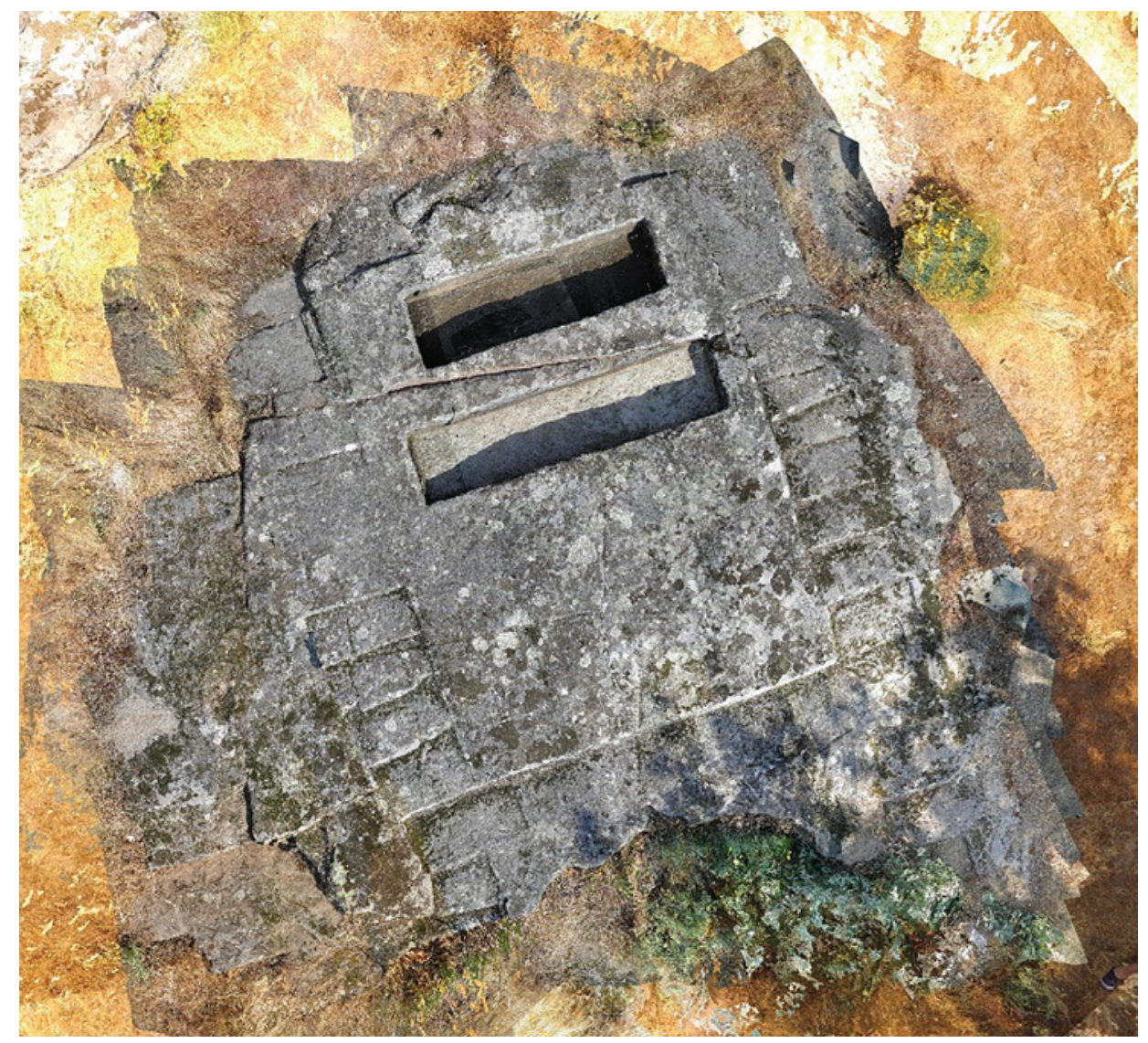

Figura 9 - Santuário de Argeriz. Ortofotografia prévia à intervenção no sítio. 


\title{
ARQUEOLOGIA NA CIDADE DE PENICHE
}

\author{
Adriano Constantino ${ }^{1}$, Luís Rendeiro ${ }^{1}$
}

\begin{abstract}
RESUMO
A valorização e o conceito de interpretação do património têm variado ao longo dos últimos cem anos em Peniche. Até meados do século XX assistiu-se a uma destruição constante do património edificado (religioso e militar) em prol "do progresso". Como resposta a esta destruição e na tentativa de defender o património existente, na segunda metade do mesmo século surge a classificação de vários monumentos através da publicação de decretos-lei. No entanto o património arqueológico foi descuidado, e será preciso esperar pelo final do século XX e inícios do seguinte para a arqueologia urbana ganhar papel de destaque e fonte de informação. Palavras-chave: Peniche, Arqueologia, Património, Oeste, Portugal.
\end{abstract}

\begin{abstract}
The valuation and concept of heritage interpretation has changed over the last hundred years in Peniche. Until the middle of the 2oth century, there was a constant destruction of the built heritage (religious and military) in favor of "progress". In response to this destruction and in an attempt to defend the existing heritage, in the second half of the same century the classification of several monuments emerged through the publication of decree-laws. However, the archaeological heritage has been neglected, and it will be necessary to wait for the end of the 2oth century and the beginning of the next for urban archeology to gain a prominent role and source of information.
\end{abstract}

Keywords: Peniche, Archeology, Heritage, West, Portugal.

\section{INTRODUÇÃO}

A arqueologia das cidades é um ramo da arqueologia confundido, por vezes, com a arqueologia urbana, embora o objeto de estudo seja a cidade, esta última centra-se na escavação que está a ser realizada e toda a problemática da ocupação daquele espaço intervencionado. A arqueologia das cidades pretende compreender a urbe como um todo, O planeamento das cidades em Portugal ao longo do século XX alterou-se com a introdução de várias leis de defesa do património. A arqueologia das cidades vem consequentemente ganhando importância não só no planeamento das urbes mas na salvaguarda, valorização do património e produção de conhecimento. $\mathrm{O}$ estudo aqui apresentado procura analisar a arqueologia na cidade de Peniche, com base na recolha bibliográfica dos trabalhos arqueológicos realizados, de achados, e produção científica. Para tal foi imprescindível a pesquisa nos motores de busca Google e o Endovélico, no arquivo do jornal local A voz do Mar (de 1957 até 2016), de alguns números do Jornal de
Peniche (1980 a 1982), e do Correio Popular (20072009). Promoveu-se ainda às análises do Plano Director Municipal e da Carta Magna de Peniche de forma a compreender o papel traçado para a arqueologia na cidade.

\section{CONTEXTO GEOLÓGICO E GEOGRÁFICO}

O concelho de Peniche situa-se na região Oeste, distrito de Leiria, tendo como limites Norte e Sul os municípios de Óbidos e de Lourinhã respetivamente, e a Oeste com o oceano Atlântico, encontra-se dividido pelas freguesias de Atouguia da Baleia, Ferrel, Serra d'El Rei e Peniche. Na Carta Militar de Portugal, escala 1: 25 ooo, localiza-se na folha n. ${ }^{\circ} 337$ (Figura 1), enquanto na Carta Geológica de Portugal à escala 1:50 ooo corresponde à folha 26-C.

Em termos geomorfológicos o concelho localiza-se no extremo ocidental da Península Ibérica, na Orla Mesocenozóica Ocidental ou Lusitânica, uma mega bacia sedimentar oceânica desenvolvida a partir do Mesozoico na Margem Ocidental Ibérica pela frag-

1. Patrimonium - Centro de Estudos e Defesa do Património da Região de Peniche; Patrimoniumpeniche@outlook.com. 
mentação da Pangeia durante a abertura do Atlântico Norte (Kullberg \& alii 2006, p.317). Em termos de geologia, a carta explicativa de 1960 (França \& alii 1960) apresenta uma variedade de formações geológicas presentes no concelho. Formações que passam pelo "Complexo cristalofílico" e o Quaternário Moderno. As Berlengas inserem-se no grupo das rochas eruptivas bem como as Estelas, Medas e Cerro da Velha. Por fim, importa referir referir a existência de uma brecha vulcânica na Papôa.

Para a leitura da ocupação de Peniche é fundamental compreender a transformação geográfica ocorrida no território. A insularidade de Peniche encontra-se atestada na crónica da conquista de Lisboa aos mouros em 1147, da qual citamos: "No dia seguinte aportámos com felicidade à ilha de Peniche, distante do continente de 800 passos..." (Calado 1994).

O progressivo assoreamento do porto medieval de Atouguia verificado desde o século XV culmina com a criação de um istmo que ligaria Peniche ao continente no século XVI, transferindo o centro económico para a florescente localidade. Após a Restauração em 1640, face ao perigo iminente de um ataque espanhol, na zona leste de Peniche é construída uma muralha com os meios baluartes da Misericórdia, Calçada, São Vicente e Cambôa e o Baluarte da Ponte. Esta imponente construção irá em algumas partes assentar na antiga linha de costa. A leitura das cartas topográfica e geológica, permite verificar um conjunto de cotas muito próximas entre si a rondar os $5 \mathrm{~m}$, nos antigos lugares banhados pelo mar. Desta forma, a rua da Alegria, Av. 25 de Abril, Rua Alexandre Herculano, Lagoinha, Praça Jacob Rodrigues e Largo 5 de Outubro, delimitam o antigo esteio.

\section{A OCUPAÇÃO HUMANA}

Os trabalhos arqueológicos realizados em Peniche permitiram verificar a presença humana em Peniche desde a Pré-história. A gruta da Furninha, escavada ainda na segunda metade do século XIX por Nery Delgado, apresenta um conjunto importante de materiais atribuíveis ao Neolítico e Calcolítico (Cardoso e Carvalho, 2011) e um conjunto faunístico de grande relevância (Brugal \& alii 2012). A par deste local emblemático, destaca-se ainda a publicação nos anos 70 do século passado por Zbyszewski , de várias jazidas do Paleolítico em Peniche (Zbyszewski 1970).

A peugada humana só volta a ser identificada já em período romano. São vários os vestígios que se têm vindo a descobrir nos últimos 20 anos, desde uma olaria de produção de ânforas (Cardoso et all 2016), a possível área portuária (Neto \& alii 2007), e um cipo encontrado ainda no século XIX.

Após o fim da ocupação romana, o estado atual do conhecimento demonstra um hiato ocupacional terminado em 1340, através da construção de armazéns. O progressivo assoreamento do porto de Atouguia levará a uma gradual transferência económica e populacional para Peniche. Este desenvolvimento tem o apoio da coroa como demonstra o documento D. Manuel de 1505 sobre a doação de terrenos para a construção de habitações (Calado 1999, p. 26). Este crescimento irá se refletir em 1516 com a criação da paróquia de Santa Maria da Ajuda e no recenseamento de 1527 . Neste censo verifica-se um maior número de população em Peniche (Peniche de Cima 47 vizinhos, Peniche de Baixo 144) face à então sede de concelho, Atouguia da Baleia (121 vizinhos) (Calado 1991),

A leitura do recenseamento permite também verificar a existência dentro de Peniche de dois núcleos, Peniche de Cima e Peniche de Baixo, com predomínio deste último. Esta realidade demonstra um maior desenvolvimento e consequente concentração populacional em torno do porto. O florescimento de Peniche levará à criação ainda das paróquias de São Pedro e de São Sebastião culminando em 1609 com a elevação a vila e sede de concelho, separando-se administrativamente de Atouguia embora se regesse pelo mesmo foral.

Deste período datam importantes construções religiosas como o Convento do Bom Jesus, a igreja de São Pedro, a maior de todas, em finais do século XVI, a igreja da Misericórdia em 1629 e respetivo hospital e a ampliação igreja de Nossa Senhora da Ajuda em 1569. A necessidade de fortificar Peniche pela sua posição estratégica leva à construção em 1557 do Redondo, a génese da Fortaleza. Com a Guerra da Restauração assiste-se à construção de um importante conjunto de fortificações de que fazem parte os Fortes das Cabanas e da Luz e a cinta de muralhas, além da conclusão da Fortaleza. Afastado da vila é ainda construído no cabo Carvoeiro o forte de Nossa Senhora da Vitória (Calado 2000) (Figura 2).

Após estes acontecimentos o urbanismo pouco ou nada muda até ao século XIX, assistindo-se neste século à construção de novas fortificações no Porto Areia Norte e o fortim de Santo António no Campo da Torre, Peniche de Baixo (Calado 200o). Com a 
entrada no século XX o panorama de Peniche altera-se. Em 1910 instala-se a primeira fábrica de conservas de peixe seguida de outras indústrias conserveiras. A instalação das unidades fabris ocorre em terrenos periféricos da vila, normalmente terrenos agrícolas. O início do século fica marcado pela introdução da traineira em 1912 e mais tarde já nos anos 20 a sua motorização (Russo 2014).

Estes dois fatores, industrialização e desenvolvimento da pesca, serão responsáveis pela chegada de pescadores de todo o litoral para Peniche, aumentando a pressão demográfica. Raul Brandão na sua obra Pescadores caracteriza a situação de Peniche neste período como " horrível para mim porque é um tipo de pesca industrializada, o barracão, a fábrica, a caserna da sardinha..."(Brandão 2010).

Aos poucos são construídos bairros de pescadores e de operários, enquanto os armadores das embarcações, com os rendimentos da pesca, investem na remodelação das suas habitações, descaracterizando a zona histórica de Peniche de Baixo. Devido a este grande crescimento piscatório, o porto recebe importantes obras de alteração em finais de 1935. Este desenvolvimento portuário levará ao aumento do tráfego automóvel, associado ao escoamento do pescado, optando-se pelo alargamento da Avenida do Mar. As obras iniciam-se em 1950 com a destruição do topo da Cortina do Cais e com a construção de um novo paredão, aumentando desta forma a largura da Avenida. O Largo do Município sofre também alterações com a destruição de parte do meio baluarte da Misericórdia. Nesta década algum património edificado é demolido, como a capela de São Marcos, Paiol da Pólvora, os paços da Misericórdia e o forte de Nossa Senhora da Vitória (Cabo Carvoeiro), e assiste-se ao alargamento dos denominados portões de Peniche de Cima.

O pós 25 de Abril é marcado por um novo aumento da construção, surgindo novos bairros de forma a resolver o problema da habitabilidade em Peniche. Este novo período de expansão urbana avança para o interior da península ocupando os antigos terrenos agrícolas ladeados por muros de pedras solta. No lado oposto da frente abaluartada verificando-se a instalação de armazéns e indústria na zona da Prageira.

Desta forma podemos afirmar que são conhecidos, até agora, dois momentos de ocupação e urbanização de Peniche distintos. Uma em época clássica, vocacionada para o fabrico cerâmica utilitária e de ânforas para envase de produtos piscícolas. E outra que se inicia no final da Idade Média e que se prolongou até aos dias de hoje, caracterizada com a ascensão de Peniche a sede de concelho. Em ambas as situações as atividades marítimas são preponderantes.

\section{PENSAR A CIDADE E O PATRIMÓNIO}

O crescimento desordenado ao longo do século XX levou ao conceituado arquiteto nacional e nascido em Peniche, Paulino Montez, a realizar um plano de ordenamento para a península de Peniche, em 1974, e publicado em 1976, abordando o "Traçado da rede viária", o "traçado do zonamento" e, ainda, o "traçado do equipamento" (Gregório 2014 p. 217), contudo estes projetos nunca chegaram a ser implementados. Sensivelmente deste período surgem a classificação de vários monumentos. A igreja de Nossa Senhora da Ajuda é o primeiro edifício a ser classificado como Imóvel de Interesse Público, através do Decreto $\mathrm{n}^{\circ} 45$ 327, DG, 1. ${ }^{\mathrm{a}}$ série, n. ${ }^{\circ} 251$ de 25 outubro 1963. Segue-se classificação da Fortaleza e da frente abaluartada, inseridas na categoria de Monumento Nacional, (Decreto no 28 536, DG, 1. ․ㅡ série, n. .066 de 22 março 1938 / ZEP / Zona “non aedificandi”, Portaria, DG, 2. ․ㅗ́rie, n. . 71 de 24 março $1967^{*}$ 1). Este conjunto abaluartado estende-se desde Peniche de Baixo até Peniche de Cima, sendo constituído pelos meio-baluartes da Misericórdia, Calçada, São Vicente e Gamboa e pelo Baluarte da Ponte, e pela cortina de muralha (Figura 3). Mais tarde a igreja da Misericórdia, construída ainda na primeira metade do século XVII, é classificada como Imóvel de Interesse Público, ( Decreto no $95 / 78$, DR, 1. ․ㅗ série, n.․ำ 210 de 12 setembro 1978).

Em setembro de 1994, é constituído o grupo de trabalho, Gabinete Técnico Local (GTL), pertencente à Câmara Municipal de Peniche. Este Gabinete coordenado pela Arquitecta Cristina Salvador, é constituído por uma equipa multidisciplinar, incorporando o Engenheiro Civil José Mazarelo, Gabirela F. Silva, assistente social; Filomena Sousa, desenhadora; e Ivete Carmo, administrativa, um ano depois entra para a equipa Duarte Jorge, técnico de informática (Salvador 1996a, pp. 6-7). O GTL teve como principal objetivo a reabilitação e Património Histórico de Peniche, chegando a demarcar duas áreas de interesse prioritário (Salvador 1996 a pp. 1 e 7). Este estudo sobre a malha urbana permitiu realizar inclusive uma caracterização da população residente nas zonas de intervenção (Voz do Mar 21 de Março de 1996b, pp.4-5), e um levanta- 
mento dos logradouros (Salvador 1996 c, p.3). Além do trabalho de caracterização do património, realizou várias sessões de esclarecimento dos trabalhos no jornal local A Voz do Mar como o artigo Património Cultural A Capela de Santo António, referindo à necessidade de reabilitar aquele espaço urbano, incluindo o Jogo da Bola e o fortim de Santo António (Salvador 1995 B, pp. 6-7). Nos inícios do ano de 1996 já estavam concluídos vários projetos ou em fase de conclusão: Levantamento e análise da Área de Intervenção Prioritária zona 2 e 3 (concluído); Levantamento geral e análise de Intervenção Zona 4,5,6 (em conclusão); Levantamento e análise da Área de Intervenção Zona 1, bairro Alto da Vela (levantamento concluído e análise em estudo); Plano de Reabilitação e Ordenamento do Campo da República e Alto da Vela (em fase de candidatura); Regulamento Preliminar de Intervenção Urbanística (concluído e aguardando aprovação); Estudo da pavimentação do Largo 5 de Outubro (estudo prévio); Projeto de Reabilitação e Restauro da Capela de Santo António e fortim de Santo António (Negociação da C.M.P. para aquisição das parcelas); Projeto de Reabilitação e ordenamento do Forte das Cabanas (em curso), Projeto de arranjo do Largo entre Rua José Estevão e Rua Vasco da Gama (em curso); Projeto de reabilitação do Largo envolvente à igreja de São Pedro (em curso); Projeto de reabilitação da gruta da Furninha (estudo prévio) entre outras atividades de sensibilização junto de escolas (Salvador 1996a p.7).

Estes trabalhos permitiram ainda classificar a igrejas de Nossa Senhora da Conceição, São Pedro e capela/ Santuário de Nossa Senhora dos Remédios como Imóvel de Interesse Público, através do Decreto no 2/96, DR, 1. ․ㅗ série, n. ${ }^{\circ} 56$ de 06 março 1996.

Ainda deste período, em 1995 é elaborado pela Câmara Municipal de Peniche o Plano Diretor Municipal sendo dedicado o capítulo IV ao Património. Neste ponto fica clarificado no artigo $22^{\circ}$ o que é Património: "Entende-se por património histórico o conjunto dos bens culturais, sociais e económicos, de carácter natural ou produto da cultura e que estruturam a identidade do concelho". Os Artigos $23^{\circ}$ e $24^{\circ}$ bordam os princípios gerais do património e as suas categorias, dividindo em: a) Imóveis Classificados incluindo os Monumentos Nacionais, Imóveis de Interesse Público e Valores Concelhios; b) Outros Valores a proteger incluindo Núcleos Urbanos, Património Arquitectónico incluindo Edificios ou Conjuntos e Valores Arqueológicos.

O Artigo $25^{\circ}$ clarifica os princípios gerais dos imó- veis classificados alertando para a zona de proteção mínima de $50 m$ bem como a autorização do então Instituto Português do Património Arquitetónico e Arqueológico, bem como no futuro a possível classificação de monumentos de interesse municipal estarem também abrangidos pelas mesmas premissas. Os dois artigos seguintes são sobre a proteção do núcleo histórico, definindo os seus princípios gerais e remete-lo para a proteção da muralha de Peniche, deixando o resto sem proteção.

Em 2009 na redação da Carta Magna surge pela primeira vez um capítulo dedicado ao património com a referência à arqueologia: "No respeita ao património arqueológico, no Museu Municipal de Peniche, existem colecções arqueológicas pré-históricas (nomeadamente relativas à gruta da Furninha) $e$ de achados submarinos (nomeadamente relativos ao naufrágio do S. Pedro de Alcântara), além de um acervo de arqueologia romana ainda em fase de estudo. A Câmara Municipal tem nos seus quadros um arqueólogo que acompanha as obras efetuadas no município e exerce actividade genérica na área da identificação, preservação e valorização do património arqueológico, nas três vertentes acima indicadas: arqueologia pré-histórica, arqueologia romana e arqueologia subaquática. Está em curso o inventário do acervo conservado no Museu, mas não existe carta arqueológica do concelho, nem para a superficie terrestre nem para os seus fundos marinhos" (Carta Magna 2009, p 62).

Sobre o património edificado da cidade destacam apenas a Fortaleza, igreja da Misericórdia, igreja de São Pedro, Santuário de Nossa Senhora dos Remédios, Fonte do Rosário e gruta da Furninha (Carta Magna pp. 124-126). Propondo a criação de uma rota associada ao património militar com interesse e a sua reabilitação (Carta Magna p.136). Atualmente encontra-se em revisão o PDM de 1995.

\section{A ARQUEOLOGIA NA CIDADE}

Os anos 80 do século passado marcam o arranque dos trabalhos arqueológicos na cidade de Peniche, todavia anteriormente existem relatos de achados em algumas partes da cidade. A notícia mais antiga surge no inquérito promovido pela Academia Real da História Portuguesa, em 1721 em que o pároco responde: "Presentemente mandei abrir (que estava fechada a dita casa e olha para a parte do poente), uma porta por onde se dizia principiava a entrada 
do dito tanque e mandei cavar dentro efora bastante altura e se não achou o que pretendia, mais que uns alicerces de pedra e cal, muito juntos uns aos outros, sem proporção de que fossem fundamente para nenhum género de edificio" e mais adiante acrescenta terem sido encontradas duas pedras com inscrições "de letra antiga" que estavam no chafariz e desta forma não era possivel de as ler, todavia existia a referência a que numa dela se podia ler Júlio César (Calado 1996 p.22-23).

Com o terramoto de 1755 e consequente maremoto é posto a descoberto junto ao Portinho do Meio um muro que se encontrava enterrado na areia e que não havia registo do seu conhecimento, tendo sido aproveitada a sua pedra para reparar o cais (Constantino \& alii 2016).

No século XIX é descoberto em Peniche de Cima, num muro próximo à igreja de Nossa Senhora da Ajuda, por Pedro Cervantes Figueira em 1858 um cipo romano (Calado 1991 p.63-64; Calado 1999, p. 67; Venâncio 2001). Ainda neste século realizam-se os primeiros trabalhos arqueológicos em Peniche, promovidos por Nery Delgado na gruta da Furninha, na altura distante do perímetro urbano.

As notícias de achados em Peniche, na parte terrestre, só surgem já nos anos 70 do século XX em três artigos do jornal A Voz do Mar sobre uns canhões encontrados no decorrer das dragagens e ampliação do porto de pesca. Ainda na mesma década inicia-se a investigação sobre o navio espanhol São Pedro de Alcântara, no Porto de Areia Norte, sob a coordenação de Jean Yves Blot e Maria Luisa Blot. Os trabalhos arqueológicos na necrópole associada ao naufrágio deste vaso de guerra em 1786, decorre em 1985 com a prospeção magnética da necrópole e no ano seguinte arrancam os trabalhos arqueológicos prolongando-se até 1988, e retomados em 1993 até 1997 (Blot 2008).

O ano de 1998 marca o início da arqueologia de salvamento e de emergência em Peniche. No decorrer de trabalhos de terraplanagem para a construção de campos de ténis é encontrado um forno romano, na rua Calouste Gulbenkian. As investigações desde então têm sido sistemáticas, seja em escavação seja em laboratório.

No total foram encontrados quatro fornos de produção de ânforas com início no reinado de Augusto. O forno 1 apresenta $3,25 \mathrm{~m}$ de diâmetro interno, conservando uma parede com 1,1m de altura na camara de cozedura. O forno 3 é o maior, apresentan- do 3,95m de diâmetro inteiro (Cardoso e Rodrigues 2005; Cardoso \& alii 2006), os fornos 2 e 4 são mais pequenos e mais destruídos não permitindo avançar com o diâmetro correto (Cardoso \& alii 2016).

Os fornos apresentam planta circular com corredor central aberto no geológico, as paredes rondam os o.8m de espessura, ligadas com argila. As áreas de acesso ao praefurnia dos fornos 1 e 3 estavam protegidas por um telheiro apoiado em muros de alvenaria seca (Cardoso e Rodrigues 2005). As câmaras expunham de uma grelha de tijoleira como separação da fornalha, apoiada em arcos de tijolo perpendiculares à abertura central e separados entres si de forma a permitir uma maior passagem do calor da fornalha para a camara de cozedura (Cardoso \& alii 2018).

O estudo dos materiais permitiu caracterizar a produção cerâmica composta por doze tipos de ânforas, cerâmica comum e pesos de rede. Associado à olaria encontra-se a marca de oleiro Lucio Arvenio Rustico. O encerramento da produção ocorre no início do século III (Cardoso \& alii 2016).

Nas proximidades do Morraçal da Ajuda, foi colocado a descoberto em 2007, na rua Azeredo Perdigão, diversos vestígios associados à época romana. Este sítio arqueológico foi identificado pelo arqueológo camarário no decorrer dos trabalhos de terraplanagem para a construção de um empreendimento. Os trabalhos de escavação ficaram a cargo da empresa Neoépica Arqueologia e Património sob a direção dos arqueólogos Raquel Santos e Tiago Fontes. Foram exumados sobretudo ânforas de produção local, a que se juntam alguns fragmentos de sigillata, cerâmica comum, cavilhas em bronze e placas em chumbo com caracteres possivelmente etiquetas de ânforas que indicavam o seu destino. Durante a escavação foi identificada uma estrutura com vários compartimentos sem que até ao momento se tenha aferido a sua função. Atendendo a sua localização próxima aos fornos romanos e junto à antiga linha de costa poderemos estar perante estruturas de apoio à atividade portuária ou ao complexo de produção. Os dados preliminares apontam para uma cronologia em torno do século I d.C (Neto \& alii 2007).

Durante a ampliação do porto de pesca, na construção dos novos cais, entre Maio de 2001 e Outubro do ano seguinte, decorreu o acompanhamento arqueológico da empreitada. No desenvolvimento dos trabalhos foram identificados vários materiais de cronologia diversas, em contexto secundário, desde a época romana até ao século XX destacando-se 
ânforas do tipo Almagro 50, Dressel 7-11 e Dressel 14, canecas tardo-medievais e materiais de construção. (Venâncio 2005, 2006).

A última década caracteriza-se pela realização de trabalhos arqueológicos durante a construção de novas habitações localizadas nas áreas de proteção dos monumentos (fig.4). Em 2010 procedeu-se às escavações do convento franciscano do Bom Jesus, com a coordenação de Cláudia Cunha. No decorrer dos trabalhos identificou-se um conjunto de estruturas associadas ao convento quinhentista, destacando-se uma fonte do século XVIII e o seu pátio (Cunha \& alii 2012). Em 2012 na Rua Afonso de Albuquerque, foram colocadas a descoberto estruturas e materiais quinhentistas e seiscentistas. O espólio encontra-se atualmente a ser estudado pelos signatários, tendo sido já identificado formas de pão-de-açúcar (Constantino 2017).

Os trabalhos mais recentes permitiram identificar outras realidades até então ausentes no registo arqueológico de Peniche. A intervenção realizada pela Patrimonium, na rua José Estevão ํㅜ 133-135, colocou a descoberto o resto de um tanque de salga de peixe. Associados a esta estrutura estão materiais do século XVI e XVII, como uma majólica, faiança azul sobre azul, loiça Malagueira, pesos de rede, e restos ictiológicos.

Nas intervenções arqueológicas na rua de São Mar$\cos n^{\circ} 17$ e 19 (Rendeiro no prelo), Travessa da Fé no 14 (Filipe 2020) e Rua Afonso de Albuquerque (Filipe 2019) permitiram a identificação pela primeira vez de cisternas destinadas à recolha das águas pluviais. A sua utilização em Peniche encontra-se intimamente relacionada com a carência de água doce que Peniche enfrentou até ao século XX.

Por fim importa salientar a presença de materiais quatrocentistas no decorrer da abertura de sondagens na rua Francisco Seia no 9 (Filipe 2019 b) e de materiais associados a meados do século XVIII no Largo 5 de Outubro no 18 (Filipe 2019 c). Se o primeiro local corresponde à ocupação mais antiga conhecida após a presença romana em Peniche, o segundo poderá estar relacionado com terramoto de 1755 .

\section{CONCLUSÕES}

As leituras dos dados apresentados no decorrer deste trabalho demonstram uma primeira fase, caracterizada pela destruição e alteração do património, nomeadamente as obras verificadas na Av. do Mar, com a afectação do meio-baluarte da Misericórdia, a destruição da capela de São Marcos, Passos da Misericórdia, Paiol e Forte de Nossa Senhora da Vitória e o alargamento dos portões de Peniche de Cima. Em resposta a estes acontecimentos são classificados a Fortaleza (a data prisão política) e a frente abaluartada e a igreja de Nossa Senhora da Ajuda, marcando o início da valorização do património.

Contudo será necessário a chegada de meados dos anos 90 do século XX para se assistir à criação de um gabinete que se debruce sobre os problemas do Património local. A ação do GTL permitiu a classificação de novos monumentos e a elaboração de vários projetos que visavam a valorização do centro-histórico, realidade que não se chegou a verificar na sua totalidade.

Com a viragem de milénio, assistiu-se timidamente à chegada da arqueologia de salvamento. Os trabalhos e a informação produzida, permitem verificar a ocupação romana em Peniche de Cima. Em Peniche de Baixo verifica-se ausência de contextos romanos, remontando os materiais mais antigos para o século XV.

\section{BIBLIOGRAFIA}

BLOT, Jean Yves (2009) - Concerto para Mar e Orquestra. San Pedro de Alcântara, 1786. Edição Câmara Municipal de Peniche.

BLOT, Maria Luísa (2003) - Os Portos na Origem dos Centros Urbanos. Trabalhos de Arqueologia, n.ำ 28, Instituto Português de Arqueologia.

BRUGAL, Jean-Philip, ARGANT, Jacqueline, CRISPIM, José António; FIGUEIREDO, Silvério; SERRA, Alberto; PALMQVIST, Paul (2012) - The Complex Carnivore-rich Assemblages from Furninha (Peniche, Portugal): a Multidisciplinary Approach, in Journal of Taphonomy, Volume 10, pp. 417-438.

BRANDÃO, Raul (2010) - Os pescadores, $2^{\underline{a}}$ Edição, Estante Editora.

CALADO, Mariano (1991) - Peniche na História e na Lenda, $4^{\underline{a}}$ edição. Edição do autor.

CALADO, Mariano (1994) - Da ilha de Peniche. Edição de autor.

CALADO, Mariano (1996) - Peniche no Século XVIII (As Memórias Paroquiais). Edição do autor.

CALADO, Mariano (1999) - Visão Cronológica de Peniche. Edição do autor.

CALADO, Mariano (200o) - Fortificações da Região de Peniche. Edição do autor. 
CARDOSO, Guilherme; RODRIGUES, Severino (2005) Olaria romana do Morraçal da Ajuda. Bombarral, Actas do Congresso A Presença Romana no Oeste, p. 57-64.

CARDOSO, Guilherme; RODRIGUES, Severino; SEPÚLVEDA, Eurico (2006) - A olaria romana do Morraçal da Ajuda. Actas do Simpósio Produção e comércio de Preparados de Piscícolas durante a Proto-História e a Época Romana no Ocidente da Península Ibérica, pp. 253-278.

CARDOSO, Guilherme; RODRIGUES, Severino; SEPÚLVEDA, Eurico; RIBEIRO, Inês (2011) - Vestígios de uma olaria romana no Morraçal da Ajuda - Peniche, PAIDEIA. Revista da Escola Secundária de Peniche, nº 2, pp. 47-58.

CARDOSO, Guilherme; RODRIGUES, Severino; SEPÚLVEDA, Eurico; RIBEIRO, Inês; (2016) - Production during the Principate in Peniche (Portugal). Raw Materials, Kilns and Amphora Typology; in Lusitanian Amphorae: Production and Distribution, Roman and Late Antique Mediterranean Pottery 10, pp. 3-17.

CONSTANTINO, Adriano (2017) - Novos dados acerca das formas de pão-de-açúcar: o caso do estudo das formas descobertas na Rua Afonso de Albuquerque, Peniche (centro de Portugal), in ARNAUD, José e MARTINS, Andrea (coords.) A Arqueologia em Portugal - Estado da Questão, Edição Associação Arqueólogos Portugueses. pp. 1657-1666.

CONSTANTINO, Adriano; ANDRADE, Daniela; LOURENÇO, Inês; RENDEIRO, Luís (2016) - O Terramoto de Lisboa: o caso de Peniche, Arqueologia \& História, Vol. 68, Edição Associação dos Arqueológos Portugueses, pp. 127-138.

CUNHA, Cláudia; VILELA, Carlos; SIMÕES, Sónia; TOMÉ, Tiago; MOREIRA, João; GINJA, Mónica; GONÇALVES, Gerardo (2012) - Convento quinhentista do Bom Jesus de Peniche - primeira intervenção arqueológica, in Velhos $e$ Novos Mundos, Estudos de Arqueologia Moderna, Vol. 1, pp. 517-526.

FILIPE, Vanessa (2019) - Relatório Final, Rua Afonso de Albuquerque s/n, Peniche, texto policopiado.

FILIPE, Vanessa (2019 b) - Relatório Final, Rua Francisco Seia $n^{o}$ 9, Peniche, texto policopiado.

FILIPE, Vanessa (2019 c) - Relatório Final, Largo 5 de Outubro $n^{\circ} 18$, Peniche, texto policopiado.

FRANÇA, José Camarate; ZBYSEWSKI, Georges.; ALMEIDA, Fernando Moitinho de (1960) - Carta Geológica de Portugal, Notícia Explicativa da Folha 26-C Peniche. Serviços Geológicos de Portugal.

GREGÓRIO, Sofia; (2014) - Arquitectura ou revolução: estudos de urbanismo em Peniche: a obra do arquiteto Paulino Montez. Tese de Mestrado apresentado no ISCTE-IUL, edição policopiada.

NETO, M.; REBELO, Paulo.; SANTOS, Raquel; FONTES, Tiago; (2007) - Neoépica Lda: Principais intervenções em 2007. Al madan, IIํㅡ́rie, p. 156.
RENDEIRO, Luís (no prelo) - Relatório Final, Rua de São $\operatorname{Marcos} n^{\circ} 17$ e 19 .

RUSSO, Jorge (2014) - A Pesca da Sardinha em Peniche: 1900-1950, in Jornadas do Mar, Uma onda de Progresso, pp. 212-223.

SALVADOR, Cristina (1995 A) - Reabilitação e Património Histórico em Peniche, in A Voz do Mar, edição nº 910, pp.1-11.

SALVADOR, Cristina (1995 B) - Património Cultural A Capela de Santo António, in A Voz do Mar, edição de 20 de abril, pp. 6-7.

SALVADOR, Cristina (1996a) - Exposição do trabalho do GTL e seminário sobre antropologia marítima, in A Voz do Mar, edição de 19 de janeiro, pp. 6-7.

SALVADOR, Cristina (1996b) - Alguns aspectos sócio-económicos que caracterizam a população residente nas zonas de intervenção prioritária do GTL, in A Voz Do Mar, edição de 21 de março, pp. 4-5.

SALVADOR, Cristina (1996 C) - A face semi escondida do interior dos quarteirões da zona de intervenção prioritária do GTL, in A Voz do Mar, edição de 21 de abril, p. 3 .

VENÂNCIO, Rui (200o) - De uma inscrição encontrada em Peniche à história de uma importante família olisiponense. Conimbriga, XXXIX, pp. 259-273.

VENÂNCIO, Rui (2005) - Relatório de Acompanhamento Arqueológico da Obra de Alargamento do Porto de Pesca de Peniche $2^{\underline{a}}$ fase. Texto policopiado.

VENÂNCIO, Rui (2006) - Acompanhamento Arqueológico da Obra de Alargamento do Porto de Pesca de Peniche: resultados e conclusões. Actas do $3^{\circ}$ Seminário do Património da Região do Oeste, pp.79-9o.

ZBYSZEWSKI, G (1970) - Indústrias Paleolíticas da Região de Peniche. O Arqueólogo Português, serie 3, Vol IV. pp. 19-43.

\section{CARTOGRAFIA}

Carta Geológica de Portugal, folha 26-D (Peniche), Escala 1/ 50 ooo, Direcção Geral de Minas e Serviços Geológicos, Serviços Geológicos.

Carta Militar de Portugal, folha 337 (Peniche), Escala 1/25 ooo, Serviço Cartográfico do Exército

\section{Arquivos}

A Voz do Mar

\section{Biblioteca de Peniche}

Correio Popular

Correio de Peniche 


\section{Biblioteca Nacional}

AZEDO, Eusébio Dias, fl. ca 18oo - Planta da Praça de Peniche, e de parte da Peninsula, em que está situada, com o projecto das obras de fortificação necessarias para a pôr em estado de defensa / levantada de ordem do Sr. Marechal General junto á Real Pessoa pelos oficiaes do Real Corpo de Engenheiros, que comanda o Tenente Coronel do mesmo Corpo Euzebio Dias Azedo, encarregado do dito projecto, e sua execução.

\section{Outros documentos}

Plano Diretor Municipal de 1995

Carta Magna 2009

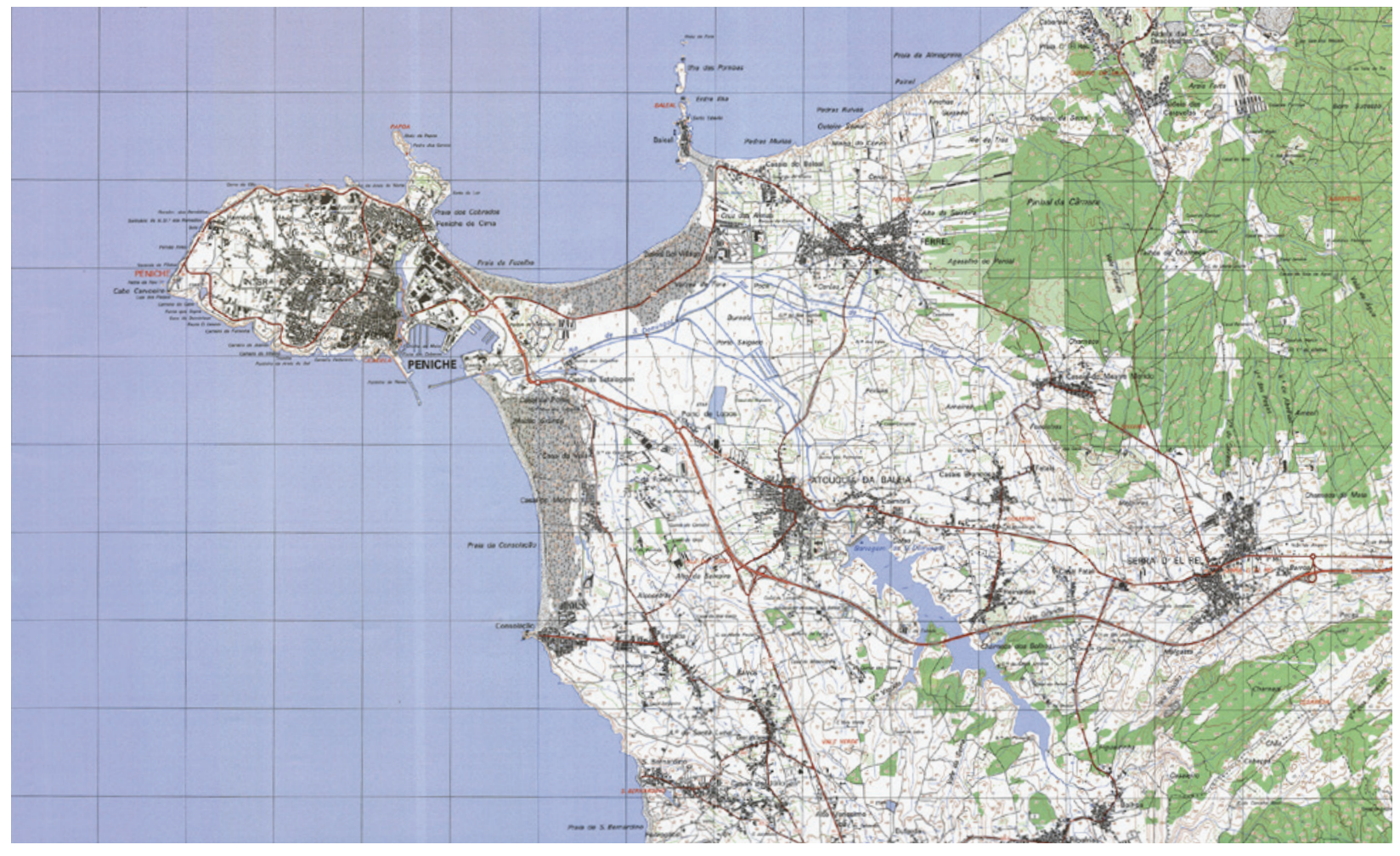

Figura 1 - Localização de Peniche na Carta Militar de Portugal, escala 1: 25 0oo, folha n.․․ 337. 


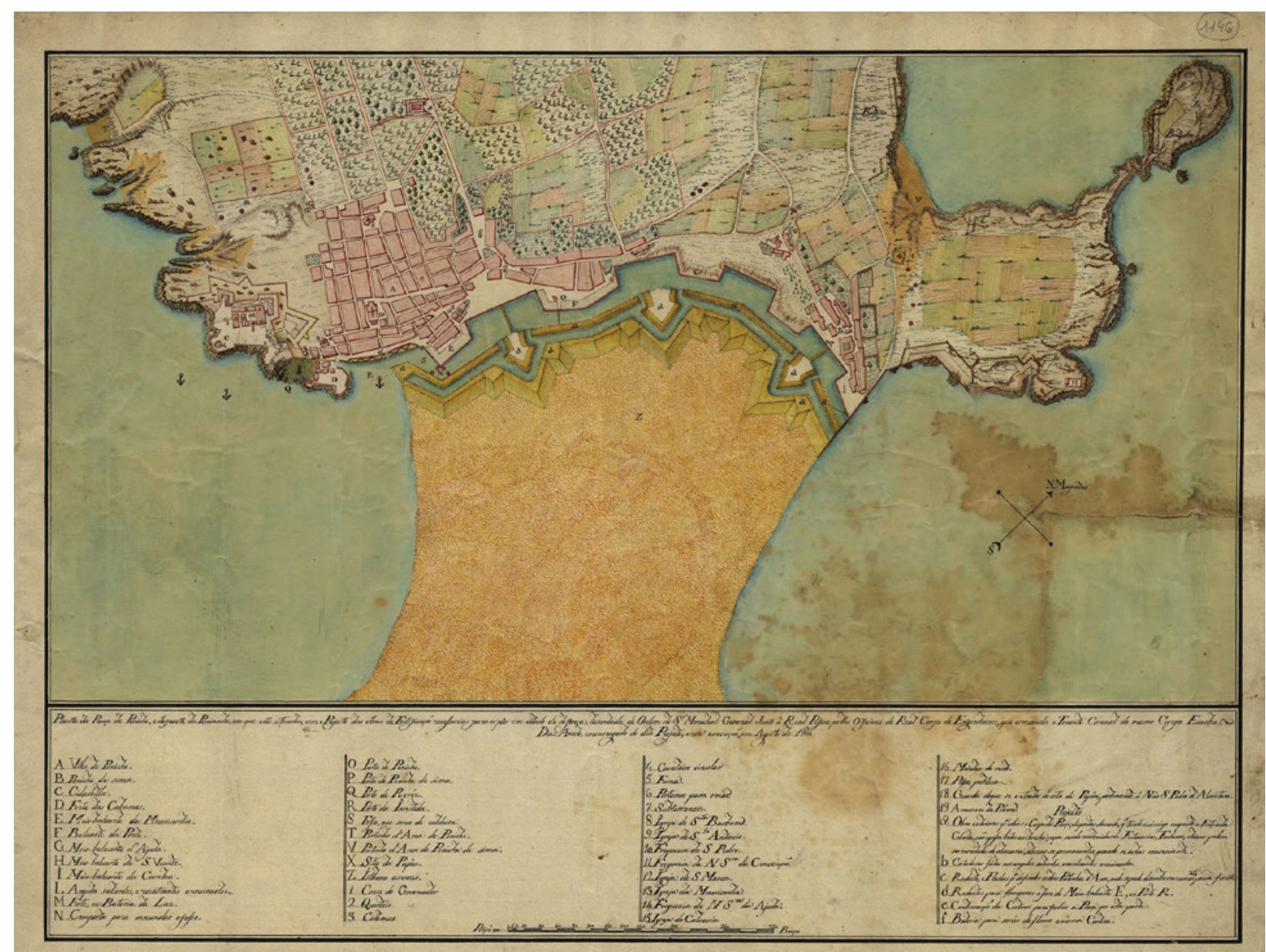

Figura 2 - Planta de Peniche no século XIX, com o projeto de Eusébio Dias Azedo. Na cartografia observam-se dois núcleos habitacionais, Peniche de Baixo e Peniche de Cima. Fonte: Biblioteca Nacional. 


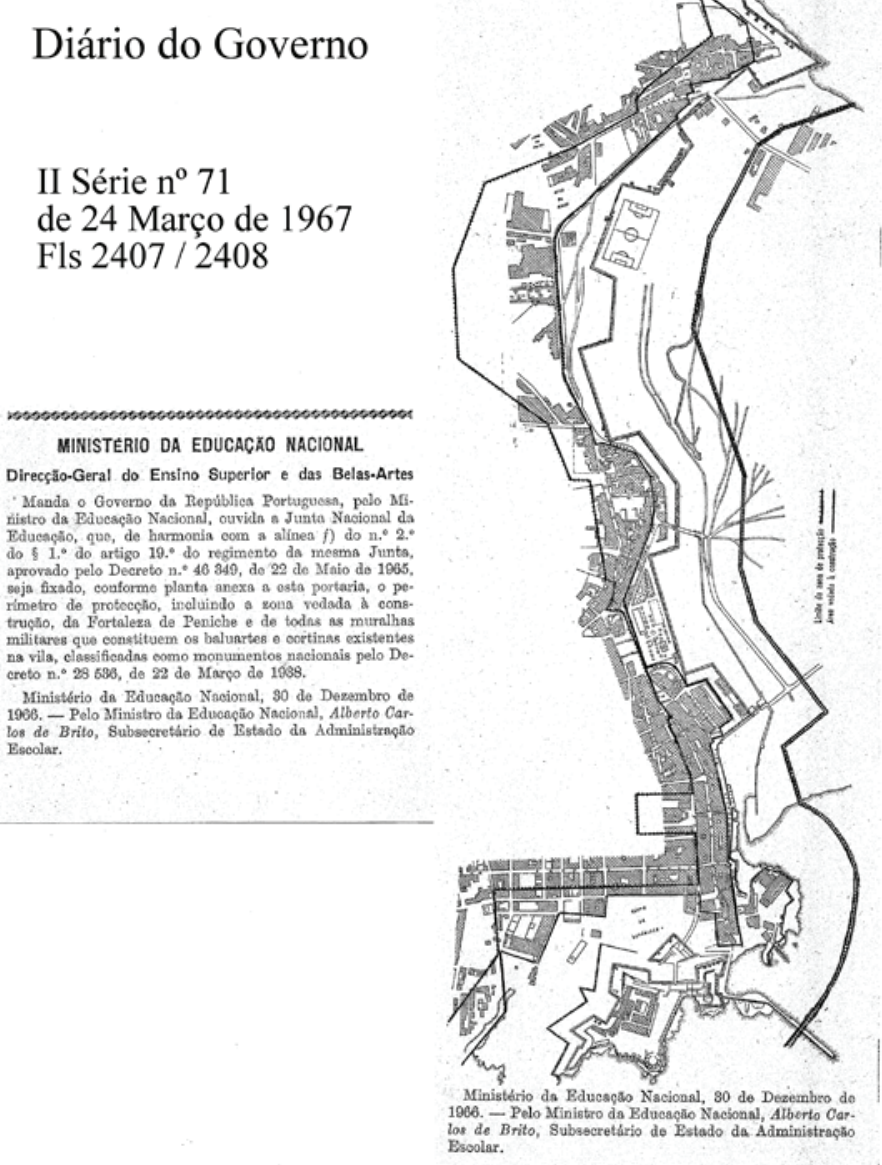

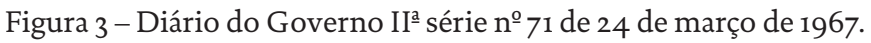

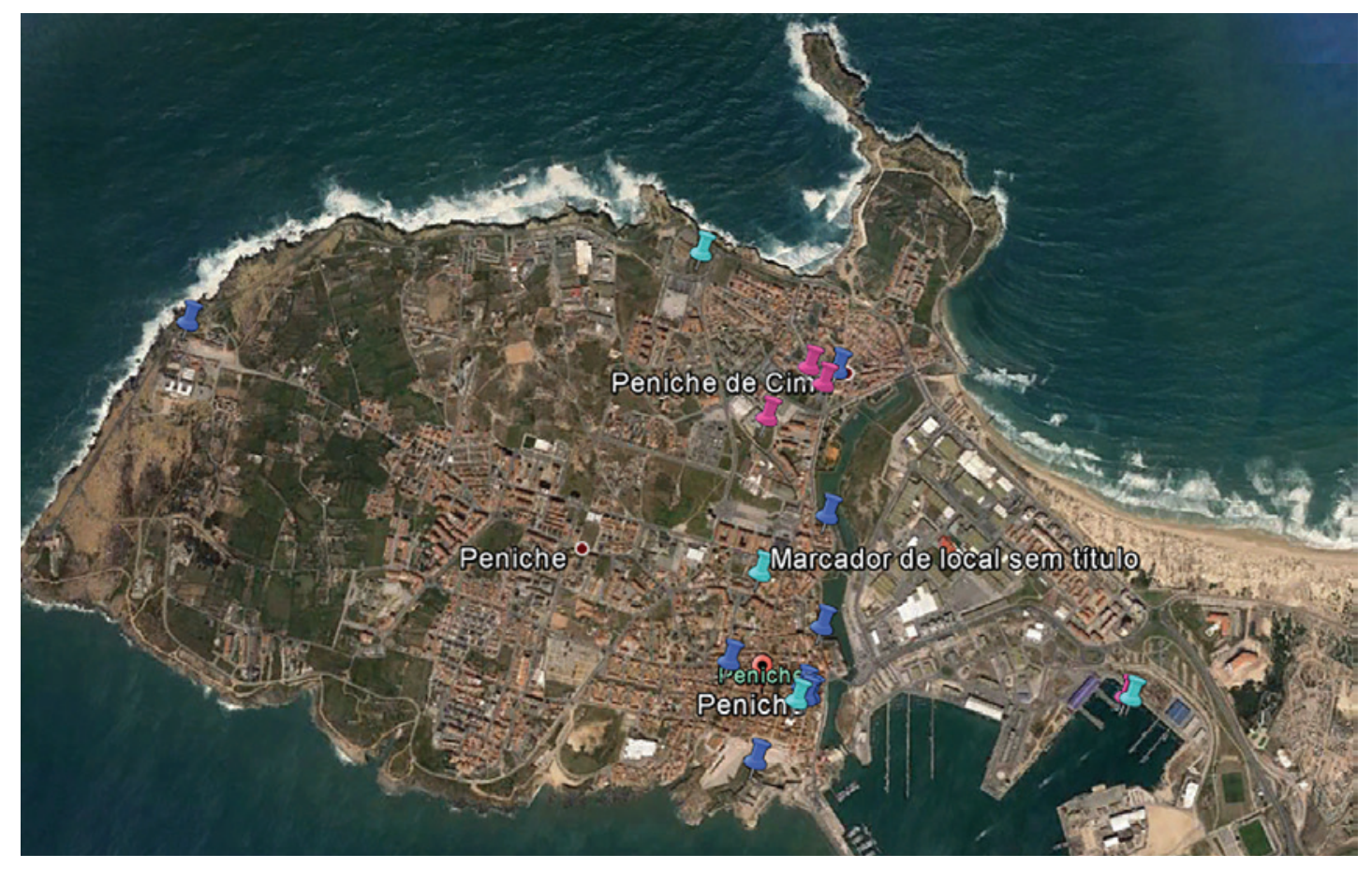

Figura 4 - Localização dos Monumentos classificados a azul escuro, sítios arqueológicos romanos a rosa, e a azul claro sítios de cronologia moderna. Imagem retirada de Google Earth. 


\title{
ARQUEOLOGIA URBANA: A CIDADE DE LAGOS COMO CASO DE ESTUDO
}

\author{
Cátia Neto ${ }^{1}$
}

\begin{abstract}
RESUMO
Devido ao acelerado ritmo de desenvolvimento urbano actual de muitas das cidades, a Arqueologia urbana tende a projetar-se, contribuindo para um novo enquadramento regulamentar que exige este tipo de trabalhos nos centros históricos, sendo necessário adaptar e desenvolver métodos para trabalhar em ambientes urbanos. Uma das principais problemáticas, se não a principal, associada à Arqueologia urbana é justamente a questão de a Arqueologia de salvamento/preventiva desempenhada por empresas de Arqueologia ser vista por muitos dos especialistas como um impedimento à produção de conhecimento acerca da cidade e da sua história, pelo que se tentará perceber porque é que a Arqueologia Preventiva é vista como um impedimento à produçao de conhecimento.
\end{abstract}

Palavras-Chave: Arqueologia Urbana, Arqueologia Preventiva, Lagos (Portugal).

\begin{abstract}
Due to the rapid pace of urban development in many cities, urban archaeology tends to project itself, contributing to a new regulatory framework that requires this type of work in the historic centers, being necessary to adapt and develop methods to work in urban environments. One of the main problems, if not the main one, associated with urban archaeology is precisely the question of the rescue/preventive archaeology performed by archaeology companies being seen by many of the specialists as an impediment to the production of knowledge about the city and its history, so one will try to understand why Preventive Archaeology is seen as an impediment to the production of knowledge.
\end{abstract}

Keywords: Urban Archaeology, Preventive Archaeology, Lagos (Portugal).

\section{INTRODUÇÃO}

A Arqueologia estava inicialmente muito relacionada com a pré-história, com o avançar do tempo passou a aplicar-se a períodos cada vez mais recentes, como a Idade Média, a história contemporânea, a época moderna e mesmo o período industrial. Perdendo o seu carácter maioritariamente académico e sazonal, de quando era levada acabo apenas no verão em locais remotos e rurais, passando para os centros urbanos onde há intervenções a decorrer diariamente. Devido ao acelerado ritmo de desenvolvimento urbano actual de muitas das cidades, a Arqueologia urbana tende a projetar-se, contribuindo para um novo enquadramento regulamentar que exige este tipo de trabalhos nos centros históricos (Madeira, s.d.) e não só. Mas não sem os seus desafios, pois foi necessário adaptar e desenvolver mé- todos para trabalhar em ambientes urbanos (Madeira, s.d.).

Os meios urbanos centralizam instituições políticas e administrativas, importantes espaços de culto (ou com carga simbólica), economias complexas com espacialização do trabalho e estratificação social. (Madeira, s.d.). Francisco Sande Lemos entende a cidade "como espaço vivido em comunidade é um lugar único, onde se poderá discutir, sem axiomas ou imposições, os caminhos que se pretendem seguir." (Lemos, 2002: 252). As cidades são um arqueossítio por excelência (Lemos, 2002), uma vez que os locais de preferência para o estabelecimento de comunidades têm sido essencialmente os mesmos ao longo dos tempos, o que se verifica é que com a evolução estes se vão expandindo mas mantêm, regra geral, o seu núcleo primitivo. Para além de que simples fragmentos cerâmicos abandonados em níveis de ater-

1. Mestranda em Arqueologia pela Faculdade de Letras da Universidade de Lisboa; catia.neto@campus.ul.pt. 
ro, por exemplo, poderão contribuir para identificar relações comerciais ou alterações socioeconómicas, tanto ou mais que certos registos escritos (Madeira, s.d.). A Arqueologia urbana pode recuperar informações sobre estes e outros aspetos das comunidades do passado através de métodos de trabalho de campo e laboratório cada vez mais em crescente especialização e desenvolvimento (Madeira, s.d.). Este é um domínio da Arqueologia que se tem desenvolvido e regido por leis, protocolos e políticas concretas, procurando fornecer informações independentes e complementares à documentação escrita (Madeira, s.d.), e que em última análise procura não deixar que as memórias e identidades se percam.

Apesar das dificuldades que têm encontrado, os arqueólogos têm contribuído para uma melhor compreensão das origens da urbanização e de aspetos relacionados com o saneamento, transporte, habitação e relações sociais e económicas (Madeira, s.d.). Uma das principais problemáticas, se não a principal, associada à Arqueologia urbana é justamente a questão de a Arqueologia de salvamento/preventiva desempenhada por empresas de Arqueologia ser vista por muitos dos especialistas como um impedimento à produção de conhecimento acerca da cidade e da sua história.

Assim o objectivo inicial deste trabalho foi olhar para um centro urbano do território português em que se verifica um crescente número de intervenções arqueológicas e um papel ativo dos órgãos municipais no que toca a Arqueologia, com o objectivo de compreender de que forma a integração de equipas de Arqueologia nas autarquias, a dominante presença da Arqueologia preventiva e as empresas de Arqueologia têm contribuído para o conhecimento acerca da cidade. Pelas atípicas circunstâncias dos últimos tempos, não foi possível a recolha de parte da informação necessária, pelo que se tentará perceber porque é que a Arqueologia Preventiva é vista como um impedimento à produçao de conhecimento.

\section{LAGOS, CIDADE HISTÓRICA}

Porquê a cidade de Lagos como caso de estudo? Desde há muito que a Administração Central portuguesa olha para a cidade de Lagos como cidade histórica, cuja preservação seria a preservação da memória identitária dos portugueses (Morán e Parreira, 2009), sobretudo devido aos indícios da sua longa ocupação (Morán, 2006). Pela sua posição geográfica e mor- fologia costeira apresenta as condições ideias para o acolhimento de tráfego marítimo, nomeadamente proveniente do Mediterrâneo, com destino ao Atlântico, o que conduziu à predominância de Lagos como principal cidade marítima na zona do Barlavento Algarvio (Fraga, 2013).

Foi Estácio da Veiga quem conduziu ao reconhecimento da importância arqueológica do Centro Histórico de Lagos, através da valorização o achado de numerosas moedas romanas ao desentulhar os edifícios da cidade arrasados pelo terramoto de 1755 e da referência à presença de alicerces de construção romana na Rua de Nossa Senhora da Graça (explorados parcialmente em 1878 ), bem como ao acentuar do potencial arqueológico de outros locais da área de expansão da cidade (Veiga, 1910: 220-221; Veiga, 2006: 127).

Leite de Vasconcelos, em 1894, sublinha o interesse arqueológico dos antigos cemitérios urbanos, nomeadamente o da paróquia de Santa Maria da Graça, e mais tarde, em 1900, explora parte da necrópole do Monte Molião (Diaz-Guardamino et al., 2006; Pereira, 1997: 49).

Algumas décadas mais tarde, José Formosinho, fundador do Museu Regional de Lagos em 1930, regista numerosas ocorrências de interesse arqueológico no Centro Histórico da cidade e na sua envolvente próxima, fazendo recolhas e pesquisas que incorpora no museu, dando a conhecer vários locais de achados conduziu ao reconhecimento da importância arqueológica do Centro Histórico de Lagos (Morán e Parreira, 2009: 902).

A ocupação humana do que hoje consideramos Lagos inicia-se no $5^{\circ}$ milénio (Morán,2006), teve depois uma ocupação pré-romana, já com características marítimas (Blot,2003:275) e durante o período clássico terá sido um dos principais portos da antiguidade - inicialmente estaria localizado no sítio de Monte Molião e mais tarde transferiu-se para a atual localização da cidade. Durante a época Medieval/Islâmica, é uma das localidades fortificadas que protegem a capital muçulmana estabelecida em Silves (Coutinho, 2001: 13), mais tarde ao ser incorporada no território nacional torna-se parte da linha costeira de defesa (Fragas, 2013) e continua a desenvolver relações comerciais com os territórios muçulmanos, tornando-se num importante porto de escala nas rotas internacionais que na época ligavam o Mediterrâneo aos principais centros mercantis do Norte de África (Loureiro, 1991 :16-17 apud 
Fragas, 2013). Estas rotas e as tensões entre cristãos e muçulmanos, são o palco perfeito para o corso português (Barbosa, 1993: 25) e mais tarde o Infante D. Henrique escolhe a cidade de Lagos como base marítima para as expedições dos Descobrimentos (Coelho, 1992: 13 apud Fragas, 2013). O acesso a água potável, as boas zonas de varação e as amplas áreas de ancoragem, são as razões que fazem de Lagos o ponto de paragem de preferência mantendo-se um dos principais portos de abastecimento do Algarve (Fragas,2013) mesmo depois da transferência para Lisboa de companhias como a Casa da Guiné (Paula, 1992: 38). O declínio de Lagos inicia-se com o terramoto de 1775, que arrasou por completo a cidade e foi responsável pelo assoreamento da barra de acesso ao porto (Fragas, 2013).

Porém a ideia de Lagos como "cidade dos Descobrimentos" e a forte associação à figura do Infante de Sagres levaram à desconsideração de outros tantos testemunhos materiais de uma longa trajetória histórica e de grande relevância nacional (Morán e Parreira, 2009).

A actividade arqueológica sistemática assegurada ao longo da primeira década do presente milénio contribuiu para que amplos sectores da população juntamente com responsáveis e técnicos que gerem o território municipal compreendessem que a cidade atual se sobrepõe a ocupações pré-históricas, proto-históricas, romanas, medievais e modernas, pelo que a "cidade dos Descobrimentos" constitui apenas um momento de um amplo e complexo processo histórico (Morán e Parreira, 2009: 905).

Mas não pode ser esquecido que Lagos é também uma estância balnear, por excelência, sobretudo desde a década de cinquenta, o que fez com que fosse submetida às pressões urbanísticas que pouco a pouco alteram a fisionomia da paisagem cultural e que por vezes colidem com o património arqueológico pré-existente (Morán e Parreira, 2009). Durante a década de oitenta o interesse imobiliário incidiu essencialmente na área imediatamente circundante ao Centro Histórico da cidade, definido pela fortificação quinhentista, mas a partir da década de noventa devido à falta de incentivos à política de reabilitação e ao favorecimento da política de renovação urbana ouve frequentes demolições que deram lugar a novas construções que foram destruindo a imagem tradicional da cidade (Morán e Parreira, 2009). Simultaneamente, decorre a expansão dos bairros periféricos com uma política de so- brevalorização do solo edificável, o que contribuiu para a construção em altura, tal como o afastamento entre a cidade e o mar, consequência da renovação das ligações rodoviárias dos anos cinquenta e sessenta, dois factores que contribuíram para a descaracterização da silhueta tradicional da cidade (Morán e Parreira, 2009).

\section{ARQUEOLOGIA URBANA: CONCEITO E EVOLUÇÃO}

O crescimento exponencial dos centros urbanos tornou indispensável refletir acerca do seu passado, evolução e presente, procurando compreender de forma aprofundada os elementos dinâmicos que podem assegurar a sua continuidade futura em termos harmoniosos (Martins e Ribeiro, 2009/2010: 149). O papel da Arqueologia é, no geral, reconhecido como fundamental para este processo, pelo seu contributo para a articulação do passado e presente das cidades, para revelar a sua origem, comprovar ou desmentir teorias da sua fundação ou interpretações acerca da sua evolução (Martins e Ribeiro, 2009/2010; Lemos e Martins,1992).

O conceito de Arqueologia urbana, de acordo com a sua origem e evolução nos textos especializados, em particular na Europa do pós-guerra, deve ser aplicado exclusivamente ao estudo arqueológico das cidades atuais (Lemos e Martins, 1992).

Foi a partir das décadas de sessenta e setenta do século $\mathrm{XX}$, com o crescimento demográfico das cidades e a renovação dos centros históricos, que o Estado, os municípios e a própria Arqueologia se viram confrontados com a questão do estudo e salvaguarda das evidências materiais da história urbana (Lemos e Martins, 1992). Datam dos anos sessenta do século $\mathrm{XX}$ as primeiras experiências que farão nascer a Arqueologia urbana, com a aprovação da Carta de Veneza em 1964 (um dos primeiros documentos a referir a importância da cidade como monumento histórico) a cidade passa a ser um sítio único, pluri-estratigrafado, cuja escavação permite resolver problemas histórico (Martins e Ribeiro, 2009/2010). Isto pressupunha que para cada cidade existisse um projecto de investigação consistente, com objetivos concretos, que permitissem avaliar e valorizar as suas particularidades evolutivas (Martins e Ribeiro, 2009/2010:150).

A sistematização de intervenções em cidades históricas foi uma consequência direta da actividade cons- 
trutiva que se deu no pós-guerra (Martins e Ribeiro, 2009/2010: 153). Esta realidade está particularmente bem documentada no Reino Unido, onde a renovação urbanística, resultante do crescimento económico das décadas de cinquenta e sessenta, sem qualquer atenção ao património, acabou por gerar o descontentamento e a alteração das políticas do uso do solo (McGill, 1995:). Cenário que permite considerar o Reino Unido como berço da moderna Arqueologia urbana (Martins e Ribeiro, 2009/2010). A Arqueologia urbana inglesa rapidamente afirmou conceitos, objetivos e metodologias para este ramo, afectando a sua prática noutros países, definindo que o desenvolvimento das cidades atuais deveria ser acompanhado por uma correta investigação do seu passado e da prática do acompanhamento arqueológico dos novos empreendimentos (Martins e Ribeiro, 2009/2010; Biddle e Hudson, 1973).

A Arqueologia urbana passou assim a ser entendida como Arqueologia na cidade e da cidade, sendo o seu objectivo conhecer a cidade como facto histórico, em termos temporais, espaciais e materiais (Martins e Ribeiro, 2009/2010:150).

A aceleração do ritmo construtivo, a modernização dos centros históricos e o aumento da capacidade de intervenção na estrutura urbanística, sob pressão da especulação imobiliária, são factores que condicionaram a evolução da Arqueologia urbana na Europa (Martins e Ribeiro, 2009/2010:150).

Durante os anos 70 assistiu-se a uma renovação das metodologias e na conceptualização das bases teóricas, tendo sido definido um objectivo claro para a Arqueologia urbana: "investigação da cidade, como fenómeno urbano, na sua integridade, variabilidade e longa duração, procurando-se, deste modo, equiparar as escavações urbanas a quaisquer outras realizadas com fins científicos." (Martins e Ribeiro, 2009/ 2010: 153).

Os fundamentos teóricos e metodológicos da Arqueologia urbana essencialmente os mesmo que da Arqueologia no geral, mas apresenta algumas especificidades, resultantes de as cidades enquanto objecto de estudo, serem espaços de constante e contínua renovação (Madeira, s.d.). Pelo que sob uma perspectiva estritamente técnica a Arqueologia urbana implica métodos próprios, tendo em conta a complexidade estratigráfica dos subsolos das cidades históricas em que os sucessivos níveis de ocupação se sobrepõem, recortam, etc... (Lemos e Martins, 1992). O que exige um rigoroso registo, bem como um profundo conhecimento dos materiais de diferentes épocas (Lemos e Martins, 1992). E deverá promover a conservação dos vestígios in situ, o que implica desenvolver e aplicar métodos de análise e de registo não destrutivos e instrumentos, tais como a avaliação da potencialidade arqueológica dos solos e cartas de risco, que devem ser tidos em consideração aquando da planificação urbana (Martins e Ribeiro, 2009/2010: 168).

A sua prática passou por esta razão a exigir equipas interdisciplinares e profissionais, responsáveis por realizar as escavações, gerir a informação, elaborar e processar os dados e pela produção de conhecimento (Martins e Ribeiro, 2009/2010: 153). A investigação de uma cidade era encarada como um projecto a longo prazo, pelo que a defesa/manutenção destas equipas, ou urban units como Biddle (1974) as designa, passa também a ser um aspeto importante (Biddle, 1974: 95-112). Foi-se, assim, criando um novo mercado de trabalho que permitiu a profissionalização de jovens arqueólogos (Martins e Ribeiro, 2009/2010).

No nosso país realizaram-se sérios esforços para que se desenvolvesse uma política estruturada, mas estes são pouco conhecidos, ficando o seu registo perdido em arquivos de jornais, diários e seminários e nos volumosos processos do IPPC (Lemos e Martins, 1992). A influência do paradigma da Arqueologia urbana inglesa faz-se sentir em Portugal com o lançamento do "Projecto de Salvamento de Bracara Augusta”, em 1976, e a criação da equipa permanente do Campo Arqueológico de Braga, cuja direção científica e técnica estava afeta à Universidade do Minho (Martins e Ribeiro, 2009/2010:154). Este foi um projecto pioneiro, pois até então praticamente não existia Arqueologia urbana em Portugal (Delgado et ali, 1989). Seguiram-se mais algumas iniciativas, nomeadamente: em Setúbal, graças ao Museu de Arqueologia e Etnografia de Setúbal; em Évora, com o apoio do Serviço de Arqueologia do IPPC; em Mértola e Silves, graças ao interesse dos respetivos municípios; em Faro graças à Unidade de Arqueologia da Universidade do Algarve (Lemos e Martins, 1992).

$\mathrm{Na}$ fase inicial da Arqueologia urbana, durante a segunda metade da década de setenta e nos primeiros anos da década de oitenta, houve de facto um ensaio de resposta, que progressivamente se foi diluindo, face às grandes dificuldades que os salvamentos urbanos oferecem (Lemos e Martins, 1992). O pro- 
gressivo desinvestimento por parte do Estado na Arqueologia urbana, que se sentiu em vários países, a partir dos anos 8o, veio impossibilitar quer a formação quer a sobrevivência de equipas destinadas ao estudo das cidades, criando-se um panorama em que a Arqueologia de contrato surge como resposta ao número crescentes de intervenções de caráter preventivo desencadeadas pelo crescimento e renovação urbana e pela aplicação de condicionantes aos solos das cidades (Martins e Ribeiro, 2009/2010: 151). As intervenções arqueológicas nas cidades nunca chegaram a adquirir um estatuto de Arqueologia urbana, nem mesmo o caso de Bracara Augusta, pois esse estatuto exigia meios financeiros e infraestruturas humanas ao dispor das entidades responsáveis pelo salvamento, sejam elas Universidades, Camaras Municipais ou os próprios serviços do IPPC (Lemos e Martins, 1992).

A Arqueologia urbana começou a distanciar-se da Arqueologia académica - pois esta segunda é cronologicamente orientada e marcadamente sazonal -, foram definidos novos parâmetros de atuação, nomeadamente quanto à avaliação da potencialidade informativa dos solos urbanos, através de cartas de risco, com o objectivo de minimizar os impactos negativos (Biddle e Hudson, 1973). A catalogação dos recursos do subsolo urbano, a sua integração nas normativas de planificação e o estabelecer de condicionantes sobre a edificabilidade das áreas urbana, de acordo com o seu potencial arqueológico, tornaram-se prática corrente em algumas cidades europeias, se bem que os modelos de gestão e os objetivos variam substancialmente de cidade para cidade (Martins e Ribeiro, 2009/2010: 155).

Porém o crescimento das cidades ocorreu quase sempre à margem de planos de urbanização aprovados, o que impedia ações programadas, mesmo nas cidades em que existem equipas de intervenção (Lemos e Martins, 1992). De modo que a pressão construtiva e o consequente aumento do número de escavações acabaram por conduzir ao crescimento das intervenções de salvamento, acompanhado por um progressivo desaparecimento das unidades permanentes de intervenção urbana, por serem economicamente insustentáveis (Martins e Ribeiro, 2009/2010:155).

São raros os casos em que a Arqueologia urbana conheceu um forte investimento por parte dos organismos de tutela, salvo no Reino Unido, França, Itália e países nórdicos, que empreenderam programas de investigação arqueológica tendo em vista estudar a evolução das suas cidades (Martins e Ribeiro, 2009/2010).

Isto levou a que nos anos oitenta se generalizasse um novo entendimento do conceito, que passava pele Arqueologia em meio urbano, que designa as escavações ad hoc, resultado da necessidade de realizar intervenções prévias à execução de obras (Martins e Ribeiro, 2009/2010). Estas eram destituídas de qualquer problemática ou objetivos científicos relacionados com o estudo das cidades (Martins e Ribeiro, 2009/2010), para além de que forneciam substancial quantidade de dados, os quais não eram processados e estudados em tempo útil, de modo a se transformarem em conhecimento científico e a permitirem o seu retorno social (Carver, 1996 apud Martins e Ribeiro, 2009/2010). O que constitui um dos maiores desafios, pois por vezes é necessário esperar anos até que seja possível articular os dados obtidos, pois tornou-se habitual que os trabalhos arqueologicos a decorrer em ruas vizinhas sejam desenvolvidos sem qualquer ligação ou consonância (Lemos e Martins, 1992; Madeira, 2011). É certo que a publicação nunca foi uma preocupação da Arqueologia preventiva, mas a implementação do princípio do "poluidor/pagador" (divulgado em Inglaterra e que rapidamente se difundiu por outros países) veio agravar esta situação, uma vez que raramente estão contemplados nos cadernos de encargos o estudo e publicação de resultados (Rodríguez Tamiño, 2004; Martins e Ribeiro, 2009/2010).

$\mathrm{O}$ alheamento da Arqueologia urbana face à divulgação do conhecimento acentuou-se também com o desenvolvimento da Arqueologia contratual, realidade especialmente bem documentada na Península Ibérica (Rodríguez Tamiño, 2004), entre os anos de 1976 e 2000 realizaram-se apenas três colóquios de Arqueologia Urbana e destes apenas os dois primeiros tiveram as suas atas publicadas, tornando clara a ausência de uma plataforma nacional, com periodicidade, onde sejam discutidos aspetos como politicas, leis, métodos e conflitos ou se divulguem descobertas, noticias preliminares ou sínteses (Lemos, 2002). O crescimento da Arqueologia de salvamento fez-se acompanhar do crescimento da Arqueologia contratual, pois só esta era capaz de dar resposta à crescente procura no mercado de entidades competentes para a realização de escavações prévias ao início das obras (Martins e Ribeiro, 2009/2010: 157). 
Isto fez com que as escavações urbanas se traduzissem numa acumulação de dados por tratar, estudare publicar que não reverteu num efetivo conhecimento sobre o passado das cidades e com que a prática da Arqueologia urbana se tenha reduzido a simples acompanhamentos e escavações preventivas que não enquadram um projecto de investigação (Martins e Ribeiro, 2009/2010: 159). (Martins e Ribeiro, 2009/2010: 158).

De modo que a Arqueologia urbana deve ser entendida como a investigação do património arqueológico da cidade, que atua para o conhecimento da história urbana mas também quando novas construções e infraestruturas implicam a substituição de antigos edificados ou a remoção de depósitos pluri-estratigrafados que conformam o subsolo, quando é impossível evitar a sua afetação (Martins e Ribeiro, 2009/2010: 168).

\section{QUESTÕES PROCESSUAIS: LEGISLAÇÃO}

Em Portugal durante as décadas de setenta e oitenta decorreu um expressivo debate sobre os objetivos, métodos, modelos e regulamentação jurídica da Arqueologia urbana (Lemos, 2006: 15). Uma das consequências da urbanização é a perda rápida de dados arqueologicos. A promulgação de legislação de protecção dos recursos arqueológicos urbanos é uma forma de retardar essa perda, todavia a aplicação prática destas diretivas legais não se tem provado eficaz em todos os casos (Madeira, s.d.).

Em 1985 existia um artigo específico na Lei de Bases do Património que contemplava a Património Arqueológico Urbano (Lemos, 2006). Em 1992 foi assinada a Convenção Europeia para a Protecção do Património Arqueológico, embora a Carta de Malta não se refira expressamente ao património arqueológico urbano, efetuaram-se reuniões sobre esse domínio no Concelho da Europa, das quais resultou um abrangente relatório, Report on the situation of Urban Archaeology in Europe, no qual não existe qualquer relatório sobre Portugal (Lemos, 2006). Existe ainda o European Code of Good Practice: Archaeology and the Urban Project, divulgado em 2000, que apesar da sua importância está pouco divulgado no nosso país (Lemos, 2006).

A carta de Malta foi ratificada em 1997, em 1998 é plenamente adoptada pelo Estado Português (Lemos, 2008/o9) e os seus princípios foram introduzidos em vários textos legais, nomeadamente na
Lei de Bases do Património de 2001 (Lemos, 2006). Importa ainda realçar que a aplicação da Carta de Malta em Portugal teve os seus aspetos positivos e negativos; quanto aos primeiros tem-se a criação de mais postos de trabalho na Arqueologia, a multiplicação de medidas preventivas e minimizadoras, de entre as quais os trabalhos prévios e os acompanhamentos de obras, no que toca aos segundos, tem-se o facto de uma série de processos distintos acabarem por ser colocados "no mesmo saco", a Arqueologia de salvamento (Lemos, 2006).

No caso concreto da cidade de Lagos foi sobretudo a partir de 2005 que a Arqueologia passou a desempenhar um papel mais interventivo no licenciamento de obras no Centro Histórico e aro urbano envolvente, existindo ainda uma Licença Única para a execução de demolições e construções que incluam trabalhos arqueológicos, onde são listadas todas as condicionantes (Morán e Parreira, 2009: 913). Nos casos em que se verifique o incumprimento das condicionantes a autarquia dispõe de capacidade de atuação autónoma, podendo impor medidas corretivas, nomeadamente, em casos em que o património arqueológico não classificado é afetado (não por ser património arqueológico mas pelo incumprimento das condicionantes impostas) (Morán e Parreira, 2009: 913). Mas estas normas não foram pensadas exclusivamente para os erros cometidos pelos promotores. Nos casos em que há um erro processual por parte da autarquia, seja quando há licenciamento de obras em áreas onde se presuma existir vestígios, em que cabe à autarquia executar diretamente os trabalhos preventivos, seja quando o erro processual é detetado após a execução de trabalhos que afetaram património arqueológico, compete à autarquia a avaliação dos danos e a implementação dos trabalhos que pareçam necessários, acarretando com os seus custos (Morán e Parreira, 2009).

Posteriormente em 2008 foi criado o Serviço de Arqueologia Urbana, dentro da Divisão de Gestão Urbana, do Departamento de Planeamento e Gestão Urbanística, cujos objetivos eram a implementação de uma política marcadamente preventiva e o desenvolvimento em simultâneo de uma investigação de qualidade, através de parcerias com Universidades e Centros de Investigação, (Morán e Parreira, 2009). Havia, portanto, um entendimento de que a justificação do investimento em Arqueologia é o processamento dos dados técnicos, e a sua conversão em conhecimento histórico que permita a sua 
devolução à comunidade (Morán e Parreira, 2009). Apesar de a divisão do estudo de uma cidade em várias parcelas cronológicas e espaciais ter um duplo efeito negativo - pois por um lado diminui a possibilidade de serem produzidas monografias e sínteses, e por outro multiplica as vozes que assumem discursos científicos sobre a cidade de tal modo que esta ignora quem são os seus interlocutores sobre matérias de património arqueológico (Lemos,2006) - estas possibilitam a redução (e se bem aplicadas a longo prazo talvez a extinção) do fosso que neste momento existe entre as escavações realizadas e o estudo e publicação dos bens culturais retirados de campo. Elena Morán e Rui Parreira afirmam, face aos resultados positivos da parceria estabelecida entre a Camara de Lagos e a Faculdade de Letras da Universidade de Lisboa para o estudo do sítio arqueológico de Monte Molião, que estas parcerias são "uma tendência que deverá ser aprofundada, com a desejável integração do meio académico no estudo da cidade e do seu território envolvente, não a penas com acções de investigação plurianual programadas mas capitalizando os dados adquiridos nas acções de prevenção, disponibilizando para estudos académicos os materiais e a documentação que os contextualiza" (Morán e Parreira, 2009: 911).

Ainda em 2008 foi feita uma revisão do Regulamento Municipal de Urbanização, Edificado, Taxas e Compensações Urbanísticas do Município de Lagos, que passa a abranger todas as obras de edificação do Município e não só do Centro Histórico (Morán e Parreira, 2009). E a partir de 2009 houve uma normalização da articulação com a Administração Central, em áreas patrimonialmente protegidas por lei. Quanto aos regulamentos em vigor no presente, existem três Planos de Urbanização (de Lagos, da Meia Praia e da Vila da Luz, este último encontra-se em revisão), as condicionantes que apresentam são bastantes semelhantes e em ambos estão identificados os sítios arqueologicos e as zonas de sensibilidade. Existem ainda onze Planos de Pormenor e apenas um, o da Zona Envolvente à Estação de Lagos não apresenta qualquer referência ao património arqueológico ou a valores culturais. Os restantes são relativamente semelhantes entre si, apresentado sempre a condicionante de que ao serem encontrados elementos arqueologicos a obra deve ser interrompida e que deve ser aplicado o disposto na Lei de Bases da Política e Regime de Proteção e Valorização do Património Cultural.
Por fim, existe ainda o atual PDM de Lagos, que data de 2015, em que encontramos o Artigo 10 ${ }^{\circ}-$ Salvaguarda do património arqueológico que estipula as condicionantes, que fazem eco da política preventiva do Serviço de Arqueologia Urbana, e que se encontram essencialmente replicadas nos Planos de Pormenor, e pode-se ler o seguinte:

1. Os processos de licenciamento ou comunicação prévia de operações urbanísticas destinadas a sítios ou zonas de sensibilidade arqueológica e paeloambiental, são instruídos com parecer relativo à componente arqueológica subscrita por arqueólogo do Município ou, na sua ausência, pela entidade de tutela.

2. Exceciona-se do disposto no número anterior os processos relativos a obras de alteração e obras de conservação desde que não afetem o subsolo em área arqueológica.

3. O aparecimento de vestígios arqueológicos durante a realização das obras abrangidas pelo n.ำ 1 obriga à paragem imediata dos trabalhos no local e à comunicação da ocorrência à Câmara Municipal e à entidade de tutela do património arqueológico ou à autoridade policial.

4. Os trabalhos só poderão ser retomados após a emissão de parecer por parte da Câmara Municipal e da entidade de tutela do património arqueológico, no prazo de 30 dias úteis, findos os quais, a omissão de pronúncia por parte de ambas as entidades determinam o levantamento automático da suspensão e a retoma dos trabalhos.

5. A suspensão da obra devido a trabalhos arqueológicos acarreta a suspensão dos prazos de vigência da licença ou comunicação prévia da obra em causa.

6. Para a salvaguarda do património arqueológico, aplica-se o regime legal em vigor.

7. A eventual atualização da Planta de Património, que acompanha o PDM, será efetuada em sede de regulamento municipal.

\section{LAGOS E A PRÁTICA ARQUEOLÓGICA}

A prática da Arqueologia de salvamento na antiga área urbana de Lagos, remonta à década de oitenta (Morán e Parreira, 2009: 903). Altura em que alguns técnicos dos Serviços de Arqueologia do IPPC, ao serem alertados pela autarquia se deslocam a Lagos com o intuito de minimizar o impacte negativo 
criado por algumas construções (Morán e Parreira, 2009: 903). Também por esta altura, Virgílio Correia escavou contextos com materiais romanos re-depositados no interior de uma conduta que, em época-moderna, encanou a Ribeira dos Touros, e foram identificadas estruturas de uma oficina de preparados de peixe romana na Rua Silva Lopes, afetadas por uma construção (Morán e Parreira, 2009: 903-904).

Situação que levou a Camara Municipal de Lagos a ponderar equipar a autarquia com pelo menos um arqueólogo (Morán e Parreira, 2009). Logo no final da década de oitenta, a arqueóloga Marta Gordilho procurava confirmar no terreno e atualizar a cartografia arqueológica do concelho de Lagos, como primeiro passo para a implementação de medidas preventivas de salvaguarda do património (Morán e Parreira, 2009: 904). Porém a partir de 1993 a autarquia ficou novamente sem arqueólogo, verificando-se um retrocesso na política de gestão do património arqueológico no Município de Lagos. De modo que a pratica da Arqueologia preventiva na área urbana de Lagos se impunha a custo, num panorama em que a criação do IPA, a reorganização do IPPAR e a alteração dos instrumentos legais de gestão do património arqueológico entre 1997 e 2001, contribuíram de forma positiva para a imposição de medidas de salvaguarda eficazes, com adopção dos dois princípios básicos pelos quais a Arqueologia preventiva e paliativa se passou a regular: a extensão ao património cultural arqueológico do princípio do "poluidor-pagador" e a aplicação metódica do princípio da conservação pelo registo científico (Morán e Parreira, 2009: 904). Os anos de 1998 e de 2001 foram marcados, em Lagos, pela destruição deliberada e sem registo por parte dos promotores, de importante património arqueológico (Morán e Parreira, 2009). Atualmente e como vai ser visto mais a frente, existem mecanismos que procuram impedir este tipo de situações.

Este panorama levou a Câmara de Lagos a reagir às insistências da tutela para que implementasse de uma maneira eficaz as medidas cautelares de salvaguarda do património arqueológico, quer nas obras de iniciativa municipal quer nas de iniciativa privada (Morán e Parreira, 2009). Por forma a dar resposta às exigências e obrigações legais decorrentes das convenções internacionais, a Arqueologia passou a ser entendida como uma especialidade incontornável na reabilitação urbana e no ordenamento do ter- ritório, como já foi visto, o que conduziu à incorporação de um sector de Arqueologia no Gabinete do Centro Histórico de Lagos e à posterior constituição do Serviço de Arqueologia Urbana, no âmbito da Divisão de Gestão Urbana da Camara Municipal de Lagos (Morán e Parreira, 2009: 904-905). O poder local passou a assumir as responsabilidades na gestão patrimonial, em consequência de a área urbana de lagos passar a ser encarada com um sítio arqueológico que contem informação relevante para o conhecimento histórico e que caracteriza identidade cultural (Morán e Parreira, 2009: 905).

Atualmente o património cultural histórico-arqueológico está naturalmente inserido na ordem cultural, social e económica contemporânea, contribuindo cada vez mais para a caracterização e identidade da cidade, mediante a preservação e valorização das suas preexistências (Morán e Parreira, 2009:905). Durante o período em que a autarquia manteve uma pequena equipa técnica operacional, ou seja, até 2005, as intervenções por parte dos arqueólogos municipais são expressivas, posteriormente continuaram a assegurar algumas intervenções no terreno mas há uma crescente externalização da prestação dos serviços (Morán e Parreira, 2009: 911-912), consequentemente uma crescente intervenção da Arqueologia empresarial, o que tem impedido que a cidade seja assumida como objecto de estudo de um projecto de investigação (Morán e Parreira, 2009). Mas a meu ver não pode ser ignorado que se não fosse a intervenção das empresas de Arqueologia, a autarquia não tinha meios humanos ou técnicos para dar resposta ao crescente número de intervenções que ocorreu na cidade devido a projetos de reabilitação urbana, entre outros. Os trabalhos arqueológicos são maioritariamente promovidos e financiados por particulares (Morán e Parreira, 2009) o que faz com que uma parte significativa dos trabalhos sejam os de acompanhamento, e esse tipo de intervenção requer uma colaboração muito estreita entre os arqueólogos e os restantes responsáveis e intervenientes, sejam os projetistas, os empreiteiros, os serventes ou os técnicos de fiscalização (Madeira, s.d.). Na maioria das vezes a tensão entre as partes e a pressão de obra requerem uma especial inteligência na gestão e no poder de negociação por parte dos arqueólogos envolvidos (Madeira, s.d.). É indiscutível que em Lagos domina a Arqueologia preventiva, que pode ser encarada como uma variante da Arqueologia urbana, havendo essencial- 
mente trabalhos de prospeção, sondagem e acompanhamento (Gráfico 2.). Mas existem também casos em que pelo valor e promessa dos vestígios encontrados as ações de prevenção deram lugar a projetos de investigação, como é o caso de Monte Molião.

No centro histórico de Lagos, as intervenções executadas ao longo dos últimos anos permitiram uma avaliação de risco dos vestígios preservados no subsolo urbano, cujos dados foram usados para criar a Carta de Risco com índices diferenciados de potencialidade (Morán e Parreira, 2009). O mapeamento de gradientes de sensibilidade arqueológica permite justificar uma normativa de medidas de salvaguarda e/ou valorização, condicionantes dos projetos de construção, sejam de iniciativa publica ou privada, como o acompanhamento arqueológico de desaterros e/ou demolições, o exame parietal para salvaguardar possíveis preexistências no cerne das construções, as escavações de diagnostico, escavações em área e ausência de medidas preventivas de impacte sobre o património arqueológico enterrado (Morán e Parreira, 2009).

A adopção de procedimentos de salvaguarda diferenciados por gradientes de sensibilidade, permitiu adotar um normativo que se concretizou no artigo $19^{\circ}$. Do Regulamento do PUMP e se ambiciona vir a plasmar nos Regulamento do PU e PP de lagos (Morán e Parreira, 2009). o que se sucedeu com a revisão do PDM feita em 2015.

\section{CONCLUSÕES}

Parece-me necessário começar por realçar o facto de que neste trabalho foram usados os dados disponíveis no Portal do Arqueólogo, que, como é já de conhecimento geral, não se encontra atualizado. Para além de que na cidade de Lagos existem alguns sítios intervencionadas em contextos de Arqueologia preventiva aos quais não foi atribuído CNS e que portanto não se incluem nos trabalhos aqui contabilizados mas que merecem uma referência, uma vez que sítios como o Cemitério de Escravos ou a fábrica de preparados de peixe da Rua Silva Lopes resultaram na produção de conhecimento científico através da publicação de artigos e de conferências e contribuíram para o conhecimento de períodos e aspetos concretos da história da cidade. Sítios que se não fosse pela legislação atual, estariam perdidos e destruídos.

É defendido desde o início que a Arqueologia urba- na deve construir um projecto específico para cada cidade, mas isso não implica necessariamente que tenha que ser sempre a mesma equipa em campo, apenas que quem está em campo cumpra as mesmas regras e procedimentos e que todos os trabalhos estejam coordenados entre si, sendo para tal necessário que haja um núcleo central responsável pela coordenação e pelo cumprimento dos mesmos procedimentos. O que permite que a cidade tenha um projecto específico e uma direcçao única, ainda que coletiva e dinâmica (Lemos,2006).

Embora sejam sempre discutidas as faltas cometidas pelos promotores, a sua falta de cooperação, etc... não pode ser ignorado o facto de que por vezes a falta de qualificação técnica das equipas de Arqueologia contratadas diretamente pelos empreiteiros, ou o interesse vincadamente comercial de algumas empresas de Arqueologia, pode colocar em risco não só a salvaguarda patrimonial como desajustar o financiamento previsto (Morán e Parreira, 2009). Pelo que a existência deste núcleo central para coordenar, guiar e em ultima instancia avaliar as equipas, ou mesmo no lugar de ser dada ao promotor a escolha da equipa de Arqueologia a contratar que seja este grupo central a dar uma lista de equipas que a seu ver estejam equipadas com as técnicas e conhecimentos necessários à atuação no meio urbano e a cidade em causa, em concreto.

No que há divulgação científica respeita, fica claro que há uma dispersão dos conhecimentos, apesar do aumento do número de trabalhos, para além de que as autarquias terem tendência a privilegiar a divulgação dos resultados locais, como processo identitário e diferenciador.

A situação atual de trabalho não é de todo favorável à produção de conhecimento, tendo em conta que acuam em campo essencialmente equipas de empresas de Arqueologia que assim que terminam um trabalho estão a partir para o próximo, pois o ritmo de avanço e de reabilitação urbana está ao rubro, especialmente em locais como Lagos que são estâncias balneares e consequentemente sítios de eleição para o turismo, e que raramente os cadernos de encargos contemplam o estudo e publicação. Panorama que na minha opinião veria pelo menos parte dos seus problemas solucionados pela existência destes núcleos centrais aptos a coordenar e a processar os dados obtidos em campo, por forma a produzir uma imagem coerente da história da cidade, e responsável pelo retorno deste conhecimento à população. 
Penso que seja ainda relevante comentar que ao realizar este trabalho se tornou evidente que as questões levantadas por vários autores há dez anos atrás quando às Arqueologias Urbana e Preventiva, qual o seu papel e como melhor as gerir, se mantém as mesmas. O que é um indicador de que alguns problemas primários destes ramos permanecem sem solução.

\section{BIBLIOGRAFIA}

BARBOSA, P. G. (1993) - O porto de Lagos no final da Idade Média: algumas reflexões. Cadernos Históricos. IV, pp. 15-26.

Biddle, M. (1974) - The Future of the Urban Past, in Rathtz, P. (ed), Rescue Archaology, Harmonds-worth: 95-112.

Biddle, M. e Hudson, M. D. (1973) - The future of London's Past. A survey of the archaeological implications of planning and development in the nation's capital, Londres.

BLOT, Maria Luísa Pinheiro (2003) - Os portos na origem dos centros urbanos. Lisboa: Instituto Português de Arqueologia.

COUTINHO, Valdemar (2001) - Dinâmica defensiva da Costa do Algarve do Período Islâmico ao século XVIII. Portimão: Instituto de Cultura Ibero Atlântica.

DELGADO, M.; MARTINS, M.; LEMOS, F. S. (1989) Dossier - Salvamento de Bracara Augusta. Fórum 6, Braga. p.3-39.Disponívelem:http://repositorium.sdum.uminho. pt/handle/1822/13335

DÍAZ-GUARDAMINO, M.; MORÁN, E.; FILIPE, I. (2006) - Intervenção arqueológica no Largo de Santa Maria da Graça e a sua área envolvente (Centro Histórico de Lagos): A igreja, o cemitério e a muralha junto à Porta da Vila. Xelb, Silves, 6 [Actas do 30 Encontro de Arqueologia do Algarve. Silves, 20 a 22 de Outubro de 2005]: pp. 111-124.

FRAGAS, T. M. (2013) - Projecto de Carta Arqueologica do Concelho de Lagos (2006-2010): Historia e Desenvolvimentos. ARNAUD; J. M.; MARTINS, A.; NEVES, C. (coords.) Arqueologia em Portugal: 150 anos. Associação dos Arqueólogos Portugueses. Lisboa. pp. 1207-1212.

LEMOS, F. S. (2002) - Arqueologia Urbana em Portugal: a cidade, o poder e o conhecimento. Arqueologia e História. Vol. 54, Associação dos Arqueólogos Portugueses. Lisboa, pp. $245-253$.

LEMOS, F. S. (2006) - A lei e Arqueologia urbana. Praxis Archaeologica. 1, pp. 15-21.

LEMOS, F. S.; MARTINS, M. (1992) - A Arqueologia Urbana em Portugal. Penélope. Fazer e Desfazer a História. N. 7 , pp. 93-103. Disponível em: https://www.researchgate.net/ publication/28224506_A_Arqueologia_Urbana_em_Portugal

MADEIRA, S. (s.d.) - Arqueologia Urbana, subsídios para a sua compreensão. Disponível em https://www.cm-coimbra.pt/index.php/areas-de-intervencao/urbanismo/ gabinete-para-o-centro-historico/grupo-de-arquelogia/ item/1852-investigacao

MADEIRA, S. P. F. (2011) - O Museum of London e a Arqueologia Urbana, um exemplo de gestão arqueológica do espaço urbano e a sua possível aplicação ao território português. Coimbra: [s.n.], 2011. Tese de Mestrado apresentada à Faculdade de Letras da Universidade de Coimbra, orientada por Pedro Carvalho.

MARTINS, M; RIBEIRO, M. C. (2009/2010) - A Arqueologia urbana e a defesa do património das cidades. Fórum 44-45, Braga. pp. 149-177. Disponível em: https://www. google.pt/url?sa $=t \& r c t=j \& q=\&$ esrc $=s \&$ source $=w e b \& c d=$ $3 \& \mathrm{cad}=$ rja\&uact $=8 \&$ ved $=$ oahUKEwip $3 \mathrm{OHh}_{5}$ JbZAhVBIR QKHeaTDwIQFggzMAI\&url=https\%3A\%2F\%2Frepositori um.sdum.uminho.pt $\% 2$ Fbitstream $\% 2{ }_{21} 1822 \% 2 \mathrm{~F}_{1} 3351 \% 2 \mathrm{~F}_{1} \%$ 2FFourm\%252044-45.pdf\& usg=AOvVaw3fvIqu2BdLl7CT hAP7PUKC

MORÁN, E. (2006) - Arqueologia urbana no centro histórico de Lagos: Estratégia de intervenção e balanço dos resultados obtidos. Xelb.6, pp. 103 -110.

PARREIRA, R. (1997) - O salvamento arqueológico das ruínas romanas da Praia da Luz (Lagos): As oficinas de salga a oriente do balneário (escavações de 1987-88). Setúbal Arqueológica, Setúbal, 11-12, pp. 241-248.

PAULA, R. M. (1992) - Lagos, Evolução Urbana e Património. Lagos: Câmara Municipal de Lagos.

RODRIGUEZ TEMINO, I. R. (2004) - Arqueologia urbana en Espana. Barcelona: Ariel Patrimonio.

VEIGA, S. P. M.E. DA (1910) - Antiguidades monumentaes do Algarve: Capítulo V: Tempos históricos. O Archeologo Português, Lisboa, XV, pp. 209-233.

VEIGA, S. P. M. E. DA (2006) - Antiguidades Monumentais do Algarve, V: Tempos Históricos. Silves: Câmara Municipal de Silves / Museu Nacional de Arqueologia. 


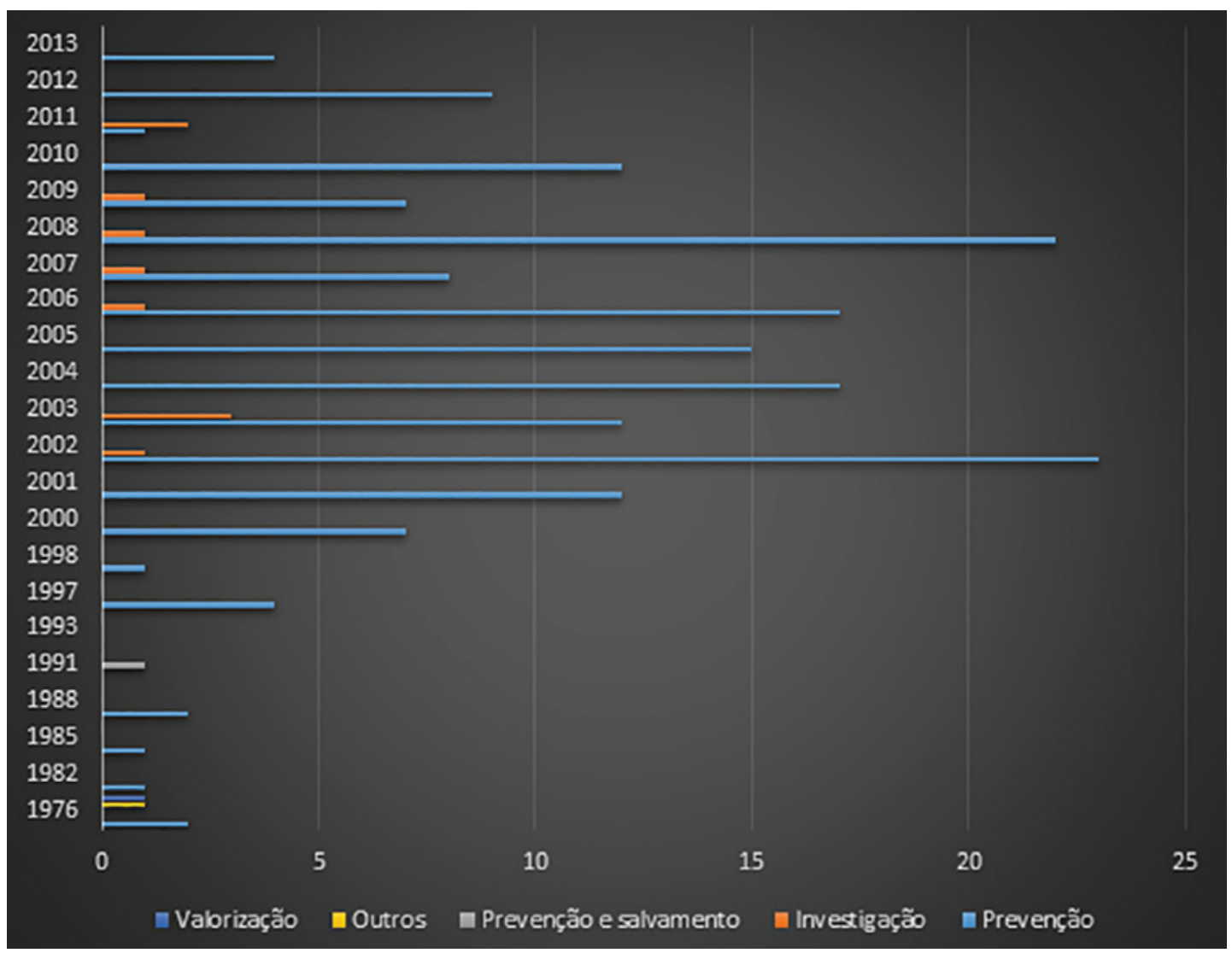

Gráfico 1 - Distribuição das categorias de trabalho por ano.

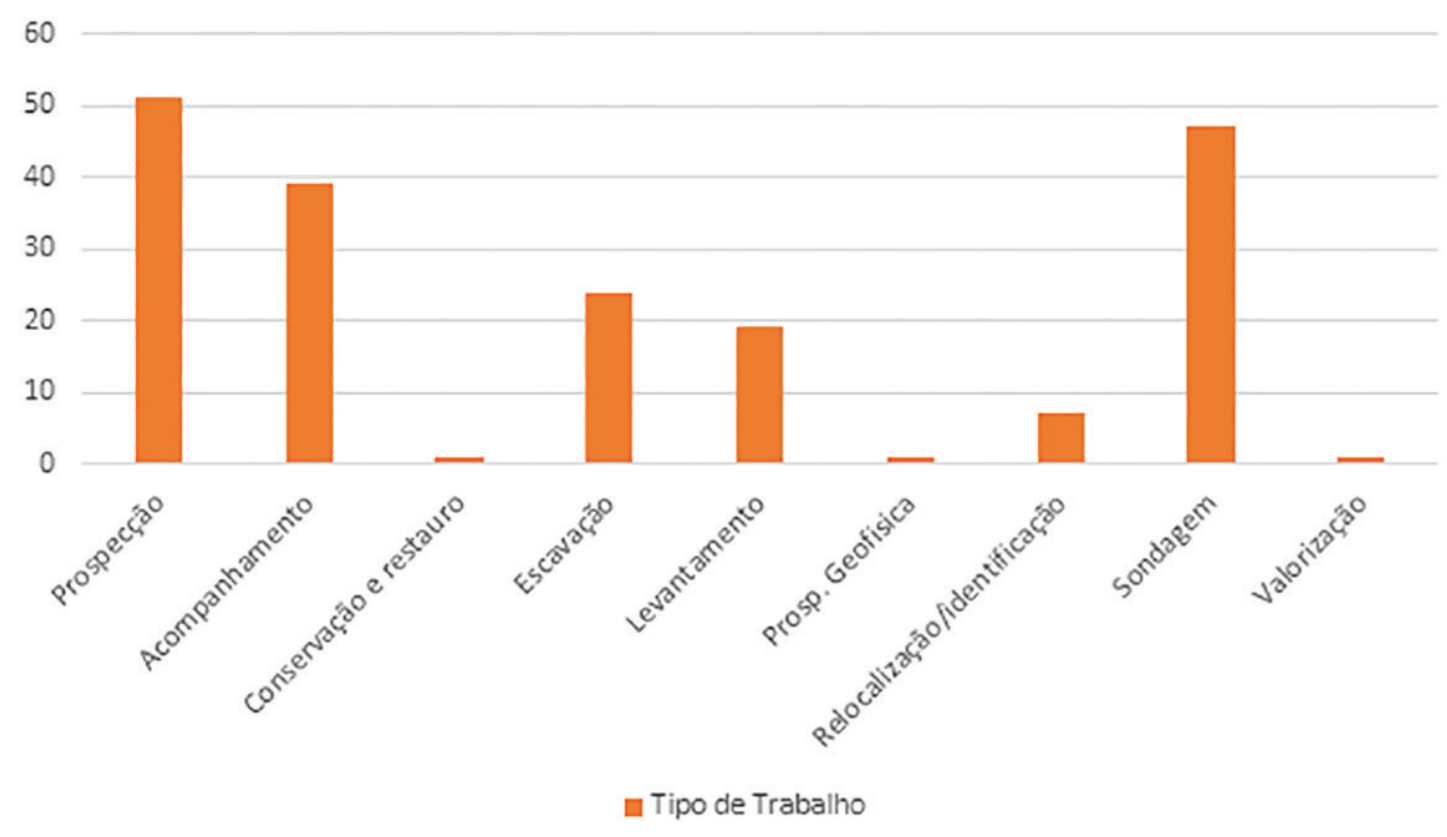

Gráfico 2- Quantificação dos tipos de trabalho. 


\begin{tabular}{|c|c|c|c|c|c|c|c|c|c|c|c|c|c|c|c|c|c|c|c|c|c|c|}
\hline $\begin{array}{l}\text { Ano } \\
\text { de Traballo }\end{array}$ & $\stackrel{\circ}{5}$ & $\ddot{\mathscr{\&}}$ & $\dddot{\&}$ & $\stackrel{\infty}{\mathscr{\&}}$ & $\Phi$ & 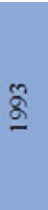 & 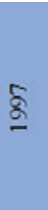 & $\stackrel{\infty}{\Sigma}$ & 8 & $\overline{8}$ & శ్ & $\tilde{8}$ & ¿্ণ & ๕్ & 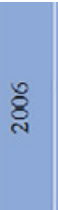 & 8 & 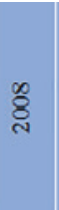 & \&े & $\frac{\mathrm{N}}{\sqrt{2}}$ & $\bar{c}$ & 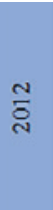 & $\frac{m}{\infty}$ \\
\hline Prevenção & 2 & 1 & 1 & 2 & & & 4 & 1 & 7 & 12 & 23 & 12 & 17 & 15 & 17 & 8 & 22 & 7 & 12 & 1 & 9 & 4 \\
\hline Investigação & & & & & & & & & & & 1 & 3 & & & 1 & 1 & 1 & 1 & & 2 & & \\
\hline $\begin{array}{l}\text { Prevenção e } \\
\text { salvamento }\end{array}$ & & & & & 1 & & & & & & & & & & & & & & & & & \\
\hline Outros & & & & & & 1 & & & & & & & & & & & & & & & & \\
\hline Valorização & & & & & & & & & & & & 1 & & & & & & & & & & \\
\hline Prospeção & 2 & & & 2 & & 1 & & & & 3 & 1 & 6 & 9 & & 3 & & 15 & & 3 & 1 & 5 & \\
\hline Acompanhamento & & & & & & & & & & & 5 & 2 & 5 & 4 & 7 & 6 & 3 & 3 & 3 & & 1 & \\
\hline Conservação e restauro & & & & & & & & & & & 1 & & & & & & & & & & & \\
\hline Escavação & & 1 & 1 & & & & 4 & & & 4 & 5 & 1 & 1 & & 1 & 1 & 1 & 1 & 2 & 1 & & \\
\hline Levantamento & & & & & 1 & & & & 6 & 3 & 5 & & 2 & 2 & & & & & & & & \\
\hline Prosp. Geofisica & & & & & & & & & & & & & & 1 & & & & & & & & \\
\hline $\begin{array}{c}\text { Relocalização/identific } \\
\text { ação }\end{array}$ & & & & & & & & & & & 2 & 1 & & & & & & & & & & 4 \\
\hline Sondagem & & & & & & & & 1 & 1 & 2 & 5 & 5 & & 8 & 7 & 2 & 4 & 4 & 4 & 1 & 3 & \\
\hline Valorização & & & & & & & & & & & & 1 & & & & & & & & & & \\
\hline
\end{tabular}

Tabela 1 - Distribuição dos trabalhos arqueológicos realizados na área urbana de Lagos entre 1976 e 2013, em categorias e tipos de trabalhos. 


\title{
ESTRATÉGIAS DE PROMOÇÃO DO PATRIMÓNIO CULTURAL ŞUBAQUÁTICO NOS AÇORES
} O CASO DA ILHA DO FAIAL

\author{
José Luís Neto ${ }^{1}$, José Bettencourt ${ }^{2}$, Luís Borges ${ }^{3}$, Pedro Parreira ${ }^{4}$
}

\begin{abstract}
RESUMO
Sendo o arquipélago dos Açores um dos palcos pioneiros da arqueologia subaquática, em contexto nacional, a ilha do Faial foi uma das mais intervencionadas, nesse âmbito, ao longo das últimas duas décadas, tendo produzido importantes contributos para o estudo das embarcações da Época Moderna que por ali passaram. Recentemente, esforços conjuntos entre as entidades institucionais e investigadores de instituições académicas permitiram estabelecer novas estratégias de promoção desse património cultural subaquático, e enquadrá-lo numa rede de valorização internacional, que beneficia a sua proteção e a sua ativação, enquanto ferramenta de crescimento socioeconómico da Região. Propõe-se, presentemente, apresentar esses desenvolvimentos e deixar alguns contributos para o estudo e gestão do património cultural subaquático em Portugal.

Palavras-Chave: Arqueologia subaquática, Arqueologia nos Açores, Gestão do património, Promoção do património cultural.
\end{abstract}

\begin{abstract}
Considering the Azores archipelago was one of the pioneer stages of underwater archaeology, on the Portuguese reality, the island of Faial was one of the more intervened, over the last two decades. These archaeological works have produced new contributes towards studying ships from the Early Modern Age, that crossed the Atlantic. Recently, joint efforts between governmental authorities and academic institutions have created new strategies for the promotion of said underwater cultural heritage, allowing for its inclusion on international networks, which have reinforced its protection and activated its potential, being a socioeconomically valid resource for the Region. Presently, we present these developments and its contributes towards the management and studying of the cultural underwater heritage in Portugal.
\end{abstract}

Keywords: Underwater Archaeology, Archaeology in the Azores, Heritage management, Cultural heritage promotion.

\section{CONTEXTUALIZAÇÃO}

Os Açores, estão historicamente e geograficamente ligados ao mar. Todo o arquipélago, desde a génese do seu povoamento, foi crescendo económica e demograficamente, com base na sua integração nas grandes rotas marítimas, tornando-se num ponto de escala essencial à globalização. Os movimentos expansionistas das potências europeias desenvolveram-se em torno dessas rotas, bem como as revoluções sociais do século XIX, os conflitos bélicos mundiais e as redes comerciais.

A cidade da Horta, na ilha do Faial, foi uma das que mais profundamente esteve ligada a essas rotas,

\footnotetext{
1. Direção Regional da Cultura do Governo Regional dos Açores; jose.lp.neto@azores.gov.pt

2. CHAM - Centro de Humanidades, FCSH, Universidade Nova de Lisboa; jbettencourt.cham@gmail.com

3. Direção Regional da Cultura do Governo Regional dos Açores; luis.cs.borges@azores.gov.pt

4. Direção Regional da Cultura do Governo Regional dos Açores; pedro.tc.parreira@azores.gov.pt
} 
pelas excelentes condições de segurança da sua baía, abrigada de intempéries. Primeiramente reconhecida em 1451, a ilha foi povoada durante as décadas seguintes, sendo o lugar da Horta escolhido para estabelecer o principal centro populacional, pelas aludidas condições naturais. Próxima a um curso de água potável abundante, e em zona relativamente abrigada, plana e com boas condições de acessibilidade ao mar, assumia-se como a escolha óbvia. A utilização da costa englobava duas áreas distintas, uma delas entre a Ponta da Espalamaca e o Monte Queimado, formando a atual baía da Horta, e a outra na enseada natural do Porto Pim.

Nas últimas décadas, através de um esforço multidisciplinar entre arqueólogos, historiadores, mergulhadores e outros especialistas, diversos setores do Governo Regional dos Açores e centros de investigação, têm procurado, em estreita colaboração, desbravar uma parte das histórias desse património. Desde o final da década de 90 , por meio de vários projetos pluridisciplinares, o Faial tem sido alvo de trabalhos arqueológicos, que têm permitido melhor compreender a herança cultural relacionada com o mar.

Mais recentemente, nos últimos cinco anos, o arquipélago dos Açores tem assistido ao crescimento exponencial de ações de divulgação, investigação e proteção do seu vasto manancial de património cultural subaquático. Esse trabalho deve-se, em boa parte, à colaboração internacional no projeto Margullar, cujo objetivo é o de assumir a vinculação do binómio $\mathrm{Pa}$ trimónio e Turismo, através de trabalhos de arqueologia subaquática e de conservação e preservação do património cultural subaquático, valorizando-o e promovendo-o enquanto ativo económico.

O trabalho de investigação científica permitiu identificar um conjunto de novos sítios de interesse cultural subaquático, levando à criação de roteiros visitáveis e à implementação de estratégias de ação, tais como a realização de intervenções de prospeção subaquática, em vários pontos do arquipélago, e a formação de técnicos especializados, nas vertentes práticas da arqueologia subaquática.

Outra ação desenvolvida no plano de atividades do projeto Margullar foi a realização de pesquisa documental no Arquivo Histórico da Marinha. Procurou-se levantar dados sobre naufrágios, encalhes e outras pertinentes informações sobre os mares dos Açores. O propósito foi o de angariar material documental para suportar a integração de novos sítios visitáveis no roteiro existente bem como registar outras infor- mações associadas ao património cultural da Região e a sua fortíssima ligação com o mar (Figura 1).

\section{PATRIMÓNIO CULTURAL SUBAQUÁTICO NA ILHA DO FAIAL}

Muito antes de serem efetuados trabalhos arqueológicos, com vista à deteção de vestígios de património cultural subaquático, na ilha do Faial, já as autoridades de épocas anteriores demonstraram preocupação em recuperar partes da história de embarcações ali soçobradas. Documentados, até ao momento, encontramos pelo menos dois casos, em momentos muito diferentes da história da ocupação da ilha, e demonstrando duas prioridades distintas.

Se, por um lado, houve a preocupação em recuperar a preciosa carga de uma nau portuguesa seiscentista, com o episódio do afundamento da Nossa Senhora da Luz, já amplamente estudado e profundamente analisado, por vários investigadores, o outro caso a que nos referimos, corresponde ao fatídico episódio do navio corsário americano, General Armstrong, tendo-se verificado a necessidade de resgatar uma memória, oitocentista, que importava devolver aos interessados (Bettencourt e Dutra, 2015).

Para além dos estudos históricos e arqueológicos já elaborados sobre as duas embarcações a que nos referimos anteriormente, a ilha do Faial, durante a primeira década do século XXI, foi palco de vários momentos de descoberta, e redescoberta, do seu património cultural subaquático. Essas ocorrências centraram-se, essencialmente, na baía da Horta, principal ponto de ancoragem, onde vários investigadores foram, ao longo dos anos, detetando novos sítios de interesse, no âmbito de mergulhos recreativos, mas, principalmente, no contexto da mitigação de impactos associados às obras de ampliação e construção de novas infraestruturas portuárias.

O que primeiro se materializou numa intervenção arqueológica de avaliação de impacte ambiental, no que concerne ao descritor patrimonial, acabou por se desmembrar num conjunto de ações de prospeção, escavações pontuais e monotorização de sítios de naufrágio, que elevaram a baía da Horta a um dos locais com mais relevante interesse para o estudo desse património, no arquipélago dos Açores, mas também a nível nacional. O trabalho, coordenado e efetuado por uma equipa do CHAM - Centro de Humanidades, da Universidade Nova de Lisboa, decorreu de forma faseada, ao longo de vários anos, 
tendo-se iniciado em 2008 e terminado, no terreno, em 2013 (Bettencourt, 2016).

Os resultados dessa intervenção, que acabou por se tornar num projeto plurianual de investigação, foram já publicados e disseminados entre a comunidade arqueológica portuguesa. Importa, todavia, relembrar que foram descobertos vários sítios de naufrágio que, devido às suas caraterísticas tipológicas, não foram identificados na documentação histórica, sendo designados pelo acrónimo $B H$ (Baía da Horta) seguido do respetivo número.

O começo dos trabalhos levou à sinalização de um sítio de naufrágio de embarcação setecentista, designado BH-oor, com mais de uma centena de presas de elefante, exumadas e incorporadas na reserva do Museu da Horta. O estudo dos vestígios materiais detetados na área de dispersão envolvente prosseguiu durante os anos seguintes, até 2012, quando foi possível balizar o afundamento no começo do século XVIII, pela presença de um conjunto vasto de cachimbos fragmentados e algumas peças de cerâmica, com origem inglesa, tipicamente associadas a essa cronologia. Avançou-se com a hipótese de se tratar de uma embarcação britânica, que passara por África, onde recolhera o marfim, e naufragara nos Açores, no primeiro quartel de setecentos (Bettencourt e Carvalho, 2010) (Figura 2).

O acompanhamento das dragagens na bacia de manobra do porto, registou um vasto conjunto de fragmentos de cerâmica, detetando, igualmente, novo sítio de interesse patrimonial elevado, designado como BH-oo3. Aí, identificou-se um grupo de canhões em ferro, optando-se por efetuar, posteriormente, uma prospeção com recurso a magnetómetro, que se revelou inconclusiva. A retoma dos trabalhos de dragagem permitiu recuperar mais canhões, num total de treze, avançando-se com a hipótese de se tratar de um local de naufrágio de embarcação da segunda metade do século XVIII (Silva e Bettencourt, 2016). Sobre esse local, daremos notícia dos desenvolvimentos (Figura 3).

Para além do conjunto de peças de artilharia, o acompanhamento arqueológico e ações pontuais de prospeção, revelaram a presença de, pelo menos, mais três sítios de interesse arqueológico com possível relação com afundamentos de embarcações, designados como BH-oO2, BH-004 e BH-005.

Nos sítios arqueológicos em $\mathrm{BH}-0 \mathrm{O} 2$ e BH-004, detetaram-se vestígios de chaparia metálica antiga, durante as dragagens, que permitiram balizar cronologicamente o material no século XIX, acrescendo ainda vestígios dispersos de madeirame e forro em liga de cobre, técnica que se popularizou no final do século XVIII e se democratizou na centúria seguinte.

Em 2013, novos trabalhos de investigação permitiram registar, de forma mais detalhada, o que se veio a confirmar ser um afundamento, em BH-oo4. Esse trabalho foi possível, porquanto a zona sinalizada localizava-se fora da área de afetação direta da empreitada. Constatou-se a utilização de madeiras de carvalho, nas balizas, e pinho, no forro. Pela caraterização do sítio arqueológico, levantou-se a hipótese de estar associado a uma embarcação oitocentista, que ali soçobrou e foi, posteriormente, alvo de desmonte, para aproveitamento das suas madeiras, algo que acontecia com alguma frequência, no arquipélago dos Açores.

Quanto à área designada por BH-oo5, a intervenção arqueológica registou - entre outros vestígios que poderão estar, ou não, associados a um afundamento - um mastro, elaborado com recurso a chapas metálicas, rebitadas, em liga de ferro, com um comprimento de cerca de 17 metros. A investigação posterior revelou que se enquadrava numa tipologia naval inserível no final do século XIX, ou começo do XX. Por fim, entre 2012 e 2013, trabalhos adicionais de monotorização e acompanhamento arqueológico na bacia do porto da Horta permitiram registar um novo sítio arqueológico, $\mathrm{BH}$-oo6. A intervenção arqueológica que se seguiu assentou, numa primeira fase, no registo exaustivo em fotogrametria da estrutura do navio, seguindo-se a exumação de algum espólio arqueológico, para análise, assegurando uma metodologia não intrusiva, e terminando com um trabalho de proteção da estrutura, com areia e rede de polipropileno, uma vez que foram detetados processos de deterioração da madeira da embarcação. Atendendo à presença de elementos de forro com fixação feita com cavilhas em liga de cobre, cronologicamente, o BH-oo6 corresponderá, muito provavelmente, a uma embarcação do século XIX. Na sequência das análises laboratoriais efetuadas em amostras de madeira exumadas durante os trabalhos de campo, identificou-se a presença de dois tipos distintos, de origem americana. Conjugando os dados apresentados, avançou-se a hipótese de ter sido descoberto um barco associado à história da baleação americana, intrinsecamente ligada ao arquipélago dos Açores (Bettencourt et al., 2017) (Figura 4). 


\section{PATRIMÓNIO CULTURAL SUBAQUÁTICO VISITÁVEL NA ILHA DO FAIAL}

Além dos referidos trabalhos, a investigação arqueológica permitiu, até ao presente, sinalizar seis sítios, ao largo da ilha do Faial, que reúnem as adequadas condições para a sua visitação, pelo público de mergulho, de forma sustentável. Os critérios aplicados, para selecionar esses locais, incluem a sua acessibilidade, a estabilidade estrutural dos vestígios materiais, a segurança dos visitantes e a salvaguarda do património natural associado, entre outros (Figura 5).

\subsection{Iate do Morro de Castelo Branco}

Comecemos por relatar o episódio mais recente da longa história de tragédias marítimas associadas à ilha do Faial. No dia 12 de maio de 2019, por volta das 10 horas da manhã, encalhou, junto às rochas do Morro de Castelo Branco um iate de recreio, com dois tripulantes. A embarcação navegava com a bandeira da Antígua e Barbuda, tendo sofrido problemas mecânicos que levaram ao seu encalhe.

A tripulação, de origem alemã, foi imediatamente socorrida pelas autoridades locais, da Capitania do Porto da Horta, sendo que, desde logo, iniciaram-se esforços para salvar o navio, e recuperá-lo ao mar. Todavia, e atendendo às condições climatéricas, bem como à violência do embate nos rochedos, que destroçou a estrutura da embarcação, tal não se verificou possível.

Assim, e dando cumprimento às boas práticas adequadas à situação, elementos da Autoridade Marítima Nacional colaboraram na transladação dos vestígios do naufrágio, para zona próxima à costa, mas em profundidade suficiente para impedir a afetação da navegação, criando assim uma área de reserva visitável, associada à já existente Reserva Natural do Morro do Castelo Branco. Em curso, estão os trabalhos para integrar o local no Roteiro do Património Cultural Subaquático dos Açores (Figura 6).

\subsection{O naufrágio da loiça}

Primeiramente sinalizado, por trabalho arqueológicos, em 1998, durante uma campanha coordenada por Kevin Crisman (1999), do Institute of Nautical Archaeology da Universidade A\&M do Texas, localiza-se no lugar coloquialmente conhecido como Ponta da Greta, no lado nascente do Monte da Guia, um sítio de naufrágio que foi alvo de campanha de prospeção arqueológica subaquática, mais de duas décadas volvidas, em 2019, por parte de uma equipa da Direção Regional da Cultura, contando com o apoio de José Bettencourt, da Universidade Nova de Lisboa.

O local conhecido como naufrágio da loiça, pela elevada quantidade de vestígios de cultura material presente, é enquadrado por uma seção de casco de navio construído em ferro, a cerca de 33 metros de profundidade. Durante as prospeções, atestou-se a presença de faiança industrial, esmaltada a branco, enquadrável na tipologia conhecida como Opaque white stonewares, produzida desde a década de 1830, e popularizada nas duas décadas seguintes, tendo continuidade até ao final do século (Samford, 2003). Não existem certezas acerca da verdadeira origem desse afundamento, ainda que muitas das circunstâncias do sinistro documentalmente identificado, da embarcação E. H. Oaks, proveniente da Nova Escócia e soçobrado ao largo do Faial, em 1874, sejam concordantes com o observado in situ. O que é certo é que foi assinalado o naufrágio de navio oitocentista, ou de começo do século XX, que reúne condições para integrar o Roteiro do Património Cultural Subaquático dos Açores. Futuros trabalhos arqueológicos poderão ajudar a resolver as questões levantadas, acerca da sua proveniência.

\subsection{Viana}

Na madrugada de 16 de abril de 1994, encontrava-se amarrado no porto da cidade da Horta um navio de pesca, com 75 metros de comprimento e 1485 toneladas de arqueação bruta, abastecido com 430 toneladas de gasóleo no porto de Vigo, alguns dias antes. Tratava-se do Viana, um arrastão da Sociedade de Pescas de Aveiro, tripulado por 37 pessoas.

Nesse dia, por motivos nunca devidamente esclarecidos, deflagrou um incêndio a bordo da embarcação, que resultou na morte de um dos tripulantes. A sua posição, no interior do porto, e a substancial carga de combustível, fizeram da situação uma emergência, com possíveis consequências graves. A Autoridade Marítima Nacional, com o apoio da Associação Humanitários dos Bombeiros Voluntários Faialenses, bem como a Corporação de Bombeiros do Aeroporto da Horta e a Proteção Civil acionaram todos os mecanismos disponíveis para assegurar uma resolução segura da iminente catástrofe.

Em colaboração com o Governo Regional e a Universidade dos Açores, optou-se por rebocar o navio até zona segura, para procurar estabelecer um recife na- 
tural, sem provocar danos ambientais. Por questões de segurança, avançadas pela Autoridade Marítima Nacional, optou-se por estabelecer esse sítio a uma profundidade de cerca de 46 metros. O trabalho foi efetuado por consórcio privado, tendo depositado o esqueleto da embarcação com a quilha para cima, o que dificulta a visitação do local, porquanto o convés acabou por ficar a mais de 50 metros de profundidade. Não obstante, o Viana enquadra-se no grupo de sítios visitáveis integrados no Roteiro do Património Cultural Subaquático dos Açores, sendo o local que reúne as condições mais difíceis para visitação na Região, em paralelo com o naufrágio do Olympia, nos ilhéus das Formigas, ainda que, de acordo com os operadores de turismo local, essas visitas continuem a ser efetuadas, apenas com mergulhadores altamente especializados.

\subsection{Pontão 16}

Situação semelhante ocorreu com o caso do Pontão 16, cujo nome original era Pontoon 16. Draga de apoio à construção naval, o navio participou na empreitada de construção do porto da Madalena, na ilha do Pico, na década de 80 do século XX, sendo que, em 2003, estava já parado, não tendo sido possível aferir as circunstâncias que levaram a essa aposentação. Certo é que o seu nome foi avançado por especialistas da Universidade dos Açores, como candidato viável ao afundamento para criação de recife artificial e ponto de visitação de património cultural subaquático.

Assim se procedeu, no dia 5 de dezembro de 2003 , junto à Praia do Almoxarife, num fundo de areia, a 26 metros de profundidade. Trabalhos de monitorização do sítio, coordenados pelos especialistas universitários, permitiram verificar que o local não apresentava risco de poluição ambiental e que a estrutura do navio apresentava aumento dos depósitos de areia, propícios aos estudos científicos preconizados. Presentemente, o local, que se encontra arrolado no Roteiro do Património Cultural Subaquático dos Açores, integra a lista de sítios de visitação proposta pelos operadores de mergulho local aos seus clientes.

\subsection{O Núcleo de Canhões da Baía da Horta}

Retomando a questão dos trabalhos arqueológicos na baía da Horta, entre 2008 e 2013, importa agora referir que, tanto em $\mathrm{BH}$-oo1 como em $\mathrm{BH}-003$ foram detetadas peças de artilharia, num total de dezassete canhões, bem como outros vestígios arqueológicos de maior dimensão, que necessitaram de relocalização, por se encontrarem na área de afetação direta da empreitada de dragagem dos fundos. Assim, o grupo de investigadores responsáveis pela intervenção, em coordenação com as autoridades competentes em matéria de cultura, propuseram a criação de uma reserva subaquática, porquanto a mesma asseguraria a preservação possível das peças, sem as remover do seu ambiente subaquático. O local ficou conhecido como núcleo de canhões da baía da Horta, apesar de lá se encontrarem outras peças diversas, de maior dimensão. O nome deveu-se, naturalmente, ao número considerável de peças de artilharia que foram transladadas até à nova reserva. A reserva visitável situa-se na baía de Entre os Montes, em profundidade variável entre os 15 e os 20 metros. Trata-se de um dos sítios de excelência para o mergulho em património cultural subaquático na ilha do Faial, integrando o Roteiro do Património Cultural Subaquático dos Açores.

\subsection{Main}

Em dias de boa visibilidade, na baía do Porto Pim, junto ao Monte da Guia, qualquer pessoa que por ali passe poderá avistar facilmente a silhueta de uma embarcação, naufragada, a muito baixa profundidade. Trata-se do sítio de afundamento do vapor inglês, Main, soçobrado em 1892, após ter aportado, primeiramente, à baía da Horta, com um incêndio a bordo. O episódio marcou a história local, porquanto o navio foi forçado a rumar ao Porto Pim, por estar a colocar em perigo a atividade portuária na Horta, tendo-se seguido um processo de salvamento da tripulação, e tentativa de resgate da sua carga de gado bovino, malsucedida, que acabou com os animais a fugirem por terra, provocando alguns estragos na economia agrícola local.

Os vestígios do Main localizam-se a profundidade inferior a 5 metros, tendo-se preservado praticamente todo o costado da embarcação, com várias balizas. Constitui aquele que é, certamente, o sítio de mergulho patrimonial de excelência, na ilha do Faial, porquanto permite visitação por mergulho de apneia, ou com escafandro autónomo, sendo de acesso fácil, feito a partir da costa. Integra o Roteiro do Património Cultural Subaquático dos Açores. Recentemente, as movimentações marítimas deixaram uma boa parte do naufrágio visível, mesmo a partir de terra, em dias de boas condições meteorológicas (Figura 7). 
4. NAUFRÁGIOS DETETADOS

NO ARQUIVO HISTÓRICO DA MARINHA, PARA A ILHA DO FAIAL

O Arquivo Histórico da Marinha é dependente organicamente da Biblioteca Central da Marinha. Encontra-se localizado na antiga Fábrica Nacional de Cordoaria, com acesso através da rua da Junqueira, cidade de Lisboa. Remonta a sua existência a 1843, reunindo fundos documentais que, se podem recuar até ao século XVIII, assumem-se, todavia, fundamentais para a investigação nos séculos XIX e XX. Dentro da riquíssima coleção presente no Arquivo, procedeu-se a uma análise do fundo documental dedicado aos naufrágios e encalhes, que abrange os territórios de Portugal Continental, Açores, Madeira, Cabo Verde, Angola, Moçambique, e demais regiões ultramarinas.

Confrontou-se a informação descoberta com os naufrágios já previamente registados, bem como informação referente a questões de gestão dessas questões, sempre associadas ao património cultural subaquático na ilha do Faial.

$\mathrm{Na}$ Carta Arqueológica Subaquática dos Açores, publicada, pela primeira vez, em 1999 (Monteiro, 1999), e transposta para Sistema de Informação Geográfica, em 2019, estão inventariados 91 episódios de naufrágio ou encalhe, na ilha do Faial, entre o ano de 1539 e o de 1922.

Através da pesquisa efetuada no referido Arquivo, foi possível detetar, no fundo documental, $24 \mathrm{ca}$ sos, sendo que, 13 não estavam registados na aludida Carta. São eles, por ordem cronológica: $1853-4$ embarcações não identificadas no porto da cidade da Horta; 1855 - navio americano não identificado no porto da cidade da Horta; 1867 - escuna inglesa na baía da Horta; 1874 - patacho inglês na freguesia do Salão; 1876 - brigue alemão no lugar de Pedras dos Frades; 1879 - barca francesa na baía da Horta; 1887 - escuna portuguesa na baía da Horta; 1898 embarcação de pesca no porto da Horta e patacho português ao largo do Faial; 1909 - iate inglês na freguesa do Salão.

Assim, constatamos que mais de $50 \%$ dos sítios identificados correspondem a naufrágios inéditos, perfazendo um total de 104 registados documentalmente, ao largo do Faial.

Os afundamentos registados no Arquivo Histórico da Marinha estão balizados cronologicamente entre o ano de 1846 e 1909, sendo que não se verifica uma média constante, por década. Destacamos números mais baixos nas décadas de 1860 e de 1880 , possivelmente devido a ações como a identificada, no ano de 1868, por parte das autoridades marítimas nacionais, que decretaram o impedimento da navegação entre ilhas, na zona do "triângulo" - correspondente às ilhas do Faial, São Jorge e Pico -, durante os meses de inverno, precisamente com vista a prevenir o número crescente de naufrágios que se verificara em anos anteriores.

Quanto à dispersão geográfica, como seria já expectável, a grande maioria dos naufrágios registados ocorreram no interior da baía da Horta (14), acrescendo mais dois naufrágios na adjacente baía do Porto Pim, outros dois na Ponta da Espalamaca, próxima à cidade, e ainda um outro no lugar de Entre os Montes, também confinante com a cidade. Registaram-se dois episódios ao largo da freguesia do Salão, um no lugar de Pedras dos Frades, e dois casos cuja localização certa não foi registada, encontrando-se apenas a designação genérica de "ao largo da ilha do Faial." A investigação da documentação e histórica assume-se como de fundamental interesse para o estudo do património cultural subaquático. Através das pesquisas efetuadas, a título de exemplo, podemos afirmar que foram várias as embarcações de origem americana assinaladas, que se podem enquadrar nas tipologias assinaladas pelas intervenções arqueológicas em sítios como o BH-004 ou o BH-oo6.

Ainda que não seja possível avançar com certezas, a multidisciplinariedade é essencial para o desenvolvimento de investigações desse género, que permitem, por um lado, reconstruir o sítio arqueológico, através da sua cultural material, como se de uma máquina do tempo se tratasse, e por outro, reviver a narrativa associada a cada episódio e que integra uma herança universal comum.

\section{GESTÃO DO PATRIMÓNIO CULTURAL SUBAQUÁTICO}

O Governo Regional dos Açores avançou, nos últimos anos, com uma estratégia de gestão do património cultural subaquático do arquipélago, assente em três pontos fundamentais: investigação; proteção; promoção. Esse trabalho continua a ser aplicado, presentemente, devidamente adaptado a cada realidade de ilha, uma vez que, não obstante a unidade sociopolítica da Região, cada contexto territorial assume-se como substancialmente diferente. 
No caso da ilha do Faial, conforme foi possível atestar nos anteriores capítulos, foram efetuados grandes avanços na investigação do seu património arqueológico subaquático, ao longo das últimas décadas. A descoberta de mais de uma dezena de sítios com interesse patrimonial, e o estudo exaustivo de alguns deles, permitiu trazer novos contributos para a área. Alicerçadas no trabalho já efetuado, foram preparadas estratégias de salvaguarda e divulgação desse património, que vão produzindo resultados cada vez mais bem-sucedidos.

Um dos mais importantes pilares da estratégia de gestão e promoção patrimonial, em curso, prende-se com o estabelecimento de um protocolo de salvaguarda, com a Associação de Operadores Marítimos dos Açores, que definiu as regras de visitação dos sítios arqueológicos subaquáticos, assegurando que os centros de mergulho assumem funções enquanto guardiões desse património, porquanto são essas empresas que regularmente mergulham nos locais. O estrito cumprimento das boas práticas, entretanto publicadas em Manual (Neto e Parreira, 2018), e difundidas entre todos os operadores do arquipélago, bem como junto das delegações da Autoridade Marítima Nacional no arquipélago, certificam que o mergulho é feito de forma segura, sustentável e enriquecedora.

A promoção do património cultural subaquático dos Açores assenta num modelo de criação de conteúdos, para divulgação em diversas plataformas, algumas delas já existentes, e outras em vias de criação. Tendo por base o Roteiro do Património Cultural Subaquático dos Açores, foram preparados sete documentários, com a preciosa colaboração do realizador José Serra, que foram transmitidos pela RTP-Açores, durante o ano de 2018, seguindo-se outros cinco programas, dentro do ciclo denominado Máquina do Tempo, exibidos no final de 2019 e começo de 2020. Essa divulgação, em horário nobre, e nas diversas ferramentas de divulgação digital disponíveis, trouxeram, pela primeira vez, o património arqueológico subaquático da Região à casa de todas as pessoas, mesmo a todas as que nunca mergulharam, ou tencionam mergulhar. Os documentários foram, posteriormente, traduzidos, para divulgação no estrangeiro.

Entre 2019 e 2020, a Direção Regional da Cultura tem vindo a preparar a criação de Centros de Sensibilização do Conhecimento, cujo objetivo é tornar ainda mais acessível esse património aos que não podem mergulhar, e complementar o conhecimento dos que irão ou já foram visitar os sítios. Esses Centros serão equipados com material referente aos mais relevantes episódios históricos associados ao mar, em cada ilha, onde se incluirão os já referidos documentários, bem como painéis expositivos e a exibição de material arqueológico, quando possível. Serão complementados com outros equipamentos, estando prevista a incorporação das novas tecnologias, através da produção de conteúdos em $3 \mathrm{D}$, com o apoio de investigadores nacionais, e de fotomosaicos dos naufrágios. No caso do Faial, encontra-se em fase de finalização o modelo 3D do já mencionado naufrágio do Main, na baía de Porto Pim.

A promoção do património cultural subaquático da Região, ao nível internacional, tem sido assegurada por um esforço conjunto, com a Associação Turismo dos Açores, através da participação em feiras da especialidade, tendo, até ao momento, levado os conteúdos complementares produzidos até Lisboa, Loulé, Paris e Düsseldorf.

Em 2019, a estratégia de trabalho do Governo Regional dos Açores, no que concerne à arqueologia subaquática, foi premiada pela UNESCO. O prémio atribuído foi o de Best Practices in Protection of the Underwater Cultural Heritage, que tem sido atribuído, ao longo dos anos, às regiões que se destacam na inovação e criação de mecanismos de defesa do património cultural subaquático. O roteiro de sítios visitáveis implementado nos últimos anos, foi também galardoado com a Marca do Património Europeu, em 2020, atribuída pela Comissão Europeia a sítios, ou conjuntos patrimoniais que melhor representem a identidade comum europeia, e assegurem as boas práticas da gestão desse património.

A ligação da cidade da Horta, maior centro populacional da ilha do Faial, à sua baía continua a fazer-se sentir no presente, através de instituições centenárias, como o Peter Café Sport, ou no seu próprio planeamento urbano, como se constata pela abertura da urbe à sua frente marítima. Esse vínculo é também sentido no que concerne ao património cultural subaquático. Procura-se, cada vez mais, estimular essa relação de proximidade, através das já referidas estratégias de gestão patrimonial. Não esquecendo o trabalho já efetuado anteriormente, prevê-se um futuro onde se afiram os detalhes da implementação desse modelo, que se enquadra na vanguarda do que se tem feito pela proteção e promoção do património cultural subaquático, ao nível mundial. 


\section{BIBLIOGRAFIA}

BETTENCOURT, José (2008) - A nau Nossa Senhora da Luz (1615) no contexto da Carreira da Índia e da escala dos Açores: uma abordagem histórico-arqueológica. Dissertação de mestrado em Arqueologia pela Faculdade de Ciências Sociais e Humanas da Universidade Nova de Lisboa.

BETTENCOURT, José e CARVALHO, Patrícia (2010) - “A história submersa na baía da Horta: resultados preliminares dos trabalhos arqueológicos no "naufrágio do marfim" (primeiro quartel do século XVIII)." In Actas do V Colóquio "O Faial e a Periferia Açoriana nos séculos XV a XIX.” Horta: Núcleo Cultural da Horta. pp. 139-152.

BETTENCOURT, José (2012a) - Arqueologia de salvamento em contextos subaquáticos: abordagem preliminar ao caso da baía da Horta (Faial, Açores). Actas das IV Jornadas de Jovens em Investigação Arqueológica. Faro: Universidade do Algarve, Promontoria Monográfica 16. Vol. II, pp. 49-55.

BETTENCOURT, José (2012b) - O porto da Horta na História do Atlântico (sécs. XVI a XX) a partir do registo arqueológico: alguns exemplos. Jornadas do Mar: O reencontro com o mar no século XXI. Lisboa: Base Naval de Lisboa. pp. 330-336.

BETTENCOURT, José; FONSECA, Cristóvão e SILVA, Tiago (2014) - Dragagem da bacia de manobra do terminal de passageiros do Porto da Horta, à cota de $-8.5 \mathrm{~m}$ (ZH): Relatório dos trabalhos subaquáticos realizados em 2013 no sítio BH-oo6., Lisboa: CHAM-Centro de Humanidades.

BETTENCOURT, José António e DUTRA, Márcia (coord.) (2015) - Actas do Colóquio "The Wonderful Battle of the Brig Gen. Armstrong at Faial, 1814”: no bicentenário do combate naval ocorrido na Baía da Horta a 27 de setembro de 1814. Horta: OMA - Observatório do Mar dos Açores.

BETTENCOURT, José (2016) - "Coastal construction projects and rescue archaeology: the case of Horta bay (Azores, Portugal).” In NEGUERUELA MARTÍNEZ, I., CASTILLO BELINCHÓN, R. and RECIO SÁNCHEZ, P. (coord.) - Proceedings of the $5^{\text {th }}$ International Congress on Underwater Archaeology (IKUWA) - A heritage for mankind. Cartagena: Museo Nacional de Arqueología Subacuática. pp. 120-130.

BETTENCOURT, José et. al. (2017) - Baía da Horta 6 (BHoo6): um provável naufrágio americano do século XIX. Arqueologia em Portugal. 2017: Estado da questão. Lisboa: Associação dos Arqueólogos Portugueses. pp. 1993-2009.

CARDIGOS, Frederico (2015) - Viana. Carta Arqueológica dos Açores. Disponível em http://www.culturacores.azores.gov.pt/paa/ca/Default.aspx

CARDIGOS, Frederico (2015) - Pontão 16. Carta Arqueológica dos Açores. Disponível em http://www.culturacores. azores.gov.pt/paa/ca/Default.aspx
CARVALHO, Ana e NETO, José Luís (coord.) (2017) - Guia do Património Cultural Subaquático dos Açores. Angra do Heroísmo: Turismo dos Açores e Direção Regional da Cultura.

COSTA, Ricardo Madruga da (2011) - “A propósito da Horta dos cabos submarinos. A relevância da ilha do Faial na construção da "Civilização Atlântica". In O Porto da Horta na História do Atlântico. O tempo dos cabos submarinos. Horta: Museu da Horta e Associação dos Antigos Alunos do Liceu da Horta. pp. 69-8o.

COSTA, Ricardo Madruga da (2012) - A ilha do Faial na logística da frota baleeira americana no "século Dabney". Horta: Observatório Marítimo dos Açores.

CRISMAN, Kevin (1999) - Looking for ships: the 1998 Central Azores Shipwreck Survey. The INA Quaterly. Texas: Universidade A\&M. Vol. 26, n. ํㅜ 1, pp. 3-9.

FRUTUOSO, Gaspar (1998) - Saudades da Terra. Ponta Delgada: Instituto Cultural de Ponta Delgada. Livro VI.

GARCIA, Ana Catarina e MONTEIRO, Paulo Alexandre (1999) - Relatório final relativo à prospeção arqueológica subaquática no âmbito das obras de ampliação da marina da Horta. Lisboa: Centro Nacional de Arqueologia Náutica e Subaquática.

MONTEIRO, Paulo Alexandre (1999a) - O naufrágio da nau da Carreira da Índia Nossa Senhora da Luz: 7 de novembro de 1615, ilha do Faial, Açores. Lisboa: Centro Nacional de Arqueologia Náutica e Subaquática.

MONTEIRO, Paulo Alexandre (1999b) - Carta Arqueológica Subaquática dos Açores. Metodologia resultados e sua aplicação na gestão do património subaquático da Região Autónoma dos Açores. $3^{\circ}$ Congresso de Arqueologia Peninsular. Vila Real: ADECAP/Universidade de Trás-os-Montes. pp. 497-519.

MONTEIRO, Paulo Alexandre (2001) - The Azores Underwater Cultural Heritage: Strategies, Surveys, Excavations and Results (1995-200o). Proceedings of the 6th Annual Meeting of the European Association of Archaeologists. Lisboa: Associação Europeia de Arqueologia.

NETO, José Luís e PARREIRA, Pedro (2018) - Manual de Boas-Práticas do Património Arqueológico Subaquático dos Açores. Angra do Heroísmo: Direção Regional da Cultura.

SAMFORD, Patricia (2003) - "Post-Colonial Ceramics: White Granite.” Diagnostic Artifacts in Maryland. Disponível em https://apps.jefpat.maryland.gov/diagnostic/PostColonial\%2oCeramics/White\%2oGranite/index-whitegranite.html

SILVA, Tiago e BETTENCOURT, José (2016) - “Baía da Horta 3 (Faial Island, Azores, Portugal) - the Cannon Site.” In NEGUERUELA MARTÍNEZ, I., CASTILLO BELINCHÓN, R. and RECIO SÁNCHEZ, P. (coord.) - Proceedings of the 5 th International Congress on Underwater Archaeology (IKUWA) - A heritage for mankind. Cartagena: Museo Nacional de Arqueología Subacuática. pp. 1034-1035. 


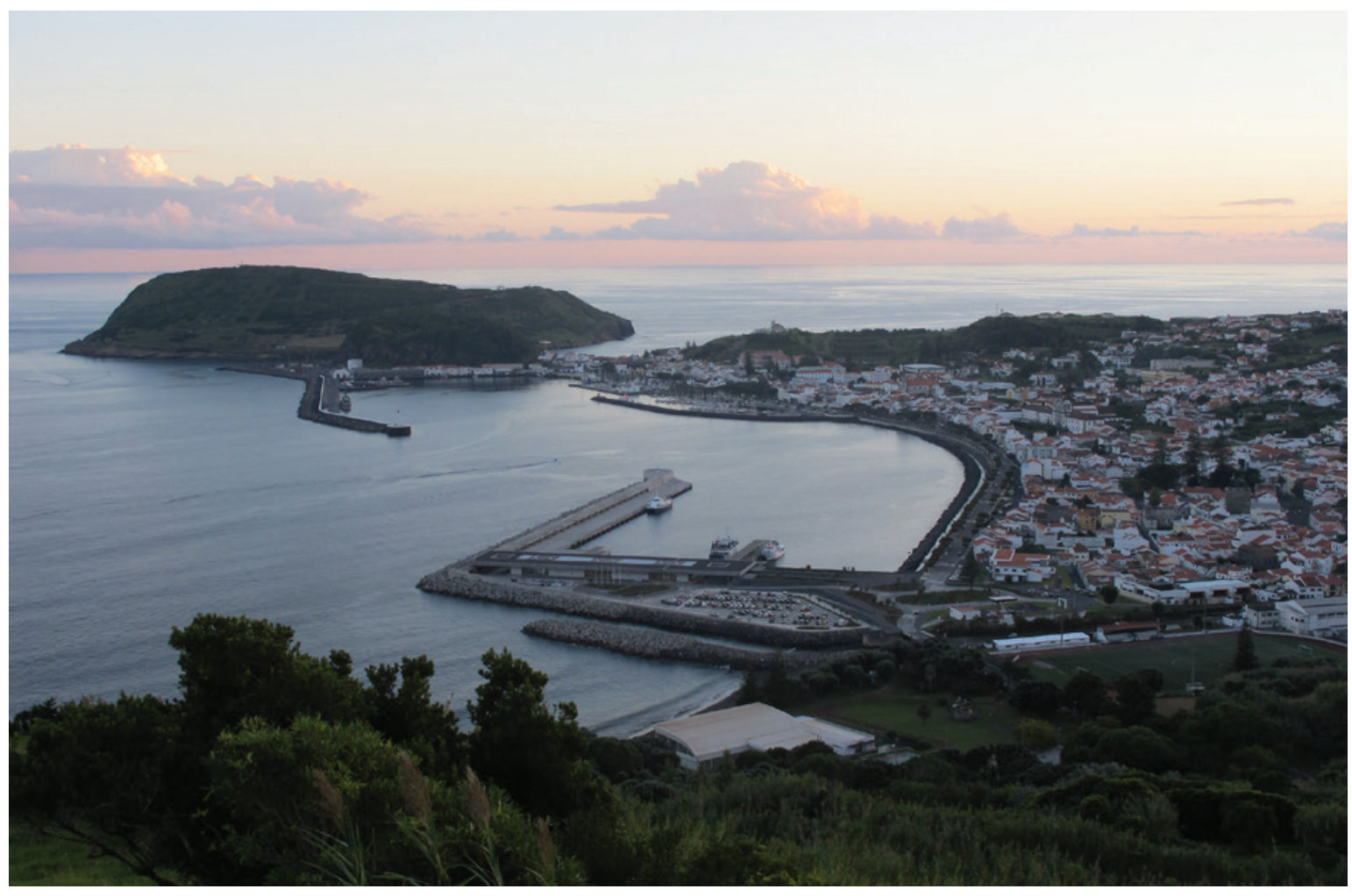

Figura 1 - A cidade da Horta, na ilha do Faial. Autor: José Bettencourt.

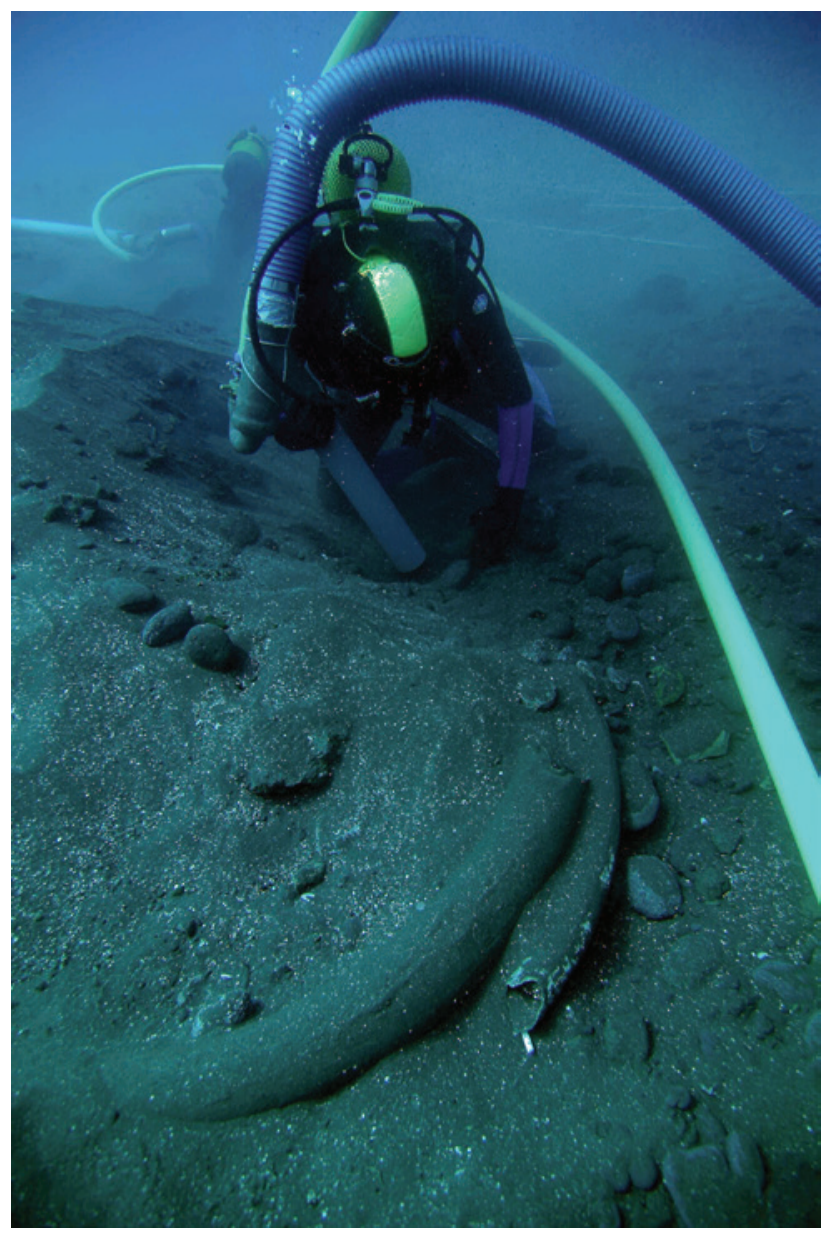

Figura 2 - Escavação arqueológica no sítio do BHo01. Autor: José Bettencourt. 


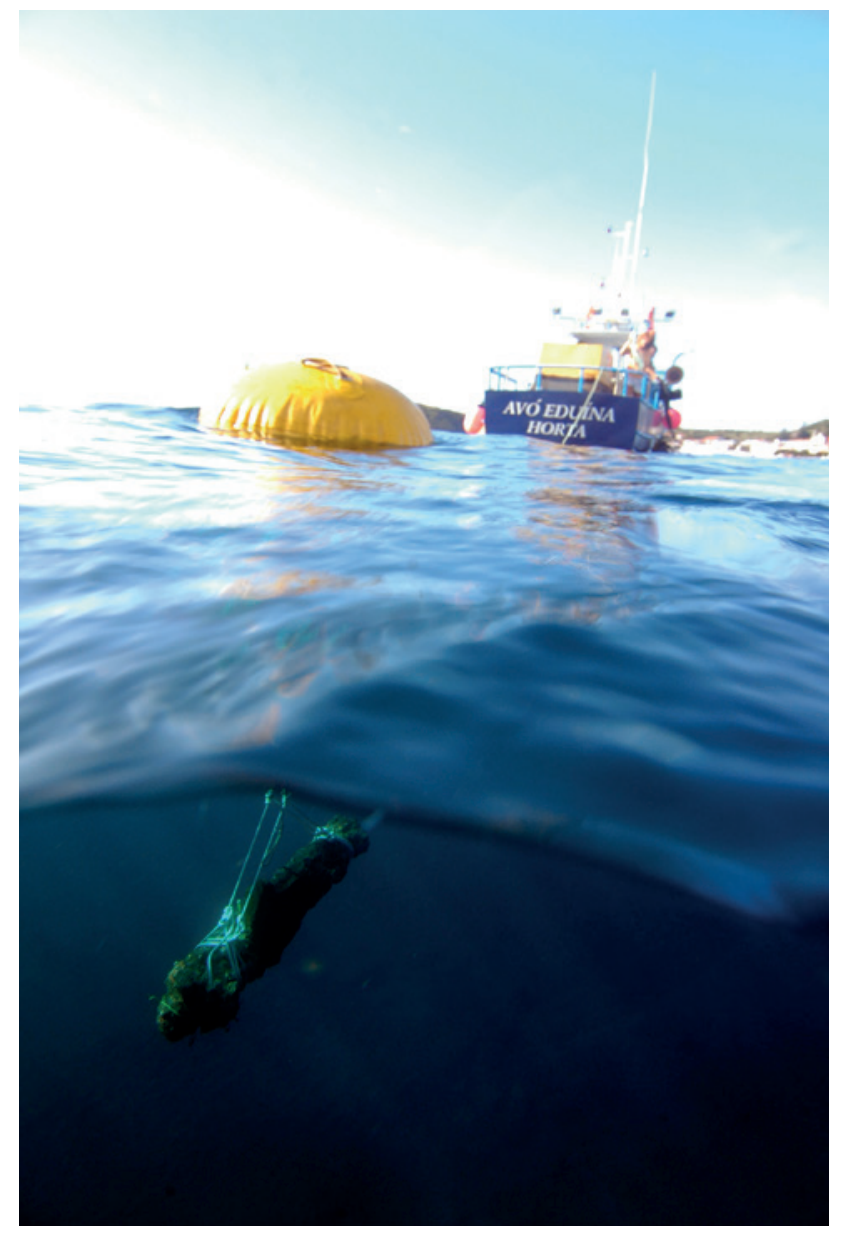

Figura 3 - Recuperação de peça de artilharia proveniente do sítio do BH-oo3. Autor: José Bettencourt.

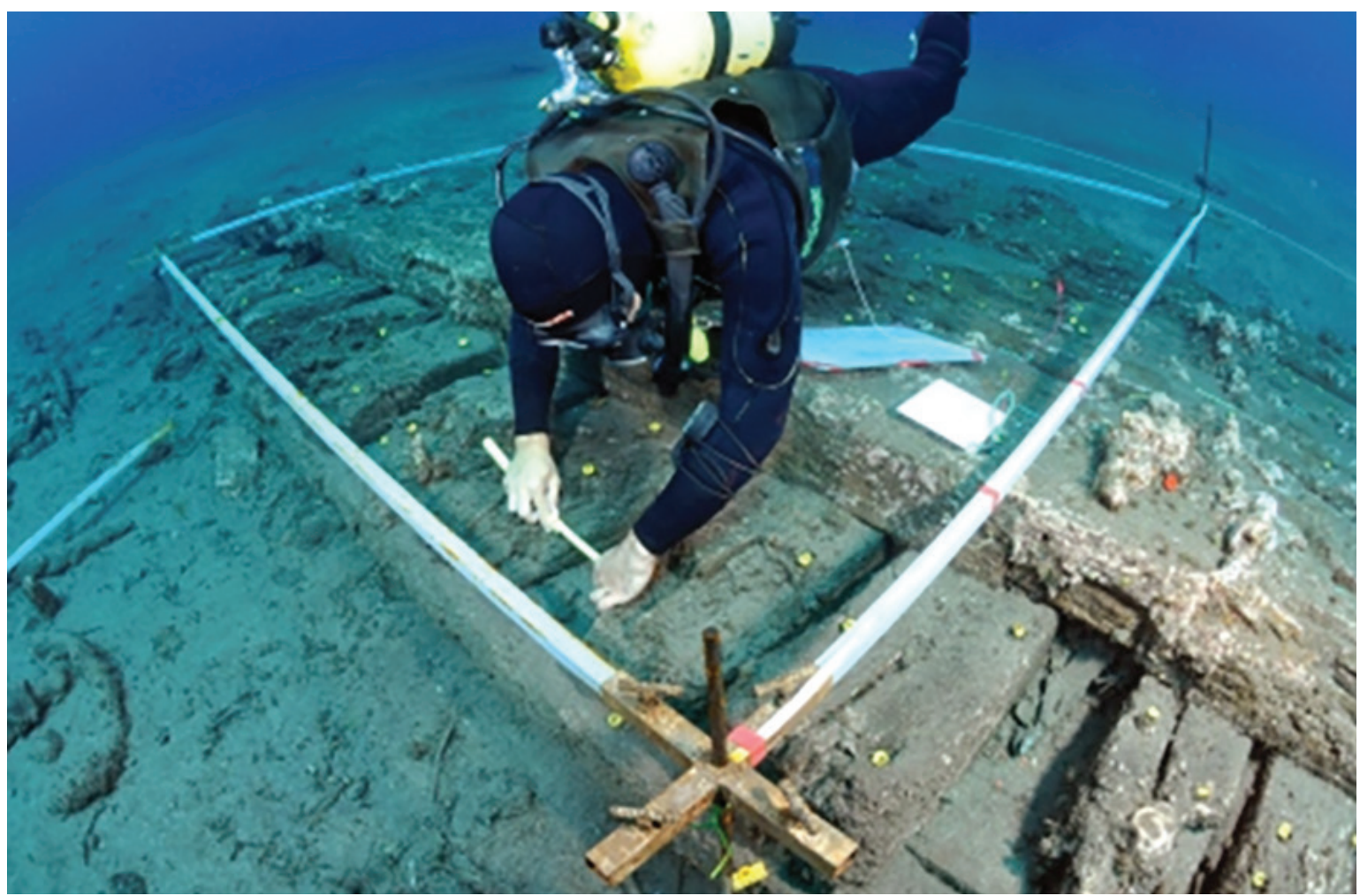

Figura 4-Trabalhos de registo arqueológico no sítio do BH-oo6. Autor: Friederike Kremer-Obrock 


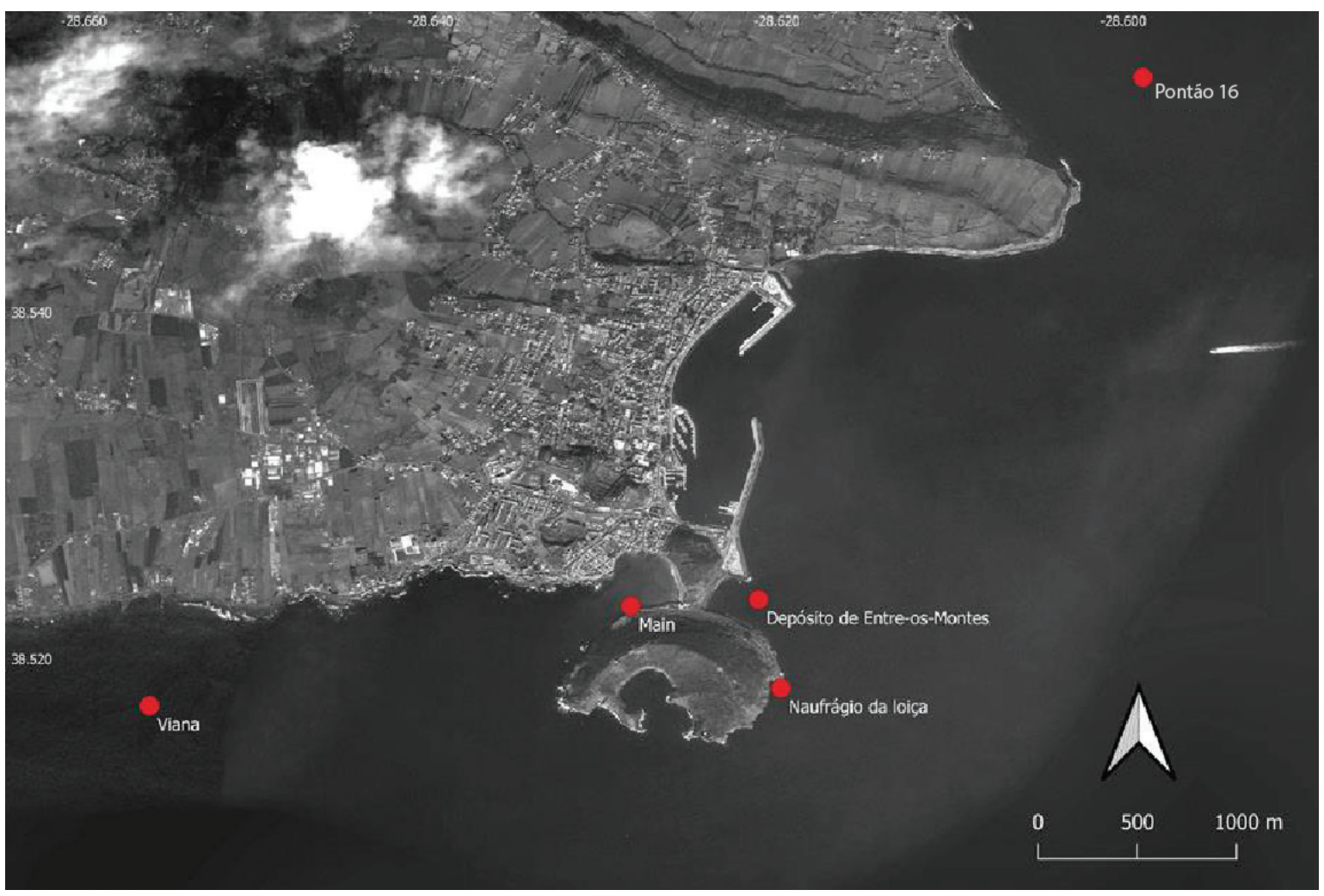

Figura 5 - Mapa da cidade da Horta com respetiva localização dos naufrágios visitáveis adjacentes. Autor: José Bettencourt.

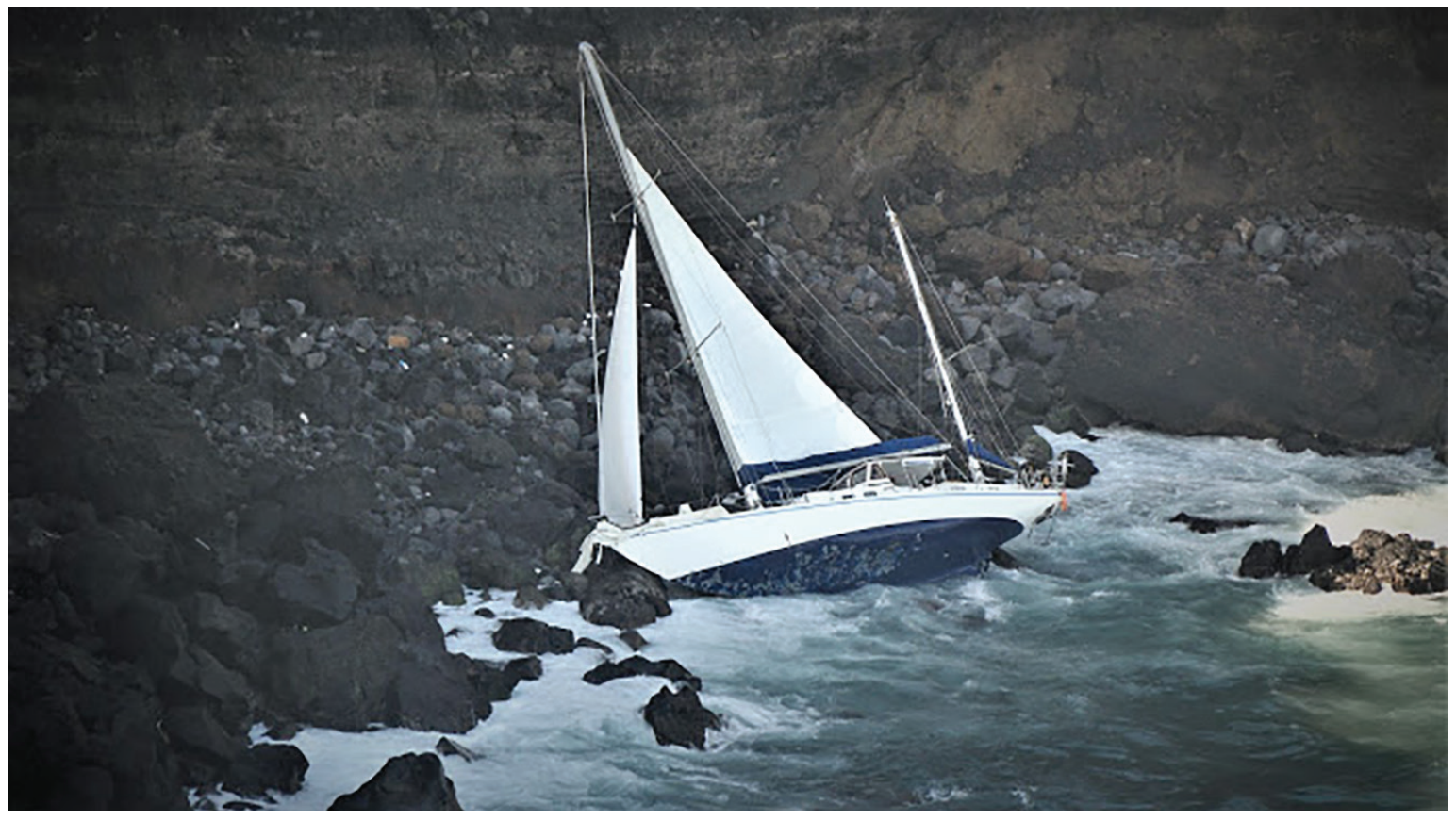

Figura 6 - Iate encalhado no lugar de Morro de Castelo Branco, Faial. Autor: Souto Gonçalves (imagem retirada do blog "Faial Global”). 


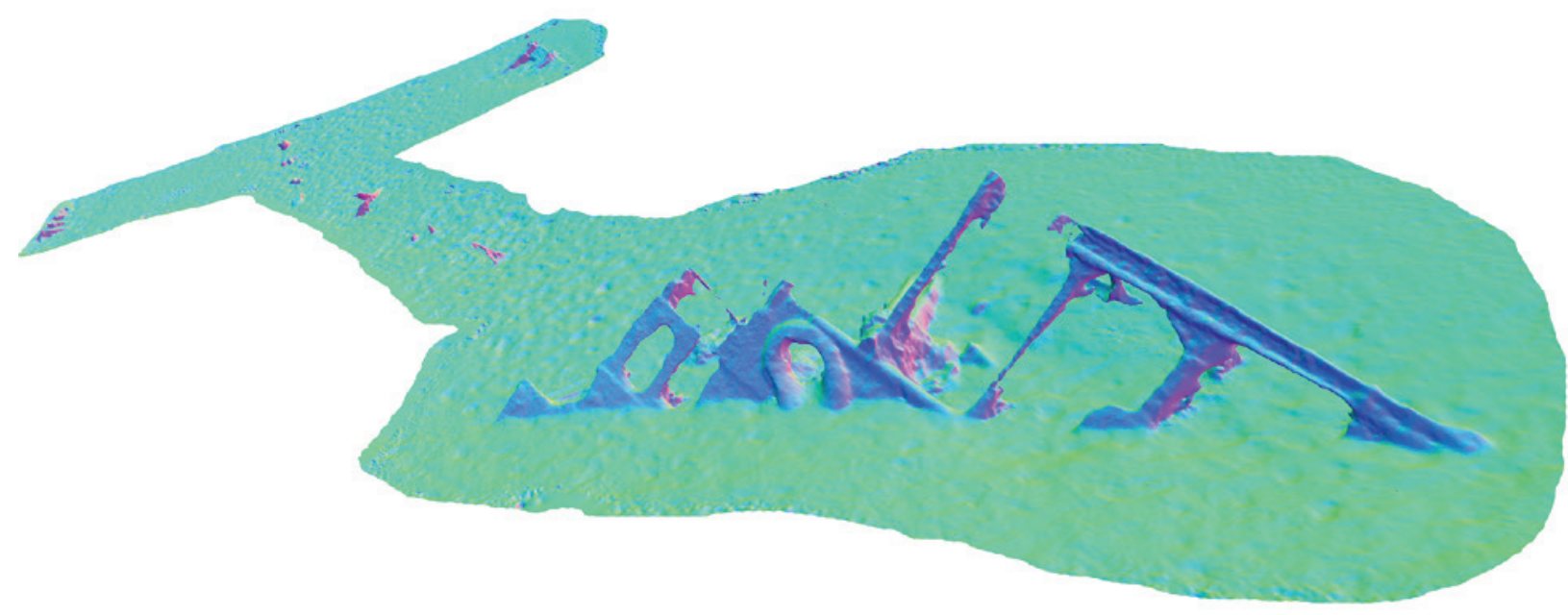

Figura 7 - Reconstituição 3D do sítio de naufrágio do Main. Autor: José Bettencourt. 


\title{
CARTA ARQUEOLÓGICA DA CIDADE VELHA: UMA PRIMEIRA ABORDAGEM
}

\author{
Jaylson Monteiro ${ }^{1}$, Nireide Tavares ${ }^{2}$, Sara da Veiga ${ }^{3}$, Claudino Ramos ${ }^{4}$, Edson Brito ${ }^{5}$, Carlos Carvalho ${ }^{6}$, \\ Francisco Moreira ${ }^{7}$, Adalberto Tavares ${ }^{8}$
}

\begin{abstract}
RESUMO
O conhecimento do património cultural sito numa determinada região, constitui um elemento basilar para o desenvolvimento de ações e estratégias eficazes para sua salvaguarda e gestão. O conjunto histórico da Cidade Velha, classificado como Património da Humanidade conserva ainda vestígios arqueológicos que, exigem a sua preservação. Neste sentido, apresenta-se uma primeira abordagem à Carta Arqueológica da Cidade Velha, com a identificação e o inventário de todos os vestígios localizados dentro da área protegida do sítio, que engloba o Vale da Ribeira Grande e o centro histórico, e representam sobretudo, as áreas primordialmente povoadas e a expansão urbana nos séculos XVI e XVII. Os vestígios identificados são autênticos testemunhos da diversidade cultural que caracteriza a trajetória histórica da Cidade Velha.

Palavras-Chave: Cidade Velha, Prospeção, Inventário, Carta arqueológica.
\end{abstract}

\begin{abstract}
The knowledge of cultural heritage in a specific region is a basic element for the development of actions and skills necessary to save and manage. The historic set of Cidade Velha, classified as a World Heritage Site, still preserves traces that allow its conservation. In this sense, a first approach to the Archaeological Map of Cidade Velha is presented, with the identification and inventory of all vestiges, within the protected area of the site, which encompasses the Ribeira Grande valley and the historic center, and represents mainly as primordial populated areas, and urban expansion in the $16^{\text {th }}$ and $17^{\text {th }}$ centuries. The vestiges identified are authentic testimonies of cultural diversity that characterize a historic trajectory of the Cidade Velha.
\end{abstract}

Keywords: Cidade Velha, Inventory, Prospecting, Archaeological maps.

\section{INTRODUÇÃO}

O projeto Carta Arqueológica da Cidade Velha, enquadra-se no Plano de Gestão da Cidade Velha Património Mundial horizonte 2019-2022, concretamente, dentro do Eixo Estratégico II - Desenvolvimento Urbano: Conservação e Valorização da Paisagem Urbana Histórica, cujo principal objetivo prende-se a uma nova abordagem da paisagem histórica e gestão urbana, ou seja, a preservação e a valorização do património da Cidade Velha, através da conciliação dos desafios da preservação e o desenvolvimento urbanístico, para dar respostas as aspirações das gerações presentes (residentes e visitantes) e futuras. O projeto foi financiado pelo Governo de Cabo Verde através do Gabinete do Ensino superior, Ciência e Tecnologia (GESCT) do Ministério da Educação, e constitui um contributo importante para o conhecimento, gestão e valorização do património arqueológico da Cidade Velha.

\footnotetext{
1. Instituto do Património Cultural; mjaylson95@gmail.com nireidapereira.cv@hotmail.com

3. Instituto do património Cultural; sashabj.21@gmail.com

4. Instituto do Património Cultural; claudio.ipc.gov@gmail.com

5. Instituto do Património Cultural; edson.brito@iipc.gov.cv

6. Instituto do Património Cultural; carlosiipc@yahoo.com.br

7. Instituto do Património Cultural; franciscolopesmoreira@gmail.com

8. Instituto do Património Cultural; Adalberto.Tavares@iipc.gov.cv
}

2. Bolseira de Doutoramento da FCT; UNIARQ - centro de arqueologia da universidade de Lisboa; Instituto do património Cultural; 


\section{CIDADE VELHA: BREVE ENQUADRA- MENTO GEOGRÁFICO E HISTÓRICO}

A Cidade de Ribeira Grande de Santiago popularmente conhecida por Cidade Velha, localiza-se no flanco sudoeste da ilha de Santiago (Figura 1), constitui um pequeno núcleo demográfico, o mais antigo de Cabo Verde, situado junto à costa, numa pequena baía e na foz da ribeira que lhe deu o nome. A cidade possui uma superfície estimada em $164 \mathrm{~km}^{2}$ distribuídos por duas freguesias: Santíssimo Nome de Jesus e São João Baptista.

Falar da história da Cidade Velha remete-nos para os primórdios da ocupação das ilhas do arquipélago de Cabo Verde, uma vez que, foi na cidade onde tudo começou. As ilhas foram descobertas por navegadores ao serviço da coroa portuguesa, a partir de 146o. Desabitadas na altura, a sua posição geográfica estratégica constituiu um fator decisivo para sua colonização. Assim, a partir de 1462 começaram-se a estabelecer as bases para o assentamento, primordialmente na região sul da ilha de Santiago (Ribeira Grande) que apresentava as condições mais favoráveis, sobretudo, a abundância de água, o que facilitava a prática da agricultura, tendo sido este motivo, determinante para escolha do sítio como centro do povoamento (PEREIRA, 2005, p. 32). Administrativamente a ilha de Santiago foi dividida em duas capitanias: a do Norte com sede em Alcatrazes, e a do Sul com sede na Ribeira Grande, doada a António da Noli em 1462. O povoamento desenrolou-se com alguns europeus estimulados pelos benefícios comerciais garantidos na Carta de Privilégios de 1466, e por escravos, provenientes da costa ocidental da África. A região serviu de laboratório onde se criavam e testavam espécies animais e agrícolas tanto da Europa como da África que foram introduzidas no continente americano, e vice-versa. A nível cultural, a sucessiva chegada de grupos humanos de diversas regiões e etnias na então vila de Ribeira Grande e a consequente necessidade de comunicação entre eles, contribuíram para o processo de crioulização da ilha de Santiago e para moldar os contornos do povoamento e colonização do arquipélago.

A vila de Ribeira Grande, precocemente transformou num dos principais portos de escala nas rotas atlânticas, facilitando a expansão colonial em direção à África, América e Índias, um importante interposto do comércio esclavagista, um ponto de reparação e reabastecimento de navios com manti- mentos frescos, o que resultou no grande progresso económico acompanhado das mudanças urbanas, sociais, e aumento do poder dos seus moradores. Em 1533, a vila tornou-se sede da primeira diocese da costa ocidental africana e foi elevada à categoria de cidade, tornando-se na primeira capital do arquipélago de Cabo Verde, e na primeira cidade fundada pelos europeus a sul de Saara (BRÁSIO, Vol II, $2^{\underline{a}}$ série p. 249-254) (Figura 2).

Recebeu muitos investimentos por parte da coroa portuguesa, fisicamente refletida na construção de vários edifícios de cariz militar, civil e religioso, que contribuíram para que houvesse uma morfologia e uma traça urbana relativamente bem definida. Todo este investimento, resultante da importância geoestratégica do arquipélago e sobretudo decorrente do tráfego de escravos, despertava muita cobiça por parte de piratas e corsários estrangeiros que por diversas vezes atacaram a região, e obrigou a organização de uma defensiva militar na cidade.

A partir do século XVII, com a perda da posição estratégica da Ribeira Grande, devido ao desvio das rotas do comércio dos escravos e a abertura dos portos da Guiné para o comércio aos estrangeiros, e o nível de insegurança que reinava na cidade, esta começou a entrar em declínio, e na segunda metade do séc. XVIII, concretamente em 1769, perde o estatuto de capital, que foi transferida para a vila da Praia. A cidade foi abandonada de forma progressiva entrando em ruína, posteriormente, reocupada por populações vindas do interior da ilha, com a construção de singelas habitações, caracterizadas pelo uso de alvenaria de pedra e reutilização de cantarias recolhidas nas ruínas dos monumentos, estes praticavam agricultura e pesca de subsistência.

Importante referir que a cidade foi um local de encontro de culturas que influenciaram fortemente na estruturação da identidade cultural do homem cabo-verdiano. Hoje, a Cidade Velha é um espaço de memória extremamente importante no contexto nacional, com vários testemunhos dos seus velhos tempos, e por excelência um lugar de voluptuosidade para todos os que visitam a ilha de Santiago.

\section{CLASSIFICAÇÃO DA CIDADE VELHA COMO PATRIMÓNIO DA HUMANIDADE}

Em 2009, o conjunto histórico da Cidade Velha foi classificado como Património Mundial resultante do grande esforço e amplo trabalho de salvaguarda 
realizado pelo Governo de Cabo Verde. A Unesco reconhecendo a integridade e autenticidade do sítio declara-o como Património Mundial baseado na confirmação de que os vestígios, os monumentos e as paisagens presentes ainda na Cidade Velha: são testemunhos do papel importante que esta paragem outrora representou, e da organização das primeiras trocas marítimas intercontinentais (Critério II); testemunhos das origens e o desenvolvimento do tráfico atlântico, sendo um local importante para a sua organização comercial e experiência precoce de valorização esclavagista de um território colonial (Critério III); a Cidade Velha como um local de encontro de culturas africanas e europeias, dando origem à primeira cultura crioula, e lugar de partida para sua difusão em diferentes contextos coloniais das Caraíbas e das Américas - a cidade como um ponto decisivo de reunião de um património imaterial compartilhado entre África, Américas, e Europa (Critério VI) ${ }^{9}$. A Unesco reconheceu a importância histórica da Cidade Velha, mas, chamou atenção para a sua fragilidade, e principalmente, para a necessidade de uma política contínua de salvaguarda do sítio histórico.

\section{ARQUEOLOGIA NA CIDADE VELHA}

A segunda metade do séc. XX marca o início das intervenções a nível patrimonial na Cidade Velha, com o registo das primeiras ações de salvaguarda dos monumentos do sítio. Dispostas cronologicamente e de uma forma sucinta, as intervenções arqueológicas na cidade são as que se seguem:

- Escavações arqueológicas na Sé Catedral, nos finais da década de 80 e inícios de 9o, sob a coordenação do arqueólogo Clementino Amaro (IPPAR) em colaboração com arqueólogos cabo-verdianos (ÉVORA, 2015 p. 22). Estes realizaram escavação no interior da Sé, com a recuperação da planta original do edifício, e diversas tipologias de cultura material (AMARO, 1995, p. 85-87; FREIRE, 1993, p. 65-73).

- Nos finais da década de 90 houve outra campanha de escavação arqueológica na Sé Catedral, dirigidas por Ana Carvalho Dias, enquadrada noutro projeto arquitetónico, também desenvolvido pelo IPPAR e coordenado por Alexandre Braz Mimoso.

9. Cidade Velha, Historic Centre of Ribeira Grande (Site da Unesco: http://whc.unesco.org/en/list/1310).
- No mesmo período, nasceu um projeto de salvaguarda do património histórico e arqueológico de Cidade Velha, entre a Agencia Espanhola de Cooperación Internacional (AECID) e o Ministério da Cultura de Cabo Verde. Dentro do projeto foram realizadas escavações na Fortaleza Real de São Filipe e no Convento de S. Francisco, dirigidos por Jorge Juan Silva Ares e Yasmina Cáceres. Nestes, identificaram muitos artefactos arqueológicos de diversas cronologias, tipologias e proveniências que são testemunhos da relação a vários níveis que Cabo Verde, no caso específico, a Cidade Velha mantinha com diversas áreas do globo.

- Nos inícios dos anos 200o, através do projeto internacional do Fórum UNESCO: "Universidade e Património: O itinerário dos Jesuítas pelas Ilhas Atlânticas" surge um projeto de recuperação do espaço do Colégio dos Jesuítas na Cidade Velha, tendo como Investigador responsável Konstantin Richter. Os trabalhos de recuperação do Colégio dos Jesuítas incluíam também a recuperação da Igreja de Nossa Senhora da Conceição, datada do séc. XV. Em 2004/2005, deu-se o início da primeira fase do projeto de escavação na igreja de Nossa Senhora da Conceição, Convento de Jesuítas e Hospital/ Igreja de Misericórdia, estas coordenadas por arqueólogos da universidade de Cambridge em parceria com o Instituto do Património Cultural, Universidade Jean Piaget de Cabo Verde e a Câmara Municipal da Ribeira Grande de Santiago. Os trabalhos tiveram continuidade nos anos seguintes, sobretudo, na igreja de Nossa Senhora da Conceição, mas também, prospeções que facultaram novos dados a nível arqueológico.

- Em 2015, o forte e a ermida de Santo António, foram alvos de intervenções arqueológicas e consolidações das ruínas. Os trabalhos foram realizados pela Escola $\mathrm{Al}$ - Sud (Mértola - Portugal), coordenados pelo arqueólogo Virgílio Lopes, auxiliado por alunos da referida escola e trabalhadores locais em parceria com o Instituto do Património Cultural e a Câmara Municipal de Ribeira Grande de Santiago.

- Recentemente (2018-2020), enquadrados no projeto Concha "The construction of early modern global Cities and oceanic networks in the Atlantic: An approach via Ocean's Cultural 
Heritage”, foram realizadas escavações arqueológicas sob a coordenação de André Teixeira, num contexto habitacional no final da rua Banana - bairro de São Pedro. E, incluídos nos trabalhos de reabilitação arquitetónica da igreja Nossa Senhora do Rosário, decorreram escavações arqueológicas, que culminaram com a redescoberta da segunda capela lateral da igreja, que se encontrava ocultada por escombros caídos da encosta;

- Os trabalhos de acompanhamento arqueológico das obras de reabilitação arquitetónica estiveram sob a responsabilidade dos técnicos do Instituto do Património Cultural.

De uma forma geral, os trabalhos arqueológicos na Cidade Velha, decorreram nos principais monumentos e muitos deles em função de programas de restauros arquitetónicos (Figura 4).

\section{CARTA ARQUEOLÓGICA DA CIDADE VELHA}

A carta arqueológica assume-se como um inventário georreferenciado de sítios com interesse arqueológico e patrimonial, em permanente atualização. Tendo em consideração a necessidade da salvaguarda dos bens localizados na cidade, assume-se como condição fundamental para sua concretização, o conhecimento de todos os vestígios através da investigação histórica, arqueológica de terreno. Assim, revelou-se imprescindível um inventário onde constem a localização de todos os vestígios arqueológicos, independentemente da sua categoria ou cronologia. Para o caso, foi pensada numa carta arqueológica adaptada à Cidade Velha, tendo em consideração, algumas das suas particularidades: cidade classificada como Património Mundial, onde vivem pessoas, com diferentes níveis e intensidades de ocupação, os desafios de gestão do sítio histórico, e as ameaças a que os vestígios estão expostos. Portanto, constituíram objetivos deste trabalho a identificação e reunião num único suporte, dos vestígios dentro do grande sítio arqueológico que é a Cidade Velha, realçando assim o seu potencial arqueológico e patrimonial, a elaboração de um documento que garanta a salvaguarda, a valorização e consequentemente a divulgação do seu legado histórico e patrimonial.

\section{METODOLOGIAS UTILIZADAS}

Um conjunto de metodologias foram utilizadas para a realização da Carta Arqueológica: previamente pesquisas documentais, seguidas da reunião e processamento dos dados recolhidos nas fontes bibliográficas. Tendo em conta, a extensão geográfica da cidade de Ribeira Grande, assumimos como área prioritária para a execução desta primeira fase da carta arqueológica: a Zona Protegida do Sítio Histórico Património Mundial (Figura 5).

Nesta primeira abordagem deu-se uma certa prioridade à revisão de sítios já conhecidos através das bibliografias, mas também, a identificação de vestígios inéditos.

Para o registo dos sítios, foram elaboradas fichas de inventário que comportam a conjugação de diferentes dados relativos aos mesmos: referências bibliográficas, informações recolhidas oralmente, conjugadas com os dados recolhidos no campo (ex: localização por coordenadas, documentação fotográfica geral e detalhada, descrição do acesso e do meio, acessibilidade, descrição física, materiais arqueológicos, etc.). A combinação destes dados, por sua vez, foi importante para avaliar diferentes aspetos fundamentais como: o marco crono-cultural, a periodização histórica, a funcionalidade, o estado de conservação, a avaliação de risco, e determinar precauções e medidas necessárias para a salvaguarda do vestígio inventariado.

A nível dos trabalhos de terreno, várias saídas de campo com a identificação e o inventário dos sítios, através do programa collector for Arcgis. Todas as informações recolhidas foram armazenadas e analisadas dentro de um Sistema de Informação Geográfica (com recurso ao programa ArcGis).

\section{LEITURA DOS DADOS OBTIDOS}

Da agregação dos dados recolhidos relativamente aos sítios inventariados, há uma demonstração prévia e clara da significativa ocupação do território, sobretudo do centro histórico. Baseados na realidade presente e dos sítios identificados, pode-se adiantar que o número dos sítios e vestígios de interesse arqueológico tende a aumentar, uma vez alargada a área de prospeção dentro da cidade de Ribeira Grande de Santiago (Figura 6).

Todos os sítios identificados encontram-se dentro da área protegida do sítio histórico, exceto dois que 
se inserem na zona tampão, estes, devido à sua contiguidade com a zona protegida foram incluídos no inventário.No total foram identificados 58 registos de inventário, sendo:

-48 Sítios arqueológicos;

- 10 trincheiras com vestígios identificados no subsolo de algumas ruas do centro histórico (tomando cada uma um registo de inventário). Dos sítios identificados 41 são conhecidos pela bibliografia e 17 são inéditos, estes localizam-se em todos os bairros e zonas integrantes da área protegida do sítio histórico, o que remete para uma ocupação alargada na cidade, embora, com maiores registos nalguns bairros em detrimento de outros. Nota-se uma maior concentração dos sítios no centro histórico à volta do porto, indicando uma intensidade de ocupação nessa área, uma vez que, a cidade esteve profundamente conectada e dependente durante muito tempo do seu porto para a sua subsistência e desenvolvimento, principalmente, por causa das atividades comerciais que ali desenrolavam. Estamos, portanto, perante uma cidade que se desenvolveu ao redor e a partir do seu porto, e isso reflete na localização dos vestígios inventariados, algo que também é confirmado pela diminuição e dispersão dos vestígios, à medida que se entra pela ribeira adentro.

Algumas ruas localizadas no centro histórico foram incluídas no inventário, por terem sido identificados vestígios arqueológicos móveis e imóveis no subsolo (trincheiras), vestígios estes registados no decorrer de intervenções arqueológicas e outros trabalhos, em que foi fundamental o acompanhamento técnico a nível de arqueologia. Da análise de todos os casos dos vestígios no subsolo, pode se concluir de uma forma geral, que os níveis primordiais de ocupação da cidade (Séculos XV, XVI, XVII) estão abaixo do nível atual, devido principalmente, às mudanças ambientais decorridas ao longo dos tempos.

\section{TIPOLOGIA}

Diversas foram as tipologias construtivas dos vestígios inventariados, o que vem ao encontro dos dados alusivos na documentação escrita e a dinâmica da cidade ao longo do tempo, o que exigia diferentes estruturas e infraestruturas para encaixar na organização urbana, auxiliando no seu bom funcionamento (Figura 7 ).

Os vestígios inventariados inserem em sete categorias tipológicas, com destaque para as estruturas religiosas e militares. Fazem parte dos edifícios religiosos: igrejas, capelas, ermidas, convento, catedral, seminário e palácio episcopal. O elevado número de estruturas religiosas em comparação a pequena urbe, deve-se a importância que a cidade detinha: como escala essencial nas rotas de expansão marítima pelo atlântico, um dos pontos chaves no tráfego de escravos, e, como sede do bispado da costa ocidental africana. Os edifícios militares refletem o grande desenvolvimento que a Cidade de Ribeira Grande teve por volta dos Séculos XVI e XVII, que a tornou alvo de muita cobiça, por parte de estrangeiros, sendo, por diversas vezes atacada por piratas e corsários. Perante esta situação, foi organizada uma defensiva militar na cidade, sobretudo, no Período Filipino (1580-1640), com a construção de vários aparelhos defensivos, constituindo o maior e mais eficiente sistema defensivo do arquipélago na altura. Para a implantação dos edifícios militares escolheram-se locais estratégicos, e uso de materiais e técnicas construtivas de excelentes qualidades. No inventário, encontram também inseridos estruturas residenciais, equipamentos $\mathrm{e}$ infraestruturas, estrutura comercial e judicial/prisional, embora, em menores quantidades. Não foi possível atribuir uma categoria tipológica específica a 15 registos, que, correspondem essencialmente a muros e vestígios de construções antigas, em ruínas, ao ponto de não serem categorizados a priori.

\section{ESTADO DE CONSERVAÇÃO}

Os sítios arqueológicos da Cidade Velha, apresentam uma certa fragilidade, por um lado pela sua cronologia, e por outro, pelas constantes ameaças naturais e humanas a que estão expostos. Desse modo, constitui um elemento importante na gestão do conjunto, o controle, a manutenção, a salvaguarda e a divulgação dos mesmos. Regista-se no geral, uma grande quantidade de sítios em mau estado de conservação, o que constitui um alerta para a salvaguarda e gestão do conjunto histórico. As ameaças que causam a deterioração e condicionam a preservação dos sítios identificados, estão relacionadas com o ambiente natural (erosão solar, marinha, eólica, a aridez do clima) e por ações humanas (lixo/ depósitos, vandalismo, atividades agrícolas e criação de animais dentro ou nas imediações dos vestígios, desrespeito pelos monumentos, etc.).

Reconhece-se que é preciso um grande trabalho de sensibilização patrimonial, através, da transmissão 
dos conhecimentos sobre o património em apreço. A carta arqueológica é importante neste processo, por constituir uma síntese do património da cidade, indicando especificamente para cada vestígio inventariado as ameaças, precauções e medidas de melhoramento a serem tomadas (Figura 8).

\section{CRONOLOGIA}

Desconhece-se a maior parte da classificação cronológica dos vestígios inventariados. Os vestígios identificados ao qual pode-se aferir uma cronologia, inserem-se entre os finais do século XV e século XVIII. Destes, destaque para os vestígios do século XVI, com maiores números de registo, que correspondem também ao período de maior desenvolvimento da cidade e do seu espaço urbano (Figura 9).

\section{1. ÁREAS DE RISCO / ÁREAS DE SENSIBILIDADE ARQUEOLÓGICA}

Após a identificação dos vestígios na área protegida do sítio histórico Património Mundial, revelou-se necessário a definição de diferentes graus de riscos e ou sensibilidades arqueológicas num contexto mais alargado dentro da cidade, como forma a acautelar possíveis impactos sobre os vestígios.

A carta de risco constitui um documento que regista a delimitação de zonas submetidas a um determinado tipo de risco, no caso específico, riscos sobre os vestígios históricos e arqueológicos frente a um determinado tipo de ocupação, podendo ser ela urbana, rural, agrícola, etc., como o caso da Cidade Velha. A carta considera e classifica os diferentes graus de riscos, com a determinação de medidas e precauções a serem efetuadas a fim de salvaguardar os vestígios. O conhecimento e análise dos riscos e perigos a que os vestígios estão expostos auxiliam na prevenção, permitem que as precauções e decisões sejam tomadas com bases em informações seguras, e, caso surjam intempéries uma boa gestão dos riscos proporciona a tomada de resoluções eficazes para minimizar os impactos (Figura 10).

Como referido, a determinação dos graus de riscos e ou sensibilidades arqueológicas, abrangeram um contexto mais amplo dentro da urbe, incluindo a zona protegida do sítio histórico e grande parte da sua zona de Tampão. Foram definidos previamente, cinco graus de riscos desde Muito elevada a Muito reduzida, em função dos vestígios já identificados e da potencialidade de identificação de novos vestígios em diferentes áreas. As áreas com maior potencialidade, localizam-se essencialmente no centro histórico e na extensão da ribeira.

De uma forma geral, em todas as áreas mencionadas há que se ter algumas precauções devido a probabilidade da existência de vestígios importantes para a compreensão de aspetos identitários do país, ainda que essa probabilidade seja maior numas zonas em detrimento de outras.

\section{CONSIDERAÇÕES}

Os bens patrimoniais são considerados essenciais por serem testemunhos e memórias da história e da identidade, e estes em especial, por se localizarem na Cidade Velha, berço da nação cabo-verdiana, classificada como Património Mundial, onde é essencial a salvaguarda do seu valor universal excecional.

Tem-se criado e executado algumas medidas e soluções para a preservação do centro histórico, aliás, uma das advertências da Unesco, encarando particularmente, a Cidade Velha como um grande sítio histórico-arqueológico com diversos vestígios que necessitam de ser identificados e conhecidos. Nesta perspetiva, pensou-se na materialização de um instrumento de gestão dos vestígios muito importante, que fazia falta num centro histórico classificado como Património Mundial, e era inconcebível a sua inexistência: a carta arqueológica.

Sobre o projeto "Carta arqueológica da Cidade Velha", dos trabalhos realizados e dados recolhidos, apesar do pouco tempo e de algumas limitações que caracterizaram alguns momentos da sua execução, são sobretudo reveladores do potencial arqueológico da região. Este potencial, constitui por si só um forte motivo para a continuação do projeto, incluindo outras vertentes investigativas, para além, do alargamento das áreas de prospeção à área de tampão do sítio histórico, por exemplo, a realização de sondagens e escavações arqueológicas em sítios potenciais, o planeamento de melhores estratégias de gestão dos vestígios.

Dito isto, os resultados desta primeira fase são considerados satisfatórios, principalmente, pela oportunidade de georreferenciar, caracterizar, identificar os sítios, as ameaças a que estão sujeitos e indicar medidas de conservação eficientes e alargadas. Com estes dados identificados, agora será possível de uma forma mais fácil e abrangente planear programas e 
medidas de atuação nos vestígios identificados, de forma a materializar a política contínua de salvaguarda exigida pela Unesco.

\section{BIBLIOGRAFIA}

ALBURQUERQUE, L. de; SANTOS, M. E. M. (Eds.) (1991) - História Geral de Cabo Verde. Vol. I. Lisboa e Praia: Instituto de Investigação Científica Tropical e Direção Geral do Patrimônio Cultural de Cabo Verde, 478 p.

ALBURQUERQUE, L. de; SANTOS, M. E. M. (Eds.) (1995) - História Geral de Cabo Verde. Vol. II. Lisboa e Praia: Centro de Estudos de História e Cartografia Antiga, Instituto de Investigação Científica Tropical e Instituto Nacional da Cultura de Cabo Verde, 596 p.

AMARAL, I. do. (1964) - Santiago de Cabo Verde: a terra e os homens. Lisboa: Memórias da Junta de investigação do ultramar, $\mathrm{n}^{-0} 482^{2}$ série, (1964), 444 p.

AMARO, C. (2012) - Sé da Cidade Velha, República de Cabo Verde, Resultados da $1^{\underline{a}}$ fase de campanhas arqueológicas. Velhos e Novos Mundos: Estudos da Arqueologia Moderna, Vol. I. p. 451-464.

ARES, J.; CÁCERES, Y. (200o) - Restabelecimento do passado: I. Investigações arqueológicas na Real Fortaleza de São Filipe. In: Cabo Verde, fortaleza, gentes e paisagem, ed. Bilingue Agencia Espanhola Cooperação Internacional, pp. $133-163$.

ARES, J.; CÁCERES, Y. (2002) - A história de Cabo Verde através dos seus monumentos emblemáticos. A escavação do Convento de S. Francisco - Cidade Velha, Cabo Verde. IV Colóquio Internacional de estudos sobre África e Ásia. Elche, Alicante: Instituto de cultura Juan Gil-albert, Diputación Provincial de Alicante, concejalia de cultura de Elche, pp. 209-229.

ARES, J.; CÁCERES, Y. (2005) - Una Fortaleza Filipina en las islas de Cabo Verde. La Fortaleza Real de San Filipe en Ribeira Grande. II Congresso Internacional de castellología Ibérica, 8-11 de Novembro de 2001. Alcala de la Selva (Turuel). Diputación de Turuel, Madrid, pp. 765-778.

BARCELLOS, C. J. de S. (1899) - Subsídios para a História de Cabo Verde e Guiné. Tomo I, partes I e II. Lisboa, Typographia da Academia Real das Sciencias.

BRÁsIO, A. (1960) - Monumentos sacros de Santiago. In Boletim de Propaganda e Informação: Ano XI, n. ${ }^{\circ} 130$ (Julho de 1960), pp. 28-31.

BRÁSIO, A. (1963) - Monumenta Missionária Africana. África Ocidental (1500 -1569). 2픈 Série, Vol. II. Lisboa: Agência Geral do Ultramar, $581 \mathrm{p}$.

CARREIRA, A. (1985) - Notícia corográfica e chronológica do bispado de Cabo Verde desde seu princípio até ao estado presente, com um catálogo dos excelentíssimos Bispos, governadores e ouvidores e os seus sucessos mais memoráveis e verí- dicos, tirados de livros e papéis antigos. E assim mais algumas insinuações dos meios mais conducentes para o restabelecimento dele, por se achar na última decadência composta pela infatigável diligência de um amante da pátria e leal vassalo de sua majestade fidelíssima 1784. Apresentação, notas e comentários por António Carreira. Lisboa: Instituto Caboverdiano do Livro, $116 \mathrm{p}$.

DIAS, A. C. (200o) - Relatório da intervenção arqueológica na Sé da Cidade Velha Cabo Verde - Outubro/Novembro de 1999, 98 p.

EVANS, C.; SORENSEN. M. L. S.; HILL, J.; RICHTER, K. (2006) - Cidade Velha, Cape Verde, Archaeological Excavations: The 2006 Season. Unpublished archive report: University of Cambridge, $37 \mathrm{p}$.

EVANS, C.; SORENSEN, M. L. S.; HILL, J.; RICHTER, K. (2007) - Cidade Velha, Cape Verde, Archaeological Excavations: The 2007 Season. Unpublished archive report: University of Cambridge, $70 \mathrm{p}$.

EVANS, C. (2009) - Cidade Velha, Cape Verde - Archaeological Fieldwork. Cambridge Archaeological Unit/University of Cambridge, $7 \mathrm{p}$.

EVANS, C.; SORENSEN, M. L. (2010) - Cidade Velha, Cape Verde, Archaeological Fieldwork Dec.2009-Feb. 2010. Dept. of Archaeology/University of Cambridge, [S/p].

EVANS, C.; SORENSEN, M. L. S.; NEWMAN, R.; CASIMIRO, T. (2014) - Cidade Velha, Cape Verde 2014 - Church Excavations. University of Cambridge, 21p.

ÉVORA, J. S. (2015) - O Futuro da Arqueologia em Cabo Verde \& Outras reflexões sobre a história e o Património das ilhas. Praia: Arquivo Nacional de Cabo Verde.

FREIRE, V. dos. R. (1993) - A experiência Cabo Verdiana, no domínio do património. Africana. Porto, Universidade Portucalense, $\mathrm{n}^{\circ}$ Especial, 1993, p. 65-73.

PEREIRA, D. A. (1988) - Marcos Cronológicos da Cidade Velha. Praia: Instituto Caboverdiano do Livro - Estudos e Ensaios, $152 \mathrm{p}$.

PEREIRA, D. A. (2005) - Estudos da História de Cabo Verde. Praia: Alfa comunicações, $2^{\underline{a}}$ ed. (revista e aumentada) Junho de 2005, 366 p.

PIRES, F. de, J. M. dos, R. (2004) - Da cidade de Ribeira Grande à Cidade Velha em Cabo Verde Análise Histórico-Formal do Espaço Urbano Séc. XV-Séc. XVIII. Praia. Câmara Municipal da Praia, 221 p.

TAVARES, N. P. (2017) - Inventário arqueológico de Cabo Verde contributo para uma ferramenta de gestão e valorização do património cultural. Dissertação de mestrado em Arqueologia apresentada a Faculdade de Letras da Universidade de Lisboa, Vol. I 161p; VOL. II. 97 p. 


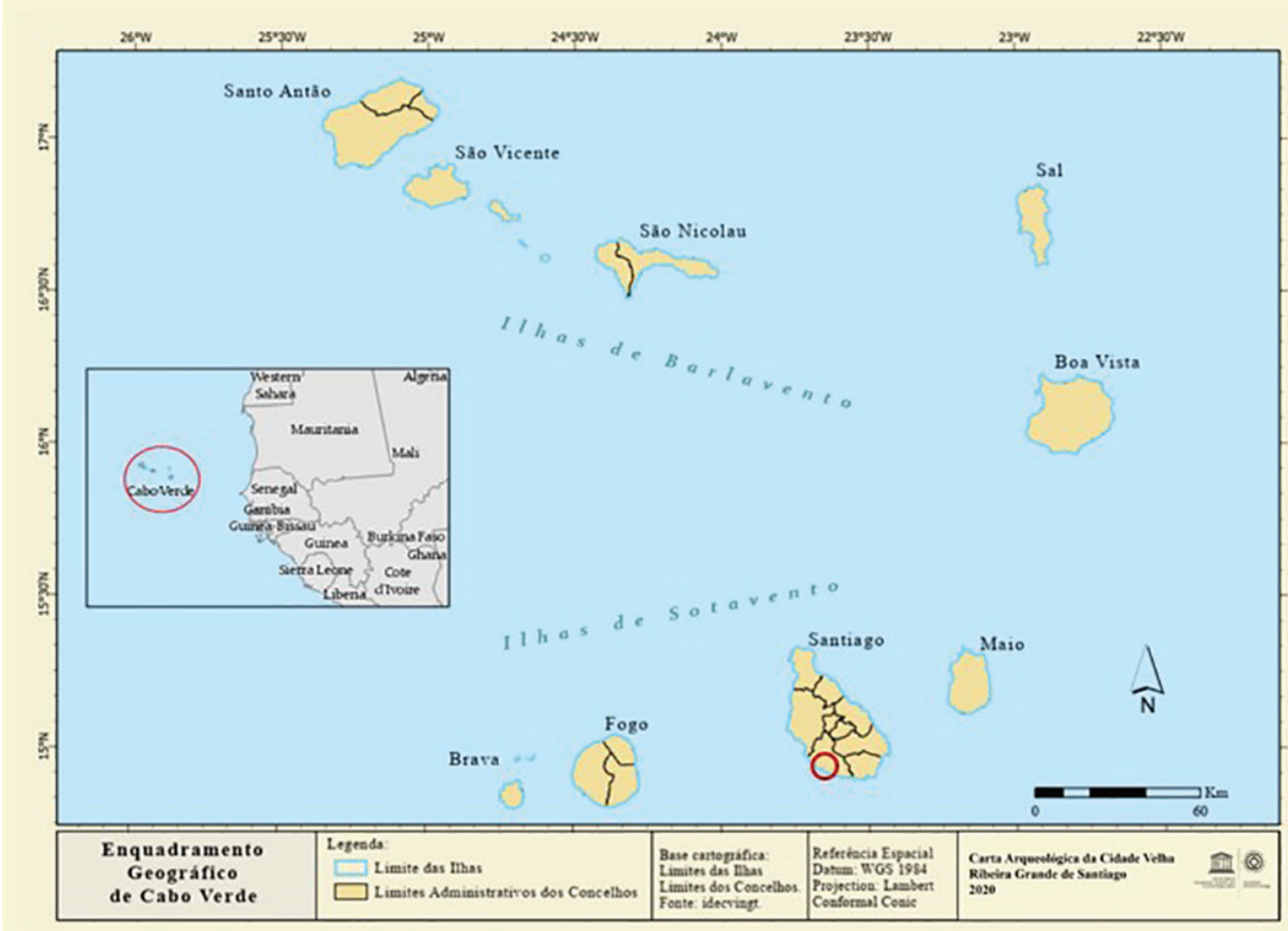

Figura 1 - Enquadramento Geográfico do arquipélago de Cabo Verde e da Cidade Velha (Fonte: representação cartográfica realizada no âmbito do projeto “Carta arqueológica da Cidade Velha”).

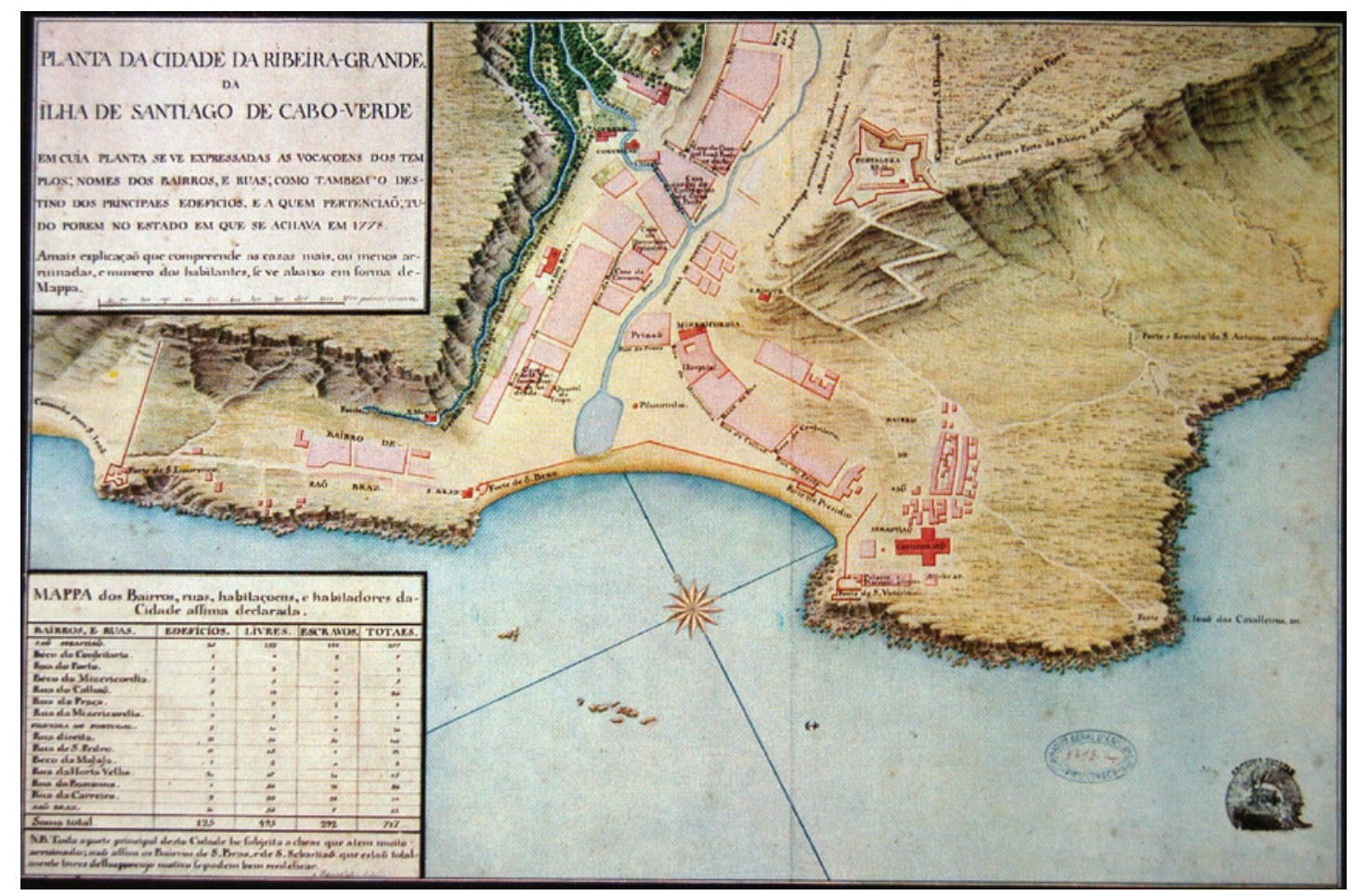

Figura 2 - Planta da Cidade da Ribeira Grande da ilha de Santiago de Cabo Verde” António Andréis Ca. 1778, AHU. 


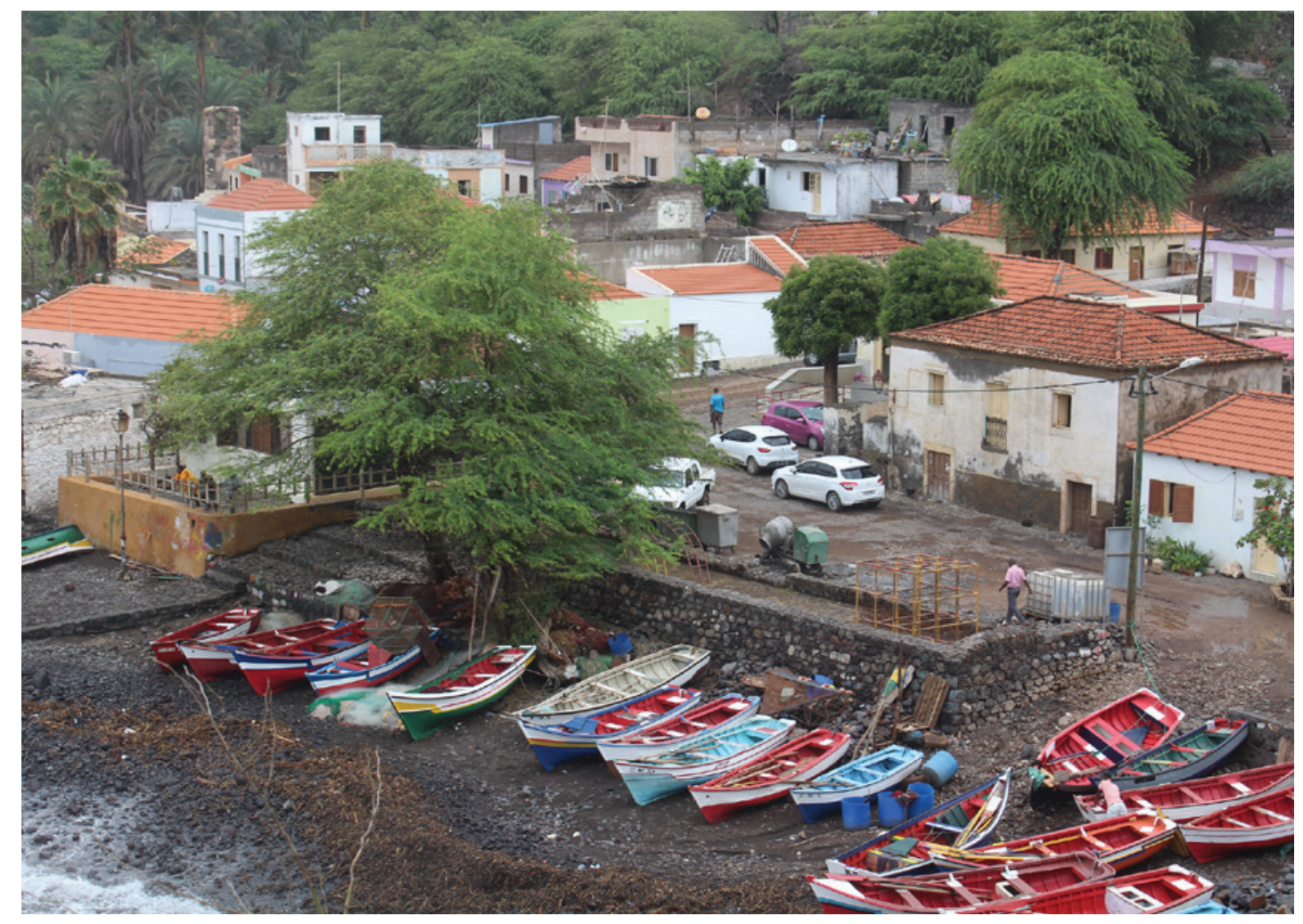

Figura 3 - Vista da Cidade Velha (Fotografia: IPC, 2019).

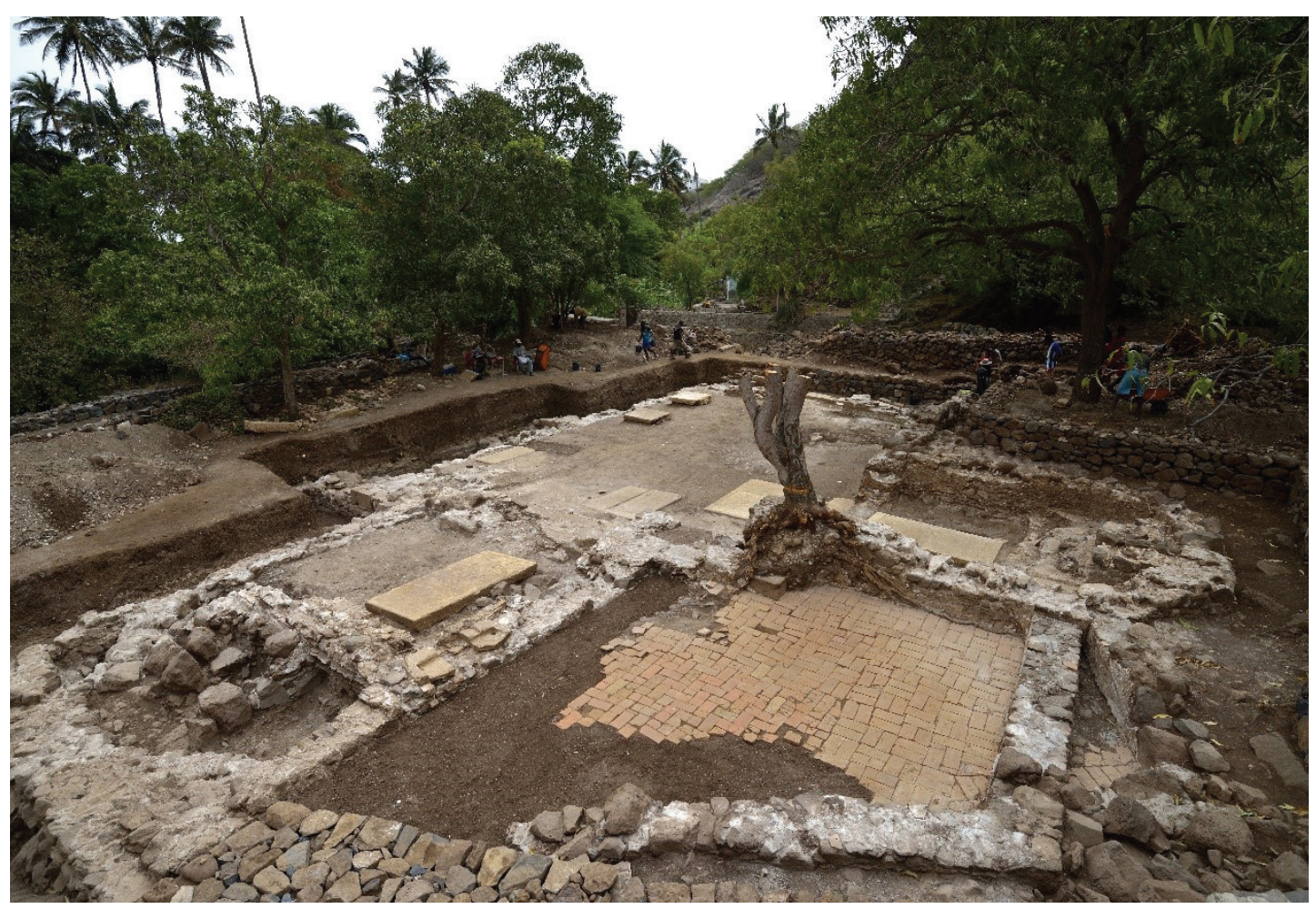

Figura 4 - Escavação arqueológica da Igreja de N. S. da Conceição Séc. XV (Fotografia: IPC, 2015). 


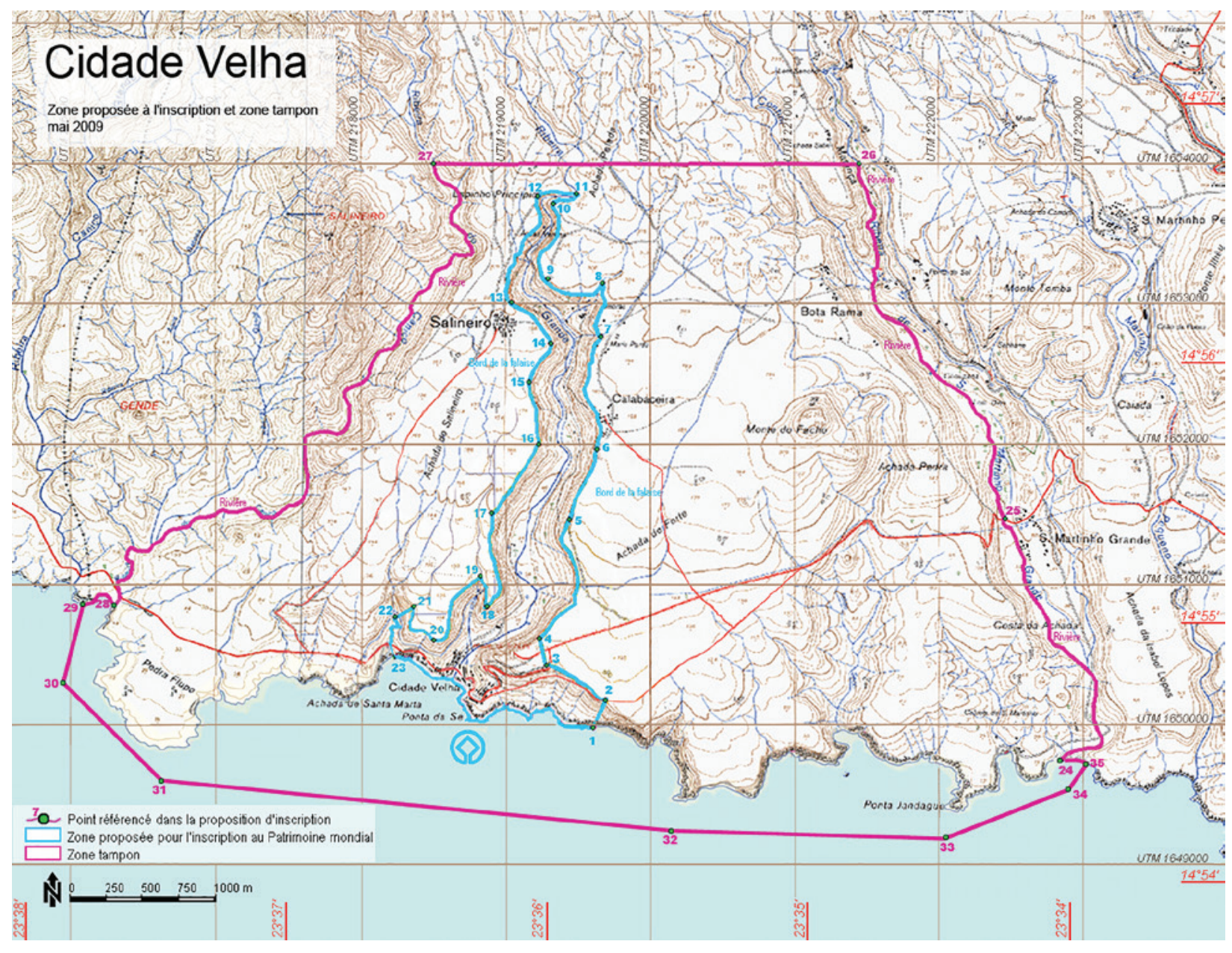

Figura 5-Áreas classificadas - Cidade Velha Património Mundial. 


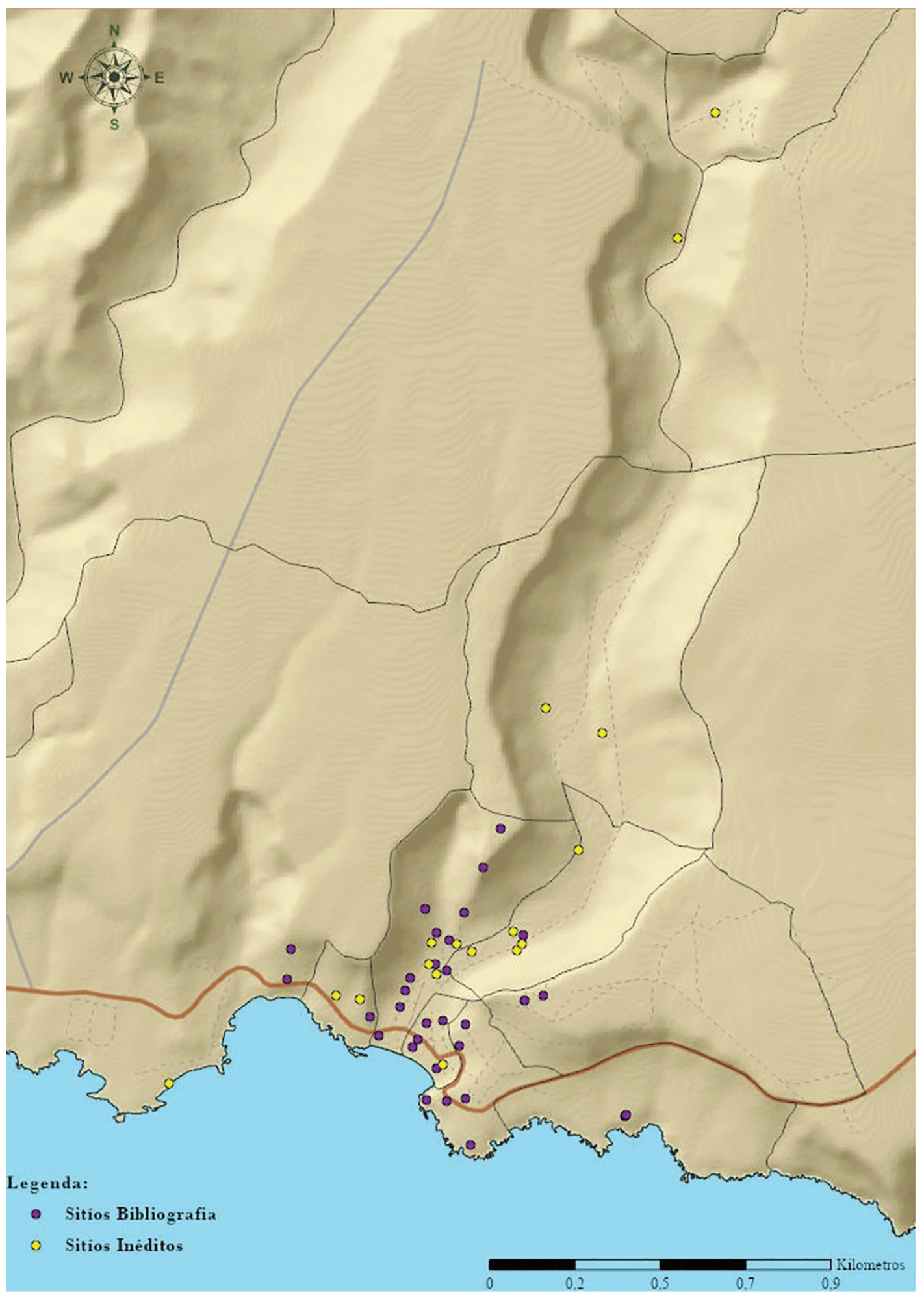

Figura 6 - Sítios arqueológicos conhecidos pela Bibliografia e inéditos da Cidade Velha (Fonte: Representação Cartográfica realizada no âmbito do projeto Carta Arqueológica da Cidade Velha). 


\section{Tipologias}

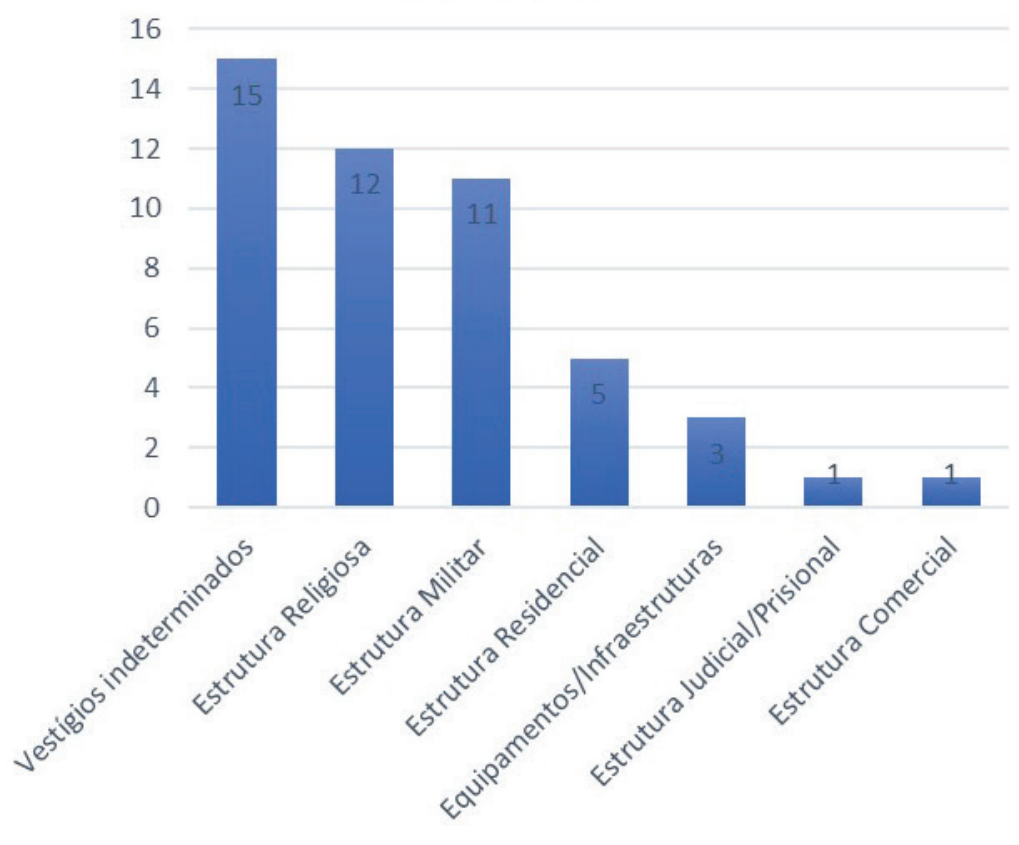

Figura 7 - Tipologias dos vestígios inventariados.

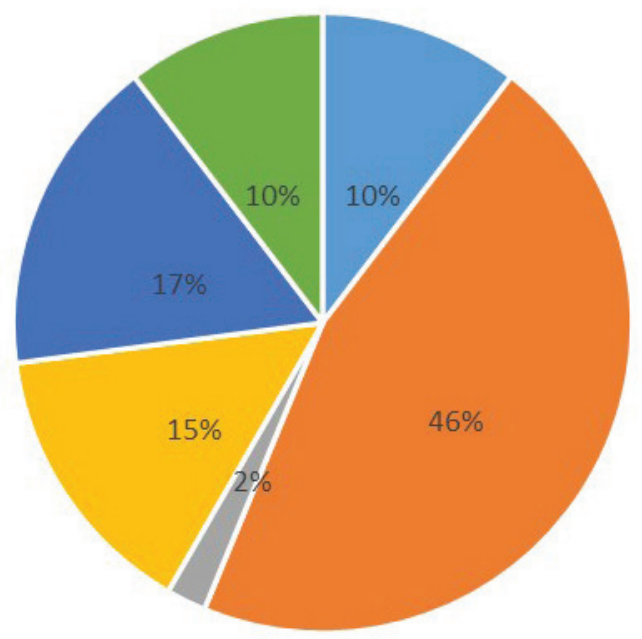

- Bom - Mau = Obra = Rázoavel - Ruínas/Indeterminado = Subterrado

Figura 8 - Estado de conservação dos vestígios inventariados. 


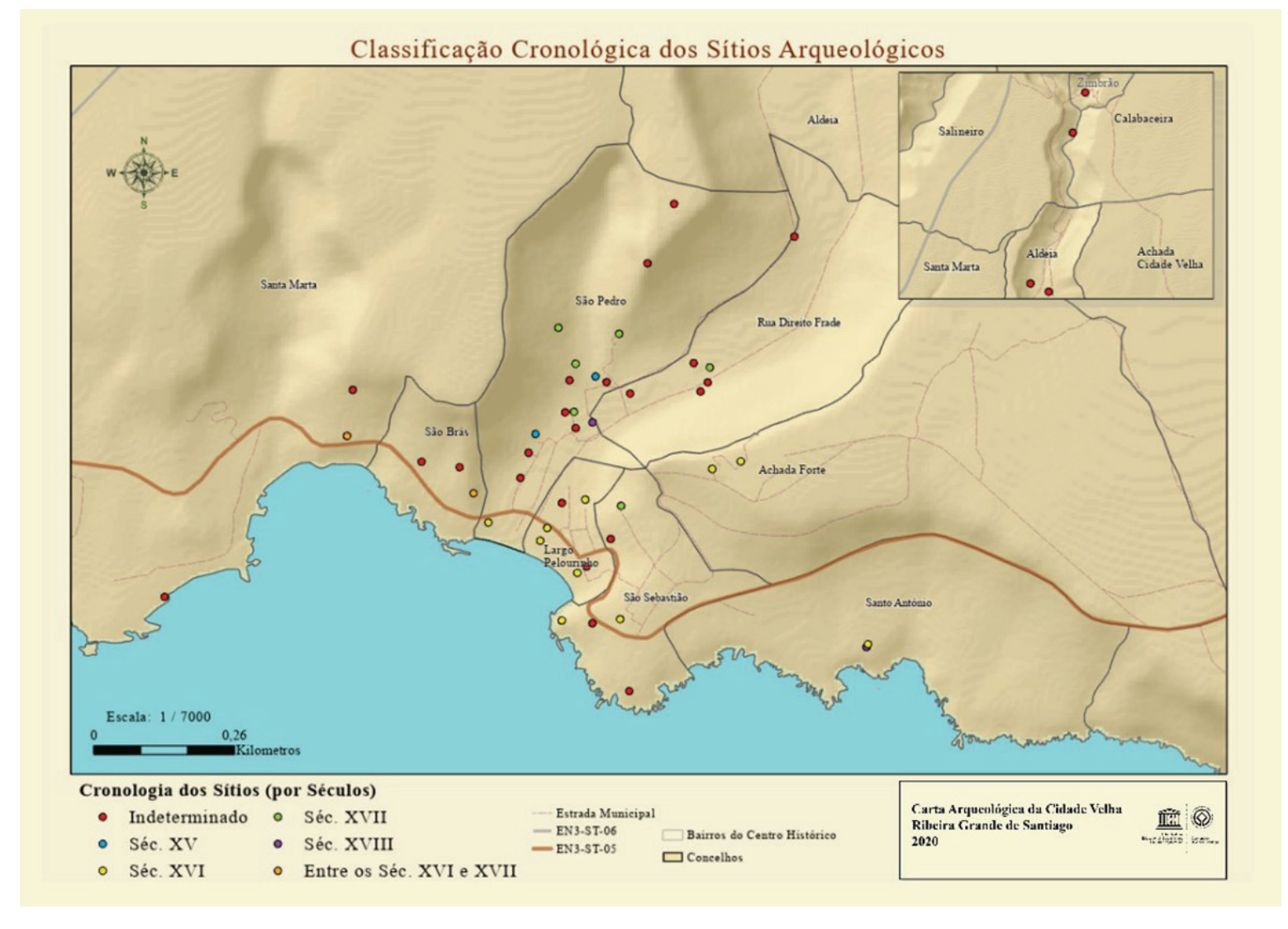

Figura 9 - Cronologias dos sítios (Fonte: Representação Cartográfica realizada no âmbito do projeto Carta Arqueológica da Cidade Velha). 


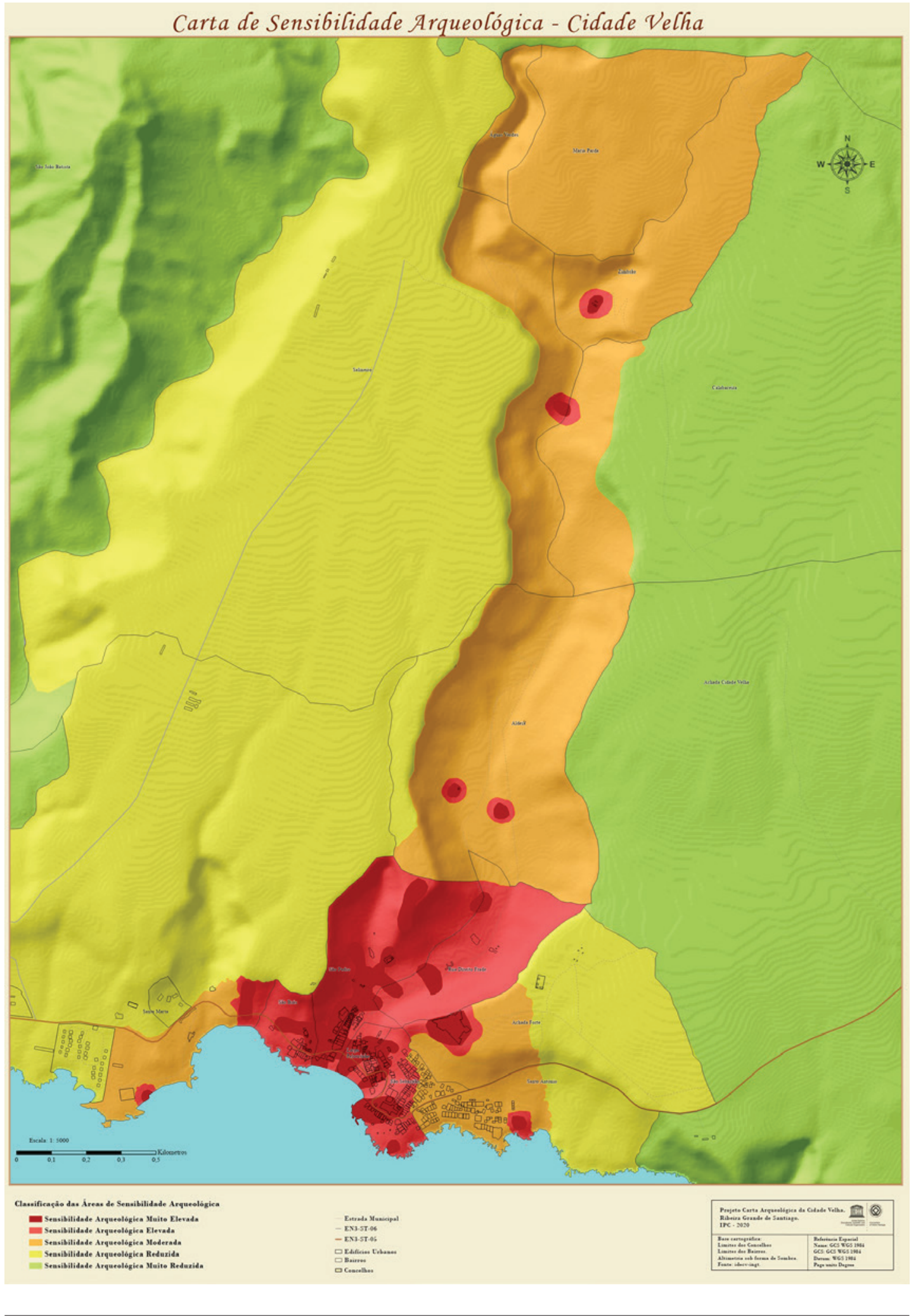

Figura 10 - Áreas de risco ou áreas de sensibilidade arqueológica - Cidade Velha. 


\title{
ANTROPOLOGIA VIRTUAL: NOVAS METODOLOGIAS PARA A ANÁLISE MORFOLÓGICA E FUNCIONAL
}

\author{
Ricardo Miguel Godinho' ${ }^{1}$, Célia Gonçalves ${ }^{2}$
}

\begin{abstract}
RESUMO
A Bioantropologia examina frequentemente a morfologia óssea para inferir diversos aspectos do comportamento funerário e da paleobiologia de populações humanas passadas. A análise morfológica métrica (morfometria) convencional utiliza tipicamente medidas lineares, rácios e ângulos, contudo estas medidas não permitem a visualização das diferenças morfológicas em análise nem prever o desempenho mecânico dos ossos (que pode induzir diferenças morfológicas entre populações com diferentes hábitos). A Antropologia Virtual, combinando várias técnicas que se desenvolveram com a evolução tecnológica das últimas décadas, permite novas abordagens para a análise e compreensão das populações em estudo. Neste trabalho apresentamos uma breve síntese das técnicas mais importantes assimiladas pela Antropologia Virtual e de como esta pode melhorar a compreensão das populações em estudo.

Palavras-chave: Digitalização, Morfometria Geométrica, Arqueologia, Forma e função, Análise de Elementos Finitos.
\end{abstract}

\begin{abstract}
Bioanthropology examines skeletal morphology to infer diverse aspects of the funerary behaviour and palaeobiology of past populations. Conventional morphological metric (morphometrics) analysis has typically used linear measurements, ratios and angles. Yet, such quantifications do not allow visualization of the morphological differences nor prediction of the mechanical performance of bones (which may induce morphological differences between populations with diverse behaviours). Virtual Anthropology, which musters several techniques deriving from the exponential technological development of the past decades, provides new approaches to the analysis and understanding of the examined populations. Here, we summarize the techniques used in Virtual Anthropology and how this discipline may augment our understanding of the populations under study.
\end{abstract}

Keywords: Digitization, Geometric Morphometrics, Archaeology, Form-function, Finite Element Analysis.

\section{INTRODUÇÃO}

A Antropologia Biológica (Bioantropologia, também conhecida como Antropologia Física) estuda a dimensão biológica do Homem de uma perspectiva evolutiva e/ou bio-cultural (Jurmain, Kilgore \& Trevathan 2010). Neste contexto, o estudo morfológico de esqueletos humanos é fundamental para o conhecimento de populações passadas. A bioantropologia tem, assim, focado aspectos como a com- posição demográfica de populações (Chamberlain 2006; Bocquet-Appel \& Bar-Yosef 2008), comportamentos funerários (Valera et alii 2010; Filipe et alii 2013; Godinho, Gonçalves \& Valera 2019; Evangelista \& Godinho 2020), afinidades biológicas entre diferentes grupos (Scott \& Irish 2017; Delgado et alii 2019), padrões de actividade física (Ruff, Holt \& Trinkaus 2006; Henderson et alii 2016), adaptação mecânica do crânio à dieta (Carlson 1976; Carlson \& Van Gerven 1977), e aspectos paleopatológicos

1. ICArEHB, Universidade do Algarve; ricardomiguelgodinho@gmail.com

2. ICArEHB, Universidade do Algarve; cmgoncalves@ualg.pt 
(Ortner 2003; Rodríguez-Martín 2006; Waldron 2009). Para avaliar estes aspectos tem tipicamente analisado a morfologia esquelética usando frequentemente craveiras, tábuas osteométricas e fitas métricas (entre outros instrumentos). Embora estas abordagens mais convencionais sejam fundamentais para o conhecimento de populações passadas, o desenvolvimento tecnológico das últimas décadas possibilita a utilização de diversas técnicas que permitem a digitalização de espécimes (Weber \& Bookstein 2011; Katz \& Friess 2014; Errickson 2017), a sua reconstrução virtual (Benazzi et alii 2011; Benazzi et alii 2014; Amano et alii 2015; Godinho \& O’Higgins 2017; Godinho, O’Higgins \& Gonçalves 2020), a sua análise morfológica computadorizada (von Cramon-Taubadel 2011; Godinho et alii 2019; Godinho, Umbelino \& Gonçalves em preparação), e a realização de simulações mecânicas que permitem compreender a relação entre a forma e a função mecânica óssea (Godinho et alii 2017; Godinho et alii 2018; Godinho \& O’Higgins 2018; Godinho, Spikins \& O’Higgins 2018). Estas técnicas têm vindo a ser utilizadas na Antropologia Virtual, e outras áreas análogas, para realizar múltiplos estudos que de outra forma não seriam possíveis (O'Higgins et alii 2011; Weber \& Bookstein 2011; O'Higgins et alii 2012; Weber 2015; O’Higgins, Fitton \& Godinho 2019). Nas próximas secções sintetizamos algumas das técnicas utilizadas na Antropologia Virtual e como esta pode ser usada para oferecer novos dados sobre populações passadas.

\section{DIGITALIZAÇÃO}

A Antropologia Virtual utiliza tipicamente digitalizações dos espécimes físicos nas suas análises. O processo de digitalização pode ser realizado de diversas formas, incluindo digitalizações de superfície (através de fotogrametria, scanners a laser, scanners de luz estruturada) ou a Tomografia Axial Computadorizada (TAC; Weber \& Bookstein 2011; Katz \& Friess 2014; Errickson 2017). As digitalizações de superfície (Figura 1A e 1B) permitem a visualização e subsequente análise da superfície externa dos espécimes (ver abaixo Quantificação de forma). Embora este tipo de digitalização seja suficiente na maioria dos estudos, em que a análise foca a superfície exterior dos ossos, não permite visualizar e, consequentemente, analisar estruturas internas como, por exemplo, os seios paranasais do crânio ou os dife- rentes tecidos dentários (Weber \& Bookstein 2011). Para este efeito é necessário digitalizar os espécimes através de TAC (Figura ${ }_{1} C$ ) ou micro-TAC ( $\mu$ TAC). Estas técnicas permitem visualizar detalhadamente tanto a superfície quanto o interior dos espécimes (Figura 1D e 1E), embora com diferentes graus de resolução. A TAC também permite digitalizar vários espécimes (ou fragmentos de espécimes) ao mesmo tempo, sendo, assim, mais rápida que as digitalizações de superfície.

Este processo de digitalização de espécimes é fundamental porque:

i. diminui a necessidade de manuseamento directo dos espécimes, contribuindo assim para a sua preservação (Betts et alii 2011; Errickson 2017).

ii. salvaguarda os espécimes (pelo menos a sua informação morfológica, de acordo com a tecnologia utilizada) de eventuais desastres como aquele ocorrido no Museu Nacional do Brasil. Neste incêndio foi irremediavelmente destruído um inestimável acervo de $\sim 20$ milhões de espécimes (Cunha 2018; Kury, Giupponi \& Mendes 2018; França 2019; Silva 2019), incluindo o crânio de Luzia ( 1300o BP).

iii. permite análises subsequentes que de outra forma não seriam possíveis (ver secções seguintes).

\section{RECONSTRUÇÃO DE ESPÉCIMES FRAGMENTADOS E/OU INCOMPLETOS}

Os espécimes fósseis/arqueológicos estão frequentemente fragmentados e/ou incompletos (Gunz et alii 2009; Arbour \& Brown 2014; O’Higgins et alii 2019; Godinho, O’Higgins \& Gonçalves 2020). Este estado de conservação resulta frequentemente em amostras reduzidas e, subsequentemente, em resultados pouco fiáveis devido à reduzida representatividade das amostras utilizadas (Cardini \& Elton 2007; Brown \& Vavrek 2015; Cardini, Seetah \& Barker 2015). Para ultrapassar este problema a reconstrução física era frequente no passado (Weidenreich 1937; Leakey 1959; Tobias 1967; Tattersall \& Sawyer 1996), contudo esta abordagem apresenta problemas para a conservação dos espécimes, sendo o caso do crânio Neandertal de Le Moustier 1 um exemplo paradigmático de um espécime que foi progressivamente destruído devido ao seu repetido manuseamento e reconstrução física (Weber \& Bookstein 2011). Para além disso, a reconstrução física é fundamentalmente baseada na perícia individual do investigador e 
apresenta, assim, limitações na sua fiabilidade e replicabilidade (Gunz et alii 2009).

Actualmente, as técnicas da Antropologia Virtual permitem reconstruções que utilizam recursos computacionais, geométricos e estatísticos que são, assim, mais fiáveis e replicáveis (Weber \& Bookstein 2011; Weber 2015). Utilizando esses recursos é possível realizar "colagens virtuais" (Figura 2A e 2B) sem ser necessário aplicar forças físicas nos fragmentos (que podem causar mais fragmentação) nem utilizar colas ou consolidantes. É também possível explorar a simetria bilateral de diversas estruturas ósseas (e.g., crânios e mandíbulas) que mantenham um dos lados preservados (Gunz et alii 2009). Nestes casos reflecte-se o lado preservado para o lado fragmentado ou incompleto. Pode também utilizar-se a morfologia existente para estimar geometricamente a localização das regiões inexistentes utilizando "grelhas de transformação" (denominadas de Thin Plate Splines, TPS; Gunz et alii, 2009; Neeser et alii, 2009; Senck et alii, 2015; Godinho et alli, 2020). Nestes casos utiliza-se uma forma completa como referência e utilizam-se pontos anatómicos homólogos comuns para estimar a localização dos pontos anatómicos ausentes na forma alvo (Figura $2 \mathrm{C}$ ). Esta abordagem tem a vantagem de poder usar apenas um espécime como referência, mas também vários espécimes a partir dos quais é calculada uma média que é usada como referência (Gunz et alii 2009; Neeser, Ackermann \& Gain 2009; Godinho et alii 2020). Por fim, pode usar-se a regressão multivariada para se explorar a covariação estatística entre pontos anatómicos e assim utilizar a morfologia existente para estimar a morfologia inexistente (Gunz et alii 2009; Neeser et alii 2009; Arbour \& Brown 2014). Embora esta abordagem estatística possa proporcionar melhores resultados que a abordagem geométrica (isto é, a TPS) requer amostras de referência muito grandes e que são frequentemente inexistentes (como é comum em populações arqueológicas).

\section{QUANTIFICAÇÃO DE FORMA}

No contexto da Antrologia Biológica, a forma tem sido tipicamente quantificada através de medidas lineares (comprimentos, larguras, perímetros, ...). Estas medidas fornecem dados importantes para a análise morfológica e consequentemente continuam a ser usadas na Antropologia Virtual para analisar estruturas que não estariam facilmente disponíveis sem o recurso a, por exemplo, TAC e $\mu \mathrm{TAC}$. Estas tecnologias permitem expor, seccionar e analisar virtualmente estruturas internas, como os diferentes tecidos dentários (García-Campos et alii 2018; Godinho et alii 2019) e os seios paranasais cranianos (Rae, Koppe \& Stringer 2011; Godinho \& O’Higgins 2018; Buck et alii 2019), sem destruição dos espécimes. Porém, resultam fundamentalmente na análise do tamanho e não necessariamente da geometria esquelética (Adams, Rohlf \& Slice 2004; Slice 2005). Para esse efeito, têm-se utilizado rácios (por exemplo, o índice facial em que se dividem a largura e altura faciais) ou ângulos (por exemplo, o ângulo da base do crânio; Slice, 2005). Estas diferentes quantificações podem ser combinadas na análise multivariada da forma, contudo apresentam limitações estatísticas e não permitem a visualização das diferenças morfológicas em análise (Adams et alii 2004; Slice 2005). Em oposição à morfometria convencional, a Morfometria Geométrica (GM), uma das técnicas usadas na Antropologia Virtual, utiliza conjuntos de coordenadas (com duas ou três dimensões) de pontos anatómicos de espécimes (e.g., crânios ou mandíbulas; Figura $3 \mathrm{~A}$ ) para capturar a forma dos espécimes de interesse. Estes pontos devem ser homólogos (biologicamente "equivalentes") e relevantes para a questão que se pretende responder (O’Higgins 200o). A forma, da perspectiva da sua análise estatística, é composta por tamanho e geometria (Dryden \& Mardia 1998). A última (geometria) pode ser definida como as características morfológicas que são independentes do tamanho, localização e orientação (Zelditch et alii 2012). Após a recolha das coordenadas o primeiro passo da GM consiste na sobreposição das configurações de coordenadas utilizando o método da Análise Generalizada de Procrustes (GPA - Generalized Procrustes Analysis). Este método redimensiona os conjuntos de coordenadas removendo o tamanho (isométrico). Realiza também a sua translação e rotação (minimizando as distâncias entre os conjuntos de coordenadas) para remover o efeito da localização e orientação (Figura 3 B). As coordenadas originais são, assim, convertidas em variáveis geométricas que são subsequentemente utilizadas na análise morfológica através da estatística multivariada (Zelditch et alii 2012). Tipicamente, a GM utiliza a Análise de Componentes Principais (PCA) para reduzir dimensionalidade e avaliar a relação entre os diferentes espécimes. Esta abordagem é frequentemente com- 
binada com a utilização de grelhas de transformação para visualizar as diferenças morfológicas entre os diferentes espécimes (Figura ${ }_{3} \mathrm{C}$ ) e tem sido aplicada para examinar, por exemplo, diferenças morfológicas inter e intra-específicas (Delson et alii 2001; Bastir, O’Higgins \& Rosas 2007) e diferenças nos padrões de crescimento e desenvolvimento (Cobb \& O'Higgins 2007; Mitteroecker \& Bookstein 2009; Zollikofer \& Ponce de León 2010; Freidline, Gunz \& Hublin 2015). A regressão multivariada é também utilizada para examinar a relação entre variáveis de interesse, como por exemplo a relação entre tamanho e forma (Gonzalez, Perez \& Bernal 2011; Freidline et alii 2012; Freidline et alii 2015). A regressão por mínimos quadrados parciais (PLS - Partial Least Squares) também tem sido utilizada, por exemplo, para avaliar a relevância de aspectos biomecânicos e ecológicos (Noback, Harvati \& Spoor 2011; Noback \& Harvati 2015).

\section{ANÁLISE FUNCIONAL}

Uma das principais funções do esqueleto é converter as forças musculares em movimento e resistir às forças a que o corpo é permanentemente sujeito (Marieb 1992; Larsen 2002; Kerr 2010). Estas forças deformam os ossos (a uma escala micro-métrica), sendo estas deformações percepcionadas pelos ossos e desencadeando um processo de adaptação óssea que pode causar mudanças na morfologia óssea (Currey 2006; Cowin \& Doty 2007; Ethier \& Simmons 2007; Katz 2008). A Bioantropologia tem, assim, examinado a relação entre forma esquelética e função mecânica uma vez que diferenças na função mecânica óssea podem reflectir-se na morfologia (Ruff et alii 2006). Para esse efeito diversos investigadores têm usado a morfometria convencional e a GM para examinar, por exemplo, como diferenças na dieta se reflectem na morfologia craniana e mandibular (Carlson 1976; Carlson \& Van Gerven 1977; von Cramon-Taubadel 2011; Galland et alii 2016; Katz, Grote \& Weaver 2017), e como diferenças na mobilidade se reflectem na forma femoral (Püschel \& Benítez 2014). Tem-se também utilizado a morfologia seccional para examinar a relação entre morfologia mandibular e estratégia de subsistência/ dieta (May et alii 2018; Toro-Ibacache et alii 2019), e morfologia dos ossos dos membros inferiores e padrões de mobilidade (Ruff et alii 2015). Mais recentemente, com o desenvolvimento da imagiologia e da capacidade computacional, tem-se examinado o osso trabecular para inferir diferenças nos estímulos mecânicos de diferentes populações (Chirchir et alii 2015; Ryan \& Shaw 2015; Chirchir et alii 2017).

Estas abordagens têm proporcionado dados fundamentais para a compreensão da relação entre a forma esquelética e a sua função mecânica, e para a compreensão de como certas diferenças morfológicas entre diferentes populações se relacionam com factores mecânicos. Contudo, não permitem quantificar/estimar as deformações experienciadas pelos ossos (sendo estas que despoletam a adaptação mecânica óssea). Para estimar estas deformações, têm-se usado extensómetros em estudos in vivo (i.e., com espécimes vivos) ou in vitro (i.e., com ossos de indivíduos completamente esqueletizados; Hylander, Picq \& Johnson 1991; Ross \& Hylander 1996; Ross 2001). Estes estudos apresentam, porém, limitações éticas e técnicas. As limitações éticas devem-se à utilização de indivíduos vivos para a execução de experiências. As limitações técnicas devem-se à limitação do número de extensómetros que podem ser usados (o que inevitavelmente limita a área em que as deformações estão a ser medidas) e à impossibilidade da utilização de espécimes arqueológicos e/ou fósseis (a aplicação de forças físicas poderia danificar estes espécimes). Para ultrapassar estas limitações tem-se usado a Análise de Elementos Finitos (FEA - Finite Element Analysis,). A FEA é uma técnica numérica que se desenvolveu no contexto da engenharia, que permite simular cenários complexos de função mecânica e que estima as deformações experienciadas pelos espécimes (Fagan 1992; Logan 2007). Na FEA criam-se modelos virtuais ( $2 \mathrm{D}$ ou $\left.{ }_{3} D\right)$ que são constrangidos no espaço virtual, nos quais são modeladas as propriedades materiais (i.e., definidas características mecânicas como o módulo de Young e coeficiente de Poisson) dos diferentes materiais e aos quais se aplicam forças em que se especifica a sua magnitude e direcção. Naturalmente, toda a modelação virtual deverá replicar os casos reais, para que os resultados das simulações sejam fiáveis e relevantes. Para garantir esta fiabilidade são frequentemente realizados estudos de validação e sensibilidade em que se comparam os resultados de experiências no mundo real e em ambiente virtual. Os resultados destes estudos demonstram consistentemente que a FEA proporciona resultados fiáveis para a análise dos padrões de deformação (Strait et alii 2005; Fitton et alii 2015; Toro-Ibacache 
et alii 2016; Godinho et alii 2017). A FEA tem, assim, sido utilizada em estudos de evolução humana para analisar, por exemplo, a relação entre forma craniana e função mastigatória (Ledogar et alii 2016; Ledogar et alii 2017; Godinho et alii 2018; Godinho \& O’Higgins 2018; Godinho et alii 2018) (Figura 4).

\section{CONSIDERAÇÕES FINAIS}

A Antropologia Virtual cresceu a par do desenvolvimento exponencial das tecnologias de digitalização, da computação e de novas ferramentas estatísticas que permitem o processamento de grandes volumes de informação. A aglutinação de múltiplas novas técnicas potencializa a análise antropológica e, consequentemente a nossa compreensão da morfologia óssea e das populações que estuda. As actuais tecnologias de digitalização permitem a criação de modelos $3 \mathrm{D}$ que, quando incompletos, podem ser reconstruídos utilizando diversos programas de visualização e manipulação $3 \mathrm{D}$. A morfologia dos espécimes físicos pode ser capturada digital e detalhadamente utilizando novas técnicas de análise morfológica como a Morfometria Geométrica. Esta permite análises morfológicas mais completas que a morfometria convencional ao mesmo tempo que disponibiliza visualizações claras das diferenças morfológicas entre populações estudadas. Por fim, a função e adaptação mecânica dos ossos pode ser examinada através de análises detalhadas do osso trabecular ou de simulações mecânicas que permitem uma estimativa das deformações que despoletam a adaptação óssea a estímulos mecânicos.

\section{AGRADECIMENTOS}

Ricardo Miguel Godinho é financiado pelo Fundo Europeu de Desenvolvimento Regional (FEDER), através do Programa Operacional CRESC Algarve 2020, do Portugal 2020 (projecto ALG-01-0145FEDER-2968o e PTDC/HAR-ARQ/2968o/2017). Célia Gonçalves é financiada pela Fundação para a Ciência e Tecnologia (FCT, contrato DL 57/2016/ CP1361/CToo29).

\section{BIBLIOGRAFIA}

ADAMS, Dean C; ROHLF, F James; SLICE, Dennis E (2004) -Geometric morphometrics: Ten years of progress following the 'revolution'. Italian Journal of Zoology, 71:1, pp. 5-16.

AMANO, Hideki; KIKUCHI, Takeo; MORITA, Yusuke; KONDO, Osamu; SUZUKI, Hiromasa; PONCE DE LEÓN, Marcia S.; ZOLLIKOFER, Christoph P. E.; BASTIR, Markus; STRINGER, Chris; OGIHARA, Naomichi (2015) - Virtual reconstruction of the neanderthal amud 1 cranium. American Journal of Physical Anthropology, 158:2, pp. 185-197.

ARBOUR, Jessica H.; BROWN, Caleb M. (2014) - Incomplete specimens in geometric morphometric analyses. Methods in Ecology and Evolution, 5:1, pp. 16-26.

BASTIR, M.; O’HIGGINS, P.; ROSAS, A. (2007) - Facial ontogeny in neanderthals and modern humans. Proceedings of the Royal Society B-Biological Sciences, 274:1614, pp. 1125-1132.

BENAZZI, S.; BOOKSTEIN, F. L.; STRAIT, D. S.; WEBER, G. W. (2011) - A new oh5 reconstruction with an assessment of its uncertainty. Journal of Human Evolution, 61:1, pp. $75-88$.

BENAZZI, Stefano; GRUPPIONI, Giorgio; STRAIT, David S.; HUBLIN, Jean-Jacques (2014) - Technical note: Virtual reconstruction of $\mathrm{knm}$-er 1813 homo habilis cranium. American Journal of Physical Anthropology, 153:1, pp. 154-16o.

BETTS, Matthew W.; MASCHNER, Herbert D. G.; SCHOU, Corey D.; SCHLADER, Robert; HOLMES, Jonathan; CLEMENT, Nicholas; SMUIN, Michael (2011) - Virtual zooarchaeology: Building a web-based reference collection of northern vertebrates for archaeofaunal research and education. Journal of Archaeological Science, 38:4, pp. 755.e751-755.e759.

BOCQUET-APPEL, Jean-Pierre; BAR-YOSEF, Ofer (2008) - The neolithic demographic transition and its consequences. Springer Science \& Business Media.

BROWN, Caleb Marshall; VAVREK, Matthew J. (2015) Small sample sizes in the study of ontogenetic allometry; implications for palaeobiology. PeerJ, 3, p. e818.

BUCK, LT; STRINGER, CB; MACLARNON, AM; RAE, TC (2019) - Variation in paranasal pneumatisation between mid-late pleistocene hominins. Bulletins et Mémoires de la Société d'Anthropologie de Paris, 31, pp. 14-33.

CARDINI, Andrea; ELTON, Sarah (2007) - Sample size and sampling error in geometric morphometric studies of size and shape. Zoomorphology, 126:2, pp.121-134.

CARDINI, Andrea; SEETAH, Krish; BARKER, Graeme (2015) - How many specimens do i need? Sampling error in geometric morphometrics: Testing the sensitivity of means and variances in simple randomized selection experiments. Zoomorphology, 134:2, pp. 149-163. 
CARLSON, David S. (1976) - Temporal variation in prehistoric nubian crania. American Journal of Physical Anthropology, 45:3, pp. 467-484.

CARLSON, David S.; VAN GERVEN, Dennis P. (1977) Masticatory function and post-pleistocene evolution in nubia. American Journal of Physical Anthropology, 46:3, pp. 495-506.

CHAMBERLAIN, Andrew T (2006) - Demography in archaeology. New York: Cambridge University Press.

CHIRCHIR, Habiba; KIVELL, Tracy L.; RUFF, Christopher B.; HUBLIN, Jean-Jacques; CARLSON, Kristian J.; ZIPFEL, Bernhard; RICHMOND, Brian G. (2015) - Recent origin of low trabecular bone density in modern humans. Proceedings of the National Academy of Sciences, 112:2, pp. 366-371.

CHIRCHIR, Habiba; RUFF, Christopher B.; JUNNO, JuhoAntti; POTTS, Richard (2017) - Low trabecular bone density in recent sedentary modern humans. American Journal of Physical Anthropology, 162:3, p. e23138.

COBB, S. N.; O'HIGGINS, P. (2007) - The ontogeny of sexual dimorphism in the facial skeleton of the african apes. Journal of Human Evolution, 53:2, pp. 176-19o.

COWIN, Stephen; DOTY, Stephen (2007) - Tissue mechanics. New York: Springer.

CUNHA, Murilo Bastos da (2018) - Um museu em chamas: O caso do museu nacional do rio de janeiro. Revista Ibero-Americana de Ciência da Informação, 12:1, pp. 1-3.

CURREY, J. D. (2006) - Bones, structure and mechanics. New Jersey: Princeton University Press.

DELGADO, Miguel; RAMÍREZ, Luis Miguel; ADHIKARI, Kaustubh; FUENTES-GUAJARDO, Macarena; ZANOLLI, Clément; GONZALEZ-JOSÉ, Rolando; CANIZALES, Samuel; BORTOLINI, Maria-Catira; POLETTI, Giovanni; GALLO, Carla; ROTHHAMMER, Francisco; BEDOYA, Gabriel; RUIZ-LINARES, Andres (2019) - Variation in dental morphology and inference of continental ancestry in admixed latin americans. American Journal of Physical Anthropology, 168:3, pp. 438-447.

DELSON, E.; HARVATI, K.; REDDY, D.; MARCUS, L. F.; MOWBRAY, K.; SAWYER, G. J.; JACOB, T.; MARQUEZ, S. (2001) - The sambungmacan 3 homo erectus calvaria: A comparative morphometric and morphological analysis. Anatomical Record, 262:4, pp.380-397.

DRYDEN, I. L.; MARDIA, K. V. (1998) - Statistical shape analysis. Wiley-Blackwell.

ERRICKSON, David (2017) - Shedding light on skeletal remains: The use of structured light scanning for $3 \mathrm{~d}$ archiving. In ERRICKSON, D., THOMPSON, T.s eds. - Human remains: Another dimension. London: Academic Press pp. 93-101.

ETHIER, C. Ross; SIMMONS, Craig A. (2007) - Introductory biomechanics - from cells to organisms. New York: Cambridge University Press.
EVANGELISTA, Lucy Shaw; GODINHO, Ricardo Miguel (2020) - Estudo bio-antropológico do sepulcro 4 dos perdigões. In VALERA, A. C.s ed. - O sepulcro 4 dos perdigões. Um tholos da segunda metade do $3^{\circ}$ milénio a.C. Lisboa: Núcleo de Investigação Arqueológica (NIA) \& Era Arqueologia, S.A. pp. 57-102.

FAGAN, M. (1992) - Finite element analysis - theory and practice. Malaysia: Pearson Educational Ltd.

FILIPE, Victor; GODINHO, Ricardo Miguel; GRANJA, Raquel; RIBEIRO, Artur; VALERA, António (2013) - Bronze age funerary spaces in outeiro alto 2 (brinches, serpa, portugal): The hypogea cemetery. Zephyrus, 71, pp. 107-129.

FITTON, Laura C.; PRÔA, Miguel; ROWLAND, Charlie; TORO-IBACACHE, Viviana; O'HIGGINS, Paul (2015) The impact of simplifications on the performance of a finite element model of a macaca fascicularis cranium. The Anatomical Record, 298:1, pp. 107-121.

FRANÇA, Bianca (2019) - Acervos etnográficos do museu nacional: Preservação digital como sugestão pós incêndio.

FREIDLINE, S. E.; GUNZ, P.; HARVATI, K.; HUBLIN, J. J. (2012) - Middle pleistocene human facial morphology in an evolutionary and developmental context. Journal of Human Evolution, 63:5, pp. 723-740.

FREIDLINE, Sarah E.; GUNZ, Philipp; HUBLIN, JeanJacques (2015) - Ontogenetic and static allometry in the human face: Contrasting khoisan and inuit. American Journal of Physical Anthropology, 158:1, pp. 116-131.

GALLAND, Manon; VAN GERVEN, Denis P.; VON CRAMON-TAUBADEL, Noreen; PINHASI, Ron (2016) - 11, 0oo years of craniofacial and mandibular variation in lower nubia. Scientific Reports, 6, p. 31040.

GARCÍA-CAMPOS, Cecilia; MARTINÓN-TORRES, María; MARTÍN-FRANCÉS, Laura; MARTÍNEZ DE PINILLOS, Marina; MODESTO-MATA, Mario; PEREA-PÉREZ, Bernardo; ZANOLLI, Clément; LABAJO GONZÁLEZ, Elena; SÁNCHEZ SÁNCHEZ, José Antonio; RUIZ MEDIAVILLA, Elena; TUNIZ, Claudio; BERMÚDEZ DE CASTRO, José María (2018) - Contribution of dental tissues to sex determination in modern human populations. American Journal of Physical Anthropology, 166:2, pp. 459-472.

GODINHO, R. M.; O’HIGGINS, P (2017) - Virtual reconstruction of cranial remains: The h. Heidelbergensis, kabwe 1 fossil. In ERRICKSON, D., THOMPSON, T.s eds. - Human remains - another dimension: The application of $3 \mathrm{~d} \mathrm{im-}$ aging in funerary context. London: Elsevier pp. 135-147.

GODINHO, Ricardo Miguel; FITTON, Laura C.; TOROIBACACHE, Viviana; STRINGER, Chris B.; LACRUZ, Rodrigo S.; BROMAGE, Timothy G.; O'HIGGINS, Paul (2018) - The biting performance of homo sapiens and homo heidelbergensis. Journal of Human Evolution, 118, pp. 56-71.

GODINHO, Ricardo Miguel; GONÇALVES, David; VALERA, António Carlos (2019) - The preburning condi- 
tion of chalcolithic cremated human remains from the perdigões enclosures (portugal). International Journal of Osteoarchaeology, 29:5, pp. 706-717.

GODINHO, Ricardo Miguel; O’HIGGINS, Paul (2018) The biomechanical significance of the frontal sinus in kabwe 1 (homo heidelbergensis). Journal of Human Evolution, 114, pp. 141-153.

GODINHO, Ricardo Miguel; O’HIGGINS, Paul; GONÇALVES, Célia (2020) - Assessing the reliability of virtual reconstruction of mandibles. American Journal of Physical Anthropology, n/a:n/a, p. e24095.

GODINHO, Ricardo Miguel; OLIVEIRA-SANTOS, Inês; MANUEL FRANCISCO C, Pereira; MAURÍCIO, António; VALERA, António; GONÇALVES, David (2019) - Is enamel the only reliable hard tissue for sex metric estimation of burned skeletal remains in biological anthropology? Journal of Archaeological Science: Reports, 26, p. 101876.

GODINHO, Ricardo Miguel; SPIKINS, Penny; O’HIGGINS, Paul (2018) - Supraorbital morphology and social dynamics in human evolution. Nature Ecology $\&$ Evolution, 2:6, pp. 956-961.

GODINHO, Ricardo Miguel; TORO-IBACACHE, Viviana; FITTON, Laura C.; O'HIGGINS, Paul (2017) - Finite element analysis of the cranium: Validity, sensitivity and future directions. Comptes Rendus Palevol, 16:5, pp. 6oo-612.

GODINHO, Ricardo Miguel; UMBELINO, Cláudia; GONÇALVES, Célia (em preparação) - Mandibular morphological variation in the mesolithic.

GONZALEZ, Paula N.; PEREZ, S. Ivan; BERNAL, Valeria (2011) - Ontogenetic allometry and cranial shape diversification among human populations from south america. The Anatomical Record, 294:11, pp. 1864-1874.

GUNZ, P.; MITTEROECKER, P.; NEUBAUER, S.; WEBER, G. W.; BOOKSTEIN, F. L. (2009) - Principles for the virtual reconstruction of hominin crania. Journal of Human Evolution, 57:1, pp. 48-62.

HENDERSON, C. Y.; MARIOTTI, V.; PANY-KUCERA, D.; VILLOTTE, S.; WILCZAK, C. (2016) - The new 'coimbra method': A biologically appropriate method for recording specific features of fibrocartilaginous entheseal changes. 26:5, pp. 925-932.

HYLANDER, W. L.; PICQ, P. G.; JOHNSON, K. R. (1991) Masticatory-stress hypotheses and the supraorbital region of primates. American Journal of Physical Anthropology, 86:1, pp. 1-36.

JURMAIN, Robert; KILGORE, Lynn; TREVATHAN, Wenda (2010) - Essentials of physical anthropology. Cengage Learning.

KATZ, David C.; GROTE, Mark N.; WEAVER, Timothy D. (2017) - Changes in human skull morphology across the agricultural transition are consistent with softer diets in preindustrial farming groups. Proceedings of the National Academy of Sciences.

KATZ, David; FRIESS, Martin (2014) - Technical note: 3d from standard digital photography of human crania - a preliminary assessment. American Journal Of Physical Anthropology, 154:1, pp. 152-158.

KATZ, J (2008) - Mechanics of hard tissue. In PETERSON, D. R., BRONZINO, J. D.s eds. - Biomechanics: Principles and applications: Boca Raton, Florida: CRC Press pp. 1-20.

KERR, Andy (2010) - Introductory biomechanics. Edinburgh: Churchill Livingstone Elsevier.

KURY, Adriano B.; GIUPPONI, Alessandro P. L.; MENDES, Amanda C. (2018) - Immolation of museu nacional, rio de janeiro - unforgettable fire and irreplaceable loss. The Journal of Arachnology, 46:3, pp. 556-558.

LARSEN, William J. (2002) - Anatomy: Development, function, clinical correlations. Saint Louis: Saunders.

LEAKEY, Louis SB (1959) - A new fossil skull from olduvai. Nature, 184:4685, pp. 491-493.

LEDOGAR, Justin A.; BENAZZI, Stefano; SMITH, Amanda L.; WEBER, Gerhard W.; CARLSON, Keely B.; DECHOW, Paul C.; GROSSE, Ian R.; ROSS, Callum F.; RICHMOND, Brian G.; WRIGHT, Barth W.; WANG, Qian; BYRON, Craig; CARLSON, Kristian J.; DE RUITER, Darryl J.; PRYOR MCINTOSH, Leslie C.; STRAIT, David S. (2017) - The biomechanics of bony facial "buttresses" in south african australopiths: An experimental study using finite element analysis. The Anatomical Record, 300:1, pp. 171-195.

LEDOGAR, Justin A.; SMITH, Amanda L.; BENAZZI, Stefano; WEBER, Gerhard W.; SPENCER, Mark A.; CARLSON, Keely B.; MCNULTY, Kieran P.; DECHOW, Paul C.; GROSSE, Ian R.; ROSS, Callum F.; RICHMOND, Brian G.; WRIGHT, Barth W.; WANG, Qian; BYRON, Craig; CARLSON, Kristian J.; DE RUITER, Darryl J.; BERGER, Lee R.; TAMVADA, Kelli; PRYOR, Leslie C.; BERTHAUME, Michael A.; STRAIT, David S. (2016) - Mechanical evidence that australopithecus sediba was limited in its ability to eat hard foods. Nat Commun, 7.

LOGAN, DL (2007) - A first course in the finite element method. Delhi: Thomson.

MARIEB, EN (1992) - Human anatomy and physiology. Redwood City, California: Curnmings Publishing Company, Inc.

MAY, Hila; SELLA-TUNIS, Tanya; POKHOJAEV, Ariel; PELED, Nathan; SARIG, Rachel (2018) - Changes in mandible characteristics during the terminal pleistocene to holocene levant and their association with dietary habits. Journal of Archaeological Science: Reports.

MITTEROECKER, P.; BOOKSTEIN, F. (2009) - The ontogenetic trajectory of the phenotypic covariance matrix, with examples from craniofacial shape in rats and humans. Evolution, 63:3, pp. 727-737. 
NEESER, Rudolph; ACKERMANN, Rebecca Rogers; GAIN, James (2009) - Comparing the accuracy and precision of three techniques used for estimating missing landmarks when reconstructing fossil hominin crania. American Journal of Physical Anthropology, 140:1, pp. 1-18.

NOBACK, Marlijn L.; HARVATI, Katerina (2015) - Covariation in the human masticatory apparatus. The Anatomical Record, 298:1, pp. 64-84.

NOBACK, Marlijn L.; HARVATI, Katerina; SPOOR, Fred (2011) - Climate-related variation of the human nasal cavity. American Journal of Physical Anthropology, 145:4, pp. 599-614.

O'HIGGINS, P. (200o) - The study of morphological variation in the hominid fossil record: Biology, landmarks and geometry. Journal of Anatomy, 197, pp. 103-120.

O’HIGGINS, P.; COBB, S. N.; FITTON, L. C.; GRONING, F.; PHILLIPS, R.; LIU, J.; FAGAN, M. J. (2011) - Combining geometric morphometrics and functional simulation: An emerging toolkit for virtual functional analyses. Journal of Anatomy, 218:1, pp. 3-15.

O’HIGGINS, P.; FITTON, L. C.; PHILLIPS, R.; SHI, J. F.; LIU, J.; GRONING, F.; COBB, S. N.; FAGAN, M. J. (2012) - Virtual functional morphology: Novel approaches to the study of craniofacial form and function. Evolutionary Biology, 39:4, pp. 521-535.

O’HIGGINS, Paul; FITTON, Laura C.; GODINHO, Ricardo Miguel (2019) - Geometric morphometrics and finite elements analysis: Assessing the functional implications of differences in craniofacial form in the hominin fossil record. Journal of Archaeological Science, 101, pp. 159-168.

ORTNER, Donald J. (2003) - Identification of pathological conditions in human skeletal remains. San Diego: Academic Press.

PÜSCHEL, Thomas A; BENÍTEZ, Hugo A (2014) - Femoral functional adaptation: A comparison between hunter gatherers and farmers using geometric morphometrics. International Journal of Morphology, 32, pp. 627-633.

RAE, Todd C.; KOPPE, Thomas; STRINGER, Chris B. (2011) - The neanderthal face is not cold adapted. Journal of Human Evolution, 6o:2, pp. 234-239.

RODRÍGUEZ-MARTÍN, Conrado (2006) - Identification and differential diagnosis of traumatic lesions of the skeleton. In SCHMITT, A., CUNHA, E., PINHEIRO, J.s eds. - Forensic anthropology and medicine: Complementary sciences from recovery to cause of death. Totowa, NJ: Humana Press pp. 197-221.

ROSS, C. F. (2001) - In vivo function of the craniofacial haft: The interorbital "pillar". American Journal of Physical Anthropology, 116:2, pp. 108-139.

ROSS, C. F.; HYLANDER, W. L. (1996) - In vivo and in vitro bone strain in the owl monkey circumorbital region and the function of the postorbital septum. American Journal of Physical Anthropology, 101:2, pp. 183-215.

RUFF, Christopher B.; HOLT, Brigitte; NISKANEN, Markku; SLADEK, Vladimir; BERNER, Margit; GAROFALO, Evan; GARVIN, Heather M.; HORA, Martin; JUNNO, Juho-Antti; SCHUPLEROVA, Eliska; VILKAMA, Rosa; WHITTEY, Erin (2015) - Gradual decline in mobility with the adoption of food production in europe. Proceedings of the National Academy of Sciences, 112:23, p. 7147.

RUFF, Christopher; HOLT, Brigitte; TRINKAUS, Erik (2006) - Who's afraid of the big bad wolff? "Wolff's law" and bone functional adaption. American Journal of Physical Anthropology, 129, pp. 484-498.

RYAN, Timothy M.; SHAW, Colin N. (2015) - Gracility of the modern homo sapiens skeleton is the result of decreased biomechanical loading. Proceedings of the National Academy of Sciences, 112:2, pp. 372-377.

SCOTT, G Richard; IRISH, Joel D (2017) - Human tooth crown and root morphology. Cambridge University Press.

SILVA, Daniel B. Domingues da (2019) - Lost to fire: The african collection of the national museum of brazil. African Arts, 52:3, pp. 13-15.

Author (2005) - Modern morphometrics in physical anthropology. SLICE, D., Ed. New York: Kluwer Academic.

STRAIT, D. S.; WANG, Q.; DECHOW, P. C.; ROSS, C. F.; RICHMOND, B. G.; SPENCER, M. A.; PATEL, B. A. (2005) - Modeling elastic properties in finite element analysis: How much precision is needed to produce an accurate model? Anatomical Record Part a-Discoveries in Molecular Cellular and Evolutionary Biology, 283A:2, pp. 275-287.

TATTERSALL, Ian; SAWYER, G. J. (1996) - The skull of "sinanthropus" from zhoukoudian, china: A new reconstruction. Journal of Human Evolution, 31:4, pp. 311-314.

TOBIAS, P. V. (1967) - Olduvai gorge vol. 2: The cranium and maxillary dentition of australopithecus (zinjanthropus) boisei. Cambridge: Cambridge University Press.

TORO-IBACACHE, Viviana; FITTON, Laura C.; FAGAN, Michael J.; O’HIGGINS, Paul (2016) - Validity and sensitivity of a human cranial finite element model: Implications for comparative studies of biting performance. Journal of Anatomy, 228:1, pp. 70-84.

TORO-IBACACHE, Viviana; UGARTE, Francisco; MORALES, Cristina; EYQUEM, Andrea; AGUILERA, José; ASTUDILLO, Williams (2019) - Dental malocclusions are not just about small and weak bones: Assessing the morphology of the mandible with cross-section analysis and geometric morphometrics. Clinical Oral Investigations.

VALERA, António; GODINHO, Ricardo Miguel; CALVO, Ever; MORO BERRAQUERO, Javier; FILIPE, Victor; SANTOS, Helena (2010) - Um mundo em negativo: Fossos, fossas e hipogeus entre o neolítico final e a idade do bronze 
na margem esquerda do guadiana (brinches, serpa). In SILVA, A. C., REGALA, F. T., MARTINHO, M. eds. Beja: EDIA pp. 55-73.

VON CRAMON-TAUBADEL, Noreen (2011) - Global human mandibular variation reflects differences in agricultural and hunter-gatherer subsistence strategies. Proceedings of the National Academy of Sciences, 108:49, pp. 19546-19551.

WALDRON, Tony (2009) - Palaeopathology. Cambridge: Cambridge University Press.

WEBER, G. W.; BOOKSTEIN, F. L. (2011) - Virtual anthropology - a guide for a new interdisciplinary field. Wien: Springer-Verlag.

WEBER, Gerhard W. (2015) - Virtual anthropology. American Journal of Physical Anthropology, 156, pp. 22-42.

WEIDENREICH, Franz (1937) - Reconstruction of the entire skull of an adult female individual of sinanthropus pekinensi. Nature, 140:3554, p. 1010.

ZELDITCH, Miriam L.; SWIDERSKI, Donald L.; SHEETS, H. David; FINK, William L. (2012) - Geometric morphometrics for biologists: A primer. New York: Elsevier.

ZOLLIKOFER, Christoph P. E.; PONCE DE LEÓN, Marcia S. (2010) - The evolution of hominin ontogenies. Seminars in Cell \& Developmental Biology, 21:4, pp.441-452. 

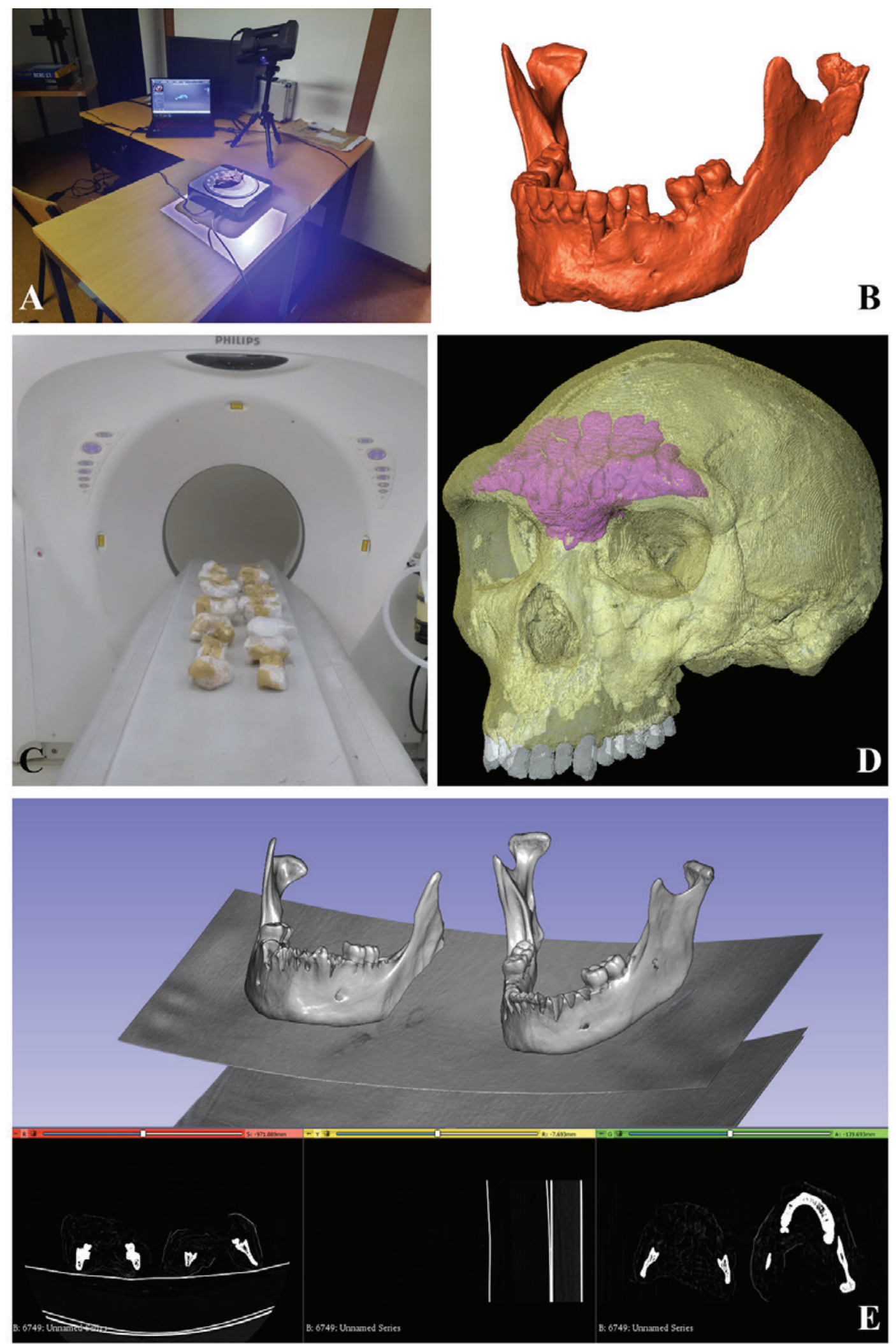

Figura 1 - Exemplos de digitalização de espécimes. A) Processo de digitalização de superfície de uma mandíbula humana. B) Resultado da digitalização de superfície de uma mandíbula humana. C) Processo de digitalização através de TAC, com vários espécimes sobre a plataforma do scanner TAC para digitalização. D) Segmentação e renderização de um crânio fóssil hominíneo (Kabwe 1, Homo heidelbergensis) com individualização dos seios frontais (destacados a roxo). C) Renderização de duas mandíbulas digitalizadas através de TAC e das respectivas secções tomográficas. 

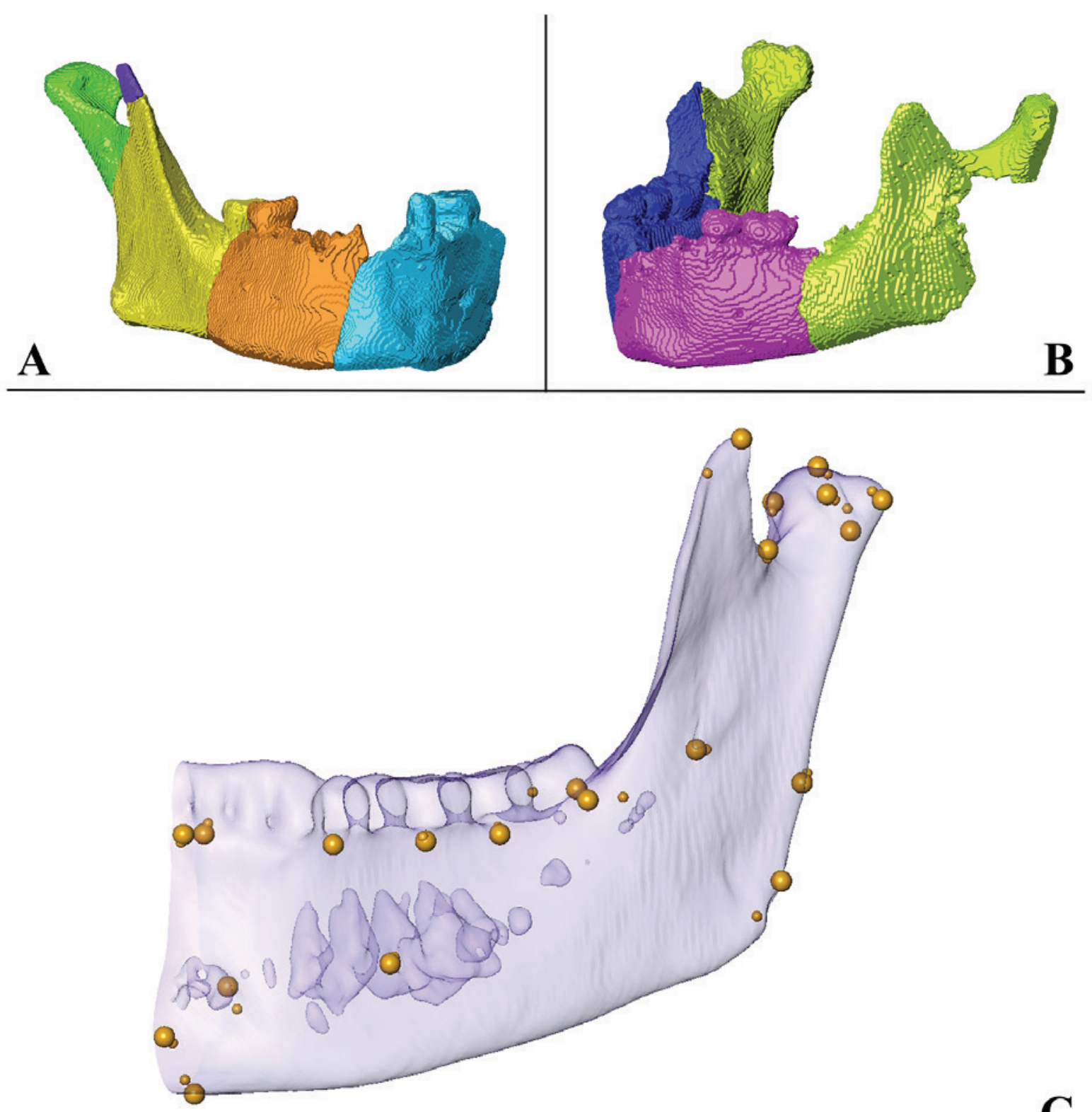

Figura 2 - Exemplos de reconstrução virtual de mandíbulas humanas. A e B) Exemplos de colagens virtuais de duas mandíbulas humanas. C) Exemplo de estudo sobre a fiabilidade da estimativa da localização de ponto anatómicos utilizando a abordagem geométrica (i.e., TPS). As esferas de maior dimensão representam a localização original e as esferas de pequena dimensão a localização estimada desses mesmos pontos anatómicos. 

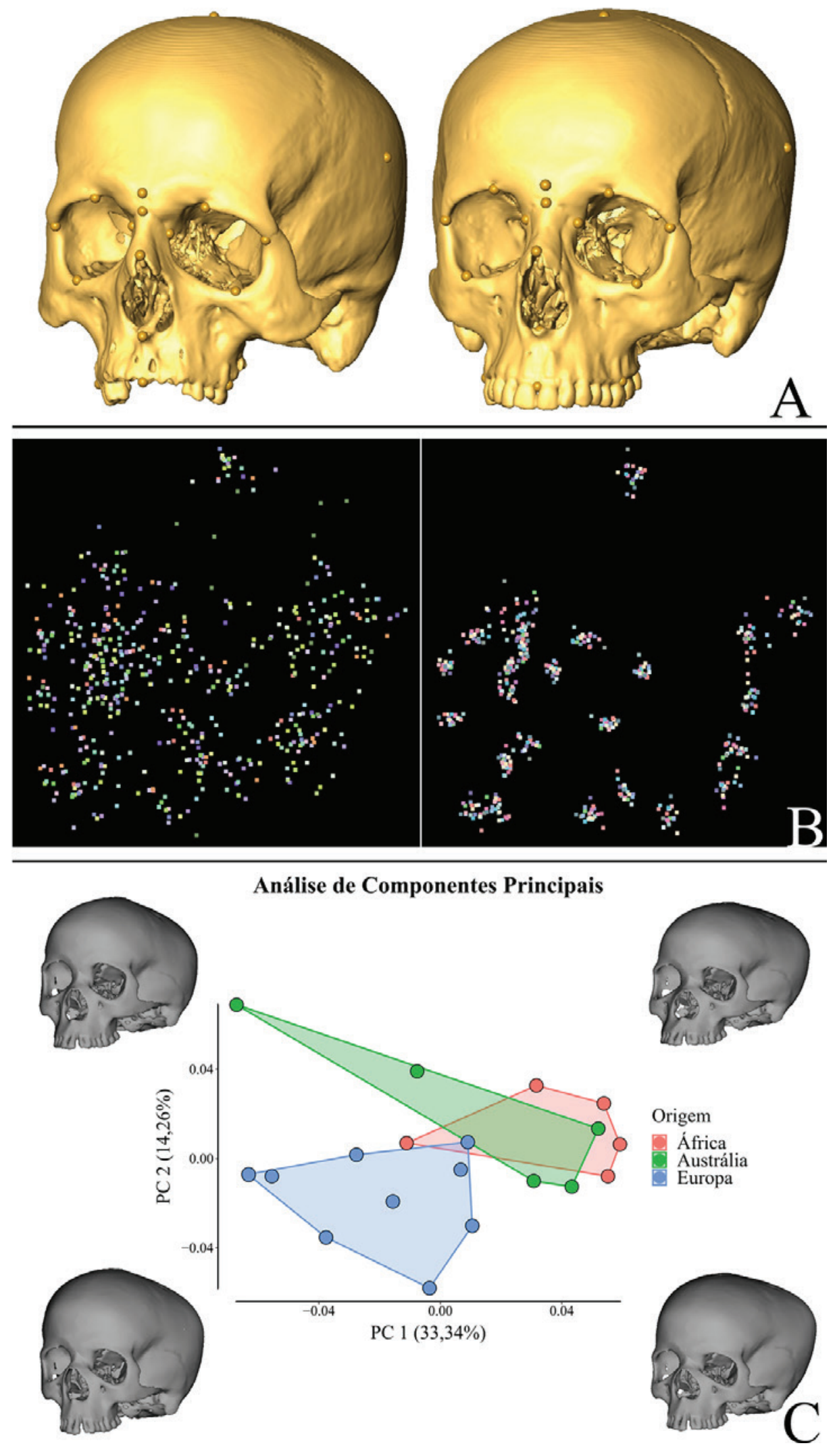

Figura 3 - Exemplo de análise GM. A) Dois crânios em que foi recolhido um conjunto de coordenadas de pontos homólogos. B) Exemplo de GPA com 20 espécimes (crânios, entre os quais os ilustrados em A); a imagem à esquerda ilustra o conjunto de pontos homólogos pré sobreposição e a imagem à direita o conjunto de pontos homólogos sobrepostos (cada ponto representa uma coordenada tridimensional). C) PCA com os espécimes sobrepostos em que cada ponto representa um indivíduo; as cores codificam a origem geográfica dos espécimes e as imagens dos crânios representam as diferenças morfológicas nos extremos dos eixos dos componentes principais. 


\section{Homo sapiens}

(espécime recente)
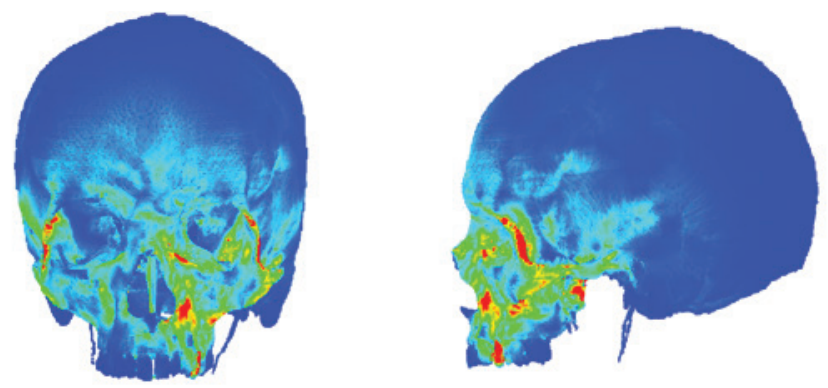

\section{Homo heidelbergensis} (Kabwe 1)
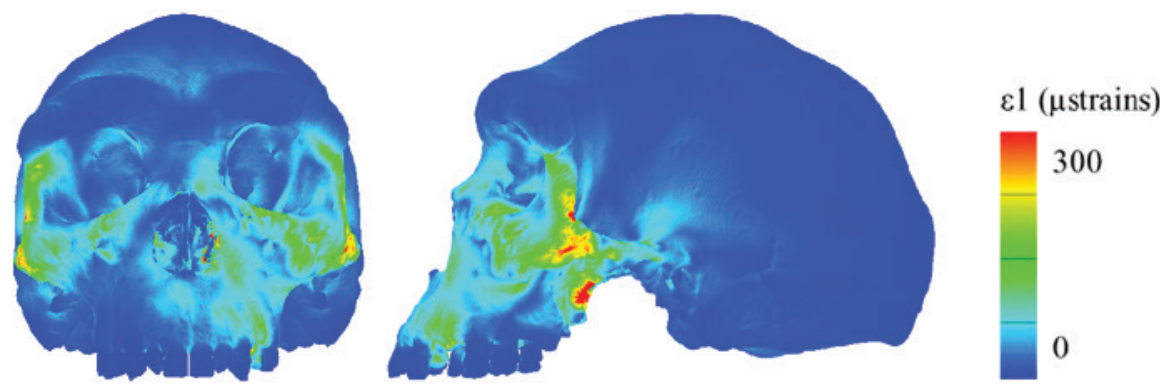

Figura 4 - Exemplo de FEA em que se compara o desempenho mecânico de um H. sapiens com um H. heidelbergensis (imagens não estão à escala). Neste caso (deformações principais máximas), as cores frias representam deformações de reduzida magnitude e as cores quentes deformações de elevada magnitude. 
3
Didáctica
da Arqueologia

3
Didáctica
da Arqueologia

\author{
-
}

3
Didáctica
da Arqueologia

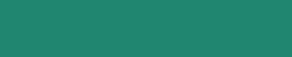

(

(

3
Didáctica
da Arqueologia

(x)

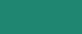

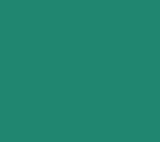

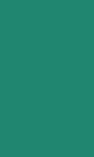

, 


\title{
COMO OS PROJETOS DE ARQUEOLOGIA PODEM CONTRIBUIR PARA UMA COMUNIDADE CULTURALMENTE MAIS CONSCIENTE
}

\author{
Alexandra Figueiredo ${ }^{1}$, Claúdio Monteiro ${ }^{2}$, Adolfo Silveira ${ }^{3}$, Ricardo Lopes ${ }^{4}$
}

\begin{abstract}
RESUMO
O projeto da Carta Arqueológica do concelho Caldas da Rainha é um projeto plurianual, aprovado pela DGPC. Além do trabalho de recolha e análise dos dados e da prospeção e descoberta de sítios arqueológicos, pretende contribuir para uma melhor educação patrimonial, correspondendo desta forma à vertente tão importante da sensibilização cívica cultural. Integra nos seus objetivos componentes que se prendem na didática da arqueologia, pela realização de diversas atividades com a comunidade local, no sentido de sensibilizar a população para a preservação do património arqueológico.

Assim, pretendemos neste artigo apresentar as ações desenvolvidas e algumas conclusões observadas, bem como demonstrar a necessidade destas atividades para o incremento de uma sociedade mais esclarecida e sensível para a salvaguarda dos vestígios das ocupações humanas passadas.

Palavras-chave: Educação Patrimonial, Sensibilização, Consciência Cívica Cultural, Arqueologia.
\end{abstract}

\begin{abstract}
The project Caldas da Rainha Archaeological Chart is a multiannual project, approved by the DGPC. In addition to the work of collecting, analyzing, surveying and discovering archaeological sites it's our aims to contribute to a better heritage education, thus corresponding to the very important aspect of civic cultural awareness. The guidelines include components that are linked to the ways of transfer cultural knowledge, by carrying out various activities with the local community, to sensitize the population to the preservation of the archaeological heritage.

We intend in this article to present the actions developed and some conclusions observed, as well as to demonstrate the need for these activities to increase a more enlightened and sensitive society to safeguard the traces of past human occupations.
\end{abstract}

Keywords: Heritage Education, Awareness, Civic Cultural Awareness, Archeology.

\section{A EDUCAÇÃO PATRIMONIAL NO PROJETO CARACA}

O projeto CARACA é um projeto de 4 anos, que teve início em 2017. Nos seus objetivos está estipulado, para além dos trabalhos arqueológicos, o de- senvolvimento de um conjunto de atividades com a comunidade local (Figueiredo, et al. prelo).

Atualmente, as técnicas de educação e sensibilização patrimonial apresentam-se como ferramentas cruciais para a divulgação e reconhecimento por parte da população dos trabalhos desenvolvidos e da impor-

\footnotetext{
1. Instituto Politécnico de Tomar; alexfiga@ipt.pt

2. CAAPortugal; claudio.monteiro.cr@gmail.com

3. Universidade Autónoma de Lisboa; aasilveira@autonoma.pt

4.ricardoantuneslopes@gmail.com
} 
tância da preservação dos vestígios culturais, nomeadamente os arqueológicos. Estas desempenham um papel social fundamental, mediando e estimulando o conhecimento sobre a história e o património cultural. A realidade acaba por estar ligada à identidade, que é traduzida pela pertença de um indivíduo a uma comunidade e logo ao património que ela sustenta. Utilizando estratégias de contacto formativo, com vista a uma educação mais consciente do património, tem-se observado uma dinâmica cada vez mais participativa e interessada por parte da população, contribuindo, incluindo, na recolha oral e na identificação de alguns sítios arqueológicos inéditos. Observamos que a escolha por atividades e ações didáticas assertivas e adaptadas ao interesse e à faixa etária da comunidade com que contactamos, têm possibilitado ao indivíduo fazer a leitura do mundo que o rodeia, educando-os e formando-os como agentes culturais mais ativos. Esta ligação deve ser um processo permanente e sistemático se possível conectado às entidades de suporte cultural numa dada região, de forma a que essa ponte possa ser realizada e as sementes, depositadas em cada ação, germinadas numa participação ativa da comunidade.

Dentro do que pretendemos atingir no projeto, estas atividades têm o pressuposto de criar uma relação simbiótica com a população, no sentido em que, à medida que os trabalhos de reconhecimento do terreno vão decorrendo, vão sendo desenvolvidos diversos eventos culturais com as Associações locais, Lares, Centros de dia, Juntas de Freguesia e Escolas. Assim, no âmbito do processo de Educação Patrimonial esta relação foi desenvolvida em 2 fases, sendo que a fase final, devido ao confinamento e situação sanitária atual em que vivemos, encontra-se por terminar. Desta forma, ainda que se apresentem somente algumas conclusões, estes dados são já reveladores de progressos de consciência cívica e sensibilização para a salvaguarda de bens.

De acordo com o planeamento estratégico, estas fases vão incrementando o conhecimento da população, sensibilizando-a para o património, garantindo um olhar atendo das pessoas contactadas sobre a paisagem e sobre os possíveis sítios arqueológicos. Neste processo, elementos culturais passivos, como idosos de lares ou funcionários, trabalhadores agrícolas ou simples membros da comunidade que receberam as nossas palestras ou connosco tiveram conversas e discussões sobre o trabalho arqueológico, tornaram-se seres ativos na preservação do pa- trimónio e até na descoberta de novos sítios arqueológicos (Lopes et al. prelo).

Logo na primeira fase muitos acabavam por integrar o projeto como colaboradores, tendo desenvolvido prospeções físicas no terreno com membros da equipa. Esta relação não só foi efetiva para o registo de vestígios, como para uma relação com a comunidade onde os nossos trabalhos de campo eram realizados.

\section{METODOLOGIA DESENVOLVIDA}

\section{1. $1^{\mathrm{a}}$ fase}

Esta primeira fase passou por um contacto inicial dirigindo-nos aos diversos locais para apresentação do projeto. Conforme o meio, a idade e o interesse foram criadas e adaptadas estratégias que mais se coadunassem com o público e com os objetivos que pretendíamos atingir.

Assim, de forma simplificada, para não estender na exposição, pois o fator organizacional do evento, muitas vezes era redirecionado ou readaptado conforme o decorrer do desenvolvimento da ação, da capacidade de motivação que podia ser trabalhada e da abertura do público a discussões mais profundas ou a outras interações, consideramos 3 estratégias:

\subsubsection{Estratégia Informal-Emotiva}

Esta estratégia foi sobretudo adotada para os Lares e Centros de Dia.

Desta forma, dirigíamos normalmente uma equipa com dois membros. Em alguns casos associavam-se os próprios funcionários. Esta equipa tinha por objetivo criar um vínculo emotivo entre o passado - território - pessoa.

Iniciávamos o processo contando histórias daquela freguesia que eram conhecidas pela comunidade ou criávamos um enredo em torno de algo, de um sítio arqueológico, de um elemento patrimonial ou de um símbolo cultural, como por exemplo um Pelourinho. Associado fazíamos uma transição expositiva, com base em fotografias, lugares conhecidos, como um café, um moinho ou uma paisagem local para retroceder no tempo. A ideia era conectar emocionalmente a experiência de vida do público com o mundo que os rodeava, para depois chegar ao tempo dos seus avós, tetravós, Época Medieval, Romana e Pré-história.

A par das fotografias iam sendo introduzidos objetos arqueológicos, em alguns casos réplicas, que eles manuseavam e outras imagens, mostrando exem- 
plos de como os vestígios podem aparecer no campo. Ligando tudo isto chamávamos à atenção para os comportamentos do Homem do passado, dos cultos, das crenças e da organização social, tentando ativar o gosto pela história, pela necessidade de preservação do património e salvaguarda dos bens e memórias, garantindo depois uma transposição para o futuro, de forma a refletir como que em espelho, o que agora se vive para as gerações seguintes. Na linguagem informativa introduzíamos algumas expressões sobre o património sempre de forma muito descontraída. A ideia passava por moldar a imaginação para que se pudessem projetar o Homem quer no passado, quer no futuro e tornar o público mais conhecedor sobre o Património e o que ele abarca.

Após esta fase mais informal de exposição, puxávamos à participação, com conversas espontâneas, em jeito de tertúlia, tentando dirigir o discurso aos intentos do projeto. De acordo com a nossa experiência alguns locais foram muito acolhedores e dinâmicos, noutros, por circunstâncias diversas, não conseguimos ir para além de simples respostas muito curtas, normalmente sim/não.

Em termos quantitativos, em alguns lares, numa percentagem superior a $60 \%$ foi possível o preenchimento de inquéritos (Figueiredo et al. 2017), e a realização de conversas sobre a história. Em alguns locais, próximo aos $30 \%$, foi desenvolvido um registo sobre as lendas da região, bem como as discussões puderam estender-se a conversas sobre a etnografia. Na quase totalidade dos sítios foi abordado eventos históricos e alguns sítios arqueológicos, bem como foi dado enfase à relevância que isto tudo terá se o Património puder ser herdado pelos nossos descendentes. Parte desses registos levaram-nos à publicação de duas obras, uma sobre os moinhos (Figueiredo e Lopes, 2018) e outra sobre as lendas das Caldas da Rainha (Figueiredo e Lopes, 2019).

Por fim, colocámo-nos à disposição quer para futuros encontros, quer para conversas mais individuais, pois alguns idosos, pela sua lucidez e gosto inerente à terra tornaram-se agentes colaborantes no projeto, passando-os a uma segunda fase de contacto e a uma interação mais ativa.

Ao todo foram trabalhados 12 lares ou centros de dia de 2017 a 2019 (Centro Cultural de Congressos de Caldas da Rainha ; Casa do Povo de A-dos-Francos; Associação de Desenvolvimento Social da Freguesia de Alvorninha; Associação de Solidariedade Social da Foz do Arelho; Centro Social Paroquial de San- ta Catarina; Centro Social e Paroquial № $\mathrm{Sr}^{\mathrm{a}}$ da Piedade dos Vidais; Centro de Desenvolvimento Comunitário do Landal; Associação de Solidariedade e Educação de Salir de Matos; Centro Social Paroquial № Sr ${ }^{a}$ das Mercês; Associação de Desenvolvimento Social de Salir do Porto; Centro Social Serra do Bouro). A idade média era de cerca de 70 anos e relativamente mais pronunciada em termos de participantes femininos do que masculinos (Figura1).

\subsubsection{Estratégia Técnico-Científica}

Nas associações locais e escolas, a estratégia considerada foi mais dirigida com base nos propósitos pretendidos no projeto e na demonstração do que é a ciência da Arqueologia e o nosso trabalho como arqueólogos.

Assim, como as associações locais eram essencialmente culturais, numa percentagem de $80 \%$, centralizamos a nossa apresentação no projeto, nos objetivos arqueológicos e no que pretendíamos dos membros associados, referindo as vantagens económicas e culturais da salvaguarda do património para a região. Tratava-se, na maioria, de um público masculino, profissionalmente ativo, rondando a média nos 45 anos, com presença de muito poucos jovens, menos de $5 \%$, com idade inferior a 30 anos.

Nas associações de caçadores a percentagem era quase total de elementos masculinos entre os 30 e os 60 anos. Também aqui não existe um padrão na receção, em alguns locais eram mais amáveis e críticos do tipo positivo-construtivo ao seu património, noutras situações, observávamos uma certa desconfiança nas nossas intenções. Contudo, na generalidade, mostravam-se curiosos, querendo, em alguns casos, auxílio para a compreensão de algumas "pedras", como eles as descreviam, que às vezes encontravam nos terrenos agrícolas ou durante as caçadas.

Nas associações para além da palestra expositiva do projeto, onde mencionávamos os sítios já conhecidos e alguns objetos encontrados, que também eram mostrados, deixávamos folhetos informativos (figura 1) para que os participantes levassem para casa com os nossos contactos email, telefónico e redes sociais, permitindo-os acompanhar o projeto por Facebook https://www.facebook.com/CaldasRainha.CARACA/.

Os mais interessados eram filtrados na nossa avaliação geral e os contactos trocados para um segundo encontro. Estes segundos encontros eram feitos em cafés ou nas propriedades dos participantes, passan- 
do à segunda fase do processo, mais interventiva. Também nas escolas o processo era um pouco semelhante (Figueiredo et al. 2018). As palestras foram dirigidas a turmas do terceiro ciclo das Escolas Secundárias Rafael Bordalo Pinheiro e Raul Proença. Aos alunos explicava-se o que é a Arqueologia, o projeto de trabalho para a região e os fundamentos para a salvaguarda do património. As palestras teóricas, sempre munidas de muitas imagens, eram curtas, não ultrapassando os 20 minutos. No final discutiam-se as matérias tratadas, dando-se sempre maior relevância às opiniões e dúvidas dos alunos. Nesta interação os alunos também tinham oportunidade de manusear materiais arqueológicos que associavam à matéria lecionada na disciplina de História. No término do encontro era-lhes pedido que levassem para casa um formulário para preencherem com os pais sobre: O que conheciam na região? Se já alguma vez tinham visto algum sítio arqueológico? Se os pais ou avós possuíam conhecimento de vestígios patrimoniais antigos na localidade? etc. Posteriormente os vários elementos das turmas entregavam os formulários aos professores que os faziam chegar à equipa do projeto. Somente $34 \%$ dos formulários distribuídos foram devolvidos. Ao todo foram distribuídos 150 formulários. Todos foram convidados para integrar o programa Jovens em Férias, desenvolvido pelo projeto e pela Ciência Viva. Este projeto foi realizado com 11 participantes jovens da região (Figura 2). Alguns destes trabalhos foram seguidos jornalisticamente ${ }^{5}$, permitindo incrementar a divulgação e a sensibilização para o património.

\subsubsection{Estratégia informativa}

Nas Juntas de Freguesia foram distribuídos folhetos e realizadas conversações com diversos Presidentes de Junta. Em alguns casos, também estes se juntaram ao projeto, tendo percorrido áreas e realizado sobretudo o levantamento dos Moinhos das Caldas com a equipa (Figueiredo e Lopes, 2018).

Os mapas resultantes dos trabalhos dos levantamentos eram enviados para fixação nas paredes das Juntas (Figura 3 e 4), também a todos foram ofertados exemplares dos livros publicados pelo projeto para arquivo e consulta da população local.

5. Ex. Gazeta das Caldas de 24 agosto 2018 - https://gazetadascaldas.pt/emprego-classificados-caldas-da-rainha/ estao-a-decorrer-os-estagios-da-ciencia-viva-na-carta-arqueologica-das-caldas/
Nas reuniões com os Presidentes das Juntas eram apresentados os locais mais relevantes conhecidos na localidade, bem como se pretendia que a Junta pudesse fazer uma ponte com a comunidade local, no sentido de averiguar outros possíveis vestígios. Este trabalho de consciencializar os polos políticos que gerem as diferentes freguesias fez com que parte do Património, por exemplo a ponte romana da Feteira, em Salir de Matos, fosse limpa pela Junta, sem realização de um pedido expresso da equipa do projeto, demonstrando um maior cuidado com o património. Também todos os anos desenvolvemos workshops, Jornadas (Figura 5), Seminários e visitas de estudo para a comunidade científica e regional (Figura 6).

\section{2. $2^{\underline{a}}$ fase}

Podemos associar a segunda fase de trabalho de consciencialização e sensibilização a um segundo contacto e ao levantamento de novos inquéritos.

Depois de filtradas as pessoas que mais se mostraram interessadas e participativas no primeiro contacto, estas, conforme a sua vontade e possibilidades, foram introduzidas nos trabalhos de terreno. Assim, de forma informal combinávamos os melhores dias para nos mostrarem as localidades, os locais onde cresceram, os possíveis sítios que foram referindo como sendo do tempo dos mouros, as ruínas das antigas capelas, já inexistentes, dos moinhos, ou das lendas que lhes eram contadas em criança (Figueiredo e Lopes, 2019). Esta participação em alguns casos foi de tal forma interessante que chegamos a fazer pequenos grupos, reunindo quer em zonas públicas, quer mesmo na casa dos participantes (Figura 7).

Noutras situações, com a população mais ativa, marcaram-se encontros para nos mostrarem os sítios com as "pedras estranhas", os materiais que tinham em casa e que foram recolhendo desde tempos nos campos agrícolas, onde depois também nos levavam para confirmação da existência ou não de vestígios à superfície. Alguns desses materiais acabaram por ser doados ao projeto, para arquivo, para que um dia possam integrar a exposição arqueológica das Caldas da Rainha.

Este trabalho de contacto ainda decorre, pois quer pelo Facebook, email ou telefone frequentemente recebemos contactos, ou porque alguém lhes contou ou descobriram mais "coisas estranhas". Estas pessoas, como referido, tornaram-se eles próprios seres consciencilizadores da comunidade. Chegamos a re- 
ceber telefonemas de pessoas que vieram por conhecimento de outras e não porque passaram pela nossa $\mathrm{I}^{\underline{\mathrm{a}}}$ fase, demonstrando que o processo empreendido tinha entrado num ciclo autoprodutivo. Alguns jovens, vendo, por exemplo o valor e a publicação dos Moinhos das Caldas da Rainha (Figueiredo e Lopes, 2018), decidiram desenvolver trabalhos académicos etnográficos, recolhendo testemunhos e memórias dos locais. Um destes trabalhos foi apresentado nas Jornadas que organizamos em 2019.

Associado a esta fase pretendíamos desenvolver novamente em determinadas associações e centros de dia novos inquéritos, no sentido de perceber a existência de evolução na compreensão de conceitos, na sensibilização para a salvaguarda ou no interesse pelo Património, podendo quantificar em resultados o esforço empreendido.

\section{CONCLUSÃO}

A oralidade é a uma das marcas identitárias de uma comunidade e é através dela que conseguimos muitas vezes retratar as vivências, o modo de vida e as tradições de um povo de determinada zona.

A análise a este registo não deve ser feita somente a algumas esferas da sociedade, mas a todas, devendo ser transversal aos jovens, aos grupos de profissionais ativos, às comunidades associativas e aos centros e grupos sénior.

Ao todo aquando do início do projeto, em 2017, conheciam-se cerca de 30 sítios arqueológicos. Estes locais registavam-se sobretudo na zona sul do concelho das Caldas da Rainha, onde se observaram sobretudo estudos de impacte ambiental e patrimonial para o desenvolvimento de obras públicas ou privadas.

Atualmente, até final de 2019, incrementámos o número de sítios em $155 \%$, reconhecendo vestígios que remontam até ao período da Pré-história Antiga, bem como evidenciando ocupações e levantamentos em todas as freguesias.

Metodologicamente não quisemos deixar de lado nenhuma das ferramentas que nos permitira traçar um quadro prévio de viabilidades, para depois passar ao trabalho efetivo de prospeção em campo, seja ele intensivo, como realizado em algumas pequenas áreas da região, seja não sistemático, isto é direcionado. Desta forma foram desenvolvidas análises aos topónimos; à fotografia aérea e satélite; aos mapas realizados por levantamento LIDAR existentes junto à cos- ta; a documentos históricos, como forais, obituários ou cartas; a mapas e desenhos antigos; às lendas; aos levantamentos e estudos científicos; a obras e artigos literários e descritivos sobre as Caldas da Rainha e naturalmente, naquilo que este artigo se prende, na informação e conhecimento oral da comunidade.

Ainda que seja uma ferramenta relevante para a compreensão da ocupação de uma região, a informação oral possuí um pequeno destaque nos resultados que dela se obtêm na construção de uma carta arqueológica. Isto porque acarreta uma certa complexidade metodológica para podermos chegar a um vasto público e um esforço logístico e de recursos humanos extenso que às vezes não se possui. A sua inclusão e tratamento de dados no projeto em questão permitiu debruçar-nos de uma forma equacionada num conjunto de estratégias que pudessem cumprir dois objetivos: sensibilizar a população local para a preservação e reconhecimento do Património das Caldas da Rainha, normalmente desconhecido, como é o arqueológico e intensificar, com o apoio da informação oral, a descoberta de novos sítios. Desta forma estruturamos a aproximação à comunidade em duas fases, uma breve, facilmente mesurada nos resultados e outra extensiva no tempo, não tão quantificável. A aproximação teve em conta o público alvo e o conhecimento que este poderia ter guardado na sua memória vivida.

Após a primeira fase de educação patrimonial registamos na segunda etapa que o trabalho foi muito eficaz junto de Lares e de Centros de dia, bem mais produtiva que junto das Associações culturais ou desportivas ou até das Juntas de Freguesia. Isto sobretudo no que se refere ao segundo objetivo a atingir. As escolas foram as que tiveram menor rendimento na descoberta de novos sítios, demonstrando, este grupo, um maior conhecimento sobre a atividade e ciência da Arqueologia e do Património. Acreditamos que os alunos que depois, na segunda fase, se integraram no projeto, tendo estado diariamente connosco durante 15 dias, saíram mais seguros sobre a atividade e a profissão de arqueólogo e conhecedores de como os vestígios podiam ser observados no terreno, mas nenhum voltou a contactar o projeto por qualquer razão, nem mesmo sobre um potencial novo local ou deles proveio algum outro contacto de outro elemento da comunidade. Esta questão leva-nos a entender os jovens de um ponto de vista pragmático para cumprir o primeiro objetivo, o da sensibilização, mas não tanto o segundo, a 
descoberta de novos locais, pois a motivação deles prende-se a pouco mais que umas férias em grupo com colegas ou ocupação dos seus tempos livres. Ao contrário os Centros de dia e os Lares permitiram incrementar a descoberta de novos locais em 30\% dos sítios inéditos atualmente conhecidos pelo projeto. Não só houve uma relação equipa-elemento da comunidade, como eles mesmos tiveram a iniciativa de nos contactar e de passar o nosso contacto a outros. De um ponto de vista formativo e de uma avaliação qualitativa registamos um aumento de interesse e consciência cívica mais profunda e responsável. Alguns elementos que colaboraram do grupo sénior sentiram uma experimentação de inclusão na vida ativa, mesmo com as idades já avançadas que possuíam, demonstrando nas prospeções de terreno uma motivação clara não só em aprender como em se tornar úteis e dinamizadores dos próprios trabalhos. Desta forma, torna-se visível que este processo, neste grupo, para alem de efetivo na captação e reconhecimento de novos sítios, "leva ao reforço da autoestima dos indivíduos ..., permitindo a valorização da cultura compreendida e tornando-se, cada um, como agentes dinamizadores desses mesmos conceitos e de uma nova realidade mais sensível para a salvaguarda do património e sua valorização" (Figueiredo, e Berezowski 2017).

Por fim, parece-nos relevante destacar, quanto ao segundo objetivo, que ainda que não tenhamos cruzado estes dados com outros obtidos noutros projetos, pela falta de uma certa objetividade na avaliação dos resultados e da subjetividade inerente a uma avaliação formativa realizada pela equipa, é entendível pelos vários membros que a compõem, que no caso de se estender a duração do projeto, esta classe deve ser novamente contactada e sempre valorizada na realização de trabalhos de levantamento para cartas arqueológicas. Numa análise geral e conclusiva não só auxiliam na descoberta de novos sítios, como se tornam em elementos ativos na salvaguarda destes bens, incluindo na consciencialização das classes mais jovens, como pudemos observar nas conversas entre estes e os jovens estagiários Ciência Viva.

\section{BIBLIOGRAFIA}

FIGUEIREDO, Alexandra e BEREZOWSKI, Walderez (2017) - A educação patrimonial como via para uma comunidade arqueologicamente mais consciente, In Temporis (ação). Periódico académico de Historia, Letras e Educação, vol. 17, no 1 ISSN 2317-5516.7 pp. 65-87.

FIGUEIREDO,Alexandra;LOPES, Ricardo(2018)-Moinhos das Caldas da Rainha, CMCRainha, CAAPortugal e IPT/ LABACPS - publicação financiada CMCR, Tomar. ISBN 978 989-8840-24-O

FIGUEIREDO, Alexandra. LOPES, Ricardo (2019) - Lendas e Fotografias antigas das Caldas da Rainha, CMCRainha, CAAPortugal e IPT LABACPS, Tomar. ISBN 978-989-8840 $-34-9$

FIGUEIREDO,Alexandra;LOPES,Ricardo;SIMÕES,Sónia. MONTEIRO, Cláudio; SILVEIRA, Adolfo. (2017) - A memória como ferramenta de pesquisa e investigação arqueológica. In atas Arqueologia em Portugal, 2017. Estado em questão. Associação dos Arqueólogos Portugueses Lisboa, ISBN: 978-972-9451-71-3. 227-235. pp.227-236.

FIGUEIREDO, Alexandra; LOPES, Ricardo; MONTEIRO, Cláudio; SILVEIRA, Adolfo (2018) - Educar os mais jovens para o património cultural, CMCR, página do site do município, publicações do projeto CARACA. Site http://www. $\mathrm{cm}$-caldas-rainha.pt/, consultado em 13 julho 2020.

FIGUEIREDO, Alexandra; LOPES, Ricardo; MONTEIRO, Cláudio; SILVEIRA, Adolfo (prelo) - A Carta Arqueológica das Caldas da Rainha: resultados preliminares de um projeto em curso, in atas do Congresso de História e Património da Alta Estremadura e Terras de Sicó, Alvaiázere, 21 e 22 de setembro de 2019, Leiria.

LOPES, Ricardo; FIGUEIREDO, Alexandra; MONTEIRO, Cláudio; SILVEIRA, Adolfo; SIMÕES, Sónia (prelo) - A importância da Educação Patrimonial para a salvaguarda e reconhecimento do património local, in atas do Congresso de História e Património da Alta Estremadura e Terras de Sicó, Alvaiázere, 21 e 22 de setembro de 2019, Leiria. 


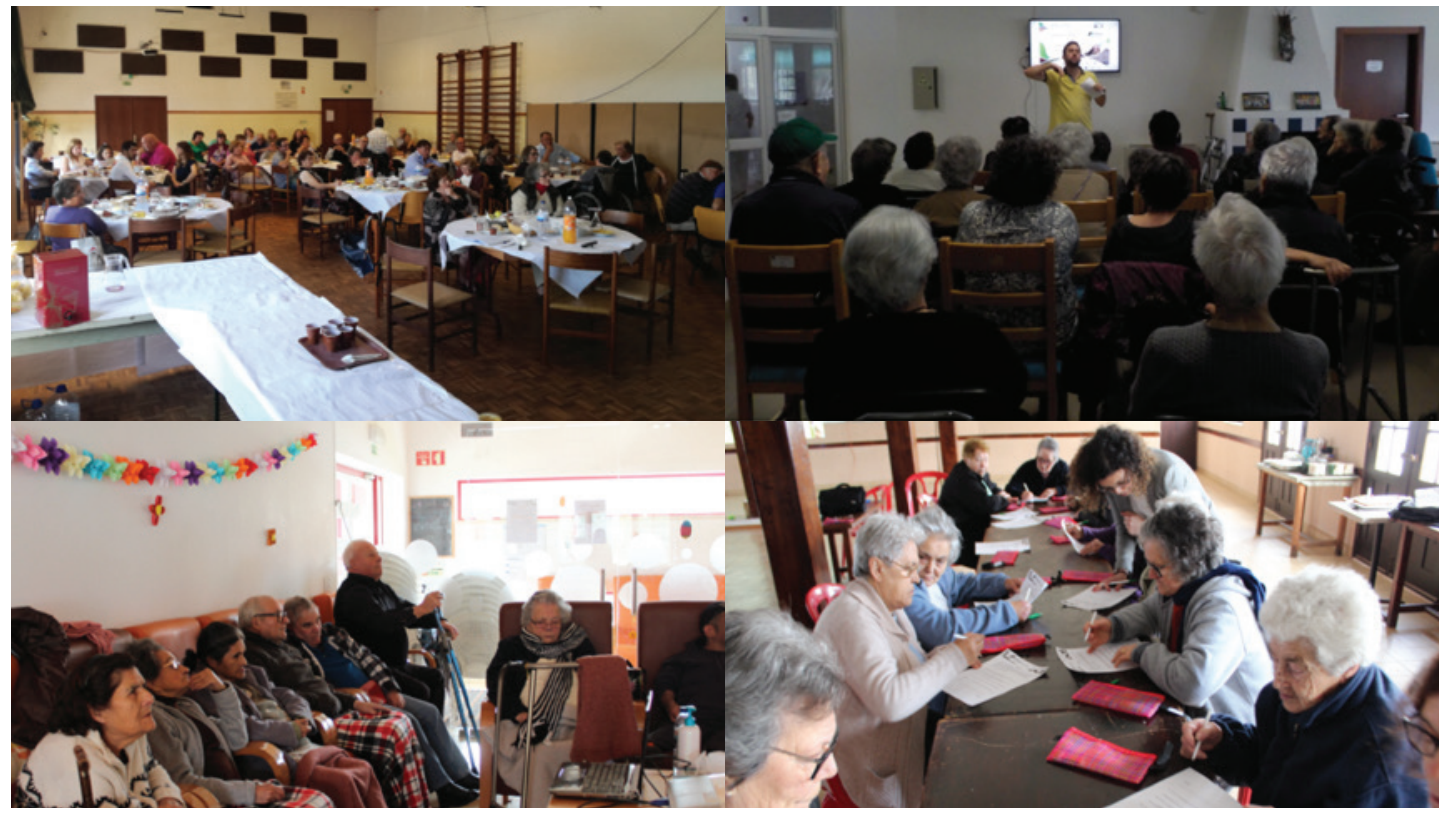

Figura 1 - Imagens dos trabalhos de Educação Patrimonial nos Centros de dia e Lares.

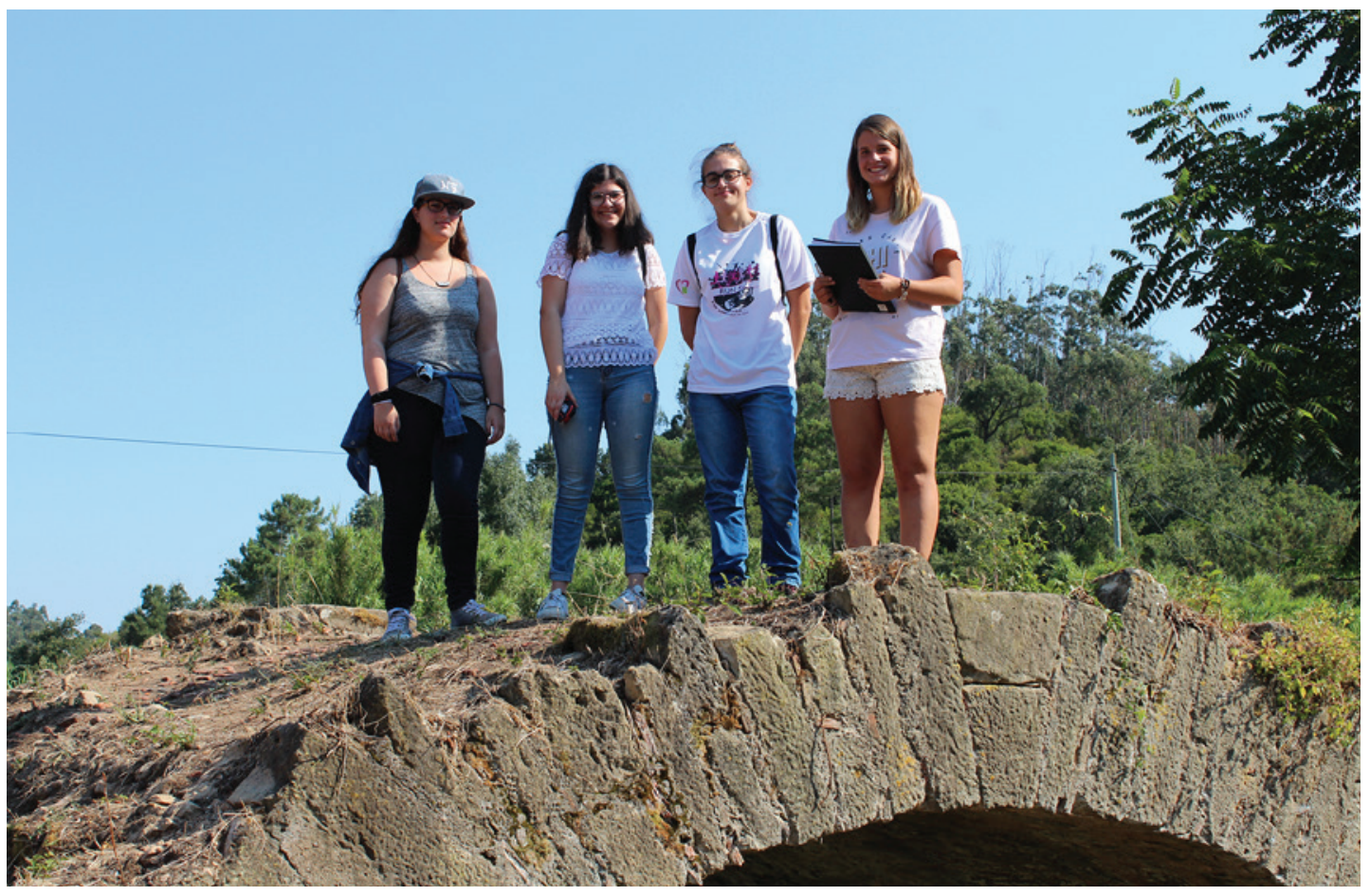

Figura 2 - Foto de 4 estudantes participantes nos trabalhos de prospeção. Sítio arqueológico - Ponte da Feteira, Salir de Matos. 


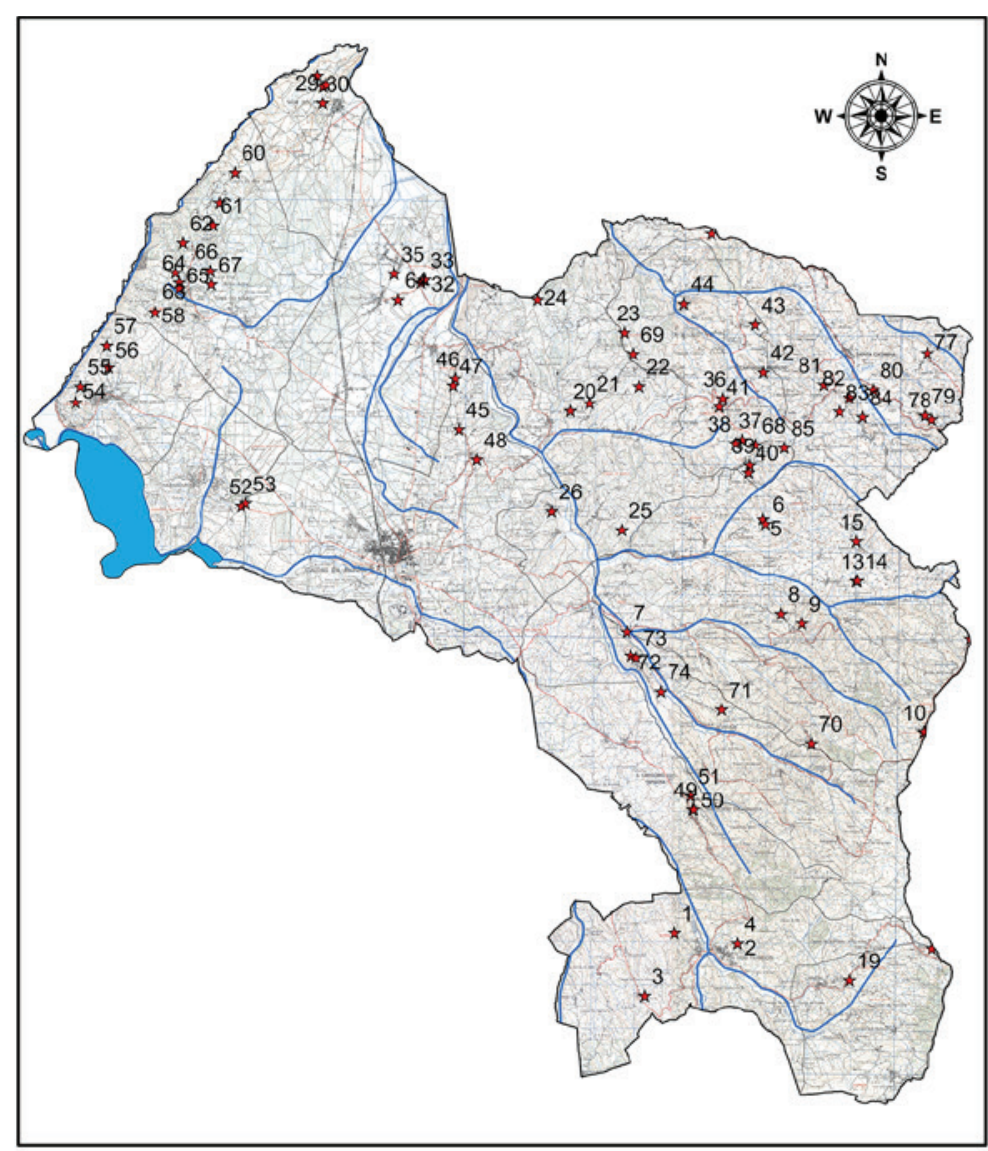

Moinhos das Caldas da Rainha

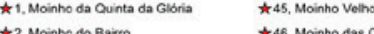

\2, Moinho do Bairo $\quad$ \46, Moinho das Carrascas

$\star \star 47$, Moinho do Casal coss Moinnos

¿48, Moinho do Lameirä

\#5, Moinho da Laranjeira $1 \quad$ \$49, Mainho de S\$o Gregónio 1

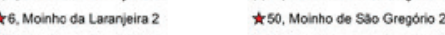

«7, Moinho do Casal Frade $\quad$ \51, Moinho de Sto Gregario 3

$\star 8$, Mainho dos Chatos 1 „52, Mainho do Nadadouro

\9. Moinhos dos Cháos 2

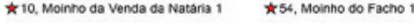

$\star 11$, Moinho da Venda de Nataria $2 \quad \star \quad 55$, Moinho do Facho 2

\12. Moinho de Santana $\quad$ \$56, Moinho da Estrada Atantica 1

$\star 13$, Moinho do Casal do Rodo $1 \quad$ ॠ57, Moinho da Estrada Atlantica 2

\14, Moinho do Casal do Rodo $2 \quad$ \58, Moinho do Nazaré

\$15, Mointo da Ramalhosa

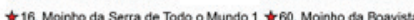

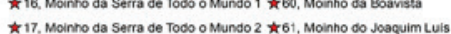

$\star 18$, Mointo das Bairradas $\quad \star 62$, Moinho do Lararia

\19. Moinho de Ferro de Santa Suzana $\quad$ \63, Moinho do Joaquim Antunes

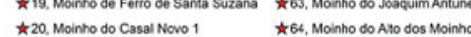

\21, Moinho do Casal Novo 2

\#22, Moinho das Cruzzes $\quad$ \#65, Moinho do Casal Colao

$\star 23$, Moinho dos Catreiros

\24, Moinno do Casal da Galega

ॠ26. Moinho da Torre

$\star 66$, Moinho do Atredo

\#67, Moinno do Salvador

$\star 68$, Moinho das Antas 5

$\star 69$. Moinhos das Cruzes

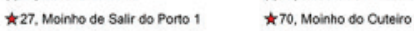

$\star 28$. Moinho de Salir do Porto $2 \quad \star 771$, Moinho do Casal das Canas

\$29. Moinho de Salir do Porto $3 \quad$ \$72, Moinho de Cortem !

$\$ 30$, Mointo de Salir do Porto $4 \quad \star 73$, Moinho de Cortem 2

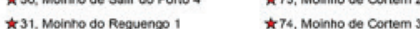

$\star 32$, Moinho do Reguengos 2

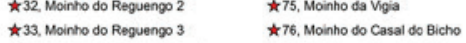

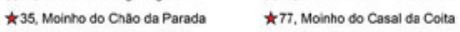

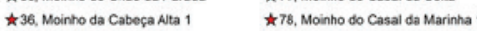

$\star$ 37, Moinho das Antas 1

Ł38. Moinho das Antas 2

\79, Mainho do Casal da Marinha 2

$\star 80$, Moinho do Siopa

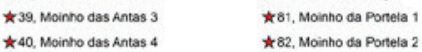

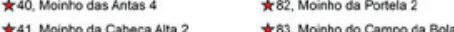

\42. Moinno do Pedrogho

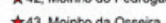

ॠ 84 , Moinho 00 Nario

ॠ85, Moinho dos Henriques

Figura 3 - Mapa do levantamento de Moinhos das Caldas da Rainha, distribuído nas Juntas de Freguesia.

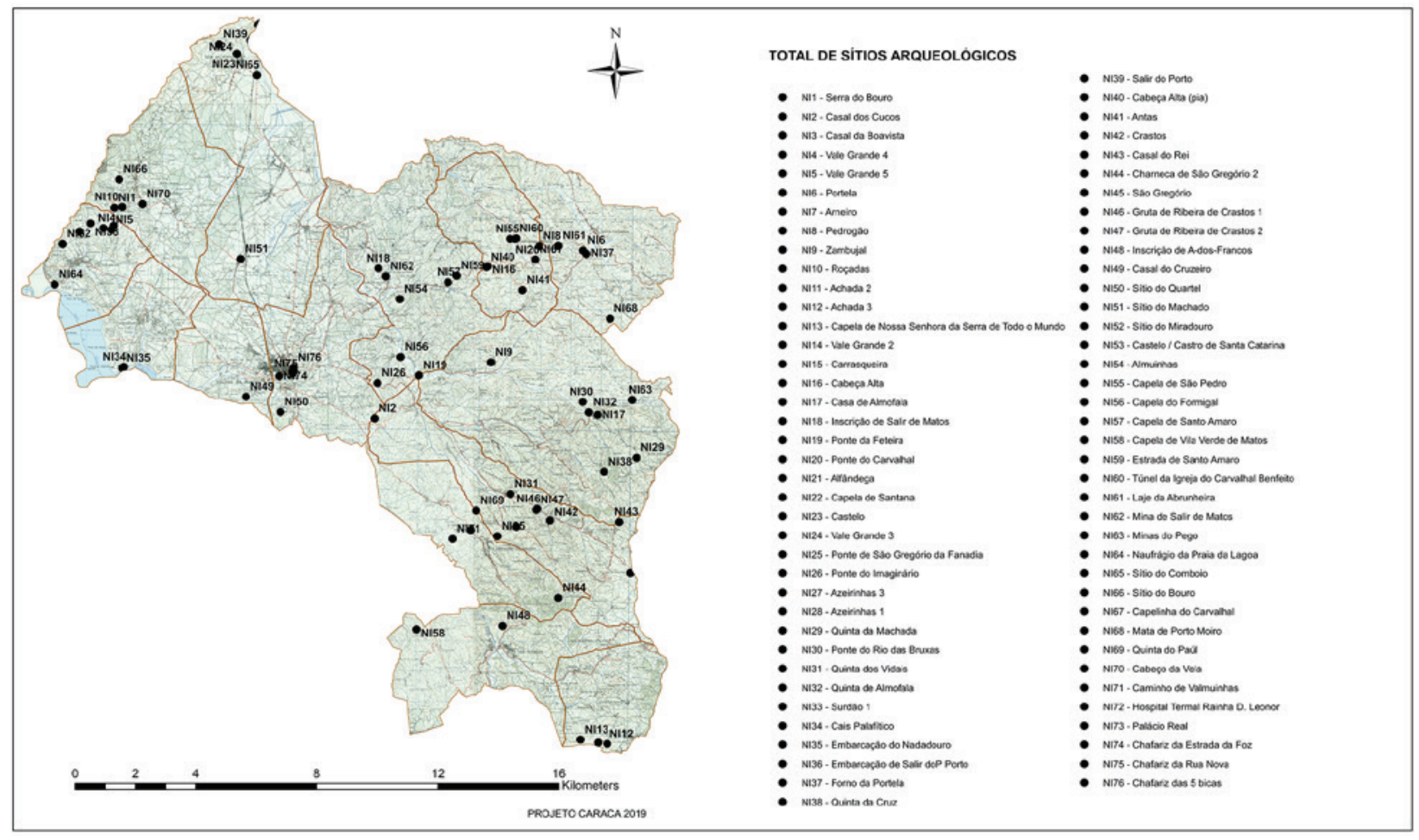

Figura 4-Carta Arqueológica com o levantamento de sítios arqueológicos inventariados até 2019. 


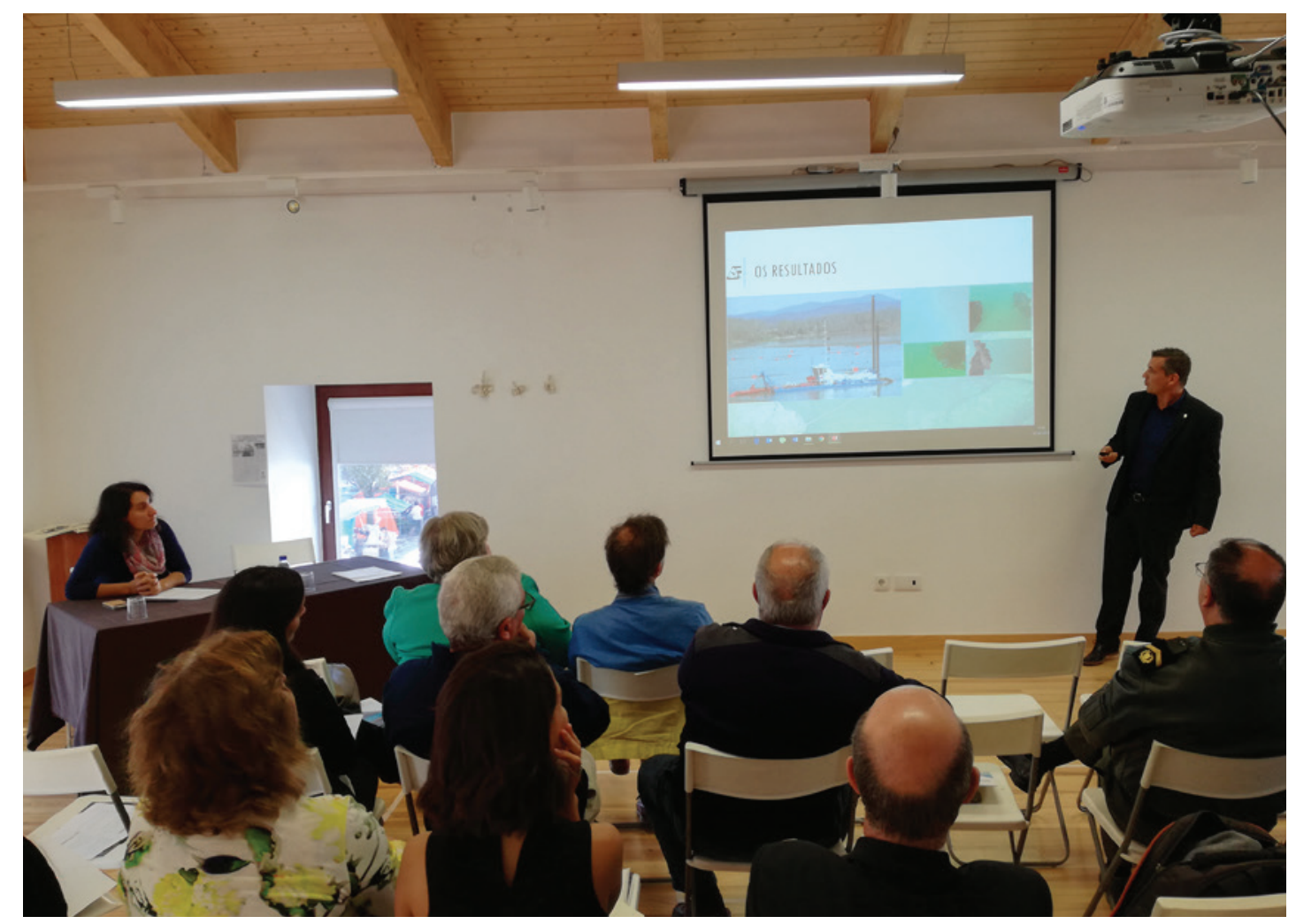

Figura 5 - Jornadas científicas, onde se realizou a apresentação do projeto das Caldas da Rainha, organizado pelo CARACA, em 2017.

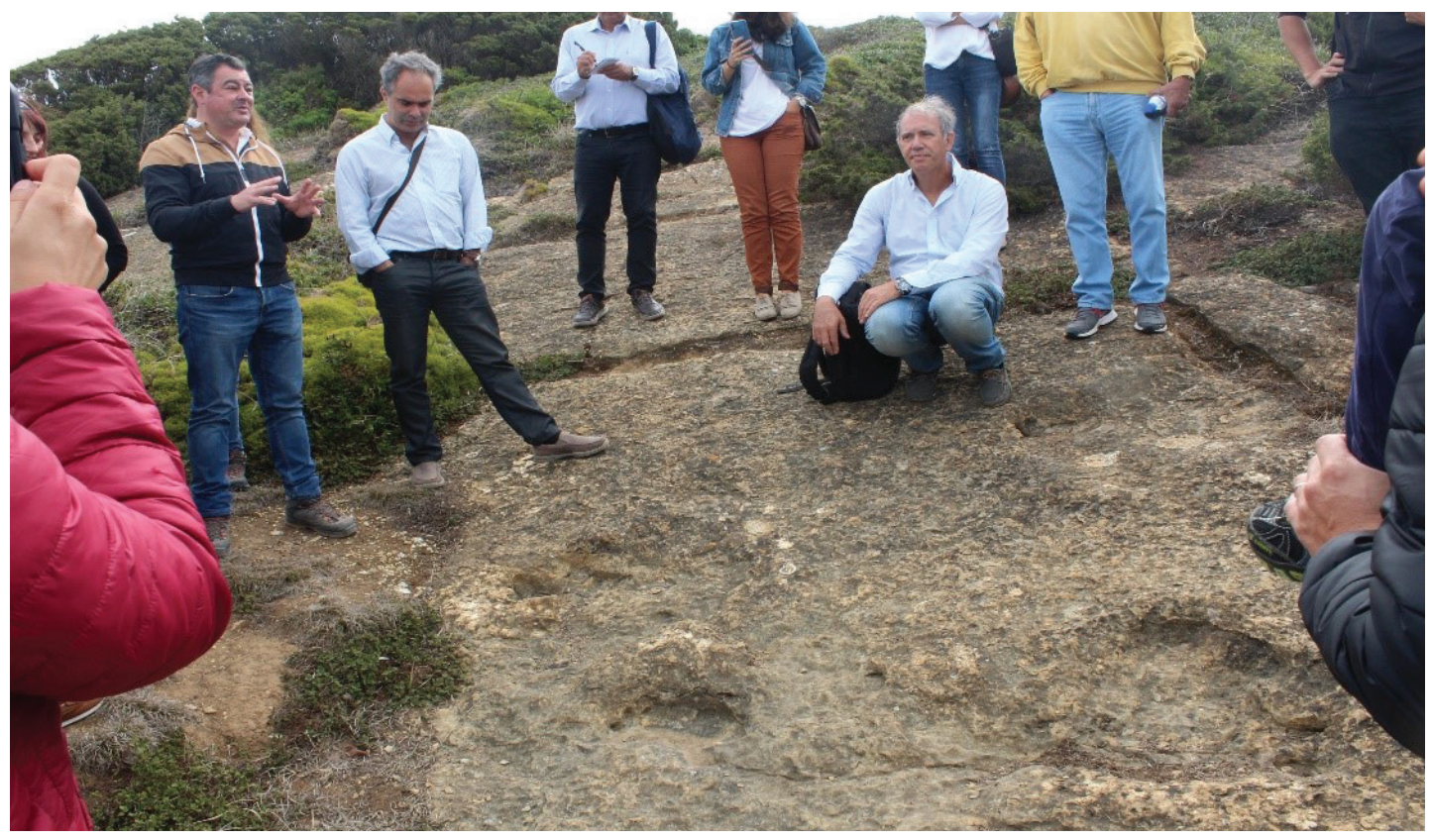

Figura 6 - Fotografia da Visita/Workshop ao património Paleontológico Caldas da Rainha, organizado em 2019, projeto CARACA. 


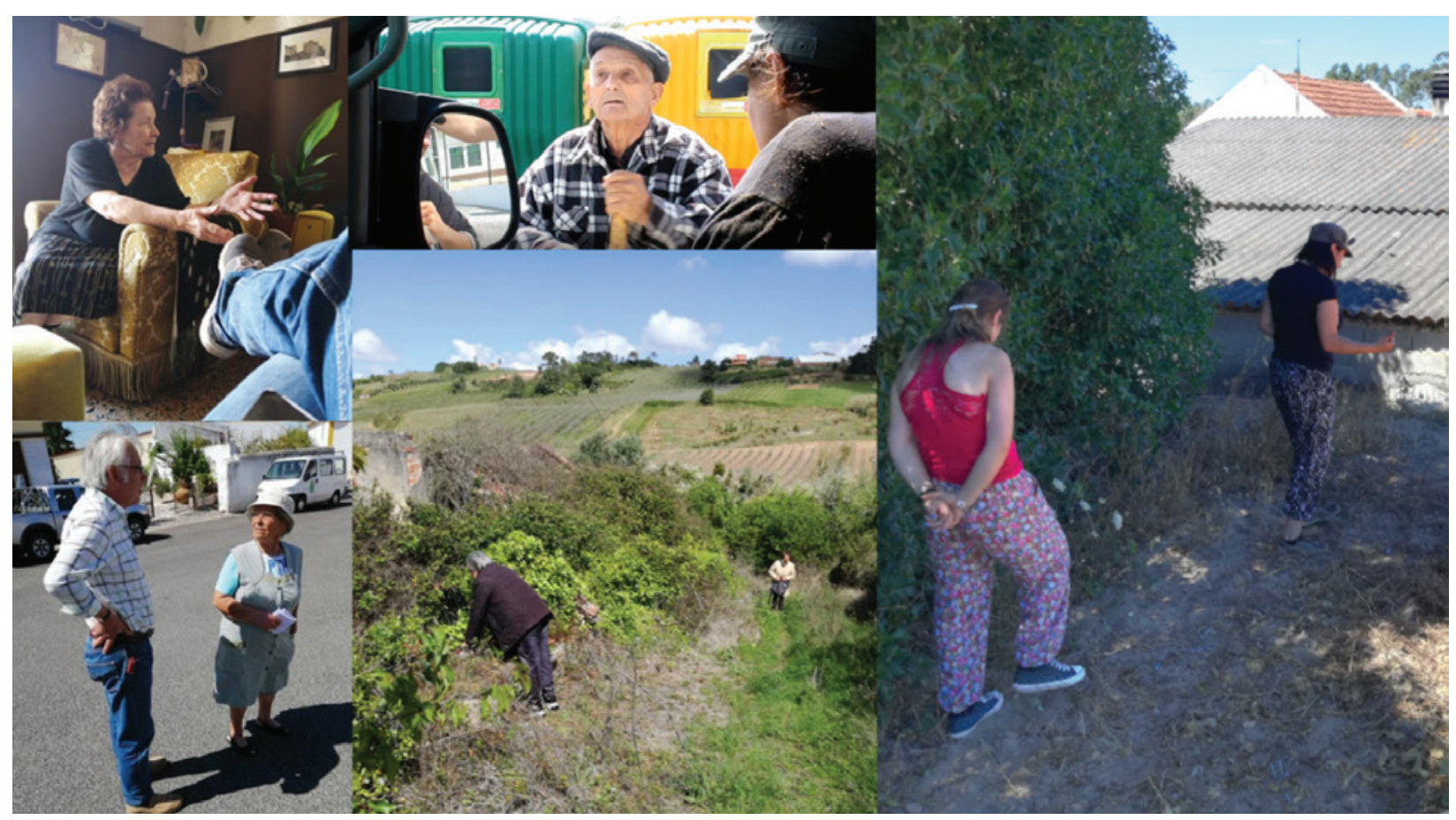

Figura 7-Algumas imagens da população local que colaborou nos trabalhos de prospeção. 


\title{
EDUCAÇÃO PATRIMONIAL - UM CIDADÃO ESCLARECIDO É UM CIDADÃO ATIVO!
}

\author{
Ana Paula Almeida ${ }^{1}$
}

\section{RESUMO}

O Património é um testemunho que mantém viva a Memória dos povos, contribuindo para o reforço da sua Identidade. O programa de dinamização do Serviço de Património Cultural (SPC) do Município de Esposende integra um conjunto de atividades decorrentes de múltiplos programas de pesquisa arqueológica realizados pelo Serviço e pelos seus parceiros (universidades e centros de investigação). Concebido para diferentes públicos, estimulam a aproximação física e emocional ao Património, nomeadamente através de atividades destinadas à comunidade educativa e ao público em geral. Educar e sensibilizar, de forma pedagógica e divertida para áreas como a Arqueologia, a História, o Património, a Inclusão ou a Cidadania são alguns pressupostos dos projetos da presente comunicação: “Eu Sou Património!” e PASO - Projeto de Arqueologia Sem Obstáculos. Palavras-chave: Identidade, Inclusão, Património Arqueológico, Educação Patrimonial, Castro e Centro Interpretativo de S. Lourenço, Arqueologia Sem Obstáculos.

\begin{abstract}
Heritage is a testimony that keeps our Memory alive, contributing to the reinforcement our Identity. The promoting program of the Cultural Heritage Service of Esposende Municipality integrates a set of activities resulting from multiple archaeological research programs carried out by the Service and its partners (universities and research centers). Designed for different publics, they encourage physical and emotional approximation to Heritage, namely through activities designed for the educational community and the general public. Educating and sensitizing, in a pedagogical and fun way, to areas such as Archeology, History, Heritage, Inclusion or Citizenship are some assumptions of the two projects of this communication: "I am Heritage!" and PASO (Projeto de Arqueologia Sem Obstáculos - Archeology Project Without Obstacles).

Keywords: Identity, Inclusion, Archaeological Heritage, Heritage Edcation, Castro and Centro Interpretativo de S. Lourenço, Archeology Without Obstacles.
\end{abstract}

"O património, hoje, não pertence nem à administração, nem aos políticos, nem sequer aos seus titulares ou mecenas, é da sociedade e das gentes que veem nele a sua identidade."

Javier Rivera Blanco (2002)

\section{PROJETO “EU SOU PATRIMÓNIO” - 2019/20}

Porque afinal, só se protege aquilo que se conhece e um cidadão esclarecido é um cidadão ativo!

\section{3 | PROGRAMA DE EDUCAÇÃO PATRIMONIAL}

O Projeto "Eu Sou Património" decorre o Programa de "Educação Patrimonial”, este último concebido em 2003, na sequência de uma reflexão centrada na função do Património na sociedade. Este programa tem como objetivo principal (in)formar, proteger, valorizar e divulgar o património do Município de 
Esposende, assegurando a transmissão de uma herança patrimonial.

Todo o trabalho de investigação desenvolvido em torno do Património - resultante da dedicação de diversos investigadores, dezenas de achadores e centenas de voluntários nacionais e estrangeiros - só é válido se for visto como um instrumento fundamental para o conhecimento e compreensão dos vestígios do passado, que merecem o respeito, a preservação e a manutenção por parte dos munícipes.

Assim, a política educativa só pode ter sucesso se se desenvolver a par de uma formação de públicos. A Educação é perspetivada como componente fundamental da política de Educação Patrimonial e, simultaneamente, um potencial motor de salvaguarda do Património. Abraçamos uma missão que se centra no auxílio aos cidadãos em geral, mas particularmente aos munícipes para que estes entendam qual é o seu lugar no mundo e compreendam a sua identidade, contribuindo assim para aumentar o respeito por si próprio e pelos outros.

$\mathrm{Na}$ nossa sociedade os objetos têm uma função de comunicação muito importante. Assim, a experiência de animação pedagógica usa o objeto e/ ou o monumento, procurando descobrir as histórias que eles contêm. Serve de meio para lhes inventar linguagens diversas, dando espaço à imaginação criativa inerente a todo o ser humano. Pretende-se que a experiência de aprendizagem proporcionada pelas atividades do Projeto seja um instrumento distinto, mas complementar ao processo desenvolvido ao longo da vida. (Tabela 1)

\section{1 | CENTRO INTERPRETATIVO DE S. LOURENÇO}

O Centro Interpretativo de S. Lourenço (CISL) é um espaço de visitação aberto ao público desde 2011 e que nos últimos 5 anos tem ultrapassado as 11.000 pessoas entre visitantes e participantes em atividades. O ponto de partida do Centro Interpretativo é o próprio castro, articulado com os restantes elementos de identidade local. Tem como objetivo principal estabelecer a "ponte" entre o estudo arqueológico do atual território de Esposende e sua valorização através da dinamização e divulgação

O CISL promove a exposição e a divulgação seletiva do espólio arqueológico, reconstruindo a História da ocupação do território, através dos dados e dos vestígios arqueológicos. Procura veicular informa- ções sobre o património do monte de S. Lourenço natural, cultural, tangível ou intangível - conferindo acessibilidade a toda a comunidade, dispondo de duas áreas expositivas e de serviço educativo.

\section{9 | PROJETO “EU SOU PATRIMÓNIO”}

Em 2019 o Serviço de Património Cultural deu início ao projeto "Eu Sou Património!", dirigido exclusivamente à comunidade educativa, englobando alunos e professores. Este projeto aborda o "Eu" enquanto património, sendo que as viagens e descobertas realizadas através do Património permitem-nos conhecer e dar a conhecer outras realidades, bem como a diversidade cultural, através dos usos e costumes de outras épocas e locais.

$\mathrm{O}$ presente artigo cinge-se à programação concebida para o ano letivo $2019 / 2 \mathrm{O}^{2}$, a qual integrou uma oficina de formação para docentes, atividades de exploração do Castro S. Lourenço e das exposições do Centro Interpretativo, bem como propostas de Visitas Orientadas Únicas. O programa também dedicou uma componente à conservação do Património Cultural através de um programa próprio. Todas as atividades foram concebidas em franca articulação com a disciplina de Cidadania, mas principalmente com os programas curriculares das disciplinas de Estudo do Meio, de História e de Química.

Porque o Património é um testemunho que mantém viva a memória dos povos, contribuindo para o reforço da sua identidade.

Assim, decorreu uma oficina de formação para docentes, na qual se pretendeu envolver a comunidade educativa no projeto "Eu sou Património". No Centro Interpretativo deu-se continuidade à exploração da exposição temporária "Mar de Histórias". As dinâmicas educativas para esta exposição centraram-se na Época Quinhentista, enquadradas pelas celebrações do V Centenário da Circum-navegação. O programa integrou atividades como " $D$. Sebastião, o menino que foi rei de Portugal", "Esposende Quinhentista e Carta Régia D. Sebastião”, a "A viagem de Fernão de Magalhães” ou o "Naufrágio Quinhentista de Belinho". Contou igualmente com a mais recente exposição permanente do CISL intitulada "IDENTIDADE(S): o Homem e o Território -

\footnotetext{
2. A programação do ano letivo $2019 / 20$ foi interrompida em meados de março de 2020 , em virtude da pandemia causada pela COVIDig.
} 
Esposende nas origens da Cultura Castreja" e inaugurada em outubro de 2019. O Castro S. Lourenço também teve lugar de destaque na programação, por exemplo através das atividades "Pão Galaico" e "Ofícios no Castro". A programação incluiu também um programa de Visitas Orientadas Únicas ao Património Arqueológico designado "VOU Patrimoniar”. Neste ano letivo abarcou ainda sessões temáticas relacionadas com a Conservação do Património Cultural, através das atividades "A química do PC" e "O PC em redução".

Seguidamente são apresentadas as atividades de dinamização e exploração relativas ao programa do ano letivo $2019 / 20$, sendo que sempre que a atividade se destina a mais de um ciclo de ensino, a mesma é adaptada ao nível de ensino.

\section{1. "EU SOU PATRIMÓNIO"| FORMAÇÃO DE PROFESSORES}

Público-alvo: Docentes dos Ensinos Básico e Secundário

A Câmara Municipal de Esposende acredita que a Escola é o principal âmbito de educação nos valores coletivos, devendo integrar na escala de valores dos futuros cidadãos o respeito ativo pelo passado comum. Com esta ação, à qual se pretende dar continuidade, pretendeu-se envolver a comunidade educativa no projeto “Eu sou Património", numa ótica de participação na construção de uma escola de saberes numa estreita relação com o Património material e imaterial na dimensão histórica e cultural; refletir e partilhar conceitos com os diferentes docentes, sobre a nossa identidade cultural, o que implica um conhecimento do património local, contextualizado no âmbito nacional, para reforçar laços de cidadania; ao encontro da necessidade de formação manifestada ao nível de aprendizagens diferenciadas e atualizadas, no desenvolvimento dos aspetos programáticos ligados à História e Património Cultural Local; avaliar as possibilidades do Património ser um elemento formativo nas políticas educativas; incentivar a construção de materiais e recursos educativos sobre diferentes Patrimónios Locais.

Assim, os docentes tiveram oportunidade de partilhar ideias, criar recursos e participar na reflexão conjunta sobre a implementação de diferentes práticas pedagógicas, nos diversos contextos educativos, para potenciar a curiosidade e a criatividade dos seus alunos (Figura 1).

\section{CISL | CENTRO INTERPRETATIVO DE S. LOURENÇO}

Intimamente relacionado com as duas exposições patentes ao público, o programa desconstrói as temáticas da exposição temporária "Mar de Histórias e a mais recente exposição "IDENTIDADE(S): o Homem e o Território - Esposende nas origens da Cultura Castreja". A primeira aborda a ocupação humana do território e a sua relação com a água, desde a Pré-História até à Idade Moderna. O segundo espaço expositivo dedica-se à ocupação humana entre o final do III milénio e o final do I milénio a.C., nomeadamente a implantada em pontos elevados e estratégicos.

2.1. "Mar de Histórias"| exposição temporária A exposição "Mar de Histórias" centra-se na relação do Homem com a água - mar, rios e ribeiros - um elemento marcante na história de Esposende. Nesta exposição dá-se a conhecer a dinâmica do território concelhio, associado ao nosso inestimável e marcante Património Arqueológico. É um convite a percorrer um circuito cronológico, que se inicia com a Pré-História e termina nos recentes achados arqueológicos de Época Moderna.

No Passado, tal como hoje, o espaço aquático era visto como uma implacável barreira física, um ambiente não controlado, pleno de surpresas, perigos e tragédias. No entanto, rios, ribeiros e o mar significaram também uma potencial via de comunicação e de aproximação entre as sociedades, ao invés de as dividir. Todos os conteúdos têm como base o Plano Diretor Municipal de Esposende e as Cartas Arqueológicas (terrestre e subaquática). Paralelamente assenta no conhecimento científico resultante da colaboração da Universidade do Porto, da Universidade do Minho, da Universidade Portucalense e das Universidades Nova de Lisboa e da Texas A\&M, bem como da Escola Profissional de Arqueologia.

Por fim, é de realçar que esta exposição muito deve à entrega de centenas de voluntários, orientados por dedicados investigadores, bem como da ação cívica de diversos achadores (Figura 2).

Atendendo à temática desta exposição, propôs-se um conjunto diversificado de atividades de exploração, desde jogos de exploração a palestras temáticas, passando por visitas orientadas únicas, onde os alunos podem descobrir diferentes temas e períodos abordados na exposição. 
Partindo das navegações do século XVI, descodificamos um naufrágio descoberto no concelho de Esposende em 2014, na praia de Belinho: o Naufrágio Quinhentista de Belinho.

O tipo de atividades disponibilizadas teve em consideração a abrangência de diferentes ciclos de ensino, desde o teatro de sombras, a palestras e contos, passando por visitas orientadas à exposição temporária "Mar de Histórias".

2.1.1. "O gigante que vivia ao lado do rio" | teatro de sombras

Público-alvo: 1..$^{\circ}$ e 2. ${ }^{\circ}$ ciclos

Partindo da imagem do prato de oferendas de S. Cristóvão - oriunda do naufrágio quinhentista de Belinho e integrado na exposição temporária - é abordada a lenda de S. Cristóvão, através do teatro de sombras "O gigante que vivia ao lado do rio". Segue-se a desconstrução da iconografia presente no prato relativamente à lenda e o desafio para cada aluno criar o seu próprio prato de oferendas, inspirado no objeto original.

Esta ação visa dar a conhecer o património cultural local e explorar a iconografia de peças arqueológicas e o seu significado.

2.1.2. "O Naufrágio Quinhentista de Belinho, Esposende e a Carta Régia de D. Sebastião" | palestra Público-alvo: $2 .{ }^{\circ}$ e $3 .^{\circ}$ ciclos

Dando consistência à divulgação das mais recentes descobertas sobre o naufrágio quinhentista do sítio arqueológico subaquático "Belinho I", a abordagem desta temática inclui o conhecimento atualizado sobre o naufrágio. Paralelamente procede-se ao enquadramento do quadro político de Portugal no século XVI, bem como às características de Esposende na época. Estas últimas partem das informações constantes no documento régio de elevação de Esposende à categoria de Vila.

Esta ação visa dar a conhecer o património cultural subaquático e arquivístico local, numa articulação entre a arqueologia e os documentos de arquivo (Figura 3).

2.1.3. "Esposende Quinhentista e Carta Régia D. Sebastião" | palestra

Público-alvo: $2 . .^{\circ}$ e.$^{\circ}$ ciclos

A Carta Régia de D. Sebastião é o ponto de partida para se conhecer a importância que este documento teve para Esposende, o seu impacto na vida quo- tidiana, bem como na criação e desenvolvimento do concelho.

Em parceria com o Serviço de Arquivo, esta atividade explora o texto da Carta Régia de D. Sebastião que eleva Esposende à categoria de Vila, sendo possível conhecer detalhes sobre como era o território e como ficou com a elevação a Vila, informações só passíveis de entender com a "desconstrução" do documento.

Paralelamente, são abordadas as características deste importante documento, como o tipo de documento, o suporte utilizado, a letra e as iconografias existentes, entre outros detalhes (Figura 4).

\subsection{4. "A viagem de Fernão de Magalhães" | jogo} lúdico-didático

Público-alvo: 1. . e 2.. ciclo

O português Fernão de Magalhães fez a primeira viagem de circum-navegação no século XVI ao serviço da coroa castelhana. Na Época dos Descobrimentos exploraram-se novas rotas marítimas que permitiram a circulação de vários produtos como ouro, sedas, especiarias, entre outros artigos.

Através de um jogo lúdico-didático sobre a viagem de Fernão de Magalhães, é dado a conhecer aos mais novos o trajeto e as rotas que foram realizadas, as descobertas e o comércio de novos produtos! (Figura 5)

2.1.5. “D. Sebastião, o menino que foi rei de Portugal" | conto e atividade plástica

Público-alvo: pré-escolar e 1.ํ ciclo

No século XVI Esposende foi elevado à categoria de Vila, pelo rei D. Sebastião. Mas quem foi esta importante personagem da história de Esposende? A partir de um conto infantil sobre D. Sebastião, dá-se a conhecer a história de um rei, outrora um menino que teve que crescer rápido para governar Portugal!

Esta ação é complementada por uma atividade de expressão plástica, por exemplo com a construção de puzzles de D. Sebastião e/ou construção de coroas.

2.2. "IDENTIDADE(S): o Homem e o Território - Esposende nas origens da Cultura Castreja”| exposição permanente

A fixação dos nossos antepassados em povoados situados em pontos elevados e estratégicos do vasto território que compõe o Noroeste Peninsular remonta ao período entre o final do III milénio e o final do I milénio a.C. Com cronologias e especificidades geográficas distintas, cada habitat teve a sua 
própria especificidade e um percurso que não teve forçosamente de se conciliar com os demais.

Com base nesta realidade, esta exposição aborda questões de gestão e de ocupação do território, indissociáveis do potencial da sua envolvente para a aquisição e produção de meios de subsistência, existência de espaços com recursos naturais, o controlo e defesa dos respetivos territórios, de passagens terrestres e fluviais e bem como da navegação fluvial e marítima. No espaço de auditório, o público tem à sua disposição dois filmes:

"Caturo o pequeno guerreiro": um filme para os mais novos, apresentado pela personagem Caturo, no qual é abordada a evolução da ocupação do Castro de S. Lourenço, desde as primeiras ocupações até aos séculos XII-XIII;

"Quem somos e de onde vimos... Castro de S. Lourenço": um documentário para o público em geral sobre o Castro de S. Lourenço, enquadrando-o na ocupação do período pré-romano no atual concelho de Esposende (Figura 6).

\section{CSL | CASTRO S. LOURENÇO}

Uma das estações de eleição para a dinâmica da didática patrimonial é, por excelência, o Castro de S. Lourenço. Contando com escavações arqueológicas e trabalhos de conservação e restauro (totais ou parciais) desde 1985, o universo de exploração é inesgotável. No ano letivo 2019/20, para além das visitas orientadas, tanto ao Castro como às exposições patentes no CISL, disponibilizou-se uma programação mais interativa, que de alguma forma envolvesse os sentidos e a experimentação.

\subsection{Pão Galaico | oficina gastronómica}

\section{Público-alvo: pré-escolar e 1. ${ }^{\circ}$ ciclo}

Desde a Pré-História que a castanha e a bolota eram usadas como complemento na alimentação humana. A bolota é um fruto produzido por árvores da família do carvalho (género "Quercus”). Aqui no Norte, a bolota é, essencialmente, de carvalho. Já Estrabão, geógrafo e historiador romano (58 a.C. -25 d.C.) na sua obra "Geografia”, refere no livro III que “(...) Na quarta parte do ano não se mantêm senão de bolotas, que secas e trituradas, se moem para fazer pão, o qual pode guardar-se por muito tempo (...)”.

Então, partindo das fontes escritas e aliando-as aos dados da Arqueologia e da Arqueobotânica, é possível reconstituir uma técnica de moagem e os há- bitos alimentares de então. Divulgar a importância destes frutos na alimentação galaico-romana é uma das finalidades da atividade, onde os participantes têm oportunidade de confecionar e degustar o seu próprio pão! (Figura 7).

3.2. Ofícios no Castro $^{3}$ | visitas com recriação de ambiências e ofícios

Público-alvo: $2^{\circ}$ e $3^{\circ}$ ciclo dos Agrupamentos de Escolas de concelho

No âmbito das atividades desenvolvidas no Castro de S. Lourenço com as Escolas, esta atividade tem uma forte componente lúdico-pedagógica, assegurando aos participantes a vivencia e experimentação de alguns ofícios praticados neste povoado castrejo romanizado.

Tratam-se de iniciativas promovidas anualmente por cada Agrupamento de Escolas, alicerçada numa forte componente do património Cultural, aliando a componente ambiental, a participação no âmbito da Cidadania e o fomento do Desporto e hábitos de vida saudáveis.

Estão desenvolvidas as seguintes iniciativas escolares:

- CAMINHADA DA SAÚDE | Agrupamento de Escolas António Rodrigues Sampaio - todos alunos do $5^{\circ}$ ano;

- MARCHA DA MONTANHA | Agrupamento de Escolas António Correia de Oliveira - todos alunos do 6ano;

- DIA DA FLORESTA | Escola Secundária Henrique Medina - todos alunos do $7^{\circ}$ ano (Figura 8).

\section{VOU PATRIMONIAR | VISITAS ORIENTADAS ÚNICAS - PATRIMÓNIO ARQUEOLÓGICO}

Público-alvo: pré-escolar ao $3 . .^{\circ}$ ciclo

Promoção de visitas orientadas a diversas estações arqueológicas visitáveis no concelho de Esposende, como meio de divulgação e sensibilização dos nossos jovens para o conhecimento, a preservação e o respeitado pelo Património, especialmente na região em que vive.

Pretende-se fomentar o contacto direto dos nossos jovens com os monumentos arqueológicos conce-

3. Atendendo que estas iniciativas decorrem anualmente entre março e junho, devido à COVID-19 este ano não foi suspensa. 
lhios e cativar a atenção ou consolidar os conhecimentos adquiridos pelos alunos.

Existem diversos percursos propostos: Roteiro 1 | Megalitismo (Menir de S. Paio de Antas, Dólmen do Rapido III ou Dólmen da Portelagem); Roteiro 2 | Idade do Ferro/ Romanização (Castro e Centro Interpretativo de S. Lourenço ou Castro do Sr. dos Desamparados); Roteiro $3 \mid$ Medieval (Cemitério Medieval das Barreiras); Roteiro 4 | Megalitismo à Romanização (Menir de S. Paio de Antas, Dólmen do Rapido III e Castro e Centro Interpretativo de S. Lourenço); Roteiro 5 | Megalitismo à Época Medieval (Menir de S. Paio de Antas, Dólmen III do Rapido, Castro e Centro Interpretativo de S. Lourenço e Cemitério Medieval das Barreiras). Sempre que oportunamente requerido, é possível a adaptação e realização de visitas orientadas a outros locais, adaptando-se sob proposta.

\section{CONSERVAÇÃO PATRIMÓNIO CULTURAL}

Com o objetivo de despertar os alunos para cuidados e a sensibilização do Património Cultural pretende-se, através dos conteúdos programáticos de Ciências Físico-Química, de Física e Química A permitir aos alunos perceber que para a conservação do $\mathrm{Pa}$ trimónio Cultural também é necessário ter conhecimentos de química.

5.1. “A química do PC" | palestra e experimentação Público-alvo: 3. . ciclo | 8.ำ ano de escolaridade

A aprendizagem das Ciências Químicas é iniciada no $3^{\circ}$ ciclo de escolaridade e os alunos aprendem a compreender as reações químicas. Como nem sempre contactam com casos práticos, nesta atividade pretende-se realizar atividades de experimentação em articulação com os conteúdos e objetivos da disciplina e simultaneamente proporcionar a aprendizagem das técnicas de execução da conservação de artefactos e processos físicos e químicos inerentes. Partindo dos casos práticos de conservação do Serviço de Património Cultural, explica-se a corrosão dos metais, (um material que é muitas vezes usado em objetos produzidos pelo homem), as reações de oxidação-redução (Figura 9).
5.2. “O PC em redução"” | palestra e experimentação Público-alvo: ensino secundário | 11. a ano de escolaridade Uma das metas específicas e transversais da atividade laboratorial de Física e Química A do $11^{\circ}$ ano está associada à série eletroquímica, cujo objetivo é organizar uma série eletroquímica a partir de reações entre metais e soluções aquosas de sais contendo catiões de outros metais.

Partindo dos casos práticos de conservação do SPC, explica-se a corrosão dos metais (um material que é muitas vezes usado em objetos produzidos pelo homem), as reações de oxidação-redução e o processo de eletrólise.

Propomos através desta atividade a participação dos alunos num caso prático de conservação de um artefacto do Serviço de Património Cultural realizada através da experimentação da eletrólise como processo de conservação.

\section{PASO | PROJETO DE ARQUEOLOGIA SEM OBSTÁCULOS}

No âmbito nacional é evidente a existência de numerosos obstáculos que inviabilizam a plena fruição do Património Cultural. Estes podem-se traduzir em barreiras arquitetónicas/físicas, deficiências de comunicação como a documentação disponibilizada, a sinalética, a identificação dos espaços e objetos. Neste contexto, surgiu na década de 1980 o primeiro documento relativo às pessoas com necessidades especiais ${ }^{5}$. Posteriormente, tornou-se obrigatório a adoção de normas técnicas de eliminação de barreiras arquitetónicas em edifícios públicos, equipamentos coletivos e via pública para a melhoria da acessibilidade das pessoas com mobilidade condicionada ${ }^{6}$. Seguiu-se a iniciativa nacional para os cidadãos com necessidades especiais na sociedade da informação, bem como o programa nacional para a sua participação na sociedade da informação ${ }^{7}$. Já no início do século XXI, surgiu legislação que proíbe e pune a discriminação em razão da deficiência e da existên-

\footnotetext{
4. Atendendo que o calendário programado para estas iniciativas, devido à COVID-19 não foi possível realizar.

5. Lei n. $9 / 89$.

6. Decreto-Lei n. ${ }^{\circ}$ 123/97.

7. Resoluções do Conselho de Ministros no 96 e $97 / 99$ e n.ำ $110 / 2003$.
} 
cia de risco agravado de saúde ${ }^{8}$, foram definidas as condições de acessibilidade a satisfazer no projeto e na construção de espaços públicos, equipamentos coletivos e edifícios públicos e habitacionais ${ }^{9}$, viu-se aprovado o Plano Nacional para a Promoção da Acessibilidade ${ }^{\circ}$, bem como a Convenção sobre os Direitos das Pessoas com Deficiência (adotada em Nova Iorque em 30 de Março de 2007) ${ }^{11}$. Mais recentemente a Assembleia da República recomendou ao Governo uma estratégia para promover o turismo acessível em Portugal ${ }^{12}$, tendo sido aprovada a revisão do Plano Estratégico Nacional do Turismo (PENT) para 2013-2015 ${ }^{13}$

Atualmente o conceito de "acessibilidade" é percecionado como uma questão de direitos humanos reconhecidos nas leis de vários países do mundo - o direito à igualdade de oportunidades, à não discriminação, à inclusão e à participação em todos os aspetos da vida em sociedade. É, pois, fundamental promover-se o acesso físico, intelectual, social, cultural ou económico ao nosso Património Cultural, pelo que é nesta ótica que estamos a trabalhar. Assim, pretendemos que o serviço público que oferecemos seja cada vez mais acessível a um maior número de pessoas, sejam visitantes, como participantes em atividades.

Nesta linha de pensamento, o Projeto Arqueologia Sem Obstáculos (PASO), concebido em 2008, implementado em 2011 e amplamente dinamizado desde 2013, tem por objetivo combater a discriminação e promover a igualdade de oportunidades, procurando contribuir de forma eficaz para uma mudança de atitudes da sociedade face às reais potencialidades das pessoas, nomeadamente as que têm alguma incapacidade.

Pretende-se, pois, conferir uma substancial melhoria no acolhimento e informação aos visitantes, eliminando obstáculos sociais, físicos e comunicacionais, sensoriais e intelectuais nas áreas arqueológicas visitáveis do Município de Esposende e serviços a elas associados.

\footnotetext{
8. Lei n. ${ }^{\circ} 46 / 2006$.

9. Decreto-lei n. ${ }^{-163 / 2006}$.

10. Resolução do Conselho de Ministros n.. 9/2007.

11. Resolução da Assembleia da República n.ํ56/2009.

12. Resolução da Assembleia da República n.ํำ13 e 132/2012.

13. Resolução do Conselho de Ministros n. ${ }^{\circ}$ 24/2013.
}

Com este projeto pretende-se conferir uma melhoria substancial no acolhimento e informação aos visitantes com deficiência, promovendo o acesso físico, social e intelectual - à participação cultural, eliminando obstáculos sociais, físicos e comunicacionais, sensoriais e intelectuais nas áreas arqueológicas e serviços associados.

Para tal, foi (e é) importante ter presente os conceitos que cada barreira em geral implica, nomeadamente: barreira física - obstáculo natural ou infraestrutural que limita a aproximação ou circulação no espaço, mobiliário ou equipamento urbano de pessoas com mobilidade condicionada - barreira social - situação social que constitua uma dificuldade no acesso aos espaços e à oferta cultural - e finalmente, barreira intelectual, aquela que obstrua ou dificulte a fruição integral da oferta cultural de, por exemplo, pessoas com baixa literacia, sem conhecimento técnico-científico especializado, com deficiências ou limitações sensoriais, défice de atenção, deficiência intelectual (entre outras) ou pessoas cuja primeira língua não seja o português ${ }^{14}$.

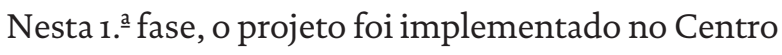
Interpretativo de S. Lourenço (CISL) e nas atividades lúdico-pedagógicas disponíveis, nomeadamente:

\section{Acessibilidades:}

1.1. Ao Centro Interpretativo de S. Lourenço, com a adequação dos espaços exterior $\mathrm{e}$ interior.

1.2. À informação, com a disponibilização de diversos níveis de informação e em diversos formatos e línguas;

1.3. Ao espólio através, por exemplo, de formas de acesso táctil.

2. Programação de atividades integradas e adaptadas, através da diversificação da oferta, da sua divulgação junto associações de pessoas com necessidades especiais e espaços de acolhimentos recreativos socioculturais, sempre em estreita articulação, colaboração e avaliação com os técnicos responsáveis.

Neste âmbito, o CISL dispõe de diversos níveis e formatos de informação. Até final de 2019, a componente expositiva tinha soluções com recurso às novas tecnologias da informação e complementarmente soluções que promoviam a interação através da motricidade, nomeadamente materiais de ma-

\footnotetext{
14. Definições adaptadas da "Acesso Cultura", in https:// acessocultura.org/quem-somos/missao-e-objectivos/ [consultado em junho 2020].
} 
nipulação direta (reais, réplicas e miniaturas). Nas soluções - tecnológicas ou tradicionais - o visitante era estimulado a utilizar os seus sentidos na descoberta dos conteúdos. A visita com invisuais ou pessoas com baixa visão era mais intuitiva e funcional, com conteúdos também disponíveis em pontos áudio e em Braille Português. É de destacar que estas soluções auferiram do contributo da Dra. Cristina Leites, funcionária cega que integrava o quadro de pessoal da Autarquia.

No que respeita ao programa de atividades, o Serviço Educativo dispõe de uma oferta diversificada, parcialmente resultante de projetos em parceria com diversas instituições, de entre os quais se destaca a associação APPACDM de Braga - Complexo de Esposende e de forma mais pontual as associações ACAPO - Delegação de Braga e Íris Inclusiva. A título de exemplo, foram realizadas diversas atividades como
"Caturo, o pequeno guerreiro" (teatro, que implicou a criação dos adereços e acessórios, culminando com a dramatização), diversas oficinas - "Adornos e Guerreiros", "Casas castrejas" e "Olaria” - "Arqueólogo por 1 dia”, "Em busca do passado... Pré-Histórico: Construtores da Pré-História e Artistas da Pré-História”, bem como visitas orientadas. Articulação entre a APPACDM - Esposende e o Lar de Idosos da Santa Casa de Misericórdia de Fão, nomeadamente "Bordados galaicos" (confeção de vestuário), bem como a apresentação de uma peça de teatro.

Estamos conscientes que há muito trabalho a desenvolver e implementar, pois é um caminho inesgotável. Por este motivo, estamos abertos a parcerias e colaborações de e com instituições, entidades que tenham objetivos semelhantes e de alguma forma entendam que juntos podemos contribuir para a melhoria da fruição cultural (Figura 10).

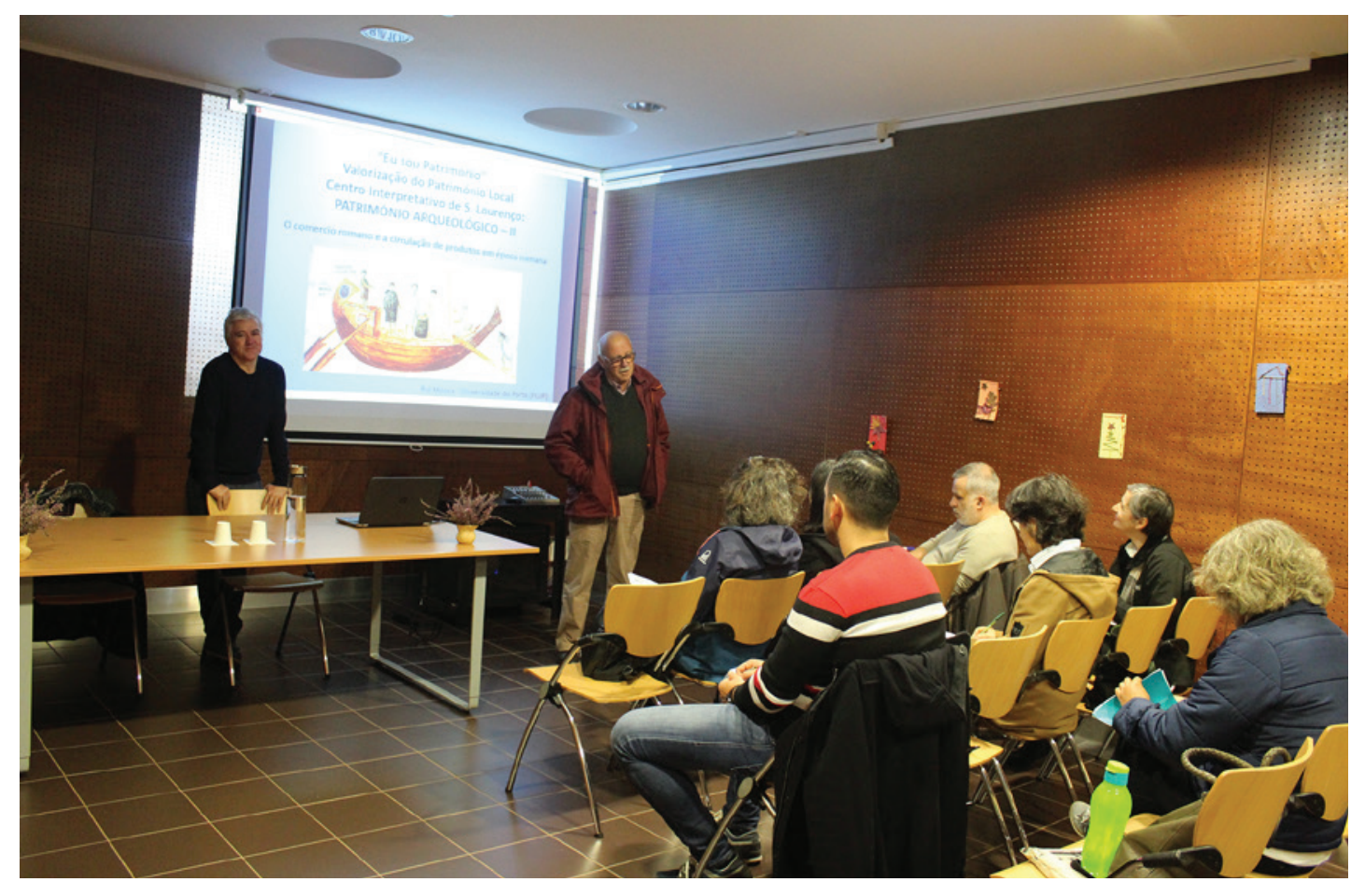

Figura 1 - "Eu Sou Património"| formação de professores. 


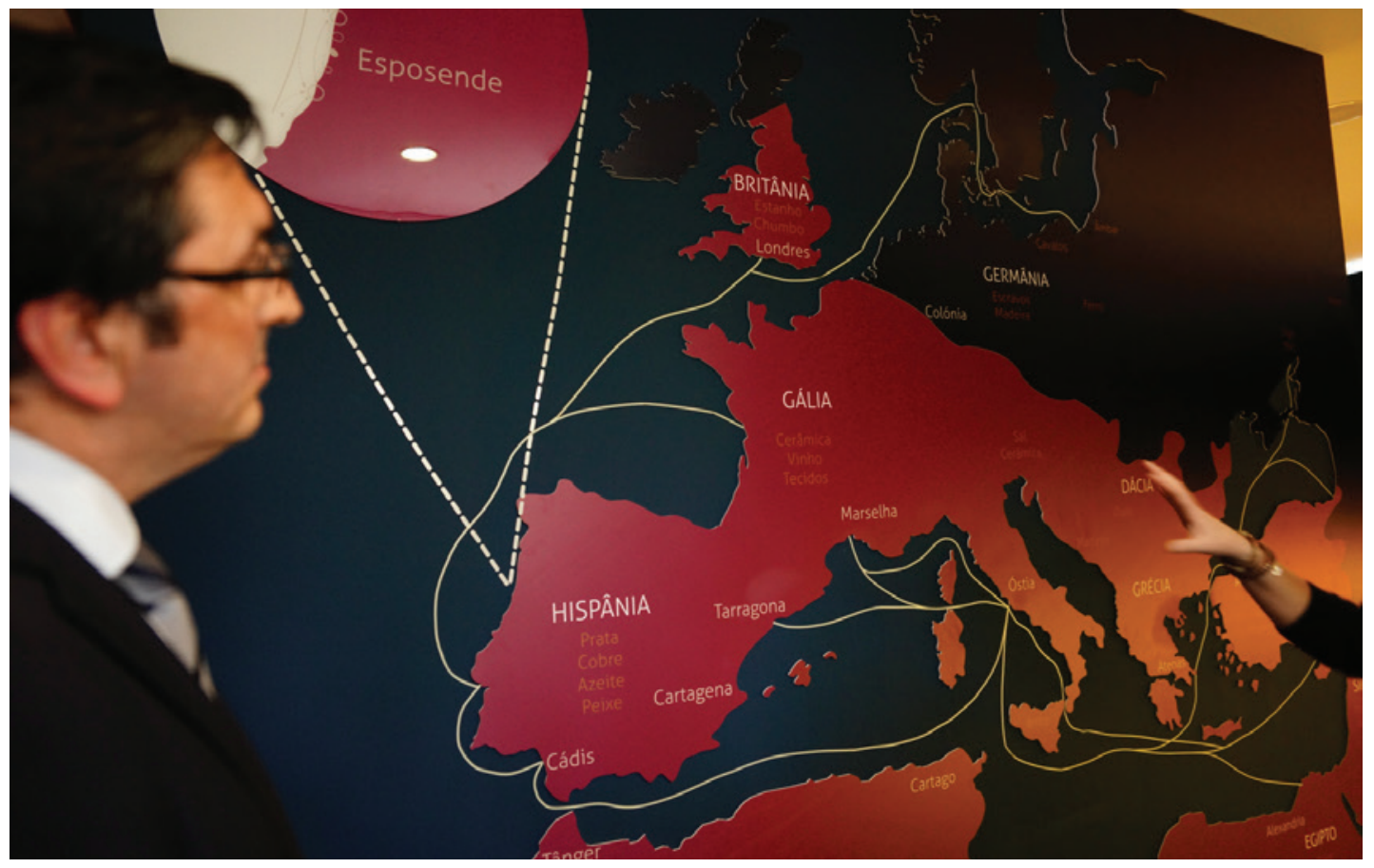

Figura 2 - "Mar de Histórias” | Exposição Temporária.

\section{Mar de Histórias:}

\section{O naufrágio quinhentista de Belinho}

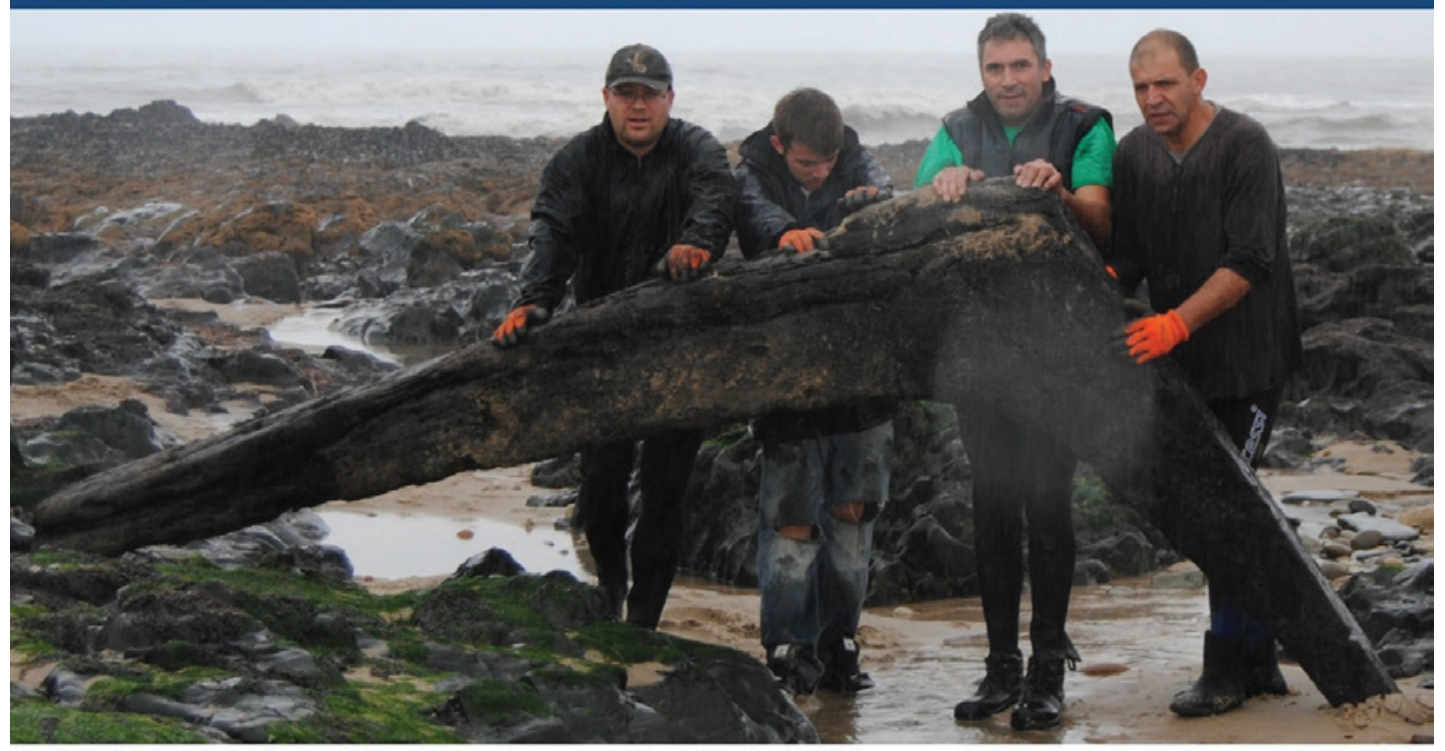

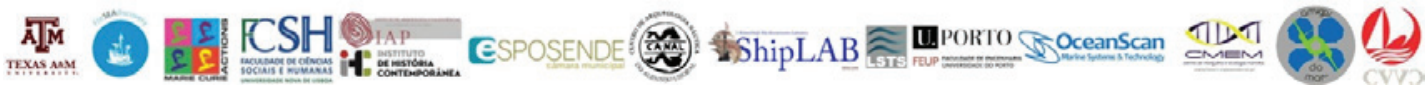

Figura 3 - "Mar de Histórias: O Naufrágio Quinhentista de Belinho. 


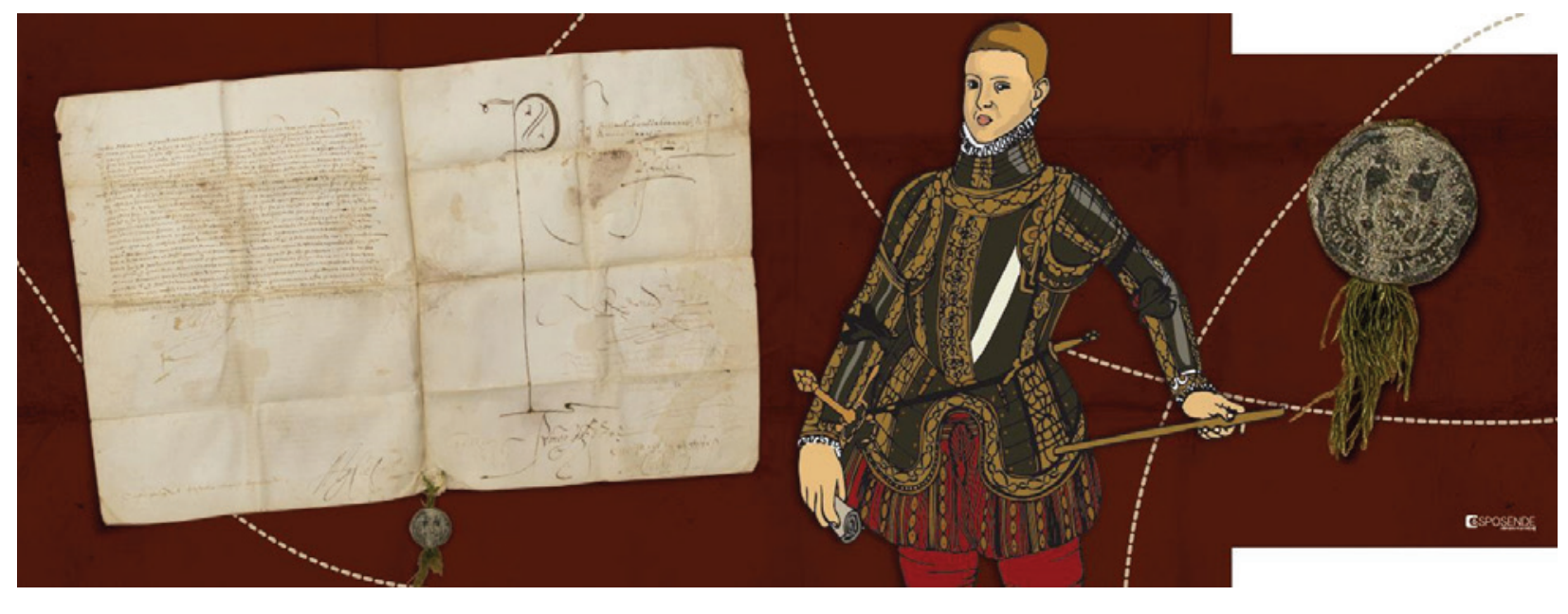

Figura 4 - Esposende Quinhentista e a Carta Régia de D. Sebastião.

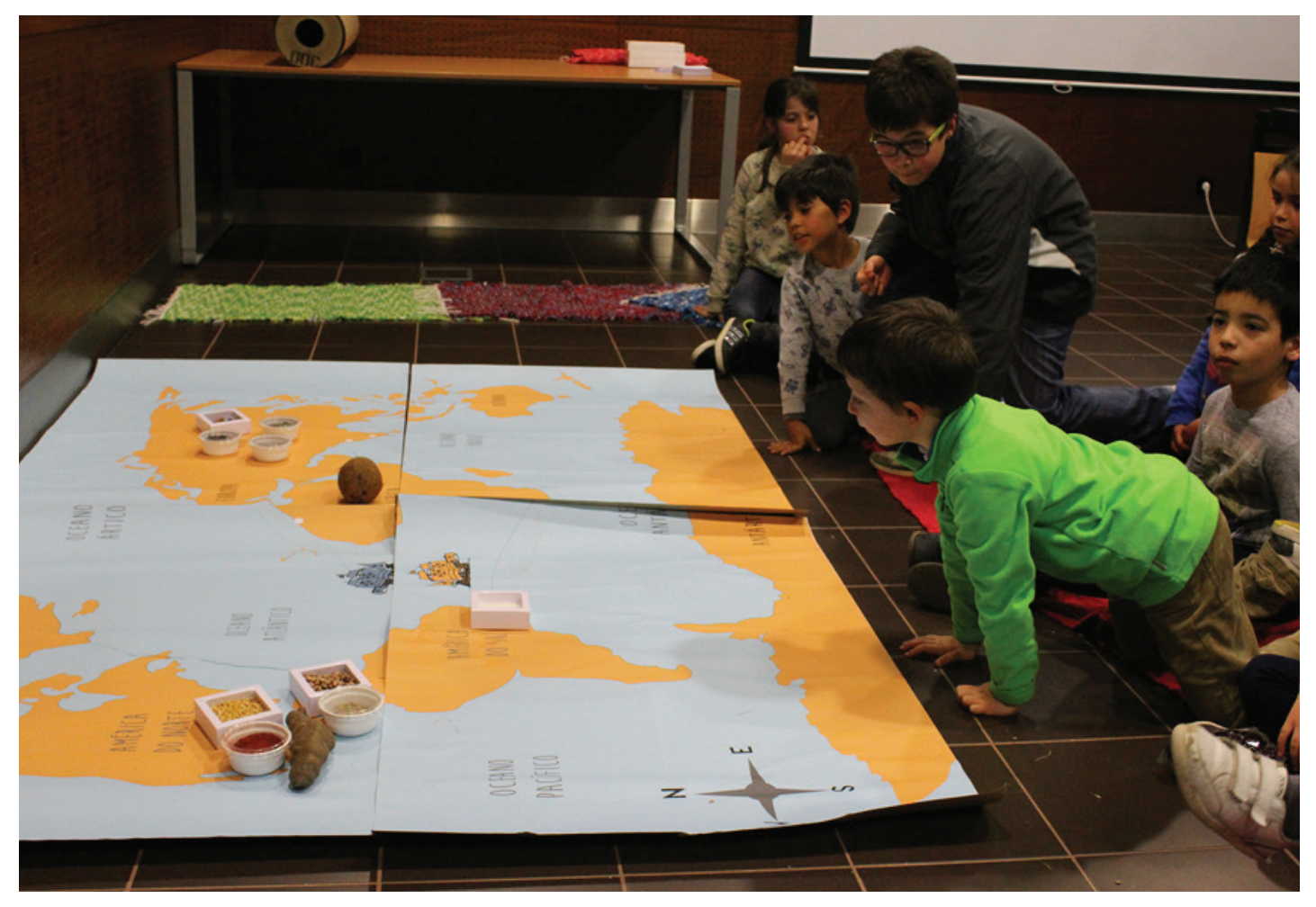

Figura 5-A viagem de Fernão de Magalhães. 


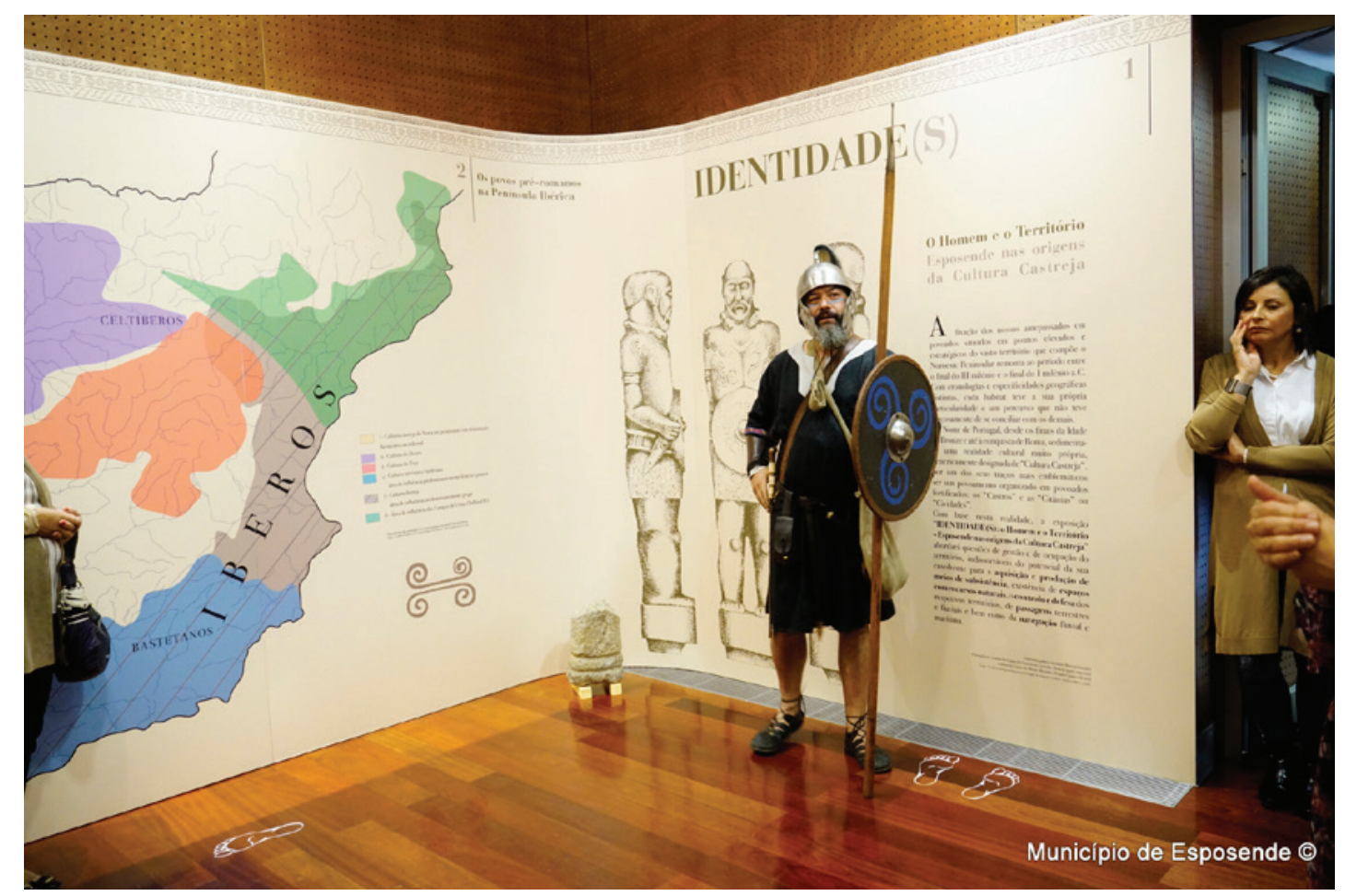

Figura 6 - “IDENTIDADE(S): O Homem e o Território -Esposende nas Origens da Cultura Castreja” | Exposição Permanente.

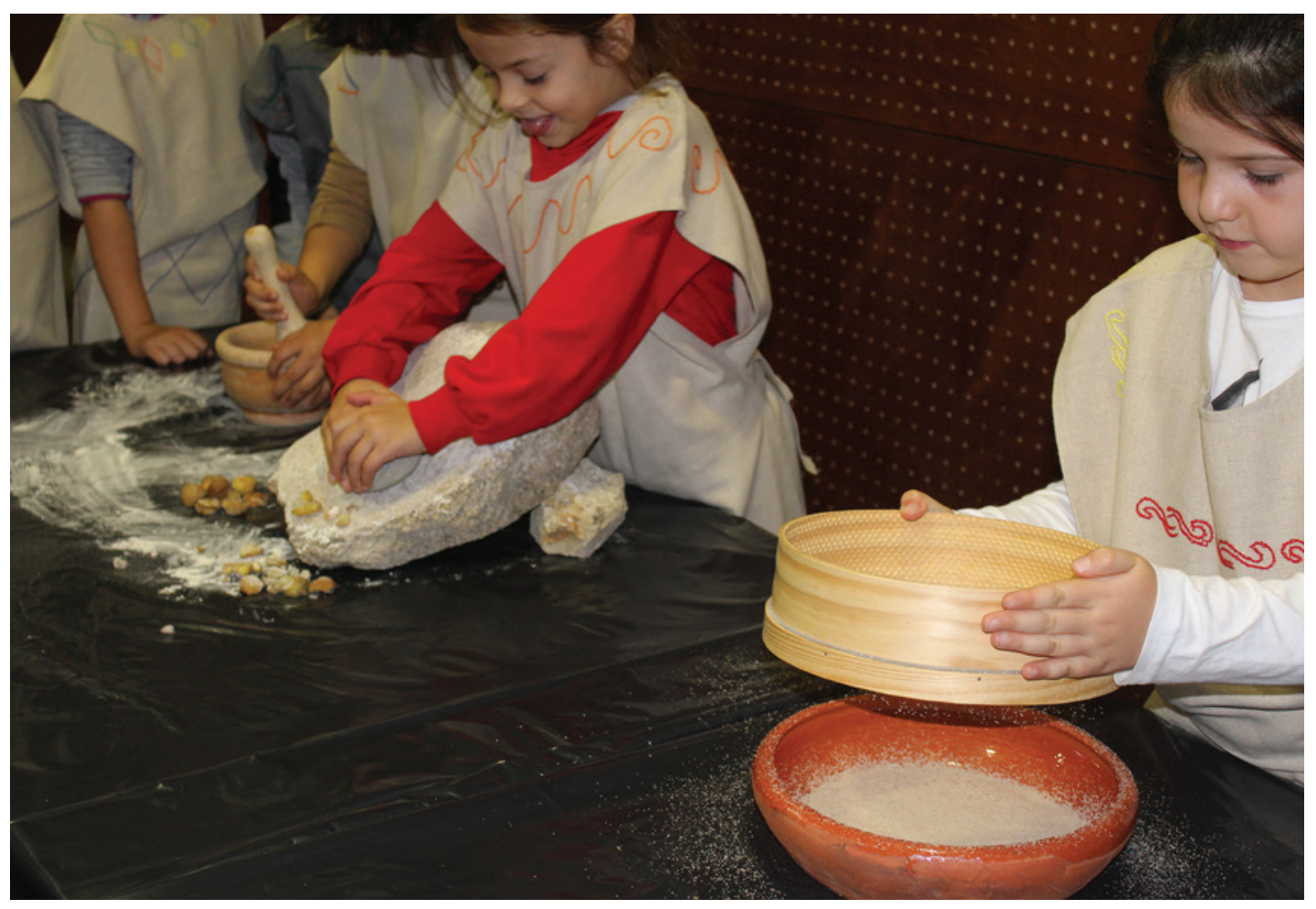

Figura 7 - Pão Galaico | Oficina gastronómica. 


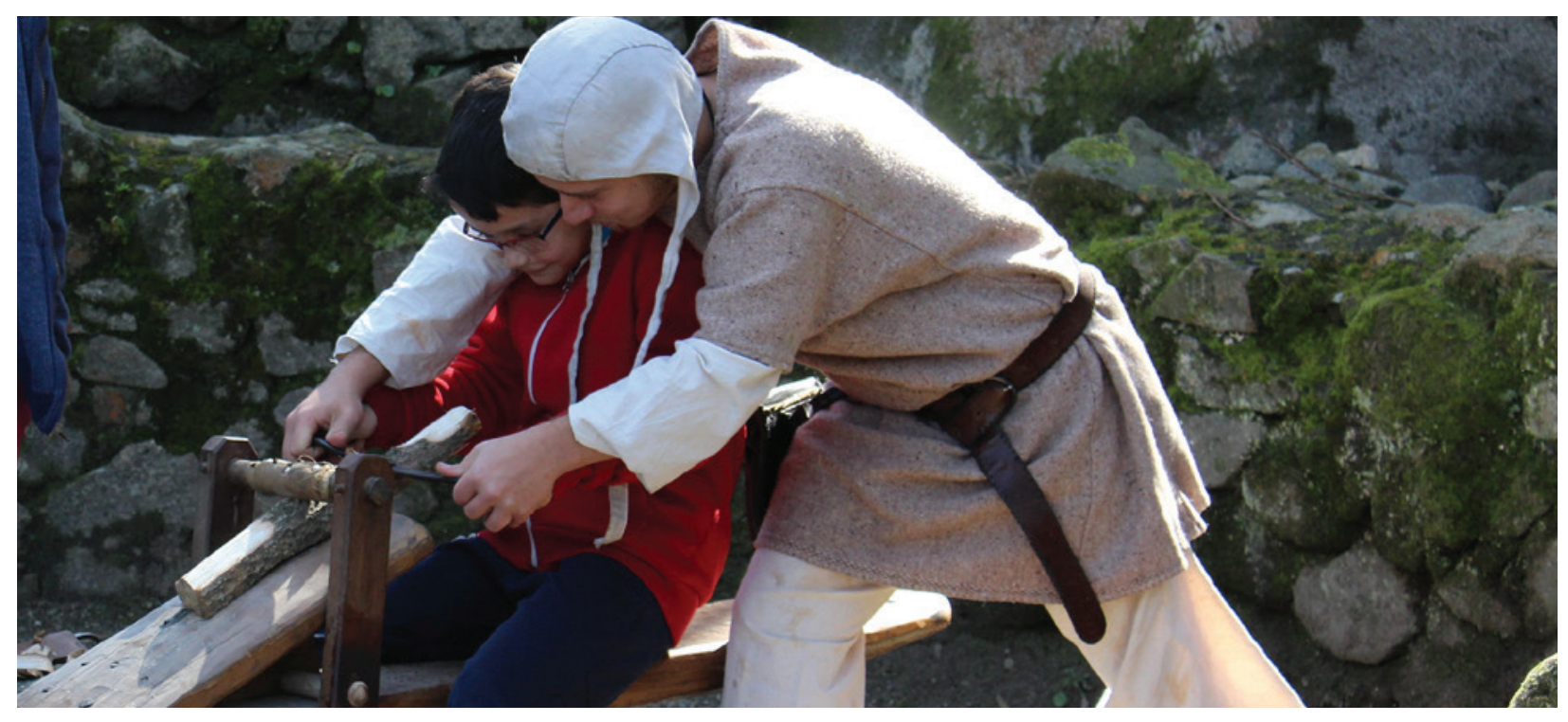

Figura 8 - Ofícios no Castro.

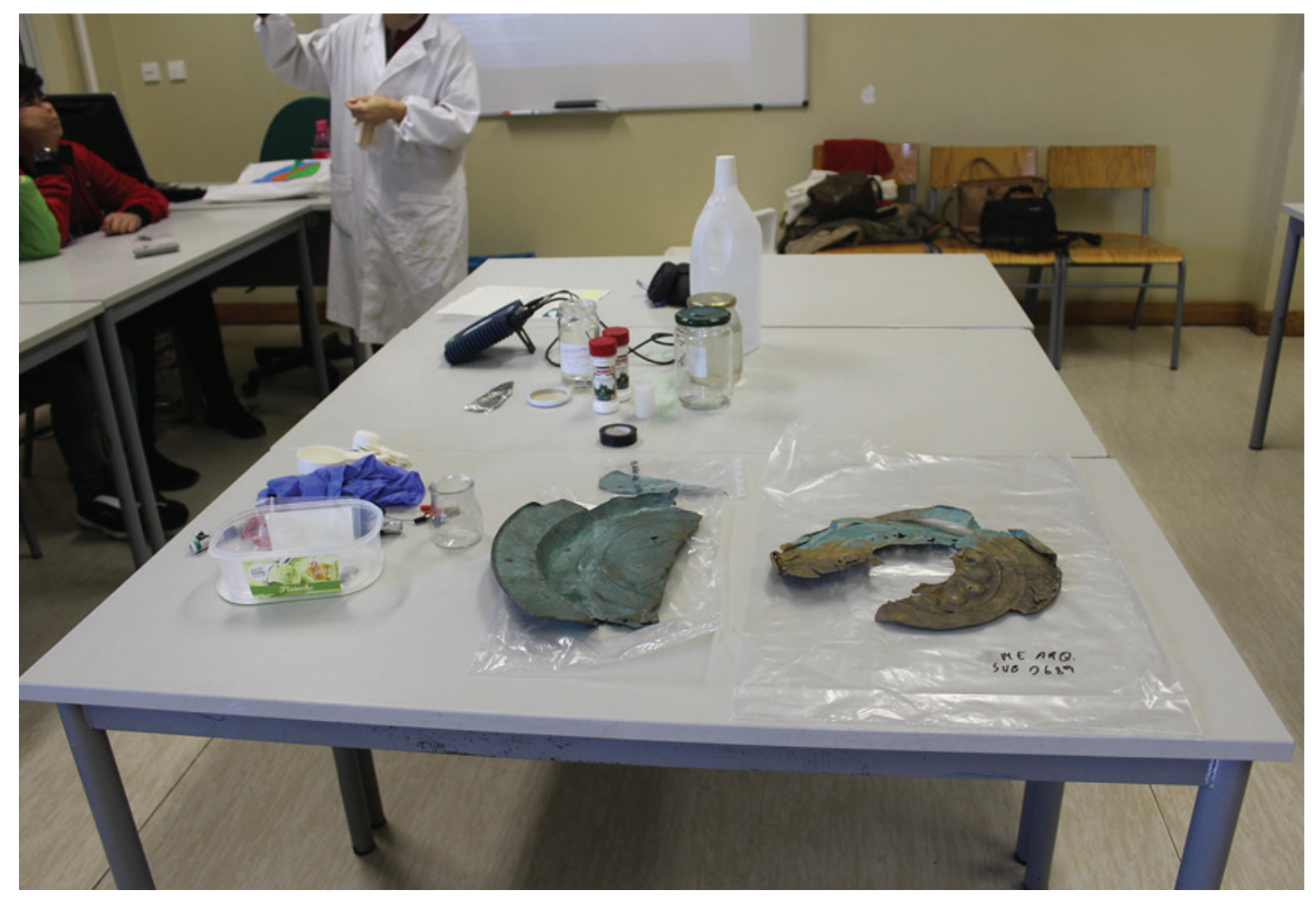

Figura 9-A química do PC. 


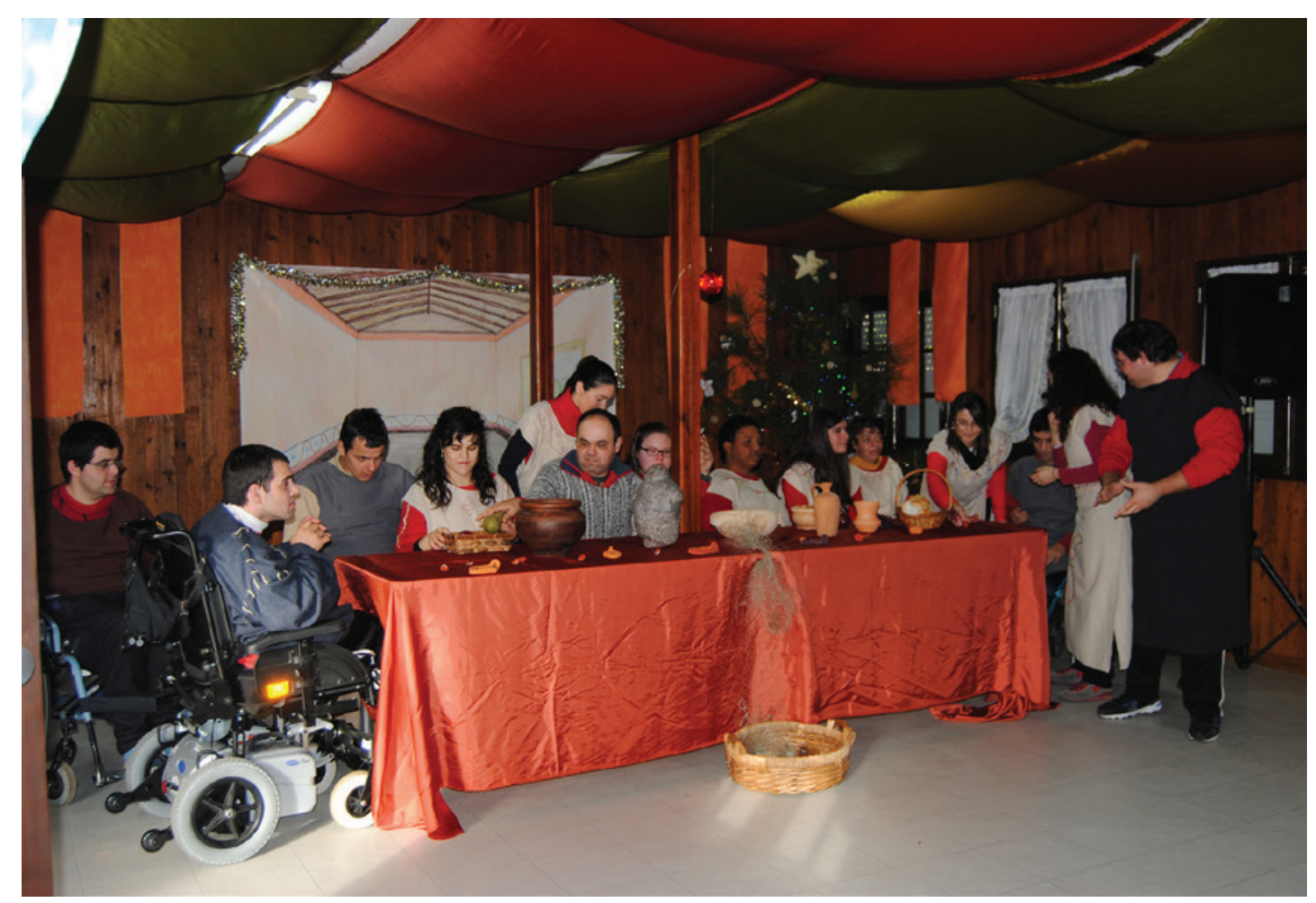

Figura 1o - PASO | Projeto de Arqueologia Sem Obstáculos.

\begin{tabular}{|c|c|}
\hline Objetivos Gerais & Objetivos Específicos \\
\hline \multirow{2}{*}{$\begin{array}{l}\text { i. Promover a igualdade de oportunidades } \\
\text { no que concerne ao acesso à educação } \\
\text { e à cultura; }\end{array}$} & $\begin{array}{l}\text { 1. Explorar e promover, de forma lúdica, o património } \\
\text { natural e cultural do município. }\end{array}$ \\
\hline & $\begin{array}{l}\text { 2. Fomentar o interesse pelo conhecimento e a } \\
\text { preservação dos vestígios de povos que habitaram } \\
\text { a região em que vive. }\end{array}$ \\
\hline \multirow{2}{*}{$\begin{array}{l}\text { ii. Assegurar a qualidade dos espaços } \\
\text { educativos e culturais, propiciadores de } \\
\text { novas aprendizagens e da interação social; } \\
\text { iii. Promover a igualdade de oportunidades } \\
\text { educativas e culturais; }\end{array}$} & $\begin{array}{l}\text { 3. Sensibilizar para a importante função que o } \\
\text { património cultural desempenha na sociedade. }\end{array}$ \\
\hline & $\begin{array}{l}\text { 4. Fomentar o papel ativo que a comunidade deve ter } \\
\text { na defesa e valorização do património cultural. }\end{array}$ \\
\hline $\begin{array}{l}\text { iv. Contribuir para a promoção de uma } \\
\text { educação pública de qualidade; } \\
\text { v. Promover uma política educativa e cultural } \\
\text { potenciadora de experiências nos campos } \\
\text { da educação não formal e informalv }\end{array}$ & $\begin{array}{l}\text { 5. Dar a conhecer o Património (material e imaterial) } \\
\text { associado às origens e desenvolvimento das } \\
\text { sociedades modernas e promover a sua compreensão } \\
\text { por parte da comunidade, nomeadamente a juvenil. }\end{array}$ \\
\hline \multirow{2}{*}{$\begin{array}{l}\text { vi. Promover a Formação Cultural } \\
\text { dos munícipes; } \\
\text { vii. Promover a Democracia participativa } \\
\text { e a Educação para os Valores; } \\
\text { viii. Promover a valorização da História } \\
\quad \text { e da Identidade Cultural local. }\end{array}$} & $\begin{array}{l}\text { 6. Potenciar na sociedade a consciencialização para } \\
\text { a necessidade de proteção/defesa e valorização } \\
\text { do Património, uma vez que ao compreendê-lo, } \\
\text { percecionam que este foi, é e será o legado da sua } \\
\text { comunidade, região e país. }\end{array}$ \\
\hline & $\begin{array}{l}\text { 7. Pretende-se promover a consciencialização de um } \\
\text { fundo que é comum aos povos da Europa, através } \\
\text { de múltiplas abordagens. }\end{array}$ \\
\hline
\end{tabular}

Tabela 1 


\title{
A APROXIMAÇÃO DA ARQUEOLGIA À SALA DE AULA: UM CASO DE ESTUDO NO $3^{\circ} \mathrm{CICLO}$ DO ENSINO BÁSICO
}

Luís Serrão Gil ${ }^{1}$

\begin{abstract}
RESUMO
No presente artigo pretendemos sintetizar parte das actividades desenvolvidas durante a realização da nossa Prática de Ensino Supervisionada (PES) no âmbito da tese de mestrado, (A utilização de artefactos no ensino da História), em ensino da História pela Faculdade de Ciências Sociais e Humanas. Esta assumiu uma abordagem metodológica qualitativa e quantitativa que pretendia tornar os artefactos em ferramentas pedagógicas fundamentais para o ensino da História.

Palavras-chave: Arqueologia, Ensino, História, Artefactos, Pedagogia.
\end{abstract}

\begin{abstract}
In this article we intent to synthesize part of the activities developed during the realization of our Supervised Teaching Practice (PES) within the scope of the master's thesis, (The use of artifacts in the teaching of history), in history teaching by the Faculty of Social and Human Sciences. This took on a qualitative and quantitative methodological approach that aimed to make the artifacts into fundamental pedagogical tools for the teaching of history.

Keywords: Archaeology, Teaching, History, Artifacts, Pedagogy.
\end{abstract}

\section{INTRODUÇÃO}

O presente artigo resulta do relatório da Prática de Ensino Supervisionada (PES), realizada no âmbito do Mestrado de Ensino da História no $3^{\circ}$ Ciclo do Ensino Básico e no Ensino Secundário. Este foi desenvolvido na Escola Secundária Miguel Torga (Agrupamento de Escolas Miguel Torga), localizada em Monte Abraão, durante o ano lectivo de 2018/2019 e sob a orientação científica da Professora Doutora Leonor Medeiros, a co-orientação da Professora Doutora Raquel Pereira Henriques, docentes na Faculdade de Ciências Sociais e Humanas da Universidade Nova de Lisboa, e a supervisão pedagógica da professora Helena Neto. Este estudo procurou contribuir para a pesquisa sobre a consciência histórica na perspectiva arqueológica, defendendo que o uso das fontes históricas em contexto de sala de aula, dando especial enfoque ao uso de artefactos arqueológicos como ferramenta pedagógica, é fundamental para o ensino da História. O relatório, intitulado A utilização de artefactos no ensino da História, pretende através desta abordagem pedagógica: Perceber se o uso dos artefactos aumenta a capacidade de compreensão de matérias abstractas e ajuda a desenvolver a capacidade de interpretação e o espírito crítico; Entender se o uso dos artefactos aumenta a motivação dos alunos, no contexto de sala de aula; Compreender se este método aumenta o interesse dos alunos pela disciplina de História; Descobrir como fazer dos artefactos elementos centrais do currículo e não meros elementos decorativos dos manuais; Demostrar como a capacidade de interpretar artefactos ajuda na nossa interpretação do "mundo"; Desenvolver através da análise dos artefactos as competências patentes no Perfil do aluno à saída da escolaridade obrigatória.

A sociedade Contemporânea tem sido pautada, sobretudo graças ao desenfreado avanço da tecnologia, nomeadamente, a partir de 1940 (Kempf, 1961, pp.19-39), por profundas alterações políticas, sociais e culturais que se reflectem e afectam também a es-

1. CHAM, FCSH, Universidade Nova de Lisboa; luis_sgil@hotmail.com 
trutura escolar (Pessoa, 1999, p. 13). Este novo cenário veio exigir um significativo aumento das competências instrumentais, cognitivas e relacionais dos alunos, para irem de encontro às necessidades de uma sociedade em constante mutação, resultado de uma nova "ordem global estabelecida" (Trindade, 2002, p. 11).

No entanto, uma das “críticas que, normalmente fazem à escola vão no sentido da sua inoperância, face à incapacidade na criação de destrezas significativas que dêem resposta às mudanças que vão surgindo na sociedade" (Rodrigues-Pimenta, 2011, p. 49). Assim, numa sociedade em mudança é fundamental que a escola tome a posição dianteira, funcionando como um bastião da renovação de modo a estimular e motivar os alunos para a aprendizagem, uma vez que, segundo Richard Arends, é esta que “orienta a acção dos alunos” (1999, p. 122). Perante este cenário, um dos nossos objectivos foi, ao longo da PES, utilizar no decorrer das aulas, sempre que possível, artefactos, de modo a tentar estimular a sua aprendizagem e promover bons resultados.

No entanto, a escolha do tema supracitado prende-se ainda com mais dois elementos fundamentais. Por um lado, o facto de pretendermos alterar algumas práticas de ensino que colocam os alunos numa posição passiva, isto é, de meros "receptáculos de informações, conteúdos, currículos, livros e materiais didácticos" (Schimdt, 2008, p. 56). Por outro, o de dar destaque ao uso de artefactos como recurso didáctico no ensino da História, de modo a aproximar o aluno da disciplina, da sua matéria, do papel do historiador/arqueólogo e da valorização do património material.

Nesta perspectiva questionamo-nos sobre: Qual a importância dos artefactos no ensino da História? Qual a importância do professor na criação de uma ligação entre esta fonte e o aluno? Quais as vantagens do seu uso na aprendizagem dos alunos? Como podem a Arqueologia e os artefactos arqueológicos contribuir e fazer parte do quotidiano lectivo do aluno? Mas antes de tentarmos dar resposta a estas interrogações devemos ter em conta a importância e os motivos pelos quais a disciplina de História faz, e sempre fez, parte do programa curricular, tal como, a sua relevância na formação humanística dos alunos, muitas vezes, pouco valorizada ou mesmo incompreendida.

A disciplina é fundamental para a compreensão dos processos históricos e para a sua articulação com a vida actual, isto é a "História dá sentido ao presente" (Amaral et ali, 2012, p. 4). Por isso, o ensino da História pode adquirir um significativo papel na superação da exclusão social, através de uma padronização dos conhecimentos e das influências externas, na formação da cidadania e na autonomização social e política dos sujeitos históricos (Fonseca, 2003, p. 52; Alvino-Borba; Mata-Lima, 2011, pp. 224-226). Estes itens encontram-se, actualmente, bem plasmados no artigo $3^{\circ}$ da Lei de Bases do Sistema Educativo e nos valores presentes no Perfil dos Alunos à saída da escolaridade obrigatória, facto que poderá dar à História um papel de charneira na formação dos discentes e num âmbito mais lato colocar a escola em equilíbrio com a sociedade actual (2017, p. 11).

No entanto, “a disciplina da História, que se supõe ser tão necessária para a formação cívica e para a compreensão da sociedade, torna-se assim, eminentemente aborrecida" (Mattoso, 1999, p. 142). Esta afirmação de José Mattoso torna-se pertinente aquando de uma reflexão sobre o modo como o ensino da História, que recorre muitas vezes a "aulas expositivas [ao] verbalismo e [ao] emprego exagerado de palavras. Como resultado, o aluno, em grande parte das vezes, apenas decora, sem compreender, e é incapaz de aplicar em situações concretas aquilo que deveria ter sido ensinado" (Gil, 2009, p. 93).

Segundo o relatório Estado da Educação de 2016, redigido pelo Conselho Nacional de Educação, Portugal é um dos países europeus com maior taxa de reprovações de alunos entre os anos de 2012 e 2015, facto também motivado pela utilização destes métodos de ensino mais tradicionais (Xavier, 2010, p. 1097). Com o intuito de inverter esta situação em 2016 deu-se início à construção de um documento, o Perfil do aluno para o Século XXI, entretanto (2017) designado Perfil dos Alunos à saída da escolaridade obrigatória, que pretende ajudar e nortear as competências que o aluno deve ter adquiridas na saída da escolaridade obrigatória, ao nível: das linguagens e textos; da informação e comunicação; do raciocínio e resolução de problemas; do pensamento crítico e criativo; do relacionamento interpessoal; autonomia e desenvolvimento pessoal; do bem-estar e saúde; da sensibilidade estética e artística; do saber técnico e tecnologias; da consciência e domínio do corpo.

A este documento somou-se o despacho 5908/2017 referente à Flexibilização Curricular que entre outros aspectos promove a aposta na diferenciação pedagógica (artigo 19ํ) e ainda o decreto 55/2018, 
que estabelece o currículo dos ensinos básico e secundário e os princípios orientadores da avaliação das aprendizagens. É com base nestes fundamentos e nesta alteração de paradigma que achamos que o uso de artefactos, associado a outros métodos, no contexto de sala de aula, podem potenciar a aprendizagem da História, estimular a aquisição de competências do aluno ${ }^{2}$ e modernizar as práticas na sala de aula.

Com o intuito de ajudar reforçar a importância da disciplina de História nos currículos escolares e alcançar um papel de destaque na formação pessoal dos alunos, as fontes, em especial os artefactos, podem desempenhar um papel relevante, não só como ferramenta didáctica, mas também como mediador, ajudando o professor a deixar de ter um mero papel de transmissor de conhecimentos e a tornar-se o principal mediador entre o aluno e o objecto a ser apreendido (Xavier, 2010, p. 1097). Assim, o aluno assume também um papel interventivo e pedagógico, tornando-se ele próprio portador de ideias históricas e a sala de aula num local de construção de conhecimento.

Porém, não se pretende tornar o aluno num pequeno historiador, mas levá-lo a conseguir estabelecer relações no tempo e no espaço histórico. Desta forma, também se tornam as aulas e o próprio ensino da História mais dinâmico, menos expositivo e livresco, tornando o professor num agente que questiona mais do que responde.

Como o próprio título indica, o presente relatório de estágio para a PES tem como principal objectivo abordar o uso de artefactos na sala de aula como ferramenta pedagógica para o ensino da História. No entanto, importa primeiramente esclarecer a definição de artefacto que nos norteia, sendo a significado dado por Timothy Darvill aquele que melhor se enquadra nos nossos intentos, uma vez que este autor define artefacto como: "Any object which has been modified, fashioned, or manufactured according to set of humanly imposed attributes, including tools, weapons, ornaments, utensils, houses, buildings, etc. Artefacts are the basic components of material culture" (2008, p.26). Porém, um objecto contém em si mais conhecimento que aquele que as suas fronteiras físicas encerram, um conhecimento invi-

2. Pensamento crítico e pensamento criativo; Sensibilidade estética e artística; Saber técnico (Perfil dos Alunos à saída da escolaridade obrigatória, 2017, p.21). sível que vai muito além da sua forma, construção ou função, um conhecimento que muitas vezes passa pelo campo das intenções.

A Arqueologia é uma ciência que estuda as sociedades do passado e os seus ambientes através da recolha e análise sistemática da cultura material e dos vestígios físicos deixados pelo Homem. Esta na sua prática recupera, regista, analisa e classifica os vestígios arqueológicos exumados, de modo a poder descrever e interpretar o comportamento humano e as razões que levaram à criação destes objectos e à sua integração no quotidiano. "Ao compreender a arqueologia enquanto uma prática interpretativa, que constrói socialmente e de forma activa o passado no presente (e não meramente como um reflexo passivo das coisas que ocorreram em tempo remoto), esta disciplina deixa de tratar apenas de eventos ou de cultura material. Passa a ser compreendida enquanto um evento e uma produção material, pois elabora todo o conhecimento sobre o modo de viver de sociedades antigas" (Copé \& Rosa, 2008, p. 97). A interpretação arqueológica pressupõe que toda a informação adquirida seja relacionada com o seu contexto, com outros objectos, com outras ciências, nomeadamente, com a História, fazendo deste objecto de consulta um objecto construtivo, isto é, da análise arqueológica resulta sempre conhecimento histórico. Como refere Hodder (1992) a cultura material tem uma dupla valência que fascina as pessoas, isto é, o seu estudo abarca simultaneamente as ciências sociais e humanas, as ciências exactas, e os conceitos abstractos e concretos. Neste âmbito, a minha formação e experiência enquanto arqueólogo poderá trazer esta visão bipartida da análise histórico-arqueológica e um olhar treinado e sensibilizado para o objecto arqueológico enquanto fonte de conhecimento. Podendo este facto acrescentar valências no modo de análise, interpretação e transmissão de conhecimentos no âmbito do ensino da História, dando aos alunos uma nova forma de olhar e entender esta disciplina.

Usando as palavras de Neil MacGregor é também nosso objectivo "contar histórias utilizando objectos” (2013, s.p.), pois estes cruzam as fronteiras do conhecimento. Através da utilização de artefactos, isto é, objectos arqueológicos, réplicas, reproduções, entre outras abordagens, de modo a dar resposta, aos objectivos anteriormente referidos. A eficácia desta proposta em sala de aula será medida através da análise da evolução da participação dos 
alunos, assim como através de avaliações, de exercícios de metacognição, questionários, e inquéritos de satisfação.

Através da experiência prática em sala de aula pretende-se ainda, descobrir como fazer dos artefactos elementos centrais do currículo e não meros elementos decorativos dos manuais, mostrar como a capacidade de interpretar objectos ajuda na nossa interpretação do "mundo" e a desenvolver através da análise da cultura material as competências patentes no Perfil do Aluno à saída da escolaridade obrigatória. Por fim, pretendemos abordar a problemática do acesso e obtenção de artefactos arqueológicos por parte dos professores, assim como propor possíveis soluções e técnicas de substituição destes objectos por outros que desempenhem igual função e/ou propósito.

\section{A CULTURA MATERIAL COMO FERRAMENTA PEDAGÓGICA}

Com esta PES pretendemos dar enfoque à utilização dos artefactos como ferramenta pedagógica no ensino da História. Isto é, dar a esta fonte eminentemente "sensorial" e táctil a importância devida, não só nos processos psicológicos da empatia, ligação ao passado, motivação, estimulação, diferenciação ou mesmo diversidade, mas sobretudo como fonte primordial para a aproximação ao quotidiano do passado a estudo e como forma de ampliação das ferramentas dadas aos alunos para entender a realidade material que os rodeia. Esta fonte material apresenta-se, segundo Marcelo Rede, de grande importância, pois como fonte, num primeiro momento, "fala por si" e de forma mais directa através do contacto, não passando pelos códigos da linguagem do documento escrito (1992).

No entanto, este autor não retira o ónus e a necessidade de investigar e analisar o objecto, aliás os dois tipos de fonte, material e escrita, devem funcionar em uníssono e uma em complemento da outra. Muitas vezes, o objecto dá-nos informações que se encontram ausentes na fonte escrita, nomeadamente, no que diz respeito ao quotidiano dos grupos sociais mais desconhecidos, isto é, as pessoas anónimas da sociedade (Funari, 2008, p. 100), seja por não dominarem a escrita, seja porque não são incentivadas a registar a sua História. Para conhecer efectivamente e globalmente a História da Humanidade temos de usar fontes escritas, mas também os arte- factos. Por isso, "uma história ideal reúne textos e objetos" (Macgregor, 2013, pp.16-17). Assim, ao entendermos o objecto como fonte podemos analisar também o seu contexto de criação e a finalidade para a qual foi fabricado. Deste modo, a sua componente física e as características que o definem ganham uma nova função, passando este do ponto de vista da investigação a "identificar as alterações e explicar suas razões” (Rede, 1996, p. 276; Ferreira, 2013, p.156).

A cultura material passa a poder ser entendida como todo o "segmento do meio físico que é socialmente apropriado pelo homem" (Meneses, 1983, p.112), ou seja, "entendemos, portanto, que o objeto ultrapassa o limiar de sua criação no momento em que é pensado seu contexto, se enquadrando no trabalho do historiador. Dado esse panorama geral acerca do conceito de cultura material e suas diferentes abordagens, passaremos agora a pensar a materialidade relacionada com o ensino de história, em outras palavras pensar a utilização da cultura material utilizada como fonte nas salas de aula" (Ferreira, 2013, p.156; Rede, 1996, p. 276; Costa, 2018, pp. 68-69). Por outro lado, segundo Soraia Dutra, o uso de objectos como meio de obtenção de conhecimento é fundamental, uma vez que as crianças no seu estádio de evolução (6-14 anos) ainda não possuem um nível de abstracção suficiente para compreender o método histórico. Por isso, o conhecimento histórico não pode ser cognitivamente assimilado pelo aluno através do recurso à leitura e memorização, sendo neste campo que o artefacto tem um papel fundamental de modo a permitir ao aluno uma melhor construção da realidade histórica. Este tipo de fonte torna-se num meio mais fácil e acessível para a compreensão do aluno por se tratar de "evidências mais concretas", isto é, fazendo um processo de passagem do real ou concreto para o abstracto (Dutra apud Ferreira, 2013, p. 156). Mas o uso de artefactos traz também outros benefícios ao nível da aprendizagem das crianças, pois compreender como se interpreta um objecto cria um vínculo positivo entre a criança e as sociedades do passado. Uma vez que neste processo elas encontrarão problemas semelhantes aos seus, nomeadamente, nas pequenas tarefas e problemas quotidianos e como afirma Agnes Heller "a vida cotidiana é a vida de todo ser humano. Todos a vivem, sem nenhuma exceção" (Heller, 2008, p. 31).

Os objectos têm ainda uma notável capacidade para motivar, uma vez que têm a aptidão de desenvolver 
o "need to know", isto é, despertam na criança primeiro o seu interesse e de seguida a sua curiosidade, criatividade, estimulando a sua necessidade de investigar. Por isso, manusear objectos é uma forma activa de aprender que agarra a criança de um modo que outros métodos normalmente não conseguem, uma vez que estes providenciam uma experiência concreta que auxilia na compreensão de pensamentos abstractos. O interesse no objecto e o poder de motivar é cumulativo, isto é, para o apreenderem as crianças colocam-se numa posição de almejar saber mais sobre o mesmo.

Os objectos providenciam ainda estímulos criativos e emocionais, mas também material para a criação artística, fornecendo ideias e sentimentos que podem ser expressos de formas mais amplas que as palavras. Esta evidência prende-se pelo facto de os objectos serem reais e não abstractos e deste modo ajudam a memória, isto é, criam sensações físicas, experiências e emoções que, ao contrário dos factos e ideias, permanecem por mais tempo na mente (Durbin \& Wilkinson, 1996, p. 4-5).

Por outro lado, os objectos permitem-nos abarcar um alargado grupo de faixas etárias, de estádios de desenvolvimento e ter um abrangente leque de hipóteses de uso, diminuindo assim as barreiras do ensino. Como explicam Durbin e Wilkinson: "A new object could be used for a historical end, or a historical object for a contemporary one. For instance, take any leather shoe. It can became the starting-point in a study of the leather industry, shoemaking techniques, travel, trade, health, costs and values, the nature of historical survival, the effects of wear and ageing; it can generate a detective story identifying the owner of the shoe, a discussion on geographical differences between male and female shoes, adult and children's shoes or formal, work (...) and so on" (1996, p. 3).

O manuseamento de artefactos permite ainda desenvolver um elevado número de habilidades (localizar; reconhecer; identificar; planificar; comparar; etc.), conhecimentos (diferenciar materiais; vocabulário de construção e decoração; a forma como as pessoas viam o mundo; o contexto social, histórico e económico em que se enquadra o objecto; etc.) e conceitos (cronologia, mudança, continuidade e progresso; moda, estilo e gosto; património, colecção, conservação, preservação, etc.) (Durbin \& Wilkinson, 1996, pp. 5-6).

\section{AS ACTIVIDADES DESENVOLVIDAS EM CONTEXTO DE SALA DE AULA}

Com o referido estudo pretendeu-se integrar a abordagem da investigação arqueológica no âmbito da investigação em Educação Histórica, através da utilização de actividades educativas que utilização os artefactos em articulação com os currículos de História num contexto generalizado/nacional e com a possibilidade de aplicação a contextos locais e ou regionais. Neste estudo pretendemos analisar a possibilidade de ensinar História através do uso de artefactos no âmbito dos currículos de História do $3^{\circ}$ ciclo do ensino básico e secundário.

As actividades ao longo da PES foram desenvolvidas em sala de aula com as turmas do $7^{\circ} \mathrm{C}$ e do $10^{\circ} \mathrm{L}$ de escolaridade, apesar de aqui apenas reportarmos algumas das actividades realizadas com a turma do $7^{\circ}$ ano de escolaridade.

Numa primeira fase, e antes de iniciarmos a PES e de colocarmos em prática o referido projecto de estágio, assistimos a um significativo conjunto de aulas da turma leccionada pela professora Helena Neto. Esta primeira fase permitiu-nos observar os alunos, de modo a conhecê-los melhor e perceber a sua dinâmica entre pares e com a professora cooperante e ainda constatar os pontos fortes e as fragilidades de aprendizagem dos alunos.

A turma do $7^{\circ} \mathrm{C}$ era composta por um total de 28 alunos, 17 do género masculino e 11 do género feminino. Nesta turma havia uma grande heterogeneidade de comportamentos na sala de aula, havendo um número constante, mas reduzido, de alunos com uma participação efectiva e regular (cerca de 10 alunos). Por parte destes a participação era sempre efectuada de forma muito desorganizada, mas demonstrando motivação e vontade de conhecer as temáticas abordadas. Em contraponto, havia um segundo grande grupo (cerca de 18 alunos), que apresentava uma grande desmotivação que se reflectia na pouca participação oral e na realização das tarefas propostas, resultando, muitas vezes, em comportamentos inadequados na sala de aula e nos fracos resultados obtidos.

Ao longo da nossa observação também denotámos que os alunos apresentavam grandes dificuldades na análise e interpretação das fontes históricas, sobretudo nas iconográficas. A percepção da mensagem explícita ou implícita na fonte ou mesmo a sua simbologia ou intenção produtiva eram incompreendidas pelos alunos, resultando a sua análise numa 
simples transcrição de parágrafos ou na descrição da imagem $^{3}$. Para ajudar a minorar este facto privilegiámos ao longo da PES diferentes experiências pedagógicas de cariz investigativo, recorrendo à análise de fontes documentais, iconográficas e artefactuais. Estas foram efectuadas de forma individual, em grupo e em díades, de modo a estimular a partilha de saberes entre os alunos e tentar criar um maior equilíbrio dos conhecimentos da turma.

A primeira acção realizada, de modo a ter uma base quantitativa e qualitativa da opinião da amostra, foi a realização de um questionário aos 28 alunos para perceber o seu historial pessoal e familiar, interesse pela disciplina de História, percurso académico, gosto cultural e interesse pela Arqueologia. Quanto ao gosto pela disciplina de História, $26 \%$ dos alunos demonstravam ter pouco interesse, enquanto que $44 \%$ disseram ter algum interesse e $30 \%$ muito interesse (Figura 1).

Para o presente artigo seleccionámos cinco das actividades realizadas e para as quais foram utilizadas quatro metodologias distintas: a criação/fabrico de artefactos; a utilização/manuseamento de artefactos arqueológicos; a recriação de objectos e uma actividade à descoberta. A primeira actividade, mais didáctica, intitulada $O$ que é a Arqueologia?4 teve como principal objectivo fazer uma primeira abordagem ao tema do relatório de estágio, assim como perceber os conhecimentos prévios dos alunos sobre a Arqueologia e as suas práticas.

Nesta aula foi abordado o significado da palavra Arqueologia, os mitos que envolvem esta ciência, a realidade da actividade arqueológica, as ferramentas utilizadas, os métodos de trabalho de um arqueólogo (no campo, no laboratório, no museu, na universidade), as metodologias e a investigação arqueológica, tendo terminado com uma tentativa de reconstituição do passado através dos dados arqueológicos, usando o exemplo da cidade de Pompeia.

As novas tecnologias foram incluídas, com os recursos didácticos de um Power Point, fortemente ilustrado, e vídeos exemplificativos de algumas das temáticas abordadas (Arqueologia; Intervenção arqueológica e trabalho de laboratório; Reconstitui-

3. Este tipo de análise ao manuseamento das fontes históricas pode ser aprofundado no estudo de Maria Moreira (2004).

4. Esta aula foi enquadrada no primeiro ponto das Aprendizagens Essências (2018, p. 5). ções do passado através do caso de Pompeia). A aula baseou-se numa dinâmica oral com preferência pelo diálogo e debate com os alunos, de modo a explicar o tema e a esclarecer as suas dúvidas sobre o mesmo. Nesta etapa de sensibilização, pretendíamos não só aumentar o seu conhecimento sobre o tema, mas também deixá-los mais despertos para a temática da Arqueologia e a sua actividade, a defesa deste património e a sua importância para o conhecimento da História. Mas também dar-lhes conhecimento de algumas temáticas, metodologias, nomenclaturas e ferramentas que iriam ser importantes ao longo do desenvolvimento da PES. Esta aula foi marcada por uma intensa participação dos alunos, com o intuito de conhecer mais e esclarecer as suas dúvidas e curiosidades sobre a Arqueologia.

O segundo conjunto de actividades integrou-se no conteúdo programático $O$ mundo romano no apogeu do Império (Aprendizagens Essenciais, 2018, p.7; Neto et al., 2014, pp. 78-97), integrado no domínio A herança do Mediterrâneo antigo e no subdomínio $O$ mundo romano no apogeu do Império das Aprendizagens Essenciais (2018, p. 7). As actividades desenvolvidas para este tema foram pensadas como um todo e integrou todos os conteúdos programáticos relativos ao Império Romano. Um dos principais objectivos foi testar a eficácia da aplicação desta metodologia no desenvolvimento dos conteúdos de uma unidade curricular.

O nosso objectivo era utilizar sempre, que possível, artefactos para abordar os conteúdos programáticos. O estudo desta temática iniciou-se com uma situação/problema, Como podemos conhecer a civilização romana através das legiões e dos seus objectos?, que seria respondida ao longo das aulas e durante a análise dos diferentes temas. No caso da abordagem ao Império Romano, quisemos que os alunos compreendessem o quotidiano desta civilização, as suas particularidades, a sua história e de que modo somos hoje fruto ou muito influenciados por dela. A abordagem a este assunto começou com a realização de uma avaliação preliminar dos conhecimentos dos alunos. Para tal, construímos uma ficha constituída por um texto que sintetizava toda a matéria do capítulo e no qual faltavam algumas palavras e expressões que se encontravam em caixas no final do texto. $O$ aluno deveria selecionar a palavra que achava mais correcta para o preenchimento de cada um dos espaços, de modo a o texto fazer sentido. Esta ficha viria a ser repetida no final do capítulo 
para se proceder à comparação dos seus resultados (metacognição).

A próxima actividade, que passamos a descrever, integrou-se no conteúdo curricular $O$ poder dos imperadores (Aprendizagens Essenciais, 2018, p. 7; Neto et alii, 2014, pp. 92-93). Para abordar o tema decidimos recorrer a um artefacto, uma moeda romana (denário do tempo do imperador Trajano), construida a partir de moedas de chocolate e da impressão em papel das faces, materiais fáceis de adquirir e de baixo custo (Figura 2).

No início da aula foi distribuída a cada aluno uma moeda e uma ficha de observação do objecto. Numa primeira fase os alunos tiveram de olhar atentamente para as suas moedas e desenhá-las (cara e coroa) na ficha, numa área delimitada por papel milimétrico. Esta acção imitava o procedimento do arqueólogo na análise deste tipo de artefacto. Posteriormente, $\mathrm{o}$ aluno teve de responder a três questões que interrogavam os seus conhecimentos prévios: Diz que o pensas que podes saber sobre este objeto?; Que importância teria este objeto para as pessoas que o utilizaram? E para ti?) e instigavam a sua curiosidade (Que pergunta(s) gostarias de fazer para saber mais sobre este objecto?). Em seguida, e depois de auscultadas algumas das respostas, passámos em conjunto à análise da moeda e dos símbolos que a constituíam. O objectivo desta aula era explicar a importância do imperador no contexto das instituições políticas do império. Deste modo, pretendíamos estudar o poder dos imperadores romanos através de uma das suas ferramentas de propaganda mais eficazes e difundidas, a moeda, cuja sua análise nos permitiu falar da moeda enquanto objecto, da sua função prática e quotidiana, mas, também, da importante e poderosa mensagem política transmitida através dos seus símbolos.

A análise foi feita através de um diálogo orientado com a turma, interrogando-os sobre o que viam, a sua função e opinião, fazendo sempre que possível uma ponte para o quotidiano dos alunos e as semelhanças e diferenças que este tem com o período romano.

A observação da efígie permitiu aos alunos consolidarem os conhecimentos sobre as formas de governo na antiga Roma, nomeadamente, o Império, mas também perceber a importância da "cara" do imperador nestes objectos de larga circulação. Por outro lado, a análise das inscrições, nomeadamente, o seu nome, os seus diferentes títulos honoríficos, de ordem política, militar e religiosa, que nos permitiram não só estudá-los por si, como analisar a organização política do império romano. $\mathrm{Na}$ análise da "coroa" foi observada a divindade, os seus atributos e os símbolos, assim como as restantes inscrições que mais uma vez remetiam para os poderes do imperador.

Toda a actividade teve desde o início uma positiva aceitação por parte dos alunos e uma elevada e empenhada participação.

A terceira actividade integrou-se no conteúdo curricular: Uma economia urbana, rural, comercial e monetária (Aprendizagens Essenciais, 2018, p.7; Neto et alii, 2014, pp. 86-87). Para estudar a economia romana nada melhor que a análise do artefacto mais icónico da pragmática civilização romana, a ânfora. Para tal, os alunos foram divididos em pequenos grupos de 5 a 6 elementos, aos quais foi entregue um fragmento de ânfora romana (bico fundeiro, parede e/ ou asa). A cada aluno foi ainda entregue uma ficha, igual à distribuída para a análise da moeda romana, e numa primeira fase tiveram de olhar atentamente para os seus fragmentos de ânfora, desenhá-los na ficha, numa área delimitada por papel milimétrico, e responder a três questões que interrogavam os seus conhecimentos prévios e instigavam a sua curiosidade (Diz o que pensas que podes saber sobre este objeto?; Que importância teria este objeto para as pessoas que o utilizaram? E para ti?; Que pergunta(s) gostarias de fazer para saber mais sobre este objeto?). Posteriormente, e depois de auscultadas algumas das respostas, passámos a uma segunda ficha de observação analítica do objecto contendo distintos campos de análise (Cronologia; Características fisicas; Fabrico; Função; Outra utilização; Design; Valor; Outras informaçôes). Estávamos a levar a cabo, mais uma vez, uma acção que imitaria o procedimento do arqueólogo na análise deste tipo de artefacto. Os alunos deveriam construir esta ficha através da análise do seu artefacto e do diálogo entre si, solicitando sempre que necessário a ajuda do professor. No final da actividade, e através da participação de todos os grupos e do diálogo com o professor e entre pares preenchemos em conjunto uma ficha.

Terminada a tarefa, utilizámos o Power Point para mostrar e dialogar com os alunos sobre o processo de fabrico das ânforas, a sua selagem, os diferentes modelos de ânfora, os produtos que continham e que objectos têm actualmente a função das antigas ânforas. Por fim, através da projecção e análise de um mapa analisámos as diferentes rotas de comércio, os produtos comercializados e a importância do 
comércio para os romanos, fazendo para tal também uso do manual.

$\mathrm{O}$ quarto conjunto de actividades integrou-se no conteúdo curricular: A vida quotidiana (Aprendizagens Essenciais, 2018, p. 7; Neto et al., 2014, pp. 9091). Como elemento motivador começámos com a análise e discussão em torno da célebre frase " $\mathrm{Pa}$ nem et circenses", tentando fazer com que os alunos ultrapassassem a barreira linguística e depois o seu significado simbólico. Após esta abordagem projectámos uma imagem que reconstituía o quotidiano de uma rua no período romano e um documento que retractava a mesma situação. Ao efectuarmos a análise da frase e da imagem fomos discutindo o modus operandi e as diferentes características do dia-a-dia de uma cidade romana.

Tratado de um modo geral o quotidiano, passámos a particularizar alguns dos temas em estudo, nomeadamente, os dois distintos tipos de habitação, as suas características e os seus habitantes. Mas também o tipo de alimentação consumida pelos romanos e a sua associação aos utensílios de cozinha e mesa. Para tal, recorremos a reproduções de ambientes domésticos, conseguidas através da Arqueologia, a imagens de peças arqueológicas e à distribuição pelos alunos de alguns fragmentos de cerâmica romana (terra sigillata e cerâmica comum).

Em seguida abordámos o tema do vestuário, vendo imagens de diferentes peças, acentuando as suas diferenças face ao género e grupo social que os envergava, mostrando como a roupa era e contínua a ser um elemento de distinção social. Aproveitámos este tema para um pequeno atelier de recriação ou actividade experimental, através da reprodução de uma toga romana. Para tal, fizemos uso de um lençol branco e utilizámos um dos alunos como modelo. Ainda neste contexto mostrámos uma fíbula romana, em bronze, e como esta era utilizada no vestuário romano.

A aula terminou com a realização da ficha de avaliação preliminar dos conhecimentos dos alunos que havia sido feita na primeira aula leccionada com este conteúdo programático. Procedemos a uma análise quantitativa dos dados e percebemos que a evolução dos conhecimentos foi bastante significativa havendo, na primeira avaliação, 25 resultados negativos num universo de 25 alunos, que passou na segunda avaliação para 7 resultados negativos e 25 positivos no mesmo universo de alunos (Figura 3).

No final da temática, cujas actividades foram ante- riormente descritas, efectuámos novamente o questionário de satisfação aos alunos. Como podemos verificar no gráfico em baixo $24 \%$ da avaliação situou-se entre 8 e 9 valores, tendo a maioria dos alunos atribuído uma avaliação de $10(76 \%)$ às actividades desenvolvidas. A actividade eleita pelos alunos no questionário como a sua preferida foi o manuseamento dos artefactos arqueológicos (A vida de um legionário romano II) $)^{5}$ (Figura 4). A estes dados podemos agregar outros que foram sendo progressivamente sistematizados e analisados ao longo da PES e que nos permitem aferir a crescente participação oral dos alunos ao longo do desenvolvimento das aulas e o aumento significativo das suas competências, que se traduz também no significativo aumento dos resultados positivos das avaliações escritas.

Por fim, a última actividade que constituiu a realização de uma visita de estudo ao Museu Nacional de Arqueologia. Esta visita tinha como principal objectivo promover o contacto dos alunos com um espaço museológico, a sua história e as suas peças, assim como aproveitar o seu espólio como forma de motivação e consolidação de conhecimentos. Mas, também, como forma de sensibilização para a importância, valorização e protecção destas instituições e dos seus acervos. Para tal, foi criada uma visita à descoberta, na qual se organizou a turma em grupos de 5 e 6 elementos e aos quais se distribuiu um guião. Este começava com um resumo da história do museu e à qual se seguiam três partes distintas, que correspondiam às três salas de exposição permanente do museu (Sala das Antiguidades Egípcias; Sala dos Tesouros da Arqueologia Portuguesa; Exposição das Religiões da Lusitânia). Em cada uma das salas os alunos deveriam efectuar diferentes actividades que lhes permitiam conhecer as peças, a sua história e relacioná-las com as diferentes matérias apreendidas ao longo do ano lectivo. No entanto, isso era feito de forma dinâmica, partilhando tarefas e conhecimentos com os diferentes elementos do grupo e em competição saudável com os restantes grupos. No final, todos os grupos realizaram uma visita guiada pela exposição Loulé: Territórios, Memórias e Identidades, que permitiu fazer uma viagem no tempo, através dos artefactos, desde a Pré-História até à Idade Média.

\footnotetext{
5. "A actividade em que vimos o pedaço da ânfora. Porque nunca tinha visto" (12 anos, masculino, $7 \mathrm{C}$ ); "Quando o stor trouxe algumas partes da ânfora” (12 anos, feminino, $7 \mathrm{C}$ ).
} 


\section{BREVES REFLEXÕES FINAIS}

Ao longo da PES e das actividades desenvolvidas percebemos, a partir dos resultados obtidos, e respondendo às nossas interrogações iniciais que os artefactos são fundamentais para o ensino da História, quer na construção do conhecimento histórico quer na formação e crescimento dos alunos. O contacto e compreensão dos artefactos, através da sua problematização, facilita a percepção e interiorização dos conteúdos, muitas vezes, abstractos e distantes, fazendo com que haja uma apropriação dos mesmos, tornando-os seus e dando-lhes um uso objectivo na orientação da sua vida. Por outro lado, o professor tem uma acção fundamental e decisiva na criação de uma ligação entre esta fonte e o aluno, apresentando-lhe a fonte e ajudando-o a ver para além do objecto e das suas funcionalidades, mas integrando-o no tempo e no espaço. Como vimos o uso de artefactos traz algumas vantagens para a aprendizagem dos alunos, pois pretende-se que estes sejam utilizados pelo aluno não apenas como suporte teórico, ou simples ilustrações do manual, mas como principal ferramenta para a construção do conhecimento histórico numa dialéctica passado-presente em que o aluno deixa de ter uma função de mero espectador e passa a ter um papel interventivo na apropriação e construção do conhecimento histórico. O uso das fontes, e em particular de artefactos, pode também ajudar a destruir o mito da História como disciplina aborrecida e inútil, sobretudo através da dialéctica artefacto-aluno, do fomento da problematização, da investigação ou simplesmente da motivação e imaginação. Como refere Ashby, "as fontes históricas seriam as evidências do passado que certamente poderiam auxiliar a imaginação histórica do aluno" (Ashby, 2006, pp.151-168 apud Xavier, 2010, p.645). No entanto é importante perceber: Como podem a Arqueologia e os artefactos arqueológicos contribuir e fazer parte do quotidiano lectivo do aluno? A resposta a esta questão traz em si mais questões e algumas das dificuldades que sentimos ao longo da realização da nossa PES. Aproximar a Arqueologia das escolas é fundamental, mas para tal é necessário aproximar as instituições ligadas ao património (Câmaras Municipais; Centros de Arqueologia; Empresas de Arqueologia, Museus, etc.) das escolas, pois só assim a escola terá acesso a artefactos arqueológicos. O acesso a objectos arqueológicos foi uma das muitas dificuldades sentidas durante a realização da nossa investigação e que tentamos minorar através de soluções alternativas e criativas, nomeadamente, a construção de artefactos, como vimos na segunda actividade e com resultados muito positivos, ou recorrer a réplicas, como é comummente feito pelos professores História ${ }^{6}$. No entanto, esta solução traz alguns constrangimentos, nomeadamente, na obtenção das réplicas, o elevado custo associado ou mesmo a discrepância da relação número de peças versus número de alunos. Seria neste contexto que a relação entre as entidades detentoras do património e a escola seria profícua. Possivelmente, poderíamos reutilizar soluções do passado (Bruno, 1999) como a criação de "colecções arqueológicas de referência" para as escolas. Uma solução que não só beneficiaria a escola ao nível didáctico e pedagógico, mas que poderia ajudar a dar resposta, embora simbolicamente do ponto de vista do número, à questão da gestão dos espólios arqueológicos ${ }^{7}$. Por fim, referir a importância do estreitamento da relação museu-escola, nomeadamente, na necessidade de os museus adaptarem parte das suas ofertas educativas à realidade escolar, uma vez que actualmente, e apesar da liberdade de acção que alguns museus dão às iniciativas dos professores, existe um grande desfasamento entre a oferta dos museus e as necessidades das escolas.

No entanto, se à primeira vista as questões por nós colocadas nos parecem apenas do foro prático elas são na realidade uma maneira de tornar os artefactos instrumentos pedagógicos e didácticos, tão importantes como os manuais escolares, mas também uma ferramenta fundamental para criar nos alunos, desde de tenra idade, uma noção da importância do estudo e preservação do património. Deste modo, fazendo com que estes objectos deixem de ser apenas peças de museu visitadas em ocasiões especiais, mas sim objectos próximos e elementos participantes do quotidiano dos alunos.

6. Como revelou o questionário realizado aos professores do grupo de História da escola secundária Miguel Torga.

7. Recomendação de boas práticas na gestão de espólios arqueológicos: recolha, selecção e descarte, 2019. 


\section{BIBLIOGRAFIA}

ALVINO-BORBA, Andreilcy; MATA-LIMA, Herlander (2011) - Exclusão e inclusão social nas sociedades modernas: um olhar sobre a situação em Portugal e na União Europeia. São Paulo. Serv. Soc. Soc. 106, (Abr./Jun. 2011), pp. 219-240.

AMARAL, Cláudia; ALVES, Eliseu; JESUS, Elisabete; PINTO, Maria Helena (2012) - Sim, a História é importante! O trabalho das fontes na perspetiva da Educação Histórica. Porto: Porto Editora.

ARENDS, Richard (1999) - Aprender a Ensinar. Lisboa: McGraw-Hill.

BRUNO, Maria, C. (1999) - Primeiro capítulo - A Musealização da Arqueologia. Caderno de Sociomuseologia. Lisboa. 17(17), pp. 35-150.

COPÉ, Silvia; ROSA, Carolina (2008) - A arqueologia como prática interpretativa sobre o passado no presente: perspectivas teórico-metodológicas. In PINTO, C. R. J.; GUAZZELLI, C. A. B., org. - Ciências Humanas: pesquisa e método. Porto Alegre: Editora da UFRGS, pp. 97-124.

COSTA, Beatriz (2018) - A Cultura Material da Antiguidade como potencialidade para ensino de História Antiga na Educação Básica. EBR - Educação Básica Revista. São Paulo. 4:1, pp.65-82.

DARVILL, Timothy (2008) - Concise dictionary of Archeology. Oxford: Oxford University Press.

DURBIN, Gail; MORRIS, Susan; WILKINSON, Sue (1996) - Learning from objects. S.1.: English Heritage.

FERREIRA, Maria Azevedo (2013) - Cultura Material e o Ensino de História: perspectivas acerca das culturas indígenas enquanto parte integrante na formação do povo brasileiro. In Primeira Jornada Paranaense PIBID e PET de História. Maringá: UEM, pp. 153-157.

FONSECA, Selva Guimarães (2003) - Didática e prática de ensino de História. Campinas: Papirus.

FUNARI, Pedro. (2008) - Os historiadores e a cultura material. In PINSKY, Carla Bassanezi, org. - Fontes históricas. São Paulo: Contexto, pp. 81-110.

GIL, Antônio Carlos (2009) - Metodologia do Ensino Superior. São Paulo: Atlas.

HELLER, Agnes (1987) - O cotidiano e a história. São Paulo: Paz e Terra.

HODDER, I. (1992) - Theory and Practice in Archaeology. London / New York: Routledge.

KEMPF, Karl (1961) - Historical Monograph: Electronic Within the Ordnance Corps. Maryland: Aberdeen Proving Ground; U.S. Army Ordnance Corps.

MACGREGOR, Neil (2013) - A História do Mundo em 100 Objetos. Rio de Janeiro: Editora Intrínseca Lda.
MATTOSO, José (1999) - A importância do texto literário no ensino da História. In No branco do sul as cores dos livros: encontro sobre literatura para crianças e jovens: atas. Beja: Instituto Politécnico de Beja/Escola Superior de Educação, pp. 135-150.

MENESES, U. T. B. de (1983) - A Cultura Material no estudo das civilizações antigas. Revista de História. São Paulo. 115, pp. 103-117.

NETO, Helena; NETO, Jorge; Luís, Abrantes, SANTOS; Luís, Aguiar, SANTOS (2014) - O Projecto Desafios 7 ano. Lisboa: Santillana.

PESSOA, Ana (1999) - Movimento da Escola Moderna Portuguesa (1966-1996), Lisboa, Universidade de Lisboa - Faculdade de Psicologia e de Ciências da Educação (Tese de mestrado, policopiada).

REDE, Marcelo (1996) - História através das coisas: tendências recentes nos estudos de cultura material. Anais do Museu Paulista. São Paulo. 4, pp. 265-82.

RODRIGUES-PIMENTA, Maria (2011) - A escola do futuro: Uma reflexão necessária! In Revista EDUSciense. Porto. 1, pp. 48-54.

SCHIMDT, M. Auxiliadora (2008) - A Formação do professor de História e o cotidiano em sala de aula. In BITTENCOURT, Circe, coord. - O saber histórico na sala de aula. São Paulo: Contexto, pp. 115-128.

TRINDADE, Rui (2002) - Experiências educativas e situaçôes de aprendizagem. Lisboa: Asa.

XAVIER, Erica (2010) - O uso das fontes históricas como ferramentas na produção de conhecimento histórico: a canção como mediador. Antíteses. 3:6 (Jul.-Dez), pp. 1097-1112.

\section{LEGISLAÇÃO}

Lei n. ${ }^{\circ}$ 46/86, D.R., n.ํㅜ 237/1986, Série I de 1986-10 - Lei de Bases do Sistema Educativo (versão mais recente - Lei n.․․ 85/2009, de 27/o8).

Despacho 5908/2017, D.R., n.ำ 128/2017, Série II de 201707-052 - Resumo: Autoriza, em regime de experiência pedagógica, a implementação do projeto de autonomia e flexibilidade curricular dos ensinos básico e secundário, no ano escolar de 2017-2018.

Despacho n. 6478/2017, D.R., n.ำ 143/2017, Série II de 2017-07-26 - Resumo: Homologa o Perfil dos Alunos à Saída da Escolaridade Obrigatória.

Decreto-lei 55/2018, D.R., n.o 129/2018, Série I de 201807-06 - Resumo: Estabelece o currículo dos ensinos básico e secundário e os princípios orientadores da avaliação das aprendizagens.

Perfil dos Alunos à Saída da Escolaridade Obrigatória (2017). Lisboa: Ministério da Educação. Disponível em https://dge. 
mec.pt/sites/default/files/Noticias_Imagens/perfil_do_aluno.pdf. (Consultado a: 30/9/2018).

Aprendizagens Essênciais (2018). Lisboa: Ministério da Educação. Disponível em https://dre.pt/application/file/a/ 11574227 (Consultado a: 30/9/2018).
Justino, D., (Dir.) (2016). Estado da Educação 2016. Lisboa: Conselho Nacional de Educação (CNE). Disponível em http://www.cnedu.pt/content/noticias/CNE/CNEEE 2016_web.pdf (Consultado a: 5/10/2018).

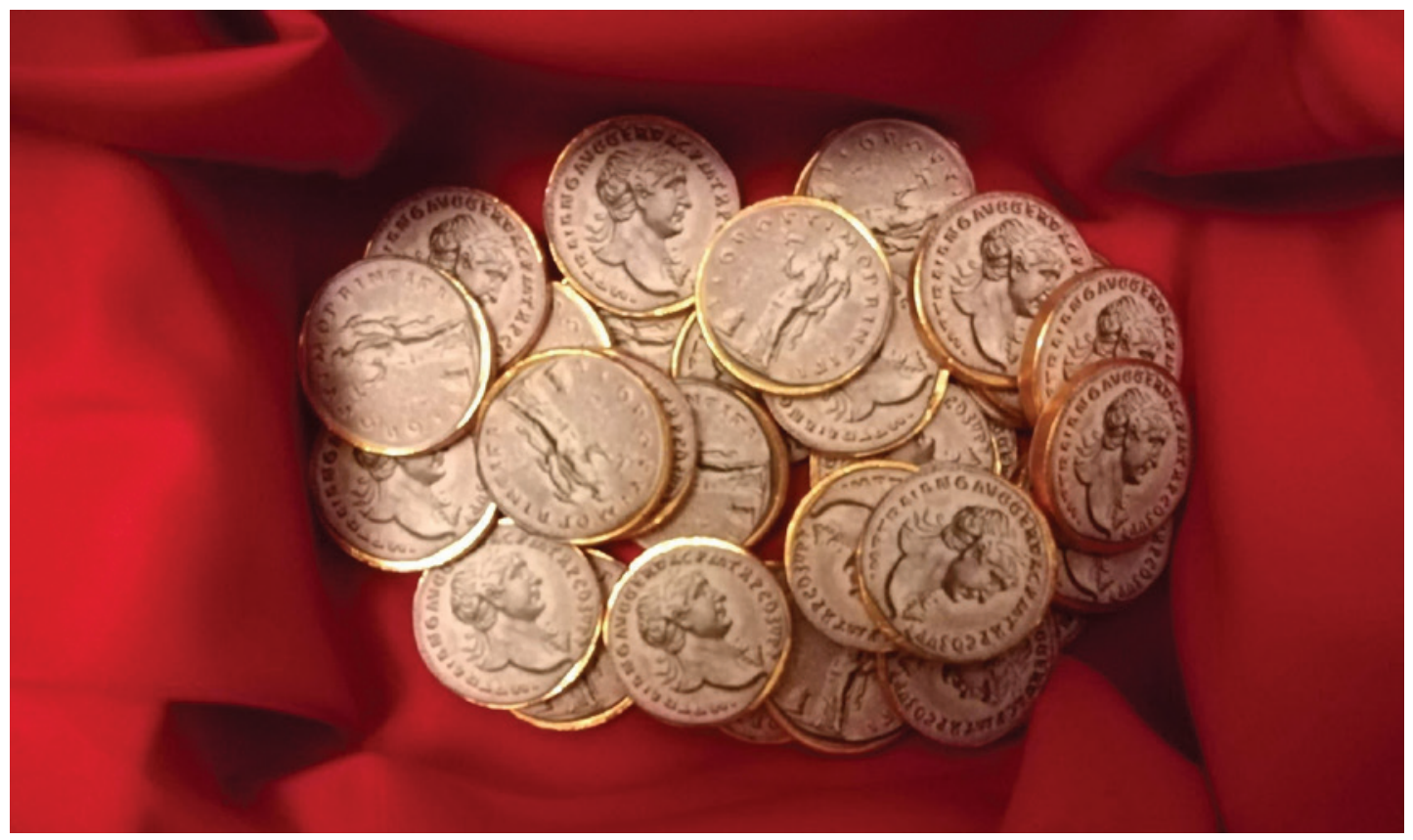

Figura 1 - Denários construídos a partir de moedas de chocolate.

Interesse pela disciplina de História

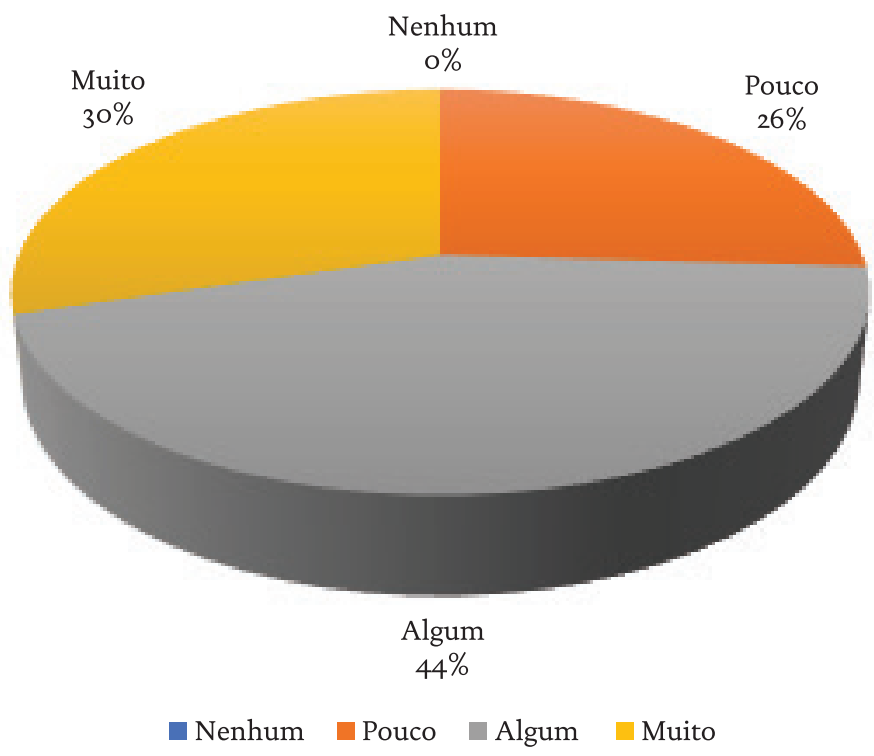

Figura 2 - Gráfico realizado a partir da análise dos questionários sobre o interesse dos alunos pela disciplina de História. 


\section{Avaliação da evolução dos conhecimentos}

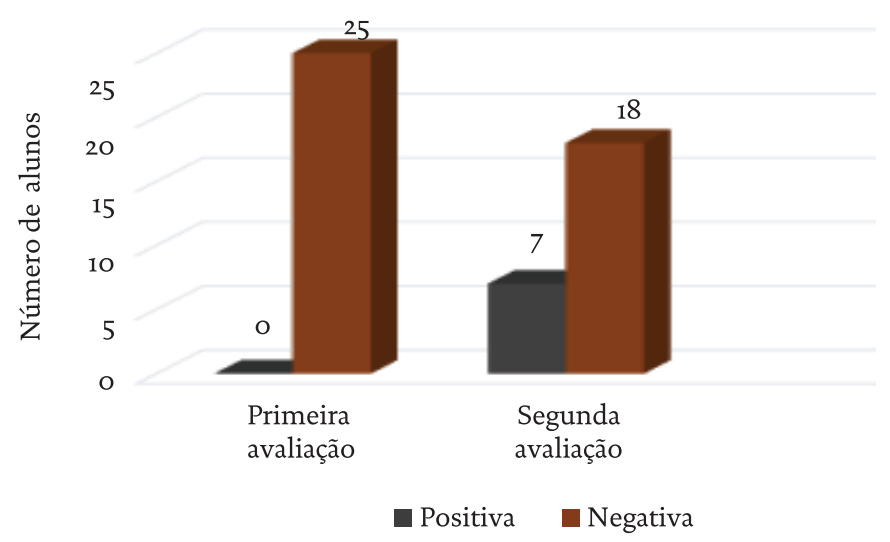

Figura 3 - Gráfico realizado a partir dos resultados obtidos nas duas avaliações realizadas (metacognição).

Avaliação das aulas efectuada pelos alunos

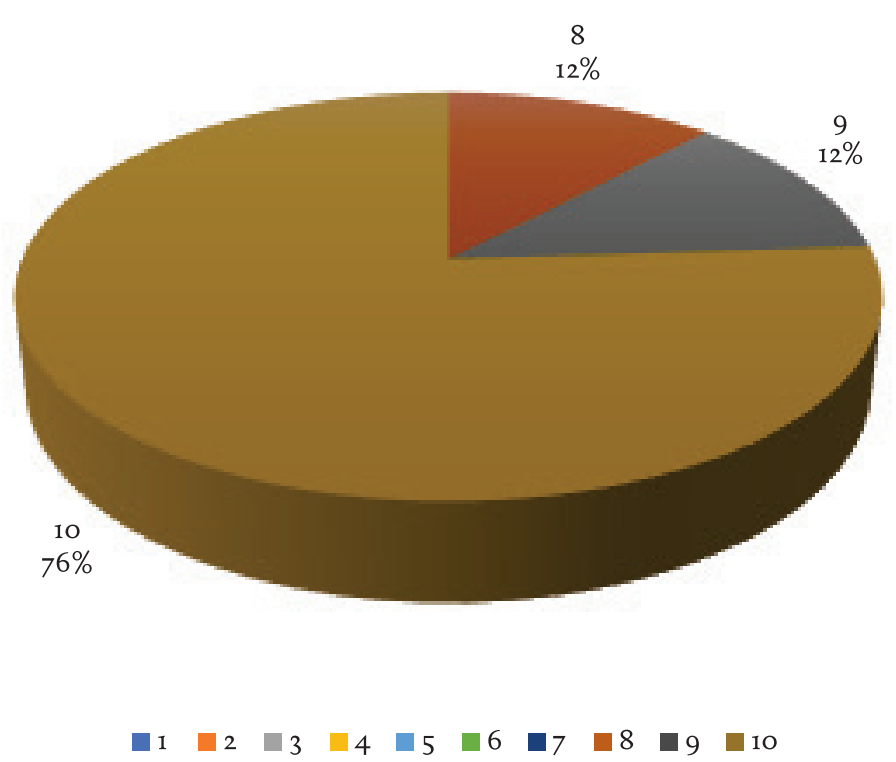

Figura 4 - Gráfico realizado a partir da análise dos questionários de satisfação efectuado pelos alunos no final da abordagem da temática do mundo romano. 


\title{
ARQUEOLOGIA 3.0-PENSAR E COMUNICAR A ARQUEOLOGIA PARA UM FUTURO SUSTENTÁVEL
}

\author{
Mónica Rolo ${ }^{1}$
}

\begin{abstract}
RESUMO
No presente artigo dá-se a conhecer o projeto Arqueologia 3.o, uma iniciativa que resultou da parceria do Museu-Biblioteca da Casa de Bragança - Fundação da Casa de Bragança com a Universidade de Évora, e que se materializou num conjunto de três edições de workshops internacionais, de periodicidade anual, realizados entre os anos de 2017 e 2019. As diferentes edições seguiram uma linha condutora comum - abordar a questão do estudo, divulgação e valorização do património arqueológico à luz de novas formas de encarar e comunicar a Arqueologia. É nossa intenção apresentar um balanço do projeto Arqueologia 3.o e lançar as bases para uma eventual nova fase do mesmo.
\end{abstract}

Palavras-chave: Arqueologia, Divulgação, Gestão do Património, Socialização.

\begin{abstract}
The project of scientific dissemination Arqueologia 3.0 is the outcome of a partnership established between Museu-Biblioteca da Casa de Bragança - Fundação da Casa de Bragança and Évora's University (Portugal). From 2017 until 2019, three annual editions of the International Workshop Arqueologia 3.o have taken place, with one common objective - to debate the issue of study, communication and enhancement of archaeological heritage, in articulation with the new perspectives over archaeological praxis and its social impact. In the present paper, one intends to look back over the main goals and results of this project and to lay the foundations for the future of Arqueologia 3.o.
\end{abstract}

Keywords: Archaeology, Dissemination, Heritage Management, Socialization.

\section{INTRODUÇÃO}

O projeto de divulgação científica e patrimonial denominado Arqueologia 3.o nasceu em 2017 e resultou de uma parceria entre o Museu-Biblioteca da Casa de Bragança (Vila Viçosa) e a Universidade de Évora, através do CHAIA - Centro de História de Arte e Investigação Artística. Esta parceria traduziu-se na soma das principais valências destas duas instituições na área da Arqueologia - por um lado, o amplo trabalho de formação e investigação desenvolvido neste âmbito pela Universidade de Évora, em particular em território alentejano, e, por outro, a larga tradição no apoio e proteção ao património arqueológico associada à Casa de Bragança e, desde 1933, à Fundação da Casa de Bragança. Em comum, ambas as instituições partilham a ligação à comunidade territorial e os ideais de preservação e conhecimento dos recursos patrimoniais na região, pelo que a organização conjunta resultou numa harmoniosa articulação institucional. Nas palavras de A. Carneiro, "são as instituições com mais História e Saber adquirido na salvaguarda e divulgação do Património as que mais habilitadas estão para antecipar o futuro" (2018, p. 13).

Assumindo o formato de Workshop Internacional, este projeto converteu-se num evento promovido anualmente pelas duas instituições parceiras ${ }^{2}$, so-

1. UNIARQ - Centro de Arqueologia da Universidade de Lisboa (Portugal); monicasrolo@gmail.com

2. Ao longo das várias edições do Workshop Arqueologia 3.o, foi possível contar com o apoio institucional do Centro de Arqueologia da Universidade de Lisboa (UNIARQ), do Museu Nacional de Arqueologia (MNA), ou da Direção Regional de Cultura do Alentejo (DRCA). 
mando já três edições realizadas - 2017 (Vila Viçosa e Évora), 2018 (Vila Viçosa e Estremoz) e 2019 (Vila Viçosa), e a publicação de três volumes intitulados Arqueologia 3.o, alusivos a cada um dos eventos (http://www.fcbraganca.pt/biblioteca_dig/biblioteca-digital.html). Nas três edições, o mesmo princípio norteador - abordar as questões do estudo, valorização e divulgação do património arqueológico sob novas formas de pensar e comunicar a Arqueologia, e de olhos postos num desenvolvimentos sustentável e integrado da profissão.

\section{ARQUEOLOGIA 3.0-UMA INICIATIVA DE DIVULGAÇÃO CIENTÍFICA DE OLHOS POSTOS NUM FUTURO SUSTENTÁVEL}

\subsection{Os objetivos}

O Arqueologia 3.o nasceu da percepção da urgência de encontrar novas formas de fazer, pensar e comunicar a Arqueologia, consentâneas com as exigências impostas pelo século XXI. Neste sentido, resultou também da necessidade de trazer para reflexão e debate algumas temáticas que, apesar de serem consideradas indissociáveis das boas práticas deontológicas atuais, nem sempre têm espaço nos currículos académicos e no percurso formativo de estudantes e profissionais. Isto porque os desafios da sociedade contemporânea ocorrem sempre a uma velocidade mais ampla do que os esforços adaptativos das competências pedagógicas, mais difíceis de atualizar.

Esta percepção ganhou especial importância em virtude do contexto geográfico de atuação e recrutamento das instituições envolvidas na iniciativa. Importa realçar que estamos perante uma região periférica em relação aos grandes centros urbanos, em acelerado processo de regressão demográfica, e que tem na cidade de Évora o principal polo de atração para um universo estudantil composto, na sua larga maioria, por autóctones e jovens oriundos dos concelhos-satélite daquela capital de distrito. Neste enquadramento, e não obstante a facilidade de acesso a diferentes recursos pedagógicos e fontes de informação potenciada pelas designadas novas tecnologias, considerou-se que uma iniciativa como o Arqueologia 3.0 poderia representar uma mais-valia, quer enquanto espaço de divulgação da atividade e património arqueológicos, quer como oportunidade de debate e partilha de conhecimentos e experiências. A par disso, o importante papel desempenhado pelo Museu-Biblioteca da Casa de Bragança (Vila
Viçosa) na ligação à história local e na salvaguarda do património arqueológico da região $0^{3}$, justificava plenamente a dinamização e acolhimento de uma iniciativa com as características do Arqueologia 3.o. Foi assim que, desde a primeira edição do Workshop Internacional Arqueologia 3.o, se procurou dar forma a um desses "espacios de encuentro de conocimientos, experiencias, fórmulas organizativas y opiniones como territorios de afirmación individual y colectiva de la arqueología” (Ruiz Zapatero, 2016, p. 62), fundamentais no quadro de construção de uma "agenda arqueológica" para o séc. XXI. Ao longo das três edições do evento, assumimos como fio condutor a valorização e divulgação do património arqueológico sob diferentes perspectivas. Para tal, contámos com a imprescindível presença de um conjunto de oradores, portugueses e estrangeiros, com larga e reconhecida experiência no estudo, gestão, salvaguarda e comunicação do património arqueológico, adaptada aos desafios da contemporaneidade.

$\mathrm{Na}$ esteira da crescente implementação no panorama nacional dos conceitos de Educação Patrimonial, Arqueologia Pública ${ }^{4}$ e socialização do património, apostou-se na valorização de uma visão integrada da ciência arqueológica, entendida como condição sine qua non para um futuro sustentável da profissão. De igual forma, teve-se em atenção o exponencial crescimento do turismo cultural registado nos últimos anos, atividade económica que, até ao início da atual crise pandémica, correspondia àquela que mais crescia em todos os sectores geradores de riqueza, com nulo impacto ecológico. Assim, em paralelo com o reconhecimento da importância da Arqueologia enquanto indiscutível instrumento de avanço científico, defendeu-se o seu potencial enquanto recurso pedagógico, socioeconómico e de desenvolvimento

\footnotetext{
3. Recorde-se a coleção de Arqueologia da Fundação da Casa de Bragança, exposta no Castelo de Vila Viçosa. Trata-se de uma coleção de referência a nível nacional, quer pela representatividade numérica do espólio reunido, quer pelo facto de se tratar de um conjunto maioritariamente proveniente de escavações arqueológicas realizadas no território alto alentejano, e que, portanto, fornece um retrato abrangente da Arqueologia regional.
}

4. Ao longo do presente trabalho, deve entender-se o conceito de 'Arqueologia Pública' conforme definido por Richardson \& Almansa - "as both a disciplinar practice and a theoretical position, which can be exercised through the democratization of archaeological communication (...)" (2015, p. 1). 
territorial. Neste sentido, a concepção do projeto Arqueologia 3.0 em geral, e a estruturação de cada edição do evento em particular, assentaram em duas pedras basilares: 'levar as pessoas à Arqueologia' e 'levar a Arqueologia às pessoas'. A primeira ideia-chave passou por dar a conhecer diferentes projetos e case-studies nas áreas do estudo, valorização, divulgação e socialização da Arqueologia. Neste âmbito, a escolha dos oradores convidados contemplou projetos de Arqueologia Pública de sucesso, implementados em regiões económica e demograficamente deprimidas [vejam-se, por exemplo, o projeto Terra Levis, na Serra de Ávila (Castilla y León, Espanha), ou o modelo de gestão de Los Bañales (Uncastillo, Zaragoza, Espanha)]. Fomentando a partilha de conhecimento e experiências entre oradores e assistência, procurou-se chamar a atenção, sobretudo do público estudantil, para o vasto potencial do património arqueológico e das suas inúmeras abordagens. A segunda premissa está diretamente relacionada com a intenção de promover o binómio Arqueologia/ Património Arqueológico - Sociedade/ Comunidade e a ideia de transferência de conhecimento. Procurou-se realçar a importância da socialização do património arqueológico, não só como meio para a divulgação do conhecimento científico e preservação da memória comum, mas como um dever que se impõe de compartilhar e 'devolver' à comunidade o conhecimento, o protagonismo e a responsabilidade sobre uma herança que é de todos e, por isso mesmo, a todos diz respeito.

\section{2. $O$ contributo, em jeito de balanço}

Em 2017 o Arqueologia 3.o deu os primeiros passos, iniciando-se "um ciclo de debates relacionados com a contemporaneidade da Arqueologia" (Carneiro, 2018, p. 14). Realizaram-se, atéà data, três workshops internacionais que, conforme sublinhado anteriormente, tiveram como matriz comum o reconhecimento da importância da prática e património arqueológicos, enquanto recursos científicos e fatores de dinamização e desenvolvimento socioeconómico sustentável dos territórios e respetivas comunidades. A primeira edição, designada Da escavação ao ${ }_{3} D$. Gestão, Inovação e Divulgação em Arqueologia, decorreu nos dias 6 e 7 de Abril de 2017. Teve lugar no castelo de Vila Viçosa (espaço que alberga a exposição da Coleção de Arqueologia da Fundação da Casa de Bragança) e em Évora, nas instalações do Laboratório HERCULES, parceiro institucional desta primeira edição do Arqueologia 3.o. Centrámo-nos nas questões relacionadas com a gestão, tratamento e estudo de espólio arqueológico em contexto de pós-escavação e na divulgação deste tipo de património (móvel e imóvel). Tomando em linha de conta exemplos tão diversos como a gestão das reservas de materiais arqueológicos tutelados pela $\mathrm{Di}$ reção Regional de Cultura do Alentejo, as coleções do Museo Arqueológico Provincial de Badajoz, ou o espólio à guarda da Associação de Arqueologia da Amadora $^{5}$, pretendeu-se ilustrar e promover o debate sobre normas e boas práticas no tratamento de coleções de Arqueologia. Paralelamente, chamou-se a atenção para a multiplicidade de novos recursos e potencialidades que a aplicação das novas tecnologias veio colocar à disposição do estudo, valorização e divulgação do património arqueológico. Exemplo paradigmático disso mesmo foram as sessões práticas realizadas no Laboratório HERCULES (fotogrametria e $3 \mathrm{D}$, fluorescência e difração de raios-X, microscopia óptica e microscopia electrónica), bem como as comunicações apresentadas sobre conservação e restauro de espólio arqueológico ${ }^{6}$, ou sobre a questão da preservação e difusão da informação digital produzida sobre o património (arqueológico e arquitectónico $)^{7}$. No âmbito da aplicação das ferramentas de realidade virtual e comunicação digital ao serviço da divulgação do património arqueológico, destacaríamos ainda a apresentação do projeto Morbase (Câmara Municipal de Montemor-o-Novo) ${ }^{8}$ (Figuras 1 e 2).

A segunda edição do workshop Arqueologia 3.o decorreu nos dias 15 e 16 de Março de 2018, em Vila Viçosa e em Estremoz, contando com o Centro de Ciência Viva de Estremoz como instituição parceira e anfitriã do evento. Nesta segunda edição, subordi-

5. Referimo-nos, respetivamente, às comunicações apresentadas por Rafael Alfenim (DGPC/DRCA), Guillermo Kurtz (Museo Arqueológico Provincial de Badajoz), e Vanessa Dias (Câmara Municipal da Amadora).

6. Aludimos, em concreto, às comunicações a cargo de Margarida Santos (MNA) e Lília Esteves (DGPC/ Laboratório José de Figueiredo); de Elsa Murta e Paula Monteiro (DGPC/Laboratório José de Figueiredo); e de Carina Maurício (Fundação Cidade da Ammaia).

7. Comunicação apresentada por José Manuel Valle (Universidad del País Vasco - UPV/EHU).

8. Comunicação apresentada por Carlos Carpetudo e Sira Camacho (Cromeleque) - https://montemorbase.com/. 
nada ao tema Comunicação, Divulgação e Socialização da Arqueologia, deu-se especial relevo à percepção da Arqueologia e do património que lhe está associado como reserva de valor histórico, científico, mas também sociocultural e económico. Tomámos como ponto de partida a noção abrangente de 'gestão' do património arqueológico (Almansa, 2014, p. 22), bem ilustrada pelos exemplos dos modelos de gestão e comunicação desenvolvidos no arqueossítio de Tróia (Grândola), na Herdade da Maroteira (Redondo), ou em Los Bañales (Uncastillo, Zaragoza) ${ }^{9}$. Em comum, estes projetos mostram como a base patrimonial pode servir para a transmissão de conteúdos adaptados ao público escolar, turistas e comunidades locais.

Procurou-se também analisar, através de diversos casos de estudo de referência nacional e internacional, quais as abordagens e as ferramentas necessárias para trabalhar com as comunidades e implementar o conceito de 'Arqueologia pública'. Tal como defende Jaime Almansa Sánchez, coordenador do projecto \#PubarchMED, "la arqueología busca crear nuevo conocimiento, y la arqueología pública que ese conocimiento sea útil en el contexto social" (idem, p. 24). Nesta linha de pensamento, destacamos as iniciativas de UNDERGROUND Arqueología (Cáceres, Espanha) e do coletivo internacional Romanarmy.eu, bem como a atividade na área da educação patrimonial desenvolvida pela Câmara Municipal de Montemor-o-Novo, ou o já mencionado projeto Terra Levis, de Arqueologia em comunidade na Serra de Ávila (Espanha) ${ }^{10}$. A propósito desta temática, recorde-se que, já na edição de 2017, tínhamos tido a oportunidade de contactar com o projeto Arqueologia somos todos (http://www.arqueocordoba.com/

9. Respetivamente, a comunicação da autoria da equipa de Arqueologia do Troia Resort, apresentada por Ana Patrícia Magalhães; a comunicação a cargo de José Inverno (Herdade da Maroteira \& Corktrekking); e a comunicação de Javier Andreu Pintado (Universidad de Navarra/ Fundación Uncastillo - Los Bañales).

10. Comunicações apresentadas por Sabah Walid e Juanjo Pulido (UNDERGROUND Arqueología Património \& Gente - https://www.underground-arqueologia.com/); Jesús García Sánchez (Instituto de Arqueologia de Mérida, CSIC) e Manuel Gago Mariño (Universidad de Santiago de Compostela) - http://romanarmy.eu/pt/; Hermínia Santos e Maria Galego (Câmara Municipal de Montemor-o-Novo); e Juan Pablo López García (director do projeto Terra Levis https://www.terralevisarqueologia.com/). arqueologiasomostodos/), dinamizado na cidade de Córdova ${ }^{11}$. No âmbito da divulgação e comunicação do património arqueológico, ficámos a conhecer a atividade do grupo emeritense de recriação histórica Ara Concordiae, e fomos confrontados com os desafiantes projetos museológicos da premiada empresa nacional Glorybox, como, por exemplo, o museu PO.RO.S (Condeixa-a-Nova) ${ }^{12}$ (Figuras 3 e 4).

A terceira e mais recente edição deste workshop intitulou-se 'Resgatar Memórias' - Sítios, Territórios e Comunidades, e decorreu nos dias 14 e 15 de Março de 2019, em Vila Viçosa. À semelhança das edições anteriores, tratou-se de uma iniciativa conjunta do Museu-Biblioteca da Casa de Bragança (Fundação da Casa de Bragança) e da Universidade de Évora Centro de História de Arte e Investigação Artística (CHAIA).

Para este evento assumiu-se como mote de reflexão a necessidade do estudo, reabilitação e dinamização de sítios (ou coleções) há muito escavados e/ou votados ao esquecimento. Contrariando a tendência para continuar a escavar incessantemente e, não raras vezes, de forma pouco criteriosa, pretendeu-se chamar a atenção para os arqueossítios já intervencionados e subaproveitados, quer enquanto recurso científico, quer enquanto potencial recurso socioeconómico e de desenvolvimento territorial. Ao mesmo tempo, procurou-se trazer a debate a ideia de 'resgatar memórias' como parte integrante de uma visão integrada (e sustentável) do exercício da profissão de arqueólogo, que implique 'devolver' tais memórias às comunidades. Esta ideia de retorno à sociedade deve ser encarada como um compromisso ativo e participativo (Almansa, 2014, pp. 20-21), em prol do património arqueológico, da sua valorização e de uma gestão responsável a longo prazo, mas também das próprias comunidades e da dinamização ou revitalização dos contextos (paisagens patrimoniais, naturais e humanas) em que atuamos. Neste sentido, considerou-se pertinente analisar de que modo a aplicação do conceito de 'Arqueologia Pública', ainda tão pouco trabalhado em Portugal, pode, de facto, estabelecer a ponte entre herança

\footnotetext{
11. Comunicação apresentada por Desiderio Vaquerizo Gil, na primeira edição do workshop Arqueologia 3.o.

12. Comunicações a cargo de Abel Morcillo Léon (Presidente da Associação Ara Concordiae) e Pilar Caldera de Castro (Museo Nacional de Arte Romano de Mérida); e de Paulo Monteiro (Glorybox).
} 
cultural, comunidades e territórios, e converter-se em motor de arranque para uma sociedade consciente do valor sociocultural e económico do património arqueológico e comprometida com a defesa e salvaguarda do mesmo. Assim, na terceira edição do Arqueologia 3.o ficámos a conhecer o inovador projeto \#PubarchMED (http://pubarchmed.tdjp.es/), e os exemplos de socialização da Arqueologia postos em prática em Cuenca (Espanha) e em San Nicolás (Burgos, Espanha) ${ }^{13}$. Abordámos, a propósito da cidade de Córdova, o conceito de 'falso histórico' e os efeitos perniciosos das campanhas de restauros historicistas (e das 'agendas políticas' subjacentes) ${ }^{14}$. Para além de um olhar pelo legado das coleções arqueológicas do $17^{\circ}$ Marquês de Cerralbo, Enrique de Aguilera e Gamboa (1845-1922, Madrid); fomos ainda desafiados a pensar em "Como tornar a Arqueologia sexy"15. Tivemos também a oportunidade de aprender com os exemplos do Museu do Teatro Romano de Lisboa e Museo Nacional de Arte Romano de Mérida (Badajoz), centros de investigação e espaços de educação e sensibilização patrimonial por excelência ${ }^{16}$ (Figuras 5 e 6).

Importa assinalar que se procurou que cada evento contasse com espaços reservados ao debate e a atividades práticas. A apreciação feita pelo público (mediante o preenchimento de fichas de avaliação) da segunda edição do Arqueologia 3.o revelou a importância dada à componente prática, levando-nos a reforçá-la no programa da terceira edição. Outra das observações do público de que tomámos nota, ao longo destas três edições, prende-se com a represen-

13. Comunicações apresentadas por Jaime Almansa (Instituto de Ciencias del Patrimonio, CSIC); Miguel Ángel Valero (Universidad de Castilla-La Mancha); e Alberto Polo Romero e Diana Morales Manzanares (Universidad Rey Juan Carlos, Madrid).

14. Comunicação a cargo de Desiderio Vaquerizo Gil (Universidad de Córdoba).

15. Comunicações apresentadas por Carmen Jiménez Sanz (Subdiretora General de Museos Estatales, Ministerio de Cultura e Deporte de España); e Pedro Sobral (EON, Indústrias Criativas).

16. Comunicações da autoria de Lídia Fernandes e Carolina Grilo (Museu de Lisboa - Teatro romano/ EGEAC, Câmara Municipal de Lisboa); e Trinidad Nogales Basarrate ( $\mathrm{Mu}-$ seo Nacional de Arte Romano/ MNAR, Mérida). De referir que, sobre a atividade do museu emeritense, contou-se também com a comunicação apresentada por Nova Barrero (MNAR), aquando da primeira edição do workshop (2017). tatividade de oradores estrangeiros ${ }^{17}$. Do conjunto de 52 oradores convidados que passaram pelo $\mathrm{Ar}$ queologia 3.0, 21 deles (ou seja, 40\%) eram oradores estrangeiros (neste caso, espanhóis). Convém, pois, esclarecer que verificámos, desde a primeira edição e ao contrário do expectável, que tínhamos muito mais dificuldades em obter resposta aos convites endereçados a profissionais portugueses, do que a estrangeiros. Deparámo-nos, recorrentemente, com a total ausência de resposta (positiva ou negativa). Em alguns casos, e apesar de uma resposta inicial positiva, fomos confrontados com a ausência de resposta a posteriores tentativas de contacto (para resolução de questões logísticas do evento) e, a escassos dias do workshop, com o cancelamento da participação. Pelo contrário, a adesão dos convidados estrangeiros ao projeto Arqueologia 3.o foi, de um modo geral, quase imediata. Naturalmente que, mais do que ninguém, os membros da Comissão Científica e Organizadora do evento lamentam as dificuldades em poder contar com uma presença massiva e entusiasta dos investigadores e profissionais portugueses. Todavia, não podemos deixar de nos congratular pelo interesse e participação dos nossos colegas estrangeiros. Se, por um lado, ao longo das diferentes edições, ficou perceptível a importância que os exemplos da experiência e know-how nacionais (pela sua proximidade, pelo contexto e referentes comuns) assumiram para o público presente; por outro, a participação de oradores estrangeiros e a divulgação de projetos e case-studies internacionais foi uma inquestionável mais-valia, que muito enriqueceu o Arqueologia 3.o. Acima de tudo, houve a preocupação de elaborar programas o mais equilibrados possível, em termos de conteúdos e atividades, de forma a valorizar ao máximo, em cada evento, os contributos dos distintos oradores e aquela que era, para todos os presen-

\footnotetext{
17. Na maioria dos casos, e sobretudo entre o público estudantil, constatou-se que esta observação estava relacionada com as dificuldades de compreensão do idioma. Note-se, porém, que os únicos idiomas falados nas três edições foram o português e o castelhano.

Registe-se que foram convidados oradores de outras nacionalidades, disponíveis para fazerem as suas comunicações em inglês. Apesar do feedback positivo, tomámos consciência da inviabilidade desta ideia, uma vez que o facto de não podermos assumir o inglês como língua oficial do evento rapidamente se revelou uma barreira intransponível para os oradores falantes de outros idiomas, que não o português ou castelhano.
} 
tes, uma irrepetível oportunidade de aprendizagem e partilha (Figuras 7 e 8).

No que diz respeito ao público-alvo desta iniciativa, cremos ser pertinente recordar o texto de apresentação do volume relativo à primeira edição do Workshop (Rolo, 2018), no qual se manifestava uma intenção - "chamar os profissionais da área, em especial os técnicos de autarquias, que estão mais próximos das populações, e sensibilizar os alunos e as novas gerações para diferentes modos de trabalhar o património arqueológico, de modo a que as populações não fiquem excluídas do processo" (Carneiro, 2018, p. 14). De facto, os conteúdos das diferentes edições do Arqueologia 3.0 tiveram como principais destinatários alunos dos $1^{\circ}$ e $2^{\circ}$ Ciclos de Arqueologia, e profissionais de Arqueologia (em especial, técnicos de autarquias), de Museologia e de Educação Patrimonial. Em relação aos primeiros, a nossa intenção terá sido amplamente cumprida, visto que cerca de $70 \%$ do público do conjunto das três edições foi composto por estudantes (num universo total de 63 participantes, 44 eram estudantes). Esta adesão do público estudantil é reveladora do interesse que o evento despertou e, sobretudo, da forma como os conteúdos selecionados terão ido ao encontro das expectativas dos estudantes, incluindo alunos de formação avançada e, portanto, mais próximos do mercado de trabalho. É de realçar que, para além da oportunidade de tomada de conhecimento de diferentes experiências no domínio do estudo e valorização do património arqueológico, o contacto direto com os oradores, especialistas e profissionais com backgrounds distintos mas partilhando larga experiência nesta área, revelou-se um aspeto particularmente valorizado pelo público destas edições. Exemplo ilustrativo do sucesso desta experiência foi a presença fiel de vários destes estudantes nas três edições do evento, e a possibilidade que alunos do $1^{\circ}$ Ciclo de Estudos tiveram de participar em escavações arqueológicas em Espanha, sob a direção de alguns dos oradores convidados. Na impossibilidade de avaliar o impacto do Arqueologia 3.o nas gerações dos futuros arqueólogos e profissionais do património que nos acompanharam desde 2017, apraz-nos pensar que ficou clara a importância do compromisso colectivo (Almansa, 2014, p. 24) e do espírito construtivo na hora de refletir e debater para fazer mais e melhor Arqueologia.

No que se refere à presença de técnicos de autarquias e profissionais de Arqueologia, esta ficou aquém das expectativas, correspondendo a uma percentagem minoritária do público contabilizado. Pela relevância desta franja de público-alvo, enquanto profissionais no terreno e agentes privilegiados de ligação à comunidade, espera-se poder vir a contar, em eventuais futuras edições, com um maior número de profissionais entre a assistência.

Por último, e tal como já mencionado, cada edição do Workshop Internacional Arqueologia $3 . o$ deu origem a uma publicação homónima, na qual se reuniram os contributos de todos os oradores que generosamente se dispuseram a fazer parte deste 'registo para a posteridade'. Os três volumes editados ${ }^{18}$ encontram-se disponíveis online, em acesso livre, no site da Fundação da Casa de Bragança (http://www.fcbraganca.pt/biblioteca_dig/biblioteca-digital.html). Saliente-se o esforço de publicar anualmente os resultados de cada edição, algo incomum no panorama português e só possível pelo empenho dos comunicantes e das instituições mentoras dos evento.

Face ao acima exposto, considera-se que o balanço geral do Arqueologia 3.0 é muito positivo. Através desta iniciativa pretendeu-se questionar o papel da Arqueologia na sociedade atual, refletir sobre novos desafios e delinear caminhos de futuro. Valorizou-se a divulgação de novos discursos museológicos, novos modelos de gestão e difusão do património arqueológico, encarado, simultaneamente, como instrumento de avanço científico e elemento gerador de novas dinâmicas sociais e económicas. Colocaram-se em evidência as potencialidades das novas tecnologias ao serviço do estudo, salvaguarda e dinamização deste património, e debateu-se a aplicabilidade do conceito de 'Arqueologia Pública' - em que moldes e de que forma pode e deve ser implementada. Para tal contámos com a apresentação de variados exemplos, entre os quais, o do centro histórico de Córdova, o Campo Arqueológico de Mértola ${ }^{19}$, Los Bañales, as ruínas romanas de Tróia, o Museu do Megalitismo (Mora) ${ }^{20}$, o Teatro Romano de Lisboa, ou o Museo Nacional de Arte Romano de Mérida. Por seu turno, a apresentação de projetos de divulgação e/ou socia-

18. Rolo (coord.), 2018; 2019; 2020.

19. Comunicação apresentada por Susana Gómez e M. a de Fátima Palma (Campo Arqueológico de Mértola), na primeira edição do Arqueologia 3.o.

20. Comunicação da autoria de Leonor Rocha e Daniela Anselmo (Universidade de Évora), apresentada na primeira edição do Arqueologia 3.o. 
lização da Arqueologia como Morbase, Arqueología somos todos, Underground Arqueología, e \#PubarchMED, ou ainda o exemplo de mobilização da sociedade civil do projeto Urbs Regia ${ }^{21}$, colocaram em evidência não apenas o valor científico e o impacto social do património arqueológico, mas também as inúmeras possibilidades do quanto permanece ainda por fazer neste âmbito (Gráfico 1 e Figura 9).

\section{E DEPOIS DO ARQUEOLOGIA 3.O- O FUTURO 4.o NUM MUNDO PÓS-COVID?}

Três edições realizadas, duas questões essenciais e transversais - como valorizar e defender a profissão de arqueólogo e o património arqueológico? Como comunicar e sensibilizar para a Arqueologia públicos cada vez mais vastos e comprometidos? Longe de estarem respondidas, estas questões reforçam a ideia da pertinência da continuidade do projeto $\mathrm{Ar}$ queologia 3.o, cujos princípios norteadores e a condição de oportunidade de partilha e reflexão conjunta sobre a praxis e património arqueológicos faz sentido ampliar e consolidar. Porém, o mundo mudou muito desde a última edição do workshop, em Março de 2019. Vivemos um momento de feições distópicas e de generalizada incerteza, motivado pela crise de saúde pública, à qual se somam todos os demais problemas com que a sociedade atual se debatia até ao aparecimento do COVID-19 (Brogiolo \& Chavarría, 2020, p. 9). Tal como o impacto da crise financeira e económica que marcou os finais da primeira década do século XXI, também a crise pandémica (e a decorrente crise económica) que se propagou ao longo do corrente ano vem forçar-nos a repensar o exercício da profissão de arqueólogo e do respectivo impacto social. Numa sociedade sujeita a um momento tão traumático e de profunda mudança, a Arqueologia, à semelhança de todos os sectores ligados ao património cultural, é forçada a reavaliar o seu papel e contributo para esta mesma sociedade, e a gizar novas estratégias de sustentabilidade (Gould, 202O, p. 31). É neste sentido que, em nosso entender, as palavras de Fritz \& Plog, escritas nos inícios da década de 70 do século passado, permanecem inusitadamente atuais - "unless archaeologists find ways to make their research increasingly relevant to the modern world, the modern world

21. Comunicação a cargo de Pilar Tormo, apresentada na segunda edição do Arqueologia 3.o - http://urbsregia.eu/. will find itself increansingly capable of getting along without archaeologists" (1970, p. 412, apud Richardson \& Almansa, 2015, p. 2).

Assim, no atual quadro de recessão económica e de imprevisibilidade ${ }^{22}$, somos, uma vez mais, impelidos a reinventar-nos e a desenvolver novas formas de divulgação científica e patrimonial, sem comprometer o rigor e a acuidade da investigação arqueológica. Mantém-se inabalável a convicção de que a nossa atuação deve focar-se na sociedade / comunidade (Almansa, 2014, pp. 23-24) e na ideia de transferência de conhecimento; um conhecimento que se quer sólido e exigente, mas 'desencriptado', de modo a favorecer uma comunicação eficaz e a apropriação do conhecimento produzido com um valor acrescentado para a vida dos territórios e das comunidades. De igual modo, estamos seguros de que hoje, mais do que nunca, se impõe "the need for a responsible and ethical practice. This practice must be placed front and centre the commitment of archaeology professionals to a better, sustainable archaeology through public archaeology, one which moves beyond trends and the requirements of funding bodies, in order to consider and accommodate the needs and values of the communities and colleagues with whom we work with" (Richardson \& Almansa, 2015, p. 13).

Assim, numa época em que os recursos digitais se transformaram em ferramentas imprescindíveis da 'nova normalidade' (durante e após o confinamento), com a generalização de recursos em open access, a formação de 'comunidades digitais' e o trabalho em rede (Brogiolo \& Chavarría, 2020, pp. 14-15; Gould, 202O, p. 30), estamos em crer que também um eventual futuro para o projeto Arqueologia 3.0 terá de passar pelas ferramentas web. É certo, porém, que nenhuma ferramenta informática substitui o deslumbramento de visitar um sítio arqueológico, um museu, ou de contemplar in loco uma obra de arte. $O$ virtual não substitui o real, apenas cria novas dimensões. No entanto, à luz do momento atual, e em linha com o 'espírito de democratização da Arqueologia' (Vaquerizo, 2019, p. 6), os recursos tecnológicos oferecem a possibilidade de "new audiences, new markets and new ways to bring the story

22. Imprevisibilidade da duração e das repercussões da crise económica provocada pela pandemia, bem como da própria evolução da doença (Brogiolo \& Chavarría, 2020, p. 10; Gould, 202O, p. 22). 
of archaeology and history alive through artefacts, sites, lectures, games and other means we have yet to imagine" (Gould, 2020, p. 32), e convertem-se numa esperança para enfrentar os novos desafios que temos pela frente.

\section{AGRADECIMENTOS}

À Dra. Maria de Jesus Monge, Diretora do Museu-Biblioteca da Casa de Bragança, e ao Professor Doutor André Carneiro, da Universidade de Évora, mentores da ideia do projeto Arqueología $3 . o$ e seus principais impulsionadores.

A todos aqueles que se dispuseram a fazer parte desta iniciativa e que contribuíram para o seu êxito - oradores, instituições parceiras, e público. À equipa do Museu-Biblioteca da Casa de Bragança e, em especial, à equipa afeta ao Museu de Arqueologia, e aos elementos das Comissões Organizadora e Executiva das três edições do evento.

\section{ABREVIATURAS UTILIZADAS}

CSIC - Consejo Superior de Investigaciones Científicas.

DGPC - Direção Geral do Património Cultural.

DRCA - Direção Regional de Cultura do Alentejo.

FCB - Fundação da Casa de Bragança.

MBCB - Museu-Biblioteca da Casa de Bragança.

MNA - Museu Nacional de Arqueologia.

MNAR - Museo Nacional de Arte Romano (Mérida).

UÉ - Universidade de Évora.

UPV/EHU - Universidad del País Vasco/Euskal Herriko Unibertsitatea.

\section{BIBLIOGRAFIA}

ALMANSA SÁNCHEZ, Jaime (2014) - Arqueología pública y gestión del património: condenados a entenderse. Debates de Arqueología Medieval. 4, pp. 11-28. http://www. arqueologiamedievaldebates.com/

ALMANSA SÁNCHEZ, Jaime (2017) - You of All People Ask Me? Public Archaeology is You: A Response to Grima and the Wider Debate on the Meaning of Public Archaeology. Public Archaeology, DOI: 10.1080/14655187.2016.1264841

BROGIOLO, Gian; CHAVARRÍA ARNAU, Alexandra (2020) - Archeologia e sostenbilità nell'era post (?) COVIC-19. Post-Classical Archaeologies. 10, pp. 21-33. http:// www.postclassical.it/PCA_Vol.1o.html
CARNEIRO, André (2018) - Arqueologia 3.o. In ROLO, Mónica, coord. - Arqueologia 3.o, I. Da escavação ao 3 D. Gestão, Inovação e Divulgação em Arqueologia. [s.1.]: Fundação da Casa de Bragança, pp. 11-14.

GOULD, Peter (2020) - Resilience and innovation: an economic contemplation on public-facing archaeology after COVID-19. Post-Classical Archaeologies. 10, pp. 7-20. http://www.postclassical.it/PCA_Vol.1o.html

FRITZ, John; PLOG, Fred (1970) - The Nature of Archaeological Explanation. American Antiquity. 35 (4), pp. 405-412.

OLDHAM, Mark (2018) - Bridging the Gap: Classification, Theory and Practice in Public Archaeology, DOI: 10.1080/ 14655187.2017.1499398

RICHARDSON, Lorna-Jane; ALMANSA SÁNCHEZ, Jaime (2015) - Do you even know what public archaeology is? Trends, theory, practice, ethics. World Archaeology. 47 (2), pp. 194-211. DOI: 10.1080/o0438243.2015.1017599

ROLO, Mónica, coord. (2018) - Arqueologia 3.o, I. Da escavação ao 3 D. Gestão, Inovação e Divulgação em Arqueologia. [s.l.]: Fundação da Casa de Bragança. http://www.fcbraganca.pt/biblioteca_dig/arqueologia2.pdf

ROLO, Mónica, coord. (2019) - Arqueologia 3.o, II. Comunicação, Divulgação e Socialização da Arqueologia. [s.1.]: Fundação da Casa de Bragança. http://www.fcbraganca.pt/ biblioteca_dig/arqueologia.pdf

ROLO, Mónica, coord. (2020) - Arqueologia 3.o, III. 'Resgatar Memórias'-Sítios, Territórios e Comunidades. [s.1.]: Fundação da Casa de Bragança.

RUIZ ZAPATERO, Gonzalo (2016) - Presente y Futuro de la Arqueología em España. Luces, Sombras y Desafíos. In VAQUERIZO, D.; RUIZ, A. B.; DELGADO, M., eds.-RESCATE. Del registro estratigráfico a la sociedade del conocimiento: el patrominio arqueológico como agente de desarrollo sostenible. Córdoba: UCOPress. Vol. I, pp. 53-75.

VAQUERIZO GIL, Desiderio (2019) - Hacia una arqueología de carácter integral... In ROLO, Mónica, coord. (2019) - Arqueologia 3.o, II. Comunicação, Divulgação e Socialização da Arqueologia. [s.1.]: Fundação da Casa de Bragança, pp. 5-11.

VICENT, Naiara; RIVERO GRACIA, M.․ Pilar; TORRUELLA, M. Feliu (2015) - Arqueología y tecnologias digitales en Educación Patrimonial. Educatio Siglo XXI. 33, pp. 83-102. https://doi.org/10.6018/j/222511 


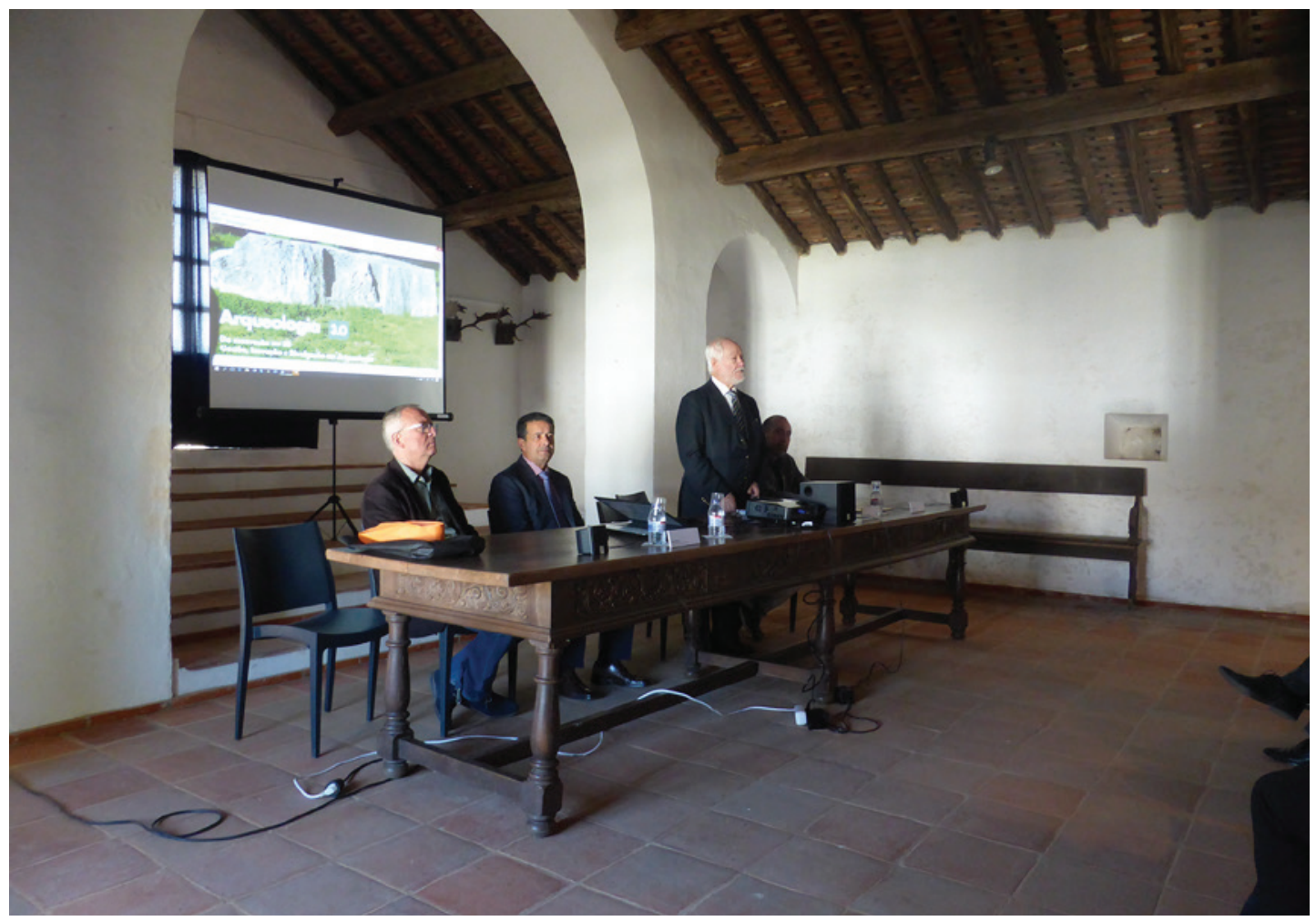

Figura 1 - Sessão de Abertura da I edição do Workshop Internacional Arqueologia 3.o (Abril 2017), pelo Presidente do Conselho Administrativo da Fundação da Casa de Bragança, Dr. Alberto Ramalheira. (C MBCB-FCB)

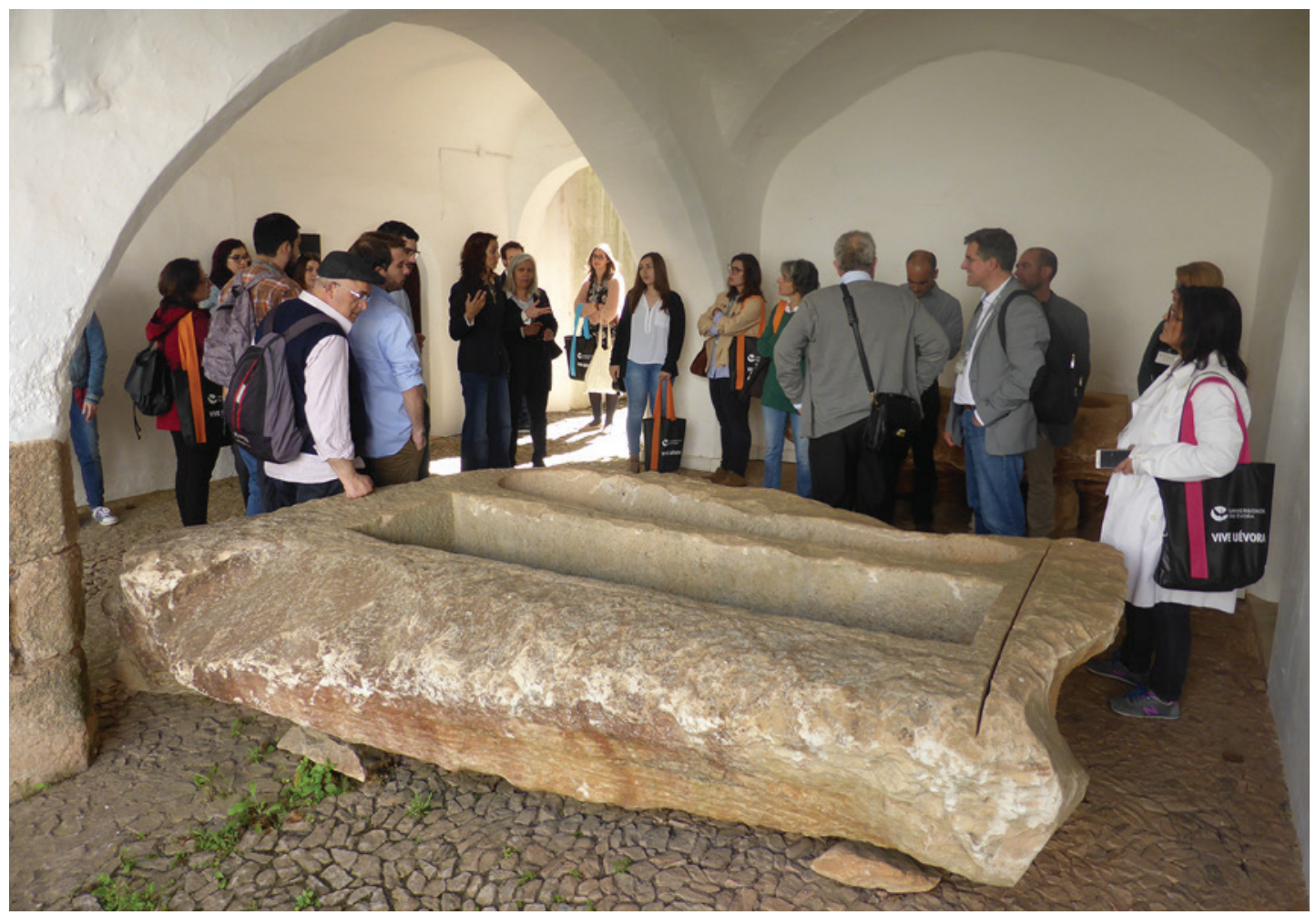

Figura 2 - Visita guiada pela exposição da Coleção de Arqueologia da Fundação da Casa de Bragança, por ocasião da I edição do Workshop Internacional Arqueologia 3 (Abril 2017). (@ MBCB-FCB) 


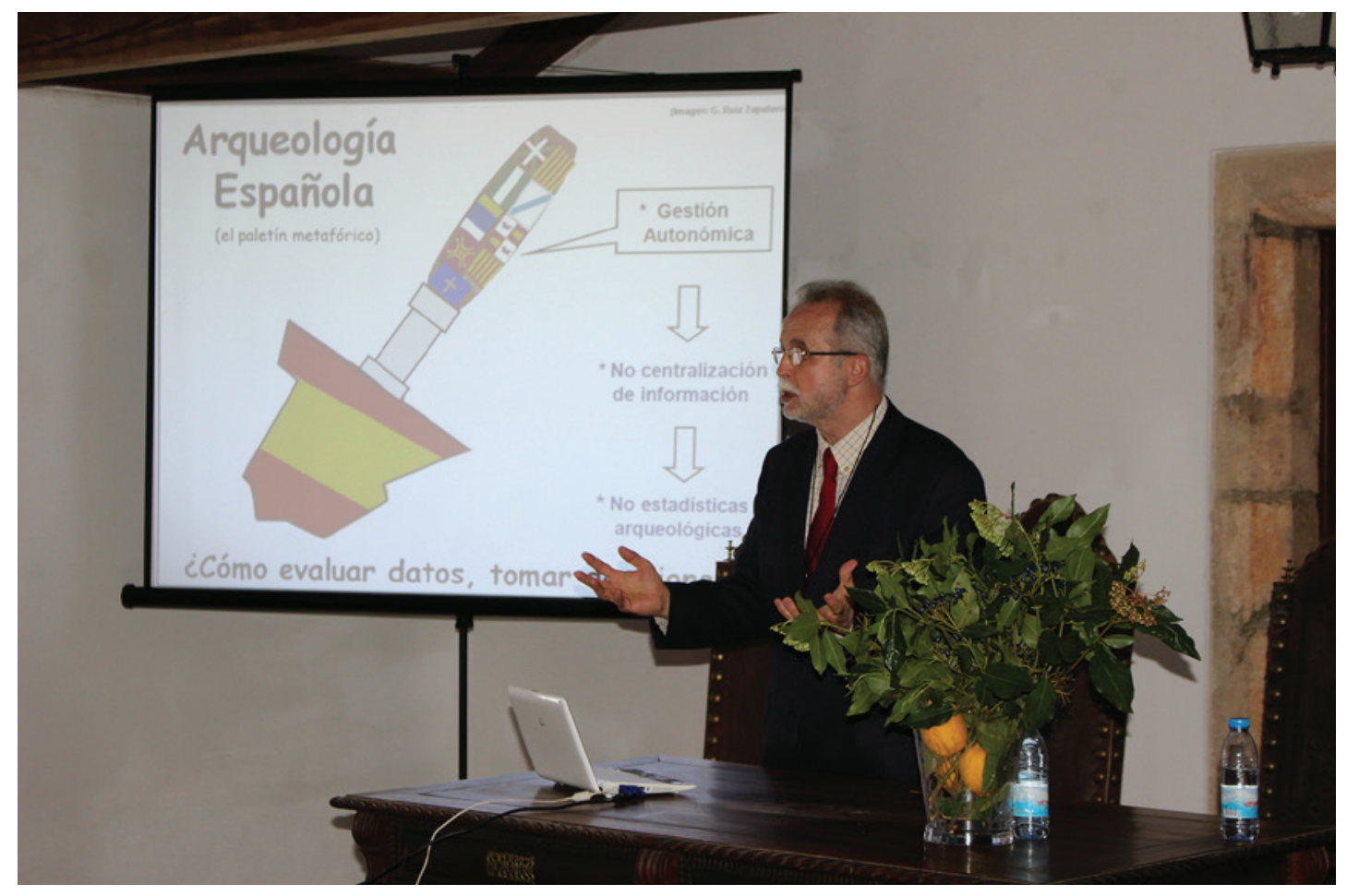

Figura 3 - Apresentação da Comunicação "Cuando (no sempre) hablan 'las piedras'. Hacia una arqueología integral como recurso de futuro en España. Reflexiones desde Andalucía”, por Desiderio Vaquerizo Gil (Universidad de Córdoba), na II Edição do Workshop Arqueologia 3.o (Março 2018). ( A. Martins)

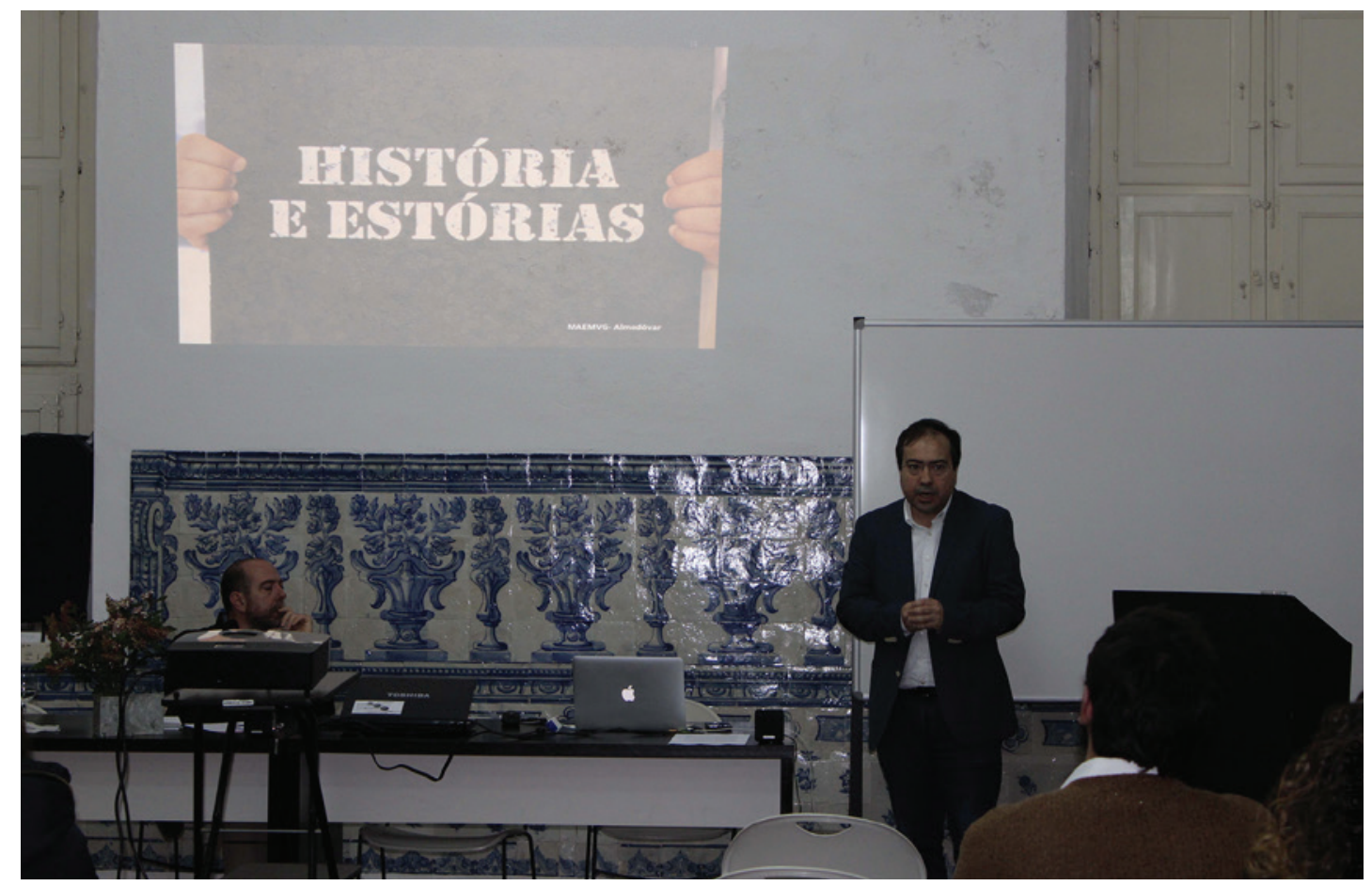

Figura 4 - Apresentação da Comunicação “E os tempos mudam...”, por Paulo Monteiro (Glorybox), no Centro de Ciência Viva de Estremoz, por ocasião da II Edição do Workshop Arqueologia 3.o (Março 2018). (C S. Malhado, MBCB-FCB) 


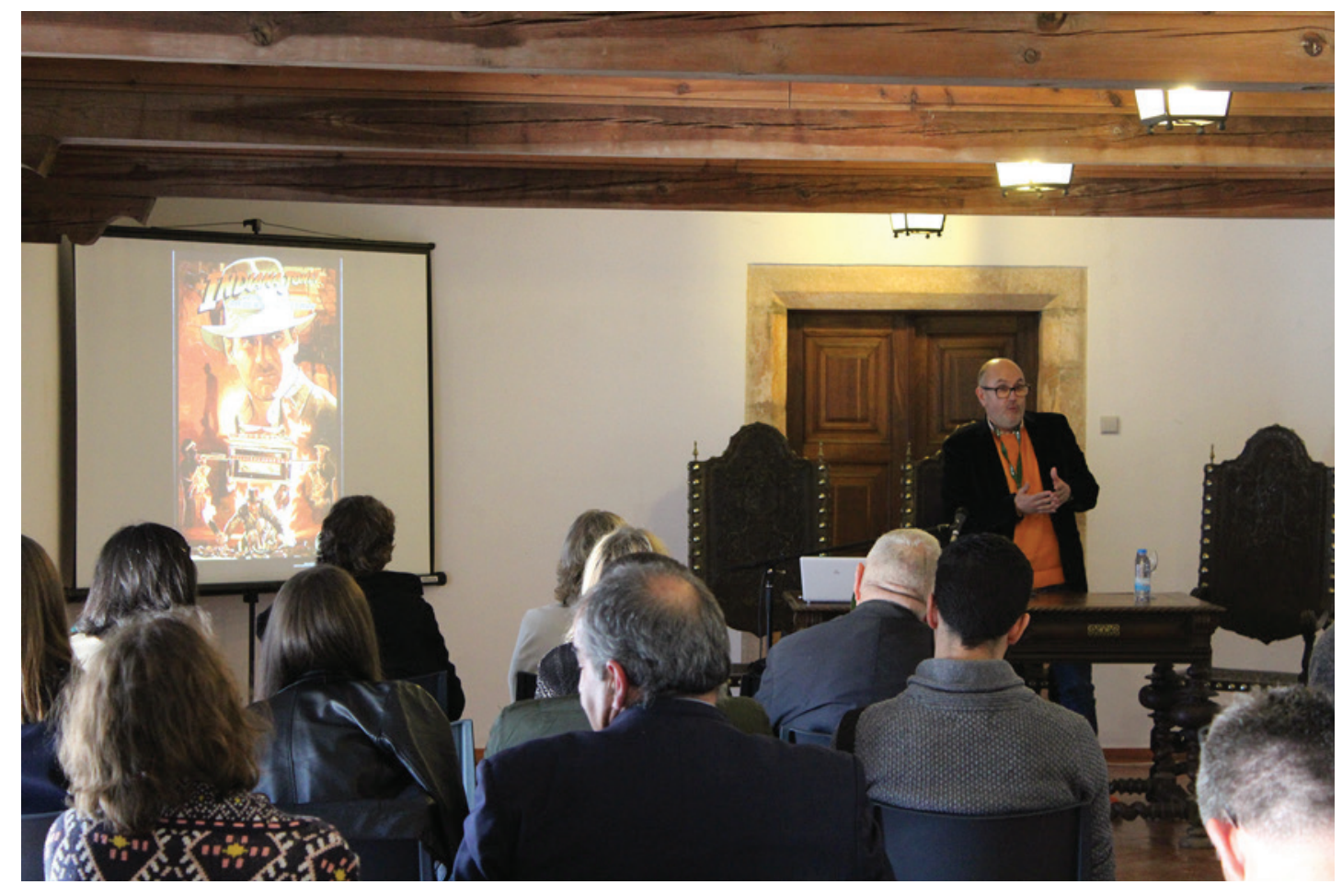

Figura 5-Apresentação da Comunicação “Como tornar a Arqueologia sexy”, por Pedro Sobral (EON, Indústrias Criativas), na III Edição do Workshop Arqueologia 3.o (Março 2019). (C S. Malhado, MBCB-FCB)

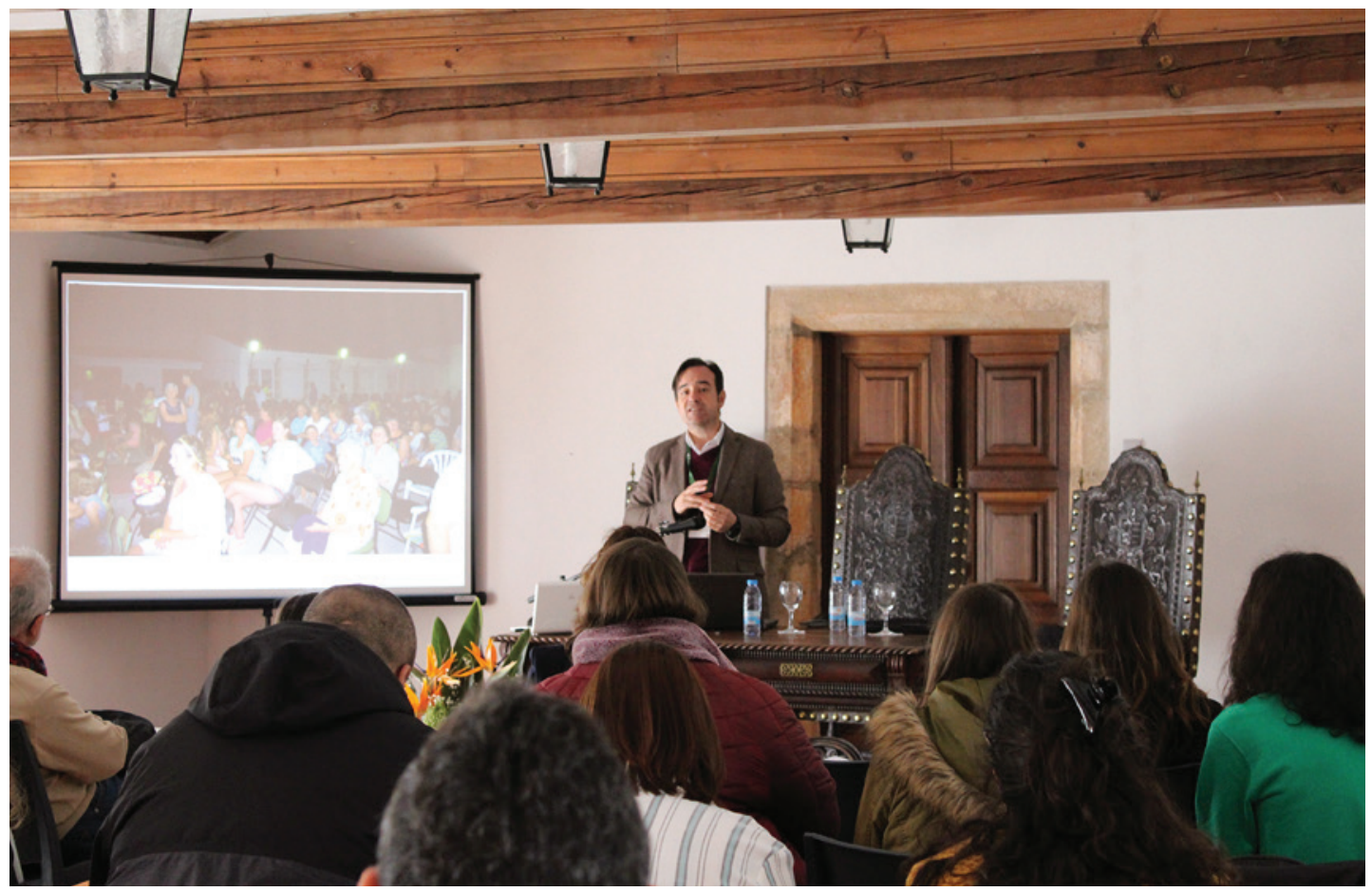

Figura 6 - Apresentação da Comunicação “La arqueología como factor de desarrollo. De la "Sibera Española” al “poder de las piedras” por Miguel Ángel Valero (Universidad de Castilla-La Mancha), na III Edição do Workshop Arqueologia 3.o (Março 2019). (C S. Malhado, MBCB-FCB) 


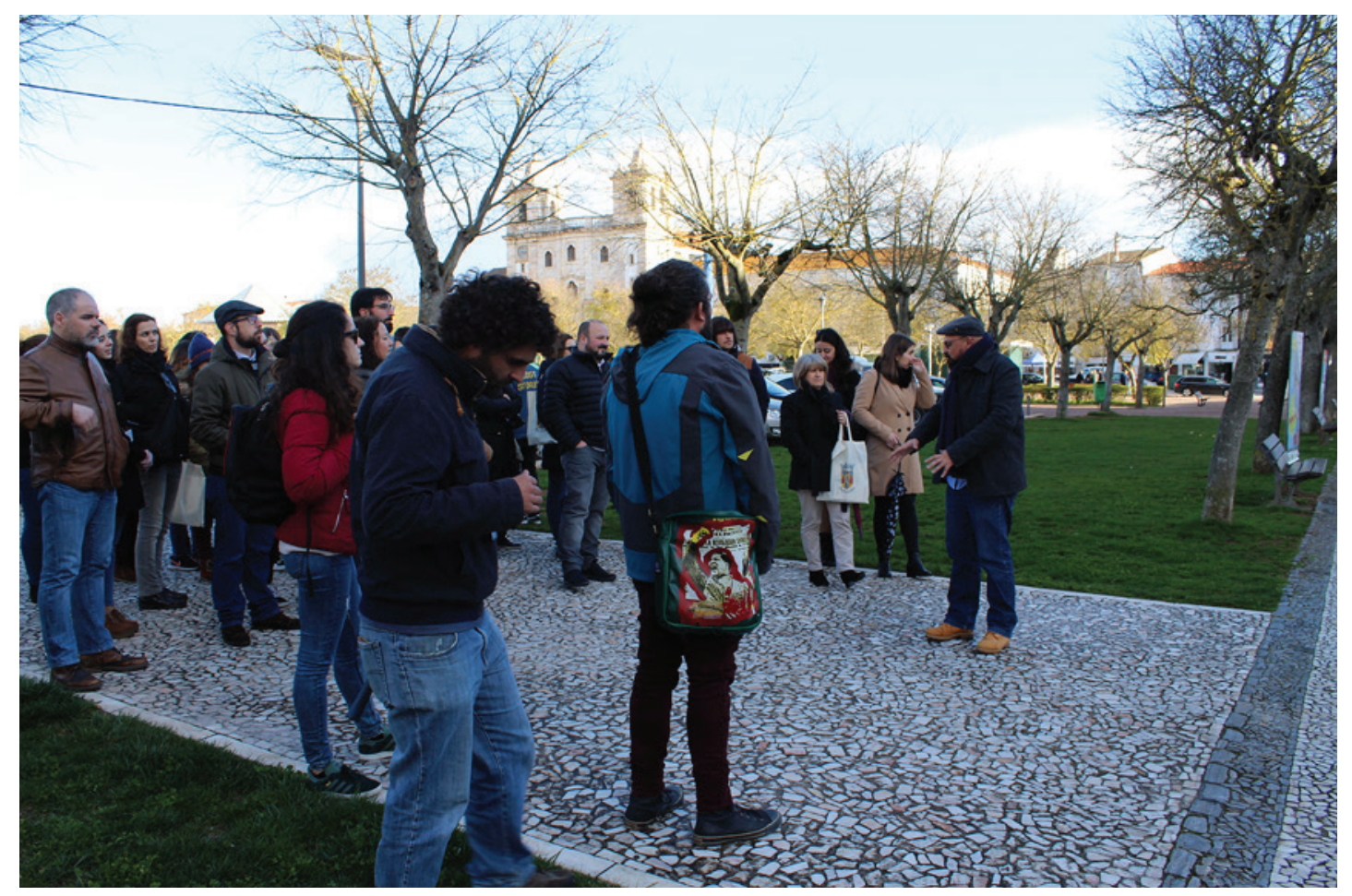

Figura 7 - Visita guiada pela cidade de Estremoz, intitulada “As Histórias por detrás da História; um Percurso pelo Património Histórico Edificado de Estremoz”, por Noel Moreira e Nuno Mourinha, na II Edição do Workshop Arqueologia 3.o (Março 2018). (C S. Malhado, MBCB-FCB)

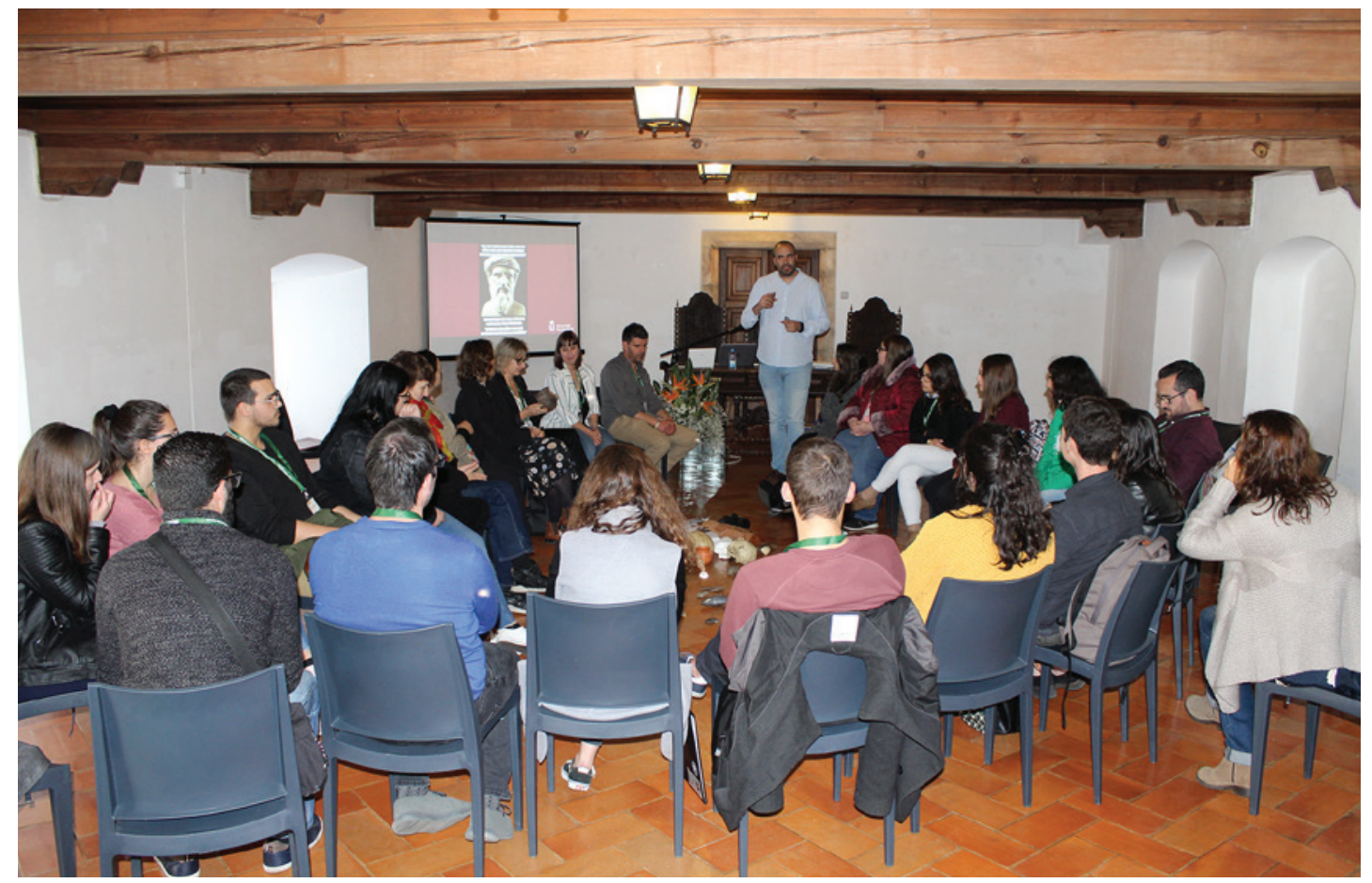

Figura 8 - Sessão de demonstração de atividades didáticas relacionadas com o património arqueológico, orientada por Alberto Polo Romero e Diana Morales Manzanares, na III Edição do Workshop Arqueologia 3.o (Março 2019). (C S. Malhado, MBCB-FCB) 


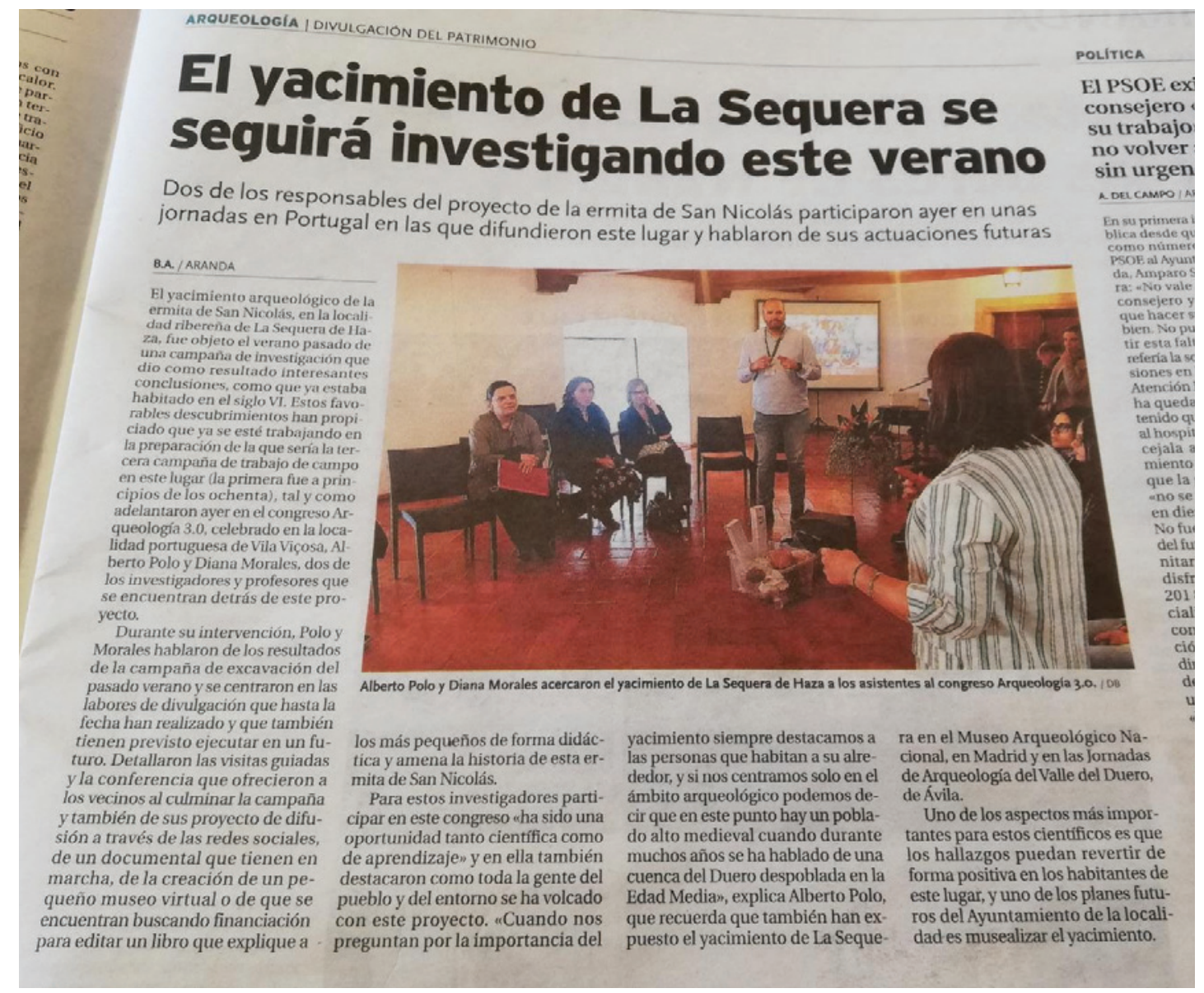

Figura 9 - Excerto de notícia do jornal Diario de Burgos, de 16 de Março de 2019, na qual é feita alusão ao "congreso Arqueologia 3.o, celebrado en la localidad portuguesa de Vila Viçosa”. (Cortesia de Alberto Polo Romero e Diana Morales Manzanares)

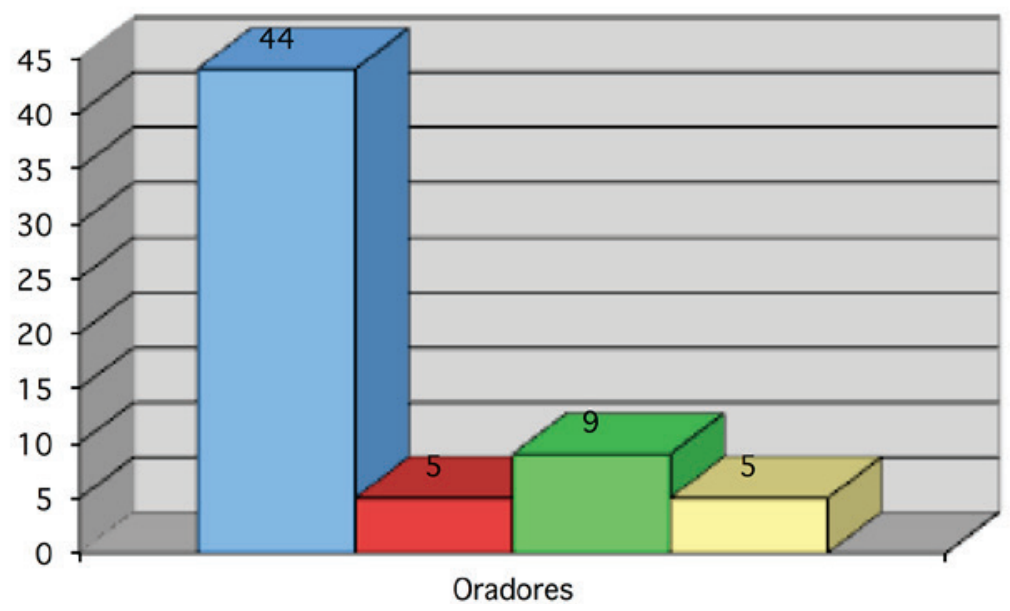

口Estudantes

口Arqueólogos

口Técnicos de Autarquias

口Outros

Gráfico 1-Representatividade do público das três edições do Workshop Internacional Arqueologia 3.o. (C) autora). 


\title{
“CONVERSA DE ARQUEÓLOGOS”- DIVULGAR A ARQUEOLOGIA EM TEMPOS DE PANDEMIA
}

Diogo Teixeira Dias ${ }^{1}$

\begin{abstract}
RESUMO
As “Conversas de Arqueólogos" foram eventos informais de divulgação da Arqueologia em Portugal, realizadas em streaming, em direto, a partir dos Açores, nos meses de maio e junho de 2020, e promovidas pela Fundação Manuel Sousa de Oliveira, com sede em Ponta Delgada, orientada para a promoção da Arqueologia nos Açores. A iniciativa à distância tornou-se uma solução alternativa aos habituais "Clubes de História”, que a Fundação organizava desde 2018, mas que por razão do confinamento obrigatório, provocado pela pandemia Covid-19, foram suspensas.

Este artigo patenteia sumariamente a atividade da Fundação, do seu fundador e expõe os objetivos das "Conversas de Arqueólogos”, a sua metodologia e os seus resultados, em prol da divulgação e acessibilidade digital do Património Arqueológico e do seu processo científico.

Palavras-chave: Arqueologia, Açores, Divulgação, Streaming, Acessibilidade.
\end{abstract}

\begin{abstract}
The "Conversas de Arqueólogos" were informal events for Archaeology dissemination in Portugal, held live stream, broadcasted from the Azores Islands, in May and June 2020, and promoted by the Manuel Sousa de Oliveira Foundation, based in Ponta Delgada, oriented to the promotion of Archaeology in the Azores.

The online initiative has become an alternative solution to the usual "Clubes de História", which the Foundation organized since 2018, but which, because of the mandatory confinement caused by the Covid-19 pandemic, have been suspended.

This article summarily patents the activity of the Foundation, its founder's life and shows the aims of the "Conversas de Arqueólogos", its methods and its results, in favor of the dissemination and digital accessibility of the Archaeological Heritage and its scientific process.
\end{abstract}

Keywords: Archaeology, Azores, Sharing, Streaming, Accessibility.

\section{ENQUADRAMENTO}

Desde o início do ano de 2020 que o mundo inteiro foi obrigado a reestruturar o seu quotidiano, em todas as suas dimensões. A cultura e a ciência não foram exceção.

Assistiu-se à proliferação de várias iniciativas em streaming que, de alguma forma, permitiram a aproximação de dimensões em que, outrora, a distância física se constituía como impedimento, não obstante da tecnologia atualmente ao dispor.

O confinamento inerente à pandemia Covid-19 constituiu-se numa oportunidade não tanto de re- pensar formas de contacto com o público, mas de as aplicar de modo mais sistemático e recorrente.

Com isso, permaneceram e permanecem largamente beneficiados todos os públicos, mas particularmente os residentes nas zonas ultra-periféricas da Europa, como é o caso dos Açores.

Em maio deste ano, a Fundação Sousa de Oliveira, sediada em Ponta Delgada, homónima do pioneiro da Arqueologia nos Açores, promoveu um encontro público, disseminado em direto para a rede social Facebook, de forma gratuita, e em disponibilização permanente, designado "Conversa de Arqueólogos". Augura-se apresentar o conceito e a experiência da

1. (AAP/CMVFC) 
iniciativa, os objetivos a que se propôs, a metodologia que os permitiu atingir e os resultados alcançados, de forma eficaz e eficiente.

Dado o carácter recente da criação da entidade promotora do evento, irá proceder-se a uma introdução com uma digressão pela história da instituição e a vida do arqueólogo homónimo.

\section{MANUEL SOUSA DE OLIVEIRA}

Manuel Sousa de Oliveira, o "pioneiro da Arqueologia nos Açores” (BENTO, 1990; NETO, 2018), nasceu a 18 de julho de 1916, em Cambridge (Massachussets, E.U.A.), filho de emigrantes açorianos, que regressaram precocemente à Ilha de S. Miguel (BAIROS, 2018; BENTO, 1990). Realizou praticamente todo o seu percurso escolar nos Açores, tendo-se licenciado em Ciências Históricas e Filosóficas, na Universidade de Coimbra (25 de julho de 1942). Na cidade universitária, que o próprio assume como tendo sido a mais marcante da sua vida (Figura 1), pratica com mérito uma série de modalidades desportivas, inclusive futebol, na Associação Académica de Coimbra² . Interrompe a vida académica para cumprir serviço militar. Entre 1947 e 1951, dedica-se ao ensino particular em quatro colégios. Nos anos 50 , inicia a sua carreira na função pública, como Diretor do Museu Regional de Viana do Castelo, conhecendo, trabalhando e publicando com Abel Viana (VIANA e OLIVEIRA, 1954), que o inicia na Arqueologia (Figura 2). Nos anos 6o, leciona no Liceu Nacional de Aveiro e na Escola Industrial e Comercial Avelar Brotero (Coimbra), e nos finais da década é bolseiro da Gulbenkian, para a recolha do Teatro Popular nos Açores (BAIROS, 2018). Em 1971, que funda o "Clube de História" - uma associação com orientação para o estudo e divulgação da Arqueologia e Etnografia de Caldas da Rainha, onde lecionava na altura (BAIROS, 2018; BENTO, 1990).

Entre 1967 e 1982 dirigiu várias intervenções arqueológicas no concelho de Vila Franca do Campo, tendo inaugurado a "segunda fase" da Arqueologia nos Açores, que se estenderá até ao ano de 2004 (NETO, 2018). Os resultados foram extensos e diversos em

\footnotetext{
2. Manuel Sousa de Oliveira era conhecido como o "estudante de Oxford" não por ter estudado em Oxford mas devido às suas semelhanças com o ator Robert Taylor e o papel por este assumido no filme de Jack Conway A Yank at Oxford, de 1938 (BAIROS, 2018).
}

termos materiais, tendo sido produzidos cadernos de campo (chamados “diários de escavação"), nunca estudados na sua dimensão de conjunto.

Das campanhas em Vila Franca do Campo, os materiais foram exumados, os diários escritos, mas o conhecimento ficou por produzir e publicar. Em 2018, por nossa proposta, foram entregues à Câmara Municipal de Vila Franca do Campo os diários, em formato digital, para efeitos de estudo e investigação. Perspetiva-se a sua publicação integral, anotada e comentada.

A 24 de agosto de 1985, com os recursos da época, promove a primeira iniciativa de Didática da Arqueologia nos Açores ${ }^{3}$, direcionada a crianças, com recurso a puzzles e kits de simulação de montagem de peças cerâmicas, no Campo de São Francisco, em Ponta Delgada, tendo captado o interesse e recebido a visita do então Presidente do Governo Regional dos Açores, João Bosco Mota Amaral (Figura. 3).

Em 1988, escava no Convento de Jesus, da Ribeira Grande (NETO, 2018), com o apoio de Mário Moura.

\section{SOBRE A FUNDAÇÃO}

Com a morte de Manuel Sousa de Oliveira (4 de agosto de 2001) e por sua disposição testamentária, foi criada a fundação homónima, herdeira de todos os seus bens, onde se depositam, atualmente, parte dos materiais recolhidos em Vila Franca do Campo (BENTO, 1990) ${ }^{4}$.

A Fundação Sousa de Oliveira (Figura 4), instituição de direito privado, e de utilidade pública, tem por fins, conforme disposto nos seus Estatutos, nomeadamente, "promover o fomento dos estudos de arqueologia e trabalhos arqueológicos no arquipélago dos Açores", para além de promover o estudo do espólio em seu depósito, disponibilizando-o aos investigadores interessados (Estatutos FSO, 2004, Art. $\left..{ }^{\circ} .{ }^{\circ}\right)$.

\footnotetext{
3. Integrada na "Associação Arqueológica do Arquipélago dos Açores", que só é oficialmente criada a 5 de novembro de 2002, já após a morte de Sousa de Oliveira. A Associação existe formalmente mas não apresenta qualquer atividade. Os membros dos seus órgãos sociais são, à data, alguns dos membros da Fundação Sousa de Oliveira.

4. Estes materiais foram inventariados e acondicionados em 2019, com o apoio do Gabinete de Arqueologia e História da Câmara Municipal de Vila Franca do Campo, estando a ser diligenciada, por parte da autarquia, a proposta da sua entrega ao Museu Municipal.
} 
Para além disso, e em estreita colaboração com as autarquias locais dos Açores, com as quais tem realizado protocolos de colaboração, "promover conferências, seminários e exposições, ou outras iniciativas similares." (Estatutos FSO, 2004, Art.. 3.o.).

A Fundação Sousa de Oliveira dinamizou, desde a sua criação recente, várias iniciativas de cariz cultural, presenciais e pontuais. Por seu incremento, arqueólogos regressam ao diálogo com a comunidade na FSO a 1 de fevereiro de 2018, com N'zinga Oliveira e João Gonçalves Araújo, numa comunicação sobre Manuel Sousa de Oliveira e o impulso da Arqueologia nos Açores. Porém, só a partir de junho desse ano, a instituição cria o seu primeiro evento recorrente, dedicado à divulgação do Património Cultural, recuperando a designação de "Clube de História”, numa homenagem e perspetiva de continuidade do trabalho didático do fundador.

Para Manuel Sousa de Oliveira, a divulgação dos resultados da Arqueologia ao público em geral, através da comunicação social, e em iniciativas expositivas, numa linguagem acessível, era tão fundamental como o processo científico em si (BAIROS, 2018; BENTO, 1990).

\section{OS "CLUBES DE HISTÓRIA"}

De frequência mensal, e moderados geralmente pelo Presidente do Conselho de Administração da Fundação Sousa de Oliveira, Carlos Melo Bento, iniciaram-se a 6 de julho de 2018 sobre "Os Açores e a Heráldica".

De referir e destacar, a título de exemplo, o de 7 de janeiro de 2019, sobre "O que foram os Descobrimentos Portugueses?”, com João Paulo Oliveira e Costa; "Os Açores após o 25 de abril", com João Bosco Mota Amaral, a 22 de abril de 2018 e, a 4 de setembro de 2019, assinalando o primeiro aniversário do "Clube de História", "O papel da Arqueologia na defesa do Património Cultural, com N’zinga Oliveira, João Gonçalves Araújo e Diogo Teixeira Dias - os três arqueólogos com atividade na ilha de São Miguel.

Adotou-se nos "Clubes" uma configuração informal do evento, sem recurso a uma mesa que estabelecesse a divisão, ou diferença de cota, entre a audiência e os oradores, que se sentavam em poltronas, orientados diagonalmente, de frente para o público, disposto em fileiras curvas.

Potenciou-se uma adesão presencial constante de cerca de dez a trinta espectadores por evento, ten- do-se feito sempre institucionalmente representar quer o Governo Regional quer a Câmara Municipal de Ponta Delgada e, pontualmente, a Câmara Municipal de Vila Franca do Campo - o que era sintomático quer do interesse para o público, quer do impacto político inerente 5 .

A última sessão, a 30 de janeiro de 2020, contou com um balanço do ano de 2019, pelos jornalistas Paulo Simões (Diretor do Açoriano Oriental) e Emanuel Carreiro (RTP - Açores).

No mês seguinte ao de cada encontro, era publicado o boletim "O Pioneiro", de edição da Fundação, com um resumo do evento, elaborado pelo orador e pela redação. A produção destes elementos só foi possível com o apoio financeiro da Câmara Municipal de Ponta Delgada, integrada numa política de aquisição de publicações de cariz cultural e científico, para distribuição nas escolas do concelho (Diário dos Açores, 16/12/18).

Não se tratou, portanto, analogamente ao que viriam a ser as "Conversas de Arqueólogos", de um fórum científico da História ou da Arqueologia, pese embora tenha contado com a participação de vários investigadores das áreas.

O cerne era a divulgação informada, em envolvente informal.

O resultado alcançado foi, sobretudo, para além da fidelização de um público não académico, que manteve o interesse nas áreas referidas, bem como o contributo para o seu conhecimento das linhas gerais e método de abordagem ao Património Cultural.

\section{AS “CONVERSAS DE ARQUEÓLOGOS” AS IMPOSIÇÕES DO CONFINAMENTO OBRIGATÓRIO}

$\mathrm{O}$ vírus SARS-CoV-2, uma doença respiratória originária em Wuhan, na República Popular da China, classificada como pandemia (Covid-19) pela Organização Mundial de Saúde a 11 de março de 2020, alastrou-se a todo o mundo de forma galopante.

Por conseguinte, impôs-se, pela primeira vez no

5. Destaque-se a importância da realização de convites institucionais para os eventos, por forma a promover uma proximidade profícua entre as instituições e associações de defesa do Património Cultural e os decisores políticos. A formalização de um convite institucional e a presença de uma entidade, mesmo em eventos de cariz informal, implica forçosamente um protocolo, que não deve ser desconhecido dos arqueólogos. 
século, um recolhimento obrigatório à população mundial, decretado pelos estados soberanos, com vista à minoração da sua dispersão.

Em Portugal, o Decreto do Estado de Emergência, declarado pelo Presidente da República previa confinamento ao domicílio e limites muito restritos à circulação de pessoas, a partir das oohoo do dia 19 de março.

Naturalmente, e como é do conhecimento e experiência geral, e que dispensa qualquer referência ou citação, o choque com o quotidiano de todos nós em geral implicou a necessária reversão de prioridades domésticas, sociais, económicas, políticas e não menos culturais ou académicas.

A acessibilidade da Cultura e da Ciência correu o seu maior risco, dadas as afetações não só na procura, como também na oferta. Os agentes culturais e os impulsionadores da ciência encaravam um novo desafio: produzir e chegar ao público.

\section{A PROPOSTA DA FUNDAÇÃO}

Dados os constrangimentos, o "Clube de História" tinha vindo já desde fevereiro a cessar a sua atividade, e em março consuma-se a sua interrupção definitiva, da mesma forma que a grande maioria dos eventos culturais, que promovessem ajuntamentos. Para todos os efeitos, raros seriam os que não se encontravam nessas circunstâncias.

Em abril, recebida a proposta pelo João Figueiredo, Relações Públicas da Fundação Sousa de Oliveira, que sugeriu a conceção e execução de um evento que possibilitasse a divulgação da Arqueologia, mas em formato à distância, avançamos com o projeto. Os recursos eram praticamente nulos.

Ainda assim, propôs-se a realização de um evento em streaming, ou seja, por via de difusão de dados, ao vivo, com recurso à plataforma Zoom, e transmitido em Live Stream, no Facebook da Fundação Sousa de Oliveira ${ }^{6}$.

Não deixe de ser notado que, tempos antes, o Centro de Arqueologia da Universidade de Lisboa (UNIARQ), promovera um conjunto de apresentações similares, recorrendo ao Zoom e através do Youtube, abertas à comunidade, integradas no Seminário de Mestrado da FLUL "Arqueologia e o Mundo Contemporâneo", e que serviram de orientação e modelo para este projeto da Fundação Sousa de Oliveira.

6. https://www.facebook.com/FundacaoSousaDOliveira/

\section{OBJETIVOS}

O objetivo geral foi aproximar os açorianos e açorianas das realidades arqueológicas de todo o país, servindo como plataforma de contacto e, sobretudo, de divulgação do trabalho que se tem concretizado. Os residentes das regiões ultra-periféricas insulares da Europa assistem, muitas vezes, ao condicionamento do acesso a conteúdos culturais que extravasem as suas fronteiras, quanto mais não seja por não haver uma proximidade geográfica com realidades museológicas mais abrangentes que as locais. Em boa verdade, os museus da Região Autónoma dos Açores mantêm, e praticamente em exclusivo, um cariz marcadamente etnográfico, mesmo nas ilhas com um maior Índice de Desenvolvimento (SOUSA, 2009). Assiste-se assim a um certo condicionamento da mundividência dos residentes com interesses culturais, na medida em que, para se imbuírem de outra realidade, mesmo apenas de envergadura nacional, se veem forçados a assumir custos elevados de deslocação aérea.

Os objetivos específicos foram contribuir para a transição do conhecimento arqueológico, do meio científico para o público em geral e, necessariamente, captar o seu interesse e abrir caminho à sua sensibilização para o papel da Arqueologia na comunidade.

A Arqueologia é uma ciência muito recente nos Açores (NETO, 2018), pelo que urge um posicionamento de proximidade dos técnicos e investigadores com o contexto social em que se integram. Particularmente numa altura de reabilitação urbana dos centros históricos, em cujos projetos e execuções não era comum, até há bem pouco tempo, a participação ativa e a intervenção de arqueólogos e arqueólogas.

Não deixou de ser também nosso desígnio concreto apoiar o discernimento público para o questionamento de afirmações, alegadamente científicas, sem suporte de facto e sensacionalistas, e de alegados achados arqueológicos, que têm encontrado acolhimento na comunicação social regional, nacional e internacional, inclusive integrando a produção de documentários e difusão através dos canais de televisão, que mais facilmente chegam ao público em geral, e captam a sua atenção.

Maior dificuldade de despertar o público têm os resultados das investigações arqueológicas com seriedade e respeito pela deontologia científica. Desta feita, e constatada a carência de eventos de divulgação didática e acessível dos resultados de trabalhos 
arqueológicos, procedemos à criação das "Conversas de Arqueólogos".

Cumpria-nos promover o esclarecimento do público, sem cair no erro de entrar em determinadas polémicas e enredamentos. (Tabelas 1, 2)

\section{EFEMÉRIDES}

As "Conversas de Arqueólogos" assinalaram as seguintes efemérides, com os respetivos convidados/ as e temas associados:

- Noite Europeia dos Museus (16 de maio);

- Dia dos Açores (1 de junho);

- Dia Mundial dos Oceanos (8 de junho);

- Dia Internacional do Refugiado (20 de junho)

(Figura 5).

\section{PARCERIAS INSTITUCIONAIS}

Algumas das "Conversas de Arqueólogos" foram realizadas em parceria institucional, sem implicação de custos para as instituições envolvidas, com:

- Museu do Côa (16 de maio);

- Governo dos Açores / Direção Regional da Cultura dos Açores (1 de junho);

- Instituto Politécnico de Tomar (8 de junho);

- Associação dos Arqueólogos Portugueses (26 de junho) (Figura 6);

- Câmara Municipal de Vila Franca do Campo (29 de junho).

A parceria institucional, para além de prestigiar os eventos, beneficia largamente a divulgação das iniciativas, na medida em que se solicitou a disseminação dos cartazes respetivos e links associados. É também um ponto de partida para futuras cooperações, pois proporciona um primeiro contacto formal e a existência de precedente relacional.

\section{CONSIDERAÇÕES PRÁTICAS DE EXECUÇÃO}

Dada a perspetiva didática que se pretendia, e pese embora se careça de trabalhos de referência de Didática da Arqueologia, ou de Didática Digital, socorremo-nos da interdisciplinaridade, nomeadamente de algumas publicações de Didática da História (ALARCÃO, 2002; FERREIRA, 2010; PROENÇA, 1992) e de Didática da Geografia (BRITO e POEIRA, 1991). A escolha da designação foi propositadamente restritiva, na medida em que, tratando-se de conversas "de" arqueólogos, somente teriam voz os técnicos e as técnicas da referida área, numa altura e num contexto geográfico onde, como referimos, têm surgido alegadas investigações e alegados achados arqueológicos por não arqueólogos.

Foi uma definição com propósito retificativo e não propriamente discriminatório na aceção de inferiorização. Recorrer ao próprio colherim, símbolo associado ao nome do evento (ver figuras 5, 6 e 7), também não foi inocente. Sobretudo tendo em conta que se trata de um instrumento, não só mas também, de retificação dos perfis estratigráficos, para uma melhor perceção das diferenças das camadas, da inversão estratigráfica e das intrusões.

Nunca é excesso recordar que a investigação arqueológica é feita por arqueólogos credenciados, não obstante do seu carácter interdisciplinar e da perspetiva de envolvimento de participantes não académicos em trabalhos arqueológicos. Essa mensagem ficou sempre explícita e implícita nas conversas.

A escolha dos convidados, por proposta do moderador e aprovação do Presidente do Conselho de Administração da Fundação Sousa de Oliveira, não foi arbitrária. Muito menos, infelizmente, incluiu todos os arqueólogos ou arqueólogas que se entendia deverem ser convidados.

Por opção, as reuniões do Zoom da "Conversa de Arqueólogos" apenas integravam os intervenientes diretos (moderador e convidado), podendo a assistência interagir através dos comentários no Facebook. Foi aberta uma exceção, para o dia 29 de maio, cujo tema era "Arqueologia e Imaginário - fakenews de uma Ciência” (Figura 7), com André Donas-Botto, para que se possibilitasse um esclarecimento mais direto de algumas dúvidas de eventuais interessados, acerca das complexidades do processo científico na área, e das suas especificidades.

Procurou-se também, nesta sessão, esclarecer as diferenças entre o que representa a Arqueologia no imaginário popular e o que é efetivamente na prática (HOLTORF, 2007).

A interação da assistência processou-se geralmente através dos comentários do Facebook, na transmissão em direto, sendo que por essa via ficava inviabilizada a participação ativa dos espectadores sem registo na rede social. No entanto, a visualização do direto era sempre possível, mesmo para quem não tinha perfil de Facebook.

Não houve qualquer recurso a profissionais intérpretes de língua gestual portuguesa por indisponibi- 
lidade financeira, não se tendo, portanto, concretizado a inclusão de deficientes auditivos. Nesse aspeto, as "Conversas de Arqueólogos" ficaram aquém do expectável, em termos do que perspetivava - inclusão e acessibilidade integrais.

Todos os convidados iniciavam a conversa, por desafio do moderador, com uma breve explicação do conceito de "Arqueologia" e com as memórias de um sítio arqueológico à escolha, começando com a expressão tradicional de conto de histórias, "Era uma vez...”, procurando apelar ao espírito criativo e didático do orador, que era previamente e atempadamente informado.

As sessões tiveram duração de entre 45 minutos a uma hora e trinta minutos, não se tendo estipulado duração.

Junto dos convidados, apelou-se sempre a um espírito de síntese e de simplificação, o que nem sempre se tornou possível. A simplificação era, por vezes, incentivada pelo moderador, aquando da utilização por parte do convidado ou convidada de terminologia técnica demasiado específica, e por isso muitas vezes inacessível ao público não académico.

Nos cartazes era sempre indicado o fuso horário, junto com a hora agendada, tendo em conta que a assistência poderia estar em qualquer parte do mundo. Mesmo Portugal tem diferença de fuso horário, visto que na área continental e arquipélago da Madeira soma uma hora à do arquipélago dos Açores. Era necessário prestar essa informação, chamando à atenção para o desfasamento horário. Recomenda-se procedimento análogo para eventos similares.

A hora foi padronizada praticamente nas 18 hoo (Fuso horário +oo Açores), embora houvesse flexibilidade, o que aconteceu por duas vezes, nomeadamente por razões de quotidiano familiar, e uma por motivo de coincidir com a efeméride (Noite Europeia dos Museus). Há que descartar a rigidez desnecessária neste tipo de eventos, sobretudo quando se tratava de uma experiência nova, quer para o promotor, quer para o moderador, quer para a maioria dos convidados.

A última sessão foi realizada com o apoio da Câmara Municipal de Vila Franca do Campo, e em formato presencial, transmitida em direto para o Facebook da Fundação Sousa de Oliveira e, em simultâneo, para o Facebook da autarquia ${ }^{7}$.

7. https://www.facebook.com/CamaraMunicipalDeVilaFrancaDoCampo/
Com os custos assumidos pela Câmara, recorreu-se a uma produtora audiovisual e o espaço escolhido foi o Salão Nobre do Solar dos Viscondes do Botelho, hoje Museu Municipal de Vila Franca do Campo (Figura 8).

Não se tratando de arqueólogos, à exceção do moderador, participaram na conversa o Presidente do Conselho de Administração da Fundação Sousa de Oliveira, Carlos Melo Bento, o Presidente da Câmara Municipal de Vila Franca do Campo, Ricardo Rodrigues, e o cirurgião ortopedista António Tavares de Melo.

A iniciativa propunha-se, por um lado, a recuperar memórias dos participantes nas escavações em Vila Franca do Campo, nos anos 70, com Manuel Sousa de Oliveira e, por outro, a incentivar ao regresso presencial aos espaços de fruição cultural, ainda que com as condicionantes ainda em vigor.

A realização das "Conversas de Arqueólogos" implicou um custo de $€_{34,42 \text {, correspondente a duas }}$ subscrições mensais de Plano Profissional da plataforma Zoom. Os cartazes e restantes elementos gráficos de divulgação foram executados com meios próprios.

Todas as gravações das "Conversas de Arqueólogos" estão disponíveis no separador de "Vídeos" da página de Facebook da Fundação Sousa de Oliveira.

\section{IMPACTO NA COMUNICAÇÃO SOCIAL}

Tal como Sousa de Oliveira durante as escavações em Vila Franca do Campo (BENTO, 1990), bem como nos "Clubes de História", procurou-se divulgar atempadamente a informação junto da comunicação social, nomeadamente da imprensa, que com frequência semanal registava referência aos eventos, quer anunciando, quer registando o balanço (Correio dos Açores, 16/o6/2020).

Da mesma forma, o moderador foi convidado a falar sobre a iniciativa, no programa Açores Hoje, da jornalista Vera Santos, na RTP-Açores, no dia 29 de maio.

\section{CONSIDERAÇÕES FINAIS}

A adaptação e simplificação de conceitos científicos exigiu uma dimensão de capacidades e um esforço que, provavelmente, colheu benefícios da obrigatoriedade do recurso às tecnologias digitais.

Em condições de segurança sanitária, com recurso a um diálogoacessível, predominantemente direciona- 
do para a população não académica, foram realizadas, no espaço de dois meses, dezassete sessões, tematicamente diversas e cronologicamente abrangentes. Proporcionou-se ao público em geral, e ao açoriano em particular, a fruição do Património Cultural, e a perceção genérica do processo científico da Arqueologia, não procurando forçosamente desmanchar estereótipos do público perante a área, mas capitalizando-os, de forma construtiva, para uma aproximação do público ao saber.

Sobretudo, promoveu-se o alargamento de horizontes, num contexto desfavorável. Tornou-se a adversidade numa oportunidade.

Ficou evidente também que ao arqueólogo convém ser, para além de um cientista, um divulgador da sua ciência, razão pela qual porventura se justifica a integração de disciplinas como Didática e Pedagogia nos programas curriculares universitários, das Licenciaturas em Arqueologia, de modo a poder autonomamente conceber, com o apoio da tecnologia digital, instrumentos de transição do conhecimento da esfera académica para a fruição pública, plena e acessível.

\section{AGRADECIMENTOS}

Um agradecimento pessoal à Fundação Manuel Sousa de Oliveira, pela confiança.

Um cumprimento particular a todos os convidados e convidadas da "Conversa de Arqueólogos".

\section{BIBLIOGRAFIA}

ALARCÃO, Isabel (2002) - De que se fala quando se fala de Didáctica. in MEDEIROS, EMANUEL OLIVEIRA (Ed.) I Encontro de Didácticas nos Açores. Universidade dos Açores ed. Ponta Delgada. p. 31-48.

BAIROS, Sandra Sousa (2018) - Contributo para a criação do serviço educativo da Fundação Sousa d'Oliveira - o desenvolvimento de laços entre o espólio arqueológico e os públicos mais jovens. Ponta Delgada: Universidade dos Açores (Dissertação de Mestrado).

BENTO, Carlos Melo (1990) - Escavações Arqueológicas em Vila Franca do Campo (1967-1982). Ponta Delgada: Associação Arqueológica do Arquipélago dos Açores.

BRITO, Raquel Soeiro de; POEIRA, Maria de Lurdes (1991) - Didáctica da Geografia. Lisboa: Universidade Aberta.

Diário dos Açores (2018) - Câmara de Ponta Delgada adquire 50 exemplares das 12 edições do boletim "O Pioneiro" - (16 dez. 2018). 7 .
Correio dos Açores (2020) - Combater as fakenews de que nos Açores está a Atlântida ou uma civilização fenícia - (16 jun. 2020). 4-5.

Estatutos da Fundação Doutor Manuel Sousa de Oliveira. Diário da República n.ำ 276/o4 - III Série (26197-26198).

FERREIRA, Octávio Amado (2010) - Ao serviço da didáctica da História: trabalhos de apoio ao ensino da História. Coimbra: Minerva.

HOLTORF, Cornelius (2007) - Archaeology is a Brand! The meaning of Archaeology in Contemporary Popular Culture. New York: Archeopress.

NETO, José Luís (2018) - Arqueologia nos Açores - uma breve História. Angra do Heroísmo: Instituto Açoriano de Cultura.

PROENÇA, Maria Cândida (1992) - Didáctica da História. Lisboa: Universidade Aberta.

SOUSA, Sílvia Fonseca e (2009) - A Museologia na Ilha de São Miguel: 1974-2008. Ponta Delgada: Universidade dos Açores (Dissertação de Mestrado).

VIANA, Abel; OLIVEIRA, Manuel Sousa D' (1954) "Cidade Velha" de Santa Luzia: Viana do Castelo. Guimarães: Revista de Guimarães. 

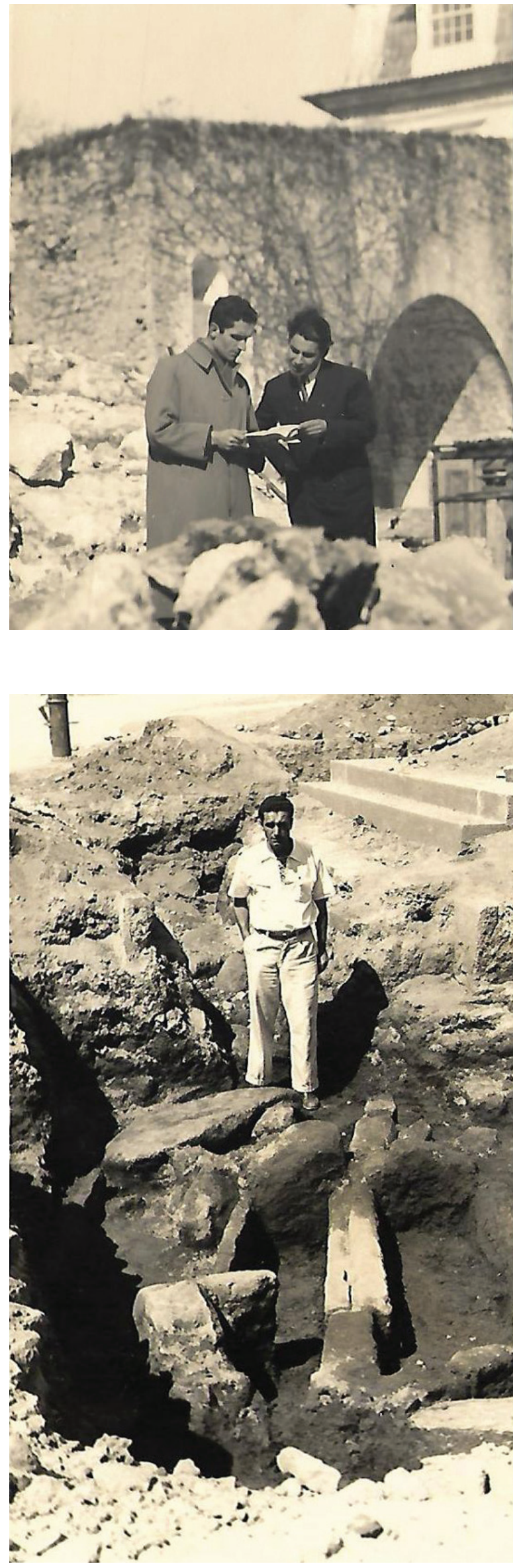

Figura 1 - 1947: Sousa de Oliveira (à esquerda), no atual Largo D. Dinis, em Coimbra. Arquivo FSO.

Figura 2 - 1952: Manuel Sousa de Oliveira numa escavação em Viana do Castelo. Arquivo FSO. 


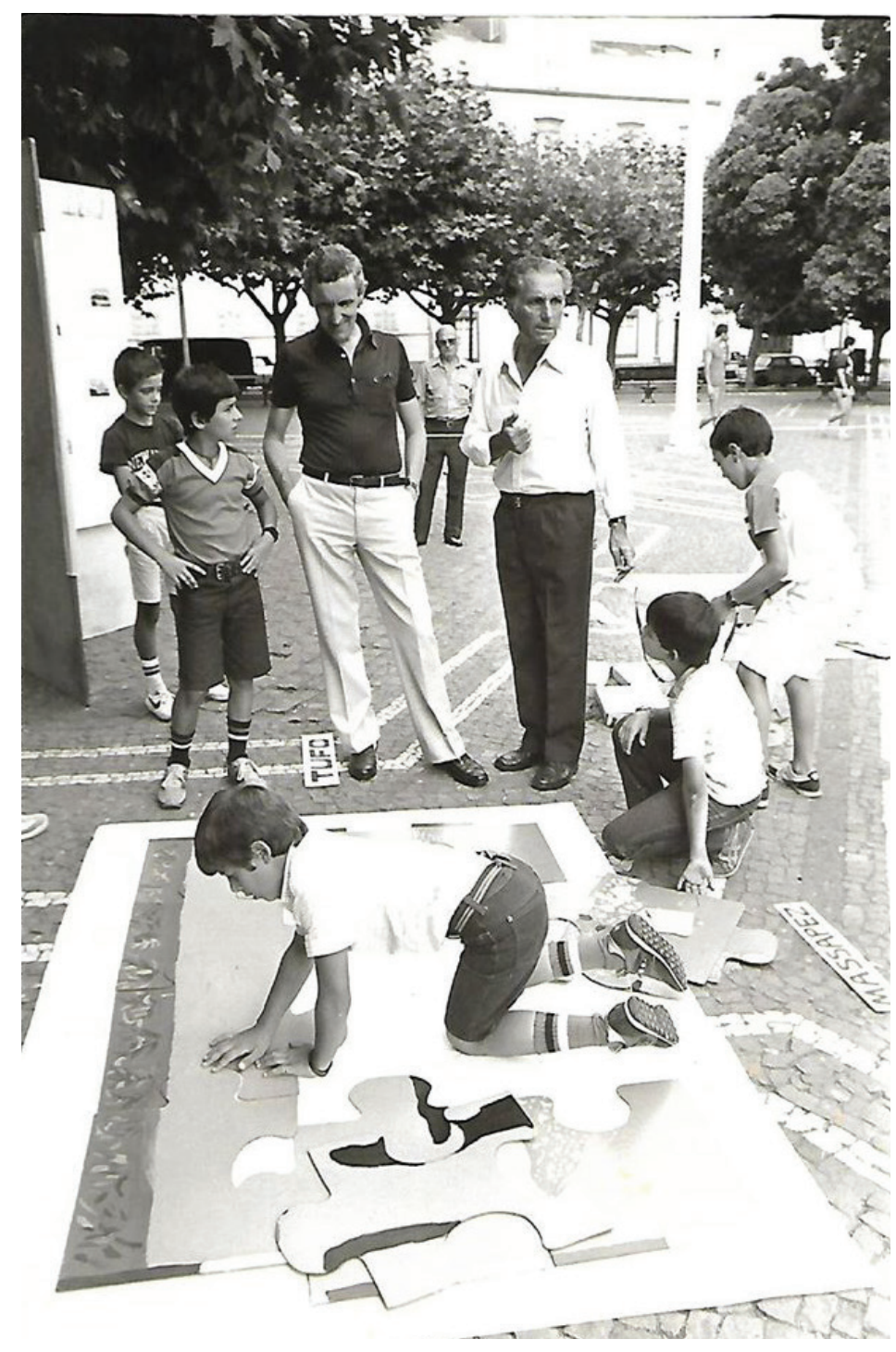

Figura 3-1985: Os puzzles de materiais e estratigrafia arqueológica. Em segundo plano, Mota Amaral (à esquerda) e Sousa e Oliveira (à direita). Arquivo FSO.

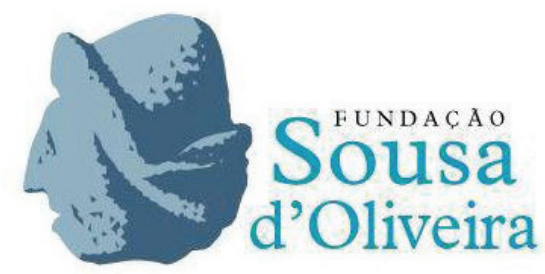

Figura 4 - Logótipo da Fundação Sousa de Oliveira. Arquivo FSO. 


\begin{tabular}{|l|l|l|l|}
\hline Dia & Hora & Convidado/a & Título \\
\hline 8 & $18 \mathrm{~h}$ & Catarina Quinteira & Da Escavação para o Museu - Arqueologia para o Público \\
\hline 11 & $18 \mathrm{~h}$ & José d’Encarnação & Quando as Pedras Falam - A Ciência da Epigrafia \\
\hline 15 & $18 \mathrm{~h}$ & João Gonçalves Araújo & Cidade da Horta - Arqueologia e Urbanismo \\
\hline 16 & $20 \mathrm{~h} 30$ & Luís Simões Luís & O que é a Arte Rupestre? \\
\hline 22 & $18 \mathrm{~h}$ & $\begin{array}{l}\text { Liliana Carvalho } \\
\text { Susana Henriques }\end{array}$ & $\begin{array}{l}\text { Mil Esqueletos e Um Hospital: Outras Histórias do Castelo } \\
\text { de S. Jorge }\end{array}$ \\
\hline 25 & $18 \mathrm{~h}$ & Santiago Macias & Arqueologia e Política - da Teoria à Prática \\
\hline 29 & $18 \mathrm{~h}$ & André Donas-Botto & Arqueologia e Imaginário - Fakenews de uma Ciência \\
\hline
\end{tabular}

Tabela 1 - Calendarização / maio 2020

\begin{tabular}{|c|c|c|c|}
\hline Dia & Hora & Convidado/a & Título \\
\hline 1 & $18 \mathrm{~h}$ & $\begin{array}{l}\text { José Luís Neto } \\
\text { Pedro Parreira }\end{array}$ & Arqueologia nos Açores: Passado, Presente e Futuro \\
\hline 5 & $17 \mathrm{~h}$ & Tânia Casimiro & $\begin{array}{l}\text { “Isso nem é Arqueologia..." - Arqueologia Contemporânea } \\
\text { em Portugal }\end{array}$ \\
\hline 8 & $18 \mathrm{~h}$ & $\begin{array}{l}\text { Alexandra Figueiredo } \\
\text { Cláudio Monteiro }\end{array}$ & Conservação do Património Subaquático: o dia de amanhã \\
\hline 12 & $18 \mathrm{~h}$ & Alexandre Monteiro & Os naufrágios nos Açores \\
\hline 15 & $18 \mathrm{~h}$ & Luís Campos Paulo & $\begin{array}{l}\text { Tecnologia e Arqueologia - A preservação digital } \\
\text { do Património }\end{array}$ \\
\hline 19 & $18 \mathrm{~h}$ & Jacinta Bugalhão & Arqueologia das Catástrofes - Lisboa 1755 \\
\hline 20 & $18 \mathrm{~h}$ & Rui Gomes Coelho & Arqueologia das Migrações Contemporâneas \\
\hline 22 & $17 \mathrm{~h}$ & João Luís Sequeira & Arqueologia Industrial - Um conceito intemporal \\
\hline 26 & $18 \mathrm{~h}$ & José Morais Arnaud & O Associativismo e a Arqueologia \\
\hline 29 & $18 \mathrm{~h}$ & $\begin{array}{l}\text { Carlos M. Bento } \\
\text { Ricardo Rodrigues } \\
\text { António T. Melo }\end{array}$ & Eu escavei com o Sousa! \\
\hline
\end{tabular}

Tabela 2 - Calendarização / junho 2020 


\section{streaming CONVERSA IDE ARQUEÓLOOAOS}

com Diogo Teixeira Dias

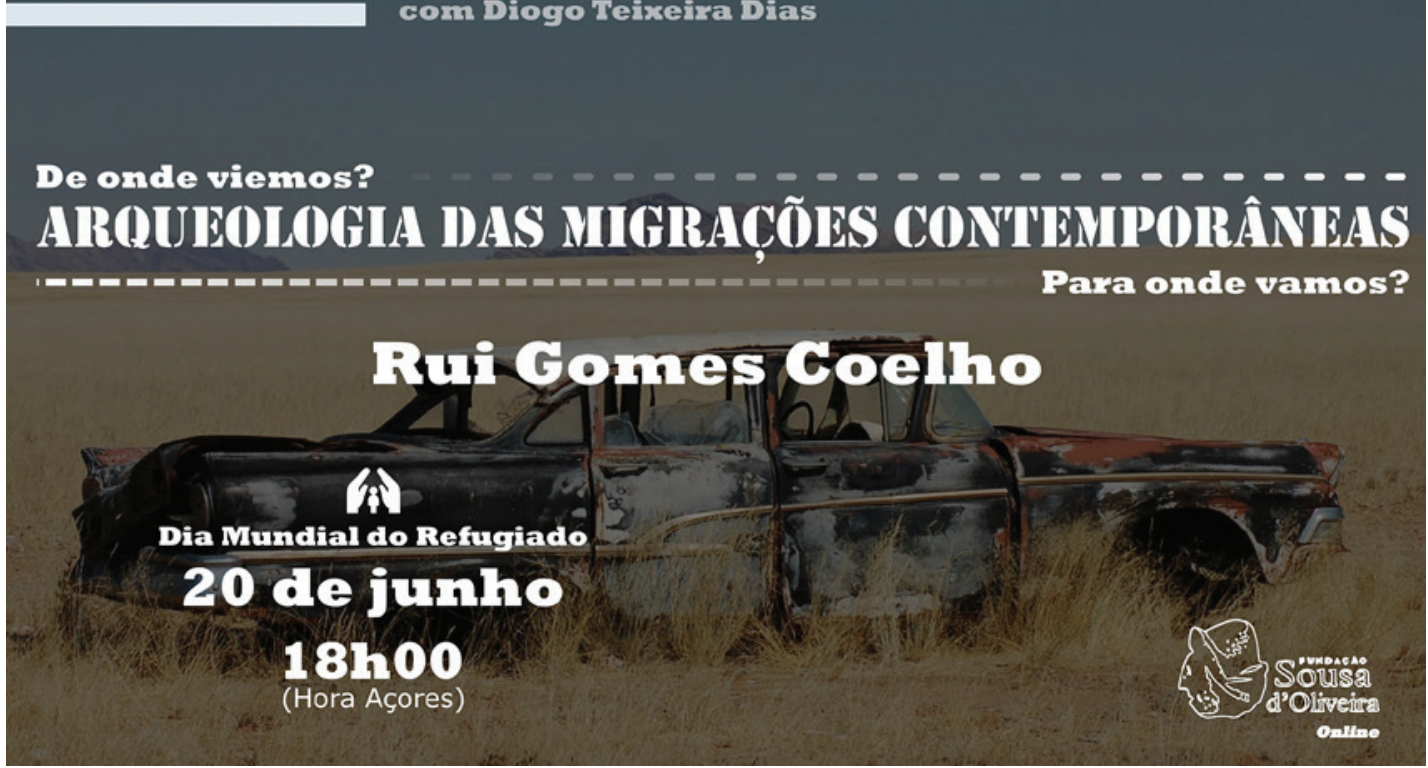

Figura 5-Cartaz de uma “Conversa de Arqueólogos” assinalando uma efeméride (Dia Mundial do Refugiado), com a referência acima da data e hora.

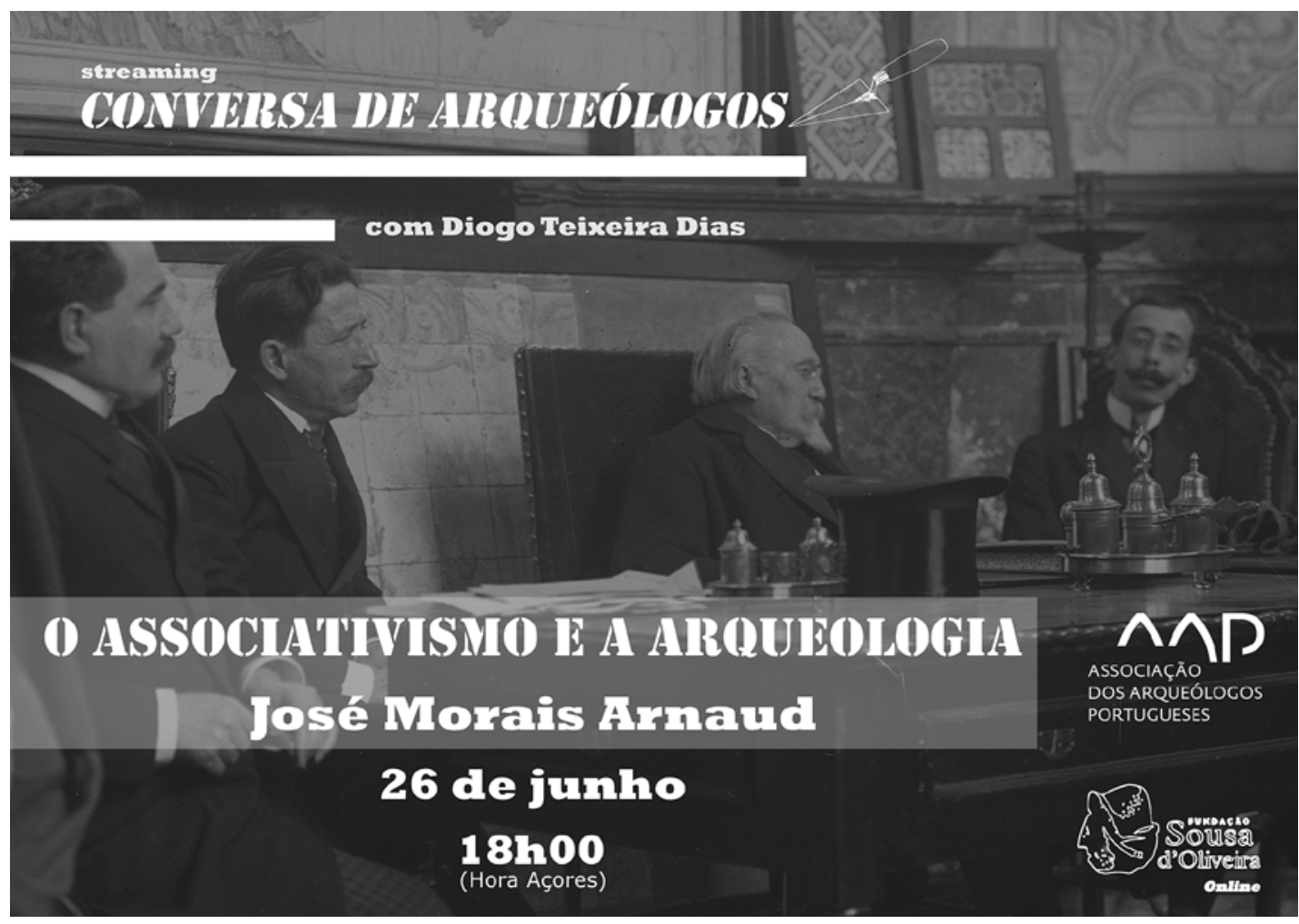

Figura 6- Cartaz de uma "Conversa de Arqueólogos” indicando uma parceria institucional (Associação dos Arqueólogos Portugueses). 


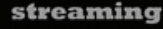 \\ CONVERSA DE ARQUUÉLIOGOS}

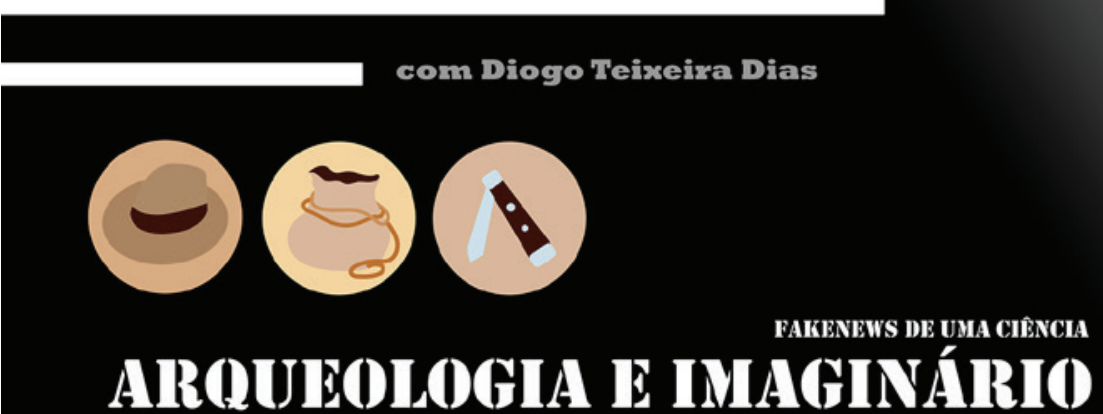

ANIRÉ́ DONAS-BOTYO

29) MAIO

181100

(Hora Açores)

f

HTTPS://WWW.PACEBOOK.COM/FUNIDACAOSOUSADOUIVEIRA/

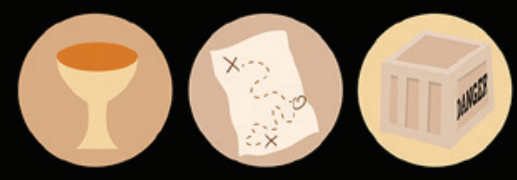

Figura 7-Cartaz da iniciativa “Arqueologia e Imaginário - fakenews de uma Ciência”, com André Donas-Botto.

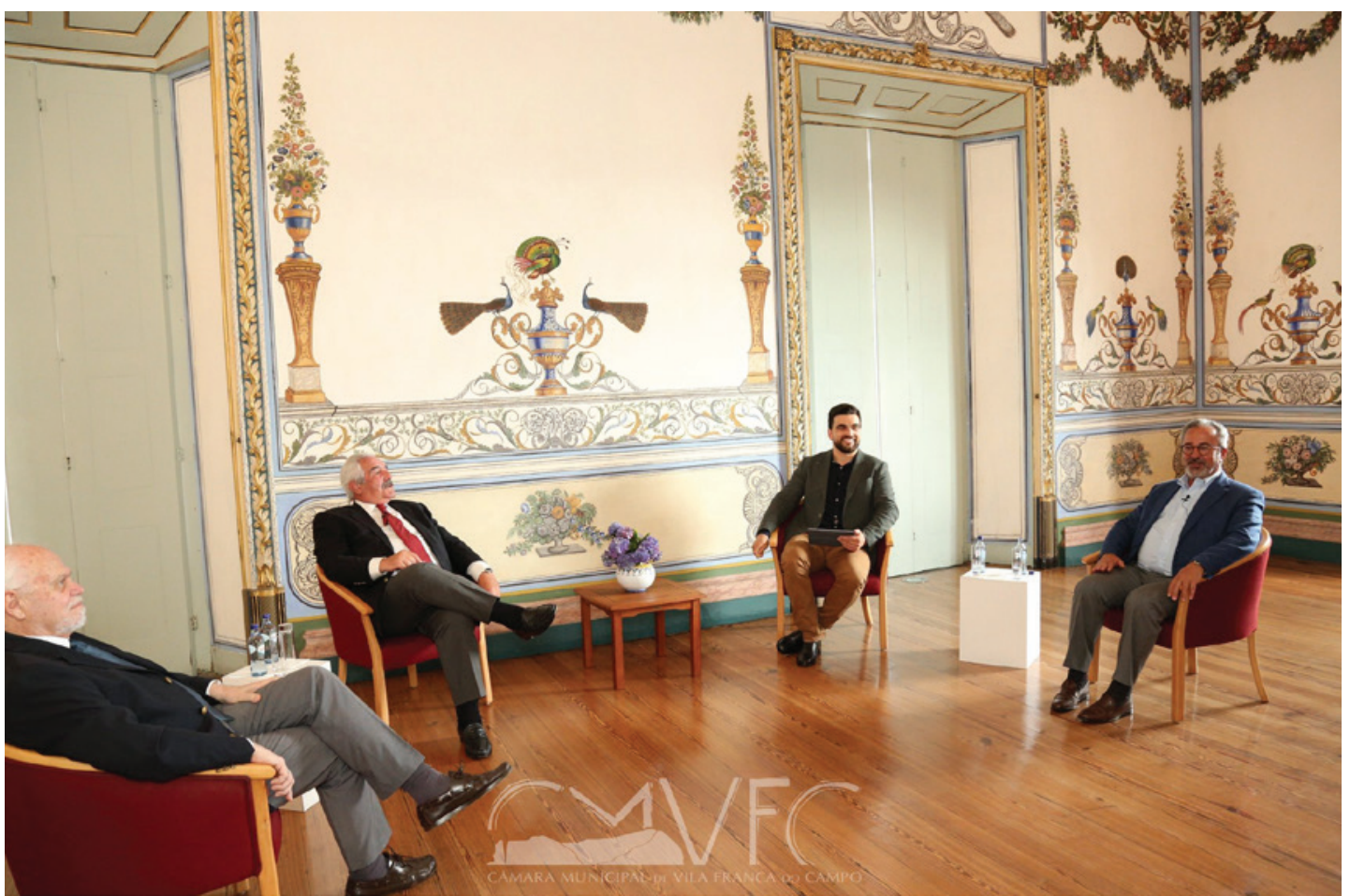

Figura 8 - Encerramento das “Conversas de Arqueólogos”, na sessão de memórias da Arqueologia “Eu escavei com o Sousa!”. CMVFC. 


\title{
ESCOLA PROFISSIONAL \\ DE ARQUEOLOGIA: DESAFIOS E OPORTUNIDADES
}

\author{
Susana Nunes ${ }^{1}$, Dulcineia Pinto ${ }^{2}$, Júlia Silva ${ }^{3}$, Ana Mascarenhas ${ }^{4}$
}

\begin{abstract}
RESUMO
O desafio permanente da educação, e do ensino profissional em particular, exige uma permanente adaptação das práticas pedagógicas ao mundo global em que vivemos. As gerações mais novas fazem emergir a necessidade de estratégias que tornem as práticas pedagógicas mais motivadoras e adequadas a um mundo em constante mudança.

Em resposta a este desafio, a Escola Profissional de Arqueologia (EPA) tem vindo a desenvolver projetos e atividades, que permitem, por um lado, dotar os nossos alunos das competências técnicas específicas da área da arqueologia; e por outro, divulgar e fomentar o gosto e respeito pelo património cultural, particularmente arqueológico.
\end{abstract}

Palavras-chave: Ensino profissional, Arqueologia, Aprendizagem, Práticas pedagógicas, Projetos.

\begin{abstract}
The permanent challenge of education in general, and vocational education in particular, requires a permanent adaptation of pedagogical practices to the global world in which we live. The younger generations raise the need for strategies that make pedagogical practices more motivating and appropriate to a world in constant change. In response to this challenge, the Professional School of Archeology (EPA) has been developing projects and activities that allow, on the one hand, to equip our students with specific technical skills in the area of archeology; and on the other hand, to disseminate and promote the taste and respect for cultural heritage, particularly archaeological.
\end{abstract}

Keywords: Vocational education, Archeology, Learning, Pedagogical practices, Projects.

\section{INTRODUÇÃO}

A Escola Profissional de Arqueologia (EPA) é uma instituição pública de ensino profissional dedicada à área do Património Cultural, implantada na aldeia de Santa Maria do Freixo, em plena Área Arqueológica do Freixo, espaço de cerca de 50 hectares classificado como Monumento Nacional - a cidade romana de Tongobriga (Figura 1).

A sua criação surge associada ao aumento do mercado de trabalho na área da Arqueologia, nas décadas de 80 e 90 do séc. XX, com a necessidade de cria-

\footnotetext{
1. Escola profissional de Arqueologia; susananunes@epa.pt

2. Escola profissional de Arqueologia; dulcineiapinto@epa.pt

3. Escola profissional de Arqueologia; juliasilva@epa.pt

4. Escola profissional de Arqueologia; anamascarenhas@epa.pt
}

ção de um corpo profissional de arqueólogos capaz de responder de forma competente aos normativos legais e às crescentes solicitações que o desenvolvimento urbanístico e as obras públicas acarretavam. A Escola Profissional de Arqueologia é então criada em 1990, através de um contrato-programa celebrado entre o Gabinete de Educação Tecnológica, Artística e Profissional e o Instituto Português do Património Arquitetónico e Arqueológico, em representação, respetivamente do Ministério da Educação e Ministério da Cultura, propondo-se a formar um corpo de técnicos em arqueologia capazes de 
apoiar os arqueólogos formados pelas universidades. Com a promulgação da Portaria no ${ }^{\circ}$ 795/200o, de 20 de setembro, a escola é integrada na rede pública de estabelecimentos de ensino, sendo o seu financiamento assegurado em partes iguais pelos Ministérios da Educação e da Cultura.

O primeiro curso a avançar foi o de Assistente de Arqueólogo, seguindo-se o Curso de Técnico de Museografia e Divulgação do Património e o de Assistente de Conservação e Restauro. Mais recentemente a Escola apostou no curso de Técnico de Recuperação do Património Edificado, em resposta às necessidades identificadas no mercado. Na implantação dos cursos vocacionais, em 2015 inicia-se o curso de Técnico Operacional do Património e Turismo para o $3^{\circ}$ ciclo. No ano letivo de 2016-2017 inicia-se o curso de educação e formação (CEF) de Operador de Fotografia, também para o $3^{\circ}$ ciclo e em 2018 e 2019 os cursos de Técnico de Animação em Turismo e Técnico de Fotografia, respetivamente.

\section{A FORMAÇÃO TECNOLÓGICA DO ASSISTENTE DE ARQUEÓLOGO}

O Assistente de Arqueólogo éo técnico que, sob a supervisão do Arqueólogo, executa "ações conducentes à investigação, registo, análise e conservação de sítios e materiais arqueológicos, através da utilização de equipamentos e aplicação de técnicas necessárias para a execução de trabalhos de escavação, prospeção, topografia, cartografia, desenho, fotografia, conservação e restauro de bens arqueológicos (Catálogo Nacional de Qualificações, Referencial de Formação, código 225021) (Figura 3). Além disto, dele se espera que participe em atividades de estudo, conservação e valorização do Património Arqueológico

Os Cursos Profissionais destinam-se a formandos com o $9^{\circ}$ ano de escolaridade ou formação equivalente, que valoriza o desenvolvimento de competências para o exercício de uma profissão, sendo um ensino mais prático e voltado para o mundo do trabalho, com duração de 3 anos, conferem dupla certificação: Diploma de Certificação Profissional de nível 4 de acordo com o Quadro Nacional de Qualificação (QNQ) e Quadro Europeu de Qualificações (QEQ), reconhecido em todos os Estados Membros (Portaria no 782/2009) e Diploma do Ensino Secundário com equivalência ao $12^{\circ}$ ano de escolaridade com possibilidade de acesso ao ensino superior.
No ensino profissional a "formação é organizada em módulos, unidades significativas de aprendizagem de natureza e duração variáveis, que se combinam entre si formando uma Estrutura Modular. Esta organização permite integrar formandos com níveis de formação e características muito diferenciadas e responde, entre outros, a três pressupostos subjacentes à criação destas escolas: (i) orientação educativa diferenciada; (ii) apoio personalizado; (iii) significado formativo da avaliação."

O Curso de Assistente de Arqueólogo inclui-se na área de Formação de História e Arqueologia (225), e é um curso profissional durante o qual os formandos aprendem a recolher, registar, tratar, analisar e conservar sítios e materiais arqueológicos, através da utilização de equipamentos e aplicação de técnicas apropriadas.

Os formandos têm aulas de disciplinas da componente geral, científica e da componente técnica, intercalados com períodos de Formação em Contexto de Trabalho (FCT) (ver tabela com Plano Curricular). Assim, para além de disciplinas da Componente Sócio Cultural - Português, Inglês, Área de Integração, Técnicas de Informação e Comunicação e Educação Física, os alunos têm disciplinas da componente científica, a fixar em regulamentação própria, em função das qualificações profissionais a adquirir (ANQEP), designadamente Matemática, História e Cultura das Artes e Físico-Química. A grande maioria das horas de formação correspondem a módulos da componente tecnológica e a períodos de FCT. A componente tecnológica inclui disciplinas de natureza tecnológica, técnica e prática estruturantes da qualificação profissional visada conforme referido pela ANQEP. No caso do curso de Assistente de Arqueólogo, esta pode ser dividida em três áreas: Técnicas de Investigação em Arqueologia ${ }^{5}$, Técnicas de

5. * UFCD: 4077. Técnicas de investigação arqueológica; 4078. Cultura material em arqueologia; 4079. Contextos específicos em arqueologia; 408o. Instrumentos e metodologias de trabalho em arqueologia; 4081. Métodos e técnicas de prospeção arqueológica; 4082. Trabalho de campo em prospeção arqueológica; 4083. Estratigrafia arqueológica; 4084. Cartografia arqueológica; 4085. Análise de materiais arqueológicos; 4086. Análise de estruturas arqueológicas; 4087. Legislação em arqueologia e património; 4088. Atividades complementares na investigação arqueológica; 4089. Projeto de investigação em arqueologia. 
Registo em Arqueologia ${ }^{6}$ e Técnicas de Conservação em Arqueologia 7 .

A Formação em Contexto de Trabalho "visa a aquisição e o desenvolvimento de competências técnicas, relacionais e organizacionais relevantes para a qualificação profissional a adquirir" (ANQEP), proporcionando ao formando períodos de aprendizagem mais próximos do que será o contexto de trabalho real. Na EPA estes períodos decorrem ao longo dos três anos, de forma a que possam ter uma experiência mais diversificada. Normalmente o primeiro período de FCT é realizado na escola, mas os restantes são preferencialmente realizados externamente, sob a forma de participação em trabalhos arqueológicos (escavações, prospeções, tratamento de material, entre outros), e têm a duração de uma semana a um mês (em setembro, na Páscoa e em junho/ julho).

No final do curso o aluno tem de apresentar um projeto, designado por Prova de Aptidão Profissional (PAP), onde demonstra as competências e conhecimentos que desenvolveu ao longo da formação.

As aulas decorrem nas instalações da EPA, em casas de habitação adaptadas a salas de aula, nas ruínas, no gabinete da Área Arqueológica e no centro interpretativo.

6. UFCD: 409o. Técnicas de inventário de património cultural; 4091. Técnicas de registo em arte rupestre; 4092. Desenho de estruturas arqueológicas; 4093. Desenho de estratigrafia arqueológica; 4094. Desenho arqueológico de edifícios; 4095. Desenho arqueológico de materiais cerâmicos; 4096. Desenho arqueológico de objetos; 4097. Desenho arqueológico de materiais líticos; 4098. Tratamento gráfico de desenho arqueológico; 4099. SIG 'S Arqueologia; 410o.Matemática aplicada à topografia; 4101. Técnicas de registo em cartografia arqueológica; 4102. Métodos e técnicas de levantamentos topográficos; 4103. Trabalho de campo em topografia arqueológica; 4104. Fotografia; 4105. Fotografia arqueológica.

7. UFCD: 4106. Conservação preventiva; 4107. Técnicas de registo e diagnóstico; 4108. Técnicas de limpeza e manutenção; 4109. Ambientes e técnicas de estabilização; 4110. Técnicas de conservação in situ; 4111. Técnicas de restauro em arqueologia; 4112. Técnicas de conservação em ruínas arqueológicas; 4113. Técnicas de conservação de rochas e argamassas; 4114. Técnicas de conservação de cerâmica e vidro; 4115. Técnicas de conservação de metais e ligas; 4116. Técnicas de conservação de mosaico e pintura mural; 4117. Técnicas de conservação de materiais orgânicos; 0349. Ambiente, segurança, higiene e saúde no Trabalho.

\section{OS PROJETOS E ATIVIDADES COMO FORMAS DE APRENDIZAGEM SIGNIFICATIVAS}

A articulação entre as várias disciplinas, em especial entre as da Componente Técnica, foi sempre comum na EPA, uma vez que o próprio trabalho em Arqueologia (como na Museografia e na Conservação e Restauro) é, necessariamente, interdisciplinar e colaborativo.

Atualmente a EPA desenvolve uma série de projetos, de que destacamos o Projeto Museus pelo Mundo, Arqueopólio e Olimpíadas da Antiguidade.

O fato de estes dois últimos projetos terem iniciado no ano letivo de 2016-2017 mostra bem o trabalho que vem ser desenvolvido na EPA, numa lógica da Aprendizagem Baseada em Projetos, onde se procura a articulação entre as diferentes componentes dos cursos e uma maior ligação dos alunos à escola, a partir da adesão a um projeto comum a que os próprios deram forma desde a conceção à apresentação final e disseminação.

Desde o ano letivo 2015-2016 que a EPA realiza as Oficinas de Educação Patrimonial, com o objetivo de incrementar a defesa, gosto e respeito pelo património cultural, particularmente o arqueológico, objetivos para o qual contribuiu também a exposição intitulada "Arqueologia. Ciência que estuda o passado”, concebida no ano letivo 2016-2017 (e que vai já na sua quarta edição).

O Arqueopólio é um jogo de tabuleiro criado para dar a conhecer o Património Cultural Português com uma configuração baseada no Monopólio (Figura 4). Este projeto interdisciplinar foi desenvolvido em contexto de sala de aula, numa lógica da aprendizagem por projetos. O objetivo era transmitir, de forma motivadora, os conteúdos programáticos de disciplinas dos cursos profissionais de AA e TMGP, nomeadamente a classificação do património cultural português e os vários tipos de sítios arqueológicos, temas abordados no $1^{\circ}$ ano desses cursos.

Assim em sala de aula, foram desenvolvidas as seguintes tarefas: 1) levantamento do património arqueológico classificado português; (2) seleção dos sítios a constar no jogo e recolha de fotografias representativas; (3) organização do "Layout" do tabuleiro; (4) vetorização dos vários ícones (categorias, cartas, serviços e peões); (5) criação das notas e cartões de concessão de espaços.

Daqui resultou o Arqueopólio, um jogo de tabuleiro 
cujo objetivo é fazer a gestão do Património Cultural Português através da concessão/ exploração de bens patrimoniais.

O projeto foi criado no âmbito da participação na $14^{\underline{a}}$ edição do prémio Fundação Ilídio Pinho - Ciência na Escola 2016-2017, tendo sido um dos 100 finalistas.

O projeto foi concebido segundo a lógica da interdisciplinaridade e transdisciplinaridade.

O Projeto Museus pelo Mundo é um projeto de divulgação de património cultural inserido noProjeto de Autonomia e Flexibilidade Curricular. Com este projeto pretende-se angariar o maior número possível de postais de museus por forma a constituir uma coleção de postais de todo o mundo (Figura 5).

Até ao momento recebemos mais de 700 postais de países de todo o mundo; temos escolas e professores interessados em trabalhar o projeto e temos dois museus a trabalharem no projeto.

Numa primeira etapa transformou-se uma sala de aula (laboratório) numa sala de exposição do projeto, onde os postais são acondicionados e expostos. Este espaço pode ser visitável e receber grupos, que podem vir aqui conhecer o projeto e realizar atividades programadas.

A médio e longo prazo coleção está a ser trabalhada, através do seu registo sob a forma de inventário e fotografia, em várias disciplinas: Comunicação Visual, Património, Divulgação de Património, Inglês. A mais valia deste projeto é serem os postais instrumentos/meios pedagógicos para se atingirem as aprendizagens essenciais.

No dia 1o de maio de 2017, a Escola Profissional de Arqueologia organizou as primeiras Olimpíadas da Antiguidade, tendo sido adiadas as quartas Olimpíadas para 2021 devido ao COVID. As Olimpíadas da Antiguidade da EPA realizam-se no Fórum romano de Tongobriga, e incluem as seguintes modalidades:

- stadio - prova de corrida de velocidade com o comprimento do Fórum de Tongobriga (cerca de $60 \mathrm{~m})$;

- lampadedromía - prova de corrida de estafetas (4X6om), constituída por quatro atletas, semelhante à corrida de estafetas atual. O desafio é correr com uma tocha acesa e passá-la ao companheiro de equipa sem que ela se apague;

- dískos - prova de lançamento de um disco de metal à maior distância possível.

-ákon - prova de lançamento de um dardo de forma a atingir a maior distância possível.
- pédema - prova de salto, com os pés juntos, sem correr e com pesos nas mãos, de forma a atingir a maior distância possível.

Para além das provas físicas estas Olimpíadas integraram também um torneio de jogos de tabuleiro romanos-Centurium (C).

Desde o ano letivo 2015-2016 que a EPA integra de forma sistemática na sua missão, a divulgação do património cultural. Esta divulgação, que começou com a realização de oficinas pedagógicas e palestras direcionadas sobretudo para a arqueologia, tem vindo a reinventar-se ao longo do tempo, apostando em novos formatos e abrangendo outras áreas do património cultural.

As atividades com mais sucesso são a Oficina de Mosaicos e a Simulação de escavação arqueológica.

Na primeira, os participantes recriam a técnica romana do mosaico. Estas sessões são dirigidas aos alunos entre os 10-15 anos, com a duração de 45 a 90 mins. Com base nas técnicas, materiais, motivos e organização das composições geométricas, são abordadas questões relacionadas com a vida doméstica e quotidiana romana. Alguns dos motivos baseiam-se, também, no pavimento em mosaico datado do século V-VI d.C., identificado na igreja de Santa Maria do Freixo, mesmo em frente à Escola Profissional de Arqueologia.

Uma das primeiras atividades desenvolvidas e que mais sucesso tem é a denominada Arqueólogo por um dia, que se constitui comum uma simulação de escavação arqueológica. (Figura 6) Em áreas de escavação portáteis são recriados contextos arqueológicos de diferentes épocas, de modo a permitir reconstituir as ações das pessoas do passado. Consiste numa oficina prática com introdução ao trabalho próprio do arqueólogo e à prática simulada de todos os procedimentos inerentes à escavação arqueológica, tratamento preliminar de espólio arqueológico e interpretação de resultados. De acordo com cada problema, cabe aos alunos, interagindo com os investigadores, a utilização de todos os recursos disponíveis com vista à apresentação de hipóteses explicativas. As atividades são avaliadas através da discussão entre pares e com os orientadores da atividade. Com esta oficina pretende-se que os participantes compreendam a importância da escavação arqueológica para a construção do conhecimento e apliquem os princípios do método científico na recolha, classificação e análise dos dados arqueológicos, desenvol- 
vendo competências de iniciativa, planificação, execução e interpretação. Destinadas a crianças e jovens dos 4-15 anos e com uma duração entre 45 a 90 mins, são antecedidas de uma apresentação de introdução à arqueologia e ao trabalho do arqueólogo.

Esta prática simulada de escavação arqueológica é um meio utilizado em duas abordagens distintas, quanto ao rigor e aprendizagens:

- uma enquanto estratégia de aprendizagem aplicada aos alunos que iniciam o curso de assistente de arqueólogo, em que o objetivo principal é a introdução à escavação arqueológica com todas as problemáticas inerentes à mesma, a saber: i) registo e compreensão da estratigrafia arqueológica, ii) recolha e registo de artefactos e ecofactos; iii) métodos de escavação apropriados e não apropriados e iv) introdução aos métodos de registo (croquis, desenho, fotografia e topografia). (Figura 7)

- outra enquanto estratégia de aprendizagem e divulgação da prática arqueológica a um público mais vasto, crianças e jovens entre os 4 aos 15 anos constituindo-se como um espaço pedagógico.

Em setembro de 2019, a EPA e a Área Arqueológica do Freixo conceberam um espaço pedagógico que inclui uma exposição e uma oficina para o público que objetiva a ideologia da salvaguarda de uma área arqueológica, monumento nacional, a valorização do profissional em arqueologia e sua ligação à sociedade civil (Mascarenhas et all: 2020). Para além de uma exposição que permite conhecer todos os aspetos diretamente relacionados com a investigação arqueológica de campo, este espaço engloba uma oficina de simulação de escavação arqueológica, inserida na zona habitacional de Tongobriga. Esta oficina, recria três momentos de ocupação do sítio: Idade do Ferro, Período Romano e Época Medieval, incluindo réplicas de estruturas e materiais arqueológicos. Este espaço pedagógico é um upgrade das áreas de escavação portáteis da oficina Arqueólogo por um dia, integrando-se em plena zona habitacional de Tongobriga.

\section{DIDÁTICA DA ARQUEOLOGIA EM "SALA DE AULA"}

O espaço pedagógico sendo uma simulação da escavação arqueológica é o local ideal para a prática experimental e inicial da arqueologia. A simulação da escavação confere seriedade na prática pois reproduz unidades estratigráficas reais e suas relações, permite testar procedimentos ao nível da escavação e registo (escavar, limpar, definir, registar) preparando o técnico para contextos de escavação reais. (Figura 8) Num só local é possível avaliar os alunos a vários módulos técnicos parcelares pois a escavação integra tarefas complexas, exige ao mesmo tempo conhecimentos distintos. A prática com sucesso por parte dos alunos exige conhecimentos técnicos da escavação por camadas, do entendimento da estratigrafia (TIAo7 - Estratigrafia arqueológica), do seu registo (TRAo4 - Desenho de estratigrafia arqueológica), da recolha adequada dos artefactos encontrados em cada camada e da sua posterior análise em fichas de identificação (TIAog - Análise de materiais arqueológicos). E por último, do desenho de materiais (TRAo6, 07, e o8 - Desenho de materiais cerâmicos, objetos e líticos) e da vetorização dos desenhos de campo (TRAog - Tratamento gráfico de desenho arqueológico) em gabinete.

Deste modo, surge naturalmente a ideia de uma avaliação conjunta de dois módulos técnicos TIA o7 Estratigrafia Arqueológica e TIA o9 - Tratamento gráfico de desenho arqueológico, algo compreensível para os arqueólogos. Contudo, uma avaliação modular conjunta não é algo comum pois exige prática colaborativa entre os docentes, como numa escavação entre arqueólogos. Hoje os módulos de diferentes disciplinas ainda são compreendidos pelos docentes como algo estanque e a prática pedagógica é geralmente individual. É também desta necessidade de uma prática docente conjunta que se enquadra a autonomia e a flexibilidade curricular que põe em marcha uma cooperação, em primeiro lugar entre os docentes e em segundo entre os docentes e discentes. O futuro da arqueologia e da educação deve seguir o caminho que aqui apontamos e tentamos realizar. O futuro da arqueologia depende do envolvimento do público em geral e do seu compromisso com o património orientado e fomentado pelos profissionais em arqueologia. Por outro lado, na educação é fundamental a articulação entre disciplinas em prol de um ensino global, integrador e inclusivo. 


\section{BIBLIOGRAFIA}

MASCARENHAS, Ana; SILVA, Júlia; NUNES, Susana; PINTO, Dulcineia; PATRÍCIO, Daniel (2020) - A aprendizagem da arqueologia como agente de desenvolvimento pessoal e social. o estudo de caso da oficina pedagógica em Tongobriga. Comunicação apresentada no TaG Iberico (8ㅁ sessão - No todo es lo que parece: Repensando la educación pública y la divulgación en la Arqueología y en la gestión del Patrimonio de la Península Ibérica. Coord.: Laura Coltofean e Tiago Gil, Lisboa. Faculdade de letras da Universidade de Lisboa. 13-14 de fevereiro de 2020.

Portaria 795/200o, de 20 de setembro - Cria a Escola Profissional de Arqueologia, situada na área arqueológica do Freixo, em Marco de Canaveses - Diário da República n.ำ 218/200o, Série I-B de 2000-09-20.

Portaria 782/2009, de 23 de julho - Regula o Quadro Nacional de Qualificações e define os descritores para a caracterização dos níveis de qualificação nacionais - Diário da República $\mathrm{n} .{ }^{\circ}$ 141/2009, Série I de 2009-07-23.

Catálogo Nacional de Qualificações: http://www.catalogo. anqep.gov.pt/

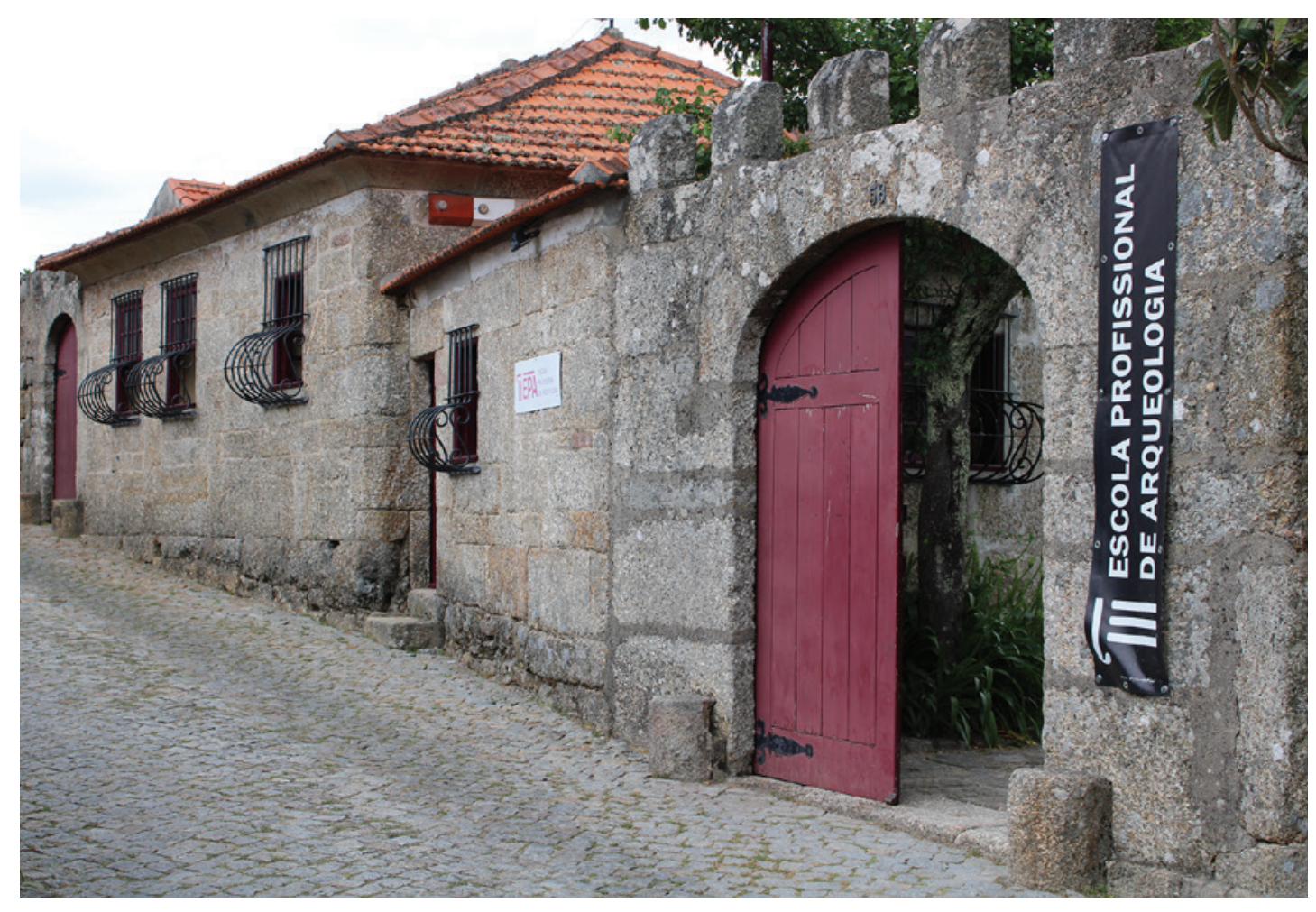

Figura 1 - Escola Profissional de Arqueologia, Freixo. 2020, Escola Profissional de Arqueologia (C. 


\begin{tabular}{|l|l|}
\hline \multicolumn{2}{|l|}{ PLANO MODULAR DO CURSO PROFISSIONAL DE ASSISTENTE DE ARQUEÓLOGO } \\
\hline DISCIPLINAS & TOTAL 3 ANOS \\
\hline Componente Socio Cultural & 1000 horas \\
\hline Português & 320 \\
\hline Inglês & 220 \\
\hline Área de Integração & 220 \\
\hline Tecnologias de Informação e Comunicação & 100 \\
\hline Ed. Física & 140 \\
\hline Componente Científica & 500 horas \\
\hline Física e Química & 200 \\
\hline História da Cultura e das Artes & 200 \\
\hline Matemática & 100 \\
\hline Total de Horas da Componente & 500 \\
\hline Formação Tecnológica - UFCD’s* & 1300 horas \\
\hline Formação em Contexto de Trabalho & 630 horas \\
\hline Total do Plano Curricular & 3430 horas \\
\hline
\end{tabular}

Figura 2 - Plano modular do curso profissional de Assistente de Arqueólogo.

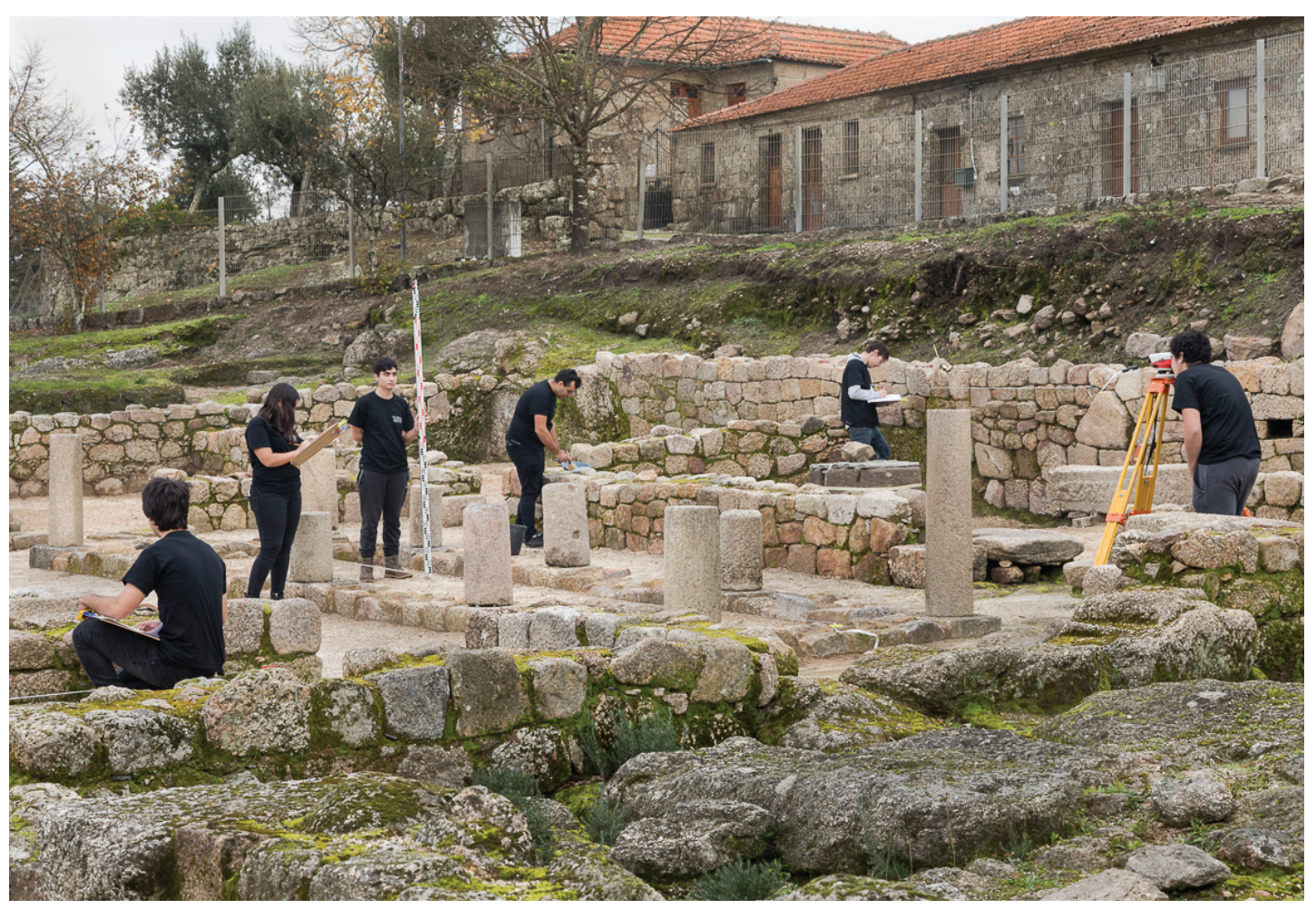

Figura 3 - Momento formativo na Área Habitacional 1 de Tongobriga. 2019, Ricardo Raminhos (C) 


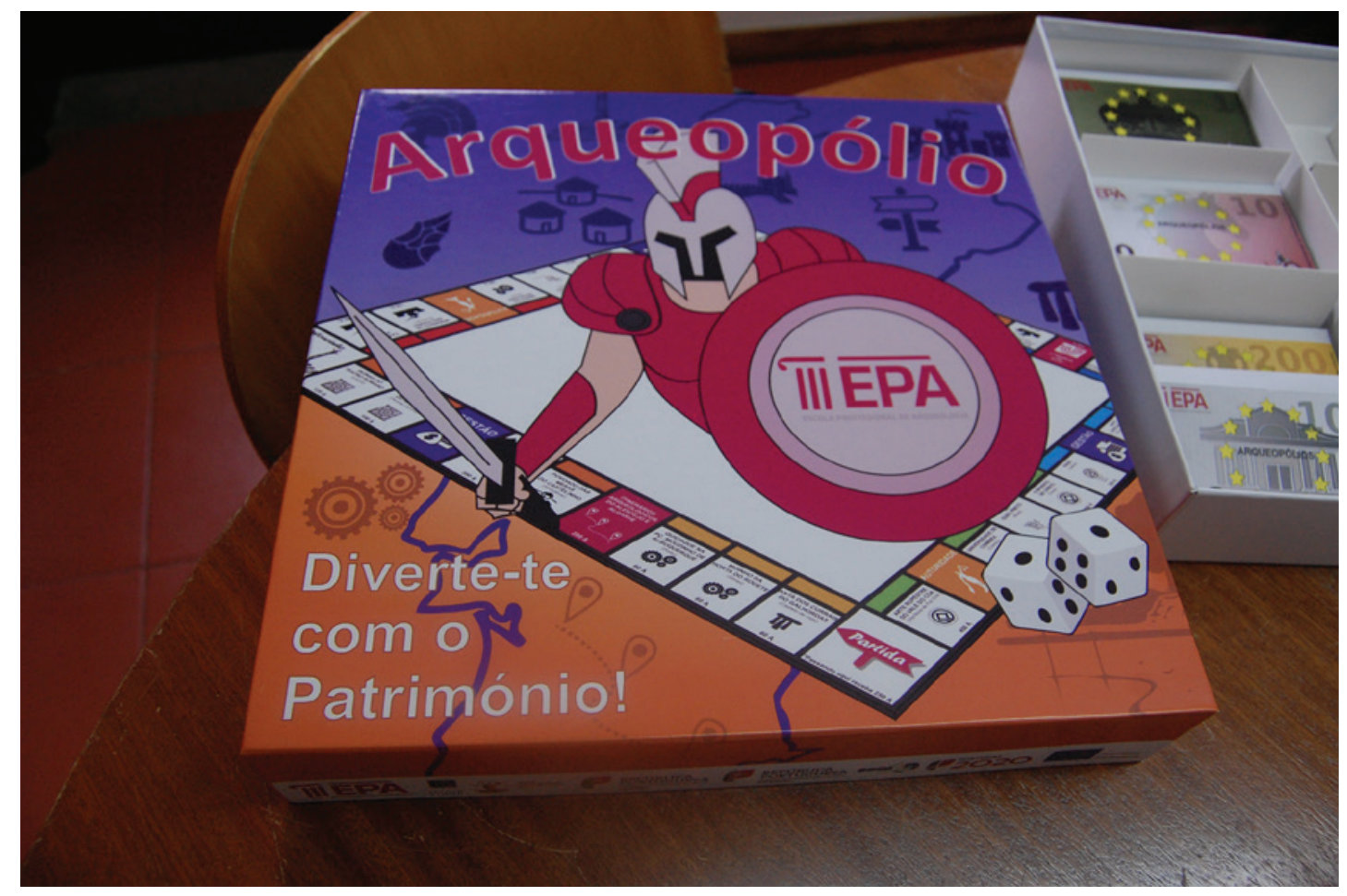

Figura 4 - Jogo de tabuleiro Arqueopólio, desenvolvido no âmbito da 14 a Edição do Prémio Fundação Ilídio Pinho "Ciência na Escola”. 2017, Escola Profissional de Arqueologia (C).

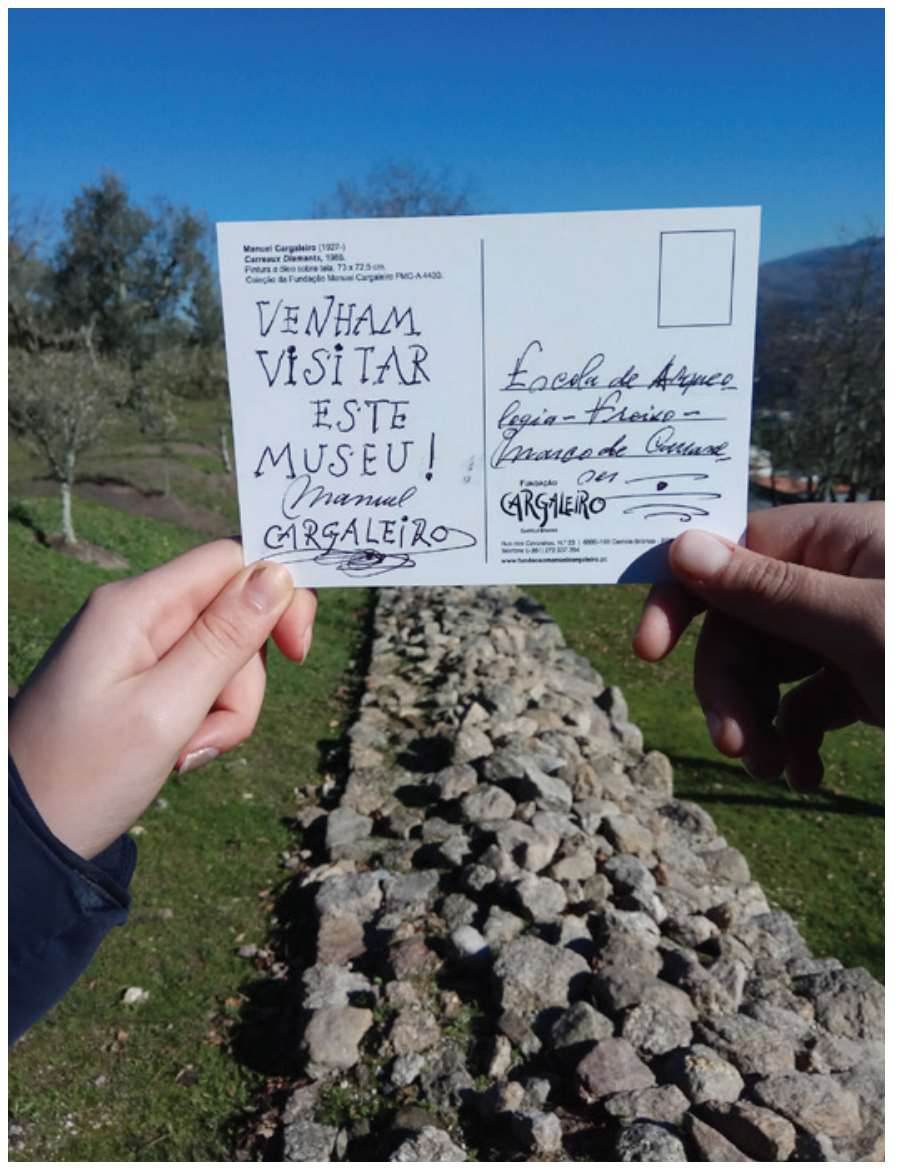

Figura 5-Postal do museu Cargaleiro, enviado pelo próprio artista. 2017, Escola Profissional de Arqueologia (C). 


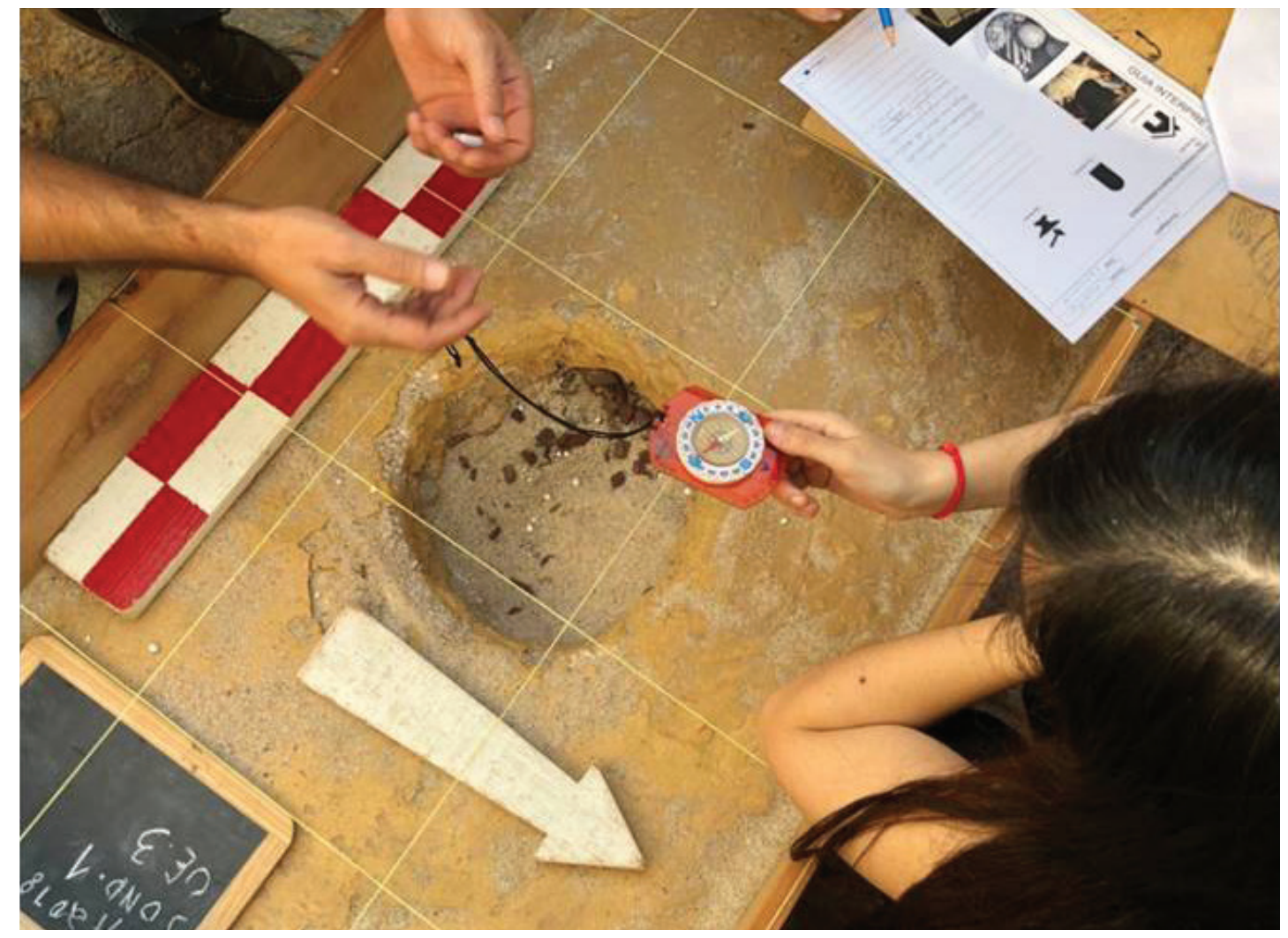

Figura 6 - Oficina Arqueólogo por um dia (2018, Escola Profissional de Arqueologia ( )).

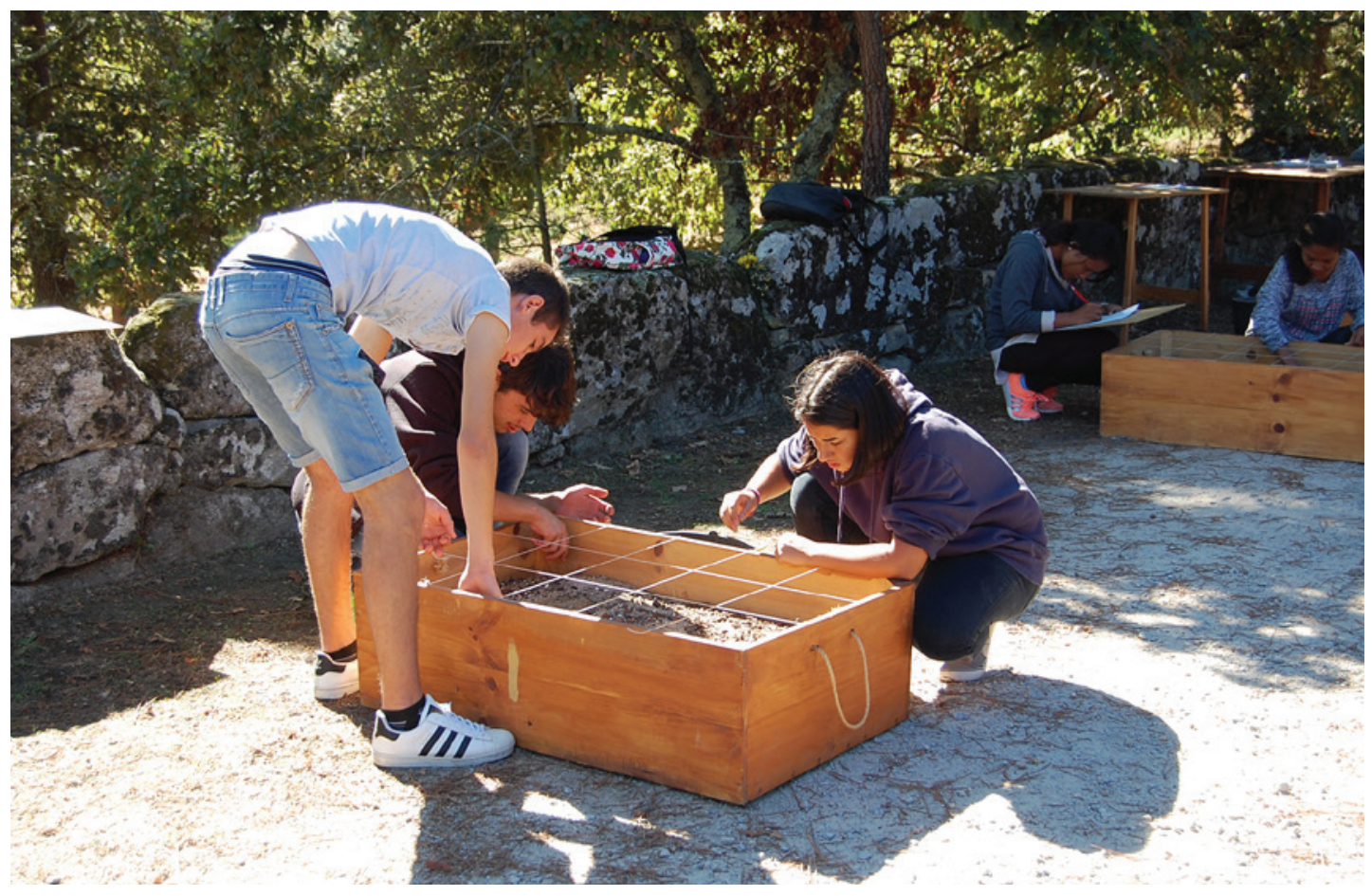

Figura 7 - Simulação de escavação arqueológica por alunos do 1o ano do curso de Assistente de Arqueólogo (2016, Escola Profissional de Arqueologia (C). 


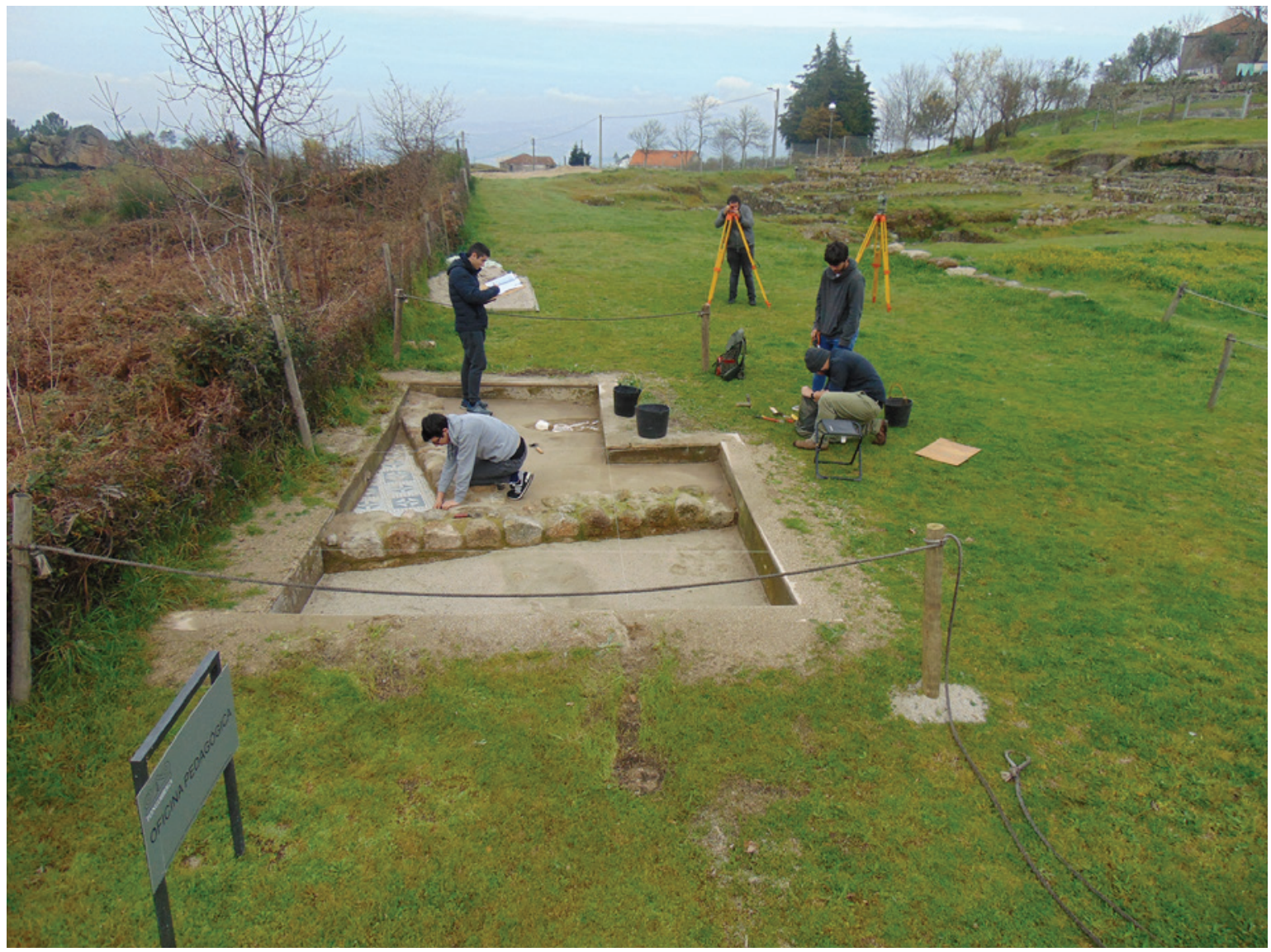

Figura 8 - Oficina de simulação de escavação incluída na Zona Habitacional de Tongobriga. 2019, Escola Profissional de Arqueologia (C). 


\title{
OS MUSEUS DE ARQUEOLOGIA E OS JOVENS: A OFERTA EDUCATIVA PARA O PÚBLICO ADOLESCENTE
}

\author{
Beatriz Correia Barata ${ }^{1}$, Leonor Medeiros ${ }^{2}$
}

\begin{abstract}
RESUMO
A dinâmica dos serviços educativos dos museus tem vindo a desenvolver-se de forma significativa como resposta à valorização e divulgação do património junto dos diferentes públicos. Contudo, os visitantes e os interesses mudam, levando não só à adaptação por parte dos museus, mas também à necessidade de captar audiências e ir de encontro aos novos interesses.

É dentro do âmbito de captação de novos públicos em museus de arqueologia que se foca este artigo, mais precisamente no público entre os 13 e os 17 anos, que se tem provado um desafio. O adolescente é um público com necessidades específicas e numa fase de transição. No entanto, este é um período fundamental para a educação e formação do futuro adulto/visitante.
\end{abstract}

Palavras-chave: Arqueologia, Adolescentes, Museus, Educação, Atividades.

\begin{abstract}
In the last decades, the museums have shown a strong growth in the dynamics of their educational services, both at national and international level. These dynamics appeared, above all, in response to the need to conserve and enrich the cultural heritage and to educate the different audiences.

However, the audiences and the interests change over time and the museums need to adapt and pursue these changes. Therefore, the need to meet the new interests and to attract new audiences has become increasingly relevant and substantial.

This study focuses on the necessity of attracting new audiences in archaeological museums, more precisely on the teen audience between $13^{\text {th }}$ and $17^{\text {th }}$ years old, that has proved to be a challenge.

Keywords: Archaeology, Teen, Museums, Education, Activities.
\end{abstract}

\section{A ARQUEOLOGIA E O ADOLESCENTE - UM DESAFIO À COMUNICAÇÃO}

A arqueologia detém nos dias de hoje um grande interesse por parte do público, tanto de "miúdos" como de "graúdos". A popularidade da disciplina não se deve tanto aos materiais arqueológicos, embora pesem as descobertas que os envolve, mas ao que tem vindo a ser "fantasiado" desde as grandes descobertas dos finais do século XIX e século XX. Para o grande público a arqueologia é sinónimo de aventura e mistério em locais exóticos, e o arqueólogo é o protagonista, um "detetive" que investiga o passado juntando várias peças do puzzle (HOLTORF, 2004). A televisão e as produções cinematográficas têm grande destaque relativamente à produção desta imagem, uma vez que se tornaram desde cedo num importante veículo para apresentar o passado ao grande público e consecutivamente atingir grandes índices de audiência (BAHN, 1997), variando das representações mais fantasiosas como os filmes Indiana Jones, às mais científicas como a série televisiva britânica Time Team. A imagem apresentada ao grande público através dos media e outras entidades ligadas ao desenvolvimento de atividades culturais tendem a ser, na sua grande maioria, bastante fan-

1. beatrizcorreiabarata@gmail.com

2. Faculdade de Ciências Sociais e Humanas da Universidade Nova de Lisboa; lapmedeiros@gmail.com 
tasiosas e inclusive pouco éticas no que toca à representação da arqueologia e do arqueólogo. É efetivamente face a esta imagem incorreta e dominante junto do grande público que há a necessidade crescente de uma maior valorização e proteção do património arqueológico, onde a educação patrimonial se torna essencial, uma vez que o seu objetivo primordial é educar e criar uma ligação próxima entre a sociedade e o seu património artístico, histórico e arqueológico.

Éprecisamentenoâmbitodaeducaçãoecomunicação patrimonial que os museus de arqueologia surgem como um agente importante, uma vez que são locais onde se promove a importância e preservação do objecto arqueológico, a valorização e investigação de coleções arqueológicas, a divulgação e a educação patrimonial (ANTAS, 2013). Por comunicação educativa em museus de arqueologia entenda-se todas as atividades realizadas, apoiadas por mediadores de aprendizagem, com base em recursos didáticos e museográficos que permitem uma comunicação unilateral e interativa com diversos públicos (ANTAS, 2013) e possibilitam novas formas de aprendizagem da arqueologia.

Contudo, para que esta comunicação patrimonial seja eficaz, deve ser considerada a importância da sua adaptação aos diversos tipos de público e não a um "público geral". Assim, os museus têm vindo a intensificar a investigação dos seus públicos de modo a desenvolver novas estratégias de captação (SANTOS, 2014; LOURENÇO, 2014, MATSUDA, 2004, 2016), aperfeiçoar as atividades e consequentemente a ampliar os seus públicos (ALMEIDA, 2005).

Na estrutura orgânica dos museus, o serviço educativo desempenha um papel essencial nesta comunicação educacional, uma vez que o seu principal objetivo é precisamente o desenvolvimento de estratégicas pedagógicas educacionais e a mediação natural do público. Ao serviço educativo compete, portanto, o desenvolvimento de programas, projetos e atividades pedagógicas adaptadas, a aprendizagem ativa e entretenimento de todos os tipos de público.

Os museus de arqueologia não são excepção. Aqui os serviços educativos dedicam-se à descodificação, comunicação e divulgação da mensagem arqueológica de forma clara e interativa. Os programas não devem reduzir-se à construção de materiais didáticos ou à adaptação do discurso científico a um discurso descodificado para os diferentes públicos. Com efeito, os programas desenvolvidos pela maioria dos ser- viços educativos de hoje são bastante diversificados, porém dirigem-se essencialmente ao público infanto-juvenil, grupos escolares e adultos.

Contudo, existe um público que tende a ser um pouco negligenciado pelos serviços educativos dos museus de arqueologia e museus em geral: o adolescente. É notório que este público é dos mais difíceis de cativar no âmbito de uma visita, porém poucos são os esforços da maioria dos serviços educativos para uma comunicação eficiente junto deste. Estes jovens detêm características demarcadas não só pela condição sociocultural onde estão inseridos (CARDOSO, 2013), mas também pelas características inerentes ao próprio período da adolescência. Estas particularidades devem ser assumidas pelos museus, considerando o adolescente como um tipo de público específico que não se integra no público infantil ou no público adulto. Face às suas caraterísticas especificas, têm vindo a ser desenvolvidos estudos que procuram identificar as principais razões relacionadas à baixa participação dos jovens nos museus.

A imagem do museu como um "local aborrecido" tem sido identificada como o principal motivo para o baixo número de visitantes adolescentes. Os jovens veem os museus como instituições pouco atraentes e fortemente estruturadas, onde as exposições, para além de aborrecidas, são inacessíveis e extramente protegidas (KELLY, BARTLETT, 2009). Este público deseja interagir com as exposições e testar as suas habilidades, no entanto, a maioria das atividades interativas são destinadas às crianças e, portanto, não se adequam à sua idade (SHRAPNEL, 2012).

Outro aspeto importante é o facto de o adolescente considerar o museu como um espaço que não vai de encontro às suas necessidades e desejos. Com a introdução das redes sociais, a forma como os jovens recebem informações mudou profundamente e, com estas mudanças, vieram novos valores, necessidades e desejos. $\mathrm{O}$ adolescente deseja contruir conhecimento em conjunto e num ambiente social onde se sinta à vontade para aprender e partilhar ideias (KORN, 2008).

Um outro factor identificado é o impacto de experiências negativas na percepção do jovem em relação aos museus. Memórias de visitas obrigatórias condicionadas ao plano escolar influenciam significativamente na decisão de futuras visitas (KELLY, BARLETT, 2009), porque estão associadas simplesmente a um complemento educativo e não a entretenimen- 
to (ANDERSON, HORLOCK, JACKSON 2000).

A questão financeira é identificada como uma outra barreira importante sendo que a maioria dos jovens são estudantes com uma restrição significativa de dinheiro (KELLY, BARLETT, 2009). E por fim, o factor da "zona de conforto", ou falta dela, é uma importante condicionante. A maioria dos jovens veem os museus como instituições formais e pouco convidativas (MCCARTHY, MANSON, 2006; KORN, 2008).

Com base nestes factores, acreditamos ser essencial não só transformar o modo de interação com os jovens, mas também repensar os programas educativos a eles dirigidos, o que por sua vez requer o desenvolvimento de estratégias de mediação e comunicação. No que respeita ao público adolescente, a estratégia do museu deve atender a três fatores importantes: compromisso, envolvimento e programas. Os programas precisam de compromisso institucional para atender às necessidades deste público, isto é, colaborações e parcerias, apoio ao programa, tempo, recursos e trabalho em equipa (KELLY, BARTLETT, 2009). Os programas e exibições devem explorar temas que cativem e atendam às necessidades e interesses deste público (KELLY, BARTLETT, 2009).

Um outro fator reside em tornar o museu mais participativo, um local onde os visitantes possam criar, partilhar e conectar-se tanto com a exposição como com outros visitantes (SIMON, 2010).

Por fim, é necessário fazer da instituição museológica um espaço menos formal do ponto de vista educativo e mais informal e convidativo, que possa ser considerado como um destino atrativo para os jovens (SHRAPNEL, 2012). O adolescente gosta de socializar, de ser participativo e de demonstrar o seu potencial, e o museu, como uma instituição cultural com impacto social, tem capacidade não só de integrar os jovens nestes aspetos, como também mostrar o seu potencial (BIRKETT, 2012).

Estes jovens não consideram o museu como parte dos seus circuitos de lazer, o que por sua vez leva a uma grande diminuição das suas visitas (CARDOSO, 2013). A educação formal ocupa boa parte do seu tempo, e o próprio museu tem sido apresentado como um complemento educacional pelas próprias instituições escolares, logo a perceção de que o museu é um local formal e disciplinado está presente na maioria dos adolescentes (FAUSTINI, 2012). Desta forma, o museu deve tornar-se para o jovem num local onde seja possível desenvolver sentido de identidade pessoal, fortalecer relações pessoais, adquirir novos conhecimentos, talentos e habilidades (KELLY, BARTLETT, 2009).

É importante captar este segmento de público e atender ao conjunto de factores que visam melhorar a comunicação com o mesmo, não só porque são uma parte da audiência substancial, mas também porque são a próxima geração de adultos e, consequentemente, futuros visitantes (KELLY, BARLETT, 2009).

Relativamente à relação do jovem com os museus arqueológicos, em termos teóricos, as instituições podem ter bastante sucesso junto deste público pois é uma ciência que detém um certo fascínio e curiosidade, devido essencialmente às ideias fantasiosas transmitidas por filmes, literatura e videojogos que fazem da disciplina um tema popular junto dos jovens. Do ponto de vista educacional a arqueologia tem capacidade de consciencializar os jovens do espaço envolvente, desenvolver o pensamento lógico e raciocínio científico, estimular a investigação, interpretação e a multidisciplinaridade, uma vez que trabalha em conjunto com outras ciências, como a química, a biologia, a geografia e as ciências tecnológicas (CRACKNELL, CORBSIHLEY 1986).

Considerando os fatores enunciados, que poderão justificar a baixa participação do adolescente nos museus de arqueologia, estarão estes preparados a nível de estruturação comunicativa para trabalhar com o público entre os 13 e os 17 anos? De modo a compreender de forma mais directa as relações dos museus de arqueologia com os jovens foram selecionados um conjunto de casos nacionais e internacionais.

\section{PROGRAMAS NACIONAIS E INTERNACIONAIS - ANÁLISE E DISCUSSÃO}

A seleção de um conjunto de projectos para análise deveu-se essencialmente à necessidade de avaliar programas educativos em museus de arqueologia, nacionais e internacionais, que considerámos exemplares e inovadores no que respeita à comunicação educativa. Apesar de ser nosso objectivo estudar o panorama nacional, considerámos importante apresentar também alguns modelos internacionais de forma a analisar alguns paralelos e contrastes em relação aos programas educativos selecionados em Portugal.

A seleção foi realizada a partir de diversos factores que avaliámos como "boas práticas" no desenvolvi- 
mento de atividades de comunicação do património arqueológico. Destes fatores considerámos não só o serviço e programa educativo, mas também a conceção do próprio espaço museológico para uma sensibilização e comunicação eficiente junto do público adolescente, entre os 13 e os 17 anos.

Os museus nacionais, mais do que exemplos de boas práticas foram ainda o centro de um estudo de caso, em que a análise dos seus programas foi colmatada com a realização de breves entrevistas, de forma a analisar directamente a sua oferta educativa e relação com o público em estudo.

Relativamente ao programa dos casos internacionais, patente na tabela apresentada (Tabela 1), podemos concluir que muitas das atividades baseiam-se essencialmente em projetos com base no manuseamento de materiais arqueológicos, hands-on, e em atividades criativas. Uma vez que se trata de museus arqueológicos revela-se uma forte presença da arqueologia experimental. Este tipo de atividade, para além de ser um método educativo extremamente eficaz, providencia ao visitante a experiência de assistir aos processos e ações que definiram o quotidiano do passado (COLOMER, 2002).

Uma característica importante são as atividades desenvolvidas para o público em estudo. Estas são direcionadas para intervalos de idade específicos, isto é, entre os 12 e os 14 anos e entre os 15 e os 18 anos. Existe, portanto, uma preocupação por parte dos serviços educativos destes museus em completar o seu programa com atividades criativas e participativas que sejam dirigidas a este público específico.

Quanto aos parques arqueológicos, não se pode deixar de examinar a sua forte componente comunicacional. Mais do que museus ou centros interpretativos são locais imersivos onde se tenta recriar uma realidade do passado, o que por sua vez atrai uma maior diversidade de público, incluindo os jovens. Os ambientes não são fantasiosos, mas sim do próprio quotidiano, permitindo aos visitantes estabelecer uma ligação entre o passado e o presente. A educação, contudo, não é a única razão para a criação de reconstruções arqueológicas. Há a parte da componente comunicativa, estes parques contribuem também para a publicidade e promoção do património arqueológico.

Dos casos nacionais analisados destaca-se a realização de atividades diversificadas e interativas que não só são dedicadas aos diversos públicos como estimulam a participação social (Tabela 2). A reali- zação de oficinas, ateliês e visitas jogos direcionados essencialmente para o público infantil, público juvenil e, por vezes, ao público sénior, têm não só fortes capacidades criativas e educativas como também estimulam a socialização entre público através da partilha de ideias e sugestões. Os workshops, palestras e conferências são dedicadas ao público adulto, sénior e público especializado, também com uma forte componente social e educacional. São atividades direcionadas para a descodificação e partilha de informação arqueológica a todo o público. Outra característica importante é a adaptação de todas estas atividades ao público com necessidades especiais, que vai desde a preparação do próprio espaço museológico à monitorização profissional por parte do serviço educativo.

Uma outra boa prática destes museus é o seu carácter participativo que permite aos visitantes estabelecer um contacto direto com a exposição e acervo do museu, permitindo uma leitura mais pessoal. Esta iniciativa não é apenas fundada nas atividades que permitem o manuseamento de objetos arqueológicos, como as oficinas de arqueologia experimental do Museu Arqueológico do Carmo e do Museu do Côa, mas também na própria exposição, como no museu Portugal Romano em Sicó, cuja exibição é à base da interatividade com a integração de recursos didáticos que captam o público.

Destacam-se também os serviços informativos dedicados aos visitantes, reais e virtuais, a partir de uma comunicação presencial ou à distância. Como é o caso da Rede de Clubes de Arqueologia do Museu Nacional de Arqueologia que através de uma plataforma online procura estender a educação patrimonial às escolas, ou o Ludi Saecularis do Museu Regional de Arqueologia D. Diogo de Sousa, um jogo simples baseado nos típicos jogos de tabuleiro, que dá a conhecer diversos aspetos acerca da presença romana no território português.

Por fim destaca-se a Festa da Arqueologia realizada nas ruínas do Convento do Carmo, um evento sobre arqueologia num contexto informal. Para além de se realizar num importante ponto turístico da cidade, é um excelente método de comunicação educativa que se tem mostrado cada vez mais eficiente.

Uma educação patrimonial acessível e inclusiva, exposições participativas que apelam a uma aprendizagem ativa e a realização de atividades interativas e criativas, que possibilitam uma participação de todo o tipo de públicos, são estratégias que fazem destes 
museus modelos exemplares na comunicação educativa em arqueologia.

Contudo, considerando todos estes aspectos positivos verificamos que os programas incluem o público em estudo, mas são escassas as atividades direcionadas especificamente aos adolescentes entre os 13 e os 17 anos. Em muitos dos casos estas atividades são concebidas para os jovens desde os 6 aos 14 anos (1ํㅜㄴㅡㅜ e $3^{\circ}$ Ciclo do Ensino Básico) sendo as atividades para os jovens entre os 15 e os 17 anos (Secundário) praticamente integradas no mesmo programa.

As visitas guiadas aos Tesouros da Arqueologia Portuguesa e Antiguidades Egípcias no MNA são a única atividade que abrange os jovens entre os $15 \mathrm{e}$ os 17, as restantes incluem os jovens entre os 13 e os 14, mas incluem também crianças desde os 6 anos. No MAC, a visita-jogo da temática da Idade Média, a visita-jogo da Salvaguarda do Património e as atividades temáticas relacionadas com o 25 de Abril são as únicas que abrangem o público em estudo, sendo a visita-jogo da Idade Média é a única específica para jovens entre os 16 e os 18 anos.

O Museu Regional D. Diogo de Sousa, por sua vez, não tem atividades dedicadas ao público com mais de 14 anos, excetuando um jogo de tabuleiro. No Museu do Côa verifica-se o mesmo, em que apenas uma atividade pedagógica abrange parte do nosso público, e as visitas guiadas, que são dedicadas a todos os contextos escolares.

Nos exemplos internacionais podemos ver algumas diferenças neste aspeto em que, apesar da mesma estratificação do público por nível escolar e algumas atividades em comum entre diferentes níveis de ensino, é possível identificar a existência de atividades dedicadas exclusivamente aos jovens entre os $12 \mathrm{e}$ os 14 ( $3^{\circ}$ ciclo do Ensino Básico), e outras exclusivas aos jovens entre os 15 e 18 (Ensino Secundário). Esta é uma estratificação do programa que, quando comparada com o nosso modelo, consideramos mais eficiente.

\subsection{Análise e Discussão}

O fator da educação patrimonial nos programas não só visa promover a difusão cultural e transmitir conhecimentos à sociedade, como também é essencial para a preservação e valorização do próprio património arqueológico. Uma educação patrimonial em arqueologia tem como principal objetivo criar uma ligação entre o património arqueológico e a socieda- de e, consequentemente, fortalecer os sentimentos de identidade, cidadania e inclusão.

No caso dos museus de arqueologia, uma comunicação educativa eficiente tem de analisar novas formas de aprender arqueologia, e deve ser interativa e adequada aos diversos públicos (ANTAS, 2013). É na realização do próprio programa que o serviço educativo do museu deve ter em consideração os fatores seguidamente identificados.

A importância da arqueologia e do objeto arqueológico, não só a nível didático, mas também como um objeto comunicante com características específicas. Aqui a organização da exposição é igualmente importante. Mais do que uma ordem cronológica e legendas de identificação, as peças devem integrar um contexto e uma ou várias temáticas. $\mathrm{O}$ museu PO.RO.S, por exemplo, organiza a sua exposição de uma forma essencialmente temática, onde em espaços distintos são apresentados diferentes aspetos do tema romano, desde as legiões à vida quotidiana, estabelecendo sempre um paralelo com o presente e com a própria arqueologia.

Os recursos didáticos são outro fator essencial que pode fazer parte da própria exposição ou ser utilizado em ações específicas para os públicos. Obstante ao seu contexto, todos têm o mesmo objetivo, auxiliar, melhorar e facilitar a comunicação educativa ao público. Aqui é importante destacar as salas de realidade aumentada, réplicas de tamanho original e maquetas ${ }_{3}$ D interativas do museu PO.RO.S, e também o jogo "Ludi Saeculares" do Museu D. Diogo de Sousa, um recurso didático que pode ser usado no museu, na escola e em casa. No caso dos museus nacionais identificados a maioria destes recursos tecnológicos tomam a forma de quadros e maquetas interativas integradas na exposição, mas nos exemplos internacionais muitos dos programas educativos integram estes recursos nas atividades, como é o caso da utilização de tablets no Museu Britânico e Museu da Acrópole.

Um outro fator essencial é a adaptação do programa aos diferentes visitantes. Esta adaptação passa, inicialmente, pela formação do serviço educativo do museu, uma vez que a formação dos monitores é essencial para uma comunicação eficaz. Para além da formação, é fundamental a disponibilidade da equipa para a conceção de um plano educativo que tenha em consideração os diferentes tipos de públicos, incluindo os adolescentes. Esta adaptação passa também pelo desenvolvimento de estratégias dinâ- 
micas e diversificadas, que conduzam a diferentes formas de criação de conhecimento e participação, e sejam adaptadas aos diferentes públicos.

Nos programas educativos dos museus selecionados, nacionais e internacionais, é clara a preocupação em adaptar o programa ao público escolar. Nos casos nacionais predominam as atividades ao ensino básico e em menor número ao ensino secundário. Isto deve-se, essencialmente, ao facto de ao longo do $1^{\circ}, 2^{\circ}$ e $3^{\circ}$ Ciclo do ensino básico ser lecionada a disciplina de História, sendo que a partir do Secundário apenas a área de Línguas e Humanidades tem esta disciplina, onde é lecionada, essencialmente, História Contemporânea. Nos casos internacionais, contudo, verifica-se não só um maior número de temáticas, mas também uma maior presença de atividades dedicadas ao ensino secundário.

O último fator essencial é a realização de atividades dinâmicas e diversificadas. Devem-se realizar num clima agradável, de acordo com os interesses do individuo, e com base num processo educativo que permite não só aprender, mas também partilhar. São ações que se baseiam no Modelo Educacional, que tem como objetivo promover a aprendizagem básica da arqueologia e os seus métodos, assim como a importância de proteger e conservar o património arqueológico, e Modelo de Relações Públicas, cujo objetivo é dar a conhecer a popularidade da arqueologia e a sua função na sociedade contemporânea, em que o público é visto como o objeto de intervenção, a quem é necessário comunicar e educar.

O museu PO.RO.S refere a existência de “(...) oficinas de arqueologia, oficinas de mosaicos, oficinas de vestuário romano e oficinas de escrita", o MAC também menciona que "no que respeita aos tipos de atividades podemos destacar(...)as visitas jogo, oficinas de férias, workshops e visitas orientadas" e o MNA "(...) oferece um vasto e diversificado conjunto de ações pedagógico-formativas (vistas orientadas, visitas orientadas com dramatização, ateliês, oficinas, entre outras)". Também no programa educativo do Museu D. Diogo de Sousa e Museu de Foz Côa o mesmo se verifica, diversas iniciativas à base de oficinas, ateliês, jogos, apresentações e visitas guiadas.

Nos programas educativos dos museus internacionais analisados destacam-se atividades similares dedicadas a diversos temas onde se procura explorar não só o acervo, mas também a característica multidisciplinar da arqueologia.

De forma geral, museu nacionais e internacionais se- guem uma estratégia educativa semelhante. A partir destas oficinas, ateliês, workshops e outras atividades procura-se interagir diretamente com o público de uma forma participativa e criativa que promove uma aprendizagem ativa.

Porém, serão estas linhas de acção suficientes para os museus de arqueologia nacionais conseguirem captar o público adolescente? A partir das entrevistas realizadas aos museus é possível verificar que, apesar do seu programa educativo exemplar, a sua captação continua um desafio (Gráfico 1).

O gráfico apresentado mostra que a maioria dos jovens se desloca ao museu no contexto de visitas escolares e em família, sendo que as visitas entre pares ou com amigos e as visitas individuais são pouco ou nada frequentes. O museu PO.RO.S e o MNA identificaram que as visitas em grupo escolar são "bastante frequentes", as visitas em família "frequentes", as visitas entre pares "pouco frequentes" e visitas individuais "nada frequentes". O MAC, por sua vez, identificou que as visitas em grupo, em família e entre pares são "pouco frequentes" e as visitas individuais "nada frequentes". Relativamente às visitas entre pares e as visitas individuais são pouco ou nada frequentes nos três museus, o que consideramos que vai de encontro às investigações de Kelly (2009) e de Cardoso (2013), os jovens não têm interesse em visitar museus fora do contexto escolar excetuando quando o fazem com familiares. Assim, consideramos que é essencial começar a cativar os jovens para a visita entre pares e individual. A segmentação deste público-alvo por "grupo escolar" é importante especialmente devido ao papel educativo, no entanto, observamos também que é necessário começar a encarar este público de uma forma mais específica, em que sejam considerados os seus interesses e necessidades pessoais.

Posteriormente foi colocada a questão de como é avaliada a capacidade do museu em captar o público jovem entre os 13 e os 17 anos (Gráfico 2).

O MAC e o MNA identificaram a capacidade do seu museu como "difícil”, o PO.RO.S foi o único a identificar a sua capacidade como "muito fácil”. Isto deve-se essencialmente ao facto de o museu ser um Centro Interpretativo profundamente interativo enquanto o MNA e o MAC têm um carácter mais tradicional. Consideramos, efetivamente, que a capacidade do museu PO.RO.S em atrair os jovens é superior quando comparada com os restantes museus analisados. 
Contudo, quando questionados pela capacidade da própria arqueologia em captar este público, as respostas foram semelhantes. Os museus acordam que é "difícil" no caso do MNA e MAC e "muito difícil" segundo o PO.RO.S (Gráfico 3).

Consideramos que isto se deve ao facto de os jovens não verem interesse na arqueologia que lhes é apresentada. O que eles veem, por outro lado, é um grande número de peças e objetos arqueológicos espalhados, uns mais interessantes que outros, mas sem contexto e sem uma história visível. Outro fator é que a arqueologia que lhes é apresentada é a real e não a versão fantasiosa. Por outro lado, acreditamos que a arqueologia tem fortes capacidades de cativar os jovens, simplesmente tem de ser apresentada tendo em conta os seus interesses. É importante estabelecer uma ponte entre a arqueologia real a aquela apresentada na cultura popular, mostrar que a arqueologia pode ser imersiva e cativante de uma forma autêntica e ética.

\section{PROPOSTAS PARA CAPTAÇÃO DO PÚBLICO ADOLESCENTE}

Os museus de arqueologia como instituições que visam a proteção, valorização e divulgação do património arqueológico, e os seus serviços educativos, que têm como principal objetivo uma comunicação educativa e o desenvolvimento de estratégias pedagógicas dedicadas a todos os públicos, são agentes imprescindíveis na educação patrimonial juntos dos jovens. No entanto, podemos concluir que os adolescentes são um público que os museus têm vindo a ter dificuldade em cativar. Ainda assim acreditamos que existem procedimentos que podem obter sucesso na sua captação.

Numa primeira fase, acreditamos que uma ação fundamental é começar a dissolver o conceito do museu como uma "instituição aborrecida", formal e pouco convidativa, e começar a divulgar uma imagem mais informal, social e passível de entretenimento. Apostar num museu participativo que passe não só pela conceção da própria exposição e atividades pedagógicas, como também se estenda a todos os funcionários do museu (SIMON 2010). Assim, propomos um contacto próximo entre funcionários, desde monitores a assistentes de sala, e jovens. Comunicar com o jovem não só através das repreensões, muitas vezes necessárias, mas também através da própria exposição ou atividades. Incentivar o jo- vem a dar a sua opinião, a discutir a exposição com os amigos e familiares.

Uma outra proposta é a divulgação mais extensiva do museu e das suas atividades, eventos e projetos. Esta deve ser realizada tanto a nível presencial como à distância, a partir de plataformas digitais. A Festa da Arqueologia realizada pelo Museu Arqueológico do Carmo, por exemplo, tem uma grande capacidade divulgativa junto do público, especialmente por ser gratuita e se realizar num ponto turístico da cidade. A organização de eventos à noite, como as "Noites no Museu" que se têm vindo a desenvolver e outros eventos temáticos, podem ter também uma forte componente divulgativa que fornece ao museu uma imagem mais informal e convidativa.

Propomos também uma abordagem mais direta e pessoal. É importante sair à rua e falar com os jovens sobre o que o museu tem para oferecer, questionálos sobre o que eles gostariam de ver num museu de arqueologia, conhecer os seus interesses e interagir pessoalmente.

Ainda no âmbito da divulgação acreditamos que é também importante inserir o museu no dia-a-dia do adolescente, isto é, introduzir o museu no mundo e realidade dos jovens. Aqui não propomos apenas a utilização das redes sociais como Facebook, Twitter e Instagram, que também podem ser eficazes, mas a utilização de outras plataformas de comunicação digital como o Youtube ou Twitch, que podem ser aplicadas em diversas funções, desde a partilha em direto de um determinado evento a ocorrer no museu, até à criação de pequenos episódios semanais ou mensais que abordam um determinado objeto, exposição ou temática específica relacionada com o museu.

Relativamente às estratégias de comunicação e mediação educativa, propomos a criação de atividades que sejam destinadas especificamente ao jovem, isto é, programas divididos em $1^{\circ}$ e $2^{\circ}$ Ciclo, $3^{\circ}$ Ciclo e Ensino Secundário, isto porque não consideramos viável a conceção de uma atividade que seja destinada a um público que vai desde os 6 aos 18 anos, mas sim atividades segmentadas, concebidas e dedicadas especificamente ao adolescente.

Um outro fator a ter em consideração, aquando do desenvolvimento de estratégias educativas, é o reconhecimento do jovem como um membro ativo da sociedade. Assim, propomos um incentivo ao desenvolvimento de projetos nos museus criados pelos próprios jovens, como se sucedeu com o pro- 
jeto Londinium $2012^{3}$ em que os jovens criaram e desenvolveram o seu próprio projeto com base na coleção Romana do Museu de Londres. Um projeto semelhante nos museus nacionais podia ser igualmente interessante e eficiente na captação deste público. Para a sua realização é, contudo, importante que haja algum tipo de compensação que motive os jovens. Como por exemplo a facultação de um passe combinado para transportes ou reembolso dos custos de deslocação, um certificado do próprio museu e, essencialmente, a oportunidade de partilharem os seus projetos com a comunidade através de uma exposição temporária ou um evento social.

Dentro deste âmbito também sugerimos a integração dos adolescentes na própria orgânica do museu, à semelhança da Junction Youth Panel ${ }^{4}$ do Museu de Londres, permitindo que um grupo de jovens não só desenvolva projetos, em cooperação com o museu e serviços educativos, como também partilhe as suas ideias, perspetivas e estratégias.

Relativamente aos programas educativos propomos a realização de atividades mais diversificadas, interativas e desafiantes. É importante conceber projetos em que os jovens possam manipular a sua própria experiência museal, com base nos seus interesses e temáticas. Os ateliês, oficinas e jogos são boas estratégias, porém é necessário diversificar a oferta educativa. Para além destas atividades, seria interessante incorporar debates temáticos em torno de questões recentes, mas com ligação ao passado, e que incentivem a participação do jovem, como concursos de arte, fotografia ou até de curta-metragem relacionados com a exposição do museu, dando posteriormente oportunidade de partilhar os resultados com a comunidade. Dentro dos programas propomos também abordagens ligadas à cultura popular da arqueologia, isto é, atividades que permitam criar paralelos entre os filmes, séries televisivas ou videojogos e, simultaneamente, desmistificar a imagem que os jovens têm da arqueologia.

Quanto aos recursos didáticos sugerimos também

3. Projeto criado e desenvolvido por cerca de 100 jovens londrinos, com o objetivo de dar a conhecer uma nova perspetiva da coleção Romana do Museu de Londres (GUARDIAN, 2012).

4. Um grupo de jovens consultantes que trabalha em conjunto com o Museu de Londres para assegurar que os diferentes projetos, eventos e exposições atarem os jovens (SHRAPNEL, 2012). uma diversificação, não só a nível expositivo, mas também relativamente aos recursos utilizados nas atividades dirigidas a públicos específicos. A integração de réplicas manuseáveis na exposição, a utilização de tablets, máquinas fotográficas ou telemóveis como parte da atividade pedagógica, ou a criação de uma plataforma online, seja um blog ou website, são recursos que captam a atenção do adolescente, especialmente se forem utilizados em contexto de exposição ou atividade. Os recursos de caráter tecnológico e inovador têm especial impacto na captação deste público, não só porque se trata de uma geração que tem crescido num ambiente rodeado de tecnologia, mas também porque os próprios recursos são interativos e imersivos. Nos museus que tenham a oportunidade, consideramos viável a integração destes tipos de recursos, que podem ir de simples maquetes e quadros interativos a salas imersivas de realidade aumentada.

A terminar, propomos uma exploração mais intensiva da característica multidisciplinar da arqueologia, assim como a sua importância para a sociedade de hoje. É essencial apresentar a arqueologia e a visita ao museu arqueológico não só como um complemento escolar, mas também como um local passível de adquirir novos conhecimentos, de modo a que o jovem crie uma ligação e, sucessivamente, sinta a necessidade de proteger e valorizar esse mesmo património. No desenvolvimento destas propostas não foram negligenciados os aspectos burocráticos, como a carência de funcionários dos serviços educativos de alguns museus, ou o baixo financiamento da maioria dos museus públicos. Contudo, muitas das sugestões podem ser postas em prática, essencialmente aquelas dirigidas à adaptação e realização de estratégias educativas dedicadas especificamente ao público adolescente.

\section{CONSIDERAÇÕES FINAIS}

Ao longo das últimas décadas os museus de arqueologia têm demonstrado uma forte evolução não só a nível educativo e comunicativo, mas também como espaços de entretenimento cada vez mais diversificados e inclusivos. Ainda assim, são poucos os adolescentes que visitam estes museus por iniciativa própria e como forma de entretenimento pessoal, não apenas devido á existência de uma grande panóplia de locais que vão mais de acordo com os seus interesses, mas também porque não encaram o museu 
e as suas exposições como um local de socialização. Por outro lado, os próprios museus não consideram os adolescentes como um grupo de indivíduos com interesses e necessidades específicas, que não se enquadram no público infantil nem no público adulto. Apesar das dificuldades de captar este público, acreditamos que os museus de arqueologia detêm as ferramentas necessárias para criar ofertas atrativas e determinantes no aumento destes visitantes. São espaços preparados para receber o público, são versáteis do ponto de vista temático e formados por equipas de profissionais qualificados na adaptação da mensagem científica e na criação de projetos e atividades. As realizações destas atividades não só são fundamentais na aprendizagem não-formal, como têm forte influência na imagem do museu. Com efeito, as apostas em projetos inovadores têm impacto na imagem transmitida aos adolescentes, são ações que dão ao museu uma representação mais juvenil e menos formal que o afasta de uma imagem meramente educativa, tornando-o, aos olhos do jovem, num espaço menos aborrecido e mais interativo.

Assim, consideramos que existem três soluções fundamentais para a baixa procura por parte dos adolescentes. Variar nas formas de divulgação e difundir a imagem do museu como um local de entretenimento informal, reconhecer o público adolescente como um novo tipo de público e, fundamentalmente, diversificar a oferta educativa para os adolescentes entre os 13 e os 17 anos.

A concluir, é de grande importância que exista uma preocupação com a educação e captação do público jovem no contexto dos museus arqueológicos. A adolescência, por ser uma fase de transição, é um período fundamental na formação do adulto e, com efeito, a altura ideal para fomentar o conceito e importância da valorização e proteção do património arqueológico. A captação deste público é também um importante fator para o museu, uma vez que não só implica o aumento das visitas, mas também pode causar impactos positivos no ciclo da instituição.

\section{BIBLIOGRAFIA}

ALMANSA SÁNCHEZ, Jaime (2011) - Arqueologia para todos los publicos. Hacia de una definición de la arqueologia publica "a la española". In Arqueweb: Revista sobre arqueologia en Internet, Vol. 13, pp. 87-107.

ALMEIDA, A. (2005) - O contexto do visitante na experiência museal: semelhanças e diferenças entre museus de ciência e de arte. In História, Ciências, Saúde. Vol. 12, pp. 31-53.
ANDERSON, D.; HORLOCK, N.; JACKSON, T. (2000) - Testing the Water: Young people and galleries. Liverpool University Press: Liverpool.

ANTAS, Mário (2013) - A Comunicação Educativa como factor de (re)valorização do Património Arqueológico: Boas Práticas em Museus de Arqueologia Portugueses. Dissertação de doutoramento em Museologia apresentada à Universidade Lusófona de Humanidades e Tecnologias.

BAHN, Paul (1997) - Arqueologia. Uma breve introdução. Gradiva: Lisboa.

BIRKETT, Dea (2012) - Kids in Museums. In MENDES, Luis (org.) - Reprograme Comunicação, Branding e Cultura numa nova era de museus, Vol. 1, pp. 118-122.

CARDOSO, Cristina (2013) - Jovens, Museus e Redes Sociais: Intervir em prol da relação através de um serviço educativo. Dissertação de mestrado em Ciências da Educação apresentada à Faculdade de Psicologia e de Ciências da Educação da Universidade do Porto.

COLOMER, Laia (2002) - Educational facilities in archaeological reconstructions: Is a image worth more than a thousand words. In: Public Archaeology, Vol. 2, pp. 85-94.

CRACKNELL, Stephen, CORBISHLEY, Mike (1986) - Presenting archaeology to young people. Council for British Archaeology: Research Report $\mathrm{Nr}^{\circ} 64$.

FAUSTINI, Marcus (2012) - A relação entre museus e jovens. In MENDES, Luis (org.) - Reprograme Comunicação, Branding e Cultura numa nova era de museus, Vol. 1, pp. 123-129.

GUARDIAN (2012) - Museum of London - Junction - Introducing the Museum of London's youth panel. The Guardian: https://www.theguardian.com/culture-professionalsnetwork/culture-professionals-blog/2012/mar/13/museums-junction-engage-young-people. Acedido a o8, Julho, 2020.

HOLTORF, Cornelius (2004) - Doing Archaeology in popular culture. In The Interplay of the Past and Present, Lund University, pp. 41-49.

JAMESON JR, Jonh; BAUGHER, Sherene (2007) - Past Meets Present archaeologist partnering with Museum Curators, Teachers, and Community Groups. Springer: New York.

KELLY, Lynda; BARTLETT, Allison (20o9) - Young People and Museums. Acedido a 11, Junho, 2020 em: https://australianmuseum.net.au/young-people-and-museums

KORN, R. (2008) - Audience Research: Young Adult Study. Randi \& Korn Associates: Boston.

LOURENÇO, Andreia Vale (2014) - Reflexões sobre diversidade de representações de públicos e de estratégias interpretativas. In: MIDAS: Revista Online, Nroำ 4, pp. 213.

MATSUDA, AKIRA (2004) - The Concept of "the Public" and the Aims of Public Archaeology. In Papers from the Institute of Archaeology, Vol. 15, UCL: Institute of Archaeology, pp. 66-74. 
MATSUDA, Akira (2016) - A consideration of public archaeology theories. In: Public Archaeology, Vol. 15, pp. 15, pp. 40-49.

MCCARTHY, C., MANSON, D. (2006) - The feeling of exclusion: young people's perceptions of art galleries. In $\mathrm{Mu}$ seum Management and Curatorship, Vol. 21, Nrº. 1, pp. 20-31.

RAMALHO, Maria Magalhães (1993) - O arqueólogo, o público, o passado e os seus amantes. In: Almadan: IIo Série, $\mathrm{Nr}^{2}$ 2, pp. 5657 .
SANTOS, Joana Cristina (2014) - Públicos dos museus: um estudo qualitativo sobre as visitas em família: o caso do Museu da Eletricidade. Dissertação de mestrado em Gestão e Estudos da Cultura apresentada ao Instituto Universitário de Lisboa.

SHRAPNEL, Emma (2012) - Engaging Young adults in the museums An Audience Research Study. Acedido a 11, Junho, 2020 em: https://australianmuseum.net.au/document/ engaging-young-adults-in-museums

SIMON, Nina (2010) - The Participatory Museum. MUSEUM: California.

\begin{tabular}{|c|c|}
\hline Casos Internacionais & Resumo Programa de Atividades \\
\hline Museu Britânico & $\begin{array}{l}\text { - Atividades de contexto escolar ( } 3 \text { aos } 16 \text { anos } />16 / \text { necessidade especiais. } \\
\text { - Ateliê de Culturas e Contextos Históricos }(3 \text { aos }>16) \\
\text { - Ateliês de Tópicos específicos (arqueologia/arte/etc) }(3 \text { aos }>16) \\
\text { - Londinium } 2012 \\
\text { - Junction Youth Panel }\end{array}$ \\
\hline Museu da Acrópole de Atenas & $\begin{array}{l}\text { - Visitas temáticas e orientadas }(7 \text { aos }>16) \\
\text { - Ateliês, Workshops e Jogos Lúdicos }(7 \text { aos }>16)\end{array}$ \\
\hline $\begin{array}{l}\text { Jorvik - Centro Viking (Parque Arqueológico de York, Reino } \\
\text { Unido) }\end{array}$ & $\begin{array}{l}\text {-Workshop Periodo Viking/Anglo-saxónico (Público em geral) } \\
\text { - Escavações / Manuseamento de Material (Público em geral) }\end{array}$ \\
\hline $\begin{array}{l}\text { Parque Nacional do Património Irlandês (Parque } \\
\text { Arqueológico) }\end{array}$ & $\begin{array}{l}\text {-Workshops educacionais (Público escolar) } \\
\text { - Visitas Guiadas (Público em geral) } \\
\text { - Atividades temáticas (Público em geral) } \\
\text { - "The Big Dig" (+ } 10 \text { anos) }\end{array}$ \\
\hline
\end{tabular}

Tabela 1 - Resumo do Programa de atividades dos Casos de Estudo Internacionais Selecionados.

\begin{tabular}{|c|c|}
\hline Casos Nacionais & Resumo Programa de Atividades \\
\hline Museu Arqueológico do Carmo (MAC) & $\begin{array}{l}\text { - Atividades temáticas (6 aos } 18 \text { anos) } \\
\text { - Visitas Jogo (6 aos } 18 \text { anos) } \\
\text { - Atividades de Arqueologia (6 aos } 15 \text { anos) } \\
\text { - Festa da Arqueologia }\end{array}$ \\
\hline Museu Regional de Arqueologia D. Diogo de Sousa & $\begin{array}{l}\text { - Visitas temáticas à exposição permanente ( } 3 \text { aos } 14 \text { anos) } \\
\text { - Oficinas lúdico-pedagógicas ( } 3 \text { aos } 14 \text { anos) } \\
\text { - Histórias e Contos ( } 3 \text { aos } 7 \text { anos) } \\
\text { - Jogos lúdico-pedagógicos ( } 8 \text { aos } 18 \text { anos; Ensino Profissional) } \\
\text { - Ludi-Saeculares. }\end{array}$ \\
\hline Museu Portugal Romano em Sicó (PO.RO.S) & $\begin{array}{l}\text {-Visitas Orientadas (6 aos } 18 \text { anos) } \\
\text { - Visitas Temáticas (6 aos } 18 \text { anos) } \\
\text { - Exposição tecnológica e interactiva. }\end{array}$ \\
\hline
\end{tabular}

Tabela 2 - Resumo do Programa de atividades dos Casos de Estudo Nacionais Selecionados. 
Frequência e Contexto da Visita

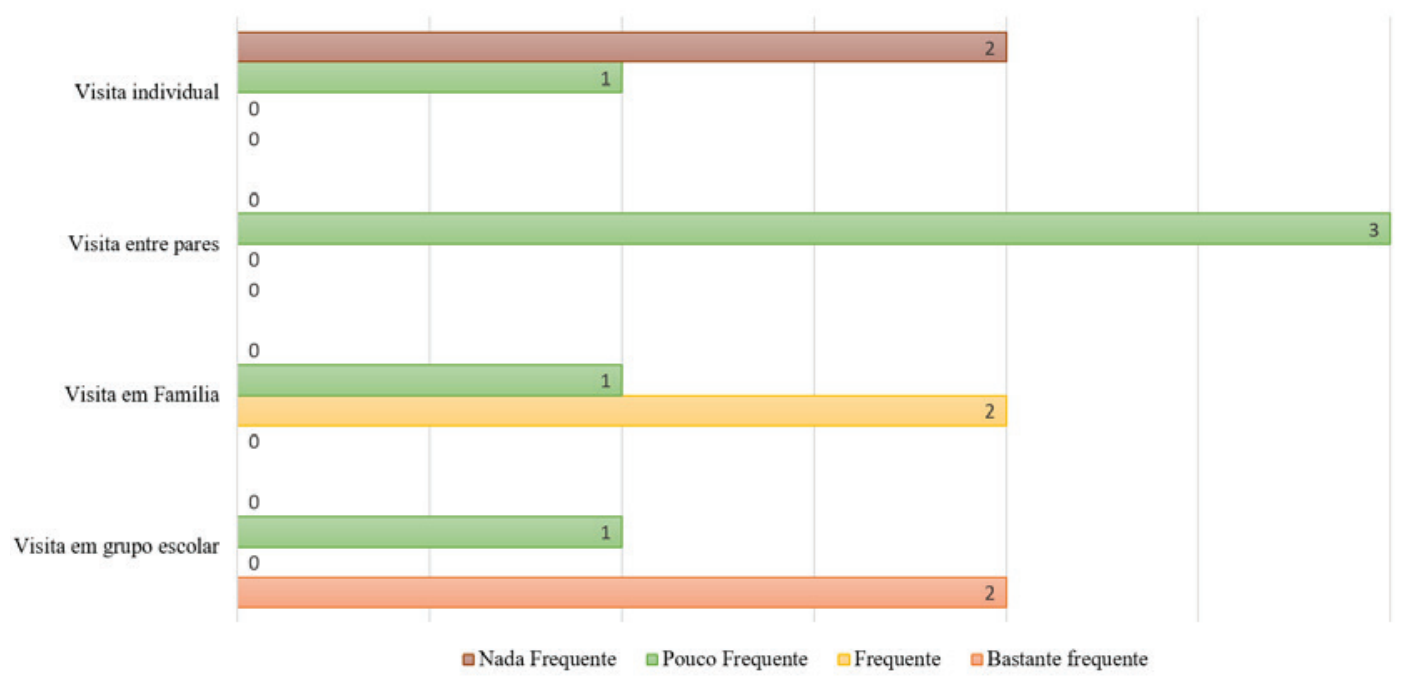

Gráfico 1 - Frequência e contexto em que os jovens entre os 13 e os 17 visitam os museus em estudo.

\section{Capacidade do Museu}

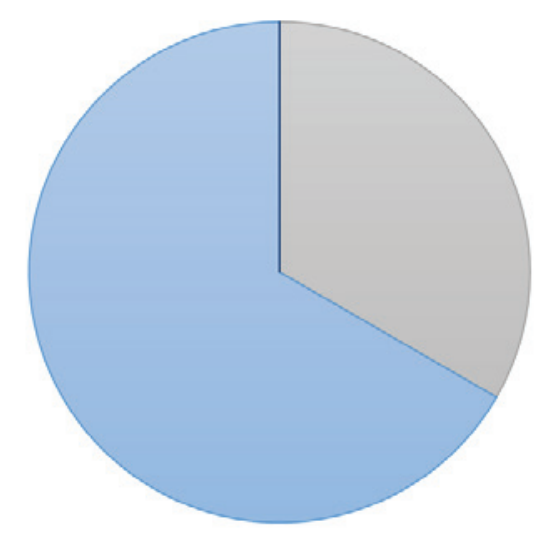

$\square$ Fácil $\square$ Muito Fácil $\square$ Dificil $\square$ Muito Dificil

Gráfico 2 - Capacidade dos museus em estudo em captar o público entre os 13 e os 17 anos.

\section{Capacidade da Arqueologia}

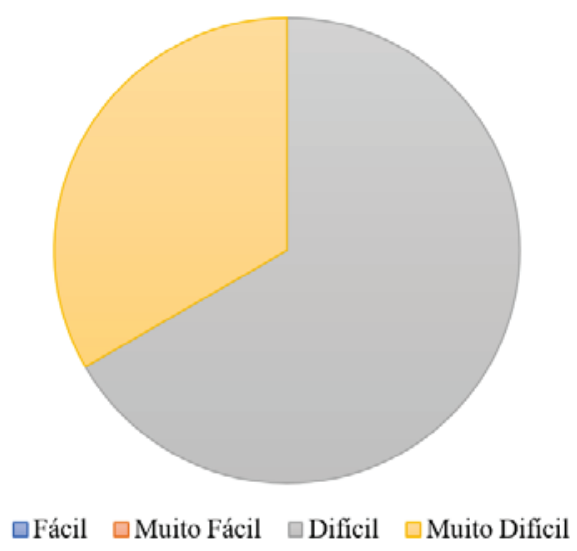

Gráfico 3 - Capacidade da arqueologia na captação do público jovem entre os 13 e os 17 anos. 


\title{
O MUSEU UNIVERSITÁRIO COMO MEDIADOR ENTRE A CIÊNCIA E A SOCIEDADE: O EXEMPLO DA SECÇÃO DE ARQUEOLOGIA NO MUSEU DE HISTÓRIA NATURAL E DA CIÊNCIA DA UNIVERSIDADE DO PORTO (MHNC-UP)
}

\author{
Rita Gaspar ${ }^{1}$
}

\begin{abstract}
RESUMO
Os museus universitários têm uma responsabilidade acrescida na posição de mediadores entre a produção de conhecimento científico e a sua transferência para os diferentes públicos. Ainda que inicialmente mais centralizados no apoio ao ensino, atualmente têm uma missão mais alargada de transferência de conhecimento produzido na academia para a comunidade onde se inserem. Serão aqui apresentados alguns exemplos de abordagens desenvolvidas na secção de Arqueologia e Etnografia do Museu de História Natural e da Ciência da Universidade do Porto ao longo da história da instituição.

Palavras-chave: Museu universitário, Coleções arqueológicas, Transferência de conhecimento.
\end{abstract}

\begin{abstract}
University museums have an increased responsibility, as mediators between the production of scientific knowledge and its transfer to different audiences. Although they were initially more focused on supporting teaching activities, currently they have the broader mission of transferring knowledge produced in university to the community where they operate. Will be presented some examples of approaches developed in the Archaeology and Ethnography section of the Natural History and Science Museum of the University of Porto throughout the institution's history.

Keywords: University museum, Archaeological collections, Knowledge transfer.
\end{abstract}

\section{INTRODUÇÃO}

Os museus, enquanto instituições detentoras de coleções, articulam a salvaguarda do património com a comunicação do mesmo (Bruno, 1997). Aliam a produção e sistematização do conhecimento, independentemente da disciplina representada, à salvaguarda dos resultados e processos e sua comunicação, numa multiplicidade de formas. O potencial de intervenção dos museus é, pois, bastante vasto.

O envolvimento dos museus com o seu público cria um incentivo à participação, criando uma sociedade mais sensibilizada e empenhada. O seu papel transformador e de responsabilidade social é de extrema importância e deve ser tido em conta aquando da interação com as comunidades. Os museus universitários, apesar das suas especificidades, não são uma exceção. Efetivamente, os museus universitários, ainda que no seio de uma instituição de ensino, têm hoje uma missão mais alargada, também de envolvimento com as comunidades onde se inserem e com os públicos que as visitam.

O Museu de História Natural e da Ciência da Universidade do Porto (MHNC-UP) foi constituído for- 
malmente em 2015, resultando da unificação do Museu de História Natural (MHNFCP) e do Museu da Ciência (MCFCP) da Faculdade de Ciências da Universidade do Porto. Ainda que o MCFCP tenha sido criado apenas em 1996 o MHNFCP resultou da união dos quatro museus-laboratórios da Faculdade de Ciências, criada em 1911. Estes museus de departamento, o Museu e Laboratório de Antropologia, o Museu de Zoologia, o Museu do Instituto de Botânica Gonçalo Sampaio e o Museu de Mineralogia e Estratigrafia, eram detentores de importantes coleções, tendo tido um papel fundamental no apoio ao ensino no seio da academia.

Iremos centrar este artigo no papel que este museu universitário, nomeadamente as coleções de Arqueologia da secção de Arqueologia e Etnografia, teve ao longo dos tempos, no envolvimento entre a universidade e o público, num esforço de divulgar e promover a ciência.

\section{MUSEU UNIVERSITÁRIO - MISSÃO TRIPARTIDA}

As universidades foram das primeiras instituições públicas a acolher coleções. Entre elas surge o exemplo do Ashmolean Museum da Universidade de Oxford, aberto no século XVII e tido como o mais antigo museu universitário (Simpson, 2019). Através das coleções, constituídas na sua maioria para utilização em ambiente de ensino, a universidade conseguia cumprir o seu principal propósito de transmitir conhecimento, ainda que apenas a uma pequena franja da sociedade. Ao longos dos tempos, a democratização do ensino alargou também o âmbito da comunicação de conhecimento e os museus universitários encontram-se agora abertos a vários públicos, promovendo o envolvimento das comunidades em que se inserem, mas também inserindo-se nas dinâmicas associadas aos grandes movimentos turísticos do século XXI.

Como tão bem refere Simpson (2019), os museus universitários têm uma missão tripartida que define, atualmente, a sua atuação:

-Ensino, transmissão de conhecimento. Este processo poderá ser, ou não, apoiado em objetos e coleções. No entanto, a utilização de objetos incrementa o potencial de compreensão da mensagem por parte do recetor, ao mesmo tempo que multiplica as abordagens possíveis aos temas a explorar. As coleções podem inclusive ser utilizadas em abordagens multidisciplinares, em cenários de ensino formal, mas também em ensino informal.

- Investigação, geração de conhecimento. As coleções universitárias têm vindo a ser revisitadas, sendo excelentes repositórios para a ciência atual. As aproximações e abordagens são constantemente atualizadas o que permite um incremento da produção de conhecimento a partir das coleções. O cruzamento de disciplinas potencia, inclusive, a obtenção de resultados extraordinários. As coleções biológicas arqueológicas, nomeadamente, estão a ser utilizadas na caracterização da população humana antiga a nível molecular e das suas dinâmicas, com grande sucesso. Estas coleções devem estar, com as devidas questões da salvaguarda da sua integridade asseguradas, acessíveis para a aplicação de novos métodos e técnicas científicas, de forma a responder a novas questões que agora se colocam.

- Envolvimento e impacto na sociedade. Existem vários exemplos de estratégias levadas a cabo pelos museus universitários de modo a potenciar o envolvimento da comunidade. Em Portugal muito se tem feito também e é fundamental que os museus universitários se assumam enquanto os mediadores entre a comunidade científica, que produz conhecimento nas universidades, e os diferentes públicos. O seu papel é traduzir este conhecimento, associado a uma linguagem mais técnica, e torná-lo acessível aos diferentes públicos. O museu universitário tem ainda a especial missão de "apresentar" a universidade à comunidade. Algumas universidades desenvolveram, inclusive, a sua identidade distintiva recorrendo ao património existente nos seus próprios museus (Simpson, 2012). O museu universitário pode, hoje, constituir-se como um mediador entre a instituição e os públicos (geral ou especializado), salientando a importância da investigação e ações que enceta e promovendo a fruição do seu património.

Expressa na Declaração de Halle, de 16 de abril de 20oo, elaborada por representantes de 12 universidades europeias, está a importância das coleções universitárias, apresentadas como "recursos ativos para o ensino e investigação" e "arquivos históricos únicos e insubstituíveis". No mesmo documento assume-se o potencial de utilização destas coleções junto de um público mais alargado, constituindo 
como testemunhos do papel das universidades na "definição e interpretação da nossa identidade cultural" (https://www.universeum-network.eu/ the-declaration-of-halle/).

\section{1. $O$ ensino no seu código genético}

A utilização de coleções no processo de transmissão de conhecimentos facilita a compreensão de conceitos que de outro modo poderiam permanecer abstratos. A observação do objeto tridimensional, a possibilidade de observação de séries e a integração dos objetos em contextos, possibilitadas pelas coleções de museu, aumentam o potencial pedagógico das mesmas, independentemente do objetivo da sua constituição.

De acordo com Simpson (2012), o envolvimento com o objeto continua a ser uma estratégia fundamental no processo de aprendizagem. $\mathrm{O}$ autor afirma mesmo que é na sua capacidade de estabelecer ligações entre distintas áreas de saber que reside o elevado potencial pedagógico dos objetos (Simpson, 2019). As coleções dos museus universitários são, na generalidade dos casos, iniciadas com o objetivo de apoiar o ensino e a comunidade académica. Alguns casos existem também de constituição com base em coleções de gabinetes de curiosidades (Gil, 2005). De qualquer modo, as coleções refletem também a história da instituição detentora e, no caso que aqui iremos destacar, o modo como a própria instituição interagiu com os seus diferentes públicos e utilizadores.

Enquadrados numa universidade, os museus que constituem atualmente o MHNC-UP estavam intimamente ligados aos sectores de ensino e investigação da Faculdade de Ciências (Gil, 2005). As coleções que inicialmente os constituíam encontram-se muito vocacionadas para o ensino, numa perspetiva de representação dos conteúdos lecionados. A secção de Arqueologia e Etnografia não é exceção, como veremos, ainda que a componente da investigação esteja fortemente representada.

\section{CONSTITUIÇÃO DAS COLEÇÕES}

Tendo em conta a necessidade de resposta aos três tipos de público, tão distintos entre si (público geral, estudantes e investigadores), são também constituídos diferentes tipos de coleções nos museus universitários (Gil, 2005). Também no MHNC-UP este processo está bem patente no devir da instituição. A par da seleção de exemplares emblemáticos e bem conservados para apresentação pública, nomeadamente em exposição, constituíram-se coleções de ensino, que incluíam, com grande frequência, réplicas e modelos de determinados exemplares e mesmo material didático bidimensional como slides de projeção ou "reportagens". As coleções científicas foram constituídas de acordo com os projetos a decorrer, sendo hoje em dia bastante procuradas por investigadores nacionais e estrangeiros para a integração em novos estudos e análises. Estas coleções de Arqueologia foram sendo revisitadas ao longo de décadas e estão hoje referenciadas nas mais atuais dinâmicas de investigação como sejam a domesticação de espécies animais ou o estudo de população humana antiga, através de ADN ou isótopos.

Á semelhança do que acontece noutros museus universitários, a génese das coleções é também diversa no MHNC-UP. De entre os vários casos possíveis, incluindo a integração de instituições ou a herança de coleções que posteriormente levam à criação de museus, o MHNC-UP surge de um longo processo ao longo do qual os vários departamentos e institutos criaram os seus próprios museus. Efetivamente, uma parte das coleções foi constituída com o objetivo de transmitir o conhecimento científico, com um propósito didático. Criada em 1911, a Universidade do Porto, partindo da estrutura da anterior Academia Politécnica, dotou-se de algumas infraestruturas com vista a apoiar o ensino. Entre elas o Museu e Laboratório de Antropologia, criado por António Mendes Correia. No caso das coleções arqueológicas, elas surgem no contexto do Museu e Laboratório de Antropologia, criado por António Mendes Correia em 1912, imediatamente na sequência da reforma universitária de 1911, e do Instituto de Antropologia, criado um pouco mais tarde, em 1923.

Inicialmente mais vocacionado para a Antropologia biológica, rapidamente o acervo do museu compreendeu também coleções de Arqueologia e Etnografia. É notória a preocupação de adquirir elementos que ajudassem a estruturar a narrativa pedagógica, ainda que muitas das aquisições cumprissem uma função dupla, também de comunicação com o público. Serão aqui apresentados alguns exemplos.

\subsection{Modelos e réplicas}

Os modelos e réplicas foram, desde sempre, um recurso ao serviço do ensino tanto na Academia Politécnica como na Universidade do Porto (Vieira et al., no prelo). A produção ou aquisição destes elemen- 
tos permitia, por um lado, ter no museu peças que, de outro modo, não estariam disponíveis (como sejam, por exemplo, réplicas de fósseis humanos ou de arte rupestre móvel e parietal) e, por outro lado, ilustrar conceitos (como seja o caso do Homo afer taganus). A existência destas peças permitiu que durante todo o século XX, e ainda hoje, os diferentes públicos tivessem acesso a este tipo de património. A aquisição destes elementos a diversos comptoires é complementada pela execução de réplicas, realizadas internamente.

Ainda da fase da Academia Politécnica é possível identificar réplicas em gesso de dois machados de pedra polida, cuja etiqueta faz a referência a Estácio da Veiga. No entanto, a quase totalidade dos modelos e réplicas foi adquirida a partir da década de 1920, já no âmbito da Universidade do Porto. Um dos conjuntos mais antigos corresponde ao das réplicas em gesso, realizadas internamente, a partir do conjunto arqueológico recolhido pelos padres Rafael Rodrigues e José Brenha em Carrazeda do Alvão em 1895 (Rodrigues, 1895). Trata-se de um conjunto de figuras zoomórficas e antropomórficas, bem como algumas placas com gravuras e a designada escrita do Alvão. Terá sido realizado por volta de 1927, indicação patente em alguns dos moldes em gesso. Desta fase surge ainda uma réplica de uma pequena placa gravada de Glozel (França), sítio que foi utilizado à época como referência para no polémico estudo da escrita do Alvão.

Da década de 1930 existe um conjunto, também de réplicas em gesso, de pegadas, digitações e alguma arte rupestre de grutas como sejam Tuc d'Audoubert e Bedeilhac. Este conjunto foi oferecido por Henri Begouen.

Ainda na mesma década, na sequência das escavações arqueológicas realizadas nos sítios de Muge, Mendes Correia encomenda um modelo do seu Homo afer taganus ao artista madeirense Agostinho Rodrigues (Figura 1), materializando assim a sua teoria relativamente à presumível nova espécie humana identificada no nosso território (Vieira et al., no prelo). Efetivamente, as réplicas integradas na temática da evolução humana são em grande número, tendo sido adquiridas desde a década de 1950. Permitiam aos diferentes utilizadores do museu a observação das características distintivas ao nível sobretudo do crânio de cada fóssil humano representado. Inicialmente vocacionadas para o ensino da evolução humana, estas réplicas vão sendo atualizadas ao ritmo das atualizações técnicas da sua produção bem como ao ritmo das descobertas científicas realizadas, e no último quartel do século XX é colocada em exposição no museu uma secção de evolução humana, onde se integra também um painel com as pegadas de Laetoli e um conjunto de réplicas do fóssil diretor Australopithecus afarensis conhecido por Lucy. A última aquisição realizada, em 2019, foi uma réplica do esqueleto conhecido como Neo, o mais completo identificado como Homo naledi. A preocupação da atualização de conteúdos de acordo com a produção científica atribui a esta coleção um verdadeiro efeito mediador entre a ciência e o público.

Um outro conjunto considerável de réplicas, adquiridas, mas igualmente produzidas internamente, remete para utensílios em pedra lascada, pedra polida ou indústria óssea pré-histórica. Mais uma vez, nas réplicas adquiridas, estão representados elementos provenientes de jazidas emblemáticas como La Madeleine, Le Moustier ou Koobi Fora. Apenas na década de 1980, já após a reestruturação do museu posterior ao incêndio de 1974, são incorporadas réplicas de materiais de cronologia romana, como sejam fíbulas, lucernas e aras votivas, provenientes do Museu Monográfico de Conimbriga.

Ainda que atualmente se privilegie o original em detrimento da réplica, os modelos conhecem uma nova valorização. O hiper-realismo conseguido por alguns artistas especializados na representação dos vários elementos da grande família humana permite transmitir o conhecimento de um modo único e próximo do público. Tomamos como exemplo os modelos recentemente adquiridos para a futura exposição permanente do MHNC-UP, de Kennis e Kennis Reconstructions. Estes modelos surgem como um excelente modo de aproximar a ciência e o cidadão.

\subsection{A coleção Museus de Berlim}

O exemplo da Coleção Museus de Berlim é paradigmático no que refere á utilização de objetos e coleções no ensino universitário, paralelamente ao engajamento da comunidade e à construção de uma identidade de grupo.

Esta coleção foi constituída em 1925 em Berlim, através de uma recolha junto dos Staatliche Museen zu Berlin - Museus Estatais de Berlim, sob coordenação do arqueólogo Walter Andrae. Este processo decorre de uma longa negociação diplomática entre os estados Português e Alemão, na sequência do aprisionamento do navio Cherusquia que transportava 
a coleção resultante das escavações de Assur, entre outros, em 1916. Este episódio, que levou á participação de Portugal na $1^{\underline{a}}$ Guerra Mundial, é sobejamente conhecido (Morais; Gaspar; Reis, 2019). Em 1926, após acordo entre os estados, decorre a troca da coleção de Assur por uma coleção de estudo com peças que, segundo as palavras de Walter Andrae, representassem "bons exemplos das linhas históricas” (Cholidis, 2019). Esta coleção marcadamente didática, recolhida dos vários museus estatais de Berlim, chega ao Porto em 1927 e é imediatamente integrada no Museu de Arqueologia Histórica da Faculdade de Letras da Universidade do Porto (FLUP). Posteriormente, em 1940, foi transferida para a Faculdade de Ciências (FCUP) e integrada no Museu de Antropologia, na sequência do encerramento da $1^{\underline{a}}$ FLUP. Em ambas as faculdades a coleção foi utilizada como apoio às aulas. Nesta coleção, arqueológica e etnográfica, existem conjuntos provenientes dos cinco continentes sendo representativos de algumas culturas como sejam a azteca e chiriqui da Meso-América, da Mesopotâmia, do antigo Egipto entre muitas outras. A subcolecção egípcia (Figura 2), especificamente, tem um papel especial na identidade da universidade. Qualquer aluno que se tenha formado nas últimas décadas na FCUP se lembra da visita de estudo realizada à coleção. De tal modo a Coleção Museus de Berlim e a sua história pertencem ao ADN da Universidade do Porto que esta foi selecionada para a realização de uma exposição temporária (2019/2O2O) - Culturas e Geografias - comemorativa do centenário da primeira FLUP. Esta coleção é um perfeito exemplo do envolvimento de uma comunidade em torno de uma coleção museológica.

\subsection{A coleção de Muge}

Outra coleção emblemática do MHNC-UP é a coleção de Muge, que reúne vários sítios mesolíticos. Decorrente das intervenções dirigidas por Mendes Correia na década de 1930, esta coleção detém um extenso conjunto de indivíduos de cronologia mesolítica, a par de restos faunísticos e um alargado conjunto de indústria lítica. Foi uma coleção constituída a partir de um processo de investigação, tendo sido revisitada por várias gerações de investigadores desde a sua entrada no Museu de Antropologia, atual MHNC-UP. Ainda hoje é frequentemente procurada por investigadores de diferentes áreas disciplinares, com novas questões e metodologias de trabalho. Exemplo de que estas coleções nunca se esgotam em termos de abordagem é o trabalho que tem vindo a ser desenvolvido por Rita Peyroteu Sterna (2016) recorrendo a estudos moleculares para caracterizar esta população humana antiga.

Também a Coleção Baixo Sabor, incorporada no MHNC-UP em 2015, é frequentemente requisitada para investigação. Compreende a componente bio-arqueológica (esqueletos humanos, restos faunísticos e restos antracológicos e carpológicos) resultante das escavações arqueológicas no vale do Sabor entre 2008 e 2014. Entre os inúmeros estudos que têm sido realizados e publicados salientamos o exemplo de Alice Toso (2018), que, partindo da análise de isótopos, aborda a questão da dieta alimentar destas populações e a implicação desta na organização socio-cultural das comunidades. Os resultados destes estudos facilmente poderão ser divulgados junto do público não especializado utilizando o museu como mediador do processo de transmissão de conhecimento.

\section{ACESSIBILIDADE DE COLEÇÕES}

O acesso ás coleções é uma das questões mais prementes. Pretende-se que as coleções fiquem acessíveis aos diferentes tipos de público de modo a potenciar as leituras construídas e a fomentar respostas criativas nas gerações futuras. Desde 2016 que o MHNC-UP integra a Portuguese Research Infrastruture of Scientific Collections - PRISC (https:// www.prisc.pt/) tendo como parceiros o Museu Nacional de História Natural e da Ciência da Universidade de Lisboa e o Museu de Ciência da Universidade de Coimbra. Os três museus universitários estão comprometidos com a preservação e acessibilidade das coleções científicas portuguesas.

Neste âmbito tem sido realizada uma recuperação das reservas e das coleções, com respetivo acondicionamento dos objetos e coleções seguindo as normas atuais. Os inventários encontram-se em fase de atualização e revisão, de modo a incrementar a utilização pelo público geral e investigadores. Este processo de reestruturação, que também implica a digitalização de coleções, permite generalizar o acesso aos objetos e potenciar as abordagens de estudo e usufruto das coleções. Esta profunda reestruturação da organização das coleções arqueológicas e etnográficas no MHNC-UP tem permitido uma atualização da estrutura das coleções de acordo com os parâ- 
metros normalizados utilizados por outros museus. Desde então foi possível aumentar o número de estágios curriculares, mestrados, doutoramentos e estudos realizados com base nas coleções do MHNC-UP, alargando as possibilidades de acesso da comunidade académica. A realização de empréstimos para exposições temporárias ou ações de divulgação pontuais são outro modo de transmitir conhecimento científico. É disso exemplo o protocolo de empréstimo temporário (2018-2020 e 2020-2022) da coleção proveniente do megalitismo do Crato, recolhida por Agostinho Farinha Isidoro. Estabelecido entre a Universidade do Porto e o Município do Crato, este protocolo tem tornado possível à população desse município tomar contacto e usufruir de um conjunto de materiais pré-históricos que de outro modo lhes estaria geograficamente distante. Este tipo de soluções tem sido replicado com outras entidades, fazendo com que o património do MHNC-UP se torne veículo de transmissão de conhecimento fora de portas.

\section{ENVOLVIMENTO COM A COMUNIDADE - ATIVIDADES DE DIVULGAÇÃO}

Inscrita na missão do MHNC-UP integra-se também a promoção da cultura científica. Como tal, nestes últimos anos têm sido realizadas várias atividades, desenvolvidas tendo em consideração os diferentes públicos participantes. As ações integradas e transversais às diferentes áreas disciplinares representadas no MHNC-UP envolvem os curadores e estabelecem a ponte entre a ciência e a comunidade. A arqueologia, no qual nos iremos centrar aqui, está também representada desenvolvendo atividades de cariz mais expositivo ou mais prático, numa tentativa de adaptação da transmissão de conhecimento. A participação na Noite Europeia dos Investigadores (NEI) em 2016 e 2107 foi estruturada a partir de atividades Hand on, de modo a que os participantes tirassem o máximo de partido da ação. Na transmissão de conhecimento privilegiou-se a experimentação (Figura 3 e 4).

Foram também desenhadas algumas atividades para participação nos programas da Ciência Viva - Agência Nacional para a Cultura Científica e Tecnológica. Tomamos como exemplo a ação Ao Leme com a Ciência Viva, que decorreu no verão de 2016. Com um foco muito específico no mar, a chamada à participação solicitava uma abordagem de sensibilização para a proteção dos oceanos. A abordagem definida na atividade desenvolvida pela secção de Arqueologia e Etnografia focou-se na importância da exploração dos recursos marinhos pelas comunidades humanas ao longo dos tempos, salientando a estreita relação de algumas comunidades com o mar. Exemplos como a produção de preparados piscícolas em época romana permitiram trabalhar tanto o tema de conservação dos oceanos como a vivência das comunidades, atividades económicas e técnicas utilizadas no passado.

Neste esforço de criar pontes com os vários públicos integra-se também a colaboração com outras entidades locais, na divulgação do património pertencente ao MHNC-UP. É o caso da Câmara Municipal do Porto, com a sua ação Um objeto e seus discursos por semana (Figura 5). Esta excelente iniciativa permite pôr em diálogo especialistas e público, em torno de um objeto e sua história e/ou significado.

O serviço educativo do MHNC-UP, estruturado em 2019 e coordenado pelo professor Nuno Teles, desenvolve um programa integrado, onde as ações promovidas desenvolvem-se em estreita colaboração com os curadores das coleções.

Num outro registo, o ano de 2020 irá ficar marcado definitivamente pela dinâmica das relações museu-público. O facto de, pela primeira vez no mundo, se terem confinado populações e cidades em massa, impedindo a deslocação das pessoas aos museus, levou ao reforço da presença destas instuições on line, numa tentativa de continuidade no envolvimento com os seus públicos. No MHNC-UP, em articulação com a Casa Comum, estabeleceu-se um programa de podcasts, que inclui a série Terras sem fim (https:// mhnc.up.pt/podcasts-terras-sem-fim/ ou https:// up.pt/casacomum/terras-sem-fim/, também disponíveis no Spotify), na qual são apresentadas as coleções de Arqueologia e Etnografia. Pretende-se, além de transmitir conhecimento de um modo alternativo, mas potencialmente mais difusor, desenvolver uma relação com diferentes públicos cativando-os a uma visita posterior ao museu.

Este material disponível on line poderá ser utilizado, futuramente, enquanto recurso de ensino pela comunidade escolar.

\section{CONCLUSÃO}

Sendo amplamente assumido o papel das coleções dos museus enquanto veículos de transmissão de 
saber, importa definir estratégias que permitam potenciar o acesso dos diferentes tipos de público às mesmas. O processo de envolvimento na comunidade pode ser conseguido através do estabelecimento de inúmeras estratégias, cabendo a cada instituição definir as abordagens junto da sua comunidade, que deverão passar pela inclusão dos diversos públicos e pelo estabelecimento de abordagens múltiplas. A compartimentação das disciplinas científicas não ajuda estes propósitos, logo uma abordagem integrada e integradora lança as sementes para o usufruto do museu por todos e para a implementação da criatividade enquanto motor da sociedade.

Os museus universitários surgem com uma responsabilidade acrescida, na posição de mediadores entre a produção de conhecimento científico e a sua transferência para os diferentes públicos. Não podemos deixar de concordar com Gil (2005, p. 49) quando indica que um dos objetivos dos museus universitários é "estudar, conservar e apresentar convenientemente as coleções que possui, usando-as em acções científico-pedagógicas da sua iniciativa ou em colaboração com outros organismos, com prioridade para os restantes departamentos universitários”.

No MHNC-UP implementam-se estratégias nesse sentido, assumindo este papel mediador. Foram aqui apresentados alguns exemplos ligados à Arqueologia.

\section{AGRADECIMENTOS}

Este artigo beneficiou da utilização da Infraestrutura Portuguesa de Coleções Científicas (Portuguese Infrastructure of Scientific Collections - PRISC.pt).

\section{BIBLIOGRAFIA}

BRUNO, M. C. O. A. (1997) - A indissolubilidade da pesquisa, ensino e extensão nos museus universitários. Cadernos de Sociomuseologia. Lisboa, 10, pp. 47-51

CHOLIDIS, Nadja (2019) - "Entregues a Portugal em troca dos achados de Assur.” Um capítulo da história museológica luso-alemã (1914-1927). In Morais, Rui; Gaspar, Rita; Reis, José da Costa, ed. Culturas e Geografias. Centenário da Faculdade de Letras da Universidade do Porto (1919-2019)/ Cultures and Geographies. Centenary of the Faculty of Arts and Humanities of the University of Porto (1919-2019). Porto: Arte e Ciência - Universidade do Porto, pp. 65-96.

GIL, Fernando Bragança (2005) - Museus universitários: sua especificidade no âmbito da museologia. In: Semedo, Alice; Silva, Armando Coelho da, coord., Coleções de ciências fisicas e tecnológicas em museus universitários: home- nagem a Fernando Bragança Gil. Porto: Faculdade de Letras da Universidade do Porto, pp. 33-52.

MORAIS, Rui; GASPAR, Rita; REIS, José da Costa, ed. Culturas e Geografias. Centenário da Faculdade de Letras da Universidade do Porto (1919-2019)/Cultures and Geographies. Centenary of the Faculty of Arts and Humanities of the University of Porto (1919-2019). Porto: Arte e Ciência Universidade do Porto.

RODRIGUES, Rafael (1895) - Dolmens ou antas de Vila Pouca de Aguiar. O Arqueólogo Português. Lisboa. Série I, Vol. 1, pp. 36-37.

SIMPSON, Andrew (2012) - Modelling governance structures for university museums and collections. In: Jandl, S. \& Gold, M., eds., A Handbook for Academic Museums: Beyond Exhibitions and Education. Edinburgh \& Boston: Museums Etc, pp. 178-218.

SIMPSON, Andrew (2019) - Museums and collections, epistemic convergence and higher education. In: Bueno, David et al., ed, Humanities and higher education: synergies between science, technology and humanities. Barcelona: Global University Network for Innovation, pp. 209-215.

STERNA, Rita Peyroteo (2016) - On Death in the Mesolithic or the Mortuary Practices of the Last Hunter-Gatherers of the South-Western Iberian Peninsula, $7^{\text {th }}-6^{\text {th }}$ Millennium BCE. Uppsala: Uppsala Universitet.

TOSO, Alice (2018) - Diet in Medieval Portugal: exploring inter-faith and social dynamics through stable isotope analysis. PhD thesis, University of York.

VIEIRA, Cristiana; MUCHAGATA, João; GASPAR, Rita; GONÇALVES, Helena; MATEUS, Simão, FONSECA, Maria João (no prelo) - From abstractionism to hyperrrealism: 150 years of biological models and replicas at the Museu de História Natural e da Ciência da Universidade do Porto. Edinburgh: Archives of Natural History. 

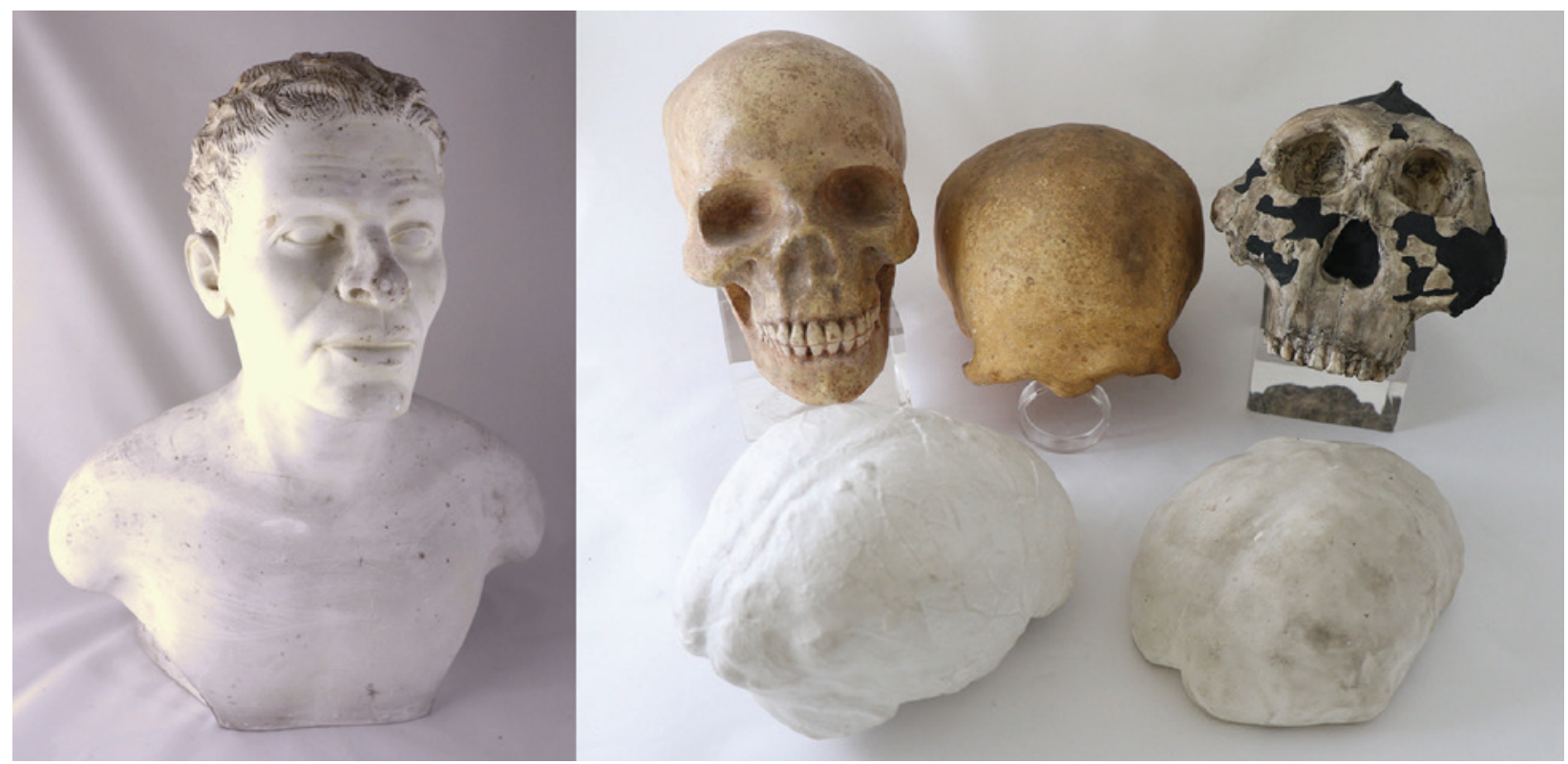

Figura 1 - Busto de Homo afer taganus por Agostinho Rodrigues (esquerda) e pequena seleção de replicas de crânios e modelos de cérebros adquiridos Anatomical Laboratory of Charles H. Ward (direita). Créditos MHNC-UP.

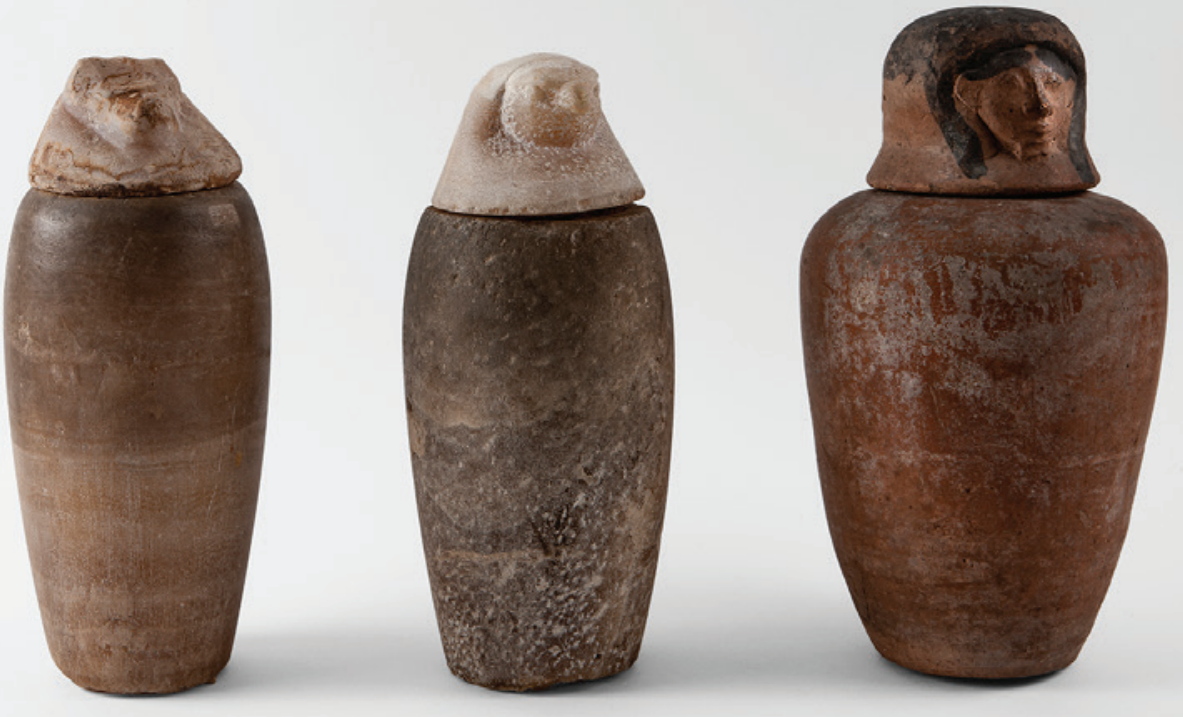

Figura 2-Conjunto de vasos de vísceras pertencentes à Coleção Museus de Berlim. Créditos MHNC-UP / José Eduardo Cunha. 


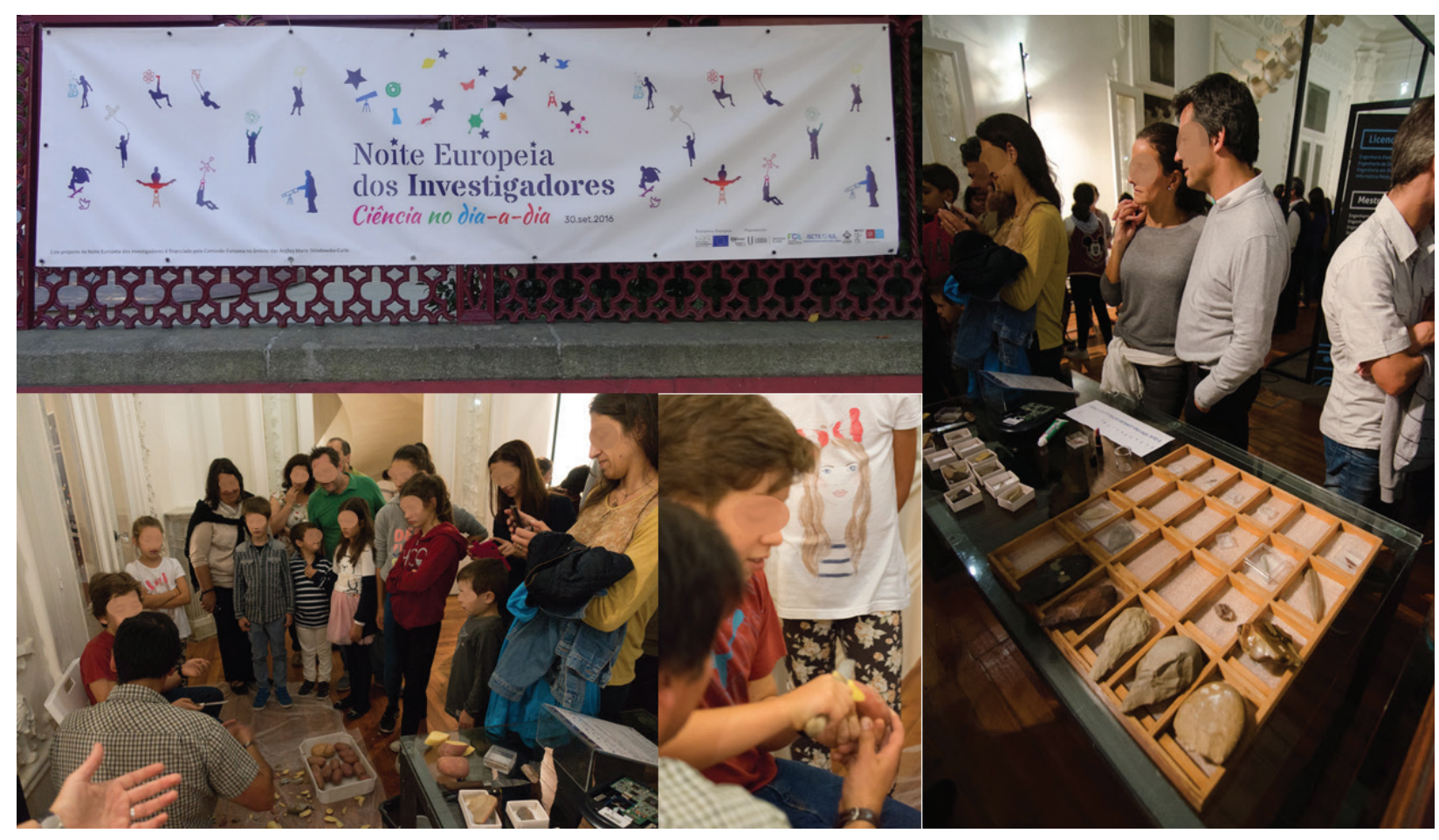

Figura 3-Participação na Noite Europeia dos Investigadores em 2016 onde se discutiu a aplicação do sílex ao longo dos tempos. A atividade Hands on permitia o contacto dos participantes com a as técnicas de talhe. Créditos MHNC-UP / Ricardo Lopes.

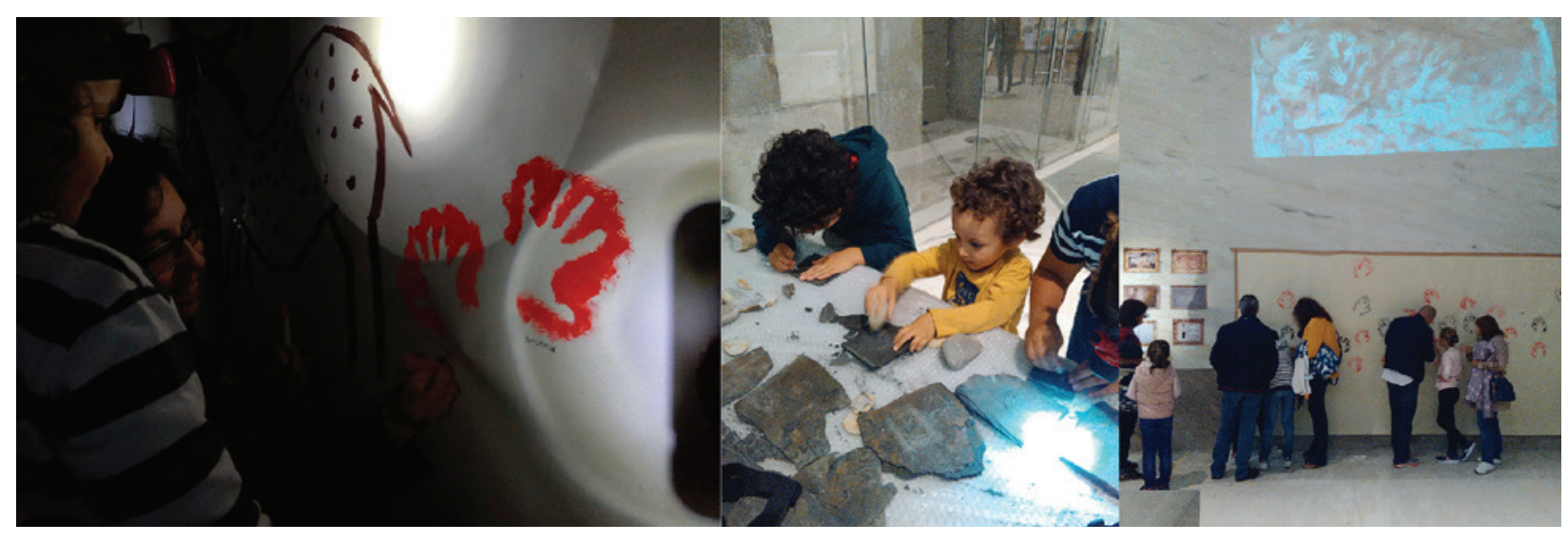

Figura 4 - Atividade preparatória para a Noite Europeia dos Investigadores (NEI) em 2017 realizada num estabelecimento do pré-escolar local (esquerda) e participação na NEI (centro e direita) onde se apresentaram técnicas de representação gráfica desde a Pré-História. A atividade Hands on permitiu o contacto dos participantes com as técnicas e materiais envolvidos na pintura e na gravura rupestre. Créditos MHNC-UP. 


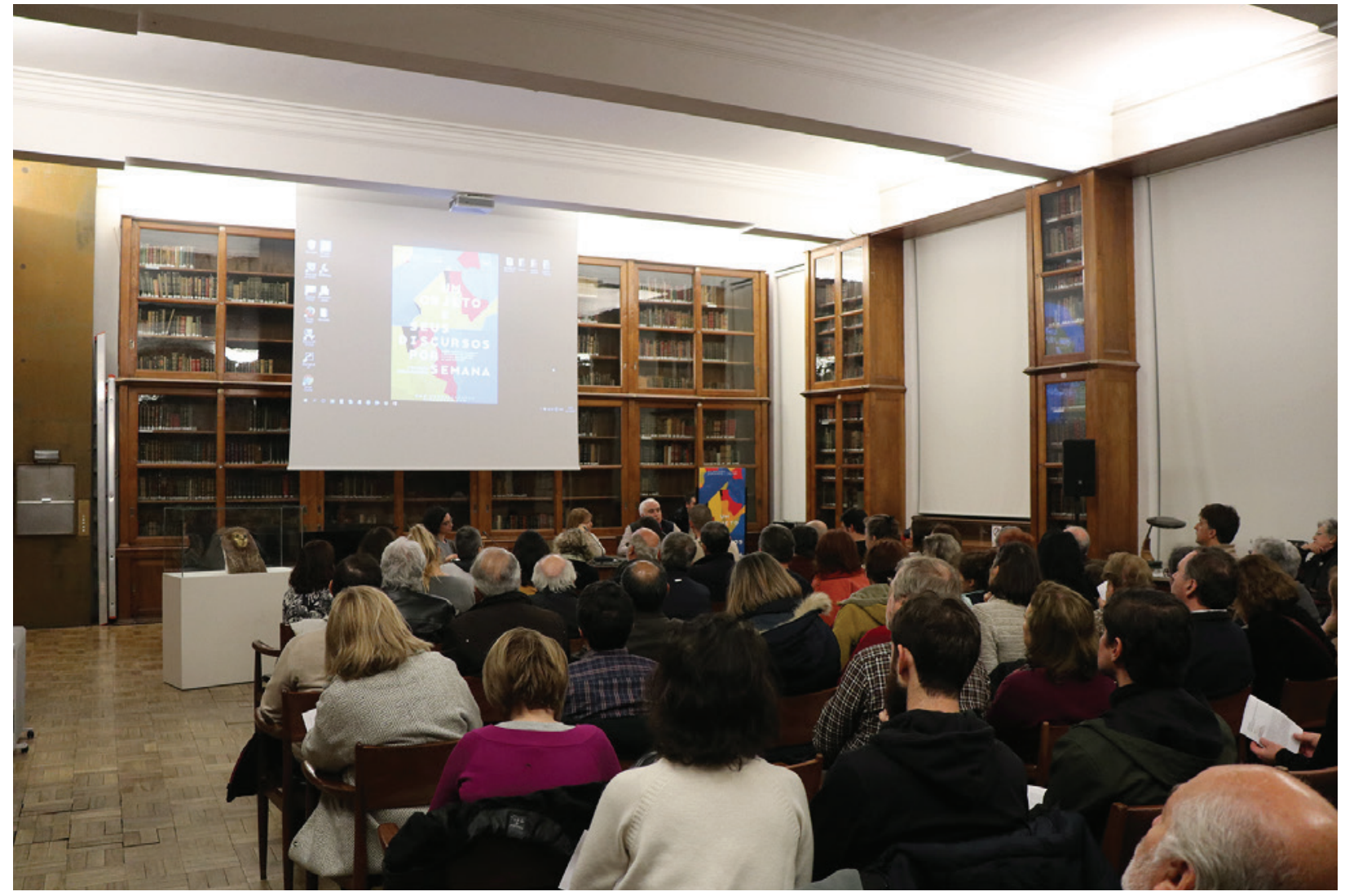

Figura 5- Sessão de Um objeto e seus discursos realizada em novembro de 2019, em torno da Máscara egípcia do MHNC-UP. Créditos MHNC-UP. 


\title{
MUSEU DE LANIFÍCIOS: REAL FÁBRICA DE PANOS. ATIVIDADES NO ÂMBITO DA ARQUEOLOGIA
}

\author{
Beatriz Correia Barata ${ }^{1}$, Rita Salvado ${ }^{2}$
}

\begin{abstract}
RESUMO
O Museu de Lanifícios, fundado em 1992 na Covilhã, está desde sempre ligado à arqueologia. Em 1975 foram expostas as Tinturarias Setecentistas da Real Fábrica de Panos e com a sua descoberta iniciou-se um importante projecto de conservação e salvaguarda que desempenhou um papel pioneiro no panorama da Arqueologia Industrial Portuguesa.

Face à sua missão de divulgação da indústria e património têxtil, o museu tem desenvolvido um programa extenso de atividades lúdicas, workshops, palestras e exposições temporárias dedicadas ao público.

O programa, apesar de diversificado, centra as atividades sobretudo na história da manufactura dos lanifícios e tradição têxtil. Perante as reduzidas atividades ligadas à arqueologia, iniciou-se em 2019 um projecto de introdução do tema arqueológico no plano divulgativo e pedagógico do museu.
\end{abstract}

Palavras-chave: Lanifícios, Museu, Arqueologia, Atividades, Público.

\begin{abstract}
The Wool Museum, located in Covilhã, was founded in 1992 and has kept a close relationship with archaeology since then. The $18^{\text {th }}$ Century Dye-House structures of the Royal Textile Factory were exposed in 1975 and with their discovery began an important project for conservation and safeguarding, which played an important role in Portuguese Industrial Archaeology.

In view of its mission to publicize the textile industry and heritage, an extensive program with public activities has been developed over the years, such as workshops, lectures, and temporary exhibitions. However, these activities were mainly focused on wool manufacture and textile tradition. Considering the limited events related to archaeology, in 2019 began a project to introduce the archeological theme in the museum activities plan. Keywords: Wool, Museum, Archaeology, Activities, Public.
\end{abstract}

O Museu de Lanifícios da Universidade da Beira Interior, inaugurado em 1992, localiza-se na cidade da Covilhã e é constituído por três núcleos: Real Fábrica de Panos (séc. XVIII), Real Fábrica Veiga (sécs. XIX e XX) e Râmolas de Sol (séc. XX).

Em 1975, durante as obras de adaptação do local para integrar o Instituto Politécnico da Covilhã, foram descobertas as estruturas arqueológicas das Tinturarias Setecentistas da Real Fábrica de Panos. Com esta descoberta a Universidade da Beira Interior viu-se ligada à arqueologia desde o início da sua construção. A escavação desempenhou um papel importante no desenvolvimento da Arqueologia Industrial impulsionada pelos trabalhos de investigação realizados. (CUSTÒDIO; SANTOS; PINHEIRO, 1990). Em 1982 a área foi classificada como imóvel de Interesse Público (Decreto-lei no 28/82 de 26 de Fevereiro). Localizada junto à Ribeira da Goldra (a sul) e de oficinas de tecelagem e de acabamentos pré-existentes nasce em 1764 a Real Fábrica de Panos, fundada por Marquês de Pombal como manufatura do Estado.Um projecto de "fábrica modelo" e pretexto para fazer crescer a localidade enquanto polo industrial e instigador de desenvolvimento (ALBUQUERQUE, 2012).

1. Museu de Lanifícios da Universidade da Beira Interior; beatrizcorreiabarata@gmail.com

2. Museu de Lanifícios da Universidade da Beira Interior; lrbss@ubi.pt 
Este núcleo museológico in-situ visa reconstruir os processos manufactureiros do fabrico e tingimentos dos tecidos de lã utilizados nos finais do séc. XVIII e contextualizar esta atividade na área da Serra da Estrela com o centro histórico na Covilhã (PINHEIRO, 1998), afirmando-se também como um centro interpretativo da rota turística peninsular "Rota da Lã-TRANSLANA". É um museu de ciência e tecnologia que tem como missão a salvaguarda e conservação ativa das tecnologias articuladas ao processo de industrialização dos lanifícios, assim como a sua investigação e divulgação junto do público e comunidade científica (PINHEIRO, 1998).

Face à sua missão de comunicação do espólio e tecnologia industrial, o museu desenvolveu desde cedo um plano de atividades diversificado que procurou sempre abordar as diferentes temáticas associados ao sítio. Contudo, as atividades pedagógicas desenvolvidas centravam-se, sobretudo, na história da manufactura dos lanifícios e tradição têxtil.

Assim, com o objectivo de integrar o tema de introdução à arqueologia no plano divulgativo do museu, iniciou-se em 2019 um projeto de atividades que tiveram como principal foco o núcleo arqueológico do século XVIII, a Real Fábrica de Panos.

Com o objetivo de aproximar a comunidade, local e turística, do património industrial, estas atividades focaram-se na arqueologia do local, dando relevância às estruturas arqueológicas, à sua descoberta, ao projeto de intervenção elaborado pela Associação Portuguesa de Arqueologia Industrial (APAI) e à sua importância no panorama da arqueologia industrial em Portugal.

A primeira apresentação da narrativa ao público foi através de "Uma Visita, um Vestígio..." (Figura 1) que integrou três visitas distintas, cada uma dedicada a um importante vestígio arqueológico. A primeira visita centrou-se nos poços de tingimento, as estruturas mais emblemáticas do museu, passando pela Tinturaria dos Panos, Tinturaria dos Panos de Lã, Tinturaria das Lãs em Meada e a Tinturaria das Dornas. A segunda visita desenvolveu-se em torno do Tanque de água, do sistema hidráulico da Serra da Estrela e dos Pisões. O tema da terceira e última visita foi o Corredor das Fornalhas e o plano de integração museológica e arquitetónica.

Apesar de cada visita ser dedicada a uma estrutura, procurou-se dar sempre uma contextualização histórica da cidade da Covilhã no panorama dos lanifícios, uma breve introdução à intervenção ar- queológica e sensibilização para a importância da preservação e salvaguarda do sítio. Estas visitas foram gratuitas, realizadas nos primeiros domingos de Fevereiro, Março e Abril, sendo o público alvo as famílias. Relativamente ao número de participantes, a primeira visita contou com trinta e dois, a segunda com vinte e a terceira com vinte e um participantes, maioritariamente adultos, resultados que consideramos bastante satisfatórios e que permitiram dinamizar as tardes de entrada gratuita.

Após esta atividade procurou-se apresentar o tema a um público mais jovem. A oportunidade surgiu durante o ATL (atividades de tempo livre) de Verão do Museu (Figura 2), desenvolvido pelo Serviço Educativo. Neste programa participaram seis crianças e jovens entre os sete e os catorze anos de idade que demostraram um grande interesse pelo tema.

Na sua essência esta atividade foi similar à "Uma Visita...Um Vestígio", mas com discurso adaptado ao público alvo e uma menor duração. Contudo, apesar da participação positiva do grupo, considerámos que era necessário desenvolver uma atividade mais interativa, que fosse para além da visita guiada.

Assim foi criada a visita-jogo "Arqueólogo Por Uma Tarde" a ser integrada no programa "Famílias ao Museu” (Figura 3) nas tardes dos primeiros domingos de cada mês, períodos de entrada gratuita.

O objectivo de "Arqueólogo por uma tarde" é, através de um jogo lúdico e informal, divulgar ao público entre os oito e os catorze anos a história e arqueologia do local, o que a sua descoberta representou e o que os estudos arqueológicos e históricos desvendaram. A visita-jogo é uma simbiose de enigmas com "caça ao tesouro" recorrendo à exploração e cooperação entre os jovens do grupo. Na criação da atividade consideramos importante abordar o maior número de temas possível, desde a construção à vida quotidiana da fábrica, o quartel, a descoberta arqueológica e por fim, o museu.

Apesar do feedback positivo o crescimento do número de participantes ficou aquém das nossas expectativas com um total de catorze jovens, seis inscrições em janeiro e oito em fevereiro de 2020.

De uma forma geral consideramos que os resultados das atividades no âmbito deste projeto têm sido positivos, permitindo dinamizar e diversificar as atividades do museu. Contudo, é necessário no futuro apostar numa comunicação mais apelativa, eficaz e direta, não só a nível de design, mas também da divulgação nas diversas redes sociais, nomeadamente 
Instagram, Facebook e outras plataformas. Sobretudo será importante melhorar e desenvolver novos programas direcionados à arqueologia, ao projeto científico de recuperação, restauro e musealização da área, elaborado pela APAI.

O Museu de Lanifícios, para além de ser um local interessante e único do ponto de vista da arqueologia industrial, é também um projeto científico com a capacidade de cativar os diversos públicos, sejam eles da comunidade ou turistas, crianças, jovens ou adultos. O benefício de se localizar no centro da cidade, onde também se encontram outros pontos de interesse patrimonial, permite a criação de atividades não só no espaço confinado do museu mas também por toda a cidade, estabelecendo assim uma ligação entre o espólio do museu e o património disseminado pela cidade.

Porém o MUSLAN enfrenta também alguns obstáculos. A sua localização, apesar dos aspetos positivos, também traz alguns negativos. Por estar numa cidade localizada no interior tem uma grande percentagem de população envelhecida com dificuldades de mobilidade. Por outro lado, os jovens demonstram uma fraca participação nos programas desenvolvidos, tendo sido uma das razões que nos levou a desenvolver um programa dedicado ao público entre 8 e 14 anos.

Uma outra barreira é o museu deter uma equipa profissional reduzida, trazendo entraves não só no desenvolvimento de atividades de divulgação, mas também na limitação de realização de investigação interna. Todavia é importante continuar a desenvolver novas atividades direcionadas aos diferentes públicos que o visitam (Figura 4).

Na próxima fase deste projecto pretendemos não só aperfeiçoar e reestruturar alguns aspectos do nosso programa, para um melhor progresso junto do público alvo, mas também criar mais atividades no âmbito da arqueologia e estender as mesmas para os restantes núcleos do MUSLAN e à própria cidade.

Relativamente à visita-jogo "Arqueólogo Por uma Tarde" acreditamos que o número reduzido de participantes ficou aquém do esperado devido essencialmente por uma falha na divulgação, uma vez que o cartaz apresentado "Famílias ao Museu" descreve apenas uma "visita guiada" para os "filhos" entre os 8 e os 14 anos não sendo anunciada a atividade especificamente. Assim, acreditamos que é necessário proceder a algumas melhorias na estratégia de divulgação, de forma a ter uma comunicação mais abrangente a nível de redes sociais, mas também mais clara e directa que permita aos interessados compreender do que se trata a atividade e para quem é dirigida.

A concluir, é também nosso objectivo no futuro estender as atividades para além do público jovem entre os 8 e os 14 anos. Desejamos cativar o público adolescente entre os 15 e os 18 anos e, potencialmente, os jovens adultos que frequentam a Universidade da Beira Interior, beneficiando do espaço que é partilhado entre estudantes e museu (Corredor das Fornalhas).

Este ciclo de atividades lúdicas, ligadas à arqueologia no Núcleo da Real Fábrica de Panos do Museu de Lanifícios da Universidade da Beira Interior, ajudou-nos a compreender o público e seus interesses, permitindo-nos adquirir experiência para continuarmos a melhorar e a desenvolver novos projectos.

\section{BIBLIOGRAFIA}

ALBUQUERQUE, Ana Isabel da Silva (2012) - Museus feitos de têxteis: comunicar o património laneiro na Beira Interior e Alto Alentejo. As novas ferramentas de dinamização local e regional. Dissertação de Mestrado em Arte, Património e Teoria do Restauro apresentada à Faculdade de Letras da Universidade de Lisboa.

CUSTÓDIO, Jorge; SANTOS, Luisa; PINHEIRO, Elisa Calado (1990) - As Fábricas de José Mendes Veiga e Sucessores. Exposição Temporária 30 de Abril a 19 de Julho 1987. In Cadernos de Arqueologia, Arqueologia Industrial e Património Arquitectónico - 1. Covilhã: Universidade da Beira Interior, Centro de Estudo e Protecção do Património.

PINHEIRO, Elisa Calado (1998) - A Covilhã, Centro Histórico dos Lanifícios Portugueses. In PINHEIRO, Elisa Calado (coord.) - Catálogo do Museu de Lanificios da Universidade da Beira Interior. Núcleo da Tinturaria da Real Fábrica de Panos. Covilhã: Universidade da Beira Interior (UBI), Museu de Lanifícios, pp. 44-54.

PINHEIRO, Elisa Calado (1998) - Da Real Fábrica de Panos ao Museu de Lanifícios. In PINHEIRO, Elisa Calado (coord.) - Catálogo do Museu de Lanificios da Universidade da Beira Interior. Núcleo da Tinturaria da Real Fábrica de Panos. Covilhã: Universidade da Beira Interior (UBI), Museu de Lanifícios, pp. 16-38. 

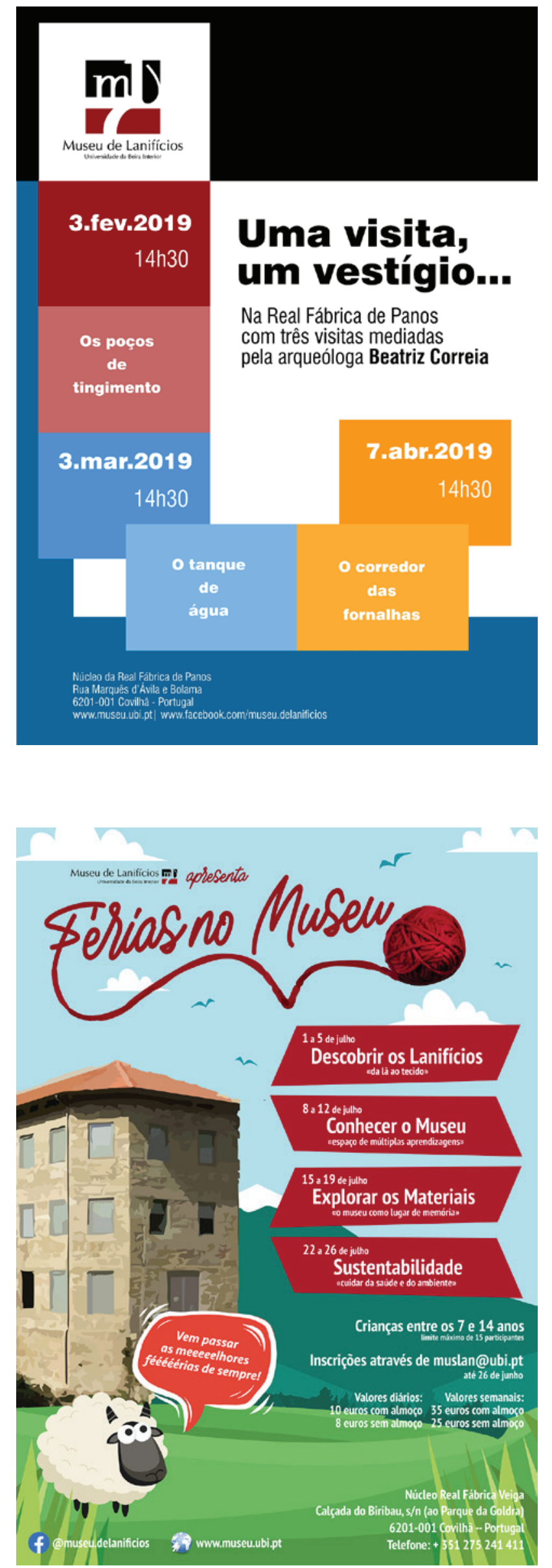

Figura 1 - Cartaz da atividade "Uma visita, um Vestígio”. Museu de Lanifícios.

Figura 2 - Cartaz da atividade "Férias no Museu". Museu de Lanifícios. 


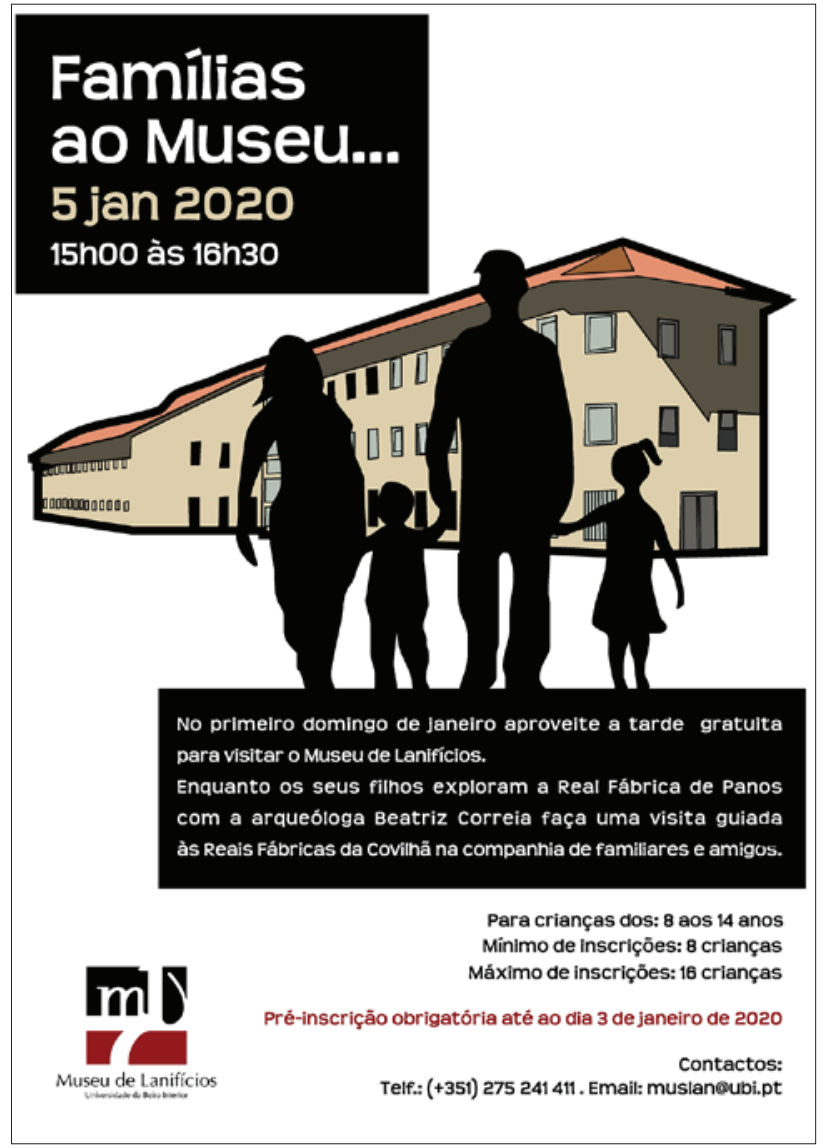

Figura 3 - Cartaz da atividade "Famílias ao Museu”. Museu de Lanifícios.

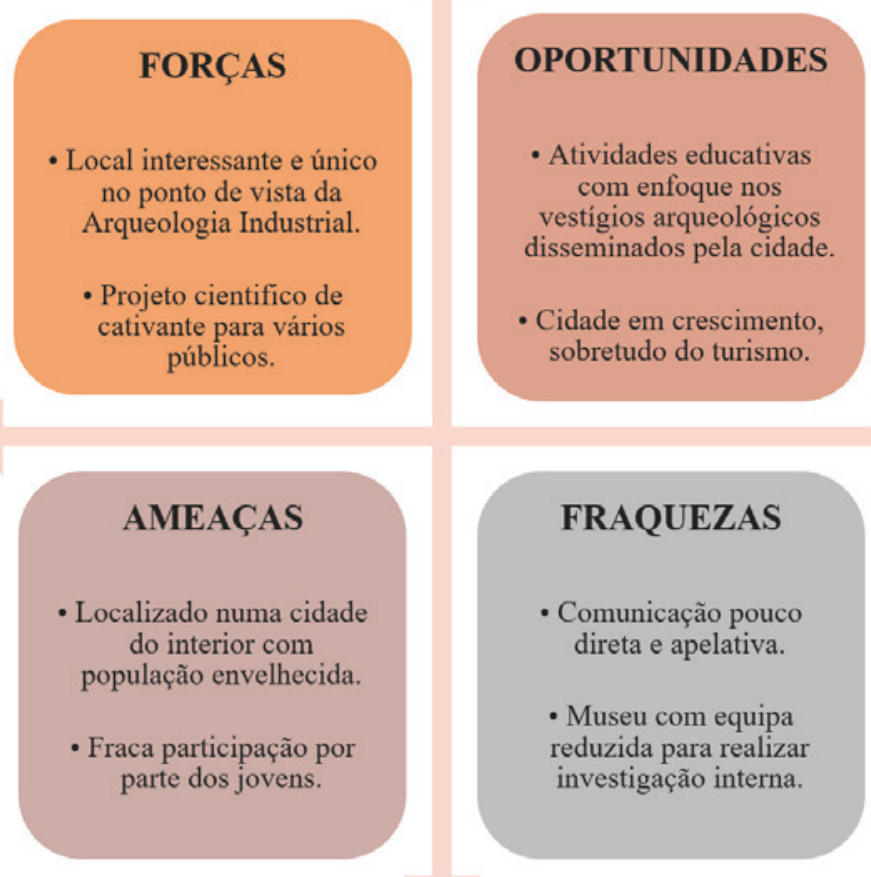

Figura 4 - Análise das Forças, Oportunidade, Fraquezas e Ameaças do Museu de Lanifícios. 


\title{
ARQUEOLOGIA PÚBLICA E O CASO DA LOCALIDADE DA MATA (TORRES NOVAS)
}

\author{
Cláudia Manso ${ }^{1}$, Ana Rita Ferreira ${ }^{2}$, Cristiana Ferreira ${ }^{3}$, Vanessa Cardoso Antunes ${ }^{4}$
}

\begin{abstract}
RESUMO
Discutem-se formulações de 'valor', 'identidade' e 'lugar', partindo de M. Díaz-Andreu (2017: 2-6) e de P. G. Gould (2016:1-18), bem como os termos em que se estrutura uma abordagem participativa e crítica da comunidade na gestão cultural local com base na seleção comparativa de convenções internacionais do património. Palavras-chave: Valor patrimonial, Micro gestão pela comunidade.
\end{abstract}

\begin{abstract}
Formulations of 'value', 'identity' and 'place' are discussed, according to M. Díaz-Andreu (2017: 2-6) and P. G. Gould (2016:1-18), as well as the terms in which a participatory and critical approach by the community on local cultural management is structured, grounded on the comparative selection of international heritage conventions. Keywords: Heritage value, Micromanagement by the community.
\end{abstract}

A formulação do conceito de valor numa perspetiva top-down é doutrinalmente patente no normativo internacional das primeiras concertações acerca do património cultural. A Carta de Atenas (1931), enquanto referência no estabelecimento de diretrizes para o património existente em contexto urbano, estipula uma noção estanque de monumento e da envolvente, assentes na intervenção mínima sobre essas materialidades, uma perspetiva do ato de conservação que é, tecnicamente, garantia de antiguidade e de autenticidade. Alternativamente, a Carta de Veneza (1964) assume o caráter permanente das alterações resultantes de operações realizadas na conservação do monumento, processo que implica a integração da componente histórica associada, mas sobretudo centrado na manutenção por reutilização do elemento edificado. Ambas as convenções partilham, todavia, a ideia de uma transmissão da mensagem do Passado através de um filtro disciplinar e da racionalização do valor patrimonial. Se, por um lado, a indispensabilidade do bem provém da significação coletiva, reiteradamente associada ao pendor civilizacional dessa legibilidade cultural, por outro, formaliza-se uma necessidade coetânea de quantificar a respetiva valoração através dos ditames das ciências aplicadas ao património. A dinâmica específica de salvaguarda do património influencia diretamente o valor social e, em última instância, condiciona a tipologia e o número de testemunhos a preservar.

A invariabilidade do conceito de valor é ainda o esteio da Convenção do Património Mundial (1972), e das subsequentes Orientações Técnicas para a integração do património cultural e/ou natural ${ }^{5}$, qualificado pelo seu Valor Universal Excecional, em Listas do Património Mundial. Esta imutabilidade conceptual de valor assegura a argumentação objetiva e científica que está na base da tomada de decisões pelo Comité do Património Mundial no decurso do processo de avaliação dos bens indicados como passíveis

\footnotetext{
1. Direção-geral do Património Cultural; claudiamanso@dgpc.pt

2. Centro Português de Geo-história e Pré-história; aaritaferreira@gmail.com

3. Centro de Geociências (Universidade de Coimbra, ulD73-FCT) e Centro Português de Geo-história e Pré-história; ferreira.cris.oo@gmail.com
}

4. Centro Português de Geo-história e Pré-história; vanessanx@yahoo.com.br

5. As definições de património cultural e de património natural são descritas no conteúdo dos artigos 1.. e 2.. da Convenção para a Proteção do Património Mundial, Cultural e Natural (Paris, 1972). 
de inscrição nessas listas. A pirâmide decisória, encimada pelo Comité, define então o Valor Universal Excecional do bem, entendido na sua inestimável singularidade cultural e/ou natural, transfronteiriça e transgeracional, por serem cumpridos critérios de avaliação preestabelecidos ${ }^{6}$, por se verificar a existência de um sistema específico de proteção e gestão e, também, por se estabelecerem as condições de autenticidade e/ou de integridade.

Entre os documentos normativos exarados pelo Conselho da Europa, a Convenção de Granada (1985) foi além do âmbito de acordos anteriores, ao considerar a importância do uso contemporâneo dos monumentos a par do respetivo valor histórico e artístico, balanço que seria alargado pela Convenção de Malta (1992) cujo texto reconhece o valor dos costumes e/ou tradições na compreensão e investigação científica do Passado humano. Em sede de arqueologia pública, essa visão integral da paisagem arqueológica assenta na consideração de que valores sociais, culturais e estéticos conjugados vêm conformar as relações entre os residentes e intensificar a perceção simbólica do lugar como herança cultural comum (Richardson \& Almansa-Sánchez, 2015).

A inversão da formulação do conceito de valor através de uma abordagem bottom-up, agora alicerçada na participação ativa do público e das entidades locais e regionais no processo decisório, deriva das circunstâncias normativas proporcionadas pela Carta de Lausanne (1990) e pela Convenção de Florença (2000) no que concernem as questões ambientais e do património arqueológico. E, no mesmo sentido, a Carta de Cracóvia (200o) equipara o contributo de indivíduos e instituições na conservação do património construído, valorizando os monumentos enquanto traduções individuais da memória coletiva e assumindo o peso que uma gestão descentralizada tem no desenvolvimento sustentável, económico e social das comunidades.

A Convenção de Faro (2005) alargaria o alcance desses princípios ao estabelecer taxativamente que o envolvimento prático na vida cultural é um direito fundamental que complementa o próprio exercício

6. As versões de 1977, 1980, 1983, 1984, 1988, 1992, 1994, 1996, 1997/1999, 2005 e 2008 das Orientações Técnicas para a Aplicação da Convenção do Património Mundial apresentam, ainda que reformulados, seis critérios supletivos de definição do Valor Universal Excecional do património cultural. da liberdade cultural. E arroja a definição de comunidade patrimonial como o conjunto de pessoas que, por vontade individual, seleciona quais os aspetos a valorizar no próprio património cultural. O teor inerente é simultaneamente conciliador das eventuais contradições valorativas que surgem em contextos de grande diversidade cultural como os que advieram da migração massiva historicamente coincidente com as transformações sociopolíticas e geoestratégicas do último decénio.

Em Portugal, raros serão os exemplos de comunidades que espontaneamente atribuem um valor social inequívoco ao património arqueológico e, ainda mais raros os casos em que esse ativismo se traduz, a nível local, na salvaguarda patrimonial através de um claro compromisso político-financeiro. O paradigma comum será talvez o que resulta de uma perceção mormente centralizadora da gestão patrimonial e, ainda que vigorando um quadro legislativo promotor do entrosamento entre público e património, existem mecanismos de bloqueio à participação do cidadão comum na atividade arqueológica quando efetuada sem a orientação de pessoal formado em arqueologia.

Uma significativa percentagem dos investigadores e dos técnicos públicos e privados do património condescende à suspeição de que as iniciativas encetadas por leigos em matérias da arqueologia redundam na produção de discursos cientificamente duvidosos. Tal tendência tem uma relação direta com a ética académica e a ética profissional dos cientistas humanos, e explica-se sobretudo pela marcada distinção que existe entre a arqueologia e os costumes (Van Den Vries, 2014). Esta disposição não cooperante entre a arqueologia e as tradições prolongar-se-á em países herdeiros de uma ética eurocêntrica, reconduzível à Carta de Veneza, descurando-se o significado do sítio - i.e. o valor que, sendo inerente ao lugar, supera o sentido utilitário do espaço -, e silenciando-se perspetivas do património conduzidas por vozes amadoras locais (Díaz-Andreu, 2016).

Veja-se o caso da localidade da Mata, onde, no âmbito do acompanhamento arqueológico da Empreitada Águas do Ribatejo Subsistemas Torres Novas - Chancelaria / Pedrogão, foram registadas 45 estruturas negativas maioritariamente de cariz antrópico, patentes no substrato geológico, cuja morfologia, contexto estratigráfico e materiais associados, compeliriam preliminarmente à pluralização de hipóteses funcionais e de atribuições cronológicas na 
avaliação do conjunto que seria intervencionado. À plausibilidade desses dados arqueológicos ambivalentes, seguiu-se a conservação pelo registo, com posterior destruição dos achados.

No concelho de Torres Novas, o caso da comunidade da Mata poderá constituir um baluarte da defesa do património arqueológico a partir de uma perspetiva de tipo identitário. Porém, tal afirmação depende da motivação subjacente ao movimento de contestação dos residentes e dos termos em que se valorou aquele património e se alicerçou a defesa dos vestígios por serem dos seus antepassados. Por conseguinte, importa avaliar se a população da Mata congregará um ou ambos os tipos de comunidade que se apresentam como hipóteses (Marshall, 2002):

a) Um conjunto de residentes cujo ativismo resulta da valorização dos recursos específicos do lugar natal, reforçados pela descoberta de vestígios arqueológicos cuja antiguidade e autenticidade foram metodologicamente atestadas;

b) Um conjunto de residentes que conota emocionalmente as descobertas arqueológicas enquanto ligação à progénie e tenciona transmitir, aos seus descendentes, factos e/ou bens concernentes a um antepassado comum, porque circunscritos ao lugar da génese comunitária.

Para tal realizar-se-á uma pesquisa de opinião, por ora metodologicamente apresentada em fase bastante prematura (Gould, 2016). Este inquérito autoadministrado permitirá a obtenção de dados necessários ao ensaio de cariz sociométrico sobre o qual assentará um modelo de sustentabilidade orientado para projetos de pequena dimensão com o benefício da presença de atividade arqueológica (vide infra).

\begin{tabular}{|l|l|l|l|}
\hline \multicolumn{4}{|l|}{ 1. Avalio a importância dos achados arqueológicos para a história da aldeia: } \\
\hline Sem importância & Pouco importantes & Muito importantes & Essenciais \\
\hline
\end{tabular}

\begin{tabular}{|l|l|l|l|}
\hline 2. Avalio a relevância dos achados arqueológicos na história da minha família: \\
\hline Sem relevância & Pouco relevantes & Muito relevantes & Fundamentais \\
\hline
\end{tabular}

\begin{tabular}{|l|l|l|l|}
\hline 3. O valor dos achados arqueológicos resulta de serem: \\
\hline Raros/Antigos & $\begin{array}{l}\text { Conhecidos pelas pessoas } \\
\text { da aldeia }\end{array}$ & $\begin{array}{l}\text { Importantes para } \\
\text { os arqueólogos }\end{array}$ & Uma atração turística \\
\hline
\end{tabular}

\begin{tabular}{|l|l|l|l|}
\hline 4. Identifico-me como 'matense' porque: \\
\hline Nasci na aldeia & $\begin{array}{l}\text { Conheço as tradições } \\
\text { e costumes }\end{array}$ & $\begin{array}{l}\text { A minha família mora } \\
\text { na aldeia }\end{array}$ & Valorizo o património \\
\hline
\end{tabular}

\begin{tabular}{|l|l|l|l|}
\hline 5. Os achados arqueológicos interessam-me porque: \\
\hline É património da aldeia & $\begin{array}{l}\text { Arqueólogos os consideram } \\
\text { únicos }\end{array}$ & São raros no concelho & Não me interessam \\
\hline
\end{tabular}

\begin{tabular}{|l|l|l|l|}
\hline 6. Os achados arqueológicos são antigos porque: \\
\hline São romanos & $\begin{array}{l}\text { Já eram conhecidos pelos } \\
\text { meus avós }\end{array}$ & $\begin{array}{l}\text { Contam a história } \\
\text { da aldeia }\end{array}$ & $\begin{array}{l}\text { Foram escavados } \\
\text { por arqueólogos }\end{array}$ \\
\hline
\end{tabular}

\begin{tabular}{|l|l|l|l|}
\hline 7. Defendo os costumes/tradições da minha aldeia porque: \\
\hline $\begin{array}{l}\text { Celebro as festas locais em } \\
\text { família }\end{array}$ & Defendo qualquer património & $\begin{array}{l}\text { Perpetuam a memória } \\
\text { dos avós }\end{array}$ & Não defendo \\
\hline
\end{tabular}

\begin{tabular}{|l|l|l|l|}
\hline 8. O património arqueológico conduz a benefícios económicos à aldeia porque: \\
\hline Atrai visitantes & Dinamiza o comércio & Cria emprego & Não traz benefícios \\
\hline
\end{tabular}

\begin{tabular}{|l|l|l|l|}
\hline \multicolumn{2}{|l|}{ 9. As descobertas arqueológicas mudaram a minha perspetiva do património porque: } \\
\hline É uma atividade científica & $\begin{array}{l}\text { A aldeia é mais antiga } \\
\text { do que pensava }\end{array}$ & $\begin{array}{l}\text { Observei vestígios } \\
\text { de perto }\end{array}$ & $\begin{array}{l}\text { Atrasam a conclusão } \\
\text { das obras }\end{array}$ \\
\hline
\end{tabular}




\section{BIBLIOGRAFIA}

(1990) - Carta sobre a Proteção e a Gestão do Património Arqueológico. Carta de Lausanne, Comité Internacional para a Gestão do Património Arqueológico.

(1931) - Conferência Internacional de Atenas sobre o Restauro dos Monumentos - Carta de Atenas. Atenas, 21 a 30 de outubro de 1931 .

(200o) - Conferência Internacional sobre Conservação. Carta de Cracóvia, Princípios para a Conservação e o Restauro do Património Construído. Cracóvia, 26 de outubro de 2000.

(1972) - Conferência Geral da Organização das Nações Unidas para a Educação, Ciência e Cultura - Recomendação de Paris, Convenção para a Proteção do Património Mundial, Cultural e Natural. Paris, 17 de outubro a 23 de novembro de 1972.

(200o) - Convenção Europeia da Paisagem - Convenção de Florença, Conselho da Europa. Florença, 20 de outubro de 2000 .

(1992) - Convenção Europeia para a Proteção do Património Arqueológico - Convenção de Malta, Conselho da Europa. La Valetta, 16 de janeiro de 1992.

(1985) - Convenção para a Salvaguarda do Património Arquitetónico da Europa, Convenção de Granada, Conselho da Europa. Granada, 3 de outubro de 1985.

(2005) - Convenção Quadro do Conselho da Europa Relativa ao Valor do Património Cultural para a Sociedade, Convenção de Faro. Faro, 27 de outubro de 2005.

(1964) - II Congresso Internacional de Arquitetos e Técnicos de Monumentos Histórico, Carta de Veneza, Carta Internacional sobre a Conservação e Restauro dos Monumentos e Sítios. Veneza, 25 a 31 de maio de 1964.

(2010) - Orientação para a elaboração de Declarações de Valor Universal Excecional para bens do Património Mundial - Centro do Património Mundial da UNESCO. Organização das Nações Unidas para a Educação, Ciência e Cultura. Julho de 2010, Anexo 3: Alterações aos critérios do Património Mundial em diferentes versões das Orientações Técnicas (OG), pp.19-22.

(2013) - Orientações Técnicas para Aplicação da Convenção do Património Mundial do Comité Intergovernamental para a Proteção do Património Mundial, Cultural e Natural. Organização das Nações Unidas para a Educação, Ciência e Cultura. Julho de 2013, Cap. II., Número do Parágrafo. 45-88.

DÍAZ-ANDREU, Margarita (2016) - Heritage Values and the Public. Journal of Community Archaeology \& Heritage. 4:1, pp. 2-6.

GOULD, Peter G. (2016) - On the Case: Method in Public and Community Archaeology. Public Archaeology. 15:1, pp. 5-22.
GRIMA, Reuben (2016) But Isn't All Archaeology 'Public' Archaeology? Public Archaeology. August issue, pp. 1-16.

HOLTORF, Cornelius (2007) - Can you hear me at the back? Archaeology, communication and society. European Journal of Archaeology. 10: 2-3, pp. 149-165.

MARSHALL, Yvonne (2002) - What is community archaeology? World Archaeology . 34:2, pp. 211-219.

MASCARENHAS, José Manuel; SOARES, Joaquina; SILVA, Carlos Tavares da (1986) - O Património Histórico-Cultural e os Estudos de Impacte Ambiental: proposta de metodologia para a avaliação do impacte das barragens. Trabalhos de Arqueologia do Sul. 1, pp. 7-16.

MATSUDA, Akira (2004) - The Concept of 'the Public' and the Aims of Public Archaeology. Institute of Archaeology. 15, pp. 66-76-

MOSHENSKA, Gabriel (2017) - Key Concepts in Public Archaeology. Londres: UCL Press, 238 p.

MOSHENSKA, Gabriel; DHANJAL, Sarah (2011) - Community Archaeology: Themes, Methods and Practices. Oxford: Oxbow Books, $135 \mathrm{p}$.

OKAMURA, Katsuyuki; MATSUDA, Akira (2011) - New Perspectives in Global Public Archaeology. Nova Iorque: Springer, $275 \mathrm{p}$.

OLDHAM, Mark (2018) - Bridging the Gap: Classification, Theory and Practice in Public Archaeology. Public Archaeology. August issue, pp. 1-16.

PEREIRA, João Paulo; MARTINS, Ivone Pereira (1995) Estudos de Impacte Ambiental: a vertente arqueológica. Almadan. Almada. Série II. 4, pp. 87-93.

RICHARDSON, Lorna-Jane; ALMANSA-SÁNCHEZ, Jaime (2015) - Do you even know what public archaeology is? Trends, theory, practice, ethics. World Archaeology. 47:2, pp. 195-211.

SCHADLA-HALL, Tim R. (1999) - Editorial: Public Archaeology. European Journal of Archaeology. 2:2, pp. 147-58.

SIMPSON, Faye (2008) - Community Archaeology Under Scrutiny. Conservation and Management of Archaeological Sites. 10:1, pp. 3-16.

TULLY, Gemma (2007) - Community archaeology: general methods and standards of practice. Public Archaeology. 6:3, pp. 155-187.

VAN DEN DRIES, Monique H. (2014) - Community Archaeology in the Netherlands. 'Journal Of Community Archaeology and Heritage'. 1:1, pp. 69-88. 


\title{
DO SÍTIO ARQUEOLÓGICO AO MUSEU: UM PERCURSO (TAMBÉM) DIDÁTICO
}

\author{
Lídia Fernandes ${ }^{1}$
}

\begin{abstract}
RESUMO
Qualquer sítio arqueológico, per si, permite questionar o sentido da arqueologia enquanto ciência que "produz" ruína. O conhecimento histórico, no que respeita à arqueologia, passa inevitavelmente pela consequente atuação em relação a tais estruturas que, musealizadas ou deixadas ao abandono, são testemunhas da memória histórica. A abordagem que atualmente se realiza é muito diversa consoante o objeto arqueológico em causa, o seu contexto ou o protagonismo que se pretende. Com efeito, a musealização de sítios arqueológicos tem, recentemente, suscitado interesses ambivalentes passando as ruínas a servir de mote a projetos icónicos que ultrapassam, em muitos casos, o objetivo para o qual foram criados. Nem tudo carece de musealização, mas tudo o que é musealizado carece, obrigatoriamente, de um enquadramento que dignifique o próprio objeto.

Palavras-chave: Estruturas arqueológicas, Musealização, Ruína, Preservação, Dinamização.
\end{abstract}

\begin{abstract}
Any archaeological site, by itself, allows to question the meaning of archaeology as a science that "produces" ruin. The historical knowledge inevitably leads to consequent action in relation to its structures, which musealized or left to abandon, are witnesses of historical memory.

The approach currently perceived is distinct according to the archaeological object in question, its context or its intended role. In fact, recently, the musealization of archaeological sites has aroused ambivalent interests, as the ruins serve as a motto for iconic projects which, in many cases, go beyond the purpose for which they were created. Not everything deserves musealization, but all that is musealized requires a dignified framework for the object itself.
\end{abstract}

Keywords: Archaeological structures, Musealization, Ruin, Conservation, Dynamization.

\section{INTRODUÇÃO}

A musealização de locais arqueológicos em Portugal constitui uma problemática de contornos indefinidos. Os sítios arqueológicos detêm uma posição secundária e ambivalente situando-se entre o que se considera um espaço museológico - por vezes diretamente relacionado com um museu - e áreas de recreio/passeio, sem que aquela perspetiva de entendimento se aplique, na maior parte dos casos, a esta última situação.

A dificuldade na leitura das estruturas, a ausência de suportes explicativos ou o afastamento dos sítios relativamente aos centros urbanos, tem suscitado dificuldades num correto e adequado usufruir destes espaços, verdadeiros locais de conhecimento que permitem alcançar múltiplos objetivos pedagó- gicos. Permanecemos, hoje, sem uma política de dinamização verdadeiramente instituída e instruída, sem balizas de atuação definidas dependendo, cada sítio arqueológico, da autonomia, dos recursos económicos ou da voluntariedade e dinamização das respetivas equipas de trabalho que sustentam políticas de divulgação e salvaguarda mais ou menos pertinentes e ou adequadas ou, na maior parte dos casos, as possíveis de serem implementadas.

É o próprio sítio arqueológico que possibilita questionar o sentido da arqueologia enquanto ciência que "produz" ruína, uma vez que coloca a descobertas estruturas em deficiente estado de conservação. O conhecimento histórico passa inevitavelmente pela consequente atuação em relação a tais vestígios que, musealizadas ou deixadas ao abandono, ficarão sempre como testemunhos da memória.

1. Arqueóloga. Coordenadora do Museu de Lisboa - Teatro Romano / EGEAC; lidiafernandes@egeac.pt 
A abordagem que atualmente se realiza em tais espaços é de índole muito diversa consoante o objeto arqueológico em questão, o contexto em que se insere ou, na maior parte dos casos, o protagonismo que se pretende atingir. Com efeito, e mais recentemente, a musealização destes sítios tem suscitado interesses ambivalentes passando as ruínas a servir de mote a projetos icónicos que ultrapassam, em muitos casos, o objetivo para o qual foram criados. Nem tudo carece de musealização, mas tudo o que é musealizado carece, obrigatoriamente, de um enquadramento que dignifique o próprio objeto.

$\mathrm{Na}$ breve abordagem que realizamos apresenta-se uma reflexão sobre a musealização de sítios arqueológicos e do seu entendimento enquanto espaços museais, colocando-se o acento no facto de eles próprios poderem ser perspetivados como objetos museológicos. Pelo facto de grande parte dos sítios arqueológicos abrangerem extensas áreas, possibilitam e suscitam perspetivas de visualização diversificadas a partir de pontos de observação distintos. Em muitos casos é possível percorrê-los, ao invés de os visualizar estaticamente, proporcionando uma aproximação visitante/objeto, distanciando-se da tradicional relação presente nos museus com os objetos encerrados em vitrinas.

Os sítios arqueológicos permitem, deste modo, aproximações distintas por parte do visitante e constituem, em primeira mão, uma experiência única de ensinamento e de perceção e apreensão do passado. A cultura de um local, de uma região, de um país ou território, é expressa por aquilo que se mostra num museu, ainda que o museu não represente a cultura de um país. As noções de cultura são muito mais vastas e não podem, nem devem, ser exclusivamente encerradas em edifícios dedicados à sua preservação. No entanto, esta impossibilidade de representação sublinha a tarefa primordial de cada museu: o de preservar o que expõe, o de estudar e perceber o melhor possível o que guarda e divulgar o que possui.

Outra questão a colocar é perceber se os sítios arqueológicos podem ser considerados também como espaços museais. Quando existe um na proximidade daqueles, criado em função dos vestígios identificados e destinado à sua interpretação, pensamos que tal questão é de resposta simples, pois tal equipamento apenas existe em função do sítio colocado a descoberto, destinando-se a explicá-lo e a interpretá-lo. $\mathrm{Na}$ ausência de tal equipamento - seja um museu ou centro interpretativo - a questão que colocamos é se um local arqueológico musealizado também pode ser encarado como tal, isto é, se pode ser classificado como museu. Esta questão, que justificaria um profundo debate, conduz-nos a questionar a própria classificação de muitos espaços como museu.

Por fim, coloca-se a questão de saber o que é, de facto, um "sítio musealizado", assim como perceber qual a distinção que estabelece em relação a um "sítio arqueológico musealizado" ou, simplesmente, um "sítio" ou "área arqueológica". Esta questão apresenta uma outra vertente se, na equação, adicionarmos um outro conceito: o de "ruína". Alguns sítios arqueológicos não são, de facto, mais do que isso, embora o conceito possa encerrar uma perspetiva menos negativa do que a que geralmente lhe conferimos.

\section{A RUÍNA E O SÍTIO ARQUEOLÓGICO}

Numa abordagem imediata estes dois conceitos são distintos. Na verdade, uma ruína pode não ser um sítio arqueológico, mas raras vezes um sítio arqueológico não é ruína. Abstemo-nos quase sempre de empregar o termo "ruína" pois, de imediato, a sua carga negativa leva a considerar um sítio arqueológico como uma derrota, algo que já não serve o seu original propósito ou outro qualquer. No entanto, estamos rodeados por ruínas e não precisam de ser arqueológicas para o serem.

$\mathrm{Na}$ verdade, há algo de profundamente verdadeiro nas ruínas. Elas são, pela sua própria condição, garantes de autenticidade e integridade. Também, na maior parte dos casos, não sofreram restauros posteriores, intencionalmente realizados com o objetivo de as tornar "não ruínas". O ponto unificador é o de serem estruturas arquitetónicas e o facto de ser devido à ação humana, ou à sua ausência, que se deu a sua grande transformação. A ruína é afinal "o paradigma do incompleto" (Pérez-Prat Durbán, 2018, 91).

O conceito de "ruína", embora não tenha sido alvo de uma definição jurídica deveria, segundo alguns autores, ser regulada de forma a salvaguardar quer a sua manutenção, bem como o seu acesso (veja-se a este propósito, o texto de Pérez-Prat Durbán, 2018, 89-101). No entanto, há uma substancial diferença entre "ruína" e "ruína cultural" e é precisamente este último aspeto que nos interessa ${ }^{2}$.

2. Ainda assim, nem esta última distinção é pacífica e uma ruína que não é considerada cultural pode, a partir de dada altura, passar a sê-lo. 
Algo que todas as ruínas têm em comum e que as distingue da maioria dos objetos dentro de um museu, é o facto de terem um contexto, o seu contexto. É algo que não foi deslocado e no qual o seu entorno, embora se possa ter modificado ao longo dos tempos, continua a ser o seu e tem uma história. É este o aspeto a sublinhar, é esta a premissa da qual se deve partir, e é isto que não se encontra num museu pois os seus objetos são sempre deslocados. Uma ruína ou um sítio arqueológico são eles próprios e o seu contexto e não existem um sem o outro. Esta razão, além de outras, leva a aproximar um sítio arqueológico a uma ruína. A diferença estabelece-se bem mais no nosso imaginário do que propriamente numa distinção concetual do objeto em causa.

Quando falamos de ruína, invocamos o contributo dos arquitetos do renascimento ou os do séc. XVIII, os registos magníficos dos desenhos de Piranesi onde as ruínas e a vegetação fazem parte de um mesmo ser vivo, ou os contributos do séc. XIX, como os de Alexandre Laborde onde os seus desenhos são tão mais explícitos que os textos. É impossível empregar a designação de "ruína" sem que tal carga histórica lhe esteja associada e será ela - por um intencional distanciamento com a experiência do passado - que nos leva a preterir o termo.

Hoje em dia queremos sublinhar a ideia de que um sítio arqueológico é o produto de uma intencional ação humana, a descoberta de algo até então escondido. No entanto, são mais os casos em que os sítios arqueológicos são também ruína do que aqueles em que tal não se verifica. A nosso ver, ruína e sítio arqueológico não são precisamente a mesma coisa, embora tenham inúmeros pontos de contacto, e haverá benefícios se o conceito de "ruína" for legislado, concedendo algum grau de proteção às estruturas, arqueológicas ou não, que não se encontram conservadas, musealizadas ou restauradas ${ }^{3}$. Como refere Pedro Cardim "Sendo património arqueológico um conceito distinto do de ruína, integrará e afirmará distinto significado. Efectivamente, à obra patrimonial atribui-se um valor não só material como simbólico. A ruína enquanto não é reconhecida como valor patrimonial, apenas aguarda que a reabilitem ou substituam..." $(2018,8)$.

3. A Lista do Património Mundial da UNESCO, por exemplo, não reconhece este termo embora “... las ruínas podriam llegar a abarcar cerca del veinte por ciento de los lás de mil bienes inscritos" (Pérez-Prat Durbán, 2018, 89).

\section{SÍTIO ARQUEOLÓGICO VERSUS SÍTIO MUSEALIZADO}

Na verdade, quando pensamos na Acrópole de Atenas, ou na cidade romana de Dougga, na Tunísia, não nos ocorre classificar tais sítios como "museu" ou designá-los por "sítios musealizados". Museus e sítios musealizadas têm um significado distinto que, embora não se estabeleça uma evidente diferença, não são confundíveis. Designamo-los, como tantos outros, por sítios arqueológicos, mas não por sítios musealizados.

A distinção entre aqueles dois conceitos impõe-se, uma vez que, embora um sítio musealizado possa ser arqueológico nem todos os sítios musealizados são sítios arqueológicos. A primeira grande distinção estabelece-se com os sítios históricos. Um castelo medieval, um forte do séc. XVI, uma casa senhorial do séc. XVIII, ou uma casa rural do séc. XX podem não ser sítios arqueológicos, pois não foram descobertos sob o solo e o seu bom estado de conservação ao longo dos tempos foi o garante da sua manutenção até à atualidade. Mesmo a classificação de "sítio arqueológico" não é clara. $\mathrm{Na}$ verdade, podemos considerar como tal, qualquer local, ou sítio específico onde se registam vestígios da atividade humana. Aproximamo-nos, assim, do conceito amplo e geral de Paul Bahn (1996, p. 70), ainda que outras perspetivas possam ser aceites, como o caso de àreas com limites definidos, ou um sítio descontínuo que preserva testemunhos da ação humana os quais podem ser colocados a descoberto por ação da arqueologia (Feder, 1997) ou, de forma ainda mais circunscrita, sítios, "locais onde são identificados mais materiais arqueológicos que na paisagem envolvente" (Carman, 1999, p. 23).

Estes conceitos, no entanto, não têm aplicabilidade em variadissimos casos, epecialmente no que à arqueologia urbana diz respeito, uma vez que muitas cidades com um passado histórico recuado, albergam no seu interior um contínuo de estruturas e materiais arqueológicos impedindo, assim, a delimitação de áreas onde tais vestígios surgem. Nestes casos, como acontece em Lisboa, a inexistência de áreas sem sítios arqueológicos corresponde, afinal, a áreas ainda não intervencionadas ou, em muitos casos, de sítios arqueológicos que já não o são, pela sua escavação e consequente destruição, termo ao qual se substitui o de "desmontagem”, a bem de descanso de algumas consciências e 
como se tal não fosse sinónimo, no que respeita ao universo arqueológico.

Numa outra perspetiva, a distinção entre "sítio arqueológico" e "sítio musealizado" introduz-nos no conceito de "museu comunitário", definido em 1979 por Hugues de Varine, inaugurando a distinção entre museu dito tradicional e museu comunitário. Não deixando de sublinhar a relevância do conceito (tema que retomaremos), especialmente aquando da sua introdução, dificilmente o poderíamos aplicar no âmbito de muitos sítios arqueológicos e até de alguns museus.

Em alguns casos e cada vez mais, os sítios arqueológicos e sítios musealizados podem não nascer de uma exigência social da comunidade. Neste sentido, não correspondem a qualquer tipo de "museu comunitário", não sendo criados pela necessidade de partilha de um passado comum ou de algo que polarize a noção de identidade ou enraizamento de uma memória conjunta.

Não raras vezes, quer no passado ou também no presente $^{4}$, o nascimento ou a criação de sítios arqueológicos é fruto de uma legislação específica de salvaguarda dos bens culturais e bens arqueológicos, assim como, e especialmente, do tipo de intervenção fisica que se realiza em determinado país, seguindo legislação internacional estabelecida. Veja-se o caso do Núclo Arqueológico da Rua dos Correeiros ou o das estruturas arqueológicas conservadas no atual Hotel Eurostars Museum, em Lisboa. Em ambos os casos foi uma decisão entre a tutela que gere o património arqueológico português e o dono de obra, que tornou possível a manutenção das estruturas arqueológicas e a sua respetiva musealização, a qual ficou, no que respeita aos custos envolvidos, a cargo dos respetivos proprietários (Figura 1).

Falamos também de sítios onde a decisão da manutenção das estruturas à vista e da promoção da sua visualização e visitação não é recente, antes tomada há muito tempo, perdurando até à atualidade, tentando-se em alguns casos uma atualização das condições de visita, limpeza e manutenção das estruturas arqueológicas, como o caso do Castro de Vila Nova de S. Pedro, mais recentemente alvo de novas campanhas de escavação no âmbito de um projecto

4. Especialmente no presente devido, apenas e tão somente, ao maior número de intervenções arqueológicas realizadas. que envolveu várias instituições ${ }^{5}$. Inserido neste contexto iniciativas como o "Dia Aberto" à comunidade e demais visitantes, com visitas guiadas e ateliers de arqueologia experimental. Não obstante, o sítio não oferece informação detalhada e as muitas peças recolhidas desde o séc. XIX, quando o local foi escavado por Afonso do Paço, encontram-se no Museu Municipal de Torres Vedras e no Museu do Carmo, em Lisboa, sem que exista qualquer menção ao facto no próprio local.

Também neste caso, a autarquia procura uma regularização da posse dos terrenos, tendo estado em cima da mesa várias soluções como o da sua expropriação ou o pagamento de aluguer uma vez que os terrenos são privados e a continuação da escavação do sítio mais não fará que alargar a área de propriedade privada a ser afetada.

São pois situações herdadas do passado, não raras vezes suscitando grandes problemas de foro administrativo, especialmente relacionados com a propriedade dos terrenos onde os sítios arqueológicos se localizam. Veja-se o caso paradigmático da antiga cidade de Balsa, próximo de Luz de Tavira.

Infelizmente, são raros os casos onde o desejo coletivo de transformar um sítio arqueológico num sítio visitável e musealizado ocorre. Ainda que tal possa acontecer, não significa que o sentido de pertença seja universal. A área arqueológica do Freixo ou o sítio do Castelo Velho, em Freixo de Numão, por exemplo, são casos onde a salvaguarda foi, no embrião dos projetos, consensual na comunidade científica ainda que à margem da comunidade local.

Em muitos casos, a musealização de um sítio arqueológico não é, sequer, especialmente acarinhada pela comunidade próxima, a qual lhe é praticamente indiferente, ainda que se imponha quando, progressiva e lentamente, essa comunidade vai percebendo o valor patrimonial em causa. É neste preciso campo que gostariamos de centrar a questão. A ausência de um investimento por parte da tutela, quer na salvaguarda e proteção de um sítio arqueológico, quer especialmente no seu conhecimento e divulgação diretamente relacionada com o da sua musealização

\footnotetext{
5. Equipa de arqueólogos da Associação dos Arqueólogos Portugueses, da Faculdade de Letras da Universidade de Lisboa, com o apoio da Fundação para Ciência e Tecnologia, da Câmara Municipal da Azambuja e da União das Freguesias de Manique do Intendente, Vila Nova de São Pedro e Maçussa.
} 
- é a responsável por um processo autofágico onde nem a população nem os investidores, públicos ou privados, perspetivam os benefícios de defender e criar sítios musealizados nos seus territórios.

Naturalmente que esta responsabilidade caberá aos organismos estatais competentes, mas uma sociedade não se pode limitar à iniciativa pública nem a um papel por parte do estado que determine as suas opções culturais, especialmente quando estas representam a essência de um povo ou de uma determinada população, quando estão em causa valores civilizacionais determinantes que possibilitem o entendimento de uma sociedade, de uma região ou de um local, através dos vestígios culturais por ela deixados.

Outros intervenientes podem e devem entrar em cena promovendo objetivos, que não apenas os enunciados, que influnciem o destino de um sítio arqueológico.

A partir do momento em que a presença de locais arqueológicos confere um sentido diferencial a sítios que, à partida, seriam iguais a muitos outros, promovem-se fatores como a surpresa, o inusitado, a singularidade mas também o conhecimento, a partilha, o património, a cultura, valores que se tornam, em si mesmos, uma mais-valia.

O caso relativamente recente de unidades hoteleiras onde a presença de estruturas arqueológicas, colocadas a descoberto no decorrer das obras de construção ou de reconversão de antigos edifícios, tem suscitado, mediante um adequado enquadramento arquitetónico, um motivo diferenciador, constitui um exemplo por demais evidente. Confere-se assim um novo sentido à justificativa museológica, como no caso do Corpo Santo Lisbon Historical Hotel, em Lisboa, onde um troço de cerca de $30 \mathrm{~m}$ da Muralha Fernandina, além de outros vestígios ${ }^{6}$, foram identificados, sendo preservados e integrados nas áreas públicas da instalação hoteleira.

Não queremos com isto dizer que não concordamos com tal procedimento. Muito pelo contrário, uma vez que este será um dos casos onde os objetivos justificam os meios. No entanto, esse fim, que pode ser justificável por parte do promotor, não poderá nunca ser o que subjaz a quem decide pela conservação ou não das estruturas e pela sua transformação de sítio arqueológico num sítio arqueológico musealizado.

6. Além de muitos outros vestígios, como a Torre de João Bretão e o Palácio dos Côrte-Real.
Em contexto urbano estas questões são ainda mais difíceis de equacionar. Nestes casos, apesar de a decisão não depender de um só interlecutor, não pode ser a comunidade a decidir uma vez que não detém o real e mais informado conhecimento técnico sobre os vestígios em questão. Serão sim os decisores políticos baseados, naturalmente, em pareceres técnicos válidos, fundamentados e esclarecidos que devem prevalecer. Outros casos há, no entanto, que é o interesse da comunidade que obriga a classe política a optar pela manutenção de algo, quando o que está em causa é particularmente relevante para a comunidade local. Veja-se o caso, por exemplo, do museu ao ar livre Beamish Museum, Inglaterra, no condado de Durham. Independentemente de gostarmos ou não do conceito de museu subjacente, e sem que exista algo verdadeiramente patrimonial a defender, este museu só existe pelo contributo e trabalho da comunidade, assim como pelo financiamento exclusivo das instituições da região7.

Mesmo neste caso, ou especialmente noutros, tais situações só são possíveis de alcançar quando é a investigação que subjaz e sustenta eventuais decisões políticas. Tudo o que vem depois, respeitante ao futuro do sítio arqueológico e/ou eventual sítio musealizado, só poderá ser alvo de tais transformações se a investigação sustentar as decisões políticas e económicas concernentes à criação de tais sítios.

\section{O QUE SIGNIFICA MUSEALIZAR?}

Musealizar é, literalmente tornar museu. A palavra "museu" provém do grego, significando os templos ou santuários onde as musas, filhas de Zeus e Mnemósine, habitavam. O termo significa também a biblioteca ou espaço criativo, pois era o local dedicado à música e às artes. Museu é, deste modo, sinónimo de casa e memória, de criação e resguardo. E não se pode, ontem como hoje, dissociar estas duas vertentes do conceito de museu: a proteção do passado e da memória, mas também o da sua reani-

7. Trata-se de um museu, criado na década de 1970, que procura recriar de foma mais fidedigna possível, o tipo de vida de uma pequena povoação dos inícios do séc. XX, tendo sido construídos vários equipamentos típicos da época, como restaurantes, lojas, armazéns, tipografia, dentista, banco, padaria, fábrica de doces, cafés, lojas e casas particulares diversas. Em muitos casos os objetos foram oferecidos pela comunidade local. O bilhete de entrada permite visitar, durante um ano inteiro, o museu ao ar livre. 
mação e interpretação. Fazer prevalecer uma destas componentes corresponde a truncar a essência de um museu no seu completo e correto significado e entendimento.

"Tornar museu" pode, no entanto, suscitar um sentido negativo do conceito, que aproximaríamos à ideia de "congelar no tempo" ou eternizar algo que já não vive.

Um local musealizado, seja arqueológico ou não, é um espaço que é tratado como tradicionalmente se tratam as peças de um museu: há um caminho direto para chegar até elas, através de sinalética específica que encaminha o visitante; estão identificadas, através de uma legenda que nos diz o que é o objeto, de que material é feito e quando foi produzido; podem estar associadas outras informações, como textos, mais ou menos longos, que nos integrem no âmbito cultural ou cronológico sobre determinado objeto; mapas, desenhos de reconstituição, filmes, maquetas, etc, etc. O objetivo é sempre o mesmo: a identificação do objeto, a explicitação da sua origem e formas de produção/fabrico, a sua função e as razões subjacentes à criação.

Assim, uma das explicações do que é um sítio musealizado leva a equiparar um objeto em exposição num museu e numa vitrina, ou outro suporte, com o objeto "sítio construído" que se pretende mostrar. Em ambos os casos, existe uma explicação do que é, independentemente do grau de pormenor ou da quantidade de informação fornecida.

Naturalmente que existem diferenças entre o tipo e quantidade de informação que se fornece sobre peças num museu e a que se disponibiliza num sítio arqueológico que ocupa largos metros quadrados. Em ambos os casos, a informação em demasia também pode ser antagónica ao objetivo pretendido. Não obstante, será sempre preferível fornecer mais e melhor informação do que nada ter que explique uma edificação que, pelo seu estado de "ruína", pode ser parcamente ilustrativa. Mesmo em bom estado de conservação, tal como ocorre com monumentos que vemos ou visitamos, por vezes ainda em funcionamento, desconhecemos, em variadíssimos casos, respostas às muitas questões que cada um deles nos pode suscitar: o que é, qual a função, quando e como foi construído.

Vários níveis de informação, quando fornecidos separadamente, quer se trate de peças em museu, quer de sítios arqueológicos, são sempre a melhor opção uma vez que suscitam e possibilitam a escolha, não obrigando à respetiva leitura/visualização ${ }^{8}$. Deste modo, disponibiliza-se ao visitante várias possibilidades de informação, que variam entre o grau e quantidade de conteúdos que o próprio pretenda, a cada momento, visualizar e rececionar, ao longo da visita que realiza. Neste âmbito, damos o exemplo do Parque Arqueológico Cerro del Molinete, em Cartagena (Espanha), onde suportes digitais, com plantas e reconstituições das várias estruturas arqueológicas convivem, lado a lado, com informações impressas em suportes rígidos, de caráter mais tradicional (Figuras. 2 e 3 ).

Outro exemplo é-nos oferecido pelos subterrâneos do Museu d'Historia de Barcelona-MUHBA. Nestes dois casos a quantidade e tipo de informação fornecida é totalmente distinta. No primeiro, assistimos a uma pormenorização de conteúdos, complementados por audioguias, onde desenhos, reconstituições e descrição escrita é acompanhada por imagens digitais, sendo disponibilizada mais informação. No segundo caso, os dados fornecidos são em muito menor escala, encontrando-se remetidos para explicações mais generalistas em "textos de sala" destacados em pontos precisos do percurso (Figura 4). Pontualmente, e de forma muito simples, é disponibilizada em locais específicos alguma informação. Algumas peças são expostas com uma descrição sumária. São, diríamos, chamadas de atenção pontuais que animam o percurso e retêm o olhar de quem passa, enriquecendo a informação visual dada pelas estruturas aqrueológicas.

Dois casos muito distintos que refletem objetivos diferenciados e adaptados a distintas situações. Em Barcelona o volume de visitantes será substancialmente maior que em Cartagena, sendo que aqui o percurso pedonal ao longo das estruturas arqueológicas, realiza-se num nível fisicamente mais elevado, um mezanino largo, existindo a possibilidade de descer ao nível dos vestígios, onde a informação é bem mais sucinta.

\footnotetext{
8. Em tempos realizei um curso de formação que tratava da qualidade e quantidade de informações que um museu deveria ter. Dizia a formadora que, se toda a informação escrita num museu demorasse mais de 1 hora a ler era um erro pois o tempo máximo de concentração do ser humano não ultrapassa tal período. Em nossa opinião, tais generalizações são inteiramente incorretas. Pessoalmente já me ocorreu ficar 30 minutos num museu sem intenção de regressar e, em outros casos, aí me de demorar 5 horas com vontade de prolongar a visita.
} 
Distintas soluções, diferentes níveis de informação, adequada, sempre, aos espaços em questão e aos distintos públicos que se pretende informar. Não existem receitas imutáveis, nem soluções estereotipadas para todos os casos. Os locais são sempre diferentes e é sempre distinto o público que os visita. Não obstante esta ausência de linhas reguladoras ou orientadoras, a presença de informação fundamentada e fidedigna constitui o ponto de partida, o único válido aliás, para um trabalho consequente do ponto de vista de utilizar da melhor forma possível os recursos disponíveis.

Por vezes, os sítios arqueológicos transformam-se em ícones, o que pode ocorrer pela relevância dos vestígios, mas também, e especialmente nos últimos tempos, quando os projetos de arquitetura, destinados à sua proteção, se tornam nos verdadeiros ícones.

O caso paradigmático das termas de Vals, na Suiça, com projeto de arquitetura de Peter Zumthor, trouxe à ribalta as termas romanas aí existentes. $\mathrm{O}$ mesmo aconteceu com o edifício de proteção das estruturas de abrigo, de cronologia romana, em Chur (Graubunden, nos Alpes suiços). Em ambos os casos, são os projetos arquitetónicos bem mais conhecidos no mundo da arquitetura do que da arqueologia. Ambos da década de 1980, não deixam de ter presente a primordial relevância do objetivo a cumprir. Outros há em que tal objetivo se perde perante o inusitado do projeto arquitetural, figurando este como o ponto fulcral da visita ao local, sobrepondo-se ao objeto alvo do projeto. Veja-se o caso, por exemplo do complexo conhecido por "Las Setas", designação dada popularmente ao Metropol Parasol, construído no centro de Sevilha, na Plaza de la Encarnación, com projeto do arquiteto Jürgen Hermann (Figura 5).

Neste último caso o sítio arqueológico constitui mais um pólo de atração no conjunto de várias valências que se congregam no espaço.

Nem sempre, no entanto, é possível ou aconselhável enveredar por projetos de arquitetura icónicos, sensacionalistas ou grandiosos. Por um lado porque, simplesmente, não são necessários, por outro porque o mais sensato é abraçar uma integração dos vestígios arqueológicos adequado ao espaço onde surgem e optar pela potenciação de verbas para a sua conservação, estudo e divulgação. Veja-se, a este propósito, o caso da estação de combóios de Braga, onde a modesta integração arquitetónica dos vestígios arqueológicos dos banhos pré-romanos, com adequada infor- mação, constitui o suficiente para a sua salvaguarda e correta disponibilização de informação9.

E este tema sugere-nos, naturalmente, o da função social da musealização das estruturas arqueológicas e, afinal, a própria função social da arqueologia.

\section{A FUNÇÃO SOCIAL DA ARQUEOLOGIA E DOS SÍTIOS ARQUEOLÓGICOS}

É uma verdade absoluta que, se a arqueologia não conta uma história não serve para nada. O ideal é servir para contar muitas história e, através delas, múltiplas perspetivas, pois a história não tem um sentido único, um princípio, um meio e um fim. A história tem factos, tem datas mas é feita de pessoas que a fazem e, deste modo, nunca é línear, simples ou unidirecional. A ideia defendida de que a sociedade, território e objeto se encontrem em espaços como museus, os tais "museus comunitários", definindo-os na sua essência, poderá constituir uma aspiração ou até um sucesso, em alguns casos, mas está claramente afastada na grande maioria deles.

Quando falamos de musealização de sítios arqueológicos falamos de partilhar estruturas arqueológicas que se encontram in situ, não tendo sido pré-determinado que tais vestígios se localizassem num determinado local. Se musealizar significa, a par de outras vertentes, tornar museu, não é obrigatóio pensarmos que falamos de espaços criados pela comunidade, aproximando-nos do ideal de "museu comunitário" definido por Hugues de Varine (200o). Como vimos, a trilogia "sociedade, território e objeto", não tem de estar presente e há sítios musealizados que cumprem um papel crucial sem que tenham sido desejados pela comunidade ou tido a sua participação ou colaboração direta.

\section{O CASO DO TEATRO ROMANO DE LISBOA}

O exemplo do teatro romano de Lisboa é paradigmático do que expusemos.

Descobertas as suas ruínas no longínquo ano de 1798, na sequência da reconstrução da cidade após a catástrofe de 1755, a manutenção a descoberto das mesmas não viria a ser concretizada devido ao con-

9. Em 2007, quando conhecemos o local coincidiu deparamo-nos com uma turma de crianças do ensino básico que faziam uma visita. 
turbado período político que o país atravessava, com a invasão napoleónica em 1807 e a consequente fuga da família real para o Brasil. Tal contexto impediu a concretização da ideia do arquiteto italiano Francisco Xavier Fabri - responsável por parte do trabalhos de exumação dos vestígios, embora não do seu descobrimento ${ }^{10}$ - que pugnava pela manutenção à vista daquelas ruínas.

Remonta a este período e àquele arquiteto, a ideia precoce da musealização das estruturas, preconizando a continuação dos trabalhos de escavação, inclusivamente a compra de novos terrenos, a proteção dos vestígios com a delimitação da área por eles abarcada e construção de um muro que protegesse $o$ local e, por fim, o "restauro" das estruturas através da recolocação dos vestígios no seu lugar original ${ }^{11}$. Temos assim, um precoce entendimento de musealização nos finais do séc. XVIII em Portugal. Curioso é o facto do arquiteto explicitar as vantagens do processo: o de mostrar a antiguidade e relevância das estruturas, “... como coiza útil e necessária, pela singularidade do Monumento, que merece todo o empenho de se dar ao Publico com a maior exacçaõ, e desempenho" (Lisboa, 7 de janeiro de 180o, in Carvalho, 1979, p. 153). Demonstrava-se à população a relevância do país, comprovando-se a grandeza da nação pela antiguidade e natureza das ruínas a descoberto. Naturalmente que, em 1798, Fracisco Xavier Fabri não terá gozado do particular apreço da população que, decerto, não terá visto com bons olhos a manutenção da cratera em local destinado à abertura da Rua de São Mamede (Fernandes, 2013, p. 51-62). A 16 de março de 1799, Jozé António Dias e Manuel Loureiro, proprietários do terreno onde se havia feito a descoberta, requerem a continuação dos trabalhos de edificação do seu imóvel (idem, p. 141). Teríamos de esperar por 1964 para que uma pequena sondagem realizada no $\mathrm{r} / \mathrm{c}$ do edifício, possibilitasse vislumbrar o que havia ficado, por tantos anos. subjacente ao imóvel de cinco pisos e águas furtadas sobreposto às vetustas pedras.

10. Cf. a este propósito Fabião, 2013, pp. 389-409.

11. Ou seja, tal como enumera “... Conservar o antigo Monumento no mesmo lugar, em que se achou, sou de parecer, que se compre o Terreno, e a parede dos Edificantes; e se torne a colocar outra vez no seu lugar parte das Pedras da Inscripção, que se tirarão para fora, antes de eu ser encarregado de vigiar sobre a indagação daquelas Antiguidades" (Carvalho, 1979).
A escavação arqueológica realizada naquele ano e depois continuada por Irisalva Moita até 1967 (Fernandes, em publicação) não correspondeu a um desejo da população, que desconhecia por completo o que permanecia no subsolo, antes a uma decisão de um restrito número de pessoas, letradas, académicas e de espírito empreendedor. Não fora tal circunstância, que aliou outras premissas ainda mais fundamentais - como a de convencer o poder político num investimento que a todos parecia estranho não teríamos tido no país um dos primeiros casos de arqueologia urbana e não teriamos hoje um sítio arqueológico musealizado e um museu a ele dedicado. É de sublinhar que o impacto que a escavação da década de 1960 teve nesta área da cidade foi considerável. A compra de vários edifícios e a demolição de cinco deles tendo por exclusivo objetivo aspetos culturais e científicos fez da operação imobiliária um caso absolutamente inédito. Um plano desta magnitude apenas poderia ter tido lugar num período de tempo tão rápido, no então contexto político. Apesar desta redescoberta auspiciosa, o destino das ruínas não seria ditoso. A "Revolução de Abril" trouxe novas premissas e as ruínas entre as ruas da Saudade e de São Mamede, foram apelidadas de "anti-revolucionárias". Num artigo de 16 de junho de 1974 no jornal A Capital, dizia-se (citando uma fonte, a propósito da expropriação dos edifícios a demolir) que “. .. uma descoberta de mero valor arqueológico (...) "é contrário aos principios democráticos do 25 de abril»".

As descobertas arqueológicas podem, afinal, ter um claro significado político e representar um atentado à própria comunidade, ou servir de arma de arremesso ao poder instituído. Não podemos deixar de mencionar que o baixo-assinado então apresentado à Junta Nacional da Câmara Municipal de Lisboa, contando com 86 assinaturas e manifestando-se contra o prosseguimento dos trabalhos arqueológicos, foi encabeçado por uma personagem revolucionária, Ary dos Santos, célebre poeta e compositor, embora não representando, em absoluto, a população. Na verdade, a grande maioria dos moradores ansiava pela expropriação dos imóveis e obtenção de novas casas com infraestruturas mais adequadas do que as que detinham.

Várias tentativas de impulsionar os trabalhos de descoberta do monumento cénico foram sendo pontualmente realizadas. A colocação de um tapume em redor da área, a manutenção de um guarda em per- 
manência, visitas guiadas a grupos específicos (especialmente académicos), ou o levantamento gráfico das estruturas arqueológicas, constituíram investimentos pontuais, mas sem traduzir uma verdadeira aposta na defesa do sítio arqueológico. A pessoa que se encontrava à frente de tal desígnio, Irisalva Moita, havia abraçado outras lutas. A população, por seu lado, nunca sentiu o local como seu, não percebendo o real interesse na manutenção à vista de tais pedras. O valor destas nunca lhes havia sido comunicado, explicitado, demonstrado ou valorizado (Figura 6 e 7 ).

Em 1989 a edilidade cria um Gabinete Técnico o qual promove novas intervenções arqueológicas. Este recomeço sublinhou a clivagem já existente entre a população local e a continuação do projeto de descoberta do monumento, devido à ausência de comunicação. A população não foi alertada do encerramento de uma das artérias (Rua da Saudade) ao trânsito viário, tal como não foram comunicados o reinício dos trabalhos de arqueologia e o objetivo subjacente a tais ações.

A criação de um museu em 2001 não alterou a situação, embora tenha pressuposto um substancial investimento económico por parte da edilidade. $\mathrm{Na}$ verdade, "Quando, em 2001, o Museu do Teatro Romano foi inaugurado, pouco se sabia do monumento cénico ao qual se dedicava um espaço museológico. (...) o espólio a expor era, por um lado, diminuto e, por outro, carecia de interpretação que não, a que ele próprio, poderia fornecer" (Fernandes, 20122013, p. 110).

A inexistência de um quadro técnico e de verbas destinadas ao museu e ao sítio arqueológico mais não fez que prolongar a situação de abandono do espaço, tendo a criação de um museu a ele dedicado sido a verdadeira prova, caso tal fosse necessário, que a criação de equipamentos não é o garante da defesa do património. Tal só viria a ocorrer a partir de 2016 quando a gestão do espaço transitou da edilidade para a empresa municipal EGEAC ${ }^{12}$. A partir desse momento foi possível planear verbas destinadas à programação cultural, promover novas intervenções arqueológicas, assegurar a publicação de vários trabalhos e, especialmente, criar um leque de atividades que promovessem o museu, o teatro e o reconhecimento do património latino na cultura atual.

12. Empresa de Gestão de Equipamentos e Animação Cultural.
Embora as campanhas arqueológicas e investigação sempre estivessem asseguradas, não existiam formas de divulgação acessível nem de captação de novos públicos ou dos residentes. Somente a partir de 2016, com a realização de exposições temporárias, publicações várias, atividades de sensibilização do património, tal panorama viria a ser alterado (cf. entre outros títulos: Fernandes, 2017-a, pp. 7-20; Fernandes, Grilo, 2020, pp. 69-87).

Atualmente o museu não se constitui como um espaço monográfico. A sua missão alicerça-se no estudo, salvaguarda e preservação do sítio arqueológico do teatro, mas esse é o ponto de partida da investigação diacrónica do lugar anterior à edificação do monumento e após o seu abandono. As estruturas arqueológicas preservadas no interior do museu, dos sécs. XVII/XVIII, são tão relevantes quanto aquelas de cronologia romana. São as várias estruturas que aproveitam o monumento romano - que nele se apoiam e lhe retiraram pedras e materiais que explicam a sua desagregação e destruição, mas, de igual modo, permitem perceber a reconstrução contínua da cidade até à atualidade.

Uma das primeiras exposições temporárias realizada pelo museu após a sua reabertura em 2015 foi Saudades da Rua da Saudade - o teatro romano e a sua envolvente nas memórias da cidade (2017). Tratou-se de um trabalho de recolha de depoimentos, escrito e em registo fílmico, da população local ainda residente e de outra, mais recente, que passou a habitar esta zona histórica. A ligação com a Junta de Freguesia foi imediata, sendo a instituição que melhor conhece a população. O local escolhido foi precisamente a Galeria de Exposições Temporárias da Junta de Freguesia de Santa Maria Maior.

A "Hora de Baco", outra das iniciativas realizadas no museu, tenta recriar o ambiente dos antigos teatros, como ocorria originalmente no teatro de Pompeu, em Roma. Uma vez por mês o museu abre as portas gratuitamente, com horário de visitas alargado. Após cinco anos, esta iniciativa já se tornou num momento de encontro da população, amigos, residentes e de público sénior e também jovem.

O museu pretende ser um espaço de partilha e de encontro, um local seguro onde as ruínas arqueológicas sejam vistas, vividas e sentidas mas onde todas as iniciativas têm, subjacente, uma fundamentação científica, pedra basilar da sua estrutura programática.

A missão do museu tem sido norteada pela inclusão, onde a comunidade local assume especial rele- 
vância. Tem sido dada especial atenção a temas da cultura clássica, salvaguarda do património e à arqueologia, através de palestras, exposições e festividades que procuram comemorar datas relevantes do calendário romano, como ocorre com a celebração das festas da Parentalia, Lupercalia ou Saturnalia. O Festival de Teatro Clássico, realizado no mês de julho é já uma marca identitária do museu, levando à cena no sítio arqueológico, algumas obras clássicas marcantes, como A Paz de Aristófanes, O Misantropo de Menandro, Édipo Rei de Sófocles ou a Medeia de Eurípides (Figuras 8 e 9). Esta é precisamente, a maior vocação do sítio arqueológico: devolver à população um dos palcos mais antigos do território nacional.

Cumpre-se assim o que consideramos a inteira vocação museológica deste sítio arqueológico: promover a sua vivência pela população de hoje, cumprindo a vocação para a qual foi edificado: o de ser teatro!

\section{CONSIDERAÇÕES FINAIS}

As ruínas, entendidas como sítios arqueológicos contêm histórias. Em espaços urbanos, especialmente, são muitas as histórias que encerram, paralelas ao número de construções e derrubes, reconstruções e remodelações que o espaço habitado é alvo. As histórias encerradas num sítio arqueológico não comunicam intencionalmente uma ou outra informação. Não foram construídos com esse objetivo e as informações que encerram apenas cumprem o seu objetivo se forem descobertas, interpretadas e transmitidas.

As ruínas são verdadeiramente democráticas pois pertencem a todos e surgem em todo o lado. No entanto, essa democratização só se cumpre se houver concenso na decisão da sua manutenção à vista e se a informação que encerram conseguir alcançar quem as vê, transformando-se, como refere Huges de Varines, em "património vivo".

O património é de todos e para todos e todos temos o direito, mas também o dever, de participarmos na sua construção (Schofield, 2015, p.418). Esta participação exige-se enquanto usufruidores do património, mas, de igual modo, como elementos valorizadores do mesmo, entendido o objeto e o visitante como elos de uma mesma ligação onde apenas os dois, em simbiose, fazem viver o outro.

Se esta ligação biunívoca é expectável num museu, mais pertinente se torna nos sítios arqueológicos.
Entendidos os visitantes como "valorizadores do património" a ligação próxima que se estabelece com um sítio arqueológico - por ser algo compreensível e materialmente reconhecível - tem de ser valorizado. A musealização de um sítio arqueológico é a sua vocação natural se o sentido de pertença for partilhado.

\section{BIBLIOGRAFIA}

A Capital (1974), Jornal diário, 19 junho, p. 14.

ALARCÃO, Pedro (2018) - Construir na Ruína, entre a Reconstrução e a Reabilitação. Ed. Afrontamento

BAHN, Paul G. (1996) - Archaeology: A Very Short Introduction. Oxford University Press

CARVALHO, Ayres de (1979) - Os três arquitectos da Ajuda do "Rocaille" ao Neoclássico. Manuel Caetano de Sousa (1742-1802) José da Costa e Silva (1747-1819) Francisco Xavier Fabri (1761-1817). Lisboa, Academia Nacional de Belas-Artes, pp. 135-153.

CARMAN, J. (1999) - Settling in sites: constraining concepts. In BRUCK, J, \& GOODMAN, M. Ed. Making places in the prehistoric world. London, University College London, pp. 20-30.

FABIÃO, Carlos (2013) - Escavando entre papéis: sobre a descoberta, primeiros desaterros e destino das ruínas do teatro romano de Lisboa. Vir bonus peritissimus aeque. Estudos de homenagem a Arnaldo do Espírito Santo. Centro de Estudos Clássicos. Faculdade de Letras de Lisboa. Lisboa, pp. 389-409.

FEDER, K. L. (1997) - Site Survey. In Hester. Methods in Archeology, (T. H., Feder, K. L. \& Shafer, H. J., Field). Connecticut: Mayfield Publishing.

FERNANDES, Lídia (2012-2013) - O Museu do Teatro Romano (Lisboa): um teatro, um museu e um projecto de investigação. Revista Arqueologia \& História, vol. 64-65, pp. 109-123.

FERNANDES, Lídia (2013) - Museu do Teatro Romano (2001-2013): Balanço de uma década de intervenção e novos projectos para o espaço museológico. Revista Almadan. Centro de Arqueologia de Almada. IIª série, p. 51-62.

FERNANDES, Lídia (2017) - Museu de Lisboa - Teatro Romano: um museu e um monumento romano na cidade. I Encontro de Arqueologia Urbana: uma cidade em escavação (Teatro Aberto, 26-28 novembro 2015). Lisboa, p. 193-211.

FERNANDES, Lídia (2017-a) - Teatro Romano de Lisboa: as ruínas e o seu museu ou como a arqueologia promove o diálogo educacional. Revista Temporis [ação]: 17, nº 2, pp. 7-20.

FERNANDES, Lídia (em publicação) - Irisalva Moita e o processo de escavação do teatro romano de Lisboa. Revista Scaena, $\mathrm{n}^{\circ} \mathbf{2}$. 
FERNANDES, Lídia; GRILO, Carolina (2020) - Teatro Romano de Lisboa: para além do museu e do sítio arqueológico. $3^{\underline{a}}$ Edição Workshop Internacional ARQUEOLOGIA 3.o. 'Resgatar Memórias' (14 - 15 Março 2019 (Fundação da Casa de Bragança - Museu-Biblioteca da Casa de Bragança Universidade de Évora - CHAIA) pp. 69-87.

PÉREZ-PRAT DURBÁN, Luis (2018) - Las ruinas en la lista del Patrimonio Mundial de la UNESCO. Las Ruinas, Concepto, Tratamiento y Conservación. Maria del Valle G. de Terreros Guardiola, Luis Pérez-Prat Durbán (Eds.). Universidad de Huelva, pp. 89-101.

Saudades da Rua da Saudade - o teatro romano e a sua envolvente nas memórias da cidade (2017). VV autores (Org. Museu de Lisboa - Teatro Romano / EGEAC).
SCHOFIELD, John (2015) - Thinkers and Feelers: A Psychological Perspective on Heritage and Society E. Waterton e S. Watson, eds., The Palgrave Handobook of Contemporary Heritage Research, Basingstoke and New York, Palgrave Macmillan, pp. 417-425.

VARINES, H. de (200o) - O Ecomuseu. Ciências e Letras, 27, Porto Alegre, pp. 61-9o.

https://commons.wikimedia.org/w/index.php?curid= 17309641. De Anual - Trabajo propio, CC BY-SA 3.o (Acedido a 8 julho, 2020).

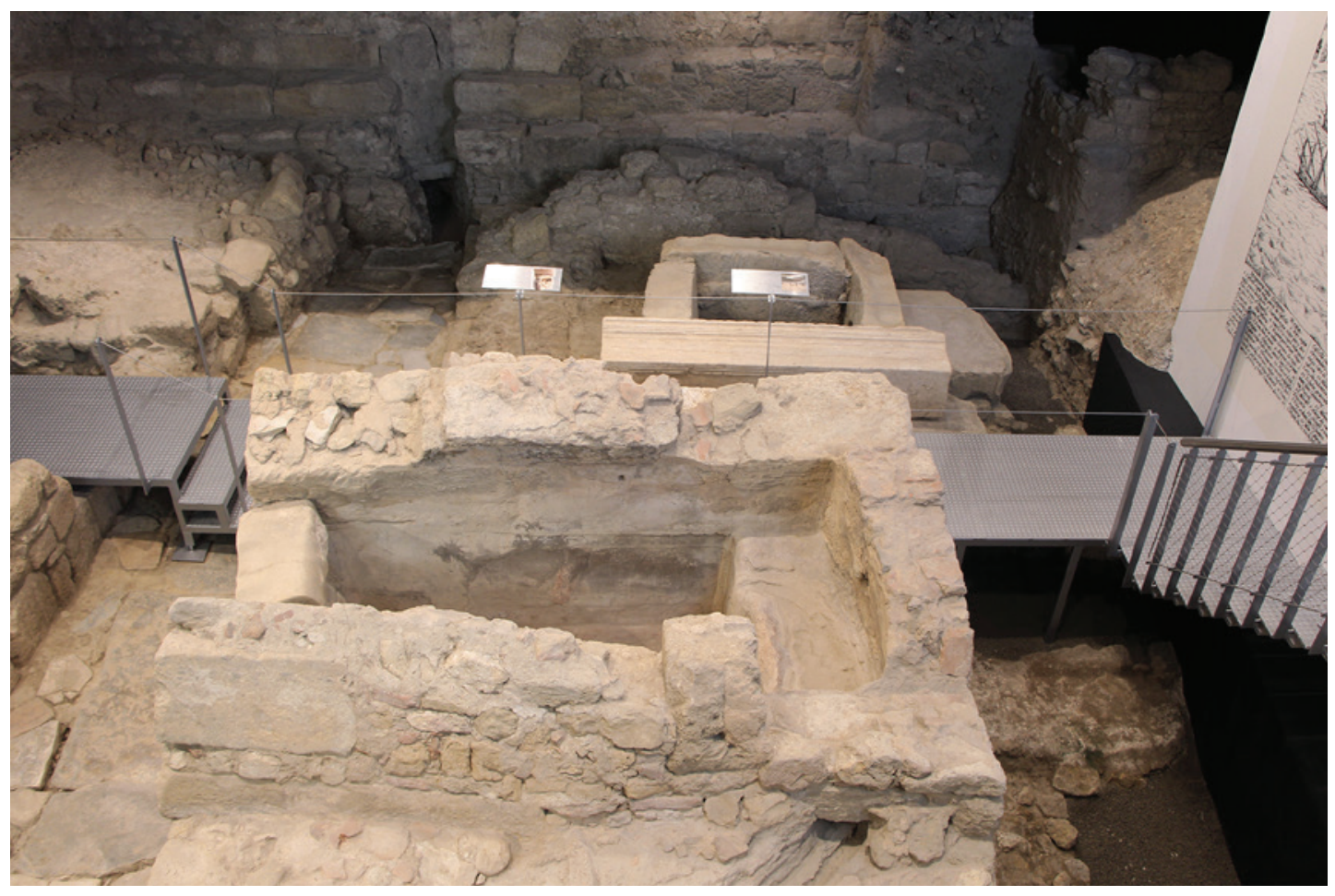

Figura 1 - Estruturas arqueológicas musealizadas no Hotel Eurostars Museum, em Lisboa. (Fotografia de Lídia Fernandes). 


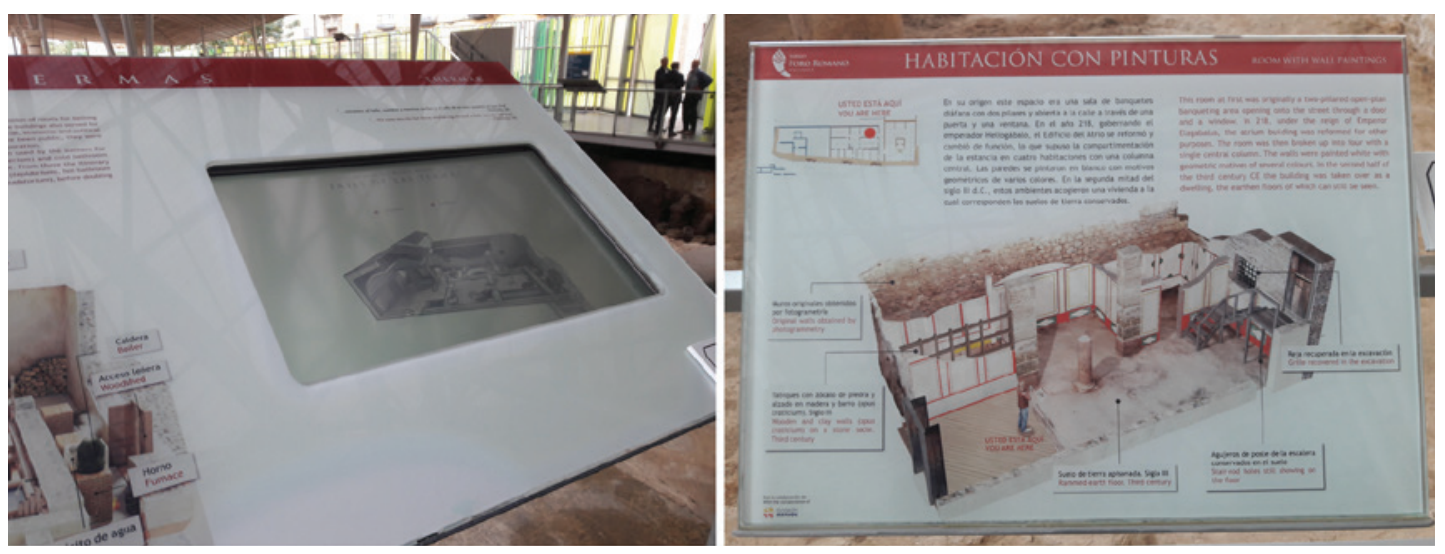

Figura 2 - Parque Arqueológico Cerro del Molinete (Cartagena, Espanha). Diversos suportes, diferentes meios de informação: digital, reconstituições 2D e 3D, auscultadores, textos informativos, legendas. (Fotografia de Lídia Fernandes).

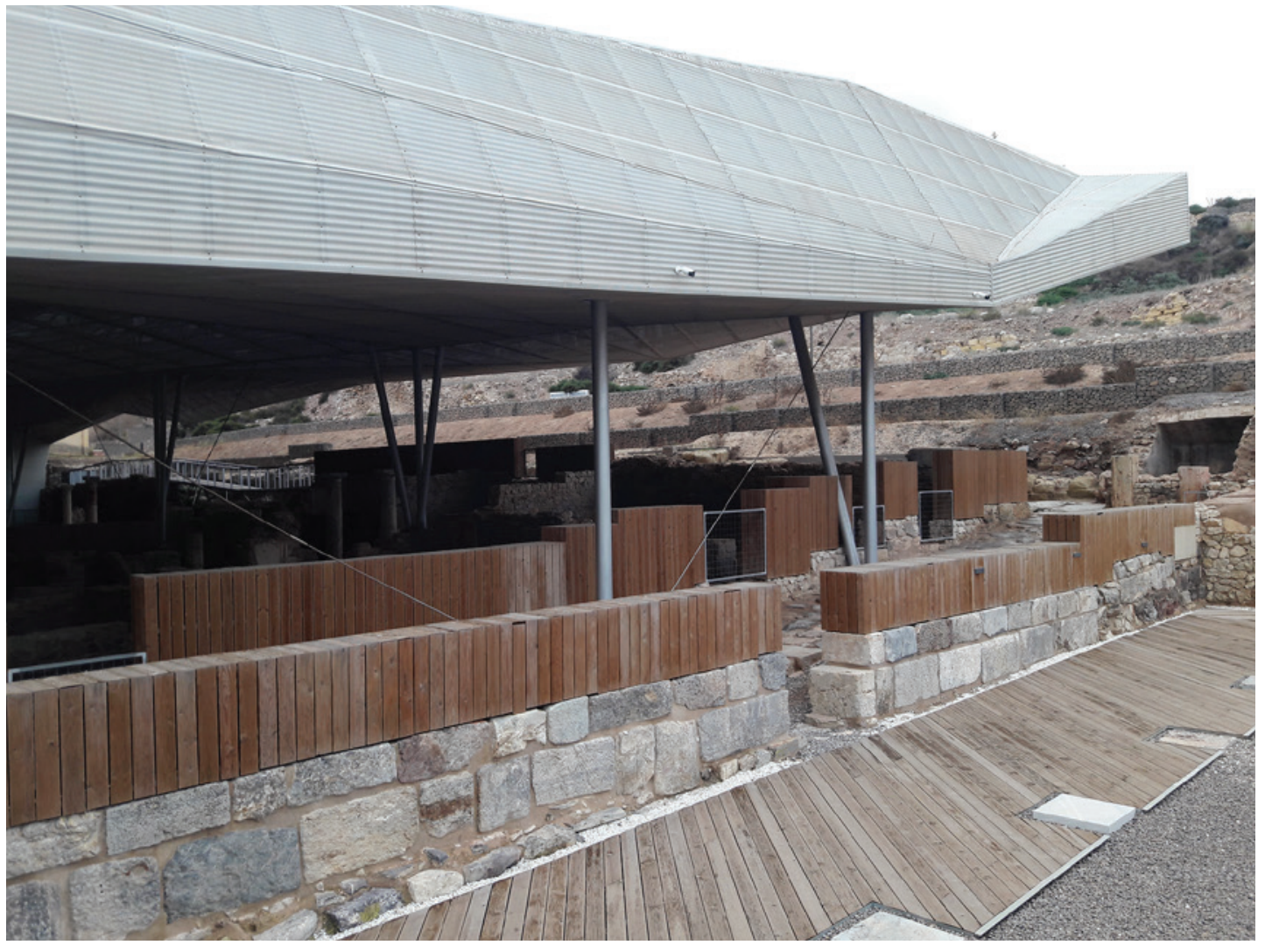

Figura 3 - Parque Arqueológico Cerro del Molinete (Cartagena, Espanha). Cobertura, pavimentos e separação da área coberta das estruturas ao ar livre (Fotografia de Lídia Fernandes). 


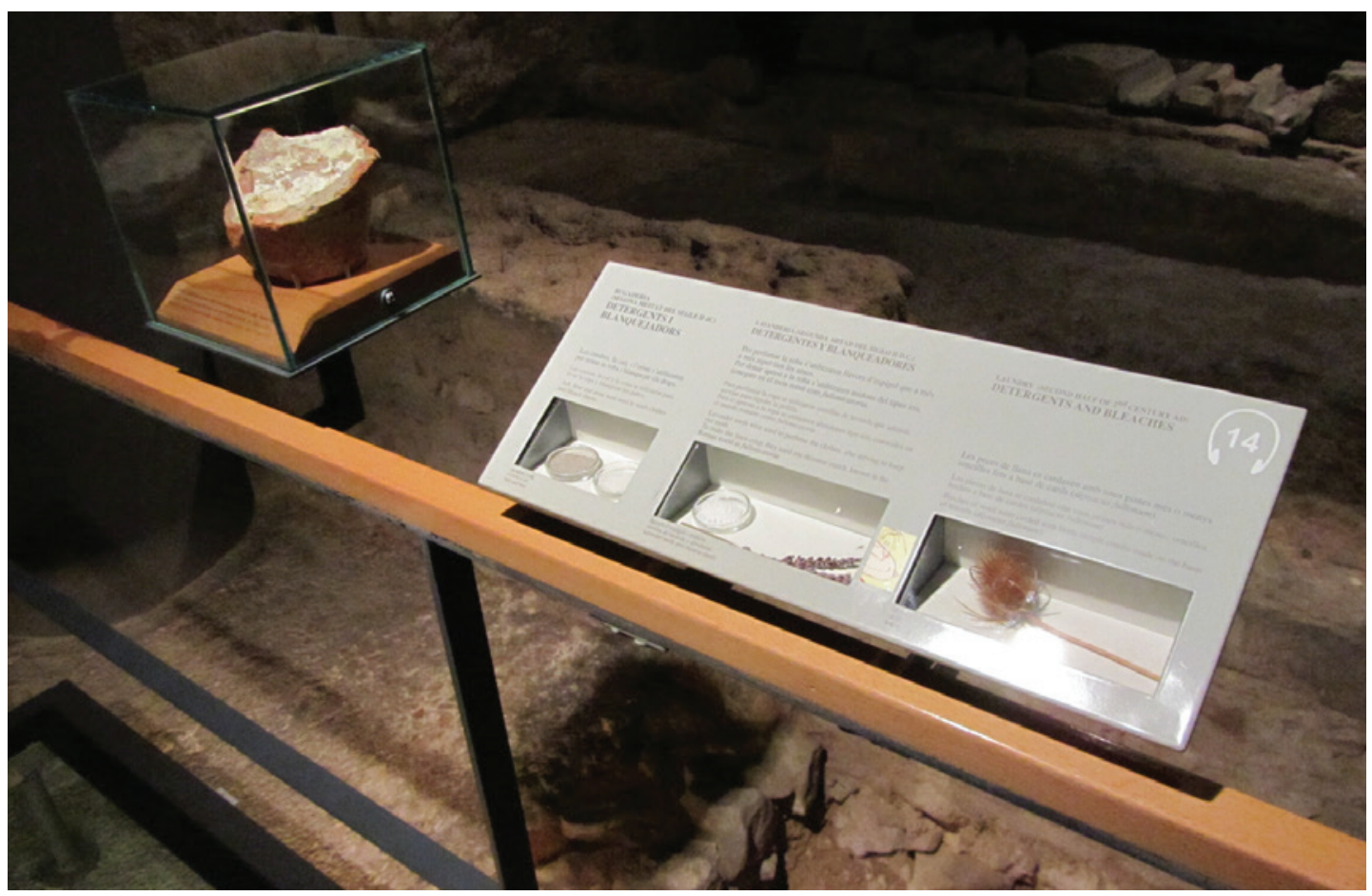

Figura 4 - Subterrâneos do Museu d'Historia de Barcelona. Exposto está o fundo de um recipiente cerâmico com vestígios de pigmentos, ao lado estão plantas e produtos usados no branqueamento e lavagem de tecidos. Estes elementos encontram-se diante das estruturas arqueológicas de uma lavandaria romana do séc. II d.C. (Fotografia de Lídia Fernandes).

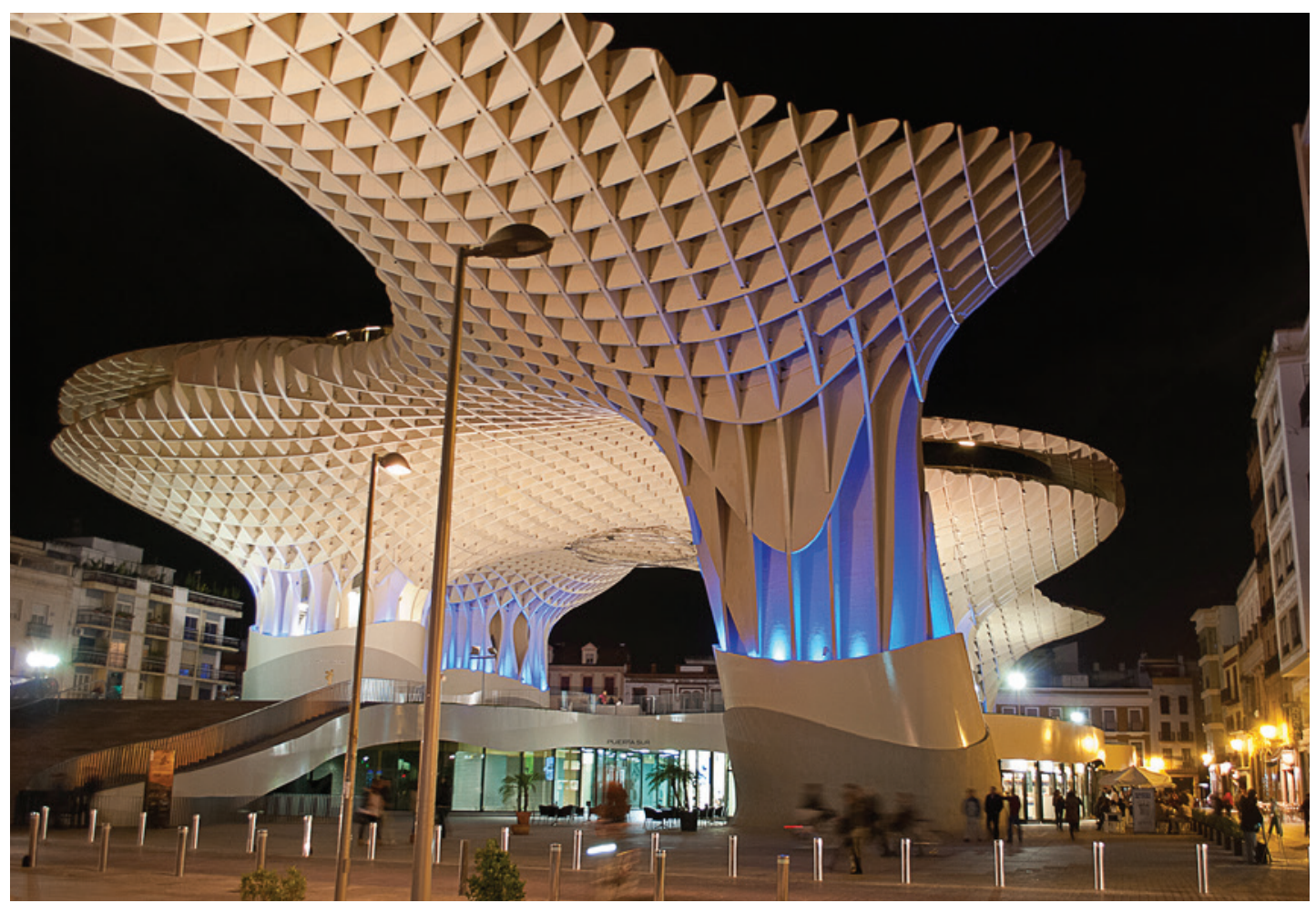

Figura 5 - Metropol Parasol (Plaza de la Encarnación, Sevilha). https://commons.wikimedia.org/w/index. php?curid=17309641. De Anual - Trabajo propio, CC BY-SA 3.0 (Acedido a 8 julho, 2020). 


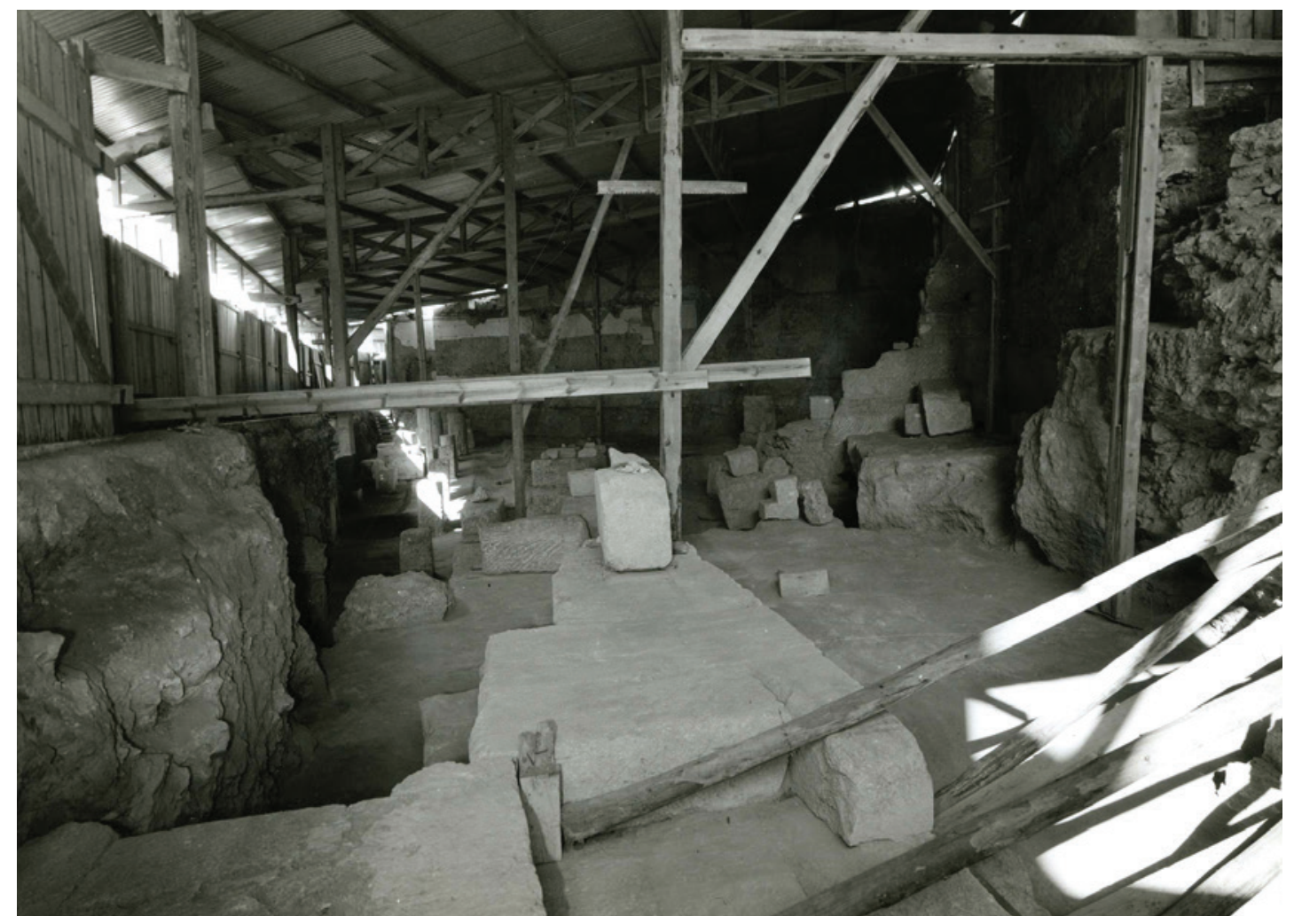

Figura 6 - Ruínas do teatro romano no final das campanhas de escavação da década de 196o. (Arquivo Municipal de Lisboa).

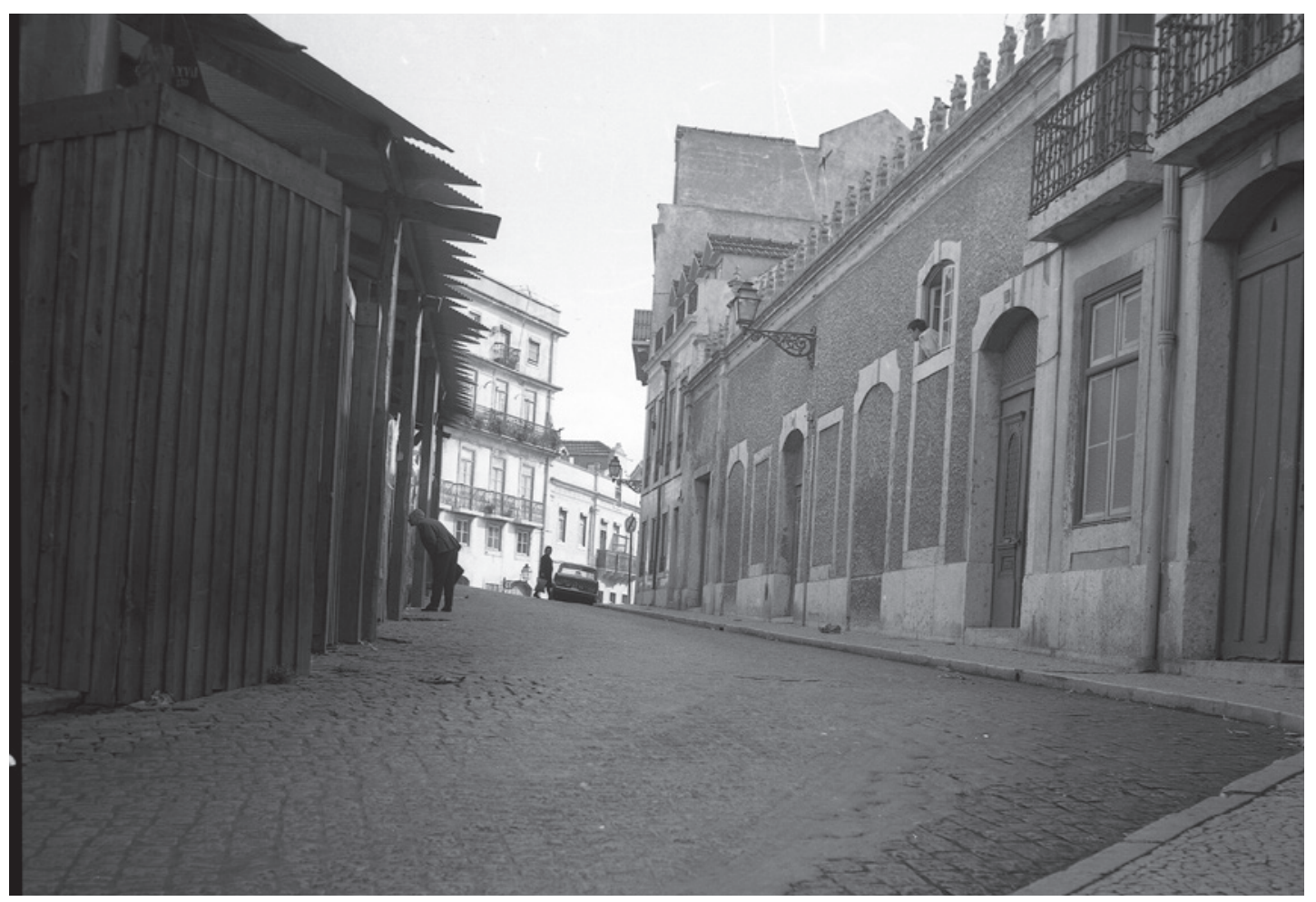

Figura 7 - Tapume de madeira colocado na década de 1960 para proteção das ruínas na Rua de São Mamede. (Arquivo Municipal de Lisboa). 


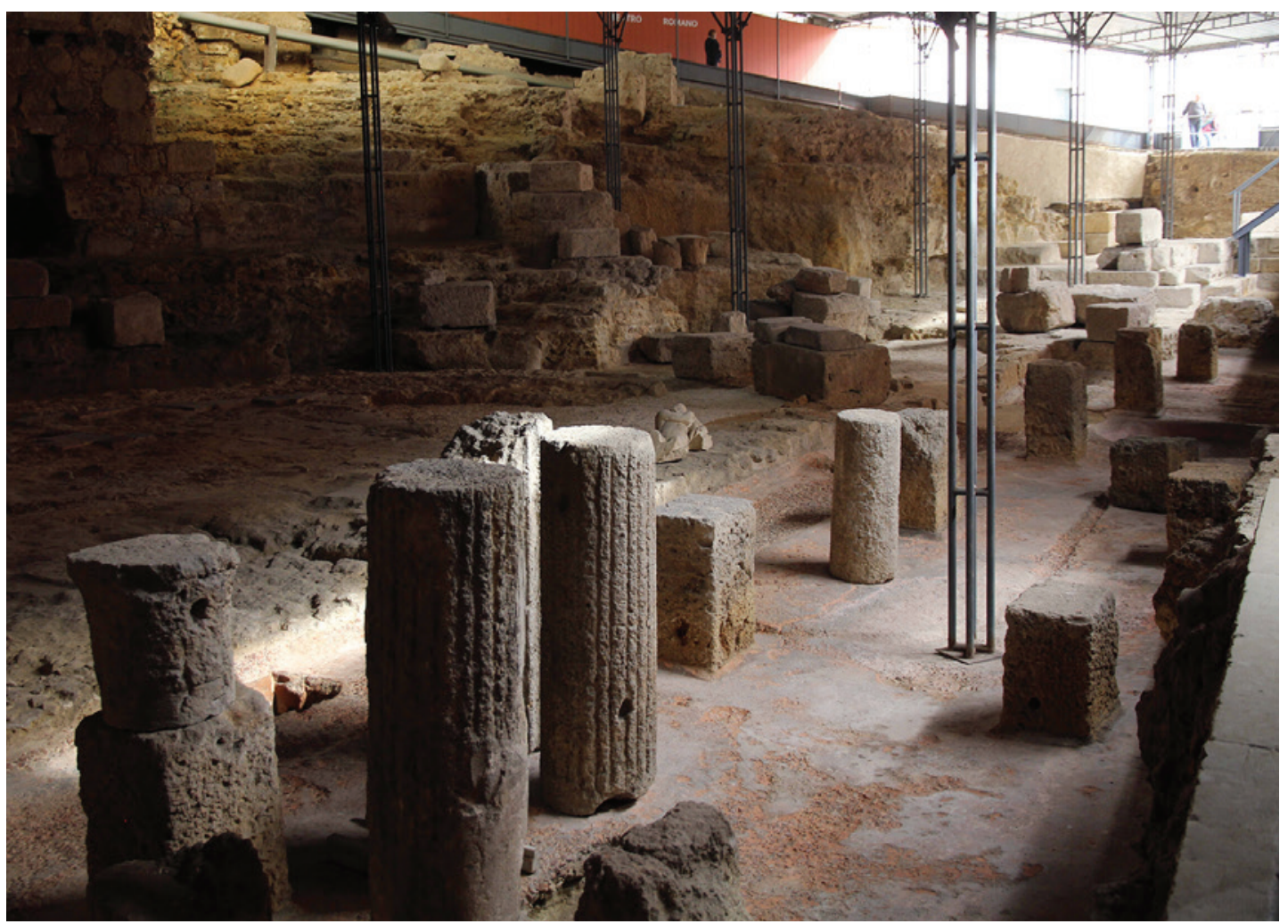

Figura 8 - O sítio arqueológico do teatro romano. (Fotografia de José Avelar).

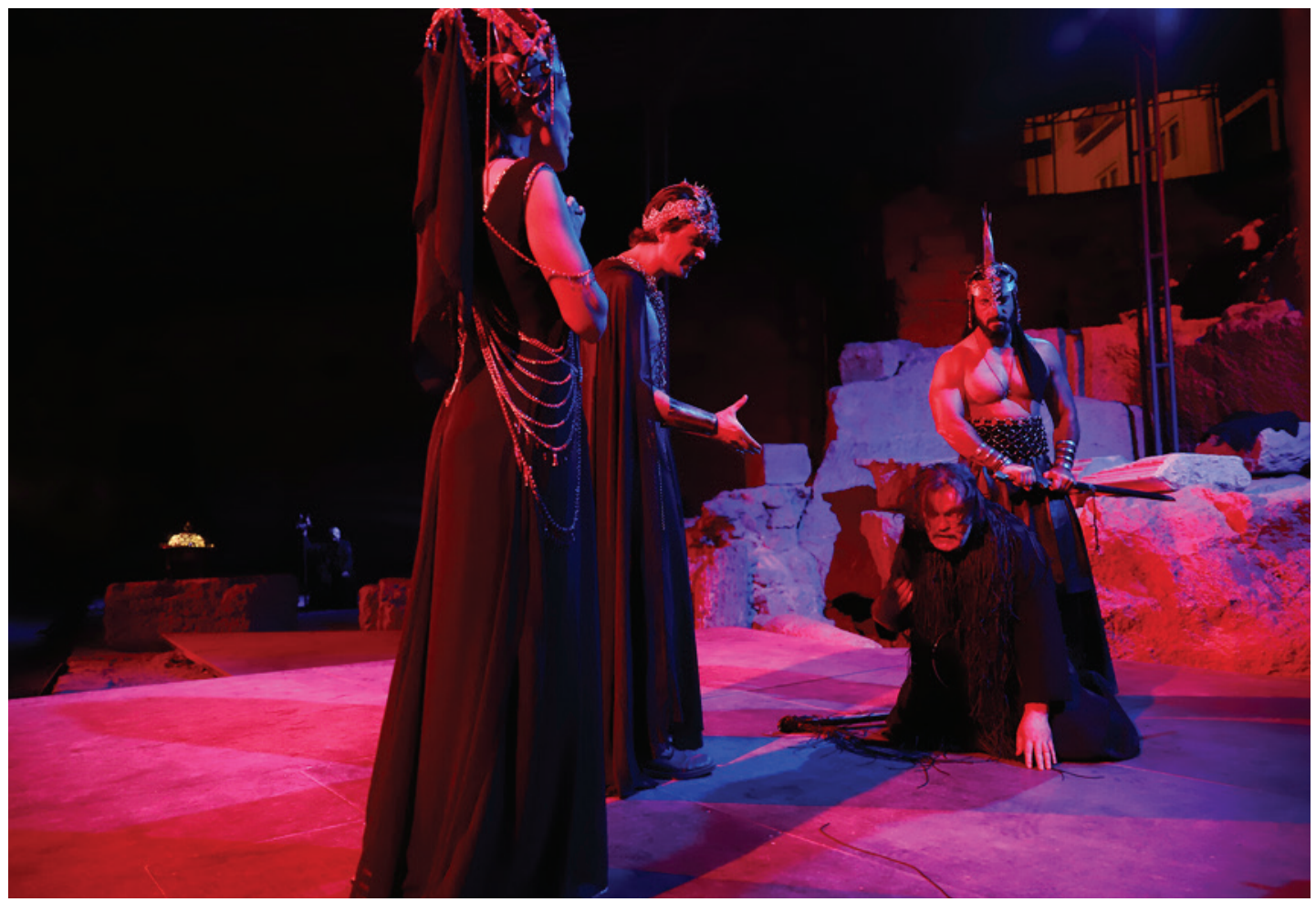

Figura 9 - A peça Rei Édipo encenada pelo Teatro Livre em 2019 (Fotografia de José Avelar). 


\title{
ESTÃO TODOS CONVIDADOS PARA A FESTA! E PARA DANÇAR TAMBÉM... O PROJECTO DO SERVIÇO EDUCATIVO DO MUSEU ARQUEOLÓGICO DO CARMO NA $5^{\mathrm{a}}$ EDIÇÃO DA FESTA DA ARQUEOLOGIA
}

\author{
Rita Pires dos Santos ${ }^{1}$
}

\begin{abstract}
RESUMO
Criado em 2003, o Serviço Educativo do Museu Arqueológico do Carmo (MAC) tem como objectivos principais estimular o conhecimento e a vivência do Museu e da sua Coleção junto de um cada vez maior e mais diversificado público.

Mas como possibilitar e estimular uma participação activa por parte dos públicos? Que estratégias poderemos utilizar para convidar alguém a “dançar” connosco? Qual o papel social e educativo de um museu? Partindo duma breve análise em torno destas questões iremos em seguida dar a conhecer o projecto desenvolvido pelo Serviço Educativo no âmbito da $5^{\mathrm{a}}$ edição da Festa da Arqueologia, que teve lugar em Abril de 2019, sob o tema Revoluções e Resistências - Das Origens à Revolução Industrial.

Palavras-chave: Arqueologia, Museu Arqueológico do Carmo, Serviço Educativo, Diversidade, Inclusão.
\end{abstract}

\begin{abstract}
The Education Department of the Carmo Archaeological Museum, created in 2003, has the mission to ensure that people of all ages and abilities can enjoy, experience, and understand the history of the Museum and its collection.

But how do we go about to make that happen? To get people to participate and get involved? What strategies can we use to ask someone to "dance" with us? What is the social and educational role of the museums?

Taking this questions as our starting point our aim is to analyze the project developed by the Educational Department for the $5^{\text {th }}$ edition of the event Festa da Arqueologia that took place in April 2019 with the theme Revolutions and Resistances - From the Origins to the Industrial Revolution.
\end{abstract}

Keywords: Archaeology, Carmo Archaeological Museum, Museum Education, Diversity, Inclusion.

Let me assure you that I'm only human. I don't enjoy being attacked. But it's a whole lot better than being irrelevant. (CASEY, 2007, p. 298)

\section{PARA QUE SERVE UM MUSEU? - BREVES ANOTAÇÕES SOBRE O PAPEL SOCIAL DOS MUSEUS}

Os museus são organizações complexas, resilientes e inspiradoras, fruto e reflexo, por vezes conturba- do, das sociedades onde se inserem. Temos assistido nas últimas décadas a um incremento, com maior ênfase na sociedade Ocidental, ainda que alvo de muita controvérsia no universo museológico, da capacidade e vontade por parte dos museus de tentar corresponder às expectativas das novas audiências, das políticas culturais e de uma sociedade em constante mudança. O museu do século XXI é suposto, assim, explicar a complexidade do mundo actual, e o que significa ser humano nos nossos dias - numa

1. Museu Arqueológico do Carmo; servicoeducativo@arqueologos.pt 
perspectiva histórica. (SMEDS, 2019, p. 11). Neste sentido, e como refere Christina Kreps, nem os museus, nem as práticas museológicas existem no vazio, mas sim enquanto parte integrante de sistemas socioculturais que influenciam a forma como estas práticas são levadas a cabo. O reconhecimento da dimensão social, quer dos objectos, quer da própria museologia permite, ainda segundo a autora, transcender os actuais debates polarizados entre uma visão do museu centrado no objecto e o museu centrado nas audiências, não sendo estas duas posições mutuamente exclusivas. (KREPS, 2003, p. 312)

O questionamento acerca do papel social dos museus não é algo de novo², e se, à pergunta "Deverão os museus ser instituições socialmente responsáveis?" a resposta quase imediata seria "sim", talvez o que importe verdadeiramente questionar seja, como refere Elaine Gurian (2006, p. 73), se os museus são efctivamente e actualmente instituições socialmente responsáveis. Teríamos, certamente, um leque mais variado de respostas.

E, claro, importa também questionar sobre o que se entende por um museu socialmente responsável. Uma definição simples e concreta, em jeito de fórmula "mágica" poderá não ser nem viável nem realista, uma vez que um trabalho socialmente responsável pressupõe múltiplas possibilidades e abordagens, e não se compadece com procedimentos ou regras fixas. Entendemos, então, que o desenvolvimento de um trabalho socialmente responsável por parte dos museus seria, certamente, facilitador do envolvimento cívico, actuando como agente de mudança social e podendo, inclusive, assumir um papel mediador face a tópicos socialmente sensíveis. Acreditamos, ainda, que qualquer instituição museológica, independentemente do seu âmbito, tem ao seu alcance a oportunidade de explorar e descobrir qual a forma mais adequada e apropriada de desenvolver um trabalho socialmente responsável. (JANES, 2007, p. 141) (Figura 1).

Como refere Robert Janes (2007, p. 141) “First, being socially responsible is not about lowering the intellectual or substantive content of museum work and latching onto what is the most popular and trendy.

2. O papel social dos museus tem sido alvo de debate desde meados dos anos 80 do século XX, nomeadamente com o surgimento do movimento da "Nova Museologia”. Para este tema ver a incontornável obra de VERGO, Peter (Ed.) The New Museology. London: Reaktion Books, 1989.
(...). Second, being socially responsible is not about abandoning collections. (...). Third, being socially responsible is not an either/or proposition." E se, acreditamos que este um é trabalho essencial para que as instituições se tornem relevantes para as comunidades, e que deve ser assumido pelo museu de forma integral e estrutural, abrangendo todas as áreas que o compõem, cremos, também, que a mediação cultural e os serviços educativos constituem-se como a face mais visível e determinante no seu desenvolvimento, essenciais para a criação de pontes entre a instituição e a sociedade.

\section{MEDIAÇÃO E EDUCAÇÃO - COM QUE PREMISSAS?}

Learning in museums and other cultural organisa-
tions is potentially dynamic and profound, producing
self-identities. (HOOPER-GREENHILL, 2007a, p. 9)

Temos assistido, em resposta às rápidas e constantes transformações da sociedade nas últimas décadas, a um reforço e consolidação da educação em museus ou Educação Museal ${ }^{3}$ entendida "enquanto campo de estudos transversal e fundamental para o desenvolvimento de um trabalho educativo consolidado e estruturado em torno dos desafios da contemporaneidade (...), reforçando e validando a tomada de consciência do valor educativo dos museus e contribuindo para este campo com conceitos e instrumentos que têm ajudado a delinear novos paradigmas de actuação, novos pontos de partida e novas relações, nomeadamente no âmbito dos serviços educativos e suas funções." (SILVA, 2006, p. 1) Deste modo, a nosso ver, caberá aos serviços e projectos educativos, "o papel de interfaces de comunicação com as audiências e de lugares privilegiados para a construção de saberes e o estabelecimento de relações duradouras e exigentes." (BARRIGA, SILVA, 2007, p. 9) (Figura 2).

Mas de que forma e com que premissas entendemos esta "construção de saberes"? Acreditamos que os museus são espaços que possibilitam um leque muitíssimo variado de experiências, onde a educação não

\footnotetext{
3. Tradução do termo inglês Museum Education. De notar que em Portugal ainda não se adoptou um termo único para designar o trabalho com os públicos desenvolvido pelos museus, sendo comum encontrar designações como serviço educativo, mediação, extensão cultural, entre outros.
} 
formal e a experimentação encontram terreno fértil ao seu desenvolvimento. Partimos, também, do pressuposto de que a aprendizagem é um processo que envolve participação activa dos indivíduos com o que os rodeia (HEIN, 1998, p. 6), que é um processo continuo, natural, e nem sempre especificamente educacional, que envolve não só o intelecto mas também as emoções e o corpo (hands-on, minds-on, hearts-on ${ }^{4}$ ), que é simultaneamente táctil e verbal, que pode deixar marcas profundas ou ser somente superficial. (HOOPER-GREENHILL, 2007, p. 9) Cremos, ainda, que a aprendizagem e a construção de saberes parte sempre dos conhecimentos prévios que cada um possui (HOOPER-GREENHILL, 2007, p. 39), que não somos nunca uma tela em branco à espera de ser preenchida, que tudo o que nos rodeia nos influencia e nos forma (Figura 3 ).

É de realçar, também, o importante papel desempenhado pela educação/mediação cultural no estabelecimento e reforço das relações entre as instituições e os indivíduos, na medida em que se constitui como uma ponte entre os dois ou mais lados, como um elemento facilitador de encontros, tendo ainda, a nosso ver, um poder transformador, uma capacidade de ir mais além.

Deste modo, acreditamos e defendemos uma programação educativa delineada tendo por base os princípios construtivistas da aprendizagem, ainda que tal se possa revelar muito mais complexo, incerto e repleto de inquietações. (HEIN, 1998, pp. 155-156)

\section{O SERVIÇO EDUCATIVO DO MUSEU ARQUEOLÓGICO DO CARMO (MAC)}

É, então, e tendo por base as premissas anteriormente referidas que se têm desenvolvido os eixos estruturais da programação do Serviço Educativo do MAC. Criado em 2003, o Serviço Educativo tem procurado, através da sua programação, fomentar a construção de espaços de encontro e de experiências significativas; potenciar a construção de conhecimento numa perspectiva construtivista e onde têm lugar múltiplas vozes e leituras; e estimular a criação de espaços de comunicação e aprendizagem ao longo da vida.

4. Esta perspectiva de aprender-fazendo, fazer-pensando, pensar-implicando-se é da autoria de Susana Gomes da Silva, a quem muito agradecemos a partilha destes, e de inúmeros outros, ensinamentos.
Neste sentido, temos vindo a desenvolver uma programação educativa regular destinada quer a públicos organizados, nomeadamente o público escolar (Ensino Básico, Secundário, Universitário) e associações e organizações culturais, quer a público não organizado, nacional e internacional. As actividades levadas a cabo abrangem diversas tipologias, como por exemplo visitas orientadas, oficinas, visitas-jogo, workshops, encontros, ateliers de continuidade, tendo sempre por base a história e a envolvente do edifício da antiga Igreja do Carmo e/ou a colecção do MAC, com especial ênfase para as vertentes de História, História da Arte e Arqueologia 5 . (Figura 4 e 5). De notar, ainda, as várias parcerias desenvolvidas nos últimos anos nomeadamente com universidades seniores, clubes de empresas e escolas da área de Lisboa que em muito têm contribuído para uma maior dinamização e divulgação do MAC junto dos mais diversificados públicos.

Neste âmbito gostaríamos de destacar a parceria com a Câmara Municipal de Lisboa, celebrada em 2013, através da inclusão do MAC no projecto Passaporte Escolar que "assenta numa proposta de educação não formal que tem por base quatro áreas de conhecimento, designadamente: Educação Científica e Ambiental, Educação Desportiva, Educação Cultural e a Educação Cívica. Este visa promover e criar as condições para o desenvolvimento e aprofundamento de competências, conhecimentos e aptidões das crianças, através de visitas a espaços, contactos com profissionais, participação directa em actividades, etc." ${ }^{\prime 6}$ Acresce ainda que no âmbito desta parceria o Serviço Educativo do MAC tem participado na Semana do Passaporte Escolar, evento que congrega as escolas da rede pública de Lisboa e que ocorre anualmente no Museu de Lisboa - Palácio Pimenta. Igualmente significativa é também a presença, desde 2018, do Serviço Educativo do MAC através de actividades educativas na Feira do Livro de Lisboa e na Feira do Livro de Belém, a convite das Bibliotecas Municipais de Lisboa (BLX) (Figura 6 e 7 ).

Estas iniciativas contribuem, conforme anteriormente referido, para uma divulgação do MAC, e

5. Para uma informação mais completa sobre o MAC e a programação educativa ver www.arqueologos.pt .

6. Guia da Oferta Educativa 2019/2O2O - Passaporte Escolar - Câmara Municipal de Lisboa, p.5 https://issuu.com/ camara_municipal_lisboa/docs/guia_passaporte_1ciclo_ 2019_20 
acreditamos no seu enorme potencial enquanto veículo de comunicação. Nesse sentido, e com o propósito de fazer chegar o MAC aos mais diversos públicos, o Serviço Educativo desenvolve desde 2017 o projecto educativo Fora de Portas dirigido às escolas e instituições culturais da área de Lisboa, através do qual se pretende dar a conhecer a história e colecção do Museu, e simultaneamente estimular futuras visitas/actividades contribuindo de forma significativa para o estabelecimento de uma relação douradora entre as pessoas e a instituição.

\section{O PROJECTO EDUCATIVO NA FESTA DA ARQUEOLOGIA}

"Diversity is being invited to the party; inclusion is being asked to dance"

Verna Myers

A Festa da Arqueologia, cuja primeira edição ocorreu em 2010, é um evento dinamizado pela Associação dos Arqueólogos Portugueses e o Museu Arqueológico do Carmo, sendo o resultado do esforço conjunto entre vários profissionais e instituições ligadas à Arqueologia. Como referido no convite dirigido às várias instituições aquando da preparação para a realização da $5^{\underline{a}}$ edição da Festa da Arqueologia, em 2019, este é um evento dirigido ao público em geral, vocacionado para a divulgação do papel desempenhado pela Arqueologia em Portugal e que tem como principal objectivo fortalecer a ligação entre os conhecimentos gerados pelos arqueólogos e a sociedade, a partir da realização de várias actividades interactivas de conteúdo científico e da difusão dos seus objectivos, métodos e ferramentas. De notar que, e como refere Swain (2007, p. 4), é nos museus que a grande maioria das pessoas têm um primeiro contacto com a Arqueologia, "with real archaeology, the archaeology of stratigraphy and stone tools, and broken pots and skeletons." Ainda que a presença física destes artefactos nas vitrines dos museus contribua em grande medida para a sua descontextualização e consequente perda ou transformação de significado para grande parte dos visitantes. (SWAIN, 2007, p. 4)

Cabe então, a nosso ver, ao museu, e designadamente aos serviços educativos e de mediação, o papel de estabelecer pontes entre os objectos, os especialistas, e os públicos através de estratégias potenciadoras de relações duradouras baseadas numa co- municação aberta e franca que requer por parte das instituições uma grande capacidade de escuta activa e por parte dos públicos uma vontade activa de envolvimento. Este evento é, em nosso entender, um excelente exemplo de boas práticas na comunicação do património arqueológico. Na sua procura de aproximar os especialistas dos públicos, através da sua sensibilização para a salvaguarda, valorização, conservação e divulgação do património arqueológico português, é um evento que estimula e apela à diversidade. Ou por outras palavras, somos todos muito bem-vindos a esta festa.

Mas como possibilitar e estimular uma participação activa por parte dos públicos? Que estratégias poderemos utilizar para convidar alguém a "dançar" connosco? A nossa abordagem educativa para a Festa da Arqueologia pautou-se, como aliás tem sido uma constante na programação do Serviço Educativo do MAC, por um conjunto de estratégias que espelham por um lado a procura de um rigor científico e de uma excelência educativa e simultaneamente abrem caminhos para uma maior e mais desejável democratização do museu.

Foi, então, tendo por base estas premissas que desenvolvemos um conjunto de actividades que decorreram quer no espaço/stand do Serviço Educativo quer nas salas do museu. Passaremos de seguida a uma descrição e análise do processo de concepção dos conteúdos e materiais didácticos realizados para a $5^{\underline{a}}$ edição da Festa da Arqueologia. De notar que todas as actividades tiveram como ponto de partida o tema desta edição da Festa da Arqueologia: Revoluções e Resistências - Das origens à Revolução Industrial, e o acervo do MAC. Pareceu-nos ainda relevante que no âmbito do nosso projecto educativo coexistissem actividades de diferentes tipologias com diferentes níveis de envolvimento de modo a suscitar o interesse e a participação dos vários públicos que participaram neste evento.

Iniciamos, assim, a nossa análise pela actividade "Acorda Museu" destinada a famílias e que tinha como objectivo principal dar a conhecer parte do acervo do MAC, concretamente a parte da colecção que se encontra em exposição nas salas do museu, e que abrange diversos objectos de períodos distintos. Optámos por uma tipologia de visita-jogo porque tal permite, em nosso entender, uma maior abrangência de conteúdos sem, no entanto, descurar a parte lúdica e interactiva, fundamentais para o envolvimento dos participantes. Os conteúdos 
foram estruturados em torno das duas premissas acima referidas - tema da Festa da Arqueologia e acervo do MAC - tendo sido concebido para cada uma das cinco salas do museu conteúdos teóricos e práticos que procuravam cruzar a informação da colecção do museu com as diferentes "revoluções e resistências" que tiveram lugar no mesmo período. Os materiais didácticos da actividade "Acorda Museu” foram concebidos tendo por base a própria estrutura do MAC, nomeadamente através da disposição de parte da colecção do MAC em cinco salas organizadas de forma cronológica, abarcando um espaço temporal que se inicia na Pré-História e termina no século XIX. A forma como a actividade foi estruturada permitia, ainda, que a mesma fosse passível de ser realizada quer com a mediação da equipa do Serviço Educativo quer de forma livre pelas famílias. Nesta actividade foi também tido em conta que uma grande parte do público que visita o Museu é composta por turistas das mais diversas nacionalidades, e nesse sentido, o material didático desta actividade foi concebido, também, em inglês, italiano e espanhol (Figura 8):

No espaço consignado ao Serviço Educativo do MAC foi possível desenvolver diversas actividades cujos conteúdos, e à semelhança da actividade referida anteriormente, procuravam cruzar a colecção do museu e o tema central da Festa da Arqueologia, designadamente um quiz para adultos e famílias com questões alusivas ao tema da Festa e que permitia também, uma vez finalizado, a visualização de uma fotografia da fortificação de Vila Nova de São Pedro (VNSP), numa clara alusão ao acervo que se encontra em exposição na sala 1 do MAC, e a já longa relação entre a Associação dos Arqueólogos Portugueses, o MAC e a escavação de VNSP7 ${ }^{7}$. De notar que todas as actividades presentes neste espaço tinham como tema central o acervo, a história e a comunidade de VNSP.

Do projecto educativo em análise fariam ainda parte integrante um conjunto de actividades hands on, minds on, heart on, numa clara procura de estimular uma participação activa, física, intelectual e emocional, junto dos públicos. Era, então, nosso objectivo que os visitantes e participantes da Festa da Arqueologia pudessem experienciar e sentir como

7. Para informação mais detalhada sobre o projecto Vila Nova de São Pedro, de novo no $3^{o}$ milénio veja-se https:// vnsp.arqueologos.pt/ teria sido a vivência da comunidade pré-histórica e do povoado fortificado de VNSP, cuja ocupação remonta ao $3^{\circ}$ milénio a.C. (período Calcolítico) e se estenderá até ao início da Idade do Bronze. Para tal dispúnhamos de uma maleta pedagógica com réplicas de uma selecção de artefactos provenientes de VNSP representativos das vivências desta comunidade. Associada à maleta pedagógica, e porque o contexto é essencial ao estudo e entendimento da Arqueologia (SWAIN, 2007, p. 4), algo ainda mais premente e necessário para quem não é especialista, optámos por apresentar uma maqueta que ilustra uma possível reconstrução do povoado. Ainda no âmbito de VNSP, mas num registo essencialmente lúdico os visitantes, os mais novos e não só, eram convidados a experimentar uma das facetas, sem dúvida a que mais permanece no imaginário de todos, do trabalho dos arqueólogos - a escavação, através da actividade "Escavações em ponto pequeno!" (Figura 9).

Por último, e porque acreditamos que as histórias têm o potencial de criar relações mais duradouras entre os públicos e as instituições e as suas colecções, tínhamos ainda a proposta de construção de um livro de bolso cujo conteúdo retratava a história do arqueólogo Afonso do Paço, sócio da AAP e responsável pelas primeiras campanhas de escavação em VNSP na década de 30 do século XX. Os participantes eram, então, convidados a construir quer a parte física do livro (capa e contracapa) quer a escolher quais os momentos da história de Afonso do Paço mais revelantes para eles (Figura 10).

\section{CONSIDERAÇÕES FINAIS}

O questionamento em torno do papel social dos museus não é novo. No entanto, temos assistido nas últimas décadas, com especial foco na primeira década do século XXI, a constantes mudanças dos valores sociais, políticos e éticos na sociedade que suscitam questões em torno do papel social dos museus, da sua representatividade e relevância.

Como referem Janes e Sandell (2019, p. 16), os museus poderão ou não serem capazes de contribuir para muitos dos problemas mundiais que necessitam de solução, mas museus de todos os tipos estão numa posição de criar um novo futuro para eles próprios e para as suas comunidades, ou pelo menos ajudar na criação de uma imagem de um futuro desejável - o primeiro passo essencial para a sua 
concretização. Os museus estão numa posição única para o fazer, tendo em conta a sua capacidade de agregar humanismo, ciência, conhecimento histórico e social.

Papel central na concretização da visão de um museu socialmente responsável é, em nosso entender, ocupado pela mediação entendida enquanto espaço estrutural onde se encontram múltiplas vozes e visões (internas e externas à instituição), enquanto espaço facilitador de encontros, de experiências, de reflexão, de diálogo, de questionamento. Em suma, enquanto espaço de construção partilhada de saberes e experiências.

Acreditamos numa mediação que partilha objectivos comuns, que assume riscos e abraça a experimentação, que possibilita o questionar da tradicional autoridade do museu numa atitude de abertura e escuta, e que acrescenta algo de novo, de transformador, concretizada através de projectos educativos capazes criar relações duradouras entre as instituições e as pessoas contribuindo para algo que consideramos essencial à sobrevivência das instituições culturais: a arte da relevância.

Neste sentido, estamos em crer que o projecto desenvolvido pelo Serviço Educativo para a $5^{\underline{a}}$ edição da Festa da Arqueologia, entendido enquanto proposta de mediação potenciadora de um maior envolvimento e experimentação, possibilita a concretização no terreno do que acreditamos ser um dos eixos estruturais dos museus: a comunicação e mediação com os públicos. Acreditamos, ainda, que é através da partilha de projectos como este, que podemos não só contribuir para uma maior disseminação de conteúdos educativos no âmbito da Arqueologia, como também estimular um diálogo franco, aberto e enriquecedor.

\section{BIBLIOGRAFIA}

ARNAUD, José Morais e FERNANDES, Carla Varela (Coord.) (2005) - Construindo a Memória. As Coleccções do Museu Arqueológico do Carmo. Lisboa: Associação dos Arqueólogos Portugueses.

ARNAUD, José Morais e PEREIRA, Célia Nunes (Coord.) (2019) - Guia do Museu Arqueológico do Carmo. Lisboa: Associação dos Arqueológos Portugueses.

BARRIGA, Sara e SILVA, Susana Gomes (Coord.) (2007) Serviços Educativos na Cultura. Porto: SETEPÉS.

BLACK, Graham (2005) - The Engaging Museum. Developing Museums for Visitor Involvement. London and New York: Routledge.
CASEY, Dawn (2007) - "Museums as Agents for Social and Political Change", WATSON, Sheila (Ed.), Museums and their Communities. London and New York: Routledge, pp. 292-299.

GURIAN, Elaine (2006) - Civilizing The Museum. The collected writings of Elaine Heumann Gurian. London and New York: Routledge.

HEIN, George E. (1998) - Learning in the Museum. London and New York: Routledge.

HOOPER-GREENHILL, Eilean (Ed.) (1995) - Museum, Media, Message. London and New York: Routledge.

HOOPER-GREENHILL, Eilean (Ed.) (1999) - The Educational Role of the Museum. (Second Edition) London and New York: Routledge.

HOOPER-GREENHILL, Eilean (2004) - Changing Values in the Art Museum: Rethinking Communication and Learning. CARBONELL, Bettina M. (Ed.). Museum Studies. Blackwell Publishing.

HOOPER-GREENHILL, Eilean (2007) - Interpretive Communities, Strategies and Repertoires. WATSON, Sheila (Ed.). Museums and their Communities. London and New York: Routledge.

HOOPER-GREENHILL, Eilean (2007a) - Museums and Education. Purpose, Pedagogy, Performance. London and New York: Routledge.

JANES, Robert R. (2007) - Museums, social responsibility and the future we desire. KNELL, Simon J.; MACLEOD, Suzanne; WATSON, Sheila (Ed.). Museum Revolutions. How museums change and are changed. London and New York: Routledge, pp. 134-146.

JANES, Robert and SANDELL, Richard, (Ed.) (2019) - Museum Activism. New York. Routledge. 2019.

KREPS, Christina (2003) - Curatorship as Social Pratice. Curator, Vol. 46, pp. 311-323.

Museu Arqueológico do Carmo - www.arqueologos.pt

Projecto VNSP 3000 - https://vnsp.arqueologos.pt/

SANDELL, Richard (Ed.) (2002) - Museums, Society, Inequality. London and New York: Routledge.

SHRAPNEL, Emma (2012) - Engaging Young Adults in Museums. An Audience Research Study. [online] Disponível em https://media.australianmuseum.net.au/media/dd/ Uploads/Documents/26111/Final+Project.e3d7707.pdf [Consult. Junho 2020].

SILVA, Susana Gomes - Para Além Do Olhar: a construção e negociação de significados a partir da educação museal [online] Disponível em https://dialnet.unirioja.es/servlet/articulo?codigo=2172520 [Consult. Maio 2020]. 
SIMON, Nina (2016) - The Art of Relevance. Museum 2.o.

SMEDS, Kerstin (Ed.) (2019) - The Future of Tradition in Museology, Materials for a discussion. ICOFOM.
SWAIN, Hedley (2007) - An Introduction to Museum Archaeology. Cambridge University Press.

VERGO, Peter (Ed.) (1989) - The New Museology. London: Reaktion Books, 1989.

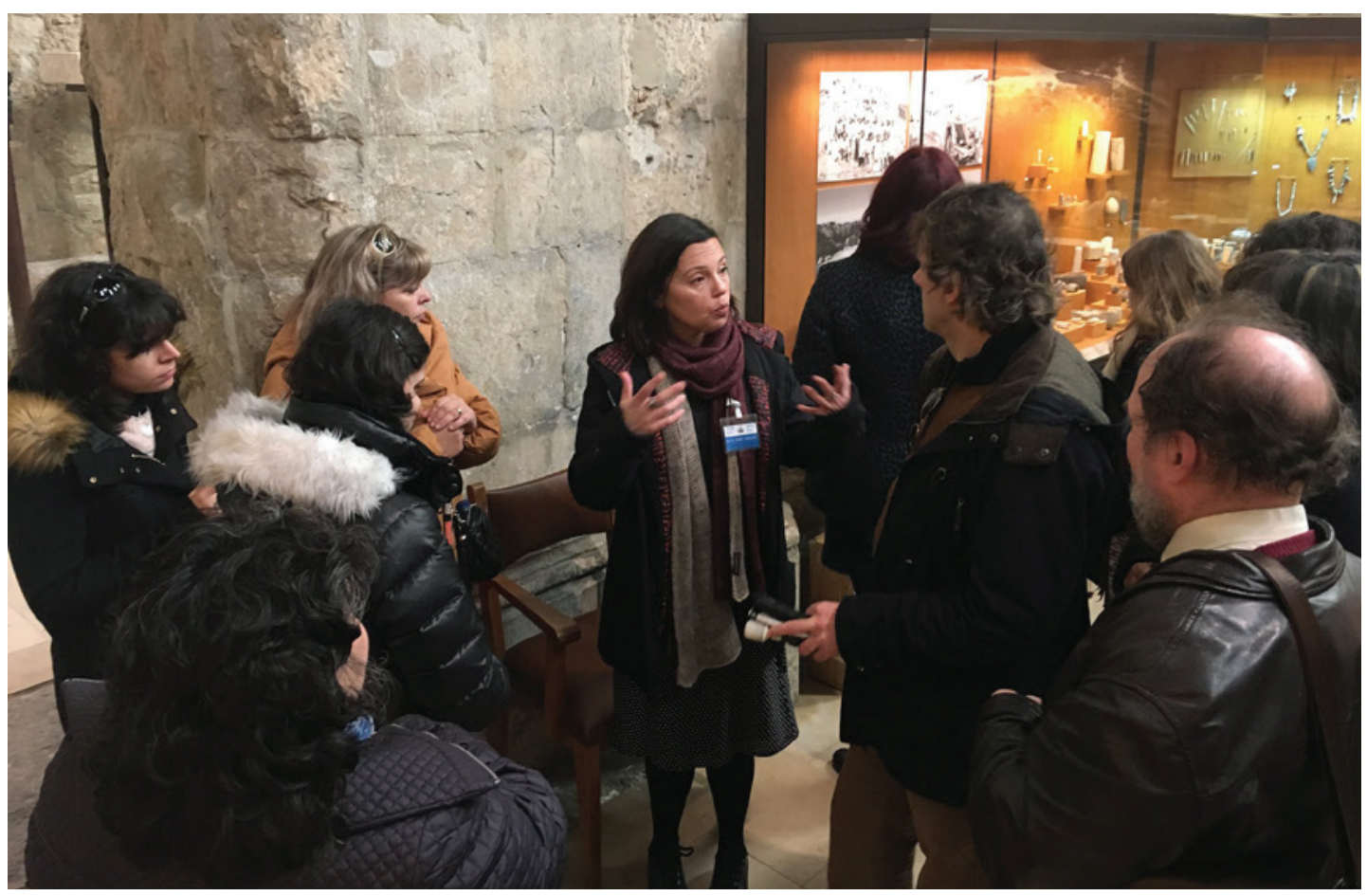

Figura 1 - Visita em parceria com a Locus Acesso, 2018. Autor: Serviço Educativo MAC.

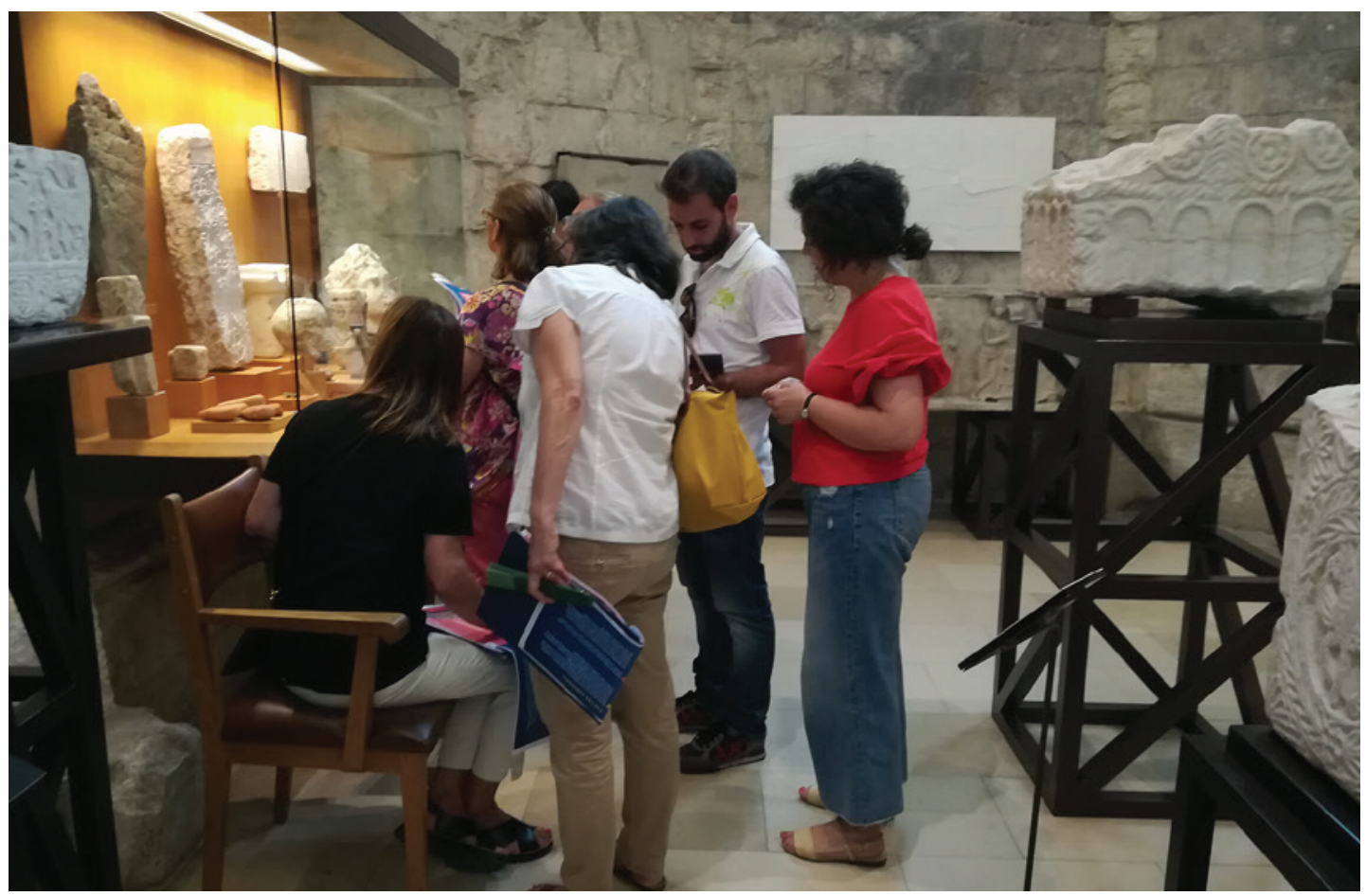

Figura 2 -Encontro de Professores, 2018. Autor: Serviço Educativo MAC. 


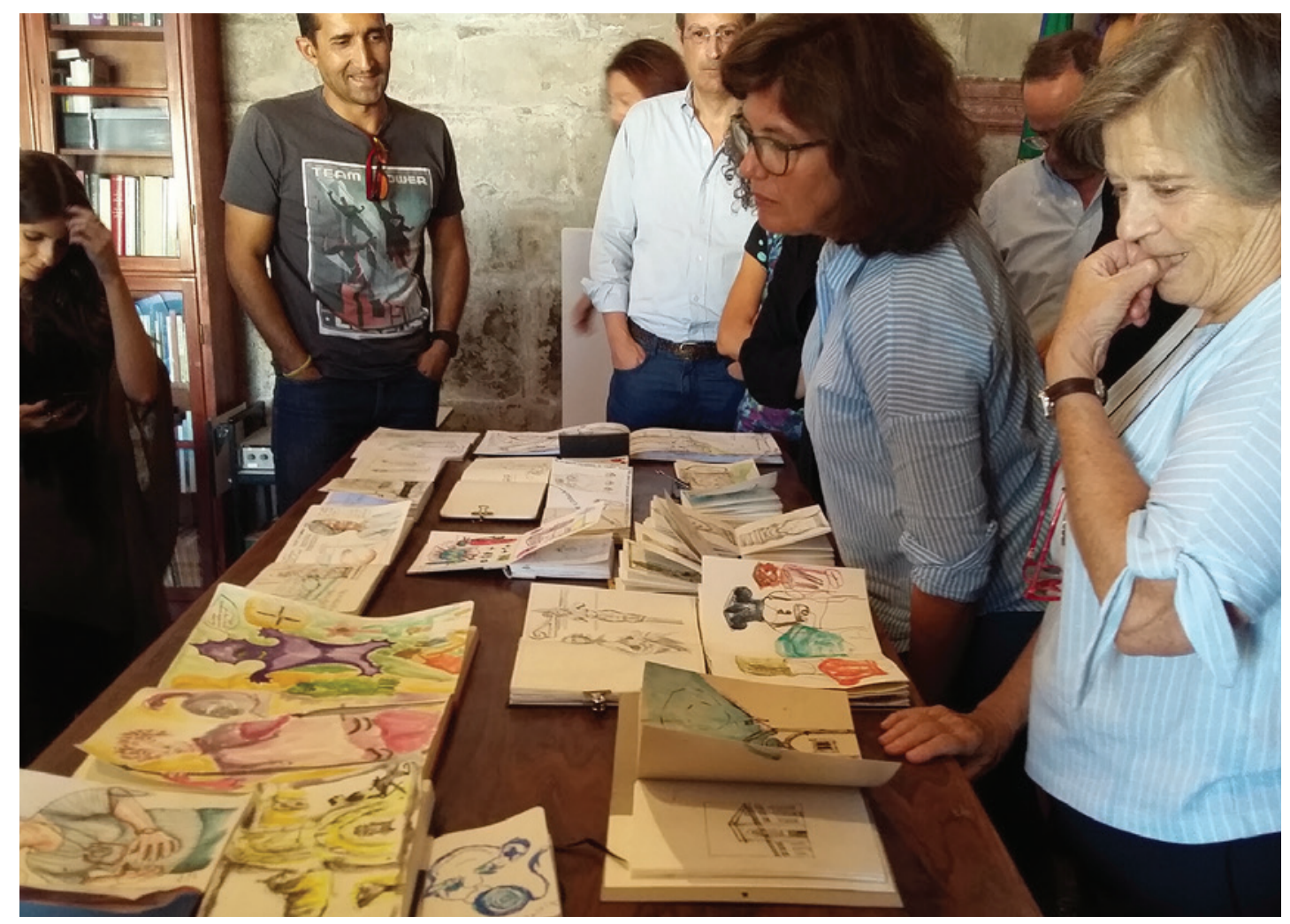

Figura 3-Workshop de Diários Gráficos, 2017. Autor: Serviço Educativo MAC.

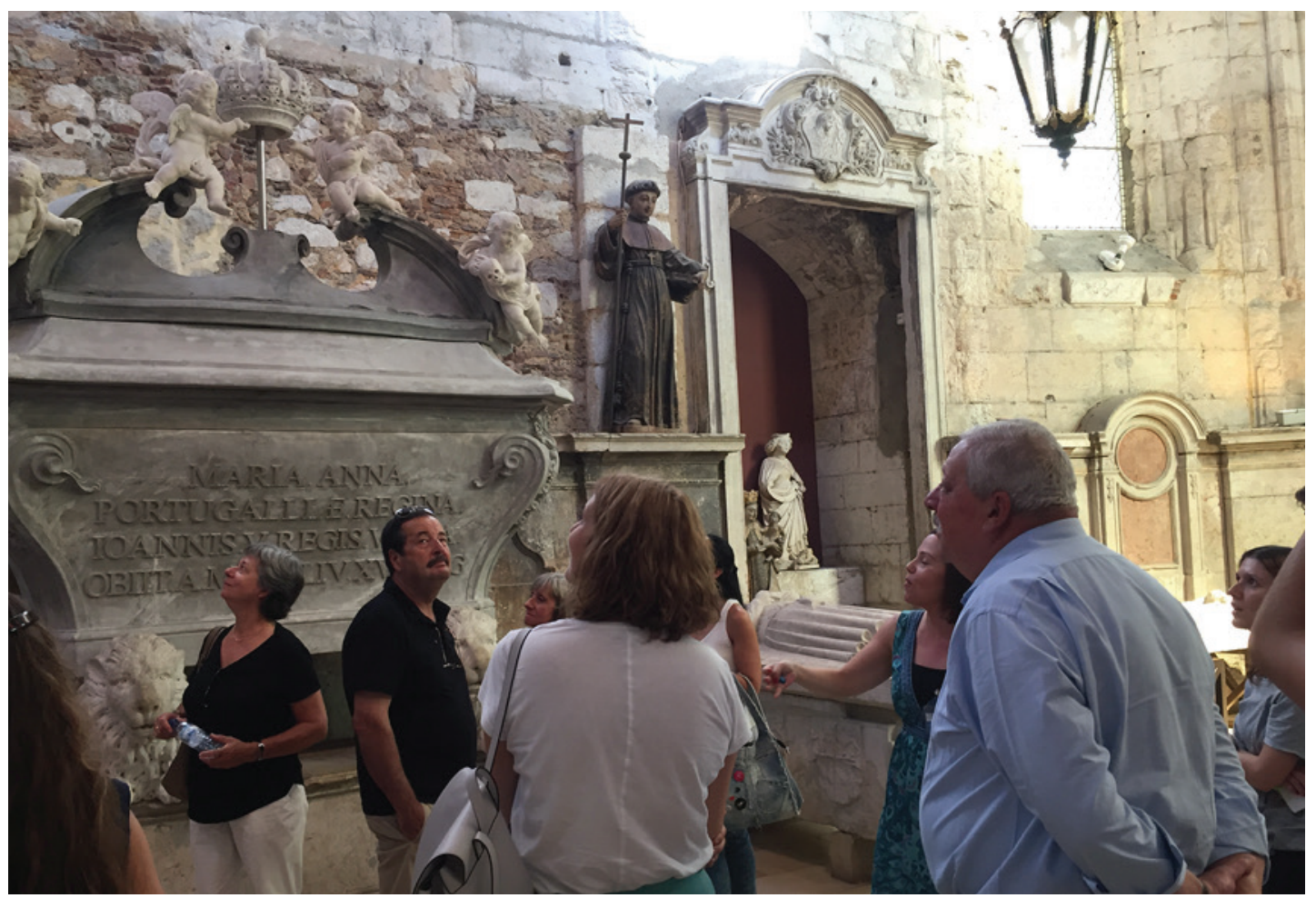

Figura 4 - Visita orientada ao MAC, Grupo Histórias com História, 2018. Autor: Serviço Educativo MAC. 


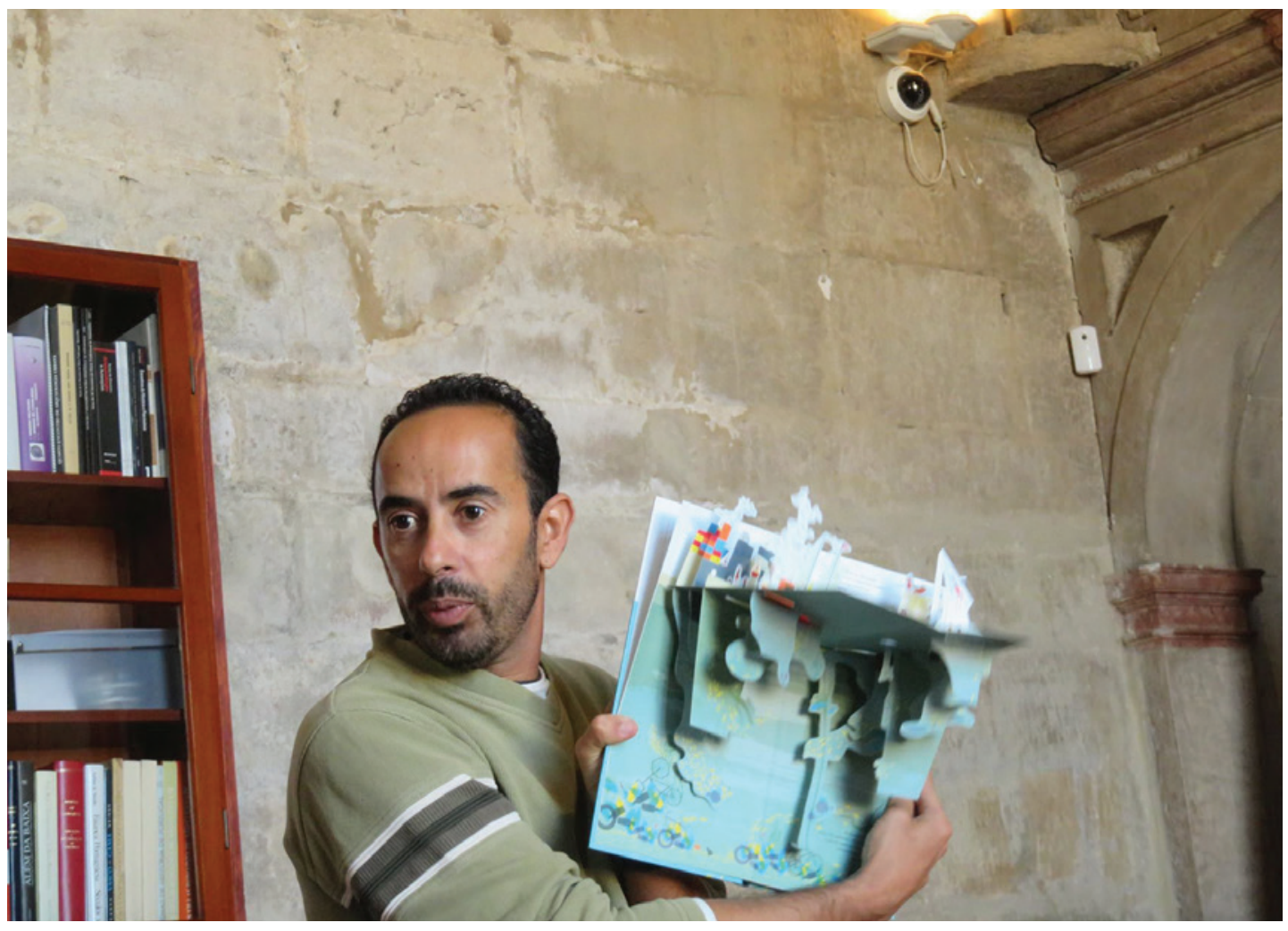

Figura 5- Workshop Livros PopUp com Marco Taylor, 2017. Autor: Serviço Educativo MAC.

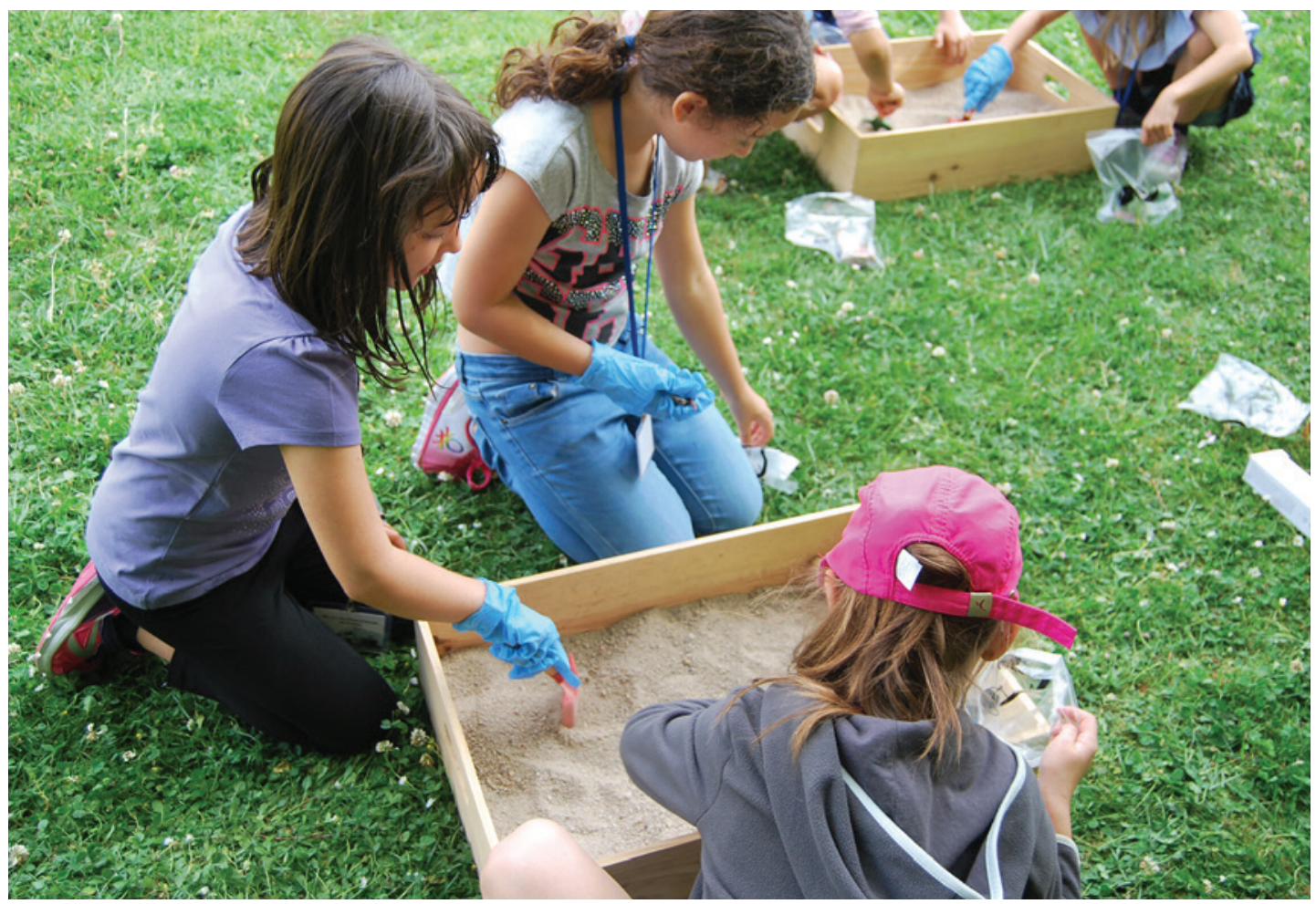

Figura 6 - Actividade do Serviço Educativo do MAC na Semana do Passaporte Escolar, 2017. Autor: Serviço Educativo MAC. 


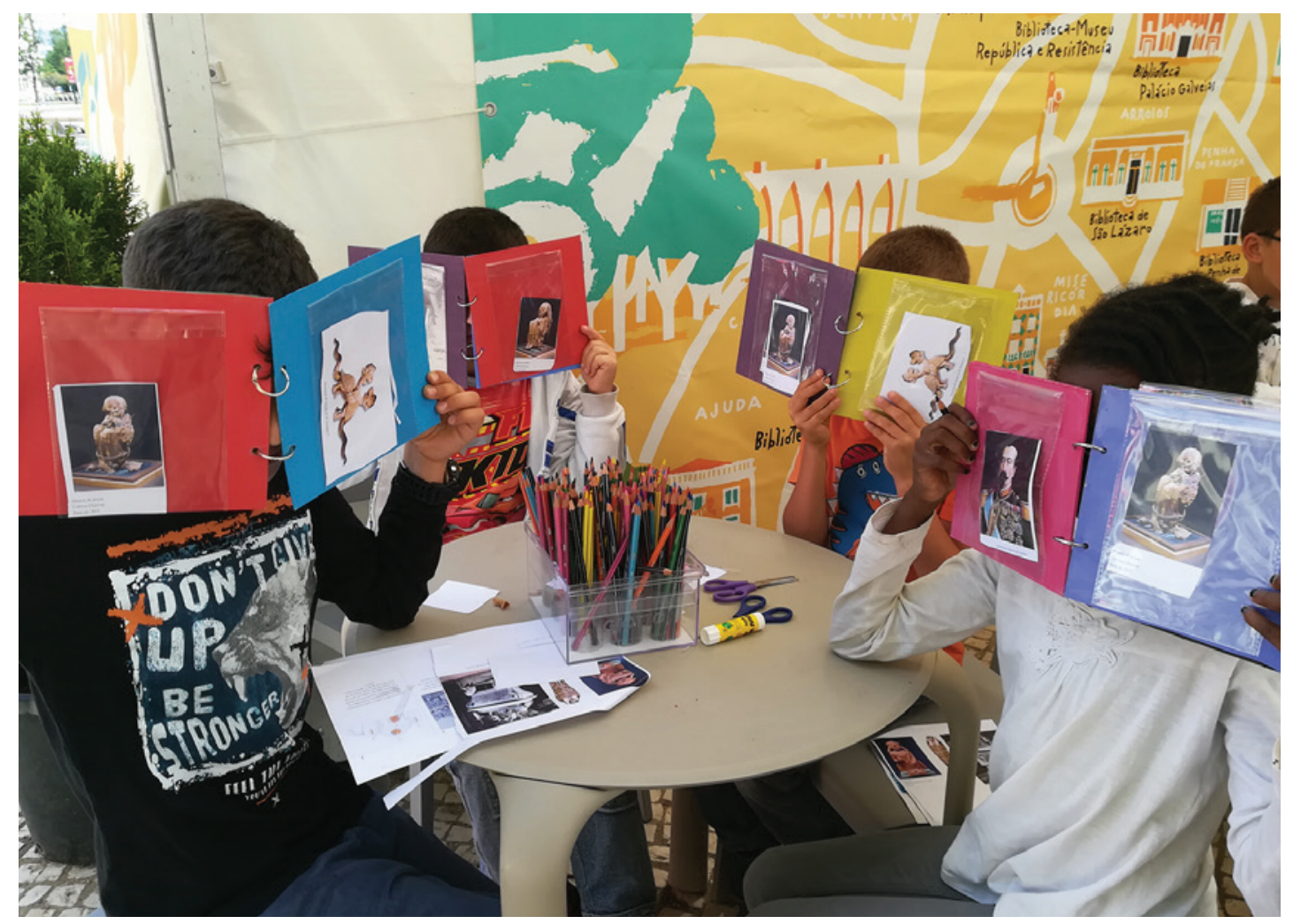

Figura 7 - Actividade do Serviço Educativo do MAC na Feira do Livro de Lisboa, 2018. Autor: Serviço Educativo MAC.

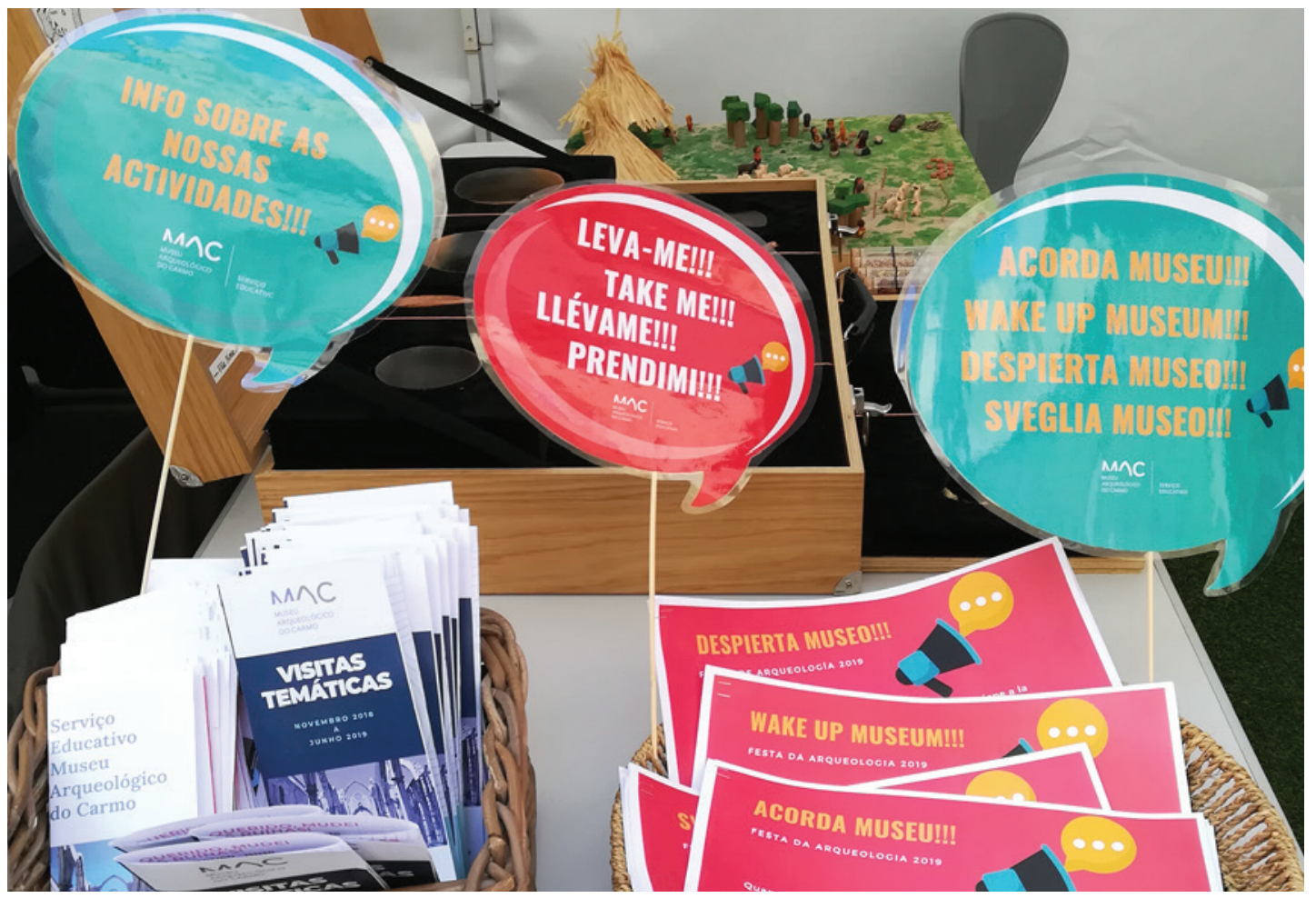

Figura 8 - Actividade Acorda Museu!, $5^{\mathfrak{a}}$ edição da Festa da Arqueologia, 2019. Autor: Serviço Educativo MAC. 


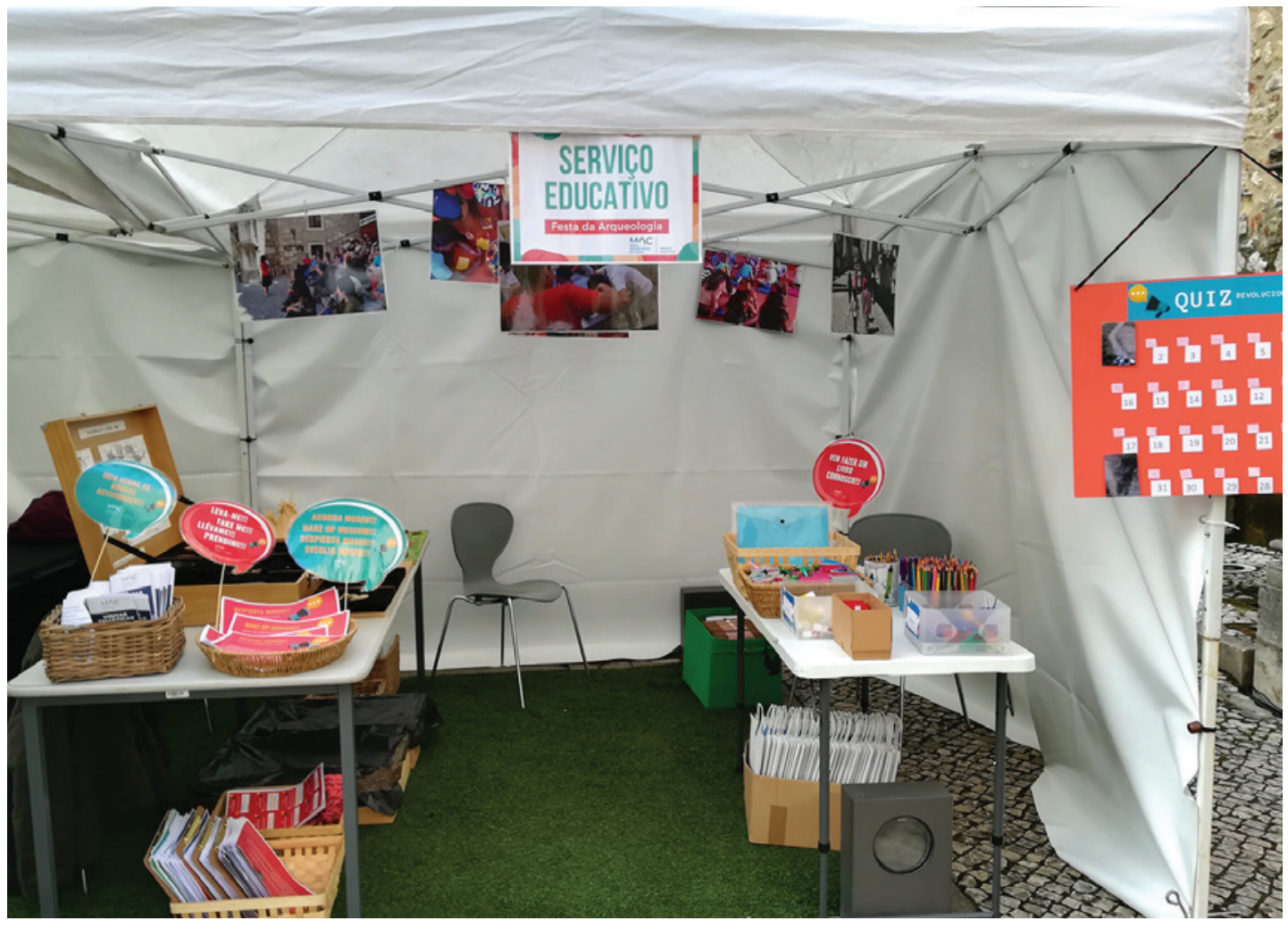

Figura 9 - Espaço do Serviço Educativo do MAC na $5^{\underline{a}}$ edição da Festa da Arqueologia, 2019. Autor: Serviço Educativo MAC.

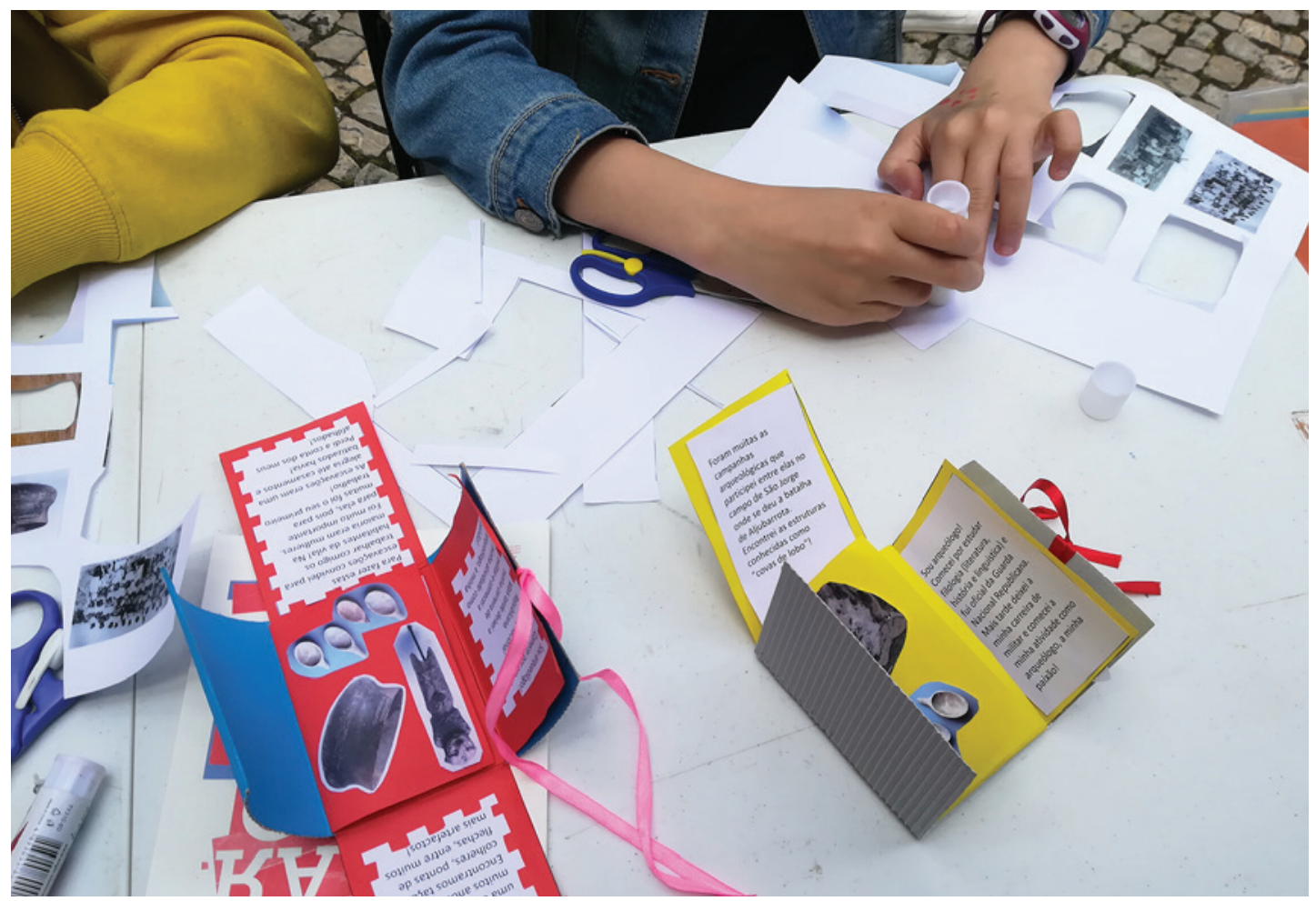

Figura 10 - Actividade Construção de um Livro, Serviço Educativo MAC, $5^{\underline{a}}$ edição da Festa da Arqueologia, 2019. Autor: Serviço Educativo MAC. 


\title{
O “CLÃ de CARENQUe”, UM PROJETO DIDÁTICO DE ARQUEOLOGIA
}

\author{
Eduardo Gonzalez Rocha ${ }^{1}$
}

\begin{abstract}
RESUMO
O projeto didático "Clã de Carenque” visa recriar uma comunidade do Neolítico Final português, integrável na cultura megalítica, associada a edificação de antas, menires e grutas artificiais, como as existentes na Necrópole de Carenque. Surgiu com o propósito de divulgar este sítio arqueológico localizado na Amadora, pese embora atualmente tenha alargado as suas áreas e geografias de atuação.

Este projeto foi desenvolvido com o intuito de dar a conhecer de uma forma interativa e didática, o modo de vida das comunidades desse período, quer ao público que assiste às representações, quer aos próprios membros do Clã, facilitando a interpretação dos vestígios arqueológicos associados. A procura de formas de dinamização cultural da Necrópole de Carenque conduziu à sua criação em 2002, pretendendo-se expor na presente comunicação as várias vertentes de atuação e linhas de desenvolvimento, que conheceu no seu percurso evolutivo. Palavras-chave: Recriação, Didática de arqueologia, Neolítico, Necrópole de Carenque.
\end{abstract}

\begin{abstract}
The didactic project "Clã de Carenque" aims to recreate a community of the Portuguese Final Neolithic, integrated in the megalithic culture, responsible for the construction of dolmens, menhirs and rock-cut tombs, such as those existing in the Necrópole of Carenque. It arose with the central objective to increase the visibility of this archaeological site located in Amadora.

This project was developed with the purpose of allowing the public that attends the representations and the members of the "Clã" themselves, to know in an interactive and didactic way the lifestyle of the communities of that period. The search for forms to promote the Necropolis of Carenque led to its creation in 2002, registering along this period several areas of activity and lines of development, which we intend to expose in this presentation.
\end{abstract}

Keywords: Recreation, Didactic Archeology, Neolithic, Necrópole de Carenque.

\section{A GÉNESE DE UM PROJETO DIDÁTICO}

A promoção de iniciativas didáticas sempre constituiu, desde a sua criação, um dos polos centrais de atuação da ARQA. Cedo se tornou evidente que em paralelo à intervenção arqueológica, deveriam decorrer ações de divulgação junto da população sobre as descobertas e os estudos efetuadas. Com os necessários padrões de rigor pedagógico e histórico, estas iniciativas visaram desenvolver a compreensão e empatia da sociedade civil sobre o património arqueológico local, contribuindo desta forma para a sua preservação e salvaguarda, bem como para o incremento do seu papel cultural, social e mesmo económico.
Procurou-se por esta via incrementar o conhecimento sobre o património da Amadora por parte da sua população, para além de se sensibilizar o poder local para a necessidade da sua proteção e valorização. Trata-se de uma realidade desafiante, dado que os habitantes do município tem maioritariamente origens exógenas ao território e exercem a sua atividade diária muitas vezes fora da Amadora, apresentado bases culturais e níveis de formação bastante diversificados, tornando muitas vezes os laços existentes com a história e património local reduzidos. Esta situação é ainda mais evidente relativamente aos períodos mais recuados da nossa história, como é o caso do Neolítico, pois aos aspetos referidos e ao distanciamento temporal, acresce a ainda reduzida

1. ARQA - Associação de Arqueologia e Proteção do Património da Amadora; eduardo.g.rocha@gmail.com 
abordagem em contextos escolares e a escassa divulgação na comunicação social. Desta forma, privilegiou-se iniciativas que pela sua interatividade na abordagem dos temas, facilitassem a aprendizagem informal e lúdica, tornando a interiorização de conhecimentos mais eficaz nesta população.

Neste contexto surge o "Clã de Carenque", projeto de recriação histórica que tem sido desenvolvido pela associação desde 2002 (Figura 1). Teve a sua génese no âmbito de uma parceria que existe entre a ARQA e a Câmara Municipal da Amadora (CMA) desde 1995 e inicialmente centrou-se na valorização do espaço musealizado da Necrópole de Carenque, na Amadora. Trata-se de um sítio arqueológico constituído por três sepulcros coletivos implantados nos afloramentos calcários do Tojal de Vila Chã, na Amadora, genericamente designados de "grutas artificiais" ou hipogeus, conjunto enquadrável na cultura megalítica, com provável edificação no Neolítico Final e utilização durante o Calcolítico. O projeto acabou por conhecer ao longo destes anos novas vertentes de atuação, extravasando atualmente os limites de atuação na Necrópole de Carenque.

Na criação do "Clã de Carenque” a ARQA inspirou-se em projetos didáticos similares, que foram implementados com critérios de rigor científico, normalmente associados a sítios arqueológicos e respetivos projetos museológicos. A partir destas referências procurou-se um modelo adequado para o contexto local, refletindo a realidade arqueológica em que se enquadra a Necrópole de Carenque.

\section{RECONSTITUINDO O PASSADO - CONTEÚDOS PROGRAMÁTICOS, ARTE- FACTOS E ADEREÇOS}

Este projeto foi desenvolvido com o intuito de dar a conhecer de uma forma interativa e didática o modo de vida das comunidades do Neolítico Final português (estendendo-se ao período Calcolítico), quer ao público que assiste às representações, quer aos próprios membros do Clã, muitos deles sem formação académica em arqueologia. Pretendeu-se enquadrar funcionalmente os artefactos encontrados em contexto arqueológico e facilitar a perceção do quadro em que foram utilizadas as sepulturas da Necrópole de Carenque, que aos olhos de um leigo não será intuitiva a partir da mera observação das estruturas escavadas na rocha.

Na elaboração do seu conteúdo programático privi- legiou-se um enquadramento abrangente do processo de neolitização e da transição para o Calcolítico, centrando-se nas questões da implementação da agricultura e transformações económicas e sociais associadas. Foram abordados temas como o desenvolvimento agrícola e o surgimento das primeiras peças cerâmicas, a continuidade da importância dos utensílios líticos até generalização da metalurgia (Figura 2), a chamada "Revolução dos Produtos Secundários" e o aparecimento da tecelagem neste período, e por fim a diferenciação dos espaços de povoamento e das necrópoles, salientando-se naturalmente o quadro funerário deste sítio arqueológico. Um dos princípios subjacentes seria tornar evidente que o local de assentamento destas comunidades seriam os diversos povoados em redor e que a deslocação à área da necrópole seria temporário num cenário específico.

A implementação de todo este projeto atravessou diversas etapas, sendo logo de início realizado um trabalho de investigação detalhado, com análise artefatual e bibliográfica, de forma a se obter uma reconstituição o mais fiel possível de utensílios, vestuário e acessórios. Recorreu-se não só a dados nacionais, mas também à informação proporcionada pela arqueologia experimental e por descobertas excecionais, como as associadas ao "Homem no Gelo" ou aos povoados lagunares suíços, entre outros, como forma de colmatar as lacunas no registo arqueológico português relativas aos componentes dos artefactos produzidos com materiais perecíveis. Como referimos, foram analisados projetos similares e foi consultada diversa bibliografia de cariz didático e pedagógico de modo a tornar as ações o mais instrutivas possíveis e construir uma narrativa com uma linguagem clara e simples para o público em geral, nomeadamente o escolar.

Desta forma procurou-se que a execução dos artefactos e vestuário das personagens se aproximasse o mais possível das técnicas e processos utilizadas pelas populações deste período da pré-história recente. Contudo, essa tarefa mostrou-se naturalmente bastante complexa, não só a nível da obtenção de paralelos completos para os utensílios e para a sua produção, mas igualmente a nível da matéria-prima utilizada, pelo que nos centramos no carácter ilustrativo da peça no âmbito da recriação, com intuito meramente didático. Com o evoluir do projeto, por forma a complementar o conjunto de artefactos existentes e tornar igualmente essa fase num pro- 
cesso pedagógico em si mesmo, foram implementados processos de produção própria de artefactos, muitas das vezes em contexto de formação pela experimentação aberta ao público em geral, como adiante referimos (Figura 3). Pese embora o mencionado, importa salientar que não se trata de um projeto de arqueologia experimental, em termos de procedimentos científicos.

As soluções encontradas enquadram-se nesta realidade, nomeadamente no que concerne às espécies de madeira utilizadas na elaboração da componente perecível de alguns dos artefactos (nomeadamente arcos, setas, lanças), em que dada a dificuldade em obter algumas das espécies autóctones se optou por recorrer a outras espécies mais comuns, mantendo no entanto a fidelidade da forma do artefacto.

O mesmo ocorreu no caso do vestuário, procurando-se evitar o quanto possível a utilização de fibras sintéticas, sendo as peles essencialmente de cabra doméstica (capra hircus) e as peças têxteis elaboradas a partir de diversos tipos de serapilheira e de linho. Posteriormente desenvolveu-se esta área partindo da elaboração de dois teares, com base em modelos hipotéticos para a época, permitindo a produção de pequenos troços de tecido em contexto de ateliê didático nas recriações, complementado com a apresentação de amostras de matéria-prima, nomeadamente lã e linho, em diversas fases de tratamento. Foram igualmente efetuadas algumas experiências de tingimento de tecidos e de fio. Ao nível do calçado, adquiriram-se inicialmente exemplares que pelas suas características (elaborados maioritariamente em couro) permitiam colmatar esta necessidade, mas mais recentemente, no âmbito de ações formativas próprias, foram produzidas peças de calçado recorrendo a paralelos antropológicos e arqueológicos mais apurados, com base em dois modelos básicos, partindo de suportes em couro e de cordame enrolado. No caso particular da execução da aljava, esta teve como modelo a encontrada junto do Homem de Hauslabjoch (popularmente conhecido por "Homem do Gelo" ou Otzi), recorrendo-se a pele de cabra para a bolsa, estruturada por varas de madeira.

A elaboração inicial do vasilhame cerâmico contou com a colaboração de uma oficina de olaria, que procurou reproduzir algumas das tipologias mais utilizadas neste período, como os copos canelados, as taças carenadas, as taças hemisféricas, entre outras, mas com as limitações inerentes a nível de argilas utilizadas, e especialmente na produção a torno e cozedura em forno. Desenvolvemos entretanto experiências de produção própria de cerâmicas com recurso a técnicas mais próximas da época, igualmente no âmbito formação pela experimentação, com elaboração de peças que após o devido período de secagem, são cozidas em fogueiras do tipo "soenga” ao ar livre, normalmente aquando da recriação na Necrópole de Carenque (Figura 4).

Atendendo aos condicionalismos que já referimos, os artefactos líticos utilizados inicialmente eram réplicas em resina de poliéster de artefactos exumados na Necrópole de Carenque e em povoados vizinhos. Posteriormente, implementámos algumas experiências de talhe lítico e produção de artefactos em pedra polida, que culminaram na elaboração de parte dos utensílios utilizados atualmente na representação. Por contraposição aos utensílios líticos foi apenas elaborado um quadro alusivo ao aparecimento da metalurgia, com a representação esquemática da fundição de uma peça.

De referir igualmente que foram executados diversos instrumentos em osso, de acordo com as tipologias do período, como agulhas, alfinetes de cabelo, furadores, botões, um braçal de arqueiro e representações de elementos zoomórficos.

\section{A RECRIAÇÃO NA NECRÓPOLE DE CARENQUE}

Nos primeiros dois anos da recriação foi definido que o público-alvo seria a população escolar, com visitas organizadas pelas instituições de ensino, ilustrando-se por intermédio de uma pequena dramatização, várias ações do quotidiano de uma comunidade do Neolítico Final. Nesta fase teve-se presente a necessidade de transmitir de uma forma simples e atrativa, o contexto histórico em que se integra o local, sensibilizando os alunos para a sua valorização e divulgação.

A dramatização procurava retratar os hábitos mais comuns de uma comunidade, sendo apresentada pelo arqueólogo "Manuel Heleno", executando cada uma das personagens uma atividade social (caça, agricultura, pastorícia, moagem, tecelagem, e talhe lítico), culminando com a "morte" de um dos intervenientes e a reconstituição possível do seu enterramento. Após este simulacro, os alunos e professores eram convidados a visitar as sepulturas e o espaço interpretativo na receção, onde existe uma peque- 
na exposição explicativa da escavação do local, bem como de outros locais pré-históricos existentes na zona.

Estas apresentações decorriam com uma periodicidade mensal de acordo com as marcações das escolas, sendo o agendamento efetuado em articulação com o Museu Municipal de Arqueologia da Amadora (MMA). O projeto captou logo de início a atenção dos alunos, que viam na ação uma forma simples e divertida de apreenderem as matérias que eram lecionadas. No entanto, as dificuldades de logística e de conciliação com datas escolares, bem como as limitações inerentes à própria disponibilidade dos membros da ARQA, levaram ao gradual abandono deste formato.

A recriação na Necrópole de Carenque adotou assim um carácter mais generalista, destinado ao grande público e em particular às famílias com membros em idade escolar, sendo realizada ao fim de semana, registando atualmente uma periodicidade anual. A sua implementação é efetuada em conjunto com o MMA, contando com o apoio da CMA.

Para além da apresentação geral da Necrópole e da comunidade que a edificou, nos moldes referidos, foram incluídos diversos ateliês (caça, moagem, cerâmica, tecelagem e talhe de sílex) destinados à experimentação pelo público. Descrevendo os mesmos de forma sucinta, no ateliê de caça quem assiste à demonstração pode utilizar o arco e flecha, experimentando atirar a um alvo fixo, normalmente uma figura sobre um fardo de palha. Já no de moagem manual de cereais, ensina-se o gesto simples de deslocar o movente sobre os grãos para provocar a abrasão dos mesmos, para além da apresentação dos cereais mais comuns no período retratado, trigo e cevada. No de cerâmica, experimenta-se a técnica do rolo de argila sobreposto, para a execução de peças, recorrendo-se para os acabamentos e decoração a seixos, estiletes, matrizes ou punções em osso e madeira (Figura 5). Ao nível da tecelagem, para além de poder experimentar o tear, é proporcionado ao público o contacto com matérias-primas em bruto, nomeadamente lã, linho e esparto (Figura 6). Por fim, no ateliê de talhe lítico, é feita uma pequena demonstração de produção de lascas a partir de núcleos de sílex, permitindo-se o retoque das mesmas com recurso a um utensílio em haste de cervídeo. São igualmente descritas as matérias-primas utilizadas na sua realização, desde o sílex ao quartzo e quartzito, passando pelo anfibolito.
Ao longo do tempo foram sendo introduzidos novos elementos didáticos, nomeadamente a referida cozedura de cerâmicas durante o período da recriação, produzidas em workshops prévios, a elaboração de refeições pré-históricas com os meios e recursos alimentares disponíveis na época, destinadas aos membros do "Clâ" mas abertas à participação interativa dos visitantes, bem como diversos ateliês de pintura.

A simulação de um enterramento num dos sepulcros constitui o epílogo da recriação, constituindo sem dúvida o momento mais apelativo e de maior impacto junto dos visitantes, conferindo o papel didático de dar a conhecer a função destes sepulcros e seu enquadramento histórico. Procurando-se que a mesma se enquadre na realidade arqueológica conhecida, mas com um carácter essencialmente educativo e de simples perceção, optando-se por efetuar a deposição do "defunto" maioritariamente em posição contraída em decúbito lateral e encostado à parede da câmara funerário, sendo acompanhado do respetivo conjunto votivo, que inclui peças dos diversos períodos de utilização da Necrópole, desde réplicas de placas de xisto a ídolos em calcário. Toda a cerimónia e rituais associados possuem naturalmente elementos de improvisação, reforçados pela necessária interação com os mais jovens (Figura 7).

Salienta-se que esta interação é um aspeto essencial da recriação, incentivando-se o contacto dos visitantes com os membros do "Clã", podendo estes manusear e utilizar os artefactos existentes nas várias atividades. Esta abordagem educativa com forte estímulo sensorial possibilita uma aprendizagem mais simples, contribuindo para a memorização de conhecimentos.

Como complemento à recriação, foi produzido o livro "Clã de Carenque, uma comunidade do Neolítico" editado pela ARQA em 2008 com o apoio da CMA e da Neoépica, publicação didática sobre as diversas vertentes da recriação e largamente ilustrada com imagens do quotidiano do "Clã", da agricultura à tecelagem e talhe lítico, passando pela caracterização dos tipos de povoamento e rituais fúnebres, com o devido enquadramento histórico.

\section{A DIVERSIFICAÇÃO DA ATIVIDADE DO "CLÃ DE CARENQUE"}

Em paralelo à atividade principal na Necrópole de Carenque e aproveitando a dinâmica e experiência 
adquirida, foram implementadas novas vertentes de atuação, extravasando a dimensão local do projeto. Neste âmbito, desde 2003 realizaram-se apresentações pontuais noutros sítios arqueológicos, referindo-se a título de exemplo a Necrópole de Alapraia em Cascais e o povoado fortificado de Vila Nova de São Pedro, esta última integrada num programa da RTP da série Planeta Azul. O “Clâ” participou igualmente em diversos eventos e encontros de recriação histórica, nas Feiras de Réplicas e Material Didático de Arqueologia, organizadas conjuntamente pela ARQA e o Museu Nacional de Arqueologia, e mais recentemente nas Festas da Arqueologia levadas a cabo pela Associação dos Arqueólogos Portugueses e o Museu Arqueológico do Carmo (Figura 8).

Destaca-se nos últimos anos a implementação de um projeto de recriação histórica no Rio Seco em Lisboa, associado ao sítio arqueológico da Travessa das Dores e realizado em parceria com o Centro de Arqueologia de Lisboa (CAL). A apresentação segue grosso modo o modelo já referido, mas neste caso centrado num contexto de povoado, sendo realizado previamente um workshop de Cerâmica Pré-Histórica nas instalações do Centro Interpretativo do Monsanto em Lisboa. As cerâmicas resultantes desta formação são posteriormente cozidas em "soenga" no âmbito da recriação no Rio Seco. Ambas as iniciativas tem registado uma periodicidade anual (Figura 9).

Todas estas participações possibilitaram para além da divulgação do próprio "Clã de Carenque”, o contacto direto e a troca de experiências com outros grupos e projetos de recriação histórica, nacionais e estrangeiros, apresentando filosofias e metodologias diversas, assim como particularidades específicas inerentes a cada período e local retratado.

\section{BALANÇO E PERSPETIVAS FUTURAS}

Consideramos que o balanço deste projeto é globalmente positivo, não só ao nível da divulgação e visibilidade do próprio sítio arqueológico alvo das principais atuações do "Clã", mas igualmente no aumento da sensibilidade do público em geral e do poder local para as questões da preservação do património arqueológico deste período histórico e da Necrópole de Carenque em particular.

Este núcleo monográfico tem beneficiado de melhorias nas condições de acesso e visita ao longo deste período, implementadas pelo MMA / CMA, com a colaboração da ARQA, sendo importante o papel do "Clã de Carenque" neste âmbito, como ferramenta para a promoção e desenvolvimento cultural do sítio. Realça-se que em termos de visitas à Necrópole, o peso da afluência do publico durante a recriação é bastante significativo, sendo igualmente uma forma de incentivar futuras visitas noutro contexto, quer sejam guiadas por elementos da ARQA ou do MMA ou por livre iniciativa das pessoas que estiveram na recriação ou de terceiros estimuladas por estas.

Apesar da ausência de dados estatísticos concretos, constatamos na interação com o público que assiste às recriações que, pese embora a literacia e conhecimento sobre a arqueologia e o período retratado em particular ainda esteja longe do desejável, existe uma evolução no sentido pretendido, associada ao incremento das iniciativas didáticas desta natureza que se tem realizado nos últimos anos.

Cientes de que com este tipo de iniciativas contribuímos para aumentar a empatia e o envolvimento das populações na preservação da nossa memória coletiva, de futuro pretende-se continuar a ampliar a componente de experimentação do projeto, reforçando a parte formativa para os membros do "Clâ" e público em geral, tendo em vista o incremento do número de participantes que assumem um papel ativo, permitindo o seu crescimento sustentado. Pretende-se igualmente a diversificação e renovação de alguns aspetos da recriação, ajustando e atualizando os conceitos científicos subjacentes e processos pedagógicos utilizados, procurando-se manter o mesmo formato apelativo e didático a quem nos visita.

\section{BIBLIOGRAFIA $^{2}$}

ALFARO GINER, Carmen (1980) - Estudio de los materials de cesteria procedentes de la cueva de los murcielagos (Albuñol, Granada). In: Trabajos de Prehistoire, 37, p. 109-139.

CARDOSO, João L. (2002) - Pré-História de Portugal. Lisboa: Editorial Verbo.

CLUTTON-BROCK, Juliet (2002) - História da Domesticação dos Mamíferos: Dos primórdios à actualidade. Lisboa: Editora Replicação.

DIAMOND, Jared (2015) - Armas, Germes e Aço: Os destinos das sociedades humanas. Lisboa: Temas e Debates - Circulo de Leitores.

2. Nota dos editores: bibliografia que não se encontra citada no texto. 
EGG, Markus (1997) - L'homme dans la glace. L'équipement de l'homme de l'âge du cuivre trouvé momifié dans un glacier alpin de l'Otztal au Tyrol. In L'homme des glaces. Dans les Alpes ily a 5000 ans, Dossiers d'Archeologie, 224, p. 27-35.

ENCARNAÇÃO, Gisela; MIRANDA, Jorge (2010) - Baútas Povoado: Trabalhos arqueológicos de emergência efetuados em 1989 e 1990. Amadora: ARQA - Associação de Arqueologia da Amadora/Câmara Municipal da Amadora. Relatórios, 8 .

ENCARNAÇÃO, Gisela; ALMEIDA, Nelson (2017) - O povoado da Espargueira/Serra das Éguas: Trabalhos arqueológicos realizados entre 2003 e 2008. Amadora: ARQA - Associação de Arqueologia da Amadora/Câmara Municipal da Amadora. Relatórios, 10.

ENCARNAÇÃO, Gisela; MIRANDA, Jorge; ROCHA, Eduardo (1999) - Do Paleolítico ao Romano: Catálogo da exposição. Amadora: Câmara Municipal da Amadora.

FARINHA, Paulo (2003) - Um dia no Calcolítico: Crianças revivem o passado distante na Amadora. Lisboa: National Geographic, 24, p. 24.

GONÇALVES, Victor S. (2003) - Sítios, "Horizontes» e Artefactos. Cascais: Câmara Municipal de Cascais.

HELENO, Manuel (1933) - Grutas artificiais do Tojal de Vila Chã (Carenque). Lisboa: Tipografia da Empresa do Anuário Comercial.
MIRANDA, Jorge; ENCARNAÇÃO, Gisela; VIEGAS, João; ROCHA, Eduardo; GONZALEZ, António (1999) - Carta Arqueológica da Amadora: do Paleolítico ao Romano. Amadora: Câmara Municipal da Amadora.

ROCHA, Eduardo; NETO, Nuno (2007) - Clã de Carenque: Da animação interactiva à experimentação em Arqueologia, linhas evolutivas de um projecto pedagógico. In Arqueologia Experimental: Recriações do passado em ritmos do nosso tempo, Fórum Valorização e Promoção do Património Regional: actas das sessões. 4, p. 66-75.

ROCHA, Eduardo; NETO, Nuno; LUCAS, Jorge (2008) Clã de Carenque: Uma comunidade do Neolítico. Amadora: Edições FOR.

SOARES, Joaquina (2003) - Os Hipogeus da Quinta do Anjo (Palmela) e as Economias do Simbólico. Setúbal: Museu de Arqueologia e Etnografia do Distrito de Setúbal/Assembleia Distrital de Setúbal.

SPINDLER, Konrad (1995) - O Homem no Gelo. Mem-Martins: Editorial Inquérito.

SPINDLER, Konrad (1997) - L'homme gele - Une momie de 5000 ans dans un glacier dês Alpes de l'Otztal. In L'homme des glaces. Dans les Alpes il y a 5000 ans, Dossiers d'Archeologie, 224, p. 8-27.

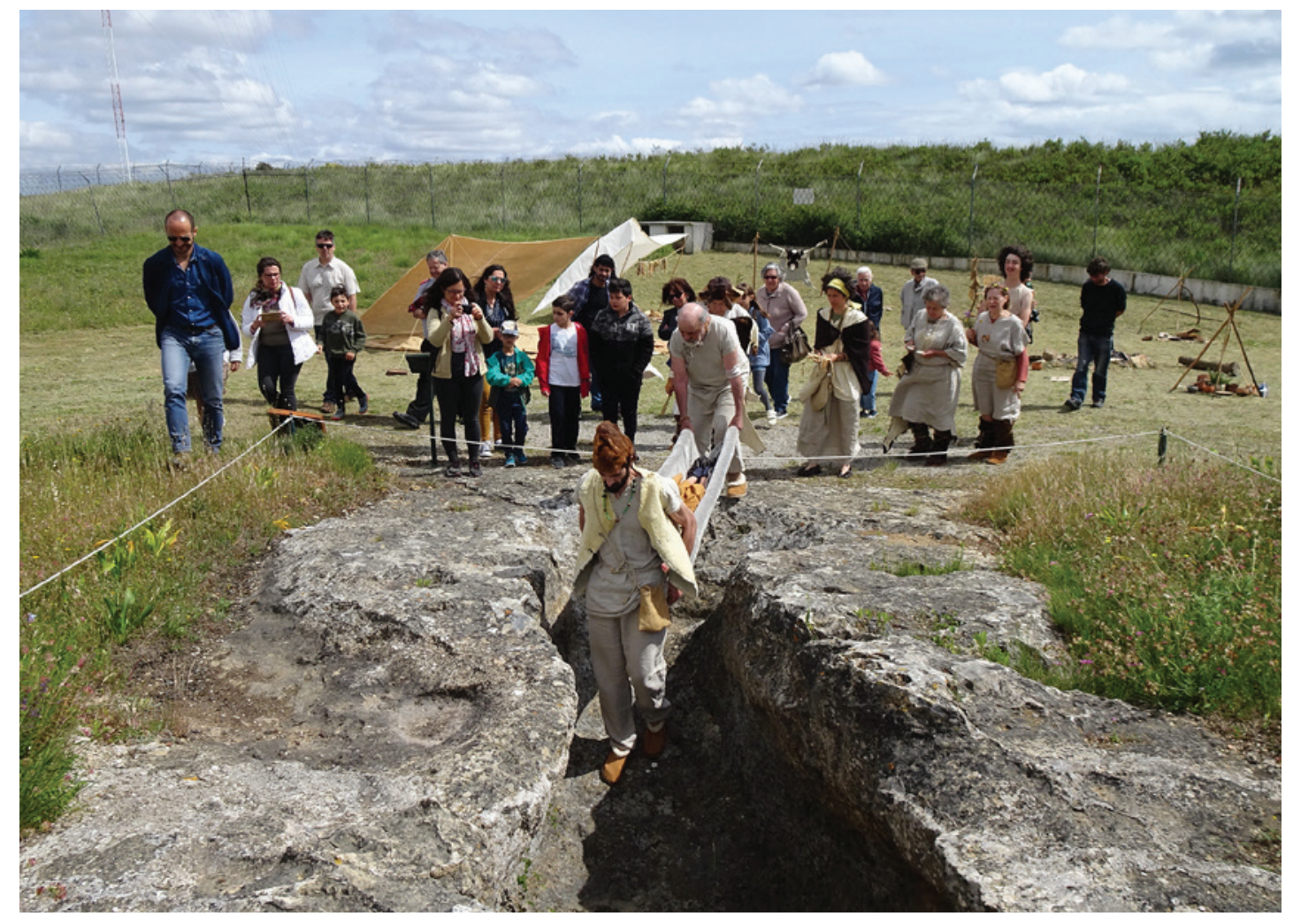

Figura 1 - Recriação na Necrópole de Carenque. (Eduardo Rocha/ARQA). 


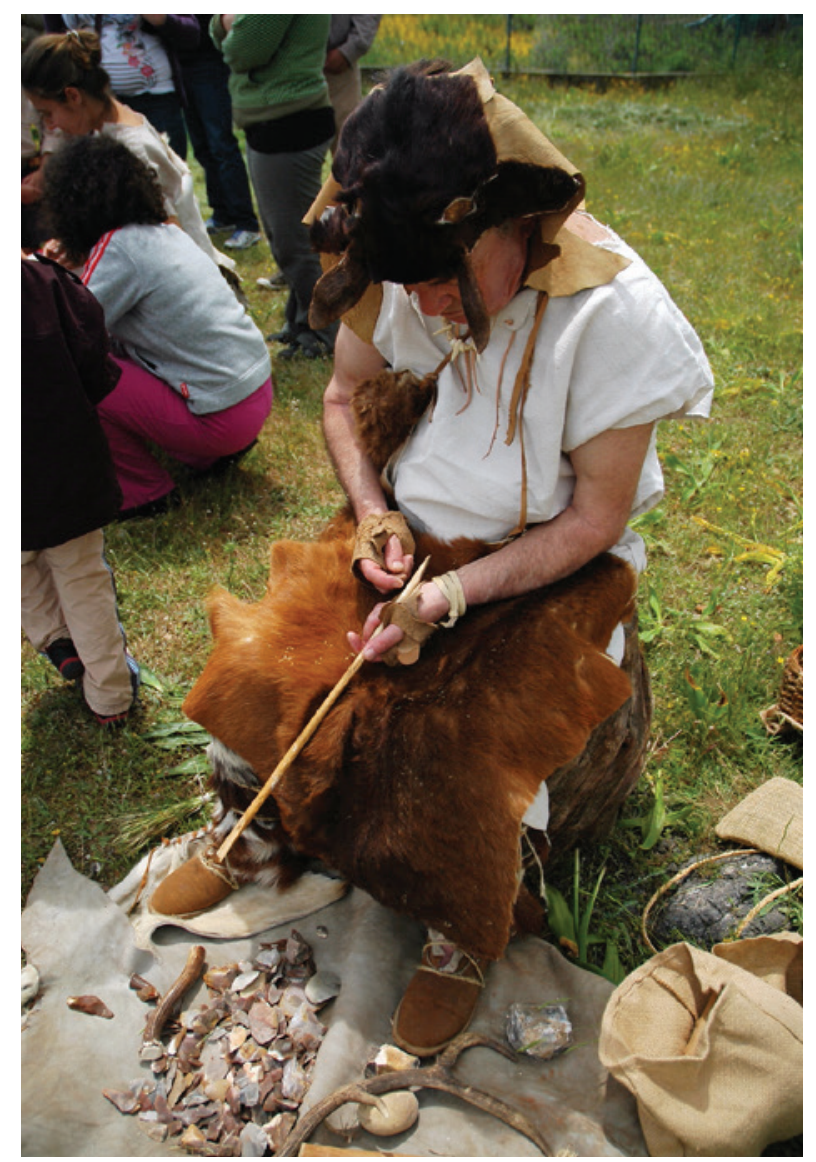

Figura 2 - Preparação de utensílios durante a recriação (Eduardo Rocha/ARQA).

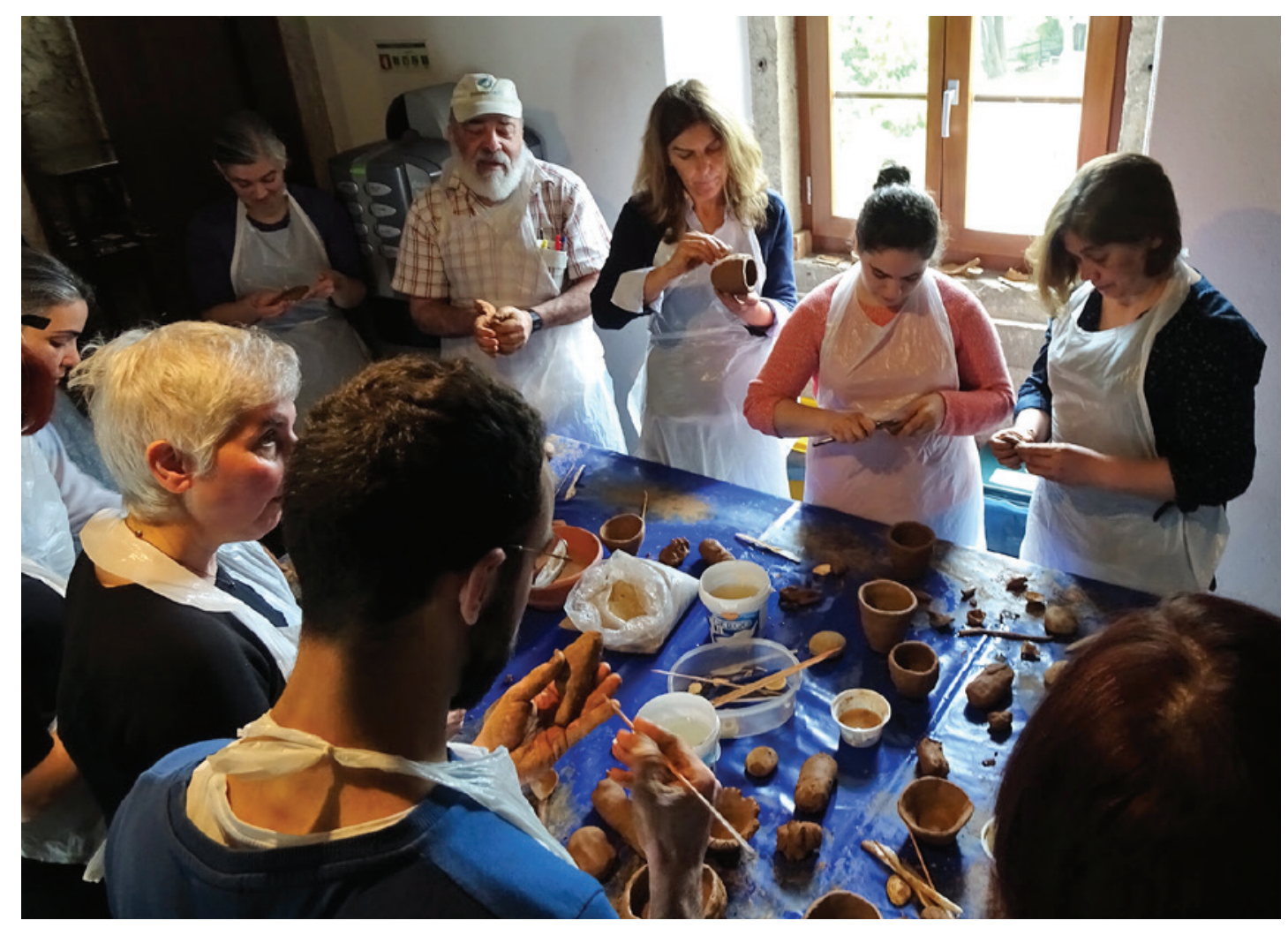

Figura 3 - Workshop de cerâmica Pré-Histórica (Eduardo Rocha/ARQA). 


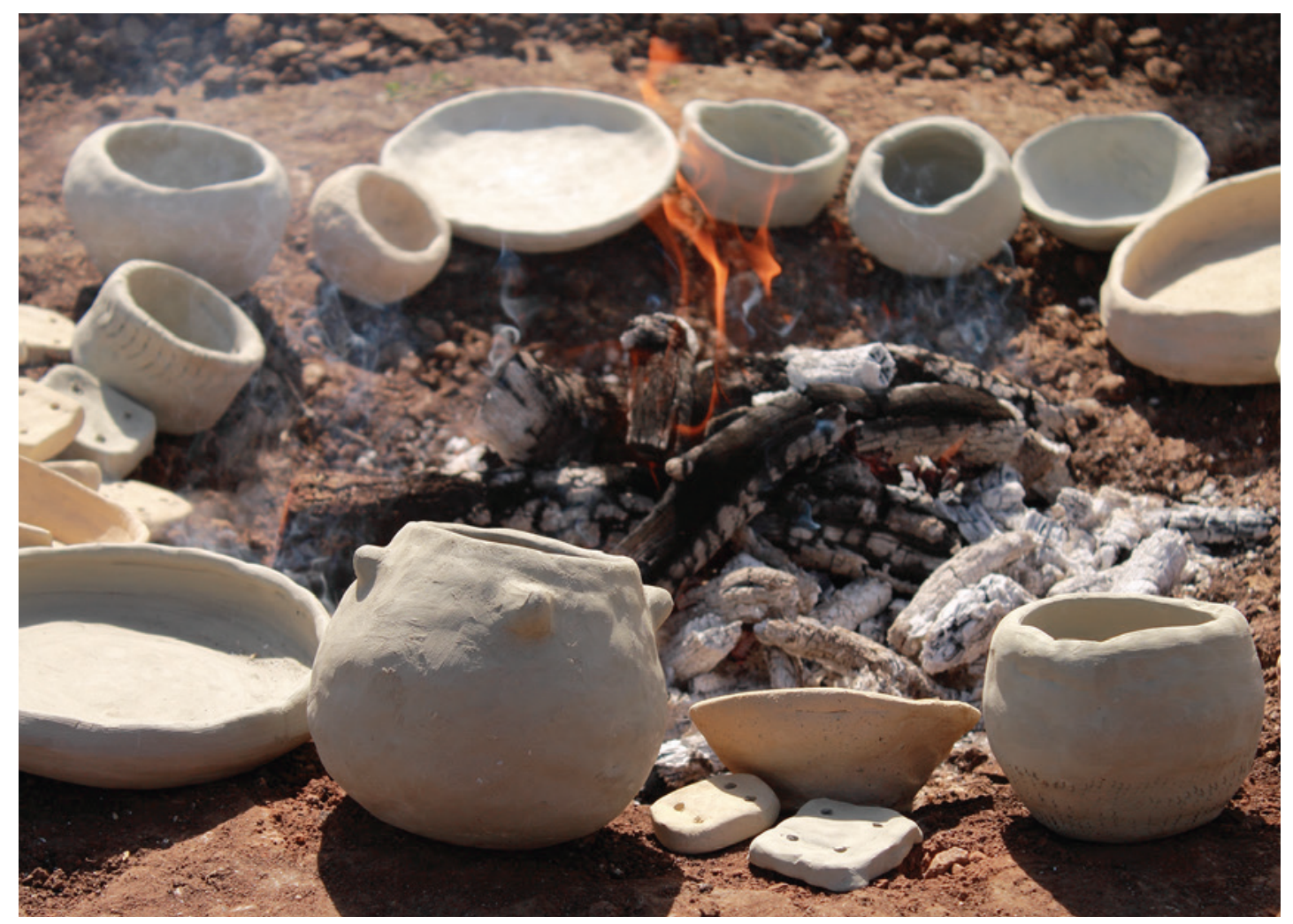

Figura 4 - Cozedura de peças cerâmicas.(Eduardo Rocha/ARQA).

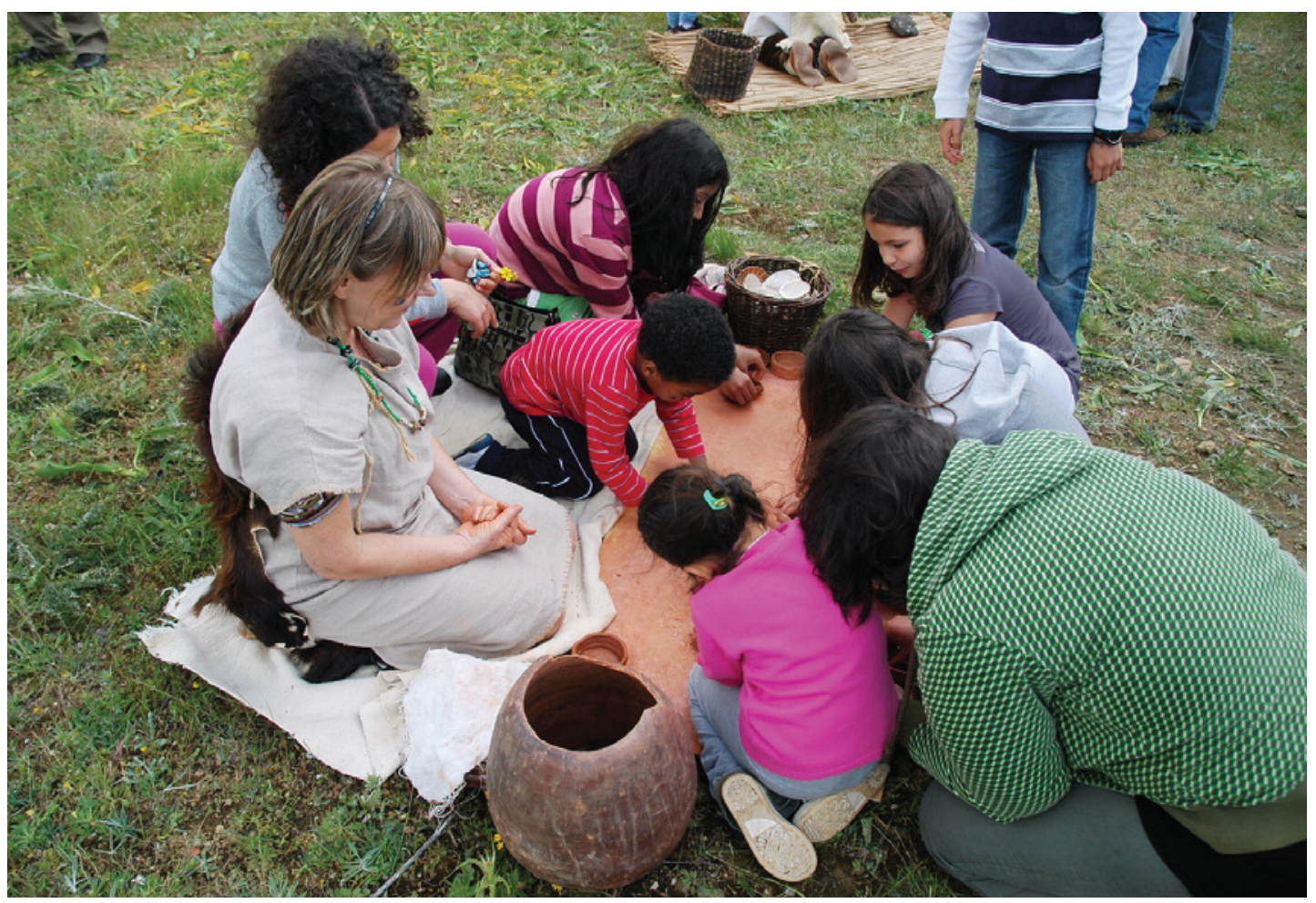

Figura 5-Ateliê de cerâmica.(Rui Dinis/ARQA). 


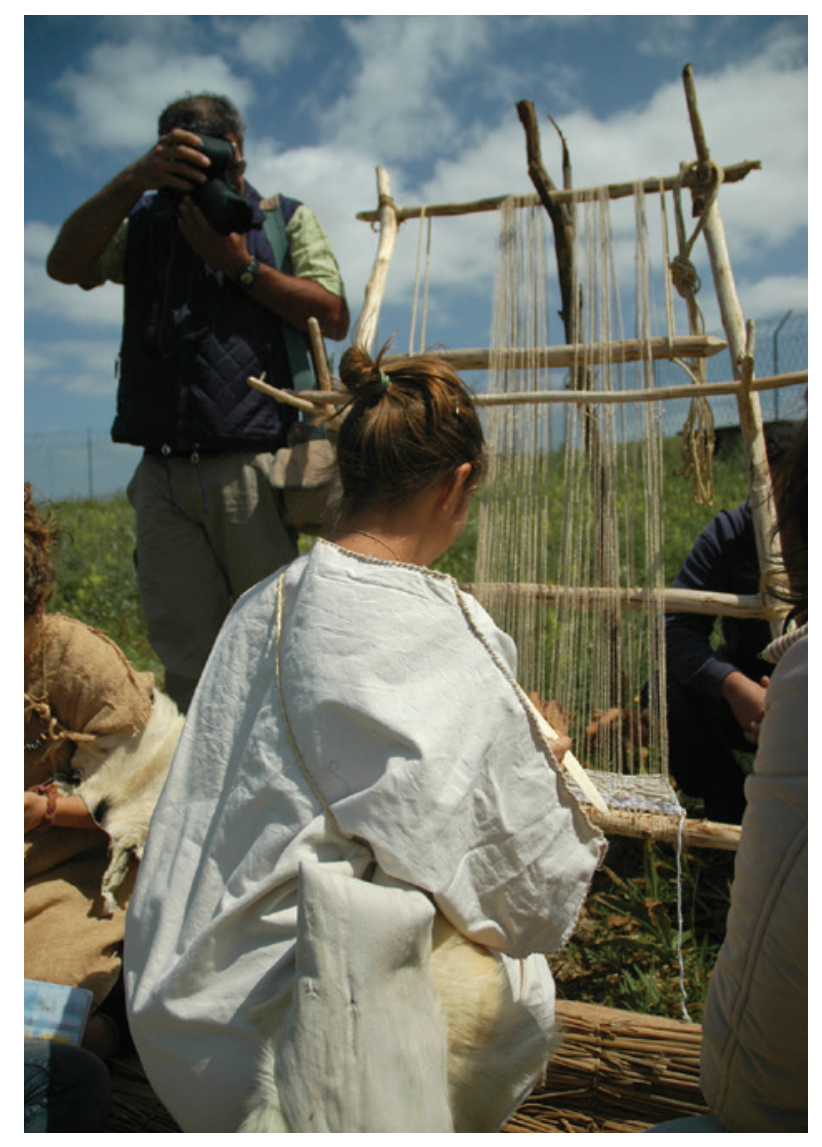

Figura 6 - Ateliê de tecelagem.(Rui Dinis/ ARQA).

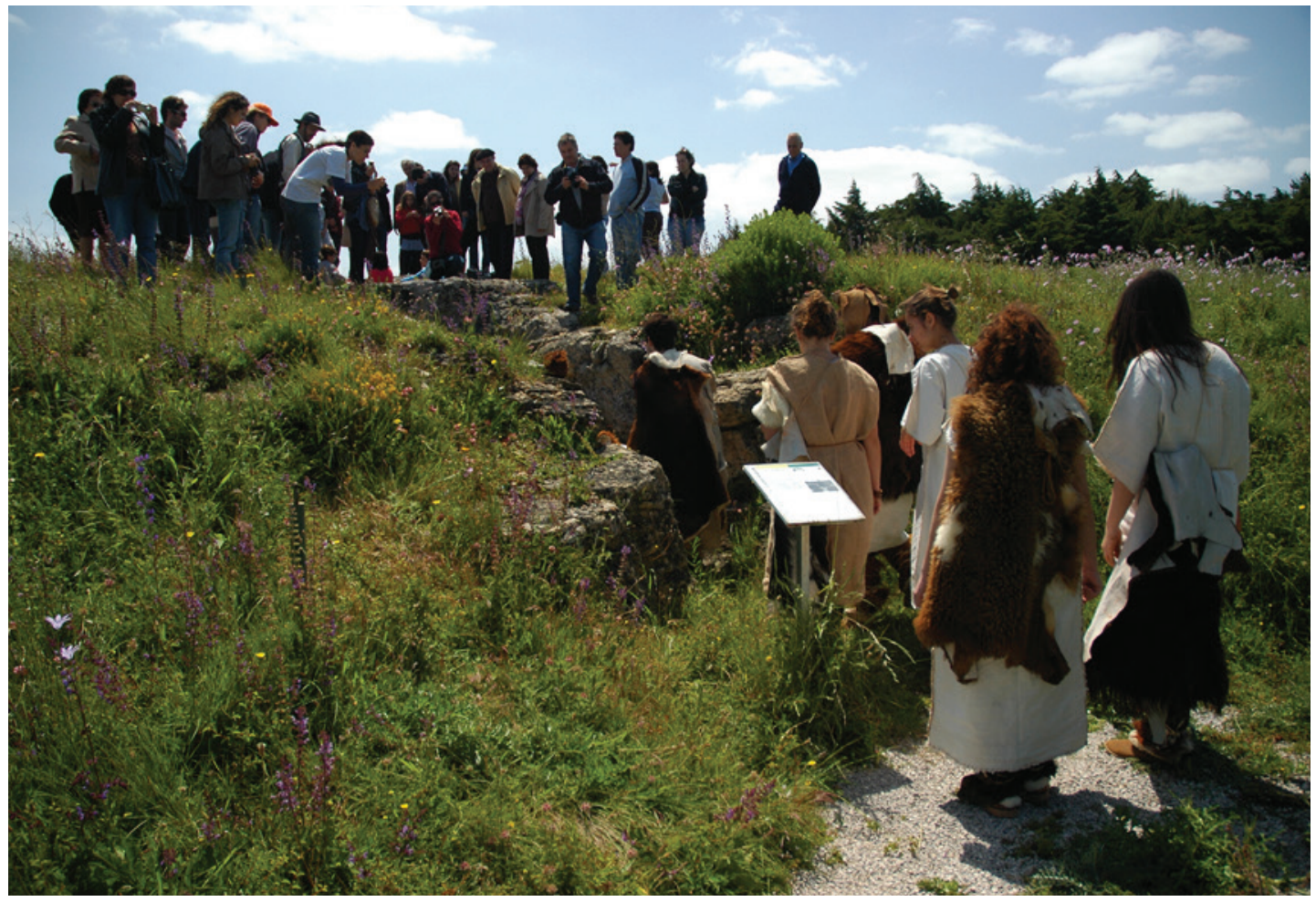

Figura 7 - Simulação de enterramento num dos sepulcros da Necrópole de Carenque. (Rui Dinis/ARQA). 


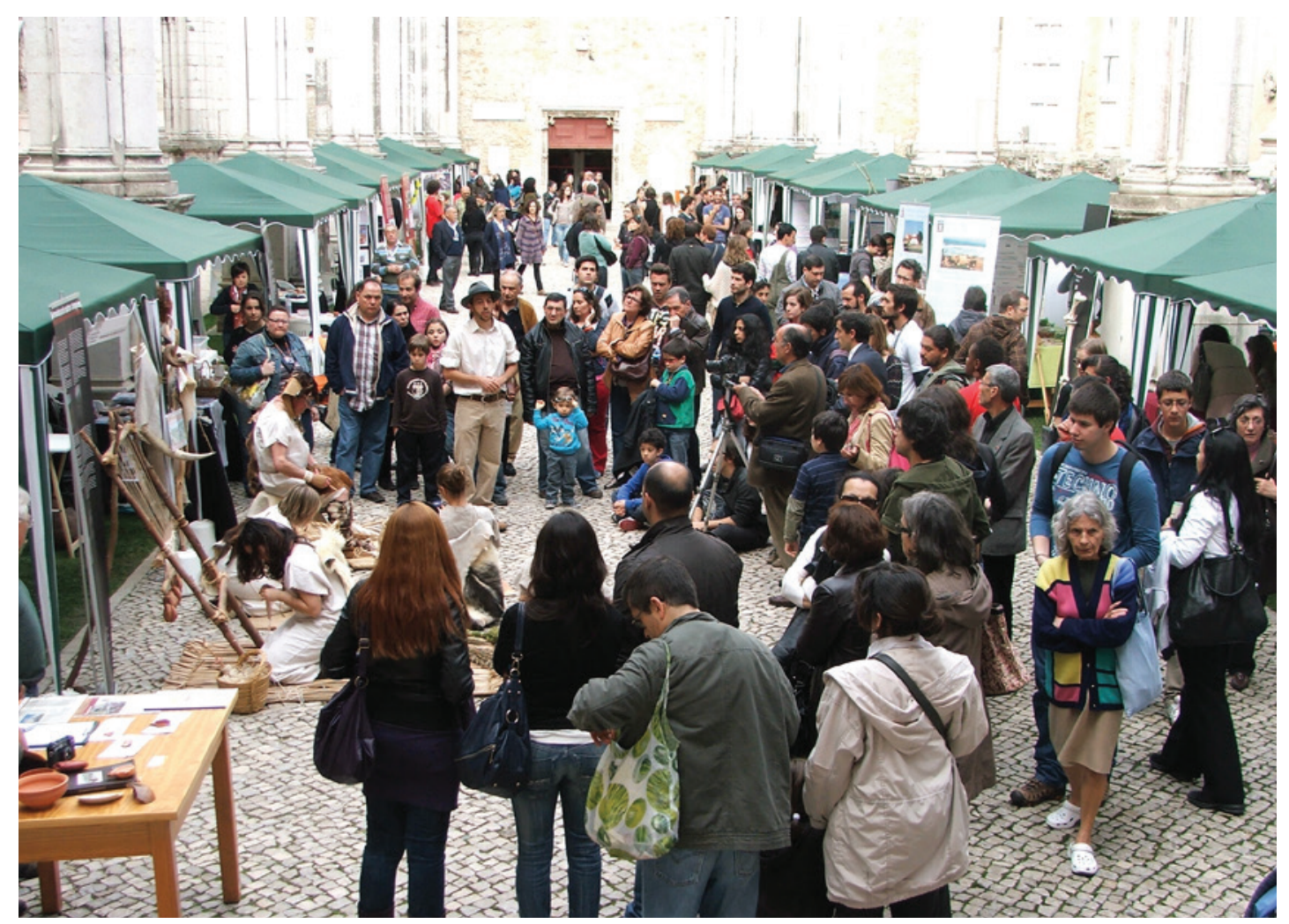

Figura 8 - Apresentação na Festa da Arqueologia de 2012.(Cristina Figueiredo/ARQA).

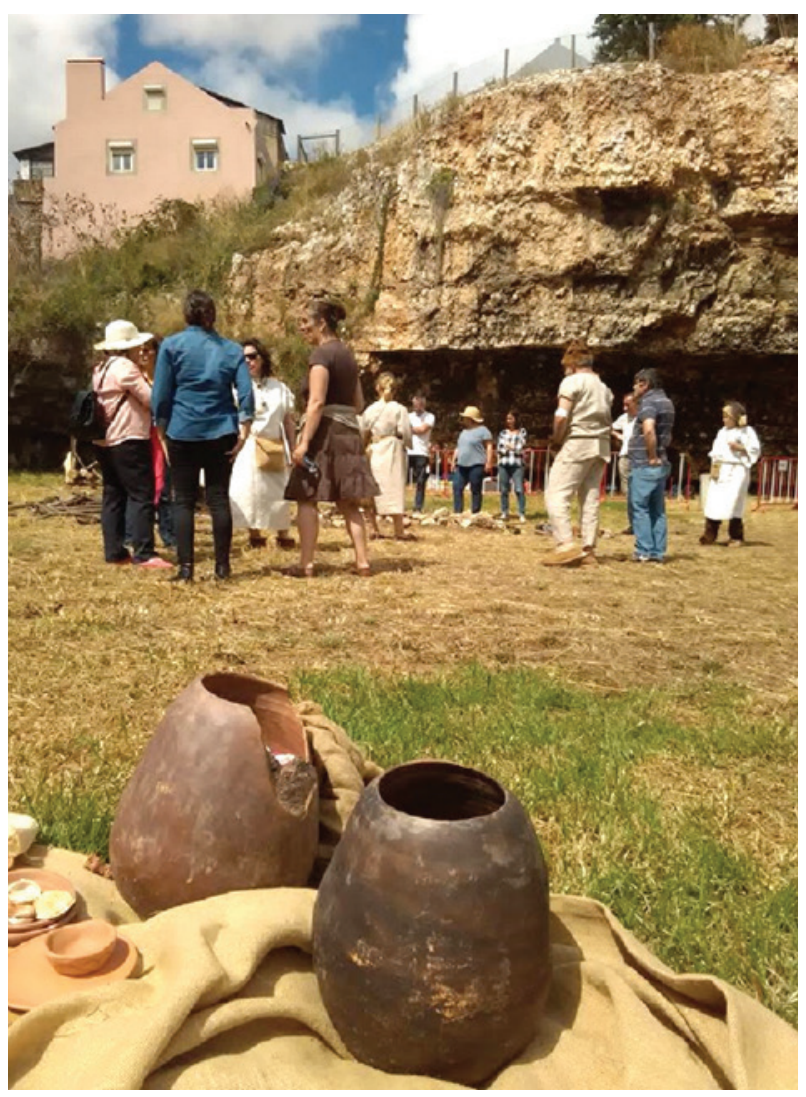

Figura 9 - Recriação histórica no Rio Seco. (Sofia Correia/ARQA). 


\title{
MEDIAÇÃO CULTURAL: PEIXE QUE PUXA CARROÇA NAS RUÍNAS ROMANAS DE TROIA
}

Inês Vaz Pintoํ, Ana Patrícia Magalhães², Patrícia Brum³ ${ }^{3}$ Filipa Santos 4

\begin{abstract}
RESUMO
O projeto de valorização do centro de produção de salgas de peixe romano de Troia, iniciado em 2006, tem uma forte componente de mediação cultural em resposta, à partida, ao interesse do público. Prosseguiu como um desenvolvimento natural da investigação e da valorização do sítio arqueológico, aberto ao público em 2011, e tornou-se uma proposta de atividades culturais e um forte investimento na educação patrimonial.

Esta mediação cultural tem tido múltiplas “carroças”, salientando-se a visita ao sítio, em particular a visita guiada, mas também os programas escolares e as animações temáticas para crianças e adultos, através de pequenos e grandes eventos. O seu objetivo último é o conhecimento e reconhecimento do monumento como herança cultural que importa respeitar e preservar.

Palavras-chave: Mediação cultural, Comunicação de ciência, Educação Patrimonial, Ruínas Romanas de Tróia, Troia.
\end{abstract}

\begin{abstract}
The enhancement project of the Roman fish-salting production centre of Troia began in 2006 with a strong component of cultural mediation answering the demand of the public. This mediation continued as a natural development of the investigation and valorization of the site, opened to the public in 2011, and became a proposal of cultural activities and a strong investment in heritage education.

Several "carts" have been pulling this cultural mediation, such as the visit of the site, and specially the guided tour, but also school programs and thematic animations for children and adults through small and large events. The main goal is the knowledge and the recognition of the monument as cultural inheritance to be respected and preserved.

Keywords: Cultural mediation, Science communication, Heritage education, Roman Ruins of Troia, Troia.
\end{abstract}

\section{OS CAMINHOS QUE SE ABREM: INTRODUÇÃO}

Com o projecto de valorização das Ruínas Romanas de Troia (Pinto, Magalhães e Brum, 2014) abriram-se ao público formalmente, pela primeira vez, as portas deste sítio arqueológico com séculos de investigação. A necessidade já vinha sendo sentida e, mesmo sem percursos instalados, muitas foram as visitas que se foram realizando ao longo dos anos.
Recentemente, antes da abertura, várias equipas, como as do Museu de Arqueologia e Etnografia do Distrito de Setúbal (MAEDS) e do Instituto do Património Arquitectónico e Arqueológico (IPPAR) já vinham proporcionando visitas ao sítio de forma não regular, respondendo à já existente procura. Desde o início do referido projecto de valorização, foi necessário integrar e respeitar o interesse dos visitantes pelo sítio arqueológico e pelos trabalhos em curso. A partir de Agosto de 2008, criou-se um

\footnotetext{
1. Troia Resort; CEAACP - Univ. Coimbra; ivpinto@troiaresort.pt

2. CECH - Univ. Coimbra |FCT - Fundação para a Ciência e a Tecnologia, I.P.; a.patriciamagalhaes@gmail.com

3. Troia Resort; CFE-HTC; psbrum@troiaresort.pt

4. filipa.ar.santos@hotmail.com
} 
calendário de visitas, que concentrou os visitantes, para que os trabalhos a decorrer não fossem interrompidos. Em 2010, com a instalação de um percurso de visita numa parte das Ruínas Romanas de Tróia e respectivo horário de funcionamento, as visitas passaram a ser cobradas aos visitantes. De notar que o cobrar de um valor de visita não implicou uma quebra nos números de visitantes, antes pelo contrário, verificou-se uma valorização da mesma, e foi possível manter a gratuitidade para crianças até aos 14 anos, escolas, IPSS e outras instituições afins, que, desta forma, não perderam o acesso e usufruto do Monumento Nacional.

Foram instalados sete painéis explicativos e sinalética de orientação que tornaram possível visitar uma parte representativa do sítio arqueológico sem guia, a partir do dia 1 de Março de 2011. A inauguração oficial do novo percurso de visita decorreu no dia 1 de Junho desse mesmo ano.

O número de visitantes foi gradualmente aumentando, como era expectável (Figura 1), ainda que com uma quebra em 2015, relacionada com a diminuição de participantes no Mercado Romano, adiante referida, e novo aumento em 2018, quando, já sem este grande evento, se alarga o horário de visita de Março a Outubro, de quarta a domingo.

As visitas guiadas, calendarizadas a partir de 2008, foram fonte de experimentação e de recolha de conhecimento para o desenvolvimento dos próprios percursos. Desde 2008 que se realizavam visitas guiadas regulares, mas com a implantação dos percursos em 2010, estas foram cada vez mais frequentes e divulgadas.

Contudo, a experiência de mediação cultural neste sítio arqueológico, que pretendemos apresentar neste artigo, não se limitou às visitas guiadas/ orientadas.

\section{O PUXAR DA CARROÇA: A EXPERIÊNCIA DOS ÚLTIMOS DEZ ANOS DE MEDIAÇÃO CULTURAL EM TROIA}

Convidando-se e permitindo-se, a partir de então e cada vez mais, o usufruto deste espaço, as experiências foram muito diversas. Apresentamos, genericamente, algumas das que foram produzidas pela equipa de arqueologia do Troia Resort.

Desde 2009, os diversos programas de Passagem de Ano, Carnaval, Páscoa e Verão do Troia Resort passaram a integrar actividades relacionadas com o sítio arqueológico especiais para crianças e promoveram-se animações para adultos, como, por exemplo, passeios pedestres ou sessões de alongamentos, procurando atrair ao sítio quem estava hospedado sazonalmente nas proximidades (Figura 2).

Por outro lado, contrariando a sazonalidade deste território, um conjunto de três encontros deram a conhecer a região envolvente do maior centro de produção de salga de peixe do Império Romano, intimamente ligada a esta indústria com a já mais recente tradição conserveira. O objectivo desta acção era dar a conhecer a riqueza dos recursos naturais e patrimoniais da região, mas esta possibilitou igualmente uma maior integração da equipa recém-chegada e abriu as portas deste "tesouro científico" dos arqueólogos (Leite de Vasconcelos, 1897: 265) a um público mais vasto. Três edições tiveram lugar: Memórias de Tróia, em 2012; Memórias da Arrábida, em 2013 e Memórias do Sado, em 2014 (Figura 3).

Entretanto, em 2013 inicia-se o Mercado Romano (Santos, et al., 2017: 159; Magalhães, 2019), uma recriação histórica de época romana, com muita animação histórica, quadros vivos, espectáculos, música, actividades temáticas, espaços lúdicos e actividades próprias para crianças, área de mercado com bancas de artesanato e produtos regionais alusivos à época romana e espaço de restauração (tabernae). O Mercado Romano teve a sua primeira edição a 30 de Março de 2013 e recebeu cerca de 1.600 visitantes. Em 2014 e 2015, o evento foi alargado a dois e três dias, em Abril e Maio, respectivamente, e ultrapassou os 4 mil visitantes em cada uma destas edições. Na quarta edição, em 2016, com a duração de dois dias, em Abril, acolheu cerca de 3.280 visitantes. Na sua última edição, em 2017, num fim-de-semana de Abril, recebeu 1.641 visitantes. Estes números refletem a adesão do público a este tipo de evento e a oscilação do número de visitantes reflete condicionantes locais, como uma greve da empresa de ferries de acesso a Tróia em 2015, que limitou o transporte de Setúbal, e condições atmosféricas, como a chuva ou o excesso de calor, uma vez que é inteiramente desenvolvido no exterior. Em cada um dos anos foi escolhido um tema: em 2013 e 2014, a "Páscoa Romana"; em 2015, os "Ludi Florales"; em 2016, o "Festival do Garum" e, em 2017, "Em nome do deus Mitra". Todas as edições deste evento contaram com o apoio da Câmara Municipal de Grândola, da Câmara Municipal de Setúbal, da Infratróia, do MAEDS, do Museu Arqueológico de São Miguel 
de Odrinhas, do Museu de Lisboa - Teatro Romano e, pontualmente, de outras entidades (Figura 4).

A par deste grande evento anual, outros mais pequenos foram sendo criados e evoluindo. A partir de 2013, um Protocolo com a Associação Mutualista Montepio deu origem aos Sunsets Musicais, com direcção artística de Luís Filipe Canelas Martins, em época alta (nas quartas-feiras da segunda quinzena de Julho e de Agosto). Estes pequenos eventos de música ao vivo permitiram que os visitantes usufruíssem gratuitamente de um pequeno concerto e da visita ao sítio. Ao todo, participaram neste evento, no período de 2013 a 2017, 1032 pessoas. Em 2018 e 2019, os concertos continuaram com o patrocínio da Associação Mutualista Montepio, mas à música associaram-se as provas vínicas, com o apoio da Rota dos Vinhos da Península de Setúbal, promovendo as adegas regionais da península de Setúbal e da costa alentejana, e a entrada passou a ser paga. Esta reformulação trouxe ao sítio arqueológico um novo tipo de público e, no conjunto dos sete Sunsets de cada ano, participaram um total de 427 pessoas.

Em 2015, criou-se um novo pequeno evento de Verão no sítio arqueológico, a Noite de Estrelas. Esta consiste numa parceria com a Sky4All, na qual um astrónomo amador, com dois telescópios, acompanha os visitantes na descoberta dos astros e das estrelas do céu noturno, enquanto as arqueólogas contam os mitos relacionados com os planetas e as constelações que se podem observar. O evento tem lugar dentro de uma oficina de salga e tem a lotação de 50 pessoas. Em Agosto de 2015 concretizou-se a primeira sessão; em 2016 tiveram lugar três, em Julho e Agosto; em 2017 realizaram-se quatro em Agosto; em 2018, foram seis sessões em Julho e Agosto, e em 2019, foram quatro nos mesmos meses. Pode-se considerar um dos programas com maior sucesso, uma vez que as sessões esgotam a capacidade sistematicamente, e muitos participantes repetem de ano para ano, e por vezes regressam para descobrir o sítio à luz do dia, verificando-se uma grande aproximação do público ao monumento propriamente dito, talvez pelo caracter intimista da própria atividade em si (Figura 5).

Em 2017, escolheu-se como tema condutor da programação mensal das Ruínas Romanas de Troia, os deuses romanos. Assim, cada mês foi adoptado um deus e desenvolveram-se actividades ajustadas a cada um. Por exemplo, no mês de Baco houve uma prova de vinhos e no mês de Diana, uma exibição de voo de aves de rapina, no mês de Julho, dedicado a Apolo, organizou-se um Arraial com várias valências, além da incontornável sardinhada. Os alunos da CEAACP-Troia Summer School (adiante apresentada) mostraram os resultados das escavações terminadas na véspera e o Museu do Trabalho Michel Giacommeti, de Setúbal, organizou uma actuação teatral de um grupo de antigas trabalhadoras das fábricas de conservas, e todos os participantes foram convidados a visitar o sítio arqueológico.

Em 2018, promoveu-se uma "Bienal de Teatro", inaugurada com a peça ao ar livre "Viriato", do grupo Fatias de Cá, encenada pela primeira vez em Tróia. No ano seguinte, a Décadas de Sonho produziu o "O Cavalo de Troia", um espetáculo que combina teatro, acrobacia, dança, luz e som, especificamente criado para a margem da lagoa da Caldeira junto ao sítio arqueológico.

Também nos anos de 2018 e 2019 se desenvolveu um novo programa, a Noite Assombrada, que contou com a participação de muitos voluntários, nomeadamente do grupo de teatro ENSAIARTE, da Faculdade de Letras de Lisboa e da Escola Secundária Inácio da Cruz, Grândola, além de outros que participaram individualmente. Este evento decorreu pela primeira vez a uma sexta-feira 13, em Julho de 2018, guiando diferentes grupos pelas histórias mais sombrias que as escavações têm permitido conhecer. Este programa foi repetido a 19 de Julho de 2019, e a sua preparação contou com um workshop de teatro imersivo coordenado pelo encenador Prof. Newton de Sousa no Museu de Arqueologia e Etnografia do Distrito de Setúbal (MAEDS), que serviu para formação dos voluntários que fariam parte da encenação (Figura 6).

\section{ALGUNS PEDAIS: A COMUNIDADE ESCOLAR}

O serviço educativo não é dedicado apenas à comunidade escolar, mas, na perspectiva desta equipa, ela desempenha um papel fundamental na captação de futuros públicos e na educação não formal dos jovens. Papel esse que foi logo considerado ao ter-se instalado um projecto de valorização acessível (Pinto, Magalhães e Brum, 2014), com painéis explicativos à altura de visitantes mais pequenos e com ilustrações que reconstituem o que veem.

De início, foi feito um "Mini-Guia" com algumas actividades, que acompanhava e auxiliava a visita 
ao sítio. Os primeiros programas, iniciados com o ATL do Carvalhal, envolveram mascarar as crianças de Romanos e proporcionar-lhe uma actividade que se designou por "Romaninhos em Troia", no qual as crianças seguiam diversas pistas ao longo das ruínas. Esta realizou-se ainda antes da instalação dos percursos, pelo que o contacto com o monumento era em alguns casos mais próximo, como no caso das termas, onde as crianças podiam então entrar. Houve uma forte aposta na promoção das Ruínas Romanas de Tróia junto da comunidade escolar, como ponto estratégico do desenvolvimento do projecto de valorização. Identificaram-se, nas metas pedagógicas do Ministério da Educação, os anos escolares cujos conteúdos abarcavam a cronologia romana ( $5^{\circ}, 7^{\circ}$ e $10^{\circ}$ anos de escolaridade) e estes foram assinalados como público-alvo.

Foram criadas várias propostas especificamente para escolas: Actividades pedagógicas; Passeio pedestre; A salga de peixe e o arroz: indústrias do passado e do presente; Arqueologia e Ambiente; Visita e piquenique e Arqueologia e Golf, com a possibilidade de as escolas usufruírem de um preço especial na travessia do Sado pela Atlantic Ferries. A grande maioria das escolas opta simplesmente pelas actividades pedagógicas com o preço e o período de tempo mais reduzido na oferta existente. Os programas envolvendo o piquenique e o golf não tiveram procura e deixaram de fazer parte dos conteúdos promocionais produzidos em 2017.

A partir de 2013, e baseado no romance Um gladiador só morre uma vez de Steven Saylor, construiu-se o jogo de pista "O garum roubado", no qual os alunos são divididos em povos bárbaros (Gauleses, Egípcios, Bretões e Lusitanos, seguindo as imagens da banda desenhada Astérix e Obélix), após uma curta visita guiada. Os alunos são então deixados à sua própria exploração do sítio e testando o conhecimento recentemente adquirido, encontram as letras (P-O-Ç-O) espalhadas nas pistas deixadas em diferentes núcleos do percurso visitável. O jogo narra a história de uma garrafa de garum roubada, que afinal está esquecida no poço, e onde no final as crianças podem degustar o dito garum, substituído pelo molho de peixe produzido na Tailândia, nuoc mam. Segue-se nesta actividade o princípio de que "uma vez criados laços de alguma familiaridade com o ambiente, os alunos tendem a desenvolver um crescente grau de concentração" (Silva, 2007: 61) (Figura 7).
O conhecimento empírico obtido com esta actividade revelou que não era desafiante para o público do $7^{\circ}$ ano de escolaridade, pelo que foi necessário desenvolver uma acção específica para esta faixa etária. Essa nova actividade consiste na recriação de contextos arqueológicos, que são repartidos entre diferentes grupos de alunos que devem registar, desenhar e interpretar as peças do seu contexto conforme o procedimento arqueológico, apresentando-o no final aos restantes grupos, e realçando-se o trabalho de equipa que se desenvolve em arqueologia.

De realçar ainda dois programas específicos que procuraram fazer chegar o sítio arqueológico mais directamente à escola: "Adota uma ruina" e "Garum nostrum". O programa "Adota uma ruína" (Santos, et al., 2017: 158) decorreu nos anos letivos de 2015/2016 e 2016/2017. Os objetivos deste projeto foram "estimular o interesse das crianças e jovens pelo património cultural local e incentivá-los a valorizá-lo".

O "Garum nostrum" teve o objectivo de ajudar as pessoas (das gerações mais jovens, mas naturalmente através de um público mais amplo) a formar uma visão mais complexa do cenário europeu, facilmente demonstrada pelos vestígios romanos que foram determinantes neste território, esperando dar uma ideia melhor sobre o que cada um pode contribuir no panorama europeu.

Assim, o público escolar nas Ruínas Romanas de Tróia cresceu nos últimos anos (Figura 8), sendo particularmente notório o ano lectivo 2017/2018, possivelmente reflexo do investimento continuado nos programas escolares em Tróia (Figura 8).

Por outro lado, as escavações fizeram sempre parte do trabalho desenvolvido nas Ruínas Romanas de Troia, e desde 2007 que se envolveram estudantes de várias universidades do país. Em 2014, iniciou-se a CEAACP-Troia Summer School, uma parceria com o Centro de Estudos de Arqueologia, Artes e Ciências do Património da Universidade de Coimbra e com o apoio da Universidade do Arizona. Aqui procurou criar-se uma escola de verão, onde os alunos participavam na escavação do sítio arqueológico, sendo o programa complementado com aulas proporcionadas pela equipa residente e por oradores convidados. Este programa de Verão começou por ter como público-alvo estudantes universitários internacionais, mas desde 2018 foi direcionado, com apoio da AFAR (American Foreign Academic Research), ao segmento de pré-universitários do ensino secundário. 


\section{AS CORREIAS DA CARROÇA: PARCERIAS E INTEGRAÇÃO EM PROGRAMAS EXISTENTES}

Para além da programação acima apresentada e originalmente criada para este sítio arqueológico, também foi acolhida a participação em feiras, festas e outros encontros que são vistos como motores conjuntos para a promoção do património cultural. A título de exemplo, as Ruínas Romanas de Tróia participaram, desde 2012, na Festa da Arqueologia, promovida pela Associação dos Arqueólogos Portugueses e Museu Arqueológico do Carmo, na recriação histórica iniciada em S. Miguel de Odrinhas em 2018 e em iniciativas promovidas pelo Museu de Lisboa - Teatro Romano.

As Ruínas Romanas de Troia desenvolveram programação nas edições do Dia Internacional dos Monumentos e Sítios, dia instituído a 18 de Abril de 1982 pelo Conselho Internacional dos Monumentos e Sítios (ICOMOS). Integraram as celebrações, geralmente, com um Dia Aberto e com acções criadas de acordo com o tema do ano. No primeiro ano, em 2011, pouco tempo depois da abertura ao público, foram acolhidos, com surpresa, 155 visitantes (Figura 9).

Para além do acesso gratuito, em 2012 decorreu uma visita guiada com o tema "A singularidade do sítio arqueológico de Tróia”, e em 2013 e com o tema "Memória e Identidade das Ruínas Romanas de Tróia". Em 2014, a comemoração foi integrada no evento Mercado Romano. Em 2015, a programação dedicou-se à Basílica Paleocristã, com apresentações sobre as suas pinturas e os trabalhos de conservação e restauro no Golf de Tróia, e visitas guiadas gratuitas a este núcleo. Em 2016, foram disponibilizados jogos de tabuleiro para que os visitantes pudessem usufruir de um desafio diferente, e no dia 18, sábado, foi realizado um ensaio para o desfile do Mercado Romano. Em 2017, no âmbito do projeto europeu STORM e do projeto pedagógico "Adota uma ruína”, alunos de duas escolas do concelho vizinho de Setúbal desenvolveram actividades que alertavam para as ameaças ao património cultural, nomeadamente a erosão fluvial e o vandalismo. Nos anos de 2018 e em 2019, decorreram dias abertos, sem programação adicional.

Por seu turno, as Jornadas Europeias do Património, uma iniciativa conjunta da Comissão Europeia e do Conselho da Europa desde 1999, foram integradas na programação a partir de 2013 , realizando-se anualmente um passeio pedestre na orla do estuário do Sado, sensibilizando para o património arqueológico ameaçado pela erosão costeira e que ainda não foi objeto de valorização.

Desenvolveram-se ainda parcerias mais pontuais e locais, fruto de algumas oportunidades que serão já resultado de uma maior proximidade com a comunidade local. $\mathrm{O}$ ano de 2017 teve duas iniciativas nas freguesias mais próximas: o desfile de Carnaval com temática romana (Santos, et al., 2017: 162), em Melides, e o arraial do Carvalhal, com uma marcha e música personalizadas. No ano seguinte, no âmbito do desafio do Ano Europeu do Património Cultural, a Sociedade Musical Filarmónica Operária de Grândola - Música Velha tocou o Hino da Alegria no sítio arqueológico, tendo o concerto sido divulgado nas redes sociais a 9 de Maio, celebrando o Dia da Europa (Figura 10).

O envolvimento de outros agentes culturais não é efectuado apenas ao nível da divulgação e programação, mas foi procurado na própria investigação. Em parceria com a Câmara Municipal de Setúbal, e mais concretamente com o Museu do Trabalho Michel Giacometti, desenvolveu-se a partir de 2016, o Centro de Memórias das Ruínas Romanas de Tróia. O sítio arqueológico vem sendo escavado desde o século XVIII, com intensas campanhas de escavação nos anos 50 e 6o. Com o intuito de não perder as memórias daqueles que vêm contactando com o sítio arqueológico e que contribuíram para o desenvolvimento do seu conhecimento, este projecto propõe-se recolher os testemunhos da relação com o sítio daqueles que estiveram de alguma forma envolvidos na investigação deste sítio arqueológico.

\section{OS EIXOS DA CARROÇA: DISCUSSÃO}

Can we say with as much confidence that heritage interpretation has played an important role in enhancing peoples awareness, understanding and appreciation of time and place? (Uzzell, 1998: 1)

Tal como Tilden (1977), entendemos a interpretação/mediação como o início de um processo que leva à protecção do património. Como referido noutra parte: "No nosso trabalho percebemos como as pessoas só se ligam ao sítio depois de compreenderem a sua história. Então, temos de contar a história milhares de vezes e de muitas formas diferentes." (Santos, 2018). 
Os programas que ora se apresentaram, têm por base a investigação da equipa residente de arqueólogas, que procuram no mundo romano a inspiração para as recriações históricas, teatros ou o contar de mitos. Como a equipa de investigação é simultaneamente a equipa do serviço educativo, anula-se a barreira investigação/mediação. Quem planeou, investigou e "produziu a exposição permanente" é simultaneamente quem faz a difusão e divulgação da mesma, recebendo directamente a reacção do público que a visita.

As actividades aqui apresentadas foram originalmente criadas para desenvolver a atractividade do destino turístico com uma nova oferta cultural, diferente do turismo de praia e sol, reconhecendo-se neste projecto que o turismo poderá favorecer o respeito pelos valores patrimoniais e a preservação da herança cultural (Pinto et al., 2019: 19). Ao mesmo tempo, visava provar o apelo do sítio e ampliar os públicos, incentivando a criação de novos empregos e oportunidades de negócios na região e promovendo a sustentabilidade do património cultural.

Através de muitos destes programas, mas talvez sobretudo das recriações do Mercado Romano, Noites Assombradas e programas educativos, foi possível um maior envolvimento e participação das comunidades, complementando a capacidade da equipa que coordenava os eventos. O envolvimento de instituições de teatro amador, escolas e universidades nas actividades, a promoção de um concurso entre famílias locais ou o desenvolvimento do mercado com artesãos desenvolveram novas perspectivas para o património, usando a história para aproximar as pessoas e corresponder às suas expectativas.

Com o desenvolver de um circuito de visita, o palco estava montado para uma nova fase na Tróia romana. A visão para este sítio tornou-se mais clara: "constituir-se como pólo cultural de qualidade, tornando-se local de referência do turismo cultural internacional, atraindo simultaneamente públicos locais e estrangeiros e actuando como factor diferenciador do Troiaresort" (Brum, 2014).

A existência de recursos humanos com elevada formação e a clara definição de uma missão/visão permitiram mediar o envolvimento de todos os agentes ligados a este sítio, incrementando o significado cultural do sítio e estimulando a sua funcionalidade, de forma a assegurar o compromisso de todas as partes na salvaguarda do bem (ICCROM, 2015).

Dez anos depois, o serviço educativo deste equi- pamento cultural não só alargou a transmissão de conhecimento em formato de visita guiada, mas também procurou reinventar-se, compreendendo a importância das comunidades que a rodeiam e que estavam arredadas do sítio, com "a liberdade e o poder de explorar a sua imaginação e a sua ligação pessoal com o sítio" (Santos, 2018). Foi caminho da equipa que assina este artigo procurar transformar as Ruínas Romanas de Troia num espaço convidativo, entendido como espaço de sociabilidade e de contacto directo com o património, em que se ensina que peixe puxa carroça!

\section{BIBLIOGRAFIA}

BRUM, P. (2014) - Contributos para a programação museológica do acervo arqueológico romano de Tróia. Museu ou Centro de Interpretação?, Tese de Mestrado. Faculdade de Ciências Sociais e Humanas-Universidade Nova de Lisboa, Lisboa.

MAGALHÃES, A. P. (2019) - Roman market (Portugal), European heritage strategy for the $21^{\text {st }}$ century - the golden collection of good practices, pp. 77-79.

PINTO, I. V.; MAGALHÃES, A. P.; BRUM, P. (2014) - Ruínas Romanas de Tróia: a valorização de um património singular, Revista Musa 4, MAEDS, Setúbal, pp. 29-40.

PINTO, I. V.; MAGALHÃES, A. P.; BRUM, P. e SANTOS, F. (2019) - Entre o valor Patrimonial e o Interesse turístico: como usufruir do maior centro de preparados de peixe do Império romano, Arqueologia 3.o, Fundação da Casa de Bragança, pp. 14-24.

SANTOS, Filipa (2018) - What do you think and feel cultural heritage really means? Roman Ruins of Troia archaeologists team (Portugal). <http://patrimoni.peu-uji.es/es/ noticias/1423-what-do-you-think-and-feel-cultural-heritage-really-means-contribution-of-filipa-araujo-santosroman-ruins-of-troia-archeologists-team-portugal>. [Consulta realizada em 24/o2/2018].

SANTOS, F., BRUM, P., PINTO, I. V., MAGALHÃES, A. P. (2017) - O envolvimento da comunidade escolar com as Ruínas Romanas de Troia, XXIV Congresso Internacional de Animação Sociocultural, APDASC - Associação Portuguesa para o Desenvolvimento da Animação Sociocultural, pp. 155-164.

SAYLOR, S. (2009) - Um gladiador só morre uma vez. Bertrand Editora.

SILVA, S. G. (2007) - Enquadramento teórico para uma prática educativa nos museus. PRAÇA, J.H. (Ed.), Serviços Educativos na Cultura (57-66). Porto: SETEPÉS, pp. 57-65.

TILDEN, F (1977) - Interpreting our heritage, Chapell Hill Books. 
UZZELL, DL (1998) - Interpreting Our Heritage: A Theoretical Interpretation, UZZELL DL e BALLANTYNE, R. (eds.) Contemporary Issues in Heritage and Environmental Interpretation: Problems and Prospects, London: The Stationery Office. pp. 11-25.

VASCONCELOS, J. L. (1897) - Escavações reais em Tróia. O Archeólogo Português. Lisboa: Museu Etnológico Português, vol. III, págs. 2-31, p. 156-265.
ICCROM (2015) - People-Centred Approaches to the Conservation of Cultural Heritage: Living Heritage. Rome: ICCROM.

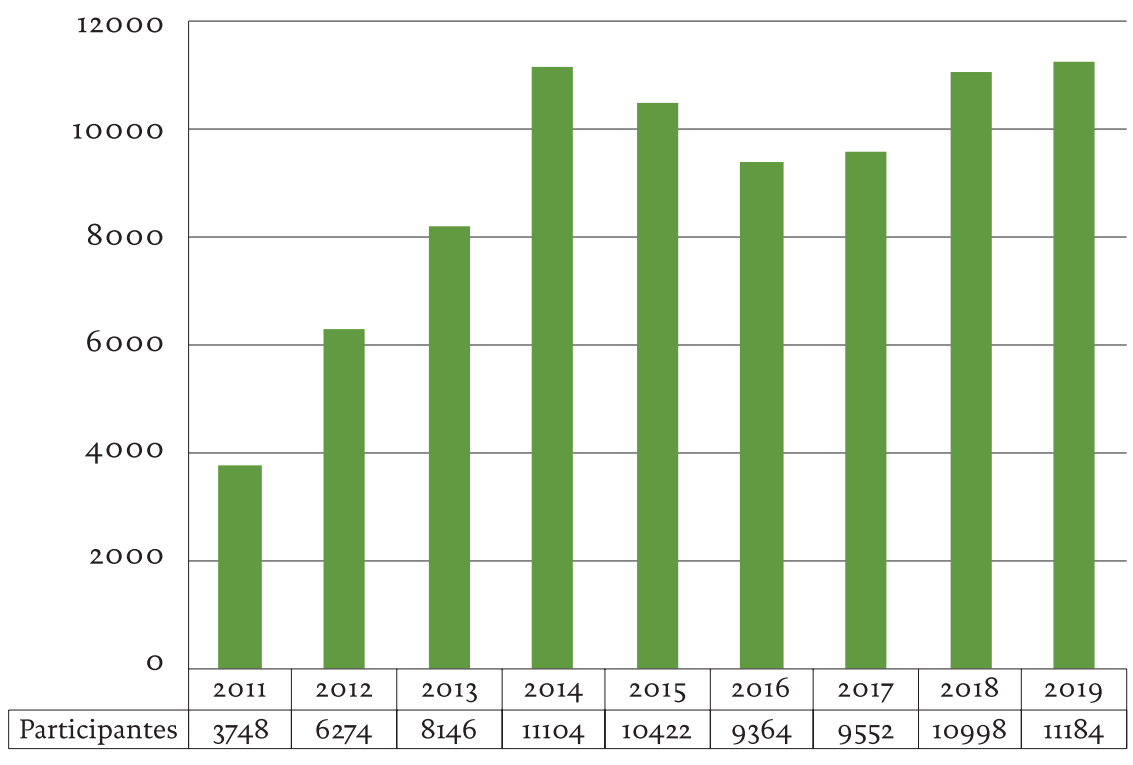

Figura 1 - № de visitantes de 2011 a 2019.

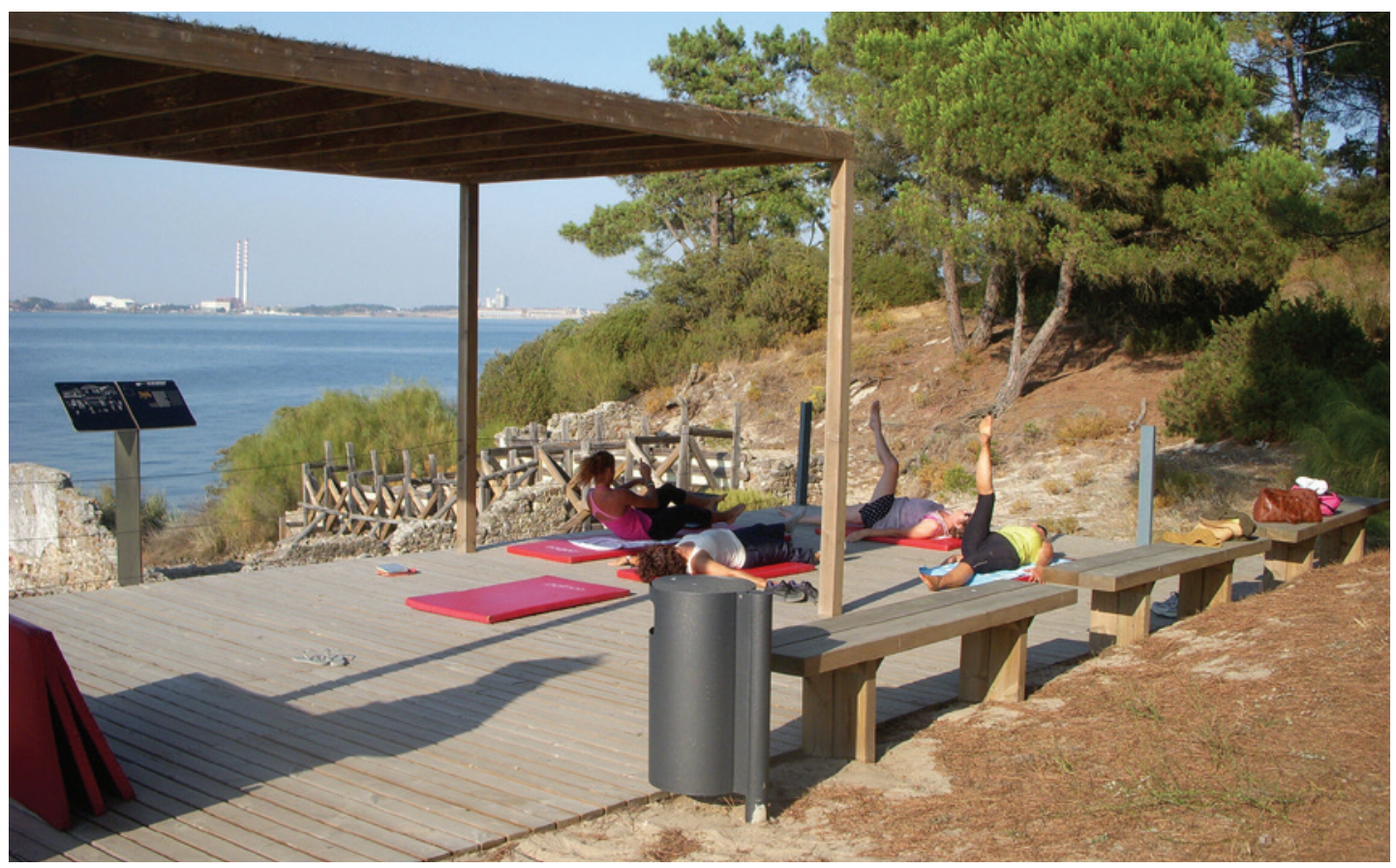

Figura 2 - Sessão de alongamentos com vista para o núcleo da Rua da Princesa. Foto de Inês Vaz Pinto. 


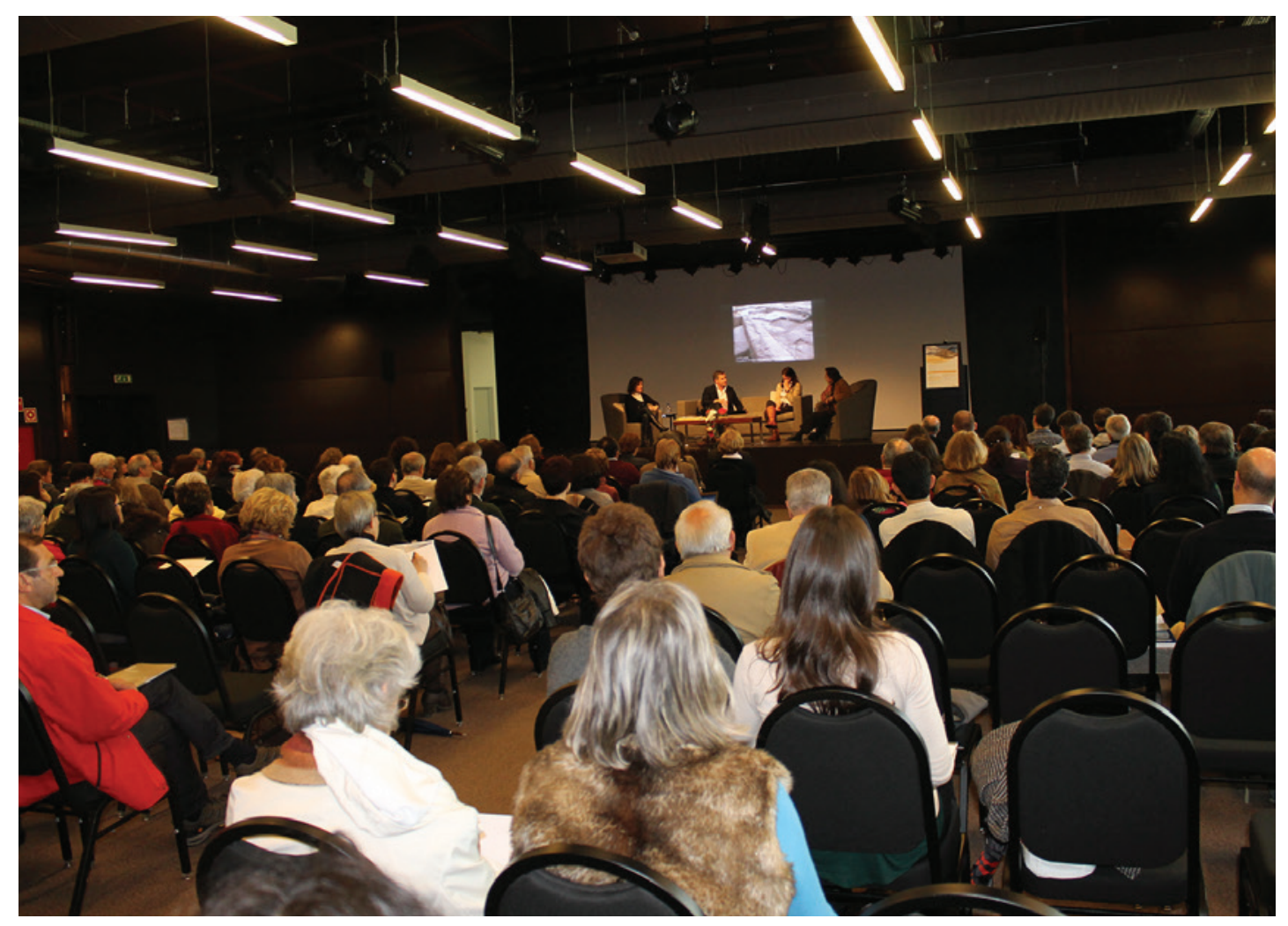

Figura 3 - Sessão das Memórias da Arrábida. Foto de Inês Vaz Pinto.

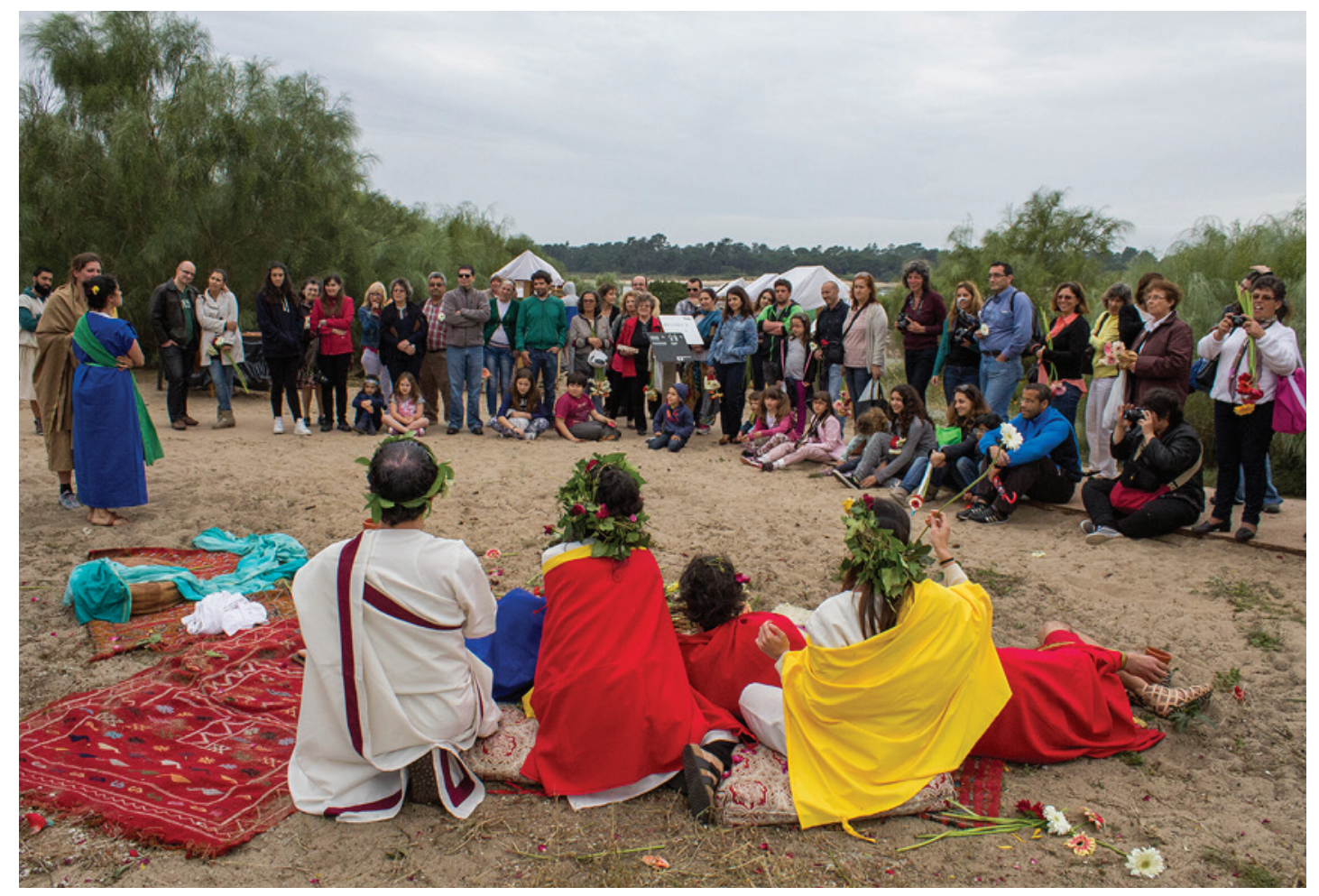

Figura 4 - Edição “Ludi Florales” do Mercado Romano. Foto de Inês Vaz Pinto. 


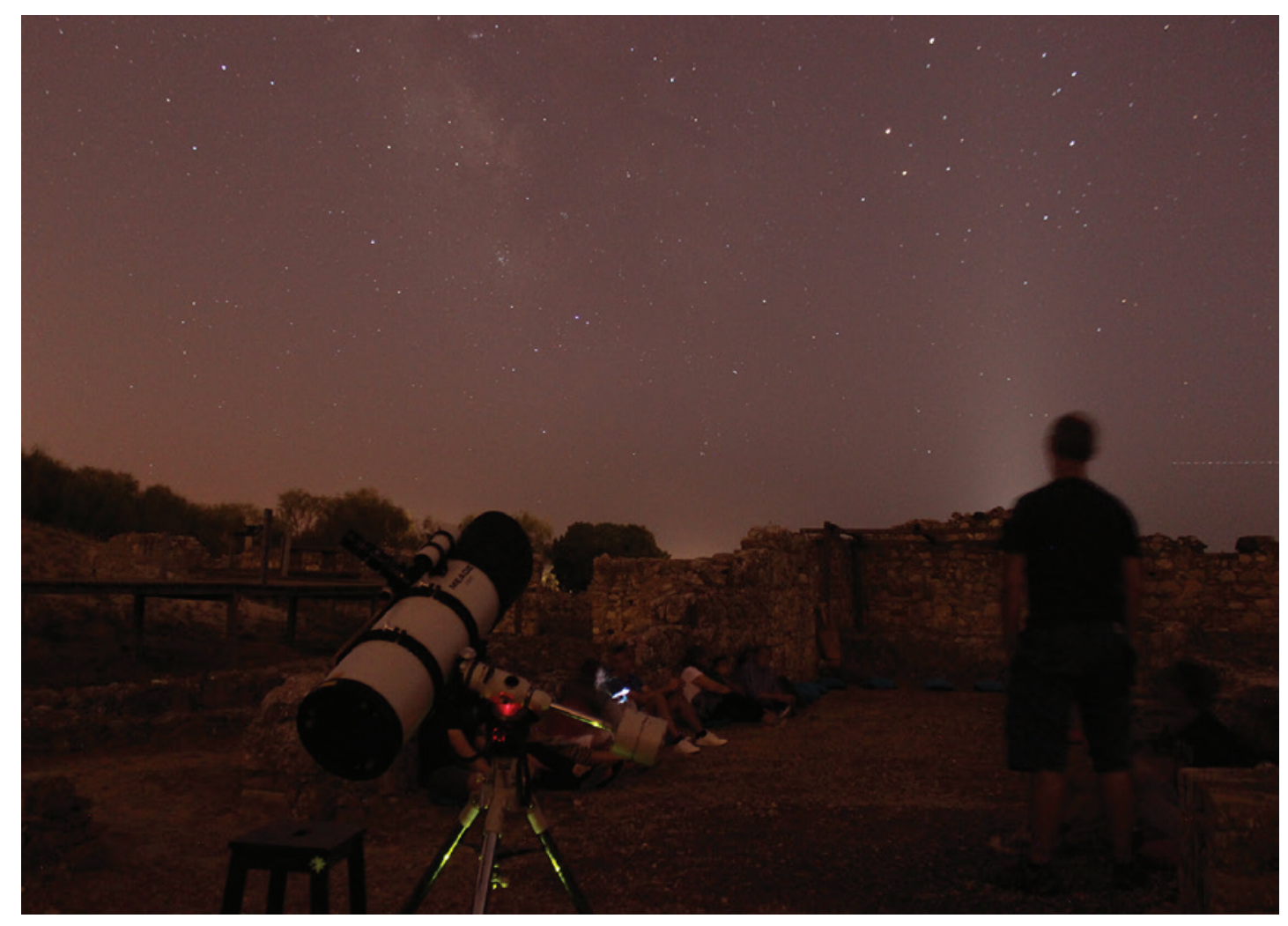

Figura 5- Noite de Estrelas a 26 de Agosto de 2016. Foto de Luís Gabriel.

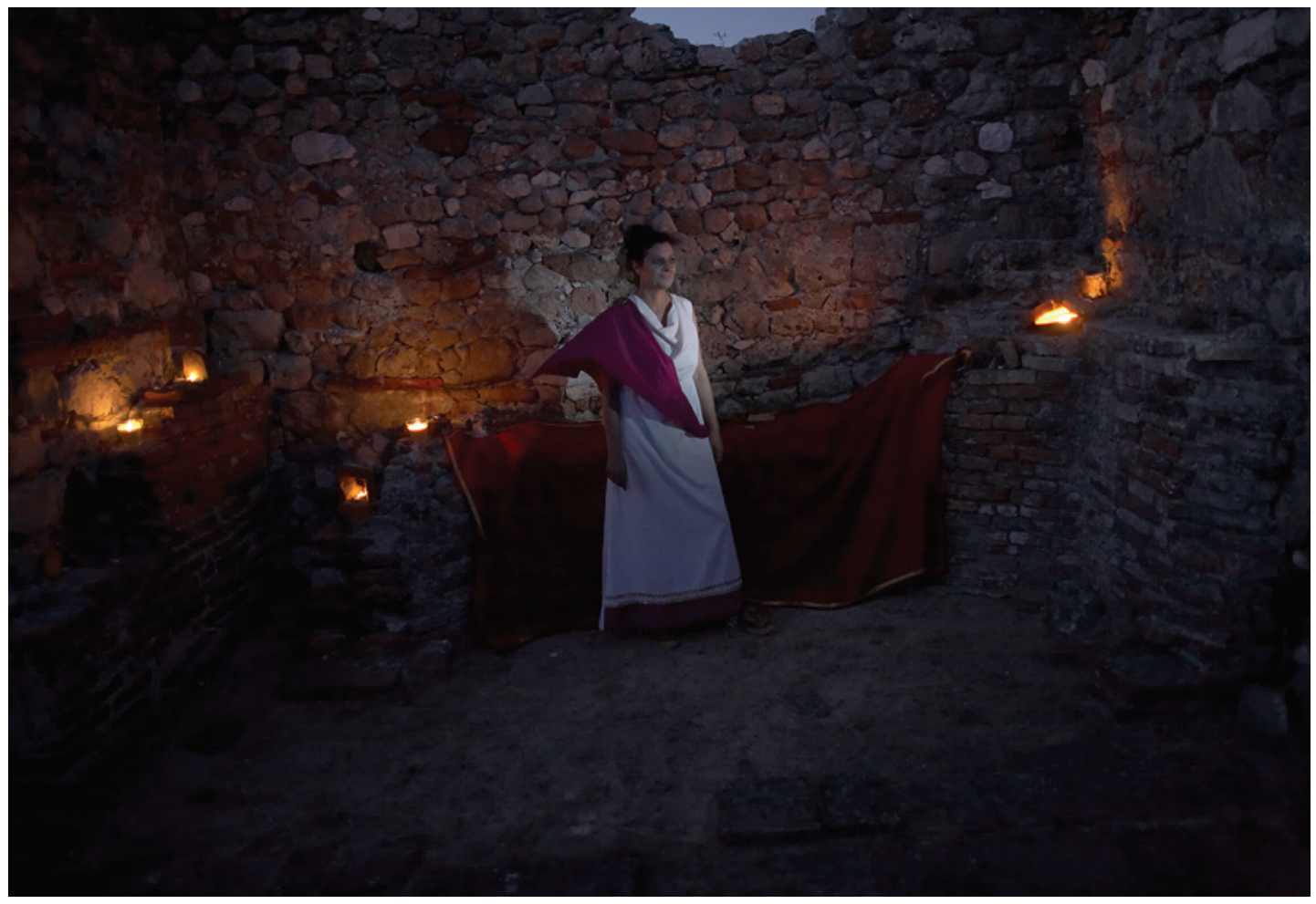

Figura 6 - Noite Assombrada em 2019. Foto de Inês Vaz Pinto. 


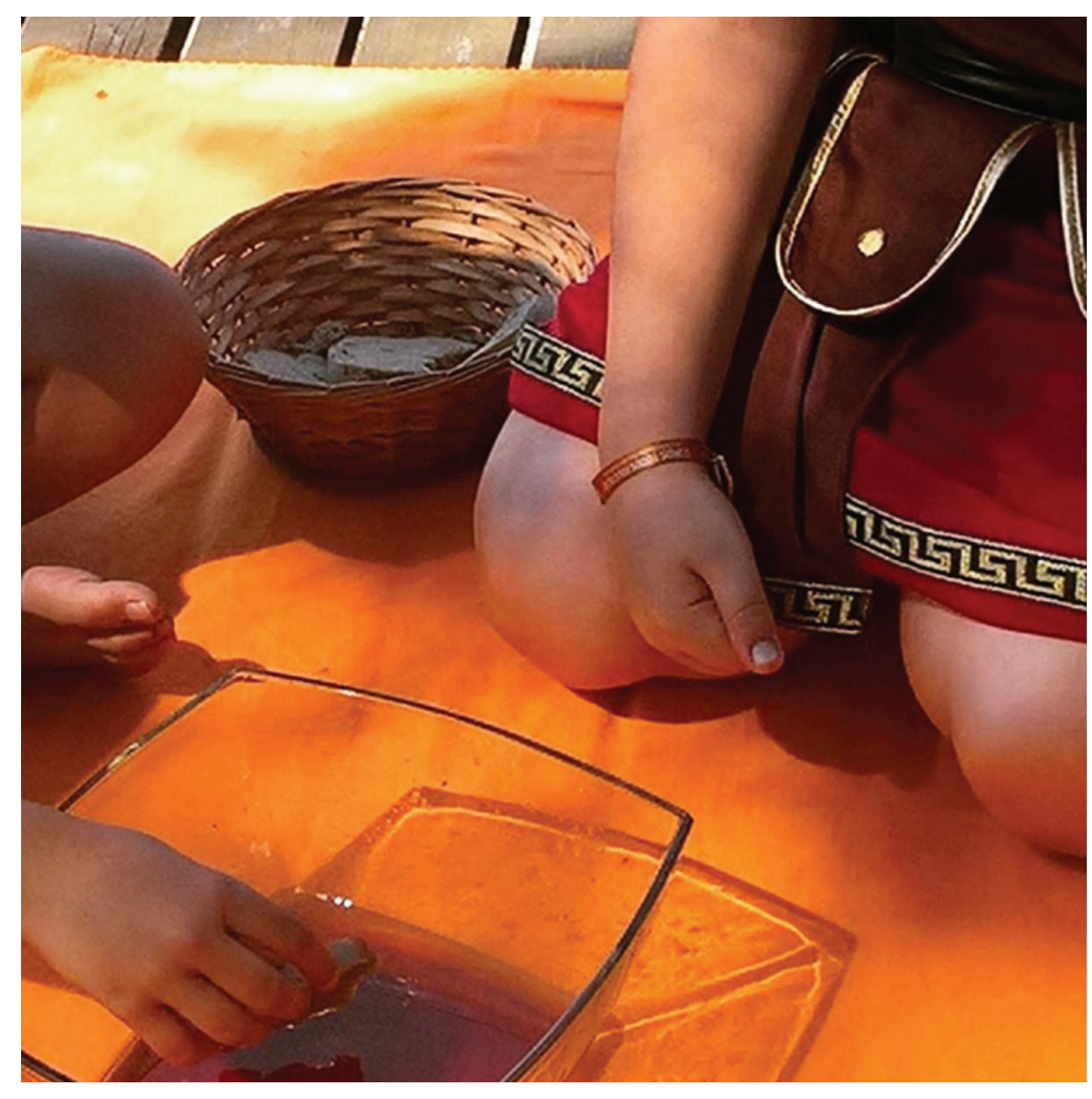

Figura 7 - Prova de garum no Dia Mundial da Criança em 2019. Foto de Patrícia Brum.

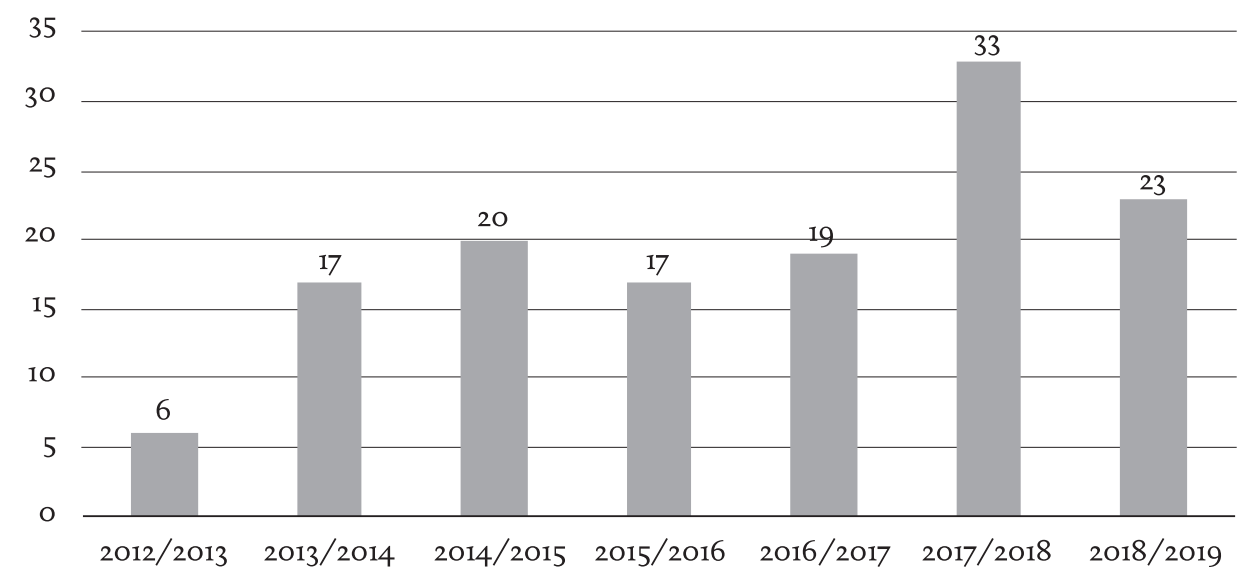

Figura 8 - Gráfico do público escolar por ano lectivo. 


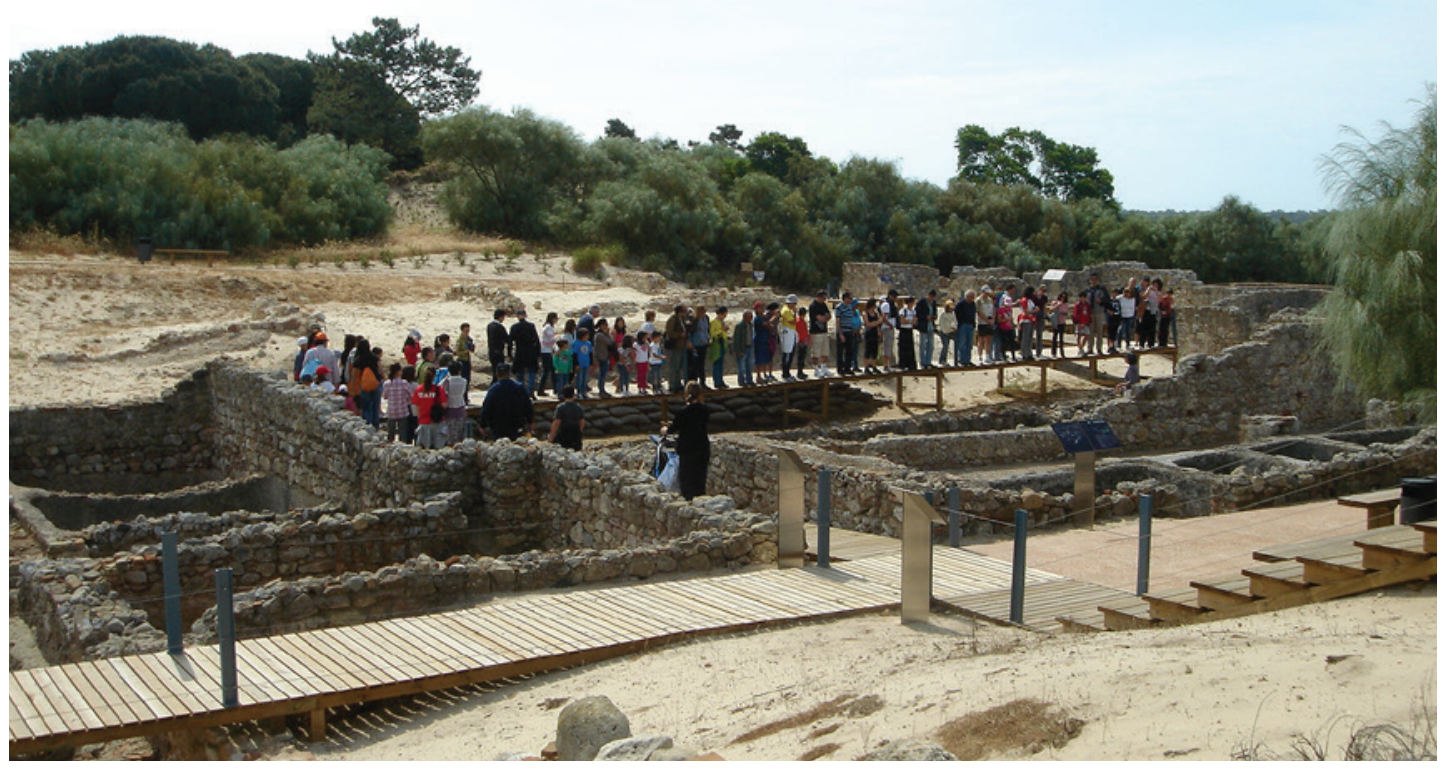

Figura 9 - Primeira edição do Dia Internacional dos Monumentos e Sítios nas Ruínas Romanas de Tróia. Foto de Patrícia Brum.

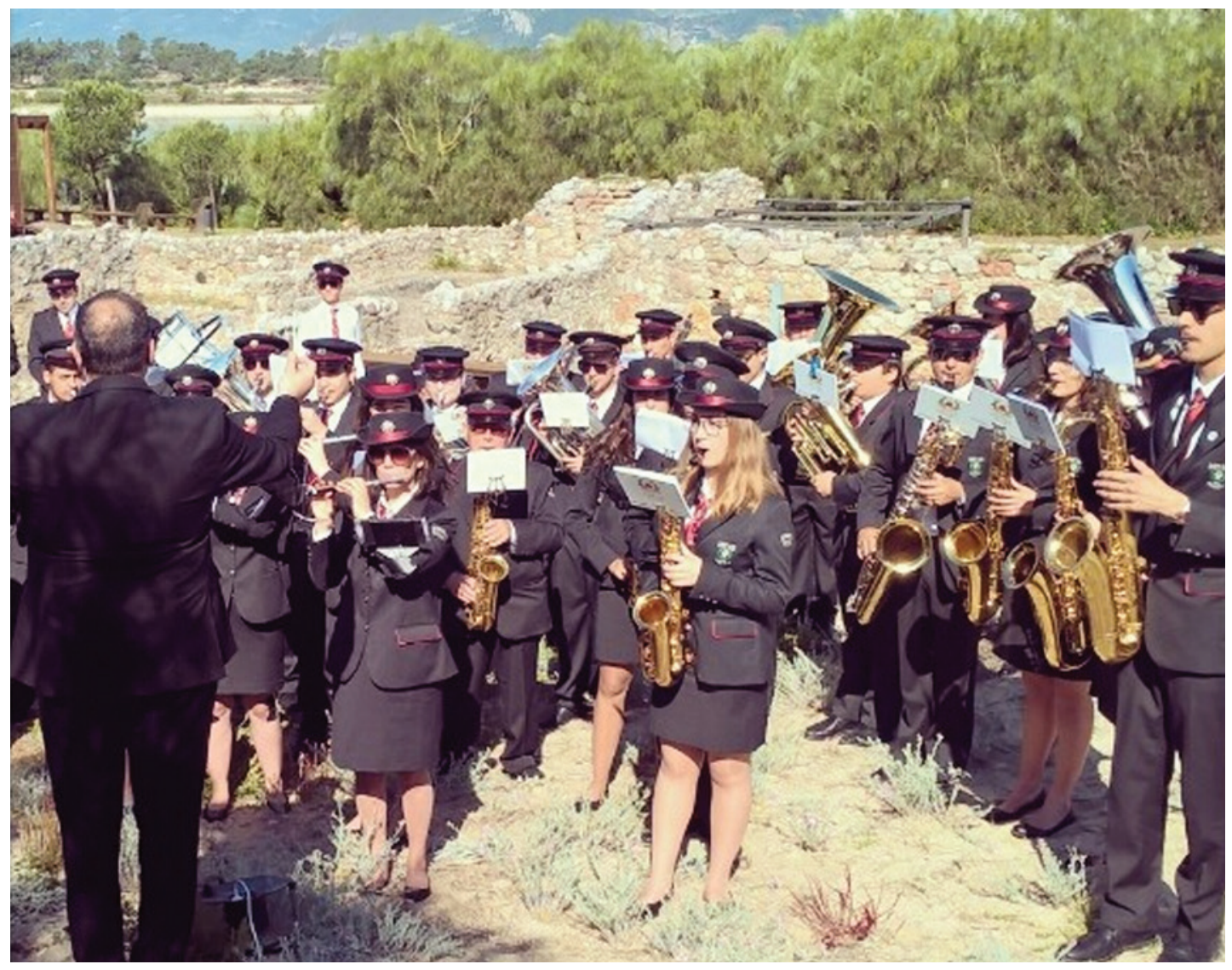

Figura 10 - Sociedade Musical Filarmónica Operária de Grândola - Música Velha nas Ruínas Romanas de Tróia. Foto de Patrícia Brum. 


\title{
DIDÁTICA ARQUEOLÓGICA, EXPERIÊNCIAS DO PROJETO MÉRTOLA VILA MUSEU
}

\author{
Maria de Fátima Palma ${ }^{1}$, Clara Rodrigues $^{2}$, Susana Gómez ${ }^{3}$, Lígia Rafael ${ }^{4}$
}

\begin{abstract}
RESUMO
Em 2018, o projeto Mértola Vila Museu, uma experiência única de preservação e divulgação patrimonial, completou 40 anos de existência. Baseado no estudo, pesquisa, conservação, salvaguarda e divulgação, este projeto tem sido experienciado das mais diversas formas, com resultados visíveis em termos científicos e com uma importante ligação à comunidade local, com o objetivo de sensibilizar para a preservação do património histórico e arqueológico. Neste texto abordamos a didática arqueológica através da experiência de Mértola, apresentando as práticas e as abordagens que têm no património o elemento estruturante do desenvolvimento local e do envolvimento da comunidade. São explicitados os pressupostos do projeto e as experiências do Campo Arqueológico de Mértola e do Museu de Mértola levadas a cabo em sítios arqueológicos, em contacto direto com a comunidade escolar e local, com o objetivo de criar laços identitários e de pertença.
\end{abstract}

Palavras-chave: Educação patrimonial, Didática, Mértola, Arqueologia cidadã.

\begin{abstract}
In 2018 the Mértola Vila Museu project, an unique experience of preservation and heritage diffusion, completed 40 years of existence. Based on study, research, conservation, safeguard and exposure, this project has been experienced in the most diverse ways with visible scientifical output and with an important connection with the local community, all this with the goal of educating and sensitizing for the preservation of historic and arqueological heritage. In this text we approach the arqueological didactic through the experience of Mértola, presenting the practices and approaches that have in heritage the structural element for the local development and community engagement. The premises of the project and of the experiences of the Campo Arqueológico of Mértola and the Museum of Mértola are clarified in direct contact with the school and local community, with the aim of creating identitary bonds and a sense of belonging.
\end{abstract}

Keywords: Heritage Education, Didactic, Mértola, Identitary bonds.

\section{INTRODUÇÃO}

O Projeto "Mértola Vila Museu" nasce de uma experiência científica, museográfica e pedagógica que não se pode desassociar de um programa estruturante, com um cariz marcadamente político, num interior empobrecido e sobretudo despovoado. O trabalho científico desenvolvido em torno do património local levou a uma redescoberta da história do lugar, dig- nificando os seus espaços e contribuindo para a criação de espaços museográficos e consequentemente um poderoso fator de desenvolvimento cultural e económico (Torres, 1989; Torres, 1993; Rafael, 2010; Rafael e Palma, 2013; Gómez, Rafael e Torres, 2016; Gómez, 2016; Palma e Rodrigues, 2019).

Muitas são as atividades pensadas e desenvolvidas no âmbito deste projeto, num contacto estreito entre instituições parceiras e que trabalham em prol

\footnotetext{
1. FCT/CAM/CEAACP/Universidade de Granada; tuchapalma @hotmail.com

2.CAM/CEAACP; clara.r.guerreiro@hotmail.com

3. Universidade de Évora/CAM/CEAACP; susanagomez@sapo.pt

4. Câmara Municipal de Mértola; ligiarafael@cm-mertola.pt
} 
do desenvolvimento local, mas que também pretendem estar presentes na comunidade, tentando incutir um sentimento de pertença sobre o património que é seu. Desta forma, através da educação patrimonial direcionada a diversas faixas etárias, temos vindo a realizar um trabalho que tenta incutir um sentimento de pertença e apropriação do seu património através de diversas experiências de arqueologia participativa. Apesar de não existir um serviço educativo estruturado, uma pequena equipa de técnicos das mais diversas áreas das duas instituições, tem vindo a pensar e a desenvolver atividades que pretendem consciencializar e sensibilizar para a preservação do património local fazendo dos alunos e demais participantes nas atividades agentes da salvaguarda do seu património.

\section{O CAMPO ARQUEOLÓGICO DE MÉRTOLA}

Em Mértola os trabalhos arqueológicos principiaram no final dos anos setenta do século XX, com uma continuidade regular até ao presente. Desde o primeiro momento, iniciaram-se as recolhas de materiais arqueológicos, etnográficos e religiosos por uma equipa multidisciplinar, liderada pelo Professor Cláudio Torres, que se instalou em Mértola e começou a desenvolver em continuidade trabalhos de arqueologia e levantamento do património histórico, antropológico e artístico, sempre com o apoio da Câmara Municipal de Mértola (CMM). Neste âmbito, não podemos deixar de referir a figura que impulsionou o início do projeto, António Serrão Martins, o primeiro Presidente da Câmara eleito democraticamente e que trouxe a Mértola os seus professores da Faculdade de Letras da Universidade de Lisboa, Cláudio Torres, António Borges Coelho e José Luís de Matos.

Os primeiros anos de trabalhos de arqueologia e património foram intensos e desenvolvidos no âmbito da Associação para a Defesa do Património de Mértola (ADPM), que posteriormente daria origem ao Campo Arqueológico de Mértola (CAM), legalmente constituído como uma associação cultural e científica sem fins lucrativos, de utilidade pública, com os objetivos de fomentar o levantamento, estudo e pesquisa do património da região de Mértola e a sua conservação e salvaguarda, podendo, para tal, cooperar com entidades públicas ou privadas em ações científicas ou de promoção cultural e social.
Ao longo de mais de 40 anos sucederam-se projetos de investigação que levaram, em 2003 à constituição de uma unidade de investigação reconhecida pelo Ministério de Ciência e Tecnologia e em 2008, à união com o agora denominado Centro de Estudos em Arqueologia e Ciências do Património (CEAA$\mathrm{CP}$ ), com polos nas Universidades de Coimbra, do Algarve e em Mértola. A parceria com diversas Universidades e outras instituições de ensino deu lugar a cursos de Formação Profissional (em colaboração com EPBJC, ALSUD, IEFP, ADPM), mestrados (em colaboração com as Universidades do Algarve, Évora e Lisboa), estágios no âmbito de pós-graduações (Universidades de Granada, Sevilha ou Huelva), cursos livres e atividades de divulgação e educação patrimonial com a comunidade.

Muitos dos projetos de investigação eram simultaneamente projetos de valorização patrimonial e tiveram como corolário a divulgação para o público geral através do vasto programa editorial do CAM e da musealização de sítios ou em forma de exposições temporárias ou permanentes. Ao longo destas 4 décadas de investigação e divulgação patrimonial, resultado da necessidade de apresentar e partilhar conhecimento, nasceram, em 2004, os diversos núcleos museológicos do Museu de Mértola (MM), 14 na atualidade, 11 instalados no Centro Histórico e arrabalde da Vila de Mértola e os restantes nas localidades de Mosteiro, Mina de S. Domingos e Alcaria dos Javazes.

\section{MUSEU DE MÉRTOLA - MISSÃO E OBJETIVOS}

Para o visitante a arqueologia ganha vida através dos objetos e dos cenários criados nas vitrinas dos museus, onde a informação histórica e arqueológica se transforma numa linguagem simples, que pretende transmitir conhecimentos e enriquecer, a nível pessoal e cultural, os seus públicos. Um museu não é só um local onde se mostram objetos e se preservam as memórias de um espaço e de um tempo. É, acima de tudo, um importante elo de ligação com as pessoas e representa a sua identidade coletiva.

O caso de Mértola é referência nacional pela forma como estuda, analisa e apresenta o Património, numa abordagem global que se estende ao território e às pessoas, estas últimas, principais agentes de conhecimento, transformação e divulgação. A apresentação de estruturas arqueológicas in situ e inte- 
gradas em museus é inovadora e interessante como forma de exposição, mas também como meio para manter a autenticidade histórica de cada local, ajudando num melhor entendimento do território e da sua ocupação humana ao longo dos tempos.

O Museu de Mértola não se encerra nos seus 14 núcleos museológicos temáticos. Trata-se de um grande museu disseminado pelo território, com espaços privilegiados de análise e interpretação do espaço, do tempo e das suas gentes. A sua Missão é estudar, inventariar, conservar, documentar e divulgar o seu acervo, e apoiar e colaborar na salvaguarda, estudo e divulgação do património cultural, material e imaterial, do concelho de Mértola, através da colaboração com outros museus e instituições nacionais ou estrangeiras.

Esta unidade museológica tem como objetivos principais:

a) Estudar, inventariar, conservar e divulgar as coleções que integram o seu acervo;

b) Valorizar as coleções entendidas como testemunho da cultura material e da identidade das gentes de Mértola ao longo dos tempos;

c) Enquanto Museu da Rede Portuguesa de Museus, integrar no seu acervo todos os bens procedentes de intervenções arqueológicas ou de recolhas realizadas no concelho promovendo o seu inventário, acondicionamento, conservação e estudo;

d) Apoiar e colaborar na salvaguarda, estudo e divulgação do património cultural, material eimaterial, do concelho de Mértola no âmbito nacional e internacional;

e) Promover e desenvolver estudos e investigação que contribua para o conhecimento da História Local;

f) Desenvolver estratégias de trabalho que permitam captar novos públicos e fortalecer os laços identitários e de pertença da comunidade local;

g) Estabelecer parcerias e colaborações com instituições locais, nacionais e estrangeiras tendo em vista o estudo, a preservação, a valorização, a divulgação e a fruição do património local.

h) Apoiar a criação, organização e consolidação de novos núcleos museológicos ou museus a serem criados no concelho de Mértola, muito especificamente aqueles criados pela Autarquia, ajudando a promover e difundir as boas práticas inerentes à museologia, sempre com uma preocupação social e pedagógica e tendo em conta o desenvolvimento de um turismo cultural de qualidade.

I) Participar em projetos integrado em redes de âmbito local, regional, nacional e internacional como é o caso da Rede de Museus Rurais do Sul, da Rede de Museus do Baixo Alentejo, da Rede de Recursos Museológicos do Alentejo e da Rede Portuguesa de Museus.

\section{EDUCAÇÃO PATRIMONIAL: EXPERIÊNCIAS PARTILHADAS NA DIDÁTICA ARQUEOLÓGICA E PATRIMONIAL EM MÉRTOLA}

Educação Patrimonial - Heritage Education - é um conceito antigo que pretende explicitar a transmissão do conhecimento histórico de forma a criar públicos informados e participativos. Em Portugal, este conceito começou a ser utilizado durante o Estado Novo, como forma de valorização e de exaltação de uma memória nacional. Após o 25 de Abril de 1974, o conceito sofreu alterações relacionadas com novos ideais e novas formas de entender a importância do Património e da Cultura na formação dos indivíduos o que resultou na constituição de associações de defesa do património por todo o país (Custódio, 200o, p.10) e na necessidade crescente de uma educação patrimonial como forma de salvaguarda e valorização do património. Na década de 90 continuaram e desenvolveram-se múltiplos mecanismos que incentivaram o desenvolvimento da temática da educação para o património, no mesmo âmbito da educação ambiental, mas em menor escala e com menor incidência.

A Lei de Bases do Património Cultural, de 8 de Setembro de 2001, apresenta uma noção abrangente do conceito património, reflete as preocupações surgidas na década anterior, mas está ainda aquém de uma verdadeira preocupação com a educação patrimonial. Como refere Jorge Custódio, "reconhecem-se como deveres do Estado, das Regiões Autónomas e das Autarquias locais o conhecimento, o estudo, a proteção, a valorização e a divulgação do património cultural, ainda sem menção expressa e inequívoca ao dever de uma educação dirigida e orientada para a formação de uma consciência patrimonial, em todas as classes e para todos os cidadãos" (Custódio, 2000, p. 10).

A Educação Patrimonial utiliza o património como fonte para a construção do saber histórico de uma forma pedagógica e didática. No caso de Mértola alia 
a investigação ao impacto afetivo na população local, com repercussões na preocupação com o seu património e na curiosidade de o conhecer, adquirindo uma dimensão cívica, que começa nos mais jovens (3 a 1o anos) com o objetivo de incutir respeito e criar laços identitários com o património que é pertença de todos (Palma e Rodrigues, 2019). Em Mértola, desde o início do Projeto em 1979, que a Educação Patrimonial tem sido uma constante. Mesmo não estando debaixo deste "chapéu", sempre houve a consciência de que era necessário o envolvimento da comunidade local no processo que se iniciava, de resgaste do passado e sobretudo da História de uma pequena Vila do interior alentejano, capaz de dar a conhecer à população, de uma forma simples e intuitiva, o seu património. Isto é, formar cidadãos conscientes dos seus bens e dos recursos, da sua terra, também permite que estes os relacionem com os outros bens culturais do país e do mundo. Trata-se de usar os diferentes patrimónios com o objetivo de educar para a identificação, a proteção, a valorização e a "apropriação" do Património Cultural como "coisa" de todos.

Desde o seu início que o CAM, e mais tarde o MM, pretendem ser presenças assíduas na comunidade local, de uma forma direta, tentando educar para a valorização e preservação do património. Durante muitos anos o trabalho com as escolas foi sendo feito de forma não muito assídua, só em situações pontuais como visitas, alguns trabalhos de ATL e atividades temáticas feitas de forma muito esporádica. Esta realidade veio a alterar-se a partir de 2010, altura em que o CAM, em parceria com o MM, começou a realizar, de forma sistemática, várias atividades temáticas de educação para o património, inseridas num programa geral, destinados a alunos do Pré-escolar ( 3 a 6 anos) e 1ํㅡㄹ Ciclo (6 a 1o anos) do Agrupamento de Escolas de Mértola. As abordagens tentam ser diversificadas e alternadas para que as crianças possam ter, durante o seu percurso escolar, a perceção do património existente, as diferentes culturas que deixaram vestígios, e o conhecimento dos processos que os materiais arqueológicos sofrem desde a sua descoberta até serem expostos no Museu. Com estas atividades pretendemos criar raízes identitárias com o vasto e diversificado património existente no concelho, educando para a preservação e valorização do património local. As nossas atividades encontram-se, sobretudo, dentro do contexto da educação não formal, isto é, educação nos museus, associações locais, monumentos, sítios, centros culturais, centros históricos, entre outros e educação informal através de ações de formação para docentes e profissionais da área. No contexto de educação formal, promovida através das escolas participamos na forma de visitas guiadas, aulas temáticas e palestras.

Apresentamos algumas das experiências partilhadas na didática arqueológica e patrimonial desenvolvidas pelo CAM e MM, com incidência nos últimos anos:

- Escavações: Muito do trabalho desenvolvido ao longo dos últimos quarenta anos foi materializado por jovens estudantes de Mértola e de fora que, trocaram o seu tempo livre por trabalho voluntário na descoberta da história do passado desta Vila. Os trabalhos de escavação na Alcáçova e Encosta do Castelo, o sítio primordial das intervenções arqueológicas em Mértola, foi continuamente intervencionado, pondo a descoberto os níveis da Necrópole Medieval/Moderna, Criptopórtico, os Batistérios, os mosaicos, o Bairro Islâmico, através da leitura das sucessivas camadas de terra que guardavam as memórias das civilizações passadas. Pretende-se um maior conhecimento desta zona e das diversas estruturas que tem vindo a surgir, sempre num ambiente de aprendizagem e partilha entre os jovens investigadores vindos de fora, os jovens locais e a equipa de investigação (Palma, 2019) (Figura 1).

- Ocupação de Tempos Livres: Este é um programa do Instituto Português do Desporto e Juventude (IPDJ) que proporciona aos jovens experiências em contexto de aprendizagem não-formal ou em contextos ativos de trabalho e pretende desenvolver capacidades e competências pessoais e sociais. No CAM este tipo de atividades foi sempre uma prática, sobretudo nos finais dos anos 90 e inícios de 2000, com a forte participação de jovens locais, que durante as suas férias de verão, participavam nas escavações arqueológicas e em toda a dinâmica a elas associada.

- Campos de Trabalho Internacionais: Este tipo de campo de trabalho foi dinamizado pela equipa do CAM, como apoio do IPDJ, visando a promoção do intercâmbio de jovens (portugue- 
ses e de outros países europeus) e da troca de experiências interculturais, ao mesmo tempo que se divulgava o trabalho arqueológico e patrimonial realizado em Mértola. Os jovens praticaram trabalhos de escavação arqueológica na Alcáçova do Castelo de Mértola e tiveram contacto com todas as metodologias realizadas durante todo o processo da escavação ao Museu, obtidas através de processos educativos não formais. Todos os trabalhos têm acompanhamento técnico especializado nas várias áreas de intervenção arqueológica.

- Dinamização de recriações históricas: Numa dinâmica de divulgação da história local, que estava a ser descoberta através da arqueologia, nos anos 9o, diversas instituições (CAM, CMM, MM, ADPM e Agrupamento de Escolas) estimularam atividades de recriação de ambientes medievais, feiras, chegada de reis através do rio, envolvendo toda a comunidade escolar, a população e as instituições locais. O CAM contribuiu com a documentação histórico-arqueológica como base para uma melhor caracterização dos ambientes e figurinos. Após um trabalho com as escolas e professores, durante o ano letivo, os alunos e professores tornaram-se figurantes destas recriações, onde as vestes e os adereços utilizados foram realizados durante as aulas de trabalhos manuais. Dinamizaram-se diversas atividades, centradas no núcleo dentro das muralhas, a denominada Vila Velha, com o foco no Castelo, na praça Luís de Camões ou no Rio Guadiana, a grande via comercial e de comunicação em tempos idos. Atualmente, promovida pelo grupo de História do Agrupamentos de Escolas, realiza-se anualmente um Mercado Rural do início do século XX. As crianças, vestidas à época, recriam um antigo mercado, onde não faltam os produtos tradicionais da época e da região, vendidos a granel. Há um envolvimento da comunidade através dos professores, alunos, famílias e da população local.

- Exposições: Uma das principais componentes do Projeto Mértola Vila Museu é a divulgação, e durante estas últimas quatro décadas foram promovidas com regularidade algumas exposições temporárias e itinerantes, sempre que possível acompanhadas dos seus respetivos catálogos e com itinerâncias em Portugal e no estrangeiro. A primeira exposição temporária realizou-se em 1982, na Igreja da Misericórdia, e teve como principal objetivo dar a conhecer os resultados das intervenções arqueológicas realizadas na Alcáçova, o levantamento e recolha patrimonial realizado em todo o concelho de Mértola. Foi também um importante momento de apresentação de todo o processo de recolha e tratamento de materiais, de valorização e reconhecimento do envolvimento dos diversos técnicos, onde se incluíam muitos jovens de Mértola. Ao longo dos tempos foram sendo trabalhadas, no âmbito de projetos de investigação, algumas exposições com realce para as seguintes: "Cerâmica Islâmica Portuguesa" (1987), "O Islão entre Tejo e Odiana” (1998), "Mértola. O último Porto do Mediterrâneo" (2005), "Mértola e Niebla en la confluência de dois territórios" (2006), "Os signos do quotidiano - gestos, marcas e símbolos no Al-Ândalus" (2011), "O Sudoeste Peninsular entre Roma e o Islão" (2014), "No extremo do Al-Ândalus - Mértola e o Guadiana” (2014), entre outras.

- Conferências e Congressos: A divulgação do trabalho desenvolvido assenta sobretudo na divulgação em Congressos, Encontros científicos e em revistas da especialidade. Contudo, é frequente a realização de conferências para o público local, Ciclos de Conversas, tertúlias entre outros.

- Cursos Livres: Esta tipologia de cursos tem como objetivo formar e diversificar o conhecimento intrínseco à Arqueologia e ao Património. Os destinatários destes cursos de livre configuração são sobretudo estudantes de Arqueologia e profissionais da área do Património que sentem a necessidade de aprofundar conhecimentos em áreas pouco desenvolvidas na sua formação profissional e académica. Estão também disponíveis para o público em geral.

- Universidade Sénior de Mértola: Em colaboração com a Universidade Sénior têm sido realizadas algumas ações que visam sensibilizar e dar a conhecer o trabalho que se faz em Mértola relacionado com o património e com a divulgação patrimonial. Neste âmbito têm sido realizadas 
nos diversos polos da Universidade (por todo o concelho) sessões de sensibilização, visitas guiadas aos núcleos museológicos e aos gabinetes do Museu de Mértola, ateliers de conservação de cerâmica, de artes plásticas, de antropologia (Figura 2) e o desenvolvimento de conteúdos para exposições temáticas. Como é o caso da que se irá realizar no Núcleo Museológico de Alcaria dos Javazes com o tema "No tempo em que não havia torneiras”, que alia a temática do património à da educação ambiental.

- “Arqueologia para todos": Pensada numa ótica de Ciência Cidadã, esta atividade tem como objetivo divulgar uma arqueologia participativa junto dos cidadãos locais, das mais diversas faixas etárias, mas também dos visitantes, turistas e voluntários envolvendo-os de forma ativa e dinâmica em experiências comunitárias e participativas com o objetivo de incutir sentimentos identitários e de pertença. Na ação Museu Vivo, um programa diversificado, pretende levar o público a conhecer as descobertas da investigação e as peças dos museus nos locais mais frequentados pela população (Centro de Saúde, Bancos, Repartições Municipais e das Finanças, Juntas de Freguesia, entre outros). As Oficinas de Ciência Cidadã, dirigidas às famílias, convidam-nas à participação em ateliers temáticos. O Campo de trabalho em arqueologia inicia os jovens na aprendizagem e nas dinâmicas da prática arqueológica (Figura 3 ).

- Ações de Formação com professores: Tendo em conta a enorme riqueza patrimonial de Mértola, com grande expressão nas temáticas e conteúdos dos núcleos do Museu de Mértola, e as possibilidades que esta realidade confere enquanto instrumento de trabalho e de abordagem dos diversos períodos históricos, o contacto direto com os professores do Agrupamento de Escolas de Mértola é essencial. Neste âmbito realizam-se apresentações e visitas guiadas com o objetivo de sensibilizar os professores para as temáticas e conteúdos dos núcleos museológicos realçando as suas potencialidades e abrindo portas a parcerias e colaborações que permitam enriquecer os currículos dos diversos níveis de ensino.
- Visitas Guiadas a grupos locais: Cumprido com os objetivos do CAM e Museu de Mértola e com o privilégio dado à comunicação com a comunidade local, realizam-se ações de sensibilização e divulgação junto de diversos públicos locais, que têm nas visitas guiadas aos núcleos museológicos o seu principal ponto de interesse. Estas visitas constituem momentos interessantes de partilha e convívio que permitem a criação de laços e a disseminação de informação, estando de uma forma genérica também relacionadas com instituições locais como o Campo Arqueológico de Mértola, a Associação de Defesa do Património de Mértola, a Escola Profissional ALSUD, o Agrupamento de Escolas de Mértola, as Juntas de Freguesia, a Santa Casa da Misericórdia, entre muitas outras.

- Projetos Transfronteiriços: "Arqueocultura - Salvaguarda e Valorização dos Recursos Arqueológicos, Patrimoniais e Culturais", promovido pela Câmara Municipal de Mértola, a Câmara Municipal de Moura e o Ayuntamiento de Aroche (Huelva-Espanha) e financiado pelo programa comunitário INTERREG IIIA (2006-2008), tinha numa das suas vertentes o intercâmbio e a dinamização de atividades entre jovens dos três concelhos, por forma a conhecerem o património das três localidades, numa troca de experiências transfronteiriças. Do projeto resultou o desenvolvimento de um Jogo de tabuleiro sobre o património das três localidades, visitas guiadas aos locais de interesse patrimonial das três localidades e outras intervenções no âmbito da preservação e valorização do Património.

Práticas Educativas com a comunidade escolar do Concelho de Mértola:

- "A Minha Escola tem um Museu”: Pretende dar a conhecer o Núcleo Museológico da Ermida e Necrópole de S. Sebastião, que se localiza dentro do recinto escolar da Escola EB2/3 ES de Mértola. Ao contrário de outras escolas que adotam um Museu, em Mértola a escola tem um Museu in situ. Assim, no Dia da Escola, dia 20 de Janeiro, realizam-se várias atividades, que pretendem dar a conhecer à comunidade escolar o Núcleo Museológico da Ermida e Necrópole 
de São Sebastião. Com a mais-valia de complementar os conteúdos de algumas disciplinas, dá-se a conhecer o trabalho que é realizado desde a escavação até à chegada dos objetos ao Museu. Demonstra-se, também, como se realiza todo o processo de escavação, podendo os alunos participar numa escavação fictícia. Por outro lado é relembrado aos alunos, professores e funcionários a importância da salvaguarda do património, sobretudo aquele que têm dentro da Escola.

- "O Património da Minha Vila": Esta atividade decorre nas diversas escolas do concelho de Mértola, levando até às crianças a importância da preservação do Património local. Pretendemos dar a conhecer os distintos meios de divulgação do património, enunciar e distinguir as diferentes definições e tipos de património existentes na Vila de Mértola e seu concelho (arqueológico, arquitetónico, natural e oral), como o podemos preservar e valorizar, criando laços identitários com o mesmo (Figura 4).

- "Vamos Escavar": Numa caixa arqueológica com estratigrafia e artefactos arqueológicos de diversas épocas, crianças e jovens transformam-se em pequenos arqueólogos utilizando as ferramentas e técnicas da profissão. A atividade completa-se com as fases de registo arqueológico (caderno de campo, desenho, fotografia), criando momentos de descoberta, disciplina e metodologia. Os alunos têm a oportunidade de contatar com diferentes práticas do trabalho arqueológico e sentir o prazer da descoberta inerente a esta profissão.

- "Vamos ao Laboratório de Materiais não cerâmicos": Visita ao Laboratório de Conservação de Metais Arqueológicos, observação de objetos através da lupa binocular e identificação de materiais. Reconhecimento do trabalho do conservador restaurador através da utilização de materiais pedagógicos (jogos, puzzles, etc.).

- "Conservação e restauro de cerâmica arqueológica": Sendo os fragmentos de cerâmica os mais abundantes numa escavação, e tendo os alunos passado pelo Atelier de Escavação, é importante que reconheçam as formas de os restaurar e conservar. Desta forma, dá-se a conhecer aplicando na prática, as técnicas de conservação e restauro de cerâmica. Pretende-se que as crianças apreendam o processo que uma peça cerâmica passa desde a sua descoberta na escavação até à sua exposição no Museu (Figura 5).

- "Identificar os Ossos Humanos": Identificação dos ossos do corpo humano através do recurso a esqueletos encontrados nas Necrópoles da Antiguidade Tardia de Mértola, bem como aprofundar os conhecimentos de diversas formas de enterramento consoante os períodos históricos. Pretende-se também um reconhecimento e distinção do trabalho do Antropólogo e do Arqueólogo, com o objetivo de proporcionar às crianças do $4^{\circ}$ ano a aprendizagem, de forma lúdica, do corpo humano, indo ao encontro do plano curricular para este ano.

- “A Casa Islâmica”: Visita e dinamização da atividade na réplica da Casa Islâmica, mostrando aos alunos as diferenças e semelhanças das casas atuais e de uma casa do período islâmico, identificando cada compartimento, os objetos utilizados e as formas de construir. De seguida realiza-se uma visita dinamizada às estruturas arqueológicas das casas islâmicas que se encontram escavadas na Alcáçova de Mértola.

- "Atividades Tradicionais: A Tecelagem": A atividade decorre na Oficina de Tecelagem onde os alunos podem ter contato com parte final do processo de transformação da lã, tendo oportunidade de tocar na lã e nos seus derivados. É possível ver a tecedeira no tear, ver a roca a fiar e tocar em diferentes texturas da lã. A atividade complementa-se com uma parte prática em que os alunos têm a oportunidade de fazer o trabalho num pequeno tear e realizar diversas atividades lúdicas que complementam e fortalecem os seus conhecimentos sobre este saber-fazer tradicional cada vez menos usual.

- "Visitas Guiadas ao Núcleos Museológicos": Esta atividade realiza-se durante o ano escolar e consiste em dar a conhecer aos alunos os diversos núcleos museológicos do Museu de Mértola, tentando que a visita complemente os planos curriculares das disciplinas, sobretudo de História e Estudo do Meio. 
- “O que contam os objetos?”: O objetivo desta atividade é dar a conhecer os objetos arqueológicos e etnográficos, sensibilizando os participantes para a história que cada objeto pode conter, sendo ele antigo ou não. Pretende-se a salvaguarda e conservação do património móvel.

- "Os árabes de Martulah": Esta atividade consiste em dar a conhecer aos alunos a presença árabe em Mértola e a importância que esta Vila teve durante os quase seis séculos da sua permanência, em que foi uma importante cidade do mediterrâneo. Integrada no Festival Islâmico de Mértola 2019, esta atividade teve vários momentos durante o ano letivo, tal como uma série de ações, como uma primeira sessão explicativa de quem eram os árabes e os vestígios que ainda existem em Mértola, seguido de uma visita ao núcleo museológico do Museu de Mértola Museu de Arte Islâmica e à réplica da Casa islâmica. Os alunos foram convidados a recriarem os seus trajes de influência árabe durante o ano escolar, para no primeiro dia do festival, visitarem o souk, vestidos com os trajes, sentindo-se integrados em todo o ambiente da festa, culminando numa grande atividade com várias ações lúdicas, como por exemplo, a pintura de desenhos árabes, o que comiam os árabes, palavras árabes, a recriação dos espaços de uma casa, entre outras (Figura 6).

- “Os romanos de Myrtilis": Esta atividade surge na sequência das grandes descobertas arqueológicas realizadas no verão de 2017, na Casa Cor de Rosa. A monumentalidade das estruturas e da riqueza das estátuas postas a descoberto despertou na comunidade local alguma curiosidade sobre estas descobertas, mas também sobre os Romanos que habitaram Mértola e a importância da cidade nessa altura. Sugerimos que fosse realizado o "Dia do Romano de Myrtilis", onde as crianças desfilaram com os seus fatos de romanos ao mesmo tempo que se realizam outras atividades. Foram recriados pequenos espaços de época romana (casa, templo, ruas...) e das vivências que os romanos tinham em Mértola e a importância que a cidade teve durante este período histórico (ex. cunhagem de moeda). As crianças realizaram um desfile para mostrar as suas vestes de romanos (imperadores, guerreiros, imperatrizes, togados...) (Figura 7). Durante toda a atividade a população e turistas também foram convidados a participar, tirando fotografias com as estátuas ou as crianças com os seus familiares.

Estas atividades de Educação Patrimonial realizadas pelo CAM, com o apoio do Museu de Mértola, tem como objetivo promover a identidade local, a consciencialização do valor do Património e da necessidade da sua preservação. Por outro lado, temos como objetivo aproximar os residentes aos núcleos museológicos, dos locais de interesse patrimonial e do conhecimento do património no seu sentido mais lato e abrangente, e dar a conhecer o património local incutindo um sentimento de pertença. Para isso, a forma que nos parece mais assertiva é trabalhar com todas as faixas etárias. No entanto, o trabalho com as crianças afigurar-se-nos como a melhor maneira de implicar as novas gerações nos processos de conservação, salvaguarda e divulgação do seu Património, desde tenra idade.

Todas estas atividades realizadas, pelo CAM em parceria com o Museu de Mértola, são acompanhadas da produção de recursos didáticos, fruto da experiência continuada e da necessidade de materiais que facilitem a aprendizagem: "Caderno do Pequeno Arqueólogo”, Jogos de mesa, Jogos de memória, Puzzles (Figura 8), Cartas, pinturas, entre outros (Palma e Rodrigues, 2019, p.122). Tanto para os mais pequenos como para o público geral, como é o caso da publicação de 2016, "Mértola da escavação arqueológica ao Museu” (Palma e Rodrigues, 2016). Esta publicação, através de uma linguagem simples explica todo o processo, desde o momento da escavação até à exposição no Museu, para além de mostrar algumas das principais descobertas, assim como o seu processo de investigação, conservação, valorização e divulgação, os quais são as principais chaves do projeto "Mértola Vila Museu" que cumpriu, em 2018, quarenta anos de trabalho em prol do património.

Com a restante comunidade trabalhamos de diversas formas, através de conferências, sessões de conversas, publicações, exposições e com o programa que foi implementado em 2017 e 2018, "Arqueologia para Todos" - uma atividade de ciência para todos, que contempla diversas ações como conferências, exposições, conversas temáticas, ateliers e escavações arqueológicas. 


\section{CONSIDERAÇÕES FINAIS}

Com estas atividades e estes recursos pretendemos criar e transmitir às diferentes gerações o valor do património de Mértola e a importância da sua preservação e divulgação, criando laços identitários e um forte sentimento de pertença e sentido de missão na sua transmissão para as gerações futuras. Convictos que a valorização e divulgação do património é o caminho certo, pretendemos continuar com as nossas atividades anuais com o Agrupamento de Escolas de Mértola, com os professores, educadores, instituições locais e comunidade em geral. No entanto, muito mais se pode fazer no âmbito da educação para o património. A divulgação e sensibilização devem ser práticas contínuas, dinâmicas, com resultados visíveis na formação pessoal e no sentido de grupo. No caso de Mértola, o património arqueológico tem um papel fundamental devido à sua presença no dia-a-dia da população. Trabalhamos para que haja uma arqueologia cidadã, participativa e que não esteja longe dos assuntos importantes desta comunidade, pois o património é seu, é testemunho das suas raízes e cultura. Desta forma entendemos que a Educação Patrimonial não é mais do que uma Educação para a Cidadania, que deve ser ativa e que se deve incutir desde tenra idade nos membros da comunidade local. A didática e as aprendizagens realizadas no âmbito do Projeto Mértola Vila $\mathrm{Mu}$ seu, desenvolvidas pelo CAM e Museu de Mértola, privilegiam as experiências, o contacto direto com o património, são facilitadores e promotores de novas aprendizagens no domínio da História Local.

\section{BIBLIOGRAFIA}

CUSTÓDIO, Jorge (200o) - Educação patrimonial. Revista da Associação Portuguesa dos Municípios com Centro Histórico, 1 (4), 10-11.

GÓMEZ MARTÍNEZ, Susana (2016) - Mértola, Vila Museu. Un proyecto cultural de desarrollo. In VAQUERIZO, D.; RUIZ, A.B.; DELGADO, M. (Eds.) RESCATE. Del registro estratigráfico a la sociedad del conocimiento: el patrimonio arqueológico como agente de desarrollo sostenible. Córdoba: Editorial Universidad de Córdoba, 2016. ISBN 978-84-9927-282-5. Tomo 1, p. 269-286.

GÓMEZ MARTÍNEZ, Susana; RAFAEL, Lígia; TORRES, Cláudio (2016) - Mértola Vila Museu. Um projecto arqueológico de desenvolvimento integrado. Revista Arqueologia Pública. [Em linha] Campinas: LAP/NEPAM/UNICAMP. Vol.1o, nํㅜ 3, pp. 55-8o. DOI: http://dx.doi.org/10.20396/ rap.v1oi3.8645842. Disponível em http:// periodicos. sbu. unicamp.br/ojs/index.php/rap/article/view/8645842/ 14463. ISSN: 2237-8294.

PALMA, Maria de Fátima (2019) - Campanhas de Escavações em Mértola, uma experiência de Arqueologia participativa. Agenda Cultural de Mértola, Outubro, Novembro e Dezembro. Mértola, Câmara Municipal de Mértola, pp. 33-34.

PALMA, Maria de Fátima; RODRIGUES, Clara (coord.) (2016) - Mértola: da escavação arqueológica ao museu. Mértola: Campo Arqueológico de Mértola. ISBN 978-972-9375 $-50-7$.

PALMA, Maria de Fátima; RODRIGUES, Clara (2019) - Atividades de Educação Patrimonial - Campo Arqueológico de Mértola, Revista Al-Madan online, №22, Tomo 4, pp.12O122. ISSN2182-7265. Disponível em: https://issuu.com/ almadan/docs/al-madanonline22_4.

PALMA, Maria de Fátima; LOPES, Virgílio (2019) - Campo Arqueológico e Museu de Mértola experiências partilhadas. In BUGALHÃO, Jacinta - Gestão Publica do Património Arqueológico, Revista Al-Madan, II série №22, pp. 55. ISSN o871-066X.

RAFAEL, Lígia (2010) - Os trinta anos do Projecto Mértola Vila Museu [Texto policopiado]: balanço e perspectivas. Évora. Dissertação de mestrado apresentada ao Departamento de História da Universidade de Évora.

RAFAEL, Lígia; PALMA, Maria de Fátima (2013) - Os museus como espaços de sociabilidade: as experiências educativas do museu de Mértola. Simpósio Internacional Arte, Património e Museus. Disponível em www: http://hdl. handle.net/10400.26/4427

TORRES, Cláudio (1989) -Arqueologia, história local e desenvolvimento. Lisboa, Instituto Nacional de Investigação Científica, Centro de Estudos de Etnologia.

TORRES, Cláudio (1993) - Dignidad regional y desarrollo. In Jornadas andaluzas sobre: la función de la cultura en el desarrollo local. Córdoba: Diputación Provincial de Córdoba, 1993, pp. 15-18.

Nota: Agradecimento a Maria João Martins pela tradução do resumo a inglês. 


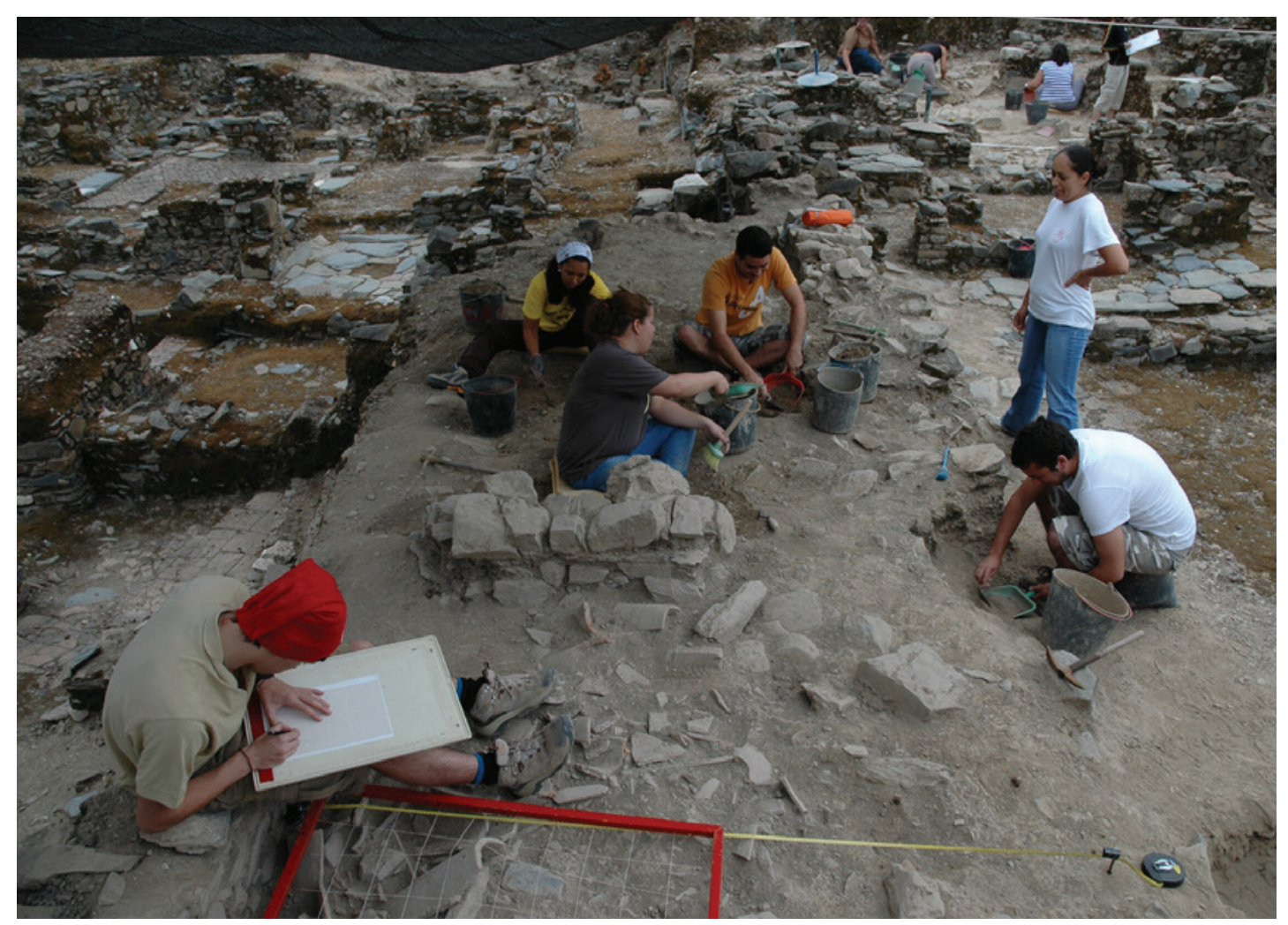

Figura 1 - Campanhas de escavações arqueológicas de verão.

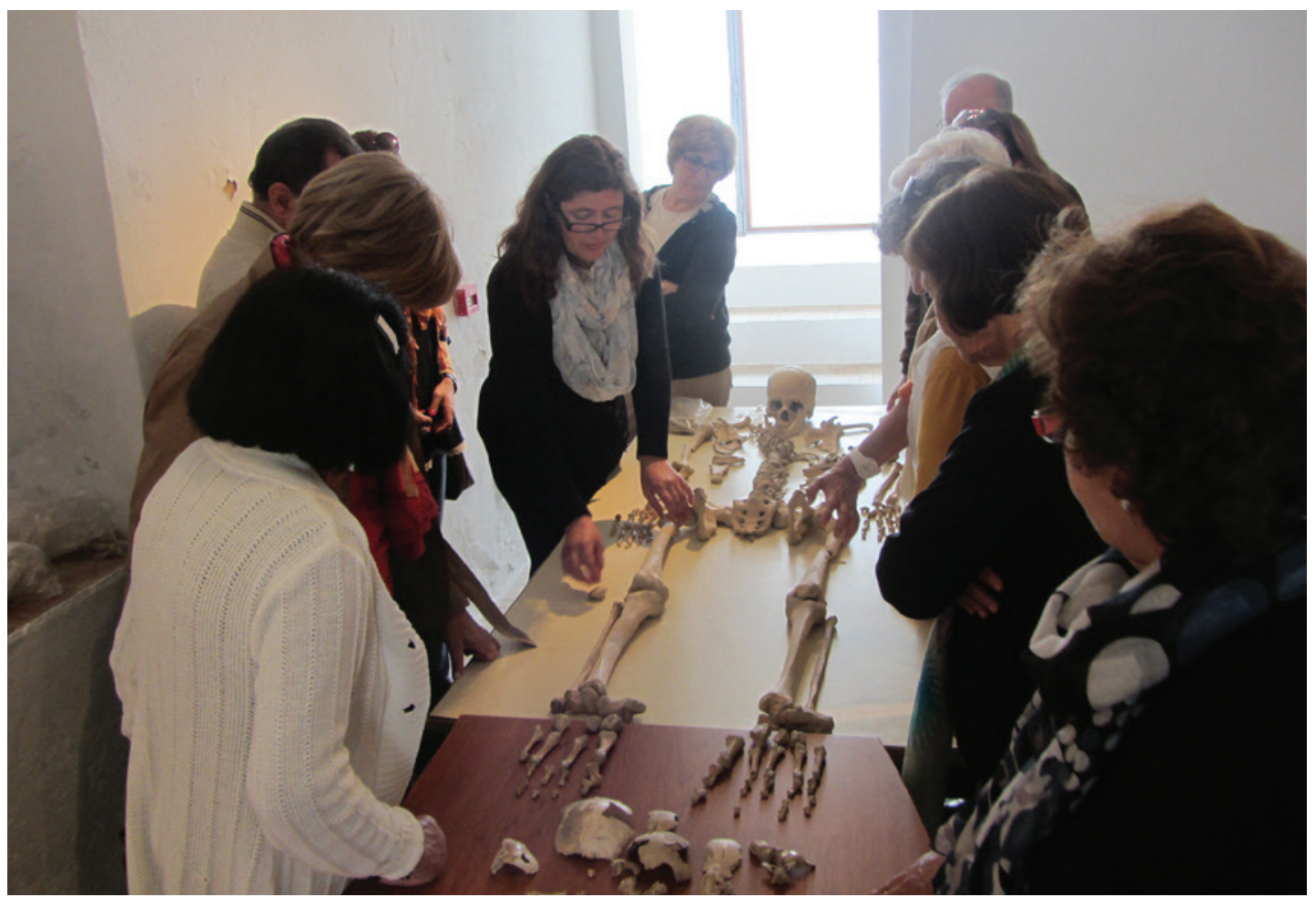

Figura 2 - Atividade de Antropologia Física com a Universidade Sénior - Pólo de Mértola. 


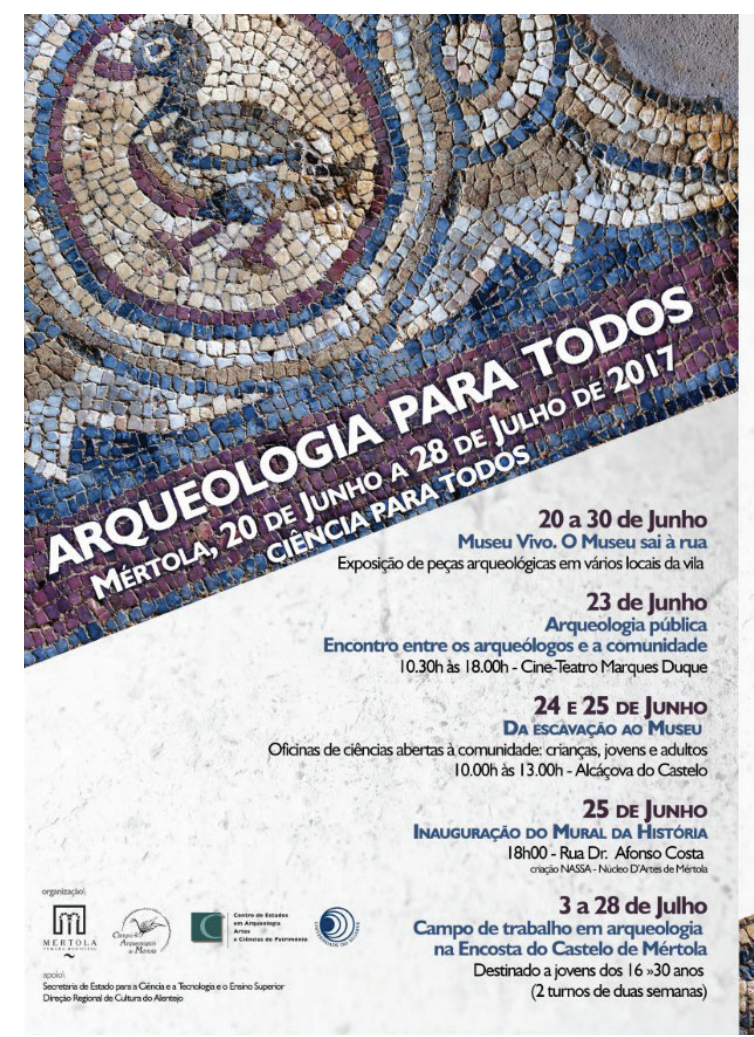

O Património Arqueológico constitui uma parte muito importante da Herança Cultural que a todos pertence. É uma Herança feita de camadas sucessivas de História, por vezes oculta ao nosso olhar, mas que com a ajuda da ciência podemos trazer à luz com rigor e paciência. Também é uma Herança frágil. Para que continue a ser um Legado para o futuro, todos devemos contribuir para protegê-la

Para proteger temos primeiro que conhecer. Por isso, convidamos todos os cidadãos a participar na descoberta científica do nosso passado e a colaborar na sua preservação.

Mértola é uma vila milenar. Aqui a arqueologia está presente em cada canto e oferece-nos imensas possibilidades de descobrir vestígios e marcas deixadas pelas gentes que habitaram esta terra ao longo de muitas centenas de anos. Podem ser edificios monumentais, objetos belos e por vezes exóticos ou, simplesmente, a marca deixada pelos gestos quotidianios das pessoas que aqui viveram.

Neste verão, propomos à população várias atividades para conhecer e participar na Arqueologia:

Venham a descobrir o nosso Património!

Figura 3 - Cartaz divulgativo Arqueologia Para Todos - 2017.

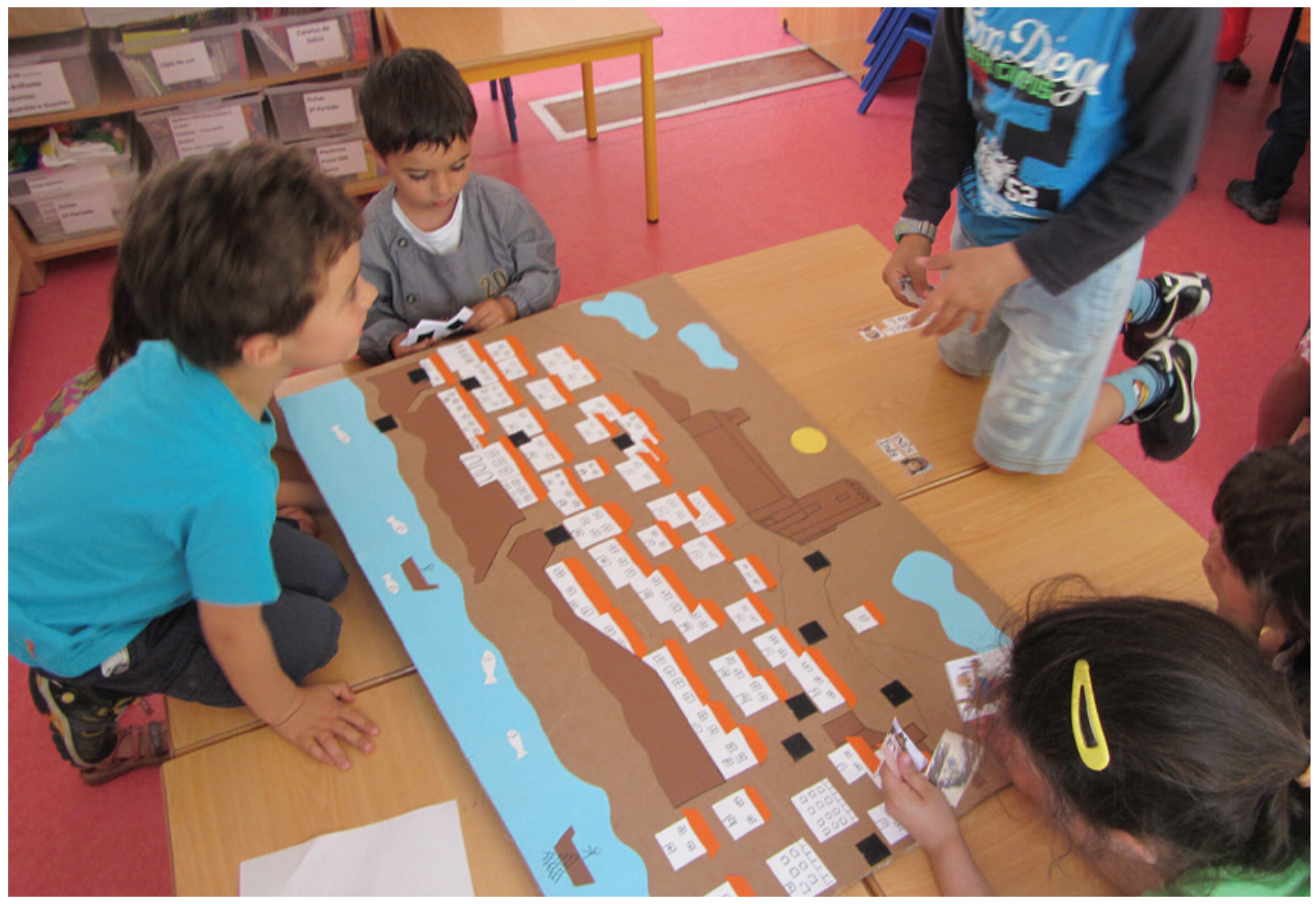

Figura 4 - Dinamização da Atividade "Património da minha Vila”. 


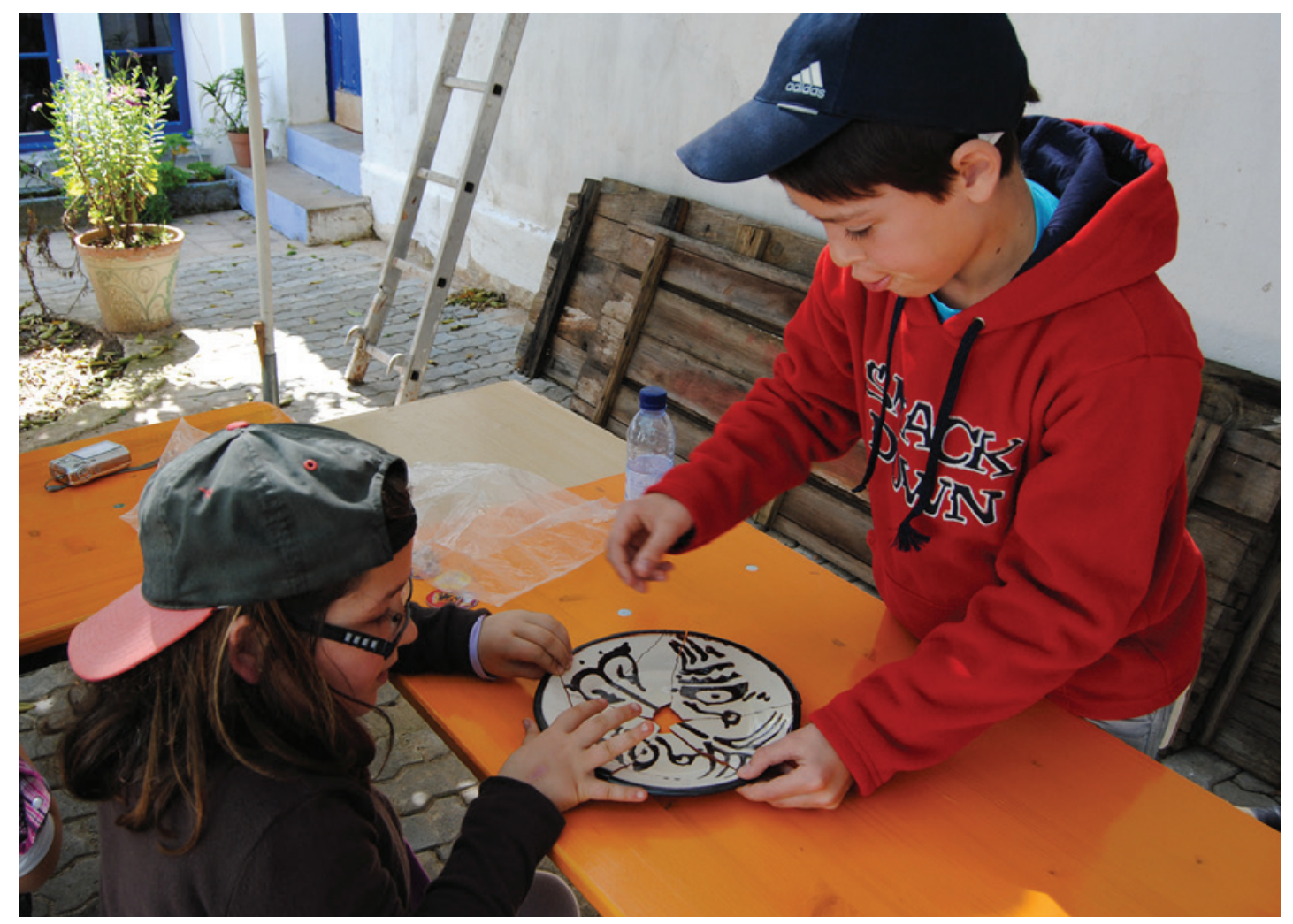

Figura 5 - Dinamização da Atividade “Conservação e restauro de cerâmica arqueológica”.

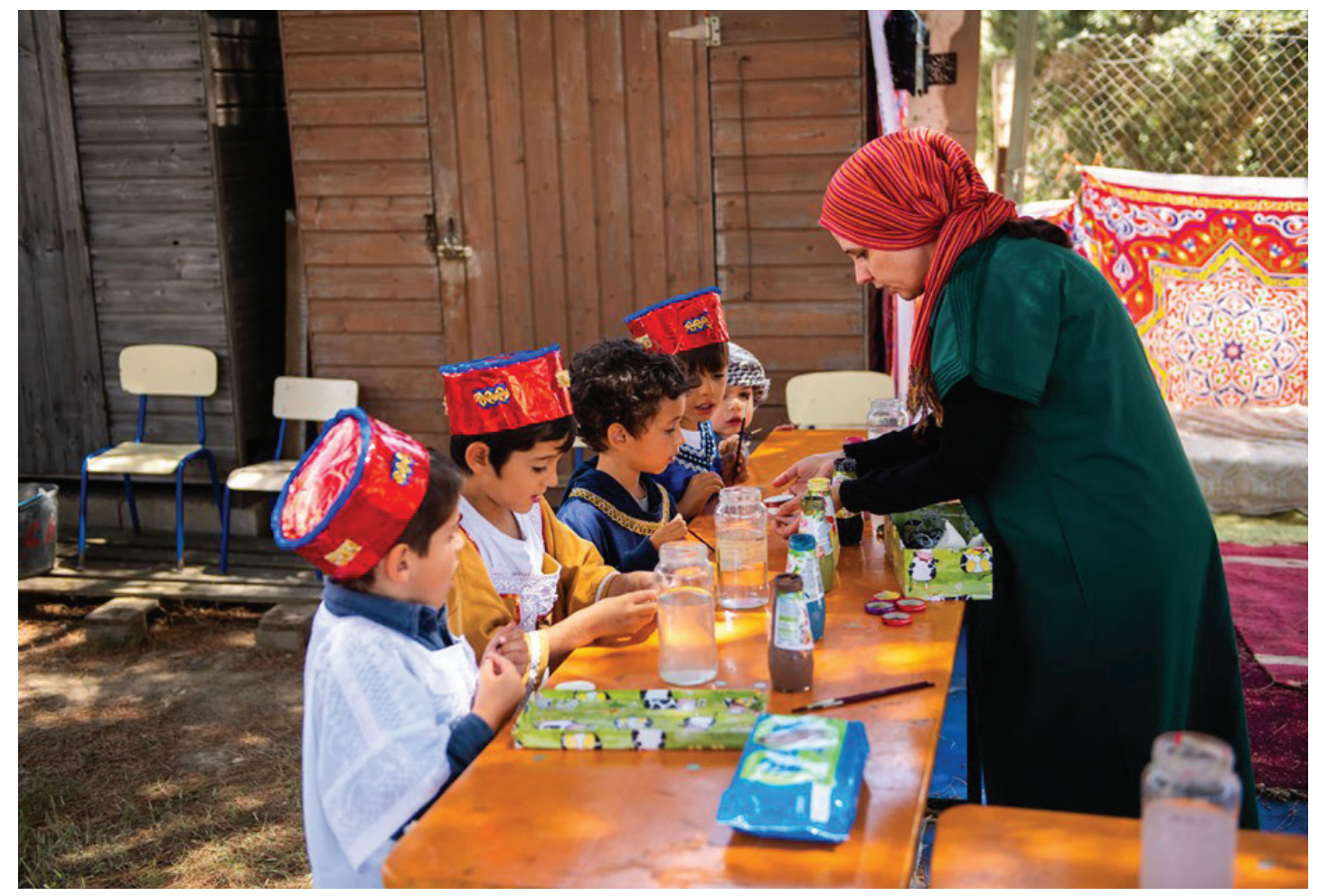

Figura 6 - "Os árabes de Martulah", dinamização de atividade com todas as Salas do Pré-Escolar e 1ํㅡㄹㅣo do Agrupamento de Escolas - Festival Islâmico de Mértola - 2019. 


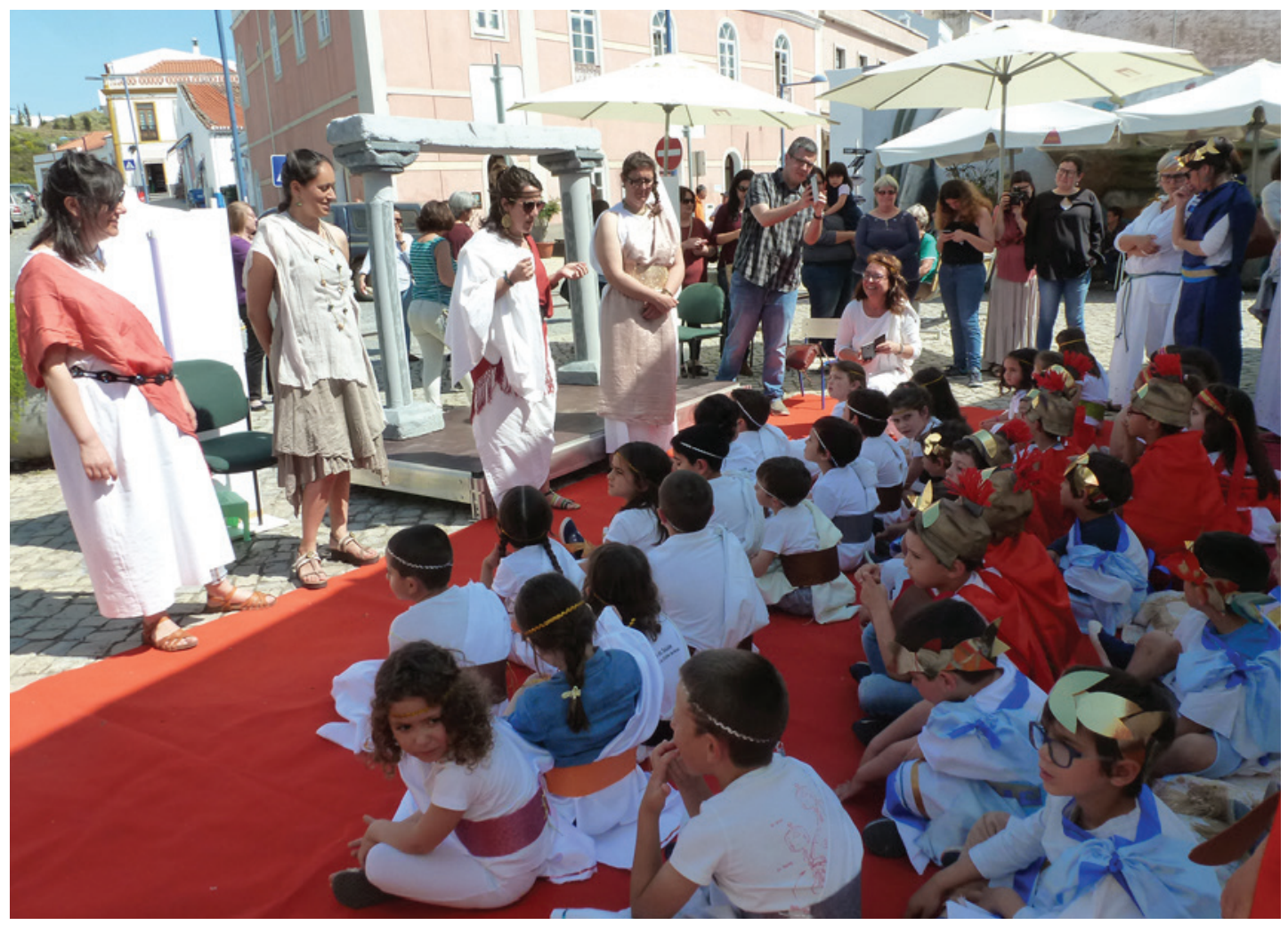

Figura 7 - Dinamização da Atividade "Os romanos de Myrtilis"com a participação das Salas do Pré-Escolar de Mértola-2018.

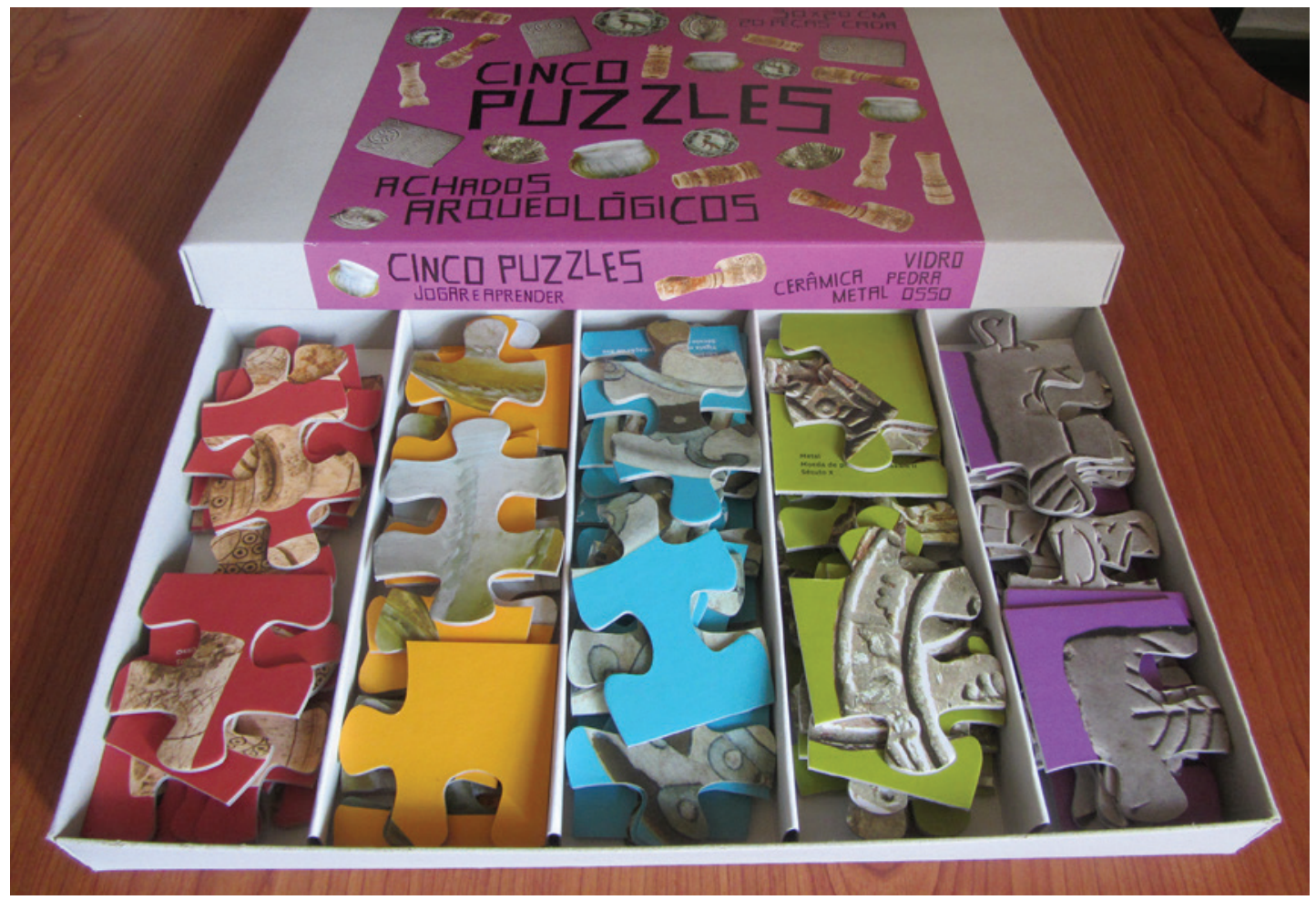

Figura 8 - Recursos Didáticos: Caixa com 5 puzzles refentes a diferentes materiais encontrados na escavação. 
4
Arte Rupestre

4
Arte Rupestre

\section{Arte Rupestre \\ (a)

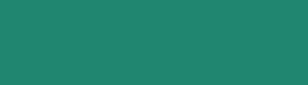




\title{
OS INVENTÁRIOS DE ARTE RUPESTRE EM PORTUGAL
}

\author{
Mila Simões de Abreu ${ }^{1}$
}

\begin{abstract}
RESUMO
Apresenta-se uma história das listas e inventários de sítios com arte rupestre em território português, partindo das primeiras referências no séc. XVII, passando pelas sinalizações publicadas por estudiosos como Francisco Martins Sarmento, José Leite de Vasconcelos e Francisco Manuel Alves, os primeiros inventários feitos por Rui Serpa Pinto e Joaquim Rodrigues Santos Júnior até ao projeto "Gravado no tempo" - o inventário total da arte rupestre portuguesa, iniciado em 1991. A criação do "Corpus” das gravuras e pinturas rupestres, na primeira década do séc. XXI e algumas das suas conclusões.

Palavras-chave: Arte Rupestre, Inventário, História, Gravuras, Corpus.
\end{abstract}

\begin{abstract}
This paper presents a history of the lists and inventories of rock art sites in Portuguese territory. It starts with the first references in the XVII century followed by notes published by scholars such as Francisco Martins Sarmento, José Leite de Vasconcelos and Francisco Manuel Alves. Inventories include the first ones by Rui Serpa Pinto and Joaquim Rodrigues Santos Júnior until the project "Gravado no Tempo"(Etched in time) - a total inventory of Portuguese rock art that started in 1991, and the creation of the "Corpus" of rock engravings and paintings in the first decade of the century XXI and some of its conclusions.
\end{abstract}

Keywords: Rock Art, Inventories, History, Engravings, Corpus.

\section{INTRODUÇÃO}

Os primeiros textos sobre a existência de arte rupestre em Portugal estão entre os mais antigos da Europa, tendo vindo à luz no início do século XVII. António Carvalho da Costa (1650-1715), dedica algumas linhas, na sua "Corografia Portugueza...", publicada em 1706, a uma parede com pinturas nas margens do rio Douro. Referida pelos locais como "Curral das Letras" é na atualidade conhecida como Cachão da Rapa. Está localizada em cima do túnel da Alegria linha de $\mathrm{CP}$, nas proximidades da estação em Ribalonga, concelho de Carrazeda de Ansiães. Tais figuras pintadas são descritas, com maior detalhe, alguns anos depois pelo erudito Jerónimo Contador de Argote (1676-1749), no seu livro Memórias para a História Eclesiástica de Braga Primaz das Hespanhas (1734: 486-489, 492-493). O mesmo autor, em 1738 , noutro dos seus livros, intitulado "De antiquitatibus conventus bracaraugustani" volta a fazer referencia a "quadrados em parte se parecem com os do jogo do xadrez" (Argote 1738: 332). Acompanha essa descrição com um bela gravura de Debrie (1735) que é provavelmente a mais antiga representação de pinturas rupestres no mundo ocidental. Argote publica também a primeira referência a gravuras rupestres ao descrever o sítio da "Mão do Homem" em Escariz (Adoufe), no conselho de Vila Real (Argote 1738: 332).

Teremos no entanto que esperar pela segunda metade do século XIX para que voltem a ser publicadas esporádicas descrições de estações rupestres. Uma breve referência, mais uma vez às pinturas do Cachão, aparece no livro de Júlio Maximo de Oliveira Pimentel, Visconde de Vila Maior (1809-1884), "O Douro Ilustrado: Álbum do Rio Douro e Paiz Vinhateiro" (Villa Maior 1876: 105-106) e tem uma versão em inglês.

Augusto Filipe Simões (1835-1884) no final da sua "Introdução à Arqueologia da Península Ibérica"

1. Unidade de Arqueologia, Dep. Geologia, Universidade de Trás-os-Montes e Alto Douro CETRAD - Centro de Estudos Transdisciplinares para o Desenvolvimento; msabreu@utad.pt 
(Simões 1878: 177) menciona a presença de espirais gravadas na Citânia de Briteiros notando que são semelhantes a outras conhecidas na Irlanda. Joaquim Possidónio da Silva (1806-1896), o fundador da "Real Associação dos Architectos Civis e Archeologos Portuguezes", antecessora da Associção dos Arqueólogos Portugues, vai ao Congrès Association Française pour l'Avancement des Sciences, em Grenoble, com a comunicação "Inscription très ancienne et rare gravée e peinte sur un rocher en Portugal" (Silva 1887a:105106) e publica o texto "Sinais sôbre um penhasco no lugar de Linares na Provincia do Douro - Explicação da estampa" que inclui uma interessante cópia de 1/4 e a cores das pinturas (Silva 1887b: 78-8o).

No texto Possidónio da Silva escreve que as pinturas estiveram em perigo de serem destruídas a quando da construção da linha de caminho de ferro Porto-Barca d'Alva e mas foram salvas graças a intervenção do Visconde de Seabra, que nas Cortes, pede que se fosse "(...) que se evitasse um tal vandalismo" (Silva 1887b: 79) o que levou à construção do túnel que ainda existe.

\section{AS REFERÊNCIAS DE FRANCISCO MARTINS SARMENTO}

Entre esses primeiros estudiosos que descreveram arte rupestre destaca-se sem dúvida a figura de Francisco Martins Sarmento (1833-1899), um erudito minhoto, que durante a sua vida escreveu centenas de páginas dedicadas à arqueologia. Nos seus $9 \mathrm{ca}$ dernos escritos, entre 23 de Março de 1878 e 10 de Dezembro de 1898 , diligentemente anotou referências a sítios com gravuras. Muitas dessas notas foram publicadas em diversas publicações da época e na Revista de Guimarães, a publicação que fundou e que dirigiu até a morte (Sarmento 1878; 1879a,b; 1822; 1883-84; 1884; 1884-5; 1885a,b; 1888a, b; 1895; 1896). Depois da sua morte coube a João Oliveira Guimarães, o abade de Tagilde, organizar os seus escritos e publicar diversos artigos póstumos (Sarmento 1902a, b; 1904a, b; 1905a, b; 1906, 1909a, b). Nas décadas seguintes continuaram a vir à luz outros textos (Sarmento 1944; 1989; 1990a, b) incluindo "Antiqva - Apontamentos de Arqueologia” (Sarmento 1999). No total Martins Sarmento identificou 89 sítios, principalmente a zona do Minho (98\%). Muitos são o resultado das suas "caminhadas" ou referencias dadas por amigos e conhecidos e assim estão localizados em grande parte à volta da cidade de Guima- rães onde vivia e Briteiros, uma das suas propriedades (75\%). Apesar das descrições e dos numerosos esboços produzidos, não conseguimos identificar no terreno a maioria dessas referências (90\%). Sarmento não era um amador desprevenido, era muito culto e conhecia a bibliografia de referência da época, as suas descrições devem pois ser factuais. Nalguns casos os nomes são muito semelhante e facilmente se confundem as referencias. Embora nos últimos anos se tenha intensificada a pesquisa de arte rupestre em todo o Minho muitos sítios continuam por ser identificados. infelizmente, é provável que muito do descrito por Martins Sarmento esteja para sempre desaparecido por ter sido destruído.

\section{AS REFERÊNCIAS DE JOSÉ LEITE DE VASCONCELOS}

No final do século do XIX e ínicio do século XX, José Leite de Vasconcelos (1958-1941), o fundador do Museu de Ethonologia (hoje Museu Nacional de Arqueologia), na sua obra monumental "Religiões da Lusitânia", em especial no volume I, publica descrições de sítios com arte rupestre São sítios um pouco por todo o país mas principalmente na zona das Beiras (Vasconcelos 1897: 360-39o). Trata-se, na maioria dos casos, de rochas de granito com "covinhas", semelhantes às que aparecem em muitos monumentos megalíticos. Outras gravuras geométricas são para Vasconcelos jogos “(d)os cantinhos" (Vasconcelos 1897:365).

$\mathrm{O}$ investigador nota que muitos dos sítios rupestres tem associadas histórias sobre de tesouros de mouros ou lendas de Santos como S. Gonçalo, S. Martinho, S. Hilario e S. Miguel (Vasconcelos 1897: 391). Na Revista "O Arqueólogo Português", de que Leite de Vasconcelos era diretor, o investigador publica muitas outras referências a rochas gravadas (Vasconcelos, 1901a e b 1901b, 1902, 1903, 1910, 1917a, b). No total são 31 referências. (Tabela 1)

\section{O PRIMEIRO INVENTÁRIO DE RUI SERPA PINTO}

Em 1929, o jovem investigador Rui de Serpa Pinto (1907-1933), publica o verdadeiro primeiro inventário de arte rupestre em Portugal. Num artigo publicado na revista "Nós" do Seminario de Estudos Galegos - seizón de Arqueoloxia, intitulado "Petroglifos de Sabroso e arte rupestre em Portugal", 4 anos antes 
da sua prematura morte aos 25 anos, Serpa Pinto, parte da descoberta de gravuras do castro de Sabroso, Freguesia de S. Lourenço de Sande, Concelho de Guimarães, para fazer um apanhado do que tinha sido publicado sobre gravuras e pinturas em território português.

A lista publicada (Pinto, 1929:7) inclui 37 localidades com gravuras (no $1-37)$ um com pinturas ( $\left.n^{\circ} 42\right)$ e seis com estátuas-estelas (n⿳o 38, 39, 40, 41 e 43) e pela primeira vez é acompanha por um mapa com a respetiva localização dos sítios (Figura 1).

No texto, as gravuras de antropomorfos estilizados, os círculos concêntricos, as "covinhas" e as espirais, presentes no Castro de Sabroso são comparadas com outras conhecidas noutras localidades no país. De todos os sítios da lista de Serpa Pinto conseguimos atualmente localizar apenas 14 nalguns casos tal é muito difícil pois são referidos de forma muito genérica como no caso de "Marco de Canavese" ( $\mathrm{n}^{\circ}$ 19). (Tabela 2)

\section{A LISTA DE ABADE BAÇAL}

Em meados dos anos trinta do século passado Francisco Manuel Alves (1865-1947), mais conhecido como Abade Baçal, inicia a publicação da sua monumental obra com onze volume "Memórias Arqueológico-Históricas do Distrito de Bragança" (1934-1938). No volume IX (Alves 1934: 555-718) dedica um capitulo às"Insculturas e arte rupestre. Novos elementos para a sua interpretação", onde publica descrições e imagens de muitas localidades com gravuras em território Transmontano.

Mais informações sobre de arte rupestre aparecem no vol. X (Alves 1938: 823-828), e no vol. XI (Alves 1938: 351, 441) assim como nos textos "por terras de Mirandesas" (Alves 1938: 810-812), "Chaves-Apontamentos arqueológicos" (1931) e "Vimioso, Notas Monográficas", escrito com Adrião Martins Amado e publicado postumamente em 1968. A analise de todos os textos permitiu publicar uma lista de todas as referências (Abreu 2015). Ao todo, o Abade Baçal ,publica notas sobre mais de 100 localidades rupestres (106), a maioria são no Distrito de Bragança mas inclui algumas esporádicas referencias no Distrito de Vila Real. Em alguns dos sítios descritos e depois de observações e analises no campo chegamos à conclusão que se tratavam fenómenos naturais como é o caso da Fonte dos Engenhos, Serapicos.

É interessante notar que Baçal não tinha dúvidas que existissem gravuras e até mesmo pinturas, semelhantes às da zona Franco-Cantábrica, ou seja de época Paleolítica mas não faz nenhuma referência às gravuras em estilo paleolítico de Mazouco (Freixo de Espada-à-Cinta), Ribeira da Sardinha (Torre de Moncorvo) ou Sampaio e Pousadouro (Bragança), todas localizadas na zona estudada. Descreve e faz um desenho da "Fraga Escrevida", em Paradinha Nova (Bragança), uma parede coberta com numerosas, cruzes, cruzeiros e até "calvários" mas não vê sobrepostas as duas grandes figuras de auroque, em estilo paleolítico (Alves 1934: 643-645).

Muitas das rochas descritas têm apenas gravadas "covinhas". Baçal recorda que os habitantes da zona usam o termo "alfar" or "ir alfar", ou seja, fazer ou avivar os pequenos buracos feitos na rocha, tal faz sem dúvida que seja ainda mais difícil atribui-lhes uma cronologia precisa. Já nas chamadas "marras", rochas com cruzes gravadas, Baçal, vês vestígios do antigo costume, com raízes visigóticas, de marcar os confines das propriedades periodicamente.

Em 1975, Joaquim Neto, publica no livro O Leste do Território Bracarense, uma lista de estações rupestre onde praticamente decalca as referências feitas por Baçal.

\section{O INVENTÁRIO DE JOAQUIM RODRIGUES DE SANTOS JÚNIOR}

Joaquim Rodrigues de Santos Júnior (1901-1990), teve uma formação em Ciências Histórico-Naturais e Medicina mas destacou-se na área da antropologia e etnologia. Foi o discípulo preferido do famoso antropólogo A. A. Mendes Correia, tendo acabado por o substituir à frente do "Instituto de Antropologia" da Universidade do Porto e da "Sociedade Portuguesa de Antropologia e Etnologia de Antropologia”. Desde sempre teve ainda um grande interesse em arqueologia e em especial por arte rupestre tendo descoberto, estudo e publicado muitos sítios em Portugal e no território das ex-colónias.

No início dos anos 30, Santos Jr. re-localiza e publica as pinturas do Cachão da Rapa (Figura $2 \mathrm{C}$ ), que muitos tinham dadas como perdidas (Santos Jr. 1933a) e estuda o abrigo da Pala Pinta (Santos Jr. 1933b), em Alijó, descoberto por Horácio Mesquita em 1921. Seguindo as indicações do Abade Baçal, J. R. Santos Júnior, como muitas vezes assinava os seus escritos, visita e estuda gravuras do castro Baldoeiro (Santos Jr. 1930), Linhares (fig. 2, Carrazeda de Ansiães (San- 
tos Jr. 1933C) entre muitas, tornando-se no maior conhecedor de gravuras e pinturas em Portugal.

Em 1940, por ocasião do "Congresso do Mundo Português", na sessão Pré e Proto-História de Portugal, que se realizou em julho no Porto, Santos Júnior, apresenta uma comunicação com o titulo "Arte Rupestre" que será publicada em 1942 (Santos Júnior 1942: 327-376). Esse texto trata-se da primeira verdadeira tentativa de fazer um inventário total de todas as estações com figuras rupestres (pinturas e gravuras). No texto o investigador clarifica no entanto que "No inventario que segue estão seriadas as gravuras rupestres. Excluem-se aquelas onde aparecem sòmente covinhas e as que são apontadas como tendo um único sinal gravado, cruz, pègada, ferradura, etc." (Santos Júnior 1942: 355), o que por outras palavras quer dizer, que exclui não só muitas das localidades publicadas tanto por Martins Sarmento como o Abade Baçal, como deixa de fora na verdade a maioria das rochas gravadas em território Português.

Da lista fazem parte 106 sítios com gravuras e 3 com pinturas e inclui um mapa com a localização (Figura 2 A). Os primeiros estão maioritariamente localizados a norte do Douro, em particular no Distrito de Bragança. Nas segundas incluem-se os abrigos da Serra de Arronches, Portalegre (Alentejo) publicados por Henri Breuil (1917).

Da lista não fazem parte localidades rupestres nos vales do rios Tejo ou Guadiana, no sul, ou do Côa no norte, que só serão identificadas muitos anos depois, assim como a gruta do Escoural cuja a existência só seria conhecida em 1963. Tal como tinha sucedido com o Abade Baçal, Santos Jr. faz referência à "Fraga Escrevida de Paradinha” ( $\left.n^{\circ}{ }^{5} 8\right)$ mas igualmente não vê os auroques publicando assim apenas gravuras e pinturas de época pós-paleolítica. (Tabela 3)

$\mathrm{Na}$ maioria dos casos a descrição é muito breve limitando-se nalguns casos apenas ao nome como no caso "Quinta do Cardio, Ponte Lima” (nº 4 ) ou "Fraga do Cavalo" (n⿳0 67). Do total 47 dos sítios foram referidos pelo Abade Baçal. Outros tinham sido publicado por Serpa Pinto e aparecem por uma razão que desconhecemos em múltiplos (nº 13, 14, 15 e 17 e no $26,27,28)$. Alguns classificação de "inédito" como os no 9 - "As Ferraduras"; no 20 - "Pedra Partida"; no 24 - "Pegadinhas de S. Gonçalo"; no 25 - "Lumar"; no 31 - "Outeiro da Moeda"; nํㅜ 32 - "Outeiro do Salto"; nº 79 - "Pedra Escrita do Poço da Moura"; nº 85"Fraga da Ferradura Serrinha"; n. 86 - "Murancho" e no 87 - "Eira da Codeceira”. Algumas dessas esta- ções são mais tarde publicadas com outros nomes com é o caso de "Pedra Partida", que foi publicada como "Pedra de Ardregães” (Anati 1968; Shee 1981). No texto, do ponto de lista geológico, Santos Júnior, afirma que "A grande maioria das estações rupestre ao livre são em rochedos. Há porém um certo número, embora muito menor, em que para a realização de tais monumentos foram utilizada rochas de xisto (Santos Jr. 1942: 366). Quando à técnica o investigador nota que a maioria foi feita por picotagem embora existam alguma gravuras a polissoir (litotrípticas) como é o caso de Sortes ( $\mathrm{n}^{\circ}$ 53), Ridevides ( $\mathrm{n}^{\circ}$ 77), e Poço da Moura ( $\left.n^{\circ} 78\right)$.

J. R. Santos Júnior expressa o desejo de seguir o exemplo de Ramón Sobrino-Buhigas e do seu Corpus Petroglyphorum Gallaeciae, (1935) e de publicar um Corpus Petroglyphorum transmontanum (Santos Júnior 1944: 1) coisa que nunca realizará.

\section{OUTROS SÍTIOS}

Nas décadas seguintes são diversos os autores que publicam textos sobre gravuras e pinturas em Portugal. A maioria deles tem caracter monográficos e tratam de localidades a norte do Douro, como por exemplo, Monte Eiró (Brandão 1961), Montedor, (Lanhas 1969), Ridevides (Santos Júnior 1963) e na vizinhança de Viseu (Tavares e Silva 1971; Silva 1978, 1979).

Nos início dos anos setenta, com a descoberta de gravuras rupestres no leito do rio Tejo onde são identificado pelos menos 30 sítios (Serrão et al. 1972a, b) houve no nosso país um renovado interesse pela arte rupestre que levou a que diversos investigadores como, Eduardo Serrão, Mário Varela Gomes, Jorge Pinho Monteiro, António Martinho Baptista publicassem numerosos artigos sobre a arte tagana mas também de outras áreas do território português. Maria Jesus Sanches faz nos anos oitenta e noventa diversos estudos monográficos de áreas principalmente do nordeste Trasmontano (por exemplo, Sanches 1997). Algumas listas de carácter regional são publicadas no inicio do século XXI. O Pe. João Parente apresenta no livro "O Castro de S. Bento (Concelho de Vila Real) e o seu ambiente arqueológico" um catálogo com a descrição de 130 sítios rupestres (Parente 2003). A maioria deste estão localizados nos distritos de Vila Real e Bragança indo Parente beber informações aos trabalhos de Baçal, mas acrescenta sítios como "São Salvador do Mundo", em São João da Pesqueira (Parente 2003: 268) e figuras 
de serpentiformes no Minho em Vieira do Minho (Parente 2003: 212, 271). Para sul, Manuel Calado, no Alentejo, graças a curadas prospeções nos concelhos de Alandroal, Arraiolos, Borrba, Estremoz, Évora, Mora, Redondo, Reguengos de Monsaraz, e Vila Viçosa, identifica e publica 101 localidades com gravuras (Calado 2001) de notar que nesse caso 99,7\% são “covinhas" em rochas de granito.

\section{O PROJETO “GRAVADA NO TEMPO” E O “CORPUS” DA ARTE RUPESTRE}

A entrada de Portugal na então Comunidade Económica Europeia e com a chegada os fundos de coesão assistimos a um aumento de obras públicas o que levamos-nos a tem consciência do perigo que muitos sítios rupestres corriam.

Constatando tal realidade e com a colaboração da equipa italiana da Cooperativa "Le Ormedell "Uomo" criámos, em 1991, o projeto "Gravado no Tempo - Portugal: inventário total da arte rupestre portuguesa" é aprovado pelo IPPC (Abreu \& Jaffe 1995). O objetivo do projeto era fazer o "corpus" com todos os sítios com gravuras e pinturas em território nacional de modo a que tal informação fosse passível de ser consultada e avaliada por todos os interessados. Os trabalhos do projeto iniciam-se seguindo nas pegadas dos trabalhos do Abade Baçal no verão de 1992 e continuaram nos dois anos seguintes. Esses primeiros anos fizeram-nos compreender a dificuldade que o terreno apresentava, constatamos que a falta de acessos e o abandono que essa parte do território estava votada. Tal traduzia-se na quase ausência de habitantes e, portanto, de possíveis informadores que nos fossem úteis. A descoberta todavia de estações como Castro Curisco, no Parque Natural de Montesinho, a pouco quilómetros da fronteira com a Espanha (Abreu \& Jaffe 1995) demonstrou que existiriam muitos mais sítios de arte rupestre dos que pensávamos e que o trabalho seria muito mais longo do previsto. Quando foi divulgada, em 1994, a existência da arte rupestre no Vale do Côa, ficou claro que não só existiam muitas gravuras paleolítica ao ar livre mas que tínhamos muitas mais estações de arte rupestre no nosso território. No espaço de alguns anos foram descobertas muitas mais localidades com arte paleolítica noutros rios como o Sabor, Ocreza, Zêzere e Guadiana e inúmeros sítios com cronologia pós-paleolítica tantos gravados como pintados por todo o país.
A partir de 1995, compreendemos que para continuar com o projeto de inventário, devíamos-nos concentrarem primeiro numa acurada pesquisa bibliografia de tudo o que teria sido publicado de todo o pais. Assim foram extraídas informações publicadas por 645 autores, em 1461 textos, em 172 revistas e publicações periódicas num período que vai de 1706 a 2010. Essa pesquisa, conjugada com conhecimentos adquiridos em trabalho de campo e outras informações disponíveis, levou a elaboração de um primeiro "corpus" da arte rupestre em Potugal. Uma síntese desse trabalho foi publicada no âmbito da nossa tese de doutoramento (Abreu 2012, volume 2).

Foram assim identificados 1206 referências, porém, tivemos suficientes informações e confirmação da existência de apenas 745 sítios (Figura 3). tendo ficado por verificar 461 sítios. Os sítios com figuras pinturas identificados foram 58 (Figura 4). Essas listas podem ser ser consultadas em www.msabreu.utad.pt.

A maioria os casos que não foi possível incluir no "Corpus" foi porque as referências eram muito vagas e, portanto, impossível verificar a sua existência na atualidade. $O$ fato de muitas localidades serem publicadas como nome iguais, ou muito semelhantes, como "Letreira" ou "Ferraduras", aliada a falta de referências geográficas foi o que tornou a identificação e localização muitas vezes impossível.

\section{EM CONCLUSÃO}

Dos diversos inventários e listas podemos concluir que a maioria dos sítios de arte rupestre em Portugal são gravuras, em rochas de granito, embora as figuras gravadas em xisto sejam mais numerosas. A técnica mais comum é a picotagem e cronologicamente, embora o territorio português tenha a maior concentração de gravuras paleolíticas ao ar livre na Europa, a maioria das figuras foram feitas em época pós-paleolítica.

Infelizmente a maioria dos sitos rupestres não são classificados e, portanto, permanecem completamente desprotegidos do ponto de lista legal. 


\section{BIBLIOGRAFIA}

ABREU, Mila Simões de (2012) - Rock-art in Potugal. History, Methodology and Traditions. Tese de doutoramento. Vila Real: Universidade deTrás-os-Montes e Alto Douro. 4 volumes.

ABREU, Mila Simões de; JAFFE, Ludwig (1995) - Projecto Gravado no Tempo, Portugal, inventário total da arte rupestre: 1991-1993. Trabalhos de Antropologia e Etnologia, 35 (2) 417-428.

ABREU, Mila Simões de (2015) - The abbot of Baçal and rock-art Studies in Portugal, BCSP , 4O, pp. 49-62.

ALVES, Francisco Manuel (1931) - Chaves-Apontamentos arqueológicos. Chaves: Câmara Municipal de Chaves.

ALVES, Francisco Manuel (1934) - Memórias Arqueológico-Históricas do Distrito de Bragança-Arqueologia, Etnografia e Arte, Tomo IX. Porto: Tipografia da Empresa Guedes, Lda.

ALVES, Francisco Manuel (1948) - Memórias Arqueológico-Históricas do Distrito de Bragança-Arqueologia, Etnografia e Arte, Tomo XI. Porto: Tipografia da Empresa Guedes, Lda.

ALVES, Francisco Manuel de \& AMADO, Adrião Martins (1968) - Vimioso, Notas Monográficas, pp. 374-398. Coimbra: Publicação da Junta Distrital de Bragança.

ARGOTE, Jerónimo Contador de (1734) - Memorias para Historia Ecclesiastica do Arcebispado de Braga, Primaz das Hespanhas, Tomo II. Lisboa Occidental: Officinas de Joseph Antonio da Sylva, Impressor da Academia Real.

ARGOTE, Jerónimo Contador de (1738) - Antiquitatibus Conventus Bracaugustani. Ulyssipone Occidentali: Typis Silvianis, Regalis Academie.

BREUIL, Henri (1917) - La roche peinte de Valdejunco, à la Esperança, près Arronches. Terra Portuguesa, 3 (13-14), pp. 17-27.

CALADO, Manuel (2001) - Os Menires do Alentejo central. 1, 2, 3. Grupo de Estudos do megalitismo alentejano. Edition Online.

COSTA, António Carvalho da (1706) - Corografia portugueza e descripçam topografica do famoso reyno de Portugal. Tomo I, Lisboa: Off. de Valentim da Costa Deslandes.

NETO, Joaquim Maria (1975) - O Leste do Território Bracarense, Torres Vedras: A União.

PARENTE, João (2003) - O Castro de S. Bento. (Concelho de Vila Real) e o seu ambiente arqueológico. Vila Real: Edição do Autor.

PINTO, Rui de Serpa (1929) - Petroglifos de Sabroso e a arte rupestre em Portugal. Seminario de Estudos Galegos - Sessión Aqueoloxia, "Nós”, 11 (62), pp. 19-26.

SANCHES, Maria de Jesus (1997) - Pré-História recente de Trás-os-Montes e Alto Douro. O abrigo do Buraco da Pala (Mirandela) no contexto regional, 1. Porto: Sociedade Portuguesa de Antropologia e Etnologia.
SANTOS JÚNIOR, Joaquim Rodrigues dos (1931) - As serpentes gravadas do Castro do Baldoeiro (Moncorvo - Trás-os-Montes). XVe Congrès International d'Anthropologie 8 Archéologie Préhistorique (Portugal), 1, pp. 413-417. Paris: Librairie E. Nourry.

SANTOS JÚNIOR, Joaquim Rodrigues dos (1933a) - O Abrigo Pré-Histórico de "Pala Pinta". Trabalhos da Sociedade Portuguesa de Antropologia e Etnologia, 6 (1), pp. 31-43.

SANTOS JÚNIOR, Joaquim Rodrigues dos (1933b) - Gravuras rupestres de Linhares (a Fraga das Ferraduras). Trabalhos Sociedade Portuguesa de Antropologia e Etnologia, 6 (2), pp. 141-148.

SANTOS JÚNIOR, Joaquim Rodrigues dos (1933c) - As pinturas pré-históricas de Cachão da Rapa. Trabalhos da Sociedade Portuguesa de Antropologia e Etnologia, 6 (3) pp. 185-222.

SANTOS JÚNIOR, Joaquim Rodrigues dos (1942) - Arte Rupestre. Congresso do Mundo Português. Memórias e comunicações apresentadas ao Congresso de Pre e Proto-História e Portugal (I Congresso) i Pré e Proto-História de Portugal, 1, pp.327-376. XVIII ests. Lisboa: Comissão Executiva dos Centenários.

SANTOS JÚNIOR, Joaquim Rodrigues dos (1944) - Nova contribuição sobre a arte rupestre Transmontana - os petroglifos de Ribalonga. Las Ciências, 9 (2): 1-11 + I-II ests.

SANTOS JÚNIOR, Joaquim Rodrigues dos (1945) - Gravuras de Lomar (Penafiel), pp. 77-82. Lisboa: Câmara Municipal de Penafiel.

SARMENTO, Francisco Martins (1878) - Signaes gravados em rochas. A Renascença, pp. 118-25.

SARMENTO, Francisco Martins (1879a) - Observações à Citânia do Snr. Emílio Hübner. Porto: Tipografia de António José da Silva Teixeira.

SARMENTO, Francisco Martins (1879b) - Arte pré-romana. O Occidente 2: 157.

SARMENTO, Francisco Martins (1882) - Se antes da invasão romana havia uma arte entre nós. A Arte Portuguesa. 1 (1): 1-3; 1 (2), pp. 1 \& 19-21; 1 (3), pp. 26-27.

SARMENTO, Francisco Martins (1883-84) - A propósito de castros. O Panorama Contemporâneo, $\mathrm{I}^{\circ}$ ano, 9, pp. $17 \& 25$.

SARMENTO, Francisco Martins (1884) - Materiais para a arqueologia do concelho de Guimarães, Revista de Guimarães, 1 (4), pp. 161-189.

SARMENTO, Francisco Martins (1884-95) - Materiais para a arqueologia da comarca de Barcelos. Revista de Sciencias Naturaes e Sociaes, 3, pp. $62 \& 186$.

SARMENTO, Francisco Martins (1885a) - Materiais para a arqueologia do concelho de Guimarães 1. Revista de Guimarães, 2 (4), pp. 189-202.

SARMENTO, Francisco Martins (1885b) - A civilização da pedra polida no Minho. Revista Scientifica, Sociedade Ateneu do Porto, 3, pp. 77-86. 
SARMENTO, Francisco Martins (1888a) - A propósito dos "Roteiros dos Tesouros". Revista de Guimarães. 5(1), pp. 5-11.

SARMENTO, Francisco Martins (1888b) - Antigualhas. Revista de Guimarães, 5 (4), pp. 157-163.

SARMENTO, Francisco Martins (1895) - Materiaes para a archeologia da comarca de Barcelos. Revista de Sciências Naturais e Sociais, 3, pp. 193-194.

SARMENTO, Francisco Martins (1896) - Materiais para a arqueologia do concelho de Guimarães. Revista de Guimarães, 13 (4), pp. 149-168.

SARMENTO, Francisco Martins (1902a) - Materiais para a arqueologia do concelho de Guimarães. Citânia. Revista de Guimarães, 19 (1), pp. 19-33.

SARMENTO, Francisco Martins (1902b) - Materiais para a arqueologia do concelho de Guimarães. Citânia. Revista de Guimarães, 19 (3), pp. 109-119.

SARMENTO, Francisco Martins (1904a) - Materiais para a arqueologia do concelho de Guimarães. Citânia. Revista de Guimarães, 21 (2), pp. 49-63.

SARMENTO, Francisco Martins (1904b) - Materiais para a arqueologia do concelho de Guimarães. Citânia. Revista de Guimarães, 21 (3-4), pp. 97-120.

SARMENTO, Francisco Martins (1905a) - Materiais para a arqueologia do concelho de Guimarães. Citânia. Revista de Guimarães, 22 (1-2), pp. 5-32.

SARMENTO, Francisco Martins (1905b) - Materiais para a arqueologia do concelho de Guimarães. Citânia. Revista de Guimarães, 22 (3-4), pp. 97-123.

SARMENTO, Francisco Martins (1906) - Materiais para a arqueologia do concelho de Guimarães. Citânia. Revista de Guimarães, 23 (2), pp. 41-51.

SARMENTO, Francisco Martins (1909a) - Materiais para a arqueologia do concelho de Guimarães. Citânia. Revista de Guimarães, 26 (1-2), pp. 5-19.

SARMENTO, Francisco Martins (1909b) - Materiais para a arqueologia do concelho de Guimarães. Citânia. Revista de Guimarães, 26 (4), pp. 129-139.

SARMENTO, Francisco Martins (1933) - Sinais Gravados em Rochas. Dispersos: colectânea de artigos publicados, desde 1876 a 1899, sobre arqueologia, etnologia, mitologia, epigrafia e arte pré-histórica: obra comemorativa do $1^{\circ}$ centenário do nascimento do autor. Coimbra: Universidade de Coimbra.

SARMENTO, Francisco Martins (1944) - Cartas de Martins Sarmentoao AbadedeTágilde.RevistadeGuimarães, 54(3-4), pp. 91-104.

SARMENTO, Francisco Martins (1989) - Manuscritos inéditos de Francisco Martins Sarmento. ANTIQVA (Informes, reconhecimentos e prospecções). Revista de Guimarães, 99 pp. 16-66.
SERRÃO, Eduardo da Cunha; LEMOS, Francisco Sande; MONTEIRO, Jorge Pinho; QUEROL, Maria dos los Angeles; JORGE, Susana Oliveira \& JORGE Vítor Oliveira (1972a) - O Complexo de Arte Rupestre do Vale do Tejo. Primeiras Hipóteses de programa de trabalhos. O Arqueólogo Portu-

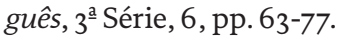

SERRÃO, Eduardo da Cunha; LEMOS, Francisco Sande; MONTEIRO, Jorge Pinho; QUEROL, Maria dos los Angeles; LOPES, Susana Rodrigues [Oliveira JORGE] \& JORGE Vítor de Oliveira (1972b) - O Complexo de Arte Rupestre do Tejo (Vila Nova de Rodão - Nisa). Notícia preliminar. Arqueologia e História, 9s, pp. 349-397. Lisboa.

SILVA, Joaquim Possidónio da (1887a) - Inscription très ancienne et rare gravée e peinte sur un rocher en Portugal. Congrès de Grenoble, Association Française pour l'Avancement des Sciences, pp. 105-106. 1 map.

SILVA, Joaquim Possidónio da (1887b) - Explicação da Estampa 5, $\mathrm{n}^{\circ} 78$ - Sinais sôbre um penhasco no lugar de Linares na Provincia do Douro. Boletim da Associação dos Architectos Civis e Archeólogos Portuguêzes, 5(5), pp. 78-80 + 1 fig.

SIMÕES, Augusto Filipe (1878) - Introdução à Arqueologia da Península Ibérica, Lisboa: Livraria Ferreira.

SOBRINO-BUHIGAS, Ramón(1935)-CorpusPetroglyphorum Gallaeciae, Seminario de Estudos Galegos. LXXXVII ests. Gallaecia, C. Bermejo: S. Tiago de Compostela.

VASCONCELOS, José de Leite de (1897) - Religiões da Lusitânia, Quarto centenário do descobrimento da India. Contribuições da Sociedade de Geographia de Lisboa. 1. Lisboa: Imprensa Nacional.

VASCONCELOS, José Leite de (1897) - Religiões da Lusitânia, I. Quarto centenário do descobrimento da India. Contribuições da Sociedade de Geographia de Lisboa. Lisboa: Imprensa Nacional.

VASCONCELOS, José Leite de (1901a) - Cartas de Francisco Martins Sarmento. Publicadas e Annotadas. Lisboa: Imprensa Nacional.

VASCONCELOS, José Leite de (1901b) - Cartas de Francisco Martins Sarmento. Publicadas e Annotadas. O Arqueólogo Português, 1ํㅗㅅ Série, 6 (8-12), pp. 172-196.

VASCONCELOS, José Leite de (1902) - Noticias Varias. Antigualhas de Monção. Castelo dos Milagres e Cova da Moura. O Arqueólogo Português, 1를érie, 7, pp. 285-286.

VASCONCELOS, José Leite de (1903) - A freguezia de S. Christovam de Nogueira (Concelho de Sinfães). O Arqueólogo Português, $1^{\underline{a}}$ Série, 8 (2-3), pp. 58-72 [70].

VASCONCELOS, José Leite de (1910) - Esculpturas prehistoricas do Museu Ethnologico Português. O Arqueólogo Português, 1른 Série, 15 (1-12) pp. 31-39.

VASCONCELOS, JoséLeite de (1917a) - Por Trás-os-Montes. O Arqueólogo Português, 1ํㅡㄹ Série, 22 (1-12), pp. 12-13. 
VILLA-MAIOR, Julio Maximo de Oliveira Pimentel [Visconde de Vila Maior] (1876) - O Douro Ilustrado-Álbum do Rio Douro e Paiz Vinhateiro, pp.105-106. Lisboa: Imprensa Nacional-Casa da Moeda.

VIANA, Abel (1959-1960) - Insculturas rupestres do Alto Minho (Lanhelas e Carreço - Viana do Castelo - Portugal). Boletin de la Comision de Monumentos de Orense, 20, pp. 209-231.

\begin{tabular}{|c|c|c|c|c|}
\hline № & Nome & Concelho & Tipo & Bibliografia \\
\hline 1 & Antas-de-Penalva & (Beira) & Covinhas (5) & 1897: 372 \\
\hline 2 & Aviz & Aviz & Cruz (Marra?) & 1917: 121 \\
\hline 3 & Barreiros, Carvalhas, “Santa Custodia” & Senhorim & Covinhas, cruzes & 1897: 369 \\
\hline 4 & Braçaes, Outeiro-de- Espinho & Mangualde & Covinhas & 1897: 371 \\
\hline 5 & Briteiros & [Guimarães] & Covinhas & 1897: 377 \\
\hline 6 & Cachão da Rapa “Letras” & Carrazeda de Ansiães & Geométricos símbolos & 1897: $360-365$ \\
\hline 7 & Carrascal "Pedra com letras" & Leiria & "Letras" & 1917b: 166 \\
\hline 8 & $\begin{array}{l}\text { Carviças - Castro da Cigadonha, } \\
\text { Fraga do Gato }\end{array}$ & Torre de Moncorvo & Gato (?) & 1917b: 164 \\
\hline 9 & Castello-N. Sra do Bom Sucesso & $\begin{array}{l}\text { Chãos de Tavares (?) } \\
\text { Mangualde? }\end{array}$ & Covinhas & 1897: 373 \\
\hline 10 & Castro de Neiva [Castelo] & Neiva [Viana do Castelo] & Covinhas & 1897: 377 \\
\hline 11 & “Castro” de Santa Luzia & Viana do Castelo & Covinhas (52), Suástica (?) & 1897: 380 \\
\hline 12 & $\begin{array}{l}\text { Cova da Moura - "Pégadinhas } \\
\text { de São Tiago" }\end{array}$ & Monção & $\begin{array}{l}\text { Covinhas ? Pegada? } \\
\text { Canal com Covinhas }\end{array}$ & 1903: \\
\hline 13 & Cristello, Santa Comba & Felgueiras, Regilde & Covinhas & 1897: 375 \\
\hline 14 & Espinho & Mangualde & Geométricos & 1897: 366 \\
\hline 15 & Fajão, “Buracos de Mouros” & Coimbra & Covinhas & 1917b: 133 \\
\hline 16 & Fòz [Foz] do Sabor Castanheira & [Torre de Moncorvo] & "Letras" & 1917b: 167 \\
\hline 17 & Monte das Pucarinhas & Felgueiras [Eulália] & Covinhas & 1897: 378 \\
\hline 18 & Outeiro-de-Espinho “Pedras Pombeiras” & Mangualde & Covinhas, canais & 1903: 8 \\
\hline 19 & Pedra com Letras & Gouveia & Covinhas & 1917b: 167 \\
\hline 20 & Pedraça & Senhorim & Covinhas, cruzes geométricos & 1897: 365 \\
\hline 21 & Penedo de S. Gonçalo, Arriconha & ? [Baião] & Covinhas & 1897: 377 \\
\hline 22 & S. Cláudio & Taipas & ? 200 & 1897: 377 \\
\hline 23 & S. João da Festa & Mangualde & Covinhas & 1917b: 115-116 \\
\hline 24 & S. Martinho de Penacova "Buraquinhas" & (Minho) & Covinhas & 1897: 374 \\
\hline 25 & $\begin{array}{l}\text { S. Paio de Vizella "Pegadinhas de } \\
\text { S. Gonçalo }\end{array}$ & ? [Vizela] & Covinhas & 1897: 374 \\
\hline 26 & Sabroso, (Castro) & Guimarães & Pegada, círculos, concêntricos & 1897: $380-381$ \\
\hline 27 & Santa Marta, "Fraga da Pomba” & Vila Pouca de Aguiar & “Letras” e a Pomba & 1917b: 163 \\
\hline 28 & Santo Antão, (monte) & Caminha & Covinhas, oval & 1897: 377 \\
\hline 29 & Soutello, Venade & Caminha & Covinhas, figura "Phi” & 1897: 376 \\
\hline 30 & Tagilde & [Vizela] & Covinhas (30) & 1897: 375 \\
\hline 31 & Telões, Penedo da Passada S. Cristovão & Vila Pouca de Aguiar & Pegadas & 1917b: $159-160$ \\
\hline
\end{tabular}

Tabela 1 - Lista dos sítios com arte rupestre publicados por José Leite de Vasconcelos. As palavras entre [ ] são nossas. 


\begin{tabular}{|c|c|c|c|}
\hline № & Sítio & Localidade & Bibliografia \\
\hline 1 & Azevedo & (Minho) [Caminha, Azevedo] & Vasconcelos 1901: 183 \\
\hline 2 & Bagunte [Cividade de] & (Vila do Conde) & $?$ \\
\hline 3 & Baldueiro [Baldoeiro] & (Vilariça), [Torre de Moncorvo] & Nota pessoal de Santos Jr. \\
\hline 4 & Briteiros & $\begin{array}{l}\text { ?Guimarães] } \\
\text { [G }\end{array}$ & $\begin{array}{l}\text { Cartailhac 1886; Sarmento 1901; } 1899 \text { 1903; } \\
\text { 1904 a, b, c; 1905 a, b; Fortes } 1906\end{array}$ \\
\hline 5 & Cividade de Cossourado & (Paredes de Coura) & Pereira A. 1924 \\
\hline 6 & Eiró [Monte] & (Penha-Longa) & Vitorino 1924 \\
\hline 7 & Entre-os-Rios & [Castro, Entre-os-Rios] & Andarade 1918 \\
\hline 8 & $\begin{array}{l}\text { Espinho } \\
\text { [Passal da Abadia de Espinho] }\end{array}$ & (Mangualde) & Vasconcelos 1897 \\
\hline 9 & Ferraduras (San Miguel do Outeiro) & ? [Tondela] & Girão 1925 \\
\hline 10 & Ferradura Pintadas e Cantinhos & $\begin{array}{l}\text { (Bem-feitas) } \\
{[\text { [Destriz Oliviera de Frades] }}\end{array}$ & Girão 1925 \\
\hline 11 & Gândara do Fial & (Tondela) & $?$ \\
\hline 12 & Gândara e Eiras da Seixa & $?$ & Girão 1925 \\
\hline 13 & Garfe & (Guimarães) & $\begin{array}{l}\text { Sarmento 1901; } 1899 \text { 1903; } 1904 \text { a, b, c; } \\
1905 \text { a, b }\end{array}$ \\
\hline 14 & Gião & (Arcos de Valdevez) & Fontes 1927 \\
\hline 15 & Gondesende & (Bragança) & Idem. \\
\hline 16 & Guadramil - Penas Escrevidas & (Bragança) & Nota pessoal Barata Rocha \\
\hline 17 & Lanhelas & Caminha & Jalhay 1926: 373 \\
\hline 18 & Loriga & $?$ & ? \\
\hline 19 & Marco de Canavezes & ? [Monte Eiró?] & $?$ \\
\hline 20 & Outeiro dos Mouros & ? [Sejães] & Girão 1925 \\
\hline 21 & Outeiro Machado & (Chaves) & Corrêa 1928:169 \\
\hline 22 & Pedra da Escrita & $\begin{array}{l}\text { (San Pedro do Sul) } \\
\text { [São Pedro do Sul] }\end{array}$ & Girão1925 \\
\hline 23 & Pedraça & (Senhorim) & Vasconcelos 1897 \\
\hline 24 & Penas Escrevidas Guadramil & (Bragança) & Nota pessoal Barata Rocha \\
\hline 25 & Penedo do Cobrão & (Moncorvo) & Nota pessoal Santos Jr. \\
\hline 26 & Penedo dos Mouros & (Ronfe) [Guimarães, Vermil] & Sarmento 1901; 1899 1903; 1904 a, b, c; 1905 a, b \\
\hline 27 & S. Martinho & (Barco) & Sarmento 1901; 1899 1903; 1904 a, b, c; 1905 a, b \\
\hline 28 & S. Tecla & (Ronfe) [Guimarães, Vermil] & Sarmento \\
\hline 29 & Sabroso & [Guimarães] & $\begin{array}{l}\text { Cartailhac 1886; Sarmento 1901; 1899; 1903; } \\
1904 \text { a, b, c; 1905 a, b }\end{array}$ \\
\hline 30 & Saia & (Carvalhas, Barcelos) & Sarmento 1895 \\
\hline 31 & Samil & (Bragança) & ?[Alves 1938: 828] \\
\hline 32 & Sant'Ana do Campo & (Arraiolos) & Correia 1921 \\
\hline 33 & Santa Marta & (Braga) & Bellino 1909: 1 \\
\hline 34 & Sardoura & (Castelo de Paiva) & inédito \\
\hline 35 & Sejães & $?$ & Girão1925 \\
\hline 36 & Viana do Castelo & ? [Viana do Castelo] & Jalhay 1926: 373 \\
\hline 37 & Vila-Meã & (Pedras Salgadas) & Corrêa 1928 \\
\hline $38(1)$ & Casal & (Paredes de Coura) [Insale] & Paredes de Coura \\
\hline $39(2)$ & Moncorvo & ? & [Torre de Moncorvo] \\
\hline $40(3)$ & Vide & (Moncorvo) & [Torre de Moncorvo] \\
\hline $41(4)$ & S. Martinho & (Castelo Branco) & (Castelo Branco) \\
\hline $42(5)$ & Esperança & Arronches [Portalegre] & Arronches [Portalegre] \\
\hline $43(6)$ & Crato & ? [Portalegre] & [Portalegre] \\
\hline
\end{tabular}

Tabela 2 - O inventário de Rui Serpa Pinto(em ordem alfabética). As palavras entre [ ] são nossas. 


\begin{tabular}{|c|c|c|c|}
\hline № & Nome do sitio & Conselho, freguesia & № Santos Jr. \\
\hline 1 & Bagunte & Vila do Conde & 18 \\
\hline 2 & Baldoeiro, Vilariça & Moncorvo & 77 \\
\hline 3 & Cantinhos, Bouça Velha & Oliviera de Frades, Destriz & 94 \\
\hline 4 & Cividade de Cossourado & Paredes de Coura & 3 \\
\hline 5 & Crato & ? [Portalegre] & 107 \\
\hline 6 & Cova da Moura e Pegadinhas de S. Tiago & Monção & 1 \\
\hline 7 & Eira da Codeceira, Ribalonga & Carrazeda de Ansiães, Ribalonga & 87 \\
\hline 8 & Eira do Castro & Vinhais, Móas & 42 \\
\hline 9 & $\begin{array}{l}\text { Eira do Castro, Fraga do Gato, Cabeço de Cabrões, } \\
\text { Frgas do Lagarto, Fraga do Cavalo Branco }\end{array}$ & Vinhais, Vila Verde & 43 \\
\hline 10 & Eira dos Mouros & Barcelos & 11 \\
\hline 11 & Eira dos Mouros & Vilar de Luz, Maia & 21 \\
\hline 12 & Eiras da Seixa & Oliveira de Frades, Seixa & 96 \\
\hline 13 & Entre-os-Rios (castro) & ? [Entre-os-Rios] & 23 \\
\hline 14 & Esperança, Arronches & Portalegre, Arronches & 108 \\
\hline 15 & (As) Ferraduras & Trofa, Maganha Santiago & 19 \\
\hline 17 & Ferraduras, S. Miguel do Outeiro & Tondela & 98 \\
\hline 18 & Fonte do Pácio, Braçal & Bragança, Baçal & 49 \\
\hline 19 & Fornos dos Mouros, Serra do Arestal & Sever do Vouga & 91 \\
\hline 20 & Fraga da Cortinha do Poço, Trás-da-Torre & Miranda do Douro, Malhadas & 62 \\
\hline 21 & Fraga da Estrela, Sendim & Vinhais, Edral & 34 \\
\hline 22 & Fraga da Falgueira Rúbia & Casares & 39 \\
\hline 23 & Fraga da Lameira da Mular & Miranda do Douro, Malhadas & 63 \\
\hline 24 & Fraga da Moura & Carrazeda de Ansiães, Zêdes & 81 \\
\hline 25 & Fraga da Penhalta & Miranda do Douro, Malhadas & 64 \\
\hline 26 & Fraga da Ponte de Moimenta & Vinhais, Moimanta & 44 \\
\hline 27 & Fraga da Ramada, Espinhosela & Bragança & 46 \\
\hline 28 & Fraga das Cruzes & Mogadouro, Sampaio & 71 \\
\hline 29 & Fraga das Cruzes, Carviçais & Moncorvo, Cigadonha & 76 \\
\hline 30 & Fraga das Ferraduras, Pombal & Carrazeda de Ansiães, Pombal & 85 \\
\hline 31 & Fraga das Ferraduras de Belver & Carrazeda de Ansiães, Belver & 82 \\
\hline 32 & Fraga das Ferraduras, Capela N. S. de França & Vinhais, Rebodelo & 33 \\
\hline 33 & Fraga das Ferraduras, "Da Casa” & Bragança, Paradinha Nova & 57 \\
\hline 34 & Fraga das Ferraduras, Cabeço das Freiras, Sabor & Bragança, Valbom (?) & 60 \\
\hline 35 & Fraga das Ferraduras, Linhares & Carrazeda de Ansiães, Linhares & 83 \\
\hline 36 & Fraga das Ferraduras, Capela da Senhora da Graça & Carrazeda de Ansiães & 84 \\
\hline 37 & Fraga das Ferraduras, Cerdedo & Montouto, Vinhais & 37 \\
\hline 38 & Fraga das Ferraduras, Chairas & Macedo de Cavaleiros & 55 \\
\hline 39 & Fraga das Ferraduras, Fonte do Milagre & Bragança, Rebordãos, & 52 \\
\hline 40 & Fraga das Ferraduras, Fragas & Vinhais, Edral & 35 \\
\hline 41 & Fraga das Letras, Rabiscos da Vinha do Judeu, Outeiro & Bragança, Outeiro & 61 \\
\hline 42 & $\begin{array}{l}\text { Fraga das Patinhas da Burrinha da Nossa Senhora, } \\
\text { Ribeira de Carviças }\end{array}$ & Vinhais, Travanca & 40 \\
\hline 43 & Fraga de Boa-Vista, Casares & Vinhais, Montouto & 38 \\
\hline 44 & Fraga do Campanário & Mogadouro, Lamoso & 73 \\
\hline 45 & Fraga do Cavalo, Pôça do Galo, Póvoa & Miranda do Douro & 67 \\
\hline 46 & Fraga do Perde do Galego & Mogadouro, Travanca & 72 \\
\hline 47 & $\begin{array}{l}\text { Fraga do Poço do Seixo \& Fraga do Poço do Cavalo, } \\
\text { Rio de Igrejas }\end{array}$ & Bragança, Vale de Lamas & 50 \\
\hline 48 & Fraga do Sarilho, Pinheiro Novo & Vinhais & 36 \\
\hline 49 & Fraga dos Mouros, Freixel & Vila Flor & 80 \\
\hline 50 & Fraga Escrevida, Ribeira Ansiães & Bragança, Paradinha & 58 \\
\hline 51 & Fraga Medideira, Lama Onzelhas & Montesinho, França & 47 \\
\hline 52 & Gândara da Seixa & Oliviera de Frades, Seixa & 95 \\
\hline 53 & Gião & Arcos de Val de Vez & 2 \\
\hline 54 & "Insculturas" de S. Fagundo, Picote & Miranda do Douro & 69 \\
\hline
\end{tabular}

Tabela 3 - Lista por ordem alfabética dos sítios rupestre publicados por Santos Júnior (1942). 


\begin{tabular}{|c|c|c|c|}
\hline № & Nome do sitio & Conselho, freguesia & № Santos Jr. \\
\hline 55 & Insculturas de Marcão & Travanca, Vinhais & 41 \\
\hline 56 & Lage da Chã da Carvalheiras & Caminha, Lanhelas & 6 \\
\hline 57 & Lage das Fogaças, Chã da Carvalheiras & Caminha, Lanhelas & 7 \\
\hline 58 & Letras do Cabeço da Velha, Labiados & Labiados, Bragança & 51 \\
\hline 59 & Letras, Rio Alge & Aguda, Figueiró dos Vinhos & 105 \\
\hline 60 & Lombreiro de Maqueiros, Baceiros, Gondesende & Gondesende, Bragança & 45 \\
\hline 61 & Lumar & Luzim, Penafiel & 2 \\
\hline 62 & Marco de Canaveses [I] & Marco de Canaveses & 26 \\
\hline 63 & Marco de Canaveses [II] & Marco de Canaveses & 27 \\
\hline 64 & Marco de Canaveses [III] & Marco de Canaveses & 28 \\
\hline 65 & Monte do Castelo & Penafiel & 22 \\
\hline 66 & Murancho, Parambos & Carrazeda de Ansiães & 86 \\
\hline 67 & Outeiro da Moeda, Mairos & Chaves & 31 \\
\hline 68 & Outeiro do Salto, Mairos & Chaves & 32 \\
\hline 69 & Outeiro dos Mouros, Vale do Cando & ? & 97 \\
\hline 70 & Outeiro dos Risco & Vale Cambra, Cepelos & 90 \\
\hline 71 & Outeiro Machado, Aboboleira & Chaves & 30 \\
\hline 72 & Passal da Abadia de Espinho & Mangualde & 102 \\
\hline 73 & Pé da Moura, Teliques, Póvoa & Miranda do Douro & 68 \\
\hline 74 & Pedra Balouçada e Fraga das Ferraduras & Mogadouro, Algosinho & 74 \\
\hline 75 & Pedra da Escrita, Serrazes & S. Pedro do Sul, Serrazes & 99 \\
\hline 76 & Pedra Partida, Ardegãis [Ardegães] & Maia & 20 \\
\hline 77 & Pedra Ride Vides, Vilariça & Alfândega da Fé & 78 \\
\hline 78 & Pedras com Letras, Vale de Fontes & Miranda do Douro, Vale de Fontes & 66 \\
\hline 79 & Pegadas da Rodela e Curvaceira & Miranda do Douro, Ifanes & 65 \\
\hline 80 & Pègadinhas de S. Gonçalo & Penafiel, Luzim & 24 \\
\hline 81 & Pena do Gato & Mogadouro, Saldanha & 70 \\
\hline 82 & Pena Escrita or Fraga dos Fusos, (Senhora da Serra) Sortes & Bragança, Sortes & 53 \\
\hline 83 & Penas Escrevidas, Guadramil & Bragança, Guadramil & 48 \\
\hline 84 & Penedo Bouça da Velha, Outeiro da Capela de S. Martinho & Caminha, Lanhelas & 8 \\
\hline 85 & Penedo da Cobra do Prado do Junco, & Mogadouro, Estevais & 75 \\
\hline 86 & Penedo do Gato & S. Pedro do Sul, Gomei & 100 \\
\hline 87 & Penedo do Trinco ou Pedra Picadeira & Caminha, Lanhelas & 5 \\
\hline 88 & Penedo, Braçais & Mangualde & 101 \\
\hline 89 & Penedo, Pedraça & Nelas, Senhorim, & 104 \\
\hline 90 & Penhasco Insculpido, Sabor & [Bragança] Paradinha & 59 \\
\hline 91 & Poço da Moura, Vilariça & Vila Flor [Carrazeda de Ansiães], Assares & 79 \\
\hline 92 & Quinta do Cardido & Ponte de Lima & 4 \\
\hline 93 & Rasto dos Mouros & Oliveira de Frades & 92 \\
\hline 94 & S. Martinho & Castelo Branco & 106 \\
\hline 95 & Sabroso [I?] & [Guimarães] & 13 \\
\hline 96 & Sabroso [II?] & [Guimarães] & 14 \\
\hline 97 & Sabroso [III?] & [Guimarães]? & 15 \\
\hline 98 & Sabroso [IV?] & [Guimarães]? & 17 \\
\hline 99 & Sabroso, [castro] & [Guimarães]? & 1 \\
\hline 100 & Saia [Monte] & Carvalhas, Barcelos & 10 \\
\hline 101 & Sant'Ana do Campo & Arraiolos & 109 \\
\hline 102 & Santa Custódia, Barreiros & Nelas, Senhorim & 103 \\
\hline 103 & Santa Marta & Braga & 12 \\
\hline 104 & Sardoura & Castelo de Paiva & 89 \\
\hline 105 & $\begin{array}{l}\text { Serapicos, Fonte dos Engaranhos, Santuário da Nossa } \\
\text { Senhora do Aviso }\end{array}$ & Bragança, Serapicos & 56 \\
\hline 106 & Serra da Pena Mourisca, Bousende & Macedo de Cavaleiros & 54 \\
\hline 107 & Sítio das Ferraduras, Ribalonga & Carrazeda de Ansiães, Ribalonga & 88 \\
\hline 108 & Vale de Avelames & Vila Pouca de Aguiar, Vila Meã & 29 \\
\hline 109 & Viana do Castelo? & Viana do Castelo & 9 \\
\hline
\end{tabular}

Tabela 3 (Continuação). 


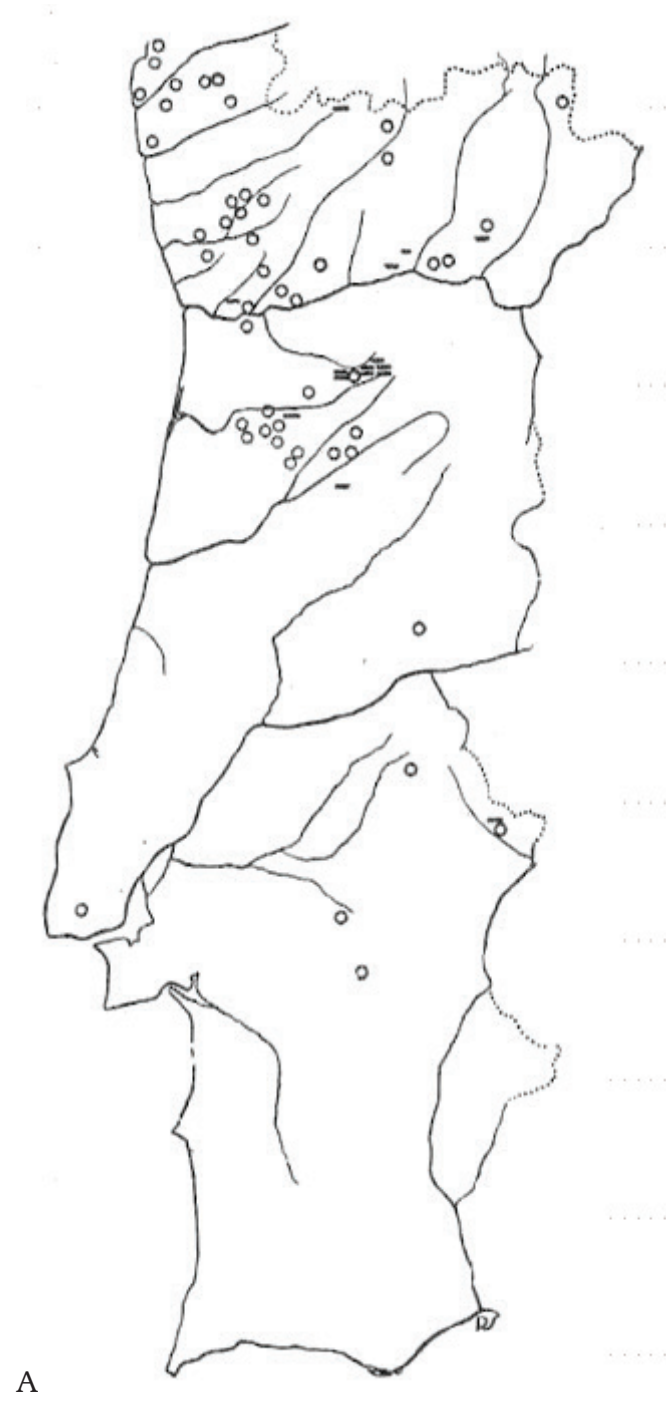

\section{Petroglifos de Sabroso e a arte rupestre em Portugal \\ por \\ R. de Serpa Pinto}

\section{PUBRICACIÓNS do \\ SEMINARIO de BSTUDOS GALBGOS}

SEIZÓN de ARQUEOLOXIA

B

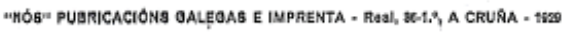

Figura 1 - A - Mapa de Portugal com a localização doas sítios descritos no texto. Os círculos são localidades com gravuras (insculturas) e os traços com pinturas; B - A capa do artigo. 

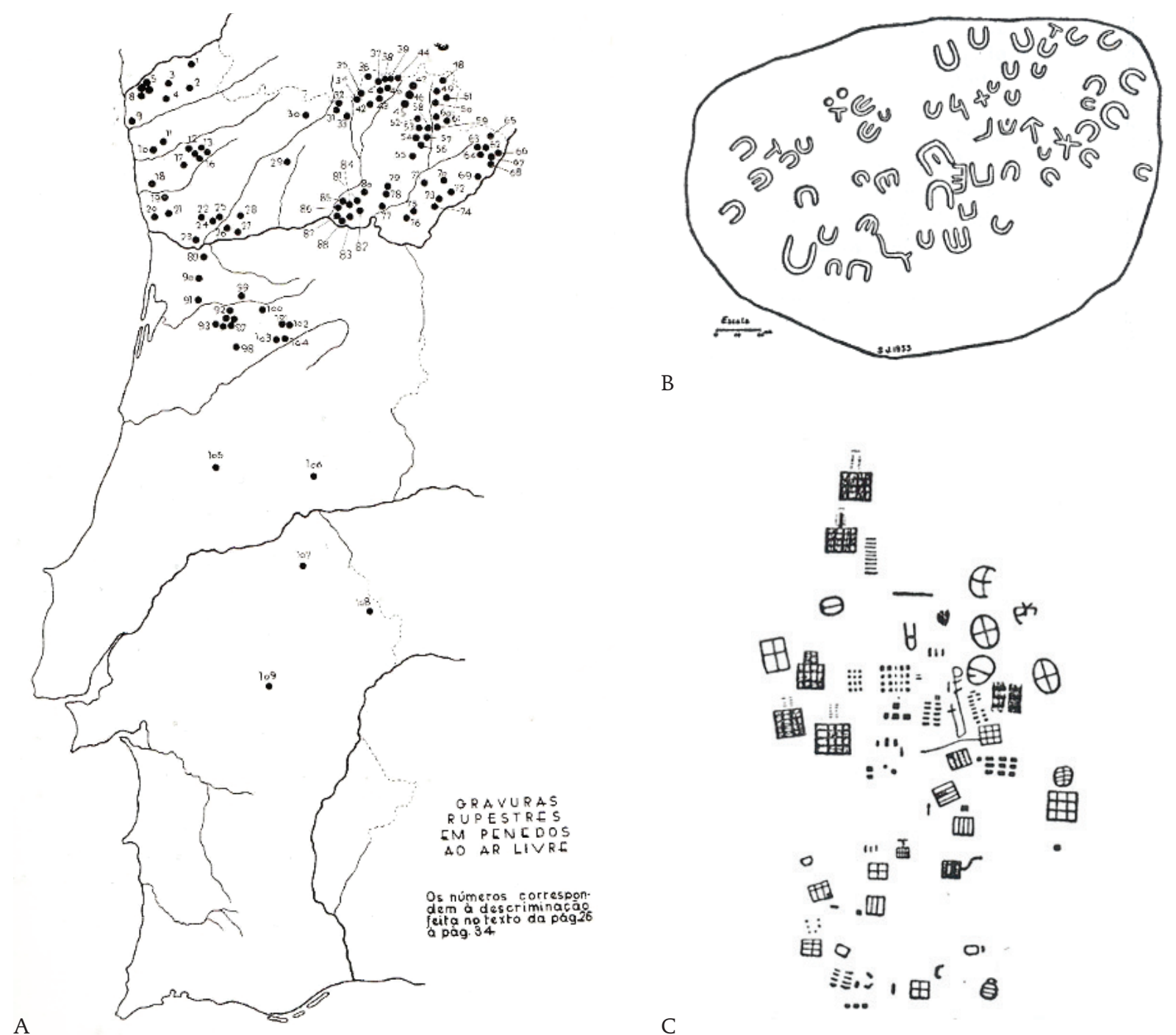

B

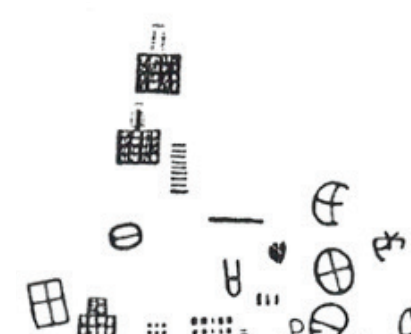

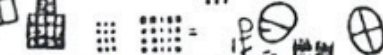

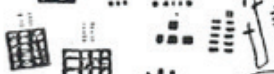

걸

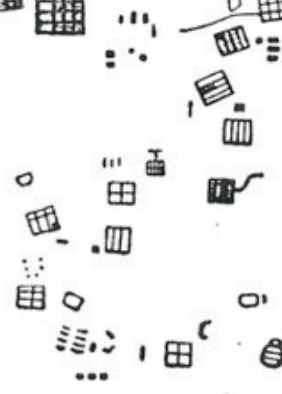

C

Figura 2 - A - "Carta da distribuição das gravuras rupestres em penedos ao ar livra” (Santos Jr. 1942: Est XVII). Dois exemplos de gravuras e Pinturas em Carrazeda de Ansiães. Bragança; B - A fraga das Ferradura de Linhares; C - Desenho das pinturas do Cachão da Rapa. 


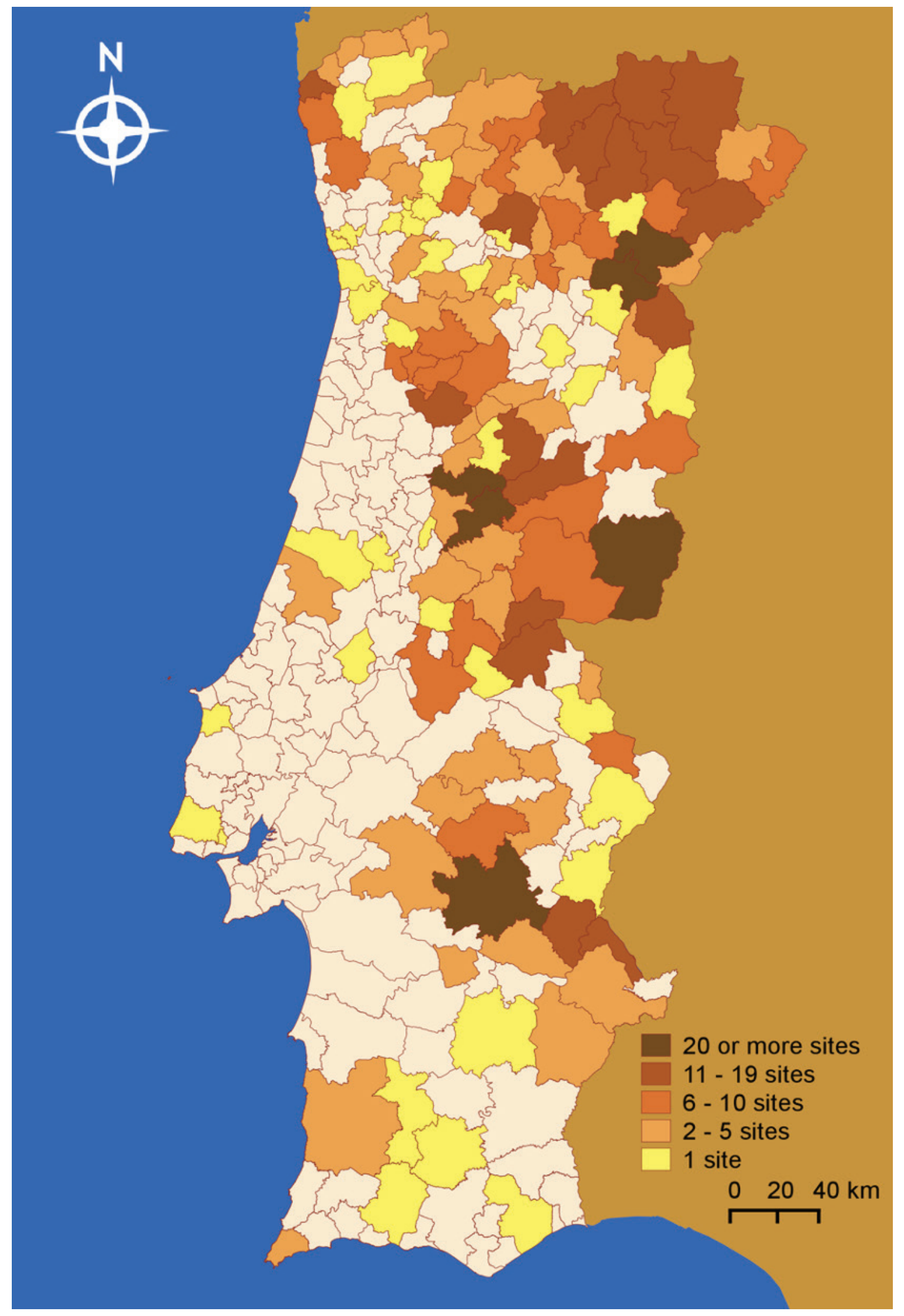

Figura 3 - O mapa da densidade da distribuição dos sítios de arte rupestre (gravuras e pinturas) em Portugal. Amarelo-1 sítio; Amarelo torrado e 2-5 sítios; Laranja de 6-1o sítios; Castanho de 11-19 sítios; Castanho escuro 20 ou mais sítios (Abreu 2012, 2, pp. 172). 


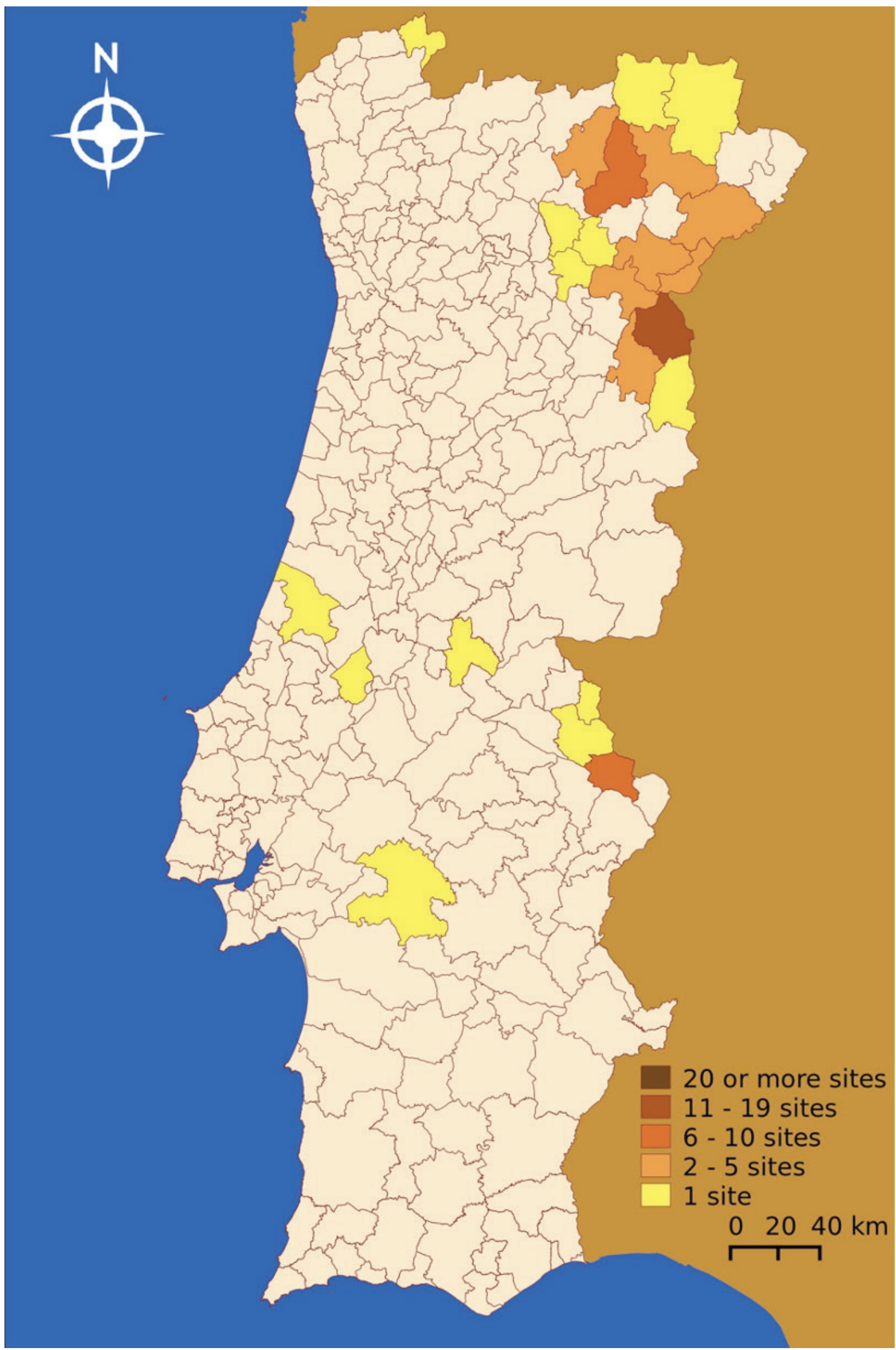

Figura 4 - O mapa da densidade da distribuição dos sítios com pinturas em Portugal. Amarelo - 1 sítio; Amarelo torrado de 2-5 sítios; Laranja de 6-10 sítios; Castanho de 11-19 sítios; Castanho escuro 20 ou mais sítios. (Abreu 2012, 2, pp. 173). 


\title{
O PROJETO FIRST-ART - CONSERVAÇÃO, DOCUMENTAÇÃO E GESTÃO DAS PRIMEI- RAS MANIFESTAÇÕES DE ARTE RUPESTRE NO SUDOESTE DA PENIINSULA IBÉRICA: AS GRUTAS DO ESCOURAL E MALTRAVIESO
}

\author{
Sara Garcês ${ }^{1}$, Hipólito Collado ${ }^{2}$, José Julio García Arranz ${ }^{3}$, Luiz Oosterbeek ${ }^{4}$, António Carlos Silva, Pierluigi \\ Rosina $^{5}$, Hugo Gomes ${ }^{6}$, Anabela Borralheiro Pereira ${ }^{7}$, George Nash $^{8}$, Esmeralda Gomes ${ }^{9}$, Nelson Almeida ${ }^{10}$, Carlos \\ Carpetudo $^{10}$
}

\begin{abstract}
RESUMO
As grutas do Escoural e Maltravieso são as únicas grutas com arte rupestre paleolítica do Sudoeste Peninsular. Estes dois contextos assemelham-se nas suas características geológicas, circunstâncias das suas descobertas, estado de conservação, localização fora do âmbito territorial preferencial da arte paleolítica e na ausência de uma tradição de investigação científica. Este conjunto de fatores rege-se pela necessidade de priorizar a conservação de ambas as cavidades no contexto do crescente interesse social pelas primeiras manifestações de arte rupestre. O projeto FIRST-ART pretende melhorar o conhecimento de ambas as grutas tendo em conta os seus aspetos técnicos, estilísticos e iconográficos através de uma investigação multidisciplinar e da aplicação de novas tecnologias de análise e de documentação recorrendo ao digital e ao tridimensional.

Palavras-chave: Escoural, Maltravieso, Documentação, Difusão, Conservação.
\end{abstract}

\section{ABSTRACT}

The caves of Escoural and Maltravieso are the only caves with Palaeolithic rock art in the Southwest Peninsula. These two contexts are similar in their geological characteristics, circumstances of their discoveries, state of conservation, location outside the preferential territorial scope of Palaeolithic art and in the absence of a tradition of scientific research. This set of factors is governed by the need to prioritize the conservation of both cavities in the context of the growing social interest in the first manifestations of rock art.

The FIRST-ART project intends to improve the knowledge of both caves taking into account their technical, stylistic and iconographic aspects through multidisciplinary research and the application of new analysis and documentation technologies using digital and ${ }_{3} \mathrm{D}$.

Keywords: Escoural, Maltravieso, Documentation, Diffusion, Conservation.

\footnotetext{
1. Instituto Politécnico de Tomar; Centro de Geociências (Universidade de Coimbra); Instituto Terra e Memória.

2. Junta de Extremadura, Espanha.

3. Universidade de Extremadura, Espanha.

4. Instituto Politécnico de Tomar; Centro de Geociências (Universidade de Coimbra); Instituto Terra e Memória.

5. Instituto Politécnico de Tomar; Centro de Geociências, Universidade de Coimbra.

6. Centro de Geociências (Universidade de Coimbra).

7. Museu de Arte Pré-Histórica e do Sagrado do Vale do Tejo, Município de Mação.

8. Instituto Politécnico de Tomar; Centro de Geociências (Universidade de Coimbra).

9. Direção Regional de Cultura do Alentejo.

10. Município de Montemor-o-Novo.
} 


\section{INTRODUÇÃO}

Os recentes dados cronológicos sobre arte rupestre paleolítica ( \pm 67 ooo anos), obtidos em motivos pictóricos da Gruta de Maltravieso (Cáceres, Espanha), fizeram recuar, de forma significativa, os dados cronológicos sobre as origens das primeiras manifestações gráficas, implicando uma discussão sobre a sua eventual relação com os Neandertais (Hoffman, et al., 2018). Perante estes resultados, e considerando a proximidade geográfica-cultural entre aquela cavidade estremenha e a Gruta do Escoural, bem como os respetivos contextos arqueológicos conhecidos, é premente, num âmbito de cooperação científica transfronteiriça, a retomada da investigação da arte rupestre da cavidade portuguesa, associada a um projeto mais amplo de salvaguarda, conservação e valorização de ambos os monumentos e dos respetivos testemunhos gráficos neles contidos.

Nesse sentido, o projeto FIRST-ART pretende enquadrar a componente de investigação na Gruta do Escoural e gruta de Maltravieso, como parte integrante de um amplo enquadramento aprovado por financiamentos europeus no âmbito do INTERREG V, Espanha-Portugal (POCTEP) denominado "Conservação, documentação e gestão das primeiras manifestações de Arte Rupestre no SW Ibérico: Grutas do Escoural e Maltravieso (FIRST-ART)". O projeto FIRST-ART é promovido pela Junta da Extremadura, estando nele envolvidos pela parte portuguesa, a Direção Regional de Cultura do Alentejo (que tutela a Gruta do Escoural), o Município de Montemor-o-Novo e o Município de Mação através do Museu de Arte Pré-histórica e do Sagrado do Vale do Tejo.

Com efeito, interrompida há algumas décadas a investigação sobre a arte rupestre da gruta do Escoural, nomeadamente na sua vertente estilística e iconográfica, interessa que esta seja retomada à luz de novas metodologias de registo, analíticas e de novos conceitos interpretativos. Em paralelo, e na sequência de recentes ensaios analíticos promovidos pela DRCA em colaboração com o Laboratório HERCULES (Silva, et al. 2017), justifica-se também continuar a desenvolver a vertente analítica sobre a arte rupestre do Escoural com recurso às mais recentes técnicas laboratoriais disponíveis.

O objetivo geral do projeto visa estabelecer um marco de cooperação entre investigadores de várias disciplinas que desenvolverão estratégias comuns que permitirão a renovação do conhecimento dos ves- tígios gráficos da gruta do Escoural, contribuindo para a melhoria das suas condições de conservação assim como para a atualização e melhoria dos programas de difusão turístico-cultural das suas manifestações rupestres. Este objetivo geral prende-se de forma direta com o objetivo de proteger, fomentar e valorizar o Património Natural e Cultural.

O projeto tem como objetivos específicos os seguintes aspetos:

1. Rever de forma sistemática e completar, com recurso às novas metodologias de deteção e registo, o "corpus" ou "catálogo" das figuras rupestres identificáveis em ambas as cavidades;

2. Sistematizar e atualizar tanto quanto possível os dados referentes à contextualização arqueológica dos vestígios rupestres de ambas as cavidades;

3. Desenvolver estudos analíticos sobre os motivos rupestres, em particular sobre as pinturas, no que se refere à composição e uso dos respetivos pigmentos, tentando paralelamente obter as primeiras datações absolutas (no caso do Escoural) e ampliar a discussão das mesmas no caso de Maltravieso;

Pretende-se, para aqueles efeitos, criar uma equipa de investigação multidisciplinar que implemente as mais recentes metodologias e técnicas na documentação, datação e interpretação da arte rupestre, tendo como base os resultados recentemente alcançados em alguns contextos espanhóis (Hoffman et al., 2018). A elaboração de um catálogo atualizado dos conteúdos gráficos da gruta do Escoural recorrerá ao emprego de metodologias novas, nomeadamente no âmbito do tratamento digital de imagens. O scanner tridimensional de alta resolução permitirá registar os suportes das manifestações parietais e a modelização integral da cavidade (galerias com arte rupestre). Por outro lado, recorrer-se-á a novas metodologias de análise de composição de pigmentos e aglutinantes, complementada se possível pela datação cronológica e a eventual determinação de presença de ADN humano na sua composição.

Os resultados obtidos, para além do seu interesse científico intrínseco, poderão ainda ser utilizados no desenvolvimento de um plano de conservação preventivo com metodologias conjuntas que abordem e garantam no futuro a conservação da gruta e da arte rupestre, novos projetos de investigação e uma gestão turística responsável, sustentável e atualizada. 


\section{OBJETIVOS DO PROJETO}

O objetivo geral do projeto visa a retoma e renovação dos estudos dos motivos rupestres tanto da gruta do Escoural como de Maltravieso através da cooperação entre investigadores de várias disciplinas que desenvolverão estratégias comuns, garantindo a melhoria das suas condições de conservação assim como a atualização e modernização dos respetivos programas de difusão turístico-cultural. Este objetivo geral prende-se de forma direta com o objetivo de proteger, fomentar e desenvolver o Património Cultural da região. No caso português, importa referir que o Escoural é o único exemplar do tipo de manifestação rupestre paleolítica em gruta de Portugal.

O projeto tem como objetivos específicos os seguintes pontos: atualizar os dados referentes à contextualização arqueológica e conteúdos artísticos das grutas, uma completa descrição das suas características técnicas estilísticas e iconográficas, o estabelecimento dos seus marcos cronológicos através de datações absolutas e a compreensão da composição dos pigmentos usados pelos autores das pinturas. Será ainda conduzida uma metodologia de caracterização de ADN humano nas pinturas. A metodologia a utilizar centrar-se-á na documentação tridimensional de todos os painéis e da totalidade das representações que surgem na gruta do Escoural. Para isso, desenvolver-se-á um protocolo exaustivo de aquisição sistemática de dados que permite obter o máximo de informação objetiva no presente, e que poderá ser avaliada por outros investigadores no futuro. A metodologia de documentação geométrica integral das manifestações de arte rupestre e a estandardização dos dados obtidos em alta resolução que propomos, permitirá conhecer de maneira objetiva e mensurável os valores volumétricos e colorimétricos tanto das superfícies como das representações rupestres estudadas. O processo de trabalho desenvolver-se-á em várias etapas:

1. A análise prévia de cada um dos painéis em que se vão recolher os dados: tendo em conta todos os levantamentos/decalques que foram realizados na gruta do Escoural desde a sua descoberta, analisar-se-ão todos os painéis previamente identificados como contendo manifestações artísticas e desenvolver-se-á um protocolo de prospeção interna à gruta para a possível identificação de mais figuras. Este protocolo será realizado recorrendo ao plugin @DStretch para uma compreensiva identificação de pinturas através do aprimoramento da visualização das mesmas. 2. A documentação digital $2 \mathrm{D} / 3 \mathrm{D}$ das representações parietais terá em conta o rápido desenvolvimento tanto da qualidade como da definição das câmaras digitais para a documentação de todo o tipo de manifestações rupestres, e recorrerá a sistemas de tratamento informático das imagens obtidas cujo uso permite obter resultados muito satisfatórios na melhoria da visibilidade das representações rupestres independentemente da figura original apresentar problemas de conservação que dificultem a sua observação. Este objetivo terá também em conta a importância dos suportes na hora da seleção dos espaços gráficos onde as pinturas ou gravuras foram realizados. É cada vez mais evidente que as irregularidades dos suportes tiveram um papel importante durante os processos de seleção dos espaços gráficos. Teremos aqui em conta também o quão fundamental é hoje em dia um levantamento tridimensional como recurso virtual ou como ação de realidade imersiva que atualmente são imprescindíveis para a elaboração de recursos didáticos em centros museográficos e espaços expositivos. O processamento da informação digitalizada será efetuada em laboratório.

3. Tendo em conta o ponto de vista científico e o máximo interesse em produzir dados fundamentais para o conhecimento da gruta e sua aplicação na sua conservação, será aplicado um rigoroso protocolo de recolha de amostras de pigmentos das pinturas rupestres para a sua caracterização mineralógica e datação absoluta. Enquanto que a caracterização mineralógica seguirá uma metodologia já anteriormente aplicada com sucesso em contextos rupestres variados (Gomes et al., 2013; Collado Giraldo, et al. 2014; Gomes, et al., 2015; Rosina et al., 2018), a metodologia da recolha de amostras de pigmentos e a sua possível datação seguirá um protocolo desenvolvido recentemente e que apresenta resultados em contextos em gruta (Hoffman et al., 2018). Com este objetivo pretendemos aprofundar o conhecimento da composição dos pigmentos e aglutinantes que foram utilizados durante o período pré-histórico na gruta do Escoural e a partir da compreensão destes dados, compreender as características e composição 
dos suportes parietais para ser possível aprofundar o conhecimento sobre as causas da sua degradação, e de como a minimizar.

4. Tendo em conta os mais recentes dados relativos à autoria Neandertal das pinturas rupestres de alguns contextos peninsulares, propõe-se este conjunto de ações multidisciplinares de modo a questionar a autoria das manifestações artísticas da gruta do Escoural. Este objetivo terá o seu reforço argumentativo nos resultados da metodologia de datação de Urânio-Tório a ser aplicada às pinturas e gravuras rupestres e da aplicação de uma metodologia experimental para a determinação (ou não) da autoria Neandertal através da análise da eventual presença de ADN dos mesmos, nas amostras de pigmento.

5. Resumindo, pretende-se levar a cabo três ações concretas: a elaboração de um catálogo atualizado dos conteúdos gráficos da gruta do Escoural mediante o emprego de metodologias novas e de tratamento digital de imagens; o scanner tridimensional de alta resolução dos suportes das manifestações parietais e modelização integral da cavidade; e a aplicação de um conjunto multi-proxy de metodologias de análise de composição de pigmentos e aglutinantes, datação cronológica absoluta e determinação de presença de ADN Neandertal na composição dos pigmentos.

Do ponto de vista da difusão do conhecimento, tem-se em conta vários fatores: as grutas de Escoural e Maltravieso estão localizadas no coração do território da EUROACE, um espaço que nasceu com o objetivo geral de incentivar a cooperação transfronteiriça $e$ inter-regional entre as três regiões, para promover o desenvolvimento integral dos seus territórios e melhorar as condições de vida dos seus cidadãos.

Neste sentido, o projeto FIRST-ART é também concebido com uma clara vocação de colaboração transfronteiriça para enfrentar os desafios decorrentes da necessidade de assegurar a conservação, renovar os conhecimentos e promover a exploração cultural e turística de dois sítios arqueológicos preferenciais, as grutas de Escoural e Maltravieso. As grutas são únicas em termos do seu conteúdo patrimonial, pois são as duas únicas grutas da zona EUROACE com representações da arte paleolítica e infelizmente em ambos os casos de momento a enfrentar diversos dilemas: questões urgentes de conservação decorrentes das condições peculiares da sua descoberta nos anos 50 e 6 o do século passado (ambas as cavernas foram localizadas como resultado da extração de pedra calcária e mármore); a falta de estratégias adequadas para proteger e manter as suas condições ambientais; a escassez e necessidade de renovação dos estudos e análises da sua arte rupestre e contextos arqueológicos aplicando metodologias atualizadas, incluindo a implementação de sistemas de registo e processamento de imagem digital e digitalização tridimensional dos seus suportes; o impacto limitado ou nulo dos seus recursos didáticos e estratégias de difusão e de atracão turística, isto apesar do facto de ambas as grutas estarem localizadas nos arredores de sítios Património Mundial (Évora e Cáceres) e da crescente atração que a sociedade demonstra ter com arte rupestre e visitas aos sítios e grutas com arte rupestre.

O projeto FIRST-ART foi criado para que da melhor forma se pudessem ultrapassar estes problemas comuns: agindo de modo conjunto e coordenado entre as equipas responsáveis pela gestão, conservação e estudo de ambas as cavidades, desenvolvendo metodologias de investigação conjunta e propondo eficazmente uma divulgação turística e cultural comum de ambos os recursos patrimoniais.

Da mesma forma, e de acordo com outro dos propósitos e funções da EUROACE, um dos objetivos do projeto FIRST-ART centra-se na conceção e desenvolvimento de uma estratégia conjunta para a divulgação do conteúdo arqueológico e cultural de ambas as grutas através de um pacote turístico de qualidade que parte da utilização de novas tecnologias e melhoramento da qualidade dos produtos oferecidos a uma sociedade que, cada vez mais, exige experiências através da sua imersão total em conteúdos digitais ou através de visita direta a espaços culturais míticos, como as grutas de Escoural ou Maltravieso (onde recentemente a mais antiga representação de arte rupestre do mundo, com mais de 67.00o anos, foi documentada (Hoffman et al., 2018)).

\section{REVISÃO DO ESTADO ATUAL DOS CONHECIMENTOS FACE AOS OBJETIVOS QUE SE PRETENDEM ALCANÇAR COM O PROJETO}

Até aos anos 6o do Século XX, não estavam registados no território português quaisquer sítios com vestígios rupestres atribuídos ao período Paleolítico. A descoberta da gruta do Escoural (1963) e o 
posterior reconhecimento de vestígios rupestres (pinturas e gravuras) no seu interior atribuídos ao Paleolítico, por Manuel Farinha dos Santos (Santos, 1964) com o apoio de André Glory, veio finalmente colmatar aquela lacuna. Esta gruta, que ainda hoje continua a ser a única cavidade com arte rupestre paleolítica identificada em território português, permaneceu durante décadas como o único testemunho deste tipo de manifestação artística até à descoberta e interpretação da arte rupestre do vale do Côa (Clottes, 1995) e outros contextos similares. Entretanto, algumas descobertas de arte móvel foram adicionando dados ao conhecimento de arte rupestre paleolítica em território português: a placa da gruta do Caldeirão (Zilhão, 1988), a placa do sítio de Vale Boi (Bicho et al., 2010) e as coleções de placas incisas do sítio do Fariseu, no Côa (Aubry \& Sampaio, 2008) e no terraço do Medal, no vale do rio Sabor (Figueiredo et al., 2014).

Apesar de comumente aceite a atribuição de uma cronologia paleolítica aos vestígios de pintura e de gravura descobertas na gruta do Escoural, na falta de datações absolutas diretas e de contextos arqueológicos seguros, a respectiva fundamentação nunca foi muito além de considerações de carácter estilístico-formais. Pese embora os projetos de salvaguarda, gestão patrimonial e valorização pública de que foi alvo, a gruta do Escoural não tem atraído nos últimos tempos o interesse da comunidade arqueológica (Silva, 2017). Com efeito, considerando o tempo decorrido após os trabalhos pioneiros de Farinha dos Santos (Santos, 1964) e de Varela Gomes (1994), ou dos projetos promovidos pelo Serviço Regional de Arqueologia do Sul (Araújo \& Lejeune 1995), é visível a necessidade de desenvolvimento de novos projetos de investigação tendo em conta a constante atualização de conteúdos comparando com outros contextos europeus.

A gruta do Escoural foi ainda alvo de ações mais diretamente relacionadas com as ocupações arqueológicas da cavidade e de ações de diagnóstico de âmbito geomorfológico, ambiental e biológico para avaliação do impacto e alterações provocadas pela visita pública nos últimos anos (Montes, 2015). No que se refere à documentação dos motivos rupestres, pouco tempo após a sua descoberta, Farinha dos Santos regista e publica 9 figuras pintadas (Santos, 1964). Glory, na sequência da sua visita de janeiro de 1965, aponta em relatório sumário, para cerca de 33 figuras (Glory et al., 1965) assinalando, pela primeira vez, algumas gravuras. No final dos anos 7o Farinha dos Santos, com a especial colaboração de Jorge Pinho Monteiro e Varela Gomes (Santos et al., 1980) retomaria o estudo sistemático da gruta, interpretando esta, na linha da visão estruturalista de Leroi-Gourhan, como um "santuário rupestre". No entanto, o grande esforço de documentação então realizado privilegiaria as gravuras em detrimento das pinturas (Silva, 2017). A primeira tentativa de se construir um corpus exaustivo da arte rupestre da gruta do Escoural resulta do projeto luso-belga promovido pelo Serviço Regional de Arqueologia do Sul, sendo publicado em meados dos anos 9o. No que respeita à cronologia, a falta de datações absolutas, fazem com que as sucessivas e diversas propostas fossem construídas utilizando apenas critérios estilístico-formais. Recentemente, uma equipa internacional procedeu à recolha de amostras de crostas de calcite das paredes da gruta para datação pelo método Urânio-Tório. Este projeto inseriu-se numa tentativa de datar várias grutas com arte rupestre paleolítica da Península Ibérica (Pike, et al., 2012). As amostras foram selecionadas tendo como objetivo a datação absoluta sobre a respectiva formação calcítica e com o fim de se obterem datações mínimas para as pinturas. No entanto, no que respeita ao Escoural, ainda não há resultados conhecidos. Foram, entretanto, realizadas caracterizações mineralógicas de pigmentos, juntamente com fotografias e macrofotografias e reflectografia de infravermelhos. A caracterização de pigmentos seguiu as seguintes metodologias: microespectroscopia de infravermelhos (micro-FTIR), microscopia electrónica de varrimento acoplada a espectrómetro de raios X (MEV-EDX), Microespectroscopia Raman e Micro-difracção de raios X (micro-DRX). Foram assim caracterizados dois tipos de pigmentos negros (de origem mineral e de origem orgânica) e um tipo de pigmento vermelho (de origem mineral) (Silva, 2017).

No que se refere à gruta do Escoural, neste momento, é urgente rever, completar e publicar um corpus das manifestações artísticas. Este deve ser realizado recorrendo às mais novas tecnologias de documentação em $2 \mathrm{D}$ e $3 \mathrm{D}$ e interpretada em contexto e em sintonia com os resultados da caracterização dos pigmentos, da análise das ocupações arqueológicas do sítio e datada à luz dos novos métodos de datação por Urânio-Tório, tendo em conta as mais recentes discussões em torno deste tema em outros contextos peninsulares (Hoffman et al., 2018). 
Será também relevante registar a importância que o levantamento tridimensional terá ao ser disponibilizado ao público em geral através de uma plataforma de depósito de conteúdos $3 \mathrm{D}$ de fácil acesso. Este, permitirá tanto a investigadores como ao público em geral aceder e interagir com o conteúdo tridimensional da gruta visualizando no seu contexto (ou suporte) original as pinturas e gravuras destacadas digitalmente. Este tipo de conteúdo foi já desenvolvido por membros da equipa noutros contextos e os resultados deverão ser publicados internacionalmente, mas também deverão ser disponibilizados ao público através de recursos didáticos e utilizados como atrativos turísticos.

\section{PROPOSTA DE ABORDAGEM TÉCNICO-CIENTÍFICA}

Consideramos que a melhor forma de pôr em prática um projeto desta natureza e com estes objetivos na gruta do Escoural, passa pela coordenação de uma equipa multidisciplinar e internacional envolvendo responsáveis pela gestão, conservação e estudo da cavidade aplicando metodologias conjuntas de investigação e construindo de maneira efetiva, uma estratégia de difusão turístico-cultural sustentável e atual. Ao nível do levantamento 3D, foi já efetuada uma campanha de levantamento digital em 2019 pela Global Digital Heritage. O foco dessa campanha foi o levantamento geral do interior e exterior, e o levantamento de peças em núcleos museológicos. Interessa agora colmatar os levantamentos de pormenor de cada pintura e gravura no contexto da gruta. Tendo este cenário em conta, propomos o seguinte plano de trabalhos:

1. Na $1^{a}$ fase será compilada a informação básica de estudos precedentes, planimetrias existentes e definição dos objetivos básicos prévios à documentação. Resultados esperados: conhecer as particularidades de cada conjunto e reduzir o tempo de trabalho dentro da gruta.

2. Documentação digital $2 \mathrm{D} / 3 \mathrm{D}$ das representações parietais, em cada conjunto, e com o fim de agilizar os trabalhos dentro da gruta, realizar-se-á um método de documentação duplo. Metodologia e técnicas: o levantamento tridimensional será realizado mediante a técnica da fotogrametria. Esta, define-se como uma técnica físico-matemática que permite gerar, com precisão, representações métricas-tridimensionais de objetos e espaços a partir de imagens emparelhadas ou múltiplas. Este procedimento está apoiado na topografia com a qual se contextualiza espacialmente objetos e terá um controlo métrico absoluto. Os avanços na fotografia digital e em aplicações informáticas permitiram o progresso da fotogrametria com a qual se obtém resultados de alta precisão na documentação e reprodução virtual com um ótimo rendimento. O levantamento ${ }_{3} \mathrm{D}$ por fotogrametria segue dois grandes blocos de trabalho: (1) o planeamento e a recolha de dados; e (2) processamento dos dados em laboratório. O plano e a recolha de dados serão realizados mediante o uso de uma estação topográfica, várias câmaras fotográficas Reflex com objetivas angulares e iluminação LED de luz fria. Elaborar-se-á um croqui espacial do entorno e registar-se-á a rede topográfica de base e pontos de apoio à fotogrametria. Segue-se o levantamento topográfico: os pontos do levantamento realizado na gruta são transferidos da estação total para o computador que, mediante o software topográfico $M d t$ passa a informação para a aplicação Cad para desenvolver a representação espacial e a elaboração da planimetria de referência. Com estes dados, constrói-se uma malha de pontos, uma superfície com a qual se pode gerar um plano curvado. Depois da georreferenciação, inicia-se o processo fotogramétrico que passa por várias fases: orientação das fotos, deteção dos pontos de controlo, construção de uma nuvem de pontos densa, criação de uma malha seguida de uma textura, completando-se assim o processo gerador do modelo tridimensional.

Para o caso de ser necessário, dependendo da análise preliminar dos painéis pintados e da sua complexidade, será utilizado um scanner $3 \mathrm{D}$ de luz branca estruturada, conhecido por scanner $3 \mathrm{D}$ de modelo MHT. Este scanner $3 \mathrm{D}$ foi testado em vários ensaios metodológicos prévios, sobre suportes rochosos de características similares aos de uma gruta e em condições de humidade equivalentes. O scanner ${ }_{3} \mathrm{D}$ de modelo MHT, é de tipo manual e incorpora uma câmara e um projetor de franjas de luz branca que permite capturar pontos correspondentes à área coberta por o padrão de luz numa só captura e com uma precisão nominal no campo de trabalho específico de $500 \mu \mathrm{m}$. Estes tipos de sistemas móveis realizam, habitualmente, a alineação das diferentes capturas 
mediante o uso de marcadores. Dada a impossibilidade de colocação de marcadores sobre os painéis em estudo, recorrer-se-á a uma unidade ótica que projeta pontos de referência, uma técnica não-invasiva no objeto de estudo. Os pontos fixos projetados com o segundo sistema ótico servirão de referências de alineação para as capturas do primeiro, de modo a que seja possível a digitalização de uma área sem necessidade de marcadores físicos colocados sobre as superfícies com representação rupestres e, portanto, totalmente inócua para a sua conservação. O scanner ${ }_{3} \mathrm{D}$ MHT permite ainda a obtenção de imagens desde diversos pontos de vista combinada com a realização de ajuste "bundle" a partir da deteção fiducial natural. Trata-se de uma técnica não-invasiva dado que o registo tridimensional se baseia na deteção automática de pontos correspondentes em imagens a partir das características físicas das paredes scanneadas. Esta técnica permite a obtenção de uma malha tridimensional da zona em estudo. Os dados do scanner realizados são transferidos em tempo real a um computador portátil onde ficará depositado o arquivo digital. Uma das vantagens do uso deste tipo de scanner é a relação direta entre o fotograma (frame) que captura e a geração direta da malha. A velocidade de captura deste sistema é de aproximadamente de 15 fotogramas por segundo (fps), suficiente para a assegurar a sobreposição das áreas de marco adjacentes. Desta maneira, as áreas sobrepostas utilizam-se para a alineação automática das malhas capturadas em cada um dos diferentes fotogramas, permitindo, através do seu processamento, obter um modelo $3 \mathrm{D}$ texturizado apto para ser publicado online. Previamente ao registo interno dos dados adquiridos em cada painel na gruta, é imprescindível pré-processar o material scanneado. Esta fase é rápida, e realizada ainda na gruta, de modo a assegurar que os dados tomados estão corretos e que existe cobertura suficiente para a zona scanneada. Uma vez realizado o levantamento de dados mediante o scanner ou através da técnica de fotogrametria, dependendo das necessidades que surjam, proceder-se-á a uma análise de imagem em $2 \mathrm{D}$, prévia à reconstrução, para detetar o contorno das zonas de interesse baseado em mudanças de cor e em deteção dos bordos. Esta aproximação permite a comparação tridimensional direta de cada um dos pontos mediante ajuste por quadrados mínimos sem influência do resto dos elementos da imagem. Ao mesmo tempo, séries fotográficas serão realiza- das em alta resolução dos painéis e das representações de arte rupestre.

Estudos recentes de arte rupestre manifestam a importância dos suportes na seleção dos espaços gráficos onde as pinturas e gravuras rupestres foram realizadas. É evidente que a irregularidades das superfícies tiveram um papel importante durante os processos de realização das manifestações parietais. Torna-se assim, fundamental a incorporação dos critérios que permitem analisar o suporte das representações. Resultados esperados: gerar modelos tridimensionais das superfícies das grutas configura-se como elemento indispensável para o desenvolvimento de levantamentos virtuais ou ações de realidade imersiva que atualmente são imprescindíveis tanto para a vários campos de ação da investigação arqueológica como para a elaboração de recursos didáticos em contextos museográficos e espaços expositivos. Tendo em conta o exposto, há que assinalar a fiabilidade destes registos com margens de erro mínimos, convertendo-se em ferramentas de grande utilidade para a monitorização da evolução do grau de conservação e deteorização física dos suportes físicos da gruta.

3. Aplicação dos mais recentes métodos tecnológicos de análises arqueométricas. São cada vez maiores as preocupações com a conservação e questões de ética no que se refere a análises químicas a pigmentos, no entanto, estas aplicam-se seguindo algumas regras simples, como uma intervenção mínima, o uso de materiais e métodos apropriados para reduzir possíveis problemas no futuro, e seguindo uma documentação completa dos procedimentos. Estes procedimentos seguem as normas éticas (AIC, 2015) e as amostras são localizadas na pintura e selecionadas de modo a que o impacto na mesma seja mínimo ou inexistente. Para proteger a integridade das pinturas, a amostra é retirada de fraturas ou de camadas de pintura mais grossas e o pigmento recolhido é na ordem dos microgramas. Metodologia e técnicas: as técnicas arqueométricas a implementar serão as seguintes: Microscopia ótica, que permite a observação microscópica e microfotográfica de amostras de pinturas possibilitando a delineação de cortes estratigráficos e a caracterização de espessura, sequência de camadas, cor, texturas e distribuição de camadas de material; Espectroscopia Raman, que proporciona rapidamente e em alta resolução informa- 
ção química e estrutural de qualquer material, composto orgânico ou inorgânico, permitindo assim a sua rápida identificação, processos de produção, reações químicas posteriores e processos de degradação; Espectroscopia de Fluorescência por raios-X (EDXRF), uma técnica de análise da composição química de materiais não-destrutiva e multielementar; Microscopia Eletrónica de Varrimento (SEM) que permite a observação morfológica de materiais orgânicos e inorgânicos; a Cromatografia Gasosa que permite a identificação de possíveis elementos aglutinantes; e a Espectroscopia no Infravermelho por Transformada de Fourier (FTIR), que permite a análise de uma composição elementar e um aumento da sensibilidade da análise e possível registo da presença de possíveis elementos orgânicos. Resultados esperados: os resultados podem estender-se para além da identificação e caracterização de pigmentos. É possível tentar encontrar relações entre os compostos utilizados de pigmentos específicos ao longo de um período, região ou cultura. Informação sobre a cronologia, a produção de "receitas" ou sobre os métodos aplicados podem ajudar a decidir sobre as ações de conservação futuras.

4. Dataçõesabsolutas. Pretende-seaplicaro processo de datação por séries de Urânio 230Th/234U. Propõe-se a aplicação desta técnica de datação às pinturas da gruta do Escoural tendo em conta os mais recentes resultados obtidos na Gruta de Matravieso, La Pasiega e Ardales (Hoffman, 2018). Metodologia e técnicas: esta é uma metodologia que tem obtido excelentes resultados na datação de arte rupestre. A datação por séries de Urânio $230 \mathrm{Th} / 234 \mathrm{U}$ é baseada no declínio do urânio, nas crostas de calcite e espeleotemas. À medida que as crostas calcíticas se formam nas paredes das grutas, o urânio fixa-se e, neste estágio, praticamente não há tório. Uma vez que a crosta de calcite é selada, o urânio decompõe-se em nuclídeos-filhos, incluindo o tório. Como este é um processo gradual, as proporções de urânio e tório dentro da crosta de calcite podem ser comparadas para determinar quando a crosta de calcite se formou. A técnica U-Th é aplicada a amostras das camadas de calcite que cobrem e/ou sustentam as pinturas: é importante entender que as próprias pinturas não são datadas usando este método. A série resultante de datas surge com a mais recente camada que cobre as pinturas, e a mais antiga subjacente a elas. Como tal, as datas resultantes das pinturas são relativas e não diretas; estas fornecem um intervalo máximo e mínimo. Todas as amostras serão removidas com recurso a bisturis e o material recolhido será diretamente armazenado em tubos de plástico esterilizados. Resultados esperados: Deveremos introduzir a gruta do Escoural nas mais recentes discussões científicas sobre as datações antigas e a sua possível autoria pertencer à espécie Homo neanderthalensis (tendo em conta os recentes resultados para a gruta de Maltravieso e a sua similitude com a gruta do Escoural).

5. Análises de ADN nos pigmentos pré-históricos. Metodologia e técnicas: Análise molecular de amostras de pigmentos para determinar a presença de possíveis restos de ADN humano que permita identificar a autoria das representações. Resultados esperados: tendo em conta o pressuposto dos pigmentos pré-históricos terem sido manipulados com as mãos, boca e o uso da saliva, será tentada a determinação da autoria Neandertal ou Sapiens à arte rupestre através de análises de ADN dos pigmentos pré-históricos.

Nota conclusiva: devido aos efeitos da atual pandemia de Covid-19 não foi possível proceder aos trabalhos na gruta em tempo útil para a apresentação no presente trabalho, no entanto, na apresentação oral já será possível incorporar os respetivos trabalhos de campo.

\section{BIBLIOGRAFIA}

AIC (2015) - American Institute for Conservation - Code of Ethics and Guidelines for Practice. AIC - www.conservationus.org

ARAÚJO, Ana Cristina; LEJEUNE, Marylise (1995) - Gruta do Escoural: Necrópole Neolítica e Arte Rupestre Paleolítica. Lisboa, Trabalhos de Arqueologia, no 8, IPPAA.

AUBRY, Thierry y SAMPAIO, Jorge (2008) - Fariseu: cronologia e interpretação funcional do sítio. En A. Santos e J. Sampaio (eds.): Pré-história, gestos intemporais. Actas del III Congresso de Arqueologia de Trás-os-Montes, Alto Douro e Beira In-terior, I. Associação Cultural Deportiva e Recreativa de Freixo de Numão. Oporto, pp. 7-3o.

BICHO, Nuno; GIBAJA, Juan Francisco; STINER, Mary; MANNE, Tiina (2010) - Le paléolithique supérieur au sud 
du Portugal: le site de Val Boi. En L’Anthropologie, 114. Elsevier. Paris: 48-67.

CLOTTES, Jean (1995) - Palaeolithic Petroglyphs at Foz Côa, Portugal. INORA - International Newsletter on Rock Art, p. 10:2.

COLLADO GIRALDO, Hipólito; ROSINA, Pierluigi; GARCÍA ARRANZ, José Julio; GOMES, Hugo; NOBRE, Luís; DOMÍNGUEZ-GARCÍA, Isabel; DUQUE ESPINO, David; FERNÁNDEZ VALDES, José María; BLASCO LAFFÓN, Emilia; TORRADO CÁRDENO, José María; RODRÍGUEZ DORADO, Lázaro; RIVERA RUBIO, Esther; NACARINO DE LOS SANTOS, Magdalena; CAPILLA NICOLÁS, José Enrique; PÉREZ ROMERO, Samuel (2014) - El arte rupestre esquemático del Arroyo Barbaón (Parque Nacional de Monfragüe, Cáceres): contextualización arqueológica y caracterización de pigmentos. Zephyrus, LXXIV, pp. 9-14.

FIGUEIREDO, Sofia; NOBRE, Luís; GASPAR, Rita; CARRONDO, Joana; CRISTO ROPERO, Araceli; FERREIRA, João; SILVA, Maria João; MOLINA, Francisco José (2014) Foz do Medal Terrace - an open-air settlement with Paleolithic Portable art. INORA - International Newsletter on Rock Art, 68, pp. 12-20.

GOMES, Mário Varela (1994) - Escoural et Mazouco: deux sanctuaires paléolithiques du Portugal. Les Dossiers d'Archéologie, 198 (01/11/1994), pp.4-9.

GOMES, Hugo; ROSINA, Pierluigi; HOLAKOOEI, Parviz; SOLOMON, Tadele y VACCARO, Carmela (2013) - Identification of pigments used in rock art paintings in Gode Roriso-Ethiopia using Micro-Raman spectroscopy. Journal of Archaeological Science. https://doi.org/10.1016/j.jas.2013. 04.017.

GOMES, Hugo; COLLADO, Hipólito; MARTINS, Andrea; NASH, George; ROSINA, Pierluigi; VACCARO, Carmela y VOLPE, Lisa (2015) - Pigment in western Iberian schematic rock art: An analytical approach. Mediterranean Archaeology and Archaeometry, 15 (1), pp. 163-175. https://doi.org/ 10.5281/zenodo.15050.

GLORY, André; VAULTIER, Maxime; SANTOS, Manuel Farinha dos (1965) - La grotte ornée d'Escoural (Portugal), Bulletin de la Société Préhistorique Française, 62: 1, Paris, pp. 285-295.

HOFFMAN, Dirk; STANDISH, Chris; GARCÍA-DÍEZ, Marcos; PETTITT, Paul; MILTON, James Andy; ZILHÃO, João; ALCOLEA-GONZÁlEZ, José J.; CANTALEJO-DUARTE, Pedro; COLLADO, Hipólito; BALBÍN, Rodrigo; LORBLANCHET, Michel; RAMOS-MUÑOZ, José; WENIGER, Gerd-Christian; PIKE, Alistair (2018)-U-Th dating of carbonate crusts reveals Neandertal original of Iberian cave art. Science, Vol. 359, Issue 6378, pp. 912-915.

MONTES, Ramón (2015) - Estudio ambiental y medidas de conservación preventiva de las manifestaciones rupestres de la gruta de Escoural (Alentejo, Portugal). Actuaciones 2010-2012, Almansor, $3^{\underline{a}}$ série, nํㅜ 1, pp. 9-50.
ROSINA, Pierluigi; GOMES, Hugo; COLLADO, Hipólito; NICOLI, Maria; VOLPE, Lisa, y VACCARO, Carmela (2018) - Micro-Raman spectroscopy for the characterization of rock-art pigments from Abrigo del Águila (Badajoz - Spain). Optics and Laser Technology, 102, pp. 274-281. https://doi. org/10.1016/j.optlastec.2018.01.015.

PIKE, Alistair; HOFFMANN, Dirk; GARCÍA-DÍEZ, M.; PETTITT, Paul; ALCOLEA, José; BALBÍN, Rodrigo; GONZÁLEZ-SÁINZ, César; DE LAS HERAS, Carmen; LASHERAS, José Antonio; MONTES, Ramón; ZILHÃO, João (2012) - U-Series Dating of Paleolithic Art in 11 Caves in Spain. Science 336 (6087), pp. 1409-1413.

SANTOS, Manuel Farinha dos (1964) - Vestígios de pinturas rupestres descobertas na Gruta do Escoural. O Arqueólogo Português. Lisboa ( $2^{\underline{a}}$ série) pp. 5-47.

SANTOS, Manuel Farinha dos; GOMES, Mário Varela; MONTEIRO, Jorge Pinho (1980) - Descobertas de arte rupestre na Gruta do Escoural (Évora, Portugal). Altamira Symposium, Madrid: Ministério de Cultura, pp. 205-243.

SILVA, António Carlos; MAURAN, Guilhem; ROSADO, Tânia; MIRÃO, José; CANDEIAS, António; CARPETUDO, Carlos; CALDEIRA, Ana Teresa (2017) - A Arte Rupestre da Gruta do Escoural - novos dados analíticos sobre a pintura paleolítica. IN: Arnaud, J.M. \& Martins, A. (Coords.) Arqueologia em Portugal. 2017 - Estado da Questão. II Congresso da Associação dos Arqueólogos Portugueses. Lisboa, pp. 1003-1019.

ZILHÃO, João (1988) - Plaquette gravée du Solutréen supérieur de la Gruta do Caldeirão (Tomar, Portugal). Bulletin de la Sociéte Préhistorique Française, 85 (4). París, pp.105-109. 


\title{
TRABALHOS DE DOCUMENTAÇÃO DE ARTE PALEOLITICA REALIZADOS NO ÂMBITO DO PROJETO PALAEOCÔA
}

\author{
André Tomás Santos ${ }^{1}$, António Fernando Barbosa ${ }^{2}$, Luís Luís ${ }^{3}$, Marcelo Silvestre ${ }^{4}$, Thierry Aubry 5
}

\begin{abstract}
RESUMO
Apresenta-se uma síntese dos resultados dos estudos de arte paleolítica levados a cabo no âmbito do projeto PalæoCôa (PTDC/EPH-ARQ/o326/2014). Adoptou-se uma abordagem arqueológica que pressupunha o estudo integrado da arte no seu contexto geológico e arqueológico, o que permitiu uma melhor caraterização do ciclo gráfico paleolítico do Vale do Côa, sobretudo no que se refere às suas fases magdalenenses e aos momentos imediatamente anteriores e posteriores.
\end{abstract}

Palavras-chave: Arte rupestre, Arte móvel, Paleolítico Superior, Vale do Côa.

\begin{abstract}
We provide a synthesis of the results delivered by the rock art studies carried out in the context of the project PalæoCôa (PTDC/EPH-ARQ/O326/2014). We have adopted an archaeological approach that had at its core the need of an integrated study of prehistoric art within its archaeological and geological context. This approach has able us to better define the Palaeolithic graphic cycle of the Côa Valley, especially of its Magdalenian phases and the moments immediately previous and after.
\end{abstract}

Keywords: Rock art, Portable art, Upper Palaeolithic, Côa Valley.

\section{INTRODUÇÃO}

Uma das particularidades que fazem da arte paleolítica do Vale do Côa um elemento fundamental para a compreensão da arte paleolítica europeia prende-se com o número de rochas gravadas ao ar livre que aí se conhecem, número esse que ascende atualmente a 533 (Reis, 2014, p. 33). Este número vem reforçar a ideia da arte ao ar livre ter sido muito mais comum do que se pensava e de, muito provavelmente, ter sido até mais usual que a das grutas (e.g. Zilhão, 1997, p. 29). Este é, seguramente um dos aspetos da arte paleolítica do Vale do Côa que levaram a considerar a sua descoberta como uma "revolução coperniciana” (Zilhão, 1997, p. 29).
Mas a arte paleolítica do Vale do Côa apresenta uma outra particularidade que a distingue dos restantes conjuntos ao ar livre do sudoeste europeu, a saber - a profunda relação com um contexto arqueológico coevo (e.g. Aubry, ed., 2009). Esta integração do conjunto rupestre num contexto arqueológico mais amplo onde se contam diversos tipos de sítios (Figura 1) é, a este nível, mais comparável à das regiões com arte paleolítica em ambiente cársico, como sejam a região cantábrica ou o Sudoeste francês. Por outro lado, pelo menos numa estação do Vale do Côa - o sítio de Fariseu - o dispositivo gráfico encontra-se em relação com uma sequência de unidades sedimentares que embalam vestígios de diferentes momentos da ocupação paleolítica do sítio, algo

\footnotetext{
1. Fundação Côa Parque; UNIARQ, Faculdade de Letras da Universidade de Lisboa; andresantos@arte-coa.pt

2. Fundação Côa Parque; fernandobarbosa@arte-coa.pt

3. Fundação Côa Parque; UNIARQ, Faculdade de Letras da Universidade de Lisboa; luisluis@arte-coa.pt

4. Fundação Côa Parque; marcelosilvestre@arte-coa.pt

5. Fundação Côa Parque; UNIARQ, Faculdade de Letras da Universidade de Lisboa; thierryaubry@arte-coa.pt
} 
que permitiu a inferência de diferentes cronologias para os diversos tipos de grafismos aí encontrados e relacionar cada um daqueles com diversos momentos da ocupação do sítio (e.g. Aubry, Santos \& Luís, 2014; Santos et al., 2018; Aubry et al., 2020 A). Ora, esta relação direta entre um dispositivo gráfico e um contexto de ocupação é bastante raro, mesmo em ambiente cársico (e.g. Medina-Alcaide et al., 2018). O conhecimento das ocupações do Paleolítico Superior da região, que hoje se sabe estender entre o Aurignacense final e o Azilense recente (Aubry, 2009, pp. 348-350; Aubry \& al., 2017; 2018; 2020 A), só foi conseguido graças a um contínuo trabalho de escavações e prospecções (e.g. Zilhão, dir., 1997; Aubry, 2009) que, com altos e baixos, se foi desenvolvendo desde que o país optou pela salvaguarda deste património em detrimento da construção de uma barragem.

Paralelamente, também o estudo da arte se foi desenvolvendo se bem que de forma mais intermitente. Assim, depois de um primeiro fôlego que resultou na publicação de um importante conjunto de levantamentos de rochas gravadas e respetivas descrições (Baptista \& Gomes, 1997), atravessou-se um largo período durante o qual, embora se fossem publicando em trabalhos de cariz mais interpretativo ou mesmo de divulgação, os decalques de diversas rochas que se iam fazendo no contexto do Centro Nacional de Arte Rupestre (e.g. Baptista, 1999; 2009; Baptista, Santos \& Correia, 2006; 2008a; 2008b; Santos, 2012; 2015), não se publicou nenhum dispositivo rupestre de forma aturada, mesmo se os números de rochas identificadas não parassem de crescer graças essencialmente ao trabalho de $\mathrm{M}$. Reis (e.g. Reis, 2014, pp. 29-31). Esta lacuna apenas foi obviada em 2017, em trabalho académico no qual se procedeu à inventariação e descrição exaustiva de todas as rochas com grafismos paleolíticos levantadas até àquela data (Santos, 2019, pp. 441-737). Este trabalho permitiu o tratamento estatístico desta informação, tendo dele resultado uma proposta de faseamento para a arte paleolítica da bacia do Douro, conformada por quatro fases (Santos, 2019, pp. 76-195). A atribuição cronocultural de cada uma destas fases alicerçou-se nas inferências resultantes dos trabalhos de escavação nos sítios intervencionados da região (e.g. Aubry, 2009), naquilo que se foi começando a perceber das dinâmicas de acreção e erosão do vale (e.g. Aubry et al., 2010) e na comparação estilística com grafismos de outras regiões.
A atribuição cronocultural da fase 1 a um momento compreendido entre a vigência do Gravettense e a do Solutrense médio encontra-se confirmada pela relação entre a estratigrafia sedimentar e a estratigrafia figurativa da rocha 1 do Fariseu (Aubry, Santos \& Luís, 2014), assim como a atribuição da fase 4 ao Azilense recente se fundamenta no facto da quase totalidade da arte móvel do Fariseu provir da sua camada 4 (Santos et al., 2018). Mas a atribuição cronocultural das fases 2 e 3 assenta apenas na comparação estilística e no facto da análise da estratigrafia figurativa das rochas onde se encontram motivos de várias fases confirmar que estas não só se seguem como também foram feitas entre a vigência das fases 1 e 4 .

Ora, cedo nos apercebemos que não só estas questões, como outras de carácter mais interpretativo (e.g. Aubry, Luís \& Santos, 2020), só poderiam ser aprofundadas se o conjunto rupestre da região passasse a ser estudado de forma integrada com os restantes vestígios coevos da região e não da forma autónoma como tinha vindo a ser feito até aqui. Os estudos sobre os grafismos paleolíticos da região levados a cabo no âmbito do projeto PalæoCôa foram norteados por esta perspetiva e os resultados foram, quanto a nós, francamente animadores, como em seguida se procurará demonstrar.

\section{ESTRATÉGIAS E METODOLOGIA}

A escolha dos sítios com arte paleolítica que acabaram por ser intervencionados durante a execução do projeto PalæoCôa foi condicionada por diversos factores: o mais significativo foi a necessidade de afinação cronológica das fases intermédias. Com este intuito procedeu-se ao levantamento integral das rochas da Quinta da Barca e Vale de José Esteves com grafismos integrados numa daquelas fases.

Também uma das razões pelas quais se voltou a escavar na Cardina teve que ver com o facto dos trabalhos anteriores aí realizados terem detetado ocupações datadas daquelas fases, testemunhadas quer por materiais arqueológicos (Aubry, Carvalho \& Zilhão, 1997, p. 168), quer por uma data TL (Valladas et al., 2001), o que nos levou a pensar que poderíamos encontrar no sítio níveis conservados desse período (Aubry et al., 2015, p. 11). Tal não se veio a verificar, mas apareceram 35 peças gravadas na sua U.E. 4 , que se formou entre o final do Gravettense e o Pré-Boreal (Aubry et al., 2015, p. 16; 2018, pp. 69-70). Para além 
da descoberta de arte móvel no sítio, os trabalhos revelaram que as camadas abaixo da U.E 4 eram todas de origem aluvial, o que atestava que o sítio era regularmente inundado até há cerca de 28.000 anos. Uma vez que o sítio se encontra atualmente $20 \mathrm{~m}$ acima do leito atual do rio, a interrupção da acreção aluvial do sítio evidencia uma alteração importante do sistema fluvial entre o final do Gravettense e o Solutrense médio (cronocultura identificada já em ambiente coluvial), cujas consequências sobre a dinâmica hidrológica do rio para jusante deste ponto poderiam eventualmente ligar-se com um evento erosivo que se atesta em diversas sítios dos vales do Côa e Douro e que uma análise da distribuição topográfica dos painéis atribuídos às fases 1 e 2 em alguns sítios do vale indiciava ter ocorrido entre a vigência de ambas (Santos, 2019, pp. 151-155).

Por forma a testar as inferências proporcionadas pela escavação da Cardina, voltou-se a escavar na Penascosa, por um lado a cota mais alta na vertente relativamente às duas sondagens de 1995 (onde, teoricamente, se poderia identificar ocupações antigas) e, por outro, na zona mais baixa do sítio de forma a verificar a existência de uma rocha que relatos orais diziam ter sido observada aquando da movimentação de terras no sítio em 1996 e observar o estilo das gravuras aí presentes. Nem a ocupação gravettense nem a putativa rocha se identificou, mas a escavação num outro sector junto à base da vertente veio, de facto, revelar a existência de novas rochas apenas com gravuras das fases mais recentes (Aubry et al., no prelo). Foi ainda com o intuito de identificar níveis magdalenenses conservados que se voltou a escavar no sítio do Fariseu, uma vez que se percebeu que os eventos erosivos que ocorrem no vale são atenuados neste sítio devido à relação entre a orientação das diáclases e a direção do curso do rio, que aqui se dispõem perpendicularmente entre si, contrariamente ao que ocorre nos restantes sectores do vale. Já se identificou ocupações pleistocénicas, ainda não datadas, assim como uma rocha gravada que se destaca pela presença de um grande auroque (Aubry et al., 2020 B) e uma peça de arte móvel.

Já o estudo da rocha 7 da Faia foi motivado por outras razões, desde logo pelo sua singularidade, correspondendo ao único caso do Vale realizado sob abrigo, em zona de penumbra (Santos, Luís \& Aubry, 2019). Por outro lado, o seu estudo correspondeu também à conclusão da documentação da arte paleolítica no sítio da Faia.
O decalque direto executado em ambiente noturno ou escurecido, e apoiado por luzes artificiais, foi o método de documentação privilegiado no estudo das superfícies historiadas, parietais e móveis. Trata-se de uma das formas de levantamento possíveis, sendo atualmente interdito o seu uso nas paredes das grutas, devido a questões de conservação. Não se colocando estes problemas no caso das superfícies rochosas do Côa e correspondendo a maior parte dos painéis do Côa a superfícies direitas, o que não levanta problemas significativos de distorção do registo, optou-se por este método, que julgamos ser ainda o mais preciso sobretudo no que toca aos grafismos incisos. Como outros autores (e.g. Lorblanchet, 1995; Fritz \& Tosello, 2007; Petrognani \& Robert, 2020) advogamos que o levantamento é a pedra-angular de qualquer estudo de arte rupestre, nele se devendo registar todos os elementos de origem antrópica, assim como os que, sendo de natureza geológica, contribuem para a construção das composições estudadas (Figura 2). Complementarmente, a fotografia foi utilizada quer como registo dos trabalhos, quer como registo de composições, figuras e detalhes das mesmas.

\section{OS SÍTIOS INTERVENCIONADOS}

\subsection{Faia}

O sítio da Faia localiza-se em ambiente granítico, a cerca de $7 \mathrm{~km}$ para montante da primeira grande concentração de gravuras paleolíticas, conformada pelos sítios da Foz da Ribeirinha/ Quinta da Barca/ Penascosa. As primeiras figurações paleolíticas do sítio, da rocha 6, são descobertas por Manuel Almeida e João Félix, sendo referidas por Nélson Rebanda em 1995. Em 1999 A. Martinho Baptista dá a conhecer o decalque dessa rocha, efetuado por um de nós (AFB). A rocha 7 é identificada posteriormente, também por J. Félix e M. Almeida, e referida pela primeira vez em 2003 (García et al., 2003, p. 181). Estes autores identificam o animal aí presente como uma cerva, mas tal interpretação não era consensual (Reis, 2012, p. 48).

Os trabalhos de decalque (Santos, Luís \& Aubry, 2019) vieram confirmar que estamos efetivamente em presença de uma cerva disposta na vertical, à qual se associa um traço anguloso que pode corresponder a uma primeira versão do garrote do animal ou a uma unidade não figurativa angular (Figura 3). $\mathrm{O}$ animal destaca-se pela animação, patente na extensão do 
seu membro anterior e pela utilização do volume do espaço parietal, particularmente evidente na zona da cabeça. A sua integração em análises estatísticas que combinam a análise de correspondências múltiplas com a classificação hierárquica ascendente, a par da comparação estilística vieram apontar para a sua atribuição a um momento final da fase 1 da atividade gráfica da bacia do Douro (Solutrense inferior ou médio) assim como profundas analogias gráficas com figuras da região cantábrica. A atribuição cronocultural desta figura é assim semelhante à que já se havia apontado para a rocha 6 do sítio (Santos, 2019, pp. 204-205).

\subsection{Cardina}

A Cardina foi identificada em 1995 pela equipa que estava a estudar o contexto arqueológico das gravuras paleolíticas que haviam sido recentemente divulgadas (Zilhão et al., 1995), tenso sido alvo de escavações antes dos trabalhos no âmbito do projeto Palæocôa (Zilhão et al., 1995; Zilhão, 1997; Aubry, 2009; Aubry et al., 2015).

Os grandes contributos dos trabalhos mais recentes para a compreensão da arte do Côa são indiretos, como os que têm que ver com a datação do evento erosivo que terá ocorrido entre a vigência das fases 1 e 2. Por outro lado, os vestígios arqueológicos encontrados no sítio reforçam a ideia de que a arte do Vale se relaciona com o facto da região ter sido, durante a fase mais antiga, palco de eventos de agregação de comunidades que exploravam outros territórios (e.g. Aubry, Luís \& Santos, 2020), da mesma forma que evidenciam de forma clara analogias ao longo de diversas fases do Paleolítico Superior entre a visibilidade e distribuição da arte e os diferentes tipos de estruturas que se identificaram na Cardina (Luís, Aubry \& Santos, 2015).

De forma mais direta, os trabalhos na Cardina contribuíram para o aumento da arte móvel da região, aí se tendo exumado 35 peças (oito seixos e vinte e sete plaquetas). A série carateriza-se pelo elevado estado de fragmentação e por uma apreciável heterogeneidade formal, o que é compatível com a natureza do seu contexto sedimentar, que se formou entre o Gravettense final e o Pré-Boreal. Apenas se identificaram seis figurações animais seguras e duas prováveis, distribuídas por seis peças. Algumas figuras apresentam caraterísticas muito semelhantes às que se exumaram no Fariseu (Figura 4a), atribuída, no essencial, ao Azilense recente (Santos, et al.,
2018), mas outras apresentam caraterísticas mais naturalistas (Fig. 4b). Pelo menos numa das peças (Fig. 4c), a cérvico-dorsal de um cavalo deste último tipo coexiste com um provável zoomorfo muito esquemático. O facto deste último se encontrar enquadrado pelo bordo superior da peça e do primeiro ser interrompido pela fratura da base, a par da notória diferença técnica entre a cérvico-dorsal e os restantes grafismos da peça, que de resto a sobrepõem parcialmente, induz-nos a pensar que podemos estar perante um exemplo de "reenquadramento" da composição após fracturação da peça, tal como documentado no Fariseu (Santos et al., 2018, p. 48) ou no Périgord (Tosello, 2003, p. 15).

\subsection{Penascosa}

A Penascosa é um dos sítios conhecidos desde a publicação dos primeiros trabalhos na região, (Rebanda, 1995). A maior parte dos trabalhos publicados sobre o sítio debruça-se sobre a sua arte rupestre (e.g. Baptista \& Gomes, 1997; Baptista, Santos \& Correia, 2006; Santos, 2019), mas antes da nossa intervenção já se tinham aí realizado sondagens arqueológicas e geofísicas que haviam demonstrado que os cerca de $4 \mathrm{~m}$ de sedimentos que preenchem esta área do vale são de cronologia holocénica (e.g. Zilhão, 1997; Almeida, 1997).

Como se referiu acima, os nossos trabalhos no sítio revelaram duas novas rochas que se encontravam cobertas por sedimentos recentes. Na rocha $37 \mathrm{ob}-$ serva-se um dispositivo muito simples. Um macho de cabra-montês orientado para a direita encontra-se no centro da composição. O animal foi conseguido por um tipo de picotado cuja morfologia dos impactos e o espaçamento entre eles são mais caraterísticos da fase 2 (e.g. Santos, 2019, 146). Também outras caraterísticas da figura - como a sua cabeça modelada, delimitação interna da barriga, bordos do corpo pouco pronunciados ou o casco globular na pata traseira contribuem para esta atribuição. Um conjunto de incisões que se descobre no painel, entre as quais se distingue dois quartos traseiros de figuras interrompidas pela zona mais erodida do painel, poderá ser também atribuído a esta fase. Para a direita da cabra-montês observa-se um cervídeo executado por um picotado cujos impactos circulares apresentam uma dimensão mais reduzida que na outra figura, sendo mais espaçados entre eles. Estilisticamente destaca-se pelo corpo retangular, pela cabeça subtriangular preenchida interiormente e 
pelas hastes dispostas em perspetiva biangular oblíqua. Deverá ser já atribuído à fase azilense, tal como duas figuras estriadas - entre as quais uma cerva localizadas abaixo da cabra-montês. Junto à base da rocha identificou-se uma camada conservada entre blocos que embalava vestígios líticos, provavelmente pleistocénicos (Aubry et al., no prelo). Note-se que a rocha se situa entre as rochas 4 e 5 , cujo dispositivo já tinha sido atribuído a um momento entre o final da fase 1 e os inícios da fase 2, devido à inclusão de muitas das suas figuras nas classes 2 das nossas análises estatísticas (Santos, 2019, p. 154).

A rocha 38 localiza-se mais abaixo, entre a 37 e a 5 , nela se distinguindo, diversos painéis, embora em apenas dois se tenham identificado grafismos figurativos. Num deles apenas se observa duas cervas, uma incisa e outra picotada e abradida, com a cabeça parcialmente definida por ressalto da rocha e com dois membros anteriores. A principal composição é, no entanto, dominada por uma série de auroques fêmeas (Figura 5), mas onde se descobrem também cavalos, pelo menos um veado e dois bovinos machos, correspondendo um deles seguramente a um auroque. O outro, para além das notórias diferenças com o auroque seguro, apresenta uma cérvico-dorsal muito próxima dos bisontes da região franco-cantábrica. A maior parte do dispositivo foi gravado por incisão, por vezes tão profunda que já se poderá considerar estarmos perante casos de abrasão. A picotagem está atestada somente na zona superior do painel, aí se observando possíveis restos de figuras que existiram mais para cima. O que destacamos no dispositivo desta rocha é a sua clara integração na fase Magdalenense da arte do Côa, como se atesta pelos membros modelados dos auroques, a presença de detalhes nas cabeças dos animais, como marrafas (no caso dos auroques), a delimitações do focinho, olhos, narinas, bocas ou mesmo a barbada no caso de um dos cavalos.

Os trabalhos na Penascosa vieram assim reforçar a ideia de uma fase erosiva entre as fases 1 e 2, como se atesta pela ausência de gravuras mais antigas abaixo de uma determinada cota. Esta fase erosiva deverá corresponder à que levou o solo coevo da gravação da rocha 1 do Fariseu (Aubry, Luís \& Santos, 2014) e relacionar-se-á com a alteração da dinâmica fluvial do rio responsável pela interrupção da sedimentação aluvial na Cardina a partir do Gravettense médio (Aubry et al., no prelo).

\subsection{Quinta da Barca}

O sítio da Quinta da Barca foi descoberto por J. Félix e M. Almeida em 1995 (Rebanda, 1995), tendo a sua arte rupestre, sobretudo a da fase mais antiga, sido dada paulatinamente a conhecer ao longo dos anos (e.g. Baptista, Santos \& Correia, 2006; 2008; Santos, 2019). A sua arte magdalenense é, no entanto, pouco conhecida (Santos, 2019, pp. 231-233), lacuna essa cuja campanha que aqui se dá conta pretendia colmatar. Os trabalhos consistiram no decalque das rochas 30 , 31 e 34, tendo-se também contado com a colaboração de Lucia Díaz, do Museu de Altamira. Estas rochas já tinham sido brevemente aludidas anteriormente (idem, pp. 232-233). Como expectável, o seu estudo veio precisar o número de animais aqui existentes. Assim, se na rocha 30 se confirmou a existência de três veados incisos, não se detetando mais nenhuma unidade figurativa, na rocha 31 a interpretação do auroque como macho parece-nos agora mais discutível. Já a rocha 34 revelou-se bastante mais complexa que o previamente observado (Fig. 2).

De facto, ao cavalo e dois quadrúpedes orientados para a direita anteriormente identificados, juntam-se agora um outro cavalo e uma cerva, ambos orientados para a esquerda e ligeiramente inclinados para cima. Os dois quadrúpedes correspondem a auroques fêmeas com os cornos alongados, dispostos em perfil biangular. As semelhanças do pequeno cavalo agora identificado com os da base da estratigrafia figurativa da rocha 23 (Santos, 2019, 478-487), atribuídos à fase 2 (Solutrense final- Magdalenense antigo), são forte argumento para a sua contemporaneidade. Também as restantes figuras, em particular o cavalo anteriormente identificado, cuja caraterização foi agora precisada, aponta nesse sentido. Os seus paralelos mais próximos no Vale do Côa são Pio5-O1 (Santos, 2019, p. 543), Clo3-o6, Clo3-10 ou Clo3-11 (idem, p. 647), embora a cabeça do cavalo da rocha da Quinta da Barca seja bastante mais proporcionada e oferecendo detalhes, como o olho, ausente daquelas figuras (Fig. 2).

Muito interessante foi a identificação no topo da rocha 34 (e, portanto, em frente da 31) de um possível anel escavado no xisto. É provável que se trate de uma perfuração histórica, relacionada, por exemplo, com a travessia do rio, mas é preciso não perder de vista que este tipo de vestígio é relativamente habitual em diversos sítios paleolíticos, essencialmente sob abrigos calcários, com cronologias compreendidas entre o Aurignacense e o Magdalenense (Guigue, 2016). 


\subsection{Fariseu}

O sítio do Fariseu foi descoberto por M. Almeida e J. Félix em 1994, tendo sido pela primeira vez referido três anos mais tarde (Baptista \& Gomes, 1997, pp. 214-215). Em 1999 uma escavação dirigida por um de nós (TA) vai colocar o sítio definitivamente no mapa da Arqueologia europeia, ao demonstrar que a fase antiga da arte do Côa era necessariamente anterior a um evento erosivo ocorrido antes de 22.0oo calBP (Aubry, Santos \& Luís, 2014) e que a arte pleistocénica mais recente se deveria datar em torno de 12.0oo calBP (Santos et al., 2018).

A hipótese de no Fariseu se poderem ter preservado camadas pleistocénicas levadas pelo rio nos restantes sítios do vale, devido ao facto das diáclases aí presentes apresentarem uma orientação perpendicular ao curso do Côa, levou-nos a retomar aí as escavações. Estas realizaram-se mais a montante, num sector onde a vegetação denunciava uma forte potência sedimentar e onde 4 rochas gravadas haviam sido identificadas, duas delas - rochas 5 e 10 - com grafismos atribuídos ao Magdalenense e uma - a rocha 9 - visivelmente sedimentada, onde apenas se observava um traço picotado (Santos, 2019, pp. 26o-261). Os nossos trabalhos concentraram-se em frente desta última, os quais revelaram que o traço que se via à superfície era a garupa de um auroque macho cujas dimensões fazem dele a maior figura gravada da arte paleolítica europeia (Aubry et al., 2020 B). Este animal sobrepõe uma cabra-montês que, por sua vez sobrepõe fêmea de auroque que se associa a um possível vitelo, também sobreposto pelo grande auroque (Figura 6). Esta composição é ainda composta por prótomo de cerva localizado abaixo da cernelha do auroque. Note-se que na base da sequência encontra-se uma associação fêmea de auroque/vitelo cujo paralelo mais claro, também ao nível morfológico, corresponde à associação Pi24-139 e Pi24-142 (Santos, 2019, p. 593), que ocorre em painel coberto por um nível atribuído com reservas ao Magdalenense antigo (Luís, 2009) ${ }^{6}$.

6. Um vitelo (CI11-03) aparece também representado num dispositivo atribuído à fase antiga, na rocha 11 da Canada do Inferno, verosimilmente associado a uma das fêmeas situadas à sua frente, (Santos, 2019, p. 658), mas o paralelo com Piscos é também morfológico, apresentando ambas as fêmeas a mesma forma dos cornos e a cauda enrolada sobre a coxa. Uma outra associação fêmea/cria, desta feita com cavalos, surge no dispositivo da rocha 5 de Piscos, também atribuído à fase 2. Também neste caso, a fêmea parece ter a sua cauda recolhida sobre a coxa (Santos, 2019, p. 542).
Na mesma rocha, mais para a direita, identificou-se uma segunda composição que se distingue pela organização do painel, que se carateriza pela intensidade das sobreposições, e por uma morfologia dos animais mais próxima da que se encontra na rocha 1 do sítio. Até ao momento identificaram-se nesta composição auroques fêmeas, cavalos e, pelo menos, um veado (Aubry et al., 2020 B).

Mas a escavação não só revelou a existência de um complexo dispositivo rupestre, como demonstrou a sua associação a camadas arqueológicas. As semelhanças entre as camadas mais antigas (UE's $3 \mathrm{a} / \mathrm{b}$, 3 b e 4) e as que se encontravam em frente da rocha 1 apontam para a sua cronologia pleistocénica. A composição da direita encontrava-se parcialmente coberta pela camada mais antiga do sítio que, por outro lado, embalava também fragmentos gravados que remontavam no painel. Como no caso da rocha 1 , o solo pisado pelos gravadores desta composição desapareceu e aquando da deposição da camada 4, a rocha estava já a fraturar-se. Já a composição da esquerda estava apenas coberta pela camada za, encontrando-se a pata dianteira do grande auroque a poucos centímetros do topo da 3 b (já pleistocénica, mas ainda não datada).

Note-se que não apareceu qualquer vestígio que se possa atribuir ao Azilense, pelo que as camadas, a serem pleistocénicas, serão anteriores àquela cronocultura. Note-se também que a estratigrafia não descarta a possibilidade da composição da direita ser efetivamente mais antiga que a da esquerda. Destaque-se, por fim, o aparecimento de mais uma peça de arte móvel que, embora proveniente de um contexto estratigráfico pouco seguro (base da UE2), apresenta uma figura de quadrúpede que, sendo difícil de classificar devido ao seu esquematismo, não apresenta as caraterísticas mais típicas da arte azilense (Figura 7). De qualquer forma, os trabalhos vieram comprovar o maior potencial de conservação de camadas pleistocénicas no sítio do Fariseu, assim como levantar a suspeita que o sítio será também crucial para precisar a relação entre as figurações das fase 1 e 2 da atividade gráfica paleolítica da bacia do Douro.

\subsection{Vale de José Esteves}

Este sítio é também conhecido desde as primeiras publicações (e.g. Rebanda, 1995) sobre a arte paleolítica da região, tendo igualmente sido identificado por M. Almeida e J. Félix. Duas das três rochas estudadas - rochas 4 e 12 - foram descobertas por estes 
colegas, tendo a remanescente - rocha 36 - sido já identificada por M. Reis. Dois painéis da rocha 4 tinham sido já publicados e descritos (Santos, 2019, pp. 707-710). Importava terminar os trabalhos de registo desta rocha, assim como do restante dispositivo com grafismos atribuídos ao Magdalenense (idem, pp. 299-302).

Estes trabalhos (Santos et al., 2020) vieram precisar algumas observações relativas à caraterização e relação entre as fases 3 e 4 . Assim, os nossos trabalhos vieram reforçar os paralelos entre a arte da fase $3 \mathrm{e}$ os grafismos magdalenenses da região cantábrica, tendo-se vindo juntar aos paralelos já evidenciados entre os animais naturalistas da rocha $4 \mathrm{e}$ os daquela região, os que se observam entre o macho de cabra-montês da rocha 36 (Figura 8) e os da fase 5 de Llonín, atribuída ao Magdalenense médio e superior (Rios \& Castro, 2007, pp. 90-94 e bibliografia anterior aí citada).

Os trabalhos permitiram também a identificação de algumas figuras no espaço parietal B da rocha 36 (Fig. 8), cujos paralelos remetem mais para a fase 2, o que abona em favor de uma primeira fase de gravação do sítio anterior à das figuras da fase 3 , como já havia sido insinuado pela presença na rocha 4 de uma cabra-montês integrada pelas análises fatoriais na classe 1 deste tema (Santos, 2019, p. 120), classe que comporta algumas figuras que poderão ser já atribuídas à fase 2 (idem, p. 155).

Finalmente, refira-se também o importante contributo destes trabalhos para o conhecimento dos signos magdalenenses do Côa, destacando-se no sítio a presença de triângulos e ramiformes, cujos paralelos, tal como as figuras de animais, se distribuem mais pela área norte da distribuição sudeuropeia da arte paleolítica que pelo sua área sul, em contextos essencialmente magdalenenses (Santos et al., 202O).

\section{BALANÇO}

Graças aos trabalhos desenvolvidos no âmbito do projeto, foi possível confirmar a ausência de figurações da fase 1 na zona mais baixa da Penascosa, o que reforça a hipótese de um evento erosivo ter ocorrido entre a vigência das fases 1 e 2 no vale do Côa. Este evento relacionar-se-á com as alterações da dinâmica fluvial atestadas na Cardina e que terão ocorrido entre o Gravettense final e o Solutrense médio.

Algumas figuras integradas pelas análises factoriais nas respetivas classes 1 e que já haviam sido inter- pretadas como pertencentes à sua fase final ou até já à fase 2, deverão necessariamente ser posteriores ao Gravettense final, designadamente as que se encontram nas rochas 4 e 5 da Penascosa. Os paralelismos destes auroques com os da rocha 6 da Faia são notórios, designadamente ao nível das marrafas e da forma das orelhas. Tal é compatível com a adscrição não só do dispositivo desta rocha, como também do da rocha 37, estudada no âmbito deste trabalho, a momentos finais da fase 1 .

As diferenças entre as figuras do painel da direita e o da esquerda da rocha 9 do Fariseu também permitem levantar a hipótese deste último - cujos auroques apresentam a mesma perspetiva dos cornos presentes no painel direito da Faia e em outros sítios adscritos já à fase 2 ou a momentos terminais da fase 1 (Santos, 2019, p. 205) e cujos paralelos mais evidentes para a associação fêmea/ vitelo se encontram também entre composições desta fase - ser ligeiramente mais recente. Tal só será passível de ser esclarecido com a continuação das escavações no sítio, com a obtenção de datas absolutas para as camadas que cobrem o painel direito e com o estabelecimento das relações topográficas precisas entre estas camadas e a base do painel esquerdo.

Mais seguramente da fase 2 serão os dispositivos estudados da Quinta da Barca e os grafismos mais antigos das rochas 37 da Penascosa e das 4 e 36 do Vale de José Esteves. Como a cerva da rocha 7 da Faia, estes grafismos paralelizam-se sobretudo com as manifestações gráficas da área de distribuição setentrional da arte paleolítica, algo que se vai intensificar durante a fase 3 (Magdalenense médio/final), como já se havia sugerido, e cujos estudos levados a cabo no Vale de José Esteves, quer a nível dos grafismos figurativos como não figurativos vem confirmar. Esta inferência encontra um equivalente na tipotecnologia da utensilagem lítica da região que denuncia igualmente estreitos contactos com a área franco-cantábrica desde pelo menos o Gravettense antigo (e.g. Aubry et al., 2018, p. 70) até ao final do Paleolítico (e.g. Aubry et al., 2017, p. 410).

\section{BIBLIOGRAFIA}

ALMEIDA, Francisco (1997) - Prospecção geofísica dos depósitos quaternários. In Zilhão, João, dir. - Arte rupestre e Pré-história do Vale do Côa. Lisboa: Ministério da Cultura, pp. 55-73.

AUBRY, Thierry (2009) - Abordagem tipológica dos conjuntos líticos: contribuição para a definição da sequência 
crono-estratigráfica de ocupação humana do Vale do Côa In AUBRY, Thierry, ed. - 200 séculos de história do Vale do Côa: Incursões na vida quotidiana dos caçadores-artistas do Paleolítico. Lisboa: IGESPAR, I. P. (Trabalhos de Arqueologia, 52), pp. 348-356.

AUBRY, Thierry, ed. (2009) - 20o séculos de história do Vale do Côa: Incursões na vida quotidiana dos caçadores-artistas do Paleolítico. Lisboa: IGESPAR, I. P. (Trabalhos de Arqueologia, 52).

AUBRY, Thierry, ed. (2009) - 200 séculos de história do Vale do Côa: Incursões na vida quotidiana dos caçadores-artistas do Paleolítico. Lisboa: IGESPAR, I. P. (Trabalhos de Arqueologia, 52).

AUBRY, Thierry; BARBOSA, António F.; GAMEIRO, Cristina; LUÍS, Luís; MATIAS, Henrique; SANTOS, André T.; SILVESTRE, Marcelo (2015) - De regresso à Cardina, 13 anos depois: resultados preliminares dos trabalhos arqueológicos de 2014 no Vale do Côa. Revista Portuguesa de Arqueologia. Lisboa. 18, pp. 5-26.

AUBRY, Thierry; BARBOSA, António F.; LUÍS, Luís; SANTOS, André T.; SILVESTRE, Marcelo (2020) - Fariseu, 20 anos depois. Novidades da arte paleolítica do Côa. Al-madan on-line. 23: tomo 2, pp. 15-27.

AUBRY, Thierry; BARBOSA, António F.; LUÍS, L.; SANTOS, André T.; SILVESTRE, Marcelo (2018) - Os Neandertais e os primeiros Homens Anatomicamente Modernos no Vale do Côa: Novidades da Cardina. Côavisão. Vila Nova de Foz Côa. 20, pp. 57-71.

AUBRY, Thierry; CARVALHO, António M. F. de; ZILHÃO, João (1997) - Arqueologia. In ZILHÃO, João, dir. - Arte rupestre e Pré-história do Vale do Côa. Lisboa: Ministério da Cultura, pp. 76-209.

AUBRY, Thierry; DIMUCCIO, Luca Antonio; BERGADÀ, Maria M.; SAMPAIO, Jorge D.; SELLAMI, Farid (2010) - Palaeolithic engravings and sedimentary environments in the Côa River Valley (Portugal): implications for the detection, interpretation and dating of open-air rock art. Journal of Archaeological Science. Amsterdam. 37, pp. 3306-3319.

AUBRY, Thierry; DIMUCCIO, Luca Antonio; BARBOSA, António F.; LUÍS, Luís; SANTOS, André T.; SILVESTRE, Marcelo; THOMSEN, Kristina Jørkov; RADES, Eike; AUTZEN, Martin; MURRAY, Andrew S. (2O2O A) - Timing of the Middle-to-Upper Palaeolithic transition in the Iberian inland (Cardina-Salto do Boi, Côa Valley, Portugal). Quaternary Research. Washington. 43. DOI:10.1017/qua.2020.43

AUBRY, Thierry; GAMEIRO, Cristina; SANTOS, André T.; LUÍS, Luís (2017) - Existe Azilense em Portugal? Novos dados sobre o Tardiglaciar e o Pré-Boreal no Vale do Côa. In ARNAUD, José M. \& MARTINS, Andrea, eds. - Arqueologia em Portugal 2017: Estado da Questão. Lisboa: Associação dos Arqueólogos Portugueses, pp. 403-418.
AUBRY, Thierry; LUÍS, Luís; SANTOS, André T. (2020) Territórios e mobilidade dos caçadores-recolectores do Vale do Côa a diferentes escalas. In VILAÇA, Raquel; AGUIAR, Rodrigo S. de, eds. - (I)mobilidades na Pré-história. Pessoas, recursos, objetos, sítios e territórios. Coimbra: Imprensa da Universidade de Coimbra, pp. 51-89.

AUBRY, Thierry; SANTOS, André T.; LUÍS, Luís (2014) Stratigraphies du panneau i de Fariseu: analyse structurelle d'un système graphique paléolithique à l'air libre de la vallée du Côa (Portugal). In PAILLET, Patrick, ed. - Les arts de la Préhistoire: micro-analyses, mises en contextes et conservation. Actes du colloque "Micro-analyses et datations de l'art préhistorique dans son contexte archéologique», MADAPCA - Paris, 16-18 novembre 2011. Les Eyzies: SAMRA (Paleo, numéro spécial), pp. 259-27o.

AUBRY, Thierry; SANTOS, André T.; LUÍS, Luís; BARBOSA, António F.; SILVESTRE, Marcelo (no prelo A) - Fluvial dynamics and Palaeolithic settlement: new data from the Côa Valley (Portugal). Comptes Rendus Palevol. Grenoble.

BAPTISTA, António M. (1999) - No tempo sem tempo. A arte dos caçadores paleolíticos do Vale do Côa. Com uma perspectiva dos ciclos rupestres pós-glaciares. Vila Nova de Foz Côa: Parque Arqueológico do Vale do Côa.

BAPTISTA, António M.; GOMES, Mário V. (1997) - Arte rupestre. In ZILHÃO, João, dir. - Arte rupestre e Pré-história do Vale do Côa. Lisboa: Ministério da Cultura, pp. 211-406.

BAPTISTA, António M.; SANTOS, André T.; CORREIA, Dalila (2008a) - O santuário arcaico do Vale do Côa: novas pistas para a compreensão da estruturação do bestiário gravettense e/ou gravetto-solutrense. In BALBÍN BEHRMANN, Rodrigo, ed. - Arte prehistórico al aire libre en el Sur de Europa. Junta de Castilla y León/ Consejería de Cultura y Turismo (Documentos PAHIS, 9), pp. 89-144.

BAPTISTA, António M.; SANTOS, André T.; CORREIA, Dalila (2008b) - Estruturação simbólica da arte Gravetto-Solutrense em torno do monte do Fariseu (Vale do Côa). In SANTOS, André T.; SAMPAIO, Jorge D., eds. - Pré-história - gestos intemporais. Vila Nova de Foz Côa: ACDR Freixo de Numão (Actas das Sessões do III Congresso de Arqueologia de Trás-os-Montes, Alto Douro e Beira Interior, pp. 38-61.

BAPTISTA, António M.; SANTOS, André T.; CORREIA, Dalila (2006) - Da ambiguidade das margens na grande arte de ar livre no Vale do Côa. Reflexões em torno da organização espacial do santuário gravetto-solutrense na estação da Penascosa / Quinta da Barca. Côavisão. Vila Nova de Foz Côa. 8, pp. 156-184.

FRITZ, Carole; TOSELLO, Gilles (2007)-The hidden meaning of forms: methods of recording paleolithic parietal art. Journal of Archaeological Method and Theory. Berlin. 14: 1, pp. 48-79. 
GARCÍA DÍEZ, Marcos; MARTINS, Andrea; MAURÍCIO, João; RODRIGUES, Ana; SOUTO, Pedro (2003) - Prospecção arqueológica no Alto Côa. Novas descobertas de arte rupestre. Al-madan. Almada. IIํㅡㄴ série, 12, pp. 180-181.

GUIGUE, Aurore (2016) - Les anneaux pariétaux du Paléolithique supérieur européen. Perforations anthropiques sur support rocheux (bloc, paroi, plafond) des abris ornés du Grand Sud-Ouest français. Toulouse: Université de Toulouse Le Mirail (Mémoire de Master I).

LORBLANCHET, Michel (1995) - Les grottes ornées de la Préhistoire. Nouveaux regards. Paris: Éditions Errance.

LUÍS, Luís (2009) - Rocha 24 da Ribeira de Piscos: contexto estratigráfico de uma rocha gravada. In AUBRY, Thierry, ed. - 200 séculos de história do Vale do Côa: Incursões na vida quotidiana dos caçadores-artistas do Paleolítico. Lisboa: IGESPAR, I. P. (Trabalhos de Arqueologia, 52), pp. 84-93.

LUÍS, Luís; AUBRY, Thierry; SANTOS, André T. (2015) Directing the eye. The Côa valley Pleistocene rock art in its social context. In COLLADO GIRALDO, Hipólito; GARCÍA ARRANZ, José Julio, eds. -Symbols in the landscape: rock art and its context. Proceedings of the XIX International Rock Art Conference IFRAO 2015 (Cáceres, Spain, 31 August - 4 September 2015). Tomar: Instituto Terra e Memória (Arkeos, 37), pp. 1341-1348.

MEDINA ALCAIDE, Maria Á.; GÁRATE MAIDAGÁN, Diego; RUIZ REDONDO, Aitor; SANCHIDRIÁN, José L. (2018) - Beyond art: The internal ar4chaeological context in Paleolithic decorated caves. Journal of Anthropological Archaeology. Chicago. 49, pp. 114-128.

PETROGNANI, Stéphane; ROBERT, Éric (2020) - Dating without dates: Stylistic and thematic chronologies in the Paleolithic painted caves of Les Bernoux and Saint-Front (Dordogne, France). Journal of Archaeological Science: Reports. Amsterdam. 31, 10226o.

REBANDA, Nelson (1995) - Os trabalhos arqueológicos e o complexo de arte rupestre do Côa. Lisboa: IPPAR.

REIS, Mário (2012) - “Mil rochas e tal...!”: Inventário dos sítios da arte rupestre do Vale do Côa. Portvgalia. Porto. Nova Série, 33, pp. 5-72.

REIS, Mário (2014) - “Mil rochas e tal...!": Inventário dos sítios da arte rupestre do Vale do Côa (conclusão). Portvgalia. Porto. 35, pp. 17-59.

SANTOS, André T. (2012) - Reflexões sobre a arte paleolítica do Côa: a propósito de uma persistente dicotomia conceptual. In SANCHES, Maria de J., ed. - I $I^{\underline{a}}$ Mesa Redonda "Artes Rupestres da Pré-história e da Proto-história: paradigmas e metodologias de registo. Lisboa: DGPC (Trabalhos de Arqueologia, 54), pp. 39-67.
SANTOS, André T. (2015) - Em torno da arte paleolítica do Vale do Côa. In SANZ MÍNGUEZ, Carlos, ed.-El Bestiario vacceo. Vaccearte. $8^{\underline{a}}$ exposición de arte contemporáneo de inspiración vaccea. Valladolid: Ayuntamiento de Valladolid, pp. 18-26.

SANTOS, André T. (2019) - A arte paleolítica ao ar livre da bacia do Douro à margem direita do Tejo: uma visão de conjunto. Lisboa: Associação dos Arqueólogos Portugueses (Monografias AAP, 9).

SANTOS, André T.; BARBOSA, António F.; AUBRY, Thierry; GARCÍA DÍEZ, Marcos; SAMPAIO, Jorge D. (2018) - O final do ciclo gráfico paleolítico do Vale do Côa: a arte móvel do Fariseu (Muxagata, Vila Nova de Foz Côa). Portvgalia. Porto. 39, pp. 5-96.

SANTOS, André T.; BARBOSA, António F.; LUÍS, Luís; SILVESTRE, Marcelo; AUBRY, Thierry (2020) - Contributos para o conhecimento da arte rupestre do Vale do Côa. Novos dados sobre o Vale de José Esteves (Vila Nova de Foz Côa, Guarda). Côavisão. 22 , pp. 159-19o.

SANTOS, André T.; LUÍS, Luís; AUBRY, Thierry (2019) Arte da sombra: A rocha 7 da Faia (Figueira de Castelo Rodrigo, Guarda, Portugal). Um exemplo de arte paleolítica sob abrigo no Vale do Côa. Conimbriga. 58, pp. 5-45.

TOSELLO, Gilles (2003) - Pierres gravées du Périgord Magdalénien: art, symboles, territoires. Paris: CNRS (Supplément à Gallia Préhistoire, 36).

VALLADAS, Hélène; MERCIER, Norbert; FROGET, Laurence; JORON, Jean-Louis; REYSS, Jean-Louis; AUBRY, Thierry (2001) - TL dating of upper Palaeolithic sites in the Coa Valley (Portugal). Quaternary Science Reviews. Amsterdam. 20: 5-9, pp. 939-943.

ZILHÃO, João (1997) - Súmula dos resultados científicos. In ZILHÃO, João, dir. - Arte rupestre e Pré-história do Vale do Côa. Lisboa: Ministério da Cultura, pp. 12-37.

ZILHÃO, João, dir. (1997) - Arte rupestre e Pré-história do Vale do Côa. Trabalhos de 1995-1996. Lisboa: Ministério da Cultura.

ZILHÃO, João; AUBRY, Thierry; CARVALHO, António M. F. de; ZAMBUJO, Gertrudes; ALMEIDA, Francisco (1995) - O sítio arqueológico paleolítico do Salto do Boi (Cardina, Santa Comba, Vila Nova de Foz Côa). Trabalhos de Antropologia e Etnologia. Porto. 35: 4, pp. 471-485. 


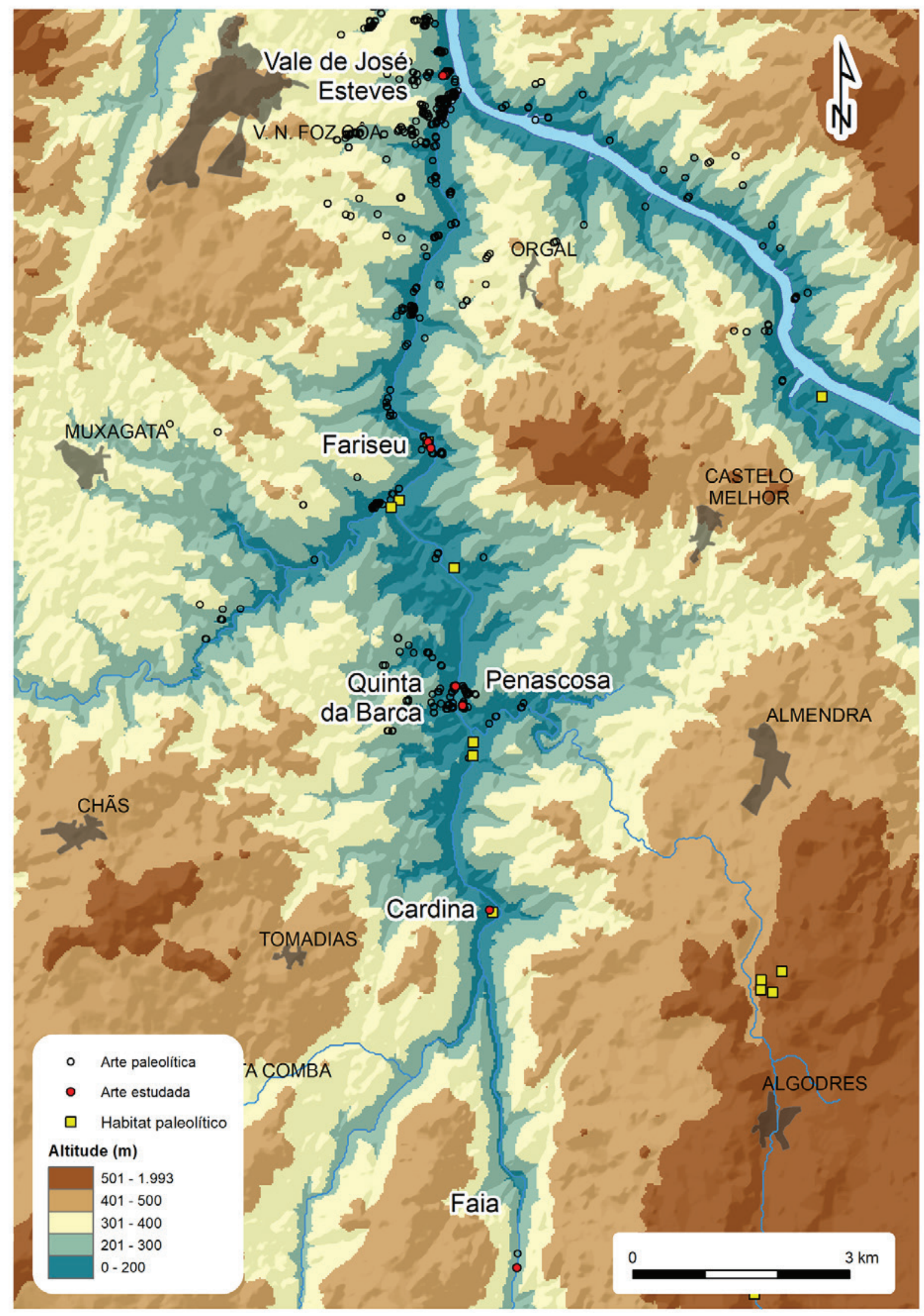

Figura 1 - Distribuição dos sítios do Vale do Côa com vestígios do Paleolítico Superior, destacando-se os que são objeto de atenção no presente trabalho. 


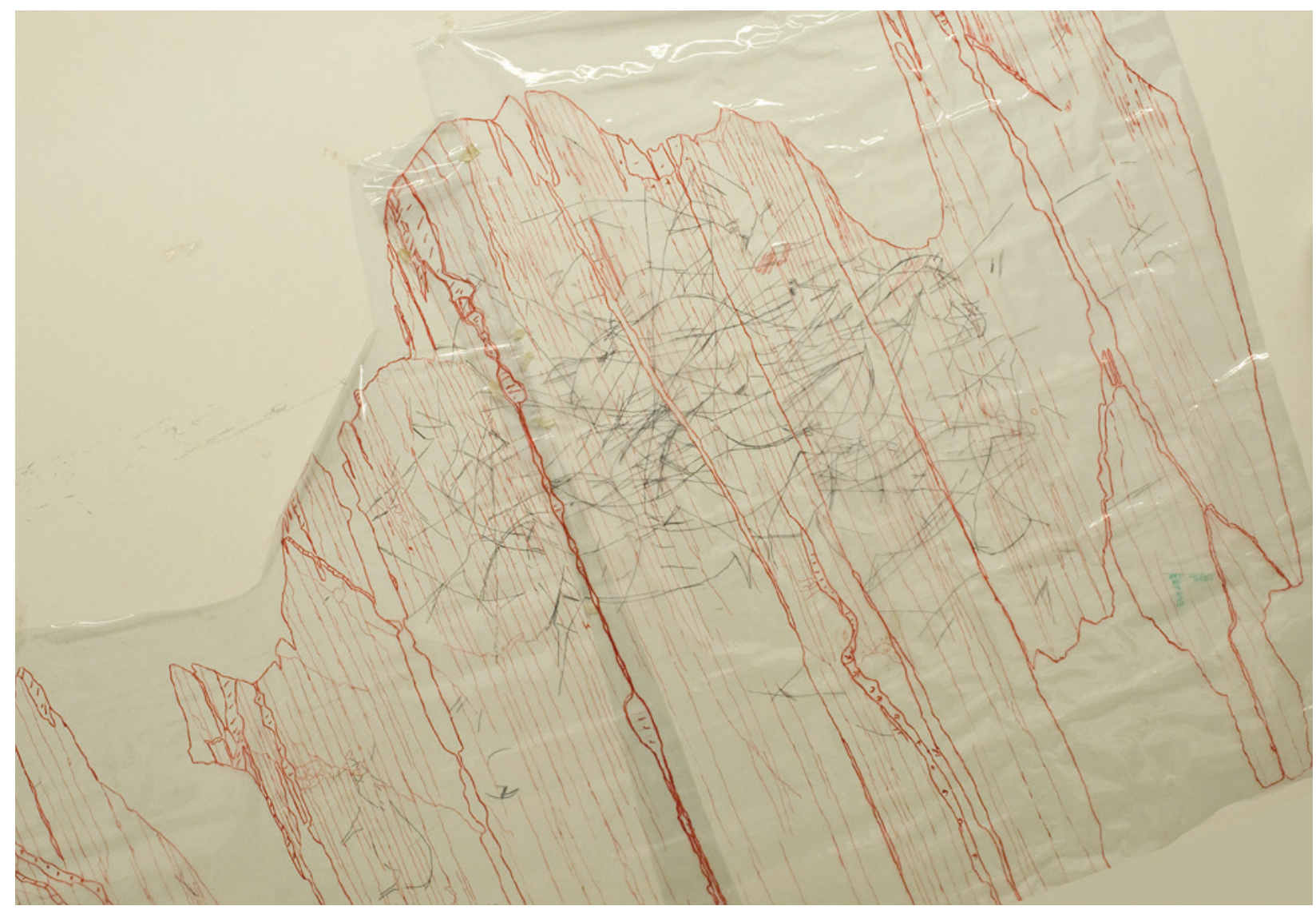

Figura 2 - Decalque “em bruto” da rocha 34 da Quinta da Barca, nele se observando as diferentes cores utilizadas no registo dos elementos antrópicos (negro) e geológicos (vermelho) do painel, e na indicação do plano horizontal do painel, obtido com nível de bolha, e dos autores do decalque (verde). 

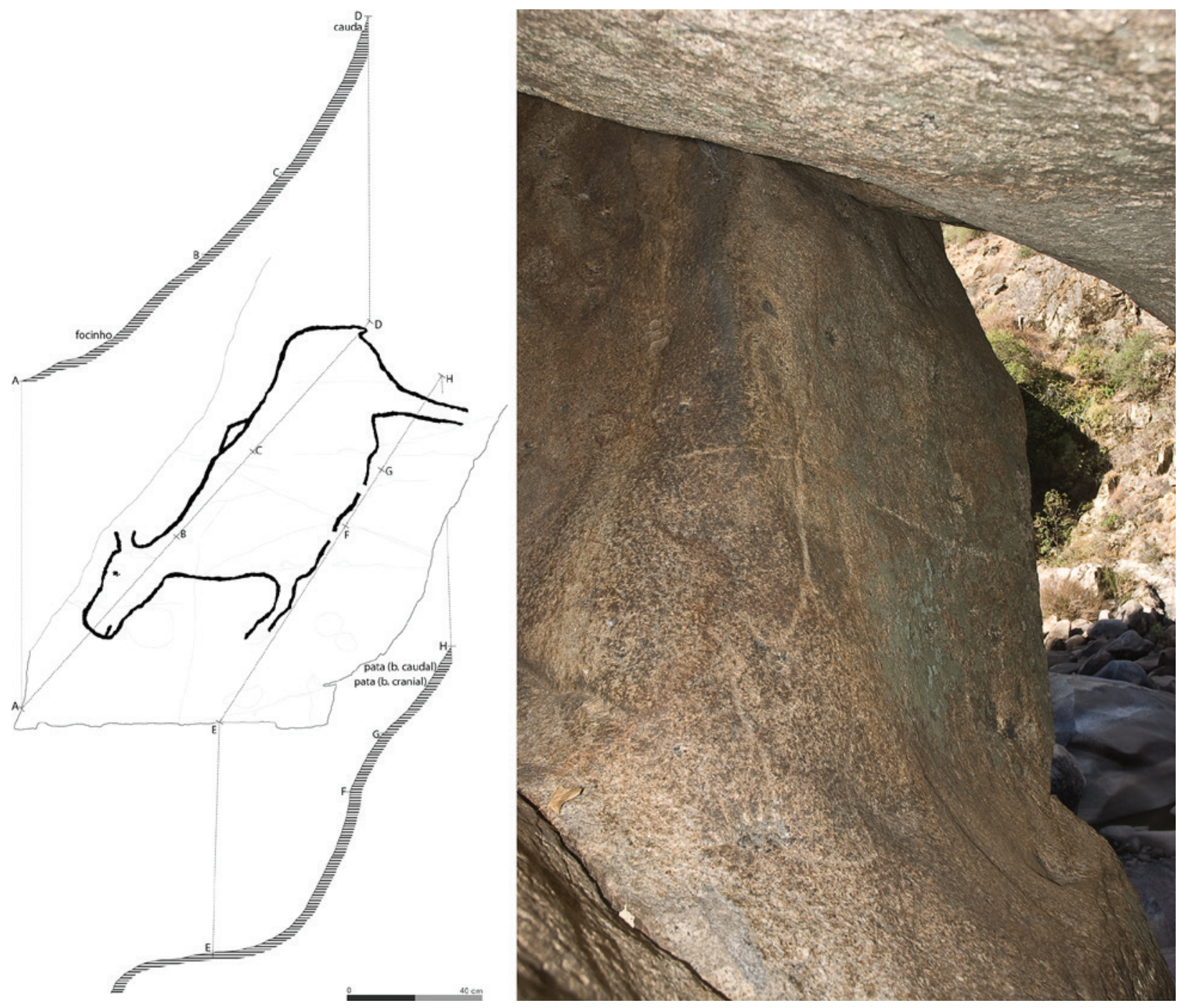

Figura 3 - Rocha 7 da Faia. À esquerda, decalque e duas secções do painel que ilustram a irregularidade do suporte. À direita, foto obtida desde o interior do abrigo.
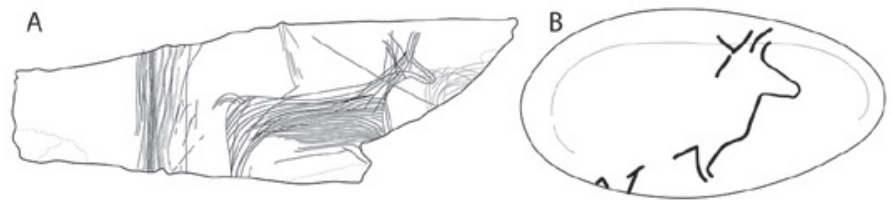

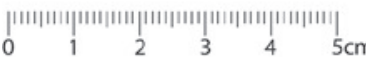

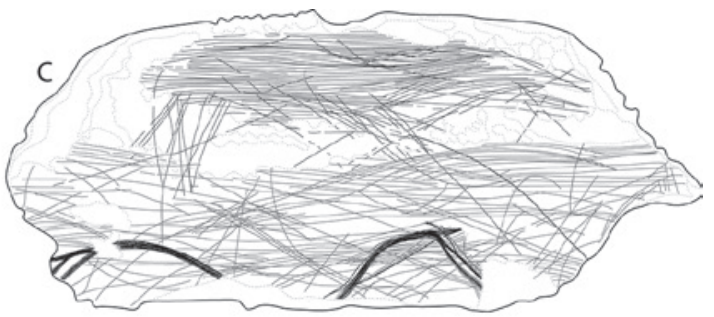

Figura 4 - Variedade morfológica das figuras animais da arte móvel da camada 4 da Cardina. A - peça 18; B - peça 5: C - peça 30. 


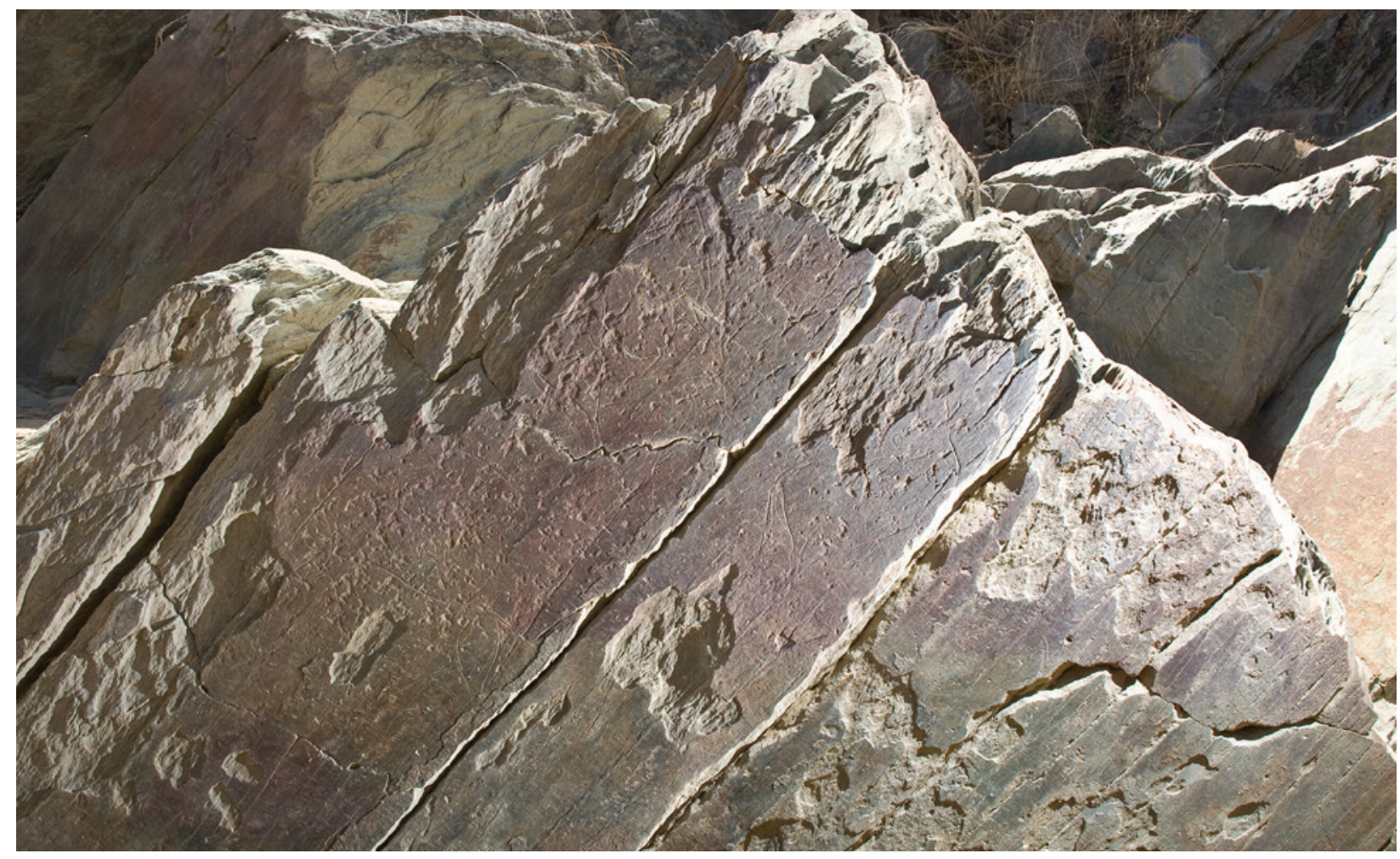

Figura 5-O painel principal da rocha 38 da Penascosa.

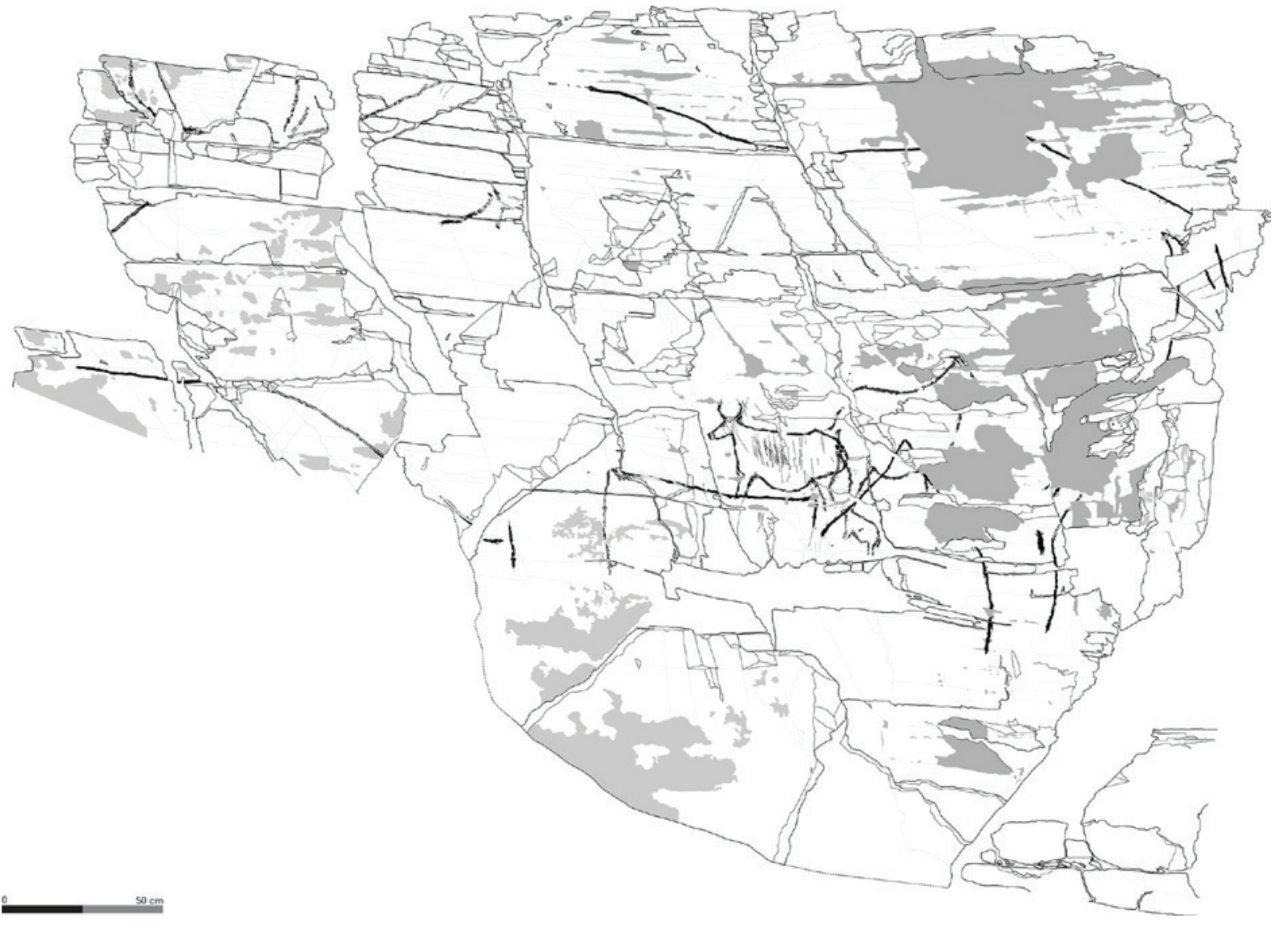

Figura 6 - Painel esquerdo da rocha 9 do Fariseu. 

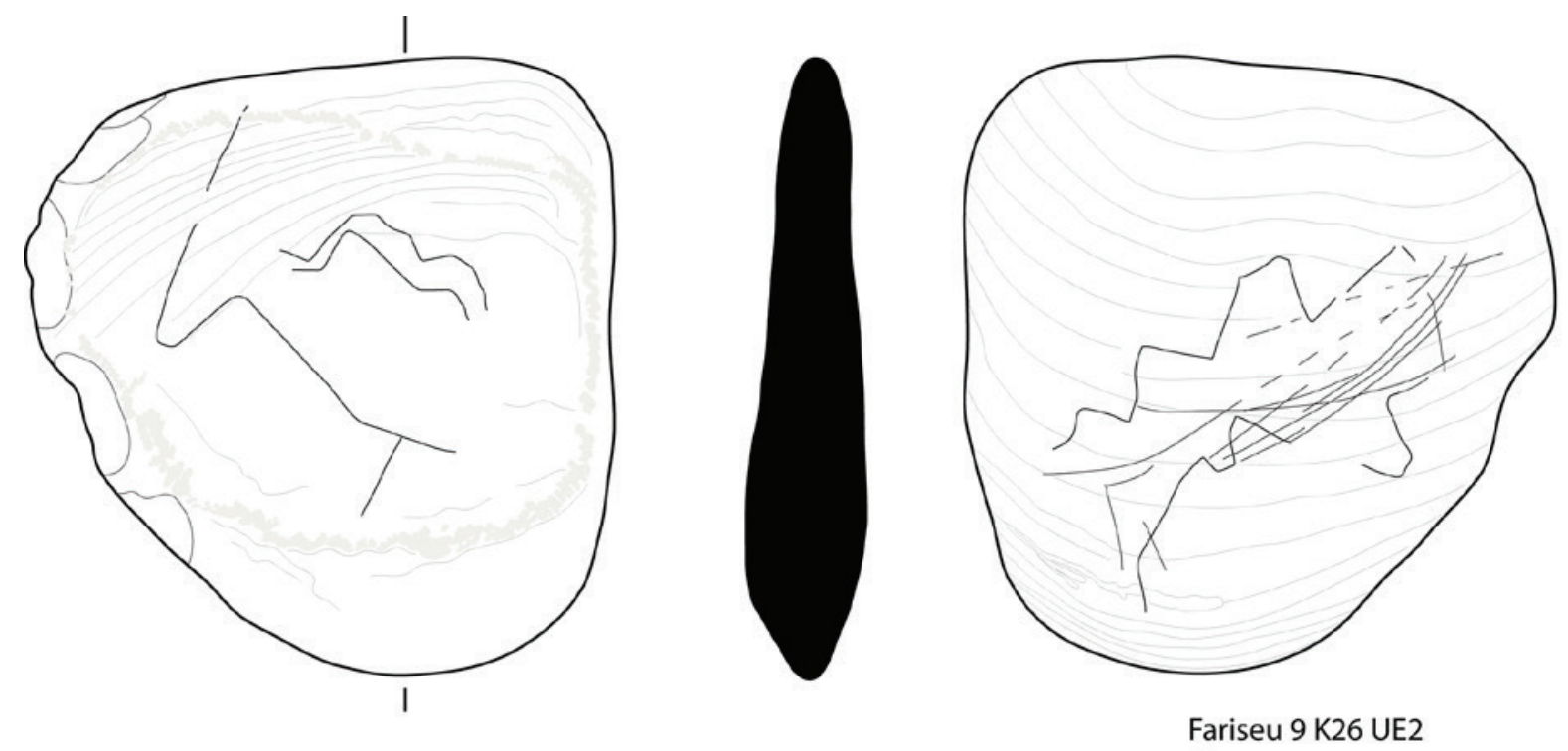

Placa

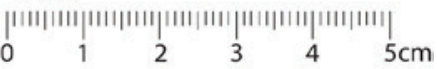

Figura 7 - Seixo gravado exumado na U.E 2 das escavações de 2020 em frente da rocha 9 do Fariseu.

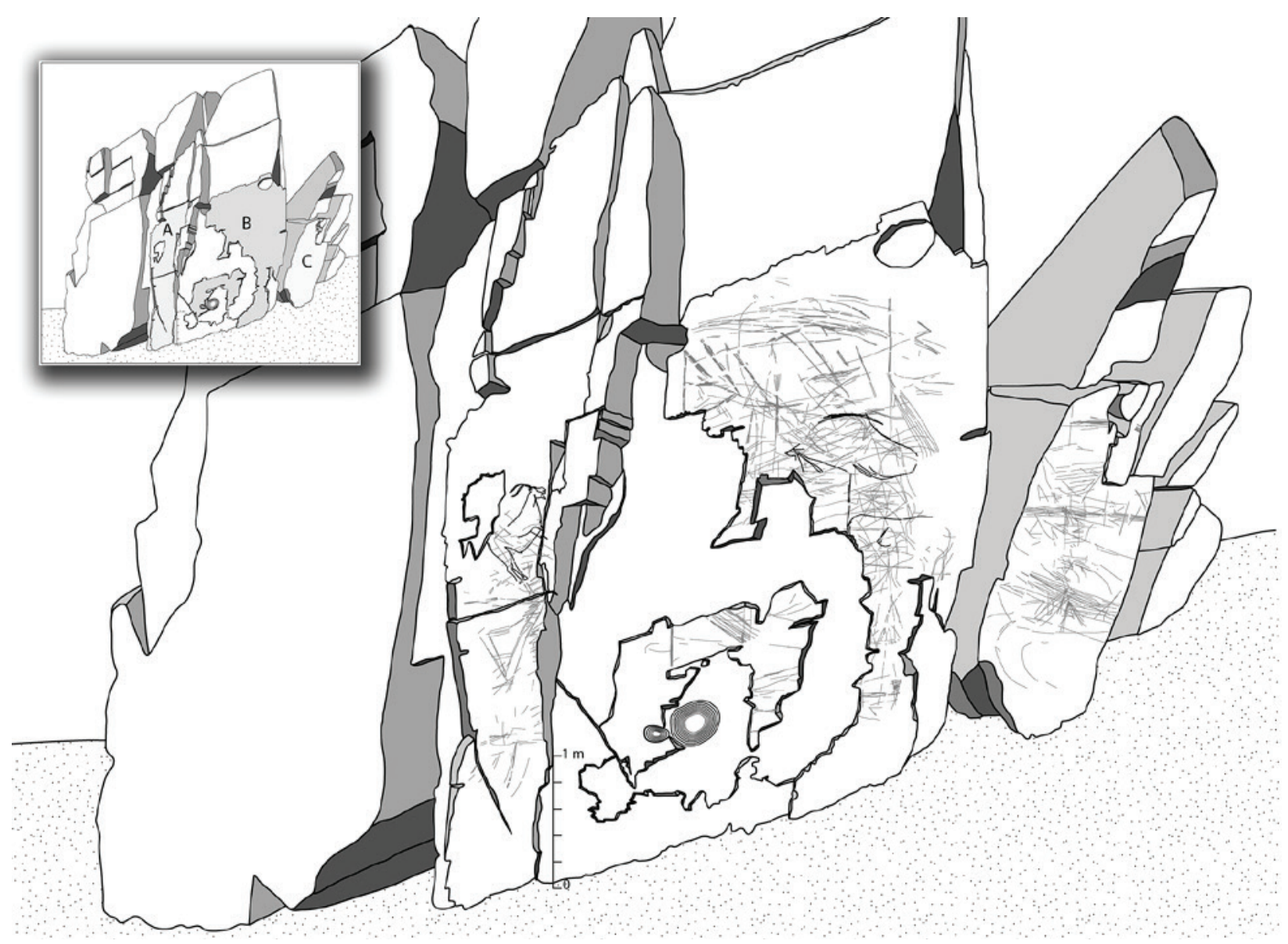

Figura 8 - Rocha 36 do Vale de José Esteves, com indicação dos seus espaços parietais. 


\title{
IMAGENS FANTASMAGÓRICAS, SILHUETAS ELUSIVAS: AS FIGURAS HUMANAS NA ARTE DO PALEOLÍTICO SUPERIOR DA REGIÃO DO CÔA
}

\author{
Mário Reis ${ }^{1}$
}

\begin{abstract}
RESUMO
A representação da figura humana é rara na arte paleolítica europeia, e a região do Côa não é excepção, embora desde o início se conheçam antropomorfos paleolíticos na sua arte de ar livre. Inicialmente restringidos a dois sítios, a sua quantidade e dispersão territorial expandiu-se consideravelmente nos últimos anos, com os continuados trabalhos de prospecção, registo de rochas decoradas e revisão das já conhecidas, ascendendo actualmente a quase meia centena, pesem embora as dúvidas na classificação de várias entre elas. Este texto apresenta o conjunto completo destas figuras inventariadas na arte do Côa, dividindo-as nos seus principais grupos cronológicos e tipológicos, e reflectindo sucintamente sobre a sua possível continuação para a fase cultural subsequente ao Paleolítico Superior.
\end{abstract}

Palavras-chave: Arte rupestre, Figuras antropomórficas, Paleolítico Superior, Epipaleolítico, Região do Côa.

\begin{abstract}
The representation of the human figure is rare in European Paleolithic art, and the Côa region is no exception, although Paleolithic anthropomorphs have been known in its open-air art since the beginning. At first restricted to two sites, their quantity and territorial dispersion has considerably expanded in recent years, with the continued work of survey, review and registration of decorated rocks, and currently amount to almost half a hundred, despite the doubts concerning the classification of several among them. This text presents the complete set of these figures in the Côa art, divided in their main chronological and typological groups, and briefly reflecting on their possible continuation for the cultural phase subsequent to the Upper Paleolithic.

Keywords: Rock art, Anthropomorphic figures, Upper Paleolithic, Epipaleolithic, Côa Region.
\end{abstract}

\section{INTRODUÇÃO}

Apesar da sua raridade, as representações antropomórficas paleolíticas fazem parte do imaginário associado à arte do Côa, pois desde a revelação deste complexo de arte rupestre ao mundo em finais de 1994 que a existência de uma destas figuras foi desde logo conhecida e amplamente divulgada na comunicação social e nos meios científicos. Para mais, não se tratava de um motivo qualquer, e o "Homem de Piscos", como ficou designado na gíria, continua a ser uma das mais impressionantes figuras da arte paleolítica do Côa. A sua descoberta ocorreu em No- vembro de 1994 por intermédio dos técnicos ao serviço do "Projecto Arqueológico do Côa" (Rebanda, 1995, ficha 17), escassos dias antes do desencadear da imensa polémica científica e mediática do Côa. Durante anos manteve-se como a única figura do seu género dentro do imenso corpus figurativo da arte do Côa que ia sendo estudado e revelado. A partir de 1999, as fulcrais escavações arqueológicas no terraço fluvial do Fariseu permitiram o início da identificação de algumas raras figuras humanas na abundante arte móvel exumada neste sítio, algumas reveladas de imediato, outras aguardando por estudos mais detalhados do conjunto das peças, recentemente

1. Fundação Côa Parque / Centro de Estudos em Arqueologia, Artes e Ciências do Património da Universidade de Coimbra (CEAACP); marioreissoares@sapo.pt 
publicadas em pleno (Santos $\&$ alii, 2018). No mesmo sítio, o ano 2000 assiste à inventariação de várias novas rochas decoradas, com o estudo das rochas $4 \mathrm{e}$ 8 a permitir identificar novas figuras humanas, desde logo a partir de 2002 na rocha 8 , mas só mais tarde na rocha 4, com um palimpsesto de figuras incisas de dificílima decifração e onde só o levantamento completo em 2010 permitiu a identificação de duas novas figuras humanas. Antes disso, e num retorno ao vizinho sítio da Ribeira de Piscos, o ano de 1999 assistiu à descoberta da rocha 24 , que estava quase toda oculta por sedimentos e cuja escavação em 2000 e 2003 (Luís, 2009), permitiu o acesso a todos os seus muitos painéis decorados, permitindo a plena revelação de uma das mais extraordinárias rochas com arte rupestre do complexo do Côa, e também da sua abundante colecção de antropomorfos paleolíticos, cerca de uma vintena. Este era, aproximadamente, o quadro do conhecimento destas figuras na altura da sua primeira publicação conjunta em 2009, em que quase todas as figuras atrás mencionadas são referidas (Baptista, 2009, pp. 66, 90-107), faltando apenas as figuras da rocha 4 do Fariseu e algumas da arte móvel deste mesmo sítio.

Este quadro permitia uma constatação, que era a circunscrição das figuras humanas paleolíticas a uma zona restrita dentro do vale do Côa, definida pelos sítios vizinhos da Ribeira de Piscos e Fariseu. Essa restrição mantém-se válida para as figuras de um determinado tipo (o Tipo I, maioritariamente Magdalenense, e referido a seguir), as quais ainda hoje são conhecidas unicamente nesta área. Mas já não é válida para outros tipos de figuras, genericamente assignáveis aos momentos finais do Paleolítico Superior, numa fase que designarei neste trabalho como Tardiglaciar (abrangendo os dois ou três milénios correspondentes ao final do período glaciar e o princípio do Holoceno). Estas têm vindo paulatinamente a ser identificadas, em quantidades reduzidas mas numa ampla área territorial dentro do complexo do Côa, que se estende ao longo deste rio e avança para dentro do Douro. A sua identificação decorre desde logo dos trabalhos de prospecção de arte rupestre que tem decorrido continuadamente desde o início até aos dias de hoje, e dos consequentes trabalhos de estudo e registo das novas rochas que vão sendo descobertas, e da sempre importante revisão daquelas já conhecidas, que permite a actualização de conhecimentos e correcção de impressões iniciais, nem sempre acertadas, pela imensa dificul- dade em interpretar à vista desarmada a difícil arte do Côa. Para além da figura da rocha 17 da Penascosa, cedo identificada mas atribuída a cronologias mais recentes, e à qual só agora proponho uma cronologia paleolítica Tardiglaciar (ver abaixo), as restantes têm sido identificadas sobretudo por mim próprio desde 2005, ano em que a prospecção realizada na Foz do Côa permitiu a primeira referência, ainda hesitante, a figuras humanas paleolíticas externas ao referido duo de sítios (Baptista \& Reis, 2008, pp. 84-85). Algumas outras serão mencionadas de passagem em publicações posteriores de inventário geral da arte do Côa (Reis, 2012; 2013; 2014), e uma outra, no sítio do Vale Escuro, foi primeiramente atribuída ao Paleolítico Superior numa publicação recente (Santos $\&$ alii, 2018, pp. 59, 94), havendo ainda outras que se mantêm inéditas. Neste momento, entre figuras confirmadas, prováveis ou incertas, as representações humanas paleolíticas na região do Côa ascendem a quase meia centena, número que poderá futuramente subir com mais trabalhos de prospecção e estudo das rochas decoradas da região.

Neste trabalho apresento um inventário total das figuras humanas paleolíticas actualmente conhecido (Figura 1), com imagens da maioria (Figuras 2, 3 e 4). Todas foram executadas por gravação, exclusivamente pela técnica da incisão, com excepção das pouco evidentes figuras pintadas das peças 85 e 86 da arte móvel do Fariseu. Como se verá a seguir, podem separar-se em três tipos principais, e a sua cronologia divide-se entre o Magdalenense e o Tardiglaciar. Mas neste trabalho abordo também, de forma sumária, um outro conjunto de figuras, que chegam às três dezenas, integralmente realizadas por pintura e cujo inventário também está presente na Figura 1. São estilisticamente relacionáveis com um dos tipos principais das figuras paleolíticas, que abrange a maioria das figuras humanas Tardiglaciares, mas a sua cronologia e assignação cultural está ainda em aberto. Presentemente, coloco-as no Epipaleolítico, como parte da expressão artística comummente designada como arte Subnaturalista, de que são exemplos partes importantes da arte Levantina ou da arte do Tejo. No entanto, há questões que se levantam sobre a sua correcta classificação cultural e cronológica, que abordarei de forma muito sucinta no final deste texto, mas que são um dos temas principais da investigação sobre arte rupestre pré-histórica, neste momento e no futuro próximo, na região do Côa e na Península Ibérica. 
Contextualizando quantitativamente as 48 figuras humanas inventariadas no todo da arte paleolítica do Côa, distribuídas por apenas 15 registos (14 rochas mais a arte móvel do Fariseu) em nove dos 61 sítios (com 602 registos) com arte paleolítica, constata-se a sua raridade neste complexo, sendo apenas cerca de 1,1\% das figuras paleolíticas inventariadas (num universo superior a 4300), confirmando a norma europeia da escassez na representação deste tipo de figuras.

É importante referir que, questões cronológicas à parte, nem todas as figuras aqui inventariadas têm igual grau de confiança na sua classificação como representações humanas. A maioria das consideradas Magdalenenses têm um aspecto humano indubitável mas, do abundante conjunto da rocha 24 de Piscos, cinco levantam dúvidas na sua classificação: uma no painel 4 (Figura 2, no 8), duas no painel 7 (Figura 2, $\mathrm{n}^{\circ}{ }_{13}$ e 14), outra no painel 13 (Figura 2, ํำ16), e também a do painel 23. No Alto da Cotovia, uma das figuras da rocha 3 merece também algumas dúvidas (Figura 3, no 3 ), o mesmo acontecendo com a da rocha 1 da Vermelhosa embora, em ambos os casos, me pareça crível a sua classificação. Na rocha 148 da Foz do Côa, a semelhança estilística das figuras inventariadas com o universo das figuras "FFS" (ver a seguir) é indubitável, mas a falta de detalhes anatómicos explícitos permite dúvidas legítimas. $\mathrm{Na}$ arte móvel do Fariseu, as figuras das peças I (Baptista, 2009, p. 66; Santos \& alii, 2018, pp. 11, 83) e 4 (Baptista, 2009, p. 104; Santos $\&$ alii, 2018, pp. 14, 83) têm um aspecto humano claro, mas a da peça 48 (Santos \& alii, 2018, pp. 30-31, 89) não é evidente, com um conjunto de inúmeros traços com um formato apenas genericamente reconhecível como humano. É de classificação tipológica difícil, embora com mais parecenças com as do Tipo II, e poderia também tratar-se de um signo, ou de um conjunto de signos. Quanto às figuras pintadas das peças 85 e 86 (Santos \& alii, 2018, pp. 44-45, 93), têm um formato humano claro, mas o seu estado de conservação e extremo apagamento levanta algumas dúvidas quanto à sua identificação, e seria essencial o aparecimento de mais exemplares semelhantes que permitissem comparações fiáveis.

\section{REVISÃO DE ALGUMAS FIGURAS PUBLICADAS}

É importante apresentar uma revisão de um grupo de figuras relevantes para este texto. Três foram publicadas como antropomorfos paleolíticos, opinião que presentemente não partilho. Outra foi referida como pós-paleolítica, mas havendo agora razões para recuar essa cronologia aos momentos finais do Paleolítico Superior.

Dois exemplos surgem na rocha 1 do sítio da Vermelhosa, já sobre o Douro (Figura 4, nำ1). Nos primeiros trabalhos aqui realizados foi anunciada a possível existência de três figuras antropomórficas femininas paleolíticas, sendo apresentados esboços de duas delas (Abreu \& alii, 1998; Arcá, 1996). Este anúncio passou largamente despercebido, sendo referente a uma das rochas mais complexas da arte do Côa, com dezenas de figuras e milhares de traços, formando um dos densos palimpsestos presente em variadas rochas da região, de muito difícil apreciação. Ainda não desenhada, fiz um inventário da sua iconografia a partir de 2015, quando realizei um registo completo e com centenas de fotografias de todas as suas gravuras. Consegui identificar um dos motivos atrás mencionados, interpretado como uma figura feminina em perfil. Na realidade, não é um antropomorfo, sendo bastante maior do que o interpretado, prolongando-se acentuadamente para cima e para baixo, formando um longo meandro ondulado. Quanto à segunda figura, não consegui encontrar a sua correspondente no intrincado emaranhado de traços e motivos daquela superfície. Mas, à luz do conhecimento obtido sobre a arte paleolítica do Côa, não é difícil olhar para a imagem publicada e afirmar que não se trata de uma figura humana, nem mesmo híbrida, mas simplesmente uma representação zoomórfica, num estilo perfeitamente reconhecível nas representações animais da fase Tardiglaciar do Paleolítico Superior do Côa. Quanto à terceira figura, na falta de uma imagem publicada e de uma indicação precisa da sua localização na superfície, não foi possível a sua identificação, mas é improvável que se trate da possível e nova figura humana que eu próprio identifiquei nesta rocha, e que não tem nada que sugira ser feminina (ver Figura 3, no 12).

Outro caso de revisão classificativa ocorre com a única figura da rocha 18 da Quinta da Barca (Figura 4 , no 2). Feita num traço picotado largo, profundo e muito facilmente visível, foi sugerido que se tra- 
taria de uma figura híbrida paleolítica, de provável cronologia no período Gravetto/Solutrense (Baptista, 2009, p. 9o; Baptista, Santos \& Correia 2006). Uma opinião semelhante é reiterada recentemente, incluindo na cronologia, salientando o seu aspecto zoomórfico, mas referindo igualmente o seu possível lado humanoide (Santos, 2017, Vol. II, pp. 39-40). No entanto, creio que se pode colocar outra hipótese interpretativa, a nível tipológico e cronológico. Estilisticamente, tem semelhanças com representações zoomórficas da Pré-história pós-paleolítica, com vários exemplos na região do Côa. Com o corpo longo e estreito, patas e cabeça curtas, esta última com pequenos cornos, as maiores semelhanças são com a figura da rocha 3 da Canada do Inferno (Baptista \& Gomes, 1997, pp. 221-222, 268): representações zoomórficas pouco naturalistas, cuja identificação da espécie é difícil ou impossível, e numa semelhança que se estende às características do traço picotado, mais solto e disperso do que é a norma das figuras paleolíticas mais antigas. Reafirmando uma hipótese anteriormente expressa (Reis, 2012, pp. 34-35), a figura não é um híbrido paleolítico, mas sim um animal indeterminado da arte Subnaturalista do Epipaleolítico.

Por fim, a original figura da rocha 17 da Penascosa (Figura 3, no 5 ). De apreciáveis dimensões e com um grande falo erecto, colocada imediatamente por detrás de um animal paleolítico no que se encarou como uma possível cena de bestialismo encenada com uma figura muito mais antiga, foi cedo publicada como de cronologia pós-paleolítica, eventualmente neolítica, integrando-a no universo da Arte Esquemática (Baptista, 1999, pp. 112-113). Mesmo sem entrar em considerações estilísticas tão específicas, a sua atribuição a uma cronologia plenamente holocénica (no sentido cronológico e cultural) mantém-se em textos recentes (por exemplo, Santos, 2017, Vol. II, p. 93), e incluindo por mim próprio (Reis, 2012, p. 35), mas onde já relevo um aspecto importante: a semelhança estilística entre esta figura e alguns dos antropomorfos pintados da Faia.

Há algum tempo, no entanto, que revi a minha opinião sobre esta figura, tendo passado a incluí-la no universo cronológico do Tardiglaciar. Esta nova opinião baseia-se na comparação com várias novas descobertas na região do Côa, que referirei no capítulo 4, com a óbvia conclusão de que as características estilísticas deste conjunto de figuras são semelhantes, inseridas em contextos que apontam para os momentos finais do Paleolítico Superior. Baseia-se também na comparação com figuras conhecidas e datadas no exterior, de que o conhecido "Brujo" da Cueva Palomera de Ojo Guareña, em Burgos, Espanha, será o melhor exemplo (Corchón \& alii, 1996). E, finalmente, baseia-se na análise da figura no seu contexto imediato: a superfície onde foi gravada e as restantes figuras que a acompanham. A comparação relevante não é com a figura zoomórfica que lhe surge à frente e que inspirou a ideia da cena de bestialismo (a qual, embora possível, me parece improvável, sendo talvez apenas uma coincidência posicional). Pelo traço muito mais patinado e, sobretudo, pelo seu estilo muito cuidado e naturalista, é evidente que é uma figura muito mais antiga, seguramente Magdalenense, e que não pode ser emparelhada cronologicamente com esta. A comparação pode ser feita com outra figura que aparece imediatamente à direita da sua mão, e que passou despercebida porque no desenho que foi feito e posteriormente publicado (Santos, 2017, Vol. II, p. 94) não foi correctamente levantada: aparece como um mero feixe de traços mas, na realidade, é um pequeno cervídeo (ou caprino) estriado, cujo estilo remete indubitavelmente para o Paleolítico Tardiglaciar (ver Figura 4 , no 3 ). O aspecto relevante não está tanto na proximidade entre ambas as figuras, mas sim nas características do traço gravado. As linhas da gravura correspondem a uma espécie de "incisão raspada", muito diferente do traço da figura Magdalenense, mas comum ao caprino e ao antropomorfo, e aparecendo em outros conjuntos de traços na rocha. A semelhança sugere a sua contemporaneidade, talvez até a mesma autoria e, juntando com as outras comparações acima referidas, sugere com clareza a pertença da figura humana aos momentos finais do Paleolítico Superior. É bem possível que seja já holocénica, dado que o Tardiglaciar se prolonga para tempos pós-glaciares, mas a sua pertença cultural vincula-se ainda ao Paleolítico Superior.

\section{A FIGURA HUMANA NO MAGDALENENSE: RIBEIRA DE PISCOS E FARISEU}

As primeiras figuras humanas paleolíticas claramente identificadas na região (Baptista, 2009, pp. 90-107), para além de se circunscreverem a apenas dois sítios numa zona muito restrita do Côa, formam um conjunto estilisticamente bastante homogéneo, do qual não parece haver grandes dúvidas na sua atri- 
buição cronológica e cultural ao Magdalenense, seja por comparações com outras figuras europeias, seja pela sua contextualização local, nomeadamente nas próprias rochas onde surgem. É certo que em duas das quatro rochas onde estas figuras foram identificadas aparecem pontualmente algumas (raras) figuras da fase Tardiglaciar do Paleolítico Superior, mas parecendo assegurada a sua ausência das rochas 2 da Ribeira de Piscos e 4 do Fariseu. Ou seja, estes motivos mais tardios não fornecem uma apta contextualização às figuras humanas das quatro rochas. Pelo contrário, todas as quatro, sem excepção, apresentam em abundância um conjunto variado de figuras de clara cronologia Magdalenense, caracterizada pelo elevado naturalismo e detalhe das figuras zoomórficas, muitas das quais se associam, de forma mais ou menos directa, a algumas das figuras antropomórficas, como na rocha 8 do Fariseu ou nalguns casos da rocha 24 de Piscos.

Quanto à distribuição, o Fariseu congrega apenas três figuras: uma na rocha 8 , bem evidente e colocada por cima de um caprino (Baptista, 2009, pp. 106-107; Santos, 2017, Vol. II, p. 196). Na rocha 4 as duas figuras são menos evidentes, mas a análise do desenho indica bem a sua existência (Santos, 2017, Vol. II, p. 191). Na Ribeira de Piscos, a rocha 24 tem 2o figuras antropomórficas, uma extraordinária coleção no mundo da arte paleolítica e que faz juz à que é, em todos os aspectos, uma extraordinária rocha decorada (ver Santos, 2017, Vol. II, pp. 121-168). E claro está, é na rocha 2 que se encontra o famoso Homem de Piscos (Baptista, 1999, pp. 122-123, 126-127), que congrega em si o ser a primeira figura humana identificada na arte rupestre da região (paleolítica e não só) e, dentro do conjunto das de cronologia paleolítica, ser também a de maior dimensão (cerca de $50 \mathrm{~cm}$ de altura) e a mais expressiva, com uma clara simbologia de cariz sexual, curiosamente semelhante à da figura da Penascosa.

\section{A EXPANSÃO DO TARDIGLACIAR. DO CÔA AO DOURO}

As novas figuras antropomórficas identificadas nos últimos anos juntam várias características distintas do grupo anterior: são todas mais recentes (com dúvidas pontuais numa ou outra situação), têm uma distribuição na região muito ampla e dispersa, são tipologicamente diferentes das figuras do grupo Piscos/Fariseu, mas também apresentam maior diversidade, dividindo-se em dois grandes tipos: um corresponde às conhecidas silhuetas femininas designadas habitualmente por "FFS" (Figures Féminines Schématiques) ou figuras femininas "tipo Gönnersdorf”, e é reduzido, estando limitado a uma única figura na peça 1 da arte móvel do Fariseu e a um conjunto de pelo menos sete figuras na rocha 148 da Foz do Côa. Todas as restantes, em número de quinze, pertencem a um mesmo tipo, pesem embora algumas dúvidas na caracterização tipológica de uma ou outra, e distribuem-se por 9 rochas em sete sítios (Alto da Cotovia, Penascosa, Broeira, Foz do Côa, Vale de José Esteves, Vermelhosa e Vale Escuro) e por algumas das peças da arte móvel do Fariseu, embora estes últimos casos sejam precisamente dos que levantam dúvidas tipológicas. Para além destas últimas e do exemplar da rocha 17 da Penascosa, quase todas são inéditas, exceptuando a figura da rocha 11 do Vale Escuro (Santos $\mathbb{\&}$ alii, 2018, pp. 59, 94). A sua distribuição é vasta, começando no importante sítio do Alto da Cotovia, a mais de 30 quilómetros de distância da foz do Côa, seguindo-se a Penascosa, a uma dezena de quilómetros deste ponto geográfico, do qual já se aproximam os restantes exemplares, na rocha 11 da Broeira e nas rochas 151 e 170 da Foz do Côa (ainda no Côa), ou nas rochas 4 do Vale de José Esteves, 1 da Vermelhosa e 11 do Vale Escuro, sobre o Douro.

A sua contextualização cronológica por associação a outras figuras tipicamente Tardiglaciares é semelhante à das figuras Magdalenenses do Tipo I, estando presente em quase todas as rochas em que surgem a estas figuras. Para além do caso já analisado da rocha 17 da Penascosa, existe uma associação a figuras zoomórficas Tardiglaciares também na rocha 11 do Vale Escuro, e uma associação particularmente forte e evidente nas rochas 151 da Foz do Côa e 1 da Vermelhosa. Também na rocha 170 da Foz do Côa essa contextualização é evidente, por razões que serão detalhadas mais abaixo, enquanto que no Alto da Cotovia a contextualização pode ser estendida a todo o conjunto das rochas paleolíticas do sítio, muito homogéneas do ponto de vista estilístico e onde também pontuam figuras zoomórficas estriadas Tardiglaciares. Menos evidente é o caso da rocha 11 da Broeira, cujos dois antropomorfos se associam apenas a signos, e estando a rocha imediatamente por cima da rocha 1, com motivos tanto Magdalenenses como Tardiglaciares. Também pouco clara é a associação do antropomorfo da rocha 4 do Vale 
de José Esteves, num sítio onde os motivos Tardiglaciares são extraordinariamente abundantes e dominantes, mas sendo a rocha 4 precisamente uma excepção, com raros motivos Tardiglaciares e enorme abundância de figuras Magdalenenses. As três figuras da arte móvel do Fariseu (peças 48, 85 e 86) têm uma contextualização cronológica evidente, mas são das mais atípicas dentro do Tipo II. Uma situação menos evidente ocorre na contextualização das figuras da rocha 148 da Foz do Côa. Desde logo, e aceitando a sua inclusão no Tipo III das "FFS", estas têm uma larga diacronia na arte Paleolítica Europeia (cf. Bosinski, 2011), pela que a sua classificação cronológica por comparação estilística é difícil. A rocha 148 apresenta numerosas outras figuras paleolíticas, todas Tardiglaciares, mas a zona do sítio onde se insere é precisamente onde aparece a maior concentração de rochas com figuras Magdalenenses, algumas bem perto desta, pelo que, também por aqui, contextualizar localmente estas figuras seja tarefa árdua. Parece-me, tendo em conta a realidade da arte do Côa, que uma cronologia Tardiglaciar é a mais provável, pela imensa abundância das figuras desta fase face às anteriores, mas é uma questão que se mantém aberta.

\section{OS TRÊS PRINCIPAIS TIPOS DE FIGURAS HUMANAS PRESENTES NA REGIÃO DO CÔA}

Olhando para o quadro das figuras humanas actualmente inventariadas no Côa, é possível fazer uma separação em três grandes tipos: o Tipo I é o das figuras humanoides, frequentemente grotescas mas de laivos naturalistas, com ampla variedade e usualmente datáveis do Magdalenense; o Tipo II é das figuras estilizadas e estereotipadas do Tardiglaciar; o Tipo III, mais raro, é o das figuras femininas de perfil.

O Tipo I está circunscrito a dois sítios vizinhos no Côa, a Ribeira de Piscos e o Fariseu, sendo composto por 25 exemplares (Figura 2). É o tipo de figura mais abundante, mas presente em apenas quatro rochas, duas em cada um dos sítios, e ainda na peça 4 da arte móvel do Fariseu. Tipologicamente, definem-se sucintamente como figuras de representação subnaturalista e não estereotipada, em que o desenho da forma humana assume algum realismo e proporcionalidade, com as silhuetas da cabeça, corpos e membros a serem facilmente reconhecíveis, por vezes com detalhes anatómicos (olhos, orelhas, se- xos,...), em alguns casos raros até com peças de roupa reconhecíveis. No entanto, não se podem considerar como representações naturalistas de seres humanos, e uma das suas características essenciais e unificadoras é o seu aspecto tendencialmente grotesco, por vezes animalesco ou mesmo deformado. No Côa, o Homem de Piscos é talvez a mais naturalista de todas as figuras humanas da região, mas a sua expressão é grotesca e as proporções corporais têm notórias incorrecções; uma ou outra das figuras da rocha 24 da Ribeira de Piscos entram no que se pode considerar o domínio do fantástico ou monstruoso, enquanto que outras não passam de silhuetas mal reconhecíveis como seres humanos ou até reduzidas a uma forma circular que se presume corresponder a uma cabeça, como nos painéis 4 e 13. Assim, dentro de um ar de família reconhecível, a variedade e a não conformação estereotípica é outro dos principais aspectos deste tipo específico de figuras, a que se junta a sua forte expressividade cénica. Há muitas figuras humanas europeias associáveis a este tipo, entre as quais o homem da cena do Poço de Lascaux; o chamado feiticeiro da gruta de Saint-Cirq; as figuras humanas da gruta de Le Portel ou, num dos casos que mais evoca as figuras do Côa, a figura híbrida da gruta de Hornos de La Peña (ver, por exemplo, Clottes, 2008, pp. 120-121, 136-137, 171, 216). Também as abundantes figuras da arte móvel de La Marche se poderão integrar neste tipo, neste caso com exemplares naturalistas, até mesmo retratistas, da fisionomia humana (Pales \& Saint Péreuse, 1976). O Homem de Piscos, na sua cena sexual onanista, é a maior e mais conhecida figura humana paleolítica da arte do Côa, notavelmente expressiva, nomeadamente na expressão facial grotesca, e anatomicamente muito detalhada, sobretudo na cabeça e na representação do falo. A rocha 24 da Ribeira de Piscos apresenta outras figuras, com grande variedade de detalhes e contextos "cénicos". Por exemplo, o par de figuras dos painéis $2 \mathrm{e} 3$, uma feminina e outra masculina colocadas quase lado a lado, numa localização talvez intencional, ambas com aparente representação de vestimentas (que poderá eventualmente aparecer também numa das figuras da rocha 4 do Fariseu), e que olham de frente para o observador. Também a olhar de frente estão as peculiares figuras do painel 4 que se "abraçam fraternalmente" pelos ombros. Plenamente de perfil encontra-se uma figura do painel 7, de forma plenamente humana e em movimento dinâmico, de perna e braço 
avançado, e com uma cabeça de formato dilatado e quase animalesco. De muito difícil percepção mas absolutamente notável é uma possível representação de uma mulher grávida no painel 17, segurando a barriga dilatada com as mãos, infelizmente sem a cabeça, perdida por fracturação. Evocando o mundo fantástico ou monstruoso estão a figura do painel 5 , de forma humanoide simples e de cuja face emerge um auroque, numa extraordinária composição, ou a muito estranha figura do painel 6 , intencionalmente sem cabeça e mesclando o humano com o grotesco e monstruoso, e que aparenta estar relacionada com duas figuras animais anexas, sobreposta a um auroque de forma que sugere o acto de "cavalgar", e com o braço estendido de forma a que a mão parece segurar um pequeno caprino. A evocação do acto de cavalgar surge de novo na figura da rocha 8 do Fariseu, com uma figura de forma humana simples mas colocada sobre o dorso de um caprino (na Figura 2, no 24 , o desenho desta figura foi feito por mim a partir de fotografia e tem pequenas diferenças face ao publicado, onde a figura animal sugere um misto de cavalo e caprino).

Uma última figura a merecer menção encontra-se na peça 4 da arte móvel do Fariseu, tipologicamente apartada dos restantes antropomorfos neste conjunto. Representa um antropomorfo visto de frente, com a cabeça redonda e a parte superior do corpo, tendo-se o resto perdido por fracturação, e tendo também impactos de picotagem no interior da face, assim como um conjunto de traços que emanam da cabeça para o exterior. Desde logo, esta figura chama a atenção pela questão cronológica. Todas as outras figuras humanas incluídas no Tipo I podem ser colocadas no Magdalenense, pelas razões atrás mencionadas. Mas esta peça foi encontrada na U.E. 4 da escavação do Fariseu, bem datada do Tardiglaciar (cf. Aubry \& Sampaio, 2008), pelo que surge num contexto bastante posterior. No entanto, estilisticamente, é claramente comparável com as figuras Magdalenenses do Tipo I. Essa comparação advém da forma do corpo, de formas humanóides redondeadas. Mas, sobretudo, prende-se com o conjunto de traços que emanam para fora da cabeça. De sentido muito obscuro, uma vez que não parece tratar-se de representação de cabelo, este tracejamento surge em quatro outras figuras Magdalenenses, todas na Ribeira de Piscos, com o Homem de Piscos na rocha 2 e mais três figuras na rocha 24, incluindo o par masculino/ feminino atrás mencionado, e a sua presença nalgu- mas das mais notáveis figuras antropomórficas da região torna-o um detalhe estilístico muito relevante e, na ausência de dados em contrário, como um "fóssil director" do Tipo I dentro da região do Côa (pelo menos). A discrepância cronológica desta figura face às restantes poderá talvez ser explicada por duas hipóteses: em primeiro lugar, uma sobrevivência para dentro do Tardiglaciar de uma característica estilística própria do Magdalenense; ou, em alternativa, uma origem Magdalenense daquela peça em particular, e a sua sobrevivência "funcional" até ao seu descarte no Tardiglaciar.

O Tipo II é representado por 15 figuras, na região do Côa. São assinalavelmente distintas das figuras do Tipo I e muito mais uniformes e estereotipadas (Figura 3, no 1 a 13). Caracterizam-se por um formato corporal longo e esguio, os membros também longos e estreitos, com frequente desproporcionalidade. $\mathrm{O}$ uso do traço estriado é comum a todas as figuras da região. Os detalhes anatómicos são poucos, quase sempre toscamente desenhados. A representação fálica é frequente, e não há figuras com características femininas. As cabeças são geralmente pouco esboçadas, por vezes inexistentes, raramente assumindo uma forma arredondada. Os membros só por vezes são rematados por pés ou mãos, destacando-se estas últimas, geralmente com enormes dedos. Assim, em termos gerais, caracterizam-se como figuras estriadas, pouco naturalistas, pouco variadas, predominando um formato grandemente estereotipado, com escassa expressividade. A comparação mais evidente dentro da arte paleolítica europeia é com o já mencionado "Brujo" da Cueva Palomera de Ojo Guareña, num tipo de figuras particularmente relevante em contexto ibérico.

Olhando para os exemplares representados na Figura 3, é fácil compreender a inclusão da figura da rocha 17 da Penascosa neste conjunto. Tem alguma originalidade própria, nomeadamente por parecer repetir a cena de onanismo presente na bem mais antiga figura da rocha 2 da Ribeira de Piscos. A figura da rocha 170 da Foz do Côa merece uma menção especial. É o motivo central de um alinhamento de três, em que os dois laterais correspondem a peixes, de corpo oval estriado, e tendo uma clara cronologia Tardiglaciar. A figura central tem também longo corpo oval estriado, assim como dois longos apêndices inferiores interpretáveis como a cauda, semelhantes às das figuras laterais. No entanto, seja como acrescento posterior seja como composição de raiz, a figu- 
ra apresenta igualmente dois pés, um possível braço e, sobretudo, uma cabeça redonda, que lhe confere um aspecto indubitavelmente humano, sem perder a conexão, seguramente de simbolismo importante, com as figuras de peixe, podendo assim ser considerada uma figura híbrida. Quanto ao sítio do Alto da Cotovia, assume grande importância no tocante às figuras antropomórficas: no denso aglomerado de cinco rochas paleolíticas inventariadas neste sítio, duas apresentam figuras humanas, e outras duas têm alguns motivos indeterminados que, pelo formato, poderiam ser também antropomorfos, embora lhes faltem detalhes anatómicos mais explícitos.

O Tipo III é representado por oito figuras: uma na peça 1 da arte móvel do Fariseu, e sete num notável conjunto da rocha 148 da Foz do Côa (Figura 3, nº 14 e 15). Integram um tipo de figuras bem conhecido da arte paleolítica europeia, o das figuras femininas em perfil, um grupo muito específico dentro da representação humana paleolítica (ver Bosinski, 2011). A imagem de marca destas figuras é a sua silhueta em perfil com acentuada curvatura nas nádegas, conferindo-lhes uma tipologia inconfundível, independentemente da existência de outros detalhes anatómicos humanos. A figura da peça 1, de minúsculas dimensões, não é das mais típicas, mas apresenta a conhecida silhueta em perfil com a exagerada curvatura da nádega. O mesmo sucede nas figuras da rocha 148 da Foz do Côa, que se apresentam em sequência ordenada por baixo e ao longo de uma linha em semicírculo emergindo de um caos de linhas à esquerda para um alinhamento de sete figuras individualizadas, que recordam as possíveis danças que surgem como interpretação para alguns conjuntos semelhantes na Europa paleolítica, sendo relativamente frequentes os grupos de figuras em alinhamentos (cf. Bosinski 2011). Na falta de detalhes anatómicos mais explícitos nomeadamente braços ou seios, é importante recordar que se mantém a possibilidade de serem simplesmente um grupo de meandros, mas a hipótese antropomórfica continua a parecer-me a mais provável.

\section{CONCEPTUALIDADES: O TARDIGLACIAR E O EPIPALEOLÍTICO NA REPRESENTAÇÃO HUMANA}

Apesar do seu estatuto ultraminoritário no conjunto das figuras paleolíticas da região do Côa, é clara a importância simbólica da representação humana, assim como a sua mais longa diacronia face ao conhecido inicialmente. Mas, para finalizar este texto, falta conectar as figuras gravadas, bem inseridas dentro de um contexto paleolítico, com as figuras pintadas, cuja contextualização é, actualmente, menos evidente do que se pensava. Há um ar de família estilístico muito forte entre um grupo particular de representações antropomórficas pintadas na região do Côa, com as mais conhecidas a situarem-se no sítio da Faia, a que se juntam outros exemplares mais recentemente identificados no sítio do Ervideiro (ver Figura $4, n^{\circ} 7$ ). Num estado de conservação deplorável, é menos certo que se possam juntar a este conjunto duas figuras do abrigo da Ribeirinha, cuja inclusão neste inventário é, para já, hipotética. Também incerta é a inclusão do conhecido antropomorfo de mãos ao alto da rocha 1 da Faia (Baptista, 1999, p. 16o), embora me pareça provável, até pelo seu afastamento dos cânones mais típicos da Arte Esquemática. As restantes figuras seguem, com algumas variantes, um esquema semelhante: corpo alto e esguio, por vezes inclinado, cabeças apenas esboçadas e pouco detalhadas, por vezes inexistentes, membros longos, por vezes com o nítido desenho das mãos. Ou seja, são figuras estilisticamente semelhantes às do Tipo II, com a diferença de que são pintadas, e tendencialmente maiores. Um exemplo típico é a grande figura da rocha 3 da Faia (Baptista, 1999, p. 158), similar às duas figuras da rocha 5 do mesmo sítio. E, como já foi referido, são também semelhantes à figura pintada da peça 85 do Fariseu (cf. Santos \& alii, 2018, p. 56). E esta semelhança levanta naturalmente algumas questões. Deve-se incluir este conjunto de figuras dentro da arte paleolítica, nos seus momentos Tardiglaciares? Se sim, deve juntar-se-lhes as figuras zoomórficas que lhes são normalmente associadas dentro do estilo subnaturalista, de que no Côa os exemplos mais conhecidos são o veado picotado da rocha 1 de Vale de Cabrões e os bovinos pintados da rocha 1 da Faia (Baptista, 1999, pp. 138-139, 159)? Ou, em alternativa, deve-se assumir o parentesco estilístico destas figuras, humanas e animais, com as da fase final do Paleolítico Superior (o que parece, de uma ou outra forma, ser uma evidência actual), mas considerá-las como pertencentes a uma posterior fase cultural, normalmente denominada por Epipaleolítico? Estas questões, de resposta complexa, são hoje candentes na investigação da arte rupestre pré-histórica europeia e peninsular, também importantes nos conjuntos 
artísticos do Tejo português e do Levante espanhol, entre outros. Serão também um dos objectivos primordiais da investigação recentemente iniciada, no âmbito do projecto "LandCRAFT - os contextos socio-culturais da arte da Pré-história Recente no vale do Côa", que se espera venha trazer nova informação a este assunto (Alves, 202O).

\section{BIBLIOGRAFIA}

ABREU, Mila Simões; ARCÀ, Andrea; FOSSATI, Angelo; JAFFE, Ludwig (1998) - Palaeolithic rock engravings at Vermelhosa, Côa Valley Archaeological Park, Portugal. In CREMONESI, Renata Griffoni; TOZZI, Carlo; VIGLIARDI, Alda; PERETTO, Carlo, eds., - Proceedings of the XIII International Congress of Prehistoric and Protohistoric Sciences Vol. 3. Forli: A.B.A.C.O. Edizioni, pp. 121-125.

ALVES, Lara Bacelar (2020) - LandCRAFT. A arte da Pré-história Recente no vale do Côa. Kairós. Coimbra. 5, pp. 6-21.

AUBRY, Thierry; SAMPAIO, Jorge Davide (2008) - Chronologie et contexte archéologique des gravures paléolithiques de plein air de la Vallée du Côa (Portugal). In BEHRMANN, Rodrigo de Balbín, ed., - Arte Prehistorico al aire libre en el Sur de Europa. Salamanca: Junta de Castilla y Léon, pp. 211-223.

ARCÀ, Andrea (1996) - Palaeolithic figures in rock n. 1 of the Vermelhosa-Côa Valley area. Tracce Online Rock ArtBulletin. Valcamonica. 5. http://www.rupestre.net/tracce/?p=1033.

BAPTISTA, António Martinho (1999) - No tempo sem tempo: A arte dos caçadores paleolíticos do Vale do Côa. Com uma perspectiva dos ciclos rupestres pós-glaciares. Vila Nova de Foz Côa: Parque Arqueológico do Vale do Côa/Centro Nacional de Arte Rupestre.

BAPTISTA, António Martinho (2009) - O paradigma perdido. O Vale do Côa e a Arte Paleolítica de ar livre em Portugal. Vila Nova de Foz Côa: Edições Afrontamento / Parque Arqueológico do Vale do Côa.

BAPTISTA, António Martinho; GOMES, Mário Varela (1997) - Arte Rupestre. In ZILHÃO, João, ed., - Arte rupestre e pré-história do Vale do Côa. Trabalhos de 1995-1996. Lisboa: Ministério da Cultura, p. 213-406.

BAPTISTA, António Martinho; REIS, Mário (2008) - Prospecção da Arte Rupestre na Foz do Côa. Da iconografia do Paleolítico superior à do nosso tempo, com passagem pela II I Idade do Ferro. In Actas do III Congresso de Arqueologia de Trás-os-Montes, Alto Douro e Beira Interior. Vol. o1 - Pré-história. Gestos Intemporais. Vila Nova de Foz Côa: Associação Cultural Desportiva e Recreativa de Freixo de Numão, pp. 62-95.

BAPTISTA, António Martinho; SANTOS, André Tomás; CORREIA, Dalila (2006) - Da ambiguidade das margens na Grande Arte de ar livre no Vale do Côa. Reflexões em torno da organização espacial do santuário Gravetto-Solutrense na estação da Penascosa / Quinta da Barca. Côavisão. Vila Nova de Foz Côa. 8, pp. 156-184.

BOSINSKI, Gerhard (2011) - Femmes sans tête. Une icône culturelle dans l'Europe de la fin de l'époque glaciaire. Paris: Éditions Errance.

CLOTTES, Jean (2008) - Cave Art. New York: Phaidon.

CORCHÓN, Maria Soledad; VALLADAS, Hélène; BÉCARES, Julián; ARNOLD, Maurice; TISNERAT, Nadine; CACHIER, Hélène (1996) - Datación de las pinturas y revision del arte paleolítico de Cueva Palomera (Ojo Guareña, Burgos, España). Zephyrus. Salamanca. 49, pp. 37-6o.

LUís, Luís (2009) - A rocha 24 da Ribeira de Piscos: contexto estratigráfico de uma rocha gravada. In AUBRY, Thierry, ed., - 200 séculos da história do Vale do Côa: Incursões na vida quotidiana dos caçadores artistas do Paleolítico. Lisboa: Instituto de Gestão do Património Arquitectónico e Arqueológico, pp. 84-93.

PALES, León; SAINT PÉREUSE, Marie Tassin (1976) -Les Gravures de La Marche. II.-Les Humains. Bordeaux: Ophrys.

REBANDA, Nelson (1995) - Barragem de Vila Nova de Foz-Côa. Breve balanço dos trabalhos arqueológicos. Relatório policopiado, Lisboa: Instituto Português do Património Arquitectónico e Arqueológico (Processo 9o/1(374), Arquivo da Arqueologia Portuguesa, Direcção-Geral do Património Cultural).

REIS, Mário (2012) - 'Mil rochas e tal...'? Inventário dos sítios da arte rupestre do vale do Côa. Portvgalia. Porto. 33, pp. 5-72.

REIS, Mário (2013) - 'Mil rochas e tal...!': Inventário dos sítios da arte rupestre do vale do Côa ( $2^{\mathrm{a}}$ parte). Portvgalia. Porto. 34, pp. 5-68.

REIS, Mário (2014) - 'Mil rochas e tal...'?': Inventário dos sítios da arte rupestre do vale do Côa (Conclusão). Portvgalia. Porto. 35, pp. 17-59.

SANTOS, André Tomás Pinto da Silva e Conceição (2017) - A arte paleolítica ao ar livre da bacia do Douro à margem direita do Tejo: uma visão de conjunto. Tese de Doutoramento policopiada. Porto: Universidade Porto.

SANTOS, André Tomás; AUBRY, Thierry; BARBOSA, A. F.; GARCÍA DIEZ, Marcos; SAMPAIO, Jorge Davide (2018) - O final do ciclo gráfico paleolítico do Vale do Côa: A arte móvel do Fariseu (Muxagata, Vila Nova Foz Côa). Portvgalia. Porto. 39, pp. 5-96. 


\begin{tabular}{|c|c|c|c|c|c|c|c|c|c|}
\hline \multirow[t]{2}{*}{ Registo } & \multicolumn{3}{|c|}{ Magdalenense } & \multicolumn{3}{|c|}{ Tardiglaciar } & \multicolumn{3}{|c|}{ Epipaleolítico } \\
\hline & I & II & III & I & II & III & I & II & III \\
\hline R. Piscos 2 & 1 & - & - & - & - & - & - & - & - \\
\hline R. Piscos 24 (2) & 1 & - & - & - & - & - & - & - & - \\
\hline R. Piscos 24 (3) & 3 & - & - & - & - & - & - & - & - \\
\hline R. Piscos 24 (4) & 3 & - & - & - & - & - & - & - & - \\
\hline R. Piscos 24 (5) & 1 & - & - & - & - & - & - & - & - \\
\hline R. Piscos 24 (6) & 1 & - & - & - & - & - & - & - & - \\
\hline R. Piscos $24(7)$ & 4 & - & - & - & - & - & - & - & - \\
\hline R. Piscos 24 (12) & 1 & - & - & - & - & - & - & - & - \\
\hline R. Piscos 24 (13) & 2 & - & - & - & - & - & - & - & - \\
\hline R. Piscos 24 (17) & 1 & - & - & - & - & - & - & - & - \\
\hline R. Piscos 24 (21) & 1 & - & - & - & - & - & - & - & - \\
\hline R. Piscos 24 (23) & 1 & - & - & - & - & - & - & - & - \\
\hline R. Piscos 24 (28) & 1 & - & - & - & - & - & - & - & - \\
\hline Fariseu a. m. (1) & - & - & - & - & - & 1 & - & - & - \\
\hline Fariseu a. m. (4) & - & - & - & 1 & - & - & - & - & - \\
\hline Fariseu a.m. (48) & - & - & - & - & 1 & - & - & - & - \\
\hline Fariseu a.m. (85) & - & - & - & - & 1 & - & - & - & - \\
\hline Fariseu a. m. (86) & - & - & - & - & 1 & - & - & - & - \\
\hline Fariseu 4 & 2 & - & - & - & - & - & - & - & - \\
\hline Fariseu 8 & 1 & - & - & - & - & - & - & - & - \\
\hline Foz do Côa 148 & - & - & - & - & - & 7 & - & - & - \\
\hline Foz do Côa 151 & - & - & - & - & 1 & - & - & - & - \\
\hline Foz do Côa 170 & - & - & - & - & 1 & - & - & - & - \\
\hline V. J. Esteves 4 & - & - & - & - & 1 & - & - & - & - \\
\hline Penascosa 17 & - & - & - & - & 1 & - & - & - & - \\
\hline Vermelhosa 1 & - & - & - & - & 1 & - & - & - & - \\
\hline Broeira 11 & - & - & - & - & 2 & - & - & - & - \\
\hline Vale Escuro 11 & - & - & - & - & 1 & - & - & - & - \\
\hline Alto da Cotovia 2 & - & - & - & - & 2 & - & - & - & - \\
\hline Alto da Cotovia 3 & - & - & - & - & 2 & - & - & - & - \\
\hline Faia 1 & - & - & - & - & - & - & - & 1 & - \\
\hline Faia 3 & - & - & - & - & - & - & - & 1 & - \\
\hline Faia 5 & - & - & - & - & - & - & - & 2 & - \\
\hline Faia 8 & - & - & - & - & - & - & - & 7 & - \\
\hline Ervideiro 1 & - & - & - & - & - & - & - & 5 & - \\
\hline Ervideiro 2 & - & - & - & - & - & - & - & 12 & - \\
\hline Ribeirinha 1 & - & - & - & - & - & - & - & 2 & - \\
\hline TOTAL & 24 & - & - & $\mathbf{1}$ & 15 & 8 & - & 30 & - \\
\hline
\end{tabular}

Figura 1 - Relação das figuras antropomórficas de cronologia Paleolítica e Epipaleolítica da região do Côa, indicando-se os sítios e registos de origem e o tipo em que se inserem. Na arte móvel do Fariseu indica-se a número da peça, e na rocha 24 da Ribeira de Piscos indica-se o número do painel. 


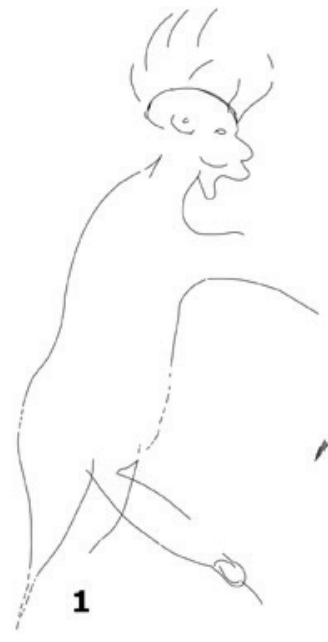

Tipo I
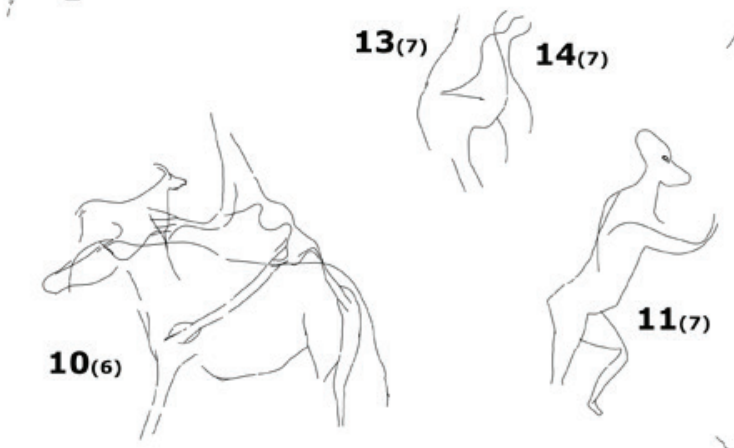

$4(3)$

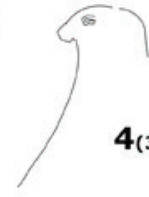

$5(3)$
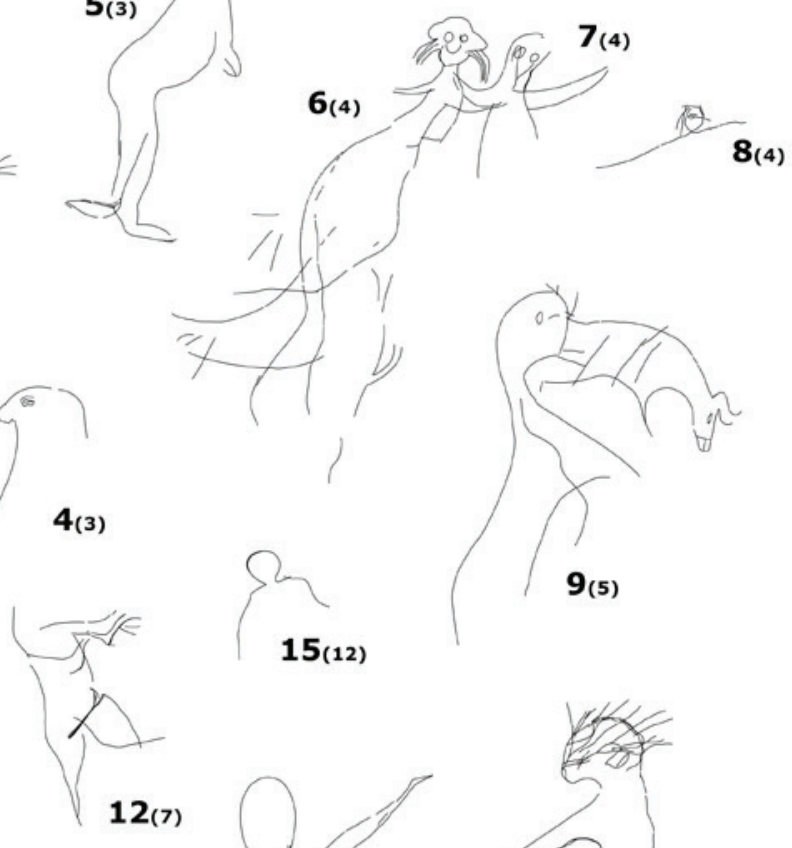<smiles></smiles>
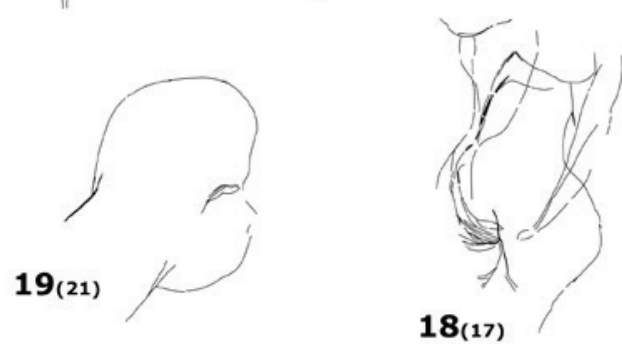

17(13)

$16(13)$

15(12)

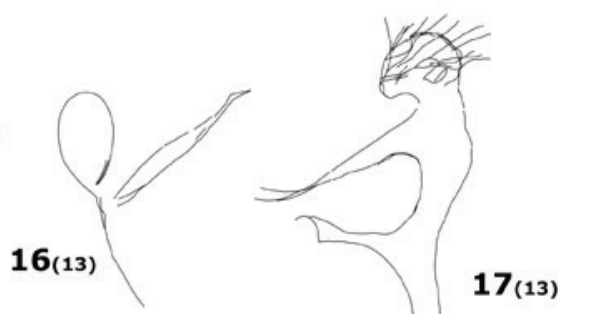

22
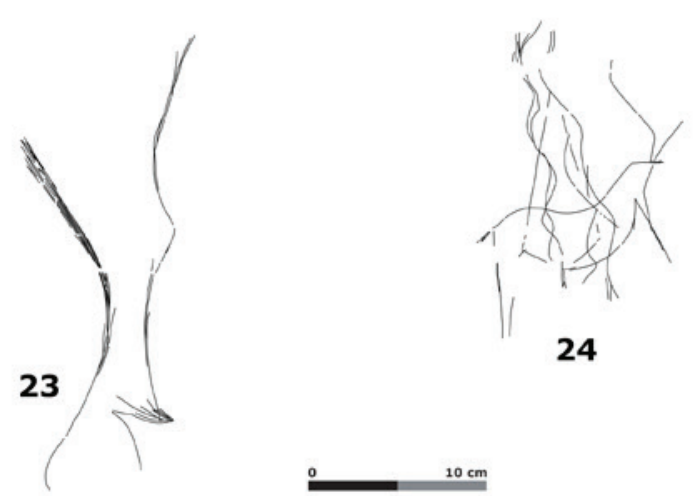

21(28)
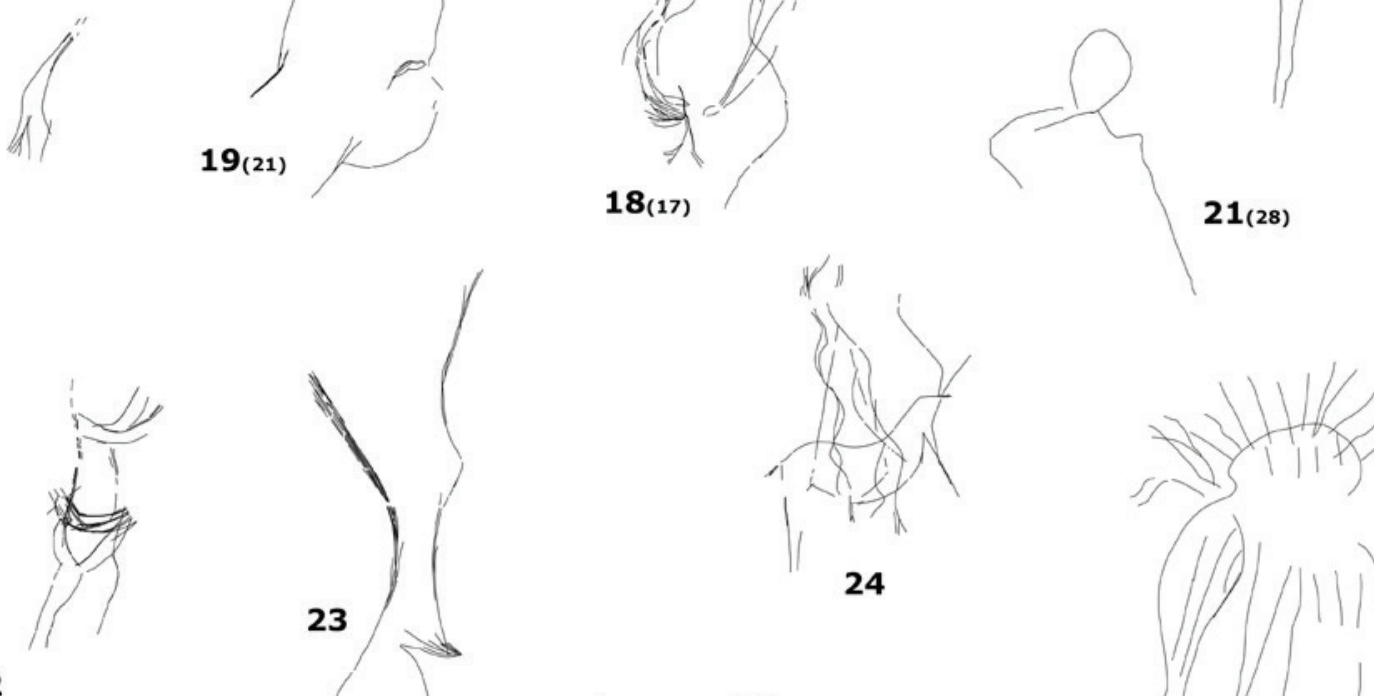

25

Figura 2 - Antropomorfos Paleolíticos de Tipo I. 1 - Ribeira de Piscos 2; 2 a 21 - Ribeira de Piscos 24 (entre parêntesis indica-se o número do painel); 22 e 23 - Fariseu 4; 24 - Fariseu 8; 25- Arte móvel do Fariseu (peça 4). Todos os desenhos são do PAVC/ CNART/Fundação Côa Parque, excepto o n⿳o 24, feito pelo autor a partir de fotografia. Todas as figuras foram reduzidas à mesma escala, excepto a n⿳o 25 , aumentada 5 vezes em relação a essa escala. 

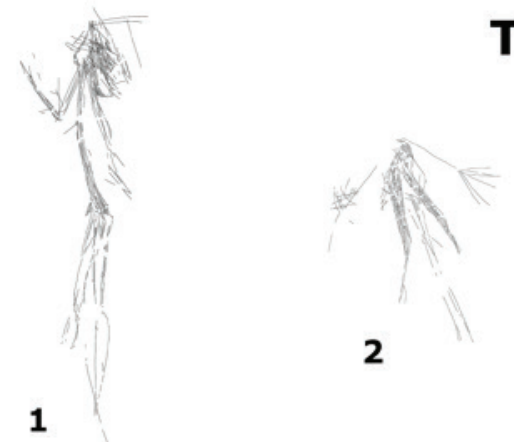

Tipo II

6

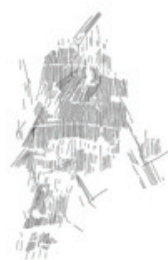

7
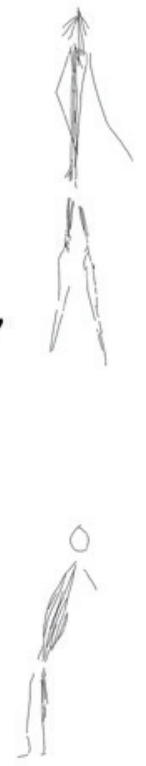

10

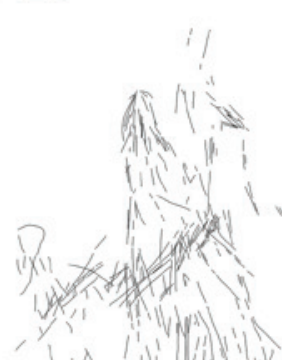

3

N.

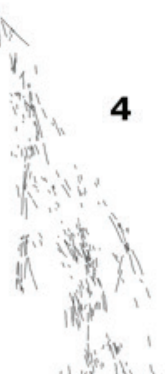

5

8
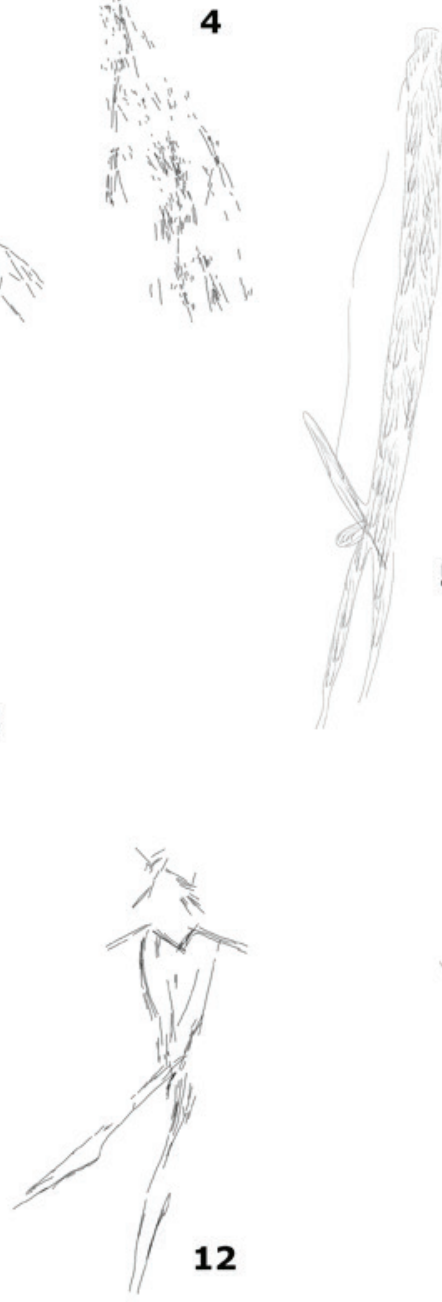

12

9

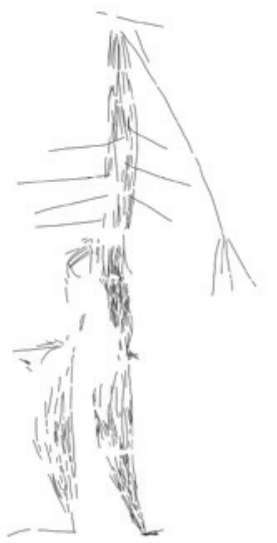

14

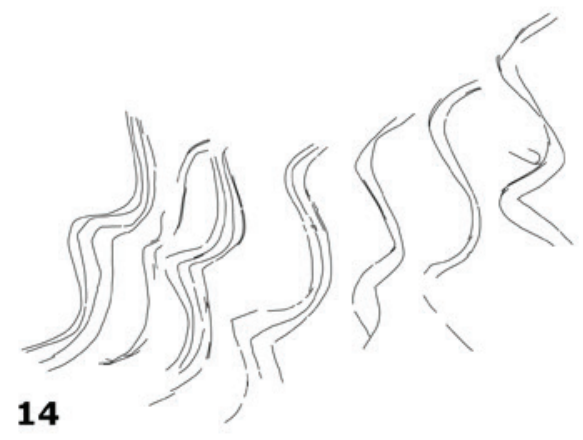

\section{Tipo III}




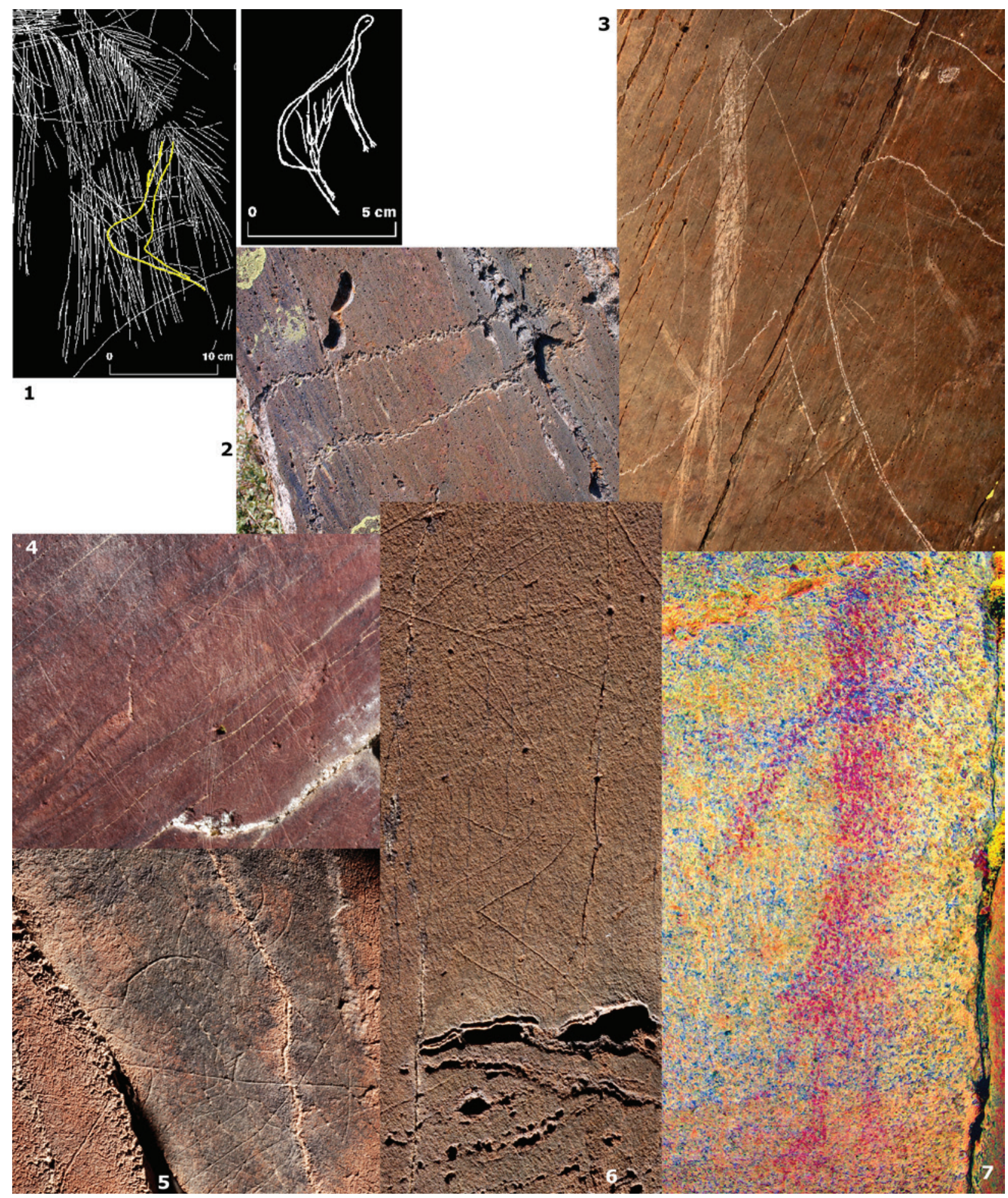

Figura 4 - Em cima, três exemplos de revisão cronológica de figuras: 1 - Vermelhosa 1 (a partir de Arcà, 1996); 2 - Quinta da Barca 18; 3 - Penascosa 17 (note-se o cervídeo Tardiglaciar à direita da mão do antropomorfo). Em baixo, exemplos diversos de figuras antropomórficas: 4 - Alto da Cotovia 2 (parte superior); 5-Ribeira de Piscos 24, painel 3 (detalhe da cabeça, notem-se os traços que emanam desta); 6 - Foz do Côa 148 (detalhe da figura na extremidade direita do conjunto); 7 - Ervideiro 2 (figura pintada possivelmente Epipaleolítica, talvez feminina, numa imagem tratada com DStretch). Todas as fotografias são do autor. 


\title{
OS MOTIVOS ZOOMÓRFICOS \\ REPRESENTADOS NAS PLACAS DE \\ TEAR DE VILA NOVA DE SÃO PEDRO \\ (AZAMBUJA, PORTUGAL)
}

\author{
Andrea Martins ${ }^{1}$, César Neves ${ }^{2}$, José Morais Arnaud ${ }^{3}$, Mariana Diniz ${ }^{4}$
}

\begin{abstract}
RESUMO
Do abundante espólio recolhico nas escavações realizadas entre 1936 e 1967 no povoado calcolítico de Vila Nova de São Pedro destacam-se cerca de 500 elementos em cerâmica comummente designados por "placas de tear" que apresentam distintas tipologias, dimensões e, a maioria, as superfícies decoradas. O dispositivo iconográfico presente nas placas é bastante diversificado, sendo predominantes os motivos geométricos, existindo também motivos soliformes, antropomórficos e zoomórficos. Desta última categoria encontram-se identificados 11 exemplares, no espólio depositado no Museu Arqueológico do Carmo, cuja tipologia se divide em dois tipos: quadrúpedes - cuja espécie não é identificável - e representações de cervídeos.

Estes motivos iconográficos fazem parte do universo simbólico e conceptual das comunidades peninsulares do $3^{\circ}$ milénio a.C., surgindo igualmente em diversas categorias artefactuais tais como cerâmicas, estatuetas, placas, gravuras e pinturas rupestres. Compreender os mecanismos que potenciam esta uniformidade temática, bem como a importância do cervídeo para estes grupos agro-pastoris, permitirá mais uma aproximação ao enquadramento cultural e social destas comunidades.

Palavras-chave: Vila Nova de São Pedro, Placas de tear, Zoomorfos, Cervídeos, Iconografia.
\end{abstract}

\section{ABSTRACT}

From the excavations carried out between 1936 and 1967 in the Chalcolithic settlement of Vila Nova de São Pedro (Azambuja, Portugal), there were recovered more than 500 ceramic elements usually known as "loom weights" with different shapes, dimensions and, in the majority, with decorated surfaces. The iconographic repertoire is quite diverse, with the geometric motifs in higher representation, followed by soliforms, anthropomorphic and zoomorphic motifs. For the zoomorphic motifs there were identified eleven decorated surfaces, whose typology is split into two categories: quadruped - whose species are not identifiable; deer representations.

These iconographic motifs are part of the symbolic and conceptual universe of Iberian communities from the $3^{\text {rd }}$ Millennium BC, also appearing in several artifactual categories such as ceramics, figurines, plates, engravings and rock art paintings. Understanding the mechanisms that create and increase this thematic uniformity, as well as the meaning of the deer for these agro pastoral groups, will allow a closer approach to the cultural and social behavior of these communities.

Keywords: Vila Nova de São Pedro, Loom weights, Zoomorphic figures, Cervids, Iconography.

\footnotetext{
1. Uniarq, Centro de Arqueologia da Faculdade de Letras da Universidade de Lisboa / FCT/ Associação dos Arqueólogos Portugueses; andrea.arte@gmail.com

2.Associação dos Arqueólogos Portugueses / Centro de Arqueologia da Faculdade de Letras da Universidade de Lisboa; c.augustoneves@gmail.com

3. Associação dos Arqueólogos Portugueses; jemarnaud@gmail.com

4. Uniarq, Centro de Arqueologia da Faculdade de Letras da Universidade de Lisboa / FCT/ Associação dos Arqueólogos Portugueses; m.diniz@fl.ul.pt
} 


\section{VILA NOVA DE SÃO PEDRO E AS PLACAS DE TEAR: ÍCONES DESDE A PRIMEIRA HORA}

Escrever sobre o espólio de Vila Nova de São Pedro (Azambuja, Portugal) (Figura 1) implica obrigatoriamente referir um dos ícones desta colecção - as placas de tear. Estes artefactos foram identificados logo em 1937, sendo referidos ao longo das $31 \mathrm{cam}$ panhas de escavações realizadas por Afonso do Paço e Eugénio Jalhay (este último até 1950), bem como nas intervenções efectuadas no âmbito do projecto VNSP 3000 - Vila Nova de São Pedro, de novo, no $3^{\circ}$ milénio (Arnaud et al, 2017; Martins et al, 2019).

Este trabalho visa a apresentação de 11 placas, depositadas no Museu Arqueológico do Carmo (MAC), que apresentam em uma das suas superfícies representações iconográficas interpretadas como zoomórficas. No espólio existente no Museu Hipólito Cabaço (Alenquer), encontra-se outra com representação de cervídeo, placa esta publicada por A. Paço e E. Jalhay em 1939 e recolhida numa das duas primeiras campanhas (Paço e Jalhay, 1939: fig. $21-\mathrm{n}^{\circ}{ }^{\mathrm{O}}$ ). Até à data, não temos conhecimento de outras representações zoomórficas nos pequenos conjuntos de placas de VNSP que se encontram em outras instituições, podendo por isso este número ser aumentado em trabalhos futuros.

A sua singularidade levou a que, logo em 1940, estas fossem apresentadas por Afonso do Paço no Congresso do Mundo Português, realçando as suas particularidades face a outros exemplares da Península Ibérica (Paço, 1941). Nessa publicação, os desenhos esquemáticos de 58 placas encontram-se organizados por categorias iconográficas, apresentando paralelos com representações em outros artefactos (vasos cerâmicos ou pinturas rupestres), da Península Ibérica. Neste primeiro trabalho é também abordada a temática funcional, realçando que as perfurações não apresentam sinais de desgastes, levantando a hipótese de que Vila Nova de São Pedro fosse também um centro produtor destes objectos (Paço, 1941).

Ao longo das últimas décadas as placas de tear de VNSP foram sendo referidas em diversos trabalhos (e.g. Diniz, 1994), encontrando-se a sua sistematização tipológica, iconográfica e enquadramento crono-cultural num artigo de síntese (Arnaud, 2013), antecedendo o trabalho monográfico de inventariação e estudo que se encontra em preparação pelos signatários.

\section{O OBJECTO DE ESTUDO: AS PLACAS COM REPRESENTAÇÕES ZOOMÓRFICAS}

$\mathrm{Na}$ colecção de placas de tear do MAC estão identificadas 11 placas com 13 representações zoomórficas, sete destas de cervídeos (machos) e seis de quadrúpedes sem identificação da espécie.

\subsection{Técnica de execução e decoração}

No MAC encontram-se 515 placas de tear, todas elas de cerâmica, claramente padronizadas, de formato quadrangular ou rectangular, apresentando na grande maioria quatro perfurações. A técnica de execução da placa é manual, efectuando-se a perfuração com um objecto de perfil circular, procedendo-se ao alisamento das superfícies e arestas, bem como dos rebordos das perfurações. Foi possível observar em alguns destes objectos um pequeno rebordo exterior à perfuração, revelando-nos assim a direcção de perfuração e que, como esperado, esta foi feita previamente à cozedura.

Das 515 placas 246 não apresentam decoração, estando identificados 364 motivos iconográficos, existindo placas com apenas uma das superfícies e outras com as duas superfícies decoradas. No conjunto do MAC a maior percentagem de placas decoradas poderia ser entendida como resultante de uma opção de recolha, no campo porém, os trabalhos efectuados no âmbito do projeto VNSP3ooo, não levaram à identificação de placas lisas entre os vários "depósitos" de materiais ainda visíveis nas imediações do sítio arqueológico, como acontece com a cerâmica lisa ou com os restos de fauna (Martins et al, 2019; Francisco et al, 2020). Consideramos por isso que esta paridade, ou ligeira predominância, das placas decoradas face às lisas corresponde a uma opção técnica e ideo-tipológica nesta categoria artefactual. Os futuros trabalhos de inventariação de placas depositadas noutros museus poderão proporcionar novas leituras (Gráfico 1).

Relativamente à técnica de execução da decoração verifica-se que a grande maioria foi realizada através de incisão e apenas em 38 motivos foi usada a impressão. As incisões mostram as margens bem definidas, tendo perfil em $\mathrm{V}$ ou $\mathrm{U}$, podendo ser de reduzida espessura, correspondendo a uma incisão filiforme. Terão sido realizadas por elementos vegetais ou objectos metálicos num momento prévio à cozedura, sendo alisadas juntamente com a superfície da placa. 
Através do programa de arqueologia experimental realizado no âmbito do projecto $\mathrm{VNSP}_{3} \mathrm{Ooo}$ podemos afirmar que a decoração é realizada num momento posterior à execução da placa, numa fase adiantada da secagem, estando a argila já mais compactada e resistente. A incisão feita imediatamente depois da placa estar moldada apresenta as margens indefinidas e com rebordos exteriores, ficando o motivo iconográfico imperfeito e irregular.

Algumas placas mostram ainda o motivo seccionado pela perfuração, revelando-nos que a abertura do orifício foi realizada num momento posterior ao da execução da decoração.

Os motivos decorativos encontram-se, por agora, divididos em quatro tipologias iconográficas fundamentais: antropomórficos; zoomórficos; soliformes ou astrais e geométricos. A última categoria é a mais representada no conjunto.

Para efeitos descritivos foi designada como Superfície A aquela que tem o motivo zoomórfico e como Superfície B a oposta, podendo esta apresentar ou não gravações.

\subsection{Descrição iconográfica dos motivos zoomórficos}

VNSP3000/MAC/236 - Placa rectangular, com cantos arredondados, alisada e parcialmente fracturada. Apresenta marcas de acção de fogo e as superfícies estão muito erodidas. As perfurações não apresentam evidências de desgaste, nem o rebordo do processo de execução(Figura 2$)^{5}$.

Superficie A - Motivo interpretado como uma representação zoomórfica - um cervídeo, orientado para a esquerda. É formado por uma linha horizontal com $6,5 \mathrm{~cm}$, localizada no centro da placa, existindo na parte inferior desta linha dois conjuntos de traços verticais, paralelos entre si, com cerca de $1 \mathrm{~cm}$ de comprimento e $0,5 \mathrm{~cm}$ de distância entre cada conjunto de traços - as patas. O conjunto de traços mais à esquerda é oblíquo. Na parte superior da linha horizontal, na área à esquerda, surgem dois traços verticais, paralelos entre si, com cerca de $2,5 \mathrm{~cm}$ de comprimento e o, $5 \mathrm{~cm}$ de distância, dos quais parte um conjunto de pequenos traços oblíquos - as hastes. O primeiro tem 4 traços oblíquos e o segundo 6 traços. A técnica de execução utilizada foi a incisão,

5. Os desenhos das placas com representações zoomórficas foram realizados por César Neves. sendo as hastes e os membros inferiores filiformes. Estamos assim perante a representação de um cervídeo - macho/adulto, caracterizado pelas hastes ramificadas e membros inferiores dianteiros e traseiros. A disposição oblíqua dos membros inferiores dianteiros revela movimento, não sendo uma figura estática.

Superficie B - Não apresenta decoração. A superfície está bastante deteriorada não sendo possível afirmar se possuiu originalmente algum motivo iconográfico.

VNSP300o/MAC/269 - Placa rectangular, com cantos arredondados, alisada e parcialmente fracturada. Apresenta marcas de acção de fogo disseminadas e as superfícies erodidas. Apenas tem uma perfuração, de pequena dimensão, que não apresenta sinais de desgaste (Figura 3).

Superficie A - Motivo decorativo interpretado como uma representação zoomórfica - um cervídeo, orientado para a esquerda. É formado por duas linhas horizontais com cerca de 2,3 cm de comprimento, paralelas entre si que representam o dorso e ventre do animal. Na zona inferior surgem dois traços verticais de disposição oblíqua, paralelos entre si, com $0,5 \mathrm{~cm}$ de distância e 1, $8 \mathrm{~cm}$ de comprimento. Na parte superior surge representado o pescoço e com outros dois traços paralelos a cabeça com representação do olho e focinho. Sobre a extremidade da cabeça surgem onze traços verticais e oblíquos, com cerca de $1,5 \mathrm{~cm}$ de comprimento, que representam as hastes ramificadas. A técnica de execução utilizada foi a incisão.

Trata-se de uma representação de um cervídeo - macho/adulto, caracterizado pelas hastes ramificadas e membros inferiores dianteiros que estão dispostos obliquamente revelando movimento. A cabeça mostra pormenores anatómicos como o olho e focinho. Superficie B - Não apresenta decoração. A superfície está bastante deteriorada não sendo possível afirmar se possuiu originalmente algum motivo iconográfico.

VNSP3000/MAC/305 - Placa rectangular, com cantos angulosos, alisada e parcialmente fracturada. Apresenta marcas de fogo disseminadas e as superfícies erodidas. Possui duas perfurações, sem evidências de desgaste, mostrando uma delas ainda sedimento no seu interior (Figura 4).

Superficie A - Motivo interpretado como uma representação zoomórfica - um cervídeo, orientado para a direita. É formado por um conjunto de linhas horizontais com cerca de $4 \mathrm{~cm}$ de comprimento, 
paralelas entre si que representam o dorso e ventre do animal. Na zona inferior surgem dois traços verticais, paralelos entre si, com $0,5 \mathrm{~cm}$ de distância e $2 \mathrm{~cm}$ de comprimento, existindo outro traço vertical com a mesma dimensão na área mais à esquerda - as patas. Na parte superior surgem dois traços verticais, com cerca de 1,2 cm de comprimento, paralelos entre si, tendo o traço mais à esquerda 4 pequenos traços oblíquos e o traço mais à esquerda 3 traços oblíquos - as hastes. A técnica de execução utilizada foi a incisão, sendo as hastes filiformes.

Corresponderá a uma representação de um cervídeo - macho/adulto, caracterizado pelas hastes ramificadas, mostrando os membros inferiores rígidos correspondendo a uma figura estática.

Superfície $B$ - Superfície muito erodida, com gravação por incisão de um motivo considerado geométrico. É formado por dois traços horizontais paralelos entre si tendo na zona inferior dois pares de traços paralelos dispostos na vertical, estando a extremidade superior direita partida. Esta morfologia poderá ser caracterizada como zoomórfica, porém, não apresenta pormenores como as outras representações (cabeça ou hastes), por se encontrar fracturada no centro superior direito. Por questões estilísticas, optou-se, nesta fase, por incluir esta morfologia nos motivos geométricos estando, assim, fora desta análise.

VNSP300o/MAC/306 - Placa rectangular com cantos ângulosos e superfície alisada, estando fracturada no centro, mas permitindo a sua reconstituição integral. Mostra quatro perfurações que não apresentam evidências de desgaste, nem o rebordo da perfuração, indicando um alisamento pré-cozedura. Apresenta marcas de fogo pontuais e a decoração foi realizada por incisão (Figura 5 ).

Superficie A - Motivo interpretado como uma representação zoomórfica - um quadrúpede, orientado para a esquerda. É formado por uma linha horizontal com $6,5 \mathrm{~cm}$, que atravessa toda a superfície da placa. Na parte inferior desta linha surgem dois conjuntos de traços verticais, paralelos entre si, com cerca de $2 \mathrm{~cm}$ de comprimento e $0,5 \mathrm{~cm}$ de distância entre cada conjunto de traços. O último traço - mais à direita - poderá corresponder ao prolongamento do traço horizontal superior. Na parte superior da linha horizontal, na área mais à direita, surgem dois traços verticais, paralelos entre si, com cerca de 1,5 cm de comprimento e 0,5 cm de distância, dis- postos na oblíqua. É uma figura que ocupa todo o espaço operativo.

Confirma-se a representação de um quadrúpede, sendo impossível determinar a espécie. Tem membros inferiores dianteiros e posteriores, e os dois traços na área superior poderão representar orelhas ou chifres.

Superficie B - Morfologia enquadrável na categoria de motivos geométricos. Enquadrado nas linhas zig-zagueantes, com 7,2 cm de comprimento, composto por 9 segmentos curvos, tendo uma pequena bifurcação no topo. Este motivo poderia também ficar incluído nos motivos zoomórficos, correspondendo a um serpentiforme. No entanto, condicionantes estilísticas e interpretativas levam-nos a colocá-lo, por agora, nos motivos geométricos. Ocupa todo o espaço operativo estando ao centro da placa.

VNSP30oo/MAC/345 - Fragmento de placa com uma perfuração, com cantos angulosos e superfície polida. Mostra marcas de fogo em toda a superfície e a decoração foi realizada por incisão. A perfuração não apresenta sinais de desgaste (Figura 6).

Superficie A - Motivo interpretado como uma representação zoomórfica - parte das hastes de um cervídeo, orientado para a direita. Trata-se de uma peça muito fracturada, estando apenas conservada a porção superior direita de uma placa que deveria ter formato rectangular. A decoração é formada por um traço vertical, inclinado obliquamente e com cerca de $2 \mathrm{~cm}$ de comprimento, unindo uma série de 12 pequenos traços paralelos entre si, com cerca de $0,5 \mathrm{~cm}$, dispostos obliquamente. Corresponderá assim à representação parcial das hastes ramificadas de um cervídeo.

Superficie B - Não apresenta decoração. A superfície está bastante deteriorada não sendo possível afirmar se teve originalmente algum motivo iconográfico.

VNSP300o/MAC/403 - Placa rectangular, com cantos angulosos, alisada e parcialmente fracturada. Não tem marcas de fogo mas as superfícies encontram-se muito erodidas. Apresenta duas perfurações, com algum desgaste, mostrando rebordo resultante da perfuração pré-cozedura (Figura 7).

Superficie A - Motivo interpretado como uma representação zoomórfica - um cervídeo, orientado para a esquerda. É formado por duas linhas horizontais com cerca de $2 \mathrm{~cm}$ de comprimento, paralelas entre si que representam o dorso e ventre do ani- 
mal. Na zona inferior surgem dois traços verticais, de disposição oblíqua, paralelos entre si, com o, $5 \mathrm{~cm}$ de distância e $2 \mathrm{~cm}$ de comprimento - as patas. $\mathrm{Na}$ parte superior surge um traço vertical, com cerca de 1,5 cm de comprimento, tendo do lado direito quatro traços horizontais, paralelos entre si, e do lado esquerdo seis traços horizontais, paralelos entre si - as hastes. A técnica de execução utilizada foi a incisão, sendo as hastes filiformes.

Considera-se estar perante a representação de um cervídeo-macho/adulto, caracterizado pelas hastes ramificadas, mostrando os membros inferiores dianteiros numa posição oblíqua revelando movimento. Superficie B - Não apresenta decoração. A superfície está bastante deteriorada não sendo possível afirmar se teve originalmente algum motivo iconográfico.

VNSP300o/MAC/409 - Fragmento de placa com uma perfuração, com cantos arredondados e superfície erodida. Mostra marcas de fogo disseminadas e a decoração foi realizada por incisão. A perfuração não apresenta sinais de desgaste (Figura 8).

Superfície A - Motivo interpretado como uma representação zoomórfica - um quadrúpede, orientado para a direita. Localiza-se na parte direita da placa entre as duas perfurações. É formado por uma linha horizontal com $1,5 \mathrm{~cm}$, existindo na área inferior desta linha dois conjuntos de traços verticais, paralelos entre si, com cerca de $2 \mathrm{~cm}$ de comprimento e $0,2 \mathrm{~cm}$ de distância entre cada conjunto de traços. $\mathrm{Na}$ parte superior da linha horizontal, na área mais à esquerda, surgem dois traços verticais, paralelos entre si, com cerca de o, $8 \mathrm{~cm}$ de comprimento e o, $2 \mathrm{~cm}$ de distância. À direita desta figura surgem dois traços verticais que poderiam fazer parte de um outro motivo, impossibilitando a sua caracterização devido ao mau estado de conservação e fractura da placa.

Interpretado como uma representação de um quadrúpede, não sendo possível determinar a espécie. Possui membros inferiores dianteiros e posteriores, e os dois traços na área superior poderão representar orelhas ou cornos.

Superfície B - Não apresenta qualquer decoração.

VNSP300o/MAC/446 - Placa quadrangular, com cantos arredondados, alisada e parcialmente fracturada. Apresenta as quatro perfurações sem marcas de desgaste. As marcas de acção de fogo são cobridoras e a decoração foi feita por incisão (Figura 9). Superficie A - Motivo interpretado como uma re- presentação zoomórfica - um quadrúpede, orientado para a direita. É formado por duas linhas horizontais, com $5,5 \mathrm{~cm}$ de comprimento, paralelas entre si, existindo na área inferior desta linha dois conjuntos de traços verticais, paralelos entre si, com cerca de $3 \mathrm{~cm}$ de comprimento e $0,7 \mathrm{~cm}$ de distância entre cada conjunto de traços. Na parte superior da linha horizontal, na área mais à direita, surgem dois traços verticais, paralelos entre si, com cerca de 1,7 cm de comprimento e o, $4 \mathrm{~cm}$ de distância. Ocupa todo o espaço operativo da placa, estando enquadrada entre as 4 perfurações.

Estamos assim perante a representação de um quadrúpede, sendo impossível determinar a espécie. Tem membros inferiores dianteiros e posteriores, e os dois traços na área superior poderão representar orelhas ou cornos.

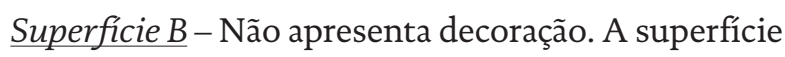
está bastante deteriorada, não sendo possível afirmar se teve originalmente algum motivo iconográfico.

Arestas - As quatro arestas estão também decoradas com traços incisos horizontais.

VNSP300o/MAC/475 - Placa quadrangular, com cantos angulosos, alisada e parcialmente fracturada. Apresenta marcas de acção de fogo pontuais e as três perfurações não mostram sinais de desgaste. A decoração foi realizada por incisão. Encontra-se em muito mau estado de conservação (Figura 10). Superficie A - Motivo zoomórfico interpretado como um cervídeo, orientado para a esquerda. É formado por duas linhas horizontais com cerca de $4 \mathrm{~cm}$ de comprimento, paralelas entre si que representam o dorso e ventre do animal. $\mathrm{Na}$ zona inferior surgem dois conjuntos de traços verticais de disposição oblíqua, paralelos entre si, com $0,2 \mathrm{~cm}$ de distância e 1,8 cm de comprimento - as patas. Na extremidade esquerda do traço superior inicia-se outro, de disposição vertical, ramificando-se na extremidade por 12 traços de disposição oblíqua, paralelos entre si e com cerca de 1,5 cm de comprimento - as hastes. Surgem ainda de ambos os lados dois pares de pequenos traços horizontais.

Representação de um cervídeo - macho/adulto, caracterizado pela haste ramificada e membros inferiores dianteiros que estão dispostos obliquamente, revelando movimento. $O$ conjunto de pequenos traços laterais poderão estar relacionados com a cabeça do animal.

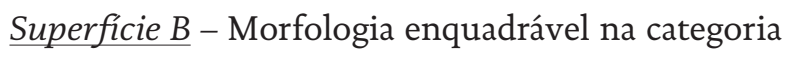


de motivos geométricos, formado por um conjunto de quatro linhas quebradas.

VNSP300o/MAC/490 - Placa rectangular, com cantos angulosos, alisada e parcialmente fracturada. Apresenta marcas de fogo pontuais e as quatro perfurações não mostram evidências de desgaste. A decoração foi realizada através de incisão (Figura 11). Superficie A - Motivo interpretado como uma representação zoomórfica - um quadrúpede, orientado para a direita. É formado por uma linha horizontal com $5,7 \mathrm{~cm}$, que atravessa toda a superfície da placa. Na parte inferior desta linha surgem dois conjuntos de traços verticais, paralelos entre si, com cerca de $2 \mathrm{~cm}$ de comprimento e $0,5 \mathrm{~cm}$ de distância entre cada conjunto de traços. Na parte superior da linha horizontal, na área mais à direita, surgem dois traços verticais, paralelos entre si, com cerca de $2 \mathrm{~cm}$ de comprimento e o, $5 \mathrm{~cm}$ de distância. Ocupa todo o espaço operativo da superfície da placa.

Representação de um quadrúpede, não sendo possível determinar a espécie. Apresenta membros inferiores dianteiros e posteriores, surgindo no membro direito um pequeno traço horizontal que poderá corresponder à representação de pata. Os dois traços na área superior representarão orelhas ou cornos.

Superfície $B$ - Morfologia enquadrável na categoria de motivos soliformes, formado por um conjunto de linhas radiais. Encontra-se muito fracturada.

VNSP3000/MAC/491 - Placa rectangular, com cantos angulosos, alisada e parcialmente fracturada. Apresenta marcas de fogo pontuais e três perfurações, sem evidência de desgaste. A decoração foi realizada através de incisão (Figura 12).

Superficie A - Apresenta três motivos zoomórficos. No topo da peça surge um motivo zoomórfico muito esquemático, orientado para a direita e formado por duas linhas horizontais, paralelas entre si, com cerca de $3 \mathrm{~cm}$ de comprimento, que se juntam à esquerda. Neste ponto iniciam-se duas linhas verticais, com $1 \mathrm{~cm}$ de comprimento. Trata-se assim de um quadrúpede muito esquemático, tendo representado corpo e extremidades na cabeça - cornos ou orelhas.

Ao centro da placa surge outro motivo zoomórfico, orientado para a direita, sendo observáveis dois traços, paralelos entre si e com $5 \mathrm{~cm}$ de comprimento, existindo na extremidade esquerda outros dois, com 1,5 cm de comprimento, de disposição vertical com inclinação oblíqua. Trata-se da representação de um quadrúpede muito esquemático, que mostra ventre e dorso e os membros inferiores traseiros.

Sob o zoomorfo anterior, na área central da placa, surge a terceira representação zoomórfica. Está orientada para a esquerda e é formada por um conjunto de traços horizontais, com cerca de $2 \mathrm{~cm}$ de comprimento, paralelos entre si, sendo que na área mais à esquerda surgem outros dois pequenos traços de disposição vertical com inclinação oblíqua. Na parte superior, dois traços verticais, paralelos entre si e com cerca de 1,3 cm de comprimento, formam o pescoço, surgindo da extremidade seis traços de reduzida dimensão e disposição circular. Estamos perante um quadrúpede, possivelmente um veado com início de hastes ou cornos, mostrando pormenores como a cabeça e focinho. Os membros inferiores dianteiros dispostos obliquamente revelam movimento.

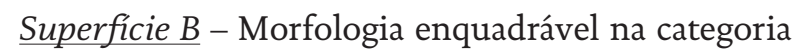
de motivos geométricos. Trata-se de um espinhado formado por um conjunto de seis linhas horizontais, paralelas entre si, cruzadas por uma série de traços oblíquos de diferentes orientações. Ocupa todo o espaço operativo da superfície da placa.

\section{PROVENIÊNCIA E CONTEXTO ARQUEOLÓGICO}

O povoado calcolítico de Vila Nova de São Pedro foi escavado de forma intensiva durante 31 anos, sendo que a metodologia utilizada não permite uma clara correlação estratigráfica entre materiais arqueológicos recolhidos e contextos de proveniência. Como referido anteriormente, desde a primeira publicação em 1939 que as placas de tear são descritas e representadas quer por desenho esquemático, quer em fotografia (Paço e Jalhay, 1939; 1942; 1943; Jalhay e Paço, 1945; Paço, 1941, Paço e Costa Arthur, 1952), não sendo, no entanto, referida a origem, no campo, destes materiais.

Através da análise dos dados publicados sabemos que as placas foram recolhidas na zona entre o reduto central - "1aㅗ linha de muralha" - e " $2^{\underline{2}}$ linha de muralha", espaço onde foram identificadas diversas áreas habitacionais com fundos de cabana e outras estruturas pétreas mas, também, no centro do povoado, no interior do reduto central, surgindo dispersas por toda a área escavada. Não foi referida nenhuma concentração de placas que poderia indicar áreas funcionais de execução, armazenamento ou produção têxtil. 
Na descrição estratigráfica do corte efectuado por H. Savory é referida a presença de placas perfuradas nos três estratos identificados (Savory, 1970), revelando assim que esta categoria artefactual encontrava-se presente desde a fundação do povoado até ao seu abandono, enquadrando-se cronologicamente ao $3^{\circ}$ milénio A.C.. Outras correlações possíveis entre placas decoradas e placas lisas ou entre motivos iconográficos não são referidas nos registos disponíveis.

Nas sondagens realizadas no âmbito do projecto VNSP 3000 , foram recolhidos alguns destes elementos artefactuais, a maioria fragmentados. Num contexto datado de meados do $3^{\circ}$ milénio cal BC foi recolhida uma placa inteira quadrangular com apenas duas perfurações - em ângulos opostos da mesma extremidade - e um fragmento com decoração geométrica (Martins et al, 2019).

Das 11 placas aqui apresentadas quatro encontravam-se inéditas (placas 236, 305, 403 e 409), sendo que a placa 269 poderá corresponder à peça publicada em 1940 e 1945, surgindo incompleta sem a representação da cabeça e hastes do cervídeo (Paço, 1941: 48 - fig. 1 nº 7; Jalhay e Paço, 1945: 66 - fig. 8 $\mathrm{n}^{\circ} 7$ ). As placas 446, 475 e 490 foram também dadas à estampa mais recentemente (Arnaud, 2013: 453) (Figura 13).

Em suma, as placas de tear, constituem em VNSP um artefacto de ampla dispersão cronológica e espacial no entanto, o papel dos factores pós-deposicionais na dispersão destes materiais não é fácil de avaliar.

\section{REPRESENTAÇÕES ZOOMÓRFICAS DAS SOCIEDADES CAMPONESAS: ARTEFACTOS MÓVEIS E IMÓVEIS,} ANIMAIS MITIFICADOS E ANIMAIS REAIS

Estudar as sociedades agro-pastoris implica necessariamente uma abordagem de conjunto, onde o debate sobre os elementos da cultura material se relaciona com os dados sobre restos faunísticos e com as manifestações rupestres, móveis ou imóveis. Os motivos representados em diferentes suportes tais como recipientes domésticos, objectos ideotécnicos ou grafismos rupestres esquemáticos farão parte do mesmo universo conceptual e simbólico destas comunidades, levando-nos a aceitar que poderão ter significados e papéis similares.

O esquematismo inerente a estas representações im- pede-nos de, em algumas destas placas, identificar categoricamente a espécie representada, e por isso o motivo é classificado apenas como figura quadrúpede. Nestes casos, a ausência de pormenores anatómicos foi uma opção prévia à execução do motivo, e fez parte de um discurso gráfico reconhecido pela comunidade onde a determinação da espécie não parece ser valorizada.

A identificação do quadrúpede é-nos permitida pela presença de membros posteriores ou anteriores, corpos geralmente alongados e de formato sub-rectangular, sendo que outros pormenores anatómicos como hastes, cornos, focinho, cauda, pelagem, patas e cascos poderão permitir a identificação da espécie. A representação de pormenores anatómicos como as hastes, o falo ou morfologia do ventre permitirá uma atribuição sexual, sendo que a associação entre animais semelhantes de diferentes tamanhos poderá representar machos e fêmeas ou adultos e juvenis. Para além destes pormenores anatómicos, em diferentes suportes, encontram-se também relacionados quer com o meio natural envolvente (coberto vegetal e estações do ano), quer com cenas de cópula ou fases do ciclo reprodutivo dos animais, demonstrando o cruzamento sistemático entre as actividades económico-sociais e simbólicas destas comunidades.

Entre os motivos zoomórficos, os quadrúpedes surgem frequentemente na arte esquemática, da Península Ibérica, em pintura e em gravura, surgindo nos mais variados suportes (abrigos, rochas ao ar livre) e com algumas variantes estilísticas como os motivos pectiniformes (Sanchidrián, 2001: 447) ou, classificados como não quadrúpedes, nos quais se incluem aves, anfíbios, peixes e colubrídeos. Encontramos paralelos estilísticos com as representações de Vila Nova de São Pedro, sugerindo uma efectiva uniformidade simbólica e conceptual das comunidades agro-pastoris (Martins, 2016).

No território actualmente português destaca-se o ciclo artístico de gravuras esquemáticas do Vale do Tejo pela diversidade e quantidade de representações zoomórficas cujas características estilísticas possibilitaram a definição de numerosas espécies, selvagens e domésticas (Gomes, 2010), onde os quadrúpedes são dominantes. De Norte a Sul do país encontram-se diversos abrigos com algumas representações zoomórficas pintadas - Forno da Velha, Fonte Santa, Fraga do Gato, Fraga d'Aia, Faia 1, Ribeiro das Casas, Lapa dos Gaivões, Abrigo Pinho Monteiro (Martins, 2013), e entre uma maioria de quadrúpedes indeter- 
minados, destacam-se os cervídeos como a espécie mais identificável.

A semelhança iconográfica entre motivos presentes em suportes rupestres e em artefactos móveis tem sido abordada por diversos investigadores peninsulares, sendo de referir os trabalhos desenvolvidos nas áreas de Valência e Alicante com a definição de horizontes artísticos relacionando cerâmicas cardiais com motivos macro-esquemáticos (Martí Oliver e Hernández Pérez, 1988; Martí Oliver, 2006; Hernández Pérez e Segura Martí, 2002). A utilização de representações gráficas em artefactos provenientes de contextos estratigráficos seguros permite uma atribuição cronológica relativa a motivos idênticos existentes em suportes rupestres e, para os quais, não é possível efectuar uma datação directa. Diversos estudos têm permitido a definição de sequências crono-estilísticas para alguns motivos esquemáticos, tendo em conta artefactos, contextos, tipologias e semelhanças formais, levando a uma aproximação dos conteúdos simbólicos destas comunidades agro-pastoris (Carrasco Rus et al, 2006; Martins, 2016).

A nível estilístico encontram-se diferenças entre representações em artefactos móveis e em suportes rupestres. Se em artefactos, como as placas de tear ou recipientes cerâmicos, os motivos são maioritariamente lineares, sem profundidade ou espessura, nas gravuras e pinturas surgem com contornos e preenchimento interior, correspondendo a figuras com volume, formas anatómicas e uma maior impressão de movimento. No caso dos quadrúpedes indiferenciados torna-se ainda mais difícil efectuar paralelismos entre figuras, pois a ambiguidade destas representações não permite considerações objectivas.

\subsection{Quadrúpedes indeterminados}

No conjunto analisado foram definidas quatro representações de zoomorfos cujas características tipológicas não permitem a atribuição de espécie, ficando assim classificados como quadrúpedes indeterminados. Nenhum deles apresenta pormenores anatómicos claramente identificáveis, podendo as extremidades existentes nas cabeças dos motivos 306, 409, 446 e 490 ser consideradas como cornos ou chifres, estando assim perante a representação de um bovídeo ou de uma cabra/bode (Figuras 5, 8, 9 e 11). Esta última hipótese é particularmente proposta no quadrúpede da placa 306 cujos traços oblíquos (cornos) têm paralelo estilístico com as representa- ções de cabras do Vale do Tejo (Gomes, 2010: 273). Os motivos existentes nas placas 306 e 490 mostram grande semelhança formal, tendo ambos o prolongamento do traço central até à extremidade do membro inferior posterior, podendo assim ter sido executados pelo mesmo indivíduo (Figuras 5 e 11).

Na placa 409 observa-se uma cena em que participam, possivelmente, dois motivos zoomorfos, um completo e de pequena dimensão, enquanto do outro apenas temos a representação de dois traços (Figura 8). Esta cena tem paralelo com a existente na placa 491 (Figura 12), bem como em diversos painéis com figurações rupestres onde está presente a associação de zoomorfos, possivelmente relacionados entre si por laços familiares - fêmea e cria.

Exceptuando o motivo existente na placa 409, todos os zoomorfos indeterminados ocupam o espaço operativo da superfície da placa, enquadrando-se entre as quatro perfurações, sendo figuras equilibradas e facilmente reconhecíveis.

\subsection{Cervídeos}

Os cervídeos (veados, gamos e/ou corços), são a família animal, identificável, mais representada na iconografia das comunidades neolíticas e calcolíticas, apresentando caracteres anatómicos que permitem esta fácil identificação. A representação das hastes ramificadas, típicas dos machos adultos, que atingem o auge no Verão e caem no Inverno, reportam-nos imediatamente para o veado (Cervus elaphus) macho, sendo mais difícil de definir as fêmeas, os juvenis ou mesmo os machos adultos após acasalamento e perda de hastes. O dimorfismo sexual acentuado nos veados permite uma maior diferenciação sexual, factor menos presente no que diz respeito aos corços (C. capreolos). Durante a maior parte do ano, os veados reúnem-se em manadas, de machos, fêmeas e crias, existindo, porém, alguns machos solitários, que apenas se reúnem em período de acasalamento que ocorre no Outono.

Do ponto de vista simbólico seria certamente um animal muito especial, selvagem, forte e que todos os anos se regenera, mudando as grandes hastes e recomeçando um novo ciclo. Seria uma importante fonte de proteína mas também objecto de aproveitamento de recursos secundários como as hastes, matéria-prima base de utensilagem diversificada e mesmo em possíveis cerimónias ou rituais com manipulação de partes do esqueleto como o crânio e respectivas hastes. 
O peso destes animais no universo simbólico encontra-se plasmado nas inúmeras representações existentes em todo o tipo de suportes: rupestres (pintura e gravura), cerâmicas domésticas, indústria óssea e artefactos ideotécnicos, mas é na denominada cerâmica simbólica campaniforme que encontramos diversas representações de cervídeos, geralmente associados a motivos oculados ou soliformes, bem como a composições geométricas mais ou menos elaboradas, gravadas por incisão nas áreas mais visíveis e destacadas das taças ou vasos. Tradicionalmente associada a contextos funerários, esta cerâmica surge igualmente em níveis de habitat, sendo os cenários da sua utilização e os possíveis conteúdos muito discutidos (Bueno Ramírez et al, 2017; Garrido Pena e López-Astilleros, 200o).

$\mathrm{Na}$ Estremadura portuguesa encontramos representações de cervídeos em recipientes cerâmicos com decoração simbólica campaniforme em contextos funerários, como as taças provenientes do Casal do Pardo - Palmela, sendo numa delas observáveis dois cervídeos, um claramente macho e outro fêmea ou juvenil (Horta e Bubner, 1974: 123) e ainda no Tholos da Tituaria (Cardoso et al., 1996: fig. 58) com a representação de um veado macho com hastes ramificadas. Este tipo de cerâmica simbólica surge também em contextos domésticos, como no Castro da Portucheira (Harrison, 1977), ou na ocupação calcolítica de Freiria (Cardoso et al., 2013: 532).

No Sul do território português, no sítio de planície da Quinta do Estácio 14 (Beja), fazendo parte num conjunto de recipientes de estilo Ciempozuelos, foi identificado um fragmento de cerâmica simbólica com a representação de dois veados machos caracterizados pelas hastes ramificadas de cariz esquemático (Soares, 2017: 52).

Nos Perdigões foi também identificado, na fossa 7 , um fragmento de cerâmica com representação de diversas hastes de cervídeos (Valera, 2015: 17), e num contexto funerário - Tholos 2 - datado entre 2575-220o BC, uma admirável estatueta de marfim representando um cervídeo (Valera et al, 2014: 25). No numeroso conjunto de artefactos ideotécnicos recolhidos em contextos funerários deste complexo sítio, surgem diversas falanges de cervídeos afeiçoadas e/ou decoradas com linhas zigzagueantes, idênticas às existentes em ídolos cilíndricos com tatuagens faciais (Valera, 2015: 10).

Permanece como um dos exemplares mais icónicos a taça do Tholos 15 de Los Millares que, além da re- presentação dos olhos oculados/solares, apresenta três veados, sendo um claramente macho e os restantes, provavelmente, fêmeas (Leisner e Leisner, 1943, est.20). Esta mesma composição surge noutra taça do Tholos 7 de Los Millares onde um veado macho com hastes ramificadas encontra-se rodeado por outros cinco cervídeos, possivelmente fêmeas, apresentando também possíveis representações soliformes ou oculados (Leisner e Leisner, 1943, est. 12). Nestas peças, temos uma composição que engloba os dois motivos mais representados na decoração da cerâmica simbólica calcolítica - cervídeos e motivos solares -, mostrando a importância desta associação, tal como se verifica na placa 409. Um pormenor destas duas composições é que em ambas alguns dos cervídeos encontram-se com a cabeça virada para trás, olhando directamente para o grande macho, podendo corresponder a algum tipo de diferenciação sexual ou etária.

Outra peça icónica é a taça campaniforme com decoração simbólica do povoado de Las Carolinas (Madrid), onde surgem diversos cervídeos, alinhados e ao redor de toda a taça, acompanhados por motivos soliformes (Leisner, 1961). As representações de cervídeos mostram na extremidade superior as ramificações das hastes, sendo que os membros inferiores surgem em número de seis, podendo representar movimento. Estaremos assim perante uma parada ou desfile de cervídeos relacionados directamente com o astro solar, observáveis de todos os lados da taça. Um dos motivos soliformes encontra-se exactamente no meio das hastes de um cervídeo, lembrando a adição e transmutação verificada na rocha 158 do núcleo de São Simão do Vale do Tejo (Gomes, 2010: 266).

A temática de alinhamento de cervídeos está presente em outros exemplares campaniformes, como na taça de Brenes (Carmona) (Harrison et al, 1976), ou, com apenas uma representação de cervídeo, como em El Ventorro (Madrid) (Priego e Quero, 1992: 232) ou em La Escarapela (Toledo) (Munoz, 1998). No Tholos de San Blas (Cheles, Badajoz) foi identificado um vaso globular com decoração impressa representando um alinhamento de zoomorfos esquemáticos interpretados como cervídeos ou cabras (Hurtado, 2004: 107).

As representações de cervídeos presentes nas placas de tear de Vila Nova de São Pedro apresentam igualmente paralelos estilísticos com as numerosas representações existentes em sítios com arte rupestre 
em toda a Península Ibérica, quer em gravuras quer em pinturas (Figura 14). Desde os grandes penedos e blocos horizontais com arte Atlântica aos abrigos inacessíveis com pinturas esquemáticas as representações de cervídeos surgem como elemento estruturante de diversas cenas e mitografias.

Destacando o já referido núcleo de gravuras do Vale do Tejo, axis mundi de um santuário rupestre, onde as representações de cervídeos têm um papel estruturante na organização crono-cultural e simbólica, surgem representações de grandes veados desde o Epipaleolítco até ao Neolítico final, fazendo parte de cenas e de transmutações simbólicas (Gomes, 2010: 263). As características ecológicas desta espécie são referenciadas, surgindo animais adultos com as hastes no auge do seu desenvolvimento, animais juvenis, fêmeas que poderão estar grávidas e crias. Os paralelos estilísticos com as representações de Vila Nova de São Pedro são abundantes, destacando-se a armação rígida do cervídeo da rocha 56.4 do Cachão do Algarve com a existente na placa 305 (Figura 4), ou as exuberantes hastes de vários veados da rocha 49 do Fratel (Gomes, 2010: 265), com as representações das placas 269, 345 e 475 (Figuras 3, 6 e 10). Nos abrigos com arte esquemática pintada surgem igualmente diversas cenas onde o cervídeo - o grande veado - é o protagonista, quer numa cena explícita de caça, como na Fraga d'Aia (Jorge et al, 1988), ou numa cena de caracter ritual ou simbólico, como na Lapa dos Gaivões (Martins, 2016). Neste grande abrigo, do maciço quartzítico da Serra de São Mamede (Arronches), temos uma cena onde uma figura antropomórfica, munida de uma corda ou laço, encontra-se rodeada por quatro cervídeos - dois veados machos e outros dois prováveis, fêmeas ou juvenis (Idem, 2016). O antropomorfo lança a corda sobre um dos veados, sendo esta acção possivelmente ritual ou mitográfica, visto dificilmente ser possível este tipo de caçada, revelando assim a importância desta espécie no universo simbólico destas comunidades.

A caça ao veado surge também representada no interior de monumentos megalíticos, como observamos na extraordinária cena existente num dos esteios da Orca dos Juncais, onde um conjunto de antropomorfos, munidos de arco e acompanhados por canídeos, confrontam diversos zoomorfos definidos como veados (Cruz, 200o).

\section{OS ZOOMORFOS DAS PLACAS DE VILA NOVA DE SÃO PEDRO E A TECELAGEM}

As representações zoomórficas existentes nas placas de tear de Vila Nova de São Pedro integram-se assim no vasto universo da simbólica das comunidades do $3^{\circ}$ milénio A.C., sendo que até ao momento, no povoado, não foram registadas semelhantes representações zoomórficas em outros artefactos, podendo, porém, alguns objectos ser interpretados como representações de animais (Arnaud e Fernandes, 2005: 213). Destaca-se ainda a estatueta de osso classificada como antropo-zoomórfica, que representará uma hibridação entre mulher/homem e felino, evidenciada pelo prognatismo da face, com nariz largo e longo e orelhas muito pequenas (Gomes, 2005: 168). Estes objectos móveis que representam figuras mistas poderão estar relacionados com prácticas rituais e simbólicas, de influências muito diversificadas, mas também com acções quotidianas do grupo.

Outra questão que se levanta relativamente a VNSP é que apesar da abundância de cerâmica campaniforme, dominando o estilo internacional ou marítimo, não estão registados motivos zoomórficos nos fragmentos recuperados. Esta ausência pode traduzir uma questão cronológica - em que os cervídeos são representações próprias da cerâmica campaniforme tardia? ou a representação destes animais é, sobre vasos campaniformes, que para além de tardios, são próprios de espaços de necrópole?

O papel que os animais possuem na construção dos sistemas simbólicos pré-históricos e, a mais ou menos, equívoca relação estabelecida com o seu significado económico continua em discussão. Os cervídeos fazem parte da abundante fauna de VNSP (Detry et al, 2020; Francisco et al, 2020) resultante da sua utilização quer como fonte primária de alimentação, quer como de aproveitamento de recursos secundários.

$\mathrm{Na}$ abundante indústria óssea (furadores, agulhas, cabos) de VNSP, são numerosos os artefactos executados sobre hastes de veados que podem ter sido recolhidas no período pós-acasalamento, quando estas caem naturalmente.

A presença de representações de cervídeos nas placas de tear insere-se num complexo universo gráfico onde diversas tipologias de símbolos (geométricos, antropomórficos, estiliformes), foram escolhidas para ficarem gravadas na argila. Esta escolha, sem- 
pre intencional, corresponderá a programas compositivos que poderão ou não ser predefinidos antes da execução, podendo também existir uma especialização técnica.

O desconhecimento dos sistemas de produção locais, bem como da organização social da comunidade impedem-nos, por agora, de tecer mais considerações sobre a produção das placas de tear e iconografia associada. Admite-se, no entanto, que a face gravada pudesse ser vista por quem tece, sugerindo assim uma posição particular para estes objectos, num tear horizontal ou vertical. Ao mesmo tempo, certos motivos podem representar um determinado movimento na acção de tecer, que poderá originar padrões distintos, funcionando como uma mnemónica visual. Noutra hipótese, os próprios motivos geométricos gravados nas placas corresponderão ao padrão produzido por determinada organização e disposição das mesmas no tear horizontal ou vertical. A relação símbolo-artefacto-acção poderá ser efectiva e esperamos levantar hipóteses através do programa de arqueologia experimental que temos vindo a desenvolver.

A escassez de representações explícitas da natureza (elementos vegetais, nuvens, água, solo, entre outros) nos programas iconográficos das sociedades pré-históricas é colmatada com a representação de animais que fazem parte das paisagens quotidianas e simbólicas destas comunidades.

Os zoomorfos, reais ou mitificados, eram representados em distintos suportes, fazendo parte do quotidiano, quer pela presença efectiva, quer em relatos transmitidos oralmente, materializados em gravações ou pinturas. Mais do que uma possível atribuição cronológica, os paralelos iconográficos permitem confirmar uma uniformidade cultural, em que o universo conceptual e simbólico é idêntico, conduzindo à execução de motivos análogos em comunidades distintas e espacialmente distantes.

As placas de tear de Vila Nova de São Pedro permitem uma abordagem transdisciplinar, desde a cadeia operatória da sua produção, execução iconográfica, funcionalidade e método de utilização, levando a que aspectos como organização social, económica e simbólica sejam alcançados com o estudo desta categoria artefactual.

Os cervídeos como elemento gráfico circulam entre diferentes ambientes, presentes em habitats, necrópoles e santuários rupestres. A sua funcionalidade simbólica concretiza-se em ambientes formalmente metafisicos como os esteios de uma anta ou um painel rochoso, mas também em objectos de eminente natureza doméstica, como esses meios de produção que são as placas de tear, numa demonstração óbvia da rede complexa de significados e usos que marca as sociedades humanas.

\section{BIBLIOGRAFIA}

ARNAUD, José M.; FERNANDES, Carla V., eds. (2005) Construindo a Memoria - As Colecções do Museu Arqueológico do Carmo. Lisboa. Associação dos Arqueólogos Portugueses.

ARNAUD, José M. (2013) - "Reflexões em torno das placas de cerâmica com gravuras de Vila Nova de S. Pedro (Azambuja)". ARNAUD, MARTINS e NEVES (coords.) Arqueologia em Portugal - 150 Anos. Associação dos Arqueólogos Portugueses, Lisboa, pp. 447-455.

ARNAUD, José M.; DINIZ, Mariana; NEVES, César; MARTINS, Andrea (2017) - Vila Nova de São Pedro - de novo, no 3. milénio. Um projecto para o futuro. Arqueologia e História, 66-67, Associação dos Arqueólogos Portugueses, Lisboa, pp. 7-17.

BUENO RAMÍREZ, Primitiva; BARROSO BERMEJO, Rosa; BALBÍN-BEHRMANN, Rodrigo (2017) - Redefining Ciempozuelos. Bell-Beaker culture in Toledo? Sinos e Taças - Junto ao oceano e mais longe. Aspectos da presença campaniforme na Península Ibérica, Estudos e Memórias, 10, Uniarq, pp. 324-341.

CARDOSO, João Luís; LEITÃO, Manuel, FERREIRA, Octávio da Veiga; NORTH, Christopher Thomas, MEDEIROS, J. P. e SOUSA, Fialho de (1996) - O monumento préhistórico de Tituaria, Moinhos da Casela (Mafra), Estudos Arqueológicos de Oeiras, 6, Oeiras. pp. 135-193.

CARDOSO, João Luís; CARDOSO, Guilherme; ENCARNAÇÃO, José (2013) - O Campaniforme de Freiria (Cascais). Estudos Arqueológicos de Oeiras, 20, Oeiras, Câmara Municipal, pp. 525-588.

CARRASCO RUS, Javier; NAVARRETE ENCISO, María; PACHÓN ROMERO, Juan (2006) - Las manifestaciones rupestres esquemáticas y los suportes muebles en Andalucía. Martínez García, J. e Hernández Pérez, M. (eds) - Arte Rupestre Esquemático en la Península Ibérica - Congreso, Comarca de Los Vélez, pp. 85-118.

CRUZ, Domingos (200o) - Roteiro Arqueológico de Vila Nova de Paiva, Vila Nova de Paiva: Câmara Municipal de Vila Nova de Paiva, 46 p.

DETRY, Cleia; FRANCISCO, Ana Catarina; DINIZ, Mariana; MARTINS, Andrea; NEVES, César; ARNAUD, José M. (2O2O) - Estudo zooarqueológico das faunas do Calcolítico final de Vila Nova de São Pedro (Azambuja, Portugal): Campanhas de 2017 e 2018. ARNAUD, J. M., NEVES, C. e MARTINS, A. (coords.) - Arqueologia em Portugal - 2020 - Estado da Questão. 
DINIZ, Mariana (1994) - Pesos de tear e tecelagem no calcolitico em Portugal. Trabalhos de Antropologia e Etnologia. Porto. Actas do Primeiro Congresso de Arqueologia Peninsular, 34: 3-4, pp. 133-149.

FRANCISCO, Ana Catarina; DETRY, Cleia; NEVES, César; MARTINS, Andrea; DINIZ, Mariana; ARNAUD, José M. (2020) - As faunas depositadas no Museu Arqueológico do Carmo provenientes de Vila Nova de São Pedro (Azambuja): as campanhas de 1937 a 1967, ARNAUD, J. M., NEVES, C. e MARTINS, A. (coords.) - Arqueologia em Portugal 2020 - Estado da Questão.

GARRIDO PENA, Rafael; LÓPEZ-ASTILLEROS, Kenia (200o) - Visiones sagradas para los líderes. Cerâmicas campaniformes com decoración simbólica en la Península Ibérica, Complutum, 11, pp. 285-300.

GOMES, Mário Varela (2005) - O sagrado em Vila Nova de São Pedro. Antigas e novas perspectivas. In: Arnaud, J. M. e Fernandes, C. V., eds. Construindo a Memoria - As Colecções do Museu Arqueológico do Carmo. Lisboa. Associação dos Arqueólogos Portugueses, pp. 165-178.

GOMES, Mário Varela (2010) - Arte Rupestre do Vale do Tejo - Um Ciclo Artístico-Cultural Pré e Proto-Histórico, Faculdade de Ciências Sociais e Humanas, Universidade Nova de Lisboa, 3 vols, (Dissertação de Doutoramento, texto policopiado).

HARRISON, Richard J. (1977) - The Bell Beaker Cultures of Spain and Portugal. American School of Prehistoric Research Bulletin, 35. American School of Prehistoric Research, Cambridge-Massachussets.

HARRISON, Richard J.; BUBNER, Thomas; HIBBS, V. A. (1976) - The beaker pottery from El Acebuchal, Carmona (Prov. Sevilla). Madrider Mitteilungen, XVII, pp. 79-141.

HERNÁNDEZ PÉREZ, Mauro; SEGURA MARTÍ, Josep, coord. (2002) - La Sarga. Arte rupestre y território, Ediciones del Museu de Alcoi, Caja de Ahorros del Mediterráneo, Alcoy, $213 \mathrm{p}$.

HORTA, Maria Amélia; BUBNER, Thomas (1974-1977) Novos materiais de Palmela, O Arqueólogo Português, Serie III, VII-IX, Lisboa, pp. 113-124.

HURTADO, Víctor Hurtado (2004) - San Blas, the discovery of a large chalcolithic settlement by the Guadiana river, Journal of Iberian Archaeology, Vol. 6, Porto: ADECAP, pp. 93-116.

JALHAY, Eugénio; PAÇO, Afonso (1945) - El castro de Vilanova de San Pedro. Actas y memorias de la Sociedad Espanola de Antropologia: Etnografia y Prehistoria. Madrid, 20, pp. 5-93.

JORGE, Vítor Oliveira; BAPTISTA, António Martinho; JORGE, Susana Oliveira; SANCHES, Maria de Jesus; SILVA, Eduardo; SILVA, Margarida; CUNHA, Ana Leite da (1988) O abrigo com pinturas rupestres da Fraga d'Aia (Paredes da Beira - São João da Pesqueira) - Notícia preliminar, Arqueologia, nํ18, Dezembro de 1988, Porto, pp. 109-130.
LEISNER, Georg; LEISNER, Vera (1943) - Die Megalithgräber der Iberischen Halbinsel.I. Der Süden. Romisch-Germanische Komission, 17. Berlín.

LEISNER, Vera (1961) - Innenverzierte Schalen der Kupferzeit auf der Iberischen Halbinsel. Madrider Mitteilungen, 2: 11-33.

MARTÍ OLIVER, Bernat; HERNÁNDEZ PÉREZ, Mauro (1988) - El Neolític Valencià - Art rupestre i cultura material, Servei d'Investigació Prehistòrica, Diputació de València, $114 \mathrm{p}$.

MARTÍ OLIVER, Bernat (2006) - Cultura material y arte rupestre esquemático en el País Valenciano, Aragón y Cataluña, In MARTÍNEZ GARCÍA, Julian; HERNÁNDEZ PÉREZ, Mauro, eds., Arte Rupestre Esquemático en la Península Ibérica - Congreso, Comarca de Los Vélez, pp. 119-147.

MARTINS, Andrea (2013) - A Pintura Rupestre Esquemática em Portugal: muitos sítios, mesmas pessoas?, in Arnaud, José; Martins, Andrea e Neves, César (Coord.) Arqueologia em Portugal - 150 anos, Associação dos Arqueólogos Portugueses, pp. 495-505.

MARTINS, Andrea (2016) - Abrigos de Arte Esquemática Pintada do Centro de Portugal: mundo simbólico e antropização da paisagem. Lisboa: Associação dos Arqueológos Portugueses (Monografias AAP, 3 ).

MARTINS, Andrea; NEVES, César; DINIZ, Mariana; ARNAUD, José (2019) - O povoado calcolítico de Vila Nova de São Pedro (Azambuja). Notas sobre as campanhas de escavação de 2017 e 2018. Arqueologia e História, $\mathrm{n} \times$ 69, Associação dos Arqueólogos Portugueses, pp. 133-167.

MUÑOZ, Isabel Kenia (1998) - El poblamiento desde el Neolítico Final a la Primera Edad del Hierro en la cuenca media del río Tajo. Universidad Complutense, Madrid (Tesis Doctoral inédita).

PAÇO, Afonso; JALHAY, Eugénio (1939) - A póvoa eneolítica de Vila Nova de S. Pedro: Notas sobre a $1^{\underline{a}}$ e $2^{\underline{a}}$ campanha - 1937 e 1938. Brotéria. Separata Lisboa. Vol. XXVIII: 6, pp. $2-46$.

PAÇO, Afonso (1941) - Placas de Barro de Vila Nova de S. Pedro. Congresso do Mundo Português, Porto. 1, pp. 233-251.

PAÇO, Afonso; JALHAY, Eugénio (1942) - A póvoa eneolítica de Vila Nova de S. Pedro. Notas sobre a $3^{\underline{a}}, 4^{\underline{a}}$ e $5^{\underline{a}}$ campanhas - 1939, 1940 e 1941. Brotéria, Separata, Lisboa, Vol. XXXIV: 6, pp. 2-31.

PAÇO, Afonso; JALHAY, E. (1943) - A póvoa eneolítica de Vila Nova de S. Pedro: Notas sobre a 6 ( $^{\mathrm{a}}$ campanha - 1942. Brotéria. Separata Lisboa. Vol. XXXVII: 1, pp. 4-27.

PAÇO, Afonso; COSTA ARTHUR, Maria Lourdes (1952) Castro de Vila Nova de São Pedro. I-1 $5^{\underline{a}}$ campanha de escavações (1951), Brotéria, Vol. LIV, Fasc. 3, Março 1952, pp. 6-25.

PRIEGO, Carmen; QUERO CASTRO, Salvador (1992) - El Ventorro, un poblado prehistórico de los albores de la metalurgia. Estudios de Prehistoria y Arqueologia Madrilenas, 8. 
SANCHIDRIÁN TORTI, José (2001) - Manual de arte prehistórico, Barcelona: Ariel Prehistoria, 549 p.

SAVORY, H. N. (1970) - A section through the innermost rampart of the chalcolithic castro of Vila Nova de S. Pedro, Santarem (1959). Actas das I Jornadas Arqueológicas. 1. Lisboa, Associação dos Arqueólogos Portugueses, pp. 133-148.

SOARES, Joaquina (2017) - Para uma leitura sociopolítica do campaniforme do Guadiana. Longas viagens com curta estada no Porto das Carretas. Sinos e Taças-Junto ao oceano e mais longe. Aspectos da presença campaniforme na Península Ibérica, Estudos e Memórias, 10, Uniarq, pp. 38-57.

VALERA, António Carlos; EVANGELISTA, Lucy Shaw; CASTANHEIRA, Patrícia (2014) - Zoomorphic figurines and the problem of Human Animal relationship in the neolithic and chalcolithic Southwest Iberia. MENGA - Revista de Prehistoria de Andalucía, noㅇ, pp. 15-41.

VALERA, António Carlos (2015) - "Ídolos falange”, Cervídeos e Equídeos. Dados e problemas a partir dos Perdigões. Apontamentos de Arqueologia e Património, 10, pp.7-20.
Placas de Tear - VNSP / MAC

Decoração

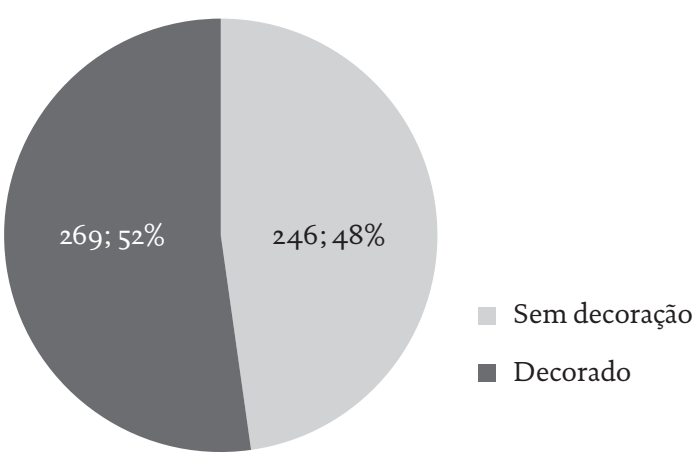

Gráfico 1 - Quantificação das placas de tear face à decoração.

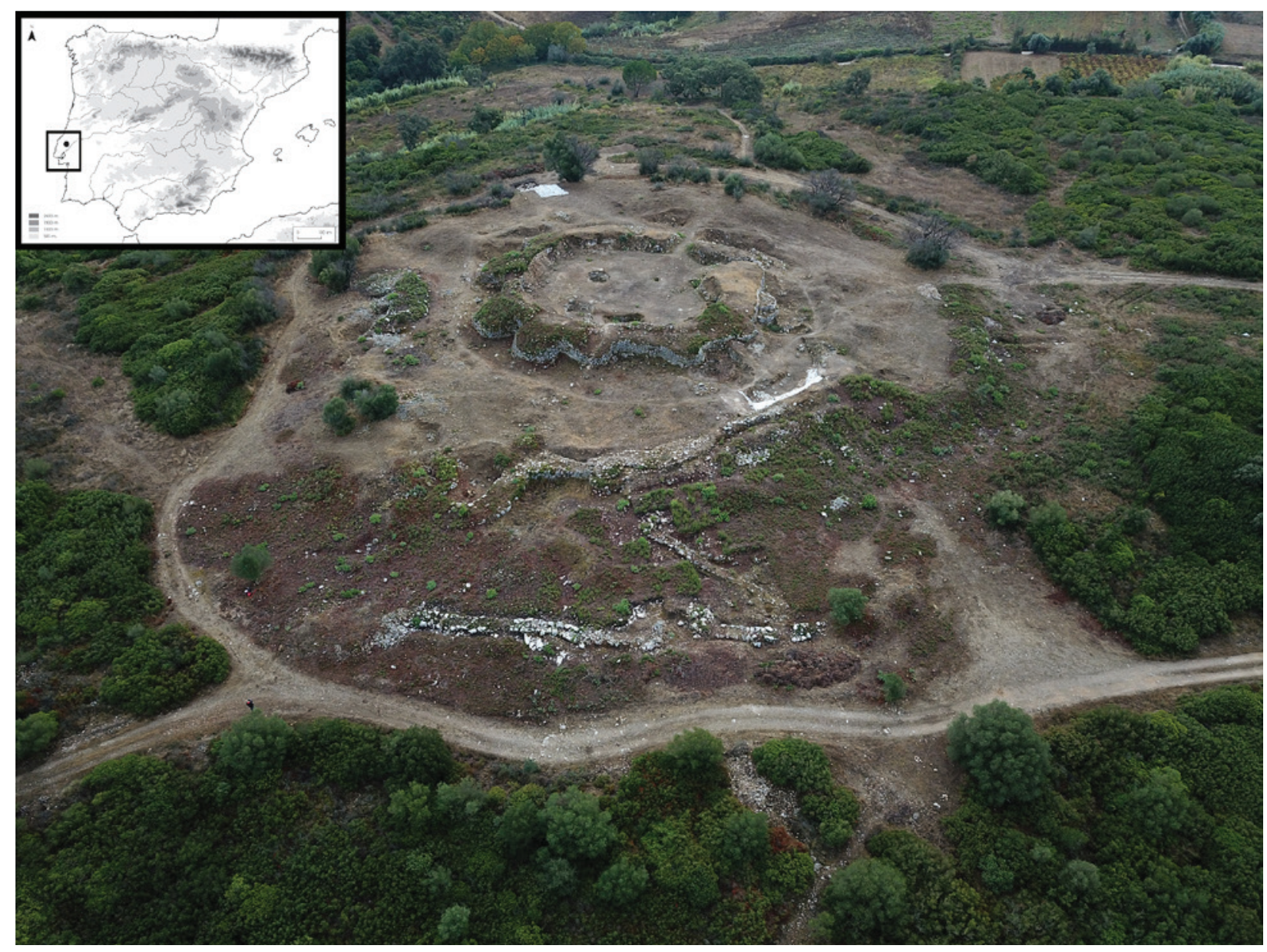

Figura 1 - Vila Nova de São Pedro. 


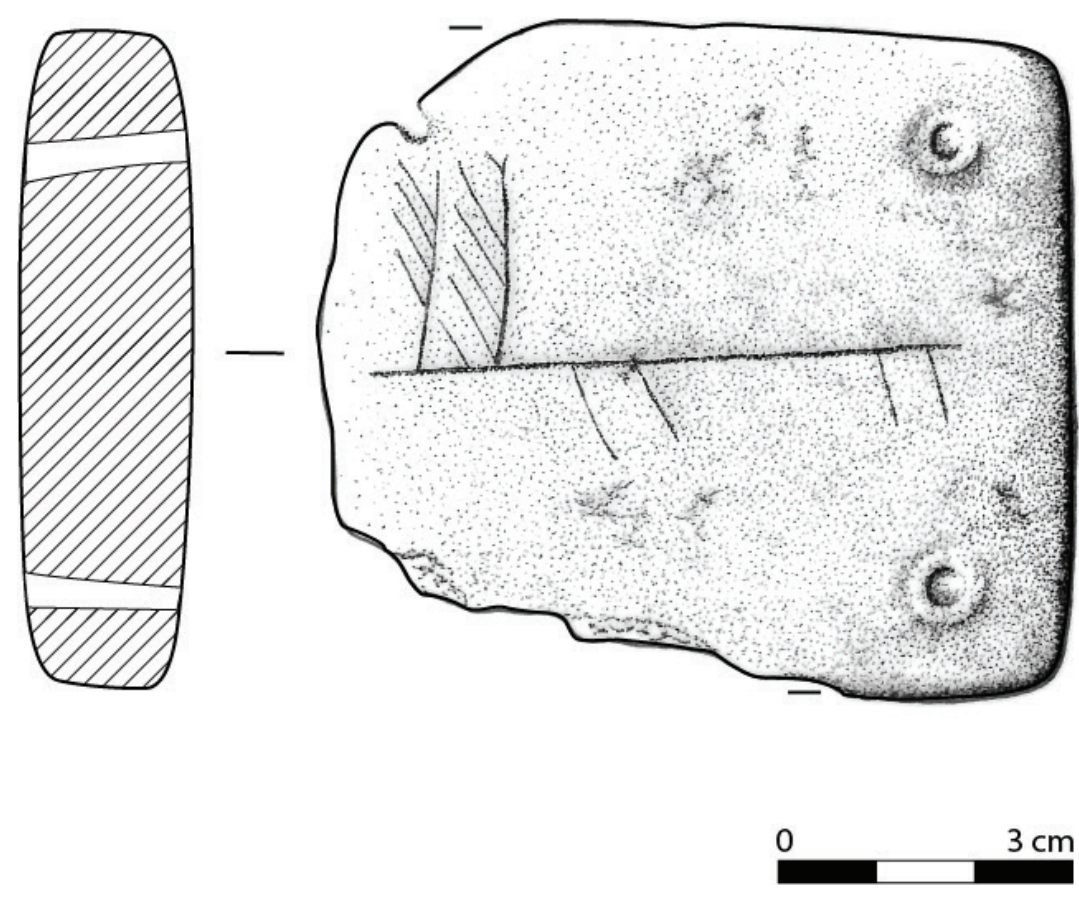

Figura 2 - Placa de tear VNSP3ooo/MAC/236. Autoria: César Neves.
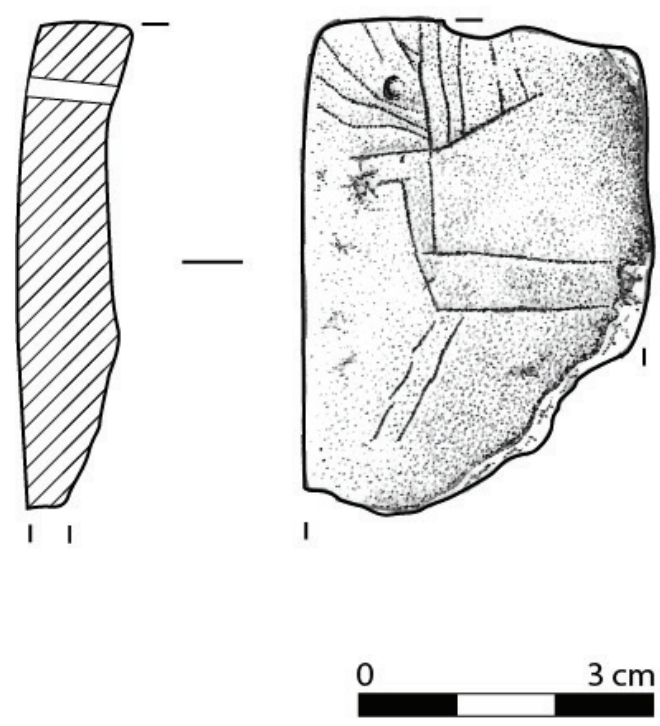

Figura 3 - Placa de tear VNSP3ooo/MAC/269. Autoria: César Neves. 

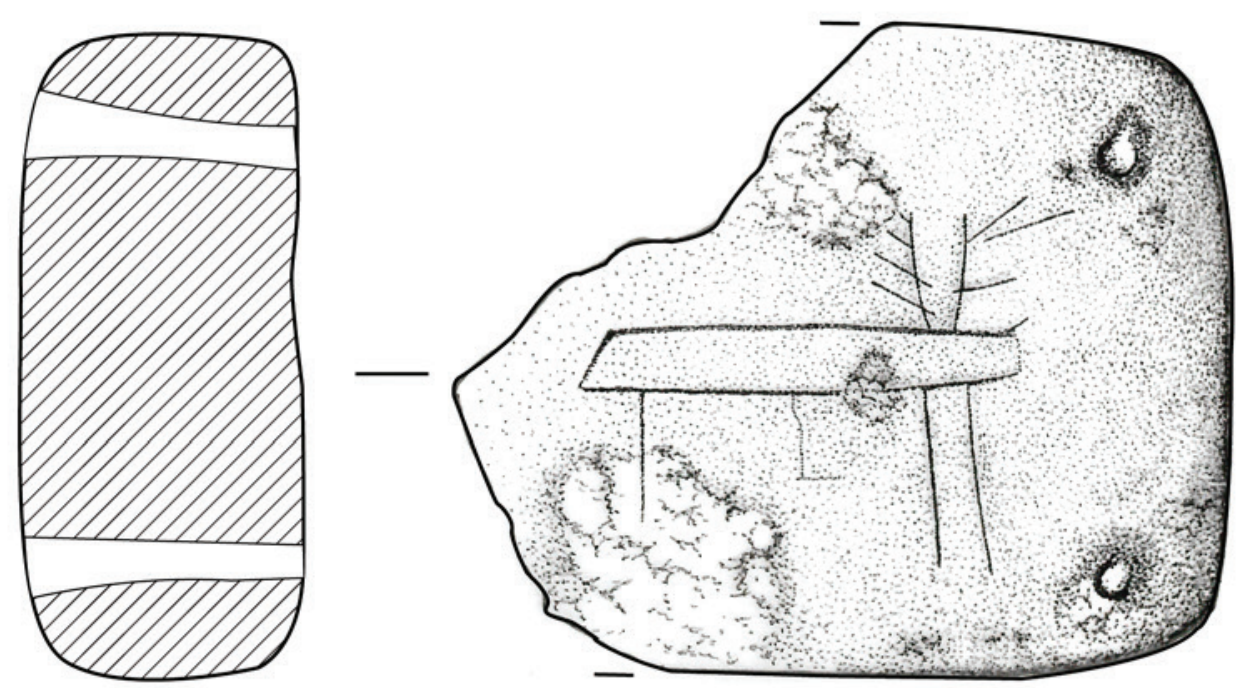

Figura 4 - Placa de tear VNSP3ooo/MAC/305. Autoria: César Neves.
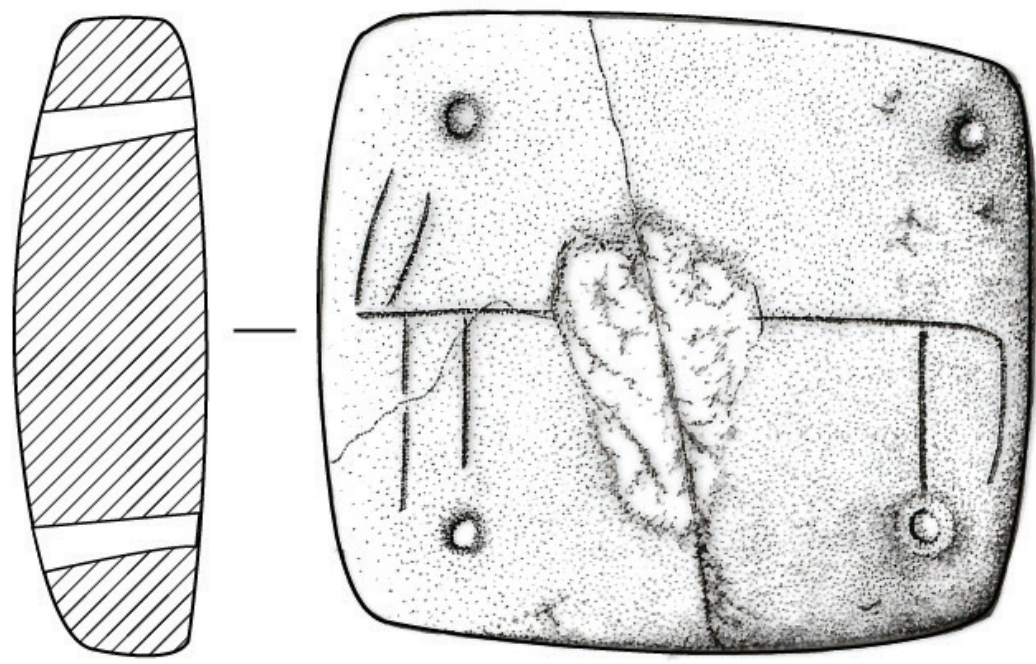

0

$3 \mathrm{~cm}$

Figura 5 - Placa de tear VNSP3ooo/MAC/306. Autoria: César Neves. 


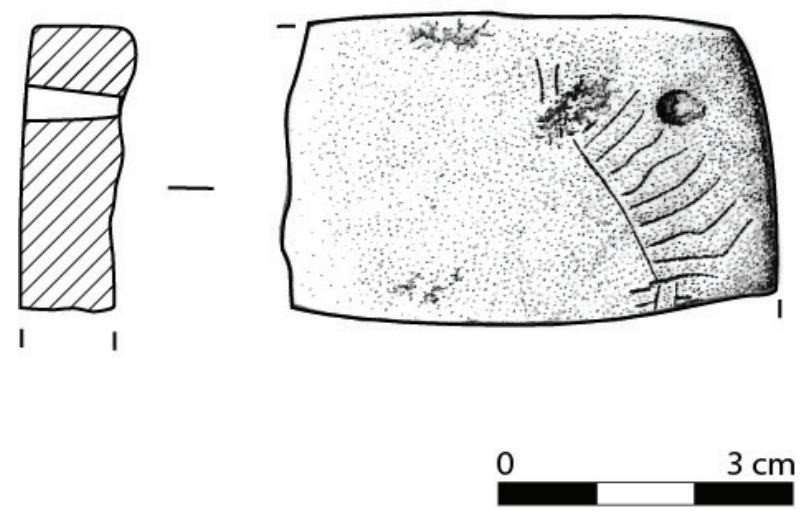

Figura 6 - Placa de tear VNSP3ooo/MAC/345. Autoria: César Neves.
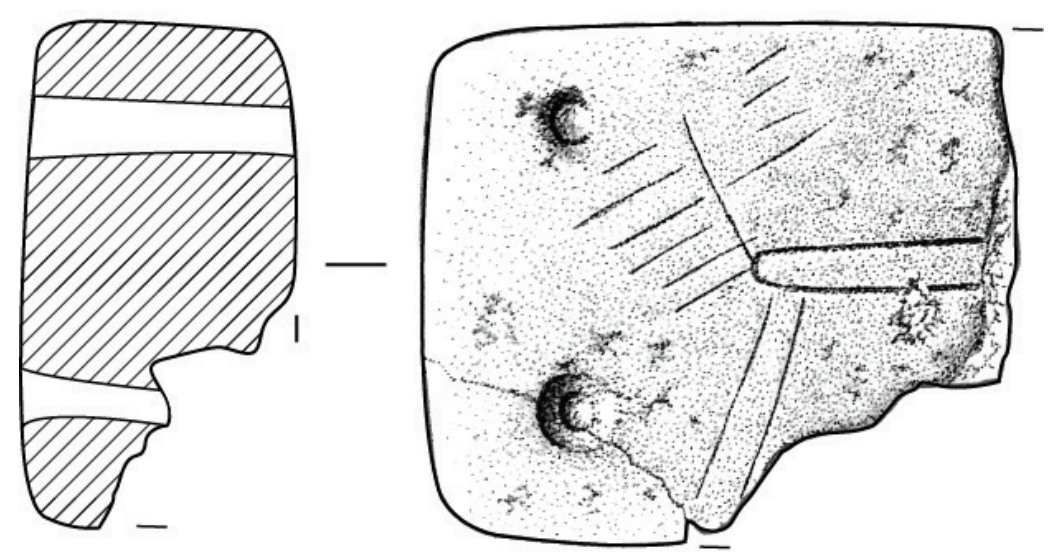

0

$3 \mathrm{~cm}$

Figura 7 - Placa de tear VNSP3ooo/MAC/403. Autoria: César Neves.

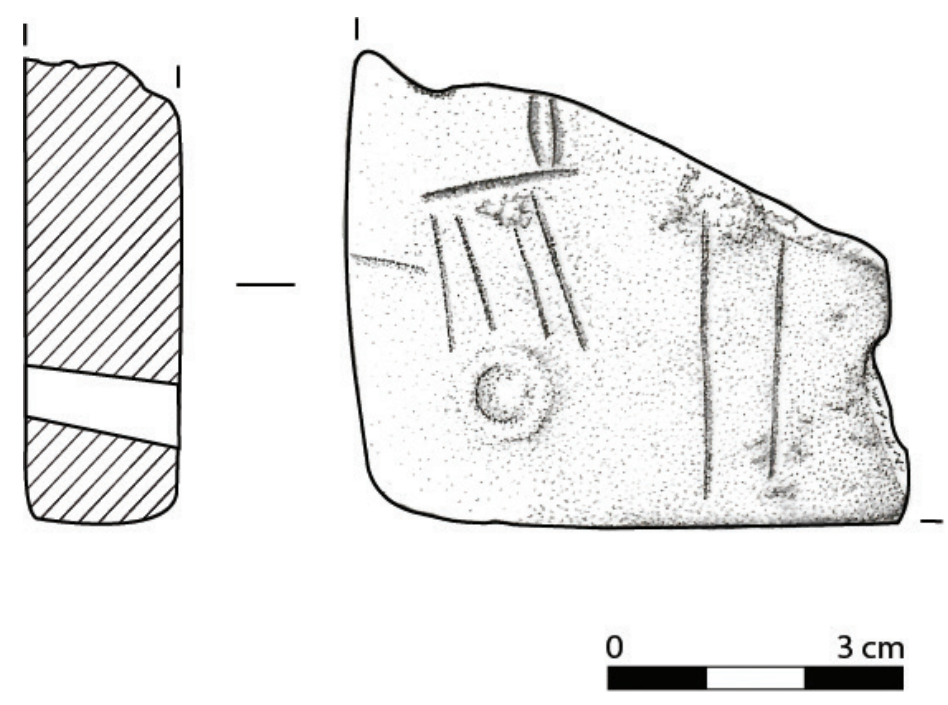

Figura 8 - Placa de tear VNSP3ooo/MAC/409. Autoria: César Neves. 

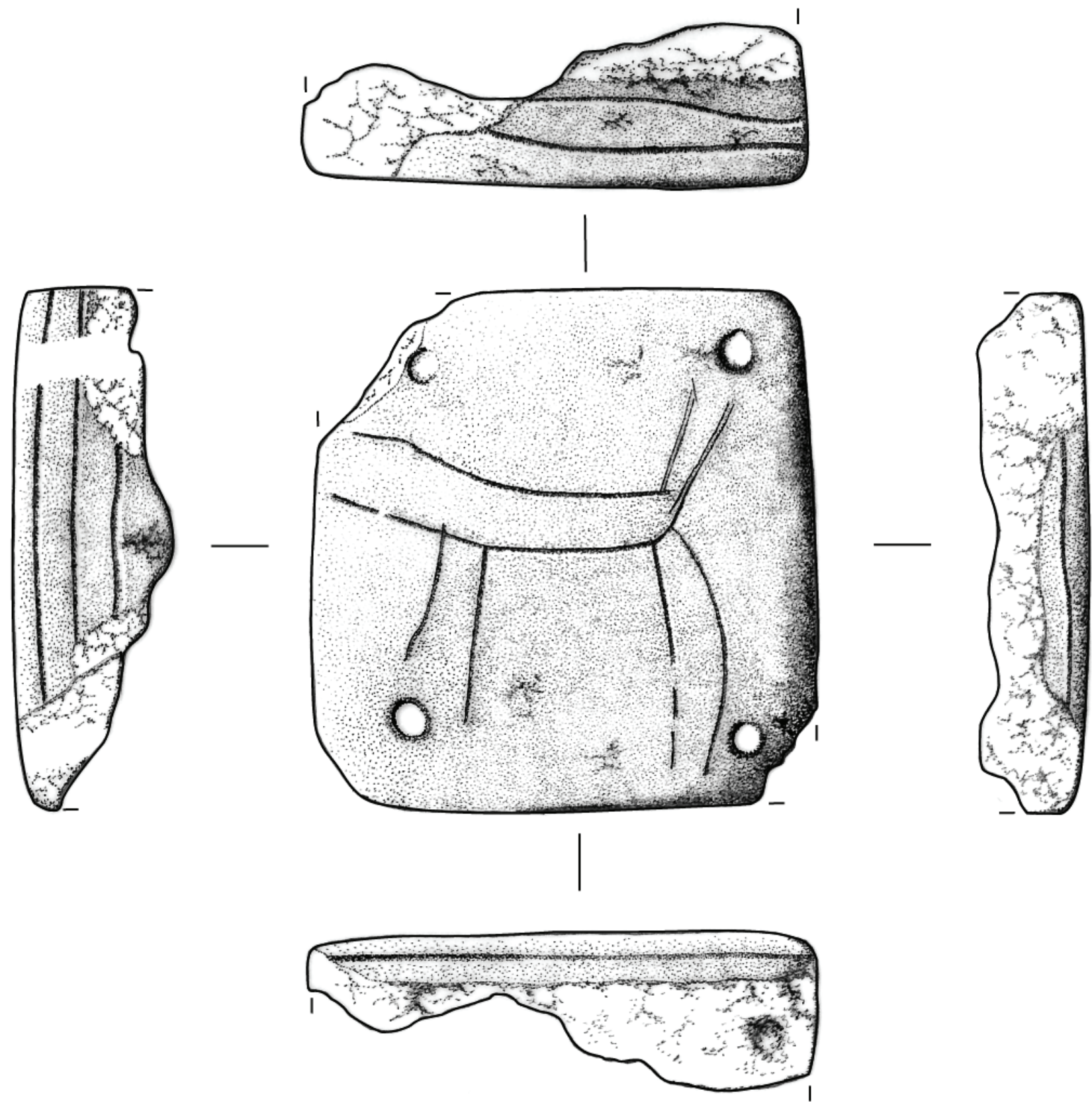

Figura 9 - Placa de tear VNSP3ooo/MAC/446. Autoria: César Neves. 

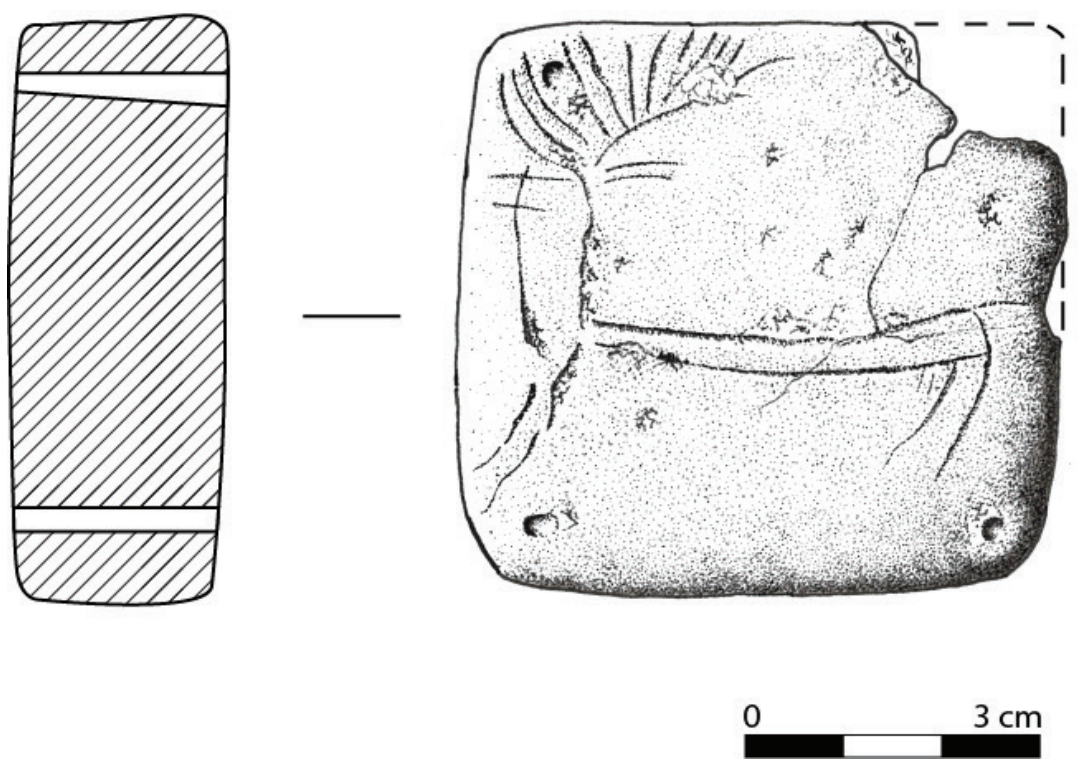

Figura 10 - Placa de tear VNSP3ooo/MAC/475. Autoria: César Neves.
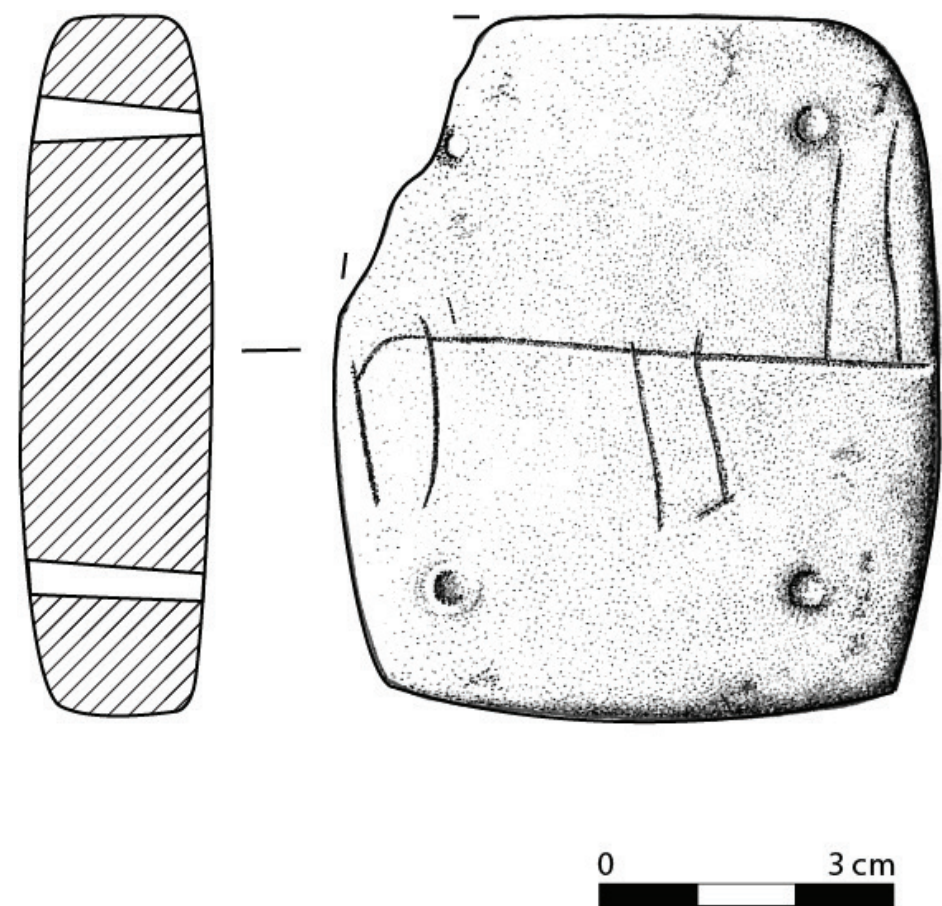

Figura 11 - Placa de tear VNSP3ooo/MAC/49o. Autoria: César Neves. 

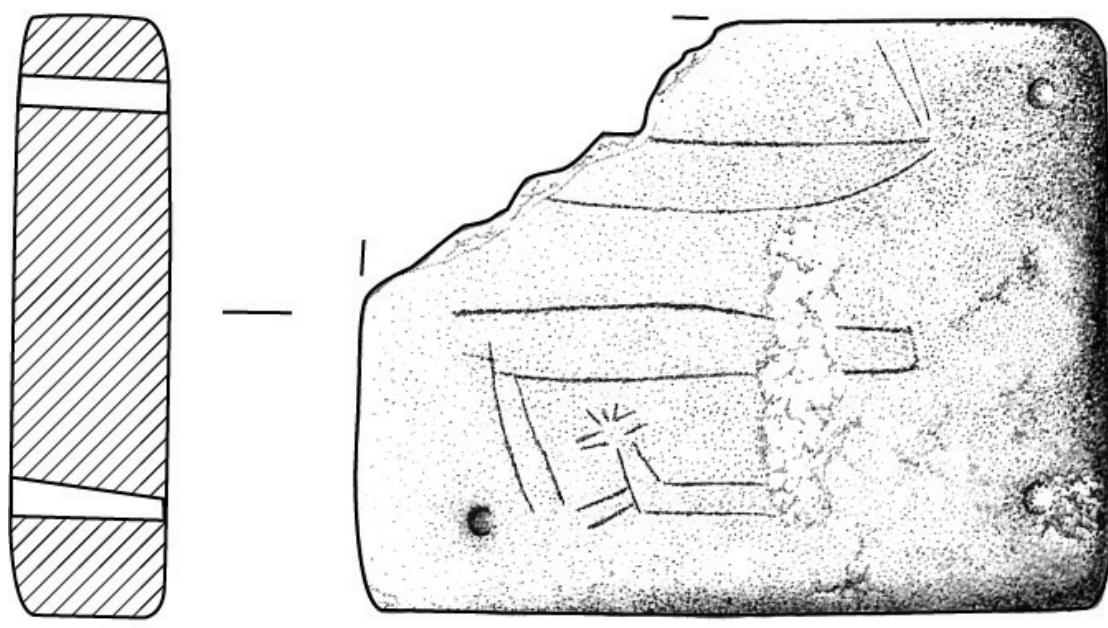

0

$3 \mathrm{~cm}$

Figura 12 - Placa de tear VNSP3ooo/MAC/491. Autoria: César Neves.
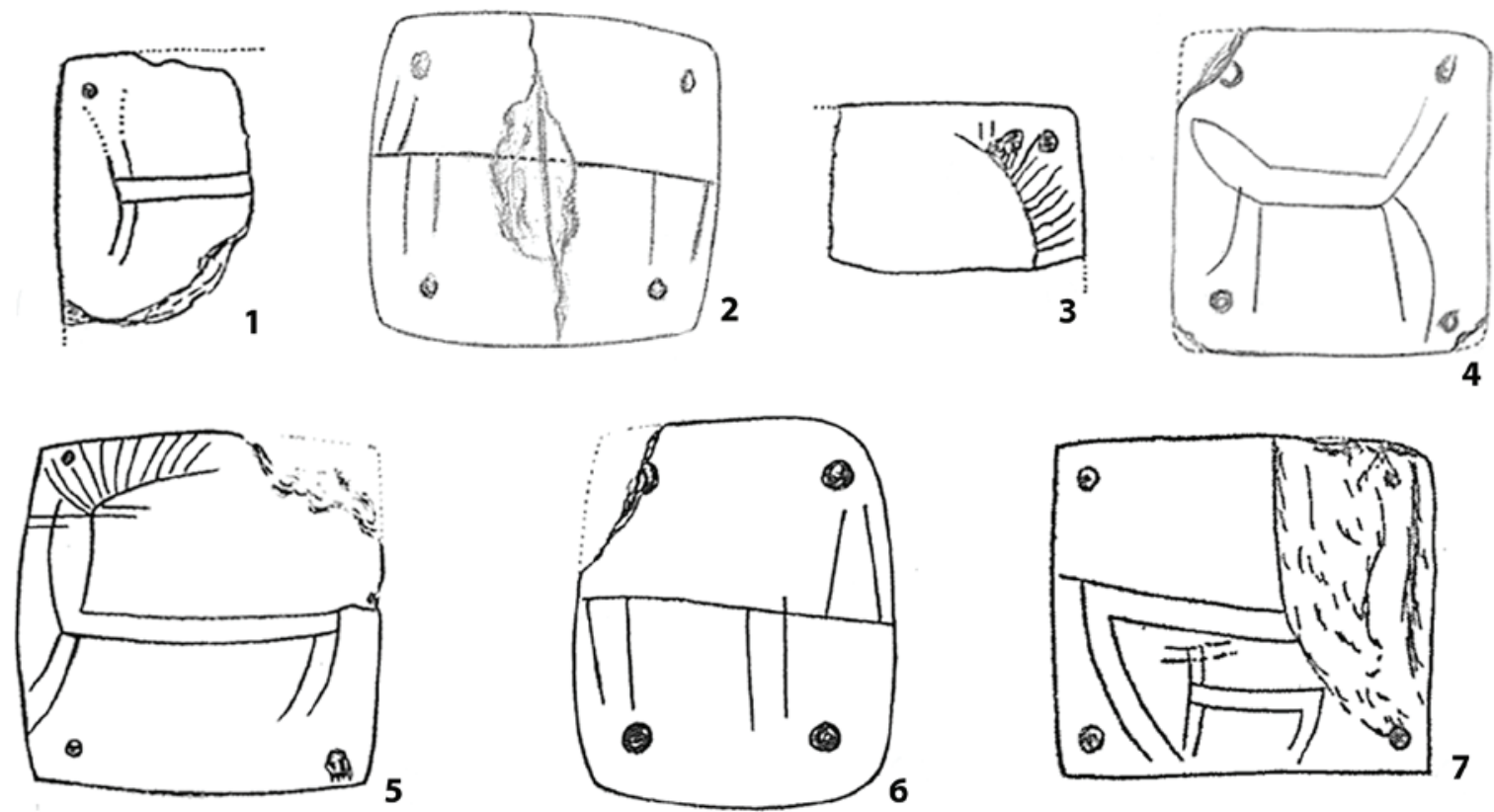

Figura 13 - I - Placa VNSP30oo/MAC/269 - publicada em 1941 (Paço, 1941: 48 - fig. 1 no 7; 2 - placa VNSP30oo/ MAC/306 - publicada em 1942 (Paço e Jalhay, 1942: fig. 25 - nº 2); 3 - placa VNSP3ooo/MAC/345 - publicada em 1941 (Paço, 1941: fig. 1- nº 5); 4- placa VNSP30oo/MAC/446 - publicada em 1942 (Paço e Jalhay, 1942: fig. 25 - nº 1); 5- placa VNSP300o/MAC/475 - publicada em 1939 (Paço e Jalhay, 1939: fig. 25-no 1); 6 - placa VNSP3ooo/MAC/49o publicada em 1939 (Paço e Jalhay, 1939: fig. 25-nº 2); 7 - placa VNSP3ooo/MAC/491 publicada em 1941 (Paço, 1941: fig. 1-nº 4). 


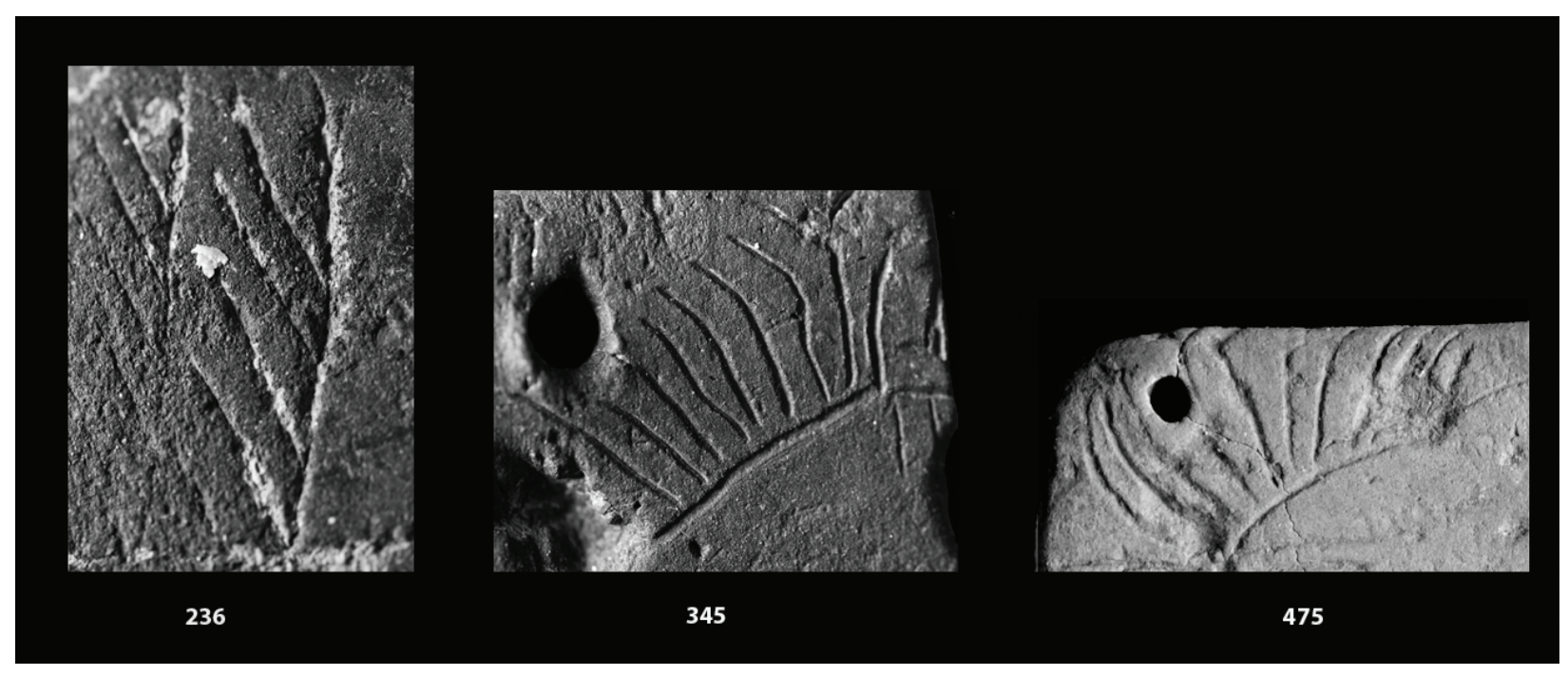

Figura 14 - Pormenor das representações das hastes de veados nas placas VNSP3ooo/MAC/236, VNSP300o/MAC/345 e $\mathrm{VNSP}_{3} \mathrm{OoO} / \mathrm{MAC} / 475$. 


\title{
ARTE RUPESTRE DO MONTE DE GÓIOS (LANHELAS, CAMINHA). SÍNTESE DOS RESULTADOS DOS TRABALHOS EFECTUADOS EM 2007-2009
}

\author{
Mário Varela Gomes ${ }^{1}$
}

\begin{abstract}
RESUMO
A nossa intervenção na arte rupestre do Monte de Góios, relevo da margem esquerda do fundo do estuário do Rio Minho, ocorrida de 2007 a 2009, deveu-se a projecto de minimização do impacto, na paisagem e no património cultural, devido à construção de via (A28/IC1 - Ligação a Caminha). Após a prospecção pormenorizada do terreno, foram documentadas dezoito rochas com arte rupestre, cinco das quais eram já conhecidas. As quase novecentas gravuras inventariadas, antropomorfos esquemáticos, zoomorfos (cavalos, colubrídeos e outros) e significativo conjunto de signos de carácter geométrico, apresentam longa diacronia pré e proto-histórica, suportada por relações estratigráficas, graus de desgaste e aspectos morfo-estilísticos. Elas integraram santuários, com diferentes dimensões e registos iconográficos, de amplo espaço sócio-religioso correspondente ao Monte de Góios.
\end{abstract}

Palavras-chave: Monte de Góios, Gravuras rupestres,Santuário, Pré-História, Proto-História.

\begin{abstract}
Monte de Góios is a relief on the left bank of the Minho River estuary inner part. Our archaeological work on Monte de Góios, between 2007 and 2009, was framed by a project to minimize the impact, of a new highway (A28/IC1 - Ligação a Caminha), in the landscape and cultural heritage. After thorough archaeological prospecting of the field, eighteen rocks, containing rock art, were detected, of which five were already known of. The almost nine hundred engravings catalogued - schematic anthropomorphs, zoomorphs (horses, snakes, and others) and a significant set of geometric signs - present a large pre and proto-historic diachrony, supported by stratigraphic relations, degrees of erosion and morphologic and stylistic aspects. They form sanctuaries, with different dimensions and iconographic records, in a broad socio-religious space corresponding to Monte de Góios.
\end{abstract}

Keywords: Monte de Góios, Rock art engravings, Sanctuary, Prehistory, Proto-history.

\section{INTRODUÇÃO}

O presente texto deriva dos trabalhos, de campo e de gabinete, efectuados por exigência da actual legislação, que conduziu à efectivação do "Projecto de minimização do impacto e implementação de medidas compensatórias, devido à construção do troço da via A28/IC1, Viana do Castelo - Caminha, ligação a Caminha".

Aqueles, decorreram de finais de Outubro de 2007 a Março de 2009, tendo como principais objectivos, a detecção, protecção, registo e estudo da arte rupestre do Monte de Góios.

Não podemos deixar de expressar a nossa gratidão para com a Dr. . Anabela Lebre e Dr. Pedro Faria, então arqueólogos do IGESPAR que, semanalmente, acompanharam a obra e o desenrolar dos trabalhos arqueológicos, defendendo firmemente o património e apoiando-nos de diferentes modos, mas procurando no diálogo as soluções para os problemas que foram surgindo.

Importa, ainda, registar que, de facto, o património 
arqueológico e, designadamente, o importantíssimo conjunto de gravuras pré e proto-históricas do Monte de Góios, não sofreu qualquer impacto negativo directo com a construção da via acima referida mas, bem pelo contrário, foi possível identificar muitas novas ocorrências de rochas decoradas, descobrir numerosas gravuras em superfícies já conhecidas e elaborar monografia, ainda inédita, que deve contribuir para a valorização científico-cultural e a divulgação daquele importante acervo, que se encontrava oculto ou abandonado, mas que ainda necessita da tomada de medidas tendo em vista a sua conservação.

\section{LOCALIZAÇÃO}

A Serra ou Monte de Góios, conforme localmente é mais conhecido o alto relevo que se ergue quase sobranceiramente à margem esquerda do fundo do estuário do rio Minho, situa-se a cerca de $8 \mathrm{~km}$ do Oceano. Trata-se de formação granítica, alongada no sentido nordeste-sudoeste, que atinge $344 \mathrm{~m}$ de cota máxima, possuindo encostas por vezes íngremes e contrafortes, sobretudo no lado sudoeste, como a elevação conhecida por Góios Pequeno, com $159 \mathrm{~m}$ de altura.

A norte e a nascente observam-se terrenos acidentados, serpenteando, a sudeste e a sul, o rio Coura, tal como dois dos seus afluentes da margem norte, o regato das Amoladouras e o rio de Ouro. Para sudoeste encontramos os terraços baixos da bacia do Coura e sucessão de pequenas elevações integrando a península que aquele curso de água e o rio Minho abraçam, enquanto a poente e a noroeste ocorre sequência de estreitos patamares e terraços aluvionares, que mal totalizam $1 \mathrm{~km}$ de largura, banhados na base por aquele último rio (cf C.M.P., no 14, Caminha, I.G.E., 1997). O Monte de Góios abrange parte das freguesias de Lanhelas e Vilar de Mouros, pertencentes ao concelho de Caminha, tal como de Gondarém e Sopo, que integram o concelho de Vila Nova de Cerveira.

\section{GEOLOGIA E AMBIENTE NATURAL}

O Monte de Góios insere-se, em termos geomorfológicos, no conjunto de relevos, constituídos por rochas graníticas, que se desenvolve, em anfiteatro, a poente da Serra de Arga (747 m no v.g. Pedra Alçada), a chamada "montanha santa" pelas gentes da região, rodeados por terrenos xistentos, mais precisamente entre os sectores terminais das bacias hidrográficas dos rios Minho e Coura.

Aquela elevação, constitui espécie de "ilhota granítica", com forma subcónica, apresentando maior inclinação a vertente voltada a nascente, enquanto no lado contrário se observa sucessão de terraços que sobem a partir da estreita planície aluvionar do rio Minho (Teixeira e Assunção, 1961: 10). Mariano Feio (1948), observou que, na região mencionada, a plataforma litoral é muito estreita (1 a $4 \mathrm{~km}$ ) e as linhas de relevo aproximam-se do mar, aspecto que raramente acontece na restante costa portuguesa.

A mole granítica, a que pertence o Monte de Góios, é da Idade Hercínica e faz parte do sector noroeste do Maciço Ibérico Antigo, ocorrendo a sudeste terrenos metamórficos do Silúrico, formados por xistos andaluzíticos e alguns gneisses.

Os granitos do Monte de Góios oferecem grão médio e sobretudo grosseiro, são do tipo alcalino, de duas micas, com cor branca acinzentada ou alaranjada e negra (biotite), normalmente, contendo turmalina. Mostram, não raro, espessos veios de quartzo branco, ali ocorrendo ainda rochas filoneanas, em veios ou massas aplito-pegmatíticas encaixadas (Teixeira e Assunção, 1961: 26, 33). No seu topo observam-se cristas rochosas, devido à erosão diferencial, com diáclases ortogonais e, nas vertentes, zonas constituídas por acumulações de blocos, de arestas boleadas intercalando com afloramentos.

Conforme escreveu Orlando Ribeiro (1961: 27) também aqui "Nos aspectos da natureza e nas obras humanas, o granito é um traço essencial da paisagem de maior extensão (...)", caracterizando solos de alteração, com potencial agrícola.

Os vales envolventes apresentam-se, em geral, estreitos e declivosos, no fundo dos quais correm, principalmente durante o Inverno, linhas de água.

$\mathrm{Na}$ base da vertente poente, junto ao rio Minho, identificaram-se formações quaternárias em sucessão de terraços, contendo seixos rolados, de quartzito e quartzo, tal como indústrias paleolíticas (acheulenses e moustierenses) e epipaleolíticas, um deles entre os $5 \mathrm{~m}$ e $8 \mathrm{~m}$, o segundo medindo de $15 \mathrm{~m}$ a 25 $\mathrm{m}$, o terceiro situado entre os $30 \mathrm{~m}$ e os $40 \mathrm{~m}$, o quarto entre $45 \mathrm{~m}$ e $55 \mathrm{~m}$, encontrando-se o mais elevado entre os 60 m e os 70 m (Teixeira e Assunção, 1961: 14, 15). Contudo, tais indústrias ali ocorrem, igualmente, em altitudes superiores aos $100 \mathrm{~m}$.

$\mathrm{O}$ actual coberto vegetal do Monte de Góios reflecte 
a presença de ventos marítimos carregados de humidade, devidos à influência oceânica, provocando precipitação abundante, Invernos temperados e desenvolvendo paisagem verdejante. Ele apresenta colónias residuais de carvalhos e de castanheiros, embora esteja, em grande parte, invadido por pinheiros, espécie própria das terras litorais, e eucaliptos, encontrando-se, não raro, bouças, com os seus rudes muros graníticos de protecção.

Algumas zonas mostram profundas feridas devido à exploração de granito, que ocorreu, pelo menos, desde o século XVI e até à actualidade, conforme numisma cunhado no reinado de D. Sebastião que encontrámos em uma delas. Ali ficaram crateras, mais ou menos largas e profundas, blocos cortados, montões de fragmentos e caminhos, alguns abertos nos afloramentos rochosos, tendo em vista melhor permitirem a passagem dos carros de bois e das pesadas cargas que transportavam.

Tais explorações de pedra afectaram, tanto a grande laje gravada do sítio das Carvalheiras, como o conjunto de rochas do Cruzeiro Velho, passando caminho, com rodados escavados no substrato, junto a rocha decorada do Castelhão. Também o alargamento de via adjacente à grande laje profusamente decorada das Fogaças, amputou parte desta, hoje nos limites da povoação de Lanhelas.

\section{INVESTIGAÇÃO}

A grande figura tutelar e pioneira da Arqueologia do Norte de Portugal, Francisco Martins Sarmento (1999: 386) refere, em 1887, laje com gravuras, no sítio da Chã, em Lanhelas, de que lhe fizeram um desenho e que estava a ser destruída. Contudo, a sua preservação foi conseguida graças à intervenção daquele investigador junto do então presidente da Câmara Municipal de Caminha. O mesmo arqueólogo menciona machado de bronze, com dois anéis, procedente de Lanhelas, citando outros artefactos, no mesmo metal, provindos do Castro de Mouros (Castro de Vilar de Mouros), situado a 1 km para sudeste daquela povoação (Sarmento, 1999: 446).

Decorrida mais de meia centúria sobre a notícia e as diligências de F. Martins Sarmento, Mário Cardozo (1951: 47-49, fig. 53) publicou nota avulsa daquele sobre a resolução camarária de impedir o despedaçamento da laje insculturada referida e informa que esta se encontrava "em terreno baldio no sítio da Fogaça, logar da Boucinha, junto à Bouça do Covê- llo". É, ainda, Mário Cardozo que relata as diligências tomadas pela Sociedade Martins Sarmento, em 1926, junto do pároco de Lanhelas, acerca do estado de conservação da superfície gravada, hoje conhecida por Laje das Fogaças. Aquele terá respondido que a mesma se encontrava intacta e que a cerca de $100 \mathrm{~m}$ existia outra rocha gravada, que presumimos poder corresponder à maior das existentes na Chã das Carvalheiras.

Todavia, novas diligências efectuadas, em 1948, davam conta que a Laje das Fogaças se conservava, embora junto habitasse fogueteiro, o que condiz com informação de A. Viana (1929: 283, nota 1) que regista ali existirem "pavilhões de uma oficina de pirotecnia", aliás activa até aos finais do século XX e pertença da empresa "Libório Fernandes, Lda".

Importa, igualmente, registar a observação feita por F. Martins Sarmento (1999: 112), em 1879, dada a confusão em que alguns autores incorrem ao classificarem gravuras pré-históricas como históricas, nomeadamente quando se trata de cruciformes, tendo aquele deixado explícito: "Em Vilar de Mouros vi ainda o costume do rapazio gravar cruzes em lajes". Esta prática, ao que parece então isenta de simbolismo, deve, pois, explicar a abundância de cruciformes encontrados em algumas zonas do Monte de Góios e, portanto, próximo de Vilar de Mouros, tal como em outros lugares vizinhos.

Quase quarenta anos depois da notícia de F. Martins Sarmento, E. Jalhay, a quem também muito deve a investigação arqueológica nacional, volta sumariamente a referir as mesmas rochas gravadas (1926; 1932: 128, ests X, XI, figs 6, 7; 2002: 41, figs 6, 7). Mas, deve-se ao infatigável A. Viana, que foi professor em Lanhelas, notícia mais completa das gravuras do Monte de Góios, principalmente de duas das suas mais importantes rochas decoradas.

$\mathrm{O}$ último autor mencionado, elaborou um primeiro texto, publicado em 1929 na revista Portucale, onde descreve, sinteticamente, quarenta e uma figuras da Laje das Fogaças, que situa na Chã das Castanheiras e de que oferece levantamento, tal como treze figuras da Laje da Chã das Carvalheiras, a par de conjunto de gravuras do Penedo do Trinco ou Pedra Picadeira e de outro existente em laje da Bouça Velha (Viana, 1929).

Em 1960 A. Viana deu à estampa artigo sobre os mesmos testemunhos, descrevendo igualmente penedos insculturados de Carreço, infelizmente hoje destruídos. 
Ali se repetem as descrições das figuras reconhecidas na Laje das Fogaças, as da Laje da Chã das Carvalheiras, Penedo do Trinco e Bouça Velha, onde também existiam cruciformes modernos, sem, contudo, mostrar preocupação em relação à integração cultural ou à atribuição cronológica de tais ocorrências. Trabalho de síntese, do mesmo autor (Viana, 1963: 62 , fig. 68), contém figura com os principais motivos detectados nas lajes insculturadas de Lanhelas, sem que sobre elas ofereça novas informações.

Rui de Serpa Pinto (1929: 23), haveria igualmente de registar aqueles testemunhos, tal como uma década depois J. R. dos Santos Júnior (1940: 356), sem elaborarem quaisquer considerações sobre os mesmos, então quase caídos no esquecimento.

R. S. Lorenzo-Ruza (1957: 55) que, tal como seu pai R. Sobrino-Buhigas dedicou parte do seu labor científico aos petróglifos do Noroeste Peninsular, a que por vezes denomina de "galego-portugueses", estudou os exemplares minhotos, tendo referido as gravuras de Lanhelas.

Pequena nota sobre jazidas arqueológicas da região de Caminha, inserida na "Notícia Explicativa" da sua Carta Geológica, não deixou de mencionar as gravuras de Lanhelas (Teixeira e Assunção, 1961: 37).

Raúl Proença (1965: 1065), no "Guia de Portugal”, dedicado ao Minho, não esqueceu de referir os " $p e$ nedos com insculturas rupestres" da Chã dos Castanheiros, no Monte de Góios, em Lanhelas.

Aquelas significativas manifestações artísticas rupestres foram, apenas, cartografadas por E. Anati (1968: 8) na sua importante obra "Arte Rupestre nelle Regioni Occidentali della Penisola Iberica”, autor que, embora tivesse percorrido os mais importantes arqueossítios com arte rupestre da Galiza e do Norte de Portugal, não as visitou.

Em 1972, M. Farinha dos Santos publicou síntese, com grande divulgação, sobre a Pré-História portuguesa, ali aludindo, muito imprecisamente, às gravuras da Laje das Fogaças e da Chã das Carvalheiras, embora ilustrasse o seu texto com duas fotografias coloridas daquela primeira rocha (Santos, 1972: 116, 117, 122, 123, figs. 109, 110).

Trabalho monográfico, sobre o concelho de Caminha, trata da freguesia de Lanhelas e apenas sintetiza o que sobre as gravuras do Monte de Góios escreveu A. Viana (Alves, 1985: 180).

No entanto, a Laje das Fogaças e a Laje da Chã das Carvalheiras foram mencionadas em texto, sobre a arte rupestre holocénica portuguesa, da autoria de
A. M. Baptista (1986: 47, 48), como contendo “zoomorfos semiesquemáticos”, que integrariam grupo de gravuras datáveis "entre o Calcolítico e o Bronze Final-Ferro Inicial”. Não obstante, este mesmo autor não lhes dedicou qualquer referência em um seu importante texto sobre a arte rupestre do Norte de Portugal (Baptista, 1983-84).

F. J. Costas Goberna e P. Nóvoa Álvarez (1993: 76, 94, 95, 120), confundiram cavaleiro da laje 1 da Chã das Carvalheiras com cena de equitação de veado, em livro onde publicam fotografia e "frottage" de cervídeo daquela rocha, sob a designação genérica de Lanhelas, tal como acontece com fotografia da grande corça da Laje das Fogaças. Também dão a conhecer dois equídeos, um deles com cavaleiro, da laje 1 da Chã das Carvalheiras, embora os indiquem, erradamente, como de Parada (Campo Lameiro, Pontevedra), mostrando a pouca atenção que as gravuras de Lanhelas lhes despertaram.

Não deixámos de registar a descoberta e as referências existentes às gravuras de Lanhelas, em artigos de síntese sobre a arte rupestre portuguesa, sublinhando o reconhecimento da importância daquelas por parte de F. L. Cuevillas (1943) ao alargar a distribuição geográfica do seu Grupo C, dos petróglifos do Noroeste Peninsular, à margem esquerda do rio Minho (Gomes, 2002: 145, 147, 153; 2007: 123).

Em Abril de 2004, Lara Bacelar Alves e Margarida da Silva Monteiro procederam à prospecção das áreas do Monte de Góios a serem afectadas pela construção da via A28/IC1- Ligação a Caminha, com o objectivo de realizarem estudo de impacto no património, provocado por tal empreendimento. Os trabalhos decorreram, apenas, de 26 a 30 do mês citado, e deles foi apresentado relatório no mês seguinte.

Naquele consta "Inventário das Ocorrências Patrimoniais", elencando-se quinze sítios com manifestações de arte rupestre, tidos como pré ou proto-históricos, incluindo somente dois dos divulgados por A. Viana, dado que os outros dois não foram detectados. No entanto, alguns de tais sítios correspondem a rochas contendo acidentes naturais ou o resultado da acção erosiva provocada por agentes meteóricos, embora tenham sido tomados por gravuras $\left(\mathrm{n}^{\mathrm{os}} 38,39\right)$. Importa referir que as rochas inventariadas não foram limpas, da terra, líquenes e musgos que, pelo menos em parte, as cobriam, nem foi registada a sua principal iconografia, tendo em vista uma correcta avaliação científica, o que viria a reflectir-se, negativamente, no estudo de impacto elaborado e nas 
opções subsequentes de minimização daquele, no projecto da obra a realizar.

Nova prospecção, da responsabilidade de Lara Bacelar Alves, foi efectuada em Março e Abril de 2005 e, uma terceira, em Novembro e Dezembro desse mesmo ano, que durou seis dias, após incêndio, ocorrido nesse Verão, na encosta meridional do Monte de Góios, e que eliminou a densa vegetação que aí existia. Dão conta dos trabalhos efectuados e dos resultados alcançados, dois relatórios; um com data de Dezembro de 2005 e outro de Fevereiro de 2006, que o completa. É neste momento que se passou a referir e a tentar caracterizar o "Santuário com Arte Esquemática do Monte de Góios”, que se diz ser formado por 39 rochas decoradas, situadas sobretudo na zona denominada Tapada das Cruzes (Alves, 2005; 2006).

Os trabalhos no Monte de Góios, realizados por Lara Bacelar Alves fizeram despertar esta para a importância daquele tão esquecido acervo, sendo resultante de tal tomada de consciência dois textos publicados em 2005. Em um deles mostram-se duas fotos da Laje das Fogaças (Silva e Alves, 2005), escrevendo-se no outro, espécie de breve roteiro dos petróglifos do Minho, que elas "guardam os melhores exemplares destes motivos clássicos de uma tradição artística pré-histórica que se expande pela fachada atlântica do Noroeste Peninsular" (Silva e Alves, 2005a: 190-196). Em 2010, Joana Valdez apresentou gravuras do Monte de Góios, no estudo de tal técnica de representação na arte esquemática, em abordagem a que importou sobretudo a localização dos testemunhos. A mesma autora haveria de discorrer sobre a arte rupestre dita esquemática e a chamada atlântica, a partir das gravuras do Monte de Góios (Valdez, 2013).

\section{METODOLOGIAS}

Parece actualmente incontestável que o sucesso de qualquer investigação arqueológica, depende em grande parte das metodologias usadas, designadamente na recolha e tratamento da informação disponível, ou empírica. Nesta assentarão os pressupostos teóricos e os modelos, tanto capazes de explicarem as materialidades, como de provocarem as questões que elas reflectem, nos âmbitos económico, social, tecnológico e cognitivo, ou espiritual, das comunidades que foram responsáveis pelos testemunhos arqueológicos chegados até nós.
O registo fiável das manifestações de arte rupestre é, reconhecidamente, tarefa importante e, desde logo, uma das mais complexas no estudo daquelas. Ele respeita à elaboração de levantamentos exaustivos e de inventários completos das rochas decoradas, das suas características e dos motivos nelas gravados, integradas na paisagem envolvente.

Os nossos trabalhos de campo no Monte de Góios iniciaram-se com a prospecção sistemática de rochas decoradas, durante o dia e à noite, com luz artificial rasante, o que viria a mostrar-se proveitoso, dado termos reconhecido novas superfícies gravadas. Para haver completa certeza de que não seriam esquecidos quaisquer de tais testemunhos, libertaram-se da vegetação rasteira, de finas camadas de terra, como de mantos de musgos, líquenes e algas, todas as superfícies que suspeitámos poderem conter gravuras.

Nas rochas onde já se conheciam gravuras e nas onde aquelas foram então identificadas, puseram-se à vista os seus limites naturais e fez-se a prospecção exaustiva da iconografia.

Registaram-se, através de decalque directo e, portanto, à escala natural (esc. 1/1), sobre plástico transparente de polivinilo, todas as gravuras como os principais acidentes, naturais ou devidos a acção antrópica, existentes nos suportes. Este trabalho foi produzido durante a noite, utilizando-se luz artificial rasante, tendo em vista melhor visualizarmos as gravuras e podermos estudar a sua constituição. Todos os decalques foram executados pelo signatário. Elaborou-se, para cada superfície decorada, ficha descritiva contendo a sua localização e as características do suporte, identificadas no campo, catálogo do seu reportório iconográfico, com os principais atributos de cada gravura e comentário, de carácter arqueológico e cultural.

No catálogo das gravuras constam a forma reconhecida, a localização no suporte e atributos essenciais, como técnica de execução, forma e dimensões dos levantamentos que as enformam, tipo de linhas ou de manchas que eles constituem, graus de desgaste, estratigrafias verticais e horizontais ou associações, quando existem, outros aspectos julgados pertinentes e dimensões.

Quando o número de motivos identificados em certas rochas é elevado e, sobretudo, se detectaram diferentes fases de realização, foram elaborados quadros-síntese da sua iconografia, com as diacronias relativas observadas. 
Nas diferentes tarefas de campo, colaboraram os arqueólogos Joana Gonçalves, Tânia Casimiro e Telmo Silva. Levantamentos, utilizando sistema de varrimento tridimensional por luz estruturada (Mephisto ${ }_{3} \mathrm{D}$ ) das rochas 1 da Boucinha, 1 das Carvalheiras e Laje das Fogaças, elaborados por Hugo Pires, da empresa Superfície - Geomática, permitiram, no terceiro sítio, identificar algumas novas gravuras e completar aspectos do registo tradicional.

\section{INFORMAÇÃO EMPÍRICA}

A apresentação que segue fez-se de norte para sul e, além do micro-topónimo atribuído a cada rocha, incluiu-se o número de ordem correspondente ao registo da totalidade das ocorrências de superfícies gravadas, mesmo que se tratasse de inscrições ou de cruciformes modernos.

\section{Bouça Velha (r. 69)}

Localização: Situa-se a cerca de $100 \mathrm{~m}$, para norte, do Cruzeiro Velho e $200 \mathrm{~m}$, para sudeste, da capela de São Martinho, não muito longe do Km 98 da EN 13, constituindo a superfície gravada a cota mais baixa e mais a norte do conjunto rupestre do Monte de Góios (c.g. -53901.3848; 249475.5710, altitude: $56,6 \mathrm{~m})$.

Suporte: Trata-se de enorme afloramento de granito possuindo grão médio, com forma hemisférica achatada (batólito), embora mostrando, na parte superior, duas superfícies planas; uma menor voltada para norte e outra, a maior, dirigida para sul e onde se encontram as gravuras. Esta mede $6,70 \mathrm{~m}$ de comprimento, 5,60 m de largura máxima e apresenta $15^{\circ}$ de inclinação.

(Quadro I)

\section{Cruzeiro Velho I (r. 97)}

Localização: No topo de elevação, situada $300 \mathrm{~m}$ a nordeste do Cruzeiro Velho e a $750 \mathrm{~m}$, para noroeste, do v.g. Monte de Góios (c.g. -53784.574; 249467.508, altitude: $74,62 \mathrm{~m}$ ).

Suporte: Grande afloramento de granito, de grão médio a grosseiro, contendo, no topo, superfície sub-horizontal. As gravuras, muito erodidas, devido à acção dos agentes meteóricos, conservam-se, no canto sudeste, zona naturalmente mais protegida. Mede 6,25 m de comprimento e 6,45 $\mathrm{m}$ de largura máxima, na área mesial. A diferença de cotas, entre a zona decorada e o solo, no lado poente, é de 3,oo m.
Foram reconhecidos três motivos gravados; dois conjuntos de círculos concêntricos e trapézio, de linhas mais largas e profundas, talvez ulterior àqueles, dispostos em linha orientada, aproximadamente, no sentido sudeste-noroeste.

\section{Cruzeiro Velho 2 (r. 5)}

Localização: No cimo de grande afloramento rochoso, situado a pouco mais de uma centena de metros, para nascente, do Cruzeiro Velho e a 250, para sudeste, da capela de São Martinho. No mesmo local encontram-se as rochas decoradas, denominadas Cruzeiro Velho 3, 4 e 5 (c.g. -53887.441; 249357.707; altitude: $86,53 \mathrm{~m}$ ).

Suporte: Laje de granito, com grão médio, na metade superior sub-horizontal e na restante área inclinada cerca de $3 \mathrm{O}^{\circ}$, no sentido norte-sul, encontrando-se definida por profundas fracturas. Mede 12,60 m de comprimento e 4,20 $\mathrm{m}$ de largura máxima.

(Quadro II)

\section{Cruzeiro Velho 3 (r. 96)}

Localização: No topo de grande afloramento onde se encontram as superfícies denominadas Cruzeiro Velho 2, 4 e 5 (c.g. -53893.212; 24955.214, altitude: $86,32 \mathrm{~m})$.

Suporte: Grande laje, de granito, com grão médio a grosseiro, mostrando largos veios de quartzo branco, dispostos no sentido nascente-poente. Encontra-se inclinada para poente. Mede $13 \mathrm{~m}$ de comprimento por 2,70 m de largura. Reconheceram-se, apenas, um trapézio e uma covinha.

\section{Cruzeiro Velho 4 (r. 95)}

Localização: No grande afloramento que temos vindo a referir, mas em zona de cotas mais baixas (c.g. -53893.212; 249355.214, altitude: 84,55 m).

Suporte: Superfície, de granito com grão médio a grosseiro, sub-horizontal, parcialmente amputada, devido à exploração de pedra. Mede 3,20 m de comprimento por 2,20 de largura máxima. A zona decorada, no lado norte, apresenta 1,50 m de comprimento e $1,00 \mathrm{~m}$ de largura máxima.

(Quadro III)

\section{Cruzeiro Velho 5 (r. 10o)}

Localização: Situa-se perto do topo do afloramento rochoso que temos vindo a mencionar, entre as superfícies denominadas Cruzeiro Velho 3 e Cruzeiro Velho 2, das quais se encontra separada por profun- 
das fracturas (c.g. -53887.441; 249357.707, altitude: $86,37 \mathrm{~m})$.

Suporte: Superfície de granito, fazendo parte de extenso afloramento que se impõe na paisagem devido à sua altura. Encontra-se inclinada no sentido nordeste-sudoeste, com a parte mais alta correspondendo àquela primeira direcção. Mede $2,80 \mathrm{~m}$ de comprimento, no sentido norte-sul, e 1,6o m de largura máxima. As gravuras ocupam área da metade nascente, medindo $1,00 \mathrm{~m}$ por $\mathrm{o}, 8 \mathrm{o} \mathrm{m}$.

(Quadro IV)

\section{Cruzeiro Velho 6 (r. 3)}

Localização: $\mathrm{Na}$ vertente ocidental do Monte de Góios, próximo do afloramento onde se encontram as rochas Cruzeiro Velho 2 a 5 (c.g. -53961, 154;249338,345; altitude: 59,34 m).

Suporte: Superfície superior de bloco granítico, de grão médio. Oferece contorno poligonal e é sub-horizontal, mostrando $15^{\circ}$ de inclinação, no sentido sudeste-noroeste. Mede 1,39 m de comprimento e 1,29 m de largura máxima, na área mesial. Mostra duas covinhas e antropomorfo em forma de duplo $\Phi$.

\section{Boucinha 1 (r. 34)}

Localização: Pertence a enorme afloramento, situado a cerca de $500 \mathrm{~m}$ para nascente de Lanhelas e a 200 $\mathrm{m}$ para nor-noroeste da rocha conhecida por Carvalheiras 1 (r.53). Na mesma zona encontram-se as rochas Boucinha 2 e 3 (c.g. -53964,019; 249022,400; altitude: $96,98 \mathrm{~m}$ ).

Suporte: Grande laje de granito, de grão médio, sub-horizontal, com a zona mais alta no lado poente e $8^{\circ}$ de inclinação, no sentido este-oeste. Mede 14,80 $\mathrm{m}$ de comprimento e 12,00 $\mathrm{m}$ de largura máxima, na área mesial. Apresenta, no lado norte, sector mais alto e decorado, medindo $2,80 \mathrm{~m}$ de comprimento e 1,50 m de largura máxima. Oferece, quase ao centro, outro núcleo de gravuras, encontrando-se as restantes dispersas pela sua superfície. Contém largos veios de quartzo, de cor branca, sobretudo orientados no sentido nascente-poente.

(Quadro V)

\section{Boucinha 2 (r. 9o)}

Localização: Faz parte de extenso afloramento, situado $500 \mathrm{~m}$ a nascente do local conhecido por Anta, hoje integrado em Lanhelas, e a cerca de $250 \mathrm{~m}$, para nor-noroeste, da superfície decorada denominada Carvalheiras 1 (r. 53) (c.g. -53975,382; 249042,090; altitude: 95,06 m).

Suporte: Grande laje, sub-horizontal, de granito de grão médio. Ao centro da metade norte observa-se figuração de ofídio e, no topo, daquele lado, a cerca de cinco metros, covinha. O sector que contém a imagem de ofídio, delimitado por fracturas profundas, mede 4,32 $\mathrm{m}$ de comprimento por 2,20 m de largura máxima.

\section{Boucinha 3 (r. 31)}

Localização: Grande afloramento, situado a cerca de $600 \mathrm{~m}$, para este-noroeste, do v.g. Monte de Góios e a $40 \mathrm{~m}$, para nordeste, da rocha Boucinha 2 (r. 9o) (c.g. -53954,403; 249078,006; altitude: 96,05 m). Suporte: Enorme superfície granítica, de grão médio, plana e inclinada para norte. O sector que apresenta gravuras mede 6,60 $\mathrm{m}$ de comprimento e 4,50 $\mathrm{m}$ de largura máxima. Aquelas surgem, apenas, na metade superior, ou seja, no seu lado sul. Detectaram-se vinte e duas gravuras (podomorfo, círculo, barra, espiral de covinhas e dezoito covinhas dispersas).

\section{Carvalheiras I (r. 53)}

Localização: No lado sul da Chã das Carvalheiras, em zona, que foi utilizada como pedreira, possivelmente no século XVI, dado numisma que ali descobrimos.

Suporte: Trata-se de grande afloramento, com a superfície inclinada, encontrando-se a zona superior no lado poente, delimitado e atravessado por profundas fracturas. Apresenta espessos veios de quartzo branco, orientados nordeste-sudoeste. A área decorada mede $11,90 \mathrm{~m}$ de comprimento, 6,50 $\mathrm{m}$ de largura máxima, na zona mesial, e tem $16^{\circ}$ de inclinação (c.g. -53967.355; 248808.930, altitude: 107,67 m).

(Quadro VI)

\section{Carvalheiras 2 (r. 66)}

Localização: No lado nascente da Chã das Carvalheiras, a cerca de $100 \mathrm{~m}$ para nascente da laje 1 das Carvalheiras (c.g. -53887.06o; 248822.231, altitude: $112,77 \mathrm{~m}$ ).

Suporte: Trata-se de grande afloramento, elevado acima do nível do solo, orientado, segundo o comprimento, no sentido norte-sul. Apresenta grande desnível no lado poente, onde é quase vertical e, no lado contrário, assenta muro de pedra solta, construído com grandes blocos de granito. Mede $18 \mathrm{~m}$ de comprimento e 6,5 $\mathrm{m}$ de largura máxima.

(Quadro VII) 


\section{Carvalheiras 3 (r. 93)}

Localização: Na Chã das Carvalheiras, a aproximadamente $80 \mathrm{~m}$, para norte, da laje 1 das Carvalheiras (c.g. -53951.826; 248905.182; altitude: 100,23 m).

Suporte: Grande laje, sub-horizontal, com contorno poligonal e pouco elevada acima do solo. Jazia parcialmente coberta por fina camada de sedimentos, depositados há não muito tempo e onde crescia alguma vegetação rasteira. Encontra-se delimitada e subdividida por profundas fracturas. Mede 10,08 m de comprimento e 3,46 $\mathrm{m}$ de largura máxima.

(Quadro VIII)

\section{Carvalheiras 4 (r. 94)}

Localização: Na vertente voltada para poente, do Monte de Góios, cerca de $400 \mathrm{~m}$, para nascente, da rocha denominada Carvalheiras 1, perto de caminho que percorre, a meia altura, aquele relevo, aproximadamente a $300 \mathrm{~m}$, para ocidente, do v.g. Monte de Góios (c.g. -53826,202; 2488,476; altitude: 143 m). Suporte: Grande afloramento de granito, de grão médio a grosseiro, possuindo desenvolvida superfície voltada para sul, inclinada cerca de $45^{\circ}$. Encontra-se parcialmente coberto por terra e mostra acentuada erosão, designadamente na zona a menor cota. Mede 5,34 m de comprimento e 4,52 m de largura máxima, no sentido nascente-poente.

(Quadro IX)

\section{Laje das Fogaças (r. 52)}

Localização: Encontra-se à entrada da denominada, Chã das Castanheiras, na parte alta da povoação de Lanhelas, junto à rua da Boavista e é propriedade da Drª Maria de Deus Carro Fernandes. Até ao ano 2000 ali funcionou indústria de pirotecnia da empresa Libório Fernandes, Lda (c.g. -54100.348; 248913.859, altitude: $67,57 \mathrm{~m}$ ).

Suporte: Trata-se de enorme afloramento de granito, com grão médio a grosseiro, atravessado por largos veios de quartzo branco, com superfície, inclinada cerca de $30^{\circ}$, voltada a Sul. A zona superior, quase horizontal, foi parcialmente cortada e em parte coberta por camadas de cimento. Na zona oposta, de cota mais baixa, a superfície rochosa foi desmontada, possivelmente quando do alargamento do caminho que ali passa e da construção do muro que delimita a propriedade. Mede 16,60 $\mathrm{m}$ de comprimento, no sentido norte-sul e $12 \mathrm{~m}$ de largura máxima. Todavia, as gravuras ocupam área medindo $14 \mathrm{~m}$ de comprimento por $9 \mathrm{~m}$ de largura, ou seja, com $126 \mathrm{~m}^{2}$. No lado noroeste esta superfície encontra-se sobreposta por escada, com dez degraus e patamar, de cimento. (Quadro X)

\section{Cachadinha I (r. 99)}

Localização: Em pequeno planalto, situado a norte das casas da Cachadinha, pertencente aos contrafortes de vertente sul do Monte de Góios. A cerca de $200 \mathrm{~m}$ para poente corre o rio de Ouro, afluente da margem direita do Coura (c.g. -53899.618; 247501.951, altitude: 56,43 m).

Suporte: Corresponde ao sector sudeste de grande afloramento de granito, com grão médio, sub horizontal e apenas parcialmente coberto por delgada camada de terra. A sua superfície encontra-se muito erodida, devido à acção dos agentes meteóricos, mostrando, nas zonas mais expostas àqueles, cor cinzenta escura, tal como fissuras e estalamentos diversos. A zona decorada mede 2,30 $\mathrm{m}$ de comprimento e 1,6o m de largura. Apresenta, actualmente, três conjuntos de dois círculos concêntricos e uma covinha.

\section{Cachadinha 2 (r. 43)}

Localização: Encontra-se quase no topo da encosta sul de pequena linha de água, afluente da margem direita do rio Coura, a nordeste da aglomeração de casas do sítio da Cachadinha (c.g. -53798.524; 247537.556, altitude: $37,33 \mathrm{~m}$ ).

Suporte: Superfície pertencente a enorme afloramento granítico, de grão médio a grosseiro, oferecendo forte inclinação, na direcção norte, e delimitado por profundas fracturas. Mede $8,40 \mathrm{~m}$ de comprimento e 5,20 m de largura. Mostra onze covinhas dispostas em linha recta e círculo contendo covinha no centro.

\section{Castelhão 1 (r. 45)}

Localização: A sul do Monte de Góios, na encosta sobranceira à margem esquerda do rio Coura e a cerca de $150 \mathrm{~m}$ deste. No lado sul desta rocha passava antigo caminho, mostrando restos de rodados escavados no substrato (c.g. -53393.2511; 246662.1346, altitude: 41,05 m).

Suporte: Afloramento de granito, possuindo grão médio a grosseiro, de cor cinzenta clara, oferecendo três grandes planos sub-horizontais, delimitado por profundas fracturas. Encontrava-ses parcialmente coberto por sedimentos modernos e as suas superfícies exibem elevado grau de erosão, tal como fracturas e fissuras diversas. Mede 7,50 m de com- 
primento e 6,50 $\mathrm{m}$ de largura.

(Quadro XI)

\section{CONCLUSÕES}

Os testemunhos de arte rupestre, conhecidos desde os finais do século XIX e os recentemente identificados, permitem que consideremos o Monte de Góios, uma montanha sagrada, da Pré e Proto-História, cuja localização e características naturais terão sido determinantes para tal reconhecimento.

As quase novecentas gravuras estudadas, distribuídas principalmente por meia dezena de sítios da vertente poente do relevo mencionado, apresentam longa cronologia, possivelmente ainda ascendendo aos finais do Paleolítico Superior e atingindo os Tempos Históricos. Todavia, a grande maioria das representações rupestres chegadas até nós pertence aos finais da Pré-História e à Proto-História, nomeadamente às Idades do Bronze Inicial, Médio e Idade do Bronze Final, tal como a diferentes momentos da Idade do Ferro, talvez mesmo alcançando os primórdios da Romanização. Podemos, em breve síntese, indicar que a um primeiro momento corresponde à presença de grandes animais, de estilo subnaturalista, a um segundo raros zoomorfos de estilo estilizado dinâmico, enquanto a um terceiro atribuímos antropomorfos esquemáticos, idoliformes e alguns ideograma geométricos. Um quarto momento integra vasta iconografia de carácter geométrico, como círculos, simples ou organizados em conjuntos concêntricos, círculos com ponto ou covinha central e espirais, podendo ser classificado na Idade do Bronze Inicial ou Médio (II milénio a.C.), quando se desenvolveu, no Noroeste Peninsular, forte interacção económica e cultural, tanto com o Mundo Atlântico como com o Mediterrâneo, devido à presença de ouro e de minério de estanho, de que se reconheceram restos de explorações nas proximidades do Monte de Góios. Por fim, repertório constituído pelas representações de pequenos equídeos, longos colubrídeos, alguns enrolados em espiral, quadrados, rectângulos, subdivididos ou reticulados, círculos com diâmetros cruzados, covinhas, escutiformes e podomorfos, entre outros motivos, deve pertencer aos tempos proto-históricos, designadamente à Idade do Bronze Final e à Idade do Ferro, quando ocorreu a denominada Cultura Castreja, pervivendo em período da colonização romana.
As gravuras rupestres denunciam a presença de santuários, onde se desenrolaram diversas actividades de carácter sócio-religioso, da responsabilidade de xamãs ou sacerdotes sendo, por vezes, reutilizados ao longo de milénios e de que aquelas são os únicos vestígios da acção antrópica, chegados até nós.

O rico acervo iconográfico do Monte de Góios, constitui importante legado da vida cognitiva ou espiritual das populações por ele responsáveis, informando-nos sobre a sua organização social, economia, tecnologias disponíveis e vida espiritual, como também sobre o ambiente natural, ao longo de larga diacronia.

Importa relevar, entre as manifestações de arte rupestre ali existentes, a Laje das Fogaças, devido à sua variada iconografia, constituída por mais de quatro centenas de imagens, ou seja, quase $50 \%$ das identificadas em todas superfícies estudadas, correspondendo, ainda, ao mais amplo espectro cronológico observado. Esta rocha decorada, verdadeiro palimpsesto, é, por certo, uma das mais importantes do Noroeste Peninsular.

Embora as gravuras resultem de linguagem codificada ou metafórica e de saberes diversos, é possível nelas identificar aspectos mitográficos, que constituem verdadeiros paradigmas do pensamento humano ou, mais especificamente, de certas culturas europeias.

Ilustram este facto os pares de longos colubrídeos, cavalo transformado em veado, idoliformes, pares de podomorfos, serpente e toirão afrontados, círculos solares, cavalos associados a círculos, cavaleiros, etc. Apesar dos paralelos que a arte do Monte de Góios evidencia em relação com outras ocorrências rupestres do Noroeste Peninsular, ou com a arte de outros complexos rupestres, como o do Vale do Tejo, ela possui características peculiares, de carácter artístico, ambiental e cultural, de que são exemplo as representações sidéricas de pequenos cavalos ou garranos. Às clássicas questões que nos colocam os testemunhos arqueológicos, como quando foram feitos, por quem e com que finalidades, somam-se às manifestações rupestres, que por comodidade chamamos artísticas, características enigmáticas e polissémicas, mas elas têm a capacidade de atraírem a nossa atenção e despertarem emoções, mesmo sem conhecermos o seu significado. Será que as imagens rupestres continuam a ser mágicas, como os nossos antepassados certamente as consideraram? 


\section{BIBLIOGRAFIA}

ALVES, Lara Bacelar (2005) - Concessão Scut do Norte Litoral A 28/IC1 - Viana do Castelo - Caminha, Troço Ligação a Caminha, Relatório de Conformidade Ambiental do Projecto de Execução (RECAPE). Património, Amb\&Veritas, Lisboa.

ALVES, Lara Bacelar (2006) - IC1 - Viana do Castelo - Caminha, Ligação a Caminha, Relatório Técnico - Científco da Prospecção Arqueológica entre PKS 1+80o e 2+30o, Amb\&Veritas, Lisboa.

ALVES, Lourenço (1985) - Caminha e o seu Concelho. Caminha: Câmara Municipal de Caminha.

ANATI, Emmanuel (1968) - Arte Rupestre nelle Regioni Occidentali della Penisola Iberica. Capo di Ponte: Edizioni del Centro Camuno di Studi Preistorici.

BAPTISTA, António Martinho (1983-84) - Arte rupestre do Norte de Portugal: uma perspectiva, Portugália, nova série, vols IV/V, pp. 71-82, IV ests.

BAPTISTA, António Martinho (1986) - Arte rupestre pós-glaciária. Esquematismo e Abstracção, História da Arte em Portugal. Do Paleolítico à Arte Visigótica, pp. 31-55. Lisboa: Publicações Alfa.

CARDOZO, Mário (1951) - Monumentos arqueológicos da Sociedade Martins Sarmento, Revista de Guimarães, vol. LXI, pp. 5-8o.

COSTAS GOBERNA, Fernando Javier; NÓvOA ÁLVAREZ, Pablo (1993) - Los Grabados Rupestres de Galicia. A Coruña: Museu Arqueolóxico e Histórico de A Coruña.

CUEVILLAS, Florentino Lopez (1943) - Las insculturas del Outeiro da Cruz, Boletín del Museo Arqueológico Provincial de Orense, vol. I, pp. 95-101.

FEIO, Mariano (1948) - Notas geomorfológicas. I - Reflexões sobre o relevo do Minho. II - Em torno da interpretação dos terraços do Rio Minho, Boletim da Sociedade Geológica de Portugal, vol. VII, pp. 31-54.

GOMES, Mário Varela (2002) - Arte rupestre em Portugal perspectiva sobre o último século, Arqueologia $\&$ História, vol. 54, pp. 139-194.

GOMES, Mário Varela (2007) - Arte rupestre em Portugal. Os últimos 25 anos, Al-Madan, II série, nํ15, pp. 120-124.

JALHAY, Eugénio (1926) - Los grabados rupestres del extremo sudoeste da Galicia: Alrededores de Oya. Provincia de Pontevedra, Boletin de la Comisión Provincial de Monumentos de Orense, vol. VII, pp. 373-385

JALHAY, Eugénio (1932) - Novas descobertas pré-históricas no Sudoeste da Galiza e Norte de Portugal, Asociación Española para el Progreso de las Ciencias, pp. 121-128, XIII ests, Madrid.

JALHAY, Eugénio (2002) - Nuevos descobrimientos prehistóricos en el Suroeste da Galicia y Norte de Portugal, Estu- dios Arqueológicos de Eugenio Jalhay, pp. 31-53. A Guarda: Padroado do Monte de Santa Trega.

LORENZO-RUZA, Ramón Sobrino (1957) - Bosquejo para un estudio de los petroglifos portugueses, Caesaraugusta, vols 7,8 , pp. 49-65.

PINTO, Rui de Serpa (1929) - Petroglifos de Sabroso e a arte rupestre em Portugal, Nós, ano XI, n62, pp. 19-26.

PROENÇA, Raúl (1965) - Guia de Portugal. Entre Douro e Minho. II. Minho. Lisboa: Fundação Calouste Gulbenkian.

RIBEIRO, Orlando (1961) - Geografia e Civilização. Temas Portugueses. Lisboa: Centro de Estudos Geográficos da Universidade de Lisboa.

SANTOS JÚNIOR, Joaquim Rodrigues dos (1940) - Arte rupestre, Congresso do Mundo Português, vol. I, pp. 327-376, XVIII ests. Lisboa: Comissão Executiva dos Centenários.

SANTOS, Manuel Farinha dos (1972) - Pré-História de Portugal. Lisboa: Editorial Verbo.

SARMENTO, Francisco Martins (1999) - Antíqva. Apontamentos de Arqueologia. Guimarães: Sociedade Martins Sarmento.

SILVA, António Manuel dos Santos Pinto da; ALVES, Lara Bacelar (2005) - Arte rupestre pós-glaciar no Noroeste de Portugal, Arte Rupestre Prehistórica do Eixo Atlántico, pp. 171-187. Vigo: Eixo Atlántico.

SILVA, António Manuel dos Santos Pinto da; ALVES, Lara Bacelar (2005a) - Roteiro de arte rupestre do Noroeste de Portugal, Arte Rupestre Prehistórica do Eixo Atlántico, pp. 189-213. Vigo: Eixo Atlántico.

TEIXEIRA, Carlos.; ASSUNÇÃO, Carlos Fernando Torre de (1961) - Carta Geológica de Portugal na escala 1/50 ooo. Notícia Explicativa da Folha 1-C. Caminha. Lisboa: Serviços Geológicos de Portugal.

VALDEZ, Joana (2010) - A Gravura na Arte Esquemática do Noroeste Peninsular. O Caso do Monte de Góios (Lanhelas, Caminha). Dissertação de Mestrado em Arqueologia. Porto: Faculdade de Letras da Universidade do Porto.

VALDEZ, Joana (2013) - Schematic and Atlantic rock art: A comparative study. The case study of Monte de Góios (Lanhelas, Caminha), Journal ofIberian Archaeology, vol.13, pp. 7-34.

VIANA, Abel (1929) - As insculturas rupestres de Lanhelas (Caminha, Alto-Minho), Portvcale, vol. II, $\mathrm{n}^{\mathrm{os}} 10,11$, pp. 282-290, 350-356.

VIANA, Abel (1959-6o) - Insculturas rupestres do Alto Minho (Lanhelas e Carreço - Viana do Castelo, Portugal), Boletin de la Comisión de Monumentos de Orense, tomo XX, pp. 209-231.

VIANA, Abel (1963) - Cividade de Âncora - Sua importância - explorações de 196o e 1961, Lvcerna, vol. 3, pp. 167-178. 


\begin{tabular}{|c|c|c|c|c|c|}
\hline & P I & P II & P III & Total & $\%$ \\
\hline colubrídeos & & & 2 & 2 & 3,23 \\
\hline círculos & 5 & & & 5 & 8,07 \\
\hline dois círculos concêntricos & 2 & & & 2 & 3,23 \\
\hline três círculos concêntricos & 2 & & & 2 & 3,23 \\
\hline quatro círc. concêntricos & 1 & & & 1 & 1,61 \\
\hline círculo c/ covinha central & 3 & & & 3 & 4,84 \\
\hline dois círculos c/ cov. central & 3 & & & 3 & 4,84 \\
\hline três círculos c/ cov. central & 3 & & & 3 & 4,84 \\
\hline círc. c/ cov. c. e círc. de cov. & & 3 & & 3 & 4,84 \\
\hline círculo c/ cov. e diâmetro & 1 & & & 1 & 1,61 \\
\hline círculo c/ disco central & & 1 & & 1 & 1,61 \\
\hline disco & & 1 & & 1 & 1,61 \\
\hline covinhas & & & 31 & 31 & 50,00 \\
\hline covinhas em quadrado & & & 1 & 1 & 1,61 \\
\hline seis cov. em rectângulo & & & 1 & 1 & 1,61 \\
\hline raqueta & 1 & & & 1 & 1,61 \\
\hline grelha & & & 1 & 1 & 1,61 \\
\hline total & 21 & 5 & 36 & 62 & 100,00 \\
\hline$\%$ & 33,87 & 8,06 & 58,07 & 100,00 & \\
\hline
\end{tabular}

Quadro I - Síntese iconográfica da rocha da Bouça Velha (r. 69).

\begin{tabular}{|c|c|c|c|c|c|c|}
\hline & PI & PII & PIII & PIV & $\mathrm{P} ?$ & Total \\
\hline antropomorfo & 1 & & & & & 1 \\
\hline cavalo & & & & 1 & & 1 \\
\hline colubrídeos & & 1 & 1 & & & 2 \\
\hline rectângulo & & & 1 & & & 1 \\
\hline círculo & & 1 & & & & 1 \\
\hline oval & & 1 & & & & 1 \\
\hline octógono de cov. & & & 1 & & & 1 \\
\hline covinhas & & 4 & 1 & & 8 & 13 \\
\hline linha & & & & 1 & & 1 \\
\hline total & 1 & 7 & 4 & 2 & 8 & 22 \\
\hline
\end{tabular}

Quadro II - Síntese iconográfica da rocha Cruzeiro Velho 2 (r. 5). 


\begin{tabular}{lccccc} 
& P I & P II & P III & P IV & Total \\
\hline círculo concêntrico & I & & & & 1 \\
\hline círculo c/ cov. central & 1 & & & & 1 \\
\hline covinhas & & 4 & & & 4 \\
\hline serpentiforme & & 1 & & 1 \\
\hline trapézio & 2 & 4 & 1 & 1 & 8
\end{tabular}

Quadro III - Síntese iconográfica da rocha Cruzeiro Velho 4 (r. 95).

\begin{tabular}{|c|c|c|c|c|c|}
\hline & P I & P II & P III & $\mathrm{P}$ ? & total \\
\hline cavalo & & & 1 & & 1 \\
\hline podomorfos & & 4 & & & 4 \\
\hline barra & & & & 1 & 1 \\
\hline círculos & 3 & & & & 3 \\
\hline círculo c/covinha central & 1 & & & & 1 \\
\hline círculo c/ ponto central & 1 & & & & 1 \\
\hline covinhas & & & & 2 & 2 \\
\hline total & 5 & 4 & 1 & 3 & 13 \\
\hline
\end{tabular}

Quadro IV - Síntese iconográfica da rocha Cruzeiro Velho 5 (r. 10o).

\begin{tabular}{|c|c|c|c|c|c|c|c|}
\hline & P I & P II & P III & PIV & $\mathrm{PV}$ & $\mathrm{P}$ ? & total \\
\hline cavalos & 2 & & & & 2 & & 4 \\
\hline colubrídeos & & & 2 & & & & 2 \\
\hline círculos & & 6 & & & & & 6 \\
\hline dois círculos conc. & & 2 & & & & & 2 \\
\hline três círculos conc. & & 1 & & & & & 1 \\
\hline círc. de cov. & & & & 1 & & & 1 \\
\hline linha de cov. & & & & 1 & & & 1 \\
\hline covinhas & & & & 2 & 5 & & 7 \\
\hline composição & & & & 1 & & & 1 \\
\hline linha & & & & & & 1 & 1 \\
\hline total & 2 & 9 & 2 & 5 & 7 & 1 & 26 \\
\hline
\end{tabular}

Quadro V-Síntese iconográfica da rocha Boucinha 1 (r.34). 


\begin{tabular}{|c|c|c|c|c|c|c|c|c|c|c|c|}
\hline & P I & P II & P III & PIV & $\mathrm{PV}$ & P VI & P VII & P VIII & $\mathrm{P}$ ? & Total & $\%$ \\
\hline antropomorfos & & & 3 & & & 1 & & & & 4 & 3,58 \\
\hline podomorfos & & & & 2 & & & & & & 2 & 1,79 \\
\hline par de podomorfos & & & & 1 & & & & & & 1 & 0,89 \\
\hline cavalos & 1 & 3 & & & & 7 & & & & $11(+1)$ & 9,82 \\
\hline veado & 1 & & & & & & & & & 1 & 0,89 \\
\hline cabra & & 1 & & & & & & & & 1 & 0,89 \\
\hline furão & & & & & & & & & 1 & 1 & 0,89 \\
\hline colubrídeos & & & & 3 & 7 & 5 & & & & 15 & 13,39 \\
\hline viperídeo & & & & & & 1 & & & & 1 & 0,89 \\
\hline machado (?) & & & & & & 1 & & & & 1 & 0,89 \\
\hline semicírculo & & & & 1 & & & & & & 1 & 0,89 \\
\hline círculos & & & 1 & 3 & & & & & 3 & 7 & 6,25 \\
\hline dois círc. conc. & & & & 3 & & & & & & 3 & 2,68 \\
\hline três círc. conc. & & & & 2 & & & & & & 2 & 1,79 \\
\hline quatro círc. conc. & & & & 2 & & & & & & 2 & 1,79 \\
\hline círc. c/ cov. central & & & & 2 & & & & & & 2 & 1,79 \\
\hline dois círc. c/ cov. central & & & & 3 & & & & & & 3 & 2,68 \\
\hline três círc. c/ cov. central & & & & 1 & & & & & & 1 & 0,89 \\
\hline quatro círc. c/ cov. central & & & & 1 & & & & & & 1 & 0,89 \\
\hline disco & & & & 1 & & & & & & 1 & 0,89 \\
\hline coroa circular & & & & 1 & & & & & & 1 & 0,89 \\
\hline ovais & & & & 2 & & & & & 2 & 4 & 3,58 \\
\hline covinhas & & & & & & 4 & 26 & & & 30 & 26,79 \\
\hline círc. de cov. c/ cov. central & & & & & & & 1 & & & 1 & 0,89 \\
\hline $\begin{array}{l}\text { dois círc. de cov. c/ cov. } \\
\text { central }\end{array}$ & & & & & & & 1 & & & 1 & 0,89 \\
\hline rectângulos & & & & & 2 & & & & & 2 & 1,79 \\
\hline rectângulo picotado & & & & & 1 & & & & & 1 & 0,89 \\
\hline rectângulo reticulado & & & & & 1 & & & & & 1 & 0,89 \\
\hline ziguezagues & & & 2 & & & & & & & 2 & 1,79 \\
\hline linhas & & & & & & & & 5 & 1 & 6 & 5,36 \\
\hline barra & & & 1 & & & & & & & 1 & 0,89 \\
\hline leteriforme & & & & & & & & 1 & & 1 & 0,89 \\
\hline Total & 2 & 4 & 7 & 28 & 11 & 19 & 28 & 6 & 7 & 112 & 100 \\
\hline$\%$ & 1,79 & 3,58 & 6,25 & 25,00 & 9,82 & 16,96 & 25,00 & 5,36 & 6,25 & 100 & \\
\hline
\end{tabular}

Quadro VI - Síntese iconográfica da rocha 1 das Carvalheiras. 


\begin{tabular}{lccccc} 
& P I & P II & P III & P ? & Total \\
\hline cavalos & 5 & & & & 5 \\
\hline covinhas & 5 & & & 5 \\
\hline linha & 1 & & & 1 \\
\hline mancha & & & 1 & 1 \\
\hline cruciforme & 5 & 6 & 1 & 1 & 13
\end{tabular}

Quadro VII - Síntese iconográfica da rocha 2 das Carvalheiras.

\begin{tabular}{lcc} 
& Total & $\%$ \\
\hline covinhas & 61 & 87,14 \\
\hline covinhas geminadas & 1 & 1,42 \\
\hline círculos de covinhas c/ cov. central & 1 & 1,42 \\
\hline círculos c/ cov. central & 2 & 2,87 \\
\hline hexágono de covinhas c/ cov. central & 1 & 1,42 \\
\hline rectângulos & 2 & 2,87 \\
\hline linhas & 2 & 2,87 \\
\hline total & 70 & 100
\end{tabular}

Quadro VIII - Síntese iconográfica da rocha Carvalheiras 3 (r. 93).

\begin{tabular}{lccccc} 
& P I & P II & P III & P ? & Total \\
\hline cavalos & & 2 & & & 2 \\
\hline podomorfos & 2 & & & & 2 \\
\hline covinhas & 2 & 2 & 3 & 14 & 21 \\
\hline total & 2 & & 3 & 14 & 17 \\
\hline
\end{tabular}

Quadro IX - Síntese iconográfica da rocha Carvalheiras 4 (r. 94). 


\begin{tabular}{|c|c|c|}
\hline & Total & $\%$ \\
\hline antropomorfo & 1 & 0,25 \\
\hline equídeos & 11 & 2,71 \\
\hline quadrúpede ind. & 1 & 0,25 \\
\hline colubrídeos & 21 & 5,17 \\
\hline serpentiforme & 1 & 0,25 \\
\hline ziguezagues & 2 & 0,49 \\
\hline podomorfos & 13 & 3,20 \\
\hline par de podomorfos & 2 & 0,49 \\
\hline linhas & 10 & 2,46 \\
\hline triângulo & 1 & 0,25 \\
\hline quadrados & 7 & 1,72 \\
\hline quad. cont. diâm. cruz. & 2 & 0,49 \\
\hline quadrado reticulado & 1 & 0,25 \\
\hline trapézio & 1 & 0,25 \\
\hline rectângulos & 13 & 3,20 \\
\hline rectângulo subdividido & 5 & 1,23 \\
\hline rectâng. cont. diâm. cruz. & 1 & 0,25 \\
\hline rectângulo reticulado & 7 & 1,72 \\
\hline círculos & 96 & 23,65 \\
\hline dois círc. concêntricos & 20 & 4,93 \\
\hline três círc. concêntricos & 4 & 0,98 \\
\hline seis círc. concêntricos & 1 & 0,25 \\
\hline círc. cont. ponto central & 4 & 0,98 \\
\hline dois círc. conc. c. ponto central & 6 & 1,47 \\
\hline dois círc. conc. c. cov. central & 3 & 0,73 \\
\hline disco cont. ponto central & 1 & 0,25 \\
\hline círc. cont. cov. central & 12 & 2,95 \\
\hline três círc. cont. c. cov. central & 2 & 0,49 \\
\hline quatro círc. conc. c. cov. central & 1 & 0,25 \\
\hline círc. cont. cov. e raio & 1 & 0,25 \\
\hline círc. cont. dois diâm. cruzados & 23 & 5,66 \\
\hline círc. cont. cinco raios & 1 & 0,25 \\
\hline círc. cont. três diâm. cruzados & 1 & 0,25 \\
\hline círc. cont. cov. e diâm. cruzados & 1 & 0,25 \\
\hline coroas circulares & 5 & 1,23 \\
\hline discos & 3 & 0,73 \\
\hline disco cont. dois diâm. cruzados & 1 & 0,25 \\
\hline ovais & 28 & 6,90 \\
\hline oval cont. diâm. & 2 & 0,49 \\
\hline oval reticulada & 1 & 0,25 \\
\hline oval subdividida & 1 & 0,25 \\
\hline oval c. circ. radiado & 1 & 0,25 \\
\hline mancha oval & 1 & 0,25 \\
\hline idoliformes & 9 & 2,22 \\
\hline escutiformes & 12 & 2,96 \\
\hline cruciformes & 4 & 0,98 \\
\hline covinhas & 59 & 14,53 \\
\hline artefacto (?) & 1 & 0,25 \\
\hline canaleto & 1 & 0,25 \\
\hline total & 406 & 100,00 \\
\hline
\end{tabular}

Quadro X - Síntese iconográfica da Laje das Fogaças. 


\begin{tabular}{lcc} 
& Total & $\%$ \\
\hline covinhas & 64 & 88,89 \\
\hline covinha geminada & 1 & 1,39 \\
\hline córculinha c/ apêndice c/ covinha central & 1 & 1,39 \\
\hline losango c/ covinha central & 5 & 6,94 \\
\hline total & 1 & 1,39 \\
\hline
\end{tabular}

Quadro XI - Síntese iconográfica da rocha Castelhão 1 (r. 45).

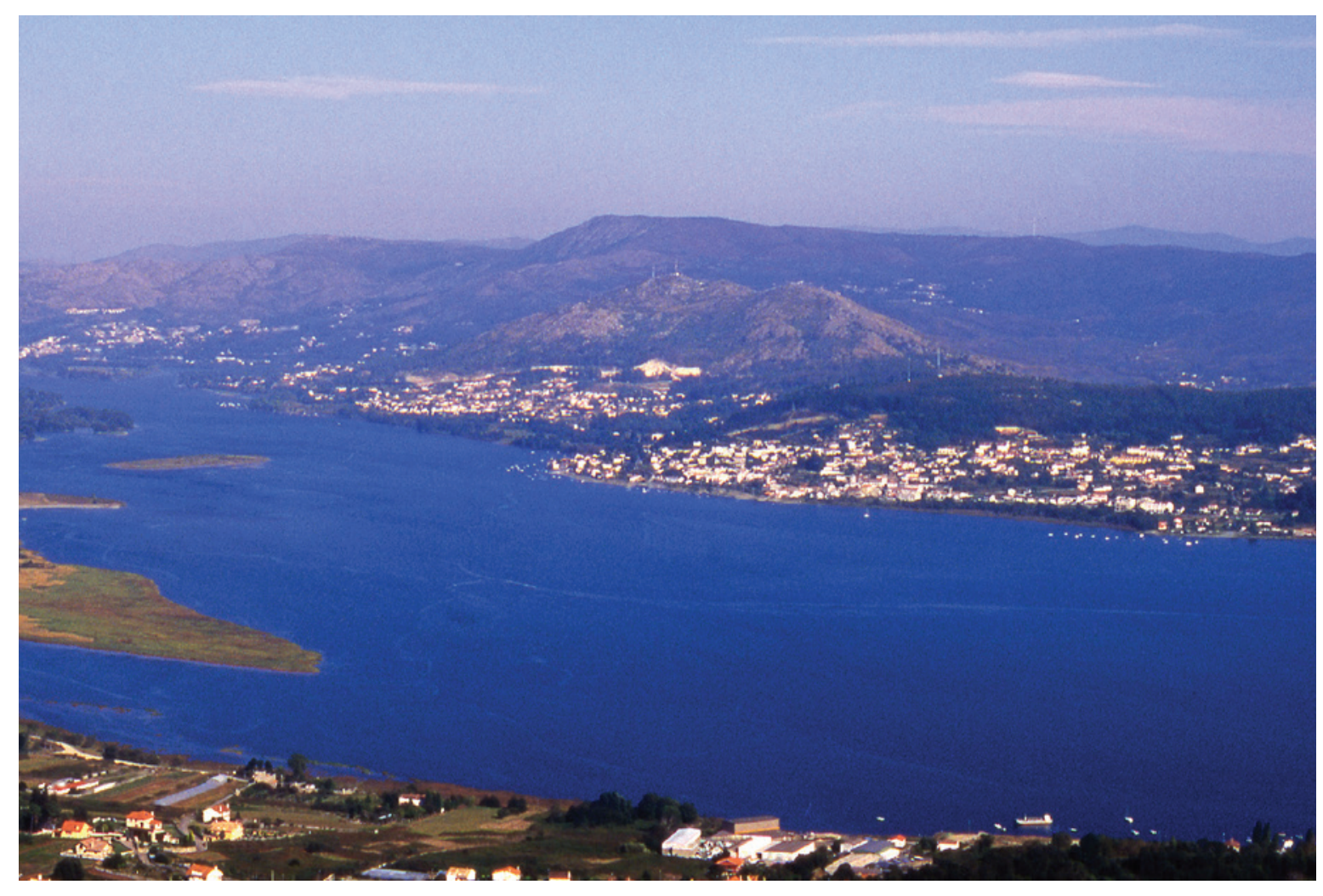

Figura 1 - Vista do Monte de Góios e da Serra da Gávea, a partir de Santa Trega (foto M. V. Gomes). 


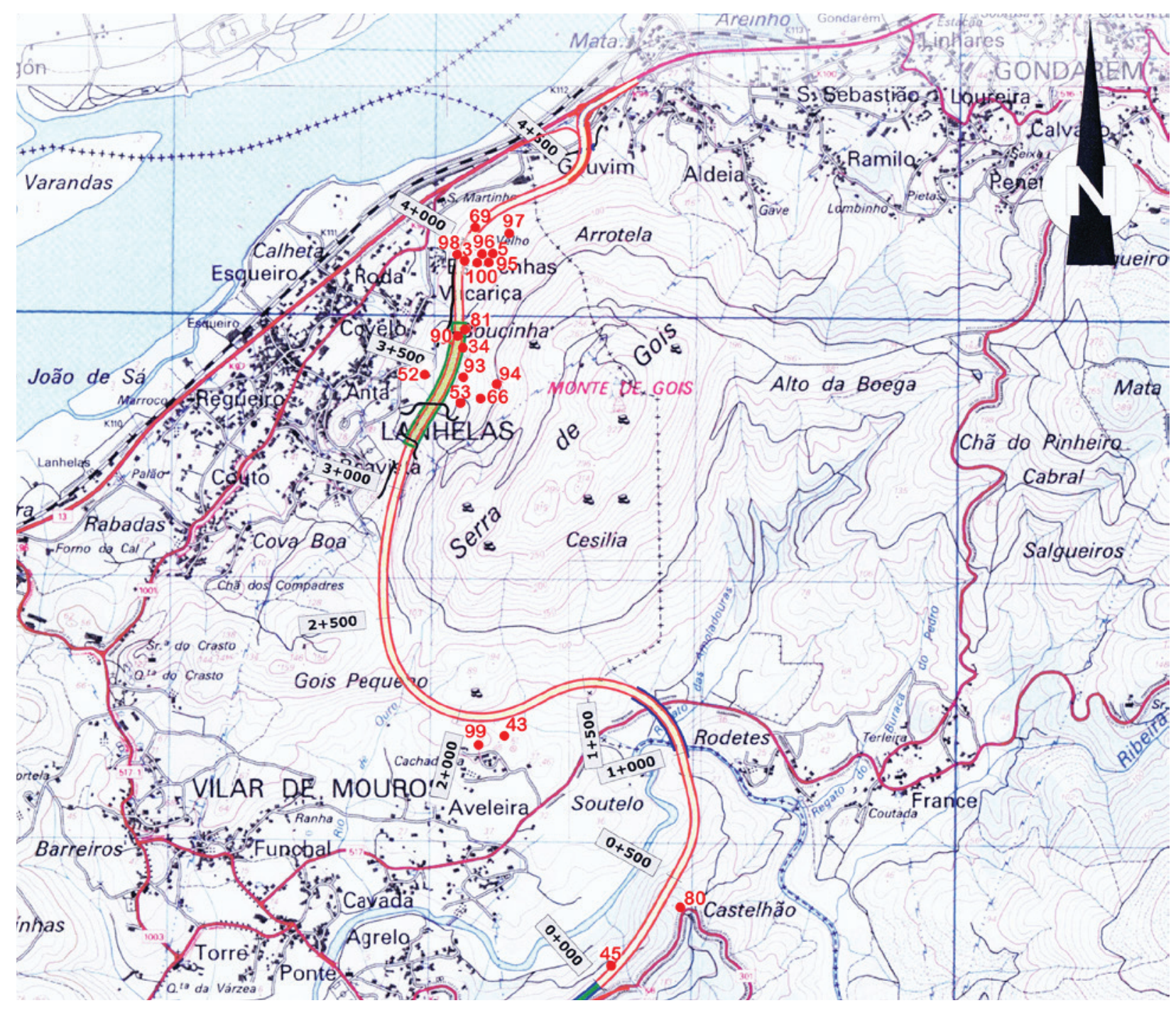

Figura 2 - O Monte de Góios, Lanhelas, e as rochas decoradas pré e proto-históricas (seg. a C.M.P., nº 14, Caminha). 


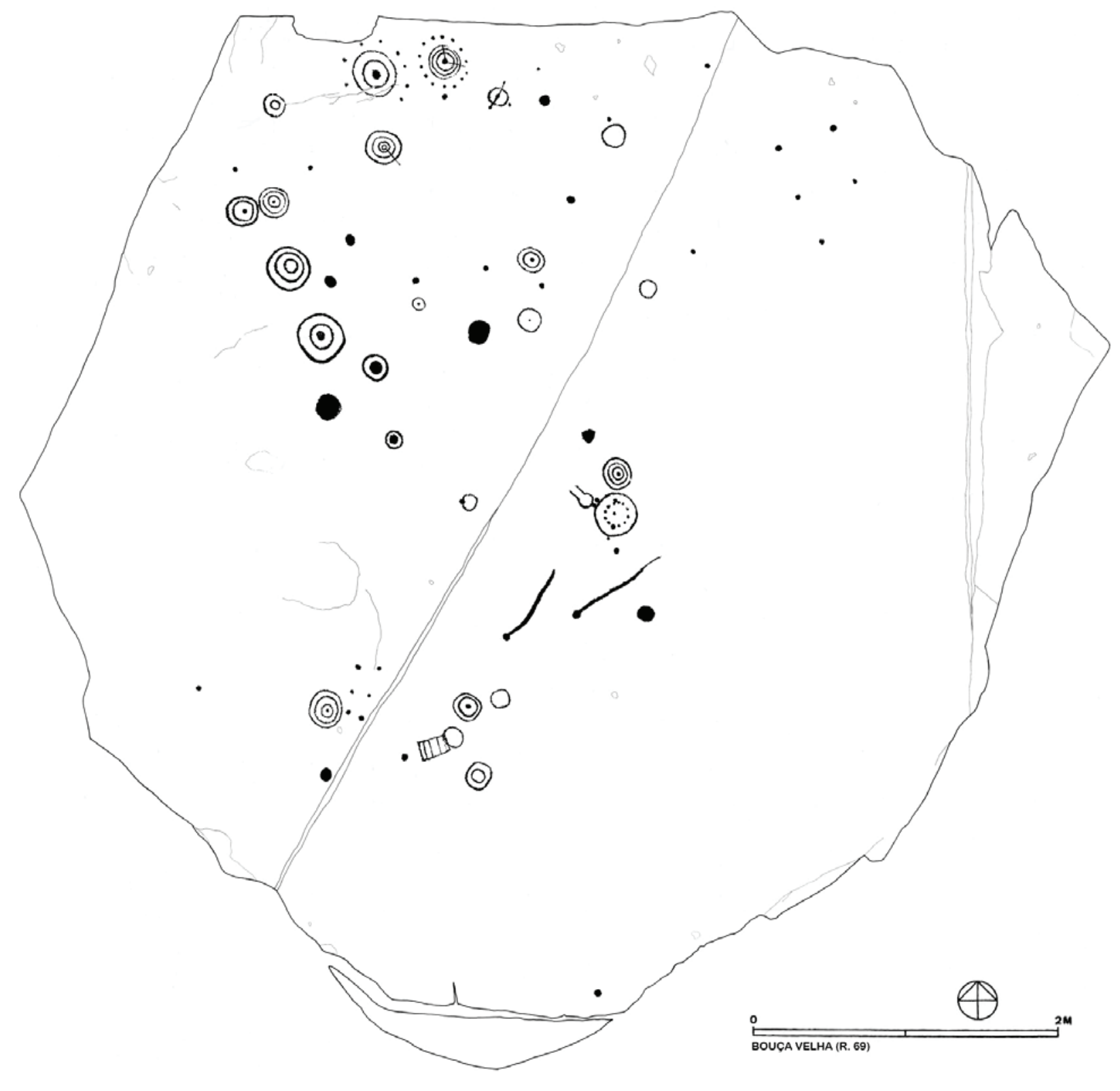

Figura 3 - Bouça Velha (r. 69). Levantamento das gravuras (seg. M. V. Gomes). 


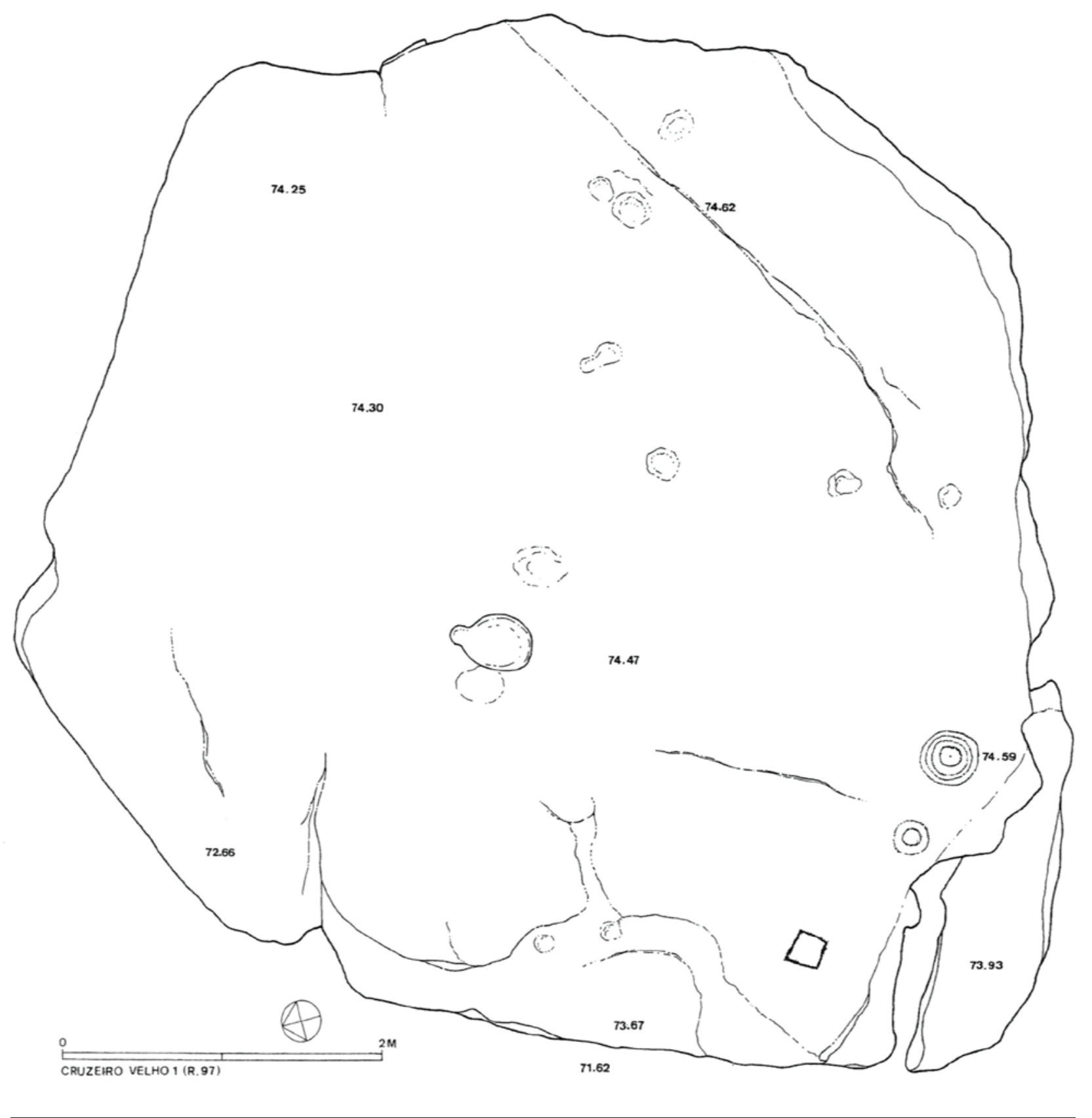

Figura 4-Cruzeiro Velho 1 (r. 97). Planta (seg. M. V. Gomes). 


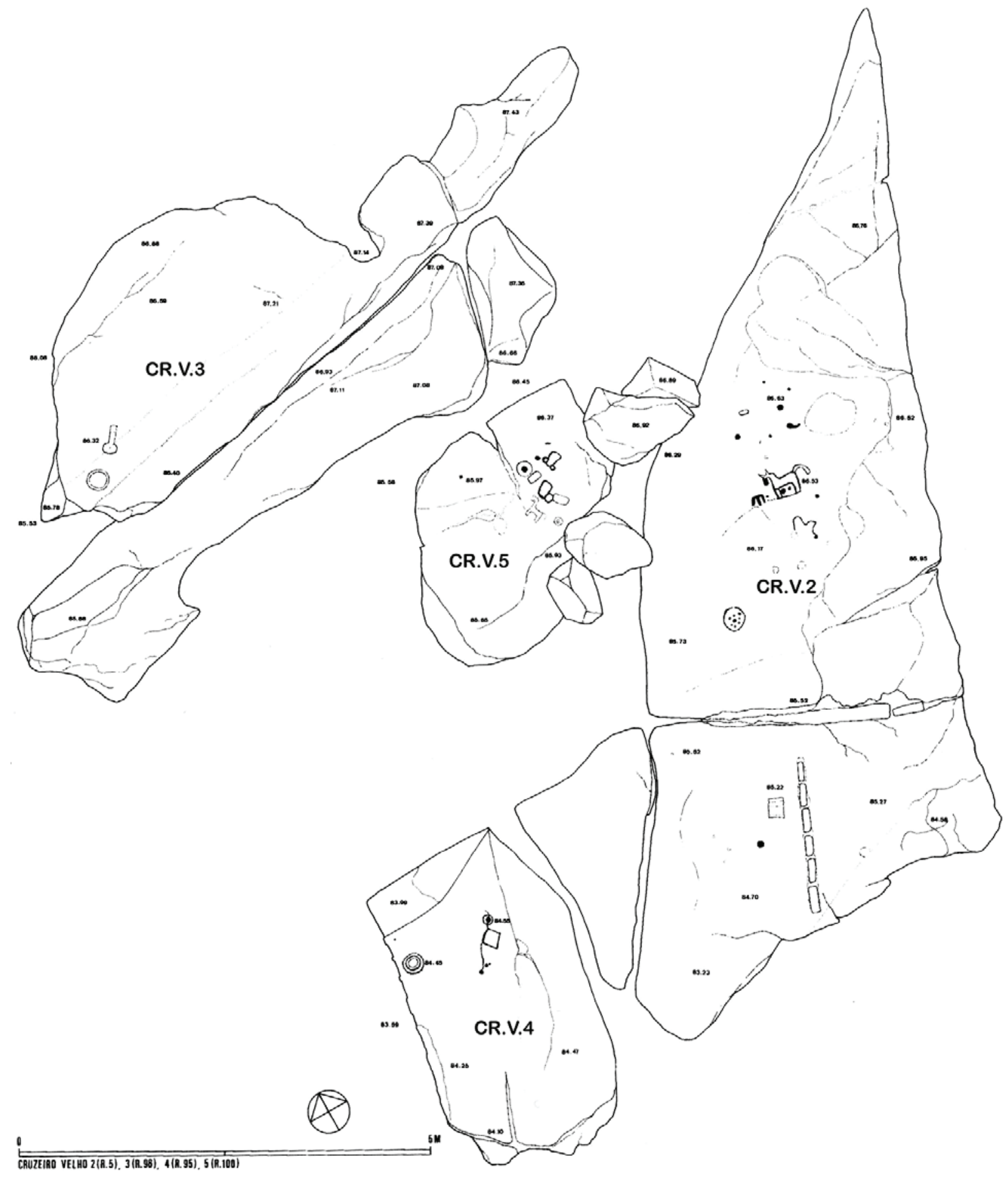

Figura 5 - Cruzeiro Velho 2 (r. 5), 3 (R.96), 4 (R.95) E 5 (Rioo). Levantamento das gravuras (seg. M. V. Gomes). 

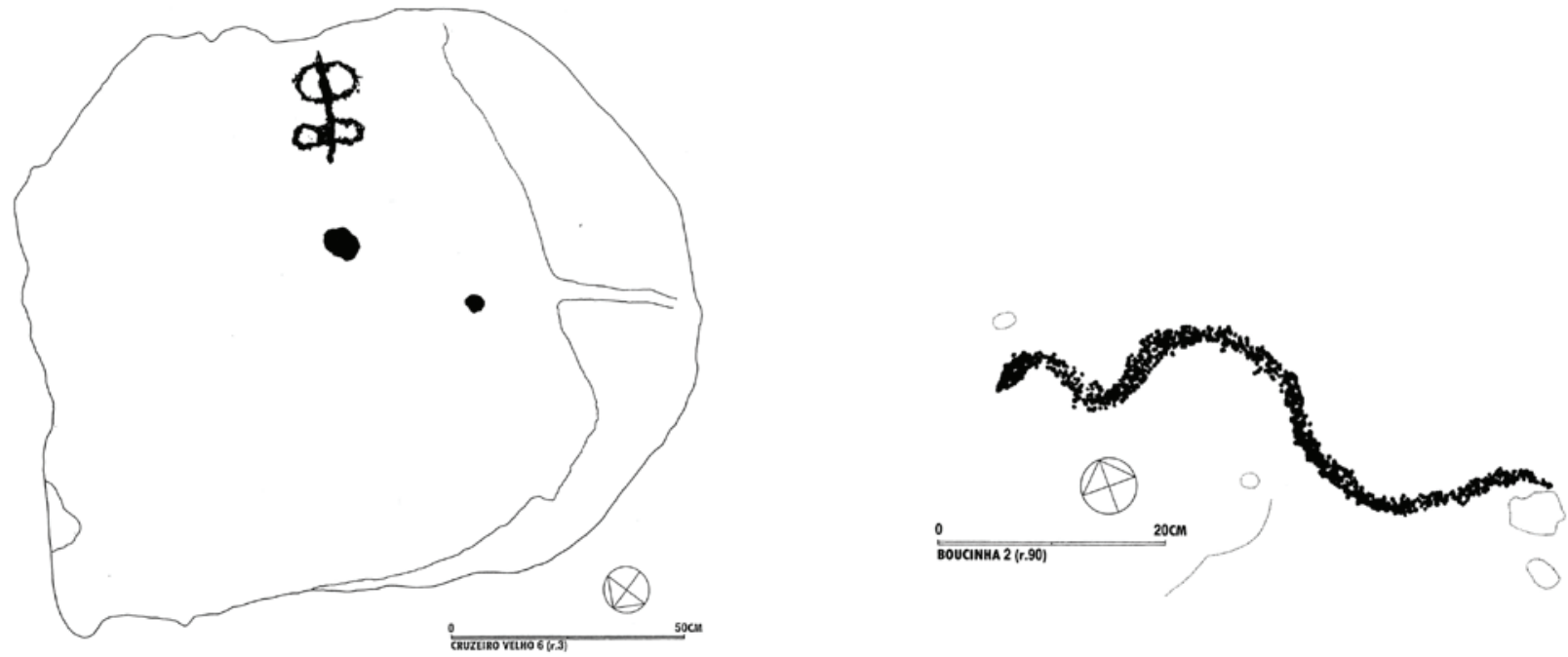

Figura 6 - Cruzeiro Velho 6 (r.3) e Boucinha 2 (r. 9o). Levantamento das gravuras (seg. M. V. Gomes).

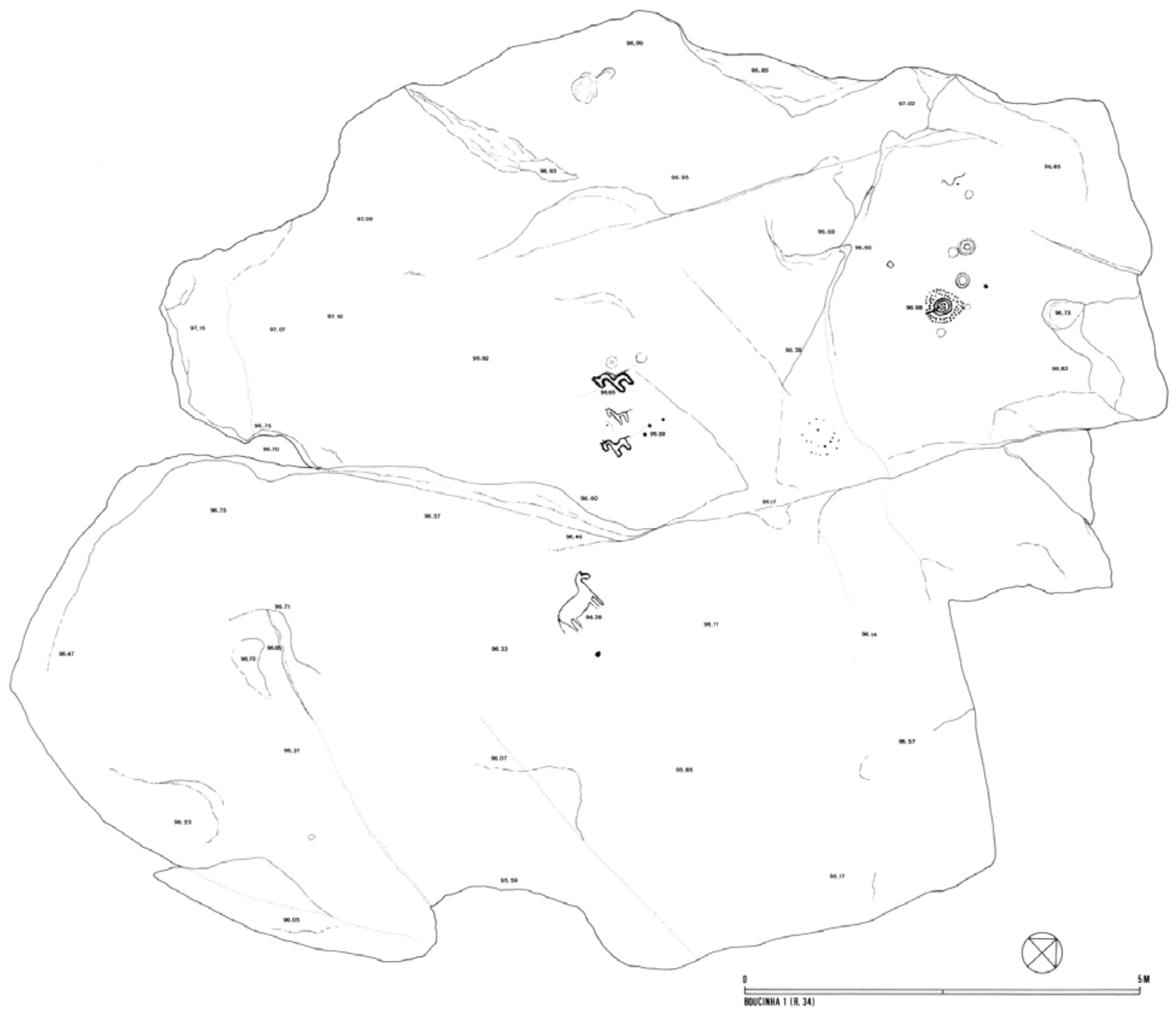

Figura 7 - Boucinha 1 (r. 34). Levantamento das gravuras (seg. M. V. Gomes). 


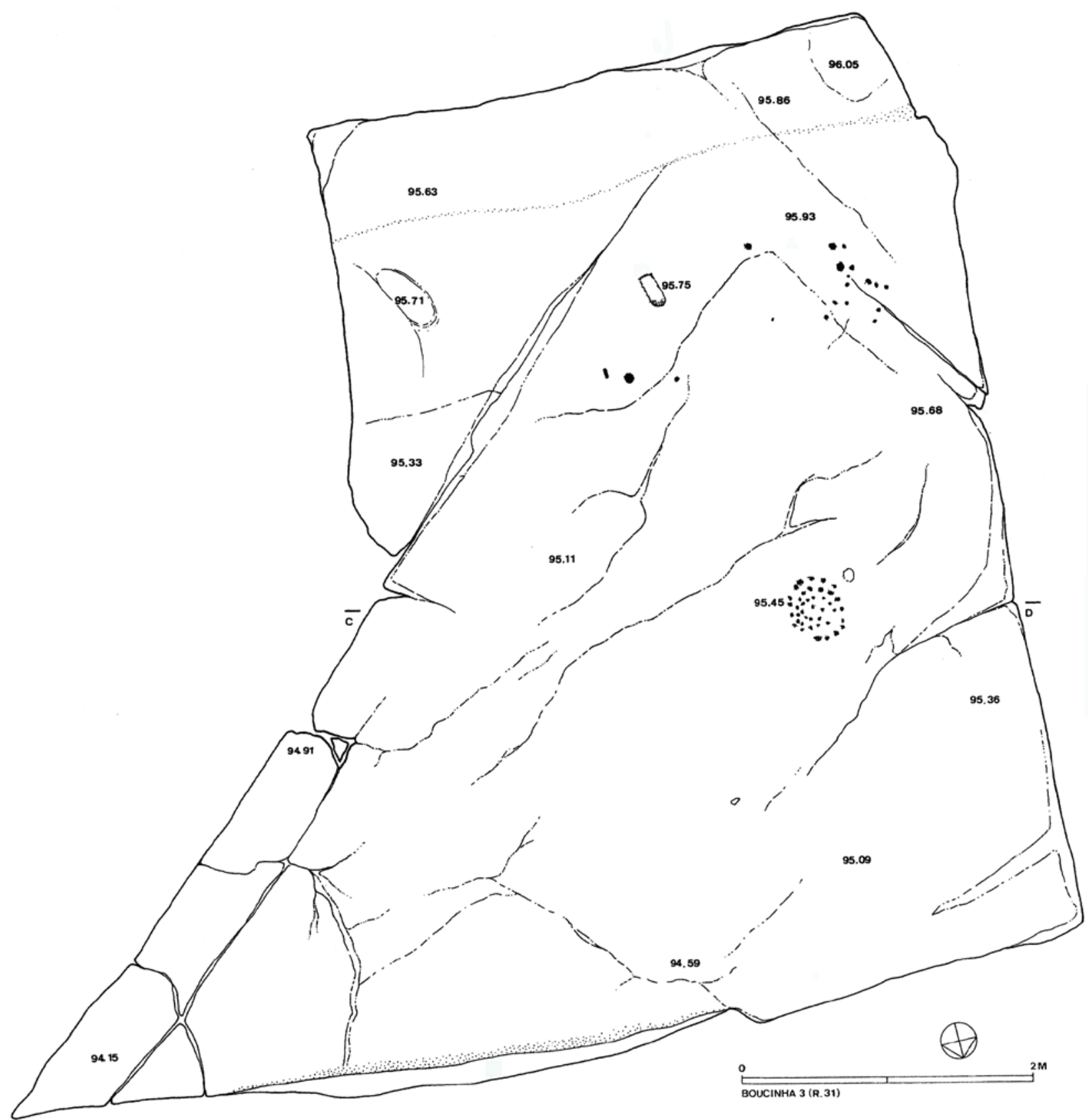

Figura 8 - Boucinha 3 (r. 31). Levantamento das gravuras (seg. M. V. Gomes). 


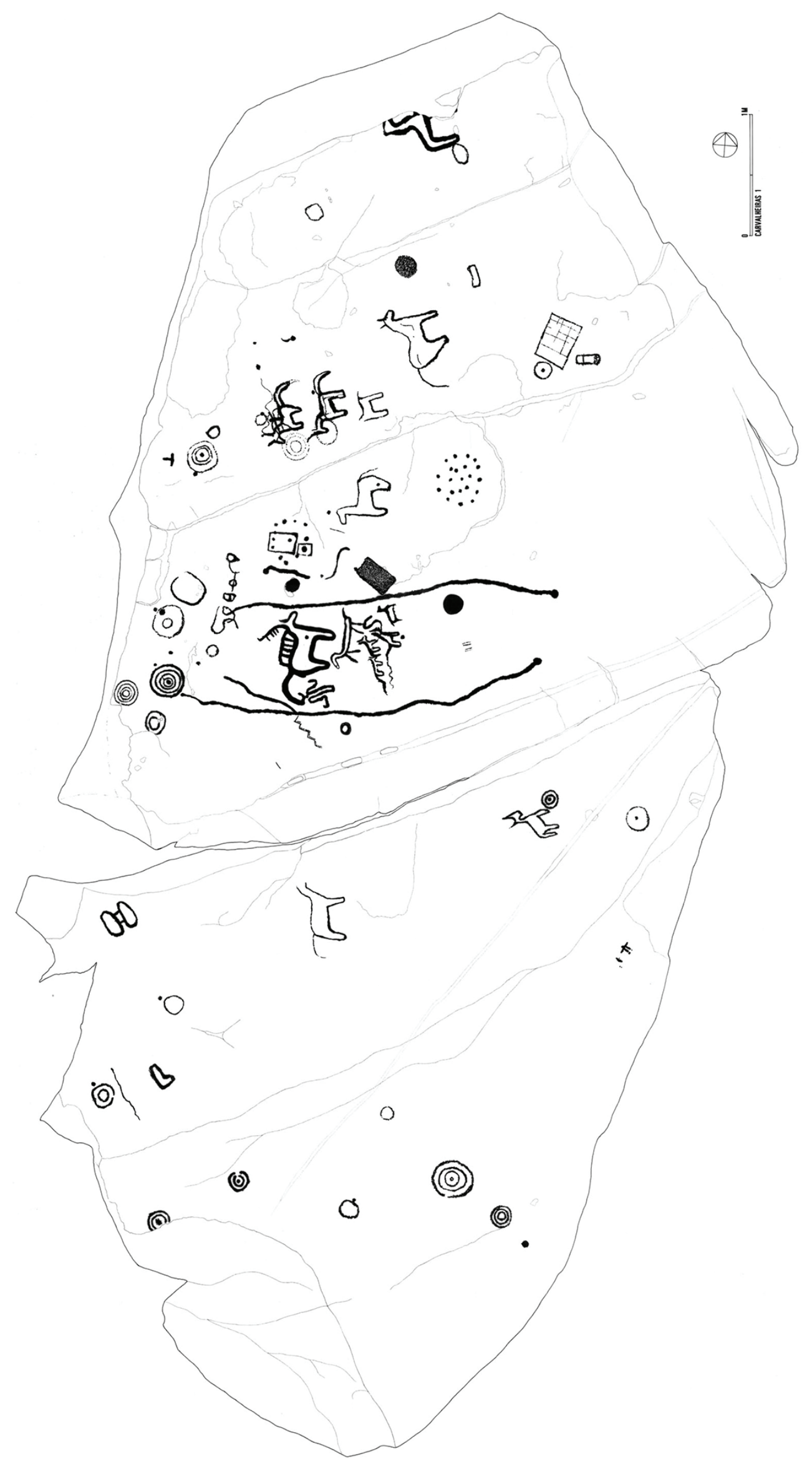

Figura 9 - Carvalheiras 1 (r. 53). Levantamento das gravuras (seg. M. V. Gomes). 


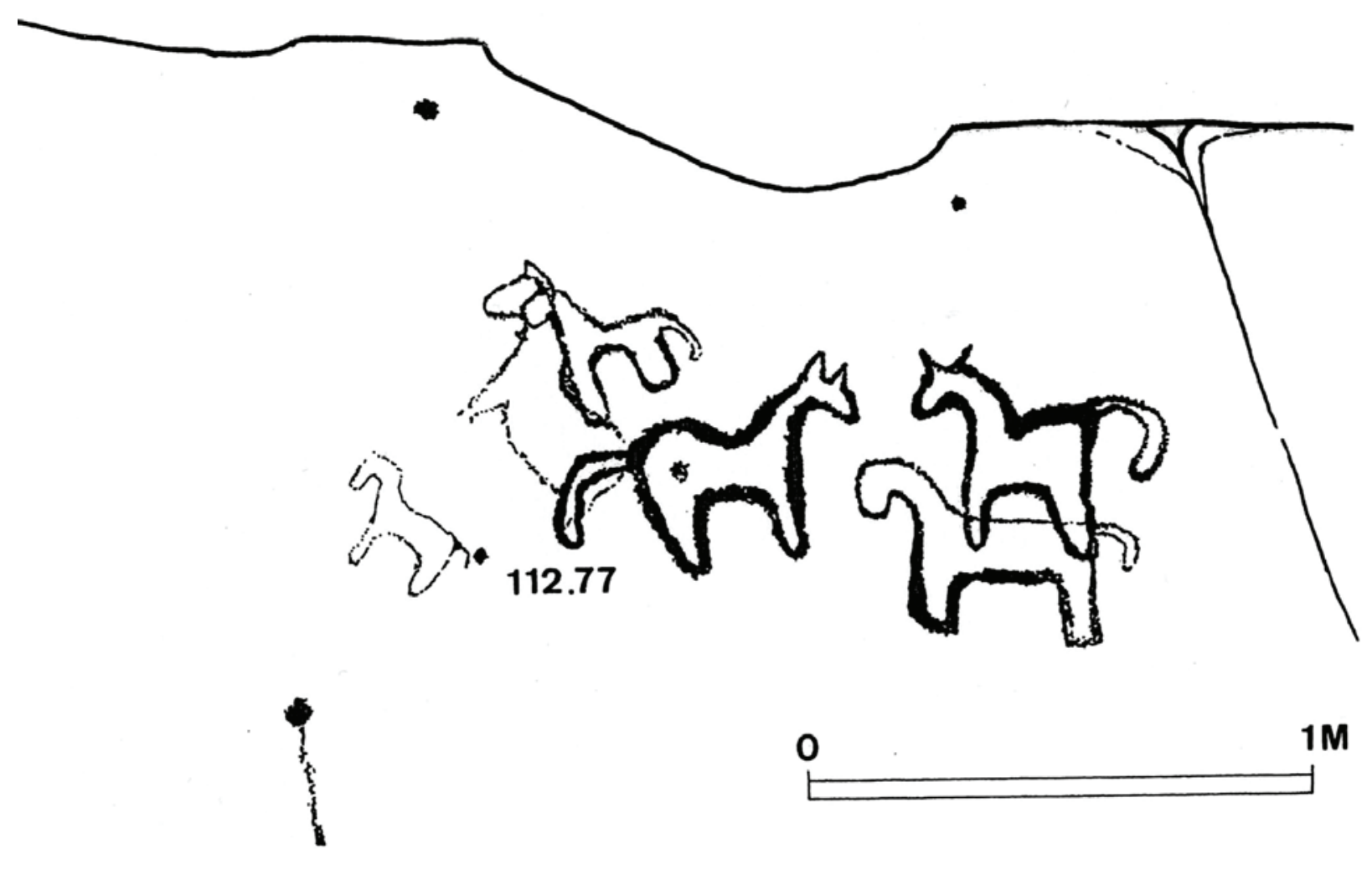

Figura 1o - Carvalheiras 2 (r. 66). Levantamento das gravuras (seg. M. V. Gomes).

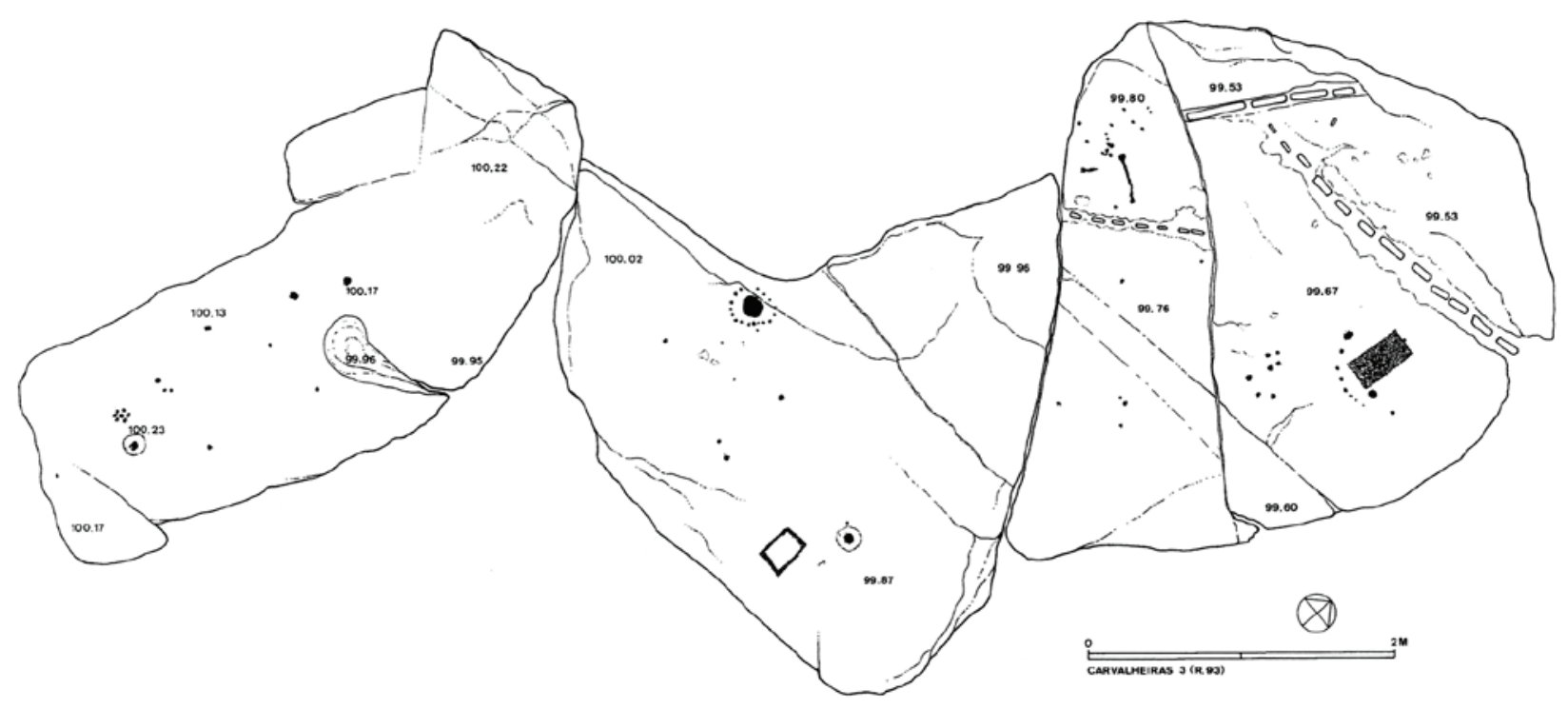

Figura 11 - Carvalheiras 3 (r. 93). Levantamento das gravuras (seg. M. V. Gomes). 


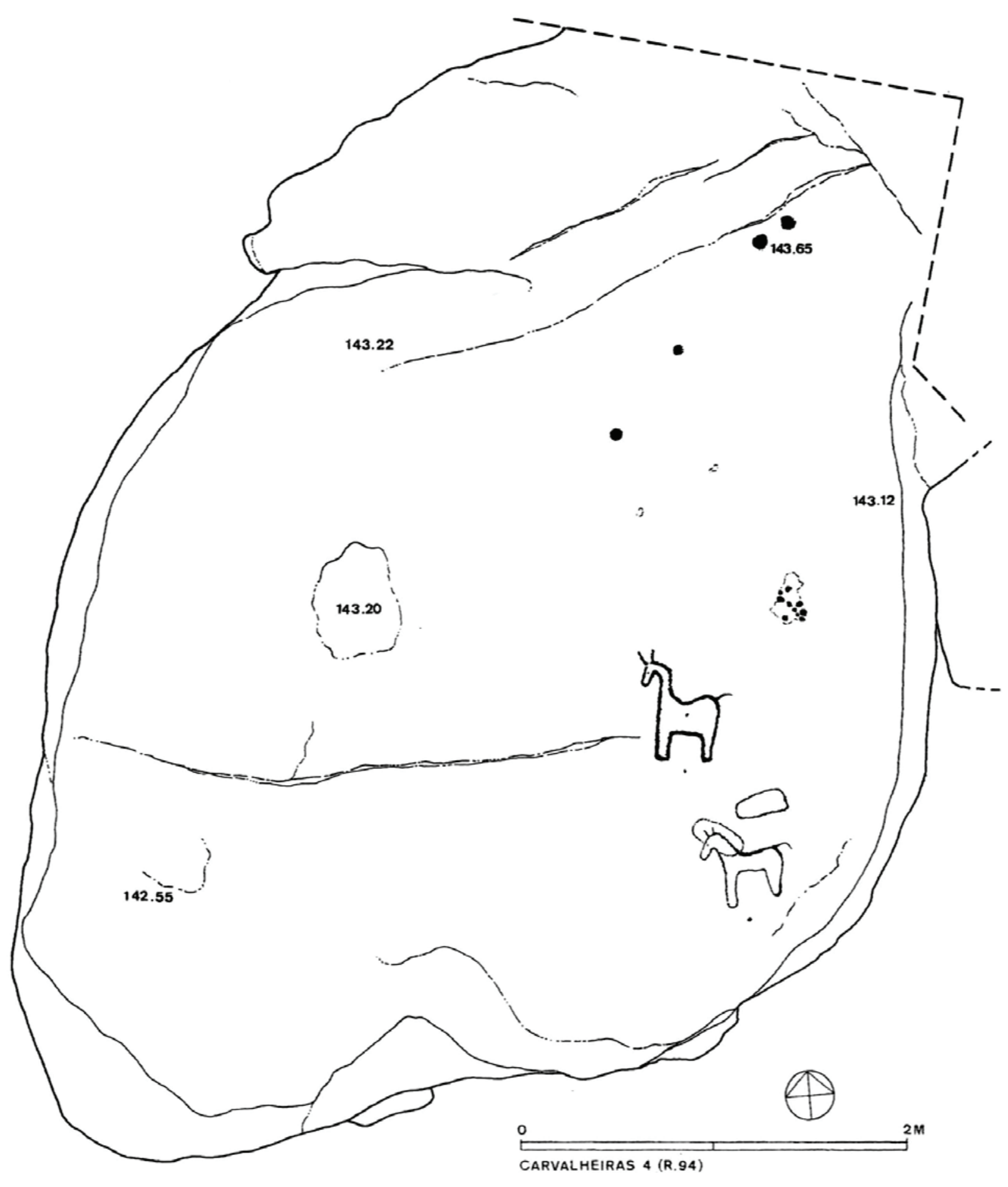

Figura 12 - Carvalheiras 4 (r. 94). Levantamento das gravuras (seg. M. V. Gomes). 


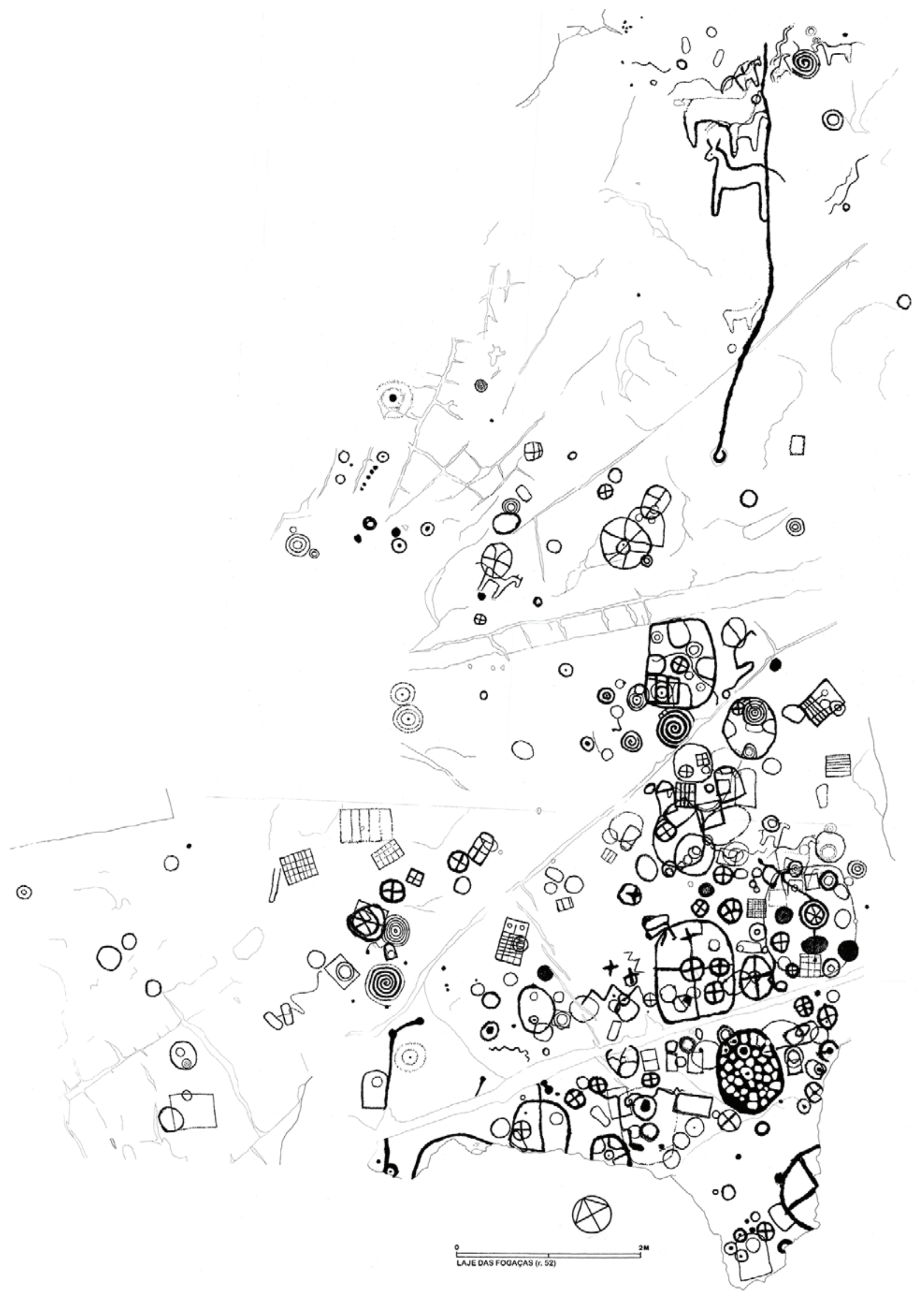

Figura 13 - Laje das Fogaças (r. 52). Levantamento das gravuras (seg. M. V. Gomes). 


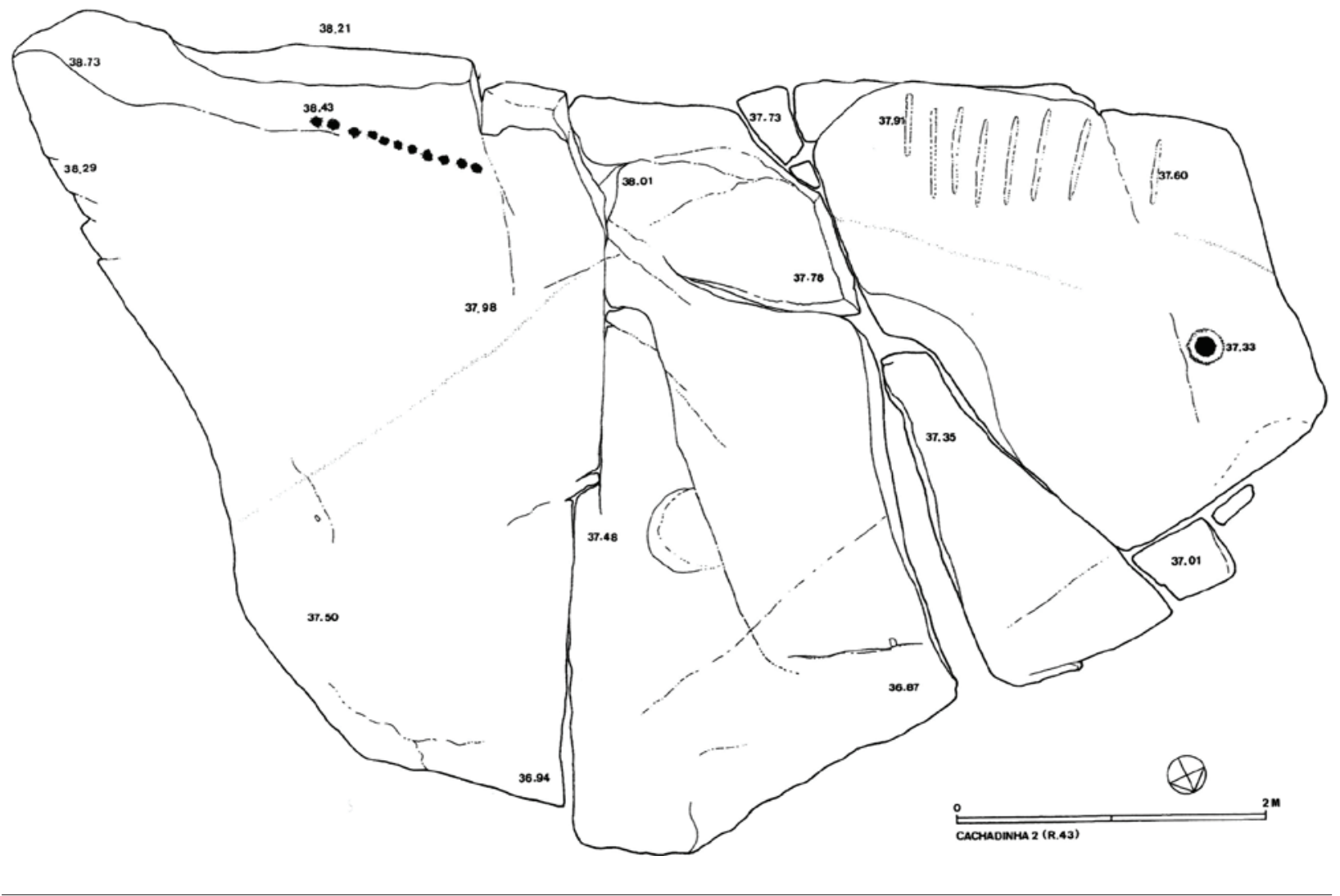

Figura 14 - Cachadinha 2 (r. 43). Levantamento das gravuras (seg. M. V. Gomes). 


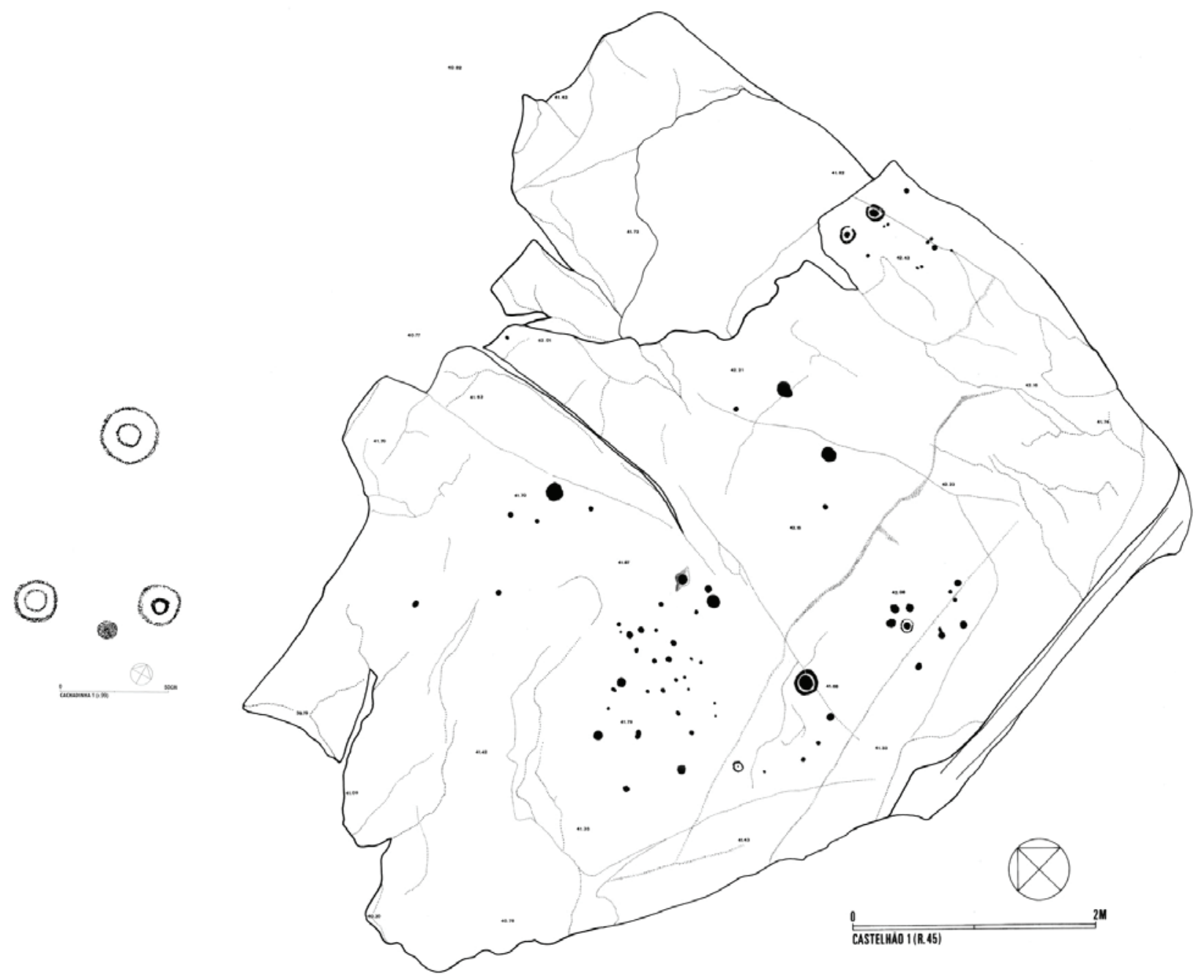

Figura 15 - Cachadinha 1 (r. 99) e Castelão 1 (r. 45). Levantamento das gravuras (seg. M. V. Gomes). 


\title{
GRAVURAS RUPESTRES DE BARQUIFORMES NO MONTE DE S. ROMÃO, GUIMARÃES, NOROESTE DE PORTUGAL
}

\author{
Daniela Cardoso ${ }^{1}$
}

RESUMO

O Monte de S. Romão localiza-se na margem direita do rio Ave, no concelho de Guimarães, no Noroeste de Portugal.

A primeira referência de arte rupestre no Monte de S. Romão deve-se a Martins Sarmento que no século XIX relatou a existência de gravuras (Sarmento, F., 1901; 1904; 1905; 1933). Investigações recentes concentraram-se num conjunto substancial de arte rupestre que está disperso por grande parte do local (Cardoso, D., 2011, 2015, Nash, G., Cardoso, D., Ferreira, E., 2013).

O objetivo deste trabalho é o de apresentar três suportes gravados do Monte de S. Romão, sendo que dois deles, em nossa opinião, foram publicados em posição invertida. Com esta nova abordagem, colocamos a hipótese de que estes representam barquiformes pré-históricos. Apesar de preliminar, este trabalho pretendeu contribuir para aumentar os conhecimentos sobre a arte rupestre pós-paleolítica de ar livre do Noroeste português e em especial do enigmático Monte de S. Romão (onde se localiza a Citânia de Briteiros), bem como promover novas questões sobre o local.

Palavras-chave: Arte Rupestre, Barquiformes, Monte de S. Romão, Noroeste de Portugal, Valorização Patrimonial.

\begin{abstract}
Monte de S. Romão is located on the right bank of the river Ave, in the municipality of Guimarães, in the northwest of Portugal. The first reference of rock art in Monte de S. Romão is due to Martins Sarmento who in the 19th century reported the existence of engravings (Sarmento, F., 1901; 1904; 1905; 1933). Recent investigations have focused on the substantial set of rock art that is dispersed over a large part of the site (Cardoso, D., 2011, 2015, Nash, G., Cardoso, D., Ferreira, E., 2013).

The purpose of this work is to present three outcrops recorded from Monte de São Romão, from which, in our opinion, two of them were published in an inverted position. With this new approach, we hypothesize that they represent prehistoric boats. Despite being preliminary, this work intended to contribute to increase knowledge about post-paleolithic rock art in the Portuguese Northwest and especially the enigmatic Monte de S. Romão (where is located Citânia de Briteiros), as well as to promote new questions about the occupation of this place and adjacent territory.

Keywords: Rock Art, Boats, Mount of S. Romão, Northwest of Portugal, Valorization of heritage.
\end{abstract}

\section{INTRODUÇÃO}

O objetivo do presente trabalho é o de dar notícia da existência de três representações de embarcações do
Monte de S. Romão. Uma delas está gravada num bloco granítico atualmente exposto no Museu Arqueológico da Sociedade Martins Sarmento (SMS) e faria parte de um afloramento de maiores dimen-

1. Sociedade Martins Sarmento, Guimarães, Portugal; Centro de Geociências da Universidade de Coimbra; Laboratório de Paisagens, Património e Território - Lab2pt; daniela.cardoso@msarmento.org 
sões que existiu junto ao balneário sul da Citânia de Briteiros (Cardozo, M., 1932, p. 22), ou seja, a meia vertente , a nordeste do Monte de S. Romão. A outra representação encontra-se igualmente localizada a meia vertente do Monte de S. Romão, no meio de um caminho antigo que fazia ligação entre Donim e a Citânia de Briteiros e foi detetada em 2011 no âmbito do projeto de doutoramento intitulado "A Arte Atlântica do Monte de S. Romão (Guimarães) no Contexto da Arte Rupestre Pós-paleolítica da Bacia do Ave-Noroeste Português", e de um projeto mais vasto designado "Espaços naturais, arquitecturas, arte rupestre e deposições na pré-história recente da fachada ocidental do centro norte português: das ações aos significados - Enardas”. Nessa altura, o afloramento gravado Bouça da Miséria foi estudado, realizando-se o seu levantamento topográfico, fotográfico e gráfico (Cardoso D., 2015, pp. 59-6o).

A última representação, que ainda não foi relocalizada encontrar-se-á na área adjacente ao cemitério da Citânia de Briteiros, próxima do topo do Monte de S. Romão. Para esta pedra gravada dispomos apenas dos dados de Martins Sarmento (Sarmento, F., 1905, p. 23).

As figuras de embarcações gravadas eram consideradas uma temática rara no Noroeste Peninsular, mas trabalhos recentes de alguns autores (Santos, A., 2014; Bettencourt, A., 2017) vieram clarificar esse tipo de representações nesta área geográfica. Nesse sentido, o Monte de S. Romão apresenta novos dados sobre este tipo de motivos e introduz novas interpretações, merecendo por esse motivo a continuidade do seu estudo e valorização patrimonial.

Neste trabalho coloca-se a seguinte questão: que tipo de narrativa está por detrás destas representações?

\section{CARATERIZAÇÃO ADMINISTRATIVA, FÍSICA E AMBIENTAL}

O Monte de S. Romão (336 m) localiza-se no Noroeste de Portugal, no distrito de Braga, concelho de Guimarães, na freguesia de S. Salvador de Briteiros, na margem direita do rio Ave.

A área geográfica da bacia hidrográfica do rio Ave situa-se na região do Baixo Minho. Encontra-se rodeada pela costa Atlântica, a oeste; pela bacia do Cávado e o Parque Nacional da Peneda-Gerês, a norte; pela região Transmontana, a este e pelas bacias do Leça e Douro, a sul. O rio Ave, que percorre cerca de $100 \mathrm{~km}$, tem a sua nascente a mais de $1050 \mathrm{~m}$ de alti- tude, na Serra da Cabreira, e vai desaguar no Oceano Atlântico entre Vila do Conde, a norte, e Azurara, a sul (Figura 1).

O Monte de S. Romão corresponde a um esporão, sobranceiro ao Ave, que faz parte de um maciço orográfico que separa os vales do Ave e do Cávado, destacando-se da serra da Cabreira. "Esse esporão perfeitamente recortado na direção N-S, desce desde o Monte Alto (cota 417), em declive pouco acentuado, até ao local da Citânia, de cota 336" (Cardozo, M., 1990, p. 9) (Figura 2).

Neste monte existe uma grande abundância de nascentes, derivadas do substrato granítico, uma rocha favorável à formação de lençóis de água subterrâneos (Lemos \& Cruz, 2011, p. 38). Vestígios dessas nascentes, são um reservatório de água e as condutas que foram construídas na Citânia de Briteiros. Dos cursos de água que o circundam são de destacar o ribeiro que nasce na Sobreposta, freguesia vizinha de S. Salvador de Briteiros, com o nome de Agrela, também conhecido por Briteiros ou Febras e que desagua, por fim, com o nome de Rabelo (?), na margem direita do Ave, um pouco a montante das Caldas das Taipas. (Cardozo, M., 1990, pp. 9-10).

De acordo com informações recolhidas no mapa geológico da bacia hidrográfica do rio Ave (Costa, F., 2007, p. 139), o tipo de rocha predominante no Monte de S. Romão é o denominado "granito de Briteiros". "Desta variedade de granito ocorrem várias manchas, sendo a mais extensa a que ocorre no centro da carta e que se estende da Serra do Carvalho à povoação de Briteiros”. A composição do granito de Briteiros corresponde a um leucogranito moscovítico-biotítico de grão fino. Tem ainda na sua constituição “moscovite por vezes em grande concentração, turmalina, frequentes encraves metassedimentares e pequenos encraves micáceos que contêm silimanite” (Ferreira \& alii 200o, p. 29) (Figura 3).

\section{CONSIDERAÇÕES TEÓRICAS E METODOLÓGICOS}

Em termos metodológicos optou-se por uma posição eclética baseada numa postura interpretativa que tem como base as premissas de que todo o conhecimento é subjetivo e de que as ações são tanto reflexo do pensamento simbólico das comunidades, como agentes no seu quotidiano, numa perspetiva próxima de Gell (1998) e de Ingold (2000). 
No tocante à praxis, o trabalho foi estruturado em momentos diferentes (entre 2011 e 2019), tendo em conta etapas distintas: trabalho preparatório de gabinete, trabalho de campo, trabalho de laboratório e trabalho avançado de gabinete.

A primeira etapa consistiu na pesquisa bibliográfica sobre a história das investigações e contexto arqueológico. Foi também consultada cartografia, nomeadamente cartas militares, cartas geológicas, mapas hidrográficos que nos forneceram informações sobre o território em estudo, muito especialmente sobre a geologia e a hidrografia, o que foi crucial para a compreensão do contexto envolvente aos lugares gravados.

Na segunda etapa, foram contemplados o trabalho de prospeção arqueológica ou relocalização, limpeza mecânica não abrasiva e levantamento fotográfico e gráfico do afloramento gravado da Bouça da Miséria (Figuras 4a e b) e do bloco musealizado exposto na SMS, ambos do Monte de S. Romão.

Relativamente à relocalização de uma gravura mencionada por Martins Sarmento no séc. XIX, e que neste trabalho se coloca a hipótese de se tratar de um barquiforme, dada a densidade de líquenes existente nos suportes pétreos da Citânia e as informações genéricas de Martins Sarmento, até ao momento ainda não foi possível relocalizá-la.

Numa terceira etapa, procedeu-se à digitalização dos plásticos polivinílicos utlizados na fase de levantamento gráfico e realizou-se o trabalho de edição e tratamento de imagem através do programa Photoshop. Para o caso especifico do bloco granítico musealizado, exposto no jardim anexo ao claustro de S. Domingos, na Sociedade Martins Sarmento, foi ainda ensaiado um modelo $3 \mathrm{D}$ baseado em fotografias capturadas pela aplicação DJI Phantom e foi gerado usando 3 DF Zephyr v. 4009, software de fotogrametria. (Figura 4c). Este processo foi dificultado pela existência de uma grande concentração de líquenes no suporte granítico pelo que numa fase posterior tornou-se necessário proceder-se a uma limpeza mecânica.

\section{BREVE DESCRIÇÃO DOS SUPORTES GRAVADOS NO MONTE DE S. ROMÃO}

\subsection{Afloramento gravado da Bouça da Miséria}

Localiza-se na freguesia de Briteiros (S. Salvador), a meia vertente, a nordeste no Monte de S. Romão, ainda, dentro da zona especial de proteção da Citânia de Briteiros e próximo de linhas de água e de nascentes, sendo de assinalar o rio Febras, na margem direita do Ave. O afloramento gravado encontra-se localizado numa zona de fácil acesso e de onde é possível usufruir de uma ampla visibilidade destacando-se no horizonte, para nordeste, a Serra do Gerês, as Serras da Cabreira, das Alturas e do Barroso e a sudeste o Monte da Penha.

O afloramento gravado da Bouça da Miséria, detetado em 2006 e posteriormente estudado em 2011, no âmbito do projeto de investigação da arte rupestre do Monte de S. Romão, apresenta um motivo peculiar de um barquiforme, entre outros (Nash, G., Cardoso, D., Ferreira, E., 2013; Cardoso, D., 2015, pp. 173-175). Em 2011 foi realizado o levantamento fotográfico diurno e noturno com máquina digital (Figura 5a), levantamento topográfico e decalque direto (Figura $5 \mathrm{~b}$ ). Durante o processo de registo deu-se especial importância a todos os detalhes morfológicos e técnicos dos motivos gravados.

A Bouça da Miséria corresponde a uma laje granítica bastante erodida, de grandes dimensões, medindo cerca de 9,75 $\mathrm{m}$ por 5,31 $\mathrm{m}$ com uma diagonal de 9,35 m., embora parte dela ainda esteja soterrada. Tem uma superfície bastante regular, rasante ao solo, de cor acinzentada, formato semi-retangular. Apresenta um reportório iconográfico incomum, mais precisamente um motivo barquiforme com o,59m por o,30 m., um antropomorfo sexuado medindo $33 \mathrm{~cm}$ por $20 \mathrm{~cm}$, dois círculos concêntricos com e sem covinha central medindo entre 0,26 e 0,27 m de diâmetro e diversas covinhas. Todos os motivos foram realizados por intermédio da técnica de percussão, e em alguns casos seguidos de abrasão (Cardoso, D., 2015, p. 173).

\subsection{Bloco gravado musealizado}

O bloco granítico atualmente musealizado, foi descrito e desenhado por Martins Sarmento no séc. XIX (Sarmento, F., 1904, p. 61). Em 26 de junho de 1876, escreveu Martins Sarmento nas suas notas sobre o achado: "O signal que lhe corresponde do lado da Cavada (quasi a sul) e que fica na linha que se tirasse da capela para a poça da Cavada, n'uma lage que fica à beira do caminho (direita subindo) por onde foi a "pedra formosa", é muito diferente. Espiral (...) O outro sinal é (...) Ambos eles estão gravados no lado noroeste da lage. Este segundo sinal tem alguma cousa com os cinco dedos? Estes signaes nas lages devem ser mais.” Mais tarde, Mário Cardoso 
(1932) menciona novamente as gravuras rupestres num texto publicado na Revista de Guimarães: (...) “E' oportuno dizer que também junto ao novo monumento citaniense se encontram numerosos penedos com insculturas, algumas bastante originais, como a que reproduzimos na fig. 15, já notada por M. Sarmento (8). Infelizmente muitos desses penedos desapareceram, soterrados ou partidos, na ocasião da abertura da nova estrada, tendo sido sacrificados às necessidades do traçado. Daquele, cuja gravura reproduzimos, salvou-se apenas uma parte, não tendo escapado ao camartelo a espiral que Sarmento reproduziu no mesmo agrupamento." (...) (Cardozo, M., 1932, p. 22). Nessa mesma publicação, o investigador produz um novo desenho, mais detalhado do que o anterior, mas sem a representação da espiral.

De acordo com as informações de Martins Sarmento e de Mário Cardoso, depreendemos que o bloco gravado faria parte de um afloramento de maiores dimensões que se encontrava próximo do balneário sul na Citânia de Briteiros. Aquando da construção da estrada EN 309, em 1930, a Sociedade Martins Sarmento teve uma intervenção no sentido de salvaguardar este emblemático monumento bem como de outros vestígios que se encontravam nas imediações do mesmo, como é o caso do bloco gravado em análise (Cardoso, M., 2015, pp. 180-181).

Este fragmento foi transferido para o Museu arqueológico da SMS em 1934 e aí se encontra desde essa data (Figura 6a). Mede $113 \mathrm{~cm}$ por $87 \mathrm{~cm}$, apresenta-se erodido e apresentava uma grande concentração de líquenes. Tem um reportório iconográfico incomum, nomeadamente a gravura de um barquiforme, medindo $25 \mathrm{~cm}$ por $26 \mathrm{~cm}$, um motivo indeterminado com $18 \mathrm{~cm}$ por $23 \mathrm{~cm}$ e vestígios de um outro, inconclusivo, uma vez que se encontra extremamente erodido.

Em 2019 foi realizado o decalque direto do bloco gravado (Figura 6b) e um modelo em $3 \mathrm{D}$ com vista a obter uma melhor compreensão dos motivos ali gravados e complementar o estudo do mesmo.

Todos os motivos foram realizados por intermédio da técnica de percussão, seguida, aparentemente, de abrasão.

\subsection{Pedra gravada referida por Sarmento}

De acordo com a descrição e registo gráfico (Sarmento, F., 1905a, p. 23) e fotografias pertencentes aos álbuns fotográficos de Martins Sarmento, obteve-se a informação de que o motivo se encontrava na estrutura de uma parede, localizada na proximidade do cemitério da Citânia de Briteiros (Figuras. 7a, b e c). Até à data ainda não nos foi possível relocalizá-la, tornando-se, portanto interessante analisar o texto referente à notícia da descoberta desta pedra gravada: (...) "O desaterro tem continuado no taboleiro inferior ao outro contiguo ao cemiterio. Passa adiante da casa onde o Luciano Cordeiro encontrou a figura d'um animal com cornos, cuja figura, aliás sem cornos, é: (...)” (Sarmento, F., 1905a, p. 23).

Não existindo mais dados sobre a pedra gravada e contrariando a indicação de que poderia tratar-se da gravação da figuração de um animal, entende-se agora que a figura aí representada poderá corresponder a um hipotético barquiforme, com base em semelhanças estilísticas de outros motivos análogos e estudos realizados por vários investigadores sobre a temática das embarcações.

Apesar de não dispormos de dados mais detalhados sobre a gravura do barquiforme, parece-nos que os motivos foram realizados por intermédio da técnica de percussão.

\section{DISCUSSÃO DE DADOS: PROPOSTA CRONOLÓGICA E INTERPRETAÇÕES}

A paisagem da bacia do Ave, repleta de rios e inúmeras linhas de água que alimentam a riqueza da biodiversidade e da paisagem, ditou a ocupação pelo Homem, durante milhares de anos, de todo um vasto território. As barcas e barcos, nas suas diferentes tipologias, terão sido um dos meios privilegiados de comunicação e transporte fluvial desde os cumes dos montes até ao atlântico.

No monte de S. Romão obtém-se um controlo visual para o vale do Ave, sendo possível observar desde o seu topo, na linha do horizonte, a zona litoral, onde desagua o rio Ave. De acordo com estudiosos da antiguidade clássica, como Estrabão, as águas do rio Ave banhavam as faldas do monte de S. Romão, o que fortalece a tese de que os habitantes do monte teriam contactos estabelecidos entre este local e a zona costeira atlântica.

Poderão formular-se perguntas tais como: será que os povos que por ali circulavam representavam o que viam? Terão sido estes povos testemunhas da memória destes contactos?

Considerando a possibilidade do controlo visual da costa a partir do interior pode pois hipotetizar-se que as embarcações fariam parte deste cenário e que 
a sua representação ocorreu no Monte de S. Romão. Atualmente torna-se difícil equacionar todas estas hipóteses dado que o rio Ave designado pelos romanos de Avus, é presentemente apenas navegável numa curta extensão de $2 \mathrm{Km}$, junto à foz, uma vez que sua possível navegabilidade para montante foi interrompida pela construção de diversos açudes e barragens (Cardoso, 2015 , p. 23). Terá então que ser feito um exercício de mudança de olhar ou de diferentes formas de olhar.

Graças aos arquivos fotográficos de coleções privadas e públicas, do final do século XIX e primeiro quartel do século XX, conhecemos a riqueza e a variedade dos barcos e barcas de carga e de passagem nos rios do Noroeste peninsular. A título de exemplo, e através do espólio fotográfico pertencente à fototeca da SMS, é possível observar-se no início do séc. XX, um troço do rio Ave e suas embarcações (Figura 8), herdeiras de alguma da materialidade dos barcos e barcas produzidas pelas comunidades humanas durante milhares de anos.

Interpretar estes lugares e os motivos ali gravados é uma tarefa difícil, tanto mais que o Monte de S. Romão, no âmbito da sua ampla diacronia, poderá ter sido palco de vários sentidos.

É a partir destas e de outras possíveis considerações que podemos realizar um exercício de reflexão a partir das gravuras de barquiformes do Monte de S. Romão.

Relativamente ao bloco gravado, atualmente musealizado, tal como foi atrás mencionado, foi realizado em 1876 um primeiro esboço muito rudimentar por Martins Sarmento (Figura 9a) (Sarmento, F., 1904, p. 61). Já em 1878, o mesmo autor publica o seu segundo álbum de fotografias e aí coloca a imagem gravada numa posição que em nossa opinião será a mais correta, (Figura 9b) pois foi ele a primeira pessoa a visualizá-la no seu contexto original. Posteriormente, foi realizado um segundo registo gráfico mais detalhado, por Mário Cardozo (Figura 9c) (1932, p. 22) mas publicado em posição invertida, sendo de deduzir que aquando do transporte deste fragmento para o Museu da SMS se tenha optado por colocá-lo nessa posição, não correspondendo à original in situ. Desse modo, os motivos nele gravados poderão ter uma leitura diferente. Se invertermos a pedra, em relação à posição em que se encontra na atualidade, um dos motivos parece representar um barquiforme com a proa alteada. Esta experiência foi realizada com o desenho de Mário Cardozo (Figura 9d).
Com esta nova abordagem, colocamos a hipótese de que o motivo gravado representa um barquiforme pré-histórico, gravado através da técnica de percussão, com a representação de uma proa e apresentando um casco ligeiramente curvo. No mesmo bloco encontram-se ainda gravados dois motivos indeterminados, um deles, por sinal, bastante curioso e bastante bem conservado. Porém, não podemos tecer nenhuma consideração, já que até ao presente, ainda não foi encontrado nenhum motivo análogo.

Apesar da representação de barquiformes se tratar de uma temática pouco comum na Península Ibérica, ainda assim, recentemente, têm aparecido principalmente no norte da zona litoral portuguesa, novas representações de embarcações.

No Minho, no contexto da Arte Atlântica, foram encontrados vários tipos de barquiformes na Laje da Churra, em Carreço, Viana do Castelo (Santos, A., 2013), (Figura 10a) Eira do Louvado, Viana do Castelo e Santo Adrião 2, (Figura 1ob) no concelho de Caminha (Bettencourt A., 2017; Santos Estévez \& Bettencourt, 2017). Já na Galiza são conhecidos alguns exemplares, como os barquiformes de Oia, em Pedornes (Santa María de Oia) (Alonso Romero, 1974), barquiformes de Borna, (Figura 10c) em Meira, Galiza (García Alén \& Peña Santos, 1980) e barquiforme de Auga dos Cebros (Costas Goberna \& Peña Santos, 2006, p. 289).

Perante a falta de paralelos no Noroeste Peninsular, para o barquiforme localizado no bloco musealizado do Museu Arqueológico da SMS, foram, no entanto, encontradas semelhanças estilísticas nas embarcações do Norte de Tanumm, Bohuslãn, Suécia (Figura 1od) (Goldhahn, J.; Ling, J., 2013, p. 276). De acordo com Bettencourt (Bettencourt, A., 2013a, 2013b; Santos, A., 2014) este tipo de representações surge desde a Idade do Bronze, momento, a partir do qual se intensificam as navegações na fachada atlântica. É de referir a presença de contactos entre a Ibéria e a Escandinávia, durante a Idade do Bronze, nomeadamente durante o Bronze Final. Esta hipótese tem vindo a ser defendida através de dados arqueológicos e arqueométricos por Ling Stos-Gale (2015, p. 215-217).

Já no que se refere ao barquiforme da Bouça da Miséria, (Figura 1oe) apesar do afloramento rochoso ter grandes dimensões, o reduzido número de motivos ali gravados pode ter tido um propósito diferente por parte do(s) seus autor(es) uma vez que a sua iconografia é bastante distinta relativamente a todos 
os outros sítios do monte. Apesar do afloramento granítico rasante ao solo apresentar uma aparência muito regular, os motivos encontram-se dispersos ao longo de toda a sua superfície, ocorrendo duas figurações circulares (dois círculos concêntricos) covinhas, o motivo do barquiforme e um possível antropomorfo sexuado. Entre todos estes motivos não parece existir uma clara ligação entre eles, pelo que será de questionar, tendo em conta aspetos como a técnica de execução que se afigura também diferente, se as gravuras foram realizadas em épocas distintas. Referimo-nos, por exemplo, ao eventual antropomorfo de traço mais profundo e mais avivado (Cardoso, D. 2015, p. 278).

O barquiforme da Bouça da Miséria é representado através de um esquema simples preenchido no seu interior por várias linhas gravadas na horizontal. De notar, provavelmente na proa, uma parte sobreleva$\mathrm{da}$, de onde saem dois pequenos traços horizontais (Nash, G., Cardoso, D., Ferreira, E., 2013, p. 48).

Relativamente ao domínio das comparações técnico estilísticas, até ao momento não foram encontrados paralelos na Península Ibérica. Contudo, esta representação rupestre apresenta algumas analogias com algumas representações de barcos da Escandinávia da Idade do Bronze. Como paralelo possível encontram-se semelhanças estilísticas numa embarcação existente no painel V de Evenhus na Noruega (Figura 1of), atribuída ao início da Idade do Bronze, tendo como referência os estudos de Malmer (1981) (citado em Nash, 2008, p. 97).

Se bem que diferente no que caracteriza o "corpo" da embarcação, um dos barquiformes de tipo canoa da Laje da Churra, também apresenta uma proa elevada com um traço horizontal (Figura 10a).

Em suma, perante a escassez de paralelos no Noroeste Peninsular, de sobreposições e de escavações arqueológicas adjacentes ao afloramento gravado, propomos, sob reserva, que o barquiforme da Bouça da Miséria se possa inscrever na Idade do Bronze ou mesmo nos inícios da Idade do Ferro, momento em que se intensificam as navegações na fachada atlântica (Cardoso, D., 2015, p. 236).

Por último, é de registar que no decorrer de estudos mais recentes sobre a temática das embarcações no Monte de S. Romão, a colocação de uma nova hipótese relativamente a um motivo de um barquiforme numa pedra referida por Sarmento (Sarmento, 1905, p. 23). (Figura 10g). Esta representação apresenta algumas analogias com algumas representações de embarcações da Península Ibérica e da Escandinávia. No entanto, em termos estilísticos, é de realçar a sua semelhança com a composição gravada num dos ortostatos do dolmen de Mané Lud (Morbihan, Bretanha francesa), atribuída ao V-IV milenio a.C (Cassen \& alii 2005, p. 362, fig. 16; Cassen, S., 2007) (Figura 1oh) e do barquiforme de forma triangular, do painel 18 da Laje da Churra, a autora propõe uma cronologia situada entre o Calcolítico Final/Idade do Bronze Inicial. Porém não exclui a possibilidade dos barquiformes da Laje da Churra terem sido gravados num momento mais tardio, entre o Bronze Final ou Idade do Ferro (Santos, A., 2014, p. 106).

Assim, perante os dados obtidos e a analogia estilística com as representações de embarcações gravadas no dolmen del Mané Lud, (Morbihan, Bretanha francesa), parece-nos admissível, sob reserva, colocar a hipótese de que o barquiforme em análise possa ter sido gravado entre o IV milénio e o III milénio a.C., embora admitamos poder ser posterior, já que se encontra na Citânia de Briteiros, um povoado dos finais da Idade do Bronze que teve como momento áureo a Idade do Ferro. Somente com a relocalização da pedra gravada e com um exame mais minucioso se poderá confirmar ou invalidar esta proposta pelo que a sua inserção cronológica se mantém em aberto. Resta a expectativa de que seja feita a sua relocalização, para que se possam tecer mais algumas considerações, já que a pedra poderá ter sido reutilizada na estrutura onde se encontra, situação que ocorre recorrentemente em muitos sítios arqueológicos.

Quanto ao domínio das possíveis interpretações para os motivos de embarcações do Monte de S. Romão, cabe-nos perguntar: que tipo de narrativa estará por detrás destas representações? Existirá alguma relação direta com a navegação ou com o curso do rio Ave? Para a Idade do Ferro tem sido defendido que a Citânia de Briteiros, localizada no Monte de S. Romão, constituiu em tempos (...) "um ponto estratégico onde a navegação do Ave, para mercadorias, terminava do alto das suas imponentes muralhas” (...) (Lemos \& Cruz, 2011, p. 48). Será que o espelho de água mantinha as mesmas caraterísticas no momento da gravação das gravuras e na Idade do Ferro? Seria interessante a realização de uma investigação mais aprofundada que clarificasse esta e outras questões. Outra via de abordagem para se tentar compreender a narrativa que se encontra por detrás destes motivos será a de que estas representações poderão estar associadas ao mundo metafó- 
rico e simbólico das comunidades que habitaram o Monte de S. Romão. Nesse sentido, podemos colocar a hipótese de que a representação dos barquiformes poderia estar relacionada com a religiosidade e crenças das comunidades da época, já que o símbolo do barco se encontra presente em várias culturas do mundo, onde a barca é conhecida por ser um símbolo da viagem ou da travessia efetuada pelos vivos ou mortos (Cardoso, D., 2015, p. 283).

\section{CONSIDERAÇÕES FINAIS}

Tendo em conta as embarcações gravadas no Monte de S. Romão (Nash, G., Cardoso, D., Ferreira, E., 2013; Cardoso, D., 2015), consideramos que o número deste tipo de representações é significativo para esta área interior.

Em termos estilísticos devemos dar destaque ao facto de que cada uma das representações apresenta um "desenho" diferente, como se representassem tipos de embarcações distintas, contendo em comum a representação das proas e dos cascos achatados, excetuando o caso do bloco musealizado, cujo casco apresenta uma ligeira curvatura.

A maior representação, com o,59m por o,30 m, localiza-se no afloramento gravado da Bouça da Miséria, a meia vertente, a nordeste do Monte de S. Romão, ainda, dentro da zona especial de proteção da Citânia de Briteiros e próximo de linhas de água e de nascentes, sendo de assinalar o rio Febras, na margem direita do Ave. Tal como já tinha sido mencionado, da Bouça da Miséria é possível usufruir de uma ampla visibilidade, destacando-se no horizonte, para nordeste, a Serra da Cabreira, lugar onde nasce o rio Ave. Os vestígios mais antigos de que temos conhecimento na envolvente da Bouça da Miséria remontam à Pré-história Recente, entre eles algumas mamoas em Donim e na Quinta do Paço (Sarmento, F., 1902a, pp. 19-30), o povoado da Boavista, localizado no sopé do Monte de S. Romão e inserível na Idade do Bronze, bem como vários afloramentos gravados inseríveis na designada Arte Atlântica, correspondente aos finais do IV milénio e parte do III milénio a.C. Perante todo este contexto, e partindo do pressuposto que os afloramentos eram conhecidos pela comunidade ou por uma parte dela, certamente que no ato de gravação todas as "experiências" e "vivências" seriam de certa forma tidas em conta aquando da representação. Nesse sentido, e sendo o Monte de S. Romão portador de uma longa história, a representação do barquiforme da Bouça da Miséria poderá corresponder a uma adição, provavelmente no âmbito de uma revisitação do lugar na Idade do Bronze, já que a primeira fase de gravação deste afloramento corresponde a um momento anterior, mais precisamente ao final do IV milénio a.C., ou entre os finais do Neolítico/Calcolítico.

Para as restantes representações de barquiformes, e uma vez que não detemos todas as informações necessárias para retirar as devidas ilações, poderão estas, ainda, reservar-nos algumas surpresas, devendo assim ser encaradas com muita prudência. As hipóteses interpretativas e as propostas cronológicas apoiaram-se essencialmente nas analogias estilísticas e nas técnicas utilizadas.

Perante os dados adquiridos até ao presente, pode dizer-se que os suportes gravados representam barquiformes pré-históricos, tradicionalmente atribuídos à Idade do Bronze e por vezes com prolongamento até à Idade do Ferro, ou seja, ao I milénio a.C., momento, a partir do qual se intensificam as navegações na fachada atlântica (Bettencourt, A., 2013, p. 167; Cardoso, D., 2015, p. 236). Porém, no caso da pedra gravada mencionada por Martins Sarmento no séc. XIX (Sarmento, F., 1905a, p. 23) poderá equacionar-se a hipótese de que o barquiforme em questão poderá eventualmente fazer recuar a cronologia deste tipo de motivos para um momento anterior, ou seja, entre o IV e o III milénio a.C.. A proposta desta cronologia, baseia-se nas semelhanças estilísticas dos barquiformes gravados no dolmen de Mané Lud (Morbihan, Bretanha francesa) e do barquiforme de formato triangular localizado no painel 18 da Laje da Churra, Viana do Castelo. Admite-se, pois, que esta hipótese é problemática e audaciosa, dado que o suporte onde o motivo se encontra gravado não foi ainda relocalizado.

Quanto à localização destes motivos no Monte de S. Romão, verificou-se que até ao momento os suportes gravados com representações de barquiformes situam-se na vertente média/alta do Monte de S. Romão, a nordeste e sudeste do mesmo. O que terá levado os autores destas manifestações a gravar este tipo de motivos no lado nordeste/sudeste do monte, tendo sido preterido o lado oeste? Poderá a explicação relacionar-se com o contexto circundante? A questão fica em aberto.

Apesar das muitas dúvidas suscitadas e da falta de resposta para muitas delas, este trabalho pretendeu levantar algumas hipóteses e tecer algumas consi- 
derações; mas não nos podemos alhear de que estas suposições têm de ser bem alicerçadas e fundamentadas. Deste modo, as propostas aqui apresentadas devem ser encaradas como hipóteses de trabalho, tendo em conta o teor da base empírica utilizada, mas acima de tudo proporcionar novos caminhos interpretativos assim como promover e ampliar os conhecimentos sobre a arte rupestre pós-paleolítica de ar livre do Noroeste português.

\section{AGRADECIMENTOS}

Giorgos Iliadis, pela realização do modelo em 3D do bloco gravado musealizado e no apoio ao levantamento gráfico do mesmo.

\section{BIBLIOGRAFIA}

ALONSO ROMERO, Fernando (1974) - Hallazgo de un petroglifo con representaciones esquemáticas de embarcaciones de la Edad del Bronce. Zephyrus. Salamanca. 25, pp. 295-308.

BETTENCOURT, Ana (2017) - Gravuras rupestres do Noroeste para além das artes atlânticas e esquemática. In Arnaud, J.; Martins, A. eds. - Arqueologia em Portugal - 2017. Estado da Questão. Lisboa: AAP.

BETTENCOURT, Ana (2013) - O Bronze Final no Noroeste português. Uma rede complexa de lugares, memórias e ações. Estudos Arqueológicos de Oeiras. Oeiras. 20, pp. 145-162.

CARDOSO, Daniela (2011) - Um olhar sobre os últimos trabalhos desenvolvidos, no âmbito da investigação da arte rupestre da Citânia de Briteiros em Guimarães. Acta das IV Jornadas de Jovens em Investigação Arqueológica (JIA 2011), Faro: Universidade do Algarve, pp. 163-168.

CARDOSO, Daniela (2015) - A Arte Atlântica do Monte de S. Romão (Guimarães) no Contexto da Arte Rupestre Pós-paleolítica da Bacia do Ave-Noroeste Português. Vila Real: Universidade de Trás-os-Montes e Alto Douro.

CARDOZO, Mário (1932) - A última descoberta arqueológica na Citânia de Briteiros e a interpretação da «Pedra Formosa». Revista de Guimarães. Guimarães. 42: 1-2, p. 22.

CARDOZO, Mário (199o) - Citânia de Briteiros e Castro de Sabroso. Guimarães: Sociedade Martins Sarmento ( $8^{\circ}$ edição), pp. 9-10.

CASSEN, Serge. (2007) - Le Mané Lud en images. Interprétations de signes graves sur les parois de la tombe à couloir néolithique de Locmariaquer (Morbihan). Gallia Préhistoire. Paris. 49, pp. 197-258.

CASSEN, Serge; LEFEÉBVRE Benoit; LASTRES, Jacobo; COLLIN, Clément (2005): Le Mané Lud en sauvatage (Locmariaquer, Morbihan): enregistrement et restitution des signes graves dans une tombe à couloir néolithique. L'Anthropologie. Paris. 109, pp. 325-384.

COSTA, Francisco (2007) - A gestão das Águas Públicas O caso da Bacia Hidrográfica do Rio Ave no período 1902-1973. Braga: Universidade do Minho.

COSTAS GOBERNA, Fernando; PEÑA SANTOS, António

(2006) - Los barcos de los Petroglifos de Oia. Los tesoros del hechicero y una nueva embarcación. Glaucopis. Vigo. 12, pp. 277-292.

FERREIRA, Narciso, DIAS, Graciete, MEIRELES, Carlos \& BRAGA Maria (2000) - Carta Geológica de Portugal. Notícia Explicativa da Folha 5-D. Braga: Instituto Geológico e Mineiro.

GARCIA ALEN, Alfredo; PENA SANTOS, António (1980) - Grabados rupestres de la provincia de Pontevedra. A Coruna: Fundación Barrié de la Maza.

GELL, Alfred (1998) - Art and Agency: An Anthropological Theory. Oxford, Clarendon Press.

GOLDHAHN, Joakim; LING, Johan (2013) - The Oxford Handbook of European Bronze Age, Chapter: 15. - Oxford University Press, pp. 270-29o.

INGOLD, Thomas (2000) - The Perception of the Environment. Essays on Livelihood, Dwelling and Skill. London and NewYork, Routledge.

LEMOS, Francisco; CRUZ, Gonçalo (2011) - Citânia de Briteiros - Povoado Proto-histórico / The Protohistoric Settlement. Guimarães: Sociedade Martins Sarmento.

LING, Joan; STOSGALE, Zofia A. (2015) - Representations of oxhide ingots in Scandinavian rock art: the sketchbook of a Bronze Age traveller. Antiquity, 89: 343, pp. 191-207.

NASH, George (2008) - Northern European hunter/fisher/ gatherer and Spanish Levantine rock-art: A study in performance, cosmology and belief. Trondheim: NTNU.

NASH, George, CARDOSO, Daniela \& FERREIRA, Eduardo (2013) - What lies beneath? Understanding the artistic stratification of Citânia, an Iron Age proto-hillfort in Northern Portugal. Current World Archaeology Magazine. London. 6o, pp. 44-48.

SANTOS, Ana (2013) - The rock engravings of Laje da Churra, Paçô, Carreço, Viana do Castelo/As gravuras rupestres da Laje da Churra, Paçô, Carreço, Viana do Castelo. In A.M.S. Bettencourt. The Prehistory of the Northwestern Portugal / A Pré-História do Noroeste Português, Territórios da Pré-História em Portugal. Vol.2. Braga/Tomar: CITCEM/CEIPHAR, pp. 196-200.

SANTOS, Ana (2014) - A Lage da Churra (Carreco, Viana do Castelo). Estudo Monográfico de um Lugar Gravado. Braga: Universidade do Minho. 
SANTOS-ESTEVEZ, Manuel; BETTENCOURT, Ana (2017) - O conjunto de gravuras rupestres de Santo Adrião (Caminha, Portugal). Embarcações, armas, cavalos e ex-votos. in J. M. ARNAUD; A. MARTINS eds. - Arqueologia em Portugal 2017 - Estado da Questão. Lisboa: Associação de Arqueólogos Portugueses.

SARMENTO, Francisco (1901) - Materiais para a arqueologia do concelho de Guimarães. Revista de Guimarães. Guimarães. 18: 1-2, p. 19.

SARMENTO, Francisco (1902) - Materiais para a arqueologia do concelho de Guimarães. Revista de Guimarães. Guimarães. 19: 1, pp. 22-23.
SARMENTO, Francisco (1904) - Materiais para a arqueologia do concelho de Guimarães. Citânia. Revista de Guimarães. Guimarães. 21: 2, p. 61.

SARMENTO, Francisco (1905) - Materiais para a arqueologia do concelho de Guimarães. Citânia. Revista de Guimarães. Guimarães. 22: 1-2, p. 17-23.

SARMENTO, Francisco (1933) - Dispersos: colectânea de artigos publicados, desde 1876 a 1899, sobre arqueologia, etnologia, mitologia, epigrafia e arte pré-histórica: obra comemorativa do $1^{\circ}$ centenário do nascimento do autor. Coimbra: Universidade de Coimbra.

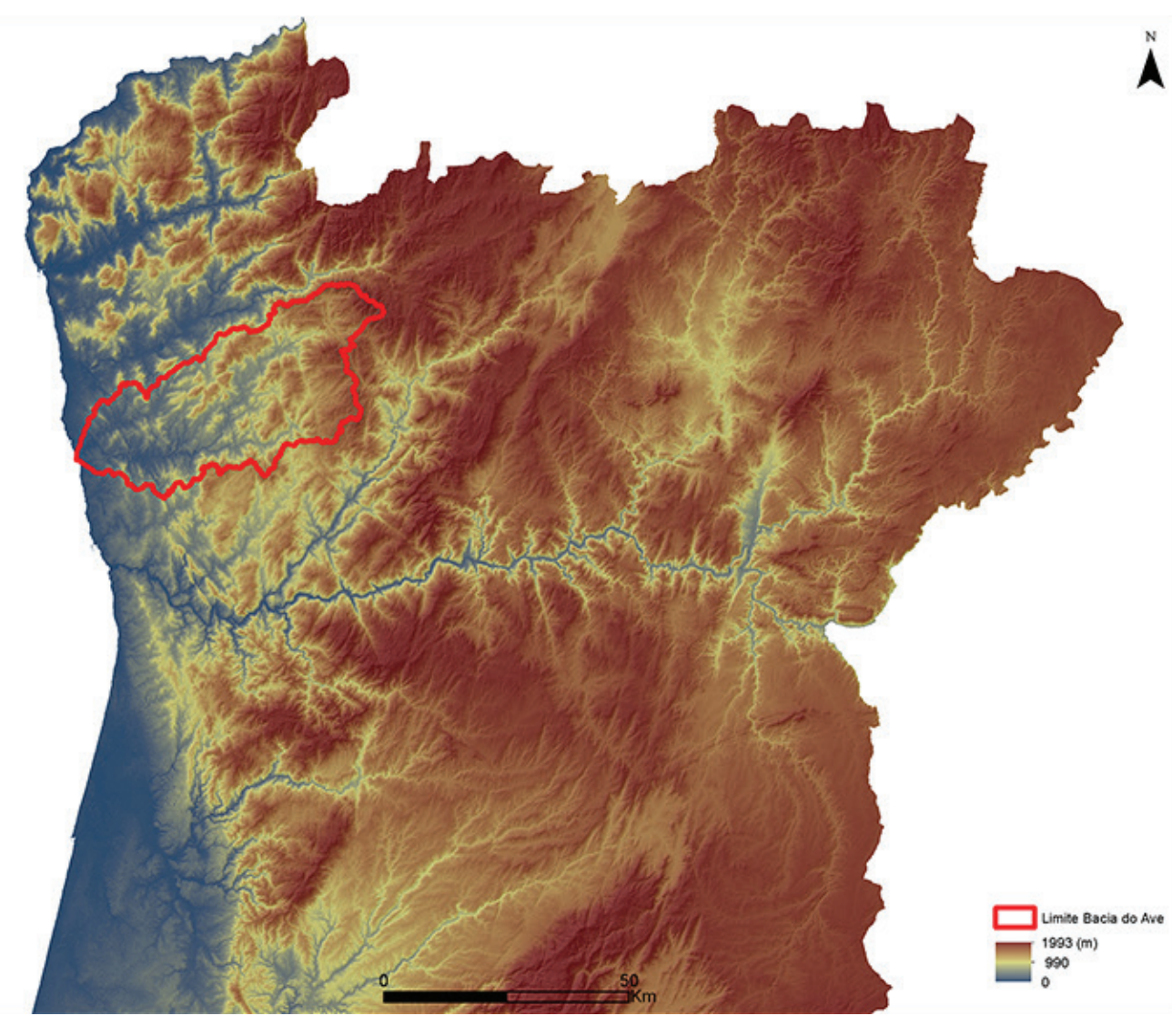

Figura 1 - Mapa de Portugal com a localização da bacia do Ave (Cardoso, D., 2015, p. 27). 


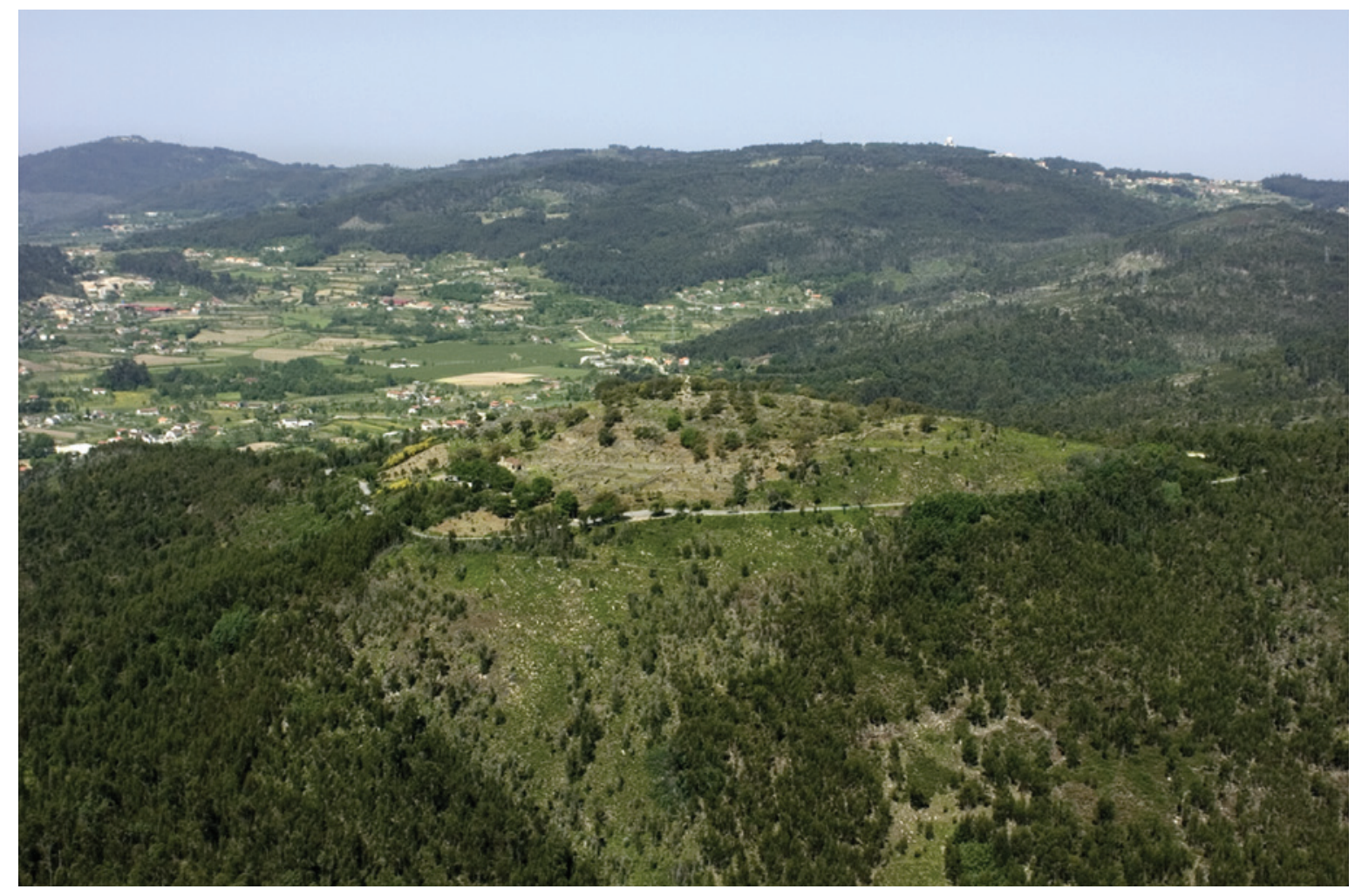

Figura 2 - Enquadramento do Monte de S. Romão face ao vale do Ave (Fonte: SMS).

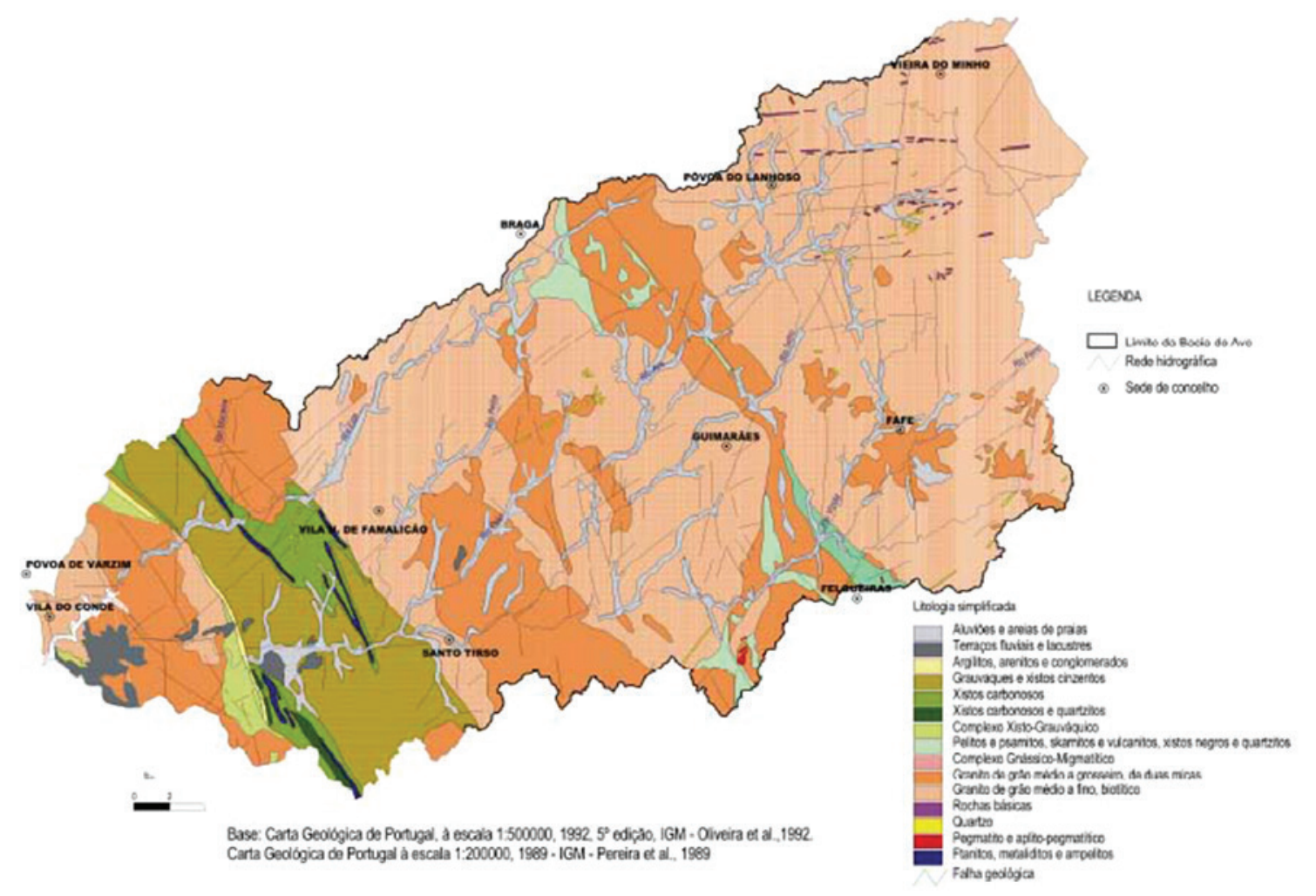

Figura 3 - Mapa geológico da bacia hidrográfica do rio Ave. O relevo é assinalado com cores diferenciadas (Fonte: Costa, F., 2007, p. 139, fig. 26). 


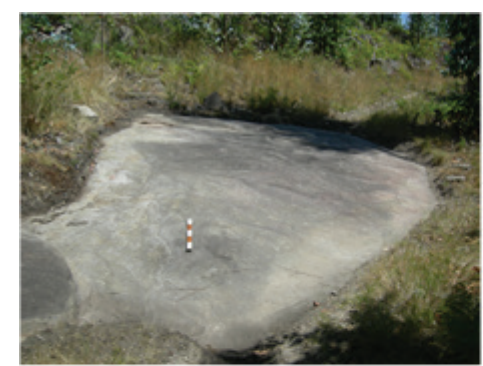

A

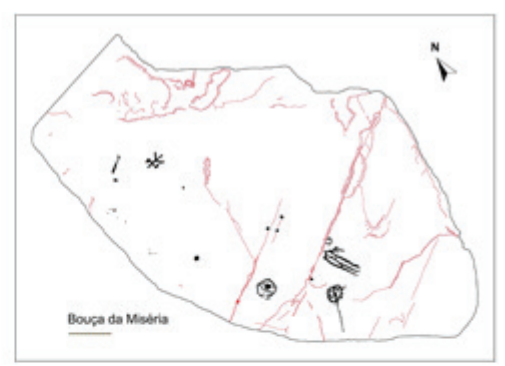

B

\section{C}

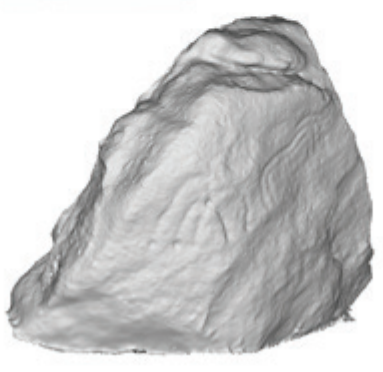

Figura 4- A - Vista geral do afloramento gravado da Bouça da Miséria, Monte de S. Romão (Cardoso, D., 2015, p. 173); B - Decalque do afloramento gravado da Bouça da Miséria, Monte de S. Romão (Cardoso, D., 2015, p.176); C-Vista geral do modelo em $3 \mathrm{D}$ do bloco gravado com o motivo de um barquiforme, exposto no Museu Arqueológico da Sociedade Martins Sarmento (Fonte: Giorgos Iliadis).
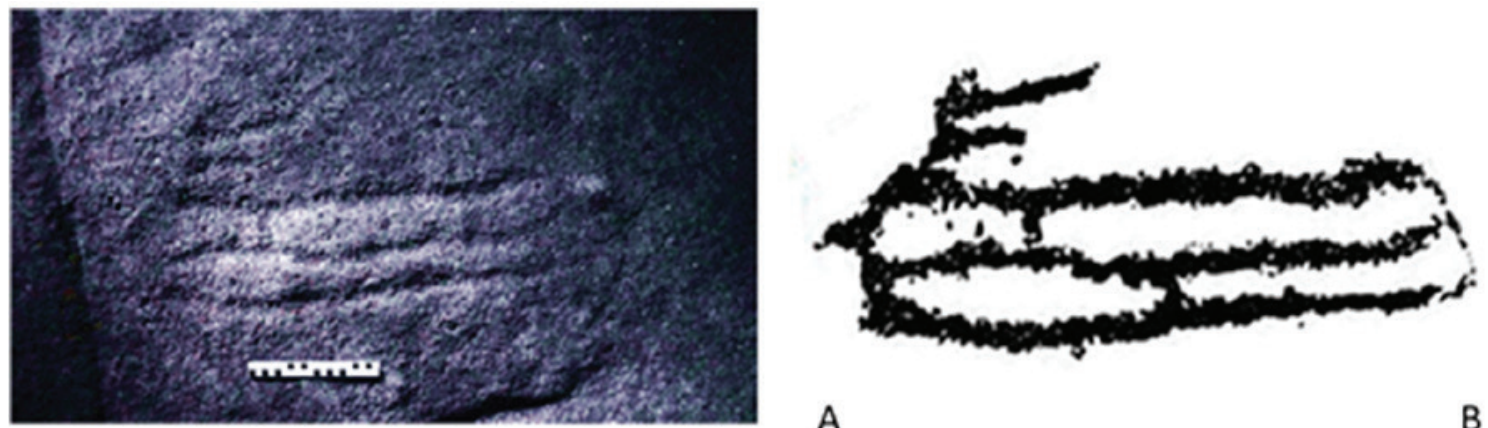

A

Figura 5-A - Fotografia de pormenor do barquiforme da Bouça da Miséria, Monte de S. Romão, através da utilização de luz rasante (Cardoso, D., 2015, p. 218); B - Pormenor do barquiforme proveniente do decalque da Bouça da Miséria, Monte de S. Romão (Cardoso, D., 2015, p. 176). 


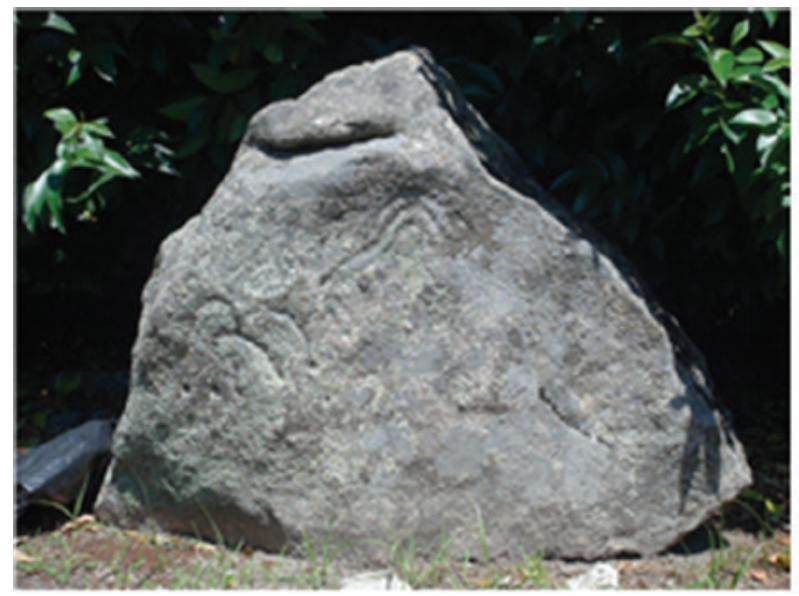

A

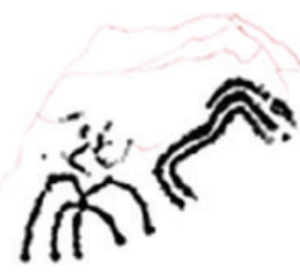

B

Figura 6 - A - Vista geral do bloco gravado proveniente do Monte de S. Romão e exposto no Museu Arqueológico da SMS; B - Decalque do bloco gravado proveniente do Monte de S. Romão e exposto no Museu Arqueológico da SMS.

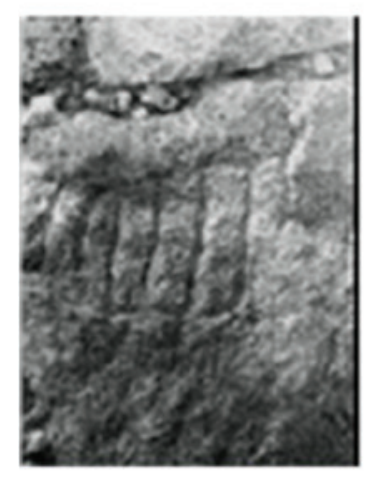

A

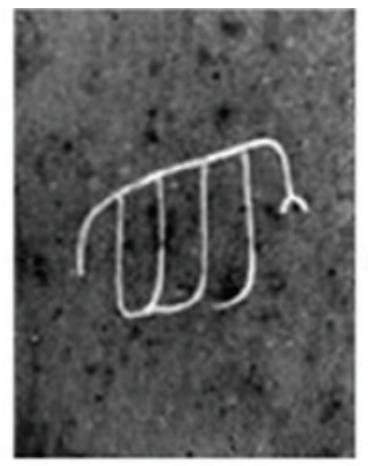

B

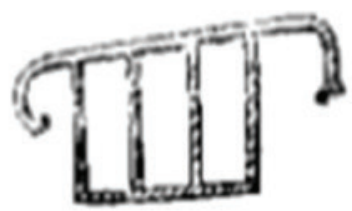

C
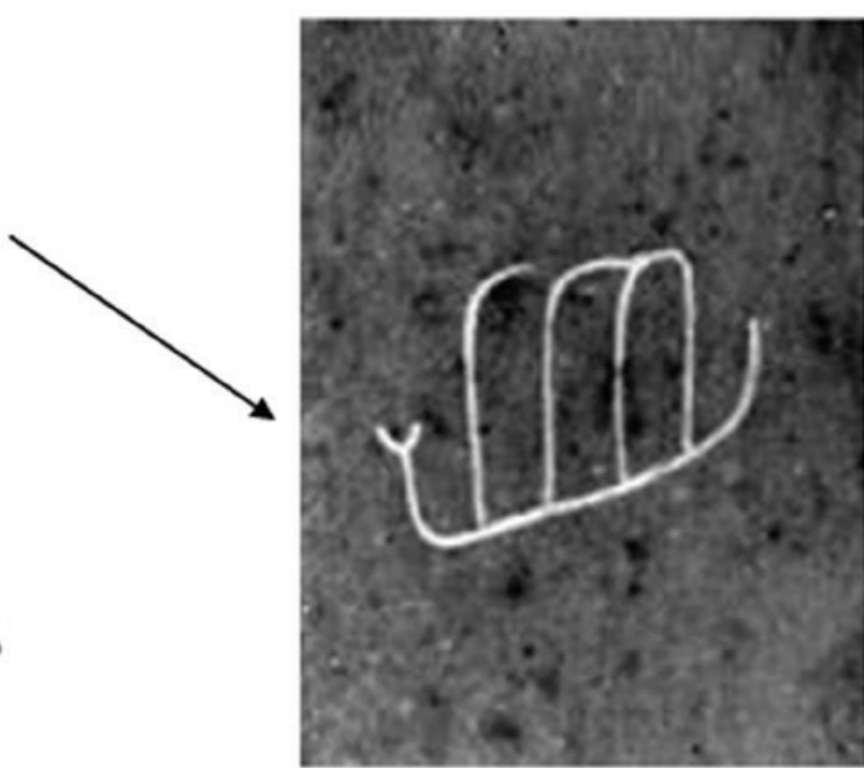

D

Figura 7 - A - Fotografia de Sarmento (Fonte: Fototeca da SMS, Est. XV); B - Fotografia de Sarmento (Fonte: Citânia - Álbum de fotografias - 2, 1992, Est. XIV); C - Desenho de Martins Sarmento (Fonte: Sarmento, F., 1905, p. 23); D - Fotografia de Sarmento invertida (Fonte: adaptado de Citânia - Álbum de fotografias - 2, 1992, Est. XIV). 


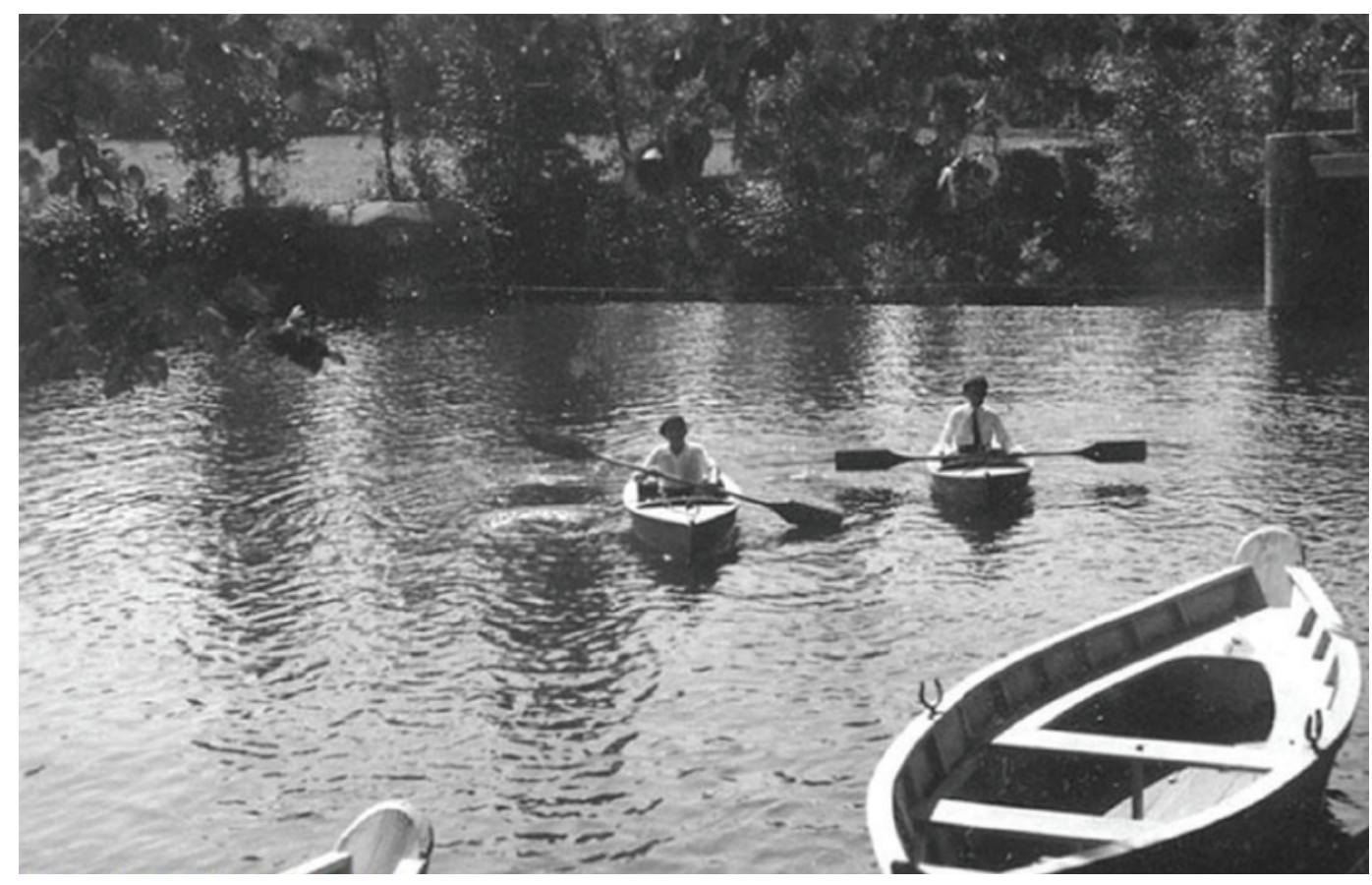

Figura 8 - Vista de um troço do rio Ave e suas embarcações nos anos zo do séc. XX (Fonte: Fototeca da SMS).
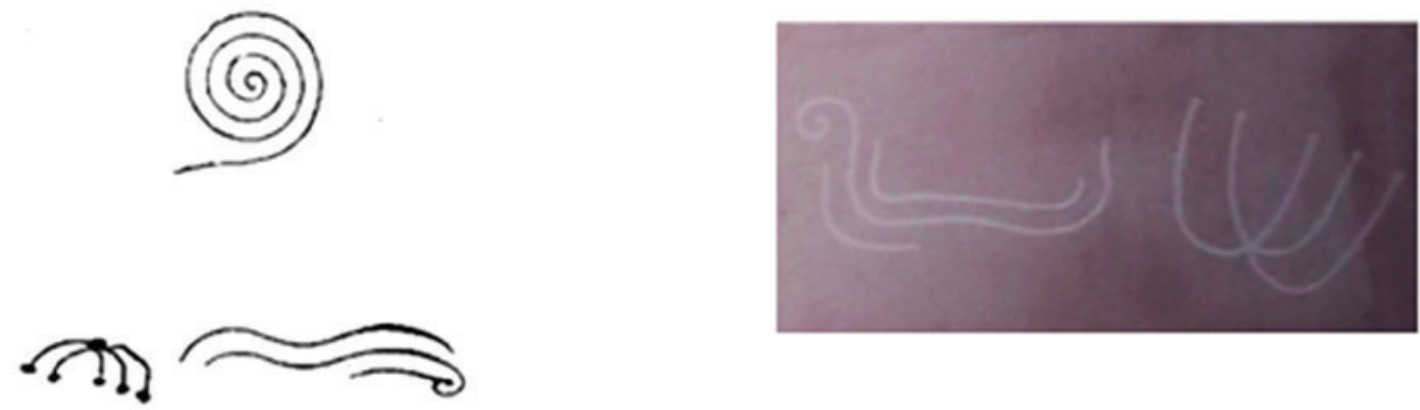

A

B
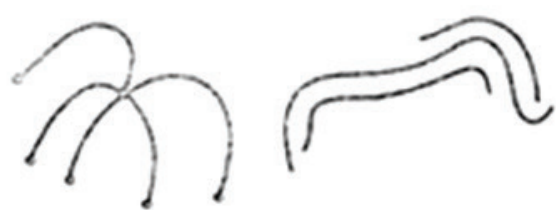

C

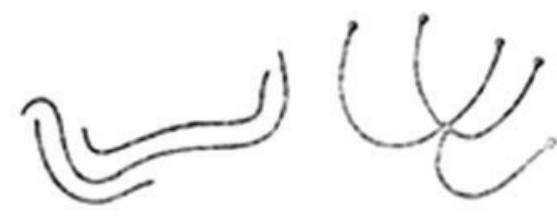

D

Figura 9-A - Desenho de Sarmento (Fonte: Sarmento, F., 1904, pág. 61); B - Fotografia de Sarmento (Fonte: Citânia - Álbum de fotografias - 1, 1992, Est. XVII); C - Desenho de Mário Cardozo (Fonte: Cardozo, M., 1932, fig. 15, p. 22); D - Desenho adaptado de Mário Cardozo e colocado em posição invertida (Fonte: Cardoso, D., 2015, p. 181). 


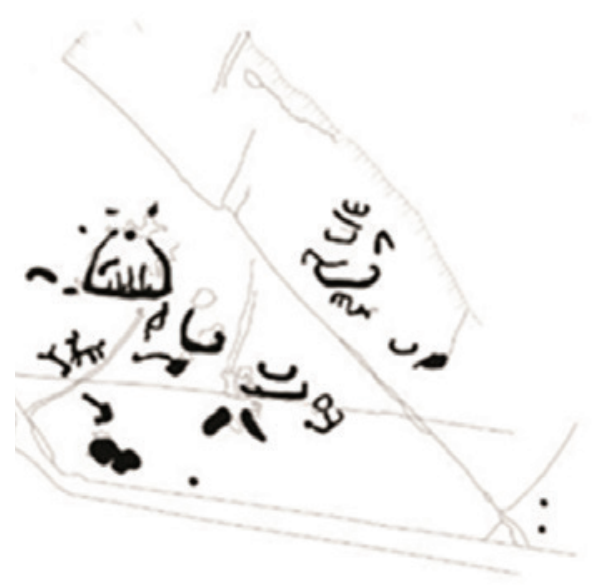

A

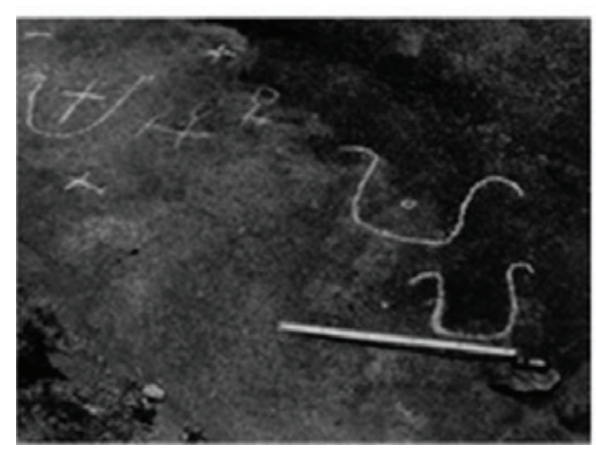

C

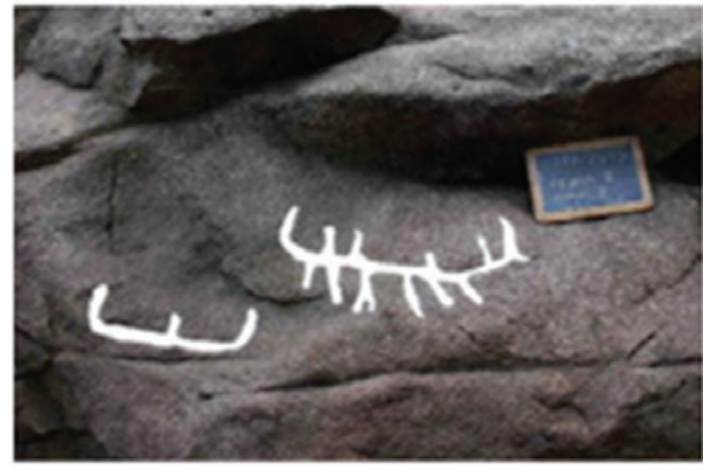

B

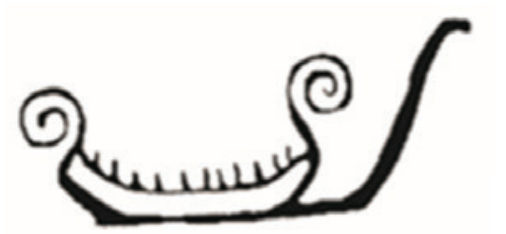

D-1

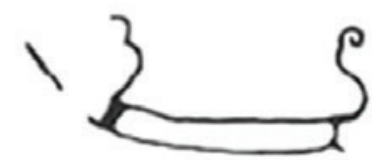

D-2

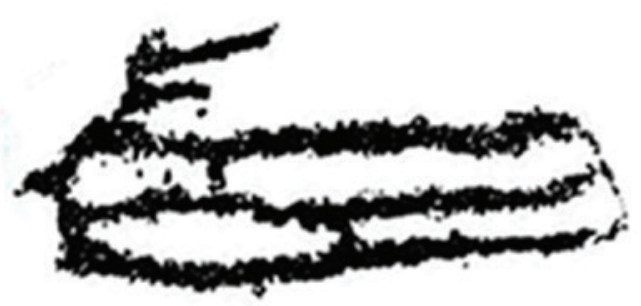

E

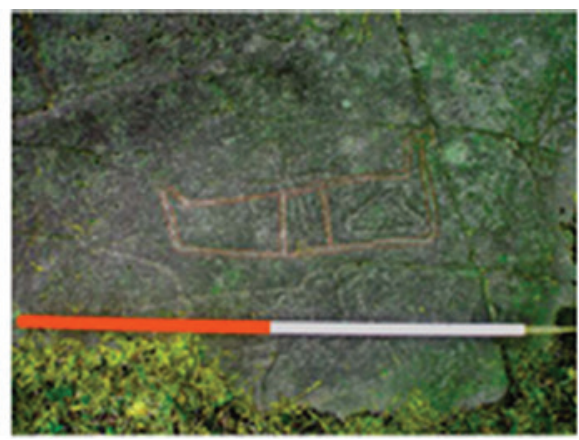

F

G
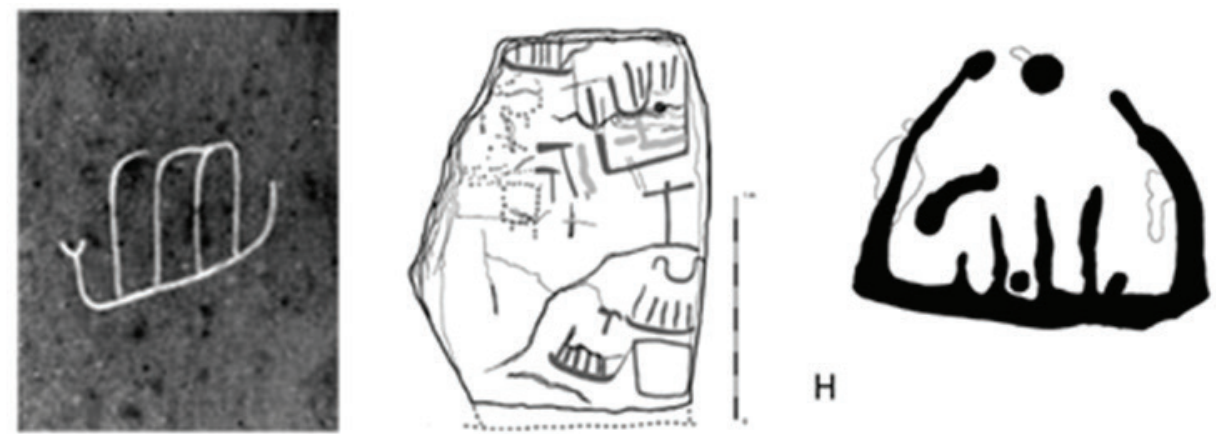

H

Figura 10 - A - Barquiformes da Laje da Churra (Fonte: Santos, A., 2014, p. 71); B - Barquiformes de Santo Adrião (Fonte: Santos-Estévez \& Bettencourt, A., 2017, p. 1066, adaptado); C - Barquiformes de Borna (Fonte: Alonso Romero, 1974, p. 296); D-1, D-2 - Barquiformes Tanumm, Bohuslãn, Suécia (Goldhahn, J. \& Ling, J., 2013, p. 276, adaptado); E - Detalhe adaptado do decalque do barquiforme da Bouça da Miséria, Monte de S. Romão (Cardoso, D., 2015, p. 176); F- Barquiforme do painel V de Evenhus na Noruega (Nash, G., 2008, p. 97); G - Fotografia de Sarmento invertida (Fonte: Adaptada do álbum fotografias de Martins Sarmento, nº2, 1992, Est. XIV); H - Barquiforme Grabados del dolmen de Mané Lud, Morbihan, Bretanha francesa (Cassen \& alii. 2005, p. 362); I - Barquiforme da Laje da Churra, Viana do Castelo (Santos, A., 2014, p. 72). 


\title{
CÍRCULOS SEGMENTADOS GRAVADOS NA BACIA DO RIO LIMA (NOROESTE DE PORTUGAL): CONTRIBUTOS PARA O SEU ESTUDO
}

\author{
Diogo Marinho ${ }^{1}$, Ana M.S. Bettencourt ${ }^{2}$, Hugo Aluai Sampaio ${ }^{3}$
}

\begin{abstract}
RESUMO
A arte rupestre como prática das comunidades do passado pode ser dividida em arte paleolítica e em arte pós-paleolítica. Este trabalho incidirá na arte pós-paleolítica de ar livre na qual se inserem, por sua vez, as Artes Atlântica e Esquemática entre outras difíceis de definir segundo Bettencourt (2017a, 2017b). É dentro destas últimas que se enquadra o nosso objeto de estudo, os círculos segmentados gravados que, de acordo com aquela autora, pertenceram a um universo estilístico emergente na Idade do Bronze. A área de estudo é a bacia do rio Lima onde, apesar de raros, estes motivos aparecem quer no litoral como no interior, em associação com diferentes gramáticas figurativas. Pela observação macroscópica da sua orientação indiciam relação com cultos celestes ou celebrações em determinados momentos do ano.
\end{abstract}

Palavras-chave: Arte Rupestre, Arte pós-paleolítica, Círculos segmentados gravados, Bacia do rio Lima.

\begin{abstract}
Rock art as a practice of past communities can be divided into Palaeolithic and post-Palaeolithic arts. Considering the later, which in turn can be divided into Atlantic and Schematic Arts, among other styles difficult to define (Bettencourt, 2017a, 2017b), this work will focus Atlantic rock art. Our selected object of study is the recorded segmented circles that, according to that author, will belong to a stylistic universe emerging in the Bronze Age. The geographic area is the Lima River basin. Although these motifs are rare, they appear both on the coast and inland, in association with different figurative grammars. By the macroscopic observation of its orientation they indicate a relation with celestial cults or celebrations during certain moments of the year.

Keywords: Rock Art, Post-paleolithic art, Engraved segmented circles, Lima River basin.
\end{abstract}

\section{INTRODUÇÃO}

A arte rupestre pós-paleolítica do Noroeste Ibérico é uma temática que tem vindo a ser amplamente trabalhada desde o século passado. Os primeiros trabalhos culminaram nas publicações de Obermaier (1923, 1925), seguido de Lopez Cuevillas (1943), Bosh-Gimpera (1954) e Anati (1968). Na segunda metade do séc. XX desenvolvem-se importantes trabalhos no território galego, com destaque para Peña Santos e colaboradores (Peña Santos e Vásquez Varela, 1979; Peña Santos e Rey García, 2001; Peña Santos e Costas Goberna, 2001, entre muitos outros), referindo-se à arte rupestre daquela região como Arte Galaico-Portuguesa. Numa primeira fase, esta arte foi caracterizada por combinações circulares como elemento predominante e mais comum, sendo posteriormente dividida em dois grupos: o naturalista e o geomé-

\footnotetext{
1. Mestrando em Arqueologia da Universidade do Minho, Braga; diogomarinhog81@gmail.com

2. Laboratório de Paisagens, Património e Território (Lab2PT); Departamento de História da Universidade do Minho, Braga, Portugal; anabett@uaum.uminho.pt

3. Escola Superior de Hotelaria e Turismo do Instituto Politécnico do Cávado e do Ave (ESHT/IPCA); Centro de Investigação, Desenvolvimento e Inovação em Turismo (CITur); hugoaluai@gmail.com
} 
trico (Peña Santos e Costas Goberna, 2001). O grupo naturalista incluía motivos de animais, antropomorfos e armas. O geométrico definia-se por combinações circulares, covinhas, círculos concêntricos, espirais e labirintos (Peña Santos, 1979; Peña Santos e Costas Goberna, 2001). Em termos cronológicos estes autores inseriam a Arte Galaico-Portuguesa na Idade do Bronze, entre a segunda metade do III milénio a.C. e os inícios do II milénio a.C.. Esta aproximação cronológica foi conseguida através das representações de armas, pois é neste período que se encontram as primeiras evidências materiais destes artefactos. Vázquez Varela (1983, p. 6) procedeu a uma subdivisão cronológica individualizando a datação de vários motivos. Esta subdivisão resultou em 11 grupos de motivos: (1) combinações circulares, datadas desde a cultura megalítica até à cultura castreja; (2) espirais, datadas do Calcolítico e Idade do Bronze; (3) labirintos, datados da fase final da Idade do Bronze; (4) cenas de equitação, datadas do Bronze Final; (5) serpentes, datadas da Idade do Bronze, podendo ser também atribuídas à Idade do Ferro; (6) figuras humanas, datadas da Idade do Bronze; $(7)$ idoliformes, datados do Calcolítico; (8) armas, datadas do Calcolítico até à Idade do Bronze; (9) paletas, datadas do período da Idade do Bronze Final; (10) covinhas, atribuídas a todos os períodos de arte rupestre; (11) cistas, datadas da Idade do Bronze Inicial.

Em Portugal, Baptista $(1983-1984,1986)$ propõe, na década de 1980, a divisão dos motivos gravados no Noroeste em dois grupos, os grupos I e II do Noroeste. O grupo I correspondia a manifestações rupestres, sobretudo litorais, e o grupo II a áreas mais interiores, diferenciando-se através da temática, técnica e cronologia. O grupo I tinha como elementos principais as composições circulares, figuras proto-labirínticas ou labirintiformes, espirais, em menor expressão, as armas, zoomorfos e antropomorfos, podendo aparecer em algumas estações idoliformes (Baptista, 1984). Este autor atribuiu-lhe uma cronologia da Idade do Bronze (Baptista, 1984). O grupo II caracteriza-se por incluir antropomorfos esquemáticos, quadrados e retângulos segmentados internamente, e círculos simples e ferradura, com ou sem covinha central. Motivos mais raros seriam os 'ganchos", pequenas espirais, podomorfos, paletas, suásticas, etc. (Baptista, 1984). A nível cronológico, o autor situa estas manifestações entre o Bronze Final e a Alta Idade Média (Baptista, 1984).

No início da década de 1990 investigações protago- nizadas por Richard Bradley e outros investigadores galegos e portugueses no Noroeste Ibérico culminaram num estudo exaustivo sobre a Arte Atlântica, designação esta usada para caracterizar as artes galaico-portuguesas e o grupo I do Noroeste (Bradley, 1997). Esta obra vai considerar a Arte Atlântica como manifestação emergente entre os finais do IV milénio e os inícios do III milénio a.C., com término na Idade do Bronze. No início do século XXI o autor escreve um importante artigo demonstrando a diferença entre Artes Atlântica e Esquemática no Noroeste, em especial no que concerne a acessibilidades e audiências (Bradley, 2002).

A designação de Arte Atlântica vem amplamente sendo adotada por muitos autores em Portugal, mas ainda sofre de certa resistência no território Galego. Já Alves (2003, 2009), perante o que se considera a originalidade da Arte Atlântica no Noroeste (com motivos zoomorfos e armas) preferiu o termo de arte de tradição atlântica. Esta autora recua a origem da Arte Atlântica para o IV milénio a.C., por comparação de alguns motivos com os existentes na arte megalítica. Esta cronologia foi, posterior e paulatinamente, adotada por vários outros autores (Dinis e Bettencourt, 2009; Santos-Estévez, 2012; Bettencourt, 2009; 2013; Cardoso, 2015, entre outros).

No que diz respeito à Arte Esquemática de ar livre, a necessidade da sua revisão tem sido defendida por alguns autores, nomeadamente Jorge (1986) e Alves e Reis (2009). Tal foi timidamente tentado por Cardoso (2015) e por Cardoso e Bettencourt (2015), para o caso específico da bacia do Ave, e por Bettencourt (2017a, 2017b) em termos mais generalistas. A subdivisão da Arte Esquemática de ar livre contempla, nestas propostas, duas fases. A primeira, inserível no Neolítico e no Calcolítico, inclui motivos antropomorfos esquemáticos, reticulados simples e complexos, soliformes e círculos simples. A segunda, inserível na Idade do Bronze e persistindo até à Idade do Ferro, caracteriza-se pela presença de motivos em "U'" ou semicirculares, com ou sem sulco e covinha central, e representações de falos.

Nestes trabalhos Bettencourt (2017a, 2017b) adota, ainda, a expressão de Arte Atlântica apenas para a sua primeira fase, precisamente a que tem afinidades com as artes identificadas no Reino Unido e Irlanda e considera que os restantes motivos existentes no Noroeste ibérico (armas, cervídeos, equídeos, barquiformes, círculos segmentados, paletas, podomorfos, entre outros) fazem parte de um ter- 
ceiro grupo, que terá surgido nos inícios da Idade do Bronze e que acompanha as alterações estruturais socioeconómicas ocorridas naquele período (Bettencourt, 2020). Este terceiro grupo, de difícil definição, mas designado de figurativo (Bettencourt, 2019), comporta motivos que podem estar associados a grafismos de Arte Atlântica ou de Arte Esquemática, mas que podem ocorrer em afloramentos ou áreas novas.

Atendendo a estes pressupostos, o objetivo geral deste trabalho é o estudo de um destes motivos em específico, os círculos segmentados gravados, cuja presença é rara no Noroeste Ibérico. A área escolhida para o seu estudo corresponde aos cursos inferior e médio da bacia do rio Lima, no Noroeste de Portugal, e ribeiras litorais que a integram.

$\mathrm{Na}$ perspetiva de contribuir para o estudo destes símbolos, definem-se como objetivos específicos deste trabalho (1) a inventariação dos lugares com esta simbologia no território delimitado; (2) o estudo da sua distribuição espacial, à macro escala de análise, com o intuito de identificar eventuais padrões de distribuição topográfica; (3) a descrição dos afloramentos gravados, à micro escala de análise, por forma a observar como se relacionam os círculos segmentados com outros símbolos, eventualmente contemporâneos, ou com símbolos típicos de outros estilos de arte rupestre e de outras cronologias; (4) o estudo da sua inter-relação com outros contextos arqueológicos considerados contemporâneos; e (5) o estudo da sua inter-relação com recursos naturais mineiros, nomeadamente o estanho, o ouro e a prata.

\section{METODOLOGIA}

Este trabalho foi iniciado com a pesquisa de gabinete através da consultou de bibliografia da especialidade sobre as problemáticas das artes rupestres do Noroeste Ibérico. Esta pesquisa foi alargada, também, a todas as publicações que contemplavam afloramentos gravados da bacia do Lima para identificar a presença de círculos segmentados. Recorreu-se, igualmente, ao Corpus Virtual de Arte Rupestre do Noroeste - CVARN (www.cvarn.org), assim como à base de dados que lhe deu origem e que tem sido várias vezes atualizada (ainda que muitas dessas atualizações ainda não estejam disponíveis online). Foi, também, consultada cartografia, nomeadamente, as Cartas Militares de Portugal folhas nํ..27 e 40, à esca- la 1:25000, e as Cartas Geológicas de Portugal, folhas no. . 1-C, 1-D, 5-A e 5-B, à escala 1:500oo, relativas à área de influência da bacia do rio Lima. $\mathrm{O}$ trabalho de campo foi limitado, atendendo à conjuntura atual imposta pela presença do vírus COVID-19, mas foi realizada a visita a alguns afloramentos gravados, como Chã da Rapada 3 (Ponte da Barca). Com esta visita foi possível recolher dados que se mostraram pertinentes para o presente estudo. Por fim, a utilização de Sistemas de Informação Geográfica (SIG) auxiliou na análise da distribuição espacial dos afloramentos gravados e da sua relação com diferentes variáveis consideradas.

Teoricamente foi tida em consideração que o conhecimento é subjetivo e interpretativo, assente num conjunto de dados empíricos e que a arte rupestre é uma manifestação das comunidades que reflete o seu universo ideológico e a sua interação com o espaço que vivenciaram e experienciaram.

\section{OS DADOS}

\subsection{Inventário}

O inventário teve em conta os seguintes sete critérios: (1) localização administrativa; (2) coordenadas geográficas decimais do local segundo o sistema WGS 84 e altimetria; (3) localização física e ambiental dos afloramentos; (4) contexto arqueológico; (5) descrição dos afloramentos e da distribuição dos motivos; (6) descrição da técnica de gravação observada; e (7) estado de conservação.

\subsubsection{Concelho de Arcos de Valdevez}

\section{Gião 1 - rocha 1 e rocha 15}

Lugar: Gião; Freguesia: Cabana Maior.

Latitude: 40.605318. Longitude: -8.135474.

Altitude: cerca de 800 metros.

Localização física e ambiental: o sítio arqueológico localiza-se na margem direita do rio Lima e permite ser visualizado a grande distância. Trata-se de uma bacia de receção do ribeiro do Gião «encimada por dois cumes [...] unidos por uma cumeada mais baixa» (Alves, 2013a, p. 155), com boa visibilidade para o vale do Lima. Corresponde a uma área de lameiros, com inúmeros afloramentos e blocos erráticos graníticos cujo uso ancestral e persistente no tempo ainda hoje pode ser verificado, através de práticas de pastorícia (Alves, 2013a).

Descrição: o sítio do Gião corresponde a um espa- 
ço onde ocorrem mais de 100 afloramentos gravados, predominantemente com motivos inseríveis na Arte Esquemática de ar livre, entre outros possivelmente de época histórica. Foi descoberto por António Martinho Baptista. Este espaço encontra-se dividido em dois núcleos: Gião 1 e Gião 2, sendo na rocha 1 do núcleo 1 que se encontra o afloramento com os círculos segmentados (objeto de estudo deste trabalho).

A rocha 1 do Gião corresponde a um grande afloramento onde se inscreve um singular motivo antropomórfico em fi, com a cabeça marcada por uma covinha, braços adossados a dois retângulos da extremidade dos quais saem duas mãos, com palma e dedos bem marcados (Baptista, 1986) (Figura 1). Neste afloramento ocorrem, ainda, muitos motivos inseríveis na Arte Esquemática, como antropomorfos e quadrados e retângulos segmentados. Destaca-se, ainda, a presença de ovais segmentadas, covinhas, círculos simples e cruciformes, entre os quais dois círculos segmentados em quatro partes. O outro círculo segmentado encontra-se no meio de várias composições reticuladas, ocupando o topo do já referido motivo antropomórfico em fi com a cabeça marcada por uma covinha. Os segmentos de ambos os círculos orientam-se na mesma direção, ainda que para já não tenha sido possível verificar in loco essa direção.

$\mathrm{Na}$ rocha 15 do Gião observa-se apenas um círculo segmentado posicionado no centro do afloramento, na sua pendente oeste, estando os seus segmentos orientados para NNE-SSO e para E-O. Neste afloramento existem, ainda, vários motivos ovais, quadrados e retângulos, todos eles segmentados, podendo por vezes incorporar figuras complexas, além de cruciformes.

A técnica de gravação é o picotado seguido de abrasão. Estado de conservação: razoável em termos arqueológicas e excelente em termos paisagísticos e ambientais (Sá, 2015).

Bibliografia: Baptista, 1983-84; Alves, 2013; Sá, 2015.

\section{Pedra da Costa 1}

Lugar: Castro; Freguesia: Álvora.

Latitude: 41.937358. Longitude: -8.452223 .

Altitude: cerca de 238 metros.

Localização física e ambiental: ocupa um pequeno patamar no alto da vertente oeste do Monte do Castro, sobranceiro ao ribeiro de Frades (Figura 2), afluente do rio Vez e para o qual tem boa visibilidade.
O local tem intensa vegetação arbustiva, composta por giestas. Nas proximidades há algumas árvores. Contexto arqueológico: no topo do Monte do Castro ocorreu ocupação datada da Idade do Bronze Final (Bettencourt, 1988), entre outras da Idade do Ferro (Castro de Álvora).

Descrição: A Pedra da Costa I está classificada como Imóvel de Interesse Público (IIP) e, apesar de ser conhecida desde a década de 1980 (Baptista, 1986a, 1986b), só foi alvo de descrição mais detalhada por Sá (2015). Segundo a autora, corresponde a um afloramento granítico de cor cinzenta escura, com manchas esbranquiçadas (dada a ação dos incêndios). De grandes dimensões, encontra-se pouco destacado do solo. A sua superfície é tendencialmente aplanada, ainda que ligeiramente inclinado para oeste, e tem uma concavidade natural. Mede 4,63 $\mathrm{m}$ de comprimento por 3,66 m de largura, estando fraturado a nascente.

A sua superfície superior está profusamente gravada com composições circulares e nuvens de pontos. $\mathrm{Na}$ extremidade sul encontra-se um círculo concêntrico de duas voltas com o interior composto por nuvens de pontos. A partir do centro deste motivo sai um sulco longo e curvilíneo que percorre parte da superfície gravada e que se vai unir a um círculo concêntrico de duas voltas, existente, sensivelmente, a meio do afloramento. Deste sulco parte outro que vai sobrepor-se a uma figura retangular de cantos arredondados, preenchida por nuvens de pontos, que se encontra na extremidade oeste do afloramento. Há ainda a registar, a oeste, um círculo segmentado em quatro partes (Figura 2). Uma vez que este afloramento se encontra parcialmente coberto por sedimentos a su-sudeste e nor-nordeste, é provável que existam outras gravuras ainda soterradas. A técnica de gravação é o picotado seguido de abrasão.

Estado de conservação: O afloramento encontra-se com a cor alterada devido à acção de incêndios e pela presença de líquenes que, por sua vez, cobrem parte das gravuras. Existe ainda uma fratura do afloramento orientada a este (Sá, 2015, p. 43).

Bibliografia: Baptista, 1986a; 1986b; Sá, 2015.

\subsubsection{Concelho de Ponte da Barca}

\section{Chã da Rapada $3^{4}$}

Lugar: Britelo; Freguesia: Britelo.

4. Segundo a designação de Alves, 2012. 
Latitude: 41.83452. Longitude: -8.281541.

Altitude: cerca de 300 metros.

Localização física e ambiental: a Chã da Rapada ocupa o interior do Parque da Peneda-Gerês, situando-se numa plataforma da vertente noroeste da serra Amarela, na margem direita do rio Lima. Trata-se de uma área com densa concentração de afloramentos graníticos direcionados de noroeste para sudeste. Do local a visibilidade é reduzida no sentido norte e sul - onde se encontram as vertentes das serras do Soajo e Amarela -, ao contrário do que ocorre para poente, onde a visibilidade é mais alargada, nomeadamente, para o Monte do Castelo de Aboim da Nóbrega, já no concelho de Vila Verde (Bettencourt 2013a).

Contexto arqueológico: a cotas superiores há a registar a necrópole megalítica de Britelo.

Descrição: Neste sítio arqueológico foram identificadas inúmeras gravuras rupestres, algumas delas alvo de decalques e descritas (Baptista, 1986a, 1986b, 1997; Martins, 2006; Alves, 2012). Em 2012, Alves publica o decalque do que designa por rocha 3 da Chã da Rapada, descrevendo os motivos presentes e a sua disposição no afloramento. Trata-se de um afloramento de cor acinzentada, rasante ao solo, estando perto de outros afloramentos gravados. Tem cerca de 5 metros no sentido nordeste/sudoeste e cerca de 4,50 metros no sentido noroeste/sudeste.

Encontra-se profusamente gravado, possuindo alguns motivos que se inserem na Arte Esquemática, entre outros, mais raros e atípicos (Figura 3). No contexto da Arte Esquemática podem der inseríveis dois quadrados segmentados, cinco sulcos meandriformes rematados por uma covinha numa das extremidades (serpentiformes?) e dois eventuais antropomorfos, muito esquematizados. No âmbito de outros motivos há a registar, ainda, sete pentagramas, cinco quadrados concêntricos (por vezes segmentados em alguns lados, podendo ter sido transformados em tabuleiros de jogo), inúmeras covinhas um pouco por todo o afloramento, por vezes, sobrepondo-se aos quadrados concêntricos, um motivo sub-retangular com uma extremidade triangular de onde sai um sulco que se sobrepõe a um quadrado concêntrico, e três cruzes latinas e uma grega. Neste conjunto há a destacar dois círculos segmentados, algo distantes entre si. Em visita ao local verificou-se que um deles, situado na pendente sul, foi gravado entre dois quadrados segmentados, a que se associou um conjunto de cinco pentagramas. O outro, posicionado na extremidade oposta, na pendente nordeste, foi associado a outros dois pentagramas. Nesta área do afloramento, em posição periférica, encontra-se uma figura retangular segmentada de forma irregular que poderá ser contemporânea dos círculos segmentados. Os segmentos que subdividem estes motivos estão orientados de forma distinta. O círculo segmentado posicionado na vertente sul possui os seus segmentos orientados para norte-sul e este-oeste, encontrando-se bastante erodido. O círculo segmentado que se situa na pendente nordeste, possui os seus segmentos orientados para noroeste-sudeste/sudoeste-nordeste.

A técnica de gravação utilizada foi o picotado seguido de abrasão.

Estado de conservação: Razoável.

Bibliografia: Alves, 2012; Bettencourt, 2014 e dados inéditos.

\subsubsection{Concelho de Viana do Castelo}

\section{Breia 1}

Lugar: Portela; Freguesia: União de Freguesias de Cardielos e Serreleis.

Latitude: 41.721667. Longitude: 8.733333 .

Altitude: cerca de 54 metros.

Localização física e ambiental: ocupa um patamar na base da vertente este-sudeste do Monte de São Silvestre, sobranceiro a um curso de água intermitente que vai desaguar à ribeira de Nogueira, afluente do Lima. Trata-se, ainda, de uma área profusamente irrigada pelos cursos de água intermitentes que se formam nas partes altas do monte, sendo frequente que o afloramento gravado fique inundado. Descrição: a Breia 1 foi encontrada por Francisco Queiroga e estudada por Bettencourt (2013, 2014) e por Bettencourt e Santos-Estévez (2018). Caracteriza-se por ser um afloramento de granito de grão médio, rasante ao solo, de cor esbranquiçada e com algumas manchas negras devido à ação do fogo sobre os líquenes. Possui algumas manchas alaranjadas, possivelmente relacionadas com a presença de nódulos de ferro oxidado.

Este afloramento é de grandes dimensões $(16,40$ metros de comprimento, na direção este-oeste, por 11,8 metros de largura, no sentido norte-sul). Encontra-se profusamente gravado com motivos de Arte Atlântica clássica, entre outros motivos que se afastam desta gramática decorativa (Bettencourt, 2017a, 2017b). Segundo Bettencourte Santos-Estévez (2018, 
p. 27) subdivide-se em sete painéis, possuindo círculos segmentados gravados nos painéis 1,2 e 7 . O painel 1 possui um contorno triangular, posicionando-se a nordeste do afloramento, na área mais elevada. Apresenta uma densidade de motivos circulares, unidos por linhas sinuosas que parecem estar em conexão com uma figura idoliforme. Esta figura tem um contorno trapezoidal, fazendo lembrar uma figura antropomórfica, estando segmentada no seu interior. A maioria dos motivos são círculos concêntricos, com covinha central e de diferentes dimensões. De alguns destes motivos saem sulcos para as diaclases ou extremidades do afloramento. Há, ainda, dois sulcos meandriformes isolados na extremidade norte, podendo ser considerados serpentiformes. $\mathrm{Na}$ base do afloramento surgem quatro equídeos esquemáticos isolados, orientados a nascente. A norte do painel, encontra-se um quadrúpede muito esquemático, possivelmente um cervídeo. O seu dorso parece ter sido aproveitado como segmento de um círculo segmentado (Bettencourt e Santos-Estévez, 2018, p. 28), motivo este que se encontra a norte do painel, estando os seus segmentos orientados para noroeste-sudeste e nordeste-sudoeste (Bettencourt e Santos-Estévez, 2018, p. 29). O painel 2, de contorno hexagonal, fica a uma cota mais baixa em relação ao painel 1. Tem 4,30 metros sentido este-oeste e 3,50 sentido norte-sul. Caracteriza-se por ter, na sua maioria, composições circulares inseríveis na Arte Atlântica (Bettencourt, 2013; 2014; Bettencourt e Santos-Estévez, 2018, p. 28). No quadrante sudeste, surgem, pelo menos, quatro círculos segmentados, dois deles muito erodidos. Três destes motivos encontram-se na parte inferior do painel e um localiza-se na parte central do mesmo. Os seus segmentos orientam-se de noroeste-sudeste para sudoeste-nordeste, no que diz respeito dos dois casos posicionados na área inferior a sudeste do painel. Os outros dois casos localizam-se na parte inferior e central do painel, a este/sudeste, na periferia dos restantes motivos que nele figuram. Nestes, apenas se consegue percecionar a orientação dos segmentos de um dos casos, estando estes orientados de nordeste-sudoeste e de este-oeste.

O painel 7, descoberto e descrito recentemente (Bettencourt e Santos-Estévez, 2018, p. 31), situa-se na extremidade sudeste do afloramento e é mais elevado do que os painéis 3, 5 e 6 . Mede 6,30 metros no sentido Este-oeste por 4,20 metros no sentido norte-sul, embora esteja parcialmente fraturado. Tal- vez com exceção de um círculo, neste painel não se encontram motivos de Arte Atlântica clássica, mas apenas motivos "figurativos" com base na conceção de Bettencourt (2017a, 2017b, 2019). Observam-se, também, dois quadrúpedes, um esquemático e um semi-naturalista. O quadrúpede esquemático apresenta hastes ou orelhas pronunciadas e dirige-se para nordeste e transporta um símbolo circular no dorso. Está associada a um círculo segmentado, com os segmentos orientados para nordeste-sudoeste e para noroeste-sudeste. De destacar, ainda, a gravação de um podomorfo calçado neste painel.

A técnica de gravação utilizada foi a percussão seguida de abrasão, excetuando a gravação de um equídeo, que ocorreu em baixo-relevo. Alguns círculos segmentados, por exemplo, o do painel 1, têm um sulco menos largo do que a maioria dos motivos atlânticos. Estado de conservação: razoável, no geral, mas com áreas muito erodidas e com estalamentos antigos (Bettencourt e Santos-Estévez, 2018, p. 25).

Bibliografia: Bettencourt, 2013; 2014; Bettencourt e Santos-Estévez, 2018.

\section{Breia 5}

Lugar: Portela; Freguesia: União de Freguesias de Cardielos e Serreleis.

Latitude: 41.721667. Longitude: 8.733333.

Altitude: cerca de 86 metros.

Localização física e ambiental: localiza-se numa depressão, a meio da vertente este-sudeste do Monte São Silvestre, numa zona profundamente irrigada, por onde passa um curso de água intermitente. Trata-se de uma área com um substrato geológico predominantemente granítico onde ocorrem, também, diversos veios de quartzo leitoso. Nas proximidades encontram-se jazidas primárias e secundárias de estanho. O solo apresenta uma escassa profundidade, com vegetação predominantemente arbustiva (tojo, giesta) e herbácea. Atualmente a utilização do terreno é florestal, tendo sido área de pastoreio, até ao século XX. O local também foi usado para corte de pedra manual. Possui visibilidade fechada em todas as direções. com a exceção do quadrante sul, onde se pode observar parte do vale do rio Lima (Bettencourt e Santos-Estevez, 2018, p.55).

Descrição: recentemente publicado por Bettencourt e Santos-Estévez (2018), embora tivesse sido referido em vários trabalhos, com mais ou menos detalhe (Bettencourt, 2017a, 2017b, 2018), trata-se de um afloramento de granito de grão médio, de cor acin- 
zentada, orientado de noroeste para sudeste, de contorno sub-retangular, com elevação na parte central e em grande parte do seu eixo maior, de onde partem alguns declives acentuados para todos os quadrantes, excetuando o noroeste. É de grandes dimensões: 13 metros de comprimento, por 4 metros de largura e 1 metro de altura máxima.

O afloramento possui dois painéis, incluindo apenas no painel 1 a gravação de um círculo segmentado. Com efeito, este painel distribui-se no topo do afloramento e tem os seus declives orientados a sudoeste, sul e sudeste, numa área de 6,4 metros de comprimento por 4 metros de largura.

Neste painel, Bettencourt e Santos-Estévez (2018, p. 55-57) contabilizaram cerca de onze equídeos semi-naturalistas e um esquemático. Oito desses equídeos estão orientados para noroeste e, pelo menos três, estão orientados para sudeste. No topo de afloramento parecem existir mais dois equídeos incompletos. Em associação com o grupo de equídeos que se dirigem para sudeste, surge um círculo segmentado, com os segmentos orientados para nordeste-sudoeste e noroeste-sudeste (Figura 4).

A técnica de gravação utilizada foi a percussão seguida de abrasão.

Estado de conservação: Este afloramento encontra-se em estado grave de degradação, com vários estalamentos devido à ação de sucessivos incêndios. Bibliografia: Bettencourt 2017a, Bettencourt 2017b, Bettencourt e Santos-Estévez, 2018.

\section{Breia 9}

Lugar: Portela; Freguesia: União de Freguesias de Cardielos e Serreleis.

Latitude: 41.721667. Longitude: 8.733333 .

Altitude: cerca de 86 metros.

Localização física e ambiental: ocupa uma plataforma na parte inferior da vertente este-sudeste do Monte São Silvestre. Trata-se de uma área com substrato geológico predominantemente granítico onde ocorrem, também, diversos veios de quartzo leitoso. Nas proximidades encontram-se jazidas primárias e secundárias de estanho. O solo apresenta uma escassa profundidade, com vegetação arbustiva (tojo, giesta), arbórea (eucalipto) e herbácea. Atualmente a utilização do terreno é florestal, tendo sido área de pastoreio até ao século XX. A visibilidade para norte e noroeste é fechada, ainda que para oeste se aviste a vertente íngreme do Monte de São Silvestre. O vale do Lima é visível desde entre os quadrantes sudoeste e este (Bettencourt e Santos-Estévez, 2018, p. 70). Descrição: afloramento descoberto e publicado recentemente (Bettencourt e Santos-Estevez, 2018, p. 70-71). É de granito de grão médio, de cor acinzentada, de médias dimensões, algo destacado do solo. Tem uma parte mais elevada e aplanada, que desenvolve um declive para sul, este e oeste e mais acentuada para noroeste. Possui uma concavidade na orientação do afloramento. Atualmente, passa-lhe por cima um muro de divisão de propriedade, orientado de noroeste para sudeste.

O afloramento possui dois painéis, estando os círculos segmentados gravados, apenas, no painel 1 .

O painel 1 encontra-se na extremidade sudeste do afloramento, presente na área aplanada e dos declives norte e nordeste. Apresenta uma figura oval com eixo nordeste-sudoeste, subdividido por um sulco com covinha na extremidade sudoeste. No seu interior existem três sulcos perpendiculares que segmentam a figura. $\mathrm{Na}$ extremidade nordeste sai um sulco que se liga a um motivo tendencialmente circular. Dentro deste último encontram-se dois círculos segmentados, unidos entre si e partilhando um sulco na convergência dos mesmos. O círculo segmentado ligeiramente maior tem os seus segmentos orientados para norte-sul e este-oeste e os segmentos do círculo segmentado mais pequeno estão orientados para nordeste-sudoeste e noroeste-sudeste. Nas imediações destes motivos ocorre o que parece ser outro círculo segmentado, com os seus segmentos orientados para noroeste-sudeste e nordeste-sudoeste, apresentando-se bastante erodido e estando associado a um círculo aberto. A vertente noroeste, com declive bastante acentuado, inclui um soliforme rodeado por um círculo incompleto. Dele sai um sulco que se prolonga até à diáclase, como se estivesse a entrar dentro do afloramento, e volta a sair através de um sulco divergente (Figura 4).

Estas gravuras foram feitas através da técnica de percussão seguidas de abrasão.

Estado de conservação: Razoável.

Bibliografia: Bettencourt e Santos-Estévez, 2018.

\section{Figueiró 1 e 2}

Lugar: Troviscoso; Freguesia: Carreço.

Latitude: 41.737222 . Longitude: -8.858889 .

Altitude: cerca de 60 metros.

Localização física e ambiental: o grupo de gravuras rupestres do Figueiró ocupa numa plataforma da base da vertente oeste da serra de Santa Luzia, em 
local com grande visibilidade para a plataforma litoral e o Oceano Atlântico, a oeste, sudoeste e sul, e para a colina de Montedor, a norte e a noroeste. Nos restantes quadrantes erguem-se, imponentes, as vertentes íngremes da serra de Santa Luzia. Atualmente estes afloramentos encontram-se no meio do casario de Troviscoso, no interior de uma propriedade privada (Bettencourt e Santos, 2014).

Contexto arqueológico: existência do túmulo da Idade do Bronze da Cova da Moura, em Carreço (Viana, 1955; Bettencourt, 2013).

Descrição: Este sítio foi publicado por Viana (1960) e contextualizado por Bettencourt e Santos (2014). Inicialmente era constituído por três afloramentos gravados, porém restam apenas dois - Figueiró 1 e 2. Figueiró 1 corresponde a um afloramento de granito de grão grosseiro, destacado do solo, com cerca de 5,50 metros de altura por cerca de 10 metros de comprimento, no sentido este-oeste. Nos desenhos de Viana (1960) observa-se um círculo concêntrico, em relevo, de estilística atlântica clássica, dois círculos simples, quatro motivos ovalados ou grosseiramente retangulares preenchidos por grelhas irregulares e 8 círculos segmentados. Um deste localiza-se na pendente sul do afloramento, quatro na pendente este e três na pendente oeste. Sete destes motivos segmentam-se em quatro partes enquanto um se segmenta em cinco partes (Figura 5).

Figueiró 2, relativamente perto de Figueiró 1, também é de grandes dimensões e apresenta grande declive. Encontra-se bastante degradado devido a atos de vandalismo. Segundo Viana (1960) os motivos existentes consistiam em grandes sulcos lineares e sinuosos, covinhas, uma composição quadrangular reticulada, uma espiral, uma figura retangular internamente segmentada e vários círculos segmentados. A técnica utilizada parece ter sido a percussão seguida de abrasão e, num caso, o alto relevo.

Estado de conservação: Desconhecido.

Bibliografia: Viana, 196o; Bettencourt e Santos 2014.

\section{Laje da Churra}

Lugar: Paçô; Freguesia: Carreço.

Latitude: 41.756353. Longitude: 8.860318.

Altitude: cerca de 80 metros

Localização física e ambiental: a Laje da Churra situa-se no sopé da vertente oeste da serra de Santa Luzia. Fica sobranceira ao ribeiro da Fonte Quente, que desagua diretamente no oceano.

Contexto arqueológico: Túmulo da Idade do Bron- ze da Cova da Moura, em Carreço (Viana, 1955; Bettencourt, 2013); povoado do Bronze Final de Santo António, em Afife, a cerca de 2,7 km (Bettencourt, 2013; Oliveira e Bettencourt, 2020).

Descrição: A Laje da Churra foi descoberta pelo Padre Lourenço em 1973 e estudada monograficamente por Santos (2014). Trata-se de um afloramento de granito porfiróide, de grão fino a médio fino, de grandes dimensões, sobrelevado, sendo aquele que tem maior número de gravuras rupestres na Serra da Santa Luzia. Isto traduz-se num total de 19 painéis, sendo os painéis 2, 3, 5, 6, 8 e 11b os que contêm círculos segmentados. Trata-se, de uma forma geral, de um afloramento com escassíssimos motivos de gramática atlântica (espirais, semicírculo concêntrico e um esteliforme) e, pelo contrário, inúmeros motivos figurativos segundo a conceção de Bettencourt (2017a, 2017b). Entre muitos outros destacam-se diferentes tipos de barquiformes, armas (alabardas), ferramentas (machados), animais marinhos (golfinhos), animais terrestres (equídeos), antropomorfos, paletas de diferentes tipos, covinhas com apêndices, covinhas.

O painel 2 situa-se na parte norte do afloramento. As gravuras neste painel são pouco percetíveis e materializam algumas covinhas dispersas, podendo ser associadas a sulcos orientados para várias direções. O painel inclui uma nuvem de pontos a sudeste associada a uma paleta. Os motivos principais do painel são as composições circulares (Santos, 2014, p. 52). Por fim, surge um círculo de grandes dimensões segmentado em três partes, localizado sensivelmente no centro do painel. Este motivo tem os seus segmentos orientados para noroeste-sudeste e para nordeste. A este motivo estão associados dois sulcos rematados por covinhas, que se unem formando uma figura complexa. Este motivo parece ter sido sobreposto a sudeste (Figura 6).

O painel 3 localiza-se no extremo nordeste do afloramento, numa área de declive. Neste painel os círculos segmentados aparecem em grande número, sendo nove no total (Santos, 2014, p. 53). Cinco destes motivos situam-se no centro do painel e apresentam-se segmentados em quatro partes, estando os seus segmentos orientados de nordeste-sudoeste e de noroeste-sudeste. $\mathrm{Na}$ extremidade este há mais dois círculos segmentados: um segmentado em quatro partes, com sulco exterior, estando os seus segmentos orientados para nordeste-sudoeste e este-oeste, e um outro motivo que inicialmente foi segmentado 
em quatro partes, porém, fruto de adições, passou a ser segmentado em seis partes, estando os seus segmentos orientados para noroeste-sudeste e sudoeste-nordeste. Na extremidade oeste do painel, observa-se um círculo segmentado com sulco exterior, com os segmentos orientados para noroeste-sudeste e sudoeste-nordeste. Existe ainda nesta área um outro círculo segmentado, com sulco exterior, apenas com um segmento, estando este orientado para noroeste-sudeste. Associados a estes motivos existem paletas, antropomorfos, quadrúpedes esquemáticos (um canídeo e um equídeo montado), um semicírculo concêntrico, covinhas, covinhas associadas a sulcos, entre outros sulcos emaranhados (Figura 6). O painel 5 ocupa o topo do afloramento. A sua iconografia gira em torno de possíveis paletas, covinhas, covinhas associadas a sulcos, um possível soliforme em baixo relevo e dois círculos segmentados (Santos, 2014, p. 55). Destes últimos, um ocupa a extremidade nordeste, estando segmentado em seis partes e os seus segmentos orientados para noroeste-sudeste, sudoeste-nordeste e su-sudoeste-nor-nodeste; na extremidade sudoeste surge outro círculo, também segmentado em quatro partes, com os seus segmentos orientados para noroeste-sudeste e sudoeste-nordeste, estando, igualmente, associados a paletas e covinhas (Figura 6).

O painel 6 posiciona-se na pendente este em relação aos painéis 3,5 e 7 . Este painel inclui uma complexidade de motivos. A nascente figuram três círculos segmentados: dois subdivididos em quatro partes, estando os segmentos orientados para nordeste-sudoeste e noroeste-sudeste; um segmentado em três partes, estando o sulco completo orientado para nordeste-sudoeste e o sulco parcial para sudeste-noroeste. Estes motivos estão associados a um conjunto de sulcos que materializam figuras complexas, talvez devido a sobreposições, barquiformes de tipo canoa, um golfinho, covinhas, covinhas associadas a sulcos e uma espiral interrompida (Santos, 2014, p. 56) (Figura 6).

O painel 8 encontra-se numa zona de declive. A norte fica o painel 6 e, a noroeste e oeste, o painel 7 . Possui dois círculos segmentados em quatro partes. Ambos possuem um sulco exterior. O sulco vertical de ambos está sensivelmente orientado para norte-sul, enquanto o sulco horizontal do círculo inferior está orientado para oeste-este e o do círculo superior para nordeste-noroeste. Estes motivos encontram-se associados a covinhas, sulcos rectilíneos, orien- tados para este-oeste. De referir, também, a presença de um motivo em forma de "T" (Santos, 2014, p. 58). O painel 11 está subdividido em três, sendo apenas o painel $11 b$ o que possui círculos segmentados, sensivelmente a meio da pendente do painel 11. A sua iconografia é variada, observando-se quatro grupos de motivos. Na parte mais elevada, a norte, ocorrem, sobretudo, sulcos, covinhas associadas a sulcos, uma espiral, composições circulares e um barquiforme de tipo canoa. Destaca-se um círculo segmentado em sete partes, localizado numa zona central deste grupo, a norte. Os segmentos encontram-se orientados para nordeste-sudoeste, noroeste-sudeste, sudoeste-nordeste e este-oeste. Figura, também, um outro círculo segmentado subdividido em três partes, com os segmentos orientados para noroeste-sudeste e sudoeste-nordeste. Associados a estes dois círculos segmentados ocorre uma espiral. A sul deste painel ocorrem outros motivos, heterogéneos, alguns deles podendo ser produto de sobreposições. Destacam-se uma espiral, um serpentiforme, uma paleta circular com cabo meandriforme, quadrúpedes, barquiformes de diferentes tipologias e inúmeras covinhas, por vezes alinhadas (Santos, 2014, p. 63).

A técnica utilizada nos variados painéis foi basicamente a percussão seguida de abrasão correspondendo a $98 \%$ da gravação neste afloramento. Os restantes motivos são em baixo relevo.

Estado de conservação: Razoável.

Bibliografia: Santos, 2014.

\section{DISCUSSÃO DOS DADOS E INTERPRETAÇÕES}

Foram inventariados dez afloramentos gravados com círculos segmentados distribuídos por seis núcleos distintos e posicionados na bacia do Lima, três deles no curso médio e outros três no curso inferior (Figura 7). No curso médio há três núcleos e quatro afloramentos de caráter interior; são eles: Chã da Rapada 3, situada na margem esquerda do rio Lima, e Gião 1 (rochas 1 e 15) e Pedra da Costa 1, ambos situados na margem direita do rio Lima. Uma das características comum aos três sítios é a sua localização em altitudes elevadas, oscilando estas entre os 230 e os 800 metros, sendo Gião 1 o que se encontra mais elevado. Chã da Rapada 3 e Pedra da Costa 1 caracterizam-se por estar no topo ou a meio de vertentes viradas a noroeste e oeste, enquanto Gião 1 está localizado na base da bacia de receção do ribeiro 
do Gião. Em todos estes locais há solos irrigados nas proximidades. Chã da Rapada 3 está próximo do rio Froufe. Pedra do Costa 1 está, de igual forma, associado ao vale do ribeiro de Frades, existente nas suas proximidades e para o qual tem visibilidade. Gião 1 caracteriza-se por estar associado à nascente do ribeiro do Gião, em área com inúmeros lameiros e com controlo visual muito superior aos outros dois afloramentos, sobre o meio circundante.

No curso inferior do rio Lima existem três núcleos gravados com círculos segmentados, distribuídos por seis afloramentos, a saber: Breia 1, 5 e 9, Figueiró 1 e 2 e Laje da Churra, todos eles situados na margem direita do rio Lima (Figura 7). A característica que impera em todos estes afloramentos é a sua localização, em locais de pouca altitude, que oscilam entre 50 a 100 metros.

Os afloramentos do núcleo da Breia localizam-se quer na base da vertente sudeste do Monte de São Silvestre (Breia 1) quer a meio da vertente sudeste (Breia 5 e 9), estando vinculados com cursos de água intermitentes e lameiros. Já a Laje da Churra e Figueiró 1 e 2 localizam-se no sopé da vertente oeste da serra de Santa Luzia, também em áreas profusamente irrigadas e vinculadas com a plataforma litoral. De salientar a Laje da Churra, na base da qual passa o ribeiro da Fonte Quente.

À micro escala de análise pode afirmar-se que os círculos segmentados nunca aparecem como motivo único nos afloramentos onde se manifestam. Num caso aparecem na periferia de motivos de Arte Atlântica clássica (Pedra da Costa 1); noutro caso surgem num afloramento que, sendo gravado maioritariamente com Arte Atlântica clássica, apresenta igualmente outros motivos, como equídeos, podomorfos, etc. (Breia 1); em três casos surgem em afloramentos com escassos motivos atlânticos clássicos e outros tipos de motivos (Laje da Churra, Figueiró I e 2); noutros três casos ocorrem em afloramentos com motivos esquemáticos (rochas 1 e 15 de Gião 1 , e Chã da Rapada 3); num caso associam-se a equídeos sub-naturalistas (Breia 5) e noutro caso associam-se a motivos de difícil classificação (Breia 9). Assim, parece não existir uniformidade em relação aos motivos ou gramáticas estilísticas a que se associam. No entanto, verifica-se que, nos casos em que ocorrem em afloramentos com motivos atlânticos clássicos e esquemáticos, localizam-se quer na periferia dos painéis (Breia 1, Pedra da Costa 1) quer em posição que parece quebrar a lógica ou a harmonia inicial do conjunto gravado (rochas 1 e 15 de Gião 1 e Chã da Rapada 3), como se tivessem sido gravados posteriormente.

Nos casos em que surgem associados a equídeos sub-naturalistas e a motivos raros que podem ser contemporâneos, observa-se diferenças, sendo que a característica que se destaca é o grau de integração dos círculos segmentados nas composições. Tal é o caso da Breia 5, onde vários equídeos se articulam com um círculo segmentado que, por se encontrar numa posição superior aos equídeos, parece funcionar com um guia, indiciando a hipótese de materializarem o culto do cavalo solar existente noutras áreas da Europa Atlântica (Bettencourt e Santos-Estévez, 2018, p. 57; Bettencourt, 2019). Na Breia 9, os dois círculos segmentados integram uma composição, encontrando-se dentro de um motivo circular, mas com os segmentos orientados em direções diferentes. A esta composição associa-se um soliforme, podendo deste modo existir uma conexão entre os dois motivos, indiciando, novamente, a metaforização de um culto solar.

No caso da Laje da Churra constata-se que a disposição dos círculos segmentados nos painéis adota duas formas distintas: na periferia e no centro das composições. Nos painéis onde surgem numa área central, assumem o papel principal da composição, estando apenas associados a covinhas e sulcos (painéis 2 e 8). Com efeito, há composições na qual a sua expressão é maioritária (painel 3). Nos painéis onde estes motivos surgem numa área periférica (painéis 5 e 6), observa-se que existe um distanciamento propositado em relação a outros motivos e uma certa lógica na composição, onde os círculos segmentados parecem estabelecer, intencionalmente, os limites das composições. Bettencourt (2017a, 2017b, 2019) considera que muitos dos motivos que ocorrem nestes painéis, como barquiformes, por exemplo, poderão ser contemporâneos dos círculos segmentados. A grande concentração destes motivos a nordeste parece indiciar, segundo Santos (2014), uma área de concentração de motivos que poderão transmitir significados de histórias reais ou míticas do mundo dos vivos, podendo ainda ser associados a códigos, lugares cerimoniais, realçando assim a importância do culto solar (Santos, 2014, p. 113-114). No caso de Figueiró 1, embora com as reservas que um desenho antigo implica, nota-se a concentração de círculos segmentados a oeste e este do afloramento, com apenas um a sul, o que parece indiciar uma 
composição relativamente uniforme e intencional, talvez, relacionada, igualmente, com o ciclo solar. Com efeito, estes dados abonam a favor da hipótese cronológica apresentada anteriormente por um dos autores deste texto (Bettencourt, 2017a; 2017b), que defende que os círculos segmentados são posteriores à Arte Atlântica clássica e à Arte Esquemática antiga, representando uma imagética da Idade do Bronze.

Se aceitarmos a premissa de que estes símbolos são da Idade do Bronze, verifica-se que em sete casos se localizam nas imediações de vestígios deste período cronológico. Referimo-nos à Breia 1, 5 e 9; Figueiró 1 e 2; Laje da Churra e Pedra da Costa.

As Breias 1, 5 e 9 ficam a menos de $6 \mathrm{~km}$ para sudoeste do lugar do achado do machado de Bujões/Barcelos da Folgadoura, Vilar de Murteda, em Viana do Castelo (Zbyszewski e Ferreira,1955; Fernandes et alii, 2011). Figueiró 1 e 2 e a Laje da Churra, ficam nas imediações do túmulo da Idade do Bronze Final da Cova da Moura, Carreço (Viana, 1955; Bettencourt, 2013). A $2,7 \mathrm{~km}$ a norte da Laje da Churra, existe, ainda, o povoado do Bronze Final de Santo António (Bettencourt, 2013; Oliveira e Bettencourt, 2020). Nas imediações de ambos os locais há inúmeras pias salineiras cortadas na rocha do litoral cuja emergência tem vindo a ser associada à Idade do Bronze (Bettencourt et alli, 2020; Oliveira e Bettencourt, 2020). Quanto à Pedra da Costa 1 é de referir que fica a poucas centenas de metros para oeste do topo do Monte do Castro, onde terá existido uma ocupação do Bronze Final (Bettencourt, 1988).

Deste modo, observa-se que na área da maioria dos sítios gravados estudados há, efetivamente, vestígios da Idade do Bronze (Figura 8), embora outros estudos sejam necessários para se aferir melhor possíveis inter-relações.

Verificaram-se, também, as inter-relações possíveis entre estes motivos gravados e os recursos mineiros passíveis de terem sido explorados durante a Idade do Bronze, como o estanho, o ouro e a prata, pelo facto de, à ampla escala de análise, Bettencourt (2017a, 2017b) ter considerado que estes motivos ocorrem sobretudo em áreas ricas em estanho. $\mathrm{Na}$ análise efectuada através dos recursos mineiros referidos nas Cartas Geológicas de Portugal, na escala 1/500oo da região (Figura 9), verifica-se que, na bacia do rio Lima, esta inter-relação só é evidente para o núcleo da Breia, embora deva ser salientada a presença de três jazidas de estanho nas imediações do monte de Romarigães, no concelho de Paredes de Coura, a cerca de $5 \mathrm{~km}$ para sudoeste da Pedra da Costa 1. De sublinhar que apesar de não referidas na cartografia geológica, houve exploração de estanho no alto da serra de Santa Luzia, durante o século $\mathrm{XX}$, atividade eventualmente associada à introdução de novas imagéticas durante a Idade do Bronze, patentes na Laje da Churra e em Figueiró 1 e 2.

No curso médio da bacia do rio Lima, o facto de Gião 1 e de Chã da Rapada 3 não aparentarem relação direta com algum recurso mineiro analisado, o que não permite, por agora, extrapolar esta inter-relação para toda a região.

A continuação da investigação sobre este tema possibilitará, de futuro, confirmar ou infirmar algumas das hipóteses aqui equacionadas.

\section{AGRADECIMENTOS}

Este trabalho foi realizado no âmbito do projeto de dissertação de Mestrado de Diogo Marinho, intitulada Círculos segmentados gravados no Noroeste de Portugal que se inscreve no projeto coletivo Artes rupestres das Idades do Bronze e do Ferro do Norte de Portugal: do inventário à interpretação e divulgação, desenvolvido pelos três subscritores deste trabalho.

\section{BIBLIOGRAFIA}

ALVES, Lara Bacelar (2009) - O sentido dos signos. Reflexões e perspetivas para o estudo da arte rupestre do pós-glaciar no norte de Portugal. In BEHRMANN, Balbín, ed. - Arte Rupestre al Aire libre: investigación, protección y diffusion. Castilla y Leon: Consejeria de Cultura da Junta de Castilla y Leon, pp. 381-49o.

ALVES, Lara Bacelar (2012) - Génio e Talento do Passado. A Arte Gravada do Penedo do Encanto e da Chã da Rapada. Viseu: ADERE-PG / Arqueohoje, Lda.

ALVES, Lara Bacelar (2013) - Monte de Góis, Caminha. A Rock Art Sanctuary on the Banks of River Minho. In BETTENCOURT, Ana M. S. ed. - The Prehistory of the Northwestern Portugal, Territórios da Pré-História em Portugal, Vol. 2. Braga and Tomar: CEIPHAR and CICTEM, pp. 169-183.

BAPTISTA, António Martinho (1983/84) - A Arte rupestre do Norte de Portugal: uma perspetiva. Portugália, Nova Séria, 4/5: 71-82, IV ests.

BETTENCOURT, A. M. S. (1988) - O molde de foice de talão do Castro de Álvora, Cadernos de Arqueologia 5: 155-161.

BETTENCOURT, A. M. S. (2013) - O Bronze Final no Noroeste português. Uma rede complexa de lugares, memórias e ações. Estudos Arqueológicos de Oeiras, 20, pp. 157-172. 
BETTENCOURT, A. M. S. (2017a) - Post-palaeolithic rock arts of north-western Portugal; an approach. In BETTENCOURT, Ana M. S.; SANTOS-ESTĖVEZ, Manuel; SAMPAIO, Hugo; CARDOSO, Daniela eds. - Recorded Places, Experienced Places. The Holocene Rock Art of the Iberian Atlantic Northwest, British Archaeological Reports - BAR, Oxford: BAR Publishing, pp. 123-149.

BETTENCOURT, A. M. S. (2017b) - Gravuras rupestres do noroeste português para além das artes atlântica e esquemática. In J. M. Arnaud; A. Martins (eds.), Arqueologia em Portugal - 2017. Estado da Questão, Lisboa: Associação dos Arqueólogos Portugueses, pp. 1039-1053.

BETTENCOURT, A. M. S. (2019a) - Equídeos nos montes do noroeste português. Narrativas míticas gravadas nas rochas. In PEREIRA, Andreia ed. - O Garrano: Contributos da Investigação Histórico-Arqueológica, Antropológica e Equestre para a sua valorização, Viana do Castelo: Câmara Municipal, 135-148.

BETTENCOURT, A. M. S. (2019b) - Artes rupestres do Alto Minho. In CAMPELO, Álvaro, ed. - Património Artístico e Cultural do Alto Minho. Uma Viagem no Tempo. Viana do Castelo: Comunidade Intermunicipal do Alto Minho.

BETTENCOURT, A. M. S.; LUZ, Sara; OLIVEIRA, Nuno; SIMÕES, Pedro; Maria Isabel C.; ABAD-VIDAL, Emilio (2020) - Produção de sal marinho no Noroeste português. Alguns dados para uma reflexão. In Arqueologia em Portugal 2020 / Estado da Questão, Lisboa: Associação dos Arqueólogos Portugueses.

BRADLEY, Richard (1997) - Rock Art and the Prehistory of Atlantic Europe. Signing the Land. London: Routledge.

BRADLEY, R. (2002), - Access, Style and Imagery: The Audience for Prehistoric Rock Art in Atlantic Spain and Portugal, 400o-200o BC. Oxford Journal of Archaeology, 21, pp. 231-247. doi:10.1111/1468-0092.0016o.

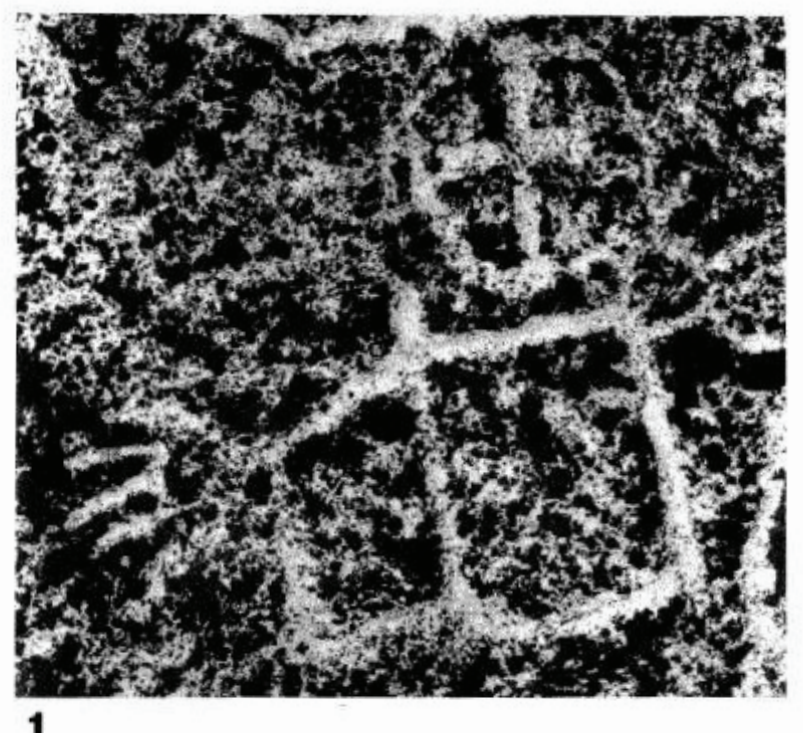

SÁ, Sofia (2015) - turismo arqueológico: um projeto de valorização da arte rupestre no vale do Lima. Braga: Universidade do Minho (Dissertação de Mestrado).

SANTOS, Ana (2014) - A Laje da Churra (Paço, Carreço, Viana do Castelo): estudo monográfico de um lugar gravado. Braga: Universidade do Minho (Dissertação de Mestrado).

VÁZQUEZ VARELA, J. (1983) - Los Petrglifos Gallegos. Zephyrus: Revista de prehistoria y arqueología, ISSN 05147336, № 36, 1983, págs. 43-51

VIANA, A. (1960) - Insculturas Rupestres do Alto Minho (Lanhelas e Carreço, Viana do Castelo Portugal). Boletim de la Comisión de Monumentos Históricos y Artísticos de Orense, 22:1-4, pp. 209-321.

BETTENCOURT, A.M.S E ABAD VIDAL, E. (2014) - Corpus Virtual de Arte Rupestre do Noroeste (www.cvarn.org).

BETTENCOURT, A. M. S.; SANTOS-ESTÉVEZ, M. (2018) - A Geografia Mágica do Monte de São Silvestre através da Arte Rupestre. Braga: Lab2PT.

CARDoso, D.; BETTENCOURT, A. M. S. (2015) - Arte "esquemática" de ar livre na bacia do Ave (Portugal, NO Ibérico): espacialidade, contexto, iconografia e cronologia, Estudos do Quaternário, 13, pp. 32-47.

DINIS, A.; BETTENCOURT, A. M. S. (2009) - A arte atlântica do Crastoeiro (Noroeste de Portugal): contextos e significados, Gallaecia, 28, pp. 41-47.

OLIVEIRA, Nuno; BETTENCOURT, Ana M. S. (2020) O povoado de Santo António (Afife, Viana do Castelo), na Idade do Bronze Final, Antrope, 13, no prelo.

PEÑA SANTOS Antonio de la; VÁZQUEZ VARELA, José Manuel_(1979) - Los petroglifos gallegos: grabados rupestres prehistóricos al aire libre en Galicia. Ediciós do Castro.

PEÑA SANTOS Antonio de la; REY GARCÍA, José Manuel (2001) - Ideología y sociedad en los grabados rupestres galaicos, Quadernos de Prehistòria i Arqueologia de Castelló, 22, pp. 235-265.

Figura 1 - Pormenor da rocha 1 do Gião 1 com representação de círculo segmentado; (Fonte: Baptista 1980, 84, in Sá, 2015). 

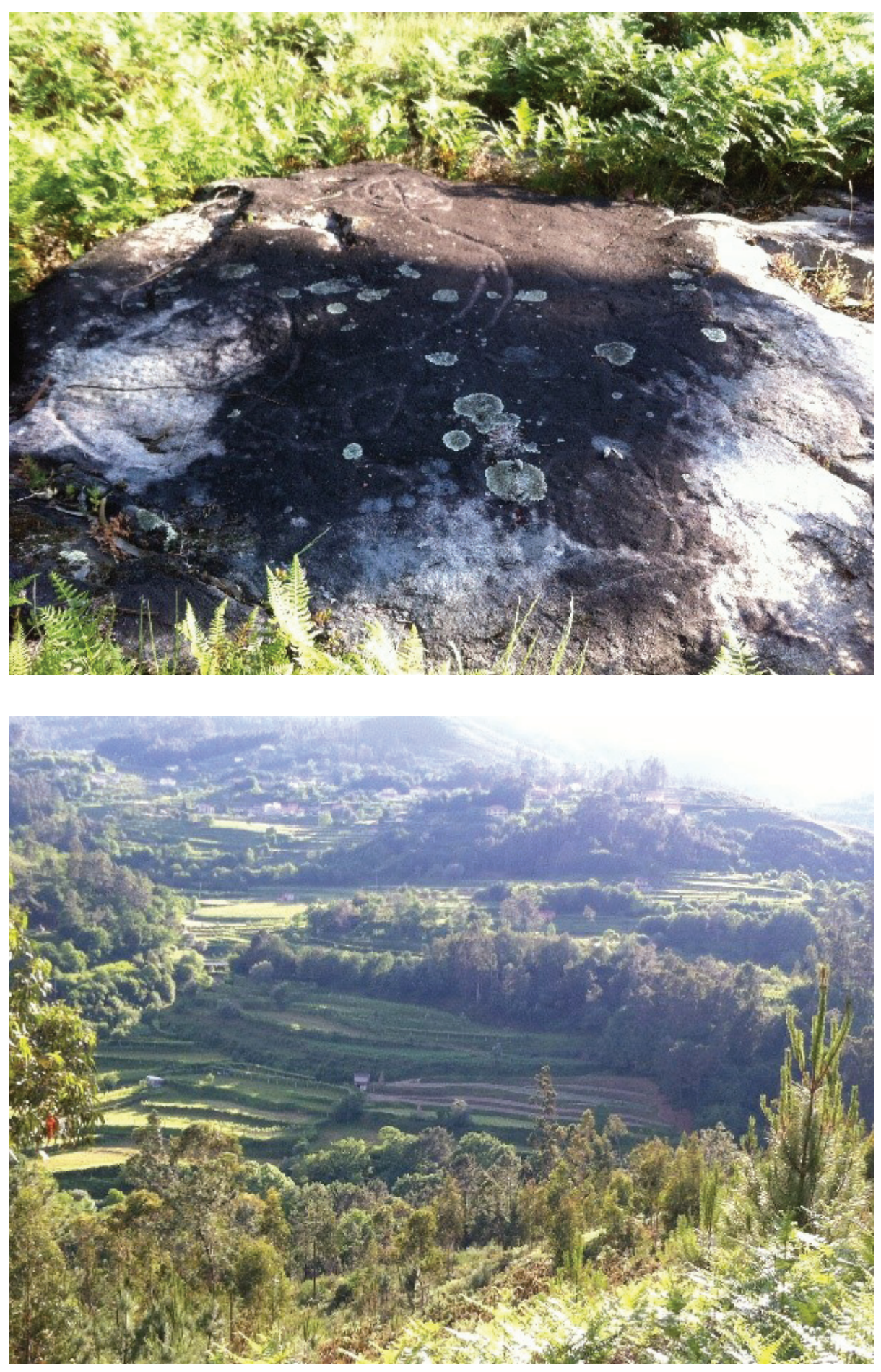

Figura 2 - Círculo segmentado da Pedra da Costa I em último plano (em cima) e Vale da ribeira de Frades (em baixo). (Fonte: Ana M. S. Bettencourt). 


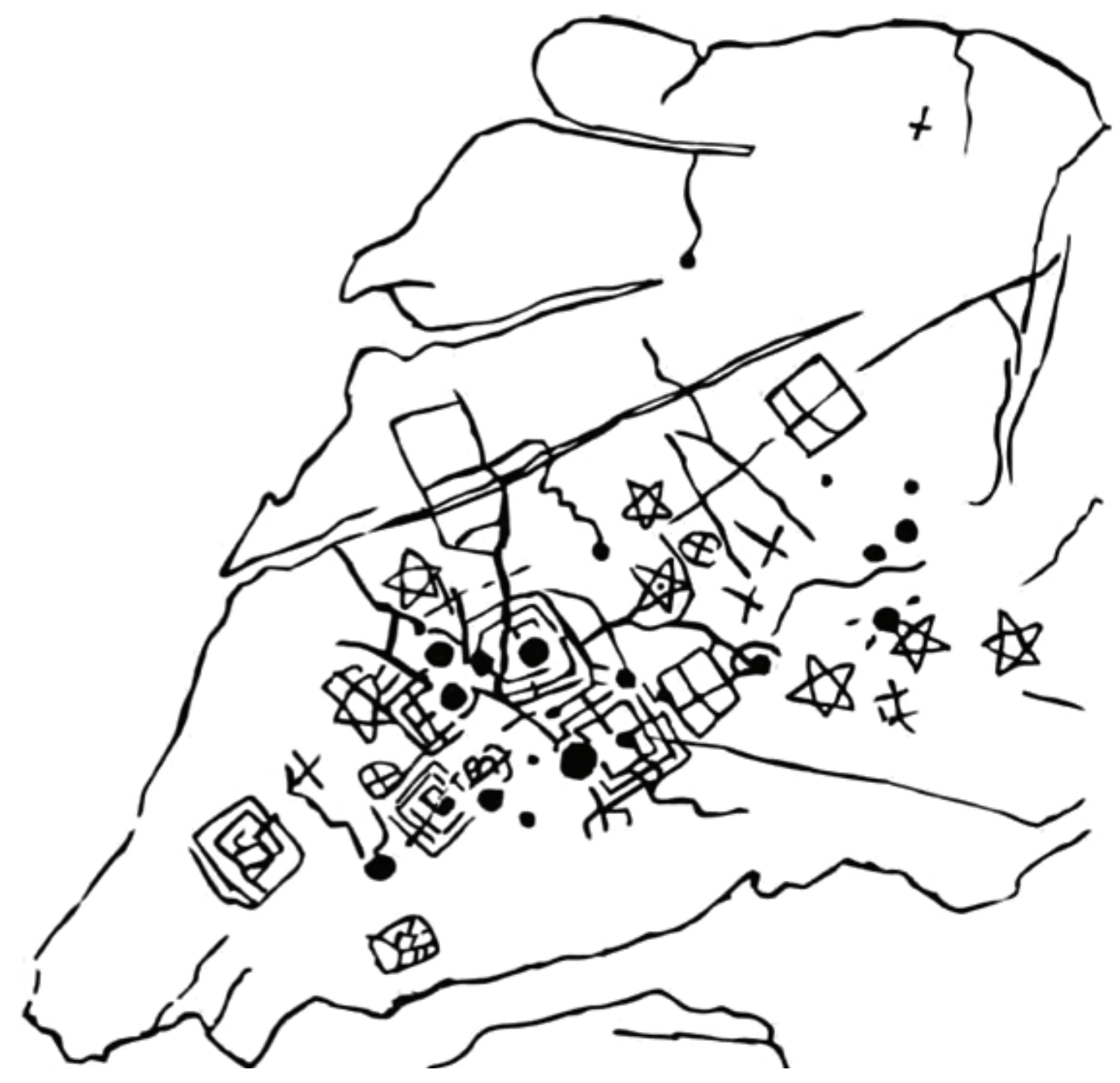

Figura 3 - Chã da Rapada 3. Esquema geral da composição (Fonte: Alves, 2012, p. 21).
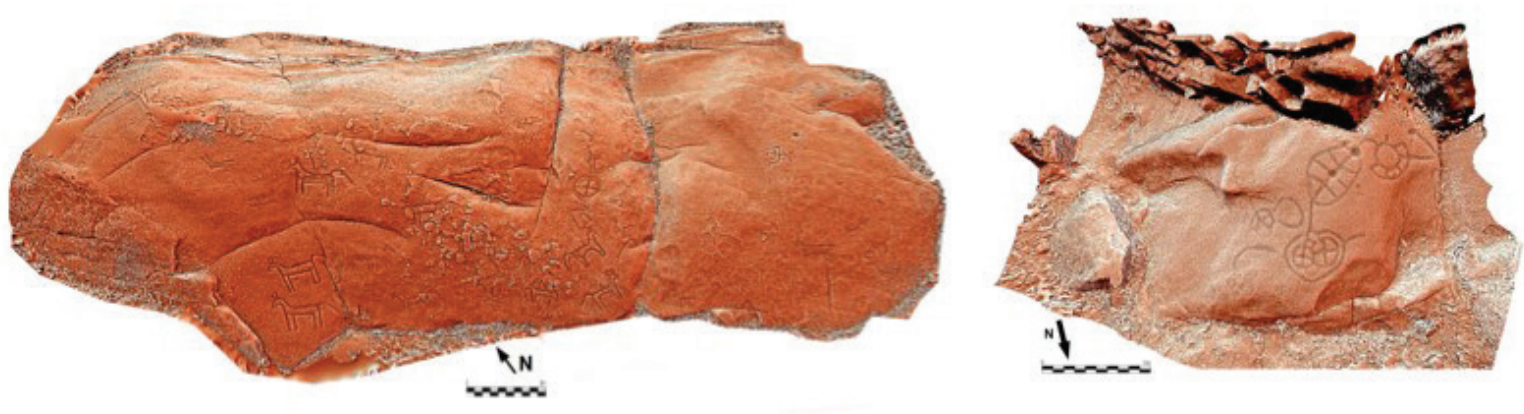

Figura 4 - Fotogrametria das Breias 5 e 9 (Fonte: Bettencourt e Santos-Estévez, 2018, p. 59 e 72 ). 


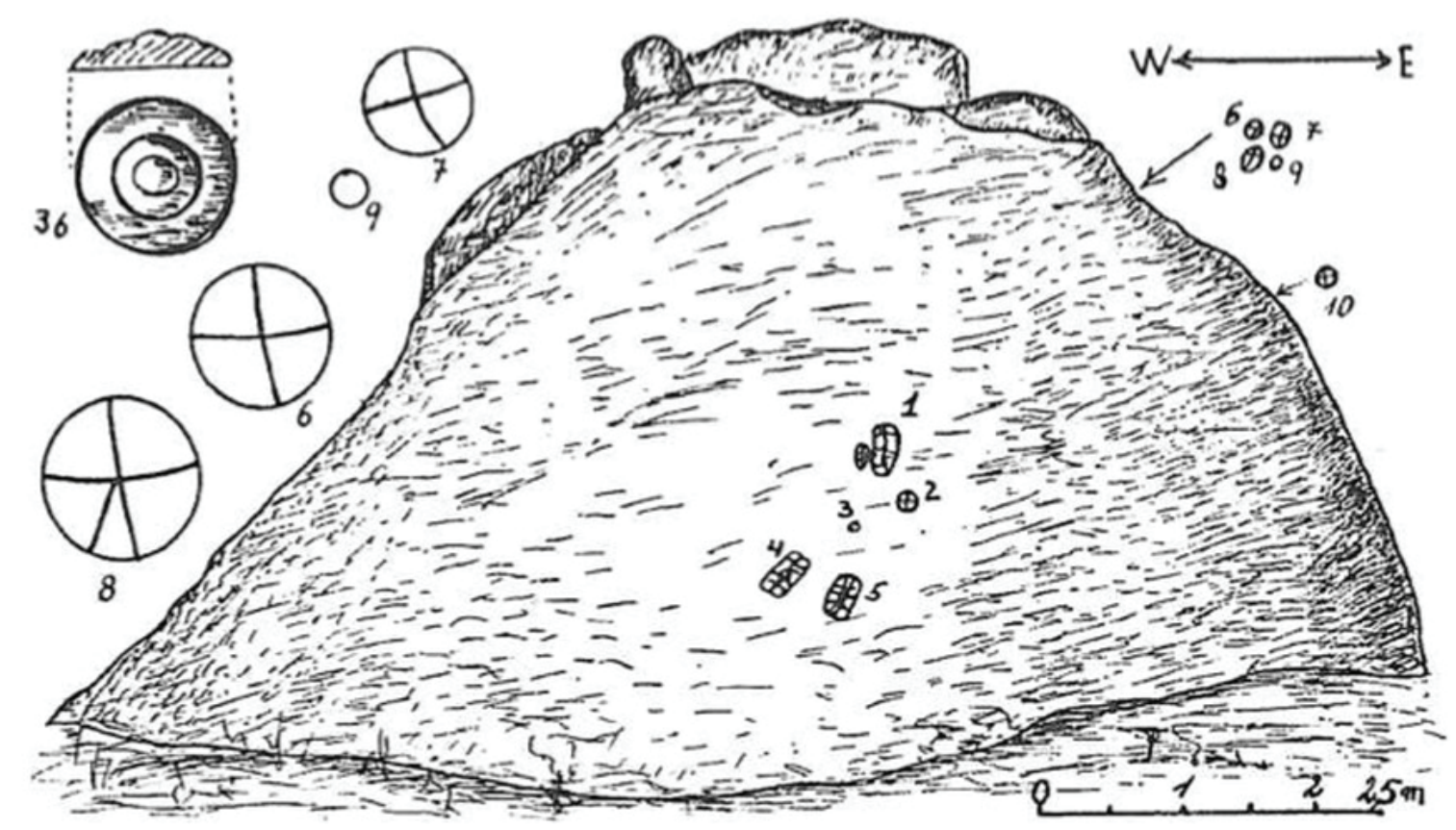

Figura 5 - Figueiró 1 segundo desenho de Viana (1960); (Fonte: Viana. A, 1960).

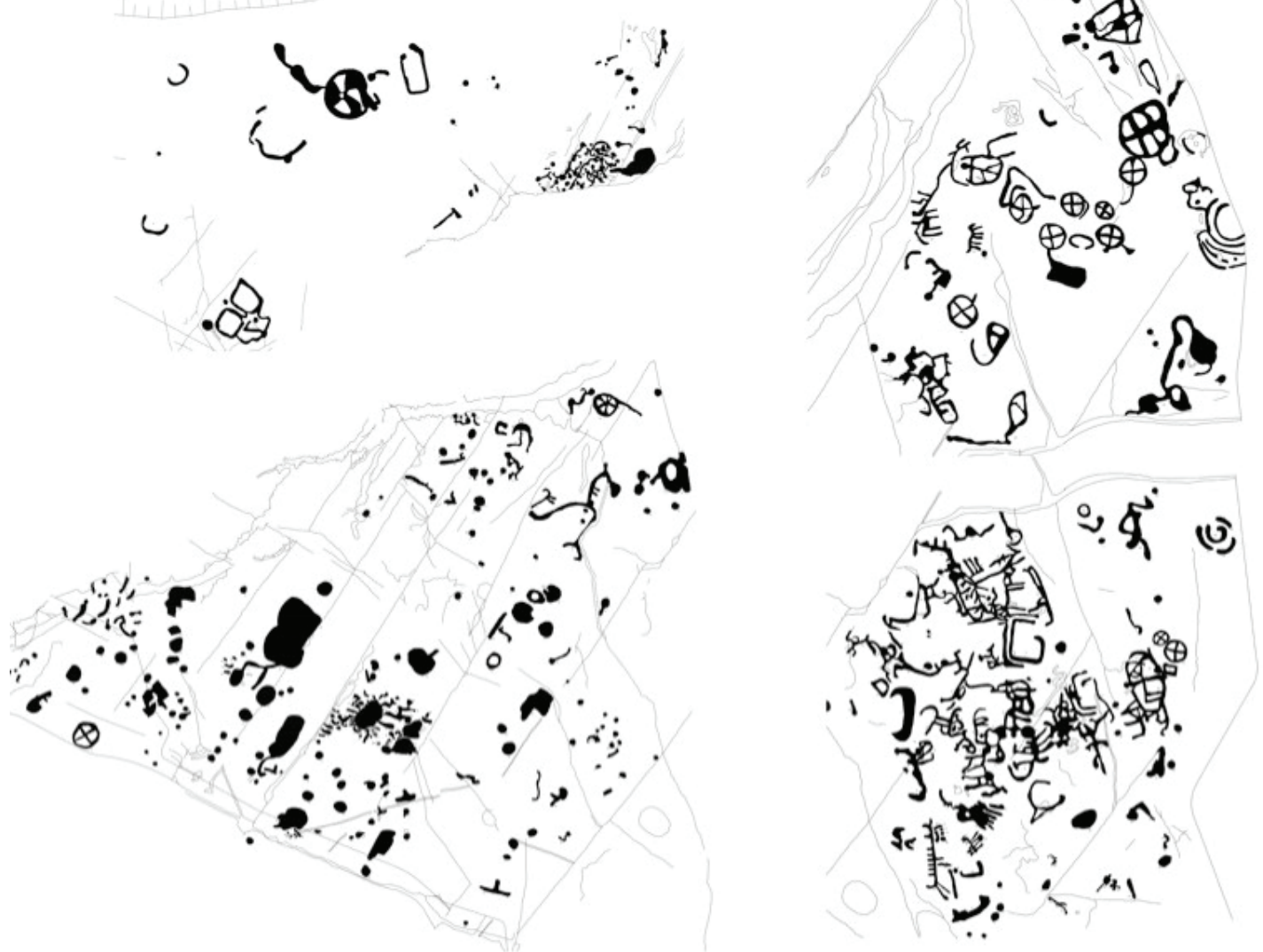

Figura 6 - Painéis 2, 3 (em cima), 5 e 6 (em baixo) da Laje da Churra (Fonte: Santos, 2014, adaptado). 


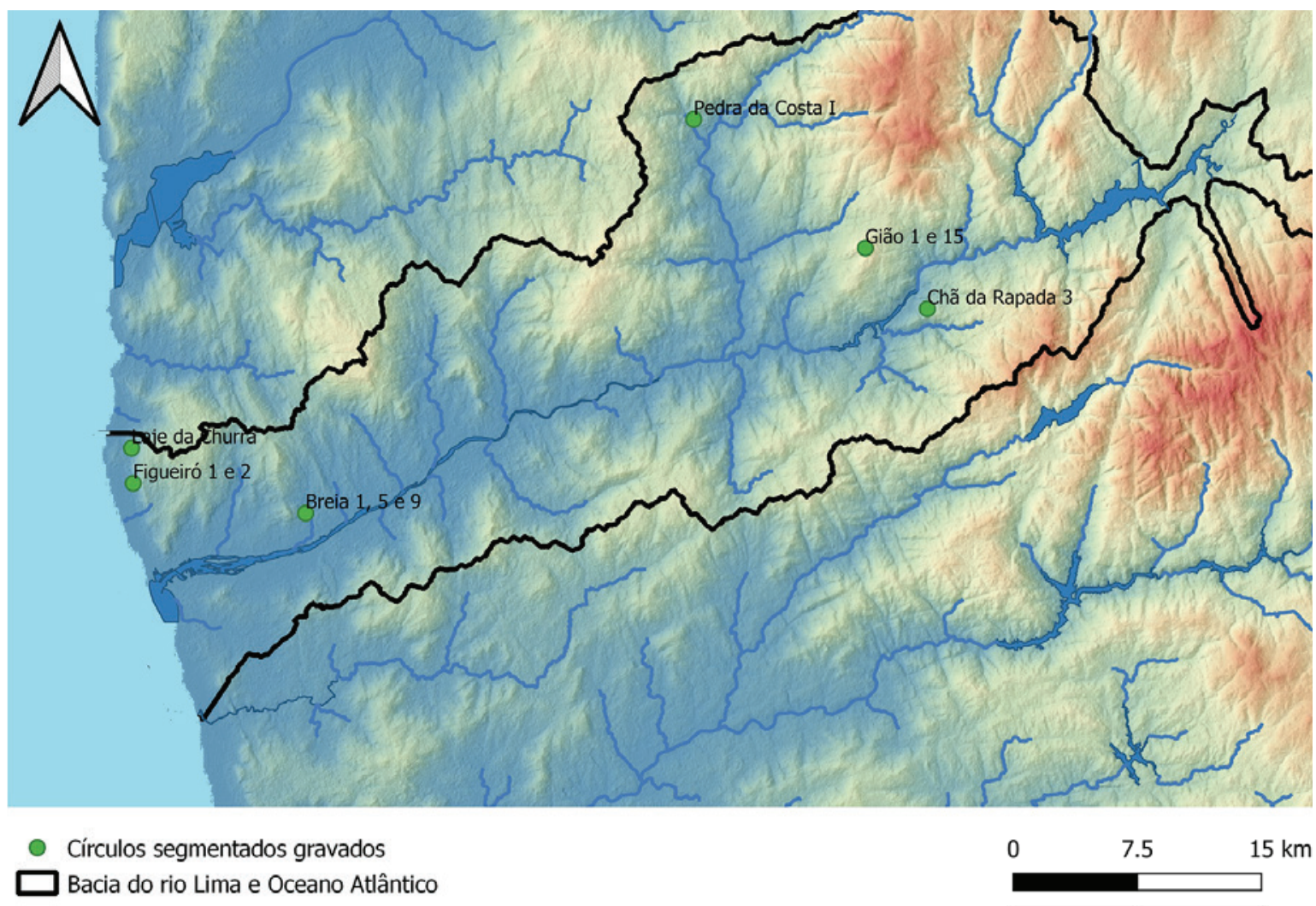

Figura 7 - Distribuição espacial dos círculos segmentados gravados nos cursos médio e inferior do rio Lima.

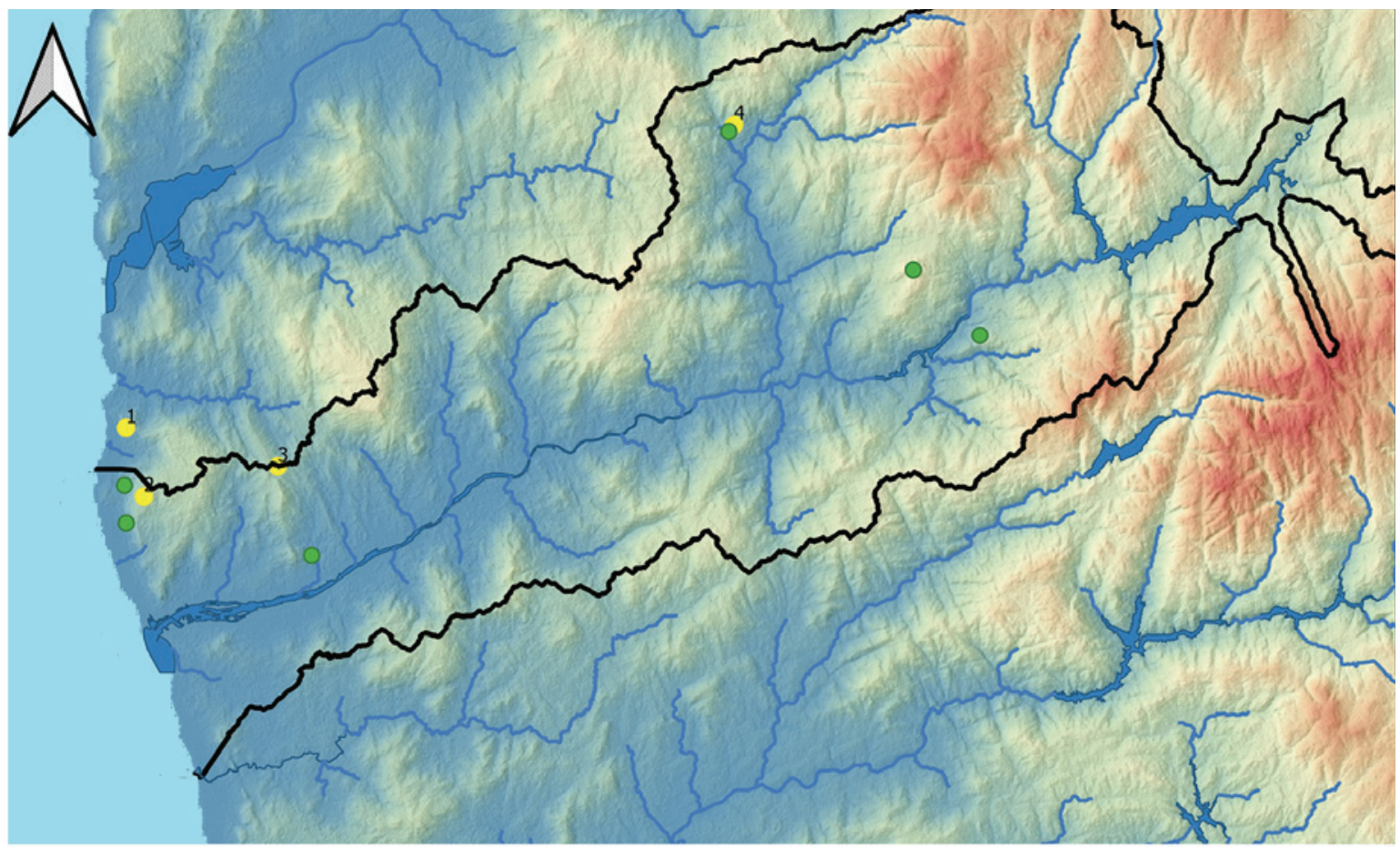

- Círculos segmentados gravados

1 - Povoado Santo António; 2 - Cova da Moura; 3 - Machado do Folgadoiro; 4 - Ocupação do Bronze Final/Monte do Crasto

Bacia do rio Lima e Oceano Atlântico

Figura 8 - Inter-relação dos afloramentos gravados com círculos segmentados e sítios arqueológicos da Idade do Bronze. 


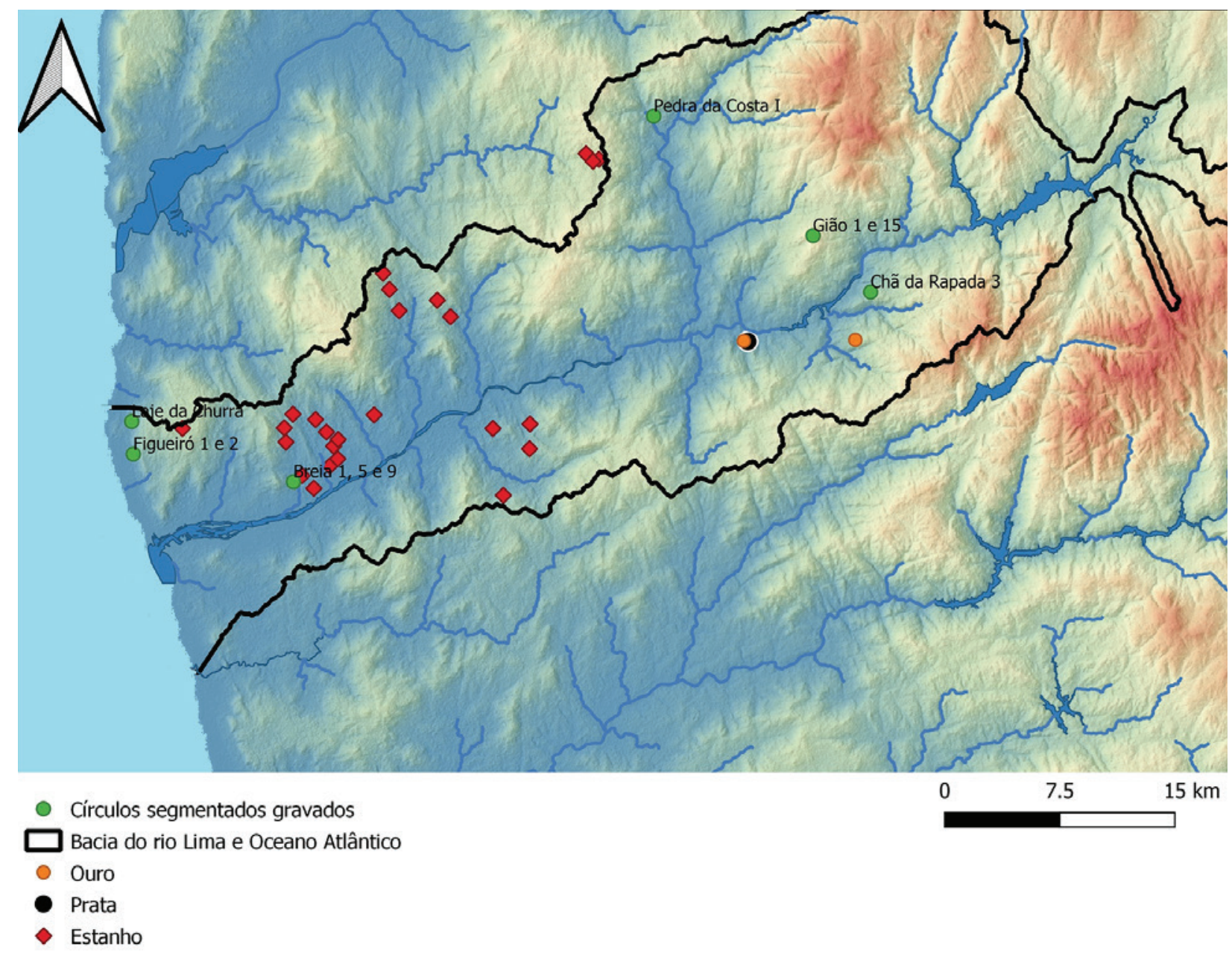

Figura 9 - Inter-relação dos lugares gravados com círculos segmentados e recursos mineiros de estanho, prata e ouro. 


\title{
EQUÍDEOS GRAVADOS NO CURSO INFERIOR DO RIO MOURO, MONÇÃO (NW PORTUGAL). ANÁLISE PRELIMINAR
}

\author{
L. M. Coutinho' ${ }^{1}$, Ana M.S. Bettencourt ${ }^{2}$, Hugo A.S. Sampaio ${ }^{2,3}$
}

\begin{abstract}
RESUMO
Este estudo, centra-se na representação de equídeos gravados na bacia do rio Mouro, afluente da margem sul do rio Minho. Tem como objetivos o estudo da sua distribuição no espaço em relação a características físicas; a especificidade de tipos de equídeos gravados; as características dos afloramentos gravados por grupo de equídeos; e as orientações dos equídeos por tipo e a sua disposição no afloramento face a outros motivos gravados. Palavras-chave: Arte Pós-paleolítica, Tipos de equídeos, Bacia do rio Mouro.
\end{abstract}

\begin{abstract}
This paper focuses on the representation of horses graved on rocks in the Mouro River basin (NW Portugal), an afluent in the south margin of the Minho River. The objectives are the study of its distribution in space, in relation to physical characteristics; the specificity of types of graved horses; the characteristics of the rocks graved by group of horses; the orientation of horses by type and their disposition in the rock compared to other graved motifs.
\end{abstract}

Keywords: Post Paleolithic Art, River Mouro Basin.

\section{INTRODUÇÃO}

O que torna especial um lugar gravado com arte rupestre? Será a gravura em si que o dota de propriedades ou o afloramento e o local foram gravados por já serem especiais ou terem visibilidade para locais significantes? Não se pode ignorar que, para as sociedades tradicionais, alguns afloramentos e lugares contêm um significado espiritual (Bradley, 20oo; Tilley, 2002) que podem estar na origem de lendas, mitos e crenças relacionadas com seres ou propriedades que habitam dentro ou entre as rochas ou em determinados montes. Tal é o caso de muitos locais do Norte de Portugal (Bettencourt et alii, 2017b: 139; Sampaio et alii, 2018: 150). Bradley (2000) afirma que, serão os motivos, enquanto signos, que conferem uma ligação entre os lugares (enquanto espaço frequentado por populações) e os poderes sobrenaturais que os povoam. Deste modo, parte-se do princípio que, através do estudo da arte rupestre de ar livre, a Arqueologia poderá interpretar memórias do passado, partindo da premissa de que a mensagem inerente à gramática imortalizada nos afloramentos resulta de um pensamento simbólico e reflete a visão cosmogónica que as comunidades que as gravaram tinham do mundo e da realidade que as rodeava (Sampaio et alii, 2018, p. 150).

Inserida no chamado ciclo da Arte Atlântica, no seu sentido clássico, a gravação de signos e gramáticas abstratas atribuíveis ao Neolítico, entre os finais do $5^{\circ}$ e/ou inícios do $4^{\circ}$ milénios a.C. (Alves, 2009; 2017; Santos-Estévez, 2012; Bettencourt, 2013; Cardoso e Bettencourt, 2015) vão sendo substituídos por novas linguagens "artísticas", especialmente a

\footnotetext{
1. Aluno de Mestrado em Arqueologia na Universidade do Minho; coutinho@dps.uminho.pt

2. Laboratório de Paisagens, Património e Território (Lab2PT); Departamento de História do Instituto de Ciências Sociais da Universidade do Minho, Portugal.

3. Escola de Hotelaria e Turismo do Instituto Politécnico do Cávado e do Ave (ESHT | IPCA); Centro de Investigação, Desenvolvimento e Inovação em Turismo (CITur).
} 
partir do fim do $3^{\circ}$ milénio a.C. (Bettencourt, 2017a, 2017b). Aos círculos concêntricos, covinhas e sulcos, mais ou menos meandriformes, vão sendo adicionados novos motivos e composições, complexificando o discurso e, desse modo, prolongando ou alterando a memória do local, na longa temporalidade. Estes também podem surgir ex nuovo.

Identificam-se agora representações de armas, barquiformes, círculos segmentados, paletas, podomorfos e quadrúpedes, onde se enquadram os equídeos. Trata-se de uma fase mais figurativa, o que leva a que alguns investigadores os classifiquem como um novo ciclo artístico, nomeado de forma provisória como "arte figurativa" (Bettencourt, 2019b). Outros autores defendem que se inserem em novas fases da Arte Atlântica, mais recentes do que a sua fase Clássica e inicial (Santos-Estévez, 2008, 2012; Alves, 2014, Cardoso, 2015, entre outros).

Partindo do estudo concreto dos equídeos gravados ao ar livre, numa análise desenvolvida numa escala regional, embora enfatizando a microescala do lugar, os objetivos deste texto são: 1) o estudo da sua distribuição no espaço em relação a características físicas; 2) a especificidade de tipos de equídeos gravados; 3) as características dos afloramentos gravados por grupo de equídeos; 4) a disposição dos equídeos por tipo; e 5) as suas orientações e inter-relações com outros motivos gravados, também por tipo de equídeos. Na prática, este estudo incidiu no espaço territorial constituído pelo curso inferior da bacia do rio Mouro, onde foram analisados 10 afloramentos com equídeos gravados.

\section{METODOLOGIA}

A primeira fase do estudo consistiu na definição dos objetivos e do quadro teórico interpretativo, na recolha de bibliografia, cartografia e documentação gráfica e na definição de critérios de estudo de acordo com os objetivos. Numa segunda fase foram feitas visitas aos locais para observações in situ dos sítios gravados e dos seus motivos, observações do seu contexto físico e recolha fotográfica dos afloramentos para aplicação fotogramétrica. Numa terceira fase, a de trabalho avançado de gabinete, foram gerados os levantamentos fotogramétricos com utilização dos softwares Agisoft Photoscan e 3 DF Zephyr Lite versão 4.530. Foi aplicada a técnica Morphological Residual Model (MRM), que representa as diferenças morfológicas existentes na rocha a partir de um código cromático e as diferentes profundidades dos sulcos das gravuras, gerando uma nuvem de pontos e de texturas que, com a utilização do software $L a$ bmesh e aplicando os filtros Radiance Scalling e Lit Spheres, dando o tratamento $3 \mathrm{D}$ à imagem, permite remarcar os sulcos existentes na rocha. Aumentando o contraste aplica-se uma maior e mais fácil leitura à imagem de forma a proporcionar melhores interpretações das gravuras, que por vezes se encontram bastante erodidas. Posteriormente, com recurso a ferramentas de sistemas de informação geográfica (software QGIS Desktop v. 3.10.2) foi possível identificar a distribuição espacial dos afloramentos gravados num mapa hipsométrico, de modo a compreender a sua localização e as suas inter relações espaciais.

\section{O VALE DO RIO MOURO}

Inserido na denominada região do Alto Minho, o vale do rio Mouro assume uma localização a nordeste no distrito de Viana do Castelo. Nasce na Portela do Lagarto, a uma altitude de cerca de $1200 \mathrm{~m}$, na serra da Peneda, no concelho de Melgaço, e desagua na margem esquerda do rio Minho, na localidade de Ponte de Mouro, no concelho de Monção. Forma um vale de morfologia pouco sinuosa, criando um eixo natural de circulação que se desenvolve de sul para norte, no seu curso inferior, e de este para oeste, no curso superior. Corre num vale profundo e estreito, a montante, e aberto a jusante (Fig. 1). Segundo a Carta Geológica de Portugal, folha 1-B, de 1985, à escala 1/50 ooo, o substrato rochoso desta área é composto por granito de duas micas, com grão variável entre o médio a fino. Segundo a notícia explicativa desta Carta Geológica (Ribeiro e Moreira, 1986, p. 35), a área teve mineralizações de ouro e volfrâmio (ver Figura 1).

\section{INVENTÁRIO}

Após consulta do Corpus Virtual de Arte Rupestre do Noroeste Português - CVARN (www.cvarn.org), foram identificados 6 afloramentos gravados com equídeos que pertencem à bacia do rio Mouro, localizados todos no concelho de Monção. A estes foi possível adicionar mais um, publicado na Revista de Estudos Miñoráns: Proxecto Equus: un novo paradigma nas escenas de caza da arte rupestre galega e do norte de Portugal (Martínez Soto et alii, 2017) que se designou por Buraca da Moura 5, atendendo ao 
local onde se encontrava. No decorrer dos trabalhos de campo foram identificados mais três inéditos, nas freguesias de Barbeita e de Longos Vales.

Através deste trabalho foi possível elaborar o inventário que se segue. Este obedeceu aos seguintes descritores: 1) localização administrativa e coordenadas; 2) pequeno historial; 3) contexto físico e ambiental; 4) descrição do afloramento; 5) descrição dos motivos; e 6) bibliografia. O mesmo está ordenado por ordem alfabética das freguesias.

\section{Gasgaia ${ }^{4}$}

Freguesia: Barbeita.

Localização: Latitude: 42.054472; Longitude: -8.40 8861; Altitude: $252 \mathrm{~m}$.

Historial: noticiada por Bettencourt (2014d).

Contexto físico e ambiental:

Descrição do afloramento: trata-se de um afloramento pouco destacado do solo, com superfície aplanada e uma ligeira pendente.

Descrição dos motivos: apresenta vários motivos dispersos, como composições circulares, nomeadamente um círculo concêntrico e círculos, covinhas, sulcos e um equídeo bastante esquemático (Figura 2). Bibliografia: Bettencourt, 2014d; dados inéditos.

\section{Buraca da Moura 5}

Freguesia: Barbeita

Localização:Latitude:42.066944; Longitude: -8.44 3333; Altitude: $242 \mathrm{~m}$

Historial: noticiada por Bettencourt (2014d).

Contexto físico e ambiental: situado na vertente nascente do Monte da Nossa Senhora da Assunção, encaixado entre dois outeiros. O local tem visibilidade a SSE para o vale do rio Mouro.

Este afloramento dista cerca de 2,10 m para NE da rocha da Buraca da Moura 2. Exibe uma divisão natural em dois painéis devido a um filão constituído maioritariamente por feldspato.

Descrição do afloramento: Trata-se de uma rocha de granito médio a fino com $3,70 \mathrm{~m}$ de comprimento no sentido SE-NE e 3,53m no sentido SW-NW, exibindo uma forma quase triangular e rasante ao solo com uma pendente suave no sentido SW.

Descrição dos motivos: na extremidade W-NW encontra-se um equídeo sub-naturalista com orelhas bem pronunciadas, encaminhando-se para NE,

4. Por engano está referenciado no cvarn.org como Buraca da Moura 1. como se estivesse a subir o afloramento e dirigindo-se para o monte da Senhora da Assunção. Mais perto do filão de feldspato, encontramos mais dois equídeos, um em cima do outro, dirigindo-se para $\mathrm{NW}$, como se estivessem a dirigir-se de um outeiro para o outro. Neste painel é possível ainda distinguir diversas covinhas, sendo que duas delas parecem estar quase unidas por um sulco. No segundo painel, um equídeo de maiores dimensões e de estilo sub-naturalista sugere estar associado a uma figura algo irregular, ligeiramente circular, como que se a transportasse.

Bibliografia: Martínez Soto et alii, 2017. Dados inéditos (Figura 3).

\section{Nossa Senhora da Assunção 15}

Freguesia: Barbeita

Localização: Latitude: 42.056367; Longitude: -8.40 7933; Altitude: $253 \mathrm{~m}$.

Historial: Foi dado a conhecer por Bettencourt (2014b) que o descreve de modo sumário.

Contexto físico e ambiental: situado na extremidade nascente de um pequeno e estreito patamar a sul do Monte de Nossa Senhora da Assunção, a visibilidade de quem se dirige ao local e visualiza alguns motivos (composições circulares e covinhas) é direcionada para o vale do rio Mouro.

Descrição do afloramento: trata-se de um dos maiores e mais imponentes afloramentos gravados nesta área, dispondo-se em patamares separados por declives mais ou menos acentuados. Devido à construção de um parque de estacionamento, este afloramento foi em parte destruído e encontra-se parcialmente aterrado ${ }^{5}$.

Descrição dos motivos: é composto, pelo menos, por 4 painéis: dois no topo, um na pendente nascente e outro num patamar virado a este. O painel 1 , no topo aplanado, apresenta uma composição circular complexa, entre outras mais simples e covinhas. O painel 2, no patamar inferior ao do topo, também apresenta composições circulares de gramática atlântica clássica, tal como um círculo concêntrico de três voltas com covinha central, entre outros sulcos pouco nítidos, um sulco unido por covinhas e covinhas

\footnotetext{
5. Foi parcialmente partido encontrando-se a parte fraturada nas proximidades, nomeadamente na vertente este do monte, junto com outros blocos partidos, como se fosse entulho. O afloramento encontra-se em perigo de destruição pelas obras dos parque de estacionamento.
} 
dispersas. O painel 3, mais ou menos a meio do declive existente a este do painel 2, apresenta dois quadrúpedes. Estes correspondem a dois equídeos muito esquemáticos, em posição estática. Estão orientados de SE para NE. Um deles, o de maior dimensão, localizado mais a nordeste, tem a cauda e a cabeça levantadas, enquanto o outro, de menor dimensão, e que está a seguir o primeiro, ostenta a cauda para baixo. Ambos têm orelhas bem pronunciadas. O painel 4, no patamar a nordeste do painel 3 , tem inúmeras covinhas de diferentes dimensões (Figura 4).

Bibliografia: Bettencourt, 2014b; dados inéditos.

\section{Nossa Senhora da Assunção 17}

Freguesia: Barbeita

Localização: Latitude: 42.056635; Longitude: -8.406635; Altitude: $223 \mathrm{~m}$.

Historial: Trata-se de um afloramento noticiado por Bettencourt (2014c) e agora alvo de estudo mais detalhado.

Contexto físico e ambiental: numa plataforma a meio da vertente sudeste do Monte de Nossa Senhora da Assunção, um local com excelente visibilidade para o vale onde corre o rio Mouro.

Descrição do afloramento: é elevado do solo, cerca de $43 \mathrm{~cm}$ pelo lado norte e $35 \mathrm{~cm}$ pelo lado sul. $\mathrm{O}$ afloramento, de grão fino, com bastante mica, apresenta uma coloração cinzenta escura em consequência da exposição a um fogo florestal. Além de se estar partido no lado oeste, apresenta depressões retangulares, recentes, realizadas para a inserção de cunhas facilitadoras do corte manual de pedra, bem como alguns sulcos de perfil em $\mathrm{V}$ feitos com pico metálico. $\mathrm{O}$ afloramento apresenta o topo aplanado. Descrição dos motivos: no topo são visíveis motivos atlânticos clássicos, muito erodidos, nomeadamente: um círculo concêntrico com covinha central, atravessado por um sulco e sobreposto por duas covinhas no seu aro exterior, um pequeno círculo concêntrico de duas voltas e, pelo menos, dois círculos simples com covinha central. Ai, existem, também, diversas covinhas. No ligeiro declive, a norte, foi gravado um equídeo sub-naturalista, em movimento (o que é sugerido pela obliquidade dos membros dianteiros). Sobre o dorso tem um sulco disposto na vertical, que poderá simbolizar um cavaleiro sem rédeas ou uma arma fincada. Mede cerca de $26 \mathrm{~cm}$. Dispõe-se na superfície como se dirigisse do fundo do vale (este) para o topo do monte (oeste), como se o seu destino fosse o topo do Monte da Senho- ra da Assunção. Este animal apresenta a particularidade de ter sobre a cabeça um grande círculo, que parece ter sido sobreposto por uma covinha. Para poente desta figura há outro círculo, de contorno algo irregular, também sobreposto por uma covinha. Em posição oposta a este animal, parece existir outro equídeo muito erodido apenas definido pela linha do dorso, parte superior da cabeça e orelhas, cauda (?) e início de um dos membros traseiros. Pela disposição no afloramento dirige-se para o vale, ou seja, para nascente. No declive sul parece existir uma cruz grega (Figura 5).

Bibliografia: Bettencourt, 2014c; dados inéditos.

\section{Nossa Senhora da Assunção 19 \\ Freguesia: Barbeita \\ Historial: inédito \\ Localização: Latitude: 42.056281, Longitude: -8.40 7950; Altitude: $249 \mathrm{~m}$.}

Contexto físico e ambiental: a cerca de $50 \mathrm{~m}$ para sudeste de Nossa Senhora da Assunção 15, a meio da vertente média do Monte de Nossa Senhora da Assunção, com um declive bastante acentuado. De costas para o parque de estacionamento do monte da Senhora da Assunção, a E-SE, existe uma ampla visão para o vale onde corre o rio Mouro. A N-NE situa-se o Monte da Senhora da Assunção.

Descrição do afloramento: trata-se de um grande afloramento dividido por diáclases bastante acentuadas, de grão fino e com alguns filões de quartzito. Em algumas áreas apresenta-se bastante escuro devido a incêndios e com alguns líquenes.

Descrição dos motivos: o afloramento está dividido em dois painéis por uma diáclase. No painel a este surge um cavaleiro montado sobre um equídeo de cerca de $15 \mathrm{~cm}$, muito esquemático, e um círculo. O painel oeste está profusamente gravado com motivos variados. Destaque para uma espiral com covinha no meio, podomorfos descalços na horizontal e na vertical, uma gravura de um objeto com um cabo e dois dentes (fúrcula/gancho de carne do Bronze Final?), uma covinha de onde parte um sulco orientado a norte e duas covinhas unidas por um sulco bem pronunciado (Figura 6).

Bibliografia: inédita.

\section{Baldio da Porqueira}

Freguesia: Longos Vales.

Localização: Latitude: 42.0428; Longitude: -8.40 71; Altitude: $179 \mathrm{~m}$. 
Historial: inédita.

Contexto físico e ambiental: este afloramento situa-se na subida do caminho do Baldio da Porqueira, no lado direito. Tem excelente visibilidade para este onde corre o rio Mouro. A norte avista-se o monte da Senhora da Assunção.

Descrição do afloramento: trata-se de um afloramento bastante sobrelevado do solo, cerca de 2,00 m na parte norte e 1,20 $\mathrm{m}$ a sul. De um granito bastante claro, tem uma forma côncava. Apresenta uma zona bastante escura no centro em parte resultante da acumulação de águas pluviais,

Descrição dos motivos: um equídeo esquemático dirige-se para um grande círculo concêntrico com pelo menos 5 voltas e covinha central que está gravado praticamente no centro do afloramento. Devido à sua forma côncava, o afloramento acumula águas pluviais que devido à gravidade escorrem para o equídeo. É possível distinguir um pequeno sulco no dorso do equídeo com o recurso à luz rasante, no entanto não é possível afirmar tratar-se de um equídeo montado (Figura 7 ).

Bibliografia: inédito.

\section{Coutada das Águas 1}

Freguesia: Longos Vales

Localização: Latitude: 42.051389; Longitude: -8.41 0556; Altitude: $242 \mathrm{~m}$.

Historial: este afloramento foi dado a conhecer por Bettencourt (2014a) tendo agora sido alvo de estudo pormenorizado.

Contexto físico e ambiental: encontra-se a cerca de $300 \mathrm{~m}$ do núcleo de gravuras da Buraca da Moura, num pequeno remate de esporão sobranceiro ao Rego das Cunhas. A nascente, visualiza-se o vale do rio Mouro, enquanto para sul a perspetiva é para o vale do Rego das Cunhas, que vai desaguar no rio Mouro. O local fica num aglomerado de blocos graníticos, de grão médio a fino.

Descrição do afloramento: afloramento gravado, bem destacado do solo, com dois declives medianos, um para nascente e outro para poente que se tornam mais abruptos perto do solo. Encontra-se em razoável estado de conservação, embora apresente alguns líquenes.

Descrição dos motivos: no declive a nascente, foram gravados dois equídeos esquemáticos, um em posição estática e outro dando a sensação de estar em movimento, sugerido pela linha do dorso e pela posição da cabeça e dos membros dianteiros. A fi- gura central do afloramento dirige-se para W-NE e é um pouco maior do que o outro que se encontra na extremidade oeste do painel. Este último dirige-se para E-SE. Ambos provocam a sensação, para quem os olha de frente, que estão a sair do vale e se dirigem para o monte. $\mathrm{O}$ declive a poente exibe um grande circulo concêntrico de quatro voltas com covinha central, um equídeo esquemático, em posição estática, que se dirige para W-NW e um outro, também esquemático, dirigindo-se em sentido contrário (Figura 8).

Bibliografia: Bettencourt, 2014d; dados inéditos.

\section{Teixugos 2}

Freguesia: Longos Vales

Localização: Latitude: 42.056417; Longitude: -8.42 5889; Altitude: $118 \mathrm{~m}$

Historial: noticiada por Bettencourt (2014d).

Contexto físico e ambiental: este afloramento localiza-se no início da vertente, numa zona aplana$\mathrm{da}$, bastante encoberto pela vegetação, o que torna difícil a sua visualização. Está rodeado por campos agrícolas.

Descrição do afloramento: trata-se de um grande afloramento, rente ao solo, com um ligeiro declive de S-SW para N-NE. Mede cerca de 6,30 m no sentido S-SW/N-NE e 2,6o m no sentido W-NW/E-SE. Apresenta algumas diaclases e um grande filão horizontal de quartzito na parte central dividindo a rocha em dois painéis. Na parte inferior são também visíveis mais alguns filões de quartzito. O afloramento está um pouco danificado em consequência de incêndios florestais. A zona mais a N-NE encontra-se bastante escurecida.

Descrição dos motivos: o afloramento é profusamente gravado. Na parte superior do painel é visível um circulo concêntrico de 3 voltas, e um motivo circular. Um pouco mais abaixo encontramos uma gravura de forma sub retangular.

Mais abaixo, e muito perto do filão de quartzito, são visíveis pelo menos 21 covinhas, sendo que duas delas estão unidas por um sulco, e quatro estão circundadas por uma forma mais ou menos ovalada.

Logo após a filão, e no que foi considerado o segundo painel, encontram-se mais algumas covinhas, pelo menos 5, ao lado de um círculo concêntrico de 4 voltas e de menor dimensão do que o do painel superior. Ao lado inicia-se um sulco de forma irregular que desce o afloramento, medindo pouco mais de um metro, com uma gravura sub rectangular ados- 
sada. Ao lado, e no alinhamento do rectângulo, surgem 3 figuras de forma mais ou menos circular e de difícil interpretação.

Mais abaixo, surge um equídeo sub naturalista, em posição estática, voltado para N-NW e para um conjunto de outros 2 equídeos que o enfrentam. Um deles, esquemático, é montado por um ginete que surge de braços abertos podendo estar a segurar alguma coisa. Num outro equídeo, sub naturalista, também montando, o ginete parece ostentar um bastão. É visível ainda mais um zoomorfo, embora pareça que não tenha sido terminado (Figura 9).

Bibliografia: Bettencourt, 2014e; dados inéditos.

\section{Teixugos 3}

Freguesia: Longos Vales

Localização: Latitude: 42,0568N; Longitude: $-8,42$ 43W; Altitude: $118 \mathrm{~m}$

Historial: inédito

Contexto físico e ambiental: situa-se a escassos metros de habitações num declive pouco pronunciado orientado de SW para NE. Apresenta visibilidade para o vale a E-SE e para o Monte da Senhora da Assunção a Este.

Descrição do afloramento: trata-se de um grande afloramento com 2,40 $\mathrm{m}$ (sentido SW para NE) por 1,30 (sentido SE para NW), rasante ao solo, formando um declive com leve inclinação. Com uma forma mais ou menos sub retangular, de granito fino e coloração cinzenta escura, está naturalmente dividido em 3 painéis através de diáclases bem pronunciadas e largas.

Descrição dos motivos: os equídeos surgem no painel 1 (que se encontra mais a NE). Aí, evidencia-se um círculo concêntrico com, pelo menos, 4 voltas. No seu centro tem 3 covinhas, um pouco mais abaixo, o equídeo sub naturalista, e bem definido, orientado de W-NW para E-SE (Figura 10).

Bibliografia: dados inéditos.

\section{Chã/Chão da Sobreira 2}

Freguesia: Podame.

Localização: Latitude: 42.04608o; Longitude: -8.35 8163; Altitude: $370 \mathrm{~m}$

Historial: foi descoberto e estudado, em 1986, por José Augusto Maia Marques, que fez o seu decalque em polivinilo após a aplicação do método biocromático.

Contexto físico e ambiental: ampla visibilidade a norte para o vale. Em plano de fundo encontra-se o Castro da Senhora da Graça. Visibilidade fechada para sul, este e oeste.

Descrição do afloramento gravado: trata-se de um afloramento granítico de grão médio, algo destacado do solo, aplanado na parte superior, com um declive para sul. Encontra-se escondido por densa vegetação, um pouco erodido e coberto com líquenes e musgos. Descrição dos motivos: apresenta três painéis gravados, separados por algumas diáclases (Fig. 10). No painel norte, destaca-se uma covinha central associada a um sulco, rodeada por dois semicírculos, várias covinhas isoladas e sulcos que formam duas composições de difícil classificação. No painel encontra-se uma espiral de duas voltas e várias covinhas, algumas associadas a sulcos.

No painel sul, encontram-se os motivos mais importantes para este estudo. Trata-se uma cena de equitação com dois equídeos esquemáticos montados, de aproximadamente $20 \mathrm{~cm}$ cada um, dirigindo-se de nascente para poente. O ginete do equídeo da frente, com uma dimensão ligeiramente maior, parece ser portador de um toucado, tem os braços abertos e ostenta um objeto de morfologia circular preso à cintura, enquanto o equídeo de trás, com um cavaleiro muito estilizado, parece percorrer um caminho representado por um sulco, segundo interpretação de Bettencourt (2014).

Todas as figuras foram gravadas por percussão seguida de abrasão (Figura 11).

Bibliografia: Marques, 1986; Bettencourt, $2014 f$.

\section{DISCUSSÃO DE RESULTADOS E INTERPRETAÇÕES}

Os equídeos aqui estudados integram 10 afloramentos (Baldio da Porqueira 1, Buraca da Moura 5, Chã da Sobreira 2, Coutada das Águas 1, Coutada das Águas 3, Nossa Senhora da Assunção 15, 17 e 19, Teixugos 2 e 3), inscritos em 6 núcleos de arte rupestre (Tab. 1).

Todos eles se localizam no curso inferior do rio Mouro, em ambas as suas margens. São frequentes em pequenos patamares de vertentes médias de montes, entre os 100 e os 300 metros de altitude e em áreas com domínio para vales subsidiários da bacia do Mouro, com exceção de Teixugos, que se situa um pouco mais afastado e num local com pouca visibilidade, talvez devido à densa cobertura arbórea. (Figura 1). (Tabela 1) 
Não existe homogeneidade na escolha da superfície gravada. Há equídeos em afloramentos rasantes ao solo e bastante horizontalizados, como é o caso da Buraca da Moura 5, Teixugos 2 e 3 e Gasgaia, mas também elevados e em painéis com declive. Encontram-se neste caso os do Baldio da Porqueira 1 e de Nossa Senhora da Assunção 15, 17 e 19.

Em 7 casos os equídeos coexistem na mesma superfície com motivos atlânticos clássicos, embora, em 3 casos sem articulação direta com eles, dando a impressão de terem sido adicionados posteriormente. É o caso de Nossa Senhora da Assunção 15, 17, Chã da Sobreira 2 e, parcialmente, da Coutada das Águas 1, onde os motivos atlânticos se encontram no topo do afloramento e os equídeos em declives ou posições muito periféricas. Já na Gasgaia, Teixugos 2, do Baldio da Porqueira 1 e no declive nascente da Coutada das Águas 2, apesar dos equídeos estarem em posição periférica, parecem ter sido colocados de forma a dialogar com círculos concêntricos. De salientar que em termos técnicos estes quadrúpedes são sempre pouco profundos e com sulcos ligeiramente menos largos que os das composições circulares, o que acentua a "impressão" da sua gravação num momento distinto. Há também três casos em que os equídeos não ocorrem com motivos clássicos de arte atlântica, parecendo formar composições únicas (Buraca da Moura 5, Nossa Senhora da Assunção 15 e Chã da Sobreira 2). Tal parece estar de acordo com as hipóteses de que a sua gravação seria posterior à arte atlântica clássica defendidas para o Noroeste por Santos-Estévez (2008, 2012), com base na premissa de a equitação não existiu até aos inícios do $1^{\circ}$ milénio a.C. (séc. IX/VIII a.C.) e por Bettencourt (2019a) a propósito dos equídeos sub-naturalistas associados a círculos segmentados que a autora considera da Idade do Bronze, por paralelos com objetos desse período com esse símbolo. Se consideramos que a arte atlântica clássica se inicia no Neolítico e perdura pelo Calcolítico (Alves, 2003, 2009, 2017; Bettencourt, 2009, 2013, 2017a, 2017b; Cardoso, 2015), também é possível admitir que os equídeos no NW da Península Ibérica possam ter sido gravados entre os finais do $3^{\circ}$ e os inícios do $2^{\circ}$ milénio a.C., ou seja, no Bronze Inicial, baseado na hipótese de o cavalo ter sido domesticado nesse período (Fábregas Valcarce, Peña Santos, Rodríguez Rellán, 2011, p. 38).

Em termos de tipos de equídeos sem cavaleiros há os que se gravaram de modo muito esquemático, em
5 afloramentos (Nossa Senhora da Assunção 15 e 19, Coutada das Águas 1 e 3 e Chã da Sobreira 2) e os com mais pormenores, sub naturalistas, onde o corpo e a cabeça são definidos por dois sulcos, em 3 afloramentos (Buraca da Moura 5, Nossa Senhora da Assunção 17, Teixugos 2). É de referir que no afloramento dos Teixugos 2, um dos equídeos é esquemático e 2 são sub-naturalistas. De uma forma geral todos apresentam orelhas bem pronunciadas, o que indicia que poderão representar zebros, um equídeo selvagem que existiu até ao séc. XV (Terrón Albarrán, 1983).

Quer os esquemáticos quer os sub-naturalistas gravaram-se quase sempre de forma estática embora, nalguns casos, o movimento seja indiciado pela inclinações dos membros.

Em termos de composição há equídeos isolados (Gasgaia), em grupos de dois (Nossa Senhora da Assunção 15, 17, 19 Coutada das Águas 1); em manadas de 3 animais (Teixugos 3 ) e de 4 animais (Buraca da Moura 5).

No caso dos equídeos em manada não parece haver grande distinção entre as dimensões dos equídeos esquemáticos, como também não surge nenhum equídeo com gravação especifica de género. Serão todos de fêmeas e crias?

Os equídeos com cavaleiros ocorrem, essencialmente, no grupo dos esquemáticos, em 4 casos (Baldios da Porqueira 1, Nossa Senhora da Assunção 19, Teixugos 2 e Chã da Sobreira 2). Em dois casos ocorrem em cavalos sub-naturalistas (Teixugos 2) em associação com outros não montados. $\mathrm{O}$ caso de Nossa Senhora da Assunção 17 oferece dúvidas sobre ser montado ou ter uma arma fincada.

Já na Assunção 19, o cavaleiro surge de braços abertos, tal como no Teixugos 2, embora este pareça segurar um bastão. Na Chã da Sobreira 2, um dos cavaleiros parece ser portador de um toucado, tem os braços abertos e ostenta um objeto de morfologia circular preso à cintura (um escudo?).

Em termos de equídeos em geral há a destacar que no caso de Nossa Senhora da Assunção 17, estes parecem ser guiados por círculos simples sobre a cabeça. Na Buraca da Moura 5 o último equídeo da manada parece puxar uma figura subcircular. Estaremos face a representações de cavalos solares? E no caso em que parecem dialogar com círculos concêntricos típicos da arte atlântica clássica? Que mensagem quererão transmitir? Este é um trabalho a desenvolver futuramente, assim como a tentativa de interpretação de outras cenas equestres aqui representadas. 


\section{AGRADECIMENTOS}

Os autores expressam um profundo agradecimento ao Sr. José Alvarez Alonso, que com a sua grande disponibilidade e simpatia, nos acompanhou ao campo mostrando os sítios inéditos referidos neste trabalho.

\section{BIBLIOGRAFIA}

ALVES, Lara B. (2009) - O sentido dos signos. Reflexões e perspectivas para o estudo da arte rupestre do pós-glaciar no norte de Portugal. In BALBíN BEHRMANN, Rodrigo , ed. - Actas Arte Prehistórico al aire libre en el Sur de Europa. Junta de Castilla y Léon: Consejaría de Cultura y Turismo, pp. 381-413.

ALVES, Lara B. (2014) - Intermitências: a arte e a Idade do Bronze no ocidente peninsular. In LOPES, Susana, ed. - A Idade do Bronze em Portugal: os dados e os problemas. Antorpe, série monográfica nํํ. Tomar: Instituto Politécnico de Tomar, pp. 15-51.

ALVES, Lara B. e REIS, Mário (2017) - Tattooed Landscapes. A reassessment of Atlantic Art distribution, research methods and chronology in the light of the discovery of a major rock art assemblage at Monte Faro (Valença, Portugal). Zephyrus Revista de Prehistoria y Arqueología, LXXX julio-diciembre 2017, Salamanca. Ediciones Universidad Salamanca, pp. 49-67. DOI: http://dx.doi.org/10.14201/ zephyrus2017804967.

BETTENCOURT, Ana M. S. (2014a) - Coutada das Águas 1, In Corpus Virtual de Arte Rupestre do Noroeste de Portugal - CVARN.

BETTENCOURT, Ana M. S. (2014b) - Nossa Senhora da Assunção 15, In Corpus Virtual de Arte Rupestre do Noroeste de Portugal-CVARN. (www.cvarn.org).

BETTENCOURT, Ana M. S. (2014c) - Nossa Senhora da Assunção 17, In Corpus Virtual de Arte Rupestre do Noroeste de Portugal-CVARN. (www.cvarn.org).

BETTENCOURT, Ana M. S. (2014d) - Buraca da Moura I, In Corpus Virtual de Arte Rupestre do Noroeste de Portugal - CVARN. (www.cvarn.org).

BETTENCOURT, Ana M. S. (2014e) - Teixugos 2, In Corpus Virtual de Arte Rupestre do Noroeste de Portugal - CVARN. (www.cvarn.org).

BETTENCOURT, Ana M. S. (2014f) - Chã da Sobreira 1, $2 e$ 3, In Corpus Virtual de Arte Rupestre do Noroeste de Portugal-CVARN. (www.cvarn.org).

BETTENCOURT, Ana M. S. (2017a) - Gravuras rupestres do Noroeste para além das artes atlânticas e esquemática. In ARNAUD, José M. e MARTINS, Andrea, eds - Arqueologia em Portugal. Estado da Questâo. Associação dos Arqueólogos Portugueses, Lisboa: AAP, pp. 1053-1067.
BETTENCOURT, Ana M. S.; SAMPAIO, Hugo A.; SANTOS -ESTÉVEZ, Manuel; CARDOSO, Daniela (2017b) - Prehistoric Rock Art and Landscape: The outcrops and its forms were certainly not simple carving surfaces. In MARTINS, R. N. e RIBEIRO, C., eds. - I International Seminar on Art and Landscape. Guimarães, Laboratório da Paisagem, pp. 137-153.

BETTENCOURT, Ana M. S. (2019a) - Equídeos nos Montes do Noroeste Português. Narrativas Míticas Gravadas nas Rochas. In PEREIRA, Andreia, ed. - O Garrano: contributos da investigação histórico-arqueológica, antropológica e equestre para a sua valorização. Viana do Castelo: Câmara Municipal, pp. 135-148.

BETTENCOURT, Ana M. S. (2019b) - Artes Rupestres do Alto Minho. In CAMPELO, Álvaro, ed. - Património artístico e cultural do Alto Minho. Uma viagem no tempo. Viana do Castelo: Comunidade Intermunicipal do Alto Minho (no prelo).

BETTENCOURT, Ana M. S. e ABAD-VIDAL, E. (2014) Corpus Virtual de Arte Rupestre do Noroeste de Portugal - CVARN (www.cvarn.org)

BRADLEY, R. (200o) - An Archaeology of Natural Places. London: Routledge, https://doi.org/10.4324/978020363 O228

CARDOSO, Daneila (2015) - A Arte Atlântica do Monte de S. Romão (Guimarães) no contexto da arte rupestre pós-paleolítica da bacia do Ave - Noroeste português. Tese de Doutoramento, Universidade do Vila Real, Vila Real, Portugal.

FÁBREGAS VALCARCE, R.; PEÑA SANTOS, A.; RODRÍGEZ RELLÁN, C. (2011) - Río de Angueira 2 (Teo, A Coruña). Un conxunto excepcional de escenas de monta, Gallaecia, 30, 29-51.

MARQUES, José A. M. (1986) - As gravuras da Chã da Sobreira e a arte rupestre do concelho de Monção, Revista de Ciências Históricas, 1, pp. 11-29.

MARTÍNEZ SOTO, Eloy; VERDE ANDRÉS, Cándido; ALVAREZ, Xosé; CENTELLES GARCÍA, Bruno; MANSO DE LA TORRE, Xilberte; VILAR PEDREIRA, Xosé Lois; LEDO BERNÁRDEZ, Manuel (2017) - Proxecto Equus: un novo paradigma nas escenas de caza da arte rupestre galega e do norte de Portugal. Revista de Estudos Miñoráns, 16/17, pp. $23-75$.

RIBEIRO, M. Luisa; MOREIRA, Armando (1986) - Carta Geológica de Portugal na escala 1/500oo - 1B. Notícia explicativa da folha 1-B - Monção. Serviços Geológicos de Portugal. Lisboa.

SAMPAIO, Hugo A. S., BETTENCOURT, Ana M. S.; SANTOS-ESTÉVEZ, Manuel; MOREIRA, José; CACHETAS, Henrique; BARBOSA, Aléssia, (2018) - Preservando a Memória das Pedras. Vista, Revista de Cultura Visual, 2, pp. 148-163.

SANTOS-ESTÉVEZ, Manuel (2008) - A new proposal for the chronology of Atlantic rock art in Galicia (NW Iberian 
Peninsula). In NASH, George; CHILDREN, George eds. The Archaeology of Semiotics and the Social Order of Thinks (140-152). Oxford: Bar International Series 1833.

SANTOS-ESTÉVEZ, Manuel. (2012) - Da "Arte Atlântica" no contexto europeu: conceitos, problemáticas e perspectivas - unha visión diacrónica da Arte Atlântica dentro dun novo marco cronolóxico. In SANCHES, Maria de Jesus ed. - Artes Rupestres da Pré-História e da Proto-História: Paradigmas e Metodologias de Registo. $1^{\circ}$ Mesa Redonda. Trabalhos de Arqueologia 54, Lisboa: MC, pp. 226-235.

SANTOS-ESTÉVEZ, Manuel (2014) - Curros na Idade do Ferro? Unha proposta etnoarqueolóxica. Fol de Veleno. Anuario de Antropoloxía e Historia de Galiza, 4, pp.135-146.
TERRÓN ALBARRÁN, M. (1983) - Los asnos salvajes, cebros o encebros en la España medieval y Extremadura. Aspectos histórico-geográficos y caza. In Memorias de la Real. Academia de Extremadura de las Letras y las Artes, I, pp. 413-474.

TILLEY, C. (2002) - Metaphor, materiality and interpretation. In BUCHLI, V. ed. - The Material Culture Reader. Oxford: Berg. pp. 23-26.

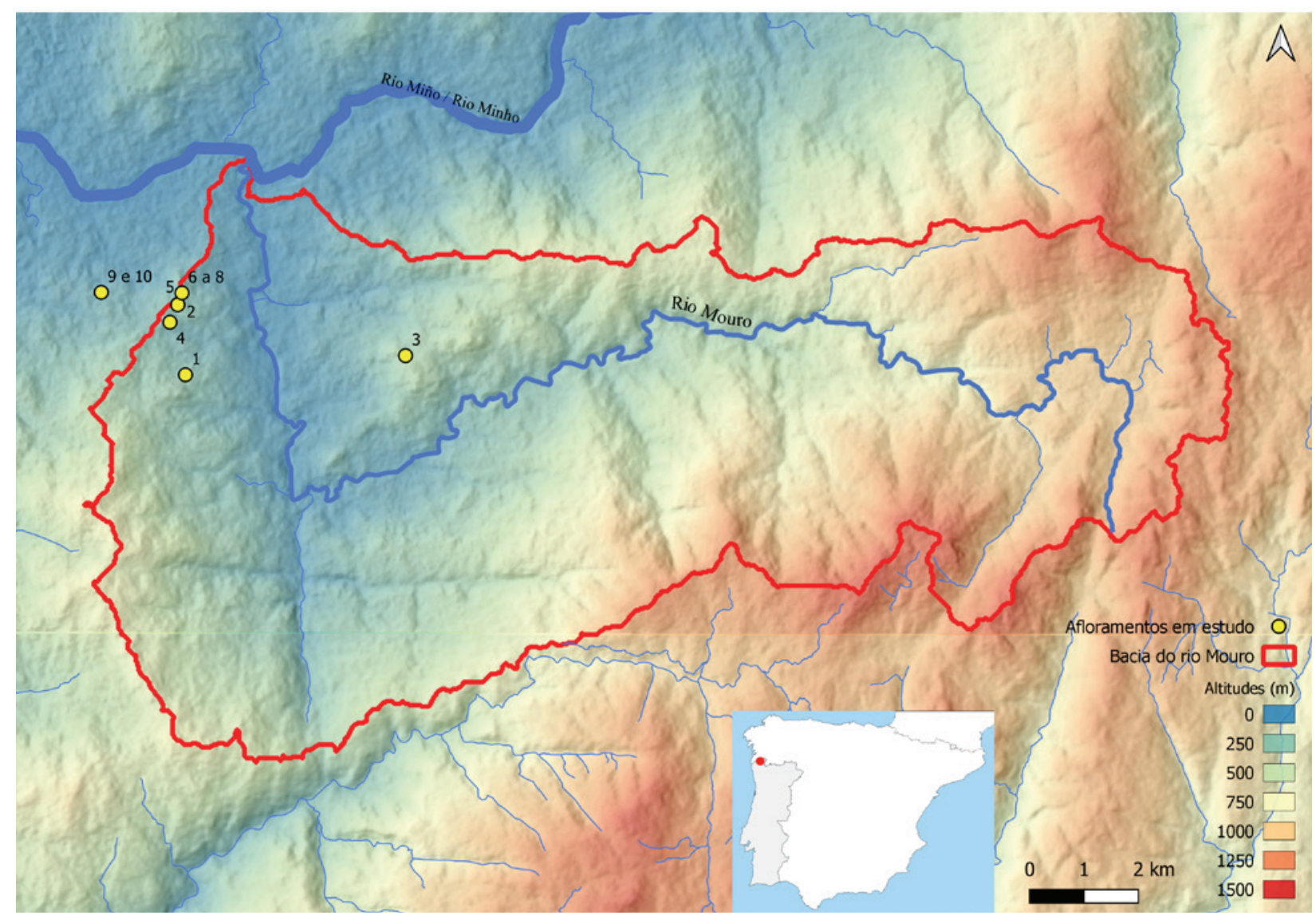

Figura 1 - Localização da Bacia do rio Mouroe das gravuras rupestres citadas no texto. 


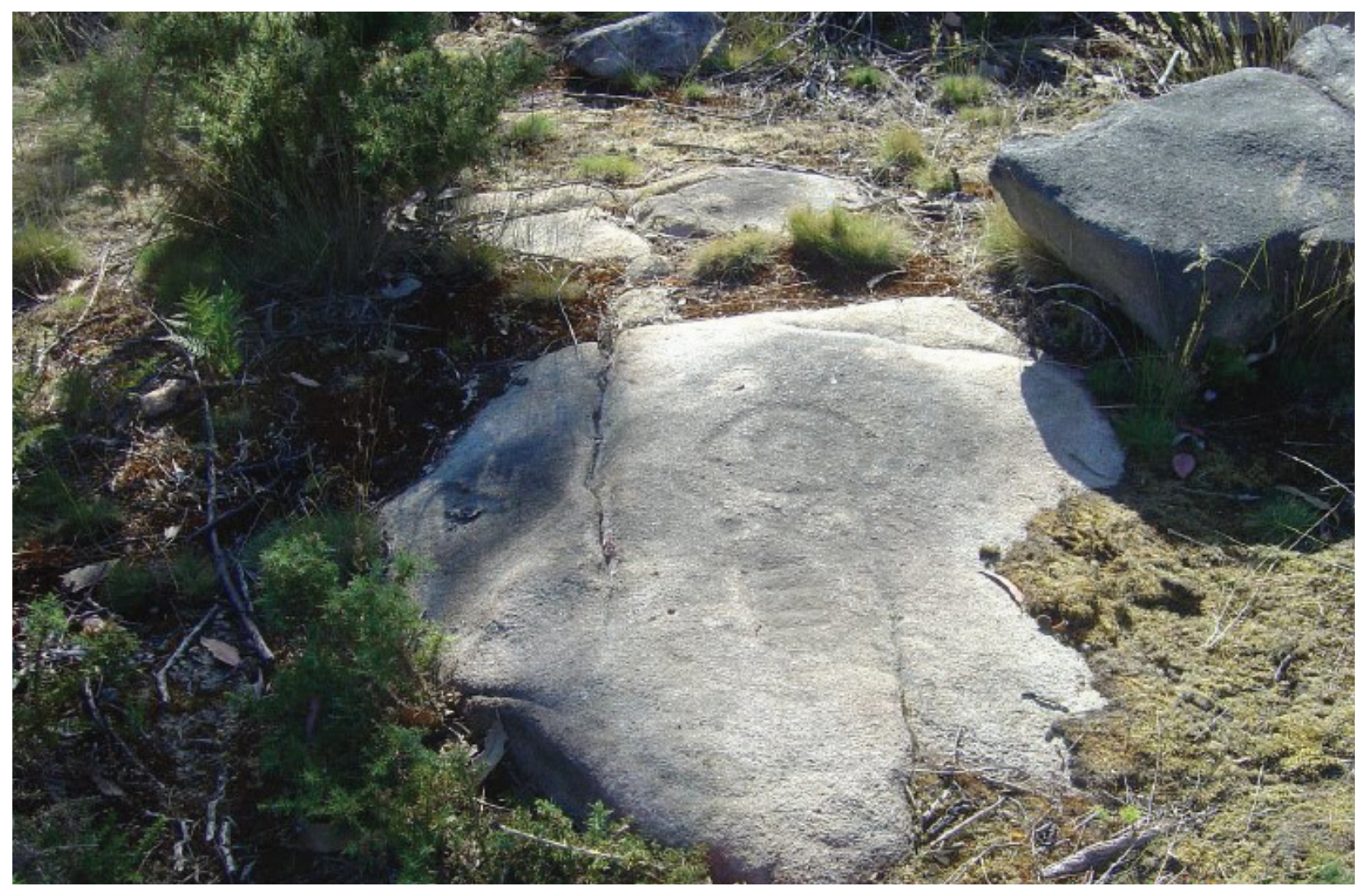

Figura 2 - Gasgaia. Vista geral do afloramento (seg. Bettencourt, 2014d).
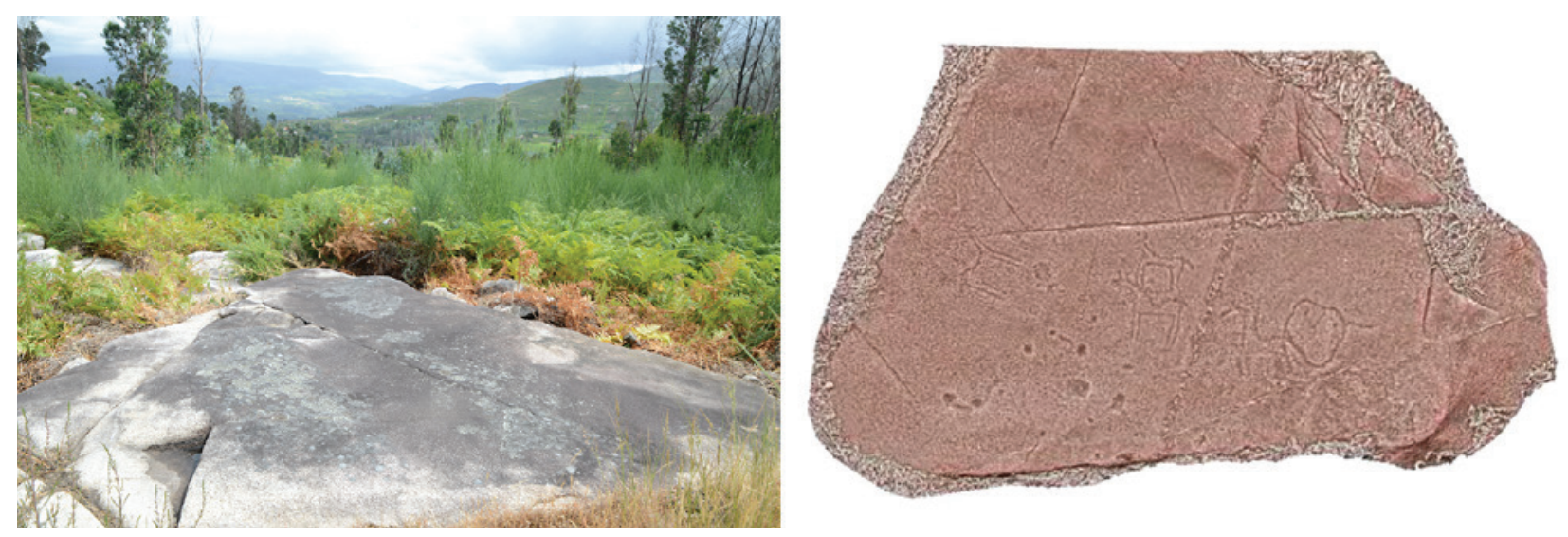

Figura 3 - À esquerda uma vista geral para o vale do rio Mouro a partir da Buraca da Moura 5. À direita fotogrametria da Buraca da Moura 5 (seg. MARTÍNEZ-Soto, et alli (2017). 

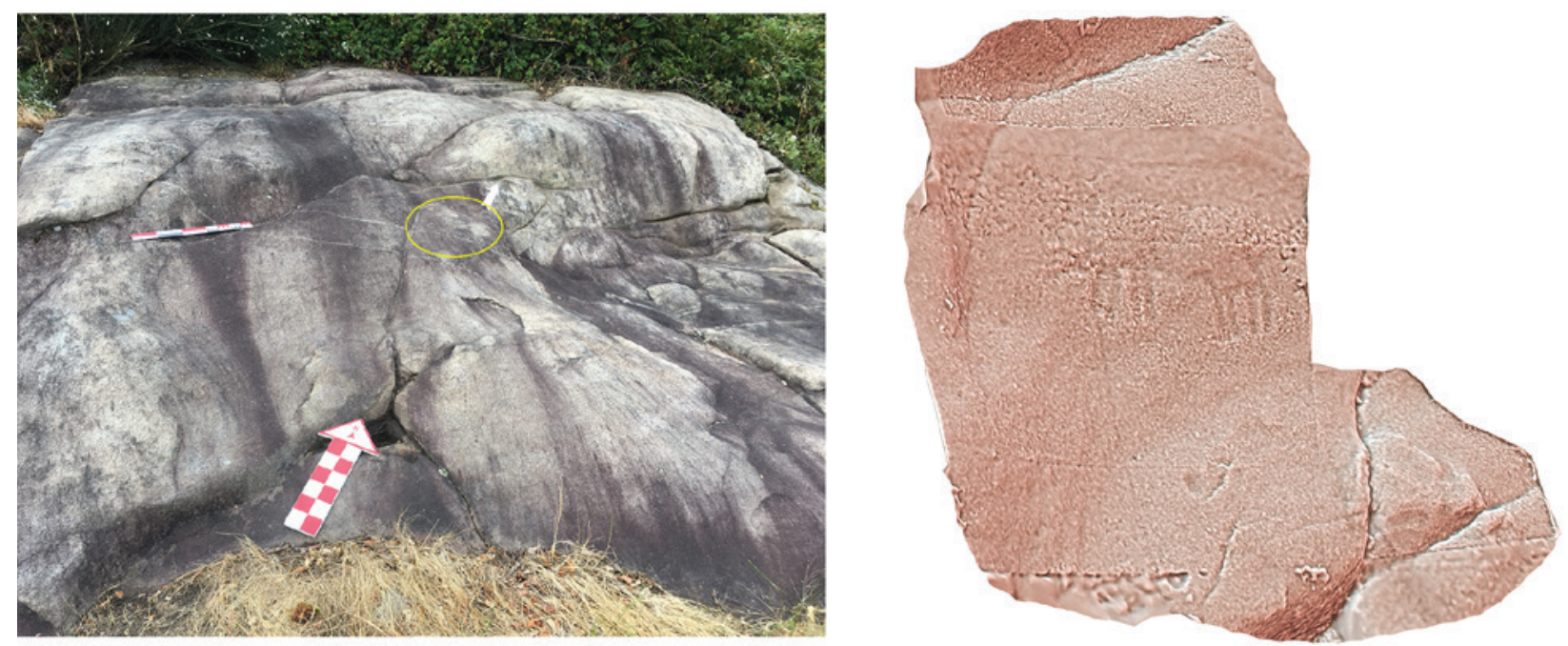

Figura 4 - À esquerda: Vista geral de Nossa Senhora da Assunção 15 com localização do painel com equídeos; à direita: fotogrametria dos equídeos gravados.
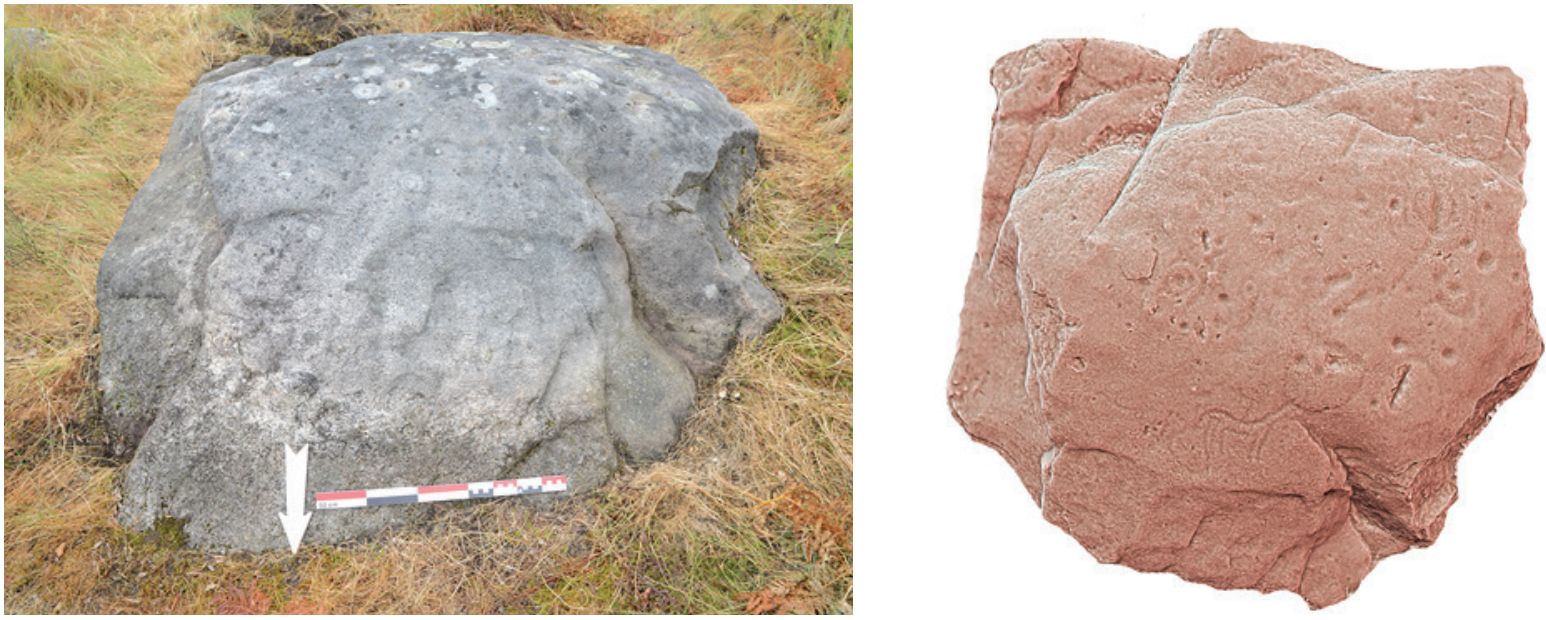

Figura 5 - Fotografia e levantamento fotogramétrico de Nossa Senhora da Assunção 17.

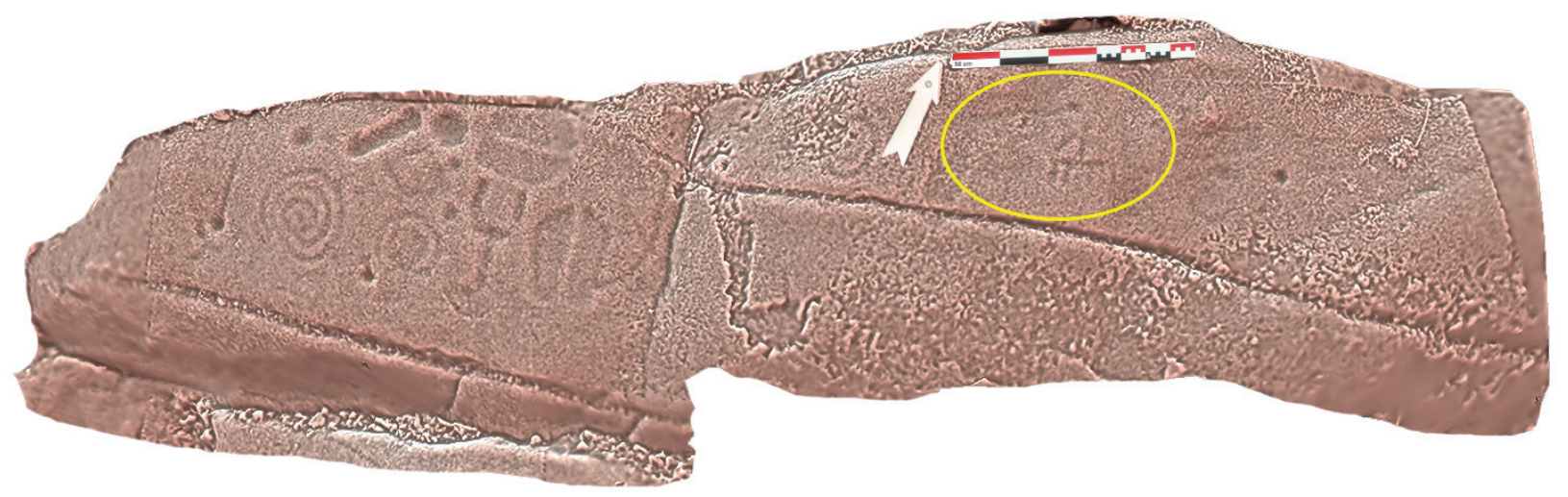

Figura 6 - Levantamento fotogramétrico do afloramento da Nossa Senhora da Assunção 19. 

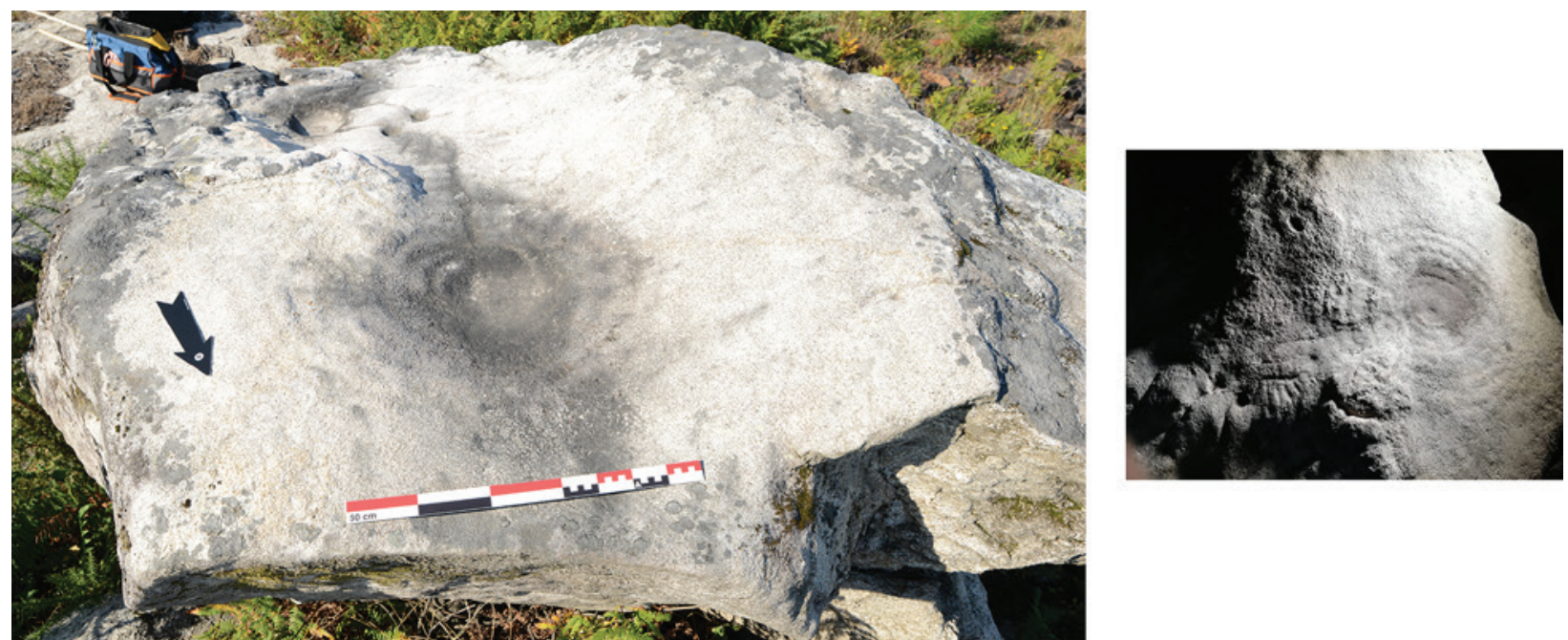

Figura 7 - Afloramento do Baldio da Porqueira. à direita com luz rasante (foto: José Alvarez Alonso).
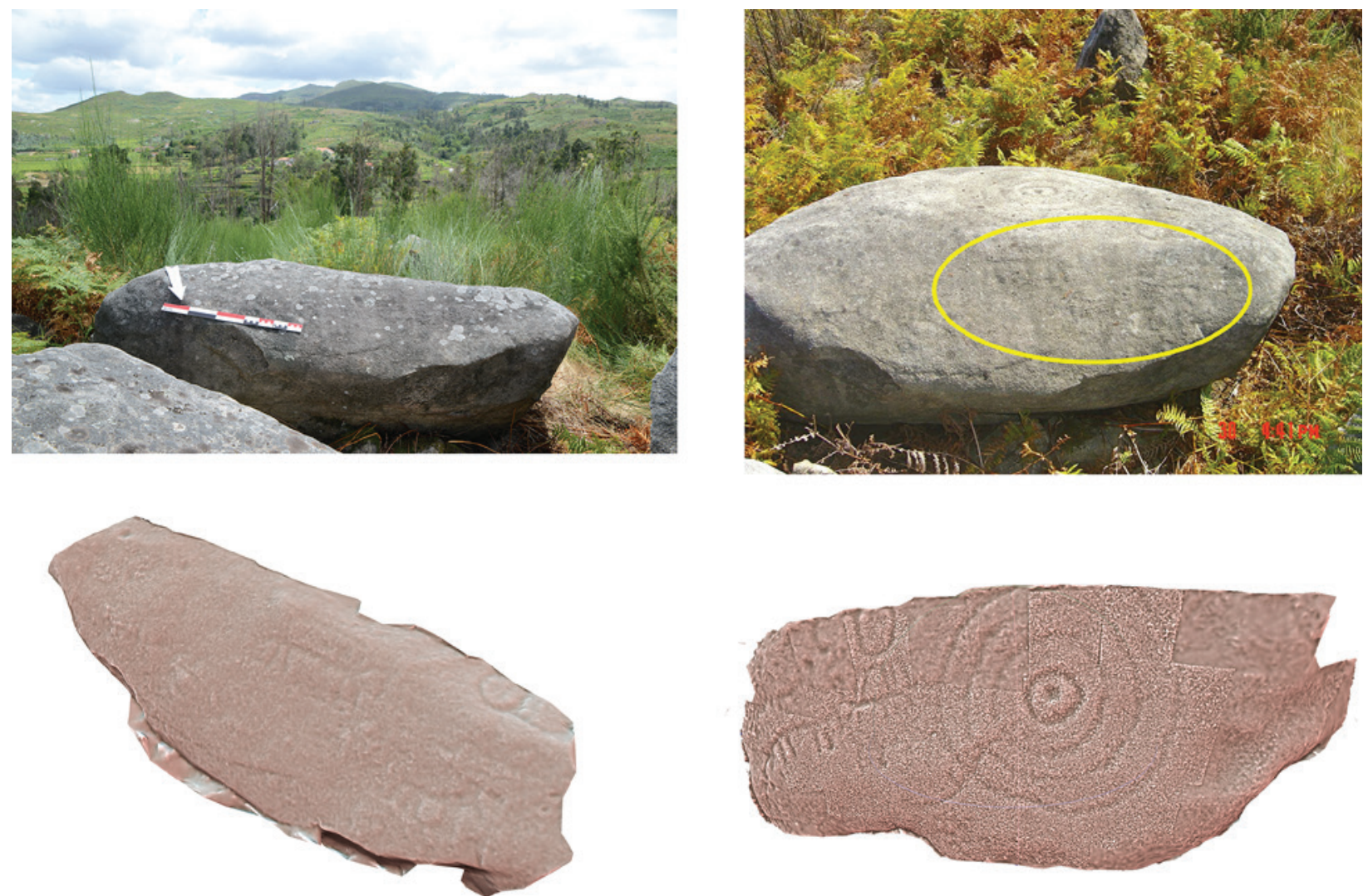

Figura 8 - Em cima, enquadramento paisagístico da Coutada das Águas 1 (à esquerda), e pormenor da vista do declive a nascente (à direita - Imagem: Bettencourt, Ana M. S. e Abad-Vidal, E. (2014d). Em baixo, levantamento fotogramétrico do declive a nascente (à esquerda) e poente (à direita). 


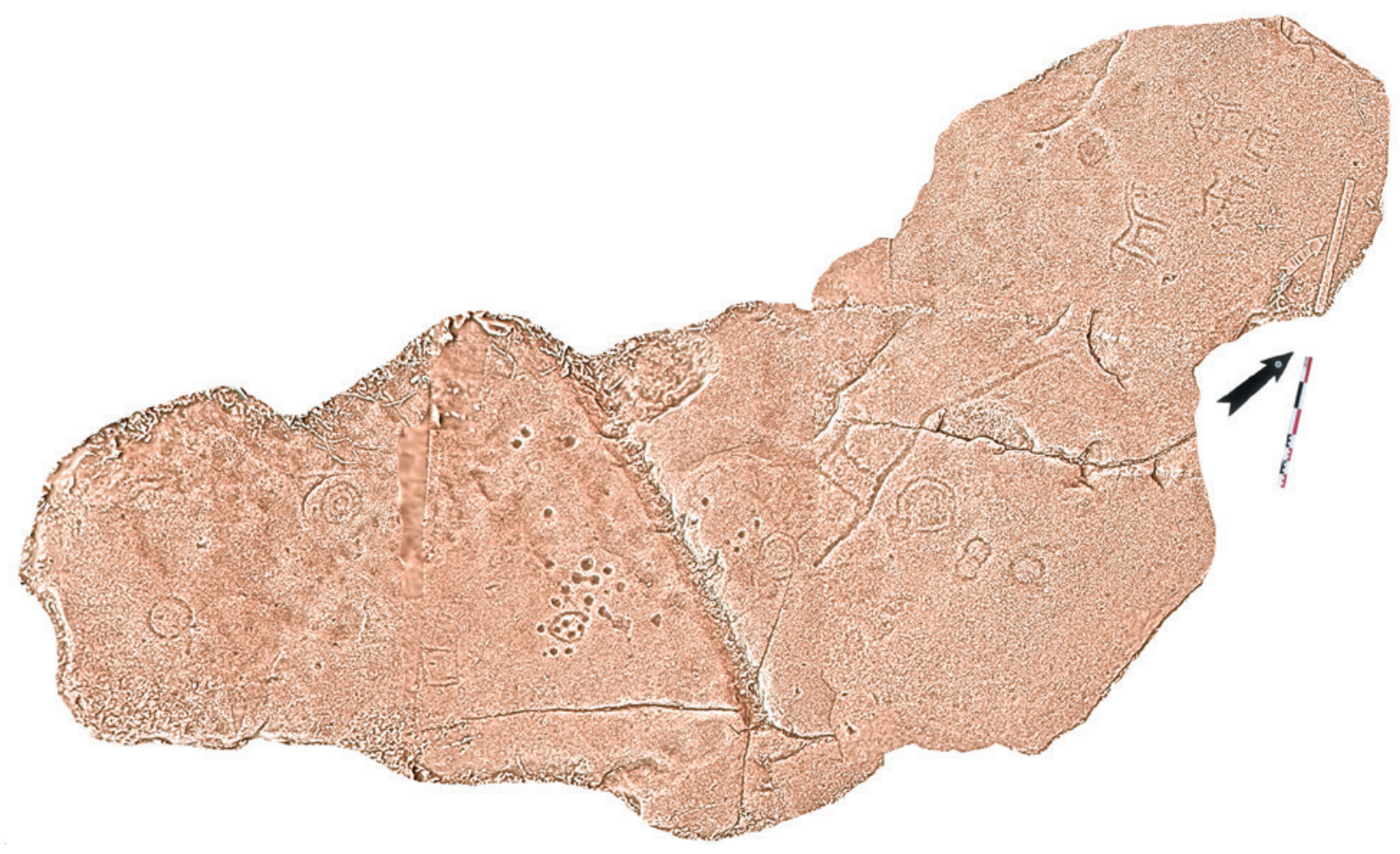

Figura 9- Fotogrametria do afloramento Teixugos 2.
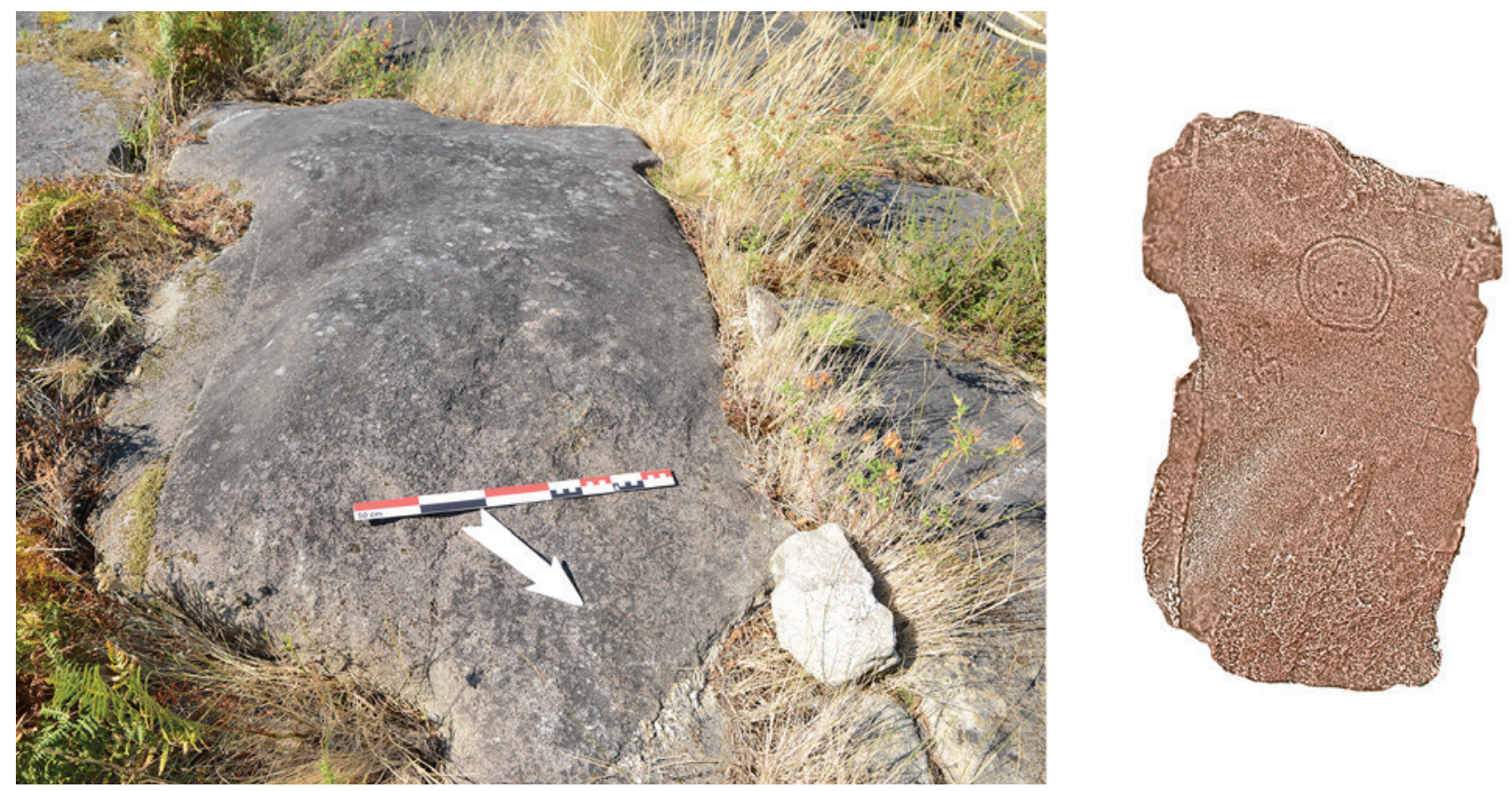

Figura 10 - Teixugos 3. Vista geral do painel 1 (à esquerda) e levantamento fotogramétrico (à direita). 

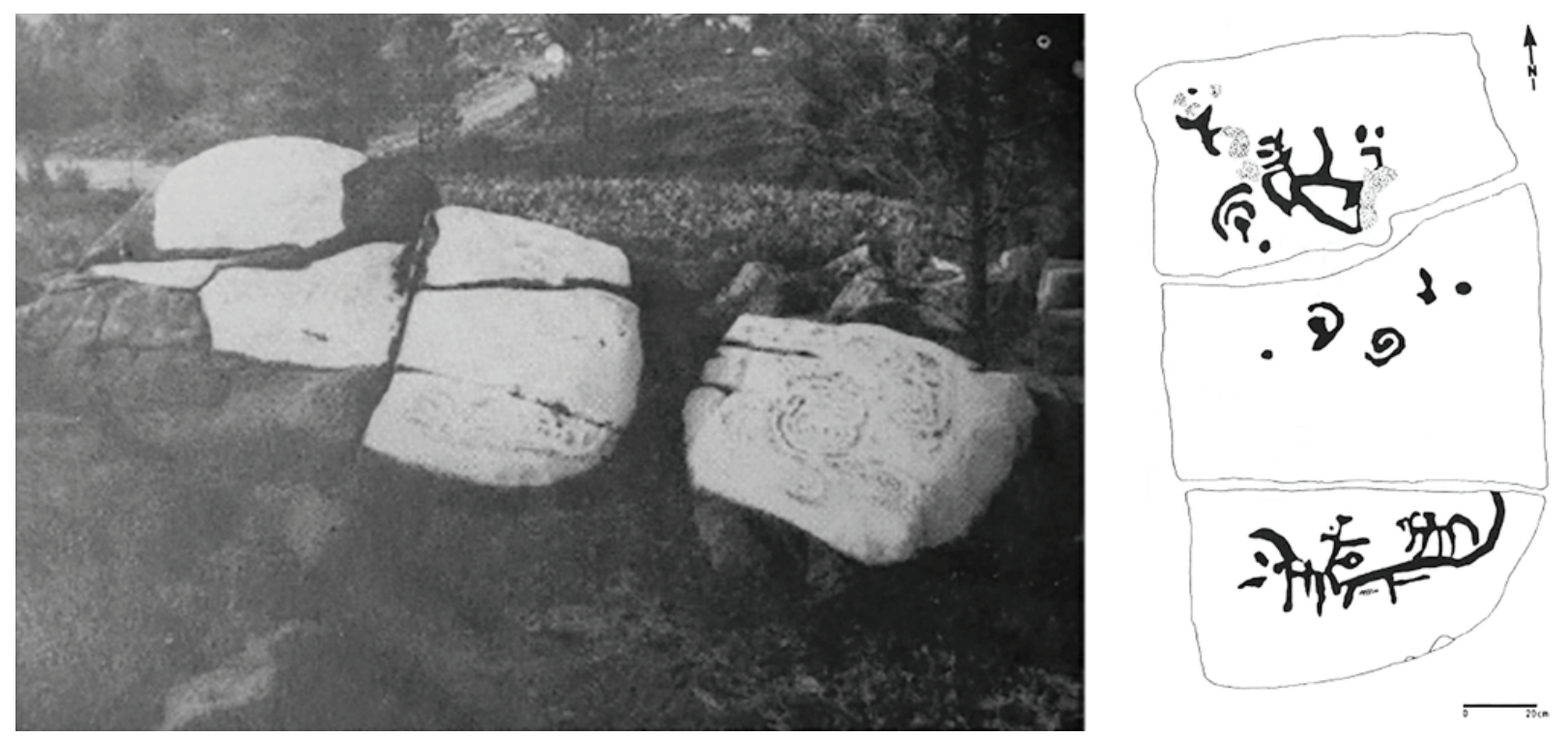

Figura 11 - À esquerda: decalque da Chã da Sobreira 1, 2 e 3 (seg. Marques, 1986, p. 19) e à direita: fotografia do sítio com bicromático (seg. Marques, 1986, p. 26).

\begin{tabular}{|l|l|l|l|}
\hline \multicolumn{1}{|c|}{ Sítio } & Freguesia & Concelho & \multicolumn{1}{|c|}{ Referência bibliográfica } \\
\hline Baldio da Porqueira 1 & Longos Vales & Monção & Inédito \\
\hline Buraca da Moura 5 & Barbeita & Monção & Martínez-Soto, et alii 2017 \\
\hline Chã da Sobreira 2 & Podame & Monção & Marques, 1986; Bettencourt, 2014f \\
\hline Coutada das Águas 1 & Longos Vales & Monção & Bettencourt, 2014a \\
\hline Gasgaia & Barbeita & Monção & Bettencourt, 2014d \\
\hline Nossa Senhora da Assunção 15 & Barbeita & Monção & Bettencourt, 2014b \\
\hline Nossa Senhora da Assunção 17 & Barbeita & Monção & Bettencourt, 2014c \\
\hline Nossa Senhora da Assunção 19 & Barbeita & Monçã̃o & Inédito \\
\hline Teixugos 2 & Longos Vales & Monção & Bettencourt, 2014e \\
\hline Teixugos 3 & Longos Vales & Monção & Inédito \\
\hline
\end{tabular}

Tabela 1 - Sítios arqueológicos com equídeos da bacia do rio Mouro. 


\title{
PALETAS NA ARTE RUPESTRE DO NOROESTE DE PORTUGAL. INVENTÁRIO PRELIMINAR
}

\author{
Bruna Sousa Afonso ${ }^{1}$, Ana M. S. Bettencourt ${ }^{2}$, Hugo A. Sampaio ${ }^{2,3}$
}

\begin{abstract}
RESUMO
As paletas são pouco frequentes na arte rupestre do Noroeste de Portugal. Encontram-se tanto em contextos de Arte Atlântica Clássica, como de Arte Esquemática de ar livre, mas também noutros contextos com motivos de difícil classificação. Apesar de conhecidos não existe um inventário de sítios com este motivo nem um quadro tipológico dos mesmos, apesar de alguma subdivisão realizada por Bettencourt (2017a). Também não são conhecidos os contextos culturais e físicos em que se encontram.

O objetivo deste trabalho é o de colmatar estas ausências através de um primeiro inventário, da criação de uma tipologia de motivos e de uma tentativa de inserção espacial e cultural dos mesmos.

Palavras-chave: Noroeste de Portugal, Gravuras rupestres, Paletas, Tipologia e espacialidade.
\end{abstract}

\begin{abstract}
Palettes are rare in the rock art of Northwest Portugal. They are found both in Classical Atlantic Art and openair Schematic Art contexts, but also in other contexts of difficult classifications. Although known, there is no inventory of sites with this motif or a typological table of them, despite some subdivision made by Bettencourt (2017a). The cultural and physical contexts, in which they are found, are also not known.

The aim of this work is to rectify these absences through a first inventory, the creation of a typology of motifs and an attempt at their spatial and cultural integration.

Keywords: Northwest of Portugal, Rock engravings, Palettes, Typology and spatiality.
\end{abstract}

\section{INTRODUÇÃO}

O motivo designado por "paleta", apesar de raramente gravado, encontra-se em contextos de Arte Atlântica Clássica, de Arte Esquemática de ar livre e noutros de difícil classificação.

As paletas ocorrem no Noroeste da Península Ibérica, especialmente na Galiza e no Norte de Portugal, embora também sejam conhecidos no Norte de Itália (Fossati, 2007).

Quanto à definição morfológica daquilo que é uma paleta, Peña Santos e Vázquez Varela (1979, p. 97), afirmam que “(...) obedecem a un mismo tipo, es- tando rematado su apéndice inferior por un ensanchamiento circular que puede ser macizo o hueco a modo de anillo". Costas Goberna e Novoa Alvaréz (1993, p. 199) consideram que correspondem "una figura definida por rebaje de planta rectangular o cuadrada que presenta en un extremo en el centro un surco a modo de mango acabado com más o menos detalle". Fossati (2007, p. 135), para os Alpes italianos, define as paletas como a representação de um objeto "quadrangular (rarely circular) engraving with a handle (often also with a pommel)". Abreu (2012) chama-lhes "shovel-like shape". Recentemente, Bettencourt (2017a, p. 1058), defende

\footnotetext{
1. Aluna de Mestrado em Arqueologia da Universidade do Minho; bruna-ooo5@live.com.pt

2. Laboratório de Paisagens, Património e Território (Lab2PT); Departamento de História da Universidade do Minho, Braga, Portugal; anabett@uaum.uminho.pt

3. Escola de Hotelaria e Turismo do Instituto Politécnico do Cávado e do Ave (ESHT/IPCA); Centro de Investigação, Desenvolvimento e Inovação em Turismo (CITur); hugoaluai@gmail.com
} 
uma conceção alargada da paleta considerando que pode incluir qualquer objeto com a parte superior de forma circular, oval, quadrangular ou retangular, e a parte inferior com uma espécie de "cabo" ou "pega". Este "cabo" pode ser perpendicular ou curvo, dando continuação ao corpo do objeto e podendo, em certos casos, terminar de forma pontiaguda, horizontal, circular ou irregular. Será esta a conceção usada neste trabalho.

Relativamente às propostas cronológicas, Peña Santos e Vázquez Varela (1979) atribuem as paletas ao Bronze Final. Baptista (1984, p. 76) também integra a sua origem no Bronze Final embora considere que persistem para a Idade do Ferro enquanto Santos-Estévez (2007, p. 52) propõe uma cronologia desde o Bronze Final até à Idade Média, considerando que o seu apogeu ocorre na Idade do Ferro. Para Valcamónica, nos Alpes italianos, Fossati (2007), atribui-as à $3^{\underline{a}}$ fase cronológica do sítio que corresponde à Idade do Bronze Final (final do $2^{\circ}$ milénio a.C.), por se sobreporem a espirais e punhais, motivos habitualmente inseridos no Neolítico ou Calcolítico. Admite que persistam para a Idade do Ferro, período que se manifesta na $4^{\underline{a}}$ fase (finais do séc. VI a.C.). Bettencourt e Rodrigues (2013) consideram-nas da Idade do Ferro, a propósito do estudo do Fieiral 2, em Melgaço. Posteriormente, Bettencourt (2017a; 2017b) insere as paletas de pá quadrangular, oval ou semi-oval, na Idade do Bronze Final, usando para tal o paralelo que se pode estabelecer com algumas tipologias de navalhas de barbear desta cronologia. Esta autora considera, ainda, as paletas de pá circular, da mesma cronologia, por similitude aos espelhos representados nas estelas do Sudoeste Ibérico. Em relação às suas interpretações, Ferri (1975) coloca a hipótese de que podem ser espelhos, opinião refutada por Marinis (1975) que defende que estes objetos não podiam corresponder a espelhos porque o ferro não é um material refletor. Fossati (2007, p. 135) sugere que as paletas são a representação de um símbolo de "admissão" feminina porque ocorrem depósitos de paletas em bronze (e mais tarde em ferro), em sepulturas femininas do Bronze Final, como nas culturas Golasecca (Bronze Final e Ferro Inicial), Villanova (Idade do Ferro Inicial) e Venética, (em 1000 a.C.). Defende, ainda, que em Valcamónica, estão localizadas espacialmente no que se poderá interpretar como a "entrada" da rocha, simbolizando, desta forma, uma restrição, como é o caso das rochas 35 e 5o, em Naquane, e da rocha
4, em In Valle. Na Idade do Ferro, verifica que estão associadas a guerreiros. A propósito de uma paleta encontrada, entre outros objetos para manejar com o fogo (como espetos e colheres tipo concha), no túmulo feminino de Nerca Tomb, em Este, Pádua, Fossati (2007, p. 135) sugere que estes objetos poderiam servir para remover cinzas ou retirar o pão do fogo, simbolizando assim o fogo ou algo relacionado com ele, servindo, apenas, para propósitos rituais. Já Abreu (2012, p. 525) sugere que este motivo poderá corresponder a pás de trabalho, em madeira, a pequenos objetos ritualistas para recolher cinzas dos mortos, a espelhos de bronze ou a um misto de todas estas funções.

Apesar destes trabalhos, o estudo destes motivos gravados, em Portugal, é ainda incipiente. Não há inventários, nem se conhece a sua distribuição geográfica e o seu contexto físico e cultural; não há estudos tipológicos sistemáticos que individualizem os diferentes grupos designados pelo mesmo nome; não há estudos que relacionem cada grupo tipológico com outros motivos gravados no mesmo afloramento e não há estudos espaciais que relacionem estes motivos com outros contextos arqueológicos mais próximos que possibilitem novas hipóteses cronológicas e interpretativas. Considerando o que foi dito, pretende-se, com este trabalho, contribuir para o inventário deste tipo de motivos, para a individualização morfológica dos diferentes motivos designados por paletas e para o estudo da localização geográfica e espacial de cada um dos tipos identificados, na ampla escala de análise. Através deste trabalho, pretende-se, ainda, identificar eventuais padrões geográficos para cada tipo estabelecido. O espaço de trabalho, será o Noroeste de Portugal, com limite oriental na sub-bacia do rio Tâmega.

\section{METODOLOGIA}

A metodologia usada na elaboração deste trabalho compreendeu pesquisa bibliográfica e em portais, como o Corpus Virtual de Arte Rupestre do Noroeste Português - CVARN (www.cvarn.org). Foi também consultada cartografia, como as Cartas Militares de Portugal, na escala 1: 2500o, de Chaves, Fafe, Mondim de Basto, Ponte da Barca e Viana do Castelo. Não houve oportunidade de efetuar qualquer saída de campo. Após a recolha de dados, estes foram tratados num Sistema de Informação Geográfica, com vista a uma melhor análise da distribuição 
geográfica das paletas e das relações dos afloramentos em que se encontram, com o território.

\section{INVENTÁRIO}

O inventário está organizado por ordem alfabética dos distritos. No âmbito de cada distrito também está organizado pela ordem alfabética dos concelhos e das freguesias.

Os descritores de análise são: 1) a localização administrativa; 2) o contexto físico e ambiental; 3) o contexto arqueológico; 4) a caraterização do afloramento gravado; 5) a descrição dos motivos gravados e 6) a biografia do afloramento.

\subsection{Distrito de Braga}

\subsubsection{Concelho de Fafe}

\section{Cabanas}

Localização administrativa: Lugar: Lameira; Freguesia: São Gens.

Contexto físico e ambiental: localiza-se no topo do planalto da Lameira, a $679 \mathrm{~m}$ de altitude.

Caraterização do afloramento gravado: afloramento de granito, pouco destacado do solo, com a face superior horizontalizada.

Descrição dos motivos gravados: Cabanas foi publicada por Sampaio e Garcia Diez (2000) que não identificaram as paletas. Estas foram identificadas por Cardoso (2015, p. 85) que aí individualiza 4 destes motivos ao identificar três fases de gravação neste sítio, sendo a primeira composta por círculos, círculos com covinha central e covinhas; a segunda, por paletas, que data da proto-história e a terceira correspondente a um momento de cristianização onde inscreve as cruzes latinas que se terão adossado a alguns círculos. Esta autora, observa ainda, que os sulcos correspondem a destruições de época mais recente. Quanto às paletas, 3 são de pá sub-retangular e 1 de pá trapezoidal. Três delas encontram-se na periferia do afloramento e uma no seu centro. Orientam-se para várias direções. Duas estão sobrepostas por covinhas e por um motivo em baixo relevo. As paletas foram gravadas em baixo relevo (Figura 1). Bibliografia: Sampaio e Garcia Diez, 200o; Cardoso, 2015 .

\subsection{Distrito de Viana do Castelo}

\subsubsection{Concelho de Melgaço}

\section{Fieiral 2}

Localização administrativa: Lugar: n/a; Freguesia: Castro Laboreiro.

Contexto físico e ambiental: numa pequena plataforma do Alto dos Piornais, no topo do planalto de Castro Laboreiro, a $1169 \mathrm{~m}$ de altitude, nas imediações das Corgas do Fieiral, dos Piornais e do Vale das Antas, tributárias do rio Laboreiro. Há uma nascente contígua. Do local há domínio visual para prados próximos e para o vale do Castro Laboreiro.

Contexto arqueológico: o Fieiral 2 fica nas imediações das gravuras rupestres do Fieiral 1, distanciando-se destas cerca de 10 metros. Localiza-se, ainda, no seio da necrópole megalítica do planalto de Castro Laboreiro (Bettencourt e Rodrigues, 2013, p. 132). Caraterização do afloramento gravado: afloramento de granito, elevado do solo, de superfície superior irregular, com algumas diaclases significativas e áreas deprimidas (Bettencourt e Rodrigues, 2013, p. 132).

Descrição dos motivos gravados: Bettencourt e Rodrigues (2013) publicam uma ficha descritiva deste local tendo aí identificado, entre motivos da arte esquemática, como quadrados e retângulos segmentados e antropomorfos esquemáticos, inúmeras paletas de pá quadrangular com cabo delimitado por covinha. Identificaram, ainda, um machado plano de gume alargado, um círculo segmentado e podomorfos. Verificam que as paletas estão presentes na área mais interna da rocha, algumas sobrepondo-se a antropomorfos esquemáticos, como que alterando os signos anteriores. Observações recentes possibilitaram verificar que também existem na periferia este do afloramento, perto de um par de podomorfos (Figura 2). As paletas orientam-se para diversas orientações. Foram gravadas em baixo relevo e os cabos por picotagem seguida de abrasão (Bettencourt e Rodrigues, 2013). Cronologicamente, as autoras atribuem à Idade do Bronze, o machado plano de gume alargado e o círculo segmentado e, deste período ou posterior, um par de podomorfos. Sobre as paletas, afirmam serem motivos que se inserem na Idade do Ferro.

Bibliografia: Bettencourt e Rodrigues, 2013; dados inéditos. 


\subsubsection{Concelho de Ponte da Barca}

\section{Chã da Rapada 6-A}

Localização administrativa: Lugar: n/a; Freguesia: Britelo.

Contexto físico e ambiental: numa plataforma da vertente noroeste da serra Amarela, em local de portela natural entre as terras de vale e os patamares mais altos da serra. Deste sítio avistam-se as vertentes das serras do Soajo e Amarela e ainda o vale do Lima (Bettencourt, 2013, p. 162). O local é delimitado a norte e a sul por linhas de água que correm para o rio Lima.

Contexto arqueológico: no topo da serra encontra-se a necrópole megalítica do Britelo. A Chã da Rapada 6-A corresponde a um núcleo com inúmeros afloramentos gravados, maioritariamente com Arte Esquemática, embora ocorram motivos mais recentes.

Caraterização do afloramento gravado: afloramento granítico de grão médio a grosseiro, localizado na área central do núcleo de gravuras da Chã da Rapada, nas imediações das rochas 4 e 5 (Martins, 2006). Descrição dos motivos gravados: Martins (2006) estudou os afloramentos deste sítio, identificando uma paleta de pá quadrangular no que define como a rocha $n^{\circ} 6$, além de antropomorfos esquemáticos de mãos grandes, um antropomorfo esquemático de braços erguidos, quadrados simples e segmentados, que se encaixam na Arte Esquemática. Ocorrem, ainda cruciformes que parecem mais recentes (Fig. 1). Baptista (1986) considera duas fases de gravação para o conjunto da Chã da Rapada: uma primeira com motivos esquemáticos, circulares e idoliformes do Bronze Final e uma segunda, que atribui à época Medieval ou Moderna, onde insere os cruciformes. Seguindo esta proposta, Martins (2006) considera grande parte destes motivos à primeira fase de gravação, ou seja, à Proto-histórica, maioritariamente à Idade do Bronze, exceto a paleta que atribui à Idade do Ferro. Os cruciformes seriam também da Idade Média ou Moderna. Bettencourt (2013) sugere uma biografia mais complexa para este afloramento, defendendo que esteve simbolicamente ativo desde a Pré-história Recente até momentos históricos, sendo sujeito a adições ou alterações que mudaram o seu significado original, como é o que acontece na Idade do Ferro, através da paleta. Admite, ainda, que alguns antropomorfos possam ter sido gravados no
Neolítico Médio/Final, dado a sua organização com motivos reticulados inseríveis na arte Esquemática e associados a este período.

Bibliografia: Martins, 2006; Bettencourt, 2013.

\subsubsection{Concelho de Viana do Castelo}

\section{Laje da Churra}

Localização administrativa: Lugar: Paçô; Freguesia: Carreço.

Contexto físico e ambiental: no sopé da vertente oeste da Serra de Santa Luzia, sobranceiro ao ribeiro da Fonte Quente que desagua diretamente no oceano atlântico, a cerca de $44 \mathrm{~m}$ de altitude. É um afloramento com visibilidade restrita para o meio envolvente, pelo que talvez este lugar fosse intencionalmente "escondido" (Santos, 2014, p. 5).

Contexto arqueológico: da Laje da Churra há visibilidade para o monumento funerário da Cova da Moura, atribuível ao Bronze Final e para o Castro de Montedor (Santos, 2014, p. 5). A cerca de 2,7 km fica o povoado do Bronze Final de Santo António, em Afife.

Caraterização do afloramento gravado: afloramento de granito porfiróide de grão fino, ou médio a fino com aproximadamente $400 \mathrm{~m}^{2}$ (Santos, p. 5). É destacado do solo, com uma plataforma superior pequena a norte, de onde parte um desnível acentuado para oeste provocado por extração de pedra. Para este e sul, existem declives suaves. Após o primeiro declive, a este, há um grande patamar horizontalizado, de onde partem novos declives para nascente e sul. Verificam-se, também, declives a oeste e sudoeste (Santos, 2014, p. 45-47).

Descrição dos motivos gravados: Santos (2014) identifica 1170 motivos, entre eles círculos segmentados, zoomorfos, barquiformes, antropomorfos, armas e ferramentas, covinhas, raras espirais e algumas paletas variadas, segundo os critérios usados neste trabalho (Figura 3), como as de pá quadrangular, retangular, semicirculares, ovais, etc.

Distribuem-se nos painéis 2, 3, 5 e 11a, 11b e 11c.

As sobreposições, diferentes motivos e técnicas levou (Santos, 2014, p. 5) a considerar que a Laje da Churra foi gravada entre o Neolítico/Calcolítico e a Idade do Ferro, embora existam alguns elementos de períodos históricos, como cruzes.

Bibliografia: Santos, 2014. 


\subsection{Distrito de Vila Real}

\subsubsection{Concelho de Chaves}

Outeiro da Moeda 1, 2 e 3

Localização administrativa: Lugar: Quinta do Salgueirinho; Freguesia: Mairos.

Contexto físico e ambiental: o Outeiro da Moeda corresponde a um aglomerado de afloramentos graníticos, de entre 20 a $30 \mathrm{~m}$, dispostos no sentido norte-sul. É nessa área que se localizam as gravuras rupestres. A nascente deste local existe um curso de água.

Contexto arqueológico: a cerca de $500 \mathrm{~m}$ para sul fica o conjunto de gravuras do Outeiro do Tripe. Segundo Mário Reis Soares, no âmbito dos trabalhos de Relocalização, Identificação e Inspeção de Sítios pela extensão do IPA - Macedo de Cavaleiros, realizados em 2004, foram encontrados no Outeiro da Moeda, alguns indícios de vestígios arqueológicos, provavelmente pré-históricos.

Caraterização dos afloramentos gravados: segundo a descrição de Mário Reis (Portal do Arqueólogo, CNS 3619), as gravuras localizam-se na área do afloramento mais destacado, existente a norte do Outeiro da Moeda, onde há um pequeno abrigo definido por uma pala bem evidente.

Caraterização dos motivos gravados: o local é conhecido deste os anos 40 do séc. XX (Santos Júnior, 1940) mas a descrição mais detalhada pertence a Mário Reis (Portal do Arqueólogo, CNS 3619). Aqui ocorrem três afloramentos gravados apenas com paletas de pá retangular e cabo rematado por pequena covinha. Todas foram gravadas em baixo relevo. No afloramento com maior número de motivos, o Outeiro da Moeda 1, identificaram-se cerca de uma vintena de paletas gravadas numa pendente orientada para poente. Pelo lado exterior da pala do abrigo, e contíguo ao afloramento anterior, encontra-se o Outeiro da Moeda 2, de pequenas dimensões, com uma superfície aplanada e contorno trapezoidal. Aí foi gravada uma única paleta que se encontra muito erodida. O Outeiro da Moeda 3, fica no interior do abrigo, num bloco granítico irregular, de superfícies tendencialmente horizontais onde se gravaram três paletas de pequenas dimensões.

Bibliografia: Santos Júnior, 1940; Portal do arqueólogo, CNS 3619 .
Tripe 8

Localização administrativa: Lugar: n/a; Freguesia: Mairos.

Contexto físico e ambiental: no interior de um vasto "anfiteatro" natural, suavemente afunilado para sul e sudoeste (Baptista, 1984) a cerca de 770 $\mathrm{m}$ de altitude. Do local há visibilidade para o vale do Tâmega.

Caraterização dos afloramentos gravados: Trata-se de um bloco solto (Valdez, 2010) feito de granito de grão fino a médio (Baptista, 1984).

Caraterização dos motivos gravados: Pelo decalque de António Martinho Baptista e pela fotografia de Valdez (2010, p. 198), verifica-se que os motivos de Tripe 8 correspondem a uma paleta de pá retangular e cabo vertical atravessado por um traço perpendicular espessado junto ao cabo, um ou dois possíveis antropomorfos inseríveis na Arte Esquemática, e vários cruciformes (Figura 4).

Técnica de percussão é picotagem, na sua maioria, mas a paleta é em baixo relevo.

Bibliografia: Baptista, 1984; Valdez, 2010.

\section{Outeiro Machado 1}

Localização administrativa: Lugar: Boqueiro; Freguesia: Vale de Anta.

Contexto físico e ambiental: O Outeiro Machado I localiza-se num patamar da serra do Boqueiro a $436 \mathrm{~m}$ de altitude, com visibilidade para o vale do Tâmega.

Caraterização dos afloramentos gravados: Trata-se de uma afloramento muito destacado do solo, de forma alongada e de contorno sensivelmente ovalado, com uma superfície superior ligeiramente abaulada. Apesar de partido numa das extremidades, mede, ainda, cerca de $18 \mathrm{~m}$ de comprimento, por 6 $\mathrm{m}$ de largura e $3 \mathrm{~m}$ de altura.

Caraterização dos motivos gravados: O Outeiro Machado é referido na bibliografia arqueológica desde os inícios do séc. XX (Vasconcelos, 1917; Sampaio, 1928; Corrêa, 1929; Santos Júnior, 1940; Cardoso, 1942). Apesar de ter sido classificado como IIP - Imóvel de Interesse Público, pelo Decreto n.ำ

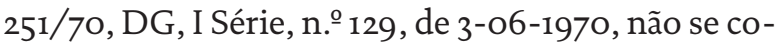
nhece nenhum trabalho monográfico, recente, sobre este local.

No seu topo Santos Júnior identificou mais de 500 motivos gravados, distribuídos pela superfície superior e início das pendentes, seguindo diversas 
orientações e normalmente sem articulação entre eles. Destacam-se quadrados segmentados, alguns deles cristianizados posteriormente, antropomorfos de diferentes configurações (em "fi" e em arco ultrapassado), figuras semicirculares, tradicionalmente conhecidas como "ferraduras" (algumas delas com covinha ou sulco no interior) e retângulos segmentados ou escaleriformes e um eventual idoliforme, inseríveis na Arte Esquemática. Ocorrem, ainda, dois possíveis machados encabados que estão na origem da designação do lugar, círculos segmentados, paletas de diversos tipos (de pás quadrangulares, circulares e semicirculares, entre outras, com distintos tipos de cabos), covinhas, covinhas associadas a sulcos curvos, inúmeros cruciformes de diferentes estilos (alguns deles representando cruzes latinas, outros podendo ser marcas de termo), entre outros motivos que só um estudo detalhado e com técnicas mais sofisticadas do que as usadas por Corrêa (1929) e Santos Júnior (1978) permitirá identificar. As paletas distribuem-se, essencialmente, pela periferia do afloramento e orientam-se para várias direções (Figura 5).

Bibliografia principal: Vasconcelos, 1917; Sampaio, 1928; Corrêa, 1929; Santos Júnior, 1940; Cardoso, 1942.

\subsubsection{Concelho de Mondim de Basto}

\section{Campelo 1}

Localização administrativa: Lugar: Campos; Freguesia: Mondim de Basto.

Contexto físico e ambiental: Campelo 1 localiza-se numa plataforma estreita da vertente oeste do Monte da Senhora da Graça ou Monte Farinha, rodeada a noroeste e a sudoeste por pequenos outeiros, a 420 $\mathrm{m}$ de altitude. Do local apenas há boa visibilidade para este. Nas imediações há uma nascente e uma linha de água que corre para a ribeira do Ramilo. $\mathrm{O}$ substrato rochoso é composto por granito de duas micas, de grão médio (Dinis, 2011).

Caraterização dos afloramentos gravados: de grandes dimensões, tem uma volumetria arredondada e a sua superfície é bastante irregular apresentando protuberâncias e fendas (Dinis, 2011).

Caraterização dos motivos gravados: Campelo 1 é subdivisível em 2 painéis de composições circulares (espirais e círculos concêntricos, com e sem covinha central) unidas por sulcos, inseríveis na Arte Atlântica (Dinis, 2011). Este autor identifica, ainda, sulcos bastante espessos, sobrepostas a algumas composições circulares ou rodeando-as, de onde saem inúmeras paletas, pelo que estas se localizam, essencialmente, na periferia dos motivos atlânticos. As paletas são de pá quadrangular, de pá retangular ou sub-retangular e de pá subcircular (Figura 6).

\section{Campelo 3}

Localização administrativa: Lugar: Campos; Freguesia: Mondim de Basto.

Contexto físico e ambiental: numa plataforma estreita da vertente oeste do Monte da Senhora da Graça ou Monte Farinha, rodeada a noroeste e sudoeste por pequenos outeiros, a $420 \mathrm{~m}$ de altitude. Do local apenas há boa visibilidade para este. Nas imediações há uma nascente e uma linha de água que corre para a ribeira do Ramilo.

Caraterização dos afloramentos gravados: O substrato rochoso é composto por granito de duas micas, de grão médio (Dinis, 2011). A sua superfície é sobrelevada, de contorno ovalado, porém o topo é aplanado (Dinis, 2011).

\section{Caraterização dos motivos gravados:}

Dinis (2011) identifica os motivos dividindo-os em 3 conjuntos, aos quais vamos entender como painéis. Identifica aí paletas, quadrados, covinhas e sulcos. As paletas neste afloramento são apenas de pá quadrangulares ou subcirculares.

Dinis (2011) observa que as paletas quadrangulares, diferentes em dimensão e disposição dos cabos, orientam-se para diferentes posições. As paletas circulares são mais uniformes entre elas, em termos morfológicos e das suas dimensões. As gravuras são todas feitas a baixo relevo (Figura 7).

\section{DISCUSSÃO DOS DADOS E INTERPRETAÇÕES}

As paletas são motivos muito raros no Noroeste de Portugal sendo conhecidas apenas em 11 afloramentos (Cabanas, Campelo 1 e 3, Chã da Rapada 6-A, Fieiral 2, Laje da Churra, Outeiro Machado 1, Outeiro da Moeda 1, 2 e 3 e Tripe 8) distribuídos por 8 núcleos. De uma forma geral localizam-se em áreas interiores e montanhosas, sendo a Laje da Churra o único sítio que se situa no litoral. Nota-se, igualmente, uma maior concentração de sítios com paletas na bacia do Tâmega, como Cabanas, Campelo 1 e 3, Outeiro Machado 1, Outeiro da Moeda 1, 2 e 3 e Tripe 8 (Figura 8). 
Em termos das características das superfícies gravadas as paletas localizam-se, maioritariamente em afloramentos sobrelevados (Campelos 1 e 3, Fieiral 2, Laje da Churra, Outeiro Machado 1, Outeiro da Moeda 1 e 2). A exceção encontra-se em Cabanas e na Chã da Rapada 6-A.

Encontram-se quer em contextos de Arte Atlântica Clássica, quer de Arte Esquemática de ar livre, embora também possam ocorrer em afloramentos onde são motivo único ou com motivos similares. No primeiro caso, encontra-se Campelo 1 e Laje da Churra, embora este último sítio tenha poucos motivos atlânticos clássicos. No segundo caso, maioritário, insere-se Cabanas (segundo Cardoso, 2015, p. 854), Chã da Rapada 6-A, Fieiral 2, Outeiro Machado 1 e Tripe 8. As paletas são motivo único no Outeiro da Moeda 1, 2 e 3 e associam-se a motivos similares, em Campelo 3.

No caso de Campelo 1, pela disposição dos motivos no conjunto e pela técnica (baixo relevo e sulcos mais alargados) que as paletas pertencem a um último momento de gravação do local, ou seja, sendo, portanto, posteriores aos motivos atlânticos. Segundo Dinis (2011) as composições circulares que correspondem ao momento mais antigo, têm sulcos menos profundos, sendo, muitas vezes, sobrepostos por motivos similares, mas com sulcos mais profundos e largos. Por último, gravaram-se vários sulcos sobrepostos aos círculos, que muitas vezes desembocam em paletas circulares ou retangulares. Neste caso, os sulcos onde se interligam as paletas parecem reorganizar a composição primitiva, como se a fechassem. No caso da Laje da Churra não há qualquer interação das paletas com os motivos atlânticos clássicos. Aqui elas parecem articular-se com outros motivos em baixo relevo, principalmente covinhas e covinhas com sulcos associados e um motivo que foi interpretado como um possível soliforme (painel 5). No caso dos sítios em que as paletas coincidem com motivos de arte esquemática, encontram-se, maioritariamente, na sua periferia ou distinguindo-se deles pela técnica de gravação (Cabanas, Chã da Rapada 6-A, Fieiral 2, Outeiro Machado 1, Tripe 8). De destacar o Fieiral 2 onde, pelo menos uma paleta, se sobrepõe a um antropomorfo esquemático, usando-o como cabo (Bettencourt e Rodrigues, 2013).

4. Afirme que os motivos da primeira fase cronológica de Cabanas corresponderem a um repertório que se encaixa na Arte Esquemática de ar livre.
Perante o conjunto de dados pode considerar-se que são posteriores cronologicamente às Artes Atlântica Clássica e Esquemática Antiga, que tem vindo a ser datadas do Neolítico e do Calcolítico (Alves, 2003, 2009; Cardoso, 2015; Bettencourt 2013, 2017a, $2017 \mathrm{~b}$, entre muitos outros). Assim, as paletas terão de ser posteriores, de acordo com muitas das propostas referidas na introdução deste texto, e pertencer a um outro grupo estilístico específico e emergente a partir da Idade do Bronze, tal como tem vindo a defender Bettencourt (2017a, 2017b, 2019).

Se tivermos em conta o número de afloramentos de Arte Atlântica Clássica conhecidos na fachada mais ocidental do Noroeste de Portugal, da ordem das muitas centenas (Alves, 2003; Cardoso, 2015; Bettencourt, Abad-Vidal, Rodrigues, 2017; Alves e Reis, 2017; Sampaio e Bettencourt, 2017; Bettencourt e Santos-Estévez, 2018) ou os de Arte Esquemática de ar livre, que se distribui, essencialmente, nas áreas mais interiores do Norte de Portugal (Baptista, 1983-1984; Abreu, 2012; Cardoso, 2015; Gomes, 2014) os locais com paletas parecem obedecer a outra ordem ideológica que privilegia, apenas, determinados lugares. De salientar que estes motivos também parecem raros na Galiza (Santos-Estévez, 2007, entre muitos outros).

Na conceção ampla de paleta, ou seja, de objetos com pá e cabo, distinguimos uma grande variedade que se podem subdividir em 6 grandes grupos consoante a forma da pá. Estabeleceram-se, também subgrupos, no contexto de cada grupo, consoante as orientações dos cabos face às pás (Tabela 1).

O grupo 1 caracteriza-se por pás quadrangulares, de diferentes dimensões, com cabos verticais ( $(\mathrm{A}$ ) ou curvos (1B). É de salientar que as terminações dos cabos destas paletas podem apresentar grande diversidade (Figura 9). Estes podem ser aguçados, circulares (fechados ou abertos), retangulares e trapezoidais. Aparecem em Campelo 1, Campelo 3, Chã da Rapada 6-A, Fieiral 2, Outeiro da Moeda 1, 2 e 3 e Outeiro Machado 1, sendo o grupo com maior representatividade. O grupo 2 é definido por pás retangulares ou sub-retangulares, dispostas na vertical, e cabos verticais $(2 \mathrm{~A})$ ou curvos $(2 \mathrm{~B})$. Constitui um grupo mais heterogéneo do que o anterior. Ocorrem em Cabanas, Campelo 1, Laje da Churra e Tripe 8. O grupo 3 caracteriza-se por pás circulares ou subcirculares e cabos verticais $(3 \mathrm{~A})$ ou curvos $\left({ }_{3} \mathrm{~B}\right)$. Ocorrem em Campelo 1, Campelo 3, Laje da Churra e Outeiro Machado 1. O grupo 4 define-se por paletas de 
pá semicircular, apenas presentes na Laje da Churra e Outeiro Machado 1. As identificadas tem apenas o cabo vertical. Trata-se de um grupo minoritário. O grupo 6 diz respeito a paletas de pá oval. É conhecida apenas uma na Laje da Churra. Finalmente, o grupo 6, de pá trapezoidal e cabo vertical com apenas um exemplar reconhecido, em Cabanas.

Se tivermos em conta a localização geográfica das paletas, à ampla escala de análise, as do grupo 1 , de pás quadrangulares, distribuem-se, totalmente, em áreas de altitude, entre 300 e 1169. Estas ocorrem apenas em Campelo 1 e 3 na Chã da Rapada 6-A, no Fieiral 2, em Outeiro da Moeda 1, 2 e 3 e no Outeiro Machado 1. As paletas do grupo 2, de pá retangular ou sub-retangular, também estão presentes essencialmente no interior, com exceção da Laje da Churra, localizada nas imediações da plataforma litoral. O mesmo se poderá dizer das paletas do grupo 3 e 4. A paleta do grupo 5 apenas ocorre no litoral.

Devido aos paralelos das paletas quadrangulares e retangulares com as de Valcamónica, em Itália, e das de pá circular, com os espelhos representados nas estelas do Sudoeste Ibérico, a introdução das paletas dos grupos 1, 2 e 3, no Noroeste de Portugal parece ser um fenómeno de influência mediterrânica que poderá ter sido introduzido na Idade do Bronze Final, no âmbito do intercâmbio suprarregional.

É provável que a estes grupos morfológicos correspondam artefactos distintos com funções distintas ou mesmo com discrepâncias cronológicas, mas esse tipo de análises efetuar-se-ão futuramente no decorrer de novos trabalhos sobre o assunto.

\section{BIBLIOGRAFIA}

ABREU, Maria Emília (2012) - Rock-Art in Portugal: History, Methodology and Traditions, Vila Real: Universidade de Trás-os-Montes e Alto Douro (Tese de Doutoramento).

ALVES, Lara (2003) - The Movement of Signs: Post-Glacial Rock Art in Northwestern Iberia. Reading: University of Reading (Tese de Doutoramento).

ALVES, Lara (2009) - O sentido dos signos. Reflexões e perspectivas para o estudo da arte rupestre do pós-glaciar no norte de Portugal In BALBÍN BEHRMANN, Rodrigo de, ed. - Arte prehistórico al aire libre en el sur de Europa, pp. 381-414.

ALVES, Lara; REIS, Mário (2017) - As gravuras rupestres do Monte Faro (Valença, Viana do Castelo) - um exemplo maior da Arte Atlântica peninsular. Portugália. Porto. Vol. 38, pp. 49-86.
BATISTA, António (1984) - Arte rupestre no norte de Portugal: uma perspetiva. Portugália. Vol. IV/V, pp. 71-86.

BETTENCOURT, Ana M. S. (2013) - A Pré-história do Noroeste Português. Braga/Tomar: Centro Europeu de Investigação da Pré-História do Alto Ribatejo.

BETTENCOURT, Ana M. S. (2017b) - Pos-Palaeolithic rock art of north-western Portugal: an approach, In BETTENCOURT, Ana; SANTOS-ESTÉVEZ, Manuel; SAMPAIO, Hugo; CARDOSO, Daniela, eds. - Recorded Places, Experienced Places: The Holocene rock art of the Iberian Atlantic northwest, pp. 123-150.

BETTENCOURT, Ana M. S. (2017a) - Gravuras Rupestres do Noroeste português para além das Artes Atlântica e Esquemática In ARNAUD, José M.; MARTINS, Andrea (eds.), Arqueologia em Portugal - 2017. Estado da Questão, Lisboa: AAP, pp. 1053-1067.

BETTENCOURT, Ana M. S. (2019) - Artes rupestres do Alto Minho. In CAMPELO, Álvaro, ed. - Património Artístico e Cultural do Alto Minho. Uma Viagem no Tempo. Viana do Castelo: Comunidade Intermunicipal do Alto Minho.

BETTENCOURT, Ana; RODRIGUES, Alda (2013) - “As gravuras rupestres do Fieiral, Castro Laboreiro, Melgaço" In BETTENCOURT, Ana. The Prehistory of the Northwestern Portugal, Territórios da Pré-história em Portugal, vol. 2, Braga/Tomar: CEIPHAR/CITCEM (E. Bilingue), 132-138.

CARDOSO, Daniela (2015) - Arte Atlântica do Monte de S. Romão (Guimarães) no Contexto da Arte Rupestre Pós-Paleolítica da Bacia do Ave-Noroeste Português. Vila Real: Universidade de Trás-os-Monte e Alto Douro (Tese de doutoramento).

CORRÊA, António (1929) - L’art rupestre en Traz os Montes (Portugal). Revue Archéologuique, 29: 121-136.

COSTAS GOBERNA, Fernando; NOVOA ALVARÉZ, Pablo (1993) - Los grabados rupestres de Galicia. Coruña: $\mathrm{Mu-}$ seu Arqueológico e Histórico, A Coruña.

DINIS, António P. (2011) - O santuário rupestre de Campelo, Mondim de Basto (Norte de Portugal). Oppidum, 5, pp. 11-26.

FERRI, Silvio (1975) - Il significato delle palette nell'arte rupestre della Valcamonica, in Les Religions de la Préhistoire, Valcamonica Symposium '72, 1975, pp. 263-269.

FOSSATI, Angelo (2007) - Figures and Male Sites in the Rock Art of Valcamonica, Italy in XXII Valcamonica Symposium 2007, Itália, pp. 131-144.

GOMES, Nuno (2014) - Estudo do Sítio com Gravuras Rupestres de Lamelas (S. Salvador) - Ribeira de Pena). Porto: Universidade do Porto (Dissertação de mestrado).

MARTINS, Andrea (2006) - Gravuras rupestres do Noroeste Peninsular: a Chã da Rapada, Revista Portuguesa de Arqueologia 9:1, pp. 47-70. 
PEÑA SANTOS, António; VASQUEZ VARELA, José (1979)

- Grabados rupestres prehistóricos al aire libre en Galicia, Cuadernos del Seminario de Estudios Cerámicos de Sargadelos 3o, Sada, La Coruña.

SAMPAIO, \& GARCIA DIEZ (200o) - A arte rupestre do Planalto da Lameira, Celorico de Basto e Fafe. Revista de Guimarães, 110, 189-207.

SANTOS, Ana F. (2014) - A Laje da Churra (Carreço, Viana do Castelo). Estudo Monográfico de um Lugar Gravado, Braga: Universidade do Minho (Dissertação de Mestrado).

SANTOS-ESTÉVEZ, Manuel (2007) - Petroglifos y Paisaje Social en la Prehistoria Reciente del Noroeste de la Península Ibérica In Instituto de Estudios Gallegos Padre Sarmiento, Traballos de Arqueoloxía e Patrimonio (TAPA), TAPA 38, Santiago de Compostela, pp. 13-215.
SANTOS JÚNIOR, Joaquim (1940) - Arte rupestre. I Congresso do Mundo Português. Memórias e Comunicações Apresentadas ao Congresso da Pré e Proto-História de Portugal. Lisboa: Bertrand e Comissão Executiva dos Centenários. Secção de Congressos. Vol.1, pp. 327-376.

SANTOS JÚNIOR, Joaquim (1978) - As gravuras rupestres do Outeiro Machado (Vale d'Anta-Chaves). Trabalhos de Antropologia e Etnologia, 23, 2-3, pp. 207-234

VALDEZ, Joana (2010) - Gravura na Arte Esquemática do Noroeste Peninsular. O caso do Monte de Góios (Lanhelas, Caminha). Porto: Faculdade de Letras da Universidade do Porto (Dissertação de Mestrado).
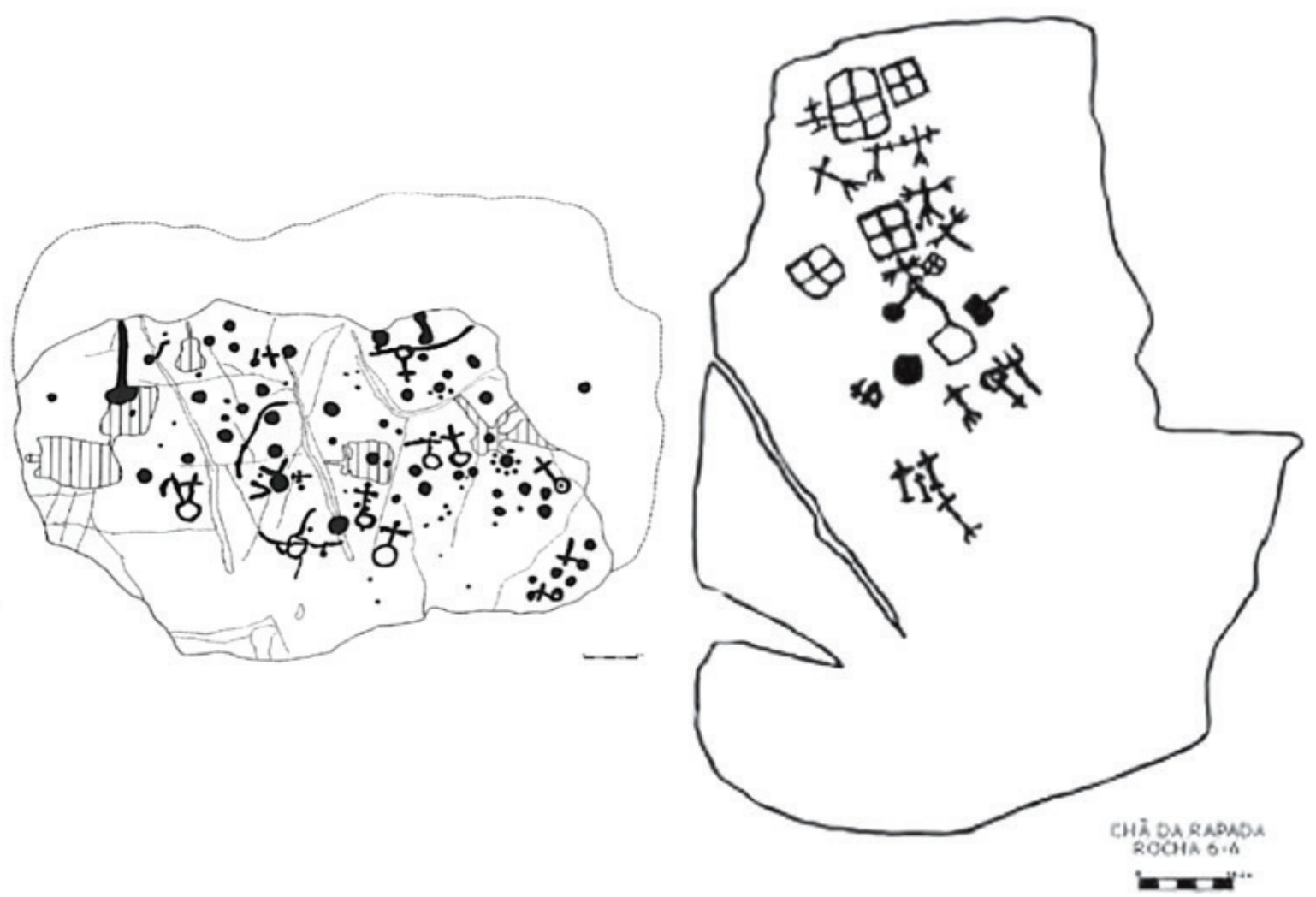

Figura 1 - À esquerda: decalque de Cabanas (seg. Sampaio e Garcia Diez, 200o). Á direita: decalque da Chã da Rapada 6-A (seg. Martins, 2006). 

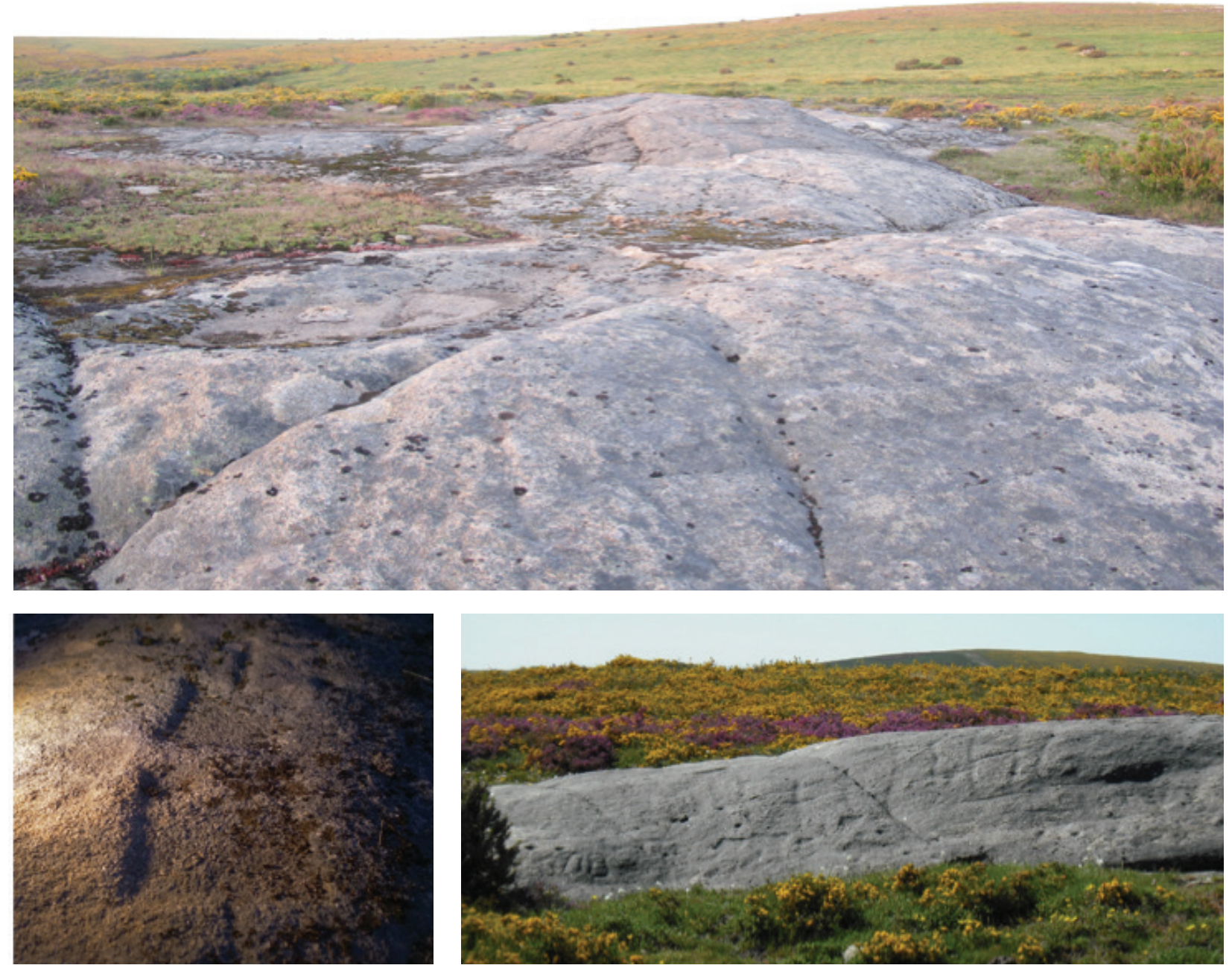

Figura 2-Em cima: aspeto geral do Fieiral 2. Em baixo, à esquerda: paletas da parte interna do afloramento. Em baixo, à direita: grupo de paletas na base da pendente este (a meio). 


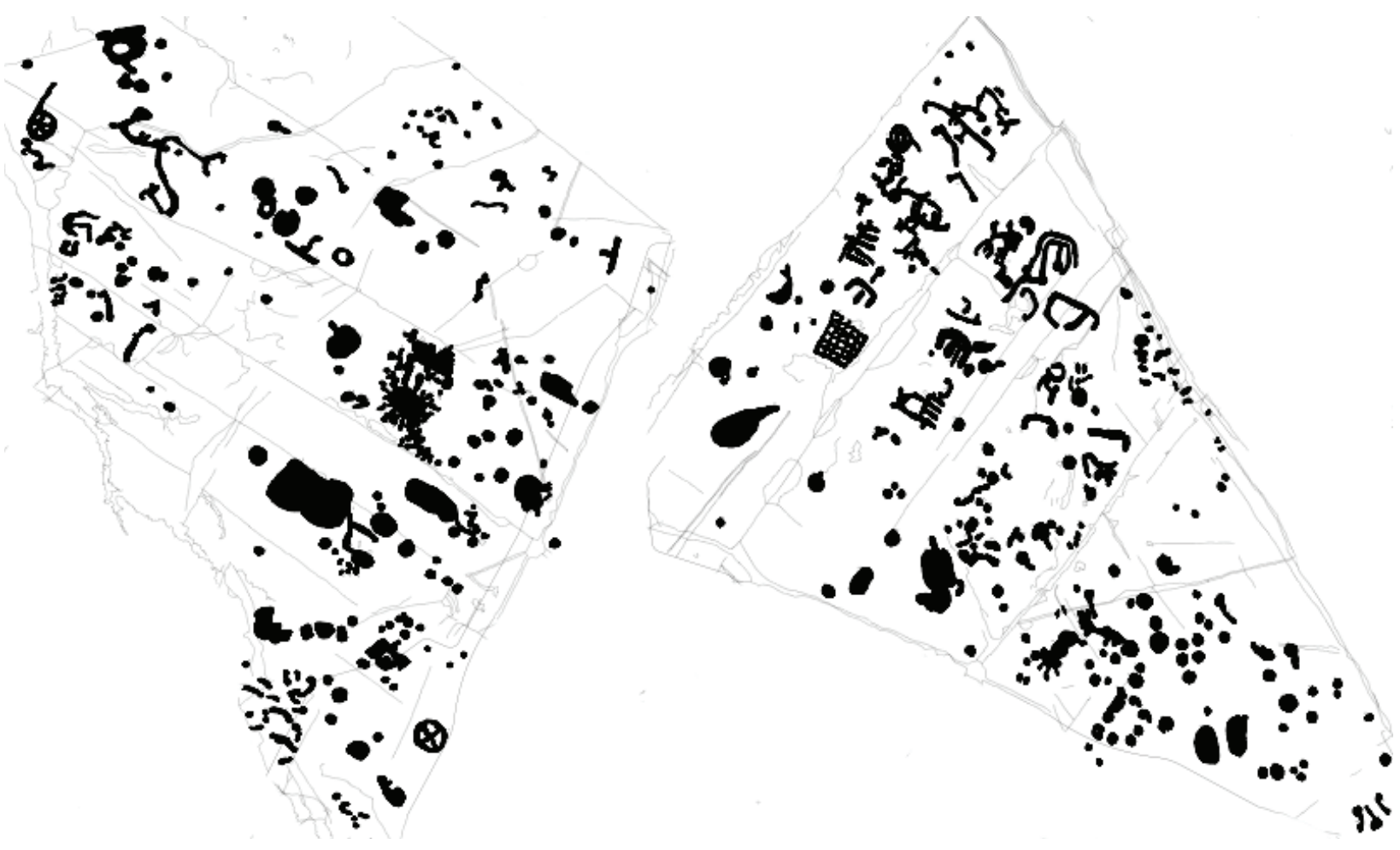

Figura 3 - Decalque dos painéis 5 e 11 A da Laje da Churra onde se podem observar paletas de vários tipos (seg. Santos, 2014, p. 55,62 , adaptado).
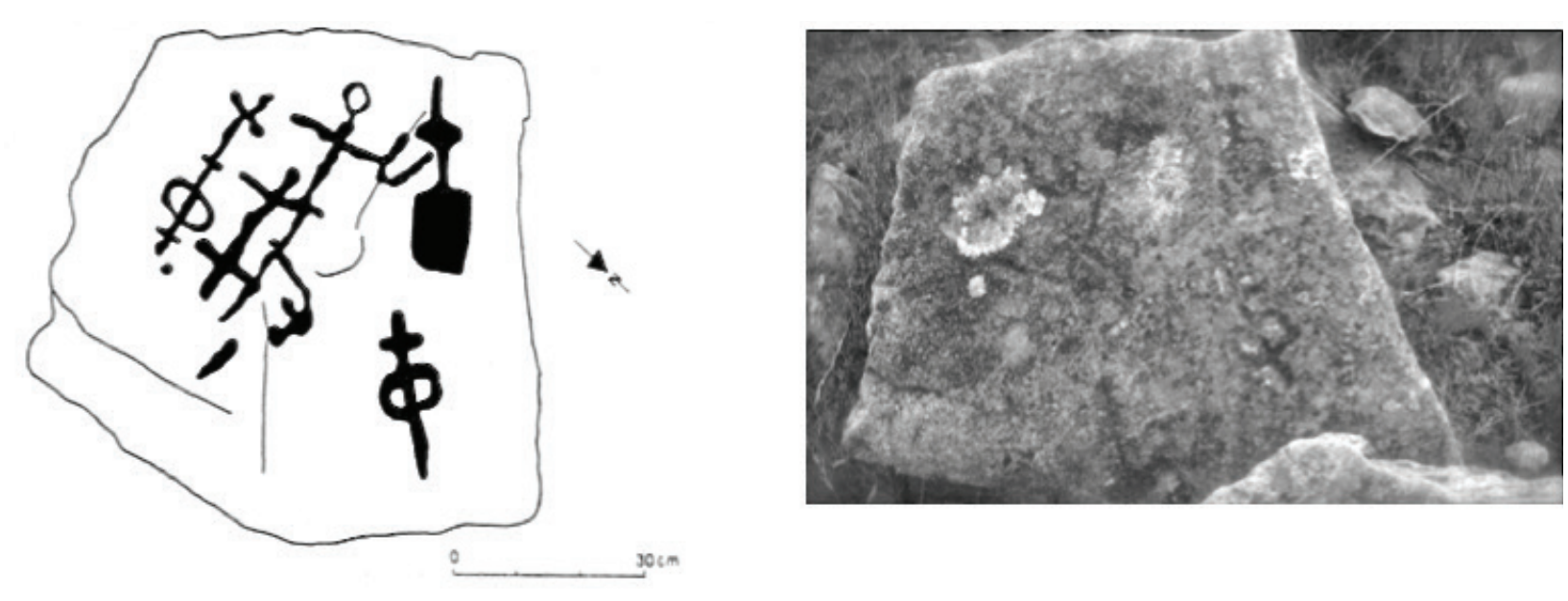

Figura 4 - Decalque realizado por António Martinho Baptista (seg. Jorge e Jorge, 1991) e fotografia deste bloco gravado (seg. Valdez, 2010, p. 198). 


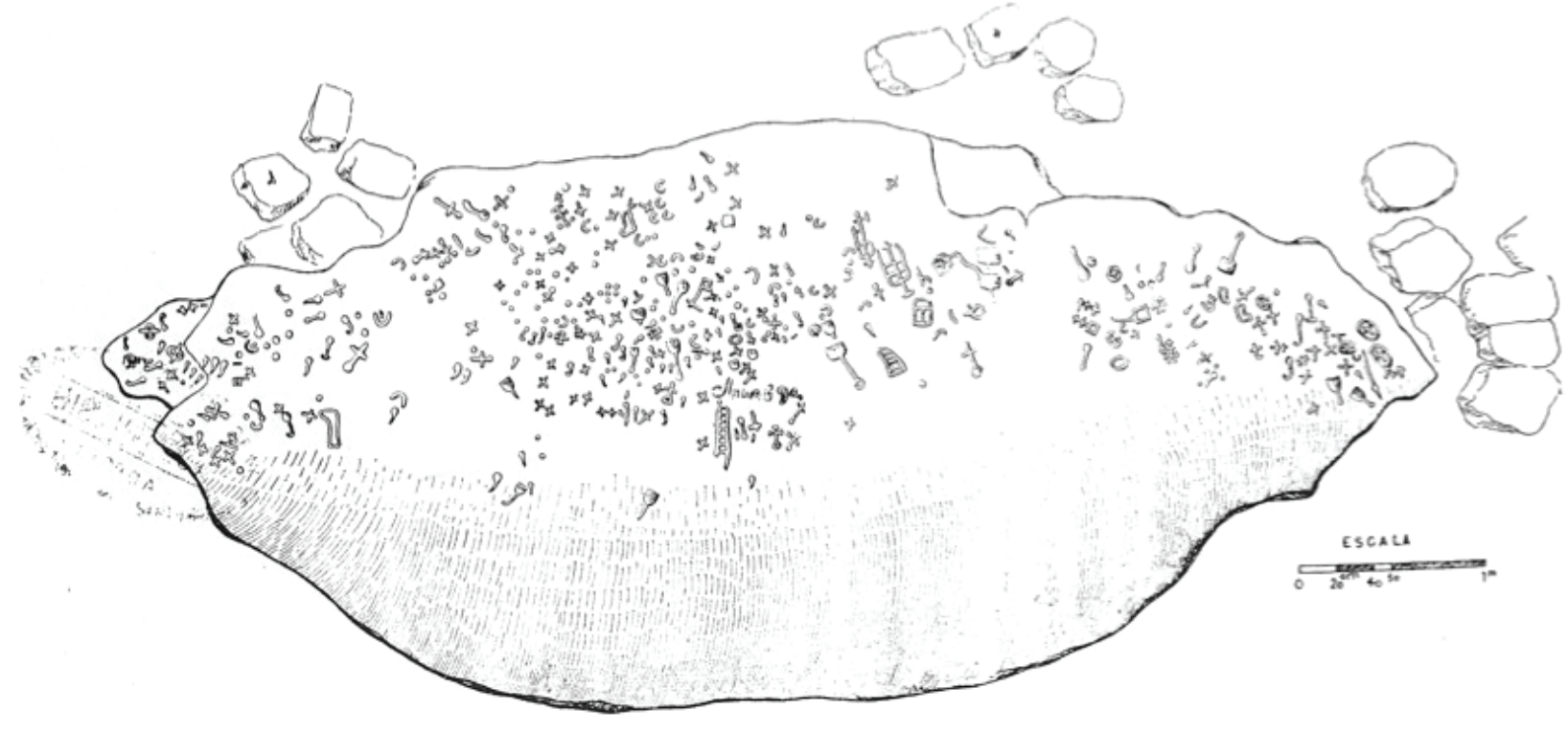

Figura 5 - Desenho de Outeiro Machado 1 (seg. Mendes Corrêa, 1929).

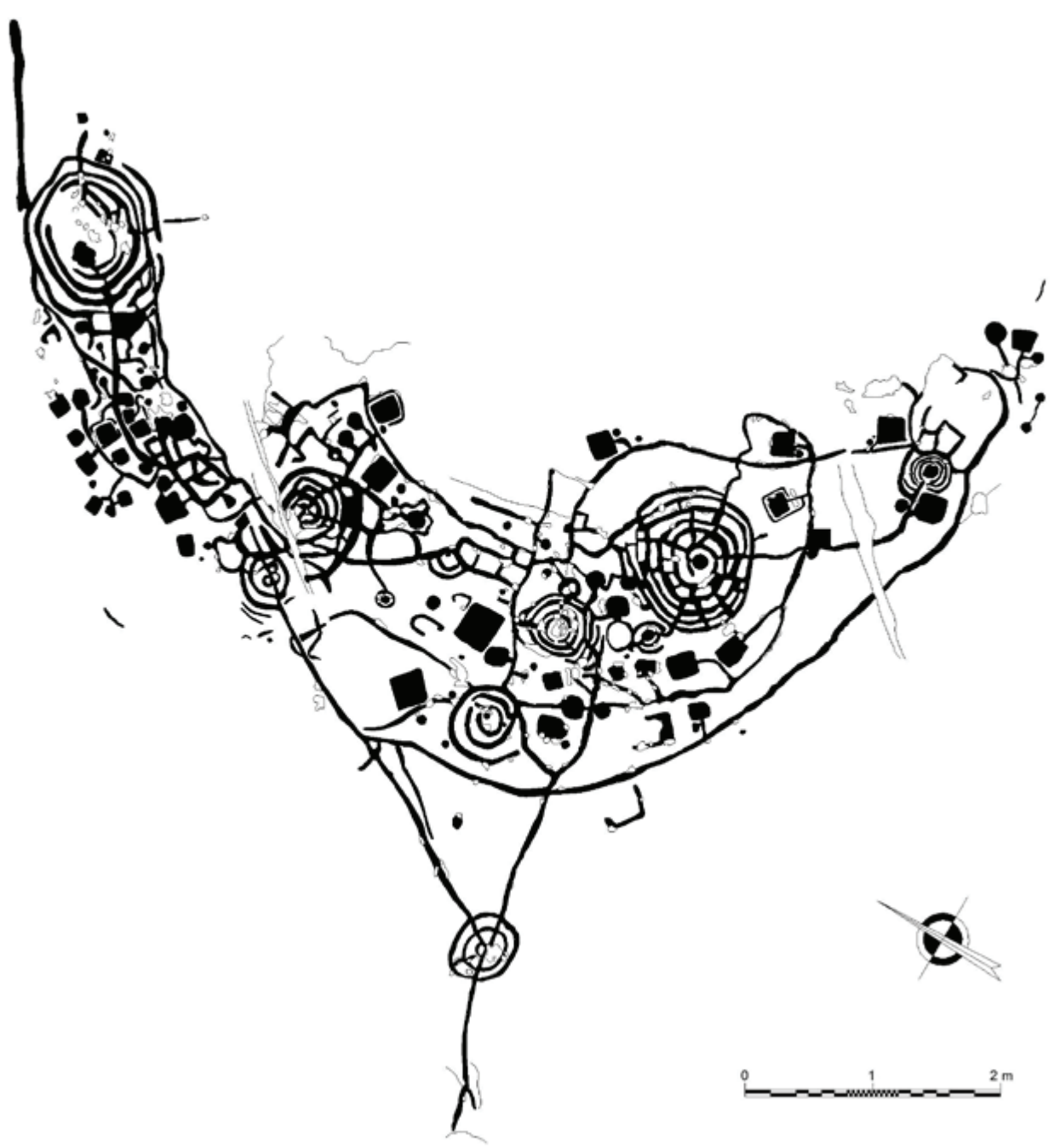

Figura 6 - Decalque de Campelo 1 (seg. Dinis, 2011). 

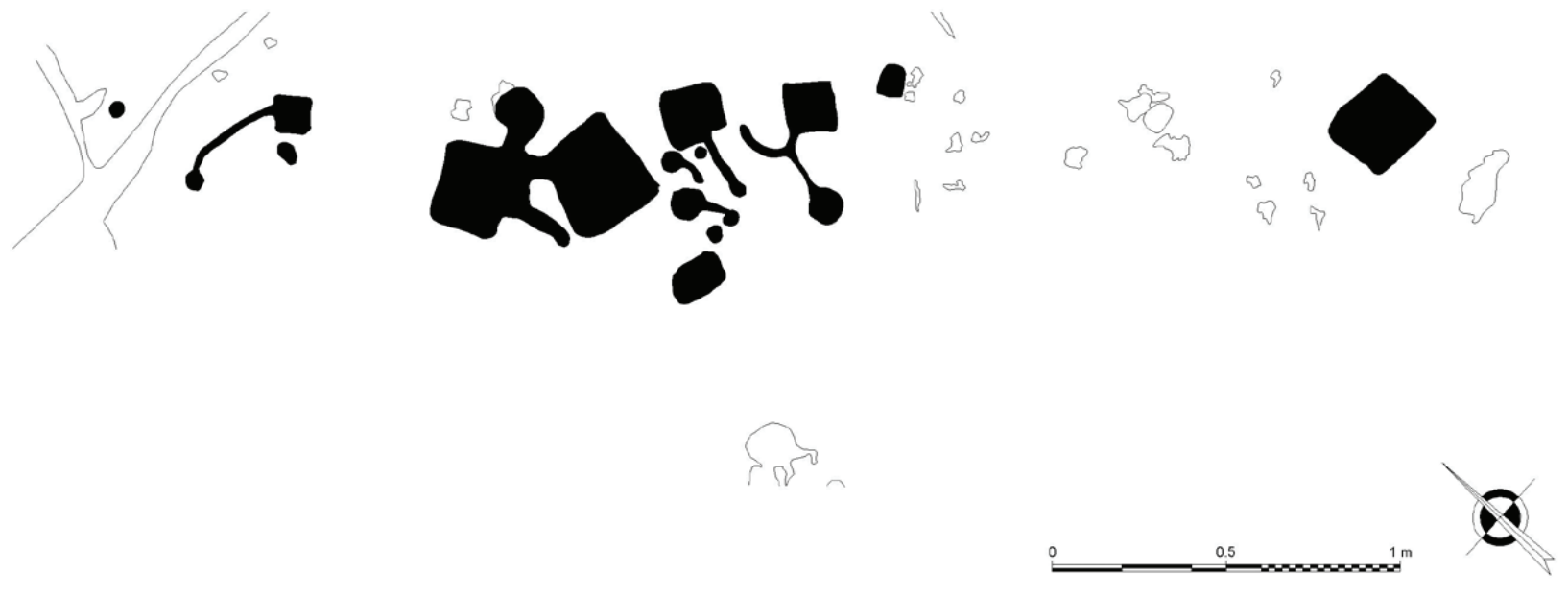

Figura 7 - Decalque de Campelo 3 (seg. Dinis, 2011).

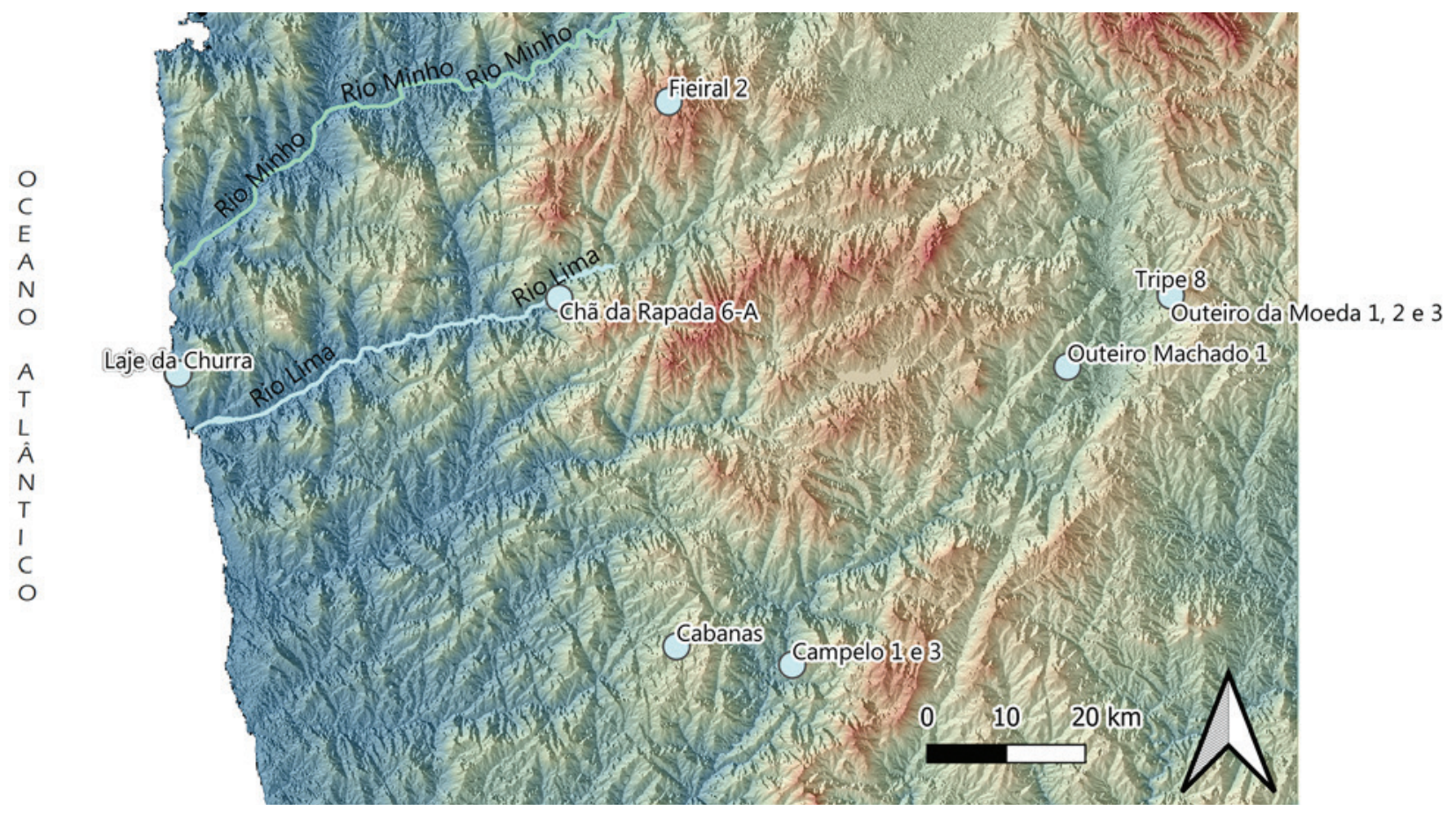

Figura 8 - Localização dos núcleos de arte rupestre com paletas estudados no texto, no Noroeste de Portugal. 


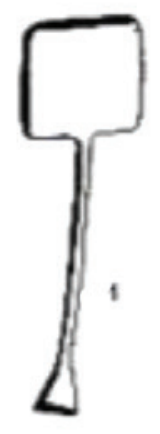

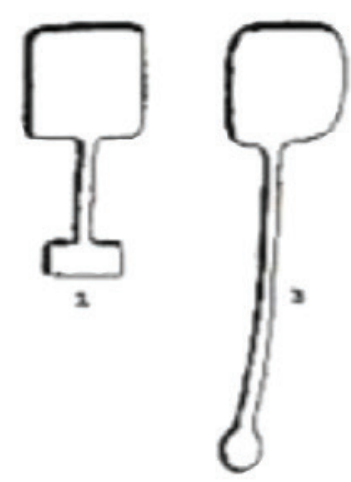

A

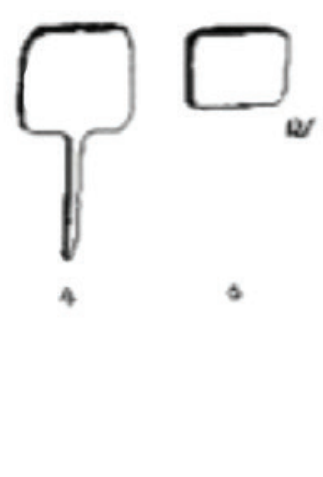

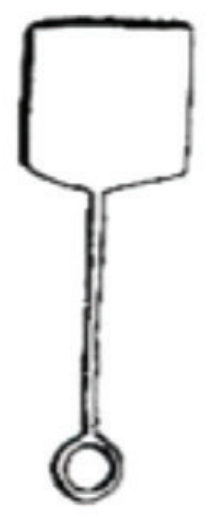

B

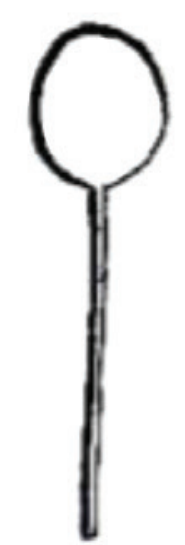

2.

Figura 9 - Diferentes tipos de paletas dos grupos 1 e 3 de Outeiro Machado 1 (seg. Corrêa 1929, p. 129). Note-se a diversidade da terminação dos cabos.

\begin{tabular}{|c|c|c|}
\hline \multirow{2}{*}{ Grupo 1} & \multicolumn{2}{|l|}{ Pá quadrangular } \\
\hline & A - Cabo vertical & B - Cabo curvo \\
\hline \multirow{2}{*}{ Grupo 2} & \multicolumn{2}{|c|}{ Pá retangular ou sub-retangular } \\
\hline & A - Cabo vertical & B - Cabo curvo \\
\hline \multirow{3}{*}{ Grupo 3} & \multicolumn{2}{|c|}{ Pá circular ou subcircular } \\
\hline & A - Cabo vertical & B - Cabo curvo \\
\hline & \multicolumn{2}{|l|}{ Pá semicircular } \\
\hline Grupo 4 & & \\
\hline \multirow[b]{2}{*}{ Grupo 5} & \multicolumn{2}{|l|}{ Pá oval } \\
\hline & & \\
\hline \multirow[b]{2}{*}{ Grupo 6} & \multicolumn{2}{|l|}{ Pá trapezoidal } \\
\hline & & \\
\hline
\end{tabular}

Tabela 1 - Quadro morfológico das paletas. 


\title{
O PROJETO MIÑO/MINHO: BALANÇO DE QUATRO ANOS DE TRABALHOS ARQUEOLÓGICOS
}

Sérgio Monteiro-Rodrigues ${ }^{1}$, João Pedro Cunha-Ribeiro² ${ }^{2}$ Eduardo Méndez-Quintas ${ }^{3}$, Carlos Ferreira ${ }^{4}$, Pedro Xavier ${ }^{5}$, José Meireles ${ }^{6}$, Alberto Gomes ${ }^{7}$, Manuel Santonja $^{8}$, Alfredo Pérez-González ${ }^{9}$

RESUMO

Apresentam-se os resultados mais significativos do projeto Miño/Minho, após quatro anos de trabalhos de campo (2016-2019). Os principais sítios intervencionados - Pedreiras 2 e Bela, Monção, e Carvalhas (loci 1, 2, 3 e 4), Melgaço -, associados a depósitos fluviais do rio Minho ou a formações deles derivadas, forneceram indústrias líticas talhadas, genericamente enquadráveis no tecno-complexo Acheulense. Tendo em conta outros dados obtidos na região, mais especificamente na margem direita do rio Minho (Galiza), estas indústrias datarão de diferentes momentos dentro do Pleistocénico médio.

Palavras-chave: Acheulense, Rio Minho, Monção, Melgaço.

\begin{abstract}
The most significant results of the Miño-Minho project after four years of fieldwork (2016-2019) are presented. The main sites - Pedreiras 2 and Bela, Monção, and Carvalhas (loci 1, 2, 3 and 4), Melgaço -, associated with fluvial deposits of the Minho River or with formations derived from them, provided lithic assemblages that can be connected with the Acheulean techno-complex. Taking into account data obtained in the region, more specifically on the right bank of the Minho River (Galicia), these assemblages may date from different moments within the Middle Pleistocene.
\end{abstract}

Keywords: Acheulean, Minho River, Monção, Melgaço.

\section{INTRODUÇÃO}

Os trabalhos de investigação sobre os terraços do rio Minho e sobre as indústrias líticas a eles associadas remontam aos finais do século XIX, desenvolvendo-se ao longo do século XX tanto no território portu- guês como na Galiza, embora a ritmos bastante diferenciados (Cunha-Ribeiro $\&$ alii, 2017).

No novo milénio, as investigações na região prosseguiram, sendo de destacar dois projetos independentes entre si, com objetivos e áreas de intervenção distintos. O primeiro projeto - no quadro de uma

\footnotetext{
1. Faculdade de Letras, Universidade do Porto; Centro de Investigação Transdisciplinar “Cultura, Espaço e Memória” (CITCEM); sergiomonteirorodrigues@gmail.com

2. Faculdade de Letras, Universidade de Lisboa; Centro de Arqueologia da Universidade de Lisboa (UNIARQ); Lab2pt; jpcunharibeiro@letras.ulisboa.pt

3. Grupo de Estudos de Arqueoloxía, Antigüidade e Territorio (GEAAT), University of Vigo, Campus As Lagoas, 32004 Ourense, Spain; eduardo.mendez.quintas@uvigo.es

4. Faculdade de Letras, Universidade de Lisboa; carlos.felipe11@gmail.com

5. UMinho; Lab2pt; pedroxavy@gmail.com

6. UMinho; Lab2pt; jmeireles@uaum.uminho.pt

7. Faculdade de Letras, Universidade do Porto; Centro de Estudos de Geografia e Ordenamento do Territorio (CEGOT); albgomes@gmail.com

8. Centro Nacional de Investigacion sobre la Evolucion Humana (CENIEH), Burgos; manuel.santonja@cenieh.es.

9. IDEA, Instituto de Evolución en África, Covarrubias 36, 28010 Madrid; alfredopg41@hotmail.com
} 
tese de doutoramento defendida em 2013 na Universidade de Wageningen, Holanda - centrou-se na análise do controlo exercido pela tectónica na evolução do sistema de terraços fluviais, de origem glacio-eustática, do Baixo Minho (Viveen, 2013; Viveen \& alii, 2013a, 2013b, 2014). Realizado em ambas as margens do rio, este estudo permitiu identificar 10 níveis de terraço, dispostos em escadaria a partir da atual planície aluvial, tendo as respetivas interpretações conduzido à realização de um registo cartográfico das várias formações sedimentares (Viveen \& alii, 2013a). A combinação de datações obtidas por OSL e por isótopos cosmogénicos $\left({ }^{\circ} \mathrm{Be}\right)$ em depósitos da margem esquerda do rio Minho, a jusante de Valença (Viveen $\&$ alii, 2012), confirmaram o alargado período de tempo em que terá decorrido a formação dos terraços fluviais, considerando-se os mais elevados anteriores à transição do Pleistocénico Inferior para o Pleistocénico Médio (>780 Ka), e distribuindo-se os restantes entre o início do Pleistocénico Médio e o Pleistocénico Superior.

A par do trabalho de W. Viveen, exclusivamente de âmbito geomorfológico, desenvolveu-se, na margem direita do Minho, um outro programa de investigação centrado no estudo geoarqueológico das ocupações paleolíticas aí existentes (Méndez-Quintas, 2017; Méndez-Quintas \& alii, 2019a; Méndez-Quintas \& alii, 2020a). Com ele pretendeu-se (e pretende-se ainda) dar continuidade aos projetos pontuais iniciados nos anos oitenta e nos finais da década de noventa (Cunha-Ribeiro $\&$ alii, 2017), seguindo-se agora uma perspetiva mais atualizada e com forte cariz interdisciplinar, fruto de avanços técnicos e metodológicos, que procurou também integrar a realidade arqueológica regional no âmbito mais alargado da Península Ibérica (Méndez-Quintas \& alii, 2019a, 2O2Oa; 2O2Ob; Demuro \& alii, 2020).

A existência ou não de uma ocupação anterior ao Pleistocénico Médio e a caracterização das indústrias acheulenses localmente representadas, tanto no que diz respeito à sua "origem" como ao seu devir, foram algumas das problemáticas que E. Méndez-Quintas almejou esclarecer. Para o efeito privilegiou o estudo de sítios e de materiais líticos que se encontravam associados a contextos estratigráficos bem definidos, promovendo concomitantemente o estudo desses mesmos contextos, em geral correspondentes a terraços fluviais ou a depósitos deles derivados. Neste sentido, não só se recuperaram os trabalhos anteriormente realizados na jazida de As Gándaras de
Budiño (Aguirre, 1964; Butzer, 1967; Vidal Encinas, 1982a, 1982b; Texier, 1984; Texier \& alii, 1981; Giles Pacheco \& alii, 2000; Méndez-Quintas, 2007, 2008; Méndez-Quintas $\mathbb{Z}$ alii, 2019b), como também se procedeu ao estudo de novas jazidas, que determinaram a realização de sondagens e de escavações, nalguns casos com resultados excecionais. Foi o caso de O Cabrón, no concelho de Arbo, onde foi possível reconhecer materiais líticos talhados associáveis ao tecno-complexo Acheulense, com uma datação mínima de 119.000 anos (Méndez-Quintas $\&$ alii, 2018c). Na jazida de Porto Maior, no concelho de As Neves, identificaram-se quatro distintos níveis de ocupação acheulense, datados de 300.0000 a 200.000 anos, destacando-se a descoberta num desses níveis, em posição primária, de uma inusitada concentração de bifaces, machados de mão e triedros, com morfologias e dimensões que encontram paralelo apenas em contextos africanos (Méndez-Quintas \& alii, 2018) (Figura 1).

Os projetos de W. Viveen e de E. Méndez-Quintas foram por nós assumidos como o ponto de partida para a realização do nosso próprio projeto, que denominámos Miño/Minho. De momento, os trabalhos daqueles investigadores reúnem a informação mais atualizada sobre os terraços fluviais do Baixo Minho e sobre as indústrias líticas acheulenses a eles associadas.

\section{O PROJETO DE INVESTIGAÇÃO MIÑO/MINHO}

O projecto Miño/Minho - Os primeiros habitantes do Baixo Minho. Estudo das ocupações pleistocénicas da região, submetido em 2015 à Direção Geral do Património Cultural como Projeto de Investigação Plurianual de Arqueologia (PIPA), teve como principal objetivo, como se referiu, dar continuidade aos trabalhos levados a cabo nos últimos anos na Galiza, no setor do Baixo Minho (Cunha-Ribeiro \& alii, 2017), conduzidos por Eduardo Méndez-Quintas, Manuel Santonja Gómez e Alfredo Pérez González (Méndez-Quintas, 2017; Méndez-Quintas \& alii, 2018, 2019a, 2019c; Méndez-Quintas \& alii, 2020a). O projecto Miño/Minho pretende, assim, estudar os mais antigos vestígios da presença humana na área do curso final do rio Minho, entre a confluência com o rio Trancoso, na sua margem esquerda, e a foz, 75 $\mathrm{km}$ a jusante. Os referidos vestígios, correspondendo a indústrias líticas de idade paleolítica, surgem 
conservados em formações sedimentares pleistocénicas, nomeadamente em terraços fluviais, que se desenvolvem ao longo de ambas as margens do rio (Cunha Ribeiro \& alii, 2017) (Figura 2).

Os diversos trabalhos arqueológicos realizados entre 2016 e 2019 - que incluíram prospeções e escavações - permitem uma primeira caraterização do Paleolítico Inferior do Baixo Minho, nomeadamente da margem portuguesa, até há pouco tempo conhecido apenas através de pequenos conjuntos artefactuais provenientes de contextos algo imprecisos (Cunha-Ribeiro \& alii, 2017, 2018; Méndez-Quintas $\&$ alii, 2020b).

\subsection{Concelho de Monção: os sítios de Pedreiras 1, Pedreiras 2 e Bela}

\section{Pedreiras 1 e Pedreiras 2}

Em 2016 e 2017, os trabalhos arqueológicos efetuados em Monção concentraram-se na área da União de Freguesias de Messegães, Valadares e Sá, mais precisamente junto à povoação de Bemposta, incidindo nas jazidas de Pedreiras 1 e Pedreiras 2.

A importância arqueológica de Pedreiras 1 foi assinalada por um arqueólogo amador de nacionalidade espanhola, Manuel Ledo, que relatou ter ali identificado diversos artefactos líticos talhados, aquando da abertura da variante à EN 202, que liga Monção a Melgaço. Segundo M. Ledo, parte dos artefactos líticos surgiram no talude que ladeia a norte a referida variante.

Em função desta informação - mais tarde sustentada pela descoberta de um biface e de um núcleo na área em questão por um dos membros do projeto Minho/Miño (J. P. Cunha Ribeiro) - procedeu-se, em 2016, à abertura de uma sondagem de $2 \mathrm{~m}^{2}$ na parte superior do talude com o objectivo de aferir a real importância arqueológica do local. No entanto, a sondagem viria a ser rapidamente abandonada porque depois da remoção do delgado solo vegetal logo se atingiu o substrato granítico. Os trabalhos voltaram-se, então, para a limpeza e regularização de um pequeno corte que ladeia um caminho, um pouco mais para poente, onde era visível um depósito com seixos rolados de quartzito e quartzo. Estas acções permitiram constatar que se estava perante uma formação coluvionar, com pouca possança (Figura 3), muito pobre do ponto de vista arqueológico. De facto, nas Pedreiras 1 não foi recolhido qualquer artefacto suscetível de diagnosticar a co- leção exumada, tanto em termos tecno-tipológicos, como em termos cronológico-culturais.

Terminada a intervenção inicial, e ainda em 2016, optou-se por dirigir a atenção para um outro ponto mais a oeste - que foi denominado Pedreiras 2 onde um derrube do talude de um caminho de terra batida havia exposto alguns artefactos líticos associáveis ao tecno-complexo Acheulense, nomeadamente um biface de grandes dimensões, sobre seixo rolado de quartzito (Figura 4). A sua descoberta ocorreu quando um dos autores (Alberto Gomes) procedia a um dos vários reconhecimentos geomorfológicos da área em torno das jazidas de Pedreiras. No sentido de compreender o contexto estratigráfico dos referidos artefactos procedeu-se não só à limpeza da vegetação na totalidade do talude, como também à sua verticalização e posterior registo detalhado. Estes trabalhos permitiram a recolha de mais material lítico, que, entretanto, se verificou estar associado exclusivamente a depósitos coluvionares canalizados, que se embutiam em sedimentos arenosos finos de origem fluvial (possivelmente de inundação) (Figura 4). Tal situação aconselhou a abertura de uma sondagem na parte superior do talude (sondagem 1), visando-se dois objetivos: verificar o desenvolvimento em profundidade dos depósitos coluvionares e avaliar a sua real extensão, nomeadamente para o lado sul da jazida.

Relativamente ao primeiro objetivo, a sondagem revelou a existência, a cerca de $2 \mathrm{~m}$ de profundidade, de uma camada cascalhenta-matriz-suportada, composta por areias grosseiras, seixos rolados de quartzito e de quartzo e blocos de granito - à qual se associava a indústria lítica das Pedreiras 2 (Figura 4). Embora em posição secundária, o estado físico dos artefactos líticos, essencialmente com arestas vivas, sugere um transporte de curta distância, possivelmente de uma zona próxima de cota ligeiramente mais alta, em fluxos de muito baixa energia. Os trabalhos realizados em 2017 - que consistiram, essencialmente, na abertura de mais sondagens na parte superior do talude (Figura 4) - mostraram que os artefactos tendiam a concentrar-se numa área relativamente restrita, o que corrobora a hipótese de se estar perante uma coleção homogénea.

Relativamente ao segundo objetivo, as intervenções de 2017 permitiram constatar que as coluviões se circunscreviam às imediações do talude, não se conhecendo ainda com rigor nem o desenvolvimento nem a orientação dos canais que estas originam (Figura 4). 
No que concerne especificamente aos materiais exumados (200 peças), em excelente estado físico, os resultados obtidos permitem registar a presença de uma indústria enquadrável no tecno-complexo Acheulense, associada ao predomínio de cadeias operatórias de debitagem relativamente expeditas e simples. Com efeito, paralelamente à presença de produtos configurados característicos deste tecno-complexo (bifaces e machados de mão), provavelmente introduzidos no local já em fase de uso, documenta-se a existência de um conjunto principal constituído por produtos de debitagem relativamente expeditos, elaborados maioritariamente a partir da exploração de seixos rolados de quartzito (Ferreira \& alii, neste volume).

Em suma, o valor da indústria lítica de Pedreiras 2, em sintonia com a realidade documentada nas jazidas do Baixo Minho, com uma cadeia operatória com uma composição análoga à documentada nas jazidas da margem direita, e ainda noutros conjuntos acheulenses peninsulares (Ferreira \& alii, neste volume), expressa-se pelo facto de se estar perante a primeira estação arqueológica Acheulense na área do Concelho de Monção, onde até há poucos anos se conheciam apenas artefactos líticos isolados.

\section{Bela}

Com o objectivo de aprofundar os conhecimentos sobre a evolução geomorfológica do setor do rio Minho compreendido entre Monção e Melgaço, realizou-se, em abril de 2018, uma saída de campo que visou essencialmente o reconhecimento de alguns terraços fluviais assinalados na cartografia geológica. Durante os trabalhos levados a cabo na freguesia de Bela, a cerca de $5 \mathrm{Km}$ a leste de Monção, detetaram-se algumas peças talhadas num talude subjacente à EN 202. Após a sua limpeza sumária, verificou-se que o material arqueológico era abundante, pelo que se decidiu proceder à realização de sondagens de diagnóstico na área, o que veio a acontecer em maio de 2019 (Figura 5).

Apesar de duas das sondagens se revelarem estéreis do ponto de vista arqueológico (mas ainda assim com dados importantes para o entendimento da morfogénese do sítio), noutras duas foi possível verificar a associação de artefactos líticos a um depósito constituído por sedimento arenoso fino de origem fluvial e por material mais grosseiro, essencialmente granítico, proveniente da vertente localizada a sul da área intervencionada. Tais condições de jazida sugerem que as ocupações humanas da área terão ocorrido numa zona arenosa, ribeirinha, sujeita quer à dinâmica fluvial, quer a processos de erosão na vertente (Figura 6). O baixo, ou quase nulo, grau de rolamento dos artefactos líticos indicia algum transporte, todavia de curta distância. Alternativamente, este ligeiro rolamento das peças poderá decorrer do facto de elas se encontrarem num meio arenoso que seria periodicamente remexido pelas águas do Minho, criando-se assim condições favoráveis à sua abrasão.

A presença de bifaces entre os artefactos recolhidos na jazida de Bela permite relacioná-los com o tecno-complexo Acheulense. Ao contrário do que sucede nos loci 2 e 3 das Carvalhas, Melgaço (vide infra) e em alguns sítios da Galiza, nomeadamente Porto Maior (na margem direita do Minho, praticamente em frente à jazida de Bela) (Méndez-Quintas, 2017; Méndez-Quintas $\&$ alii, 2018), estes bifaces apresentam dimensões bastante reduzidas, aproximando-se assim dos exumados no locus 1 das Carvalhas (vide infra). Tendo sido alvo apenas de uma intervenção pontual, a jazida de Bela carece ainda de mais investigação, que será levada a cabo assim que possível.

\subsection{Concelho de Melgaço: os sítios das Carvalhas e Monte Crasto}

\section{Carvalhas}

No concelho de Melgaço, os trabalhos até agora realizados no âmbito do projeto Miño/Minho concentraram-se essencialmente na Veiga de Remoães, mais precisamente na denominada jazida de Carvalhas. Esta jazida foi por nós identificada em 2014, no decurso de prospeções arqueológicas levadas a cabo na área envolvente às Termas de Melgaço, onde Abel Viana, ainda na primeira metade do século $\mathrm{XX}$, havia assinalado a presença de materiais líticos talhados, que associou ao Paleolítico (Cunha-Ribeiro \& alii,, 2017). A identificação de materiais similares na superfície de alguns terrenos e em acumulações de seixos que servem para delimitar propriedades corroboraram as informações que nos foram dadas por colegas espanhóis que, em 2010, haviam visitado o local durante trabalhos de surriba numa das vinhas da área. Logo em 2014 confirmou-se a associação dos materiais líticos a terraços fluviais do rio Minho, o que motivou a realização dos trabalhos geoarqueólogicos subsequentes (Cunha-Ribeiro \& alii, 2017). 
A jazida das Carvalhas abrange uma área considerável, que inclui os loci 1, 2, 3 e 4. Nestes loci foi possível detetar distintos conjuntos artefactuais, de cronologia paleolítica, integrados em contextos sedimentares diversificados (Figura 7).

\section{Locus 1}

Apesar de extremamente antropizado - nomeadamente devido a trabalhos agrícolas e à abertura de uma vala, em tempos históricos, para drenagem de terrenos - o locus 1 conservou, nas depressões de um patamar granítico que ladeia um paleocanal do rio Minho (Figura 7), um depósito fluvial, que embala material lítico talhado com alguma abundância. Tendo em conta as suas características sedimentogenéticas, trata-se, muito provavelmente, de um depósito de inundação acumulado em ambientes de baixa energia (Figura 8), numa etapa em que o paleocanal estaria já colmatado e o rio Minho ainda acima do seu leito atual.

A coleção de artefactos líticos exumada no locus 1 inclui bifaces, que se caracterizam pelas suas reduzidas dimensões (Figura 8), e um número muito expressivo de produtos de debitagem, alguns dos quais retocados. As arestas vivas das peças e a sua concentração numa área relativamente restrita corrobora a hipótese de se estar perante uma coleção que sofreu pouco transporte.

\section{Loci 2 e 3}

Os loci 2 e 3 abrangem uma faixa que se estende, aproximadamente, desde o sopé do Monte Prado até ao patamar granítico onde se localiza o locus I (Figuras 7 e 9). Com recurso a meios mecânicos, abriu-se, no local, uma vala com cerca de $14 \mathrm{~m}$ de comprimento, que permitiu identificar um possante depósito fluvial ( $>4 \mathrm{~m}$ de espessura), que colmata um antigo canal (ou paleomeandro?) do rio Minho, cuja base se implanta a cerca de 10-15 $\mathrm{m}$ acima do leito atual. No extremo da vala, junto à base do Monte Prado, detetou-se uma interestratificação de sedimentos fluviais e sedimentos provenientes da vertente, que indicam a ocorrência de fluxos de detritos, de tipo debris flow, possivelmente controlados por fatores de ordem climática.

Muito embora o material lítico talhado ocorra tanto no depósito fluvial como nos depósitos de vertente, sugere-se, provisoriamente, que ele será proveniente de antigos depósitos existentes na base da encosta do Monte Prado, onde ainda hoje se conser- vam sob a forma de pequenas relíquias, tendo, no passado, deslizado em direção ao canal. De facto, as peças talhadas recolhidas em contexto de vertente não possuem boleamento das arestas. No entanto, esta característica física, ainda que pouco acentuada, observa-se no material que surge nos depósitos fluviais, tendo sido adquirida após a sua deposição no paleocanal do Minho.

Do ponto de vista cronológico-cultural, a indústria lítica dos loci 2 e 3 das Carvalhas é enquadrável no tecno-complexo Acheulense, sendo de destacar a presença de bifaces e de machados de mão de grande dimensão, produzidos a partir de seixos rolados de quartzito (Figura 9).

\section{Locus 4}

O locus 4, localizado junto à entrada da Quinta da Veiga (Figura 7), foi identificado em 2014, aquando de uma breve visita ao local. Nessa altura, por casualidade, detetou-se um biface semi-enterrado num caminho que conduz ao rio Minho, junto do qual se observou também um pequeno talude que cortava o rebordo de um terraço fluvial (Figura 10). Aquando do início dos trabalhos de campo nas Carvalhas, já no âmbito do projeto Miño/Minho (2016), identificaram-se nesse mesmo talude mais alguns artefactos líticos, nomeadamente um biface e um machado de mão. Em função destas descobertas, decidiu-se, em 2017, proceder à abertura de uma sondagem na superfície do terraço (Figura 10). Não obstante as reduzidas dimensões da sondagem $\left(4 \mathrm{~m}^{2}\right)$ e toda uma série de outros contratempos que impediram a sua escavação integral, foi possível recolher um pequena coleção de objetos líticos, enquadráveis no tecno-complexo Acheulense. Tais objetos, com vestígios de rolamento muito ténues e alguma eolização, surgem exclusivamente nos níveis arenosos da parte superior do terraço fluvial. Trabalhos arqueológicos posteriores permitiram reconhecer o revolvimento do setor sul do terraço, resultante da exploração mineira outrora aí desenvolvida. Os vestígios desta última atividade, testemunhados pela presença de pequenas conheiras, não eliminam, porém, o potencial arqueológico do locus 4 junto do talude inicialmente intervencionado, onde se tentará ainda desenvolver uma pequena escavação em área, que permita não só aumentar o número de artefactos líticos, como também melhor compreender os processos de formação do contexto geoarqueológico aí preservado. 


\section{Monte Crasto}

No concelho de Melgaço assinala-se ainda a existência de uma outra jazida acheulense, localizada na vertente meridional do Monte Crasto, na freguesia de Penso, a uma altitude absoluta próxima dos 230 $\mathrm{m}$. Os respetivos materiais líticos talhados foram ali recolhidos por um particular aquando de trabalhos de revolvimento do subsolo para a criação de uma pequena área de lazer.

No sentido de se detetar o depósito arqueológico, abriram-se com meios mecânicos diversas valas em vários pontos estratégicos, não se conseguindo, todavia, identificar qualquer formação antiga com a qual os materiais líticos se pudessem relacionar (Figura 11). De facto, nas referidas valas, que atingiram sempre o substrato granítico, observaram-se unicamente depósitos arenosos, de textura grosseira, nos quais se desenvolve um solo orgânico, de cor negra, muito pouco evoluído, com cerca de $1 \mathrm{~m}$ de espessura. Na periferia da área, os depósitos revelam claras perturbações de origem antrópica, havendo mesmo pontos com aterros recentes.

As peças líticas do Monte Crasto incluem produtos configurados e diversos produtos de talhe em proporções relativamente equilibradas, mesmo não descartando a possibilidade de na sua recolha ter existido alguma seleção dos objetos mais expressivos. O conjunto revela ainda uma manifesta homogeneidade, tanto pelas matérias-primas utilizadas, como pelas arestas muito boleadas de todas as peças. Tal facto não deixa de ser curioso dada a inexistência de qualquer linha de água nas imediações do sítio arqueológico. Perante esta situação, importa continuar a desenvolver trabalhos no local no sentido de se poder vir a determinar as reais condições de jazida destes artefactos líticos talhados, associáveis à presença do homem paleolítico numa posição topográfica do vale até agora desconhecida na área do projeto Miño/Minho.

\section{DATAÇÕES ABSOLUTAS NO ÂMBITO DO PROJETO MIÑO/MINHO}

No decurso das intervenções em Monção e em Melgaço recolheram-se, nas várias jazidas arqueológicas (Pedreira 2, Bela e Carvalhas), diversas amostras de sedimentos com o objetivo de realizar datações por OSL. Tais amostras foram extraídas por Lee Arnold e Martina Demuro, da Universidade de Adelaide, Austrália, tendo sido eles os responsáveis pelo seu processamento laboratorial no âmbito de um projeto de datações para jazidas pleistocénicas ibéricas. Os resultados entretanto obtidos (a publicar) corroboram a idade pleistocénica dos depósitos que embalam o material lítico talhado, não se afastando das datas conhecidas noutras áreas da região (Demuro et alii, 2020; Méndez-Quintas 2017, Méndez-Quintas $\&$ alii, 2020a).

\section{CONCLUSÕES}

Num balanço preliminar dos trabalhos realizados entre 2016 e 2019 no âmbito do projeto Miño/Minho, pode afirmar-se que os dados coligidos testemunham a inegável importância arqueológica da margem esquerda do Baixo Minho para o estudo do Paleolítico peninsular, justificando plenamente o objetivo originalmente delineado de se vir a desenvolver tal estudo associando de forma integrada ambas as margens do rio.

Mesmo se os resultados obtidos têm levado a uma reprogramação dos trabalhos, concentrando-se esforços nas intervenções desenvolvidas nalgumas jazidas localizadas numa pequena área repartida entre os concelhos de Melgaço e de Monção, o número de jazidas já identificadas e as problemáticas a elas associadas permitem reformular de forma inovadora o nosso conhecimento sobre o Paleolítico da região, sendo também certo que o estudo das coleções de materiais líticos talhados entretanto recolhidos, e que se encontra já a ser desenvolvido, não deixará de reforçar tal situação.

Os materiais reunidos encontram-se associados tanto a contextos fluviais (de fundo de canal e níveis de inundação), como a depósitos coluvionares, revelando a presença do homem paleolítico em distintas posições na topografia do vale. Por outro lado, as indústrias líticas, genericamente associáveis ao tecno-complexo Acheulense, permitem vislumbrar a presença de alguns produtos configurados de grandes dimensões, elaborados quer a partir de grandes lascas, quer a partir de grandes seixos rolados, a par de outros conjuntos com materiais configurados de menor volumetria, nos quais os produtos de debitagem apresentam uma maior representatividade.

Urge, portanto, dar continuidade a este projeto, quer num quadro forçosamente interdisciplinar, quer numa necessária colaboração transfronteiriça, visando uma melhor caracterização das indústrias líticas localmente representadas, apurando o seu enqua- 
dramento cronológico e procurando a modelização da evolução da paisagem do vale, com o estudo da história da formação da bacia hidrográfica do rio Minho, desde as suas etapas mais antigas atéà formação da rede hidrográfica atual.

\section{BIBLIOGRAFIA}

AGUIRRE, Emiliano (1964) - Las Gándaras de Budiño, Porriño (Pontevedra). (Excavaciones Arqueologicas en España 31), Madrid: Ministerio de Educacion Nacional, Direccion General de Bellas Artes, Servicio Nacional de Excavaciones Arqueologicas.

BUTZER, Karl W. (1967) - Geomorphology and Stratigraphy of the Paleolithic Site of Budiño (Prov. Pontevedra, Spain). Eiszeitalter und Gegenwart, Band 18, Ohringen/ Württ, pp. 82-103.

CUNHA-RIBEIRO, João Pedro; MONTEIRO-RODRIGUES Sérgio; GOMES, Alberto; MÉNDEZ-QUINTAS, Eduardo; MEIRELES, José; PÉREZ-GONZÁLEZ, Alfredo; SANTONJA, Manuel (2017) - Ocupações Pleistocénicas na margem esquerda do Baixo Minho (Miño/Minho 2). Objetivos e primeiros resultados de um projeto transfronteiriço. In ARNAUD, J. M.; MARTINS, A., eds. - Arqueologia em Portugal/2017 - Estado da Questão. Lisboa: Associação dos Arqueólogos Portugueses, pp. 303-318.

CUNHA-RIBEIRO, João Pedro; MONTEIRO-RODRIGUES Sérgio; MÉNDEZ-QUINTAS, Eduardo; GOMES, Alberto; MEIRELES, José; PÉREZ-GONZÁLEZ, Alfredo; SANTONJA, Manuel (2017) - O Paleolítico de Melgaço. Vestígios dos primeiros habitantes do Concelho. Boletim Cultural de Melgaço, 10, pp. 117-15o.

DEMURO, Martina; ARNOLD, Lee. J.; DUVAL, Mathieu; MÉNDEZ-Quintas,Eduardo;SANTONJA,Manuel;PÉREZ-GONZÁLEZ, Alfredo (2020) - Refining the chronology of Acheulean deposits at Porto Maior in the River Miño basin (Galicia, Spain) using a comparative luminescence and ESR dating approach. Quaternary International (2020).

FERREIRA, Carlos; CUNHA-RIBEIRO, João Pedro; MONTEIRO-RODRIGUES, Sérgio; MÉNDEZ-QUINTAS, Eduardo; XAVIER, Pedro; MEIRELES, José; GOMES, Alberto; SANTONJA, Manuel; PÉREZ-GONZÁLEZ, Alfredo (2020) - A ocupação paleolítica da margem esquerda do Baixo Minho: a indústria lítica do sítio de Pedreiras 2 (Monção, Portugal) e a sua integração no contexto regional. (Neste volume).

GILES PACHECO, F.; CANO PAN, J. S.; SANTIAGO PÉREZ, A.; GUTIÉRREZ LÓPEZ, J. M.; MATA ALMONTE, E.; GRACIA PRIETO, J.; AGUILERA RODRÍGUEZ, L.; PRIETO REINA, O. (200o) - Poblamiento paleolítico en la cuenca media-baja del rio Miño. Sector la Guardia-Tuy (Pontevedra) - Cortegada (Orense). Secuencia cronoestratigráfica. In Actas do $3^{\circ}$ Congresso de Arqueologia Peninsular, Vol. II, Porto: ADECAP, pp. 101-121.
MÉNDEZ-QUINTAS, E. (2017) - Caracterización y variabilidad tecnomorfológica de las industrias achelenses de la Cuenca Baja del Río Miño (NO de la Península Ibérica). Tesis Doctoral, Universidad de Burgos, Escuela Interuniversitaria de Posgrado en Evolucion Humana, CENIEH, Universidad de Alcalá, Universidad de Oviedo, p. 628.

MÉNDEZ-QUINTAS, E.; SANTONJA, M.; PÉREZ-GONZÁlEZ, A.; ARNOLD, L. J.; CUNHA-RIBEIRO, J. P.; DEMURO, M.; DÍAZ-RODRÍGUEZ, M.; DUVAL M.; GOMES, A.; MEIRELES, J.; MONTEIRO-RODRIGUES, S.; SERODIO DOMÍNGUEZ, A. (2018a) - El Yacimiento Achelense de As Gándaras de Budiño: Síntesis y perspectivas después de 50 años de desencuentros. Estudos do Quaternário/ Quaternary Studies, 19, pp. 1-22. DOI: https:// doi.org/10.30893/eq.voi19.182

MÉNDEZ-QUINTAS, E.; SANTONJA, M.; PÉREZ-GONZÁlEZ, A.; DUVAL, M.; DEMURO, M.; ARNOLD, L. J. (2018b) - First evidence of an extensive Acheulean large cutting tool accumulation in Europe from Porto Maior (Galicia, Spain). Scientific Report 8:3082 doi: 10.1038/ S41598-018-21320-1

MÉNDEZ-QUINTAS, E.; SANTONJA, M.; PÉREZ-GONZÁlEZ, A.; DEMURO, M.; ARNOLD, L. J.; DUVAL, M. (2019a) - Límites cronológicos de la presencia humana durante el Pleistoceno medio en la cuenca baja del Río Miño (Pontevedra, España). In XV Reunión Nacional de Cuaternario (Bilbao 2019), AEQUA, pp. 51-54.

MÉNDEZ-QUINTAS, E.; DEMURO, M.; ARNOLD, L. J.; DUVAL, M.; PÉREZ-GONZÁlEZ, A.; SANTONJA, M. (2019c) - Insights into the late stages of the Acheulean technocomplex of Western Iberia from the Arbo site (Galicia, Spain). Journal of Archaeological Science: Reports, 27, p. 101934 .

MÉNDEZ-QUINTAS, Eduardo; SANTONJA, Manuel; PÉREZ-GONZÁLEZ, Alfredo, ARNOLD, Lee J.; DEMURO, Martina; DUVAL, Mathieu (2020a) - A multidisciplinary overview of the lower Miño River terrace system (NW Iberian Peninsula). Quaternary International (2020).

MÉNDEZ-QUINTAS, E.; SANTONJA, M.; ARNOLD, L. J.;CUNHA-RIBEIRO, J. P.; SILVA, P. X. da; DEMURO, M.; DUVAL, M.; GOMES, A.; MEIRELES, J.; MONTEIRO-RODRIGUES, S.; PÉREZ-GONZÁLEZ, A. (2020b) - The Acheulean Technocomplex of the Iberian Atlantic Margin as an example of technology continuity through the Middle Pleistocene. Journal of Paleolithic Archaeology. https://doi. org/10.1007/s41982-020-00057-2

TEXIER, Jean-Pierre (1984) - Le site paléolithique de Budiño. Portugália, IV-V, pp.34-35.

TEXIER, J.-P.; VIDAL ENCINAS, J. (1981) - Nuevas excavaciones arqueológicas en las Gándaras de Budiño. Primeros resultados. La estratigrafía. In DÁZ DEL OLMO, F.; MARQUEZ FERNÁNDEZ, D.; RUBIO RECIO, J. M., eds. - Actas de la VReunión del Grupo Español de Trabajo del Cuaternario, pp. 210-220. 
VIDAL ENCINAS, J. M. (1982a) - Las Gándaras de Budiño: balance preliminar de dos campañas de excavaciones (19801981). Pontevedra: Museo de Pontevedra, Tomo XXXVI, pp. 91-113.

VIDAL ENCINAS, J. M. (1982b) - O Paleolitico Inferior no Baixo Miño, Marxe galega: unha aproximación. Brigantium, Vol. 3, pp. 7-32.

VIVEEN, Willem (2013) - Multi-scale Tectonic Controls on Fluvial Terrace Formation in a Glacioeustatically-dominated River System. Inferences from the Lower Miño Terrace Record. Wageningen University, The Netherlands (Phd thesis, 222 p.).

VIVEEN, W.; BRAUCHER, R.; BOURLÈS, D.; SCHOORL, J. M.; VELDKAMP, A.; van BALEN , R. T.; WALLINGA, J.; FERNANDEZ-MOSQUERA, D.; VIDAL-ROMANI, J. R.; SANJURJO-SANCHEZ, J. (2012) - A o.65 Ma chronology and incision rate assessment of the NW Iberian Miño River terraces. Global and Planetary Change, 94-95, pp. 82-10o.
VIVEEN, W.; SCHOORL, J. M.; VELDKAMP, A.; van BALEN, R. T.; VIDAL-ROMANI, J. R. (2013a) - Fluvial terraces of the northwest Iberian lower Miño River. Journal of Maps, Vol. 9, 4, pp. 1-10.

VIVEEN, W.; SCHOORL, J. M.; VELDKAMP, A.; van BALEN, R. T.; DESPRAT, S.; VIDAL-ROMANI, J. R. (2013b) - Reconstructing the interacting effects of base level, climate, and tectonic uplift in the lower Miño River terrace record. A gradient modelling evaluation. Geomorphology, 186, pp. 96-118.

VIVEEN, W.; SCHOORL, J. M.; VELDKAMP, A.; van BALEN, R. T. (2014) - Modelling the impact of regional uplift and local tectonics on fluvial preservation. Geomorphology, 210, pp. 119-135.

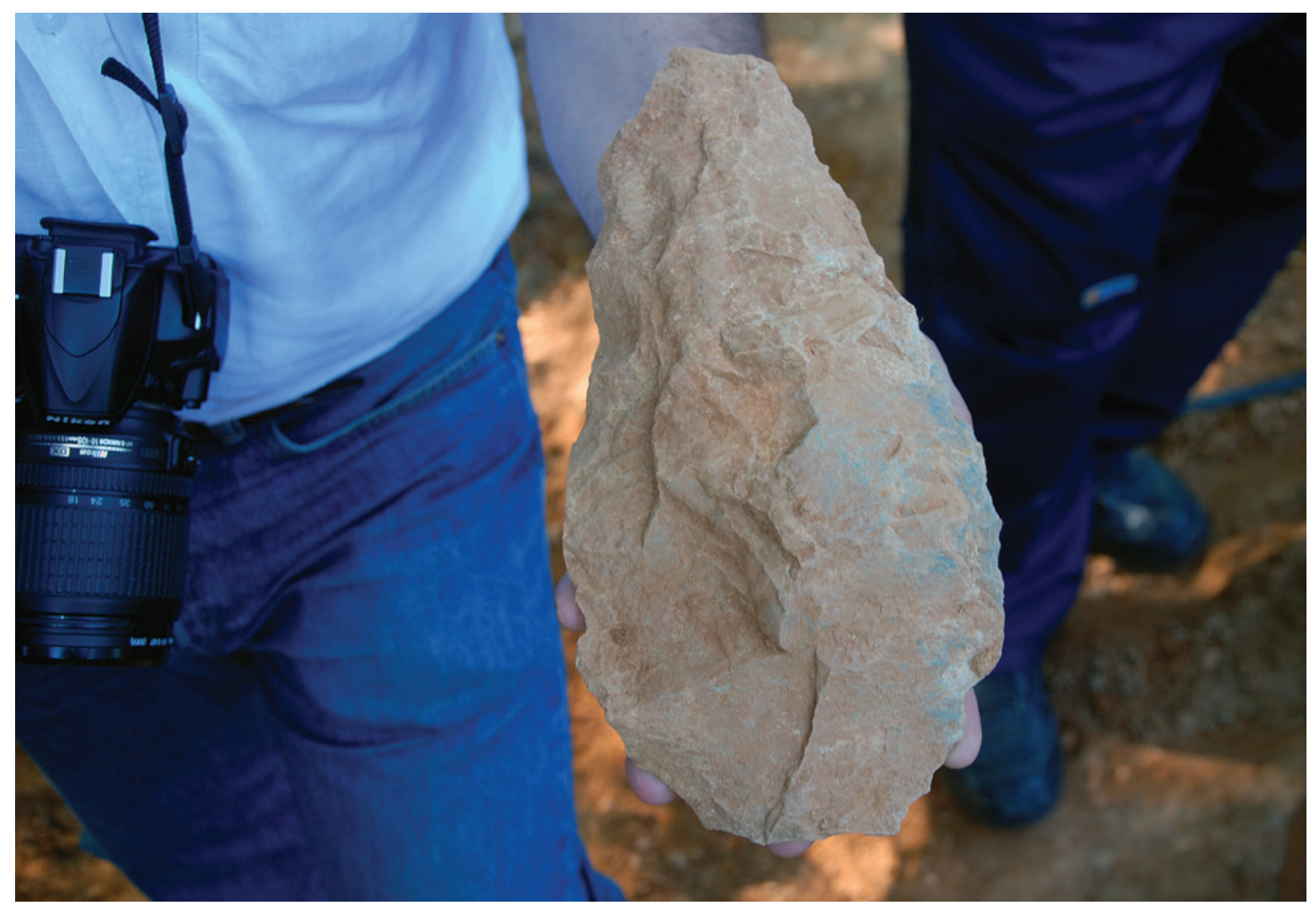

Figura 1 - Biface de grandes dimensões da jazida de Porto Maior, As Neves (Galiza). 


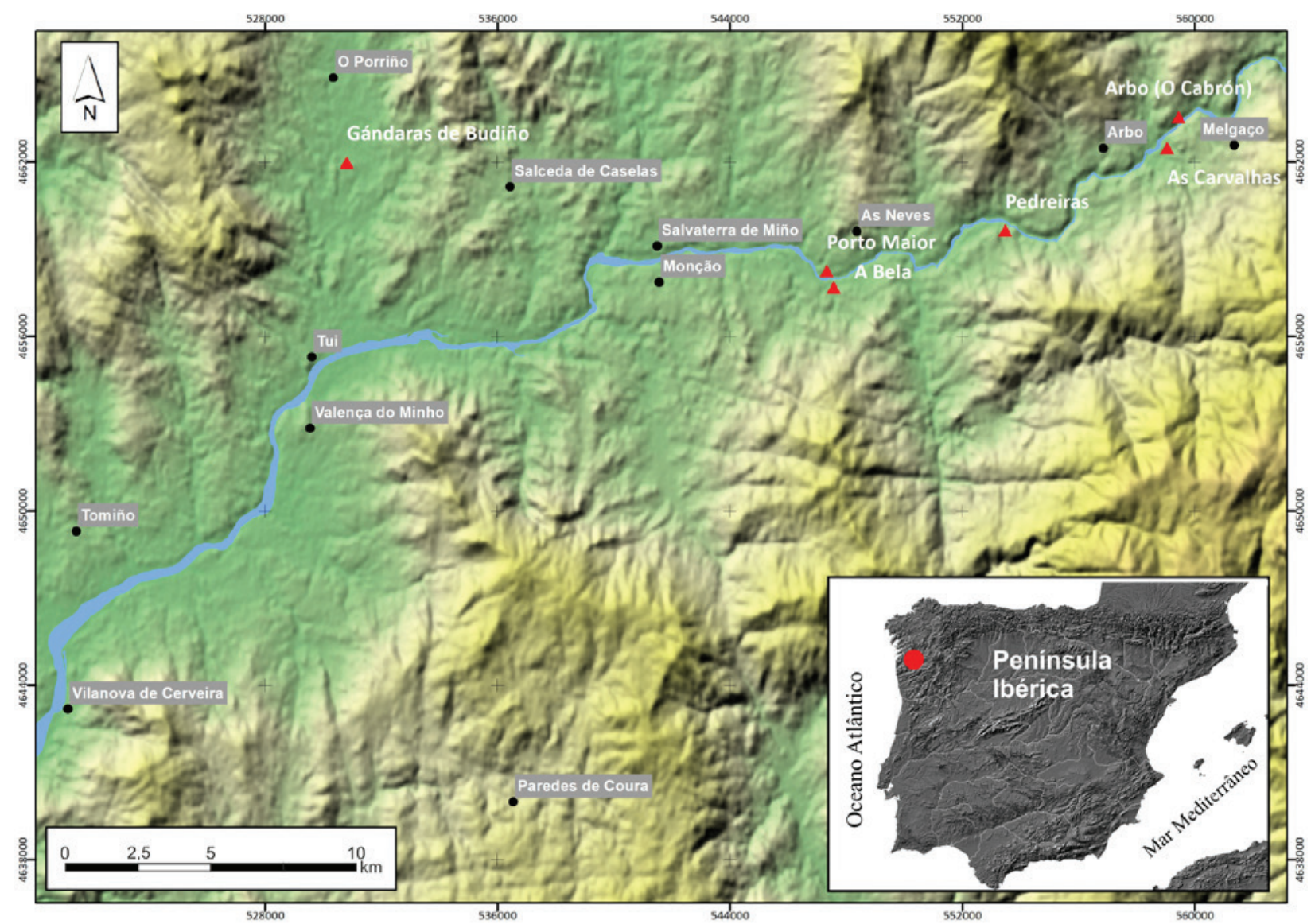

Figura 2 - Delimitação aproximada da área abrangida pelo Projeto Miño/Minho. Triângulos: principais jazidas paleolíticas intervencionadas, quer no âmbito do projeto Miño/Minho, quer no âmbito de outros projetos desenvolvidos na Galiza.

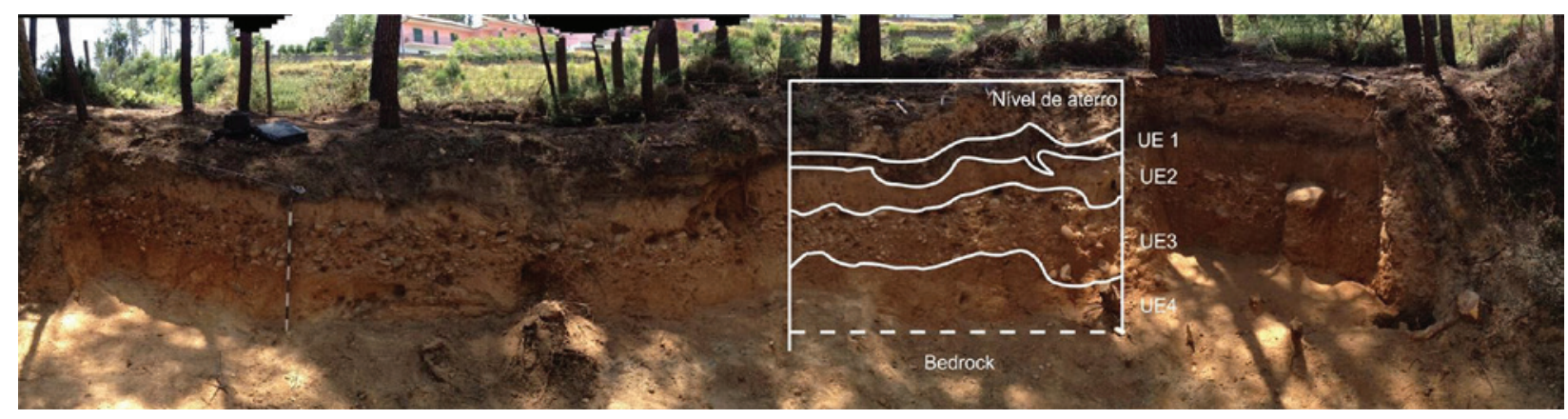

Figura 3 - Jazida de Predreiras 1, Monção. Corte regularizado durante os trabalhos de campo de 2016. Descrição estratigráfica sumária: UE1 - Solo orgânico recente enterrado por um nível de aterro; UE2 - Depósito silto-arenoso, maciço, de cor alaranjada, possivelmente de origem eólica, com um número muito reduzido de artefactos líticos talhados; UE3 - Depósito rico em seixos rolados de quartzito e quartzo e com clastos angulosos de granito, matriz-suportados, sem qualquer estruturação sedimentar, no qual se encontrou a maior parte da indústria lítica talhada; UE4 - Alterite granítica parcialmente remobilizada e com evidências de bioturbação. 


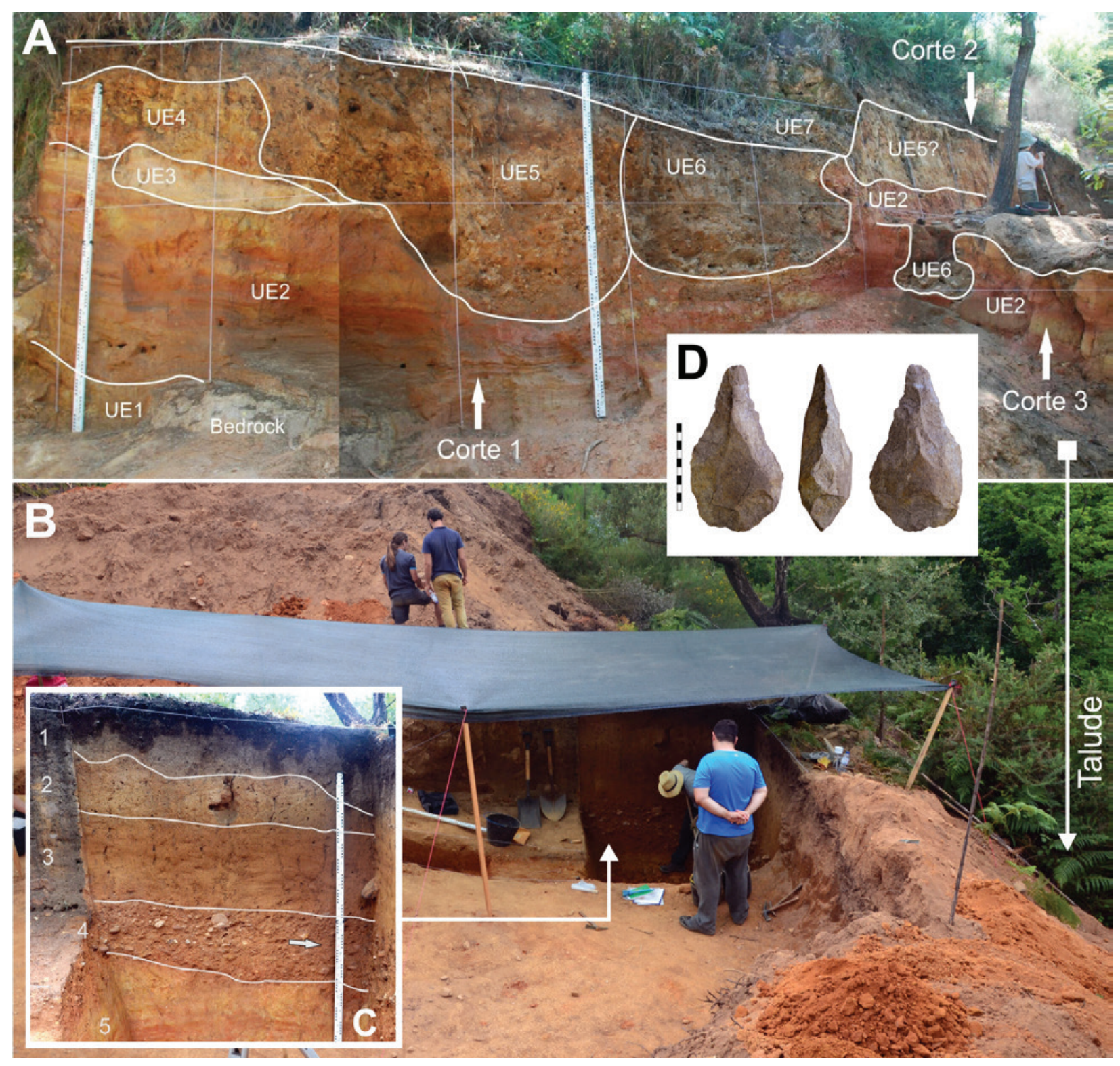

Figura 4 - Jazida de Pedreiras 2, Monção. A - Talude onde se identificou o biface (foto D) que conduziu à descoberta da estação arqueológica. Descrição estratigráfica sumária: UE1, UE2, UE3 - Depósitos fluviais arenosos com estratificação horizontal, arqueologicamente estéreis (cota da base: $35 \mathrm{~m}$ acima do leito atual do rio Minho); UE4, UE5, UE6 - Depósitos coluvionares em canais que se entrecortam; UE7 - Solo atual. B - Plataforma sobre o talude, intervencionada em 2016 (sondagem 1) e 2017. C - Sequência estratigráfica observada na área da sondagem 1: UE1 - Solo atual; UE2 e UE3 - Depósito silto-arenoso, possivelmente eólico; UE4 - Depósito coluvionar onde surge o material lítico talhado; UE5-Depósito fluvial arenoso, correspondente à UE2 do talude. 


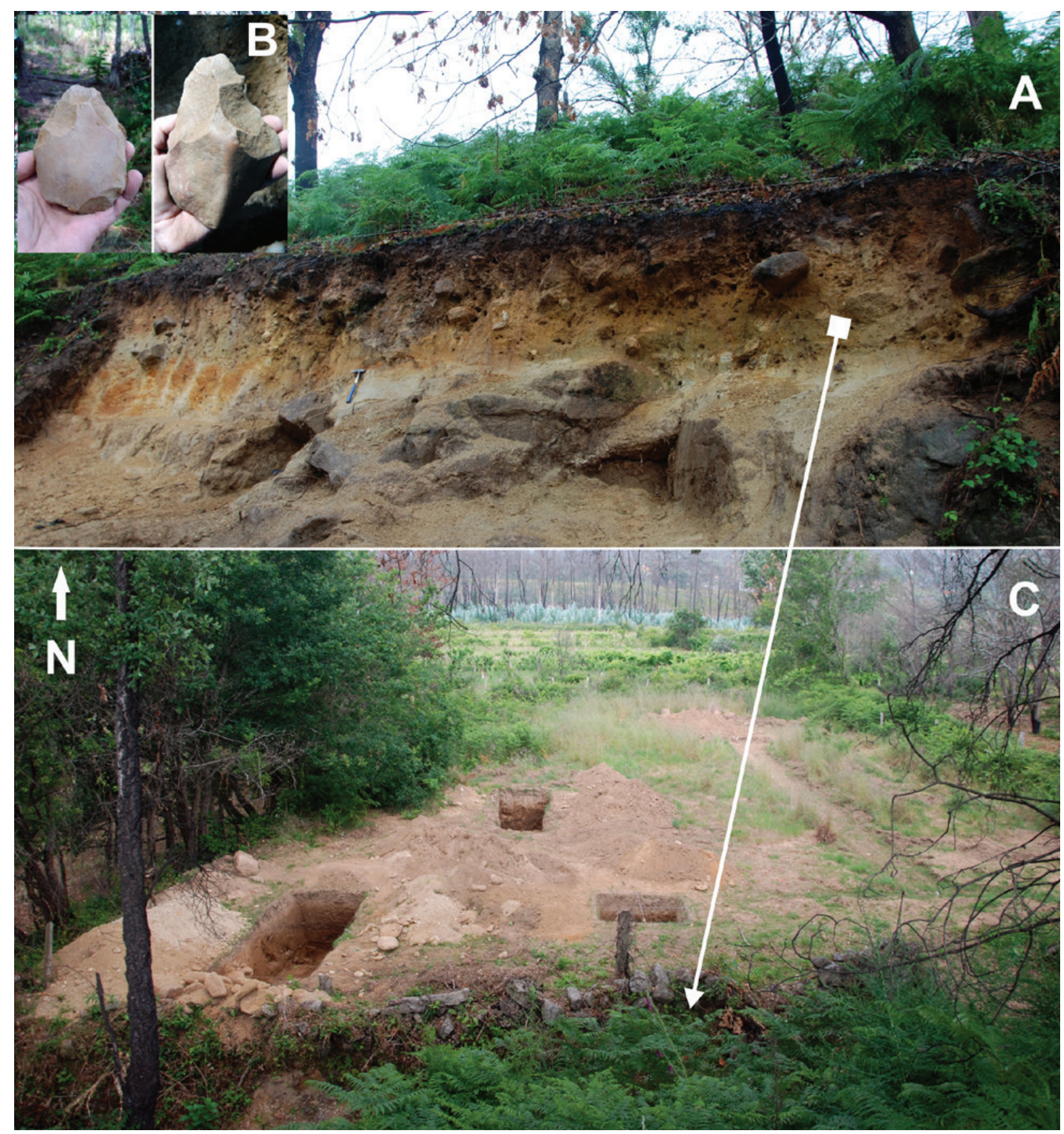

Figura 5 - Sítio de Bela, Monção. A - Talude subjacente à EN 202, limpo em 2018; B - Bifaces recolhidos no local durante a limpeza do talude; C - Implantação das sondagens sobre o terraço fluvial, em 2019. 

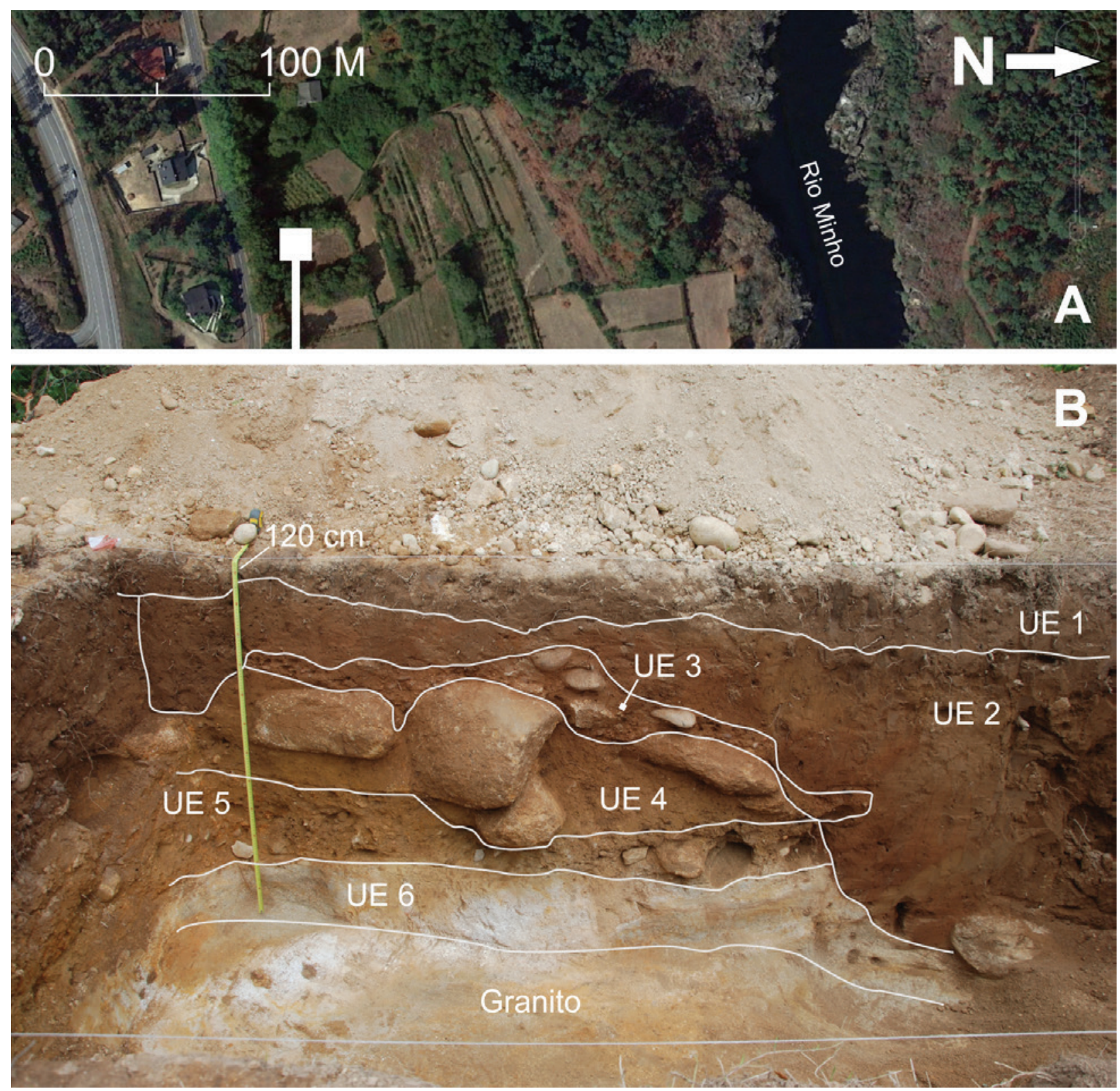

Figura 6 - Sítio de Bela, Monção. A - O quadrado branco assinala o talude da EN 202 limpo em 2018 e a área intervencionada em 2019. B - Estratigrafia observada numa das sondagens. Descrição sumária: UEı - Solo atual (afetado pelos trabalhos agrícolas); UE2 - Depósito silto-arenoso aluvionar; UE3 - Depósito coluvionar; UE4 - Depósito coluvionar claramente relacionado com o desmantelamento da vertente localizada a sul; UE5 - Depósito areno-siltoso constituído por areias fluviais e material de vertente, que embala artefactos líticos talhado: UE6 - Areias finas fluviais, na base das quais aparecem pontualmente seixos rolados de quartzito. Este material, que assenta no substrato granítico, faz parte da cobertura sedimentar do terraço do Minho implantado a cerca de $25 \mathrm{~m}$ acima do curso atual. 

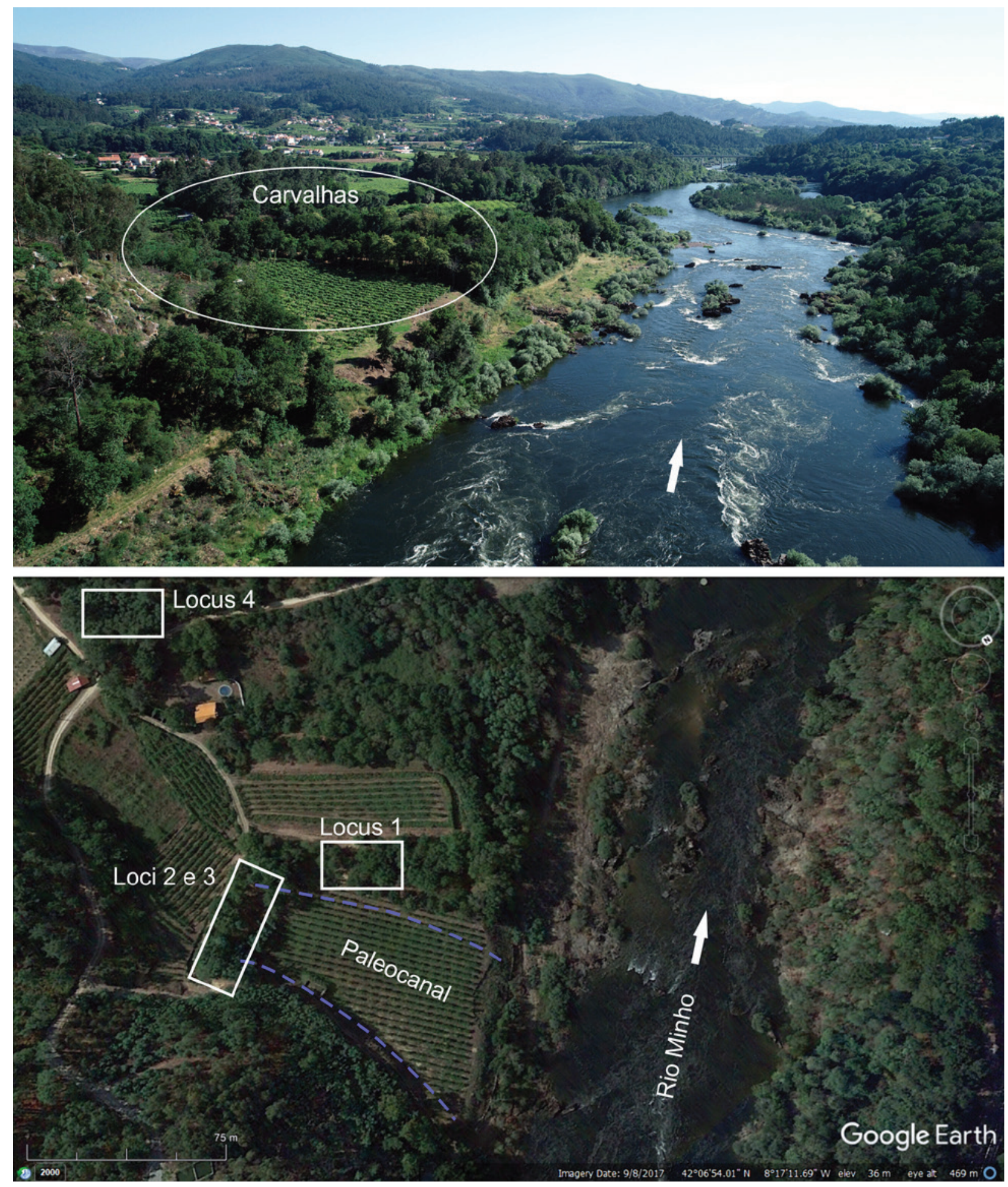

Figura 7 - Vista aérea para SW da jazida das Carvalhas, Melgaço, indicando-se os diversos loci intervencionados e um paleocanal do rio Minho. 


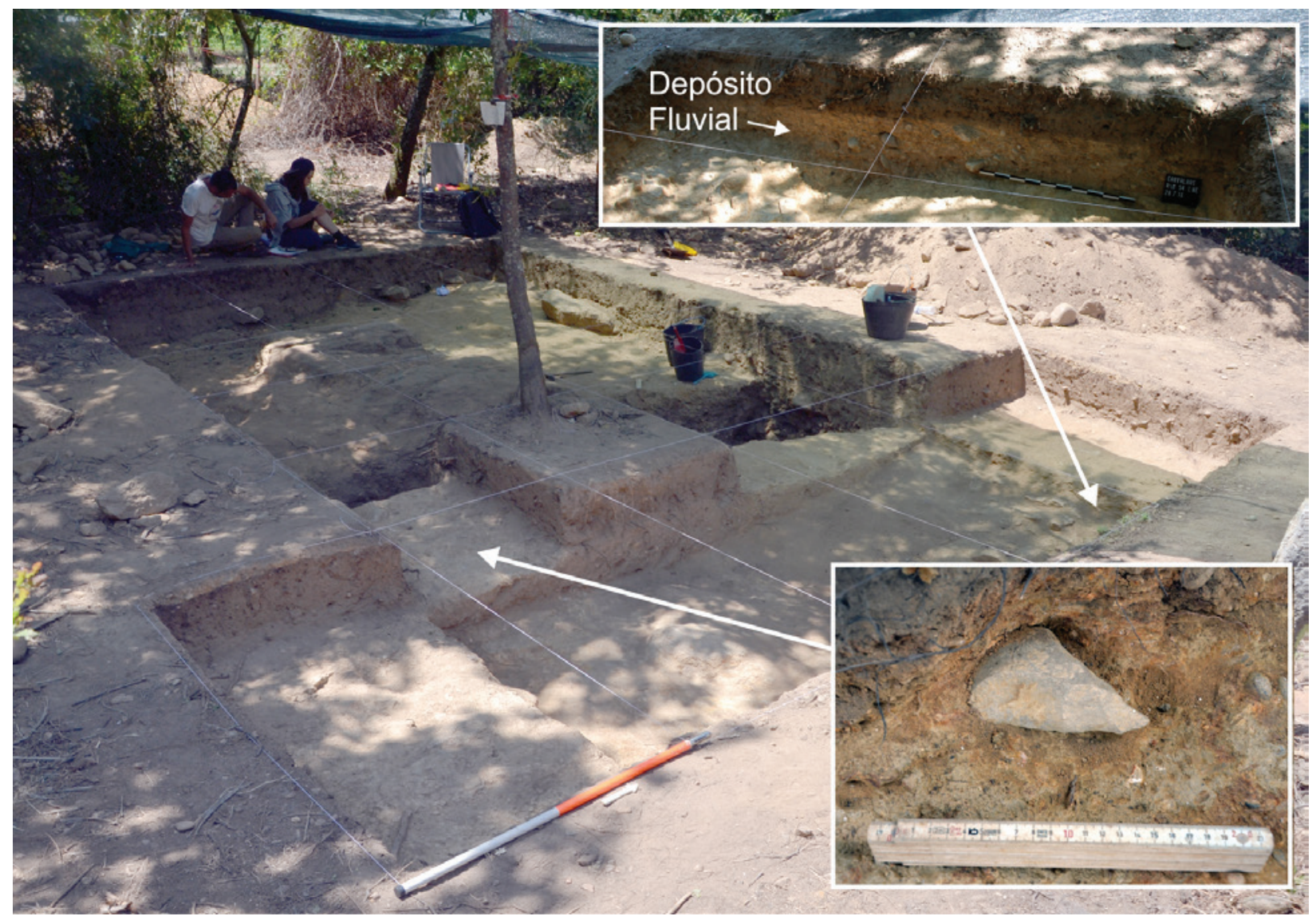

Figura 8 - Locus 1 durante a campanha de escavação de 2017. O material lítico associa-se a um depósito de origem fluvial, que se conserva apenas nas depressões do bedrock granítico. Trata-se de um depósito com matriz arenosa fina, de cor alaranjada, muito concrecionado, que embala pequenos seixos rolados de quartzito, bem imbricados. A superfície granítica que lhe subjaz, implantada a cerca de $20 \mathrm{~m}$ acima do curso atual do Minho, apresenta vestígios de erosão fluvial, nomeadamente polimento. 


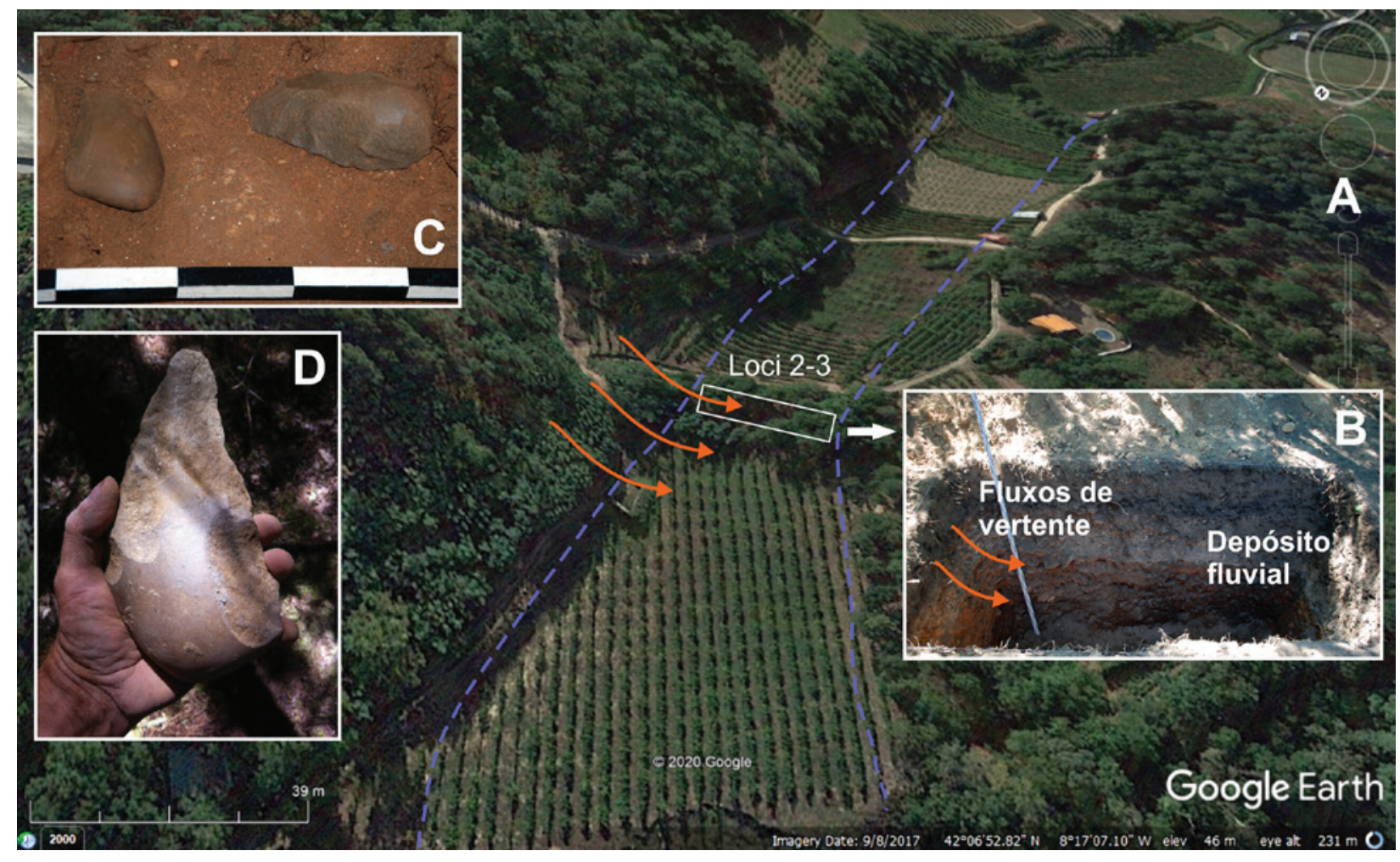

Figura 9 - Localização dos loci 2 e 3 da jazida das Carvalhas. A - Posição dos loci no paleocanal do rio Minho, assinalando-se os fluxos de vertente no sentido do canal, a partir do sopé do Monte do Prado. B - Interestratificação de sedimentos fluviais (conglomeráticos, clasto-suportados) e sedimentos de vertente (conglomeráticos, matriz-suportados, ricos em fragmentos angulosos de granito) numa sondagem aberta em 2016. C - Bifaces recolhidos no depósito fluvial, na zona de interestratificação. D - Biface de grandes dimensões recolhido no depósito fluvial. Observe-se o ténue boleamento das arestas. 


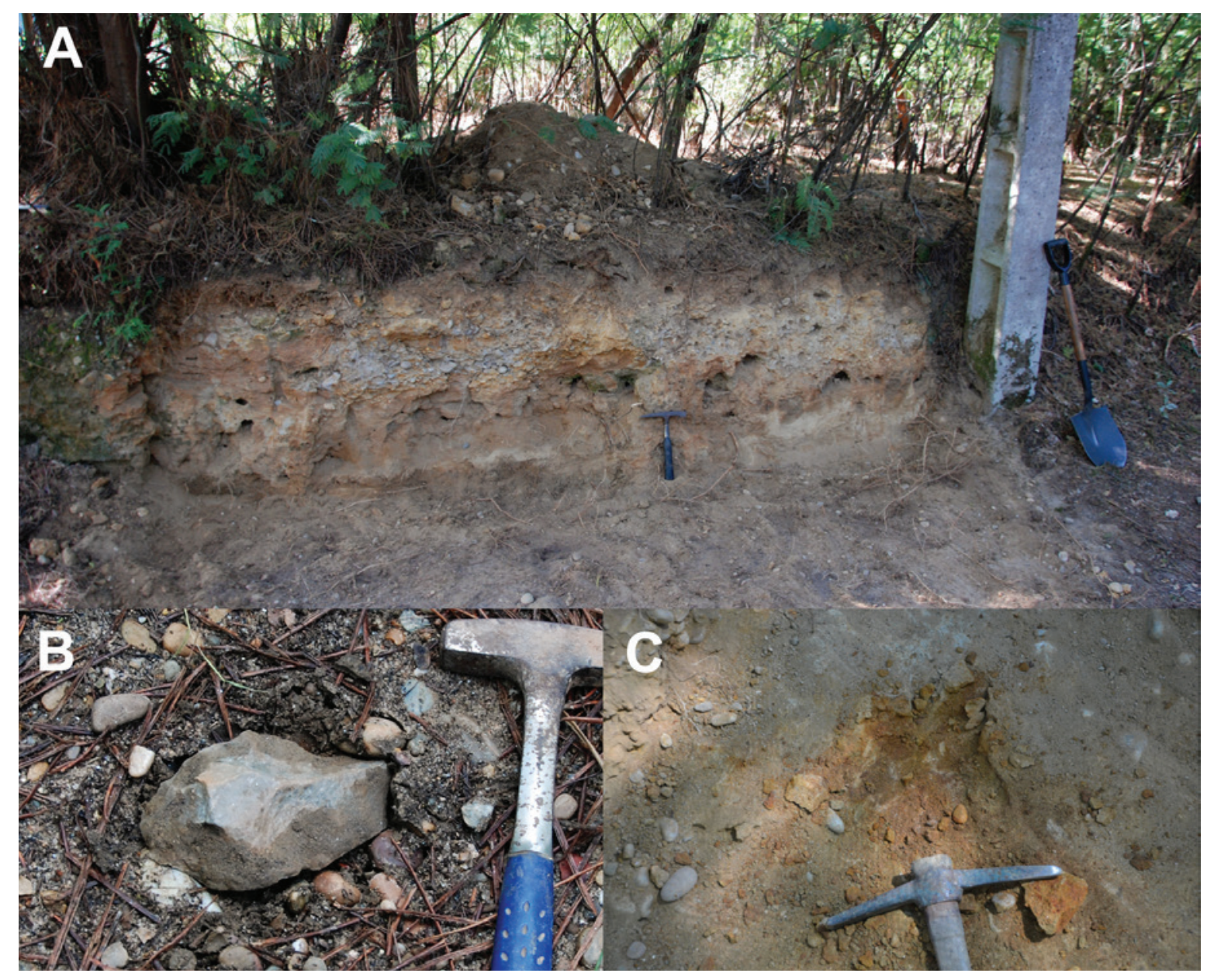

Figura 1o - Locus 4 das Carvalhas. A - Talude junto ao caminho que conduz ao rio Minho, onde se observam sedimentos que fazem parte de um terraço fluvial implantado à cota de $20 \mathrm{~m}$ acima do leito atual do rio. B - Biface encontrado em 2014, que permitiu a identificação do sítio arqueológico. C - Sedimento arenoso que embala o material lítico talhado (níveis superiores), observado na sondagem realizada em 2017.

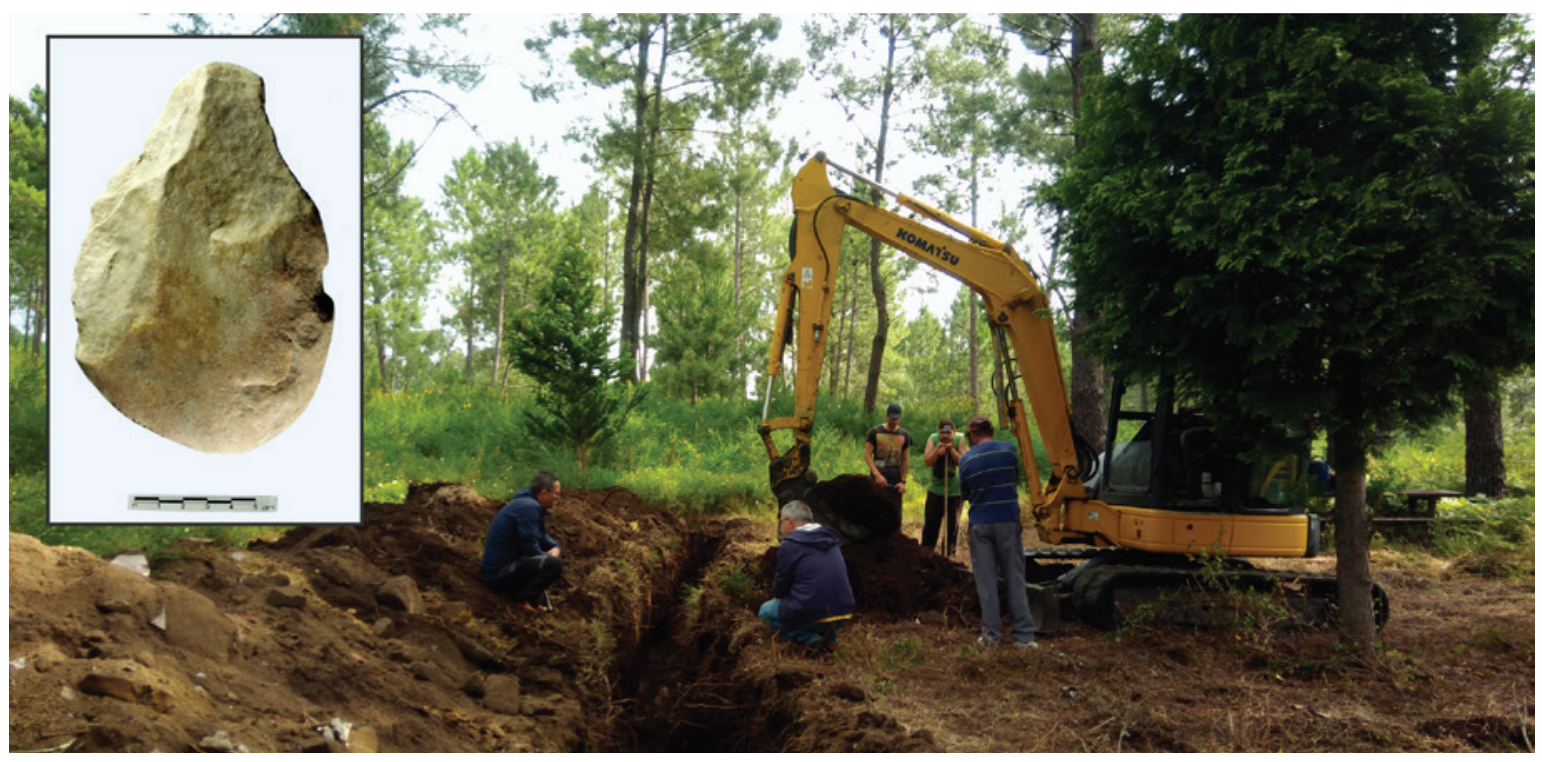

Figura 11 - Monte Crasto, Penso. Abertura de valas com recurso a meios mecânicos e exemplar de biface pertencente à coleção recolhida no local (pelo Sr. José Cardoso, de Penso). 


\title{
A OCUPAÇÃO PALEOLÍTICA DA MARGEM ESQUERDA DO BAIXO MINHO: A INDÚS- TRIA LIITICA DO SIITIO DE PEDREIRAS 2 (MONÇÃO, PORTUGAL) E A SUA INTEGRAÇÃO NO CONTEXTO REGIONAL
}

\author{
Carlos Ferreira ${ }^{1}$, João Pedro Cunha-Ribeiro² ${ }^{2}$, Sérgio Monteiro-Rodrigues ${ }^{3}$, Eduardo Méndez-Quintas ${ }^{4}$, \\ Pedro Xavier ${ }^{5}$, José Meireles ${ }^{6}$, Alberto Gomes ${ }^{7}$, Manuel Santonja ${ }^{8}$, Alfredo Pérez-González ${ }^{9}$
}

\begin{abstract}
RESUMO
A crescente realização de trabalhos arqueológicos em jazidas paleolíticas permite atualmente uma melhor compreensão do tecno-complexo Acheulense à escala peninsular, e a sua integração no contexto africano e euroasiático. No presente trabalho pretende-se aprofundar a discussão em torno das características tecnológicas das indústrias líticas peninsulares da segunda metade do Pleistocénico Médio, através da análise da indústria lítica da jazida de Pedreiras 2 (Monção, Alto Minho). Da realização de trabalhos de campo no local, no contexto do Projeto Miño-Minho, resultou a recolha de materiais associáveis ao tecno-complexo Acheulense, que testemunham a ocupação da região numa área onde até recentemente se conheciam achados isolados de materiais coevos, e cujos dados cronométricos permitem enquadrar a sua cronologia na segunda metade do Pleistocénico Médio. Palavras-chave: Pleistocénico Médio; Paleolítico Inferior; Indústria lítica; Acheulense de grandes lascas; Baixo Minho.
\end{abstract}

\begin{abstract}
The recent increase of archaeological survey has allowed a better definition of the Acheulean techno-complex in the Iberian Peninsula, and its integration in the African and Eurasian context. This paper aims to extend the discussion around the technological features of the peninsular lithic industries of the second half of the Middle Pleistocene, through the presentation of the data from Pedreiras 2 (Monção, Alto Minho). The site excavation, on the scope of the Miño-Minho Project, allowed to recover lithic artefacts associated with the Acheulean techno-complex, testifying human occupation in a region where, until recently, only isolated remains were known, and whose chronological data fits its chronology into the second half of the Middle Pleistocene.

Keywords: Middle Pleistocene; Lower Palaeolithic; Lithic industry; Large flake Acheulean (LFA); Lower Minho basin.
\end{abstract}

1. Faculdade de Letras, Universidade de Lisboa; carlos.felipeı1@gmail.com.

2. Faculdade de Letras, Universidade de Lisboa; Centro de Arqueologia da Universidade de Lisboa (UNIARQ); Lab2pt; jpcunharibeiro@letras.ulisboa.pt.

3. Faculdade de Letras, Universidade do Porto; Centro de Investigação Transdisciplinar "Cultura, Espaço e Memória” (CITCEM); sergiomonteirorodrigues@gmail.com.

4. Grupo de Estudos de Arqueoloxía, Antigüidade e Territorio (GEAAT), University of Vigo, Campus As Lagoas, 32004 Ourense, Spain; eduardo.mendez.quintas@uvigo.es.

5. UMinho; Lab2pt; pedroxavy@gmail.com.

6. UMinho; Lab2pt; jmeireles@uaum.uminho.pt.

7. Faculdade de Letras, Universidade do Porto; Centro de Estudos de Geografia e Ordenamento do Territorio (CEGOT); albgomes@ gmail.com.

8. Centro Nacional de Investigacion sobre la Evolucion Humana (CENIEH), Burgos; manuel.santonja@cenieh.es.

9. IDEA, Instituto de Evolución en África, Covarrubias 36, 28010 Madrid; alfredopg41@hotmail.com. 


\section{INTRODUÇÃO}

Os trabalhos arqueológicos de prospeção e de escavação realizados ao longo das últimas décadas têm fornecido novos dados acerca do tecno-complexo Acheulense peninsular, e o seu enquadramento no contexto africano e euroasiático. Em termos cronológicos, documenta-se a multiplicação exponencial do número de jazidas com indústrias tecno-tipologicamente enquadráveis num LFA (large flake Acheulean - Sharon, 2007, 2008, 2009, 2010, 2011) a partir do MIS 13, estendendo-se até ao MIS 6 (Rubio-Jara \& alii, 2016; Santonja \& Villa, 1990; Santonja \& Pérez-González, 2010; Santonja \& alii, 2016; Méndez-Quintas \& alii, 2019; 2020a; 2020b), embora alguns autores considerem as indústrias dos sítios de La Boella (Tarragona), e de Cueva Negra del Estrecho del Río Quípar (Múrcia), como testemunhos das primeiras indústrias acheulenses peninsulares numa cronologia compreendida entre 1.o Ma e o.8 Ma (Mosquera \& alii, 2015; Vallverdú \& alii, 2014; Walker \& alii, 2013).

A maioria dos dados disponíveis para o estudo do Acheulense peninsular, que evidencia manifestas afinidades face ao Acheulense africano, provém do estudo dos materiais líticos recolhidos nos terraços fluviais das principais bacias hidrográficas atlânticas (associados aos terraços médios, a cotas compreendidas entre os $+40-20 \mathrm{~m}$ ), em função deste tipo de formas conterem depósitos sedimentares e, consequentemente, conservarem vestígios das ocupações humanas do passado, não obstante o facto de a sua integridade ser condicionada pelas dinâmicas de sedimentação/erosão fluvial (Chauhan \& alii, 2017; Santonja \& Villa, 199o; Santonja \& Pérez-González, 2010; Santonja \& alii, 2016). Neste sentido, e englobados num contexto mais amplo, destacam-se os estudos realizados recentemente na bacia hidrográfica do rio Minho (Cunha-Ribeiro $\&$ alii, 2017, 2018; Demuro \& alii, 2020; Méndez-Quintas, 2007, 2008, 2017; Méndez-Quintas \& alii, 2018a, 2018b, 2018c, 2019, 2020a, 2020b).

As diferenças de ritmo e de intensidade que caracterizaram o estudo do Paleolítico do Baixo Minho no século passado (Cunha-Ribeiro \& alii, 2017, 2018; Méndez-Quintas, 2017; Méndez-Quintas $\mathbb{Z}$ alii, 2018a, 2019, 2020a) materializaram-se no desenvolvimento irregular da exploração do potencial arqueológico da região. Consequentemente, a produção de um conhecimento assimétrico entre as duas margens constituía uma anomalia no estudo do Paleolítico Inferior da Península Ibérica, tendo em conta, justamente, que a maior parte do registo arqueológico desta época se concentra nos depósitos das principais bacias fluviais da vertente atlântica (Méndez-Quintas \& alii, 202ob). Por outro lado, embora a investigação arqueológica tenha sido pontualmente acompanhada pela realização de estudos geomorfológicos (Lautensach, 1945; Teixeira, 1944, 1952), só recentemente foi possível ultrapassar a impossibilidade de correlacionar sequências relativas entre os terraços fluviais e os materiais arqueológicos (Demuro \& alii, 2020; Méndez-Quintas \& alii, 2020a; Viveen $\&$ alii, 2012).

Estimulado pela multiplicação dos trabalhos na margem direita, e reunindo investigadores nacionais e estrangeiros, o projeto Miño/Minho (Os primeiros habitantes do Baixo Minho. Estudo das ocupações pleistocénicas da região), surgiu, precisamente, da tentativa de ultrapassar a assimetria no estudo das ocupações pleistocénicas em cada uma das margens do Baixo Minho. A realização de trabalhos de prospeção e de escavação no território entre Melgaço e Caminha, ao longo dos últimos quatro anos, tem permitido redefinir e aprofundar o entendimento da ocupação paleolítica da margem esquerda do Baixo Minho, correlacionando materiais arqueológicos e depósitos fluviais (Cunha-Ribeiro \& alii, 2017, 2018). Efetivamente, o esforço combinado das novas investigações permite assimilar, de forma mais detalhada, as características tecnológicas das primeiras ocupações humanas da região, cronologicamente enquadráveis na segunda metade do Pleistocénico Médio (Demuro \& alii, 202O; Méndez-Quintas \& alii, 2019, 2020a, 2020b). Neste contexto, destaca-se, na sua margem esquerda, a jazida de Pedreiras 2 (Monção, Alto Minho), cujos resultados do estudo da indústria lítica, tendo em conta a caracterização tecno-morfológica e tecno-económica das indústrias acheulenses peninsulares, se apresentam em seguida.

\section{PEDREIRAS 2: ENQUADRAMENTO GEOGRÁFICO E GEOMORFOLÓGICO}

O sítio arqueológico de Pedreiras 2 (CNS - 35273) localiza-se no Concelho de Monção, na área da União de Freguesias de Messegães, Valadares e Sá. Situado perto do túnel que passa por baixo da ligação de Monção a Melgaço (EN 202), encontra-se em relação com um afloramento do terraço fluvial do rio 
Minho implantado a +40 m acima do nível atual do rio (Figura 1).

A bacia hidrográfica do rio Minho, com uma extensão de cerca de $17027 \mathrm{~km} 2$, é a bacia hidrográfica mais relevante do Noroeste peninsular, contendo um importante registo sedimentar do Pleistocénico, composto principalmente por terraços fluviais e leques aluviais (Ribeiro, Moreira, 1986; Méndez-Quintas $\mathbb{E}$ alii, 2020a). No seu percurso, o rio Minho, que desagua no Oceano Atlântico, erode variadas litologias, gerando distintas paisagens, sendo que as suas condições geográficas e climáticas permitem defini-lo como um rio atlântico, com um fluxo máximo após as chuvas de inverno (Méndez-Quintas \& alii, 202Oa). A região conhecida como "Baixo Minho" cobre os $85 \mathrm{~km}$ mais ocidentais de um rio com mais de 350 $\mathrm{km}$, preservando um extenso registo morfológico, sedimentar e arqueológico do Pleistocénico Médio (Méndez-Quintas \& alii, 202Ob). Como referido anteriormente, ao longo do século passado realizaram-se, de forma pontual, estudos geomorfológicos que pretendiam distinguir os terraços fluviais do Baixo Minho "potentes niveles con asociaciones de litofacies Gh, Gp y Gt características de rellenos de estruturas acanaladas. Intercalados o a techo de estas facies clásticas, como respuesta a la fase final de colmatación de estos canales o a procesos de acreción vertical, se identifican facies de arenas y fangos" (Méndez-Quintas, 2017, p. 524). Procurando ultrapassar a variedade de perspetivas relativamente ao número e à altimetria dos terraços (que exibem uma variabilidade espacial ao longo da bacia devido a fatores litológicos e à interação com redes de falhas pré-existentes), nos últimos anos têm-se realizado estudos interdisciplinares centrados no mapeamento e na caracterização geomorfológica do sistema de terraços e dos depósitos fluviais associados. Paralelamente, têm-se desenvolvido pesquisas centradas na análise estratigráfica, na caracterização das diferentes unidades geológicas, e na correlação entre depósitos e vestígios de ocupações humanas do passado, através da escavação de um conjunto de sítios arqueológicos de maior interesse, e da obtenção de datações absolutas por ressonância paramagnética eletrónica (ESR) e luminescência opticamente estimulada (OSL) em quartzo sedimentar (Méndez-Quintas \& alii, 2020a).

Os dados resultantes das investigações recentemente realizadas possibilitam uma melhor compreensão das características da bacia hidrográfica do Baixo
Minho, individualizando-se geomorfologicamente nove níveis de terraços, "with relative heights above the current floodplain of +4-7 $\mathrm{m}(\mathrm{Tr}),+13-17 \mathrm{~m}\left(\mathrm{~T}_{2}\right)$, +21-29 $\mathrm{m}\left(\mathrm{T}_{3}\right),+3 \mathrm{O}-39 \mathrm{~m}\left(\mathrm{~T}_{4}\right),+45-51 \mathrm{~m}\left(\mathrm{~T}_{5}\right),+53-61$ $\mathrm{m}$ (T6), +65-77 m (T7), +78-89 $\mathrm{m}$ (T8) and +91-108 m (T9)" (Méndez-Quintas $\&$ alii, 2020a, p. 6). Os terraços fluviais do rio Minho, sobretudo de acumulação, e associados essencialmente às dinâmicas sedimentares do rio, foram formados entre o Pleistocénico Inicial e o Pleistocénico Final, propondo-se a seguinte cronologia provisória "as plausible for the lower Miño terrace system: $\mathrm{T} 1=<\mathrm{MIS}_{4}, \mathrm{~T}_{2}=$ MIS 6-5, T3 = MIS 8-7, T4 = MIS 9-8, T5 = MIS 12-11, $\mathrm{T} 6=\mathrm{MIS} 14-12, \mathrm{~T} 7=\mathrm{MIS} 17-15, \mathrm{~T} 8=21-17$ and T9 $=$ 25-22" (Idem, p. 9). Embora estes dados cronométricos possam vir a ser otimizados mediante a realização de datações complementares, permitem situar a formação dos terraços T2-T7 no Pleistocénico Médio. É justamente a este período cronológico que se têm associado numerosos sítios paleolíticos identificados entre $+40 \mathrm{~m} \mathrm{e}+13 \mathrm{~m}$ (a.l.a.), com indústrias líticas características de um LFA, mas também indústrias do Paleolítico Médio (Figura 2), dados que sugerem uma relevante ocupação humana da bacia hidrográfica do rio Minho a partir da segunda metade do Pleistocénico Médio (Méndez-Quintas \& alii, 2018b; 2019; 2020a; 2020b). Além disso, é importante referir que, apesar de ter sido proposta a presença de artefactos líticos de indústrias mais arcaicas em terraços acima dos $+40 \mathrm{~m}$ (a.l.a.), e, consequentemente, com cronologias anteriores a 500 ka, (Cano Pan \& alii, 1997; Villar Quinteiro, 2012), a potencial insegurança estratigráfica da localização dos materiais, e o debate em torno da sua natureza antrópica, não permitem assegurar a existência de evidências que testemunhem uma presença humana anterior ao Pleistocénico Médio na região (Méndez-Quintas $\&$ alii, 2O2Ob).

\section{O TRABALHO DE CAMPO}

O sítio de Pedreiras 2 foi alvo de trabalhos de escavação entre 2016 e 2017 por uma equipa de investigadores ibéricos. Destes trabalhos, resultou a recolha de materiais líticos talhados acheulenses em excelente estado físico, integrados em depósitos coluvionares canalizados, clásticos e matriz-suportados, que se encaixam em sedimentos finos de origem fluvial com apreciável potência (Cunha-Ribeiro \& alii, 2017). 


\section{METODOLOGIA}

No desenvolvimento do presente trabalho aplicou-se um conjunto de princípios metodológicos centrados na análise e caracterização tecno-tipológica da indústria lítica de Pedreiras 2. Os parâmetros tecnológicos e tipológicos aferidos seguem critérios de análise anteriormente descritos por Cunha-Ribeiro (1999) e Méndez-Quintas (2017), visando, deste modo, criar condições que permitam integrar o sítio de Pedreiras 2 nos resultados conhecidos para a margem direita, e estabelecer, eventualmente, outros paralelos. O estudo realizado baseou-se na abordagem subjacente ao conceito de cadeia operatória (Bar Yosef \& Van Peer, 2009; Boëda, Geneste \& Meignen, 1990; Inizan \& alii, 1995; Soressi \& Geneste, 2011), apesar da identificação de cadeiras operatórias no Paleolítico Inferior ser bastante complexa, em função da variabilidade que caracteriza este tipo de indústrias (Boëda, Geneste \& Meignen, 1990).

Tendo em conta que os materiais arqueológicos recolhidos em 2016 e em 2017 provêm de áreas fisicamente distintas (Figura 3), embora próximas (Cunha-Ribeiro \& alii, 2017), optou-se por estudar isoladamente os artefactos das duas campanhas. Os materiais de 2016 procedem de uma intervenção realizada no corte de um caminho relativamente paralelo à variante da EN 202, a partir do qual se estabeleceu uma sondagem para sul, e no talude anexo ao mesmo. O seu contexto sedimentar corresponde a depósitos de génese coluvionar canalizados em sedimentos fluviais finos areno-siltosos, que se integram numa estratigrafia complexa, onde, a par de algumas bolsas de areias, surgem vestígios de canais seccionados de depósitos coluvionares. Por outro lado, os materiais de 2017 foram recolhidos nos trabalhos realizados na plataforma sobranceira ao talude, a sul da área intervencionada em 2016. Apesar de se ter concluído que os níveis de coluvionamento apresentavam uma orientação e desenvolvimento diferentes do esperado, o contexto sedimentar dos artefactos exumados em 2017 permite a sua articulação com os identificados no ano anterior.

\section{RESULTADOS DO ESTUDO DO MATERIAL LÍTICO DE PEDREIRAS 2}

Embora o material de ambas as campanhas seja proveniente de áreas fisicamente isoladas, mas próximas, o estudo global do espólio, e o seu contex- to sedimentar, confirmam a hipótese inicialmente avançada de que estamos na presença de uma coleção homogénea (ao nível das matérias-primas, do estado físico das peças, da estatística das principais dimensões de ambos os conjuntos, e das suas características tecno-tipológicas), pelo que, em segui$\mathrm{da}$, se apresentam os resultados do estudo global da indústria.

Da análise da totalidade do material (200 peças) destacam-se algumas tendências acerca das características da indústria lítica do sítio de Pedreiras 2. Relativamente à matéria-prima utilizada, à semelhança do que se reconhece noutros sítios da região, constata-se que os tipos de rochas selecionados para a sua manipulação e transformação correspondem a dois grandes grupos: os quartzitos e os quartzos, disponíveis de forma abundante nos terraços fluviais próximos da jazida, sob a forma de seixos rolados. Assinala-se o predomínio do quartzito (65\%) sobre o quartzo (35\%), não se registando diferenças notáveis entre as distintas categorias tecnológicas, à exceção dos LCTs (large cutting tools), elaborados exclusivamente em quartzitos (Gráfico 1). Paralelamente, quanto ao seu estado físico, as peças apresentam um bom estado de conservação (146 peças classificadas como "arestas vivas", 46 peças classificadas como "pouco roladas" e apenas 8 peças "muito roladas"). Em relação à distribuição do material por categoria tecnológica (Gráfico 2), documenta-se o predomínio dos produtos de debitagem ("debitage" - 40\%; "debris" - 17\%), seguidos dos núcleos $(17 \%)$, e dos produtos configurados (utensílios $12 \%$; LCTs $-10 \%$ ), para além dos seixos rolados não trabalhados de origem exógena (4\%), maioritariamente de quartzo (cinco peças em seis).

Relativamente aos núcleos inventariados, destaca-se a utilização preferencial do quartzito (68\%) como matéria-prima, tendo-se excluído desta análise os seixos testados (incluídos na fase de aquisição). Explorados a partir de calhaus rolados, e através de percutores duros, prevalecem os núcleos com um só plano de percussão (73\%), predominando os planos de percussão corticais (83\%). Os padrões de redução são, regra geral, muito simples e expeditos, sendo notório o domínio dos esquemas monopolares unifaciais (14 núcleos). Para além dos esquemas monopolares, também existem exemplos de estratégias bipolares bifaciais (três), periféricas unifaciais (duas) e ortogonais bifaciais (duas). Com exemplos únicos, registou-se um núcleo multipolar unifacial, 
um núcleo monopolar bifacial, um núcleo periférico bifacial, um núcleo centrípeto, um núcleo discoide (em quartzo), e a utilização da técnica de redução bipolar sobre bigorna num núcleo de quartzo, realçando-se a presença de um giant core de quartzito na jazida. Os núcleos apresentam uma exploração sumária, com um número médio de cinco levantamentos (dois o valor mais baixo, e doze o valor mais alto), conservando em mais de $90 \%$ dos casos um volume suficiente para continuar a produzir suportes.

Em relação às lascas, ressalta igualmente a utilização preferencial do quartzito $(74 \%)$, sendo comum a existência de lascas fraturadas, essencialmente devido a acidentes de tipo Siret. Evidenciam-se as lascas de talão cortical (52\%) face às lascas de talão liso (35\%), estando também presentes exemplares residuais com talão diedro ( $9 \%)$, facetado ( $2 \%$ ), suprimido ( $1 \%$ ) e punctiforme (1\%). Em termos da percentagem de vestígios de córtex, regista-se a presença assinalável de lascas não corticais (<25\% - 29 lascas), para além de oito lascas semi-corticais (50$75 \%$ ), seis lascas corticais ( $>75 \%$ ), e três lascas com vestígios corticais (25-50\%), resultados compatíveis com uma produção realizada na própria jazida. Fora deste âmbito, documenta-se a presença significativa de lascas com dorso natural (25 lascas), tendencialmente aplanado e invasor, ou marginal e abrupto, o que indicia o desenvolvimento lateral da debitagem, correlacionável com a exploração de seixos rolados de quartzito enquanto suportes predominantes da matéria-prima utilizada. Além disso, registaram-se também cinco lascas resultantes da configuração de LCTs, duas lascas discoides, uma lasca kombewa, uma lasca bipolar sobre bigorna, uma lasca de reavivamento de peças retocadas, e uma ponta levallois. Os bolbos estão bem desenvolvidos, e o padrão das extrações anteriores à obtenção da lasca evidencia uma variabilidade reduzida, dominando os padrões de natureza monopolar (70\%), sobre os padrões ortogonais (11\%), multipolares (10\%), bipolares (5\%), centrípetos (3\%) e periféricos (1\%). As lascas apresentam uma média de 2,7 levantamentos (variam entre zero e onze levantamentos), assinalando-se a diferença entre o número médio de negativos das lascas de quartzito $(2,9)$ e de quartzo $(2,1)$.

Os produtos configurados encontram-se representados na indústria lítica por um conjunto de utensílios diversos e LCTs. Tendo em conta os utensílios diversos, 18 peças correspondem a utensílios sobre lasca, e 6 a utensílios sobre seixo. Relativamente aos utensílios sobre lasca, predominam os suportes não corticais (onze), para além da presença de suportes com vestígios corticais (quatro) e de lascas com dorso natural (três). As peças apresentam um número reduzido de retoques, sendo o retoque maioritariamente marginal. Em termos tipológicos, não existe qualquer tipo de estandardização, identificando-se "simples" lascas retocadas (seis), repartindo-se os restantes exemplares entre cinco entalhes, três denticulados, dois raspadores (um dos quais sobre uma lasca entame), um furador, e um utensílio compósito. Quanto aos utensílios sobre seixo, realça-se um grande seixo apontado. Dentro dos LCTs, exclusivamente em quartzito, destacam-se os machados de mão e os bifaces, estando também presentes exemplares de esboços de peças bifaciais. Relativamente aos machados de mão, desde um ponto de vista tecno-tipológico (Tixier, 1956), a forma mais representada é o "tipo o" (cinco exemplares), documentando-se apenas um exemplar de "tipo 1 ", e os materiais foram elaborados tanto em lascas com vestígios corticais (três peças), como em lascas semi-corticais (três peças). A configuração dos bordos realizou-se mediante a utilização de percutor duro, e, como é habitual neste tipo de peças, a intensidade da configuração não é muito elevada. Regra geral, as peças exibem uma configuração marginal, também direcionada para suprimir o talão e o bolbo, registando-se uma configuração/regularização mais intensa de ambos os bordos em duas peças. Os bifaces analisados correspondem a bifaces-outil (Böeda, Geneste \& Meignen, 1990), e, apesar de ser um conjunto numericamente reduzido, apresentam variabilidade formal (Bordes, 1961), com morfologias amigdaloides (um biface amigdaloide com talão, um biface amigdaloide típico), discoides (um biface discoide com talão), e limandes (um biface proto-limande com talão), para além de um proto biface. Para a sua elaboração selecionaram-se tanto seixos (duas peças), como lascas (duas peças), não sendo possível determinar o suporte de um dos exemplares. A intensidade da configuração é bastante elevada, no sentido em que o anverso de todas as peças está quase, ou totalmente, sem córtex, constatando-se que os bifaces elaborados a partir de seixo rolado são os que apresentam uma maior transformação por talhe. Além disso, é relevante referir que a sua configuração se realizou maioritariamente através de percutor duro, reconhecendo-se, pelo menos num caso, a aplicação de percutor brando/mole na regularização da peça. 
Em termos gerais, o valor reduzido da amostragem, e o facto de os atributos apresentarem uma grande variação, não permite perspetivar mais correlações entre o suporte, a dimensão, a morfologia, a silhueta e a simetria da peça, ou com uma maior intensidade de intervenção e transformação de determinadas formas e/ou suportes.

\section{DISCUSSÃO: A INDÚSTRIA LÍTICA DE PEDREIRAS 2}

Com base na interpretação da indústria lítica, e do seu contexto estratigráfico, é possível destacar algumas tendências. De um ponto de vista geoarqueológico, o material é proveniente de um contexto secundário, integrado em depósitos coluvionares, atestado, por exemplo, no rácio desproporcional aproximado de um núcleo para duas lascas. No entanto, o bom grau de conservação da grande maioria do material, e a presença simultânea de artefactos de diferentes tamanhos e pesos (desde pequenas lascas e subprodutos não específicos, inferiores a $30 \mathrm{~mm}$, a um giant core), são observações pertinentes que sugerem, e pressupõem, uma mobilização reduzida do conjunto, conferindo-lhe uma relativa homogeneidade. Estes argumentos serão indicadores de uma origem próxima do local, correlacionando-se, provavelmente, com depósitos de baixa energia de natureza fluvial.

Como referido anteriormente, não obstante o facto de o material ser proveniente de duas áreas fisicamente isoladas, mas próximas, estamos perante uma coleção homogénea. Neste sentido, podem salientar-se algumas observações, nomeadamente o facto de se constatarem duas realidades diferenciáveis. Por um lado, a presença de LCTs na jazida, ou a presença residual de lascas de configuração deste tipo de peças, é sugestiva de uma realidade associada ao uso e à manutenção de produtos configurados, característicos das indústrias acheulenses. À semelhança da situação registada nos conjuntos estudados na margem direita, onde os LCTs são habitualmente configurados fora das jazidas (Méndez-Quintas, 2017), estes materiais teriam sido introduzidos na jazida já em fase de uso. Por outro lado, constata-se a existência de uma realidade principal, maioritária, relacionada com uma indústria mais expedita, focada na produção de lascas. Relativamente aos núcleos, é nesta dinâmica que se interpreta a presença de seixos testados (embora a abundância de matéria-prima justifique a parca relevância dos elementos associados à fase de aquisição, e a reduzida exploração dos volumes); o facto de cerca de $71 \%$ dos núcleos ter apenas um plano de percussão; e, sobretudo, o predomínio de esquemas elementares (monopolares), à semelhança do padrão de exploração dos levantamentos da face dorsal das lascas. Quanto às lascas, o estudo da sua variabilidade tecno-tipológica, e do seu grau de corticalidade, também evidenciam resultados compatíveis com uma produção realizada no local, destacando-se a presença maioritária de lascas com dorso natural, ou de lascas não corticais ( $>25 \%$ ), que remetem para diferentes fases da exploração de um núcleo. Além disso, é de assinalar a reduzida dimensão dos produtos de debitagem (em concordância com a dimensão média da última lasca identificável nos núcleos), para além da presença de um conjunto de subprodutos de talhe não específicos, que atestam a realização de atividades de talhe no local, reforçando o predomínio dos elementos associados à fase de produção.

Consequentemente, o estudo da coleção permite associar a indústria lítica de Pedreiras 2 não a uma cadeia operatória direcionada para a obtenção e configuração de grandes lascas suporte, que foram introduzidas no local já em fase de uso, mas antes com uma realidade paralela que visa a obtenção de produtos de debitagem relativamente expeditos e simples, por vezes sumariamente retocados, elaborados maioritariamente a partir de seixos rolados de quartzito. Todavia, é importante ressalvar que a interpretação arqueológica do conjunto se encontra, naturalmente, subordinada à dimensão da amostragem (200 peças), e à sua posição estratigráfica. Efetivamente, ao analisar materiais provenientes de depósitos fluviais, é preciso ter em conta que existe um conjunto de fatores que condicionam a análise, nomeadamente:

- A dificuldade em definir a dimensão e a extensão da área ocupada;

- O impacto do contexto sedimentar e da natureza dos processos de formação do sítio na integridade da sua indústria lítica;

- O tempo envolvido na formação da jazida, visto que, muitas vezes, os conjuntos correspondem a acumulações de material descartado durante um período incerto, ao longo do tempo, sendo excecionais os casos em que se conservam períodos de ocupação curtos;

- E, por último, que a realização de compara- 
ções entre locais com base numa análise tecno-tipológica pode produzir observações ilusórias, se as diferentes variáveis envolvidas nos processos de formação não forem consideradas, uma vez que as disparidades podem ser consequência, não da funcionalidade da jazida, mas antes dos processos geoarqueológicos envolvidos na sua formação (Santonja \& Villa, 199o).

\section{EPÍLOGO: O SÍTIO DE PEDREIRAS 2 NO CONTEXTO DO PLEISTOCÉNICO MÉDIO DO BAIXO MINHO E DO OCIDENTE PENINSULAR}

A identificação da jazida paleolítica do sítio de Pedreiras 2 permitiu reunir duas centenas de materiais líticos talhados, entre os quais produtos configurados (bifaces e machados de mão) característicos das indústrias acheulenses, que, pelas suas características, e pela sua posição estratigráfica, testemunham a ocupação paleolítica da região durante a segunda metade do Pleistocénico Médio, inserindo-a num contexto muito mais amplo que abrange o território peninsular.

De um ponto de vista tecnológico, as indústrias acheulenses peninsulares caracterizam-se, à semelhança dos conjuntos africanos, pela gestão e consumo de grandes volumes de matéria-prima (giant cores), essencialmente de caráter local. Através de esquemas de exploração monopolares, bifaciais, ou multipolares, visa-se a produção de lascas de pequeno/médio formato, e de grandes suportes ( $>10 \mathrm{~cm}$ ), retocados, ou configurados, para a produção de utensílios como LCTs (large cutting tools), diferenciando-se, deste modo, dos conjuntos de lascas e núcleos olduvaienses (Méndez-Quintas \& alii, 2018a, 2019, 2O2ob; Santonja \& Pérez-González, 2010; Santonja, \& alii, 2016; Sharon, 2009; Sharon, 2010; Sharon \& Barsky 2016). No entanto, é essencial ter em conta que, em certas ocasiões, se tende a definir exclusivamente as indústrias acheulenses com base na presença, ou ausência, deste tipo de materiais configurados: "Realmente no es así, ya que la presencia o no de LCTs en un yacimiento, tiene componentes de índole funcional, sedimentario, de la disponibilidad de materias primas o de otros factores difíciles de diferenciar" (Méndez-Quintas, 2017, p. 39). Com efeito, paralelamente às cadeias operatórias de façonna$g e$, as cadeias operatórias de débitage teriam também uma importância assinalável (Santonja \& alii, 2016), dinâmica com a qual o sítio de Pedreiras 2 se parece relacionar: "Estos procesos aportaban lascas de pequeño o mediano formato y filo cortante, obtenidas mediante sistemas de explotación sencillos (monopolares longitudinales, multipolares y discoides) y podían ser transformadas posteriormente por retoque en utensilios más complejos" (Méndez-Quintas \& alii, 2018a, p. 17).

A segunda metade do Pleistocénico Médio é um período que, do ponto de vista tecnológico, se caracteriza no território peninsular pela coexistência de dois tecno-complexos claramente diferenciados: a presença de um conjunto significativo de sítios com abundantes concentrações de indústrias características de um LFA, que, após o MIS 9, coexistem com exemplos isolados de indústrias de tecnologia Early Middle Palaeolithic (EMP), associadas a cadeias operatórias ramificadas, com estratégias estandardizadas de exploração dos núcleos (discoide e Levallois), direcionadas para a produção de lascas, e de pequenos utensílios morfologicamente repetitivos, registando-se um decréscimo significativo do número de peças bifaciais (que, quando presentes, perdem a sua função de "utensílios", convertendo-se em suportes para a obtenção de utensílios sobre lasca). No entanto, durante todo este período, e sobretudo entre o intervalo do MIS 9-6, prevalece uma estabilidade tecnológica que reforça as afinidades africanas do Acheulense do sudoeste europeu, por oposição à realidade do noroeste europeu (Cologne $\&$ alii, 2013; Méndez-Quintas $\&$ alii, 202ob; Santonja $\mathbb{\&}$ alii, 2016; Turq $\&$ alii, 2010; Sharon, 2009; Sharon, 2010; Sharon \& Barsky, 2016).

Uma das regiões que regista uma extensa concentração de indústrias características de um LFA, é, precisamente, a zona do Baixo Minho, sendo que o intervalo cronológico para a presença humana nesta bacia hidrográfica (terraços entre $+40-20 \mathrm{~m}$ a.l.a.) durante a segunda metade do Pleistocénico Médio (MIS 9-6), como referido anteriormente, apresenta correspondência com as grandes bacias ibéricas, e com algumas do sudoeste europeu (Méndez-Quintas $\mathbb{8}$ alii, 2020b). Efetivamente, a realização de trabalhos arqueológicos na área tem documentado sítios com indústrias típicas de um LFA, com vastos conjuntos de bifaces e machados de mão (elaborados em grandes lascas obtidas a partir da exploração de giant cores), tais como os sítios de Arbo (Méndez-Quintas $\&$ alii, 2018c, 2019), As Gándaras de Budiño (Méndez-Quintas, 2007, 2008; Méndez-Quintas \& alii, 
2018a), Fillaboa e Porto Maior (Méndez-Quintas $\mathbb{E}$ alii, 2018c), na margem direita, e o sítio de Carvalhas (Cunha-Ribeiro $\&$ alii, 2017), em fase de estudo, na margem esquerda. Neste contexto, o sítio de Pedreiras 2 contribui para reforçar a relevância da ocupação humana na região durante a segunda metade do Pleistocénico Médio, associável ao tecno-complexo Acheulense. A composição da sua cadeia operatória (Gráfico 3 e Tabela 1), caracterizada pelo predomínio dos produtos relacionados com a fase de produção (57,5\%), face aos elementos da fase de consumo $(21,5 \%)$, para além da reduzida importância dos elementos de aquisição (3,5\%), é análoga à composição das cadeias operatórias das jazidas da margem direita (e do documentado na generalidade dos contextos acheulenses peninsulares), à exceção do nível PM4 de Porto Maior. Com efeito, a fase de consumo é aquela que apresenta uma maior variabilidade entre sítios, caracterizando-se este nível por uma cadeia operatória dominada por elementos de consumo (91,9\%), com um conjunto notável de LCTs com densidade e dimensões que apenas regista paralelos nos contextos africanos e levantinos, dados relevantes a favor da hipótese da origem africana do Acheulense peninsular (Méndez-Quintas, 2018b). Além disso, a indústria lítica de Pedreiras 2 apresenta um conjunto de características que, uma vez mais, estão em sintonia com a realidade documentada nas jazidas do Baixo Minho, e noutros conjuntos acheulenses peninsulares, nomeadamente:

- A prevalência de esquemas de exploração mais elementares, fundamentalmente monopolares;

- A total ausência de sistemas de redução levallois;

- O predomínio de lascas simples, ou de lascas com dorso natural;

- A presença maioritária de talões corticais, face aos talões lisos, e a presença muito reduzida de talões diedros e facetados;

- A existência residual de suportes provenientes de núcleos com um padrão de exploração organizada (exclusivamente discoide);

- A preponderância de padrões de exploração monopolares na face dorsal das lascas;

- A presença comum de utensílios retocados sobre lasca, caracterizados pela aplicação de retoques de extensão marginal, que transformam de forma limitada a morfologia original dos suportes;

- E, por último, a frequência generalizada de LCTs, maioritariamente bifaces-outil, e machados de mão tipo o.
Em síntese, a análise do espólio da indústria lítica de Pedreiras 2, baseada na exploração dos recursos locais de matéria-prima (essencialmente seixos rolados de quartzito), testemunha, globalmente, o predomínio de cadeias operatórias de debitagem relativamente expeditas e simples, o que, à semelhança do verificado noutros conjuntos das principais bacias hidrográficas ibéricas, se correlaciona com a abundância local da matéria-prima utilizada. Paralelamente ao predomínio de produtos de debitagem resultantes de estratégias de exploração pouco elaboradas, assinala-se a presença de um conjunto de LCTs, provavelmente introduzidos no local em fase de uso. Neste sentido, a coleção de Pedreiras 2, articulada com o terraço fluvial a $+40 \mathrm{~m}$ (a.l.a.), associada ao tecno-complexo Acheulense (no contexto da variabilidade tecno-tipológica e tecno-económica que exibe à escala peninsular), e coerente com o contexto cronológico e tecnológico das jazidas da margem direita (e de outros pontos da Península Ibérica), contribui para consolidar o panorama da ocupação humana da região durante a segunda metade do Pleistocénico Médio. Adicionando novos dados sobre as características tecnológicas que definem esta etapa, testemunha a importância arqueológica da margem esquerda para o estudo do Paleolítico do curso final do Rio Minho, uma zona estratégica do ponto de vista da diversidade de recursos e da abundância de matéria-prima. Consequentemente, fornece-se um contributo para ultrapassar a assimetria entre as duas margens, ao dar um novo impulso ao conhecimento do Paleolítico da região, anteriormente documentado de forma esparsa e dissemina$\mathrm{da}$, esperando-se que o desenvolvimento favorável de novos trabalhos contribua para ampliar o nosso entendimento acerca do comportamento humano na região, e as suas características tecnológicas.

\section{Nota}

O presente trabalho foi elaborado pelo primeiro signatário a partir do estudo da indústria lítica por si realizado no contexto do seminário de fim de Licenciatura, no âmbito da sua participação no projeto Minho-Miño ao longo dos últimos quatro anos. 


\section{BIBLIOGRAFIA}

BAR-YOSEF, Ofer; VAN PEER, Philip (2009) - The Chaîne Opératoire approach in Middle Paleolithic archaeology. Current Anthropology, Vol. 5o, issue 1, Chicago: University of Chicago Press, pp. 103-131.

BOËDA, Eric; GENESTE, Jean-Michel; MEIGNEN, Liliane (1990) - Identification de Chaînes Opératoires Lithiques du Palaeolithique Ancien et Moyen. Paléo, 2, pp. 43-80.

BORDES, François (1961) - Typologie du Paleolithique ancien et moyen. CREP, Bordeaux.

CANO PAN, Juan; AGUIRRE, Emiliano; GILES PACHECO, Francisco; GRACIA PRIETO, Javier; SANTIAGO PÉREZ, Antonio; MATA ALMONTE, Esperanza; GUTIÉRREZ LÓPEZ, José; DÍAZ DEL OLMO, Fernando; BAENA ESCUDERO, Rafael;BORJA, Francisco (1997) - Evolución del Pleistoceno en la cuenca baja del Miño, sector La Guardia-Tuy. Secuencia de los primeros poblamientos humanos y registro arqueológico. In RODRÍGUEZ VIDAL, Julio, ed. - Cuaternario Ibérico, pp. 201-212.

CHAUHAN, Parth; BRIDGLAND, David; MONCEL, Marie-Hèlene; ANTOINE, Pierre; BAHAIN, Jean-Jacques; BRIANT, Rebecca; CUNHA, Pedro Proença; DESPRIÉE, Jackie; LIMONDIN-LOZOUET, Nicole; LOCHT, Jean-Luc; MARTINS, António; SCHREVE, Danielle; SHAW, Andrew; VOINCHET, Pierre; WESTAWAY, Rob; WHITE, Mark; WHITE, Tom (2017) - Fluvial deposits as an archive of early human activity: progress during the 20 years of the Fluvial Archives Group. Quaternary Science Reviews, 166, pp. 114-149.

COLOGNE, David; HERNÁDEZ, Marion; LELOUVIER, Laure-Amélie; MERCIER, Norbert; MOURRE, Vincent; BUSSEUIL, Nathalie (2013) - Paléolithique ancien et Paléolithique moyen ancien dans le piémont pyrénéen occidental: relations entre chaînes opératoires, continuités et ruptures. In JAUBERT, Jacques; FORUMENT, Nathalie \& DEPAEPE, Pascal, eds. - Transitions, ruptures et continuité en Préhistoire. Société préhistorique française, Volume 1, pp.119-137.

CUNHA-RIBEIRO, João Pedro (1999) - O Acheulense no Centro de Portugal: o Vale do Lis. Contribuição para uma abordagem tecno-tipológica das suas indústrias líticas e problemática do seu contexto cronoestratigráfico. Tese de Doutoramento, Lisboa: Universidade de Lisboa, 3 vols, p. 692.

CUNHA-RIBEIRO, João Pedro; MONTEIRO-RODRIGUES, Sérgio; GOMES, Alberto; MÉNDEZ-QUINTAS, Eduardo; MEIRELES, José; PÉREZ-GONZÁLEZ, Alfredo; SANTONJA, Manuel (2017) - Ocupações pleistocénicas da margem esquerda do Baixo Minho (Miño/Minho 2). Objetivos e primeiros resultados de um projeto transfronteiriço. In ARNAUD, José \& MARTINS, Andrea, eds. - Arqueologia em Portugal / 2017 - Estado da Questão, Associação dos Arqueólogos Portugueses, pp. 303-318.
CUNHA-RIBEIRO, João Pedro; MONTEIRO-RODRI-GUES, Sérgio; MÉNDEZ-QUINTAS, Eduardo; GOMES, Alberto; MEIRELES, José; PÉREZ-GONZÁLEZ, Alfredo; SANTONJA, Manuel (2018) - O Paleolítico de Melgaço. Vestígios arqueológicos dos primeiros habitantes do Concelho. Boletim de Cultura de Melgaço, pp. 117-150.

DEMURO, Martina;ARNOLD, Lee; DUVAL, Mathieu; MÉNDEZ-Quintas, Eduardo; SANTONJA, Manuel; PÉREZ-GONZÁLEZ, Alfredo (2020) - Refining the chronology of Acheulean deposits at Porto Maior in the River Miño basin (Galicia, Spain) using a comparative luminescence and ESR dating approach. Quaternary International (2020).

LAUTENSACH, Hermann (1945) - Formação dos terraços interglaciários do Norte de Portugal e suas relações com os problemas da época glaciária. Publicações da Sociedade Geológica de Portugal, Porto, p. 44.

MÉNDEZ-QUINTAS, Eduardo (2007) - El yacimiento achelense de As Gándaras de Budiño. La industria en facies fluvial. Complutum, 18, pp. 27-45.

MÉNDEZ-QUINTAS, Eduardo (2008) - La industria lítica de las facies coluviales del Yacimiento Achelense de as Gándaras de Budiño. El Locus V en las excavaciones de Vi- dal Encinas. Zephyrus, LXII (2), Salamanca, pp. 41-61.

MÉNDEZ-QUINTAS, Eduardo (2017) - Caracterización y variabilidad tecnomorfológica de las industrias achelenses de la Cuenca Baja del Río Miño (NO de la Península Ibérica). Tesis Doctoral, Universidad de Burgos, Escuela Interuniversitaria de Posgrado en Evolucion Humana, CENIEH, Universidad de Alcalá, Universidad de Oviedo, p. 628.

MÉNDEZ-QUINTAS, Eduardo; SANTONJA, Manuel; PÉREZ-GONZÁlEZ, Alfredo; ARNOLD, Lee; CUNHA-RIBEIRO, João Pedro; DEMURO, Martina; DÍAZ-RODRÍGUEZ, Mikel; DUVAL, Mathieu; GOMES, Alberto; MEIRELES, José; MONTEIRO-RODRIGUES, Sérgio; SERODIO DOMÍNGUEZ, Andrea (2018a) - El yacimiento achelense de As Gándaras de Budiño: Síntesis y perspectivas después de 50 años de desencuentros. Estudos do Quaternario, 19, pp. 1-22.

MÉNDEZ-QUINTAS, Eduardo; SANTONJA, Manuel; PÉREZ-GONZÁLEZ, Alfredo; DUVAL, Mathieu; DEMURO, Martina; ARNOLD, Lee (2018b) - First evidence of an extensive Acheulean large cutting tool accumulation in Europe from Porto Maior (Galicia, Spain). Scientific Reports, $8(1), 3082$.

MÉNDEZ-QUINTAS, Eduardo; PÉREZ-GONZÁLEZ, Alfredo; LEDO BERNÁRDEZ, Manuel; SERODIO DOMÍNGUEZ, Andrea (2018c) - La industria lítica del yacimiento achelense de Arbo (Pontevedra). Variables del paleolítico antiguo de Galicia en el contexto peninsular. Zephyrus, LXXXII, pp. 3-34.

MÉNDEZ-QUINTAS, Eduardo; DEMURO, Martina; ARNOLD, Lee; DUVAL, Mathieu; PÉREZ-GONZÁLEZ, Alfredo; SANTONJA, Manuel (2019) - Insights into the late 
stages of the Acheulean technocomplex of Western Iberia from the Arbo site (Galicia, Spain). Journal of Archaeological Science: Reports, 27, 101934.

MÉNDEZ-QUINTAS, Eduardo; SANTONJA, Manuel; PÉREZ-GONZÁlEZ, Alfredo, ARNOLD, Lee; DEMURO, Martina; DUVAL, Mathieu (2O2Oa) - A multidisciplinary overview of the lower Miño River terrace system (NW Iberian Peninsula). Quaternary International (2020).

MÉNDEZ-QUINTAS, Eduardo; SANTONJA, Manuel; ARNOLD, Lee; CUNHA-RIBEIRO, João Pedro; DA SILVA, Pedro; DEMURO, Martina; DUVAL, Mathieu; GOMES, Alberto; MEIRELES, José; MONTEIRO-RODRIGUES, Sérgio; PÉREZ-GONZÁLEZ, Alfredo (2020b) - The Acheulean Technocomplex of the Iberian Atlantic Margin as an Example of Technology Continuity Through the Middle Pleistocene. Journal of Paleolithic Archaeology (2020).

MOSQUERA, Marina; SALADIÉ, Palmira; OLLÉ, Andreu; CÁCERES, Isabel; HUGUET, Rosa; VILLALAÍN, Juan José; CARRANCHO, Angel; BOURLÈS, Didier; BRAUCHER, Régis; VALLVERDÚ, Josep (2015) - Barranc de la Boella (Catalonia, Spain): an Acheulean elephant butchering site from the European late Early Pleistocene. Journal of Quaternary Science, 30 (7), pp. 651-666.

RIBEIRO, Maria Luísa; MOREIRA, Armando (1986) - Notícia Explicativa da Folha 1-B: Monção, escala 1:50.00o. Serviços Geológicos de Portugal, Lisboa.

RUBIO-JARA, Susana; PANERA, Joaquín; RODRÍGUEZDE-TEMBLEQUE, Juan; SANTONJA, Manuel; PÉREZGONZÁLEZ, Alfredo (2016) - Large flake Acheulean in the middle of Tagus basin (Spain): Middle stretch of the river Tagus valley and lower stretches of the rivers Jarama and Manzanares valleys. Quaternary International, 411, pp. 349-366.

SANTONJA, Manuel; VILLA, Paola (1990) - The Lower Paleolithic of Spain and Portugal. Journal of World Prehistory, 4 (1), pp. 45-94.

SANTONJA, Manuel; PÉREZ-GONZÁLEZ, Alfredo (2010) - Mid-Pleistocene Acheulean industrial complex in the Iberian Peninsula. Quaternary International, 223-224, pp. $154-161$.

SANTONJA, Manuel; PÉREZ-GONZÁLEZ, Alfredo; PANERA, Joaquín; RUBIO-JARA, Susana; MÉNDEZ-QUINTAS, Eduardo (2016) - The coexistence of Acheulean and Ancient Middle Palaeolithic technocomplexes in the Middle Pleistocene of the Iberian Peninsula. Quaternary International, 411, pp. 367-377.

SHARON, Gonen (2007) - Acheulian Large Flake Industries: Technology, Chronology, and Significance. BAR International Series 1701, $236 \mathrm{p}$.

SHARON, Gonen (2008) - The impact of raw material on Acheulian large flake production. Journal of Archaeological Science, 35 (5), pp. 1329-1344.
SHARON, Gonen (2009) - Acheulian Giant Core Technology. Current Anthropology, 50 (3), pp. 335-367.

SHARON, Gonen (2010) - Large flake Acheulian. Quaternary International, 223-224, pp. 226-233.

SHARON, Gonen (2011) - Flakes Crossing the Straits? Entame Flakes and Northern Africa-Iberia Contact During the Acheulean. African Archaeological Review, 28 (2), pp. 125-140.

SHARON, Gonen; BARSKY, Deborah (2016) - The emergence of the Acheulian in Europe - a look from the east. Quaternary International, 411, pp. 25-33.

SORESSI, Marie; GENESTE, Jean-Michel (2011) - The History and Efficacy of the Chaîne Opératoire Approach to Lithic Analysis: Studying Techniques to Reveal Past Societies in an Evolutionary Perspective. PaleoAnthropology, pp. 334-350.

TEIXEIRA, Carlos (1944) - Tectónica Plio-Pleistocénica do Noroeste Peninsular. Boletim da Sociedade Geológica de Portugal, Vol. IV, fasc. 1-2, pp. 19-41.

TEIXEIRA, Carlos (1952) - Os terraços da parte portuguesa do rio Minho. Comunicações dos Serviços Geológicos de Portugal, Tomo XXXIII, Lisboa, pp. 221-246.

TIXIER, Jacques (1956) - Le hachereau dans l'Acheuléen Nord-Africain. Notes typologiques. Congrès Préhistorique de France, $X V^{e m e}$ sesión. Poitiers, pp. 914-923.

TURQ, Alain; BRENET, Michel; COLONGE, David; JARRY, Marc; LELOUVIER, Laure-Amélie; O’FARRELL, Magen; JAUBERT, Jacques (2010) - The first human occupations in southwestern France: a revised summary twenty years after the Abbeville/Saint Riquier colloquium. Quaternary International, 223-224, pp. 383-398.

VALLVERDÚ, Josep; SALADIÉ, Palmira; ROSAS, Antonio; HUGUET, Rosa; CÁCERES, Isabel; MOSQUERA, Marina; GARCIA-TABERNERO, Antonio; ESTALRRICH, Almudena; LOZANO-FERNÁNDEZ, Iván; PINEDA-ALCALÁ, Antonio; CARRANCHO, Ángel; VILLALAÍN, Juan; BOURLÈS, Didier; BRAUCHER, Régis; LEBATARD, Anne; VILALTA, Jaume; ESTEBAN-NADAL, Montserrat; BENNASAR, Maria; BASTIR, Marcus; LÓPEZ-POLÍN, Lucía; OLLÉ, André; VERGÉS, Josep; ROS-MONTOYA, Sergio; MARTÍNEZ-NAVARRO, Bienvenido; GARCÍA, Ana; MARTINELL, Jordi; EXPÓSITO, Isabel; BURJACHS, Francesc; AGUSTÍ, Jordi; CARBONELL, Eduald (2014) - Age and date for early arrival of the Acheulian in Europe (Barranc de la Boella, la Canonja, Spain). PLoS One 9 (7), e103634.

VILLAR QUINTEIRO, Rosa (2012) - Primeras ocupaciones humanas en el noroeste peninsular. Gallaecia, 31, pp. 5-16.

VIVEEN, Willem; BRAUCHER, Régis; BOURLÈS, Didier; SCHOORL, Jeroen; VELDKAMP, Tom.; VAN BALEN, Ronald.;WALLINGA, Jakob; FÉRNANDEZ-MOSQUERA, 
Daniel;VIDAL-ROMANI, Juan Roman; SANJURJO-SANCHEZ, Jorge (2012) - A o.65 Ma chronology and incision rate assessment of the NW Iberian Miño River terraces. Global and Planetary Change, 94-95, pp. 82-10o.

WALKER, Michael John; LÓPEZ-MARTÍNEZ, Mariano; CARRIÓN-GARCÍA, José; RODRÍGUEZ-ESTRELLA, Tomás; SAN-NICOLÁS DEL-TORO, Miguel; SCHWENNINGER, Jean-Luc; LÓPEZ-JIMÉNEZ, Antonio; ORTEGA-
-RODRIGÁÑEZ, Jon; HABER-URIARTE, María; POLO-CAMACHO, Juan Luis; GARCÍA-TORRES, Jesús; CAMPILLO-BOJ, Matías; AVILÉS-FERNÁNDEZ, Azucena; ZACK, Winston (2013) - Cueva Negra del Estrecho del Río Quípar (Murcia, Spain): A late Early Pleistocene hominin site with an "Acheulo-Levalloiso-Mousteroid" Palaeolithic assemblage. Quaternary International 294, pp. 135-159.

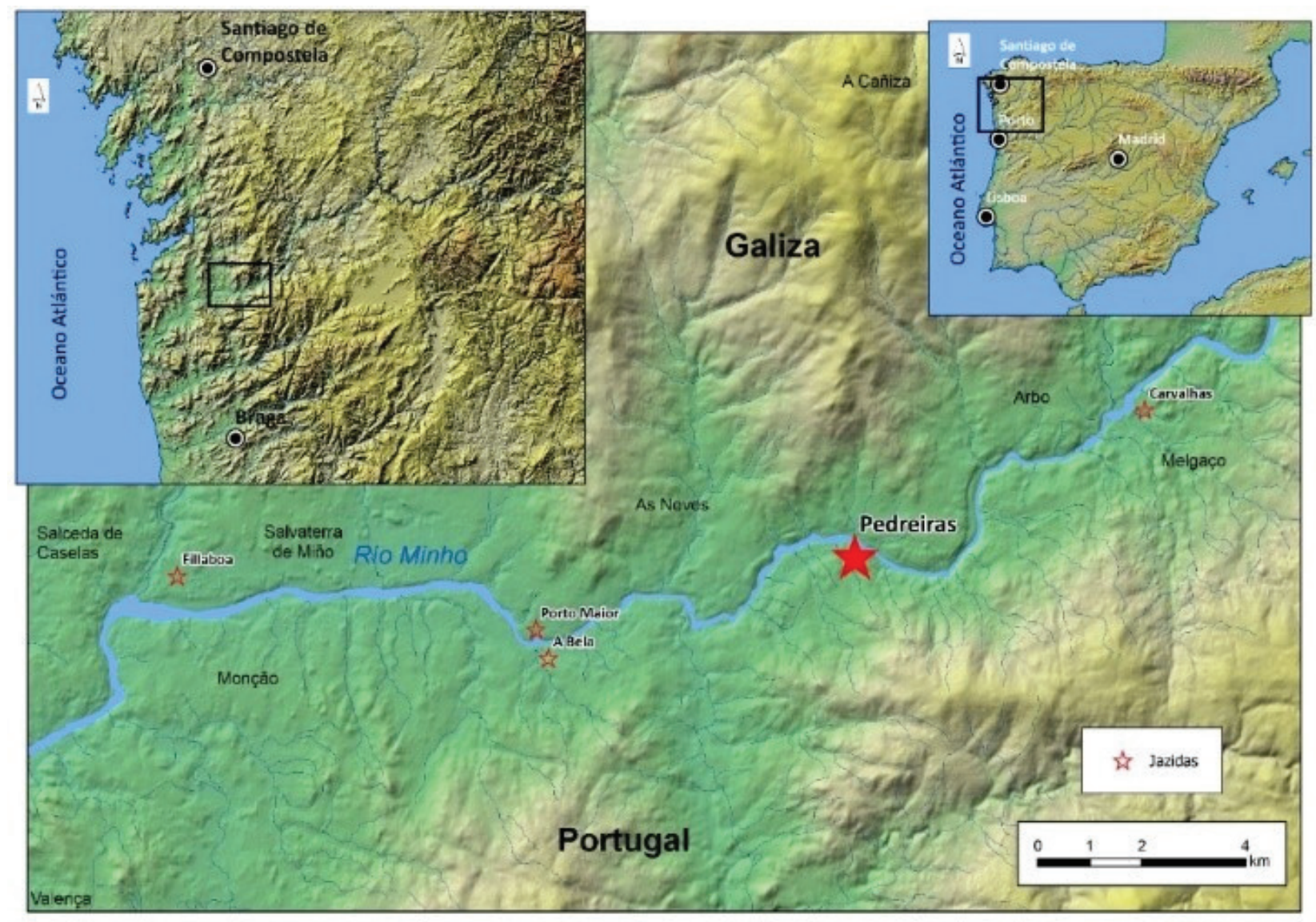

Figura 1 - Localização geográfica da jazida de Pedreiras 2.

$\mathrm{N}$

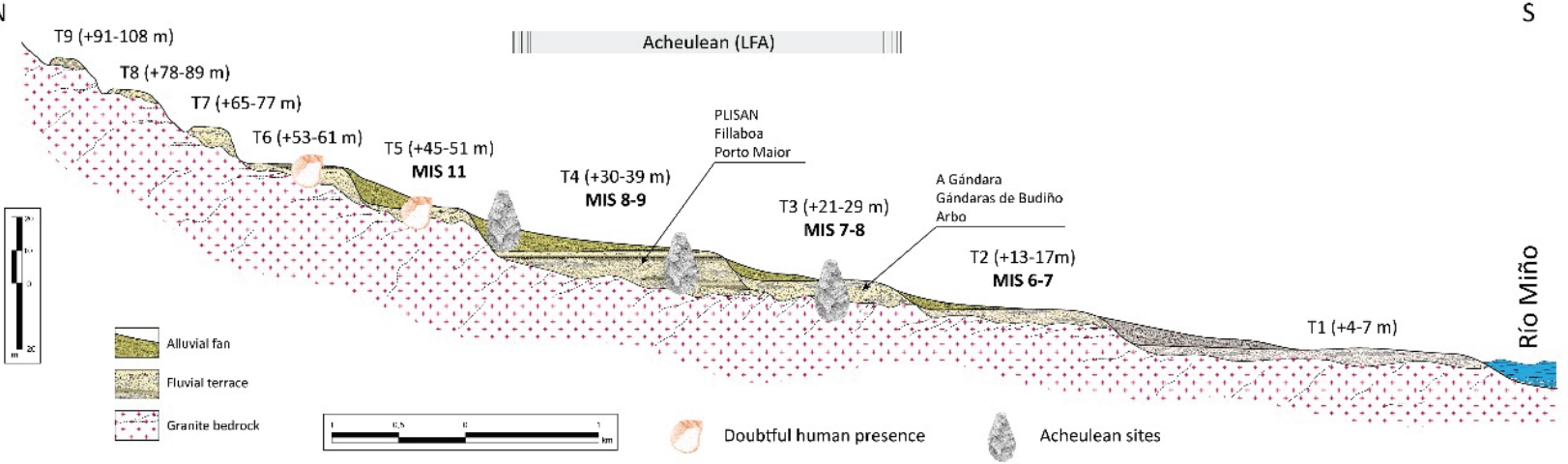

Figura 2 - Esquema dos níveis de terraços fluviais do Baixo Minho (Méndez-Quintas \& alii, 2020a). 

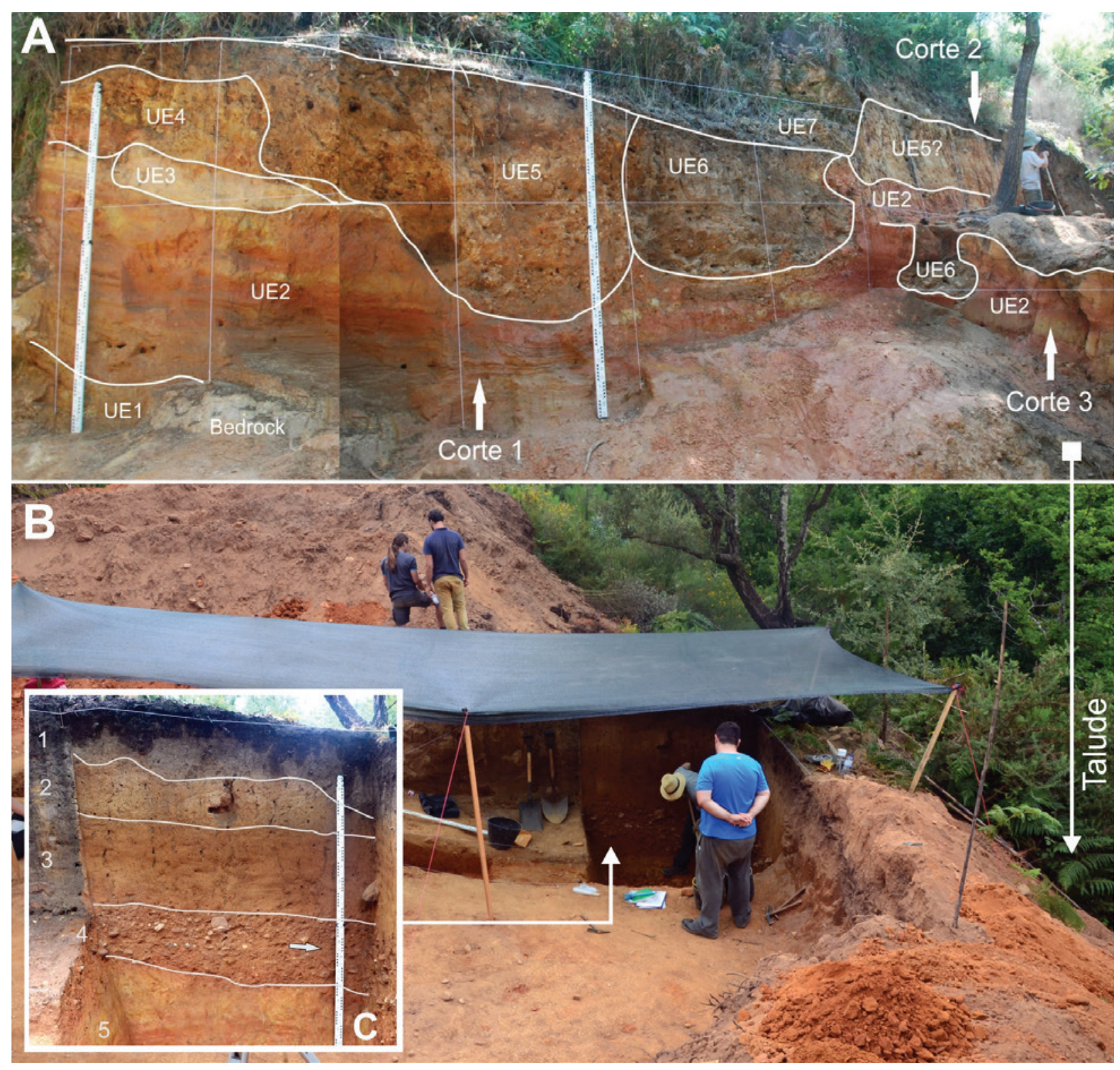

Figura 3 - Jazida de Pedreiras 2 (Monção). A - Talude onde se identificou o biface que conduziu à descoberta da estação arqueológica. Descrição estratigráfica sumária: UE1, UE2, UE3 - Depósitos fluviais arenosos com estratificação horizontal, arqueologicamente estéreis (cota da base: $35 \mathrm{~m}$ acima do leito atual do rio Minho); UE4, UE5, UE6 - Depósitos coluvionares em canais que se entrerrecortam; UE7 - Solo atual. B - Plataforma sobre o talude, intervencionada em 2016 (sondagem 1) e 2017. C - Sequência estratigráfica observada na área da sondagem 1: UE1 - Solo atual; UE2 e UE3 - Depósito areno-siltoso, possivelmente eólico; UE4 - Depósito coluvionar onde surge o material lítico talhado; UE5 - Depósito fluvial arenoso, correspondente à UE2 do talude. 

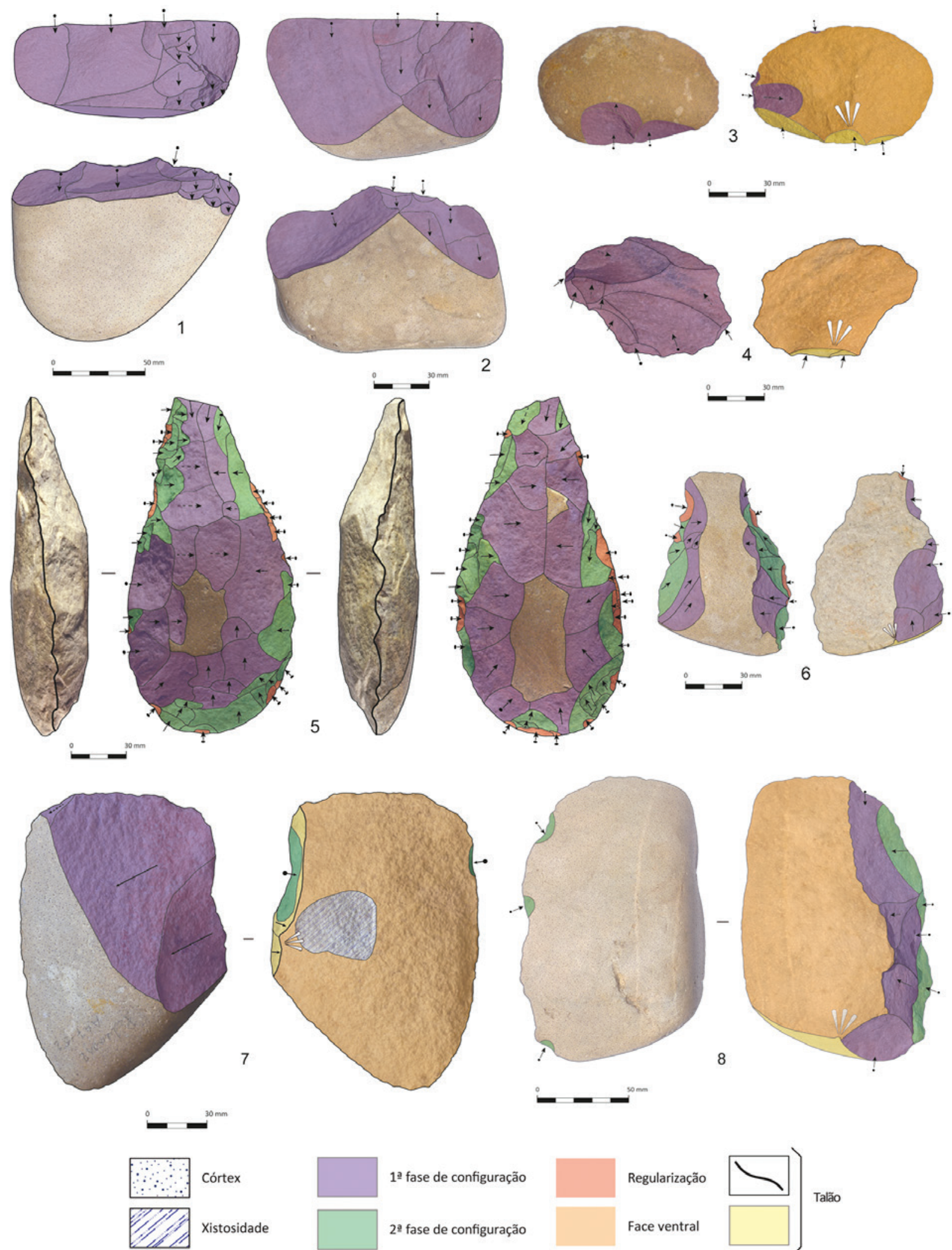

12 fase de configuração

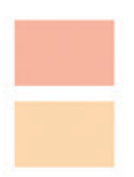

Regularização

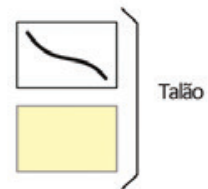

Figura 4 - Jazida Acheulense de Pedreiras 2: Núcleos monopolares unifaciais sobre seixos rolados de quartzito (1-2); Lascas de configuração de LCT em quartzito (3-4); Biface configurado sobre seixo rolado de quartzito (5); Machados de mão "tipo o" sobre lascas de quartzito (6-8). 


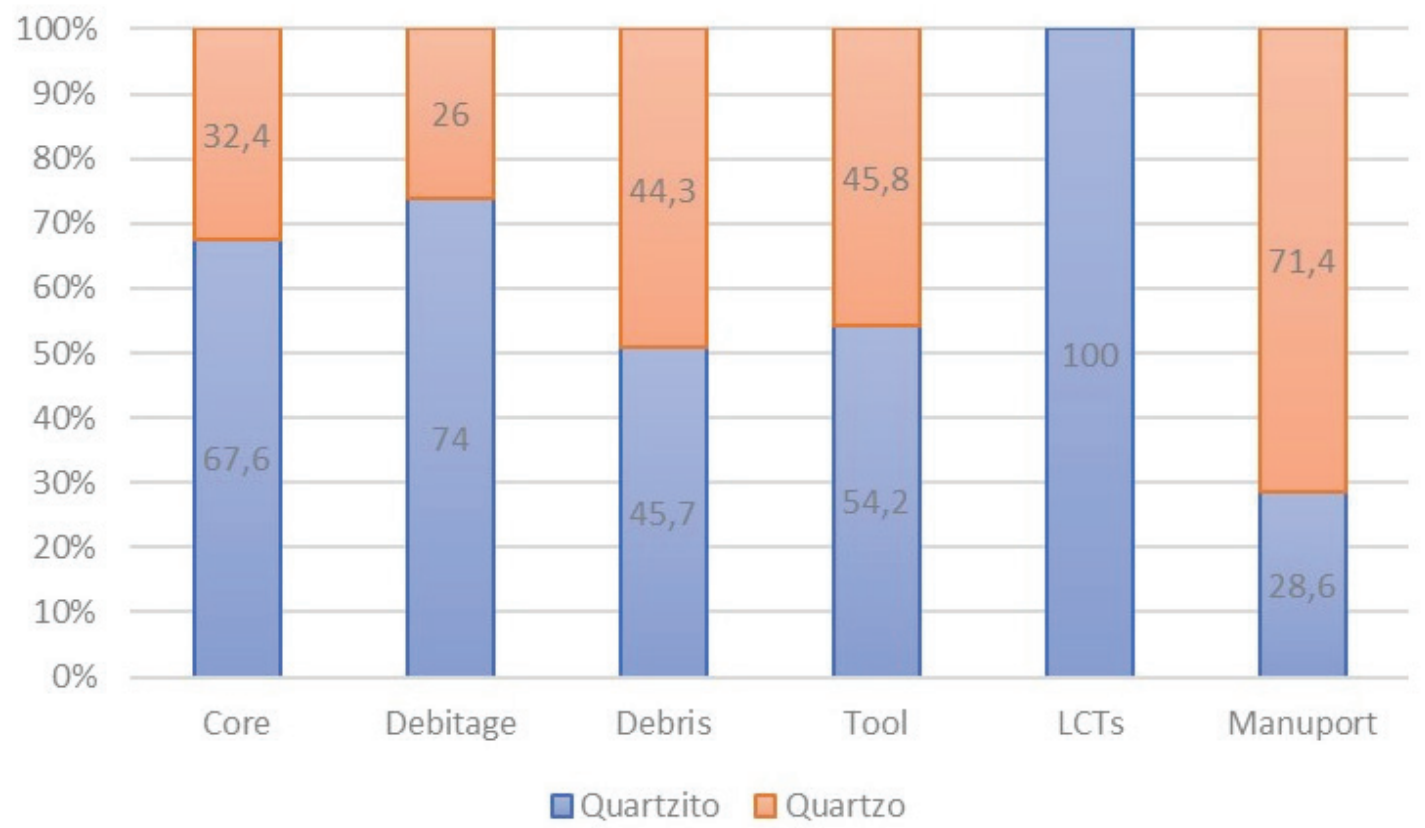

Gráfico 1 - Distribuição de efetivos por categorias tecnológicas com base na matéria-prima.

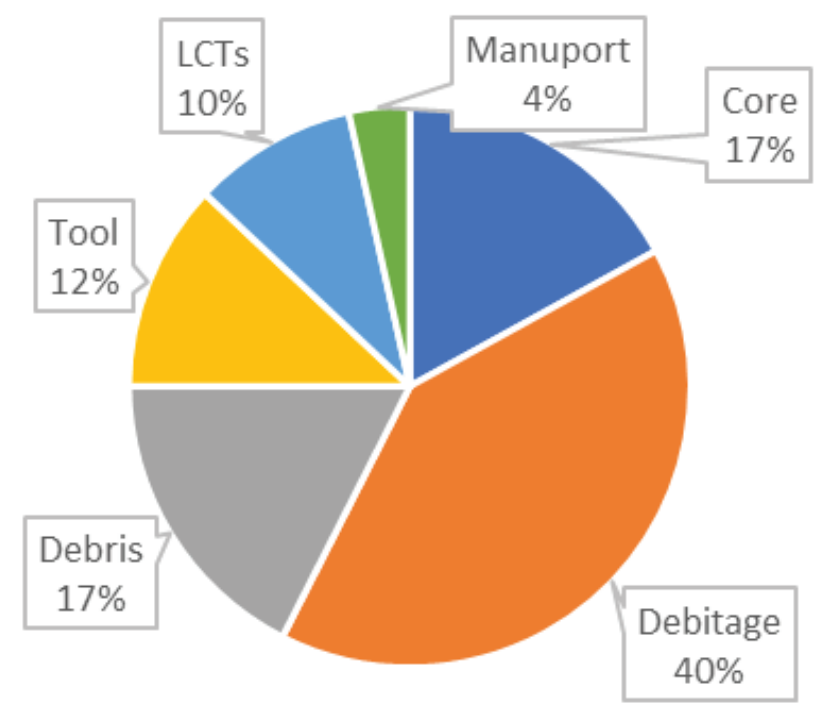

- Core " Debitage " Debris " Tool " LCTs " Manuport

Gráfico 2 - Distribuição do material por categoria tecnológica. 


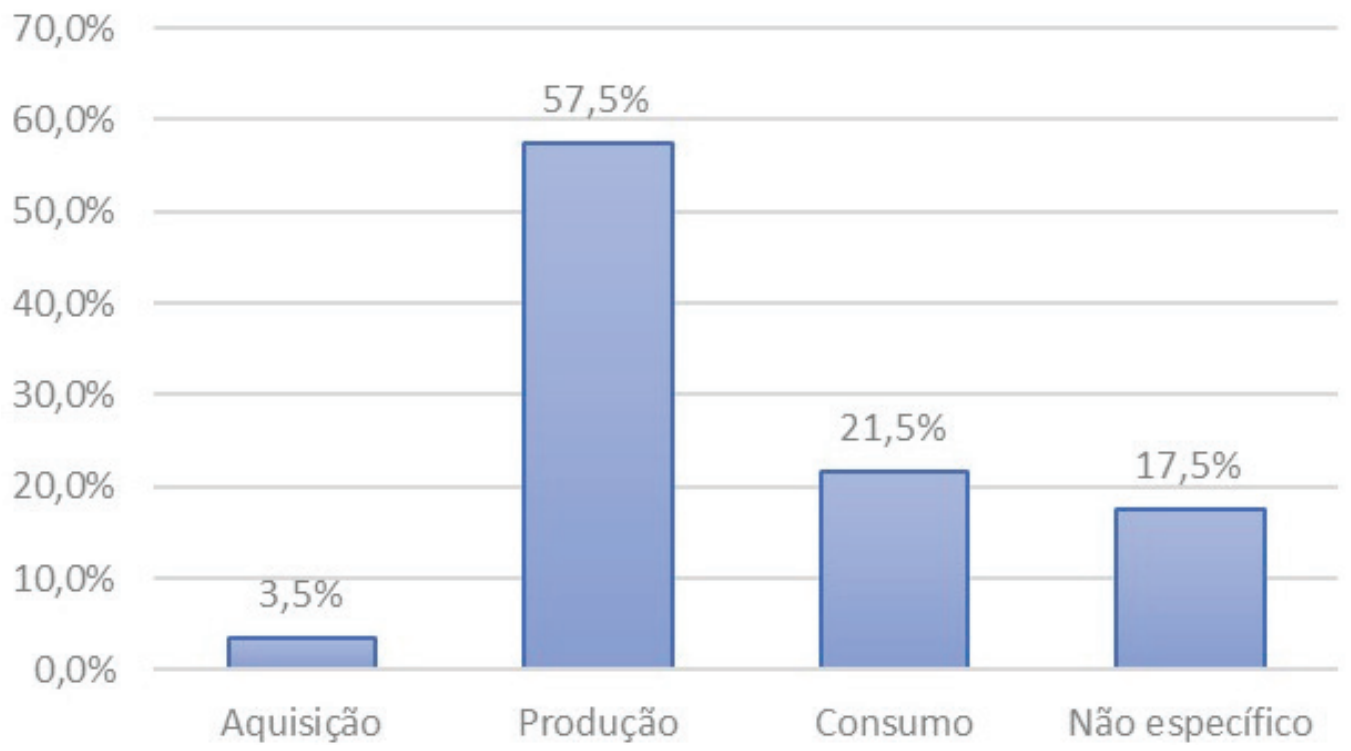

Gráfico 3-Representatividade das diferentes fases da cadeia operatória.

\begin{tabular}{|c|c|c|c|c|c|c|c|c|c|c|c|c|c|c|c|c|c|c|c|c|c|c|c|c|c|}
\hline \multirow{3}{*}{\multicolumn{2}{|c|}{ Elementos tecnológicos }} & \multicolumn{8}{|c|}{ Campanha de 2016} & \multicolumn{8}{|c|}{ Campanha de 2017} & \multicolumn{8}{|c|}{ Total } \\
\hline & & \multicolumn{4}{|c|}{ Quartzito } & \multicolumn{4}{|c|}{ Quartzo } & \multicolumn{4}{|c|}{\begin{tabular}{l|l} 
Quartzito & \\
\end{tabular}} & \multicolumn{4}{|c|}{ Quartzo } & \multicolumn{4}{|c|}{ Quartzito } & \multicolumn{4}{|c|}{ Quartzo } \\
\hline & & \multicolumn{2}{|c|}{ Total } & \multicolumn{2}{|c|}{ Utensilios } & \multicolumn{2}{|c|}{ Total } & \multicolumn{2}{|c|}{ Utensilios } & \multicolumn{2}{|c|}{ Total } & \multicolumn{2}{|c|}{ Utensilios } & To & tal & Uter & sílios & To & tal & Uter & isilios & & tal & Uter & isilios \\
\hline & 0. Aquisição & $\mathrm{n}$ & $\%$ & $\mathrm{n}$ & $\%$ & $\mathrm{n}$ & $\%$ & $\mathrm{n}$ & $\%$ & $\mathrm{n}$ & $\%$ & $\mathrm{n}$ & $\%$ & $\mathrm{n}$ & $\%$ & $n$ & $\%$ & $\mathrm{n}$ & $\%$ & $\mathrm{n}$ & $\%$ & $\mathrm{n}$ & $\%$ & $\mathrm{n}$ & $\%$ \\
\hline 0.1 & Seixos rolados & 0 & 0,0 & 3 & 50,0 & 0 & 0,0 & 0 & 0,0 & 0 & 0,0 & 2 & 28,6 & 0 & 0,0 & 1 & 14,3 & 0 & 0,0 & 5 & 38,5 & 0 & 0,0 & 1 & 9,1 \\
\hline 0.2 & Seixos rolados não trabalhados & 1 & 1,2 & 0 & 0,0 & 5 & 11,1 & 0 & 0,0 & 0 & 0,0 & 0 & 0,0 & 0 & 0,0 & 0 & 0,0 & 1 & 0,8 & 0 & 0,0 & 5 & 8,9 & 0 & 0,0 \\
\hline 0.3 & Percutores/bigornas & 0 & 0,0 & 0 & 0,0 & 0 & 0,0 & 0 & 0,0 & 1 & 2,9 & 0 & 0,0 & 0 & 0,0 & 0 & 0,0 & 1 & 0,8 & 0 & 0,0 & 0 & 0,0 & 0 & 0,0 \\
\hline 0.4 & Seixos testados & 2 & 2,3 & 0 & 0,0 & 2 & 4,4 & 0 & 0,0 & 0 & 0,0 & 0 & 0,0 & 0 & 0,0 & 0 & 0,0 & 2 & 1,7 & 0 & 0,0 & 2 & 3,6 & 0 & 0,0 \\
\hline & 1. Descorticagem & $\mathrm{n}$ & $\%$ & $\mathrm{n}$ & $\%$ & $\mathrm{n}$ & $\%$ & $\mathrm{n}$ & $\%$ & $n$ & $\%$ & $\mathrm{n}$ & $\%$ & $\mathrm{n}$ & $\%$ & $\mathrm{n}$ & $\%$ & $\mathrm{n}$ & $\%$ & $\mathrm{n}$ & $\%$ & $n$ & $\%$ & $\mathrm{n}$ & $\%$ \\
\hline 1.1 & Lascas corticais (>75\%) & 3 & 3,5 & 0 & 0,0 & 3 & 6,7 & 0 & 0,0 & 0 & 0,0 & 0 & 0,0 & 0 & 0,0 & 0 & 0,0 & 3 & 2,5 & 0 & 0,0 & 3 & 5,4 & 0 & 0,0 \\
\hline 1.2 & Lascas semi-corticais $(50-75 \%)$ & 4 & 4,7 & 0 & 0,0 & 0 & 0,0 & 0 & 0,0 & 4 & 11,8 & 0 & 0,0 & 0 & 0,0 & 0 & 0,0 & 8 & 6,7 & 0 & 0,0 & 0 & 0,0 & 0 & 0,0 \\
\hline & 2. Produtos ordinários & $\mathrm{n}$ & $\%$ & $\mathrm{n}$ & $\%$ & $n$ & $\%$ & $\mathrm{n}$ & $\%$ & $\mathrm{n}$ & $\%$ & $\mathrm{n}$ & $\%$ & $\mathrm{n}$ & $\%$ & $n$ & $\%$ & $\mathrm{n}$ & $\%$ & $n$ & $\%$ & $n$ & $\%$ & $n$ & $\%$ \\
\hline 2.1 & Lascas não corticais (<25\%) & 9 & 10,5 & 1 & 16,7 & 11 & 24,4 & 2 & 50,0 & 6 & 17,6 & 2 & 28,6 & 3 & 27,3 & 6 & 85,7 & 15 & 12,5 & 3 & 23,1 & 14 & 25,0 & 8 & 72,7 \\
\hline 2.2 & Lascas com restos corticais (25-50\%) & 0 & 0,0 & 1 & 16,7 & 1 & 2,2 & 2 & 50,0 & 2 & 5,9 & 1 & 14,3 & 0 & 0,0 & 0 & 0,0 & 2 & 1,7 & 2 & 15,4 & 1 & 1,8 & 2 & 18,2 \\
\hline 2.3 & Lascas Kombewa & 1 & 1,2 & 0 & 0,0 & 0 & 0,0 & 0 & 0,0 & 0 & 0,0 & 0 & 0,0 & 0 & 0,0 & 0 & 0,0 & 1 & 0,8 & 0 & 0,0 & 0 & 0,0 & 0 & 0,0 \\
\hline & 3. Produtos com dorso & $\mathrm{n}$ & $\%$ & $\mathrm{n}$ & $\%$ & $n$ & $\%$ & $n$ & $\%$ & $\mathrm{n}$ & $\%$ & $n$ & $\%$ & $n$ & $\%$ & $n$ & $\%$ & $n$ & $\%$ & $n$ & $\%$ & $n$ & $\%$ & $n$ & $\%$ \\
\hline 3.1 & Lascas com dorso desbordante & 0 & 0 & 0 & 0 & 0 & 0 & 0 & 0 & 0 & 0 & 0 & 0 & 0 & 0 & 0 & 0 & 0 & 0 & 0 & 0,0 & 0 & 0 & 0 & 0 \\
\hline 3.2 & Lascas com dorso natural & 15 & 17,4 & 1 & 16,7 & 2 & 4,44 & 0 & 0 & 7 & 20,6 & 2 & 28,6 & 1 & 9,09 & 0 & 0 & 22 & 18,3 & 3 & 23,1 & 3 & 5,36 & 0 & 0 \\
\hline & 4. Produtos de padrão organizado & $\mathrm{n}$ & $\%$ & $\mathrm{n}$ & $\%$ & $\mathrm{n}$ & $\%$ & $\mathrm{n}$ & $\%$ & $\mathrm{n}$ & $\%$ & $\mathrm{n}$ & $\%$ & $\mathrm{n}$ & $\%$ & $n$ & $\%$ & $\mathrm{n}$ & $\%$ & $\mathrm{n}$ & $\%$ & $\mathrm{n}$ & $\%$ & $n$ & $\%$ \\
\hline 4.1 & Lascas levallois & 0 & 0,0 & 0 & 0,0 & 0 & 0,0 & 0 & 0,0 & 0 & 0,0 & 0 & 0,0 & 0 & 0,0 & 0 & 0,0 & 0 & 0,0 & 0 & 0,0 & 0 & 0,0 & 0 & 0,0 \\
\hline 4.2 & Pontas levallois & 1 & 1,2 & 0 & 0,0 & 0 & 0,0 & 0 & 0,0 & 0 & 0,0 & 0 & 0,0 & 0 & 0,0 & 0 & 0,0 & 1 & 0,8 & 0 & 0,0 & 0 & 0,0 & 0 & 0,0 \\
\hline 4.3 & Lascas discoides & 1 & 1,2 & 0 & 0,0 & 0 & 0,0 & 0 & 0,0 & 1 & 2,9 & 0 & 0,0 & 0 & 0,0 & 0 & 0,0 & 2 & 1,7 & 0 & 0,0 & 0 & 0,0 & 0 & 0,0 \\
\hline 4.4 & Pontas pseudo-levallois & 0 & 0,0 & 0 & 0,0 & 0 & 0,0 & 0 & 0,0 & 0 & 0,0 & 0 & 0,0 & 0 & 0,0 & 0 & 0,0 & 0 & 0,0 & 0 & 0,0 & 0 & 0,0 & 0 & 0,0 \\
\hline & 5. Núcleos & $\mathrm{n}$ & $\%$ & $\mathrm{n}$ & $\%$ & $n$ & $\%$ & $n$ & $\%$ & $\mathrm{n}$ & $\%$ & $n$ & $\%$ & $\mathrm{n}$ & $\%$ & $n$ & $\%$ & $\mathrm{n}$ & $\%$ & $\mathrm{n}$ & $\%$ & $n$ & $\%$ & $\mathrm{n}$ & $\%$ \\
\hline 5.1 & Núcleos sobre seixo & 15 & 17,4 & 0 & 0,0 & 3 & 6,7 & 0 & 0,0 & 4 & 11,8 & 0 & 0,0 & 2 & 18,2 & 0 & 0,0 & 19 & 15,8 & 0 & 0,0 & 5 & 8,9 & 0 & 0,0 \\
\hline 5.2 & Núcleos sobre lasca & 0 & 0,0 & 0 & 0,0 & 0 & 0,0 & 0 & 0,0 & 0 & 0,0 & 0 & 0,0 & 0 & 0,0 & 0 & 0,0 & 0 & 0,0 & 0 & 0,0 & 0 & 0,0 & 0 & 0,0 \\
\hline 5.3 & Núcleos em suporte indeterminado & 0 & 0,0 & 0 & 0,0 & 4 & 8,9 & 0 & 0,0 & 0 & 0,0 & 0 & 0,0 & 0 & 0,0 & 0 & 0,0 & 0 & 0,0 & 0 & 0,0 & 4 & 7,1 & 0 & 0,0 \\
\hline 5.4 & Fragmentos de núcleo & 2 & 2,3 & 0 & 0,0 & 0 & 0,0 & 0 & 0,0 & 0 & 0,0 & 0 & 0,0 & 0 & 0,0 & 0 & 0,0 & 2 & 1,7 & 0 & 0,0 & 0 & 0,0 & 0 & 0,0 \\
\hline & LCTs e prod.configuraçăo/regularizaçăo & $n$ & $\%$ & $\mathrm{n}$ & $\%$ & $n$ & $\%$ & $n$ & $\%$ & $\mathrm{n}$ & $\%$ & $n$ & $\%$ & $n$ & $\%$ & $n$ & $\%$ & $\mathrm{n}$ & $\%$ & $n$ & $\%$ & $\mathrm{n}$ & $\%$ & $n$ & $\%$ \\
\hline 6.1 & Lascas de regularização de retocados & 1 & 1,2 & 0 & 0,0 & 0 & 0,0 & 0 & 0,0 & 0 & 0,0 & 0 & 0,0 & 0 & 0,0 & 0 & 0,0 & 1 & 0,8 & 0 & 0,0 & 0 & 0,0 & 0 & 0,0 \\
\hline 6.2 & Lascas de configuração de LCT & 4 & 4,7 & 0 & 0,0 & 0 & 0,0 & 0 & 0,0 & 1 & 2,9 & 0 & 0,0 & 0 & 0,0 & 0 & 0,0 & 5 & 4,2 & 0 & 0,0 & 0 & 0,0 & 0 & 0,0 \\
\hline 6.3 & Fragmentos de peças retocadas & 0 & 0,0 & 0 & 0,0 & 0 & 0,0 & 0 & 0,0 & 0 & 0,0 & 0 & 0,0 & 0 & 0,0 & 0 & 0,0 & 0 & 0,0 & 0 & 0,0 & 0 & 0,0 & 0 & 0,0 \\
\hline 6.4 & LCTs e fragmentos & 16 & 18,6 & 0 & 0,0 & 0 & 0,0 & 0 & 0,0 & 3 & 8,8 & 0 & 0,0 & 0 & 0,0 & 0 & 0,0 & 19 & 15,8 & 0 & 0,0 & 0 & 0,0 & 0 & 0,0 \\
\hline & 7. Subprodutos não específicos & $\mathrm{n}$ & $\%$ & $\mathrm{n}$ & $\%$ & $\mathrm{n}$ & $\%$ & $\mathrm{n}$ & $\%$ & $\mathrm{n}$ & $\%$ & $\mathrm{n}$ & $\%$ & $\mathrm{n}$ & $\%$ & $\mathrm{n}$ & $\%$ & $\mathrm{n}$ & $\%$ & $\mathrm{n}$ & $\%$ & $\mathrm{n}$ & $\%$ & $\mathrm{n}$ & $\%$ \\
\hline 7.1 & Debris e peq. lascas (<30 mm) & 1 & 1,2 & 0 & 0,0 & 0 & 0,0 & 0 & 0,0 & 2 & 5,9 & 0 & 0,0 & 3 & 27,3 & 0 & 0,0 & 3 & 2,5 & 0 & 0,0 & 3 & 5,4 & 0 & 0,0 \\
\hline 7.2 & Fragmentos de lasca & 1 & 1,2 & 0 & 0,0 & 6 & 13,3 & 0 & 0,0 & 1 & 2,9 & 0 & 0,0 & 1 & 9,1 & 0 & 0,0 & 2 & 1,7 & 0 & 0,0 & 7 & 12,5 & 0 & 0,0 \\
\hline 7.3 & Chunks & 4 & 4,7 & 0 & 0,0 & 6 & 13,3 & 0 & 0,0 & 0 & 0,0 & 0 & 0,0 & 1 & 9,1 & 0 & 0,0 & 4 & 3,3 & 0 & 0,0 & 7 & 12,5 & 0 & 0,0 \\
\hline 7.4 & Fragmentos e lascas térmicas & 5 & 5,8 & 0 & 0,0 & 2 & 4,4 & 0 & 0,0 & 1 & 2,9 & 0 & 0,0 & 0 & 0,0 & 0 & 0,0 & 6 & 5,0 & 0 & 0,0 & 2 & 3,6 & 0 & 0,0 \\
\hline & Indeterminados & 0 & 0,0 & 0 & 0,0 & 0 & 0,0 & 0 & 0,0 & 1 & 2,9 & 0 & 0,0 & 0 & 0,0 & 0 & 0,0 & 1 & 0,8 & 0 & 0,0 & 0 & 0,0 & 0 & 0,0 \\
\hline & Total & 86 & & 6 & & 45 & & 4 & & 34 & & 7 & & 11 & & 7 & & 120 & & 13 & & 56 & & 11 & \\
\hline
\end{tabular}

Tabela 1 - Fases e subfases da cadeia operatória (organizada por matérias-primas). 


\title{
O SÍTIO ACHEULENSE DO PLISTOCÉNICO MÉDIO DA GRUTA DA AROEIRA
}

\author{
Joan Daura ${ }^{1,2}$, Montserrat Sanz ${ }^{1,2}$, Filipa Rodrigues ${ }^{2}$, Pedro Souto $^{3}$, João Zilhão ${ }^{2,4,5}$
}

\begin{abstract}
RESUMO
Datado de cerca de 400 ka (estádio isotópico marinho 11), o sítio da Gruta da Aroeira (Torres Novas, Portugal)é uma das poucas jazidas do Plistocénico Médio que entregou um crânio fóssil de hominídeo associado a bifaces acheulenses em contexto de gruta. A nossa abordagem multi-analítica do registo arqueológico incidiu sobre diferentes categorias de vestígios: o crânio humano (Aroeira 3), os restos faunísticos, os restos de combustão e a indústria lítica. O crânio fóssil Aroeira 3 possui um labirinto ósseo primitivo e apresenta uma fractura óssea perimortem. A indústria lítica sugere uma mobilidade limitada; as actividades de talhe realizadas no sítio incluem a exploração de núcleos, mas os bifaces foram introduzidos já como utensílios acabados. A análise dos restos faunísticos confirma a presença do primata Macaca sylvanus e documenta uma grande diversidade de cervídeos, incluindo o veado mediterrânico Haploidocerus mediterraneus, nunca antes documentado no Plistocénico Médio da Península Ibérica. A reconstrução paleo-ambiental baseada nos pequenos vertebrados indica uma paisagem florestal aberta com condições semi-húmidas. Por outro lado, a presença de subprodutos de combustão prova utilização controlada do fogo entre as populações do Acheulense.
\end{abstract}

Palavras-chave: Restos humanos, Bifaces, Fogo.

\begin{abstract}
Dated to ca. 400 ka (Marine Isotope Stage 11), the site of Gruta da Aroeira (Torres Novas, Portugal) is one of the very few Middle Pleistocene localities that have yielded a fossil hominin cranium associated with Acheulean bifaces, in a cave context. Our multi-analytical approach to the site's archaeological record focused on different aspects: the human cranium (Aroeira 3), the faunal remains, the use of fire, and the lithic industry. The Aroeira 3 fossil cranium displays a primitive bony labyrinth and a perimortem bone fracture. The lithic assemblage suggests limited mobility, with on-site knapping; the bifaces, however, were brought to the site as finished tools. Among the faunal remains, the primate Macaca sylvanus is present and cervids, including the Mediterranean deer Haploidocerus mediterraneus, previously undocumented in the Middle Pleistocene of the Iberian Peninsula, predominate. Paleoenvironmental reconstruction using the small vertebrate assemblage suggests an open woodland landscape with semi-humid conditions. The presence of combustion by-products supports the controlled use of fire by the peoples of the Acheulean.
\end{abstract}

Keywords: Human remains, Bifaces, Fire.

1. Grup de Recerca del Quaternari (GRQ) del Seminari Estudis i Recerques Prehistòriques (SERP), Dept. d'Història i Arqueologia. Universitat de Barcelona; J. Daura: jdaura_lujan@ub.edu; M. Sanz: montsesanzborras@ub.edu

2. UNIARQ-Centro de Arqueologia da Universidade de Lisboa. Faculdade de Letras. Universidade de Lisboa, 16oo-214 Lisbon, Portugal; F. Rodrigues; a.filipa.castro.rodrigues@gmail.com

3. STEA - Sociedade Torrejana de Espeleologia e Arqueologia, Quinta da Lezíria, 2350-510 Torres Novas, Portugal; P. Souto: pedrojsouto@gmail.com

4. Institució Catalana de Recerca i Estudis Avançats (ICREA), Passeig Lluís Companys 23, o8010 Barcelona, Spain; J. Zilhão: joao.zilhao@ub.edu

5. Departament d'Història i Arqueologia. Universitat de Barcelona, Carrer Montalegre, 6, o8oor Barcelona, Spain. 


\section{INTRODUÇÃO}

O Plistocénico Médio ( 700-125 ka) é um período durante o qual se observam duas importantes novidades: a expansão do Acheulense (Santonja e Villa 2006) e as primeiras provas da utilização generalizada, sistemática e controlada do fogo (Roebroeks e Villa 2011). Tanto na Península Ibérica como no resto da Europa, porém, o conhecimento do Acheulense em geral, e do Estádio Isotópico Marinho (MIS) 11 em particular, está fortemente determinado por sítios de ar livre em contexto de terraço fluvial (Santonja et al. 2014, Méndez-Quintas et al. 2018, 2019) ou de margem de lago (Santonja et al. 2016). Apesar de serem os mais numerosos, os sítios de ar livre apresentam uma série de condicionantes, nomeadamente a nível sedimentológico e dos processos pós-deposicionais, que limitam o seu potencial para a reconstrução do passado.

Menos numerosos, os sítios de gruta representam no entanto contextos mais "fechados" onde as acumulações de materiais arqueológicos resultam, normalmente, de actividades humanas realizadas in loco. Ainda assim, existem outros factores que podem intervir na génese dessas acumulações, tais como processos geológicos ou agentes biológicos (por exemplo, os carnívoros). Este tipo de sítios oferece um leque mais amplo de possibilidades de estudo e permite a aplicação de múltiplas técnicas de análise. Além disso, os sítios de gruta e os abrigos constituem, pela sua própria natureza, bons exemplos de residential camp site com potencial para a reconstrução das actividades dos grupos de caçadores-recolectores.

$\mathrm{Na}$ Península Ibérica, os sítios de gruta do Paleolítico Inferior são em número limitado: Cueva del Ángel (Barroso Ruíz et al. 2011), Galería (García-Medrano et al. 2014) ou La Garma (Arias e Ontañón 2012).

A descoberta da Gruta da Aroeira veio acrescentar a este pequeno grupo uma das poucas jazidas do Plistocénico Médio que possui um registo arqueológico claramente acheulense, com presença de bifaces, restos humanos e provas claras de uso e controlo do fogo. Apresentam-se neste artigo os últimos desenvolvimentos no conhecimento deste sítio arqueológico desde a descoberta em 2014, e publicação em 2017, do crânio Aroeira 3 (Daura et al. 2017b, 2017a, 2017c). Os estudos mais recentes centraram-se no crânio, nomeadamente a nível do ouvido interno e da tafonomia, na indústria lítica, nos restos faunísticos e, finalmente, no estudo das provas de fogo.

\section{O SÍTIO}

A Gruta da Aroeira ( $39^{\circ} 30^{\prime} 20^{\prime \prime} \mathrm{N}$; $08^{\circ} 36^{\prime} 57^{\prime \prime} \mathrm{W}$ ) (Figura 1) localiza-se no complexo cársico do Almonda (Torres Novas, Portugal), concretamente no alto da escarpa sobre a nascente que também alberga outras cavidades com um registo arqueológico já explorado (como a Gruta da Oliveira e a Lapa dos Coelhos). O sítio foi descoberto em 1991, a partir de vestígios arqueológicos identificados no interior do sistema cársico, nomeadamente nas chamadas Galerias Pesadas (Zilhão et al. 1993). Posteriormente, localizou-se a entrada colmatada - Gruta da Aroeira - e realizaram-se as primeiras escavações arqueológicas (1997-2002), as quais incidiram também sobre a zona externa da jazida, a chamada Brecha das Lascas, ou seja, a zona da cavidade que a erosão e o recuo da escarpa deixaram ao ar livre (Marks et al. 2002a, 2002b, Trinkaus et al. 2003). Em 2013 teve início uma nova fase do projecto, focada na escavação dos níveis inferiores da sequência.

Do ponto de vista crono-estratigráfico, a sequência apresenta cinco fases. A Fase 5 corresponde ao momento anterior à abertura da gruta ao exterior e inclui a camada XII (unidade 3) e a formação da grande coluna estalagmítica que divide a sala principal; a camada mais exterior desta coluna foi datada de $406 \pm 30 \mathrm{ka}$, o que dá uma idade máxima para os eventos posteriores. A Fase 4 está representada pelas camadas X e XI, por sua vez seladas por uma espessa crosta estalagmítica cuja base está datada de 418/+37/-27 ka. A conjugação destas duas datações restringe a acumulação do preenchimento acheulense ao intervalo compreendido entre 390 e $436 \mathrm{ka}$. A Fase 3 corresponde a um hiato de sedimentação, durante o qual se formaram tanto essa crosta estalagmítica (cuja parte superior tem uma idade de $326.4 \pm 13.4 \mathrm{ka}$ ) como uma outra que sela a Brecha das Lascas (para essa outra crosta temos uma idade mínima dada pela datação de $278.5 \pm 12.7$ ka obtida para uma estalagmite que sobre ela cresceu). A Fase 2 relaciona-se com o abatimento de parte do tecto, nas fiadas 10-14 da quadrícula de escavação, e subsequente acumulação de um depósito sedimentar. A Fase 1 corresponde à formação da crosta estalagmítica "AROr", que cobre a totalidade do preenchimento na zona interior da jazida e cuja base foi datada de $44.8 \pm 2.0 \mathrm{ka}$. Estes resultados permitem propor a seguinte correlação com o registo global: Fase 5, MIS 11c ou anterior; Fase 4, MIS 11c, 390- 
420 ka; Fase 3, MIS 7a-11b, 190-39o ka; Fase 2, MIS 4-7a, 6o-19o ka; e Fase 1, MIS 3c 40-6o ka (Daura et al. 2017c).

\section{RESTOS HUMANOS}

O sítio da Aroeira ofereceu três restos humanos. Dois são dentes isolados (Aroeira 1 e 2) recuperados durante as campanhas de 1997-2002 (Trinkaus et al., 2003); o terceiro é o crânio fragmentado (Aroeira 3) de um indivíduo adulto (Daura et al. 2017c). Este último corresponde a uma porção considerável do lado direito da caixa craniana a que falta o occipital mas que conserva parte do lado esquerdo da escama frontal e do toro supraorbital, bem como a região interorbital (incluindo a parte vertical dos ossos nasais). O fóssil Aroeira 3 apresenta alguns traços primitivos presentes em certos fósseis do Plistocénico Médio mas ausentes nos Neandertais (Daura et al. 2017a).

A aplicação da microtomografia computorizada (mCT) ao crânio Aroeira 3 permitiu a reconstrução virtual da estrutura do ouvido interno, disponibilizando assim informação sobre a respectiva morfologia (Conde-Valverde et al., 2018) e possibilitando a sua comparação com outros restos humanos actuais e fósseis. A análise revelou a ausência de características derivadas, próprias dos Neandertais: não se observam nem as proporções típicas destes últimos nem a posição inferior da parte posterior do canal, outra das características mais diagnosticantes do respectivo labirinto ósseo. Com base nestas características, Aroeira 3 é um fóssil mais primitivo que os da Sima de los Huesos de Atapuerca (SH). Comum a Aroeira 3 e aos fósseis de Atapuerca (SH) é porém a forma da volta basal da cóclea, diferente da que se encontra entre os Neandertais.

Estes resultados proporcionam novos contributos para o conhecimento das dinâmicas populacionais do Plistocénico Médio, na origem do clado neandertal. Por exemplo, apesar da cercania geográfica e cronologia idêntica, a existência de diferenças significativas entre o ouvido interno de Aroeira 3 e o dos fósseis de Atapuerca (SH) sugere um certo grau de isolamento demográfico.

O estudo tafonómico do crânio Aroeira 3 proporciona informação sobre a possível causa de morte do indivíduo e o papel dos agentes biológicos e geológicos na formação do depósito. O crânio está partido obliquamente em relação ao plano sagital, com a porção preservada orientada diagonalmente, desde a parte anterior do arco supraorbital esquerdo, atravessando a linha média imediatamente antes do bregma, e continuando no sentido posterior em direcção ao astério direito. Observa-se perda substancial da superfície externa dos arcos supraorbitais direito e esquerdo e da escama frontal.

A maioria das fracturas apresenta características próprias das lesões post-mortem. A fractura da região posterior do osso parietal, contudo, apresenta características mais habitualmente presentes nas fracturas ósseas perimortem (Figura 2). A perda de matéria óssea na escama frontal e no arco supraorbital pode ser atribuída a diferentes causas, não sendo possível descartar totalmente um evento traumático como origem dessas alterações, mas não foram observadas lesões que pudessem ter resultado de violência interpessoal. Tão-pouco foi identificada qualquer prova de modificação antropogénica ou por carnívoros. Como o canibalismo e o tratamento secundário do cadáver podem ser postos de parte, acidente é a explicação mais plausível para a fractura craniana (Sanz et al. 2018).

\section{INDÚSTRIA LÍTICA}

A indústria lítica procedente da zona escavada em 2013-2017 corresponde a um conjunto de 393 artefactos, incluindo bifaces acheulenses $(\mathrm{n}=17)$ (Figura 3 ) e outras peças bifaciais $(n=2)$, outras peças retocadas $(n=45)$, núcleos $(n=47)$, lascas e fragmentos de lascas ( $n=207$ ), e seixos (testados ou não, e talvez manuportes) ( $\mathrm{n}=99)$. A amostra inclui sete tipos diferentes de rochas e minerais ígneos, sedimentares e metamórficos, mas a matéria-prima de eleição é o quartzito, sendo o sílex escasso (mas existem bifaces talhados sobre ambos). O método Levallois não está representado.

A análise de núcleos e lascas mostra que o talhe seguiu principalmente um esquema centrípeto (Daura et al., 2018). Os núcleos esgotados, tanto de quartzo como de quartzito, apresentam mais frequentemente uma organização bipiramidal, embora uma pequena percentagem seja unipolar ou bipolar; a debitagem bipolar sobre bigorna está representada por alguns exemplares de quartzo. Um número significativo de núcleos foram pouco trabalhados, o que parece reflectir uma exploração oportunista. Embora haja também alguns núcleos unifaciais centrípetos, a maioria dos núcleos são discóides e foram talhados bifacialmente mediante levantamentos 
centrípetos ou cordais utilizando superfícies alternadas. A elevada percentagem de lascas corticais (inteiramente ou em mais de 50\% do anverso) indica a realização de sequências de talhe completas.

Morfologicamente, os 17 bifaces identificados neste conjunto são cordiformes, lanceolados e amigdalóides. Na maioria das peças não foi possível determinar o suporte original, mas em alguns casos tratava-se de lascas. A maioria destes bifaces são de pequena dimensão: ou porque foram feitos pequenos de raiz, ou por corresponderem à fase final da vida útil destes artefactos, antes do respectivo abandono.

A colecção inclui também utensílios sobre lasca. $\mathrm{Na}$ maior parte dos casos trata-se de raspadores simples cujos bordos laterais foram modificados por retoque directo, mas alguns dos raspadores apresentam retoque bifacial. Os denticulados são a segunda categoria mais numerosa.

Os bordos e superfícies estão bem conservados. Vários bifaces e lascas ostentam marcas que proporcionam informação sobre as matérias-primas trabalhadas, que em geral são materiais duros como a madeira, a haste ou o osso. Onde foi possível identificar tanto a dureza do material como a direcção do movimento, os vestígios apontam, na maioria dos casos, para actividades de transformação de madeira por percussão, tanto longitudinal como transversal. Em dois bifaces, o polimento que denota percussão sobre madeira está associado ao esmagamento e abrasão do gume utilizado, e em três outros está associado a trabalho de corte (indicado pelo tipo de desgaste dos bordos laterais).

\section{RESTOS FAUNÍSTICOS}

Os restos de fauna com marcas de modificação antropogénica provêm da camada X e estão muito fragmentados, pelo que os elementos anatómicos identificáveis se limitam a peças dentárias isoladas, ossos dos membros, e epífises maciças. A camada XI contém restos acumulados por outros agentes biológicos. No total, foram coordenados na camada Xb 209 restos, na maioria cervídeos (NISP=58) e equídeos $(\mathrm{NISP}=46)$. Entre as espécies mais raras contam-se o castor (Castor fiber NISP=3), um rinoceronte $(\mathrm{NISP}=2)$ (provavelmente Stephanorhinus cf. hundsheimensis), o urso ( $\mathrm{NISP}=4$ ) (Ursus sp.), e ainda um grande bovídeo (Bos/Bison), um caprídeo (Caprinae) e uma tartaruga terrestre (Testudo sp.) (NISP = I de cada). Os desenvolvimentos mais significativos ao nível do estudo da fauna correspondem ao estudo i) dos cervídeos, ii) dos restos de cercopitecídeos e iii) da microfauna.

Em relação aos cervídeos, durante os trabalhos de campo previamente desenvolvidos no sítio (1997-2002) foram identificadas duas espécies de veado, Cervus elaphus e Dama vallonnetensis (Marks et al. 2002b). Já os restos de cervídeos recuperados durante os trabalhos mais recentes incluem quatro espécies de veado: Cervus elaphus, Praedama cf. savini, Haploidoceros mediterraneus, e Dama cf. vallonnetensis, tornando a Gruta da Aroeira no primeiro sítio da Península Ibérica em que o género Haploidoceros é documentado no Plistocénico Médio. Praticamente todos os cervídeos documentados no sítio revelam um certo grau de endemismo, incluindo modificações evolutivas do crânio, das hastes e da dentição ou uma redução do tamanho do corpo. A invulgar riqueza dos cervídeos da Gruta da Aroeira pode estar relacionada com as condições biogeográficas específicas do Plistocénico Médio da Península Ibérica. Assim, se a ligação geográfica da Península Ibérica com a zona temperada da Eurásia ocidental facilitou a chegada de cervídeos de origem paleárctica, impediu por outro lado a entrada de ruminantes de zonas mais quentes e áridas. O carácter endémico destes cervídeos e a biodiversidade da Península Ibérica devem ser tidos em conta na avaliação da paleobiogeografia dos hominídeos ibéricos, das suas estratégias de caça, e da sua economia (Croitor et al. 2019).

Brugal (2004), Marks et al. (2002a, 2002b) e Trinkaus et al. (2003) mencionam a recuperação de restos de macaco durante a primeira fase das escavações. Atribuídos a Macaca sylvanus ? florentina, esses restos ainda não foram descritos. As escavações de 20132017 deram uma mandíbula de macaco juvenil no topo da camada X: o exemplar ARO \#934. O fóssil preserva a sínfise e a maioria dos dois corpos mandibulares, bem como a maioria do ramo esquerdo, excepto o processo coronóide e o côndilo mandibular. $\mathrm{O} \mathrm{dP}_{3}$ e $\mathrm{M} 1$ direitos e a série $\mathrm{dP}_{4}-\mathrm{M}_{1}$ esquerda estão presentes e apresentam erupção completa, mas o $\mathrm{dP}_{3}$ esquerdo não se conservou. A reconstrução virtual a partir de imagens $C T$ revela, dentro dos respectivos alvéolos, os germes de incisivos, caninos, pré-molares e segundos molares permanentes. A morfologia, tamanho e proporções dos dentes, tanto decíduos como permanentes, indicam que o fóssil da Aroeira corresponde provavelmente a um indivíduo feminino de M. sylvanus subsp. - menor 
do que Paradolichopithecus spp. mas maior do que Macaca majori (Alba et al. 2019)

E. Peman realizou um estudo preliminar dos mamíferos pequenos (insectívoros, morcegos e roedores) recuperados durante as campanhas de 1997-1999, infelizmente com um contexto estratigráfico pouco preciso (Marks et al. 2002b). Os pequenos vertebrados das actuais escavações (camada Xc) incluem pelo menos 17 taxa. Os répteis estão representados por restos indeterminados de Salamandridae (NISP=1), Pelodytes sp. (NISP=2), Bufo spinosus $(\mathrm{NISP}=2)$, Anura indet $(\mathrm{NISP}=1)$, Lacertidae indet $(\mathrm{NISP}=2)$, cf. Coronella girondica (NISP=1), Natrix cf. maura (NISP=3) e Ophidia indet (NISP=5). Os pequenos mamíferos estão representados por Sorex sp. (12), Crocidura sp., Rhinolophus ferrumequinum, (2), Rhinolophus sp. (tamanho pequeno) (3), Myotis myotis (12), Myotis sp. (tamanho médio) (3), cf. Miniopterus schreibersii (2), Iberomys brecciensis (61), Pliomys episcopalis (4), Apodemus cf. A. flavicollis (134), Allocricetus bursae (47) e Eliomys quercinus (17). A reconstrução paleo-ambiental, utilizando os pequenos vertebrados como indicador climático, aponta para uma paisagem de floresta aberta e para condições relativamente suaves e húmidas, provavelmente relacionadas com o final do MIS i1c.

\section{FOGO}

Foram recuperados restos de ossos queimados, carvões e vários seixos provavelmente queimados (Figura 4). Estes elementos foram encontrados em dois horizontes arqueológicos distintos e separados, numa área reduzida da caverna, sugerindo utilização controlada do fogo. A concentração situada na parte basal da camada X (nível Xc) parece ser a mais importante.

Os ossos termo-alterados são 43. A intensidade da alteração é variável, estando representados todos os termos da escala de cores proposta por Stiner et al. (1995) para o estudo de restos arqueológicos, incluindo alguns calcinados (Figura 4). A análise por espectroscopia de raios $\mathrm{X}$ confirma que a coloração negra não é manganês. Trata-se, em todos os casos, de fragmentos pequenos e a termo-alteração dos ossos foi confirmada por análise FTIR. Oito objectos líticos apresentam alterações cromáticas (Figura 4) mas, como as propriedades magnéticas não são concludentes, não é possível assegurar que as alterações em causa tenham sido causadas por exposição ao fogo.

\section{CONCLUSÕES}

Da escavação arqueológica da camada X da Gruta da Aroeira, datada de há cerca de 400 ooo anos, podemos extrair as seguintes conclusões:

- Crânio Aroeira 3: O labirinto ósseo revelou uma ausência de características derivadas neandertais; trata-se de um labirinto ósseo bastante primitivo, mais semelhante ao que se encontra entre formas mais antigas do género Homo. Uma morte natural, acidental ou por doença, é a explicação mais plausível, neste caso como no da maioria dos casos de restos humanos isolados.

- Indústria lítica: O território percorrido pelos ocupantes da gruta parece ter estado limitado às terras baixas da planície do Tejo. O sítio regista talhe a partir de fontes de matéria-prima local e descarte de artefactos trazidos de outros locais. Os utensílios foram utilizados para trabalhar madeira e provavelmente também no processamento de carcaças. A associação deste conjunto lítico com um crânio humano reforça a noção de que a emergência e difusão do Acheulense na Europa não podem ser relacionadas com uma entidade específica da taxonomia corrente em Paleontologia Humana e têm de ser entendidas nos seus próprios termos, como processos culturais.

- Restos faunísticos: Estão representados quatro tipos de cervídeos: Praedama cf. savini, Cervus elaphus, Haploidoceros mediterraneus e Dama cf. vallonnetensis. O tamanho relativamente pequeno do corpo significa que teriam constituído presas ideais, permitindo que as carcaças fossem transportadas para o acampamento-base; trata-se de adultos jovens e de adultos, ou seja, os alvos típicos dos caçadores paleolíticos. Os pequenos vertebrados indicam uma paisagem dominada por floresta aberta e condições relativamente suaves e semi-húmidas.

- Fogo: Foram identificados subprodutos de combustão, nomeadamente ossos queimados (alguns dos quais expostos a temperaturas elevadas), carvão e seixos possivelmente alterados pelo calor, confirmando o uso controlado do fogo entre as populações do Plistocénico Médio do sudoeste da Europa. 


\section{AGRADECIMENTOS}

Esta investigação foi apoiada pela FCT (Fundação para a Ciência e a Tecnologia, Portugal) através dos projetos PTDC/HIS-ARQ/o98164/2008 e PTDC/ HAR-ARQ/30413/2017). O trabalho de campo foi financiado pela Câmara Municipal de Torres Novas e pela FCT, com apoio logístico da Fábrica de Papel A Renova e da STEA (Sociedade Torrejana de Espelologia e Arqueologia). A investigação foi ainda apoiada pelos projectos HAR2017-86509 e 2017SGR-ooo11. J.D. foi financiado através de um contrato Ramon y Cajal (RYC-2015-17667) e M.S. através de um contrato Juan de la Cierva (IJCI-2017-33908).

\section{BIBLIOGRAFIA}

ALBA, David M.; DAURA, Joan; SANZ, Montserrat; SANTOS, Elena; YAGÜE, Almudena S.; DELSON, Eric; ZILHÃO, João (2019) - New macaque remains from the Middle Pleistocene of Gruta da Aroeira (Almonda karst system, Portugal). Journal of Human Evolution. 131, pp. 40-47.

ARIAS, Pablo; ONTAÑ́́N, Roberto (2012) - Chapter 8: La Garma (Spain): long-term human activity in a karst system. Em BERGSVIK, Knut Andreas; SKEATES, Robin, eds. - Caves in Context: The Cultural Significance of Caves and Rockshelters in Europe pp. 101-1017.

BARROSO RUÍZ, Cecilio; BOTELLA ORTEGA, Daniel; CAPARRÓS, Miguel; MOIGNE, Anne Marie; CELIBERTI, Vincenzo; TESTU, Agnès; BARSKY, Deborah; NOTTER, Olivier; RIQUELME CANTAL, José Antonio; RODRÍGUEZ, Manuel Pozo; CARRETERO LEÓN, María Isabel; MONGE GÓMEZ, Guadalupe; KHATIB, Samir; SAOS, Thibaud; GREGOIRE, Sophie; BAILÓN, Salvador; GARCÍA SOLANO, José Antonio; CABRAL MESA, Antonio Luis; DJERRAB, Abderrezak; GEORGE HEDLEY, Ian; ABDESSADOK, Salah; BATALLA LLASAT, Gerard; ASTIER, Nicolas; BERTIN, Læticia; BOULBES, Nicolas; CAUCHE, Dominique; FILOUX, Arnaud; HANQUET, Constance; MILIZIA, Christelle; MOUTOUSSAMY, José; ROSSONI, Elena; VERDÚ BERMEJO, Luis; DE LUMLEY, Henry (2011) - The Cueva del Angel (Lucena, Spain): An Acheulean hunters habitat in the South of the Iberian Peninsula. Quaternary International. 243:1, pp. 105-126.

BRUGAL, Jean-Philip (2004) - First Middle Pleistocene faunas with primates ( Homo, Macaca) from Estremadura (Portugal). - $18^{\text {th }}$ International Senckenberg Conference,VI International Paleontological Colloquium in Weimar, $25^{\text {th }}-$ $30^{\text {th }}$ April 2004 Weimar: Terra Nostra, pp. 82-83.

CROITOR, Roman; SANZ, Montserrat; DAURA, Joan (2019) - Deer remains from the Middle Pleistocene site of Gruta da Aroeira (Portugal): Iberian faunal endemism and implications for hominin paleobiogeography. Quaternary Science Reviews. 225, p. 106022.
DAURA, Joan; SANZ, Montserrat; ARSUAGA, Juan-Luis; QUAM, Rolf; HOFFMANN, Dirk L.; ORTEGA, María Cruz; SANTOS, Elena; GÓMEZ, Sandra; RUBIO, Angel; VILLAESCUSA, Lucía; SOUTO, Pedro; MAURICIO, João; RODRIGUES, Filipa; FERREIRA, Artur; GODINHO, Pa; TRINKAUS, Erik; ZILHÃO, João (2017a) - The Middle Pleistocene Human Cranium from Gruta da Aroeira Acheulian site (Almonda Karst System, Torres Novas, Portugal). American Journal of Physical Anthropology.162:S64, pp. 157-158.

DAURA, Joan; SANZ, Montserrat; ARSUAGA, Juan-Luis; QUAM, Rolf; HOFFMANN, Dirk L.; ORTEGA, María Cruz; SANTOS, Elena; GÓMEZ, Sandra; RUBIO, Angel; VILLAESCUSA, Lucía; SOUTO, Pedro; RODRIGUES, Filipa; MAURICIO, João; FERREIRA, Artur; GODINHO, Paulo; TRINKAUS, Erik; ZILHÃO, João (2017b) - O crânio humano acheulense do plistocénico médio da Gruta da Aroeira. - Arqueologia em Portugal / 2017 - Estado da Questão Lisboa, Portugal, Associação dos Arqueólogos Portugueses, pp. 295-302.

DAURA, Joan; SANZ, Montserrat; ARSUAGA, Juan Luis J.L.; HOFFMANN, Dirk L. D.L.; QUAM, R.M. Rolf M.; ORTEGA, M.C. María Cruz; SANTOS, Elena; GÓMEZ, Sandra; RUBIO, Angel; VILLAESCUSA, Lucía; SOUTO, Pedro; MAURICIO, João; RODRIGUES, Filipa; FERREIRA, Artur; GODINHO, Paulo; TRINKAUS, Erik; ZILHÃO, João (2017c) - New Middle Pleistocene hominin cranium from Gruta da Aroeira (Portugal). Proceedings of the National Academy of Sciences. 114:13, pp. 3397-3402.

GARCÍA-MEDRANO, Paula; OLLÉ, Andreu; MOSQUERA, Marina; CÁCERES, Isabel; DÍEZ, Carlos; CARBONELL, Eudald (2014) - The earliest Acheulean technology at Atapuerca (Burgos, Spain): Oldest levels of the Galería site (GII Unit). Quaternary International. 353, pp. 170-194.

MARKS, An E; MONIGAL, Katherine; CHABAI, Victor P; BRUGAL, Jean-Philip; GOLDBERG, Paul; HOCKETT, Bryan; PEMÁN, Eduardo; ELORZA, Mikelo; MALLOLL, Carolina (2002a) - Excavations at the late Middle Pleistocene cave of Galeria Pesada: 1997/1999. O Arqueólogo Português. 20, pp. 7-38.

MARKS, Anthony E; BRUGAL, Jean-Philip; CHABAI, Victor P; MONIGAL, Katherine; GOLDBERG, Paul; HOCKETT, Bryan; PEMAN, Eduardo; ELORZA, Mikelo; MALLOLL, Carolina (2002b) - Le gisement Pléistocène moyen de Galeria Pesada, (Estrémadure, Portugal): premiers résultats. Paléo. 14, pp. 77-100.

MÉNDEZ-QUINTAS, Eduardo; DEMURO, Martina; ARNOLD, Lee J; DUVAL, Mathieu; PÉREZ-GONZÁLEZ, Alfredo; SANTONJA, Manuel (2019) - Insights into the late stages of the Acheulean technocomplex of Western Iberia from the Arbo site (Galicia, Spain). Journal of Archaeological Science: Reports. 27, p. 101934. 
MÉNDEZ-QUINTAS, Eduardo; SANTONJA, Manuel; PÉREZ-GONZÁLEZ, Alfredo; DUVAL, Mathieu; DEMURO, Martina; ARNOLD, Lee J (2018) - First evidence of an extensive Acheulean large cutting tool accumulation in Europe from Porto Maior (Galicia, Spain). Scientific Reports. 8:1, p. 3082.

ROEBROEKS, Wil; VILLA, Paola (2011) - On the earliest evidence for habitual use of fire in Europe. Proceedings of the National Academy of Sciences. 108:13, pp. 5209-5214.

SANTONJA, Manuel; PÉREZ-GONZÁLEZ, Alfredo; DOMÍNGUEZ-RODRIGO, Manuel; PANERA, Joaquín; RUBIO-JARA, Susana; SESÉ, Carmen; SOTO, Enrique; ARNOLD, Lee James; DUVAL, Mathieu; DEMURO, Martina; ORTIZ, José E.; DE TORRES, Trinidad; MERCIER, Norbert; BARBA, Rebeca; YRAVEDRA, José (2014) - The Middle Paleolithic site of Cuesta de la Bajada (Teruel, Spain): a perspective on the Acheulean and Middle Paleolithic technocomplexes in Europe. Journal of Archaeological Science. 49, pp. 556-571.

SANTONJA, Manuel; PÉREZ-GONZÁlEZ, Alfredo; PANERA, Joaquín; RUBIO-JARA, Susana; MÉNDEZ-QUINTAS, Eduardo (2016) - The coexistence of Acheulean and Ancient Middle Palaeolithic techno-complexes in the Middle Pleistocene of the Iberian Peninsula. Quaternary International. 411, pp. 367-377.

SANTONJA, Manuel; VILLA, Paola (2006) - The Acheulianof Western Europe. Em GOREN-INBAR, Naama; SHARON, Gonen, eds. - Axe Age-Acheulian Tool-making from Quarry to Discard London: Equinox, pp. 429-478.

SANZ, Montserrat; SALA, Nohemi; DAURA, Joan; PANTOJA-PÉREZ, Ana; SANTOS, Elena; ZILHÃO, João; ARSUAGA, Juan Luis (2018) - Taphonomic inferences about Middle Pleistocene hominins: The human cranium of Gruta da Aroeira (Portugal). American Journal of Physical Anthropology. 167:3, pp. 615-627.

STINER, Mary C; KUHN, Steven L; WEINER, Stephen; BAR-YOSEF, Ofer (1995) - Differential burning, recrystallization, and fragmentation of archaeological bone. Journal of Archaeological Science. 22:2, pp. 223-237.

TRINKAUS, Erik; MARKS, Anthony E; BRUGAL, Jean-Philip P; BAILEY, Shara E; RINK, W.Jack J; RICHTER, Daniel (2003) - Later Middle Pleistocene human remains from the Almonda Karstic System, Torres Novas, Portugal. Journal of human evolution. 45:3, pp. 219-226.

ZILHÃO, João; MAURÍCIO, João; SOUTO, Pedro (1993) Jazidas arqueológicas do sistema cársico da nascente do Almonda. Nova Augusta. 7, pp. 35-54. 

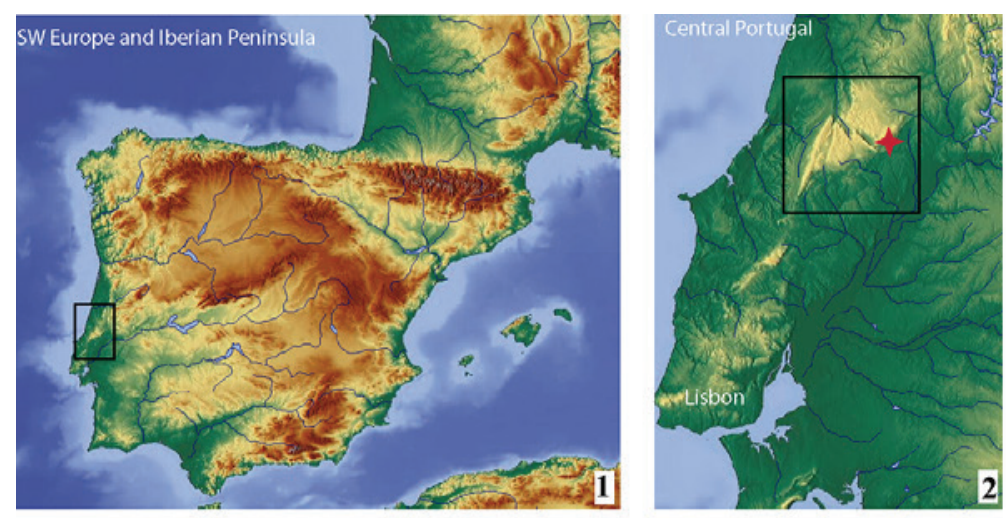

2

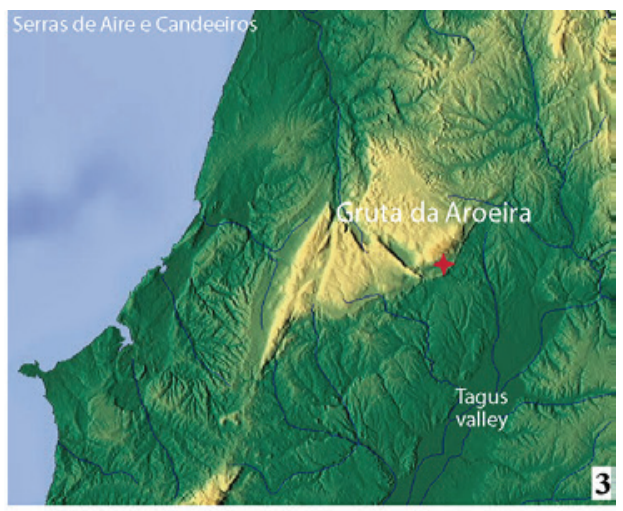

$55-6$
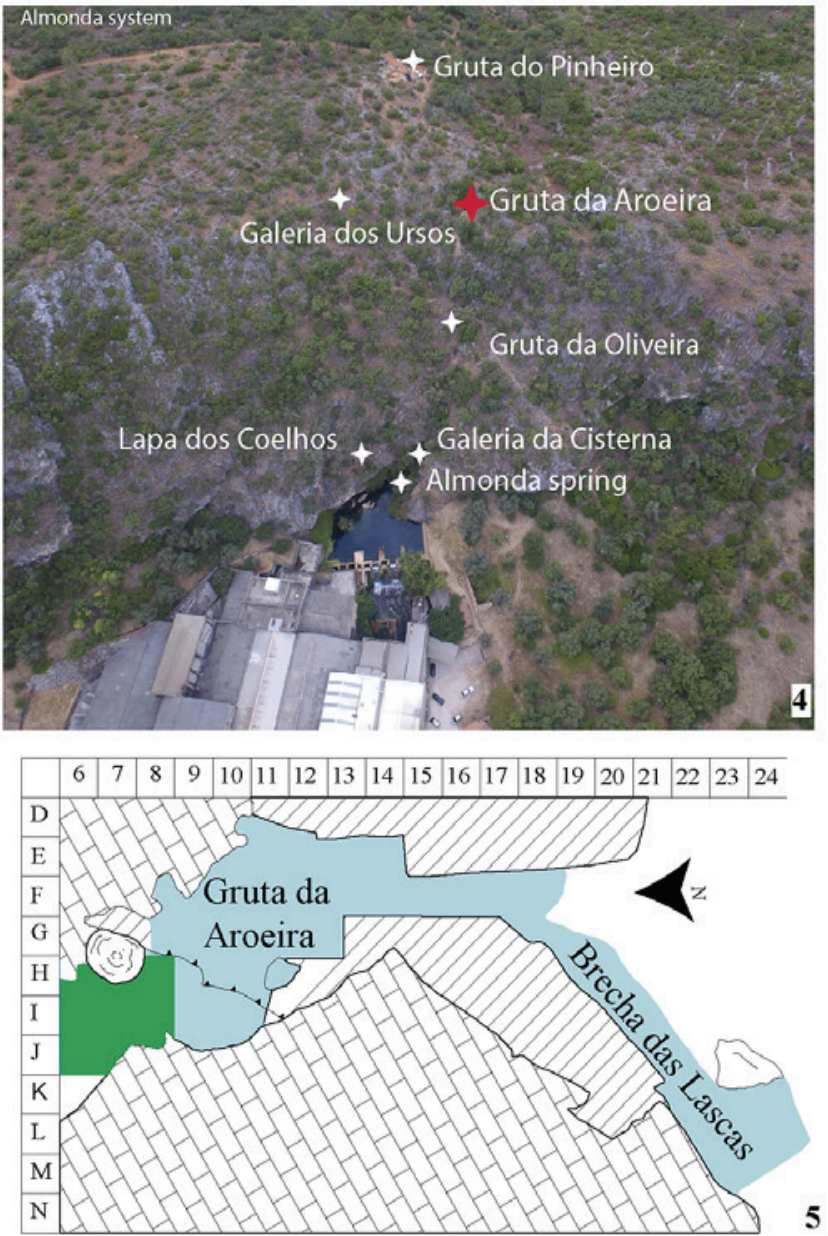

Legend

\begin{tabular}{|lc|}
\hline Cave wall / Bedrock & $\square$ 1998-2002 excavation \\
$\square$ Cave ceiling & $\square$ 2013-2017 excavation \\
Stalagmitic column & $\square$ Not excavated \\
- Layers - - Grid - Columm $\square$ Capping flowstone \\
\hline
\end{tabular}

4

5

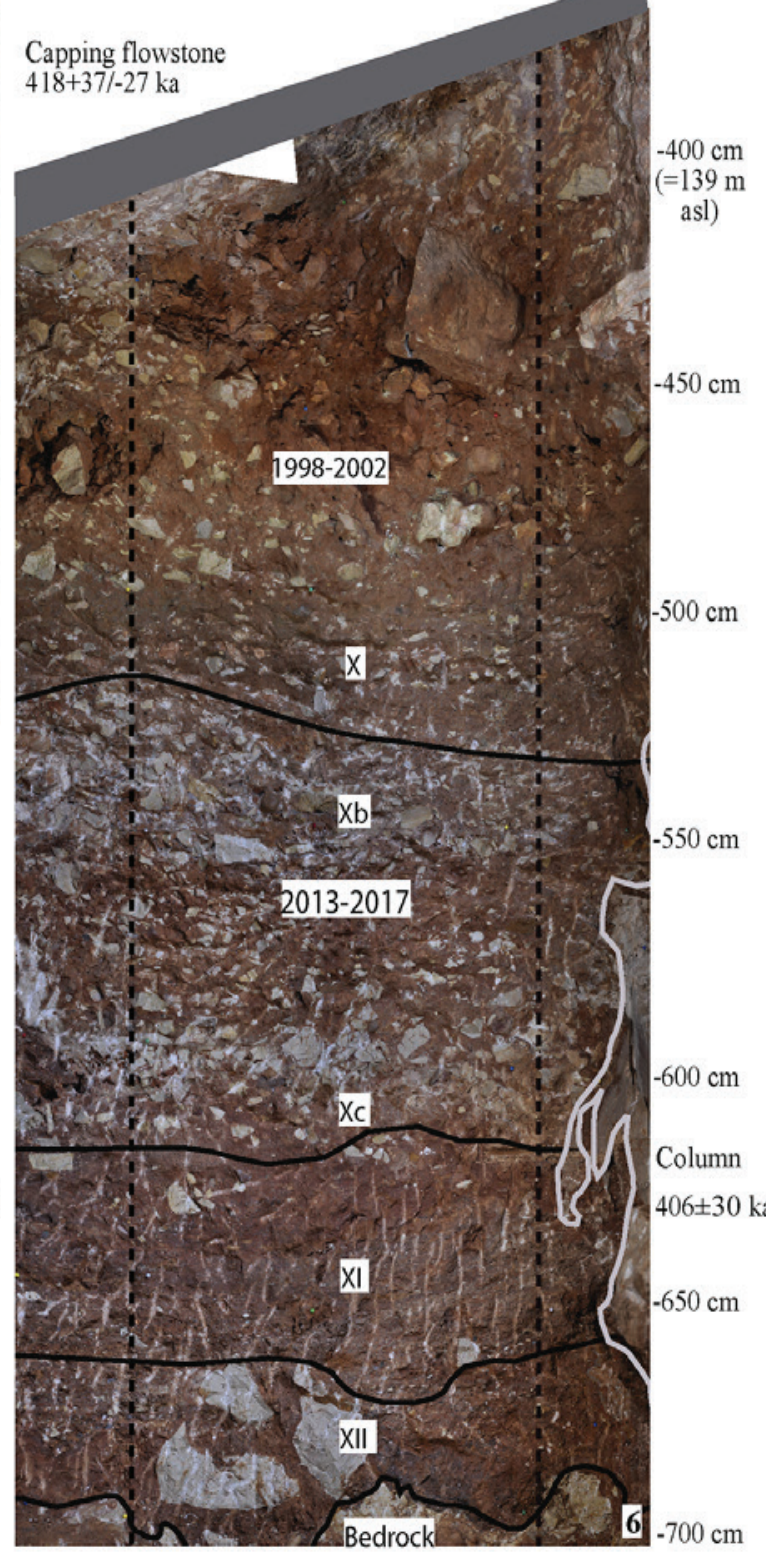

Figura 1- O sítio da Gruta da Aroeira. 1-3: Localização geográfica. 4: A escarpa do Almonda, com a posição da Gruta da Aroeira e a nascente do rio Almonda em primeiro plano. 5: Planta da Gruta da Aroeira eárea de escavação. 6: Corte estratigráfico principal. 


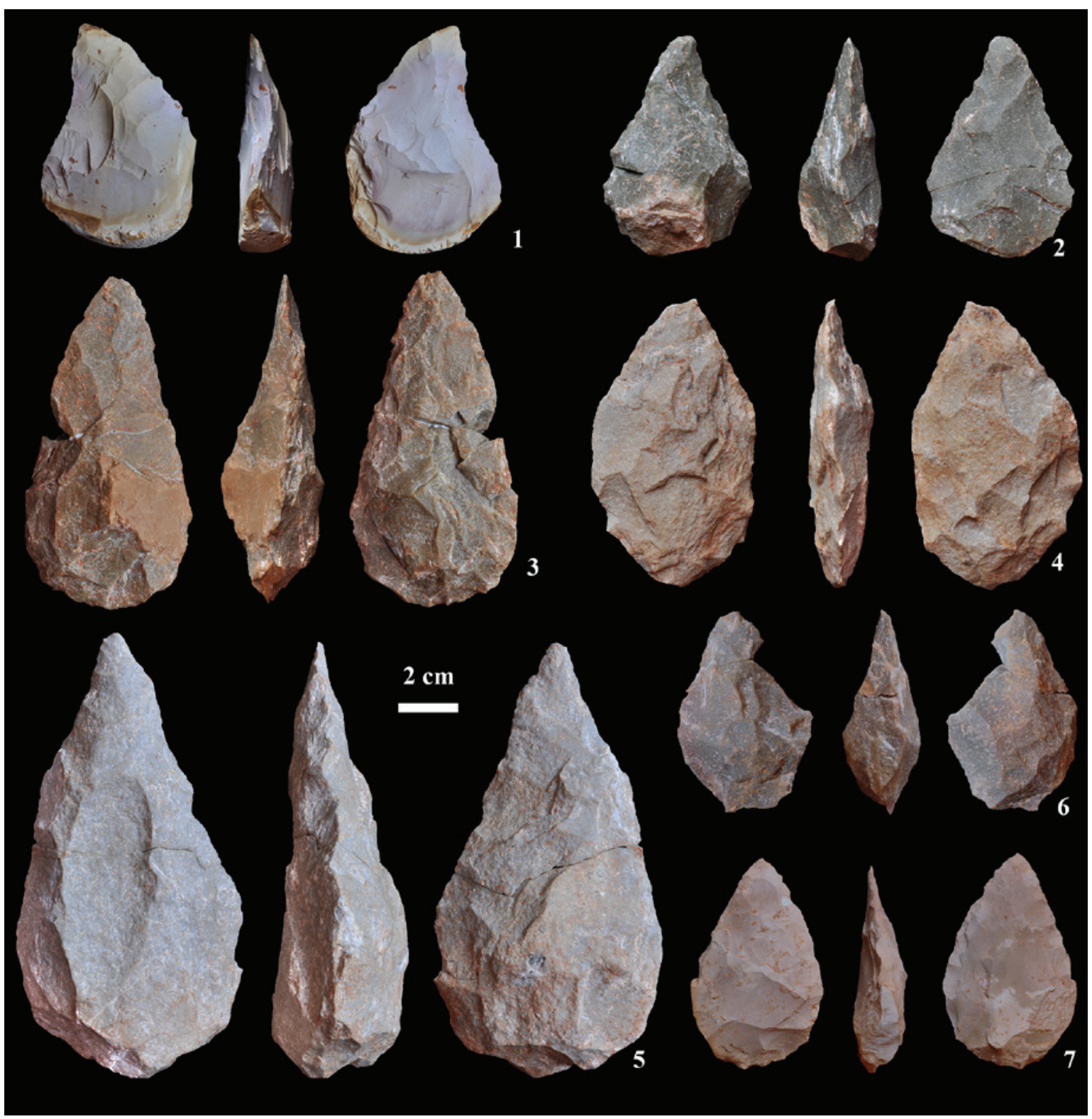

Figura 2 - Bifaces da camada X.

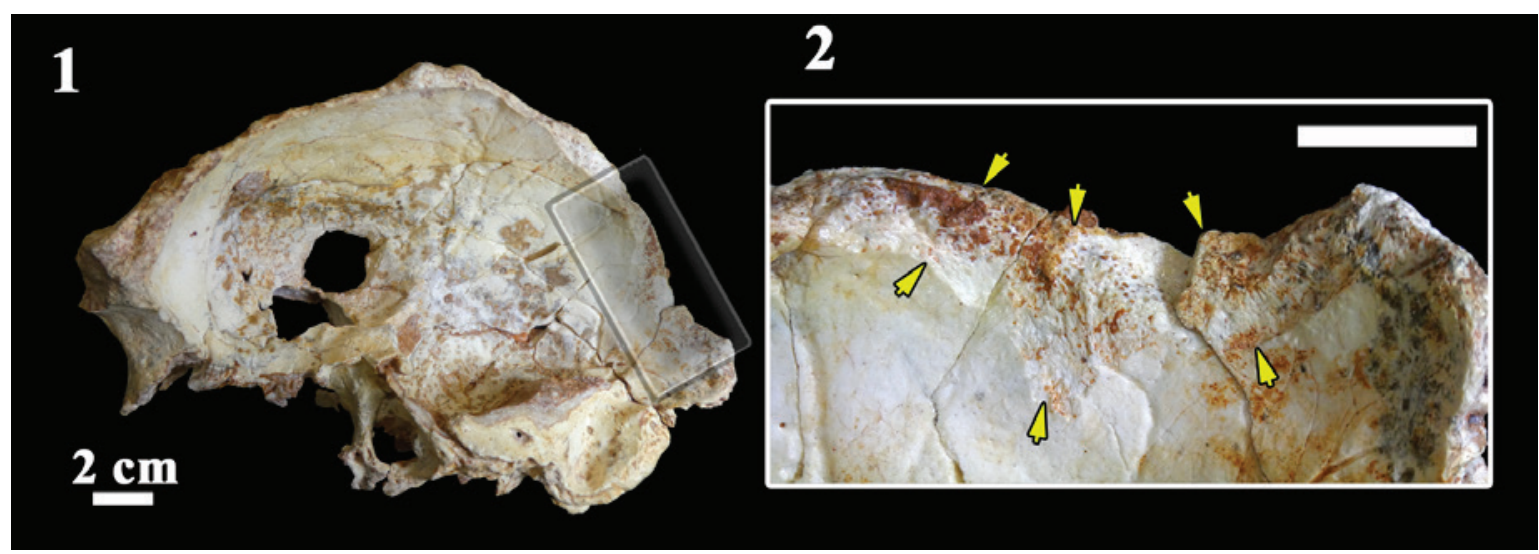

Figura 3 - Fractura perimortem da região posterior do osso parietal. 1: Vista endocraniana do fóssil. 2: Vista detalhada da fractura perimortem; as setas indicam descamações do córtex. 


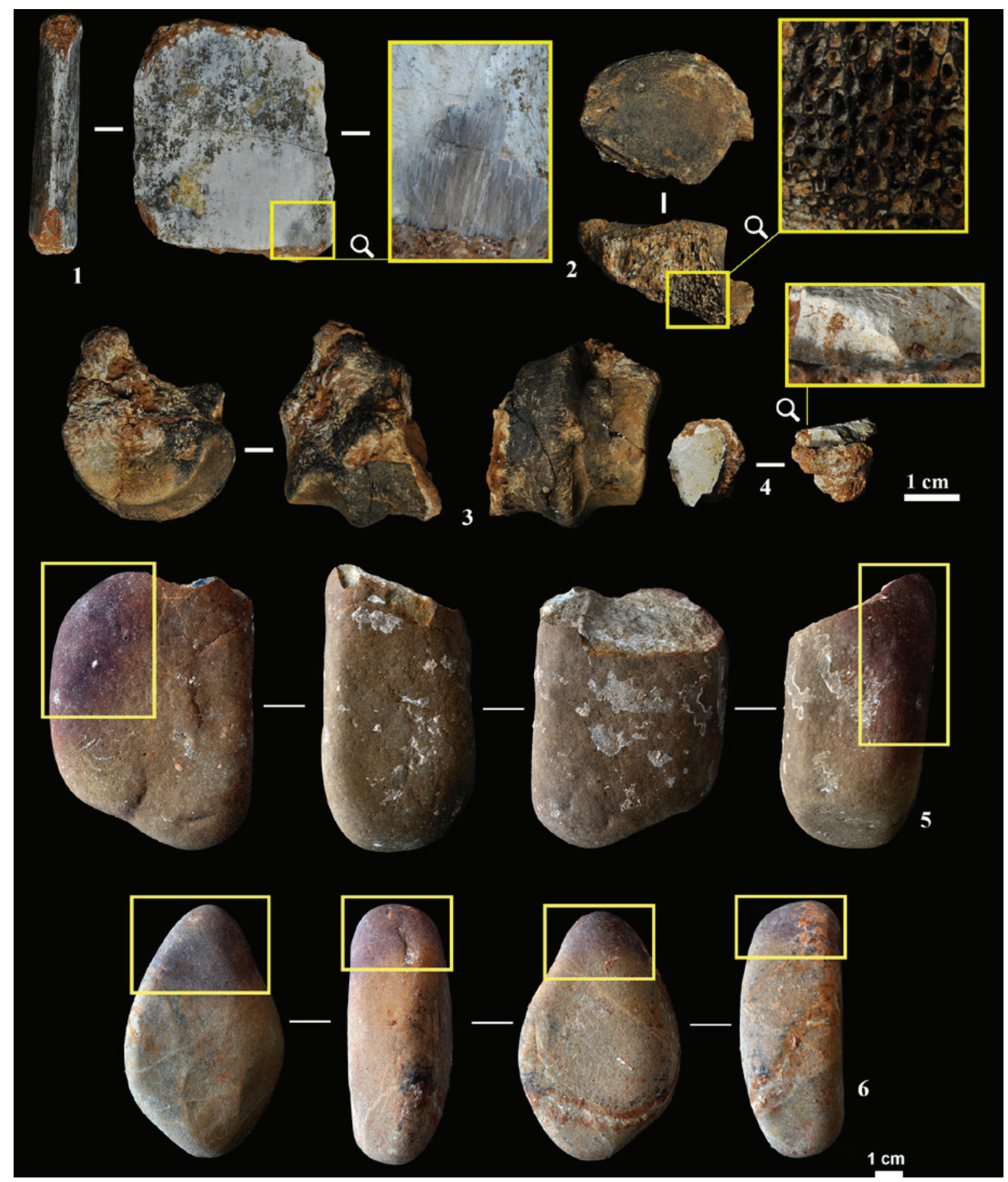

Figura 4-1-4. Ossos queimados. 5-6. Artefactos de quartzito com zonas avermelhadas e enegrecidas (assinaladas por rectângulos) possivelmente resultantes de alteração térmica. 


\title{
AS SOCIEDADES NEANDERTAIS NO BARLAVENTO ALGARVIO: MODELOS PREDITIVOS COM RECURSO AOS SIG
}

\author{
Daniela Maio ${ }^{1}$
}

\begin{abstract}
RESUMO
Os estudos relacionados com as populações de Neandertais no Barlavento algarvio indicam que os territórios ocupados se localizavam no litoral, onde a recolha de recursos aquáticos e a caça de animais de pequeno e grande porte fazia parte da dieta destas comunidades. De forma a contribuir com novos dados para o Paleolítico Médio foi criado um Modelo Preditivo Arqueológico com o intuito de analisar os padrões de ocupação e exploração do território. O presente estudo assenta numa abordagem essencialmente estatística, descritiva e univariada, com recurso a variáveis dependentes (i.e., sítios arqueológicos) e independentes (e.g., dados geomorfológicos, geográficos). Os resultados obtidos indicam uma ocupação do território pouco dispersa, junto da costa e ligada a importantes vales e rios.

Palavras-chave: Modelo Preditivo Arqueológico, Sistemas de Informação Geográfica, Paleolítico Médio, Barlavento Algarvio.
\end{abstract}

\begin{abstract}
Studies related to Neanderthal populations in the western Algarve indicate that the occupied territories were located near the coastline, where the collection of aquatic resources and the hunting of small and large animals was part of the diet of these communities. To contribute with new data for the Middle Paleolithic, an Archaeological Predictive Model was created to analyze the patterns of occupation and exploration of the territory. The present study is based on an essentially statistical, descriptive and univariate approach, using dependent variables (i.e., archaeological sites) and independent variables (e.g., geomorphological, geographic data). The results obtained indicate an occupation of the territory, close to the coastline and dispersed in the territory, linked to important valleys and rivers.

Keywords: Archaeological Predictive Model, Geographic Information Systems, Middle Paleolithic, Eastern Algarve.
\end{abstract}

\section{INTRODUÇÃO}

Os Neandertais seriam uma outra espécie ou uma variedade do Homo sapiens? Esta tem sido uma das questões mais debatidas por vários investigadores, que ao longo do tempo têm vindo a caracterizar o comportamento do H. Neandertal (e.g., Raposo, 1995; Stringer, 2002; Bicho, 2005; Zilhão, 2014). A investigação sobre o Paleolítico Médio tem fornecido novas informações integrando todo um conjunto de estudos que vão desde análises líticas (e.g., Veríssimo, 2004; Mendonça, 2009; Pereira, Haws \&
Bicho, 2012; Pereira \& Benedetti, 2013; Paixão \& alii, 2016; Bicho \& Cascalheira, 2018), análises isotópicas e genéticas (e.g., Fabre \& alii, 2011; Bocherens, Drucker \& Madelaine, 2014; Wißing \& alii, 2019) até à reconstrução das dietas alimentares (Bicho, 2004a, 2004b; Bicho, Cascalheira \& Marreiros, 2012) e padrões de povoamento e/ou exploração do território (d'Errico \& Sánchez Goñi, 2003; Bradtmöller \& alii, 2012; Maio, 2018). Afastando a hipótese de que os Neandertais seriam uma espécie primitiva, e sim incluídos no género Homo (Stringer, 2002). O sul de Portugal possui uma alta diversidade lito-

1. Interdisciplinary Center for Archaeology and Evolution of Human Behavior - ICArEHB, FCHS, Campus de Gambelas, University of Algarve, Faro 8005-139, Portugal; daniela.s.maio@hotmail.com 
lógica, o que se reflete na riqueza da sua geomorfologia (Dias, 1998), constituindo um ponto atrativo para as comunidades do Pleistocénico Final. As pesquisas sobre o Paleolítico Médio na região foram pontuais. No entanto, desde o final do século XX, a situação foi revertida e vários projetos surgiram para a região a oeste do Algarve, como por exemplo o projeto "A Ocupação Humana Paleolítica no Algarve" (Bicho, 2004a, 2004b). Deste projeto resultou a identificação de um conjunto de dez sítios arqueológicos, divido em dois grupos: (1) o primeiro caracterizado pela proximidade a zonas costeiras e de estuários - Ibn Ammar, Praia da Galé e Vale da Fonte; (2) e, um outro grupo marcado pela proximidade a lagos - Lagoa Funda 1, 2 e 3 e Lagoa do Bordoal. Os dados provenientes dos sítios arqueológicos indicam a preferência por uma posição costeira, onde a recolha de recursos aquáticos e a caça de animais de pequeno e grande porte integravam a dieta do Homo Neandertal (Bicho, 2004a, 2004b).

No entanto, as lacunas na investigação do Paleolítico Médio nesta região ainda persistem, refletindo-se nos (1) modelos de povoamento estabelecidos (apenas teóricos) e, (2) na fragmentação dos dados, que comprometem a compreensão da interação destas comunidades com o território. De modo a contribuir com novos dados para as várias questões que ainda se encontram por responder: De que forma os Neandertais exploravam e ocupavam o território? Onde se localizam os sítios arqueológicos do Paleolítico Médio? De que forma o ambiente influenciou as estratégias do uso do território? desenvolveu-se um modelo preditivo arqueológico recorrendo aos dados arqueológicos existentes. Assim, este artigo pretende mostrar os resultados preliminares obtidos através da criação do Modelo Preditivo Arqueológico (MPA) para o Paleolítico Médio no Barlavento algarvio, que resultou na dissertação de mestrado da autora. O objetivo principal é identificar padrões de ocupação e exploração do território e estabelecer novos paradigmas na relação homem-ambiente. Concretamente, pretende-se: (1) identificar áreas de maior potencial arqueológico; (2) verificar a eficácia do modelo preditivo na área da costa algarvia; (3) definir a importância que os recursos têm para as sociedades do Paleolítico Médio; e (4) estabelecer novos dados sobre a interação das comunidades com o meio ambiente (e.g., proximidade a cursos de água). O recurso aos Sistemas de Informação Geográfica (SIG) para a criação do MPA, só é possível devido ao avanço tecnológico verificado na década de 1950 e 1960, quando surgiram os primeiros conceitos e métodos na geografia quantitativa. A criação de MPA tem vindo a aumentar devido às suas potencialidades analíticas e capacidades gráficas inerentes aos SIG (Gonçalves, 2009). A metodologia adotada para a criação do MPA e seleção das variáveis dependentes (i.e., sítios arqueológicos) e independentes (e.g., litologia, altitude, declive, índice de posição topográfica, cursos de água, distância ao litoral) a incluir no modelo passou por uma abordagem estatística, descritiva e univariada. Numa primeira fase, foi coletada a cartografia da região, através das Cartas Militares de Portugal o que permitiu a criação do Modelo Digital do Terreno (MDT) e o respetivo mapeamento temático (e.g., mapas de declives, orientação de declives, radiação e exposição solar). Após a obtenção das variáveis, foram realizados testes estatísticos, como análise da variabilidade interna dos dados, com o objetivo de identificar as variáveis independentes que continham informações redundantes. Esta metodologia é justificável uma vez que pretende compreender a distribuição do povoamento durante este período, assim como prever a localização de novos sítios arqueológicos com as mesmas características.

\section{MODELOS PREDITIVOS ARQUEOLÓGICOS}

\subsection{Sistemas de Informação Geográfica}

Os SIG surgiram de forma isolada em várias empresas privadas e organismos administrativos estatais durante a década de 1970, onde o principal objetivo seria combinar diferentes dados no mesmo mapa (Nazareno, 2005). Estes podem ser descritos, genericamente, como uma ferramenta que é "aplicada direta ou indiretamente, nas mais variadas tarefas como por exemplo, modelação socioeconómica e ambiental, coordenação de projetos, padronização de dados ...” (Gonçalves, 2014, pp.107). Não obstante, o conceito mais comum encontra-se associado à produção e análise de cartografia através da tecnologia computacional, com um sistema de hardware e software que permite armazenar, manipular, recolher, guardar, pesquisar, transformar e visualizar informação georreferenciada num ambiente orientado para resolução de problemas (Cowen, 1988; Gonçalves, 2014). No sentido prático, caracteriza-se por ser um programa informático utilizado para o tratamento de dados, sendo que a informação real é discriminada através de layers (camadas informativas) de uma 
determinada área de estudo, que podem ser apresentados entre si ou isoladamente (Gonçalves, 2009).

A sua crescente utilização deve-se a fatores relacionados, em parte, com a redução do preço do hardware e software, facilidade de comunicação ao nível da visualização, gestão e evolução dos dados digitais georreferenciados, como GPS (Global Position System), e gestão geográfica do espaço (ESRI Portugal, 2020). A partir de 1990 é evidente um aumento da utilização desta ferramenta por parte dos arqueólogos, e desde então tem evoluído significativamente, principalmente em termos da informação geográfica, de análise e representação visual dos dados. Esta ferramenta multifuncional veio revolucionar a investigação arqueológica uma vez que pretende responder a questões de índole espacial, por meio da representação tridimensional do mundo onde podem ser testados padrões, hipóteses e construir Modelos Preditivos Arqueológicos (e.g., Gonçalves, 2014; Maio, 2018; Verhagen, 2018).

\subsection{Modelos Preditivos Arqueológicos}

Os MPA caracterizam-se por serem mapas que apresentam as áreas de maior e menor potencialidade arqueológico de acordo com os critérios pré-selecionados e que podem ser explicados por padrões (Project Development, 2005; Gonçalves, 2014). A construção destes modelos é realizada com recurso à análise geoestatística, através de proxys naturais (e.g., rede hidrográfica, altitude, orientação das encostas) e padrões arqueológicos. No entanto, os MPA têm sido alvo de controvérsia, tanto a nível teórico como a nível metodológico (e.g., Judge \& Sebastian, 1988; Kvamme, 1990; Kohler \& Parker, 1986; Warren \& Asch, 200o). Segundo Gonçalves (2014) as críticas podem ser agrupadas em quatro categorias:

1. Arqueológica - relacionada com o facto de muitos sítios ainda estarem por descobrir e, outros pobremente referenciados;

2. Ambiental - a paisagem atual difere da paisagem do passado, apenas utilizadas como proxis das variáveis que realmente marcaram as sociedades do passado;

3. Comportamental - a natureza do comportamento humano é muito distinta no tempo e no espaço, em que os ambientes socioculturais tornam-se impossíveis de modelar;

4. Técnicas - os dados cartográficos não têm a capacidade suficiente para representar fielmente o mundo real.
De forma a minimizar o erro, as variáveis independentes a serem usadas devem ser as que se mantiveram relativamente estáveis ao longo do tempo, como por exemplo o Índice de Posição Topográfica. A utilização de dados atuais apresenta vantagens pelo facto de o erro ser quantificável. Deve ser realçado o facto de que os modelos preditivos criam uma abordagem complementar e independente aos estudos da cultura material, na tentativa de codificar aspetos do comportamento humano, embora este não possa ser completamente reconstruído. Para criar um MPA é necessário realizar determinados passos, e, segundo vários autores este processo pode ser dividido em três fases: (1) recolha e organização dos dados; (2) desenvolvimento do modelo e testes; e (3) refinação e aperfeiçoamento (Carr, 1985; Warren, 1990).

Partindo da análise das características de implantação de um dado conjunto de sítios arqueológicos de uma mesma região, procura-se estabelecer padrões, de forma a compreender o peso que as que características ambientais tiveram no momento da escolha do sítio, sendo possível definir, de forma genérica, uma função que traduz essa relação:

$$
y=f\left(x 1, x 2, x 3, \ldots, x_{n}\right)
$$

Deste modo, $y$ representa a localização dos sítios arqueológicos e $x$ as características que condicionam a localização; consequentemente diz-se que a primeira é uma variável dependente, enquanto as últimas se denominam de variáveis independentes. Estas variáveis são essenciais no momento de avaliar os critérios que se registam numa determinada distribuição espacial, encontrando-se a sua escolha dependente das questões colocadas (Gonçalves, 2014).

\section{METODOLOGIA}

\subsection{Sítios arqueológicos e área de estudo}

Para esta análise foram selecionados um total de dez sítios arqueológicos, com níveis arqueológicos atribuíveis ao Paleolítico Médio. Estes, resultaram do projeto supracitado (com a exceção da gruta da Companheira) no âmbito da realização de trabalhos de emergência e intervenção arqueológica na região (Bicho, 2004a). O conjunto de sítios é composto por oito sítios de ar livre, nomeadamente, Praia da Galé, Curva do Belixe, Vale Santo 3, Lagoa Funda 1, Lagoa Funda 2, Lagoa Funda 3, Lagoa do Bordoal e Vale da Fonte e duas grutas, Ibn Ammar (Bicho, 2004b) e 
Companheira $^{2}$ (informação pessoal, Nuno Bicho) (Figura 1A, 1C, 1D).

$\mathrm{Na}$ sua maioria, o conjunto de sítios localiza-se no concelho de Vila do Bispo, com exceção dos sítios arqueológicos da Praia da Galé (Albufeira), gruta de Ibn Ammar (Lagoa) e gruta da Companheira (Portimão). Regra geral, os sítios de ar livre encontram-se distribuídos em áreas que apresentam uma altitude entre os $10 \mathrm{~m}$ e os $130 \mathrm{~m}$. Estes revelaram exclusivamente materiais líticos em quartzo, quartzito e sílex, sendo que apresentavam uma morfologia muito semelhante entre si (e.g., denticulados, raspadores e núcleos) (Mendonça, 2009; Bicho, 2004a, 2004b). Por sua vez, as grutas de Ibn Ammar e da Companheira localizam-se perifericamente junto das margens do rio Arade, nas arribas calcárias do Jurássico a uma altitude de c.1o $\mathrm{m}$, onde detinham uma boa visibilidade sobre o terreno adjacente assim como, um acesso facilitado ao rio. As margens do rio Arade, compostas por extensas zonas de sapal, seriam, durante o Paleolítico Médio um verdadeiro nicho ecológico. Ambas as grutas apresentaram no seu registo arqueológicos utensílios líticos atribuíveis ao Moustierense (e.g., lascas Levallois e discoide), tal como uma variedade de restos faunísticos (e.g., ossos de colho, auroque, veado) e moluscos marinhos (Bicho, 2004a, 2004b) (Tabela 1). A área de análise corresponde ao barlavento algarvio, situado no extremo sul de Portugal continental, a oeste da Península Ibérica. A zona litoral apresenta uma diversidade elevada no que diz respeito à geologia, na qual as formações vão sendo mais recentes do cabo de S. Vicente para leste (Jurássico até ao Quaternário) (Dias, 1988). A região em estudo enquadra-se na Bacia Meso-cenozoica ou Bacia Algarvia, com uma alegada extensão de $150 \mathrm{~km}$ e 30 $\mathrm{km}$ de largura, com orientação este-oeste (Moura e Boski, 1999). Atendendo às características paisagísticas e à sua diversidade a região pode ser dividida geomorfologicamente em três sub-regiões: (1) Serra (Paleozoica); (2) Barrocal (Mesozoico); e (3) Litoral (Mesocenozoico) (Figura 1B).

Por norma, os sítios arqueológicos localizam-se na zona do litoral, caracterizado por costas abruptas, lagunas recortadas, sapais, formações dunares e relevos aplanares. Esta diversidade permitiu diferenciar a zona litoral pela Costa Vicentina, litoral de arribas e

2. A gruta da Companheira foi descoberta somente em 2016 aquando da construção de uma ETAR, nas margens do rio Arade, concelho de Portimão (informação pessoal, Nuno Bicho). areal arenoso (Dias, 1988). A seleção da área de análise teve em consideração critérios relacionados com o espaço geográfico ocupado e/ou explorado pelas comunidades humanas do Paleolítico Médio, tal como critérios geológicos, geomorfológicos e hidrológicos.

\subsection{Mapeamento e análises em ambiente SIG}

A criação dos modelos implicou uma recolha aprofundada de um conjunto de dados, destacando-se, pela sua relevância, a cartografia da região do barlavento algarvio. As fontes utilizadas para a sua obtenção foram as seguintes: Direção-Geral do Território (Carta Administrativa Oficial Portuguesa, que fornece os limites administrativos de Portugal Continental), Sistema Nacional de Informação de Ambiente (Carta Litológica e Carta Batimétrica à escala 1:1 ooo ooo), Instituto Geográfico do Exército (Cartas Militares Portuguesas à escala 1:25 00o). As Cartas Militares Portuguesas forneceram a base topográfica (e.g., isolinhas, pontos de máximos e mínimos) para a criação do Modelo Digital do Terreno (MDT) (Figura 2).

Após a obtenção da cartografia procedeu-se à georreferenciação das Cartas Militares, e de seguida à vectorização de alguns dos seus elementos, nomeadamente, linha da costa, curvas de nível e cursos de água, e à edição, na tabela de atributos, dos respetivos dados (e.g., cursos de água - ordem e designação; curvas de nível - valor da altitude de cada curva).

O passo seguinte consistiu na criação do MDT, essencial para a criação de modelos preditivos, uma vez que permite representar não só as características do terreno (e.g., altimetria), como também, a criação de cartografia temática derivada (e.g., mapas de declive, orientação do declive, radiação e exposição solar, etc). Desta forma, os mapas que integram a criação do MPA foram: Altitude, Declive, Orientação do Declive e Índice de Posição Topográfica. Para se proceder à análise estatística foram selecionadas as variáveis dependentes, da qual a criação do MPA depende (conjunto de sítios arqueológicos supracitados) e as variáveis independentes, que influenciam a localização dos sítios arqueológicos (i.e., Altitude, Declive, Orientação do Declive, Índice de Posição Topográfica, Litologia, Distância ao curso de água mais próximo, Ordem de curso de água mais próximo, Distância à atual linha de costa).

3. Para esta metodologia foram utilizadas 16 Cartas Militares de Portugal à escala 1:25 ooo que abrangem os concelhos de Aljezur, Vila do Bispo, Lagoa, Portimão, Silves e Albufeira. 


\section{RESULTADOS}

\subsection{Análises estatísticas}

As análises estatísticas e exploratórias dos dados permitem estabelecer relações entre os sítios arqueológicos e os atributos de localização, tal como, possíveis padrões intra e inter sítios. Para o presente artigo recorreu-se aos testes estatísticos: Principal Component Analysis (PCA), Hierarchical Cluster Analysis (HCA), Kolmogorov-Smirnov (K-S); e Kruskal-Wallis. De forma a completar a análise recorreu-se à utilização da média, mediana, variância e desvio-padrão, em conjunto com a análise de histogramas e gráficos de frequência acumulada.

O teste PCA permite identificar padrões através da redução do número de dimensões, sem quebras na informação (Smith, 2002). Para esta análise utilizou-se, em primeira instância 8 componentes principais a partir da regra dos engeinvalues superior a 1 . Contudo, deve ser referido que o teste PCA excluiu automaticamente a variável declive, por todas as componentes apresentarem os mesmos valores. Os resultados indicaram que três componentes representam a maior parte da variabilidade dos dados, concretamente explicam $79,59 \%$ da variabilidade da amostra. A primeira componente é responsável por $33,90 \%$ e as restantes por $24,65 \%$ e $21,04 \%$, respetivamente. De forma a estabelecer-se novas relações entre as componentes foram realizadas novas correlações, no entanto os valores obtidos demonstram que o tamanho da amostra influência significativamente os resultados obtidos, não permitindo selecionar as variáveis mais significativas através deste método (Tabela 2 e Figura 3).

Numa fase seguinte foi efetuada uma análise de clusters (HCA) de modo a classificar os sítios arqueológicos em grupos homogéneos, através das similaridades observadas entre eles (Yim \& Ramdeen, 2015). A análise de clusters desenvolvida no âmbito do presente trabalho baseou-se no método de agrupamento hierárquico, através do método de aglomeração Ward e como medida de dissimilitude utilizou-se a distância euclidiana. Os resultados permitem aferir a existência de, possivelmente, três grupos principais: (1) Curva do Beliche, Praia da Galé, Vale Santo e Companheira; (2) Lagoa do Bordoal e Ibn Ammar; (3) Lagoa Funda 1, Lagoa Funda 3, Vale da Fonte, Lagoa Funda 2. $\mathrm{O}$ teste K-S permite determinar a distribuição da variável independente numa determinada amostra, a partir do cálculo da diferença entre a frequência de cada uma das observâncias (e.g., sítios arqueológicos) e a frequência acumulada que essa observação teria se a sua distribuição fosse normal (e.g., os pontos aleatórios) (Gonçalves, 2014). Os resultados da amostra indicam que as variáveis Orientação do declive (OrientDEC), Índice de Posição Topográfica (TPI) e Ordem de Linha de Água (OrdemLA) apresentam uma probabilidade igual ou superior a $5 \% \mathrm{e}$, por esta razão, foram as únicas a serem incluídas no MPA (Tabela 3).

O último teste realizado, Kruskal-Wallis, prova se a amostra em estudo provém da mesma população ou se de populações diferentes, ou se são amostras de populações com a mesma distribuição. Se o nível de significância for inferior a o,05 considera-se hipótese nula (Ho), uma vez que a distribuição da variável dependente não é aleatória em relação à variável independente, assim a dita variável independente deve ser incluída no modelo. Pelo contrário, se as variáveis apresentarem uma significância superior a 0,05 são rejeitadas, já que não influenciaram a variável dependente (Gonçalves, 2014). De acordo com o teste Kruskal-Wallis não foi possível explorar quais as variáveis a incluir no MPA uma vez que os valores obtidos para o nível de significância são todos inferiores a 0,05 (Tabela 4).

\subsection{Criação do Modelo Preditivo Arqueológico}

Importa referir que a modelação preditiva é imprecisa por defeito, e necessita de ser testada e aperfeiçoada para se obter resultados fiáveis. A criação deste MPA foi realizada num contexto de análise preliminar, sendo que o objetivo seria prever a probabilidade de encontrar novos sítios do Paleolítico Médio e verificar a eficácia deste MPA. Para a criação deste modelo foram considerados exclusivamente os resultados do teste K-S, já que os dados do teste Kruskal-Wallis foram inconclusivos. As variáveis independentes que parecem terem influenciado a localização dos sítios são a Orientação do declive (OrientDecl), o Índice de Posição Topográfica (TPI) e a Ordem do curso de água mais próximo (OrdemLA). Assim, a fórmula para criar o MPA (calculado no ArcGIS através da ferramenta Spatial Analyst Tools> Raster Calculator) é demonstrada por:

Potencial de sítios arqueológicos $=f($ OrientDecl + TPI+OrdemLA)

(Figura 4) 


\section{CONCLUSÕES}

As comunidades de Neandertais ter-se-iam adaptado ao meio ambiente envolvente e a partir do mesmo retirar proveito de todos os seus recursos, facto que pode ser comprovado pela variabilidade alimentar (e.g., animais de pequeno e grande porte, recursos marinhos) (Bicho, 2004a, 2004b) e extração de matérias-primas (e.g., Belixe Sul) próximo dos sítios de ar livre (e.g., Curva do Belixe) (Veríssimo, 2004). Através das características dos sítios arqueológicos foi possível agrupá-los em dois grupos distintos: (1) pela proximidade à linha de costa e estuários; (2) e o outro pela proximidade a lagos (Bicho, 2004a, 2004b). Importa referir que somente dois sítios, Ibn Ammar e Companheira, apresentam material arqueológico em número relevante para futuras análises, os restantes apenas facultaram conjuntos de materiais líticos.

Porém, ainda que um dos objetivos do MPA tenha sido completar esta teoria com novos dados e compreender quais as variáveis que influenciaram a localização dos sítios, de forma a estabelecer padrões de povoamento e exploração do território, tal verificou-se impossível pelo reduzido número de sítios arqueológicos e escassez de dados. Ainda assim é possível avançar com as seguintes conclusões e hipóteses:

1. O número de sítios revelou-se insuficiente para compreender quais as variáveis independentes importantes para a sua localização, como o comprova os resultados obtidos pelo teste Kruskal-Wallis que se revelaram inconclusivos;

2. Os sítios de ar livre encontram-se, na sua maioria, localizados no concelho de Vila do Bispo, enquanto as grutas ocupam, apenas o estuário do rio Arade. Teria sido preferível e de certeza mais proveitoso em termos de resultados restringir a área de estudo somente à região de Vila do Bispo e ter em consideração apenas os seis sítios aí localizados;

3. Apesar da dispersão dos sítios arqueológicos pela área de estudo é possível verificar um (suposto) padrão: as sociedades do Paleolítico Médio preferiam zonas planas, junto a afluentes de rios, incindindo na sua maioria na linha de costa, indo estes pressupostos ao encontro dos modelos teóricos estabelecidos para o Barlavento Algarvio (e.g. Bicho, 2004a; Bicho, 2005; Pereira, Haws \& Bicho, 2012).

A tentativa de criar um MPA contribuiu para se compreender que dados deverão ser tidos em consideração para realização de trabalhos futuros do mesmo género, assim como, erros a evitar.

\section{BIBLIOGRAFIA}

BICHO, Nuno Ferreira (2004a) - As comunidades humanas de caçadores-recolectores do Algarve Ocidental Perspetiva ecológica. In TAVARES, António Augusto, TAVARES, Maria José, CARDOSO, João Luís, eds. - Evolução geohistórica do litoral português e fenómenos correlativos: Geologia, História, Arqueologia e Climatologia. Lisboa: Universidade de Lisboa, pp. 359-396.

BICHO, Nuno Ferreira (2004b) - The Middle Paleolithic occupation of Southern Portugal. In CONARD, Nicholas, ed. - Settlement Dynamics of the Middle Paleolithic and Middle Stone Age II. Tübinger: Kerns Verlag, pp. 513-531.

BICHO, Nuno Ferreira (2005) - The extinction of Neanderthals and the emergence of the Upper Paleolothic in Portugal. Promontoria. Faro, 3:3, pp. 173-228.

BICHO, Nuno, CASCALHEIRA, João, MARREIROS, João (2012) - On the (L)edge: the case of Vale Boi rockshelter (Algarve, Southern Portugal)". In BERGSVIK, Knut, SKEATES, Robin, eds. - Caves in Context. Oxford: Oxbow Books, pp. 65-81.

BOCHERENS, Hervé; DRUCKER, Dorothée; MADELAI$\mathrm{NE}$, Stéphane (2014) - Evidence for a (15)N positive excursion in terrestrial foodwebs at the Middle to Upper Palaeolithic transition in southwestern France: Implications for early modern human palaeodiet and palaeoenvironment. Journal of Human Evolution. 69, pp. 31-43.

BRADTMÖLLER, Marcel, PASTOORS, Andreas, WENINGER, Bernhard; WENIGER, Gerd-Christian (2012) - The repeated replacement model e rapid climate change and population dynamics in Late Pleistocene Europe. Quaternary International. Elsevier. 247, pp. 38-49.

CARR, Christopher, ed. (1985) - For Concordance in Archaeological Analysis: Bridging Data Structure, Quantitative Technique and Theory. Kansas City: Westport Publishers.

COSTA, António (2009) - A aplicabilidade dos SIG e das imagens de satélite na identificação de áreas com potencial arqueológico: estações arqueológicas da Idade do Ferro. Porto: Faculdade de Letras da Universidade do Porto.

COWEN, David (1988) - GIS versus CAD versus DBMS: What Are the Differences?. Photogrammetric Engineering and Remote Sensing. 54:11, pp. 1551-1555.

D’ERRICO, Francesco; SÁNCHEZ GOÑI, Maria Fernanda (2003) - Neanderthal extinction and the millennia scale climatic variability of OIS 3. Quaternary Science Reviews. 22: 8-9, pp. 769-788.

DIAS, João Alveirinho (1998) - Aspetos geológicos do Litoral Algarvio. Genovas.10, 113-128. 
EBERT, James. (2000) - The state of the art in inductive predictive modeling: seven big mistakes (and lots of smaller ones). In WESTCOTT Konnie; BRANDON Joe, eds. Practical Applications of GIS for Archaeologists: A Predictive Modeling Kit. London: Taylor \& Francis, pp. 129-134.

ESRI Portugal (2020) - ArcGis for Desktop. Acedido em junho 12, 2020. In http://www.esriportugal.pt/ArcGIS-for-Desktop.

FABRE, Virginie; CONDEMI, Silvana; DEGIOANNI, Anna; HERRSCHER, Estelle (2011) - Neanderthals versus Modern Humans: Evidence for Resource Competition from Isotopic Modelling. International Journal of Evolutionary Biology. 2011, pp. 1-16. doi:10.4061/2011/689315

GONÇALVES, Célia (2009) - Modelos Preditivos em SIG na localização de sítios arqueológicos de cronologia mesolítica no Vale do Tejo. Algarve: Universidade do Algarve.

GONÇALVES, Célia (2014) - Modelos preditivos de ocupação no território no Mesolítico entre os Vales do Tejo e do Sado. Algarve: Universidade do Algarve.

JUDGE, W. James; SEBASTIAN, Lynne (1988) - Quantifying the Present and Predicting the Past: theory, method and application of archaeological predictive modelling. Denver: U.S. Department of the Interior (Bureau of Land Management Service Center).

KOHLER, Timothy; PARKER, Sandra (1986) - Predictive models for archaeological resource location. In SCHIFFER Michael, ed. - Advances in Archaeological Method and Theory. New York: Academic Press. 1: 9, pp. 397-452.

KVAMME, Kenneth (1990) - The Fundamental Principles and Practice of Predictive Archaeological Modeling. In VOORRIPS, Albertus, ed. - Mathematics and Information Science in Archaeology: A Flexible Framework. Bonn: Holos -Verlag, pp. 257-295.

MAIO, Daniela (2018) - Ocupação Paleolítica no Barlavento Algarvio: Modelos Preditivos Com Recurso aos SIG. Algarve: Universidade do Algarve.

MENDONÇA, Carolina. (2009) - A tecnologia lítica no tardiglaciar no Algarve. Algarve: Universidade do Algarve

MOURA, Delminda. e Boski, Tomasz. (1999) - Unidades litostratigráficas do Pliocénico e Plistocénico no Algarve. Comunicações do Instituto Geológico e Mineiro.86, pp. 85-106.

NAZARENO, Nilton (2005) - SIG arqueologia: aplicação em pesquisa arqueológica. Brazil: Universidade de São Paulo.

PAIXÃO, Eduardo; CANINAS, João; CARVALHO, Emanuel; FIGUEIREDO, Olívia; HENRIQUES, Fernando; MAIO, Daniela; MENDES, Cátia; NORA, David; PEREIRA, André; PEREIRA, Telmo; RAPOSO, Luís (2016) - A Jazida Moustierense de Cobrinhos, Vila Velha de Ródão (Portugal). Actas II Internacional conference of archeology of Castelo Branco region. Portugal: Castelo Branco. pp. 131-146.

PEREIRA, Telmo; BENEDETTI, Michael (2013) - A model for raw material management as a response to local and glo- bal environmental constraints. Elsevier: Quaternary International. Série XXX, pp. 1-14.

PEREIRA, Telmo; HAWS, Jonathan; BICHO, Nuno (2012) - O Paleolítico Médio no Território Português. Mainake. Série XXXIII, pp. 11-30.

PROJECT Development (2005) - The Archaeological Predictive Model: Revised Archaeological Predictive Model. Project Development 64.United States.

RAPOSO, Luís (1995) - Ambientes, territórios y subsistência en el Paleolítico Médio de Portugal. Complutum. 6, pp. 57-7.

SMITH, Lindsay (2002) - A tutorial on Principal Components Analysis. Computer Science Technical Report. Nova Zealandia: Departamento das Ciencias Computacionais da Universidade de Otago. Série OUCS-2002-12, pp. 1-26.

STRINGER, Chris (2002) - New Perspectives on the Neanderthals. Evolutionary Anthropology. Suppl 1, pp. 58-59. DOI 10.1002/evan.10057

VERHAGEN, Philip (2018) - Spatial Analysis in Archaeology: Moving into New Territories. In SIART Christoph; FORBRIGER, Markus; BUBENZER Olaf, eds. - Digital Geoarchaeology: Natural Science in Archaeology. Springer. Cham.

VERÍSSIMO, Hugo (2004) - Jazidas siliciosas da região de Vila do Bispo (Algarve). Promontoria. 2: 2, pp. 35-47.

WARREN, Robert (1990) - Predictive modeling of archaeological site location: a primer. In ALLEN, Kathleen; GREEN, Stanton; ZUBROW, Ezra, eds. - Interpreting Space: GIS and Archaeology. London: Taylor \& Francis, pp. 8o-111.

WARREN, Robert; ASHCH, David (200o) - A Predictive Model of Archaeological Site Location in the Eastern Prairie Peninsula. In WESCOTT K, BRANDON R., eds. - Practical Applications of GIS for Archaeologists: A Predictive Modeling Kit. London: Taylor \& Fisher, pp. 5-25.

WIßING, Christoph; ROUGIER, Hélène; BAUMANN, Chris; COMEYNE, Alexander; CREVECOEUR, Isabelle; DRUCKER, Dorothée; GAUDZINSKI-WINDHEUSER, Sabine; GERMONPRÉ, Mietje; GÓMEZ-OLIVENCIA, Asier; KRAUSE, Johannes; MATTHIES, Tim; NAITO, Yuichi; POSTH, Cosimo ; SEMAL, Patrick; STREET, Martin; BOCHERENS Hervé (2019) - Stable isotopes reveal patterns of diet and mobility in the last Neandertals and first modern humans in Europe. Scientific Reports. 9: 4433, pp. 2-12. https://doi.org/10.1038/s41598-019-41033-3

YIM, Odilia; RAMDEEN, Kylee (2015) - Hierarchical Cluster Analysis: Comparison of Three Linkage Measures and Application to Psychological Data. The Quantitative Methods for Psychology. 11:1, pp. 8-21.

ZILHÃO, João (2014) - The Neanderthals: Evolution, Palaeoecology, and Extinction. In CUMMINGS, Vicki; JORDAN, Peter; ZVELEBIL, Marek, eds. - The Oxford Handbook of the Archaeology and Anthropology of Hunter-Gatherers. Oxford: Oxford University Press, pp. 191-213. 

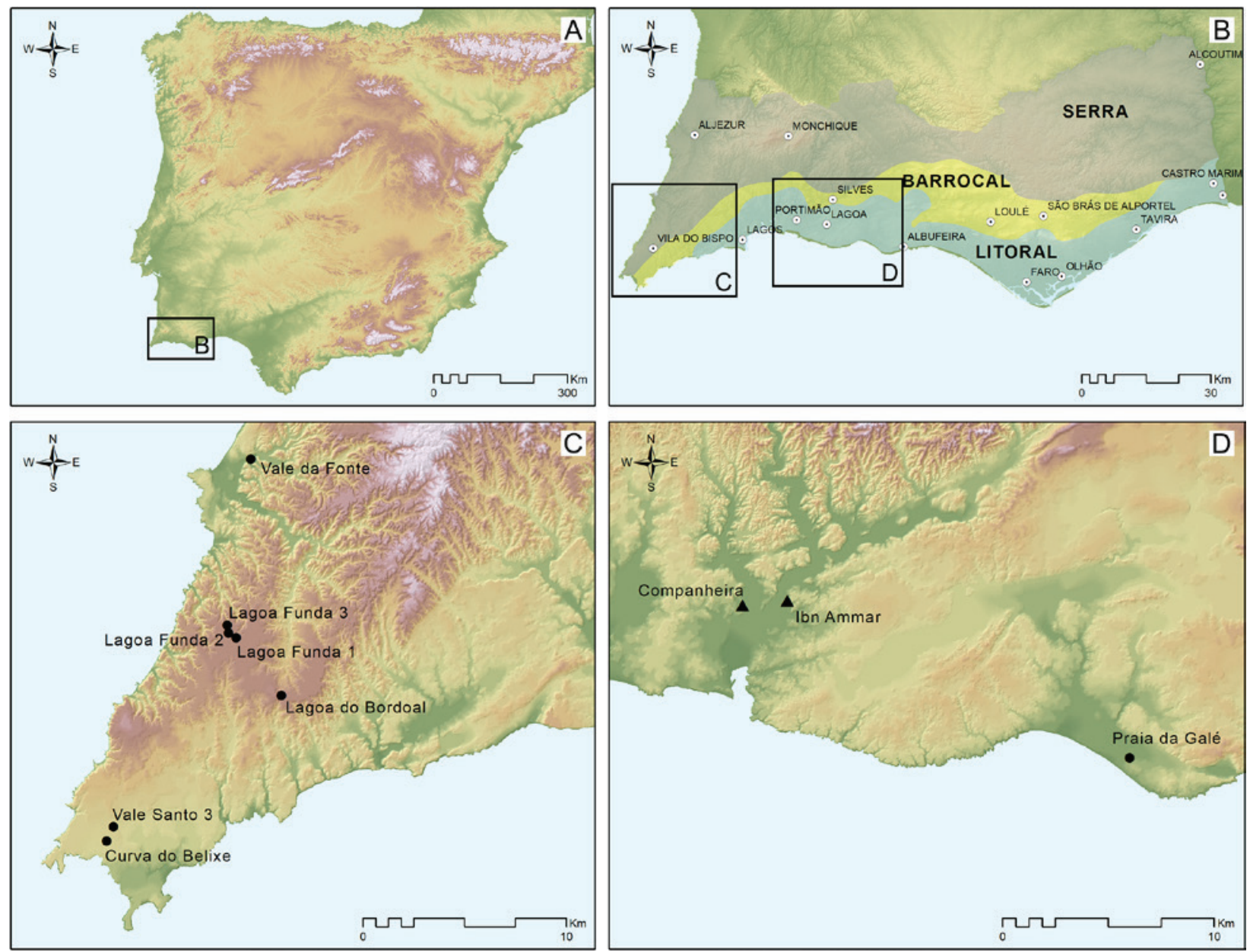

Figura 1 - Mapa da localização dos sítios arqueológicos do Paleolítico Médio no Barlavento algarvio. Legenda das Figura C e D: círculo - sítio de ar livre; triângulo - gruta.

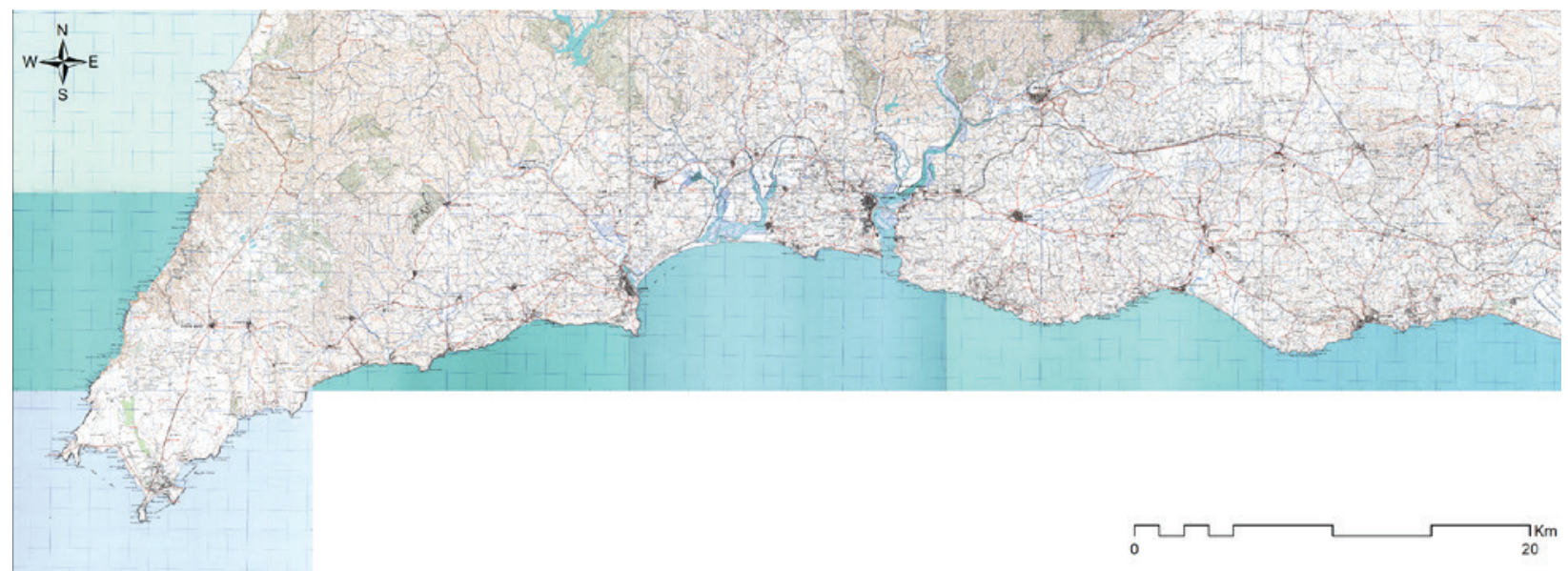

Figura 2 - Mapa das Cartas Militares Portuguesas (folhas no 583a, 584,585, 586,587, 592, 593, 594, 595, 596, 601, 602, 603, 6o, 605 e 6o9) da área de estudo (Barlavento algarvio). 


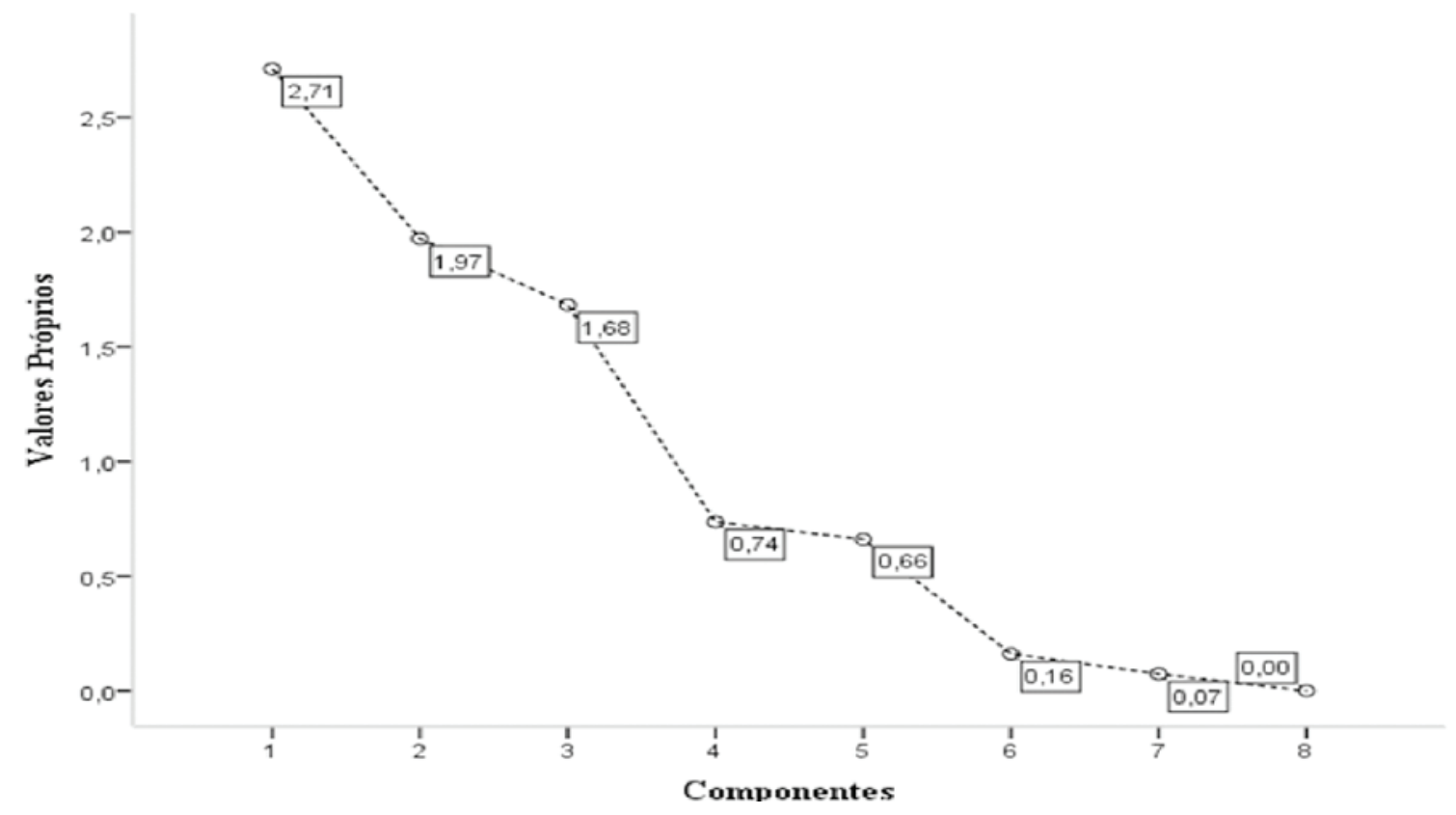

Figura 3-Gráfico scree plot dos engeinvalues e os valores decrescentes da variância explicada do teste PCA sobre as variáveis independentes, da área de estudo.

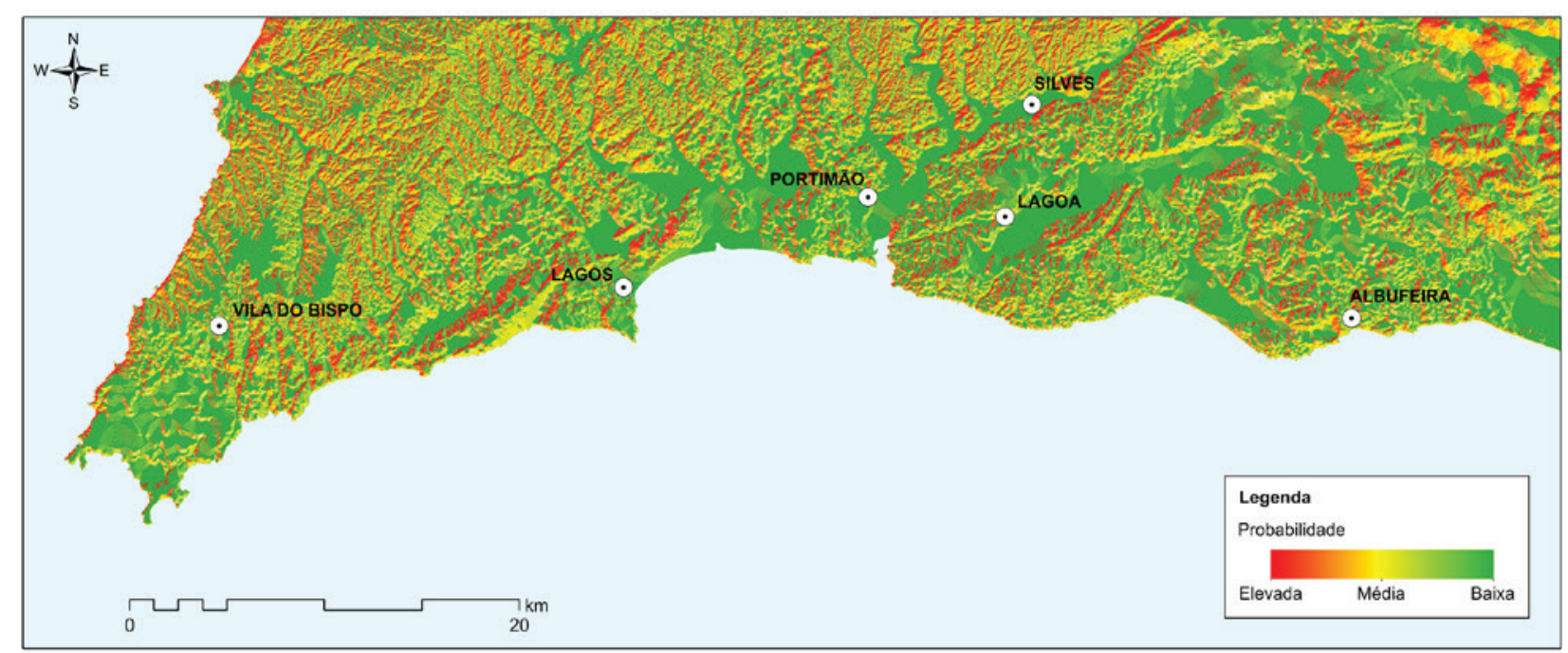

Figura 4 - Mapa de probabilidade de existência de sítios arqueológicos do Paleolítico Médio, na área de estudo, segundo os resultados do teste K-S. 


\begin{tabular}{|c|c|c|c|c|c|c|c|c|c|}
\hline $\begin{array}{c}\text { Sítio } \\
\text { arqueológico }\end{array}$ & $\begin{array}{l}\text { Altitude } \\
\text { (m) }\end{array}$ & $\begin{array}{l}\text { DistLA } \\
(\mathrm{m})\end{array}$ & OrdemLA & NomeLA & $\begin{array}{l}\text { DistLC } \\
(\mathrm{m})\end{array}$ & Declive $^{1}$ & OrientDEC & $\mathrm{TPI}^{2}$ & Litologia $^{3}$ \\
\hline Praia da Galé & 10 & 900 & 4 & $\begin{array}{c}\text { Braço do } \\
\text { Vale } \\
\text { da Vila }\end{array}$ & 670 & 1 & -1 & 3 & 7 \\
\hline Curva do Belixe & 54 & 876 & 3 & - & 770 & 1 & -1 & 3 & 6 \\
\hline Vale Santo 3 & 60 & 310 & 3 & - & 1500 & 1 & -1 & 3 & 9 \\
\hline Lagoa Funda 1 & 130 & 981 & 4 & $\begin{array}{c}\text { Ribeiro } \\
\text { do Baralho }\end{array}$ & 2762 & 1 & -1 & 3 & 7 \\
\hline Lagoa Funda 2 & 130 & 1356 & 3 & - & 3236 & 1 & -1 & 3 & 7 \\
\hline Lagoa Funda 3 & 120 & 628 & 3 & - & 2558 & 1 & -1 & 3 & 4 \\
\hline Lagoa do Bordoal & 130 & 1068 & 3 & - & 4379 & 1 & -1 & 3 & 6 \\
\hline Vale da Fonte & 20 & 47 & 3 & - & 2649 & 1 & -1 & 3 & 11 \\
\hline Ibn Ammar & 10 & 350 & 5 & Rio Arade & 5014 & 1 & -1 & 3 & 2 \\
\hline Companheira & 10 & 28 & 3 & Rio Arade & 1215 & 1 & 135 & 4 & 7 \\
\hline
\end{tabular}

Tabela 1 - Atributos dos sítios arqueológicos do Paleolítico Médio. Legenda: Declive: 1 - Muito suave a plano, 2 - Suave, 3 Acentuado, 4-Muito acentuado. TPI: 1 - Vales, 2 - Vertente curta, 3-Planicie, 4-Vertente Média, 5-Vertente longa, 6 - Crista. Litologia: 1 - aluviões; 2 - xistos argilosos, grauvaques; 3 - doleritos; 4 - grés vermelhos (de silves), conglomerados, margas; 5 - arenitos, conglomerados, calcários margosos; 6 - calcários, calcários dolmíticos, calcários margosos; 7 - areias, calhaus rolados, arenitos pouco consolidados; 8 - conglomerados, arenitos, calcários; 9 - areias e cascalheiras; 10 - arenitos, calcários mais ou menos consolidados; 11 - estuários (margens dos rios); 12 - dunas e areias eólicas; 13 - basaltos.

\begin{tabular}{lccc} 
& & & \\
\cline { 2 - 4 } & $\mathbf{1}$ & \multicolumn{1}{c}{ COMPONENTE } & \\
\cline { 2 - 4 } Altitude & $-0,76$ & 0,404 & $-0,118$ \\
\hline Declive & 0.00 & 0.00 & 0.00 \\
\hline OrientDEC & $-0,442$ & $-0,053$ & $-0,008$ \\
\hline TPI & $-0,063$ & $-0,316$ & $-0,081$ \\
\hline Litologia & 0,169 & 0,050 & $-0,405$ \\
\hline DistLA & 0,103 & 0,441 & $-0,035$ \\
\hline OrdemLA & 0,109 & $-0,104$ & 0,478 \\
\hline DistLC & 0,032 & 0,118 & 0,336 \\
\hline
\end{tabular}

Tabela 2 - Tabela do teste PCA. Análise das componentes principais e o peso de cada variável independente nas três componentes principais, sobre a área de estudo. 


\begin{tabular}{lccc}
\cline { 2 - 4 } & DMAX & NÍVEL DE SIGNIFICÂNCIA & PROBABILIDADE \\
\hline Altitude & 0,257 & 0,00 & $0 \%$ \\
\hline Declive & 0,000 & 0,00 & $0 \%$ \\
\hline OrientDEC & 0,524 & 0,05 & $5 \%$ \\
\hline TPI & 0,524 & 0,05 & $5 \%$ \\
\hline Litologia & 0,235 & 0,00 & $0 \%$ \\
\hline DistLA & 0,187 & 0,00 & $0 \%$ \\
\hline OrdemLA & 0,416 & 0,10 & $0 \%$ \\
\hline DistLC & 0,146 & 0,00 & $0 \%$ \\
\hline
\end{tabular}

Tabela 3 - Tabela do teste Kolmogorov-Smirnov. Resultados do teste Kolmogorov-Smirnov sobre as variáveis independentes referentes aos sítios do Paleolítico Médio, na área do barlavento algarvio. Sendo que, Dmax> 0,405 o nível de significância é <0,1 (menos de 10\% de probabilidade da diferença ser insignificante; Dmax > 0,451 o nível de significância é <0,05 (menos de 5\% de probabilidade da diferença ser insignificante); Dmax> 0,540 o nível de significância é <0,o1 (menos de 1\% de probabilidade da diferença ser insignificante).

\begin{tabular}{lcc}
\cline { 2 - 3 } & QUI-QUADRADO & NÍVEL DE SIGNIFICÂNCIA \\
\hline Altitude & 8,220 & 0,314 \\
\hline OrientDEC & 4,000 & 0,406 \\
\hline Litologia & 2,129 & 0,546 \\
\hline Declive & 0,000 & 1,000 \\
\hline TPI & 4,000 & 0,261 \\
\hline distLA & 9,000 & 0,437 \\
\hline OrdemLA & 2,250 & 0,325 \\
\hline DistLC & 2,000 & 0,368 \\
\hline
\end{tabular}

Tabela 4 - Tabela do teste Kruskal-Wallis. Resultados do teste Kruskal-Wallis para seleção das variáveis independentes, na área do barlavento algarvio. 


\title{
A UTILIZAÇÃO DE QUARTZO DURANTE O PALEOLITICO SUPERIOR NO TERRITÓRIO DOS VALES DOS RIOS VOUGA E CÔA
}

\author{
Cristina Gameiro $^{1}$, Thierry Aubry ${ }^{1,4}$, Bárbara Costa $^{2}$, Sérgio Gomes ${ }^{3}$, Luís Luís ${ }^{1,4}$, Carmen Manzano ${ }^{2}$, \\ André Tomás Santos ${ }^{1,4}$
}

\begin{abstract}
RESUMO
Tradicionalmente o quartzo tem sido apresentado como uma matéria-prima de menor aptidão ao talhe. Porém, o facto de estar disponível, em regiões onde não existe sílex ou silcreto, conduziu à sua frequente exploração, por parte das comunidades humanas que habitaram o território português, durante o Paleolítico. Neste trabalho, apresentamos comparativamente os dados relativos à utilização do quartzo nos sítios do Vale do Côa (Fariseu e Cardina) e do Vale do Vouga (Vau e Rôdo) durante o Gravettense, Magdalenense e Azilense. $\mathrm{O}$ volume de dados sobre as duas áreas em comparação é desigual e dispomos de poucos elementos sobre a tradição técnica e a funcionalidade dos sítios do Vouga. Apesar destas limitações, dispomos já de elementos suficientes para comparar e identificar, nestes sítios arqueológicos situados em distintas regiões, o mesmo esquema conceptual inerente às cadeias operatórias aplicadas aos diferentes tipos de quartzo.

Palavras-chave: Tecnologia lítica, Quartzo, Paleolítico Superior, Vale do Côa, Vale do Vouga.
\end{abstract}

\begin{abstract}
Quartz has traditionally been regarded as a raw material of poor knapping quality. Indeed, the structure of this mineral determines the presence of cleavage planes which generate fractures and influence débitage. The fact that it is naturally available in regions where there is no flint or silcrete, however, resulted in its frequent exploitation by the Palaeolithic human communities that inhabited the Portuguese territory. The present research focuses on comparative data on the use of quartz in the Côa Valley (Fariseu and Cardina) and the Vouga Valley (Vau and Rôdo) sites during the Gravettian, Magdalenian and Azilian. The volume of data on the two areas being compared is uneven and we have little information on the technical tradition and functionality of the Vouga sites. There is, however, enough information to compare and identify, in these archaeological sites located in two different regions, the same conceptual scheme inherent to the chaîne opératoire applied to the different types of quartz.
\end{abstract}

Keywords: Lithic technology, Quartz, Upper Paleolithic, Côa Valley, Vouga Valley.

\section{INTRODUÇÃO}

Tradicionalmente o quartzo tem sido apresentado como uma matéria-prima de menor aptidão ao talhe. Com efeito, a estrutura deste mineral pressupõe a existência de planos de clivagem que originam fraturas e podem condicionar a debitagem (Lombe- ra Hermida, 2008). Porém, o facto de estar disponível, em regiões onde não existe sílex ou silcreto, conduziu à sua frequente exploração, por parte das comunidades humanas que habitaram o território português, durante o Paleolítico. A título de exemplo excecional, refira-se a escolha preferencial desta matéria-prima durante o proto-solutrense da Estre-

\footnotetext{
1. UNIARQ - Centro de Arqueologia da Universidade de Lisboa. Faculdade de Letras de Lisboa. Universidade de Lisboa.

2. Arqueologia e Património Lda.

3. CEAACP - Universidade de Coimbra.

4. Fundação Côa Parque.
} 
madura para a produção de lamelas de dorso marginal. Durante este período, sítios em Rio Maior, situados a menos de $5 \mathrm{~km}$ de fontes de sílex de boa qualidade, apresentam percentagens de quartzo variando entre $22 \%$ e $43 \%$ (Zilhão, Aubry \& Almeida, 1997; Almeida, 2000). É também de salientar que, durante o Paleolítico Superior, em sítios localizados no maciço Hercínico (Bacia do Guadiana, do Vale do Sabor e do Vale do Côa), diferentes variedades de quartzo correspondem ao conjunto da matéria-prima mais utilizada (Aubry, 2009; Almeida, 2013; Gaspar \& alii, 2016; Gameiro \& alii, 2020b). Nos sítios localizados nas Bacias Lusitanianas (Estremadura e Algarve), apesar da disponibilidade do sílex, o quartzo (a par com o quartzito) está sempre presente nas coleções líticas do Paleolítico Superior e, por exemplo, durante o Magdalenense Superior, na Lapa dos Coelhos, a percentagem de quartzo atinge cerca de 36\% (Zilhão, 1997; Gameiro, Aubry \& Almeida, 2013; Bicho $\mathbb{\&}$ alii, 2010). Considerando a recorrência da exploração do quartzo em diferentes regiões, o seu estudo adquire uma especial relevância, viabilizando uma comparação inter-regional que permite alargar a compreensão da variabilidade cultural das comunidades do Paleolítico Superior.

No âmbito deste artigo apresentaremos, comparativamente, os dados relativos à utilização do quartzo nos sítios do Vale do Côa (Fariseu e Cardina) e do Vale do Vouga (Vau e Rôdo). Após uma breve descrição dos contextos de proveniência e dos métodos utilizados exporemos os resultados, articulando os elementos relativos ao aprovisionamento dos vários tipos de quartzo com dados referentes à tecnologia da exploração dos volumes e às modalidades de produção de suportes, com o objectivo de identificar diferenças e semelhanças na utilização dos esquemas conceptuais ao longo do Paleolítico Superior nestas duas regiões do centro de Portugal.

\section{APRESENTAÇÃO DOS CONTEXTOS}

O trabalho de longa duração desenvolvido deste a identificação, em 1995, do primeiro sítio de habitat coevo da realização das gravuras paleolíticas do Vale do Côa, permitiu a identificação de mais de 15 sítios (Figura 1) possibilitando a acumulação de dados sobre o povoamento humano da região e sobre o aprovisionamento de matérias-primas, a produção e a utilização dos artefactos líticos (Aubry, 2009). A aplicação de métodos geoarqueológicos, estabe- lecendo a correlação estratigráfica entre sequências sedimentares (Aubry $\&$ alii, 2010), resultou numa sequência crono-cultural para o Paleolítico Superior regional que tem sido paulatinamente afinada com a obtenção de dados radiométricos (Aubry $\mathbb{8}$ alii, 2020). A identificação das fontes de aprovisionamento das matérias-primas tem sido uma linha de investigação com investimento efetuado não só para o sílex e silcreto alóctones (Aubry \& Mangado Llach, 2006; Aubry, Mangado Llach \& Sampaio, 2009; Aubry, Mangado Llach \& Matias, 2014; Aubry $\&$ alii, 2012, 2016b) mas também com prospeções para matérias-primas locais, permitindo identificar filões hidrotermais e relacionar tipos distintos de quartzo com áreas de aprovisionamento (Aubry $\mathscr{\&}$ alii, 2016a). No âmbito deste artigo, retomamos os dados já publicados (Aubry $\mathbb{Z}$ alii, 2016a) sobre as ocupações do Gravettense, Magdalenense e Azilense dos sítios arqueológicos do Vale do Côa (Olga Grande 4, Olga Grande 14, Cardina, Ínsula II, Quinta da Barca Sul, Fariseu e Olga Grande 6) e completamos informação inédita proveniente dos materiais líticos recuperados na Área Z/A'-6-8 da Cardina. A escavação desta área ocorreu entre 2014 e 2018, tendo-se procedido à publicação da informação relativa à sua implantação e estratigrafia (Aubry \& alii, 2019). Serão efetuadas observações sobre os materiais provenientes dos 12 Níveis Artificiais (NA) da $\mathrm{UE}_{4}$ e dos primeiros 5 NA da UE5. Os primeiros níveis preservaram uma ocupação com estruturas do início do Holocénico (Greenlandian); um fragmento de folha de loureiro (UE4/NA6) e de lamelas de dorso (UE4/NA6 e NA7) permitem, respetivamente, documentar, respectivamente, ocupações do Solutrense médio e do Gravettense final. Uma vez que foram recuperadas lamelas retocadas até ao $\mathrm{NA}_{5} \mathrm{da}$ UE5, está ainda por caracterizar uma ocupação do Paleolítico Superior inicial. O NA1o da UE5 apresenta materiais consentâneos com uma ocupação do Paleolítico Médio (Aubry \& alii, 2019).

Em 2014, no âmbito dos trabalhos arqueológicos desenvolvidos a propósito do impacte patrimonial do Aproveitamento Hidroelétrico de Ribeiradio-Ermida foram identificados e escavados os primeiros sítios (Figura 2) do Vale do Vouga com ocupações do Paleolítico Superior: Rôdo, Vau e Bispeira 8 (Gameiro, \& alii, 2018; Gameiro, \& alii, 2020; Manzano, $\&$ alii, 2020). O estudo dos materiais está em curso, mas os elementos de diagnóstico da indústria lítica, juntamente com as datações de radiocarbono, per- 
mitiram confirmar ocupações humanas no Vau durante o Gravettense médio e talvez durante o Magdalenense final e, no Rôdo e na Bispeira 8, a análise destes elementos, remete para o Magdalenense final e/ou Azilense. O conjunto artefactual pleistocénico recolhido no sítio da Bispeira 8 é reduzido e os elementos em quartzo perfazem um total de três peças (um núcleo e duas lascas), razão pela qual não foi tido em conta nesta análise. Serão apenas considerados os materiais relativos à UEoo5 do Vau e às UEoo3 e UEoo6 do Rôdo. A realização de remontagens líticas entre a UEoo3 e a UEoo5 do Vau confirmou a existência de alterações pós-deposicionais que afetaram estes pacotes sedimentares (Manzano, $\mathbb{\&}$ alii, 2020). Alguns materiais recuperados na UEoo3 podem ser de cronologia pleistocénica e sempre que considerado pertinente serão mencionados.

\section{METODOLOGIA}

Durante o Paleolítico Superior, em regiões desprovidas de sílex, o quartzo constitui a principal fonte de matéria-prima siliciosa. Está disponível, em posição primária ou sub-primária, filões e bandas de quartzo, presentes em granitos e rochas metamórficas, podendo ser utilizado sob a forma de fragmento anguloso ou de cristal (euédrico). Em posição secundária, pode ser encontrado nas formações detríticas continentais, em depósitos fluviais recentes ou em depósitos aluviais antigos. Neste caso, e, tal como os quartzitos, pode ser explorado sob a forma de seixo rolado (Aubry, Mangado Llach \& Matias, 2014; Aubry \& alii, 2016).

O primeiro nível de análise de uma abordagem tecnológica, centrada no conceito de cadeira operatória, é o estudo relativo ao aprovisionamento das matérias-primas. O principal objetivo deste tipo de abordagem é identificar matérias-primas locais, regionais e extra-regionais (Aubry, 2009; Aubry $\&$ alii, 2012, 2016a).

O método desenvolvido no Vale do Côa, para identificação de fontes de aprovisionamento local de quartzo, usa a descrição sistemática e a comparação de amostras geológicas e arqueológicas. A distinção de tipos de quartzo e de fontes disponíveis baseia-se, por enquanto, numa observação macroscópica, mas estão em curso, análises petrográficas e geoquímicas. Para os sítios do Vale do Vouga os tipos de quartzo definidos englobam categorias mais genéricas e, apesar de já terem sido empreendidas algumas prospeções para identificar fontes de matérias-primas, existem, ainda, dúvidas quanto à disponibilidade local de quartzo euédrico.

$\mathrm{Na}$ Figura 3 são apresentados os tipos de quartzo, uma descrição abreviada e os códigos utilizados na análise dos materiais do Vale do Côa, sendo os mesmos tipos referidos no mapa da Figura 1. Para efeitos comparativos entre as duas regiões e por forma a conseguir uma análise diacrónica optámos por aglutinar todos os tipos numa categoria genérica de quartzo.

\section{RESULTADOS}

\subsection{Vale do Côa}

\subsubsection{Cardina}

A Área Z/A'-6-8 da Cardina, cuja escavação decorreu entre 2014 e 2018, permitiu a recolha de 20435 peças líticas. Ao longo da UE4 e dos primeiros quatro níveis artificiais da $\mathrm{UE}_{5}$, a maioria dos materiais líticos é em quartzo e a percentagem desta matériaprima oscila entre os $71 \%$ e os $87 \%$. A percentagem de utilização de sílex, silcreto de silicificações hidrotermais disponíveis regionalmente, varia ao longo da sequência, diminuindo a partir do final do Magdalenense/Azilense, tal como foi já reconhecido noutras áreas deste sítio arqueológico (Aubry \& alii, 2016b). Foram identificados 184 utensílios retocados e, com exceção do nível 11 da UE4, a maioria (65\%) são produzidos em quartzo. $O$ tipo de quartzo mais utilizado é o J9, sendo nesta matéria-prima que foram fabricados a maioria dos utensílios (53) e grande parte dos núcleos (52). No entanto, tendo em conta a fraca aptidão para o talhe, explicável pela existência de clivagens, muitos volumes foram testados e abandonados (26). Ao longo de toda a sequência, a maioria dos utensílios retocados é produzido sobre lasca e são numerosas as peças atípicas, lascas retocadas, entalhes, denticulados e raspadores. As peças esquiroladas são mais frequentes até ao NA6. As raspadeiras em quartzo (6) apenas foram recolhidas no NA5, NA6, NA7, NA9 e NA1o da UE4 e apenas um buril em quartzo foi identificado no NA1o da UE4. Em relação a estratégias de produção de suportes até ao NA9 da UE4 são mais numerosos os núcleos sobre lasca e os de tipo prismático. A estratégia de produção de pequenas lascas ou esquírolas através de debitagem bipolar sobre bigorna acompanha a totalidade da sequência (Figura 4 e Figura $6 n^{\circ}$ 3). No no 2 da Figura 6 podemos observar a utilização 
da aresta de um fragmento anguloso para uma exploração frontal. Um cristal de rocha, com o plano de percussão preparado, foi recolhido no $\mathrm{NA}_{3}$ da $\mathrm{UE}_{4}$ (Figura $6 \mathrm{n}^{\circ} 4$ ).

\subsubsection{Fariseu}

O conjunto lítico recolhido na UE4 do Fariseu, ao longo de três campanhas de escavação (1999, 2005 e 2007), totaliza 6142 peças (Aubry, 2009; Gameiro, 2009, 2012). O quartzo constituí $85 \%$ das matérias-primas utilizadas, revelando uma estratégia de aprovisionamento maioritariamente local, uma vez que apenas $1,4 \%$ das matérias-primas utilizadas são sílex alóctone ou silicificações disponíveis regionalmente. A debitagem é orientada para a obtenção de lascas e lamelas e apenas três lâminas de quartzo foram identificadas de entre os utensílios retocados. A maioria dos utensílios retocados é produzido sobre lasca $(67,5 \%)$ mas a utensilagem lamelar constituí $17 \%$ do total. Este último grupo é composto por lamelas e também por pequenas lascas ou esquírolas retocadas. Cerca de $60 \%$ dos utensílios retocados são fabricados sobre quartzo e $19 \%$ sobre quartzo hialino, confirmando a tendência de utilização maioritária desta matéria-prima local. A utensilagem retocada (114 exemplares) engloba um número considerável de peças de retoque irregular e atípico (43), peças esquiroladas (22), entalhes (15), raspadeiras (8) e denticulados (5). Os utensílios sobre lasca foram produzidos sem preferência por nenhum tipo de quartzo. A única diferença observada é relativa ao tamanho: os utensílios em quartzo J9 apresentam dimensões superiores. A debitagem a partir de seixos de maior dimensão terá sido, possivelmente, efetuada mais perto do local de recolha da matéria-prima, neste caso, mais perto do leito do rio, uma vez que as lascas de grande dimensão terão sido produzidas a partir de núcleos com dimensões, à partida, superiores aos recuperados na área escavada. A utensilagem lamelar foi fabricada quase exclusivamente em quartzo hialino. A análise dos núcleos em quartzo permitiu identificar nove exemplares testados e abandonados (J9); 49 núcleos para produção exclusiva de lascas (sobretudo em J9); sete núcleos lamelares e 17 núcleos para produção de pequenas lascas ou lamelas (Figura 5). Em relação à produção de lascas e ao tipo de volume inicial do quartzo tipo J9, a maioria dos casos, corresponde a um seixo (documentado pela presença de córtex em 32 exemplares); a par dos seixos, foram também explorados alguns fragmentos de quartzo filoniano (8). Em relação ao quartzo tipo Jio, quatro exemplares correspondem a seixos e dois a fragmentos de filão. A maioria dos volumes foi explorado através da criação de uma aresta pela remoção de dois grandes levantamentos criando uma convergência que simultaneamente configura os flancos. Quando a forma natural era favorável, a opção terá sido aproveitar o redondo cortical ou um diedro natural para iniciar a debitagem. Este reduzido investimento na preparação revela-se na existência de um número considerável de plataformas corticais ou lisas. A maioria dos núcleos é unipolar (30) e apresenta uma única zona de debitagem mas, em treze casos foi instalada uma segunda zona de debitagem, observando-se que, em termos de hierarquia, os planos de percussão são sucessivos opostos ou cruzados. Em relação à progressão da debitagem (Pigeot, 1987; Valentin, 1995) na maioria dos volumes foi semi-giratória contínua ou facial. A debitagem de suportes microlíticos (lamelas e pequenas lascas) foi levada a cabo recorrendo ao quartzo de melhor aptidão para o talhe: tipo J1o, tipo J12 e quartzo hialino (J8 e J13). No caso dos dois primeiros tipos de quartzo, a maioria dos volumes iniciais utilizados terá correspondido a blocos angulosos ou a lascas. O diedro natural ou a aresta da lasca terão sido utilizados para iniciada a debitagem. A reduzida dimensão dos volumes não autoriza preparação ou manutenção dos mesmos e a progressão da debitagem é sobretudo frontal, ou seja, utilizada apenas a parte mais estreita dos volumes (Pigeot, 1987; Valentin, 1995). Um dos núcleos utilizado para produzir lamelas apresenta uma morfologia piramidal, resultante de uma progressão da debitagem semi-giratória contínua paralela, com facetagem do plano de percussão. Um outro utiliza uma aresta de lasca para iniciar a debitagem, tendo a exploração sido feita perpendicularmente ao seu eixo, tipo raspadeira carenada (Newcomer \& Hivernel-GuerreI, 1974; Zilhão, 1997; Aubry \&alii, 1998; Gameiro, Aubry \& Almeida, 2013). A exploração bipolar sobre bigorna, por vezes, constitui uma reciclagem de um bloco cujas dimensões não permitem a continuação de outro tipo de estratégia de talhe. Os quatro núcleos lamelares em quartzo hialino (J8 e J13) têm um cristal como volume inicial. Neste caso as faces naturais do cristal são utilizadas para guiar a debitagem. A identificação de um cristal, que acabaria por não ser explorado, com os planos de percussão opostos preparados por micro- 
-facetagem e um ângulo de $45^{\circ}$ sugere-nos que tal seria a única preparação destes núcleos (Figura 6 $\mathrm{n}^{\circ}$ 5). É possível que alguns destes cristais tenham sido debitados apoiados sobre uma bigorna, já que as suas reduzidas dimensões tornam difícil o talhe «à mão livre». Contudo, tal operação seria igualmente possível com recurso a um percutor brando. O talhe experimental efetuado para tentar reproduzir este esquema mostrou que é muito difícil obter suportes regulares e de dimensões estandardizadas recorrendo à percussão bipolar sobre bigorna (Klaric, 2009). As 22 peças esquiroladas incluídas no grupo dos utensílios são peças menos espessas, sem negativos de levantamentos lamelares, mas podem ter sido utilizadas igualmente como peça intermédia e como núcleo (Figura 6 no 7 e 8). A maioria, cerca de catorze peças, pode ser incluída no módulo retangular ou módulo $\mathrm{C}$ de F. Le Brun-Ricalens (2006): dez com dois bordos esquirolados opostos; duas, com quatro bordos esquirolados, revelando um basculamento da direção da percussão.

\subsection{Vale do Vouga}

\subsubsection{Vau}

No conjunto lítico recuperado na UEoo5 do Vau, a maioria das peças (51\%) foi produzida utilizando sílex e silcretos. O quartzo, sob a forma de seixo rolado, de fragmentos provenientes de filão ou sob a forma de cristais está representado por $46 \%$ dos artefactos. Outras rochas de grão grosseiro e o quartzito representam, respetivamente, $2 \%$ e $1 \%$ do total do conjunto. Em quartzo está documentada a produção de lascas, de lamelas e, provavelmente, de pequenas esquírolas (Figura $8 \mathrm{n}^{\circ}$ ). Em geral, os seixos de quartzo foram utilizados para a produção de lascas e apenas um foi utilizado para a obtenção de lamelas. Relativamente ao quartzo filoniano, foi maioritariamente utilizado para produzir lascas $(65 \%$ dos núcleos), mas está igualmente presente a produção de lamelas e de esquírolas. A produção de lascas pode ser classificada como expedita, uma vez que a maioria dos núcleos são considerados "Indeterminável» quanto ao tipo de estratégia (Figura 7). Os planos de percussão são maioritariamente corticais ou constituídos por planos de clivagem próprios desta matéria-prima. A utilização da modalidade sobre bigorna foi igualmente identificada graças à existência de lascas com uma ondulação e indícios tecnológicos, característicos, da utilização deste tipo de estratégia.
As lascas de quartzo foram transformadas em raspadeira, em utensílios do fundo comum ou utilizadas como volume inicial para a produção de lamelas (núcleos tipo raspadeira carenada) (Figura $8 \mathrm{n}^{\circ}$ 1, 2 e 4). Apesar da produção lamelar em quartzo estar atestada pela presença de um número muito significativo de núcleos com negativos de levantamentos lamelares, apenas foram identificadas 15 lamelas inteiras e nenhuma delas foi utilizada como suporte para a realização de um utensílio retocado. A análise da indústria em quartzo hialino permitiu documentar a produção de lascas, sendo de destacar que pequenos cristais foram utilizados para debitar lamelas. Nestes casos apenas os planos de percussão são preparados (conferindo-lhe uma inclinação de $45^{\circ}$ ) e as arestas do cristal são utilizadas para guiar os levantamentos lamelares (Figura 8 no 5 e 6). A debitagem bipolar sobre bigorna ou de "tipo peça esquirolada» foi igualmente utilizada no quartzo hialino.

\subsubsection{Rôdo}

$\mathrm{Na}$ UEoo3 do Rôdo, o quartzo é a matéria-prima mais explorada ( $74 \%$ do total), no entanto, apenas $21 \%$ dos utensílios foram produzidos nesta matéria-prima: raspadeiras, raspadores e lascas com retoque atípico são os tipos mais comuns. A maioria do quartzo explorado é proveniente de fragmentos de filão e os diedros naturais são, frequentemente, utilizadas para iniciar a debitagem. Esta opção técnica não obriga a uma preparação dos núcleos. De salientar que alguns volumes parecem ter sido apenas testados e abandonados, provavelmente devido à fraca aptidão para o talhe da matéria-prima: diáclases que originam, frequentemente, ressaltos. Para além de uma produção intencional de lascas existiu, igualmente, uma produção de suportes lamelares. As estratégias de produção lamelar identificadas são: debitagem bipolar sobre bigorna (Figura ํㅡ 8, 9 e 12); a debitagem sobre aresta de lasca e um núcleo piramidal, que revela uma exploração giratória de toda a superfície do volume (Figura $8 \mathrm{n}^{\circ}{ }^{11}$ ). A utilização da modalidade sobre bigorna pode indicar, igualmente, uma intenção de produzir pequenas lascas (Figura 8 no 10 ). Para o quartzo hialino foram utilizadas estratégias de debitagem mais elaboradas. As lascas ocorrem em número superior, verificando-se um comprimento médio de $1,5 \mathrm{~cm}$, que documenta a produção intencional de pequenas lascas/ esquírolas sobretudo recorrendo à debitagem bipolar sobre bigorna. De um total de 72 lamelas iden- 
tificadas, apenas 20 estão completas e, apenas um exemplar foi alvo de retoque. No que diz respeito a utensílios, regista-se a presença de lascas retocadas, raspadores, raspadeiras e uma lamela com retoque marginal. Na UEoo6, com exceção de alguns macro-utensílios, a utensilagem em quartzo é efetuada sobre lasca: dominam os utensílios de fundo comum (raspadores e entalhes), as raspadeiras (Figura $8 \mathrm{n}^{\circ}$ 8) e as lascas ou fragmentos com retoque irregular. Alguns núcleos foram utilizados para a produção de pequenas lascas, sobretudo utilizando a debitagem bipolar sobre bigorna (Figura $8 \mathrm{n}^{\circ}$ 7). A debitagem de suportes lamelares está documentada mas apenas dois exemplares estão retocados: uma lamela de dorso e uma lamela retocada. O quartzo hialino foi maioritariamente utilizado para a debitagem de suportes lamelares. Foram recuperadas 78 lamelas; no entanto, apenas 17 peças estão inteiras. Este facto poderá ter relação com a ocorrência de fraturas durante a produção por utilização de debitagem bipolar. As 141 lascas identificadas são todas de reduzidas dimensões: $1,3 \mathrm{~cm}$ de comprimento em média. Apenas três núcleos produziram exclusivamente lascas e dois produziram lascas e lamelas.

\section{DISCUSSÃO}

Com exceção das ocupações do Gravettense médio do Vau (UEoo5), onde a percentagem de quartzo não ultrapassa os $46 \%$, e da Olga Grande 14 (UE3), onde num pequeno conjunto artefactual, o quartzo representa $39 \%$, os restantes conjuntos do Paleolítico Superior, tanto no Vale do Côa como no Vale do Vouga, são maioritariamente compostos por vários tipos de quartzo (Tabela 1).

A utilização maioritária de quartzo dá origem a coleções líticas de aspeto fruste, com pouca produção laminar e lamelar e com grande quantidade de restos de talhe e esquírolas. Aliás, a elevada fragmentação do quartzo, pode aumentar a proporção desta matéria-prima (Bracco \& Morel, 1998). A elevada percentagem de utensilagem comum é outra das características do uso de matérias-primas locais de menor aptidão ao talhe. Apesar da utensilagem lamelar estar sempre presente, nem sempre o quartzo é a matéria-prima escolhida para o fabrico deste tipo de peças. Aliás, frequentemente, sílex e silcreto são escolhas preferenciais (Aubry \& alii, 2016a; Gameiro, Aubry \& Almeida, 2013). Por esta razão, optámos por enfatizar as estratégias de debitagem para pro- dução de suportes, observando e comparando diacronicamente a utilização do quartzo.

Nas coleções líticas recuperadas nos sítios arqueológicos do Rôdo e Vau (Vouga) e da Cardina e Fariseu (Côa) foram identificados núcleos de quartzo prismáticos ou sobre lasca talhados à mão livre/sem apoio. Nas duas regiões é percetível um domínio das técnicas, um savoir-faire implícito à utilização e rentabilização dos recursos litológicos regionais que é levado ao seu expoente máximo com a debitagem de suportes lamelares a partir de cristais naturais. No entanto, critérios economicistas terão conduzido à utilização de metodologias mais expeditas, como a debitagem de pequenas lascas ou esquírolas através de debitagem bipolar sobre bigorna. $\mathrm{Na}$ ausência dos núcleos é, por vezes, possível antever a aplicação destas estratégias de talhe pela existência de lascas, fragmentos e restos talhe característicos. Atribuir às peças esquiroladas uma utilização como núcleo ou utensílio é uma problemática inerente a deste tipo de colecções (Shott, 1999; Lucas \& Hays, 2004; Le Brun Ricalens, 2006; Almeida, 2007; Hays \& Lucas, 2009; Gameiro, 2009; Peña, 2015; Pargeter \& Peña, 2017) e tem sido opção classificar como utensílios as peças menos espessas, sem vestígios de preparação de planos de percussão e ângulos mais fechados, não esquecendo, contudo, que algumas peças podem ter conhecido uma dupla utilização. Em alguns casos, esta estratégia, parece ter sido utilizada como reciclagem de núcleos, cujas reduzidas dimensões tornavam difícil a aplicação de outro tipo de debitagem. No entanto, esta não parece ter sido regra única. No Fariseu está documentada uma produção deliberada de pequenos suportes através de debitagem bipolar sobre bigorna. A transformação pelo retoque de suportes com dimensões $<1 \mathrm{~cm}$ patenteia uma simbiose exemplar entre economia e oportunismo (Aubry \& alii, 1998; Gameiro, 2009; Klaric, 2009). A quase ausência de utensilagem lamelar em quartzo nos sítios do Vouga, levanta outras hipóteses: produção e exportação de suportes a retocar e utilizar noutro local? Com os dados disponíveis não é possível responder a esta questão.

Na Foz do Medal, no Vale do Sabor, a utilização das diversas variedades de quartzo é sempre predominante ao longo das ocupações do Paleolítico Superior. A percentagem de quartzo diminui durante o Solutrense (43\%) mas é elevada durante o Gravettense $(83 \%)$ e Magdalenense (65\%). Relativamente às modalidades de produção de suportes, a utiliza- 
ção de cristais e a debitagem bipolar sobre bigorna, foram igualmente identificadas nos níveis do Gravettense, Solutrense e Magdalenense. Foi igualmente documentada uma produção intencional de lascas de pequena dimensão e de lamelas, estas últimas, produzidas preferencialmente em quartzo hialino e noutras variedades de quartzo de melhor aptidão para o talhe e silicificações locais e alóctones, utilizando núcleos prismáticos, núcleos sobre lasca e debitagem bipolar sobre bigorna (Gaspar \& alii, 2016). No Vale do Guadiana, o contexto do Magdalenense final e/ou Azilense da Malhada do Mercador, apresenta uma percentagem de quartzo na ordem dos $45 \%$ e a debitagem bipolar sobre bigorna também foi utilizada com frequência (Almeida, 2013; Gameiro, Aubry \& Almeida, 2013).

No Algarve, nos níveis do Gravettense, Solutrense e Magdalense de Vale Boi o quartzo apresenta-se como a segunda matéria-prima melhor representada (depois do sílex) e refere-se a presença de peças esquiroladas em quartzo no Gravettense e no Solutrense (Bicho $\&$ alii, 2010; Horta, Cascalheira \& Bicho, 2019).

\section{CONSIDERAÇÕES FINAIS}

A maioria das variedades de quartzo utilizadas nos sítios do Vale do Côa estão disponíveis em filões ou em depósitos de vertente próximos dos sítios (Aubry $\&$ alii, 2016a). No entanto, há sempre utilização de outras matérias-primas disponíveis regionalmente (20-40km), demonstrando o conhecimento do ambiente litológico regional (Aubry \& alii, 2016b).

Durante o Gravettense médio a percentagem de utilização de matérias-primas locais era mais reduzida do que nos períodos subsequentes e apresenta valores semelhantes no Vale do Vouga e no Vale do Côa (Figura 1o). A utilização maioritária de matérias-primas alóctones de boa qualidade tem sido interpretada como uma característica das "fases pioneiras de ocupação" (Mevel, 2013). Numa fase de colonização do território não existe um conhecimento da litologia regional e, é expectável, maior quantidade de matéria-prima transportada. Numa fase posterior, com a continuidade das deslocações no mesmo território, com um conhecimento consolidado sobre as fontes de matéria-prima locais, o transporte de matérias-primas exóticas tende a diminuir. Tal comportamento foi identificado nas primeiras fases de ocupação de territórios da América do Norte
(Kelly \& Todd, 1988), durante a transição Pleistocénico-Holocénico no Reino Unido (Graf \& Goebel, 2003) e nos Alpes durante o Magdalenense e Azilense (Mevel, 2013).

No Vale do Côa, estão sempre presentes matérias-primas alóctones, o seu uso é quase sempre circunscrito à utensilagem lamelar e entre o Gravettense e o Azilense parece haver uma contração da área de aprovisionamento (Aubry $\&$ alii, 2016b).

A debitagem bipolar sobre bigorna, para produção de pequenas lascas ou esquírolas, é utilizada nestas duas regiões desde o Gravettense (Aubry $\&$ alii, 1998; 2016a; Klaric, 2009; Gameiro \& alii, 2018;) continuando presente no Magdalenense e Azilense (Gameiro, 2009; 2012; Aubry \& alii, 2016; Gameiro \& Aubry, no prelo; Gameiro \& alii, 2020a). Esta estratégia tem sido interpretada como uma tentativa de rentabilizar a matéria-prima, sendo que a sua utilização durante uma longa diacronia não permite que seja utilizada como um indicador cronológico. A utilização de cristais de quartzo hialino, utilizando as faces naturais dos cristais, para a produção de suportes lamelares está igualmente documentada nestas duas regiões e encontra paralelos na região vizinha do Vale do Sabor (Gaspar \& alii, 2016).

No que concerne à transformação dos suportes produzidos apenas dispomos de elementos para comparar os utensílios sobre lasca, uma vez que são raras as armaduras em quartzo recolhidas nos sítios do Vouga. Durante todas as fases do Paleolítico Superior, o quartzo disponível localmente é sobretudo utilizado nos utensílios sobre lasca, evidenciando uma lógica de produção, consumo e descarte (Aubry \& alii, 2016a; Gameiro \& Aubry, no prelo).

$\mathrm{O}$ volume de dados sobre as duas áreas em comparação é desigual, uma vez que dispomos de poucos elementos sobre o aprovisionamento regional de matérias primas, a tradição técnica e a funcionalidade dos sítios do Vouga. Contudo, a comparação dos resultados obtidos no âmbito do estudo dos diferentes conjuntos líticos apresentados, permite-nos reconhecer que, apesar das especificidades de cada sítio arqueológico, é possível reconhecer o mesmo esquema conceptual inerente às cadeias operatórias aplicadas aos diferentes tipos de quartzo.

Entre o Gravettense e o Tardiglaciar, no Vale do Côa, está documentada a utilização dos mesmos tipos de sílex, silcreto e silicificações hidrotermais disponíveis na Meseta espanhola e na Estremadura portuguesa. A maioria destas matérias-primas foi identifi- 
cada nos sítios paleolíticos do Vale do Vouga, região situada a meio caminho entre o Vale do Côa e as fontes de sílex da Estremadura (Aubry \& alii, 2016b; Gameiro \& Aubry, no prelo). Interpretando os sítios de arte Paleolítica do Vale do Côa como um local de agregação (Santos, 2019), podemos antever a mobilidade dos grupos humanos entre estas duas regiões, separadas por mais de $15 \mathrm{okm}$, possibilitando a troca de matérias-primas líticas com diversas proveniências e a difusão do savoir faire relativo à produção de artefactos líticos.

\section{AGRADECIMENTOS}

A investigação que serviu de base a este artigo foi financiada por fundos nacionais através da FCT Fundação para a Ciência e a Tecnologia, I.P., no âmbito do projeto O Paleolítico Superior e a Arqueologia Preventiva em Portugal: desafios e oportunidades (PTDC/HAR-ARQ/30779/2017) e do projecto $A$ transição do Neandertal para o Homem Anatomicamente Moderno no Vale do Côa: ambientes, simbolismos e redes sociais (PTDC/EPH-ARQ/o326/2014).

\section{BIBLIOGRAFIA}

ALMEIDA, Francisco (200o) - The terminal Gravettian of Portuguese Estremadura. Dallas: Southern Methodist University (Dallas, EUA). [Tese de doutoramento policopiada].

ALMEIDA, Francisco (2007) - The production of lithic barbs in the context of the Core Vs Tool dichotomy: the portuguese Upper Paleolithic case. In McPHERRON, Shannon (ed.) - Tools versus Cores: Alternative Approaches to Stone Tool Analysis, Cambridge Scholars Publishing, Newcastle, pp.127-142.

ALMEIDA, Francisco (dir.) (2013) - Testemunhos do Paleolítico no Regolfo de Alqueva. Resultados do Bloco 1 do Plano de Minimização de impactes sobre o Património Arqueológico. Beja:EDIA.

AUBRY, Thierry (ed.) (2009) - 200 séculos da História do Vale do Côa: incursões na vida quotidiana dos caçadores-artistas do Paleolítico. Lisboa:IGESPAR (Trabalhos de Arqueologia 52).

AUBRY, Thierry, BARBOSA, Fernando, LUís, Luís, SANTOS, André Tomás, SILVESTRE, Marcelo, (2016a) Quartz use in the absence of flint: Middle and Upper Palaeolithic raw material economy in the Côa Valley (Northeastern Portugal). Quaternary International 424: 113-129 doi:10.1016/j.quaint.2015.11.067

AUBRY, Thierry; BARBOSA, Fernando; GAMEIRO, Cristina; LUÍS, Luís; SANTOS, André; SILVESTRE, Marcelo (2019) - Cardina I-Salto do Boi: cinco metros de arqui- vo da ocupação paleolítica no Vale do Côa. Côa Visão 21, pp. 63-74.

AUBRY, Thierry; DIMUCCIO, Luca; ALMEIDA, Miguel; NEVES, Maria; ANGELUCCI, Diego; CUNHA, Lúcio (2010) - Palaeoenvironmental forcing during the Middle-Upper Palaeolithic transition in central-wertern Portugal. Quaternary Research. Doi:101016/j.yqres.2010.11.002.

AUBRY, Thierry; DIMUCCIO, Luca; BARBOSA, Fernando; LUÍS, Luís; SANTOS, André; SILVESTRE, Marcelo; HONSEN, Kristina; RADES, Eike; AUTZEN, Martin; MURRAY, Andrew (2020) - Timing of the Middle-to-Upper Palaeolithic transition in the Iberian inland (CardinaSalto do Boi, Côa Valley, Portugal). Quaternary Research 1-21. doi:10.1017/qua.2020.43

AUBRY, Thierry; GAMEIRO, Cristina; MANGADO LLACH; Javier; LUÍS, Luís; MATIAS; Henrique; PEREIRO, Tiago (2016b) - Upper Palaeolithic lithic raw material sourcing in Central and Northern Portugal as an aid to reconstructing hunter-gatherer societies. Journal of Lithic Studies 3(2). doi:10.2218/jls.v3i2.1436

AUBRY, Thierry; LUÍS, Luís; MANGADO LLACH, Javier; MATIAS, Henrique (2012) - We will be known by the tracks we leave behind: Exotic lithic raw materials, mobility and social networking among the Côa Valley foragers (Portugal). Journal of Anthropological Archaeology 31(4). pp. 528-550.

AUBRY, Thierry; MANGADO LLACH, Javier; MATIAS, Henrique (2014) - Matérias-primas das ferramentas em pedra lascada da Pré-história do Centro e Nordeste de Portugal. In DINIS, P.; GOMES, Alberto.; MONTEIRO-RODRIGUES, Sérgio - Proveniências de Materiais Geológicos, Associação Portuguesa para o Estudo do Quaternário. pp. 165-192.

AUBRY, Thierry \& MANGADO LLACH, Javier (2006) The Côa Valley (Portugal). From lithic raw materials characterization to the reconstruction of settlement patterns during the Upper Palaeolithic. In: BRESSY, C., BURKE, A.; CHALARD, P.; MARTIN, H. dir.-Notions de territoire et de mobilité. Exemples de l'Europe et des premières nations en Amérique du Nord avant le contact européen. Actes de sessions présentées au $X^{o}$ congrès annuel de l'E.A.A. (Lyon, 8-11-09-2004). Liège: ERAUL (116), pp. 41-49.

AUBRY,Thierry;MANGADOLLACH,Javier;SAMPAIO, Jorge (2009) - Estudo do aprovisionamento em matérias-primas. In AUBRY, Thierry (ed.) - 20 o séculos da História do Vale do Côa: incursões na vida quotidiana dos caçadores-artistas do Paleolítico, Lisboa:IGESPAR (Trabalhos de Arqueologia 52), pp. 131-169.

AUBRY, Thierry; ZILHÃO, João; ALMEIDA, Francisco; FONTUGNE, Miguel (1998) - Production d'armatures microlithiques pendant le Paléolithique supérieur et le Mésolithique au Portugal. Actas del II Congresso de Arqueologia Peninsular, Zamora, pp. 259-272. 
BICHO, Nuno; MANNE, Tiina; MENDONÇA, Carolina; ÉVORA, Marina; GIBAJA, Juan; PEREIRA, Telmo (2010) - O Paleolitico superior do sudoeste da Península Ibérica: o caso do Algarve. In MANGADO LLACH, Javier (dir.) El Paleolítico superior peninsular. Novedades del siglo XXI. Universidad de Barcelona. Barcelona, pp. 219-238.

BRACCO, Jean-Pierre; MOREL, Philipe (1998) - Outillage en quartz et boucherie au Paléolithique supérieur: quelques observations expérimentales. In Économie Préhistorique: les comportements de subsistance au Paléolithique. XVIIIe Rencontres internationales d'Archéologie et d'Histoire d'Antibes. Sophia Antipolis: Éditions APDCA, pp. 387-395.

LOMBERA HERMIDA, Arturo de (2008) - Quartz morphostructural groups and their mechanical implications. Museologia Scientifica e Naturalista. Annali dell'Università degli Studi di Ferrara. 2008: 101-105.

GAMEIRO, Cristina (2009) - Utensílios e suportes microlíticos do Magdalenense final no Vale do Côa: o exemplo da U.E. 4 do Fariseu. In AUBRY, T. (ed.), 200 séculos da História do Vale do Côa: incursões na vida quotidiana dos caçadores-artistas do Paleolítico. Lisboa: IGESPAR (Trabalhos de Arqueologia, vol. 52), pp. 256-268.

GAMEIRO, Cristina (2012) - La variabilité régionale des industries lithiques de la fin du Paléolithique Supérieur au Portugal. [Tese de Doutoramento, Université de Paris IPanthéon-Sorbonne. Exemplar policopiado].

GAMEIRO, Cristina; AUBRY, Thierry (no prelo) - Rôdo, Vau e Bispeira 8: integração crono-cultural, enquadramento regional e contextualização no quadro do Paleolítico Superior Peninsular. In G. Branco, P. Abranches e F. Telles (eds), Monografia dos trabalhos de minimização do impacte patrimonial do Aproveitamento Hidroelétrico de Ribeiradio-Ermida, pp.604-671.

GAMEIRO, Cristina; AUBRY, Thierry; ALMEIDA, Francisco (2013) - A variabilidade regional das indústrias líticas do final do Paleolítico Superior em Portugal. Arqueologia em Portugal - 150 anos actas do Congresso da Associação dos Arqueólogos Portugueses, Lisboa, Associação dos Arqueólogos Portugueses, pp. 277-287.

GAMEIRO, Cristina; AUBRY, Thierry; ALMEIDA, Francisco; DIMUCCIO, Luca; GABRIEL, Sónia; GASPAR, Rita; GOMES, Sérgio; FÁBREGAS VALCARCE, Ramon; FIGUEIREDO, Sofia; MANZANO, Carmen; MARREIROS, João; OLIVEIRA, Claúdia; SANTOS, André; SILVA, Maria; TERESO, João; XAVIER, Pedro (2020a) - Archaeology of the Pleistocene-Holocene transition in Portugal: Synthesis and prospects. Quaternary International https://doi.org/10.1016/j.quaint.2020.03.018

GAMEIRO, Cristina; GOMES, Sérgio; MANZANO, Carmen; COSTA, Bárbara; AMEIJENDA, A.; OLIVEIRA, Lurdes, MONTEIRO-RODRIGUES, Sérgio, GOMES, Alberto; OLIVEIRA, Cláudia; TERESO, J.; MATIAS, H.; AUBRY, T.
(2018) - The Pleistocene-Holocene transition: new data from the sites of Rôdo, Vau and Bispeira 8 (Vouga valley, Portugal). Poster apresentado no $8^{\text {th }}$ Annual Meeting of the European Society for the study of Human Evolution, Faro, 13-15 setembro de 2018.

GAMEIRO, Cristina; MANZANO, Carmen; COSTA, Bárbara; AMEIJENDA; Alicia; GOMES, Sérgio; MONTEIRO-RODRIGUES, Sérgio; GOMES, Alberto; AUBRY, Thierry; MATIAS, Henrique (2020b) - Contributos para a caracterização do período tardiglaciar no Médio Vouga: a indústria lítica do Rôdo, Vau e Bispeira 8, Arqueologia \& História Revista da Associação dos Arqueólogos Portugueses, Vol. 70, Ano associativo 2018, Associação dos Arqueólogos Portugueses, Lisboa, pp. 149-171.

GASPAR, Rita; FERREIRA, João; CARRONDO, Joana; SILVA, Maria João (2016) - The use of quartz during the Upper Paleolithic and Early Mesolithic in Sabor valley (NW Iberia): The Foz do Medal case. Quaternary International, 424, pp. 98-112.

GRAF, Kelly \& GOEBEL, Frank (2009) - Upper Palaeolithic toolstone procurement and selection across Beringia, in ADAMS, B. \& BLADES, B.S. (ed.) Lithic material and Palaeolithic societies: Chichester: Wiley-Blackwell, pp. 54-77.

HAYS, Maureen; LUCAS, Geraldine (2007) - Pieces esquillees from Le Flageolet I (Dordogne, France): Tools or Cores? In McPHERRON, Shannon (ed.) - Tools versus Cores: Alternative Approaches to Stone Tool Analysis, Cambridge Scholars Publishing, Newcastle, pp. 107-126.

HORTA, Pedro; CASCALHEIRA, João; BICHO, Nuno (2019) - The role of lithic bipolar technology in Western Iberia's Upper Paleolithic: the case of Vale Boi (Southern Portugal). Journal of Paleolithic Archaeology, 2 (2), pp. 134-159.

KELLY, Robert \& TODD, Laurence (1988) - Coming into the country: early Paleoindian hunting and mobility. American Antiquity. 53(2). pp. 31-44.

KLARIC, Laurent (2009) - Les systèmes de production de supports d'armatures et leur place dans la gestion de ressources lithiques: une voie privilégiée pour la compréhension des sociétés gravettiennes de la Vallée du Côa. In AUBRY, T. ed. - 200 séculos da História do Vale do Côa: incursões na vida quotidiana dos caçadores-artistas do Paleolítico. Lisboa: IGESPAR (Trabalhos de Arqueologia 52), pp. 247-256.

LE BRUN-RICALENS, Foni (2006) - Les pièces esquillées: état des connaissances après un siècle de reconnaissance. Paleo. 18, pp.95-114.

LUCAS, Géraldine; HAYS, Maureen (2004) - Les pièces esquillées du site paléolithique du Flageolet I (Dordogne): outils ou nucléus? In Approches fonctionnelles en Préhistoire. XXV ${ }^{\text {ème }}$ Congrès Préhistorique de France. Paris. pp. 107-120.

MANZANO, Carmen; GAMEIRO, Cristina; GOMES, Sérgio; COSTA, Bárbara; AMEIJENDA; Alicia; MONTEIRO-RODRIGUES, Sérgio; GOMES, Alberto; AUBRY, Thierry; 
MATIAS, Henrique (2020) - A indústria lítica do Gravettense Médio do Vau (Médio Vouga): apresentação de dados preliminares, Arqueologia 8 História - Revista da Associação dos Arqueólogos Portugueses, Vol. 70, Ano associativo 2018, Associação dos Arqueólogos Portugueses, Lisboa, pp. 117-133.

MEVEL, Ludovic (2013) - Magdalenian pioneers in the northern French Alps, 17 ooo cal BP. Antiquity. 87, pp. 384-404.

NEWCOMER, Mark; HIVERNEL-GUERRE, Françoise (1974) - Nucléus sur éclat: technologie et utilisation par différentes cultures préhistoriques. Bulletin de la Société Préhistorique Française. 71, pp. 119-127.

PARGETER, Justin; PEÑA, Paloma de la (2017) - Milky Quartz Bipolar Reduction and Lithic Miniaturization: Experimental Results and Archaeological Implications. Journal of Field Archaeology. Vol.42(6), pp. 551-565.

PEÑA, Paloma de la (2015) - The interpretation of bipolar knapping in African stone age studies. Current Anthropology. Vol. 56(6), pp. 911-923.

PIGEOT, Nicole (1987) - Magdaléniens d'Etiolles. Économie de débitage et organisation sociale. Éditions du CNRS, Paris.
SANTOS, André Tomás (2019) - A arte paleolítica ao ar livre da bacia do Douro a margem direita do Tejo: uma visão de conjunto. Associação dos Arqueólogos Portugueses: Lisboa.

SHOTT, Michael (1999) - On bipolar reduction and splintered pieces. North American Archaeologist. Vol. 20(03), pp. $217-238$.

VALENTIN, Boris (1995) - Les groupes humains et leurs traditions au tardiglaciaire dans le bassin parisien. Université de Paris I, Panthéon-Sorbonne [Tese de doutoramento policopiada].

ZILHÃO, João (1997) - O Paleolitico Superior da Estremadura Portuguesa. Ed. Colibri, Lisboa.

ZILHÃO, João; AUBRY, Thierry; ALMEIDA, Francisco (1997) - L'utilisation du quartz pendant la transition Gravettien-Solutréen au Portugal. Préhistoire et Anthropologie Méditerranéennes. 6, pp. 289-303.

\begin{tabular}{|c|c|c|c|c|c|c|c|c|c|c|}
\hline \multicolumn{11}{|l|}{ Vale do Vouga } \\
\hline \multirow[b]{2}{*}{ Atribuição Cultural } & \multirow{2}{*}{$\begin{array}{l}\text { Proveniência } \\
\text { (UE/sítio } \\
\text { arqueológico) }\end{array}$} & \multirow{2}{*}{$\begin{array}{l}\text { Total } \\
\left(\mathrm{N}^{\mathrm{o}}\right)\end{array}$} & \multicolumn{2}{|c|}{ Quartzo } & \multicolumn{2}{|c|}{ Quartzito } & \multicolumn{2}{|c|}{ Silicificações* } & \multicolumn{2}{|c|}{ Outras** } \\
\hline & & & № & $\%$ & № & $\%$ & № & $\%$ & № & $\%$ \\
\hline Gravettense Médio & UEoo5 Vau & 4053 & 1865 & 46 & 64 & 1 & 2051 & 51 & 73 & 2 \\
\hline Magdalenense Final & UEo 3 Rôdo & 21343 & 14970 & 74 & 1459 & 5 & 1765 & 11 & 3144 & 10 \\
\hline Azilense (?) & UEoo6 Rôdo & 7864 & 6205 & 81 & 325 & 5 & 625 & 6 & 709 & 8 \\
\hline \multicolumn{11}{|l|}{ Vale do Côa } \\
\hline \multirow{3}{*}{ Gravettense Médio } & $\mathrm{UE}_{3}$ Olga Grande 4 & 9778 & 8525 & 87 & 971 & 10 & 236 & 2 & 46 & 0,5 \\
\hline & $\mathrm{UE}_{3}$ Olga Grande 14 & 364 & 141 & 39 & 174 & 48 & 32 & 9 & 17 & 5 \\
\hline & UE4b Cardina & 20259 & 10754 & 53 & 8608 & 42 & 839 & 4 & 58 & 0,3 \\
\hline \multirow{2}{*}{ Gravettense Final } & UE4.10 Cardina & 28213 & 15381 & 55 & 11875 & 42 & 948 & 3 & 9 & 0,0 \\
\hline & UE2 Ínsula & 1267 & 978 & 77 & 242 & 19 & 45 & 4 & 2 & 0,2 \\
\hline Proto-Solutrense & UE2c Olga Grande 14 & 1592 & 1408 & 88 & 71 & 4 & 63 & 4 & 50 & 3 \\
\hline Magdalenense Final & UE4.2-4 Cardina & 9534 & 7478 & 78 & 1452 & 15 & 279 & 3 & 325 & 3 \\
\hline \multirow{3}{*}{ Azilense } & UE4.1 Cardina & 2145 & 1770 & 83 & 284 & 13 & 44 & 2 & 47 & 2 \\
\hline & UE3 Quinta da Barca & 996 & 790 & 79 & 118 & 12 & 77 & 8 & 11 & 1 \\
\hline & $\mathrm{UE}_{4}$ Fariseu & 6142 & 5221 & 85 & 830 & 14 & 84 & 1,4 & 7 & 0,1 \\
\hline
\end{tabular}

Tabela 1 - Inventário geral por matéria-prima das principais ocupações do Paleolítico Superior do Vale do Côa e do Vale do Vouga. * Incluí sílex, silcreto e silicificações hidrotermais. ${ }^{* *}$ Inclui matérias-primas classificadas como anfibolito, micro-gabro, lidite e riólito. 


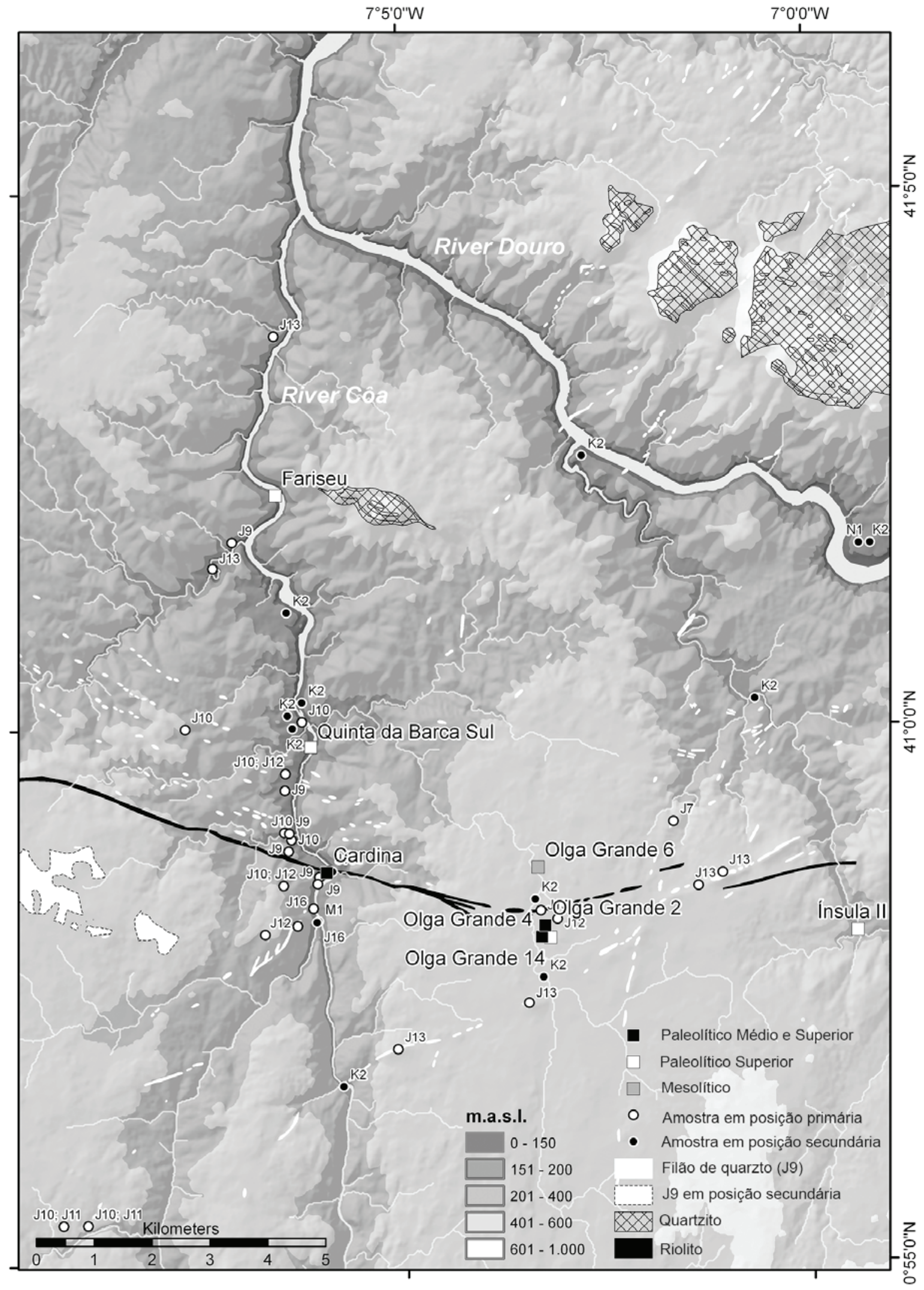

Figura 1- Os sítios do Paleolítico e Mesolítico do Vale do Côa e localização de matérias-primas locais. Mapa adaptado de Aubry \& alii, 2016a. 

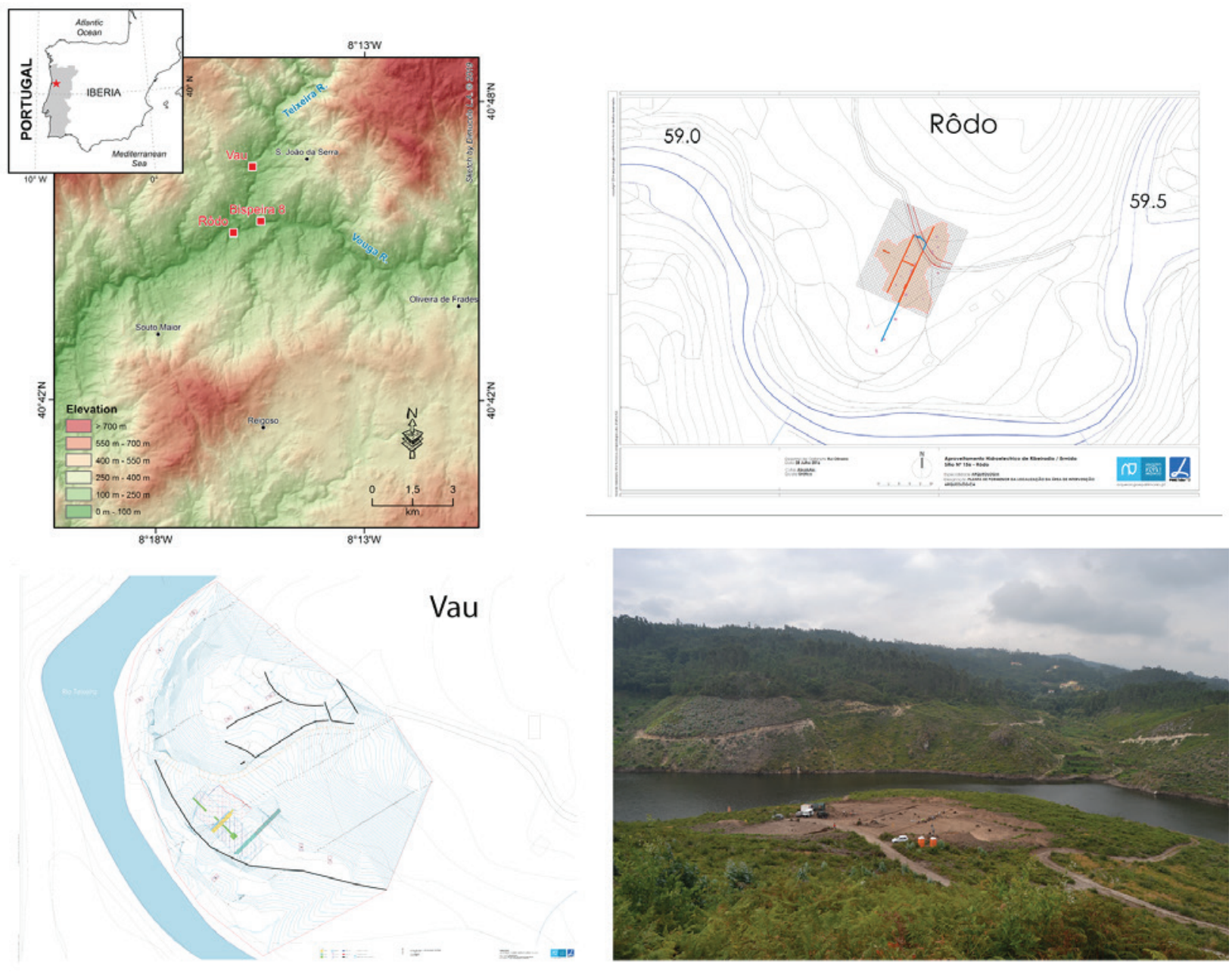

Figura 2 - Localização dos sítios paleolíticos do Vale do Vouga (mapa por L. Dimuccio), implantação das áreas escavadas e fotografia do sítio arqueológico Rôdo durante os trabalhos de escavação (Arqueologia \& Património).

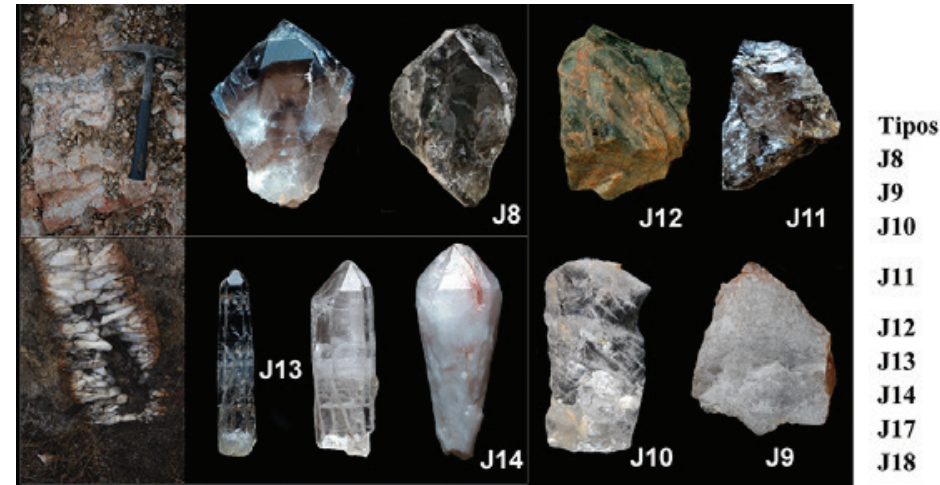

$\begin{array}{ccc}\text { Vale do Côa } & \text { I Vale do Vouga } \\ \text { Descrição } & \text { I } & \\ \text { Quartzo fumado euédrico } & \text { I Quartzo fumado } \\ \text { Quartzo leitoso e cinzento anédrico } & \text { I Quartzo filão e de } \\ \text { Quartzo translúcido e branco anédrico } & \text { I } & \text { seixo } \\ \text { Quartzo bandeado translúcido e branco } & \text { anédrico } & \text { Quartzo cinzento } \\ \text { Quartzo cinzento bandeado anédrico } & \text { I Quartzo hialino } \\ \text { Quartzo translúcido e branco euédrico } & \text { I Quartzo leitoso euédrico } & \text { Q } \\ \text { Quartzo fumado anédrico } & \text { Quartzo rosa anédrico } & \end{array}$

Figura 3-Amostras de quartzo recolhidas durante as prospeções no Vale do Côa. Descrição abreviada dos tipos de quartzo identificados com menção ao código utilizado no Vale do Côa. Para informação sobre a proveniência destas matérias primas consultar o mapa da Figura 1. Adaptado de Aubry \& alii, 2016a. As categorias utilizadas para a análise dos materiais do Vale do Vouga são, de momento, mais genéricas. 
Núcleos em quartzo

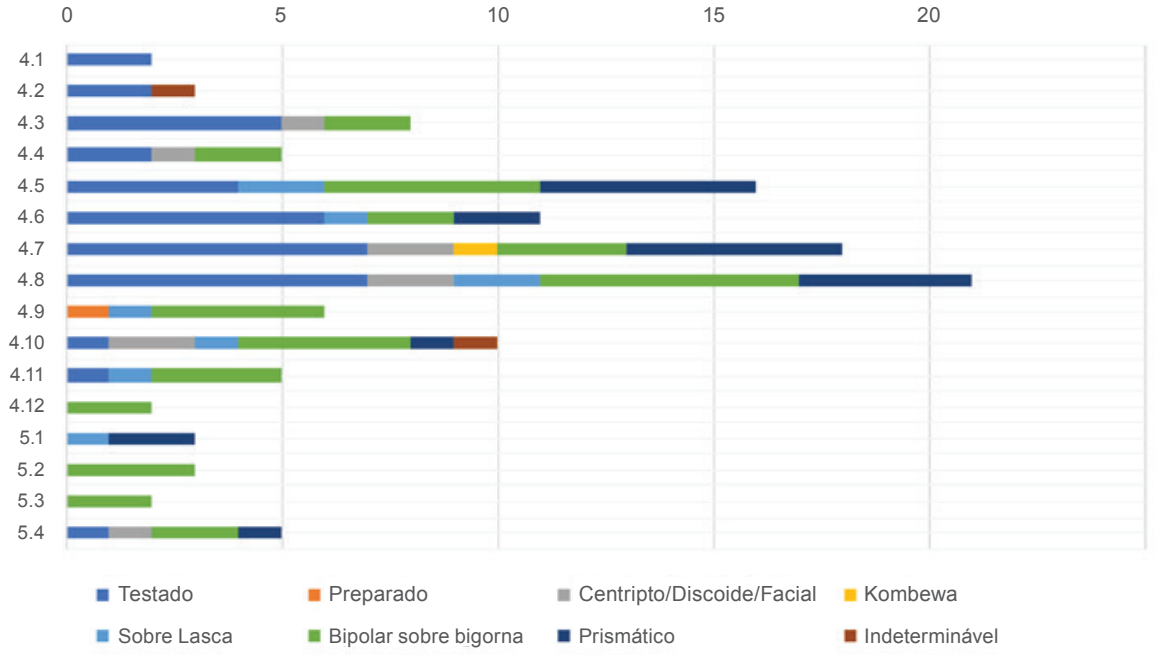

Tipo de núcleo Vs tipo de quartzo

60

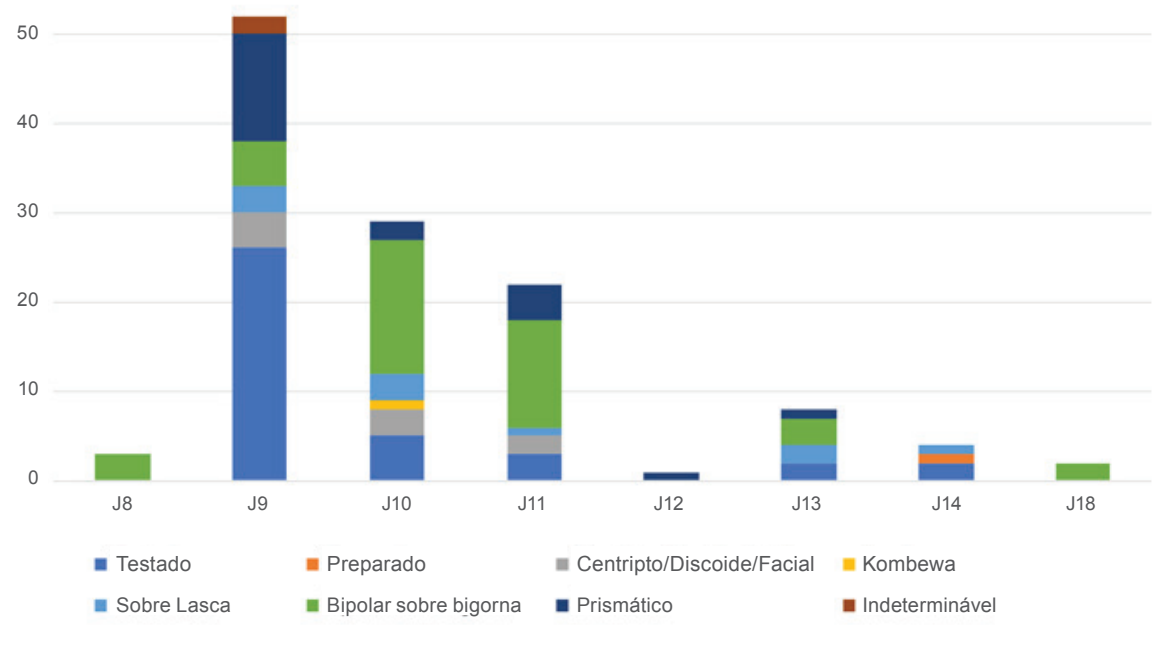

Figura 4 - Núcleos em quartzo da área Z/A'-6-8 da Cardina: estratégia de debitagem ao longo da sequência estratigráfica e relação entre estratégia de debitagem e tipo de quartzo.

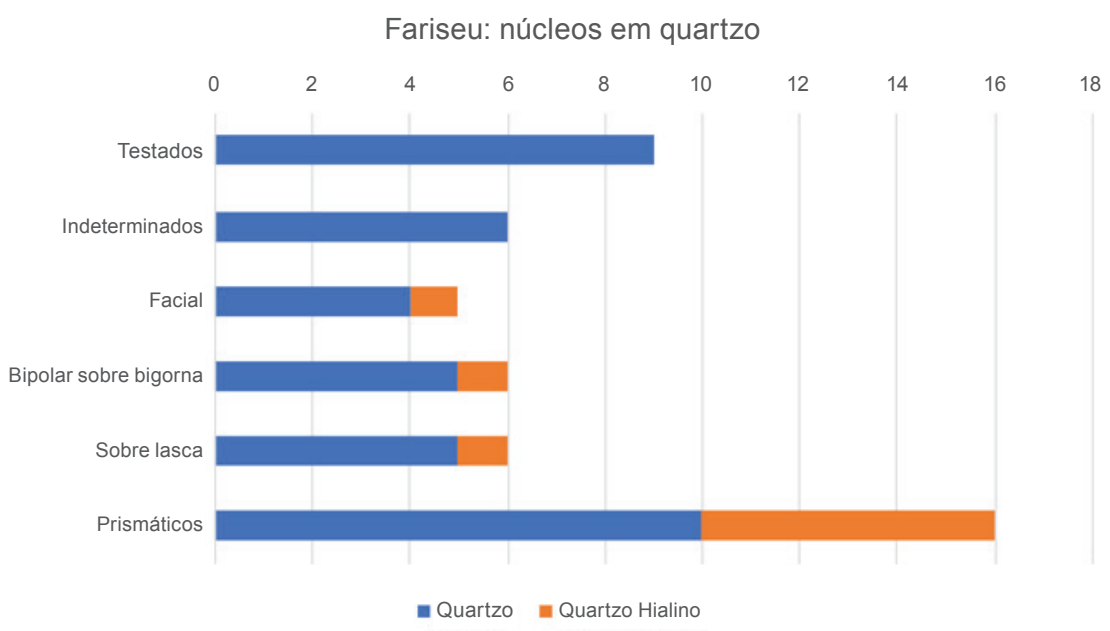

Figura 5 - Estratégia de debitagem utilizada nos núcleos em quartzo da UE4 do Fariseu. 


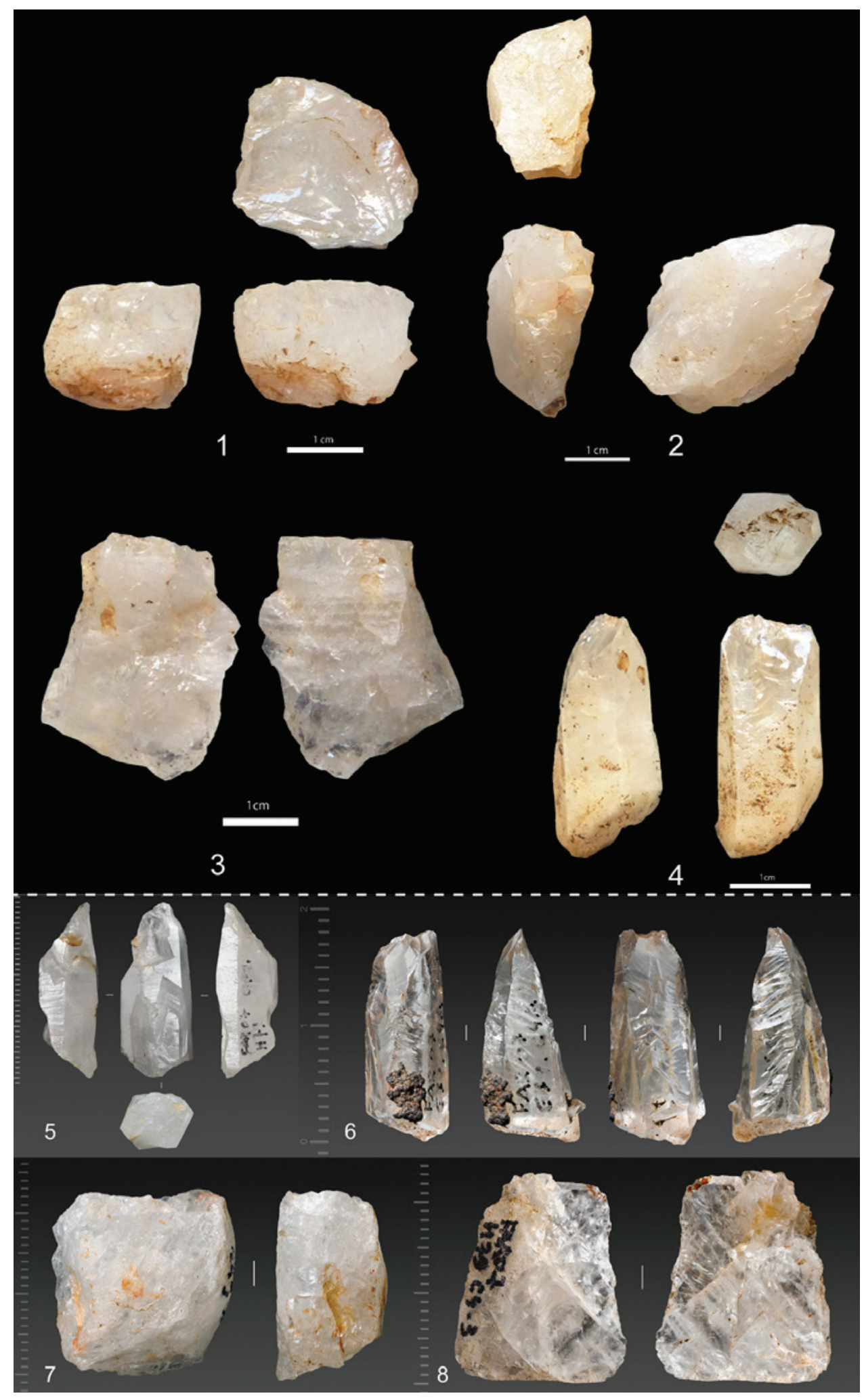

Figura 6- Núcleos em quartzo da Cardina: 1- núcleo para lamelas sobre seixo de quartzo (Ji1), com progressão da debitagem semi-giratória, UE4 NA6; 2- núcleo para lamelas sobre fragmento de quartzo (J10), exploração frontal, UE 5 NA4; 3 - núcleo bipolar sobre bigorna em quartzo (J14), UE4 NA5; 4 - cristal de rocha (J13) com preparação do plano de percussão a 45ㅜㅡㄴ UE4 NA3. Núcleos em quartzo da UE4 do Fariseu: 5 - cristal de rocha (J13) com preparação do plano de percussão a 45우 6 - núcleo para lamelas em cristal de rocha (J13) com progressão da debitagem giratória; 7 - Núcleo bipolar sobre bigorna em quartzo (J1o); 8 - Peça esquirolada em quartzo (J11). Fotografias Cristina Gameiro \& José Paulo Ruas (Fariseu). 
Vau: núcleos em quartzo

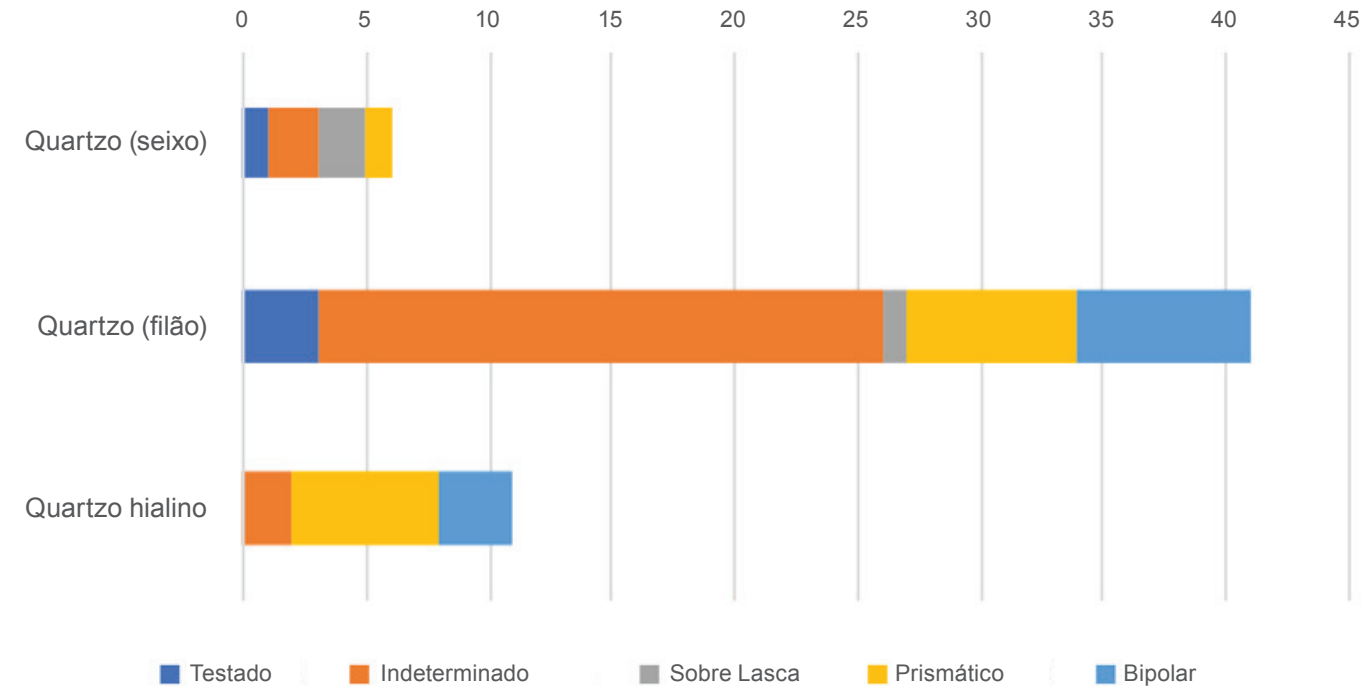

Rôdo: núcleos em quartzo

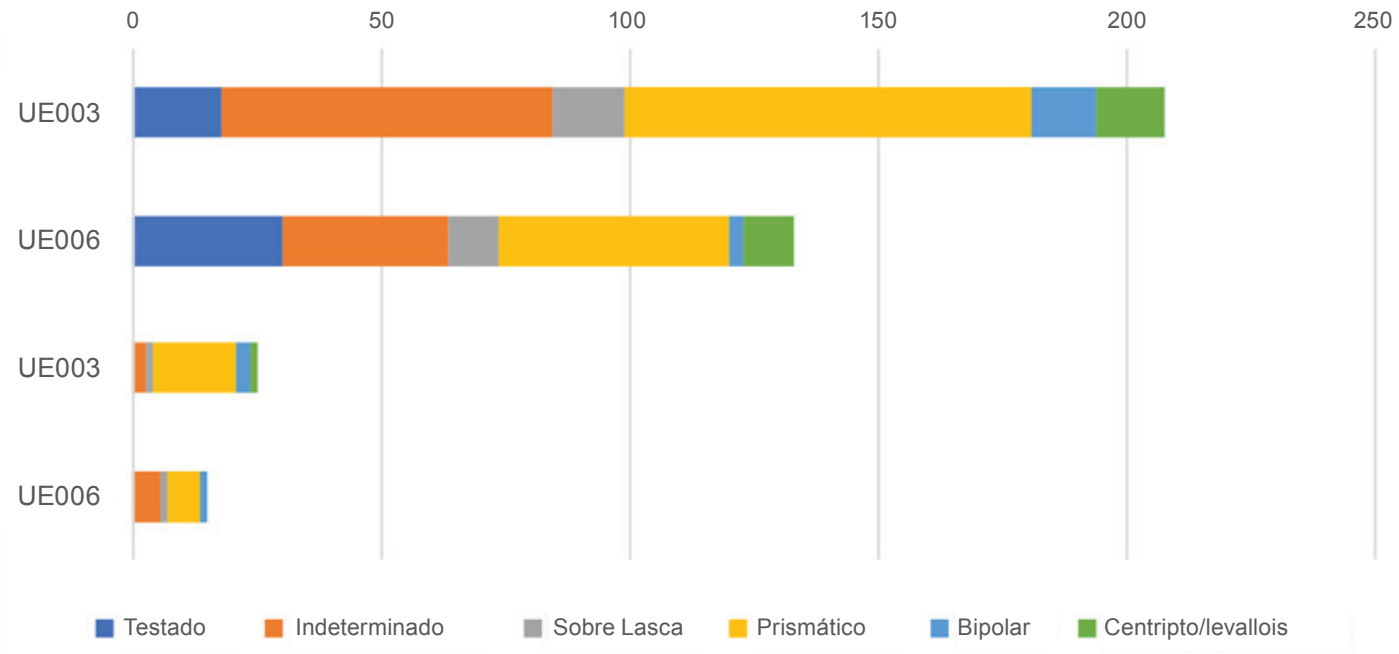

Figura 7 - Estratégia de debitagem utilizada nos núcleos em quartzo da UEoo5 do Vau (em cima) e das UEoo3 e UEoo5 do Rôdo (em baixo). De notar que no gráfico relativo ao Rôdo as duas primeiras barras concernem o quartzo e as duas últimas barras o quartzo hialino. 


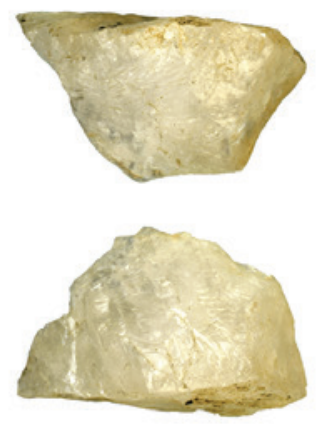

1

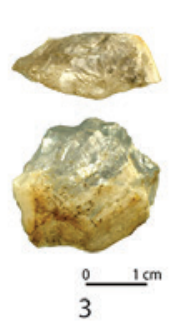

3

$1 \mathrm{~cm}$
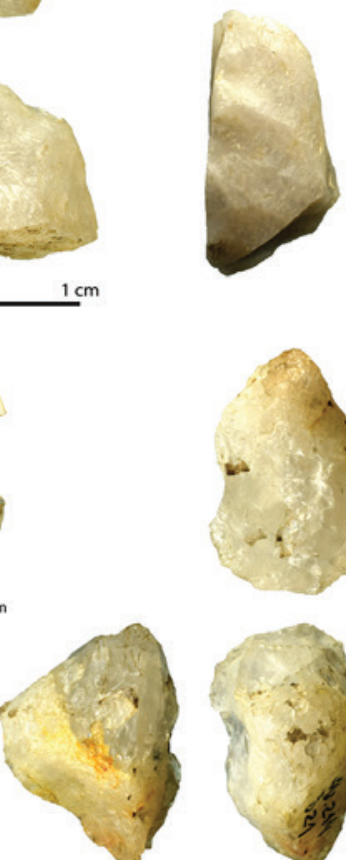

4

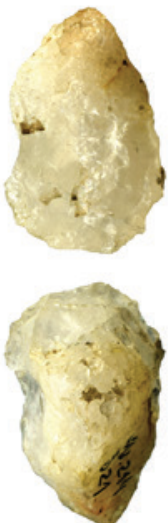

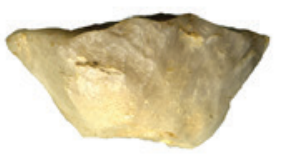
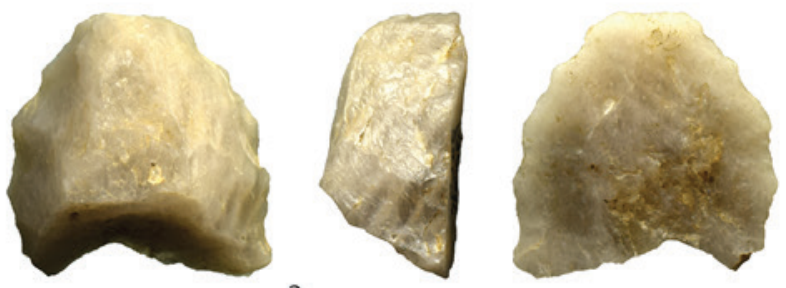

$0 \quad 1 \mathrm{~cm}$
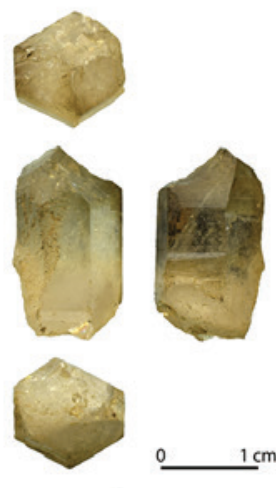

5
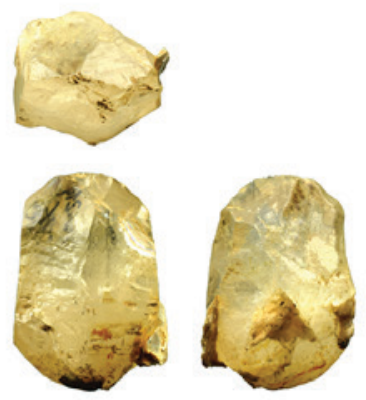

$0 \quad 1 \mathrm{~cm}$

6

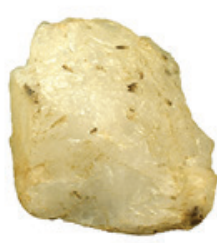

7

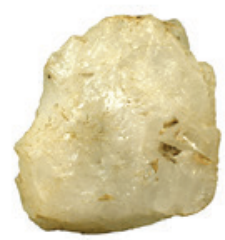

을 $1 \mathrm{~cm}$
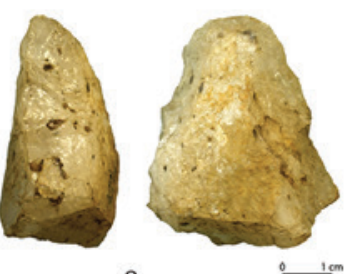

8
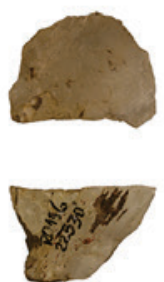

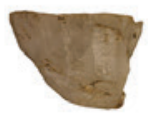

11
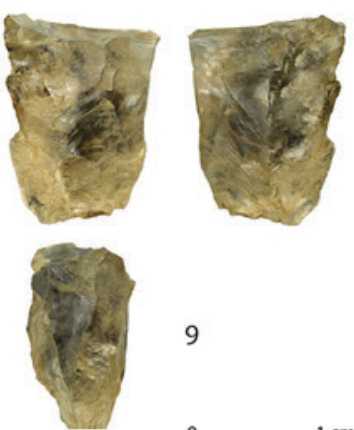

9 $1 \mathrm{~cm}$

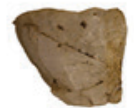

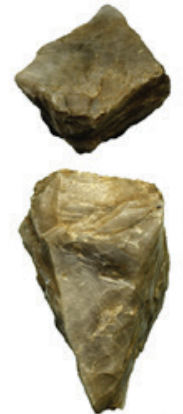

10
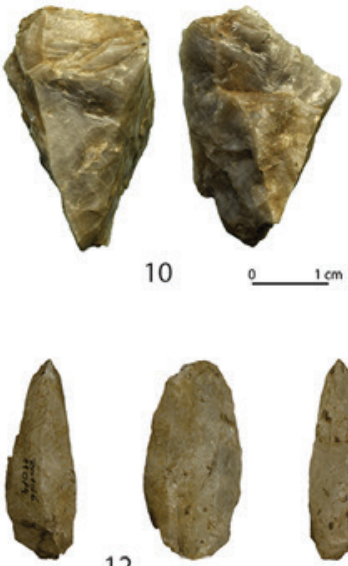

12
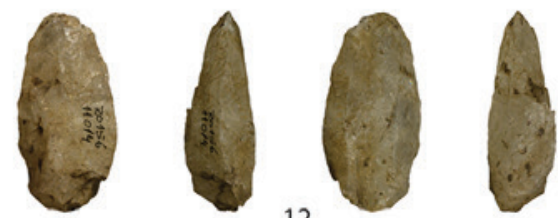

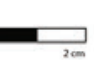

Figura 8 - Materiais em quartzo da UEoo5 do Vau: 1 - raspadeira sobre lasca; 2- raspadeira carenada atípica ou núcleo para pequenas lascas; 3- núcleo para pequenas lascas; 4-núcleo sobre lascas /raspadeira carenada para lamelas; Materiais em quartzo da UEoo3 do Vau: 5 - cristal com preparação do plano de percussão e sem debitagem; 6 - cristal testado e abandonado. Materiais em quartzo da UEoo6 do Rôdo: 7 - peça esquirolada; 8 - denticulado ou núcleo sobre lasca para produção de pequenas lascas; Materiais em quartzo da UEoo3 do Rôdo: 9 - núcleo bipolar sobre bigorna; 10 - núcleo sobre lasca para produção de lamelas, abandonado devido à existência de ressaltos; 11 - núcleo prismático para lamelas; 12 - núcleo prismático para a produção de lamelas. Fotografias Carmen Manzano \& Rui Oliveira / Arqueologia \& Património. 
Vale do Côa
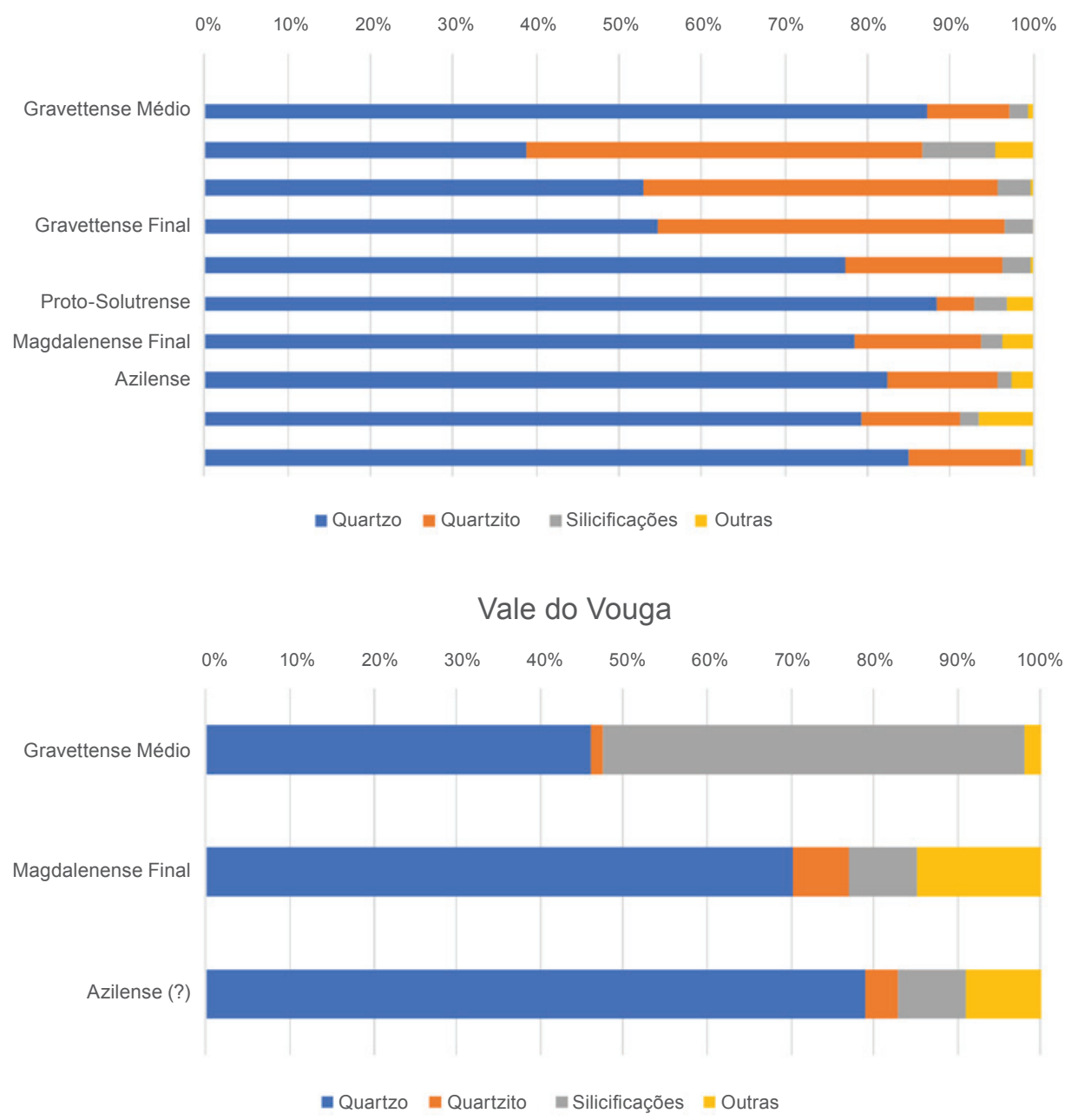

Figura 9-Comparação entre a percentagem de utilização das diferentes matérias-primas do Gravettense médio ao Azilense no Vale do Côa e no Vale do Vouga.

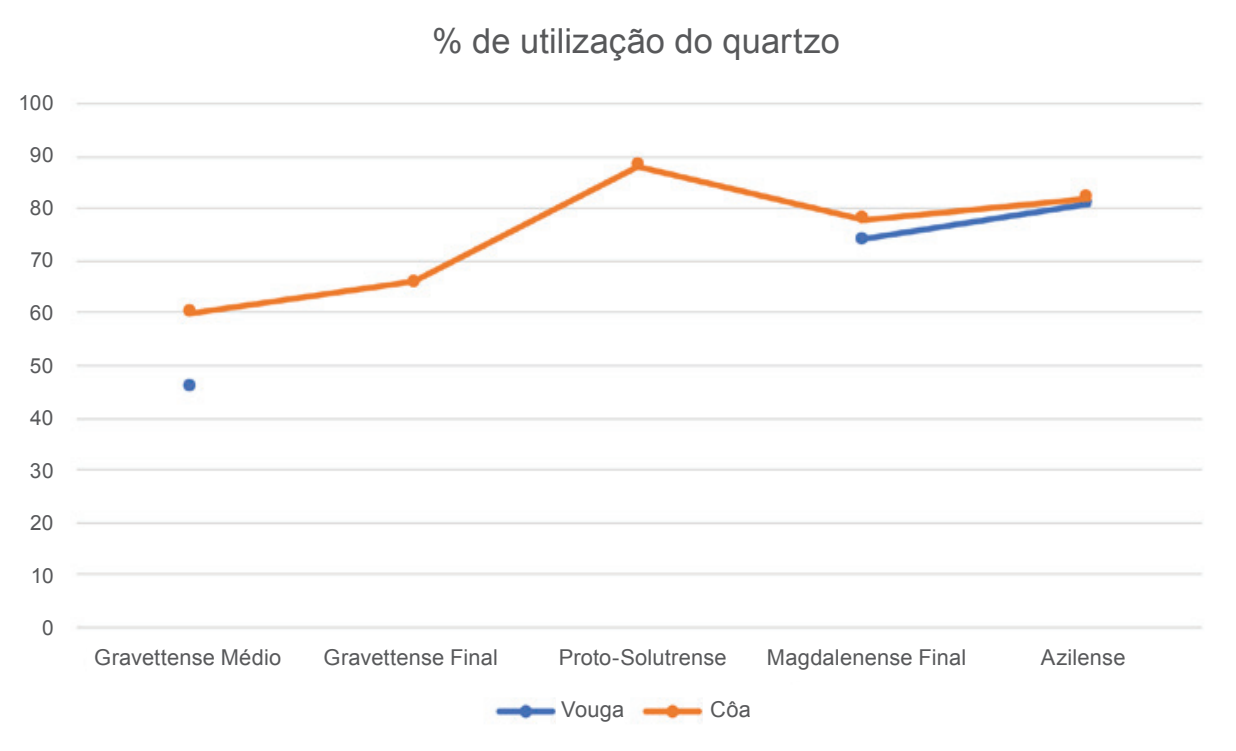

Figura 1o - Comparação da percentagem média de utilização do quartzo durante as diferentes fases do Paleolítico Superior. 


\title{
UMA PERSPETIVA DIACRÓNICA DA OCUPAÇÃO DO CONCHEIRO DO CABEÇO DA AMOREIRA (MUGE, PORTUGAL) A PARTIR DA TECNOLOGIA LÍTICA
}

\author{
Joana Belmiro' $^{1}$, João Cascalheira², Célia Gonçalves ${ }^{3}$
}

\begin{abstract}
RESUMO
O presente estudo apresenta os resultados preliminares obtidos da análise tecnológica aos materiais líticos do concheiro mesolítico do Cabeço da Amoreira (Muge, Portugal) provenientes da última década de trabalhos arqueológicos. O principal objetivo passa por explorar a variabilidade tecnológica e matérias-primas nas duas principais áreas de escavação do sítio arqueológico, de forma a caracterizar os vários momentos de ocupação. Foi aplicada uma abordagem de análise tipológica e de atributos a todos os materiais líticos. Os resultados sugerem uma diferenciação clara dos conjuntos líticos no que diz respeito à tecnologia e tipologia, sendo detetados padrões de associação destas variáveis com as diferentes composições sedimentares das camadas identificadas. As diferenças são, sobretudo, ao nível da frequência das matérias-primas, núcleos e utensílios retocados. Palavras-chave: Mesolítico, Muge, Cabeço da Amoreira, Análise lítica.
\end{abstract}

\begin{abstract}
This study presents preliminary results from a technological analysis of lithic artefacts from the Mesolithic shellmidden of Cabeço da Amoreira (Muge, Portugal). The main goal was to understand the technological and raw material variability within the two main excavation areas of the site, in order to characterize the different occupation moments. A typological and attribute approach was used in the analysis. The results suggest a clear distinction of the lithic assemblages, associated with the sedimentary differences identified in the composition of the several layers. This separation can be found mostly in the frequencies of raw materials, cores and retouched tools.
\end{abstract}

Keywords: Mesolithic, Muge, Cabeço da Amoreira, Lithic analysis.

\section{INTRODUÇÃO}

O concheiro mesolítico do Cabeço da Amoreira localiza-se no centro de Portugal, na margem esquerda da ribeira de Muge (Figuras IA e 1B). O sítio localiza-se no topo de um terraço fluvial a cerca de 20 metros acima do atual nível do mar e apresenta uma forma elíptica com c. de $90 \mathrm{~m}$ de comprimento (N-S) e 50 m de largura (E-O) (Roche, 1964/1965). Durante a ocupação do concheiro, este estaria localizado perto de um ecossistema de água salobra com recursos marinhos abundantes (van der Schriek \& alii, 2007, 2008). A utilização destes recursos pelas populações mesolíticas é evidente nas variadas ocupações e concheiros presentes ao longo dos terraços da ribeira de Muge e outros tributários do rio Tejo (Bicho \& alii, 2013). O Cabeço da Amoreira destaca-se pela sua extensão horizontal e estratigráfica, e pelas suas camadas ricas em materiais arqueológicos e uma alta frequência de enterramentos humanos (Bicho \& alii, 2011, 2013; Detry \& Cardoso, 2010; Cunha, Cardoso \& Umbelino, 2003).

O concheiro do Cabeço da Amoreira foi identificado em 1864 por Carlos Ribeiro (1884), sendo que des-

\footnotetext{
1. ICArEHB, Universidade do Algarve; jnetobelmiro@gmail.com

2. ICArEHB, Universidade do Algarve; jmcascalheira@ualg.pt

3. ICArEHB, Universidade do Algarve; cmgoncalves@ualg.pt
} 
de então, o sítio tem contado com várias escavações arqueológicas: durante o século $\mathrm{XX}$, na década de 30, por Mendes Corrêa (1933) e, na década de 6o, por Jean Roche e Veiga Ferreira (Roche, 1966). Entre 1997 e 2001 José Rolão retoma os trabalhos com o objetivo de realizar um estudo geomorfológico e paleoambiental da região, em particular entre as ribeiras Fonte da Moça e Magos (Rolão, 1999; Rolão, Joaquinito \& Gonzaga, 2006). Mais recentemente, em 2008, novos trabalhos foram iniciados no sítio arqueológico do Cabeço da Amoreira no âmbito de um projeto interdisciplinar liderado por Nuno Bicho e financiado pela Fundação para a Ciência e Tecnologia (FCT), com o objetivo de estudar o desenvolvimento regional tecnológico, económico e social dos últimos caçadores-recolectores do vale do Tejo, (Bicho \& alii, 2011).

Desde então os trabalhos arqueológicos têm continuado graças aos sucessivos projetos alvo de financiamento por instituições nacionais e internacionais, encontrando-se atualmente em curso um novo projeto sob a direção de Célia Gonçalves. Os trabalhos a partir de 2008 contaram não só com abordagens interdisciplinares, assim como com a adoção de metodologias tecnológicas inovadoras e recentes, como a utilização de estações totais, que permitem a recolha de informação espacial detalhada. A escavação é realizada através da decapagem de níveis de $5 \mathrm{~cm}$, seguindo as camadas naturais e antrópicas identificadas. Todos os materiais com dimensões superiores a $2 \mathrm{~cm}$, ou com dimensões inferiores mas inteiros (e.g., microfauna, lamelas inteiras ou pinças de caranguejo) são cotados com recurso a uma estação total aos quais são atribuídos um código de barras e informações contextuais como o tipo de artefacto e informação tridimensional. Todo o sedimento escavado é colocado num balde de 10 litros, ao qual são atribuídas coordenadas de um ponto central da área escavada, sendo todo sedimento crivado a seco com malhas $1 \mathrm{~mm}$ e $3 \mathrm{~mm}$, de forma a recolher materiais de pequenas dimensões (Bicho \& alii, 2011).

Os recentes trabalhos no Cabeço da Amoreira focaram-se, maioritariamente, em duas áreas: $\mathrm{S} 1$, a noroeste (quadrados $\mathrm{G}$ a L) e S2, a este (quadrados A e B) (Figura ${ }_{1} \mathrm{C}$ ), ainda que nas campanhas anteriores a 2012 tenha sido escavada uma área mais extensa (camada 1, 1b e 2). A metodologia de escavação empregue permitiu até ao momento a identificação de várias camadas (Tabela 1 ), com significativa varia- ção lateral (Figuras 2 e 3) e diferenças marcadas entre as duas áreas. Ao longo das diferentes camadas destaca-se a presença abundante de fragmentos de conchas, restos faunísticos, líticos, adornos, seixos e termoclastos.

Bicho \& alii (2011) sugere que o sítio apresentou uma função residencial inicialmente, provavelmente simultânea, mas espacialmente separada, de uma função funerária. Depois desse momento, há poucas evidências de ocupações de tipo residencial, sendo que o sítio provavelmente representava um local para exploração de recursos, principalmente conquíferos. Baseado nas datações obtidas através de várias amostras, os cerca de $3 \mathrm{~m}$ de depósitos ricos em fragmentos de conchas parecem ter-se depositado num período relativamente rápido, possivelmente em várias fases curtas, entre ca. 7900 e 7500 cal. BP (Bicho \& alii, 2013). A identificação de fragmentos de cerâmica e enterramentos humanos no topo do concheiro, bem como os vestígios de áreas escavadas em torno do concheiro, revelaram ainda uma importante ocupação neolítica do sítio (Bicho \& alii, 2013; Umbelino 2006).

Além do entendimento do sítio arqueológico como um espaço não residencial durante a maior parte da ocupação, estão ainda por entender as possíveis variações funcionais dentro das várias camadas, que possam permitir a identificação de momentos ou comportamentos específicos sincrónicos e diacrónicos. Através da análise micromorfológica dos sedimentos, Aldeias e Bicho (2015) salientam padrões de ocupação complexos, incluindo ações de redeposição e arrastamento de sedimentos e materiais.

Sendo que estudos recentes demonstram a existência de uma complexidade nas várias ocupações e camadas, encontra-se estabelecida a oportunidade de testar variações ocupacionais possivelmente refletidas na cultura material, em especial na indústria lítica. Paralelamente, recorrendo aos dados espaciais obtidos durante as escavações é possível correlacionar a tecnologia lítica com outros dados como a frequência de restos faunísticos ou presença de carvões, de forma a melhor entender as características das ocupações.

\section{MATERIAIS E MÉTODOS}

Para cumprir os objetivos deste estudo, foram analisados os materiais líticos recolhidos nas campanhas de escavação do concheiro do Cabeço da Amoreira 
após 2008. Foram utilizados materiais de todas as camadas arqueológicas e estruturas individualizadas durante a escavação (com exceção da camada 1 e $\mathrm{ib}$, por serem camadas significativamente afetadas por processos pós-deposicionais naturais e antrópicos; Cascalheira \& Gonçalves, 2012). De forma a reduzir a dimensão da amostra, foram analisados apenas os materiais com dimensões superiores a 2 $\mathrm{cm}$ (cotados tridimensionalmente com recurso a estação total) das duas áreas de escavação principais dentro do concheiro do Cabeço da Amoreira.

Tendo em conta a existência de uma grande variabilidade na quantidade de materiais ao longo das várias camadas, foram apenas consideradas as camadas com mais de 10 artefactos (excluindo fragmentos de debitagem). Foram também colapsadas as camadas individualizadas durante a escavação por apresentarem maiores concentrações de conchas de uma determinada espécie (e.g., PITra, PITib ou PITıc) ainda que as características sedimentares fossem iguais à camada envolvente.

Foi aplicada uma abordagem de análise de atributos tecnológicos e tipológicos, utilizando literatura especializada (Andrefsky, 1998, 2005; Brézillon, 1968; Inizan \& alii, 1999; Tixier \& Inizan, 1980), assim como outros trabalhos de análise de líticos para vários contextos da pré-história em Portugal (Bicho, 1993; Zilhão, 1997).

Todos os dados foram recolhidos com acesso ao software E4 (http://www.oldstoneage.com/software/default.shtml.) que permite a criação de uma base de dados automatizada, de forma a permitir resultados homogéneos. A análise destes dados foi feita com recurso ao software $\mathrm{R}$ (https://rstudio. com) e Rstudio (https://rmarkdown.rstudio.com), que permite a criação de scripts totalmente reproduzíveis, tendo em vista o desenvolvimento de uma ciência transparente e opensource.

\section{RESULTADOS}

A amostra é composta por 2170 artefactos líticos (excluindo esquírolas e fragmentos não identificáveis) (Tabela 2). As camadas com maior quantidade de materiais líticos são a camada PITi e camada 2 $(n=650$ e $n=511$, respetivamente), ambas com frequências superiores a $20 \%$ relativamente ao total da coleção. Seguem-se as camadas 3, 4 e 9, com um decréscimo de artefactos significativo. De uma forma geral, parece haver uma diminuição do número de artefactos líticos ao longo da estratigrafia, com uma maior frequência nas camadas superiores.

Em todas as camadas, são as lascas a classe de artefactos líticos mais presente, com frequências superiores a $35 \%$, seguidas dos produtos alongados (suportes com comprimento igual ou superior a duas vezes a largura), núcleos e utensílios retocados. A presença de produtos de preparação e manutenção de núcleos está limitada apenas às camadas 2, 3, 4, PIT1, 9 e 12, com números absolutos relativamente diminutos $(<2)$.

No total, as duas áreas apresentam 119 núcleos, sendo que em todas as camadas, esta classe apresenta valores inferiores a $10 \%$, sendo a camada 4 a que apresenta a frequência mais elevada (9.42\%).

As matérias-primas mais presentes no sítio arqueológico são o sílex (caracterizado por uma grande heterogeneidade, raramente aparecendo na forma de seixo; Pereira \& alii, 2015), quartzo e quartzito, ambos frequentemente na forma de seixos, e que podem ser encontrados com facilidade na área envolvente ao sítio arqueológico (Paixão, 2014). As percentagens destas matérias-primas ao longo da estratigrafia apresentam padrões diferentes, variando entre camadas com uma preferência marcada por um tipo de matéria-prima e camadas que apresentam percentagens semelhantes para todos os tipos de matérias-primas (Figura 4). Nas camadas 6, X e $\mathrm{Z}$, as camadas mais antigas identificadas na área $\mathrm{S} 1 \mathrm{e}$ constituindo os níveis de transição entre o concheiro e as areias base, o quartzito apresenta percentagens superiores a $50 \%$, atingindo quase os $80 \%$ na camada X. Demarca-se ainda a alta frequência de quartzo na camada PIT1 (44\%) comparativamente às outras matérias-primas. De forma semelhante, as camadas 10 e 12 apresentam frequências de artefactos em sílex mais altas que as outras camadas.

No total foram identificados 16 tipos de utensílios retocados, com uma alta frequência de geométri$\cos (\mathrm{n}=115)$, comparativamente às outras tipologias (Tabela 3). Os geométricos mais presentes são os triângulos, como de resto havia já sido atestado em estudos anteriores sobre o Cabeço da Amoreira (Paixão \& alii, 2018). As camadas com maior presença de geométricos são a camada $2(\mathrm{n}=39), 4$ $(\mathrm{n}=18), \operatorname{PIT1}(\mathrm{n}=25)$ e 9 (20), que correspondem com as camadas com maior quantidade de artefactos líticos. A única exceção é a camada 3, com considerável número de materiais, mas na qual foram apenas identificados 7 geométricos. 
As outras tipologias de retocados apresentam números mais reduzidos. As tipologias mais presentes são as lascas retocadas $(n=11)$ e entalhes $(n=10)$, ainda com a presença de truncaturas $(n=5)$, lamelas retocadas $(n=5)$, denticulados $(n=4)$, peças esquiroladas $(\mathrm{n}=3)$ e lamelas de dorso. Apesar da camada 2 apresentar uma grande quantidade dos utensílios retocados supramencionados, não parece existir um padrão tipológico evidente entre camadas ou áreas. De forma a entender melhor os padrões presentes nas várias camadas do sítio arqueológico, foi utilizada uma abordagem multivariada para explorar a interação entre as variáveis escolhidas. Sendo que estas variáveis eram categóricas, foi utilizada uma Análise de Correspondência Múltipla utilizando as seguintes variáveis: classe, matéria-prima, percentagem de córtex e camada (como variável suplementar). De forma a reduzir a grande variabilidade dentro das variáveis, todas os atributos com uma representação inferior a $5 \%$ foram colapsados numa categoria geral chamada "Outros" antes de correr a análise, e seguindo o exemplo de outros estudos onde uma metodologia semelhante foi aplicada (Cascalheira, 2019).

As duas dimensões apresentadas na Figura 5 explicam $41.1 \%$ da variabilidade da amostra. Na Dimensão 1 (23.7\%) encontra-se uma associação forte entre sílex e utensílios retocados, assim como com produtos alongados, ainda que com uma contribuição mais fraca. Parece ainda haver uma associação entre sílex e a ausência de córtex nos artefactos. Na dimensão positiva da Dimensão 1 encontra-se a associação entre quartzo e quartzito, lascas e núcleos, assim como percentagens variáveis de presença de córtex.

A dimensão 2, que explica 17.4\% da variabilidade da amostra, parece demonstrar a associação de quartzito e outras matérias primas com lascas e presença de $100 \%$ de córtex na face dorsal, em oposição ao quartzo, onde parece ocorrer a maior presença de núcleos. Apesar da maioria das camadas aparecer maioritariamente associada ao centro das duas dimensões, é possível observar alguns padrões mais evidentes, sendo estes, por exemplo, a presença de grandes quantidades de quartzito nas camadas $6, \mathrm{X}$ e Z, já acima mencionado.

No que diz respeito às variáveis métricas, de forma a entender possíveis estratégias de produção diferentes, não só entre os diferentes níveis, mas também entre matérias-primas, foi calculado um índice de alongamento (Comprimento/Largura) para lascas e produtos alongados. As diferenças entre o alongamento e a sua distribuição por matéria prima (quartzo, quartzito e sílex) e camada foram comparadas através de um teste ANOVA. Os resultados demonstram que existe uma diferença significativa real entre as matérias-primas ( $p$-value $=0.00)$, e também significativa entre as diferentes camadas (p-value $=0.01)$, relativamente ao alongamento das lascas e produtos alongados. Através de um teste Tukey, para comparações múltiplas, foi possível confirmar que existem diferenças significativas entre todas as matérias-primas (Tabela 4). A criação de boxplots permitiu então entender que, como expectável, o quartzito apresenta índices de alongamento mais baixos, sendo que o sílex apresenta os índices mais altos (Figura 6).

\section{DISCUSSÃO E CONCLUSÕES}

Apesar de preliminar, a análise dos materiais líticos do sítio arqueológico do Cabeço da Amoreira revela alguns padrões de ocupação interessantes ao longo das camadas. Numa primeira análise, é possível entender a diminuição gradual dos materiais ao longo da estratigrafia, com as camadas mais recentes (2, 3, 4 e PITI) tendo a maior quantidade de materiais, comparativamente com as camadas da base da estratigrafia. Este padrão é semelhante em ambas as áreas, S1 (camadas 2, 3 e 4) e S2 (camadas 2, 3 e PIT1). Esta mudança, que parece ser geral a toda a área escavada do concheiro, pode refletir uma alteração na intensidade da ocupação do sítio ou a mudança na sua funcionalidade, algo sugerido anteriormente tendo em conta as várias datações de radiocarbono existentes para o sítio, tipos de estruturas e enterramentos (Bicho \& alii, 2013). No entanto, esta conclusão carece de alguns dados que permitam entender de forma mais detalhada a estratigrafia de ambas as áreas. Por serem áreas escavadas separadamente, atualmente é desconhecida a relação topográfica entre as camadas de ambas as áreas, incluindo a relação temporal entre, por exemplo, a camada 4 e camada 9 (que em ambas as áreas se encontram abaixo da camada 3). De forma semelhante, o caráter espacialmente limitado da camada PITr permite entender que esta é uma deposição anterior à camada 3 , mas cuja relação cronológica com a camada 9 ou 4 é difícil de estabelecer.

Não obstante, a mudança reportada na quantidade de materiais ao longo da estratigrafia parece ser 
igualmente acompanhada por diferenças na matéria-prima. As três matérias primas aparecem de forma relativamente uniforme na maioria das camadas, ainda que com diferenças funcionais. No entanto, como foi referido, parece existir uma predominância na presença de quartzito nas camadas mais antigas da área Si (camadas 6, X e Z), que correspondem também aos níveis de transição para a base do concheiro. Assim, nesta área, não existe apenas uma diminuição da quantidade materiais, como também uma alteração visível na preferência de matéria-prima utilizada. Esta alteração de preferência parece, mais uma vez, alinhar com a interpretação de que existiram funcionalidades diferentes para o sítio ao longo da sua ocupação.

Foi possível identificar o sílex como utilizado primariamente para a produção de utensílios retocados (na sua maioria geométricos) e produtos alongados. A presença de pouco córtex na maioria dos artefactos em sílex parece revelar uma estratégia de obtenção mais complexa, com a sua obtenção e descorticamento acontecendo possivelmente no lugar de recolha da matéria prima. A presença de índices de alongamento mais altos, quando comparativamente com as outras matérias primas, permitem entender uma produção orientada para a obtenção de produtos finais específicos (lamelas e lâminas), ainda que continue a existir uma componente de lascas bastante relevante.

O quartzo e o quartzito apresentam padrões que parecem refletir estratégias de redução mais expeditas, através da recolha de seixos locais e o seu talhe, que resulta na existência de grandes quantidades de córtex nas peças, assim como a grande quantidade de lascas. Ainda assim, o quartzito é, ao longo da estratigrafia, a matéria prima utilizada de forma mais expedita, sendo que o quartzo apresenta algumas semelhanças ao sílex na produção de produtos alongados. Um padrão interessante também visível na amostra analisada é a existência de uma separação de camadas que oscilam entre a entre a presença marcada de utensílios retocados e a presença de núcleos. Este padrão pode refletir a existência de padrões de descarte diferentes, possivelmente resultado de uma separação intra-sítio entre atividades de talhe e outras atividades, ou ocupações diacronicamente e funcionalmente distintas. No entanto, a resolução temporal atualmente disponível para as várias camadas do sítio, com base nas datações de radiocarbono, não permite ainda entender de forma detalhada estes padrões.
Os padrões acima identificados e as particularidades que apresentam apontam para uma complexidade na utilização do espaço do concheiro que poderá, no futuro, ser explorada de forma mais detalhada, utilizando dados espaciais e abordagens multidisciplinares.

\section{AGRADECIMENTOS}

O trabalho em Muge não seria possível sem o financiamento da Fundação para a Ciência e Tecnologia com o financiamento de três projetos PTDC/HAH/ 64185/2006 e PTDC/HIS-ARQ/112156/2009 e, em curso, o projeto MugePortal - Concheiros de Muge: Um novo portal para os últimos caçadores-recolectores do vale do Tejo, Portugal (PTDC/HAR-ARQ/29680/2017). O apoio da Casa Cadaval tem sido também essencial não só no desenvolvimento dos projetos de investigação, mas também na proteção dos concheiros, assim como o da Câmara Municipal de Salvaterra de Magos que tem apoiado a equipa de investigação em várias dimensões de logística.

João Cascalheira e Célia Gonçalves são financiados pela Fundação para a Ciência e Tecnologia (FCT, contrato DL 57/2016/CP1361/CToo26 e DL 57/2016/ $\mathrm{CP}_{1361 / C T o o 29}$, respetivamente).

\section{BIBLIOGRAFIA}

ALDEIAS, Vera e BICHO, Nuno (2015) - Embedded Behavior: Human Activities and the Construction of the Mesolithic Shellmound of Cabeço da Amoreira, Muge, Portugal. Geoarchaeology: An International Journal oo, pp. 1-20.

ANDREFSKY, William Jr (1998) - Lithics: Macroscopic Approaches to Analysis. Cambridge University Press.

ANDREFSKY, William Jr (2005) - Lithic studies. In Handbook of Archaeological Methods. Rowman Altamira.

BICHO, Nuno (1993) - Technological change in the final Upper Paleolithic of Rio Maior, Portuguese Estremadura. Tese de Doutoramento na Southern Methodist University, Dallas, Texas, EUA.

BICHO, Nuno; CASCALHEIRA, João; MARREIROS, João; PEREIRA, Telmo (2011) - The 2008-2010 excavations of Cabeço da Amoreira, Muge, Portugal. Mesolithic Miscellany, 21, pp. 3-13.

BICHO, Nuno; CASCALHEIRA, João; MARREIROS, João; GONÇALVES, Célia; PEREIRA, Telmo; DIAS, Rita (2013) - Chronology of the Mesolithic occupation of the Muge valley, central Portugal: The case of Cabeço da Amoreira. Quaternary International, 308-309, pp. 130-139. 
BRÉZILLON, Michel (1968) - La dénomination des objets de pierre taillée, Supplément à Gallia préhistoire. Editions du Centre National de la Recherche Scientifique.

CASCALHEIRA, João e GONÇALVES, Célia (2012) - Spatial analysis and site formation processes of the mesolithic shellmiddens of Cabeço da Amoreira (Muge, Portugal). JIA 2011, 1, pp. 75-82.

CUNHA, Eugénia; CARDOSO, João; UMBELINO, Cláudia (2003) - New data on Muge Shell-middens: A contribution to more accurate numbers and dates. Estudos Arqueológicos, 1, pp. 185-198.

DETRY, Cleia e CARDOSO, João (2010) - On some remains of dog (Canis familiaris) from the Mesolithic shellmiddens of Muge, Portugal. Journal of Archaeological Science, 37, pp. 2762-2774.

CORRÊA, Mendes (1933) - Les nouvelles fouilles à Muge (Portugal). In XVe Congrès International d'Anthropologie et d’Archáeologie Préhistorique, Paris. Paris: Librairie E. Nourry, pp.1-16.

INIZAN, Marie-Louise; REDURON-BALLINGER, Michèle; ROCHE, Hélène; TIXIER, Jacques (1999) - Technology and terminology of knapped stone. Nanterre: Cercle de recherches et d'études préhistoriques.

PAIXÃO, Eduardo (2014) - A tecnologia lítica no Mesolítico da Estremadura: o caso da camada 2 do Cabeço da Amoreira. Dissertação de Mestrado na Universidade do Algarve.

PAIXÃO, Eduardo; MARREIROS, João; PEREIRA, Telmo; BICHO, N (2018) - Lithic variability in the Mesolithic shellmiddens of Western Iberian Atlantic Coast: technology, use-wear analysis and raw material sourcing from the Layer 2 lithic assemblage of Cabeço da Amoreira (Muge, Portugal). Journal of Anthropological Archaeology, pp. 1-21.

PEREIRA, Telmo; BICHO, Nuno; CASCALHEIRA, João; MARREIROS, João; PAIXÃO, Eduardo (2015) - Raw material procurement in Cabeço da Amoreira. In BICHO, Nuno; PRICE, T. Douglas; Cunha, Eugénia, eds - Muge 150 $0^{\text {th }}$ : The $150^{\text {th }}$ Anniversary of the Discovery of Mesolithic Shellmiddens: Volume 1. Cambridge: Cambridge Scholars Publishing, pp. 147-16o.

RIBEIRO, Carlos (1884) - Les kioekkenmoedings de la Vallée du Tage, rendu de la IX ${ }^{\mathrm{ème}}$ Session du Congrès International d'Anthropologie e d'Archéologie Préhistoriques. Typographie de l'Académie de Sciences, pp. 279-29o.

ROCHE, Jean (1964/1965) - Note sur la stratigraphie de l'amas coquillier mésolithique de Cabeço da Amoreira (Muge). Comunicações dos Serviços Geológicos de Portugal, XLVIII, pp. 191-199.

ROCHE, Jean (1966) - Balance de un siglo de excavaciones en los concheros mesolíticos de Muge. Empúries: revista de món clàssic $i$ antiguitat tardana, pp. 13-48.
ROLÃO, José (1999) - Del Wurm final al Holocénico en el Bajo Valle del Tajo: (Complejo Arqueológico Mesolítico de Muge). Universidad de Salamanca.

ROLÃO, José; JOAQUINITO, Ana; GONZAGA, M. (2006) - O complexo mesolítico de Muge: novos resultados sobre a ocupação do Cabeço da Amoreira. In BICHO, Nuno; VERÍSSIMO, Hugo, eds - Do Epipaleolítico ao Calcolítico na Península Ibérica: Actas do IV Congresso de Arqueologia Peninsular. Faro: Universidade do Algarve, pp. 27-42.

TIXIER, Jacques; INIZAN, Marie-Louise (1980) - Préhistoire de la pierre taillée. 1. Terminologie et technologie. Valbone: Centre de Recherches et d’Études Préhistoriques.

UMBELINO, Claúdia (2006) - Outros sabores do passado. As análises de oligoelementos e de isótopos estáveis na reconstrucão da dieta das comunidades humanas do Mesolítico Final e do Neolítico/Calcolítico do território português. Tese de doutoramento na Universidade de Coimbra.

VAN DER SCHRIEK, Tim; PASSMORE, David; STEVENSON, Anthony; ROLÃO, José (2007) - The palaeogeography of Mesolithic settlement-subsistence and shell midden formation in the Muge valley, Lower Tagus Basin, Portugal. Holocene, 17, pp. 369-385.

VAN DER SCHRIEK, Tim; PASSMORE, David; MUGICA, Franco; STEVENSON, Anthony; BOOMER, Ian; ROLÃO, José (2008) - Holocene palaeoecology and floodplain evolution of the Muge tributary, Lower Tagus Basin, Portugal. Quaternary International, 189, pp. 135-151.

ZILHÃO, João (1997) - O Paleolítico Superior da Estremadura portuguesa. Lisboa: Edições Colibri. 


\begin{tabular}{|c|c|c|c|}
\hline Camada & Descriçãao & Área SI & Área S2 \\
\hline 2 & $\begin{array}{l}\text { Presença abundante de fragmentos de concha, geralmente Cerastoderma edule, } \\
\text { com grande quantidade de artefactos líticos, conchas perfuradas de adornos } \\
\text { corporais, ossos e fragmentos de pinças de crustáceo. No interior da camada } 2 \\
\text { foram identificadas em determinadas áreas maiores concentrações de conchas, } \\
\text { frequentemente inteiras e praticamente sem sedimento, às quais foram atribuídas } \\
\text { a designação 2b, 2d, 2e e 2r, que correspondem a variações lenticulares laterais na } \\
\text { estratigrafia. Na base desta camada foi ainda exumado um esqueleto, designado } \\
\text { por Enterramento } 3 \text {. }\end{array}$ & $\mathrm{X}$ & $\mathrm{X}$ \\
\hline 3 & $\begin{array}{l}\text { Grande concentração de conhas, com diminuição no número de termoclastos em } \\
\text { relação às camadas anteriores, o desaparecimento total dos elementos cerâmicos, } \\
\text { manutenção da indústria lítica e restos faunísticos em abundância. Foram } \\
\text { identificadas variações na concentração de conchas dentro desta camada às quais } \\
\text { foram atribuídas as designações } 3 \text { a e } 3 \text { b. }\end{array}$ & $\mathrm{X}$ & $\mathrm{X}$ \\
\hline 4 & $\begin{array}{l}\text { Abundantes fragmentos de conchas (Cerastoderma edule) e artefactos líticos, } \\
\text { conchas perfuradas de adornos corporais, ossos (mamíferos, peixes, aves e } \\
\text { pequenos répteis) e fragmentos de pinças de crustáceos. Dentro desta camada } \\
\text { foi individualizada uma concentração de conchas designada 4a e uma estrutura } \\
\text { designada Feature A (Gonçalves \& alii 2018). }\end{array}$ & $\mathrm{X}$ & \\
\hline 6 & $\begin{array}{l}\text { Corresponde ainda a um nível de concheiro, constituída por bolsas arenosas e de } \\
\text { barro, com elevada densidade de seixos com dimensões inferiores a } 2 \mathrm{~cm} \text { e pequenos } \\
\text { fragmentos de fauna malacológica. Foi também identificada uma variação na } \\
\text { camada designada por } 6 \text { b. }\end{array}$ & $\mathrm{X}$ & \\
\hline $\mathrm{X}$ & $\begin{array}{l}\text { Corresponde à interface entre os níveis de concheiro e as areias base (camada Z). } \\
\text { Nesta camada foram identificadas uma estrutura (Feature 2), e um enterramento } \\
\text { (Enterramento } 4 \text { ). }\end{array}$ & $\mathrm{X}$ & \\
\hline Z & $\begin{array}{l}\text { Apresenta uma topografia irregular. A sua escavação permitiu a identificação de } \\
\text { duas estruturas negativas designadas Pit3 e Pit4, localizadas na área norte dos } \\
\text { quadrados K1 e J1. }\end{array}$ & $\mathrm{X}$ & \\
\hline Pitı & $\begin{array}{l}\text { Presença dominante de termoclastos e seixos, fauna e artefactos líticos. Existência } \\
\text { de uma divisão acentuada, em termos de composição sedimentológica e de } \\
\text { materiais arqueológicos, entre esta camada e as restantes. Foram identificadas } \\
\text { várias bolsas de concentração de conchas, designadas por PITıa, PITıb, PITıc } \\
\text { e PITıd. }\end{array}$ & & $\mathrm{X}$ \\
\hline 9 & $\begin{array}{l}\text { Elevada presença de concreções e termoclastos e diminuição do material } \\
\text { arqueológico associado. Dentro desta camada foi também identificada uma } \\
\text { concentração de fauna mamalógica de grande porte e relativamente bem } \\
\text { preservada. A boa delimitação espacial desta concentração levou á sua escavação } \\
\text { como estrutura, a qual foi nomeada Feature B. }\end{array}$ & & $\mathrm{X}$ \\
\hline 10 & Apresenta uma diminuição do número de seixos e termoclastos. & & $\mathrm{X}$ \\
\hline 11 & $\begin{array}{l}\text { Constituída quase na sua totalidade por Scrobicularia plana pouco fragmentadas } \\
\text { e carvões de grandes dimensões, com raros termoclastos e seixos. }\end{array}$ & & $\mathrm{X}$ \\
\hline 12 & $\begin{array}{l}\text { Constituída principalmente por fragmentos de conchas, apresentando também } \\
\text { algumas raízes concrecionadas. }\end{array}$ & & $\mathrm{X}$ \\
\hline
\end{tabular}

Tabela 1-Camadas de proveniência dos materiais utilizados no presente estudo e sua distribuição pelas duas áreas de escavação. 


\begin{tabular}{|c|c|c|c|c|c|c|c|c|c|c|c|c|c|c|c|c|c|c|c|c|c|c|c|c|}
\hline \multirow[b]{2}{*}{ Classe } & \multicolumn{2}{|r|}{2} & \multicolumn{2}{|c|}{3} & \multicolumn{2}{|r|}{4} & \multicolumn{2}{|r|}{6} & \multicolumn{2}{|r|}{$\mathrm{X}$} & \multicolumn{2}{|c|}{$\mathrm{Z}$} & \multicolumn{2}{|c|}{ PIT1 } & \multicolumn{2}{|c|}{9} & \multicolumn{2}{|c|}{10} & \multicolumn{2}{|c|}{11} & \multicolumn{2}{|c|}{12} & \multicolumn{2}{|c|}{ Total } \\
\hline & $\mathrm{n}$ & $\%$ & $\mathrm{n}$ & $\%$ & $\mathrm{n}$ & $\%$ & $\mathrm{n}$ & $\%$ & $\mathrm{n}$ & $\%$ & $\mathrm{n}$ & $\%$ & $\mathrm{n}$ & $\%$ & $\mathrm{n}$ & $\%$ & $\mathrm{n}$ & $\%$ & $\mathrm{n}$ & $\%$ & $\mathrm{n}$ & $\%$ & $\mathrm{n}$ & $\%$ \\
\hline Núcleo & 26 & 5.09 & 11 & 4 & 34 & $9 \cdot 42$ & 1 & 3.45 & 1 & 3.33 & 1 & 2 & 36 & $5 \cdot 54$ & 8 & 4.19 & 1 & 3.12 & - & - & - & - & 119 & 5.48 \\
\hline Frag. Núcleo & 4 & 0.78 & 5 & 1.82 & 1 & 0.28 & - & - & - & - & 1 & 2 & 2 & 0.31 & - & - & - & - & - & - & - & - & 13 & 0.6 \\
\hline EMNP & 6 & 1.17 & 3 & 1.09 & 3 & 0.83 & - & - & - & - & - & - & 5 & 0.77 & 3 & 1.57 & - & - & - & - & 1 & 4 & 21 & 0.97 \\
\hline Frag. EMNP & - & - & - & - & - & - & - & - & - & - & - & - & - & - & 2 & 1.05 & - & - & - & - & - & - & 2 & 0.09 \\
\hline $\begin{array}{l}\text { Produto } \\
\text { Alongado }\end{array}$ & 61 & 11.94 & 20 & 7.27 & 39 & 10.8 & 3 & 10.34 & 2 & 6.67 & 3 & 6 & 74 & 11.38 & 15 & 7.85 & 3 & 9.38 & 1 & 7 & 5 & 19 & 226 & 10.41 \\
\hline $\begin{array}{l}\text { Frag. Produto } \\
\text { Alongado }\end{array}$ & 36 & 7.05 & 14 & 5.09 & 22 & 6.09 & - & - & 1 & $3 \cdot 33$ & - & - & 32 & 4.92 & 5 & 2.62 & 3 & 9.38 & - & - & 3 & 12 & 116 & $5 \cdot 35$ \\
\hline Lasca & 194 & 37.96 & 138 & 50.18 & 157 & 43.49 & 18 & 62.07 & 14 & 46.67 & 23 & 46 & 385 & 59.23 & 111 & 58.12 & 20 & 62.5 & 7 & 47 & 14 & 54 & 1081 & 49.82 \\
\hline Frag. Lasca & 127 & 24.85 & 72 & 26.18 & 81 & 22.44 & 6 & 20.69 & 11 & 36.67 & 21 & 42 & 75 & 11.54 & 22 & 11.52 & 3 & 9.38 & 5 & 33 & 2 & 8 & 425 & 19.59 \\
\hline Retocado & 41 & 8.02 & 12 & $4 \cdot 36$ & 16 & 4.43 & 1 & 3.45 & o & ०\% & - & - & 31 & 4.77 & 16 & 8.38 & 2 & 6.25 & 2 & 13 & - & - & 121 & $5 \cdot 58$ \\
\hline $\begin{array}{l}\text { Frag. } \\
\text { Retocado }\end{array}$ & 16 & 3.13 & - & - & 8 & 2.22 & - & - & 1 & 3.33 & 1 & 2 & 10 & 1.54 & 9 & 4.71 & - & - & - & - & 1 & 4 & 46 & 2.12 \\
\hline Total & 511 & - & 275 & - & 361 & - & 29 & - & 30 & - & 50 & - & 650 & - & 191 & - & 32 & - & 15 & - & 26 & - & 2170 & - \\
\hline
\end{tabular}

Tabela 2 - Classes de artefactos líticos por camada.

\begin{tabular}{|c|c|c|c|c|c|c|c|c|c|c|c|c|}
\hline & 2 & 3 & 4 & 6 & $\mathrm{X}$ & $\mathrm{Z}$ & PIT1 & 9 & 10 & 11 & 12 & Total \\
\hline Raspadeira & 1 & - & - & - & - & - & - & - & - & - & - & 1 \\
\hline Raspadeira carenada & - & - & - & - & - & - & 1 & - & - & - & - & 1 \\
\hline Raspadeira carenada atipica & - & - & - & - & - & - & 1 & 1 & - & - & - & 2 \\
\hline Truncatura & 3 & - & 1 & - & - & 1 & - & - & - & - & - & 5 \\
\hline Truncatura obliqua & - & - & - & - & - & - & 1 & - & - & - & - & 1 \\
\hline Entalhe & 4 & 2 & 1 & - & - & - & 2 & 1 & - & - & - & 10 \\
\hline Denticulado & 1 & 1 & - & - & - & - & 2 & - & - & - & - & 4 \\
\hline Peca esquirolada & 1 & - & - & - & - & - & 2 & - & - & - & - & 3 \\
\hline Geometrico & 39 & 7 & 18 & 1 & 1 & - & 25 & 20 & 2 & 1 & 1 & 115 \\
\hline Lamela de dorso & - & 1 & - & - & - & - & 1 & 1 & - & - & - & 3 \\
\hline Lamela de dorso parcial & - & - & - & - & - & - & 2 & - & - & - & - & 2 \\
\hline Lamela com entalhe & - & - & 1 & - & - & - & - & - & - & - & - & 1 \\
\hline Lamina retocada & - & 1 & - & - & - & - & - & - & - & - & - & 1 \\
\hline Lamela retocada & 1 & - & 2 & - & - & - & 1 & 1 & - & - & - & 5 \\
\hline Lasca retocada & 7 & - & - & - & - & - & 2 & 1 & - & 1 & - & 11 \\
\hline Frente núcleo retocada & - & - & 1 & - & - & - & - & - & - & - & - & 1 \\
\hline Total & 57 & 12 & 24 & 1 & 1 & 1 & 40 & 25 & 2 & 2 & 1 & 166 \\
\hline
\end{tabular}

Tabela 3 - Tipo de utensílio lítico por camada (n).

\begin{tabular}{|l|l|l|l|l|}
\hline & diff & lwr & upr & P adj \\
\hline Quartzo- Quartzito & 0.16698 & 0.05025 & 0.2837 & 0.00234 \\
\hline Silex-Quartzito & 0.433 & 0.31105 & 0.55496 & 0.00 \\
\hline Silex-Quartzo & 0.26603 & 0.13848 & 0.39357 & 3.3 E-o6 \\
\hline
\end{tabular}

Tabela 4-Resultados do teste Tukey para comparações múltiplas sobre a distribuição da variável alongamento de suportes por cada matéria-prima. 

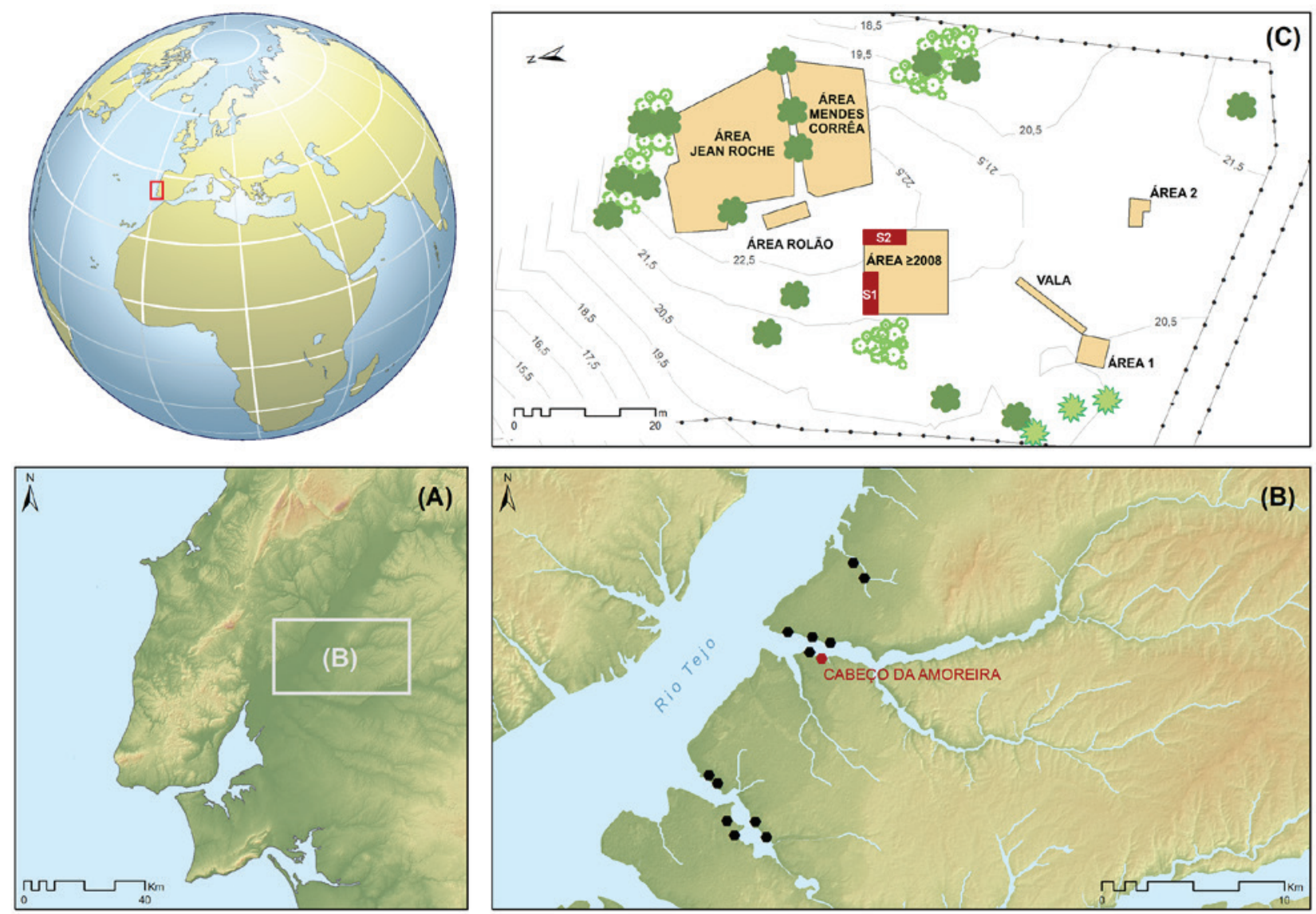

Figura 1-A e B - Localização dos concheiros mesolíticos nas margens das ribeiras Fonte da Moça, Muge e Magos; C-Planta topográfica do sítio arqueológico do Cabeço da Amoreira com a localização das várias áreas intervencionadas. Autor: Célia Gonçalves.

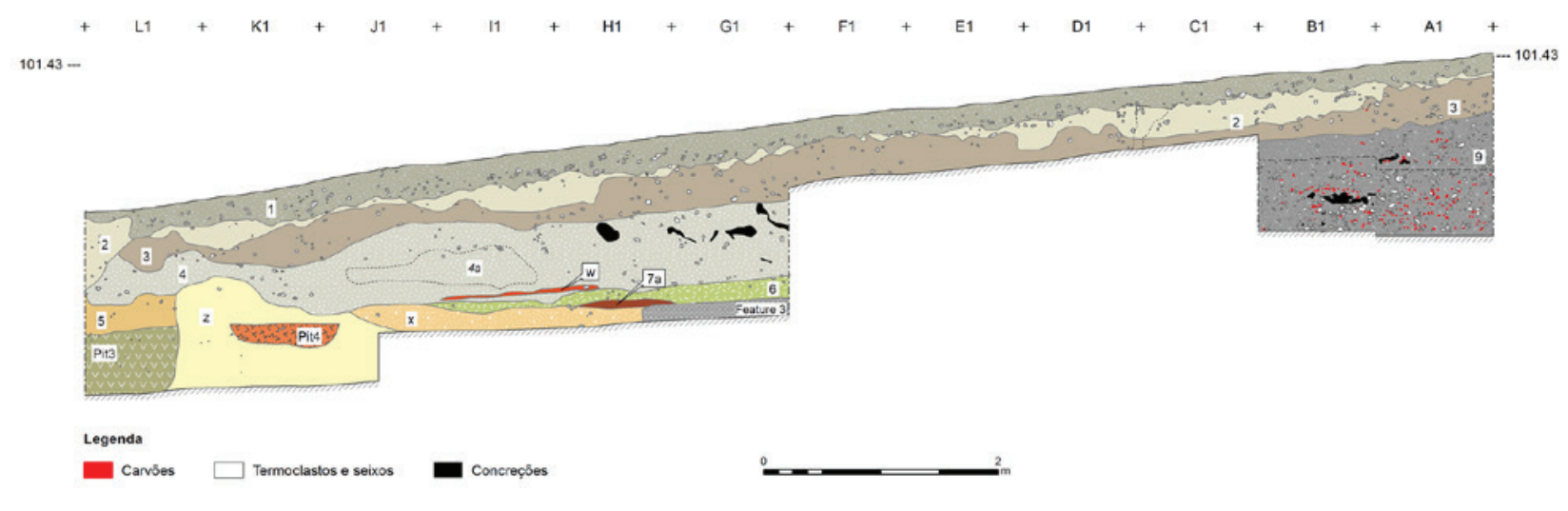

Figura 2 - Desenho do corte norte do concheiro do cabeço da Amoreira. Autor: Célia Gonçalves. 


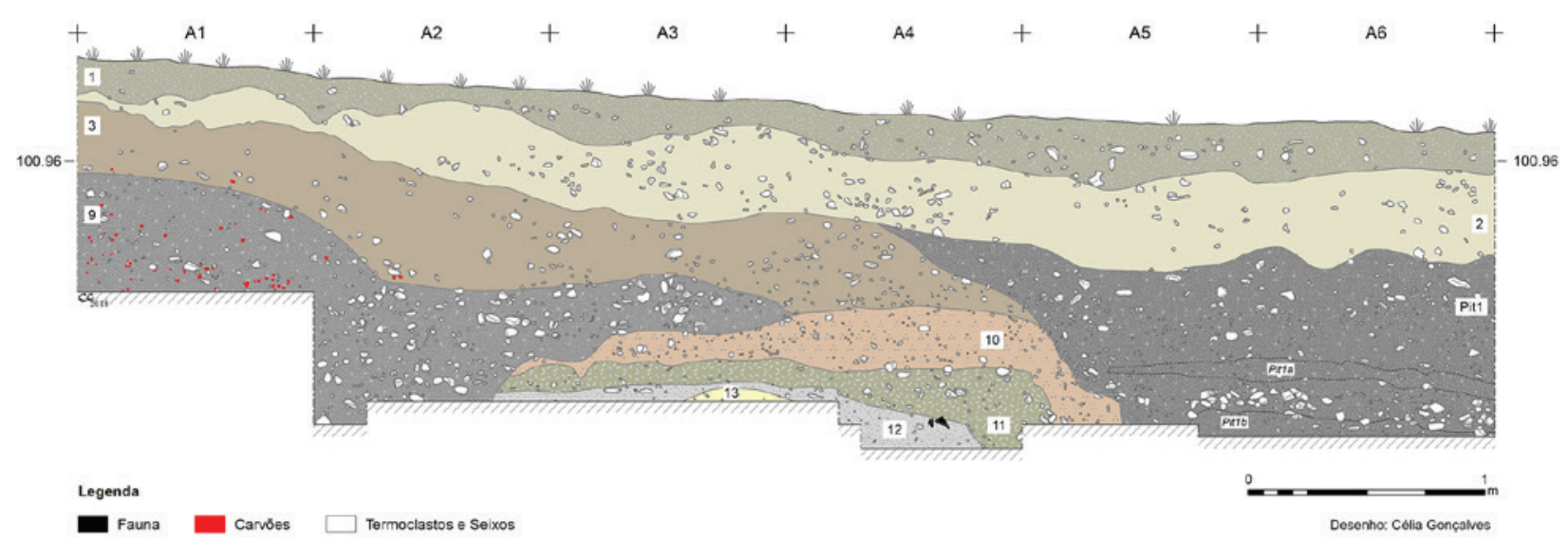

Figura 3 - Desenho do corte este da área S2 do concheiro do cabeço da Amoreira. Autor: Célia Gonçalves.

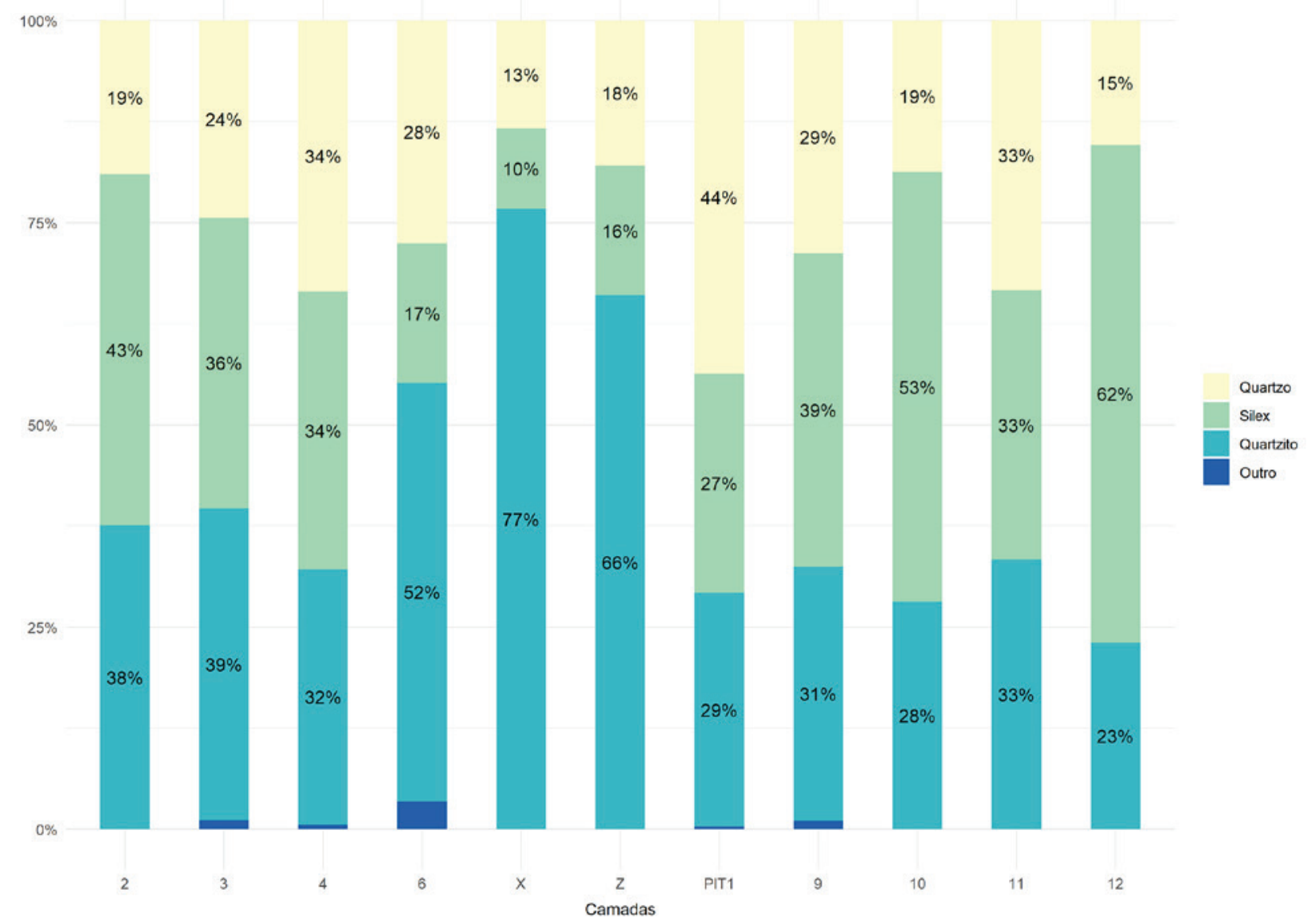

Figura 4 - Percentagem de matérias primas por camada das áreas S1 e S2 do Cabeço da Amoreira. Autor: Joana Belmiro. 


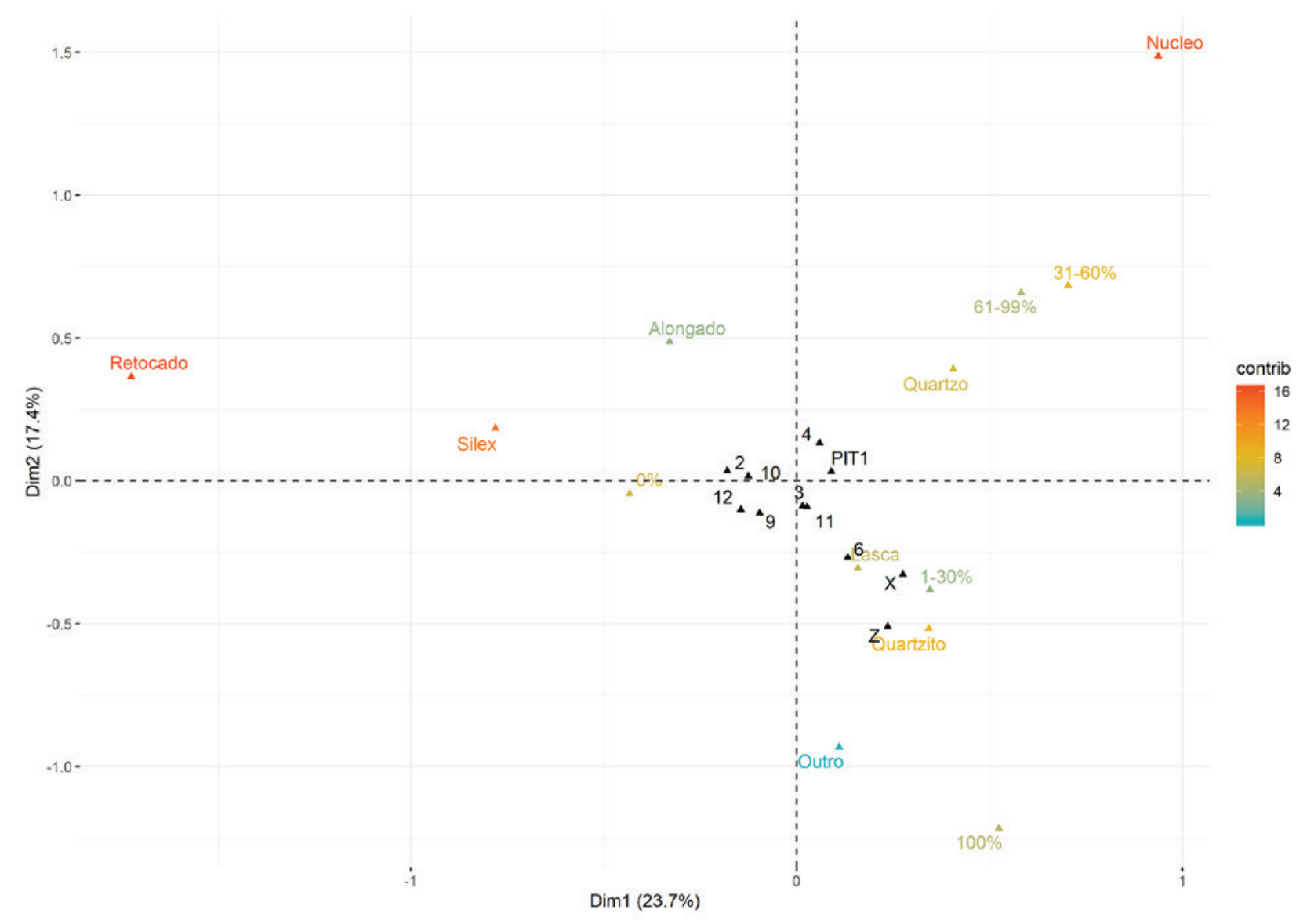

Figura 5-Análise de Correspondência Múltipla para as variáveis matéria-prima, classe de artefacto, percentagem de córtex e camada (variável suplementar). Autor: Joana Belmiro. 


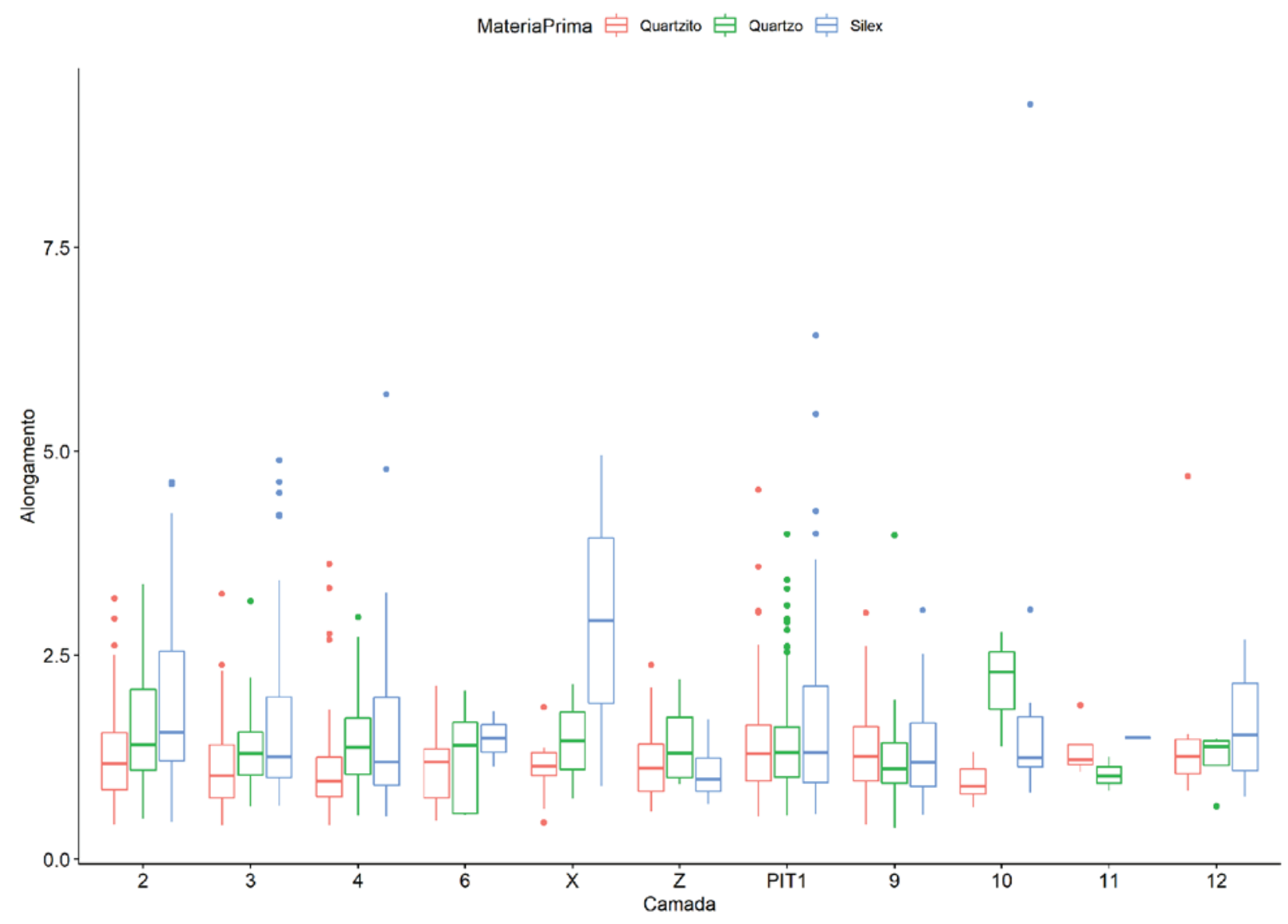

Figura 6 - Boxplot do índice de alongamento de lascas e produtos alongados, por matéria prima e camada. Autor: Joana Belmiro. 


\title{
NOVOS DADOS SOBRE A PRÉ-HISTÓRIA ANTIGA NO CONCELHO DE PALMELA. A INTERVENÇÃO ARQUEOLÓGICA NO SÍTIO DO POCEIRÃO I
}

\author{
Michelle Teixeira Santos ${ }^{1}$
}

\begin{abstract}
RESUMO
Apresentam-se os resultados da intervenção arqueológica realizada, em 2009, no sítio do Poceirão I (Palmela). Os trabalhos consistiram na realização de prospecção sistemática, por quadriculagem e de uma sondagem para diagnóstico do potencial arqueológico, registo de uma mancha de combustão e leitura estratigráfica. Os resultados obtidos permitiram individualizar dois Locus, uma dispersão considerável de artefactos de pedra lascada em sílex, quartzo e quartzitos, não tendo sido identificada a presença de cerâmicas. Porém, na área escavada Sondagem 1 - confirmou-se a forte destruição do sítio, a ausência de contextos antrópicos conservados e uma estratigrafia com reduzido potencial.

Partindo dos dados superficiais observados e do conjunto de espólio recolhido, o Poceirão I, parece corresponder a um sítio de habitat, ocupado por grupos de caçadores-recolectores do Mesolítico, da região interestuarina Tejo-Sado.

Palavras-Chave: Poceirão I, Mesolítico, Sado, Pedra Lascada, Caçadores-recolectores.
\end{abstract}

\begin{abstract}
Presentation of the results of the archaeological intervention at Poceirão I (Palmela) in 2009. The work consisted of conducting systematic prospecting using a grid and a survey to diagnose the archaeological potential, recording a combustion structure and stratigraphic reading. The results obtained, allowed to individualize two Locus, a considerable dispersion of chipped stone artifacts in flint, quartz and quartzite, but without pottery. However, the strong destruction of the site, the absence of preserved anthropic contexts and a stratigraphy with reduced potential was confirmed in the excavated area.

Based on the observed surface data and the materials exhumed, on Poceirão I settlement seems to have been occupied, during the Mesolithic, by groups of hunter-gatherers from the Tejo-Sado inter-estuarine region.

Keywords: Poceirão I, Mesolithic, Sado, Chipped stone, Hunter-gatherers.
\end{abstract}

\section{INTRODUÇÃO}

O sítio do Poceirão I - estação de ar livre -, localiza-se administrativamente no distrito de Setúbal, concelho de Palmela e na União de Freguesias de Poceirão e Marateca, no lugar do Poceirão, com as seguintes coordenadas geográficas, de acordo com o sistema de referência EPSG: 3763 (ETRS89/ PT-TMo6): Y - 115670 e X - 53100 e com $42 \mathrm{~m}$ de altitude. Ocupa uma área de antigo pinhal conhecida como «Pinhal Santos Jorge», desflorestada e em pousio, na margem lagunar do paleoestuário do Sado, junto da Ribeira da Agualva, a albufeira dos Vinte e Dois e a vala da Asseiceira, justamente entre as redes hidrográficas da ribeira das Enguias e da ribeira da Marateca, numa área plana e extensa com solos arenosos, a baixa altitude e sem condições naturais de defesa (Figura 1 e 2).

A sua centralidade neste ponto geográfico, com uma paisagem marcada pela presença de importantes cursos de água, afluentes do Tejo e do Sado, com um ambiente fluvial e uma diversidade de re-

1. Museu Municipal de Palmela; mtsantos@cm-palmela.pt 
cursos distintos do que hoje conhecemos terá sido determinante e vantajosa, para a permanência e sobrevivência neste território. Insere-se geológica e morfologicamente numa unidade caracterizada por um extenso planalto pliocénico com altitudes que variam entre os $20 \mathrm{~m}$ e $30 \mathrm{~m}$, subindo suavemente na vertente mais oriental até aos $125 \mathrm{~m}$, em que se formou o complexo greso-argiloso de Pegões, durante o Pliocénico marinho (Zbyszewski e Ferreira, 1968:5-9) (Figura 3).

A existência desta ocorrência era conhecida desde 1999, como depreendemos da informação associada a alguns materiais depositados no Museu Municipal, sem que houvesse correspondente informação na Carta Arqueológica do Concelho ou no Regulamento do Plano Director Municipal.

Esta ausência do Poceirão I no inventário do património arqueológico potenciou uma nova leitura do sítio, enquadrada nos trabalhos de prospecção na região de Palmela e Setúbal em 2005, coordenados por I. Fernandes e a signatária deste texto (Fernandes e Santos, 2012: 11-24), confirmando a existência de duas áreas distintas com concentração de materiais à superfície nomeadamente, núcleos de sílex, lamelas, lâminas e lascas residuais, raspadeiras de sílex, quartzo e quartzito e alguns seixos de quartzito talhados. Na fase do trabalho de gabinete (no tratamento, catalogação e inventário do espólio recolhido), não dispondo de informação mais detalhada decidimos, que o ano de 2005 seria a data de referência de recolha dos materiais - mantendo associado o apontamento em papel com data anterior -. O sítio integrou a Carta Arqueológica do Concelho e a Base de Dados Nacional - Endovélico, com o C.N.S. n.. 35463 (Figura 4).

Mais tarde, durante os trabalhos para a actualização da Carta Arqueológica realizados em 2009, regressámos ao local, para monitorizar as ocorrências conhecidas e inventariadas, verificando-se a expansão da pista de Aeromodelismo, mais a sul, para a área do Locus I, e a presença à superfície de uma mancha de combustão, que se encontrava exposta, em risco de destruição total (Figura 5).

Determinada a sua vulnerabilidade e exposição a ameaças várias, como a erosão eólica e as resultantes da sua localização numa pista de Aeromodelismo, um caminho em terra batida que separa os Locus I e II e a zona de extracção de areias na área do Locus II, realizámos uma sondagem no Locus I, para registar e caracterizar a estrutura de combustão que se observava à superfície e a prospecção sistemática intensiva, por quadrículas numa área circunscrita e adjacente à Sondagem 1 e nas áreas de maior dispersão de materiais.

\section{A INTERVENÇÃO ARQUEOLÓGICA}

A presença da estrutura de combustão determinou a localização da sondagem 1 (Si), implantada numa área total de $4 \mathrm{~m}^{2}$, distribuída por uma malha de $1 \mathrm{~m}$ $\mathrm{x}$ I m, e orientada a Norte, a que se seguiu a marcação da quadricula das áreas a prospectar, partindo desta sondagem.

Começámos por limpar e remover o depósito superficial arenoso e orgânico, com presença de materiais. Seguidamente, prosseguiu-se com a delimitação e definição da estrutura de combustão e contextos associados, bem como dos registos gráficos, fotográficos e topográficos. Todos os sedimentos foram removidos manualmente e crivados com malha fina.

A intervenção realizada não permitiu uma leitura segura do sítio, parecendo-nos que a mancha de combustão poderia tratar-se de uma realidade mais recente, que perturbou o nível arqueológico - correspondente ao sedimento superficial -. Não tem, além dos materiais presentes no topo da [U.E. 3], qualquer evidência de ocupação associada aos contextos arqueológicos. Os termoclastos recolhidos não são provenientes deste contexto. (Figuras 6 e 7 ). A escavação da Si terminou no Plano 5, no estrato correspondente ao Paleosolo [U.E. 5], sem presença de espólio ou estruturas associadas, a o.6o m de profundidade, registando-se no total, seis unidades estratigráficas distintas, mas apenas três reuniam escassa informação sobre a ocupação antrópica, cuja leitura se revelou muito condicionada pela exposição aos efeitos da erosão nos contextos e das perturbações ocorridas no local. A sequência estratigráfica era a seguinte:

- [U.E. o] - Sedimento superficial, com alguma vegetação rasteira, arenoso com granulometria fina, de cor amarelo-branco claro. Registou-se a presença de espólio;

- [U.E. 1] - Estrutura. Mancha de combustão, formando um covacho subcircular, aberto no paleosolo. Cortava o estrato geológico [U.E. 2] e era preenchido pelo sedimento [U.E. 3];

- [U.E. 2] - Estrato arenoso de grão muito fino, de cor amarela e húmido. Corresponde ao paleosolo, sem espólio associado. Profundidade 
atingida o,5om. A mancha de combustão [U.E. 1] assentava e cortava esta unidade que lhe servia de base;

- [U.E. 3] - Sedimento cinzento, arenoso e húmido, que preenchia a mancha de combustão [U.E. 1], composto por cinzas. Não tinha fauna associada e apenas se registava espólio no topo desta unidade, a sua percentagem diminuía em profundidade. Esta unidade era visível à superfície, a que lhe encostava a [U.E. o]; preenchia o covacho [U.E. 1] e sobrepunha-se à [U.E. 4];

- [U.E. 4] - Base do covacho. Sedimento amarelo, com manchas escuras, pontuado por cinzas e raros carvões de pequeníssima dimensão. Assentava sobre a [U.E. 2];

- [U.E 5] - Sedimento amarelo claro, arenoso de grão fino, que surgiu sob a [U.E. 2]. Não apresentava espólio, nem carvões associados;

- [U.E 6] - Pequena bolsa de uma raíz preenchida por areia fina, com algumas cinzas.

Concluída a escavação, nos dias seguintes avançou-se com os trabalhos de prospecção no Locus I e II. Como referimos, a quadricula de referência espacial foi organizada a partir da S1, distribuída ao longo de $3.400 \mathrm{~m}^{2}$ (Locus I - $2.720 \mathrm{~m}^{2}$ e Locus II $-680 \mathrm{~m}^{2}$ ), com quadrados de $2 \mathrm{~m} \mathrm{x} 2 \mathrm{~m}$ coincidentes com a área de maior concentração de materiais, que foram integralmente recolhidos. À superfície era visível a diversidade artefactual sendo notória a presença de raros termoclastos, de núcleos prismáticos (alguns esgotados) e produtos debitados maioritariamente em sílex e quartzito. A sua densidade vai diminuindo à medida que nos aproximamos do caminho de terra batida que separa as duas áreas, que distam uma da outra, aproximadamente $100 \mathrm{~m}$. Neste intervalo não foi individualizada a presença de espólio. (Figura 8) Nas áreas analisadas, o sedimento que aflora à superfície é pouco espesso, resultado da erosão e afectação que a área sofreu. Esta área denominada por "Pinhal Santos Jorge» à data da intervenção estava desflorestada e em pousio, com escassa vegetação rasteira, que oferecia uma boa leitura do solo, composto por um sedimento fino e muito arenoso, a que se associavam os materiais arqueológicos, seguido do paleosolo também arenoso e de grão fino.

A fraca conservação dos contextos arqueológicos que documentam a ocupação deste local deve-se sobretudo à exposição a fenómenos naturais e, em períodos mais recentes, às acções relacionadas com a esporádica extracção de areias (Locus II) e o desa- terro de algumas áreas, para a construção da pista de Aeromodelismo e acesso a este equipamento, adjacente ao Locus I.

\section{PRIMEIRAS LEITURAS, ALGUMAS QUESTÕES E INTENÇÕES FUTURAS}

Os territórios explorados pelos grupos humanos entre Tejo e Sado, em consequência do aquecimento climático registado a partir de 10.000 a.n.e. e dos efeitos da transgressão flandriana, transformam-se, tornam-se mais circunscritos em extensão e recursos. A capacidade de adaptação ao meio ambiente, dos grupos de caçadores-recolectores pós-glaciares é reconhecida, na prática de uma economia de subsistência de largo espectro, explorando zonas com uma diversidade de recursos alimentares (Silva e Soares, 2016; Soares e Silva, 2008), que implicariam pouco esforço, através da recolecção, da pesca e da caça de pequeno e médio porte, actividades que teriam expressão no quotidiano destes grupos interestuarinos.

Os dados que dispomos desenham uma ocupação sazonal, junto às margens de importantes cursos de água, por um grupo humano, muito provavelmente num período de curta duração para exploração do território, com excelentes condições de mobilidade e uma cultura material, ainda com aparente tradição magdalenense, onde se destaca a exploração de três tipos distintos de matéria-prima, o quartzito, o quartzo e o sílex, assumindo a indústria lamelar e laminar em sílex, particular expressão.

Não encontramos nos contextos associados ao sítio indícios de produção e armazenagem de alimentos, nem a exploração de recursos marino-estuarinos (recolhidos apenas dois pequenos restos de concha) ou consumo de cinegéticos. A reduzida área de amostragem intervencionada no ano de 2009 e, a ausência destes recursos, talvez degradados pela acidez dos solos arenosos e a erosão a que o sítio esteve exposto, não nos permitem avançar com considerações sustentadas sobre o modelo de gestão e consumo praticados.

No conjunto artefactual maioritariamente recolhido à superfície, não estavam presentes recipientes cerâmicos (também ausentes na Si), registando-se abundantes materiais em pedra lascada nomeadamente, as lascas obtidas sob quartzos e quartzitos, e a existência de uma indústria lamelar e laminar em sílex, para a produção de produtos alongados 
e de utensílios. Os restos de talhe, as peças de descorticagem e reavivamento de blocos a debitar, conjugados com a presença de núcleos esgotados e de material debitado, confirmam a prática de talhe de matéria-prima regional e exógena (Figuras 9 e 10).

Nesta leitura bastante preliminar que fazemos, parece-nos evidente que a exploração do quartzo e do quartzito aplicaria uma estratégia expedita para a produção de utensilagem de fundo comum, sobretudo de lascas retocadas ou em bruto para uso circunstancial (Carvalho, 1998b; Soares, 2013 e Neves, 2013). Contrariamente, a exploração do sílex (algum de excelente qualidade e proveniente de áreas distantes do Poceirão I) foi dirigida para a produção de suportes alongados e utensílios (estando ausentes no conjunto, os geométricos), com presença de lascas e dos suportes lamelares e laminares (os últimos em menor número) aproveitando-os quase integralmente, e em alguns casos, submetendo-os ao pré-tratamento térmico, obtendo-se um talhe mais cuidado e um melhor aproveitamento.

A presença de materiais arqueológicos à superfície e da reduzida potência estratigráfica registada podem denunciar uma ocupação sazonal, extensível ao longo desta plataforma situada próxima de importantes cursos de água, que facilitaria o acesso a recursos abundantes e à comunicação fluvial.

Partindo dos dados disponíveis e na ausência de matéria que possibilitasse a obtenção de datações absolutas, o Poceirão I, ocupado por grupos de caçadores-recolectores parece enquadrar-se crono-culturalmente, num momento inicial do Mesolítico (entre 10.000 a 7.000 a.n.e.) ou mesmo anterior, no final do Paleolítico Superior.

Os dados arqueológicos que apresentamos, resultam maioritariamente de observações e recolhas de superfície e como tal, a sua interpretação condicionada pelas limitações que lhe são oriundas é realizada com as necessárias reservas, obrigando-nos a prosseguir uma reflexão e estudo sobre estas comunidades de caçadores-recolectores, que ocuparam o território de Palmela, de que tão pouco conhecemos. Recentemente, quando começámos a redigir este texto, visitámos o local, agora com bastante coberto vegetal, e lamentavelmente percebemos, que a pequena área de extracção de inertes, que havíamos registado em anos anteriores, expandiu-se consideravelmente, e destruiu uma parte da área do Locus II (prospectada nos anos de 2005 e 2009). Para poente, no Locus I, confirma-se o crescimento da Pista de
Aeromodelismo, que se localiza agora sobre a área escavada em 2009 (sondagem 1). Procuramos neste momento averiguar a condição da situação verificada, diligenciando para que se proceda a uma avaliação dos impactos ocorridos e a pertinência de desenvolver adequadas medidas de salvaguarda arqueológica. Por fim, termino com um agradecimento ao João Nunes e ao Marco A. Andrade pelo apoio e disponibilidade no esclarecimento de algumas questões (por vezes, muitas), na elaboração dos desenhos dos materiais e no tratamento gráfico das imagens usadas no texto.

\section{Palmela, Junho de 2020}

\section{BIBLIOGRAFIA}

CARVALHO, A. F. (1998b) - Talhe da pedra no Neolitico antigo do Maciço Calcário das Serras d'Aire e Candeeiros (Estremadura Portuguesa). Um primeiro modelo tecnológico e tipológico. Textos Monográficos. Lisboa.

DAVEAU, Suzanne (1980) - Espaço e Tempo. Evolução do ambiente geográfico de Portugal ao longo dos tempos pré-históricos. Clio. Lisboa. 2, pp. 13-37.

FERNANDES, Isabel Cristina Ferreira; SANTOS, Michelle Teixeira (2012) - Carta Arqueológica do Concelho de Palmela. In Palmela Arqueológica no contexto da região interestuarina Sado-Tejo. Palmela, pp. 11-24;

NEVES, César (2013) - A Evolução do Processo de Neolitização numa paisagem estuarina: a ocupação do Monte da Foz 1 (Benavente, Portugal). In Pré-História das Zonas Húmidas, Setúbal Arqueológica. Setúbal 14, pp. 123-144.

SOARES, Joaquina (2013) - Caçadores-recolectores semi-sedentários do Mesolítico do paleoestuário do Sado (Portugal). In Pré-História das Zonas Húmidas, Setúbal Arqueológica. Setúbal 14, pp. 13-56.

SILVA, Carlos Tavares da; SOARES, Joaquina (2016) - The Pleistocene-Holocene transition on the portuguese southwest coast. A zero stage of social complexity? In Social Complexity in a long-term perspective (Session B15). Setúbal Arqueológica. Setúbal 16, pp. 21-40;

SOARES, Joaquina; SILVA, Carlos Tavares da (2008) - Camarral e Casal da Cerca: Sítios Pré-Históricos do Concelho. Acampamento Epipaleolítico do Camarral (Volta da Pedra/ Palmela). Roteiro da Exposição Palmela Arqueológica. Espaços, Vivências, Poderes. Palmela, pp. 21-25;

ZBYSZEWSKI, Georges; FERREIRA, Octávio da Veiga (1968) - Carta Geológica de Portugal: notícia explicativa da Folha 35-C, escala 1/50 ooo. Lisboa: Serviços Geológicos de Portugal. 


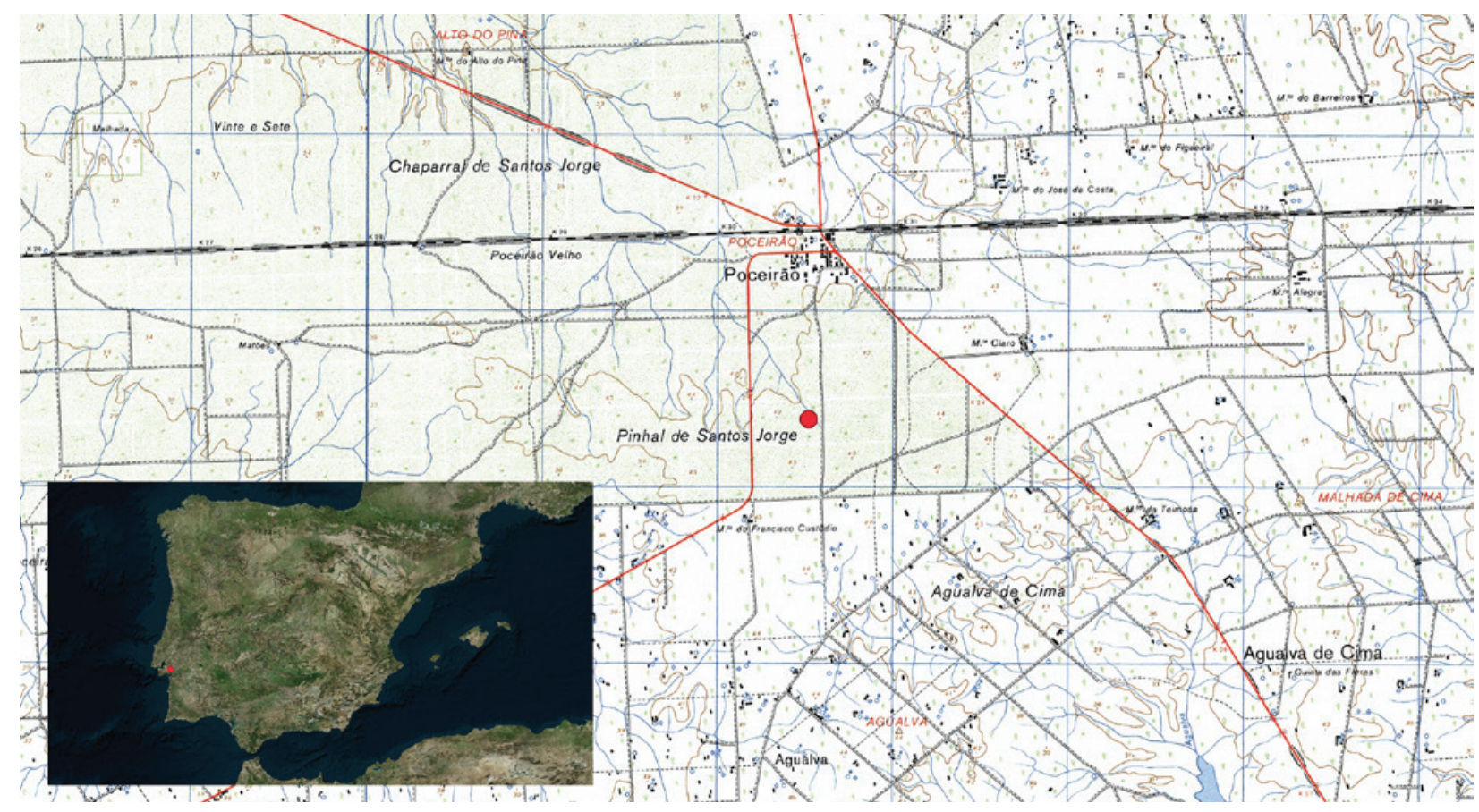

Figura 1 - Localização sobre excerto da Folha n.ํ4 44 da CMP, à escala 1:25.0oo. 


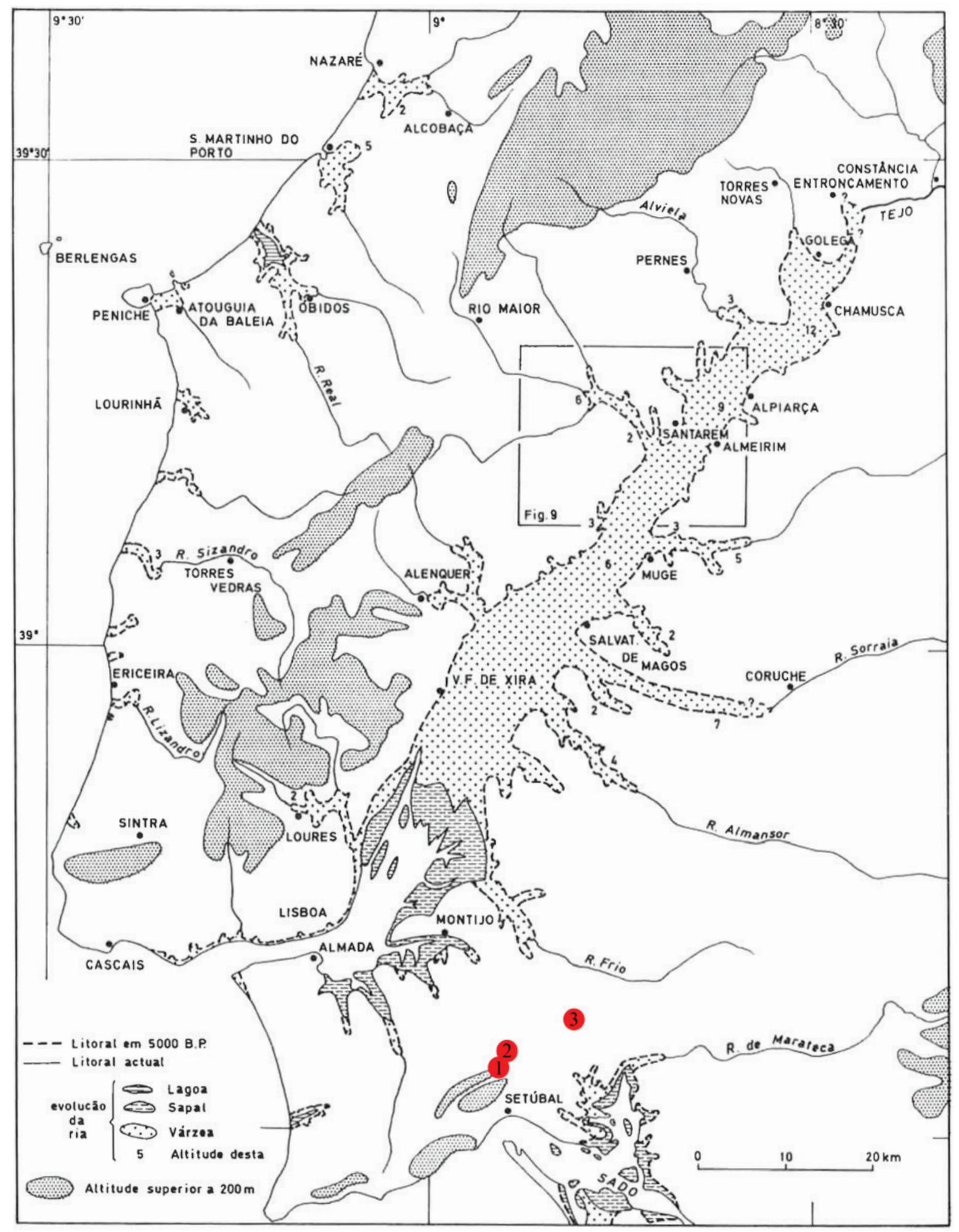

Figura 2 - Enquadramento na região interestuarina Tejo-Sado: 1. Casal da Cerca; 2. Camarral; 3. Poceirão I (base cartográfica adaptada: Daveau, 1980:26). 


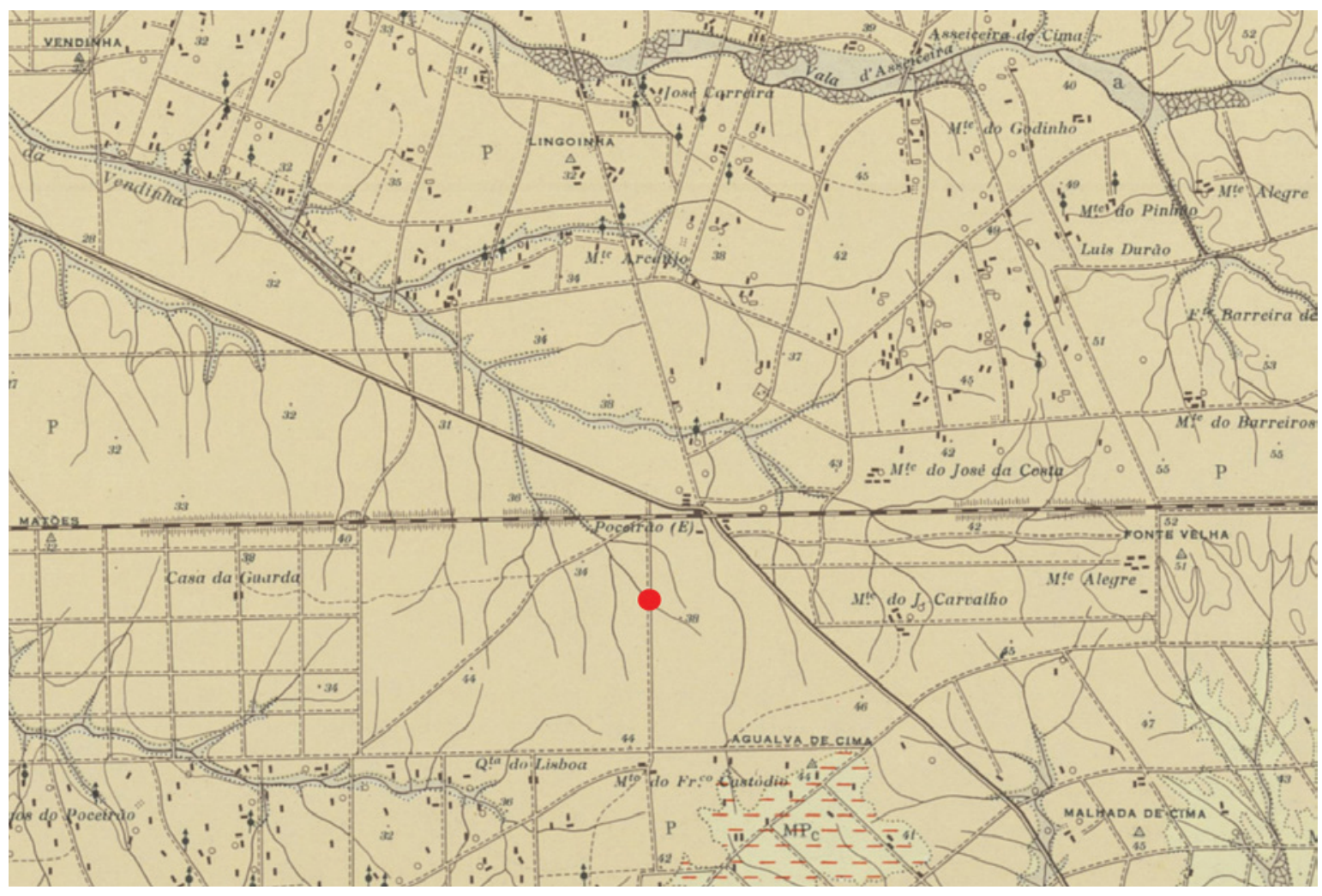

Figura 3 - A Geologia do Poceirão I - excerto da Carta Geológica de Portugal, Folha 35-C, 1:50.0oo, Serviços Geológicos de Portugal.

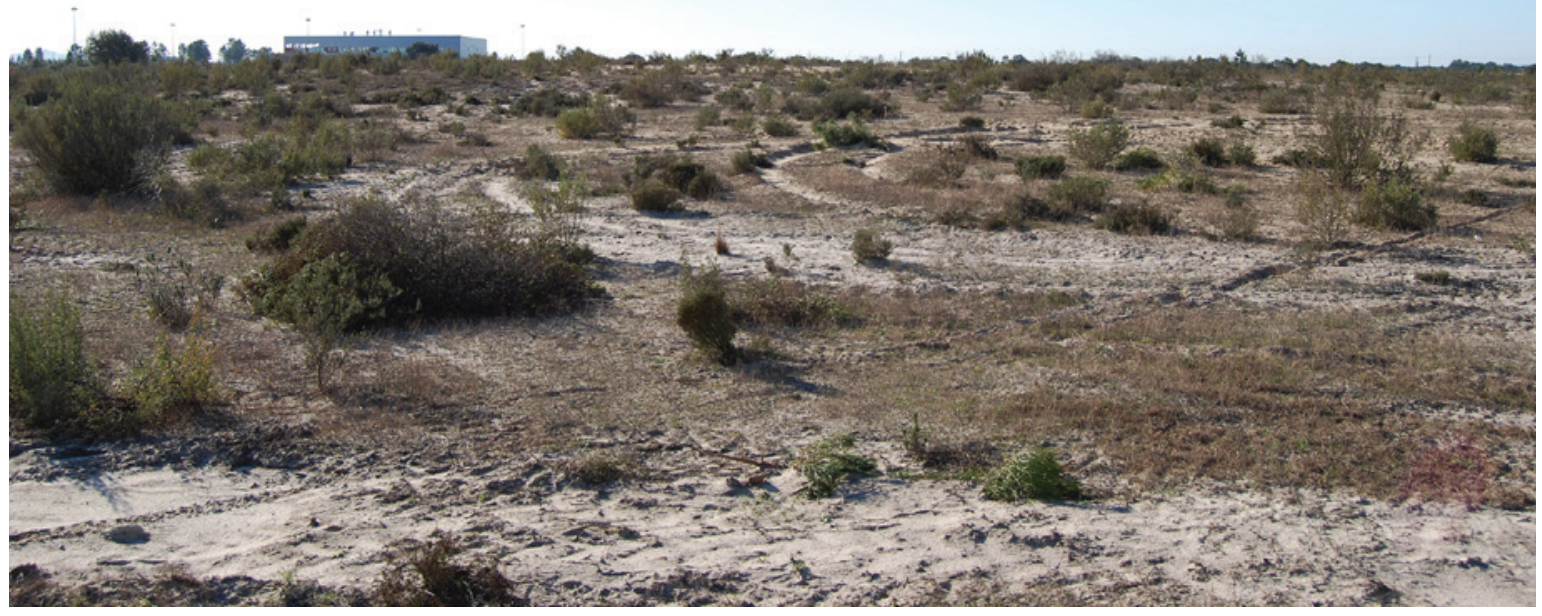

Figura 4 - Vista geral da plataforma do Poceirão I. 


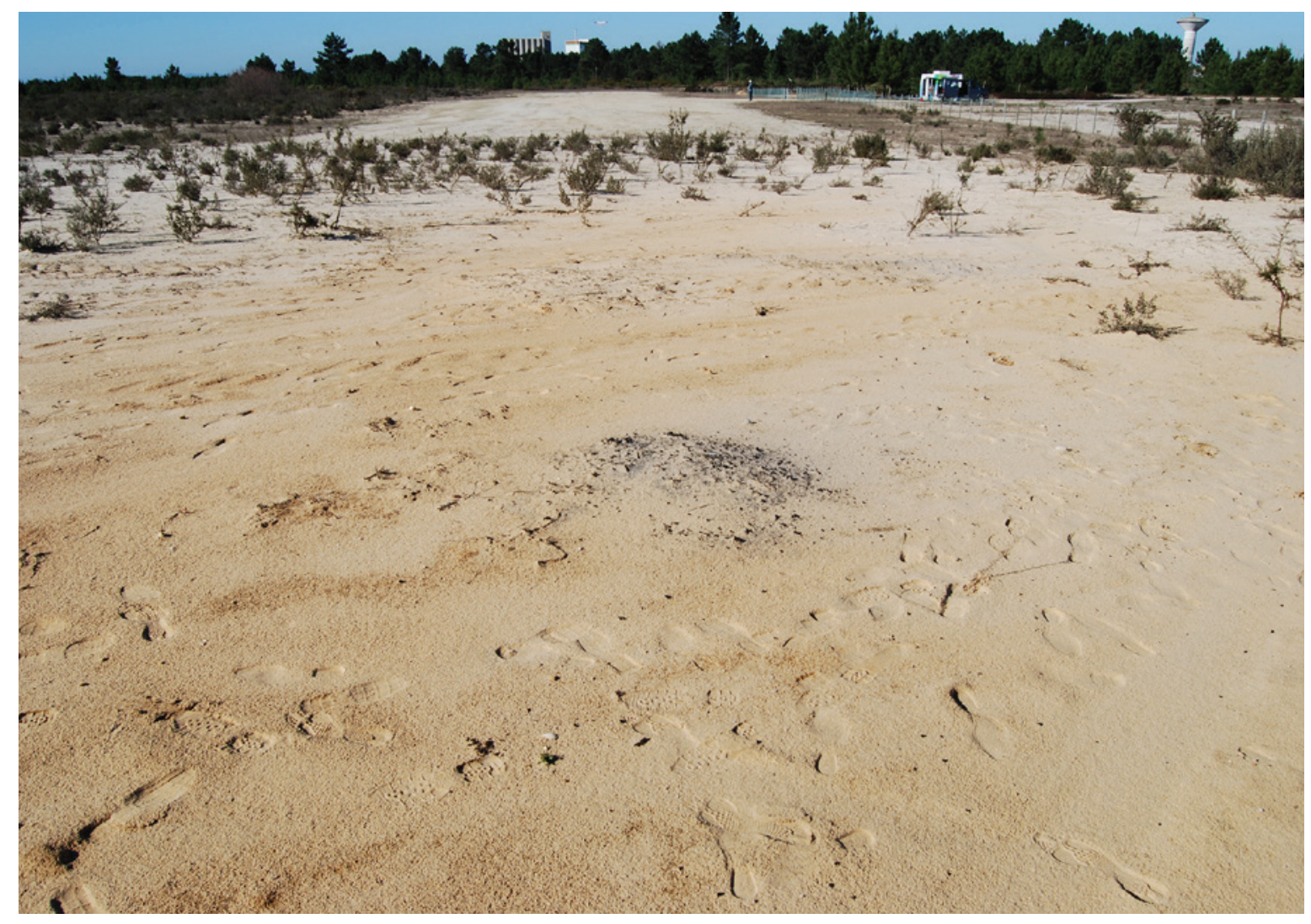

Figura 5-Área do Locus I e a Pista de Aeromodelismo, com a mancha de combustão visível ao centro da imagem.

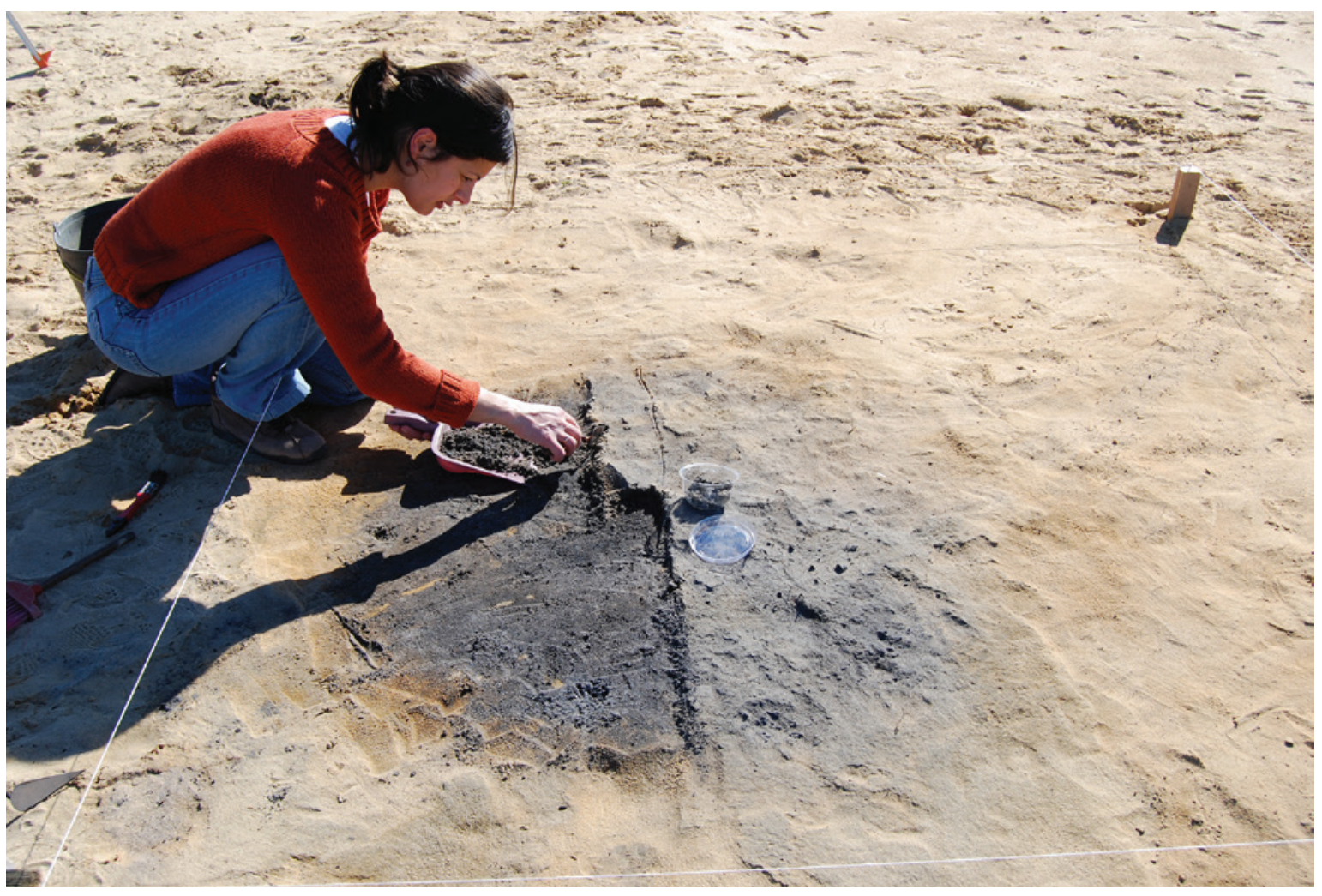

Figura 6 - Sondagem 1 - mancha de combustão. 


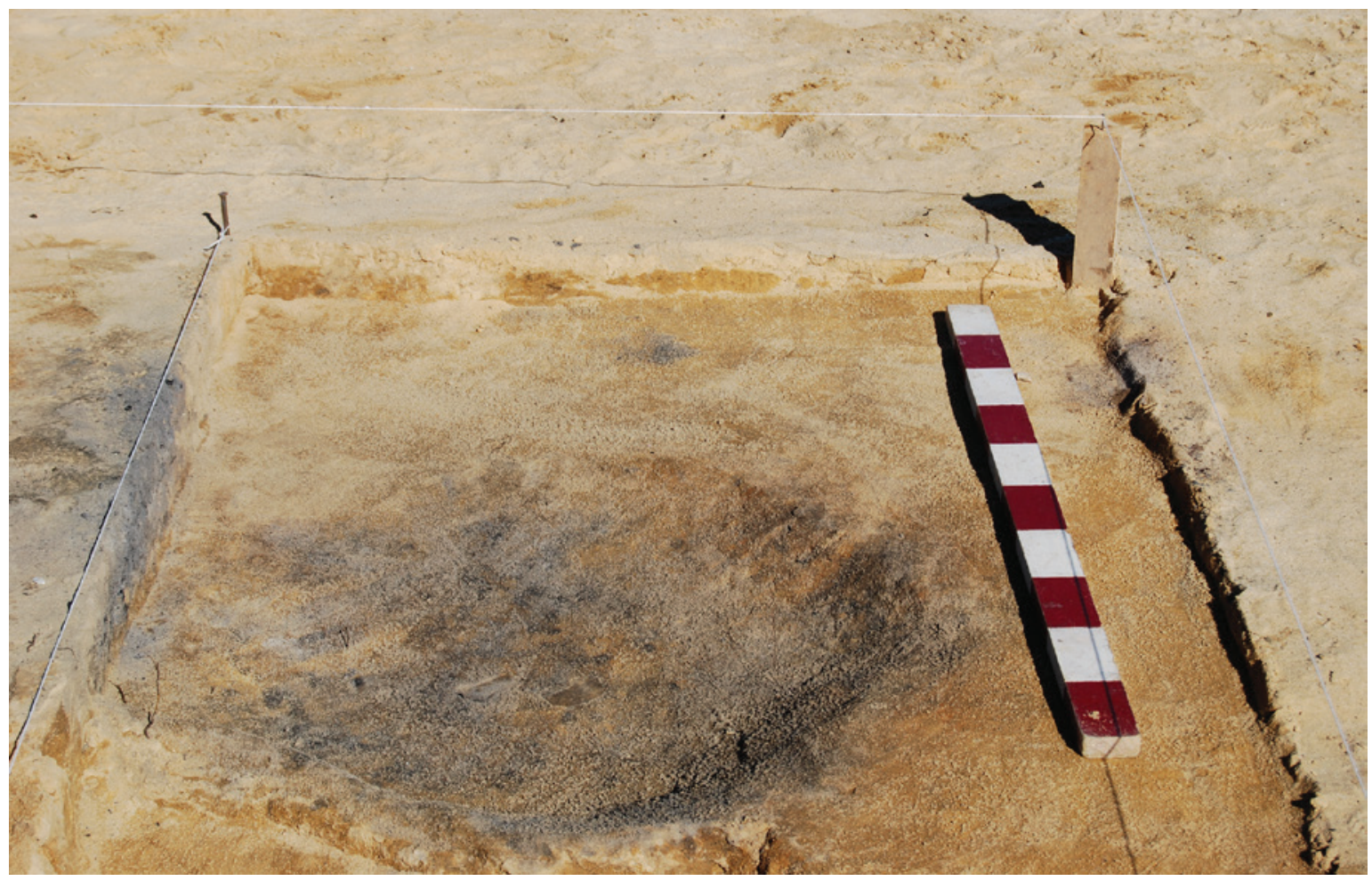

Figura 7 - Escavação do Plano 4. Pormenor do negativo da estrutura de combustão [U.E. 1].

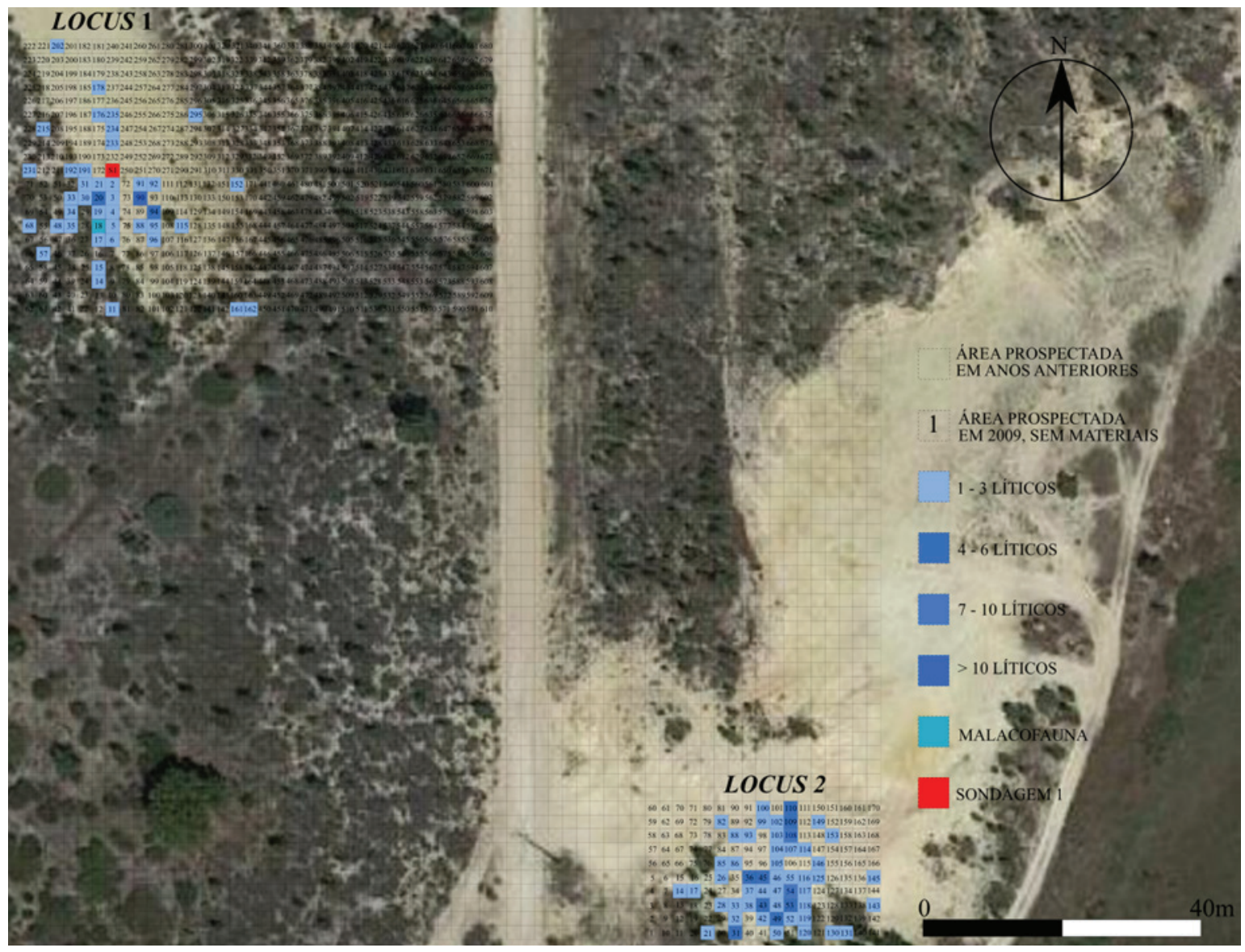

Figura 8 - Distribuição espacial dos materiais à superfície (Locus I e II). 

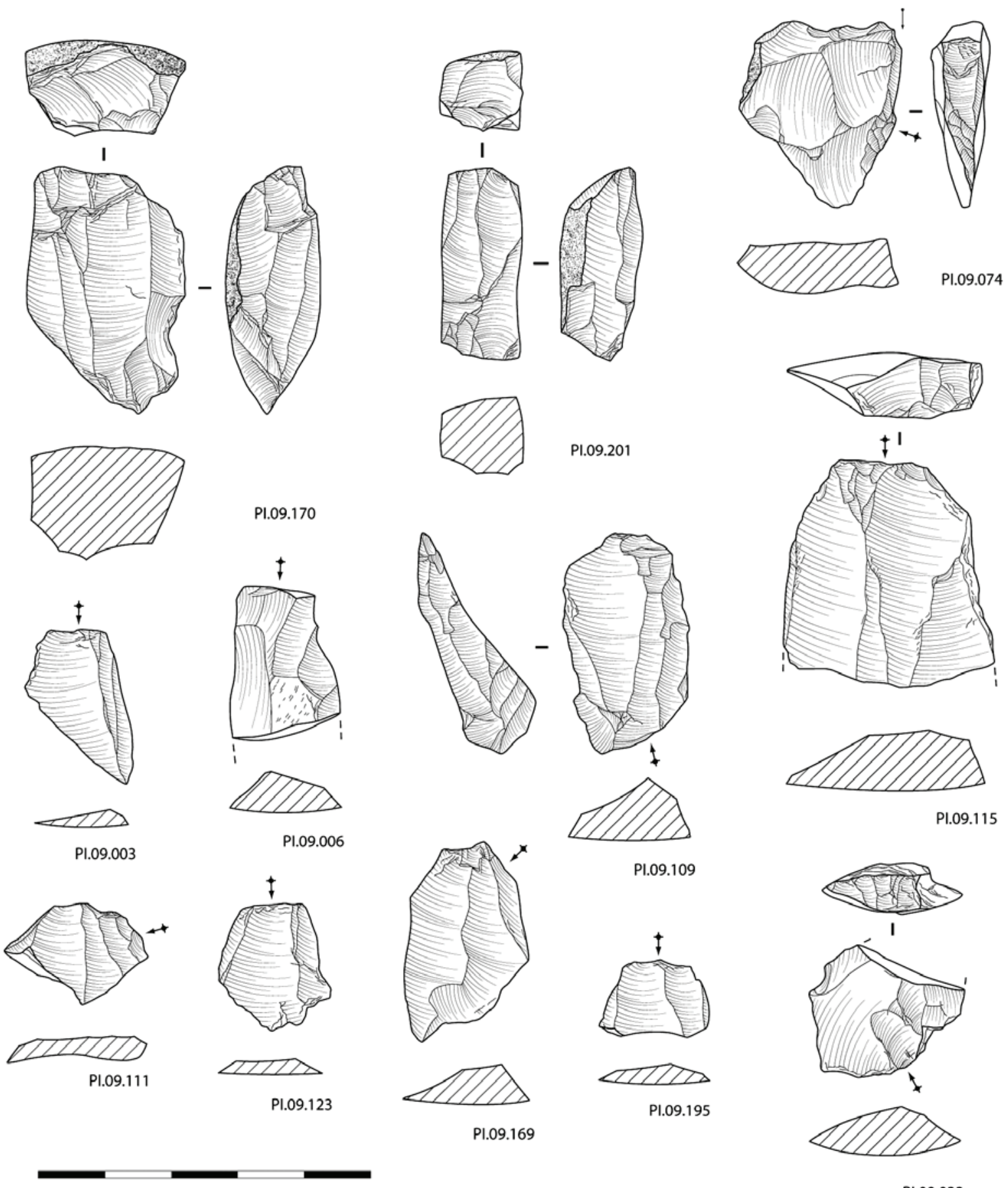

PI.09.115
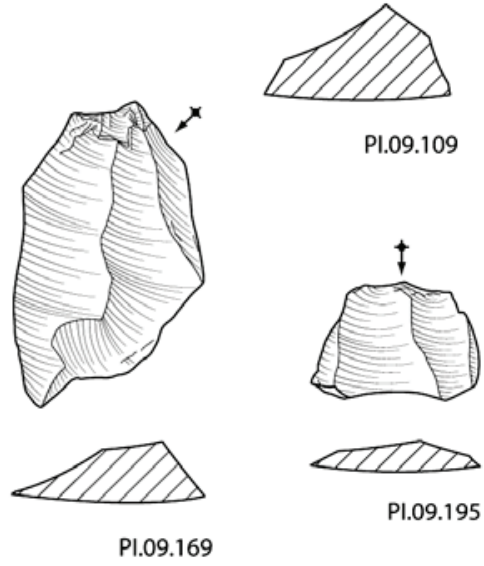

PI.09.195

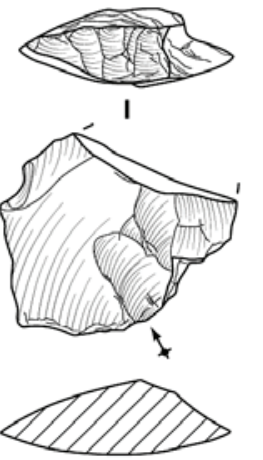

PI.09.033

Figura 9- Pedra lascada (sílex e quartzito): núcleos, material de preparação e resíduos de talhe (Desenho de Marco António Andrade). 

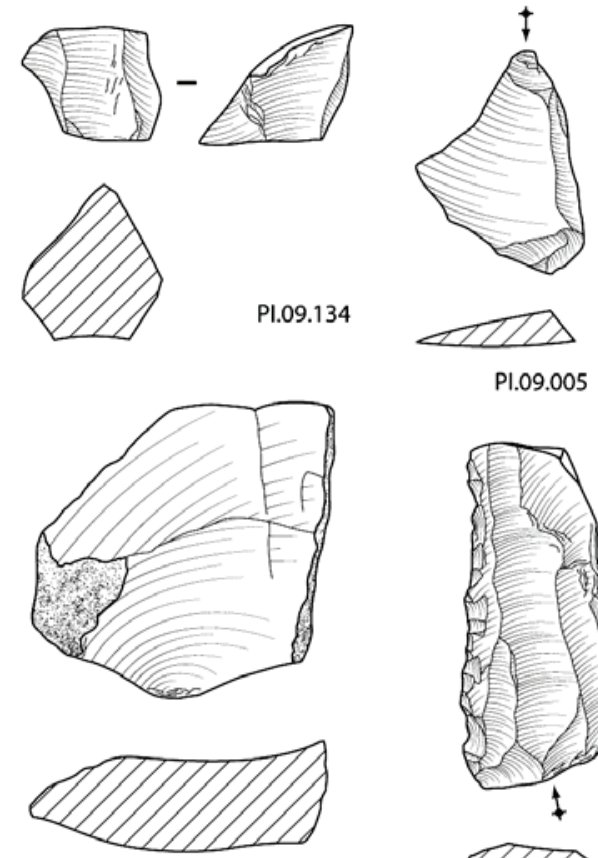

PI. 09.200
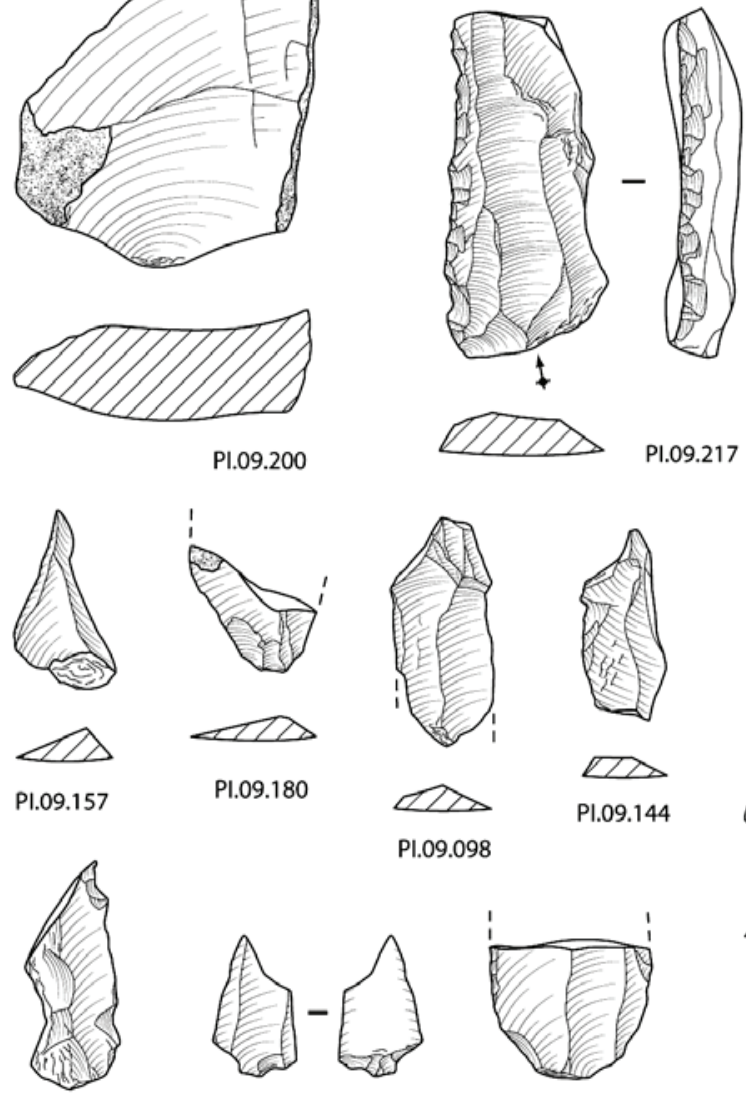

$\begin{array}{ll}\text { Pl.09.098 } & \text { Pl.09.144 } \\ & \end{array}$ P1.09.098

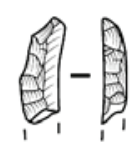

$\Delta$
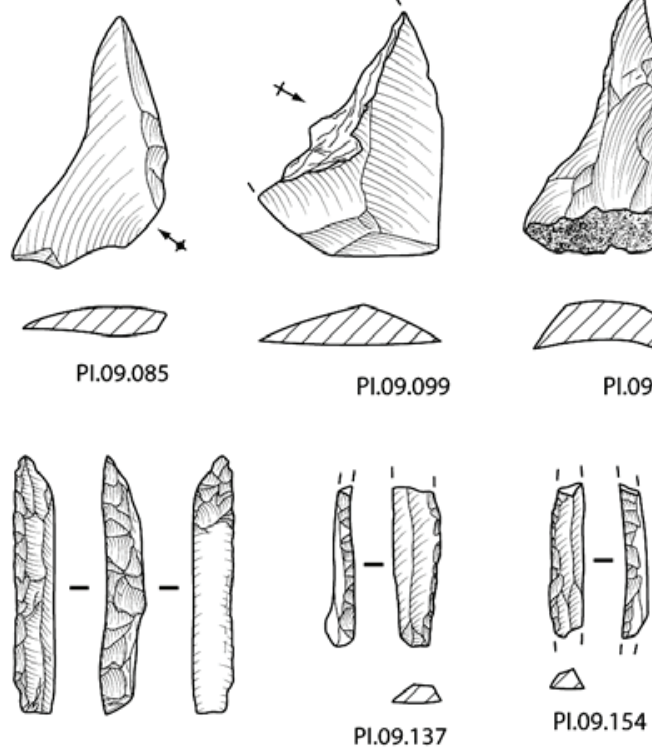

$\triangle$
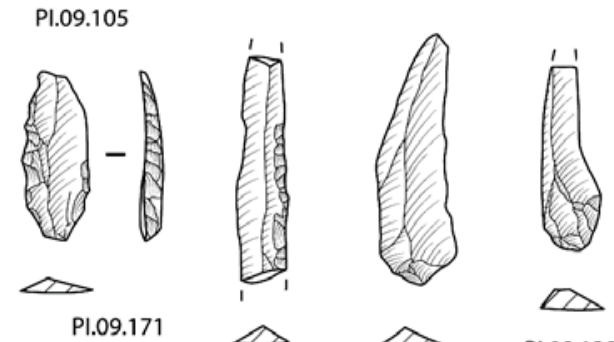

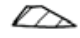

PI.09.138
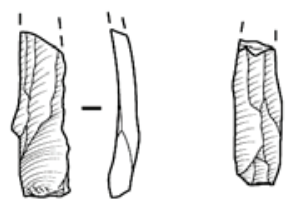

PI.09.158

PI.09.126

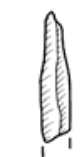

$\overbrace{\text { PI.09.066 }}$

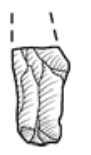

$\infty$

PI.09.075
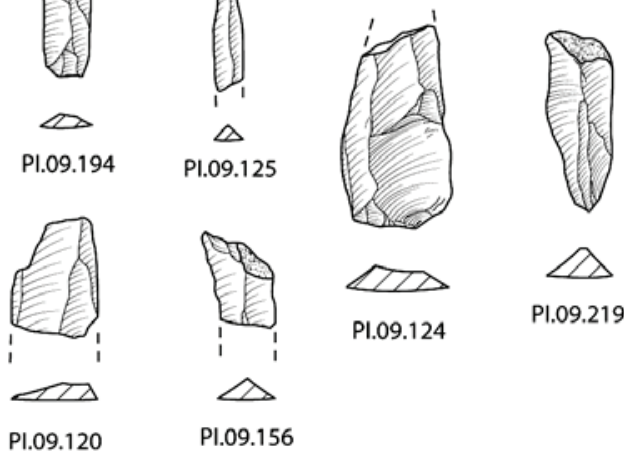

Figura 10 - Pedra lascada (sílex e quartzito): utensílios e lamelas. (Desenho de Marco António Andrade). 


\title{
PROBLEMAS EM TORNO DE DATAS ABSOLUTAS PRÉ-HISTÓRICAS NO NORTE DO ALENTEJO
}

\author{
Jorge de Oliveira ${ }^{\mathrm{T}}$
}

\begin{abstract}
RESUMO
Nesta comunicação iremos apresentar todas as datas absolutas obtidas para contextos atribuídos à Pré-história recente do Alto Alentejo, mas cujos valores questionam o posicionamento cultural de alguns dos sítios. Tentaremos compreender as datas de radiocarbono do X ao VIII milénios a.C. em abrigos com arte rupestre esquemática. Trataremos os contextos das datas absolutas do VII ao V milénios a.C. em monumentos megalíticos funerários e, finalmente, divulgaremos, de novo, as datas absolutas obtidas em carvões recolhidos em alvéolos de menhires que os recuam mais de 2000 anos do que seria inicialmente suposto. Nesta comunicação trataremos também de um conjunto de datas de históricas obtidas a partir de carvões recolhidos em sítios atribuídos à Pré-História recente, mas com ocupações, ou visitas históricas que tentaremos contextualizar.

Palavras-chave: Datas absolutas, Pré-História, Norte do Alentejo, Problemas.
\end{abstract}

\begin{abstract}
In this communication we will present all the absolute dates obtained for contexts attributed to the recent prehistory of Alto Alentejo, but whose values question the cultural positioning of some of the sites. We will try to understand the radiocarbon dates from $10^{\text {th }}$ to the $8^{\text {th }}$ millennium $B C$ in shelters with schematic rock art. We will deal with the contexts of the absolute dates from the $7^{\text {th }}$ to the $5^{\text {th }}$ millennium B.C. in funerary megalithic monuments and, finally, we will disclose, again, the absolute dates obtained from coals collected in wells of menhirs that go back more than 2000 years from what was initially supposed. In this communication we will also deal with a set of historical dates obtained from coals collected from sites attributed to recent Prehistory, but with occupations, or historical visits that we will try to contextualize.
\end{abstract}

Keywords: Absolute dates, Prehistory, Northern Alentejo, Problems.

\section{O CONTEXTO}

No curto espaço que nos faculta esta comunicação teremos que apresentar de forma resumida as diferentes problemáticas contextuais das datações obtidas para sítios conotados com a Pré-História recente. Faremos essa apresentação, quer por cronologias, quer por contextos de recolha. No fim apresentaremos uma tabela-resumo de todas as datas obtidas e imagens dos contextos em que foram recolhidas. Foi só em 1982 que se obtiveram as primeiras datas por radiocarbono para a Pré-História no Norte do Alentejo. Os trabalhos de escavação e valorização da Anta da Bola da Cera, situada no concelho de Marvão, permitiram, pela primeira vez, obter datações absolutas sobre ossos humanos carbonizados "in situ" associados a placas de xisto de recorte e decoração antropomórficos. Iniciava-se, com este estudo, um longo ciclo de recolha e datação de amostras em diversos sítios com ocupação atribuída à pré-história recente no Distrito de Portalegre e canto Noroeste da Extremadura Espanhola. Trinta e oito anos decorridos contamos agora com um já significativo número de amostras datadas, mais de 30, podendo ser mais, não fosse os eternos constrangimentos orçamentais, que nos permitem compreender e aos mesmo tempo problematizar os posicionamentos cronométricos das mais importantes manifestações culturais da Pré-História Recente para esta zona da Península (Figura 1).

1. CHAIA / Universidade de Évora. 


\section{AS DATAS HISTÓRICAS}

Os estudos realizados em dólmenes de grande e média dimensão do corredor granítico Marvão Castelo de Vide - Nisa - Alter do Chão, nos pequenos sepulcros megalíticos das margens do Tejo, em território de Nisa e Cedillo (Espanha), nos abrigos com pinturas, maioritariamente esquemáticas, das cristas quartzíticas da Serra de Mamede, nos principais menhires dos concelhos de Marvão, Castelo de Vide e Nisa e nos dólmenes com menhires do concelho de Alter do Chão, permitem-nos apresentar hoje um amplo leque de datações absolutas que variam entre o $10^{\circ}$ milénio a.C. até ao séc. XVIII A.D.. Neste amplo leque cronológico há que isolar as datas históricas que se reportam, a estranhos episódios de fogueiras acesas no interior de grutas e dólmenes, ou junto a menhires em torno ao ano $1000 \mathrm{AD}$, que poderão estar estreitamente relacionados com episódios dos muito divulgados mitos apocalípticos dos "milenarismos". Não convém também esquecer as diversas datas históricas posicionadas em torno do período da denominada Reconquista Cristã que terá obrigado ao êxodo massivo dos núcleos urbanos por parte das comunidades aí estabelecidas a procurar grutas naturais isoladas para refúgio das espadas dos cavaleiros da cristandade e, por último, o enterramento dum equídeo num dólmen, pouco tempo depois da instalação, em terras do Reguengo de Alter do Chão, da Coudelaria Real, em 1748, durante o Reinado de D. João V, quando ainda não se tinha definido o "cemitério dos cavalos" naquela coudelaria. Haveria aqui que acrescentar, se dinheiro tivesse havido para submeter a datação mais amostras, os atos de visitação e violação de dólmenes para obtenção de sílex para pederneiras das armas de fogo nos séculos XVII e XVIII, como nos confirmam os documentos escritos que compulsámos, ou as reutilizações, quer como espaço funerário durante a romanização, como ocorreu no corredor da Anta da Tapada de Matos, em Castelo de Vide, ou como habitação, provavelmente de algum pastor romano na Anta da Soalheira, na Coudelaria de Alter (Figura 2 e 3). Haveria ainda que acrescentar a presença de carvões recentes e faiança de Coimbra (Prato Ratinho) em sepulcros megalíticos de xisto em terras de Cedillo. Aqui, como eventualmente noutros locais, aproveitavam estas pequenas sepulturas, que localmente ainda hoje são denominados de "hornillos", para conterem o fogo onde confecionavam os ali- mentos durante as jornadas de monda e ceifa, pelo menos entre o século XVIII e a primeira metade do século XX, tanto em terras da Extremadura Espanhola como do Alentejo. Deveríamos, também, se espaço houvesse que registar, pormenorizadamente, algumas ocorrências de tumulação e ocultação de cadáveres em sítios e monumentos arqueológicos pré-históricos, decorrentes de assassinatos perpetrados durante a Guerra Civil Espanhola, registados nos dois lados da fronteira, mas essa matéria não será aqui e por agora tratada.

\section{A COMPLEXIDADE CONTEXTUAL DAS DATAS PRÉ-HISTÓRICAS EM MONUMENTOS MEGALÍTICOS}

A datação dos menhires, sejam eles isolados ou em grupo, foi sempre tema de discussão entre os que estudam esta matéria. Se durante muitos foram, assumidamente considerados como contemporâneos dos grandes dólmenes, sobretudo, atendendo ao paralelismo da energia necessária para o seu transporte e ereção, desde a obtenção da data, à altura considerada extravagante, do Menhir da Meada que se começou a equacionar, ainda que com algumas renitências, a maior antiguidade dos menhires em relação ao período de ereção dos dólmenes mais complexos (Figura 4 e 5 ).

Praticamente só a partir dos finais da década de setenta do século XX é que se iniciaram trabalhos de escavação, cientificamente e diretamente dirigidos a menires. Infelizmente, ou porque os alvéolos estavam muito remexidos, ou porque, na verdade, nenhuma matéria orgânica se tivesse preservado foi necessário efetuarmos a escavação e reabilitação do Menir da Meada (Castelo de Vide), em 1993, para conseguirmos obter uma datação absoluta. Tratava-se duma amostra de carvão recolhida no fundo do alvéolo, encostado ao menir, em zona perfeitamente conservada, sob os blocos que calçavam o monumento e envolta em argila. Essa amostra submetida a datação por radio carbono forneceu a seguinte data: Utc-4452: 6022 + 40 BP, que calibrada a 2 sigmas resultou em 4810 a $5010 \mathrm{cal} \mathrm{BC}$. Na sequencia da divulgação pública desta data, em 1996, embora por muitos considerada como extravagante, a partir desse momento, a contemporaneidade dos menires e das antas começou claramente a ser questionada, sobretudo em relação aos monumentos funerários mais complexos, ainda que já anteriormente e ape- 
nas por via de análises estratigráficas se reconhecesse alguma anterioridade dos menires em relação aos dólmenes. Aqui devemos destacar o singular monumento da Granja de S. Pedro, em Idanha-a-Nova. Em boa verdade os investigadores que o estudaram afirmaram perentoriamente que os menires já aí se encontravam quando o sepulcro foi construído (Almeida e Ferreira, 1971). Outros estudos entretanto promovidos vieram reforçar o mais que provável posicionamento dos menires no Neolítico mais antigo. Toda a polémica que se gerou em torno dos Menires do Padrão a propósito da ligação cultural dos menires com os carvões da camada $\mathrm{C}_{2}$ que foi possível datar de meados dos 60 milénio (5480-5242 cal AC; 5580-5350 cal AC) (Gomes, 1997: 176), ou os materiais atribuídos ao Neolítico antigo identificados junto aos menires da Caramujeira (Gomes, 1997: 175), ainda que muito contestados e objeto de várias revisões e interpretações, somados às informações decorrentes dos trabalhos efetuados nos recintos megalíticos de Almendres e Portela de Mogos, junto dos quais se registaram ocupações atribuíveis, igualmente, ao Neolítico antigo, vinham, gradualmente, a reforçar a perceção da grande antiguidade destes monumentos. Se a data do menir da Meada foi então considerada duvidosa por ser muito mais antiga em relação ao espectável, todas as outras entretanto obtidas, maior controvérsia ainda gerou porque apenas, de uma forma indireta, se podiam ligar aos menires. No decurso da recente escavação e recuperação que promovemos no menir do Patalou, no concelho de Nisa, em 2016, foi-nos possível recolher e datar uma amostra de madeira carbonizada obtida no interior do alvéolo que forneceu a seguinte data: Beta- 416341: $5420+30 B P$, que calibrada resulta em Cal BC 4340 a 4235 (Cal BP 6290 a 6185). Com esta data agora obtida validava-se a que já anteriormente possuíamos para o Menir da Meada, cuja amostra de carvão foi recolhida em situação e contexto idêntico. Confirmava-se, assim, o posicionamento cultural dos menires no seio do Neolítico antigo e reafirma-se a anterioridade dos menires em relação, pelo menos, à fase plena do megalitismo dolménico. Se neste momento e para a região em apreço, pelo menos para os menires isolados, já temos um posicionamento crono-cultural seguro, importa agora compreender e relacionar estas datas com as obtidas para alguns monumentos megalíticos funerários, sobretudo para as amostras recolhidas em mamoas, ou na base dos sepulcros que se aproximam das datas dos menires e se afastam das datas obtidas a partir de restos ósseos recolhidos no interior destes espaços funerários, sejam eles simples ou mais complexos (Figura 6).

Se as datas obtidas para depósitos funerários no interior dos dólmenes e que até agora têm servido de referência para datar o megalitismo funerário $\left(3^{\mathrm{o}} \mathrm{a}\right.$ $4^{\circ}$ milénios a.C.) se afastam substancialmente das datas confirmadas para os menires da mesma região já outro conjunto de datas, algumas obtidas para os mesmos sepulcros, mas provenientes de unidades estratigráficas distintas, aproximam-se das cronologias obtidas para os menires e das recolhidas em ambientes de habitats conotados com o Neolítico antigo da mesma região. Paralelamente, temos vindo a registar um número crescente de menhires incorporados em sepulturas megalíticas, reaproveitados integralmente ou adaptados, como o que atualmente estudamos na Anta 1 dos Saragonheiros, em Nisa (monumento em fase de estudo).

Decorrem destas observações um conjunto de questões que estão por resolver e que se prendem, em grande medida, com a sequência, ou sequências cronológicas das manifestações megalíticas desta região. Parece ser hoje consensual a existência de uma grande anterioridade dos menires em relação aos sepulcros megalíticos do tipo dólmen. Se aceitarmos essa anterioridade, a presença, que começa a ser hoje já recorrente, de menires no interior de estruturas funerárias dolménicas, poderá ter, pelo menos, três explicações possíveis. A mais simplista dir-nos-ia que devido a uma economia de recursos, os construtores de dólmenes recorreriam àquelas pedras já talhadas e aproveitavam-nas para a construção dos sepulcros. Uma segunda hipótese dir-nos-á que a inclusão dos menires se ficaria a dever a algum ritual que obrigaria os construtores de antas a remover os menires e a incluí-los na sua estrutura. Uma terceira hipótese poderá tentar explicar esta ocorrência com a construção de um sepulcro no mesmo local onde já existia um menhir. Provavelmente todas as hipóteses poderão coexistir, contudo, e independentemente da existência, ou não, de menires na estrutura construtiva dos dólmenes, estão disponíveis, há já alguns anos, um conjunto de datas, consideradas demasiado antigas, recolhidas em dólmenes do Norte-Alentejano e "Extremadura" Espanhola, que se aproximam da data do Menir da Meada e do Patalou e, ao mesmo tempo, das datas, em geral, já disponíveis para habitats do Neolítico antigo, remetendo-nos, em anos de 
calendário, para o $\mathrm{V}$ e por vezes inícios do VI milénio BC. De facto, já muitas explicações foram aventadas para minimizar o impacto que estas datas antigas teriam nas interpretações tradicionais para a origem do megalitismo, que o remete sempre para momentos de um Neolítico médio e, maioritariamente, final. Na verdade, a maior parte das datas disponíveis para os dólmenes situa-se entre o IV e o III milénios, em anos de calendário, mas, igualmente, essas datas foram obtidas, maioritariamente, a partir de material ósseo. Contudo, é hoje totalmente aceite que estes sepulcros tiveram uma vida útil e funcional muito longa e com evidentes sinais de reutilizações, reabilitações e desenvolvimentos. Haverá que questionar, coisa que raramente foi feita, se as datações obtidas a partir de restos ósseos não datarão, maioritariamente, momentos finais de utilização e não do momento fundacional. Todos reconhecemos quão raro é encontrarem-se restos ósseos, passíveis de serem datados, localizados em terrenos xistosos, ou graníticos, terrenos que pela sua acidez destroem completamente a matéria orgânica. Provavelmente, teremos vindo, sucessivamente, a datar ossos de momentos finais de utilização destes sepulcros. Recorde-se que as datas mais antigas e consideradas anormais resultam, invariavelmente, de carvões que, por sistema, foram recolhidos na base dos monumentos ou, sob as respetivas mamoas, quando bem conservadas. Essas datações, porque iam contra as teorias aceites, foram sempre rejeitadas, considerando-se que se reportariam a episódios pré-megalíticos e, portanto, muito anteriores à construção dos sepulcros.

Se constatamos sinais evidentes de contemporaneidade entre a ereção dos grandes menhires do Norte do Alentejo e as datas obtidas para base dos monumentos funerários e reconhecemos a presença de menhires, claramente reutilizados nas estruturas dolménicas da mesma região, então teremos que posicionar culturalmente o início do megalitismo funerário e dos menhires na fase mais antiga do Neolítico. Suportados nestes dados teremos que aceitar que a "moda" de ereção de menires foi relativamente curta, sendo rapidamente absorvidos nos sepulcros megalíticos. A fase de ereção de menires deverá ter sido muito efémera, ou então, a explicação para as datas muito antigas nas antas e a presença de cerâmicas do Neolítico Antigo no seu interior terá que ter outra explicação. A tese das trasladações defendida por Leonor Rocha (Rocha, 2005), seguramente que é globalmente aceitável, num sentido lato, contudo não responde ao problema das datas antigas obtidas sob as mamoas. Anteriormente e com base em evidências claras, demonstrámos que alguns dos dólmenes estudados no nordeste alentejano foram construídos sobre habitats anteriores, onde ocorriam lareiras e silos (Oliveira, 1997 e 1998). Contudo, noutros casos tal situação não foi detetada, encontrando-se os sítios de habitat, todos do Neolítico antigo, bem definidos, nas imediações dos dólmenes.

O maior problema coloca-se quanto ao posicionamento relativo para a emergência dos menires. Se, de facto, eles já existiam ao tempo da construção dos primeiros dólmenes então, durante o Neolítico Antigo teremos que encontrar, pelo menos, duas fases. Uma mais antiga, durante a qual se ergueram menires e, posteriormente, uma fase de construção de sepulcros megalíticos que incorpora menires na sua estrutura funerária. A alternativa a esta interpretação poderá ser equacionada se se vier a definir, um dia, com precisão, o que se entende por Neolítico Médio. Para reequacionar toda esta problemática há necessidade de alargar as áreas de escavação das mamoas e dos habitats e, sobretudo, procurar encontrar matéria datável para nos ajudar a esclarecer, com precisão, a periodização do Neolítico no interior alentejano. Pelas datas de radiocarbono disponíveis para a bacia hidrográfica do Sever, embora apenas existam duas para sepulcros de pequena dimensão da zona xistosa, verificamos que estas caem dentro dos valores cronológicos médios dos monumentos de granito. Duas amostras de carvão recolhidas na anta da Joaniña, situada no Termo Municipal de Cedillo, forneceram, respetivamente, as seguintes idades: amostra A $-3840+170$ anos BP; amostra B $-5400+210$ anos BP. A primeira amostra refere-se a carvões identificados sobre o lajeado da base do monumento, associados a um machado de anfibolite e a uma ponta de seta de base triangular e a uma lâmina de sílex. A segunda amostra refere-se a carvões localizados entre o lajeado da base do monumento e o solão xistoso, em terras argilosas muito compactadas, sem materiais arqueológicos associados. Se a amostra $\mathrm{B}$ parece corresponder a carvões à data da construção do monumento, a segunda encontra-se perfeitamente situada nos contextos funerários megalíticos regionais, bastante próxima da data disponível para enterramentos na Anta da Bola Cera (monumento de granito de corredor curto), situada no concelho de Marvão. Esta amostra, obtida a partir de ossos huma- 
nos queimados aos quais se associava uma placa de xisto de recorte antropomórfico, forneceu a seguinte idade: $4360+50$ anos BP. Igualmente, a amostra $1 \mathrm{da}$ Anta da Cabeçuda, monumento de corredor curto, localizado no concelho de Marvão, correspondente a carvões recolhidos na base da câmara, associados a taças abertas que forneceu a seguinte idade: 3650 +110 anos BP. Um outro monumento, este de corredor longo, a anta IV dos Coureleiros, situada no concelho de Castelo de Vide, forneceu uma amostra de carvões recolhidos no corredor, associados a uma placa de xisto de recorte geométrico, que veio a dar a seguinte idade: $4240+150$ anos BP. Reconhece-se, assim, um perfeito enquadramento da amostra $\mathrm{A} d \mathrm{da}$ anta da Joaniña nos mesmos contextos cronológicos dos monumentos megalíticos de granito do Norte-Alentejano. No que à amostra B da anta da Joaniña diz respeito também ela é igualmente enquadrável no grupo das chamadas datas antigas do megalitismo da zona granítica. Neste grupo conhecem-se os seguintes valores: Amostra 2 da Anta das Castelhanas: $6300+110$ anos BP; Amostra 2 da Anta da Cabeçuda: 7660 + 6 o anos BP e Anta da Figueira Branca: $6210+50$ anos BP.

Parece, assim, não restarem dúvidas e com base em apenas duas datas da anta da Joaniña situada no Termo Municipal de Cedillo, que os pequenos monumentos megalíticos da foz do Sever são contemporâneos dos monumentos de maiores dimensões situados no patamar granítico da Serra de S. Mamede. Em face dos dados disponíveis parece não haver dúvidas quanto à contemporaneidade dos dois grupos de monumentos. As dissemelhanças na volumetria arquitetónica e nos conjuntos artefactuais resultariam, assim, de diferentes organizações socioecónomicas impostas pela especificidade de recursos existentes em cada zona. No que à origem dos menires diz respeito ela parece conviver com um período imediatamente anterior à emergência das primeiras sepulturas megalíticas e eventualmente haver ainda alguma convivência cultural entre as duas realidades mas durante um curto espaço de tempo, vindo a "cultura menírica" a perder importância à medida que o megalitismo funerário se afirmava na paisagem, incorporando direta ou indiretamente menhires ou porções deles nas suas estruturas.

\section{AS POSSÍVEIS INTERPRETAÇÕES PARA AS DATAS ABSOLUTAS OBTIDAS EM ABRIGOS PINTADOS}

No decurso dos nossos vários projetos de investigação sobre pré-história recente no Norte do Alentejo desenvolvemos, durante vários anos, campanhas de estudo, algumas com escavação, em abrigos naturais com pinturas esquemáticas existentes nas cristas quartzíticas da Serra de S. Mamede, acidente natural que domina toda a área que temos vindo a tratar. Para além das prospeções efetuadas que nos possibilitam, neste momento, reconhecer a existência de mais de trinta sítios com arte pintada ao longo da Serra de S. Mamede e seus contrafortes e que acrescentaram substancialmente o conhecimento que se se tinha até 2005 e que se resumia apenas a quatro abrigos em território português e os que se conheciam em S. Braz, junto a Albuquerque, em território espanhol procedemos à abertura de sondagens no interior e exterior do Abrigo da Igreja dos Mouros, no exterior do Abrigo dos Gaivões e no interior do Abrigo Pinho Monteiro, todos situados na freguesia de Esperança, no concelho de Arronches. Ainda no âmbito desse projeto tivemos possibilidade de abrir uma pequena sondagem no interior da gruta com arte esquemática pintada que se esconde por trás do altar da ermida de Nossa Senhora da Lapa, situada na freguesia de Alegrete, concelho de Portalegre (Figura 7).

Decorrente dessas sondagens foi possível obter carvões que foram submetidos a datação e que, se num caso veio confirmar o que seria espectável em termos cronométricos para a fase em que as paredes do abrigo foram decoradas com arte esquemática, o Abrigo da Igreja dos Mouros, já as datas obtidas em sequências estratigráficas no interior do Abrigo Pinho Monteiro, aparentemente nada terão a ver com a arte, igualmente esquemática que decora as paredes do abrigo ou, então, teremos que rever as cronologias das sequenciações estilísticas até agora reconhecidas e aceites.

No decurso dos trabalhos desenvolvidos no abrigo da Igreja dos Mouros foi possível recolher várias amostras de carvões das quais duas foram submetidas a datação. Carvões recolhidos no quadrado E3, situado junto à "pedra de altar" e sob um dos painéis pintados, associados a pequenas concentrações de pasta de cor alaranjada e também branca, semelhantes às cores utilizadas nas pinturas parietais fornece- 
ram a seguinte idade: Beta -336388: $4320+/-30 B P$, que calibrada a 2 sigmas resulta na data: $\mathrm{Cal} \mathrm{BC} 308 \mathrm{O}$ a 3060. Esta data parece estar em linha, quer com os materiais atribuídos aos inícios do calcolítico identificados nos quadrados E5, E6 e D6, quer com as cronologias normalmente consideradas nesta região para a arte esquemática. A outra amostra de carvões submetidos a datação foi recolhida na sondagem aberta em frente do abrigo (D9), no interior do que parece ser uma estrutura em arco de círculo. Esta amostra forneceu a seguinte idade: Beta -336387: $920+/-30$ BP, que calibrada a 2 sigmas resulta numa data no intervalo de: $\mathrm{Cal}$ AD 1020 a 116o. Esta data medieval encontra paralelo com a obtida para um nível superficial de carvões recolhidos no interior do Abrigo Pinho Monteiro que forneceu a seguinte idade: Beta - 296435: 920 +/- 40 BP, que calibrada a 2 sigmas resulta numa data no intervalo de: $\mathrm{Cal}$ AD 1010 a 1170. Esta interessantíssima concordância de datas para abrigos afastados entre si cerca de $4 \mathrm{kms}$ é ainda mais relevante quando verificamos que a denominada Reconquista Cristã desta zona do Alentejo, pelos homens de Afonso Henriques, terá ocorrido entre 1160 e 1170 . Parece assim que a instabilidade que as manobras militares de cristãos e muçulmanos provocavam, especialmente nos núcleos urbanos, levaram alguns a procurar refúgio entre os abrigos naturais existentes na zona, ocupando espaços que milhares de anos antes outros também procuraram. Se para as datas históricas temos concordância entre os dois abrigos por nós escavados, já para épocas mais recuadas tal não se verifica. Observámos que na Igreja do Mouros a data pré-histórica obtida está em concordância com a idade e horizonte culturais atribuídos à Arte Esquemática e com os materiais exumados neste abrigo; contudo afasta-se em muitos milénios, das datas e igualmente dos conjuntos artefactuais identificados no Abrigo Pinho Monteiro, a escassos $4 \mathrm{kms}$ de distância. No Abrigo Pinho Monteiro as duas amostras recolhidas remetem-nos para duas ocupações distintas, uma conotada com momentos dos finais do Paleolítico: Beta - 296433: 9640 +/-50BP, que calibrada a 2 sigmas resulta em: Cal BC 9250 a 9100 e outra mesolítica: Beta - 296434: 8390 +/- 40BP, que calibrada a 2 sigmas resulta em: Cal BC 7570 a 7460 . Parece, assim, que no Abrigo Pinho Monteiro, desde, pelo menos, os finais da última glaciação o homem acendeu aqui fogueiras e, novamente no Mesolítico, voltou a ocupar o lugar e aí a acender fogueiras e onde talhou sílex e quartzos junto à entrada do abrigo. Mais tarde, já pelos finais do Neolítico e durante o Calcolítico, ou mesmo já a entrar na Idade do Bronze, o abrigo Pinho Monteiro voltou a ser ocupado e alguns dos seus utentes para além de erguerem um muro à entrada do abrigo, conforme interpretação de Mário Varela Gomes (1989) (Gomes, 1989, 6) pintaram profusamente o teto mantendo a temática esquemática e cores que variam entre o vermelho e o laranja. Deveremos, contudo, estar disponíveis para reavaliarmos se toda a arte pintada no teto do Abrigo Pinho Monteiro terá mesmo sido realizada em momentos tardios da pré-história / inícios da metalurgia, ou se alguma desta arte não poderá remontará aos finais do Paleolítico ou ao Mesolítico. Se assim for, e suportados nas datas disponíveis e nos artefactos exumados no Abrigo Pinho Monteiro e enquanto não dispusermos de datas diretas das pinturas, deveremos reequacionar o posicionamento crono-cultural, pelos menos de alguma arte, denominada esquemática, que genericamente temos vindo a considerar como mais recente (Figura 8 e 9). Da gruta do interior da Ermida de NNe. Srª . da Lapa, na Freguesia de Alegrete, submetemos a datação um dente extraído dum fragmento de mandíbula de jovem adulto humano que resultou, como seria espectável, atendendo ao contexto e aos de materiais anexos, numa data atribuível aos finais século XVIII A.D. e que corresponde à fase da reforma arquitetónica deste milenar espaço de culto.

Concluindo, porque o espaço disponível é curto, tentámos, de forma muito abreviada, expor as principais conclusões e dúvidas resultantes das mais de trinta datas, que abaixo disponibilizamos, obtidas em sítios e monumentos construídos, erguidos ou ocupados, maioritariamente, durante a Pré-História Recente na região norte do Alentejo e canto noroeste da Extremadura espanhola (Figura 10).

\section{BIBLIOGRAFIA}

BARATA, J. Pedro Martins (1965) - O Menir da Meada, Ethnos, 4, Lisboa.

BOAVENTURA, R. (2006) - Os IV e III milénios a.n.e. na região de Monforte, para além dos mapas com pontos: os casos do cluster de Rabuje e do povoado com fossos de Moreiros 2. Revista Portuguesa de Arqueologia. Lisboa: IPA, 9 (2), pp. 61-73.

BREUIL, Henri (1917) - La roche peinte de Valdejunco à la Esperança, près de Arronches (Portalegre), Terra Portuguesa, 13-14, Fev. - Mar., Lisboa. 
BUENO, Primitiva (1988) - Los Dolmenes de Valencia de Alcantara, Excavaciones Arqueologicas en España ํํำ155, Ministerio de Cultura, Madrid.

Idem (1987) - Megalitismo en Extremadura: Estado de la Cuestión, in El Megalitismo en la Península Ibérica, Ministerio de Cultura, Madrid.

Idem (1988) - Los Dolmenes de Valencia de Alcantara, Excavaciones Arqueologicas en España nํㅗ55, Ministerio de Cultura, Madrid.

Idem (1989) - Camaras Simples en Extremadura, XIX Congreso Nacional de Arqueologia, 1987, Castellón de la Plana.

CANINAS, J. C. Pires e HENRIQUES, F. J. (1985) - Testemunhos do Neolítico e do Calcolítico no Concelho de Nisa, in Actas das $1^{a s}$. Jornadas de Arqueologia do Nordeste Alentejano, Comissão Regional de Turismo e Câmara Municipal de Castelo de Vide, Portalegre.

Idem, (1987) - Megalitismo de Vila Velha de Ródão e Nisa, in Arqueologia no Vale do Tejo, I.P.P.C., Lisboa.

CASTRO, Luís de Albuquerque e; FERREIRA, Octávio da Veiga (196o-61) - As pinturas rupestres esquemáticas da Serra dos Louções, Conímbriga, vol.II-III, 1960-61, pp. 203-229.

GOMES, Mário Varela (1985) - Abrigo de Pinho Monteiro - 1982, Informação Arqueológica, nº 5, IPPC - Departamento de Arqueologia.

GONÇALVES, Vitor et alii (1981) - Anta dos Penedos de S. Miguel (Crato), Campanha 1- (81), Clio, vol. 3, INIC, Lisboa.

HENRIQUES, F.J.R. e CANINAS, J.C.P. (1980) - Contribuição para a carta arqueológica dos concelhos de Vila Velha de Ródão e Nisa, N.R.I.A. Vila Velha de Ródão.

ISIDORO, A. Farinha (1966) - Escavações em dólmenes do Concelho do Crato (Alto Alentejo), Trabalhos de Antropologia e Etnologia, Porto.

LEISNER, George e Vera (1956) - Die Megalithgraber Iberischen Halbinsel.Der Westen (1), Walther de Gruyter, Berlin.

MONTEIRO, J. Pinho, e GOMES, Mário Varela (1977) Os Menires da Charneca do Vale do Sobral - Nisa, Revista de Guimarães, LXXXVII, Guimarães.

OLIVEIRA, Jorge de (1995) - Sepulturas Megalíticas del Termino Municipal de Cedillo - Província de Cáceres - Edición del Ayuntamiento de Cedillo, Cáceres.

OLIVEIRA, Jorge de (1995) - A Recuperação do Menir da Meada - Castelo de Vide, Ed. Câmara Municipal de C. de Vide. (ed. desenvolvida de artoํ. da Ibn Maruán

OLIVEIRA, Jorge de (1997) - Monumentos Megalíticos da Bacia Hidrográfica do Rio Sever, ํํ Vol. - edição bi-lingue, patrocinada pelas Câmaras de Marvão, C. de Vide, Nisa, V. de Alcântara, Herrera de Alcântara e Cedillo e pela Delegação Regional do Ministério da Cultura, Ed. Colibri, Lisboa.
OLIVEIRA, Jorge de (2006) - Património Arqueológico da Coudelaria de Alter, Ed. Colibri / Universidade de Évora, Lisboa.

OLIVEIRA, Jorge (1996) - Datas absolutas de monumentos megalíticos da bacia hidrográfica do Rio Sever, Actas do $2^{\circ}$ Congreso de Aqueologia Peninsular, Zamora.

OLIVEIRA, Jorge (1996) - As pequenas antas de Montalvão e Cedillo, Actas do I Colóquio Internacional sobre Megalitismo de Monsaraz, C.M. de Reguengos de Monsaraz e UNIARQ, Lisboa.

OLIVEIRA, Jorge de; OLIVEIRA, Clara (200o) - Menires do Distrito de Portalegre, Extremadura Arqueológica, Número Especial de Homenagem a Elias Diegués, Cáceres.

OLIVEIRA, Jorge (1999) - Inventario, Investigacion y puesta en Valor de los Dólmenes: Termino Municipal de Cedillo, in Extremadura Restaurada, Consejería de Cultura y Patrimonio de la Junta de Extremadura, Mérida.

OLIVEIRA, Jorge (1996) - As pequenas antas de Montalvão e Cedillo, Actas do I Colóquio Internacional sobre Megalitismo de Monsaraz, C.M. de Reguengos de Monsaraz e UNIARQ, Lisboa.

OLIVEIRA, Jorge de (2001) - O Megalitismo de Xisto da Bacia do Sever Montalvão - Cedillo, Muitas antas pouca gente?, Trabalhos de Arqueologia 16, IPA, Lisboa. 2001.

OLIVEIRA, Jorge de (2003) - A arte rupestre no contexto megalítico Norte-Alentejano, Sinais de Pedra, Fundação Eugénio de Almeida, (ed. electrónica).

OLIVEIRA, Jorge de; Moitas, E; OLIVEIRA, Clara (2007) -Monumentos Megalíticos do Concelho de Arronches, Actas das zas. Jornadas de Arqueologia do Norte-Alentejano.

OLIVEIRA, Jorge de (2007) - The Tombs of the Neolithic Artist-Shepherds of the Tagus Valley, Actas da I Reunión de Estudios sobre la prehistoria reciente en el Tajo internacional, BAR (no prelo).

OLIVEIRA, Jorge de (1998) - A Anta de la Joaniña e a da Era de los Guardias no ambiente megalítico da foz do Sever, Ibn Maruán, n.․ 8, Câmara Municipal de Marvão.

OLIVEIRA, Jorge de (2016) - Cronologias y estratigrafias en el Arte Rupestre de la Sierra de San Mamede (Portugal / España), ARPIn4 4, Universidad de Alcalá de Henares, Madrid.

OLIVEIRA, Jorge de (2016) - O Menhir do Patalou - Nisa, entre contextos e cronologias, in Terra e Água, escolher sementes, invocar a Deusa, Centro de Arqueologia da Universidade de Lisboa, Lisboa.

OLIVEIRA, Jorge de (2019) - O que nos escondem as mamoas e a problemática das datações absolutas no Norte do Alentejo, Scientia Antiquitatibus, nº̣, Évora.

PINTO, Serpa Pinto (1932) - O abrigo pré-histórico de Valdejunco (Esperança), Trabalhos da Sociedade Portuguesa de Antropologia e Etnologia, nํㅜ 5, Porto. 
ROCHA, Leonor (2020) - A Anta da Tapada do Castelo, Santo António das Areias, Marvão. In Memórias de St. Ant ${ }^{\circ}$. das Areias e Beirã , (no prelo).

SOARES, A. M. e CABRAL, J. M. P. (1984) - Datas convencionais de radiocarbono para estações arqueológicas portuguesas e a sua calibração: revisão crítica, O Arqueólogo Português, vol. II, série IV, Lisboa.

\begin{tabular}{|c|c|c|c|}
\hline SÍTIO / LAB. / REF. & IDADE BP & CAL BC / AD & COMENTÁRIO \\
\hline $\begin{array}{l}\text { Anta da Bola da Cera - Marvão } \\
\text { (ICEN-66) }\end{array}$ & $4360 \pm 50$ & $3258-2900$ & $\begin{array}{l}\text { Ossos humanos carbonizados junto a placa de xisto } \\
\text { de recorte antropomórfico, na base da câmara. Anta de } \\
\text { corredor curto. }\end{array}$ \\
\hline $\begin{array}{l}\text { Anta das Castelhanas - Marvão } \\
\text { (amostra } 2 \text { ICEN-1264) }\end{array}$ & $6360 \pm 110$ & $5448-5059$ & $\begin{array}{l}\text { Carvões na base da câmara, junto a pontas de seta de base } \\
\text { reta e convexa, em xisto. Anta de corredor curto. }\end{array}$ \\
\hline $\begin{array}{l}\text { Anta das Castelhanas - Marvão } \\
(\text { ICEN-1263) }\end{array}$ & $780 \pm 60$ & $\begin{array}{l}1165-1303 \\
\text { cal AD }\end{array}$ & $\begin{array}{l}\text { Mancha de carvões a pouca profundidade no interior } \\
\text { da câmara. }\end{array}$ \\
\hline $\begin{array}{l}\text { Anta das Castelhanas-Marvão } \\
\text { (amostra ı OXA-5432) }\end{array}$ & $3220 \pm 65$ & $1630-1320$ & $\begin{array}{l}\text { Ossos humanos carbonizados, junto a vasos semiesféricos } \\
\text { lisos, pontas de seta de base convexa e fragmentos de placa } \\
\text { de xisto. Anta de corredor curto. }\end{array}$ \\
\hline $\begin{array}{l}\text { Anta da Cabeçuda-Marvão } \\
\text { (amostra 1-ICEN-977) }\end{array}$ & $3650 \pm 110$ & $2328-1698$ & $\begin{array}{l}\text { Carvões no interior de "silo" na base da câmara, junto } \\
\text { a taças abertas lisas. Anta de corredor curto. }\end{array}$ \\
\hline $\begin{array}{l}\text { Anta da Cabeçuda-Marvão } \\
\text { (amostra 2-ICEN-978) }\end{array}$ & $7660 \pm 60$ & $6593-6378$ & $\begin{array}{l}\text { Carvões no interior da câmara sobre o solão granítico. } \\
\text { Anta de corredor curto. }\end{array}$ \\
\hline $\begin{array}{l}\text { Anta da Cabeçuda-Marvão } \\
\text { (amostra } 3 \text { - ICEN 979) }\end{array}$ & $3720 \pm 45$ & $2274-1971$ & $\begin{array}{l}\text { Landes / bolotas carbonizadas sob os esteios tombados } \\
\text { no interior da câmara, junto a fragmentos de cerâmicas } \\
\text { lisas. Anta de corredor curto. }\end{array}$ \\
\hline $\begin{array}{l}\text { Anta da Figueira Branca } \\
\text { - Marvão } \\
\text { ICEN }-823\end{array}$ & $6210 \pm 50$ & $5302-5007$ & $\begin{array}{l}\text { Carvões na base da mamoa em lareira não estruturada, } \\
\text { junto a elemento de mó (dormente). Anta de corredor } \\
\text { curto. }\end{array}$ \\
\hline $\begin{array}{l}\text { Anta da Tapada do Castelo } \\
\text { - Marvão } \\
\text { Beta }-409557\end{array}$ & $2220 \pm 30$ & $295-230$ & $\begin{array}{l}\text { Ossos humanos em terras revolvidas por violação da } \\
\text { câmara. (Rocha, L.(2020); A Anta da Tapada do Castelo... } \\
\text { in Memórias de St. Ant } t^{o} \text {. das Areias e Beirã , no prelo.) }\end{array}$ \\
\hline $\begin{array}{l}\text { Anta da Tapada do Castelo } \\
\text { - Marvão } \\
\text { Beta }-506380\end{array}$ & $3560 \pm 30$ & $1980-1868$ & $\begin{array}{l}\text { Dente de ovicaprídeo . (Rocha,L.(2O20); A Anta da Tapada } \\
\text { do Castelo......in Memórias de St.Ant }{ }^{\circ} \text {.das Areias e Beirã, } \\
\text { no prelo.) }\end{array}$ \\
\hline $\begin{array}{l}\text { Anta dos Coureleiros } 1 \\
\text {-C. de Vide } \\
\text { ICEN-592 }\end{array}$ & $840 \pm 70$ & $\begin{array}{l}1010-1230 \\
\text { cal AD }\end{array}$ & $\begin{array}{l}\text { Carvões junto ao esteio de cabeceira a pouca profundidade } \\
\text { em ambiente de lareira não estruturada }\end{array}$ \\
\hline $\begin{array}{l}\text { Anta dos Coureleiros } 2 \\
\text {-C. de Vide } \\
\text { ICEN-593 }\end{array}$ & $690 \pm 130$ & $\begin{array}{l}1280-1330 \\
\quad \mathrm{cal} A D\end{array}$ & $\begin{array}{l}\text { Mancha de carvões a pouca profundidade no interior } \\
\text { da câmara. }\end{array}$ \\
\hline $\begin{array}{l}\text { Anta dos Coureleiros } 4 \\
\text { - C. de Vide } \\
\text { ICEN }-976\end{array}$ & $4240 \pm 150$ & $3335-2459$ & $\begin{array}{l}\text { Carvões no interior do corredor, junto a placa de xisto } \\
\text { de contorno e decoração geométricos. Anta de corredor } \\
\text { longo. }\end{array}$ \\
\hline $\begin{array}{l}\text { Anta da Horta - Alter do Chão } \\
\text { (AH-Oıo-BETA) }\end{array}$ & $4390 \pm 40$ & $3350-3020$ & $\begin{array}{l}\text { Ossos humanos na entrada do corredor junto a placas } \\
\text { de xisto e arenito, machados, cerâmicas várias,... }\end{array}$ \\
\hline $\begin{array}{l}\text { Anta da Horta - Alter do Chão } \\
\text { (AH-M11-BETA) }\end{array}$ & $4190 \pm 50$ & $2930-2860$ & $\begin{array}{l}\text { Ossos humanos não interior da câmara, junto a placa } \\
\text { de xisto. Anta de corredor indeterminado. }\end{array}$ \\
\hline $\begin{array}{l}\text { Anta da Várzea Grande }- \text { Alter } \\
\text { do Chão } \\
\text { Beta }-214598\end{array}$ & $180 \pm 40$ & $\begin{array}{l}1740-1810 \\
\text { cal AD }\end{array}$ & $\begin{array}{l}\text { Dente de equídeo retirado de conjunto de várias peças } \\
\text { óssea depositadas a pouca profundidade no interior } \\
\text { da câmara funerária. }\end{array}$ \\
\hline $\begin{array}{l}\text { Anta de S. Gens II - Nisa } \\
\text { Beta - 409561 }\end{array}$ & $4340 \pm 30$ & $3094-2914$ & Ossos humanos em revolvimento interior da câmara \\
\hline
\end{tabular}

Tabela 1 - Datas absolutas obtidas em sítios da Pré-História recente do Alto Alentejo. 


\begin{tabular}{|c|c|c|c|}
\hline SÍTIO / LAB. / REF. & IDADE BP & $\mathrm{CALBC} / \mathrm{AD}$ & COMENTÁRIO \\
\hline $\begin{array}{l}\text { Anta da Lomba da Barca-Nisa } \\
\text { ICEN - } 1124\end{array}$ & $950 \pm 80$ & $966-1272$ & $\begin{array}{l}\text { Carvões por entre os fragmentos dos esteios tombados } \\
\text { no interior da câmara. Pequeno sepulcro em xisto. }\end{array}$ \\
\hline $\begin{array}{l}\text { Anta da Joañina-Cedillo } \\
\text { (Espanha) } \\
(\text { amostra B-SAC-138o) }\end{array}$ & $5400 \pm 210$ & $4710-3770$ & $\begin{array}{l}\text { Carvões sob o lajeado junto ao solão de base, sem } \\
\text { materiais associados. Pequeno sepulcro em xisto. }\end{array}$ \\
\hline $\begin{array}{l}\text { Anta da Joañina-Cedillo } \\
\text { (Espanha) } \\
(\text { amostra } A-S A C-1381)\end{array}$ & $3840 \pm 170$ & $2870-2720$ & $\begin{array}{l}\text { Carvões sobre o lajeado da base do monumento, junto } \\
\text { a machado de anfibolito e ponta de seta e lâmina de sílex. } \\
\text { Pequeno sepulcro em xisto. }\end{array}$ \\
\hline $\begin{array}{l}\text { Anta da Charca Grande de la } \\
\text { Regañada-Cedillo (Espanha) } \\
\text { Beta }-409562\end{array}$ & $1110 \pm 30$ & $\begin{array}{l}895-1020 \\
\text { cal AD }\end{array}$ & $\begin{array}{l}\text { Carvões recolhidos no interior da câmara sobre o solão } \\
\text { de base }\end{array}$ \\
\hline $\begin{array}{l}\text { Menhir da Meada-C. de Vide } \\
\text { UtC }-445^{2}\end{array}$ & $6022 \pm 40$ & $5010-4810$ & $\begin{array}{l}\text { Carvões no interior do alvéolo de implantação do menhir, } \\
\text { junto à sua base. }\end{array}$ \\
\hline $\begin{array}{l}\text { Menhir do Patalou - Nisa } \\
\text { Beta }-416341\end{array}$ & $5420 \pm 30$ & $4340-4235$ & $\begin{array}{l}\text { Carvões no interior do alvéolo de implantação do menhir, } \\
\text { junto à sua base. }\end{array}$ \\
\hline $\begin{array}{l}\text { Menhir do Carvalhal } \\
\text { - C. de Vide } \\
\text { ICEN } 1126\end{array}$ & $760 \pm 50$ & $\begin{array}{l}1213-1303 \\
\text { cal AD }\end{array}$ & $\begin{array}{l}\text { Carvões no interior do alvéolo por entre os calços } \\
\text { de sustentação do menhir. }\end{array}$ \\
\hline $\begin{array}{l}\text { Menhir do Carvalhal } \\
\text { - C. de Vide } \\
\text { ICEN } 1125\end{array}$ & $420 \pm 60$ & $\begin{array}{l}1409-1641 \\
\text { cal AD }\end{array}$ & Carvões sobre os calços de sustentação do menhir. \\
\hline $\begin{array}{l}\text { Abrigo Igreja dos Mouros } \\
\text { - Arronches } \\
\text { Beta }-336388\end{array}$ & $4320 \pm 30$ & $3080-3060$ & $\begin{array}{l}\text { Carvões junto a concentrações de pasta de cor laranja } \\
\text { e branca, sob painel pintado com as mesmas cores. }\end{array}$ \\
\hline $\begin{array}{l}\text { Abrigo Igreja dos Mouros } \\
\text { - Arronches } \\
\text { Beta }-336387\end{array}$ & $920 \pm 30$ & $\begin{array}{l}1020-1160 \\
\text { cal AD }\end{array}$ & $\begin{array}{l}\text { Carvões associados a estrutura semicircular no exterior } \\
\text { do abrigo. }\end{array}$ \\
\hline $\begin{array}{l}\text { Abrigo Pinho Monteiro } \\
\text { - Arronches } \\
\text { Beta }-296433\end{array}$ & $9640 \pm 50$ & $9250-9100$ & $\begin{array}{l}\text { Carvões sobre a rocha de base no interior do abrigo } \\
\text { associado a indústria mico-laminar em quartzo. }\end{array}$ \\
\hline $\begin{array}{l}\text { Abrigo Pinho Monteiro } \\
\text { - Arronches } \\
\text { Beta }-296434\end{array}$ & $8390 \pm 40$ & $7570-7460$ & $\begin{array}{l}\text { Carvões sobre a rocha de base encostados à parede lateral } \\
\text { direita junto a indústrias micro-laminares. }\end{array}$ \\
\hline $\begin{array}{l}\text { Abrigo Pinho Monteiro } \\
\text { - Arronches } \\
\text { Beta }-296435\end{array}$ & $960 \pm 40$ & $\begin{array}{l}1010-1170 \\
\text { cal AD }\end{array}$ & $\begin{array}{l}\text { Larga mancha de carvões a } 15 \mathrm{~cm} \text { da superfície no interior } \\
\text { do abrigo }\end{array}$ \\
\hline $\begin{array}{l}\text { Gruta da Ermida da Srª. } \\
\text { da Lapa - Portalegre } \\
\text { Beta }-40956 \text { o }\end{array}$ & $130 \pm 30$ & $\begin{array}{l}1645-1685 \\
\text { cal AD }\end{array}$ & $\begin{array}{l}\text { Dente de jovem adulto humano, extraído de fragmento } \\
\text { de mandíbula, junto a derrubes do antigo altar }\end{array}$ \\
\hline $\begin{array}{l}\text { Habitat P.-H. da Pedra da Águia } \\
\text { - Alter do Chão } \\
\text { Beta }-215978\end{array}$ & $1720 \pm 40$ & $\begin{array}{l}130-350 \\
\text { cal AD }\end{array}$ & Metacarpo de bovídeo com sinais de corte. \\
\hline $\begin{array}{l}\text { Locus i Porta do Tempo } \\
\text { - Alter do Chão } \\
\text { Beta - } 194311\end{array}$ & $3220 \pm 40$ & $1530-1400$ & $\begin{array}{l}\text { Carvões de habitat aberto com cerâmicas lisas e elementos } \\
\text { de mó, nas imediações da Anta da Horta. }\end{array}$ \\
\hline
\end{tabular}

Tabela 1 (Continuação). 


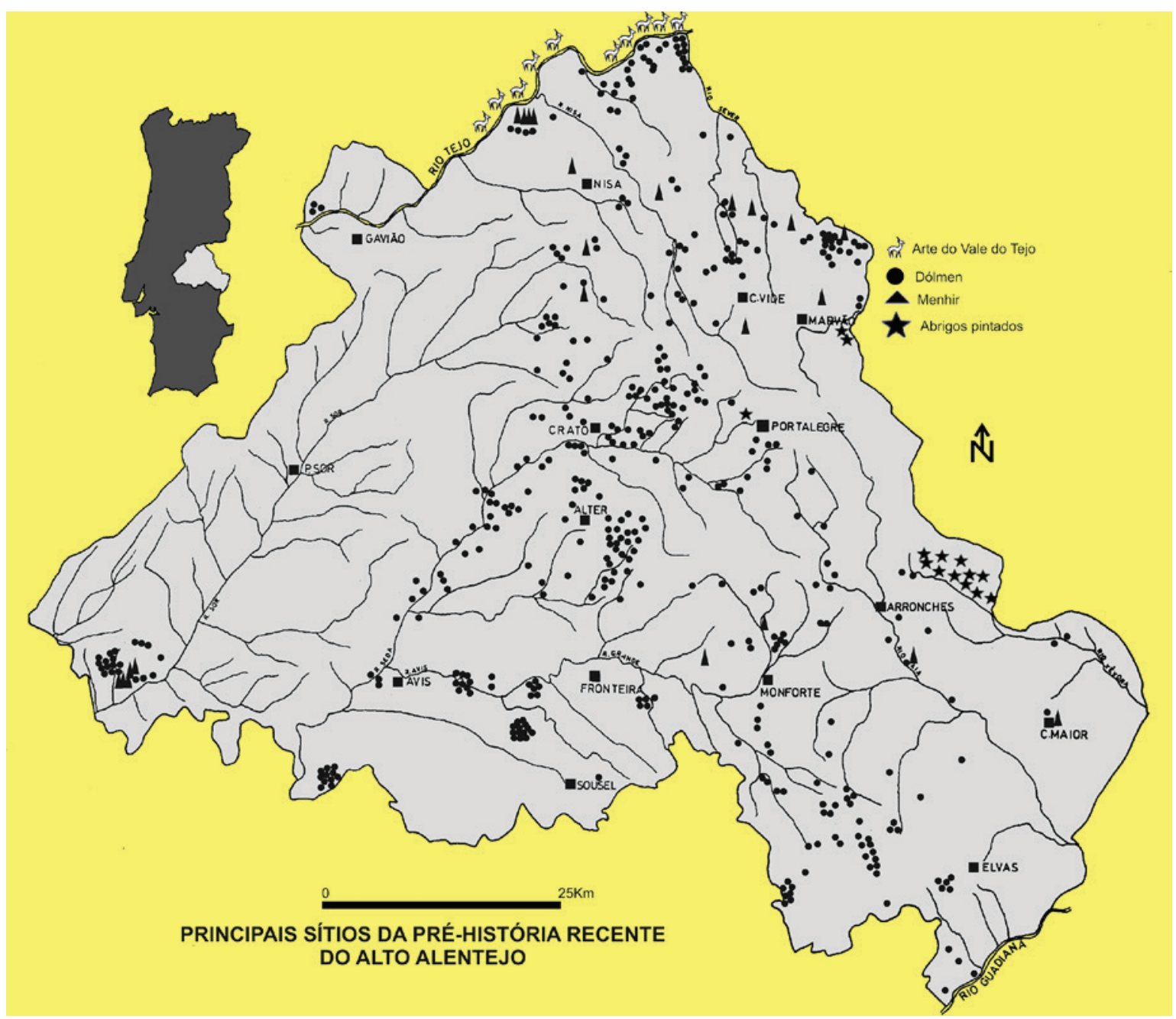

Figura 1 - Mapa: Principais sítios da Pré-História recente do Alto Alentejo.

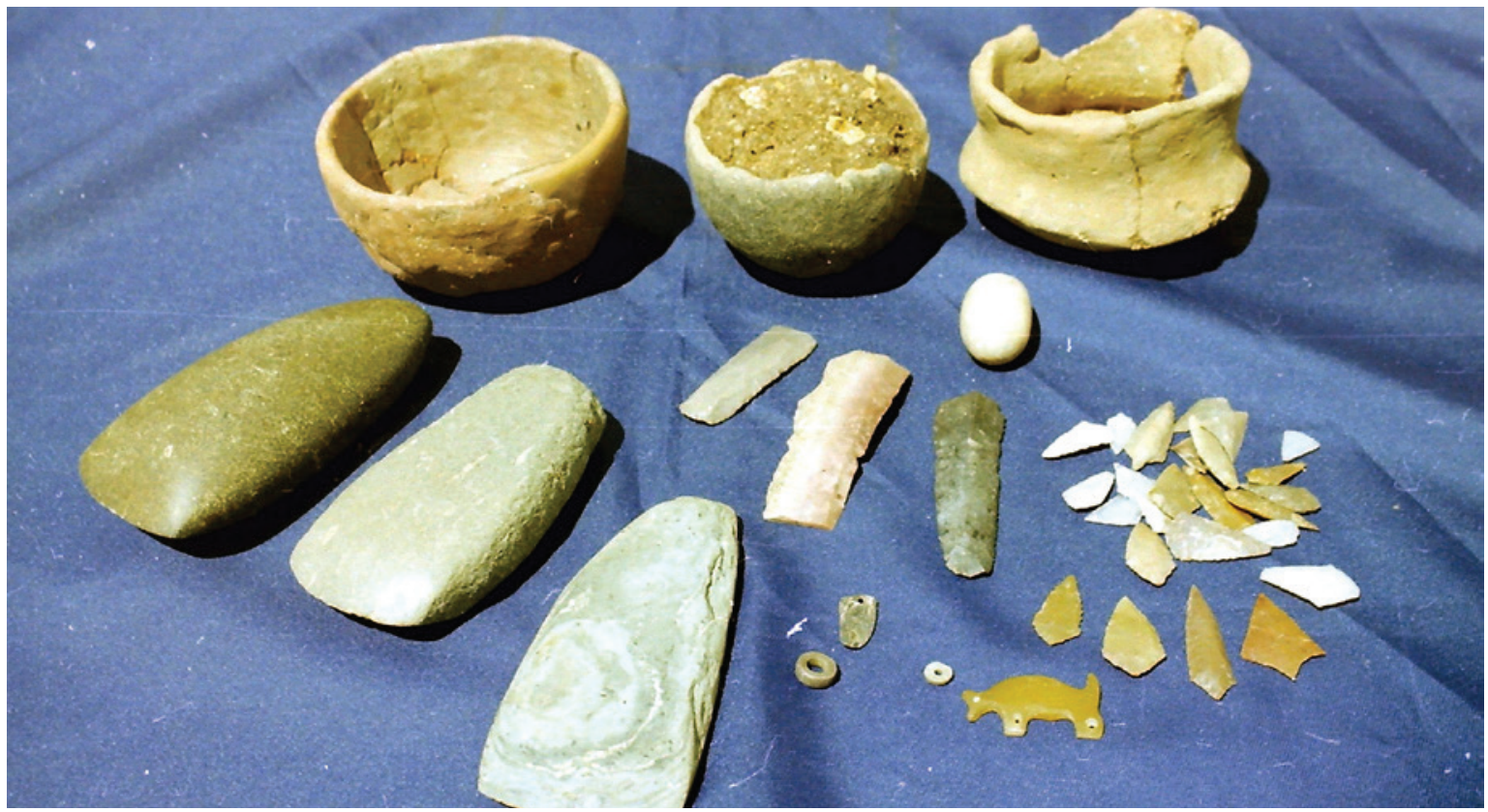

Figura 2 - Anta da Tapada de Matos (Castelo de Vide): materiais recolhidos no corredor. 


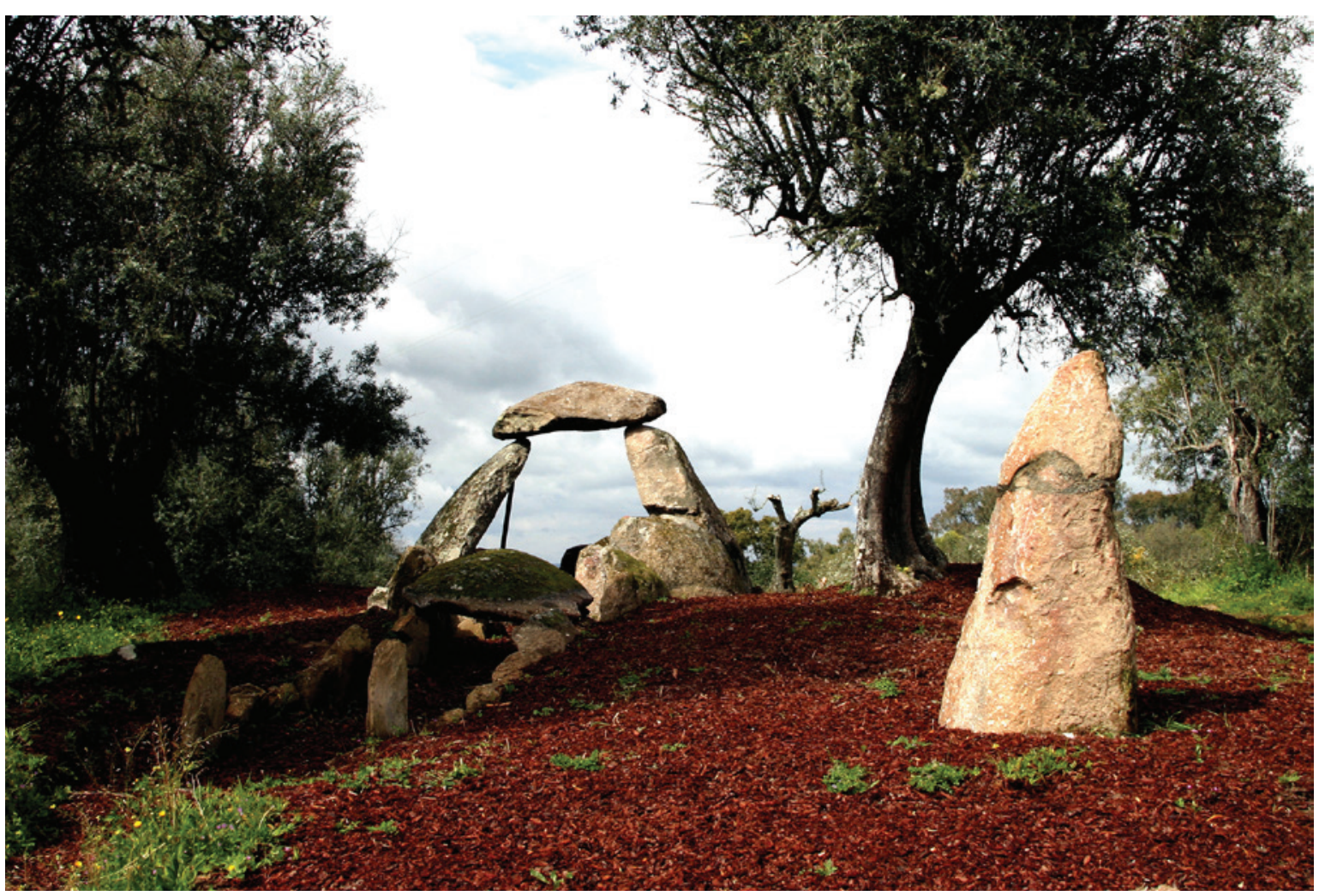

Figura 3 - Anta e Menhir da Soalheira (Alter do Chão).

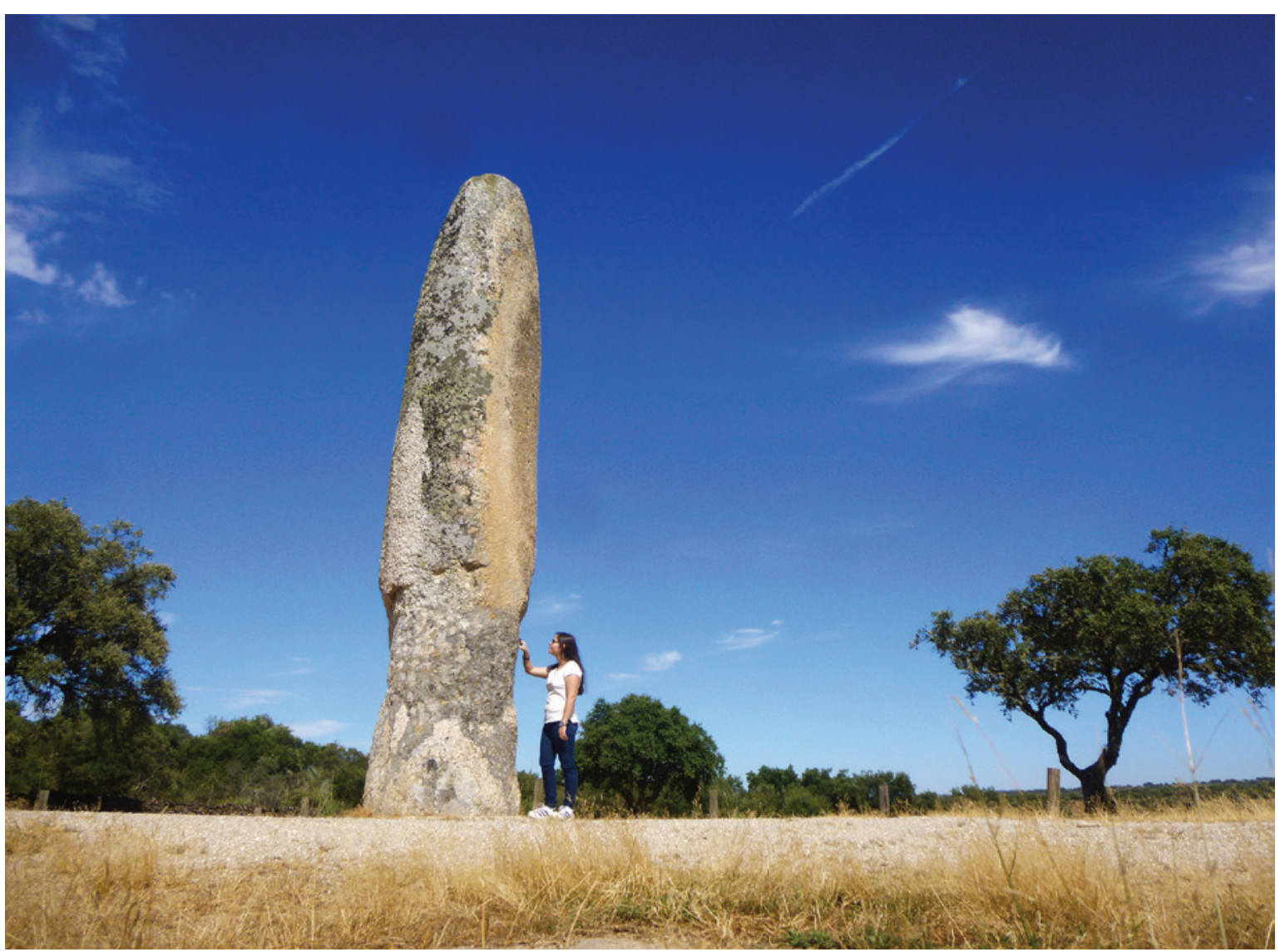

Figura 4 - Menhir da Meada (Castelo de Vide). 


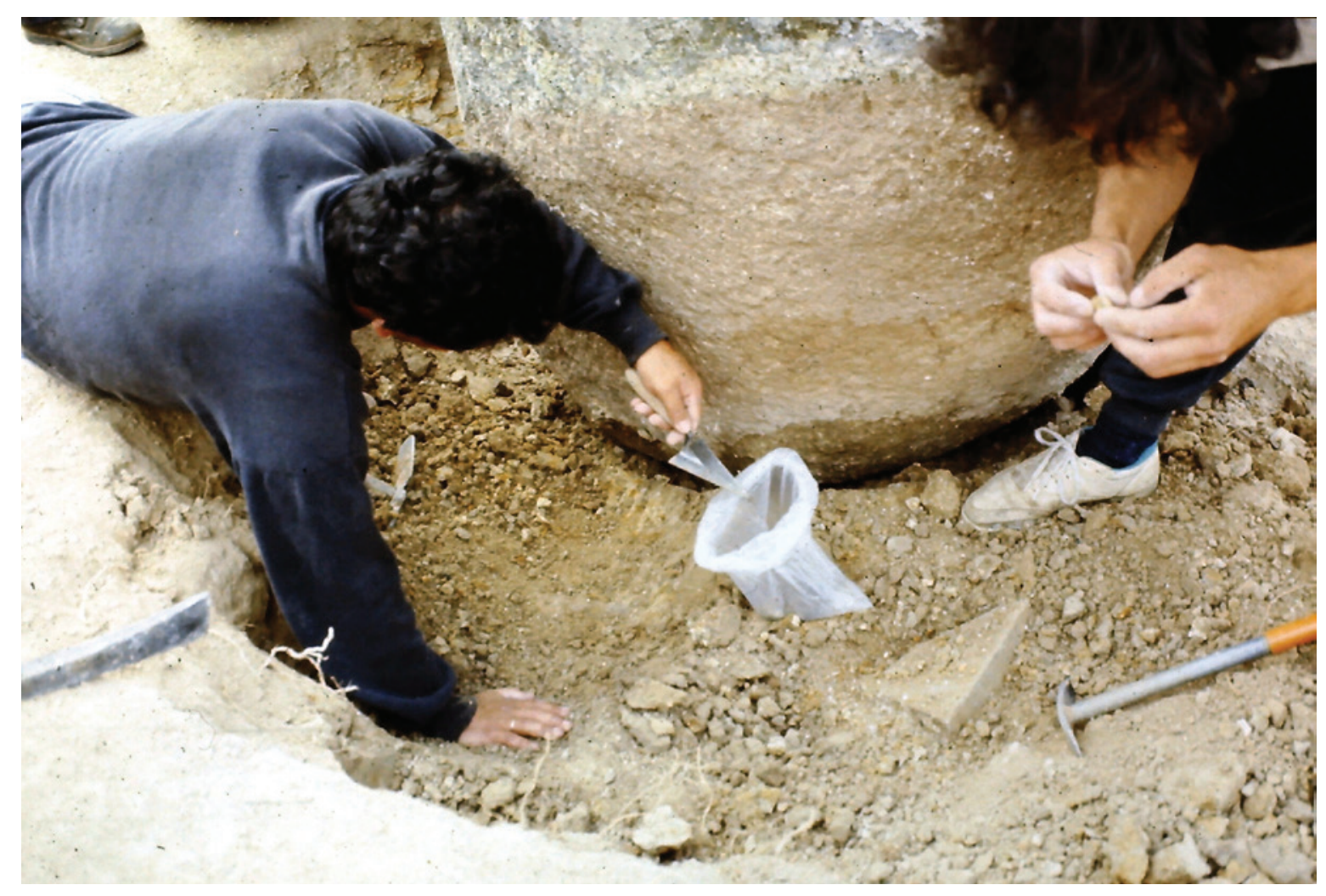

Figura 5-Menhir da Meada: recolha de carvões no interior do alvéolo, junto à base do monumento.

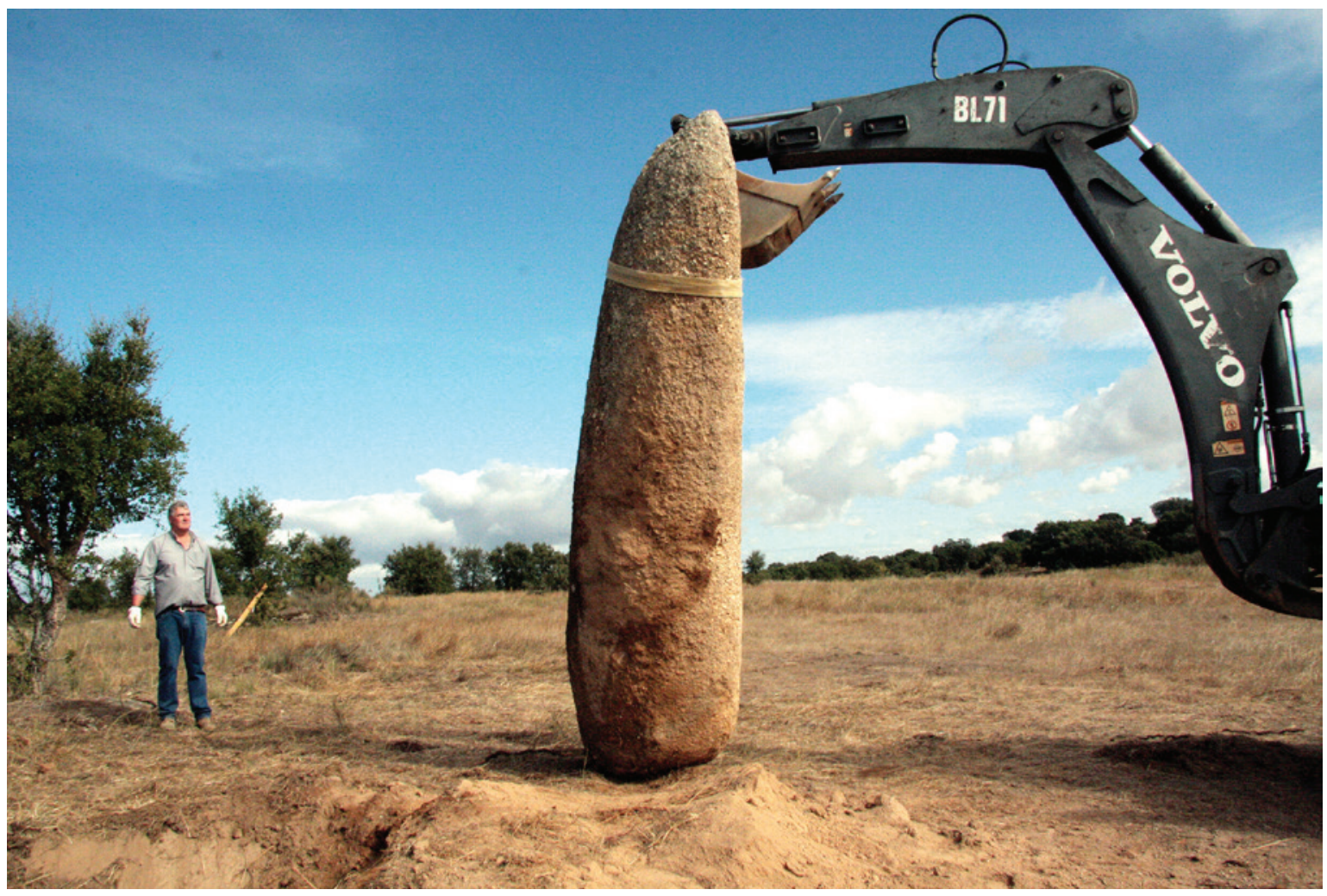

Figura 6 - Menhir do Patalou (Nisa). 


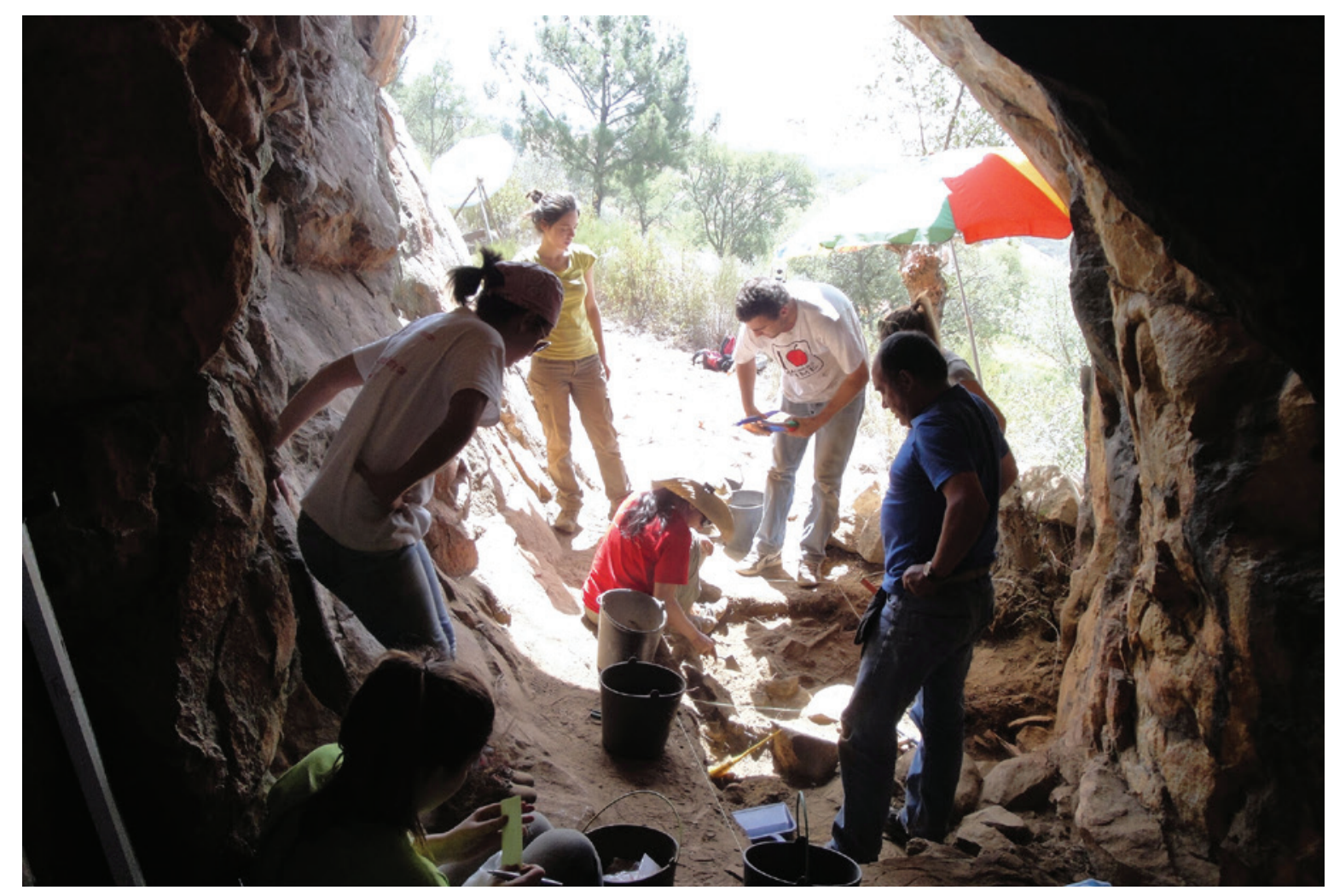

Figura 7 - Abrigo da Igreja dos Mouros (Arronches): vista geral da escavação.

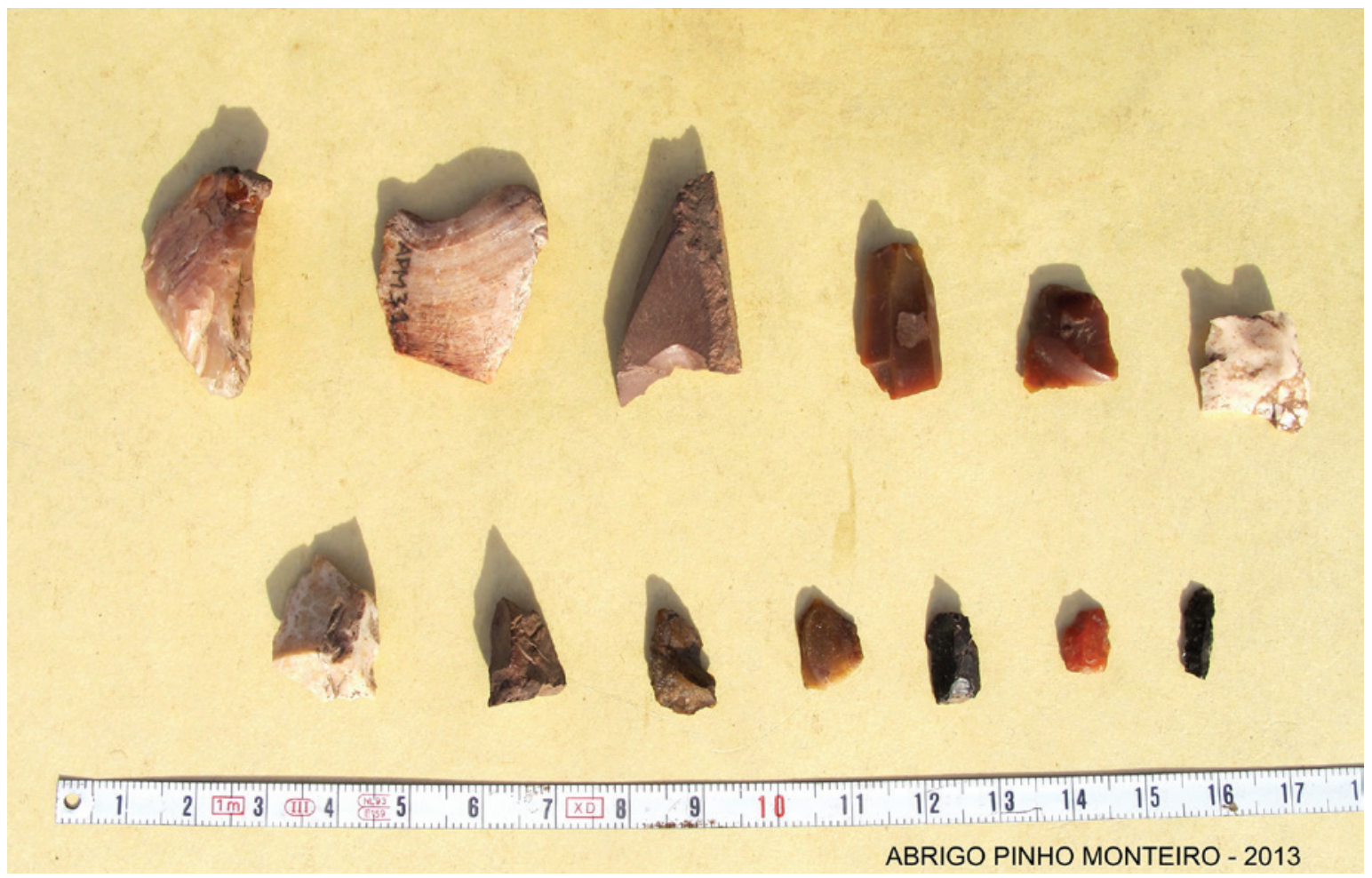

Figura 8-Abrigo Pinho Monteiro (Arronches): indústria lítica da base do abrigo. 


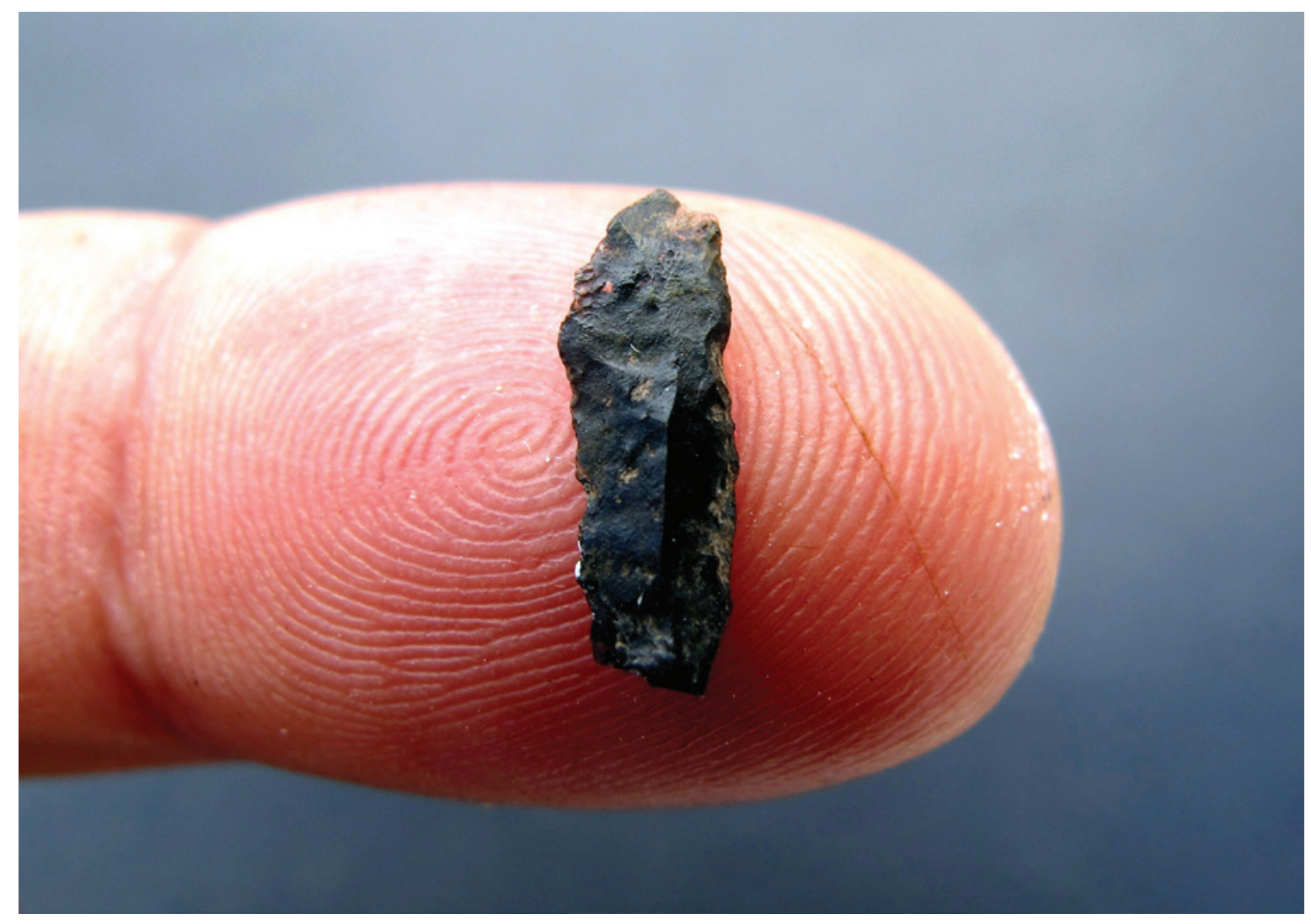

Figura 9-Abrigo Pinho Monteiro (Arronches): lamela de sílex recolhida na base do abrigo. 


\title{
POVOAMENTO PRÉ-HISTÓRICO NAS ÁREAS MONTANHOSAS DO NO DE PORTUGAL: O ABRIGO1 DE VALE DE CERDEIRA
}

\author{
Pedro Xavier ${ }^{1}$, José Meireles ${ }^{1,2}$, Carlos Alves ${ }^{3}$
}

\begin{abstract}
RESUMO
Na década de 90 do século passado, prospeções realizadas nas áreas serranas do NO de Portugal conduziram à identificação do sítio arqueológico conhecido como Abrigo 1 de Vale de Cerdeira, situado na Serra da Cabreira (NO Portugal, máx. alt. $1262 \mathrm{~m}$ ). O conjunto de evidências recuperado nas escavações arqueológicas permitem situar a ocupação da jazida entre os finais do VI/inícios do V milénio a.C. No âmbito de um projeto de doutoramento iniciado em 2017 encontra-se, atualmente, a ser estudada a coleção lítica do citado abrigo, numa dupla vertente. A primeira relativa ao estudo tecno-tipológico, identificando os objetivos da produção artefactual e, a segunda, relacionada com a classificação e caracterização das diferentes matérias-primas exploradas e manipuladas pelas comunidades pré-históricas.
\end{abstract}

Palavras-Chave: NO Portugal, Serra da Cabreira, Mesolítico Final, Matérias-primas, Indústria lítica.

\begin{abstract}
In the 1990's set of field surveys took place in the mountains of NW Portugal, leading to the discovery of the archaeological site named 'Rock Shelter 1 of Cerdeira Valley', situated in Cabreira Mountain (NW Portugal, max. alt. 1,262 m). The evidences recovered from the archaeological excavations established the shelter occupation between the end of the VI / beginning of the $5^{\text {th }}$ millennium BC. Since 2017, within the context of an ongoing Phd project, the stone tool assemblage of the shelter is being analysed, in a double perspective. The first one relates to the complete techno-typological, identifying the objectives of the stone tool production and the second concerns with the classification and characterisation of different raw-materials exploited by the prehistoric communities.
\end{abstract}

Keywords: NW Portugal, Cabreira Mountain, Late Mesolithic, Raw materials, Lithic industry.

\section{INTRODUÇÃO}

Na década de 90 do século passado desenvolveu-se, por intermédio de um dos autores do presente trabalho (J. Meireles), um programa de investigação dedicado ao reconhecimento, nas áreas serranas de média altitude do NO de Portugal, de um modelo de ocupação associado à presença dos derradeiros grupos de caçadores-recolectores pré-históricos. Este projeto teve como referência os estudos rea- lizados, na segunda metade do séc. XX, nas serras setentrionais da Galiza, a partir dos quais se identificou um conjunto de jazidas enquadráveis nos períodos Epipaleolítico e Mesolítico (Ramil Rego, 1997). Os resultados das prospeções intensivasrealizadas nos conjuntos montanhosos do NO de Portugal, permitiram eleger a Serra da Cabreira (alt. max. 1262 $\mathrm{m})$, como área preferencial de intervenção do mencionado projeto. Entre os locais referenciados e sondados, destacou-se o denominado Abrigo 1 de Vale

\footnotetext{
1. LandS/Lab2PT - Laboratório de Paisagens, Património e Território, Universidade do Minho, Braga, Portugal; pedroxavy@gmail.com

2. ICS - Instituto de Ciências Sociais, Universidade do Minho, Braga, Portugal; jmeireles@uaum.uminho.pt

3. Laboratório de Paisagens, Património e Território (FCT UID/AUR/04509/2013; FEDER COMPETE POCI-O1-0145-FEDERo07528) e Dept. Ciências da Terra/Escola de Ciências, Universidade do Minho, Braga, Portugal. Contacto: casaix@dcOt.uminho.pt
} 
de Cerdeira, cujos trabalhos de escavação e estudo do conjunto artefactual foram já objeto de um conjunto de publicações (Meireles, 2009, 2010, 2013). Mais recentemente, desde 2017, o conjunto lítico deste sítio arqueológico encontra-se a ser analisado no âmbito de um programa doutoral (P. Xavier), considerando duas abordagens de investigação. A primeira, relativa à análise tecno-tipológica e à compreensão dos sistemas técnicos de produção e respetivas cadeias operatórias e, uma segunda, que procura identificar e caracterizar as diferentes matérias-primas e recursos litológicos explorados e manipulados pelas comunidades pré-históricas da Serra da Cabreira, procurando ainda colocar e debater hipóteses de trabalho quanto à localização de pontos de aprovisionamento e recolha.

O presente texto tem como propósito a realização de um primeiro balanço das atividades desenvolvidas até ao momento. Assim, e após a apresentação das opções metodológicas e procedimentos técnicos adotados na observação das matérias-primas, serão discutidos os primeiros resultados deste estudo, juntamente com os da análise tecnológica.

\section{O ABRIGO I DE VALE DE CERDEIRA}

Neste apartado pretendemos dar a conhecer a localização do abrigo, o seu enquadramento físico e uma pequena nota referente à sequência estratigráfica e às estruturas arqueológicas identificadas. Esta caracterização será extremamente sucinta, uma vez que a descrição destes parâmetros encontra-se bastante detalhada na bibliografia já publicada sobre o sítio arqueológico (Meireles, 2009, 2010 e 2013). A este respeito, realce-se o trabalho de 2010 , onde poderá ser consultada uma descrição bastante pormenorizada, tanto da sequência sedimentar como das duas estruturas de combustão registadas na base da UE 1 . O Abrigo 1 de Vale de Cerdeira ( $41^{\circ} 37^{\prime} 30.0^{\prime \prime} \mathrm{N}, 8^{\circ}$ 05'31.3”W) situa-se na União de Freguesias de Vilar Chão e Anjos, concelho de Vieira do Minho, distrito de Braga (Figura 1).

Posicionado a $660 \mathrm{~m}$ de altitude absoluta, desfruta de uma localização privilegiada, comprovada pelo acesso a recursos hídricos (junto a uma linha de água), amplo domínio territorial (controlo de vias naturais de acesso à zona ocidental da Serra da Cabreira) e ainda pela proximidade de filões de quartzo e consequentes recursos de matérias-primas (Meireles, 2009, 2013). Esta área, vertente norte do mon- te da Feteira em plena Serra da Cabreira, enquadra-se no padrão típico de algumas regiões graníticas, compostas por granitos calcoalcalinos porfiróides de grão grosseiro, os quais, com frequência, por via de processos de evolução subárea e subcutânea, juntamente com fenómenos de meteorização química e de erosão diferencial, definem um modelado conhecido como caos de blocos que conformam espaços protegidos, seja sob a forma de abrigos, seja através de áreas ao ar-livre cercadas por conjuntos de afloramentos rochosos (Meireles, 2009, 2013). O Abrigo 1 de Vale de Cerdeira (Imagem 2) resultou da fracturação longitudinal de um grande bloco de granito porfiróide que originou duas áreas abrigadas, designando-se a superior de Abrigo 1, constituindo uma área de $36 \mathrm{~m}^{2}$, dos quais $20 \mathrm{~m} 2$ foram alvo de intervenção arqueológica (idem) (Figura 2). A sequência estratigráfica registada, inferior a $1 \mathrm{~m}$ de espessura, contempla 3 níveis, denominados, da base para o topo, como UE1, UE2 e U3 e um conjunto artefactual superior a 30 mil peças $O$ estudo que tem vindo a ser realizado incide na UE-1 e UE-2, não contemplando a UE-3, dado o carácter altamente perturbado e incaracterístico deste depósito, condicionando qualquer consideração de ordem cronológica e cultural.

Na base da UE-1 identificaram-se duas estruturas de combustão, cujas amostras de carvão vegetal permitiram a obtenção de duas datações radiométricas C14, situando a ocupação humana do abrigo entre os finais do VI (GrN-25614, 6240 \pm 50 BP: $5316-$ 5056 cal. BC $2 \sigma$ ), inícios do $\mathrm{V}$ milénio a.C. (GrN$-25613,6090 \pm 4$ o BP: $5207-4853$ cal. BC 2 o) (idem).

\section{OBSERVAÇÃO DAS MATÉRIAS-PRIMAS}

A análise das matérias-primas tem assentado, por ora, essencialmente sobre as de origem local, consistindo em diferentes variedades de quartzo. Tal decisão radica no carácter verdadeiramente hegemónico dos recursos locais que representam, tanto na UE-1 como na UE-2, mais de $98 \%$ dos efetivos totais. É nossa intenção porém, com o desenrolar dos trabalhos, efetuar um pequeno ensaio de caracterização e de hipóteses de proveniência das matérias-primas exógenas, representadas por diferentes variedades de sílex, o qual marcará presença na dissertação final de doutoramento. 


\subsection{Classificação dos Quartzos}

Como afirmado, o quartzo é a matéria-prima dominante na coleção lítica recuperada no Abrigo 1 de Vale de Cerdeira. A consulta da cartografia geológica coincidente com a localização do abrigo (Carta Geológica 6-C, Cabeceiras de Basto) e das áreas limítrofes, permite-nos compreender que este mineral é um vasto e abundante recurso à escala regional, disponível tanto através de filões associados a falhas, como em corpos geológicos aplítico-pegmatíticos.

Nos estudos anteriores de J. Meireles (2009, 2010, 2013), no que respeita aos quartzos, foi efetuada uma divisão em duas grandes categorias: quartzo hialino ou cristal de rocha e outras variedades de quartzo, de acordo com a distinção estabelecida por V. Mourre (1996), entre quartzo automorfo e xenomorfo, referentes ao hábito do cristal e às diferentes condições ambientais de formação que potenciam o surgimento de diferentes variedades.

$\mathrm{Na}$ análise que tem vindo a ser empreendida foi mantida esta primeira separação, adaptando-se ainda, para a categoria do quartzo xenomorfo, uma tipologia de base cromática e de transparência, compreendo as seguintes variedades: leitoso, translúcido, róseo, cinzento e fumado. Sendo conscientes das insuficiências apontadas por alguns autores quanto ao emprego destas classificações (e. g. Driscoll, 2010), foi mantida a sua aplicação, dada a utilização de designações idênticas em estudos mineralógicos e pela circunstância de proporcionar uma primeira ordenação de carácter expedito, de fácil aplicação e que poderá ainda relacionar-se com diferentes ambientes geológicos.

Decidiu-se ainda seguir a proposta de classificação de Martínez Cortizas e C. Llana (1996), que averigua da presença e/ou ausência de duas variáveis morfo-estruturais do quartzo: textura granulada e planos de cristalização, fissuras ou fraturas. Nesse sentido, os autores definem 4 grupos, a saber: NN (sem grão/ sem planos); NS (sem grão/com planos internos); SN (granulado/sem planos) e SS (granulado/com planos internos) (idem). Relacionando processos de formação do quartzo às suas propriedades mecânicas, esta classificação poderá auxiliar a descortinar critérios de aquisição e seleção de matéria-prima e identificar alguns constrangimentos de ordem técnica associados a cada grupo (Lombera-Hermida, 2008), sendo comum a sua aplicação por parte de um conjunto de autores se dedicam ao estudo de indústrias líticas em quartzo (e.g. Rodríguez-Rellán,
2010; Peña Alonso 2015). Com efeito, e na situação particular do conjunto de Vale de Cerdeira e ainda que esta análise não se encontre encerrada, é relevante assinalar a grande relação do quartzo hialino com a categoria ' $\mathrm{NN}$ ' e que, invariavelmente, este corresponda ao grupo mais apto para o talhe, destinado, frequentemente, à obtenção de produtos alongados e utensílios microlíticos.

Noutro sentido, os trabalhos de campo permitiram compreender que o quartzo existente na área imediatamente envolvente ao abrigo, que ocorre em filões, é de tipo cataclástico, apresentando-se finamente granulado e com cavidades, resultante da fracturação da falha aqui presente, enquadrando-se nas categorias SN e SS da referida classificação. Não obstante, a imensa maioria da matéria-prima registada nas duas unidades estratigráficas em estudo é de tipo 'NS', presente, por sua vez, noutros locais situados a maior distância da jazida arqueológica. Tal facto é revelador de um comportamento seletivo no momento da recolha de matéria-prima por parte comunidades pré-históricas da Serra da Cabreira.

\subsection{Análises Laboratoriais}

No intuito de levar a cabo uma caracterização dos distintos quartzos da coleção, tem sido aplicadas algumas técnicas laboratoriais afetas ao domínio de conhecimento das Ciências da Terra. Desde uma fase precoce do estudo, por forma a promover a inviolabilidade dos artefactos, foi conferida total primazia a técnicas de cariz não-destrutivo. Tal decisão assentou no valor patrimonial e cultural que reconhecemos ao espólio arqueológico, mas também na perspetiva de que, no futuro, outros procedimentos e projetos de investigação possam ser desenvolvidos sobre os mesmos materiais, eventualmente com recurso a técnicas de maior acuidade.

Entendemos aqui o conceito de não-destrutivo num duplo significado: primeiro, na circunstância óbvia de evitar qualquer alteração ou dano na peça sujeita a procedimento analítico e, segundo, no sentido de ser reprodutível, permitindo a repetição de testes ou a realização de diferentes análises no mesmo artefacto (Xavier e Alves, 2019). Com efeito, verificam-se técnicas que, sendo destrutivas, exigindo o corte ou fragmentação do artefacto, possibilitam, ao invés, a realização de vários conjuntos de testes, evitando continuados danos no material arqueológico.

O conjunto das técnicas laboratoriais ensaiadas consistiram: observação de peças do Microscópio 
Electrónico de Varrimento (MEV) para obtenção de caracterizações químicas e informações relativas à análise textural e estrutural; análises RAMAN, importantes para o conhecimento da composição química dos minerais; estudos por florescência de raios-X (XRF), igualmente importantes na descrição química, tanto global como pontual e, finalmente, Análises de Imagiologia Hiperespectral as quais, através da avaliação quantitativa de coordenadas cromáticas permitem, de forma reproduzível e objetiva, determinar a cor de uma determinada peça. Algumas das dificuldades recorrentemente experimentadas nestes ensaios, prenderam-se com a superfície irregular dos artefactos, restringindo a aplicabilidade de alguns procedimentos e ainda com a escassa capacidade de penetração de algumas das técnicas e equipamentos, aspeto particularmente importante na análise e deteção das inclusões fluídas e minerais, descritas no próximo ponto.

\subsection{Estudo das inclusões}

A considerável homogeneidade química e cristalográfica entre diferentes variedades de quartzo dificulta, sobremaneira, a deteção das fontes de aprovisionamento (Cousseran 2002). Uma possível aproximação aos locais de proveniência destes materiais radica na identificação de inclusões, sejam estas sólidas (outros minerais), gasosas ou líquidas, que ocorrem no seio de um mineral aquando da sua formação, providenciando informações sobre o ambiente de formação e, consequentemente, da sua origem (idem). No âmbito do nosso estudo, a observação, ao microscópio petrográfico, de artefactos elaborados em quartzo hialino e translúcido com vista ao reconhecimento de inclusões, têm-se se revelado frutífera.

Com efeito, parte substancial do esforço investido nas técnicas laboratoriais mencionadas no ponto anterior destinou-se à determinação do material constituinte das inclusões. No que concerne às de tipo mineral, os estudos realizados indiciam que possam corresponder a schorlite e elbaíte; no que respeita às fluídas, os resultados tem sido pouco claros, em função, em parte, da já referida pouca capacidade de penetração no interior das peças por parte dos equipamentos laboratoriais e da circunstância de as análises terem sido efetuadas nos artefactos por inteiro, mantendo a sua integridade e descartando qualquer corte, polimento ou fratura. Não obstante, a identificação das inclusões minerais permitiu, de certo modo, atribuir diretrizes ao trabalho de campo que discriminamos no ponto seguinte.

\subsection{Trabalhos de Campo}

Qualquer estudo de proveniência implica a realização de prospeções para o reconhecimento de corpos geológicos e recolha de amostras que possam ser contrastadas com o material arqueológico. Assumem, assim, particular importância a cartografia geológica disponível, bem como outros recursos, nomeadamente o portal SIORMINP (http://geoportal.lneg.pt/geoportal/egeo/bds/siorminp/) - Sistema de Informação de Ocorrência e Recursos Minerais Portugueses - que congrega indicações de antigas explorações mineiras.

As variedades de quartzo presentes na coleção de Vale de Cerdeira são suscetíveis de se encontrarem em filões de quartzo e formações pegmatíticas. A consulta da cartografia geológica e realização dos primeiros trabalhos de campo permitiu-nos compreender da impossibilidade logística e temporal de conhecer e caracterizar todos os corpos geológicos situados na envolvente do abrigo. Em simultâneo, a recolha da variedade de quartzo dominante na coleção-leitoso, 'NS'-, poderia ter ocorrido numa multitude de pontos distintos. Assim, de forma a tornar este estudo mais frutífero, sobretudo no que respeita à localização de eventuais pontos de aprovisionamento, tornou-se necessário reorientar a pesquisa para a busca de tipos mais raros, nomeadamente quartzo róseo, fumado, hialino e, mais recentemente, quartzo com inclusões.

O programa de prospeções empreendido até à data, insistindo, particularmente, na deteção de corpos pegmatíticos posicionados numa área até $15 \mathrm{~km}$ de distância para com a jazida, possibilitou o registo de mais de 200 ocorrências.

Apesar de constrangimentos pontuais, como problemas de acessibilidade ou destruição e fragmentação de determinados corpos geológicos, alguns dos pontos detetados são merecedores de destaque, sobretudo o local conhecido como Muro Alto, situado a cerca de $5 \mathrm{~km}$ da jazida arqueológica. Trata-se de um corpo pegmatito, providenciando diferentes tipos de quartzo, entre os quais quartzo róseo, fumado, translúcido e com inclusões. Atualmente, o local encontra-se bastante modificado daquela que seria a sua configuração natural, fruto da intensa exploração mineira de que foi alvo no decorrer das décadas de 40 e 50 (inf. pes. C. Leal Gomes). De acordo com 
a mesma fonte e com base na análise geológica da informação disponível, antes da exploração, o sítio poderia apresentar um imponente esporão de quartzo, com mais de 6 metros de altura, constituindo um verdadeiro marco paisagístico no meio envolvente.

Neste momento, o sítio foi já intervencionado no contexto do nosso trabalho, tendo-se recolhidos algumas amostras, semelhantes a algumas a algumas peças presentes na coleção arqueológica. A presença de uma densa vegetação e falta de limpeza do terreno tem impossibilitado, momentaneamente, a continuação dos trabalhos em segurança.

\section{PRIMEIROS RESULTADOS}

Seguidamente apresentaremos os primeiros resultados do estudo das matérias-primas e da análise tecnológica separados por unidade estratigráfica. Tratando-se de informações preliminares e de carác-ter provisório não será de estranhar, face ao que posteriormente se encontrará na dissertação doutoral, alterações de carácter pontual relativas a algumas percentagens e valores que serão agora mencionados.

\subsection{Unidade Estratigráfica 1}

A imensa maioria ( $75 \%$ ) das mais de 13600 peças recuperadas da UE-1 correspondem a material residual (restos de talhe + esquírolas), seguido, a uma larga distância, pelos produtos de lascamento (lascas + produtos alongados) que correspondem a $20 \%$ e os núcleos com uns meros $2 \%$. O índice de transformação assume uma importância meramente vestigial inferior a $2 \%$.

Os dados das matérias-primas, no contexto geral da coleção, encontram-se sintetizados na Imagem 3. Verifica-se uma preponderância do quartzo automorfo, de cor leitosa, seguido do translúcido. O quartzo hialino representa $12 \%$ enquanto, por sua vez, os recursos exógenos ficam-se por $1 \%$. No que concerne aos grupos morfoestruturais, a variedade NS, associada, fundamentalmente, a quartzos leitosos e translúcidos é a mais importante, enquanto a $\mathrm{NN}$, de forma geral associada com o cristal de rocha, fica-se pelos $22 \%$. O quartzo com textura granulada é, em termos globais, pouco expressivo (Figura 3 ). No domínio dos produtos de lascamento, observa-se uma grande incidência de suportes fraturados, na ordem dos $55 \%$, tanto nas lascas como nos produtos alongados. Tal circunstância encontra-se relacionada pelas características mecânicas da matéria-prima, sendo reconhecível, em ensaios experimentais, a produção de enormes quantidades de restos de talhe (Driscoll, 2011). Entre as fraturas mais comuns encontram-se, em ambos os tipos de produtos, as de tipo Buril de Siret e as transversais. Porém, se no caso das lascas, as proporções são idênticas, nos produtos alongados as transversais representam quase metade do total das fraturas e as de tipo Buril de Siret não mais do que $17 \%$. Os talões lisos são a grande maioria e correspondem, em ambas as categorias, a mais de metade. Observa-se, no caso dos produtos alongados uma maior preferência pelo emprego de cristal de rocha (33\%), face às demais matérias-primas. O quartzo de tipo NN representa $29 \%$ e $16 \%$ nos produtos alongados e nas lascas, respetivamente. Nestas, o tipo de quartzo dominante é leitoso, de tipo NS, na ordem dos $40 \%$.

No que concerne aos núcleos, as estratégias predominante são a multipolar (29\%), bipolar sobre bigorna $(24 \%)$ e prismática (14\%). Entre os volumes trabalhados sobre bigorna, identifica-se uma preferência pelos de menor dimensão e, no que concerne ao método prismático, pratica-se, usualmente, sobre os prismas de quartzo. Apesar da já referida abundância de matéria-prima no contexto geológico onde se encontra a jazida, cerca de $52 \%$ dos núcleos foram intensamente explorados e $20 \%$ encontram-se mesmo esgotados. De assinalar, a recolha de 43 prismas de quartzo, sem estigmas de exploração, parte dos quais pode ser entendida como reserva de matéria-prima. Quanto aos utensílios, o baixo índice de transformação corresponde, em termos quantitativos, a 279 unidades, contando-se 92 sobre lasca, 179 utensílios microlíticos e 8 diversos. Entre os micrólitos registam-se 9 produtos alongados retocados, 8 truncaturas, 2 microfuradores, 63 pontas. 4 indeterminados e 92 geométricos - 55 segmentos e 37 trapézios (Figura 4).

Entre os denominados 'utensílios de fundo comum', as 3 classes mais representadas, por ordem decrescente, são furadores, entalhes e lascas retocadas. Considerando as matérias-primas, não se observa uma gestão diferenciada, comparativamente aos suportes não retocados. Comportamento diferente, porém, verifica-se nos microlíticos, dado que $10 \%$ destes foram elaborados a partir de recursos exógenos; é igualmente nesta subcategoria onde é mais significativo o emprego do quartzo hialino, representando mais de $70 \%$ e da variedade $\mathrm{NN}$, superior a $80 \%$. 
O tipo de retoque predominante - com independência relativamente à matéria-prima, mas também à subcategoria, isto é, de substrato ou microlítica apresenta-se direto, contínuo, muito abrupto, marginal, escamoso, sendo ainda, por vezes, apoiado ou sobre bigorna. Quanto às pontas microlíticas, que serão, posteriormente, objeto de um estudo detalhado, imperam as de secção e morfologia triangular, embora também se conheçam de corpo fusiforme e ainda, um outro conjunto, evidenciando uma solução mais original, onde se pratica um aproveitamento das características naturais do suporte, na circunstância um produto extraído do ápice ou cabeça do cristal de quartzo, que através de retoque mínimo e, com frequência, limitado à zona distal, é transformado numa ponta.

No domínio do sistema técnico de produção, validam-se e reforçam-se as conclusões assinaladas nos trabalhos anteriores (Meireles, 2009, 2010 e 2013). Regista-se, assim, uma estratégia direcionada para a obtenção de duas categorias de produtos. A primeira, com maior significado quantitativo, representada, no essencial, por lascas de módulo reduzido e, ocasionalmente, por produtos alongados obtidos através da exploração de núcleos multipolares e bipolares; a segunda, assente no método prismático, direcionada para o fabrico de pequenas lamelas, tendo em vista a sua posterior transformação utensílios e que resulta de uma cadeira operatória particular, decorrente da exploração de prismas de quartzo hialino e leitoso, tirando o máximo partido das características morfo-estruturais do romboedro cristalino.

\subsection{Unidade Estratigráfica 2}

São significativas as semelhanças, em variados aspetos, entre ambas as unidades estratigráficas, a começar pelo valor percentual das distintas categorias. Assim, na UE-2, o material residual a volta a cifrar-se nos $75 \%$ e os produtos de lascamento nos $20 \%$. Contudo, ressalve-se uma redução do índice de transformação, desta feita 1,6\%, suportado pela redução no número de utensílios, contabilizando 154 unidades. No capítulo das matérias-primas, contrastando com a UE-1, há um significativo reforço dos recursos exógenos e do quartzo de tonalidade leitosa, que consubstancia já mais de metade da totalidade das litologias. Em sentido inverso, o cristal de rocha conhece uma diminuição global, porém com uma aplicação mais direcionada, no âmbito da obtenção de produtos alongados e da configuração de utensi- lagem lamelar. Os quartzos com textura granulada são uma pequena parte dos recursos manipulados, o que poderá estar relacionado, mais do que com a sua menor ou maior disponibilidade, com a reduzida aptidão para o talhe que, de uma forma genérica, parecem apresentar (Figura 5).

Os produtos de lascamento fraturados voltam a representar mais de 50\%, em ambas as subcategorias. É na categoria dos produtos alongados onde se regista o maior emprego do sílex surgindo, após o quartzo hialino, como o segundo recurso utilizado. Tal circunstância não se observa nas lascas onde é o quartzo leitoso e translúcido de variante NS, o que mais se destaca. Os talões lisos e bolbos desenvolvidos são os mais comuns, tanto em lascas como em produtos alongados, ainda que nestes se observe uma significativa representação de bolbos esbatidos e de talões lineares.

Apesar das grandes similitudes dos dois conjuntos, há pontuais dissemelhanças, como o número muito mais reduzido de núcleos que, por ora, contabilizam apenas 108 unidades. Destas, $38 \%$ correspondem a fragmentos dos quais não possível compreender a estratégia de exploração praticada. Regista-se um incremento dos núcleos bipolares sobre bigorna com $27 \%$, seguido dos multipolares, $23 \%$ e dos prismáticos (fundamentalmente de uma plataforma), com $20 \%$. Com a exceção dos núcleos prismáticos, os quais se encontram, grosso modo, entre o esgotado e o intensamente explorado, os demais apresentam, maioritariamente, um reduzido número de extrações. De destacar a concentração de volumes de matéria-prima do grupo NN no conjunto dos núcleos prismáticos, tanto em quartzo hialino como leitoso, associado aos maiores requisitos técnicos exigidos por este método de exploração. Registe-se ainda a presença de 56 prismas de quartzo por explorar, entendidos como reserva de matéria-prima. Ainda que, no domínio percentual, o número de utensílios não se diferencie muito entre as duas unidades, a UE-2 concentra, em termos quantitativos, um número bem mais baixo, mais concretamente 154 unidades, das 103 sobre lamela, 47 sobre lascas e 4 diversos (Figura 6).

Começando pela utensilagem lamelar, os mais representativos são os segmentos, seguidos das pontas microlíticas e dos produtos alongados retocados. Há uma notória diminuição das armaduras trapezoidais (somente duas unidades), destacando-se ainda a presença de uma forma triangular. Dentro 
das pontas microlíticas (redução muito substancial face à UE-1, de 6o para 23) continua a manifestar-se a tendência para peças de morfologia e secção triangular, não faltando, tal como mencionado para a UE-1, peças elaboradas a partir do ápice do cristal de quartzo e ainda de 3 outros exemplares, que se destacam do conjunto pelas suas maiores dimensões e pesos e cujo significado terá de ser, evidentemente, valorado. O sílex é particularmente aplicado na configuração de segmentos e de produtos alongados retocados, não sendo empregue, porém, eà imagem do observado na UE-1, na elaboração de pontas. Com efeito, nas pontas, o quartzo utilizado limita-se aos grupos NN e NS, nas variantes hialina e translúcida. Em ambas as unidades estratigráficas, a realização das armaduras microlíticas assentou na transformação, por retoque, de produtos de módulo reduzido. De modo complementar, recorreu-se à técnica da rutura transversal, conhecida pelo seu carácter expedito, consistindo na obtenção de uma superfície de fratura perpendicular ao eixo do suporte do qual se seleciona um fragmento para a realização da peça (Prieto, 2000-2001). Em sentido inverso, não há evidência do emprego da técnica do microburil.

Na utensilagem sobre lasca, mantêm-se a maior importância de lascas retocadas, furadores e entalhes, por ordem de representatividade. Neste subconjunto, não parece ter-se verificado uma particular gestão dos recursos litológicos, mantendo-se os mesmos padrões observados nos suportes não retocados.

O sistema técnico de produção da UE-2 é idêntico ao descrito para a UE-1, tanto ao nível das categorias de produções, como das cadeias operatórias. Assim, o aspeto mais distintivo do segundo nível estratigráfico prende-se com a presença de um reduzido conjunto de materiais de pedra polida, constituído por um pequeno machado em silimanite/fibrolite, 1 fragmento (talão) de um outro machado e ainda 4 diversos e, também pela recuperação de 20 fragmentos de cerâmica, a maioria sem decoração. Entre os decorados contam-se 2 com decoração incisa simples, 1 de tipo "boquique" e 1 de impressão simples, com paralelos nas cerâmicas atribuíveis ao Neolítico Antigo da estação duriense do Prazo (Monteiro-Rodrigues, 2008; Meireles, 2010, 2013),

\section{CONSIDERAÇÕES FINAIS}

Uma das motivações subjacentes à realização do estudo de caracterização das matérias-primas que contemplasse, igualmente, a discussão de potenciais pontos de aprovisionamento, deveu-se à manifesta insuficiência deste tipo de análises em regiões e contextos geológicos - do qual o NO Peninsular constitui um bom exemplo - onde o quartzo é dominante e, em sentido contrário, o sílex é raro ou mesmo inexistente (Lombera Hermida e Rodríguez-Rellán, 2010).

No que mais diretamente concerne à deteção de eventuais fontes de aprovisionamento os resultados são, até ao momento, algo limitados, em função da própria composição química monótona do quartzo, da variabilidade que, por vezes, se deteta no mesmo filão e formação geológica (podendo conter distintas variedades) e dos já assinalados constrangimentos ao nível dos trabalhos de campo e procedimentos laboratoriais. Não obstante, o estudo das inclusões permanece em aberto e a identificação de corpos pegmatíticos donde se recuperou quartzo com inclusões, entre os quais o citado Muro Alto, poderá ainda providenciar o estabelecimento de correspondências entre material arqueológico e amostras geológicas. De todo o modo, os trabalhos de campo permitiram, num raio de $15 \mathrm{~km}$ em redor da jazida, a identificação de mais de 200 pontos. A informação daqui proveniente encontra-se a ser sistematizada num software de sistema de informação geográfica (QGIS), com o propósito de ser disponibilizada numa plataforma de acesso livre. No mesmo sentido, a recolha de amostras geológicas serviu de pretexto à constituição de uma futura litoteca que servirá como coleção de referência no desenvolvimento de futuros programas de investigação.

$\mathrm{O}$ regime de aprovisionamento de recursos líticos praticado pelas comunidades pré-históricas da Serra da Cabreira seria, essencialmente, baseado nas matérias-primas locais, à semelhança do conhecido noutras regiões nacionais e ibéricas para o período do Mesolítico Final (e.g Carvalho, 2009;. Martí Oliver et al., 2009), devendo ocorrer no domínio da realização de outras atividades - embedded procurement, na expressão de L. Binford (1979) - não se descartando, contudo, uma recolha mais direta ou direcionada de determinados recursos, como o quartzo hialino. Relativamente aos recursos exógenos, que não foram abordados neste trabalho, será relevante o conhecimento da sua proveniência, dada a informação que poderá providenciar relativamente a processos de intercâmbio e de interação social entre grupos humanos. 
Relativamente à indústria lítica, dever-se-á assinalar, em primeira instância, a total adequação daquilo que são os objetivos da produção lítica aos recursos disponíveis. Tal poderá ser observado, entre outros exemplos, na cadeia operatória que tira partido das características morfo-estruturais dos prismas de quartzo e no conjunto de armaduras que são elaboradas a partir de uma extração procedente do ápice do cristal. Estes recursos permitiram a constituição de um conjunto de clara vocação cinegética, atendendo à proporção, no seio da utensilagem, de armaduras, tanto geométricas, como pontas microlíticas (Meireles, 2013).

Relativamente à UE-1, a obtenção das duas datações radiométricas mencionadas no início deste texto, juntamente com a análise do conjunto lítico, permite a sua adscrição a uma fase terminal do Mesolítico Final ou Recente. A descoberta do Abrigo de Vale de Cerdeira, ao propiciar, juntamente com a identificação de outras jazidas, entre quais o Prazo (Monteiro Rodrigues, 2008) ou a Barca do Xerez de Baixo (Araújo e Almeida, 2013), um panorama mais diverso e enriquecido, do que até então tinha sido admitido nos modelos dominantes para a compreensão do Mesolítico em território nacional (Carvalho, 2009), vem ainda contribuir para desmistificar a suposta atipicidade associada às indústrias em quartzo, já assinalada igualmente por outros autores, a propósito dos materiais pré-históricos da Galiza (Ramil Rego, Blanco Sanmartín e Rodríguez Pérez, 2016). As datas, aparentemente tardias, têm paralelo em território nacional, no estuário do Tejo ou na Costa Alentejana, onde o modo de vida caçador-recolector perdurou até cerca de $4750 \mathrm{aC}$ (Zilhão, 200o). No mesmo sentido, atendendo somente à cronologia e ao predomínio dos segmentos no quadro dos utensílios geométricos, Vale de Cerdeira tem correspondência, por exemplo, com o concheiro de Vidigal (Odemira) (Carvalho, 2009) ou com o concheiro das Amoreiras (Alcácer do Sal) (Nukushina, 2015). Finalmente, em relação à UE-2, para a qual não se possuem datações, esta reproduz, essencialmente, os mesmos processos técnicos e de gestão da matéria-prima observados na UE-1. O traço mais distintivo consiste assim no surgimento de inovações tecnológicas representadas pelo pequeno conjunto cerâmico e de artefactos em pedra polida, itens integrantes no denominado "pacote neolítico" e associáveis a comunidades produtoras. A valorização destes elementos, juntamente com a cronologia relativa permite-nos, por ora sem mais desenvolvimentos, enquadrar esta ocupação no Neolítico Antigo. Todavia, no domínio das estratégias gerais de subsistência, podermos estar perante comunidades predadoras, para as quais as "novidades" adotadas teriam, sobretudo numa primeira fase, implicações de carácter social e que, somente a longo prazo, se refletiriam na esfera económica (Monteiro-Rodrigues, 2008).

\section{AGRADECIMENTOS}

FCT - Fundação Ciência e Tecnologia - Bolsa de Doutoramento ref. SFRH/BD/120806/2016 de Pedro Xavier.

Lab2PT - Laboratório de Paisagens, Património e Território (AUR/04509) financiado pela FCT através de fundos nacionais e quando aplicável do cofinanciamento do FEDER, no âmbito dos novos acordos de parceria PT2020 e COMPETE 2020 POCI-O1-0145-FEDER-007528.

Prof. Leal Gomes, docente da Universidade do Minho e investigador afeto ao Lab2PT, pelas informações prestadas sobre fontes de matéria-prima e pela participação em algumas atividades de campo.

\section{BIBLIOGRAFIA}

ARAÚJO, Ana C.; ALMEIDA, Francisco (2013) - Barca do Xerez de Baixo. Um testemunho invulgar das últimas comunidades de caçadores-recolectores do Alentejo interior. Memória d'Odiana, 2aㅡ Série. 332 p.

BINFORD, Lewis (1979) - Organization and formation processes: looking at curated technologies. Journal of Anthropological Research 35, pp. 255-273

CARVALHO, António Faustino (2009) - O Mesolítico Final em Portugal. In Monografías Arqueológicas Vol. 44, pp. 33-68. In P. Utrilla \& Montes Lourdes (Eds.), El Mesolítico Geométrico en la Península Ibérica Monografias Arqueológicas 44 (. Universidad de Zaragoza, pp. 33-68

COUSSERAN, Sylvie (2002) - [Résumé de thèse] Les inclusions fluides, un outil pour la discrimination des quartz archéologiques: application au problème de circulation du quartz dans les Alpes occidentales et lombardes. Réalisation d'un premier référentiel de données sur les quartz. Bulletin de La Société Préhistorique Française, 99(4), pp. 833-838.

DRISCOLL, Killian, (2010) - Understanding quartz technology in early prehistoric Ireland. School of Archaeology, University College Dublin, Dublin. Unpublished PhD thesis. http:// www.lithicsireland.ie/PHD_Quartz_lithic_ technology_CONTENTS.html. 
DRISCOLL, Killian (2011) - Vein quartz in lithic traditions: an analysis based on experimental archaeology. Journal of Archaeological Science, 38(3), 734-745. https://doi. org/10.1016/j.jas.2010.10.027

FUERTES PRIETO, Natividad (2000-2001) - El modo de produción de los microlitos geométricos: el caso de la cueva de "El Espertín”, Lancia, 4, Revista de Prehistoria, Arqueología e Historia Antigua del Noroeste Peninsular, Universidad de León, pp. 51-70.

LOMBERA-HERMIDA, Arturo de (2008) - Quartz morphostructural groups and their mechanical implications. Museologia Scientifica e Naturalistica, 3 (January 2008), pp. 1-5. https://doi.org/10.1516o/1824-2707/488

LOMBERA-HERMIDA, Arturo de; RODRÍGUEZ RELLÁN, Carlos (2010) - Gestión y Estrategias de abastecimiento de las materias primas locales (cuarzo, cuarcita y pizarra) en la Prehistória del NW Peninsular. In S. Domínguez-Bella, J. Ramos Muñoz, J. M. Gutiérrez López, \& M. Pérez rodríguez (Eds.), Minerales y Rocas en las sociedades de la Prehistóris (Grupo de I, pp. 49-6o).

MARTÍNEZ CORTIZAS, Antonio; LLANA RODRÍGUEZ, César (1996) - Morphostructural variables and the analysis of their effect on quartz blank characteristics. In: Non - Flint Stone Tools and the Palaeolithic Occupation of the Iberian Peninsula. MOLONEY, Norah; RAPOSO, Luís; SANTONJA, Manuel (Eds). Tempus Reparatum, Oxford. 649, pp. 49-53.

MARTÍ OLIVER, Bernat; AURA TORTOSA, J. Emili; JUAN CABANILLES, Joaquín, GARCÍA-PUCHOL, Oreto; FERNÁNDEZ LOPEZ DE PABLO, Javier (2009) - El Mesolítico Geométrico de tipo "Cocina” en el País Valenciano. In PILLAR UTRILLA, Maria \& MONTES RAMÍREZ, Lourdes (Eds.), El Mesolítico Geométrico en la Península Ibérica Monografias Arqueológicas 44, Universidad de Zaragoza, pp. 205-258.

MEIRELES, José (2009) - Os primeiros povoadores. A Pré-história Antiga do Minho. In PEREIRA, Paulo (coord.) A Identidade do Minho. Braga: Conselho Cultural da Universidade do Minho, pp. 20-66.

MEIRELES. José (2010) - Os últimos caçadores-recolectores da Serra da Cabreira (NO de Portugal). O Abrigo 1 de Vale de Cerdeira (Vieira do Minho). In BETTENCOURT, Ana. M.S., ALVES, Maria Isabel C., MONTEIRO-RODRIGUES, Sérgio (eds.). Variações Paleoambientais e Evolução Antrópica no Quaternário do Ocidente Peninsular, pp. 83-96.

MEIRELES, José (2013) - O Abrigo I de Vale de Cerdeira, In. BETTENCOURT, Ana M.S, A Pré-História do Noroeste Português, CRUZ, Ana \& OOSTERBEEK, Luíz (eds)., Arkeos 36, Braga/Tomar, pp. 116-123.

MONTEIRO-RODRIGUES, Sérgio (2011) - Pensar o Neolítico Antigo. In Estudos Pré-Históricos: Vol. XVI, p. 393.

MOURRE, Vincent (1996) - Les industries en quartz au Paléolithique. Terminologie, méthodologie et technologie. $\mathrm{Pa}$ léo, 8(1), 205-223. https://doi.org/10.3406/pal.1996.116o.
NUKUSHINA, Diana (2014) - Geometric microliths as chronological and cultural markers in the Sado shell middens? Reflections from Amoreiras (Alcácer do Sal, Portugal). Nailos, 2, pp. 89-122.

PEÑA ALONSO, Paloma de la (2015) - A qualitative guide to recognize bipolar knapping for flint and quartz. Lithic Technology, 40(4), 316-331. https://doi.org/10.1080/0197 7261.2015.1123947

RAMIL REGO, Eduardo (1997) - La transición del Paleolítico Superior al Neolítico en las sierras septentrionales de Galicia. Una aproximación preliminar: II Congresso de Arqueología Peninsular. Tomo I. Zamora: Fundación Rei Afonso Henriques, pp. 273-285.

RAMIL REGO, Eduardo, BLANCO SANMARTÍN, Paz; RODRÍGUEZ PÉREZ, Mar (2016) - Los últimos cazadores-recolectores en el occidente cantábrico. Portvgalia, Nova Série, XXXVII, pp. 151-161.

RODRÍGUEZ RELLÁN, Carlos (2010) - Unha perspectiva tecnolóxica e experimental das industrias sobre lousa, cristal de rocha e cuarzo na Prehistoria Recente do Noroeste Peninsular. 1251 .

XAVIER, Pedro, ALVES, Carlos (2019) - Non-destructive studies of prehistoric lithic material culture in the search for sources of geologic raw materials: An overview of techniques and issues. Cadernos Do Laboratorio Xeoloxico de Laxe, 41, 123-140. https://doi.org/10.17979/cadlaxe.2019.41.1.5820

ZILHÃO, João (200o) - From the Mesolithic to the Neolithic in the Iberian peninsula In DOUGLAS PRICE, Theron (Ed.), Europe's First Farmers, Cambridge: Cambridge University Press, pp. 144-182. 


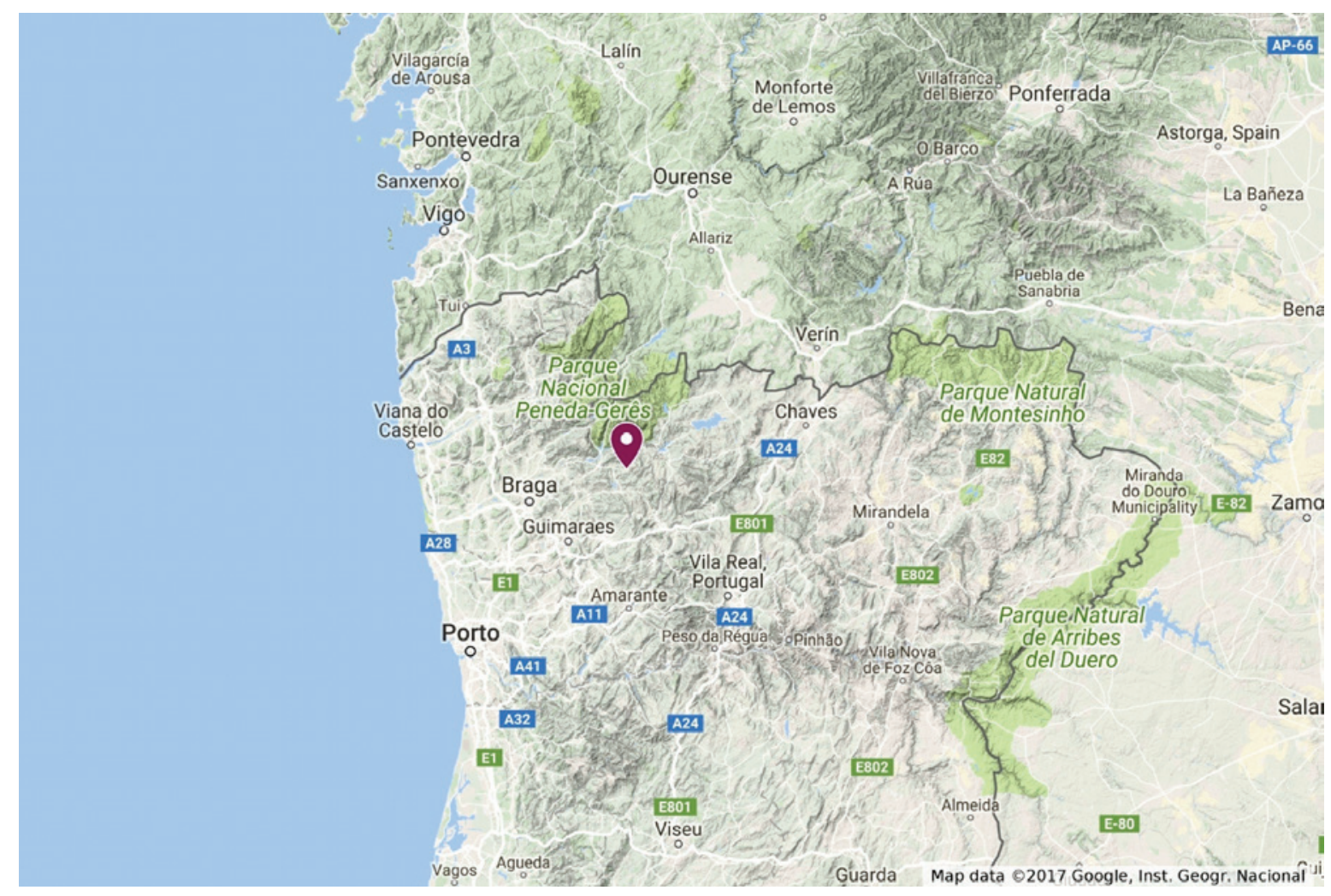

Figura 1 - Localização Abrigo I de Vale de Cerdeira.

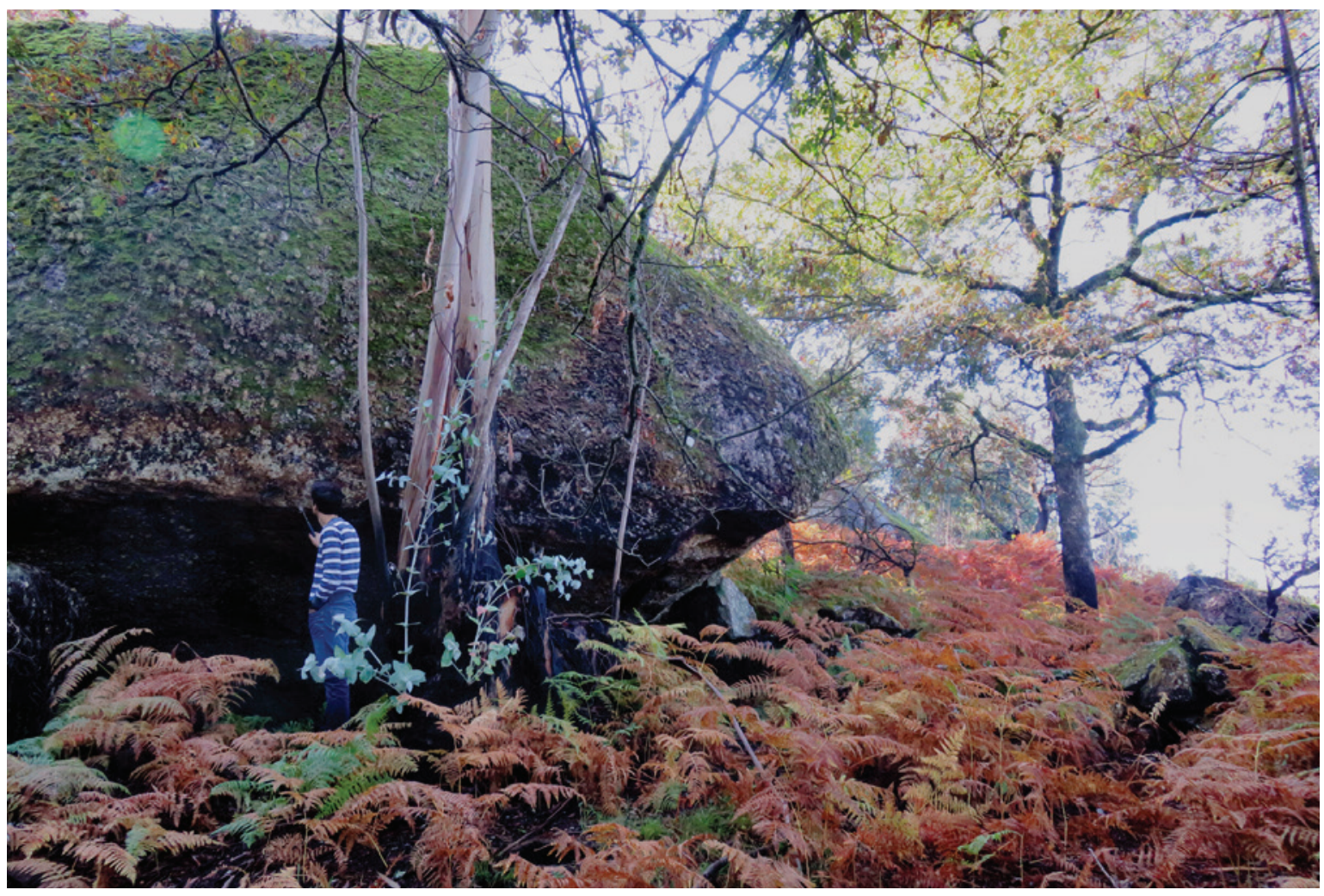

Figura 2 - Perspetiva Frontal Abrigo 1 de Vale de Cerdeira. 


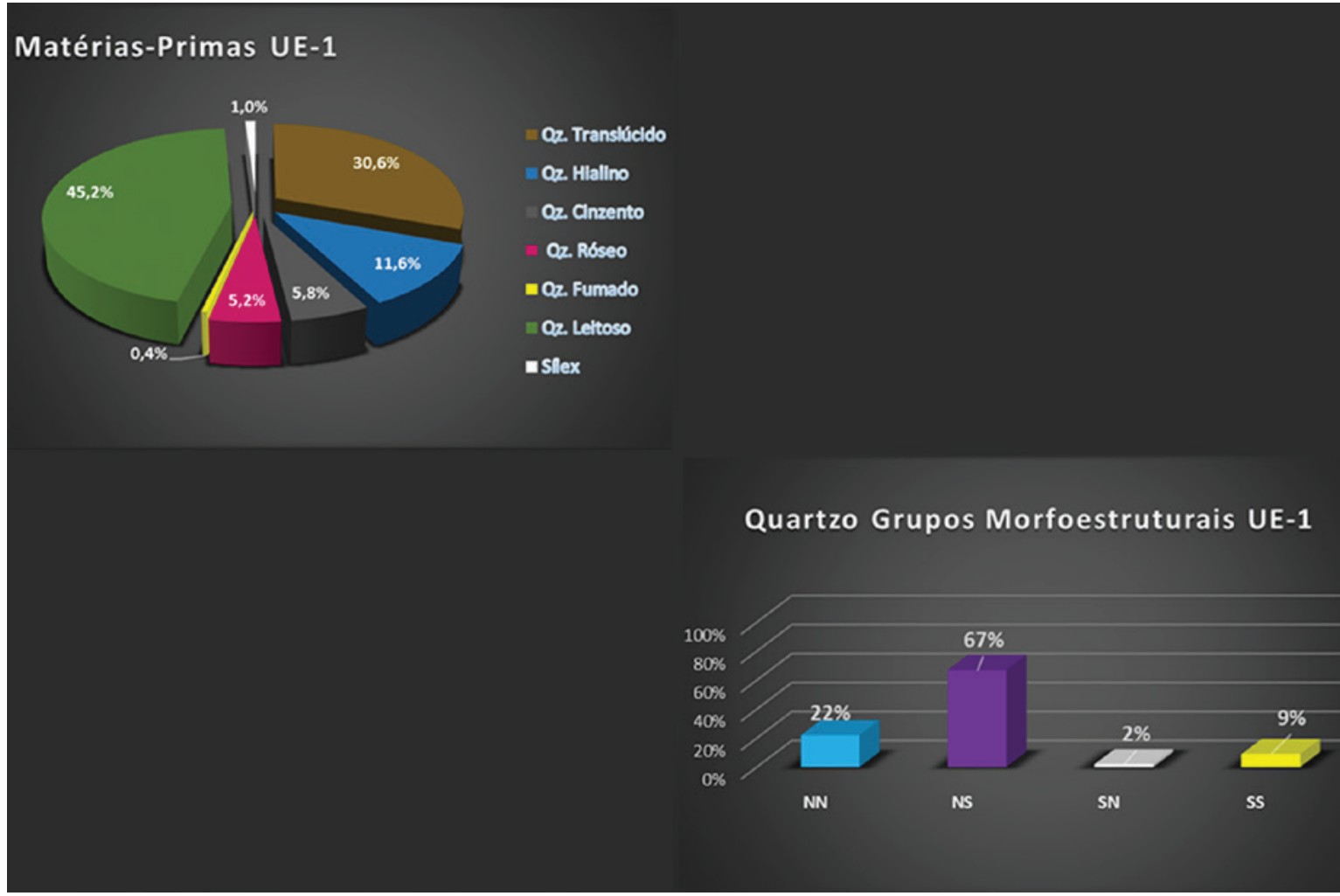

Figura 3 - Matérias-Primas UE-1.
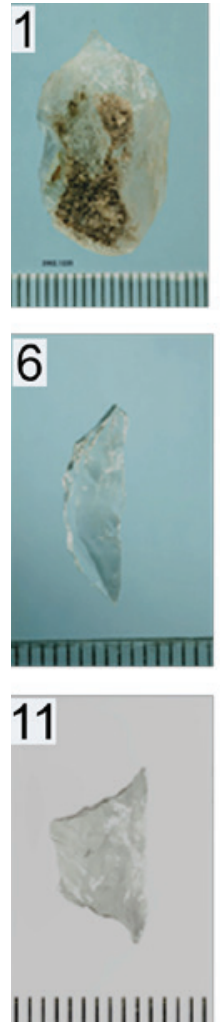
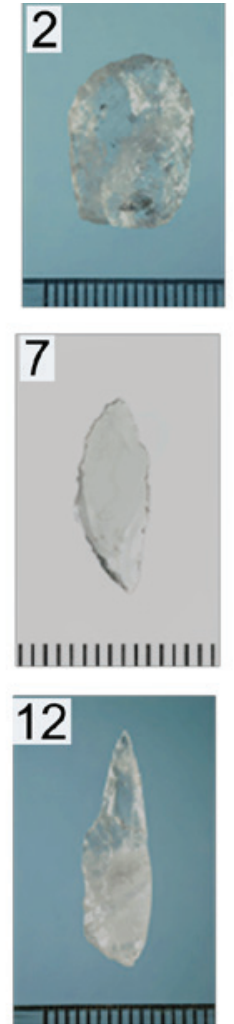
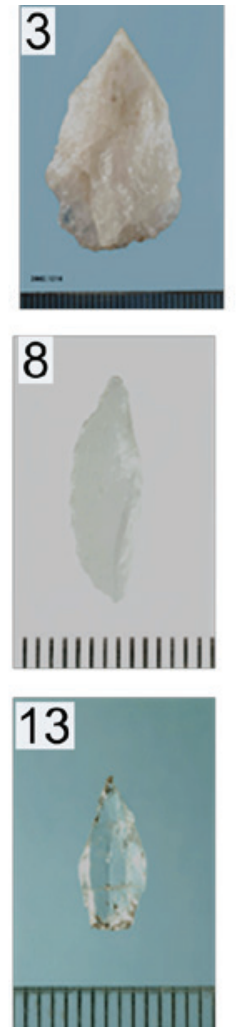
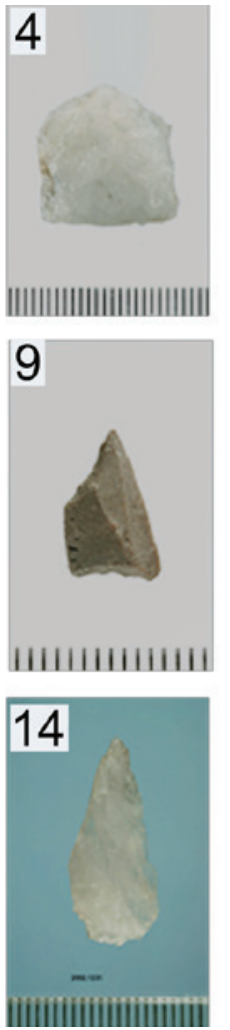

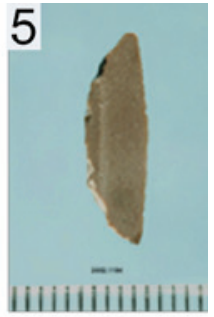

10
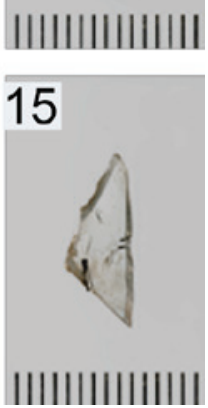

Figura 4 - Utensílios UE-1 (1. Micro-furador; 2 e 4: Raspadeiras; 3. Buril; 5 a 8: Segmentos; 9 a 11: Trapézios; 12 a 15: Pontas Microlíticas. Créditos: Manuel Santos, Museu Regional de Arqueologia D. Diogo de Sousa). 


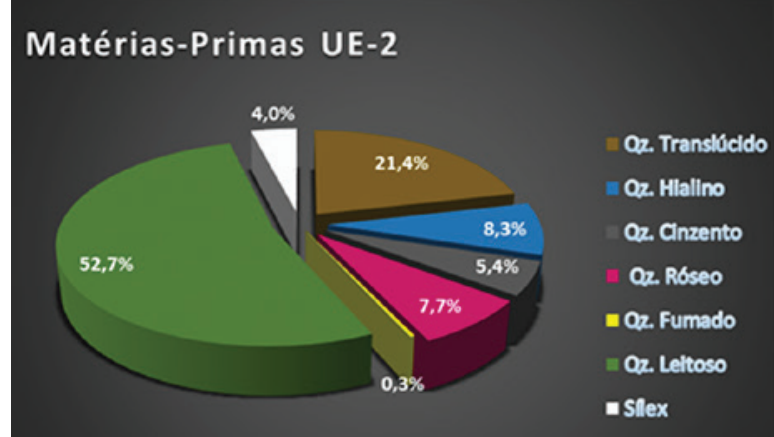

Quartzo Grupos Morfoestruturais UE-2

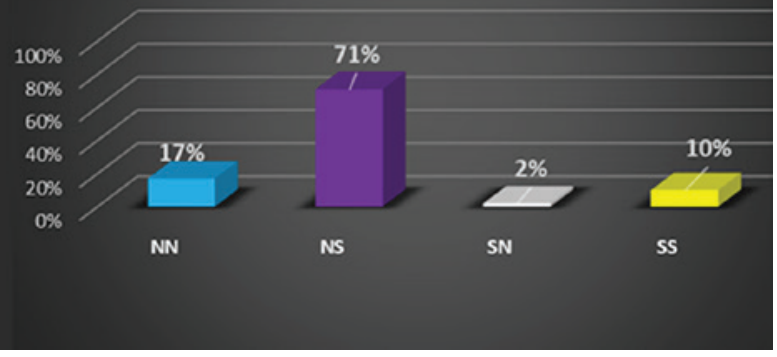

Figura 5-Matérias-Primas UE-2.
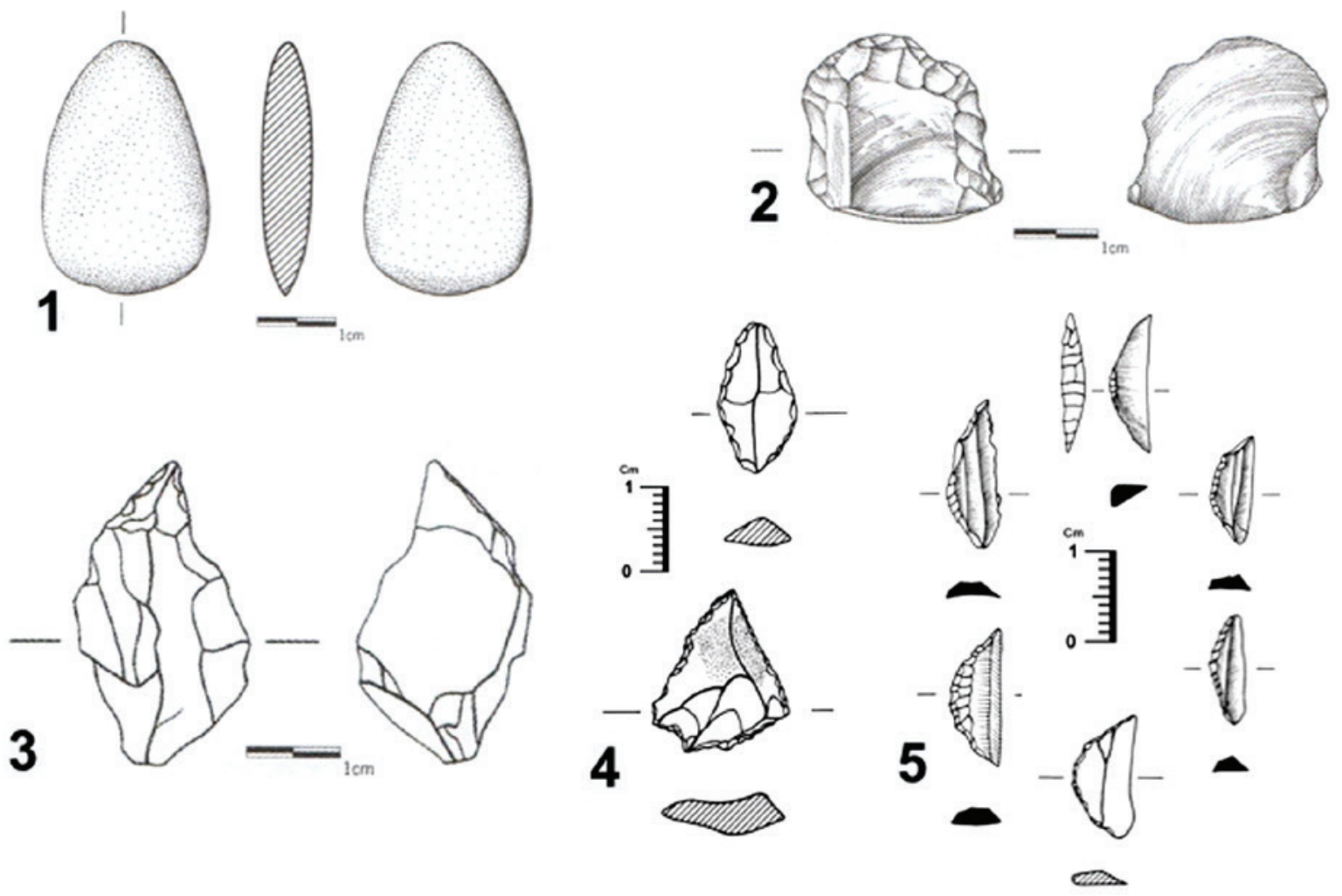

Figura 6 - Utensílios UE-2 (1. Machado de pedra polida; 2. Raspadeira; 3. Furador; 4. Pontas Microlíticas; 5. Segmentos. Créditos: Amélia Marques, Museu Regional de Arqueologia D. Diogo de Sousa). 


\title{
APRECIAÇÃO DO POVOAMENTO DO NEOLITICO INICIAL NA BAIXA BACIA DO DOURO. A LAVRA I (SERRA DA ABOBOREIRA) COMO CASO DE ESTUDO
}

\author{
Maria de Jesus Sanches ${ }^{1}$
}

\begin{abstract}
RESUMO
Este texto dedica-se à discussão da documentação arqueográfica do habitat do Neolitico inicial de Lavra I (Serra da Aboboreira), incidindo: nos fenómenos de sedimentação e formação do registo arqueológico; na definição do tipo de ocupação; no esclarecimento das datas de C14. Debate ainda o modo como a Lavra I se inscreve no início do processo de neolitização do Norte de Portugal e Baixa bacia do Douro, destacando, na Serra da Aboboreira a possibilidade temporal e espacial de se poder correlacionar com as mamoas mais antigas, no $2^{\circ}$ quartel do $5^{\circ}$ mil.a.C.
\end{abstract}

Palavras-chave: Bacia do Baixo Douro, Neolítico inicial, Tumulus, Decoração em boquique.

\begin{abstract}
This text is devoted to the discussion of the archaeographic documentation of the Early Neolithic archaeological site of Lavra I (Serra da Aboboreira; Aboboreira Mountain), bringing into focus the phenomena of sedimentation and formation of the archaeological record, the type of occupation and the explanation of the $\mathrm{Cr}_{4}$ dates. It also discusses how Lavra I is inscribed at the beginning of the neolithicization process in the North of Portugal and the Lower Douro basin, highlighting, in Serra da Aboboreira, the possibility of a temporal and spatial relationship with the oldest barrows (mamoas), in the $2^{\text {nd }}$ quarter of the $5^{\text {th }}$ mil. B.C.
\end{abstract}

Keywords: Lower Douro Basin, Early Neolithic, Tumuli/barrows, Boquique decoration.

\section{PREÂMBULO}

Começamos por esclarecer que neste artigo denominaremos o sítio da Lavra I somente como sítio, deixando para a exposição e discussão a sua natureza. Por seu turno, na ocupação pré-histórica mais recente - Lavra II - datada do séc. VIII a.C., já o entendemos como um povoado com estruturas habitacionais em negativo.

Contou este sítio com diversas publicações parcelares e referências diversas, sobretudo no âmbito do Neolitico Inicial (Sanches, 2003 e bibliografia aí citada). Mencione-se, todavia, a Monografia da Lavra, que constituiu a Dissertação de Mestrado de Cátia Mendes (Mendes, 2017) - tendo como base documental as escavações por mim desenvolvidas nos anos de 1982, 83, 84 e 88 -, e que aguarda publi- cação. Esta obra, além de toda a informação gráfica recolhida na escavação, contem ainda os resultados das diversas análises e, bem assim, a descrição de todo o material arqueológico, com ênfase para o lítico. Porque vocacionada para o estudo da ocupação do B. Final, tornava-se urgente a interpretação da ocupação mais antiga. Ou seja, (i) que caraterizasse a Lavra I à escala do sítio - com incidência nos ecossistemas antigos, nos fenómenos de sedimentação e formação do registo arqueológico e na definição da ocupação em presença; (ii) que esclarecesse a coerência das datas de $\mathrm{C}_{14}$ das estruturas de combustão, neolíticas, aparecendo por vezes referenciadas na bibliografia arqueológica como tendo contextos pouco claros; e ainda que (iii) indicasse de que modo a Lavra se inscreve no início do longo período de neolitização do Norte de Portugal e Baixa Bacia do

1. CITCEM-FLUP; mjsanches77@gmail.com 
Douro, onde ocupa temporalmente não somente o período que precede a construção de mamoas, mas outrossim que pode ser contemporâneo daquelas mais antigas da Aboboreira, uma ideia já avançada há quase duas décadas por Domingos Cruz (2001, I, p.303; Sanches, 2021, no prelo). No que respeita a este último ponto, devido ao relativamente reduzido espaço aqui concedido em termos editoriais, remetemos tanto aspetos do texto, como bibliografia ou figuras, para um outro que se encontra em publicação (Sanches 2021, no prelo); nos dois primeiros para a supracitada Dissertação (Mendes, 2017).

\section{LAVRA I. INTEGRAÇÃO BIOGEOGRÁFICA NO PRESENTE E NO PASSADO}

Lavra I situa-se numa das plataformas SW da Serra da Aboboreira-41,154661N; -8,07708W - rondado a sua alt. $640 \mathrm{~m}$. Embora localizada numa das cordas das montanhas sublitorais do NW da P. Ibérica (Aboboreira-Marão-Alvão-maciço galaico duriense), onde o pano de fundo é o clima temperado frio, de influência marítima da zona biogeográfica atlântica, vai ocupar o patamar intermédio, de transição - Terra de Transição (40o-6oo/70o m). Assim, em termos geográficos, climáticos e topográficos, Lavra I integra-se, singularmente, em local privilegiado entre os ecossistemas da zona temperada fria de mon$\operatorname{tanha}(600 / 700$ a 90o/100o m) e aqueles da zona claramente temperada (abaixo dos $400 \mathrm{~m}$ ). Cumulativamente, este patamar permite não somente $o$ acesso relativamente rápido à Serra, mas ainda aos vales dos ribeiros que configuram a bacia hidrográfica do Tâmega (a SW) e do Ovil-Douro, a SE e Sul, pois que é aqui que, sob a forma de lameiros se começam a originar tais bacias (Figura 1 ).

Similar situação fisiográfica tem o sítio da Mamoa da Lavra, situado a c. de $200 \mathrm{~m}$ a SSW de Lavra I, cujo solo antigo enterrado sob a mamoa com diversos vestígios arqueológicos (cerâmicas manuais lisas e moinho), configurando o que terá restado de um habitat similar a Lavra I na sua estratégia de implantação em termos socioecónomicos².

Assumindo desde já que a Lavra foi ocupada, como mínimo, entre 4900/480o cal BC, (ver 3.), adiantamos que não existem dados paleobotânicos completos na Serra da Aboboreira especifica e particular-

2. Informação de Domingos Cruz e Relatório de escavação inédito, que agradecemos. mente para o $6^{\circ}, 5^{\circ}$ e mesmo $4^{\circ}$ mil. a.C.. Porém, da conjugação dos vários resultados ali obtidos é-nos permitido concluir o seguinte. No solo enterrado sob a Mamoa 1 de Chã de Carvalhal (a c. de 1k a SSW da Lavra) - cam. 3 - que se terá formado em pleno Ótimo Climático Atlântico, entre c. de 6120/5640 e 406o/4045 cal BC (Cruz 1992, p.28 e 6o), a antracologia enfatiza a importância da vegetação arbórea relativamente ao estrato herbáceo, ou seja, a expansão do carvalhal misto (Quercetum mixtum), com domínio para aquele de folha caduca, e a ausência de Pinus, tornando-o assim característico do clima temperado atlântico (Cruz, 1992, p. 64). Tal informação ganha importância se comparada com aquela, embora pontual, doutros solos enterrados ou prévios à construção dos monumentos megalíticos (datados de entre os meados do $6^{\circ}$ e os finais do $5^{\circ}$ mil. a.C.) e situados em todos os patamares altimétricos, onde se regista também uma relativa importância da vegetação arbórea (além, evidentemente, da herbácea). Algumas pastagens (estrato herbáceo não relacionável com práticas agrícolas, dedutível do estudo carpológico) são já referidas para o solo enterrado da Mamoa do Monte Maninho, a 1,4 Km a Sudoeste da Lavra I e situada no mesmo patamar altimétrico $615 \mathrm{~m}$ - e que tem uma cronologia coincidente com a que propomos aqui para a Lavra (Cruz, 1988, p. 79 e 83; 2001, p. 303). Em períodos posteriores - a partir aprox. de 4300 a.C. -, nota-se uma significativa alteração nos ecossistemas, sobretudo na vizinha Mamoa 1 de Chã de Carvalhal, que exibe um considerável estrato herbáceo e arbustivo, indicando paisagem mais aberta, mas paralela a uma maior rique$\mathrm{za} /$ diversidade arbórea: pinheiro, salgueiro, bétula, carvalho caducifólio (Cruz, 1992, p. 64). Há então a reter que as atuais diferenças florísticas entre os diferentes patamares da Aboboreira não seriam tão marcadas durante o Ótimo Climático Atlântico, periodo em que se inscreve Lavra I, em que algumas matas de carvalhais teriam subido mais em altitude, onde ocupariam nichos abrigados. Todavia, e atendendo à natureza dos dados aqui manipulados, devemos ser cautelosos quanto à proporção relativa da vegetação arbórea da Serra. Nas montanhas sublitorais a palinologia reporta que o patamar meso climático de 6oo-70o m, após o evento climático/fenómeno erosivo GH-8.2, vai mostrar a expansão da floresta temperada contínua, sendo que acima dessa cota se tornaram mais acantonados os bosques e mais expressivas os matagais, as charnecas e as pastagens de 
gramíneas (Ramil Rego et al., 2010). Tais dados condizem também com o resultado polínico das turfeiras do Alto Paiva - vizinha Serra do Montemuro, a sul do Douro, (eg. Chã das Lameiras: Sáez, Figueiral \& Cruz, 2012), de modo que os ecossistemas da Lavra no início do $5^{\circ}$ mil a.C. - na qual a recolha pontual na E. Combustão 4 mostra domínio quase absoluto de Quercus de folha caduca, mas também de medronheiro e pilriteiro/espinheiro alvar (Mendes, 2017, p. 214) - evidenciariam uma floresta de clima marcadamente atlântico, mas de caraterísticas locais temperadas, ou seja, anunciam ecossistemas mesófilos, com algumas pastagens cuja riqueza relativa devemos, no seu conjunto, desde logo relevar.

\section{LAVRA I. ESTRATIGRAFIA E ESTRUTURAS HABITACIONAIS}

A estratigrafia do sítio se vista no seu conjunto, quer dizer, em articulação com a atual topografa do local (Figura 2) e desenho, também topográfico, do bed-rock (saibro) - elucidado pelos diferentes cortes transversais e longitudinais (Mendes, 2017, Figs. III, VI e VII) (Figura 3) e natureza dos estratos, permite identificar os principais fenómenos de estratificação. Configurando a cabeceira aplanada de formação de uma linha de agua que se vai manifestar a Oeste (a cotas inferiores: 63om), logo o bed-rock apresenta duas leves pendentes complementares - uma E-W (dominante) e outra S-N -, que definem uma bacia de deposição sedimentar onde se formou a camada 4. Esta tem todas as caracteristicas de um paleossolosolo espesso, embora granítico, compacto, castanho escuro com veios negros e de aspeto por vezes "gorduroso", que indicia a presença de matéria orgânica na sua formação sedimentar e pedológica. Embora sem datas absolutas, este solo poder-se-ia ter formado quer durante o aquecimento climático do Tardiglaciar, quer em fase posterior, durante o início do Holocénico, podendo estar ainda em formação/erosão aquando da ocupação humana do sítio da Lavra, se o compararmos com o supracitado solo enterrado sob a vizinha Chã de Carvalhal 1. Tem diferentes espessuras, mas estaria por certo erodido/decapitado nas cotas mais altas da zona oriental onde se abrem as estruturas datadas do Neolítico Inicial, mas ter-se-ia conservado, quase sem diferença sedimentar se comparado com a cam. 3 - que contém materiais neolíticos -, na parte média e ocidental desta área. A camada 3 é em muitos locais simplesmente o topo da camada 4, definindo-se noutros por conter sedimentos menos compactados e homogéneos que os da cam. 4. A camada 3, tal como a definimos em termos sedimentares, nunca foi detetada sobre o saibro. Porém, como se sabe, fenómenos de lixiviação em solos já pouco espessos e aflorantes - como teria acontecido sobre as Estruturas de combustão EC2 e EC 3 -, por um lado, e ocupações posteriores, da I do Bronze Final, poderão ter sido responsáveis por esse facto (Figura 2, 3, 4). Com efeito, durante aprox. 3 milénios - do $5^{\circ}$ aos inícios do $1^{\circ}$ mil. a.C. - ocorreram fenómenos climáticos-erosivos diversos - de novo atestados na M. de Chã de Carvalhal 1, sobretudo entre os inícios do $4^{\circ}$ e os finais do $3^{\circ}$ mil. a.C. (Cruz, 1992, p. 28 e 6o) -, o que, a par de eventuais usos agro-pastoris daquela área, terá provocado na Lavra lixiviação e deslocação sedimentar de baixa energia (na estratigrafia não existem vestígios de níveis de calhaus ou areias). Deste modo, no séc. $8^{\circ}$ a.C. (Mendes, 2017), o povoado da I do Bronze pode ter assentado, nas áreas mais orientais, num "solo humoso" relativamente fino porque "decapitado", resiliente, que subsistiria sobre as EC2 e EC3 (Figura 4-A), mas que não foi identificado como tal em termos sedimentares aquando da sua escavação arqueológica. Continha, mesmo assim, a maioria dos materiais arqueológicos da ocupação mais antiga, ou seja, instrumentos e restos de talhe característicos do Neolítico e ausentes dos conjuntos artefactuais do Bronze Final. Nas áreas central e sul, onde existem as cam. 4 e 3 - esta com algumas cerâmicas decoradas e materiais líticos -, algumas estruturas - como fossa $\mathrm{F} 1$ e a lareira L1 embora tendo datas antigas não podem ser associadas a esta ocupação. A ocupação do B. Final, patente na camada 2, esteve, também ela sujeita a ablações, deslocamentos e redeposições muito similares às mais antigas de modo que, quanto mais se caminha para ocidente, mais subcamadas sedimentares se registam. Todavia, seja pela deslocação antiga de sedimentos/decapitação (similar à que se verificou em Chã de Carvalhal I (Cruz, 1992, p. 28,6o), seja pelo caráter pouco marcante da ocupação neolítica na zona ocidental, a área do sítio neolítico é bem mais reduzida do que a do B. Final.

Com efeito, as estruturas neolíticas parecem concentrar-se na área aplanada, imediata ao pequeno "cabeço" (cota aprox. de $640 \mathrm{~m}$ ), do que resulta que terão sido maioritariamente destruídas pela abertura da estrada a qual cortou mesmo uma grande estrutura de combustão-EC1. As restantes três Es- 
truturas de Combustão alinham-se igualmente pelo traçado da estrada, a reduzidíssima distância desta (Figura 3) (Mendes, 2017, Fig. V). Apesar de na altura da escavação não se relacionarem com uma camada sedimentar discreta, que só poderia ter sido a cam. 3 (ver comentários precedentes), estariam ainda parcialmente cobertas de sedimentos durante o B. Final, de modo que em duas destas estruturas se conservou a $2^{\underline{a}}$ utilização acima do bordo, definido pelo saibro (Figura 4-B).

São, com efeito, muito similares entre si, tanto na sua forma como no modelo de uso e/ou condenação, pelo que são reveladoras do padrão habitacional e de organização comunitária em torno do fogo. São círculos quase perfeitos, com grande diâmetro - de 1,70 (na EC3) a 2,20 m (na EC2) -, cavadas no saibro a profundidades que variam entre 25 a $30 \mathrm{~cm}$, definindo-se como depressões regulares, de paredes algo convergentes, mas regulares e com fundo aplanado. Em dois casos ( $\mathrm{EC}_{3}$ e 4 ) este fundo está pejado de pequenos orifícios, similares a buracos de poste. De igual modo, o seu enchimento - e, por extensão, o modo de uso - é repetitivo: (i) a uma camada muito espessa de terra negra com muito carvão, por vezes de grande espessura ( 8 a $12 \mathrm{~cm}$ ) e algumas pedras pequenas, e que ocupa tanto o fundo como todo o perímetro interior, (ii) segue-se uma outra que, embora escura, não tem carvão e só ocupa a área central, formando um círculo quase perfeito cujo diâmetro varia entre $160 \mathrm{~cm}$ (na EC3) e $180-190 \mathrm{~cm}$ (na EC2) (Figura 4). Este enchimento atinge o bordo superior fossa e revela um modelo de uso em que a parte central, sem brasas, estaria reservada a fins culinários, permanecendo a substantiva parte periférica (variando entre 10 e $30 \mathrm{~cm}$ ) como calorímetro. Cumulativamente, as $\mathrm{EC}_{2}$ e $\mathrm{EC}_{3}$ registam uma segunda realização de fogo na sua parte central, que denominamos de Lareira 3 e 4, respetivamente. Embora com pequenas diferenças de pormenor, são lareiras formadas por empedrados de granito, alguns blocos de quartzito e terra com carvões. Em termos de organização espacial associam-se duas a duas (uma somente evidenciando a utilização "primeira" da fossa mais uma com uma segunda utilização), e a EC3 tem, complementarmente uma paliçada em arco e pelo menos quatro a sete buracos de poste, que também se lhe parecem associar (Mendes, 2017, Fig. IX) (Figura 3). Este último conjunto, a ser como o interpretamos, resguardaria a $\mathrm{EC}_{3}-\mathrm{L}_{4}$ dos ventos frios e húmidos de Norte e Noroeste, abrindo o es- paço a Oeste e Sudeste, onde passa a estrada. Mas é possivel que tal arco cavado no saibro também pudesse ter como finalidade a do resguardo da percolação das águas do solo.

Conjugando (i) a distribuição espacial destas estruturas na área ocidental da estrada, com (ii) a recuperação de quatro peças microlíticas do lado oriental da mesma- cujo saibro estaria, e está, a uma cota mais elevada ${ }^{3}$-, (iii) e com a distribuição espacial da cam. 3, calculamos que a área ocupada se aproximasse, por defeito, dos $500 \mathrm{~m} 2$, embora a concentração de estruturas habitacionais (incluindo a zona da estrada) incidisse numa área menor, que estimamos fosse em torno $300 \mathrm{~m} 2$.

\section{CRONOLOGIA}

As seis datas das três Estruturas de Combustão da Lavra I e das lareiras que se lhe sobrepõem já foram divulgadas e frequentemente citadas, e nesse ponto somente queremos fazer notar que embora tenham sido realizadas sobre carvões não particularmente selecionados (de vida curta), e de o Laboratório GAK apresentar grandes desvios padrão, foram submetidas a mais dois laboratórios (ICEN e UGRA) apresentando, no conjunto, resultados que nos parecem coerentes entre si, já que todas se recobrem estatisticamente no período de entre $5200-4800 \mathrm{cal}$ BC $(2 \sigma)$ (Mendes, 2017, Quadro 6 e Gráfico 21). Aceitando, por cautela, somente os resultados, sobrepostos, das 2 datas dos dois laboratórios com menor desvio padrão - que datam a base e a $2^{2}$ utilização da $E_{3}$ - o período de uso estaria entre 4900/480o e 4500 BC (datas calibradas a $2 \sigma$ ). Tal valor coincide genericamente com o intervalo da data UGRA-267, aquela que, de entre as duas, apresenta maior desvio padrão, como era expectável pois trata-se de distribuição estatística de valores. Todavia, o resultado de quaisquer dos três laboratórios não permite aferir se (e quais) as estruturas de combustão (EC1 a 4) e as lareiras (que se lhes sobrepõem em 2 casos - $\mathrm{L}_{3}$ e L4) seriam contemporâneas umas das outras, pelo que não sugerem sequer se se tratou aqui de uma ocu-

3. Segundo a lei da gravidade, estas peças, que jaziam sobre o saibro, estarão ali por motivos antrópicos. Buril diedro de ângulo e lasca cortical (D'6); lasca microlítica de dorso (E'6); lamela de sílex fragmentada (E'1 - Museu de Baião com no 209.98), jazendo encaixada numa reentrância do saibro junto de uma pequena estrutura de combustão vestigial -L2-, mas esta poderá pertencer a qualquer uma das ocupações. 
pação pontual (não repetida), se sazonal, (sujeita a retorno calendarizado ao mesmo lugar), se mesmo permanente. Com efeito, a amostra da $2^{\underline{a}}$ utilização da EC3 (L4) - ICEN-76-6o6o \pm 60 BP (5210-48o1 cal $\mathrm{BC} 2 \sigma$ ) - é, em termos de intervalo de probabilidades, aparentemente mais "antiga" que a da $1^{\mathrm{a}}$ utilização - UGRA-267: $5830 \pm 90$ BP (4900-4470 cal BC $2 \sigma)$. Nenhuma das restantes datas antigas deste sítio pode ser aceite como datando o contexto arqueológico a que se associam: a) como é o caso da Lareira 1 , já nomeada atrás; b) ou das fossas Fı e F’ı (esta última com datas muito díspares).

Tem sido por diversas vezes considerado que as datas de carvão - particularmente de grandes troncos como aqueles que se registavam na camada da base das quatro EC ( 2 a 4) - acusarão o efeito de lenha antiga. Não discordando desse raciocínio, reafirmamos a coerência dos resultados do conjunto; todavia, devemos então acrescentar que a queima de grossos troncos (por ex. de vetustos carvalhos, na EC2) indicarão um comportamento recorrente na Lavra I, que seria a da recolha de troncos já velhos ou parcialmente queimados (por incêndios naturais ou antrópicos), dado que não existe tecnologia para o abate de árvores de grandes dimensões.

\section{ALGUMAS NOTAS SOBRE OS MATERIAIS ARQUEOLÓGICOS E SUA DISTRIBUIÇÃO ESPACIAL}

O material lítico talhado, de caracter dominantemente microlítico, compreende 169 peças, respeitando a: a) núcleos $(7,6 \%)$ - informes, poliédricos e bipolares, sobretudo esgotados; b) material de debitagem $(30,18 \%)$ - sobretudo lascas, maioritariamente não corticais, com ou sem talão (por motivo de fratura), mas também três lamelas em sílex; c) material residual (29,59\%) - principalmente em quartzo (fragmentos amorfos); d) utensílios $(32,54 \%)$. Estes abarcam lascas retocadas, raspadores, raspadeiras, buris (e microburis), furadores (e microfuradores), denticulados e truncaturas, além de uma lamela retocada (em sílex) e pontas microlíticas. A matéria prima quase exclusiva é o quartzo, particularmente o quartzo leitoso de filão o que, acrescentando algumas peças de quartzo hialino e calcedónia, indica preferência pelo uso de recursos da região envolvente (material local ou regional). O sílex (quatro lamelas e um microburil) indiciaria relações com comunidades extrarregionais, e teria chegado já sob a forma de instrumentos talhados uma vez que não existem na estação vestígios do seu talhe. (Mendes, 2017, p. 33-50 e Anexo 3). Cabe aqui referir uma pequena peça faceada por fricção, de corneana, e com vestígios de corante castanho. O material lítico referido, conquanto se distribua esparsamente por quase toda a área escavada, concentra-se, em termos de repartição espacial, na área oriental do sítio, na envolvente das grandes estruturas de combustão (e até no interior destas, como é o caso da EC2-L3), e, bem assim, no espaço que medeia entre umas e outras (Figura 3). Tal evidência indica suplementarmente que aquelas estruturas de realização de fogo, e das atividades que se lhe associam, polarizam efetivamente a vida rotineira do grupo, e que a área principal do sítio arqueológico se situaria naquele espaço, pelo que calculamos que metade do habitat/acampamento terá sido destruído/"lavado" por fenómenos de deslocação sedimentar, pela ocupação posterior e particularmente pela construção da estrada, como atrás referimos. Mesmo assim, a distribuição e caracteristicas do material lítico talhado esclarece que a área em torno das EC1 e EC2 (com L3) - que forneceu quase metade do espolio lítico talhado - além das atividades rotineiras de um sítio de habitat (pois indica tratar-se de uma área multifuncional), destaca particularmente atividades de talhe/fabrico de utensílios, documentando-se aí todas as etapas das cadeias operatórias, particularmente em torno da Estrutura de Combustão 2 (Mendes, 2017, p. 50-53 e Anexo 3). Esse fabrico está mais parcamente documentado em torno da $\mathrm{EC}_{3}$.

Como instrumentos polidos destacamos os moinhos de granito (mormente moventes), e embora a maior parte deles se encontre partida, também se concentram, tal como ocorre com os líticos talhados, em torno da EC2- $\mathrm{L}_{3}-9$ moventes, dos quais 3 completos, um fragmento de dormente e mais dois fragmentos. Estes dois últimos serão indubitavelmente neolíticos já que foram reutilizados como elementos refratários no interior da EC2; os restantes, a par de um machado polido, poderão ter sido usados quer no Neolítico quer na I. do Bronze, embora a peça 178 - movente/bigorna - apele mais a um uso no Neolítico. Já o mesmo não podemos dizer dos elementos de adorno que interpretamos como neolíticos: uma conta de colar de arenito, esverdeada (do interior da Lareira 4), e do pendente oblongo em quartzito quase marmóreo, de cor cin- 
zenta/escura-negra (Figura 5), que jazia já sob uma pelicula de saibro, no que considerámos ser a base da cam. 2 (D 1o). Tratar-se-á, por certo, de objetos perdidos, embora nos custe aceitar a não recuperação do pendente, se atendermos ao esforço investido na sua conformação e polimento.

Surpreende a fraca quantidade de cerâmica, toda decorada, da cam. 3, pelo que cabe perguntar: a) só terá existido esta cerâmica? b) não se terá reconhecido no conjunto devido ao facto de a maioria da cerâmica deste sítio se encontrar muito deteriorada ${ }^{4}$ e de ser lisa, o que não permite a distinção "tipológica" clara entre a cerâmica do B. Final e daquela do Neolítico ? c) sendo um bem raro e transportável, refletiria a sazonalidade do habitat, e, ao mesmo tempo, o elevado valor social que lhe seria atribuído?

Nunca poderemos responder de modo simples, pois admitimos que, à semelhança de outros sítios da mesma cronologia da bacia do Douro e Norte de Portugal, a quantidade de cerâmicas, sendo sempre relativamente pequena (mas nunca inferior a centena e meia de fragmentos), só é quase pontual, como na Lavra I, em locais considerados de frequência sazonal e/ou naqueles que tem misturas com cerâmicas de outras épocas (Sanches, 2021, no prelo). Acresce que naqueles conjuntos, conquanto em proporções bastante variáveis, as cerâmicas (fragmentos) lisas preponderam sobre as decoradas - principalmente naquelas da região litoral, a ocidente da Padrela-Alvão-Marão (região biogeográfica atlântica e de transição) - pelo que a identificação pela tipologia decorativa é irrealizável. É o que pode ter acontecido em Lavra I onde, realmente, diversas formas - como aquelas de corpo com tendência em forma de saco ovoide/globular umas, e taças semiesféricas altas, outras (Mendes, 2017, 206, 208) - são tipologicamente admissíveis em ambos os períodos. Consta-se ainda que a área envolvente das EC1 e 2, tão rica em espolio lítico talhado foi aquela onde, de entre toda a estação, se exumou o mais reduzido número de fragmentos, o que concorreu para a reconstituição de três formas. De entre estas, somente a taça semiesférica poderá porventura ser "tipologicamente “associada à ocupação neolítica.

4. A Lavra I e II é uma estação que, atendendo à área escavada, tem pouco material cerâmico (6660 fragmentos), cuja fragmentação e deterioração permitiu a reconstituição formal de poucos (c. de 15) recipientes, estando os restantes indicados somente ao nível da inclinação do bordo e/ou do fundo (plano).
São já bem conhecidos os dois recipientes decorados com puncionamentos arrastados (K-L6) (Figura 5), havendo somente a reiterar que ambos revelam uma tendência para a organização em grinaldas, sendo que no vaso globular, a decoração puncionada de tipo boquique se organizou em função da decoração plástica (um mamilo), numa sequência operatória e organização decorativa que veremos adiante no vaso com decoração impressa da Bouça do Frade (Jorge, 1988, Fig. 43-3). Soma-se, de H6, cam.3, um pequeno bordo com incisões profundas (bordo denteado), e um fragmento de pança com incisões profundas e curtas, desenhando espiga, conhecida como de tipo folha de acácia.

\section{DISCUSSÃO E CONSIDERAÇÕES FINAIS}

Sintetizando o que atrás foi exposto, cabe destacar o que se segue.

O sítio de Lavra I ocuparia uma área em torno a $500 \mathrm{~m}^{2}$, apesar de as principais estruturas habitacionais escavadas no saibro - grandes estruturas de combustão, buracos de poste e paliçadas - indicarem uma polarização da vida rotineira do grupo ocupante na zona mais oriental, num espaço de cerca de $300 \mathrm{~m}^{2}$. Implanta-se, em termos topográficos e climáticos num ecótono, ou seja, num patamar intermédio da Serra da Aboboreira - 400-60o/70om: Terra de Transição - do qual é relativamente fácil aceder, em distâncias pedestre de entre 1 e $2 \mathrm{~h}$, a todos os ecossistemas de Terra Fria de Montanha; e igualmente aos vales mais baixos e temperados, abarcados numa distância pedestre máxima de ih. A sua cronologia que estabelecemos ter ocorrido, como limite mínimo, no intervalo de 490o/480o-450o cal BC $2 \sigma-$, situa a ocupação no Ótimo Climático Atlântico, e na sua periferia dominariam os bosques mistos, com destaque para o caducifólio (carvalhal, medronheiro), cujo elenco de frutos e tubérculos seria algo diversificado; conjugada com pequenas áreas abertas, de pastagem, haveria condições para a presença de animais de médio e pequeno porte. Nas terras baixas, além de recursos florestais mais termófilos, destacaríamos a pesca como possibilidade - ribeiras/ rios de Juncal/Galinhas/Ovelha e Tâmega por um lado, e Roupeira/Ovil/Douro, por outro (Figura 1). Deste modo, em termos de possibilidades oferecidas pelos ecossistemas envolventes, a Lavra I poderia ter sido um sítio de ocupação permanente - habitat permanente de curta duração, ou, alternativamente, 
habitat residencial — dada a facilidade de acesso à montanha - pastos de primavera-verão, caça, recoleção ou, quem sabe, alguns animais domésticos -, e ao aproveitamento mais contínuo, ao longo do ano, dos recursos da sua envolvente imediata e das zonas mais baixas.

Todavia, esta é somente uma das possibilidades baseada na localização e no investimento que as diversas estruturas habitacionais implicaram (particularmente as grandes estruturas de combustão), pois a má conservação da estratigrafia não autoriza a ilação de que se estivesse melhor conservada disponibilizaria, por ex., muitos mais instrumentos. Aqueles recolhidos indicam: atividades de moagem (provavelmente de bolota); fabrico de instrumentos líticos talhados cujas matérias primas se encontram, à exceção do sílex, na Serra da Aboboreira; caça, indiretamente assinalada pelas pontas; recolha de combustível proveniente talvez de velhos carvalhos e medronheiros já mortos e/ou sujeitos a queima para derrube. Por falta de conservação, estarão ausentes quaisquer vestígios de consumo de animais, e o uso alimentar de diversos frutos - bolota, medronho, pilrito - é deduzido do uso destas espécies arbóreas na EC2.

As atividades rotineiras, incluindo o talhe de instrumentos, centram-se em torno das grandes estruturas de combustão pelo que admitimos também que estas fossem limpas regularmente e usadas sempre segundo o mesmo modelo de aproveitamento do fogo (Figura 4). É-nos mais difícil aceitar que possam ter sido utilizadas uma só vez, o que daria ao habitat um caráter pontual. Assim, da conjugação dos diversos elementos expostos, inclinamo-nos mais para a ocupação permanente deste ecótono, admitindo, mesmo assim, que se tratasse de uma base residencial. Esta questão traz à colação a natureza do povoamento da Serra da Aboboreira, que, à semelhança do que Domingos Cruz defende também para o Alto Paiva, se parece manter com alterações pouco significativas até aos finais do $4^{\circ}$ mil. a.C. (Cruz, 2001, p. 300).

Percorrendo as diversas escavações realizadas na Aboboreira, destacamos oito sítios, sendo que seis deles são solos aprisionados sob as mamoas ${ }^{5}$ e dois são sítios de plataforma, localizados em cabeceiras

5. Contabilizamos somente aqueles com vestigios de ocupação, e não aqueles cujos solos enterrados tem datas absolutas de todo o $5^{\circ}$ mil. a.C., que são em número muito mais elevado. de formação de ribeiros: Lavra I e Penedos Altos (Sanches, 2021, no prelo). Estes têm a particularidade de se situarem em áreas com ocupações posteriores que, no caso de Penedos Altos (750 m), é temporalmente mais contínua do que na Lavra I pois a Bouça do Frade/Tapado da Caldeira tem cronologias pelo menos do Calcolitico ao B. Final (Jorge, 1988). O sítio dos Penedos Altos, escavado por Susana Oliveira Jorge, está ainda inédito, mas continha, segundo Domingos Cruz, que participou na escavação (Cruz,1992, 11-nota 90 e inf. pessoal), pequenas estruturas negativas alongadas (paliçadas?), e o material arqueológico era microlítico, destacando-se micrólitos geométricos. Situa-se numa das partes mais baixas, mas na zona aplanada, da Bouça do Frade, povoado que, como se sabe, está incompletamente escavado (Figura 1). Ora, precisamente da escavação deste povoado, do setor IIB (abaixo do estradão) (Jorge, 1988, 53 e Fig. 43-3) foram exumadas, entre outras cerâmicas mais tardias, 5 fragmentos de um recipiente cerâmico - uma taça alta, semiesférica ${ }^{6}$ - com decoração barroca, feita com impressão arrastada de pente convexo, simulando concha (Figura 5-B). Tem ainda um cordão - que se desenvolve também pontualmente em pega alongada - paralelo ao bordo. O lábio deste é profusa e cuidadosamente decorado no lábio e face exterior do bordo, com uma matriz curta, de ponta em arco. Comparando-os com os da Lavra I, destaca-se a organização decorativa em grinaldas, a decoração plástica e o bordo cuidadosamente decorado. Dada a grande mobilização de sedimentos nesta estação, é provável que, também aqui, outros fragmentos pertençam igualmente a uma ocupação mais antiga, mas que serão difíceis de destrinçar pela tipologia. Por seu lado, uma lamela retocada em sílex e, com mais reticências, um pequeno machado polido, provenientes dum setor a uma cota ainda mais baixa (S. IA) (Jorge, 1988: Fig. 36, no 5 e 6) talvez se possam associar a esta ocupação antiga, que atribuímos ao Neolítico inicial regional. Ainda que se trate de um elemento pontual, deve ser valorizado, neste contexto, o fragmento cerâmico com decoração boquique (organização em grinaldas) da Mamoa de Furnas 2 ( 850 m dealtitude) (Figura 1), atribuído a um povoado próximo, prévio à construção do tumulus,

6. Tendo sido a autora do desenho, considerei que o pequeno fragmento do bordo só autorizava a inclinação, mas não o diâmetro. 
que teria ocorrido no último quartel do $5^{\circ}$ mil. a.C. (Sanches, 2012, no prelo).

Como hipótese, teríamos então a ocupação neolítica da Aboboreira, numa fase mais antiga- centrada na $I^{\underline{a}}$ metade do $5^{\circ}$ mil. a.C. - com habitats em diversos ecossistemas - patamares altimétricos dos 620 aos 850 m (Figura 1) -, onde circulariam cerâmicas bastante decoradas com impressões /matrizes diversas, plástica e incisa (folha de acácia), em contextos com material lítico microlítico, sendo algum deste em sílex.

Todavia, tomando o conjunto dos habitats da Aboboreira no alargado período que cobre todo o $5^{\circ} \%$

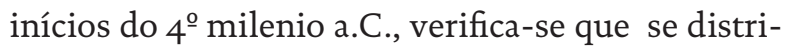
buem, afinal, por todos os patamares altimétricos da Serra: entre 500-70o metros - Mamoa da Lavra, Lavra I, Chã de Santinhos 2; de 700 a 900 m - Penedos Altos, Mamoa de Cabras, Mina do Simão, Furnas 2; $940 \mathrm{~m}$ : Meninas do Crasto 2 (Sanches, 2021 e bibliog. aí citada, no prelo) (Figura 1). Esta distribuição, por certo muito residual relativamente ao número dos primitivos habitats, parece mostrar um padrão de ocupação da Aboboreira que perdura no tempo, ou seja, coincide também com o da construção dum elevado número de mamoas, a maioria contendo dolmenes simples - entre c. de $4500 / 4300$ e 3800 cal BC 2 o (Cruz 1992; 2001). Porém, tal como tem vindo a ser apontado por Domingos Cruz, existem nesta necrópole dados antes não devidamente valorizados - relativos a algumas das mamoas muito pequenas e baixas, camufladas na paisagem ${ }^{7}$, (podendo não conterem câmaras megalíticas, mas somente um pilar/esteio ao centro, como acontece em Monte Maninho e Cabras) - cuja cronologia de fundação abrange o $2^{\circ}$ e $3^{\circ}$ quarteis do $5^{\circ}$ mil. a.C. Destaca-se neste conjunto a Mamoa de Monte Maninho por distar cerca de 1,4 Km da Lavra I (Cruz, 1988), por estar situada no mesmo patamar altimétrico, e dela se terem obtido duas datas estatisticamente semelhantes, cuja media ponderada é de 4770-4503 cal BC 2 o (Cruz, 2001, p. 303, nota 191).

Este elo de ligação entre os habitats mais antigos e os monumentos mais antigos é apelativo e tem implicações não somente ao nível da caraterização socio económica e ideológica destes grupos do Neolítico inicial desta região - que apresentariam, cremos, uma grande mobilidade logística - e a fixa-

7. Monte da Olheira (com pequena câmara ortostática); Cabras e Monte Maninho ção, em definitivo, de lugares específicos dos seus territórios através de tumuli muito pequenos. Estes articular-se-iam com a identificação da ancestralidade - naqueles relacionados com enterramentos ou cerimónias fúnebres -, com práticas coletivas relevantes que podiam ocorrer de modo repetitivo no mesmo local, ou mesmo com ambas.

Dado que o modelo de implantação dos habitats no Neolitico inicial (até meados do $5^{\circ}$ mil. a.C.) e do Neolítico médio (até ao $1^{\circ}$ quartel do $4^{\underline{0}}$ mil. a.C.) se parece manter, existirá então uma relação espacial muito estreita entre os locais de vida rotineira e aqueles que não só concatenam, mas agenciam, através das arquiteturas duráveis, os aspetos mais relevantes da reestruturação social e ideológica. Essa relação inaugura-se no $2^{\circ}$ e $3^{\circ}$ quartéis do $5^{\circ}$ milénio a.C. No seu conjunto, os oito habitats, ainda que vistos pela pequena fração conservada, tem estruturas habitacionais perecíveis, formadas por fossas (pequenas), buracos de poste, alguns valados ou paliçadas e sobretudo lareiras, nas quais se destacam as da Lavra I pela sua desmesurada dimensão. Têm pouco material arqueológico, sendo dominante o lítico talhado, atípico, de tendência microlítica, maioritariamente em quartzo filoniano, mas também surge em quartzo hialino e sílex. Nos mais antigos não se registam machados, mas antes moinhos de granito e seixos de rio, ambos frequentemente partidos. Também não se encontram adornos, a não ser em Lavra I. Relativamente à cerâmica, já falamos dos que consideramos poderem ser mais antigos. Naqueles com cronologias aproximadas da $2^{\underline{a}}$ metade/ último quartel do $5^{0}$ milénio a.C. - que são o total à exceção de Chã de Santinhos 2 - a cerâmica, sempre mal conservada, tem formas muito diversas, sendo a maioria lisa; a decorada integra-se, pela singeleza, noutros (raros) conjuntos ceramológicos de habitats da região biogeográfica atlântica da bacia hidrográfica do rio Douro, datados (ou datáveis) de todo o $5^{\circ}$ mil. a.C. (Sanches, 2021 e bibliog. aí citada, no prelo).

Se nos casos que estamos a analisar a complexidade decorativa de algumas cerâmicas indica antiguidade $-1^{\underline{a}}$ metade do $5^{\circ}$ mil. a.C., ou, talvez, finais do $6^{\circ}$ e primeira metade do $5^{\circ}$ milénio, caso consideremos o intervalo de 5200-4800 cal BC de sobreposição de todas as datas da Lavra -, igualmente aponta outras interpretações de caráter organizacional e ideológico. A sua raridade pode indiciar serem agentes de interação particular entre grupos de pequena dimensão - com fronteiras territoriais muito fluidas 
- em circunstâncias de dádivas, trocas, etc. Todavia, podemos estar a ser conduzidos por visões muito apriorísticas já que, afinal, cerâmicas decoradas com outros motivos e igualmente as não decoradas, podem ter cumprido funções similares no mesmo período (Sanches, 2021, no prelo).

Como diversos autores, através de trabalhos sérios e sistemáticos, tem referenciado, as cerâmicas estão quase ausentes das deposições dos dolmenes e mamoas do Norte de Portugal e Galiza da $2^{\underline{a}}$ met. do $5^{\circ}$ mil. a.C. Na Aboboreira surgem, outrossim, com mais frequência (por esta ordem) moinhos, seixos e cristais de quartzo, micrólitos geométricos e/ou lamelas (em silex e quartzo hialino), lascas/raspadores, objetos de adorno (em variscite e xisto), algumas enxós (pequenas, em corneana e silimanite), machados, raspadeiras, "artefactos" que evidenciam também, entre outras interpretações, a complexidade de relações entre segmentos sociais destes pequenos grupos e sua correlação quer com outros, quer com o território. Se num certo registo podemos argumentar que os espólios das mamoas se referem polissemicamente tanto a categorias do território e das pessoas envolvidas, como às atividades que evocam, no caso da Lavra I, e porventura dos Penedos Altos, seria o habitat o polo aglutinador da vida social e ideológica. Tanto pelas estruturas habitacionais de congregação coletiva, como pela presença, apesar da destruição, de objetos de adorno e de uma quantidade considerável de material lítico talhado, onde pontua o sílex (e o arenito). Mesmo tendo em conta a documentação fragmentaria que se conservou, nenhum dos restantes habitats soterrados pelas mamoas, datados de meados do $5^{\circ}$ milénio em diante, vai exibir tal diversidade, verificando-se antes um certo "deslocamento" desses materiais, à exceção da cerâmica, para as práticas coletivas ligadas às mamoas, sejam dominantemente de caráter fúnebre ou não.

Como argumenta J. Thomas (2015, p. 3), não existe na Europa Atlântica uma identidade social homogénea "mesolítica" ou "neolítica", quer argumentemos com a socio economia - proporção relativa das atividades subsistenciais, mormente das produtivas -, quer com os artefactos - sua natureza e proporção relativa -, quer ainda com as modalidades do povoamento, já que todos estes elementos surgem em combinatórias regionais muito variáveis e que vão sendo reconfiguradas ao longo do tempo. O que se verificará, no tempo longo é a tendência para o aparecimento de novas "entidades" no seio das comunidades de caçadores recolectores mesolíticos, que são criadas e manipuladas culturalmente de modo cada vez mais assertivo e estável já que os códigos dos recolectores são absolutamente contrários aos dos produtores (Thomas, 2015, p. 8-11). Se os animais domésticos, os produtos cultivados, os novos artefactos "utilitários" ou "não utilitários", implicam, é certo, uma crescente transformação das relações das pessoas entre $\mathrm{si}$ - criação progressiva de novas unidades sociais e reconfigurações da propriedade coletiva -, o que será igualmente de enfatizar é o facto de as relações entre humanos serem cada vez mais operacionalizadas através de "não humanos", sustidas por não-humanos e mesmo delegadas e esses não-humanos", entidades que são incluídas no entrosado das relações sociais, num contexto de fronteiras mais marcadas (Thomas, 2015: 10).

No caso da Serra da Aboboreira, inserida na região biogeográfica atlântica, mas também no de toda a baixa bacia do Douro, têm particular sentido os estudos dos processos históricos que regionalmente conduziram às transformações que se verificam no tempo longo, do $7^{\circ}$ ao final do $4^{\circ}$ mil. a.C., não sendo esse o objetivo deste texto. Mas, mesmo assim, insistimos em que as redes sociais amplas e as fronteiras territoriais ainda fluídas do $6^{\circ}$ e $5^{\circ}$ mil. a.C. onde circulam pessoas e artefactos, incluindo animais domésticos e produtos cultivados (e suas sementes), teriam proporcionado trocas/ofertas esporádicas, ou mais frequentes, realizadas por certo segundo os códigos dos caçadores recolectores dos inícios do Holoceno, de que existem alguns habitats e numerosos sítios com arte rupestre (Sanches, 2021 e bibliog. aí citada, no prelo). A inclusão dessas "coisas" nos parâmetros socioeconómicos e ideológicos dos grupos é espacial e temporalmente muito variável, mesmo entre comunidades vizinhas (Monteiro-Rodrigues, 2011). Embora não possa ser avaliada no seu pormenor devido a condições tafonómicas, regista-se uma tendência para a presença mais generalizada de alguns artefactos móveis (cerâmica e moinhos), animais (ovelhas ou cabras) e cereais em datas mais antigas (desde meados do 6º milénio a.C.) (López-Sáez et al., 2017), na região biogeográfica mediterrânica da bacia do Douro, onde se conecta com arte rupestre (Sanches, 2021, no prelo), ainda que, mesmo aí, a produção de alimentos de baixa escala pudesse ser ambientalmente e socialmente contingente. É provável que seja ainda neste contexto de grupos com fronteiras 
muito fluídas, porosas - por onde podiam circular pessoas a par de artefactos (Thomas, 2004) - que surgem cerâmicas, moinhos e materiais de sílex na Aboboreira (Lavra I e Penedos Altos), segundo a tradição dos caçadores recolectores mesolíticos longamente estabelecidos. Todavia, as mamoas ao começarem a marcar de modo mais estável, sobretudo na fase mais antiga (a partir do $2^{\circ}$ quartel do $5^{\circ}$ mil. a.C.), áreas de pastos, talvez estejam a integrar novas entidades ideológicas - os animais domésticos (cujos restos não se conservaram) -, na definição de novos grupos sociais, onde se articulariam com outras entidades evocadas pelos seixos, cristais de quartzo, micrólitos, lamelas, mas também moinhos, enxós e menos com machados e cerâmicas.

\section{AGRADECIMENTOS}

A autora pertence ao Grupo de investigação Territórios e Paisagens do CITCEM, inserindo-se este trabalho no projeto UIDB/04059/2020 da FCT Fundação para a Ciência e a Tecnologia.

Agradece-se a Joana Teixeira, Rafael Morais e Cláudia Manuel a colaboração nas imagens e a Domingos Cruz a assertiva e viva troca de opiniões (e cedência de documentação inédita). De qualquer modo, as opiniões expressas são exclusivamente da nossa responsabilidade.

\section{BIBLIOGRAFIA}

CRUZ, Domingos J. (2001) - O Alto Paiva: Megalitismo, Diversidade Tumular e Práticas Rituais Durante a Pré-história Recente, 2 vols., Universidade de Coimbra.

CRUZ, Domingos J. (1992) - A Mamoa I de Chã de CarvaIhal no Contexto Arqueológico da Serra da Aboboreira e da Pré-história Recente do Norte de Portugal. Coimbra: Instituto de Arqueologia da Universidade de Coimbra.

CRUZ, Domingos J. (1988) - Escavação da Mamoa de "Monte Maninho". In Trabalhos de Antropologia e Etnologia. Porto. 27:14, p. 65-84. Muito perto da Lavra; iguais datas LÓPEZ-SÁEZ, José A.; ABEL-SCHAAD, Daniel; IRIARTE, Eneko.; ALBA-SÁNCHEZ, Francisca; PÉREZ-DÍAZ, Sonia; GUERRA-DOCE, Elisa; DELIBES de CASTRO, Germán; ABARQUERO MORAS, Javier, 2017, Una perspectiva paleoambiental de la explotación de la sal en las Lagunas de Villafáfila (Tierra de Campos, Zamora), Cuaternario y Geomorfología (2017), 31 (1-2), 73-104.

LÓPEZ SÁEZ, José A.; FIGUEIRAL, Isabel e CRUZ, Domingos J. (2012) - Palaeoenvironement and vegetation dynamics in serra da Nave (Alto Paiva, Beira Alta, Portugal) during the Late Pleistocene and Holocene, Estudos Pré-históricos, 17, CEPBA, Viseu, pp.11-24.

MENDES, Cátia M. (2017) - O Povoado pré-histórico da Lavra - Serra da Aboboreira. Contributos para o estudo do Neolítico antigo e do Bronze Final no Norte de Portugal. Dissertação de Mestrado, FLUP.

MONTEIRO-RODRIGUES, Sérgio (2011) - Pensar o Neolítico Antigo. Contributo para o Estudo do Norte de Portugal entre o VII e o Vmilénios a.C., [Estudos Pré-históricos, 16.] Viseu: Centro de Estudos Pré-históricos da Beira Alta.

RAMIL REGO, P.; GÓMEZ-ORELLANA, L. \& MUÑOZ SOBRINO, C. (2010) - Cambio climático durante el último ciclo Glaciar-Interglaciar en el NW Ibérico. In BETTENCOURT, Ana; ALVES, Isabel\&MONTEIRO-RODRIGUES, Sérgio, eds.- Variações Paleoambientais e Evolução Antrópica no Quaternário do Ocidente Peninsular. Braga: APEQ/ CITCEM: 23-38.

SANCHES, Maria (2021, in press) - Current remarks on the neolitization of the Lower Douro basin and Northern Portugal. In GUERRA-DOCE, Elisa, ed., O Neolitico Interior. Univ. de Valladolid.

SANCHES, Maria (2003) - Sobre a ocupação do Neolítico inicial do Norte de Portugal. In GONÇALVES, Victor, ed.- Muita Gente, Poucas Antas? Origens, Espaços e Contextos do Megalitismo. Trabalhos de Arqueologia, 25, IPA, pp. 155-179.

STOCKLER, Carla (1998) - Em torno da cronologia do megalitismo da Serra da Aboboreira: novas datas de Carbono 14 da mamoa das Cabras (Amarante), Estudos Pré-Históricos. Viseu. 6, pp. 167-173.

THOMAS, Julian (2015) - What do we mean by 'Neolithic Societies'? In: FOWLER, Chris; HARDING, Jan \& HOFMANN, Daniela, eds. The Oxford Handbook of Neolithic Europe. Oxford: Oxford University Press, pp. 1-22.

THOMAS, Julian (2004) - Current debates on the Mesolithic-Neolithic transition in Britain and Ireland. Documenta Praehistorica, XXXI, pp. 113-130. 


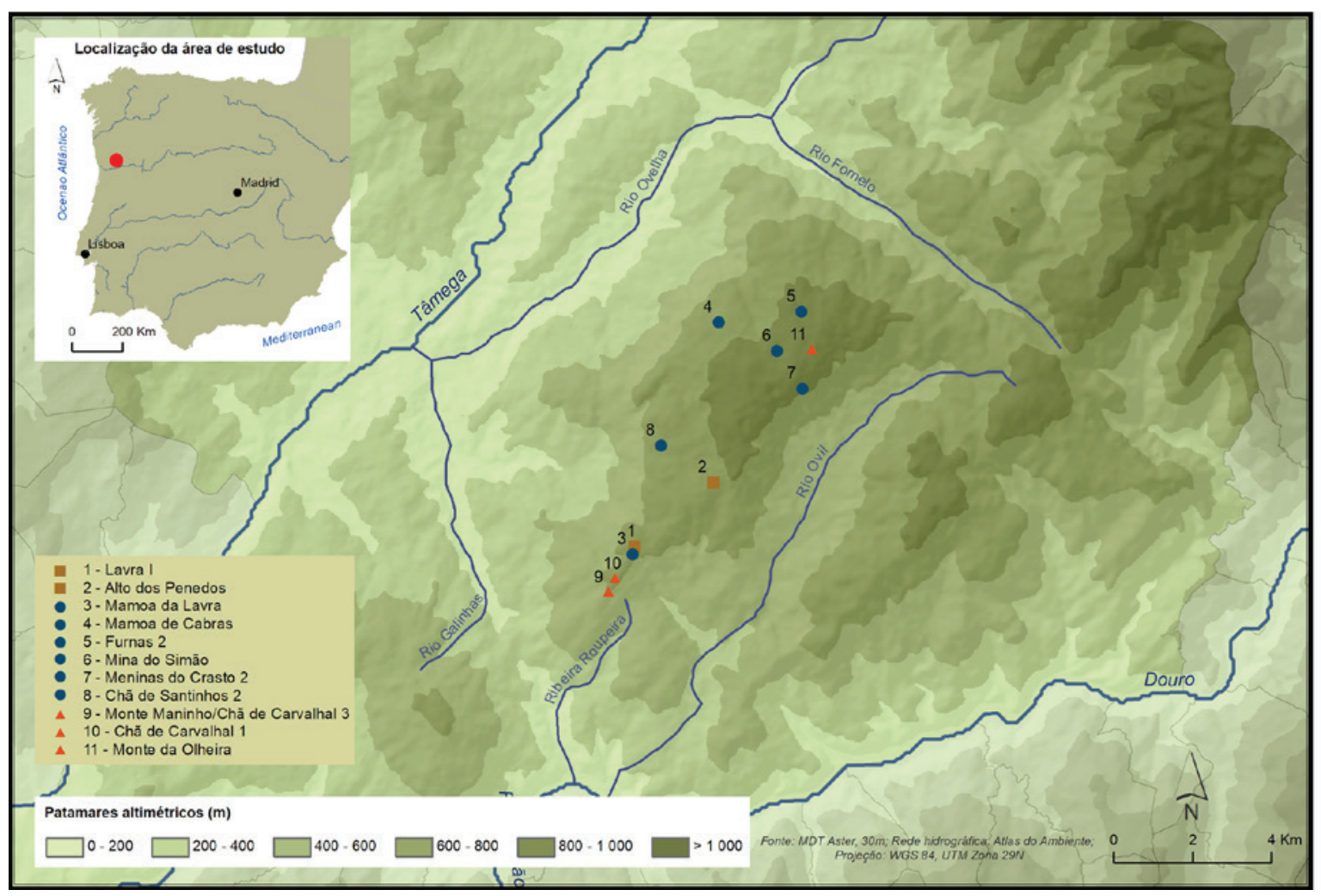

Figura 1 - Serra da Aboboreira (entre os Rios Ovelha e Ovil) e sua referência geográfica à Península Iberica. 1-2 (quadrados) - habitats; 3-8: habitats sob mamoa (círculos); 9-11: outras mamoas referenciadas no texto (figura elaborada por Cláudia Silva).

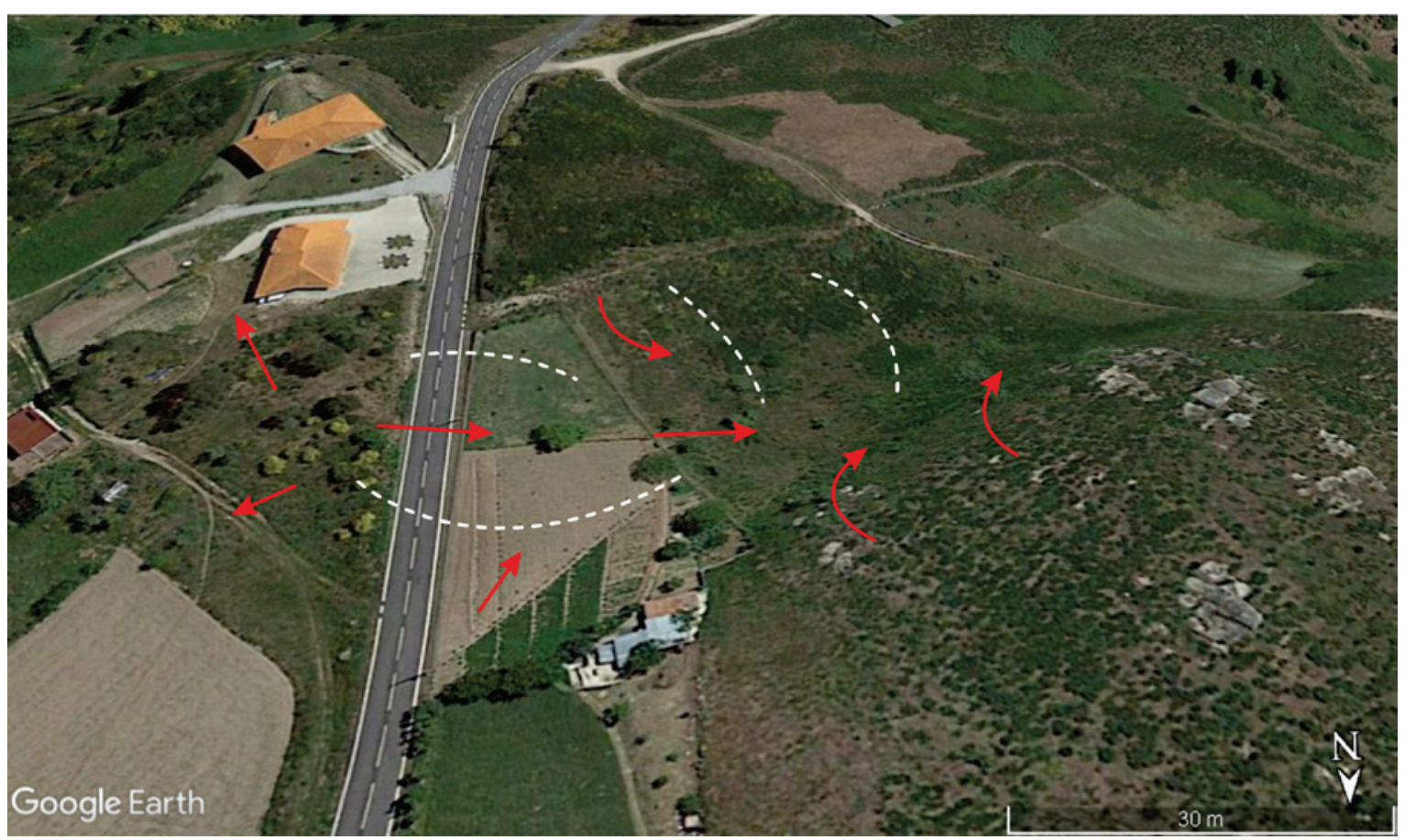

Figura 2 - Lavra e representação esquemática da sedimentação dominante (deslocação sedimentar indicada pelas setas vermelhas). As principais estruturas habitacionais de Lavra I encontram-se entre as duas linhas curvas, sobre a estra$\mathrm{da}$, aproximadamente sob a seta central, vermelha (figura elaborada por Rafael Morais). 

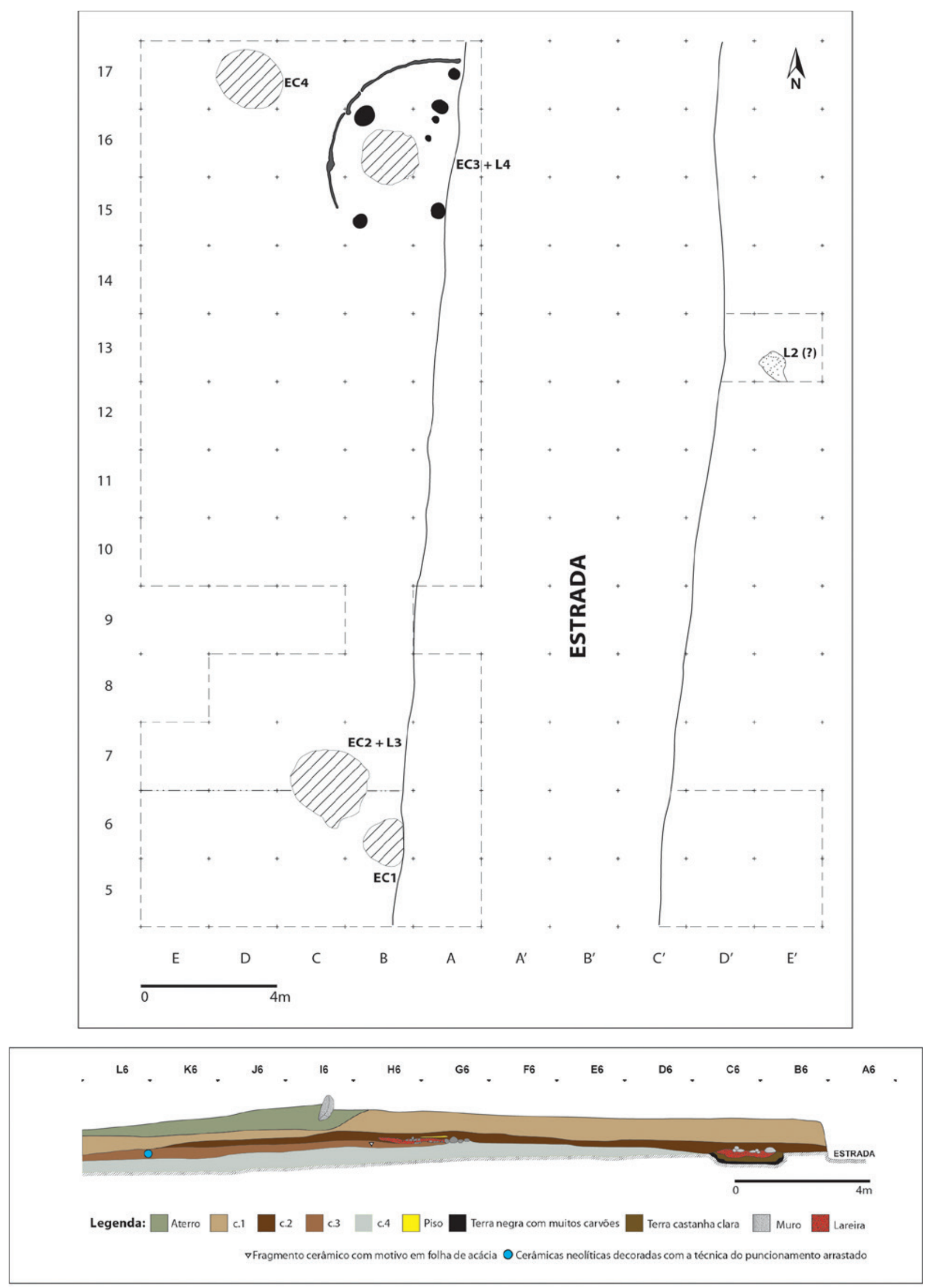

Figura 3 - A - Lavra: planta esquemática da área com estruturas. B - corte estratigráfico (ver sua marcação na planta). A estratigrafia é descrita em texto (figura elaborada por Joana Teixeira). 


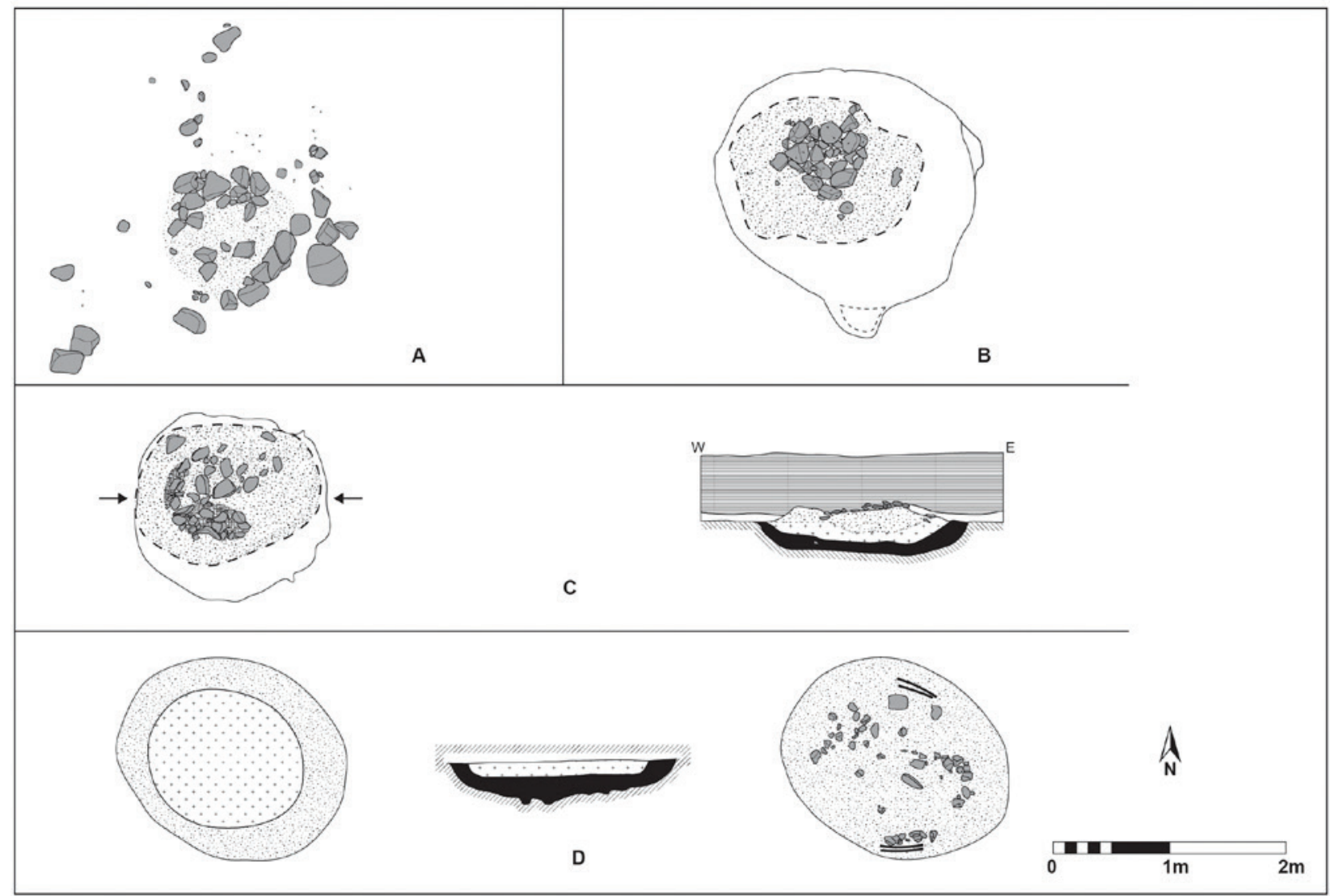

Figura 4 - Lavra I: Estruturas de Combustão. A e B - Lareira 3 (dois planos) tendo marcado, em B, o contorno da Estrutura de Combustão 2 (que lhe subjaz). C - Lareira 4 tendo marcado o contorno da estrutura de Combustão 3 (que lhe subjaz), e respetivo corte estratigráfico. D - Estrutura de Combustão 4: à esquerda no plano do seu topo, à direita no plano do topo da camada contínua de terra queimada e carvão (representam-se dois grandes troncos queimados). Ao centro, o respetivo corte estratigráfico. A estratigrafia encontra-se no texto (figura elaborada por Joana Teixeira). 


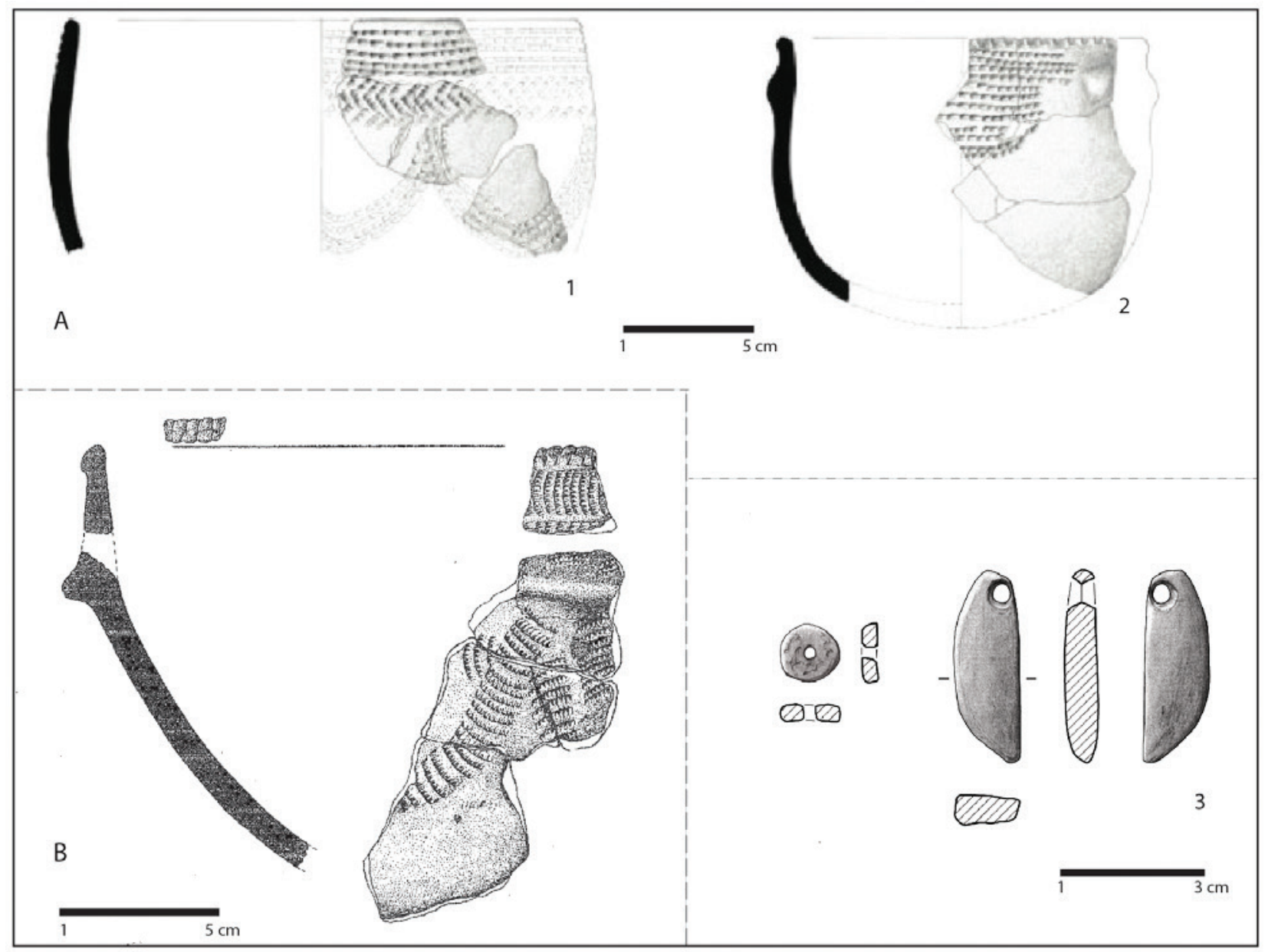

Figura 5-A - Recipientes cerâmicos (1, 2) e objetos de adorno (3) de Lavra I. B - Recipiente cerâmico de Alto dos Penedos (seg. Jorge, 1988, Fig. 43-3, adaptado) (figura elaborada por Joana Teixeira). 


\title{
O PROCESSO DE NEOLITIZAÇÃO NA PLATAFORMA DO MONDEGO: OS DADOS DO SECTOR C DO OUTEIRO DOS CASTELOS DE BEIJÓS (CARREGAL DO SAL)
}

\author{
João Carlos de Senna-Martinez ${ }^{1}$, José Manuel Quintã Ventura ${ }^{2}$ \\ Colaborações ${ }^{3}$ de: Andreia Carvalho, Cíntia Maurício
}

\section{RESUMO}

O Outeiro dos Castelos de Beijós (COCB) é um sítio bem conhecido pela sua ocupação do BF (Senna-Martinez, 1993, 1994, 1995/1996a, 2000a e 200ob; Senna-Martinez e Ventura, 2008a; Senna-Martinez e Pedro, Eds. 200o). Contudo, uma outra utilização antrópica deste espaço, no NA, encontrava-se, ainda, sem divulgação adequada. Tal sucede apesar de parte das colecções se encontrarem expostas no Museu Municipal de Carregal do Sal e integrarem o respectivo Roteiro (Pinto, 2006; Senna-Martinez, 2006).

No ano lectivo de 2004/2005 duas alunas da Licenciatura em Arqueologia da FLUL - e colaboradoras neste artigo - desenharam e procederam à análise tipológica, no âmbito do seu seminário final, respectivamente da olaria e da indústria lítica associadas à ocupação do NA. Recupera-se aqui e integra-se esse contributo escolar dentro do que tem sido a melhor tradição da Uniarq.

Procuraremos ainda integrar os novos dados de COCB no âmbito, mais alargado, da Neolitização da bacia interior do Mondego e do Centro/Norte Português.

Palavras-chave: Neolítico Antigo; Centro/Norte Português; Plataforma do Mondego.

\begin{abstract}
Outeiro dos Castelos de Beijós (COCB) is a well-known archaeological site for its Late Bronze Age occupation (Senna-Martinez, 1993, 1994, 1995/1996a, 2000a and 200ob; Senna-Martinez e Nunes, 1993; Senna-Martinez e Ventura, 2008a; Senna-Martinez and Pedro, Eds. 2000). However, another anthropic use of this space, in the Early Neolithic, was still, without adequate dissemination. This happens despite the fact that part of the collections are on display at the Municipal Museum of Carregal do Sal and are part of the respective catalogue (Pinto, 2006; Senna-Martinez, 2006).

In the 2004/2005 academic year, two students from FLUL's Degree in Archeology - and collaborators in this article - proceeded to draw and carry out the typological analysis, within the scope of their final seminar, respectively of the pottery and the lithic industry associated with the Ancient Neolithic occupation. Here we recuperate these academic efforts and integrate their contribution following what has been one of Uniarq's best traditions. We will also try to integrate the new COCB data in the broader scope of the Neolithisation of the Mondego inland basin and of the Portuguese Centre/North.
\end{abstract}

Keywords: Ancient Neolithic, Centre/North Portugal, Mondego Platform.

\footnotetext{
1. Professor Associado (aposentado) da FLUL. Investigador Integrado do Centro de Arqueologia (Uniarq) da Universidade de Lisboa. 16oo-214 Lisboa. Portugal; smartinez@fl.ul.pt

2. Investigador Colaborador do Centro de Arqueologia (Uniarq) da Universidade de Lisboa. 160o-214 Lisboa. Portugal.

3. À data de realização dos trabalhos aqui incorporados (ano lectivo de 2004-2005) eram ambas alunas do $4^{\circ}$ ano de Arqueologia da FLUL, hoje licenciadas. Além de desenho de materiais, aqui se incorporam abordagens analíticas às componentes lítica (Cíntia Maurício) e cerâmica (Andreia Carvalho) desenvolvidas enquanto trabalhos escolares sob orientação do primeiro autor. A responsabilidade final do presente texto é inteiramente dos autores.
} 


\section{O ARQUEOSSÍTIO DO CASTRO DO OUTEIRO DOS CASTELOS DE BEIJÓS (COCB), LOCALIZAÇÃO, AMBIENTE E ANTECEDENTES}

O Outeiro dos Castelos de Beijós localiza-se na povoação que é sede da freguesia do mesmo nome, a qual ocupa parte da respectiva vertente sul, concelho de Carregal do Sal, distrito de Viseu. O seu ponto mais elevado $(268 \mathrm{~m})$ tem de coordenadas 214.575/393.350 GAUSS, na Folha 199 da Carta Militar de Portugal, escala 1:2500o (Figura 1-1).

Encaixado na confluência da ribeira do Travassos com a de Beijós que mais a jusante se juntam ao Dão, o cabeço é constituído por granitos com fraca cobertura sedimentar. É dominante e controla estrategicamente a antiga via romana (herdeira de anteriores caminhos e, hoje, seguida em parte pela E.N. 337) de Oliveira do Conde a Viseu, por S. Gemil (ALARCÃO, 1988: 104 e fig.20).

Pelo facto de se encontra encaixado entre as duas ribeiras mencionadas e em cota bastante inferior à da superfície de aplanamento da Plataforma do Mondego COCB não tem qualquer controle visual directo sobre aquele espaço, numa situação aliás equivalente à do sítio do Castro de S. Cosme (CSC - Fig.1-4 - Senna-Martinez e Coelho, 1994/1988). Contudo, a cerca de quatro quilómetros para norte de COCB, no topo da vertente sueste do vale do Dão, fica o sítio do Cabeço do Cucão da Pedra Cavaleira (CCPC - Fig.1-2 - Senna-Martinez, et al. 1993) e, a distância equivalente para sudoeste, ao longo do vale da ribeira de Beijós, na sua vertente sul e em posição sobranceira à confluência desta com o Dão, fica o sítio da Malcata (MALC - Fig.1-3 - Senna-Martinez, Rocha e Ramos, 1993). Estes dois últimos sítios são interpretáveis, no primeiro caso como uma atalaia de COCB, no segundo como um "casal agrícola" na dependência daquele. Ambos possuem boa visibilidade sobre a rede fluvial em que se integram e, no caso de CCPC, sobre a Plataforma do Mondego.

A área envolvente é predominantemente constituída por cambissolos ${ }^{4}$, geralmente pouco profundos, formando algumas manchas de solos de "Classe A", nomeadamente nos terraços baixos das duas ribeiras, entremeadas por manchas de "Classe C e F", de capacidade agrícola reduzida (com limitações mo-

4. cf. "Carta dos Solos", Atlas do Ambiente, III.1, Lisboa 1978. deradas ou acentuadas) ou apenas florestal ${ }^{5}$, com alguma horticultura e cultivo de milho e da oliveira em socalcos ou nas baixas aluviais, ocupando a vinha algumas das vertentes e parte dos interflúvios entre os cursos de agua principais.

Os solos mais ricos são, contudo e fortemente, produto de um grande investimento antrópico, provavelmente pós-medieval, causador igualmente de acentuada desflorestação das vertentes e preenchimento do fundo dos vales, o que torna problemático e nos obriga a grande prudência na possível transferência dos dados actuais para eventual utilização no período que aqui nos importa.

No Bronze Final (BF - Senna-Martinez, 20oob) a ocupação do cabeço deverá ter correspondido ao seu topo aplanado que hoje se apresenta bastante afectado pelas construções da povoação, extracção de pedra e areias, e despejos vários, estando, ainda, parcialmente florestado com pinheiro, sobretudo nas vertentes do quadrante noroeste. Abrangeria uma área máxima de $150 \mathrm{~m}$ no sentido sudoeste/nordeste por $75 \mathrm{~m}$ no sentido noroeste/sueste.

Além das recolhas iniciais provenientes de duas concentrações - a primeira realizada em 1986, aquando de um reconhecimento efectuado em companhia de Horácio Peixoto e a segunda devendo-se a este último, realizada em idênticas condições e local, já em 1990 (Senna-Martinez e Nunes, 1993) - em Setembro de 1992, no decurso dos trabalhos por nós efectuados na região ${ }^{6}$, Horácio Manuel Peixoto detectou uma si-

5. cf. "Carta de Capacidade de Uso do Solo", Atlas do Ambiente, Lisboa, 1978.

6. Os trabalhos das seis campanhas efectuadas em Beijós integraram-se nos Campos Arqueológicos de Canas de Senhorim, anualmente efectuados desde 1991 a 2001, foram parcialmente financiados primeiro pelo IPPAAR e, a partir de 1996, pelo IPA e contaram com o apoio do Câmara Municipal de Carregal do Sal, Associação para o Estudo Arqueológico da Bacia do Mondego (EAM), Junta de Freguesia de Canas de Senhorim e Associação Humanitária dos Bombeiros Voluntários de Canas de Senhorim. A respectiva direcção coube ao autor, tendo a colaboração de Horácio Manuel Peixoto (da Associação Humanitária dos Bombeiros Voluntários de Canas de Senhorim) e de diversos alunos universitários.

Agradece-se, em particular, a participação e colaboração de Adolfo Miguel Parente da Conceição, Ana Cristina Nunes Martins, Ana Godinho, Ana Sofia Senna Martinez, Bernard Coutourier, Catarina Maria Santos Guerra Tente, Isabel Maria Simões, Maria Antónia Costa Pereira, Miguel Ángel González López, Paula Alexandra Chagas Perdigão, Rui António Luz Cardoso, Sandra Clara Alves Lourenço, Susana Maria Gonçalves Estrela e Teresa Araújo. 
tuação nova. Tendo-nos ambos deslocado ao local, aí pudemos constatar que, próximo do topo da vertente nordeste do cabeço, já fora das casas da povoação, a retirada recente de terra e pedra para reforço de um caminho pusera à vista, reavivando-o, um perfil onde afloravam diversas bolsas de terras escuras com restos de estruturas e abundante olaria integrável no Grupo Baiões/Santa Luzia. Em consequência desta identificação efectuaram-se três campanhas de escavação (1993/1994/1995) na área preservada do que ficou, desde então, designado como Sector-A (Figura 2-A). Já em 1995 e 1996 viemos a intervir noutra área preservada, o designado Sector-B (Fig.2-B - Senna-Martinez, 20oob: p. 48-55), onde nova ocupação do BF revelaria dados importantes sobre a metalurgia do Mundo Baiões/Santa Luzia (Id. p. 56-58).

\section{O SECTOR C: AS INTERVENÇÕES DE 1999 E 2000}

O ano de 1999 assistiu a novos desenvolvimentos em COCB. Mais uma vez foi Horácio Peixoto que nos alertou para o facto de que o alargamento, pela Junta de Freguesia de Beijós, de um caminho florestal na vertente Noroeste afectara níveis arqueológicos.

Duas campanhas, levadas a cabo nos verões de 1999 e 2000, permitiram esclarecer e minimizar a situação, permitindo ainda confirmar e caracterizar parcialmente a existência de uma ocupação do Neolítico Antigo (NA).

A área intervencionada (designada Sector-C - Fig.2-C) corresponde ao referido caminho, que se dispõe numa pendente de $20 \%$ ao longo da vertente Noroeste do cabeço. Este foi alargado e aplanado por uma máquina tendo, nesse processo, afectado irremediavelmente alguns níveis arqueológicos como é visível na foto da Fig. 3. Foi-nos, apesar de tudo, possível recuperar um bloco de terra virado pela máquina para o lado norte do caminho (Figura 3) e de cuja desmontagem se recolheu um conjunto, tipologicamente homogéneo, de materiais do NA.

No verão de 1999, optámos então por, descendo o caminho a partir da área em que apareceu o referido bloco, demarcar uma quadrícula, ocupando uma extensão de 1om por uma largura de 3m (Figura 4), para tentar encontrar ainda alguma unidade estratigráfica preservada.

Na campanha de 1999 interviemos na parte de menor cota, próxima já do fim do estradão, abrindo uma área de 4m × 3m, quadrados FGH1-4 (Figura 5).
Escavadas as terras compactadas do topo de estradão [o], sob elas afloravam (chegando por vezes à superfície do terreno) já granitos alterados formando bolsas preenchidas por terras castanho escuras [1], areno argilosas com escassos materiais arqueológicos (Figura 6). $\mathrm{Na}$ segunda campanha efectuada neste Sector, no Verão de 200o, tendo em conta os resultados da intervenção do ano anterior, optámos por abrir uma faixa de $1 \mathrm{~m}$ de largo ao longo da restante área do estradão, quadrados G5/10 (Figura 5).

A estratigrafia encontrada não se alterou em relação à determinada em 1999, com a variante de, quanto mais subíamos o estradão, menor era a cobertura sedimentar sobre os granitos de base (Figuras 7-8). Os trabalhos efectuados nas duas campanhas referidas permitiam, logo na sequência de uma primeira abordagem (ainda em campo) aos materiais recolhidos, concluir que estávamos provavelmente em presença de uma situação residual da ocupação do sítio no Neolítico Antigo, com materiais deslocados ao longo da vertente (incluindo alguns atribuíveis ao Bronze Fina), enquanto no topo desta localizar-se-ia a respectiva área de origem, ainda testemunhada pelo deslocado bloco de terra com materiais exclusivamente desta cronologia.

Existiria assim uma ocupação, mesmo que parcial, do cabeço no NA que teria sido quase totalmente afectada no BF sobrando algo no topo da vertente noroeste e que o alargamento do estradão acabaria de destruir. Toda a evidência recolhida, apesar do aspecto fresco e não rolado das fracturas dos fragmentos de olaria, aponta assim para contextos com alguma remobilização de materiais, portanto em posição estratigráfica secundária.

\section{OS MATERIAIS RECOLHIDOS}

O conjunto dos materiais recuperados distribui-se por dois sub-conjuntos artefactuais distintos: (1) Olaria -140 fragmentos da escavação do Sector-C (118 atribuíveis ao NA, para um NMI de 13 enquanto 22 pertenciam ao $\mathrm{BF}$ ) e 4 fragmentos provenientes do bloco de terra deslocado e atribuíveis ao NA; (2) Indústria lítica - da qual 79 itens provêm da escavação do Sector-C (todos atribuíveis ao NA) e mais 12 recuperados no bloco de terra deslocado (11 atribuíveis ao NA e 1 ao BF).

\subsection{A Olaria}

Conforme referido acima recuperámos, dos diver- 
sos contextos, um total de 122 fragmentos de olaria provavelmente atribuíveis ao NA. Destes, considerando todos os fragmentos com bordo (todos eles decorados) e os fragmentos com decoração enquadrável neste período, chegamos a um $\mathrm{NMI}^{7}$ de 17 recipientes (Figuras. 9-13) (Tabela 1).

Apenas foi possível reconstituir a Forma ${ }^{8}$ de 5 exemplares correspondendo a: dois esféricos (Forma 5 do "fundo comum Neo-Calcolítico" regional, cf. Senna-Martinez, 1989, 1995: fig.5 - Fig.10: 2008, 2068), um vaso tipo saco (Forma 13.1 - Senna-Martinez, 1995: fig.5 - Fig. 10: 2069) e duas tigelas (Formas 4.1 e 4.2 - Senna-Martinez, 1995: fig.5 - Fig.11: 2070, 2071/2134). Apesar da escassez da amostra, parece-nos de salientar que as Formas reconstituíveis são as predominantes nos contextos regionais próximos, tal como a maioria das gramáticas decorativas (Valera, 1998).

Dos restantes doze fragmentos que apresentam decorações enquadráveis no NA, apenas um permite propor uma orientação e diâmetro sem que, no entanto, possamos fazer-lhe corresponder uma Forma específica (Figura 12: 2133).

As respectivas pastas, são, com poucas excepções 9 , dominantemente compactas, de tendência de cozedura oxidante, acabamentos (onde a conservação das superfícies permite a observação) predominantemente alisados, elementos não plásticos de pequeno calibre (predominantemente micas, com alguns quartzos e feldspatos) e uniformemente distribuídos. Do acima exposto se pode concluir que o elemento essencial na nossa atribuição crono-cultural da maioria deste conjunto de fragmentos é a decoração, a qual perpetua elementos do já bem conhecido NA regional onde ocorre numa maioria de recipientes (Valera, 1998: p.134-139) ao contrário de alguns ambientes mais meridionais (Diniz, 2007).

7. Parâmetros de análise da olaria conforme Senna-Martinez (1993: Apêndice-I, p.118-122).

8. Conforme desde há longa data Senna-Martinez (1989) consideramos que, a designação de Forma, aplicada ao estudo de recipientes de olaria, constitui um conceito equivalente ao de Tipo segundo é definido por Clarke (1978: 205-244).

9. As condições de recolha fazem com que seja particularmente difícil separar fragmentos de bojo de recipientes lisos (i.e. sem decoração) entre o NA e BF. Pelo que qualquer contabilização estatística apenas poderia ser feita a partir do reduzido número de exemplares que integram o NMI, razão pelo que os dados aduzidos são apenas indicativos.
Particularmente interessantes na nossa amostra são os dois recipientes parcialmente reconstituíveis - o esférico COCB-C/2008 e o vaso tipo saco COCB-C/2069 - ambos com uma banda de decoração em "falsa folha de acácia" (impressão a punção lateral) em espinha múltipla, no primeiro caso sob o bordo decorado com pequenos mamilos repuxados, no segundo sobre o colo e com uma pega mamilar sobre o bordo. Também o fragmento COCB-C/2046, apesar de diminuto, apresenta uma decoração impressa a punção lateral que pode ter feito parte de um motivo semelhante (Figura 13: 2046).

Neste exemplares a decoração remete-nos para ambientes mais meridionais, por exemplo S. Pedro de Canaferrim, onde se encontra bem documentada (Sintra - cf. Simões, 1999: p.71), ou mesmo alentejanos, como a Valada do Mato (Évora - cf. Diniz, 2007: 260) onde é minoritária. Nos sítios mais próximos do Complexo 1 do Penedo da Penha (CPPI) ou do Buraco da Moura de S. Romão (BMSR) esta decoração parece estar ausente.

A decoração em "boquique a espátula", presente regionalmente quer em CPPi quer em BMSR, está presente numa taça - COCB-C/2071/2134 (Fig.11) - formando linhas verticais, num fragmento apenas orientável - COCB-C/2133 (Fig.12) - com uma banda de impressões horizontais, donde pendem grinaldas, num fragmento - COCB-C/2011 (Fig.13) - e encontramo-la ainda num esférico - COCB-C/2068 (Fig.10) - numa decoração complexa que associa métopas sob o bordo com, pelo menos, duas variantes: uma combinação multidireccional de boquiques e impressões sub-rectangulares.

Igualmente presente em CPPı está a decoração impressa com uma matriz quadrangular, formando linhas horizontais, que encontramos no bordo da taça COCB-C/2070 (Fig.11).

Para terminar esta nossa análise das técnicas e gramáticas decorativas refiramos, com particular detalhe, dois conjuntos de fragmentos de bojo de dois recipientes distintos mas de Forma não-reconstituível: COCB - C $/ 2000$ - representado por três fragmentos (Fig.9), decorados com ungulações, técnica e motivo igualmente presentes em CPPı e BMSR (Valera, 1998); COCB-C/2004 - conjunto de quatro fragmentos de bojo (Figura 9), decorados com pequenos mamilos repuxados agrupados, semelhantes aos que sublinham o lábio dos três fragmentos de bordo do esférico COCB-C/2008 (Figura 9 e 10). 


\subsection{A Indústria Lítica}

Para efeitos da respectiva análise tipológica os materiais líticos recolhidos (9o exemplares) estão agrupados dentro das seguintes categorias: (1) material de debitagem (compreendendo os produtos brutos de talhe); (2) núcleos; (3) material de reavivagem; (4) percutores; (5) utensílios (Tabela 2).

\section{Matérias-Primas}

A matéria-prima predominante em qualquer uma das categorias em análise é, preferencialmente, o quartzo leitoso (74,7\%). Conquanto minoritárias, as rochas siliciosas "de tipo sílex" to têm uma presença global significativa (15,4\%), sobretudo nas lascas $(23,3 \%)$ e material de reavivagem $(23,5 \%)$, mas mais reduzida nos utensílios (11,1\%) e núcleos $(6,5 \%)$. Estes últimos - dois exemplares exaustos e de tipo poliédrico - não se adequam à produção de suportes alongados, pelo que o único utensílio em sílex recolhido, uma lamela retocada, poderá não ter partido de um suporte de produção local.

Outras rochas, nomeadamente o quartzo hialino (5,5\%), a ágata ( $1,1 \%$ ) e o calcário silicificado ( $1,1 \%)$, têm uma presença muito vestigial (no total representam $7,7 \%$ do conjunto estudado). O seu uso pode relacionar-se com uma estratégia oportunista de aproveitamento não sistemático de outras matérias-primas disponíveis. Apenas no caso do quartzo hialino - com maior representatividade - e tendo em linha de conta a sua escolha preferencial na produção de lamelas em momentos do Neolítico Médio e Final regional, podemos por a hipótese de termos aqui um antecedente deliberado (?).

Registe-se ainda a presença de uma lasca de anfibolito, eventualmente conectada com as primeiras produções de artefactos de gume cortante em pedra polida, contudo também muito raros nos outros contextos do NA regional (Senna-Martinez e Ventura, 2008b; Ventura, 1998).

Resulta claro dos parágrafos supra que as matérias-primas locais têm, em COCB-C, uma presença maioritária, senão exclusiva (?) (Figura 14).

\section{Debitagem}

A debitagem é dominada por lascas, com apenas

10. Conhecemos regionalmente fontes de produtos siliciosos de tipo sílex, mas apenas de pequenas dimensões e permitindo apenas produção de lamelas e pequenas lascas (Valera, 1997: Anexo III). duas lamelas, ambas retocadas. Destas últimas, uma (a de calcário silicificado - COCB-C/2010, Fig.14) é um fragmento distal, a outra (em quartzo hialino COCB-C/2067, Fig.14) é ultrapassada e espessa tratando-se, provavelmente, de um acidente de talhe, embora tenha sido retocada para utilização.

Esta distribuição do material de debitagem revela uma clara orientação para a produção preferencial de suportes sobre lasca e não para a produção de suportes alongados.

\section{As lascas}

São maioritariamente realizadas em quartzo, havendo ainda uma quantidade considerável de lascas de sílex -7 num total de 30 ( $23,3 \%$ ). As suas dimensões médias são generalizadamente pequenas: Comprimento $1,7 \pm 0,4 \mathrm{~cm}$; largura $1,8 \pm 1 \mathrm{~cm}$; espessura $0,7 \pm 0,3 \mathrm{~cm}$. O desvio-padrão não é muito elevado, o que parece indicar alguma uniformidade de dimensões. No entanto, as suas formas são bastante variadas, e esta aparente uniformidade deve-se mais provavelmente às dimensões dos núcleos disponíveis.

Apenas duas lascas apresentam vestígios de córtex, pelo que a maioria do material de debitagem não se deve relacionar com a conformação final de núcleos parcialmente descorticados, derivando antes do aproveitamento local de pequenos núcleos pré-formados. Os talões das lascas são tendencialmente lisos e com alguma frequência esmagados, o que indicia o predomínio do talhe directo com percutor duro, sendo as mesmas obtidas a partir de núcleos poliédricos. As lascas resultantes da aplicação deste método não se tratam de produções normalizadas, sendo delgadas e de morfologias variadas (Carvalho, 1998: p. 81). Segundo António Faustino de Carvalho, a produção de lascas por percussão directa através da exploração de núcleos poliédricos pode ser inserida dentro dos principais sistemas técnicos de talhe de pedra durante o Neolítico Antigo (Carvalho, 1998: p. 78-82), sistema este aplicável tanto nas lascas em quartzo, como nas lascas em sílex e rochas afins. Uma boa parte destas lascas deriva provavelmente da preparação de planos de percussão e outras destinar-se-iam a servir de suporte a utensílios a posteriori, o que pode ser materializado, por exemplo, no raspador COCB-C/2076 e buril COCB-C/2124 (Figura 14).

Dadas as limitações da amostra (apenas 10,1\% são utensílios), torna-se impossível ser afirmativo em relação ao peso das lascas como suporte preferencial 
para a produção de utensílios, contudo a predominância absoluta destas dentro do material de debitagem conduz-nos a pensarmos estar perante uma indústria sobre lasca.

\section{Núcleos e Material de Reavivagem}

A proporção de núcleos no conjunto lítico recolhido é elevada (34,8\%), ainda que maioritariamente a amostra seja constituída por exemplares fragmentados (Fig.15). A utilização de duas únicas matérias primas - quartzo leitoso $(94,0 \%)$ e rochas tipo sílex $(6,5 \%)$ - está em linha com o que são, nesse particular, as características do conjunto.

Apesar denão existirem núcleos de quartzo hialino, a presença no conjunto do material de reavivagem de uma lasca/flanco é indicativa de que, certamente, haveria também a exploração de cristais desta rocha. Considerando apenas os núcleos completos, podem ser divididos da seguinte forma quanto à sua tipologia:

1. Prismáticos -5 exemplares. Talhe a partir de uma única plataforma intencionalmente seleccionada, resultando na formação de negativos dispostos de forma paralela, provavelmente originando produtos micro-laminares;

2. Poliédricos -4 exemplares incluindo os dois únicos em sílex. Debitagem efectuada de forma desordenada e aleatória, sem qualquer padrão de levantamentos, não permitindo a produção de suportes estandardizados e afectando quase toda a superfície;

3. Discóide - 1 exemplar. Apresenta um volume achatado com a plataforma de percussão constituída pela aresta irregular formada pela intersecção entre duas metades opostas do nódulo, utilizadas ambas como superfície de debitagem;

4. Irregulares e fragmentos tipologicamente indetermináveis-Respectivamente com 1 exemplar e 19 exemplares. Dos fragmentos estudados, um número significativo $(9-47,4 \%)$ podem eventualmente ser atribuíveis a núcleos prismáticos (tal como as tabuinhas de reavivagem). Tal traduziria uma tendência para a exploração preferencial de núcleos prismáticos, de resto o tipo mais adequado para a obtenção de suportes micro-laminares, ainda que o reduzido número de exemplares completos não permita maiores certezas.

A escassez de lascas corticais, inclina-nos a pensar que os núcleos provavelmente seriam previamente formatados antes de serem levados para o povoado, o que facilitaria o seu transporte.

As dimensões bastante diminutas dos exemplares recolhidos explicam o tamanho reduzido das lascas obtidas.

Na maioria os núcleos e aqueles fragmentos que permitem tal tipo de observação, nomeadamente os que utilizam quartzo hialino, estão longe de se encontrarem exaustos, pelo que deveriam ser explorados para responder às necessidades mais imediatas, sendo rapidamente descartados. A abundância lo$\mathrm{cal} /$ /regional de nódulos de quartzo permitia que a estratégia de aproveitamento deste recurso não obrigasse a uma exploração mais eficaz dos núcleos. Já os núcleos de rochas de tipo sílex apresentam-se exaustos. A maior escassez deste tipo de recurso pode assim ter conduzido a uma maior rentabilização destes materiais. Tal permite-nos falar numa gestão diferenciada das diferentes matérias-primas, consoante as suas diferentes disponibilidades.

O Material de reavivagem (17 exemplares - 18,7\%) distribui-se entre flancos de núcleo (12 exemplares $-70,6 \%$ ) e tabuinhas de reavivagem (5 exemplares $-29,4 \%$ ). Sendo indicativo do talhe local, a existência de três flancos e uma tabuinha de reavivagem em sílex confirma pela sua morfologia a utilização de núcleos prismáticos. Por outro lado o exemplar de flanco de núcleo em quartzo hialino conforma a utilização desta rocha, provavelmente também num núcleo prismático.

\section{Percutores}

A presença de dois percutores utilizando seixos de quartzo somada aos dados aduzidos anteriormente constitui mais um indicador de talhe local de matérias-primas que chegariam sob a forma de núcleos pré-formados.

\section{Utensílios}

Os 9 exemplares de utensílios, claramente minoritários na indústria recolhida (10,1\%) distribuem-se por 6 tipos diferentes (Tabela 2):

1. Geométricos -3 exemplares -2 crescentes e um triângulo. Um dos crescentes e o triângulo (Fig.14: 2127) são produzidos em quartzo leitoso enquanto o outro crescente é de quartzo hialino, sendo todos talhados a partir de suportes micro-laminares (tal como noutras situações do NA da Plataforma do Mondego - Senna-Martinez e Ventura, 2008a) como comprovam 
as respectivas dimensões médias: Comprimento $1,96 \pm 0,21 \mathrm{~cm}$, largura 0,96 $\pm 0,12 \mathrm{~cm}$, espessura $0,33 \pm 0,05 \mathrm{~cm}$;

2. Buril - 1 exemplar. Trata-se de um buril diedro em quartzo leitoso (Figura 14: 2124);

3. UAD (Utensílio de aresta distal) - 1 exemplar. Utensílios expeditos, com funcionalidade entre o buril e o raspador, normalmente obtidos sobre um cristal de quartzo - no caso vertente quartzo leitoso - ou um seu fragmento robusto, com levantamentos dando forma a um sólido gume diedro na extremidade distal, caso do exemplar de COCB-C (Fig.14: 2125). Na Plataforma do Mondego surgem em contextos habitacionais, do NF (Senna-Martinez, 1989: 528; Senna-Martinez e Luís, 2016: 156 e Tabela 2);

4. Lamelas retocadas -2 exemplares. Um fragmento distal em sílex, com retoque marginal bilateral, rasante (Fig.14: 2010) e um exemplar completo em quartzo hialino com retoque semi-abrupto, marginal e parcial no lado esquerdo da face dorsal (Figura 14: 2067). Dimensões médias ${ }^{11}$ : Largura 0,9 \pm 0,14 cm, espessura $0,35 \pm 0,21 \mathrm{~cm}$.

5. Raspador circular côncavo (COCB-C/2076) Realizado sobre uma lasca parcialmente cortical de ágata - comprimento 2,4 cm, largura $1,9 \mathrm{~cm}$, espessura 0,9 cm. Retoque bifacial, marginal, de inclinação rasante na extremidade distal, mais larga que a base. A morfologia circular do suporte foi aproveitada para a realização deste utensílio. O seu fabrico sobre uma lasca de ágata - sendo caso único - testemunha provavelmente um aproveitamento ocasional desta rocha.

6. Denticulado (COCB-C/2083) - Fragmento quebrado longitudinalmente de um denticulado sobre lasca de quartzo leitoso. O cariz irregular do suporte, na parte recuperada, leva-nos a pensar que se trata de uma peça "de oportunidade".

11. A lamela de sílex é um fragmento distal, pelo que não foi possível determinar o seu comprimento. A de quartzo hialino tem de dimensões: comprimento $1,9 \mathrm{~cm}$, largura $0,8 \mathrm{~cm}$, espessura $0,5 \mathrm{~cm}$.

\section{A OCUPAÇÃO DO NEOLÍTICO ANTIGO DO OUTEIRO DOS CASTELOS DE BEIJÓS NO CONTEXTO DA PLATAFORMA DO MONDEGO}

Localizados preferencialmente em vertentes suaves ou rechãs com boa exposição a nascente ou, ainda, em abrigos sob penedos graníticos - também no caso do Complexo 1 do Penedo da Penha o abrigo abre a nascente - os sítios associados ao Neolítico Antigo da Plataforma do Mondego parecem escolher locais abertos, sem condições especiais de controle da paisagem (Figura 16).

Alguns destes locais associam-se a aspectos particulares da topografia, casos do Folhadal (ORFOL, rechã a meia vertente do vale do Mondego, sinalizada por um Tor granítico - Senna-Martinez e Ventura, 1999, 2008a: Fig.2) e Lapa do Lobo (ORLL, ponto de cota mais elevada do planalto dos Fiais/Ameal - Senna-Martinez, 2018: Fig.4) em que os respectivos habitats são estratigraficamente sobrepostos por monumentos megalíticos de " $\mathrm{I}^{\mathrm{a}}$ geração", com construção atribuível ao Neolítico Médio (NM) regional. O caso de ORLL constitui o segundo caso confirmado em que se demonstra tal sobreposição, aliás já anunciada pela associação a mamoas de dólmens de " 1 a geração" de bolsas de terras remobilizadas contendo artefactos atribuíveis ao NA (Ventura, 1998, 1995/1996a, 1995/1996b).

$\mathrm{Na}$ ausência de evidências arqueográficas directas é difícil tirar grandes conclusões sobre as economias alimentares do NA da plataforma do Mondego. Contudo, dadas as características dos solos e o quadro hoje disponível para realidades posteriores, a partir do Neolítico Final (NF - Senna-Martinez, 1995/1996b; Senna-Martinez e Ventura, 2000), a criação da "paisagem neolítica" na nossa área de estudo não parece traduzir uma ocupação agrícola do espaço. Outros elementos que concorrem para tal opinião são: (1) A manutenção da floresta densa de carvalhos nas áreas baixas sem evidência de desbaste (cf. Knaap e Leeuwen, 1994); (2) a quase total ausência de elementos de moagem nos sítios de habitat conhecidos; (3) fraca representação (contrastando com momentos subsequentes) de instrumentos cortantes em pedra polida. Tomados em conjunto os elementos aduzidos permitem argumentar a favor da fraca componente agrícola nas economias regionais do NA. Quanto à pastorícia, quer os dados dos perfis polínicos da Serra da Estrela, quer a presença de ovi- 
caprinos nos sítios do Prazo (Monteiro-Rodrigues, 2000, 2002) e da Fraga d'Aia (Jorge, 1991; Jorge, et al. 1988), são de molde a permitir-nos a hipótese de estes fazerem igualmente parte do "pacote neolítico" nos sítios da Plataforma do Mondego.

A olaria do NA do Outeiro dos Castelos de Beijós bem como a proveniente dos sítios das Carriceiras (CARR), Quinta do Soito (QSOITO), mamoa da Orca 2 do Ameal (ORAM2), BMSR e CPPi - apresenta características que se integram nas tradições do Neolítico Antigo dito "evoluído" quer da área Estremenha Atlântica quer da Andaluzia (Valera, 1998). Tal constatação já nos conduziu a colocar a questão de uma eventual dualidade de origens para o NA da Beira Alta (Senna-Martinez e Ventura, 2008a) (Gráfico 1).

Por outro lado, o estudo dos módulos de debitagem de produtos alongados nos sítios do NA de que existe informação disponível e quantitativamente significante - CARR, ORFOL e conjuntos remobilizados nas mamoas das ORAM2 e 2 de Oliveira do Conde (OROC2) - aponta para uma debitagem de cariz predominantemente micro-laminar (larguras dos suportes inferiores a $11 \mathrm{~mm}$ - Senna-Martinez e Ventura, 2008a), o que aproxima as indústrias líticas destes contextos - em contraciclo com a de COCB$-\mathrm{C}^{12}$ - das dos contextos da Estremadura Atlântica (Gráfico-1), nomeadamente nos casos dos sítios da Gruta do Almonda, Pena de Água (Carvalho, 1998) e S. Pedro de Canaferrim (Simões, 1999).

Em COCB-C estamos perante uma indústria onde predominam os subprodutos de talhe $(89,9 \%)$, indicadores de talhe local e utilização de produtos acabados noutros locais, ou seja configurando uma situação de oficina de talhe, que a associação com a cerâmica aponta para um ambiente de cariz doméstico (povoado/acampamento temporário?). O sítio seria, deste modo, palco de duas estratégias complementares quanto á utilização das matérias-primas disponíveis para o talhe: (1) Uma, centrada na utilização de núcleos sem qualquer predeterminação formal - poliédricos e irregulares - e orientada para

12. Contudo a proporção significativa dos núcleos, fragmentos de núcleo e tabuinhas de reavivagem atribuíveis ao tipo prismático (50\%), podem querer dizer o contrário, i.e. que mesmo predominando lascas e utensílios sobre lasca neste sítio a produção, poderia também aqui, privilegiar o fabrico de suportes alongados, transportados e utilizados noutros locais. a obtenção de lascas; (2) Outra, centrada exclusivamente na utilização de núcleos prismáticos e destinada á obtenção de suportes micro-laminares.

Um cariz mais temporário do estabelecimento em COCB-C justificaria que utensílios e suportes produzidos e ainda em condições de utilização tivessem sido transportados quando este foi abandonado.

Os primeiros casos constatados de remobilização de materiais em terras das mamoas de monumentos megalíticos (casos de ORAM2 e OROC2) seguidos da identificação dos sítios de habitat de ORFOL e ORLL, demonstram que vários dos locais de estabelecimento habitacional do NA serão próximos ou coincidentes com as escolhas de implantação dos primeiros monumentos megalíticos.

Há muito que pensamos que a construção das necrópoles megalíticas no NM e NF regionais - no primeiro caso, os “dólmens de $1^{\underline{a}}$ geração, talvez ainda dentro do primeiro quartel do IV milénio a.C. (Senna-Martinez e Ventura, 2008b), no segundo, os grandes dólmens de corredor desenvolvido, provavelmente ainda dentro do terceiro quartel do IV milénio a.C. (Id., Ibid.) - vem legitimar, pela presença próxima dos antepassados aí enterrados, a reocupação sazonal dos territórios de invernia situados nas terras "baixas" da Plataforma do Mondego (Senna-Martinez, 1995, 1995-1996a, 1996 e 2018; Senna-Martinez e Ventura, 2000, 2008a e 2008b; Senna-Martinez, López Plaza \& Hoskin, 1997).

As reflexões de cariz paleodemográfico produzidas, em estudo recente, por Salvador Pardo-Gordó e António Faustino de Carvalho vêm substanciar a nossa percepção do desenvolvimento do megalitismo, no NM e na nossa região de estudo, como derivado de pressão demográfica sobre recursos disponíveis (Pardo-Gordó e Carvalho, 2020: p.10).

Para o NA e para continuar a citar o estudo acima referido parece-nos particularmente importante a proposta de uma rarefacção regional da população durante o Mesolítico (Id., Ibid.) bem como a constatação de que o Maciço Central divide, de facto, a fachada Atlântica em duas, assimétricas geograficamente - como o demonstrara já Orlando Ribeiro (1945) - mas também do ponto de vista do desenvolvimento do Neolítico.

Ao longo de mais de três décadas de ensino universitário que um de nós (Senna-Martinez, 1995, 2002) desenvolveu a ideia que Orlando Ribeiro demonstrara para Portugal e subjacente a várias das disciplinas leccionadas, de que a Península Ibérica é 
constituída por um mosaico regional cujo desenvolvimento, nomeadamente ao Longo da Pré-História das Sociedades Camponesas (do NA ao Bronze Final), teve velocidades e até processos diferentes em diversos momentos históricos. O processo de neolitização é, certamente, um desses momentos.

Lisboa, Junho de 2020

\section{BIBLIOGRAFIA}

ALARCÃO, J. (1968) - O Domínio Romano em Portugal. Mem Martins. Europa-América.

CARVALHO, A. F. (1998) - Talhe da pedra no Neolítico Antigo do Maciço Calcário das Serras D'Aire e Candeeiros (Estremadura Portuguesa). Um primeiro modelo tecnológico e tipológico. Lisboa. EAM/Colibri. «Textos Monográficos», 2.

CLARKE, D.L. (1978) - Analytical Archaeology. Methuen. Londres. $2^{2}$ Edição, com revisão de R. CHAPMAN.

DINIZ, M. (2007) - O Sítio da Valada do Mato (Évora): Aspectos da Neolitização no interior/sul de Portugal. Lisboa. Instituto Português de Arqueologia. "Trabalhos de Arqueologia», 48 .

JORGE, V. (1991) - Novos dados sobre a Fraga d'Aia (Paredes da Beira - S. João da Pesqueira). Trabalhos de Antropologia e Etnologia. 31 (1-4), pp. 181-184.

JORGE, V. et alli. (1988) - O abrigo com pinturas rupestres da Fraga d'Aia (Paredes da Beira - S. João da Pesqueira) - Notícia preliminar. Arqueologia. 18, pp. 109-130.

MONTEIRO-RODRIGUES, S. (200o) - A estação neolítica do Prazo (Freixo de Numão - Norte de Portugal) no contexto do Neolítico Antigo do Noroeste Peninsular. Algumas considerações preliminares. Neolitização e Megalitismo da Península Ibérica. Porto. ADECAP, pp. 149-168.

MONTEIRO-RODRIGUES, S. (2002) - Estação Pré-Histórica do Prazo - Freixo de Numão - estado actual dos conhecimentos. CôaVisão. Câmara Municipal de Vila Nova de Foz Côa. 4, pp. 113-126.

PARDO-GORDÓ, S. e CARVALHO, A.F. (2020) - Population dynamics during the Neolithic transition and the onset of megalithism in Portugal according to summed probability distribution of radiocarbon determinations. Archaeological and Anthropological Sciences, 12: 129.

PINTO, E. Ed. (2006) - Roteiro do Museu Municipal de Carregal do Sal. Câmara Municipal de Carregal do Sal.

RIBEIRO, O, (1945) - Portugal, o Mediterrâneo e o Atlântico. Lisboa. Sá da Costa

SENNA-MARTINEZ, J. C. (1989) - Pré-História Recente da Bacia do Médio e Alto Mondego: algumas contribuições para um modelo sociocultural. Tese de Doutoramento em
Pré-História e Arqueologia. Universidade de Lisboa. 3 Vols. policopiada.

SENNA-MARTINEZ, J. C. (1993) - O Grupo Baiões/Santa Luzia: contribuições para uma tipologia da olaria. Trabalhos de Arqueologia da EAM. 1, pp. 93-123.

SENNA-MARTINEZ, J. C. (1994) - O habitat do Bronze Final do Outeiro dos Castelos de Beijós (Carregal do Sal): a campanha 1(993). Trabalhos de Arqueologia da EAM. 2, pp. 243-252.

SENNA-MARTINEZ, J. C. (1995) - The Late Prehistory of Central Portugal: a first diachronic view. Katina T. LILIOS, $E d$. The Origins of Complex Societies in Late Prehistoric Iberia. Ann Harbour (Michigan). International Monographs in Prehistory. "Archaeological Series». 8, p. 64-94.

SENNA-MARTINEZ, J. C. (1995/1996a) - O habitat do Bronze Final do Outeiro dos Castelos de Beijós (Carregal do Sal): a campanha 2(994). Trabalhos de Arqueologia da EAM. $3 / 4$, p. $285-292$.

SENNA-MARTINEZ, J. C. (1995-1996b) - Pastores, recolectores e construtores de megálitos na Plataforma do Mondego no IV e III milénios AC: (1) O sítio de Habitat do Ameal-VI. Trabalhos de Arqueologia da EAM. 3/4, pp. 83-122.

SENNA-MARTINEZ, J.C. (1996) - Do espaço doméstico ao espaço funerário: ideologia e cultura material na Pré-História Recente do Centro de Portugal. OPHIUSSA. o, pp. 65-76.

SENNA-MARTINEZ, J.C. (200oa) - O Crasto do Outeiro dos Castelos de Beijós (Carregal do Sal). J.C. SENNA-MARTINEZ \& I. PEDRO, Eds., Por Terras de Viriato: Arqueologia da Região de Viseu. Viseu. Governo Civil do Distrito de Viseu e Museu Nacional de Arqueologia, pp. 144-145.

SENNA-MARTINEZ, J.C. (20oob) - O problema dos primeiros ferros peninsulares em contextos do Bronze Final da Orla Atlântica: os dados do "Outeiro dos Castelos de Beijós» (Carregal do Sal). Trabalhos de Arqueologia da EAM. 6, p. 43-6o.

SENNA-MARTINEZ, J.C. (2002) - Aspectos e Problemas da Investigação da Idade do Bronze em Portugal na segunda metade do século XX. Arqueologia 20oo. Balanço de um século de investigação arqueológica em Portugal. Lisboa. Associação dos Arqueólogos Portugueses, pp. 103-124.

SENNA-MARTINEZ, J.C. (2006) - Do Neolítico Antigo ao Bronze Final. E. PINTO, Ed. Roteiro do Museu Municipal de Carregal do Sal. Câmara Municipal de Carregal do Sal. pp. 48-61.

SENNA-MARTINEZ, J.C. (2018) - A shrine in the Neolithic? Orca da Lapa do Lobo, Nelas (c.5000-300o BC). J. C. SENNA-MARTINEZ, M. DINIZ, e A.F. CARVALHO, Eds. (2018) - De Gibraltar aos Pirenéus. Megalitismo, Vida e Morte na Fachada Atlântica Peninsular. Lapa do Lobo (Nelas). Fundação Lapa do Lobo. pp. 167-181. 
SENNA-MARTINEZ, J. C. e COELHO, M. N. (1994/1988) - O Castro de S. Cosme, os trabalhos de 1987. Informação Arqueológica. Lisboa. IPPC. 9, pp. 55-56.

SENNA-MARTINEZ, J. C., LÓPEZ PLAZA, S. e HOSKIN, M. (1997) - Territorio, ideología y cultura material en el megalitismo de la plataforma del Mondego (Centro de Portugal). O Neolítico Atlántico e as Orixes do Megalitismo. Actas del Coloquio Internacional. Santiago de Compostela. "Cursos e Congresos da Universidade de Santiago de Compostela». 101, pp. 657-676.

SENNA-MARTINEZ, J. C. e Luís, E. (2015) - O Sector B do Habitat do Ameal-VI e o Neolítico Final da Beira Alta. V. Gonçalves, M. Diniz e A.C. Sousa, Eds. Actas do VCongresso do Neolítico Peninsular. Lisboa. Uniarq. «Estudos e Memórias». 8, pp. 151-158.

SENNA-MARTINEZ, J. C.; NASCIMENTO, A. Q.; CARVALHO, A. F. e ALMEIDA, F. (1993) - A ocupação do Bronze Final do Cabeço do Cucão, Pedra Cavaleira (Silgueiros, Viseu): uma primeira análise. Trabalhos de Arqueologia da EAM. 1, pp. 143-147.

SENNA-MARTINEZ, J. C. e NUNES, T. S. (1993) - A ocupação do Bronze Final do Outeiro dos Castelos (Beijós): uma primeira análise. Trabalhos de Arqueologia da E.A.M. 1, pp. 137-141.

SENNA-MARTINEZ, J. C. \& PEDRO, I. Eds. (200o) - Por Terras de Viriato: Arqueologia da Região de Viseu. Viseu. Governo Civil do Distrito de Viseu e Museu Nacional de Arqueologia.

SENNA-MARTINEZ, J. C.; ROCHA, L. \& RAMOS, R. P. (1993) - A ocupação do Bronze Final da Malcata (Carregal do Sal): uma primeira análise. Trabalhos de Arqueologia da EAM.1, pp. 149-154.

SENNA-MARTINEZ, J. C. \& VENTURA, J. M. Q. (1999) - Espaço Funerário e "Espaço Cénico: a Orca do Folhadal (Nelas). Trabalhos de Arqueologia da EAM. 5, pp. 21-34.

SENNA-MARTINEZ, J. C. \& VENTURA, J. M. Q. (200o) - Os Primeiros Construtores de Megálitos. J. C. SENNA-MARTINEZ \& I. PEDRO, Eds. Por Terras de Viriato: Arqueologia da Região de Viseu. Viseu: Governo Civil do Distrito de Viseu e Museu Nacional de Arqueologia, pp. 35-38.

SENNA-MARTINEZ, J. C. e VENTURA, J. M. Q. (2008a) - Neolitização e Megalitismo na Plataforma do Mondego: Algumas Reflexões sobre a Transição Neolítico Antigo/ Neolítico Médio. Actas do IV Congreso del Neolítico en la Península Ibérica. Alicante. Tomo II, p. 77-84.

SENNA-MARTINEZ, J. C. e VENTURA, J. M. Q. (2008b) - Do mundo das sombras ao mundo dos vivos: Octávio da Veiga Ferreira e o megalitismo da Beira Alta, meio século depois. Homenagem a Octávio da Veiga Ferreira. Estudos Arqueológicos de Oeiras. Oeiras. Câmara Municipal. 16, pp. 317-350.
SIMÕES, T. (1999) - O sítio neolítico de São Pedro de Canaferrim, Sintra. Lisboa. Instituto Português de Arqueologia. "Trabalhos de Arqueologia», 12.

VALERA, A. C. (1997) - O Castro de Santiago (Fornos de Algodres, Guarda). Aspectos da calcolitização da bacia do alto Mondego. Lisboa. EAM/Colibri. «Textos Monográficos», I.

VALERA, A.C. (1998) - A Neolitização da Bacia Interior do Mondego. Actas do Colóquio A Pré-História da Beira Interior. Estudos Pré-Históricos. Viseu. 6, pp. 131-148.

VALERA, A. C. (2002-2003) - Problemas da neolitização da Bacia Interior do Mondego a propósito de um novo contexto: A Quinta da Assentada, Fornos de Algodres. Estudos Pré-Históricos. Viseu. 10-11, pp. 5-29.

VENTURA, J. M. Q. (1995/1996a) - A Orca 2 do Ameal (Oliveira do Conde, Carregal do Sal): a campanha 3(994), Trabalhos de Arqueologia da EAM. 3/4, pp. 271-276.

VENTURA, J. M. Q. (1995/1996b) - A Orca 2 de Oliveira do Conde (Carregal do Sal): a campanha 1(994). Trabalhos de Arqueologia da EAM. 3/4, pp. 277-280.

VENTURA, J. M. Q. (1998) - A Necrópole Megalítica do Ameal, no contexto do Megalitismo da Plataforma do Mondego, Dissertação de Mestrado em Pré-História e Arqueologia apresentada à Faculdade de Letras da Universidade de Lisboa. 


\section{Neolítico Antigo \\ Produtos alongados em bruto e retocados}

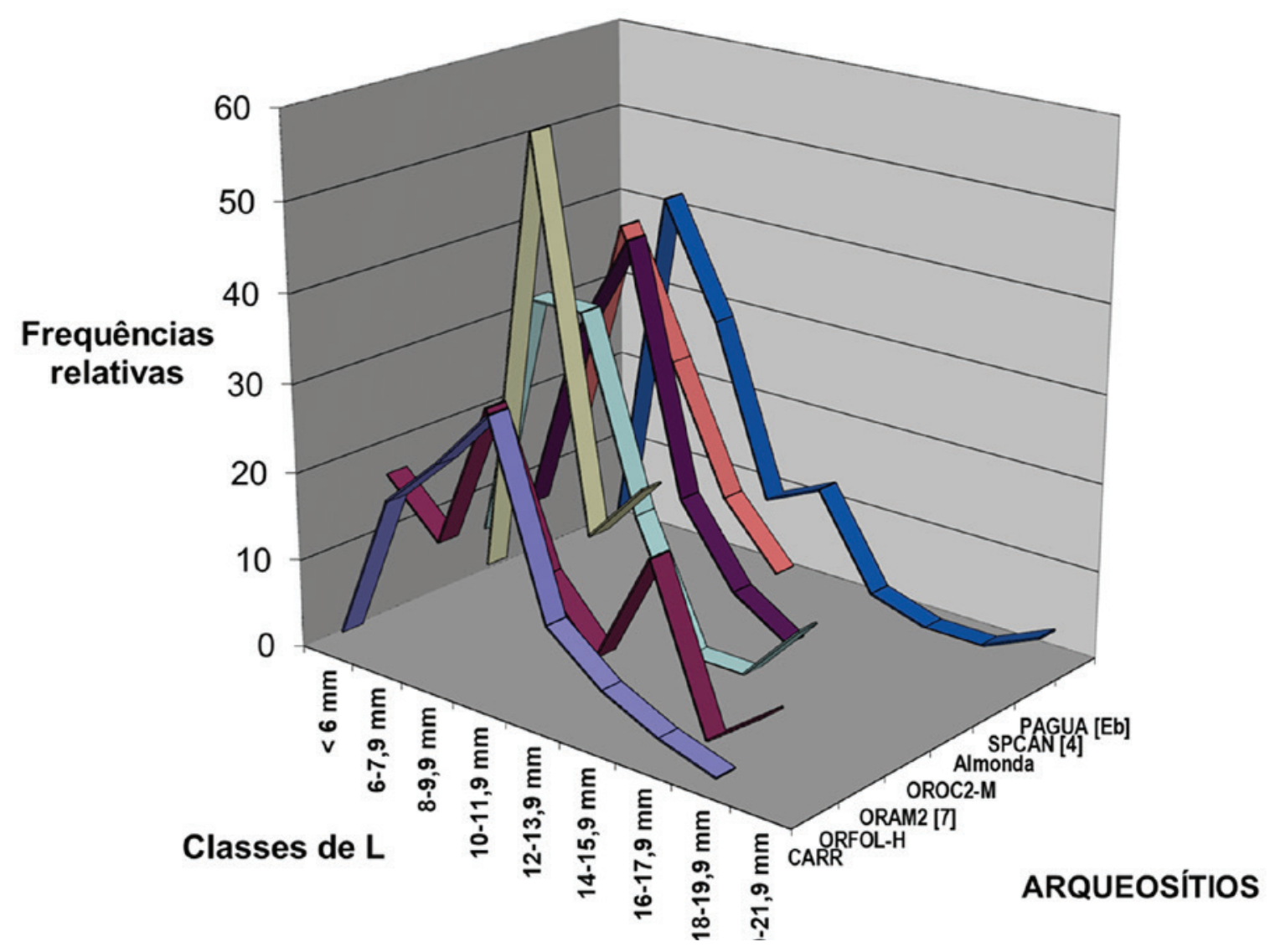

Gráfico 1 - Largura de produtos alongados. 


\begin{tabular}{|c|c|c|c|c|c|c|c|c|c|}
\hline Camp. & Sect. & № & $\mathbf{Q}$ & UE & $x$ & $\mathbf{Y}$ & $\mathrm{Z}$ & Descrição & Obs. \\
\hline $5(1999)$ & C & 2000 & H5 & 0 & 0,38 & 0,06 & $-1,99$ & Frgm. c/dec. & \\
\hline $5(1999)$ & C & 2004 & F1 & $0 / 1$ & 0,58 & 0,51 & $-2,66$ & Frgm. c/dec. & \\
\hline $5(1999)$ & C & 2008 & $\mathrm{H} 2$ & 0 & 0,87 & 0,72 & $-2,64$ & Frgm. bordo $\mathrm{c} / \mathrm{dec}$. & \\
\hline $5(1999)$ & C & 2046 & G1 & 0 & & & & Frgm.c/dec. & \\
\hline $5(1999)$ & C & 2068 & $*$ & $\mathrm{~S}$ & * & * & * & Frgm. bordo $\mathrm{c} / \mathrm{dec}$. & \\
\hline $5(1999)$ & C & 2069 & $*$ & $\mathrm{~S}$ & * & $*$ & * & Frgm. bordo $\mathrm{c} / \mathrm{dec}$. & \\
\hline $6(2000)$ & C & 2070 & Bloco topo Sector & 2 & * & * & * & Frgm. bordo $\mathrm{c} / \mathrm{dec}$. & \\
\hline $6(2000)$ & C & 2071 & Bloco topo Sector & 2 & * & * & * & Frgm.c/dec. & $=2134$ \\
\hline $6(2000)$ & $\mathrm{B} / \mathrm{C}$ & 2134 & $*$ & $\mathrm{~S}$ & * & * & * & Frgm. bordo $\mathrm{c} / \mathrm{dec}$. & $=2071$ \\
\hline $6(2000)$ & $C$ & 2072 & Bloco topo Sector & 2 & * & * & * & Frgm.c/dec. & \\
\hline $6(2000)$ & C & 2073 & Bloco topo Sector & 2 & * & * & * & Frgm. c/dec. & \\
\hline $6(2000)$ & C & 2116 & F8 & 0 & * & $*$ & * & Frgm. c/dec. & \\
\hline $6(2000)$ & $\mathrm{B} / \mathrm{C}$ & 2133 & * & $\mathrm{S}$ & * & $*$ & * & Frgm. c/dec. & \\
\hline $6(2000)$ & $\mathrm{B} / \mathrm{C}$ & 2135 & * & $\mathrm{s}$ & $*$ & $*$ & * & Frgm. c/dec. & \\
\hline $6(2000)$ & $B / C$ & 2136 & * & $S$ & * & * & * & Frgm. c/dec. & \\
\hline $5(1999)$ & $C$ & 2140 & * & $\mathrm{S}$ & * & * & * & Frgm. c/dec. & \\
\hline $5(1999)$ & C & 2141 & $*$ & $\mathrm{~S}$ & * & * & * & Frgm. c/dec. & \\
\hline $5(1999)$ & C & 2142 & * & $\mathrm{S}$ & * & * & * & Frgm. c/dec. & \\
\hline
\end{tabular}

Tabela 1 - Outeiro dos castelos de Beijós. Olaria da Ocupação do Neolítico Antigo.

\begin{tabular}{|c|c|c|c|c|c|c|c|c|}
\hline \multirow{2}{*}{ Tipo } & \multirow{2}{*}{$\begin{array}{l}\text { Quartzo } \\
\text { Leitoso }\end{array}$} & \multirow{2}{*}{$\left|\begin{array}{c}\text { Quartzo } \\
\text { Hialino }\end{array}\right|$} & \multirow{2}{*}{ Ágata } & \multirow{2}{*}{$\begin{array}{c}\text { Calcário } \\
\text { Silicificado }\end{array}$} & \multirow{2}{*}{ Anfibolito } & \multirow{2}{*}{$\begin{array}{l}\text { Silex/ } \\
\text { /Afins }\end{array}$} & \multicolumn{2}{|c|}{ Total } \\
\hline & & & & & & & $\mathrm{n}$ & $\%$ \\
\hline Material de debitagem & & & & & & & 30 & 33,7 \\
\hline Lascas e fragmentos & 20 & 2 & & & 1 & 7 & 30 & 33,7 \\
\hline & & & & & & & & \\
\hline Mat.de reavivagem & & & & & & & 17 & 19,1 \\
\hline Flancos & 8 & 1 & & & & 3 & 12 & 13,5 \\
\hline Tabuinhas de reavivagem & 4 & & & & & 1 & 5 & 5,6 \\
\hline Núcleos e fragmentos & 29 & & & & & 2 & 31 & 34,8 \\
\hline & & & & & & & & \\
\hline Percutores e fragmentos & 2 & & & & & & 2 & 2,3 \\
\hline & & & & & & & & \\
\hline Utensílios & & & & & & & 9 & 10,1 \\
\hline Geométricos - Crescentes & 1 & 1 & & & & & 2 & 2,3 \\
\hline Geométricos - Triângulo & 1 & & & & & & 1 & 1,1 \\
\hline Buril & 1 & & & & & & 1 & 1,1 \\
\hline UAD & 1 & & & & & & 1 & 1,1 \\
\hline Raspador circular côncavo & & & 1 & & & & 1 & 1,1 \\
\hline Denticulado & 1 & & & & & & 1 & 1,1 \\
\hline Lamelas retocadas & & 1 & & & & 1 & 2 & 2,3 \\
\hline SUB-TOTAL & 68 & 5 & 1 & 1 & 1 & 14 & 89 & \\
\hline TOTAIS & 76,4 & 5,6 & 1,1 & 1,1 & 1,1 & 15,7 & & 100 \\
\hline
\end{tabular}

Tabela 2 - Outeiro dos Castelos de Beijós. Indústria Lítica. 


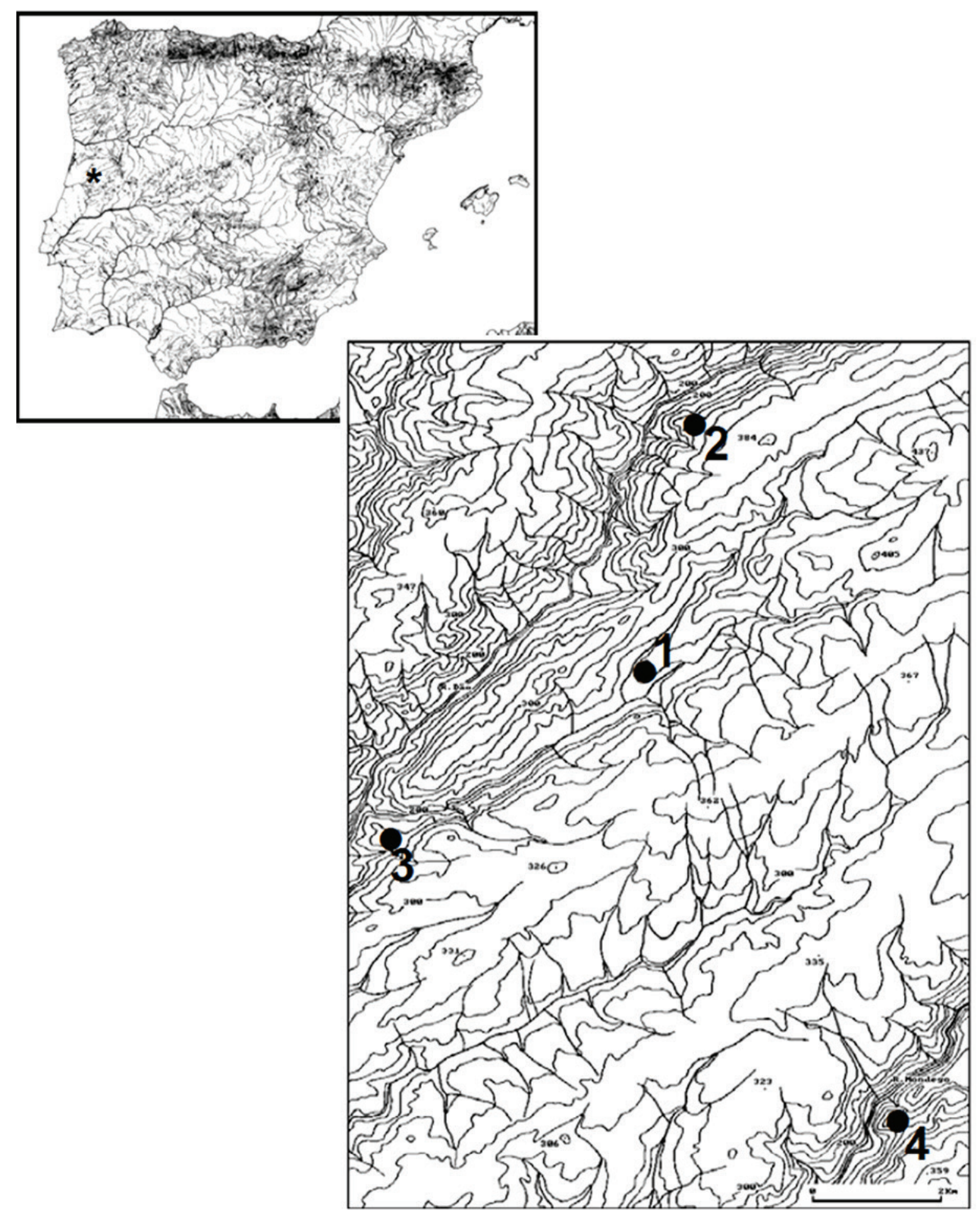

Figura 1 - Localização de COCB na Península Ibérica e na Plataforma do Mondego. 1- COCB; 2- CCPC; 3. Malcata. 


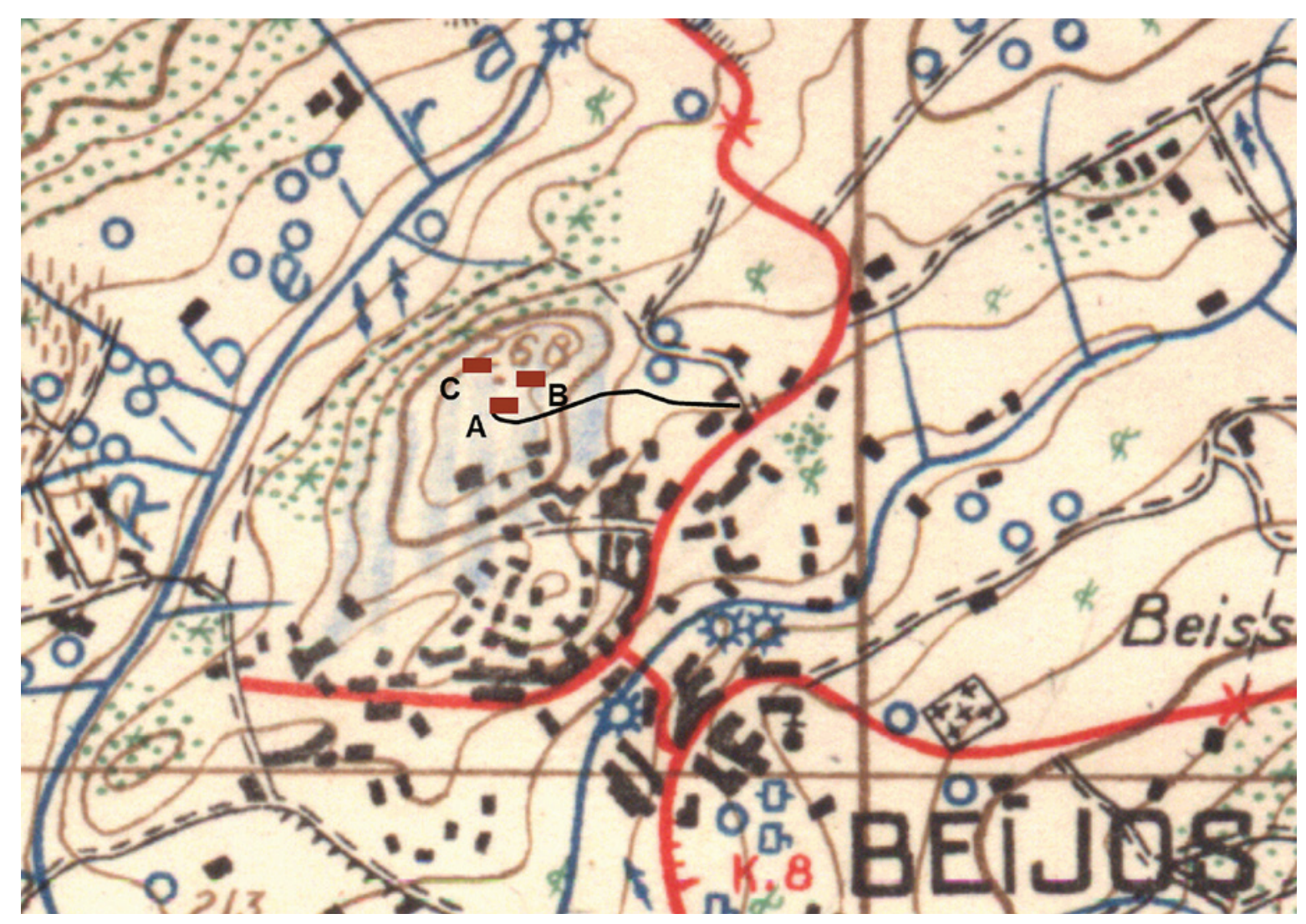

Figura 2 - COCB. Localização dos Sectores escavados na CMP 1:2500o, folha 199.

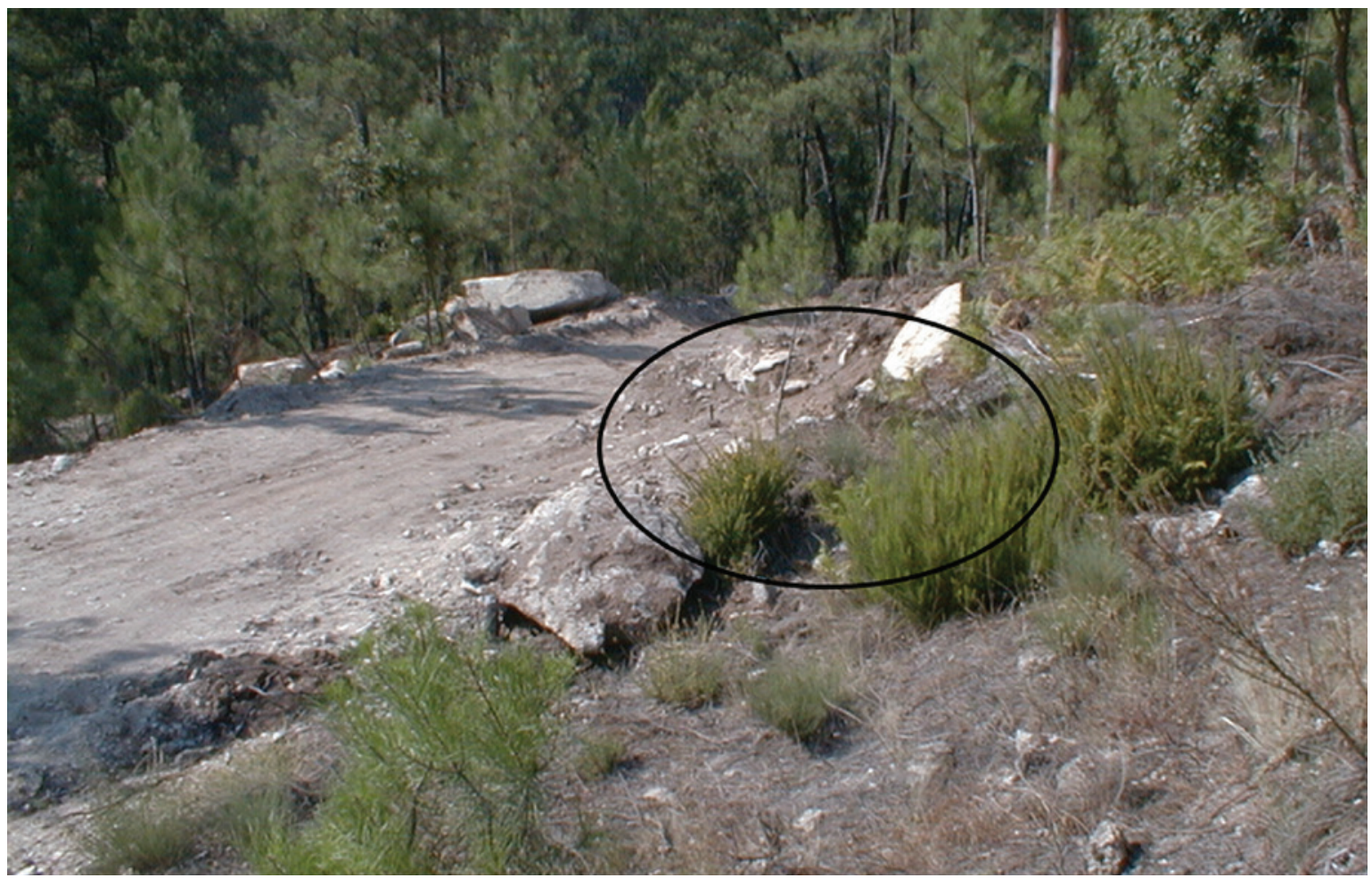

Figura 3 - COCB-C. Topo do Sector com o bloco de terra virado pela máquina assinalado. 


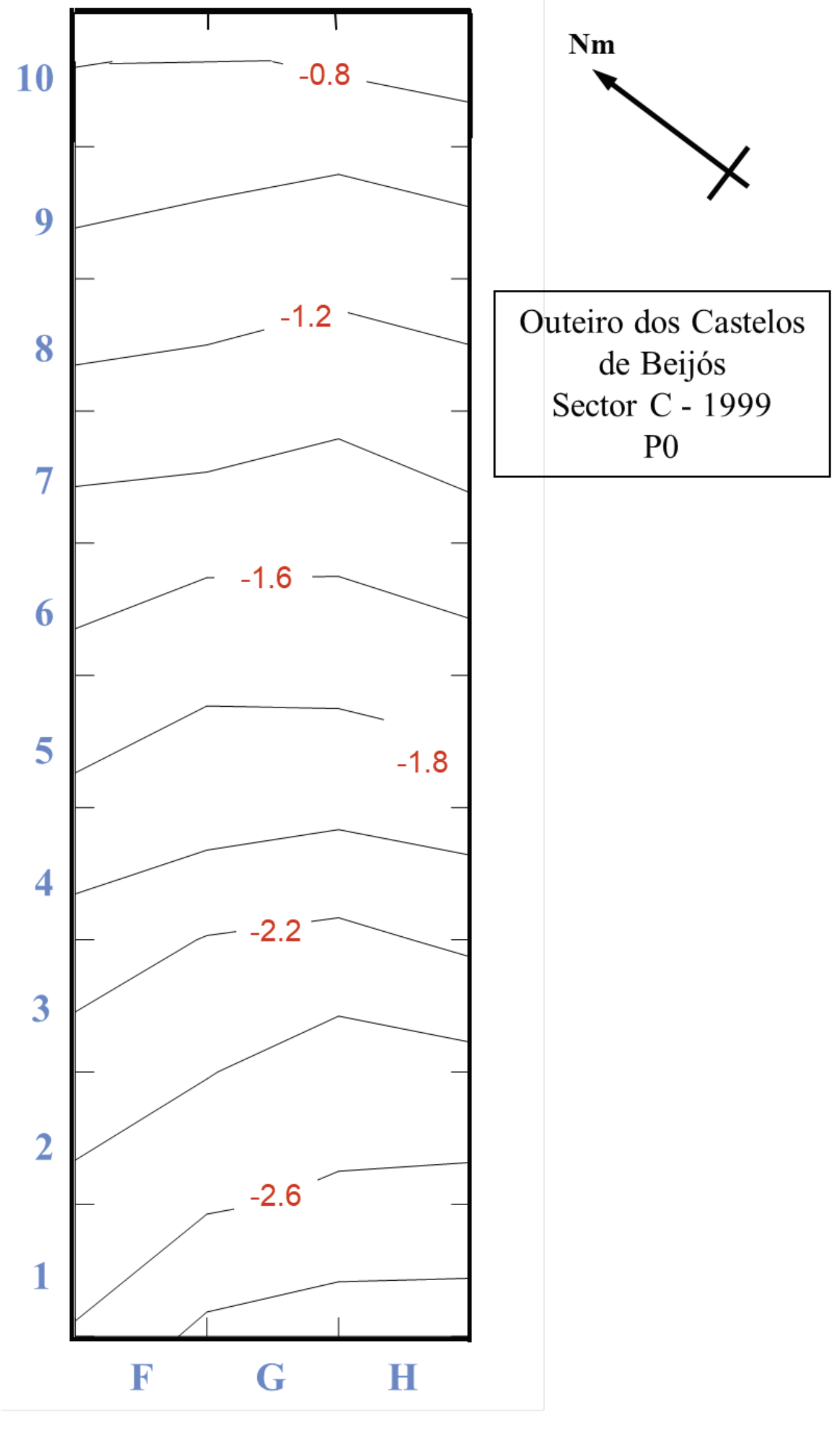

Figura 4-COCB-C. Topografia superficial do Sector C. 


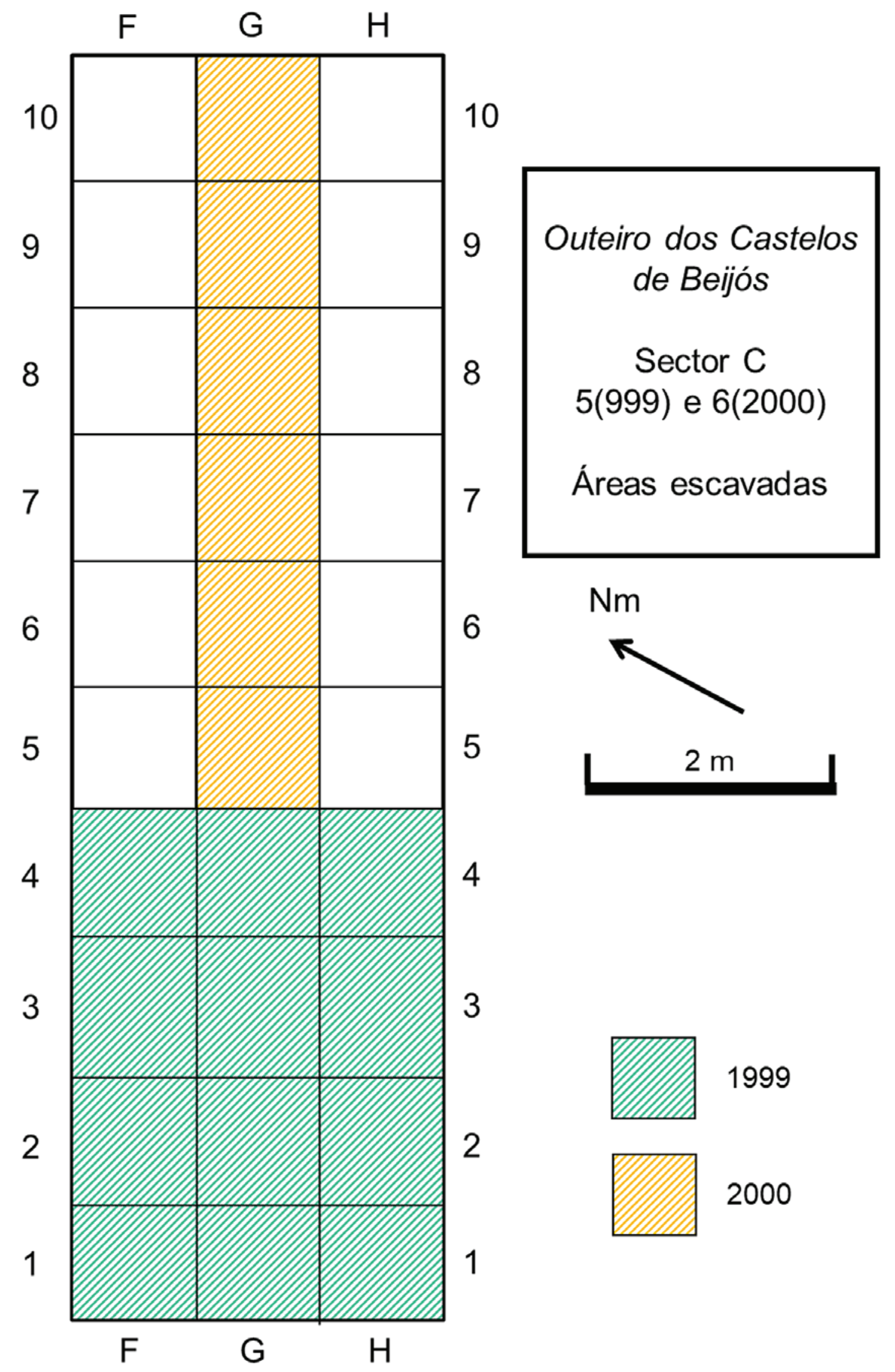

Figura 5-COCB-C. Áreas escavadas nas Campanhas de 1999 e 2000. 


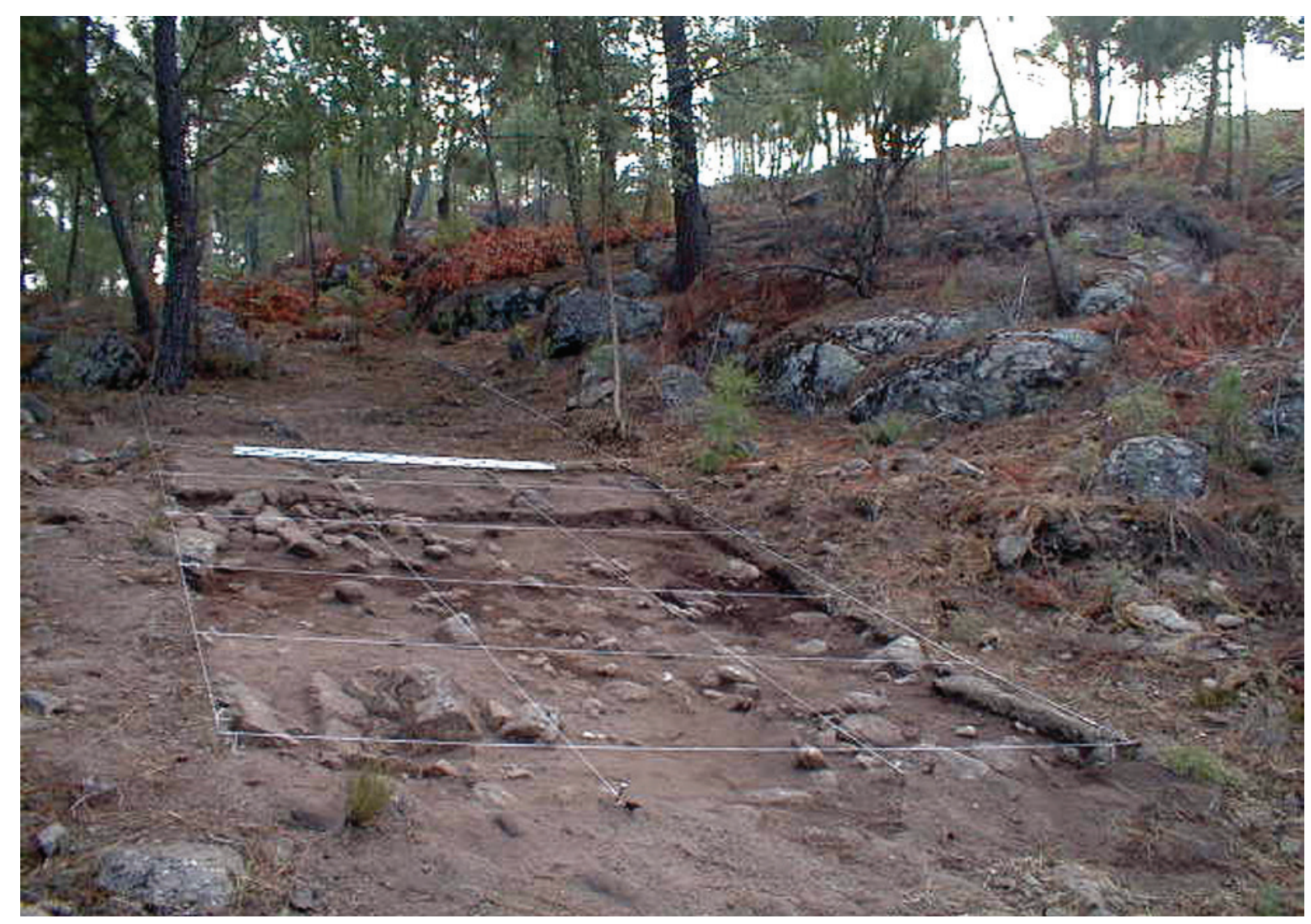

Figura 6 - COCB-C. Campanha de 1999 - Topo da unidade estratigráfica [1].

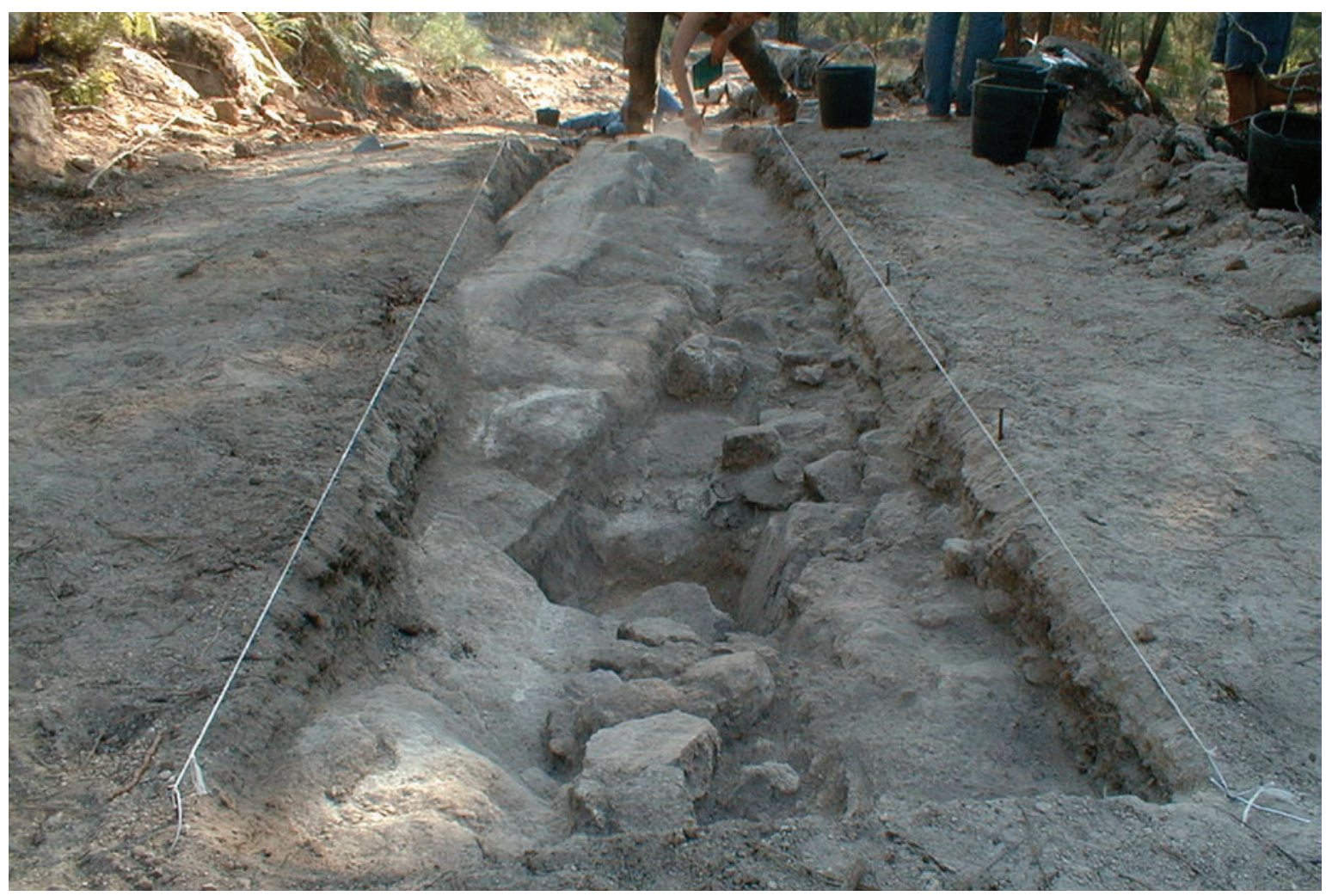

Figura 7 - COCB-C. Campanha de 200o. Início da escavação da parte superior da vala de sondagem com os granitos alterados já à vista. 


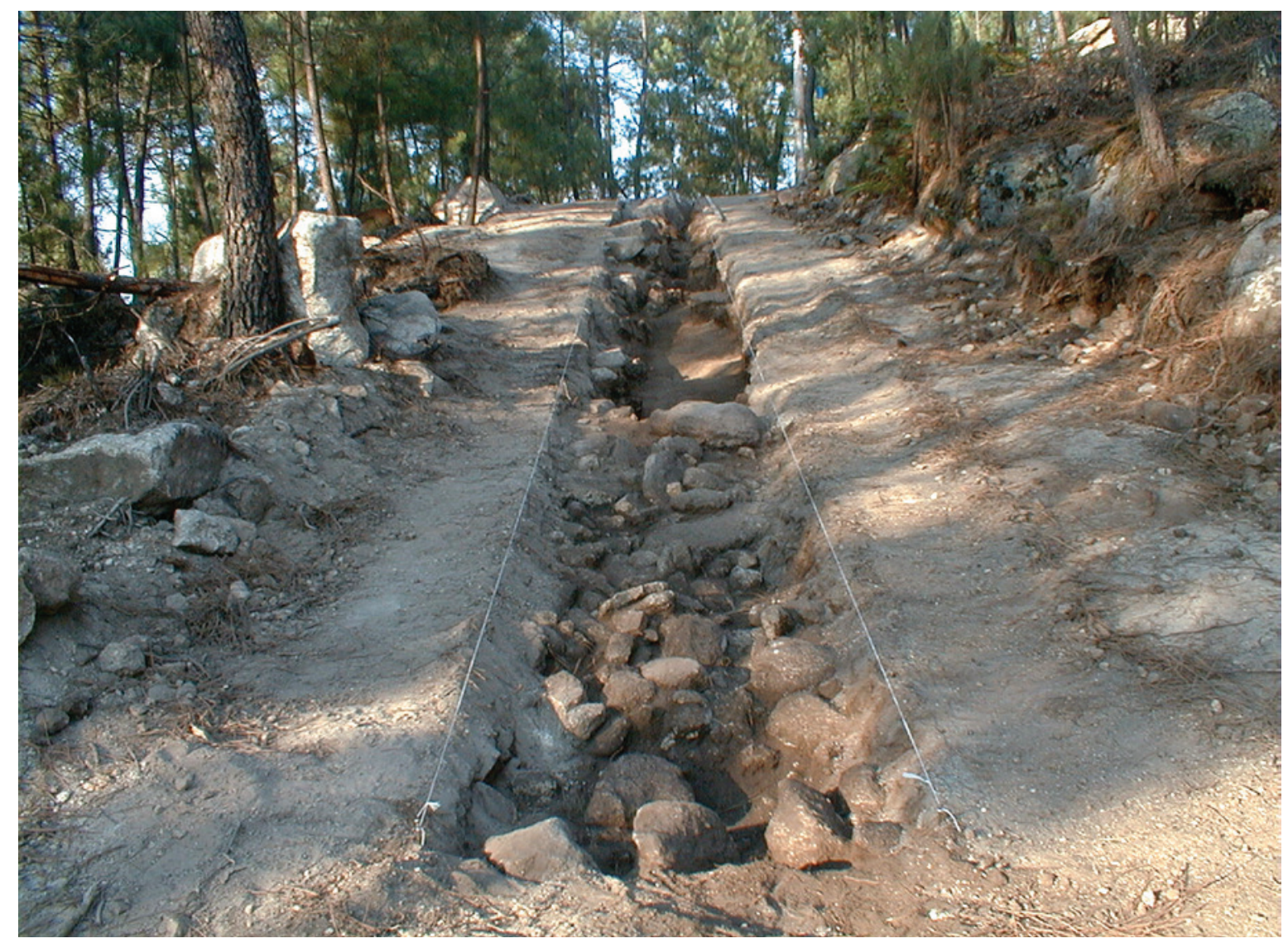

Figura 8 - COCB -C. Campanha de 200o. Final da escavação da vala de sondagem com granitos alterados à vista. 


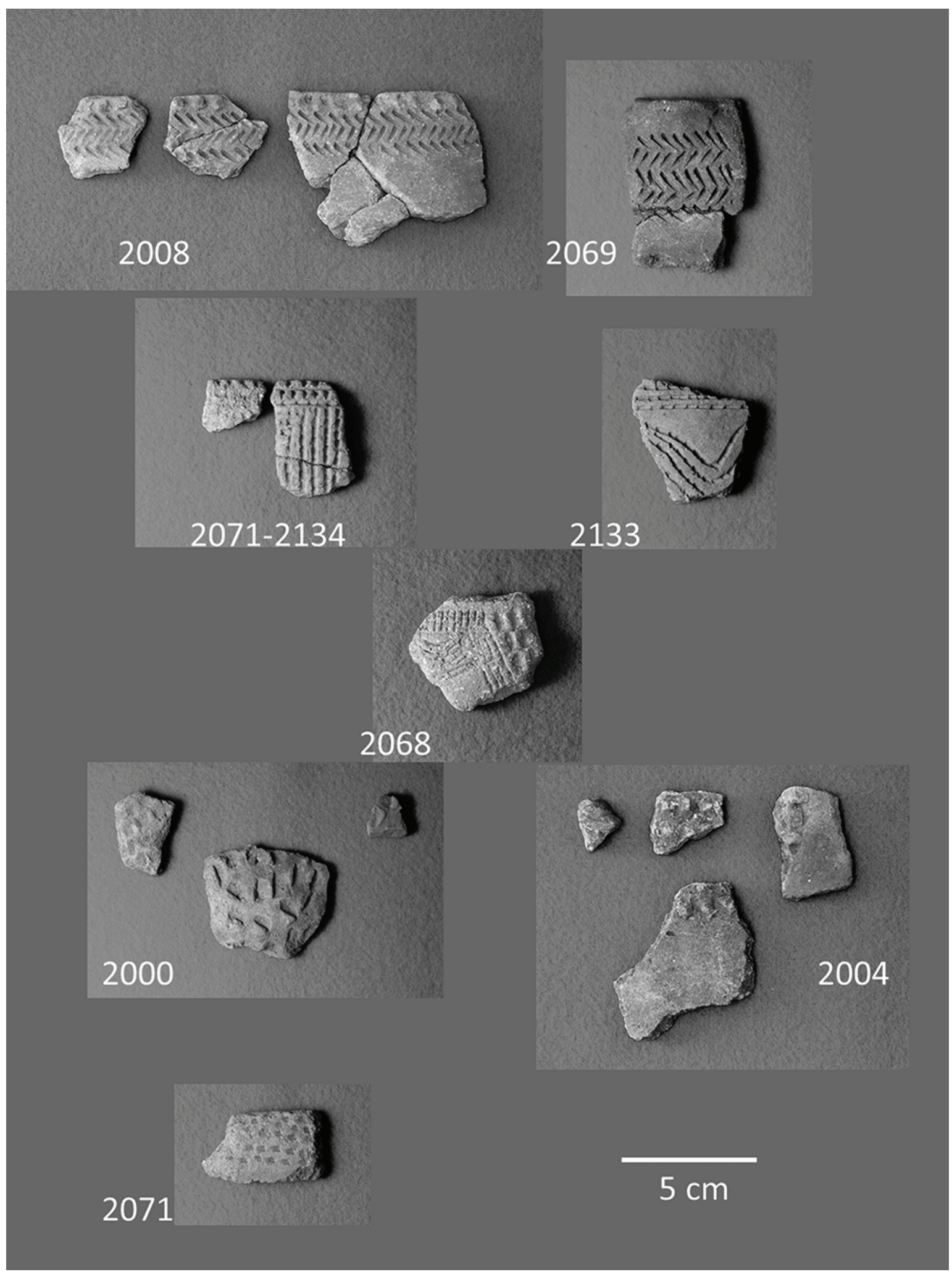

Figura 9-COCB-C. A olaria decorada do NA. 


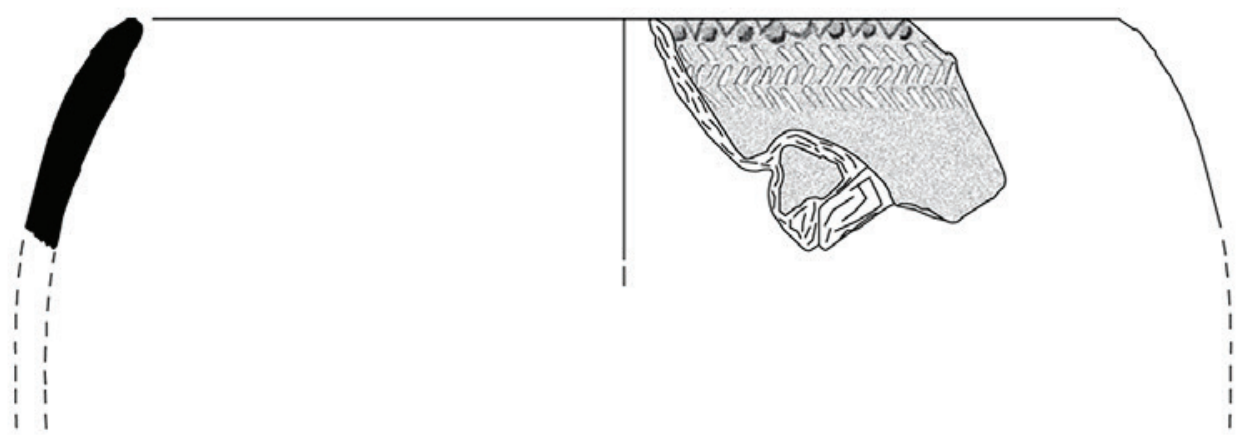

\section{$5 \mathrm{~cm}$}

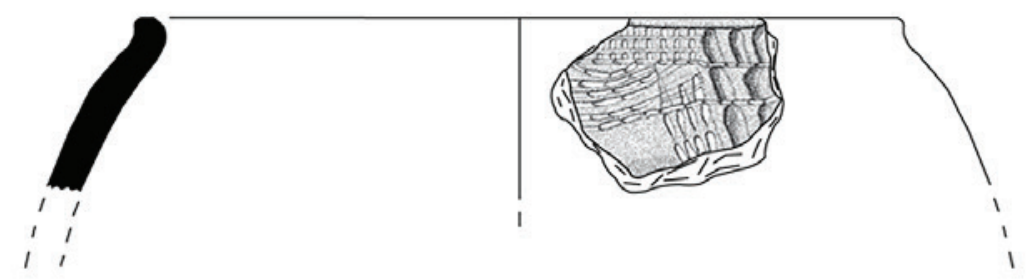

2068

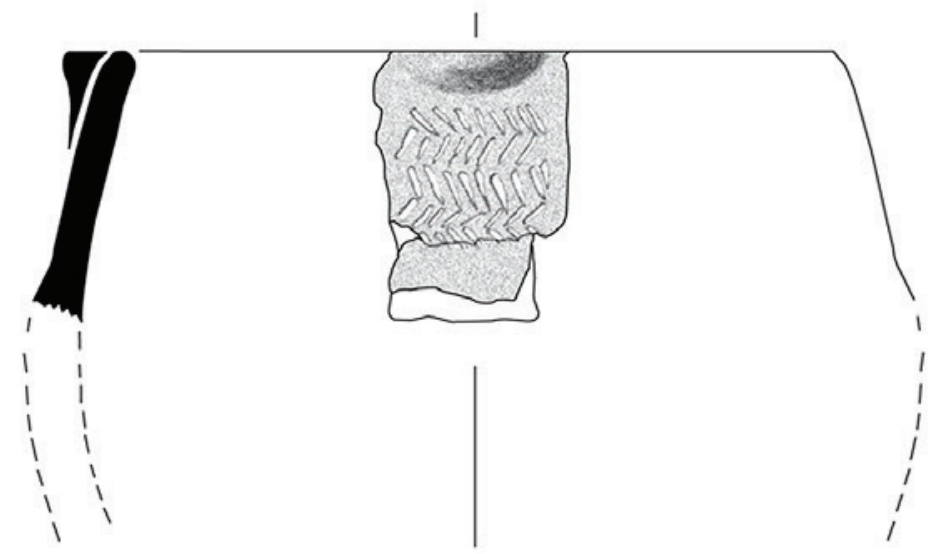

2069

Figura 10 - COCB-C. Recipientes reconstituídos graficamente do NA. 

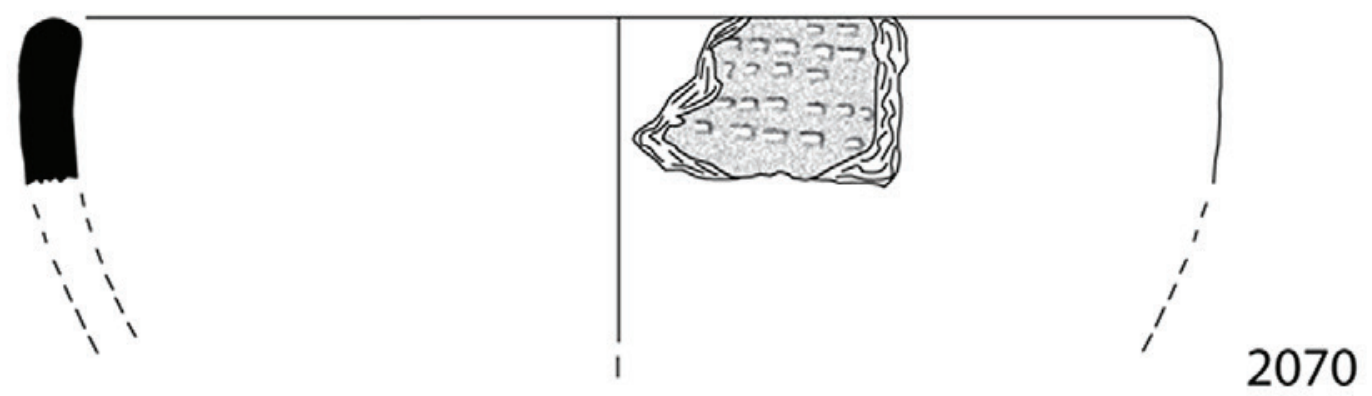

\section{$5 \mathrm{~cm}$}

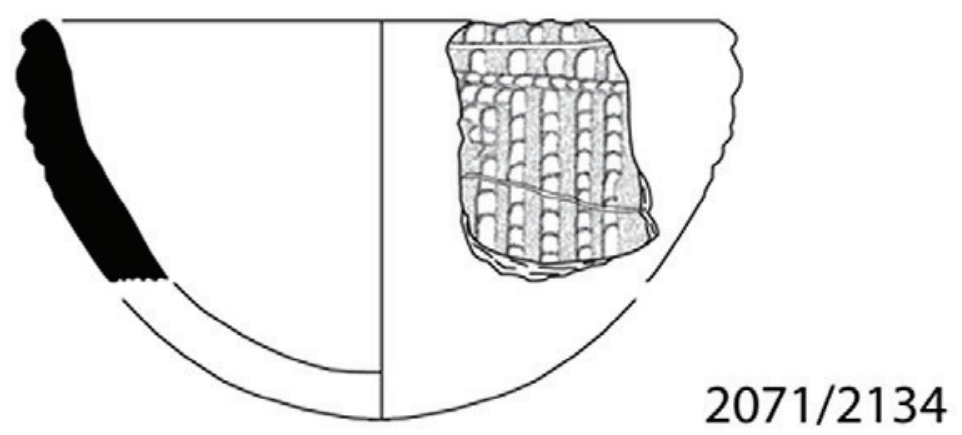

Figura 11 - COCB-C. Recipientes reconstituídos graficamente do NA. 


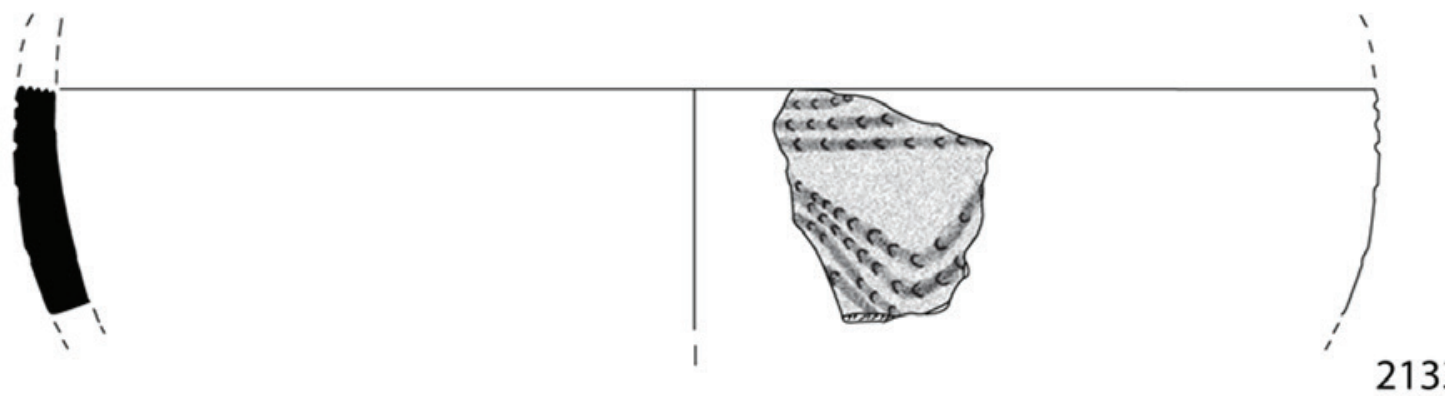

$5 \mathrm{~cm}$
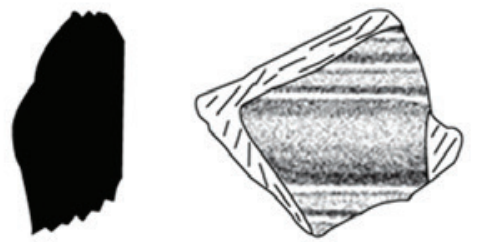

2142
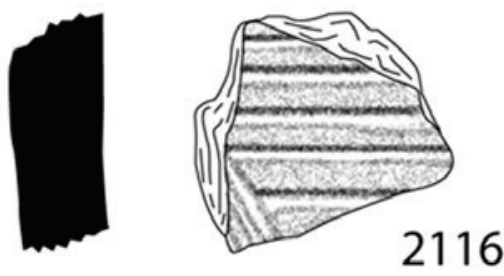

$5 \mathrm{~cm}$

Figura 12 - COCB-C. Olaria do NA. 

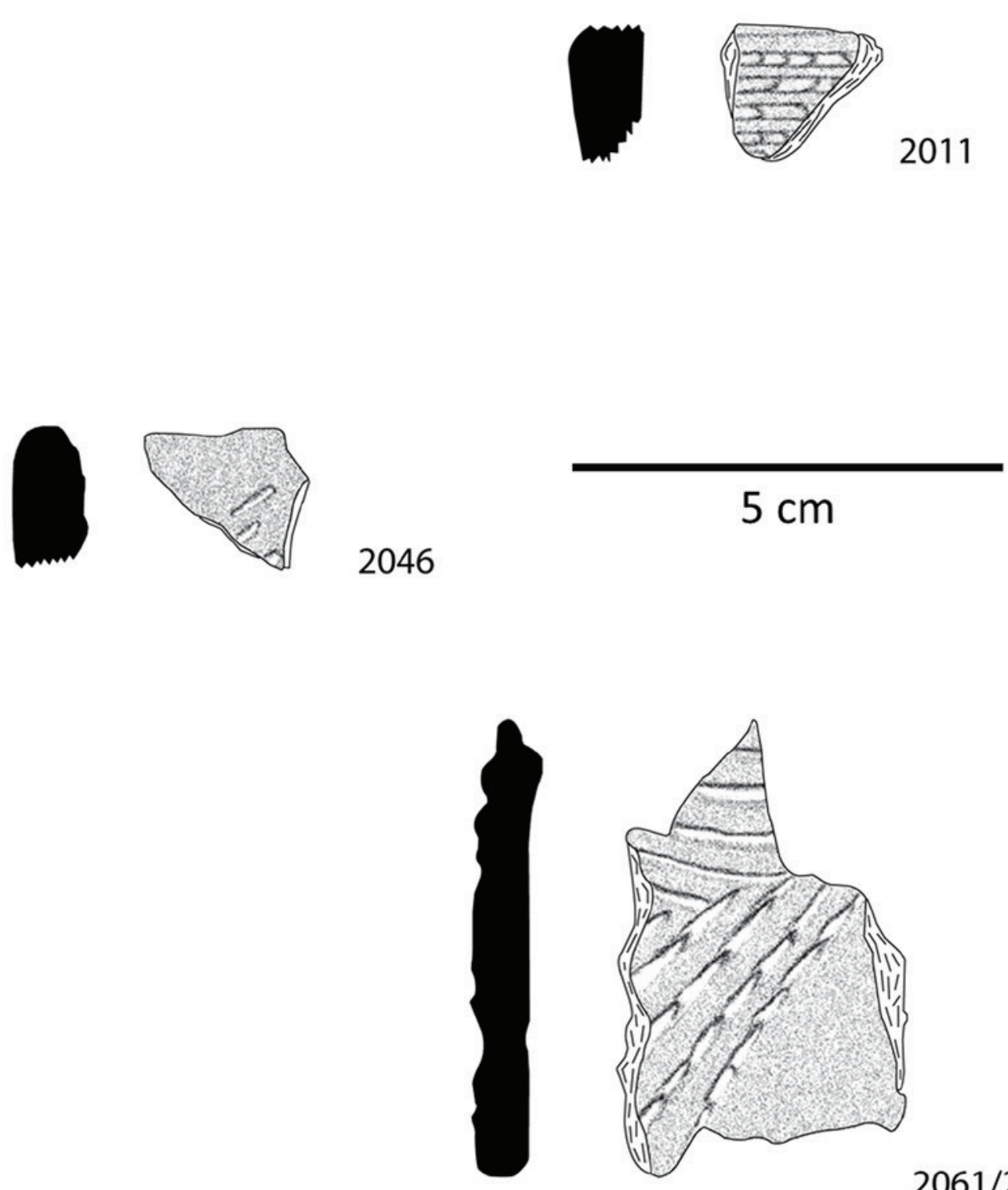

$2061 / 2062$

Figura 13 - COCB-C. Olaria do NA (2011 e 2046) e do Bronze Final (2061/2062), ilustrando diferenças na técnica de boquique. 


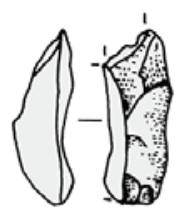

2124

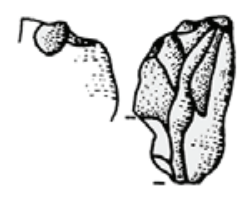

2029

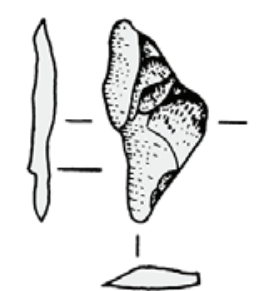

2127

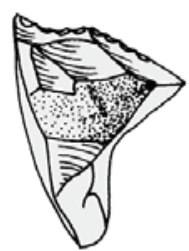

2076

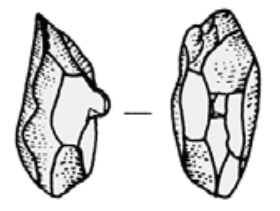

2125
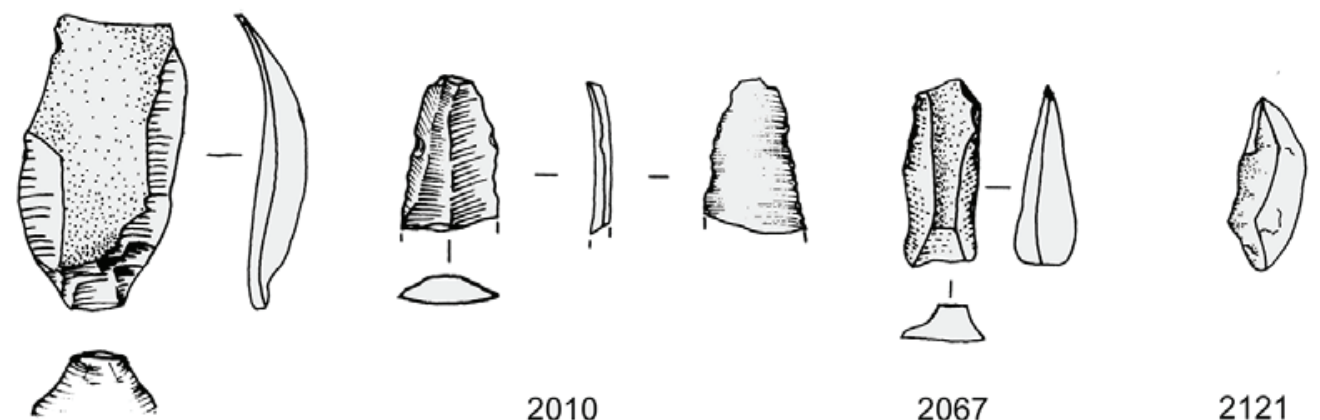

2067

2121
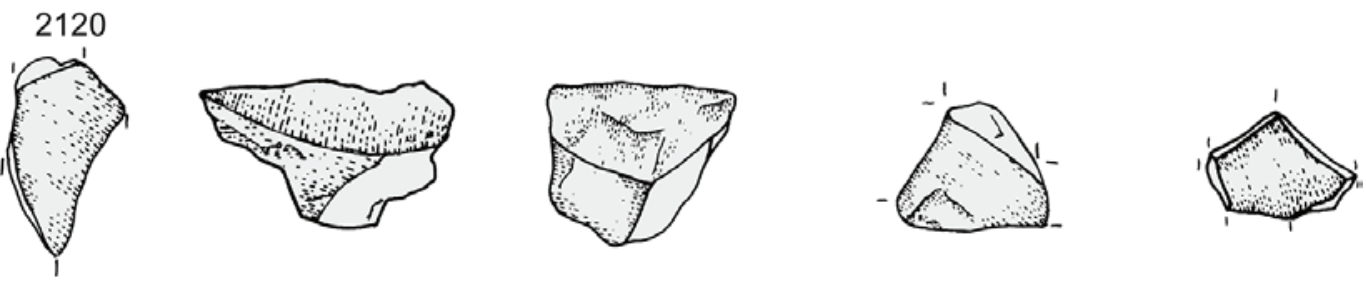

2126

2085

2082

2063

2027
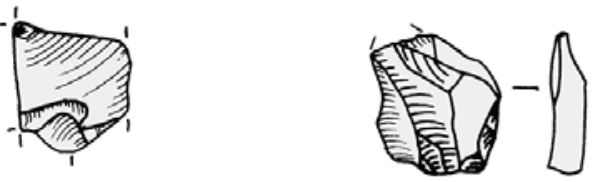

2099

2045

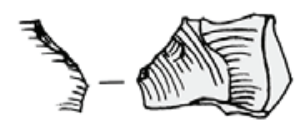

2130

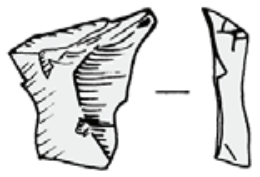

2064

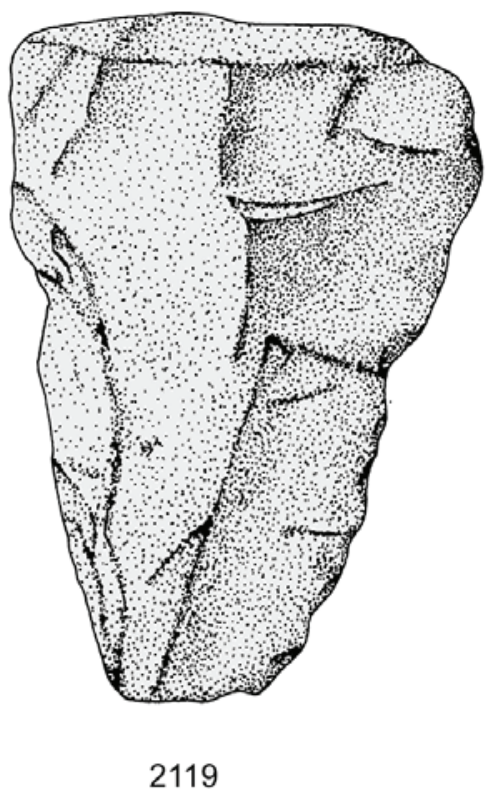

Figura 14-COCB-C. Indústria lítica. 


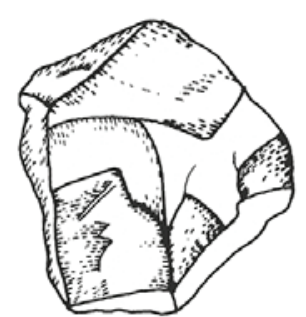

2017

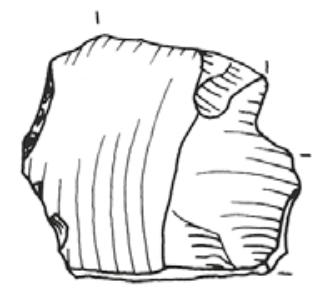

2074

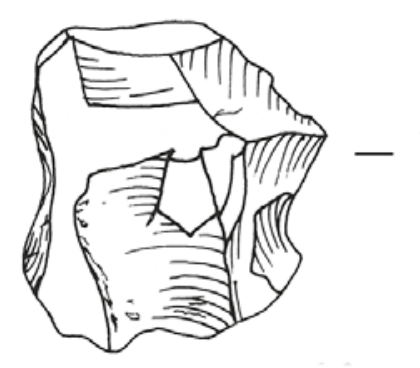

2100

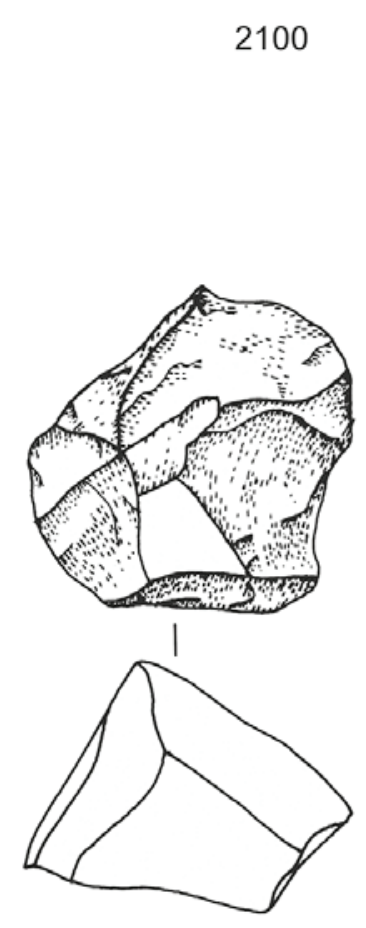

2129

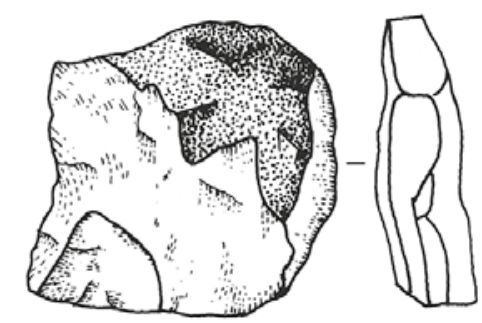

2077
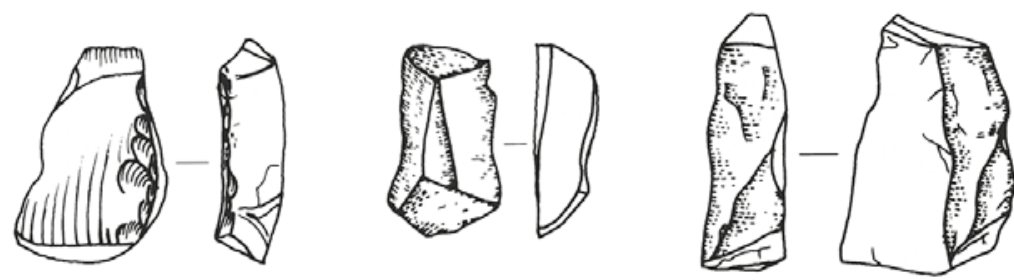

2097
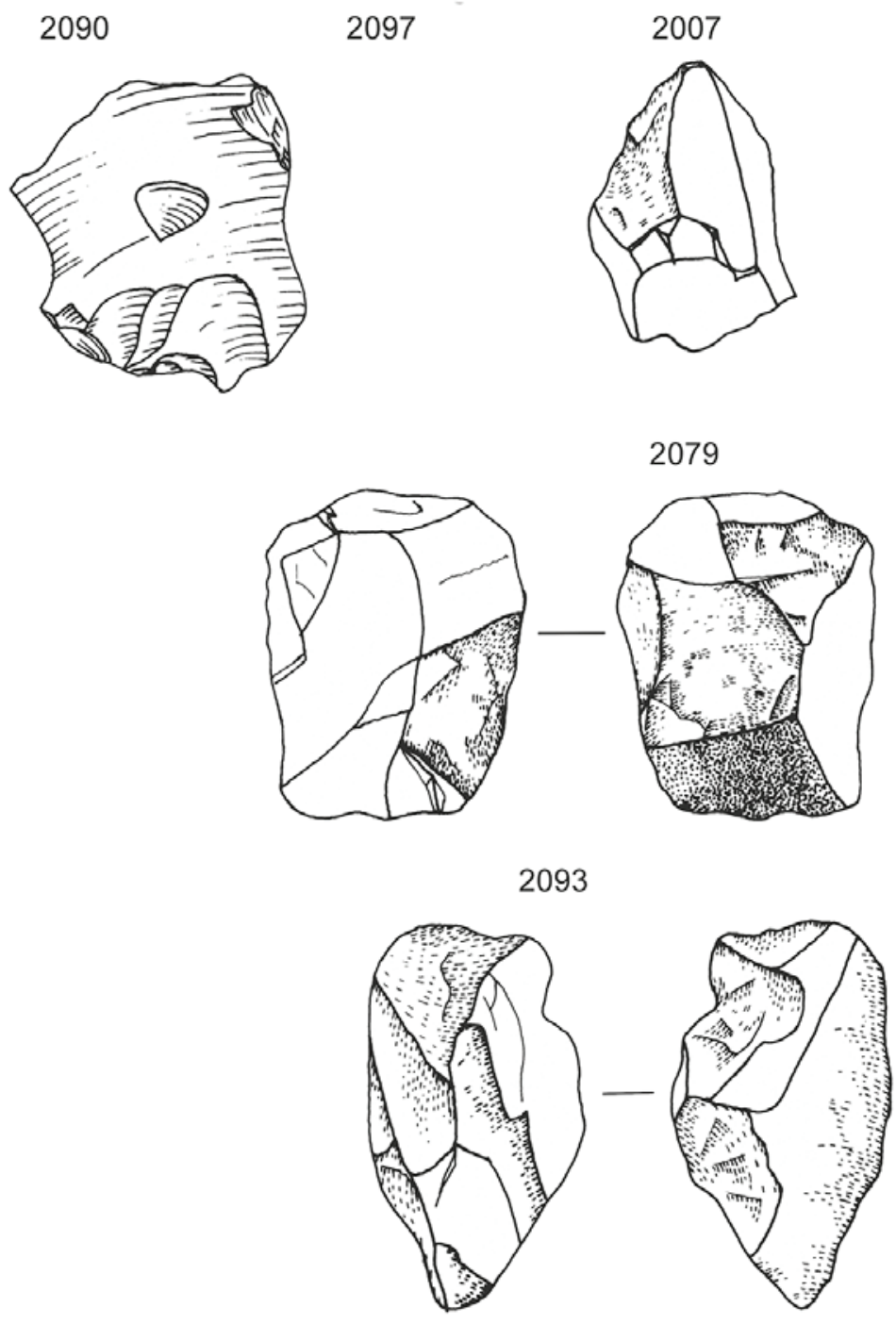

2101

Figura 15-COCB-C. Indústria lítica. Núcleos e material de reavivagem. 


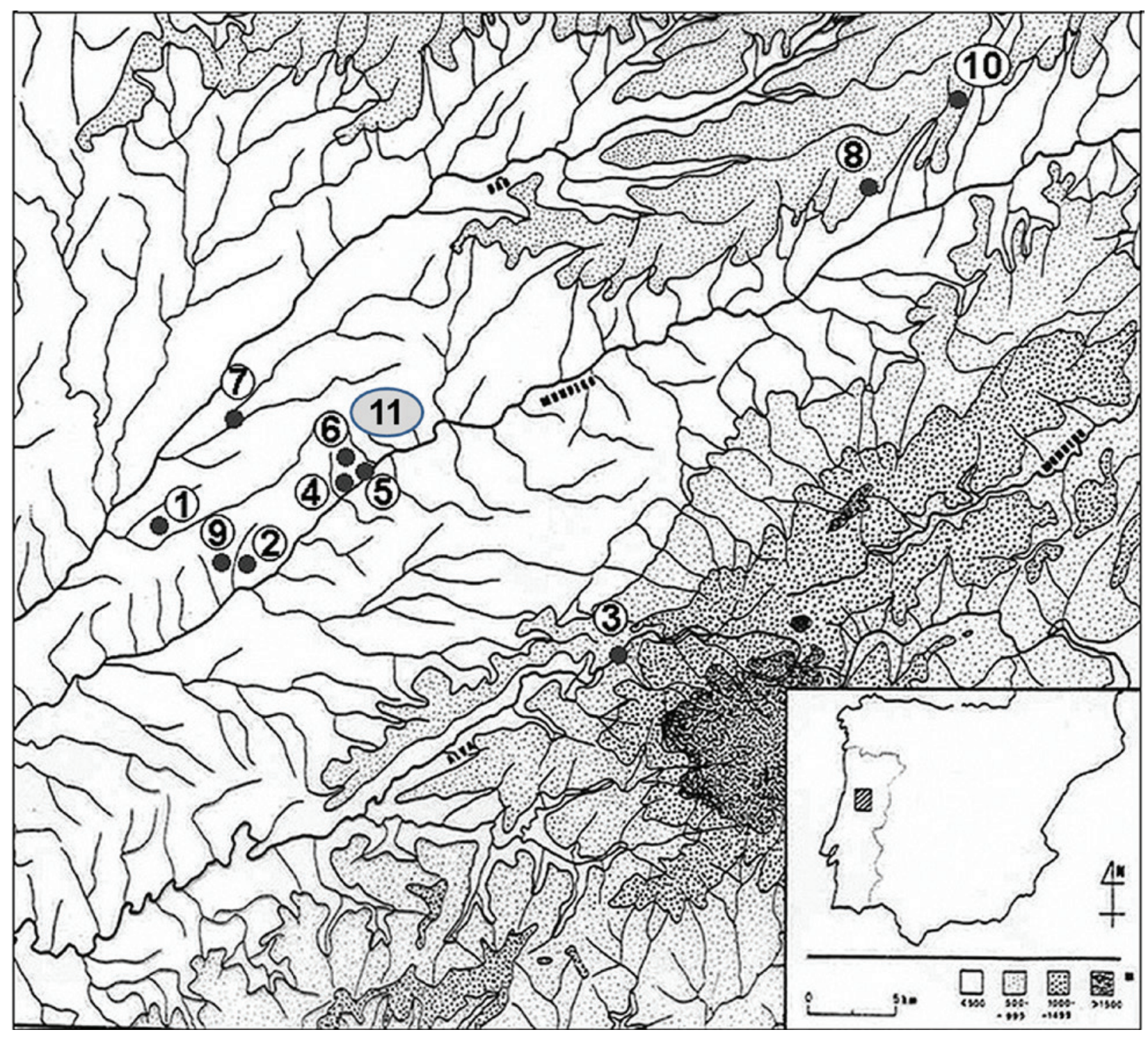

Figura 16 - Localização dos sítios do Neolítico Antigo na Plataforma do Mondego (sg. VALERA, 2003 - Modificado): 1 - Carriceiras; 2 - Mamoa da Orca 2 do Ameal; 3 - Buraco da Moura de S. Romão; 4 - Penedo da Penha; 5- Quinta do Soito; 6 - Habitat do Folhadal; 7 - Outeiro dos Castelos de Beijós; 8 - Quinta da Assentada; 9 - Mamoa da Orca 2 de Oliveira do Conde; 10 Quinta das Rosas; 11 - Habitat da Lapa do Lobo. 


\title{
NOVOS TRABALHOS NA LAPA DA BUGALHEIRA (ALMONDA, TORRES NOVAS)
}

Filipa Rodrigues ${ }^{1}$, Pedro Souto $^{2}$, Artur Ferreira ${ }^{2}$, Alexandre Varanda $^{1}$, Luís Gomes $^{1}$, Helena Gomes $^{2}$, João Zilhão ${ }^{1,3,4}$

\begin{abstract}
RESUMO
Apresentam-se os dados obtidos no primeiro ano das escavações arqueológicas realizadas na Lapa da Bugalheira (Almonda, Torres Novas) ao abrigo do projecto de investigação ARQEVO.

Esta intervenção permitiu reconhecer uma ocupação enquadrada no Neolítico Antigo, com um conjunto artefactual típico da primeira etapa da diacronia neolítica: cerâmica impressa cardial, "boquique”, geométricos e elementos de adorno. Datações absolutas sobre Ovis e restos humanos confirmam a cronologia.

Esta ocupação encontra paralelos em sítios coevos do Maciço Calcário Estremenho (MCE), entre os quais se destaca a Galeria da Cisterna (sistema cársico do Almonda).

Palavras-chave: Neolítico Antigo, Cardial, Maciço Calcário Estremenho, ARQEVO.
\end{abstract}

\begin{abstract}
We present the results of the first year of the field work carried out at Lapa da Bugalheira (Almonda, Torres Novas) by the ARQEVO research project. We have identified an Early Neolithic occupation featuring a characteristic artefact assemblage with impressed wares (both cardial and "boquique"), geometric microliths and ornaments. The age of the assemblage has been corroborated by the radiocarbon dating of sheep and human bone samples. Comparable, coeval occupation contexts exist in the Central Limestone Massif of Estremadura, paramount among which is the Galeria da Cisterna's (Almonda karst system).
\end{abstract}

Keywords: Early Neolithic, Cardial, Limestone Massif of Estremadura, ARQEVO.

\section{INTRODUÇÃO}

A Lapa da Bugalheira (Almonda, Torres Novas) localiza-se no limite sul do Maciço Calcário Estremenho, mais concretamente numa escarpa de falha com cerca de $75 \mathrm{~m}$ de altura, localmente conhecida como "Arrife do Almonda". É uma das cavidades que integra o sistema cársico associado à nascente do Rio Almonda, sendo uma surgência fóssil eventualmente relacionada com a Ribeira de Oeste, que drena o polje de Mira-Minde. Os primeiros trabalhos arqueológicos realizados nesta cavidade remontam à década de '40 do século $\mathrm{XX}$, e foram dirigidos e publicados por Afonso do Paço (A. Paço), que refere a existência de ocupações do período "Eneolítico" (Paço, et al., 1971).

Em 1946, a Lapa da Bugalheira foi classificada como Imóvel de Interesse Público (Decreto n.ํㅜ 35817, DG, I Série, n.ํㅜ 187, de 20.08.1946). Mais tarde, na década de '8o, um grupo de espeleologia local (STEA - Sociedade Torrejana de Espeleologia e Arqueologia) efectuou a desobstrução de uma passagem para uma galeria até então desconhecida - Sala do Ricardo (STEA, 1986) - na qual se identificou uma necró-

1. Centro de Arqueologia da Universidade de Lisboa (UNIARQ), Faculdade de Letras de Lisboa, Universidade de Lisboa, Alameda da Universidade, 160o-214 Lisboa, Portugal; F. Rodrigues: afrodrigues@letras.ulisboa.pt; A. Varanda: alexvarandag1@gmail.com; L. Gomes: 1p_04@hotmail.com.

2. Sociedade Torrejana de Espeleologia e Arqueologia, Quinta da Lezíria, 2350-510, Torres Novas, Portugal; P. Souto: pedrojsouto@ gmail.com; H. Gomes: maximianomariahelena@gmail.com.

3. Institució Catalana de Recerca i Estudis Avançats (ICREA), Passeig Lluís Companys 23, o801o Barcelona, Spain.

4. Universitat de Barcelona, Departament d'Història i Arqueologia, Facultat de Geografia i Història, c/Montalegre 6, o80o1 Barcelona, Spain; J. Zilhão: joaozilhao@ub.edu. 
pole superficial datada do Neolítico Médio (ICEN

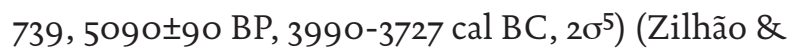
Carvalho, 1996).

Nessa altura, propõe-se uma nova campanha de escavações no Sistema Cársico associada à Nascente do rio Almonda: "b) realização [...] de sondagens arqueológicas na gruta do Almonda, com vista à avaliação da natureza da sua ocupação solutrense; e na Lapa da Bugalheira, com vista a detecção de eventuais depósitos paleolíticos sob a cascalheira de grandes blocos que constitui a base actual do preenchimento sedimentar da sala da entrada, e ao levantamento do ossuário neolítico da "sala do Ricardo" (Zilhão, 1987, 13). Porém, devido aos resultados obtidos na Galeria da Cisterna e à consequente descoberta de novas entradas obstruídas com importantes ocupações paleolíticas - Grutas da Oliveira e Aroeira e Lapa dos Coelhos - os trabalhos inicialmente previstos para a Lapa da Bugalheira só vieram a começar em 2019, ao abrigo do projecto "ARQEVO - Arqueologia e Evolução dos primeiros humanos na fachada atlântica Península Ibérica" (PTDC/ HAR-ARQ/30413/2017).

\section{SÍTIO, ESTRATIGRAFIA, CULTURA MA- TERIAL E DATAÇÕES ABSOLUTAS}

Tradicionalmente designada como "lapa", a Bugalheira é, na realidade, uma "gruta fóssil" actualmente constituída por duas salas: a sala escavada por A. Paço, através da qual se entra hoje na cavidade e a já referida Sala do Ricardo, mais interior, acessível através de um corredor estreito. Na realidade, trata-se de um espaço único separado por um estreitamento completamente preenchido por sedimentos. A escavação realizada em 2019 teve lugar na área da desobstrução efectuada pela STEA que permitiu a passagem para a Sala do Ricardo (quadrados $\mathrm{M} / \mathrm{N} / \mathrm{O}$ das fiadas 13 e 14 da quadrícula implantada; Figura 1) com os seguintes objectivos: $i$ ) avaliar a preservação do sítio; ii) registar a sequência estratigráfica e respectivas ocupações; iii) aferir a(s) cronologia(s), tipologia(s) e funcionalidade(s) da ocupação ou ocupações registadas.

\subsection{Estratigrafia}

Reconheceu-se a seguinte sequência estratigráfica:

5. Datação sobre osso humano.
- Camada 1. Camada de remeximento, pulverulenta, castanho-escura, correspondente a terras depositadas sobre os grandes blocos pétreos de desprendimento da parede da gruta ao nível dos quais havia parado a escavação de A. Paço; presença abundante de restos ósseos, muito fragmentados $(<1 \mathrm{~cm})$ e escassos materiais arqueológicos.

- Camada 2. Camada silto-arenosa, amarelada, solta, com áreas mais compactas devido à precipitação de carbonato de cálcio; presença de alguns pequenos blocos de calcário; regista-se a presença de tocas e raízes; esta camada tem uma espessura máxima de cerca de $70 \mathrm{~cm}$; corresponde ao nível arqueológico, com materiais atribuíveis ao Neolítico Antigo.

- Camada 3. Camada laranja pulverulenta, solta; no topo da camada foram recolhidos dois seixos de quartzito, tendo-se revelado, em profundidade, estéril do ponto de vista arqueológico.

- Camada 4. Camada argilosa, de cor vermelha, semi-compacta; presente em toda a área de escavação; estéril do ponto de vista arqueológico.

- Camada $\alpha$. Camada carbonatada, descontínua e irregular, de cor branca, cimentada, com inclusão de materiais arqueológicos, designadamente cerâmicas com decoração cardial; presente nos quadrantes norte da quadrícula L14, oeste das quadrículas $\mathrm{M} / 13-14$ e este das quadrículas N/13-14; removida com recurso a martelo demolidor; possivelmente um espeleotema (bandeira?) alterado e sedimento brechificado a ele aderido.

- Camada $\beta$. Depósito identificado nos quadrados $\mathrm{O} / 13-14$, concrecionado e de coloração alaranjada; no seu topo foram recolhidas três Theodoxus fluviatilis perfuradas; deverá corresponder ao contacto das camadas $2 / 3$, alterado pela proximidade à parede da gruta.

- Camada $\gamma$. Depósito constituído por grandes blocos de desprendimento das paredes da gruta; eventualmente, corresponde ao que A. Paço e colaboradores designaram por "chão da gruta"; removido com recurso a martelo pneumático.

\subsection{O conjunto artefactual}

Os materiais recolhidos durante a campanha de 2019 perfazem um total de 504 entradas no inventário de campo. Entre eles contam-se cerâmica, indústria lítica (pedra lascada e pedra polida), elemen- 
tos de adorno, indústria óssea, fauna (mamalógica e malacológica) e restos humanos. A Tabela 1 dá a distribuição destas grandes categorias.

\subsubsection{Cerâmica}

Das 223 entradas "cerâmica" que constam do inventário de campo, 135 correspondem a sacos gerais e 88 a fragmentos coordenados. Apesar de neste conjunto predominarem os fragmentos lisos, destaca-se a presença de cerâmica com decoração impressa cardial e "boquique". Com decoração impressa cardial regista-se um número mínimo de dois recipientes, com características distintas.

Um dos recipientes apresenta uma morfologia ovóide ou "em saco", com mamilo de preensão junto ao bordo; a decoração cardial organiza-se em bandas paralelas junto ao bordo; na parte superior do recipiente observam-se grinaldas com impressões cardiais. O outro recipiente apresenta uma asa de rolo junto ao bordo, estando a decoração cardial disposta em bandas junto ao mesmo.

As asas estão igualmente presentes em pelo menos dois outros recipientes:

- um fragmento recolhido durante a desobstrução efectuada pela STEA; trata-se de um bordo denteado com asa de perfuração horizontal decorada com incisões verticais paralelas; neste fragmento observa-se ainda o arranque de uma grinalda realizada com recurso a puncionamento arrastado ("boquique"), o que permitiu associá-lo a um bojo com a mesma decoração recolhido na campanha de 2019;

- um bordo com asa de fita representa o outro recipiente.

Outros elementos de preensão, tais como as pegas, estão também presentes.

\subsubsection{Pedra lascada}

Estratigraficamente, a indústria lítica distribui-se da seguinte forma: Camada $1=1$; Camada $\alpha=2$; Camada 2 [remeximento] $=8$; Camada $2=10$. Está ausente o tratamento térmico, e as categorias tecnológicas representadas são as da Tabela 2.

Um dos núcleos enquadra-se no tipo morfotécnico "prismático" (considerando os critérios de análise tecnológica definidos para o Neolítico Antigo do Maciço Calcário das Serras d'Aire e Candeeiros) (Carvalho, 1998). Trata-se de um núcleo para extracção de lâminas, embora sejam visíveis negativos de outros produtos. Este núcleo apresenta-se calcinado.
Para a análise dos produtos alongados da Lapa da Bugalheira, adoptou-se o limite dos $12 \mathrm{~mm}$ de largura para diferenciar as lamelas das lâminas. No total, foram recolhidas quatro lâminas e seis lamelas, com o padrão de fracturação apresentado na Tabela 3.

O córtex está ausente em todas as peças recolhidas, verificando-se, contudo, as diferentes secções apresentadas na Tabela 4.

Há neste conjunto uma ponta de seta de base triangular, típica dos contextos do final do Neolítico da Estremadura. Quer a sua tipologia quer o contexto de recolha - níveis de remeximento - permitem afirmar que se trata de uma intrusão residual relacionada com os horizontes arqueológicos escavados por A. Paço.

O restante material é composto por armaduras geométricas, com predomínio dos trapézios (7) sobre os crescentes (1), e uma raspadeira. No que respeita aos trapézios, há um equilíbrio entre as peças com secção trapezoidal (4) e triangular (3). Predomina o retoque curto e abrupto (6), observando-se um exemplar com retoque directo, invasor, semi-abrupto. O crescente tem uma secção triangular, com retoque directo, invasor e abrupto.

\subsubsection{Pedra polida}

São dois os elementos de pedra polida recolhidos na campanha de 2019 na Lapa da Bugalheira: uma es-

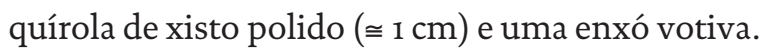

A esquírola de xisto foi recolhida na limpeza superficial da área de escavação e, por isso, deverá ser um resíduo das escavações de A. Paço. As suas reduzidas dimensões não permitem associá-la a um grupo artefactual específico, não se descartando a possibilidade de pertencer a um artefacto ideotécnico associado à necrópole eneolítica.

A enxó tem superfícies totalmente polidas, perfil biconvexo e secção sub-rectangular. As suas dimensões reduzidas (comprimento máximo $=64,75 \mathrm{~mm}$; largura máxima $=37,35 \mathrm{~mm}$ ), contexto de proveniência (O14NE, camada 2), e paralelo com os utensílios em pedra polida recolhidos na década de '8o pela STEA permitem associá-la à necrópole neolítica identificada na Sala do Ricardo.

\subsubsection{Adornos}

No total foram recolhidos 26 elementos de adorno, de tipologias e matérias-primas distintas (osso, rocha e concha), que remetem para diferentes cronologias dentro da Pré-história recente. 
O adorno em osso corresponde a um fragmento de cabeça postiça canelada, pertencente a um alfinete de cabelo, e foi recolhido na área remexida pelos trabalhos de desobstrução da STEA. Este tipo de adorno é conhecido a partir do Neolítico Final, surgindo igualmente em contextos do Calcolítico Inicial e Pleno. Tal facto, aliado à sua proveniência, permite afirmar que se trata de peça associada aos contextos escavados por A. Paço.

A mesma conclusão pode ser aplicada às contas discóides. Trata-se de três exemplares de pequenas dimensões, elaboradas sobre rocha - calcário (2) e xisto (1) - de ocorrência comum na etapa final do Neolítico e no Calcolítico e de tipologia desconhecida em contextos do Neolítico Antigo.

À fase mais antiga da diacronia neolítica podem ser atribuídos uma conta cilíndrica de Dentalium sp. e os adornos elaborados sobre concha inteira (21). Entre estes últimos foram reconhecidas duas espécies distintas: Columbella rustica (4) e Theodoxus fluviatilis (17).

Os adornos sobre concha da Lapa da Bugalheira encontram paralelos tipológicos e cronológicos não só na Galeria da Cisterna (Gruta do Almonda), mas também nos contextos cardiais de Valencia (Espanha) (e.g. Cendres, Or, Sarsa) (Pascual Benito, 1998; Zilhão, 2009).

\subsubsection{Indústria óssea}

Foi recolhido na Camada 1 um fragmento mesial de utensílio indeterminado. Este fragmento está integralmente polido e tem uma ranhura longitudinal, o que lhe confere uma secção convexo-côncava. Os seus bordos laterais são arredondados. Este fragmento pode-se enquadrar tanto na categoria dos alfinetes como na das agulhas, ou até mesmo na dos alisadores/furadores.

\subsubsection{Fauna}

No que respeita à fauna mamalógica estão presentes os ovicaprídeos, incluindo restos classificáveis com segurança como de ovelha, o veado e o coelho. $\mathrm{Na}$ fauna malacológica regista-se a presença de Unio sp., Cerastoderma edule, Glycymeris sp. e Pecten maximus. $\mathrm{O}$ estudo destes elementos encontra-se ainda em curso.

\subsection{Restos humanos}

Os ossos humanos - mandíbula, dentes soltos, clavícula, vértebras, costelas, fémur, tíbia - encontravam- -se dispersos na área de escavação, não tendo sido identificada qualquer conexão anatómica. $\mathrm{O}$ estudo deste material encontra-se ainda em curso.

\subsection{Datações Absolutas}

Foram obtidas duas datações absolutas que são compatíveis com a cultura material recolhida e confirmam a atribuição do contexto ao Neolítico Antigo (Tabela 5).

\section{CRONO-ESTRATIGRAFIA E CONTEXTUALIZAÇÃO REGIONAL}

Considerando $i$ ) a sequência estratigráfica publicada por A. Paço, ii) os dados já publicados sobre a Sala do Ricardo e iii) a campanha realizada no âmbito do projecto ARQEVO, estabeleceu-se um quadro crono-estratigráfico para as ocupações da Lapa da Bugalheira (Tabela 6).

Os trabalhos estão numa fase inicial e, por esse motivo, este quadro é preliminar. No futuro, com mais escavação e mais desobstrução, deverão ser clarificadas algumas questões que por agora se mantêm em aberto:

- haverá uma ocupação plistocénica, como sugerem Octávio da Veiga Ferreira e Jean Roche, no seu artigo sobre "Os elementos de adorno do Paleolítico superior de Portugal” (1980)?

- terá havido outra entrada para a cavidade, ainda utilizada durante as primeiras etapas do Neolítico, que permitia o acesso à Sala do Ricardo?

- estarão os níveis do Neolítico Antigo em posição primária ou são o resultado de uma redeposição (e, portanto, potencialmente, mistura) de contextos que, na Sala do Ricardo, ocorrerão estratificados?

Independentemente dos resultados futuros, está confirmada a ocupação do Neolítico Antigo com datações que a enquadram em sítios coevos da região. Efectivamente, quer as datações quer o conjunto artefactual permitem estabelecer paralelos com as ocupações já conhecidas e publicadas nas grutas-necrópole do Algar do Picoto e da Galeria da Cisterna (sistema cársico da nascente do Almonda), ambas localizadas a $<5 \mathrm{~km}$ da Lapa da Bugalheira.

Se, por um lado, são as datações do Algar do Picoto que mais se aproximam das da Lapa da Bugalheira, é por outro lado na componente artefactual da Galeria da Cisterna que se encontram os melhores paralelos para o conjunto aqui descrito. Com efeito, no 
Algar do Picoto, onde não houve qualquer escavação arqueológica (os artefactos e os restos humanos datados foram recolhidos à superfície), predominam os recipientes decorados com caneluras, tipo de decoração ausente na Bugalheira. Os paralelos para esta última encontram-se no conjunto da Galeria da Cisterna. Ainda que este represente um " [...] palimpsesto de usos funerários distribuídos ao longo de um período de tempo considerável" (Zilhão, 2009, p. 827), a tipologia das cerâmicas atribuíveis ao Neolítico Antigo sugere três fases de ocupação (Zilhão, 2009):

- Cardial antigo, com um número mínimo de dois recipientes, de "tradição cardial barroca", decorados com concha de Cardium e pente, com paralelos nas ocupações mais antigas do Neolítico da região de Valencia;

- Cardial recente, com um número mínimo de 25 recipientes, com decoração impressa, predominantemente cardial (17), registando-se igualmente impressão a pente (2);

- Epicardial, com um número mínimo de 13 vasos, estando presente a cerâmica impressa, "boquique", incisões e caneluras.

Associado a este importante conjunto cerâmico está uma extensa colecção de elementos de adorno, que, à semelhança da baixela cerâmica, encontra paralelos nos sítios de Valencia, tais como Cova de les Cendres, Cova de l'Or e Cova de la Sarsa. A maioria destes adornos - caninos de veado perfurados e suas imitações em osso, pendentes ovais em concha, pendentes em concha inteira de Theodoxus fluviatilis - terão sido depositados durante o Cardial antigo e recente. Este enquadramento cronológico é baseado i) nas datações absolutas, ii) nos paralelos valencianos e iii) nos dados da Gruta do Caldeirão (Tomar) (Zilhão, 2009).

Desta comparação resulta assim que, a partir de critérios tecno-tipológicos respeitantes tanto às cerâmicas como aos adornos, a ocupação representada pela camada 2 da nossa sondagem se enquadra na fase "Cardial recente" da Cisterna. No que respeita à indústria lítica, a prevalência dos trapézios na Bugalheira está também em conformidade com os dados publicados para o "Cardial recente" representado pelo Horizonte NA2 da Gruta do Caldeirão (Tomar). Com base nas datações absolutas, o "Cardial recente" da Cisterna seria, porém, mais antigo que o da Bugalheira e, na Cisterna, os vasos com decoração de tipo "boquique" semelhantes aos da Bugalheira foram atribuídos ao Epicardial. Deste modo, o conjunto da Bugalheira ou (a) é homogéneo e representa uma fase intermédia entre o Cardial recente e o Epicardial ou (b) é heterogéneo e inclui material procedente de duas ocupações funerárias distintas, Cardial recente e Epicardial, pertencendo as amostras datadas a esta última. São alternativas cuja validade a continuação dos trabalhos deverá esclarecer.

\section{AGRADECIMENTOS}

Ao José António Crispim e Pedro Marote, da Sociedade Portuguesa de Espeleologia (SPE), pela realização e cedência da topografia espeleológica da Lapa da Bugalheira.

Ao Simon Davis e ao David Gonçalves, do Laboratório de Arqueociências (LARC - DGPC), pela classificação da fauna e restos humanos, respectivamente. Ao António Monge Soares e Paulo Portela pela análise $\mathrm{CN}$ dos ossos datados.

Este trabalho foi apoiado pela FCT (Fundação para a Ciência e a Tecnologia, Portugal) através do projecto PTDC/HAR-ARQ/30413/2017). O trabalho de campo foi financiado pela CM Torres Novas e pela FCT, com o apoio logístico da A Renova.

\section{BIBLIOGRAFIA}

CARVALHO, António Faustino (2008) - A neolitização do Portugal Meridional. Os exemplos do Maciço Calcário Estremenho e do Algarve Ocidental. Promontoria Monográfica, 12, Universidade do Algarve, Faro.

CARVALHO, António Faustino (2018) - When the Mediterranean met the Atlantic. A socio-economic view on Early Neolithic communities in central-southern Portugal, In Quaternary International, 470, pp. 472-484.

FERREIRA, Octávio da Veiga; ROCHE, Jean (1980) - Os elementos de adorno do Paleolítico Superior de Portugal, Arqueologia, 2, Porto, pp. 7-11.

MARTINS, Haidé; OMS, Xavier; PEREIRA, Luísa; PIKE, Alistair; ROWSELL, Keri; ZILHÃO, João (2015) - Radiocarbon Dating the Beginning of the Neolithic in Iberia: New Results, New Problems. Journal of Mediterranean Archaeology, 28.1, pp. 105-131.

PAÇO, Afonso do; ZBYSZEWSKI, Georges e FERREIRA, Octávio da Veiga (1971) - Resultado das escavações na Lapa da Bugalheira (Torres Novas). Comunicações dos Serviços Geológicos de Portugal. Lisboa. 55, pp. 23-48.

STEA (1986) - Neolítico na Sala do Ricardo. In Almondinha. Torres Novas. 1, pp. 14-18. 
ZILHÃO, João (1987) - Novas perspectivas para a investigação da Pré-história da região de Torres Novas. Almondinha, Torres Novas, 2, pp. 13-15.

ZILHÃO, João (1992) - Gruta do Caldeirão. O Neolítico Antigo. Trabalhos de Arqueologia, 6. Instituto Português do Património Arquitectónico e Arqueológico, Lisboa.

ZILHÃO, João (2001) - Radiocarbon evidence for maritime pioneer colonization at the origins of farming in west Mediterranean Europe. Proceedings of the National Academy of Sciences, USA, 98, pp. 14180-14185.
ZILHÃO, João (2009) - The Early Neolithic artifact assemblage from the Galeria da Cisterna (Almonda karstic system, Torres Novas, Portugal). In De Mediterranée et d'ailleurs... Mélanges offerts à Jean Guilaine. Archives d'Écologie Préhistorique, Toulouse, pp. 821-835.

ZILHÃO, João; CARVALHO, António Faustino (1996) - O Neolítico do Maciço Calcário Estremenho. Crono-estratigrafia e povoamento. In Actes I Congrés del Neolític a la Península Ibérica 2, pp. 659-671. Gavà, Museu de Gavà.

\begin{tabular}{|c|c|c|c|c|c|c|c|}
\hline \multirow{2}{*}{ Cerâmica } & \multicolumn{2}{|c|}{ Indústria lítica } & \multirow{2}{*}{$\begin{array}{c}\text { Adornos/ } \\
\text { Ind. Óssea }\end{array}$} & \multicolumn{2}{|c|}{ Fauna } & \multirow{2}{*}{ Restos humanos } & $\begin{array}{c}\text { Amostras } \\
\text { Carvão }\end{array}$ \\
\cline { 2 - 3 } & Lascada & Polida & Ind & Ml & & 26 \\
\hline 223 & 36 & 2 & $26 / 1$ & 49 & 22 & 35 & 26 \\
\hline
\end{tabular}

Tabela 1 - Inventário Geral (materiais coordenados (campanha de 2019)*.

* Os sacos (86) pertencentes à categoria “Gerais” não estão contabilizados nesta tabela; Fauna Mm = mamalógica; Fauna Ml = malacológica.

\begin{tabular}{|l|l|c|}
\hline \multicolumn{2}{|c|}{ Categoria Tecnológica } & Sílex \\
\hline Núcleos & Núcleo prismático & 1 \\
\hline \multirow{3}{*}{ Produtos de debitagem } & Lâminas & 4 \\
\cline { 2 - 3 } & Lamelas & 6 \\
\hline \multirow{4}{*}{ Utensílios } & Raspadeira & 1 \\
\cline { 2 - 3 } & Geométricos & 8 \\
\cline { 2 - 3 } & Ponta de seta & 1 \\
\hline TOTAL & & $\mathbf{2 1}$ \\
\hline
\end{tabular}

Tabela 2 - Inventário geral dos materiais de pedra lascada, distribuídos por categoria tecnológica e matéria-prima.

\begin{tabular}{|c|c|c|c|}
\hline Fractura & Lamelas & Lâminas & TOTAL \\
\hline Inteira & 1 & - & 5 \\
\hline Proximal & 4 & 1 & 2 \\
\hline Mesial & 1 & 1 & 2 \\
\hline Distal & - & 2 & 10 \\
\hline TOTAL & 6 & 4 & 10 \\
\hline
\end{tabular}

Tabela 3 -Fracturação dos produtos alongados. 


\begin{tabular}{|c|c|c|c|}
\hline Secção & Lamelas & Lâminas & TOTAL \\
\hline Trapezoidal* & 1 & 3 & 4 \\
\hline Triangular* & 3 & 1 & 4 \\
\hline Irregular & 2 & - & 2 \\
\hline
\end{tabular}

Tabela 4 - Secção dos produtos alongados.

\begin{tabular}{|c|c|c|c|c|}
\hline $\begin{array}{c}\text { Código do } \\
\text { Laboratório }\end{array}$ & Amostra & Contexto & Datação BP & Calibração cal BC \\
\hline VERA-7047 & $\begin{array}{c}\text { LpBug.139 } \\
\text { Metápode de Ovis }\end{array}$ & $\mathrm{M} / 13, \mathrm{C} 2$, na 2 & $6084 \pm 26$ & $\begin{array}{c}5196 \mathrm{BC}(2.0 \%) 5180 \mathrm{BC} \\
5063 \mathrm{BC}(92.5 \%) 4932 \mathrm{BC} \\
4921 \mathrm{BC}(\mathrm{o} .8 \%) 4912 \mathrm{BC}\end{array}$ \\
\hline VERA-7048 & $\begin{array}{c}\text { LpBug.142 } \\
\text { Fémur humano }\end{array}$ & $\mathrm{M} / 13, \mathrm{C} 2$, na 2 & $6128 \pm 26$ & $5209 \mathrm{BC}(95.4 \%) 4992 \mathrm{BC}$ \\
\hline
\end{tabular}

Tabela 5-Datações de radiocarbono.

\begin{tabular}{|c|c|c|c|}
\hline Cronologia (BC) & Período & Componente artefactual & Contexto \\
\hline- & Vários & $\begin{array}{l}\text { "[...] moedas de bronze do princípio do século XIX, um botão } \\
\text { pombalino, objectos de ferro e de bronze; cerâmica romana } \\
\text { e de permeio uma mó manual e algumas pontas de seta } \\
\text { neolíticas [...]” (Paço et al., 1971, p. 28) }\end{array}$ & $\begin{array}{l}\text { Camada a } \\
\text { Remeximento } \\
\text { recente } \\
(\text { Paço et al., 1971) }\end{array}$ \\
\hline- & Eneolítico & $\begin{array}{l}\text { “[...] restos humanos em associação com fragmentos de } \\
\text { cerâmica, entre os quais diversos fragmentos de bordos e de } \\
\text { fundos de vasos lisos e apenas dois fragmentos de cerâmica } \\
\text { ornamentada [...]”; “ [...] o material colhido (ossos humanos, } \\
\text { cerâmica, placas de xisto, etc.) era bastante disperso e } \\
\text { fragmentado [...]” (Paço et al., p. 24) }\end{array}$ & $\begin{array}{l}\text { Camada b } \\
\text { Funerário }\end{array}$ \\
\hline $4000-3700$ & $\begin{array}{l}\text { Neolítico } \\
\text { Médio }\end{array}$ & $\begin{array}{l}\text { “[...] pedra polida e um vaso liso de boca elíptica com asas } \\
\text { verticais de perfuração em túnel [...]” (Zilhão \& Carvalho, } \\
\text { 1996, p. 665) }\end{array}$ & $\begin{array}{l}\text { Funerário } \\
\text { - necrópole } \\
\text { superficial }\end{array}$ \\
\hline $5200-4900$ & $\begin{array}{l}\text { Neolítico } \\
\text { Antigo }\end{array}$ & $\begin{array}{l}\text { Cerâmica impressa cardial, “boquique”, lamelas, } \\
\text { geométricos, adornos em concha,... }\end{array}$ & $\begin{array}{l}\text { Funerário (?) - } \\
\text { remeximento } \\
\text { antigo; camadas } \\
2, \alpha, \beta\end{array}$ \\
\hline
\end{tabular}

Tabela 6-Quadro crono-estratigráfico. 


\begin{tabular}{|c|c|c|c|}
\hline Sítio & Datação & Amostra & Componente artefactual \\
\hline \multirow[t]{3}{*}{$\begin{array}{l}\text { Algar do } \\
\text { Picoto* }\end{array}$} & $\begin{array}{l}\text { ICEN-736, } 6000 \pm 150 \mathrm{BP} \\
5256-45^{2} 8 \mathrm{cal} \mathrm{BC}(2 \mathrm{\sigma})\end{array}$ & $\begin{array}{l}\text { Osso, } \\
\text { Homo }\end{array}$ & \multirow{3}{*}{$\begin{array}{l}\text { Pedra lascada: conjunto composto por indústria } \\
\text { sobre lasca em sílex, quartzo e quartzito, e utensílios } \\
\text { retocados de "fundo comum". } \\
\text { Cerâmica: número mínimo de seis recipientes, lisos } \\
\text { (Vaso 1), decorados com caneluras (Vasos 2, } 34 \text { e 6) e } \\
\text { incisões formando triângulos preenchidos (Vaso 5). } \\
\text { Restos humanos: número mínimo de dois } \\
\text { indivíduos (jovem adulto do sexo feminino e adulto } \\
\text { do sexo masculino), com dieta típica de sociedades } \\
\text { de agricultores. }\end{array}$} \\
\hline & & & \\
\hline & $\begin{array}{l}\text { WK-17216, } 5904 \pm 36 \mathrm{BP} \\
4702-4822 \mathrm{cal} \mathrm{BC}(2 \sigma)\end{array}$ & $\begin{array}{l}\text { Osso, } \\
\text { Homo }\end{array}$ & \\
\hline \multirow{7}{*}{$\begin{array}{l}\text { Galeria da } \\
\text { Cisterna } \\
\text { (Gruta do } \\
\text { Almonda) } \\
* *\end{array}$} & $\begin{array}{l}\text { OxA-9287, } 6445 \pm 45 \mathrm{BP} \\
5477-5321 \mathrm{cal} \text { BC }(2 \sigma)\end{array}$ & $\begin{array}{l}\text { canino } \\
\text { perfurado, } \\
\text { veado }\end{array}$ & \multirow{7}{*}{$\begin{array}{l}\text { Pedra lascada: conjunto dominado pelo sílex, com } \\
\text { núcleos prismáticos, lamelas (registando-se o talhe } \\
\text { por pressão e percussão indirecta) e segmentos. } \\
\text { Cerâmica: número mínimo de } 4 \text { o vasos, dos quais } \\
18 \text { apresentam decoração cardial (dois de "tradição } \\
\text { cardial barroca”), estando também presente } \\
\text { o “boquique”, as caneluras e as incisões, com } \\
\text { diferentes temas decorativos, nos quais se inclui a } \\
\text { “falsa folha de acácia”. } \\
\text { Adornos: pendentes ovais sobre concha } \\
\text { (Glycymeris sp., Unio pictorum, Sepia officinalis), } \\
\text { pendentes sobre concha inteira (Theodoxus } \\
\text { fluviatilis, Columbella rustica, Glycymeris sp., } \\
\text { Pecten maximus, Unio pictorum, Hinia reticulata, } \\
\text { Hinia pfeifferi), pendentes sobre dente inteiro } \\
\text { (Vulpes vulpes, Canis lupus, Cervus elaphus); } \\
\text { pendentes ovais em osso, imitando os caninos de } \\
\text { veado, contas cilíndricas em concha (Dentalium sp.) } \\
\text { e contas discóides em calcário. }\end{array}$} \\
\hline & $\begin{array}{l}\text { OxA-9288, } 6445 \pm 45 \text { BP } \\
5477-5321 \mathrm{cal} \mathrm{BC}(2 \sigma)\end{array}$ & $\begin{array}{l}\text { Adorno } \\
\text { em osso }\end{array}$ & \\
\hline & $\begin{array}{l}\mathrm{OxA}-28855,628 \mathrm{O} \pm 34 \mathrm{BP} \\
5325-5209 \mathrm{cal} \mathrm{BC}(2 \mathrm{\sigma})\end{array}$ & $\begin{array}{l}\text { Osso, } \\
\text { Homo }\end{array}$ & \\
\hline & $\begin{array}{l}\text { S-EVA-27412, 6319 } \pm 22 \text { BP, } \\
5345-5322 \text { cal BC }(2 \text { б) }\end{array}$ & $\begin{array}{l}\text { Mandíbula, } \\
\text { Homo }\end{array}$ & \\
\hline & $\begin{array}{l}\text { Wk-38574, } 627 \mathrm{O} \pm 30 \mathrm{BP} \\
5314-5212 \mathrm{cal} \mathrm{BC}(2 \mathrm{\sigma})\end{array}$ & $\begin{array}{l}\text { Mandíbula, } \\
\text { Homo }\end{array}$ & \\
\hline & $\begin{array}{l}\text { Wk-38575, } 6253 \pm 30 \mathrm{BP} \\
5312-5079 \mathrm{cal} \mathrm{BC}(2 \mathrm{\sigma})\end{array}$ & $\begin{array}{l}\text { Mandíbula, } \\
\text { Homo }\end{array}$ & \\
\hline & $\begin{array}{l}\text { Wk-38576, 6312 } \pm 31 \text { BP } \\
5352-5219 \mathrm{cal} \mathrm{BC}(2 \text { б) }\end{array}$ & $\begin{array}{l}\text { Osso, } \\
\text { Homo }\end{array}$ & \\
\hline
\end{tabular}

Tabela 7 - Datações e componente artefactual das grutas-necrópole a <5 Km da Lapa da Bugalheira. 


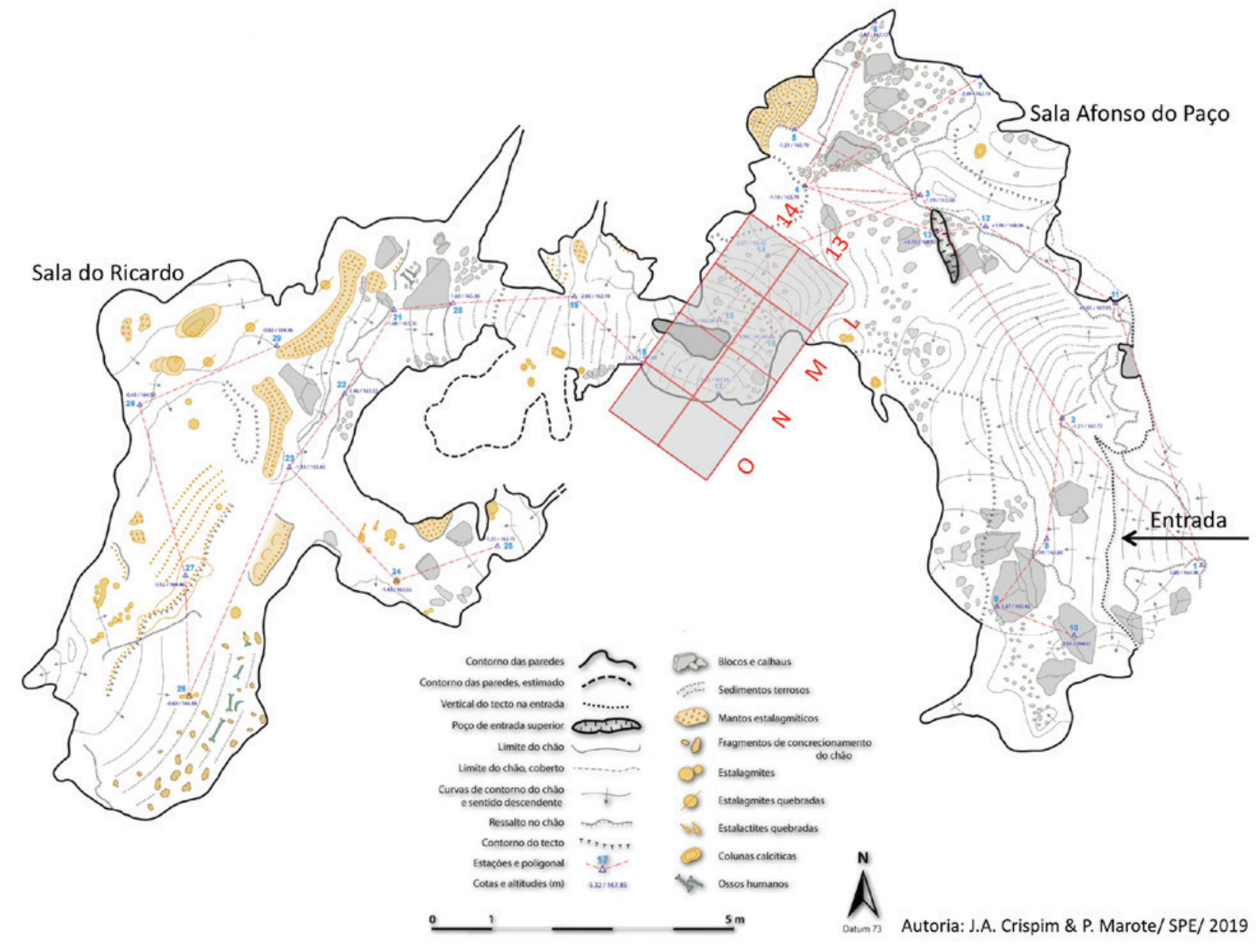

Figura 1 - Topografia espeleológica da Lapa da Bugalheira com indicação da área escavada em 2019 (autoria: J.A. Crispim \& P. Marote/SPE/ 2019). 


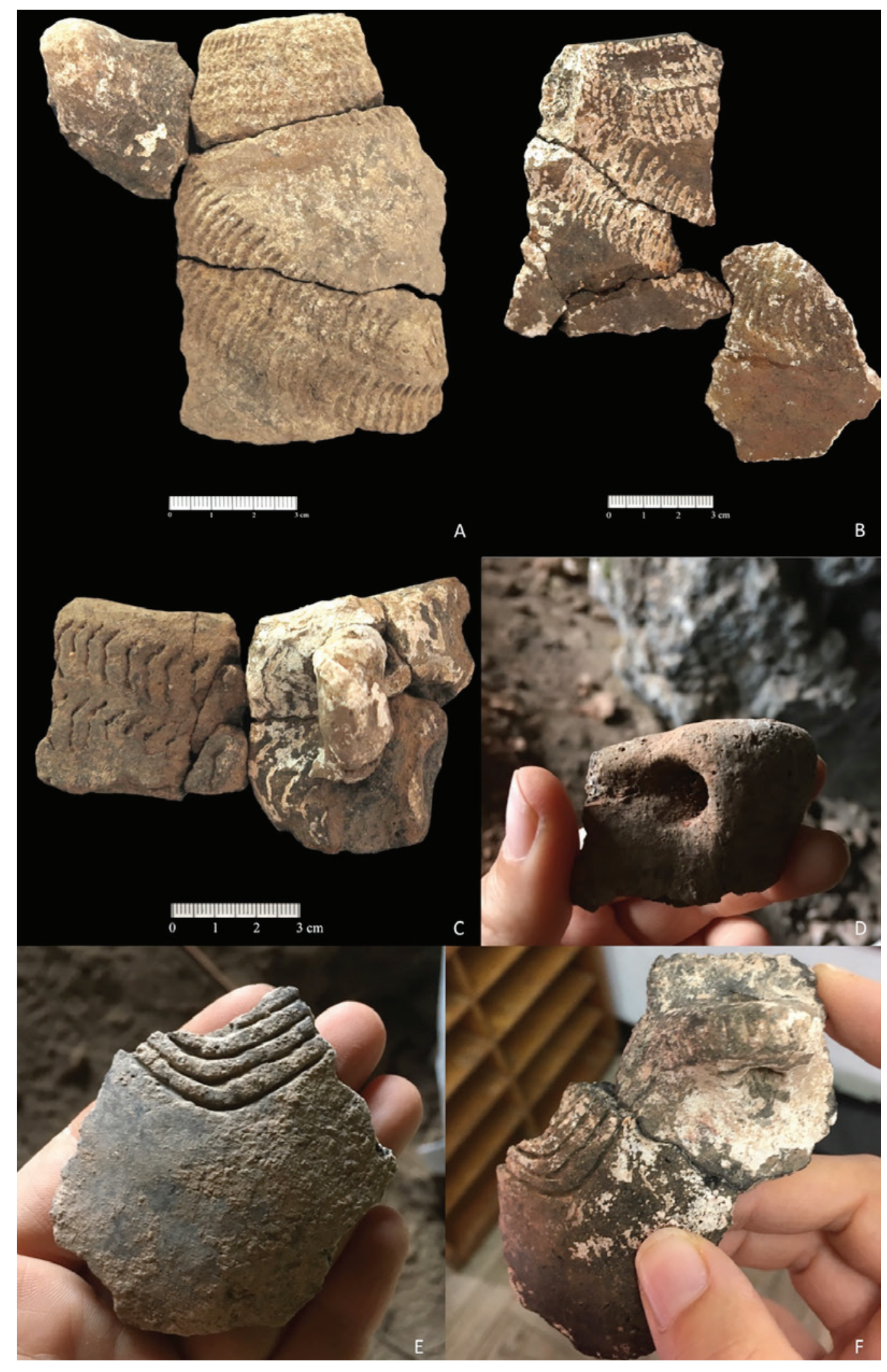

Figura 2 - Cerâmica: A e B. Recipiente ovóide de decoração compósita (impressão + decoração plástica), com banda paralela ao bordo e grinalda de impressões cardiais; C. Bordo com asa de rolo e banda paralela ao bordo composta por impressões cardiais; D. Bordo com asa de fita; E. Bojo com decoração de tipo "boquique", em grinalda; F, Colagem entre o bojo representado em E e fragmento recolhido na década de '8o pela STEA apresentando bordo denteado, asa de perfuração horizontal decorada com série de incisões, e arranque de decoração a puncionamento arrastado (Fotos: P. Souto \& F. Rodrigues). 


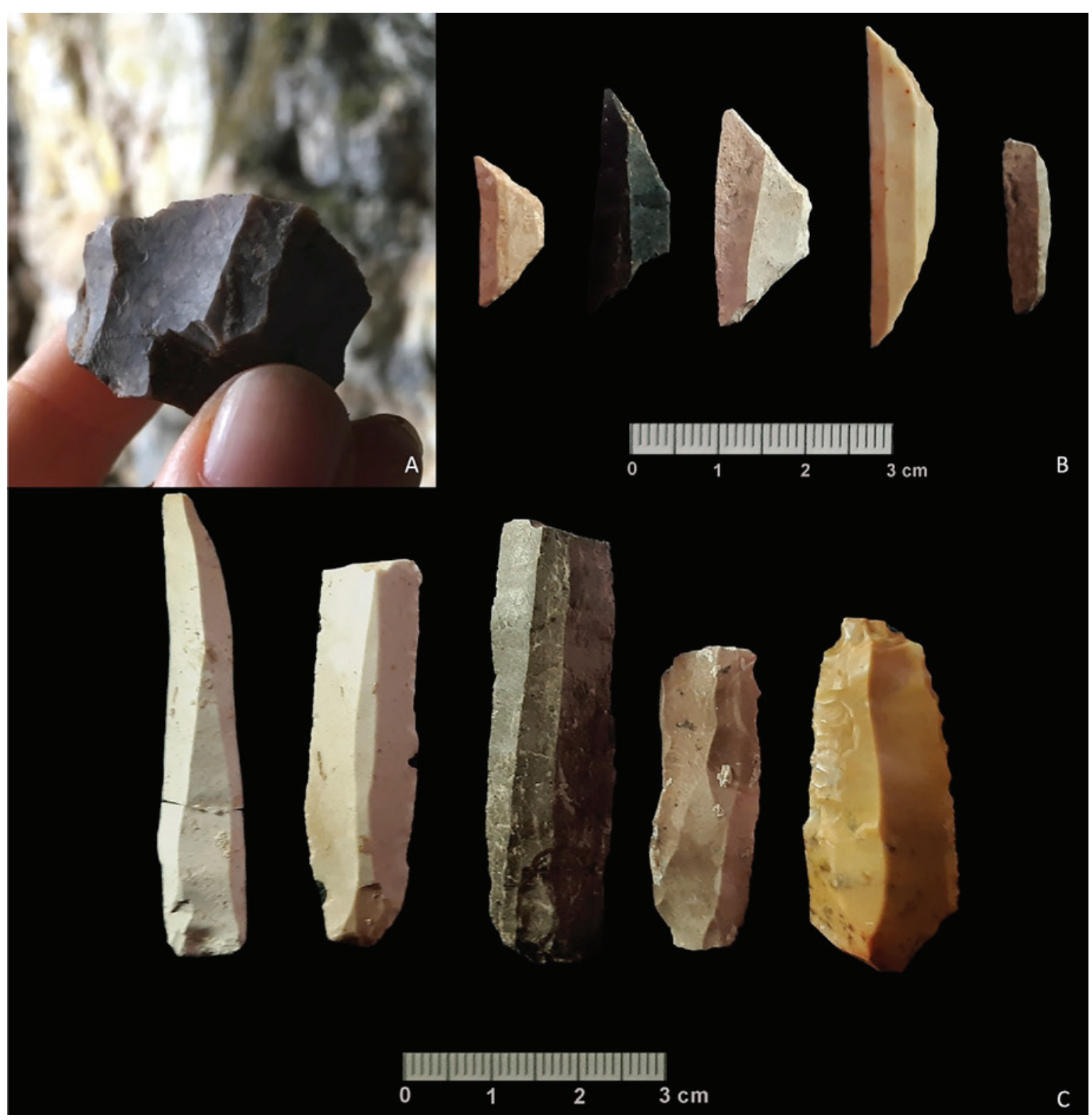

Figura 3 - Pedra lascada: A. Núcleo prismático para lâminas, calcinado; B. Geométricos (trapézios e crescentes); C. Produtos alongados (lâminas e lamelas) e raspadeira (Fotos: P. Souto \& F. Rodrigues). 


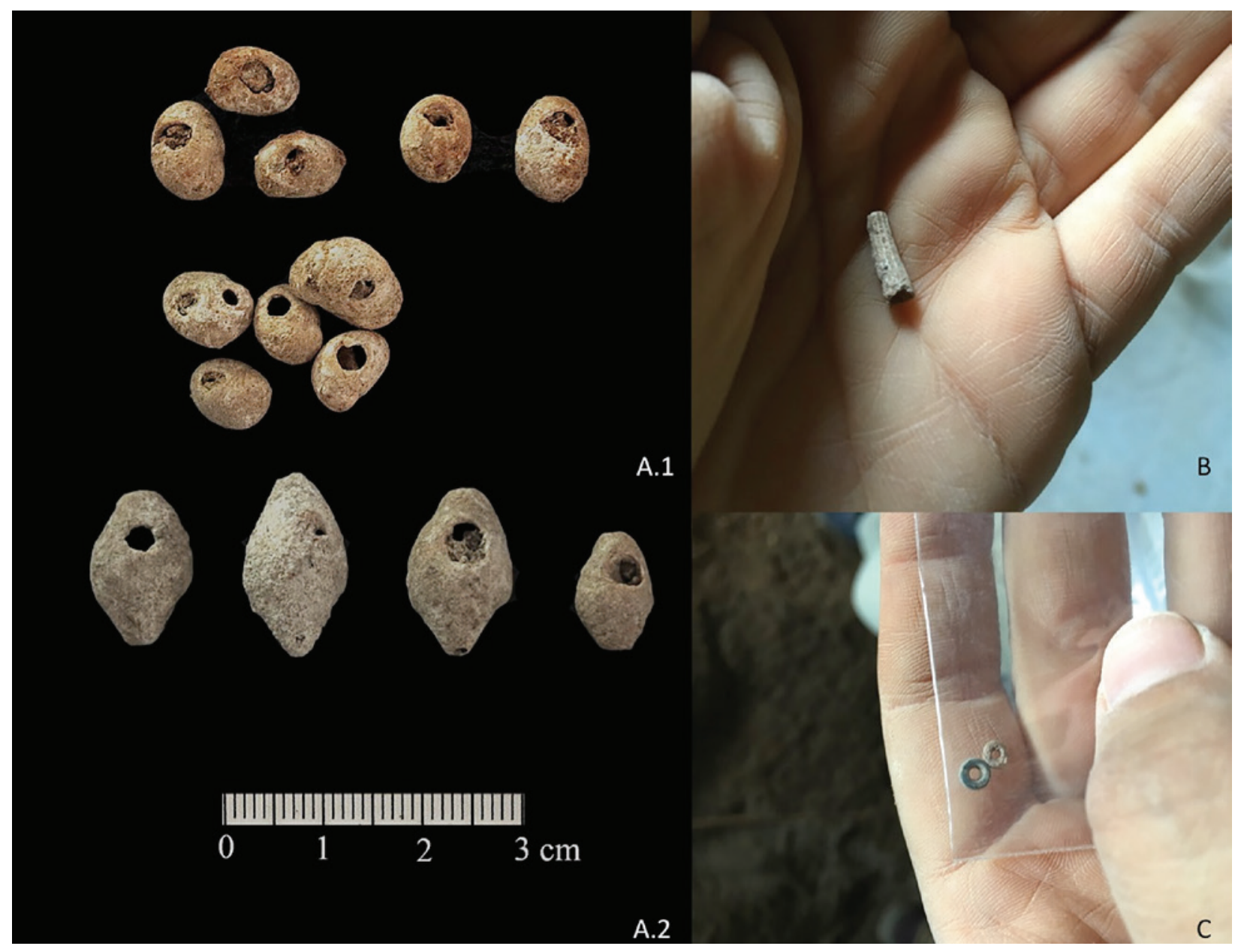

Figura 4-Adornos: A. Adornos em concha inteira: A.1. Theodoxus fluviatilis; A.2. Columbella rustica; B. Conta cilíndrica de Dentalium sp.; C. Contas discóides em calcário e xisto. 


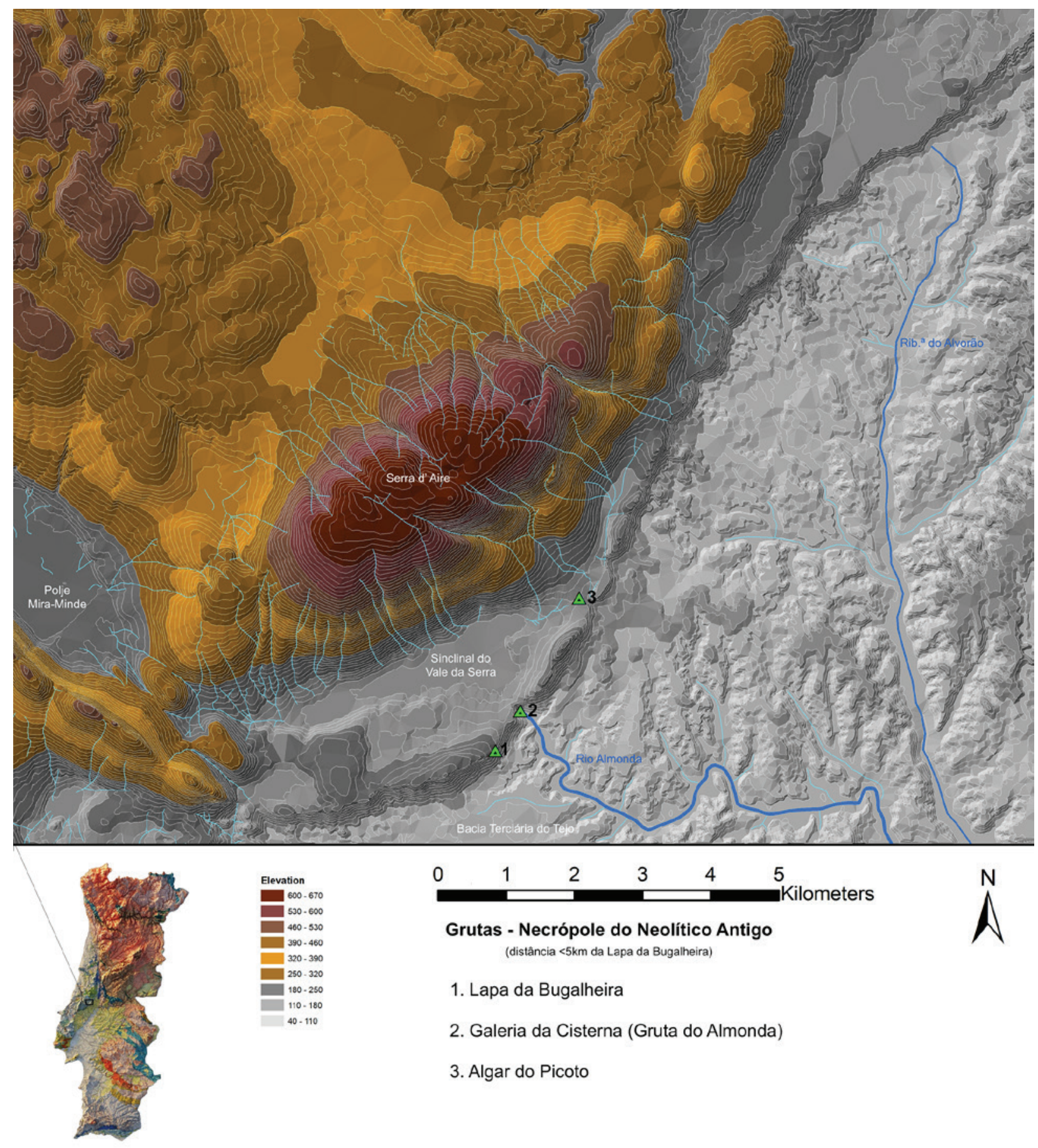

Figura 5-Grutas-necrópole do Neolítico Antigo localizadas a $<5 \mathrm{~km}$ da Lapa da Bugalheira. 


\title{
A PEDRA POLIDA E AFEIÇOADA DO SÍTIO DO NEOLÍTICO MÉDIO DA MOITA DO OURIVES (BENAVENTE, PORTUGAL)
}

\author{
César Neves ${ }^{1}$
}

RESUMO

Apresentação do conjunto de artefactos de pedra polida e afeiçoada identificado no sítio da Moita do Ourives. O universo artefactual é pouco expressivo com os exemplares em mau estado de conservação e elevado grau de fragmentação, dificultando a classificação tipológica e funcional. Para a sua produção, destacam-se os artefactos sobre matérias-primas localmente disponíveis, como o quartzito, arenito e o quartzo (85\% das ocorrências). As matérias-primas exógenas (anfibolito e granito), possivelmente obtidas a mais de 4okm do sítio, representam cerca de $15 \%$ dos elementos registados.

Apesar das limitações que dispõe, este estudo permite, em conjunto com os restantes elementos da cultura material, uma reflexão acerca da funcionalidade desta ocupação, bem como da mobilidade e actividades socioeconómicas das comunidades do Neolítico médio no ocidente Peninsular.

Palavras-chave: Moita do Ourives, Neolítico médio, Cultura material, Pedra polida, Pedra afeiçoada.

\begin{abstract}
Presentation of the polished and ground stone tools artefacts from Neolithic site of Moita do Ourives. It corresponds to a low number of artifacts in poor preservation condition and high degree of fragmentation, making the typological and functional classification quite difficult. The tools production is based mainly on locally available raw materials, such as quartzite, sandstone and quartz (85\% of the all set). Exogenous raw materials (amphibolite and granite), possibly obtained more than $40 \mathrm{~km}$ from the site, represent $15 \%$ of the recovered elements.

The results of this study allow, together with the analysis of other material culture elements, a reflection on the functionality of this settlement, as well as the mobility and socioeconomic activities of the communities of the Middle Neolithic in the Western Iberia.
\end{abstract}

Keywords: Moita do Ourives, Middle Neolithic, Material Culture, Polished and ground stone tools.

\section{INTRODUÇÃO}

O sítio da Moita do Ourives localiza-se na margem esquerda do Baixo vale do Tejo, tendo sido identificado em 2004 e alvo, até à data, de duas intervenções arqueológicas (Rodrigues, 2006; Neves et. al. 2008). Recentemente procedeu-se ao estudo integral dos dados provenientes destas escavações, o que permitiu integrar a ocupação de cariz doméstico num espaço crono-cultural denominado Neolítico médio pleno, entre o segundo e terceiro quartel do $4^{\circ}$ milénio AC (Neves, 2018).
A Moita do Ourives corresponde a uma estratégia de ocupação de um território "moldada" aos recursos naturais aí existentes, às condições de mobilidade que o mesmo permite, provavelmente integrada numa rede de povoamento que inclui sítios de outra natureza funcional e dimensão.

Ao nível dos recursos naturais, a ocupação terá tido em conta a grande proximidade com as ribeiras de Santo Estêvão, e os rios Almansor e Sorraia, afluentes de um curso principal, o Tejo, também ele, à data da ocupação, mais próximo do sítio arqueológico. Estes três elementos, o Tejo, Almansor e Sorraia

1. AAP - Associação dos Arqueólogos Portugueses; UNIARQ - Centro de Arqueologia da Universidade de Lisboa, Faculdade de Letras, Universidade de Lisboa; c.augustoneves@gmail.com 
- linhas de água com caudal expressivo devido à transgressão flandriana - bem como as vastas planícies que rodeavam a Moita do Ourives, permitiam aos grupos que aí habitavam, um ritmo de mobilidade efectivo, sem grandes condicionalismos geográficos, possibilitando a deslocação até territórios e contextos geológicos distintos - Estremadura e Alentejo interior - onde se encontrariam melhores condições para práticas agro-pastoris, bem como a existência de matérias-primas não disponíveis nas imediações da ocupação, numa necessária complementaridade que o modelo social, cultural e económico do processo de Neolitização, gradualmente, impunha.

A Moita do Ourives encontra-se num território que carece localmente de granito e rochas anfibólicas, matérias-primas tradicionalmente associadas ao registo arqueográfico de elementos de moagem e de pedra polida das comunidades neolíticas.

A presença no sítio, mesmo que escassa, de artefactos produzidos sobre estas matérias-primas apresentam-se como marcadores de proveniências a média e longa distância, contribuindo para a compreensão dos espaços de circulação, exploração de recursos e dinâmicas socioeconómicas das comunidades durante o Neolítico médio (Figura 1).

\section{PEDRA POLIDA E AFEIÇOADA DA MOITA DO OURIVES: APRESENTAÇÃO}

$\mathrm{Na}$ análise do conjunto da Moita do Ourives foram incluídos todos os artefactos de pedra polida, afeiçoada ou com traços de utilização recolhidos no decorrer das duas escavações arqueológicas, assim como um fragmento de granito, classificado como manuporte - uma vez que se trata de uma rocha que não existe no substrato geológico local, e cuja presença no sítio deverá ser intencional, logo considerada culturalmente significativa.

Incluíram-se os elementos cujo polimento corresponde ao objectivo pré-determinado de afeiçoar um instrumento funcional (pedra polida), assim como os objectos, cujo polimento/afeiçoamento corresponde a uma consequência da sua utilização (pedra afeiçoada) (Cardoso, 1999/2000, p.242).

A colecção é constituída por um número muito diminuto de elementos (21), apresentando, do ponto de vista tipológico e funcional, uma reduzida diversidade interna. O conjunto caracteriza-se pela presença de instrumentos acabados, estando praticamente au- sentes elementos que possam corresponder ao processo de produção desta utensilagem (Tabela 1).

Os elementos em análise provêm, na sua larga maioria, do nível arqueológico identificado nas duas áreas de escavação. Os artefactos registados em outras camadas, surgem no nível imediatamente superior, mostrando que o seu peso não terá permitido uma significativa dispersão vertical, mantendo-se, assim, próximos do nível de ocupação.

O mau estado de conservação e o elevado grau de fragmentação poderão estar relacionados com a intensidade e grau de utilização a que estes elementos estiveram sujeitos, tendo sido abandonados numa fase de completo esgotamento. Após o seu abandono ter-se-á verificado uma dispersão aleatória destes fragmentos pelo sítio, possivelmente sem qualquer relação com os espaços de uso. Além do grau de utilização, o estado de conservação destes artefactos também poderá estar relacionado com fenómenos pós-deposicionais contribuindo, de igual modo, para a sua desagregação. Apesar de não ser possível identificar, com toda a clareza, a existência de prováveis áreas funcionalmente especializadas, verificaram-se algumas situações, nomeadamente de associações espaciais entre artefactos (ex: movente e dormente).

\subsection{Critérios e objectivos da análise}

A ficha descritiva que serviu de suporte base à análise desta pequena colecção seguiu, no geral, os critérios de análise utilizados por Victor S. Gonçalves (Gonçalves, 1989), adoptando, também, alguns parâmetros descritivos da Ficha Descritiva apresentada por Mariana Diniz (Diniz, 2007, p.230 e 231). Os critérios e a nomenclatura referente à classificação específica dos artefactos de pedra polida, tendo em conta os atributos descritivos observados, segue a utilizada por João L. Cardoso (Cardoso, 1999/200o). A análise dos artefactos da Moita do Ourives seguiu os princípios da cadeia operatória, na tentativa de definir o contexto socioeconómico onde foram produzidos/utilizados/abandonados, focando-se nas seguintes temáticas:

\section{Matéria-prima}

- Inventário das matérias-primas presentes no conjunto;

- Identificar as áreas geográficas dos recursos explorados, definindo os possíveis espaços de origem das rochas e minerais, bem como a sua distância face à Moita do Ourives; 


\section{Utilização}

- Identificar possíveis indicadores de produção e utilização na Moita do Ourives;

\section{Classificação tipológica e funcional}

- Classificação, descrição e reflexão sobre possíveis funcionalidades específicas dos artefactos, individualizando-os pelas seguintes categorias: pedra polida, pedra afeiçoada e pedra com traços de utilização;

Para, posteriormente, se conseguir discutir e avaliar:

- Natureza e tipologia funcional da ocupação da Moita do Ourives;

- Caracterização do subsistema económico do grupo que ocupou o sítio;

- Existência de eventuais redes de troca e circulação, suas trajectórias, peso económico e social;

A Descrição e Classificação Tipológica continuam a ser uma componente essencial na análise destes objectos, uma vez que sem este passo (inicial), torna-se impossível quantificar, comparar e relacionar com outros contextos eventualmente análogos, assim como investigar a relação entre a morfologia do artefacto, a sua manufactura e reutilização, ajudando a detectar (ou não) eventuais variabilidades regionais e espaciais.

O conjunto da Moita do Ourives, que seguidamente se abordará, pretende, assim, estar disponível a integrar um quadro empírico, ainda diminuto, para o espaço crono-cultural em análise.

\subsection{Descrição e classificação do conjunto}

\section{Matérias-primas e áreas de proveniência}

A identificação das possíveis áreas de proveniência das matérias-primas, utilizadas na produção de utensilagem, é uma tarefa primordial na classificação tecno-tipológica da Cultura Material e decisiva na caracterização dos ritmos de interacção e estratégias de exploração do espaço dos grupos humanos neolíticos, no extremo Ocidente Peninsular.

Neste sentido, as leituras apresentadas para os artefactos da Moita do Ourives resultam da observação macroscópica dos mesmos, em termos de suas características geológicas. Assim, os dados apresentados não serão definitivos, mas permitem uma primeira reflexão acerca das trajectórias de obtenção das distintas matérias-primas, da sua selecção e a indicação das presumíveis zonas de proveniência, estabelecendo, assim, as bases conceptuais para futuras análises mais pormenorizadas.

$\mathrm{Na}$ Moita do Ourives, à imagem da indústria da pedra lascada, a indústria da pedra polida/afeiçoada e com traços de utilização assentou tendencialmente sobre matérias-primas localmente disponíveis. Com excepção do granito e do anfibolito, este último utilizado no único machado de pedra polida recolhido na intervenção, todas as outras rochas e minerais empregues existem nas imediações do sítio, ou num raio de poucos quilómetros (Figura 2).

A abundância, na região, de seixos de quartzito e arenito - rochas aptas para utilização directa ou afeiçoamento - permite a sua obtenção directa no território imediato de captação de recursos, apesar de não ter sido possível, até ao momento, definir com rigor esses espaços prováveis de proveniência, uma vez que não foram realizadas análises petrológicas sobre este material.

As cascalheiras existentes nos depósitos de terraços fluviais localizados nas imediações do sítio permitiam a obtenção, sem grande esforço, de seixos de quartzito (e quartzo, embora este em número muito residual), que serviram para criar utensílios relacionados com o talhe (percutores, martelo e bigorna), mas também para produção de elementos de moagem, como os moventes.

$\mathrm{O}$ arenito, exclusivamente utilizado na produção de elementos de mó - um dormente e dois fragmentos de moventes - corresponde a uma rocha de origem local/regional. Disponível nas formações sedimentares do Plio-Plistocénico e do Mio-Pliocénico, é possível recolher amostras de arenito nos depósitos de terraço, ao longo dos rios da bacia do Rio Tejo.

Os elementos artefactuais, em pedra polida e em pedra afeiçoada, produzidos em rochas de origem exógena correspondem a um machado, em anfibolito, e a um fragmento de movente, em granito.

A partir da Moita do Ourives, o anfibolito tem as suas fontes de aprovisionamento mais próximas no interior alentejano, nomeadamente nas formações sedimentares metamórficas do Complexo Precâmbrico da área de Montemor-o-Novo e Vendas Novas, situadas num raio mínimo de 40 a $50 \mathrm{~km}$. Um pouco mais distante, mas ainda no mesmo ambiente regional, surgem rochas anfibólicas na área de Arraiolos, Pavia, Évora e Viana do Alentejo (Carta Geológica de Portugal, 1992).

O outro espaço regional mais próximo da ocupação, 
onde se identificam fontes primárias desta matéria-prima, localiza-se na área de Montargil, Ponte de Sor e Mora, que dista cerca de $6 \mathrm{okm}$. Embora não esteja referida na carta litógica e geológica de Portugal, esta zona surge referenciada nos estudos de proveniência deste tipo de rocha, em outros contextos pré-históricos (Cardoso, 1999-200o, p. 266; Read, Grapes e Lillios, 1997, p.4). Outras áreas de possível proveniência, embora ainda mais distantes, situam-se na zona do médio Tejo (Abrantes e Gavião - c. de $8 \mathrm{okm})$, e na região mais próxima do nordeste alentejano, como Crato, Campo Maior e Elvas.

Relativamente ao granito, as suas possíveis áreas de proveniência não diferem muito do anfibolito, numa situação que não deixa de ser interessante na possível definição dos trajectos e áreas de circulação em que o grupo que ocupou a Moita do Ourives pode ter estado envolvido. As áreas mais próximas situam-se na região de Montemor-o-Novo e Vendas Novas, situadas num raio mínimo de 40 a $50 \mathrm{~km}$, ou no espaço situado a norte de Évora. Mais a norte da Moita do Ourives, estão registadas pequenas manchas de granito na região de Montargil e Ponte de Sor, que distam a cerca de $6 \mathrm{okm}$. As manchas de maior dimensão, e que ainda poderão se enquadrar no espaço de interacção desta comunidade, situam-se em áreas mais distantes como Portalegre, Elvas, Nisa e Castelo de Vide. Ainda no granito, importa referir a mancha localizada em Sintra a uma distância, em linha recta, de cerca de 5okm da Moita do Ourives.

Como se verá adiante, estes espaços regionais não seriam, somente, prováveis locais de captação de recursos e fontes de matérias-primas. A evidência empírica disponível para essas áreas regista a presença de ocupações domésticas e funerárias relacionadas com o Neolítico médio, presumivelmente contemporâneos da Moita do Ourives, nomeadamente na área de Évora e Montargil.

\section{Indicadores de produção e utilização local}

Perante um conjunto tão diminuto torna-se difícil tecer considerações sobre possíveis indicadores de produção local. O único artefacto de pedra polida que corresponde a um produto acabado em anfibolito apresenta, no seu gume, intensos traços de utilização. Não há, no entanto, outros elementos artefactuais desta matéria-prima, como blocos em bruto, polidores e/ou afiadores, assim como vestígios de produtos não acabados, que permitam demonstrar, de forma inequívoca, a produção destes artefactos no sítio. Por outro lado, o facto de se tratar de uma matéria-prima exógena, com origem a cerca de 40-50km de distância do sítio, seria pouco provável o transporte de blocos em bruto para, depois, se produzirem estes instrumentos, na Moita do Ourives. Os traços de utilização que o machado apresenta, bem como o seu grau de fragmentação, pode ser um bom indicador da sua utilização no local, ou nas redondezas mais imediatas.

Nos elementos de moagem surgem indícios mais consistentes de produção e utilização local. Além da maioria dos produtos ter origem em matérias-primas disponíveis nas imediações do sítio, existe uma elevada fragmentação dos mesmos que sugere um uso intensivo até ao seu esgotamento e, consequente, abandono. Aparentemente, este tipo de material terá sido produzido em contexto habitacional tendo sido, á́, utilizado e abandonado. A identificação de áreas destinadas ao exercício das actividades associadas a estes instrumentos carece de uma evidência empírica mais sólida, apesar de ocorrem algumas associações espaciais entre alguns instrumentos afeiçoados (Neves, 2018, p.318).

\section{Tipologia e funcionalidade}

\section{a) Pedra polida \\ Machado}

Relativamente à pedra polida, o conjunto artefactual da Moita do Ourives é composto por um único elemento. Seguindo o critério de classificar o artefacto pela morfologia da sua extremidade distal, isto é, a sua área funcional e útil (Cooney e Mandal, 1998; Le Roux, 1999), constatou-se que se trata de um machado.

O exemplar recuperado corresponde a um fragmento com a área mesial e distal conservada. Apresenta uma fractura dupla, perpendicular e paralela ao eixo maior da peça. Desconhece-se se o seu estado de conservação resulta, exclusivamente, da sua utilização como utensílio. No entanto, importa referir que apresenta um gume com intensos traços de uso, denotando um grau de utilização igualmente elevado. Trata-se de um fragmento com cerca de $72 \mathrm{~mm}$ de comprimento, $22 \mathrm{~mm}$ de largura e $35 \mathrm{~mm}$ de espessura conservada, pesando 66g. Possui secção sub-circular, bordos paralelos, um corpo ligeiramente polido e muito picotado, não sendo possível apurar a tipologia do talão. Quanto ao gume, este encontra- 
-se totalmente polido e convexo no que diz respeito à sua geometria (Figura 3, ํㅜㅍㅜ).

Quanto à sua funcionalidade, o facto de o número destes utensílios ser muito diminuto tem sido um entrave à realização de estudos funcionais e análises traceológicas, não muito comuns em artefactos desta natureza. Por outro lado, o facto de a larga maioria destes artefactos surgirem em contextos funerários, correspondendo geralmente a instrumentos sem traços de uso, não contribui para esclarecer esta questão. Tem sido através do registo etnográfico e de uma forte componente de arqueologia experimental que têm surgido alguns indicadores de uso (Masclans Latorre, et. al. 2017), embora ainda muito condicionados à denominação do artefacto - machado - o que pode, à partida, induzir num número restrito de práticas.

Normalmente, aos machados, tem sido atribuída uma função de "corte", associada ao trabalho em madeira (debaste e abate de árvores), distinguindo-se, também aí, das enxós, cujas tarefas, também de corte, podem estar relacionadas com o mato mais rasteiro, ou mesmo de lavra (Le Roux, 1999, p. 150). Alguns estudos funcionais, em contextos neolíticos europeus, têm incidido a sua análise para o trabalho em madeira, quer no abate de árvores, quer no corte de ramos e galhos, na remoção da casca e no aguçar/ afeiçoar de alguns troncos (Lunardi, 2008).

Outra proposta funcional que tem sido, por vezes, apontada é o de trabalho de cava de terrenos agricultados, originando, assim, algumas das marcas de percussões violentas visíveis nos gumes dos machados (e enxós), “....resultantes de impactos dos antigos gumes, de que resultaram lascas de tamanho assinalável (...) em consequência dos choques com pedras dispersas à superfície ou a pequena profundidade." (Cardoso, 1999/2000, p. 242). Ainda relacionada com esta hipótese funcional de instrumentos para sulcar a terra, alguns investigadores sugerem uma possível relação entre estes utensílios e as primeiras fases de produção cerâmica, nomeadamente na extracção de argila do terreno (Crandell, Ionescu e Mirea, 2016, p. 244).

Geralmente, verifica-se neste tipo de utensilagem, a presença de marcas de outras funções, numa utilização multifuncional, que tinha origem no aproveitamento/esgotamento máximo de um utensílio já em desuso, para outros fins. Estas funções $a$ posteriori normalmente resultam em percutores, ou em polidores (na zona do gume) (Gomes, 2002, p. 47). Esta situação não é possível confirmar no exemplar da Moita do Ourives, uma vez que não se conservou o talão (possível zona para a percussão), e o espaço do gume não indicia que tivesse sido usado como polidor.

\section{Martelo}

No decorrer da escavação foi identificado um artefacto em quartzito que levantou algumas dúvidas na sua classificação. A morfologia e a área conservada do instrumento parecem remeter para um talão convexo de um machado ou enxó, fracturado transversalmente, com um corpo picotado e bordos divergentes. Se, primariamente, terá sido parte de alguns destes utensílios, é algo que hoje não podemos avaliar. No entanto, as nítidas marcas de utilização que apresenta numa das extremidades (zona facturada), remete para um instrumento tipo "martelo". De secção circular, conserva um comprimento de $66 \mathrm{~mm}$, por $50 \mathrm{~mm}$ de largura, $44 \mathrm{~mm}$ de espessura e $238 \mathrm{~g}$ de peso (Figura 3, ํㅡㄴ). A sua possível funcionalidade estará associada à actividade de percutir, esmagar ou moer. Na Roménia, ocorrem alguns elementos de tipologia semelhante em contextos neolíticos, tendo sido referida a possibilidade de se constituírem como utensílios que podem ter ajudado a moer elementos minerais que, como elementos não plásticos, integrariam a argila usada na produção de recipientes (Crandell, Ionescu e Mirea, 2016, p. 248).

\section{b) Pedra afeiçoada \\ Moventes}

Na Moita do Ourives recuperaram-se nove moventes, recorrendo a quatro matérias-primas: o granito, o quartzito, o arenito e o quartzo. O seu peso no registo é considerável, podendo assumir um significado determinante na caracterização da tipologia funcional desta ocupação, e na avaliação do subsistema económico praticado pelo grupo.

Os recursos utilizados parecem responder ao substrato geológico imediatamente disponível, figurando quatro exemplares em quartzito, dois em quartzo (conglomerado), um em arenito e um, claramente exógeno na sua composição, em granito.

O conjunto parece corresponder a moventes de pequena dimensão, possivelmente manipulados com uma só mão. Apenas existe um único movente intacto, em arenito, que tem de comprimento $84 \mathrm{~mm}$, de largura $79 \mathrm{~mm}$ e de espessura $44 \mathrm{~mm}$. Apesar de intacto, não corresponderáà peça com maior dimen- 
são, sendo que os restantes exemplares apresentam comprimentos entre os 54 e os $99 \mathrm{~mm}$, larguras entre os 50 e os $88 \mathrm{~mm}$, com as espessuras a oscilarem entre entre os 30 e os $67 \mathrm{~mm}$. São maioritárias as peças com espessuras compreendidas entre os 40 e os $55 \mathrm{~mm}$, com largura entre os 70 e os $79 \mathrm{~mm}$, ocorrendo sete exemplares com um comprimento superior a $80 \mathrm{~mm}$. Nos elementos fragmentados, as fracturas apresentam-se como simples.

Ao nível da sua morfologia, o estado de conformação das peças é pouco variável, apresentando-se estes com forma ovalada ou discóidal (Figura 4).

Os bordos encontram-se, na sua maioria, afeiçoados ou em bruto, sendo que dois não parecem ter sido alvo de uma preparação formal, restando a superfície activa como o único indicador de conformação e utilização enquanto instrumento.

Dos nove moventes, verificou-se em seis a existência de somente uma superfície activa e, em três, a presença de duas superfícies activas, sempre opostas, correspondendo, assim, a um total de 12 superfícies activas. De notar que o exemplar em granito é dos que tem duas superfícies activas, sinal de uso intenso e optimização máxima de um recurso não disponível nas áreas cercanas da ocupação. Observando o estado das superfícies, na tentativa de avaliar a intensidade ou tipo/forma como estes utensílios poderão ter sido utilizados, constata-se que o polimento é o estado mais presente no conjunto da Moita do Ourives, demonstrando, assim, que estes artefactos terão sido alvo de um uso bastante intensivo. Em dois exemplares, só se observa o picotado, ocorrendo em quatro fragmentos, uma combinação de vestígios, entre o picotado e o polido (Tabela 2).

Tal como assinalámos anteriormente, cinco destes exemplares foram identificados em áreas próximas dos dois exemplares de dormentes, não sendo, ainda assim, indiscutível a sua clara associação. Num conjunto com um número razoável de moventes, mas que se caracteriza por um elevado grau de fragmentação, é preciso alguma cautela nas leituras a realizar. É de crer que estes exemplares estejam dispersos, de forma aleatória, pela área intervencionada, sugerindo que correspondam a utensílios abandonados durante a ocupação neolítica e cuja localização, no momento da sua descoberta, poderá não possuir uma relação directa com os espaços onde foram utilizados.

\section{Dormentes}

Nesta categoria, foram identificados dois exemplares, um em quartzo (conglomerado), e um outro em arenito. Uma vez que se trata de um conjunto muito restrito, optou-se por descrever as suas principais características, de forma individualizada.

O exemplar em quartzo é de difícil descrição e classificação. A sua reduzida dimensão devido ao elevado estado de fragmentação levantou dúvidas se se trataria de um dormente ou movente. O facto da área activa se apresentar relativamente polida e, acima de tudo, ligeiramente encovada, levou a que se integrasse nesta classe de utensílios afeiçoados. Foi observada uma única superfície activa, totalmente polida na área conservada, permanecendo as restantes superfícies em estado bruto, assim como os seus bordos. Apresenta um comprimento conservado de $72 \mathrm{~mm}$, por $70 \mathrm{~mm}$ de largura e $55 \mathrm{~m}$ de espessura, com um peso de $338 \mathrm{~g}$.

O outro dormente corresponde a uma peça produzida em arenito que, apesar de ligeiramente fracturada (fractura simples), revela um polimento intenso e de grande amplitude, afectando praticamente a totalidade da superfície funcional, que se encontra visivelmente encovada (Figura 5). Conserva um comprimento de $205 \mathrm{~mm}$, por $214 \mathrm{~mm}$ de largura, $65 \mathrm{~mm}$ de espessura e um peso de $3026 \mathrm{~g}$, apresentado, desta forma, uma dimensão bastante considerável. Apesar de não estar intacto, é possível verificar que, originalmente, apresentaria uma morfologia circular ou subcircular. Apresenta uma única superfície activa, polida, e o bordo intacto está completamente afeiçoado. O grau de polimento da superfície, assim como a sua dimensão, é compatível com acções de moagem baseadas em movimentos horizontais, embora não seja de excluir a possibilidade de ter servido como suporte a acções de trituração por esmagamento, quer de alimentos vegetais, quer de matérias minerais.

A presença destes instrumentos pode atestar a prática, na Moita do Ourives, de actividades económicas próprias das sociedades neolíticas. Trata-se de utensílios que, quando registados em contextos habitacionais, têm sido conotados na bibliografia como indicadores seguros de processamento de alimentos, nomeadamente a moagem e farinação de produtos vegetais (Roux, 1985).

Numa leitura que resulta de uma observação macroscópica, e perante um universo artefactual tão reduzido, e onde um dos exemplares está bastante 
fragmentado, não dispomos, desta forma, de sinais minimamente seguros acerca da sua funcionalidade, e temos consciência que o seu maior contributo é a própria descrição e classificação tipológica destes instrumentos.

Noutro âmbito, seria fundamental proceder a abordagens de foro experimental, mas também recorrer a análises bioquímicas e fitológicas sobre estes elementos. O objectivo seria procurar, nas superfícies trabalhadas, possíveis traços de uso, vestígios microbotânicos e resíduos (como tecido de plantas, fitólitos, resinas e lípidos), tendo consciência que esta ainda é uma prática pouco comum e que acarreta um condicionalismo logístico, uma vez que a realização de exames microscópicos em artefactos pouco móveis, e com alguma dimensão e peso, é um claro obstáculo à sua completa análise (Rowan e Ebeling, 2008).

Por fim, regista-se o facto de nenhum dos elementos se apresentar termoalterado (com sinais de estalamento térmico ou em total desagregação). Não é incomum o seu registo em estruturas ou áreas de combustão, o que leva a questionar se as actividades realizadas com estes elementos se desenvolvem junto ao fogo ou se, numa utilização secundária, integrariam estruturas de combustão. Esta situação não parece verificar-se na Moita do Ourives, mas em outros contextos neolíticos, como no sítio do Prazo, onde os elementos desta natureza surgiram "extremamente termoalterados" e "salvo raras excepções (...) detectaram-se em áreas de combustão", levando o investigador responsável a considerar tais propostas (Monteiro-Rodrigues, 2011, p. 218).

\section{c) Pedra com traços de utilização}

O grupo de utensílios de pedra com traços de utilização é composto por bigorna, percutores e manuporte.

\section{Bigorna}

O único exemplar que se enquadra nesta categoria é sobre um seixo de quartzito apresentando, numa das superfícies, a concavidade e o picotado que resulta da sucessão de impactos num mesmo ponto distinguindo-se, assim, dos restantes artefactos.

Esta bigorna apresenta o suporte em bruto (com excepção da superfície onde se verifica a referida concavidade), sem qualquer bordo polido ou bojardado, estando também ausentes outras marcas/ estigmas de percussão. Trata-se de uma peça, fragmentada, de pequena dimensão, com um compri- mento conservado de $49 \mathrm{~mm}$, larguras de $46 \mathrm{~mm}$, e espessuras de $26 \mathrm{~mm}$.

Este tipo de utensílio está normalmente associado ao talhe bipolar (Diniz, 2007, p.10o e 111; Monteiro-Rodrigues, 2011, p. 185), sendo esta uma prática atestada nesta ocupação (Neves, 2018).

\section{Percutores}

Neste ponto, menciona-se unicamente os artefactos que apresentam estigmas de percussão em áreas que não foram alvo de debitagem ou que denunciam qualquer actividade prévia. Desta forma, estes exemplares distinguem-se dos possíveis percutores em quartzito identificados na Moita do Ourives e que terão sido inicialmente núcleos para a produção de lascas (Neves, 2018).

O universo de percutores corresponde a seis exemplares, todos sobre seixo de quartzito. Trata-se de percutores duros utilizados, com probabilidade, no talhe através da percussão directa sobre núcleos de quartzito e quartzo, sendo esta uma técnica claramente documentada nos materiais de pedra lascada da Moita do Ourives.

Dos seis percutores, três estão intactos e três encontram-se fracturados. Em um dos casos, é visível que a zona de percussão terá ficado inactiva em sequência do levantamento de uma lasca pela própria percussão. Num outro caso, a fractura terá resultado de acção térmica, uma vez que este percutor terá sido, como função secundária, um termoclasto.

Quanto aos bordos, em três percutores encontram-se bojardados, permanecendo os restantes em estado bruto. Os estigmas de percussão que permitiram a sua classificação tipológica encontram-se concentrados e as superfícies activas identificadas estão percutidas. De registar que os únicos três casos onde só se verificou uma superfície activa correspondem aos três exemplares fracturados. Nos restantes, um percutor possui três superfícies com traços de utilização, e dois com duas superfícies activas. As superfícies não activas permanecem sempre em estado bruto.

Relativamente às suas dimensões, trata-se de peças de pequena e média dimensão, com comprimentos compreendidos entre os 31 e $84 \mathrm{~mm}$, larguras entre os 30 e os $75 \mathrm{~mm}$, e espessuras que variam entre os 19 e os 6 omm, sendo o peso máximo aferido de $478 \mathrm{~g}$ (Figura 6). 


\section{Manuporte}

Corresponde a um único elemento em granito, matéria-prima que não se insere no ambiente geológico da Moita do Ourives. Trata-se de um pequeno fragmento com os bordos e superfícies, conservadas, em bruto. Foi classificada como uma "lasca em bruto", sendo impossível aferir qualquer relação com um processo técnico específico.

\section{DISCUSSÃO: O QUE PODE REVELAR O CONJUNTO DE PEDRA POLIDA E AFEIÇOADA DA MOITA DO OURIVES?}

\subsection{Matéria-prima: aquisição e seus territórios}

Ao nível da aquisição de matérias-primas, constata-se alguma diversidade nas estratégias adoptadas por estas comunidades a partir do final do $5^{\circ}$ e ao longo do $4^{\circ}$ milénio. Se, por um lado, existe uma clara tendência pela opção mais conservadora - utilização preferencial pelos recursos essencialmente disponíveis - a verdade é que o registo arqueológico mostra a presença de alguns elementos artefactuais, cuja matéria-prima deverá ter sido obtida em espaços localizados a média/longa distância face ao contexto onde foram recolhidos.

$\mathrm{Na}$ Moita do Ourives, na selecção da matéria-prima para a produção de líticos, a opção recaiu sobre os recursos locais, visível nas elevadas percentagens de quartzito e quartzo no conjunto.

No entanto, e à imagem do verificado na pedra lascada onde ocorre uma percentagem de elementos de origem exógena (sílex e jaspe) que coloca as estratégias de exploração do espaço e aquisição de recursos em áreas que distam entre $\sim 30$ a $100 \mathrm{Km}$ para Norte, Oeste e Sul do sítio (Matias e Neves, 2017), verifica-se que, também, na produção de uma pequena parte dos artefactos de pedra polida/ afeiçoada a comunidade ultrapassou as imediatas proximidades da área de ocupação, na procura da matéria-prima que melhor se enquadrava, funcional, simbólica e esteticamente, no artefacto que queria produzir.

Para o granito e rocha anfibólica utilizadas nesta ocupação, as observações de proveniência detectam territórios de aquisição, revelando presumíveis trajectórias de circulação num espaço igualmente amplo (Figura 7).

Estes prováveis espaços de exploração apresentam testemunhos de ocupação humana dentro do período reconhecido para o Neolítico médio (c. 4500 -
-3200 cal BC), dando coerência científica e empírica a esta leitura. Independentemente do seu enquadramento cronológico específico inserido neste período (algumas ocupações corresponderão ao Neolítico médio inicial e, outras, a uma fase mais plena, mais próxima do horizonte crono-cultural da Moita do Ourives), o que importa assinalar é que as áreas de aquisição das matérias-primas exógenas identificadas na pedra polida e afeiçoada da Moita do Ourives foram, efectivamente, cenários de acção das populações do Neolítico médio, apresentando-se tanto como lugares de Vida como de Morte (Neves, 2018). As fontes primárias de granito e anfibolito, situadas nos afloramentos do Maciço Hespérico, mais próximas da ocupação em análise, encontram-se na área do interior alentejano, entre $\sim 40$ a $50 \mathrm{~km}$ de distância. Neste espaço, localizado na região de Vendas Novas - Montemor-o-Novo, surgem testemunhos de ocupações desde o final do Neolítico antigo (ex.: Patalim), mas essencialmente, espaços funerários com utilizações no Neolítico médio, como a Gruta do Escoural ou o sepulcro megalítico do Cabeço da Areia (Ferreira, 2005; Araújo e Lejeune, 1995; Rocha, 2005). Relativamente próximo destes locais, ligeiramente mais para Sudeste, já na região de Évora, estão atestadas ocupações de cariz residencial da fase mais inicial do Neolítico médio, em Hortinha 1, Vale Rodrigo 2 e Vale Rodrigo 3 (Rocha, 2007; Armbruester, 2006 e 2008; Larsson, 2000).

A cerca de $60 \mathrm{~km}$ de distância da Moita do Ourives, e das outras ocupações do Neolítico médio do Baixo Tejo onde foram identificados elementos em anfibolito e granito, como o Monte da Foz (Neves, 2011), na área de Montargil, Ponte de Sor e Mora, ocorrem formações geológicas que podem ter sido fontes primárias destas matérias-primas. Aqui, além dos habitats de uma fase de transição entre o Neolítico antigo e Neolítico médio do Alminho 1 e Bernardo 1, na região de Ponte Sor (Deus, 2008b), a passagem das comunidades do Neolítico médio no território está atestada na área de Mora, através da utilização funerária do sepulcro megalítico da Cabeceira 4, datado entre do $2^{\circ}$ e $3^{\circ}$ quartel do $4^{\circ}$ milénio cal BC (Carvalho e Rocha, 2016).

A uma distância ligeiramente superior, mas ainda como área de possível proveniência de anfibolito, situa-se a zona do médio Tejo, a 80-9okm da Moita do Ourives. Aqui, a presença de testemunhos associados ao Neolítico médio carece de alguma confirmação, apesar da presença de um significativo con- 
junto de monumentos megalíticos de cariz funerário com possível ocupação associada a este momento crono-cultural (Cruz, 1996; Burbidge et al, 2019). Já no espaço mais próximo de Tomar e Vale do Nabão, encontram-se as ocupações funerárias do Neolítico médio nas grutas do Caldeirão, Cadaval e Ossos, inseridas, genericamente, nos primeiros três quartéis do $4^{\circ}$ milénio cal BC (Zilhão, 1992; Lopes, 2005/2006; Oosterbeek, 1995).

As áreas de proveniência localizadas no Alentejo interior e do Médio Tejo, origem provável dos artefactos de pedra polida e afeiçoada da Moita do Ourives são, igualmente, os locais de aprovisionamento de matérias-primas para um conjunto de outros sítios com ocupações do Neolítico médio.

Neste particular, destacam-se os machados identificados entre os espólios votivos da gruta do Algar do Bom Santo, Lugar do Canto e Porto Covo, que apontam para fontes de aquisição idênticas, localizadas nas formações do Complexo Precâmbrico da área de Abrantes-Tomar e Montemor-o-Novo (Cardoso e Carvalho, 2008, p. 274; Cardoso, 2014, p. 190).

Tal como se verifica para a Moita do Ourives, a ocorrência de artefactos nestes contextos em particular, cuja matéria-prima poderá ter sido obtida a grande-distância, reflecte acções de índole económica, suportadas por uma complexidade social bem vincada. Por aferir, estará o estado em que estes produtos chegam ao seu destino, se em bruto, pré-formatados, ou já como produto final, numa leitura, por ora, impossível de definir.

Observando os locais de origem das matérias-primas/artefactos em pedra polida e afeiçoada da Moita do Ourives, constata-se que são áreas cujo acesso terá sido facilitado pelos recursos fluviais como o Sorraia e Almansor, muito próximos do sítio arqueológico que, no momento da sua ocupação durante o Neolítico médio, apresentavam um caudal ainda fortemente marcado pela transgressão flandriana (Vis, 2009).

O curso destas ribeiras coincide com pontos de "chegada a", ou "partida de" estes lugares, tanto a montante (região de Montargil, Ponte de Sor, Mora e Pavia no caso do Sorraia; região de Montemor-o-Novo e Vendas Novas, no caso do Almansor), como a jusante (na margem esquerda do Tejo, perto de Benavente, onde se localizam a Moita do Ourives e, também, o Monte da Foz 1 o sítio do Neolítico médio inicial do Monte da Foz 1 - Neves, 2011), tendo tido um papel determinante na circulação das matérias-primas, produtos, ideias e, acima de tudo, pessoas e animais.

\subsection{Subsistema económico do Neolítico} médio: os dados da pedra polida e afeiçoada

Perante a parca informação directa sobre as práticas económicas, a reconstituição do subsistema económico procura utilizar a cultura material como elemento de diagnóstico, destacando-se a presença de instrumentos de pedra polida e afeiçoada (machados, enxós, moventes e dormentes), como indicadores indirectos da presença e maior/menor peso das práticas agrícolas.

Se tomarmos, unicamente, em atenção a frequência destes elementos no registo de contextos habitacionais, então o peso das práticas agrícolas no centro e sul de Portugal é reduzido, numa leitura que já se verificava numa fase final do Neolítico antigo evolucionado (finais do $6^{\circ}$ e primeira metade do $5^{\circ}$ milénio cal BC) (Tabela 3).

Na pedra polida, a presença de machados e enxós é mesmo residual, sendo que nos contextos onde essa informação surge contabilizada, o número de cada um destes elementos não supera as duas unidades. O estado de fragmentação de muitos dos vestígios com sinais de polimento, dificulta a sua caracterização ao mesmo tempo que permite aumentar o número de ocorrências, o que pode induzir em erros de avaliação. Neste particular, a constante presença de pequenas "lascas de anfibolito" (ex.: Monte da Foz, Cerradinho do Ginete e Pena d'Água), não pode assumir, na leitura destes sítios, um peso semelhante a um instrumento inteiro ou parcialmente fracturado. De igual modo, surgem alguns contextos onde, além da ausência de contabilização exacta do número de artefactos desta natureza, não se apresenta qualquer informação quanto à sua caracterização e contexto de proveniência, o que limita a reflexão acerca destes elementos.

Quanto à pedra afeiçoada, o registo arqueográfico parece revelar uma presença/recurso maior a este tipo de instrumentos, nomeadamente os elementos de moagem (dormentes e moventes), surgindo ainda fragmentos de polidores ou de outros instrumentos por identificar, devido às reduzidas dimensões que apresentam. A ausência de informação detalhada acerca da contabilidade e descrição tipológica dos vestígios, limita qualquer interpretação. Por outro lado, a possibilidade de corresponderem a artefactos relacionados com práticas de moagem de recur- 
sos silvestres diminui o seu valor como indicador de práticas agrícolas. Para já, sem análises bioquímicas e fitológicas sobre as superfícies activas, na procura de traços de uso e vestígios microbotânicos, esta será uma questão deixada em aberto.

De notar que a maior presença de instrumentos em pedra polida e afeiçoada parece associada a contextos residenciais com ocupações mais permanentes como Castelo Belinho, Palmeirinha, Salema e Fábrica de Celulose.

A generalizada baixa presença de artefactos de pedra polida e afeiçoada nos espaços domésticos poderá estar, igualmente, relacionada com a realização das práticas agrícolas em áreas exteriores às ocupações, constituindo-se como espaços de grande invisibilidade arqueológica estando, na sua maioria, por identificar. No entanto, os valores disponíveis terão de ser levados em conta na reconstituição do subsistema económico, podendo constituir-se como indiciadores do peso que as práticas produtivas teriam neste momento.

\section{CONCLUSÃO}

Em contraste com os restantes elementos que integram o clássico "pacote neolítico”, os utensílios em pedra polida e afeiçoada apresentam-se nos contextos neolíticos, do Ocidente peninsular, em percentagens muito residuais totalmente ausentes do registo. Em conjunto com esta evidência, a presença de elementos afeiçoados ainda em contextos do Mesolítico final, como no Prazo (Monteiro-Rodrigues, 2011, p. 223), deverá levar a uma reflexão acerca da importância e real funcionalidade destes instrumentos, se estes estão, exclusivamente relacionados com práticas agrícolas e se constituem um testemunho efectivo da intervenção de uma comunidade no meio natural onde habita, conseguindo mesmo alterar o ecossistema que explora e do qual depende.

No território actualmente português, as práticas agrícolas estão atestadas desde as fases iniciais do processo de Neolitização (Lopéz-Dóriga e Simões, 2015), mas, ao contrário dos recipientes cerâmicos que surgem em percentagens significativas desde os momentos iniciais do Neolítico, os artefactos de pedra polida e afeiçoada só parecem tornar-se mais frequentes, em contextos habitacionais, já na fase final desta etapa crono-cultural.

Nos estudos da pedra afeiçoada, para a qual não existe uma tipologia de referência nem uma padroniza- ção da sua nomenclatura e metodologias de análise, verifica-se ainda uma linguagem descritiva dominada por preferências individuais, com diferentes autores a utilizar termos distintos para descrever instrumentos semelhantes e onde a funcionalidade proposta está muito dependente da com a morfologia do artefacto (Rowan e Ebeling, 2008).

Por fim, é preciso ter em conta que se trata de elementos artefactuais que, pela sua durabilidade e resistência, possuíram muitas vezes um carácter multifuncional, sendo difícil de distinguir qual o seu uso primário e secundário dificultando, adicionalmente, a avaliação do contexto físico do seu uso e abandono.

A base empírica é, assim, escassa e parcelar, pois em alguns contextos a contabilidade destes elementos não se encontra disponível, nem mesmo a sua devida descrição e caracterização tipológica.

No quotidiano de um grupo do Neolítico antigo e médio, os dados hoje disponíveis são, ainda, pouco conclusivos acerca das práticas a que os elementos de pedra afeiçoada e polida estariam relacionados, assim como na definição do seu real peso no subsistema económico nomeadamente no quadro das práticas produtivas, numa reflexão que importa retomar no futuro.

\section{BIBLIOGRAFIA}

Atlas do Ambiente. Portugal. Carta Litológica. 1 / 1000 ooo (material cartográfico). Lisboa: Instituto Hidrográfico. Comissão Nacional do Ambiente. Secretaria de Estado do Ambiente. 1982. Folha I.13.

ARAÚJO, Ana Cristina \& LEJEUNE, Marylise (1995) - Gruta do Escoural: necrópole neolítica e arte rupestre paleolítica. Lisboa: Instituto Português do Património Arquitectónico e Arqueológico (Trabalhos de Arqueologia; 8).

ARMBRUESTER, Tanya (2006) - Before the monument? Ceramics with a line below the rim (A preliminary report from Vale de Rodrigo 3, Évora). Simbolismo, arte e espaços sagrados na Pré-História da Península Ibérica: actas do $4 .^{\text {. }}$ Congresso de Arqueologia Peninsular. Faro: Universidade do Algarve, pp. 53-67.

ARMBRUESTER, Tanya (2008) - Technology neglected? A painted ceramic fragment from the dated Middle Neolithic site of Vale Rodrigo 3. Vipasca. Aljustrel. 2. 르 série. 2, pp. 83-94.

BURBIDGE, Chris; CARDOSO, Guilherme; DIAS, Isabel; OOSTERBEEK, Luiz; PRUDÊNCIO, Isabel; SCARRE, Chris (2019) - Luminescence dating at the Anta da Lajinha, In SCARRE, C. \& OOSTERBEEK, L. (eds.), Megalithic 
Tombs in Western Iberia: Excavations at the Anta da Lajinha, Oxbow Books, Oxford, pp. 68-73.

CARDOSO, João Luís (1999/200o) - Os artefactos de pedra polida do povoado pré-histórico de Leceia (Oeiras). Estudos Arqueológicos de Oeiras. Oeiras. 8, pp. 241-323.

CARDOSO, João Luís (2014) - Polished stone tools. In CARVALHO, A. F. (ed.), Bom Santo Cave (Lisbon) and the Middle Neolithic Societies of Southern Portugal. Faro: Universidade do Algarve (Promontoria Monográfica; 17), pp. 185-194.

CARDOSO, João Luís \& CARVALHO, António Faustino (2008) - A Gruta do Lugar do Canto (Alcanede) e a sua importância no faseamento do Neolítico no território português. In CARDOSO, João L. (ed.), Homenagem a Octávio da Veiga Ferreira. Oeiras: Câmara Municipal de Oeiras, pp. 269-30o (Estudos Arqueológicos de Oeiras, 16).

Carta Geológica de Portugal: 1/500.00o (material cartográfico). Lisboa: Serviços Geológicos de Portugal. 1992.

CARVALHO, António Faustino (1998) - Abrigo da Pena d' Água (Rexaldia, Torres Novas): resultados das campanhas de sondagem (1992-1997). Revista Portuguesa de Arqueologia. Lisboa. 1:2, pp. 39-72.

CARVALHO, António Faustino (2008) - A Neolitização do Portugal Meridional: os exemplos do Maciço Calcário Estremenho e do Algarve Ocidental. Promontória Monográfica, 12. Universidade do Algarve, Faro.

CARVALHO, António Faustino \& ROCHA, Leonor (2016) - Datação directa e análise de paleodietas dos indivíduos da anta de Cabeceira 4. ․ㅡ (Mora, Portugal). digitAR, nº .3 , Imprensa da Universidade de Coimbra, pp. 53-61.

CARVALHO, António Faustino \& STRAUS, Lawrence G. (2013) - New Radiocarbon dates for Algarão da Goldra (Faro, Portugal): a contribution to the Neolithic of the Algarve. In JIMÉNEZ ÁVILA, J.; BUSTAMANTE ÁlVAREZ, M. \& GARCÍA CABEZAS, M. (eds.) - VI Encuentro de Arqueología del Suroeste Peninsular, IAM, pp. 193-205. Edição electrónica.

COONEY, Gabriel \& MANDAL, Stephen (1998) - The irish stone axe project. Monograph 1 . Wicklow: Wordwell, Ltd. 229 p.

CRANDELL, Otis; IONESCU, Corina; MIREA, Pavel (2016) - Neolithic and Chalcolithic stone tools used in ceramics production: Examples from the south of Romania. Journal of Lithic Studies, vol. 3, 1, University of Edinburgh, pp. 241-258.

CRUZ, Ana Rosa (1996) - Vale do Nabão: Do Neolítico à Idade do Bronze. Braga: Universidade do Minho.

DEUS, Manuela (2008a) - Alminho 1/Álamo - Montargil, Ponte de Sor. Relatório dos trabalhos arqueológicos efectuados em 2008. Instituto Português de Arqueologia, Lisboa (Policopiado).

DEUS, Manuela (2008b) - O Neolítico antigo do baixo curso do rio Sor: os sítios Bernardo 1 e Alminho 1 (Montargil, Ponte de Sor). Promontória, Ano 6, Número 6, pp. 95-114.
DINIZ, Mariana (2007) - O Sítio da Valada do Mato (Évora): aspectos da neolitização no Interior/Sul de Portugal. Lisboa: Instituto Português de Arqueologia. (Trabalhos de Arqueologia; 48).

FERREIRA, Ângela (2005) - O sítio do Patalim (Montemor-o-Novo) no seu contexto Neolítico. Dissertação de Mestrado em Pré-história e Arqueologia. Lisboa, FLUL. Policopiado.

GOMES, Isidro M. T. (2002) - Estudo do Material Lítico do Crasto de Palheiros (Murça). Uma Primeira Abordagem Metodológica $-2^{\underline{a}}$ Parte, Portugália, Nova Série, XXIII, Porto, F.L.U.P., pp. 35-115.

GOMES, Mário Varela (2010) - Castelo Belinho (Algarve): A ritualização funerária em meados do V milénio AC. GIBAJA, J. F. \& CARVALHO, A. F. (eds.) Os Últimos Caçadores-Recolectores e as Primeiras Comunidades Produtoras do Sul da Península Ibérica e do Norte de Marrocos, Faro, Universidade do Algarve, pp. 69-8o.

GONÇALVES, Victor S. (1989) - Megalitismo e Metalurgia no Alto Algarve Oriental, uma aproximação integrada. Lisboa: INIC/UNIARQ. (2 volumes).

LARSSON, Lars (2000) - Symbols in stone: ritual activities and petrified traditions. Actas do $3 .{ }^{\circ}$ Congresso de Arqueologia Peninsular, UTAD, Vila Real, Setembro de 1999. Porto: ADECAP, vol. 3, pp. 445-458.

LE ROUX, Charles-Tanguy. (1999) - L'outillage de pierre polie enméta-dolérite du type A. Les ateliers de Plussulien (Côtesd'Armor): Production et diffusion au Néolithique dansla France de l'ouest et au-delà. Travaux du Laboratoire "Anthropologie, Préhistoire et Quaternaire Armoricains", 43, UMR 6566 "Civilisations atlantiques etArchéosciences”, Université de Rennes I.

LOPES, Ś́lvia C. (2005-2006) - Paleobiologia da gruta-necrópole do Cadaval (Tomar): Contribuição para o estudo da Neolitização no Alto Ribatejo. Master Erasmus Mundus em Quaternário e Pré-História. Tomar: Instituto Politécnico de Tomar. Policopiado.

LÓPEZDÓRIGA, Inês \& SIMÕES, Teresa (2015) - Los cultivos del Neolítico Antiguo de Sintra: Lapiás das Lameiras 98 y São Pedro de Canaferrim: resultados preliminares. In GONÇALVES, V.S.; DINIZ, M.; SOUSA, A. C., (eds.) 5..$^{\circ}$ Congresso do Neolítico Peninsular. Actas. Lisboa: UNIARQ. pp. 98-107.

LUNARDI, Anna (2008) - Experimental testing with polished green stone axes and adzes: technology and use. In LONGO, Laura e SKAKUN, Natalia (eds.) "Prehistoric Technology" 40 years later. Functional Studies and the Russian Legacy. Proceedings of the International Congress Verona (Italy) 20-23 April 2005, pp. 369-373.

MASCLANS LATORRE, Alba; PALOMO PÉREZ, Antoni; GIBAJA BAO, Juan F.; REMOLINS ZAMORA, Gerard \& GÓMEZ-GRAS, David (2016) - Use-wear analysis of Neolithic polished axes and adzes: The site of "Bòbila Madurell- 
Can Gambús-1-2” (Northeast Iberian Peninsula). Quaternary International, Elsevier, pp. 1-17.

MATIAS, Henrique \& NEVES, César (2017) - A gestão do sílex durante o Neolítico médio da Moita do Ourives (Benavente, Portugal). ARNAUD, J. M. \& MARTINS, A. (coords.) Arqueologia em Portugal: 2017 - Estado da Questão, Lisboa, Associação dos Arqueólogos Portugueses, pp. 489-504.

MONTEIRO-RODRIGUES, Sérgio (2011) - Pensar o Neolítico Antigo. Estudos Pré-Históricos. Centro de Estudos Pré-Históricos da Beira Alta, XVI, Viseu.

NEVES, César (2010) - Monte da Foz 1 (Benavente): um episódio da Neolitização na margem esquerda do Baixo Tejo. Dissertação de Mestrado em Arqueologia apresentada à Faculdade de Letras da Universidade de Lisboa. 2 Vols. (policopiado).

NEVES, César (2018) - O Neolítico médio no Ocidente Peninsular: o sítio da Moita do Ourives (Benavente), no quadro do povoamento do $5^{\circ}$ e $4^{\circ}$ milénio AC. Dissertação de Doutoramento apresentada à Faculdade de Letras da Universidade de Lisboa. 2 Vols. (policopiado).

NEVES, César \& DINIZ, Mariana (2014) - Acerca dos cenários da acção: estratégias de implantação e exploração do espaço nos finais do $5^{\circ}$ e na primeira metade do $4^{\circ}$ milénio AC, no Sul de Portugal. Estudos do Quaternário, 11, APEQ, Braga, pp. 45-58.

NEVES, César; RODRIGUES, Ana Filipa; DINIZ, Mariana (2008) - Moita do Ourives - um sítio do Neolítico médio no Baixo Tejo (Benavente, Portugal): matérias-primas e cultura material. HERNÁNDEZ PEREZ, M.; SOLER DÍAZ, J.; LÓPEZ PADILLA, J. (eds.) IV Congreso del Neolítico Peninsular. Alicante: MARQ. 2, pp. 216-221.

NUNES, André \& CARVALHO, António Faustino (2013) - O Neolítico Médio no Maciço Calcário Estremenho: estado actual dos conhecimentos e perspectivas de investigação futura, In ARNAUD, J. M.; MARTINS, A.; NEVES, C. (coords.), Arqueologia em Portugal - 150 anos, Lisboa: Associação dos Arqueólogos Portugueses, pp. 329-334.

OOSTERBEEK, Luiz (1995) - O Neolítico e o Calcolítico na região do Vale do Nabão (Tomar). In KUNST, M. (coord.) Origens, estruturas e relações das Culturas calcolíticas da Península Ibérica: Actas das I Jornadas Arqueológicas de Torres Vedras, 3-5 Abril 1987. Lisboa: IPPAR, pp. 101-111. (Trabalhos de Arqueologia, 7).

READ, Caroline; GRAPES, Rodney; LILLIOS, Katina (1997) - Petrography and Chemical Analyses of Prehistoric Amphibolite Artefacts from Portugal and Possible Source Rocks from Western Iberia. Analytical Facility Publications, 19. Victoria University of Wellington. Wellington, New Zealand, pp. 1-19.

ROCHA, Leonor (2005) - Estudo do megalitismo funerário no Alentejo Central: a contribuição de Manuel Heleno. Dissertação de Doutoramento apresentada à Faculdade de Letras da Universidade de Lisboa, policopiado.
ROCHA, Leonor (2007) - Relatório de escavação do sítio arqueológico da Hortinha 1 (Torre de Coelheiros, Évora).

RODRIGUES, Ana Filipa (2006) - Moita do Ourives: um habitat do Neolítico médio do Baixo Tejo. Do Epipaleolítico ao Calcolítico na Península Ibérica. Actas do IV Congresso de Arqueologia Peninsular. Faro: Universidade do Algarve. pp. 249-262. (Promontoria Monográfica; 04).

ROUX, Valentine (1985) - Le matériel de broyage, Paris, Éditions Recherche sur les Civilizations, Mémoire nํㅜㄷ․

ROWAN, Yorke M. \& EBELING, Jennie (2008) - Introduction: The Potential of Ground Stone Studies. In ROWAN, Y. M. \& EBELING, J. R. (eds.), New approaches to old stones. Recent Studies of Ground Stone Artifacts. (Approaches to Anthropological Archaeology).

SILVA, Carlos Tavares da \& SOARES, Joaquina (2004) - Intervenção arqueológica no sítio neolítico do Brejo Redondo (Sines). Musa, museus, arqueologia e outros patrimónios, Fórum Intermuseus do Distrito de Setúbal, pp. 83-105.

SILVA, Carlos Tavares da \& SOARES, Joaquina (2018) Para o estudo do Neolítico Médio: o sítio da Fábrica de Celulose (Mourão). Revista Portuguesa de Arqueologia, DGPC, Lisboa, 21, pp. 5-23.

SILVA, Carlos Tavares da; SOARES, Joaquina; COELHO-SOARES, Antónia (2010) - Arqueologia de Chãos de Sines. Novos elementos sobre o povoamento Pré-histórico. Actas do $2^{\circ}$ encontro de História do Alentejo Litoral, Sines, Centro Cultural Emmérico Nunes, pp. 11-34.

SIMÕES Carlos Duarte, REBELO, Paulo, NETO, Nuno \& CARDOSO, João Luís (2020) - Lisboa no Neolítico antigo: resultados das escavações no Palácio Ludovice. Estudos Arqueológicos de Oeiras, 26, Oeiras, Câmara Municipal, 2020, pp. 11-40.

SOARES, Joaquina \& SILVA, Carlos Tavares da (1980) O neolítico antigo na área de Sines. Descobertas Arqueológicas no Sul de Portugal. Centro de História da Universidade de Lisboa e Museu de Arqueologia e Etnografia da Assembleia Distrital de Setúbal, pp. 5-12.

SOARES, Joaquina \& SILVA, Carlos Tavares da (1992) Para o conhecimento dos povoados de megalitismo de Reguengos. Setúbal Arqueológica. Setúbal. IX-X, pp. 37-88.

SOARES, Joaquina \& SILVA, Carlos Tavares da (2013) Economia agro-marítima na Pré-História do estuário do Sado. Novos dados sobre o Neolítico da Comporta. Pré-história das Zonas Húmidas. Paisagens de Sal. SOARES, Joaquina (ed.), Setúbal Arqueológica, 14, MAEDS, Setúbal, pp. 145-170.

STRAUS, Lawrence G.; ALTUNA, J.; FORD, D.; MARAMBAT, L.; RHINE, J. S.; SCHWARCZ, J.-H. P.; VERNET, J.-L. (1992) - Early farming in the Algarve (Southern Portugal): A preliminary view from two cave excavations near Faro. Trabalhos de Antropologia e Etnologia, Porto, 32, pp.141-161. 
URIBE, Marta Díaz-Guardamino (2004) - As lareiras infratumulares, MORAN, E. \& PARREIRA, R. (coord.) Alcalar 7 . Estudo e reabilitação de um monumento megalítico. Cadernos, 6, Lisboa: Instituto Português do Património Arquitectónico, pp. 137-147.

VALERA, António (2006) - O Neolítico da desembocadura do Paleo Estuário do Tejo: dados preliminares do Palácio dos Lumiares (Bairro Alto, Lisboa). Era - Arqueologia, Revista de divulgação científica de estudos arqueológicos, Dafundo: Era-Arqueologia S.A.7, pp. 86-108.

VIS, Geert-Jan (2009) - Fluvial and marine sedimentation at a passive continental margin. The late Quaternary Tagus deposicional system. Ph.D. dissertation. VU University Amsterdam, 244 p.
VIS, Geert-Jan; KASSE, Cornelis; VANDENBERGHE, Jef (2008) - Late Pleistocene and Holocene palaeogeography of the Lower Tagus Valley (Portugal): effects of relative sea level, valley morphology and sediment supply. Quaternary Science Reviews. 27, pp. 1682-1709.

ZILHÃO, João (1992) - Gruta do Caldeirão. O Neolítico Antigo. Lisboa: Instituto Português do Património Arquitectónico e Arqueológico. (Trabalhos de Arqueologia; 6).

\begin{tabular}{|l|l|l|l|l|l|l|l|}
\hline \multicolumn{2}{|l}{ Utensilagem } & Anfibolito & Granito & Arenito & Quartzito & Quartzo $\begin{array}{l}\text { Total } \\
(N-\text { e } \%)\end{array}$ \\
\hline \multirow{2}{*}{ Pedra polida } & Machado & 1 & - & - & - & - & $1-4,8 \%$ \\
\cline { 2 - 9 } & Martelo & - & - & - & 1 & - & $1-4,8 \%$ \\
\hline \multirow{2}{*}{ Pedra afeiçoada } & Movente & - & 1 & 2 & 4 & 2 & $9-42,8 \%$ \\
\cline { 2 - 9 } & Dormente & - & - & 1 & - & 1 & $2-9,5 \%$ \\
\hline $\begin{array}{l}\text { Pedra com traços } \\
\text { de utilização }\end{array}$ & Bigorna & - & - & - & 1 & - & $1-4,8 \%$ \\
\hline & Percutor & - & - & - & 6 & - & $6-28,5 \%$ \\
\hline Manuportes & Lasca em bruto & - & 1 & - & - & - & $1-4,8 \%$ \\
\hline Total (Noe $\%)$ & & $1-4,8 \%$ & $2-9,5 \%$ & $3-14,3 \%$ & $12-57,1 \%$ & $3-14,3 \%$ & $21-100 \%$ \\
\hline
\end{tabular}

Tabela 1-Pedra polida, afeiçoada e com traços de utilização - Inventário geral.

\begin{tabular}{|l|l|}
\hline Estado & Total \\
\hline Picotadas & $2-16,6 \%$ \\
\hline Picotadas e polidas & $4-33,3 \%$ \\
\hline Polidas & $6-50 \%$ \\
\hline Total & $\mathbf{1 2 - 1 0 0 \%}$ \\
\hline
\end{tabular}

Tabela 2-Moventes - estado das superfícies. 


\begin{tabular}{|c|c|c|c|c|c|c|c|}
\hline \multirow[b]{2}{*}{ Sítio } & \multicolumn{3}{|c|}{ Pedra polida } & \multicolumn{3}{|c|}{ Pedra afeiçoada } & \multirow[b]{2}{*}{ Ref. Bibliográfica } \\
\hline & Machado & Enxó & $\begin{array}{c}\text { Outro / } \\
\text { Indeterminado }\end{array}$ & Dormente & Movente & $\begin{array}{c}\text { Outro / } \\
\text { Indeterminado }\end{array}$ & \\
\hline \multicolumn{8}{|l|}{ Neolítico antigo evolucionado } \\
\hline Alcalar 7 (ocup. prévia) & - & - & - & 13 & - & - & Uribe, 2004 \\
\hline Patalim & 1 & - & - & 1 & 9 & - & Ferreira, 2005 \\
\hline Salema & - & $\nabla$ & $\nabla$ & \multicolumn{2}{|c|}{$\mathrm{X}$} & - & Soares e Silva, 1980 \\
\hline CPM III & - & - & - & - & $1+1$ & - & Carvalho, 20o8a \\
\hline Laranjal Cabeço das Pias & \multicolumn{2}{|l|}{$1^{*}$} & - & - & - & - & Carvalho, 2008a \\
\hline Pena d’Água(Ea) & - & - & - & - & 1 & - & Carvalho, 2008a \\
\hline Pena d’Água (Eb-topo) & - & - & - & - & - & - & Carvalho, 20o8a \\
\hline Palácio Ludovice & $\nabla$ & $\nabla$ & 2 & 1 & - & - & Simões, et al. 2020 \\
\hline \multicolumn{8}{|l|}{ Neolítico médio inicial } \\
\hline Algarão da Goldra & - & - & - & 2 & 2 & - & $\begin{array}{l}\text { Straus, et al., } 1992 \\
\text { Carvalho e Straus, } 2013\end{array}$ \\
\hline Castelo Belinho & $\nabla$ & $\nabla$ & - & $\nabla$ & $\nabla$ & 1 & Gomes, 2010, p.70 \\
\hline Palmeirinha & 2 & 2 & - & 1 & - & - & Silva et al., 2010 \\
\hline Brejo Redondo & - & 1 & 4 & 3 & - & 5 & $\begin{array}{l}\text { Silva e Soares 2004; } \\
\text { Silva et ai, } 2010\end{array}$ \\
\hline Pontal & - & - & - & - & - & - & Soares e Silva, 2013 \\
\hline Vale Rodrigo 2 (ocup. prévia) & - & - & - & - & - & - & Armbruester, 2006 \\
\hline Vale Rodrigo 3 (ocup. prévia) & - & - & - & - & - & - & Armbruester, 2008 \\
\hline Hortinha I (ocup. prévia) & 1 & - & - & - & - & - & Rocha, 2007 \\
\hline Fábrica da Celulose & 1 & - & 4 & 6 & 3 & 7 & Silva e Soares, 2018; \\
\hline Pipas & - & - & - & 2 & - & 1 & $\begin{array}{l}\text { Soares e Silva, 1992; } \\
\text { info. oral }\end{array}$ \\
\hline Bernardo 1 & - & - & - & - & - & - & Deus, $2008 \mathrm{a}$ \\
\hline Alminho 1 & - & - & - & 1 & 1 & - & Deus, 2008a \\
\hline Monte da Foz I & - & - & 1 & - & - & 3 & Neves, 2010 \\
\hline Palácio Lumiares & - & - & - & - & - & 1 & Valera, 2006 \\
\hline Pena d'Água(Db) & - & - & 2 & - & - & - & Carvalho, 1998 \\
\hline Cerradinho do Ginete & 1 & - & 2 & - & - & - & Nunes e Carvalho, 2013 \\
\hline \multicolumn{8}{|l|}{ Neolítico médio pleno } \\
\hline Barrosinha & - & - & - & $\nabla$ & - & $\nabla$ & Soares e Silva, 2013 \\
\hline Moita do Ourives & 1 & - & - & 2 & 9 & - & Neves (2018) \\
\hline Pena d’Água (Da) & - & - & 2 & - & - & - & Carvalho, 1998 \\
\hline
\end{tabular}

Tabela 3 - Artefactos de Pedra Polida e/ou Afeiçoada em contextos domésticos do final do Neolítico antigo / Neolítico médio no Sudoeste Peninsular.

Legenda:

$\square$ - Indicação da presença mas sem especificar a quantidade;

$\mathrm{X}$ - Autores revelam a presença de "elementos de mós manuais”, sem especificar a sua tipologia e quantificação;

* Autor questiona se é "machado" ou “enxó”. 


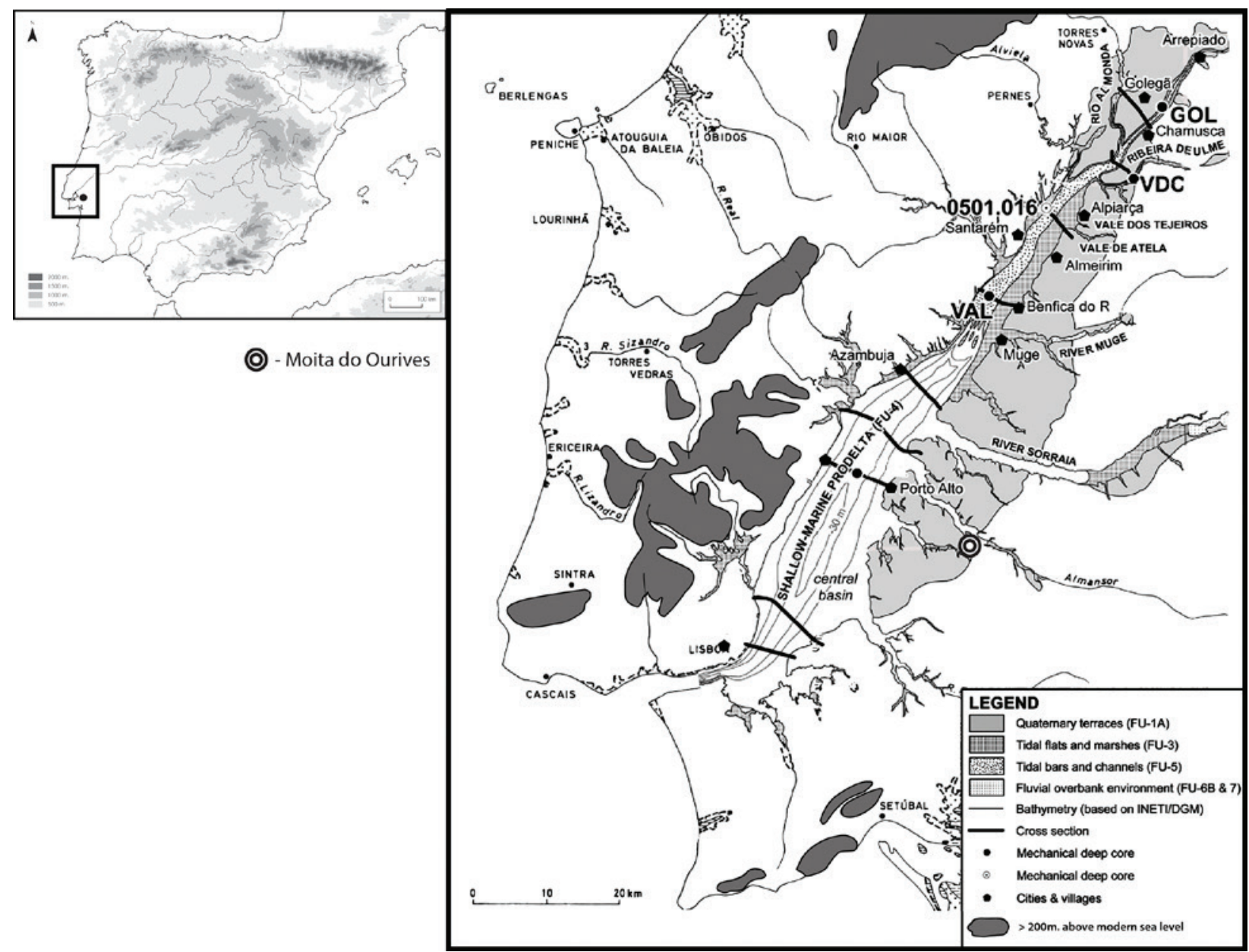

Figura 1 - Localização da Moita do Ourives na Península Ibérica e no paleoestuário existente no Holocénico Médio no Baixo Vale do Tejo (c. 500o-400o cal BC). (base cartográfica: Daveau, [1980, fig.6] e Vis, et al. [2008, fig.12] - adaptado; ideia retirada de Carvalho [2014, fig. 6.2]).

\section{Pedra polida, afeiçoada e com traços de utilização} Relação categoria tipológica / matéria-prima

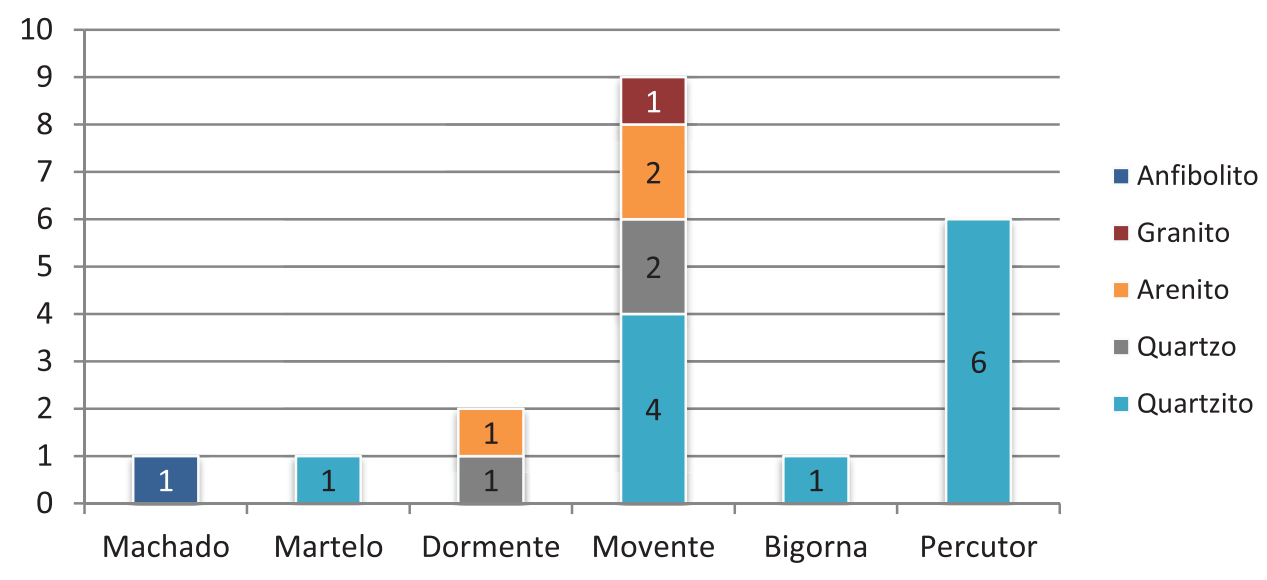

Figura 2 - Pedra polida, afeiçoada e com traços de utilização da Moita do Ourives. Relação categoria tipológica / matéria-prima. 

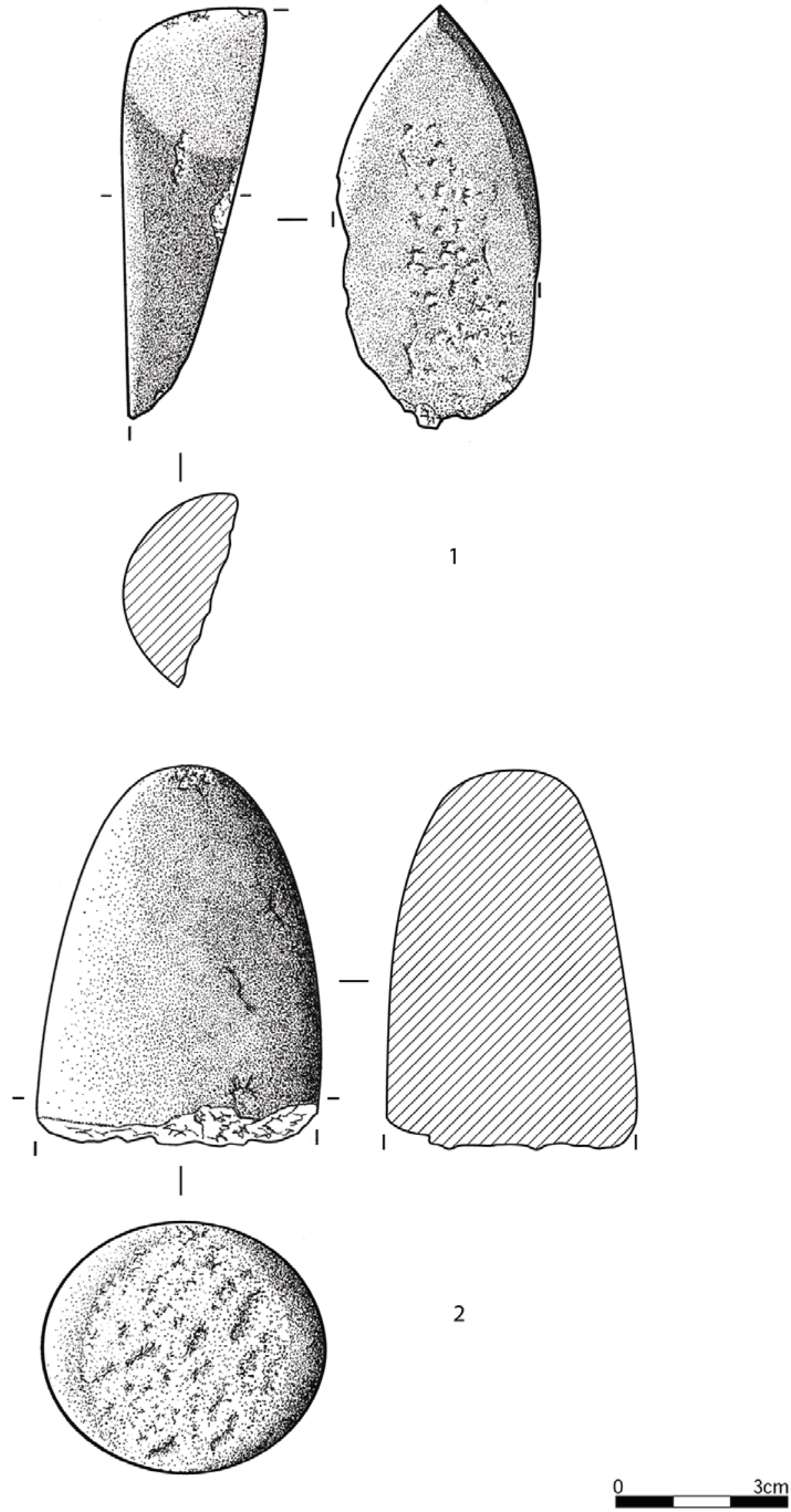

Figura 3 - Moita do Ourives. Pedra polida: 1- Machado; 2 - Martelo. 

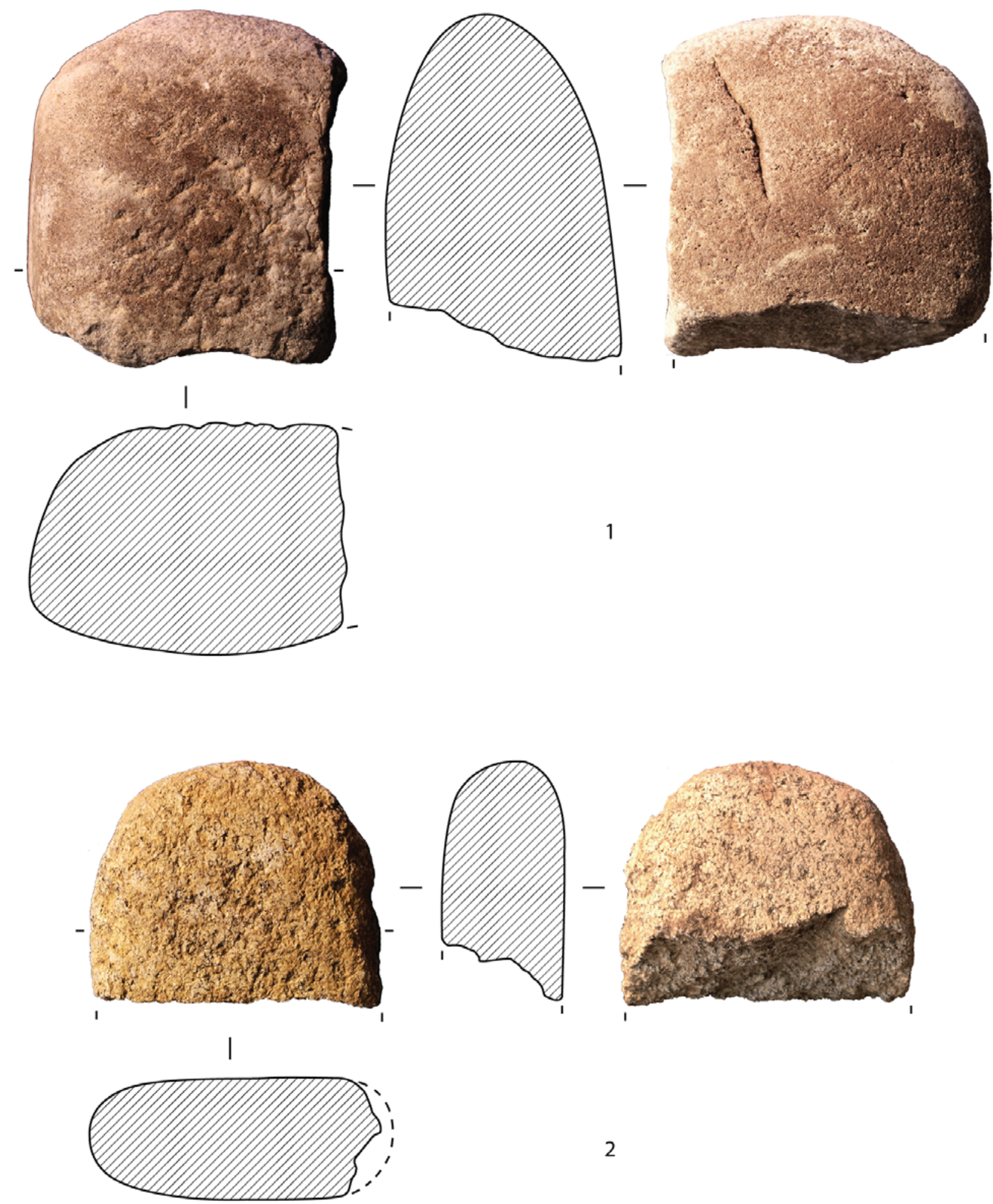

Figura 4 - Moita do Ourives. Pedra afeiçoada: 1 - Movente em quartzito; 2 - Movente em granito. 


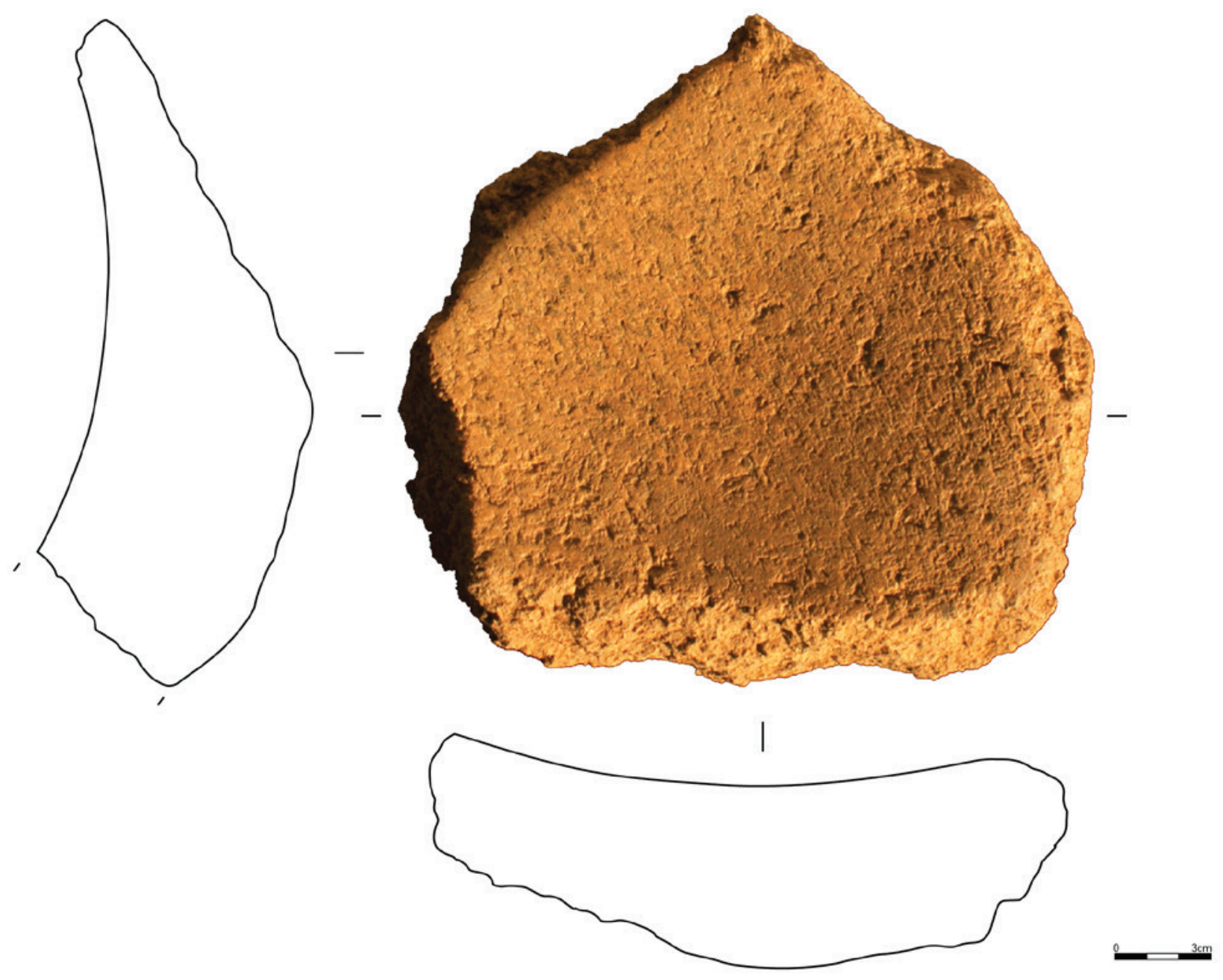

Figura 5-Moita do Ourives. Pedra afeiçoada: Dormente. 

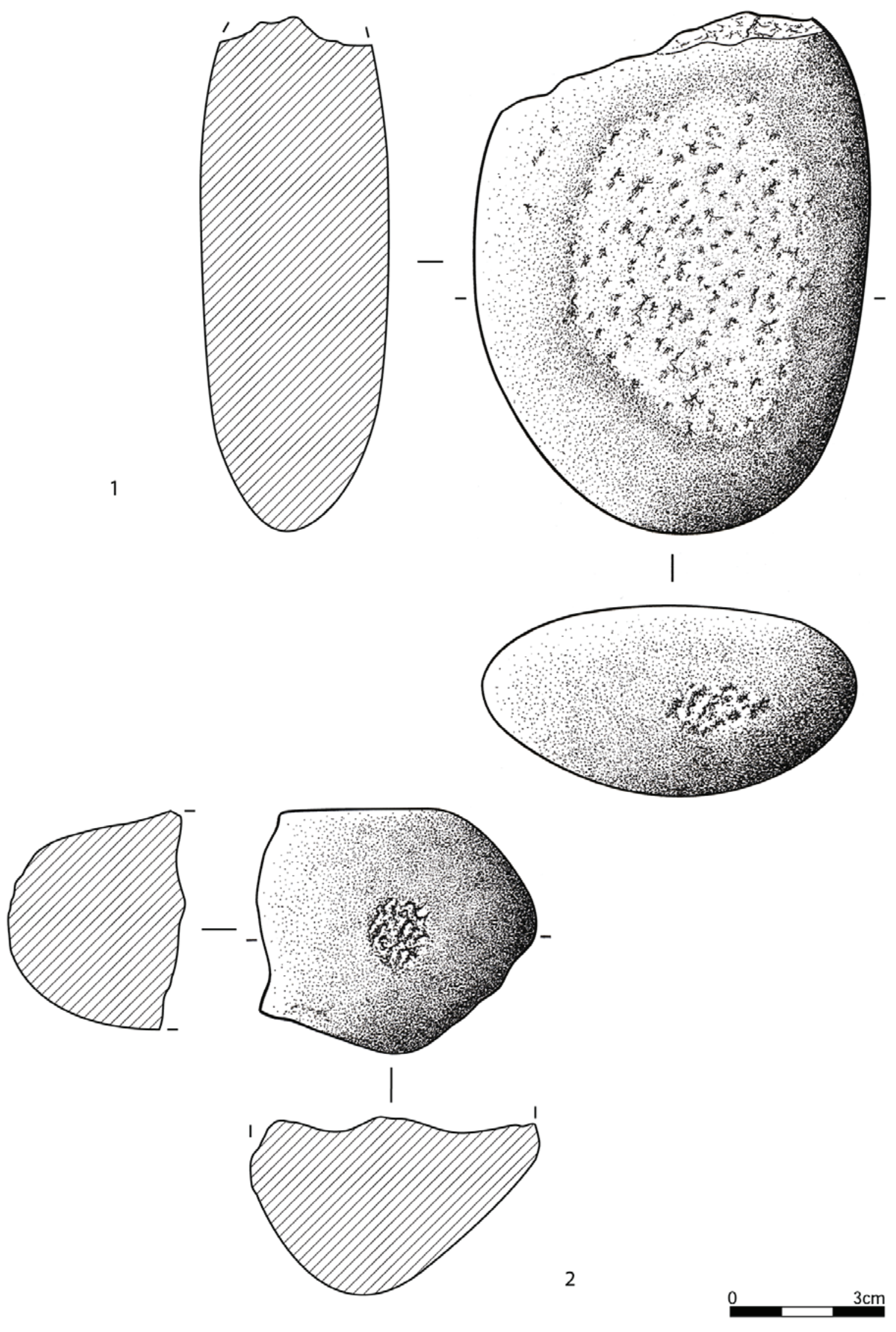

Figura 6 - Moita do Ourives. Pedra afeiçoada em quartzito: 1 - Percutor/Movente; 2 - Percutor (com fractura térmica). 


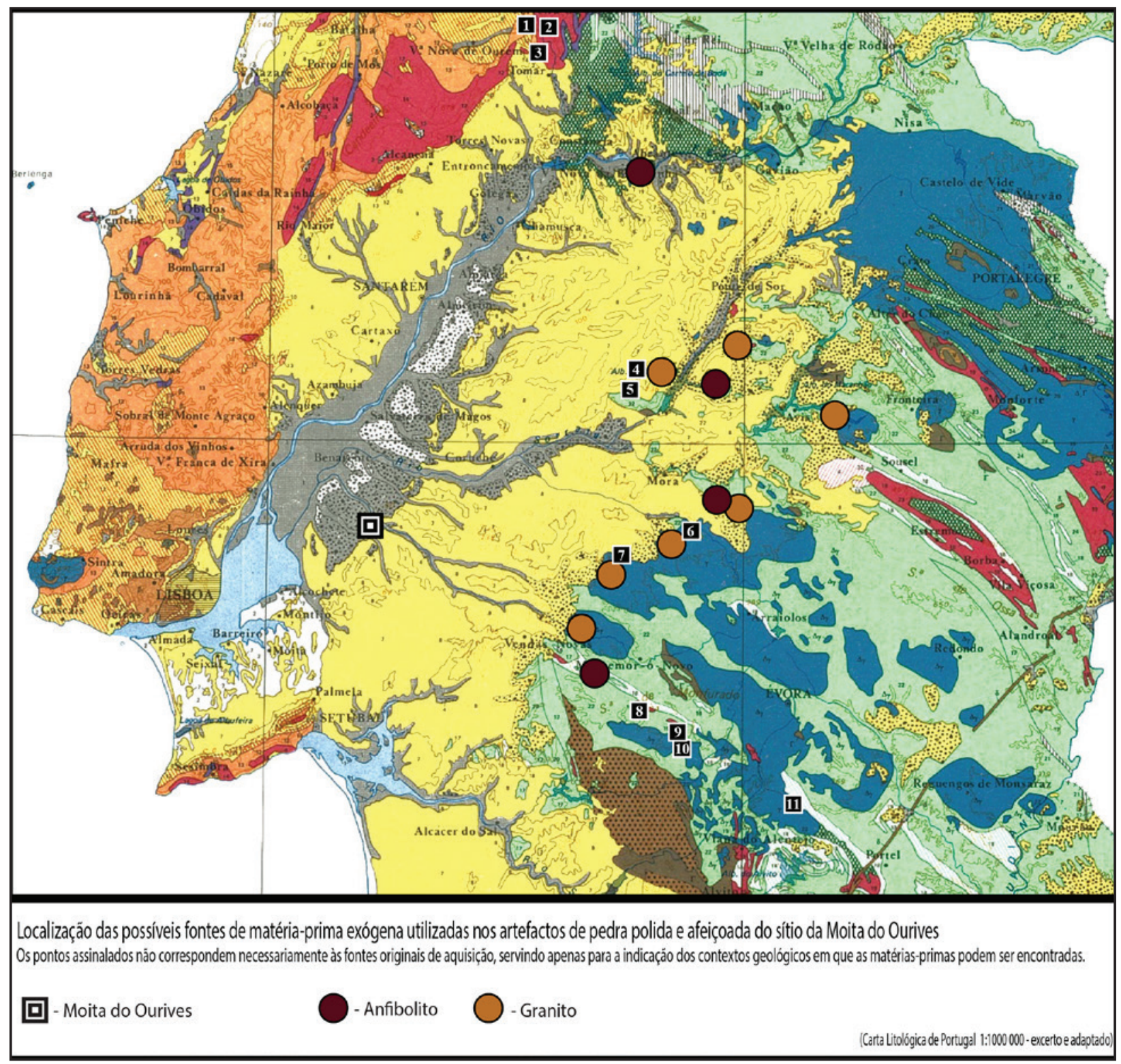

Figura 7 - Localização das possíveis fontes de matéria-prima exógena (granito e anfibolito), face à Moita do Ourives, e de ocupações atribuíveis ao Neolítico médio na sua envolvência. (base cartográfica: Carta Litológica de Portugal 1: 1000 ooo). Legenda: 1 - Gruta dos Ossos; 2 - Cadaval; 3 - Caldeirão; 4-Bernardo 1; 5-Alminho 1; 6 - Cabeceira 4; 7 - Cabeço da Areia; 8 - Escoural; 9 - Vale Rodrigo 3; 10 - Vale Rodrigo 2; 11 - Hortinha 1. 


\title{
CASAL DO OUTEIRO (ENCARNAÇÃO, MAFRA): NOVOS CONTRIBUTOS PARA O CONHECIMENTO DO POVOAMENTO DO NEOLÍTICO FINAL NA PENÍNSULA DE LISBOA
}

\author{
Cátia Delicado $^{1}$, Carlos Maneira e Costa ${ }^{2}$, Marta Miranda $^{3}$, Ana Catarina Sousa ${ }^{1}$
}

\begin{abstract}
RESUMO
O sítio do Casal do Outeiro (Encarnação, Mafra), foi identificado em 2020 no âmbito de acompanhamento de uma empreitada. Situa-se numa encosta suave, de solos arenosos e a escassos metros de uma linha de água subsidiária do Rio Safarujo. A evidência artefactual parece indicar a presença um núcleo habitacional neolítico, possivelmente da segunda metade do $4^{\underline{0}}$ milénio, incluindo evidências de debitagem local em sílex, pedra polida e cerâmica manual, incluindo um fragmento de bordo denteado. As prospecções realizadas permitiram identificar possíveis ocorrências associadas ao Casal do Outeiro como grutas e cavidades sob rocha com materiais coevos. Discute-se este sítio face ao padrão de povoamento neolítico da Península de Lisboa, concentrado na parte mais meridional. Palavras-chave: Estremadura, Povoamento, Neolítico Final.
\end{abstract}

\begin{abstract}
Casal do Outeiro site (Encarnação, Mafra) was identified in 2020. It is located on a gentle slope, with sandy soils, a few meters from a water line subsidiary of the Safarujo River. The artefactual evidence seems to indicate the presence of a small neolithic settlement possibly from the second half of the $4^{\text {th }}$ millenium, including evidence of local flint debitage, polished stone and manual ceramics, including a fragment of a denticulated rim. The surveys carried out allowed to identify other sites associated with Casal do Outeiro as caves and rockshelters with coeval materials. This site is analysed regarding the neolithic patterns settlements of the Lisbon Peninsular, mostly located in the southern part.
\end{abstract}

Keywords: Estremadura, Settlement, Late Neolithic.

\section{INTRODUÇÃO}

O sítio arqueológico do Casal do Outeiro foi identificado no início de 2020 no decorrer trabalhos de acompanhamento de uma empreitada realizada no concelho de Mafra sob direção de dois dos signatários (CD, CC). Foram também detectados outros sítios inéditos com materiais de cronologias pré-históricos em posição relativamente próxima do Casal do Outeiro aqui também apresentados.
Estas ocorrências parecem indicar a existência de um núcleo de povoamento pré-histórico localizado no Norte do concelho de Mafra, na área vestibular da Ribeira do Safarujo, eventualmente relacionado com as dinâmicas de povoamento da bacia do Sizandro, em Torres Vedras.

Considerando as dificuldades de prospeção na Estremadura (Sousa, 2009) e do reduzido número de povoados abertos de cronologia neolítica identificados, entendemos ser pertinente a publicação

\footnotetext{
1. Centro de Arqueologia da Universidade de Lisboa - UNIARQ. Faculdade de Letras da Universidade de Lisboa.

2. Amphora Arqueologia, Lda.

3. Câmara Municipal de Mafra.
} 
preliminar destes vestígios, ainda que se admita o alcance limitado de uma análise efectuada exclusivamente através de dados de prospecção.

\section{ENQUADRAMENTO}

O sítio do Casal do Outeiro encontra-se localizado na extremidade Norte do concelho de Mafra, na freguesia da Encarnação, próximo dos limites fronteiriços com Torres Vedras, freguesia de São Pedro da Cadeira (Torres Vedras), apresentando as coordenadas WGS84 $39^{\circ}$ 2'41.78” N/ 9 21'29.36”'W, com $33 \mathrm{~m}$ de altitude. (Figura 1 )

Os achados foram detectados numa encosta de inclinação suave de terrenos arenosos sobranceiros ao Rio Pequeno, afluente da Ribeira da Carregueira, subsidiária do Rio Safarujo. O local de implantação situa-se geologicamente na transição das camadas do Portlandiano para uma área de drenagem de formações aluvionares entre o rio Sizandro e o rio Safarujo.

Actualmente o sítio localiza-se a cerca de $5 \mathrm{~km}$ do oceano e a $4 \mathrm{~km}$ do Rio Safarujo, sendo provável que o Rio Safarujo no óptimo climático do Atlântico tivesse um caudal bastante maior, a avaliar pelos estudos efectuados para a evolução da linha de costa no Holénico (Dias, 1978; Daveau, 1980) como foi documentado no vale do Sizandro (Hoffmann, 1990; Hoffmann e Schulz, 1995; Dambeck et al, 2015) e para o Alcabrichel (Aleixo et al, 2014) (Figura 2).

Certamente que os recursos aquáticos teriam um papel importante na economia local, sendo muito próxima a sua captação quer da costa atlântica quer das margens da bacia do Safarujo. Os solos apresentam também aptidão agrícola, como é patente no actual uso do solo. Nos terraços do Sizandro o sílex estaria disponível (Jordão e Pimentel, 2019) sendo ainda necessário proceder ao estudo de eventuais áreas de captação mais próxima, como a mina detectada em Casal Barril, na Ericeira (Sousa, 2010).

Os recursos disponíveis nas proximidades do Casal do Outeiro terão influenciado a sua implantação nesta plataforma junto ao rio, que proporcionaria o acesso a matérias-primas, práticas agrícolas e pastorícia, bem como um controlo fluído da paisagem e meios de penetração para regiões interiores

\section{DESCRIÇÃO DO SÍTIO}

Foi o tipo de implantação e meio envolvente em que este aparente pequeno núcleo habitacional se terá desenvolvido, que nos levaram a efectuar prospecções nesta área, conduzindo posteriormente à identificação do mesmo (Figura 3).

O sítio apresenta actualmente um uso do solo agrícola, com plantação de batata, situando-se bastante próximo (20om) de um pequeno casal agrícola.

Aquando das prospecções (Janeiro de 2020), a visibilidade do solo era razoável, sendo especialmente visíveis os materiais após as chuvas. Para o panorama regional, podemos considerar que a visibilidade do solo era superior à da generalidade dos contextos de habitat da região (Sousa, 2009).

Os materiais surgiram dispersos numa área relativamente extensa (120 por 6om, no total de 720om2) (Figura 1) não se registando grandes concentrações de material. À superfície não foi detectada qualquer especificidade de coloração do solo ou micro-relevo que indicasse a presença de estruturas, mas deve salientar-se o uso agrícola destes terrenos.

\section{A CULTURA MATERIAL DE CASAL DO OUTEIRO}

O conjunto artefactual recolhido é relativamente pequeno, contudo é bastante significativo para que se possa efectuar uma leitura e identificação cronológica. Todos os materiais presentes na tabela (ver tabela 1) correspondem a recolhas de superfície, salientando-se a representatividade da indústria lítica. Pode colocar-se a hipótese de o sílex ter mais visibilidade, sobretudo no Inverno após as chuvas.

Face ao tipo de espólio, podemos aventar que Casal do Outeiro apresenta vestígios de um contexto doméstico de pequena/média dimensão. A escassez da cerâmica pode indicar uma utilização pouco prolongada. A indústria lítica é composta essencialmente de sílex $(76 \%)$, seguindo-se o quartzito ( $15 \%$ ) e o quartzo (9\%). É possível determinar que no local, com base na presença de material de preparação, reavivamento e de um núcleo poliédrico, seriam executadas tarefas de trabalho de sílex, nomeadamente o talhe da pedra para obtenção de utensilagem.

A debitagem regista a presença de suportes alongados (pequenas lâminas e lamela) e, em número mais expressivo, lascas. As três lâminas apresentam larguras entre os 13 e os $14 \mathrm{~mm}$, sendo estreitas e di- 
reitas, de bordo paralelo e secção trapezoidal (2) e triangular (1). Os dois fragmentos proximais de lâmina apresentam talão liso, não estando retocadas.

Relativamente à utensilagem, a mesma não é muito vasta ou diversificada, contudo, adequa-se à tipologia de artefactos encontrados em contextos habitacionais, como Penedo do Lexim (Mafra) onde se verifica a aproximação dimensional de lamelas e lâminas e escassos artefactos retocados (Sousa, 2003:331).

Entre os utensílios, regista-se a presença de possíveis evidências de actividade agrícola, nomeadamente um fragmento de lâmina com lustre de cereal (Fig. 7, ENC.054.01) e um denticulado (Fig. 7, ENC.054.08). O referido denticulado regista tratamento térmico e pode indicar uma cronologia mais antiga, atendendo à presença de retoque abrupto, quase abatido. Também um dos raspadores (Fig. 7 , ENC.054.10) apresenta vestígios claros de utilização no bordo esquerdo. Apenas com estudos traceológicos seria possível confirmar esta leitura macroscópica. Está ainda documentada a presença de um furador largo sobre lasca (Fig. 7, ENC.054.09).

Quanto às técnicas de talhe, uma análise preliminar poderia indicar talhe por percussão directa e indirecta. Contudo, as dimensões e uniformidade dos suportes alongados reduzidas das peças sugerem na verdade a debitagem de produtos por pressão, questão que aliás tem vindo a ser interpretada e debatida por outros autores em conjunto líticos como no concheiro O Meu Jardim (Nazaré) (Carvalho, 1998 e Valera, Carvalho e Goufa, 2017:10, 15-16). Também a reduzida largura das lâminas poderá ser um indicador da tendência arcaizante deste conjunto, uma vez que, as produções laminares tendem a evoluir de forma robusta e amplamente notória no Neolítico final e Calcolítico (Carvalho, 1995; Sousa, 2010; Cardoso, Sousa e André, 2015).

Em estudo geoarqueológico realizado por P. Jordão e N. Pimentel é registada a presença de áreas de aprovisionamento de sílex nos terraços do rio Sizandro (Jordão e Pimentel, 2019). A análise efectuada pelos autores citados sobre os terraços quaternários do Sizandro permitiu detectar a presença de sílex gerado em diferentes condições ambientais (Jordão e Pimentel, 2019:46). Nota-se a ferruginização do córtex, algo que parece ser evidente nos estratos mais antigos dos terraços quaternários superiores do rio Sizandro onde está atestada a presença de clastos siliciosos (Jordão e Pimentel, 2019:49). Na bacia de Runa, com formações do Cenomaniano, foi compro- vada a presença de níveis de sílex avermelhado nos calcários brancos e rosados, apresentando texturas mudstone (Jordão e Pimentel, 2019:50). Podemos colocar a hipótese que a origem de proveniência do sílex do Casal do Outeiro se localize nos depósitos secundários aluviais do Sizandro, distando menos de $20 \mathrm{~km}$ deste local. Apenas um estudo petrográfico do espólio do Casal do Outeiro e um levantamento geoarqueológico do seu entorno poderia confirmar as fontes de aprovisionamento deste povoado.

A presença de materiais de pedra polida reforça a cronologia neolítica do conjunto. Registou-se a presença de três fragmentos: um gume de enxó (Fig. 8, ENC.054.18) e um fragmento indeterminado de secção subrectangular (Fig. 8, ENC.054.20), ambos de anfibolito, e um talão de artefacto indeterminado de secção circular em rocha metamórfica (Fig. 8, ENC.054.19).

O uso de rocha metamórfica de possível proveniência do maciço sub-vulcânico de Sintra, também designada por xistos do Ramalhão (Cardoso e Carvalhosa, 1995), está largamente documentada na pedra polida da Baixa Estremadura, nomeadamente no Penedo do Lexim e nos povoados do $4^{\circ}$ e $3^{\circ}$ milénio da Ribeira de Cheleiros (Sousa, 1998). Verifica-se assim a possível aquisição de matéria nas proximidades de Sintra, numa zona mais próxima, mas também trocas comerciais com a região do Alentejo para obtenção de anfibolito.

A cerâmica é muito escassa, registando-se 15 fragmentos de cerâmica pré-histórica que não permitem de forma alguma a sua determinação tipológica, um bordo liso (Fig. 8, ENC.054.21) e um bordo denteado. Relativamente ao fragmento de bordo denteado (Fig. 8, ENC.054.22)., o mesmo tratar-se-á de uma forma aberta, tipo taça, com diâmetro interno máximo de $13 \mathrm{~cm}$, cuja aplicação se encontra na face externa mais próxima do bordo. A peça apresenta um bordo regular recto de pasta homogénea e semicompacta de superfície interna alisada e externa ligeiramente rugosa. Relativamente aos componentes não plásticos é visível a presença de micas numa pasta bastante depurada A decoração no bordo terá sido efectuada com recurso a um instrumento de secção angulosa uma vez que apresenta motivo em "v" de ondulação muito suave. Com as devidas prudências, a presença de um bordo denteado é especialmente importante para uma aproximação à cronologia do Casal do Outeiro. Desde K. Spindler que os bordos denteados têm sido referenciados como um dos fósseis directores do 
denominado "grupo da Parede" (Spindler, 1976), usando como sítio epónimo a Parede, sítio com enormes lacunas de registo estratigráfico, agrupando-se no referido grupo uma diversidade de sítios que possivelmente não são sincrónicos (cf. discussão em Gonçalves, 1995). Ainda que os bordos denteados não sejam exclusivos do Neolítico final, estando documentados no Neolítico antigo e até da Idade do Bronze, a tipologia de bordos denteados ou entalhados surge associada essencialmente a taças e a outras formas em povoados bem datados da transição $4^{\circ}$ / $3^{\circ}$ milénio na Península de Lisboa, nomeadamente em Leceia (Cardoso et al, 1996), Vale de Lobos (Valente, 2006) ou Serra das Éguas/ Espargueira (Encarnação, 2010).

Uma leitura global sobre o conjunto artefactual parece indicar a inserção de Casal do Outeiro numa

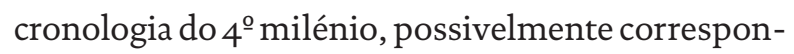
dendo à segunda metade, no Neolítico final. Numa leitura preliminar, consideram-se as presenças e as ausências dos materiais recolhidos até ao momento. Assim, não foi recolhido qualquer material de pedra lascada foliáceo (pontas de seta ou ovoides) e também estão ausentes as típicas cerâmicas decoradas do $3^{\circ}$ milénio (copos e taças caneladas, grupo folha de acácia ou campaniforme). A reduzida largura dos suportes alongados, a pedra polida, a cerâmica lisa e o bordo denteado podem corroborar a atribuição cronológica aqui preliminarmente efectuada.

Quanto à funcionalidade do sítio, a presença de elementos de pedra polida e elementos de foice, mesmo que num núcleo habitacional de menores dimensões, evidencia só por si a atribuição de um caracter mais permanente ao sítio, uma vez que, implicava a realização das actividades do quotidiano a que estes artefactos de associavam e a necessidade de utilização dos mesmos de forma recorrente.

A análise da funcionalidade de Casal do Outeiro pode também estar relacionada com a debitagem do sílex, tal como sucedeu para o povoado do Neolítico final do Carrascal (Cardoso, Sousa e André, 2015: 159) onde se regista a presença de abundantes vestígios de talhe local do sílex, num contexto misto de atelier e habitat semi-permanente. No Carrascal, as estruturas são escassas e a cultura material está esmagadoramente representada pelos materiais de talhe de sílex local (idem, ibidem).

Em contraste, nos povoados mais permanentes como Penedo do Lexim, Leceia e Vale de Lobos, as evidências de talhe local são mais circunscritas, evidenciando já a existência de uma mais complexa cadeia de obtenção de matéria-prima, com segmentação espacial da cadeia operatória (Sousa, 2010). De forma similar ao que se passa no Carrascal, também no Casal do Outeiro existe uma maior predominância de lascas, sendo elas não retocadas, enquanto no Penedo do Lexim e Leceia, existe o predomínio claro de suportes alongados tipo lamela e lâmina (Cardoso, Sousa e André, 2015:164 e Sousa, 2010).

\section{EM TORNO DO CASAL DO OUTEIRO: ALGUNS PONTOS NO MAPA E MUITOS VAZIOS}

Na área envolvente ao Casal do Outeiro, o estudo do povoamento neolítico e calcolítico tem diferentes percursos de investigação. Em Mafra, na freguesia da Encarnação onde se situa este sítio são escassos os sítios arqueológicos reportados em todas as cronologias, evidenciando de alguma forma, uma maior intensidade de investigações e de arqueologia preventiva no Sul do concelho (Sousa, 2010). Ao invés, em Torres Vedras, na bacia hidrográfica do Sizandro, a pesquisa arqueológica é muito intensa, desde as pesquisas de Manuel Heleno em jazidas do Paleolítico Superior (Zilhão, 1995) (Figura 6), às recolhas de Leonel Trindade (Trindade, Schubart e Sangmeister, 1965) e, naturalmente, as intensas pesquisas desenvolvidas pelo Instituto Arqueológico Alemão a partir de 1964 (Sangmeister e Schubart, 1981), partindo do Castro do Zambujal (Kunst, 1987) mas sempre com uma perspectiva territorial (Kunst e Trindade, 1991).

A Norte na bacia hidrográfica do Sizandro são abundantes os vestígios de ocupação pré-histórica. $O$ vale do Sizandro apresenta essencialmente vestígios do $3^{\circ}$ milénio, muito provavelmente tendo como lugar central do Castro do Zambujal, que dista apenas $7 \mathrm{~km}$ do Casal do Outeiro. Na parte mais interior do vale do Sizandro concentram-se vários povoados calcolíticos como Fórnea, Penedo ou Achada, mas neste caso a informação disponível é reduzida e antiga.

As fases mais recuadas do Neolítico estão muito mal representadas em Torres Vedras (Dambeck et al, 2015; Zilhão, 2016), apenas reportadas pontualmente em Vale da Mata, Baío e Cova da Moura. A esse respeito, os estudos paleobotânicos desenvolvidos pela equipa dirigida por Michael Kunst, vieram documentar a presença do cultivo de práticas agrícolas, com o desaparecimento do coberto vege- 
tal com carvalhos e o aparecimento de evidências de cultivo cerealífero a partir da segunda metade do $6^{\circ}$ milénio (Dambeck et al, 2015: 392). A referida equipa avança para fenómenos geoarqueológicos para explicar a ausência de povoamento neolítico, com a erosão do solo e deposições ulteriores de sedimento, ocultando os contextos arqueológicos situados em áreas abertas ou em encosta (idem, ibidem).

Também para o povoamento do Neolítico final se regista este vazio de informação que é aliás comum a toda a região do Oeste (Figura 5), com escassos indícios nos níveis subjacentes dos povoados fortificados como sucede na Ota (Texugo, 2016). O Sizandro e o Oeste são assim marcados por uma escassez de povoamento neolítico ( $6^{\circ}$ ao $4^{\circ}$ milénio) que contrasta com o mundo funerário, nomeadamente as grutas naturais como a Cova da Moura ou o hipogeu do Cabeço da Arruda, que dista apenas $8 \mathrm{~km}$ do Casal do Outeiro.

Face ao vazio arqueológico em torno do Casal do Outeiro, a presente equipa efectuou prospeções complementares na área envolvente, tendo sido detectados outros sítios que poderão de forma directa ou indirecta estar relacionados com este núcleo.

Assim, foram registados um conjunto de grutas e abrigos situados nas encostas calcárias da área de Marvão (Mafra), ao longo do vale da ribeira de Safarujo a escassos 4,5 km do Casal do Outeiro. Os abrigos apresentam sedimentação mas na sua generalidade não registam qualquer material à superfície o que não invalida a presença antrópica antiga nestas cavidades.

Foram apenas recolhidas à superfície duas cerâmicas manuais no Abrigo da Moita Longa, inserido numa bancada calcária com uma pala pétrea como tecto. No local existe bastante sedimento que se acumula praticamente até poucos centímetros do tecto da laje calcária onde foram identificadas cerâmicas (Fig. 9. ENC.057.01 e 02). Este abrigo insere-se numa área calcária com larga presença de grutas e abrigos que podem eventualmente, mediante trabalhos aprofundados, vir a fornecer novos dados que podem traduzir ocupação doméstica ou, mais provavelmente, funerária (Figura 4).

$\mathrm{Na}$ área envolvente aos abrigos de Marvão regista-se a presença de materiais que parecem indicar uma ocupação neolítica na área envolvente. Trata-se de materiais isolados, não sendo possível determinar se correspondem a sítios efectivos ou a materiais em posição secundária:
1. Na margem direita do Safarujo, a menos de $1 \mathrm{~km}$ do Abrigo da Moita Longa, foram identificadas em Valongo de Baixo uma lasca retocada e uma lamela em sílex e um fragmento de cerâmica manual (Fig. 9. ENC.056.01 e 02);

2. Registou-se a presença de outros materiais pré-históricos na Ameixoeira, tendo sido identificados vários elementos em sílex relacionados com as várias fases de debitagem do sílex (restos de talhe, flancos de núcleo e núcleo), utensilagem (um furador) e fragmento de xisto, sem que tenha sido verificada a presença de cerâmica (Fig. 9. ENC.058.01 a 04).

3. Na Arieira, foi identificado um pequeno núcleo em sílex (Fig. 9. ENC.055.01);

4. Na Quinta dos Machados - Picanceira 2 foram também recolhidos materiais líticos, salientando a presença de um bordo cerâmico brunido que remete para a presença de cronologias da Idade do Bronze (Fig. 9. ENC.059.01 a 03).

Casal do Outeiro não parece estar assim isolado, podendo antever-se uma rede de povoamento que apenas agora começa a ser identificada. A visibilidade dos contextos arqueológicos na Estremadura é muito difícil aliando-se a uma intensa ocupação antrópica e ao uso do solo. Assim, mesmo que reduzidos os materiais recolhidos, é de destacar a importância do povoamento agora identificado no Norte do concelho de Mafra.

\section{CONCLUINDO. CASAL DO OUTEIRO E O POVOAMENTO DO NEOLÍTICO FINAL DAS PENÍNSULAS DE LISBOA E SETÚBAL}

Nas Penínsulas de Lisboa e Setúbal, tal como na generalidade do Centro e Sul de Portugal, o conhecimento do povoamento neolítico centra-se nos inícios (transição $6^{\circ} / 5^{\circ}$ milénio) e na fase final prévia ao aparecimento das primeiras fortificações e da metalurgia do cobre (transição $4^{\circ} / 3^{\circ}$ milénio). Sabemos pouco dos momentos intermédios, no que se generalizou designar como Neolítico médio (Neves e Diniz, 2014; Silva e Soares, 2018), sendo provável que para sítios sem datações absolutas possa existir uma natural acumulação das classificações nos limites do balizamento cronológico.

Numa perspectiva diacrónica deve ser realçado que partir de meados do $3^{\circ}$ quartel do $4^{\circ}$ milénio se verifica uma verdadeira "explosão" de sítios, povoados e necrópoles. Nesta fase, com a consolidação das 
primeiras sociedades camponesas, parece registar-se um momento de viragem, possivelmente relacionado com a intensificação das práticas agrícolas e pastoris.

Este momento de aceleração do processo de consolidação das sociedades camponesas está reflectido na Baixa Estremadura onde se regista um elevado número de ocorrências de povoamento, especialmente na região da actual área metropolitana de Lisboa. Toma-se como base de análise o inventário apresentado em Sousa, 2016/2017 (tabela 2), devendo apenas ser acrescentado o sítio do Paço (Delicado et al, no prelo) e o Casal do Outeiro.

É na região de Lisboa que se concentram 23 das 30 ocorrências da Baixa Estremadura, estando actualmente inventariadas nos concelhos de Mafra (3), Sintra (8), Oeiras (4), Loures (3), Lisboa (3), Cascais (1), Odivelas (1), Amadora (4). Permanece por compreender o vazio a Norte, na zona Oeste. Para além das explicações geoarqueológicas atrás mencionadas deve ser também realçada a diferente intensidade de investigação das duas regiões e também das diferenças quanto à intensidade da arqueologia preventiva e do impacto no solo.

Entre os sítios de habitat integráveis no Neolítico final podemos individualizar dois grandes grupos: as ocupações subjacentes às fortificações calcolíticas (Penedo do Lexim, Ota, Leceia, Olelas, Paço e, de alguma forma, Travessa das Dores) e os povoados abertos, frequentemente com várias ocupações do Neolítico e depois Calcolítico com campaniforme inciso (Negrais, Casas Velhas, Serra das Éguas, Vila Pouca, Montes Claros, Parede).

Para além das diferenças na biografia destes sítios, refira-se também as diferenças no tipo de implantação, registando-se elevações com grande visibilidade e controlo da paisagem (nomeadamente as pré-existências dos povoados fortificados) e áreas abertas sem preocupação defensiva, como é o caso do Casal do Outeiro. Do conjunto de povoados actualmente conhecidos para a Baixa Estremadura, 17 relevam uma implantação em elevação, 11 em vertente e 2 em área aplanada.

A implantação e a dispersão dos sítios integráveis no Neolítico final parece indicar a presença de um povoamento disseminado, possivelmente constituído por pequenos núcleos, por vezes localizando-se em área muito próxima, como sucede por exemplo em Oeiras (Leceia, Carrascal, Barotas) ou em Sintra (complexo de sítios de Negrais).
Sendo escassas as informações sobre a morfologia das estruturas de habitat e a funcionalidade dos sítios, parece plausível avançar com uma hipótese de um padrão de povoamento multifacetado, onde se evidencia a pulverização do povoamento e a multiplicidade dos recursos explorados (Sousa, 2010). $\mathrm{Na}$ generalidade dos sítios, registam-se estruturas frustes, mas cita-se a complexidade das estruturas recentemente identificadas na Travessa das Dores, com fosso, fossas, estruturas de alvenaria (Neto et $a l, 2019)$ o que pode indicar uma maior complexidade da morfologia de ocupação. No caso do Casal do Outeiro, apenas a realização de levantamento geofísicos e de ulteriores escavações poderá indicar o tipo de ocupação, mas a presença de um número significativo de materiais à superfície pode indicar algum nível de perturbação resultante dos trabalhos agrícolas.

Deve ainda referir-se à existência de sítios especializados, como a exploração de sal da Ponta da Passadeira (Soares, 2013) ou o concheiro do Magoito (Soares, 2003), referindo-se ainda possíveis locais especializados na extração e processamento inicial do sílex, como Casas de Baixo (Zilhão, 1994).

O número de sítios datados integráveis no chamado "Neolítico final" éainda muito reduzido, limitando-se a sete habitats: Leceia, Carrascal, Penedo do Lexim, Lameiras, Vale de Lobos, Serra das Éguas e Parede. É especialmente importante o balizamento cronométrico de Leceia e Vale de Lobos. Em Leceia, a existência de um hiato de ocupação entre a ocupação neolítica e o povoado fortificado permite uma boa definição dos parâmetros cronológicos, balizados entre 3510-2900 cal a.C. através de 7 datações (Cardoso e Soares, 1996). Vale de Lobos apesar do mau estado de conservação dos contextos, tem uma ocupação monofásica: as duas datações absolutas (Beta-220074 e Beta-220075), indicam um intervalo entre 3340 a $2820 \mathrm{cal}$ a.C. (Valente, 2006).

Temos mais sítios, mais datas e mais contextos estudados, mas ainda não está claro o processo de aceleração registado no último quartel do $4^{\circ}$ milénio. Não sabemos ainda se a ocupação do Casal do Outeiro se restringe temporalmente a este intervalo, existindo algum arcaísmo que pode indicar fases mais antigas. A avaliar pelos materiais de superfície, o sítio terá sido abandonado no $3^{\circ}$ milénio, mas essa será uma história em aberto, dependente de futuras novas pesquisas no Casal do Outeiro e no povoamento pré-histórico regional. 


\section{BIBLIOGRAFIA}

ALEIXO,C;RAMOS-PEREIRA,A;TRINDADE,J.(2014) - A Evolução das Condições Ambientais na Várzea de Maceira (Estuário do rio Alcabrichel, oeste de Portugal) no Holocénico Superior. In Formação e ocupação de litorais nas margens do atlântico - Brasil / Portugal. Edit: Silvia D. Pereira; Joana G. Freitas; Sergio Bergamaschi; Maria A. C. Rodrigues. Corbã Editora Artes Gráficas Lda, Rio de Janeiro. Capítulo V. pp. 85-98.

CARDOSO, J. L.; CARVALHOSA, A. B. (1995) - Estudos petrográficos de artefactos de pedra polida do povoado pré-histórico de Leceia (Oeiras). Análise de proveniências. Estudos Arqueológicos de Oeiras. Lisboa. 5, pp. 123-151.

JORDÃO, P.; PIMENTEL, N. (2019) - Os terraços quaternários do rio Sizandro (Torres Vedras): caracterização de uma área-fonte de sílex. Geonovas, V. 32, pp. 93-106.

CARDOSO, J. L.; SOARES, J; SILVA, C. T. (1996)-A ocupação neolítica de Leceia (Oeiras): materiais recolhidos em 1987 e 1988. Estudos Arqueológicos de Oeiras. Oeiras: Câmara Municipal de Oeiras.№6, pp. 47-91.

CARDOSO, J. L.; SOARES, A. M. M. (1996) - Contribution d'une série de datations C14, provenant du site de Leceia (Oeiras, Portugal), à la chronologie absolue du Néolithique et du Chalcolithique de l'Estemadura Portugaise. Actes du Colloque de Périgueux. Supplément à la Revue d'Archéométrie. Rennes, pp. 45-50.

CARVALHO, A. F. (1998) - O talhe da pedra e a transição Neolítico - Calcolítico no Centro e Sul de Portugal: tecnologia e aspectos da organização da produção. Trabalhos de Arqueologia da EAM. Lisboa. 3-4, pp. 41-6o.

DAMBECK, R.; KUNST, M.; THIEMEYER,H.; KALIS, A. J.; VAN LEEUWAARDEN, W.; HERRMANN, N. (2015) - Onde é que habitaram? Novos dados sobre a Neolitização retirados do exemplo do Vale do rio Sizandro (Torres Vedras, Portugal), in Gonçalves, V. S.; Diniz, M.; Sousa, A. C. (eds.) - 5. . Congresso do Neolítico Peninsular, Lisboa, Centro de Arqueologia da Universidade de Lisboa, pp. 385-396.

DAVEAU, S. (1980) - Espaço e Tempo. Evolução do ambiente geográfico de Portugal ao longo dos tempos pré-históricos. Clio . Lisboa. 2, pp. 13-37.

DELICADO, C., RENDEIRO,L.C.;LOPES,A.; PEREIRA, A. (no prelo) - O sítio pré-histórico do Paço (Peniche): uma varanda Calcolítica sobre o oceano. Revista Portuguesa de Arqueologia, 23.

DIAS, J. A. (1987) - Dinâmica sedimentar e evolução recente da plataforma continental portuguesa setentrional. Tese de Doutoramento em Geodinâmica Externa, apresentada à Faculdade de Ciências da Universidade de Lisboa. Policopiada, $384 \mathrm{p}$.
ENCARNAÇÃO, G. (2010) - As cerâmicas carenadas do povoado da Espargueira (Serra das Éguas, Amadora). Um contributo para o seu estudo. Tese de Mestrado em Arqueologia apresentada na Faculdade de Letras da Universidade de Lisboa.

GONÇALVES, V. S. (1995) - Sítios, horizontes e artefactos: leituras críticas de realidades perdidas. Cascais.

HOFFMANN, G. (1990) - Zur Holozänen Landschaftensentwicklung im tal des Rio Sizandro (Portugal). Madrider Mitteilungen. Mainz. 31 (1990) 21-33.

HOFFMANN, G.; SCHULZ, H. (1995) - Cambio de situación de la linea costera y estratigrafía del holoceno en el valle del río Sizandro/Portugal. In KUNST, M., ed. lit. - Origens, estruturas e relações das Culturas Calcolíticas da Península Ibérica : actas das I Jornadas Arqueológicas de Torres Vedras, 1987. Lisboa: IPPAR, 1995. (Trabalhos de Arqueologia ;7). pp. 45-46.

KUNST, M. (1987) - Zambujal. Glockenbecher und kerbblattverzierte Keramik aus den Grabungen 1964 bis 1973. Verlag Philipp von Zabern, Mainz, Madrider Beitrãge 5, 2.

KUNST, M. ; TRINDADE, L. (1991) - Zur Besiedlungsgeschitchte des Sizandrotals : ergebnisse aus der Kustenforshung. Madrider Mitteilungen. 31 (1991) 34-82.

NETO, N.; REBELO, P. \& CARDOSO, J. L. (2015) - O povoado do Neolítico Final e do Calcolítico da Travessa das Dores (Ajuda - Lisboa). Estudos Arqueológicos de Oeiras. Oeiras. 22, pp. 235-28o.

NEVES, C. e DINIZ, M. (2014) - Acerca dos cenários da acção: estratégias de implantação e exploração do espaço

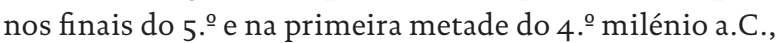
no sul de Portugal. Estudos do Quaternário. Braga. 11, pp. $45-58$.

VALENTE, A. (2006) - Cerâmicas com bordos denteados no Povoado de Vale de Lobos (Sintra). Lisboa. Dissertação de Mestrado apresentada à Faculdade de Letras da Universidade de Lisboa.

VAlerA, A. C.; CARVAlHO, A. F.; GOUFA, E. (2017) - O concheiro do Meu Jardim (Nazaré) no contexto das estratégias de produção e circulação de suportes lâmino-lamelares no Neolítico Médio da Estremadura Portuguesa. Journal of Lithic Studies. Edinburg: School of History, Classics and Archaeology, University of Edinburgh Vol. 4:3. pp. 1-24.

SANGMEISTER, E.; SCHUBART, H. (1981) - Zambujal: die Grabungen 1964 bis 1967. Mainz : Philipp von Zabern, 1981. (Madrider Beiträge ; Bd. 5).

SILVA, C. T. d. e SOARES, J. (2018) - Para o estudo do Neolítico Médio: o sítio da Fábrica de Celulose (Mourão). Revista Portuguesa de Arqueologia, 21. 5-23. ISSN o874-27-82. 
SOARES, A. M. M. (2003) - A duna de Magoito revisitada. Revista Portuguesa de Arqueologia. Lisboa. 6 (1), pp. 83-10o.

SOARES, J. (2013) - Sal e conchas na Pré-História portuguesa. O povoado da Ponta da Passadeira (estuário do Tejo). In SOARES, J. (ed.) - Pré-História das zonas húmidas. Setúbal Arqueológica. Setúbal. 14, pp. 171-196.

SOUSA, A. C. (1998) - O Neolítico final e o Calcolítico na área da Ribeira de Cheleiros. Lisboa (Trabalhos de Arqueologia; 11).

SOUSA, A. C. (2003) - O Neolítico final do Penedo do Lexim (Mafra). In GONÇALVES, V. ed - Muita gente, poucas antas. Lisboa: Instituto Português de Arqueologia. (Trabalhos de Arqueologia 25). pp. 305-338.

SOUSA, A. C. (2009) - Mapear o povoamento estremenho do 4. e 3. milénio a.C: Um caso de estudo e algumas reflexões sobre os processos de identificação. Estudos Arqueológicos de Oeiras. Oeiras: Câmara Municipal de Oeiras, 223-236.

SOUSA, A. C. (2010) - O Penedo do Lexim e o povoamento Neolítico final e Calcolítico da Península de Lisboa. Tese de doutoramento apresentada à Faculdade de Letras da Universidade de Lisboa. Exemplar policopiado. 2 vols.

SPINDLER, K. (1976) - Die Neolithishe Parede Gruppe In Mittelportugal. Madrider Mitteilungen 17: 21-75.

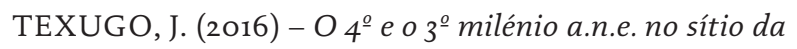
Ota (Alenquer): Perscrutando por entre colecções antigas e projectos recentes. Dissertação de Mestrado em Arqueologia apresentada à Faculdade de Letras da Universidade de Lisboa.

TRINDADE, L.; SHUBART, H.; SANGMEISTER, E. (1965) - Escavações no castro eneolítico do Zambujal (Torres Vedras - Portugal).

ZILHÃO, J. (1994) - A oficina de talhe neo-eneolítica de Casas de Baixo (Caxarias, Vila Nova de Ourém). Trabalhos de Arqueologia da EAM. Lisboa. 2, pp. 35-45.

ZILHÃO, J. (1995) - O Paleolítico Superior da Estremadura Portuguesa. Lisboa: Colibri. 2 vols.

ZILHÃO, J. (2016) - O Neolítico Antigo de Vale da Mata (Cambelas, TorresVedras), in SOUSA, A.C.; CARVALHO, A.; VIEGAS, C. (eds.) - Terra e Água. Escolher sementes, invocar a Deusa. Estudos em Homenagem a Victor S. Gonçalves. Estudos \& Memórias 9, Lisboa, UNIARQ/FL-UL, pp. 97-111. 


\begin{tabular}{|c|c|}
\hline PEDRA LASCADA & № \\
\hline \multicolumn{2}{|l|}{ Matéria-prima } \\
\hline Termoclastos em quartzito & 3 \\
\hline Seixo em quartzito & 1 \\
\hline \multicolumn{2}{|l|}{ Núcleos } \\
\hline Núcleo de lascas em sílex & 1 \\
\hline \multicolumn{2}{|l|}{ Material de preparação e reavivamento } \\
\hline Flanco de núcleo em sílex & 6 \\
\hline \multicolumn{2}{|l|}{ Produtos de debitagem } \\
\hline Fragmento de lâmina em sílex & 1 \\
\hline Fragmento de lâmina em quartzo translúcido & 1 \\
\hline Lamela em sílex & 1 \\
\hline Lasca cortical em sílex & 2 \\
\hline Lasca em sílex & 3 \\
\hline Lasca em quartzo leitoso & 2 \\
\hline \multicolumn{2}{|l|}{ Restos de talhe } \\
\hline Restos de talhe em sílex & 7 \\
\hline \multicolumn{2}{|l|}{ Utensílios } \\
\hline Lâmina em sílex com lustre de cereal & 1 \\
\hline Raspadeira em sílex & 3 \\
\hline Furador em sílex & 1 \\
\hline Denticulado sobre lasca & 1 \\
\hline \multicolumn{2}{|l|}{ PEDRA AFEIÇOADA } \\
\hline Percutor em quartzito & 1 \\
\hline \multicolumn{2}{|l|}{ CERÂMICA } \\
\hline Bordo denteado & 1 \\
\hline Bordo & 1 \\
\hline Fragmentos cerâmicos & 15 \\
\hline \multicolumn{2}{|l|}{ PEDRA POLIDA } \\
\hline Fragmento de gume de enxó em rocha metamórfica & 1 \\
\hline Talão de utensílio em anfibolito & 1 \\
\hline Fragmento de utensílio em rocha metamórfica & 1 \\
\hline TOTAL & 55 \\
\hline
\end{tabular}

Tabela 1 - Amostra de materiais arqueológicos recolhidos em contexto de superfície. 


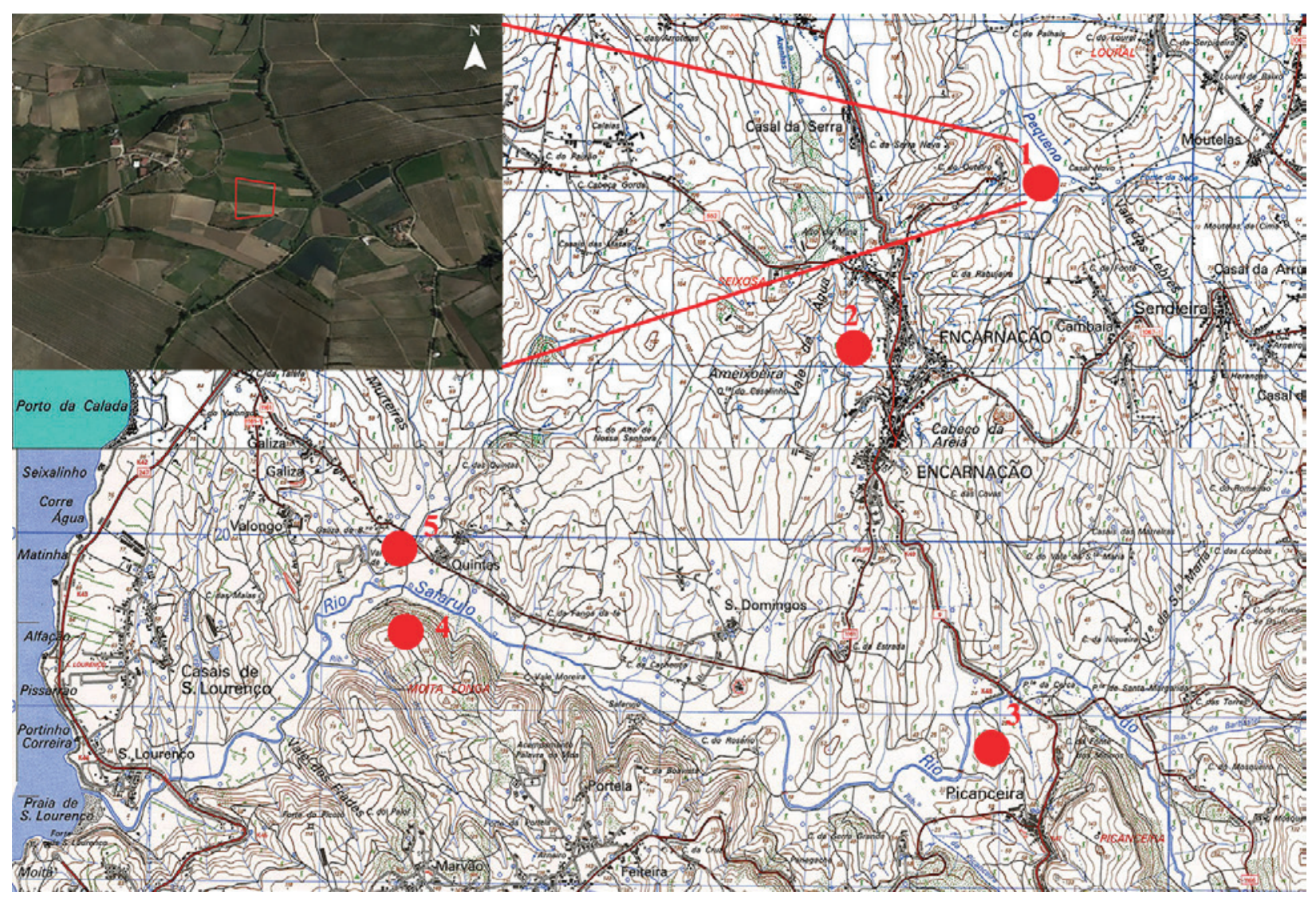

Figura 1 - Localização do sítio do Casal do Outeiro (1) e restantes identificados nas imediações (2 - Ameixoeira; 3 - Quinta dos Machados Picanceira 2; 4 - Abrigo da Moita Longa e 5 - Valongo de Baixo) na Cartografia Militar nº 374 e 388, escala 1:25 ooo. Pormenor da dispersão de materiais arqueológicos representada pelo rectângulo a vermelho. 

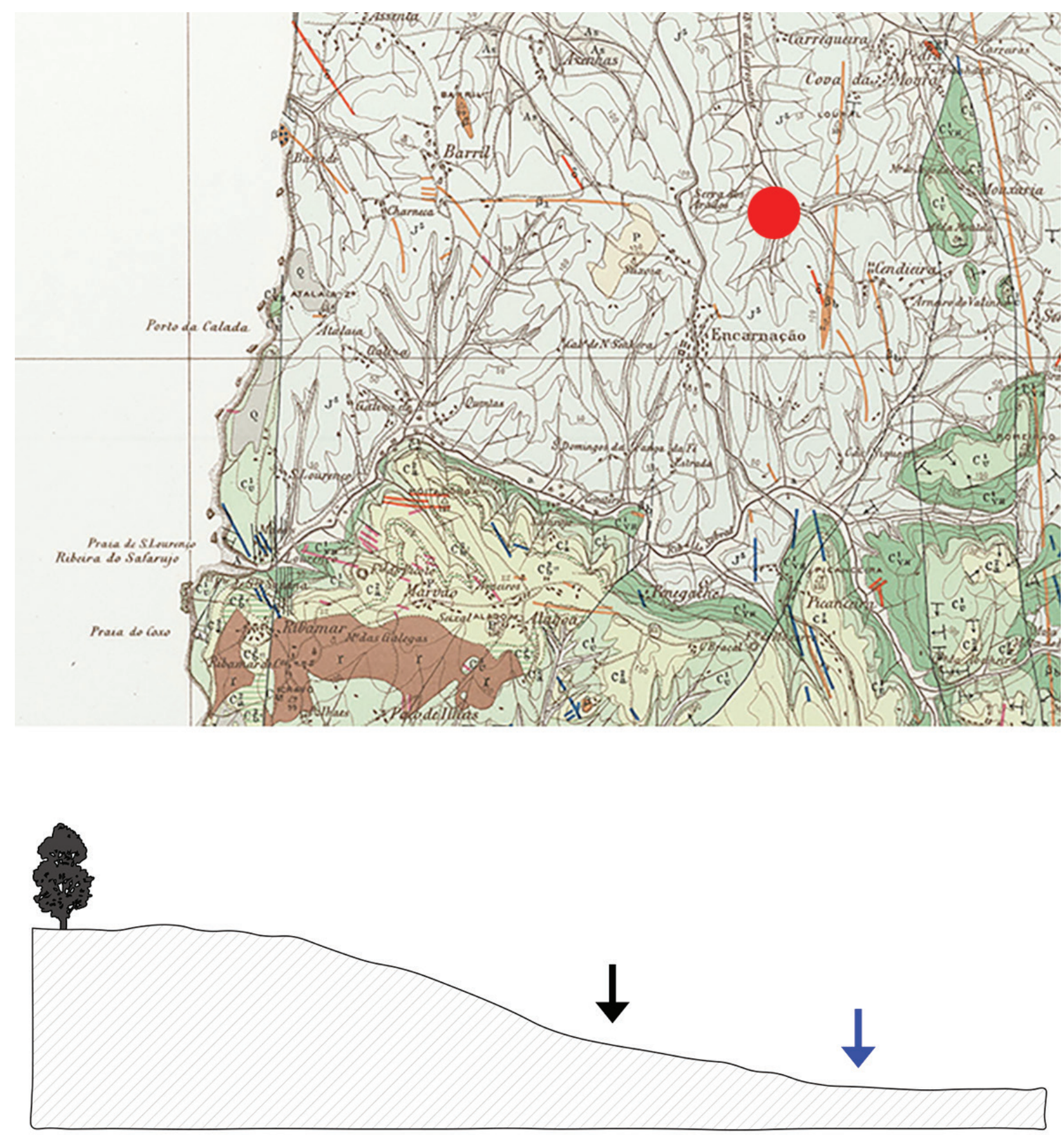

Figura 2 - Localização do Casal do Outeiro nas camadas do Portlandiano (J5) na Cartografia Geológica de Portugal, carta zo-C e altimetria do terreno com localização do sítio (a preto) e Ribeira da Carregueira (a azul). 


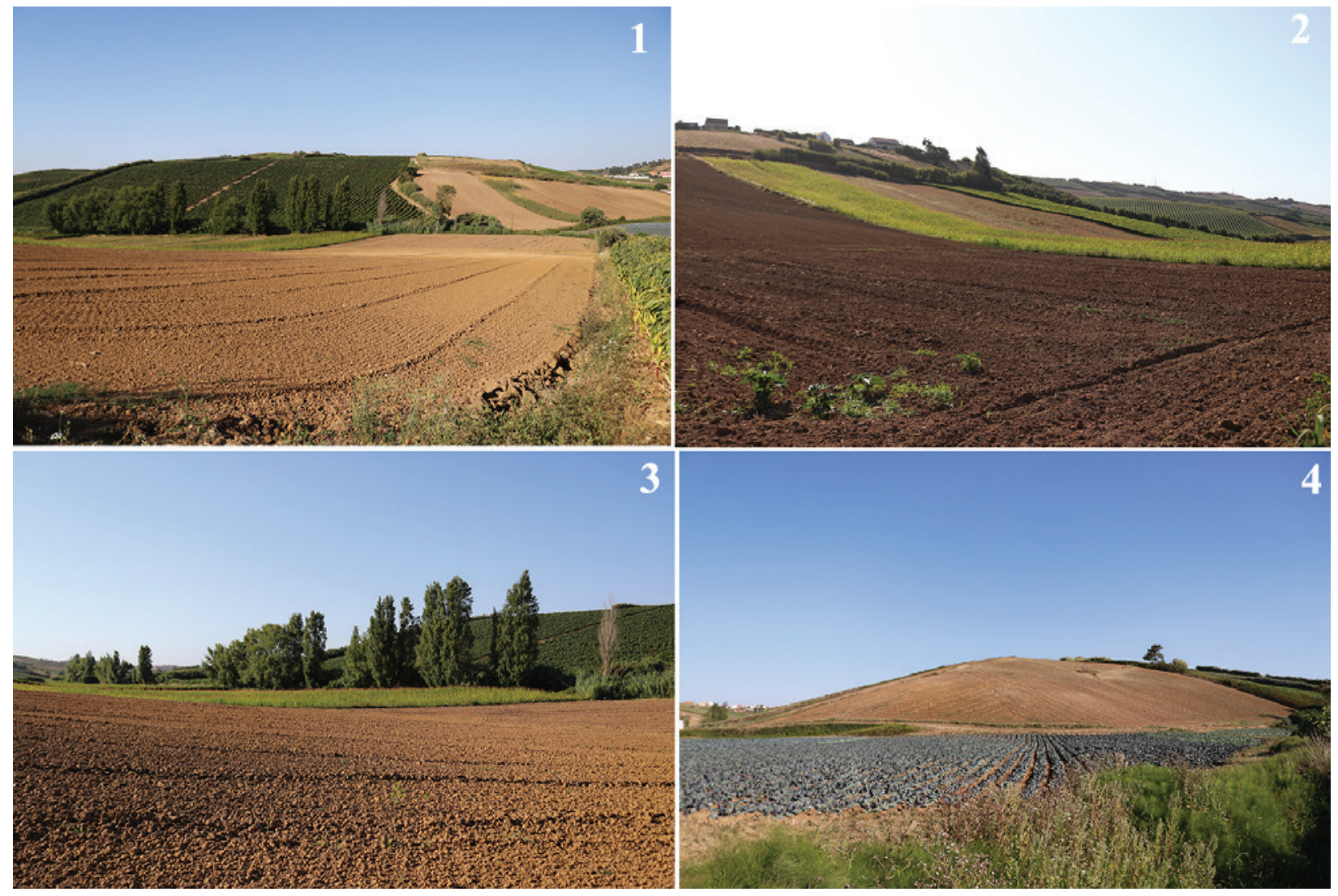

Figura 3 - Aspecto do sítio arqueológico do Casal do Outeiro. 1: vista do topo da elevação para Oeste junto da ribeira da Carregueira; 2: vista para Norte da elevação (ao lado esquerdo) e do terreno onde foram detectados os materiais arqueológicos. 3: vista sentido Nordeste, demonstrando ser um terreno de relevo suave encaixado entre elevações. 4: aspecto geral da área envolvente ao sítio arqueológico.

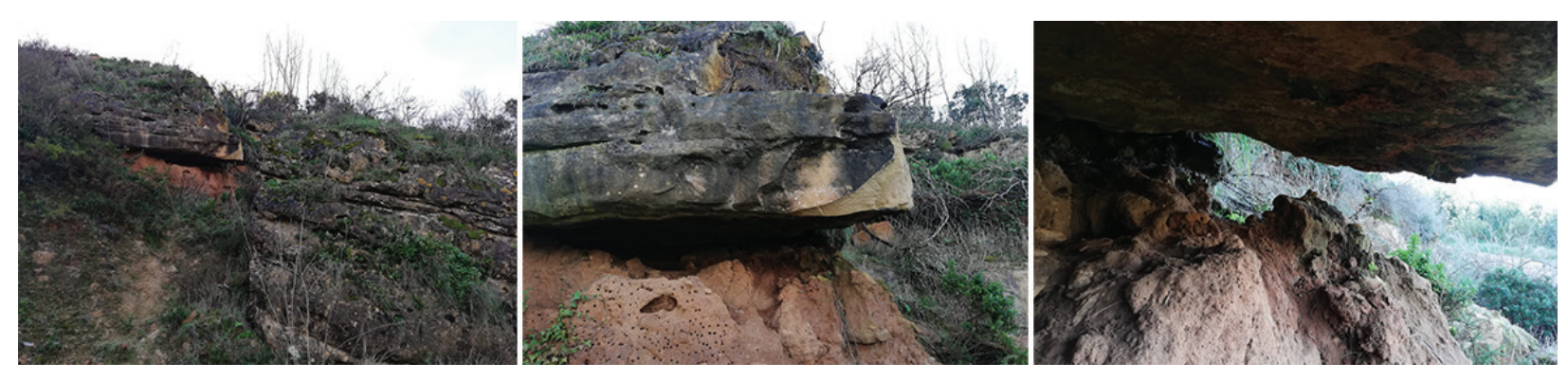

Figura 4 - Vista geral e aproximada do Abrigo da Moita Longa localizado nas escarpas calcárias de Marvão (Mafra). 


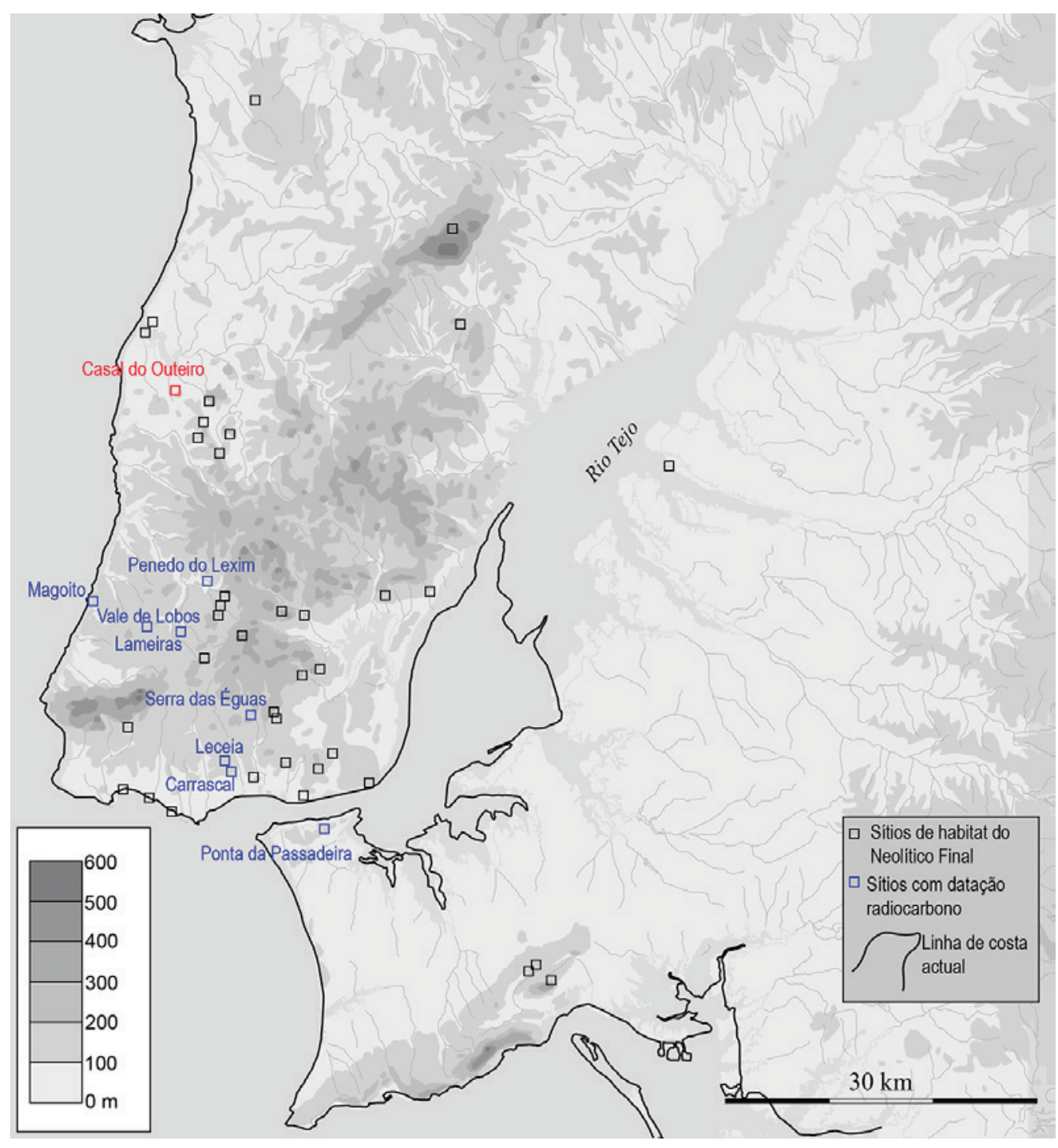

Figura 5 - Sítios de habitat do Neolítico final na região de Lisboa. Base Cartográfica Maya Langley e Rui Boaventura.

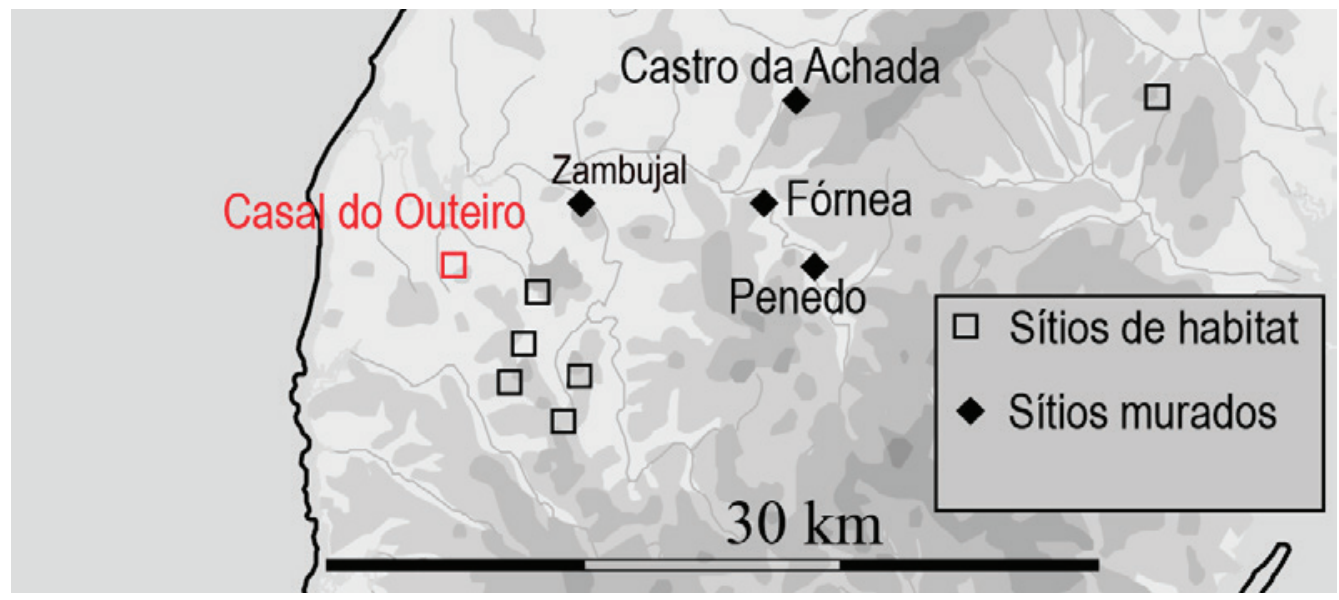

Figura 6 - Sítios de habitat e sítios murados na área envolvente ao Casal do Outeiro. Base Cartográfica Maya Langley e Rui Boaventura. 

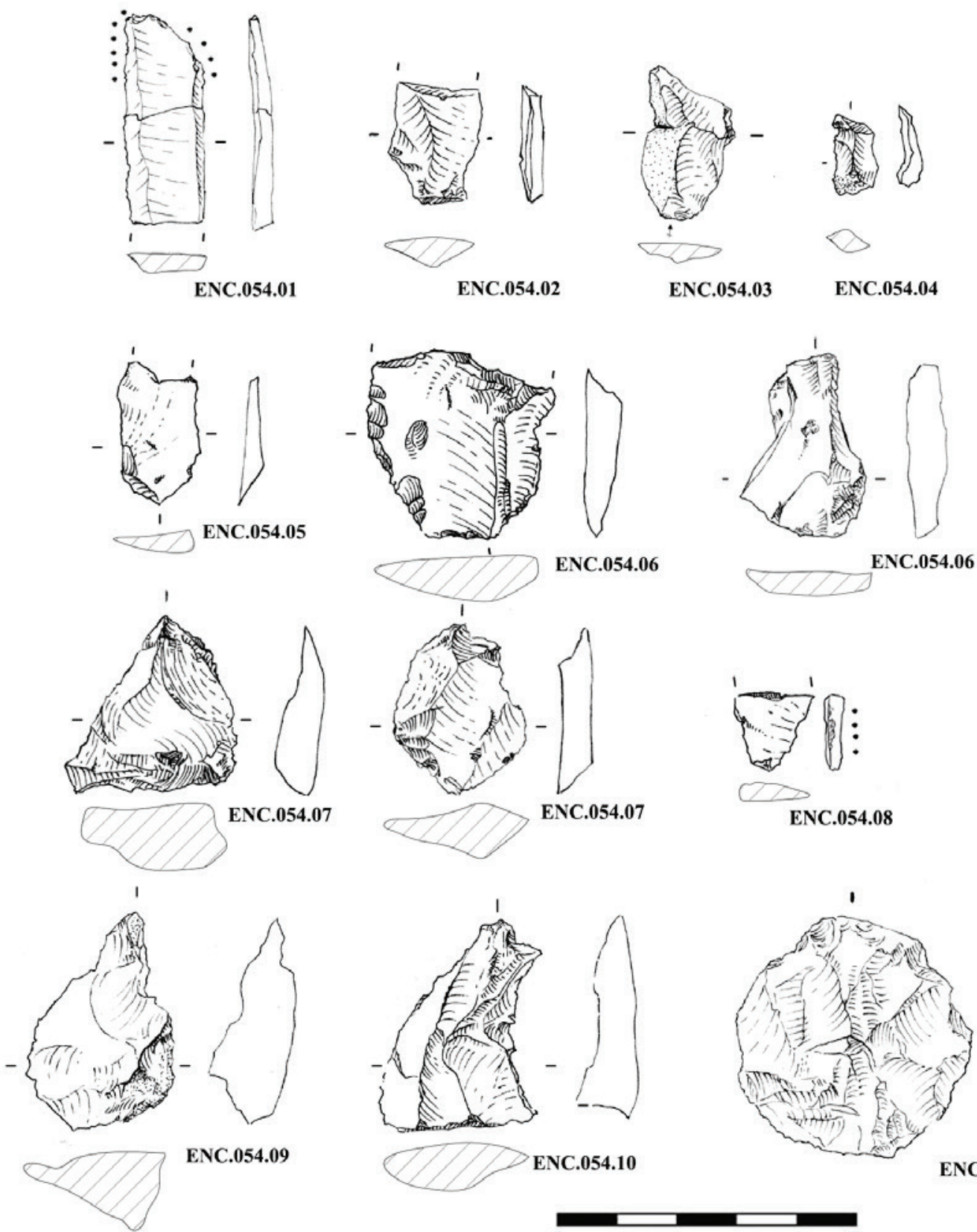

ENC.054.09
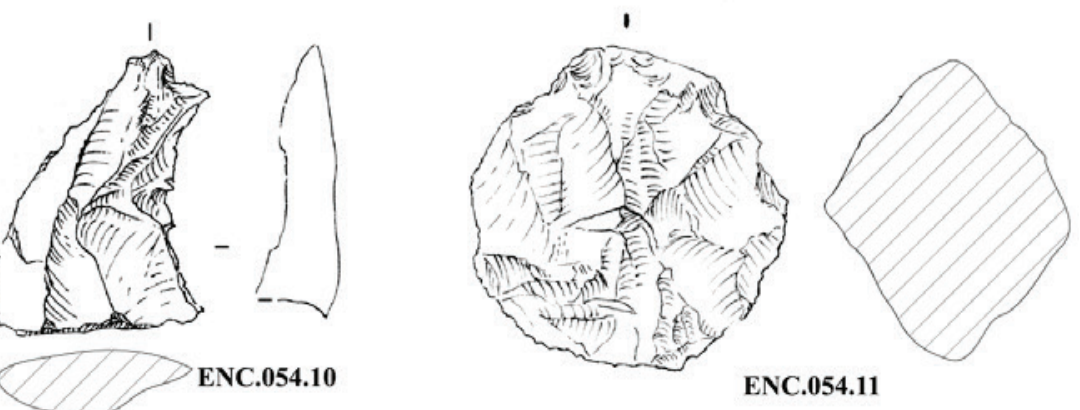

ENC.054.11
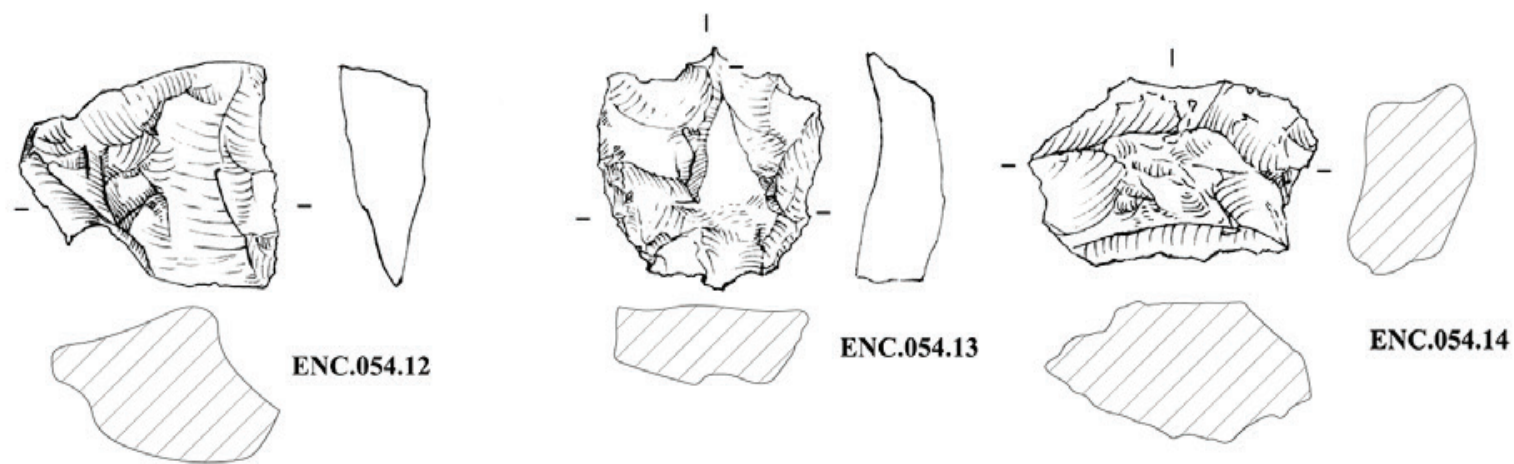

Figura 7 - Indústria lítica do Casal do Outeiro. Desenhos de Paula Bívar de Sousa. 


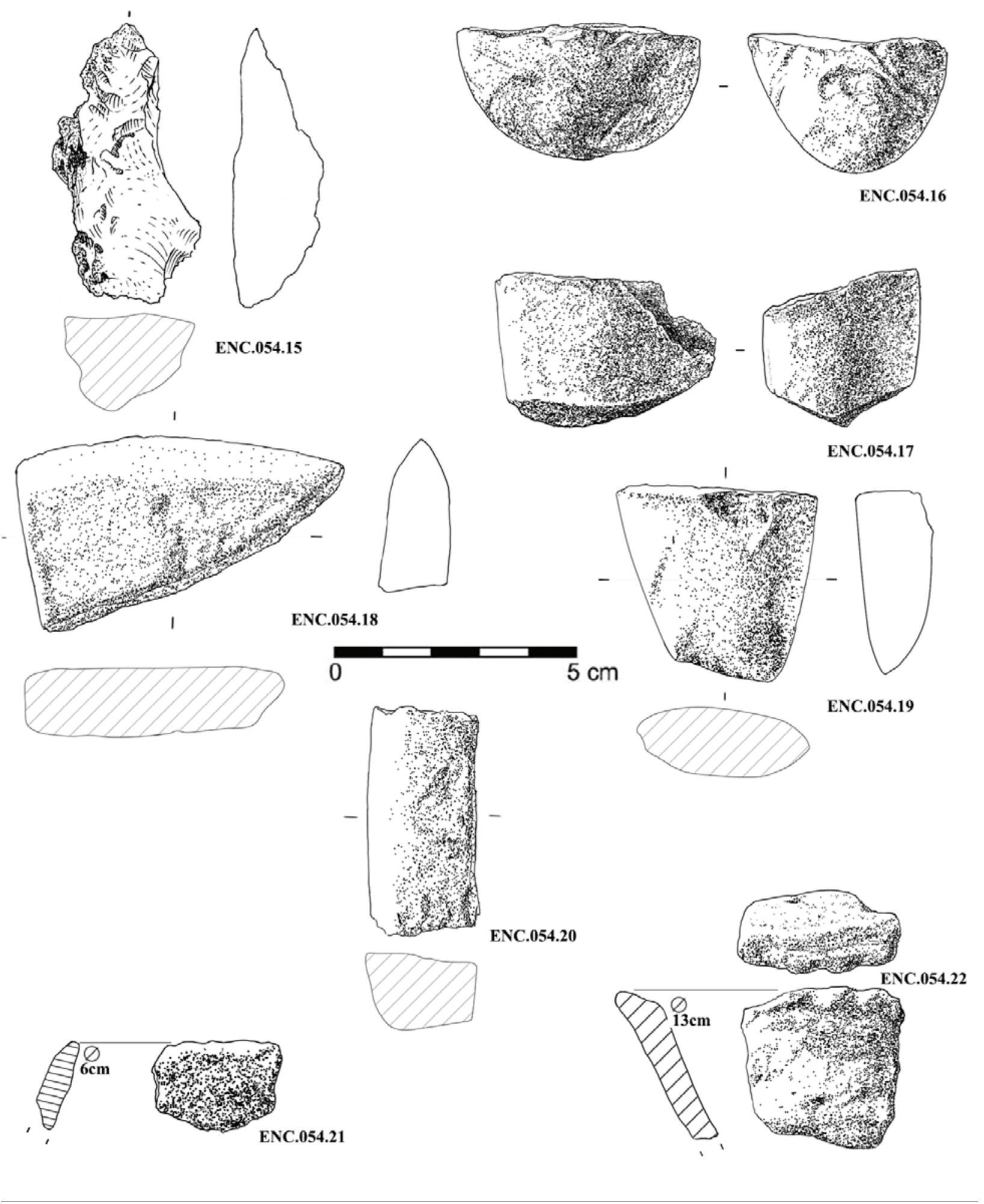

Figura 8 - Indústria lítica, pedra polida e cerâmica do Casal do Outeiro. Desenhos de Paula Bívar de Sousa. 

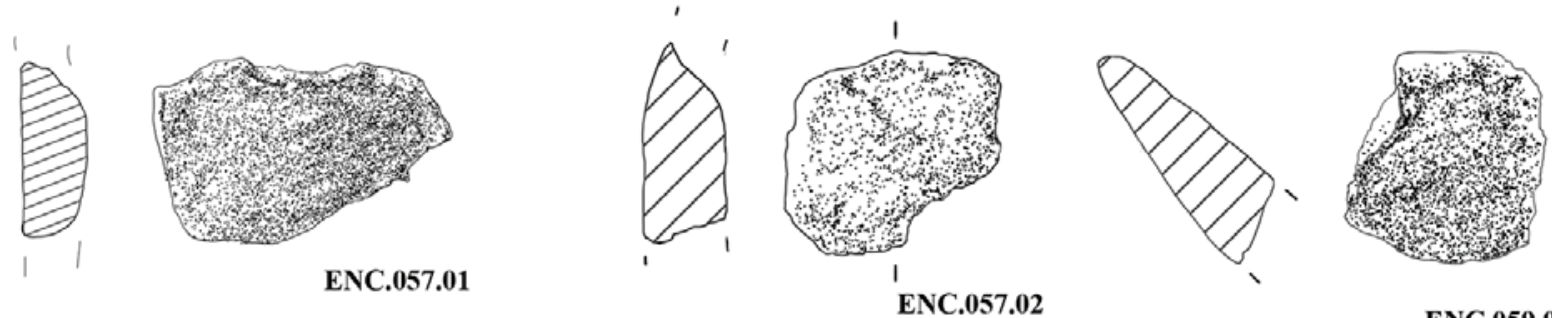

ENC.059.01
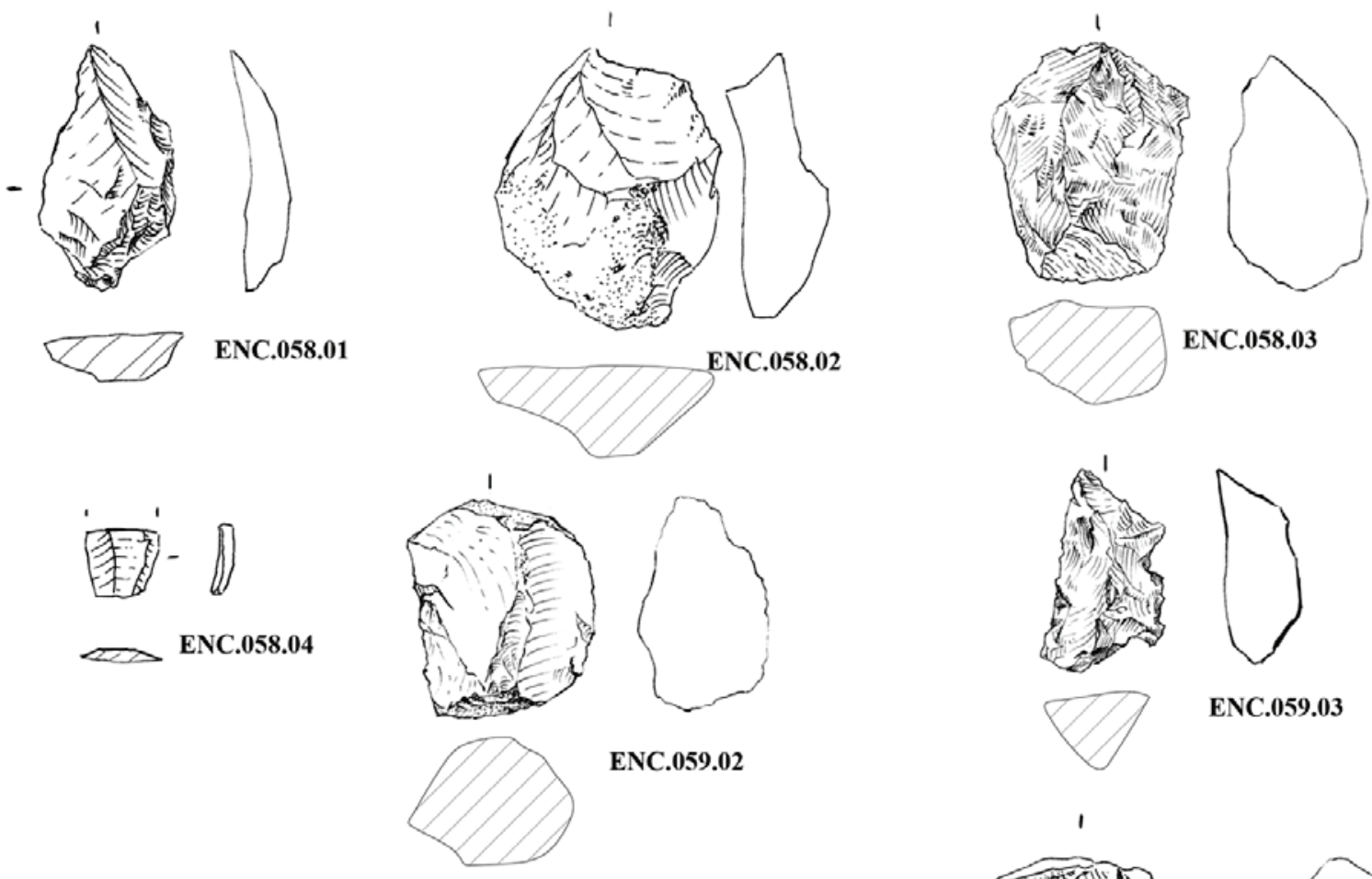

ENC.059.02

ENC.059.03
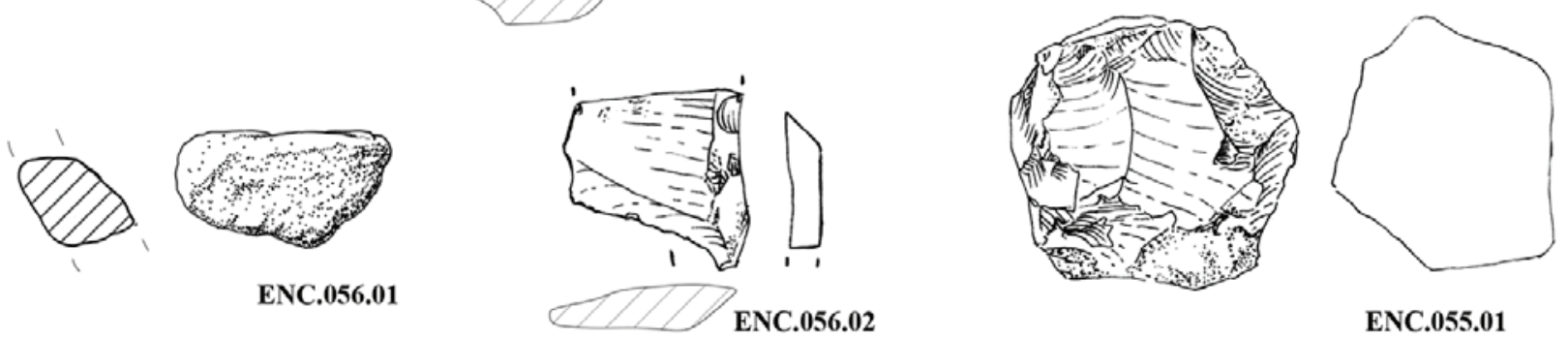

ENC.055.01

0 $5 \mathrm{~cm}$

Figura 9 - Materiais recolhidos nos sítios arqueológicos da Arieira (ENC.055), Valongo de Baixo (ENC.056), Ameixoeira (ENC.057 e Quinta dos Machados - Pincanceira 2 (ENC.059). Desenhos de Paula Bívar de Sousa. 


\title{
STRESSE INFANTIL, MORBILIDADE E MOR- TALIDADE NO SÍTIO ARQUEOLÓGICO DO NEOLÍTICO FINAL/CALCOLÍTICO $\left(4^{\circ}\right.$ E $3^{\circ}$ MILÉNIO A.C.) DO MONTE DO CARRASCAL 2 (FERREIRA DO ALENTEJO, BEJA)
}

\author{
Liliana Matias de Carvalho ${ }^{1}$, Sofia N. Wasterlain ${ }^{2}$
}

\begin{abstract}
RESUMO
As crianças passam por várias etapas de desenvolvimento/crescimento. Barker e Osmond teorizaram na hipótese "Developmental Origins of Health and Disease" que o stresse sofrido na vida intrauterina e primeira infância podia ter consequências negativas na idade adulta, inclusive na propensão à doença e na antecipação da idade de morte. Para estimar a frequência de stresse infantil numa amostra populacional do Neolítico Final/ Calcolítico e tentar perceber o seu impacto na vida adulta dos indivíduos, foi analisada, segundo a metodologia de Reid e Dean (2000, 2006), uma amostra do Monte do Carrascal 2 (Ferreira do Alentejo, Beja). Os indivíduos da amostra não demonstram ter sofrido excessivamente de stresse na infância, o que sugere algum cuidado com os membros mais novos da comunidade.
\end{abstract}

Palavras-chave: Paleopatologia, Desenvolvimento e crescimento, DOHaD, Investimento parental.

\begin{abstract}
Children go through various stages of development and growth. The Barker and Osmond "Developmental Origins of Health and Disease" hypothesis states that the stress episodes suffered in intrauterine/early childhood life have negative consequences in adulthood (propensity to diseases and anticipation of the age of death). In order to estimate the frequency of childhood stress in a sample of the Late Neolithic/Chalcolithic and understand its impact on the adult life of individuals, a sample of Monte do Carrascal 2 (Ferreira do Alentejo, Beja) was analysed following the methodology of Reid and Dean (2000, 2006). The individuals in the sample do not present many signs of childhood stress, suggesting a special care taken upon the younger members of the community.
\end{abstract}

Keywords: Paleopathology, Development and growth, DOHaD, Parental investment.

\section{INTRODUÇÃO}

A paleodemografia terá muito a ganhar se além do estudo da esperança média de vida, dos rácios de mortalidade e de natalidade e dos ritmos de crescimento, densidade e dimensão das populações do passado, também analisar os índices de saúde dos grupos populacionais (Bongarts, 2014). Segundo Lovejoy
\& alii (1990), a procura de dados sobre a saúde das populações passadas deve incidir sobre três campos individuais: mortalidade, stresse e crescimento. O termo stresse foi definido por Selye (1976) e designa a reação do organismo a uma exigência que pode ter origens diversas (ambientais, psicológicas, endócrinas, etc.) e responderá a constrangimentos ambientais, sistemas culturais e finalmente à re-

\footnotetext{
1. Centro de Investigação em Antropologia e Saúde, Department of Life Scienes, University of Coimbra, Portugal;
} liliana_m_carvalho@yahoo.com.br

2. Centro de Investigação em Antropologia e Saúde / Centre for Functional Ecology, Department of Life Sciences, University of Coimbra; Calçada Martim de Freitas, 30oo-456 Coimbra, Portugal; sofiawas@antrop.uc.pt 
sistência do hospedeiro (Goodman, Armelagos \& Rose, 1980; Goodman, Martin \& Armelagos, 1984). O stresse fisiológico observável em material esquelético indicará períodos em que os organismos dos indivíduos estiveram em sobre-esforço para colmatar um problema nutricional, patológico ou ambiental (Pinhasi \& Mays, 2008; Martin \& Harrod, 2016). As crianças passam por várias etapas ao longo do seu desenvolvimento e crescimento (Bogin, 1999), durante as quais estão muito mais suscetíveis a stresses ambientais do que os adultos (Pinhasi \& Mays, 2008; Paredes, Ferreira \& Wasterlain, 2015). Dois fatores de stresse de grande impacto são a nutrição inadequada, que leva a uma menor imunidade, eas infeções (Pinhasi \& Mays, 2008). Estas duas condições influenciam-se mutuamente num ciclo vicioso que tem muito de violência estrutural, ainda hoje observado em países em vias de desenvolvimento (King \& Ulijaszek, 1999; Farmer, 1996; 2002; Scrimshaw, 2003; Scrimshaw $\&$ alii.,1968). Estes ciclos de problemas nutritivos e doença são especialmente perniciosos após o nascimento e na primeira infância, influenciando, entre outras funções, os ritmos de crescimento (Bogin, 1999; Pinhasi \& Mays, 2008; Paredes, Ferreira \& Wasterlain, 2015). O impacto é particularmente dramático nas crianças entre os 6 e 36 meses já que este corresponde a um período de crescimento muito rápido (Pinhasi \& Mays, 2008). Segundo Briend (1998), é natural que após épocas de muito stresse fisiológico, o crescimento abrande (seguindo-se um rápido crescimento - "surto de crescimento") e, por isso, é fundamental, quando se estudam populações antigas, que se associem marcadores de stresse à estatura (Bogin, 1999; Pinhasi \& Mays, 2008; Paredes, Ferreira \& Wasterlain, 2015). Estes fatores têm ainda que ser contextualizados já que tanto em sociedades antigas como em contemporâneas, o tipo e quantidade de comida consumida, a higiene e saúde geral são afetados por variações baseadas no género e estatuto socioeconómico (Pinhasi \& Mays, 2008; DeWitte, 2010).

Em 1986, Barker e Osmond lançaram a hipótese “Developmental Origins of Health and Disease" (DOA$\mathrm{hD}$ ), inovadora e controversa, de que o stresse sofrido na vida intrauterina e primeira infância podia ter consequências negativas na idade adulta dos indivíduos, inclusive na propensão à doença e na antecipação da idade de morte. Vários estudos tentaram explorar essa associação relacionando episódios de stresse na infância com morte antecipada (Barker $\&$ alii, 1989b), doenças cardíacas (Barker \& Osmond, 1986; Barker, Os- mond \& Law, 1989a, 1989b), bronquite, asma e outras doenças respiratórias (Barker, Osmond \& Law, 1989a; Sayer $\mathbb{\&}$ alii, 2005), diabetes de tipo II (Sayer $\mathbb{\&}$ alii, 2005) e problemas endócrinos (Kapoor, Petropoulos \& Matthews, 2008), osteoporose (Sayer \& alii, 1998, 2005) e sacropenia (Sayer \& alii, 1998, 2005). A teoria DOAhD tem vindo a ser testada em coleções osteológicas comprovando-se a sua validade (Armelagos \& alii, 2009; Newman \& Gowland, 2015).

Assim pretende-se, neste estudo, e no âmbito da teoria DOHaD:

1. Estimar a frequência de stresse infantil nas amostras populacionais sob estudo de modo a que se possa aceder a diferenças entre sexos;

2. Investigar a relação entre as evidências de episódios de stresse na infância e a idade à morte;

3. Perceber se os indivíduos com stresse na infância demonstram uma maior propensão para graus mais elevados de morbilidade na idade adulta;

4. Refletir sobre o cuidado prestado à criança nestas populações do Neolítico Final/Calcolítico e o modo como este se terá refletido na qualidade de vida dos indivíduos enquanto adultos e, em maior medida, na sua esperança média de vida.

\section{MATERIAL}

O sítio Monte do Carrascal 2 (distrito de Beja, concelho de Ferreira do Alentejo, freguesia de Ferreira do Alentejo e Canhestros), implantado numa ligeira elevação de topo aplanado, sobranceira à ribeira do Vale do Ouro, corresponde a um vasto sítio arqueológico, com diversas ocupações integráveis em diferentes momentos da Pré-História (Neves, 2019). A intervenção levada a cabo, motivada no âmbito da execução do Bloco de Rega de Ferreira, Figueirinha e Valbom, promovido pela EDIA, SA, de onde resultaram os vestígios osteológicos alvos de estudo, incidiu em dois sepulcros colectivos - Hipogeu $1 \mathrm{e}$ 2 - escavados no substrato rochoso. Esta intervenção foi executada pelas empresas Dryas e Styx entre 2010 e 2011 (Neves \& Mendes, 2011) 3 .

Este sítio arqueológico localiza-se a 900 metros do

\footnotetext{
3. Este sítio já tinha sido parcialmente escavado por uma equipa da empresa ERA Arqueologia tendo as suas conclusões vindo a ser publicadas (Reis et alii, 2019; Rodrigues et alii, 2019; Santos \& Granja, 2009; Santos, 2011; Valera \& Brazuna, 2010; Valera et alii, 2014). O sítio foi ainda alvo de trabalhos arqueológicos de prospecção (Nunes \& Costa, 2011) e acompanhamento (Baião, 2011).
} 
povoado Calcolítico do Porto Torrão, de enorme dimensão, podendo integrar, juntamente com outras estruturas como os tholoi da Horta de João da Moura, Monte do Pombal ou Monte do Cardim, uma extensa necrópole polinucleada em torno desse grande povoado (Valera \& alii, 2010). Esta não é uma situação única, existindo paralelos com outras estruturas no Sudoeste da Península Ibérica, nomeadamente Alcalar (Morán \& Parreira, 2004) e Perdigões (Lago, 1998).

O Hipogeu 1 corresponde a uma estrutura escavada no substrato rochoso (caliços resultantes da meteriorização dos gabros de Beja) com uma câmara de morfologia subcircular, que se vai alargando paulatinamente do topo da estrutura para a base. Em relação ao espólio identificado regista-se a presença de material cerâmico, onde predominam as formas abertas (pratos de bordo espessado, almendrado, taças em calote, pequenos vasos), material lítico (grandes lâminas), adornos (contas de colar) e indústria sobre osso (agulha), integráveis no Calcolítico Pleno (Neves \& Mendes, 2011). Neste Hipogeu, no que diz respeito às práticas funerárias, foram identificados depósitos osteoarqueológicos sucessivos, correspondentes a seis momentos diferenciáveis de utilização funerária do hipogeu, tendo-se recuperado um total de 71 indivíduos e 4602 peças ósseas, não adultos e adultos de ambos os sexos. O ritmo das deposições dentro de cada uma das unidades sedimentares ficou bem documentado pelas diversas decapagens arqueológicas realizadas dentro de cada nível, tendo a leitura estratigráfica das deposições facilitado a perceção da intensa utilização do sepulcro durante o Calcolítico (Neves \& Mendes, 2011; Neves, 2019).

O Hipogeu 2 corresponde a uma grande estrutura subcircular com cerca de 3,50 m de diâmetro, escavada no substrato rochoso alargando-se para a base em todas as direções e com um corredor associado de cerca de $2 \mathrm{~m}$ de comprimento (Neves \& Mendes, 2011). Neste hipogeu foi recuperado material cerâmico, predominando as formas carenadas e alguns pratos, lâminas de pequeno módulo, alfinetes de cabeça postiça, machado em anfibolito, genericamente integráveis no Neolítico Final (Neves \& Mendes, 2011). No Hipogeu 2 foi possível identificar três depósitos osteoarqueológicos, correspondentes a diferentes momentos de utilização funerária, que face aos constrangimentos da intervenção, não puderam ser escavados de forma integral. Deste modo, foi apenas identificado um total de 42 indivíduos e 2986 peças ósseas, repartido por três depósitos diacrónicos (Neves \& Mendes, 2011; Neves, 2019).

Os materiais arqueológicos identificados permitem balizar a utilização deste monumento entre o Neolítico Final e o Calcolítico Pleno ( $4^{\circ}$ e $3^{\circ}$ milénio a.C.) (Neves \& Mendes, 2011) ${ }^{4}$.

\section{METODOLOGIA}

A idade à morte foi estimada com base na fusão das epífises (Buisktra \& Ubelaker, 1994), alterações morfológicas da sínfise púbica (Brooks \& Suchey, 1990) e da superfície auricular (Buckberry \& Chamberlain, 2002). Os indivíduos foram incluídos em três grandes grupos etários: adulto jovem, adulto de meia idade e adulto maduro. Sempre que a preservação óssea não permitia a inclusão num desses grupos o indivíduo foi classificado apenas como "adulto".

A diagnose sexual foi realizada conjugando métodos métricos e morfológicos. O crânio e osso ilíaco foram observados, na sua morfologia, segundo Buisktra e Ubelaker (1994), sendo o último também analisado tendo em conta o método morfológico de Bruzek (2002). Os ossos longos foram alvo de uma análise métrica (Wasterlain, 200o). Os indivíduos foram considerados de sexo feminino ou masculino. Sempre que que não se conseguiu integrar o indivíduo numa das duas categorias anteriores, este foi considerado de sexo "indeterminado".

Foram observados marcadores de stresse não específico (hipoplasias do esmalte dentário) nos dentes anteriores dos indivíduos adultos (Goodman, Armelagos \& Rose, 1980; Armelagos \& alii, 2009). As hipoplasias mais frequentes, de tipo linear ou sulco, correspondem a depressões horizontais localizadas na superfície do esmalte dos dentes e são fruto de uma interrupção de formação de esmalte quando o indivíduo está sob stresse fisiológico (Goodman \& Rose, 1990; Hillson \& Bond, 1997; Hillson, 2005; Witzel $\&$ alii, 2006). De notar que as hipoplasias apenas podem ocorrer durante o período de formação do esmalte, ou seja, dos 3 meses de vida intrauterina aos 13 anos de idade. Por outro lado, assim que são formadas, não desaparecem exceto por

\footnotetext{
4. O Monte do Carrascal tem sido alvo de várias publicações (Boaventura et alii, 2014; Neves \& Silva, 2018a, b; Rodrigues, 2014, 2018).
} 
ação do desgaste ou qualquer outra agressão à coroa dentária (Goodman \& Rose, 1990; Skinner \& Goodman, 1992).

Para o registo e classificação das hipoplasias do esmalte dentário seguiu-se a metodologia sugerida por Hillson (2001). A idade em que ocorreu cada defeito foi aferida de acordo com a metodologia proposta por Reid \& Dean (2000, 2006) para as populações europeias.

Para além das hipoplasias do esmalte dentário, foram observados outros marcadores de stresse, nomeadamente hiperostose porótica e cribra orbitália, que se teriam manifestado na idade adulta. Estes parâmetros foram usados como indicadores de morbilidade. A hiperostose porótica da caixa craniana ou das órbitas (cribra orbitália) designa a porosidade óssea causada pela hipertrofia dos tecidos hematopoéticos. Usualmente assume-se que a sua causa estará relacionada com uma condição anémica devida especificamente a ausência de ferro (indicador de stresse específico) mas pode ser também indicador de deficiências nutricionais, doenças infeciosas ou parasitismo (Buikstra \& Ubelaker, 1994; Cunha, 2015; Armelagos \& alii, 2009; Walker \& alii, 2009). Tanto a hiperostose porótica craniana como a cribra orbitália foram registadas, em separado, como presentes ou ausentes.

Para além dos marcadores de stresse também se estimou a estatura dos indivíduos de modo a ter uma perceção mais fina dos condicionalismos de desenvolvimento e morbilidade impostos pelos episódios de stresse infantil. Para tal, utilizaram-se as metodologias desenvolvidas em populações portuguesas: o método de Mendonça (200o) para os ossos longos e o de Santos (2002) para os metatársicos.

Depois de registados, os dados foram inseridos no programa SPSS de modo a serem alvo de tratamento estatístico standartizado e testado para a significânia (não aleatoriedade dos resultados) por meio do teste do qui-quadrado.

\section{RESULTADOS}

\subsection{Por Indivíduo}

Foram analisados seis indivíduos (com pelo menos um elemento da dentição anterior preservada). Estes são predominantemente femininos $(83,3 \%, 5)$ e adultos de meia idade $(50 \%, 3)$ seguidos de adultos cuja idade não foi possível especificar $(33,4 \%)$ (Tabela 1).
Todos os indivíduos tinham perdido peças dentárias em vida $(100 \%, 6)$ mas apenas um $(16,7 \%)$ perdeu dentes após a morte. A observação de HED nos dentes foi relativamente condicionada pela presença de desgaste (sobretudo superior ao grau 4 de Smith, presente em $33,3 \%$ dos indivíduos, um deles com uma média de desgaste de grau 6) na dentição dos indivíduos observados e também de cálculo dentário ( $83,3 \%, 5$ dos indivíduos).

Dos seis indivíduos, apenas um (16,7\%) possuía pelo menos uma hipoplasia do esmalte dentário (HED), indiciando esta um episódio de stresse na infância ${ }^{5}$ (Tabela 2).

O único indivíduo com hipoplasias possui três defeitos hipoplásticos. Evidenciam-se HED em duas das três áreas do dente, o que não aponta para uma ocorrência sistémica que tenha ocupado todo o período de formação do dente ${ }^{6}$.

A análise dos intervalos etários das HED (Reid \& Dean, 2000, 2006) revelam-nos uma ocorrência entre os 2,8 e os 4,9 anos de idade no único indivíduo com hipoplasias da amostra demonstrando que continuou a sofrer de episódios de stresse até uma fase relativamente tardia da primeira infância 7 . A média etária dos episódios de stresse é de 3,5 anos. ${ }^{8}$ Dos seis indivíduos observados, os dois que permitiam a observação das órbitas (100\%) exibiam cribra orbitália e dos quatro que possibilitavam a procura por hiperostose porótica apenas um (25\%) exibia esta condição. Um único indivíduo (o já referido indivíduo nํㅡㄹ do hipogeu 1; sexo feminino, adulto) tinha simultaneamente hipoplasias do esmalte dentário, cribra orbitália e hiperostose porótica (Tabela 3).

\footnotetext{
5. Indivíduo n²1, do hipogeu 1. Adulto, sexo feminino.

6. Frequência de hipoplasias por área do dente (observável) e indivíduos: terço oclusal: o\%; terço de contacto: $16,7 \%$ (1); Terço cervical: $33,4 \%$ (2).
}

7. Apresenta-se sempre o intervalo curto, aferido pelo investigador pelas medições no material dentário, no entanto de modo a reduzir o erro foi também calculado um intervalo mais alargado, com um valor etário um decil acima e um decil abaixo do intervalo curto, o que no caso deste indivíduo se expressa na ocorrência de hipoplasias do esmalte dentário entre os 2,7 e 5,6 anos.

8. Esta média foi calculada da seguinte forma: após a determinação da média dos intervalos máximos e mínimos de idade dos episódios de stresse de cada dente foi calculada a média global para cada indivíduo. 
Infelizmente o único indivíduo com hipoplasias não nos possibilitou uma avaliação da sua estatura e desse modo não foi possível compará-la com a média dos indivíduos sem HED, 153,93 $( \pm 2,94) \mathrm{cm}^{9}$ (Figura 1).

\subsection{Por Dente}

Foram observados 21 dentes anteriores. Dos 21 dentes presentes um ${ }^{10}(4,76 \%)$, embora presente, não permitiu a observação de HED devido à presença de cálculo dentário na superfície labial. Dos restantes 20 -aqueles que possibilitavam a análise de HED - 90\% (18) não exibiam qualquer defeito hipoplástico. A presença de dentes com HED seria então de $10 \%$ (2), um valor relativamente baixo. Os dentes observáveis para HED pertenciam na sua maioria a indivíduos femininos $(85 \%, 17)$. Apenas $15 \%$ (3) pertenciam a indivíduos masculinos. O maior número - 55\% (11) - de dentes observáveis pertencia a indivíduos categorizados como adultos, seguindo-se os adultos de meia idade $(35 \%, 7)$ e por último os pertencentes a adultos jovens $(10 \%, 2)$. Em termos de predominância de maxilar, observou-se que $45 \%$ (9) das peças dentárias pertenciam ao maxilar superior e $55 \%$ (11) à mandíbula. Os tipos de dentes presentes não estão representados de forma homogénea, com $20 \%$ (4) de incisivos centrais, $45 \%$ (9) de incisivos laterais e 35\% (7) de caninos.

Os dentes com HED apresentavam entre um a dois defeitos por dente (Tabela 4).

Quando se observa a porção do dente afetada, ainda que em baixas frequências, é notória a maior presença de HED na região cervical (10\% das superfícies com HED), a última a ser formada, ligando a ocorrência de eventos hipoplásticos a um momento mais tardio na infância (Tabela 5).

A relação entre a presença de HED e os maxilares, nomeadamente a sua expressividade na mandíbula, é significativa $\left(\mathrm{X}^{2}=1,818\right.$, g.l. $\left.=2, p=0,403\right)$. Os dois dentes com HED pertencem ambos à mandíbula (Tabela 6).

9. Média da estatura foi conseguida seguindo o método de Santos (2002) para os metatársicos que no caso desta amostra pôde ser aplicada a dois indivíduos. O método de Mendonça (200o) para os ossos longos apenas se consegiu aplicar a um úmero $(148,54 \mathrm{~cm})$ e fémur $(145,70$, comprimento anatómico) do mesmo indivíduo (nº 44 do hipogeu 1) resultando numa estatura média de 147,12 cm.

1o. Dente 43 do indivídio no 44 do Hipogeu 1 .
A relação entre a presença de HED e o tipo de dente não é significativa ${ }^{11}$. No estudo desta amostra as HED estão ausentes dos incisivos centrais (Tabela 7). A relação entre a presença de HED e cada dente, na amostra do Monte do Carrascal 2, também não é significativa ${ }^{12}$. Foram apenas detetadas HED num incisivo lateral e canino inferiores direitos (Tabela 8). No que diz respeito à idade inicial de manifestação de stresse fisiológico nos dentes esta ocorre entre os 2,8 e 3,1 anos de idade. O intervalo de idade máxima da manifestação de stresse ocorre entre os 3,3 e 4,9 anos de idade. Ambas as médias apontam para um momento tardio na primeira infância das crianças.

\section{DISCUSSÃO}

Devido à grelha metodológica definida para este estudo - a observação da dentição anterior de indivíduos adultos - o número de material observável foi, infelizmente, bastante condicionado. Assim a amostra analisada nesta coleção foi de seis indivíduos e 20 dentes anteriores, o que não permite uma exploração estatística satisfatória, ainda assim, os resultados obtidos são expressivos.

Uma frequência de 16,7\% de indivíduos afetados é considerada média e expectável para épocas coevas e para o território português. O Tojal de Vila Chã apresenta um valor muito semelhante, 16,6\% (Duarte, 1993) tal como o Hipogeu de Monte Canelas I (Silva, 1996), com 13,5\%. O estudo de Silva (2002), sobre várias populações costeiras, revela valores máximos de 5,2\% para Paimogo I e 3,9\% para São Paulo. Um dos valores mais elevados foi o observado por Araújo (1996) para São Pedro do Estoril I e II. Há que relembrar que este é um período de transição entre uma agricultura ainda bastante dependente das condições climatéricas (Neolítico Final) para um momento, após a revolução dos produtos secundários, em que já se praticava a transformação dos recursos alimentares de modo à sua maior preservação/disponibilidade ao longo do tempo (Calcolítico). Aliás, é atualmente aceite que essa maior disponibilidade alimentar trazida pela agricultura, nem sempre teve um reflexo positivo na saúde das crianças, sobretudo devido a um desmame menos cuidado e a alimentos de substituição inadequados

\footnotetext{
11. $\mathrm{X}^{2}=3,139, \mathrm{~g} \cdot 1 .=4, p=0,535$

12. $\mathrm{X}^{2}=18,889, \mathrm{~g} \cdot \mathrm{l} \cdot=2 \mathrm{O}, p=0,529$
} 
e que poderiam causar reações sistémicas (Cohen \& Armelagos, 1984).

Dos seis indivíduos, apenas um possuía hipoplasias do esmalte dentário (HED), indício de episódios de stresse na infância. Este único indivíduo, que possuía três defeitos hipoplásticos, era também o único a exibir cribra orbitália e hiperostose porótica já em adulto. Da pequena amostra analisada podemos afirmar que estes indivíduos, na sua generalidade, não sofreram de episódios de stresse durante a infância. No entanto, aquele que os sofreu, exibia, em adulto, vestígios de morbilidade (falta de nutrientes e presença de condições inflamatórias), o que sublinha um dos pressupostos da teoria $\mathrm{DOHaD}$, a de que aqueles que são confrontados com uma infância com maiores deficiências nutricionais ou patológicas acabam por ser acossados por maiores fragilidades biológicas na idade adulta. Note-se que um outro indivíduo, embora sem evidências de stresse na infância, exibia cribra orbitália, considerada indicadora de falta de ferro (anemia) (Armelagos $\&$ alii, 2009; Walker \& alii, 2009).

Uma análise inicial destes dados aponta para um provável desmame controlado e genericamente bem-sucedido, já que não se identificaram hipoplasias em nenhum dos indivíduos até aos 3 anos de idade. O único indivíduo com hipoplasias parece denotar vários episódios de stresse entre os 3 e pelo menos os 5 anos, uma fase tardia da infância e provavelmente já não relacionada com o desmame (embora não seja de descartar um período de desmame mais longo ou tardio), o que pode dever-se a situações de doença/imunidade reduzida. Não se conseguiu, no entanto, avançar com uma causa concreta para o episódio de stresse, que geralmente resulta de uma combinação de fatores (Suckling, 1989).

Infelizmente, o único indivíduo com hipoplasias não possibilitou uma avaliação da sua estatura e desse modo não foi possível compará-la com a média dos indivíduos sem HED: 153,93 $( \pm 2,94) \mathrm{cm}$, relativamente baixa, já que, para o neolítico europeu ocidental, Meiklejohn \& alii (1984) calcularam uma média de $167,3 \mathrm{~cm}$ para indivíduos masculinos e 154,1 cm para os femininos. Os nossos resultados podem refletir uma tendência, já observada pelos autores supracitados, de diminuição da estatura do paleolítico para o calcolítico.

Os estudos sobre a saúde no passado devem ter em consideração o "paradoxo osteológico", princípio enunciado por Wood et alii (1992), que alerta para a possibilidade de se estar a estudar uma população que efetivamente morreu, sendo por isso, eventualmente, propícia à doença. Sob outro prisma também poderá ser uma população com imunidade de tal modo baixa que a morte se dá rapidamente sem que exista resposta óssea. Em última instância a falta de consideração por estes pressupostos poderia levar a leituras erradas sobre a saúde das populações passadas. No que concerne ao estudo das hipoplasias do esmalte dentário, a teoria parece não ter tanto peso já que se tem vindo a observar mais stresse em populações menos saudáveis (Bennike et alii, 2005; Saunders \& Hopa, 1993).

Deverá ser feita uma reflexão sobre o grau de representatividade da amostra analisada e as suas condicionantes, controláveis ou não pelas autoras do estudo. Como referido, a definição da metodologia a seguir limitou o número de indivíduos analisáveis. Uma redefinição poderia alargar o número da amostra e complementar os resultados obtidos. Por outro lado, o número de indivíduos exumados nos hipogeus do Monte do Carrascal 2 foi limitado pelo tempo e condições de escavação, não se tendo terminado de intervencionar nenhum dos hipogeus, o que necessariamente fornece um retrato incompleto dos mesmos. Será ainda importante referir que devido à intervenção, em sucessão, de duas equipas de escavação diferentes, as metodologias de escavação e consequentes interpretações são distintas, o que também dificulta a integração de todo o espólio arqueológico numa mesma investigação (Neves \& Mendes, 2011; Santos \& Granja, 2009). Prospeções geofísicas feitas no local identificaram outras estruturas negativas nas proximidades que podem corresponder a hipogeus ainda por escavar e estudar, o que certamente clarificaria bastante a análise do carácter funerário deste sítio. Finalmente, o povoado de fossos do Porto Torrão, que influenciaria toda a região incluindo o Monte do Carrascal 2, parece ter em seu redor (e mesmo dentro da sua área) vários tipos de contextos funerários (hipogeus, tholos ou fossas), o que faz pensar que o Monte do Carrascal 2, e em particular os dois hipogeus parcialmente escavados, fazem parte de um contexto funerário muito mais abrangente e complexo, com dinâmicas de utilização e ocupação ainda pouco entendidas (Rodrigues, 2014). 


\section{CONCLUSÃO}

$\mathrm{Na}$ amostra analisada não só a maioria dos indivíduos não exibe HED, que se formam na infância, como igualmente não exibem marcadores de stresse em idade adulta. Por outro lado, o indivíduo que terá tido uma infância mais frágil, de tal modo que a normal formação de esmalte foi interrompida, não só exibe, em adulto, hiperostose porótica, um sinal físico de stresse fisiológico, como cribra orbitália, usualmente associada à falta de ferro no organismo (anemia). Infelizmente não foi possível correlacionar a presença de sinais de stresse com a idade à morte.

A população do Monte do Carrascal 2 parece ter tido algum cuidado com a generalidade das suas crianças, o que se terá refletido em adultos em que a exibição de problemas sistémicos nos ossos é rara.

\section{AGRADECIMENTOS}

As autoras gostariam de agradecer ao Centro de Investigação em Antropologia e Saúde, ao Centro de Ecologia Funcional e ao Grupo Dryas Octopetala e a Maria João Neves pela autorização do estudo da colecção do Monte do Carrascal 2. A co-autora Liliana M. Carvalho foi financiada pela FCT - Fundação para a Ciência e Tecnologia, sob o projecto com a referência SFRH/BD//BIA/04004/202O. A co-autora Sofia N. Wasterlain foi financiada por fundos nacionais via FCT - Fundação para a Ciência e Tecnologia, sob o projecto com a referência UIDB/o0283/2020.

\section{BIBLIOGRAFIA}

ARAÚJO, M. T. G. L. (1996) - Os dentes humanos das grutas artificiais de S. Pedro do Estoril: incidência de algumas lesões patológicas e estudo do desgaste numa amostra de dentes do Neolítico Final/Calcolítico. Dissertação de Mestrado em Arqueologia, Instituto de Ciências Sociais da Universidade do Minho.

ARMELAGOS, George; GOODMAN, Alan; HARPER, Kristin; BLAKEY, Michael (2009) - Enamel hypoplasia and early mortality: bioarchaeological support for the Barker hypothesis. Evolutionary Anthropology, 18, pp. 261-271.

BAIÃO, Francisco José Serpa (2011) - Relatório do acompanhamento técnico dos trabalhos de selagem e proteç̧ão dos contextos arqueológicos e antropológicos do Monte do Carrascal 2.

BARKER, D.; OSMOND, C. (1986) - Infant mortality, childhood nutrition, and ischaemic heart disease in England and Wales. Lancet 8489, pp. 1077-1081.
BARKER, D. J. P; OSMOND, C.; LAW, C. M (1989)-The intrauterine and early postnatal origins of cardiovascular disease and chronic bronchitis. Journal of Epidemiology and Community Health, 43: 237-240.

BARKER, D.; OSMOND, C. (1986) - Infant mortality, childhood nutrition, and ischaemic heart disease in England and Wales. Lancet 8489, pp. 1077-11081.

BARKER, D. J. P; OSMOND, C.; LAW, C. M. (1989a) - The intrauterine and early postnatal origins of cardiovascular disease and chronic bronchitis. Journal of Epidemiology and Community Health, 43, pp. 237-240.

BARKER, D. J.; OSMOND, C.; GOLDING, J.; KUH, D.; WADSWORTH, M. E. (1989b) - Growth in utero, blood pressure in childhood and adult life, and mortality from cardiovascular disease. British Medical Journal 298, pp. 564-567.

BENNIKE, P.; LEWIS, M. E.; SCHUTKOWSKI, H.; VALETIN, F. (2005) - Comparisons of child morbidity in two contrasting medieval cemeteries from Denmark. American Journal of Physical Anthropology, 128, pp. 734-746.

BOAVENTURA, Rui; FERREIRA, Maria Teresa; NEVES, Maria João; SILVA, Ana Maria (2014) - Funerary practices and anthropology during middle-late neolithic $\left(4^{\text {th }}\right.$ and $3^{\text {rd }}$ millenia BCE) in Portugal: old bones, new insights. Anthropologie, LII/2, pp. 183-205.

BOGIN, Barry (1999) - Patterns of human growth. Cambridge University Press.

BONGARTS, John (2014) - Human population growth and the demographic transition. Philosophical Transactions of the Royal Society B, 364, pp. 2985-299o.

BROOKS, S.; SUCHEY, J. M. (1990) - Skeletal age determination based on the os pubis: A comparison of the AcsádiNemeskéri and Suchey-Brooks methods. Journal of Human Evolution, 5, pp. 227-238.

BRUZEK, J. (2002) - A method for visual determination of sex, using the human hip bone. American Journal of Physical Anthropology, 117, pp. 157-168.

BUCKBERRY, J. L; CHAMBERLAIM, A. T. (2002) - Age estimation from the auricular surface of the ilium: a revised method. American Journal of Physical Antropology, 119, pp. 231-239.

BUISKTRA, Jane; UBELAKER, Douglas (ed.) (1994) Standarts for data collection from human skeletal remains. Arkansas Archaeological Survey Research Series, number 44. Arkansas Archaeological Survey.

COHEN, Mark; ARMELAGOS, George (Eds.) (1984) Paleopathology at the origins of agriculture. Academic Press, Orlando. 
CUNHA, Daniela (2015) - Contributo da análise paleopatológica e paleoparasitológica na interpretação da indicadores de stresse fisiológico: estudo de uma amostra Islâmica medieval exumada de Santarém (Portugal). Dissertação de Mestrado em Evolução e Biologia Humanas. Departamento de Ciências da Vida, Universidade de Coimbra.

DEWITTE, Sharon (2010) - Sex differentials in frailty in Medieval England. American Journal of Physical Anthropology, 143, pp. 286-297.

DUARTE, Cidália (1993) - Dental wear patterns and pathological lesions in the Neolithic site Grutas Artificiais do Tojal de Vila Chã (Carenque, Portugal). Unpublished M. A. dissertation, Department of Anthropology. Edmon-ton, Alberta, University of Alberta.

GOODMAN, Alan; ARMELAGOS, George; ROSE, Jerome (1980) - Enamel hypoplasias as indicators of stress in three prehistoric populations from Illinois. Human Biology, 52, pp. 515-528.

GOODMAN, Alan; MARTIN, Debra; ARMELAGOS, George (1984) - Indications of stress from bone and teeth. Paleopathology at the origins of agriculture. Academic Press, pp. 13-50.

GOODMAN, Alan; ROSE, Jerome (1990) - Assessment of systemic physiological perturbations from dental enamel hypoplasias and associated histological structures. Yearbook of Physical Anthropology 33: 59-110.

HILLSON, Simon (2001) - Recording Dental Caries in Archaeological Human Remains. International Journal of Osteoarchaeology. New York, Wiley-Liss, pp. 249-286.

HILLSON, Simon (2005) - Teeth. $2^{\text {nd }}$ ed. Cambridge University Press: Cambridge.

HILLSON, Simon; BOND, Sandra (1997) - Relationship of enamel hypoplasia to the pattern of tooth crown growth: a discussion. American Journal of Physical Anthropology 104: 89-103.

KAPOOR, Amita; PETROPOULOS, Sophie; MATTHEWS, Stephen (2008) - Fetal programming of hypothalamic-pituitary-adrenal (HPA) axis function and behavior by syntheticglucocorticoids. Brain Research Reviews, 57, pp. 586-595.

KING, S.; ULIJASZEK, S. J. (1999) - Invisible insults during growth and development: contemporary theories and past populations. In Human Growth in the Past, HOPPA RD, FITZGERALD CM (eds). Cambridge University Press: Cambridge, pp. 161-181.

LAGO, Miguel (1998) - Povoado dos Perdigões (Reguengos de Monsaraz): dados preliminaries dos trabalhos arqueológicos realizados em 1997. Revista Portuguesa de Arqueologia, Vol.1, nº 1: 45-152.
LOVEJOY, C. O.; MEINDL, R. S.; PRYZBECK, T. R.; MENSFORTH, R. P. (1985) - Chronological metamorphosis of the auricular surface of the ilium: a new method for the determination of adult skeletal age at death. American Journal of Physical Anthropology, 68, pp. 15-28.

MENDONÇA, M.C. (200o) - Estimation of height from the length of long bones in a Portuguese adult population. American Journal of Physical Anthropology, 112 (1), pp. 39-48.

MCMILLEN, Caroline; ROBINSON, Jeffrey (2005) - Developmental origins of the metabolic syndrome: prediction, plasticity, and programming. Physiology Review, 85, pp. 571-633.

MARTIN, Debra; HARROD, Ryan (2016) - The bioarchaeology of pain and suffering: human adaptation and survival during troubled times. In Hegmon, M (eds). Archaeology of the human experience. American Anthropological Association.

MEIKLEJOHN, Christopher; KEY, Patrick (1984) - Socioeconomic change and patterns of pathology and variation in the Mesolithic and Neolithic of Western Europe: some suggestions.

MÓRAN, Elena; PARREIRA, Rui (2004) - Alcalar 7: estudo e reabilitação de um monumento megalítico. Série Cadernos 6, Ministério da Cultura. IPPAR.

NEVES, Maria Joao; MENDES, Catarina (2011) - Intervenção de arqueologia preventiva: Monte do Carrascal 2 - Trabalhos arqueológicos e antropológicos, minimizações de impactes decorrentes do Bloco de Rega de Ferreira, Ferreirinha e Valbom - Fase de Obra (Ferreira do Alentejo, Beja).

NEVES, Maria João; SILVA, Ana Maria (2018a) - Acerca da biografia dum sepulcro colectivo do Neolítico Final/Calcolítico: o hipogeu 2 do Monte do Carrascal 2 (Ferreira do Alentejo, Beja, Portugal). Estudos do Quartenário, 18, pp. 35-52.

NEVES, Maria João; SILVA, Ana Maria (2018b) - Uma análise arqueotanatológica em três hipogeus: os contributos dos sítios de Monte Canelas I (Portimão) e do Monte do Carrascal 2 (Ferreira do Alentejo) para a compreensão das práticas funerárias nos $4^{\circ}$ e $3^{\circ}$ milénios A.C. no Sul de Portugal. De Gibraltar aos Pirinéus: megalitismo, vida e morte na Fachada Atlântica Penínsular.

NEVES, Maria João (2019) - O contributo da arqueotanatologia para a compreensão das práticas funerárias nos $40 \mathrm{~s}$ e zos milénios AC. no Sul de Portugal: os hipogeus de Monte Canelas I (Portimão, Faro) e Monte do Carrascal 2 (Ferreira do Alentejo, Beja). Dissertação de Doutoramento em Antropologia Biológica. Faculdade de Ciências e Tecnologia da Universidade de Coimbra.

NEWMAN, Sophie; GOWLAND, Rebecca (2015) - The use of non-adult vertebral dimensions as indicators of growth disruption and non-specific health stress in skeletal populations. American Journal of Physical Anthropology, volume 158, nº 1 , pp. 155-164. 
NUNES, João; COSTA, Tiago Santos Coelho Pessoa (2011) - Propsecção arqueológica do Lanço C - IP8 - Ferreira do Alentejo/Beja.

PAREDES, Joana; FERREIRA, Maria Teresa; WASTERLAIN, Sofia Neto (2015) - Growth problems in a skeletal sample of children abandoned at Santa Casa da Misericordia, Faro, Portugal ( $16^{\text {th }}-19^{\text {th }}$ centuries). Anthropological Science, vol.123 (3), pp. 149-159.

PINHASI, Ron; MAYS, Simon (Eds.) (2008) - Advances in human paleopathology. John Wiley \& Sons, England.

REID D. J., DEAN M. C. (200o) - Brief communication: the timing of linear hypoplasias on human anterior teeth. American Journal of Physical Anthropology 113: 135-139.

REID, D.J; DEAN, M.C. (2006) - Variation in modern human enamel formation times. Journal of Human Evolution 5o, pp. 329-346.

REIS, Helena; GONÇALVES, Célia; SANTOS, Helena; VALERA, António Carlos (2019) - Monte do Carrascal 2 (southern Portugal): Insights into lithic technology and intra-site spatial analysis of a Late Mesolithic hunting camp. Journal of Archaeological Research: reports, 23, pp. 674-686.

RODRIGUES, Filipa (2014) - Skeletons in the ditch: funerary activity in ditched enclousures of Porto Torrão (Ferreira do Alentejo, Beja). In: Valera, António (ed.) Recent Prehistoric Enclosures and Funerary Practices. BAR International Series, 2676, pp. 59-69.

RODRIGES, Filipa (2018) - Muitas antas e muita gente! As relações entre os recintos de fossos e os monumentos megalíticos no Alentejo Central. De Gibraltar aos Pirinéus: megalitismo, vida e morte na Fachada Atlântica Penínsular.

RODRIGUES, A. L.; DIAS, M. I.; VALERA, António Carlos; ROCHA, F.; PRUDÊNCIO, M. I.; MARQUES, R.; CARDOSO, G.; RUSSO, D. (2019) - Geochemistry, luminescence and innovative dose rate determination of a Chalcolithic calcite-rich negative feature. Journal of Archaeological Research: reports, 26.

SANTOS, Helena; GRANJA, Raquel (2009) - Relatório das sondagens arqueológicas executadas no âmbito do EIA Bloco de Rega de Ferreira do Alentejo /Valbom, Beja.

SAUNDERS, Shelley; HOPPA, Robert (1993) - Growth deficit in survivors and non-survivors: biological mortality bias in sub-adult skeletal samples. Yearbook of Physical Anthropology, 36, pp. 127-151.

SAYER, A.A; COOPER, C; EVANS, J.R; RAUF, A; WORMALD, R.P; OSMOND, C; BARKER, D.J. (1998)-Are rates of ageing determined in utero? Age and Ageing, 27, pp. 579-583.

SAYER, Avan Aihie; SYDDALL, Holly; MARTIN, Helen; DENNISON, Elaine; ANDERSON, Frazer; COOPER, Cyrus (2005) - Falls, sarcopenia, and growth in early life: findings from the Hertfordshire Cohort Study. American Journal of Epidemiology, 164, pp. 665-671.
SCRIMSHAW, Nevin (2003) - Historical concepts of interactions, synergism and antagonism between nutrition and infection. Journal of Nutrition, 133, pp. 316-321.

SCRIMSHAW, Nevin; TAYLOR, Carl Ernest; GORDON, Jonh Everett (1968) - Interaction of Nutrition and Infection. World Health Organization Monograph Series No. 57. WHO: Geneva.

SILVA, Ana Maria (1996) - O hipogeu de Monte Canelas I (IV-III A.C.): estudo paleobiológico da população humana exumada. Provas de aptidão pedagógica e capacidade científica. departamento de Antropologia. Faculdade de Ciências e Tecnologia da Universidade de Coimbra.

SILVA, Ana Maria (2002) - Antropologia funerária e paleobiologia das populações portuguesas (litorais) do neolitico final/calcolitico. Dissertação de doutoramento em Antropologia Biológica. Faculdade de Ciências e Tecnologia da Universidade de Coimbra.

SKINNER, Mark; GOODMAN, Alan (1992) - Anthropological uses of developmental defects of enamel. In Skeletal biology of past peoples: research methods, Saunders SR, Katzenberg MA (eds.). Wiley-Liss: New York; 153-174.

SUCKLING, G. (1989) - Developmental defects of enamel - historical and present-days perspective of their pathogenesis. Advances in Dental Research 3: 87-94.

WALKER, Phillip; BATHURST, Rhonda; RICHMAN, Rebecca; GJERDRUM, Thor; ANDRUSHKO, Valerie (2009) - The causes of porotic hyperostosis and cribra orbitalia: a reappraisal of the iron-deficiency hypothesis. American Journal of Physical Anthropology, 139, pp. 109-125.

WASTERLAIN, Sofia Neto (200o) - Morphé: análise das proporções entre os membros, dirmofismo sexual e estatutra de uma amostra da Colecção de Esqueletos da Universidade de Coimbra. Tese de mestrado. Departamento de Antropologia, Universidade de Coimbra.

WITZEL, Carsten; KIERDORF, Uwe; DOBNEY, Keith; ERVYNCK, Anton; VANPOUCKE, Sofie; KIERDORF, Horst (2006) - Reconstructing impairment of secretory ameloblast function in porcine teeth by analysis of morphological alterations in dental enamel. Journal of Anatomy 209: 93-110.

WOOD, J. W.; MILNER, G. R.; HARPENDING, H. C; WEISS, K. M. (1992) - The osteological paradox: problems of inferring prehistoric health from skeletal samples. Current Anthropology, 33, pp. 343-370.

VALERA, António; BRAZUNA, Sandra (2010) - Relatório da prospecção geofisica (EIA - Lanço C - IP8 - Ferreira do Alentejo/Beja).

VALERA, António; SANTOS, Helena; FIGUEIREDO, Margarida; GRANJA, Raquel (2010) - Contextos funerários na periferia do Porto Torrão: Cardim 6 e Carrascal 2. Actas do $4^{\circ}$ Colóquio Arqueológico de Alqueva. Beja. EDIA. 


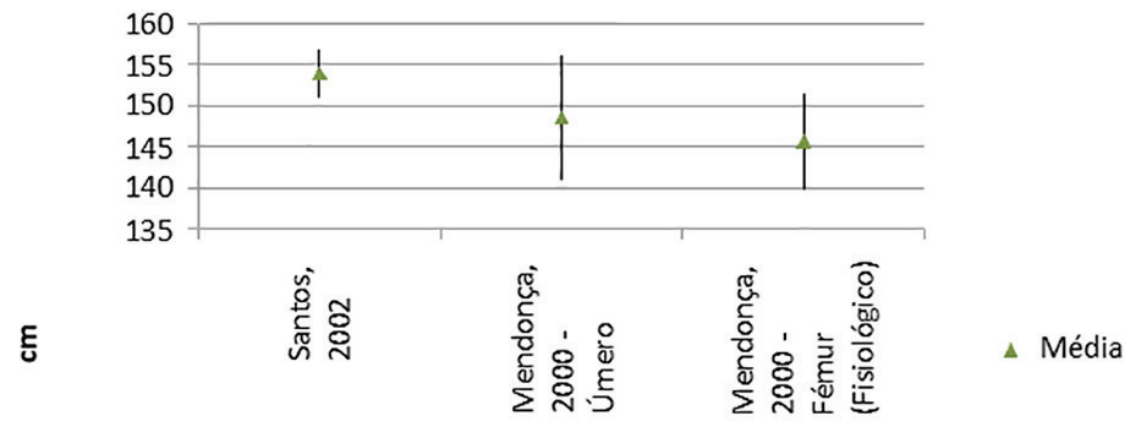

Figura 1 - Intervalos da estatura, segundo a região anatómica e metodologia utilizadas.

Tabela 1 - Perfil da amostra analisada, por sexo, intervalo de idade à morte e classe etária (\%).

\begin{tabular}{|l|c|c|}
\hline Classe Etária & Com HED (n/\%) & Sem HED (n/\%) \\
\hline Adulto Jovem & $0 / 0$ & $1 / 100$ \\
\hline Adulto Meia Idade & $0 / 0$ & $2 / 100$ \\
\hline Adulto & $1 / 33,3$ & $2 / 66,6$ \\
\hline Diagnose Sexual & & $4 / 80$ \\
\hline Feminino & $1 / 20$ & $1 / 100$ \\
\hline Masculino & 0 & \\
\hline
\end{tabular}

Tabela 2 - Frequência de HED, por sexo e classe etária.

\begin{tabular}{|l|c|c|}
\hline Classe Etária & Com HED (n/\%) & Sem HED (n/\%) \\
\hline Adulto Jovem & $0 / 0$ & $1 / 100$ \\
\hline Adulto Meia Idade & $0 / 0$ & $2 / 100$ \\
\hline Adulto & $1 / 33,3$ & $2 / 66,6$ \\
\hline Diagnose Sexual & & $4 / 80$ \\
\hline Feminino & $1 / 20$ & $1 / 100$ \\
\hline Masculino & 0 & \\
\hline
\end{tabular}

Tabela 3 - Frequências de cribra orbitália e hiperostose porótica, por indivíduo.

\begin{tabular}{|l|c|c|}
\hline & Presente $(\% / \mathrm{n})$ & Ausente $(\% / \mathrm{n})$ \\
\hline Cribra Orbitália & $100 / 2$ & $0 / 0$ \\
\hline Hiperostose Porótica & $25 / 1$ & $75 / 3$ \\
\hline
\end{tabular}


Tabela 4 - Frequência de HED, por dente (\%).

\begin{tabular}{|l|l|l|}
\hline $\begin{array}{l}N^{\circ} \text { de defeitos (por } \\
\text { dente) }\end{array}$ & Frequência & Percentagem \\
\hline 0 & 18 & 90 \\
\hline 1 & 1 & 5 \\
\hline 2 & 1 & 5 \\
\hline
\end{tabular}

Tabela 5 - Frequência de HED, por região dentária (\%).

\begin{tabular}{|c|c|c|c|}
\hline Região do dente & $\begin{array}{l}\text { Superficies observáveis } \\
\text { (n) }\end{array}$ & Superficies com HED (n) & Superficies com HED (\%) \\
\hline Oclusal & 17 & 0 & 0 \\
\hline Área de contacto & 19 & 1 & 5,3 \\
\hline Cervical & 20 & 2 & 10 \\
\hline
\end{tabular}

Tabela 6 - Frequência de HED, por maxilar (\%).

\begin{tabular}{|l|l|l|}
\hline & HED Presente & HED Ausente \\
\hline Maxilar Superior & $0(0 \%)$ & $9(100 \%)$ \\
\hline Mandibula & $2(18,18 \%)$ & $9(81,81 \%)$ \\
\hline
\end{tabular}

Tabela 7 - Frequência de HED, por tipo de dente (\%).

\begin{tabular}{|l|l|l|}
\hline Tipo de dente & Dente com HED & Dente sem HED \\
\hline 1 & $0(0 \%)$ & $4(100 \%)$ \\
\hline 2 & $1(11,11 \%)$ & $8(88,89 \%)$ \\
\hline 3 & $1(14,28 \%)$ & $6(85,72 \%)$ \\
\hline
\end{tabular}


Tabela 8 - Frequência de HED, por dente (\%).

\begin{tabular}{|l|l|l|}
\hline Dente & Dente com HED & Dente sem HED \\
\hline 12 & $0(0 \%)$ & $3(100 \%)$ \\
\hline 13 & $0(0 \%)$ & $1(100 \%)$ \\
\hline 21 & $0(0 \%)$ & $2(100 \%)$ \\
\hline 22 & $0(0 \%)$ & $2(100 \%)$ \\
\hline 23 & $0(0 \%)$ & $1(100 \%)$ \\
\hline 31 & $0(0 \%)$ & $1(100 \%)$ \\
\hline 32 & $1(50 \%)$ & $1(50 \%)$ \\
\hline 33 & $1(50 \%)$ & $1(50 \%)$ \\
\hline 41 & $0(0 \%)$ & $1(100 \%)$ \\
\hline 42 & $0(0 \%)$ & $2(100 \%)$ \\
\hline 43 & $0(0 \%)$ & $3(100 \%)$ \\
\hline
\end{tabular}




\title{
COME TOGETHER: O CONJUNTO
}

MEGALÍTICO DAS MOTAS (MONÇÃO, VIANA DO CASTELO) E AS EXPRESSÕES

CAMPANIFORMES DO ALTO MINHO

\author{
Ana Catarina Basílio ${ }^{1}$, Rui Ramos²
}

\begin{abstract}
RESUMO
O Complexo Megalítico das Motas, intervencionado entre 2014/2015, possibilitou o incremento do conhecimento deste tipo de fenómeno funerário na região do Alto Minho, preenchendo uma lacuna espacial entre os núcleos da Portela do Pau e Litoral Minhoto. Apresenta características e dinâmicas construtivas únicas que podem, eventualmente, explicar a sua larga utilização/reutilização.

Neste núcleo, a cerâmica Campaniforme foi identificada em duas das estruturas, uma delas portadora do maior conjunto de recipientes até agora identificado no Alto Minho. Esta existência conecta o sítio com o Fenómeno Campaniforme a nível regional, sendo possível entender que as comunidades com esta cerâmica, que recorreram ao Complexo das Motas, seriam extremamente abertas e permeáveis a novas ideias, tendo reinterpretado e tornado seu, um fenómeno geograficamente amplo.

Palavras-chave: Campaniforme, Alto Minho, Megalitismo, Conjunto Megalítico das Motas.
\end{abstract}

\begin{abstract}
The Motas Megalithic Complex, intervened between 2014-2015, made it possible to increase the existing knowledge of this type of funerary phenomenon in the Alto Minho region, filling a spatial gap between the Portela do Pau and Litoral Minhoto nucleus. It presents unique constructive characteristics and dynamics, which may, eventually, explain its broad use/reuse.

In this Complex, Bell Beakers were identified in two of the structures, one of them carrying the most extensive set of containers so far identified in Alto Minho. This existence connects the site with the Bell Beaker phenomenon at a regional level, making it possible to understand that the "Bell Beaker communities" who used Motas' Complex, would be extremely open and permeable to new ideas, having reinterpreted, and made it theirs, a geographically extensive phenomenon.
\end{abstract}

Keywords: Bell Beaker, Alto Minho, Megalithism, Motas Megalithic Complex.

\section{INTRODUÇÃO}

A intervenção do Conjunto Megalítico das Motas (Monção, Viana do Castelo) decorreu no âmbito do projecto de Construção do Minho Park Monção promovido pela Associação Industrial do Minho e o Município de Monção. Os trabalhos de campo ficaram a cargo da empresa Omniknos, cujo objectivo principal passava pela minimização dos impactes sobre os já referenciados monumentos megalíticos das Motas (Fontinha, 2014), numa área total de $1646,6 \mathrm{~m}^{2}$.

Entre 2014/2015 foram realizadas seis sondagens de diagnóstico (Motas 1, Motas 2, Motas 3, Motas 4 , Motas 5 e Soalhosa 1) que permitiram aferir a natureza artificial das estruturas. Considerando a impossibilidade de conciliar a execução do projecto com a presença e preservação das arquitecturas,

1.ICArEHB - Interdisciplinary Centre for Archaeology and Evolution of Human Behaviour / FCT - Fundação para a Ciência e Tecnologia; catarinasbasilio@gmail.com

2. Omniknos Arqueologia Lda.; ruiramos@omniknos.pt 
encontrava-se preconizada a escavações integral de todas as realidades. Todavia, com a interrupção do empreendimento, apenas foram intervencionados três dos monumentos (Motas 1, Motas 5 e Soalhosa 1), não sendo conhecidas as dinâmicas ocupacionais dos restantes. Ainda assim, a sua importância foi prontamente identificada, tendo sido possível enquadrar as dinâmicas construtivas e materiais no Calcolítico/Idade do Bronze, destacando-se a integração de cerâmicas com decoração campaniforme tanto em Soalhosa 1 e Motas 5. No caso de Motas 1, a identificação de cerâmica com decoração incisa metopada de "tipo Penha" corrobora as tendências dos restantes monumentos e a sua contemporaneidade com o Campaniforme (Jorge, 1983-84).

Porém, e considerando o carácter múltiplo e complexo do "Campaniforme", é necessário ler o conjunto recuperado no Complexo das Motas a uma escala local e com o seu entorno paisagístico, cultural e humano, fomentando o incremento das biografias, trajectórias e estórias deste fenómeno na região do Alto Minho (Norte do Rio Lima).

\section{A NECRÓPOLE MEGALÍTICA DAS MOTAS (MONÇÃO, VIANA DO CASTELO): ENQUADRAMENTOS, BIOGRAFIAS E MATERIALIDADES}

\subsection{Enquadramento geográfico e geológico}

A Necrópole Megalítica das Motas implanta-se no lugar das Motas que abrange a freguesia de Lara e Tropiz, no concelho de Monção, distrito de Viana do Castelo. As suas coordenadas centrais são X: 4691051.099951;Y:-702678.121144(ERTS89,EPSG: 4936). (Figura 1)

Desenvolve-se num plateaux em contexto de vale, com aproximadamente $1 \mathrm{~km}^{2}$, numa área que apresenta um controlo visual essencialmente dirigido a Oeste, Noroeste e Norte. Nestas áreas desenvolvem-se os vales do rio Gadanha (Norte), com vertentes muito acentuadas, e o vale da ribeira da Lara (Oeste), afluente do rio Minho, com declives mais suaves. Em oposição, a visibilidade para Sul, Este, Sudoeste, Sudeste e Nordeste encontra-se limitada pela primeira elevação das serranias presentes nesta região.

A nível geológico (cartas geológicas 01-A e 01-B), a área onde se desenvolve o complexo megalítico apresenta um substrato geológico granítico relacionado com fracturas frágeis, também conhecido como Granito de Monção (Carta Geológica 1:2000oo). Estes são recobertos por depósitos da Orla Ocidental, fluviais e lacustres Plio-plistocénicos (terraços fluviais). Estes cobrem áreas importantes da região marginal do rio Minho. São essencialmente de tipologia conglomerática, sendo constituídos por areias grosseiras e calhaus rolados de quartzito e algum quartzo, intercalados por horizontes mais finos, com siltes e argilas arenosas, originados pela meteorização e erosão das vertentes e posterior deposição em meio fluvial (Esteves, Fernandes e Vasconcelos, 2010).

Resta ressaltar que a implantação deste conjunto funerário, junto a uma área de vale, é relativamente incomum no panorama megalítico do Alto Minho. Nesta região as ocupações sepulcrais apresentam uma preferência de implantação nas áreas litorais e/ou em altura com alta visibilidade (Bettencourt e Vilas Boas, 2019), contrastando com o enclave dos monumentos megalíticos em estudo. Este é ainda mais acentuado quando consideramos as várias limitações visuais e paisagísticas identificadas.

\subsection{Monumentos e Arquitecturas}

O Conjunto das Motas era desconhecido da comunidade científica até à elaboração do Estudo Histórico e Arqueológico de Caracterização (Fontinha, 2014). Este trabalho, bem como as intervenções arqueológicas desenvolvidas pela Omniknos, entre 2014 e 2015, permitiram caracterizar algumas das práticas e ritmos deste aglomerado de monumentos que, pela sua dimensão e extrema complexidade, carecem de trabalhos especializados e particularizados em componentes específicas - como é o caso do Campaniforme no presente trabalho ${ }^{3}$.

De forma genérica, a necrópole corresponde a um conjunto de pelo menos sete monumentos megalíticos, não sendo descartada a existência de mais estruturas. A maioria destas foi identificada pela presença de montículos de terra correspondentes às mamoas das estruturas. As afinidades compartilhadas entre si foram prontamente identificadas no decurso das intervenções, particularmente no que concerne à organização espacial e aos elementos ar-

\footnotetext{
3. A demora na publicação e apresentação de resultados referentes ao Complexo Megalítico das Motas deveu-se ao extenso período de espera para o recomeço do processo de minimização e ao demorado cumprimento dos compromissos contratuais. Assim, encontrando-se a situação esclarecida, procede-se à publicação de parte da intervenção, como é normal no grupo Era Arqueologia S.A.
} 
quitectónicos dos monumentos. A presença de anéis de contenção, mamoas térreas, câmaras e corredores aparenta ser comum a todas as construções - sepulturas de corredor diferenciado (Silva, 2007) - ainda que se identifiquem, igualmente, algumas variações internas. Estas, espectáveis em conjuntos megalíticos com biografias que podem atingir milénios, serão o resultado das trajectórias individuais de cada monumento, sendo mesmo assim possível discernir relações entre as diversas estruturas funerárias e uma possível contemporaneidade nas suas utilizações. De forma geral, e baseando estas considerações nos dados dos três monumentos integralmente intervencionados, a utilização arqueologicamente mais visível das estruturas pode ser balizada entre o Calcolítico e a Idade do Bronze regional. No entanto, esta caracterização deve ser meramente indicativa. Por um lado, porque não foi possível clarificar a temporalidade da construção dos monumentos das Motas. No Alto Minho são conhecidas estruturas de construção Neolítica, mas também datadas do período Calcolítico (Bettencourt e Vilas Boas, 2019). Esta incerteza na cronologia tem impacto nas leituras relativas ao papel e à agência que as estruturas têm tanto na paisagem, como nas comunidades em si, afectando também as aproximações às dinâmicas dos monumentos. Por outro lado, a impossibilidade de obtenção de elementos datantes, devido à total ausência de vestígios orgânicos, impediu (até à data do presente trabalho) uma caracterização radiométrica mais aprofundada.

A nível da conservação, é necessário referir que no Complexo Megalítico das Motas foram identificados momentos de violação e saque nas áreas centrais das mamoas, que atingiram as câmaras das estruturas.

Numa perspectiva biográfica, e focando a abordagem na área aplanada de terraço das Motas, a história dos monumentos não se inicia apenas aquando da edificação destas estruturas. Isto porque a sua implantação encontra-se influenciada, ou mesmo pré-definida, pela presença de um paleosolo que conta com uma preservação diferenciada ao longo do complexo megalítico. Esta fina evidência de presença humana assenta, segundo os dados de alguns dos monumentos integralmente intervencionados, directamente no terraço fluvial que constitui a base geológica do sítio das Motas. Para além de alguns elementos materiais, como artefacto líticos (geométricos) e cerâmicos (decorações tipo boquique), não foram registadas estruturas ou outro tipo de evidências an- trópicas datáveis desta fase recuada, eventualmente enquadrada no $5^{\circ}$ milénio a.C.

Já no que concerne os monumentos em si, apenas é possível caracterizar mais extensamente as dinâmicas de Motas 1, 5 e Soalhosa 1, sendo que em apenas dois deles (Motas 5 e Soalhosa 1) foi detectada a presença de cerâmica Campaniforme. Como tal, e considerando o objectivo do presente trabalho, serão apenas apresentadas extensamente as duas estruturas com elementos Campaniformes, sendo que muitas das características e dinâmicas são partilhadas entre os diversos monumentos desta área aplanada de terraço.

A estrutura Motas 5 apresenta-se mal preservada comparativamente aos outros dois monumentos integralmente intervencionados. Contava com um montículo de 18 metros de diâmetro, que atingia os 1,40 metros de altura a cima do solo actual, não tendo sido identificada a presença do paleosolo na sua base. Ainda assim, apresentava um nível de base composto por cinzas que pode ser lido como o resultado de um processo prévio de desflorestação e preparação do terreno para a construção do monumento, uma vez que o primeiro depósito da mamoa assenta directamente neste nível, não se registando evidências de hiato. No entanto, a ausência deste tipo de solução nos outros monumentos do plateaux obriga a cautela no processo de associação directa entre ambas as realidades, já que podem igualmente corresponder a momentos e acções temporalmente desconexas. (Figura 2)

Já na fase de construção e posterior utilização do monumento, detectou-se a existência de uma câmara ortostática e um possível corredor, ambos muito afectados pelo momento de saque de cronologia incerta. Sem embargo, a câmara atinge os 2,50 metros de largura e os 20 centímetros de profundidade, não tendo sido identificados alvéolos de implantação de esteios. No entanto, um deles encontrar-se-á próximo da que seria a sua possível posição original. Este, com 2 metros de comprimento e 1,40 metros de largura, poderá corresponder à laje de cabeceira do monumento. Apresenta um sulco latitudinal nas suas duas faces, ao qual se somam duas pequenas perturberâncias longitudinais, uma delas na base do esteio e outra imediatamente sobre o sulco. Estas pré-existências sugerem que o elemento pétreo, incluído na construção do monumento, apresenta uma biografia prévia, mais rica, podendo corresponder a uma antiga estela reutilizada. Este tipo de 
incorporação, com uma carga ideológica, adiciona conteúdos, histórias e valores prévios à biografia geral da estrutura, podendo gerar novos sentidos em relação à maneira como estes grupos compreendiam e construíam o seu passado, presente ou mesmo futuro (Valera, 2019; Bueno Ramírez et al. 2016).

Do corredor foram apenas recuperados dois esteios remobilizados, implantados numa interface de planta irregular escavada no terraço fluvial. Sobre este, pode sugerir-se que seria relativamente curto e diferenciado da câmara, possivelmente orientado a Oeste, não se compreendendo se já se encontraria colmatado aquando da formação do tumulus.

A mamoa do monumento funerário é composta por dois grandes depósitos que o vão cobrindo do centro para a periferia. Estas terras eram contidas por um anel pétreo incipiente, composto por blocos de granito de pequena dimensão, directamente assente no substracto geológico. Já em época indeterminada, mas possivelmente coeva com a utilização da estrutura, o perímetro da mamoa é aumentado, com a adição de uma nova camada que cobre o anel pétreo anterior, mas que não se espalha por toda a área da mamoa. Sobre este adoçamento foi construído um segundo anel pétreo em granito, que acompanhava o novo perímetro do monumento.

Em suma, o elevado grau de afectação detectado no monumento Motas 5 impossibilitou uma maior compreensão da arquitectura e das dinâmicas inerentes à utilização desta estrutura, não tendo sido recuperados contextos preservados no interior da câmara e corredor. No entanto, foi possível discernir quatro grandes momentos: uma possível fase de preparação do terreno para a implantação da estrutura funerária (com a realização de uma possível desflorestação), um momento de construção e utilização da estrutura enquanto monumento funerário, uma reformulação provavelmente pré-histórica do espaço tumular (acrescento de perímetro na mamoa) e um momento do saque de cronologia indeterminada.

No que toca a Soalhosa 1, esta é uma das maiores estruturas da necrópole, com um tumulus cujo diâmetro ronda os 18,50 metros e uma altura de 1,20 metros. Localiza-se no extremo Norte do plateaux $\mathrm{e}$, tal como os restantes monumentos, apresentava uma depressão irregular na área central da mamoa, que indiciava a sua violação.

Contrariamente a Motas 5, em Soalhosa 1 foram detectadas algumas evidências da presença do paleo- solo, que não fará parte dos três grandes momentos individualizados na biografia da estrutura em análise. O primeiro corresponde à fase de construção e utilização antrópica da estrutura funerária. A nível arquitectónico a câmara do monumento apresentaria uma planta poligonal, composta por oito esteios de granito, dos quais dois se encontravam ligeiramente remobilizados (tombados) e ainda outros dois, muito fragmentados, mas na sua posição original. Neste último caso foi possível compreender que os esteios se encontravam implantados em alvéolos, sendo sustentados por meio de calços de seixos de quartzito e blocos toscos de granito de pequena dimensão. Foi igualmente detectada a existência de uma contrafortagem no exterior da câmara, que terá sido posteriormente coberta pelos depósitos da mamoa. (Figura 3)

Esta câmara foi afectada por uma vala de saque que não truncou a totalidade do seu preenchimento, tendo-se detectado uma pequena área inalterada que preservou deposições in situ de artefactos possivelmente relacionados com a utilização funerária. O depósito preservado estender-se-ia também para o corredor da estrutura, através da entrada na câmara, com cerca de um metro de largura. Esta estabeleceria a conexão entre o espaço tumular e o corredor, que conta com uma extensão de 4,50 metros de comprimento, por dois metros de largura, com uma orientação Es-Sudeste. O seu enchimento é realizado de forma faseada, com deposições de níveis pétreos mais ou menos abrangentes, culminando na construção de um murete perpendicular ao corredor, que condena o acesso a esta “divisão”. É de notar também a presença de uma possível cista, sem espólio (material ou osteológico), junto à entrada da câmara, sendo que inclusões semelhantes foram detectadas noutros contextos, tal como o caso da Mamoa da Chã da Mourisca, em Ponte de Lima (Vilas Boas e Oliveira, 2018; Bettencourt e Vilas Boas, 2019).

Sugere-se a existência de um pequeno átrio incipiente, materializado em três estruturas de combustão que ladeiam o corredor de Soalhosa 1, ainda que a presença desta característica arquitectónica seja muito ténue. O mesmo ocorre na Mamoa 2 do Alto da Portela do Pau, com a presença de lareiras junto à área da entrada do monumento (Jorge et al. 1997). Esta inclusão, bem como a já mencionada possível desflorestação com recurso a queimadas de Motas 5 , vem acentuar a importância e o papel desempenhado pelo fogo nas práticas funerárias das comunida- 
des Neo-Calcolíticas, não só do Alto Minho como, de forma mais abrangente, do mundo nortenho (Bettencourt e Vilas Boas, 2019).

O tumulus é composto por três momentos de formação. Um primeiro montículo delimitado por um anel pétreo, no qual tanto a câmara, corredor e o possível átrio se encontrariam em funcionamento. Uma segunda fase em que o corredor estaria já colmatado e condenado, corresponde à oclusão do anel pétreo prévio, com a construção de um segundo anel que abarca o novo perímetro do monumento. Por fim, a adição de um terceiro depósito que não abrange a totalidade da área desenhada pelo segundo anel externo e que é coberto por uma couraça de seixos de quartzito.

De forma resumida, a biografia de Soalhosa 1 é composta por três grandes momentos: a construção e utilização funerária da estrutura em si que, numa segunda fase, se vê profundamente reformulada arquitectonicamente. Por fim, tal como em Motas 5, também Soalhosa I foi alvo de um violento saque que, neste caso, não truncou a totalidade dos contextos.

Os restantes contextos intervencionados na área aplanada de terraço (Motas 1), apresentam um faseamento semelhante aos de Soalhosa 1 e Motas 5. No entanto, esta terceira estrutura vê a sua biografia ser "perlongada" pela presença de revisitações e ocupações posteriores à finalização da estrutura tumular. As revisitações esporádicas encontram-se materializadas tanto na deposição de elementos cerâmicos de cronologias não compatíveis com a utilização principal dos monumentos, como na presença de oito estruturas de combustão do tipo forno. Todas estas realidades perturbam o tumulus de Motas 1, destacando-se os oito fornos pelo seu caracter exclusivo no panorama do megalitismo nacional. Porém, e de forma mais abrangente, parece relativamente seguro afirmar que os monumentos, pelas suas biografias e trajectórias minimamente partilhadas, terão sido agentes contemporâneos quer em práticas e discursos sociais do Calcolítico da região, como também elementos transformadores na paisagem circundante.

\subsection{As materialidades das estruturas e os elemen- tos campaniformes}

O conjunto de artefactos recuperado na intervenção do Conjunto Megalítico das Motas apresenta uma notável variabilidade formal e cronológica. Esta diversidade permite compreender que o plateaux terá sido experienciado pelo menos desde o Neolítico Antigo. Os monumentos em si vão sofrendo constantes processos de transformação arquitectónica, sendo compreensíveis e justificáveis as deformações e deturpações das realidades estratigráficas, agravadas pelas acções antrópicas mais recentes. Estas, essencialmente reconhecidas devido à presença de artefactos, podem remontar até ao século I a.C., com evidências de ocupação Romana. Todavia, actividades como a abertura das valas de saque, amplamente presentes em todos os monumentos, são impossíveis de datar neste contexto. (Figura 4)

No caso dos materiais do monumento Soalhosa I, estes correspondem ao maior conjunto artefactual recuperado, atingindo as 70 peças arqueológicas. Destas salientam-se os artefactos em pedra lascada (47\%), principalmente em sílex, e os elementos cerâmicos (46\%), distribuindo-se pela câmara e o tumulus da estrutura. As tipologias artefactuais são compatíveis com uma utilização em fase plena/final do Calcolítico Peninsular (com cerâmica com decoração incisa metopada de "tipo Penha" e elementos campaniformes). $26 \%$ do total do conjunto é proveniente do paleosolo, nos qual ressalta a presença de geométricos (crescentes e trapézios). Uma breve nota vai para o pequeno nicho conservado no interior da câmara de Soalhosa 1, que preservou a deposição de parte do espólio funerário original in situ - um esférico com boca muito fechada com acentuação do colo, uma taça em calote completa com decoração incisa metopada de "tipo Penha", duas lâminas em sílex, uma lasca, também em sílex, com marcas de uso e seis pontas de seta de base triangular em quartzo-leitoso.

Já no que concerne os elementos campaniformes, foram referenciados cinco recipientes, recuperados na forma de nove fragmentos aparentemente descontextualizados. Dois deles são provenientes dos contextos revolvidos da câmara, correspondendo a um recipiente com linhas pontilhadas horizontais e paralelas entre si (Fig.4: 3) e ainda um vaso com linhas pontilhadas iguais ao exemplar anterior, mas às quais é adicionada uma banda preenchida com linhas "semi-oblíquas" (Fig.4: 1). Os restantes exemplares, foram descobertos no tumulus da estrutura, formando dois campaniformes com motivos internacionais (Fig.4: 4 e 5) e ainda um campaniforme com uma aparente afinidade aos motivos decorativos Ciempozuelos mas que neste caso, se desenvolve com recurso à técnica pontilhada (Fig.4: 2) . 
Em Motas 5, os materiais recuperados são numericamente inferiores, contando-se somente oito artefactos na sua totalidade. Destacam-se dois fragmentos de lâmina, uma ponta de seta de base recta e uma outra de base triangular, ambas em quartzo, bem como um bordo de um recipiente com decoração incisa metopada de "tipo Penha". Foi igualmente individualizado um possível bojo com decoração campaniforme que, pela sua reduzida dimensão, não permite uma descrição ou atribuição decorativa mais concreta, sendo exclusivamente possível avançar o recurso à técnica da impressão (Fig.4: 6). Outros materiais, estes já provenientes do monumento Motas 1, correspondem a elementos de destaque merecido pelo seu valor cronológico, ou pela sua conservação. É disto exemplo a deposição primária identificada no corredor/átrio desta terceira estrutura, composta por duas taças em calote de esfera, ambas profusamente ornamentadas com decoração incisa metopada de "tipo Penha". Também é de referir a presença de um vaso de largo bordo horizontal. Este, depositado numa fossa pouco profunda escavada no tumulus da estrutura aquando de uma revisitação tardia, encontra paralelos em diversos contextos da Idade do Bronze (Médio e Final) no Noroeste peninsular. Nesta área, os vasos de largo bordo horizontal encontram-se associados a deposições funerárias, enquanto espólios votivos (Bettencourt, 2010; Ataíde e Teixeira, 1940). No caso do monumento Motas 1 do Complexo Megalítico das Motas, segundo os dados estratigráficos, o recipiente não estaria enquadrado em nenhum contexto funerário, representando uma deposição isolada. Outro exemplo semelhante é o do recipiente do século I a.C. cujo contexto e intencionalidade da deposição na área tumular é, e possivelmente contrariamente ao que acontece com o vaso anterior, indeterminada.

Em suma, e na prática, as materialidades recuperadas nos monumentos que compõem o Complexo Megalítico das Motas permitem reforçar as sugestões cronológicas avançadas na análise das biografias e arquitecturas das estruturas. Assim, a ocupação prévia ao conjunto megalítico em si será possivelmente atribuível ao $5^{\circ}$ milénio a.C. - Neolítico Antigo - pela presença de geométricos e cerâmica de tipo boquique. O principal momento construtivo e de utilização será enquadrável no Calcolítico regional, com uma particular visibilidade da segunda metade do $3^{\circ}$ milénio a.C. A esta realidade seguem-se momentos de revisitação que se estendem desde a Idade do Bronze (Média e Final) até ao período romano, estando ainda por clarificar a temporalidade da realização das valas de saque.

Focando especificamente as expressões Campaniformes no Complexo Megalítico das Motas, estas são notoriamente escassas. Deste modo, considerações mais extensas acerca das dinâmicas, ritmos e temporalidades deste fenómeno e manifestação cultural e identitária estão limitadas, ainda que algumas questões e problemas possam ser explorados, focando-se a intencionalidade da inclusão e o possível papel destes elementos decorados nos monumentos funerários.

O estado fragmentado dos recipientes recuperados, o reduzido número de fragmentos decorados por recipiente, a sua própria dimensão e a incerta proveniência contextual permitem questionar a natureza e temporalidade da sua inclusão nas estruturas em estudo. Ou seja, equacionar se os recipientes com decoração campaniforme incluídos em Soalhosa 1 e Motas 5 terão sido parte integrante do espólio funerário, em contemporaneidade, por exemplo, com elementos de "tipo Penha" depositados em ambos os monumentos. Por outro lado, é possível inquirir se estes materiais correspondem a itens depositados no tumulus das estruturas, em eventuais revisitações, como detectado no recipiente de largo bordo horizontal (depositado em Motas 1).

Assim, e segundo o grau de informações disponíveis para Motas 5 e Soalhosa 1, é impossível optar, de forma minimamente segura, por algumas das hipóteses. Verifica-se então a necessidade futura de proceder a intervenções mais extensas noutros monumentos do complexo megalítico, que possibilitem, eventualmente, clarificar se o Campaniforme é uma intrusão nas tradições e práticas construtivas ou, pelo contrário, uma adição em continuidade (Rodriguez Casal, 1990; Sousa, 2012; Bettencourt, 2011), como já identificado noutras regiões nacionais (Basílio, no prelo a).

\section{O "MUNDO CAMPANIFORME" DO ALTO MINHO E O COMPLEXO MEGALÍTICO DAS MOTAS}

A expressão cultural Campaniforme é uma das mais estudadas da Pré-História europeia. Esta realidade deve-se à sua extensa abrangência geográfica que, ainda hoje, é lida como sendo o reflexo de um 
"povo" - esta perspectiva tem vindo a ser suportada pelos recentes dados de ADN antigo, ainda incipientes e insuficientes (Linden, 2019; Basílio, no prelo b). No entanto, e mesmo que novas revisões e leituras sejam necessárias para integrar, de forma crítica, estes dados, as correntes actualmente dominantes tendem a compreender o "Mundo Campaniforme" como o reflexo de processos de intensificação de contactos entre grupos, o que possibilita a disseminação de um conjunto coeso de ideias, práticas, tradições, materialidades, mensagens e cosmologias que estão por trás do "Campaniforme" (Linden, 2013; Prieto Martínez, 2013). Este conjunto "original" sofre processos de rejeição e/ou aceitação, podendo ser reinterpretado, reconceptualizado, operacionalizado e utilizado pelos grupos humanos de forma múltipla e variada.

Assim, é expectável que a negociação e a maior ou menor adesão ao Fenómeno Campaniforme se encontre fortemente influenciada, e mesmo condicionada, pela matriz e trajectória histórica de cada comunidade, bem como pela visão que têm de si próprias e do mundo onde se inserem (Rebuge, 2004; Sanches e Barbosa, 2018; Bettencourt, 2011). Isto pode auxiliar na explicação, por exemplo, das disparidades notórias que o Campaniforme adquire num território tão pequeno como o contido nas actuais fronteiras de Portugal, com dicotomias sociais, temporais, funcionais e estilísticas entre o Norte, Sul e a área da Estremadura, que podem remontar ao início do Neolítico, ou mesmo a períodos históricos mais recuados.

No caso do estudo do Fenómeno Campaniforme no Norte de Portugal, as pré-existências sociais e os distintos influxos culturais, ditam comportamentos e práticas intimamente relacionadas com o espaço (Sanches e Barbosa, 2018; Bettencourt, 2011). O Alto Minho, a área onde se implanta o Complexo Megalítico das Motas, insere-se na "sub-região cultural" do Noroeste (NO). Aqui as influências atlânticas são notoriamente mais expressivas, ganhando destaque os estudos referentes à Idade do Bronze, com uma maior visibilidade dos contextos sepulcrais, numa paisagem marcada por relevos acidentados e montanhosos (Bettencourt, 2011). A nível dos elementos campaniformes, esta expressão é compreendida como um elemento que é aplicado pelas comunidades do passado no estabelecimento e construção das identidades, tanto a nível local, como regional (Bettencourt, 2011; Sanches e Barbosa, 2018). Apresenta uma cronologia bastante recuada, ainda dentro do $2^{\circ}$ quartel do $3^{\circ}$ milénio a.C. (Bettencourt, 2011; Sanches e Barbosa, 2018), o que lhe confere uma antiguidade aparentemente coincidente com algumas datas da Estremadura Portuguesa (Cardoso, 2015), mas atípica quando introduzidas na análise as cronologias de sítios do Sul, com trabalhos mais recentes (Valera, Mataloto e Basílio, 2019). Todavia, e ainda que várias dúvidas possam ser levantadas quanto à temporalidade e origem do Campaniforme a nível nacional, este será um fenómeno necessariamente de longa duração nesta região, que não terá sido responsável pela unificação e aproximação das comunidades, mas sim pela manutenção das diferenças já instauradas (Bettencourt, 2011; Sanches e Barbosa, 2018). Isto porque, no Norte de Portugal, são conhecidos processos de reinterpretação e refuncionalização através da aplicação de técnicas/formas tradicionalmente campaniformes a estilos e motivos de fácies local, que são empregues consoante as áreas, grupos e contextos (Bettencourt, 2011; Sanches e Barbosa, 2018). Esta característica volta a sublinhar a multiplicidade deste fenómeno, sendo o comportamento aqui detectado contrário ao que ocorre em certas áreas peninsulares e da Europa Central, com altos níveis de homogeneização e padronização das práticas, principalmente funerárias (Linden, 2013). Em termos contextuais, e focando mais particularmente o NO, denota-se uma tendência de associação entre elementos campaniformes e estruturas funerárias, ainda que esta realidade possa materializar um enviesamento inerente, em primeira instância, ao número de trabalhos que versam o mundo sepulcral e, em segunda, a própria visibilidade, importância e caracter estrutural destes elementos arquitectónicos (Bettencourt, 2011; Sanches e Barbosa, 2018; Bettencourt e Vilas Boas, 2019). Já a nível estilístico, a primazia é dada a estilos realizados com recurso à técnica da impressão, com o predomínio dos motivos do estilo Internacional, tanto nas suas variantes linear e de bandas, e pelos motivos Pontilhados Geométricos (Bettencourt, 2011; Sanches e Barbosa, 2018; Rebuge, 2004). As variáveis incisas, e mesmo os elementos não decorados, são extremamente raros (Bettencourt, 2011), ainda que motivos de clara inspiração no grupo Ciempozuelos tenham sido recuperados - por exemplo, em Soalhosa 1. Este panorama permite compreender que os contactos e influências desta área podem ser ampliadas até ao ambiente calcolítico estremenho (onde 
predominam os estilos Internacional e Pontilhado Geométrico) e ainda ao interior peninsular (onde constam exemplares incisos e Ciempozuelos) (Bettencourt, 2011; Sanches e Barbosa, 2018; Rebuge, 2004). (Figura 5)

Particularizando a abordagem no Alto Minho, esta região padece igualmente de um conhecimento deficitário não só relativamente ao Fenómeno Campaniforme em si, como às próprias dinâmicas do $3^{\underline{0}}$ milénio a.C., nas quais se incluem as expressões megalíticas compostas por conjuntos semelhantes ao das Motas (Bettencourt e Vilas Boas, 2019). $\mathrm{Na}$ área em estudo, a norte do Rio Lima, são apenas conhecidos dez contextos nos quais cerâmica campaniforme decorada foi recuperada, com um número mínimo de 17 recipientes. Destes, um é proveniente do sítio de funcionalidade indeterminada do Castelo de Fraião (Valença), possivelmente correspondente a um habitat, ainda que apenas sejam conhecidas três estruturas negativas do tipo fossa, de cronologia pré-histórica (Almeida, Soeiro e Barroca, 1995). Os restantes nove contextos (e 16 recipientes) correspondem a estruturas funerárias que, quando agrupadas, materializam elementos recuperados em três grandes conjuntos sepulcrais - núcleo das Motas, da Portela do Pau e do Litoral Minhoto. Todavia, será necessário compreender se estas presenças estão directamente relacionadas com o âmbito funerário ou, pelo contrário, se reflectem revisitações posteriores. Uma vez que poucos são os exemplares completos, o estado fragmentado dos recipientes permite também pensar se a agência e mensagem por detrás destes elementos decorativos e formais é passada não só em forma de recipientes integralmente preservados, como também enquanto elementos fragmentados (Bettencourt, 2011; Valera, Mataloto e Basílio, 2019; Valera, 2010). No que concerne aos motivos e grupos decorativos, as tendências já definidas para a região NO são mantidas, sendo exclusiva a técnica pontilhada, utilizada na produção de decorações Internacionais (maioritariamente na variável bandas) e Pontilhadas Geométricas (Bettencourt, 2011; Sanches e Barbosa, 2018; Rebuge, 2004). Assim, tanto a nível contextual, como decorativo, o quadro desenhado para o Alto Minho parece replicar e perpetuar o que é apontado para a região mais ampla do NO (Bettencourt, 2011), ainda que a quantidade dos dados disponíveis seja reduzida para compreender comportamentos significativamente desviantes.
Uma característica dissonante do conjunto campaniforme das Motas, em relação aos sítios do Alto Minho, prende-se com o elevado número mínimo de recipientes sugerido para Soalhosa 1. Esta proposta baseou-se na relação entre os estilos decorativos, formas e contextos de identificação, tendo sido sugerida a presença de cinco recipientes. A Soalhosa 1, segue-se o conjunto da Mamoa 1 da Portela do Pau, com três elementos (Rebuge, 2004). (Quadro I) Paralelos foram também procurados com os territórios mais imediatos na região da Galiza, onde extensos conjuntos campaniformes têm sido identificados e estudados (Prieto Martínez, 2013; Criado Boado e Vázquez Varela, 1982). Todavia, em zonas próximas, não foram detectados sítios arqueológicos de qualquer natureza, com registo de cerâmica Campaniforme, sendo apenas de salientar que, de forma genérica, as tendências apresentadas para a área NO são essencialmente semelhantes, com uma concentração nas áreas litorais e presença de estilos regionais (Vázquez Liz e Prieto Martínez, 2016).

Estas semelhanças entre NO e o Alto Minho alargam-se também para as vertentes mais interpretativas relativamente ao Fenómeno Campaniforme, sendo este elemento material compreendido como um agente, determinante por si só, na manutenção dos distintos caminhos históricos e sociais das comunidades desta região (Bettencourt, 2011; Sanches e Barbosa, 2018; Rebuge, 2004). É, então, um elemento que ao ser aparentemente absorvido, repensado ou mesmo diluído nos discursos dos grupos humanos, é também activado como um ícone que pode materializar as distintas identidades em acção (Bettencourt, 2011). Pode ser assim utilizado na perpetuação de eventuais dicotomias, discórdias e escolhas dissonantes, funcionando como mais um elemento que é adicionado a uma trajectória Neo-Calcolítica regional de continuidade. No entanto, há que considerar que a presença e utilização destes artefactos em construções e práticas sociais torna as comunidades mais dependentes das redes inerentes à circulação destes bens, podendo esta mesma sujeição criar pontos de tenção no sistema vigente, contribuindo para a sua ruptura - eventualmente a transição entre Calcolítico e Idade do Bronze (Jorge, 1983-84). Estas hipóteses têm sido exploradas noutras áreas onde, como no Alto Minho, o Campaniforme é lido em continuidade com as realidades imediatamente antecedentes, mesmo sendo compreendido como uma novidade material (Valera, Mataloto e Basílio, 2019). 
Contrastando com estas mesmas abordagens, nas quais os sentidos "originais" do campaniforme poderão ser desvirtuados e posto em acção em contextos não funerários, no Alto Minho e no NO a cerâmica Campaniforme parece ser maioritariamente associada a sítios funerários, sejam eles isolados ou agrupados em núcleos sepulcrais (Bettencourt, 2011; Sanches e Barbosa, 2018; Rebuge, 2004). Denota-se, e isto a nível regional (NO), uma aparente primazia para a presença em revisitações posteriores destes lugares monumentais, o que acentua a multiplicidade de interpretações passíveis de associar a este fenómeno e, em simultâneo, o ainda grande desconhecimento que paira quer sobre si, como do próprio movimento megalítico (Bettencourt, 2011; Sanches e Barbosa, 2018; Rebuge, 2004; Bettencourt e Vilas Boas, 2019). Assim, esta pluralidade de significados e sentidos permite sugerir não só eventuais fenómenos de legitimação de novas ordens ou identidades, como amplamente sugerido por outros autores, como também eventos de resistência a mudanças em curso, numa cronologia possivelmente já avançada no $3^{\circ}$ milénio a.C.

\section{NOTAS FINAIS}

Para a discussão do papel (ou papéis) da cerâmica Campaniforme no Alto Minho, os parcos dados de Motas 5 e Soalhosa 1 permitiram confirmar e reafirmar o cenário já conhecido para a região. Este é, sem dúvida, um fenómeno que ainda se encontra relativamente mal conhecido e caracterizado, podendo esta realidade ser o reflexo de poucos projectos de investigação específicos ou, em simultâneo, da real ausência destes elementos no território. Também o próprio flagelo das violações, de cronologia indeterminada, de estruturas tumulares semelhantes aos monumentos do Complexo Megalítico das Motas, torna as abordagens à biografia e dinâmicas das estruturas muito difícil. Todavia foi identificada uma extensão ocupação (Neolítico Antigo - Idade do Bronze), e reocupação do espaço (Idade do Ferro e Período Romano), que enfatizam a importância destes locais e das suas paisagens ao longo da História. Ainda assim, a grande correspondência deste conjunto artefactual e contextual com o conhecido e apontado para o Campaniforme no Norte de Portugal, alinha os monumentos em estudo com as várias teorias interpretativas e explicativas, ainda que não se possa afirmar com certezas, por exemplo, a própria proveniência contextual dos elementos de Soalhosa 1 e Motas 5. São, como tal, necessários mais trabalhos e revisões pormenorizadas dos sítios, bem como datações que permitam explorar também a antiguidade deste fenómeno na região.

Como principal conclusão, o Complexo Megalítico das Motas reflecte a existência de comunidades abertas e permeáveis a novas materialidades, ideias e, possivelmente, indivíduos, que parecem gerir, incorporar e refuncionalizar as novidades (neste caso o Campaniforme) a nível identitário e em continuidade com as trajectórias em vigência, sem alterar de forma determinante, os seus percursos.

\section{BIBLIOGRAFIA}

ALMEIDA, Carlos; SOEIRO, Teresa; BARROCA, Mário (1995) - Estação Arqueológica do Castelo de Fraião (Boivão, Valença). Portugália.7, pp. 311-322.

BASÍLIO, Ana Catarina (no prelo a) - Dinâmicas ocupacionais na segunda metade do $3^{\circ}$ milénio a.C. nos Perdigões: continuidades e descontinuidades. Monografias da Associação dos Arqueólogos Portugueses.

BASÍlIO, Ana Catarina (no prelo b) - From aDNA to Archaeology: Genética da transição Calcolítico-Idade do Bronze no Sul de Portugal. Ophiussa. Lisboa: Centro de Arqueologia da Faculdade de Letras da Universidade de Lisboa.

BETTENCOURT, Ana (2011) - El vaso Campaniforme en el Norte de Portugal: Contextos, Chronologías et significados. In PRIETO MARTÍNEZ, Maria Pilar; SALANOVA, Laure, eds. - Las Comunidades Campaniformes en Galicia: Cambios Sociales en el III y II Milenios BC en el NW de la Península Ibérica (Pontevedra 2011). pp. 363-374.

BETTENCOURT, Ana; VILAS BOAS, Luciano (2019) - Monumentos Megalíticos do Alto Minho: Modelação de uma paisagem milenar. In Património artístico e cultural do Alto Minho: Uma viagem no tempo. Comunidade Intermunicipal do Alto Minho. $21 \mathrm{p}$.

BUENO RAMÍREZ, Primitiva; CARRERA RAMÍREZ, Fernando; BALBÍN BERHMANN, Rodrigo.; BARROSO BERMEJO, Rosa; DARRIBA, Xermán; PAZ, A. (2016) - Stones before stones: Reused stelae and menhirs in Galician megaliths, In FÁBREGAS, Ramón; RODRIGUEZ RELLAN, Carlos eds. - Proceedings of the XVII UISPP World Congress, Oxford: Archaeopress. pp. 1-16.

CARDOSO, João Luís (2015) - The Bell-beaker complex in Portugal: an overview. O Arqueólogo Português. 5: 4-5, pp. 275-308.

CRIADO BOADO, Felipe; VÁZQUEZ VARELA, José (1982) - La ceramica campaniforme en Galicia. Cuadernos do Seminario de Sargadelos. 42. 
CRUZ, Domingos (1992) - A mamoa 1 de Chã de Carvalhal no contexto arqueológico da Serra da Aboboreira. Conimbriga Anexos. 1.

ESTEVES, Helena; FERNANDES, Isabel; VASCONCELOS, Clara (2010) - A Margem do Rio Minho entre Melgaço e Monção: alguns aspectos do património geológico. Revista Electrónica de Ciências da Terra. 18: 23.

FONTINHA, Artur (2014) - Área de Acolhimento Empresarial "Minho Park Monção", Estudo Histórico Arqueológico de Caracterização.

JORGE, Susana Oliveira (1983-84) - Aspectos da evolução pré-histórica do Norte de Portugal durante o III e o II milénios a.C. Portugália. 4/5, pp. 97-107.

JORGE, Susana Oliveira (1986) - Povoados da Pré-história Recente (III - - inícios do II ${ }^{\circ}$ Milénios AC) da Região de Chaves $-V^{\underline{a}} P^{\underline{a}}$ de Aguiar. Porto.

JORGE, Vitor Oliveira; BAPTISTA, António Martinho; SILVA, Eduardo; JORGE, Susana Oliveira (1997) - As Mamoas do Alto da Portela do Pau (Castro Laboreiro, Melgaço): Trabalhos de 1992 a 1994. Porto: Sociedade Portuguesa de Antropologia e Etnologia.

LINDEN, Marc Vander (2013) - A Little Bit of History Repeating Itself: Theories on the Bell Beaker Phenomenon. In FOKKENS, Harry; HARDING, Anthony - The Oxford Handbook of the European Bronze Age. Oxford: Oxford University Press. pp. 68-81.

LINDEN, Marc Vander (2019) - Toward a clearer view into human prehistory. Science. 363, pp. 1153-1154.

PRIETO MARTINEZ, María Pilar (2013) - Unity and Circulation: what underlies the homogeneity in Galician bell beaker ceramic style? In PRIETO MARTÍNEZ, Maria Pilar; SALANOVA, Laure, eds. - Las Comunidades Campaniformes en Galicia: Cambios Sociales en el III y II Milenios BC en el NW de la Península Ibérica (Pontevedra 2011). pp. 209-249.

REBUGE, João (2004) - Uma proposta para reconceptualizar a materialidade arqueológica: o Campaniforme no Norte de Portugal e regiões contíguas. Trabalhos de Antropologia e Etnologia.44, pp. 111-186.

RODRIGUEZ CASAL, Antón (1990) - Problemas y cuestiones de método relativos al megalitismo: una aproximación teórica. Gallaecia.12, pp. 81-89.

SANCHES, Maria de Jesus; BARBOSA, Maria Helena (2018) - Campaniforme: chronology, pottery, and contexts of a long-term phenomenon in the Portuguese Douro Basin. Journal of Neolithic Archaeology. 20, pp. 23-58.

SILVA, Eduardo Jorge (1994) - Megalitismo do Norte de Portugal: O litoral minhoto. In Actas do Seminário sobre o Megalitismo do Centro de Portugal, Mangualde, 20 a 22 de Novembro de 1992 (Viseu 1994). pp. 157-169.
SILVA, Fernando (2007) - A Arte dos Construtores de megálitos do Norte de Portugal. In Arte e Cultura da Galiza e Norte de Portugal.

SOUSA, Maria Goreti (2012) - O fenómeno tumular e megalítico na região Galaico-portuguesa do Minho. Tese de Doutoramento apresentada na Universidade de Santiago de Compostela.

VALERA, António Carlos (2010) - Marfim no recinto calcolítico dos Perdigões (1): Lúnulas, fragmentação e ontologia dos artefactos. Apontamentos de Arqueologia e Património. 5, pp. 31-42.

VALERA, António Carlos (2019) - Segmentation and depositional practices in Prehistoric South Portugal: between ontological stability and fluidityIn VALERA, António Carlos ed. - Fragmentation and depositions in Pre and Protohistoric Portugal (Lisbon, 14 October 2017). Lisboa: NIA/Era Arqueologia S.A. pp. 9-30.

VALERA, António Carlos; MATALOTO, Rui; BASÍLIO, Ana Catarina (2019) - The South Portugal perspective. Beaker sites or sites with Beakers?. In GIBSON, A. ed. Bell Beaker settlement of Europe: the Bell Beaker phenomenon from a domestic perspective. Oxford: Oxbow Books. pp. 1-23.

VÁZQUEZ LIZ, Pablo; PRIETO MARTÍNEZ, Maria Pilar (2016) - El Yacimiento de A Devesa de Abaixo (Pontevedra): Muerte y tradición en la Prehistoria Reciente del Noroeste de La Península Ibérica. Cuadernos de Estudios Gallegos. LXIII:129, pp. 13-64.

VILAS BOAS, Luciano; OLIVEIRA, Lucínia (2018) - A Necrópole de Chã da Mourisca (Refóios do Lima, Ponte de Lima): Resultados preliminares de uma intervenção de emergência. Antrope. 9, pp. 7-19. 


\begin{tabular}{|c|c|c|c|c|c|c|c|}
\hline & $n^{o}$ & Sítio & Loc. & Tipo & Campaniforme & $N M R$ & Referências \\
\hline \multirow{3}{*}{ 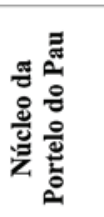 } & $1^{N}$ & $\begin{array}{c}\text { Mamoa } 1 \text { da Portela do } \\
\text { Pau }\end{array}$ & \multirow{3}{*}{ Melgaço } & Dolmen sem corredor & $\begin{array}{l}\text { Internacional: Linear e } \\
\text { geométrico }\end{array}$ & 3 & \multirow{3}{*}{$\begin{array}{c}\text { Jorge et al. } 1997 \\
\text { Bettencourt } 2011 \\
\text { Rebuge } 2004\end{array}$} \\
\hline & $2^{N}$ & $\begin{array}{c}\text { Mamoa } 2 \text { da Portela do } \\
\text { Pau }\end{array}$ & & Dolmen sem corredor & Pontilhado Geométrico & 1 & \\
\hline & $3^{N}$ & $\begin{array}{c}\text { Mamoa } 3 \text { da Portela do } \\
\text { Pau }\end{array}$ & & $\begin{array}{c}\text { Tumulus sem estrutura } \\
\text { megalítica }\end{array}$ & Pontilhado Geométrico & 1 & \\
\hline \multirow{4}{*}{ 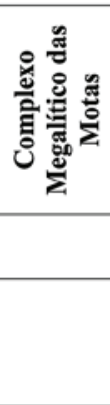 } & 4 & Soalhosa 1 & & Dolmen com corredor & $\begin{array}{l}\text { Internacional: bandas e } \\
\text { geométrico }\end{array}$ & 5 & \\
\hline & & Motas 5 & Monção & Dolmen com corredor & $\begin{array}{l}\text { Internacional: bandas e } \\
\text { geométrico }\end{array}$ & 1 & Presente trabalho \\
\hline & 6 & Castelo de Fraião & Valença & Indeterminado & Internacional & 1 & $\begin{array}{l}\text { Bettencourt } 2011 \\
\text { Rebuge } 2004\end{array}$ \\
\hline & 7 & Chã de Arcas 1 & $\begin{array}{c}\text { Arcos de } \\
\text { Valdeve } \\
\mathrm{z}\end{array}$ & Mamoa & Internacional: Linear & 1 & $\begin{array}{c}\text { Jorge } 1986 \\
\text { Cruz } 1992 \\
\text { Bettencourt } 2011 \\
\text { Rebuge 2004 } \\
\end{array}$ \\
\hline \multirow{3}{*}{ 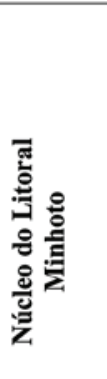 } & 8 & Mamoa de Eireira & $\begin{array}{l}\text { Viana do } \\
\text { Castelo }\end{array}$ & Dolmen com corredor & Internacional: bandas & 1 & $\begin{array}{c}\text { Cruz } 1992 \\
\text { Bettencourt } 2011 \\
\text { Rebuge } 2004\end{array}$ \\
\hline & 9 & Mamoa de Aspra & Caminha & $\begin{array}{c}\text { Tumulus sem estrutura } \\
\text { megalítica }\end{array}$ & $\begin{array}{l}\text { Internacional: bandas e } \\
\text { geométrico }\end{array}$ & 2 & $\begin{array}{c}\text { Silva } 1994 \\
\text { Bettencourt } 2011 \\
\text { Rebuge } 2004\end{array}$ \\
\hline & $\begin{array}{l}1 \\
0\end{array}$ & Dólmen da Barrosa & Caminha & Dolmen com corredor & Pontilhado Geométrico & 1 & $\begin{array}{c}\text { Jorge } 1986 \\
\text { Cruz } 1992 \\
\text { Bettencourt } 2011 \\
\text { Rebuge } 2004\end{array}$ \\
\hline
\end{tabular}

Quadro 1 - Sítios com cerâmica Campaniforme decorada no Alto Minho.
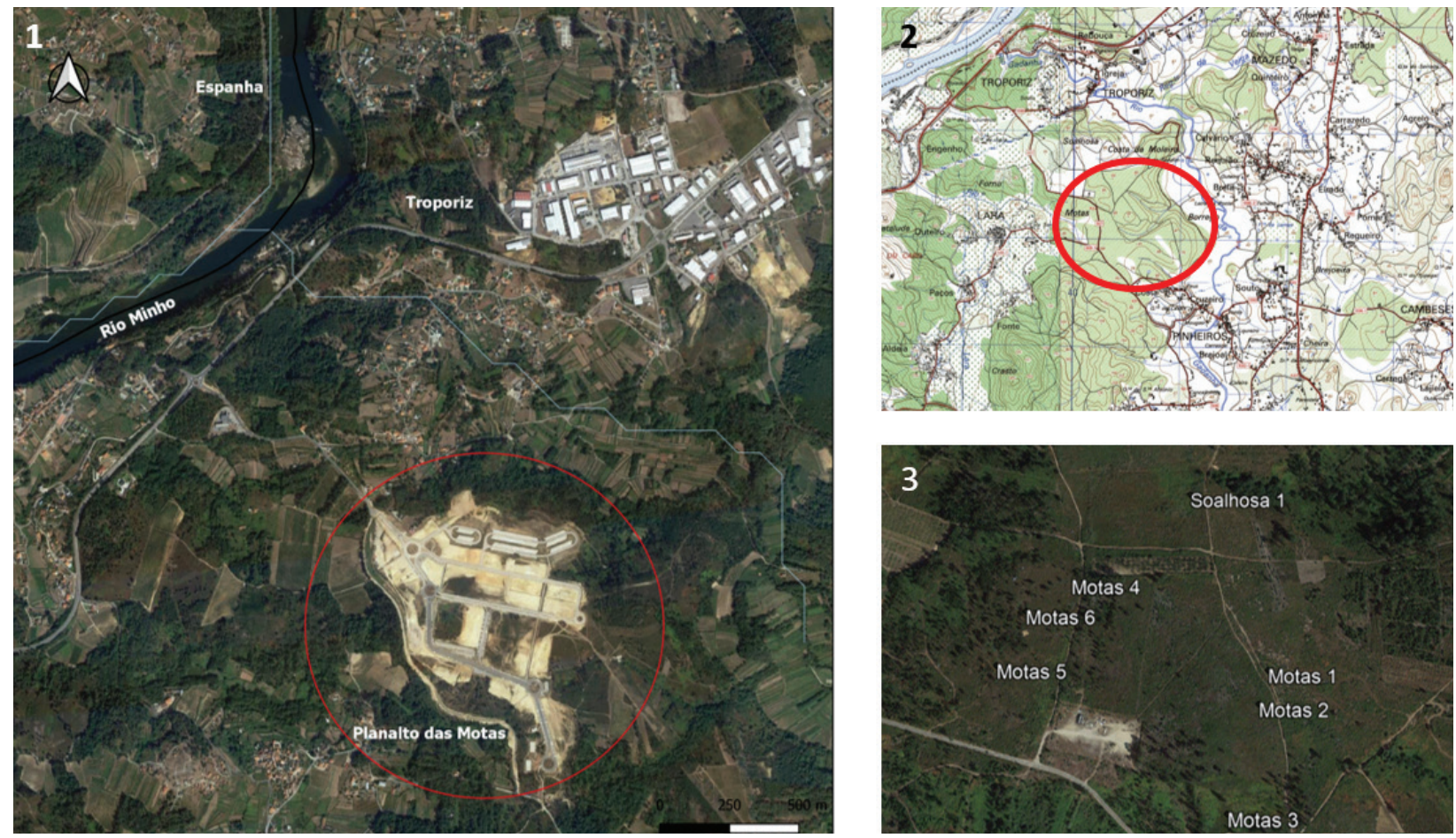

Figura 1-Localização do Complexo Megalítico das Motas no google Earth (1) e nas cartas militares 1:250oo nº 3 e 4. Espacialidade dos monumentos no planalto (3). 

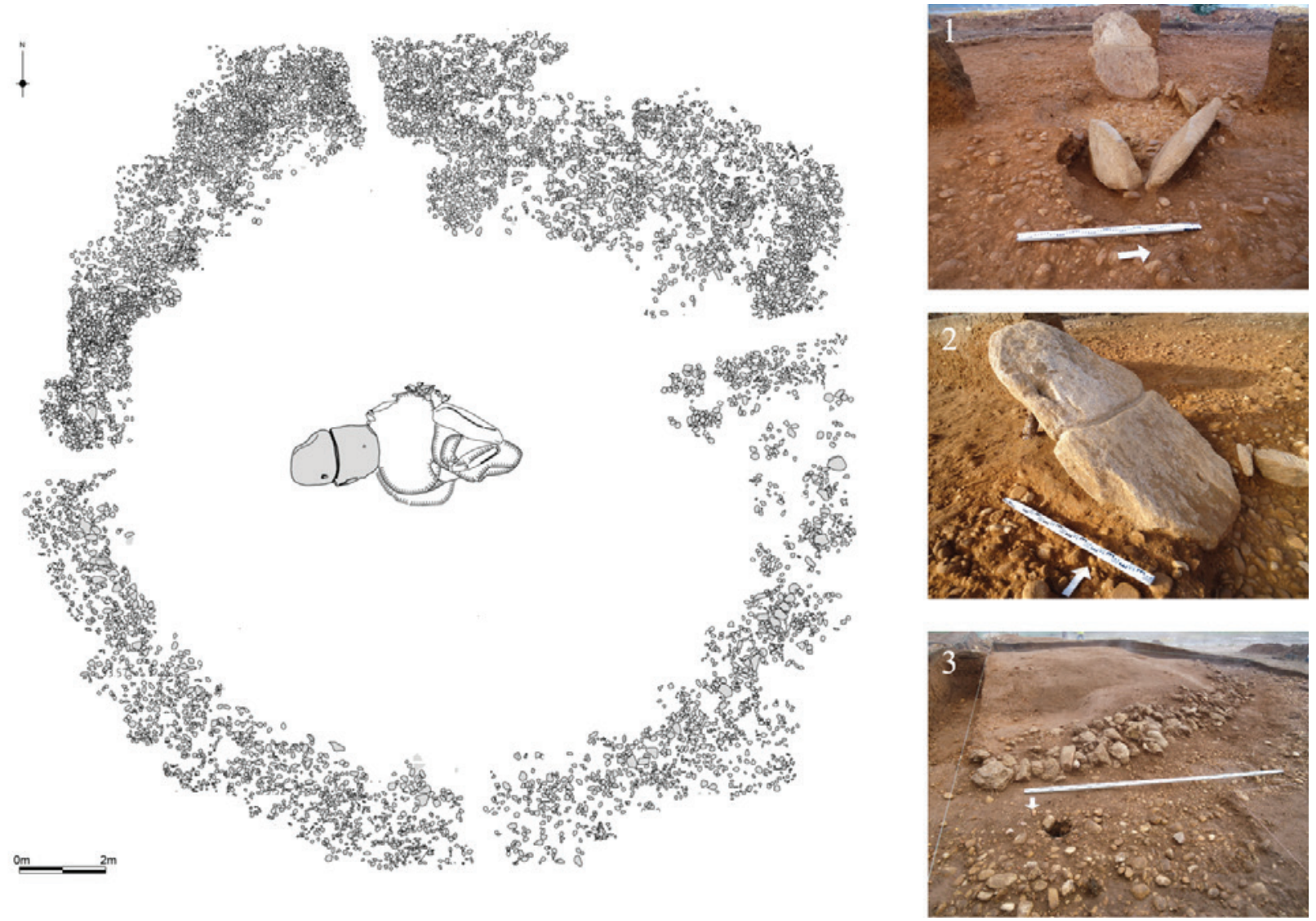

Figura 2 - Planta geral do monumento Motas 5. Pormenores do estado de conservação da câmara (1), da possível estela reaproveitada (2) e do anel pétreo (3).
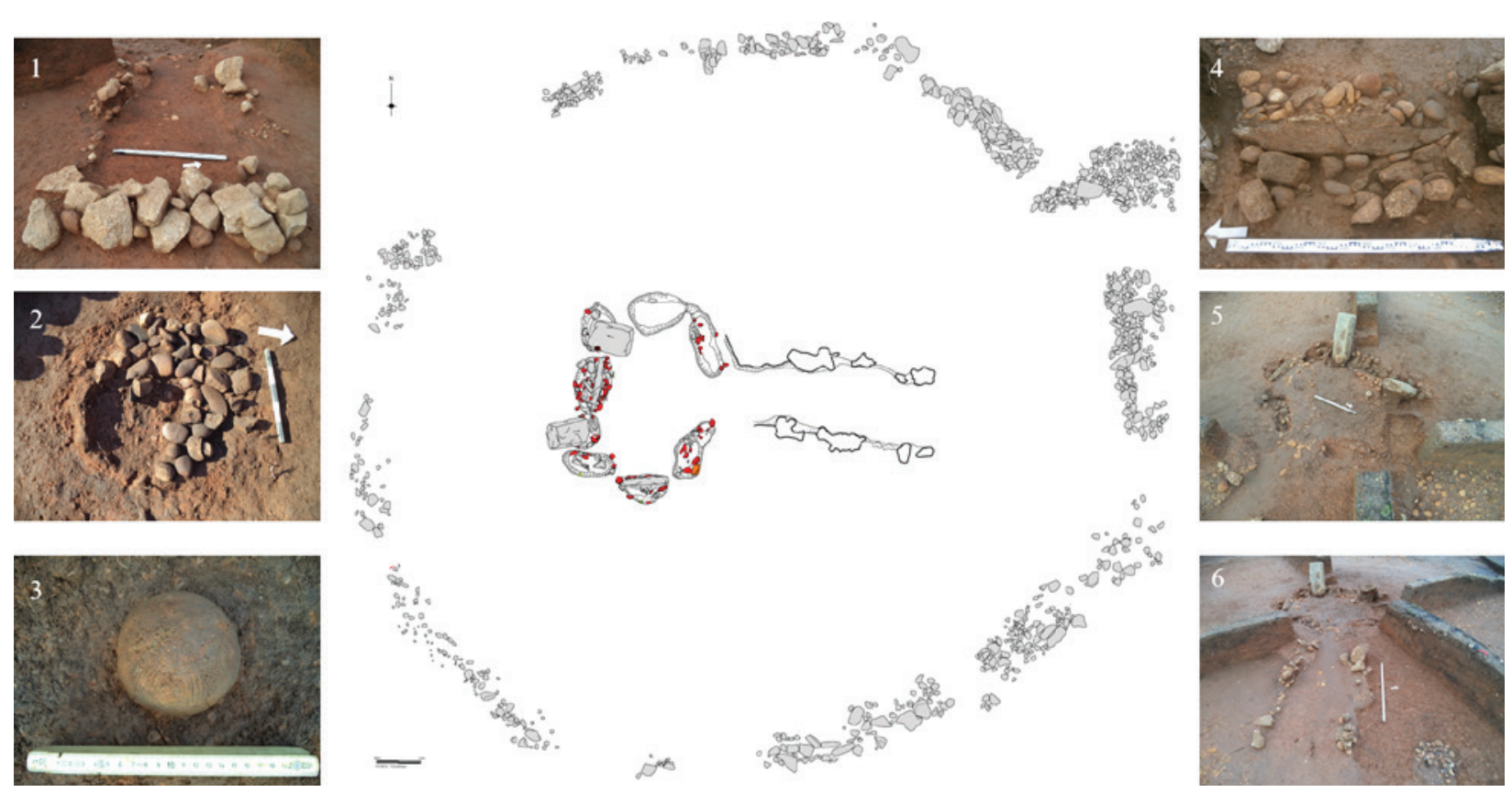

Figura 3 - Planta geral do monumento Soalhosa 1. Pormenores da condenação do corredor (1), das lareiras associadas ao átrio da estrutura (2) e da deposição de um recipiente completo com decoração incisa metopada de "tipo Penha" (3). Sublinha-se também a inclusão de calços de sustentação os esteios (4) na câmara da estrutura (5) e no corredor (6). 
1

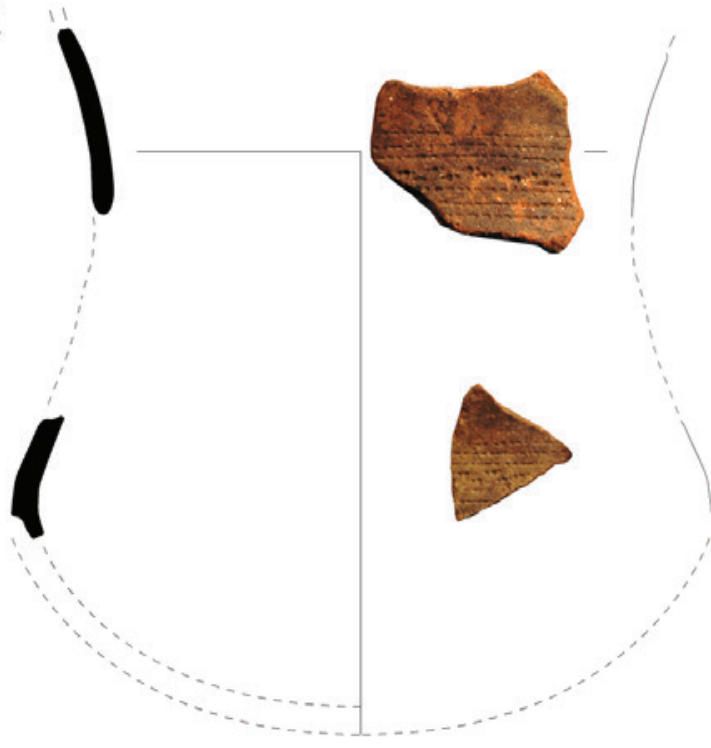

2

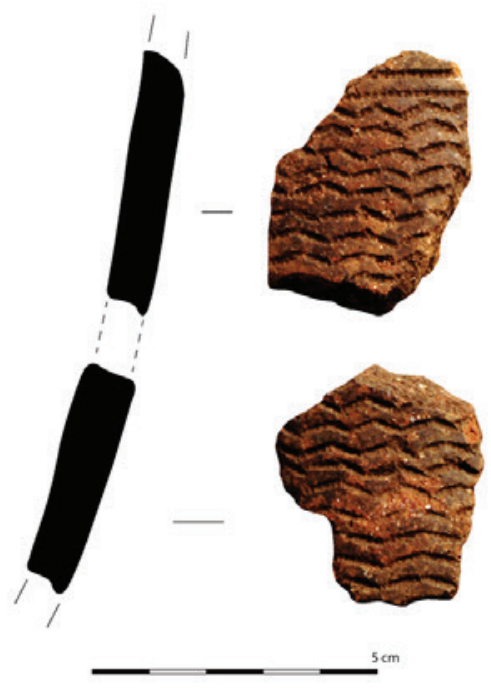

3

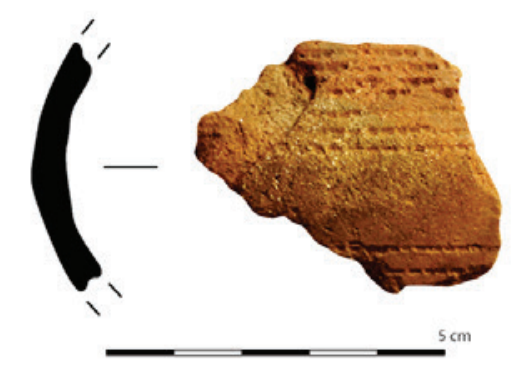

4

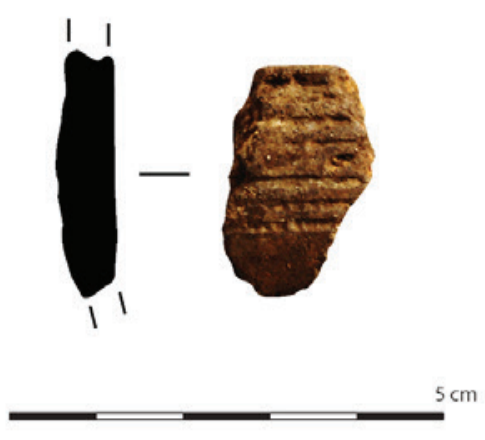

5

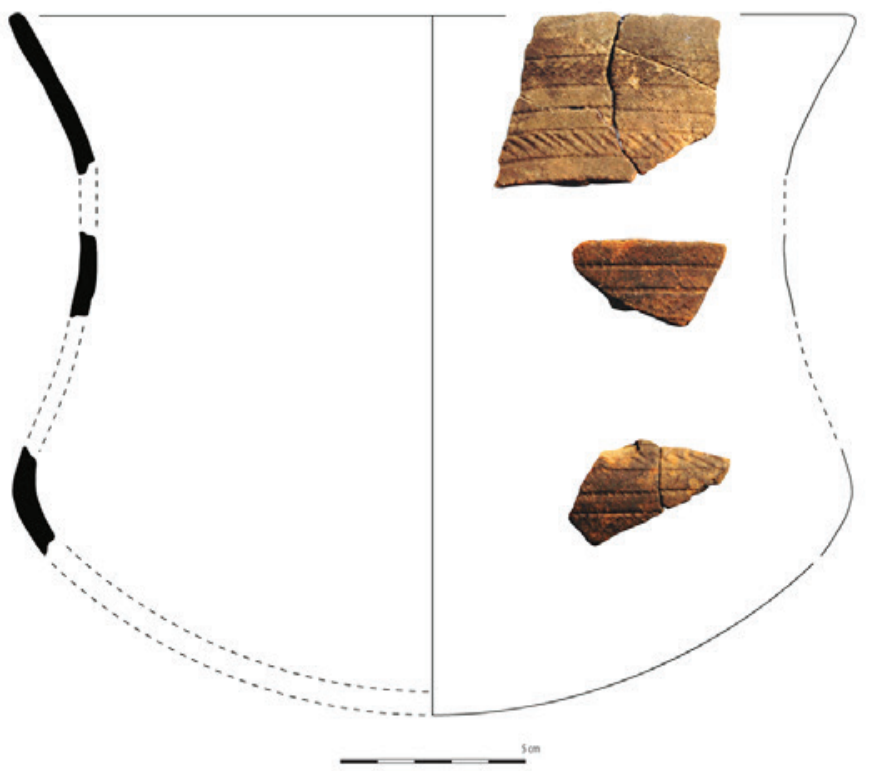

6
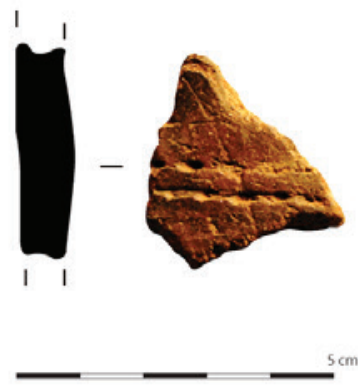

Figura 4 - Elementos Campaniformes do Complexo Megalítico das Motas: 1-5 provenientes de Soalhosa 1. 6 pertencente aos contextos de Motas 5 . 


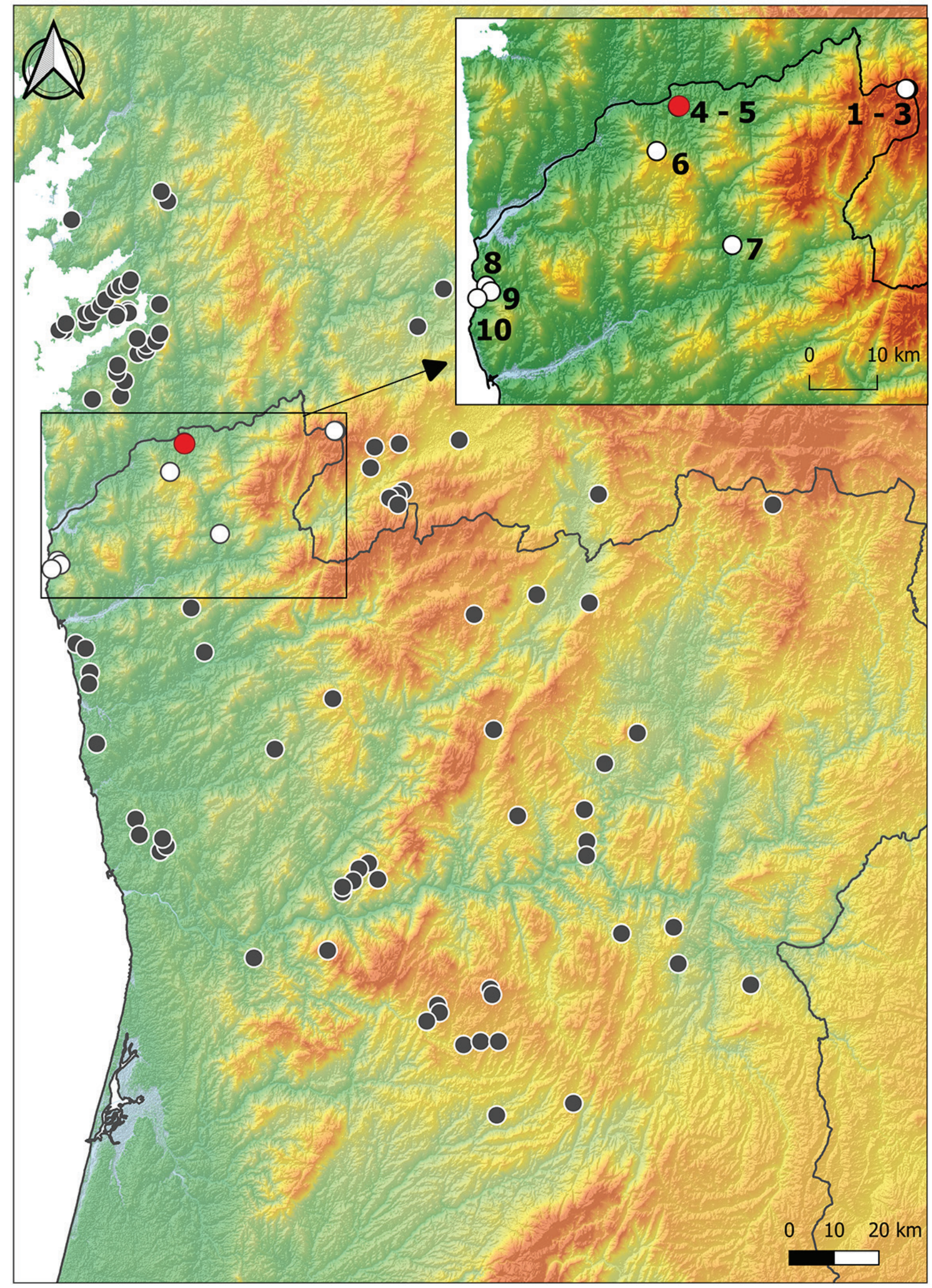

Figura 5 - Distribuição espacial dos sítios com cerâmica Campaniforme decorada no Norte de Portugal e, de forma breve, na Galiza. Pormenor da área do Alto Minho, com o Complexo Megalítico das Motas a vermelho. Mapa baseado nos dados de Sanches e Barbosa (2018), Bettencourt (2011) e Prieto Martinez (2013). 


\title{
TRABALHOS ARQUEOLÓGICOS NO SÍTIO CALCOLÍTICO DA PEDREIRA DO POIO
}

\author{
Carla Magalhães ${ }^{1}$, João Muralha² ${ }^{2}$ Mário Reis ${ }^{3}$, António Batarda Fernandes 4
}

\begin{abstract}
RESUMO
Com este artigo pretendemos dar a conhecer a intervenção arqueológica realizada em finais de 2019, na Pedreira do Poio. Estes trabalhos integram-se no Projecto de Investigação denominado "Uma investigação sobre a Pré-história Recente do Vale do Côa. Dinâmicas de uso e ocupação do território”. O sítio foi identificado por arqueólogos da Fundação Côa Parque. Localiza-se em plena área de exploração da pedreira do Poio e, quando foi reconhecido, encontrava-se já muito destruído. O principal objectivo desta intervenção consistiu na recuperação do máximo de informação possível. No final dos trabalhos duas ideias surgem: 1 - o sítio cronologicamente insere-se na Pré-história Recente; 2 - o seu tipo é inédito na região: um sítio de fossas.

Palavras-chave: Alto Douro, Pré-história Recente, Escavação, Sítio de fossas.
\end{abstract}

\begin{abstract}
This article intends to disclose the archaeological intervention carried out in late 2019, in Pedreira do Poio, as part of the Research Project "An investigation on the Late Prehistory of the Côa Valley. Dynamics of use and occupation of the territory". The site was identified by archaeologists from the Côa Park Foundation. It is located in the middle of the exploration area of the Poio quarry and, when recognized, it was already quite destroyed. The main objective of this intervention was to recover as much information as possible. At the end of the work two ideas emerge: 1 - the site chronologically falls within Late Prehistory; 2 - its type is unprecedented in the region: a pit site.
\end{abstract}

Keywords: High Douro, Late Prehistory, Excavation, Pit-site.

\section{INTRODUÇÃO}

A escavação arqueológica na Pedreira do Poio, correspondeu à primeira intervenção de campo do Projecto de Investigação denominado "Uma investigação sobre a Pré-história Recente do Vale do Côa. Dinâmicas de uso e ocupação do território" que tem como objectivo principal o estudo das dinâmicas de povoamento da Pré-história Recente no Vale do Côa. A região considerada neste projecto tem sido objecto de trabalhos orientados para a identificação e estudo de sítios arqueológicos, ao nível da construção de inventários, cartas arqueológicas e problemáticas de território (Coixão, 1996; 1999; Aubry \& alii, 1997; Carvalho, 1999; 2003; 2004, Reis, 2012; 2013; 2014).
No entanto, apesar da sua excelente qualidade, estes estudos têm deixado em aberto problemáticas mais específicas como a arqueologia da paisagem, onde a reflexão sobre implantações geomorfológicas adquire um papel importante.

É importante referir igualmente que os trabalhos de investigação no Parque Arqueológico do Vale do Côa, desde a sua fundação, não têm sido exclusivos do período Paleolítico. A cronologia compreendida entre o $3^{\circ}$ e $2^{\underline{0}}$ milénio AC tem sido abordada nos últimos anos, de uma forma consistente mas não continuada. Pesquisas como "A Pré-história Recente do Parque Arqueológico do Vale do Côa (1999-200o)", dirigido por António Faustino de Carvalho (2003, 2004); "A Idade do Bronze no Baixo Côa (2006-

\footnotetext{
1. Fundação Côa Parque; carlasmagalhaes@hotmail.com

2. CEAACP/UC; jmuralha@gmail.com

3. Fundação Côa Parque e CEAACP/UC; marioreis@arte-coa.pt

4. Direção-Geral do Património Cultural e CEAACP/UC; batarda@outlook.com
} 
-2009), liderada por Glória Donoso e “Art-Facts Uma investigação sobre os contextos arqueológicos da Arte Esquemática no vale do Côa (2013-2016)", coordenada por Lara Bacelar Alves e João Muralha Cardoso, foram projectos que trataram problemáticas relacionadas aos contextos de diferentes sítios arqueológicos na tentativa de caracterizar as ocupações humanas específicas de cada local e integrá-las em modelos de ocupação do espaço. Os dados publicados desses sítios arqueológicos, são importantes para uma reflexão sobre a construção das paisagens sociais do $3^{\circ}$ e $2^{\circ}$ milénio do Vale do Côa e da sua região maior, o Alto Douro português.

Os trabalhos decorreram entre 28 de Outubro e 5 de Novembro de 2019 e contaram com a presença de todos os elementos do projecto; Carla Magalhães, António Batarda Fernandes, Mário Reis e João Muralha. Contamos ainda com a visita de Dalila Correia e um apoio de Bárbara Carvalho na escavação e desenhos finais.

Toda a logística de trabalho de campo (escavação, organização e sistematização de materiais) foi assegurada pela Fundação Côa Parque, a qual cedeu instalações para tratamento dos materiais (lavagem e contentorização adequada), providenciou parte do transporte para o campo e parte do material utilizado para a intervenção arqueológica. Os meios fotográficos pertenciam aos investigadores do projecto. Os custos financeiros da intervenção foram praticamente nulos. Os poucos gastos existentes foram suportados pela equipa de projecto.

\section{O SÍTIO ARQUEOLÓGICO; GEORREFE- RENCIAÇÃO E CARACTERIZAÇÃO}

As Pedreiras do Poio situam-se numa elevação com cerca de 380 metros acima do nível do mar, sobranceiras ao Rio Côa, na sua margem esquerda, localizando-se na freguesia e concelho de Vila Nova de Foz Côa, distrito da Guarda.

Aproveitando um fenómeno geológico (sinforma), é aqui possível a extracção de pedra de xisto de forma a obter-se blocos coesos que podem ter diversas aplicações como materiais de construção. Contudo, nestas pedreiras, produziram-se tradicionalmente os chamados esteios, postes de pedra utilizados na plantação da vinha, aproveitando-se para a sua extracção a relação que aqui se verifica de quase perpendicularidade entre estratificação e clivagem da rocha metamórfica (Búrcio, 2004). A diversificação da produção para outros materiais de construção de aplicação mais abrangente dá-se apenas no final do século XX. Assim, devido à importância dos esteios para o plantio de vinha na região demarcada do Douro (onde se localizam as pedreiras) em que outros recursos, nomeadamente madeira, que pudessem ser usados para este fim não abundam, é comum a ideia que esta exploração será tão antiga como a própria existência da região vinícola demarcada do Douro. No entanto, a primeira fonte histórica que refere a existência das pedreiras data apenas do final do século XIX, sendo, por exemplo, que as Memórias Paroquiais de 1758 não referem a existência de qualquer pedreira no concelho de Vila Nova de Foz Côa. É apenas no XI volume do Dicionário "Portugal Antigo e Moderno", publicado em 1886, que Pinho Leal refere estas pedreiras, notando o uso da pedra extraída como esteios ou para blocos de maiores dimensões, em tanques, lagares e mesmo pontes, terminando com o encómio de que "Não se conhece em todo o Douro outra pedreira igual a esta de Foscoa" (pp. 839-840) (Figura 1).

\section{OBJECTIVOS, ESTRATÉGIA E METODOLOGIA}

O sítio arqueológico da Pedreira do Poio foi identificado por arqueólogos da Fundação Côa Parque. Localiza-se em plena área de exploração da pedreira e quando o sítio foi reconhecido, já se encontrava praticamente destruído. Desta forma, orientamos todas as nossas acções para a recuperação do máximo de informação possível. Assim, o objectivo fundamental foi encontrar, dentro da área de trabalho, bastante reduzida, uma metodologia que nos permitisse aceder a informação menos perturbada, recolher o máximo possível de materiais arqueológicos e tentar, através de uma prospecção em redor, delimitar os contornos do que teria sido o sítio arqueológico. Considerando este objectivo, utilizamos a seguinte estratégia:

a) Limpeza do corte do caminho que atravessa o sítio arqueológico.

b) Alargamento dos cortes necessários, no sentido do exterior do caminho (para áreas pouco destruídas), em duas situações.

c) Prospecção "intra-site" para tentarmos perceber a área de dispersão de materiais, com o objectivo, se possível, de aferir a dimensão original do sítio arqueológico (Figura 2). 


\section{Metodologia de escavação}

A metodologia de escavação seguiu os princípios de estratigrafia e de registo preconizados por Barker (1978), tendo em consideração a natureza dos contextos identificados. Tentamos dar resposta a todos os problemas que nos foram surgindo adoptando procedimentos enunciados por Angelucci (2003) nas questões estratigráficas e Schiffer (1987), nos problemas pós-deposicionais. O processo de escavação e registo foi conduzido no sentido da identificação e individualização de unidades contextuais.

\section{DESCRIÇÃO E INTERPRETAÇÃO DOS TRABALHOS REALIZADOS}

\subsection{Limpeza do corte e seu estudo.}

Os trabalhos de campo iniciaram-se com o desbaste de alguns arbustos que impediam uma correcta visualização e leitura dos cortes do caminho. Após esta limpeza, foram escolhidas e delimitadas as áreas a trabalhar, considerando o primeiro objectivo desta intervenção: o lado Este do caminho foi designado de corte 1, e o lado Oeste de corte 2; as áreas, inseridas nos respectivos cortes, foram assinaladas por 1.1, 1.2 e 1.3 no lado Este e 2.1, 2.2 no lado Oeste. As duas sondagens abertas foram numeradas sequencialmente; sondagem 1 e sondagem 2 (ver Figura 3). Para uma melhor sistematização da informação, optámos por fazer primeiro a descrição dos cortes e só depois a enumeração e interpretação das fossas identificadas.

\section{Corte 1.1}

Este corte, com um comprimento de $1.80 \mathrm{om}$, apresentava uma estratigrafia muito simples. A unidade estratigráfica O1, correspondia a uma camada humosa misturada com aterro relativamente recente (com cerca de 4 anos). No decorrer dos trabalhos percebemos que toda a área Este da intervenção tinha sido objecto de uma terraplanagem para a construção de um Poste de Transformação existente a cerca de $30 \mathrm{~m}$ a Norte da área de trabalhos. A unidade 02 correspondia a um nível argilo-siltoso de cor amarelada composto por poucos materiais arqueológicos, pequenas pedras de xisto (entre $0,5 \mathrm{~cm}$ e $2 \mathrm{~cm}$ ) e sedimento argiloso. Parece corresponder ao nível de ocupação pré-histórica do sítio, e foi nesta unidade que as fossas foram abertas. A última unidade detectada corresponde à desagregação do substrato geológico. Foram recolhidos poucos materiais arqueológicos.

\section{Corte 1.2}

Tinha um comprimento de $1.80 \mathrm{om}$ e a única alteração em relação ao corte anterior, consistia na existência de um nível de aterro perfeitamente visível (unidade o9). O aterro é composto por raros materiais arqueológicos, lajes aparelhadas, pedras irregulares, tijolos, cimento, telha, terra mais ou menos compacta e terra humosa revolvida.

Ao contrário do corte anterior, a limpeza desta área revelou um conjunto de materiais líticos e cerâmicos muito coerente, relativamente à sua cronologia: meados do $3^{\circ}$ milénio.

\section{Corte 1.3}

Este corte foi limpo e estudado, pois uma observação atenta, já no terceiro dia de trabalhos, identificou uma pequena fossa (fossa 6). O corte tem o comprimento de $3.80 \mathrm{om}$. A estratigrafia é um pouco mais complexa, devido à fossa. Foram apenas recolhidos seis fragmentos cerâmicos, todos na fossa 6 , maioritariamente corroídos, sem decoração e com vestígios de fogo.

\section{Corte 2.1}

Tem um comprimento de $2.50 \mathrm{~m}$ e foram aqui identificadas as fossas 1 e 2. A estratigrafia continua a ser bastante simples, apesar da existência das fossas. Foi neste corte que percebemos que estas estruturas negativas foram abertas na unidade estratigráfica $\mathrm{O} 2$.

\section{Corte 2.2}

Tem um comprimento de $2.70 \mathrm{~m}$ e foram identificadas 3 fossas (a 3, 4 e 5). A estratigrafia continua a ser simples, exceptuando os níveis identificados no interior das estruturas negativas. É interessante referir que a unidade estratigráfica correspondente ao aterro não foi identificada nos dois cortes efectuados no lado Oeste do caminho (Figura 4).

\section{Fossa 1}

Tem uma abertura média de boca de $0.80 m$ e uma profundidade de $0.50 \mathrm{~m}$. A sua morfologia é subquadrangular e tem um fundo recto. O seu enchimento parece ter acontecido de uma só vez e apresenta um sedimento argiloso com silte de cor amarela acastanhada. Foram recolhidos materiais arqueológicos (cerâmica e líticos) e fauna. Tem ainda lajes de pequeno e médio calibre (entre $5 \mathrm{~cm}$ e $20 \mathrm{~cm}$ ). O seu interface surge na unidade estratigráfica o2 e continua pela o8 que, como vimos, representa o substrato 
geológico. Os materiais recolhidos são muito homogéneos. A cronologia aponta para o calcolítico regional. As decorações cerâmicas pertencem ao universo das impressas penteadas (ondulados e rectilíneos).

\section{Fossa 2}

Identificada, como a anterior, no corte 2.1. Encontrava-se muito destruída pelo corte aberto para o caminho. Teria uma boca de cerca de $0.80 \mathrm{~m}$ e uma profundidade de $0.30 \mathrm{Om}$. Apresentava uma morfologia subquadrangular, mas o seu fundo era côncavo. Estava preenchida com um sedimento argiloso com silte de cor amarela acastanhada, com raros materiais arqueológicos. No perfil não foram detectadas lajes.

\section{Fossa 3}

Identificada no corte 2.2 e muito bem preservada. Tem uma morfologia em U com um diâmetro de boca de cerca de $1.20 \mathrm{~m}$ e uma profundidade de 1.oom. Quer no corte, quer posteriormente na sua escavação em plano, percebemos que todo o seu interior estava intacto. Esta situação permitiu recuperar toda a informação do seu enchimento. Assim temos, de cima para baixo:

UE 17- Nível de sedimento muito escuro, com raros materiais arqueológicos. Correspondem a pequena lareira, feita na boca da estrutura.

UE 10 - Nível de argila cozida, muito compacta que sela / condena a fossa. Não foram recolhidos materiais arqueológicos.

UE 18 - Corresponde ao primeiro nível de enchimento da fossa. Tinha uma espessura média de o.3om, era constituída por lajes de xisto de pequena e média dimensão, sedimento argilo-arenoso, algumas raízes apodrecidas e desagregadas, materiais arqueológicos e fauna. Os materiais recolhidos são todos da primeira metade e meados do $3^{\circ}$ milénio.

UE 21 - Segundo nível de enchimento. Tinha uma espessura média de o.3om. Composto por lajes de xisto de média a grande dimensão, argila cozida compacta, fauna, materiais líticos e cerâmicos e carvões. UE 22 - Terceiro e último nível do enchimento da estrutura em negativo. Espessura média de $0.15 \mathrm{~m}$. Corresponde à base da fossa. Estava preenchida com lajes de grande dimensão, sobrepostas, quase sem sedimento e este quando estava presente tinha uma coloração cinzenta-esverdeada, semelhante a argila misturada com cinzas. Foram recolhidos raros materiais (alguma cerâmica e fauna) Este último nível de enchimento estava já escavado na rocha de base. Uma particularidade interessante desta fossa relaciona-se à acção de condenação: uma cobertura de argila muito prensada, cozida pela instalação da lareira que estava imediatamente por cima. Por outro lado, os três momentos de "uso" desta fossa, encontram-se perfeitamente identificados. Não se detectam grandes diferenças entre eles a não ser nos sedimentos e dimensões das lajes de xisto, já que os materiais arqueológicos recolhidos são cronologicamente homogéneos (Figura 5 e 6).

\section{Fossa 4}

Estrutura muito destruída pela abertura do caminho. Foi identificada pela base, isto é, pelo corte/ escavação no substrato geológico. Impossível determinar a sua morfologia assim como as medidas. A base, aparentemente seria subquadrangular. Foram recolhidos escassos materiais. Identificada no corte 2.2.

\section{Fossa 5}

Esta estrutura foi igualmente identificada no corte 2.2, no canto Sul. Pequena fossa de $0.40 \mathrm{~m}$ de profundidade e com um diâmetro de boca de o.3om. Morfologia em U. Parece ter tido dois momentos de preenchimento:

UE 11 - Sedimento de cor castanho escura, argiloso com raros materiais arqueológicos. Parece corresponder ao último nível do enchimento da fossa.

UE 12 - Segundo nível de enchimento da fossa 5. Sedimento de cor castanha escura, argiloso, raras lajes de xisto de pequena dimensão e materiais arqueológicos. Tanto os materiais arqueológicos como as lajes recolhidas apresentavam vestígios de terem estado sob a acção de fogo.

\section{Fossa 6}

Identificada no corte 1.3. Pequena estrutura com cerca de $0.50 m$ de profundidade e de abertura de boca. A sua morfologia é igualmente em U. Teve dois momentos de enchimento.

UE 20 - Ocupa quase toda a fossa, tem uma espessura de $0.40 m$ e é constituído por terra argilosa, compacta, poucos materiais arqueológicos e pequenas lajes de xisto.

UE 23 - Segundo e último nível de enchimento da estrutura. Composto por lajes de grandes dimensões, envoltas em pouco sedimento, apresentando uma coloração cinzento esverdeada. 
Em corte era visível a existência de uma área de xisto queimado, imediatamente por baixo da base da fossa, sugerindo que, no momento em que esta estrutura é construída, é ateado um fogo na base. O sedimento da própria UE 23 remete para cinzas.

\subsection{As sondagens.}

Foram realizadas duas sondagens no prolongamento de duas áreas onde tínhamos identificado estruturas negativas.

\section{Sondagem 1}

Esta sondagem foi aberta no prolongamento do corte 2.1, com 1.0om por $0.6 \mathrm{om}$. O objectivo era escavar o remanescente da fossa 2. A estratigrafia era muito simples e a leitura da fossa em corte, manteve-se no plano. A única particularidade a assinalar foi a identificação na base da fossa de uma área muito queimada, sugerindo uma acção de queima do fundo da estrutura.

\section{Sondagem 2}

Sondagem aberta no prolongamento do corte 2.2, com $1.50 \mathrm{~m}$ por $0.6 \mathrm{om}$. O objectivo passava pela escavação da fossa 3 e tentar perceber se a estratigrafia identificada em corte se mantinha idêntica. O segundo objectivo foi atingido, pois as UE's identificadas em corte, mantiveram-se em plano. Relativamente ao primeiro, este não foi atingido plenamente. A fossa estendia-se um pouco mais para o lado Oeste da sondagem, dando origem, no entanto, a um segundo corte desenhado. O significado mais importante desta sondagem foi a recolha de material nas respectivas unidades estratigráficas. Apesar de ser bastante homogéneo, o seu estudo completo talvez permita no futuro, apreender algumas, pequenas dissimilaridades. Mais uma vez, a base desta estrutura apresentava-se queimada, sugerindo uma acção de queima das fossas antes do seu preenchimento (Figura 7 e 8).

\subsection{Prospecção "intra-site"}

O objectivo desta fase de trabalhos passava pela aferição da área original do sítio arqueológico. Apesar de conseguirmos recolher alguns materiais dispersos pela pedreira, cedo se percebeu de que as constantes alterações das áreas de extracção de pedra nos últimos 50 anos foram de tal forma grandes que seria impossível perceber qual a área original do sítio. No entanto, tendo em consideração, a recolha de material, a análise da cartografia antiga e as conversas tidas com o encarregado que há mais tempo trabalha na pedreira, podemos sugerir que esta estação arqueológica abrangeria o topo do antigo esporão sobre o rio Côa; uma área de cerca de $80 \mathrm{~m}$ por $6 \mathrm{om}$.

\section{DISCUSSÃO}

A discussão destes dados que agora podemos fazer tem de ser entendida num quadro interpretativo muito específico. A informação é muito parcelar, pois acreditamos que apenas escavamos uma área muito pequena do sítio arqueológico. $\mathrm{O}$ debate sobre que tipo de sítio será este; apenas de fossas, de fossas e fossos ou mesmo combinando uma arquitectura em positivo e negativo, é impossível de fazer e mesmo qualquer tentativa de reflexão sobre a sua organização espacial, seria meramente um exercício académico sem grande fiabilidade. Resta-nos pensar sobre um conjunto de problemáticas que poderão ser desenvolvidas a partir destes contextos precisos:

a) a importância do sítio (de fossas) no contexto geográfico do Alto Douro, considerando não só a escassez deste tipo de sítio nesta área como a particularidade da sua implantação, num remate de esporão sobre o rio Côa;

b) a interpretação destas estruturas.

Apesar da sua raridade no interior Norte de Portugal, estes contextos têm sido referenciados, escavados e estudados no Alentejo. Os trabalhos de minimização da construção da barragem do Alqueva e dos respectivos blocos de rega, no âmbito do património arqueológico, revolucionaram empiricamente o conhecimento da Pré-história Recente daquela região (Valera $\mathbb{\&}$ alii, 2010; Baptista $\&$ alii, 2012; Vale \& alii, 2015; Gomes \& alii, 2015, Gomes \& Baptista, 2017; Baptista \& Gomes, 2019). No entanto, a problemática em torno das dinâmicas diacrónicas de ocupação daqueles espaços e a sua interpretação ainda é alvo de discussão. Infelizmente o sítio da Pedreira do Poio, pelo seu grau de destruição, pouco contribuirá para este debate.

$\mathrm{Na}$ região do Alto Douro e a Sul deste rio, para o $3^{0}$ milénio, apenas eram conhecidos o sítio da Quinta da Atalaia (Trancoso) e Santa Bárbara (Sabugal), embora este último já fora daquela denominação geográfica. A Norte, conhecemos os trabalhos arqueológicos realizados no âmbito do Plano de Salvaguarda do Património (PSP), aplicados ao projecto de construção do Aproveitamento Hidroeléctrico do Baixo 
Sabor (AHBS), nos sítios da Foz do Medal (Gaspar $\mathbb{E}$ alii, 2014) e da Quinta das Laranjeiras (Gaspar \& alii, 2014). Apesar do grande interesse destes dois sítios, a sua cronologia é um pouco mais recente do que parece ser a do sítio da Pedreira do Poio e, por outro lado, a problemática que está publicada relaciona-se a contextos específicos de enterramentos.

A Sul do Douro, o sítio da Quinta de Atalaia (Velho \& Velho, 1999; Ferreira, 200o; Perestrelo \& Osório, 2005), até ser extensivamente escavado igualmente no âmbito de uma obra pública (construção do IP2, troço entre Celorico da Beira e Vila Nova de Foz Côa), era referido como um povoado com características defensivas pois era visível uma estrutura granítica na área superior do cabeço, que se poderia considerar parte de um sistema defensivo (Ferreira, 2000, p. 365). A sua inserção cronológica não oferece grandes dúvidas a todos os autores que se debruçaram sobre os materiais recolhidos em várias visitas ao sítio (Velho \& Velho, 1999, pp. 245-246). Todos apontam para o Calcolítico e a existência de alguns fragmentos de taças carenadas, pode transportar esta cronologia para o Bronze Inicial. Era impossível fazer referências à sua arquitectura, considerando que estes trabalhos eram apenas de recolha e identificação de materiais. As sondagens arqueológicas efectuadas por João Albergaria, João Rebuge, Liliana Carvalho e Pedro Peça (2009), revelaram 11 fossas escavadas no substrato geológico e a provável existência de um recinto muralhado. Os autores da escavação, baseando-se nos materiais arqueológicos recolhidos, corroboram a inserção cronológica do sítio, como sendo, maioritariamente calcolítica e prolongando-se para a Idade do Bronze e Ferro, embora existam alguns vestígios que podem apontar para cronologias mais antigas (Neolítico Médio/Final).

O sítio de Santa Bárbara no Sabugal, foi objecto de estudos mais circunstanciados (Pernadas, 2012; 2013; Vale, 2016). O trabalho de Pernadas, de âmbito académico (2012), faz a monografia dos trabalhos arqueológicos onde se identificaram 14 estruturas em negativo de tipo fossa, um provável fosso e alguns buracos de poste. As fossas são bastantes heterogéneas e pouco profundas. Segundo o autor da intervenção, foram preenchidas num curto espaço de tempo. Através do estudo da componente artefactual, Pernadas remete a datação deste sítio arqueológico para o Calcolítico regional, e avança um conjunto de propostas funcionais para estas estruturas explicadas no âmbito de contextos domésticos. O trabalho de Vale (2016) não pretende atribuir funcionalidades às estruturas, mas sim compreender a dinâmica de construção do espaço relacionando os materiais e as estruturas. Para perceber esta relação a autora analisa não só a distribuição artefactual nas diversas fossas, como estuda a sua fragmentação de forma a perceber os processos de enchimento das fossas, tentando assim estudar, possíveis momentos construtivos. Desta forma, no final do seu trabalho, a autora refere a possibilidade de os fragmentos que se encontram nas respectivas unidades estratigráficas, poderem ser considerados elementos construtivos/arquitectónicos na medida em que participam da acção de encerramento das fossas. Esta ideia parece-nos muito interessante, pois reconfigura a ideia de construção, não só ao nível dos elementos construtivos, como ao nível da própria ideia de arquitectura, de fazer arquitectura. Como refere a autora, "O preenchimento das estruturas em negativo em Santa Bárbara é feito através do arranjo de um conjunto de coisas, inteiras e fragmentadas, de diferentes matérias-primas e proveniências, com diferentes tempos associados, por exemplo, de recolha e transformação, de uso e de descarte (...)" (Vale, 2016, p. 21). Mesmo considerando o pequeno número de fossas intervencionadas na Pedreira do Poio e o seu grau de destruição, podemos dizer que o próprio preenchimento das estruturas negativas, não parece ser muito diferente, no sentido em que são utilizados materiais inteiros ou fragmentados, de diferentes matérias-primas e diferentes proveniências.

Além deste facto, o que é interessante na Pedreira do Poio é a grande diferença formal e a aparente diversidade sequencial de enchimentos distintos. Durante o processo de escavação, a análise efectuada a essas sequências de enchimento, reconhece a existência de níveis intencionais de deposição. Parece existir a formalização de uma acção construtiva do enchimento. A acção não é encher a fossa, a acção parece ser construir o enchimento da fossa.

Esta ideia tem sido convocada por vários autores a propósito de contextos semelhantes escavados no Sul de Portugal. Vale \& alii (2015) e Gomes \& Baptista (2017), entre outros, realçam o facto de alguns dos contextos estudados apresentarem características que permitem o reconhecimento de uma intencionalidade no processo de enchimento das estruturas. Os autores referem que os enchimentos são diferenciados e poderão remeter para diferentes práticas 
de cariz social; as estruturas/fossas seriam usadas enquanto contentores de cenários sociais distintos (Vale \& alii, 2015, pp. 312-313).

\section{BIBLIOGRAFIA}

ALBERGARIA, João; REBUJE, João; CARVALHO, Liliana e PEÇA, Pedro (2020) - Relatório preliminar dos trabalhos arqueológicos da minimização de impactes patrimoniais no âmbito da Subconcessão Auto-estrada Douro Interior - Lote 5-IP2 - Lanço Celorico da Beira/Trancoso (IP5) - Quinta da Atalaia (Celorico da Beira) - fase 6. Acesso em: 16 de Maio de 2020 .

ANGELUCCI, Diego (2003) - A partir da terra: a contribuição da Geoarqueologia. In MATEUS, J. E.; MORENO-GARCIA, M., Eds. - Paleoecologia humana e arqueociências: um programa multidisciplinar para a Arqueologia sob a tutela da Cultura, Lisboa: Instituto Português de Arqueologia, pp. 35-103.

AUBRY, Thierry; CARVALHO, António; ZILHÃO, João (1997) - Arqueologia, in Arte Rupestre e Pré-História do Vale do Côa, Trabalhos de 1995-1996, coordenação de João Zilhão, Lisboa, Ministério da Cultura. pp. 77-212.

BAPTISTA, Lídia; GOMES, Sérgio e COSTA, Claúdia (2012) - As dinâmicas de deposição e construção no sítio pré-histórico de Horta de Jacinto (Beringel, Beja), in Actas do V Encontro de Arqueologia Peninsular, Almodôvar, Município de Almodôvar, pp. 585-595.

BAPTISTA, Lídia; GOMES, Sérgio (2019) - Fragmentation and Architecture. Contributions to the debate on the fillings of negative structures in Baixo Alentejo's Late Prehistory. In VALERA, António, (Ed.) Fragmentation and Depositions in pre and proto-history Portugal, Lisboa, Portugal: Núcleo de Investigação Arqueológica - Era Arqueologia. pp. 85-103.

BARKER, Philip (1978) - Techniques of Archaeological Excavation, London, Routledge Press.

BÚRCIO, Mauro Daniel (2004) - Das Vinhas do Douro aos Oceanos primitivos; a origem dos esteios de xisto. Côavisão 6, Vila Nova de Foz Côa, pp. 9-14.

CAPELA, José Viriato (coord.) (2013) - As freguesias do Distrito da Guarda nas Memórias Paroquiais de 1758. Memórias, História e Património. Braga: Universidade do Minho.

CARVALHO, António (2003) - O final do Neolítico e o Calcolítico no Baixo Côa (Trabalhos do Parque Arqueológico do Vale do Côa, 1996-20oo). Revista Portuguesa de Arqueologia, 6:2, Lisboa: Instituto Português de Arqueologia, pp. 229-273

CARVALHO, António (2004) - O Povoado do Fumo (Almendra, Vila Nova de Foz Côa) e o início da Idade do Bronze no Baixo Côa (Trabalhos do Parque Arqueológico do Vale do Côa). Revista Portuguesa de Arqueologia, 7:1, Lisboa: Instituto Português de Arqueologia, pp. 185-219.
CARVALHO, António (1999) - Os sítios de Quebradas e de Quinta da Torrinha (Vila Nova de Foz Côa) e o Neolítico antigo do Baixo Côa. Revista Portuguesa de Arqueologia, 2:1, Lisboa: Instituto Português de Arqueologia, pp. 39-70.

COIXÃO, António Sá (1996) - Carta Arqueológica do Concelho de Vila Nova de Foz Côa, Vila Nova de Foz Côa, Câmara Municipal de Vila Nova de Foz Côa.

COIXÃO, António Sá (1999) - A ocupação humana na Pré-história recente na região de entre Côa e Távora, Dissertação de Mestrado em Arqueologia Pré-histórica apresentada à Faculdade de Letras da Universidade do Porto, edição policopiada.

FERREIRA, Maria do Carmo (200o) - Contributos para a Carta Arqueológica do Concelho de Trancoso. In FERREIRA, M., PERESTRELO, M., OSÓRIO, M. e MARQUES, A. (Eds), Beira Interior: História e Património: Actas das I Jornadas do Património da Beira Interior, Guarda, Outubro de 1998, Câmara Municipal da Guarda, pp. 361-373.

GASPAR, R.; CARRONDO, J.; NOBRE, L.; RODRIGUES, Z.; DONOSO, G. (2014) - Espaço para a morte. O terraço da Foz do Medal (Vale do Sabor, Nordeste de Portugal) durante a Idade do Bronze. Estudos do Quaternário / Quaternary Studies, América do Norte, o, maio 2014. Disponível em: <http://www.apeq.pt/ojs/index.php/apeq/article/ view/85>. Acesso em: 24 Maio 2020.

GASPAR, Rita; RIBEIRO, Ricardo; REBELO, Paulo; NETO, Nuno e CARVALHO, Maria (2014) - Bronze Age Funerary Contexts in Northeast Portugal, Terraço das Laranjeiras (Sabor Valley). In BETTENCOURT, Ana, COMENDADOR REY, Beatriz, SAMPAIO, Hugo, SÁ, Edite (Eds.) Corpos e Metais na Fachada Atlântica da Ibéria. Do Neolítico à Idade do Bronze, Braga, APEQ e CITCEM, pp. 49-62.

GOMES, Sérgio; BAPTISTA, Lídia, MENDONÇA, Rodry, VALE, Nelson e PINHEIRO, Rui (2015) - Estruturas em negativo e construção do espaço durante a Pré-história Recente no interior alentejano: os casos das estações de Varandas 1 e Varandas 2 (Ervidel, Aljustrel, Beja), VII Encuentro de Arqueologia del Suroeste Peninsular, Aroche-Serpa, pp. 147-158.

GOMES, S.; BAPTISTA, L. (2017) - Arquitetura e Arquivo. Contributos para uma compreensão das estruturas em negativo da Pré-história Recente das colinas entre os Barrancos da Morgadinha e da Laje (Serpa, Beja). Estudos do Quaternário / Quaternary Studies, América do Norte, o, dez. 2017. Disponível em: <http://www.apeq.pt/ojs/index. $\mathrm{php} / \mathrm{apeq} /$ article/view/258>. Acesso em: 24 Maio 2020.

PERESTRELO, Manuel Sabino e OSÓRIO, Marcos (2005) - Pré-história Recente na Região da Guarda-alguns subsídios, Côavisão, Vila Nova de Foz Côa, Câmara Municipal de Vila Nova de Foz Côa, pp. 207-232.

PERNADAS, Paulo (2012) - Estruturas em negativo da Pré-História Recente na Beira Interior: o caso de Santa Bárbara 
(Aldeia da Ponte - Sabugal). Dissertação para obtenção do grau de Mestre apresentada à Faculdade de Letras da Universidade de Coimbra, policopiada.

PINHO LEAL, Augusto Soares d'Azevedo Barbosa de (1886) - Portugal antigo e moderno: Diccionario Geographico, Estatistico, Chorografico, Heraldico, Archeologico, Historico, Biographico e Etymologico de todas as cidades, villas e freguezias de Portugal e de grande numero de aldeias. Se estas são notaveis, por serem patria d'homens celebres, por batalhas ou noutros factos importantes que nellas tiveram logar, por serem solares de familias nobres, ou por monumentos de qualquer natureza, alli existentes. Noticia de muitas cidades e outras povoações da Lusitania de que apenas restam vestígios ou somente a tradição. Lisboa: Tavares Cardoso e Irmão, XI volume.

REIS, Mário (2012) - Mil rochas e tal. ..! Inventário de Arte Rupestre do Vale do Côa. Portugália. Porto. 33. pp. 5-72.

REIS, Mário (2013) - Mil rochas e tal. ..! Inventário de Arte Rupestre do Vale do Côa. Portugália. Porto. 34. pp. 5-68.

REIS, Mário (2014) - Mil rochas e tal. ..! Inventário de Arte Rupestre do Vale do Côa. Portugália. Porto. 35. pp. 17-59.
SCHIFFER, Michael (1987) - Formation Processes of the Archaeological Record, New Mexico. University of New Mexico Press.

VALE, Ana (2016) - Dinâmicas de oclusão de estruturas em negativo no sítio de Santa Bárbara (Aldeia da Ponte, Sabugal) - Estudo de fragmentação cerâmica, in SABUCALE Revista do Museu do Sabugal. 8. pp.7-22.

VALE, Nelson; GOMES, Sérgio; BAPTISTA, Lídia; PINHEIRO, Rui e FERNANDES, Sandrine. (2015) - Vale Frio 2 (Ferreira do Alentejo, Beja) - práticas de enchimento das estruturas em negativo de cronologia pré-histórica, VII Encuentro de Arqueologia del Suroeste Peninsular, Aroche-Serpa, pp. 301-313.

VALERA, António e FILIPE, Vítor (2010) - Outeiro Alto 2 (Brinches, Serpa): nota preliminar sobre um espaço funerário e de socialização do Neolítico Final à Idade do Bronze, Apontamentos de Arqueologia e Património, 5, Lisboa, NIA-ERA Arqueologia, pp. 49-56.

VELHO, Alexandra e VELHO, Gonçalo (1999) - A estação Calcolítica da Quinta da Atalaia (Trancoso, Guarda). Estudos Pré-históricos, vol. VII, pp. 241-250.

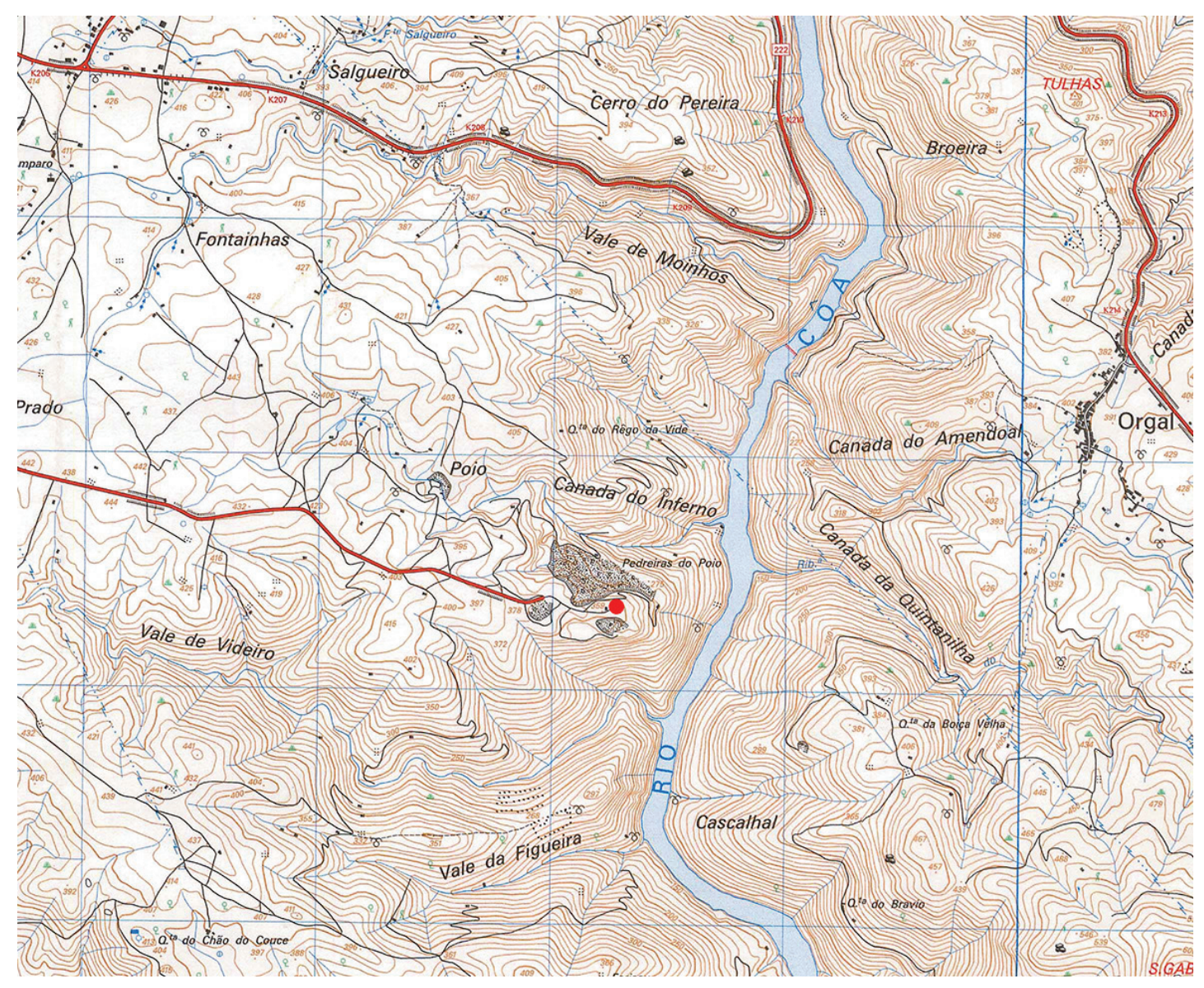

Figura 1 - Localização da intervenção arqueológica (pequeno ponto vermelho), em cartografia CMP 1:250oo,

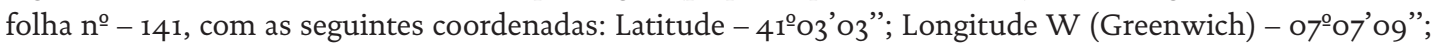
Altitude-36o $\mathrm{m}$ (ponto médio). 


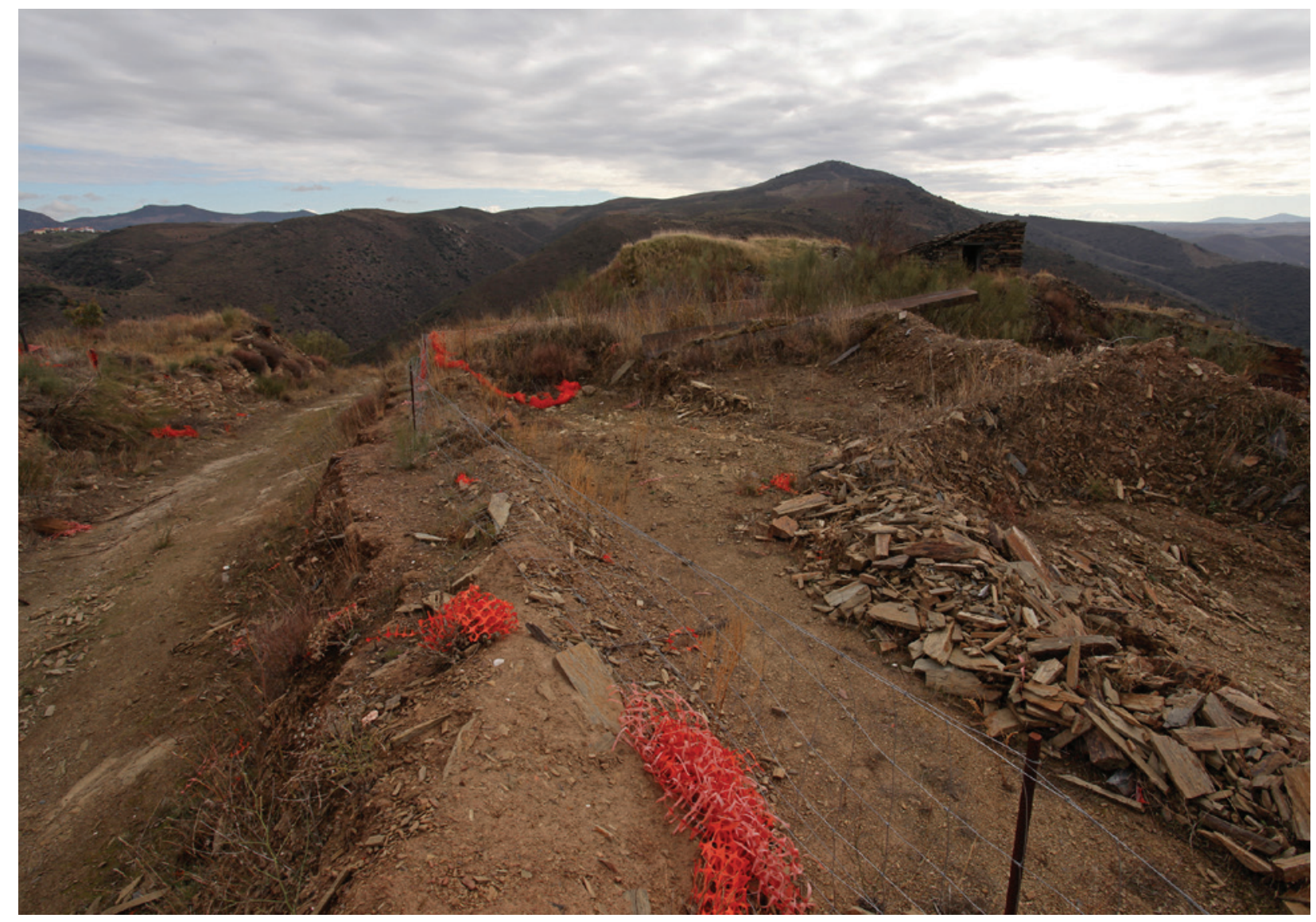

Figura 2 - Aspecto geral do sítio no início dos trabalhos de escavação. 


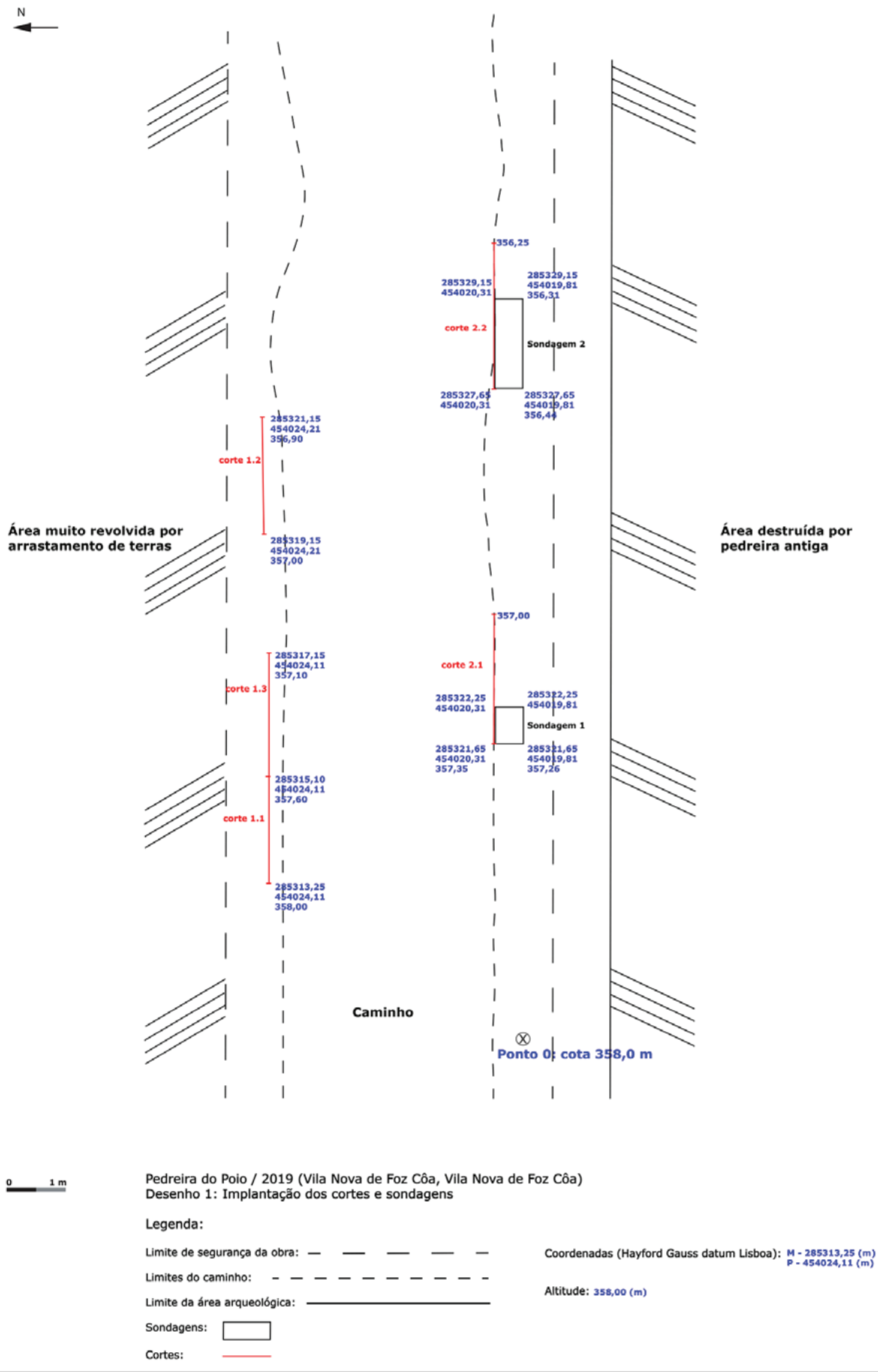

Figura 3 - Planta da área escavada com a localização dos cortes e das sondagens. 


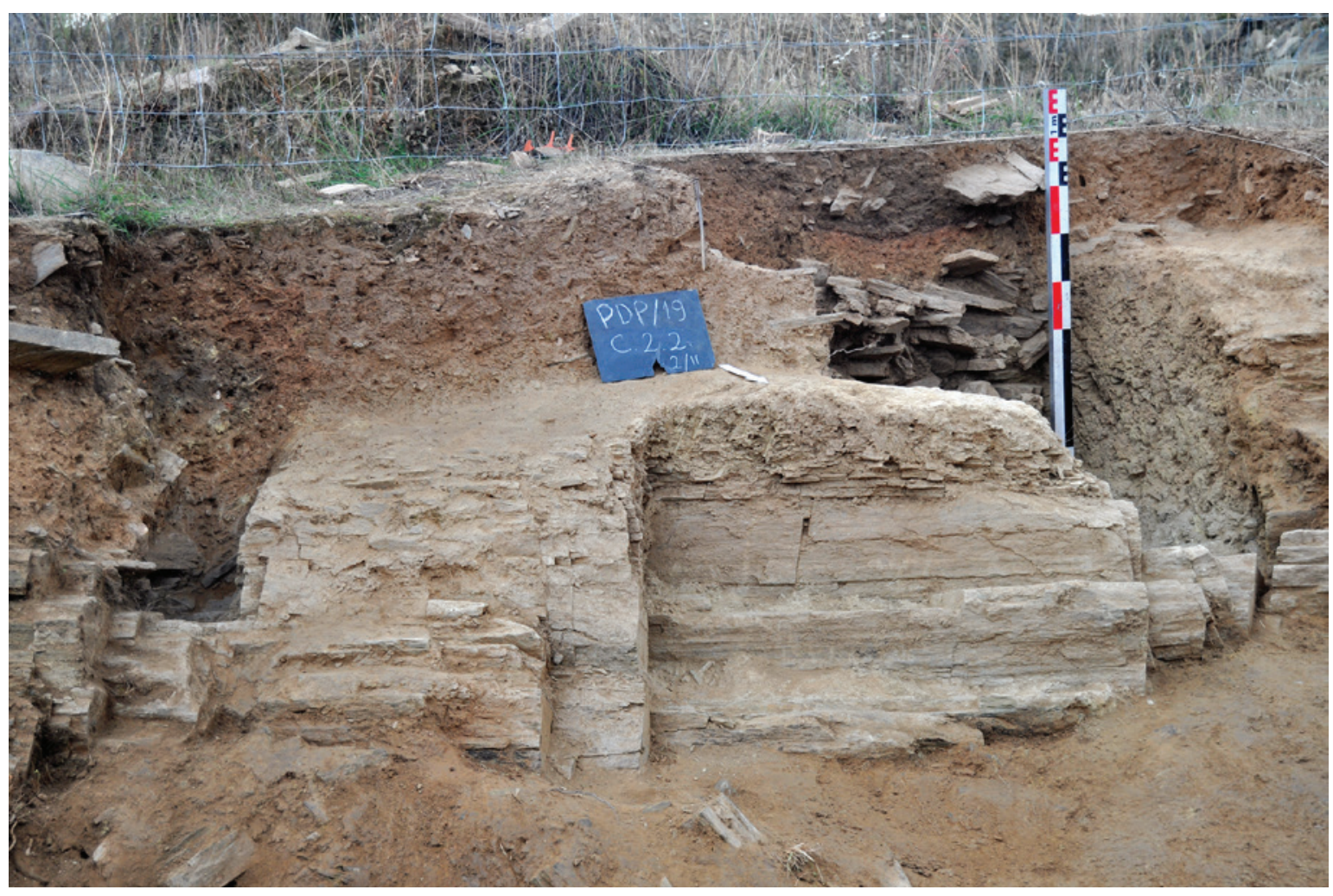

Figura 4-Vista geral do corte 2.2.

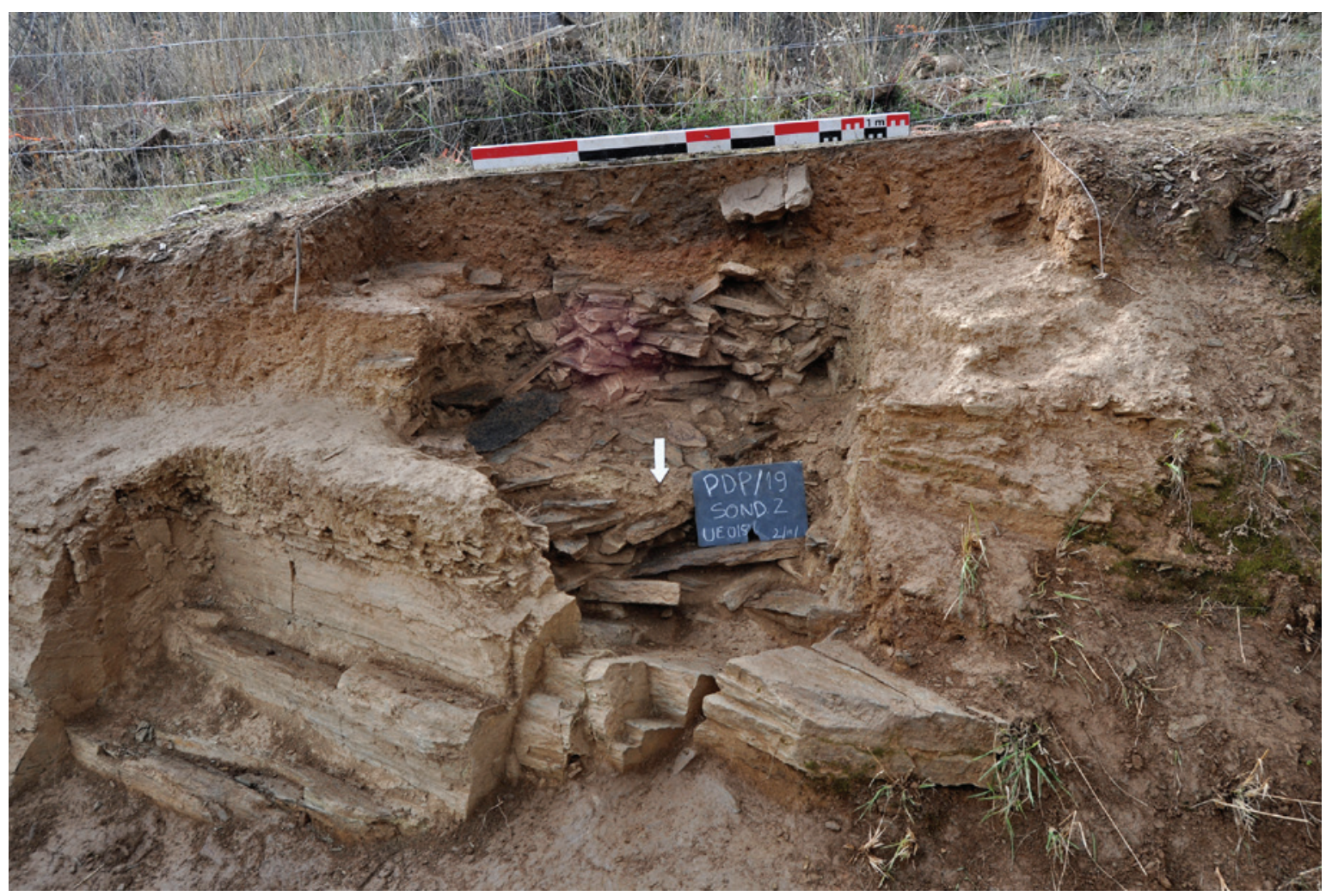

Figura 5-Pormenor da fossa 3. 


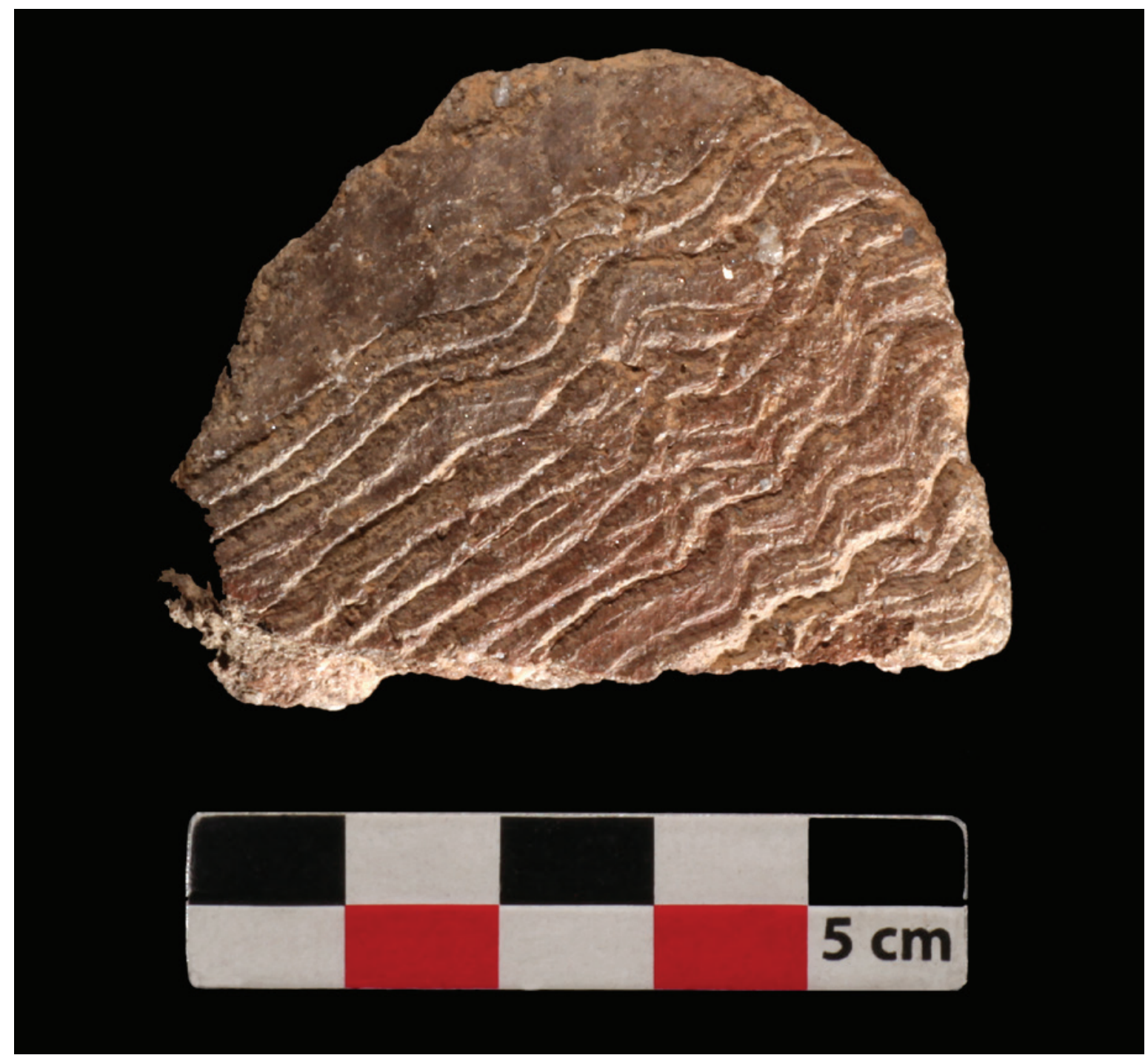

Figura 6 - Fragmento cerâmico recolhido na fossa 3. Decoração impressa penteada ondulada. É interessante reparar no afeiçoamento das arestas do fragmento. 


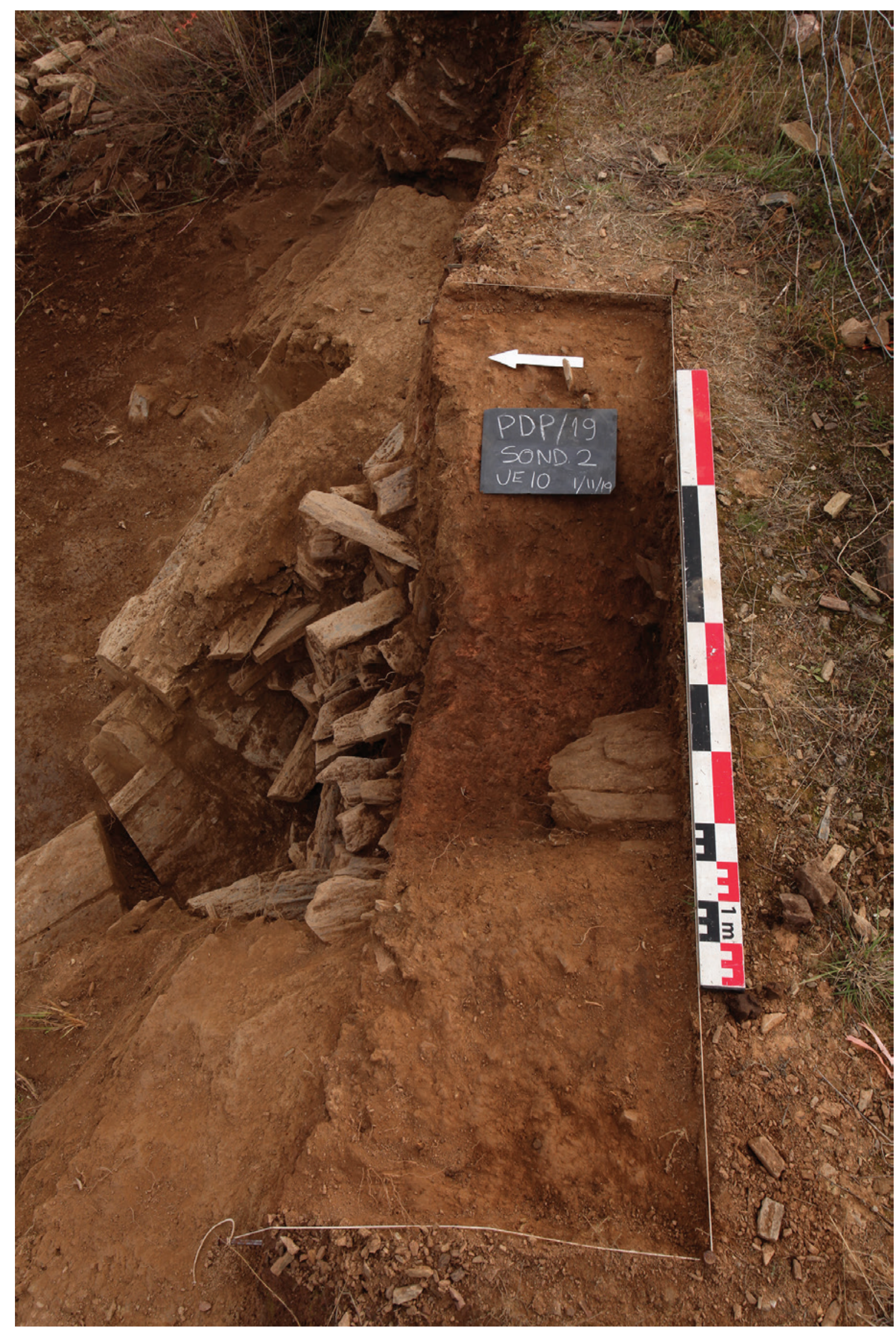

Figura 7 - Pormenor dos trabalhos na sondagem 2. 


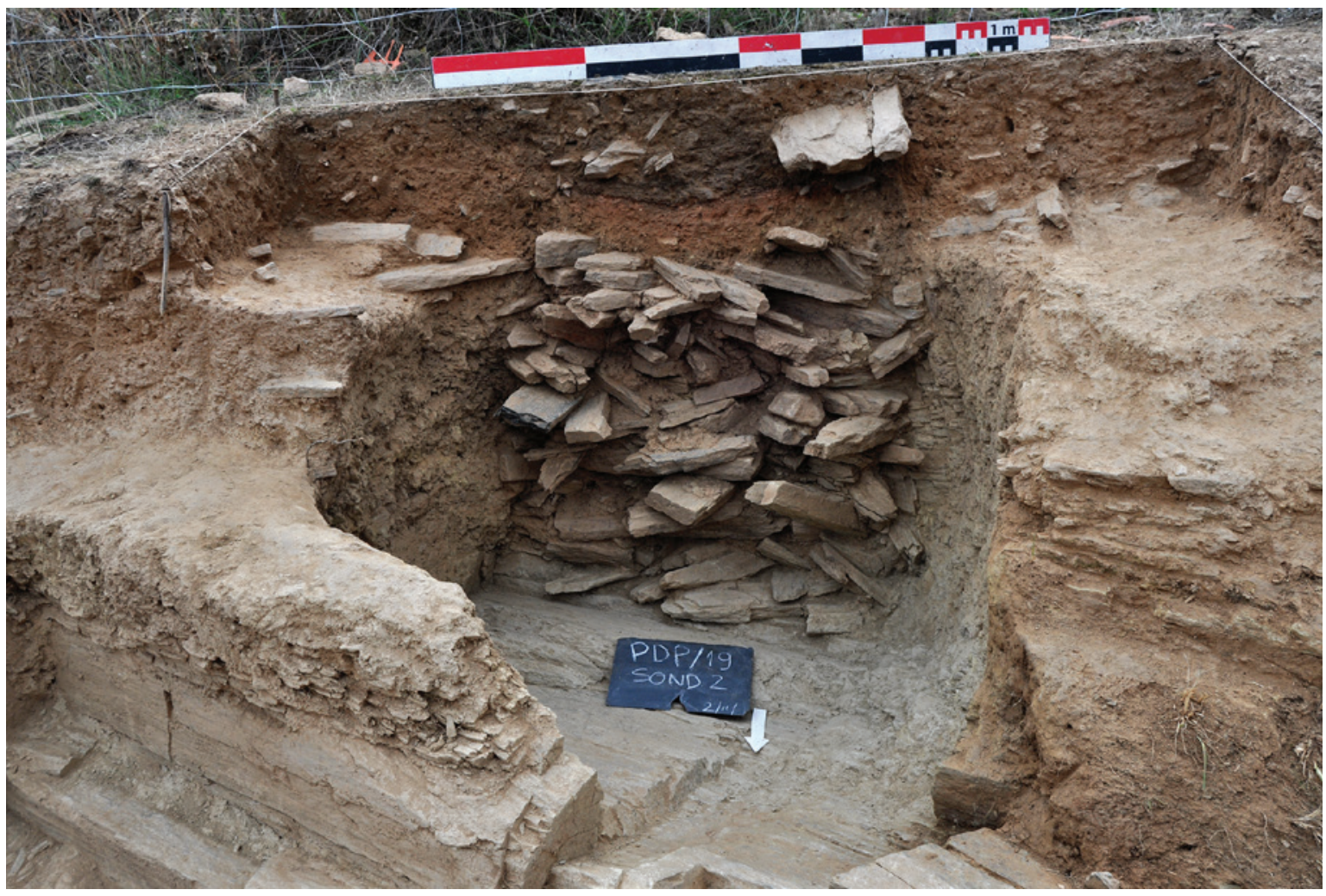

Figura 8 - Final dos trabalhos de escavação na área da sondagem 2 e fossa 3. 


\title{
O SÍTIO ARQUEOLÓGICO DE CASTANHEIRO DO VENTO. DA ARQUITECTURA DO SÍTIO À ARQUITECTURA DE UM TERRITÓRIO
}

\author{
João Muralha Cardoso
}

\begin{abstract}
RESUMO
Castanheiro do Vento é um sítio arqueológico com uma ocupação que abrange todo o $3^{\circ}$ milénio e a primeira metade do $2^{\circ}$ a.C. Situa-se no concelho de Vila Nova de Foz Côa, distrito da Guarda e tem sido investigado por uma vasta equipa. Com esta comunicação pretende-se dar a conhecer algumas reflexões sobre a forma de construir em Castanheiro do Vento e partilhar algumas ideias sobre as relações entre esse fazer arquitectura no sítio e a ideia de arquitecturar um espaço maior, um território. Se aceitarmos que construir é uma forma de estar no mundo, a arquitectura terá sempre conexões a esse mundo e consequentemente à sua organização. É importante ter em conta que durante a Pré-história recente, a paisagem do Alto Douro foi sendo alterada por parte de comunidades em processo de consolidação de um sistema agro-pastoril. Este processo de territorialização, levou a uma ocupação diversificada da paisagem. Alguns pontos dessa paisagem foram marcados através da construção de recintos murados, outros, quase que são invisíveis e ainda outros, que ocupam grandes marcadores naturais da paisagem.
\end{abstract}

Palavras-chave: Alto Douro, Pré-história Recente, Arquitectura, Arqueologia da Paisagem.

\begin{abstract}
Castanheiro do Vento is an archaeological site with an occupation that covers the entire 3rd millennium and the first half of the 2nd BC. It's located in the municipality of Vila Nova de Foz Côa, district of Guarda and has been investigated by a vast team. With this paper, we intend to present some reflections on how to build in Castanheiro do Vento and share some ideas on the relationship between doing architecture on the site and the idea of architecting a larger space, a territory. If we accept that building is a way of being in the world, architecture will always have connections to that world and consequently to its organization. It is important to bear in mind that during recent prehistory, the landscape of the Alto Douro was being changed by communities in the process of consolidating an agro-pastoral system. This territorialization process led to a diversified occupation of the landscape. Some points of this landscape were marked by the construction of walled enclosures, others, which are almost invisible and still others, which occupy great natural markers of the landscape.
\end{abstract}

Keywords: High Douro, Late Prehistory, architecture, Landscape Archaeology.

\section{INTRODUÇÃO}

O sítio arqueológico de Castanheiro do Vento (Horta do Douro, Vila Nova de Foz Côa, Guarda), foi identificado por António Sá Coixão em 1983, no âmbito de trabalhos de campo da Associação Cultural Desportiva e Recreativa de Freixo de Numão que, anos mais tarde, levaram à publicação da Carta Arqueológica de Vila Nova de Foz Côa (Coixão 1996). Dois anos depois, encontravam-se reunidas as condições para a apresentação de um projecto de investigação e para o início de intervenções arqueológicas (Cardoso 2012). Genericamente o sítio data do $3^{\circ}$ milénio a.C e primeira metade do $2^{\circ}$ milénio

1. Centro de Estudos de Arqueologia, Artes e Ciências do Património - Universidade de Coimbra / CEAACP - UC;

muralhacardoso@uc.pt 
a.C. As suas campanhas de escavação encontram-se praticamente todas publicadas (veja-se as duas últimas, Muralha, \& alii, 2019 e Muralha, Gomes e Jorge 2020) e muitas leituras do sítio têm sido realizadas (por exemplo, Vale 2011, Carneiro 2011, Cardoso 2010, Carvalho 2006, Jorge 2006) (Figura 1).

Este artigo pretende dar a conhecer algumas reflexões sobre a forma de construir em Castanheiro do Vento e partilhar algumas ideias sobre as relações entre fazer arquitectura no sítio e arquitecturar uma paisagem. Para isso, partimos das constantes acções construtivas ali detectadas, que vão conformando, alterando e mantendo o espaço para as acções que também vão acontecendo na paisagem. Existe uma conexão entre o sítio e a paisagem. A construção do recinto murado de Castanheiro do Vento e a sua constante reconfiguração, terá acontecido dentro de uma matriz de negociação, confronto, diálogo entre indivíduos, entre comunidades e o território que partilham. As comunidades estruturavam-se socialmente a fazer arquitectura ao mesmo tempo que se iam identificando com um território, onde existiam, se organizavam e consolidavam novos sistemas.

\section{ARQUITECTURA DO SÍTIO}

Ao longo dos anos, o processo de escavação em Castanheiro do Vento tem tido um conjunto de objectivos muito diversificados. Foi, desde o primeiro ano de trabalhos, uma escavação onde os alunos de arqueologia se familiarizavam com as técnicas e métodos do trabalho de campo. Foi também palco de reflexões individuais conducentes a trabalhos de investigação académicos de diversos graus (Barbosa 2003, Borges 2003, Vale 2003 e 2011, Cunha 2004, Gaspar 2004, Carvalho 2005, Costa 2007, Queirós 2007, Pinheiro 2008 e Cardoso 2010) mas acima de tudo foi um espaço de diálogo, de trabalho em equipa e de liberdade. A riqueza arqueológica do sítio, levou a equipa de coordenação a pensar sobre assuntos diferentes e a ter liberdade individual para procurar outras abordagens, para reflectir sobre outros assuntos. No entanto a questão das técnicas construtivas e dos materiais de construção, sempre esteve presente. A interacção constante com o sítio e o diálogo sistemático que uma escavação representa, levou o autor deste texto, a partir dos materiais e técnicas que conformam aquele lugar, a pensar em espaços e na sua organização.
O trabalho de campo é um processo constante de reflexão. Quando escavamos, definimos espaços, fotografamos e desenhamos áreas com estruturas e vazios, intervimos num espaço onde contemplamos vestígios de arquitectura, damos sentidos e significados a esse espaço, a essa arquitectura, tornando parte do processo arqueológico de Castanheiro do Vento uma reflexão, precisamente sobre arquitectura.

A construção que se apõe a uma determinada área, é o primeiro passo para transformar essa área em lugar. Emerge uma ideia; a construção/conformação de um espaço, o fazer arquitectura é um processo de transformação de um espaço em lugar, e essa transformação possui um carácter prático, para estas comunidades. Não existe um plano prévio, uma planta pensada, onde todas as áreas de um sítio estejam planeadas, compartimentadas e ocupadas (Cardoso 2010:291, McFadyen 2013:138). A arquitectura, neste contexto preciso, tem de ser olhada e pensada como saber e não como disciplina. É um saber prático, a construção surge pela experiência, "(...) o discurso arquitectónico é gerado através de um envolvimento prático com o ambiente e funciona através de uma rede complexa de acções." (Cardoso 2010:291). Olhemos então para a arquitectura enquanto acção. Aquilo que hoje se nos apresenta, em Castanheiro do Vento, são imagens de acção, de uma acção colectiva, comunitária. De uma acção, provavelmente negociada e representativa das negociações intersubjectivas da comunidade. São imagens que nos propõe uma arquitectura da liberdade, da política, aqui entendida como uma negociação social, interactiva e relacional destas comunidades.

É neste sentido que queremos destacar a habilidade técnica, o gesto técnico e as técnicas de configuração como um saber, e torno a referir, no contexto preciso destas comunidades, como um saber fazendo (Ingold 200o). Este saber fazer remete-nos para actos construtivos, para acções de conformação do sítio, mas acções inseridas num processo contínuo de vivências no local e não inseridas em dinâmicas construtivas. Acções que pertencem a uma matriz social e relacional dessas comunidades. A construção/ conformação do sítio são noções operatórias que ajudam ao processo construtivo da sua identidade social. O acto de elaborar, configurar, manter um espaço torna-se uma actividade recorrente, tanto no tempo como no espaço do sítio e constitui-se como um processo de entrelaçamento das relações sociais daquelas comunidades. A definição opera- 
tiva de arquitectura neste texto é a sua capacidade de interpretar a realidade, o contexto social em que é praticada e o texto que nos pode dar a ler. Negá-la enquanto disciplina, reafirmo no contexto deste trabalho, não pressupõe negar a sua especificidade, a sua criatividade e os momentos de síntese e de projecto. Estes são momentos de uma concepção de arquitectura mais recente.

A arquitectura em Castanheiro do Vento, como criadora de novos e diferentes espaços, não pode ser entendida como estanque. Tomando Heidegger como inspiração (2005:102,109), podemos dizer que o sítio não foi construído para ser habitado, o sítio é habitado porque vai sendo construído. A escavação revela-nos uma constante imbricação de estruturas e de espaços abertos, de modificações e alterações, de materiais construtivos (pedra, terra, madeira) e outros materiais (fragmentos de cerâmica, restos de moinhos, ossos de animais), que tem de ser interpretados como contextos construtivos que terão uma leitura social daquelas comunidades (Cardoso 2010, Vale 2011).

Ao longo dos anos temos conseguido identificar as características principais da forma de construir em Castanheiro do Vento. A primeira característica é ser uma arquitectura modular (Cardoso 2010). A acção construtiva baseia-se em módulos, pelo menos nas grandes linhas que definem o sítio; as quatro linhas de murete. Estes módulos que vistos em conjunto, se assemelham a diagramas permitem uma delineação estrutural do sítio, que em última análise, nunca termina. O tipo de acção construtiva em Castanheiro do Vento não objectiva um resultado, (uma obra construída e terminada), mas sim, resultados contínuos, pois a modulação arquitectónica permite alterações constantes, sem alterar significativamente as estruturas anexas à alteração que se pretende fazer. É interessante notar que o arquitecto catalão, Josep Maria Montaner, refere-se aos diagramas em arquitectura como (...) depósitos dinâmicos de experiências, percepções e intenções" (2017:62). A construção modular em Castanheiro do Vento parece consubstanciar esta ideia. A possibilidade de poder alterar pontualmente o desenho construtivo, deveria acontecer num contexto de intenções comunitárias. O trabalho desenvolvido, os materiais escolhidos, as deposições associadas, como veremos a seguir, seriam acções construtivas plenas de experiências e percepções que construiriam e promoviam a identidade colectiva daquela comunidade (Figura 2).
A segunda característica é ser uma arquitectura de acrescentos. Acrescentos que redefinem espaços, estreitam passagens, ocluem e incorporam estruturas. Tanto a arquitectura modular, como a de acrescentos existem através de diferentes formas de prática e, provavelmente em momentos específicos de tempo. Teremos de admitir que este sítio vai-se construindo, alterando, reformulando de uma forma mais ou menos contínua. Claro que existiram momentos de não construção, momentos de manutenção do lugar, de vivência mais efémera. Mas esta acção construtiva mais ou menos constante em Castanheiro do Vento, incorpora o sítio no processo histórico e identitário destas comunidades (Figura 3).

A terceira característica desta arquitectura parece acentuar esta última ideia; a utilização de materiais e/ou fragmentos de materiais em deposições estruturadas. Ana Vale tem estado atenta a esta situação (Vale 2019). O seu trabalho sobre deposições detectadas em Castanheiro do Vento e a sua relação à arquitectura do sítio oferece-nos um conjunto de observações interessantes. Como exemplo; o caso da deposição encontrada no interior do murete 1 , composta por um fragmento de peso tear e elementos em granito, remete estes elementos para a própria construção do murete. A combinação do granito e da argila com o xisto parece invocar os próprios materiais com que o sítio é feito. Estes elementos, integrados no murete, tornam-se constituintes da própria estrutura, são tanto materiais construtivos, como elementos arquitectónicos. A arquitectura, desta forma, também é deposição e os fragmentos de peças depositados são elementos construtivos, na medida em que organizam, fazem, constituem espaço (Figura 4).

O trabalho no sítio é tão importante como a vivência no local. Aliás, muito provavelmente esta diferença entre estar a viver no sítio e estar a construir o sítio, não existia. O próprio acto de construir é um acto de habitar (Heidegger 2005:109). Teremos de admitir que a construção e a estruturação deste sítio nunca foi um projecto terminado, mas sim um processo em constante configuração. Esta forma de habitar o sítio remete-nos para a ideia de que todo ele é, na sua constante elaboração, um local de tensões sociais dinâmicas. O movimento construtivo que engloba uma conformação modular, acrescentos e deposições estruturadas é um movimento inerente a toda uma comunidade. Um movimento relacional de cariz social que incorpora a elaboração do sítio, 
contrário a um movimento apenas técnico, juntar materiais e construir. Esta conformação de um espaço, acontece no tempo longo. A sua elaboração é um processo social, é uma acção de configuração das relações de sociabilidade. O tempo de construção é um tempo de corporização das próprias normas sociais destas comunidades. Esta relação constante entre pessoas, materiais e espaços, torna a arquitectura de Castanheiro do Vento estruturante de um processo social, desta forma, o sítio nunca foi um objecto terminado, da mesma forma que as relações sociais entre pessoas e entre comunidades nunca cristaliza. A escavação tem demonstrado que o processo de juntar os vários elementos configurativos do sítio parece ser um processo persistente, onde a acção é constante. Assim, a arquitectura compreende todas as acções relacionadas à prática do saber fazer. Considerando esta reflexão, ressalta aqui uma observação importante: Compartimentamos e reduzimos a história da arquitectura pré-histórica, a fases de construção, a momentos de abandono, ao fecho e abertura de estruturas. Tendemos a olhar para as fases construtivas de um sítio e pouco para o acto de construir/fazer arquitectura.

É importante olhar para estas arquitecturas (não só Castanheiro do Vento, mas também Castelo Velho de Freixo de Numão) como um espaço de interacção e interrelações dinâmicas e não apenas, como um contentor delineado por superfícies materiais (estruturas circulares, "bastiões", muretes). O espaço é fundamentalmente social e ao estudarmos formas de organização daqueles espaços, estudamos as formas de agir, relacionar e comunicar destas comunidades. As experiências arquitectónicas são acções, não objectos. Articulam relações humanas, materializam e solidificam uma ordem social e identitária. São espaços vividos. "Architectural space is lived spaced rather than physical space, and lived space always transcends geometry and measurability." (Juhani Pallasmaa 2012:68)

Esta arquitectura, além da sua dimensão técnica e temporal, possui uma dimensão social; a transformação de sítios em lugares com significado na paisagem. As práticas do fazer são acções que fazem parte de um processo de estar no mundo. E este estar no mundo acontece não só no sítio, como na paisagem. Ao longo do $3^{\circ}$ milénio a.C. esta paisagem vai sendo marcada por comunidades com grande mobilidade e em processo de consolidação do sistema agro-pastoril. Esta mobilidade e o processo de territo- rialização que está a acontecer, permitem-nos falar da ideia de arquitecturar um espaço, um território, uma paisagem.

\section{A ARQUITECTURA DA PAISAGEM}

Neste momento torna-se importante deixar de ver apenas o sítio e passar a olhar o mundo, onde o sítio também é. Castanheiro do Vento faz parte da paisagem que o envolve assim como essa paisagem também faz parte de Castanheiro do Vento.

Não só os materiais construtivos estão no sítio (própria pedreira de xisto, veios de quartzo) ou à sua volta (barreiros e nascentes), como as acções construtivas atribuem ao lugar uma certa monumentalidade, tornando a própria colina um lugar monumental (Jorge 2006, Cardoso 2010, Vale 2011) (Figura 5).

Este conceito de colina monumental, pensado por Vítor Jorge, facilmente nos transporta para a ideia de que o próprio sítio poderá ter-se constituído como um dispositivo cénico e plástico, porque ao mesmo tempo que é trabalhado, construído, mantido pela comunidade é também um elemento perdurável na paisagem. É um lugar que fixa as memórias colectivas das comunidades, dando-lhes um sentido de identidade. A sua implantação relembra, transmite e recria a ideia de identidade e organiza a matriz social destas sociedades ainda muito segmentárias.

Torna-se importante neste momento, inserir Castanheiro do Vento no contexto da paisagem e tentar perceber a sua relação com outros sítios arqueológicos. Em trabalhos anteriores $(2010,2017)$ ensaiamos leituras de relações visuais entre Castanheiro do Vento e outros locais. As observações foram interessantes, mas tivemos sempre de adicionar outros parâmetros de estudo para que as conclusões se tornassem mais significativas do que uma cartografia de bacias de visão. Os trabalhos sobre visibilidades e intervisibilidades são importantes, mas têm que ser enquadrados a vários planos; as suas visibilidades imediatas, as conectividades visuais mais longínquas e a própria linha de horizonte que daquele ponto preciso, encerra o mundo. Esta cartografia de visibilidades permite-nos vários níveis de reflexão: colocam na paisagem lugares de observação, dinâmicos e móveis consoante a nossa própria deslocação; colocam no terreno linhas de mobilidade que ao serem percorridas implantam na paisagem nós de passagem sucessivos, e por último, a própria mobilidade coloca na paisagem várias dimensões exis- 
tenciais daquelas comunidades. O conjunto destes níveis de reflexão, transformam este espaço em paisagem vivida, habitada.

O exemplo do sítio arqueológico da Quinta de Alfarela é paradigmático. É um lugar voltado ao rio Douro, perto da foz do rio Sabor. A sua posição visual estratégica é evidente, o sítio "controla" as linhas de água e a fértil várzea da Vilariça. No entanto, a implantação deste lugar e as suas linhas de horizonte e de visibilidade, remetem-no para outros sítios como Senhora do Viso, Castelo de Numão e mesmo Castanheiro do Vento, localizados a mais de $20 \mathrm{~km}$ de distância (Figura 6).

O trabalho publicado em 2010 e continuado mais tarde (2017), chamava a atenção para a importância da mobilidade nestas comunidades e de como esse andar ligava todos os espaços e religava a própria estruturação daquelas comunidades. Neste caso, podemos dar como exemplo o objecto principal deste artigo; o sítio de Castanheiro do Vento. Está geomorfologicamente implantado num grande cabeço oblongo voltado à ribeira da Teja, com grande domínio visual sobre a sua várzea. Tem uma amplitude de horizonte para Sul até à Serra da Marofa e aos grandes batólitos graníticos do Souto. A Norte, olha toda uma vasta área entre as Serras de Ansiães e a Serra do Reboredo, já no distrito de Bragança. Tem uma excelente intervisibilidade com vários sítios arqueológicos a dois níveis. Um primeiro, onde existem sítios que se observam nos planos de paisagem imediatos (Senhora do Viso, Zaralhôa, Raza I e II, Castelo de Numão, São Martinho e Santa Eufémia), e um segundo nível onde os sítios existem num horizonte quase imperceptível (Castelo Velho de Freixo de Numão, Santa Columba, São Jurges e Castelo Velho do Souto). Um outro aspecto importante neste contexto geográfico e geomorfológico é a presença próxima de dois grandes marcadores paisagísticos, duas especificidades geomorfológicas; a Senhora do Viso que polariza imediatamente Castanheiro do Vento a Norte, truncando mesmo a sua visibilidade para nordeste, mas ao mesmo acentuando o sítio arqueológico e São Martinho a nordeste, grande crista quartzítica implantada entre duas colinas, a cota mais baixa, não truncando qualquer visibilidade, mas impondo-se na paisagem e congregando em seu redor, um conjunto de sítios arqueológicos, muitos deles partilhados com o campo de visão de Castanheiro do Vento. Castanheiro do Vento torna-se assim, visível de todos os lados. Esta afirmação não pressupõe que consideremos aquela estação arqueológica como um "lugar central", pois embora seja efectivamente um lugar importante, a sua centralidade é inexistente. A paisagem existe em seu redor, como existe em redor dos outros sítios, com características específicas e diferenciadas. A ideia interessante relacionada a esta imagem de (inter)visibilidades de Castanheiro do Vento, parece ser a ideia da apreensão de uma paisagem. Os construtores daquele sítio percepcionam o mundo incorporando a percepção do lugar onde se está, onde se habita. Não existe um lugar central, um lugar de habitação, um lugar de caça, um lugar de arte, existe um processo constante de integração de uma comunidade numa paisagem e em todas as suas acções. É evidente que cada um daqueles sítios, para aquelas comunidades, é olhado e tratado de forma diferente, mas ao longo do $3^{\circ}$ milénio a.C. e, provavelmente, também ao longo da primeira metade do $2^{\circ}$ milénio a.C., a relação do homem com a paisagem é dispersa, acontecendo em muitos lugares. Não está fixa, presa. O homem vai conhecendo o mundo continuamente através da sua mobilidade, através do tempo de movimento. É um tempo importante pois é um tempo em que estas comunidades estão a consolidar o seu sistema agro-pastoril. É um tempo onde a paisagem vai sendo alterada e as próprias comunidades se vão alterando. Existe uma paisagem que se vai transformando em território. Este processo de territorialização, levou a uma ocupação diversificada da paisagem, onde Castanheiro do Vento como recinto murado, São Martinho como especificidade geomorfológica com ocupação, os sítios da Raza como locais sem delimitações estruturais, são actores constantes, importantes e centrais neste processo, onde cada um teve o seu papel (Figura 7).

Hoje dispomos de uma cartografia de sítios (Coixão 1996; Aubry, Carvalho e Zilhão 1997; Coixão, Cruz e Simão 2009; Cardoso 2010) que nos permite pensar as várias dinâmicas de povoamento que terão acontecido durante esse processo. A diversidade de sítios e a variabilidade de implantações é uma característica; a paisagem foi marcada pela construção de recintos murados, todos implantados em locais proeminentes; pela ocupação de marcadores naturais da paisagem (visíveis a grandes distâncias), mas também por sítios quase invisíveis e por outros sem estruturas delimitativas (Cardoso 2010 e 2019). Temos de perceber os sítios como lugares historicamente constituídos. A escolha de um sítio não é 
um acto isolado, é acima de tudo, um acontecimento social que acontece numa paisagem cheia de significados, de referências a usos antigos desse lugar. A ocupação de um território deverá estar intimamente ligada à biografia dos indivíduos e dos grupos. Essas biografias são feitas de redes de relações e acontecimentos que são inseparáveis dos lugares experienciados, são inseparáveis de uma sequência temporal, constituindo narrativas da identidade humana, constituindo biografias. Os lugares ocupados, são-no com especificidades próprias: um abrigo rochoso, uma parede de xisto com pinturas, uma várzea, um cerro, um pico quartzítico, todos estão integrados numa rede de relações humanas que se estendem tanto no espaço, como no tempo.

Os sítios que emergem desses lugares, através da construção, têm diferentes papéis, diferentes significados. Os recintos murados, implantados em lugares proeminentes estão directamente associados ao processo de consolidação do sistema agro-pastoril, a uma ideia de identidade comunitária e territorial. A sua relação com a paisagem é única, pois não só a sua implantação parece encaminhar o sítio para pontos específicos da paisagem, como vimos anteriormente, como vai configurando várias percepções do território e das estratégias da sua transformação.

Os sítios implantados em características marcantes da geomorfologia, ou como temos vindo a denominá-los de especificidades geomorfológicas, como cristas quartzíticas, batólitos graníticos, grandes elevações integradas em cadeias montanhosas, acentuam o papel identitário da comunidade com um território. Não podemos olhar para estes sítios como "centros" de um território ou como "fronteiras", mas sim como elementos que polarizam a(s) comunidade(s) e as integram numa paisagem. Estas características são pontos nas linhas de horizonte de quase todos os outros lugares. São marcadores, que independentemente do coberto vegetal, são visíveis e que apesar da sua cota elevada ou imponência na paisagem, têm percursos que atingem o seu topo e permitem uma aproximação visual a toda uma paisagem que ao longo do $3^{\circ}$ milénio a.C. começa a ser sentida como pertença das comunidades (Figura 8). Pensamos no monte de São Gabriel e a sua relação com o Vale do Côa. As pinturas esquemáticas aqui encontradas completamente voltadas ao extenso planalto de Algodres e ao vale do Côa (Baptista e Reis 2009:19o, Reis 2012:42), assim como os achados dispersos de cerâmicas encontradas no sopé desta crista quartzítica, remetem-nos para uma "arquitectura do território" baseada na mobilidade destas comunidades. Um território vivido, habitado e percepcionado pelo homem. Os sítios não podem ser interpretados como lugares fixos, contidos na paisagem. São lugares que têm de ser pensados através de um contexto relacional de compromisso com essa paisagem. A arquitectura de um território surge como um processo dialógico, negociado, constitutivo de comunidades que viviam, movimentavam-se e se estruturavam a si próprias ao mesmo tempo que organizavam o "seu" território. "Seu" enquanto habitado, percorrido, vivido.

E os outros sítios (Cardoso 2010, 2017, 2019), sem delimitações estruturais, como muretes, abrigos de rocha ou mesmo características físicas da geomorfologia? O trabalho de campo diz-nos que todos estão relacionados com as especificidades geomorfológicas, ou directamente no seu sopé, ou nas proximidades, ou na sua linha de horizonte. Muitos têm uma visibilidade ampla, mas ao mesmo tempo truncada (estão direccionados) e outros caracterizam-se por estarem próximos a grandes vales abertos e várzeas. Neste momento existe um projecto de investigação em campo que objectiva intervenções arqueológicas neste tipo de sítios. É necessário escavá-los para percebermos os seus elementos configurativos, as suas arquitecturas, as suas materialidades e começarmos a problematizar e a reflectir em conjunto. O projecto, aprovado pela tutela, denomina-se Uma investigação sobre a Pré-história Recente do Vale do Côa. Dinâmicas de uso e ocupação do território, coordenado pelo signatário deste texto, com Mário Reis, António Batarda e Carla Magalhães, do CEAACP e Fundação Côa Parque.

\section{CONSIDERAÇÕES FINAIS}

Ao longo deste texto temos vindo a falar da forma como a arquitectura de um sítio arqueológico, neste caso do recinto murado de Castanheiro do Vento, possui um papel identitário, sedimentando ao mesmo tempo, e através de processos de construção, reconfiguração, manutenção, de negociações e procura de consensos, um sentido de pertença a uma paisagem. Este diálogo constante entre pessoas, lugares e arquitectura faz parte do processo histórico de consolidação do sistema agro-pastoril. O número de recintos e de sítios arqueológicos nesta área, tem de ser entendido num contexto de reconfigu- 
ração das relações entre comunidades e territórios. A estruturação desse território, não existe apenas por existirem sítios, existe pelas mobilidades, pela diversidade dos vários lugares e a variabilidade das suas implantações. Existe por tudo isto e pelo próprio contexto histórico daquelas comunidades. A paisagem vai-se tornando um imbricado de acções, torna-se um contexto intrínseco ao habitar. Os sítios arqueológicos são parte integrante deste contexto, sítios com significantes diferentes que constituem uma imagem das sociabilidades dessas comunidades. Nesta perspectiva os sítios arqueológicos são lugares de acções humanas, integrados num complexo entrelaçado de outros lugares e espaços entre eles: a arquitectura de um território. O estudo desta dinâmica é o estudo das marcas na paisagem do processo de consolidação do sistema agro-pastoril. Percebemos que este processo de territorialização levou a uma ocupação diversificada da paisagem, onde a existência de vários e diferentes sítios com diferentes arquitecturas vão sedimentando um território. O estudo deve ser pensado no tempo longo. Os sítios não correspondem apenas a determinadas categorias, nem á forma como uma comunidade habita uma região. Os sítios são também exemplos de percepção de um território experiencial em oposição a um espaço cartesiano. A percepção humana da paisagem tem de ser um dado de estudo importante para se perceber o tipo de relações espaciais aí existentes. Neste contexto, os sítios/lugares de ocupação não devem ser conceptualizados como locais fechados, encerrados sobre a sua "cultura material", protegendo a sua população do exterior "selvagem". Os lugares fazem parte de uma imensa paisagem, fluída e social, onde os caminhos, as características topográficas, os homens, os animais detêm um papel significante na criação cultural.

O recinto murado de Castanheiro do Vento, a par de outros recintos, marca a paisagem da pré-história recente deste território. Percebemos que a sua arquitectura, a monumentalidade, a especificidade da sua implantação, parecem transformá-lo num dispositivo de âmbito social; a sua conformação depende de dinâmicas identitárias e de negociações intercomunitárias. O estudo da arquitectura em Castanheiro do Vento permite-nos reflectir sobre a dimensão social e temporal dos espaços, das materialidades, e das acções que aconteceram. Percebemos, assim, um sentido de pertença e sentido de território. A dinâmica de construção do sítio; o fazer arquitectura, é uma dinâmica que também encontramos no estudo da paisagem. A mobilidade e a diversidade de sítios, são uma forma de arquitecturar um espaço, um território. São uma impressão dos processos de territorialização e de consolidação do sistema agro-pastoril.

\section{BIBLIOGRAFIA}

AUBRY, Thierry; CARVALHO, António Faustino e ZILHÃO, João (1997) - Arqueologia. In Arte Rupestre e Pré-história do Vale do Côa, Trabalhos de 1995-1996, Lisboa, Ministério da Cultura.

BAPTISTA, António Martinho; REIS, Mário (2009) - Prospecção da Arte rupestre no Vale do Côa e Alto Douro Português: ponto da situação em Julho de 2006. In BEHRMANN, Balbín (ed.) Actas do colóquio "Arte Prehistórico al Aire Libre en el Sur de Europa. Salamanca (15 a 17 de Junho de 2006). Junta de Castilla y Léon, pp. 145-192.

BARBOSA, Rui Mendes (2003) - A estrutura C de Castanheiro do Vento, Análise dos materiais cerâmicos e líticos. Relatório de Seminário de Projecto da licenciatura em Arqueologia apresentada à FLUP. Edição electrónica.

BORGES, Nelson (2003) - A estrutura B de Castanheiro do Vento, Vila Nova de Foz Côa. Relatório de Seminário de Projecto da licenciatura em Arqueologia apresentada à FLUP. Edição policopiada.

CARDOSO, João Muralha (2010) - Castanheiro do Vento (Horta do Douro, Vila Nova de Foz Côa) Um recinto monumental do $3^{\circ}$ e $2^{\circ}$ milénio a.C. Problemática do Sítio e das suas Estruturas à Escala Regional, Palma de Maiorca, Vessants, arqueologia i cultura.

CARDOSO, João Muralha (2012) - Castanheiro do Vento: Uma historiografia de percursos interpretativos. In Sanches, M., Cunha-Ribeiro, J.P. e Monteiro-Rodrigues, S. (eds). Discursos em Arqueologia. Textos oferecidos ao Professor Vitor Oliveira Jorge. Coimbra-Porto. CEAUCP, pp. 67-94.

CARDOSO, João Muralha (2017) - Let's walk in the wild side! Comparing sites in the Landscape. In Ana Vale, Joana Alves-Ferreira, Irene Garcia-Rovira (eds), Rethinking Comparison in Archaeology, Newcastle: Cambridge Scholars Publishing, pp. 108-128.

CARDOSO, João Muralha (2019) - Castelo Velho de Freixo de Numão. Um sítio, uma paisagem. In. Susana Soares Lopes (ed). Olhares sobre Castelo Velho de Freixo de Numão: Revisitar um Recinto Pré-histórico do Alto Douro Português, DigitAR, 1, Coimbra, Imprensa da Universidade de Coimbra, pp. 51-94.

CARNEIRO, Ângela (2011) - As cerâmicas do terceiro e segundo milénio a.C. de Castanheiro do Vento (Horta do Douro, Vila Nova de Foz Côa). In Actas do V Congresso de Arqueologia Interior Norte e Centro de Portugal, Porto, Caleidoscópio, DRC-N. pp. 187-218. 
CARVALHO, Bárbara (2005) - O Desenho na Escavação de Castanheiro do Vento (Vila Nova de Foz Côa). Relatório de Seminário de Projecto Licenciatura em Arqueologia, apresentado à FLUP, Porto. Edição policopiada.

COIXÃO, António Sá (1996) - Carta Arqueológica do Concelho de Vila Nova de Foz Côa, Vila Nova de Foz Côa, Câmara Municipal de Vila Nova de Foz Côa.

COIXÃO, António Sá; CRUZ, Simão (2009) - Carta Arqueológica do Concelho de Mêda, Coimbra, Câmara Municipal de Mêda.

COSTA, Cláudia (2007) - Zooarqueologia e tafonomia de Castanheiro do Vento. Dissertação de mestrado apresentada à Faculdade de Ciências Humanas da Universidade do Algarve. Edição policopiada.

CUNHA, Gustavo (2004) - Contributo para o conhecimento das técnicas de construção de Castanheiro do Vento (Horta do Douro, Vila Nova de Foz Côa). Relatório de Seminário de Projecto da licenciatura em Arqueologia apresentada à FLUP. Edição electrónica.

GASPAR, Clara (2004) - Um Espaço Específico de Castanheiro do Vento (Vila Nova de Foz Côa). A Estrutura D - Materiais e Ocupação. Relatório de Seminário de Projecto da licenciatura em Arqueologia apresentada à FLUP. Edição electrónica.

HEIDEGGER, Martin (2005) - Building, Dwelling, Thinking. In Neil Leach (ed.) Rethinking Architecture, a reader in Cultural Theory. Routledge, New York, pp. 100-108.

INGOLD, Tim (200o) - The Perception of the Environment, Essays in livelihood, dwelling and skill, Londres, Routledge.

JORGE, Vítor (2006) - Breve reflexão sobre alguns problemas das Arquitecturas Pré-históricas. In Actas da 10. Mesa-Redonda da Primavera, TERRA: Forma de Construir, Arquitectura-Antropologia-Arqueologia, Lisboa-Vila Nova de Cerveira, Argumentum, Escola Superior Galaecia, pp. 106-111.

McFADYEN, Lesley (2013) - Designing with living - a contextual archaeology of dependent architecture. In A. Alberti, A. Jones and J. Pollard, J., Archaeology after Interpretation. Walnut Creek: Left Coast Press, 135-150.

MONTANER, Josep Maria (2017). Do diagrama às experiências, rumo a uma arquitectura de ação. São Paulo. Gustavo Gili.

MURALHA, João; GOMES, Sérgio; VALE, Ana e JORGE, Vítor (2019) - "Relatório dos trabalhos arqueológicos em Castanheiro do Vento/2018”, Côavisão. Cultura e Ciência, 21, 39-47.

MURALHA, João, GOMES, Sérgio e JORGE, Vítor (2020) - “A Intervenção Arqueológica de 2019 em Castanheiro do Vento”, Côavisão. Cultura e Ciência, 22, 155-162.
PALLASMAA, Juhanni (2012) - The Eyes of the Skin. Architecture and Senses. Chichester. John Willey and Sons Ltd Publications, $3^{\text {rd }}$ Edition.

PINHEIRO, Rui (2008) - Cerâmica do Bastião I de Castanheiro do Vento. Palma de Maiorca, Vessants, Arqueologia i Cultura.

QUEIRÓS, Adélia (2007) - Contributos para o estudo da estrutura sub-circular $n^{\circ} 3$ do sítio pré-histórico de Castanheiro do Vento (Horta do Douro, Vila Nova de Foz Côa). Relatório de Seminário de Projecto da licenciatura em Arqueologia apresentada à FLUP. Edição electrónica.

REIS, Mário (2012) - Mil Rochas e tal!: Inventário dos Sítios da Arte Rupestre do Vale do Côa. Portugália, Nova Série, vol. 33, Porto, DCTP-FLUP, pp. 5-72.

VALE, Ana (2003) - Castanheiro do Vento (Horta do Douro, Vila Nova de Foz Côa) Contributo para o Estudo dos Resultados das Primeiras Campanhas de Trabalho 1998-20oo. Dissertação de mestrado, Faculdade de Letras da Universidade do Porto. Edição policopiada.

VAlE, Ana (2011) - Modalidades de Produção de Espaços no Contexto de uma Colina Monumentalizada: o sítio pré-histórico de Castanheiro do Vento, em Vila Nova de Foz Côa. Dissertação de doutoramento, Faculdade de Letras da Universidade do Porto. Edição policopiada.

VALE, Ana (2019) - Depositions, Assemblages and relationships in Portugues Late Prehistory. In Valera (ed.) Fragmentation and Depositions in Pre and Proto-Historic Portugal. The Case of the Walled Enclosure of Castanheiro do Vento. Lisboa, Núcleo de Investigação Arqueológica (NIA) Era Arqueologia, pp. 31-46. 


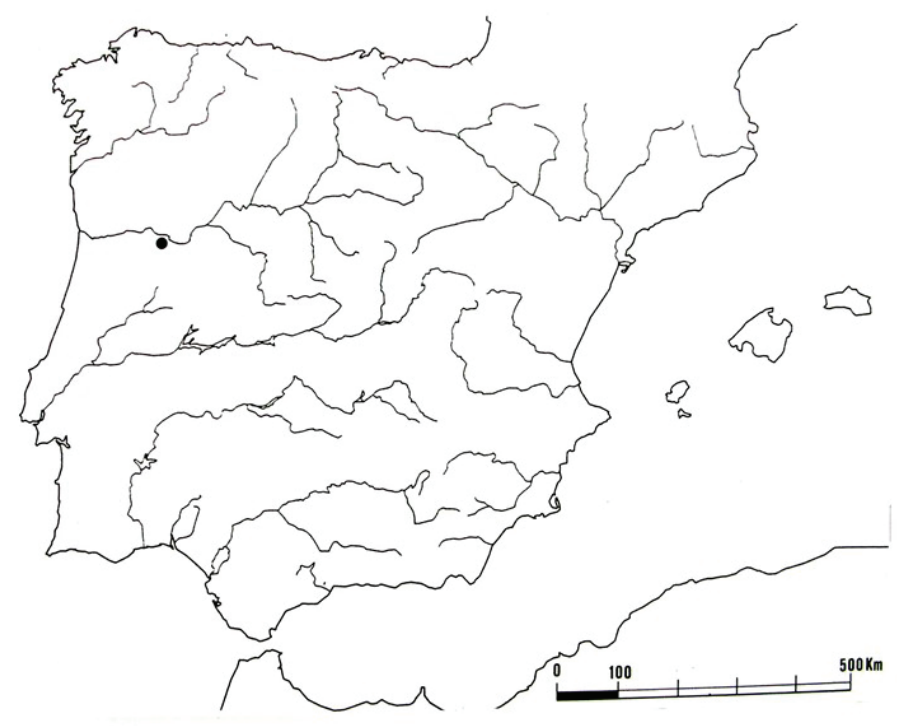

Figura 1 - Localização de Castanheiro do Vento no contexto da Península Ibérica.

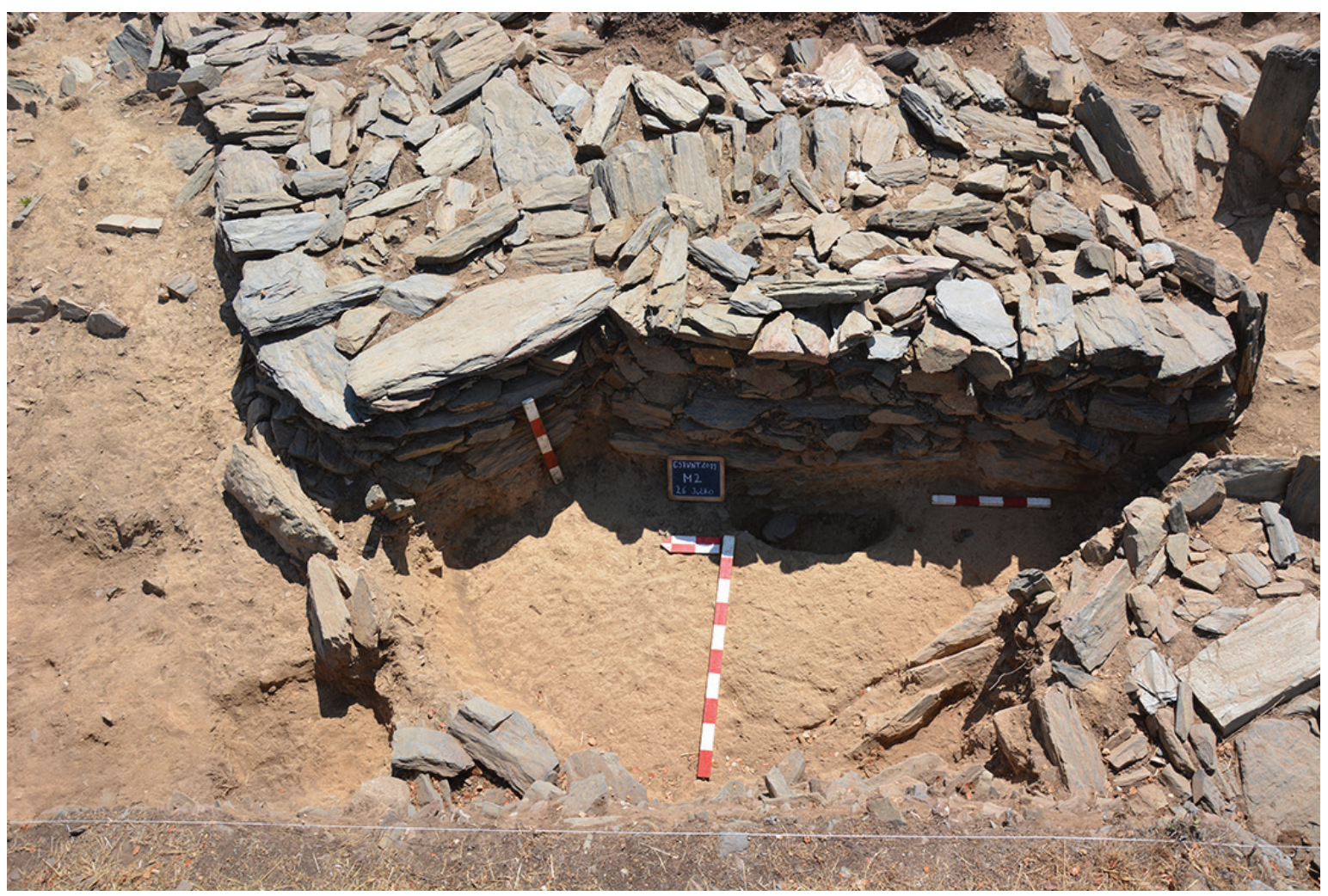

Figura 2 - Exemplo da arquitectura modular em Castanheiro do Vento. A área Sul do Bastião L encosta perfeitamente no troço de murete. 


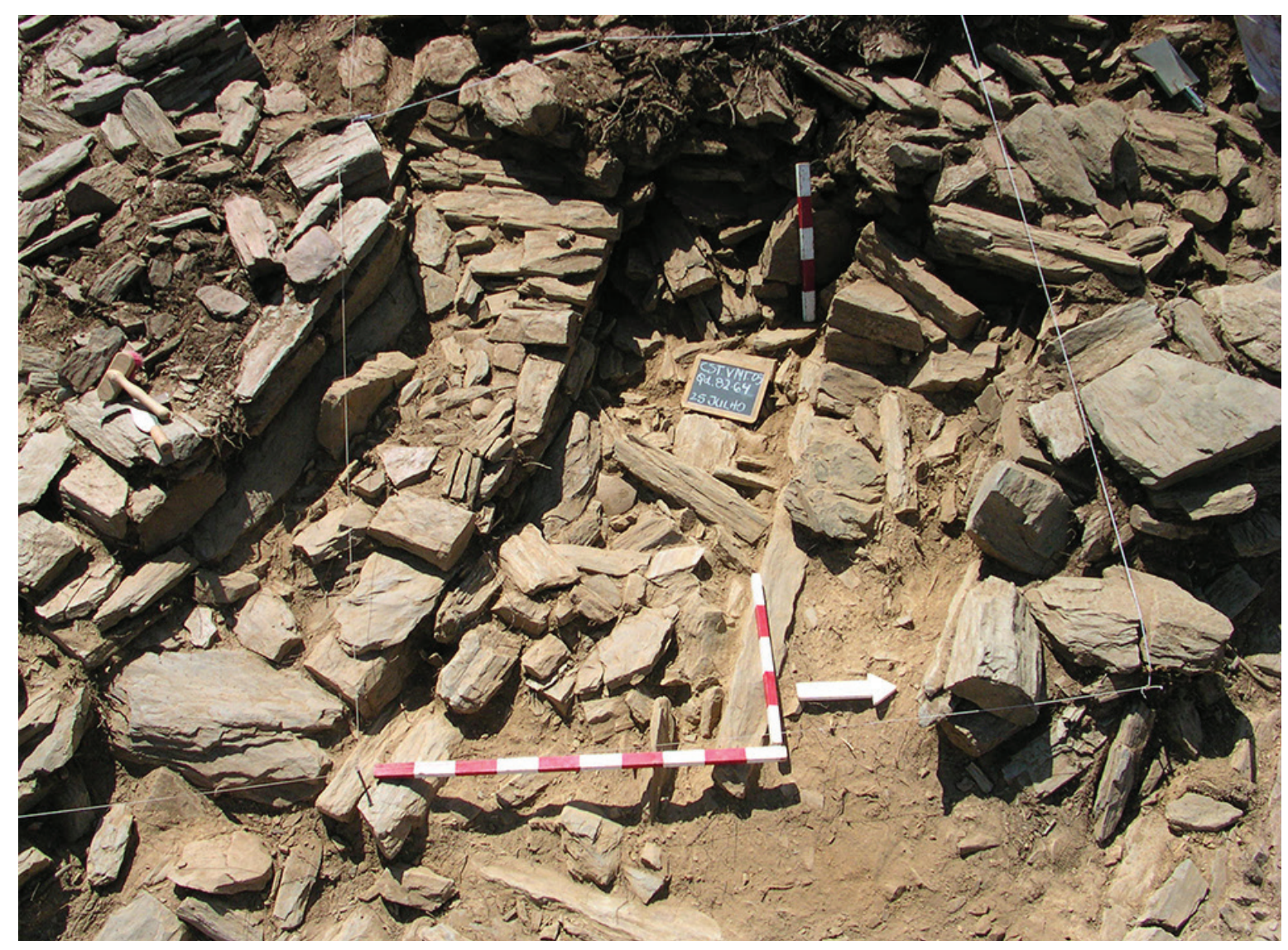

Figura 3 - Exemplo da arquitectura de acrescentos em Castanheiro do Vento, neste caso um estreitamento da passagem 5 , localizada no recinto anexo.

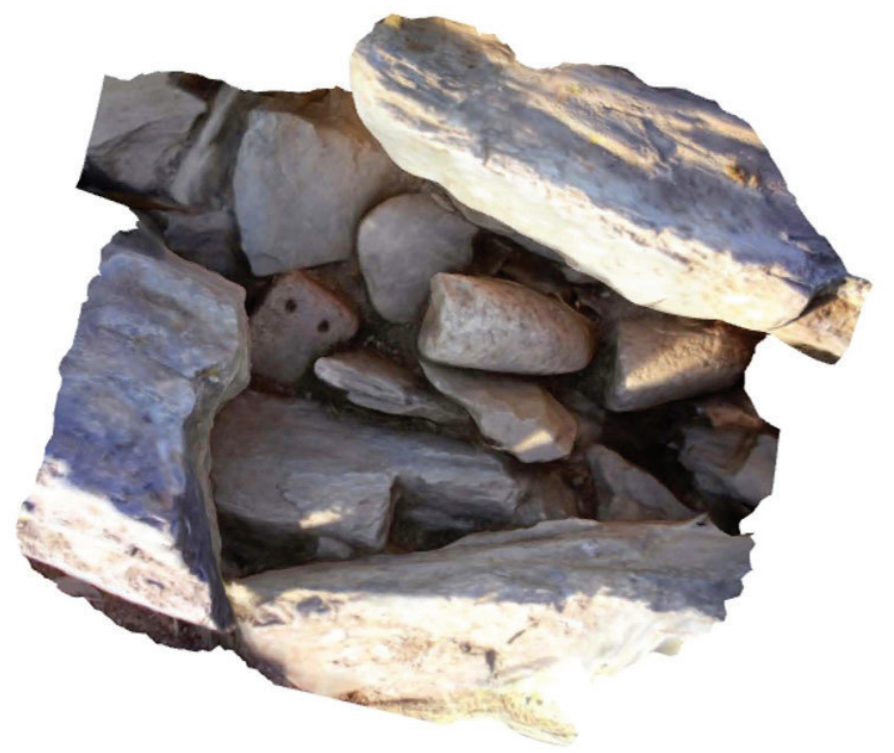

Figura 4 - Exemplo de uma deposição; um fragmento de um peso de tear e de um fragmento de um movente em granito no interior do murete 1. 


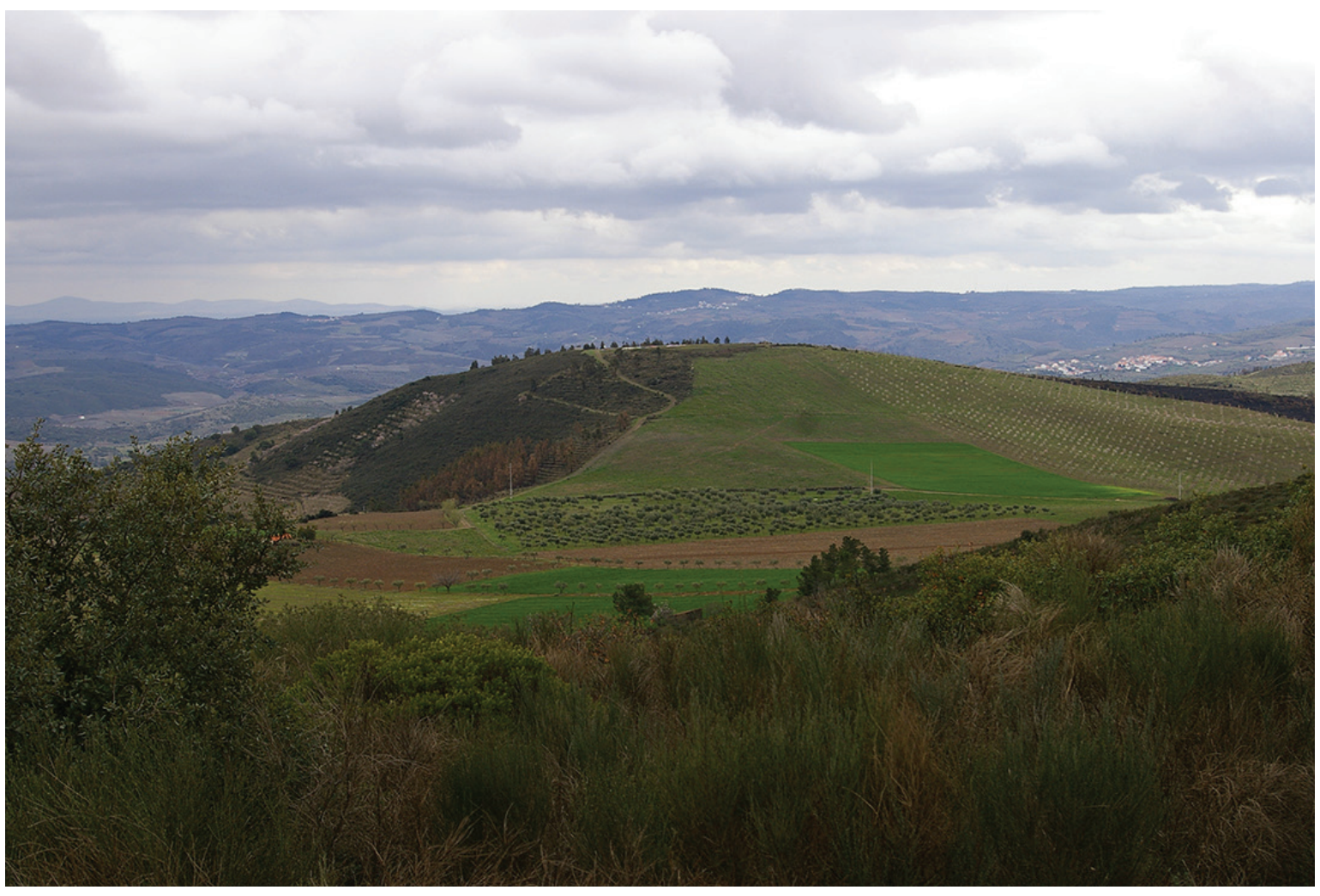

Figura 5- Castanheiro do Vento visto de Norte.

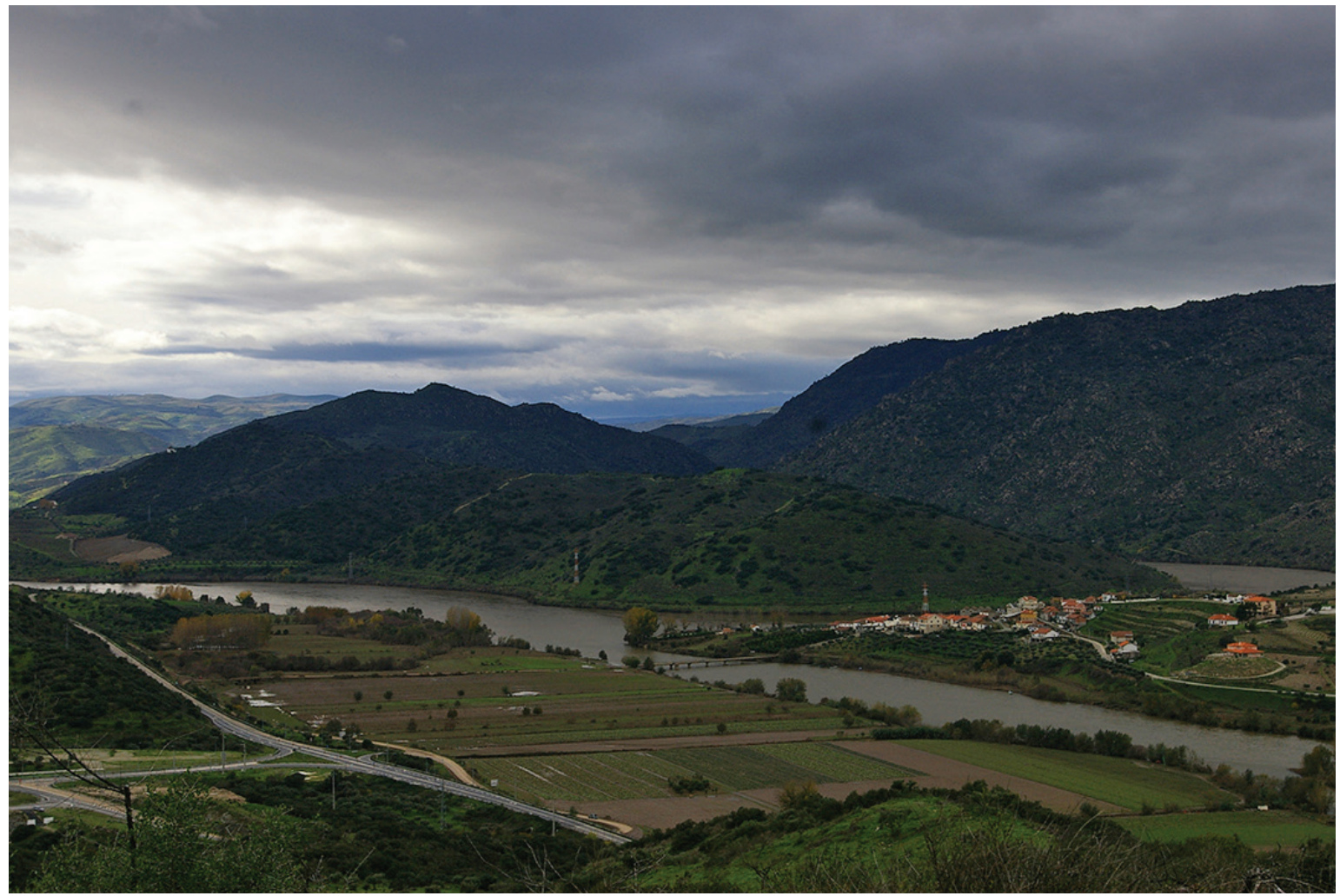

Figura 6 - Ao centro da imagem a Quinta de Alfarela, a uma cota inferior dos montes que estão por trás. É visível a sua implantação em relação à foz do rio Sabor. 


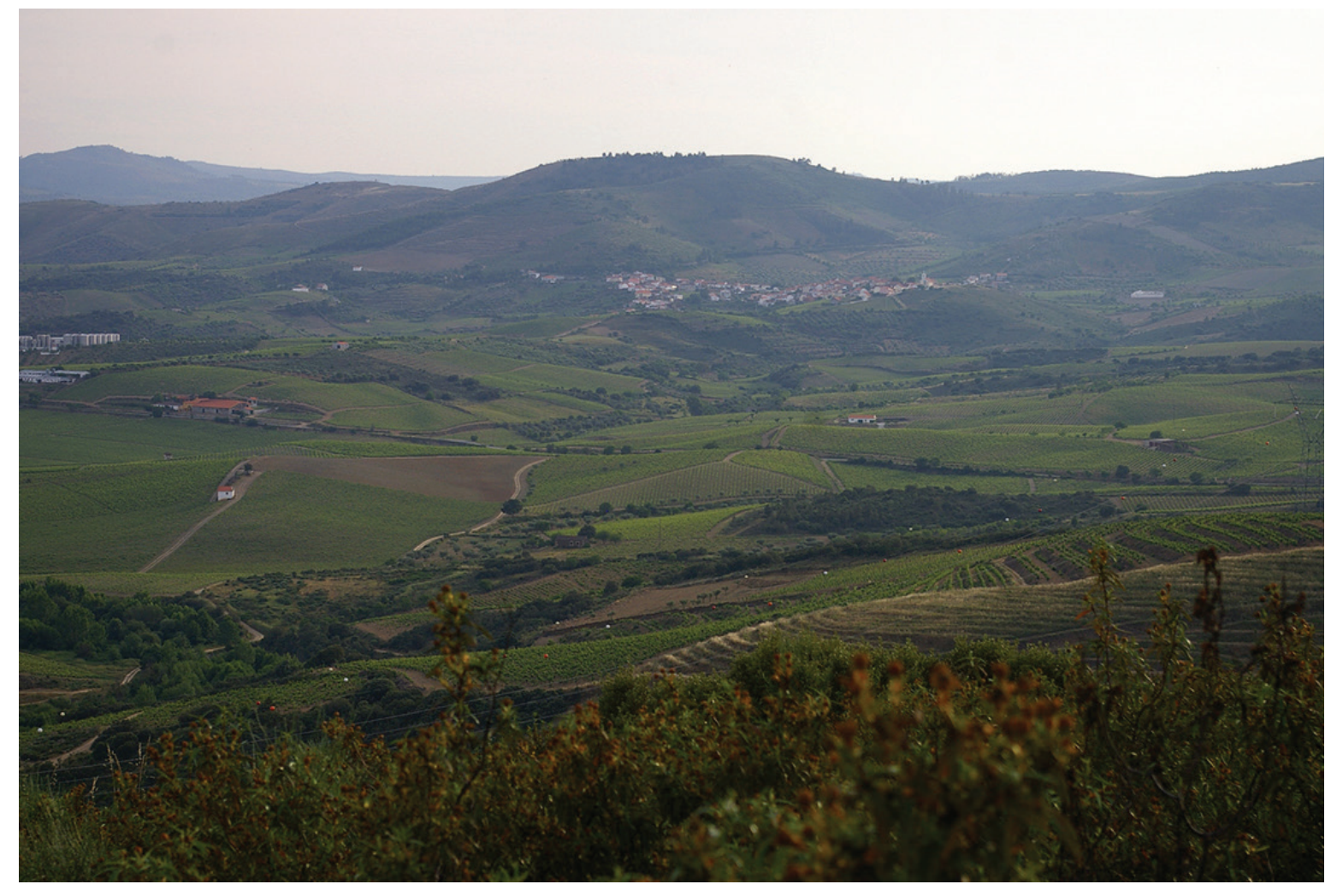

Figura 7 - Castanheiro do Vento visto do sítio da Zaralhôa a nordeste.

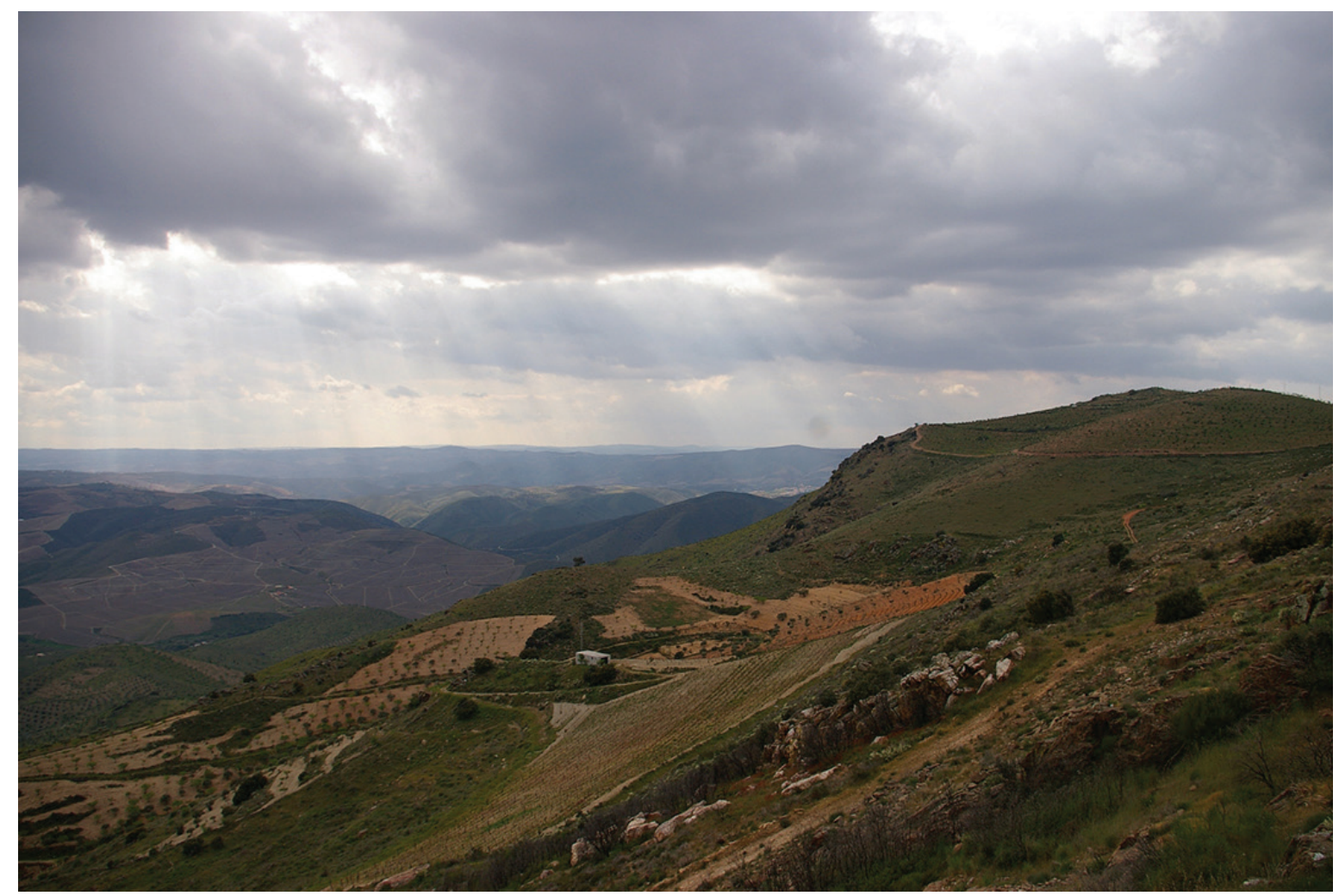

Figura 8 - O sítio arqueológico de São Gabriel. Virado ao vale do Côa (do lado esquerdo da imagem), existe o painel pintado. 


\title{
ESTUDO ZOOARQUEOLÓGICO DAS FAUNAS DO CALCOLÍTICO FINAL DE VILA NOVA DE SÃO PEDRO (AZAMBUJA, PORTUGAL): CAMPANHAS DE 2017 E 2018
}

Cleia Detry ${ }^{1}$, Ana Catarina Francisco ${ }^{2}$, Mariana Diniz ${ }^{1,3}$, Andrea Martins ${ }^{1,3,4}$, César Neves ${ }^{1,3}$, José Morais Arnaud ${ }^{1,3}$

\begin{abstract}
RESUMO
Em 2017, uma equipa da UNIARQ - Faculdade de Letras da Universidade de Lisboa e da Associação dos Arqueólogos Portugueses apresentou, à Direcção Geral do Património Cultural, um projecto de investigação intitulado Vila Nova de São Pedro, de novo no $3^{\circ}$ milénio (VNSP3ooo), com a intenção de retomar as escavações em VNSP. No âmbito de um seminário de Licenciatura em Arqueologia na FLUL, Ana Costa Francisco analisou os restos recuperados na primeira campanha de 2017. As faunas recuperadas nas campanhas seguintes foram estudadas por Cleia Detry.

Os restos de fauna doméstica demonstram a presença de ovelha/cabra (Ovis/Capra), vaca (Bos taurus) e porco (Sus scrofa domesticus). A caça também tem uma prevalência elevada com a presença de coelho (Oryctolagus cuniculus) e veado (Cervus elaphus). O auroque (Bos primigenius) e javali (Sus scrofa), embora difíceis de distinguir dos seus congéneres domesticados, foram identificados no conjunto.

Palavras-chave: Zooarqueologia, Calcolítico, Vila Nova de São Pedro.
\end{abstract}

\begin{abstract}
In 2017, a team from UNIARQ - School of Arts and Humanities of the University of Lisbon and the Association of Portuguese Archaeologists presented a research project to the Directorate-General for Cultural Heritage, entitled Vila Nova de São Pedro in the $3^{\text {rd }}$ millennium (VNSP3ooo), with the intention to resume excavations in VNSP. Within the scope of a seminar of the Degree in Archaeology at the School of Arts and Humanities of the University of Lisbon, Ana Costa Francisco, analysed the remains recovered in the first campaign of 2017. The fauna recovered in the following campaigns were studied by Cleia Detry.

The remains of domestic fauna demonstrate the presence of sheep/goat (Ovis/Capra), cattle (Bos taurus) and pig (Sus scrofa domesticus). Hunting is also highly prevalent with the presence of rabbit (Oryctolagus cuniculus) and red deer (Cervus elaphus). The auroch (Bos primigenius) and wild boar (Sus scrofa), although difficult to distinguish from their domesticated counterparts, were also identified in the assemblage.

Keywords: Zooarchaeology, Chalcolithic, Vila Nova de São Pedro.
\end{abstract}

\section{INTRODUÇÃO}

Vila Nova de São Pedro (VNSP) é um icónico povoado calcolítico da Estremadura Portuguesa, caracterizado pelas suas três linhas de muralha e intervencionado entre 1937 e 1967 por Eugénio Jalhay (até
1950) e Afonso do Paço, com o apoio, entre outras instituições, da Associação dos Arqueólogos Portugueses (Arnaud e Gonçalves 1990; 1995) (Figura 1). $\mathrm{Na}$ década de 8o, decorreram duas campanhas de escavação estando os resultados sucintamente publicados (Gonçalves, 1987; 1994), permanecendo o

1. UNIARQ, Centro de Arqueologia da Universidade de Lisboa, Faculdade de Letras da Universidade de Lisboa; cdetry@gmail.com; m.diniz@letras.ulisboa.pt

2. Aluna de Mestrado da Universidade do Algarve; afrancisco1@campus.ul.pt

3. Associação dos Arqueólogos Portugueses; c.augustoneves@gmail.com; direccao@arqueologos.pt

4. Fundação para a Ciência e a Tecnologia; andrea.arte@gmail.com 
sítio durante as três décadas seguintes afastado dos cenários da investigação arqueológica.

Em 2016, investigadores da UNIARQ - FLUL e a Associação dos Arqueólogos Portugueses (AAP) iniciaram um projecto de investigação para o povoado calcolítico de Vila Nova de São Pedro (Azambuja, Portugal) intitulado "Vila Nova de São Pedro, de novo no $3^{\circ}$ milénio - VNSP3ooo" (Arnaud et al, 2017), tendo realizado, sucessivas campanhas de terreno em 2017, 2018 e 2019 (Martins et al, 2019).

Relativamente aos restos faunísticos recolhidos neste povoado foram estudados os materiais das campanhas de A. Paço (Francisco et al, neste volume), existindo ainda um estudo não publicado de Elisabeth Wright sobre as faunas recuperadas nas escavações de 1985/86 (Wright in press).

Apresentamos neste artigo o estudo da fauna de uma unidade estratigráfica específica, identificada nas campanhas de 2017 e 2018, no âmbito do projecto VNSP30oo. A interpretação dos dados possibilitou a comparação com os sítios arqueológicos da Estremadura portuguesa, também de cronologia calcolítica, como Columbeira, Zambujal, Penedo do Lexim e Leceia.

\section{O CONTEXTO ARQUEOLÓGICO - VNSP A3 - UNIDADE ESTRATIGRÁFICA 305}

$\mathrm{Na}$ primeira campanha de campo do projeto VNSP3Ooo, teve início a escavação de uma área designada como Sondagem 1 - Área 3, que tinha como objectivo a caracterização de uma área a Este do recinto central, marcada por um talude artificial de cerca de 4 metros de altura que poderia corresponder à extensão para este sector da segunda linha de muralha (Martins et al, 2019: 143) (Figura 2).

Na plataforma inferior do talude identificou-se uma unidade sedimentar assente nos calcários de base, [305] cujas características são as seguintes:

[305] - Unidade sedimentar de matriz humosa-arenosa, muito homogénea na sua composição, muito orgânica, de coloração castanha-escura solta, com algumas zonas semi-compactas, com abundantes elementos pétreos de calcário de pequena e média dimensão e abundantes raízes. Na base da vertente criada por este talude - portanto já na plataforma inferior, esta UE cobre a rocha de base tendo surgido na área central da escavação grandes blocos pétreos de calcário, que se encontravam solidamen- te imbrincados e que colmatavam, artificialmente, a entrada de um pequeno algar (Figura 3).

A [305] representa a um nível arqueológico bem definido do ponto de vista sedimentar que corresponde às fases de ocupação terminal do sítio arqueológico. Este horizonte pedológico de reduzida potência com uma espessura da ordem dos 30-40 $\mathrm{cm}$, apresenta sinais de bioturbação, provocada fundamentalmente por raízes, ao mesmo tempo que as características do substrato fazem com que os materiais arqueológicos fiquem depositados (e preservados) nas fissuras do lapiás. Não foram identificadas estruturas antrópicas, existindo no entanto abundante material arqueológico: cerâmica manual lisa (formas abertas e fechadas, taças, pratos de bordo espessado), cerâmica manual decorada (decoração "crucífera" e campaniforme), indústria lítica maioritariamente em sílex (além de restos de talhe, lamelas e lascas, destacam-se os utensílios retocados como as pontas de seta, foliáceos e furadores), fragmentos de ídolos de cornos, vários fragmentos de placas/pesos de tear e fragmentos de queijeiras (Martins et al, 2019: 156). Surgem abundantes restos de fauna mamalógica muito fragmentada e erodida e alguma fauna malacológica.

Conforme publicado (Martins et al, 2019: 156) foram efectuadas três datações por $\mathrm{Cl}_{4}$, sobre fauna mamalógica (Cervus elaphus, Sus sp. e Bos sp.), recolhida nesta unidade cujos resultados permitem situar este nível nos meados do $3^{\circ}$ quartel do $3^{\circ}$ milénio (2577-2297 cal BC), incorporando esta algum material mais tardio, datado do $2^{\circ}$ quartel do $2^{\circ}$ milénio cal $\mathrm{BC}$, claramente intrusivo num ambiente cronológica e artefactualmente próprio do Calcolítico pleno.

\section{METODOLOGIA DE ESCAVAÇÃO E DE ANÁLISE DOS RESTOS FAUNÍSTICOS}

Os trabalhos de campo realizados no âmbito do projecto VNSP3ooo obedeceram a uma metodologia de recolha de dados em campo substantivamente distinta da utilizada nas escavações dos anos 30-6o, como já referido neste volume (Francisco et al.). Nos trabalhos agora realizados, todo o sedimento escavado - à excepção da camada superficial de manta morta - foi crivado em crivo seco com malha de $3 \mathrm{~mm}$ de lado e todos os restos faunísticos recolhidos.

Todos os ossos, dentes e conchas, recuperados na 
escavação da unidade estratigráfica [305], durante as campanhas de 2017 e 2018 , foram registados e contabilizados.

Em relação aos elementos osteológicos, quando possível, cada um foi identificado morfologicamente e taxonomicamente. Quando uma identificação taxonómica não foi possível, classificaram-se os elementos por critérios de tamanho dos animais a que poderiam pertencer, classificando-os como macrofauna (grande porte), mesofauna (médio porte) e microfauna (pequeno porte). São considerados animais de grande porte todo o gado bovino, os equídeos e o veado. Os de tamanho médio são animais como os caprinos ou suínos e os de pequeno porte são os coelhos ou animais mais pequenos.

Os dentes foram contabilizados e classificados da mesma maneira. Com este registo, foi obtido o Número de Restos (NR), isto é o total de restos contabilizados. O Número de Restos Determinados (NRD) contabilizou os que foram determinados taxonomicamente, tal como definido por Valente (1997). Para calcular o Número Mínimo de Indivíduos (NMI), registou-se ainda o Número Mínimo de Elementos (NME), recorrendo ao método de registo dos POSAC's (Parts of the Skeleton Always Counted) de Davis (1992).

A identificação taxonómica foi realizada com a ajuda da colecção de referência da UNIARQ e, em casos mais difíceis, complementada com a colecção de referência do Laboratório de Arqueociências da Direcção Geral do Património Cultural (LARC-DGPC). Para estabelecer perfis de idade à data da morte e ajudar no cálculo do NMI, foi registado o estado de fusão dos ossos: Fundido, no caso de a epífise estar completamente fundida à diáfise; Metáfise não fundida; Epífise não fundida; e ainda Fusão visível nos casos em que esta não estava completa. Com o mesmo objectivo, o de observar a idade, registámos o desgaste dos dentes dos animais domésticos usando para o efeito a escala de Grant (1982), para os suínos e bovinos e a de Payne (1987), para os caprinos.

Foram ainda registados dados que nos podem dar alguma informação tafonómica, nomeadamente a presença de marcas de corte, de fogo ou da acção de carnívoros ou roedores sobre os ossos. A influência de outros agentes como raízes ou erosão natural foram também interpretados e registados.

Os raros ossos e dentes completos foram medidos para identificar o estatuto selvagem ou doméstico do animal, no caso dos bovinos e suínos. Para isso utilizou-se uma craveira digital com erro inferior a o,1 $\mathrm{mm}$ e foram seguidos os critérios definidos por Driesch (1976).

\section{RESULTADOS E DISCUSSÃO}

Dos restos osteológicos analisados para este estudo, 2419 não foram determinados ao nível taxonómico. Com efeito, $63 \%$ dos restos eram fragmentos demasiado pequenos e/ou incaracterísticos para permitir estabelecer a sua relação com alguma das espécies conhecidas (ver Tabela 1). Em $27 \%$ da amostra foi possível a identificação por grupos de tamanho, mostrando uma preponderância da fauna de médio porte, em concordância com a prevalência das espécies que foram identificadas.

Os vestígios osteológicos obtidos nestas escavações apresentam-se, em geral, muito fragmentados e alvo de erosão acentuada - provocada por uma exposição aérea longa antes da sua cobertura pelos sedimentos que darão origem a esta UE - o que explica, em grande medida, a percentagem muito reduzida de ossos identificados taxonomicamente (10\%).

Os restos de invertebrados (gastrópodes e bivalves) são vestigiais neste conjunto. Existindo 11 restos de gastrópodes terrestres que podem corresponder a animais intrusivos já que ocorrem naturalmente em contextos com humidade e matéria orgânica. Bem como uns poucos restos (cinco fragmentos de concha) de uma única espécie de bivalve, a ameijoa (Ruditapes decussatus). Esta espécie terá de ter sido trazida da orla marítima já que não tolera salinidades muito baixas e precisa de ambiente arenoso própria de contexto marinho, eventualmente de estuário. Estes restos são compatíveis com os apresentados por Francisco et al. (2020, neste volume), para as escavações de Afonso do Paço no mesmo sítio.

Não foram encontrados restos de peixe ou anfíbios apesar da cuidadosa crivagem desta unidade estratigráfica. Estes restos poderão exigir protocolos de flutuação de sedimentos específicos a desenvolver em futuras intervenções.

\subsection{Espécies}

As espécies identificadas na [305] são na sua grande maioria de vertebrados e pertencentes a aves e mamíferos. A diversidade de animais selvagens é também bastante elevada quando comparada com 
outros estudos realizados em sítios do mesmo período cronológico.

Em relação aos restos de aves, apenas quatro ossos foram atribuídos a este grupo e apenas dois identificados como Alectoris rufa (perdiz-vermelha), um pequeno galiforme selvagem ainda hoje muito frequente na fauna portuguesa.

Os mamíferos dominam assim os restos encontrados, com a presença de espécies domésticas e selvagens. Dos 144 restos de mamíferos identificados taxonomicamente temos, desde já, três espécies raras em contextos arqueológicos, mas que aparecem em Vila Nova de São Pedro (tabelas 2 e 3).

A mais rara será o castor (Castor fiber), uma espécie actualmente extinta na Península Ibérica e que possivelmente terá desaparecido no séc. XV (Antunes, 1989). Esta foi ainda encontrada no Baixo Sabor, em contextos romanos (Detry et al., 2015), e na gruta do Caldeirão e Almonda nos níveis Paleolíticos (Antunes, 1989). Sendo uma espécie dependente dos cursos de água, terá provavelmente sido capturada nas bacias hidrográficas circundantes. Foi encontrada apenas parte de uma pélvis (Figura 4), e sem marcas de corte pelo que não conseguimos comprovar o seu consumo, mas a sua pele e o seu conhecido castoreum (substância perfumada de origem glandular), são produtos muito apreciados desde a Antiguidade. Já Afonso do Paço refere na sua lista de espécies encontradas em Vila Nova de São Pedro, a presença de castor (Paço, 1958).

Outra espécie de muito interesse, mas representada apenas por um metacarpo muito bem preservado é o urso-pardo (Ursus arctos) (Figura 5). A presença de elementos osteológicos da pata não garante a presença de um animal inteiro já que muitas vezes ao extrair-se a pele destes animais se conservavam as patas ou até mesmo o crânio. A referência de Paço e Jalhay a restos de urso, pelo menos dois animais de distintas dimensões (1943: 21 in Francisco et al., este volume), é agora confirmada.

A pele deste animal seria muito apreciada e o consumo da sua carne foi já atestado em muitos contextos (eg. Detry e Arruda, 2013, Fernandes et al. 2012), incluindo em Leceia (Pires et al. 2002).

Esta espécie terá sido relativamente frequente (para um grande carnívoro) e ter-se-á extinguido em Portugal no séc. XIX. O urso voltou a reaparecer nos últimos anos com pequenas intrusões de animais vindos de Espanha em virtude, provavelmente, do abandono rural e consequente melhoramento do habitat. Ora, esta espécie depende de zonas florestais e evitaria povoações. Os humanos competiriam na caça das mesmas presas o que terá determinado também a sua extinção. No Calcolítico poderiam estar menos afectados por esta pressão e ser mais frequentes. Ainda assim, um grande carnívoro deste tipo seria difícil de caçar.

Por fim, ainda dentro das espécies raras temos o lince-ibérico (Lynx pardinus), com quatro elementos: dois astrágalos, um calcâneo e uma falange I distal, partes que podem pertencer a um único animal. Esta espécie, hoje presente apenas no Sul de Portugal e com problemas de conservação graves, terá existido de Norte a Sul do país. Com efeito, há elementos desta espécie em vários contextos arqueológicos, quer pré-históricos como em Muge, no Mesolítico (Detry, 2007), quer em contextos de cronologias mais recentes, como no Baixo Sabor (Castelinho e Cemitério dos Mouros, Detry et al., 2015), ou em Lagos, na ocupação romana de Monte Molião (Detry e Arruda, 2013). Em Muge, as marcas de corte e de fogo, comprovam o seu consumo, ao contrário do caso de VNSP onde não se comprova nem se exclui o consumo deste animal. Dentro das espécies herbívoras com um número reduzido de elementos temos o corço (Capreolus capreolus), representado apenas por um molar superior. Esta espécie de pequeno cervídeo também terá sido frequente no passado, mas mais difícil de caçar que o veado e típica de ambiente florestal de estrato arbustivo desenvolvido. Aparece em números representativos nos concheiros mesolíticos de Muge (Detry, 2007), provável presença no povoado do Neolítico antigo da Valada do Mato (Valente in Diniz 2007), torna-se menos frequente em outros contextos pré-históricos como nos povoados calcolíticos de S. Pedro (Davis e Mataloto, 2012: 62), Castro da Columbeira (Correia, 2015:86) e Chibanes (Pereira et al, 2017: 5).

Um dente de equídeo é também o único elemento desta família podendo pertencer a cavalo ou burro (Equus caballus ou Equus asinus). Embora completo, não apresenta características passíveis de determinar a espécie, sendo mais provável que este elemento pertença a cavalo. O burro, cuja introdução foi frequentemente atribuída aos fenícios, tem a forte possibilidade de ter já existido anteriormente como demonstra o asinino encontrado no povoado calcolítico de Leceia (Cardoso et al. 2013), mas ainda assim são muito raros os seus restos em contextos pré-históricos. 
No caso do cavalo resta ainda a dúvida sobre o estatuto doméstico ou selvagem destes exemplares. O processo e a cronologia da domesticação do cavalo na Península Ibérica são ainda pouco claros já que também são poucas ou nenhumas as alterações morfológicas que permitam distinguir os equídeos selvagens dos domesticados.

Em sítios como Caseton de La Era (Valladolid, Espanha), com elevado número de equídeos, os zooarqueólogos tendem para a sua classificação como animais selvagens, confirmando-se a falta de provas sobre a presença de cavalo domesticado, na Península Ibérica, durante o Calcolítico (Araña, 2020).

Quanto aos grupos taxonómicos mais frequentes temos suídeos (porco e javali), bovinos (gado doméstico e auroque) e caprinos (ovelha e cabra). Este grupo de animais constitui cerca de 70\% dos restos de mamíferos identificados (ver tabela 1), sendo que, neste caso, poderemos ter um número relevante de restos de javali e auroque.

De facto, na figura 6 podemos observar que todos os astrágalos de Sus sp. apresentam medidas compatíveis com as do javali mesolítico dos concheiros de Muge (Detry, 2007). Já o único dente que foi possível medir, um terceiro molar inferior de Sus sp., apresentou medidas dentro do espectro do animal doméstico (L-3o,6 mm; Wa- 13,3mm; Wb$-14,3 \mathrm{~mm}$ ), quando comparadas com as referidas em Detry e Arruda (2013, fig. 5). É possível que os restos de suídeo recuperados na UE [305] pertençam, por isso, na sua maioria à espécie selvagem.

Quanto aos ossos de bovino, os astrágalos mensuráveis demonstram medidas dentro da amplitude da espécie doméstica (GLl-62,2mm; 62,6mm); veja-se as medidas referidas por Davis e Detry (2013, Fig. 5). Ao utilizarmos a largura proximal (Bp) de dois metacarpos de VNSP e comparando com as de Muge (Detry, 2007) vemos que uma se situa na margem inferior da amplitude (Bp-65,5mm) e a outra já se enquadra confortavelmente dentro do intervalo de medidas para o auroque (Bp-70,2mm). Enquanto a primeira, tendo em conta que os auroques no Mesolítico seriam mais pequenos do que no Calcolítico (Davis e Detry, 2013), se pode atribuir possivelmente ao animal doméstico, o segundo metacarpo de maiores proporções pertence seguramente a auroque.

$\mathrm{Na}$ figura 7, podemos observar uma tendência semelhante das duas falanges medidas: uma insere-se claramente nas medidas de auroque quando comparadas com as medidas de bovinos do Zambu- jal (Driesch e Boessneck, 1976), enquanto a outra, com medidas claramente inferiores, se enquadra na espécie doméstica.

Se pensarmos ter uma proporção de 1:1 de auroque $v s$. vaca em VNSP, é uma percentagem muito elevada de animais selvagens quando comparado com o Zambujal (Driesch e Boesseneck, 1976) ou Leceia (Cardoso e Detry, 2002). No entanto, atendendo à pequena dimensão do conjunto observado não é possível avançar para já com a reconstituição do peso da caça/pastorícia no quadro dos comportamentos de subsistência.

O veado e sobretudo o coelho-bravo constituem cerca de $24 \%$ da amostra de mamíferos, demonstrando mais uma vez a relevância da caça para estas populações.

Obtiveram-se poucas medidas, o que não nos permitiu confirmar a tese de Davis e Detry (2013) sobre o maior tamanho das espécies selvagens no Calcolítico. No entanto, os ossos medidos efectivamente não se apresentavam na franja inferior das medidas existentes, o que pelo menos não exclui a hipótese defendida por estes autores.

\subsection{Perfil de idades}

Em relação ao perfil de idades, pouco podemos avançar já que o número de ossos em que se podia observar a fusão era reduzido. Ainda assim, a grande maioria já se apresentava fundida e o único elemento não fundido pertence a Sus sp.

Em relação aos dentes de suídeos também o seu desgaste parecia reduzido e temos apenas a presença de dois dentes de leite de porco e dois de ovelha ou cabra. Temos igualmente a presença de animais mais velhos como sugerido pela existência de um terceiro molar inferior de Sus sp. e de um mesmo dente de ovelha, ou cabra, com o desgaste de $11 \mathrm{G}$, dentro da escala de desgaste de Payne (1987). Isso indicaria um animal de pelo menos 2 anos para o porco e de 4-6 anos para o caprino. Provavelmente seriam abatidos animais mais jovens para consumo da sua carne, bem como mantidos animais mais velhos para a reprodução (possivelmente o caso do porco) e produtos secundários (leite e lã) no caso da ovelha/cabra.

\subsection{Tafonomia}

Quanto à Tafonomia observaram-se quatro ossos com marcas de corte, três deles pertencentes a Bos sp. É possível que, tratando-se de um animal de maior porte, o desmanche produzisse mais marcas de corte, mas uma amostra reduzida como esta não 
nos permite grandes conclusões. As marcas de corte estão relacionadas com a remoção de pele (falanges, metacarpos e hastes/chifres) e desmembramento com objectivo de retirar a carne, peles e gorduras.

Apenas dois elementos não identificados taxonomicamente apresentavam marcas de fogo, o que representa uma percentagem muito reduzida, tal como já anotara A. Paço (in Francisco et al., este volume). Seis ossos apresentavam marcas de ter sido roídos por um carnívoro, mas não foi identificada, nesta UE, a presença de restos osteológicos do cão que provavelmente terá sido responsável por estas marcas, ficando assim a sua presença atestada indirectamente. Os ossos de um canídeo foram encontrados nas escavações antigas de VNSP (Idem, neste volume). Uma diáfise de tíbia apresentava marcas de roedor, constituindo um caso raro da utilização dos ossos pelos roedores para desgastarem os seus incisivos de crescimento contínuo (Figura 8). As marcas eram relativamente grandes podendo ser produzidas por animais como o rato-preto (Rattus rattus). Segundo Audoin-Rouzeau \& Vigne (1994: 132), terá sido introduzido no sul da Europa na Idade do Ferro e na Idade do Bronze - Boessneck et al. (1969) já refere elementos em Cerro del Real (Espanha). As marcas no osso podem ter sido feitas muito depois da ocupação do sítio, mas a serem contemporâneas de VNSP teriam sido feitas por um roedor mais pequeno e autóctone.

\subsection{Discussão dos dados}

Em suma, se observarmos, na Figura 9, e deste gráfico, excluímos os restos de coelho dado que estes podem ser bastante afectados pelo tipo de recolha em escavação, alterando de forma substantiva o quadro geral, a percentagem das quatro espécies mais frequentes em contextos arqueológicos calcolíticos da Estremadura Portuguesa (a norte do Tejo), podemos concluir que existe uma considerável diversidade, ao nível da exploração dos recursos faunísticos nos sítios estudados, com a excepção única do par porco/javali que é, em todos os sítios, excluindo VNSP[305], o segundo grupo de animais mais consumido. Numa leitura de conjunto, os valores percentuais da [305] de Vila Nova de São Pedro aproximam-se dos resultados obtidos no povoado do Zambujal, ao passo que Leceia, em particular no Calcolítico inicial, e o Penedo do Lexim parecem formar outro grupo. O sítio da Columbeira apresenta valores intermédios entre estes grupos.
O primeiro grupo - VNSP-[305] e Zambujal (Calcolítico Médio e Final) caracteriza-se pela elevada percentagem de vaca/auroque - cerca de $35 \%$ em ambos os sítios - logo seguida pelo peso do porco/ javali com valores que oscilam entre os c. de $40 \%$ em VNSP e $30 \%$ no Zambujal. Em ambos os casos a presença de animais inequivocamente domésticos - ovelha/cabra e inequivocamente selvagens - cervídeos - é claramente minoritária, comprometendo de forma óbvia uma leitura final acerca das espécies e das práticas dominantes nestes sítios.

O segundo grupo - Leceia (Calcolítico Inicial e Médio) e Penedo do Lexim têm como traços dominantes: a escassez, ou até ausência de animais de grande porte, - sejam eles domésticos ou selvagens (vaca, auroques e cervídeos); o peso muito expressivo da dupla ovelha/cabra que pode atingir $40 \% / 50 \%$ do conjunto, reflectindo de imediato o peso da pastorícia e por fim, numa estratégia centrada em animais de pequeno/médio porte, a importância da dupla porco/javali.

A relação pastorícia/caça em sítios onde são maioritários os grupos incertos - vaca/auroque e porco/ javali - se tem sido descrita como associada a uma economia produtora como no Zambujal (Driesch \& Boessneck), deixa em aberto, atendendo ao número significativo de auroques que parecem representados na pequena amostra da [305], o papel da caça nos ambientes da segunda metade do $3^{\circ}$ milénio (Davis e Mataloto, 2012).

No entanto, e qualquer que seja a relação pastorícia/ caça, as espécies selecionadas não são idênticas nos diferentes contextos - o par ovelha/cabra - fundamental nas economias de Leceia, Penedo do Lexim e Columbeira, parece menos significativo ou até marginal em VNSP ou Zambujal. Se a topografia acidentada da Columbeira ou do Penedo do Lexim podia explicar esta diferença expressiva face a VNSP/ Zambujal - ausência de bovinos e predilecção por ovelha/cabra - porco/javali, a integração do povoado de Leceia implantado no rebordo de uma vasta superfície aplanada, torna a explicação ambiental menos plausível.

\section{OBSERVAÇÕES FINAIS}

O presente trabalho permitiu estudar a fauna presente na unidade estratigráfica [305] da Área 3, Sondagem 1 , da intervenção realizada pelo projecto $\mathrm{VNSP}_{3} 000$. As análises taxonómica, osteométrica e tafonómica 
foram essenciais para a obtenção de informação sobre a economia alimentar no final da ocupação do sítio arqueológico de Vila Nova de São Pedro.

As campanhas de 2017 e 2018, proporcionaram registos faunísticos sistemáticos e contextualizados. A presença de espécies selvagens (Sus scrofa, Cervus elaphus, Bos primigenius, Oryctolagus cuniculus, Lynx pardinus, Castor fiber, Ursus arctos e Alectoris rufa) indica que a caça foi certamente uma atividade importante para as populações que viveram neste povoado calcolítico, revelando a especialização desta actividade face às características das espécies caçadas como o auroque, urso ou lince. A identificação de espécies domésticas (Ovis aries, Capra hircus, Sus scrofa domesticus e Bos taurus) demonstra também que estas populações dependiam igualmente de uma economia de pastorícia.

As datações obtidas para este contexto arqueológico específico mostram que a componente cinegética tem uma importância significativa no Calcolítico final, não apenas de espécies mais comuns como auroques, veados ou javalis, mas também lince, castor e urso, seguramente não apenas para consumo da carne, mas também para aproveitamento de peles. Neste período, e tendo em conta materiais arqueológicos também recolhidos neste mesmo contexto, o aproveitamento dos recursos secundários da pastorícia estaria certamente consolidado como é possível observar pelas queijeiras, bem como pelas placas de tear que, além da utilização fibras vegetais (como o linho identificado nas campanhas de A. Paço), poderiam utilizar lã. Apesar de raros, a idade avançada de alguns dos animais identificados revela-nos também esta opção de aproveitamento secundário e não apenas para consumo de carne.

Neste estudo pretendeu-se analisar um contexto específico, localizado numa área externa ao reduto central e " $2^{\underline{a}}$ linha" de muralha, não tendo sido aí identificadas estruturas domésticas. A preponderância de espécies selvagens poderá estar relacionada com uma área específica do povoado, separada da zona das espécies domesticadas que teriam estruturas de contenção (mais ou menos perecíveis) e áreas de abate e descarne de animais.

Tal como referido por A. Paço para algumas áreas do povoado (Paço, 1958) os ossos não apresentam vestígios de fogo podendo corresponder a processos de cozedura que não implicassem a acção directa do fogo.
Esta primeira abordagem ao estudo da fauna de um contexto datado de Vila Nova de São Pedro demonstra, por um lado, a consolidação do sistema agro-pastoril do $3^{\circ}$ milénio a.C., mas também, que a actividade cinegética continuou a fazer parte dos recursos sócio-económicos desta comunidade, tal como observado noutros povoados da Estremadura Portuguesa.

\section{AGRADECIMENTOS}

Ao Museu Arqueológico do Carmo e Associação dos Arqueólogos Portugueses pelo acesso aos materiais e disponibilização de meios e recursos para o presente estudo.

À UNIARQ - Centro de Arqueologia da Faculdade de Letras da Universidade de Lisboa pelas datações obtidas.

Ao Laboratório de Arqueociências da Direção Geral do Património a consulta da coleção de referência sendo uma ajuda essencial na identificação das espécies mais raras.

À Elizabeth Wright pela partilha dos seus dados não publicados sobre Vila Nova de São Pedro.

\section{BIBLIOGRAFIA}

ANTUNES, Miguel Teles (1989) - Castor fiber na gruta do Caldeirão Existência, distribuição e extinção do castor em Portugal. Ciências da Terra. 10, pp. 23-40.

ARAÑA, Maria (2020) - La gestión de los recursos ganaderos y cinegéticos durante la Prehistoria reciente en el Valle del Duero: El Casetón de la Era (Villalba de los Alcores, Valladolid) - Tese de Doutoramento. Universidad de Valladolid.

ARNAUD, José M.; GONCALVES, João Ludgero (1990) - A fortificação pré-histórica de Vila Nova de S., Pedro (Azambuja) - balanço de meio século de investigações. $1^{\underline{a}}$ parte. Revista de Arqueologia da Assembleia Distrital de Lisboa. 1. Lisboa, pp. 25-48.

ARNAUD, José M.; GONCALVES, João Ludgero (1995) - A fortificação pré-histórica de Vila Nova de S., Pedro (Azambuja) - balanço de meio século de investigações. $2^{\underline{a}}$ parte. Revista de Arqueologia da Assembleia Distrital de Lisboa. 2. Lisboa, pp. 11-40.

ARNAUD, José M.; DINIZ, Mariana; NEVES, César; MARTINS, Andrea (2017) - Vila Nova de São Pedro - de novo, no $3 .^{\circ}$ milénio. Um projecto para o futuro. Arqueologia e História, 66-67, Associação dos Arqueólogos Portugueses, Lisboa, pp. 7-17.

AUDOIN-ROUZEAU, Frédérique; VIGNE, Jean-Denis (1994) - La colonisation de l'Europe par le rat noir (Rattus rattus). Revue de paléobiologie, 13(1), pp. 125-145. 
BOESSNECK, Joachim; von den DRIESCH, Angela, SCHÜLE, Wilhelm, (1969) - Die Knochenfunde vom Cerrodel Real bei Galera (Prov. Granada); Die Fauna des "Cabezo Redondo" bei Villena (Prov. Alicante). In: Studien Über Frühe Tierknochenfunde von Der Iberischen Halbinsel. München Universitat, p. 106.

CARDOSO, João Luís; DETRY, Cleia (2002) - Estudo arqueozoológico dos restos de ungulados do povoado pré-histórico de Leceia (Oeiras). Estudos Arqueológicos de Oeiras. 10 , pp. 131-182.

CARDOSO, João Luís; VILSTRUP, Julia, EISENMANN, Vera; ORLANDO, Ludovico (2013) - First evidence of Equus asinus L. in the Chalcolithic disputes the Phoenicians as the first to introduce donkeys into the Iberian Peninsula. Journal of Archaeological Science, 40(12), p.4483-449o.

CORREIA, Francisco (2015) - O Castro da Columbeira (Bombarral): A Exploração dos Recursos Faunísticos no Calcolítico Estremenho. Tese de Mestrado UALG.

DAVIS, Simon (1992) - A rapid method for recording information about mammal bones from archaeological sites. London: Ancient Monuments Laboratory Ancient Monuments Laboratory Report; 19), pp. 1-14.

DAVIS, Simon; DETRY, Cleia (2013) - Crise no Mesolítico: Evidências Zooarqueológicas. ARNAUD, MARTINS e NEVES (coords.) - Arqueologia em Portugal - 150 Anos. Associação dos Arqueólogos Portugueses, Lisboa, pp. 297-309.

DAVIS, Simon, \& MATALOTO, Rui (2012) - Animal remains from Chalcolithic São Pedro (Redondo, Alentejo): evidence for a crisis in the Mesolithic. Revista Portuguesa de Arqueologia, 15(1), pp. 47-85.

DETRY, Cleia (2007) - Paleoecologia e Paleoeconomia do Baixo Vale do Tejo - Fauna Terrestre dos Concheiros de Muge. Tese de Doutoramento. Universidade de Salamanca.

DETRY, Cleia; ARRUDA, Ana Margarida (2013) - A fauna da Idade do Ferro e Época romana de Monte Molião (Lagos, Algarve): continuidades e rupturas na dieta alimentar. Revista Portuguesa de Arqueologia. Vol. 15: 215-227.

DETRY, Cleia, PEREIRA, Sérgio; DÓRDIO, Paulo (2015) - Estudo zooarqueológico dos materiais recuperados em Crestelos. Do Calcolítico ao Período Moderno. Relatório Final do estudo Zooarqueológico integrado no Plano de Salvaguarda do Património do Baixo Sabor.

DRIESCH, Angela von den (1976) - A guide to the measurement of animal bones from archaeological sites. Harvard: Harvard University, Peabody Museum of Archaeology and Ethnology.

DRIESCH, Angela von den; BOESSNECK, Joachim (1976) - Die fauna vom Castro do Zambujal. Studien über frühe Tierknochenfunde von der Iberischen Halbinsel. 5, pp. 4-129.
FAGES, A., Hanghøj, K., Khan, N., Gaunitz, C., SeguinOrlando, A., Leonardi, M.; Detry, Cleia; Alfarhan, A.H. (2019) - Tracking five millennia of horse management with extensive ancient genome time series. Cell.177(6), pp. 1419-1435.

FERNANDES, Isabel; CARDOSO, João Luís; DETRY, Cleia (2012) - Cozinhar e comer no Castelo Medieval de Palmela. In Susana Gómez Martinez (Ed). Memória dos sabores do Mediterrâneo. Campo Arqueológico de Mértola/ Centro de Estudos Arqueológicos de Coimbra e Porto, pp. 113-128.

FRANCISCO, Ana Catarina; DETRY, Cleia; NEVES, César; MARTINS, Andrea, DINIZ, Mariana; ARNAUD, José (2020) - As faunas depositadas no Museu Arqueológico do Carmo provenientes de Vila Nova de São Pedro (Azambuja): as campanhas de 1937 a 1967. ARNAUD, NEVES, MARTINS (Coord.) - Arqueologia em Portugal - 2020, estado da questão, Associação dos Arqueólogos Portugueses, Lisboa

GONÇALVES, Victor Santos (1987) - Trabalhos de campo. Distrito de Lisboa - Azambuja: Castelo de Vila Nova de São Pedro: 1985/86. Informação Arqueológica, Ministério da Cultura. Instituto Português do Património Cultural, Departamento de Arqueologia, no 8, pp. 41-43.

GONÇALVES, Victor Santos (1994) - O castelo de Vila Nova de S. Pedro. Lisboa Subterrânea. Lisboa: Electa, pp. 49-51.

GRANT, Annie (1982) - The use of tooth wear as a guide to the age of dome s tic ungulates. In B. Wilson, C. Grigson \& S. Payne, Ageing and sexing animal bones from Archaeological sites, Oxford: British Archaeological Reports - British series 109, pp. 91-108.

MARTINS, Andrea; NEVES, César; DINIZ, Mariana; ARNAUD, José (2019) - O povoado calcolítico de Vila Nova de São Pedro (Azambuja). Notas sobre as campanhas de escavação de 2017 e 2018. Arqueologia e História, nº 69, Associação dos Arqueólogos Portugueses, pp. 133-167.

PAÇO, Afonso do (1958) - Castro de Vila Nova de S. Pedro. X-Campanha de Escavações de 1956 (20aㅡ), Academia Portuguesa da História ANAIS, II série, vol.8, pp. 50-54.

PAYNE, Sebastian (1987) - Reference codes for wear states in the mandibular teeth of sheep and goats. Journal of Archaeological Science. Amsterdam, 14, pp. 609-614.

PEREIRA, Vera; SOARES, Joaquina; SILVA, Carlos Tavares (2017) - Understanding the First Chalcolithic Communities of Estremadura: Zooarchaeology of Castro de Chibanes, Portugal. Preliminary Results. Papers from the Institute of Archaeology, 27(1), pp. 1-11.

PIRES, Filipa; CARDOSO, João Luís; PETRUCCI-FONSECA, Francisco (2002) - Estudo Arqueozoológico dos carnívoros do povoado pré-histórico de Leceia (Oeiras). Estudos Arqueológicos de Oeiras, 10, pp. 183-247.

VALENTE, Maria João (1997) - A quantificação faunística: principais unidades, alguns parâmetros, regras e problemas. Estudos do Quaternário. Lisboa, 1, pp. 83-96. 


\begin{tabular}{|c|c|c|c|c|}
\hline & & & & \\
\hline & NRD & & NMI & \\
\hline & $\mathrm{N}$ & $\%$ & $\mathrm{~N}$ & $\%$ \\
\hline \multicolumn{5}{|l|}{ Mollusca } \\
\hline Gastropoda & 1 & $0,04 \%$ & 1 & $6 \%$ \\
\hline Cornu aspersa & 11 & $0,4 \%$ & 1 & $6 \%$ \\
\hline \multicolumn{5}{|l|}{ Bivalvia } \\
\hline Ruditapes decussata & 5 & $0,2 \%$ & 1 & $6 \%$ \\
\hline \multicolumn{5}{|l|}{ Vertebrata } \\
\hline \multicolumn{5}{|l|}{ Mammalia } \\
\hline Bos sp. (vaca e auroque) & 63 & $2 \%$ & 2 & $12 \%$ \\
\hline Ovis/Capra (ovelha/cabra) & 39 & $1 \%$ & 1 & $6 \%$ \\
\hline Sus sp. (porco e javali) & 89 & $3 \%$ & 2 & $12 \%$ \\
\hline Cervus elaphus (veado) & 15 & $1 \%$ & 1 & $6 \%$ \\
\hline Capreolus capreolus (corço) & 1 & $0,04 \%$ & 1 & $6 \%$ \\
\hline Equus sp. (cavalo e burro) & 2 & $0,1 \%$ & 1 & $6 \%$ \\
\hline Oryctolagus cuniculus (coelho) & 31 & $1 \%$ & 2 & $12 \%$ \\
\hline Castor fiber (castor) & 1 & $0,04 \%$ & 1 & $6 \%$ \\
\hline Ursus arctos (urso) & 1 & $0,04 \%$ & 1 & $6 \%$ \\
\hline Lynxpardinus (lince-ibérico) & 4 & $0,1 \%$ & 1 & $6 \%$ \\
\hline Aves & 2 & $0,1 \%$ & & \\
\hline \multirow[t]{2}{*}{ Alectoris rufa (perdiz-vermelha) } & 2 & $0,1 \%$ & 1 & $6 \%$ \\
\hline & NR & $\%$ & & \\
\hline Macrofauna & 267 & $10 \%$ & & \\
\hline Mesofauna & 441 & $16 \%$ & & \\
\hline Microfauna & 28 & $1 \%$ & & \\
\hline Indeterminado & 1683 & $63 \%$ & & \\
\hline Total & 2685 & & 17 & \\
\hline
\end{tabular}

Tabela 1 - Número de Restos (NR), Número de Restos Determinados (NRD) e Número Mínimo de Indivíduos (NMI) por grupo Taxonómico. 


\begin{tabular}{|c|c|c|c|c|c|c|c|c|c|c|c|c|c|c|c|}
\hline & $B$ & $\mathrm{O} / \mathrm{C}$ & $S$ & $C E$ & $C C$ & $A R$ & $E Q$ & ORC & $C F$ & $U A$ & $L P$ & MAC & MÊS & MIC & IND \\
\hline \multicolumn{16}{|l|}{ Esqueleto Cranial } \\
\hline Haste/Chifre & & & & 1 & & & & & & & & & & & \\
\hline Crânio & & 1 & 1 & & & & & & & & & 2 & 10 & & \\
\hline \multicolumn{16}{|l|}{ Maxilar } \\
\hline Mandíbula & 1 & 1 & & & & & & 1 & & & & 3 & 6 & & \\
\hline Dentes & 22 & 24 & 43 & 5 & 1 & 30 & 1 & $6(4)$ & & & & & & & \\
\hline \multicolumn{16}{|l|}{ Esqueleto Axial } \\
\hline Atlas & & 1 & 1 & & & & & & & & & & & & \\
\hline Costelas & & & & & & & & & & & & 3 & 21 & & \\
\hline Vértebras & & & & & & & & 2 & & & & 12 & 13 & & \\
\hline Vértebras Cervicais & & & & & & & & & & & & 11 & & & \\
\hline Vértebras Toráxicas & & & & & & & & & & & & 2 & 3 & & \\
\hline Vértebras Lombares & & & & & & & & & & & & 1 & 2 & & \\
\hline \multicolumn{16}{|l|}{ Membro Anterior } \\
\hline Escápula & & & $4(2)$ & & & & & $2(2)$ & & & & 1 & 2 & & \\
\hline Úmero & 1 & $2(1)$ & & & & & & $1(1)$ & & & & 2 & & & \\
\hline Rádio & 4 & 2 & & & & & & & & & & & & & \\
\hline Cúbito & 1 & 1 & 2 & 1 & & & & 3 & & & & 2 & & & \\
\hline Escafóide & & 2 & & & & & & & & & & & & & \\
\hline Semi-lunar & 1 & & & & & & & & & & & & & & \\
\hline Piramidal & 1 & & & & & & & & & & & & & & \\
\hline Capitato-trapezóide & & & & 1 & & & & & & & & & & & \\
\hline Os crochu & 2 & & & & & & & & & & & & & & \\
\hline Metacarpo & 4 & & 6 & & & & & & & $1(1)$ & & & & & \\
\hline \multicolumn{16}{|l|}{ Membro Posterior } \\
\hline Pélvis & 1 & $2(1)$ & $2(1)$ & $1(1)$ & & & & $6(4)$ & $1(1)$ & & & 2 & 1 & & \\
\hline Fémur & 1 & & & & & & & $1(1)$ & & & & 1 & & & \\
\hline Tíbia & & 2 & & & & & & $2(1)$ & & & & & & & \\
\hline Fíbula & & & 1 & & & & & & & & & & & & \\
\hline Calcâneo & $(1)$ & & 1 & $1(1)$ & & & & 4(4) & & & $1(1)$ & 1 & & & \\
\hline Astrágalo & $3(2)$ & & $4(4)$ & 2(1) & & & & & & & $2(2)$ & & & & \\
\hline Cubo-escafóide & 1 & & & & & & & & & & & & & & \\
\hline Navicular-Cubóide & & & & & & & 1 & & & & & & & & \\
\hline Navicular & & & & 1 & & & & & & & & & & & \\
\hline Metatarso & 2 & & & & & & & $3(2)$ & & & & & & & \\
\hline Metápode & $7(6)$ & $1(1)$ & $5(3)$ & $1(1)$ & & & & & & & & 1 & & & \\
\hline Falange I & $6(3)$ & & $10(4)$ & 1 & & & & & & & $1(1)$ & & & & \\
\hline Falange II & $1(1)$ & & $4(3)$ & $1(1)$ & & & & & & & & & & & \\
\hline Falange III & $3(1)$ & & $5(3)$ & & & & & & & & & 1 & & & \\
\hline Ossos longos & & & & & & & & & & & & 103 & 359 & 26 & \\
\hline Ossos indeterminados & & & & & & & & & & & & 119 & 24 & 2 & 1683 \\
\hline TOTAL & 63 & 39 & 89 & 15 & 1 & 30 & 2 & 31 & $\mathbf{1}$ & $\mathbf{1}$ & 4 & 267 & 441 & 28 & 1683 \\
\hline MNI & 2 & 1 & 2 & 1 & $I$ & & $I$ & 2 & I & I & 1 & & & & \\
\hline
\end{tabular}

Tabela 2 - Número de restos Determinados taxonomicamente (NRD) e não determinados (NR) por partes do esqueleto e Número Mínimo de Indivíduos (NMI). Entre parêntesis encontra-se o Número Mínimo de Elementos (NME). B - Bos sp. (gado bovino ou auroque); O/C - Ovis/Capra (ovelha ou cabra); S - Sus sp. (porco ou javali); CE - Cervus elaphus (veado); CC - Capreolus capreolus (corço); AR - Artiodactyla; EQ - Equus sp. (cavalo ou burro); ORC. - Oryctolagus cuniculus (coelho-bravo); CF-Castor fiber (castor); UA - Ursus arctos (urso); LP - Lynx pardinus (lince-ibérico); MAC - Macrofauna; MES - Mesofauna; MIC - Microfauna; IND - Indeterminado. 


\begin{tabular}{|c|c|c|c|c|c|c|c|}
\hline & Bos sp. & Ovis/Capra & Sus sp. & C. elaphus & C. capreolus & Artiodactyla & O. cuniculus \\
\hline \multicolumn{8}{|l|}{ Dentes Superiores } \\
\hline I & & & 3 & & & & \\
\hline i & & & 1 & & & & \\
\hline $\mathrm{C}$ & & & 2 & & & & \\
\hline $\mathrm{PM}$ & 2 & 2 & & & & & \\
\hline $\mathrm{P} 2$ & & 1 & & & & & \\
\hline $\mathrm{P}_{3}$ & & & 1 & & & & \\
\hline $\mathrm{P}_{4}$ & & & 1 & & & & \\
\hline $\mathrm{dp} 2$ & & & 1 & & & & \\
\hline $\mathrm{dp} 4$ & & 1 & & & & & \\
\hline \multicolumn{8}{|l|}{ Mi } \\
\hline \multicolumn{8}{|l|}{$\mathrm{M}_{2}$} \\
\hline $\mathrm{M}_{3}$ & & 1 & 1 & & & & \\
\hline $\mathrm{M}_{1} / 2$ & & 4 & 3 & & & & \\
\hline M & 1 & 5 & & 2 & 1 & & \\
\hline \multicolumn{8}{|l|}{ Dentes Inferiores } \\
\hline I & & 2 & 3 & 2 & & & 2 \\
\hline $\mathrm{C}$ & & & 2 & & & & \\
\hline $\mathrm{dp} 2$ & & 1 & & & & & \\
\hline \multicolumn{8}{|l|}{$\mathrm{dp} 3$} \\
\hline $\mathrm{dp} 4$ & 1 & & 1 & & & & \\
\hline $\mathrm{PM}$ & & & 2 & & & & \\
\hline $\mathrm{P}_{1}$ & & & 2 & & & & \\
\hline \multicolumn{8}{|l|}{$\mathrm{P} 2$} \\
\hline $\mathrm{P}_{3}$ & 1 & & & & & & \\
\hline $\mathrm{P}_{4}$ & 2 & & & & & & \\
\hline \multicolumn{8}{|l|}{ Mi } \\
\hline \multicolumn{8}{|l|}{$\mathrm{M} 2$} \\
\hline $\mathrm{M}_{3}$ & & 1 & 2 & & & & \\
\hline $\mathrm{Mi} / 2$ & 3 & 1 & 2 & & & & \\
\hline $\mathrm{M}$ & 3 & 2 & 1 & & & & 4 \\
\hline Dente Indeterminado & 9 & 3 & 15 & 1 & & 30 & \\
\hline Total & 22 & 24 & 43 & 5 & $\mathbf{I}$ & 30 & 6 \\
\hline
\end{tabular}

Tabela 3 - Número de restos por dente e por grupo taxonómico. 


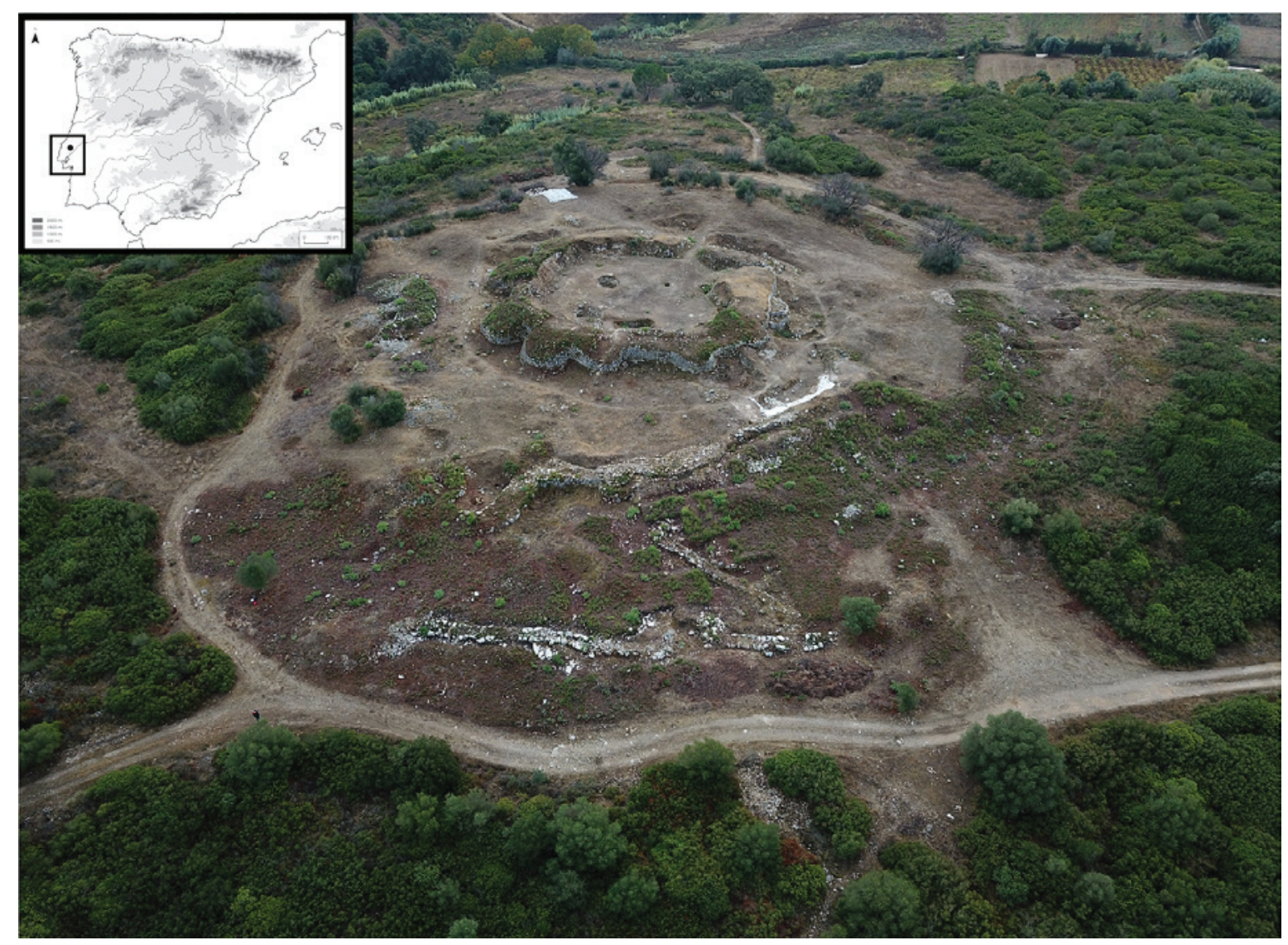

Figura 1 - Vila Nova de São Pedro - localização e aspecto geral do povoado calcolítico em 2018.

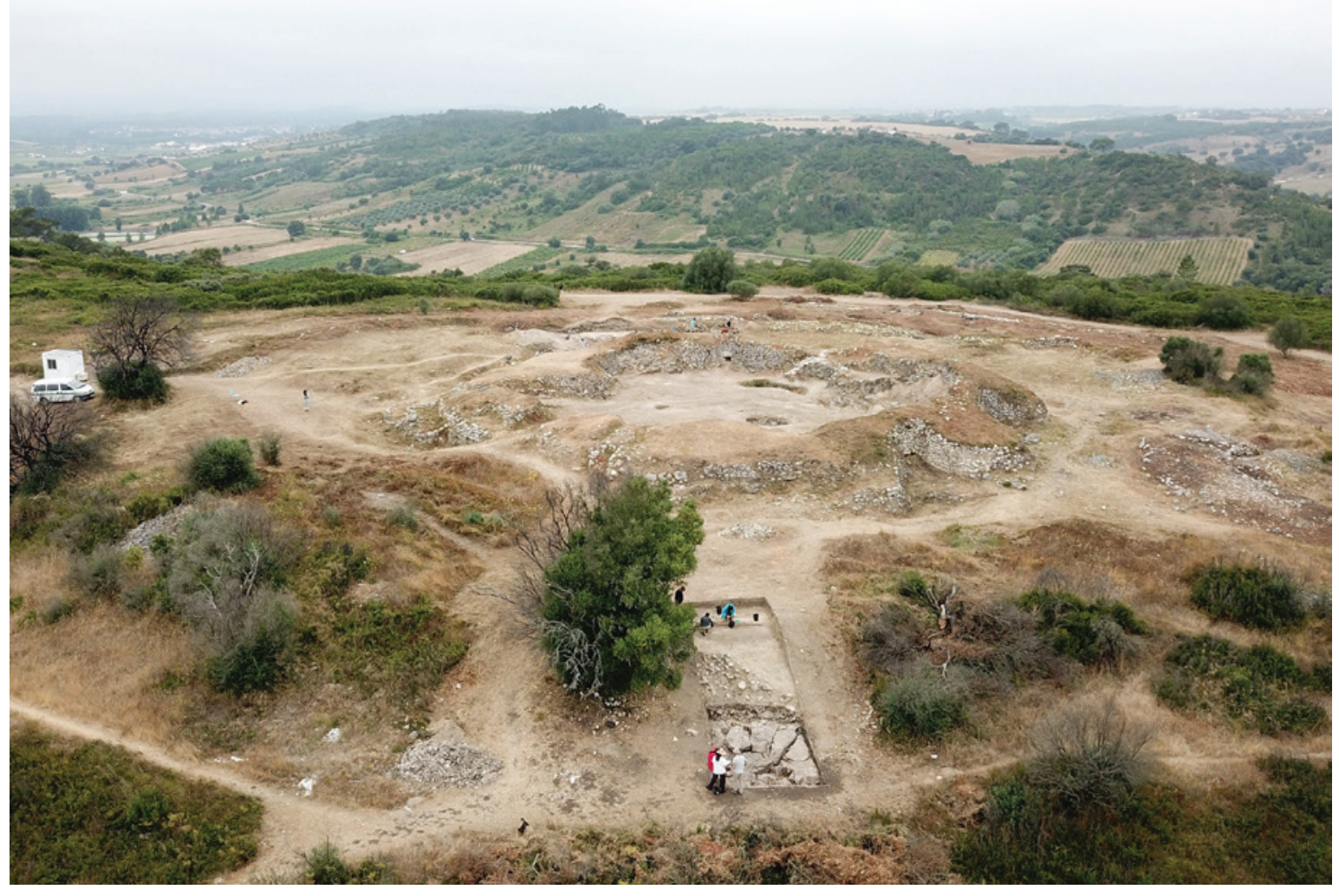

Figura 2 - Vila Nova de São Pedro visualizando-se em primeiro plano a sondagem 1 da Área 3. 


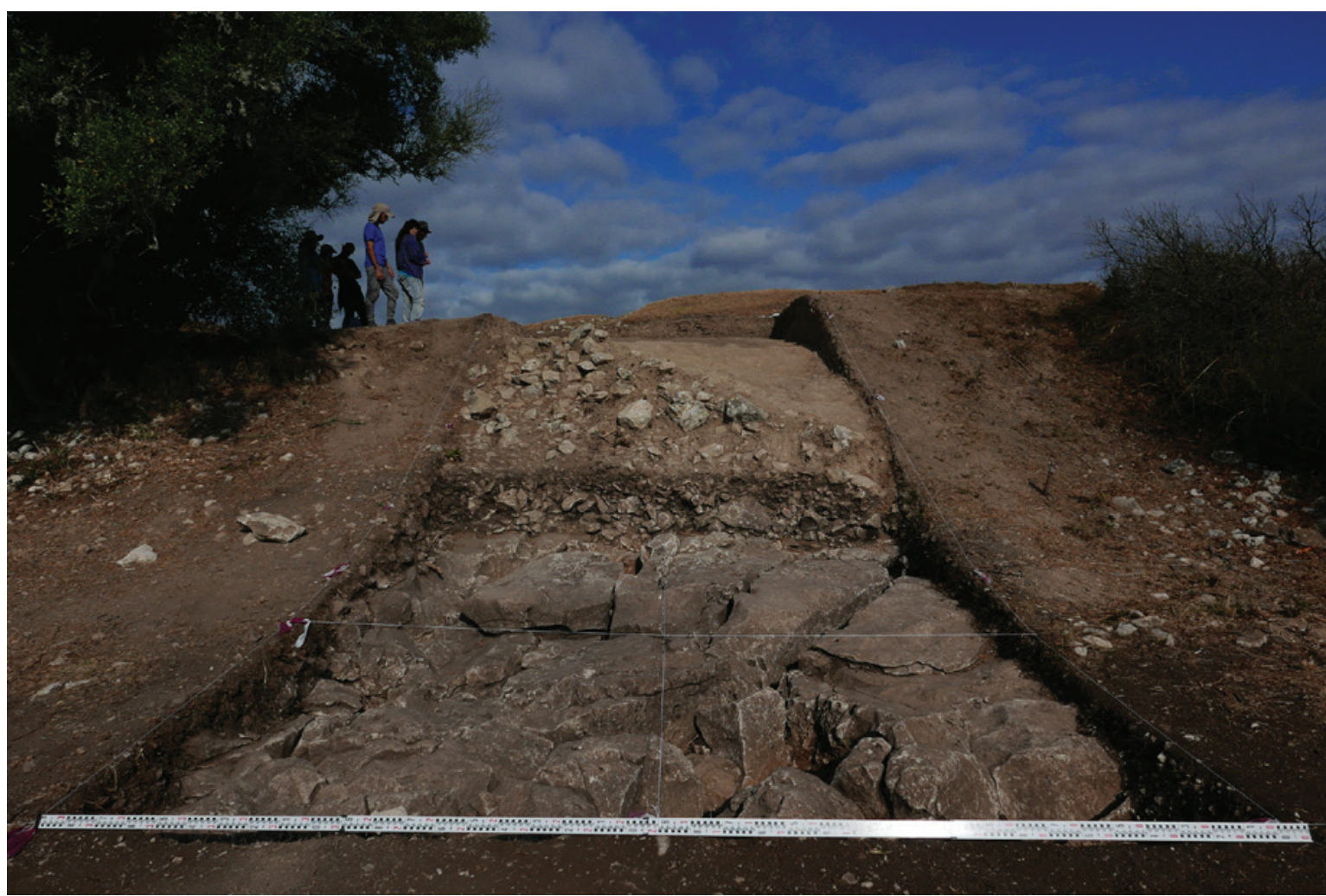

Figura 3 - Área 3, sondagem 1 - aspecto final da intervenção na plataforma inferior visualizando-se o substrato geológico e a entrada do algar.

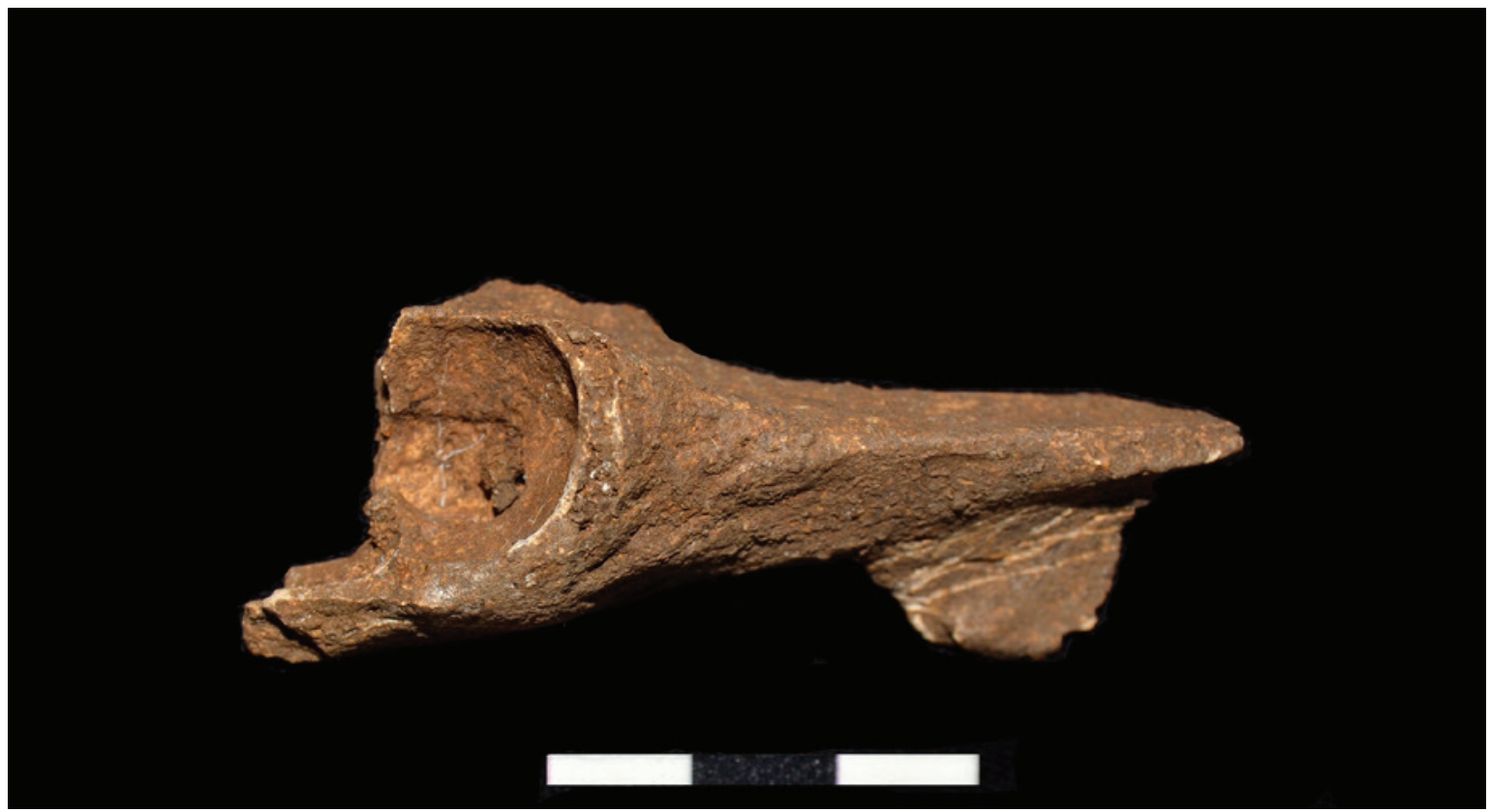

Figura 4 - Pélvis de Castor fiber (castor) recuperado na [305] - Área 3, sondagem 1, na campanha de 2017. 


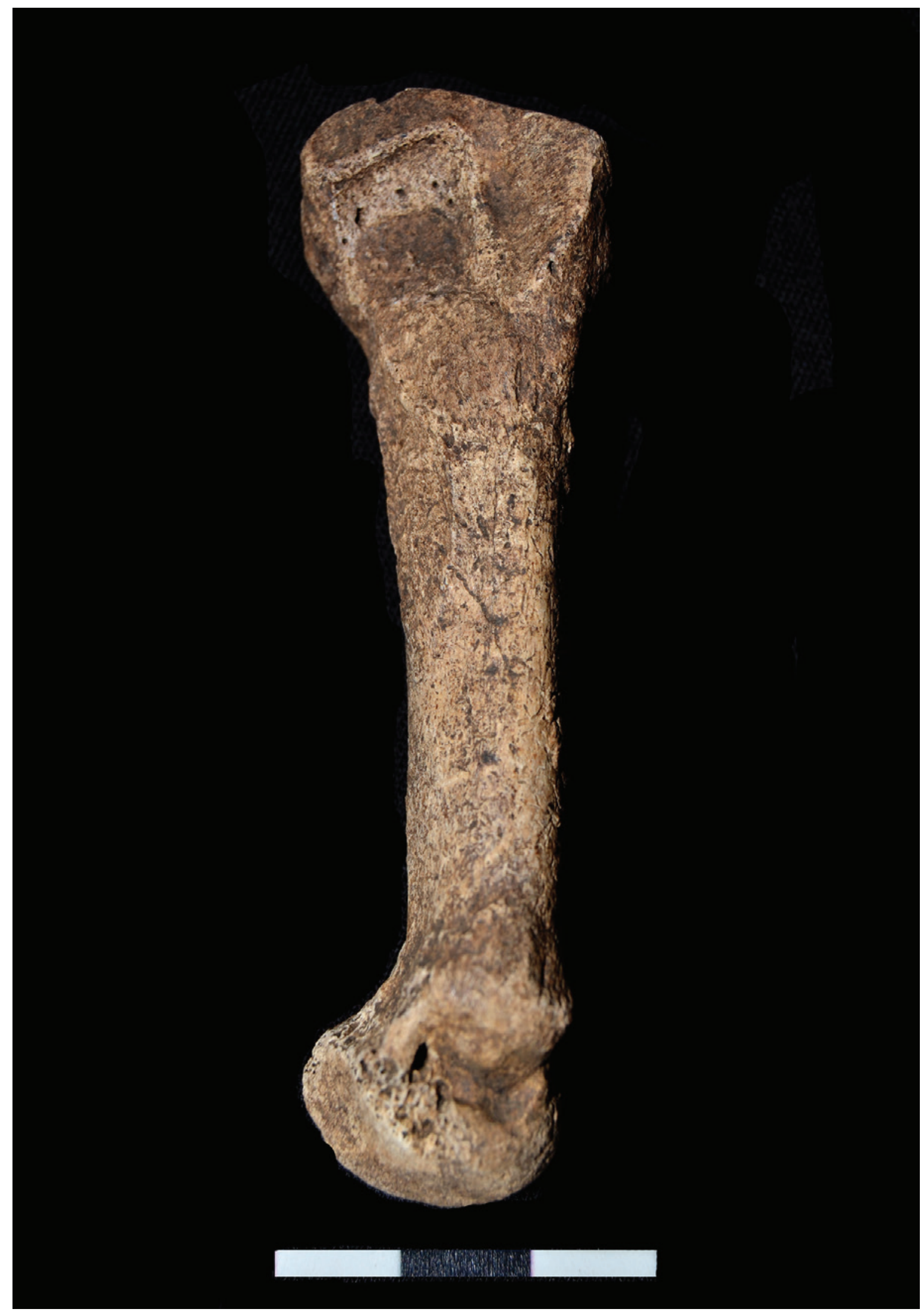

Figura 5 - Metacarpo IV completo de Ursus arctos (urso) recuperado da [305] - Área 3, sondagem 1, quadrado J5, na campanha de 2018 . 


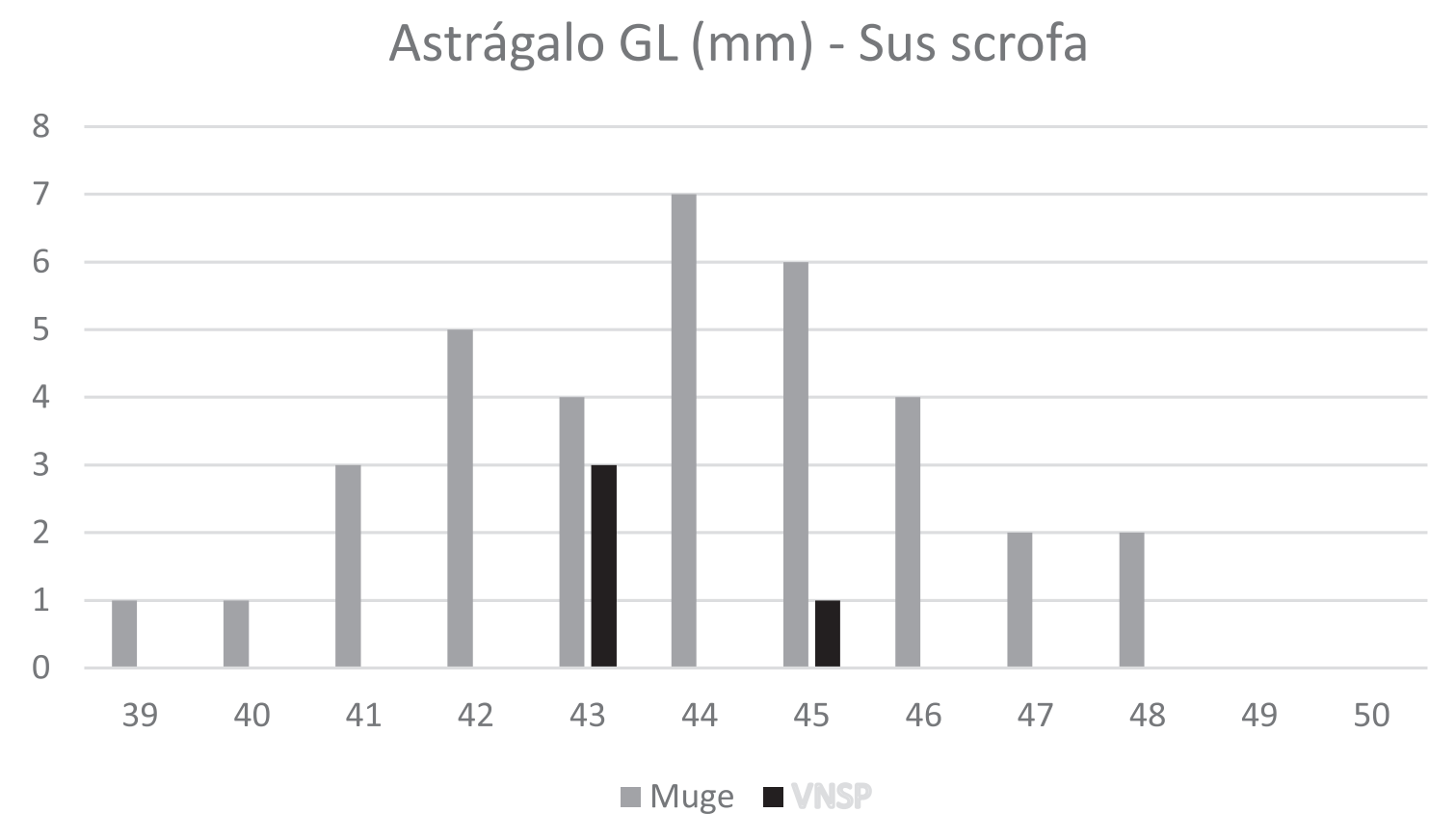

Figura 6 - Medida da altura máxima do astrágalo (GL) de Sus scrofa (em mm). Comparação das medidas de javali dos concheiros de Muge (Mesolítico, Detry, 2007) com as dos suídeos recuperados na [305] de Vila Nova de São Pedro.

\section{Falange I - Bos sp.}

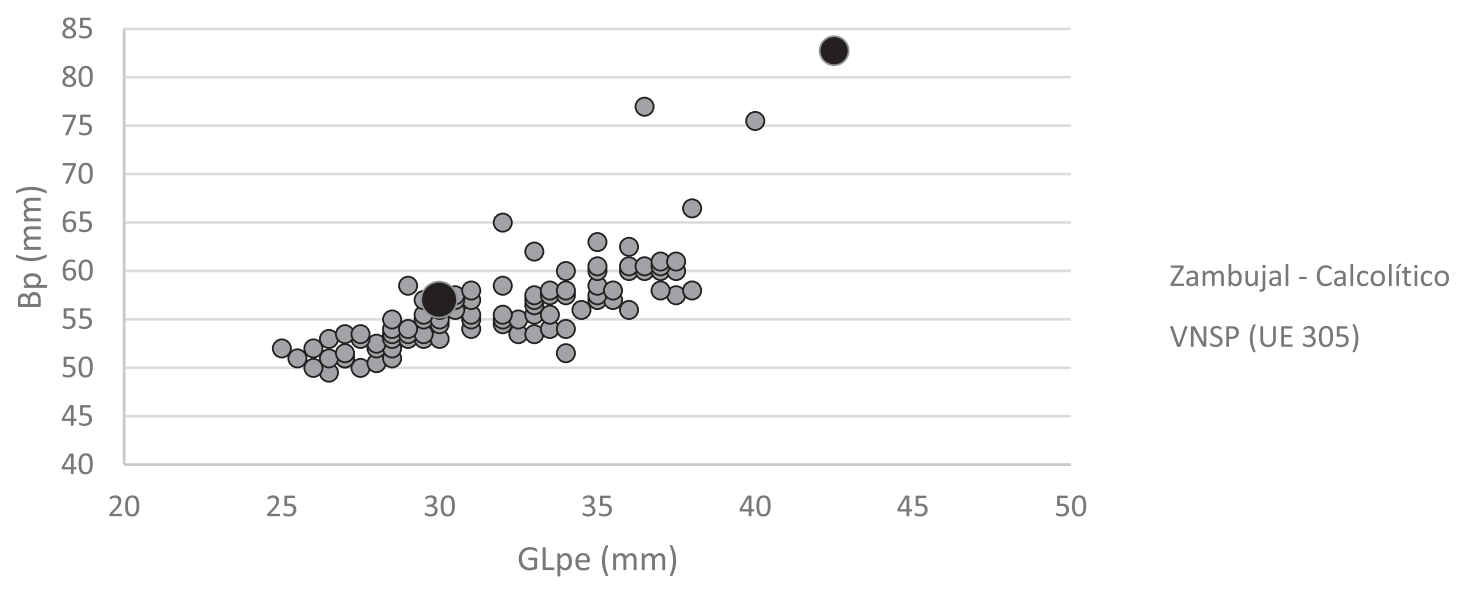

Figura 7 - Gráfico de dispersão com medidas da Falange I de Bos sp, dos sítios Calcolíticos do Zambujal e de Vila Nova de São Pedro. Medidas do Zambujal publicadas por Boessneck \& Driesch (1976). 


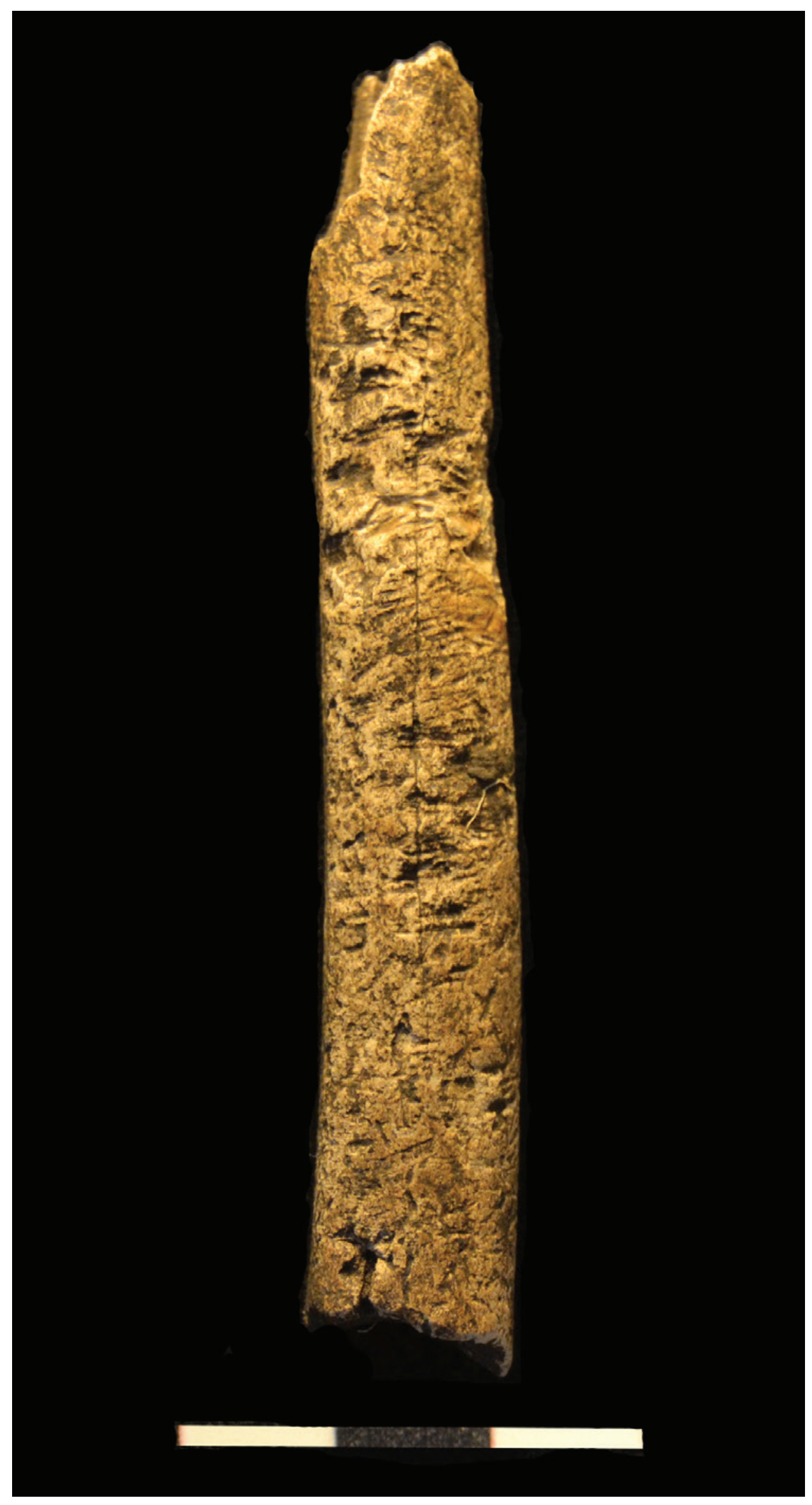

Figura 8 - Diáfise de tíbia de uma ovelha ou cabra com marcas de roedor. 


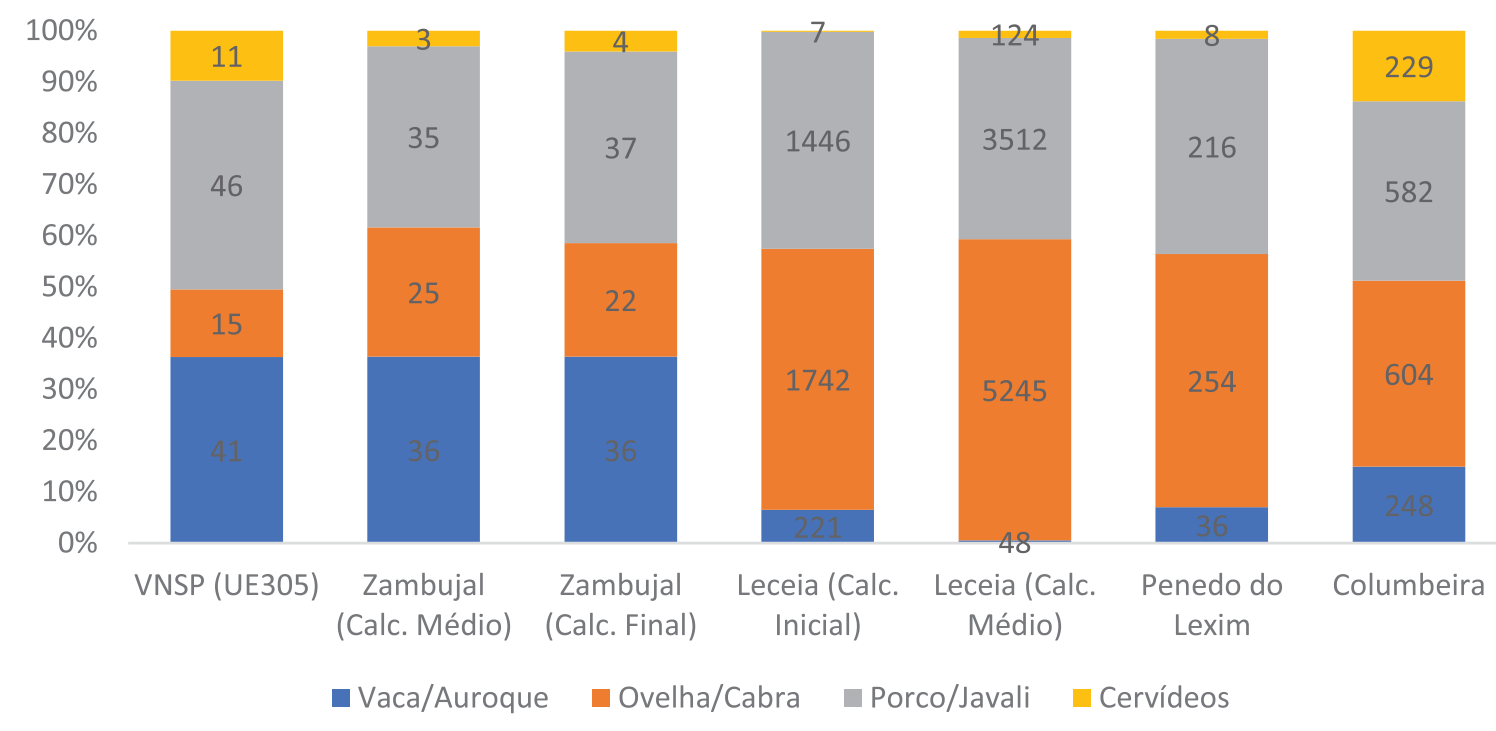

Figura 9 - Comparação dos quatro principais grupos taxonómicos presentes nos sítios arqueológicos do Calcolítico da Estremadura. Zambujal - Driesch \& Boessneck (1976); Leceia - Cardoso \& Detry (2001/2002); Penedo do Lexim - Moreno-Garcia \& Sousa (2015); Castro da Columbeira - Correia (2015). 


\section{AS FAUNAS DEPOSITADAS NO MUSEU ARQUEOLÓGICO DO CARMO PROVENIENTES DE VILA NOVA DE SÃO PEDRO (AZAMBUJA): AS CAMPANHAS DE 1937 A 1967}

Ana Catarina Francisco ${ }^{1}$, Cleia Detry ${ }^{2}$, César Neves $^{2,3}$, Andrea Martins ${ }^{2,3,4}$, Mariana Diniz ${ }^{2,3}$, José Morais Arnaud ${ }^{3}$

RESUMO

O sítio arqueológico de Vila Nova de São Pedro (Azambuja) foi descoberto em 1936 através das prospecções realizadas por Hipólito Cabaço. Em 1937, tem lugar a primeira campanha de escavação dirigida por Eugénio Jalhay e Afonso do Paço. Com a morte do primeiro, em 1950, Paço assume, com pontuais colaborações, a direcção dos trabalhos arqueológicos no sítio, até 1967.

O presente artigo tenciona fazer a análise da fauna recolhida e descrita por Afonso do Paço ao longo dessas campanhas, sobre as quais não existe, no entanto, informação sobre a proveniência estratigráfica de artefactos e ecofactos. Comparam-se ainda os dados destas campanhas com a fauna recolhida durante as escavações de 2017 e 2018, realizados no âmbito do projecto VNSP3ooo. A partir deste material faunístico sem contexto, foi, ainda assim, possível adquirir algum conhecimento sobre espécies presentes nas imediações de Vila Nova de São Pedro durante o Calcolítico.

Palavras-chave: Zooarqueologia, Afonso do Paço, Calcolítico, Vila Nova de São Pedro.

\section{ABSTRACT}

The archaeological site of Vila Nova de São Pedro (Azambuja) was discovered in 1936 through the surveys carried out by Hipólito Cabaço. In 1937, the first excavation campaign was led by Eugénio Jalhay and Afonso do Paço. With the death of the first, in 1950, Paço assumed, with occasional collaborations, the direction of the archaeological works on the site, until 1967.

This article intends to analyse the fauna collected and described by Afonso do Paço during these campaigns, about which, however, there is no information on the stratigraphic provenance of artifacts and ecofacts. The data from these campaigns are also compared with the fauna collected during the 2017 and 2018 excavations, carried out under the VNSP3ooo project. From this faunistic material without context, it was still possible to acquire some knowledge about species present in the vicinity of Vila Nova de São Pedro during the Chalcolithic. Keywords: Zooarchaeology, Afonso do Paço, Chalcolithic, Vila Nova de São Pedro.

\footnotetext{
1. Aluna de Mestrado da Universidade do Algarve; afrancisco1@campus.ul.pt

2. Uniarq, Centro de Arqueologia da Universidade de Lisboa, Faculdade de Letras da Universidade de Lisboa; cdetry@gmail.com; m.diniz@letras.ulisboa.pt

3. Associação dos Arqueólogos Portugueses; c.augustoneves@gmail.com; direccao@arqueologos.pt

4. Fundação para a Ciência e a Tecnologia; andrea.arte@gmail.com
} 


\section{INTRODUÇÃO}

O sítio de Vila Nova de São Pedro (VNSP) é um povoado que tem, identificadas, três linhas de muralha de cronologia calcolítica. Após os primeiros trabalhos de terreno, dirigidos em 1936, por Hipólito Cabaço, as escavações arqueológicas realizaram-se entre 1937 e 1967 por Eugénio Jalhay e A fonso do Paço com o apoio de várias instituições, como a da Associação dos Arqueólogos Portugueses.

A descoberta de um possível "ritual de fundação" constituído por um excepcional recipiente cerâmico e grandes cornos de bovídeo, despertou o interesse para os restos osteológicos faunísticos (Paço, 1943: 6), muito abundantes no sítio, dada a natureza básica dos calcários onde assenta, favorável à preservação desses restos. No entanto, por opção dos responsáveis das intervenções, recolha de restos faunísticos foi muito selectiva (Figura 3) não sendo hoje, possível avaliar a real dimensão do conjunto detectado. Ainda assim, alguns materiais faunísticos foram recolhidos e depositados no Museu Arqueológico do Carmo (Lisboa), sede da Associação dos Arqueólogos Portugueses, onde, para além de referências breves nas publicações de Paço, permaneceram inéditos.

No âmbito do seminário da Licenciatura em Arqueologia da Faculdade de Letras da Universidade de Lisboa, a primeira autora analisou, sob supervisão de C. Detry, o conjunto de faunas depositado no Museu Arqueológico do Carmo (MAC), provenientes das escavações dirigidas por Eugénio Jalhay e Afonso do Paço.

O conjunto em análise apresenta algumas limitações que importam ser mencionadas. Claramente truncado, e sem possuir um contexto arqueológico preciso, o conjunto denuncia um critério de selecção, no campo, evidente com uma recolha selectiva dos restos de maior dimensão e mais completos. No entanto, e apesar destes condicionalismos, este estudo procurará recuperar alguma informação zooarqueológica proveniente das extensas escavações realizadas no sítio que, no futuro, poderá ser complementada com os dados recolhidos nas escavações mais recentes, decorrentes do projecto de investigação VNSP3Ooo (Arnaud, et al., 2017; Martins et al. 2019) (Figura 1).

\section{ENTÃO E OS OSSOS? TRÊS DÉCADAS DE ESCAVAÇÕES EM VILA NOVA DE SÃO PEDRO}

Como referido anteriormente, durante três décadas foram efectuadas campanhas sistemáticas que removeram toneladas de sedimento arqueológico do povoado de Vila Nova de São Pedro. Foram recolhidos e transportados para os depósitos do Museu Arqueológico do Carmo (MAC) e do Museu de Alenquer milhares de fragmentos de cerâmica, de artefactos de pedra lascada, de pedra polida e de osso sendo, nesses depósitos, residual a fauna mamalógica e malacológica. Encontramos, depositados no MAC, algumas centenas de restos faunísticos, sabendo que, necessariamente, esta amostra é demasiado reduzida para o sítio em questão (Figura 2). A metodologia da época, que privilegiava a recolha de artefactos de mais óbvio significado crono-cultural, aliada a um efectivo problema de depósito dos materiais recolhidos, tornam-se justificações possíveis (mas não aceitáveis actualmente) para esta opção. Realça-se que estes critérios de escolha foram aplicados também a outros materiais, nomeadamente bojos de cerâmica lisa, que ficaram "armazenados" em pequenos conjuntos em áreas limítrofes da escavação.

Encontramos em todas as publicações de A. Paço e colaboradores, relativas às campanhas de escavação, referência à presença de "ossos" de animais, sendo realçado logo desde o primeiro artigo a existência de abundante indústria em osso (punções, alisadores, espátulas, alfinetes, agulhas) (Paço e Jalhay, 1939), que surge frequentemente representada graficamente nas estampas dos artigos.

Na campanha de 1939, foi identificado um contexto que se tornou icónico, pela sua singularidade, reforçada depois por uma deturpação do contexto que se tornaria vox populi entre a comunidade arqueológi$\mathrm{ca}$, de que dentro de um vaso de grandes dimensões estariam depositados os chifres de um grande auroque, estando-se assim perante um ritual de fundação do povoado com influências orientais. Porém, re-analisando a descrição estratigráfica publicada por A. Paço (Diniz et al., 2016; Paço, 1943), que corresponde a uma das descrições mais pormenorizadas de contextos arqueológicos de VNSP, percebemos que o grande auroque não se encontrava dentro do recipiente. Segundo A. Paço foi aberto um fosso 
profundo 5 , com cerca de 2,6om de profundidade, onde depositaram um bovídeo (Bos) com a cabeça orientada a Sul e restos de outros animais como Cervus, Sus e Capra e um Pecten (Paço, 1943:13), sobre os quais se acendeu uma fogueira e foi colocado um pote cerâmico. Sobre esta fogueira e animais foi deitada uma camada de barro compacto e amassado, com cerca de $50 \mathrm{~cm}$, estando no momento desta deposição a fogueira ainda em combustão. Na zona do ventre do bovídeo foi colocada ainda uma camada de pedras, sendo sobre este nível que se localizava o vaso de grandes dimensões, sem decoração, e com apenas uns fragmentos pequenos de fauna no interior. Estes foram classificados por Henri Breuil como Cervus e Sus, estando ainda no interior do recipiente pequenos fragmentos cerâmicos, um fragmento de um machado de pedra polida e uma valva de ameijoa (Paço, 1943: 14). O vaso foi rodeado de elementos pétreos criando uma maior estabilização da peça, sendo posteriormente todo o fosso colmatado pelo barro amassado, adicionando-se ainda uma nova camada de pedras sobre a área do recipiente cerâmico, coberta por mais barro até ao nível de topo. É ainda referido que no mesmo fosso, na direcção Leste, a uma cota idêntica, foram identificados restos de outro grande bovídeo, que deverá fazer parte do mesmo ritual (Paço, 1943: 15). Tendo em conta a estratigrafia identificada e a deposição quer da fauna mamalógica, como do grande recipiente que se encontrava inteiro, este contexto foi interpretado como um ritual de fundação do povoado.

Na campanha de 1940, foram escavados três silos, na área entre $1^{\underline{a}}$ e $2^{\underline{a}}$ linha de muralha, sendo referida a presença de "fauna, cinzas, conchas e cerâmica” (Paço e Jalhay, 1942: 6). Nas observações sobre enquadramento económico social deste povoado é referida a abundante presença de fauna, espalhada por todas as áreas intervencionadas, predominando veado, boi, javali, cavalo e cabra, classificação esta feita por H. Breuil (Paço e Jalhay, 1942: 24), surgindo também fauna malacológica.

É, porém, na publicação de 1943, relativa à 6 6 campanha de escavação, decorrida em 1942 (Paço e Jalhay, 1943: 21), que surge a primeira listagem da fauna encontrada - realizado pelo pré-historiador francês e repetida posteriormente - onde é referida a presença de "Bos (boi)- muito abundante e de grandes di-

5. A questão do fosso, e não fossa, de VNSP foi abordada anteriormente pela equipa VNSP3ooo (Diniz et al., 2016). mensões, Capra (cabra), Equus (cavalo)-abundante, Asinus (burro)- raro, Canis (cão)- raro, Cervus (veado) - muito abundante, Sus scrofa (javali) - muito abundante, Lupus (lobo) - raro, Ursus - restos de um grande urso e de outro mais pequeno, Hystrix (porco-espinho), Lynx (lince) e Meles taxus (texugo). Esta listagem é antecedida por uma justificação metodológica para a escassez de materiais recolhidos e guardados - "Os despojos faunísticos que temos recolhido até hoje formam montões enormes (...)”. Nas seguintes campanhas, a descrição da identificação de fauna é semelhante (sempre montões enormes, que, na sua maior parte, deixamos junto ao perímetro escavado, por impossibilidade de transporte" (Paço e Jalhay, 1943: 21). Estes "montões" foram registados durante as escavações (Figura 3), e hoje ainda é possível encontrar restos destas deposições na área limítrofe do sítio. Nas seguintes campanhas a descrição da identificação de fauna é semelhante (sempre muito abundante), referindo na campanha de 1944 que durante a escavação de um dos habituais "cinzeiros" localizados no reduto central surgiu um grande depósito de ossos queimados e fogareiros de barro (Paço, 1954). Os "cinzeiros" escavados em 1946, na área entre o reduto central e 2 a linha de muralha, apresentam pouco espólio, mas muita fauna. Entre 1947 e 1952, decorreram as grandes campanhas de escavação do reduto central sendo aí identificadas numerosas estruturas ("cinzeiros", silos, "cisterna", estruturas pétreas), nas quais foram recolhidos milhares de artefactos arqueológicos (indústria óssea incluída, destacando-se os recipientes de osso decorado), bem como abundante fauna mamalógica, alguma da qual queimada ou mesmo calcinada como no interior do poço/cisterna (Paço, 1954).

$\mathrm{Na} 5^{\underline{a}}$ campanha, a primeira realizada em colaboração com Mํㅡㄹ Lourdes Costa Arthur, que decorreu no reduto central, é referida a classificação feita por Henri Breuil e Octávio Veiga Ferreira a diversa fauna malacológica: Glyceneris glycimeris, Pecten maximus, Mytilus edulis e Tapes decussata (Paço e Arthur, 1952). No final da campanha de 1953 A. Paço enviou para o Instituto de Antropologia da Universidade de Coimbra, ao cuidado do Prof. A. Xavier da Cunha, um conjunto de fauna mamalógica para ser estudada. No relatório, enviado pelo investigador é referido que os ossos analisados estavam bastante fragmentados tendo sido a classificação efectuada principalmente através da dentição dos animais. Tendo por base o anterior inventário feito por $\mathrm{H}$. Breuil verifica-se que 
não foram localizados nesta amostra lobo, lince, porco-espinho, texugo e burro, mas identificou-se pela primeira vez, através dos primeiros molares inferiores direito e esquerdo, o castor (Castor fiber L.) (Paço, 1958: 76). Relativamente ao boi, que Henri Breui já tinha assinalado como de grande dimensão, é referido agora que os fragmentos analisados - a metade próximal de um fémur esquerdo, a metade distal de um úmero direito e alguns molares de invulgares dimensões - levam mesmo a propor a presença de Bos primigenius (Paço, 1958: 76) ou seja, auroque. Além deste sucinto relatório A. Paço refere ainda que os ossos longos surgem fracturados a meio com o objectivo de extrair a medula, enquanto os restantes surgem muito partidos não sendo predominantes os ossos queimados. Concluindo assim que a carne poderia ser confeccionada através de cozedura e não grelhada com acção directa do fogo (Paço, 1958).

$\mathrm{Na}$ denominada "campanha das muralhas" realizada em 1955, em colaboração com E. Sangmeister é referida que na camada pré-campaniforme, na base das muralhas, surge, a par da cerâmica incisa, copos canelados, machados de pedra polida, pontas de seta e abundante fauna. Sendo predominante os bovídeos na base da muralha e cervídeos em níveis superiores (Paço e Sangmeister, 1956).

A campanha de 1956 - a $20^{\mathrm{a}}$ - foi a última descrita nas habituais publicações de A.Paço apresentando um inventário de fauna produzido, tal como em 1953, pelo Prof. A. Xavier da Cunha e Drª Maria Manuela Gama que sucintamente referem a classificação das seguintes espécies: porco, coelho, cão, boi, carneiro, cavalo, burro, cabra, veado e gamo (Paço, 1958: 54). Nesta campanha, onde se intervencionou a área entre o torreão 4 e 5 , identificou-se um estrato de tufo calcário que protegia um conjunto de restos de animais que, segundo A. Paço, poderiam ter feito parte de algum festim ritual, surgindo além de ossos longos, chifres de bovino e dentes (Paço, 1958: 54). Esta "escavação" à extensa bibliografia deixada por A. Paço revela-nos por um lado a importância das releituras de documentação bem conhecida, bem como o reconhecimento pelo próprio da importância da recolha e caracterização da fauna como meio de contextualização da vida económica e social dos habitantes deste povoado calcolítico. Algumas observações e descrições mais pormenorizadas de contextos específicos possibilitam uma aproximação à realidade arqueológica, sendo fundamental na interpretação do sítio.

\section{O ESTUDO DE UMA COLECÇÃO ANTIGA - A METODOLOGIA}

A abordagem a esta colecção, começou com a inventariação dos restos faunísticos encontrados no MAC atribuídos às escavações de Afonso do Paço. Os elementos analisados foram registados numa base de dados Excel. A realização deste inventário permitiu uma triagem mais selectiva de ossos identificáveis e não identificáveis, bem como a distinção de fauna malacológica e mamalógica. Sendo também possível recolher posteriormente dados sobre a idade de abate, Osteometria e Tafonomia.

Os restos de vertebrados foram identificados ao nível da espécie ou género. Quando isso não foi possível efectuou-se a classificação ainda por tamanho atribuindo os restos a Macrofauna, no caso da fauna de grande porte, e Mesofauna no caso de serem elementos provavelmente pertencentes a animais de médio porte.

Em relação à contabilização dos moluscos, estes foram registados apenas quando a charneira se apresentava conservada ou quando o fragmento permitisse identificar até à espécie, género ou grupo taxonómico.

\section{RESULTADOS E DISCUSSÃO}

No espólio das campanhas de escavação realizadas entre 1937 e 1967, depositado no MAC, analisaram-se 675 restos, de entre os quais 522 foram determinados taxonomicamente (ver Tabela 1).

\subsection{Fauna malacológica}

Quanto a moluscos foram identificadas as seguintes espécies (139 restos): Anomia ephippium, Ostrea edulis, Glycymeris sp., Pecten maximus (fig. 4), Ruditapes decussatus (=Tapes decussata), Cerastoderma edule, Mytilus edulis e Venus verrucosa. A maioria já referidas e identificadas por Paço e Arthur (1952) (Figura 4).

Todas estas espécies são típicas de ambiente marinho de substrato rochoso ou arenoso, com origem na costa atlântica, a cerca de $42 \mathrm{~km}$ de distância do povoado. Ao contrário do verificado em outros povoados calcolíticos das penínsulas de Lisboa e Setúbal onde as mesmas espécies são encontradas, como um produto de quase imediata captação, como se verifica no Zambujal (Driesch \& Boessneck, 1976), a cerca de 22km da costa, Leceia (Guerreiro e Cardoso, 
2001/2002), a c. 4km, e Chibanes (Coelho, 2014), a c. $5 \mathrm{~km}$. Os moluscos em VNSP percorrem um trajecto de média distância, obtidos seguramente num quadro mais amplo de trocas/captações e contactos com o litoral.

\subsection{Fauna mamalógica}

O conjunto possui, no seu total, 536 restos de vertebrados, dos quais 366 são ossos e 170 dentes (ver tabela 2 e 3). As espécies identificadas são: Bos sp., Ovis/Capra, Sus sp., Cervus elaphus, Equus sp., Oryctolagus cuniculus, Ursus arctos, Lynx pardinus e Canis sp.

Os bovinos, caprinos e suídeos parecem ser os mais comuns neste contexto de Vila Nova de São Pedro, tal como seria esperado para uma comunidade de agricultores-pastores do Calcolítico. O mesmo se verifica em outros sítios do Calcolítico na Estremadura, nomeadamente no Zambujal (Driesch e Boessneck, 1976), Leceia (Cardoso e Detry, 2001/2002), Lexim (Moreno-Garcia e Sousa, 2015), (Pereira et al., 2017), bem como no estudo das faunas das escavações de V. Gonçalves, em VNSP (Wright et al., in press).

As várias partes do esqueleto estão presentes, demonstrando que provavelmente toda a carcaça seria desmontada no povoado e abandonada no mesmo local.

A caça parece ser relativamente frequente com a presença de restos de veado, auroque, javali e ainda carnívoros como o urso e o lince. Note-se que a grande abundância de restos de veado se deve muito à presença de hastes (ver Tabela 2), algumas trabalhadas, o que pode sobrevalorizar a percentagem desta espécie no conjunto (Figura 5). As hastes dos cervídeos são largadas anualmente pelos machos a seguir à época de cio, não sendo por isso necessário abater um animal para as obter.

Nos dados das escavações mais recentes podemos ver confirmada a tendência de uma elevada percentagem de animais caçados (Detry et al., neste volume). No entanto, o número significativo de restos de espécies domésticas torna o peso exacto da pastorícia versus caça uma questão ainda em aberto.

\subsection{Revisão dos dados}

No relato das campanhas de 1939, 1940, 1941 e 1942, mencionou-se a presença de bovinos, suídeos, equídeos e caprinos (Paço, 1942: 24; Paço e Sangmeister, 1956), o que coincide com o encontrado nas reservas do MAC, com excepção de burro que não foi identi- ficado nos materiais de VNSP. Foi ainda referida a presença de vários carnívoros como o cão (Canis lupus familiaris), lobo (Canis lupus), urso (Ursus arctos), lince-ibérico (Lynx pardinus) e texugo (Meles meles) (Paço, 1964: 137-138). Restos de castor (Castor fiber), também são referidos por Afonso do Paço na sua lista de espécies recuperadas (Paço, 1958), mas no material depositado no MAC não encontrámos o elemento por ele mencionado. No entanto, nas escavações recentes de VNSP (Detry et al., neste volume), identificámos esta espécie de roedor. Assim, é muito provável que essa peça tivesse existido, mas não foi encontrada durante a realização deste trabalho.

A presença de castor reflecte a existência de uma paisagem mais aquática que a actual, onde se fazem ainda sentir as consequências da transgressão flandriana na ribeira de Almoster, que corre a W do povoado e na linha de água, hoje sem caudal, que o define a NE.

O texugo, pelo contrário, não foi achado, nem nos restos do MAC, nem nas escavações do séc. XXI, mas é uma espécie muito frequente na fauna portuguesa e normalmente intrusiva nas camadas arqueológicas devido a ser um animal fossador, produzindo tocas bastante profundas, por isso é natural que tenha existido no conjunto recuperado por Afonso do Paço. Já o porco-espinho referido em Paço e Jalhay (1943: 21) é possível que tenha sido confundido com o castor dado que não é referido nenhum elemento desta espécie no Calcolítico da Península Ibérica e não foram registados restos nas escavações antigas ou recentes de VNSP. Do mesmo modo, o gamo (Dama dama) provavelmente foi confundido com o corço (Capreolus capreolus), uma espécie autóctone e que foi encontrada nas escavações dos últimos anos. O gamo é dado como extinto no Plistocénico e reintroduzido pelos romanos (Davis e Mackinon, 2009).

Um terceiro molar superior de canídeo foi encontrado nas colecções antigas do MAC, este dente provavelmente pertence a cão, mas não é possível excluir que se trate de lobo.

O lince ibérico está representado por dentes e uma peça muito particular: um furador em osso feito a partir de um cúbito (Figura 6). Desconhece-se a ocorrência de utensílios semelhantes produzidos sobre esta espécie. Os furadores em osso são frequentes em tíbias, metápodes e cúbitos de mamíferos de médio porte como a ovelha e cabra, mas muito raros em ossos de carnívoros. 
Em restos de bovinos, Bos sp., obtivemos medidas de quatro tíbias. Comparámos essas com as medidas dos bovinos de Carnide (Lisboa), datados do séc. XVII, e por isso certamente pertencentes a gado bovino doméstico (Bos taurus), e com as medidas dos bovinos de Muge, ossos datados do Mesolítico e seguramente pertencentes a auroque (Bos primigenius). Na figura 7 , podemos observar um gráfico de dispersão das medidas obtidas, permitindo-nos perceber que muito provavelmente três dos ossos de Vila Nova de São Pedro pertencem a auroque e apenas um à espécie doméstica.

Os ossos dos animais selvagens são normalmente maiores que os da espécie doméstica, tornando-se a osteometria uma metodologia muito fiável para os distinguir. A maioria dos bovinos recolhidos em VNSP é, assim, de origem selvagem. Esta prevalência pode dever-se à escolha por A. Paço e E. Jalhay de ossos particularmente grandes, como são os de auroque.

Neste conjunto, constatou-se ainda o óptimo estado de conservação dos restos osteológicos. Percebe-se a escolha de materiais mais completos e, por isso, mais apelativos. Quando observamos a figura 8 podemos constatar que, comparando com as escavações mais recentes (Detry et al., neste volume), temos muito menos restos não determinados taxonomicamente e não existem vestígios de microfauna ou de restos indeterminados.

Estes últimos, que aparecem em elevado número nas escavações recentes, não seriam simplesmente recolhidos nestas primeiras escavações em VNSP. Quando observamos a tendência em relação aos restos identificados por espécie ou género (Figura 9) podemos também ver que as espécies de maior porte parecem mais frequentes nas recolhas dos escavadores, nomeadamente de bovinos, veado e equídeos. Atribuímos esta discrepância à escolha, pelos arqueólogos, de materiais de maior tamanho e mais bem conservados e, dessa forma, mais passíveis de classificação fiável.

\section{OBSERVAÇÕES FINAIS}

Uma das principais limitações do conjunto analisado é o desconhecimento do contexto de proveniência dos elementos faunísticos. A meritória e elevada preocupação de Afonso do Paço e Eugénio Jalhay em publicar as campanhas arqueológicas não foram, infelizmente, acompanhadas pela minuciosidade em divulgar o contexto arqueológico de onde os elementos provêm. A este facto, junta-se a evidente selecção, no campo, de peças em perfeitas condições de conservação. Assim, estas características do conjunto fragilizam a tentativa de interpretar a vivência da comunidade ao longo da ocupação do sítio, apresentando, por outro lado, alguns dados que dão uma perspetiva historiográfica ao conjunto.

Podemos assim dizer que neste povoado calcolítico a economia agro-pastoril terá tido um peso determinante, com um suporte muito provavelmente também dos produtos secundários, equilibrada com a actividade cinegética. Neste período constata-se a presença de algumas espécies domésticas, como os bovídeos, suínos e caprinos. No entanto, pode-se identificar também uma relevante quantidade de restos de fauna selvagem: javali, veado, auroque, coelho, bem como alguns carnívoros.

A nossa análise demonstra que os restos de bovinos (Bos sp. - auroque e gado bovino) e suínos (Sus sp.javali e porco) são os mais abundantes. Em seguida, surge a ovelha (Ovis aries), cabra (Capra hircus), o veado (Cervus elaphus), Equídeos (Equus sp. - cavalo ou burro), coelho (Oryctolagus cuniculus) e urso (Ursus arctos).

Relativamente aos moluscos, as espécies dominantes são a ameijoa (Ruditapes decussatus), vieira (Pecten maximus) e mexilhão (Mytilus edulis). Aparecem ainda restos menos frequentes de castanhola (Glycymeris sp.) e berbigão (Cerastoderma edule). Com este trabalho pretendeu-se demonstrar as espécies presentes numa colecção em particular de um sítio de grande relevância no Calcolítico peninsular que, até ao momento, não tinham sido alvo de estudo e, consequente, publicação, podendo constituir-se como o arranque para a formulação de novas questões e trajectórias empíricas num estudo que se requer, sempre, multidisciplinar.

\section{AGRADECIMENTOS}

Ao Museu Arqueológico do Carmo e Associação dos Arqueólogos Portugueses pelo acesso aos materiais e disponibilização de meios e recursos para o presente estudo.

Agradecemos a Elizabeth Wright pela partilha dos seus dados não publicados sobre Vila Nova de São Pedro. 


\section{BIBLIOGRAFIA}

ARNAUD, José M.; DINIZ, Mariana; NEVES, César; MARTINS, Andrea (2017) - Vila Nova de São Pedro - de novo, no 3.․․ milénio. Um projecto para o futuro. Arqueologia e História, 66-67, Associação dos Arqueólogos Portugueses, Lisboa, pp. 7-17.

CARDOSO, João Luís, e DETRY, Cleia (2001/2002) - Estudo arqueozoológico dos restos de ungulados do povoado pré-histórico de Leceia (Oeiras). Estudos Arqueológicos de Oeiras. 10, pp. 131-182.

COELHO, Manuela (2014) - A fauna malacológica da ocupação calcolítica do Castro de Chibanes. Setúbal Arqueológica - II Encontro de Arqueologia da Arrábida. Homenagem a AI Marques da Costa.15, pp. 181-20o.

DAVIS, Simon; MACKINNON, Michael (2009) - Did the Romans bring fallow deer to Portugal? Environmental Archaeology, 14.1, pp. 15-26.

DINIZ, Mariana; NEVES, César; MARTINS, Andrea; ARNAUD, José (2016) - A ditch in the archaeological record: revisiting Vila Nova São Pedro's bibliography. (Azambuja, Portugal). Poster apresentado no Encontro Enclosing Worlds. Reguengos deMonsaraz,12a14 de Outubro de 2016. https:// vnsp.arqueologos.pt/publicacoes/

DRIESCH, Angela von den e BOESSNECK, Joachim (1976) - Die fauna vom Castro do Zambujal. Studien über frühe Tierknochenfunde von der Iberischen Halbinsel. 5, pp. 4-129.

GUERREIRO, António e CARDOSO, João Luís (2001/ 2002) - A fauna malacológica encontrada no povoado pré-histórico de Leceia (Oeiras): estudo sistemático e respectivo significado. Estudos Arqueológicos de Oeiras. 10, pp. 89-129.

MARTINS, Andrea; NEVES, César; DINIZ, Mariana; ARNAUD, José (2019) - O povoado calcolítico de Vila Nova de São Pedro (Azambuja). Notas sobre as campanhas de escavação de 2017 e 2018. Arqueologia e História, nº 69, Associação dos Arqueólogos Portugueses, pp. 133-167.

MORENO-GARCIA, Marta e SOUSA, Ana Catarina (2015) - A exploração de recursos faunísticos no Penedo do Lexim (Mafra) durante o Neolítico Final. In 5. ํ Congresso do Neolítico Peninsular. Actas. (pp. 67-76). UNIARQ-Centro de Arqueologia da Universidade de Lisboa, pp. 67-76.

PEREIRA, Vera; SOARES, Joaquina e TAVARES DA SILVA, Carlos (2017) - Understanding the First Chalcolithic Communities of Estremadura: Zooarchaeology of Castro de Chibanes, Portugal. Preliminary Results. Papers from the Institute of Archaeology. 27(1): Art. 6, pp. 1-11.

PAÇO, Afonso do (1958) - Castro de Vila Nova de S. Pedro. $\mathrm{X}$ - Campanha de Escavações de 1956 (20 $\mathrm{a}$ ), Lisboa: Academia Portuguesa da História ANAIS, II série, vol.8, pp. 50-54

PAÇO, Afonso do (1964) - Castro de Vila Nova de S. Pedro. Vida Económica, O Problema Campaniforme, Metalurgia e Análises Espectrográficas, Lisboa: Separatas dos "Anais», série II, vol. 14, pp. 137-139.

PAÇO, Afonso do; ARTHUR, Costa Lourdes Maria de (1952) - Castro de Vila Nova de São Pedro. 1- $15^{\underline{a}}$ Campanha de Escavações (1951), Brotéria, vol. 54(3), Lisboa, pp. 3-25.

PAÇO, Afonso; JALHAY, Eugénio (1939) - A póvoa eneolítica de Vila Nova de S. Pedro: Notas sobre a $1^{\underline{a}}$ e $2^{\underline{a}}$ campanha - 1937 e 1938. Brotéria. Separata Lisboa. Vol. XXVIII: 6, pp. 2-46.

PAÇO, Afonso do; JALHAY, Eugénio (1942) - A Póvoa eneolítica de V ${ }^{\mathrm{a}}$. Nova de S. Pedro. Notas sobre a $3^{\underline{a}}, 4^{\underline{a}}$ e $5^{\underline{a}}$ campanhas de Escavações - 1939,1940 e 1941, Lisboa: Separata da Revista Brotéria, vol. 34, p. 24.

PAÇO, Afonso; JALHAY, E. (1943) - A póvoa eneolítica de Vila Nova de S. Pedro: Notas sobre a 6 $6^{\underline{a}}$ campanha - 1942. Brotéria. Separata, Lisboa. Vol. XXXVII: 1, pp. 4-27.

PAÇO, Afonso; SANGMEISTER, Edward (1956) - Castro de Vila Nova de S. Pedro: VIII - Campanha de escavações 1955 (19ํㅗㄹ. Arqueologia e História. Lisboa. Série VIII, 7, pp. 95-114. 


\begin{tabular}{|c|c|c|c|c|}
\hline & \multicolumn{2}{|c|}{ NRD } & \multicolumn{2}{|c|}{ NMI } \\
\hline & $\mathrm{N}$ & $\%$ & $\mathrm{~N}$ & $\%$ \\
\hline \multicolumn{5}{|l|}{ Mollusca } \\
\hline Gastropoda & & O\% & & O\% \\
\hline Cf. Theba pisana & 2 & O\% & & O\% \\
\hline Bivalvia & & O\% & & $\mathrm{O} \%$ \\
\hline Anomia epiphium & 1 & O\% & 1 & $1 \%$ \\
\hline Ostrea edulis & 1 & O\% & 1 & $1 \%$ \\
\hline Glycymeris sp. & 5 & $1 \%$ & 3 & $3 \%$ \\
\hline Pecten maximus & 14 & $2 \%$ & 7 & $8 \%$ \\
\hline Ruditapes decussata & 101 & $15 \%$ & 51 & $59 \%$ \\
\hline Venus verrucosa & 1 & O\% & 1 & $1 \%$ \\
\hline Cerastoderma edule & 3 & O\% & 2 & $2 \%$ \\
\hline Mytilus edulis & 11 & $2 \%$ & 6 & $7 \%$ \\
\hline Vertebrata & & $\mathrm{O} \%$ & & $\mathrm{O} \%$ \\
\hline Mammalia & & O\% & & O\% \\
\hline Bos sp. (vaca e auroque) & 105 & $16 \%$ & 3 & $3 \%$ \\
\hline Ovis/Capra (ovelha/cabra) & 77 & $11 \%$ & 2 & $2 \%$ \\
\hline Sus sp. (porco e javali) & 85 & $13 \%$ & 2 & $2 \%$ \\
\hline Cervus elaphus (veado) & 68 & $10 \%$ & 1 & $1 \%$ \\
\hline Equus sp. (cavalo e burro) & 17 & $3 \%$ & 1 & $1 \%$ \\
\hline Oryctolagus cuniculus (coelho) & 18 & $3 \%$ & 1 & $1 \%$ \\
\hline Ursus arctos (urso) & 7 & $1 \%$ & 2 & $2 \%$ \\
\hline Canis sp. (cão ou lobo) & 1 & $\mathrm{O} \%$ & 1 & $1 \%$ \\
\hline Lynx pardinus (lince-ibérico) & 6 & $1 \%$ & 1 & $1 \%$ \\
\hline Macrofauna & 119 & $18 \%$ & & O\% \\
\hline Mesofauna & 34 & $5 \%$ & & ०\% \\
\hline Total & 676 & & 86 & \\
\hline
\end{tabular}

Tabela 1 - Número de Restos Determinados (NRD) e Número Mínimo de Indivíduos (NMI) dos restos de vertebrados e invertebrados encontrados nas reservas do Museu Arqueológico do Carmo recolhidos em Vila Nova de São Pedro por Afonso do Paço e Eugénio Jalhay. 


\begin{tabular}{|c|c|c|c|c|c|c|c|c|c|c|c|}
\hline & Bos & $\mathrm{O} / \mathrm{C}$ & Sus & C.el. & Equus & O.cun. & U.ar. & Canis & L. par. & MAC & MES \\
\hline \multicolumn{12}{|l|}{ Esqueleto Cranial } \\
\hline Haste/Chifre & 12 & 11 & & 47 & & & & & & & \\
\hline Crânio & & 1 & & & & & & & & 8 & 3 \\
\hline Dentes & 40 & 38 & 58 & 10 & 7 & 12 & & 1 & 4 & & \\
\hline \multicolumn{12}{|l|}{ Esqueleto Axial } \\
\hline Áxis & & & 2 & & & & & & & & \\
\hline Costelas & & & & & & & 3 & & & 14 & 3 \\
\hline Vértebras & & & & & & & & & & 4 & 3 \\
\hline Vértebras Cervicais & & & & & & & & & & 7 & \\
\hline \multicolumn{12}{|l|}{ Membro Anterior } \\
\hline Escápula & 1 & 3 & & & & 1 & & & & 3 & \\
\hline Úmero & 1 & 3 & 3 & & & 1 & & & & 2 & \\
\hline Rádio & 4 & & & 1 & 1 & & 2 & & & & \\
\hline Cúbito & 5 & 2 & 2 & 2 & & 1 & 2 & & 1 & & \\
\hline Carpo & 2 & & & & & & & & & 1 & \\
\hline Escafóide & 1 & & & & & & & & & & \\
\hline Os crochu & 1 & & & & & & & & & & \\
\hline Metacarpo & 4 & 2 & & 4 & 2 & & & & & & \\
\hline \multicolumn{12}{|l|}{ Membro Posterior } \\
\hline Pélvis & 2 & 2 & 2 & & & 2 & & & & 3 & 3 \\
\hline Fémur & 7 & & 1 & & 1 & & & & & & \\
\hline Patella & 1 & & & & & & & & & & \\
\hline Tíbia & 8 & 11 & 1 & 1 & 1 & & & & & 1 & \\
\hline Fíbula & & & 1 & & & & & & 1 & & \\
\hline Calcâneo & 1 & & 1 & 1 & & & & & & & \\
\hline Astrágalo & 1 & & & & & & & & & & \\
\hline Metatarso & 2 & 3 & 1 & & 1 & 1 & & & & & \\
\hline Sesamóide & & & & & & & & & & & 2 \\
\hline Falange I & 4 & & 2 & & 2 & & & & & & \\
\hline Falange II & 2 & & & & & & & & & & \\
\hline Falange III & 5 & 1 & 11 & 2 & 2 & & & & & & \\
\hline Ossos longos & & & & & & & & & & 51 & 13 \\
\hline $\begin{array}{l}\text { Ossos } \\
\text { indeterminados }\end{array}$ & & & & & & & & & & 25 & 7 \\
\hline TOTAL & 104 & 77 & 85 & 68 & 17 & 18 & 7 & 1 & 6 & 119 & 34 \\
\hline MNI & 3 & 2 & 2 & 1 & 1 & 1 & 2 & 1 & 1 & & \\
\hline
\end{tabular}

Tabela 2-Número de Restos Determinados por partes do esqueleto. Bos-gado bovino ou auroque; O/C - Ovis/Capra (ovelha ou cabra); Sus sp. (porco ou javali); C.el. - Cervus elaphus (veado); Equus - cavalo ou burro; O.cun. - Oryctolagus cuniculus (coelho); U. ar. - Ursus arctos (urso); Canis sp. (cão ou lobo); L.par. - Lynx pardinus; MAC - Macrofauna; MES - Mesofauna. 


\begin{tabular}{|c|c|c|c|c|c|c|c|c|}
\hline & Bos & $\mathrm{O} / \mathrm{C}$ & Sus & C.el. & Equus & O.cun. & Canis & L.par. \\
\hline \multicolumn{9}{|l|}{ Dentes Superiores } \\
\hline I & & & 1 & & & 1 & & \\
\hline $\mathrm{C}$ & & & 6 & & & & & \\
\hline PM & 2 & 2 & & 1 & & & & \\
\hline P1 & & & 1 & & & & & \\
\hline $\mathrm{P}_{2}$ & & & 1 & & & & & \\
\hline $\mathrm{P}_{3}$ & 1 & 1 & 3 & & & & & \\
\hline $\mathrm{P}_{4}$ & 2 & 2 & 2 & & & & & \\
\hline Mi & 1 & 2 & 4 & & & & & \\
\hline M2 & 1 & 2 & 3 & & & & & \\
\hline $\mathrm{M}_{3}$ & 1 & 3 & & & & & 1 & \\
\hline \multicolumn{9}{|l|}{$\mathrm{M} 1 / 2$} \\
\hline M & 10 & 5 & & 1 & 3 & 1 & & \\
\hline \multicolumn{9}{|l|}{ Dentes Inferiores } \\
\hline $\mathrm{i}$ & & & 1 & & & & & \\
\hline dp2 & & 2 & & & & & & \\
\hline $\mathrm{dp} 3$ & & 2 & 1 & & & & & \\
\hline dp4 & & 2 & & & & & & \\
\hline I & 1 & & 11 & 1 & 2 & & & \\
\hline $\mathrm{C}$ & & & 17 & & & & & \\
\hline $\mathrm{P}_{2}$ & 1 & & & & & & & \\
\hline $\mathrm{P}_{3}$ & 2 & 1 & & 2 & & & & 1 \\
\hline $\mathrm{P}_{4}$ & 1 & 1 & 1 & 1 & & & & 1 \\
\hline Mi & & 2 & & 1 & & & & 1 \\
\hline M2 & 4 & 3 & 1 & 2 & & & & 1 \\
\hline $\mathrm{M}_{3}$ & 8 & 5 & 2 & 1 & & & & \\
\hline $\mathrm{Mi} / 2$ & 3 & 3 & 1 & & & & & \\
\hline M & & & & & 2 & 10 & & \\
\hline Dente Indeterminado & 2 & & 2 & & & & & \\
\hline Total & 40 & 38 & 58 & 10 & 7 & 12 & 1 & 4 \\
\hline
\end{tabular}

Tabela 3 - Número de Restos de Dentes. Bos - gado bovino ou auroque; O/C - Ovis/Capra (ovelha ou cabra); Sus sp. (porco ou javali); C.el. - Cervus elaphus (veado); Equus sp. - cavalo ou burro; O.cun. - Oryctolagus cuniculus (coelho); Canis sp. (cão ou lobo); L.par. - Lynx pardinus. 


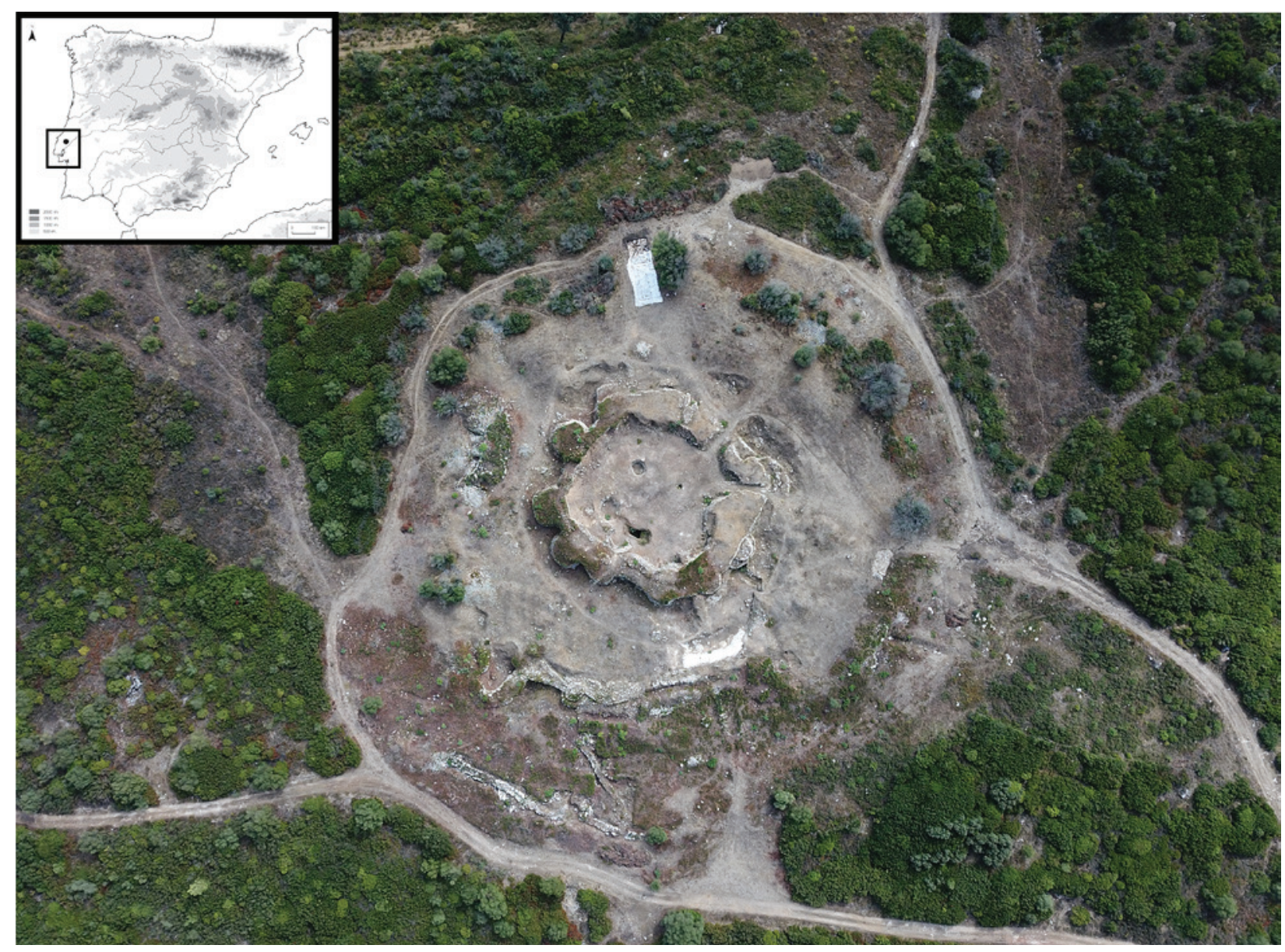

Figura 1 - Vila Nova de São Pedro. Imagem aérea tirada em 2018 no âmbito do projecto VNSP 3000.

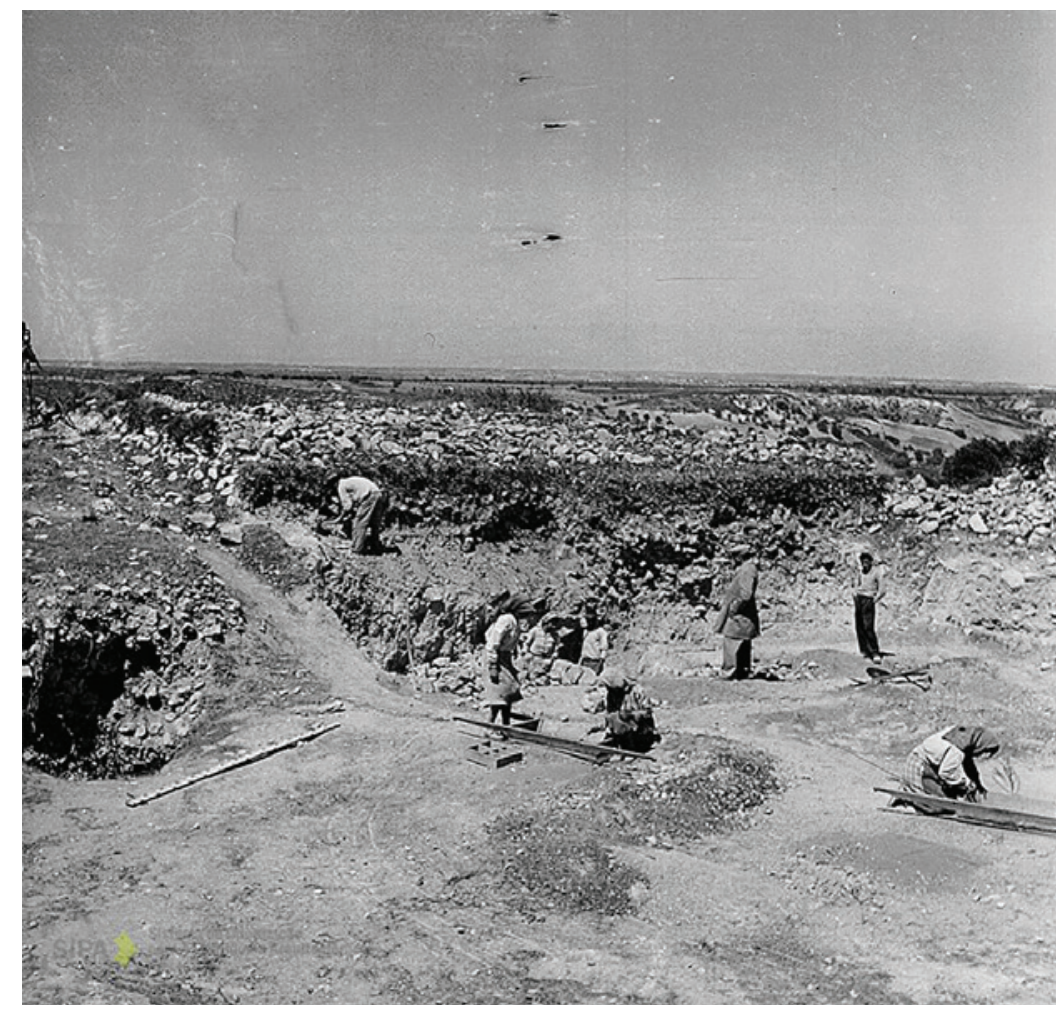

Figura 2-Aspecto geral da escavação e crivagem dos sedimentos em Vila Nova de São Pedro, sob atenta supervisão de Eugénio Jalhay, no centro da imagem de casaco e boina (Fonte: SIPA - Sistema de Informação para o Património Arquitetónico). 


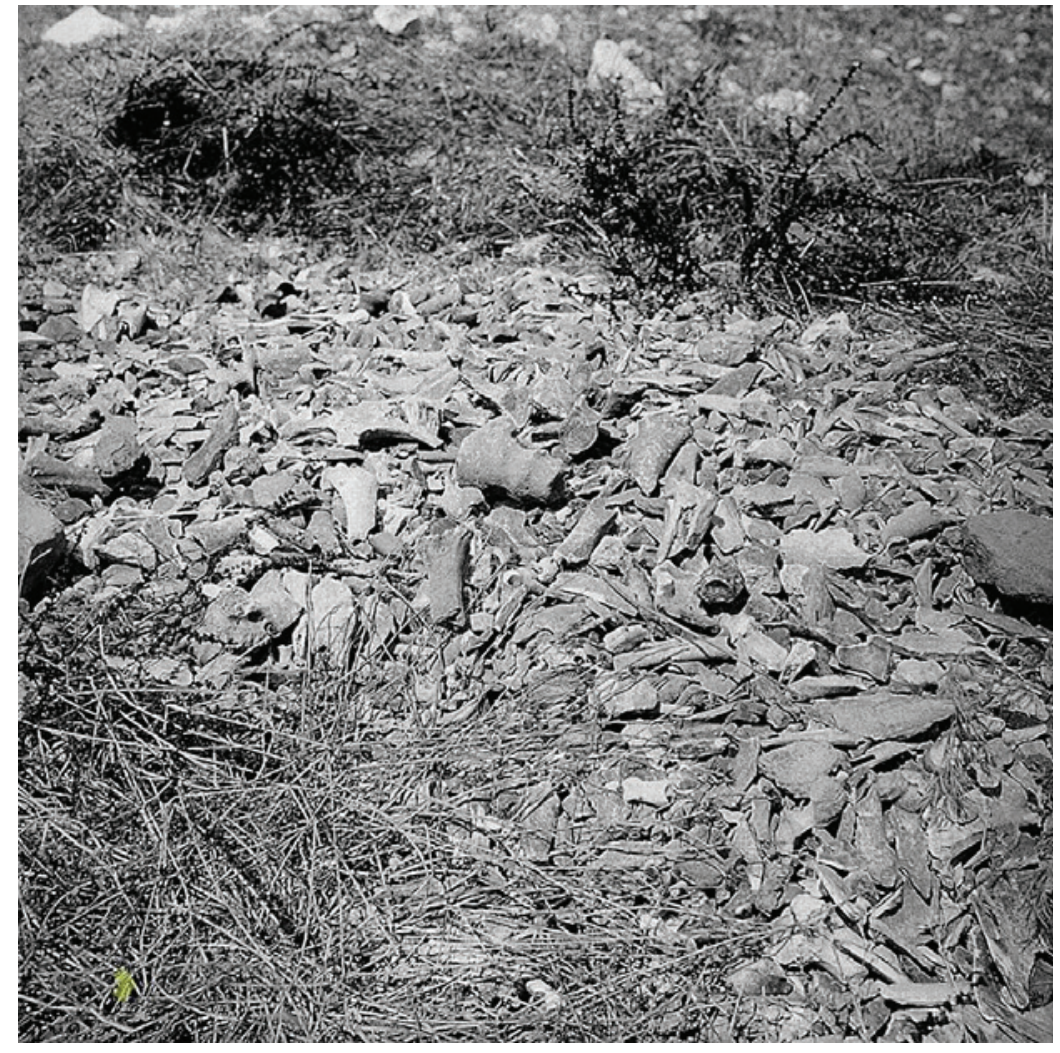

Figura 3 - Acumulação de restos faunísticos não recolhidos em Vila Nova de São Pedro, no decorrer das escavações dirigidas por Eugénio Jalhay e Afonso do Paço (Fonte: SIPA - Sistema de Informação para o Património Arquitetónico).

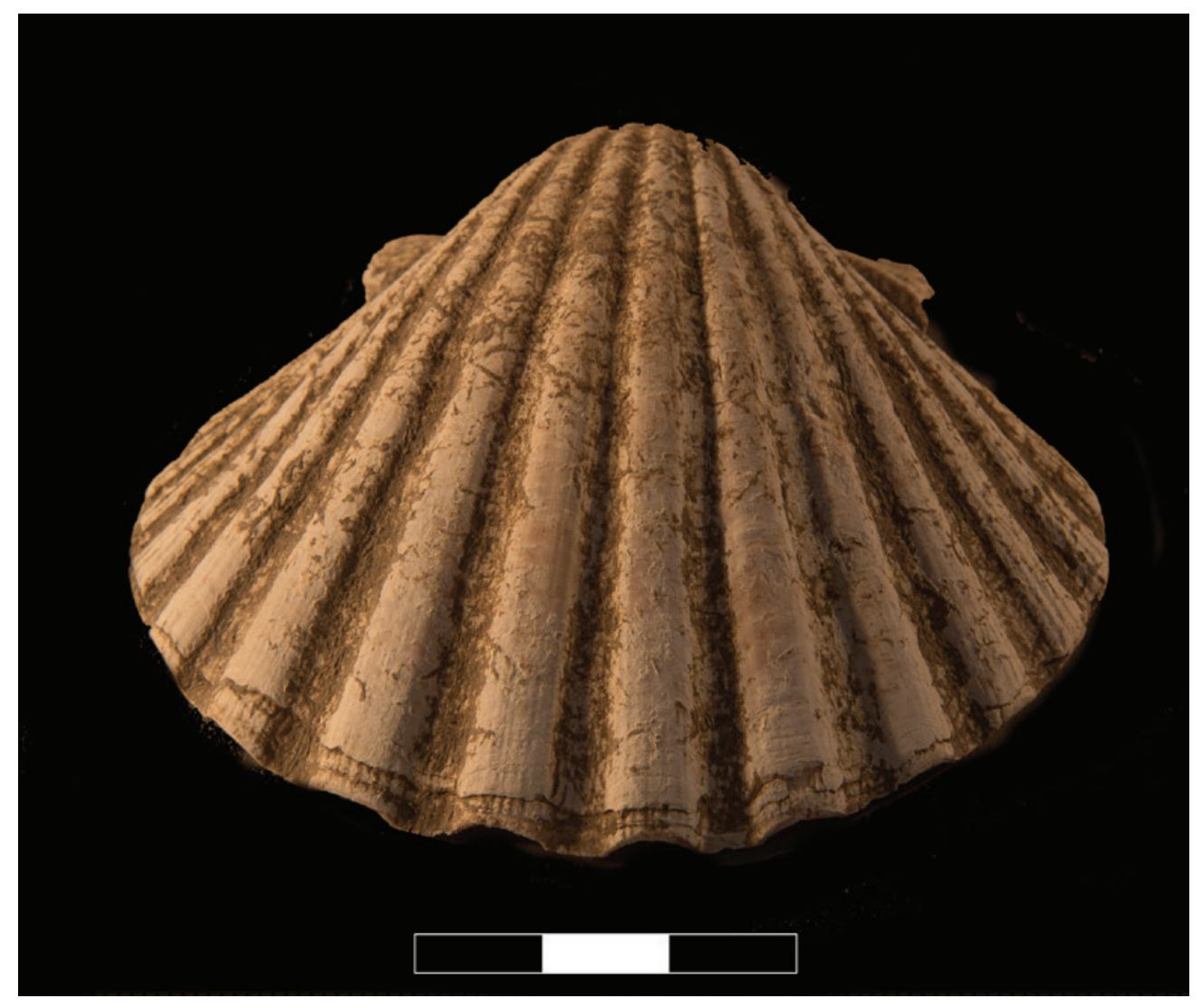

Figura 4 - Concha de Pecten maximus (vieira) depositada no Museu Arqueológico do Carmo e proveniente do povoado Calcolítico de Vila Nova de São Pedro. (Foto J. Arnaud) 


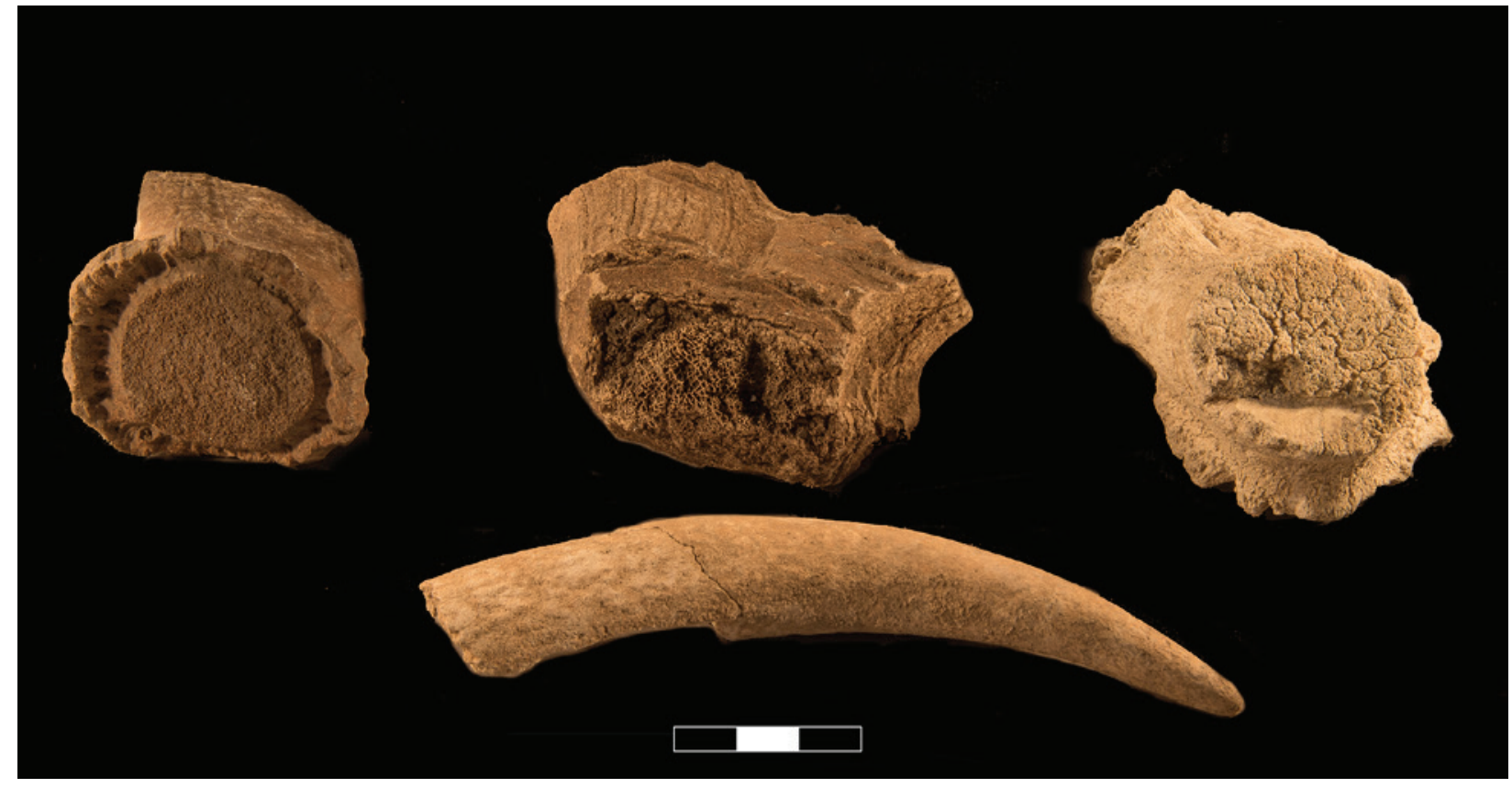

Figura 5- Vários exemplos de hastes de Cervus elaphus (veado) recolhidas nas escavações de Afonso do Paço em Vila Nova de São Pedro. (Foto J. Arnaud).

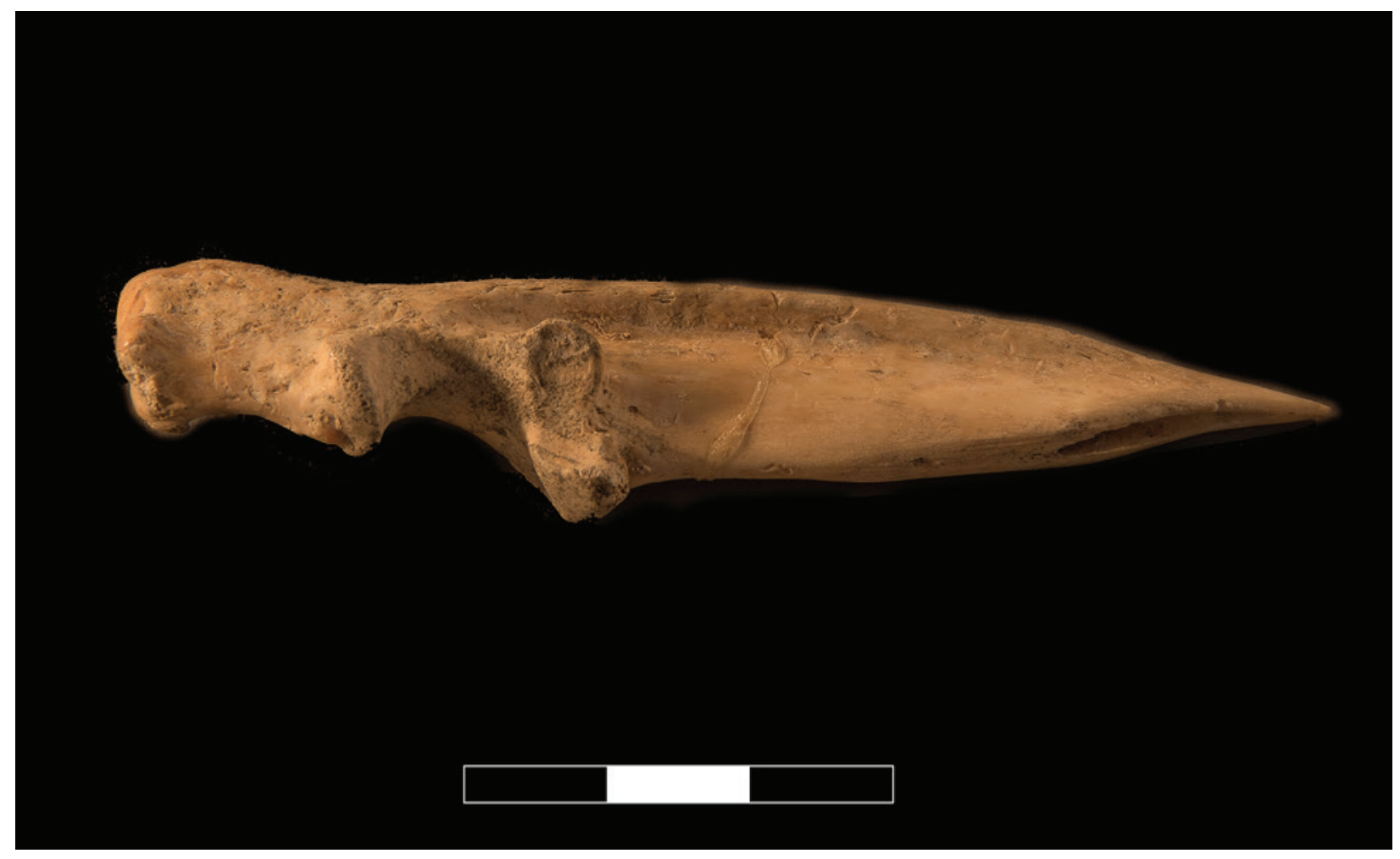

Figura 6 - Cúbito de Lince-ibérico (Lynx pardinus) trabalhado em forma de furador. (Foto J. Arnaud). 
Tíbia distal de Bos sp.

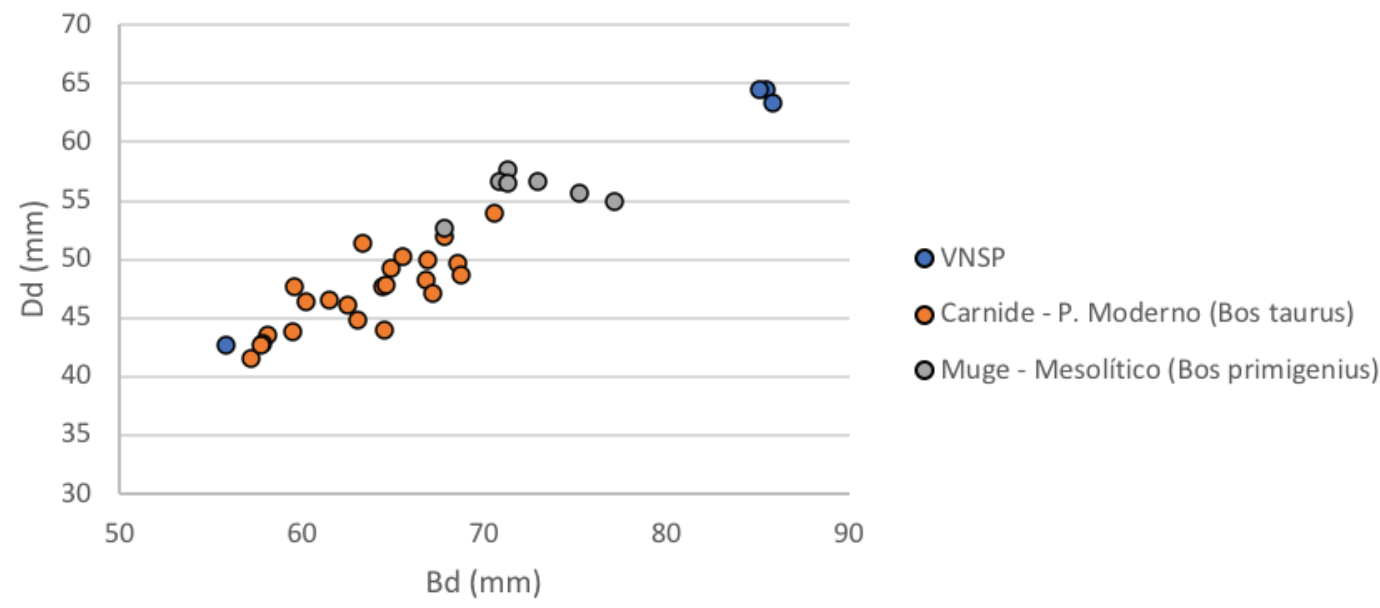

Figura 7 - Medidas de tíbia distal de Bos sp. recuperados em Vila Nova de São Pedro nas escavações de Afonso do Paço e Eugénio Jalhay, comparadas com medidas de auroque (Bos primigenius) do Mesolítico de Muge e com medidas de gado bovino (Bos taurus) de Carnide (Lisboa, Séc. XVII - Detry et al., in press.).

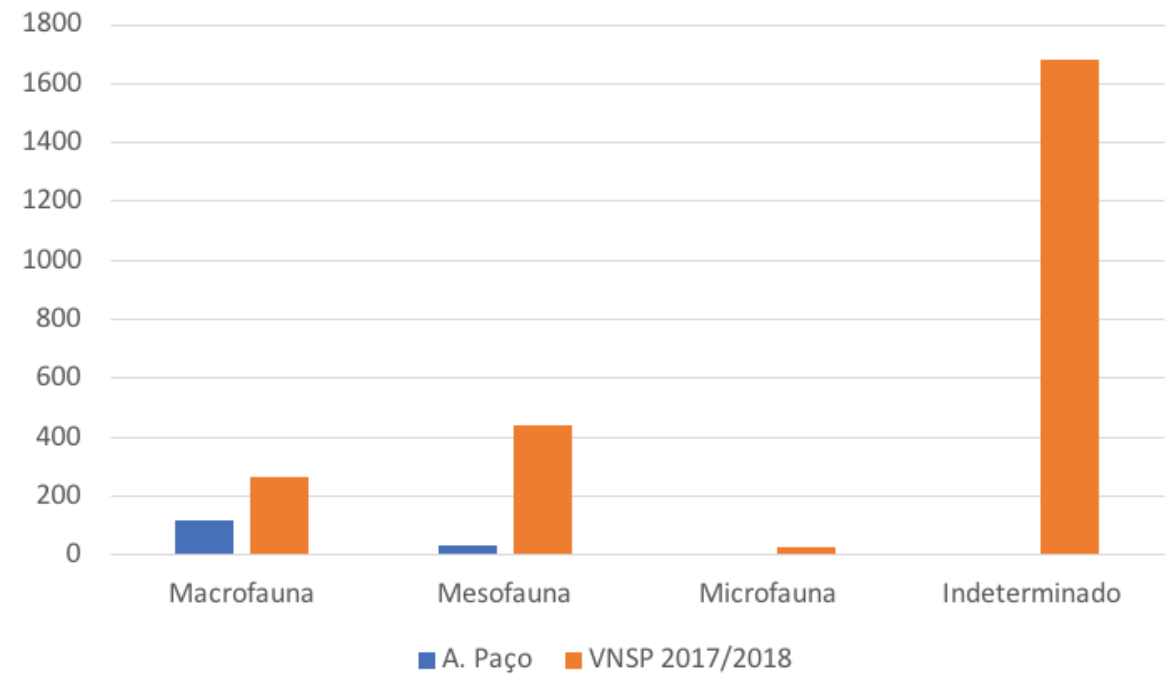

Figura 8 - Número de restos osteológicos não determinados em termos taxonómicos sendo classificados por tamanho: Macrofauna (animais de grande porte, eg. gado bovino, veado, cavalo) e Mesofauna (animais de médio porte, eg. ovelha, cabra, porco). Comparando-se os dados das escavações de Afonso do Paço e escavações de 2017/2018 (Detry et al. neste volume). 


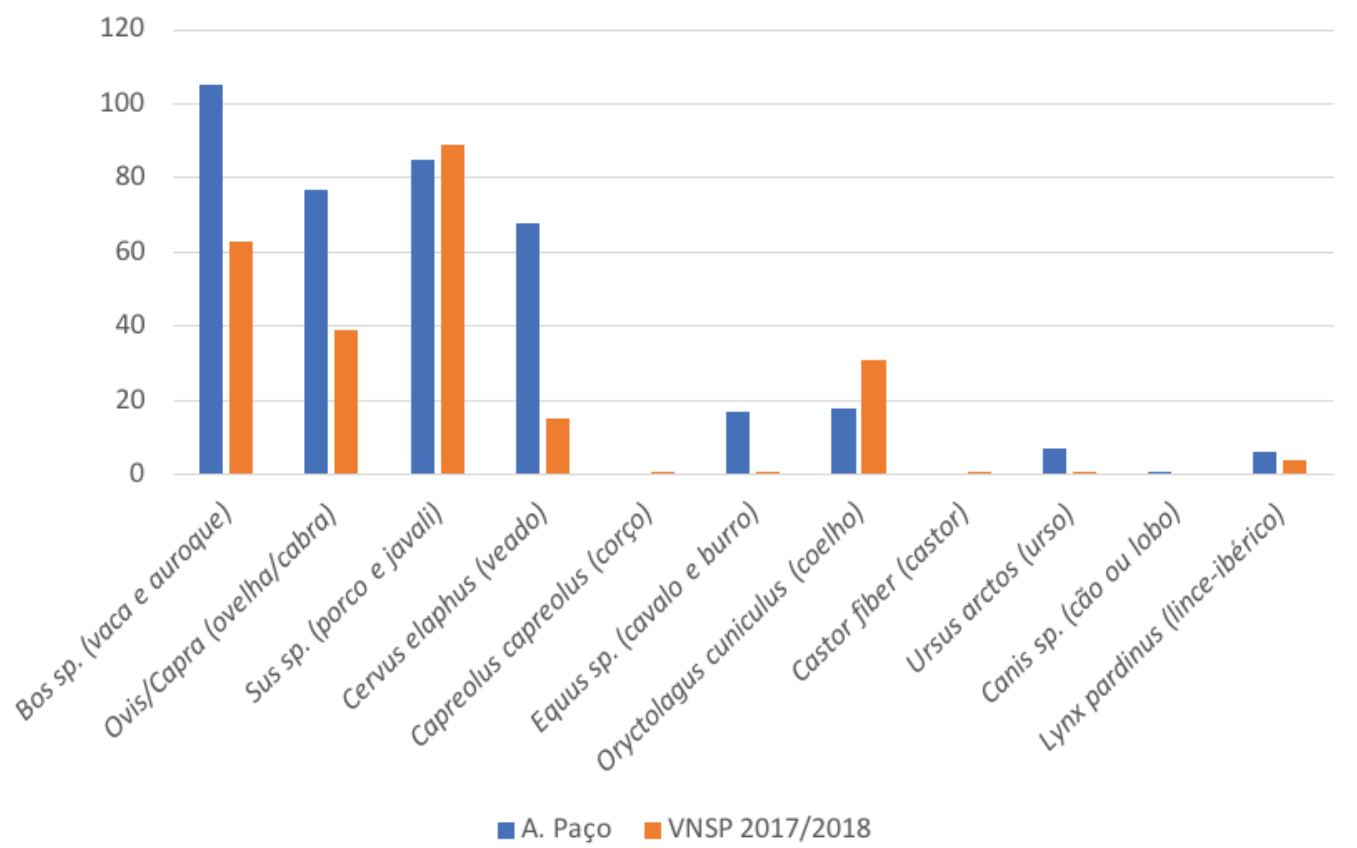

Figura 9 - Número de Restos Determinados de mamíferos recuperados em Vila Nova de São Pedro, comparando-se os dados das escavações de Afonso do Paço e escavações de 2017/2018 (Detry et al., 2020, neste volume). 


\title{
ANÁLISE FUNCIONAL DE MATERIAL LÍTICO EM SÍLEX DO CASTRO DE VILA NOVA DE S. PEDRO (AZAMBUJA, PORTUGAL): UMA PRIMEIRA ABORDAGEM
}

\author{
Rafael Lima ${ }^{1}$
}

\begin{abstract}
RESUMO
A realização de uma análise traceológica de parte do espólio de peças em sílex do castro de Vila Nova de S. Pedro vem, por um lado, indicar a possibilidade de realizar uma análise funcional sobre uma parte mais abrangente do espólio recolhido, ainda que com algumas ressalvas, e, por outro, colocar em evidência a importância de certas actividades no plano económico, ainda que se trate de uma análise preliminar.

Observa-se, para já, a importância das actividades agrícolas, através do emprego de peças para o corte de matérias vegetais/cereais, assim como o emprego de pontas de seta como pontas de projécteis. Observa-se, também, a reutilização das peças através de processos de reavivamento, o que permite, juntamente com os restantes dados funcionais, a realização de certas inferências e questões acerca dos processos económicos e comportamentais das populações que habitaram o castro de Vila Nova de S. Pedro.
\end{abstract}

Palavras-chave: Análise funcional, Calcolítico, Castro de Vila Nova de S. Pedro.

\begin{abstract}
The conduction of a traceological analysis on a part of the collection of flint tools from the Vila Nova de S. Pedro castro allows, for one part, to demonstrate the feasibility to perform a functional analysis over a wider portion of the gathered materials, although with some caveats, and, on the other, place in evidence the importance of certain activities on the economical field, even though it is a preliminary analysis.

It is observed, for now, the importance of agricultural practices, trough the employment of tools to cut soft vegetable matter/cereals, as well as the employment of arrow points as projectile tips. It is also observed the reutilization of tools trough processes of edge revival, which allows, together with the rest of the functional data, the realization of certain inferences and questions about the economic processes and the behaviour of the populations which inhabited the Vila Nova de S. Pedro castro.

Keywords: Functional analysis, Chalcolithic, Castro of Vila Nova de S. Pedro.
\end{abstract}

\section{INTRODUÇÃO}

Poucos sítios alcançam, no séc. XX, em Portugal, a importância atingida a nível internacional que o castro de Vila Nova de S. Pedro granjeou. Intervencionado primeiramente por Afonso do Paço e Eugénio Jalhay, torna-se, para o período Calcolítico, um dos sítios de referência para o seu estudo e compreensão (Jalhay et Paço, 1945). Povoado muralhado, com um extenso espólio recolhido, algum de grande qualidade, obteve (e obtém) honras de ser um dos ex libris do museu arqueológico do Carmo, em Lisboa, onde toda uma sala lhe é dedicado, atestando assim a sua importância não só no plano nacional, mas também internacional, como destaque da Pré-história recente da fachada oeste da península Ibérica (Arnaud et Gonçalves, 1990, 1995). O interesse por este sítio não permaneceria somente no séc. XX, estando actualmente em curso um novo e abrangente projecto de investigação, impulsionado, novamente, pela Associação dos Arqueólogos Portugueses (Arnaud et al., 2017).

Do total do espólio recolhido no povoado advém uma importante e variada resenha científica, no qual 
é evidente a procura pela identificação das actividades económicas aí praticadas. Se, por um lado, o volume já disponível de informação permite reconstituir parcialmente o quotidiano vivido no povoado, a ausência de estudos funcionais para os artefactos de sílex, com uma metodologia apropriada para a sua análise, constitui um potencial por explorar para uma melhor compreensão do plano económico e comportamental do castro de Vila Nova de S. Pedro. Esse potencial é o que se pretende explorar com este estudo. O presente estudo tem, então, três ordens. Numa primeira ordem, verificar a possibilidade de aplicação de uma análise traceológica no conjunto, ou seja, verificar, através do estudo de parte do total desse espólio qual o grau de preservação dos vestígios de uso no conjunto de peças em sílex e verificar a sua adequação à realização de um estudo traceológico que sirva de primeira abordagem para a realização de uma análise numa maior percentagem do total do conjunto. Numa segunda ordem, caso se observe a possibilidade da realização de uma análise traceológica, procurar observar e identificar os dados que permitam inferir acerca do uso e função das peças. Através disso, já numa terceira ordem, aludir acerca do plano económico e comportamental destas populações, ainda que se trate de dados preliminares tendo em conta o volume do conjunto estudado face ao total de espólio que constitui o acervo de peças em sílex do castro de Vila Nova de S. Pedro.

\section{MATERIAIS E METODOLOGIA}

Para o presente estudo foram analisadas 46 peças, de sílex, provenientes da intervenção de Afonso do Paço no castro de Vila Nova de S. Pedro (1937-1967): 10 lamelas, 16 pontas de seta, um núcleo, uma lâmina, sete lâminas retocadas, um furador, um fragmento retocado, um raspador, duas raspadeiras e seis lâminas ovóides. A escolha do material estudado recaiu na procura de um grupo tipologicamente distinto, de forma a evitar a ausência de certos usos/funções que possam estar restringidos a determinadas tipologias. O procedimento analítico seguiu o protocolo comumente empregue para este tipo de análises, conforme introduzido por Semenov (1964) e posteriormente desenvolvido por Keeley (1980) e Plisson (1985), entre muitos outros. As peças foram primeiramente observadas através da lupa binocular (Leica DMS 100o) para identificar potenciais zonas activas (e.g. levantamentos de impacto e fracturas) e poste- riormente recorreu-se ao microscópio metalográfico (Leica DM250o MH) de forma a observar os vestígios microscópios de uso (e. g. micropolidos e estrias). O registo fotográfico foi obtido através de máquina fotográfica (Leica ICC50 W) acoplada ao microscópio metalográfico.

Através de uma série de inferências procurou distinguir-se entre peças usadas e não usadas, assim como as respectivas zonas activas, identificar a cinemática de trabalho, determinar a matéria trabalhada (esta somente quando distinguível), a intensidade de utilização do utensílio e ainda o possível reaproveitamento das peças através de processos de reavivamento e reutilização, caso esta fosse uma realidade observável neste conjunto.

\section{RESULTADOS}

A análise funcional sobre as 46 peças estudadas trouxe alguns resultados acerca do estado de preservação dos vestígios de uso e acerca da cinemática de trabalho e das matérias trabalhadas, conforme pode ser observado na Tabela 1, e apresentado com maior descrição adiante.

\subsection{Estado de conservação dos vestígios de uso}

$O$ presente conjunto encontra-se, no seu geral, em bom estado de conservação, podendo analisar-se as peças com relativa facilidade (Figura 1), tendo em conta a boa preservação das superfícies e dos bordos das peças. Contudo, algumas peças apresentam alguns aspectos que dificultam/impossibilitam a sua análise, tais como a presença de tratamento térmico e/ou alterações pós-deposicionais (Figura 2), o que inviabiliza dessa forma a correcta aferição dos potenciais traços diagnósticos de uso, conforme referido por alguns estudos (vide e.g. Levi-Sala, 1986a, 1986b e Gutierrez Saez et al., 1988). Estas ocorrências (especialmente observáveis na generalidade das lamelas) incluem alterações térmicas, alterações pós-deposicionais como aplicação de verniz, entre outras, apresentando-se as superfícies e os bordos bastante afectados.

\subsection{Vestígios de uso}

Das 46 peças estudadas 11 apresentaram traços de uso conducentes à identificação da actividade para que foram empregues. As peças que evidenciaram utilização são duas lâminas ovóides, cinco lâminas retocadas e quatro pontas de seta. 
Tanto as lâminas ovóides (Figura 3) quanto as lâminas retocadas (Figura 4) foram utilizadas para cortar matéria vegetal macia, provavelmente cereais, empregando somente um dos gumes como ponto de contacto com a matéria a trabalhar. A presença de tratamento térmico em várias das lâminas ovóides dificultou a análise dessas peças.

Já as pontas de seta apresentam fracturas diagnósticas de impacto (FDI) que induzem ao seu emprego enquanto pontas de projéctil (Figura 5).

\section{RESULTADOS/DISCUSSÃO}

O presente conjunto refere-se a uma muito pequena percentagem do total do inventário da indústria lítica do povoado calcolítico de Vila Nova de S. Pedro, constituído por milhares de artefactos agrupados em diferentes categorias tipológicas. Tendo isso em atenção, podem, mesmo assim, retirar-se alguns dados que poderão facultar um melhor entendimento acerca do modo de vida destas populações, especialmente no que toca à gestão da matéria-prima, assim como levantar outras problemáticas.

Relativamente ao grau de conservação das peças este revela-se algo problemático. Se, por um lado, observa-se uma leitura facilitada de certas peças, principalmente devido à formação de polidos característicos como os observados para o corte de cereais evidenciado nas lâminas ovóides e nas retocadas (vide Figura 3 e Figura 4), por outro lado o grau de preservação de outras peças dificultam a sua leitura pelos factos já referidos anteriormente (vide Figura 2).

Destes aspectos destacam-se as alterações térmicas e as alterações pós-deposicionais, especialmente a colocação de verniz e tinta que prejudica qualquer leitura funcional sobre as peças. Relativamente às alterações térmicas, estas dificultam a leitura das peças, não a inviabilizando, contudo, totalmente, conforme nos afirmam alguns estudos previamente publicados (Clemente, 1995, 1997 e Gibaja e Clemente, 1997). Ainda assim, como esses mesmos estudos afirmam, as alterações térmicas dificultam mais a observação dos traços de uso em matérias moles de origem natural, o que não é o caso do corte em matéria vegetal/cereais presente neste estudo, o que não invalida, contudo, a possibilidade de menor observação dos traços de uso nestas peças.

Observa-se, no entanto, no que toca à preservação dos traços de uso, o apagamento intencional das provas dessa mesma utilização. Este "apagamento" voluntário resulta, como se pode observar na Figura 4-1A, da prática de reavivamento dos gumes para um uso continuado das peças, obtendo, dessa forma, um maior tempo de vida útil do utensílio. Esta prática de reaproveitamento das peças através do reavivamento dos gumes não aparenta ser um acto incomum tendo em conta o número de lâminas retocadas com esses indícios (3/7) - paragem abrupta do polido, presença de polido nas arestas mais elevadas das áreas retocadas e ausência nas áreas menos elevadas e presença de polido ao longo do reverso da área retocada. O facto de terem sido reavivadas reduz a leitura das peças não sendo possível em certos casos observar o grau de desenvolvimento dos traços de uso o que dificulta a observação do tempo de uso destes utensílios (agravado pelo facto de terem sofrido alterações térmicas, intencionais ou não). Apesar disso, o próprio reavivamento permite considerar que as peças teriam um desgaste suficiente que levaria à necessidade dessa acção.

Quanto à forma de emprego das peças analisadas, a ausência de certos dados como estrias, alguns tipos de micropolidos e esquirolamentos não permitem inferir acerca de algumas hipóteses tais como formas e materais de encabamento ou o seu manuseamento. Contudo, consegue observar-se que, pelo menos ao nível do uso em matéria vegetal/cereais, somente um dos gumes teria sido empregue para tal, observando-se como tal só uma frente activa nessas peças, tendo em conta a total ausência de polido e outros factores tais como estrias e microesquirolamentos típicos de uso nos restantes gumes.

Também relativamente ao emprego das pontas de flechas, o posicionamento do tipo de fracturas observado, a própria tipologia das peças e um aparente maior desgaste na parte inferior das mesmas permite com alguma segurança considerar o seu uso na forma vertical. Estas teriam dessa forma ter de ter sido encabadas ou na extremidade proximal ou ao longo do seu eixo mantendo a verticalidade da peça além da extremidade distal livre como ponto de impacto. Já o motivo da sua recuperação após serem usadas não é claro, podendo estar relacionada com práticas de reutilização como já avançado para as lâminas retocadas. A ausência de dados não permite mais do que criar essa suposição.

Observando as actividades postas em evidência pela análise funcional observa-se uma prática agrícola que não se encontra restringida a nível tipológico, mais precisamente o corte de cereais/matéria ve- 
getal macia, servindo, provavelmente, como foices. Esta prática estende-se não só pelas lâminas retocadas, mas, também, pelas lâminas ovóides. No entanto, não surgem dados que permitam supôr se se tratam de utensílios empregues indiscriminadamente para o corte de matéria vegetal macia/cereais ou se há diferenças no seu uso conforme os sugeridos pelo estudo de Clemente Conte et al. (2018) relativamente à posição de corte e à maturidade da matéria recolhida, ou que reflitam as espécies referidas por Afonso do Paço (1954) que seriam cultivadas nas proximidades do sítio.

A nível nacional o emprego das lâminas ovóides como foices tem, contudo, paralelo nos sítios da $\mathrm{Pa}$ rede e do Alto do Estoril (Igreja, 2010), assim como no castro de Chibanes (Clemente-Conte et al., 2014). Deve ter-se em atenção que o número de peças analisadas em ambos os estudos e com traços de uso registados são quase tão reduzidos quanto no presente estudo, muitas das quais se encontrem com alterações inviabilizando a sua leitura como sucede em $\mathrm{Pa}$ redes e no Alto do Estoril (Igreja, 2010), pelo que se deve ter em conta tais dados aquando da realização de conclusões acerca destes sítios. Já o uso de lâminas retocadas para o corte de cereais é observado no actual território português desde o Neolítico Antigo como comprovado, por exemplo, através do sítio de Cortiçóis (Carvalho et al., 2013). Já o seu emprego em trilhos e não só foices é visível no sítio de Chibanes (Clemente Conte et al., 2014), podendo encontrar paralelos muito semelhantes, por exemplo, em Espanha, no sítio de El Casetón de la Era, Valladolid (Gibaja et al., 2012). O uso como parte de trilho não é, contudo, ainda observável em Vila Nova de S. Pedro, não se excluindo a possibilidade de ser observado noutras peças ainda não estudadas.

Já o uso das pontas de seta aparenta estar virado, como expectável, para instrumentos de impacto, tendo em conta os traços diagnósticos, ainda que a ausência de dados como estrias e polidos não permita identificar em que matéria foram empregues. Não foram identificados outros usos, como por exemplo os referidos por Igreja para Paredes e Alto do Estoril para os raspadores (Igreja, 2010), nem os referidos por Amaro (ainda que utilizando uma metodologia insuficiente para a análise por ele pretendida), de desbaste e corte de carcaças e peles de animais para as lâminas ovóides de Vila Nova de S. Pedro (Amaro, 2004/2005). Esta ausência de outros usos deve ser, contudo, desvalorizada, tendo em conta o reduzido número de peças estudadas, sendo possível que surjam eventualmente noutras peças ainda não analisadas.

Observado então a gestão da utensilagem, não nos permitindo os dados, tendo em conta o reduzido volume de peças estudadas, fazer mais do que estas breves observações, possibilita-nos, contudo, ponderar sobre algumas questões acerca do acervo lítico de Vila Nova de S. Pedro.

Assim sendo, surge, primeiramente a questão da produção e reaproveitamento das peças. Trata-se do tratamento térmico uma técnica generalizada para a produção destas peças numa primeira parte ou constituirá novamente uma necessidade para o reavivamento das peças? De que forma pode influenciar o tratamento térmico na produção de traços de uso, principalmente tendo em conta para as actividades observadas no castro de Vila Nova de S. Pedro (corte de matéria vegetal macia/cereais)? Qual a necessidade de reavivamento dos gumes? Estaremos perante uma tentativa de contenção de escassez de matéria-prima? $\mathrm{Ou}$, pelo contrário, uma procura da manutenção do volume de matéria-prima de forma a evitar/diminuir uma possível ruptura de stock através de uma economização dos utensílios ou ainda uma simples procura de rentabilização da utensilagem? Seria essa reutilização o justificativo da recuperação das pontas de seta? Seria, também, o reavivamento um gesto expedito por parte do utilizador de forma a prosseguir o trabalho, no caso do uso das foices por exemplo, realizado por quem usa o instrumento, ou parte maior da gestão da utensilagem lítica do povoado? Somente um estudo mais abrangente poderá ou não procurar responder a tal.

\section{CONCLUSÃO}

Podemos constactar que o presente estudo mais não apresenta do que dados preliminares acerca dos traços de uso conservados na indústria lítica do povoado calcolítico de Vila Nova de S. Pedro. Destes dados preliminares concluem-se, essencialmente, três pontos. O primeiro trata da possibilidade de realização a uma maior escala da traceologia para o estudo dos materiais líticos em sílex, atendendo, contudo, a alguns pontos já explicitados. O segundo é o emprego de algumas tipologias para o corte de matéria vegetal macia/cereais, mais especificamente lâminas retocadas e lâminas ovóides, que têm, como já referido, paralelos a nível nacional. O terceiro, refe- 
rente à gestão e acções de descarte/reaproveitamento, surge o reaproveitamento destas peças através de acções de reavivamento dos gumes que poderão estender-se não só às lâminas retocadas mas, também a outros grupos tipológicos, não estando, contudo, ainda verificado.

Ainda que não pareça existir qualquer escassez de matéria-prima ou dificuldade de acesso às suas fontes, a gestão e procura de boa matéria-prima como base da indústria de pedra lascada destas populações reverteria, como acção final, num reaproveitamento desta mesma matéria para um aumento do tempo de vida útil dos utensílios. Poderia tal servir como tentativa de diminuição/contenção de uma procura dessa mesma matéria-prima que poderia não vir com uma regularidade ou facilidade que levasse estas populações ao descarte imediato aquando do desgaste dos gumes activos ou a uma simples procura de aumento de rentabilidade das peças.

Ainda que o presente estudo mais não seja que uma nota introdutória no estudo da função dos objectos em sílex do povoado de Vila Nova de S. Pedro tendo em conta o seu reduzido volume, pode complementar-se com outros sítios os quais também já foram realizados estudos funcionais, quer existentes quer futuros, e fazer comparações, ainda que breves e circunstanciais, com outros sítios de cronologia semelhante.

\section{AGRADECIMENTOS}

O autor agradece ao Museu Arqueológico do Carmo/ Associação dos Arqueólogos Portugueses a cedência dos materiais para estudo e, em especial, ao doutor César Neves todo o auxílio prestado. Os materiais foram analisados com o equipamento da UNIARQ, à qual se agradece, também, a cedência de espaço para a realização do presente estudo. Um agradecimento especial é devido ao doutor Ignacio Clemente Conte, à professora doutora Mariana Diniz e à doutora Marina Igreja, cujos comentários foram extremamente úteis para a realização deste trabalho.

\section{BIBLIOGRAFIA}

AMARO, Gonçalo (2004/2005) - Interpretação das facas ovóides (foicinhas) através do estudo dos exemplares de Vila Nova de S. Pedro. Arqueologia \& História. Lisboa. 56/57, pp. 63-8o.

ARNAUD, José Morais \& GONÇALVES, João Ludgero Marques (1990) - A fortificação pré-histórica de Vila Nova de S. Pedro (Azambuja) - balanço de meio século de investigações. $1^{\underline{a}}$ parte. Revista de Arqueologia da Assembleia Distrital de Lisboa. Lisboa. 1, pp. 25-48.

ARNAUD, José Morais \& GONÇALVES, João Ludgero Marques (1995) - A fortificação pré-histórica de Vila Nova de S. Pedro (Azambuja) - balanço de meio século de investigações. ${ }^{2}$ parte. Revista de Arqueologia da Assembleia Distrital de Lisboa. Lisboa. 1, pp. 11-40.

ARNAUD, José Morais; DINIZ, Mariana; NEVES, César \& MARTINS, Andrea (2017) - Vila Nova de S. Pedro - de novo, no $3^{\circ}$ milénio. Um projecto para o futuro. Arqueologia e História. Lisboa. 66/67, pp. 7-17.

CARVALHO, António Faustino; GIBAJA, Juan Francisco \& CARDOSO, João Luís (2013) - Insights into the earliest agriculture of Central Portugal: Sickle implements from the Early Neolithic site of Cortiçóis (Santarém). Comptes Rendus Palevol. 12: 1, pp. 31-43.

CLEMENTE CONTE, Ignacio (1995) - Silex y Lustre Termico en el Paleolítico Medio. Alteración o Técnica de Talla? El Ejemplo de Mediona I (Alt Penedès, Barcelona). In JORGE, Vitor Oliveira, ed. - Actas do $1^{\underline{0}}$ Congresso de Arqueologia Peninsular. Porto: Sociedade Portuguesa de Antropologia e Etnologia. VIII, pp. 37-43.

CLEMENTE CONTE, Ignacio (1997) - Thermal Alterations of Flint Implements and the Conservation of Microwear Polish: Preliminary Experimental Observations. In Ramos Millá, Antonio et Bustillo, Maria Angeles, eds. - Siliceous Rocks and Culture (Monográfica Arte y Arqueología). Granada: Universidad de Granada, pp. 525-535.

CLEMENTE CONTE, Ignacio; MAZZUCCO, Niccolò \& SOARES, Joaquina (2014) - Instrumentos para siega y procesado de plantas desde el Calcolítico al Bronce antíguo de Chibanes (Palmela, Portugal). Trabajos de Prehistoria. 71: 2, pp. 330-342.

CLEMENTE CONTE, Ignacio; IBÁÑEZ ESTÉVEZ, Juan José; GIBAJA BAO, Juan Francisco; MAZZUCCO, Niccolò; TERRADAS, Xavier; MOZOTA HOLGUERAS, Millán \& BORREL, Feran (2018) - Cereal Use-Wear Traces and Harvesting Methods. In BERIUHETE AZORÍN, Marian et LOZOVSKAYA, Olga, eds. - Subsistence Strategies in the Stone Age, Direct and Indirect Evidence of Fishing and Gathering. Materials of the International Conference Dedicated to the $5^{\text {th }}$ Anniversary of Vladimir Mikhailovich Lozovski 15-18 May 2018, Saint Petersburg. São Petersburgo, pp. 192-194. 
GIBAJA, Juan Francisco; CRESPO, Manuel; DELIBES, Germán; FERNÁNDEZ, Julio; FRAILE, Cristina; HERRÁN, José Ignacio; PALOMO, Antoni \& RODRÍGUEZ, José Antonio (2012) - El uso de trillos durante la Edad del Cobre en la Meseta española. Análisis traceológico de una colección de denticulados de sílex procedentes del "recinto de fosos" de El Casetón de la Era (Villalba de los Alcores, Valladolid). Trabajos de Prehistoria. 69: 1, pp. 133-148.

GIBAJA, Juan Francisco \& CLEMENTE, Ignacio (1997) - El tratamento térmico del sílex y sus repercusiones en la determinación de los rastros de uso. Algunos ejemplos del neolítico en Cataluña. Revista de Arqueología de Ponent. Lleida: Universidad de Lleida. 7, pp. 153-16o.

GUTIERREZ SAEZ, Carmen; GONZALEZ URQUIJO, Jesus Emilio \& IBÁÑEZ ESTÉVEZ, Juan José (1988) - Alteraciones microscópicas en el tratamento convencional del material lítico: su incidencia en las huellas de uso. MUNIBE (Antropologia y Arqueologia). San Sebastian: Sociedad de Ciencias Aranzadi, Suplemento 6, pp. 83-89.

IGREJA, Marina (2010) - Estudo traceológico dos furadores e lâminas ovóides do Alto do Estoril e da Parede: resultados sobre a função e o modo de funcionamento destas peças. In Gonçalves, Victor S. et SOUSA, Ana Catarina, eds. - Transformação e Mudança no Centro e Sul de Portugal: o $4^{0}$ e o $3^{\circ}$ milénios a.n.e. Actas do Colóquio Internacional (Cascais, 4-7 Outubro 2005). Cascais: Câmara Municipal, pp. 206-211.
JALHAY, Eugénio \& PAÇO, Afonso do (1945) - El Castro de Vilanova de San Pedro. In Actas y Memorias de la Sociedad Espanola de Antropologia, Etnografia y Prehistoria. Madrid: Museo Antropológico Nacional. XX, pp. 5-93.

KEELEY, Lawrence (1980) - Experimental Determination of Stone Tool Uses. Chicago: University of Chicago Press.

LEVI-SALA, Irene (1986a) - Experimental replication of post-depositional surface modification on flint”. Early Man News. Newsletter of Uman Palaeoecology. Tübingen: Archaeologica Venatoria. 9/10/11, pp. 103-110.

LEVI-SALA, Irene (1986b) - Use wear and post-depositional surface modification: a word of caution. Journal of Archaeological Science. Londres: Elsevier. 13, pp. 229-244.

PAÇO, Afonso do (1958) - Sementes pré-históricas do Castro de Vila Nova de S. Pedro. In Anais. Lisboa: Academia Portuguesa da História. Série II. 5, separata pp. 281-359.

PLISSON, Hugues (1985) - Etude fonctionelle d'outillages lithiques préhistoriques par l'analyse des micro-useres: recherche méthodologique et archéologique. Dissertação de Doutoramento apresentado à Universidade de Paris I.

SEMENOV, Sergej Aristarchovic (1964) - Prehistoric Technology. An Experimental Study of the oldest Tools and Artefacts from traces of Manufacture and Wear. Londres: Cory, Adams \& Mackay.

\begin{tabular}{|c|c|c|c|c|c|c|c|c|}
\hline \multirow{3}{*}{ Tipologia } & \multirow{3}{*}{$\begin{array}{c}\text { Peças } \\
\text { analisadas }\end{array}$} & \multicolumn{4}{|c|}{ Estado de conservação } & \multicolumn{3}{|c|}{$\begin{array}{l}\text { Cinemática de trabalho e } \\
\text { matérias trabalhadas }\end{array}$} \\
\hline & & \multirow[b]{2}{*}{ Analisável } & \multirow{2}{*}{$\begin{array}{c}\text { Sem } \\
\text { vestígios } \\
\text { de uso }\end{array}$} & \multirow{2}{*}{$\begin{array}{c}\text { Com } \\
\text { vestígios } \\
\text { de uso }\end{array}$} & \multirow{2}{*}{$\begin{array}{l}\text { Alteradas/ } \\
\text { Não } \\
\text { analisáveis }\end{array}$} & $\begin{array}{l}\text { Longitudinal } \\
\text { (corte) }\end{array}$ & Impacto & \multirow[b]{2}{*}{ Tota } \\
\hline & & & & & & $\begin{array}{l}\text { Matéria } \\
\text { vegetal }\end{array}$ & $\begin{array}{l}\text { Ponta de } \\
\text { projéctil } \\
(\text { FDI })\end{array}$ & \\
\hline Frag. retocado & 1 & 1 & 1 & - & - & - & - & - \\
\hline Furador & 1 & 1 & 1 & - & - & - & - & - \\
\hline Lamela & 10 & 2 & 2 & - & 8 & - & - & - \\
\hline Lâmina & 1 & - & - & - & 1 & - & - & - \\
\hline Lâmina ovóide & 6 & 5 & 3 & 2 & 2 & 2 & - & 2 \\
\hline Lâmina retocada & 7 & 7 & 2 & 5 & - & 5 & - & 5 \\
\hline Núcleo & 1 & 1 & 1 & - & - & - & - & - \\
\hline Ponta de seta & 16 & 14 & 10 & 4 & 2 & - & 4 & 4 \\
\hline Raspadeira & 2 & 2 & 2 & - & - & - & - & - \\
\hline Raspador & 1 & 1 & 1 & - & - & - & - & - \\
\hline Total & 46 & 34 & 23 & 11 & 13 & 7 & 4 & 11 \\
\hline
\end{tabular}

Tabela 1 - Análise funcional de espólio lítico em sílex do castro de Vila Nova de S. Pedro. 

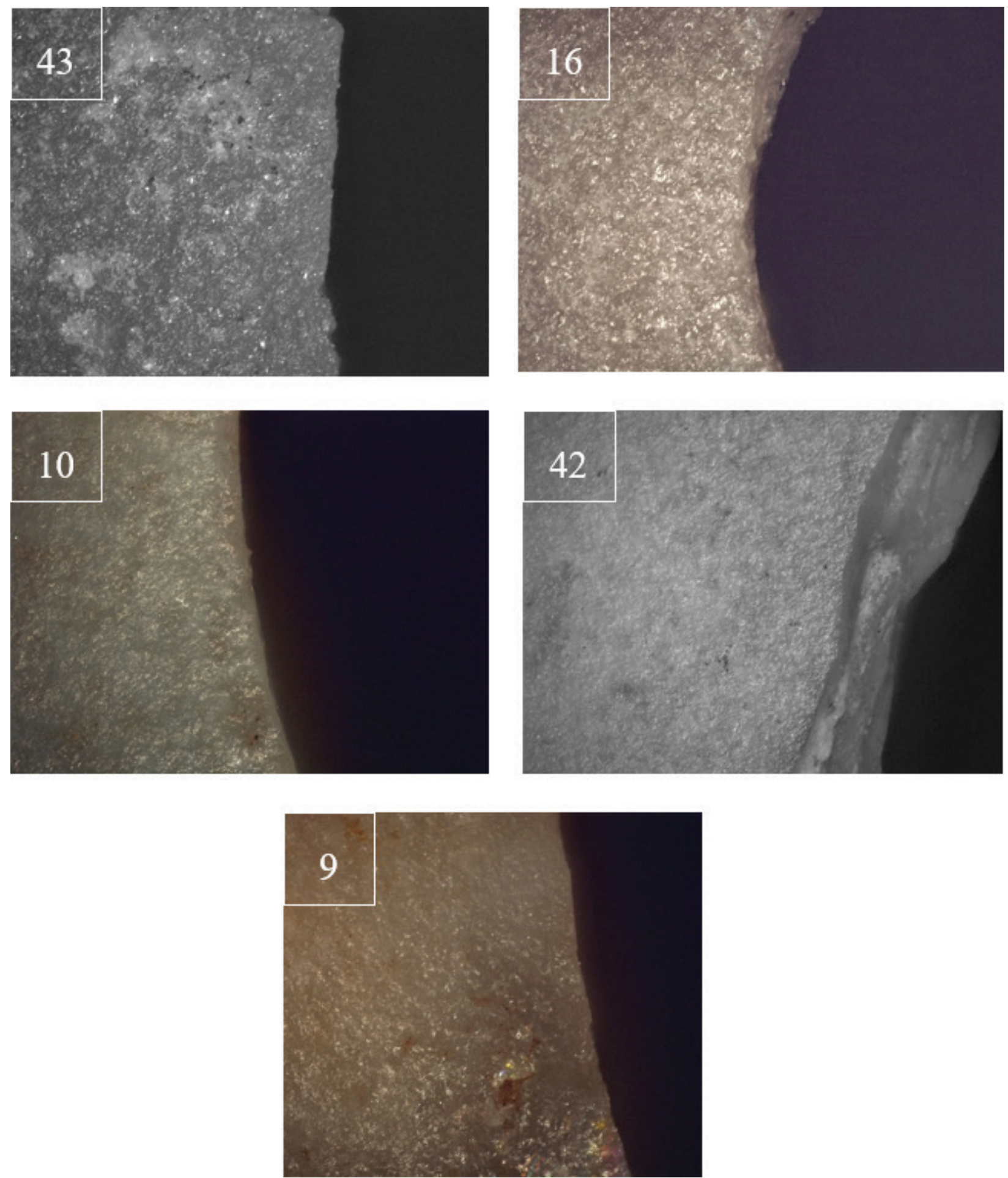

Figura 1 - Peças com bom estado de preservação das superfícies. 

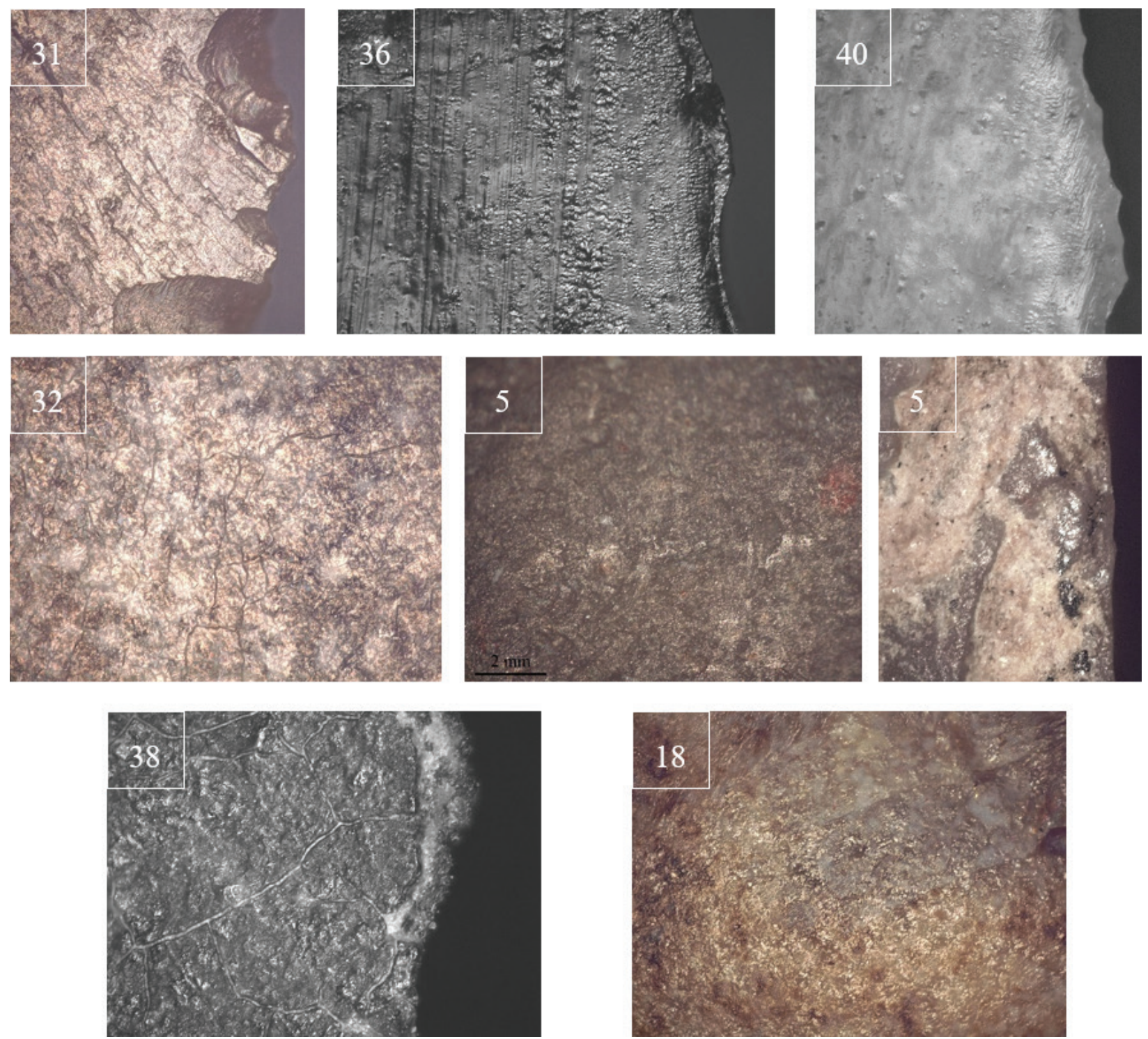

Figura 2 - Peças com inferior grau de preservação e alterações pós-deposicionais, que impossibilitam/dificultam a leitura das mesmas. Peças no 31, 32 e 38: presença de crazing; 36 e 40: verniz aplicado na peça, impossibilitando a leitura dos gumes; 5 (central): superfície da peça com alteração pós-deposicional, riscada; 5 (direita): superfície da peça riscada por grafite; 18 : queimada e com formação de patina/lustre de solo (?) (100x). 

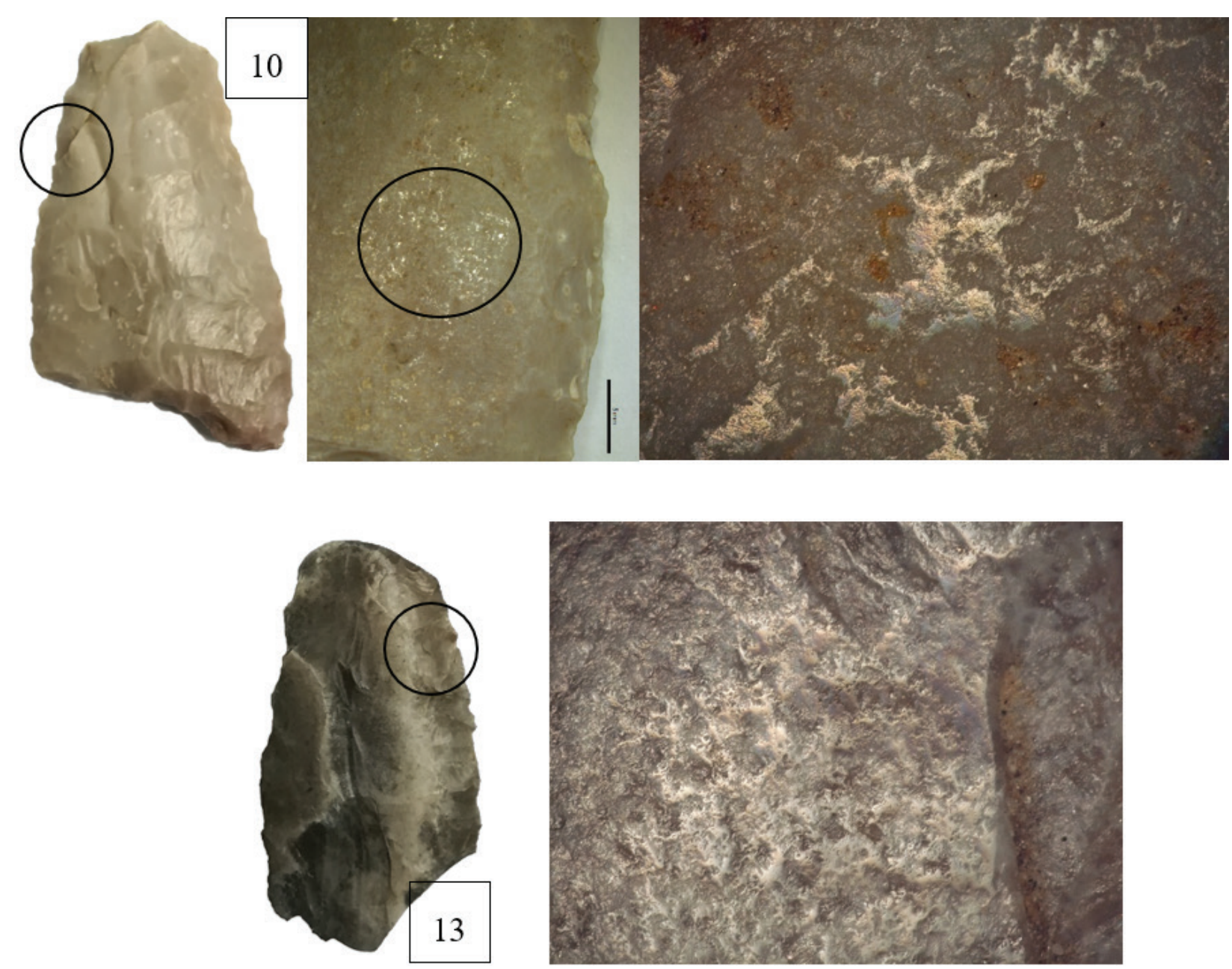

Figura 3 - Lâminas ovóides com presença de polido de matéria macia vegetal, com diferentes graus de conservação e desenvolvimento. O tratamento térmico observável na peça 13 e o facto de estar queimada prejudicaram a preservação do polido, assim como na peça 10, ainda que em menor grau. (100x). 


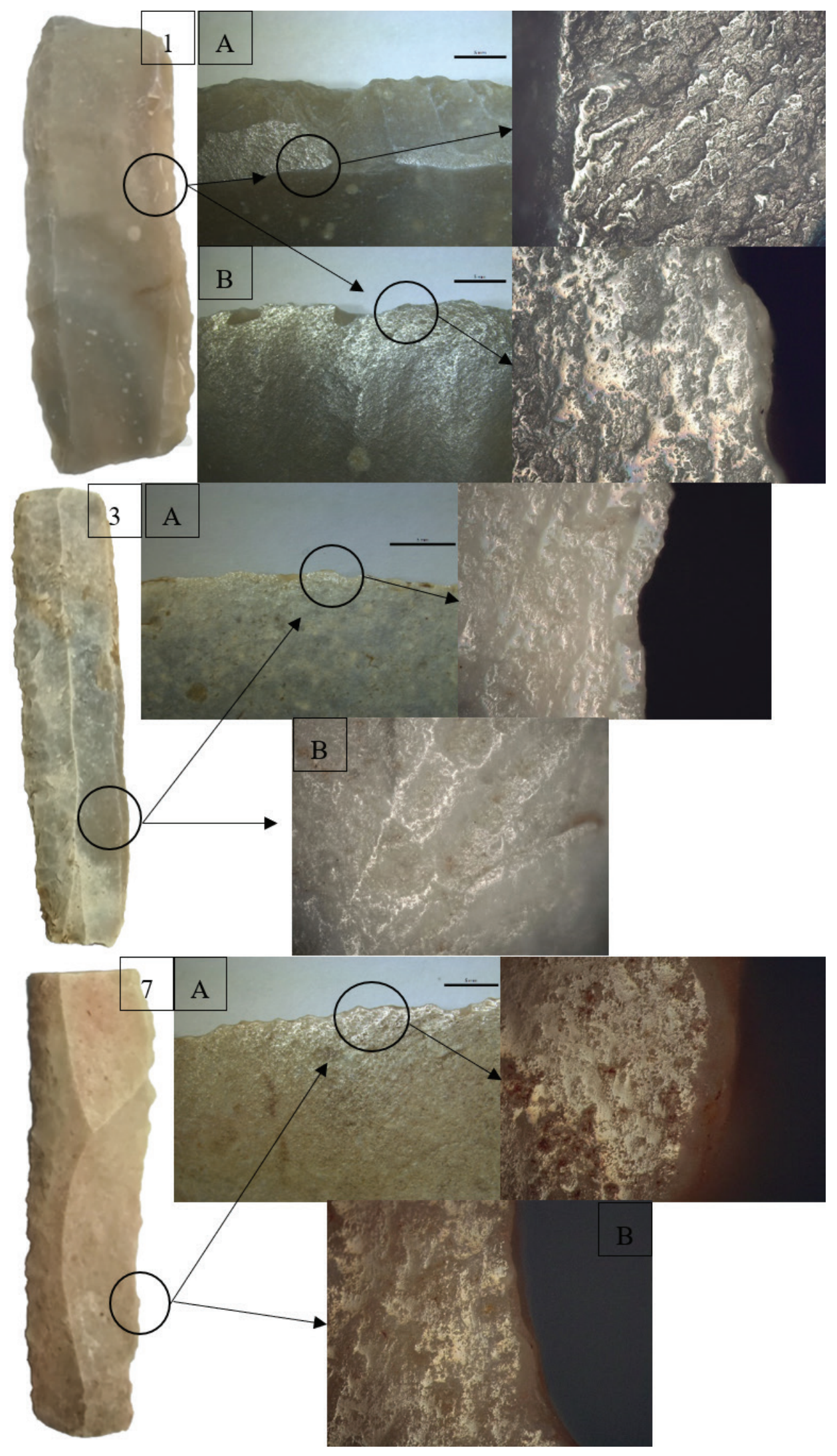

Figura 4 - Lâminas retocadas com traços de uso de corte de matéria vegetal/cereais. 1A - Lustre de corte de matéria vegetal/cereal que termina abruptamente na área retocada; $1 \mathrm{~B}$ - reverso da zona $1 \mathrm{~A} ; 3 \mathrm{~B}$ - Polido a desenvolver-se nas áreas mais elevadas; $3 \mathrm{~A}$ - polido bastante desenvolvido no reverso da mesma área; $7 \mathrm{~A}$ - Reverso e parte frontal (B) da lâmina, ambos com algum desenvolvimento do polido. (10ox). 

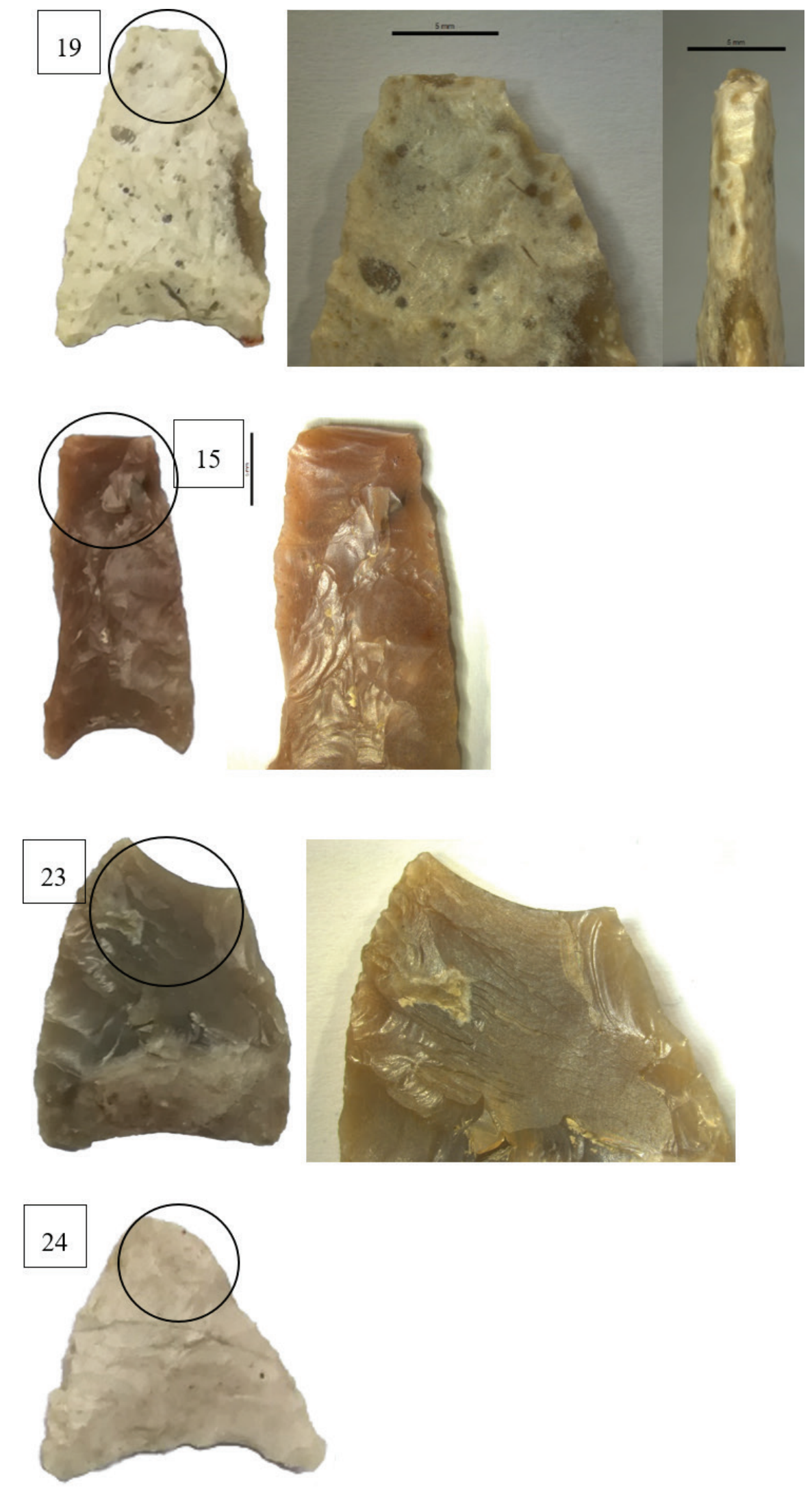

Figura 5- Pontas de flechas com fracturas diagnósticas de impacto. 19 - Vista frontal e lateral da fractura: snap terminating bending fracture com esquirolamento lateral; 1 - feather bending fracture; 23 - feather terminating bending fracture; 24 - cone initiating fracture. 


\title{
O RECINTO DA FOLHA DO OURO 1 (SERPA) NO CONTEXTO DOS RECINTOS DE FOSSOS CALCOLÍTICOS ALENTEJANOS
}

\author{
António Carlos Valera ${ }^{1}$, Tiago do Pereiro ${ }^{2}$, Pedro Valério ${ }^{3}$, António M. Monge Soares ${ }^{4}$
}

\begin{abstract}
RESUMO
Apresentam-se os primeiros resultados dos trabalhos arqueológicos realizados no recinto de fossos calcolítico da Folha do Ouro 1 (Serpa, Beja). Identificado numa imagem satélite, o sítio integrou a investigação sobre este tipo de contextos desenvolvida pelo NIA-Era Arqueologia e foi submetido a prospecção geofísica por magnetometria e a recolha de materiais arqueológicos. É realizada a análise da colecção de materiais recolhidos, da referenciação cronológica que permitem, da implantação topográfica e das características arquitectónicas observadas no magnetograma obtido. O sítio é integrado no contexto regional, através da sua comparação com as características já conhecidas para outros recintos de fossos alentejanos.

Palavras-chave: Recintos de Fossos, Calcolítico, Sul de Portugal, Geofísica.
\end{abstract}

\begin{abstract}
This paper presents the first results of the archaeological work carried out in the Chalcolithic ditched enclosure of Folha do Ouro 1 (Serpa, Beja). The site was identified in an aerial image and integrated in the research developed by NIA-Era Arqueologia regarding this type of contexts and submitted to geophysics and surface prospection with collection of archaeological materials. Here, we address the assemblage of archaeological materials, the chronological scope of the site, its topographical location and architectonic characteristics observed in the magnetogram. The site is integrated in the regional context, comparing with the known characteristics of the Alentejo's ditched enclosures.
\end{abstract}

Keywords: Ditched Enclosures, Chalcolithic, South Portugal, Geophysics.

\section{INTRODUÇÃO}

O recinto de fossos da Folha do Ouro 1, situado no Alentejo, próximo da cidade de Serpa (Fig. 1), foi identificado numa imagem aérea de 2006 do Google Earth (Fig. 2:1) no âmbito de uma linha de investigação desenvolvida pelo Núcleo de Investigação Arqueológica da Era Arqueologia orientada para a detecção e caraterização dos recintos de fossos pré-históricos em Portugal (Valera, Becker 2011). Esta identificação e a respectiva imagem foram dadas a conhecer em 2013, no I Congresso de Arqueologia da AAP (Valera, Pereiro 2013, Fig. 4: 9). Mais recentemente, foi igualmente publicada uma nova imagem aérea (Fig. 2: 2) em que o conjunto de recintos surge com melhor definição (Valera, Pereiro 2019). Ainda assim, o sítio viria a ser afectado pela construção de um pivot de rega instalado perto do seu centro, fazendo com que uma parte dos recintos fosse cortada pela vala de implantação da tubagem de alimentação do referido pivot. Assim, juntando o interesse científico em obter a planimetria do sítio e informações sobre a sua cronologia à necessidade de avaliar a afectação sofrida e definir adequada-

\footnotetext{
1. Era Arqueologia / ICArEHB-Universidade do Algarve; antoniovalera@era-arqueologia.pt

2. Era Arqueologia; tiagopereiro@era-arqueologia.pt

3. Centro de Ciências e Tecnologias Nucleares (C2TN), Departamento de Engenharia e Ciências Núcleares, Instituto Superior Técnico, Universidade de Lisboa; pvalerio@ctn.tecnico.ulisboa.pt

4. Centro de Ciências e Tecnologias Nucleares (C2TN), Departamento de Engenharia e Ciências Núcleares, Instituto Superior Técnico, Universidade de Lisboa; amsoares@ctn.tecnico.ulisboa.pt
} 
mente o perímetro do recinto com vista à sua salvaguarda numa futura revisão do PDM de Serpa, foi realizada uma campanha de prospecções de superfície e de geofísica, a qual decorreu no final de Outubro de $2019^{5}$. São os resultados desses trabalhos e da análise dos materiais arqueológicos recolhidos à superfície que agora se publicam, juntamente com uma primeira interpretação da arquitectura do sítio e do seu enquadramento no contexto dos recintos de fossos alentejanos.

\section{LOCALIZAÇÃO E ENQUADRAMENTO GEOMORFOLÓGICO}

Administrativamente, o recinto de fossos da Folha do Ouro 1 localiza-se na união de freguesias de Salvador e Sta. Maria do concelho de Serpa, distrito de Beja. O centro do sítio situa-se a cerca de $625 \mathrm{~m}$ para ESE do marco geodésico com o mesmo nome (Folha do Ouro), e a $900 \mathrm{~m}$ a NO do Monte das Oliveiras, apresentando as seguintes coordenadas: $37^{\circ} 55^{\prime} 54.38^{\prime \prime} \mathrm{N}, 7^{\circ} 32^{\prime} 26.03^{\prime \prime} \mathrm{O}$, a uma cota de $220 \mathrm{~m}$ (Fig. 1). (Figura 1 e 2)

Em termos topográficos, o sítio localiza-se no topo aplanado de uma suave elevação, sobranceira ao vale pouco encaixado do Barranco da Morgadinha, integrando o extremo Este da elevação de cota mais alta onde se localiza o marco geodésico da Folha do Ouro, com uma cota de $227 \mathrm{~m}$ (Fig. 1). Assim, a sua visibilidade é restrita para Oeste, mas também para Sul, onde é limitada pelas cotas mais altas do interflúvio onde passa a estrada Serpa - Ficalho, a $1000 \mathrm{~m}$ do centro sítio. Para Norte a visibilidade é igualmente limitada por elevações de cotas ligeiramente mais altas, prolongando-se ao longo do corredor estabelecido pelo vale do Barranco da Morgadinha, que é igualmente a área visualmente abrangida para Este. $\mathrm{Ou}$ seja, embora se localize numa elevação, a visibilidade sobre a paisagem envolvente é relativamente restrita a áreas próximas do sítio, exercendo-se essencialmente sobre o vale que a percorre pelo lado Este. Em termos geológicos, o local apresenta um substrato integrado no Complexo gabro-diorítico de Cuba, o qual é composto por gabros, dioritos, quartzo-dioritos e granófiros, e que faz parte do Maciço de Beja (Carta Geológica de Portugal, 1:200ooo, fl.8).

5. A equipa de trabalho de campo foi constituída por António Carlos Valera, Tiago do Pereiro, Nelson Almeida e Ana Catarina Basílio.

\section{PROSPECÇÃO GEOFÍSICA, MAGNETOGRAMA E INTERPRETAÇÃO ARQUITECTÓNICA}

\subsection{Metodologia}

A prospecção geofísica foi realizada com recurso ao magnetómetro Bartington 6o1/2, com dois sensores de $1 \mathrm{~m}$ de comprimento separados por $1 \mathrm{~m}$. Cada um contém dois sensores verticais (axis fluxgate magnetometers) no topo e na base, fazendo com que os detectores localizados no topo rejeitem a larga escala do magnetismo atmosférico e isolem pequenas leituras causadas pelas anomalias arqueológicas, podendo detectar anomalias de o,1 nt (nanotesla), considerando-se que o campo magnético terrestre normalmente apresenta leituras de $40.000 \mathrm{nt}$ (o,4 gauss), que podem variar durante o dia. Este equipamento permite detectar anomalias até cerca de 3 $\mathrm{m}$ de profundidade (a média é $1 \mathrm{~m}$ ). A recolha dos dados teve por base uma grelha georreferenciada, com quadrados de $30 \times 30 \mathrm{~m}^{2}$. Estes quadrados foram divididos em 30 linhas de prospecção percorridas em modo zig-zag, permitindo a recolha de medidas a cada $0,125 \mathrm{~m}$ com espaçamento entre linhas de 0,5 $\mathrm{m}$. Os dados obtidos foram processados com software Geoplot 4.o.

\subsection{O magnetograma e a sua interpretação}

A quadrícula da geofísica foi implantada de modo a abranger a totalidade do recinto perceptível nas imagens aéreas, onde se observavam quatro fossos genericamente concêntricos. Assim, foi prospectada nesta primeira abordagem uma área total de $45,900 \mathrm{~m}^{2}$ (correspondendo a 51 quadrados de 30x3om). Contudo, o complexo de recintos revelar-se-ia maior, com mais dois fossos concêntricos exteriores, os quais não foram totalmente abrangidos pela prospecção a Norte, a Oeste e a Sul. O magnetograma obtido revela, assim, um conjunto de recintos circulares ou sub-circulares concêntricos, apresentando seis fossos. Os dois recintos interiores são constituídos por um único fosso cada, enquanto que os recintos mais exteriores são definidos por duplo fosso (Fig. 2: 3).

\subsubsection{O Recinto 1}

O Recinto 1, o mais interior, apresenta um diâmetro de $30 \mathrm{~m}$ e uma área aproximada de $707 \mathrm{~m}^{2}$. O fosso que o define (Fosso 1) tem sete lóbulos que se desenvolvem a partir uns dos outros (tipo A na tipologia 
proposta em Valera 2012) e uma interrupção alinhada com outras nos restantes recintos, formando um alinhamento de entradas orientado a $114^{\circ}$. Pelo exterior, arrancando junto ao lado Sul da entrada, existe um segmento semicircular que lhe passa pela frente e se vai reunir ao lóbulo localizado mais a Norte, formando um longo corredor onde parece existir mais que uma interrupção. Trata-se de um condicionamento do acesso ao recinto interior muito semelhante ao que se observa no recinto interior de Xancra (Valera, Becker 2011) (Figura 3: 2). No interior deste recinto central são visíveis inúmeras anomalias que corresponderão a estruturas negativas de tipo fossa, contabilizando-se um número aproximado de 30.

\subsubsection{O Recinto 2}

O Recinto 2 é igualmente definido por um único fosso (Fosso 2), envolve o primeiro de forma concêntrica, distando dele cerca de $20 \mathrm{~m}$ em média. O seu diâmetro é de aproximadamente $80 \mathrm{~m}$, apresentando uma área de $5027 \mathrm{~m}^{2}$ (incluindo a área do Recinto 1). O fosso apresenta um total de 14 lóbulos também tendencialmente de tipo A e duas entradas: uma no alinhamento orientado a $114^{\circ}$ e outra num novo alinhamento de entradas com os recintos exteriores (mas não com o interior) orientado a $22^{2} 2^{\circ}$. Ambas as entradas apresentam os característicos segmentos curvos frontais, que em ambos os casos parecem arrancar do lado direita da entrada (vista a partir do exterior). No espaço interior compreendido entre o Fosso 1 e o Fosso 2 é observável um numeroso conjunto de anomalias correspondendo a estruturas negativas, que apresentam uma maior concentração no quadrante Sudeste. Foi contabilizado um número mínimo de 67.

\subsubsection{O Recinto 3}

O Recinto 3 é definido por dois fossos sub-circulres concêntricos, sendo o interior lobulado (Fosso 3 ) e o exterior linear (Fosso 4). A largura do corredor entre estes dois fossos ronda em média $10 \mathrm{~m}$, sendo que o diâmetro do recinto definido pelo Fosso 3 varia entre $140 / 150 \mathrm{~m}$ e o do recinto definido pelo Fosso 4 varia entre $160 / 180 \mathrm{~m}$. A área interior ao Fosso 3 é aproximadamente de $16513 \mathrm{~m}^{2}$ (abrangendo a dos recintos mais interiores) e a área definida pelo Fosso 4 é cerca de $22698 \mathrm{~m}^{2}$ (incluindo as anteriores). O fosso interior (Fosso 3 ) apresenta 26 lóbulos espaçados e ligados por pequenos troços lineares, corres- pondendo ao tipo B (Valera 2012). Ambos os fossos apresentam duas entradas, integradas nos alinhamentos a $114^{\circ}$ e $232^{\circ}$. Todas apresentam um troço curvo frontal pelo exterior, sendo que a entrada SE do Fosso 4 é mais ampla que as restantes (atingindo cerca de $20 \mathrm{~m}$ de abertura, enquanto todas as entradas descritas anteriormente representam aberturas entre 2 e $4 \mathrm{~m}$ ). O espaço entre os Fossos 2 e 3 (separados em termos médios por cerca de $30 \mathrm{~m}$ ) apresenta em todo o seu perímetro uma grande concentração de anomalias correspondentes a estruturas negativas, algumas delas alongadas, totalizando um número superior a duas centenas). Já no corredor entre o Fosso 3 e o Fosso 4 o número destas anomalias (cerca de quatro dezenas) é mais reduzido, mesmo tendo em conta a proporção das áreas. Tal reforça a ideia de que estes dois fossos são construções contemporâneas e que definem um recinto que é ocupado/utilizado sobretudo no espaço definido pelo fosso mais interior, sendo o corredor entre ambos essencialmente de circulação. (Figura 3)

\subsubsection{O Recinto 4}

O Recinto 4, o mais exterior, é igualmente definido por dois fossos, sendo o interior também lobulado (Fosso 5) e o exterior linear (Fosso 6). Como referido, apenas a parte Este destes fossos e alguns pequenos troços do lado Oeste estão abrangidos pelo magnetograma, pelo que a sua caracterização fica, para já, mais limitada. Assim, não é possível ter a contabilização global dos lóbulos do Fosso 5 (no magnetograma são visíveis pelo menos 17), os quais também se apresentam espaçados e ligados por troços lineares, enquadrando-se no tipo B. O corredor entre os dois fossos apresenta dimensões idênticas (cerca de $10 \mathrm{~m}$ de largura) às registadas ao espaço entre os Fossos 3 e 4, e tal como aquele apresenta um número muito reduzido de anomalias correspondentes a estruturas negativas. O cálculo dos diâmetros máximos e das áreas definidas por estes dois fossos apenas podem, de momento, ser estimadas. Assim, para o Fosso 5 estimam-se diâmetros entre 200/190 m, correspondendo a uma área aproximadamente de $29865 \mathrm{~m} 2$, e para o Fosso 6 diâmetros de $220 / 200 \mathrm{~m}$, com uma área aproximada de $34636 \mathrm{~m}^{2}$. No espaço interior, entre o Fosso 5 e o Fosso 4, existem igualmente inúmeras anomalias correspondentes a estruturas negativas. $O$ facto de este espaço não ter sido abrangido na totalidade pela prospecção geofísica impede uma aproximação ao número total 
destas anomalias. Ainda assim, foram contabilizadas mais de uma centena, com uma concentração de grandes estruturas no lado Norte (Figura 3: 6) e uma outra do lado Oeste. Na parte Sul, este espaço apresenta uma grande anomalia no magnetograma, a qual deverá ser de natureza geológica. Relativamente às entradas, estes dois recintos apresentam amplas aberturas "tracejadas" no alinhamento das entradas anteriores a $114^{\circ}$, que é o único alinhamento de entradas que percorre todos os fossos. Já no que respeita ao alinhamento de entradas a $23^{\circ}$, o Fosso 5 apresenta aí uma entrada, mas que parece não ser seguida no Fosso 6, ainda que tal observação não possa ser peremptória dadas as descontinuidades no magnetograma nesse ponto. Talvez ocorra aqui o mesmo que se regista no ponto diametralmente oposto $\left(53^{\circ}\right)$, com uma entrada ligeiramente desencontrada entre os dois fossos (Figura 3: 5). Mais nenhum dos recintos apresenta entradas com esta orientação. Estes são também os únicos fossos em que as entradas não revelam a existência de um troço curvo frontal pelo exterior.

Por último, há ainda que salientar a existências de algumas anomalias correspondentes a estruturas negativas no exterior do complexo de recintos. As áreas externas abrangidas pelo magnetograma são, contudo, residuais, pelo que não é ainda possível ter uma ideia adequada da densidade e dispersão destas estruturas no exterior.

\section{A COMPONENTE ARTEFACTUAL}

A componente artefactual reporta-se exclusivamente a material recolhido à superfície durante a realização da prospecção geofísica. As categorias artefactuais presentes são os elementos cerâmicos, a indústria lítica talhada e polida e um objecto metálico. Foram ainda recolhidos alguns escassos fragmentos de ossos inclassificáveis e um dente de Sus sp., assim como três fragmentos de concha: um de Pecten maximus, outro de Ruditapes decussatus e outro de Unio sp..

\subsection{A cerâmica}

Foram recolhidos 44 bordos e uma asa com perfuração vertical. No conjunto dos bordos, 39 permitiram reconstituição formal. Predominam os pratos (3 de bordo simples, 21 de bordo espessado e 1 carenado), seguidos das taças ( 9 abertas simples, I fechada e 1 carenada). Registaram-se, ainda, bordos de um esférico, de um recipiente tipo saco e de um recipiente de perfil em "S" (Figura 4: 1-18). Ainda em cerâmica, foi recolhido um fragmento erodido de "Ídolo de Cornos”, com parte da típica perfuração central.

\subsection{Indústria lítica talhada}

Os elementos de indústria lítica registados são em número reduzido. Em pedra talhada foram registados três segmentos de lâmina com retoque marginal (Fig. 4: 19-20), seis lascas e um seixo talhado (Fig. 5: 4), sendo a matéria prima predominante o chert, com uma lâmina em rocha ígnea, uma lasca em sílex e outra em quartzo. Ainda dentro da categoria de pedra talhada foram registados vários percutores esferóides em quartzo e granito/diorito, alguns deles simultaneamente usados como bigorna (Fig. 4: 22).

\subsection{Pedra Polida}

Relativamente a utensílios de pedra polida, foram recolhidos um machado de secção elipsoidal e de polimento abrangente, um fragmento de utensílio de pedra polida alongado de secção irregular e um esboço de utensílio de secção sub-trapezoidal (Fig. 5: 1-3). Recolheu-se igualmente um fragmento de xisto polido com orifício circular, correspondendo a um possível peso (Fig. 5: 5). Finalmente foram registados três fragmentos de dormentes de mó manual.

\subsection{Metal e análise arqueometalúrgica}

$\mathrm{O}$ artefacto em análise foi igualmente recolhido à superfície quando se procedia à prospecção geofísica no sítio da Folha do Ouro 1. A sua superfície encontrava-se coberta por concreções acastanhadas muito aderentes formando uma camada homogénea, com uma ou outra pequena área esverdeada ou avermelhada, resultantes estas da eliminação das referidas concreções devido, porventura, a deslocações que a peça sofreu durante os trabalhos agrícolas. O peso do objecto $(244,3 \mathrm{~g})$, bem como as marcas esverdeadas e avermelhadas, permitiram desde logo identificar o artefacto como sendo manufacturado a partir de um metal de base cobre. A cor acastanhada da superfície resultaria da incorporação de partículas do solo nos produtos de corrosão do metal, especialmente na camada mais superficial, como se verificou após a sua limpeza mecânica. Trata-se de um artefacto com uma patina verde, de forma tabular, prismática, de cantos arredondados, com um peso de 239,9g (após a limpeza superficial) e com cerca de $11 \mathrm{~cm}$ de comprimento por 3,6 $\mathrm{cm}$ de largura e uma espessura máxima de 1,2 $\mathrm{cm}$ (Figura 5: 6). 
A interpretação para a funcionalidade deste artefacto, que nos parece mais consentânea com a forma que apresenta, é a de se tratar de um lingote. Uma das faces maiores é convexa, enquanto a face oposta é plana. Uma observação cuidada permite verificar que, nesta, os bordos se elevam muito ligeiramente (algumas décimas de milímetro). Estes factos indiciam que a forma do objecto em causa resulta do vazamento do metal num molde rectangular, de fundo ligeiramente côncavo, muito provavelmente um daqueles artefactos cerâmicos ligados à metalurgia calcolítica vulgares no sul do país e que, habitualmente, são interpretados como cadinhos. Ao possível lingote falta, aparentemente, um fragmento num dos cantos, mas o aspecto da "fractura", algo boleada, e a inexistência de quaisquer vestígios de corte levam a colocar a hipótese de essa perda de massa metálica resultar apenas de um qualquer acidente durante a operação de vazamento.

A identificação do metal constituinte do artefacto foi realizada por espectrometria de fluorescência de raios $\mathrm{X}$, dispersiva de energias, utilizando um espectrómetro portátil Bruker Si Titan equipado com um tubo de raios $\mathrm{X}$ com ânodo de ródio, um detector SSD e um colimador para a análise de áreas de dimensão reduzida. $\mathrm{O}$ artefacto foi previamente preparado para análise através da remoção dos produtos de corrosão superficial numa área com cerca de $5 \times 5 \mathrm{~mm}^{2}$ (Valério et al. 2019). Em seguida foram efectuadas diversas análises para identificar possíveis heterogeneidades composicionais, encontrando-se na tabela seguinte os respectivos resultados. (Tabela 1).

Verifica-se, por conseguinte, que se trata de um cobre muito puro em que apenas o arsénio e o ferro foram detectados como impurezas. Composições deste tipo são típicas do Calcolítico do Sul de Portugal, cuja metalurgia se caracteriza por artefactos de cobre com teores variáveis de arsénio (Valério et al. 2016). A composição do possível lingote da Folha do Ouro 1 é também muito semelhante às dos artefactos que têm sido interpretados como lingotes com esta cronologia, como são os casos do exemplar de Leceia (Cardoso, Braz Fernandes 1995) e o de Porto Mourão (Soares et al. 1996). Deverá, no entanto, notar-se que esta composição por si só não prova a possível funcionalidade que temos atribuído ao artefacto. A análise micro-estrutural que pensamos realizar num futuro próximo é que poderá produzir os indícios que, conjugados com a forma do artefac- to e os resultados da análise composicional, justifiquem de uma forma incontroversa a funcionalidade que até agora lhe temos atribuído. Será também imperioso, nesse caso, proceder a uma análise de isótopos de $\mathrm{Pb}$ para tentar determinar a proveniência do cobre utilizado na sua manufactura. (Figura 4 e 5 )

\section{BREVE APONTAMENTO SOBRE \\ A FOLHA DO OURO I NO CONTEXTO DOS RECINTOS DE FOSSOS CALCOLÍTICOS LOBULADOS PADRONIZADOS DO ALENTEJO}

Quer pela cultura material recolhida à superfície, quer pelas características arquitectónicas evidenciadas pelo magnetograma, o recinto de fossos da Folha do Ouro 1 é enquadrável no Calcolítico do Sudoeste. Naturalmente as suas temporalidades e cronologias mais precisas são, de momento, difíceis de estabelecer sem o recurso a trabalhos de arqueologia intrusivos. Contudo, numa análise meramente prospectiva, algumas observações podem ser feitas tendo por base as suas características arquitectónicas e a sua integração no que, de momento, se conhece para os recintos de fossos da bacia do médio Guadiana.

A morfologia lobulada regular dos dois recintos centrais, assim como as suas dimensões, número de lóbulos, tendência circular e concentricidade (sempre que existe mais que um fosso), aproxima-os dos recintos do Outeiro Alto 2, de Borralhos, de Xancra, da Horta do Albardão 3 ou de Santa Vitória. Há hoje já um número suficiente deste tipo de recintos, com plantas integrais ou quase integralmente conhecidas, para se poder começar a falar de uma certa padronização arquitectónica típica da bacia do Guadiana. Este padrão manifesta-se quer em termos de dimensões aproximadas, seja dos recintos seja das distâncias internas entre fossos, quer no número, forma e na própria dimensão dos lóbulos (recente trabalho de aplicação da análise de morfometria geométrica aos lóbulos de vários destes recintos verificou esta regularidade (Valera et al. 2019), para qual já havia um primeiro ensaio interpretativo - (Valera 2020) quer ainda na predominância de entradas alinhadas, em vários casos a eventos astronómicos (Valera 2013).

No caso da Folha do Ouro 1, a este padrão regular lobulado (de Tipo A - Valera 2012) evidenciado pelos dois recintos interiores, junta-se um outro até agora ausente neste tipo de recintos de fossos: o fosso du- 
plo, com o fosso interno lobulado de Tipo B (lóbulos espaçados com um segmento recto intermédio) e um fosso linear externo. Até ao momento, esta situação só era conhecida no grande recinto da Salvada (Valera, Pereiro 2015) e em Moreiros 2 (Valera et al. 2013) (Fig. 6). O recinto da Salvada apresenta um duplo fosso onde o fosso interior é um lobulado regular (mas de Tipo A) e o fosso externo é linear. Este é também o único grande recinto de fossos conhecido (com cerca de 18 ha) que apresenta um fosso com lobulado regular). Em Moreiros 2 o duplo fosso é também exterior (numa aparente segunda fase construtiva), apresentando igualmente um fosso interno lobulado regular de tipo B e um fosso externo linear, assim como também entradas desencontradas como a registada no duplo fosso externo da Folha do Ouro. A principal diferença que se regista no duplo fosso de Moreiros é a sua tendência poligonal, com ângulos suaves e mais ou menos abertos, caso único nos recintos de fossos portugueses (e que apenas encontra paralelo nas plantas dos recintos muralhados de S. Pedro (Mataloto 2010) e Porto das Carretas (Soares, Silva 2010). Outros recintos apresentam igualmente duplos fossos que, correspondendo sempre aos mais exteriores, são nestes casos ambos lineares (Fig. 6). É essa a situação que se observa nos fossos externos dos Perdigões (Márquez Romero et al. 2011) e nos fossos externos de Montoito (Valera et al. 2015). Curiosamente, a equidistância entre os fossos que compõem estes fossos duplos é aproximadamente a mesma nos vários recintos em que ocorrem, entre 10 a 15 metros, sugerindo também aqui uma padronização. (Figura 6)

O mesmo se poderá dizer relativamente à estruturação das entradas, as quais, dentro de uma certa variabilidade (Valera, Pereiro 2020), apresentam soluções que se vão repetindo, reforçando a ideia da existência de modelos gerais que vão sendo seguidos de forma mais ou menos aproximada. É o caso dos troços alongados em frente das entradas de alguns recintos centrais, formando uma espécie de corredor de acesso lateral (casos de Xancra e Folha do Ouro 1) ou dos segmentos curvos frontais às entradas (casos da Folha do Ouro 1, Montoito, Perdigões, Xancra, Borralhos ou Monte da Contenda).

De facto, conforme se vão obtendo mais plantas completas ou tendencialmente completas destes recintos, o que em grande medida se fica a dever à utilização da geofísica como estratégia indispensável de abordagem a contextos e que dificilmente poderiam ser conseguidas por meio de intervenções arqueológicas intrusivas, mais vai emergindo um modelo que, com algumas variantes, parece marcar uma forma regionalizada de desenhar recintos de fossos.

Esta padronização poderá ser ainda maior se pensarmos que muitos dos desenhos observados traduzem temporalidades diferentes. Ou seja, alguns destes recintos terão tido vidas mais longas que outros, o que se poderá traduzir na maior complexidade e investimento arquitectónico que uns apresentam relativamente a outros. Se o Outeiro Alto 2 apresenta um único fosso, as escavações recentemente realizadas em Santa Vitória revelam que também aí terá existido inicialmente apenas um fosso e só depois se terá construído o segundo. O mesmo poderá ter acontecido em Xancra, Folha do Ouro 1 ou Borralhos, o que só a escavação arqueológica poderá esclarecer, mas que a proximidade da morfologia e tamanho dos respectivos pequenos recintos centrais sugere. Em Borralhos, contudo, a própria geofísica permite perceber que existe um processo construtivo diferido no tempo (Valera, Pereiro 2020). Por outras palavras, boa parte da variabilidade que se observa nestes recintos lobulados regulares, por exemplo ao nível do número de fossos e das dimensões, poderá ficar a dever-se aos diferentes tempos de vida e de construção que cada um apresenta.

Outra questão que emerge da padronização destes desenhos arquitectónicos, da sua regularidade surpreendente como acontece com a Folha do Ouro 1, é o facto de ela nos ser perceptível essencialmente na sua representação gráfica ou fotográfica em plantas, magnetogramas ou imagens aéreas. O facto de em Santa Vitória, para se perceber um pouco melhor a planta no local, ter sido construída uma torre é exemplificativo da dificuldade de leitura destes desenhos e da sua regularidade ao nível do terreno. Por outro lado, no caso deste tipo de recintos lobulares padronizados já escavados (Santa Vitória, Outeiro Alto 2 e Horta do Albardão 3) não se registaram quaisquer evidências de delimitações físicas verticais (taludes ou paliçadas) a acompanhar os fossos. O que os dados disponíveis vão sugerindo é a delimitação de espaços por fossos, mas sem outros elementos de constrangimento ou de grande impacto visual. À semelhança dos geoglifos de Nasca, os espaços desenhados e os trajectos delineados podem ser percorridos ao nível do terreno, mas só são perceptíveis na sua integralidade a partir de cima, como se tivessem sido feitos para ser vistos por outras en- 
tidades (Valera 2020). A ser assim, a monumentalidade que emerge nestes recintos tem mais a ver com o trabalho envolvido, com a forma como se organiza e estrutura o espaço com referenciais de ordem cosmológica e com as actividades que ocorreriam no seu interior (Valera 2013; 2020), e menos com o impacto visual das suas arquitecturas, tanto mais que existem evidências, por inúmeras vezes sublinhadas, de estes recintos funcionarem com os fossos a serem intencionalmente preenchidos, parcialmente reabertos ou construídos de forma segmentada e sequencial. Esta é mais uma linha de pensamento e investigação que este tipo de recintos, em que a Folha do Ouro 1 se integra, suscitam.

Outra é a proximidade espacial entre alguns deles que vai emergindo no mapa do Alentejo. No caso concreto da parte sul da margem esquerda portuguesa do Guadiana é, neste sentido, importante sublinhar a proximidade da Folha do Ouro 1 ao recinto do Outeiro Alto 2 (situado a 10,5 km a NO), ao recinto de Borralhos (situado a 9,5 $\mathrm{km}$ a ENE), ao grande complexo de recintos da Herdade da Corte (a $15,3 \mathrm{~km}$ a NE) e ao sítio de São Brás 3 (localizado 7 $\mathrm{km}$ a SO) e cuja implantação sugere poder tratar-se igualmente de um recinto de fossos. Naturalmente, a proximidade espacial não implica proximidade temporal, e sem boas sequências cronológicas (que na região e para estes contextos, só verdadeiramente existem para os Perdigões, com mais de uma centena de datações) não é possível estabelecer, de forma segura, uma contemporaneidade entre sítios que nos obrigue pensar os significados dessas vizinhanças. Poderão não ter todos funcionado ao mesmo tempo, tendo temporalidades diferentes. Poderão ter tido ocupações periódicas alternadas em diferentes momentos, tendo uma utilização genericamente contemporânea, mas não simultânea. Ou poderão ter estado envolvidos em estratégias de emulação social e comportamentos miméticos (Valera, 2019). Os dados actualmente disponíveis suscitam muitas questões e permitem ainda poucas respostas, mas a proximidade espacial e arquitectónica destes recintos no actual concelho de Serpa é, seguramente, outro dos problemas que obriga a repensar alguns velhos axiomas (tal como a proximidade entre os grandes recintos da Salvada e Monte das Cabeceiras 2, no outro lado do Guadiana, já vinha obrigando - Valera, Pereiro 2015; Valera 2019).

\section{CONCLUINDO}

Com a prospecção geofísica do recinto da Folha do Ouro 1, a investigação desenvolvida pelo NIA-ERA (por vezes em parceria com outras instituições) sobre os recintos de fossos pré-históricos no interior alentejano produziu o décimo terceiro magnetograma deste tipo de sítios. Este trabalho, associado a outros realizados no âmbito de projectos de investigação ou arqueologia de salvamento, evidencia a relevância, até há duas décadas insuspeita, que este fenómeno tem na região. Permite avançar na sua caracterização, definição de tendências e complexidades arquitectónicas, temporalidades e na formulação de linhas de inquérito que só podem ser desenvolvidas a partir de plantas integrais ou quase integrais. Muitas das questões levantadas precisam, contudo, de um aumento da amostragem, o qual tem essencialmente decorrido do empenhamento do NIA-ERA e das parcerias que pontualmente tem conseguido criar (como aconteceu com o município de Serpa nos levantamentos de Borralhos e Folha do Ouro 1). Outros recintos, que poderão reforçar linhas interpretativas ou sugerir novas orientações da investigação, continuam à espera que se possa realizar o seu levantamento. Situação urgente, já que noutros, igualmente importantes, este trabalho já está inviabilizado pela agricultura intensiva de olival e amendoal. Neste contexto, cada novo magnetograma que se obtém e publica, para além do que traz ao processo de investigação, é verdadeiro serviço público.

\section{AGRADECIMENTOS}

Agradece-se o apoio logístico do Município de Serpa na realização do trabalho de campo. A caracterização arqueometalúrgica foi efectuada no âmbito do Projecto UID/Multi/o4349/2019 financiado pela Fundação para a Ciência e a Tecnologia.

\section{BIBLIOGRAFIA}

CARDOSO, J.L. e BRAZ FERNANDES, F. (1995) - Estudo arqueometalúrgico de um lingote de cobre de Leceia (Oeiras). Estudos Arqueológicos de Oeiras. 5. pp. 153-164.

MÁRQUEZ ROMERO, J.E.; VALERA, A.C.; BECKER, H.; JIMÉNEZ, V. e SUÀREZ, J. (2011) - El Complexo Arqueológico dos Perdigões (Reguengos de Monsaraz, Portugal). Prospecciones Geofísicas - Campaña 2008-09. Trabajos de Prehistoria. 68-1. pp. 175-186. 
MATALOTO, R. (2010) - O 3.ำ4.ำ milénio a.C. no povoado de São Pedro (Redondo, Alentejo Central): fortificação e povoamento na planície centro alentejana. In: Gonçalves, V., Sousa, A.C. (Eds) Transformação e mudança no centro e sul de Portugal: o $4^{0}$ e o $3^{\circ}$ milénios a.n.e.. Cascais. CMC. pp. 263-295.

SOARES, A.M.M.; ARAÚJO, M.F.; ALVES, L. e FERRAZ, M.T. (1996) - Vestígios metalúrgicos em contextos do Calcolítico e da Idade do Bronze no Sul de Portugal. Miscellanea em Homenagem ao Professor Bairrão Oleiro. Lisboa. Colibri. pp. 553-579.

SOARES, J. e SILVA, C.T. (2010) - Campaniforme do Porto das Carretas (médio Guadiana). A procura de novos quadros de referência. In: Gonçalves, V. Sousa, A.C., (Eds) Transformação e mudança no centro e sul de Portugal: o $4^{\circ}$ e o $3^{\underline{0}}$ milénios a.n.e.. Cascais, CMC, pp. 225-261.

VALERA, A.C. (2012) - Fossos sinuosos na Pré-História Recente do Sul de Portugal: ensaio de análise crítica. Actas do V Encontro de Arqueologia do Sudoeste Peninsular. Município de Almodôvar, pp. 25-38.

VALERA, A.C. (2013) - Breve apontamento sobre a dimensão cosmogónica dos recintos de fossos da Pré-História Recente no Interior Alentejano. Cadernos do Endovélico, 1. Colibri/CMA. pp. 51-63.

VALERA, A.C. (2019) - Landscapes of complexityin Southern Portugal during de $4^{\text {th }}$ and $3^{\text {rd }}$ millennium BC. In: J. Müller, M. Hintz, M. Wunderlich (Eds.) Megaliths, Societies, Landscapes. Early monumentality and social differentiation in Neolithic Europe. Frühe Monumentalität und soziale Differenzierung. 18. Vol. 3/3. Bonn. Verlag Dr. Rudolf Habelt GmbH. pp. 1039-1054.

VALERA, A.C. (2020) - Ephemeral and Cosmological Monumentality: the 'strange' ditched enclosures of Chalcolithic South Portugal. In: A.B. Gebaue; L. Sorensen, A. Teather and A.C. Valera (Eds.) Monumentalizing life in the Neolithic: Narratives of continuity and change. Oxford. Oxbow, pp. 239-250.

VALERA, A.C., BECKER, H. (2011) - Cosmologia e recintos de fossos da Pré-História Recente: resultados da prospecção geofísica em Xancra (Cuba, Beja). Apontamentos de Arqueologia e Património. 7. Lisboa. NIA-ERA Arqueologia. pp. 23-32.
VALERA, A.C.; BECKER, H. e BOAVENTURA, R. (2013) - Moreiros 2 (Arronches, Portalegre): geofísica e cronologia dos recintos interiores. Apontamentos de Arqueologia e Património. 9. Lisboa. Nia-Era. pp. 37-46.

VALERA, A.C.; BECKER, H. e COSTA, C. (2015) - Os recintos de fossos Pré-Históricos de Monte da Contenda (Arronches) e Montoito 2 (Redondo). Estudos Arqueológicos de Oeiras. 21. CMO. pp. 195-216.

VALERA, A.C., GODINHO, R. e PEREIRO, T. DO (2019) - Cosmologia e padronização dos recintos de fossos lobulados: uma abordagem morfogeométrica. Comunicação no colóquio Os recintos da Pré-História Recente: avanços no estudo das suas arquitecturas e espacialidades. Lisboa. Museu Arqueológico do Carmo (Novembro de 2019).

VALERA, A.C. e PEREIRO, T. DO (2013) - Novos recintos de fossos no sul de Portugal: o Google Earth como ferramenta de prospecção sistemática. Actas do I congresso da Associação dos Arqueólogos Portugueses. Lisboa. AAP. pp. 345-350.

VALERA, A.C. e PEREIRO, T. DO (2015) - Os recintos de fossos da Salvada e Monte das Cabeceiras 2 (Beja, Portugal). Actas do VII Encontro de Arqueologia Peninsular. Aroche-Serpa.pp. 316-327.

VALERA, A.C. e PEREIRO, T. DO (2019) - A geofísica e salvaguarda do património arqueológico em meio rural. Vantagens e quando utilizar: o caso dos recintos de fossos. Scientia Antiquitatis. 1. Évora. pp. 193-205.

VALERA, A.C. e PEREIRO, T. DO (2020) - O recinto de fossos pré-Histórico de Borralhos (Serpa): aproximação à sua arquitectura através da prospecção geofísica. Apontamentos de Arqueologia e Património. 14. pp. 17-28.

VALÉRIO, P.; SOARES, A.M.M. e ARAÚJO, M.F. (2016) - An overview of Chalcolithic copper metallurgy from Southern Portugal. MENGA. Revista de Prehistoria de Andalucía.7.pp. 31-50.

VALÉRIO, P.; SOARES, J.; ARAÚJO, M.F.; ALVES, L.C. e TAVARES DA SILVA, C. (2019) - The composition of São Brás copper hoard in relation to the Bell Beaker metallurgy in southwestern Iberian Peninsula. Archaeometry. 61/2. 392-405.

\begin{tabular}{lccc}
\hline Análise & $\mathrm{Cu}(\%)$ & As (\%) & Fe (\%) \\
\hline 1 & 99,8 & 0,12 & n.d. \\
\hline 2 & 99,8 & 0,15 & 0,09 \\
\hline 3 & 99,7 & 0,16 & 0,10 \\
\hline Média & 99,8 & 0,13 & 0,03 \\
\hline
\end{tabular}

Tabela 1 - Composição do possível lingote da Folha do Ouro I (n.d.: não detectado). 

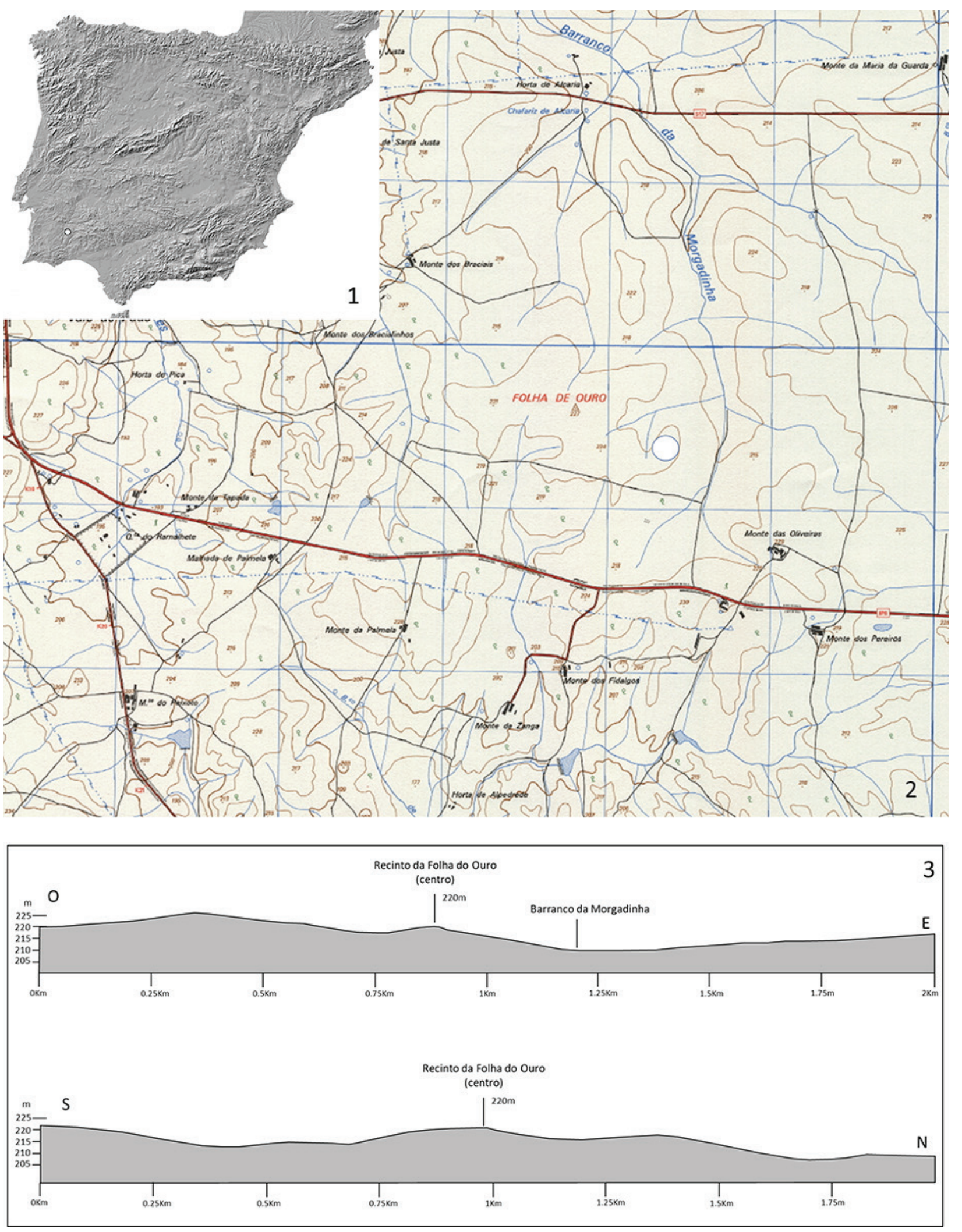

Figura 1 - Localização do recinto da Folha do Ouro 1 na Península Ibérica (1), na C.M.P., 1:250oo, fl. 533 (2) em dois perfis topográficos perpendiculares (3). 


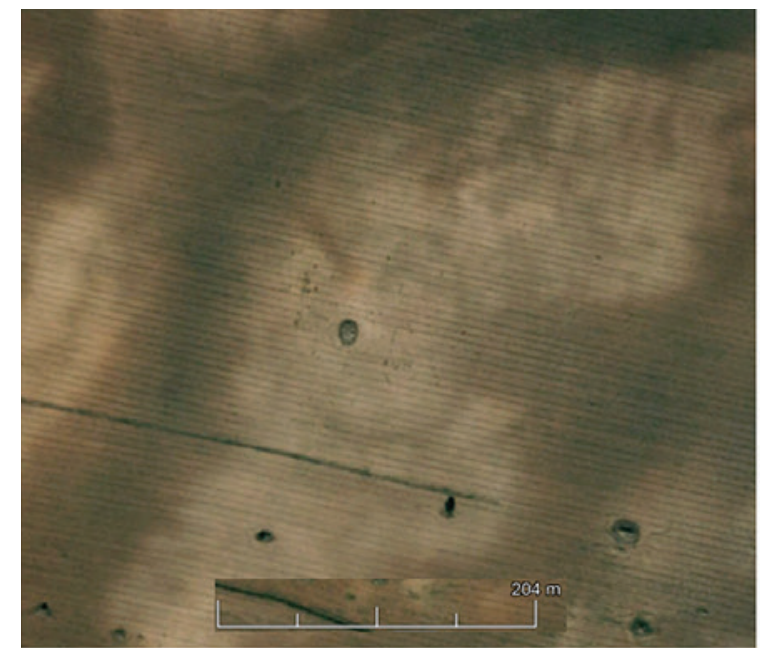

1

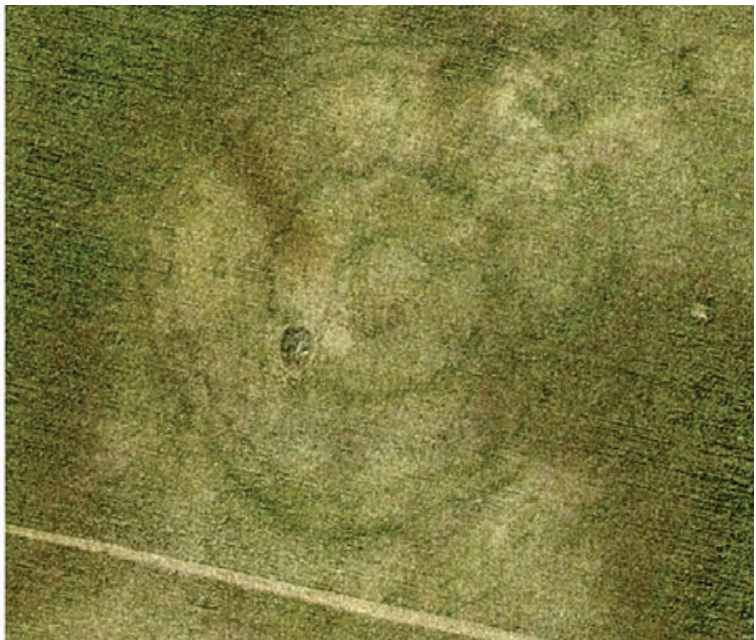

2

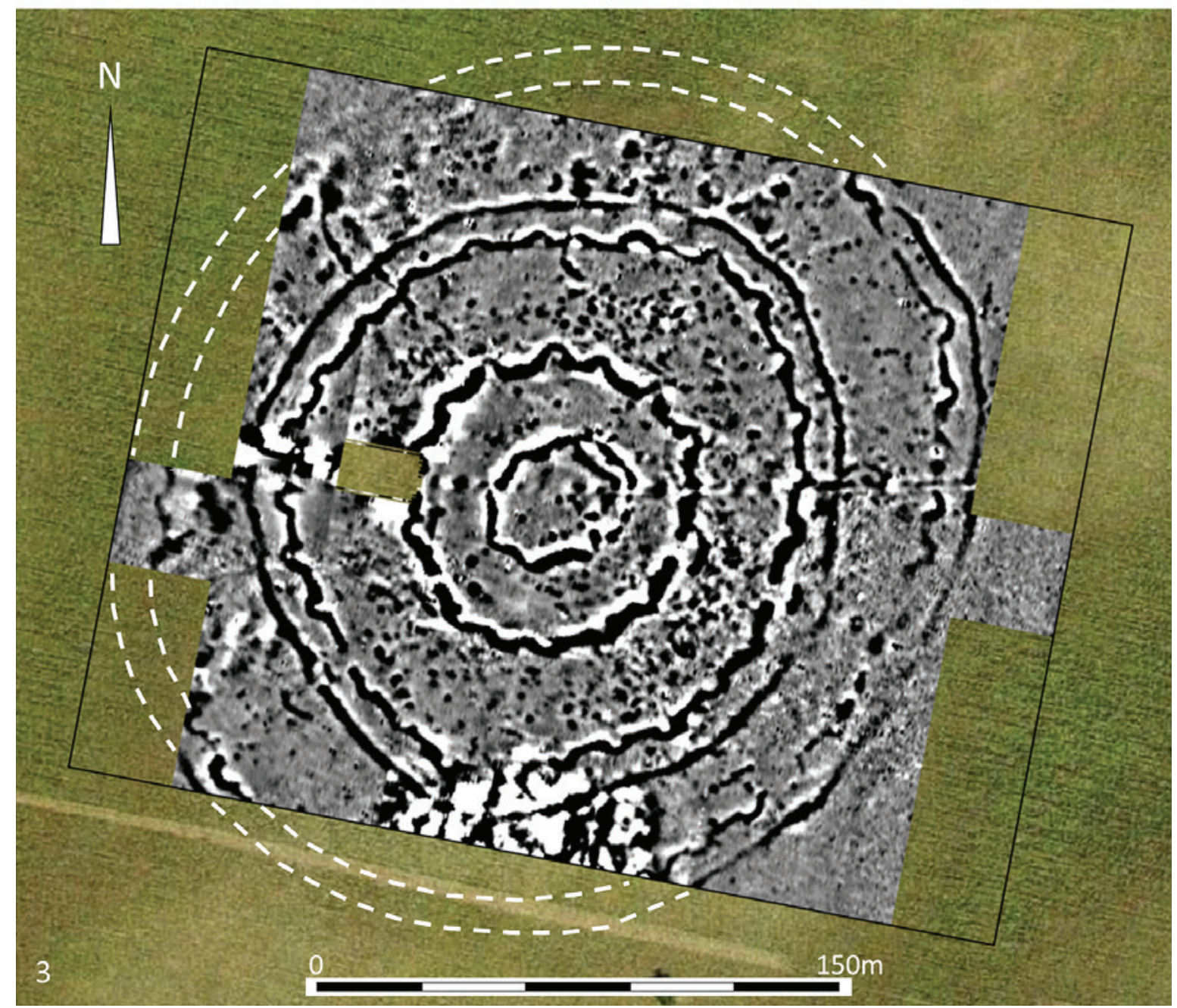

Figura 2 - (1) Folha do Ouro 1 em imagem aérea de 2006 do Google Earth; (2) Folha do Ouro em imagem aérea de 2018 (3) Magnetograma das prospecções geofísicas realizadas em 2019 na Folha do Ouro 1. 

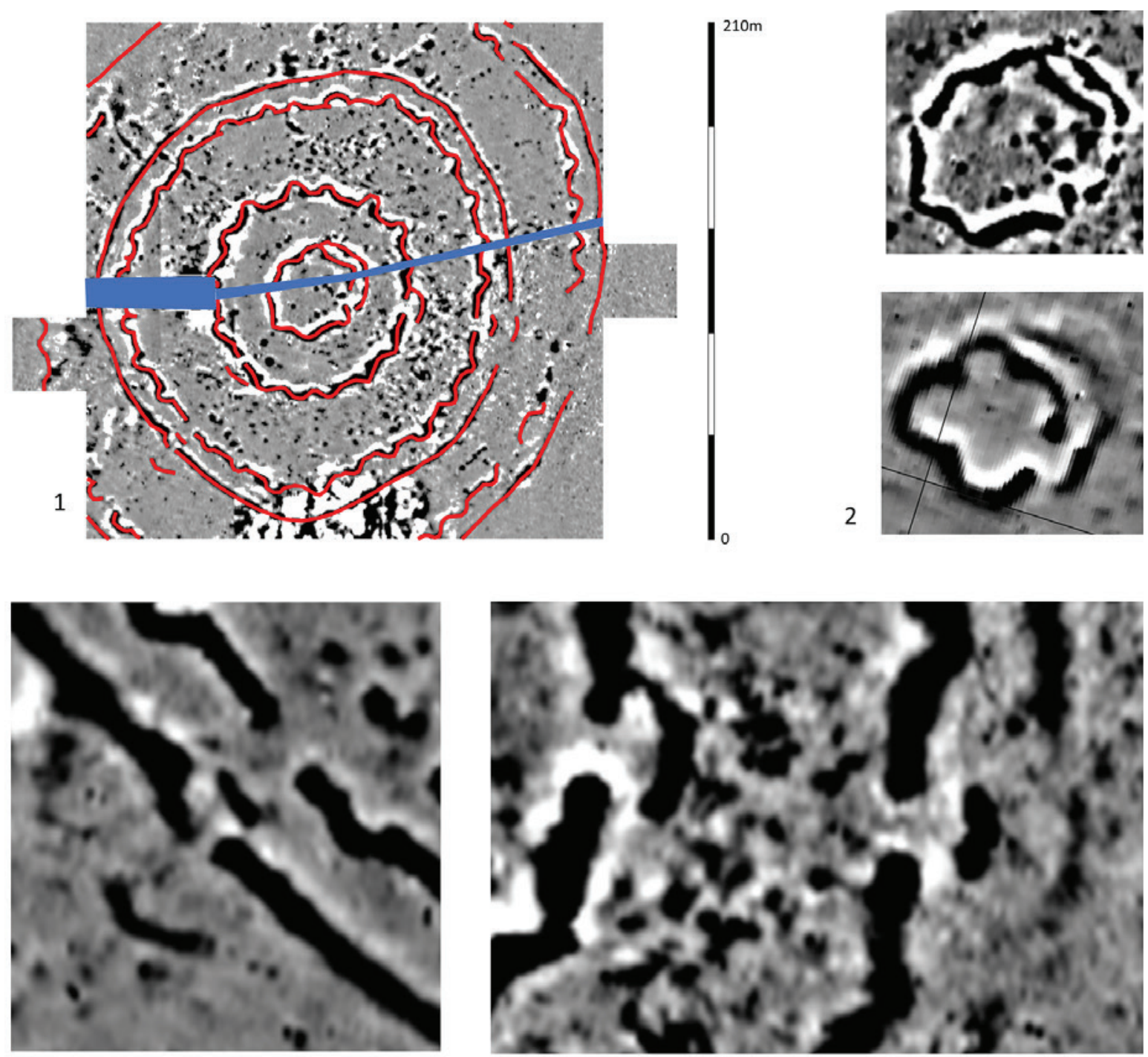

3

4

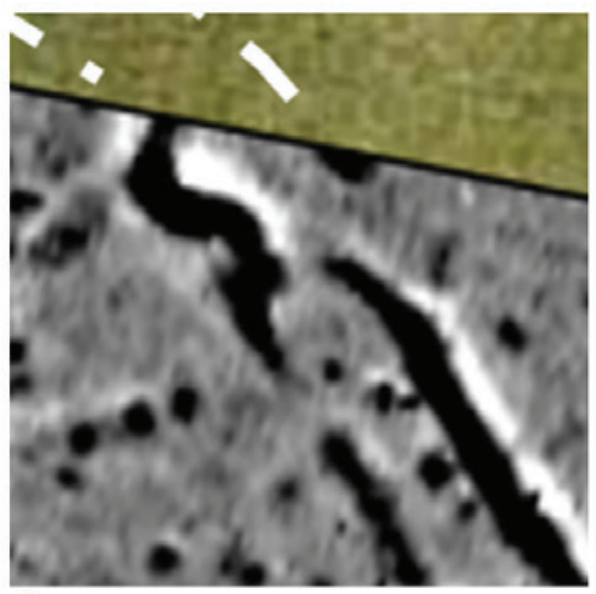

5

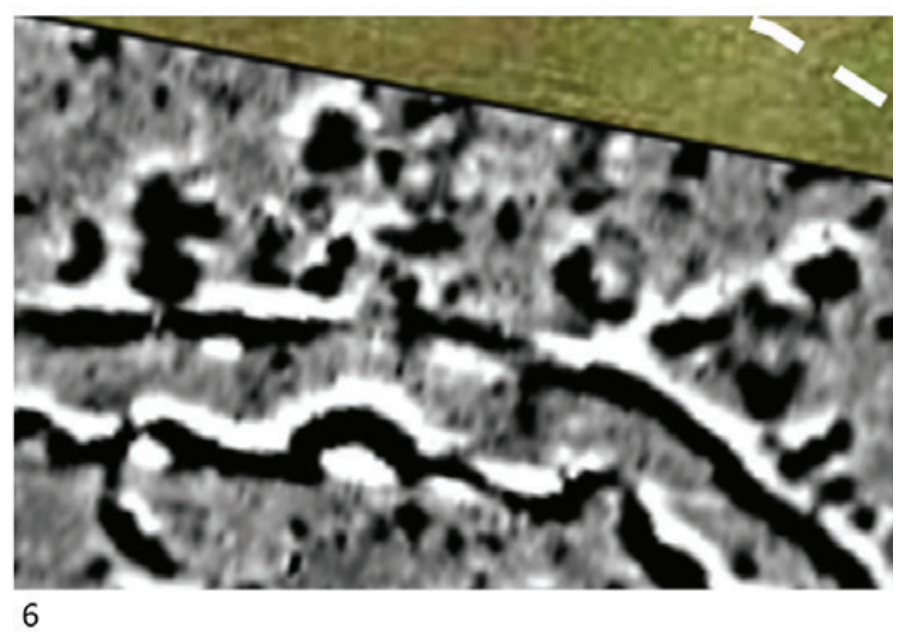

Figura 3 - (1) Magnetograma anotado, com desenho dos fossos e marcação da conduta e espaço ocupado pelo pivot; (2) comparação do recinto interior da Folha do Ouro 1 (em cima) com o recinto interior de Xancra (em baixo); (3) detalhe da entradas dos fossos 3 e 4 no alinhamento a $22^{2} 2^{\circ}$; (4) detalhe das entradas dos fossos 2 , 3 e 4 no alinhamento a $114^{\circ}$; (5) detalhe da entrada Noroeste nos fossos 5 e 6; (6) detalhe da concentração de grandes estruturas negativas na área Norte, entre os fossos 4 e 5 . 

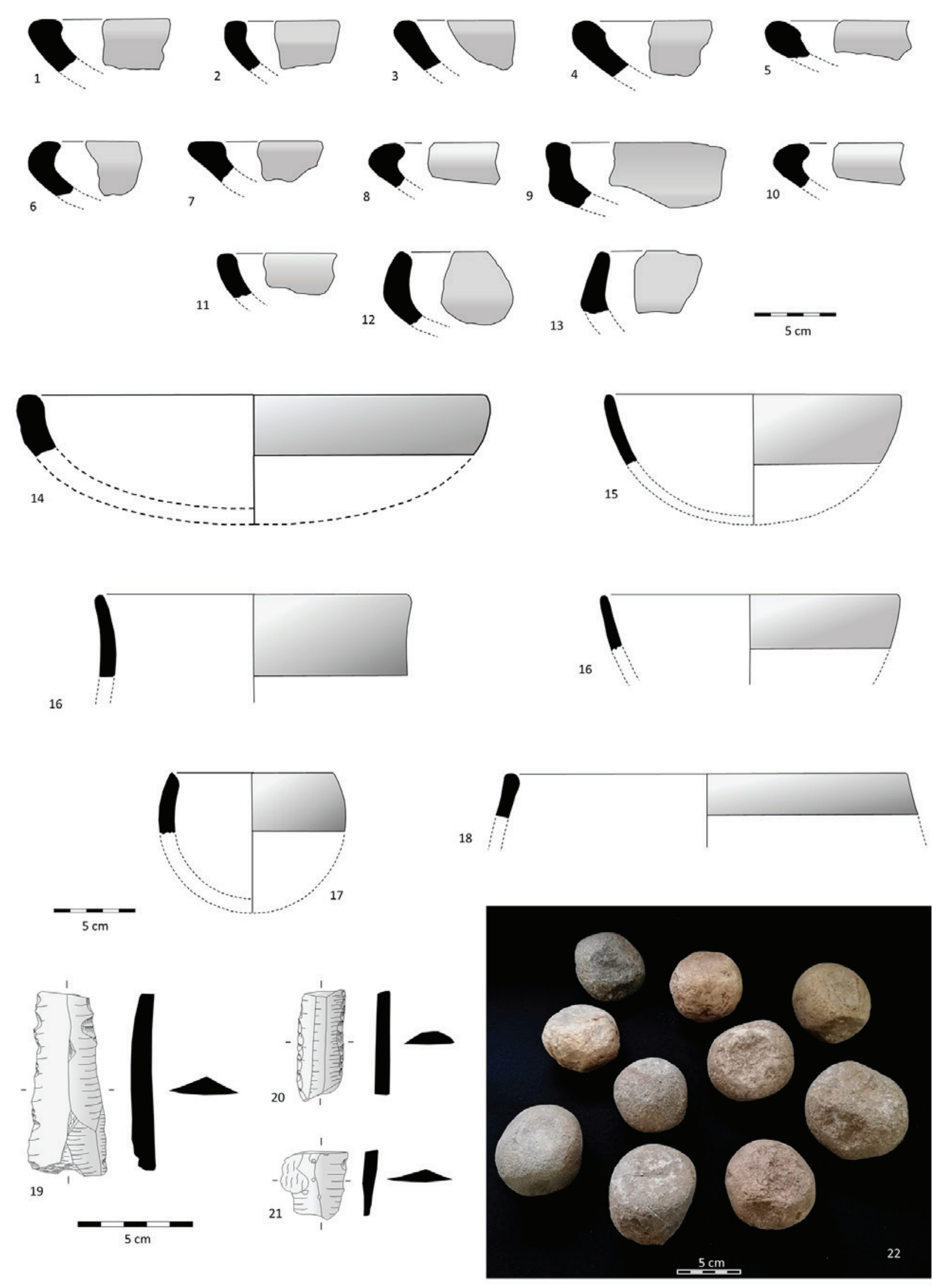

Figura 4- Materiais cerâmicos e líticos recolhidos à superfície. 

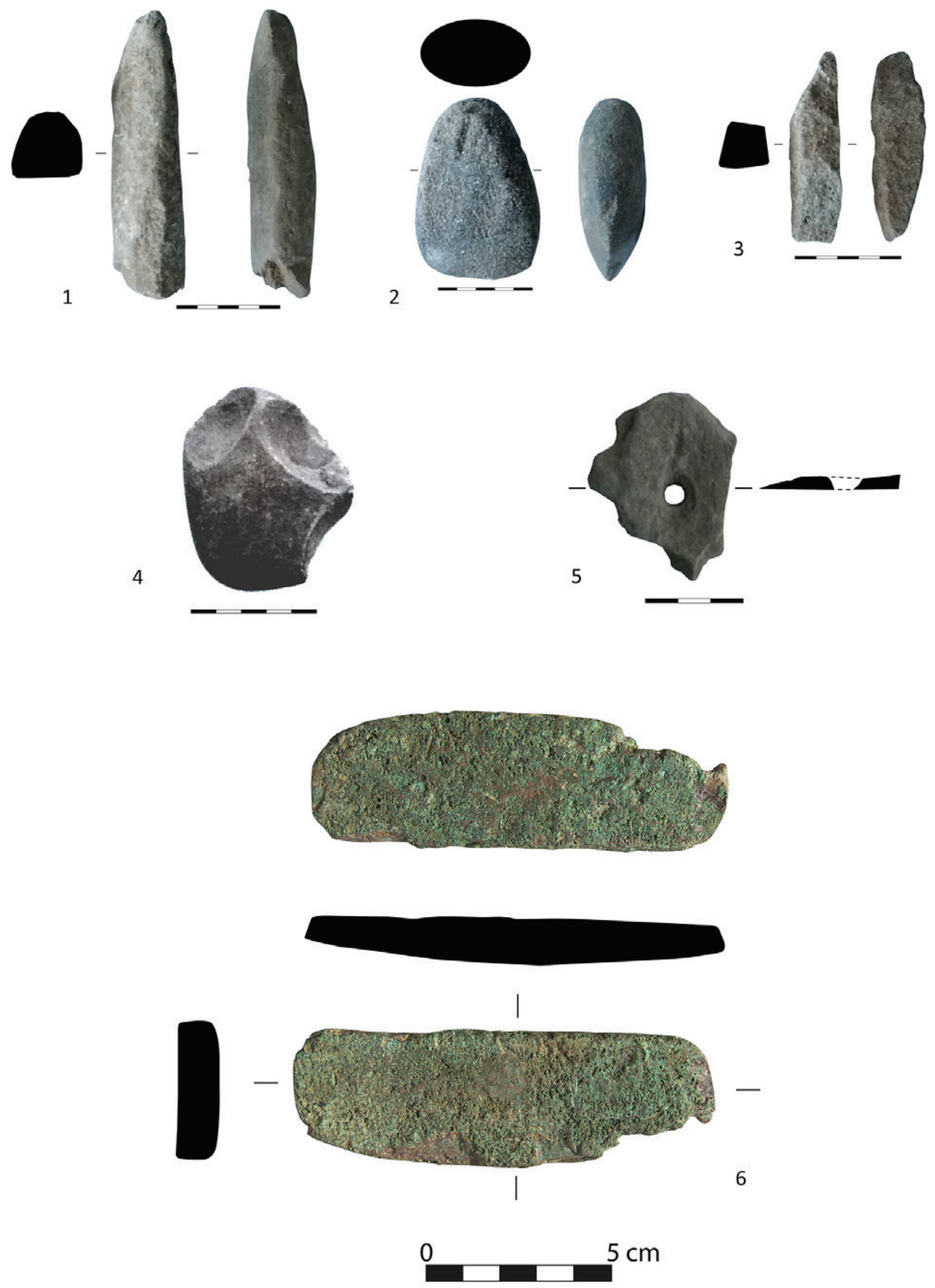

Figura 5 - Materiais líticos e metálicos recolhidos à superfície. 1 - 3 pedra polida; 4 Seixo talhado; 5 Placa de xisto perfurada; 6. Possível lingote de cobre. 


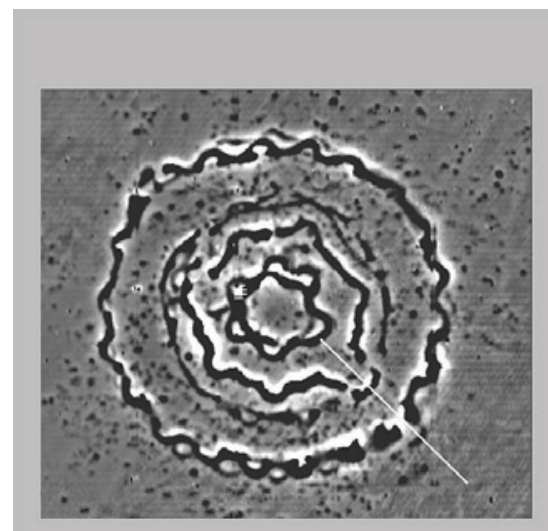

1
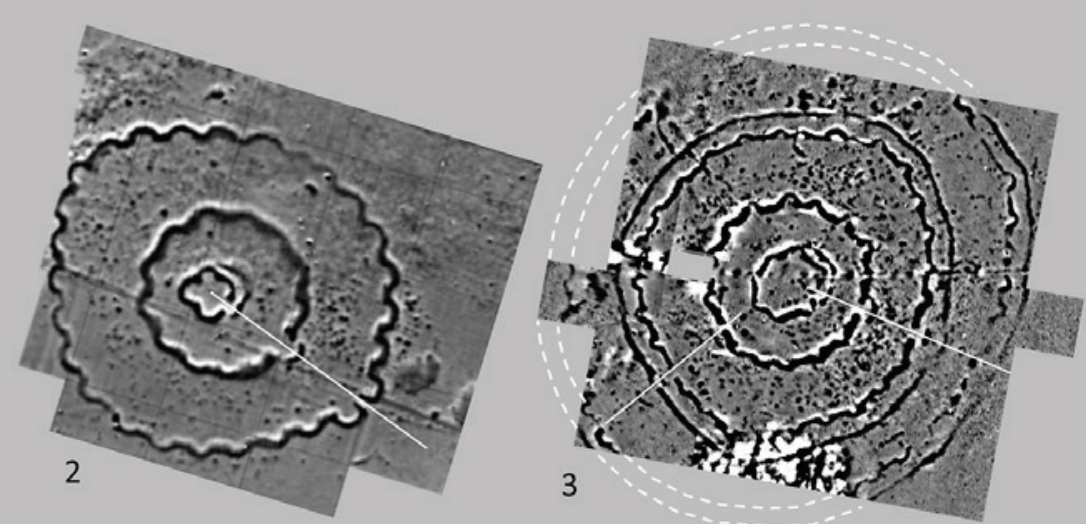

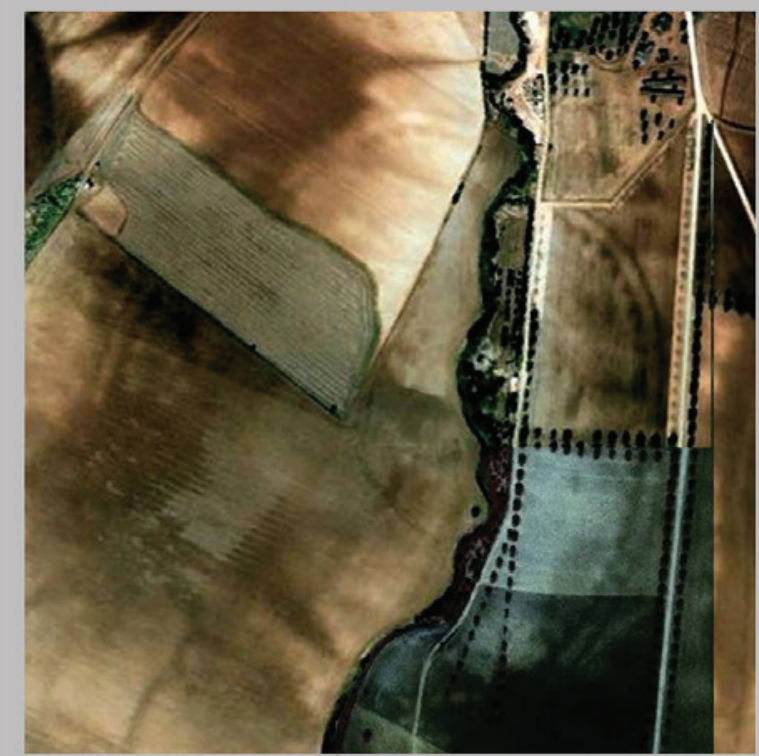

4

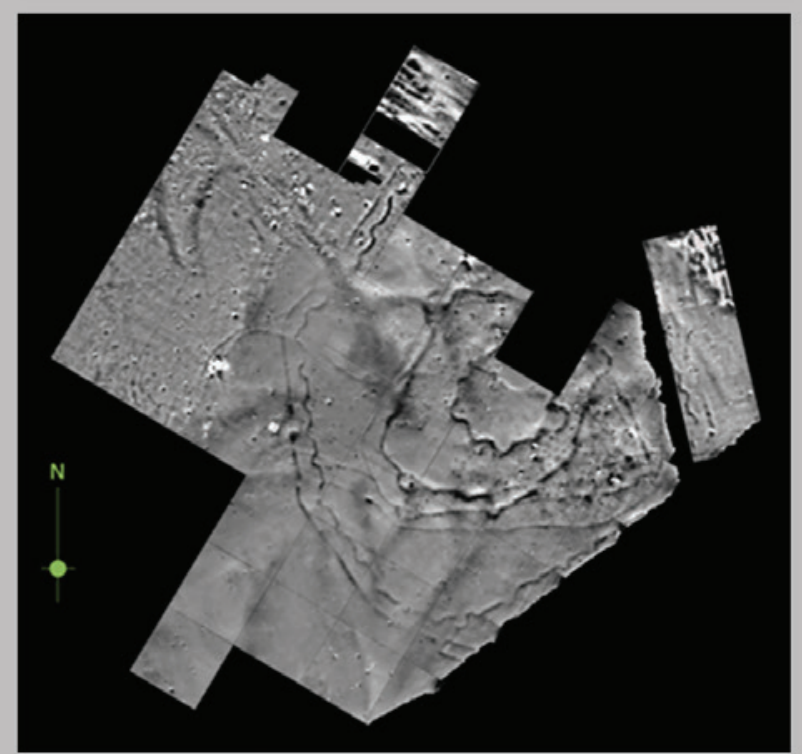

5
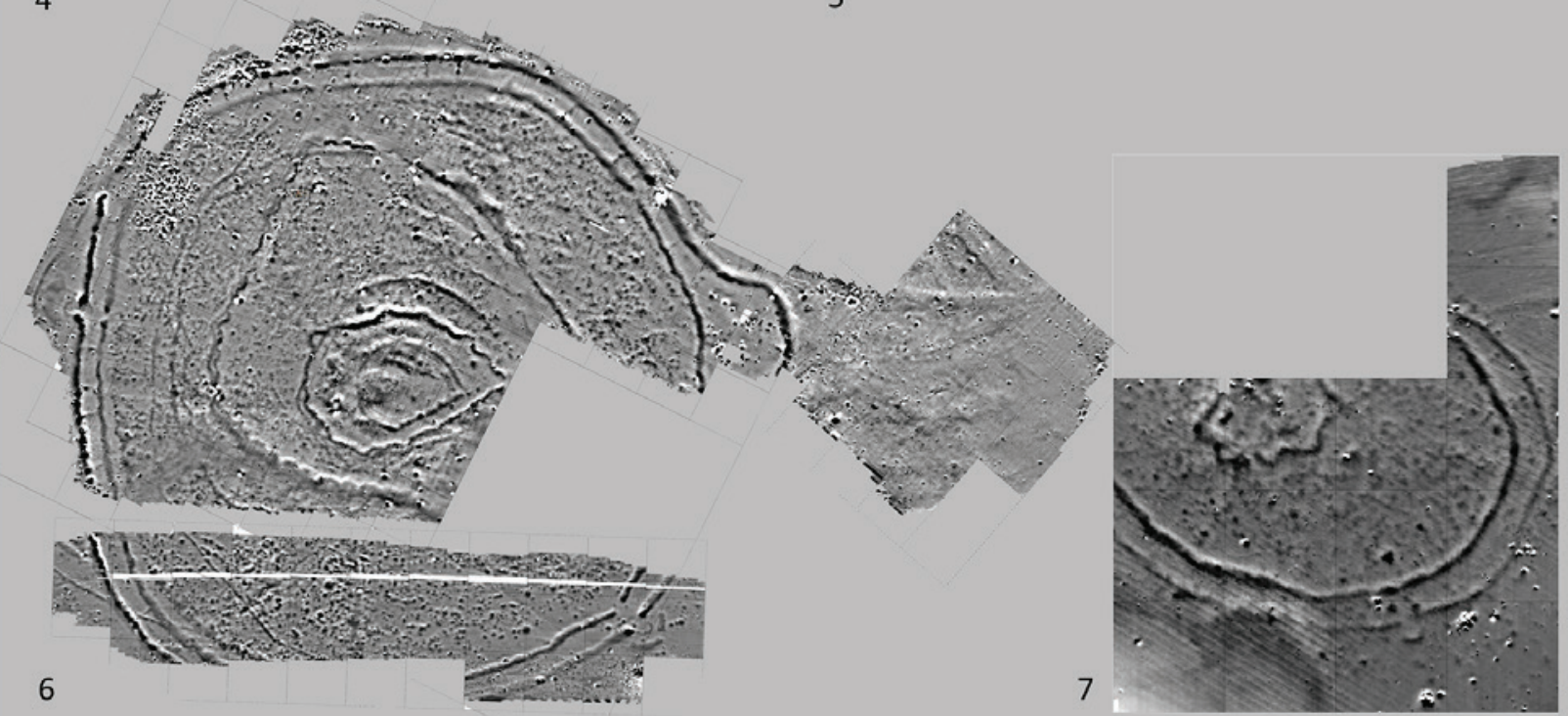

Figura 6 - Recintos de fossos lobulados padronizados ou com duplo fosso linear ou lobulado/linear. (1) Xancra; (2) Xancra; (3) Folha do Ouro 1; (4) Salvada; (5) Moreiros 2; (6) Perdigões; 7. Montoito. 


\title{
PRODUÇÃO DE SAL MARINHO NA IDADE DO BRONZE DO NOROESTE PORTUGUÊS. ALGUNS DADOS PARA UMA REFLEXÃO
}

Ana M. S. Bettencourt ${ }^{1}$, Sara Luz ${ }^{2}$, Nuno Oliveira ${ }^{3}$; Pedro P. Simões ${ }^{4}$, Maria Isabel C. Alves ${ }^{4}$, Emílio Abad-Vidal ${ }^{5}$

\begin{abstract}
RESUMO
Os primeiros indícios da produção de sal no litoral norte de Portugal são, normalmente, atribuídos à Idade do Ferro. Contudo há evidências de que esta atividade se desenvolveu na região, pelo menos, entre os finais do $3^{\circ}$, início do $2^{\underline{0}}$ milénios $\mathrm{AC}$, tendo perdurando ao longo do $2^{\circ}$ milénio AC.

Apresentam-se dados provenientes de dois sítios arqueológicos e procede-se à reavaliação de artefactos descontextualizados encontrados no litoral - as designadas pias amovíveis - e de estruturas escavadas na rocha, discutindo-se as suas técnicas de execução. O conjunto de dados foi articulado com as condições naturais e topográficas da costa e com as condições climáticas conhecidas para a época. Foram, igualmente, articulados com as estratégias de ocupação durante a Idade do Bronze.
\end{abstract}

Palavras-chave: Noroeste Ibérico, Idade do Bronze, Produção de sal marinho.

\begin{abstract}
The first signs of salt production on the northern coast of Portugal are usually attributed to the Iron Age. However, there is evidence that this activity took place in the region at least between the late $3^{\text {rd }}$ millennium, early $2^{\text {nd }}$ millennium BCE.

Data from two archaeological sites are presented and the so-called removable sinks and the sinks excavated in the rock are re-evaluated. Their execution techniques are also discussed. The data set was articulated with the natural and topographic conditions of the coast and the known climatic conditions for the time. They were also articulated with the occupation strategies during the Bronze Age.
\end{abstract}

Keywords: Northwest of Iberian Peninsula, Bronze Age, Sea salt production.

\section{INTRODUÇÃO}

Os dados mais antigos sobre a produção de sal no ocidente da Península Ibérica remontam ao Neolítico e ao Calcolítico, embora sejam conhecidos apenas para o centro/sul de Portugal (Valera et alli, 2006; Rocha, 2013; Soares, 2013; Soares e Silva, 2013; Valera, 2017). Entre o Calcolítico Final e a Idade do
Bronze I, ou seja, entre os meados do $3^{\circ}$ milénio e os meados do $2^{\circ}$ milénio $\mathrm{AC}$, conhecem-se os sítios de Molino Sanchón II e Santioste (Abarquero et alli, 2010, 2013, 2017) localizados nos arredores do complexo lagunar de Villafáfila (Zamora, Espanha).

Para o Noroeste de Portugal apenas se conhecem algumas referências bibliográficas sobre a exploração do sal marinho, atribuídas sistematicamente à Idade

\footnotetext{
1. Laboratório de Paisagem, Património e Território (Lab2PT); Departamento de História da Universidade do Minho, Braga, Portugal. anabett@uaum.uminho.pt

2. Arqueóloga; Mestranda do Curso de Mestrado em Arqueologia da Universidade do Minho

3. Arqueólogo; Doutorando de Arqueologia da Universidade do Minho

4. Laboratório de Paisagem, Património e Território (Lab2PT); Instituto de Ciências da Terra, Polo da Universidade do Minho (ICT/ UM; Departamento de Ciências da Terra da Universidade do Minho

5. Fundación Centro de Supercomputación de Galicia (CESGA), Spain.
} 
do Ferro (Almeida, 1990, 1998, 2005; Costa et alli, 2012) com base na existência de pias cortadas nas rochas do litoral, bem como de pias amovíveis escavadas em lajes de rochas xistentas.

O achado de uma pia amovível em contexto arqueológico, observações sobre o modo como foram construídas as pias cortadas na rocha e novos achados arqueológicos, no litoral norte, possibilitam repensar a origem da produção de sal no Noroeste português e colocar a hipótese de que esta prática se terá iniciado, pelo menos, a partir da Idade do Bronze.

O presente trabalho teve, ainda, em conta, o contexto costeiro dos achados e a sua articulação quer com o povoamento deste período no litoral norte, quer com o que se sabe sobre as oscilações climáticas conhecidas para a Pré-história Recente.

\section{PIAS AMOVÍVEIS}

As pias amovíveis escavadas em lajes de rochas metamórficas, principalmente xistos, xistos ardosíferos e xistos mosqueados, são sempre pequenas e inferiores a 1 metro de comprimento (quando aparecem inteiras, o que é raro), sendo rodeadas por um rebordo perímetral. Podem ter contorno sub-retangular ou ovalar, cantos internos sempre arredondados e são muito baixas, com menos de $5 \mathrm{~cm}$ de profundidade. A largura da área escavada das que foi possível medir oscila entre os $22 \mathrm{e}$ os $35 \mathrm{~cm}$.

São muito comuns em algumas áreas do litoral do Noroeste português, sendo escassamente conhecidas na Galiza (Currás, 2019). Encontram-se, essencialmente descontextualizadas, no litoral caracterizado por praias arenosas de substrato rochoso frequentemente xistento. Aparecem, frequentemente, após as grandes marés equinociais de primavera e outono, sob as areias das praias. Tal significa que os seus contextos de origem, pela sua localização, estão atualmente, a ser destruídos pelos processos de erosão em curso (Figura 1).

Almeida (2005) refere o aparecimento destas pias nas praias situadas na fronteira entre as freguesias de Estela (Póvoa de Varzim) e da Apúlia (Esposende) e nas praias das freguesias de Marinhas, Belinho e da margem sul do rio Neiva, todas no concelho de Esposende. Trabalho de campo levado a cabo por um dos autores (AMS) detectou-as, especificamente, nas praias do Rio Alto, em frente ao Parque de Campismo, (freguesia da Estela, na Póvoa do Varzim); na praia da Ramalha (freguesia da Apúlia, Esposende); na praia da Robaleira e de Rio de Moinhos (na foz da Ribeira de Peralta) (ambas na freguesia de Marinhas, Esposende); na praia das Lontreiras (freguesia de São Bartolomeu do Mar); na praia de Sublago (freguesia de Belinho) e na praia de Guilheta (freguesia de São Paio de Antas) na foz do estuário do rio Neiva (Esposende). Na praia da Robaleira, fragmentos destas pias encontram-se na mesma área de um moinho manual de granito de grão fino (rocha inexistente no local) descoberto durante uma maré baixa no equinócio do outono de 2019. Mais a norte, no concelho de Viana do Castelo, foram também encontradas evidências destes objetos, em posição secundária, nas praias do Campo do Amo/Moinho da Moca (freguesia da Areosa) e de Carreço (na freguesia do mesmo nome). Já no concelho de Caminha regista-se a ocorrência de pias amovíveis nas atuais cascalheiras a norte do Forte da Lagarteira, em Vila Praia de Âncora, numa superfície com cerca de 200 metros (Figura 1).

A única encontrada in situ foi exumadas nas escavações arqueológicas realizadas por José Meireles Baptista, nos anos 8 o do século XX, a norte da praia de Carreço. Aí, foi detectada uma ocupação datada por termoluminescência da transição do $3^{\circ}$ para o $2^{\circ}$ milénio AC (Tabela 1).

Nesta, um fragmento de pia amovível em xisto mosqueado, jazia sobre um piso de seixos rolados que servia de base a uma grande estrutura de combustão (Figura 2). Neste local, então classificado como acampamento, não se detetaram recipientes cerâmicos, mas sim inúmeros artefactos líticos sobre seixos quartzíticos rolados, como pesos de redes, o que indicia a prática de atividades costeiras, como a pesca. Em contexto de reutilização as pias amovíveis ocorreram nos povoados proto-históricos de Santo António (freguesia da Afife, concelho de Viana do Castelo) (Oliveira e Bettencourt, 2020), de São Lourenço (freguesia de Vila Chã, concelho de Esposende) (Almeida, 1998) e de São Silvestre (freguesia de Cardielos, Viana do Castelo), este no estuário do rio Lima (Costa et alli, 2019). Terão aparecido, também, fragmentos destes objetos durante a escavação da Vila Tardo Romana da Agra do Relógio, em São Paio de Antas, Esposende, em contexto secundário (Costa et alli, 2019).

Embora tenham sido consideradas principalmente da Idade do Ferro (Almeida, 2005; Costa et alli, 2019), de acordo com os dados obtidos no acampamento de Carreço-praia, pode considerar-se que 
a extração de sal através da utilização de pias amovíveis ocorreu no Noroeste, pelo menos, desde o final do $3^{\circ}$ milénio até ao início do $2^{\circ}$ milénio AC. A sua associação com um moinho manual na praia da Robaleira indicia, também, a sua inserção na Pré-história Recente. A sua reutilização desde o final da Idade do Ferro (a partir do século II AC) deve ser considerada como o terminus do seu uso.

\section{PIAS ESCAVADAS NA ROCHA}

As pias escavadas na rocha constituem as evidências mais bem documentadas de extração de sal na costa atlântica do Noroeste português, ocorrendo na ordem dos milhares. Correspondem a pias de diferentes dimensões, contornos e profundidades, cortadas na parte mais elevada dos afloramentos rochosos. Estas estruturas são mais frequentes onde o substrato rochoso é preferencialmente granítico.

Podem aparecer isoladas, normalmente no topo de pequenos afloramentos; múltiplas mas dispersas pelo afloramento, ou em grupo e contíguas umas às outras. Tal é o caso dos núcleos de Fornelos (Costa et alli, 2019) e de Sinadora (inédito), em Viana do Castelo (Portugal).

As pias têm, principalmente, contornos ovais, trapezoidais ou rectangulares e os cantos sempre arredondados. Quando realizadas em espaços exíguos no topo de pequenos afloramentos tendem, por vezes, a adaptar-se à forma da superfície rochosa ou do espaço disponível, apresentando uma morfologia mais irregular. Podem assumir várias dimensões, sendo raras as que ultrapassam im de comprimento. São sempre muito pouco profundas (menos de $5 \mathrm{~cm}$ ).

A observação macroscópica de várias destas pias permitiu perceber que foram escavadas por percussão, possivelmente com martelos de pedra e depois polidas com seixos rolados, provavelmente misturados com areia para se tornarem mais abrasivos. Não parece ter sido usado o pico metálico na sua consecução escavação pois é frequente verificar-se que os grãos de quartzo, constituinte do granito local e existente no fundo das pias, não foram partidos. Os próprios cantos arredondados não indiciam o uso de instrumento metálico no seu fabrico.

Tal como as pias amovíveis, estas estruturas terão sido usadas para a produção de sal através da evaporação da água do mar.

Francisco Martins Sarmento faz-lhe uma primeira referência, em 1879, aquando de uma visita ao vale do
Âncora e à freguesia de Afife, considerando-as "gamelas naturais" (Sarmento, 1999). Posteriormente, Lemos (1982) encontra-as na área do Forte do Cão, na Gelfa, freguesia de Vila Praia de Âncora, concelho de Caminha, designando-as por "cuvetes". Apesar dos trabalhos de prospeção serem pouco abrangentes, conhecem-se pias cortadas na rocha desde a praia da Agudela, no concelho de Matosinhos, até às praias de Moledo, em Caminha (Bettencourt et alli, no prelo). São também conhecidas na Galiza, pelo menos até à ria de Vigo (Bettencourt et alii, no prelo).

Almeida (2005) refere a existência de núcleos na foz da Ribeira de Anha (freguesia de Darque, Viana do Castelo); entre a praia de Montedor ${ }^{6}$ e o Forte de Paçô (freguesia de Carreço, Viana do Castelo); no Forte Velho da Vinha (freguesias da Areosa, Viana do Castelo); no Forte do Cão e no Forte da Lagarteira (ambos em Vila Praia de Âncora, Caminha) e na praia de Moledo, em Caminha. O núcleo da Ribeira de Anha é também conhecido por praia da Foz do Rodanho.

Outros núcleos de pias encontram-se nas praias de Campo do Amo/Moinho do Moca, Gandaral, Corgo e Cobidalto (freguesia da Areosa, Viana do Castelo), inéditos; nas praias de Estremo ou Cão, Carrasquei$\mathrm{ra}^{7}$, Ínsua, Celeiro e Bico (freguesia de Afife, Viana do Castelo), inéditos; nas praias da Sarrosa (inédito) e de Canto Marinho, ambas em Carreço (Viana do Castelo) (Costa et alli, 2012); na área da capela de Santo Isidoro, praias da Estrada Real e Ribeira de Preces (Moledo, Caminha), também inéditas. Há ainda a notícia de que ocorrem na pequena ilha da Ínsua, Caminha, à foz do rio Minho, embora tal não tenha sido verificado (Figuras 1 e 3 ).

De destacar o núcleo de Canto Marinho que ocupa uma área de cerca de 24 ha e onde foram detetadas cerca de 713 pias (Costa et alli, 2012), na zona intertidal, indicando, segundo Carvalhido (2014 e 2018), que há cerca de 4 a 5 mil anos o nível do mar estaria 1 a 2 metros abaixo da posição atual.

Muitas destas estruturas estão atualmente localizadas na praia, ficando, portanto, submersas na maré cheia, o que atesta a sua antiguidade, algumas situam-se mais distantes do mar, embora sempre perto do litoral.

6. Conhecida, também, por praia de Fornelos.

7. De referir que Faria (2019), publica uma fotografia de uma pia salineira do sítio da Carrasqueira. 
A cronologia destas estruturas não é consensual. Almeida (2005) e Costa et alli (2012, 2019) consideram-nas da Idade do Ferro, quer pela sua proximidade espacial com povoados desse período, quer pelo espólio encontrado nas escavações de parte do conjunto de pias evolucionadas de Fornelos (Costa et alli, 2019). No entanto os artefactos aí encontrados não são conclusivos em termos cronológicos pois correspondem a picos em pedra lascada (certamente em posição secundária); restos de salinas amovíveis em xisto (conhecidas a poucas dezenas de metros na jazida de Carreço praia e datadas de entre o Calcolítico Final e os início da Idade do Bronze); pesos de rede sobre seixos rolados, existentes, pelo menos, desde os inícios da Idade do Bronze (Luz, 2020) até à Idade do Ferro (Martins, 1988, entre outros) e a escassíssimos fragmentos de cerâmica romana (um bordo de ânfora e tégula), materiais que, pelo tipo de salinas conhecidas para este período (Curras, 2017), só poderão corresponder a um terminus ante quem para o local. Assim, pelas suas condições de fabrico, pela similitude com as pias amovíveis e pela sua localização na linha da costa é possível colocar a hipótese de que a sua origem poderá remontar à Idade do Bronze regional, embora possam ter persistido ou sido reaproveitadas durante a Idade do Ferro. Também se deve salientar que existem povoados, entre muitos outros vestígios da Idade do Bronze, nas proximidades destas estruturas com as quais é possível estabelecer interligações espaciais.

\section{O SÍTIO ARQUEOLÓGICO DAS AREIAS ALTAS}

No sítio das Areias Altas, freguesia de Nevogilde, concelho do Porto, foram identificadas outras evidências arqueológicas que sugerem a produção de sal marinho na costa noroeste da Península Ibérica durante a Idade do Bronze.

O local situa-se entre os 21 e 23 metros acima do nível do mar e a cerca de 300 metros da linha de costa atual. A sua descoberta data do início dos anos 50 do século XX quando foi explorado, pela primeira vez, por Russell Cortez (1952, 1984). No contexto da arqueologia empresarial, entre 2008 e 2011, foram realizados novos trabalhos arqueológicos em áreas contíguas ao local, numa área de cerca de 3000 metros $^{2}$ (Figura 4). Neste âmbito foram escavadas mais de 200 estruturas em negativo, entre as quais se destaca um grande número de fossas, e alguns buracos de poste (Luz, 2010, 2020). Desde então, o sítio tem vindo a ser estudado por uma das autoras (SL), utilizando os dados obtidos nas intervenções designadas Areias Altas I e II como "janelas" para formular novas linhas de pesquisa, nomeadamente as que remetem para a produção de sal (Luz, 2020). As estruturas de tipo fossa apresentam, na sua maioria, um contorno subcircular, perfil esférico e base côncava ou aplanada. Em média, são bastante largas e pouco profundas $(140 \mathrm{~cm}$ de largura x $30 \mathrm{~cm}$ de profundidade) (Luz, 2020). Registou-se, ainda, um conjunto de estruturas de planta compósita que, aparentemente, não resultam da ocorrência de interseções. Assemelham-se a uma forma de " 8 " ou de um " 8 " com um pequeno semicírculo numa das extremidades, com a particularidade de cada segmento apresentar profundidades distintas (Luz, 202O).

Do enchimento das fossas recuperou-se grande quantidade de artefactos, entre outros restos materiais. Referimo-nos a recipientes de cerâmica, líticos, conchas e macrorrestos vegetais. A maioria dos fragmentos cerâmicos correspondem a recipientes de fabrico manual, pastas arenosas com numerosas inclusões de e.n.p. de grande calibre, friáveis, apresentando evidências de má cozedura, ao mesmo tempo que parecem ter sido sujeitos a tensões térmicas, o que poderá ter motivado o seu estado fragilizado e elevado nível de fragmentação. Em termos morfológicos apresentam perfis entre o cónico e o ovóide, bordos sumariamente regularizados e um pé alto com base plana, frequentemente alargada (Figura 4). Quanto às superfícies salienta-se um estado de conservação e tratamento desigual, apresentando-se as superfícies externas genericamente preservadas e rugosas, por oposição às internas, maioritariamente corroídas e com vestígios de alisamento e de maior cuidado, o que é particularmente evidente na parte interna das bases.

O restante conjunto cerâmico é constituído, na sua maioria, por recipientes de perfis tronco-cónicos, subcilíndricos e ovóides, de bases planas, muitas vezes providos de asas e com decoração plástica (cordões e mamilos). Ocorrem, ainda, formas carenadas que correspondem a raros exemplares de cerâmica fina. No seu conjunto, correspondem a formas que se enquadram no reportório cerâmico da Idade do Bronze do Noroeste de Portugal (Luz, 202O).

O conjunto lítico é composto, principalmente, por matérias-primas locais, predominando o quartzito $(55 \%)$, seguido do granito, do quartzo e do xisto, 
entre outras. É de salientar a presença de uma importante indústria macrolítica sobre seixos rolados e sobre lascas, nas quais se destacam pesos de rede, e onde se incluem raspadores e outros seixos talhados. Ocorre, ainda, uma pequena indústria em quartzo, alguns percutores, elementos de moinho e um artefacto em pedra polida, de anfibolito. Contudo a principal característica da amostra reflete-se na quantidade significativa de elementos termo-alterados $(65 \%)$, que indiciam a existência de lareiras ou de estruturas de combustão (Luz, 2020) (Figura 4). As datas de radiocarbono obtidas para este local situam a sua ocupação entre o séculos XIX e o final do XVI AC, ou seja, na primeira metade do $2^{\circ}$ milénio AC (Luz, 2010, 2020). As evidências arqueológicas e a localização do sítio permitem considerar que a produção de sal ocorreu nas Areias Altas (Luz, 2020), a par de outras atividades como a pesca e a recolha de moluscos (Luz, 2010; Cabral, 2010, 2014). Esta hipótese decorre, em primeiro lugar, dos atributos distintivos da cerâmica predominante - os vasos de pé alto, os quais são consonantes com a categoria de materiais de briquetage, definida por Gouletquer e Daire (1994, apud Téran, 2011). Deste modo, parece provável que tenham sido utilizados quer como moldes de sal cristalizado, em formas e pesos predefinidos, quer como recipientes onde se processou a cristalização através de uma fonte de calor ou por ação do fogo, tendo em conta a sua morfologia, tipo de fabrico, sinais de stress térmico e elevada fragmentação, uma vez que seria necessário parti-los para retirar o bolo de sal em bom estado. Segundo Cassen e Weller (2013), os recipientes de função dupla teriam de ser submetidos a fogo lento e prolongado para obter a cristalização e o endurecimento do sal, após o qual seriam partidos para retirar o "pão" de sal em bom estado. Estes recipientes encontram os seus melhores paralelos formais nos moldes de sal de sítios arqueológicos da Europa Central e Oriental, quer do Calcolítico da Roménia (meados do $5^{\circ}$ milénio a meados do $4^{\circ}$ milénio AC) (Cassen e Weller, 2013; Sandu et alli, 2012; Weller, 2015) quer da Idade do Bronze da Polónia (Harding, 2013).

Em segundo lugar, a forte evidência de estruturas de combustão atestada pelo elevado número de líticos termo-alterados, reforça a possibilidade da produção de "pães" de sal no local. É, no entanto, de considerar, que estas estruturas possam ter desempenhado outras funções dentro da cadeia operatória da produção de sal por evaporação artificial, a que se pode- rão associar outros artefactos e estruturas, ainda em fase de estudo.

\section{ALGUMAS CONSIDERAÇÕES FINAIS}

Tendo a conta os dados enunciados pode colocar-se a hipótese de que a produção de sal marinho se tenha verificado na área costeira do Noroeste português, desde, pelo menos, os finais do $3^{\circ}$ milénio $\mathrm{AC}$, tendo permanecido ativa durante a primeira metade do $2^{\circ}$ milénio AC.

É possível admitir que, desde essa data, a extração de sal foi realizada através do uso de pias amovíveis escavadas em rochas xistentas (Bettencourt, 2009). Tendo em conta o contexto da pia da estação arqueológica de Carreço-praia, tudo indica que estas estruturas, enchidas com água salgada ou de grande salinidade $^{8}$, teriam estado sobre a ação do fogo para favorecer o processo de evaporação da salmoura até à cristalização. De salientar que, durante os finais do $3^{\circ}$ e a primeira metade do $2^{\circ}$ milénios AC as comunidades humanas viveram num período mais frio do que atualmente, embora mais quente do que no Calcolítico (Fábregas Valcarce et alli, 2003; Martínez-Cortizas et alli, 2009) pelo que o processo de aquecimento das pias de xisto poderá ter sido uma das soluções encontradas para a evaporação da água salgada. A diminuição acentuada da humidade existente durante esse período (Fábregas Valcarce et alli, 2003; Martínez-Cortizas et alli, 2009) também poderá ter favorecido o processo de evaporação da água salgada.

A existência de pias amovíveis associadas espacialmente a um moinho manual de granito na praia da Robaleira (na zona intertidal) indiciam, igualmente, a antiguidade deste fenómeno. Assim, é de presumir que o processo de evaporação da água salgada através de pias amovíveis possa ter continuado durante todo ou grande parte da Idade do Bronze. Trata-se, na verdade, de um processo de evaporação simples ${ }^{9}$ e eficaz.

\footnotetext{
8. Eventualmente, proveniente de algumas lagoas costeiras com níveis variáveis de salinidade, típicos de períodos alternados de água doce e de água do mar (Granja et alli, 2010; Granja et alli, 2016), existentes num litoral rochoso e caraterizada por um sistema complexo de lagoas e de enseadas, ainda presente na época romana (Granja, 1993).

9. Cassen e Weller (2013) referem paralelos etnográficos similares na Europa e noutros continentes.
} 
As pias, escavadas nos afloramentos rochosos de composição granítica e metamórfica (micaxistos e gnaisses graníticos), são mais difíceis de datar mas as suas características de execução, a sua semelhança formal com as pias amovíveis e o facto de se localizarem frequentemente na zona intertidal ${ }^{10}$, são factores que possibilitam colocar a hipótese da sua antiguidade e da sua emergência em data anterior à Idade do Ferro. A partir de 1400 AC, verifica-se um aquecimento acentuado da temperatura do ar (Fábregas Valcarce et alli, 2003; Martínez-Cortizas et alli, 2009) o que teria facilitado a evaporação da água salgada das referidas pias por insolação e ação eólica ${ }^{11}$, no entanto não podemos excluir a contemporaneidade entre as pias amovíveis e as pias escavadas na rocha, podendo ambas corresponderem a diferentes etapas do processo de produção de sal.

Durante a Idade do Bronze, a natureza rochosa e topográfica da costa portuguesa (mais recortada na altura), seria favorável à produção de sal, assim como algumas características climáticas. Referimo-nos, por exemplo, à descida acentuada e progressiva da humidade do ar, entre $2200 \mathrm{AC}$ até cerca de 1600 AC, acompanhada de uma ligeira subida da temperatura, importante durante a fase de degradação das condições climáticas que caracterizou o período entre os finais do IV e os meados do II milénios AC, assim como ao facto de este período genérico ser mais ventoso do que anteriormente (Fábregas Valcarce $e t$ alli, 2003; Martínez-Cortizas et alli, 2009). A partir de cerca de 1400 AC, verifica-se um aumento acentuado da temperatura do ar, tal como já foi referido, fenómeno que é acompanhado da subida da humi-

10. Se tivermos em conta os estudos de Granja (1992), Granja e Carvalho (1992, 1995), Alves (1996), Granja e Groot (1996) e Granja (1999) terão ocorrido modificações drásticas no litoral norte durante o Holocénico, ao contrário do proposto por Dias (1987) e Dias e Boski (1995) que defendem a estabilidade do nível do mar, a cotas próximas da atual, em cerca de $6 \mathrm{Ka}$ (4ํㅡㄹ milénio AC). Granja (1999) propõe que, durante essa data, o nível médio do mar estaria a cerca de 8 metros abaixo do atual, embora tendo em conta a atividade neotectónica existiriam, nessa altura, médias de levantamento a rondar os $3 \mathrm{~mm} /$ ano, com tendência a abrandar para 1.4 $\mathrm{mm} / \mathrm{ano}$, em cerca de $1500 \mathrm{AC}(3.5 \mathrm{Ka})$. Carvalhido (2018, p. 17) admite que o nível do mar estaria 1 a 2 metros mais baixo, há cerca de 5 a $4 \mathrm{Ka}$ ( $3^{\circ}$ e $2^{\circ}$ milénios $\left.\mathrm{AC}\right)$.

11. Pias salineiras similares são conhecidas em rochas calcárias, em diversas áreas geográficas, e usadas até à contemporaneidade. A este propósito consultar a síntese sobre o tema da autoria de Cassen e Weller (2013). dade, até valores próximos dos atuais, situação que permanecerá até aos meados do ํㅜ milénio AC.

Significativa é, também, a concentração de povoados e de outras manifestações da Idade do Bronze ao longo da costa do Noroeste de Portugal, fenómeno que, entre outros factores, se poderá relacionar com a exploração de sal na área costeira. Esta hipótese, já defendida para explicar o povoamento deste período na área de entre os rios Neiva e Cávado (Bettencourt, 1999: 1078), parece ser possível de equacionar, igualmente, para a Galiza, onde, por exemplo, as populações do povoado costeiro de Portocelo, datado de entre os séculos XV aos início do XII AC (Cano Pan e Vázquez Varela, 1988) teriam acesso, no seu território teórico de exploração de 15, 30 e 45 minutos, a diferentes núcleos de pias salineiras (Bettencourt et alli, no prelo).

Em Portugal há evidências, a partir do Bronze Inicial/Médio, de vários povoados, necrópoles, depósitos, estátuas-menires e gravuras rupestres em localização costeira com acesso facilitado às áreas com evidências de exploração de sal, embora, para sul do Cávado, seja necessário intensificar a prospecção no sentido de detetar novos núcleos de pias salineiras. Entre os rios Minho e Lima conhecem-se o povoado do Bronze Final do Coto da Pena, (Caminha), à foz do Coura, em pleno estuário do Minho; as gravuras rupestre da Bouça dos Feitos I (Riba de Âncora, Caminha), com um punhal longo ou espada curta, do Bronze Inicial (Bettencourt, 2017); o povoado da Idade do Bronze do Lombo da Enxurreira (Vile, Caminha), perto da foz do Âncora (Loureiro e Magalhães, 2006); as gravuras rupestres de Santo Adrião (Âncora, Caminha), com armas e barquiformes (Santos-Estévez, Bettencourt, 2017); o povoado do Bronze Final de Santo António (Viana do Castelo), à foz do rio de Cabanas (Bettencourt, 2013a) com acesso a inúmeras pias salineiras no seu território teórico de 15 a 6 o minutos terrestres (Oliveira e Bettencourt, 2020) (Fig. 5); as gravuras rupestres da Laje da Churra (Carreço, Viana do Castelo), com uma alabarda e inúmeros barquiformes (Santos, 2014); o túmulo da Cova da Moura (Carreço, Viana do Castelo) onde se depositou um artefacto metálico do Bronze Final (Viana, 1955; Bettencourt, 2013a) e o depósito metálico de machados de talão do Bronze Final do Cobidalto/Areosa (Areosa, Viana do Castelo) (Monteagudo 1977; Bettencourt et alii, 2014). Entre os rios Lima e Cávado conhecem-se as reutilizações do Bronze Inicial/Médio e Final da Ma- 
moa do Lordelo de Cima (Chafé, Viana do Castelo) (Bettencourt, 2010a); a necrópole do Bronze Médio/Final de Agra de Antas (São Paio de Antas, Esposende) (Cruz e Gonçalves, 1998/1999; Bettencourt, 1999); a necrópole do Bronze Médio de Belinho (São Paio de Antas, Esposende) (Bettencourt, 1999); os achados metálicos do Bronze Inicial/Médio do Monte de Sanfins (Belinho/São Bartolomeu do Mar, Esposende) (Bettencourt e Sampaio, 2017); a estátua menir do Pedrão (São Bartolomeu do Mar, Esposende) (Jorge, Baptista, Gonçalves, 1986; Bettencourt et alli, 2020); as reutilizações do Bronze Inicial/Médio das Mamoas da Serra, Antela da Portelagem e Rapido (Esposende) (Bettencourt, 1999; 2013b); o povoado do Bronze Final de São Lourenço (Esposende) (Bettencourt, 1999), com acesso no seu território de 45 a 60 minutos, a várias áreas onde ocorrem pias amovíveis (Figura 5) e a necrópole do Bronze Inicial/Médio da Cavaleira (Esposende) (Almeida, 1988; Bettencourt, 1999, 2011).

Entre o rio Cávado e o Douro há a registar o possível povoado do Bronze Médio do Monte do Terroso (Póvoa de Varzim) (Bettencourt, 2011; Sampaio, 2014); o povoado da Idade do Bronze de Santa Clara (Vila do Conde) ${ }^{12}$, à foz do Ave, margem norte; o povoado do Corgo (Azurara, Vila do Conde), do Bronze Médio, entre outras possíveis ocupações (Bettencourt, 2013b; Sampaio, 2014), à foz do Ave, margem sul; o povoado do Bronze Médio de Lavra (Matosinhos) com acesso, no seu território de exploração de 30 minutos pedestres, às pias salineiras de Agudela (Bettencourt et alli, no prelo) (Fig. 5); a ocupação da Idade do Bronze sob as areias da praia do Fontão/ Angeiras (Lavra, Matosinhos) (Bettencourt, 2010b); o povoado da Idade do Bronze de Monte Douro (Perafita, Matosinhos) (Pires, 2012, p. 56); o povoado da Idade do Bronze de Gatões (Matosinhos), à foz do Leça (Barbosa, 2016) que, pelas características da cerâmica se poderá inserir no Bronze Inicial/Médio, ao qual se deve acrescentar o sítio das Areias Altas (Porto) (Luz, 2010; 2020).

Perante este conjunto de dados é verosímil aceitar que o processo de evaporação da água salgada através de pias cortadas nas rochas ou de pias amovíveis, bem como a produção de bolos de sal, pode ter sido uma atividade importante e especializada ao longo da Idade do Bronze do litoral do noroeste

12. Informação gentilmente cedida por José Carvalho da Omniknos Arqueologia. português. Aliás esta região continuou a produzir sal durante a época romana, como o demonstram os achados das salinas de Angeiras (Lavra, Matosinhos) (Teixeira e Fonseca, 2011; Currás, 2017) e de muitas outras, inéditas, existentes no litoral dos concelhos de Viana do Castelo e de Caminha, similares às escavadas no decorrer do projeto Mar de Sal, no sudoeste da Galiza (Currás, 2017). Esta atividade persiste durante a Idade Média (Almeida, 2005; Currás, 2017), começando a decrescer a partir dos séculos XIV e XV (Rau, 1951) embora a atividade se mantenha, como residual, até aos séculos XVIII e XIX (Marçal, 1966; Fernandes, 1994).

\section{AGRADECIMENTOS E APOIOS}

Os autores agradecem a Horácio Faria e a José Varela algumas informações prestadas. Este trabalho foi realizado no âmbito dos seguintes projetos: Funerary, ceremonial and other practices between the $\mathrm{Ne}$ olithic and the Bronze Age approached by Archaeometry (ARQUEOM Project-Sept2O14), desenvolvido por AMSB, PPS e MICA; A Idade do Ferro do litoral Norte entre as bacias dos rios Minho e Cávado. Materialidades, intercâmbios e traços de identidade (ref. $\mathrm{SFRH} / 138105 / 2018)$, da responsabilidade de $\mathrm{NO}$ e O sítio das Areias Altas, Porto, no contexto da Idade do Bronze do Norte de Portugal, em desenvolvimento por S. Luz.

\section{BIBLIOGRAFIA}

ABARQUERO MORAS, Francisco J.; GUERRA DOCE, Elisa; DELIBES DE CASTRO, Gérman; LÓPEZ SÁEZ, José A. (2017) - La explotación de la sal durante la Prehistoria en las Lagunas de Villafáfila (Zamora): los cocederos de Molino Sanchón II y Santioste. Cuaternario y Geomorfología. 31: 1-2, pp. 7-24.

ABARQUERO MORAS, Francisco J.; GUERRA DOCE, Elisa; DELIBES DE CASTRO, Gérman; PALOMINO LÁZARO, Ángel L.; DEL VAL RECIO, Jesús (2010) - Excaviones en los "cocederos" de sal prehistóricos de Molino Sanchón II y Santioste (Villafáfila, Zamora). In: ABARQUERO, Francisco J.; GUERRA Elisa, eds. - Los yacimientos de Villafáfila (Zamora) en el marco de las explotaciones salineras de la prehistoria europea. Valladolid: Junta de Castilla y Léon, pp. 85-118.

ABARQUERO MORAS, Francisco J.; GUERRA DOCE, Elisa; DELIBES DE CASTRO, Gérman; PALOMINO LÁZARO, Ángel L.; DEL VAL RECIO, Jesús (2013) - Explorações pré-históricas de sal nos arredores das lagunas de Villafáfila (Zamora, Espanha). In: SOARES, Joaquina, ed. 
- Pré-história das zonas húmidas. Paisagens de sal (Setúbal Arqueológica 14). Setúbal: MAEDS, pp. 233-254.

ALMEIDA, Carlos Alberto B. (1988) - Carta Arqueológica do Concelho de Esposende, Boletim Cultural de Esposende 13/14. pp. 21-44.

ALMEIDA, Carlos Alberto B. (1990) - Proto-História e Romanização da Bacia Inferior do Lima. Viana do Castelo: Centro de Estudos Regionais.

ALMEIDA, Carlos Alberto B. (1998) - Esposende. Povoamento Romano do Litoral Minhoto entre o Cávado e o Minho (Boletim Cultural de Esposende, 20). Esposende: Câmara Municipal de Esposende.

ALMEIDA, Carlos Alberto B. (2005) - A exploração do sal na costa portuguesa a Norte do Rio Ave: da Antiguidade Clássica à Baixa Idade Média. In: Amorin, Inês ed. - Seminário Internacional sobre o Sal Português, 2004, Porto: Instituto de História Moderna, pp. 139-170.

ALVES, António M.C. (1996) - Causas e Processos da Dinâmica Sedimentar na Evolução Actual do Litoral do Alto Minho. Braga: Universidade do Minho.

BARBOSA, Liliana (2016) - O Lugar de Gatões (Matosinhos). Uma perspectiva diacrónica da ocupação do local, comunicação apresentada no evento A Arqueologia em Portugal. Recuperar o passado em 2015, disponível em linha em https://www.academia.edu/33242725/

BAPTISTA, José M. (1992) - As Indústrias Líticas Pré-Históricas do Litoral Minhoto. Contexto Cronoestratigráfico e Paleoambiental (Cadernos de Arqueologia - Monografias, 7). Braga: Unidade de Arqueologia da Universidade do Minho.

BETTENCOURT, Ana M.S. (1999) - A Paisagem e o Homem na bacia do Cávado durante o II e I milénios AC. Braga: Universidade do Minho.

BETTENCOURT, Ana M.S. (2009) - A Pré-História do Minho: do Neolítico à Idade do Bronze. In: PEREIRA, Paulo ed. - Minho. Traços de Identidade. Braga: Conselho Cultural da Universidade do Minho, pp. 70-113.

BETTENCOURT, Ana M.S. (2010a) - La Edad del Bronce en el Noroeste de la Península Ibérica: una análisis a partir de las prácticas funerárias. Trabajos de Prehistoria. 67:1, pp. 139-173.

BETTENCOURT, Ana M.S. (2010b) - Comunidades pré-históricas da bacia do Leça. In: VARELA, José; PIRES, Conceição, eds. - O Rio da Memória: Arqueologia no Território do Leça. Matosinhos: Câmara Municipal, pp. 33-88.

BETTENCOURT, Ana M.S. (2011) - Estruturas e práticas funerárias do Bronze Inicial e Médio do Noroeste Peninsular. In: BUENO, Primitiva; GILMAN, Antonio; MARTÍN MORALES, Concha; SÁNCHEZ-PALENCIA, Francisco J., eds. - Arqueología, Sociedad, Territorio y Paisaje (Bibliotheca Praehistorica Hispana 27). Madrid: CSIC, pp. 115-139.
BETTENCOURT, Ana M.S. (2013a) - O Bronze Final no Noroeste português. Uma rede complexa de lugares, memórias e ações. Estudos Arqueológicos de Oeiras. 20: pp. 157-172.

BETTENCOURT, Ana M.S. (2013b) - A Pré-história do Noroeste Português / The Prehistory of the North-western Portugal, Territórios da Pré-história em Portugal, vol. 2, Braga / Tomar: CEIPHAR/CITCEM (E. bilingue).

BETTENCOURT, Ana M.S. (2017) - Gravuras rupestres do noroeste português para além das artes atlântica e esquemática, In: ARNAUD, José. M.; MARTINS, Andrea, eds. Arqueologia em Portugal - 2017. Estado da Questão, Lisboa: Associação dos Arqueólogos Portugueses, pp. 1039-105.

BETTENCOURT, Ana M.S.; SAMPAIO, Hugo A. (2017) The Middle and the beginning of the Late Bronze Age in the Northwestern Iberia, In: LACHENAL, Thibault; MORDANT, Claude; NICOLAS, Théophane; VÉBER Cécile, eds. - Le Bronze moyen et l'origine du Bronze final en Europe occidentale (XVII ${ }^{-}$-XIII ${ }^{e}$ siècle av. J.-C.) (Monographies d'Archéologie du Grand Est 1), Strasbourg: APRAB, pp. 365-385.

BETTENCOURT, Ana M.S.; COMENDADOR REY, Beatriz; SIMÕES, Pedro P.; ALVES, Maria Isabel C. (2014). O depósito de machados do Bronze Final de Cobidalto, Areosa (Viana do Castelo). Novos dados para a sua contextualização e interpretação. In: BETTENCOURT, Ana M.S.; COMENDADOR REY, Beatriz; SAMPAIO, Hugo A.; SÁ, Edite, eds. - Corpos e Metais na Fachada Atlântica da Ibéria. Do Neolítico à Idade do Bronze. Braga: APEQ, CITCEM, pp. 131-142.

BETTENCOURT, Ana M.S.; SANTOS-ESTÉVEZ, Manuel; GONÇALVES, Luís; SIMÕES, Pedro, P. (2020) - A Estátua-Menir do Pedrão ou de São Bartolomeu do Mar (Esposende, Noroeste de Portugal) no contexto arqueológico da fachada costeira de entre os rios Neiva e Cávado. In: Arqueologia em Portugal / 2020 - Estado da Questão, Lisboa, pp. 17-30.

BETTENCOURT, A.M.S.; LUZ, Sara; SIMÕES, Pedro P.; ALVES, Maria Isabel C.; ABAD-VIDAL, Emilio (no prelo) - Bronze Age sea salt production in Northwest Iberian Peninsula. In MARCIGNY Cyril; MORDANT, Claude, eds. Bronze 2019: 20 ans de recherches, Dijon: Suppléments au Bulletin de l'APRAB.

CABRAL, João P. (2010) - O depósito de conchas do sítio arqueológico das Areias Altas (Porto, Portugal). Estudo morfológico e morfométrico das conchas inteiras de moluscos. In GÓMEZ, Eduardo G.; GARCÍA, Víctor B.; RODRÍGUEZ, Carlos F.; PRIETO, Nativida F. eds. - I Reunión Científica de Arqueomalacología de la Península Ibérica (Férvedes 6): Villalba: MPAV, pp. 73-82.

CABRAL, João P. (2014) - Morfologia das conchas de Phorcus Lineatus (da Costa 1778: Trochus) do sítio arqueológico de Areias Altas II (Porto, Portugal) e seu possível significado ambiental, In CANTILLO, Juán J.; BERNAL, Darío; RAMOS, José eds. - Actas de la $3^{\circ}$ Reunión Científica de Arqueomalacología de la Península Ibérica: 65-74. Cádiz: Universidad de Cádiz, Servicio de Publicaciones, pp. 65-74. 
CANO PAN, Juan A.; VÁZQUEZ VARELA, José M. (1988) - Portocelo, un yacimiento de la Edad del Bronce. Trabalhos de Antropologia e Etnologia. 28, pp. 181-187.

CARVALHIDO, Ricardo (2018) - Livro de pedra. Monumentos naturais locais de Viana do Castelo - catálogo. Viana do Castelo: Câmara Municipal.

CASSEN, Serge; WELLER, Olivié, (2013) - Idées et faites relatifs à la production de sels marins et terrestres en Europe, du VI ${ }^{\mathrm{e}}$ au III ${ }^{\mathrm{e}}$ millénnaire. In: SOARES, Joaquina, ed. - Prehistory of wetlands: Ladscapes of salt. (Setúbal Arqueológica, 14). Setúbal: MAEDS, pp. 255-304.

COSTA, Miguel; MACHADO, Jorge; LOPES, Hugo; ALMEIDA, Tiago (2012) - Pias salineiras da praia do Canto Marinho. Inventário Arqueológico, Cadernos Vianenses, 46, pp. 95-111.

COSTA, Miguel; ALMEIDA, Tiago; MACHADO, Jorge (2019) - A exploração de sal na Proto-História. O exemplo de Viana do Castelo, comunicação apresentada nos Encontros monográficos co património Cultural in situ. A prudoción de sal en época romana no sur de Galicia e Norte de Portugal, A Guarda, March 29th, 2019 (disponível em https://www. youtube.com/watch?v=leDyyodniAM in 1/4/2020).

CORTEZ, Fernando R. (1952) - Contributos para o estudo do Neolítico de Portugal. Trabalhos de Antropologia e Etnologia. 13:3-4, pp. 193-248.

CORTEZ, Fernando R. (1984) - Achados pré-históricos na área do Porto. Arqueologia.10, pp. 11-12.

CURRÁS, Brais X. (2017) - The salinae of O Areal (Vigo) and Roman salt production in NW Iberia, Journal of Roman archaeology, 30:1, pp. 325-350.

CRUZ, Domingo J.; GONÇALVES, António H.B. (1998/ 1999) - A necrópole de Agra de Antas (S. Paio de Antas, Esposende, Braga. Portugália. 19-20, pp. 5-27.

DIAS, João Manuel A.; BOSKI, Thomasz (1995) - Shoreline Evolution in Portugal since the Last Glacial Maximum: A review of current knowledge. IGCP Project. In: 367 Annual Meeting - Late Quaternary Coastal Records of Rapid Change: Application to Present and Future Conditions. Abstracts. Chile: Antofagasta, pp. 29-30.

DIAS, João Manuel A. (1987) - Dinâmica Sedimentar e Evolução Recente da Plataforma Continental Portuguesa Setentrional. Lisboa: Universidade de Lisboa.

DIAS, João Manuel A.; RODRIGUES, Aurora; MAGALHÃES, Fernando (1997) - Evolução da linha de costa em Portugal desde o último Máximo Glaciário até à actualidade: síntese dos conhecimentos. Estudos do Quaternário. 1, pp. 53-66.

FABREGAS VALCARCE, Ramón; MARTÍNEZ CORTIZAS, António; BLANCO CHAO, Ramón; CHESWORTH, Ward (2003) - Environmental change and social dynamics in the second-third millennium BC in NW Iberia. Journal of Archaeological Science. 30, pp. 859-871.
FARIA, Horácio (2019) - Martins Sarmento e as pesquisas arqueológicas em Afife. Revista Estudos Regionais. $2^{\underline{\underline{a}}}$ série, 13, pp. 77-117.

FERNANDES, Armando (1994) - Meadela Histórica, Paróquia de Santa Cristina da Meadela. Viana do Castelo: ed. autor.

GRANJA Helena M. (1992) - Zona costeira: evolução e ordenamento. Geonovas, no especial 1, 57-63.

GRANJA, Helena (1993) - Os conhecimentos actuais sobre o Holocénico do Noroeste de Portugal. In CARVALHO, Gaspar S., FERREIRA António B., SENNA-MARTINEZ, João C., eds. - O Quaternário em Portugal. Balanço e Perspectivas. Lisboa: Colibri, pp. 43-49.

GRANJA, Helena (1999) - Evidence for Late Pleistocene and Holocene sea level, neotectonic and climatic control in the coastal zone of Northwest Portugal. Geologie en Mijnbouw. 77:3-4, pp. 233-245.

GRANJA, Helena; CARVALHO, Gaspar S. (1992) - Dunes and Holocene deposits of the coastal zone of Portugal, North Mondego Cape. In: CARTER, Richard W.G.; CURTINS, Tom G.F.; SHEEHY-SKEFFINGTON, Michelin J. (eds) - Coastal Dunes: Geomorphology, Ecology and Management for Conservation. Rotterdam: Balkema, pp. 43-50.

GRANJA, Helena e CARVALHO, Gaspar S. (1995) - Sealevel changes during the Pleistocene-Holocene in the NW coastal zone of Portugal. Terra Nova. 7, pp. 6o-67.

GRANJA, Helena; de GROOT, Thomas A.M. (1996) - Sealevel rise and neotectonism in a Holocene coastal environment at Cortegaça, a beach (NW Portugal): a case study. Journal of Coastal Research.12, pp. 160-170.

GRANJA, Helena; MONTEIRO-RODRIGUES, Sérgio; DANIELSEN, Randi (2016) - Changing environments and human settlement during Mid-Holocene in Rio de Moinhos beach (Esposende, Northern Portugal). Estudos do Quaternário. 14, pp. 25-40.

GRANJA, Helena; ROCHA, Fernando; MATIAS, Manuel; MOURA, Rui; CALDAS, Francisco; MARQUES, Joana; TARECO, Hélder (2010) - Lagoa da Apúlia: A residual lagoon from the Late Holocene (NW coastal zone of Portugal). Quaternary International. 221, pp. 46-57.

GOULETQUER, Pierre L.; DAIRE, Marie Y. (1994) - Le sel de la Préhistoire et de la Protohistoire. In DAIRE, Marie Y., ed. - Le sel Gaulois. Bouilleurs de sel et ateliers de briquetages armoricains à l’Age du Fer. Saint-Malo: CNRS, pp. 5-13.

HARDING, Anthony (2013) - Salt in Prehistoric Europe. Leiden: Sidestone Press.

JORGE, Vítor O.; BAPTISTA, António M.; GONÇALVES, António A.H.B. (1986) - Menir de S. Bartolomeu do Mar (Esposende), Boletim Cultural de Esposende. 9-10: 13-20.

LEMOS, Francisco S., O Sítio Arqueológico de Gelfa. Notícia preliminar, Cadernos de Arqueologia. 1ํㅗérie, 2, pp. 21-48. 
LOUREIRO, Luís; MAGALHÃES, Ivone (2006) - O Lugar da Idade do Bronze do Lombo da Enxurreira (Riba de Âncora, Caminha), Al-Madan Online. 2ª série, 14, pp. 29-32.

LUZ, Sara (2010) - O depósito de conchas do sítio arqueológico das Areias Altas (Porto, Portugal). Discussão do enquadramento arqueológico da Estrutura 15. In GÓMEZ, Eduardo G.; GARCÍA, Víctor B.; RODRÍGUEZ, Carlos F.; PRIETO, Nativida, eds. - I Reunión Científica de Arqueomalacología de la Península Ibérica (Férvedes 6). Villalba: MPAV, pp. 141-145.

LUZ, Sara (2020) - The site of Areias Altas (Porto, Portugal): current knowledge of its occupation in the first half of the 2nd millennium BC. In LOPES, Susana S.; GOMES, Sérgio, eds. - Between the $3^{\text {rd }}$ and $2^{\text {nd }}$ millennia BC: which turning points? Oxford: Archaeopress.

MARÇAL, Horácio (1966) - As antigas salinas da Terra de Bouça. Matosinhos: Biblioteca Pública Municipal de Matosinhos.

MARTINS, Maria Manuela R. (1988) - A citânia de S. Julião, Vila Verde. Memória dos trabalhos realizados entre 1981 e 1985. (Cadernos de Arqueologia - Monografias 2.) Braga: Universidade do Minho.

MARTÍNEZ CORTIZAS, António; COSTA-CASAIS, Manuela; LOPEZ-SAEZ, José A. (2009) - Environmental change in NW Iberia between 7000 and 500 cal. BC. Quaternary International. 200, pp.77-89.

MONTEAGUDO, Luís (1977) - Die Beile auf der Iberischen Halbinsel. Prähistorische Bronzefunde. Munich: Mann Verlag. Refs: 1034, 1057, 1061, 1089, 1111, 1121, 1481, 1489.

OLIVEIRA, Nuno; BETTENCOURT, Ana M.S. (2020) - O povoado de Santo António (Afife, Viana do Castelo), na Idade do Bronze Final, Antrope 13 (no prelo).

PIRES, Conceição (2012) - Contributos para o estudo do povoamento do concelho de Matosinhos da Pré-história ao séc. VIII. Porto: Faculdade de Letras da Universidade do Porto.

ROCHA, Leonor (2013) - A praia do Forte Novo. Um sítio de produção de sal na costa Algarvia? In SOARES, Joaquina, ed. - Prehistory of wetlands. Ladscapes of salt. (Setúbal Arqueológica 14). Setúbal: MAEDS, pp. 225-232.

RAU, Virgínia (1951) - A exploração e o comércio do sal de Setúbal, Lisboa: Ed. Autor.

SAMPAIO, Hugo A. (2014) - A Idade do Bronze na Bacia do Ave (Noroeste de Portugal), Braga: Universidade do Minho.

SANDU, Ion; WELLER, Olivier; STUMBEA, Dan; ALEXIANU, Marius (2012) - Analyses archéométriques sur les moules à sel chalcolithiques de l'est de la Roumanie. In: NIKOLOV, Vassil; BACVAROV, Krum, eds. - Salt and gold: the role of salt in Prehistoric Europe. Verliko Tarnovo, pp. 143-154.
SANTOS, Ana C. (2014) - A Laje da Churra (Paçô, Carreço, Viana do Castelo). Braga: Universidade do Minho.

SANTOS-ESTÉVEZ, Manuel; BETTENCOURT, Ana M. S. (2017) - O conjunto de gravuras rupestres de Santo Adrião (Caminha, Portugal). Embarcações, armas, cavalos e ex-votos. In: ARNAUD, José M.; MARTINS Andrea, eds. Arqueologia em Portugal - 2017. Estado da Questão. Lisboa: Associação dos Arqueólogos Portugueses, pp. 1055-1070.

SARMENTO, Francisco Martins (1999) - Antiqua. Apontamentos de Arqueologia. Guimarães: Sociedade Martins Sarmento.

SOARES, Joaquina (2013) - Sal e conchas na Pré-história portuguesa. O povoado da Ponta da Passadeira (estuário do Tejo). In: SOARES, Joaquina, ed. - Prehistory of wetlands. Ladscapes of salt (Setúbal Arqueológica 14). Setúbal: MAEDS, pp. 171-196.

SOARES, Joaquina; SILVA, Carlos T. (2013) - Economia agro-marítima na Pré-história do estuário do Sado. Novos dados sobre o Neolítico da Comporta. In: SOARES, Joaquina, ed. - Prehistory of wetlands. Ladscapes of salt. (Setúbal Arqueológica 14). Setúbal: MAEDS, pp. 145-170.

TEIXEIRA, Ricardo; FONSECA Vítor (2011) - Intervenção arqueológica. Requalificação da Orla Costeira de Matosinhos, Matosinhos: Arqueologia e Património, Lda. (Relatório Técnico Científico).

TERÁN MANRIQUE, Jonathan (2011) - La producción de sal en la prehistoria de la Península Ibérica: estado de la cuestión. Arqueología y Territorio. 8, pp.71-84.

VALERA, António Carlos (2017) - Salt in the $4^{\text {th }}$ and $3^{\text {rd }}$ millennia BC in Portugal: specialization, distribution and consumption. Cuaternario y Geomorfología. 31:1-2. pp.105-122.

VALERA, António Carlos; TERESO, João P.; REBUGE, João (2006) - O Monte da Quinta 2 (Benavente) e a produção no Neolítico Final/Calcolítico do estuário do Tejo. In BICHO, Nuno F.; VERÍSSIMO, Hugo, eds. - Do Epipaleolítico ao Calcolítico na Península Ibérica. Actas do IV Congresso de Arqueologia Peninsular (Promontória Monográfica 4). Faro: Universidade do Algarve, pp. 201-305.

VIANA, Abel (1955) - A Cova da Moura. Crónica do III Congresso Nacional de Arqueologia. Zaragoza, pp. 481-497.

WELLER, Olivier (2015) - First salt making in Europe: an overview since Neolithic times. Documenta Praehistorica. 62, pp. $185-196$. 


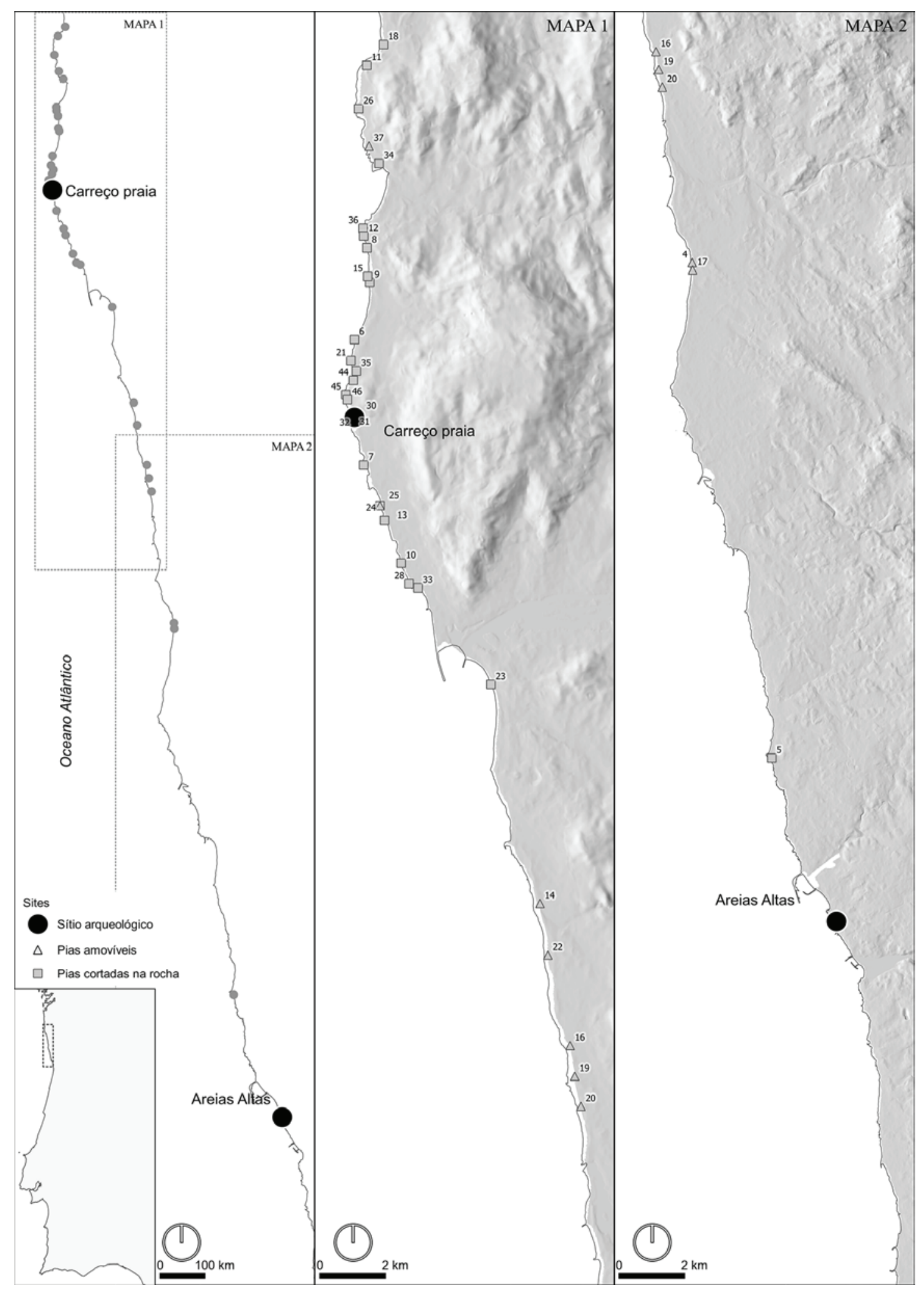

Figura 1 - Localização dos sítios arqueológicos associados à produção de sal, citados no texto (Bettencourt et alii, no prelo, adaptado). Mapa 1: área entre os rios Minho e Lima: 6 - Bico; 7 - Canto Marinho; 8 - Carrasqueira; 9 - Celeiro; 10 - Corgo; 11 - Estrada Real; 12 - Estremo ou Cão; 13 - Gandaral; 15 - Ínsua; 18 - Preces; 21 - Sarrosa; 24/25 - Campo do Amo/Moinho do Moca; 26 - Santo Isidoro; 28 - Cobidalto; 29 - Fornelos 1; 30 - Fornelos 2; 31 - Fornelos 3; 32 - Fornelos 4; 33 - Forte Velho da Vinha; 34 - Forte da Lagarteira; 35 - Forte de Paçô; 36 - Forte do Cão; 37 -Lagarteira; 40 - Outeiro Pequeno; 43-Sarrido; 44-Sinadora 1; 45-Sinadora 2; 46-Sinadora; Mapa 2: área entre os rios Lima e Douro: 4-Ramalha; 5-Agudela; 14-Guilheta; 16 - Lontreiras; 17-Rio Alto; 19 - Rio de Moinhos; 20 - Robaleira; 22 - Sublago; 23 - Foz do Rodanho. 


\begin{tabular}{|l|l|l|l|l|}
\hline Estação arqueológica & Tipo de data & Data (BP) & Cal AC (2 sigma) & Referência \\
\hline Carreço Praia & $\begin{array}{l}\text { Termoluminescência } \\
\text { média }\end{array}$ & $3855 \pm 207$ & 2280 (1865) 1450 & Baptista, 1992 \\
\hline
\end{tabular}

Tabela 1
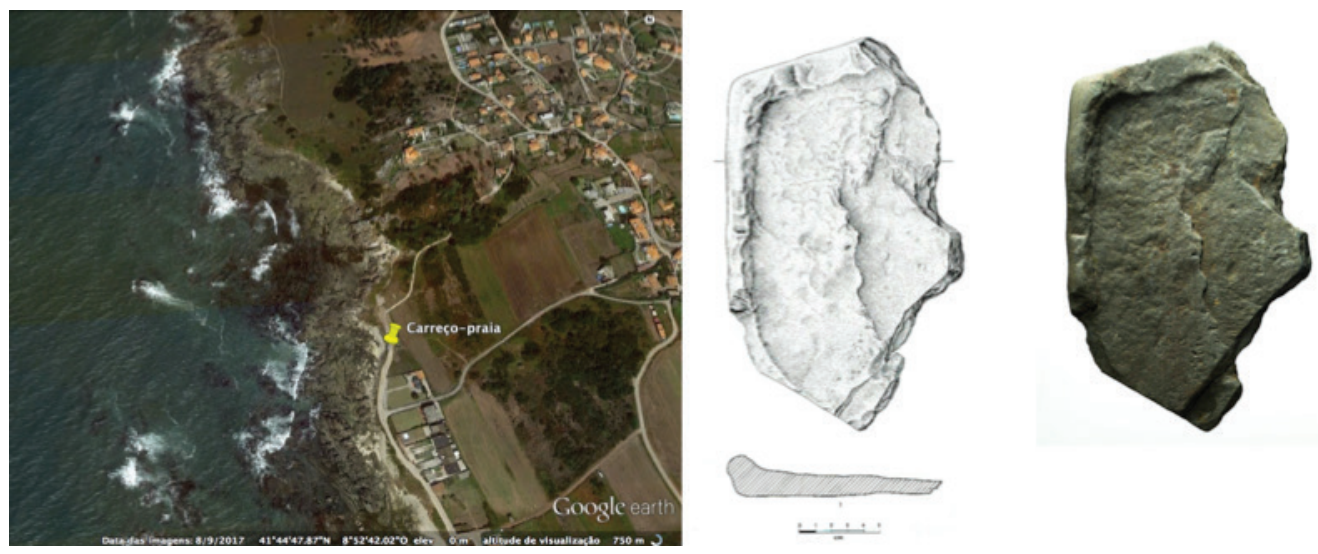

Figura 2 - Localização da estação de Carreço-praia e pia salineira aí encontrada.
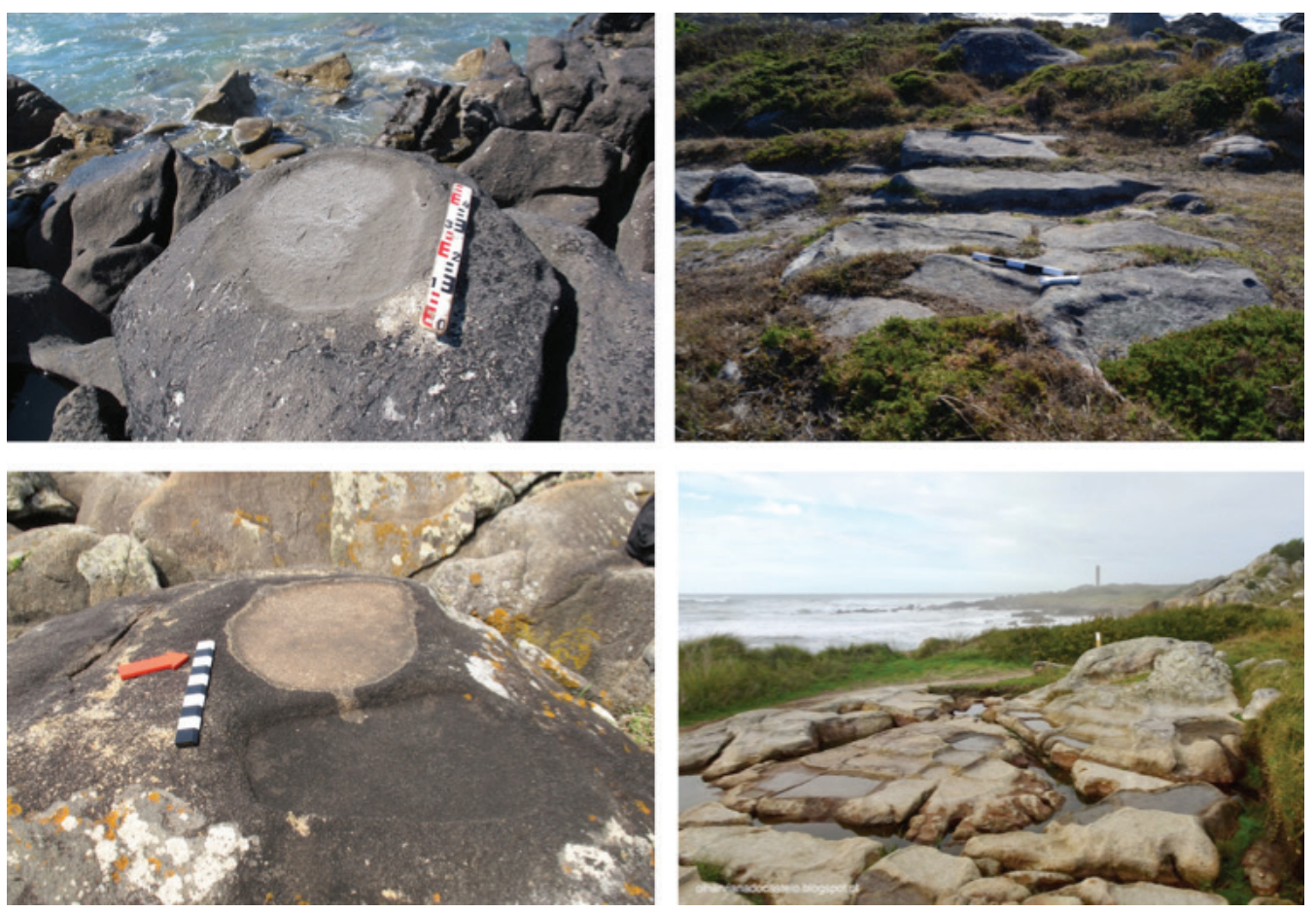

Figura 3 - Pias de vários locais do litoral norte: Em cima (da esquerda para a direita) Forte do Cão e núcleo das imediações do Forte de Paçô. Em baixo (da esquerda para a direita): Sinadora e núcleo de Fornelos (fonte de Fornelos: https://olharvianadocastelo.blogspot.com/2018/12/viana-marcas-dopassado.html) 

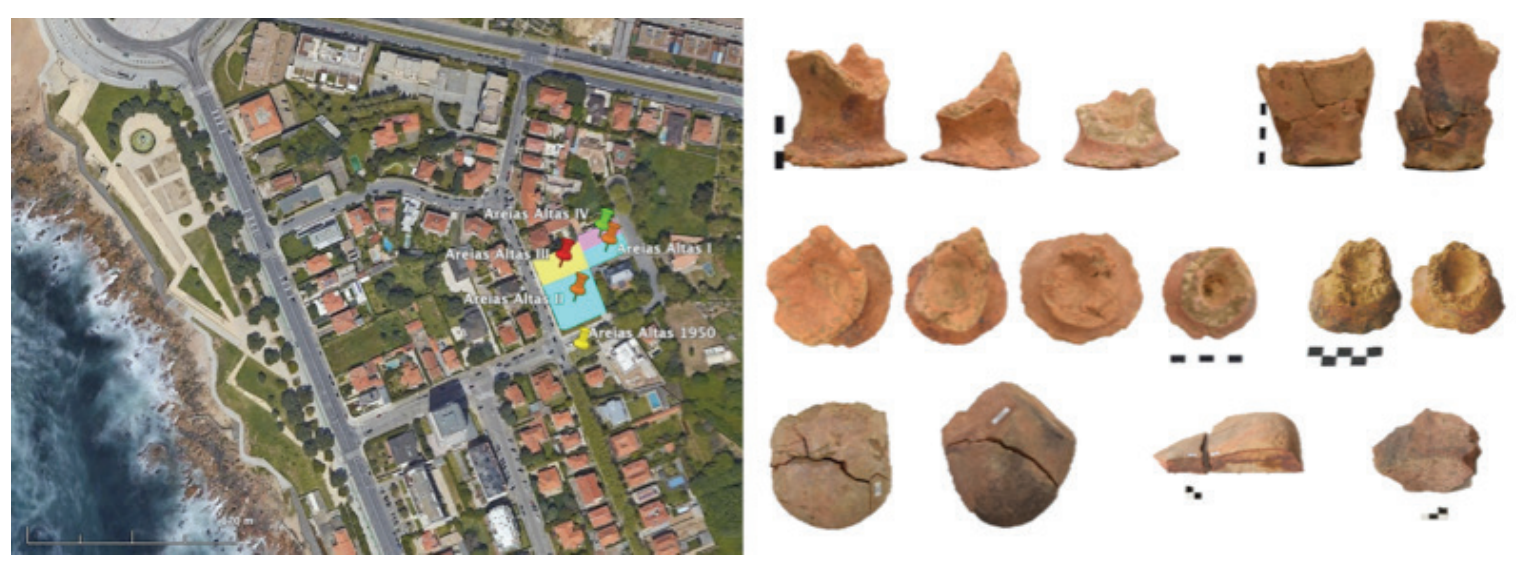

Figura 4 - Localização das Areias Altas; fragmentos de recipientes de pé alto, de vasos tronco-cónicos e de seixos rolados termo-alterados. 


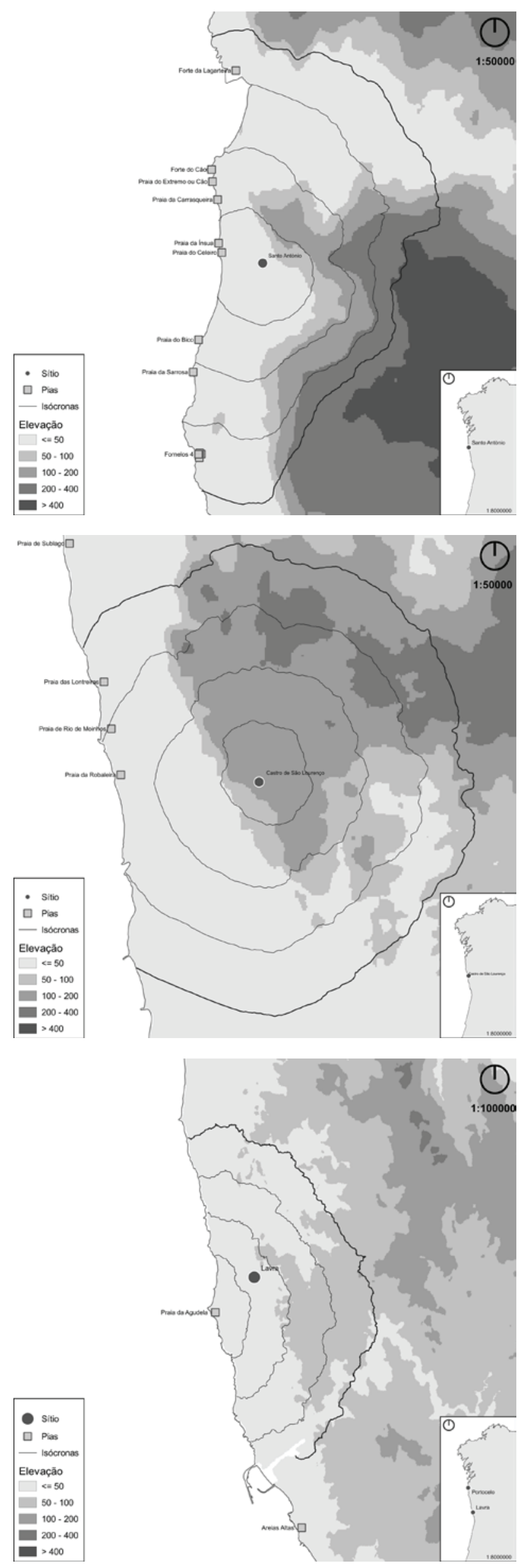

Figura 5 - Territórios teóricos de 60 minutos dos povoados de Santo António (Oliveira, Bettencourt, 2020), de São Lourenço e de Lavra (Bettencourt et alii, no prelo, adaptado), face às estruturas conhecidas para produção de sal. 


\section{A ESTÁTUA-MENIR DO PEDRÃO OU DE SÃO BARTOLOMEU DO MAR (ESPOSENDE, NOROESTE DE PORTUGAL) NO CONTEXTO ARQUEOLÓGICO DA FACHADA COSTEIRA DE ENTRE OS RIOS NEIVA E CÁVADO}

Ana M. S. Bettencourt ${ }^{1}$, Manuel Santos-Estévez ${ }^{1,2}$, Pedro Pimenta Simões ${ }^{3,1}$, Luís Gonçalves $^{3}$

\section{RESUMO}

A estátua-menir do Pedrão foi alvo de novos estudos em 2018 tendo-se verificado que teria cabeça, base arredondada e diversas gravuras, algumas destruídas pela ação antrópica. Tendo em conta a sua morfologia e a disposição das oito covinhas existentes na face sul que se unidas formariam o motivo retangular típico das estátuas-menires do Noroeste, esta deverá ser incluída neste grupo e na mesma cronologia genérica. A estátua-menir está deslocada, embora testemunhos e tradições populares indiciem que estaria perto do seu contexto original - na plataforma litoral em frente ao Monte de Sanfins. Terá funcionando como símbolo de identidade e de poder sinalizando um lugar geoestratégico de encontro entre populações, por motivos religiosos, sociais e de intercâmbio.

Palavras-chave: Estátua-menir, Idade do Bronze, Negociação, Identidade e Poder, Intercâmbio.

\section{ABSTRACT}

The statue-menhir of Pedrão was studied and revaluated in 2018 and it was found that it had a head, a rounded base and engravings, some of them destroyed by the anthropic action. It was found that the arrangement of the eight cup-marks on the south face, if joined, would form the typical rectangular motif of the northwestern Iberian Peninsula statues-menhirs, so it should be included in this group and in the same generic age. This statue-menhir is out of place, although testimonies and popular traditions indicate that it would be close to its original context: on the coastal platform in front of Mount of Sanfins. It will has functioned as a symbol of identity and power marking a geostrategic place of encounter between populations for religious, social and exchange purposes.

Keywords: Statue-Menhir, Bronze Age, Negotiation, Identity and Power, Exchange.

\footnotetext{
1. Laboratório de Paisagem, Património e Território (Lab2PT) / Departamento de História da Universidade do Minho / anabett@ uaum.uminho.pt

2. Laboratório de Paisagem, Património e Território (Lab2PT) e bolseiro de pós-doutoramento da FCT na Universidade do Minho. 3. Instituto de Ciências da Terra, Polo da Universidade do Minho (ICT/UM); Departamento de Ciências da Terra da Universidade do Minho.
} 


\section{INTRODUÇÃO}

A estátua-menir do Pedrão foi descoberta e alvo de publicação na década de 70 do século $\mathrm{XX}$, tendo sido publicada como estátua-menir de São Bartolomeu do Mar e inserida, cronologicamente, no Neo-Calcolítico (Jorge, 1978). Posteriormente foi republicada com maior detalhe (Jorge, Baptista e Gonçalves, 1986). Consta no Portal do Arqueólogo com o CNS 11114 e foi classificado como Imóvel de Interesse Público, através do Decreto ‥ 26-A/92, DR, I Série-B, n. ${ }^{-126}$, de 1-06-1992.

Em julho de 2018 foram realizados trabalhos arqueológicos na sua envolvente, da responsabilidade de dois signatários deste trabalho (AMSB; MS-E) com o apoio dos restantes elementos da área da geologia (LG; PPS) ${ }^{4}$. Estes consistiram em sondagens em redor da estátua-menir, na limpeza do monólito, na observação litológica e arqueológica do mesmo e no seu levantamento fotogramétrico. Possibilitaram, ainda, uma observação detalhada do seu contexto físico.

Os objectivos deste trabalho consistiram em apurar se o imóvel se encontrava in situ, identificar restos de atividades que se relacionassem com as ações desenvolvidas em seu redor, precisar a sua cronologia, detalhar o seu modo de fabrico, a origem da sua matéria-prima e as alterações verificadas ao longo do tempo. Por fim pretendeu-se integrar este monumento nos contextos físicos e arqueológicos locais.

\section{LOCALIZAÇÃO ADMINISTRATIVA E CONTEXTO FÍSICO E AMBIENTAL}

A estátua-menir localiza-se no local conhecido como Agra do Pedrão, no lugar de Baixo, união de freguesia de Belinho e São Bartolomeu do Mar, concelho de Esposende, distrito de Braga. As suas coordenadas geográficas decimais, no sistema WGS 84 , são: latitude: $41.34420 \mathrm{~N}$; longitude: $-8.47463 \mathrm{O}$. Encontra-se a uma altitude de aproximadamente $12 \mathrm{~m}$ (Figura 1).

\footnotetext{
4. Os trabalhos contaram com a participação de Diogo Marinho, João Sérgio Olival, Leandro Costa e Marco Almeida, alunos do $2^{\circ}$ ano do Curso de Arqueologia da Universidade do Minho, e Cláudia Vieira e Mafalda Soares, alunas do $3^{\underline{0}}$ ano do Curso de Arqueologia da Universidade do Minho. Destaca-se, ainda, a colaboração do aluno de Mestrado em Arqueologia, Jorge Guedes e do doutor Hugo Aluai Sampaio.
}

O seu acesso faz-se pela Estrada Nacional no ${ }^{13}$ (EN 13) que liga Esposende a Viana do Castelo. Fica nas traseiras da Igreja Nova de São Bartolomeu e está sinalizado na EN 13, com uma placa.

Este imóvel localiza-se na plataforma litoral, a cerca de 750 metros da linha atual da costa constituída por praias de seixos rolados e de afloramentos de metassedimentos (xistos e quartzitos). A norte da estátua-menir passa um curso de água designado por Rego e a sul o Rego da Lagoa, desaguando ambos no oceano atlântico. Nas imediações, para norte, brotam as nascentes de São Bartolomeu, ao qual a população atribuí poderes curativos. É de destacar que o monumento, se situa entre as fozes dos rios Cávado, a sul, e do Neiva, a norte.

Segundo a Carta Geológica de Portugal, na escala 1: 50 ooo, folha 5-C, de Barcelos, de Teixeira et al. (1969), o substrato geológico local é composto por depósitos de praias antigas e de terraços fluviais, sobre quartzitos com cruziana e scolithus do Ordovícico. Nas imediações, a nascente, eleva-se o Monte de Sanfins, cujo topo alcança 237 metros. Trata-se de um relevo residual granítico onde são bem visíveis inúmeros afloramentos de granitos, de duas micas, predominantemente biotíticos, e de grão médio (Figura 2), o designado Granito de São Lourenço (Pereira, 1992).

Do local usufruía-se um bom domínio visual sobre o meio circundante, nomeadamente para o oceano atlântico a noroeste, oeste e sudoeste. Para nascente, avistavam-se as vertentes íngremes do Monte de Sanfins; para norte, parte da plataforma litoral e o Monte do Castelo, já na margem oposta do Neiva, e para sul, a restante plataforma litoral.

A área de implantação deste monumento encontra-se urbanizada, encontrando-se a igreja nova de São Bartolomeu do Mar, a escassos metros, assim como diversas moradias, campos agrícolas e estufas (Figura 3).

O local, foi até há poucos anos, cultivado com milho e produtos hortícolas, nunca tendo sido alvo do plantio de árvores de fruto ou de vinha, segundo a informação oral dos moradores do local. Atualmente, está ajardinada uma pequena área em volta do monumento tendo aí sido colocada uma placa informativa com o desenho retirado da publicação de Jorge, Baptista e Gonçalves (1986) e um pequeno texto, em português, com base na referida publicação. 


\section{CONTEXTO ARQUEOLÓGICO}

Conhecem-se diversos vestígios arqueológicos da Pré-história Recente e da Proto-história no aro de São Bartolomeu do Mar, embora nada esteja registado no Portal do Arqueólogo. São de destaque: i) um importante povoado Calcolítico localizado na vertente este do Monte de Sanfins/Monte Crasto, parcialmente destruído por uma pedreira clandestina (Bettencourt, 2013a); ii) o achado de dois machados metálicos (um plano e outro de tipo Bujões/Barcelos) e de uma espada curta, provenientes de uma zona de desmonte de pedra na base da vertente oeste do Monte de Sanfins, inseríveis entre as Idade do Bronze Antigo e Médio (Harbison, 1967; Junghans, Sangmeister e Schröder, 1968; Almeida, 1987; Comendador Rey, 1998; Bettencourt e Sampaio, 2017, entre outros); iii) o achado de materiais de superfície indicadores da existência de um povoado da Idade do Ferro, na base do Monte de Sanfins (Almeida, 1987). De destacar, ainda, indicações toponímicas que indiciam a presença de monumentos megalíticos funerários na plataforma litoral, em particular nos campos a oeste e noroeste da Igreja Velha ${ }^{5}$. Na freguesia de São Paio de Antas, conhece-se a necrópole de Belinho, considerada do Bronze Médio (Bettencourt, 1999, 2001) e a necrópole de cistas dos finais do Bronze Médio, inícios do Bronze Final de Agra das Antas (Ataíde e Teixeira, 1940; Soeiro, 1988; Cruz e Gonçalves, 1998/1999; Bettencourt, 1999). Para sudeste, na freguesia de Vila Chã, há três monumentos megalíticos com reutilizações da Idade do Bronze Inicial ou Médio. Trata-se de uma das mamoas da Serra, da Antela da Portelagem e da Mamoa do Rapido (Bettencourt, 1999, 2013b). Ainda na freguesia de Vila Chã é de assinalar o povoado de Bitarados/Maindos (Bettencourt et alii, 2007; Cardoso e Bettencourt, 2008) e ocupação do Bronze Final do Castro de São Lourenço (Bettencourt, 1999). Na freguesia das Marinhas, deve assinalar-se a necrópole do Bronze Inicial/Médio da Cavaleira (Almeida, 1988; Bettencourt, 1999, 2011).

De destacar, ainda, a presença de pias salineiras amovíveis, descoberta em toda a costa desde a foz do Neiva até à praia da Robaleira, nas Marinhas (Esposende) que recentemente têm sido atribuídas à Idade do Bronze por paralelos com uma pia contextualizada no sítio arqueológico de Carreço-praia,

5. Informação particular do Padre Franklin Neiva Soares.
Viana do Castelo (Bettencourt et alii, 202O; Bettencourt et alii, no prelo).

\section{TRABALHOS ARQUEOLÓGICOS}

Para um estudo correto deste monumento foi necessário proceder-se quer à sua limpeza quer a sondagens arqueológicas na sua envolvente.

\subsection{Limpeza e estudo da estátua-menir}

A estátua menir tinha a sua coloração original alterada devido à presença de fungos, líquenes e ações antrópicas. Tornou-se imperativo a sua limpeza para facilitar a caracterização do tipo de granito e a sua origem. A limpeza foi efetuada com escovas, de diversos graus de dureza, espátulas estreitas de madeira e água corrente. Esta possibilitou, ainda, a pesquisada de novas grafias (Figura 4).

Para tal, foi efetuada observação com luz diurna e artificial e realizado o seu levantamento fotogramétrico, posteriormente trabalhado no computador através dos programas Agisoft e Meshland.

Estes trabalhos contaram com a colaboração de dois subscritores deste trabalho (PPS e LG), geólogos de formação.

\subsection{Sondagem arqueológica}

Após a remoção das cascas de árvore seca que rodeavam a base da estátua-menir, inseriu-se a área a escavar numa quadrícula composta por quatro quadrados de $4 \mathrm{~m}^{2}$ cada, designados por $\mathrm{A}_{1}, \mathrm{~A}_{2}, \mathrm{~B}_{1}$ e B2 . Esta foi efetuada pelo Gabinete de Topografia da Câmara Municipal de Esposende. A área delimitada para escavação, com cerca de $16 \mathrm{~m}^{2}$, foi a única possível, dado o revolvimento do terreno resultante de trabalhos anteriores (Figura 5).

A escavação iniciou-se com a retirada da UE oo em todos os quadrados, seguida da UE o1 e da UE o2, até se encontrar geotêxtil de colocação recente, ali colocado aquando das intervenções realizadas em volta do monumento pela Câmara Municipal de Esposende. Após o levantamento do geotêxtil nos quadrados B1 e B2 ficaram visíveis, em plano, quatro unidades estratigráficas distintas: a UE 04, a UE 05, a UE 6 e a UE 07. Nesse momento realizou-se uma limpeza do plano, que foi objeto de fotografia, descrição, desenho e interpretação. Posteriormente, iniciou-se a escavação da UE 05, no quadrados B2, inicialmente interpretada como correspondendo à vala de fundação da implantação do muro de cimento (UE 
03). No seguimento da escavação percebeu-se que a UE 05 não correspondia ao enchimento da vala de fundação do muro, bem individualizada, mas sim a solo agrícola muito perturbado pelos revolvimentos que a implantação do muro provocou. Escavaram-se, ainda, as UEs o6 e 07, correspondente a terras mais recentes e só, posteriormente, se retirou a UE 04. Paralelamente, iniciaram-se as escavações dos quadrados A1 e A2, deixando-se uma banqueta de $50 \mathrm{~cm}$ entre os quadrados para possibilitar uma leitura estratigráfica vertical.

No topo da UE o8, que corresponde a solos de deposição natural, verificaram-se inúmeras manchas preenchidas com sedimentos da UE 04, que correspondiam ao enchimento das depressões deixadas pelas relhas do arado nos depósitos sedimentares originais. A escavação da UE o8 prolongou-se em profundidade, no quadrado B2, para se perceber qual a sua espessura e facilitar o trabalho de interpretação de formação dos solos da plataforma litoral. Para tal foram retiradas amostragens de sedimentos, com o auxílio de um trado, chegando-se a cerca de 2,5 metros, profundidade a partir do qual se detetaram seixos rolados, provavelmente de um terraço marinho. Por forma a ilustrar a estratigrafia geral e a área de implantação da estátua-menir foi desenhado o perfil oeste dos quadrados $\mathrm{B}_{1}$ e B2, assim como o perfil sul dos quadrados $\mathrm{Ar}_{1}$ e $\mathrm{B} 1$ (Figura 6).

Como não foi visível a vala de fundação do monumento no perfil oeste do quadrado B2, que lhe passava a cerca de $10 \mathrm{~cm}$, optámos por escavar até ao seu limite, para obter mais dados. Antes deste trabalho foi necessário escorar o monumento ${ }^{6}$.

Esta escavação possibilitou encontrar uma pequena vala de fundação da estátua-menir (UE 11), com enchimento idêntico à $U_{4}$, embora com inclusão de seixos rolados, seixos graníticos angulosos, pedaços de cimento agarrado a tijolo e vidro. Foram tiradas fotografias gerais e de pormenor desta ocorrência, assim como efetuado um desenho do perfil que passava a nascente do monumento (Figuras 6 e 7 ).

Posteriormente o espaço de escavação foi coberto com geotêxtil e sedimentos tendo no topo sido colocada casca de árvore seca para que ficasse similar ao encontrado no início dos trabalhos.

6. Neste processo houve o cuidado de o escorar com madeira para não danificar a superfície do monumento.

\subsubsection{Unidades estratigráficas}

Tendo em conta a similitude das unidades estratigráficas encontradas nos diferentes quadrados podemos sintetizá-las deste modo: UE oo - Sedimentos de coloração castanha escura, de composição areno-argilosa, composto por areia muito fina, medianamente compacto, com raízes e calhaus angulosos. Corresponde a um aterro; UE o1 - Sedimentos de coloração castanha clara, de composição limosa, compostos por limos e argilas, medianamente compactos, com calhaus angulosos. Incluí fragmentos de plástico recentes. Corresponde a um aterro; UE 02 - Sedimentos de coloração bege clara, de composição arenosa, compostos por areias finas, de elevada compacidade, com inclusão de calhaus angulosos. Inclú fragmentos de plástico, de papel e de vidro de cronologia recente. Corresponde a um aterro; UE 03 (Só ocorre nos quadrados B2, A1 e A2) - Muro composto por blocos de cimento de delimitação de duas propriedades agrícolas, de construção recente; UE 04 - Sedimentos de coloração castanha escura, de composição areno-limosa, composta por areias finas, de fraca compacidade. Incluí calhaus rolados e restos de cimento, assim como materiais recentes, como fragmentos de plástico. Corresponde ao solo agrícola; UE o5 (Só ocorre no quadrado B2) - Sedimentos de coloração heterogénea, com manchas amarelas e castanhas claras, de composição areno-limoso, compostos por areias finas, medianamente compactas, com inclusão de calhaus angulosos, carvões e conchas de caracol. Possui, ainda, fragmentos de plástico. Corresponde ao solo agrícola; UE o6 (Só ocorre no quadrado B1). Sedimentos de coloração castanha escura, de composição areno-limosa, composto por areias finas, de fraca compacidade, com inclusão de blocos e calhaus rolados e angulosos. Possui materiais recentes, como fragmentos de plástico. Corresponde a um aterro; UE o7 (Só ocorre nos quadrados Ai, Bi e B2) - Sedimentos de composição heterogénea, que alternam entre alguns de composição limosa e de coloração castanha escura, com outros de composição arenosa, menos compacta e de coloração acinzentada. Incluí calhaus angulosos e integra fragmentos de plástico. Corresponde ao enchimento de uma vala de fundação para colocação de um tubo de plástico resultante das obras recentes; UE o8 - Sedimentos de coloração amarela escuro, de composição areno-limosa, composto por areias finas, medianamente compacto, com inclusão de calhaus. Corresponde a um solo não antrópico, proveniente de depósitos 
antigos; UE o9 (Só ocorre no quadrado B2) - Sedimentos de coloração castanha escura, de composição limosa, compostos por areias finas, de fraca compacidade, com carvões. Possível depressão intrusiva na UC 08, proveniente das atividades da UE 05; UE 10 (Só ocorre no quadrado Ai) - Bolsa sedimentar de coloração castanha escura, de composição areno-argilosa, composta por areias finas e de fraca compacidade. Incluí calhaus dispersos; UE 11 (Só ocorre nos quadrados A1 e A2, em volta da estátua-menir) - Sedimentos de coloração castanha escura, de composição areno-limosa, composta por areias finas, de fraca compacidade. Incluí seixos rolados, seixos graníticos angulosos, um pedaço de cimento agarrado a tijolo e vidro. Corresponde à vala de fundação recente de implantação da estátua-menir.

\subsubsection{Espólio}

Estando a área profundamente revolvida, a maioria do espólio encontrado é de cronologia recente. Referimo-nos a restos de plásticos, de cimento, tijolo e vidros. Entre estes destaca-se o aparecimento de um fragmento de uma pequena garrafa de Martini, de cor verde, que se encontrava no interior da pequena vala de fundação do menir (UE 11).

Nas UEs 04 e 05 foram registados alguns seixos rolado de quartzito, dispersos, assim como lascas desse material, aparentemente afeiçoadas. Provavelmente resultaram de perturbações dos terraços marinhos existentes sob a UE o8 que se foram misturando nos solos agrícolas resultantes de obras em profundidade, como a construção de poços ${ }^{7}$, etc.

$\mathrm{Na}$ UE 05, quadrado A2, foram encontrados dois seixos rolados de quartzito, com truncaturas em cada extremidade longitudinal, podendo classificar-se como pesos de rede.

Estes, muito homogéneos em termos de dimensões e de truncaturas, parecem antigos, embora se encontrassem descontextualizados ${ }^{8}$. O no 1 mede $6,5 \mathrm{~cm}$ de altura, $4,8 \mathrm{~cm}$ de largura máxima e 2,4 $\mathrm{cm}$ de espessura. O no 2 mede 5,9 cm de altura, $4 \mathrm{~cm}$ de largura máxima e 1,9 cm de espessura. Ambos são muito mais

7. De salientar que a cerca de 7 metros para sul-sudeste da estátua-menir existia um poço, atualmente tapado.

8. Apesar de existirem pesos de rede sobre seixo de quartzito até, pelo menos, o séc. XX, os que se observam no litoral norte foram realizados sob grandes seixos e apresentam truncaturas irregulares, sendo, portanto, muito distintos dos encontrados na escavação. pequenos do que os restantes seixos rolados com ou sem afeiçoamento, encontrados no solo agrícola.

\section{DESCRIÇÃO DA ESTÁTUA-MENIR}

\subsection{Descrição morfológica e grafias}

O monumento da Arga do Pedrão corresponde a uma estátua-menir (e não a um menir como é usualmente designada) dado o seu carácter tridimensional e aproximadamente antropomorfo. Caracteriza-se por uma figuração muito abstracta do corpo humano, potenciada por dois estrangulamentos intencionais realizados na metade superior da face sul, que esboçam os ombros e a cabeça, cuja extremidade foi partida. A sua fratura é evidente pelo facto da superfície fraturada apresentar uma patine distinta da do resto da peça e pela existência de entalhes de cunhas. Tem quatro faces, atualmente orientadas para sul, norte, noroeste e nordeste (Figura 8).

A face virada para sul foi aplanada intencionalmente, apesar de conter uma saliência natural, um nódulo de biotites, na parte superior, e pequenas reentrâncias de origem natural. Foi aquela onde foram gravados mais motivos, parecendo ser a superfície para onde a audiência teria preferencialmente de olhar. Aí foram gravadas oito covinhas bem pronunciadas (quatro de cada lado) em posição central, na parte média do corpo da estátua-menir e dispostas segundo o eixo maior vertical. A sua disposição sugere, se mentalmente unirmos todas as covinhas, uma figura semi-retangular, similar à que ocorre noutras estátuas-menires e a que se dá o nome de estola ou de insígnia (Figura 8).

Através da observação noturna, com luz artificial, foi ainda encontrado um pequeno sulco que parece emergir a partir dos ombro mas que se perde na parte central da face sul, numa área superior às covinhas, devido ao facto de a superfície do imóvel ter sido alterada ou picada, por objeto metálico, nessa área.

As faces noroeste e nordeste são igualmente aplanadas, sendo a que está virada a norte mais estreita e arredondada. Com exceção desta, todas as restantes foram gravadas.

A face virada a noroeste é regular, mas apresenta uma saliência, disposta na diagonal na parte inferior, formada por uma concentração de biotite. Ostenta quatro covinhas, pouco pronunciadas, na parte inferior do imóvel que formam um alinhamento ligeiramente curvo, duas covinhas na zona centro, algo distanciadas entre si, e uma na parte superior, 
na área do "ombro" da peça.

A face virada a nordeste apresenta uma superfície algo irregular, com uma saliência disposta na diagonal, na parte inferior e um estreitamento, na parte superior. Evidencia duas covinhas dispostas na diagonal, na zona centro.

A face norte, apresenta uma superfície uniforme, mas possui uma concavidade natural na parte média-inferior.

Durante a escavação verificou-se que a base da estátua-menir era arredondada, tendo sido afeiçoada para o efeito (Figuras 7 e 9), pelo que é provável que a cabeça também fosse afeiçoada.

Da base à fratura do topo o monólito mede 2,15 metros de altura. É mais espesso na base, em contacto como o solo, onde tem c. $72 \mathrm{~cm}$. Na parte média tem c. $60 \mathrm{~cm}$ e na extremidade superior, à altura dos ombros, c. $40 \mathrm{~cm}$.

Em corte tem uma forma trapezoidal com o eixo menor, arredondado, virado a norte.

Após a observação noturna foi possível verificar que esta peça foi polida em diferentes faces, provavelmente com a ajuda de seixos rolados de quartzito e, posteriormente, gravada por percussão.

Hoje encontra-se parcialmente picada, sobretudo na face virada a sul, o que terá destruído gravuras menos profundas.

Durante a escavação foi possível verificar que a estátua tinha sido pintada recentemente, com óleo queimado?.

\subsection{Características litológicas}

A rocha com que foi talhada a estátua-menir é um granito de duas micas (biotite e moscovite), de grão médio a grosseiro com presença de turmalina (Granito de São Lourenço). Este tem uma coloração que varia entre tons de cinza e amarelados, apresentando junto da base de uma das faces, uma zona com coloração avermelhada. As cores amareladas e avermelhadas são devidas à alteração do granito (oxidação da biotite) e estão associadas ao feldspato.

Ocorrem $\mathrm{n}$ bloco granítico da estátua-menir raros encraves $^{10}$ micáceos de forma lenticular com di-

9. Tal facto foi relatado por um visitante que refere que o antigo proprietário não gostava da estátua-menir, tendo-a pintado com óleo queimado pensando que, assim, lhe tirava o valor.

10. Encraves - fragmentos de outra rocha inclusa na rocha ígnea. mensões que variam entre 3 e $8 \mathrm{~cm}$. Evidenciam-se, ainda, dois bandados ${ }^{11}$ micáceos a saber: i) curto bandado na parte superior da face virada a sul, de direção oeste-este, de espessura $\pm 2 \mathrm{~cm}$ com algum quartzo e feldspato; ii) bandado penetrativo com \pm $1 \mathrm{~cm}$ de espessura, observável na parte inferior da face com orientação nordeste-sudoeste, abrindo e continuado para o lado esquerdo em associação com quartzo e feldspato, inclinação para sul.

Observa-se que o granito está orientado, com uma estrutura planar, evidente na parte superior da face do menir com orientação nordeste-sudoeste, sendo que essa disposição é dada pelas micas, encraves e bandados micáceos.

A turmalina ocorre disseminada no granito, observando-se ainda dois alinhamentos rectilíneos com disposição oblíqua de inclinação contrária na face com orientação oeste-este, na sua metade inferior.

\subsection{Lendas atribuída ao local}

Segundo depoimentos de vários visitantes, residentes ou ex-residentes em São Bartolomeu do Mar, os relatos em torno da estátua-menir podem sintetizar-se em três ideias base: i) quando tirarem a pedra o mar avança; ii) a pedra ia sendo tirada e voltava sempre a aparecer no mesmo lugar; iii) no dia de São Simão chegou o mar ao pedrão.

\section{DISCUSSÃO DOS DADOS E INTERPRETAÇÕES}

O resultado dos trabalhos arqueológicos em redor do menir da Agra do Pedrão possibilitaram perceber que este monólito não se encontrava in situ, mas que a sua mudança de local se verificou durante o séc. $\mathrm{XX}$, tendo em conta os materiais encontrados na sua vala de fundação e as fotografias publicadas por Sereno e Dórdio (1994) que o mostram na posição onde se encontra.

Algumas pessoas de idade, inquiridas sobre o seu local de implantação, referiram que, originalmente, ele estaria mais para nascente, ou seja, mais perto das traseiras da igreja e onde hoje se encontra o caminho empedrado, o que inviabilizou escavações nesse local. Referiram-nos, ainda, que estava mais perto do poço que ali existiu (hoje soterrado), e que foi mudado porque atrapalhava a extração de água

11. Bandado - estrutura ígnea com bandas de variação mineralógica. 
que ali se fazia com a ajuda de gado bovino que mal conseguia passar entre o monumento e o poço.

Ao ser assim, este monumento não estará muito deslocado da sua posição original até porque, na memória da população local, sempre esteve na propriedade conhecida como Agra do Pedrão que era mais vasta e ocupava parte dos terrenos onde hoje se encontram as estufas (a oeste), o caminho empedrado (a este) e uma moradia (a sul). De salientar que se trata de um monumento de peso considerável, pelo que a sua deslocação, por muitos metros, no âmbito da mesma propriedade, não teria grande sentido. Também é significativo que, pelo menos desde os anos 40 do século XX, as pessoas de idade comentassem que pelo S. Simão vinha o Mar ao Pedrão. Expressão que poderá, eventualmente, relacionar-se com os efeitos do tsunami no noroeste da Península Ibérica, resultante do sismo de 1755, que ocorreu no dia 1 de novembro (Amaré Tafalla, Orche García e Puche Riart, 2005), ou seja, pelo S. Simão, que se festeja desde os dias 28 de outubro a 2 de novembro, consoante as regiões. Assim sendo a estátua-menir estaria na plataforma litoral, desde, pelo menos, os finais do séc. XVIII.

Em termos dos aspectos técnicos pode afirmar-se que foi elaborada a partir de um bloco de granito de duas micas de grão médio (granito de São Lourenço), com predomínio da biotite, granito este aflorante a cerca de $0,5 \mathrm{~km}$ para leste e de $1 \mathrm{~km}$ para norte. Este facto pode, também constituir-se como mais um factor de que teria sido erguida nesta área genérica. Atendendo a que não foi possível obter dados diretos para a sua datação, esta foi estabelecida com base em paralelos para o motivo sugerido pelas oito covinhas da face sul. Trata-se de uma iconografia comum nas estátuas-menires do Centro-Norte de Portugal e sul da Galiza que têm sido datadas da Idade do Bronze ${ }^{12}$, pelo que se crê poder inserir este monumento nesta cronologia genérica.

Apesar das dificuldades em relacionar os pesos de rede com a estátua-menir e da descontextualização de ambos os achados, à microescala, é de notar que estes artefactos ocorrem, pela primeira vez, em contextos da Idade do Bronze, pelo que poderiam de certa forma estar relacionados.

Apesar de deslocada esta estátua-menir teria sido erguida na plataforma litoral que é, genericamente,

12. Sobre estátuas-menir consultar a obra coordenada por Vilaça (2011). um lugar de fácil circulação, perto de enseadas marítimas passíveis de atracagem e das fozes dos rios $\mathrm{Nei}$ va e Cávado navegáveis. Tendo em conta a própria morfologia do monumento, com mais de 2 metros de altura este seria facilmente visível de longe para quem por aqui circulasse, sendo, certamente, um marco espacial importante, um local de paragem, um locus aglutinador ou um local geoestratégico de encontro quer entre gente que viveria no território, quer entre estes e populações alógenas, conhecedoras da simbologia destes monumentos e das suas grafias, mesmo que só esboçadas (Figura 10).

Há que ter em consideração que a estátua-menir fica em frente do Monte de Sanfins, de grande impacto visual e verdadeiro marco para a circulação terrestre e para a navegação por cabotagem para quem navega quer de norte quer de sul. Trata-se de uma das orografias mais salientes da plataforma costeira, avistável de muito longe e provavelmente de grande valor simbólico para as populações (um Monte Sacro?) que, pelo menos durante o Bronze Inicial e Médio aí evocaram ou celebraram as suas propriedades através de deposições de artefactos metálicos, como um machado plano, um machado de tipo Bujões/Barcelos e uma espada curta (Junghans, Sangmeister e Schröder, 1968; Comendador Rey, 1998; Bettencourt e Sampaio, 2017).

Deste modo a estátua-menir do Pedrão, poderia ter funcionado como um símbolo identitário e de poder local das populações litorais face a outras que aqui passassem ou aportassem, quiçá representando uma divindade, um antepassado comum, um herói mítico ou um personagem real, talvez com poderes mágicos. Localizada num lugar liminar entre a terra e o mar e em rede com outros lugares vivenciados, sinalizaria um epicentro de múltiplas funções: religiosas, sociais e de intercâmbio (sal, estanho, ideias), numa sociedade onde estas divisões não teriam o sentido que hoje se lhe conferem. Seria, talvez, um lugar em que se repunha a ordem do mundo [uma heterotopia no sentido em que Foucault (1984) descreve este conceito]. Um lugar fora de todos os lugares, perfeito, meticuloso, ordenado face aos restantes, desordenados e improvisados. Um lugar onde se justapõe, num só lugar, vários espaços incompatíveis, simultaneamente fechado e aberto a diferentes comunidades.

A importância deste monumento no passado perdurou, de forma reinventada, na memória popular, através das "estórias" que sobre ele se contam 
e que subentendem que teria propriedades benéficas e protetoras (pois se sair dali, o mar entra) e que está encantada (pois foi levada mas volta sempre ao seu lugar).

Pela importância e raridade de monumentos deste tipo na fachada litoral do Noroeste Ibérico, seria de todo desejável que a sua área de proteção fosse aumentada no cumprimento da lei, e libertada de muros e de estufas que lhe tiram a espetacularidade de outrora.

Por ser um lugar muito frequentado por visitantes de nacionalidade portuguesa e estrangeira ${ }^{13}$ (há sinalética na estrada nacional que indica menir) seria conveniente uma placa sinalizadora com informação em várias línguas, pelo menos inglês e francês, atualizada em termos científicos e menos impositiva do que a existente, que por ser muito alta, tapa a visibilidade para o que se pretende mostrar.

\section{AGRADECIMENTOS E APOIOS}

Os autores agradecem à Câmara Municipal de Esposende, à união de freguesias de Belinho e de São Bartolomeu e ao agrupamento de escuteiros de São Bartolomeu do Mar os apoios prestados durante os trabalhos de campo. Este trabalho foi realizado no âmbito dos seguintes projetos: Arte Rupestre do NoroesteIbérico.Liminaridade e Heterotopia (referência SFRH/BSAB/114296/2016), da responsabilidade de Ana M. S. Bettencourt e Paisagem e Representação do Poder na Pré-história Recente: Arte Atlântica e Estátuas-Menir, desenvolvido por Manuel Santos-Estévez no âmbito da Bolsa de pós-doutoramento da FCT, ref. SFRH/BPD/93700/2013.

13. Durante as quatro semanas que duraram os trabalhos de campo foram muitos os visitantes de vários pontos de Espanha, de França, dos Países Baixos e da Alemanha que, perante falta de informação em inglês, na placa ali colocada, frequentemente nos interpelavam para saber mais sobre o monumento.

\section{BIBLIOGRAFIA}

ALMEIDA, Carlos A.B. (1987) - Carta arqueológica do concelho de Esposende, Boletim Cultural de Esposende, 11/12, pp. 93-109.

ALMEIDA, Carlos A.B. (1998) - Esposende. Povoamento Romano do Litoral Minhoto entre o Cávado e o Minho, Esposende: Câmara Municipal.

AMARÉ TAFALlA, María Pilar; ORCHE GARCÍA, Enrique; PUCHE RIART, Octavio (2005) - Efectos del Terremoto de Lisboa de 1 de Noviembre de 1755 en la Antigua provincial de Tuy (Galicia), Cuadernos Dieciochistas, 6, pp. 117-152.

ATAÍDE, Alfredo; TEIXEIRA, Carlos (1940) - A Necrópole e o esqueleto de S. Paio de Antas e o problema dos vasos de largo bordo horizontal, I Congresso do Mundo Português, Vol. I, Lisboa, pp. 667-683.

BETTENCOURT, Ana M.S. (2013a) - A Pré-história do Noroeste de Portugal, (Territórios da Pré-História em Portugal, vol. 2). Braga/Tomar: CITCEM/ARKEOS.

BETTENCOURT, Ana M.S. (2013b) - A necrópole megalítica do planalto de Vila Chã, Esposende, In BETTENCOURT, Ana M.S. A Pré-história do Noroeste de Portugal (Territórios da Pré-história em Portugal, vol. 2). Braga/Tomar: CEIPHAR, CITCEM, pp. 155-162.

BETTENCOURT, Ana M.S.; SAMPAIO, Hugo A. (2017) - The Middle and the beginning of the Late Bronze Age in the north-western Iberian Peninsula. In LACHENAL, Thibault; MORDANT, Claude; NICOLAS, Théophane; VÉBER, Cécile, eds. - Le Bronze moyen et l'origine du Bronze final en Europe occidentale (XVII ${ }^{e}$-XIII ${ }^{e}$ siècle av. J.-C.) (Monographies d'Archéologie du Grand Est 1). Strasbourg, pp. 365-385.

BETTENCOURT, Ana M.S.; DINIS, António; CRUZ, Carlos; SILVA, Isabel S. (2007) - A estação arqueológica de Bitarados, Vila Chã (Esposende - Norte de Portugal), Boletim Municipal de Esposende, série 2, 1, pp. 3-16.

BETTENCOURT, Ana M.S.; LUZ, Sara; SIMÕES, Pedro P.; ALVES, Maria Isabel C.; ABAD-VIDAL, Emilio (no prelo) - Bronze Age sea salt production in Northwest Iberian Peninsula. In MARCIGNY, Cyril; MORDANT, Claude, eds. Bronze 2019: 20 ans de recherches. (Suppléments au Bulletin de l'APRAB). Dijon: APRAB.

BETTENCOURT, Ana M.S.; LUZ, Sara; OLIVEIRA, Nuno; SIMÕES, Pedro P.; ALVES, Maria Isabel C.; ABAD-VIDAL, Emilio (no prelo) - Produção de sal marinho na Idade do Bronze do Noroeste de Portugal. Alguns dados para uma reflexão. In ARNAUD, José M., NEVES, César e MARTINS, Andrea, Arqueologia em Portugal 2020 - Estado da Questão, Lisboa.

CARDOSO, João Luís; BETTENCOURT, Ana M.S. (2008) - Caça e pastorícia no Calcolítico do Noroeste de Portugal: estudo dos restos ósseos da estação arqueológica de Bitarados, Estudos do Quaternário, 5, pp.79-86. 
COMENDADOR REY, Beatriz (1998) - Los Inicios de la Metalurgia en el Noroeste de la Península Ibérica (Brigantium 11). A Coruña: Museu Arqueolóxico e Histórico Castelo de Santo Antón.

CRUZ, Domingo J.; GONÇALVES, António H.B. (1998/ 1999) - A necrópole de Agra de Antas (S. Paio de Antas, Esposende, Braga). Portugália. 19-2O, pp. 5-27.

FOUCAULT, Michel (1984) - Dits et Écrits, Architecture, Mouvement, Continuité, 5, pp. 46-49.

HARBISON, Peter (1967) - Mediterranean and Atlantic elements in the Early Bronze Age of Northern Portugal and Galicia, Madrider Mitteilungen, 8, pp. 100-122.

JORGE, Vítor O. (1978) - O megalitismo do Norte de Portugal, Revista de Guimarães, 88, pp. 431-452.

JORGE, Vítor O.; BAPTISTA, António M.; GONÇALVES, António A.H.B. (1986) - Menir de S. Bartolomeu do Mar (Esposende), Boletim Cultural de Esposende, 9-10, pp.13-20.

JUNGHANS, Siegfried; SANGMEISTER, Edward; SCHRÖDER, Manfred (1968) - Kupfer und Bronze in den frühen Metallzeit Europa. Die Materialgruppen beim Stand von 12000 Analysen II. (Studien zu den Anfängen der Metallurgie 2). Berlin: Mann.

PEIXOTO, António M.; SOARES, Franquelim N.; MACHADO, Jaime C.; AZEVEDO, Manuel S.; CAPITÃO, Orlando M.; CEPA, Paula C. (2005) - Memórias de São Bartolomeu do Mar, geografia, cadastro, toponímia e património, Vol. 2, São Bartolomeu do Mar: Centro Social da Juventude de Mar.
PEREIRA, Eurico (coord.) (1992) - Carta Geológica de Portugal na escala 1:200ooo e notícia explicativa da folha 1. Lisboa: Serviços Geológicos de Portugal.

SERENO, Isabel; DÓRDIO, Paulo (1994) - Menir de São Bartolomeu do Mar. Portugal, Braga, Esposende, União das freguesias de Belinho e Mar, SIPA - Sistema de Informação para o Património Arquitectónico, DGPC, consultável em http://www.monumentos.gov.pt/Site/APP_PagesUser/ SIPA.aspx?id=1100

SOEIRO, Teresa (1988) - A propósito de quatro necrópoles Proto-históricas do concelho de Esposende. Actas do Colóquio Manuel de Boaventura (Esposende 1985). Esposende: Câmara Municipal, pp. 35-62.

TEIXEIRA, Carlos; MEDEIROS, Armando Cândido; ALVES, Carlos Alberto M.; MOREIRA, Maria M. (1969) - Carta geológica de Portugal na escala de 1/50.00o: notícia explicativa da folha 5-C, Barcelos: estudos petrográficos, Lisboa: Serviços Geológicos de Portugal.

VICENTE, Eduardo P.; MARTINS, Adolfo A.S. (1979) Menires de Portugal, Ethnos, 8, pp. 107-138.

VILAÇA, Raquel (2011) - Estelas e Estátuas-menires: da Pré à Proto-história. Actas das IV Jornadas Raianas. Sabugal: Câmara Municipal do Sabugal.

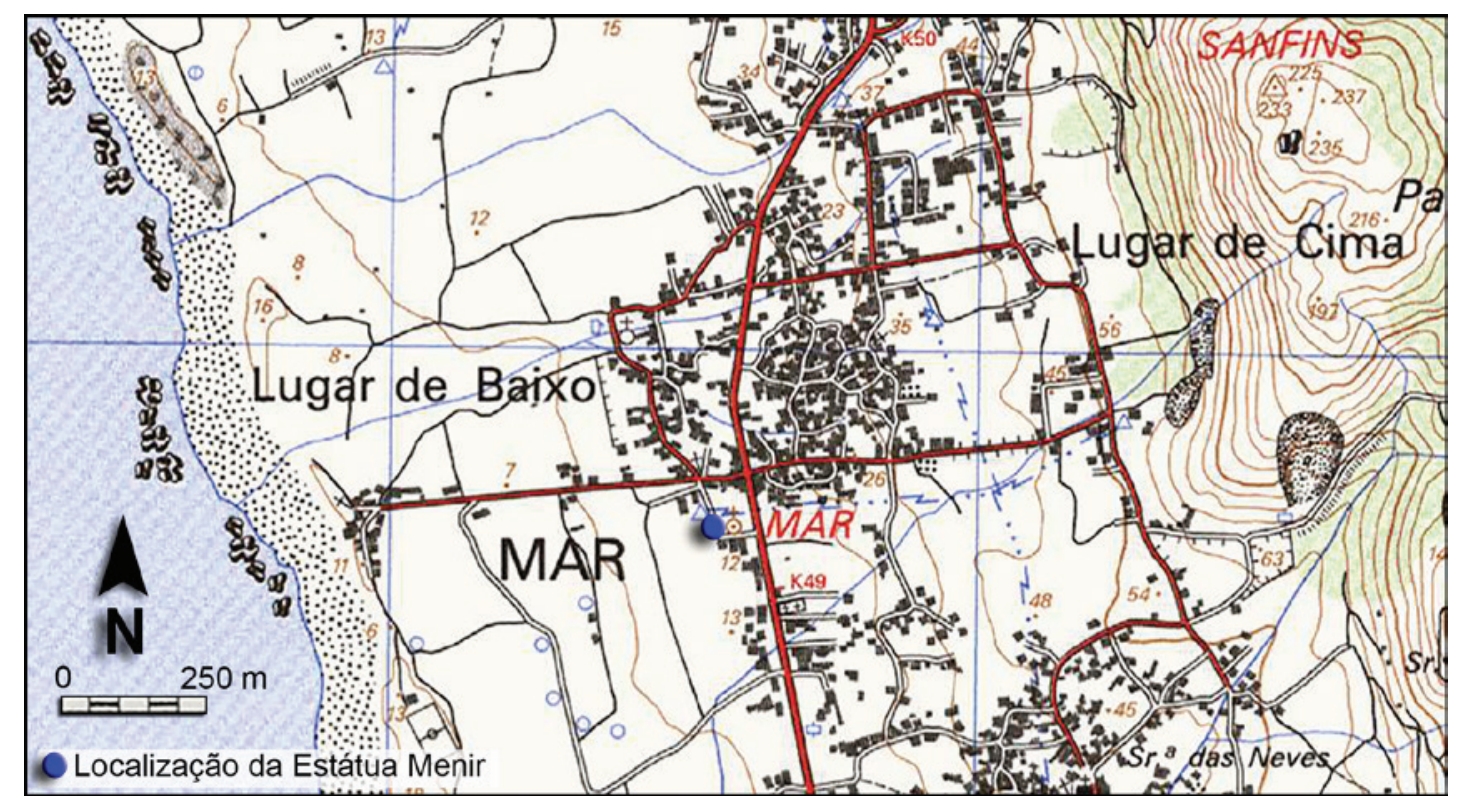

Figura 1 - Excerto da Carta Militar de Portugal, na esc. 1:25 ooo, nํ5 54 - Marinhas - Esposende, Lisboa: IGE, 1997, com a localização atual da estátua-menir. 


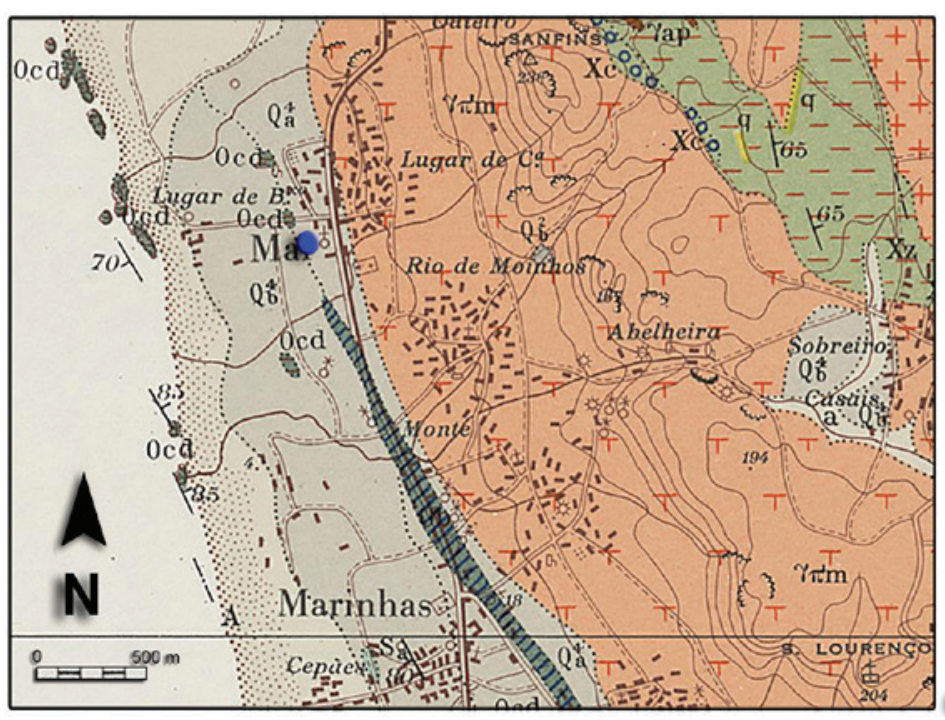

LEGENDA

a-A.Ad Aluviōes actuais (a). Areias e cascalheiras de

aAtid praia ou de Rio (A). Areias de Duna

\begin{tabular}{|l|l}
\hline Q & Depósitos de praias antigas e terraçōs fluviais \\
\hline
\end{tabular}

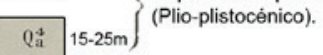

Metassedimentos do Paleozóico.

\begin{tabular}{ll}
\hline $\mathrm{cd}$ Xistos Argilosos com fósseis & \\
\end{tabular}

Quartzitos com Cruziana e Scolithus

$\mathrm{X}_{\bar{z}}^{-}$Xistos e Grauvaques fortemente metamorfizados (Complexo Xisto-grauváquico - ante-ordovicico)

Rochas Graniticas Hercínicas

Tritn Granito de S. Lourenço - granito de grão médio de duas micas, predominantemente biotítico.

Granito de Vila Chã - granito de grão grosseiro a médio, de duas micas, predominantemente biotítico.

Localização da Estátua Menir

Figura 2 - Localização da estátua-menir em extrato da Carta Geológica de Portugal na escala 1: 50 ooo, folha 5-C, de Barcelos.
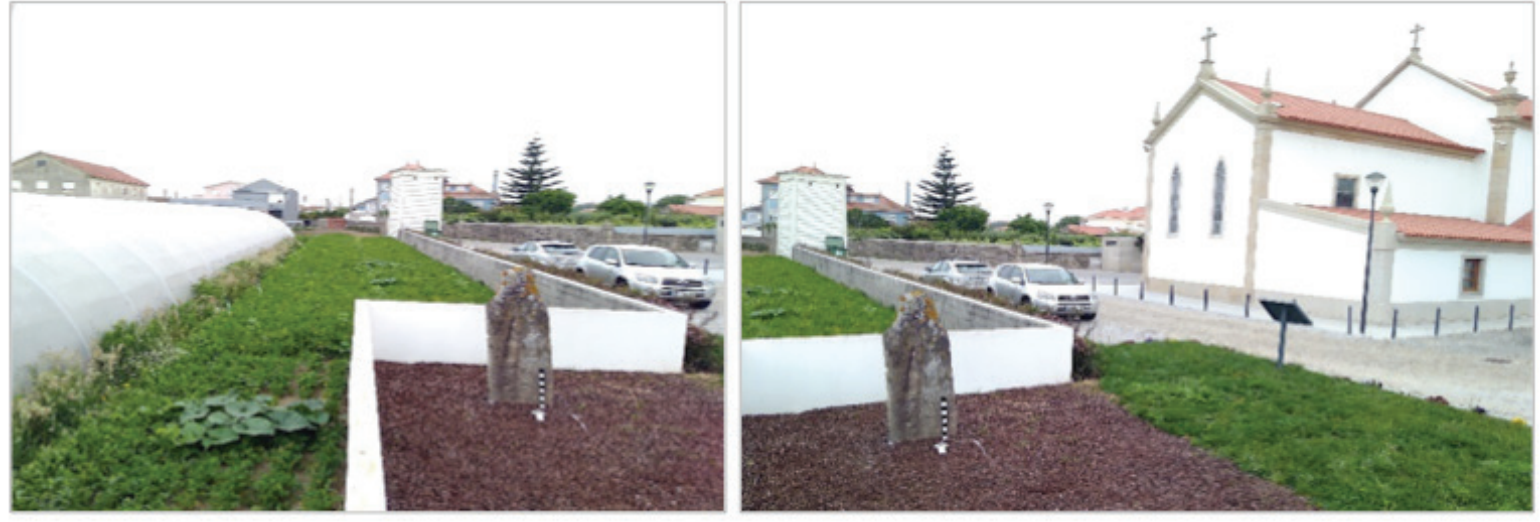

Figura 3 - Contexto atual da estátua-menir. 

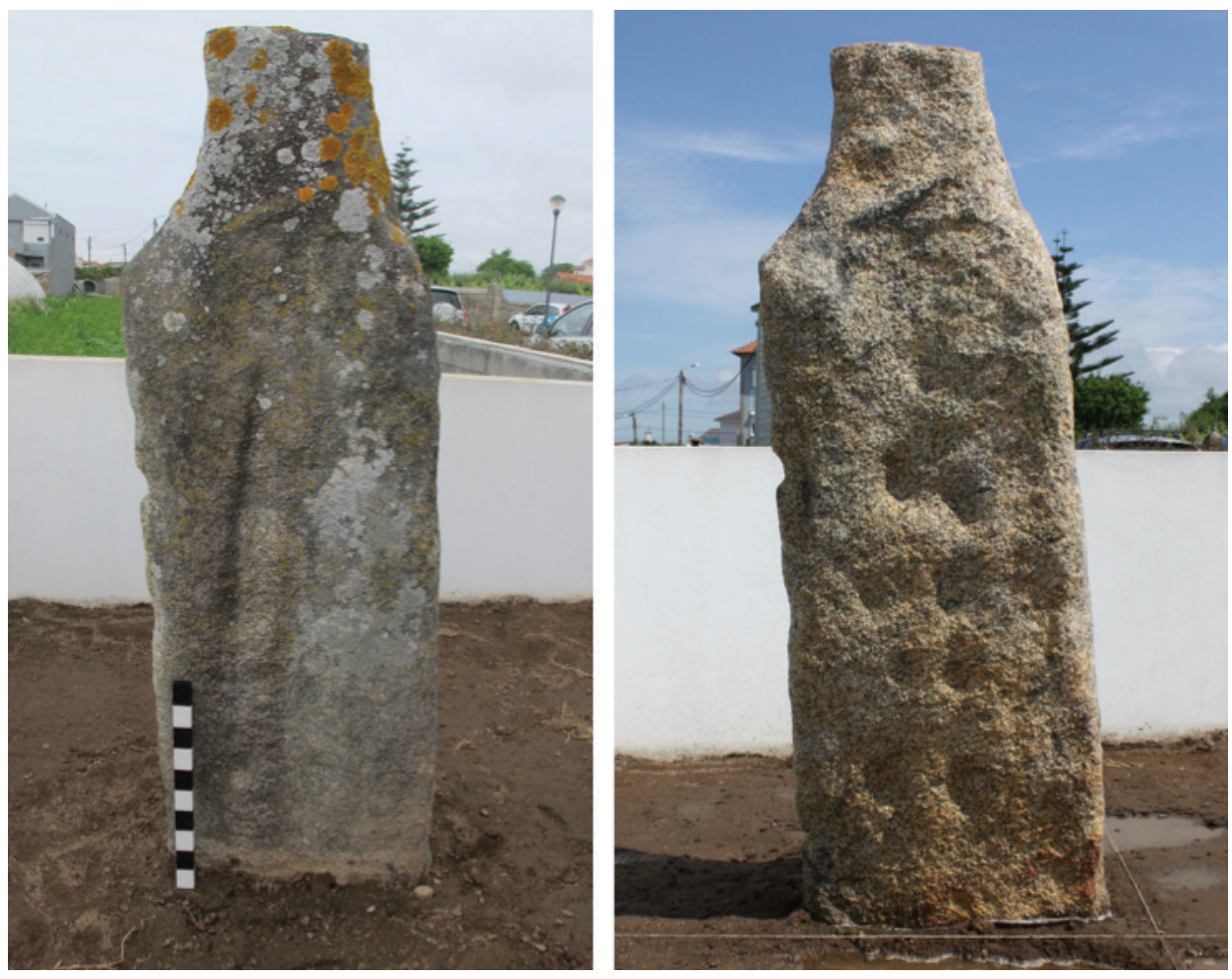

Figura 4 - Estátua-menir antes e depois da limpeza.

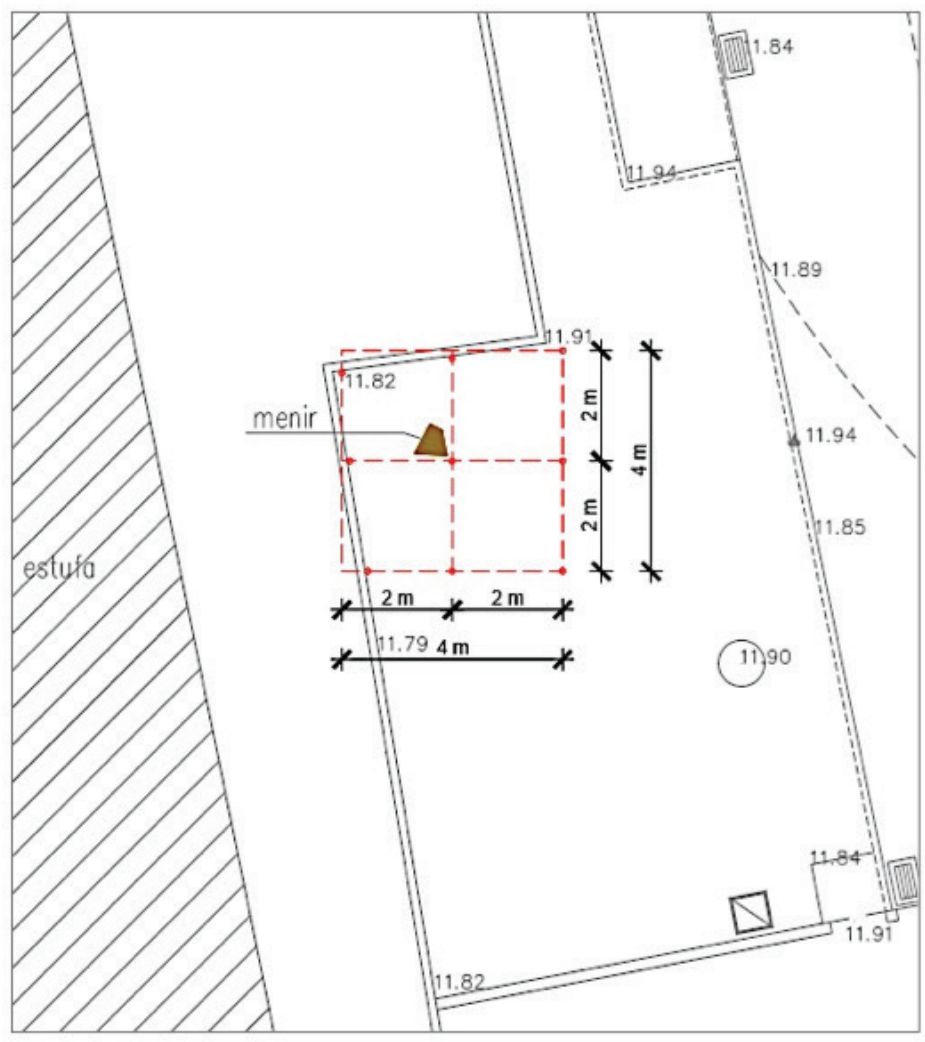

Figura 5 - Implantação da quadrícula de escavação com localização do menir (Gabinete de topografia da Câmara Municipal de Esposende). 


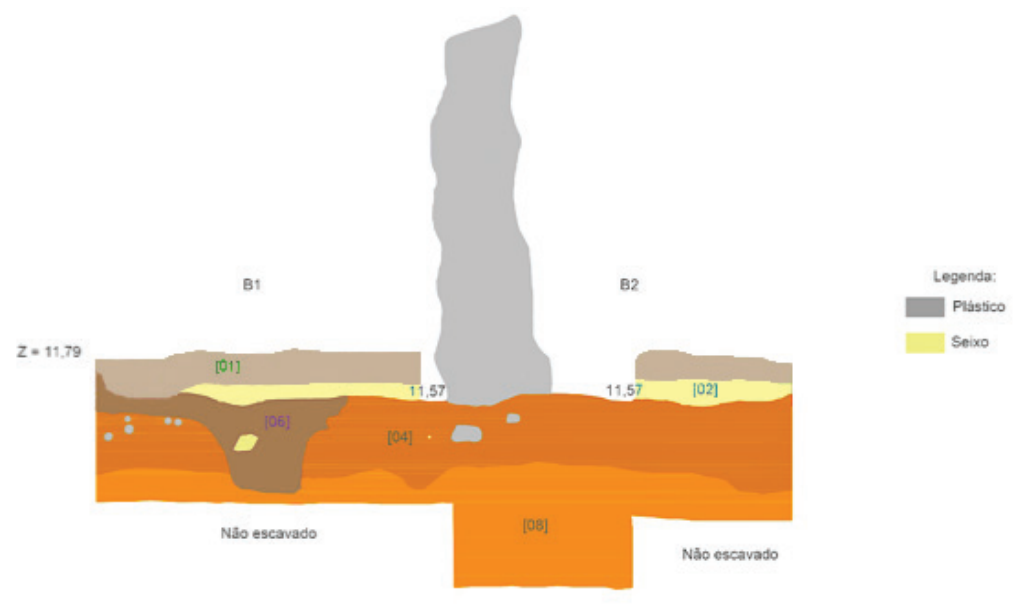

A1

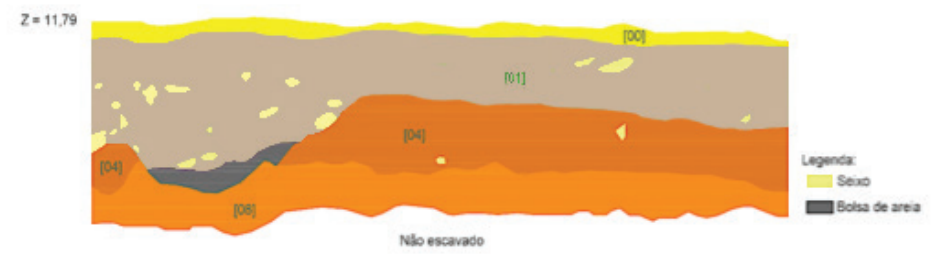

Figura 6 - Topo: perfis oeste dos quadrados $B_{1}$ e B2 onde se pode observar a vala de fundação de um tubo a inexistência de vala de fundação de implantação do menir Em baixo: perfil sul dos quadrados Bı e A1.

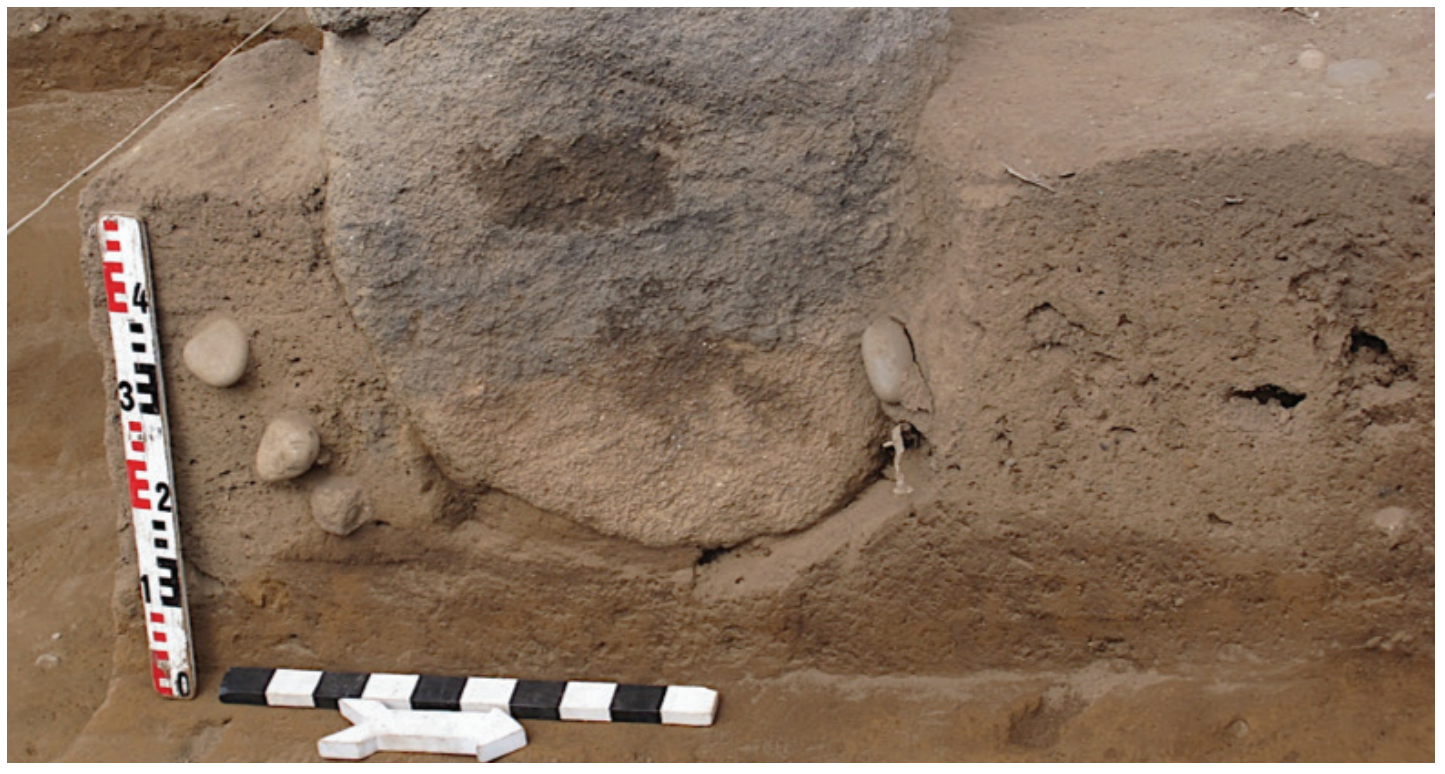

Figura 7 - Escavação da face nascente do monumento onde se pode verificar que a sua vala de fundação se abriu no solo agrícola e foi preenchida com sedimentos desse solo, motivo pelo qual a sua identificação se tornou difícil. 

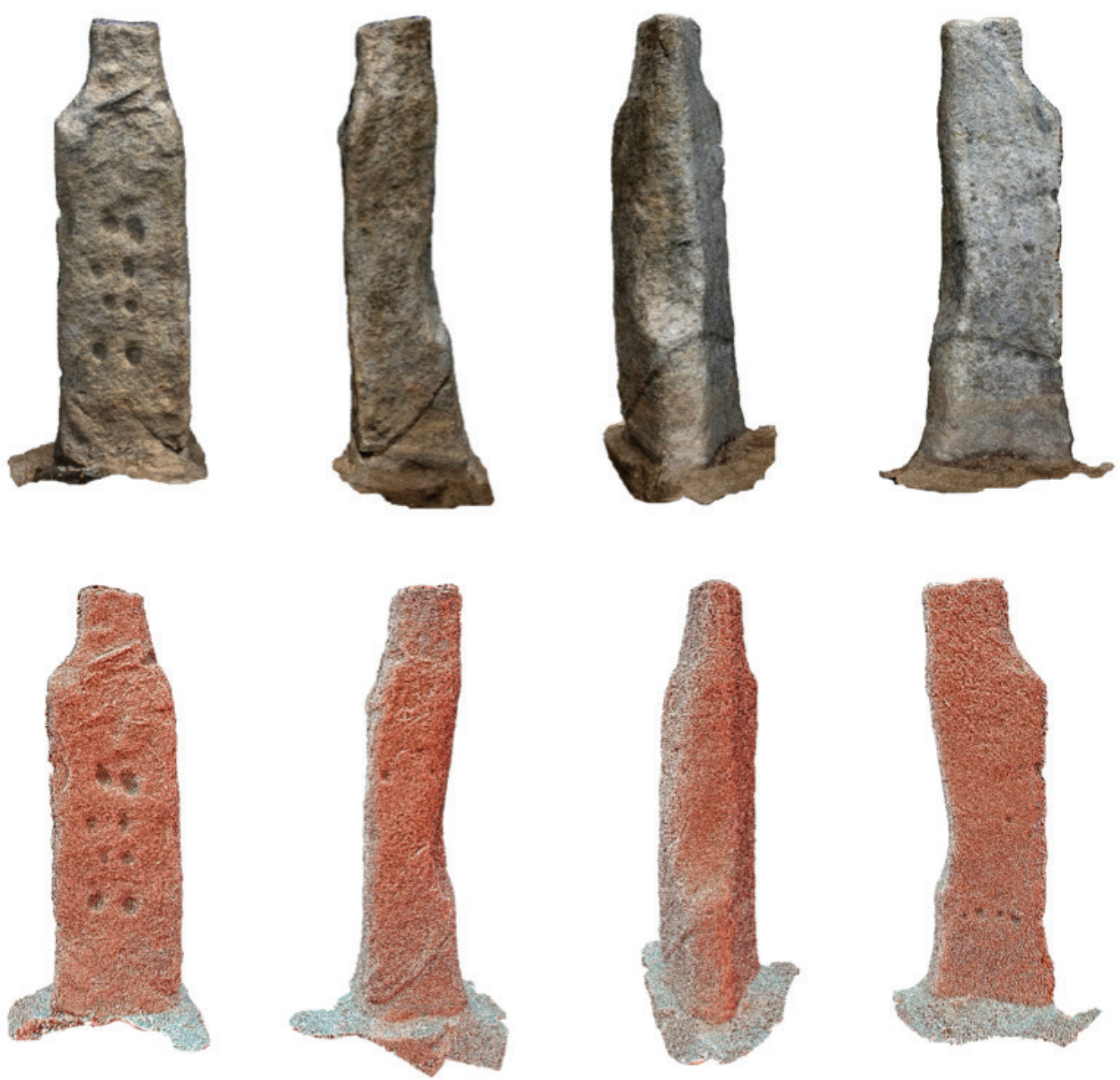

$1 \mathrm{~m}$

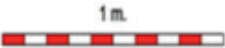

Figura 8 - Levantamento fotogramétrico da estátua-menir do Pedrão com as covinhas sombreadas. 


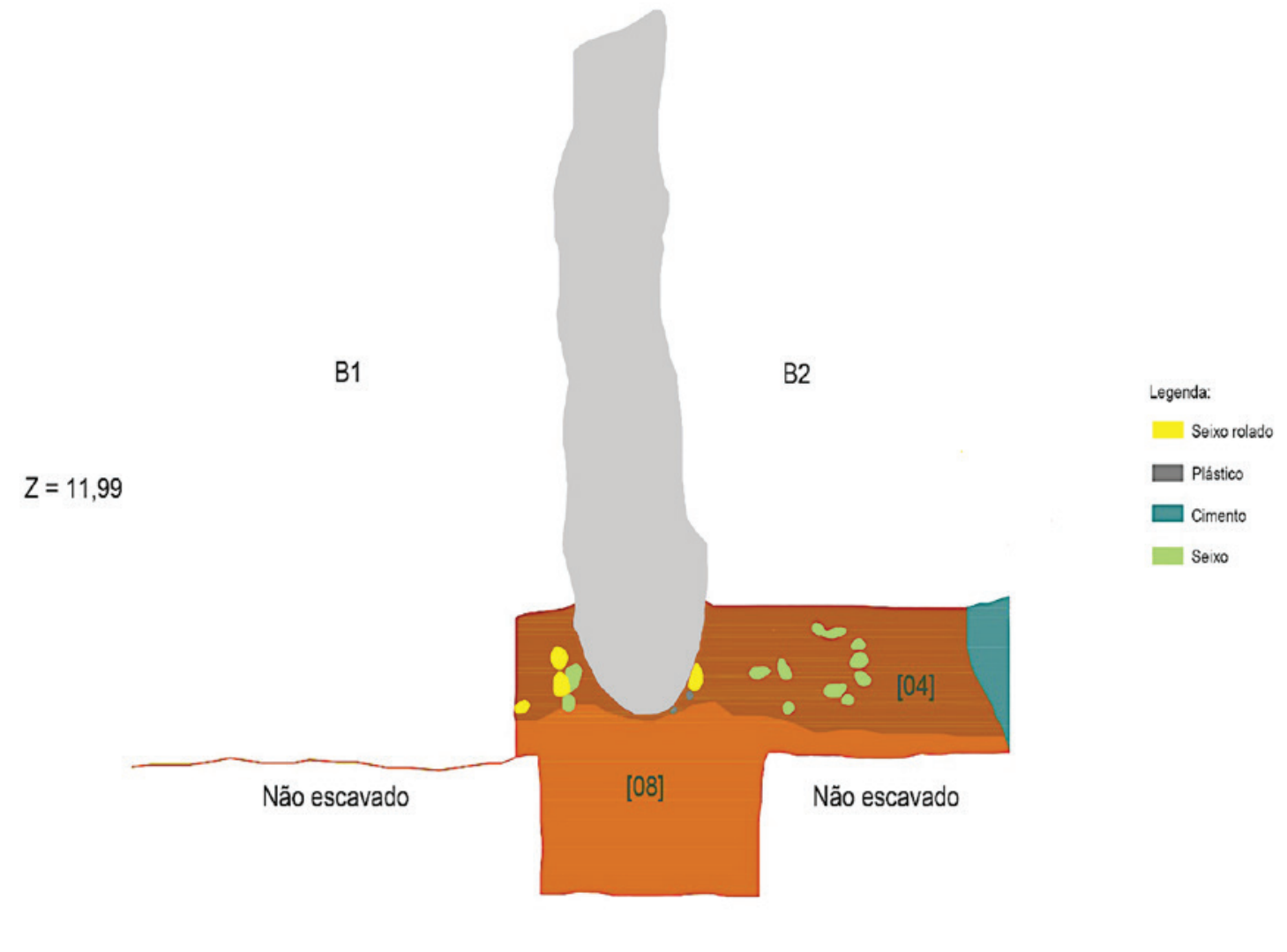

Figura 9- Perfil da estátua-menir no perfil do quadrado B2.

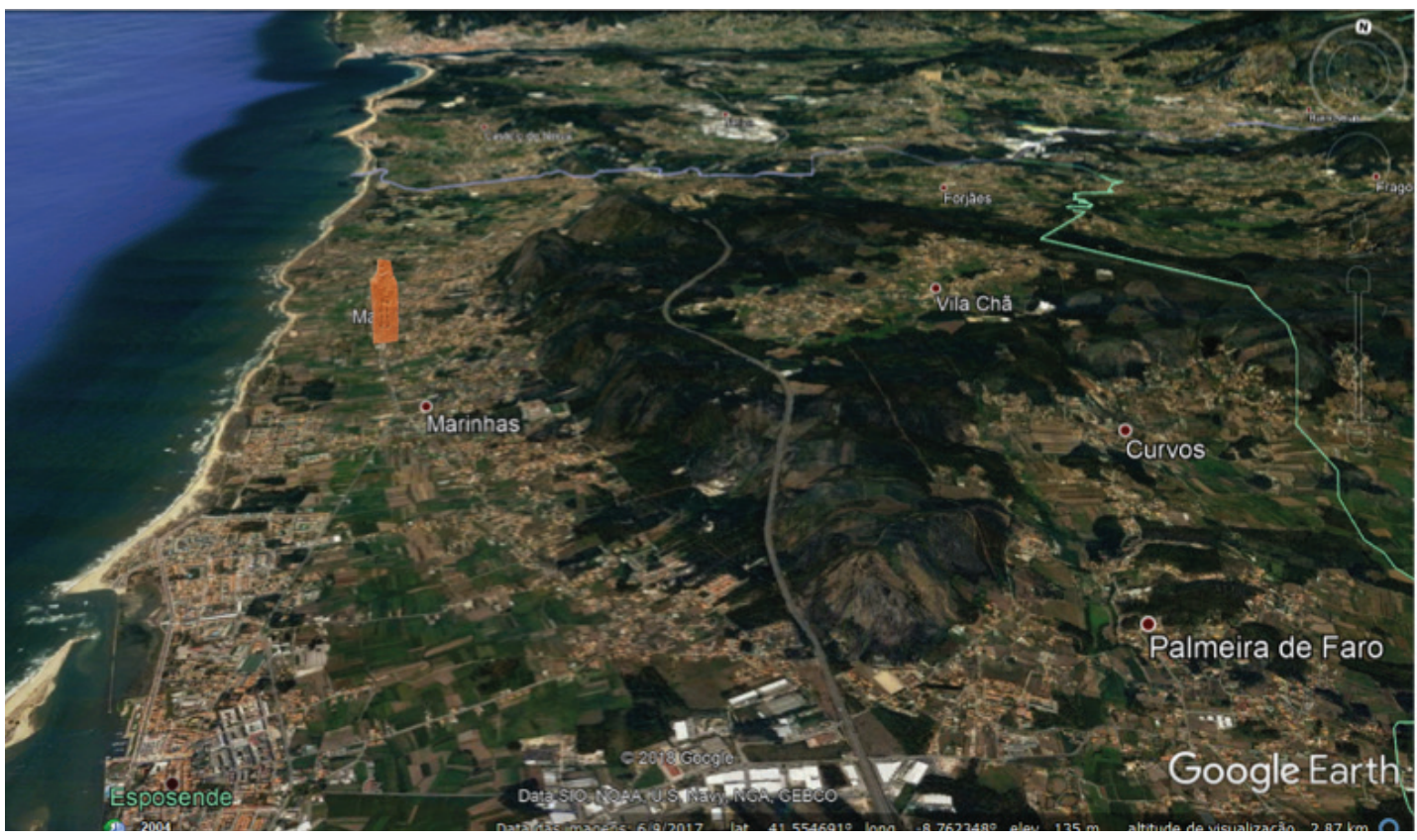

Figura 10 - Estátua - menir no contexto da plataforma litoral entre o rio Cávado, a sul, e os rios Neiva e Lima, este, em último plano, sobre imagem do Google Earth. 


\title{
O CASTRO DO MURO (VANDOMA / BALTAR, PAREDES). NOTAS PARA UMA BIOGRAFIA DE OCUPAÇÃO DA IDADE DO BRONZE À IDADE MÉDIA
}

\author{
Maria Antónia D. Silva ${ }^{1}$, Ana M. S. Bettencourt ${ }^{2}$, António Manuel S. P. Silva ${ }^{3}$, Natália Félix ${ }^{4}$
}

\begin{abstract}
RESUMO
Com o presente trabalho pretende-se fazer uma atualização dos conhecimentos relativos à ocupação humana do "Castro do Muro" desde a Idade do Bronze à Idade Média.

Este local tem significativa tradição na literatura arqueológica pela presença de um imponente circuito muralhado, cuja largura oscila entre 3,5 a 4 metros, e com um perímetro de 3,927 metros, dentro do qual foi edificado um importante povoado que emerge durante a Idade do Bronze Final e se prolonga até à Idade do Ferro Antigo. No local ocorreram, ainda ocupação romana, um provável castelo roqueiro e um mosteiro medieval, como atestam os materiais cerâmicos, líticos e metálicos recolhidos em trabalhos arqueológicos e achados de superfície.
\end{abstract}

Palavras-chave: Norte de Portugal, Paredes, Serra do Muro, Bronze Final, Povoado fortificado.

\begin{abstract}
This work intends to update the knowledge related to the human occupation of "Castro do Muro" from the Bronze Age to the Middle Ages.

This place has a significant tradition in archaeological literature due to the presence of an imposing walled circuit, whose width oscillates between 3.5 to 4 meters and a perimeter of 3.927 meters, within which was built an important settlement that emerged during the Late Bronze Age and extends to the Old Iron Age. There was also a Roman occupation, a probable rock castle and a medieval monastery, as attested by the ceramic, lithic and metallic materials collected in archaeological works and surface findings.

Keywords: Northern Portugal, Paredes, Serra do Muro, Late Bronze Age, Walled settlement.
\end{abstract}

\section{INTRODUÇÃO}

O sítio arqueológico biografado neste texto ocorre na bibliografia com várias designações. Popularizado na década de 1960 como "recinto fortificado de Baltar" "monte ou serra do Muro", ou ainda "de Vandoma" ou "do Facho" (Silva, 1963), foi inventariado como castro do (monte ou serra) do Muro na listagem dos povoados proto-históricos do noroes- te de Portugal (Silva, 1986, p. 85), designação que é a mais conhecida localmente (a par de "serra do Cruzeiro") e que por isso adotámos.

Localiza-se o "castro do Muro", no concelho de Paredes, distrito do Porto, pertencendo a sua maior parte à freguesia de Vandoma e a restante à de Baltar (Figura 1). A elevação onde se situa, com uma altitude máxima de 519 metros, corresponde a um relevo residual que emerge entre as sub-bacias dos rios Sousa

\footnotetext{
1. Arqueóloga. Município de Paredes; arqueologia@cm-paredes.pt

2. Laboratório de Paisagens, Património e Território (Lab2PT); Departamento de História da Universidade do Minho, Braga; anabett@uaum.uminho.pt

3. CITCEM - Universidade do Porto; amspsilva@hotmail.com

4. Geóloga. Município de Paredes; natalia.felix@cm-paredes.pt
} 
e Ferreira, afluentes da margem direita do Douro. Observando a litologia da área onde se implanta esta estação arqueológica na Carta Geológica, à escala 1/500oo (folha 9-D, Penafiel), verifica-se que é constituída, na sua maioria, por granitos porfiroides, de grão grosseiro e duas micas, essencialmente biotíticos, que se apresentam degradados, em resultado da intensa fraturação que os afetou, mostrando tonalidade cinzento-acastanhada, por vezes manchada de negro devido à presença de biotite. Esta rocha revela na região um grão bastante grosseiro e estrutura claramente porfiroide, com os fenocristais (megacristais) de feldspato bem desenvolvidos numa matriz mais fina. Evidencia-se ainda a presença de massas ou filões aplíticos e aplito-pegmatíticos, que preenchem fraturas com orientação NE-SW (Medeiros, Pereira \& Moreira, 1980).

Numa área próxima, verificam-se mineralizações de estanho, ouro e prata que podem ter sido de particular relevância na história da ocupação humana deste relevo. A cerca de dois a três quilómetros para noroeste, ocorrem as minas de estanho da Rebordosa. A cerca de cinco quilómetros para sul, registam-se as mineralizações de ouro de Castromil, associadas a um filão aplítico encaixado no contacto entre o granito porfiroide de duas micas e as rochas metassedimentares (xistos negros) do Silúrico; e na mesma direção, a uma distância de cerca de oito a dez quilómetros, no flanco oriental do Anticlinal de Valongo, surgem mineralizações de chumbo nos "Xistos de Valongo" e importantes jazidas de ouro (muitas vezes com prata e chumbo associados) encaixadas nas alternâncias de quartzitos e xistos do Arenig (Couto, 1993, p. 607).

A formação orográfica da "serra do Muro", de orientação NE-SO, tem uma extensão aproximada de 1900 metros (Figura 2). Caracteriza-se por uma plataforma de terrenos férteis e por declives acentuados, com 519 metros de altitude máxima no vértice geodésico de Vandoma ${ }^{5}$. A sua implantação proporciona que dos pontos mais elevados se possa visibilizar, a $360^{\circ}$, um horizonte de grande alcance, incluindo a orla marítima.

\footnotetext{
5. As coordenadas geográficas de um ponto central são 41.200077/-8.391158 (WGS84). Na base de dados oficial (Portal do Arqueólogo) o sítio arqueológico surge, desnecessariamente, duplicado, com os números de CNS $3505 \mathrm{e}$ 6586 (https://arqueologia.patrimoniocultural.pt/index. php?sid=sitios).
}

Neste local concentram-se vestígios materiais de antropização que remontam, pelo menos, ao Calcolítico, no terceiro milénio antes da nossa era, prolongando-se pela proto-história e períodos históricos subsequentes. A evidência arqueológica mais expressiva, a ponto de servir de designação orográfica, é o largo Muro, construído com largos blocos de granito, que visualmente se impõe em torno da elevação. O sítio foi objeto de trabalhos arqueológicos desde os finais do século passado, sempre em contexto de minimização de impactes, uma vez que se encontra classificado, com a designação de "Castro do Muro de Vandoma", como Imóvel de Interesse Público, desde $1993^{6}$. Registam-se, assim, pequenas sondagens de avaliação dirigidas por técnicos da administração regional do património cultural, em $1990^{7}$, e pelos serviços de arqueologia do Município (Silva, 2006), que não lograram a identificação de quaisquer estruturas ou depósitos arqueológicos. No âmbito de um estudo de impacte ambiental (Pereira, 2006), foram feitas prospeções que conduziram à recolha de materiais, mas a maior parte do espólio conhecido procede de ações de reconhecimento e prospeção realizadas, em várias alturas, pelos serviços municipais de arqueologia ou de achados avulsos, feitos nomeadamente em consequência de incêndios ou revolvimentos do solo ligados a trabalhos de florestação ${ }^{8}$ (Figura 3 ).

\section{AS PRIMEIRAS OCUPAÇÕES HUMANAS}

Não obstante as dificuldades que decorrem da atribuição de cronologias a artefactos arqueológicos provenientes de achados de superfície, sem contexto, podemos situar na pré-história recente as primeiras

\footnotetext{
6. Decreto $.^{\circ} 45 / 93, D R$, 1. ${ }^{-}$Série-B, n. $\stackrel{\circ}{2} 80$, de 30 novembro 1993 .

7. Trabalhos dirigidos por Lino T. Dias e António Baptista Lopes, dos quais não se conhece qualquer relatório ou outra publicação.

8. Trabalhos ilegais, face ao estatuto patrimonial do monte do Muro, mas que certos proprietários, desinformados, levam a cabo sem a devida comunicação prévia às autoridades administrativas. Recentemente (jan. 2019), na sequência de trabalhos de ripagem para plantio de eucaliptos foi recolhida à superfície, na encosta a norte/nordeste do topo do monte, apreciável quantidade de materiais cerâmicos, líticos e metálicos, parte dos quais se noticiam neste trabalho. Agradecemos a Filipe Silva e a Cristiano Teixeira, responsáveis por esta recolha, a cedência para estudo destes materiais.
} 
evidências de antropização deste relevo. Nesse âmbito temporal podemos situar a ocorrência superficial de um pequeno machado em pedra polida, de gume simétrico, medindo cerca de $8,6 \mathrm{~cm}$ de comprimento por 2,6 de secção máxima, ilustrado num estudo de impacte ambiental, sem que seja identificado o local preciso do achado (Pereira, 2006, p. 7). No Museu de Arte Sacra e Arqueologia do Museu do Seminário Maior do Porto encontram-se depositados seis machados em pedra polida, recolhidos por D. Domingos de Pinho Brandão no Castro do Muro, sem que se conheçam o local ou as condições.

Outros materiais recolhidos no Muro apontam, com maior segurança, para um horizonte calcolítico, nomeadamente um braçal de arqueiro e uma ponta de seta de tipo Palmela. O primeiro foi recolhido à superfície, numa plataforma do topo da vertente noroeste, próximo da sondagem arqueológica de 1990 a que fizemos referência ${ }^{9}$; a ponta de tipo Palmela, encontrada recentemente na vertente norte (a 295 $m$ do ponto mais alto), na sequência de movimentações de terras para plantio, pode descrever-se como uma peça de folha sub-ovalada, provavelmente em cobre, com os contornos irregulares por corrosão, mas apresentando o espigão completo; mede 8,5 $\mathrm{cm}$ de comprimento por 2,2 $\mathrm{cm}$ de largura máxima, com $14 \mathrm{~g}$ de peso (Fig.5, $\mathrm{n}^{\circ}{ }^{12}$ ). Estas peças, nomeadamente a ponta de seta, podem indiciar a proximidade de contextos funerários, tendo em conta que são artefactos comuns no âmbito de diferentes práticas sepulcrais deste período no Norte de Portugal, desde reutilizações de monumentos megalíticos, a monumentos de tradição megalítica (Bettencourt, 2013a, pp. 25, 240).

\section{A OCUPAÇÃO DO BRONZE FINAL}

Deixando de lado, por ora, a discussão sobre outras estruturas antigas conservadas no atual recinto do Castro do Muro, importa destacar um acervo de materiais arqueológicos já relativamente significativo e que inclui cerâmicas, metais e líticos, todos provenientes, não é de mais sublinhar, de recolhas de superfície em momentos diversos.

O conjunto cerâmico que, globalmente, inserimos neste horizonte cultural (podendo, provavelmente,

9. O achado foi presenciado por M. A. S., colaboradora voluntária daqueles trabalhos, desconhecendo-se o seu paradeiro atual. avançar para os primeiros séculos da Idade do Ferro), integra cerca de 200 fragmentos, na sua maioria muito pequenos e de difícil caracterização. É composto essencialmente por cerâmica doméstica, de fabrico manual, com pastas arenosas e texturas variáveis, de finas a grosseiras; apresenta coloração que alterna entre os tons castanhos e cinzentos, indiciando cozedura redutora, e observam-se acabamentos alisados, polidos e vassourados.

As dimensões médias dos fragmentos dificultam o reconhecimento de formas, para além de diversos bordos e fundos planos de recipientes e uma asa de rolo, de secção circular. Ainda assim, pudemos identificar uma taça carenada (Figura 4, no 2 ), alguns potes e potinhos/púcaros, formalmente assimiláveis, respetivamente, aos tipos 1, 2, 10 e 12, da tabela de formas de A. Bettencourt (1999, III, pp. 1039ss.; 20oob, pp. 13-20) (Figura 4, no 8-10).

Um dos potes é decorado com uma fiada de impressões no início da pança e no interior do bordo (Figura $4, \mathrm{n}^{\circ} 3$ ); um dos potinhos apresenta no colo e início da pança, uma banda horizontal, incisa, com composição geométrica de linhas retilíneas oblíquas e triangulares (Figura 4, nㅡㄴ). Dois bordos de lábios planos, apresentam impressões na parte superior, com paralelo próximo, por exemplo, em peças do povoado de São Julião, Vila Verde (Bettencourt 200oa, pp. 114, 121) (Figura 4, n⿳⼈) ). Dos fragmentos de recipientes, de forma indeterminada, que exibem decoração (Figura 4, 5-7), destaca-se um, ornamentado por cordões plásticos com incisões oblongas e, em especial, outro fragmento, de pasta mais depurada e melhor acabamento, com decoração grafitada geométrica, de linhas retilíneas, formando losango, correspondendo à olaria tipo Baiões e com um padrão decorativo variante do tipo A1, números 4 e 5 , da tabela de motivos de A. F. Silva (1986, Est. LXV). De um modo geral, este conjunto de materiais cerâmicos encontra paralelos seguros em povoados do Bronze Final do Noroeste de Portugal, datados de entre os séculos X e VIII/VI cal. AC., nomeadamente São Julião (Martins, 1988; Bettencourt, 200oa) e Barbudo, em Vila Verde (Martins, 1989); Santinha, em Amares (Bettencourt, 2001) ou Cabanas, em Braga (Bettencourt, 20oob). Para as cerâmicas de tipo Baiões, melhor conhecidas na Beira Alta, é muito difícil apontar indicadores estilísticos ou cronológicos, já pelo escasso número de fragmentos identificados em Vandoma, já porque os trabalhos mais recentes sobre aquele horizonte olárico, não só 
sublinham a coexistência de vários facies regionais e especificidades locais nos motivos e organizações decorativas, como também não permitem afinar cronologias, dentro de uma longa sequência que se estende entre os séculos XIV e VI a.C. (Reprezas, 2010, pp. 33-5; Senna-Martinez, 2013).

No que respeita aos utensílios líticos - se bem que considerando as dificuldade de datação - devem mencionar-se, além dos machados em pedra polida, de diferentes tamanhos, já citados, fragmentos do que poderão ter sido enxós, goivas ou polidores. A estes artefactos acrescem vários moinhos dormentes, do tipo vaivém, em granito de grão fino, de contorno ovalar, secção plano-convexa e configuração barquiforme (Bettencourt 200oa, pp. 115, 121), apresentando algumas destas mós um visível polimento, resultado de uso intensivo. Destaca-se ainda o aparecimento de um cossoiro liso, feito em rocha xistenta, de contorno subcircular e secção retangular, com orifício descentrado, peça relacionada com a atividade de fiação (Figura 5, nํำ 17).

Mais reveladores serão, porventura, os materiais metálicos provenientes do sítio arqueológico. Além da importante ponta de lança de alvado, em bronze, que recentemente publicámos (Silva \& alii, 2018), achados feitos por moradores locais, fora do recinto do castro, trouxeram ao nosso conhecimento vários objetos (Figura 5) de que aqui damos nota necessariamente sumária:

a) punhal de tipo Porto de Mós, em bronze, de secção biconvexa, com lâmina de faces simétricas, nervura central acentuada, contornada por uma linha incisa longitudinal; apresenta o espigão de fixação do cabo fraturado, com dois orifícios para apreensão. Mede 14,4 cm de comprimento, $2,4 \mathrm{~cm}$ de largura e $0,5 \mathrm{~cm}$ de espessura, pesando $38 \mathrm{~g}$. Apesar de fraturado, encontra-se em relativo bom estado de conservação (Figura $5, \mathrm{n}^{\circ}$ 11);

b) aro fechado, em bronze, maciço, de secção subcircular, medindo $3,6 \mathrm{~cm}$ de diâmetro e o, $2 \mathrm{~cm}$ de espessura, com um peso de $2 \mathrm{~g}$ (Figura 5 , $\mathrm{n}$-15);

c) pendente em bronze, em forma de sanguessuga, de perfil lunular, secção ovalada, com as extremidades adelgaçadas e a parte central acusando desgaste pelo interior. Mede 2,3 $\mathrm{cm}$ de altura, $0,8 \mathrm{~cm}$ de largura e tem $11 \mathrm{~g}$ de peso (Figura 5 , no 13$)$;

d) uma argolinha em ouro, provavelmente de colar; encontra-se amassada, exibindo contorno circular e orifício central com 0,5 cm de diâmetro (Figura 5, no 16 );

e) fragmento de escória de fundição, ainda não analisado, com oxidação superficial em tons de verde.

f) fragmento de fíbula, em bronze, de tipo Acebuchal/Ponte 9. Este objeto caracteriza-se por um aro de fita, com corrosão nas extremidades, decorado com finas caneluras longitudinais no dorso. Mede 3,1 cm de comprimento, tem $1,1 \mathrm{~cm}$ de largura máxima, $0,2 \mathrm{~cm}$ de espessura e $2 \mathrm{~g}$ de peso (Fig.5, nํㅜㄴ).

Em breve comentário, destacamos o punhal tipo Porto de Mós e a sanguessuga. Os punhais deste tipo, de expressão suprarregional, ocorrem em vários locais (Silva, 2007, pp. 254-5), com uma cronologia maioritária dentro do último quartel do segundo milénio a.C. ou um pouco posterior. Tal sucede, em particular, na região centro, com os exemplares dos povoados de Monte do Frade, Penamacor, datado de entre os séculos XIII e X cal. AC (Vilaça, 1995, p. 141; 2008, p. 140) ou da Moreirinha, Idanha-a-Nova, datados de entre os séculos XIII ao IX cal. AC (Vilaça, 1995, p. 2271; 2008, pp. 138-9). Já no Sudoeste peninsular, recorde-se a sua presença no suposto depósito da Ria de Huelva, datado de entre os séculos XII e IX cal. AC (Almagro-Gorbea, 1977; Ruiz-Gálvez Priego, 1995). Um pouco mais recentes poderão ser o contexto das peças de S. Julião, Vila Verde, enquadrado no séc. IX AC (Martins, 1988,est. XXVIII); a cronologia dos objetos do Perrinho, Vale de Cambra, datados entre os sécs X e IX (Coffyn, 1983; 1985; Bottaini \& Rodrigues, 2011) e, ainda mais avançado, o de Torroso (Mós, Pontevedra), situado entre o séc. VIII e o séc. VI cal. AC (Peña Santos, 1992). As sanguessugas, talvez um pouco mais raras e parecendo ocorrer essencialmente no Cento-Norte e Norte da Península Ibérica, apresentam, nos contextos datados, cronologias igualmente amplas e similares às dos punhais, podendo elencar-se, entre outros e como exemplo das datações mais díspares, as peças do depósito de San Esteban del rio Sil, Ourense, datado de entre os meados do século XIII a inícios do IX cal. AC (Coffyn, 1985, pp. 201-2; Rovira, 1995, p. 52; Ruiz-Gálvez Priego, 1995, pp. 81-2; Ferrer $\mathbb{8}$ alii, 1997, pp. 73-4); do povoado de Torroso, Pontevedra, com início no séc. VIII e término entre o VII e VI cal. AC (Peña Santos, 1988; 1992), ou do Coto da Pena, Caminha, povoado de cronologia mais antiga 
mas onde estas peças são datadas entre 700 e 500 a.C. (Silva, 2007, p. 266).

A fíbula de tipo Acebuchal emerge, igualmente, nos finais do Bronze Final do norte de Portugal, com ocorrências no Coto da Pena, Caminha (Silva, 1986) ena Fraga dos Corvos, Macedo de Cavaleiros (Senna-Martínez, 2013). Ponte (2006, pp. 135-44), coloca-as entre os séculos VIII e VI a.C, datas que Bettencourt (2005) considera corresponderem ao término desse período na região.

Este conjunto de elementos sugere que a comunidade que aqui se instalou durante o Bronze Final, praticando a agricultura (como se infere pela abundância de moinhos) e provavelmente a metalurgia (atendendo à presença de escórias), pode ter tido nas atividades de extração e controlo da circulação do metal, razão substancial para a escolha deste local. Admitindo esta possibilidade, e a eventual afirmação e maior visibilidade do sítio em função desta especialização, tal poderia ajudar a explicar o intercâmbio suprarregional comprovado pela cerâmica de tipo Baiões e de artefactos de ampla expressão geográfica, como os punhais de tipo Porto de Mós.

É ainda provável que a pressão fenícia no litoral, a partir do séc. IX cal. AC, tenha potenciado a necessidade de ostentação de poder e de capacidade de defesa por parte de algumas populações com controlo de recursos importantes. Assim, o processo de delimitação física ou amuralhamento correspondente a este período de ocupação ${ }^{10}$ poderá associar-se a processos assimétricos de expressão de identidade e poder (Bettencourt, 2013 b), nesse caso de um locus com eventual controlo de recursos mineiros (ouro, estanho, chumbo), da sua manufatura (atestada pela existência de escórias) e das vias fluviais de intercâmbio regional. Por fim, o depósito de uma ponta de lança na Gralheira, Baltar, a meio da vertente este deste importante monte, a 250 metros em linha reta da muralha do povoado (Silva $\&$ alii, 2018), é concorde com a hipótese, defendida por R. Vilaça (2007, pp. 42-6), de que estes depósitos poderiam assinalar as fronteiras destes locais excecionais.

10. Que, globalmente, não relacionamos com a totalidade do circuito fortificado visível - como adiante se verá - mas admitimos que possa coincidir em alguns tramos; podendo, pelo contrário, corresponder aos taludes visíveis noutros pontos do monte, questão que só uma escavação poderá esclarecer.

\section{OCUPAÇÃO DA IDADE DO FERRO}

Ocorrem no Muro alguns fragmentos de cerâmica, de fabrico manual, com cozeduras redutoras e pastas argilosas com e.n.p. de moscovite mal calibrada, que podem sugerir a continuidade da ocupação deste local, pelo menos, ao longo dos inícios da Idade do Ferro, momento em que este tipo de pastas ocorre em S. Julião (Bettencourt, 200oa, pp. 124-5). Por outro lado, a presença de cerâmica com decorações plásticas, sob a forma de cordões com impressões como também ocorrem no Muro - é assinalada com frequência neste período, nos primórdios da Idade do Ferro Antiga ou em momento mais avançado (Bettencourt, 2005, p. 26).

Pode ser ainda enquadrada na Idade do Ferro a descoberta de um fragmento arquitetónico decorado, em granito de grão fino, classificado como parte de um tríscele por Calo Lourido (1994, pp. 626-8). Embora a atribuição desta peça (presentemente conservada nos Serviços de Arqueologia do Município de Paredes) ao Castro do Muro seja genérica e não se conheça o local ou as condições do achado, a sua importância advém de apontar para uma cronologia significativamente mais avançada dentro da Idade do Ferro, compatível com um castro ou citânia romanizados de que, aparentemente, não se descortinam vestígios naquele sítio.

Almeida viu no Muro "um antigo castro com muralhas de terra, ainda hoje bem visíveis no lado Norte" (1980, p. 16), sendo a sua tipificação como "castro" do Ferro partilhada por outros autores (Silva, 1986, p. 85; Calo, 1994, p. 627; Queiroga, 2003, pp. 16970). A escassez de informação não permite considerações mais detalhadas sobre o povoado nesta fase; todavia, A. C. Ferreira da Silva, em análise de âmbito regional (Silva, 2000; 2007; 2011; 2013), tem lançado interessantes pistas interpretativas sobre o Muro, que nos limitaremos a elencar, pois a sua discussão ultrapassa este texto.

Este investigador começou por enquadrar o castro de Vandoma na organização territorial dos Callaeci pré-romanos, propondo que poderia ter sido um povoado especializado na exploração mineira, sendo Cale (Porto) o port of trade comercial e a Citânia de Sanfins (Paços de Ferreira), centro agro-pecuário e, simultaneamente, o povoado dotado de capitalidade política (Silva, 2000, pp. 100-1). Na mesma perspetiva, o Muro teria sido um "lugar central", 
avançando-se até a possibilidade de ter disposto de um balneário (Silva, 2007, pp. 25, 137).

Mais recentemente, o mesmo autor privilegiou a pesquisa étnico-linguística, tendo como referente os mitos e tradições de origem indoeuropeia do mundo celta. Armando Coelho propôs, assim, uma distribuição territorial dos povos indígenas pré-romanos do curso terminal do Douro numa "quadripartição em cinco secções" (os Danigom a sudeste; Calaicos a sudoeste; Madequisenses a noroeste e Fidueneas, a nordeste), sendo Bandoma, sensivelmente no centro geográfico destes populi, o seu centro religioso, significando aquele topónimo, originalmente, "casa de deus" e a divindade equiparada a Calaecia (Silva, 2011, p. 22). Com esta tese, assente em paralelos étnicos e históricos da Irlanda, Armando Coelho avança até para a interpretação de um grande cruciforme gravado num afloramento próximo do castro como hipotética representação simbólica daquela distribuição de povos (Silva, 2013, p. 45).

\section{5. ÉPOCA ROMANA}

A ocupação do Muro durante a época romana, ou na tardo-antiguidade, intui-se pelo frequente achado de fragmentos de material de construção, designadamente tegulae e imbrices, que ocorrem em particular na parte nascente e na vertente sudeste do castro, no interior do recinto murado. Como é habitual, em especial em contextos tardios, estes materiais cerâmicos exibem pastas, coloração e cozedura muito diversas, bem como tipologias distintas, pela variedade da forma do rebordo e da espessura. A par destes materiais, encontrou-se um peso de tear, em barro, de configuração paralelepipédica, com vestígios de decoração, ou marca, em relevo, numa das faces, tendo $10,5 \mathrm{~cm}$ de altura por $6,5 \mathrm{~cm}$ de largura. Uma epígrafe latina, hoje desaparecida, é dada como proveniente do castro. Trata-se de uma provável ara, dedicada por um habitante local a Nabiae (CIL, II, nº 2378; Vasconcelos, 1905, p. 277), uma divindade lusitano-galaica relacionada talvez com os vales e as zonas húmidas (Redentor, 2017, I, pp. 6o3-8; II, pp. 36-7).

Na envolvência próxima do Muro conhecem-se outros sítios de época romana, como uma necrópole localizada a meio da sua vertente oeste (Silva, 1992), e outras duas situadas no sopé da vertente sul, já na freguesia de Baltar, estas datadas do século III (Soeiro, 1988-89). Por outro lado, sublinhe-se, o Muro posiciona-se geograficamente numa importante relação com as vias de circulação terrestre que estabeleciam ligação do litoral para o interior, entre Cale e Tongobriga, bem como, em direção ao Douro, passando por Castromil e Banjas, áreas de intensa exploração de ouro, em época romana (Silva \& Félix, 2008; Lima \& alii, 2011).

\section{DA IDADE MÉDIA AOS TEMPOS MODERNOS}

O Muro de Vandoma é identificado num documento do ano de 985 como mons Bendoma ${ }^{11}$ designação que se repete em muitos documentos dos séculos XI e XII, por vezes com variantes como Benidoma (em 1077, 1102, etc.) ou Bendome, em 1168 (Mariani, 202ob, pp. 210-2; 739-41). O referente geográfico "subtus mons", utilizado na diplomática medieval para a localização de propriedades, é considerado como alusão a um centro de poder político-militar, genericamente, um castelo, independentemente da sua arquitetura (Almeida, 1978, pp. 25-7; 1992, pp. 372-3; Barroca, 2004, p. 189; 2017, pp. 204-6), se bem que esta interpretação mereça discussão (Lima, 1993, pp. 18-9; 2004, pp. 320-3; Marques, 2008, pp. 147-51; Mariani, 2020a; 202ob, pp. 621-4). Todavia, documentos datados de 1071 e 1110 explicitam a natureza fortificada da mesma elevação com o apelativo Castro Bendoma (Mariani, 202ob, pp. 739-40). Todos estes autores não duvidam, porém, em qualificar a Vandoma como um castelo. Até ao terceiro quartel do século XI, estava inserido no território de Anegia, e terá desempenhado um papel fundamental no "encastelamento", para defesa do território e refúgio das populações, servindo ainda a defesa do mosteiro de Cete (Almeida, 1980; Lima, 2008, p. 187). Para além do extenso muro perimetral que caracteriza o sítio, poderão constituir indícios materiais da fortificação alguns cortes de aparência retangular, e várias cavidades de configuração circular, visíveis no conjunto de afloramentos graníticos existente no topo, que poderão ter servido para encaixe ou assentamento de estruturas de madeira. Num destes penedos identificámos gravado um pequeno cruciforme. Vários estudiosos interpretam o Muro como um castro da Idade do Ferro que foi reutilizado, como fortificação, na Alta Idade Média (Al-

11. Portugalia Monumenta Historica. Diplomata et Chartae, no 146 . 
meida, 1980; Calo, 1994, II, p. 627; Mariani, 2020b, pp. 211-2), e este último considera mesmo a hipótese do seu abandono em finais do século $\mathrm{X}$, entendendo que as referências documentais posteriores, mormente as que o designam como castro, poderiam refletir meras memórias evocativas da sua imponente muralha (Mariani, ibidem).

Em data talvez anterior a 1173 (Backmund, 1959, p. 421) ter-se-á fundado no interior da muralha de Vandoma o eremitério de Santa Eulália de Bendoma, que em finais desse século terá passado à disciplina premonstratense (Mattoso, 2002, pp. 52, 130). A história e a regra deste pequeno cenóbio são obscuras (Backmund, 1959), mas terá recebido carta de couto de D. Afonso Henriques, como testemunham as Inquirições de 1258 (PMH - Inq., p. 573; Mattoso, 2006, p. 91), e foi contemplado no testamento do bispo do Porto, D. Fernando Martins, em 1186 (Censual, 1924, p. 388), tendo estado ativo, aparentemente, até 1570 (Mattoso, 2002, p. 130). Toponimicamente, o termo Couto permaneceu em uso muito tempo para designar a parte mais alta da freguesia de Vandoma, que correspondia a todos os lugares à volta da "Serra do Muro", perpetuando a terra privilegiada do mosteiro de Vandoma (Barreiro, 1922, p. 533).

Vestígios arqueológicos do Mosteiro de Vandoma, conservam-se na chã planáltica de Passais, um pequeno lugar com algumas habitações junto a terrenos férteis, onde um vetusto cruzeiro assinala o local do antigo templo. A tradição oral relata o aparecimento de sepulturas e ossadas nas proximidades (Barreiro, 1922, p. 543) e Ferreira de Almeida identificou ali "restos de túmulos medievais", uma cabeceira de sepultura e vestígios arquitetónicos da antiga igreja, designadamente duas aduelas de arco, que desenhou, propondo que pudessem corresponder a um edifício "em românico tardio, da segunda parte do século XIII” (Almeida, 1980, p. 16).

Uma sondagem arqueológica de minimização do impacte de uma obra de construção neste lugar, dirigida por um dos signatários (M.A.S.) em 2006, não identificou vestígios arqueológicos (Silva, 2006), mas em trabalhos de reconhecimento feitos pelos serviços municipais de arqueologia recolheu-se a cabeceira noticiada por aquele investigador, uma peça em granito, de configuração circular, com $57 \mathrm{~cm}$ de altura por $35 \mathrm{~cm}$ de largura, com uma cruz gravada numa das faces e tendo na outra marcas arqueadas, esculpidas em relevo, de difícil interpretação devido ao desgaste ${ }^{12}$. Acautelou-se, ainda, uma outra pedra lavrada, de configuração oblonga, decorada no topo com dois círculos concêntricos esculpidos, cuja face decorada mede $20 \times 16 \mathrm{~cm}$ e foi também identificado um sarcófago monolítico, servindo atualmente como floreira, porventura correspondendo aos túmulos observados há quarenta anos (Figura 6).

O monte do Muro é serpenteado por vários caminhos, abertos ao longo dos tempos para serventia dos proprietários, designadamente para acesso a matos e lenha. Não é fácil situar no tempo a abertura desses caminhos, alguns de calçada lajeada e atualmente abandonados, destacando-se um troço de calçada na vertente sul e outro do lado nascente, que passa junto a uma grande cruz gravada no afloramento rochoso.

No ano de 1940, a população da freguesia de Baltar construiu um "Cruzeiro da Independência", inserido no Plano Nacional dos Centenários, tendo sido argumentado em reunião de Câmara, como justificação para a iniciativa, que o local "possue as ruínas do antigo castelo da mouraria e foi teatro do grande heroísmo cristão no principio da nossa nacionalidade" e é o ponto mais alto do concelho, com horizontes vastíssimos que se estendem até ao mar (ata de 30.4.1940, apud Silva, 2009). A base deste cruzeiro, voltado para Baltar, assenta, infelizmente, sobre o lado sul da muralha, circunstância que, naturalmente, não foi valorizada na altura, mas é curioso registar que desde então, no espaço de menos de duas gerações, aquele relevo passou também a ser conhecido como Serra ou Monte do Cruzeiro, o que é ilustrativo das dinâmicas microtoponímicas.

\section{A MURALHA DO MONTE DO MURO}

Se bem que um número crescente de elementos arqueológicos permita já uma primeira aproximação à biografia deste sítio arqueológico, como pode apreciar-se do exposto, a extensa linha fortificada que o caracteriza é o seu maior referente e justifica discussão própria. A muralha desenvolve-se num circuito irregular, ajustando-se ao terreno, à cota média de $450 \mathrm{~m}$. Tem um perímetro de $3927 \mathrm{~m}$ e delimita uma superfície de $62 \mathrm{ha}^{13}$ (Fig. 2), área murada para

\footnotetext{
12. Peça que nos foi gentilmente cedida por António Sousa, o que cumpre agradecer.

13. Levantamento topográfico realizado pelo Município de Paredes no ano de 2000.
} 
a qual não encontramos paralelo, designadamente nos recintos proto-históricos do noroeste. $\mathrm{O}$ aro fortificado envolve uma elevação de maior altitude, identificada como Facho, e a plataforma de terrenos agrícolas do lugar de Passais, onde esteve o mosteiro medieval.

Embora se detetem tramos com diferenças construtivas (e provavelmente distintas cronologias), a muralha corresponde, no geral, a uma estrutura de dupla face, constituída pela acumulação, a seco, de blocos graníticos de grandes dimensões, sendo o miolo preenchido por sedimentos arenosos e calhaus (Figura 7). A largura do muro oscila entre 3,5 a 4 m de largura, observando-se do lado sul, saliências ou reforços exteriores, retangulares, com 0,40 $\mathrm{m}$ de espessura por cerca de $5 \mathrm{~m}$ de comprimento. Encontrando-se menos visível em alguns panos, a estrutura encontra-se conservada, em alguns troços, com um alçado que ronda os $2 \mathrm{~m}$.

Referenciada já em 1758 pelos vestígios e alicerces de uma muralha com dezasseis palmos de largo (Capela, 2009, p. 508) mencionada por Pinho Leal (1873, p. 315) como uma estrutura fechada, "à roda de todo o monte", as origens e a cronologia desta fortificação não suscitaram qualquer contributo relevante ao longo da maior parte do século XX, para além da vaga tradição etnográfica que atribuía aos "mouros" a sua edificação (Barreiro, 1922, p. 228). Este autor, aliás, relaciona mesmo, hipoteticamente, com a construção da fortaleza a informação de um habitante local, segundo a qual, "ao pé da muralha arqueológica de Vandoma apareceu há muitos anos um marrão de aço, que pesa dez kilos (...) e um pico, já rombo" (Barreiro, 1924, p. 696).

Como se disse, a popularização do Castro do Muro na literatura arqueológica deve-se inicialmente a José da Silva (1963 e 1966). No primeiro texto aquele autor designa-o como "recinto fortificado" de Baltar (decorrente do sector pelo qual acedeu ao monte), destaca a ampla visibilidade que dele se obtém para uma vastíssima região envolvente (1963, p. 129) e assinala também a sua importância como referente geográfico na documentação medieval. Descreve com precisão a estrutura da muralha, que mede em $4300 \mathrm{~m}$ de perímetro, assinalando no seu interior "muralhas secundárias, a pouca distância da principal" e "vestígios de construções retangulares", para além de um caminho de acesso que penetrava no interior do recinto e outras "muralhas secundárias" no exterior, por vezes articuladas com afloramentos rochosos, sugerindo uma espécie de "fortins" (1963, pp. 128-9).

Voltando ao assunto, J. Silva acrescenta outros dados de interesse sobre a Vandoma, nomeadamente acerca das referidas "construções dispersas de planta retangular”, normalmente de um só compartimento e com áreas variáveis entre os $24 \mathrm{e}$ os $84 \mathrm{~m}^{2}$ (Silva, 1966, p. 521); e a propósito de um determinado trecho da muralha, no qual, diferentemente dos restantes, observou um "muro encostado ao terreno, de uma só cara, como os socalcos que marginam tantos campos do Minho" (1966, p. 528). Acaba mesmo por elaborar uma tipologia de muralhas, por comparação com sítios que entende como análogos (Idem, pp. 528-9).

Passadas seis décadas destas observações, é difícil repetir o percurso e as impressões deste autor, tanto mais que a florestação, a exploração de pedra e outras ações alteraram a superfície do monte, mas reconhecem-se, nomeadamente no lado norte do monte do Facho, indícios de taludes defensivos e alguns vestígios das "construções retangulares" apontadas por J. Silva, evidências que requerem trabalhos de limpeza e levantamento que ainda não houve ocasião de promover.

Por outro lado, um dos aspetos em que os trabalhos de J. Silva foram pioneiros foi precisamente o de identificar um conjunto de recintos fortificados do norte do país com algumas semelhanças entre si, como circuitos de grande extensão, situados, normalmente, em pontos de passagem ou de grande dominância visual e não apresentarem, habitualmente, características ou achados que permitam enquadra-los nos grandes castros ou citânias da Idade do Ferro do noroeste (Silva, 1963; 1966). Não obstante reconhecer que em Vandoma, como nos outros sítios que lhe aparenta, não "se encontrarem os conhecidos vestígios típicos dos castros" e que "a importância do mons Benidoma residia apenas na função atribuída ao singular conjunto das suas muralhas" (Silva, 1963, p. 127), o autor atribui a construção destas fortificações à Idade do Ferro, como "redutos de recurso" regionais, ou "capitais militares de uma tribo" (Idem, p. 133), questionando-se mesmo se o recinto de Baltar não teria sido "o centro defensivo dos Calaicos e a base da sua resistência aos Romanos" (Silva, 1966, p. 524), admitindo, todavia, a sua reutilização posterior como fortificação medieval (Idem, p. 525).

A classificação do Muro de Vandoma como "recinto 
defensivo" encontra eco em Ferreira de Almeida, o qual, admitindo uma ocupação castreja prévia, entendia que a muralha (em cujo miolo encontrou um fragmento de tegula tardia) "tem todo o aspecto de alti-medieval", sendo porventura uma "muralha de tipo barragem", destinada a controlar a passagem na portela de Baltar e a servir de local refúgio das populações em tempos de guerra (1980, pp. 16-7), exemplificando assim um tipo de fortificações anteriores ao século XI com paralelos no ocidente europeu (Almeida, 1992, p. 375). Não é este o local para discutir o tema, que conta com importantes contributos recentes, na mesma linha interpretativa, quer para o norte de Portugal (Lima, 2008, p. 187; 2013, p. 191; Mariani, 2020b, pp. 210-2), quer para a Galiza (Sánchez Pardo, 2012).

Por fim, a coincidência de se encontrarem reunidos no monte do Muro os microtopónimos Penedo das Audiências (Almeida, 198o, p. 17), convocando, de certa forma, a memória de estruturas de poder e de articulação sociopolítica; e Facho, remetendo seguramente para estruturas de comunicação de carácter militar (Lima, 1993, pp. 224-7; Sanchez Pardo, 2014) acentua este horizonte de ocupação tardo-antigo ou altimedieval, sem prejuízo das documentadas ocupações anteriores.

$\mathrm{Na}$ verdade, ainda que as modalidades de ocupação do sítio durante o Bronze Final e a Idade do Ferro nos sejam ainda desconhecidas, parece plausível a existência de estruturas de delimitação, fossem essencialmente em terra, como sugeriu Ferreira de Almeida, fossem já petrificadas. Mas a tal informação só poderá chegar-se, como também advertiu o mesmo investigador, com levantamentos e análises mais minuciosas e, designadamente, com sondagens arqueológicas em áreas estratégicas para o efeito.

\section{NOTA FINAL}

Com este ensaio de revisão historiográfica e notícia de achados arqueológicos relevantes - traduzidos por um primeiro esboço da biografia do sítio nas suas dinâmicas temporais e multifuncionais - quisemos recolocar na agenda de investigação uma estação arqueológica de enorme potencial para o estudo do povoamento, ao longo de milénios, a uma escala regional e suprarregional, tal como o sugerem os artefactos e estruturas elencados e a opinião dos estudiosos que sobre ela se pronunciaram.

Do ponto de vista patrimonial, constitui igualmen- te o Muro de Vandoma e Baltar um recurso potencial e expectante, nem sempre tão salvaguardado como deveria, pese embora o seu estatuto de imóvel arqueológico classificado. Na verdade, melhor se protege o que melhor se conhece; e o Castro do Muro aguarda que um programa de investigação, planeado e sustentado, ilumine os seus muitos segredos e o acorde do silêncio da terra e das penedias para lhe garantir, como justifica, lugar de maior destaque na história e no património cultural dos nossos tempos e das gerações futuras.

\section{BIBLIOGRAFIA}

ALMAGRO-GORBEA, Martin (1977) - El bronce final y el período orientalizante en Extremadura. Madrid: Consejo Superior de Investigaciones Científicas.

ALMEIDA, Carlos A. Ferreira (1978) - Castelologia medieval de Entre-Douro-e-Minho. Desde as origens a 1220. Dissertação complementar de doutoramento apresentada à Fac. de Letras da Universidade do Porto.

ALMEIDA, Carlos A. Ferreira (1980) - Os castelos de Aguiar de Sousa e de Vandoma/Baltar. O Concelho de Paredes Boletim municipal, 3. Paredes, p. 15-17.

ALMEIDA, Carlos A. Ferreira (1992) - Castelos medievais do Noroeste de Portugal. In Finis Terrae. Estudios en lembranza do Prof. Dr. Alberto Balil. Santiago de Compostela: Univ. Santiago, p. 371-85

BACKMUND, Norbert (1959) - Les origines de l'Ordre de Prémontré au Portugal. Boletim Cultural da Câmara Municipal do Porto, 22 (3-4). Porto, p. 416-41.

BARREIRO, José do (1922) - Monografia de Paredes. Porto: Tipografia de Laura Couto \& Pinto.

BARREIRO, José do (1924) - Monografia de Paredes. Vol. 2. Correções e acrescentos. Porto: Tipografia de Laura Couto \& Pinto.

BARROCA, Mário J. (2004) - Fortificações e Povoamento no Norte de Portugal (Séc. IX a XI). Portugalia. Nova Série. 25. Porto, p. 181-203.

BARROCA, Mário J. (2017) - Prope litore maris. O sistema defensivo da orla litoral da Diocese do Porto (Séc. IX a XII). In: AMARAL, Luis C. (coord) - Um poder entre poderes. Nos 9 oo anos da restauração da Diocese do Porto e da construção do Cabido Portucalense. Porto: Cabido Portucalense; Universidade Católica Portuguesa, p. 199-243.

BETTENCOURT, Ana M. S. (1999) - A Paisagem e o Homem na bacia do Cávado durante o II e o I milénios AC. Tese de Doutoramento apresentada à Universidade do Minho, 5 vols.

BETTENCOURT, Ana M. S. (20ooa) - O povoado de S. Julião, Vila Verde, Norte de Portugal, na Idade do Bronze e na 
Transição para a Idade do Ferro, Cadernos de Arqueologia - Monografias 10. Braga: Unidade de Arqueologia da Universidade do Minho.

BETTENCOURT, Ana M. S. (20oob) - Estações da Idade do Bronze e Inícios da Idade do Ferro da bacia do Cávado (Norte de Portugal), Cadernos de Arqueologia - Monografias 11. Braga: Unidade de Arqueologia da Universidade do Minho.

BETTENCOURT, Ana M. S. (2001) - O povoado da Santinha, Amares, Norte de Portugal, nos finais da Idade do Bronze. Cadernos de Arqueologia - Monografias 12. Braga: Unidade de Arqueologia da Universidade do Minho.

BETTENCOURT, Ana M. S. (2005) - O que aconteceu às populações do Bronze Final do Noroeste de Portugal, no segundo quartel do I milénio AC, e quando começou, afinal, a Idade do Ferro? Actas Colóquio Internacional. Castro, um lugar para habitar, Cadernos do Museu 11. Penafiel: Câmara Municipal: 25-40.

BETTENCOURT, Ana M. S. (2013a) - A Pré-história do Noroeste de Portugal /The Prehistory of North-western Portugal. [Oosterbeek, Luiz, dir. - Territórios da Pré-História em Portugal, 2]. Tomar; Braga: CEIPHAR; CITCEM.

BETTENCOURT, Ana M. S. (2013b) - O Bronze Final no Noroeste português. Uma rede complexa de lugares, memórias e ações. Estudos Arqueológicos de Oeiras 20: 157-172.

BOTTAINI, Carlo; RODRIGUES, Alexandre (2011) - O conjunto de metais da Idade do Bronze de Vila Cova de Perrinho (Vale de Cambra, Portugal central) 50 anos após a sua descoberta. Estrat Critic. Revista d'Arqueologia, 5 (3), Bellaterra, p. 103-14.

CALO LOURIDO, Francisco (1994) - A Plástica da Cultura Castrexa Galego-Portuguesa. La Coruña: Fundación Pedro Barrié de la Maza, 2 tomos.

CAPELA, José V.; MATOS, Henrique; BORRALHEIRO, Rogério (2009) - As Freguesias do Distrito do Porto nas Memórias Paroquiais de 1758: Memórias, História e Património. [Colecção Portugal nas Memórias Paroquiais de 1758, 5]. Braga. Censual do Cabido da Sé do Porto... (1924). Porto: Imprensa Portuguesa.

CIL: Corpus Inscriptionum Latinarum. Vol. II: Inscriptiones Hispaniae Latinae. Berlim, 1869.

COFFYN, André (1983) - La fin de l’Âge du Bronze dans le centre-Portugal. O Arqueólogo Português, $4^{\underline{a}}$ série, 1. Lisboa, p. $169-96$.

COFFYN, André (1985) - Le Bronze Final Atlantique dans la Péninsule Ibérique. Paris: Diffusion de Boccard.

COUTO, Helena (1993) - As mineralizações de Sb-Au da região Durico-Beirã. Tese de Doutoramento apresentada à Faculdade de Ciências da Universidade do Porto.

FERRER ALBELDA, Eduardo; GARCÍA FERNÁNDEZ, F.; GONZALEZ ACUÑA, D.; MUÑOZ GARCÍA, E.; MORO
BERRAQUERO, F. (1997) - Dos notas sobre el depósito de la ría de Huelva. Spal, 6. Sevilha, p. 67-85. http://dx.doi. org/10.12795/spal.1997.i6.05

LEAL, Augusto S. A. B. de Pinho (1873) - Portugal Antigo e Moderno. Dicionário Geographico, Estatístico, Chorographico... Vol. I. Lisboa: Livraria Editora de Mattos Moreira \& Companhia.

LIMA, Alexandre; MATIAS RODRÍGUEZ, Roberto; FÉLIX, Natália; SILVA, Maria Antónia (2011) - A Mineração Romana de ouro no Município de Paredes: o exemplo da Serra de Santa Iria e Serra das Banjas. In BATATA, Carlos (ed.) - Actas do VI Simpósio sobre Mineração e Metalurgia Históricas no Sudoeste Europeu. Abrantes, p. 125-42.

LIMA, António M. C. (1993) - Castelos Medievais do Curso Terminal do Douro (Séc. IX-XII). Porto: Faculdade de Letras. 2 vols. Dissertação de mestrado em Arqueologia apresentada à Faculdade de Letras da Universidade do Porto.

LIMA, António M. C. (2004) - Arouca medieval: uma abordagem arqueológica. In SILVA, António Manuel S. P. [coord.] - Memórias da Terra. Património Arqueológico do Concelho de Arouca. Arouca: Câmara Municipal, p. 306-35.

LIMA, António M. C. (2008) - A importância estratégica do vale do Sousa na "Reconquista": propostas para uma nova leitura das fontes documentais e dos dados arqueológicos. Oppidum, no especial. Lousada, p. 185-194.

LIMA, António M. C. (2013) - Fortificações e vias de comunicação no curso terminal do Douro (Séculos IX - XI). In FERNANDES, Isabel C. (coord.) - Fortificações e Território na Península Ibérica e no Magreb - Séculos VI a XVI, Lisboa, Edições Colibri - Campo Arqueológico de Mértola, p. $183-198$.

MARIANI, Andrea (2020a) - Terminology on defensive structures in Portuguese medieval documents: elements for a comparative approach to the case of the Diocese of Oporto $\left(11^{\text {th }}-12^{\text {th }}\right.$ century). In Juvenes: the Middle Ages seen by young researchers. Évora: CIDEHUS. https://doi.org/10.400o/ books.cidehus. 9672

MARIANI, Andrea (2020b) - Le strutture fortificate medieval nel territorio della Diocesi di Porto (Nord del Portogallo) e della Brianza (Nord Italia): uno studio comparativo (IX-XII secolo). Tese de doutoramento em História apresentada à Faculdade de Letras da Universidade do Porto.

MARQUES, André Evangelista (2008) - O Casal, uma unidade de organização social do espaço no Entre-Douro-e-Lima (906-1200). Noia: Toxosoutos.

MARTINS, M. M. R. (1988) - A Citânia de S. Julião, Vila Verde, Cadernos de Arqueologia - Monografias 2. Braga: Unidade de Arqueologia da Universidade do Minho.

MARTINS, M. M. R. (1989) - O castro do Barbudo, Vila Verde. Resultado das campanhas realizadas entre 1981-1985, Cadernos de Arqueologia - Monografias 3. Braga: Unidade de Arqueologia da Universidade do Minho. 
MATTOSO, José (2002 [1968]) - O Monaquismo ibérico e Cluny [Obras completas, 12]. Lisboa: Círculo de Leitores.

MATTOSO, José (2006) - D. Afonso Henriques. Lisboa: Círculo de Leitores.

MEDEIROS, Artur C., PEREIRA, Eurico, MOREIRA, Armando (1980) - Notícia explicativa da folha 9 - D (Carta Geológica de Portugal escala 1:50 ooo - Penafiel). Lisboa: Direcção Geral de Geologia e Minas, Serviços Geológicos de Portugal.

PEÑA SANTOS, António de la (1988) - Metalurgia galaica de la transición Bronce-Hierro: el Castro de Terroso. Espacio, Tiempo y Forma. Serie I, Prehistoria, 1, Madrid, p. 339-6o.

PEÑA SANTOS, António de la (1992) - Castro de Torroso (Mos, Pontevedra): Síntesis de las memorias de las campañas de excavaciones 1984-1990. S.1.: Xunta de Galicia.

PEREIRA, Gabriel R. (2006) - Projecto de expansão do Parque Empresarial. Paredes. Estudo de Impacte Ambiental. Porto: Clepsidra, Arqueologia. Relatório policop.

PONTE, Salete da (2006) - Corpus signorum das fibulas proto-históricas e romanas de Portugal. Casal de Cambra: Caleidoscópio.

Portugaliae Monumenta Historica... Inquisitiones. Vol. I, fasc. IV-V. Lisboa, 1897.

QUEIROGA, Francisco R. (2003) - War and castros. New approaches to the northwestern portuguese Iron Age. Oxford: Archaeopress (BAR Int. Series 1198).

REDENTOR, Armando (2011) - A cultura epigráfica no Conventus Bracaraugustanus (Pars Occidentalis). Percursos pela sociedade brácara da época romana. Coimbra: Imprensa da Universidade, 2 vols.

REPREZAS, Jessica L. (2010) - A cerâmica decorada do Mundo Baiões/Santa Luzia. Dissertação de Mestrado em Arqueologia apresentada à Faculdade de Letras da Universidade de Lisboa.

ROVIRA, S. (1995) - Estudio arqueometalúrgico del depósito de la ría de Huelva. In RUIZ-GÁlVEZ, ed. - Ritos de Paso y Puntos de Paso. La Ría de Huelva en el Mundo del Bronce Final Europeo, Complutum 5, Madrid, p. 33-57.

RUIZ-GÁLVEZ PRIEGO, Marisa (1995) - Cronología de la ría de Huelva en el marco del bronce final de la Europa occidental. In RUIZ-GÁlVEZ, ed.- Ritos de Paso y Puntos de Paso. La Ría de Huelva en el Mundo del Bronce Final Europeo (Complutum, 5). Madrid, p. 79-83.

SANCHEZ PARDO, José C. (2012) - Castros, castillos y otras fortificaciones en el paisaje sociopolítico de Galicia (siglos IV-XI). In QUIRÓS CASTILLO, Juan; TEJADO SEBASTIÁN, José M. (eds.) - Los castillos altomedievales en el noroeste de la Península Ibérica. S.1.: Universidad del País Vasco, p. 29-55.

SANCHEZ PARDO, José C. (2014) - Sistemas de señales a larga distancia. Estudio de los topónimos 'faro', 'facho' y 'meda' en el noroeste peninsular. In CATALÁN, Raúl; FUENTES, Patricia; SASTRE, José C. (eds.) - Las fortificaciones en la Tardoantigüedad. Élites y articulación del território (siglos V-VIII d.C.). Madrid: La Ergástula, p. 417-23.

SENNA-MARTINEZ, João C. (2013) - Aspectos do Centro-Norte do Ocidente Peninsular no Final da Idade do Bronze: Povoamento, Metalurgia e Sociedade. Estudos Arqueológicos de Oeiras. 20. Oeiras, p. 173-9o.

SILVA, Armando Coelho F. (1986) - A Cultura Castreja no Noroeste de Portugal. Paços de Ferreira: Câmara Municipal; Museu Arqueológico da Citânia de Sanfins.

SILVA, Armando Coelho F. (200o) - Proto-história e romanização do Porto. Al-madan, 2ª s., 9. Almada, p. 94-103.

SILVA, Armando Coelho F. (2007) - A Cultura Castreja no Noroeste de Portugal. $2^{\underline{a}}$ ed., rev. e atualizada. Paços de Ferreira: Câmara Municipal; Museu Arqueológico da Citânia de Sanfins.

SILVA, Armando Coelho F. (2011) - Museu Municipal de Penafiel, memória e identidade. A fonte: fonte de estímulo intelectual. 6. Porto: Instituto Cultural D. António Ferreira Gomes, p. 20-5.

SILVA, Armando Coelho F. (2013) - A ocupação do espaço e a modelação da paisagem proto-histórica no norte de Portugal. Brathair - Revista de Estudos Celtas e Germânicos, 13 (2). São Luís [Maranhão], p. 22-51. Disponível em http:// ppg.revistas.uema.br/index.php/brathair/index

SILVA, José da (1963) - Os recintos fortificados de Baltar e do Montemuro. Lucerna. 3, Porto, p. 126-135.

SILVA, José da (1966) - Os recintos fortificados e a cultura castreja. Lucerna. 5. Porto. p. 519-525.

SILVA, Maria Antónia (1992) - A Necrópole de Vandoma - Concelho de Paredes. Revista de Ciências Históricas, 7. Porto, p. 7-14.

SILVA, Maria Antónia (2006) - Trabalhos de minimização no Castro do Muro de Vandoma. Paredes: Câmara Municipal. Relatório datilog.

SILVA, Maria Antónia (2009) - Cruzeiros da Independência: Testemunho histórico e religioso. In Actas do Centenário do Nascimento de Monsenhor Moreira das Neves (19o62006). Paredes: Câmara Municipal, p. 55-70.

SILVA, Maria Antónia; CASTRO, Fernando; BETTENCOURT, Ana M. S.; SILVA, António Manuel S. P.; MANTEIGA BREA, Alexandre (2018) - Archaeometalurgical analysis and archaeological contextualization of a bronze spearhead from Gralheira (Muro, Mountain Range, Baltar, Paredes, North Portugal). In HERNÁNDEZ GUTIÉRREZ, Noelia; LARRAZABAL GALARZA, Javier; PORTERO HERNÁNDEZ, R. (coord.) - Arqueologia en el valle del Duero: del Paleolítico a la Edad Media 6 - Actas de las VI Jornadas de Arqueología del valle del Duero (Oporto, 2016). Valladolid: Glyphos Publicaciones, p. 204-13. 
SILVA, Maria Antónia, FÉLIX, Natália (2008) - Mineração Romana no Concelho de Paredes. In Actas do I Encontro de Arqueologia das Terras de Sousa. [“Oppidum”, Número especial]. Lousada: Câmara Municipal, p. 67-81.

SOEIRO, Teresa (1988-1989) - Contribuição para o inventário arqueológico do concelho de Paredes (Porto). Portugalia. Nova Série, 9-10. Porto, p. 109-10.

VASCONCELOS, J. Leite de (1905) - Religiões da Lusitania, na parte que principalmente se refere a Portugal. Vol. II. Lisboa: Imprensa Nacional.
VILAÇA, Raquel (1995) - Aspectos do povoamento da Beira Interior (Centro e Sul) nos finais da Idade do Bronze. Lisboa: Inst. Port. Património Arquitectónico e Arqueológico.

VILAÇA, Raquel (2007) - Depósitos de bronze do território português: um debate em aberto. $2^{\underline{\underline{a}}}$ ed. Coimbra: Instituto de Arqueologia.

VILAÇA, Raquel (2008) - Através das Beiras. Pré-História e Proto-História. Coimbra: Palimage.

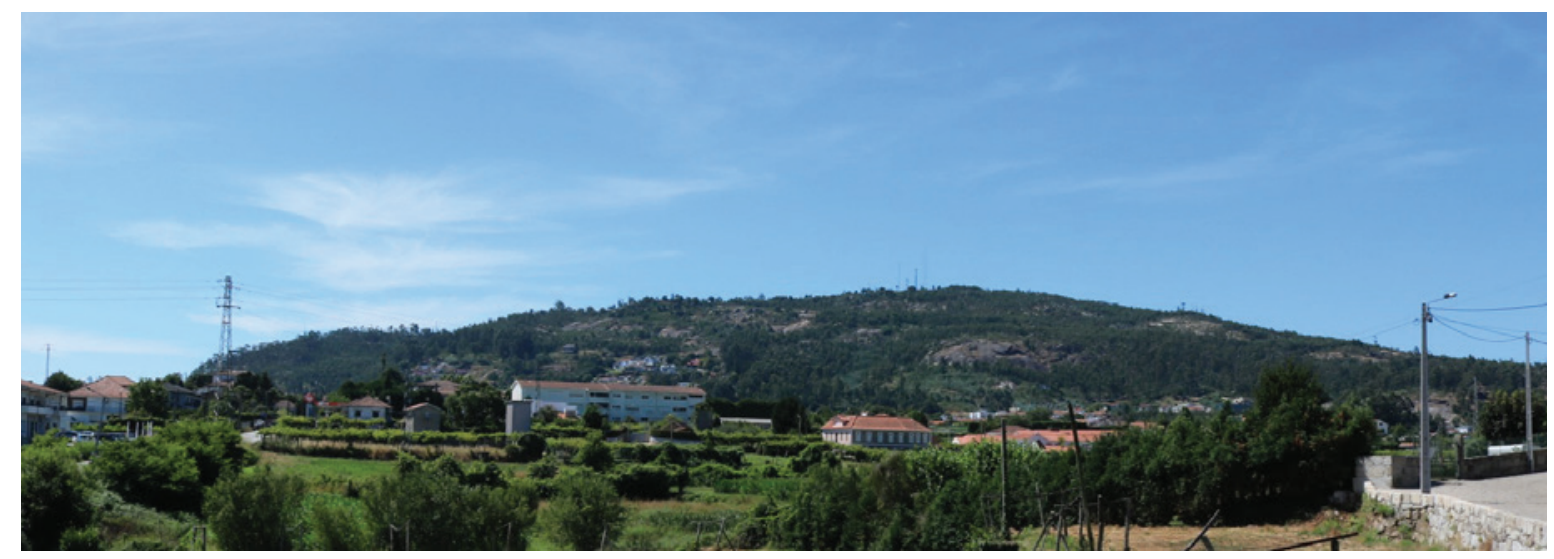

Figura 1 - Vista panorâmica do Castro do Muro, a partir de sudeste (foto: Serviço de Arqueologia/Município de Paredes).

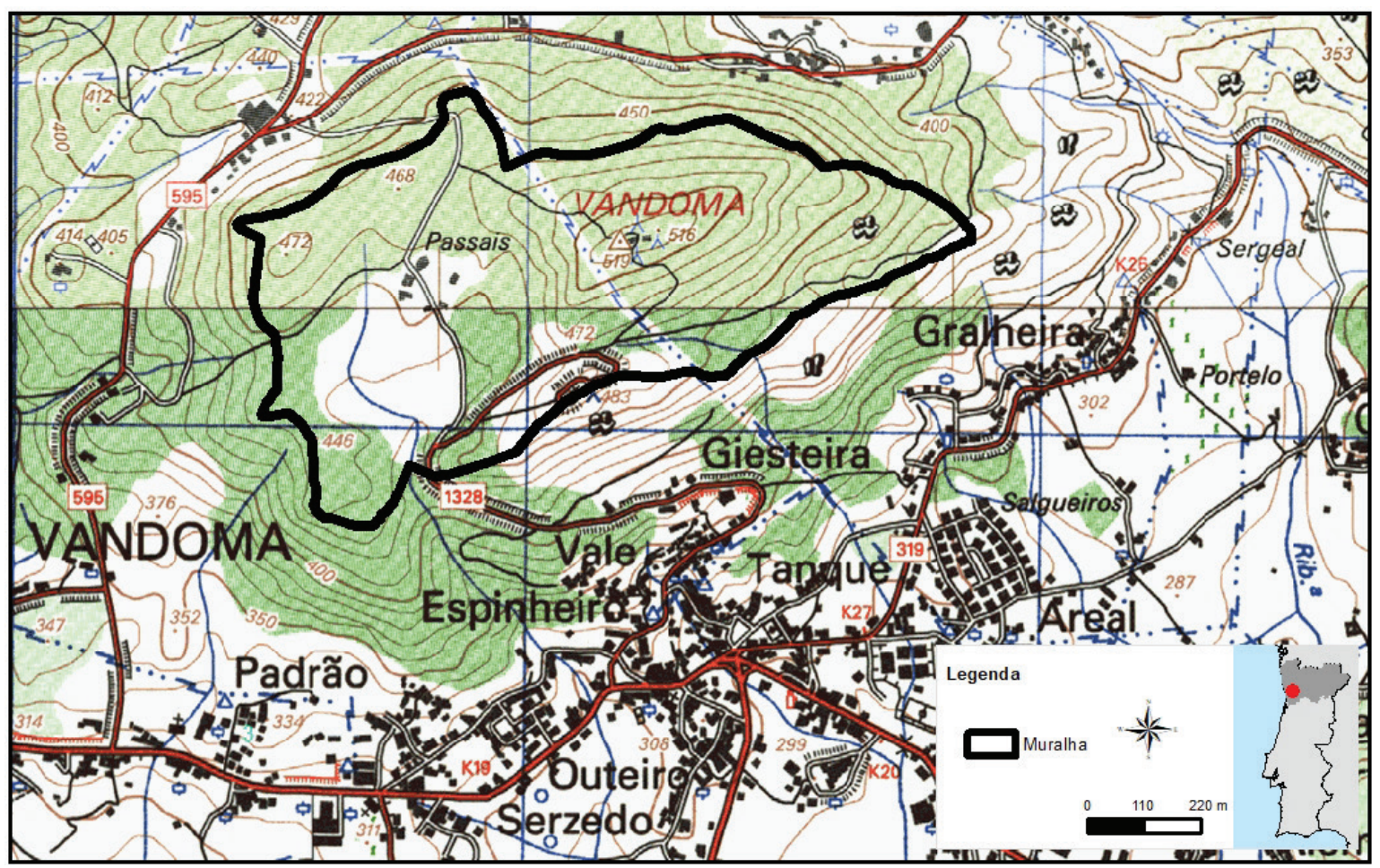

Figura 2 - Implantação do Castro do Muro, definido pelo perímetro amuralhado, sobre a Carta Militar, folhas 123 (Valongo) e 111 (Paços de Ferreira), escala 1/250oo (cartograma: Luís Carvalho, UPSIG - Município de Paredes). 


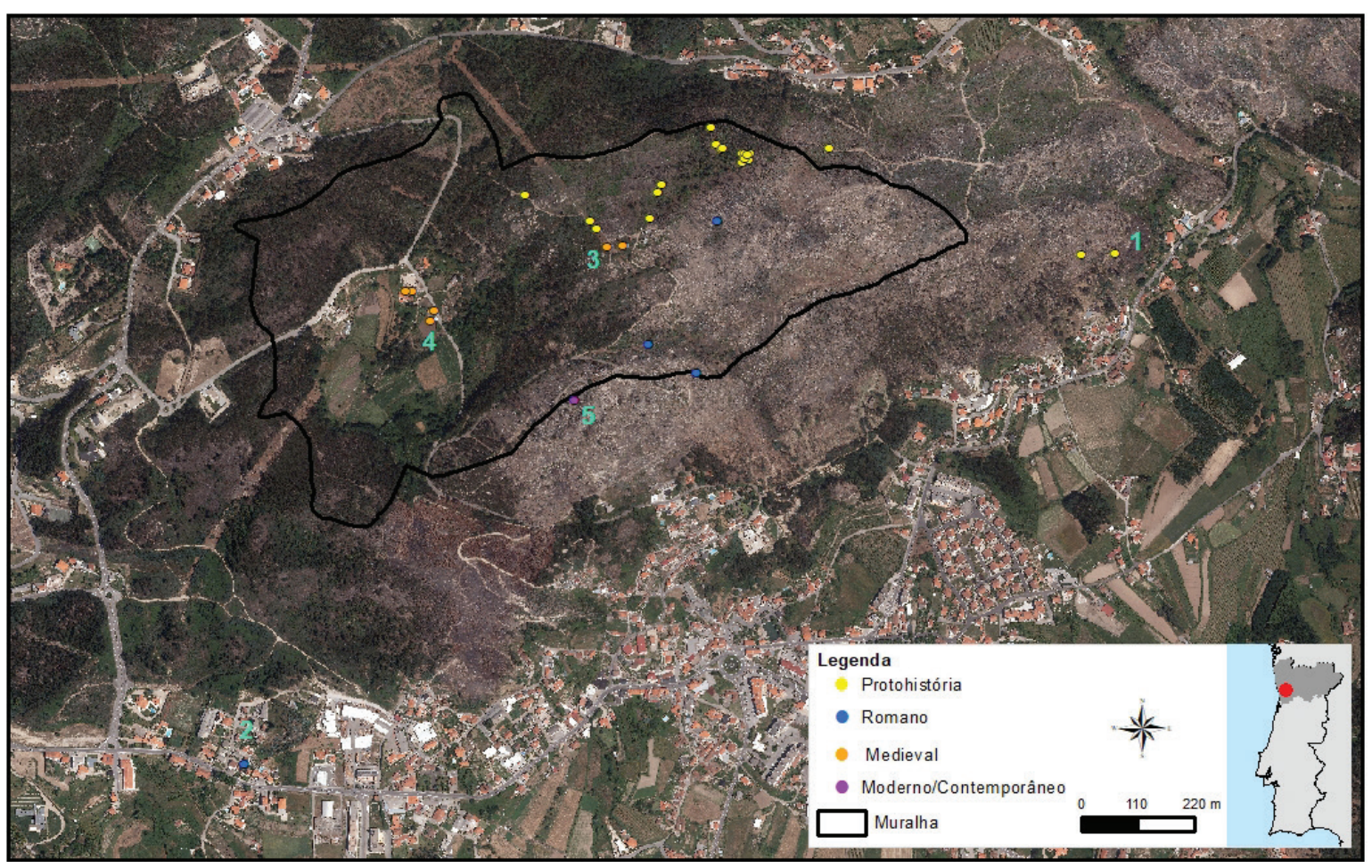

Figura 3 - Implantação do Castro do Muro, definido pelo perímetro amuralhado, sobre ortofotomapa, com localização de ocorrências arqueológicas: 1. Gravura rupestre; 2. Necrópole de Vandoma; 3. Castelo; 4. Mosteiro (Cruzeiro); 5. Cruzeiro da Independência. Dispersão de artefactos de superfície de acordo com a cronologia, conforme legenda (cartograma: Luís Carvalho, UPSIG - Município de Paredes).

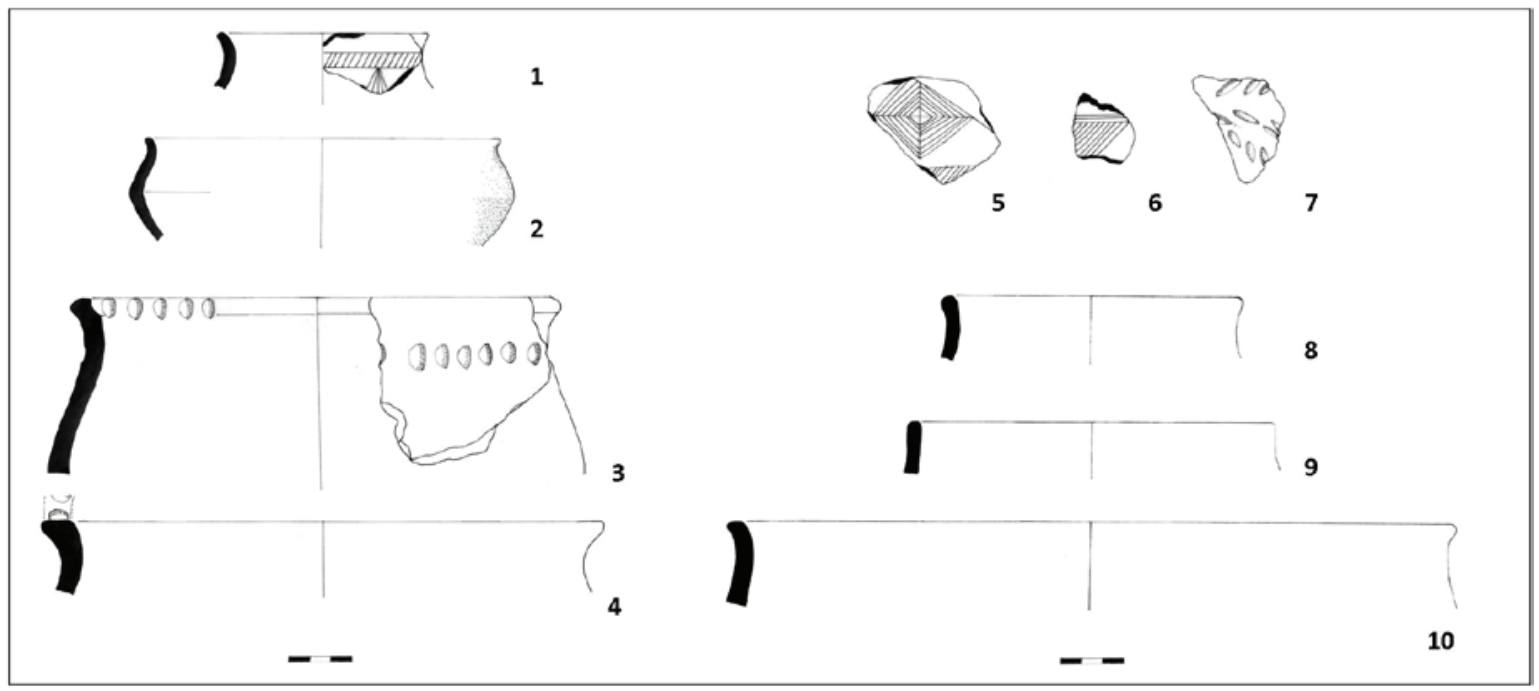

Figura 4 - Castro do Muro. Espólio cerâmico (desenho: Maria Antónia Silva; Serviço de Arqueologia/Município de Paredes). 

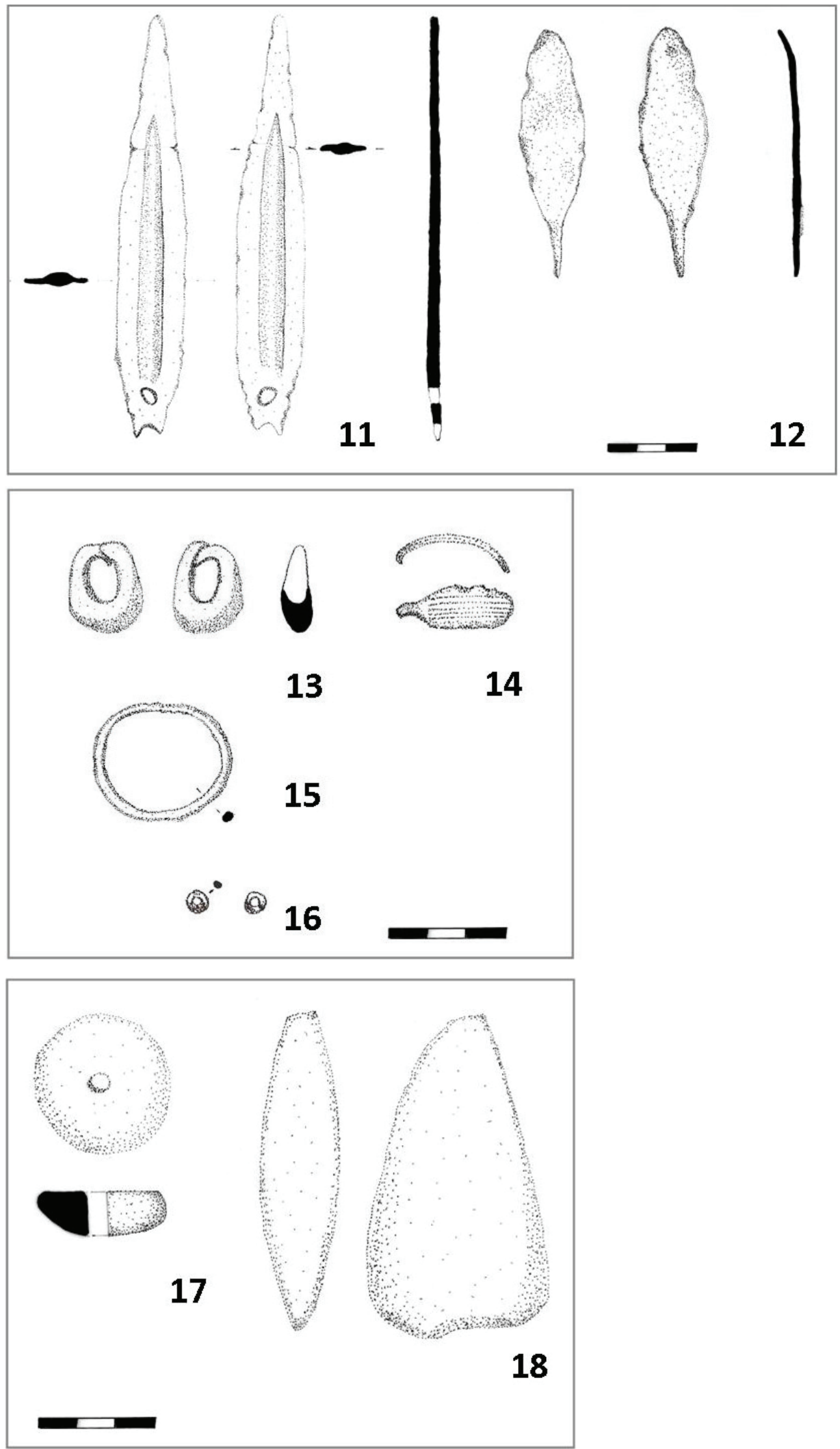

Figura 5 - Castro do Muro. Espólio metálico e lítico (desenho: Maria Antónia Silva; Serviço de Arqueologia/Município de Paredes). 

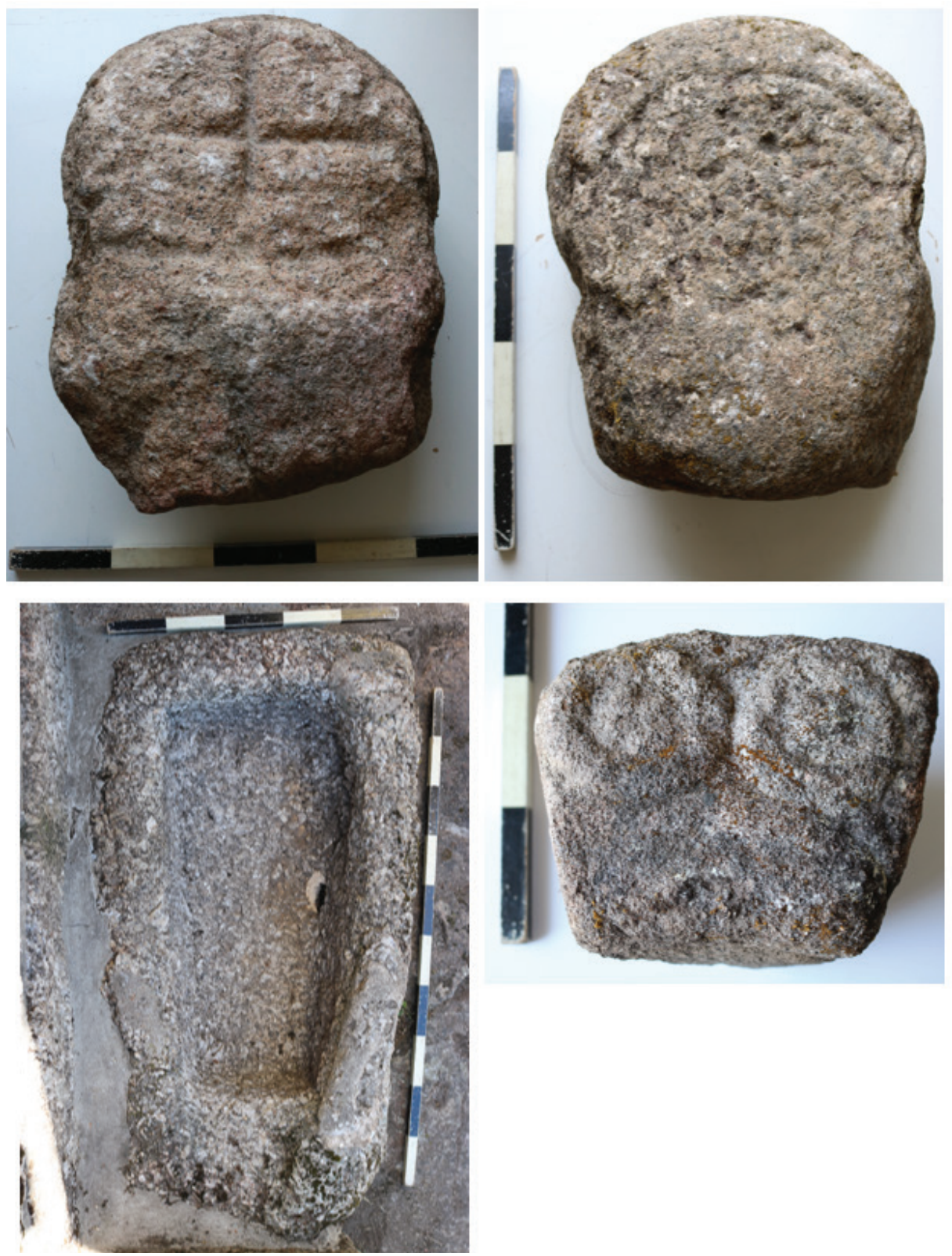

Figura 6 - Castro do Muro. Elementos arquitetónicos e funerários medievais (fotos e montagem: Serviço de Arqueologia/Município de Paredes). 


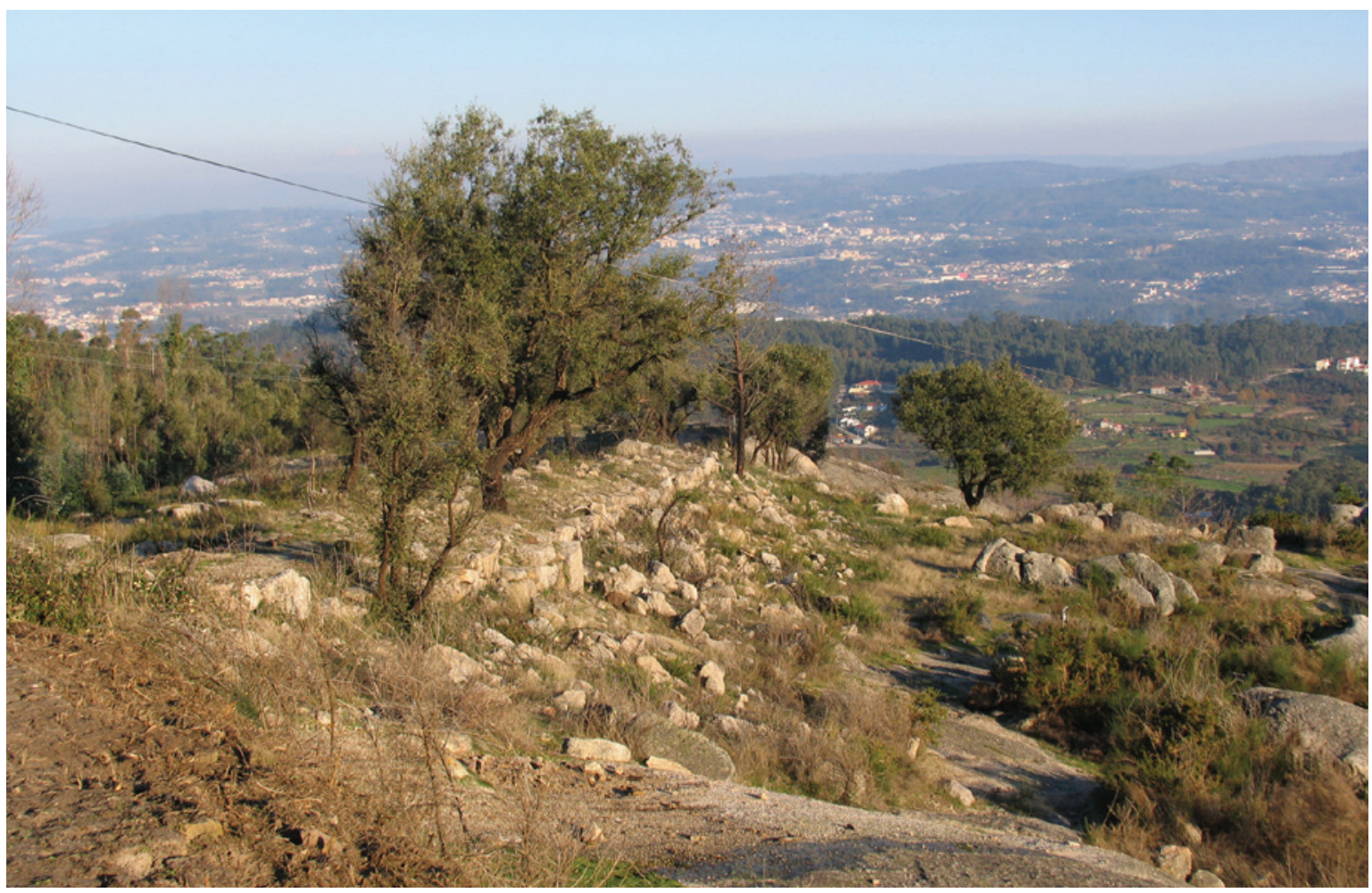

Figura 7 - Castro do Muro, aspeto da muralha (foto: Serviço de Arqueologia/Município de Paredes). 


\title{
DO BRONZE FINAL À IDADE MÉDIA - CONTINUIDADES E HIATOS NA OCUPAÇÃO DE POVOADOS EM OLIVEIRA DE AZEMÉIS
}

\author{
João Tiago Tavares ${ }^{1}$, Adriaan de Man $^{2}$
}

\begin{abstract}
RESUMO
Até à elaboração da Carta de Património Arqueológico no âmbito do primeiro PDM, nunca tinha sido feita uma caracterização de conjunto dos povoados conhecidos no território.

Esta teve por base os poucos dados provenientes de escavação e as referências bibliográficas, sobretudo na imprensa local, à recolha de objetos nos diferentes sítios. Com esses dados disponíveis criou-se a imagem de uma ocupação longa e sincrónica em quase todos os povoados.

Com a elaboração do PIPA Povoamento em Oliveira de Azeméis (POVOAZ) avançou-se para a escavação de um conjunto de povoados procurando aumentar o conhecimento sobre os mesmos e verificar se a caraterização e cronologia de ocupação eram tão uniformes como se havia descrito na Carta de Património Arqueológico. Palavras-chave: Continuidade, Hiatos, Povoamento, Território, Investigação.
\end{abstract}

\begin{abstract}
Until the elaboration of the Archaeological Heritage Chart in the scope of the first PDM, a characterization of the set of settlements in the territory had never been made.

It was based on reduced data from excavation and bibliographic references, especially in the local press, about the gathering of items in different sites. With these data available, the image of a long and synchronous occupation was created in almost al settlements.

With the presentation of the PIPA Povoamento in Oliveira de Azeméis (POVOAZ), it was decided to excavate a group of settlements, seeking to increase knowledge about them, to verify if the characterization and occupation chronology were as uniform as had been described in the Archaeological Heritage Chart.
\end{abstract}

Keywords: Continuity, Hiatus, Settlement, Territory, Research.

\section{INTRODUÇÃO}

Após o terramoto de 1755 a Igreja de santa Maria de Ul sofreu um conjunto de danos que levaram a que o edifício fosse demolido para dar lugar ao atual. Durante as obras de reconstrução, foi recolhido um conjunto de vestígios que atestavam a presença romana no território, nomeadamente um Terminus Augustalis e dois marcos miliários, um dos quais anepígrafo. A $50 \mathrm{~m}$ da Igreja situa-se o monte do Crasto, onde os muros de construções antigas ainda eram visíveis e serviam de local de abastecimento de matérias-primas para as construções dos habitantes locais.

Antes disso, na sua obra Monarquia Lusitana, Frei Bernardo de Brito tinha referido a existência de um outro testemunho epigráfico, no Castro de Ossela. Ainda que este não possa ser validado devido, não só, à ausência de um registo, mas, também, ao anacronismo do seu conteúdo. O texto da suposta epígrafe, faria referência à organização de jogos pela Legião X Fretense, que teria estado estacionada em

1. Gabinete de Arqueologia e Museologia, Município de Oliveira de Azeméis; joao.tavares@cm-oaz.pt

2. Chair of the Department of Tourism and Heritage, United Arab Emirates University; adriaandeman@uaeu.ac.ae 
Ossela. No entanto, não há registo de que essa legião tenha estado sequer na Península Ibérica, conhecendo-se a sua colocação no médio oriente entre o século I a.C. e III d.C. A referência de Frei Bernardo de Brito, é-nos útil, apenas, como demonstração do conhecimento da existência do sítio arqueológico desde o século XVI, algo que veio a ser reforçado, já em finais do século XIX com a descoberta fortuita de um conjunto de braceletes de ouro nas suas imediações (Vasconcelos, 1896).

A publicação dos Anais do município, em 1909, sintetiza o conhecimento de vestígios arqueológicos no concelho. Aos acima referidos junta um conjunto de monumentos megalíticos existentes no território, e mais alguns povoados, genericamente designados como Castros, onde teriam sido recolhidos materiais, ou seriam visíveis estruturas, que remetiam para uma ocupação em tempos antigos.

Apesar deste conhecimento da ocupação do território, desde o início do século XX, não houve um estudo sistemático dos sítios.

Rocha Peixoto levou a cabo uma intervenção no Castro de Ossela em 1908, deixou um relato sumário dos seus trabalhos, mas viria a falecer no ano seguinte, sem que houvesse qualquer continuidade na intervenção.

Apesar irem sendo publicadas pequenas notícias sobre achados realizados no concelho e alguns artigos, nomeadamente, sobre os testemunhos epigráficos acima referidos (Almeida, 1953 e Almeida, 1956), foi necessário aguardar até à década de 1980 para que se realizassem trabalhos com alguma continuidade.

Primeiro no Castro de Ul, entre 1984 e 1987, dirigidos por José Maia Marques com vista à caracterização do povoado, e depois, entre 1987 e 1988, na Mamoa 1 do Castelo sob a direção de Fernando Pereira da Silva.

Ainda que os resultados tenham dado origem a artigos publicados em revistas, pelo menos no caso de Ul (Marques, 1989), fica-se com a sensação de que o texto é demasiado sumário para o trabalho desenvolvido, sustentada na afirmação do autor de que estaria a preparar um trabalho de maior fôlego que publicaria após novos trabalhos a realizar nas estruturas defensivas e áreas habitacionais do povoado (Marques, 1989), o que não viria a acontecer.

No caso da Mamoa 1 do Castelo o artigo é bastante detalhado (Silva, 1994), faltando, talvez, uma contextualização regional dos resultados, que seria desenvolvida no âmbito da tese de doutoramento que
Fernando Pereira da Silva estava a desenvolver e que não veio a concluir.

Apesar destes trabalhos, na década de 1980, as duas décadas seguintes não beneficiaram desse impulso. A ausência de uma estratégia para o património arqueológico resultou, quase só, na realização de intervenções de emergência/salvaguarda.

\section{O PATRIMÓNIO ARQUEOLÓGICO CONHECIDO NA DÉCADA DE 1990}

Como referimos acima, o conhecimento do património arqueológico em Oliveira de Azeméis resultava de um conjunto de informações dispersas, essencialmente de cariz bibliográfico, assentes na recolha esporádica de materiais ou, na toponímia.

A necessidade de elaboração de Planos Diretores Municipais, veio obrigar a uma alteração deste cenário. A realização de uma carta de património arqueológico (Silva, 1995) levou a um esforço para concentrar e sistematizar a informação existente.

A fiabilidade dessa informação era, na maior parte dos casos, uma incógnita devido ao facto de não terem sido realizados trabalhos arqueológicos nos sítios.

Ainda assim, foi a base de conhecimento disponível até à revisão realizada no âmbito do PDM 2013, e da atualização realizada entre 2019 e 2020 para a próxima revisão do mesmo documento.

Sabemos que esse trabalho foi coordenado por Fernando Pereira da Silva, mas os recursos de que dispôs, para o levar a cabo, são desconhecidos.

Parece-nos razoável inferir que o trabalho foi realizado com base, essencialmente, nas referências bibliográficas e terá sido acompanhado da realização de ações de prospeção direcionadas para a sua confirmação. Seguindo a mesma linha de raciocínio, julgamos que o trabalho não terá sido acompanhado de ações de prospeção que procurassem identificar sítios inéditos. Sendo que, em anos mais recentes vários foram os sítios identificados para os quais não existiam referências na bibliografia.

A caracterização da generalidade dos sítios não podia ser feita em 1995, com base em dados obtidos em contexto de escavação. Acreditamos que Fernando Silva o fez com base nas notícias publicadas conjugadas com a prospeção que realizou, e usou como referência os resultados das escavações realizadas Castro de Ul aplicando-os, na medida do possível, a sítios que seriam similares. 
Assim, os povoados, apresentados como castros, e centrando-nos nos quatro em que desenvolvemos trabalhos no âmbito do projeto POVOAZ, são descritos como tendo, quase todos, uma cronologia similar, além de apresentarem características tipológicas comuns, nomeadamente com a existência de várias linhas de muralhas que os delimitavam.

Vejamos a caracterização apresentada por Fernando Pereira da Silva, no artigo que publicou a partir do relatório do PDM, para os sítios que integraram o POVOAZ (Silva, 1995).

\section{Castro de Recarei}

Descrição: Trata-se de um povoado fortificado, considerado tradicionalmente como um acampamento romano. Aparenta possuir três ordens de muralhas, de que a mais elevada é a que define o espaço de habitat interno. Não tem quaisquer outras estruturas visíveis além dos taludes que correspondem aos amuralhados, onde não se vislumbra pedra alguma. À superfície podem encontrar-se fragmentos cerâmicos diversos. [...]

Período Cronológico: Embora tradicionalmente lhe seja consignado a época romana, devido a ser considerado um "acampamento", a verdade é que se trata de um povoado fortificado, devendo a sua ocupação estender-se desde a Idade do Bronze Final, à Alta Idade Média.

\section{Castro de U1}

Descrição: O povoado ocupa um esporão na confluência dos rios Ul e Antuã. [...] Possui três ordens de amuralhados, de que uma delas se designa popularmente por "corredoura". Na vertente oeste foram abertos covachos para plantio de eucaliptos. Na plataforma designada "corredoura" foram efetuados trabalhos arqueológicos modernos, que se encontram ao ar livre, assim como na plataforma nordeste. Por toda a superfície do castro e durante os trabalhos agrícolas, é comum encontrarem-se fragmentos de cerâmica comum e cerâmica industrial romana.

Período Cronológico: A ocupação do morro remonta pelo menos à Idade do Bronze Final, prolongando-se até à Idade Média.

\section{Castro de Ossela}

Descrição: À semelhança dos povoados que temos vindo a referir, o Castro de Ossela ocupa uma posição privilegiada sobre uma linha de água, num trecho do Caima em que se dá um estrangulamento do rio.
Possui três ordens de amuralhados e um fosso que o circunda pelo Este e pelo Sul. A entrada do castro é marcada aparentemente por um estrangulamento da muralha e do fosso que corre a Este. No Topo do Castro localiza-se uma construção da capela da invocação de Nossa Senhora do Castro, de finais do séc. XIX. A construção da capela implicou a terraplanagem de parte do cabeço. [...] Por toda a superfície da estação abundam fragmentos cerâmicos de tipos e fabricos diferenciados atestando a ocupação do castro desde remotas épocas, assim como fragmentos de mós manuais. Na entrada do povoado, voltada a Norte, no talude Este abundam, misturadas nas terras, fragmentos de cerâmica comum e cerâmica industrial romana; [...]

Período Cronológico: A partir do espólio recolhido quer por Rocha Peixoto, quer em prospeções de superfície, parece detetar-se uma ocupação do morro desde a Idade do Bronze à Baixa Idade Média.

\section{Monte Calbo}

Descrição: Segundo referem os "ANNAES" no monte "[...] existiam, ainda há pouco tempo, vestígios bem visíveis de dois muros de circunvalação concêntricos, a pouca distância um do outro, e situados no alto [...].”. Em contrapartida os AA. Referiam que não se tinham encontrado "vestígios de casas redondas". Uma visita ao local confirmou a existência de amuralhados que se desenvolvem a partir dos sectores mesiais do monte, dando entender que o mesmo possui três ordens de muralhas que, no sector Sul, parecem reduzir-se duas e ao declive natural, muito acentuado, criando uma defesa natural. Na plataforma superior, apesar do matagal que a cobre, parecem detetar-se vestígios de construções habitacionais, assim como numa das plataformas definidas pelo amuralhado.

Período Cronológico: O cabeço possuirá ocupação humana que abrangerá um período desde o Calcolítico Final até pelo menos a época romana.

Como acima referimos, tanto a descrição como a atribuição cronológica dos povoados parecem procurar encontrar pontos de contacto entre os sítios, passando uma imagem de alguma homogeneidade na ocupação do território e de uma continuidade cronológica à qual se permite uma pequena variabilidade nos limites iniciais e finais.

Esta leitura é reforçada, se transpusermos para uma tabela cronológica a informação relativa às fases de 
ocupação dos doze povoados elencados por Fernando Pereira da Silva. Lendo as descrições e, sobretudo, os enquadramentos cronológicos por ele escritos, ficamos com a imagem de que 10 dos 12 povoados teriam tido uma ocupação ininterrupta, desde o Bronze Final até à Idade Média.

Apesar da sua dispersão pelo território, ainda que uma parte deles acabe por se concentrar nos vales dos rios Ul e Antuã, sempre nos pareceu que esta atribuição cronológica resultava mais do modelo de análise aplicado do que dos dados disponíveis para cada sítio que, como já referimos, eram parcos.

Ainda assim, aquando da revisão do PDM, publicada em 2013, dado o escasso trabalho de campo que havia sido desenvolvido nos povoados desde 1995, optámos por manter esse enquadramento cronológico (Figura 1).

\section{POVOAMENTO EM OLIVEIRA DE AZEMÉIS (POVOAZ) INVESTIGAÇÃO E RESULTADOS}

Em 2015 quando submetemos o PIPA Povoamento em Oliveira de Azeméis (POVOAZ) um dos objetivos que estabelecemos foi tentar perceber se a ocupação dos sítios correspondia àquele padrão cronológico traçado por Fernando Pereira da Silva.

Paralelamente, pretendíamos melhorar a qualidade de informação disponível para a caracterização dos sítios arqueológicos, uma vez que apenas dois tinham tido trabalhos arqueológicos.

A primeira questão que se colocou foi a escolha dos sítios a intervencionar.

Os Castros de Ul e de Ossela, já tinham sido escavados, em épocas distintas, pelo que levar a cabo novas intervenções poderia permitir confirmar os dados já publicados, ou obter novos elementos que possibilitassem reformular as hipóteses apontadas pelos autores dos trabalhos.

Relativamente aos restantes, entendemos que deveríamos procurar alargar a abrangência geográfica do projeto, diversificar as características orográficas dos sítios, e ter em conta, não só a informação histórica, como os dados que resultavam de visitas aos locais desde a atualização do PDM em 2013, o que levou à inclusão do Castro de Recarei e do Monte Calbo no projeto (Figura 2).

Ainda que o primeiro se situe quase no mesmo meridiano do Castro de Ul a implantação e orografia do sítio são distintas, além de haver repetidas notícias de recolhas de material à superfície.
No caso do monte Calbo, é um povoado que se afasta para o extremo nordeste do concelho, ficando a mais de $5 \mathrm{kms}$ dos restantes, mas com uma implantação e uma orografia a assemelhar-se mais aos povoados Castrejos como a citânia de Sanfins. As referências à recolha de materiais eram pouco numerosas, e as publicações locais mais recentes referiam-se à existência de estruturas habitacionais de planta circular (Silva, 1995), o que contrariava a descrição mais antiga que conhecemos sobre o sítio, feita nos Anais, onde apenas se indicava a existência de duas muralhas. Acresce que, em 2014, na sequência de uma ação de florestação no planalto existente no topo do monte, deixou à vista uma quantidade muito significativa de materiais arqueológicos.

Uma segunda questão que se colocava era a distribuição de recursos entre os diferentes sítios.

Tendo em conta os dados conhecidos, a existência de estruturas à vista resultantes dos trabalhos da década de 1980, e a envolvente cultural com a existência de um parque molinológico na base do cabeço, ainda que na margem oposta do rio Ul, que atrai um número interessante de visitantes, considerámos que o Castro de Ul deveria funcionar como um símbolo do projeto, tendo direito a 4 campanhas de escavação, uma por cada ano.

Prevíamos, em 2014, quando começámos a pensar na apresentação do POVOAZ, dedicar duas campanhas ao Castro de Ossela, por se tratar do único sítio classificado no concelho e ter sido alvo de trabalhos em 1908, havendo, ainda, relatos da existência abundante de materiais arqueológicos à superfície. No entanto, a reflorestação no Monte Calbo, realizada em 2014, levou-nos a reequacionar essa intenção. Tendo em conta a área de dispersão e o volume de materiais à superfície, conjugados com o facto de não haver notícia de intervenções no sítio considerámos que seria mais útil avançar com duas campanhas naquele local, obtendo, potencialmente, mais dados sobre um sítio inédito, e deixando apenas uma campanha para Ossela e a restante para Recarei. Ao elaborar o projeto estabelecemos como objetivos:

- Perceber se a cronologia de ocupação dos povoados era tão alargada, ou mais restrita no tempo;

- Verificar se os povoados com maiores dimensões possuíam ocupações sincrónicas;

- Estabelecer uma malha de ocupação do território tentando identificar os pontos mais importantes nos diversos períodos abrangidos pelo projeto; 
- Identificar, em cada um dos povoados, sequências de ocupação;

- Aferir, a partir dos dados adquiridos, as potencialidades concretas dos sítios.

Os trabalhos teriam a duração de 4 semanas anuais, destinando-se duas ao Castro de Ul e as restantes ao outro povoado, de acordo com o cronograma do projeto. Além dos trabalhos de escavação (sondagens de $5 \times 5 \mathrm{~m}$ ) previa-se a realização, eventual, de trabalhos de prospeção geofísica e de conservação e restauro. Foram feitas campanhas de prospeção geofísica nos Castros de Ul e Ossela, como forma de auxílio à decisão sobre os locais onde seriam implantadas as sondagens. Já no que respeita à conservação e restauro, não foi feita qualquer intervenção.

No Castro de Ul, a primeira sondagem realizada, na plataforma de topo do cabeço revelou uma estratigrafia bastante perturbada associada a uma quase inexistência de espólio arqueológico e à ausência de estruturas, o que contrastava com os dados publicados por Maia Marques que, junto ao talude Este, tinha escavado o alicerce de uma construção, um lajeado em pedra e no limite da sondagem, uma base de uma lareira. Enquanto os dois primeiros elementos foram enquadrados cronologicamente em época romana, a lareira corresponderia um período de ocupação mais antigo, atribuído à Idade do Bronze. A realização de uma campanha de prospeção eletromagnética numa clareira dessa plataforma, e na plataforma intermédia, conhecida como corredoura, levou-nos a reequacionar implantação da sondagem. De acordo com os dados obtidos, na plataforma de topo não havia indícios de anomalias que pudessem corresponder a estruturas positivas. Em contrapartida, na corredoura, as características e disposição no solo das anomalias, eram compatíveis com a presença de estruturas positivas (De Man, Tavares e Carvalho, 2017). Com estes dados, optou-se por deslocar a zona a escavar para a corredoura.

A abertura dessa nova área de sondagem veio a revelar-se proveitosa, ainda que não seja, de momento, totalmente clara a sua interpretação funcional e cronológica.

Apesar de terem sido levadas a cabo três campanhas de escavação nessa zona, devemos ter em conta que a mesma foi assegurada por equipas pequenas e, maioritariamente, inexperientes de estudantes de arqueologia.

Dito isto, no final da primeira campanha, a escavação permitia-nos perceber que a camada superficial, re- movida após a manta morta, se apresentava bastante perturbada indiciando um revolvimento acentuado. O espólio recolhido era composto por fragmentos de pequena dimensão e muito rolados, de cerâmica, vidro e material de construção em quantidade reduzida face ao que é expectável neste tipo de contexto. A grande diferença em relação à sondagem no topo do cabeço era que na base dessa camada não estávamos perante um nível geológico, ou estéril do ponto de vista arqueológico, mas antes tínhamos o que nos parecia um derrube em toda a extensão da sondagem. Esse derrube deixava antever alguns alinhamentos que poderiam corresponder a estruturas. Uma delas, seria a muralha que delimitaria esta plataforma e que Maia Marques havia identificado na sondagem que escavou a norte da nossa, na corredoura. Próximo do talude era possível ver um conjunto de blocos de pedra com uma orientação grosseira NE-SW que acompanhava o contorno do mesmo. Um outro alinhamento, com a mesma orientação, situava-se na zona central da sondagem. Ambos eram intercetados por um alinhamento NW-SE que atravessava a sondagem no sentido W-E.

A campanha seguinte, em que alargámos a sondagem em direção ao talude e escavámos parte do derrube, veio clarificar alguns aspetos e lançar dúvidas noutros. Veio clarificar, que o alinhamento NW-SE correspondia ao limite sul de três possíveis estruturas. Um delas, a mais próxima do talude corresponderia à muralha, a segunda a um possível compartimento e a terceira parecia demasiado volumosa para ser um muro de delimitação, fazendo lembrar um contraforte. No que dizia respeito aos materiais recolhidos, a sua quantidade continuava a ser pouco significativa, com o material de construção a corresponder a $98 \%$ do espólio recolhido. As dúvidas que daqui resultaram prendiam-se com a muralha que aparentava estar interrompida. Ao alargarmos a sondagem na direção do talude pretendíamos confirmar se o alinhamento que havíamos identificado como podendo corresponder à face interior da muralha tinha continuidade, uma vez que parecia continuar para o interior do corte. Feito esse alargamento, foi com alguma surpresa que verificámos que tal não parecia suceder. Ao invés, era o alinhamento NW-SE que parecia acompanhar esse alargamento. Simultaneamente, junto ao limite sul da sondagem a remoção do derrube e o alargamento da sondagem permitiu a identificação de uma nova estrutura com a mesma orientação NW-SE. Quanto à estrutura 
que, acreditávamos, poderia corresponder a qualquer compartimento adossado à muralha, a remoção da camada de derrube não foi esclarecedora quanto à sua funcionalidade. Ao contrário das faces exteriores, Sul e Este, relativamente bem marcadas, a faces interiores eram menos definidas. Essa situação levou-nos a considerar a possibilidade de não se tratar de um compartimento, mas antes de um reforço da própria muralha.

A última campanha do projeto (2018) poderia esclarecer estas questões. No entanto, tal como em 2017 , as respostas não foram mais do que as questões deixadas em aberto. Optámos por um novo alargamento da sondagem escavando-se até à base do talude, que correspondia ao limite da propriedade, para procurar dissipar as dúvidas levantadas relativamente à continuidade da muralha.

Esse alargamento permitiu perceber que o topo do talude era coroado com um murete de pedra, bastante degradado, que corresponderia a um antigo muro de separação de propriedade assente sobre o limite exterior da muralha. Simultaneamente, tornou-se claro que, sensivelmente, a meio da sondagem esse murete não estava assente na muralha, mas antes num derrube. A sua desmontagem possibilitou a identificação de uma porta na muralha, com uma soleira e respetivo gonzo, um batente na face da muralha e um encaixe para a tranca, também na muralha. A remoção da última área de derrube deixada à vista em 2016 veio permitir perceber que a estrutura com orientação NW-SE cuja face sul tinha sido deixada à vista no ano anterior, também possuía uma face do lado norte e que apresentava uma espessura de, aproximadamente, $1,5 \mathrm{~m}$, o que indiciava que a hipótese de se tratar de um contraforte ganhava alguma sustentação.

A escavação das camadas por baixo do derrube permitiu recolher um espólio cerâmico, ainda que pouco numeroso, que aponta para uma cronologia de época romana imperial. Tendo em conta que o possível contraforte está assente sobre essas camadas e que o possível reforço da muralha tem a sua base, pelo menos na face voltada a Este, assente sobre uma delas, tudo nos leva a crer que este momento construtivo corresponderá a uma fase tardia de ocupação do povoado, até porque, ainda parecem existir níveis preservados por baixo daqueles que escavámos.

A porta deixa-nos algumas dúvidas, a existência de uma soleira parece indiciar que se trata de uma estrutura contemporânea às acima referidas. Porém, por limitações de tempo e dimensão da equipa, não foi escavada a camada onde assenta para se perceber se a muralha abaixo daquela cota existia e era fechada, ou se já possuía uma abertura.

Em resumo as campanhas realizadas no Castro de Ul, em termos de materiais, só nos sugerem uma ocupação romana imperial, com as estruturas a possibilitarem a hipótese de que tenha existido uma ocupação durante a crise do império romano e a antiguidade tardia.

No Monte Calbo dada a grande dispersão de materiais foram feitas sondagens em três pontos diferentes.

Optámos, na primeira campanha, por estabelecer uma sondagem na plataforma junto ao afloramento rochoso que corresponde ao ponto mais alto do sítio e outra no planalto que lhe fica imediatamente abaixo e se estende por todo o cabeço.

As sondagens, não permitiram a identificação de qualquer tipo de estrutura que corroborasse a existência de construções de planta circular semelhantes às do Castro de Romariz, que se situa a $2 \mathrm{kms}$. Já as cerâmicas recolhidas são bastante coerentes, com a predominância de pastas sujeitas a cozeduras mistas ou redutoras, alisadas e algumas brunidas. As formas de perfil em $\mathrm{S}$ e as decorações plásticas remetem para uma ocupação durante o Bronze Final.

A segunda campanha, com uma sondagem perto do afloramento rochoso, por ter sido aí que se recolhera uma maior quantidade de espólio, veio reforçar este panorama. Sem se identificarem estruturas que correspondessem à ocupação do sítio, os materiais apontavam, novamente, para uma cronologia de ocupação durante o Bronze Final, sem que se vislumbrassem indícios de uma ocupação anterior, ou posterior.

Não excluímos a possibilidade de que o sítio tenha tido uma pequena ocupação, através da implantação de uma atalaia durante a Idade Média, afinal de contas há referências documentais à realização, em 1045, de uma batalha entre cristãos e muçulmanos na villa cesari (Lima, 2017) que corresponde à atual freguesia de Cesar e o topo do Monte Calbo, num dia limpo, permite controlar a paisagem até à costa. No entanto, não recolhemos materiais que apontem para essa cronologia.

No castro de Ossela a situação parecia ser mais clara. De acordo com as informações de Rocha Peixoto (Carqueja, 1909) existiriam estruturas de planta ortogonal e planta circular, que atribui a ocupações de época Romana e da Idade do Ferro. A estas acrescenta um conjunto de sepulturas que, de acordo com o 
espólio recolhido seriam mais tardias, enquadrando-se na Baixa Idade Média e Idade Moderna, associáveis à Capela da Senhora do Castro ali existente. Uma intervenção de emergência realizada em 2013, na sequência da abertura de uma vala no talude Este, permitiu recolher alguns fragmentos de cerâmica romana, e um fragmento de sigilatta clara datável de século $\mathrm{V}$, o que possibilitava a interpretação de uma ocupação correspondente ao período da Antiguidade Tardia e conferia alguma verosimilhança ao padrão de ocupação descrito por Fernando Pereira da Silva.

A campanha de prospeção eletromagnética, realizada em 2016, parecia confirmar, pelo menos parcialmente, o relato de Rocha Peixoto (Carqueja, 1909), ao identificar um conjunto de anomalias que pareciam corresponder a estruturas de planta ortogonal. Com essa perspetiva avançámos para a escavação em 2017. Não foi possível confirmar se as anomalias correspondiam a estruturas arqueológicas uma vez que imediatamente após a remoção da camada superficial metade da área da sondagem ficou com sepulturas à vista. Optámos por não as escavar, mas, ainda assim, o registo da área escavada foi bastante moroso e impossibilitou que se pudesse atingir a cota a que as anomalias deveriam surgir, em tempo útil. Os materiais, recolhidos apontam para uma cronologia que se enquadrará na Idade Média e Moderna, podendo estar associados à necrópole identificada com os trabalhos. Facto é que não conseguimos estabelecer uma sequência de ocupação para o sítio. Os materiais enquadráveis na Idade Moderna, nomeadamente um numisma de D João III, alargam a cronologia de ocupação do cabeço, face à descrição de 1995, porém, tanto em escavação como em qualquer dos trabalhos ali realizados, não foi possível recolher materiais que atestassem uma ocupação do Bronze Final.

Isso só veio a acontecer no cabeço onde está situado o marco geodésico, que dista, aproximadamente, 600 m para Norte do cabeço da Capela. Aí, em áreas onde o solo foi revolvido para o plantio de eucalipto, sobretudo, nas vertentes voltadas a Noroeste foram recolhidos alguns fragmentos de cerâmica, ainda que pouco numerosos, cujas características remetem para o mesmo mundo que havíamos encontrado no Monte Calbo, sem que se recolhessem materiais de cronologias mais recentes.

Estes dados levam-nos a ponderar a hipótese de o cabeço do marco geodésico ter tido uma ocupação mais antiga que se terá deslocado, posteriormente, para o cabeço onde foi contruída a capela. No en- tanto, não dispomos de elementos que o permitam atestar, dada a ausência de trabalhos conhecidos no cabeço do marco geodésico e os constrangimentos que tivemos na intervenção no cabeço da Capela, que impediram uma verificação dos resultados de Rocha Peixoto.

Por último, o Castro de Recarei, para o qual tínhamos amplos relatos de recolhas de materiais ao longo do século XX. Em diversas visitas ao sítio tínhamos recolhido alguns materiais que pareciam confirmar uma ocupação durante a Idade do Ferro e a época Romana. Como as condições do povoado não eram as ideais para a realização de trabalhos de geofísica, escolheu-se para a sondagem uma zona não arborizada e relativamente plana, perto do ponto mais alto do cabeço, onde está instalado um marco geodésico. Também aqui não conseguimos identificar estruturas positivas que comprovassem uma ocupação do sítio, e que correspondessem ao que seria expectável confirmando uma ocupação durante a Idade do Ferro e época Romana.

No entanto, registaram-se algumas estruturas negativas durante a escavação que parecem corresponder a um conjunto de buracos de poste, alguns deles com o topo ainda preenchido por bocados de argila ou pedras que estariam, inicialmente, a calçar os postes de madeira. A funcionalidade destas estruturas ainda é pouco clara, porém a recolha de possíveis pesos de telhado, sugere que se trataria de uma estrutura com cobertura de colmo.

No que aos materiais diz respeito, as camadas superficiais possibilitaram a recolha de um conjunto de cerâmica que parece enquadrar-se na Idade Média e Idade Moderna. Não estando associados a elementos que lhes forneçam grande contexto, a sua quantidade parece ser superior àquela que recolhemos em Ul, por exemplo, em contexto equivalente. Nos níveis mais profundos não temos registo de se ter recolhido qualquer fragmento de material de construção enquadrável cronológica e tipologicamente na época Romana. Mesmo no que respeita à existência de fragmentos e cerâmica a sua quantidade é extremamente reduzida, para não dizer inexistente. Os materiais recolhidos, parecem enquadrar-se, isso sim, na Idade do Ferro e no Bronze Final. Ainda assim, não se identificou qualquer vestígio das casas redondas, típicas do mundo castrejo.

Também, neste caso, o registo arqueológico não segue a linearidade da cronologia proposta por Fernando Pereira da Silva. Apesar dos materiais medie- 
vais recolhidos não é possível associá-los, expressamente a uma ocupação, e, surpreendentemente, dado que noutros pontos do povoado há fragmentos de cerâmica de construção à superfície não se identificou uma ocupação correspondente ao período romano no local da sondagem.

\section{UMA TENTATIVA DE CONCLUSÃO NUM TERRITÓRIO COM MAIS PERGUNTAS QUE RESPOSTAS}

Além das intervenções nos sítios o projeto previa a realização de ações de prospeção. Não foi possível desenvolvermos muito essa vertente, mas ainda assim, a identificação de, pelo menos, um novo povoado, Fonte do Soldado, pode contribuir para melhorar a nossa visão sobre a ocupação do território. Trata-se, pela primeira vez de um povoado identificado numa zona de encosta, sem estruturas defensivas visíveis e com materiais que remetem para o Calcolítico, cuja identificação foi possível após trabalhos de florestação. Dentro da área de dispersão de materiais, há uma zona onde surgem algumas cerâmicas comuns e de construção enquadráveis na época Romana. No entanto, não parece existir aqui uma continuidade de ocupação com materiais da Idade do Bronze, Idade do Ferro e Medievais. Este será um povoado a estudar no âmbito do POVOAZ_O2.

Relativamente aos povoados que foram alvo de intervenção, ainda que tenhamos consciência de que as áreas escavadas são demasiado restritas para podermos ter uma visão crono-estratigráfica detalhada, de cada sítio, parece-nos, apesar de tudo, evidente que a continuidade cronológica, de ocupação dos povoados, apresentada por Fernando Pereira da Silva é hoje mais aparente que real.

Se tomarmos, apenas, como referência os nossos resultados das escavações, em nenhum caso se verifica essa continuidade de ocupação. Se cruzarmos os nossos dados com os de Maia Marques e de Rocha Peixoto, ou os que resultam de visitas aos sítios em que foram recolhidos materiais, ou ainda de outros trabalhos, mesmo assim, essa continuidade de ocupação é mitigada.

No último cronograma apresentamos os dados correspondentes à cronologia dos sítios que foram escolhidos para integrar o POVOAZ.

A primeira linha corresponde à atribuição cronológica feita por Fernando Pereira da Silva, no âmbito do PDM 1995.
A segunda aos resultados que obtivemos na sequência dos trabalhos efetuados ao longo do POVOAZ, tendo considerado apenas, os que resultam das sondagens realizadas.

A última linha conjuga os nossos com os dados disponíveis, a partir dos resultados de intervenções antigas, trabalhos de emergência e prospeções. Mesmo assim, parece-nos razoável afirmar que a uniformidade cronológica proposta por Fernando Pereira Silva é muito mais aparente que real (Figura 3).

Estamos convictos de que se alargássemos o leque de intervenções aos restantes povoados elencados em 1995, assistiríamos a uma diminuição da amplitude cronológica e à identificação de hiatos na ocupação, de cada sítio.

A continuação dos trabalhos através do POVOAZ_ o2, onde se integrou, além destes, o povoado inédito Fonte do Soldado, virá possibilitar uma afinação das cronologias de cada sítio com dados mais robustos que, esperamos nós, clarifiquem a incerteza que ainda temos relativamente a alguns dos sítios.

\section{BIBLIOGRAFIA}

ALMEIDA, Fernando de (1953) - Terminus augustalis entre Talábriga e Lancóbrica. O Arqueólogo Português, Série II, 2, pp. 209-212.

ALMEIDA, Fernando de (1956) - Marcos miliários da via romana “Aeminium-Cale". O Arqueólogo Português, Série II, 3, pp. 111-116.

CARQUEJA, Bento, ed. (1909) - Annaes do Município de Oliveira de Azeméis. Porto: Livraria Chardron.

DE MAN, Adriaan, TAVARES, João Tiago e CARVALHO, Jorge (2017) - Gpr And Electromagnetic Induction Surveys at The Hilltop Site Of Ul (Oliveira De Azeméis, Portugal). Mediterranean Archaeology and Archaeometry, 17:1, pp. 179-188.

DE MAN, Adriaan; TAVARES, João Tiago (2018) - A gestão arqueológica autárquica e um projeto de investigação - um primeiro balanço do POVOAZ. Patrimónios de OAZ, Oliveira de Azeméis, ํำ1, 2018, pp. 77-89.

DE MAN, Adriaan; TAVARES, João Tiago (2019) - Oliveira de Azeméis: Gestão de uma Carta de Salvaguardas Patrimoniais e de um projeto de investigação sobre a ocupação do território (POVOAZ). SCIENTIA ANTIQUITATIS, Évora. 3:1, pp. 295-319.

LIMA, António Manuel (2017) - Fragmentos medievais de uma composição moderna. In Memórias de OAZ. Oliveira de Azeméis: MOA, pp. 45-82. 
MARQUES, José Augusto Maia (1989) - Escavações no castro de Ul (Oliveira de Azeméis). Primeira notícia. Revista de Ciências Históricas, Porto, 4 pp. 65-89.

SILVA, Fernando A. Pereira (1994) - Mamoa 1 da Mourisca, Fajões - Oliveira de Azeméis. Da pré-história à romanização. Ul-Vária, Oliveira de Azeméis. 1:1-2, pp. 23-58.
SILVA, Fernando A. Pereira (1995) - Contributo para a carta arqueológica do concelho de Oliveira de Azeméis. Da pré-história à romanização.Ul-Vária, Oliveira de Azeméis. 2:1-2, pp. 9-52.

VASCONCELOS, José Leite (1896) - Novo Achado de braceletes pre-romanos. O Arqueólogo Português, Lisboa. 2:3, pp. 86-88.

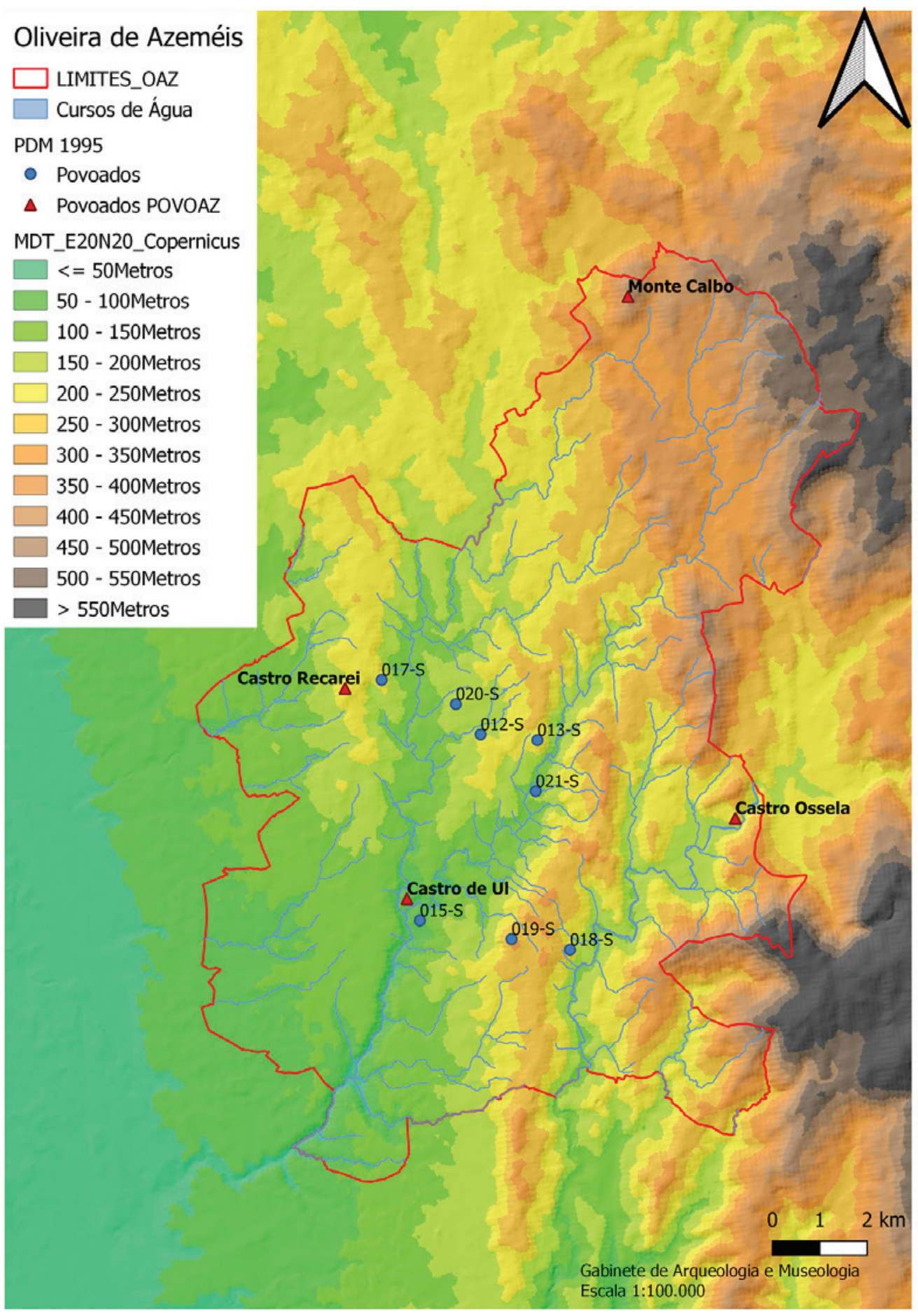

Figura 2 - Povoados conhecidos no início do POVOAZ. 


\begin{tabular}{|c|c|c|c|c|c|c|c|c|c|}
\hline & Neolitico & Calcolitico & $\begin{array}{l}\text { Idade do } \\
\text { Bronze }\end{array}$ & $\begin{array}{c}\text { Bronze } \\
\text { Final }\end{array}$ & $\begin{array}{c}\text { Idade do } \\
\text { Ferro }\end{array}$ & $\begin{array}{l}\text { Epoca } \\
\text { Romana }\end{array}$ & $\begin{array}{l}\text { Antig. } \\
\text { Tardia }\end{array}$ & $\begin{array}{l}\text { Idade } \\
\text { Média }\end{array}$ & $\begin{array}{c}\text { Idade } \\
\text { Moderna }\end{array}$ \\
\hline \multicolumn{10}{|l|}{ Castro Ossela } \\
\hline \multicolumn{10}{|l|}{ Castro Recarei } \\
\hline \multicolumn{10}{|l|}{ Castro U1 } \\
\hline \multicolumn{10}{|l|}{ Monte Calbo } \\
\hline \multicolumn{10}{|l|}{ Castelhão (12-S) } \\
\hline \multicolumn{10}{|l|}{ Outeiro do Castro (13-S) } \\
\hline \multicolumn{10}{|l|}{ Castro Damonde (15-S) } \\
\hline \multicolumn{10}{|l|}{ Castro de Vilacova (17-S) } \\
\hline \multicolumn{10}{|l|}{ Castro da Mó (18-S) } \\
\hline \multicolumn{10}{|l|}{ Monte das Flores (19-S) } \\
\hline \multicolumn{10}{|l|}{ Monte do Calvário (20-S) } \\
\hline Castelo da Lomba (21-S) & & & & & & & & & \\
\hline
\end{tabular}

Figura 1 - Cronologia dos povoados, segundo Silva (1995).

\begin{tabular}{|c|c|c|c|c|c|c|c|c|c|}
\hline & Neolitico & Calcolitico & $\begin{array}{l}\text { Idade do } \\
\text { Bronze }\end{array}$ & $\begin{array}{c}\text { Bronze } \\
\text { Final }\end{array}$ & $\begin{array}{c}\text { Idade do } \\
\text { Ferro }\end{array}$ & $\begin{array}{l}\text { Epoca } \\
\text { Romana }\end{array}$ & $\begin{array}{l}\text { Antiguida } \\
\text { de Tardia }\end{array}$ & $\begin{array}{l}\text { Idade } \\
\text { Média }\end{array}$ & $\begin{array}{c}\text { Idade } \\
\text { Moderna }\end{array}$ \\
\hline \multicolumn{10}{|l|}{ Castro Ossela FPS } \\
\hline \multicolumn{10}{|l|}{ Castro Ossela POVOAZ } \\
\hline \multicolumn{10}{|l|}{ Castro Ossela TD } \\
\hline \multicolumn{10}{|l|}{ Castro Recarei FPS } \\
\hline \multicolumn{10}{|l|}{ Castro Recarei POVOAZ } \\
\hline \multicolumn{10}{|l|}{ Castro Recarei TD } \\
\hline \multicolumn{10}{|l|}{ Castro U1 FPS } \\
\hline \multicolumn{10}{|l|}{ Castro U1 POVOAZ } \\
\hline \multicolumn{10}{|l|}{ Castro U1 TD } \\
\hline \multicolumn{10}{|l|}{ Monte Calbo FPS } \\
\hline \multicolumn{10}{|l|}{ Monte Calbo POVOAZ } \\
\hline Monte Calbo TD & & & & & & & & & \\
\hline
\end{tabular}

Figura 3 - Cronologia comparada de ocupação dos povoados integrados no POVOAZ. 


\title{
AS FAUNAS DO FINAL DA IDADE DO BRONZE NO SUL DE PORTUGAL: LEITURAS DESDE O OUTEIRO DO CIRCO (BEJA)
}

\author{
Nelson J. Almeida ${ }^{1,}$, Íris Dias $^{1}$, Cleia Detry ${ }^{1}$, Eduardo Porfírio $^{2}$, Miguel Serra $^{3}$
}

\begin{abstract}
RESUMO
Apresentam-se os resultados da análise dos restos faunísticos do povoado do Bronze Final do Outeiro do Circo (Beja), ainda inéditos, provenientes sobretudo da fossa/silo da sondagem 3 e das sondagens 7 e 8 localizadas junto ao talude defensivo. As práticas cinegéticas são acessórias neste conjunto com predomínio de restos de ovelhas e cabras, seguidas por gado bovino e suíno. Os padrões de abate, com a presença de indivíduos jovens e adultos sugerem uma economia mista, assente em recursos primários e secundários. O estudo permitiu valorizar um conjunto bastante fragmentado e afectado por processos pós-deposicionais, mas com indicadores de acção antrópica relacionáveis com o processamento das carcaças sob a forma de marcas de corte e termo-alteração por queima.
\end{abstract}

Palavras-chave: Zooarqueologia, Tafonomia, Idade do Bronze, Povoado, Sudoeste Peninsular.

\begin{abstract}
We present the results obtained from the analysis of unpublished faunal remains from the Bronze Age settlement of Outeiro do Circo (Beja). The materials provenance is diverse, corresponding mainly to one pit/ silo from trench 3 and the areas near the defensive systems designated trench 7 and 8. Hunting strategies are complementary in the assemblage, with a predominance of sheep and goat remains, followed by cattle and swine. Kill-off patterns with the presence of young and adult individuals are suggestive of a mixed economy with the exploitation of primary and secondary resources. Although highly fragmented and affected by postdepositional processes it was possible to record several anthropization indicators related to the butchering process and thermo-alteration of remains by fire.
\end{abstract}

Keywords: Zooarchaeology, Taphonomy, Bronze Age, Settlement, Southwest Iberia.

\section{INTRODUÇÃO}

A análise da componente animal nas dietas da Idade do Bronze do Sul de Portugal é problemática, não apenas devido ao pequeno número de conjuntos faunísticos preservados, estudados e publicados, como às características próprias destas colecções, com um reduzido número de restos identificáveis taxonomicamente e uma alta afectação por processos pós-deposicionais que nem sempre são avaliados.

Foi recentemente realizado o estudo de uma amostra faunística do povoado do Outeiro do Circo (Beja),

\footnotetext{
1. Uniarq, Centro de Arqueologia da Universidade de Lisboa, Faculdade de Letras da Universidade de Lisboa.

2. Núcleo de Arqueologia da Câmara Municipal de Sintra. CEAACP - Centro de Estudos de Arqueologia, Artes e Ciências do Património.

3. Câmara Municipal de Serpa. CEAACP - Centro de Estudos de Arqueologia, Artes e Ciências do Património.

* Centro de Arqueologia da Universidade de Lisboa. Faculdade de Letras da Universidade de Lisboa, Alameda da Universidade, 160o-214, Lisboa, Portugal; nelsonjalmeida@gmail.com
} 
cronologicamente enquadrado no final da Idade do Bronze (Valério \& alii. 2013), que permitiu registar uma tendência para a preponderância de espécies domésticas face às selvagens, com similitudes ao que ocorre em outros conjuntos coevos (Dias $\mathbb{\&}$ alii, no prelo).

Com vista a alargar o leque de informações disponíveis procedemos à análise zooarqueológica de uma amostra que aqui apresentamos e que resulta dos trabalhos de escavação arqueológica decorridos no âmbito do projeto de investigação " $O$ povoado do Bronze Final do Outeiro do Circo (Beja)", que decorreu entre 2014 e 2017, integrando ainda uma pequena coleção de faunas recolhidas em $2013 \mathrm{em}$ projeto anterior.

\section{MATERIAIS E MÉTODOS}

\subsection{Materiais}

Os materiais em análise foram recolhidos nas sondagens 8 (33,6\%), 7 (31,7\%), $3(28,4 \%)$ e $1(6,3 \%)$ do Outeiro do Circo (Figura 1). Destacam-se pela sua relevância quantitativa a [303] da sondagem $3 \mathrm{com}$ 118 restos e as [707] e [708] da sondagem 7 com um total de 101 e 97 fragmentos respectivamente.

Da sondagem 1, que corresponde à muralha compósita identificada no sítio, foi analisado um pequeno conjunto inédito decorrente de actividades de limpeza posteriores com um total de 40 fragmentos faunísticos. De salientar que em estudos anteriores, cerca de $81 \%$ do material analisado era proveniente da sondagem 1 (Dias \& a alii, no prelo) pelo que o conjunto apresentado deverá ser entendido como complementar a essa análise (Figura 1).

Na sondagem 3, apesar da pequena potência estratigráfica foi identificada uma estrutura negativa/fossa [311] escavada no substrato geológico, com paredes irregulares de planta tendencionalmente circular e secção de morfologia oval. Os materiais analisados são provenientes da [302] e [303], níveis sucessivos de enchimento constituídos essencialmente por pedras envoltas num sedimento de cor negra, com presença de bastante cerâmica e alguma fauna. Outros materiais da [302] e [303] foram analisados por Dias $\&$ alii (no prelo) sendo que os restos desta sondagem correspondiam a cerca de $19 \%$ dessa amostra. $\mathrm{Na}$ sondagem 7 foram registados níveis de derrube da muralha adjacente, anteriormente intervencionada na Sondagem 1. As faunas correspondem maioritariamente à [707] e [708], com apenas dois fragmentos da [702]. Na [707] o estrato argiloso era muito compacto de coloração castanha bastante escura e com presença de nódulos desagregados do substrato geológico (gabro). Pedras de calibre pequeno, incluindo algumas aparentemente expostas ao fogo [708], preenchiam uma interface escavada no geológico [709] com aparente origem antrópica. Alguns carvões, cerâmica, fauna e barro cozido foram recuperados. As faunas desta sondagem são provenientes de depósitos não afectados pelos trabalhos agrícolas, sendo os materiais cerâmicos atribuíveis ao final da Idade do Bronze.

Quanto aos restos da sondagem 8, localizada próxima do talude defensivo, são provenientes de várias unidades estratigráficas, sobretudo das posicionadas na parte inferior da estratigrafia. Salienta-se a presença de raízes em várias unidades, assim como de pequenos nódulos de barro e carvões na [810], a qual englobava $19 \%$ dos restos desta sondagem e envolvia uma possível estrutura [815] composta por uma única fiada de pedras. A esta estavam encostados outros depósitos, como o [813] (25\% da fauna desta sondagem) onde se registaram nódulos de tonalidade esbranquiçada, cerâmica, fauna, barro e indústria lítica. É de referir que esta sondagem não se encontra terminada, pelo que algumas considerações relativas à atribuição cronológica das suas unidades estratigráficas não são totalmente seguras visto que, apesar de ainda não ter sido intervencionado, foi registado um nível com cerâmicas da Idade do Ferro na campanha de 2019, sendo que não incluímos nesta análise faunas dessa campanha.

\subsection{Métodos}

A análise dos restos arqueofaunísticos seguiu metodologias comuns em Zooarqueologia e Tafonomia (Lyman, 1994; Reitz \& Wing, 2008). A identificação taxonómica levou em conta a aquisição de dados biométricos e registo de características morfológicas de espécies similares, como Ovis aries e Capra hircus (Zeder $\mathbb{\&}$ Lapham, 2010; Zeder $\mathbb{\&}$ Pilaar, 2010). A obtenção de dados osteométricos e odontométricos foi realizada com um paquímetro digital Lux seguindo critérios de Driesch (1976) com acrescentos pontuais (e.g., Payne \& Bull, 1988; Davis, 1996).

Os padrões de idade implementados (infantil, juvenil/sub-adulto, adulto, senil) basearam-se em estimativas de desenvolvimento ósseo, erupção e desgaste dentário (e.g., Grant, 1982; Payne, 1987; Zeder, 2006; Lemoine $\mathbb{\&}$ alii., 2014; Zeder $\mathbb{\&}$ alii, 
2015). Mesmo que não passíveis de identificação taxonómica, todos os restos foram tentativamente associados a um grupo genérico de peso: muito pequeno ( $\mathrm{GP} 1 ;<2 \mathrm{og})$, pequeno $\left(\mathrm{GP}_{2} ; 20-100 \mathrm{~kg}\right)$, médio ( $\left.\mathrm{GP}_{3} ; 100-300 \mathrm{~kg}\right)$ e grande $\left(\mathrm{GP}_{4} ;>300 \mathrm{~kg}\right)$. Os resultados são apresentados através do Number of Specimens (NSP), Number of Identified Specimens (NISP), Minimum Number of Elements (MNE) e Minimum Number of Individuals (MNI) (Binford, 1984; Grayson, 1984).

Todos os restos foram agrupados em categorias de dimensão máxima e os fragmentos diafisários foram analisados de acordo com a sua completude (longitude e secção), delineação (curva, longitudinal, transversal), ângulo (oblíquo, recto, misto) e superfície (suave, irregular) dos planos de fractura (Villa \& Mahieu, 1991).

A análise macroscópica e microscópica foi implementada na identificação e registo de indicadores tafonómicos presentes nas superfícies dos restos. Marcas de processamentos e/ou consumo, antropogénico ou por outros animais, foram descritas através do registo da localização, morfologia e intensidade de indicadores de fractura (e.g., fractura por flexão ou percussão), marcas de corte (e.g., incisões, golpes), marcas de dentes (e.g., mordiscos, depressões) (Binford, 1978, 1981; Brain, 1981) e termo-alterações (Stiner \& alii, 1995; Solari \& alii, 2015).

Outros indicadores foram registados consoante o seu grau de afectação (Almeida, 2017), nomeadamente a presença de vermiculações, meteorização (Behrensmeyer, 1978), pisoteio, precipitação de óxidos e formação de concreções.

\section{RESULTADOS}

O conjunto apresenta um NSP de 633 registos, tendo sido possível identificar taxonomicamente cerca de $15 \%$ do conjunto, com os restantes $85 \%$ a corresponderem a restos de mamíferos (Tabela 1). Bos sp. está presente sobretudo através de restos das extremidades apendiculares com destaque para as falanges proximais e mesiais, mas também para porções de mandíbulas (Tabela 2). Nesta análise, as sondagens 7 e 8 apresentavam restos de gado bovino que, tomados em conjunto, corresponderiam a um MNI de um adulto com mais de 36 meses de idade, como indicado pela porção distal de um metatarso com os côndilos fusionados e que sugere uma pequena dimensão do indivíduo em questão. Ainda nos ani- mais de maior porte, registou-se Cervus elaphus, circunscrito à sondagem 7 , através de um fragmento de um metacarpo, dois fragmentos de uma falange proximal e dois de um astrágalo, associáveis a um MNI de um adulto. (Tabela 1; Tabela 2)

As ovelhas e cabras, de difícil identificação específi$\mathrm{ca}$, foram maioritariamente agrupadas em Ovis/Capra, estando ausentes restos mais robustos que pudessem indiciar a presença de espécimes selvagens de Capra pyrenaica. Foi possível uma identificação mais precisa para dois fragmentos de um astrágalo de Ovis aries e um fragmento de chifre e dois dentes isolados de Capra hircus, resultando em um MNI de um adulto para cada, com mais de 40 meses de idade, aos quais acrescem um adulto ( $24 \mathrm{a} 48$ meses) e um juvenil (6 a 12 meses) de ovelha/cabra. Ainda que seja o grupo taxonómico melhor representado quantitativamente e no que respeita à diversidade de elementos dos diferentes segmentos anatómicos, de salientar que os valores para o esqueleto axial craniano se encontram sobre-representados devido ao alto número de dentes e fragmentos de dentes identificados, algo comum em conjuntos com estas cronologias e características. Efectivamente, existe uma relevante disparidade para o caso das ovelhas e cabras se considerarmos os valores NISP (48) e MNE (26) que se deverá maioritariamente à fragmentação de peças dentárias.

Sus sp. é o terceiro grupo taxonómico melhor representado, atrás do gado bovino e das ovelhas/cabras. A ausência de elementos mensuráveis que permitissem uma identificação específica é de relevar, ainda que não se tenham registado restos sugestivos de um grande porte e, como tal, da presença da espécie selvagem. À semelhança do sugerido (Dias $\mathscr{\&}$ alii, no prelo), os escassos elementos mensuráveis apontam para animais de pequenas dimensões pelo que provavelmente se tratarão de Sus scrofa domesticus. Uma vez mais, destaca-se a presença de restos do esqueleto axial craniano, especialmente de fragmentos de dentes isolados, que pela análise das idades de erupção e desgaste indicam um MNI de três indivíduos, correspondendo a um sub-adulto (18 a 30 meses), um adulto (30 a 72 meses) e um adulto/ senil (52 a 95 meses).

Foi identificada uma mandíbula de um Oryctolagus cuniculus adulto na sondagem 1 e um processo transverso de uma vértebra de Leporidae na sondagem 8. Como discutido, de uma forma geral fica demonstrada a relevância de dentes e elementos das patas des- 
tes animais, em detrimento do esqueleto axial pós-craniano e de elementos apendiculares associados a um maior aporte cárnico (Tabela 2). Entre os restos apenas identificados por grupo de peso, deixando de lado os considerados como desconhecidos, verifica-se a escassez de registos de porte muito pequeno, alguma abundância de restos de animais de porte médio a grande e um predomínio de animais de porte pequeno, com entre 20 a $100 \mathrm{~kg}$. Os últimos, que poderiam ser associados a ovelhas/cabras ou animais de porte similar, apresentam alguns elementos correspondentes às partes anatómicas menos representadas, assim como um importante número de fragmentos de ossos longos (sobretudo diáfises). Para além disso, é clara a baixa frequência de restos de ossos planos, os quais estão igualmente pouco representados nos registos identificados taxonomicamente e que se estende aos animais de porte $>100 \mathrm{~kg}$. O conjunto é composto por 161 fragmentos com

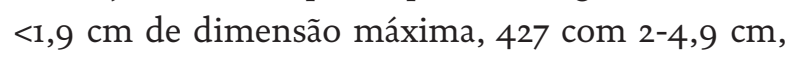
41 com 5-7,9 cm e 4 com 8-10cm, ou seja, 92,9\% do conjunto tem $<4,9 \mathrm{~cm}$ face a $7,1 \% \mathrm{com}>5 \mathrm{~cm}$. Fica comprovada a baixa preservação da amostra analisada, sobretudo tendo em conta a frequência de espécies de porte muito pequeno que poderiam inflacionar os restos de menores dimensões. De referir a quase ausência de elementos completos (o,3\%), ainda que a fragmentação moderna também deva ser mencionada (43,8\%).

De forma a melhor compreender a fracturação/ fragmentação do conjunto foi realizada a análise da completude diafisária em 85 restos e dos planos de fractura diafisários em 121 fragmentos com 312 planos (Figura 2). Verifica-se um predomínio de registos com $<50 \%$ da longitude diafisária preservada, entre estes destacando-se os que têm $<25 \%$; e uma maior frequência de $<25 \%$ da secção diafisária preservada. De salientar os valores altos de delineações longitudinais, ângulo rectos e uma ligeira maior abundância das superfícies suaves face às superfícies irregulares (Figura 2).

No que respeita aos indicadores de processamento e consumo das carcaças de animais, apesar da baixa preservação do conjunto foi possível identificar uma importante frequência de restos com marcas de corte e indicadores de fracturação dinâmica antropogénica, queima e de forma menos expressiva a possível fervura (Tabela 3; Figura 3).

As marcas de corte foram registadas em restos de Bos taurus, nomeadamente uma falange proximal com golpes paralelos, um calcâneo com incisões oblíquas paralelas, um metatarso com uma incisão isolada oblíqua e um fragmento de mandíbula com incisões isoladas e agrupadas paralelas no colo do processo condilar, relacionáveis com actividades de descarne e desarticulação, ainda que no caso da mandíbula possa associar-se à remoção da língua. Uma incisão isolada em astrágalo de Cervus elaphus, outra em diáfise de fémur de Ovis/Capra e várias incisões paralelas em calcâneo e mandíbula de Sus sp., sugerem a existência de actividades de processamento similares às supramencionadas para os restos de bovídeo. Contudo, a maioria dos registos com marcas de corte foram considerados indeterminados taxonomicamente, englobando animais de porte indeterminado (6), pequeno (5), pequeno/médio (2), médio (1) e grande (1), correspondendo a costelas (4), ossos longos (5) e planos (5) ou indeterminados (1), relacionáveis com desconexão/descarne, remoção de vísceras e segmentação (Tabela 3).

A fracturação antropogénica está representada por um impacto isolado em rádio de Ovis/Capra e fragmentos diafisários de animais de porte similar, uma extração cortical em metatarso de Bos sp. restos indeterminados de animais de porte pequeno a grande (7), ocasionalmente associados a outros estigmas como fissuras e possíveis contragolpes, tendo-se identificado um cone de percussão em diáfise de porte médio/grande (23,41x17,03 mm).

A termo-alteração por queima é relevante no conjunto, sobretudo nas sondagens 7 e 8 onde correspondem a cerca de $26 \%$ e $56 \%$ do total de restos com este indicador tafonómico. Fragmentos de astrágalo de Cervus elaphus e de Ovis aries e Ovis/Capra têm grau 2 de queima, com 1 dos fragmentos de astrágalo de veado a atingir o grau 3 de carbonização. Os restantes são registos indeterminados taxonomicamente, sobretudo fragmentos de ossos longos (24) e indeterminados (18) de porte indeterminado (23) e pequeno (15), com graus iniciais de afectação (Grau 1 e $2=24$ ), mas também carbonização (15) e, inclusive, mais avançados atingindo a calcinação (Grau 4 e $5=11$ ). A possível fervura é escassa e circunscrita a restos indeterminados taxonomicamente. Dias $\mathbb{\&}$ alii (no prelo) haviam também indicado a relevância de restos queimados nos materiais das sondagens 1 e 3 (Figura 3).

Quanto à presença de marcas de dentes, está circunscrita a perfurações opostas em planos de fractura de diáfise de animal de porte pequeno, rádio de Ovis/ 
Capra com mordiscos na diáfise e mordiscos e depressões espalhados pela diáfise e epífise do metatarso de Bos sp., as últimas morfologicamente relacionáveis com um carnívoro, provavelmente um grande canídeo. A comparação métrica demonstra que os mordiscos no metatarso de Bos sp. (OC-BT) apresentam dimensões similares a canídeos e suídeos, diferenciando-se das amostras antrópicas principalmente em tecido cortical (Figura 4). Os mordiscos no rádio de Ovis/Capra, apresentam comprimentos comparáveis a amostras com marcas de dentes de canídeos, suídeos e humanas, mas os valores obtidos para a largura parecem ter mais similitudes com as amostras de canídeos, nomeadamente Canis lupus familiaris obtidas por Andrés \& alii (2012) (Figura 4). Os restantes indicadores englobam registos vestigiais de acção hídrica e pisoteio que não foram relevantes nos contextos em estudo. A meteorização e vermiculações assumem alguma importância estando presentes em $>20 \%$ do conjunto. A meteorização foi registada principalmente em grau $1(50,4 \%)$ e 2 $(29,6 \%)$, ainda que graus mais avançados também ocorram: graus $3(17,8 \%)$ e 4 ( $2,2 \%)$. As vermiculações seguem um padrão similar, mas com ausência de grau 4 e destacando-se ainda mais a afectação de grau $1(81,7 \%)$ comparativamente aos graus $2(12,4 \%)$ e $3(5,9 \%)$.

\section{DISCUSSÃO}

Dias $\&$ alii (no prelo) estudou uma amostra de materiais das sondagens 1 e 3 do Outeiro do Circo, tendo identificado uma maior frequência de restos de Ovis/Capra, seguidas por Bos e Sus, com os registos de Cervus elaphus, Canis lupus familiaris, Equus e Lepus a terem menos expressividade. De forma similar ao sucedido, registamos uma predominância de espécies domesticadas faces às selvagens, estando ausentes os restos de Bos primigenius ou Sus scrofa entre os registos mensuráveis. Tudo parece apontar para a presença única de Bos taurus e Sus scrofa domesticus entre os restos mensuráveis e os restantes apresentam pequenas dimensões que são concordantes com esta possibilidade. Salienta-se que não identificamos qualquer elemento de canídeo, algo que havia acontecido anteriormente com base na presença de uma mandíbula e dois dentes recolhidos na Sondagem 1, ou de equídeo que havia sido identificado por uma pélvis e um dente da mesma área (Dias \& alii, no prelo).
Quanto aos padrões de idade, verifica-se um predomínio de indivíduos adultos no total do conjunto existente como demonstrado pela presença de ossos fusionados e dentição permanente com desgaste. Alguns indivíduos mais jovens foram registados em ambos os estudos, nomeadamente no caso de Sus sp. e Ovis/Capra, com Dias $\&$ alii (no prelo) a identificarem um Bos sp. juvenil entre os materiais da Sondagem 3.

A importância de ossos do esqueleto apendicular havia sido indicada, tendo-se sugerido que elementos menos densos poderiam não ter sobrevivido ao atrito diagenético. Efectivamente, Bos sp. estava representado quase unicamente por peças dentárias e mandibulares, porém Cervus elaphus também apresentava alguns ossos longos. Ovis/Capra e Sus sp., apesar de representados principalmente por dentes isolados e mandíbulas, também tinham registos das porções superiores apendiculares, num padrão que se apresenta similar ao aqui apresentado, ainda que com menos ossos das extremidades. Estes, agora registados de forma comparativamente abundante, são provenientes essencialmente das sondagens $7 \mathrm{e}$ 8 , ou seja, próximas do talude defensivo.

Do ponto de vista tafonómico, os únicos ossos considerados como tendo uma pátina sugestiva de serem intrusões são provenientes da sondagem 1 , o que nos parece compreensível dada a própria formação deste registo, correspondente a uma muralha compósita, com abundantes clastos e remobilizações (Figura 5). Os restos com indicadores de processamento (marcas de corte, fractura antropogénica) estão divididos pelas várias sondagens, salientando-se as marcas de corte nas sondagens 7 e 8 . Não obstante, enquanto $5,5 \%$ e $3,8 \%$ dos restos das sondagens 7 e 8 apresentam respectivamente marcas de corte, na sondagem 3 esse valor baixa para $0,6 \%$ e na 1 sobe para $7,5 \%$. Nas sondagens 3 e 7 destaca-se a fracturação antropogénica, sobretudo na sondagem 3 que engloba cerca de $42 \%$ dos restos com estes indicadores. Porém, em proporção, apenas $0,9 \%$ dos restos dessa sondagem estão queimados, enquanto nas restantes sondagens esse valor oscila entre os $2 \%$ da sondagem 7 e os $2,8 \%$ da sondagem 3 .

A termo-alteração por queima e possível fervura são mais abundantes na sondagem 8 onde $14,6 \%$ dos restos estão queimados. Nas restantes sondagens os valores oscilam entre $5 \%$ na sondagem 1 e os $2 \%$ da sondagem 7. A exposição ao fogo terá sido relevante entre os materiais analisados anteriormente $\mathrm{e}$ 
provenientes das sondagens 1 e 3 , tendo-se registado restos carbonizados, alguns dos quais recolhidos em unidades com carvões à semelhança do aqui descrito (Dias $\mathbb{E}$ alii, no prelo).

Compreender se os restos foram queimados durante o tratamento culinário, devido ao uso como combustível, se foram atirados para o fogo como desperdício ou queimados acidentalmente é difícil. Os animais podem ser grelhados sem grande processamento (Kent, 1993), com excepções como costelas e outros elementos axiais (Oliver, 1993). Mesmo quando os grelhados são a principal forma de tratamento culinário a representatividade de ossos queimados poderá ser bastante reduzida (Kent, 1993, p. 348). Existem diferenças na combustão consoante $o$ tipo de osso com o tecido esponjoso a ser mais combustível que o cortical (de relembrar a baixa presença de restos de ossos planos identificados ou não taxonomicamente no conjunto analisado), teor de humidade e grau de fragmentação (e.g., Théry-Parisot $\&$ alii, 2005). No conjunto do Outeiro do Circo foi registada queima em vários astrágalos o que poderia indicar a remoção das extremidades apendiculares previamente ao tratamento culinário de porções maiores. A presença de graus iniciais de afectação por queima e colorações duplas parece também sugerir o tratamento culinário, mas a presença de carbonização e calcinação poderia estar associada à acção de alimentar o fogo ou de o utilizar como forma de lidar com desperdícios. Dadas as evidências parece-nos parcimoniosa uma interpretação na qual os restos queimados se associam maioritariamente ao tratamento culinário, com as restantes hipóteses a desempenharem um papel secundário.

Quanto às marcas de dentes, apenas se verificam na sondagem 7 , ficando atestada uma baixa incidência de dano causado por carnívoros no conjunto analisado. Isto poderá contrastar com o expectável visto se tratar de um tipo de ocupação alargada, se ter identificado a presença de cão (e suínos) e algumas das marcas de dentes serem associáveis morfologicamente e metricamente à acção de um canídeo. Subsiste a possibilidade de estes restos estarem maioritariamente associados a um comportamento que dificultasse o acesso por carnívoros, sendo também de ter em conta que a frequência de marcas de dentes criadas por canídeos poderá variar consideravelmente devido à frequência na qual têm acesso aos ossos, ao tipo de tratamento culinário, tamanho e densidade dos restos (Binford, 1981; Kent, 1981, 1993).
A meteorização encontra-se dividida entre as sondagens com uma maior quantidade de restos. Quanto a abundâncias relativas ao número de registos por sondagem, a meteorização encontra-se em cerca de $17 \%$ dos restos da sondagem 8 , com as restantes sondagens a terem entre 22 e $25 \%$ dos restos afectados, o que sugere uma mais rápida sedimentação nas sondagens 1,3 e 7 comparativamente à sondagem 8 . Não obstante, seria necessária uma maior amostra ou uma diferença significativa para melhor discutir essa possibilidade, assim como estender a análise aos restantes elementos das sondagens 1 e 3 . Seria interessante, por exemplo, comparar estes dados com aqueles provenientes de uma análise à fracturação das cerâmicas comparando os resultados obtidos e verificando a validade desta hipótese. As vermiculações são mais abundantes nas sondagens $7 \mathrm{e}$ 8, salientando-se a sua baixa representatividade na sondagem 3 apesar da relevância quantitativa dessa amostra. Também na sondagem $8,34,7 \%$ dos restos apresentam vermiculações o que, em conjunto com a meteorização mais baixa, poderia uma vez mais sugerir alguma diferença na formação deste ambiente sedimentar.

No que concerne à relevância do conjunto faunístico do Outeiro do Circo para a compreensão das dinâmicas económicas do ponto de vista faunístico durante o final da Idade do Bronze, não existem muitos contextos, sobretudo com intervenções recentes e relevância quantitativa, que permitam uma comparação sustentada. Deixando de parte conjuntos publicados de realidades arqueológicas ou geográficas mais afastadas e, como tal, focando as informações existentes para a faixa que vai desde o interior alentejano português à Extremadura contamos apenas com alguns conjuntos englobados na Idade do Bronze e início da Idade do Ferro (Figuras 6 e 7).

Restringindo-nos aos conjuntos com um NISP $>50$, para a Idade do Bronze inicial apenas poderemos referir Los Barruecos (Malpartida de Cáceres) e, para a fase plena Alange (Badajoz), sendo que em ambos os contextos se denota a predominância de ovelhas/cabras e gado bovino, com uma melhor representatividade dos suínos face aos bovinos em Los Barruecos. Equídeos apenas se identificam em Los Barruecos, com a caça de cervídeos a ser reduzida neste sítio e residual em Alange. Durante o final da Idade do Bronze, o Castro de Ratinhos (Moura) e o Outeiro do Circo (Beja) apresentam abundâncias relativas similares, com predomínio de ovelhas/ca- 
bras, seguidas por gado bovino, suíno e cervídeos. Em Alange, pelo contrário, o gado bovino é maioritário, com boas representatividades de ovelhas/cabras e suínos e, como nos restantes, baixos valores de cervídeos. Saliente-se a existência de equídeos no Outeiro do Circo que, possivelmente, se tratará de Equus cf. asinus (Dias \& alli, no prelo).

Com o início da Idade do Ferro o número de conjuntos na zona em estudo aumenta, ainda que com algumas disparidades a nível de amostras passíveis de comparação. A presença escassa de equídeos verifica-se também na Idade do Ferro antigo de Cabeço Redondo (Moura), onde ovelhas/cabras são mais abundantes, seguidas por gado bovino e suíno e, uma vez mais, escassez de cervídeos. Ainda que com um conjunto mais pequeno, de salientar que apenas no Castro da Azougada (Moura) (Nabais $\mathbb{8}$ Soares, 2017) se verifica a predominância de cervídeos face aos restantes grupos. Sítios como Medellín (Badajoz), Sierra del Aljibe (Aliseda, Cáceres) e Alcazaba de Badajoz (Badajoz) demonstram um maior desenvolvimento de práticas assentes no gado bovino, sobretudo em Sierra del Aljibe, com menos abundâncias de cervídeos e suínos face às ovelhas/cabras, ainda que em Alcazaba de Badajoz exista um maior equilíbrio entre estes dois grupos. La Mata (Campanario, Badajoz), apresenta o conjunto quantitativamente mais relevante, com um predomínio destacado de gado bovino, seguido por ovelhas/cabras e frequências mais reduzidas mas similares de suínos, cervídeos e equídeos.

\section{CONCLUSÕES}

O conjunto faunístico do Outeiro apresenta uma relevância de gado bovino, caprino e suíno atestando a importância do desenvolvimento agro-pecuário durante o final da Idade do Bronze. A aquisição de produtos primários e secundários (lã, leite, tracção) terá sido uma constante na vida destes grupos para os quais as práticas cinegéticas, nomeadamente a caça de veado e, eventualmente, de outras espécies como o javali, coelho e lebre, teriam um papel secundário. Registaram-se indicadores variados de desmanche e processamento dos restos de animais de diferentes portes, com os grelhados aparentemente a destacar-se como prática culinária de eleição.

Fica em aberto a possibilidade de se verificarem diferentes representatividades anatómicas ou até de espécies consoante a zona do povoado, sendo que junto ao talude defensivo as evidências são sugestivas de se tratar de uma zona de despejo tipo "lixeira", ou de acumulação de detritos resultantes de escorrências na encosta do povoado. Com o prosseguimento dos trabalhos arqueológicos e das análises de eventuais novos restos arqueofaunísticos será possível aumentar o leque de informação existente para esta região num período para o qual o Outeiro do Circo se assume de enorme relevância devido à escassa informação arqueofaunística.

\section{BIBLIOGRAFIA}

ALMEIDA, Nelson J. (2017) - Zooarqueologia e tafonomia da transição para a agro-pastorícia no baixo e médio vale do Tejo. Mação: Instituto Terra e Memória.

ANDRÉS, M.; GIDNA, A. O.; YRAVEDRA, J.; DOMÍNGUEZ-RODRIGO, M. (2012) - A study of dimensional differences of tooth marks (pits and scores) on bones modified by small and large carnivores. Archaeological and Anthropological Sciences. 4, pp. 209-219.

BEHRENSMEYER, A. K. (1978) - Taphonomic and ecologic information from bone weathering. Paleobiology. 4:2, pp. 150-162.

BINFORD, L. (1978) - Nunamiut Ethnoarchaeology. New York: Academic Press.

BINFORD, L. (1981) - Bones: ancient men and modern myths. New York: Academic Press.

BINFORD, L. (1984) - Faunal remains from Klassies River Mouth. New York: Academic Press.

BRAIN, C. K. (1981) - The Hunters or the Hunted? An Introduction to African Cave Taphonomy. Chicago: University Press.

CARDOSO, J. L.; SOARES, R. (2013) - Faunas mamalógicas do sítio pós-orientalizante do Cabeço Redondo (Sobral da Adiça, Moura). Escavações de 2011. Al-Madan. 18, pp. 87-92.

CASTAÑOS, P. (1998a) - Evolución de las faunas protohistóricas en Extremadura. In RODRÍGUEZ DÍAZ, A., coord. - Extremadura Protohistórica: Paleoambiente, Economía y Poblamiento. Cáceres, p. 63-72.

CASTAÑOS, P. (1998b) - Estudio arqueozoológico de la fauna del Cerro del Castillo de Alange (Badajoz). In PAVÓN SOlDEVILA, I., ed. - El Cerro del Castillo de Alange (Badajoz). Intervenciones arqueológicas (1993). Mérida, p. 167-177.

CASTAÑOS, P. (1999) - Estudio de la fauna de la Sierra del Aljibe (Aliseda, Cáceres). In El poblado protohistorico de Aliseda (Cáceres). Campaña de 1995. Cáceres, p. 214-219.

CASTAÑOS, P. (2004) - Fauna y prácticas ganaderas. In Rodríguez Díaz, A., ed. - El edificio protohistórico de "La Mata" (Campanario, Badajoz) y su estudio territorial. Cáceres: Universidad de Extremadura, p. 453-467. 
DAVIS, S. J. M. (1996) - Measurements of a group of adult female Shetland sheep skeletons from a single flock: a baseline for zooarchaeologists. Journal of Archaeological Science. 23, pp. 593-612.

DELANEY-RIVERA, C.; PLUMMER, T. W.; HODGSON, J. A.; FORREST, F.; HERTEL, F.; OLIVER, J. S. (2009) - Pits and pitfalls: taxonomic variability and patterning in tooth mark dimensions. Journal of Archaeological Science. 36, pp. 2597-2608.

DRIESCH, A. (1976) - A guide to the measurement of animal bones from Archaeological sites. Harvard. Peabody Museum Bulletin 1.

GRAYSON, D. (1984) - Quantitative Zooarchaeology. London: Academic Press.

GRANT, A. (1982) - The use of tooth wear as guide to the age of domestic ungulates. In WILSON, B.; GRIGSON, C.; PAYNE, S., eds. - Ageing and sexing animal bones from archaeological sites. Oxford: Archaeopress, p. 91-198.

DIAS, I.; PORFÍRIO, E.; SERRA, M.; DETRY, C. (no prelo) - Late Bronze Age faunal remains fom Outeiro do Circo (Beja, Portugal): a preliminary study. In VALENTE, M. J.; DETRY, C.; COSTA, C., eds. - New Trends in Iberian Zooarchaeology. Oxford: Archaeopress.

KENT, S. (1981) - The dog - Archaeologists' best friend or worse enemy: spatial distribution of faunal remains. Journal of Field Archaeology. 8: 3, pp. 367-372.

KENT, S., (1993) - Variability in faunal assemblages: the influence of hunting skill, sharing, dogs, and mode of cooking on faunal remains at a sedentary Kalahari community. Journal of Anthropological Archaeology. 12, pp. 323-385.

LEMOINE, X.; ZEDER, M. A.; BISHOP, K. J.; RUFOLO, S. J. (2014) - A new system for computing dentition-based age profile in Sus scrofa. Journal of Archaeological Science. 47, pp. 179-193.

LIESAU, C.; GARCÍA, J. (2010) - La fauna de Ratinhos: estudio de la fauna y de la industria ósea procedente de la Tercera línea de muralla. In BERROCAL-RANGEL, L.; SILVA, A.C., eds. - O Castro dos Ratinhos (Barragem de Alqueva, Moura). Escavação num povoado proto-histórico do Guadiana, 2004-2007. Lisboa: Museu Nacional de Arqueologia, pp. 329-348.

LYMAN, R. L. (1994) - Vertebrate Taphonomy. Cambridge: University Press.

MORALES, A. (1977) - Los restos animales del castro de Medellín. In ALMAGRO-GORBEA, M., eds. - El Bronce Final y el Período Orientalizante en Extremadura. Biblioteca Praehistórica Hispana XIV Madrid, pp. 513-519.

NABAIS, M.; SOARES, R. (2017) - Zooarchaeological evidence from the Iron Age site of Castro da Azougada (Moura, Portugal). Revista Portuguesa de Arqueologia. 20, pp. 61-69.
OLIVER, J. S. (1993) - Carcass processing by the Hadza: bone breakage from butchery to consumption. In HUDSON, J., ed. - From bones to behavior: ethnoarchaeological and experimental contribution to the interpretation of faunal remains. Carbondale: Southern Illinois University Press, p. 200-228.

PAYNE, S. (1987) - Reference codes for wear states in the mandibular cheek tooth of sheep and goats. Journal of Archaeological Science. 14, pp. 6o9-614.

PAYNE, S.; BULL, G. (1988) - Components of variation in measurements of pig bones and teeth, and the use of measurements to distinguish wild from domestic pig remains. ArchaeoZoologia. II:1-2, pp. 27-66.

REITZ, E. J.; WING, E. S. (2008) - Zooarchaeology. Cambridge: University Press.

SALADIÉ, P. (2009) - Mossegades d'omnívors. Aproximació experimental i aplicació zooarqueològica a la Sierra de Atapuerca. Dissertação de Doutoramento. Universitat Rovira I Virgili.

SALADIÉ, P.; RODRÍGUEZ-HIDALGO, A.; DÍEZ, C.; MARTÍN-RODRÍGUEZ, P.; CARBONELL, E. (2013) Range of bone modifications by human chewing. Journal of Archaeological Science. 40, pp. 380-397.

STINER,M.;KUHN,S.;WEINER,S.;BAR-YOSEF,O.(1995) - Differential burning, recrystallization, and fragmentation of archaeological bone. Journal of Archaeological Science. 22, pp. 223-237.

SOLARI, A.; OLIVERA, D.; GORDILLO, I.; BOSCH, P.; FETTER, G.; LARA, V. H.; NOVELO, O. (2015) - Cooked bones? Method and practice for identifying bones treated at low temperature. International Journal of Osteoarchaeology. 25 , pp. 426-440.

VILLA, P.; MAHIEU, E. (1991) - Breakage patterns of human long bones. Journal of Human Evolution. 21, pp. 27-48.

THÉRY-PARISOT, I., COSTAMAGNO, S., BRUGAL, J.P., FOSSE, P., GUILBERT, R. (2005) - The use of bone as fuel during the Palaeolithic, experimental study of bone combustible properties. In MULVILLE, J.; OUTRAM, A.K., eds. - The Zooarchaeology offats, oils, milk and dairying. Oxbow Books, p. 50-59.

VALÉRIO, P.; SOARES, A.; ARAÚJO, F.; SILVA, R.; PORFÍRIO, E.; SERRA, M. (2013) - Estudo de metais e vestígios de produção do povoado fortificado do Bronze Final do Outeiro do Circo (Beja). In Arqueologia em Portugal 150 anos - Atas do I Congresso da Associação dos Arqueólogos Portugueses, 21 a 24 de Novembro de 2013. Lisboa: AAP, pp. 609-615.

ZEDER, M. A. (2006) - Reconciling rates of long bone fusion and tooth eruption and wear in sheep (Ovis) and goat (Capra). In RUSCILLO, D., ed. - Recent advances in ageing and sexing animal bones. Oxford: Oxbow Books, pp. 87-118. 
ZEDER, M.A.; LAPHAM, H.A. (2010) - Assessing the reliability of criteria used to identify postcranial bones in sheep, Ovis, and goats, Capra. Journal of Archaeological Science. 37: 11, pp. 2887-2905.

ZEDER, M. A.; PILAAR, S. E. (2010) - Assessing the reliability of criteria used to identify mandibles and mandibular teeth in sheep, Ovis, and goats, Capra. Journal of Archaeological Science. 37, pp. 225-242.

ZEDER, M. A.; LEMOINE, X.; PAYNE, S. (2015) - A new system for computing long-bone fusion age profiles in Sus scrofa. Journal of Archaeological Science. 55, pp. 135-150.

\begin{tabular}{|c|c|c|c|c|c|c|c|c|}
\hline Taxa & NISP & NISP\% & MNE & MNE\% & MNI & MNI\% & MNI Juvenil & MNI Adulto \\
\hline B & 15 & 2,4 & 14 & 23,7 & 1 & 10 & & 1 \\
\hline $\mathrm{CH}$ & 3 & 0,5 & 3 & 5,1 & 1 & 10 & & 1 \\
\hline $\mathrm{OA}$ & 2 & 0,3 & 1 & 1,7 & 1 & 10 & & 1 \\
\hline $\mathrm{O} / \mathrm{C}$ & 48 & 7,6 & 26 & 44,1 & 2 & 20 & 1 & 1 \\
\hline CE & 5 & 0,8 & 3 & 5,1 & 1 & 10 & & 1 \\
\hline S & 12 & 1,9 & 10 & 16,9 & 3 & 30 & 1 & 2 \\
\hline HER & 7 & 1,1 & & & & & & \\
\hline ORC & 1 & 0,2 & 1 & 1,7 & 1 & 10 & & 1 \\
\hline $\mathrm{L}$ & 1 & 0,2 & 1 & 1,7 & & & & \\
\hline${ }_{-}^{\mathrm{MA}}-$ & 539 & 85,2 & $-\quad-$ & $-\quad-$ & - & - & - & - \\
\hline GPind. & 274 & 50,8 & & & & & & \\
\hline$G P_{1}$ & 1 & 0,2 & & & & & & \\
\hline$G P_{1} / 2$ & 28 & 5,2 & & & & & & \\
\hline $\mathrm{GP} 2$ & 158 & 29,3 & & & & & & \\
\hline$G P 2 / 3$ & 30 & 5,6 & & & & & & \\
\hline$G P_{3}$ & 13 & 2,4 & & & & & & \\
\hline$G P_{3} / 4$ & 18 & 3,3 & & & & & & \\
\hline GP4 & 17 & 3,2 & & & & & & \\
\hline Total & 633 & 100 & 59 & 100 & 10 & 100 & 2 & 8 \\
\hline
\end{tabular}

Tabela 1 - Principais índices quantitativos aplicados na análise das faunas do Outeiro do Circo. Legenda: $\mathrm{B}=\mathrm{Bos}$ sp.; $\mathrm{CH}=\mathrm{Capra}$ hircus; OA = Ovis aries; O/C = Ovis/Capra; $\mathrm{CE}=$ Cervus elaphus; $\mathrm{S}=$ Sus sp.; HER = Herbívoro; ORC = Oryctolagus cuniculus; $\mathrm{L}$ = Leporidae; MA = Mamíferos; GP = Grupo de Peso. Os restos não identificados taxonomicamente são apresentados por Grupos de Peso. 


\begin{tabular}{|c|c|c|c|c|c|c|c|c|c|c|c|c|c|c|c|c|c|c|}
\hline Elemento & B & $\mathrm{CH}$ & $\mathrm{OA}$ & $\mathrm{O} / \mathrm{C}$ & CE & $\mathrm{S}$ & ART & ORC & $\mathrm{L}$ & GPo & GP1 & $\mathrm{GP} 1 / 2$ & $\mathrm{GP} 2$ & $\mathrm{GP}_{2} / 3$ & $\mathrm{GP}_{3}$ & $\mathrm{GP}_{3} / 4$ & $\mathrm{GP}_{4}$ & Total \\
\hline Haste/Chifre & & $1(1)$ & & & & & & & & 1 & & & & & & & & $2(1)$ \\
\hline Crânio (maxilar) & & & & $2(2)$ & & $1(1)$ & & & & 4 & & & 3 & & & 1 & & $11(3)$ \\
\hline Mandíbula & $4(3)$ & & & & & $2(1)$ & & 1 & & & & & 6 & & & & & $13(5)$ \\
\hline Incisivo solto & & & & $1(1)$ & & $2(2)$ & & & & & & & & & & & & $3(3)$ \\
\hline Pré-molar solto & $1(1)$ & $1(1)$ & & $2(2)$ & & & & & & & & & & & & & & $4(4)$ \\
\hline Molar solto & & $1(1)$ & & $31(10)$ & & $3(2)$ & 1 & & & & & & & & & & & $36(13)$ \\
\hline Dente ind. & & & & & & & 1 & & & 2 & & & & & & & & $3(0)$ \\
\hline Vértebra & & & & & & & & & $1(1)$ & & & 6 & 3 & 1 & & & & $11(1)$ \\
\hline Costela & & & & & & & & & & & & & 9 & 2 & & & 2 & $13(0)$ \\
\hline Escápula & & & & & & & & & & & & & 1 & & & & & $1(0)$ \\
\hline Úmero & & & & & & $1(1)$ & & & & & & 1 & 1 & & & & & $3(1)$ \\
\hline Rádio & & & & $2(2)$ & & & & & & & & & 1 & & & & & $3(2)$ \\
\hline Ulna & & & & & & & & & & & & & 1 & & & & & $1(0)$ \\
\hline Pélvis & & & & & & $1(1)$ & & & & & & & 1 & & & & & $2(1)$ \\
\hline Fémur & & & & $1(1)$ & & $1(1)$ & & & & & & & 2 & & & & & $4(2)$ \\
\hline Patela & $1(1)$ & & & & & & & & & & & & & & & & & $1(1)$ \\
\hline Tíbia & & & & $1(1)$ & & & & & & & & & & 1 & & & & $2(1)$ \\
\hline Metacarpo & & & & $3(2)$ & $1(1)$ & & & & & & & & & & & & & $4(3)$ \\
\hline Metatarso & $2(2)$ & & & I(1) & & & & & & & & & & & & & & $3(3)$ \\
\hline Metápodo & & & & & & & 3 & & & & & & & & & 1 & & $4(0)$ \\
\hline Astrágalo & & & $2(1)$ & $2(2)$ & $2(1)$ & & 2 & & & & & & & & & & & $8(4)$ \\
\hline Calcâneo & $1(1)$ & & & $1(1)$ & & I(1) & & & & & & & & & & & & $3(3)$ \\
\hline Carpal/tarsal & & & & & & & & & & & & 1 & & & & & & $1(0)$ \\
\hline Falange I & $2(2)$ & & & $1(1)$ & $2(1)$ & & & & & & & & & & & & & $5(4)$ \\
\hline Falange II & $3(3)$ & & & & & & & & & & & & & & & & & $3(3)$ \\
\hline Falange III & $1(1)$ & & & & & & & & & & & & & & & & & $1(1)$ \\
\hline Osso longo & & & & & & & & & & 7 & 1 & 5 & 113 & 23 & 13 & 12 & 15 & $189(0)$ \\
\hline Osso plano & & & & & & & & & & 87 & & 10 & 15 & & & 1 & & $113(0)$ \\
\hline Indeterminado & & & & & & & & & & 173 & & 5 & 2 & 3 & & 3 & & $186(0)$ \\
\hline Total & $15(14)$ & $3(3)$ & $2(1)$ & $48(26)$ & $5(3) 1$ & $12(10)$ & 7 & $1(1)$ & $1(1)$ & 274 & 1 & 28 & 158 & 30 & 13 & 18 & 17 & 633(59) \\
\hline
\end{tabular}

Tabela 2 - Number of Identified Specimens (NISP) e entre parêntesis Minimum Number of Elements (MNE) das faunas do Outeiro do Circo. Legenda: $\mathrm{B}=$ Bos sp.; $\mathrm{CH}=$ Capra hircus; $\mathrm{OA}=$ Ovis aries; $\mathrm{O} / \mathrm{C}=$ Ovis/Capra; $\mathrm{CE}=$ Cervus elaphus; $\mathrm{S}=$ Sus sp.; HER = Herbívoro; ORC = Oryctolagus cuniculus; $\mathrm{L}=$ Leporidae; MA = Mamíferos. Os números entre parêntesis correspondem ao MNE e os restos não identificados taxonomicamente são apresentados por Grupos de Peso. 


\begin{tabular}{lll} 
Indicador & $\mathrm{n}$ & $\%$ \\
\hline Marcas de corte & 23 & 3,6 \\
Fracturação antropogénica & 11 & 1,7 \\
Termo-alteração & 55 & 8,7 \\
?Fervura & 6 & 0,9 \\
Marcas de dentes & 3 & 0,5 \\
Acção hídrica & 1 & 0,2 \\
Meteorização & 135 & 21,3 \\
Vermiculações & 169 & 26,7 \\
Pisoteio & 2 & 0,3 \\
Fragmentação moderna & 277 & 43,8 \\
Pátina recente & 6 & 0,9 \\
Elementos completos & 2 & 0,3 \\
\hline
\end{tabular}

Tabela 3 - Principais indicadores tafonómicos registados nas faunas do Outeiro do Circo.
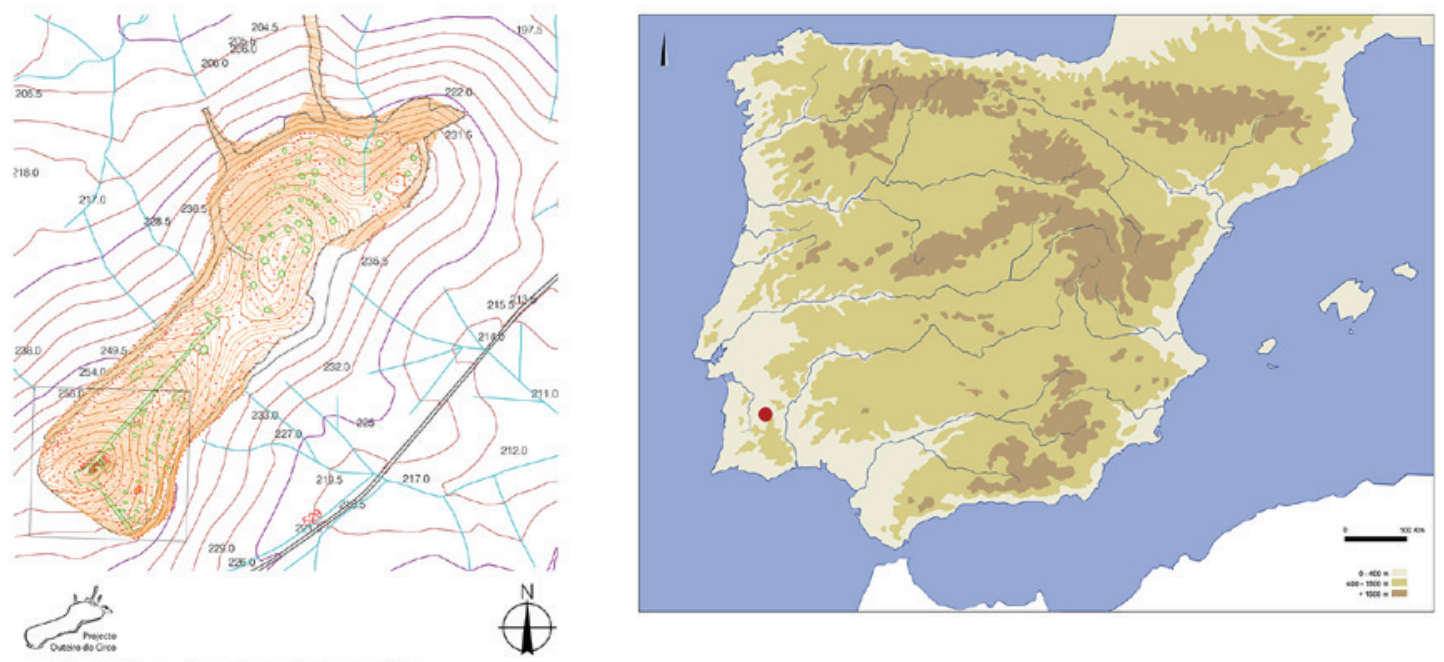

Outeiro do Circo - Levantamento Topográfico

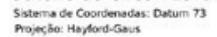

Escala 1:5000

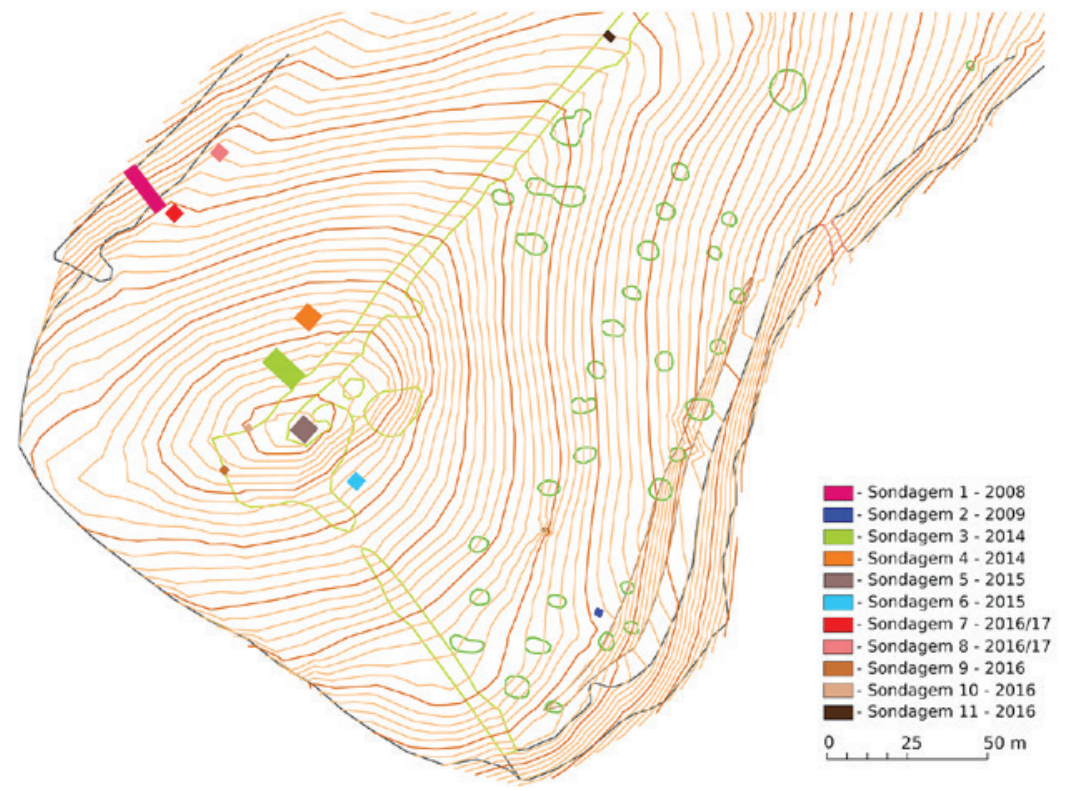

Figura 1 - Localização do Outeiro do Circo na Península Ibérica e levantamento topográfico com a localização das diferentes sondagens (2008-2017). 
Completude diafisária $(\%)$

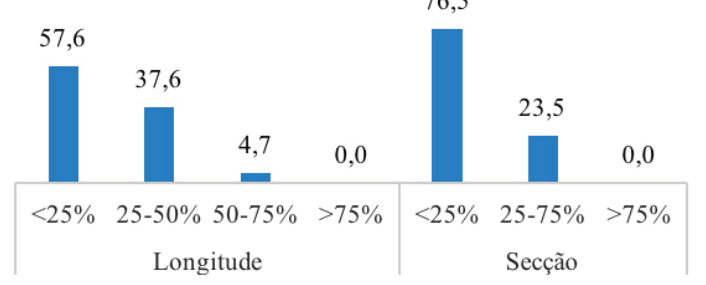

Planos de fractura $(\%)$

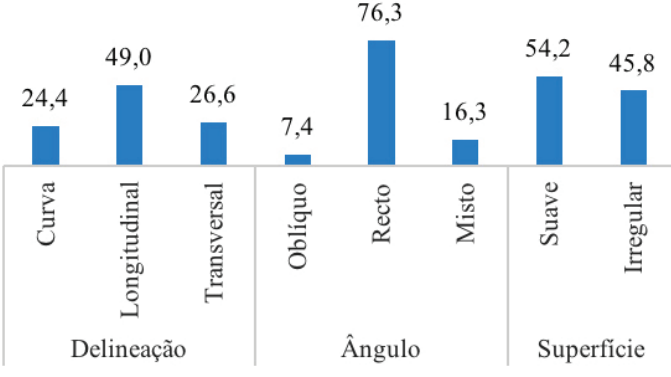

Figura 2 - Abundâncias relativas obtidas na análise da fractura e fragmentação das faunas do Outeiro do Circo para a completude diafisária consoante a longitude e secção (esquerda) e a delineação, ângulo e superfície de planos de fractura em tecido cortical (direita).

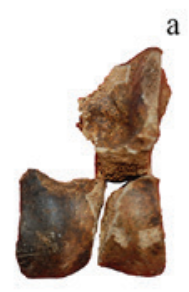

$\overline{\mathrm{cm}}$

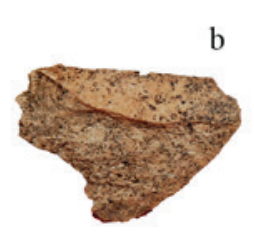

$\overline{1 \mathrm{~cm}}$

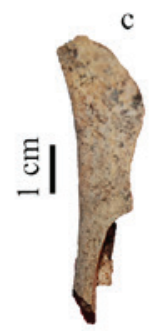

d
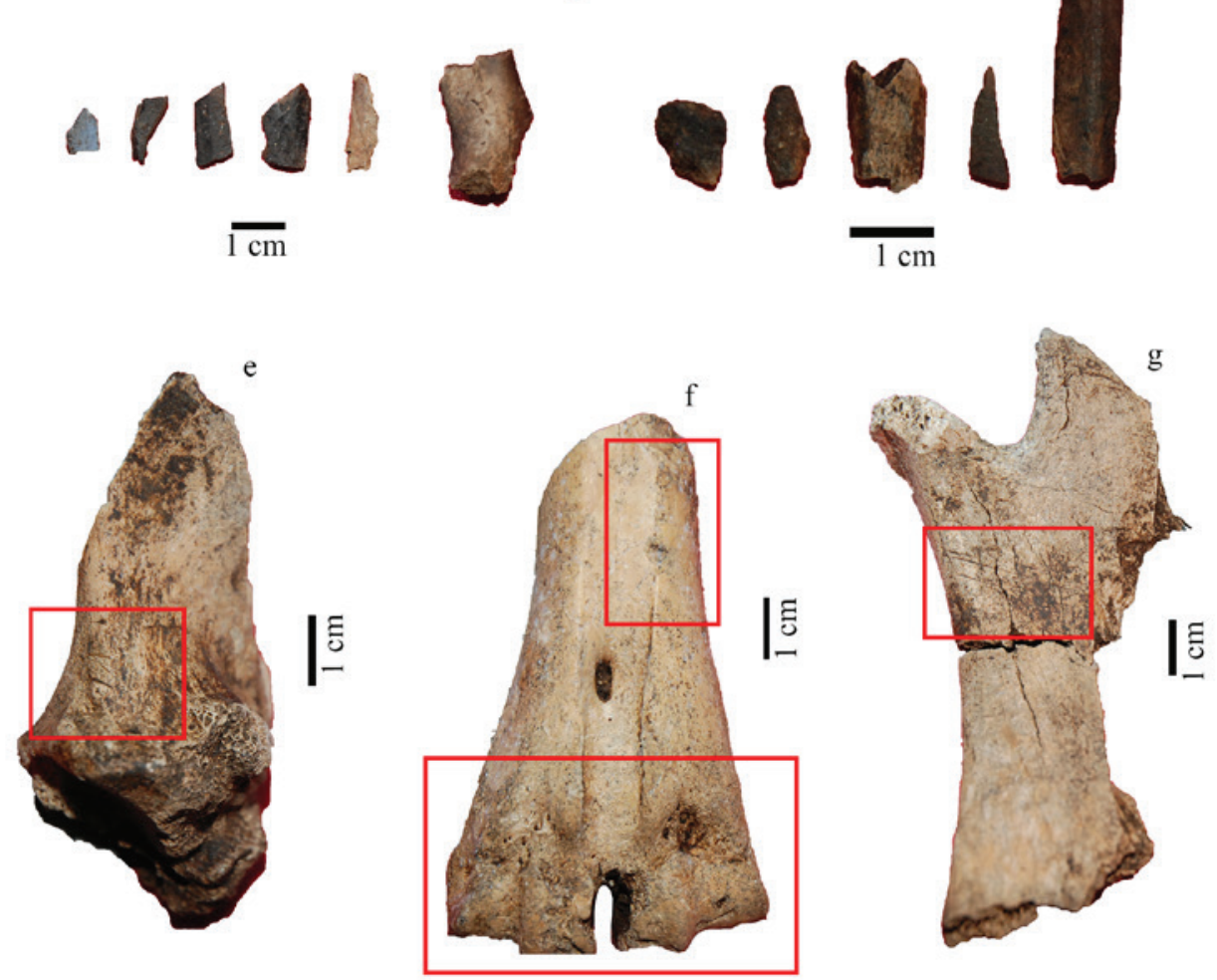

Figura 3 - Selecção de materiais do Outeiro do Circo: astrágalo de Cervus elaphus queimado (a), cone de percussão (b), fragmento diafisário com impactos de percussão antrópica (c), exemplos de ossos com dano de queima em diversos graus (d), calcâneo de Bos sp. com marcas de corte (e), metatarso de Bos sp. com marcas de dentes (f) e mandíbula de Bos sp. com marcas de corte (g). 
Comprimento canceloso

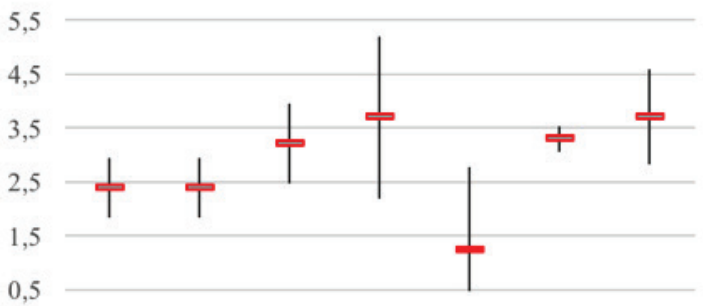

Largura canceloso

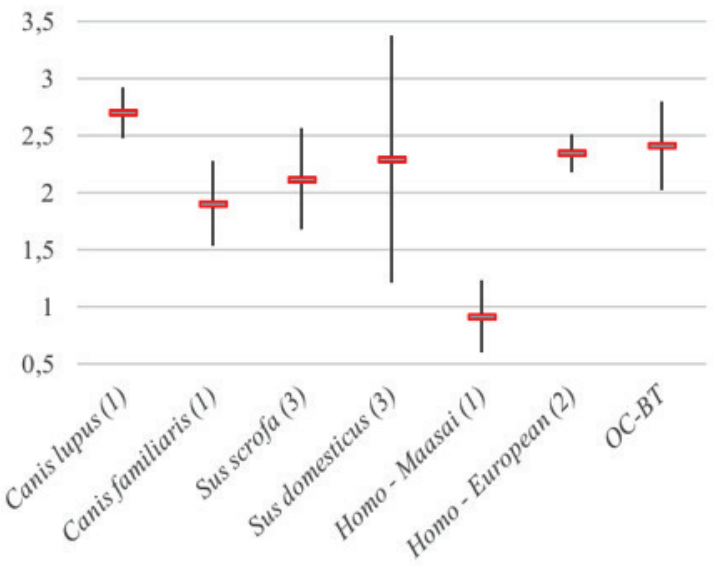

Comprimento cortical

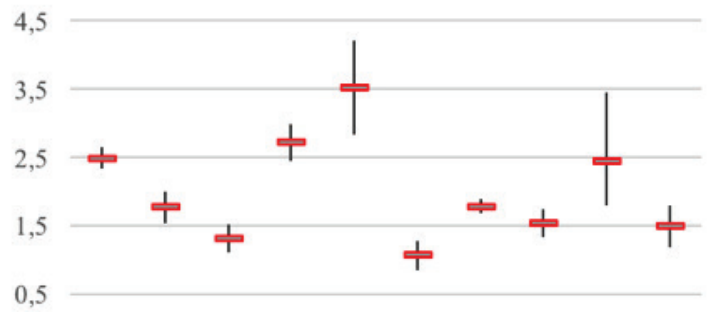

Largura cortical

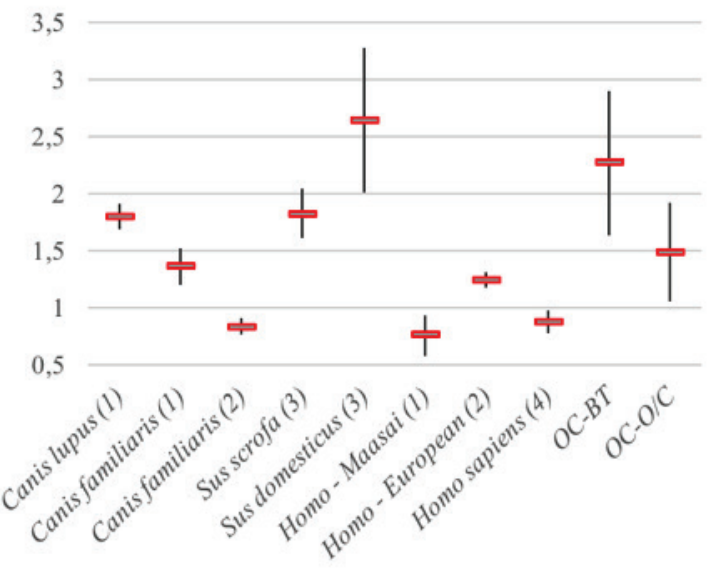

Figura 4 - Comparação dos valores obtidos (média e IC95\%) para as marcas de dentes obtidas em tecido canceloso e cortical nos materiais do Outeiro do Circo com dados publicados por (1) Andrés \& alii (2012), (2) Saladié \& alii (2013), (3) Saladié (2009) e (4) Delaney-Rivera \& alii (2009). Legenda: OC-BT = Outeiro do Circo - Bos taurus; OC-O/C = Outeiro do Circo-Ovis/Capra.

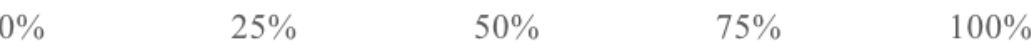

Marcas de corte (23)

Fractura antropogénica (12)

Queima (45)

(?)Fervura (6)

Marcas de dentes (3)

Meteorização (135)

Vermiculações (169)

Pátina recente (6)

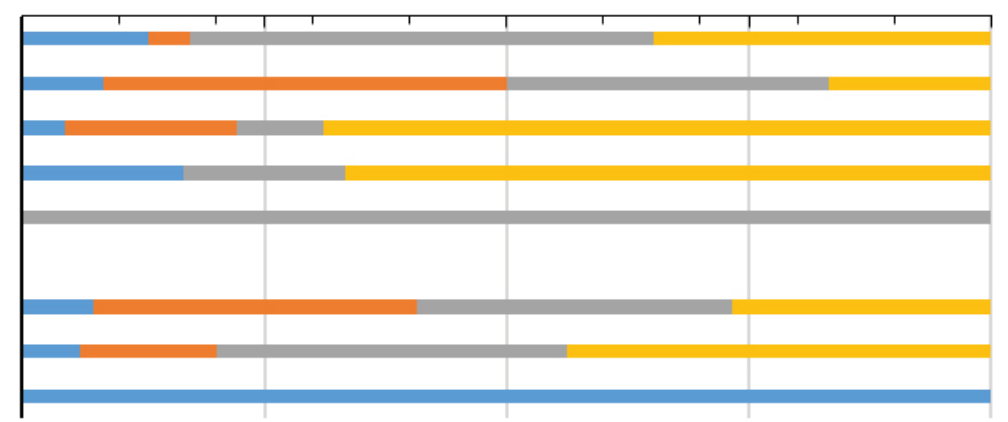

$\square \mathrm{S} 1 \quad \mathrm{~S} 3 \quad \mathrm{~S} 7 \quad \mathrm{~S} 8$

Figura 5 - Abundâncias relativas dos principais indicadores tafonómicos em relação à sua presença pelas sondagens do Outeiro do Circo analisadas no presente estudo. 


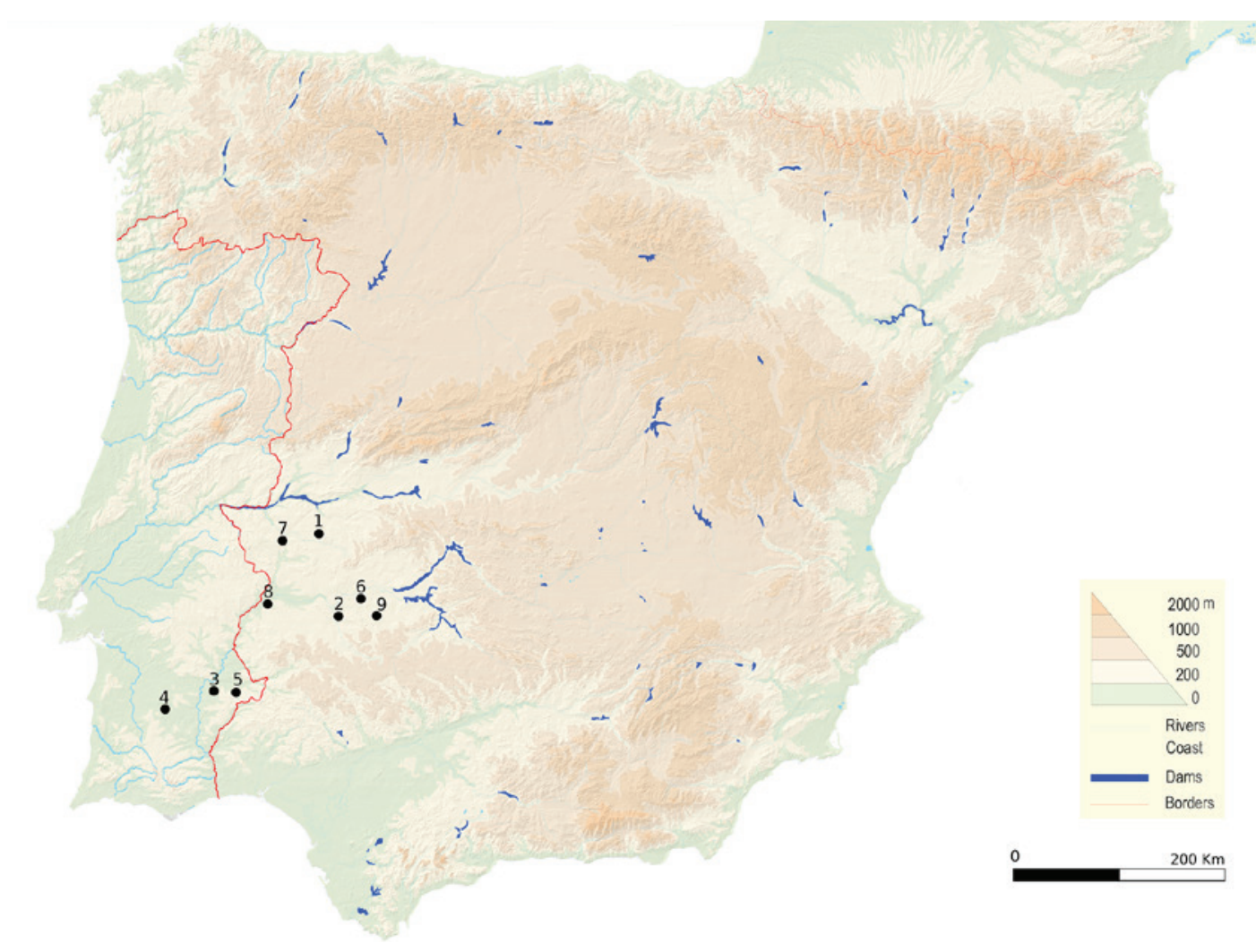

Figura 6 - Localização dos sítios mencionados no texto: 1 - Los Barruecos, 2 - Alange, 3 - Castro dos Ratinhos, 4- Outeiro do Circo, 5-Cabeço Redondo, 6-Medellín 77,7-Sierra del Aljibe, Aliseda, 8 - Alcazaba de Badajoz, 9 - La Mata. Base cartográfica de Luís Fraga da Silva, 2004, arqueotavira.com.

$\begin{array}{lllll}0 \% & 20 \% & 40 \% & 60 \% & 80 \%\end{array}$

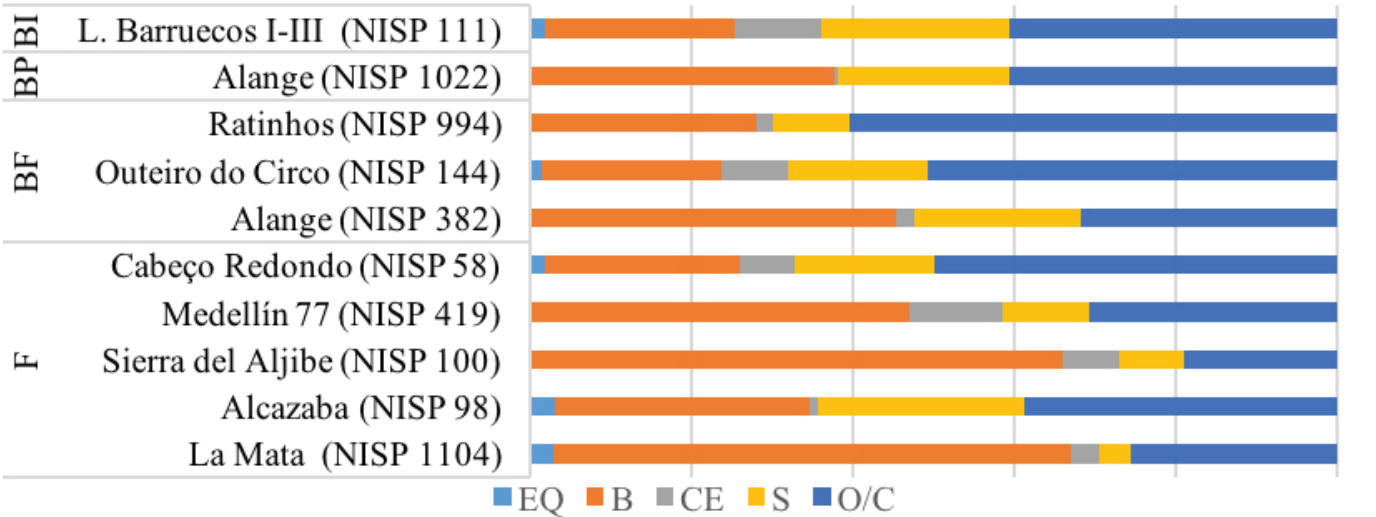

Figura 7 - Abundância relativa de Equus (EQ), Bos (B), Cervus (CE), Sus (S) e Ovis/Capra (O/C) para diferentes sítios do início da Idade do Bronze (BI), da fase plena da Idade do Bronze (BP), da fase final da Idade do Bronze (BF) e início da Idade do Ferro (F): Los Barruecos (Castaños, 1998a), Alange (Castaños, 1998b), Castro dos Ratinhos (Liesau \& García, 2010), Outeiro do Circo (Dias \& alii, no prelo e presente estudo); Cabeço Redondo (Cardoso \& Soares, 2013), Medellín 77 (Morales, 1977), Sierra del Aljibe, Aliseda (Castaños, 1999), Alcazaba de Badajoz (Castaños, 1998a), La Mata (Castaños, 2004). 


\title{
A ESPADA DO MONTE DAS OLIVEIRAS (SERPA) - UMA ARMA DO BRONZE PLENO DO SUDOESTE
}

\author{
Rui M.G. Monge Soares ${ }^{1}$, Pedro Valério ${ }^{2}$, Mariana Nabais ${ }^{1}, 3$, António M. Monge Soares ${ }^{2}$
}

\begin{abstract}
RESUMO
Nesta comunicação dá-se a conhecer uma espada, atribuível ao Bronze Pleno do Sudoeste, encontrada há vários anos em trabalhos agrícolas próximo da cidade de Serpa. A espada foi encontrada aparentemente descontextualizada, posteriormente limpa de produtos de corrosão e guardada pelo achador que, amavelmente, nos permitiu o seu estudo. A espada teria cerca de $50 \mathrm{~cm}$ de comprimento e o seu encabamento era efectuado por três rebites alojados em entalhes, dos quais se conservam dois. As cabeças destes têm a forma de calotes esféricas, encontrando-se cobertas por uma folha de ouro. A composição elementar do metal da lâmina da espada, bem como da folha de ouro que recobre as cabeças dos rebites, foi quantificada fazendo uso de um equipamento portátil de espectrometria de fluorescência de raios X. Foi assim possível determinar que a lâmina foi manufacturada com cobre arsenical, enquanto que a composição da folha de ouro indicia que a mesma corresponde a uma liga natural. Faz-se, por fim, uma comparação da espada do Monte das Oliveiras com os poucos exemplares deste tipo de arma conhecidos no sul ibérico, tomando também em consideração o tipo de encabamento que parece, até agora, uma variante única em espadas e que é relativamente raro em armas de forma similar, designadamente em punhais.

Palavras-chave: Encabamento com duplo arco em ferradura, Entalhes para rebitagem, Cobre arsenical, Liga de ouro natural.
\end{abstract}

\section{ABSTRACT}

In this paper, we present a detailed examination of a sword dating from the Southwestern Middle Bronze Age, which was found several years ago during farming activities near the town of Serpa, Portugal. The sword was apparently found out of an archaeological context. The finder of the sword, who kindly allowed us to study it, cleaned the artefact of its corrosion and kept it in good conditions. The sword is about $50 \mathrm{~cm}$ long and its handle show two rivets (another one is missing) which are kept housed in notches. The rivets' heads are spherical caps covered with a golden leaf. The use of a p-EDXRF equipment allowed us to determine and quantify the elemental composition of the blade, as well as of the golden leaf covering the rivet heads. It was thus possible to establish that the blade was manufactured with arsenical copper, while the composition of the golden leaf refers to a natural alloy. Finally, the Monte das Oliveiras sword is compared with several other coeval examples of Southern Iberia weaponry. Its hilt design, namely the three peripheral notches, seems to be of an unique variant in swords, being relatively rare in similarly shaped weapons, such as daggers.

Keywords: Hilt design with a double horseshoe arch, Peripheral notches for riveting, Arsenical copper, Natural gold alloy.

\footnotetext{
1. Centro de Arqueologia da Universidade de Lisboa (UNIARQ), Faculdade de Letras, Alameda da Universidade, 16oo-214 Lisboa, Portugal; ruigusmao@hotmail.com; mariananabais@gmail.com

2. Centro de Ciências e Tecnologias Nucleares ( $\left.\mathrm{C}_{2} \mathrm{TN}\right)$, Departamento de Engenharia e Ciências Nucleares, Instituto Superior Técnico, Universidade de Lisboa. Campus Tecnológico e Nuclear. Estrada Nacional 1o (km 139,7), 2695-o66 Bobadela LRS, Portugal; pvalerio@ctn.tecnico.ulisboa.pt; amsoares@ctn.tecnico.ulisboa.pt
}

3. Institute of Archaeology, University College London, 31-34 Gordon Square, Kings Cross, London WCiH oP, United Kingdom 


\section{INTRODUÇÃO}

A espada, objecto deste pequeno estudo que ora se publica, foi encontrada, há mais de 15 anos, durante a abertura de uma vala de drenagem junto ao Monte das Oliveiras, na margem esquerda do Guadiana, próximo da cidade de Serpa (Figura 1). Apresentava algumas pequenas torções e amolgadelas e quem a encontrou procurou endireitá-la, ao mesmo tempo que a "limpou", retirando-lhe os produtos de corrosão superficial. A espada tem-se mantido na posse do achador, residente em Safara, que durante a efectivação de uma exposição nessa aldeia, no ano passado, sobre as escavações arqueológicas realizadas no Castelo Velho de Safara, a mostrou a dois de nós (R.S. e M.N.). A espada foi encontrada a pouca profundidade, aparentemente descontextualizada, embora, segundo o achador, num moroiço, na vizinhança imediata da vala de drenagem, podia-se observar uma grande laje (de uma sepultura destruída?).

Nos arredores mais próximos do Monte das Oliveiras conhecem-se vários sítios arqueológicos, designadamente uma barragem romana, o Muro dos Mouros (Quintela et al., 1986), associada à villa romana da Cidade das Rosas (Caeiro, 1978, 1987), e, em frente desta, na outra margem do Barranco da Morgadinha, o sítio de fossas do Bronze Final do Sudoeste da Cidade das Rosas 4 (Baptista e Gomes, 2012), enquanto que, a menos de $1 \mathrm{~km}$ do Monte das Oliveiras, a noroeste, existe o recinto de fossos calcolítico da Folha do Ouro 1 (Valera et al., este volume).

As espadas pré-históricas, nomeadamente esta que pelo seu aspecto indicava que teria essa cronologia, são um tipo de arma rara no nosso território e, mesmo, em todo o sudoeste peninsular. No entanto, relativamente próximo, a cerca de $7 \mathrm{~km}$ do Monte das Oliveiras (ver Figura 1), foi encontrada a espada da Horta do Folgão, como dádiva funerária de um enterramento efectuado num hipogeu, atribuível ao Bronze Pleno do Sudoeste e datável da transição entre o $1^{\circ}$ e o $2^{\circ}$ quartel do II Milénio a.C. (Ponte et al., 2012).

\section{A ESPADA}

\subsection{Descrição sumária}

A espada do Monte das Oliveiras (MO), tal como se encontra actualmente, tem $45 \mathrm{~cm}$ de comprimento e cerca de $5 \mathrm{~cm}$ de largura máxima na zona de encabamento, a qual tem forma aproximadamente quadrangular (Figura 2). Apresenta um ligeiro estreita- mento a seguir à zona de encabamento e a lâmina, por seu lado, é uma folha triangular, plana, com afilamento nos gumes, encontrando-se fracturada na extremidade distal. Segundo o seu achador, essa fractura resultou do trabalho efectuado para a endireitar, tendo o pequeno fragmento sido perdido na oficina onde a operação se realizou. Esse fragmento teria cerca de $5 \mathrm{~cm}$ de comprimento e terminaria em ponta, pelo que a espada/estoque teria originalmente um comprimento de cerca de $50 \mathrm{~cm}$. O artefacto não apresenta, actualmente, qualquer patina, embora numa ou noutra zona surjam alguns laivos esverdeados, resquícios da patina primitiva que cobriria a peça.

O encabamento seria efectuado através de três rebites colocados em entalhes, dois laterais e um a meio na extremidade proximal. Conservam-se dois, um em cada entalhe lateral. Têm comprimentos máximos diferentes: $2,9 \mathrm{~cm}$ e 2,4 cm. Estamos em crer que um deles não estará na sua posição primitiva: o punho seria, com certeza, simétrico e por isso, logicamente, o rebite de maior comprimento não deveria estar num entalhe lateral, mas sim no entalhe mediano da zona de encabamento. Note-se que os rebites também não apresentam qualquer patina pelo que, aquando da limpeza da arma, estes deverão ter sido destacados da mesma, limpos e, por fim, colocados nos entalhes laterais, não correspondendo a sua posição actual à posição primitiva. $\mathrm{O}$ corpo cilíndrico dos rebites tem um diâmetro aproximado de $6 \mathrm{~mm}$, enquanto as extremidades dos mesmos apresentam a forma de calotes esféricas, com um diâmetro máximo de cerca de $11 \mathrm{~mm}$. As calotes esféricas encontram-se revestidas por uma folha de ouro, a qual terá sido fixada por pressão e brunimento, como é indiciado pelo seu aspecto e pelo o que se observa no reverso dessas calotes (Figura 3 ).

$\mathrm{Na}$ área de encabamento, numa das faces, apesar do "tratamento" que a espada sofreu a seguir à sua descoberta, pode observar-se a marca que o punho original, possivelmente de material perecível (madeira?), deixou - um duplo arco em ferradura, algo rebaixado (Figura 4) - cujo interesse e também importância serão sublinhados mais adiante.

\subsection{Composição elementar}

Uma vez que se desconhece o eventual contexto arqueológico, se porventura existia, a que MO estaria associada, era de importância primordial determinar as composições do metal/liga, quer da lâmina, 
quer da folha de ouro que cobre as extremidades dos rebites, composições essas que poderiam indiciar uma cronologia para esta arma. Assim, fazendo uso de um espectrómetro portátil Bruker Si Titan equipado com um tubo de raios $\mathrm{X}$ com ânodo de ródio, um detector SSD e um colimador de $5 \mathrm{~mm}$ para a análise de áreas de dimensão reduzida, foram efectuadas diversas análises nas faces opostas da lâmina e dos dois rebites. Os valores médios das diversas análises efectuadas encontram-se na Tabela 1.

Trata-se, por conseguinte, de uma espada manufacturada em cobre arsenical, enquanto que a folha de ouro que recobre os terminais dos rebites é feita de uma liga natural de ouro e prata, tendo em conta o seu teor de cobre $(<1 \%)$ (ver, por exemplo, Valério et al., 2017). A associação desta liga a um grande artefacto de cobre arsenical indicia uma antiguidade para esta técnica de douramento, para a qual ainda não existiam ligas artificiais de ouro e prata, como será discutido mais adiante.

\section{A ESPADA DO MONTE DAS OLIVEIRAS NO CONTEXTO DAS ARMAS DE BASE COBRE DA PENÍNSULA IBÉRICA}

A composição elementar de MO permite atribuir-lhe uma cronologia dentro do Bronze Pleno do Sudoeste, uma vez que as ligas de cobre arsenical são usuais durante este período (Valério et al., 2016), enquanto as de bronze são predominantes no Bronze Final (Valério et al., 2013, 2015) e os encabamentos de rebites não existem no Calcolítico, segundo Montero Ruiz et al. (2014), embora actualmente se conheçam alguns exemplos extremamente raros (ver, por exemplo, Blasco et al., 2019, Fig. 17b). Por outro lado, no sudoeste peninsular, as ligas de bronze surgem apenas na transição da primeira para a segunda metade do II Milénio (Valério et al., 2014) e se a espada fosse da segunda metade seria pouco provável que, tratando-se de um artefacto de prestígio, não fosse manufacturada nessa nova liga. Além disso, deverá ter-se em conta que a utilização de apenas três entalhes e ausência de furos para a fixação dos rebites é relativamente rara nos diversos tipos de encabamento de armas na Idade do Bronze, designadamente no que se refere aos punhais, encontrando-se completamente ausente, até hoje, nas espadas, constituindo MO caso único. A espada de Priego de Córdoba, em que o encabamento rebitado apresenta dois entalhes laterais e um orifício media- no na extremidade proximal (Hitos Urbano, 1991), será, porventura, a que mais se assemelha à do Monte das Oliveiras, embora o seu comprimento seja bastante menor $(39 \mathrm{~cm})$. A esta espada tem sido atribuída uma filiação argárica e, por conseguinte, uma cronologia do Bronze Pleno. Brandherm (2003), no estudo que efectuou sobre punhais, espadas e alabardas do Calcolítico e da Idade do Bronze da Península Ibérica, publica largas centenas de punhais e adagas que englobam apenas poucas dezenas destes artefactos com o mesmo tipo de encabamento de $\mathrm{MO}$, os quais na sua maior parte constituem o tipo $A B$ 19, que denominou de variante Periana (Tafel 69 e 70), com base nas características de um punhal (Tafel 70, no 1133) proveniente do sítio com esse nome, na província de Málaga. A solução técnica de encabamento correspondente a esta variante é, pois, relativamente rara no grande conjunto de punhais conhecidos e, segundo Brandherm (2003), datável do Bronze Pleno, da sua primeira metade (Tafel 195). No território da margem esquerda do Guadiana conhecem-se três punhais que apresentam este tipo de encabamento: o da cista do Carapetal (CRo1.o1), atribuível a um momento antigo dentro do Bronze Pleno do Sudoeste, dada a forma do vaso cerâmico que o acompanhava (Soares, 1976/77), tendo sido manufacturado em cobre arsenical (CRor: lâmina: Cu 98,9\%; As 1,1 \%; rebite: Cu 89,5\%; As 10,5\%) e os de Montinhos 6 (MT6.04711.18) e Torre Velha 12 (TV12.01011.01), pertencentes a espólios de enterramentos em hipogeu, que apresentam composições elementares muito similares à da espada MO (MT6: $\mathrm{Cu}$ 95, o \%; As 5,o \% e TV12: Cu 94,8; As 5,2\%) (Valério et al., 2016, Fig. 1 e Tab. 2). Várias datas de radiocarbono foram obtidas para diversos hipogeus de Montinho 6, permitindo atribuir uma cronologia do $2^{\circ}$ quartel do II Milénio a.C. para as respectivas manifestações funerárias, enquanto o enterramento do hipogeu de Torre Velha 12 também foi datado por radiocarbono, obtendo-se uma cronologia na transição do $2^{\circ}$ para o $3^{\circ}$ quartel (Valério et al., 2016, Tab. 1 e Fig. 2). Deverá notar-se que a espada da Horta do Folgão, já atrás referida, com um comprimento de cerca de $47 \mathrm{~cm}$ e uma composição elementar também semelhante à da MO (HF: Cu 95,7\%; As 4,3\%) difere desta última no encabamento. A da Horta do Folgão teria seis rebites, encontrando-se dois deles in situ preenchendo os respectivos orifícios circulares, enquanto os outros quatro, encontrados soltos, teriam sido colocados em quatro dos entalhes 
laterais (Ponte et al., 2012). Na área de encabamento pode observar-se ainda mais um entalhe, bem como dois orifícios circulares, que não teriam sido utilizados ou cujos rebites não foram encontrados. Contemporânea desta espada e muito semelhante a ela, quer na forma, quer na composição elementar, é a espada encontrada numa sepultura em La Mesa de Setefilla (Aubet Semmler, 1981; Aubet Semmler et al., 1983). Estas espadas, associadas a esqueletos humanos datados pelo radiocarbono na transição entre $\mathrm{o} 1^{\circ}$ e $2^{\circ}$ quartel do II Milénio a.C., seriam um pouco anteriores aos punhais de MT6 e TV12 atrás referidos, e indiciam, por conseguinte, que $\mathrm{MO}$ seria ligeiramente posterior a estas espadas.

Um dos atributos raros, até pela sua cronologia, da espada do Monte das Oliveiras é o douramento dos terminais dos rebites (Figura 3), o que sublinha o caracter excepcional desta arma. Embora se desconheça se o punho seria revestido a ouro, como acontece na célebre espada de Guadalajara (Almagro Gorbea, 1972; Brandherm, 1998), MO seria, com certeza, um artefacto de elevado prestígio. A técnica utilizada no douramento das cabeças dos rebites tem um paralelo estreito no douramento de uma tacha de bronze, certamente decorativa, encontrada em escavações arqueológicas realizadas no sítio do Bronze Final de Entre Águas 5 (Serpa), no qual existia uma oficina metalúrgica (Valério et al., 2013). Ao anverso da cabeça deste artefacto, ligeiramente cónica e larga, foi aplicada uma folha de ouro por um processo mecânico, muito provavelmente por pressão e brunimento sobre o anverso, enquanto a borda da folha foi dobrada sobre o reverso, a fim de obter uma boa adesão mecânica à sua base (Figura 5). A análise elementar da folha de ouro de Entre Águas 5 permitiu determinar que se trata de uma liga de $\mathrm{Au}-\mathrm{Ag}$, possivelmente artificial, com $11,6 \%$ de Ag e cerca de $1 \%$ de $\mathrm{Cu}$. Artefactos de ouro nativo, designadamente ligas de Au-Ag do Bronze Pleno do Sudoeste encontrados no sul de Portugal, designadamente no concelho de Serpa como, por exemplo, as cadeias de espirais de Vale de Viegas e o torques de Vila Nova de S. Bento têm percentagens de prata inferiores a $20 \%$, enquanto que o cobre aparece apenas como impureza (<1\%). Já as ligas ternárias de $\mathrm{Au}-\mathrm{Ag}-\mathrm{Cu}$ (com teores de $\mathrm{Cu}>1$ \%) surgem no Bronze Final do Sudoeste, constituindo bons exemplos as jóias da Herdade do Álamo (Sobral da Adiça, Moura) e da Herdade das Cortes (Alvito) (Armbruster e Parreira, 1993; Hartmann, 1982; Soares et al., 2004).
Por fim, também a impressão do duplo arco em ferradura, resultante do tipo de encabamento que a espada do Monte das Oliveiras sofreu, contribui para se considerar MO como um artefacto excepcional e raro. Na realidade, esta impressão de arco em ferradura duplo parece ser exclusiva das espadas (cerca de 20 exemplares - Gómez Ramos, 2001) e de raríssimos punhais (apenas três ou quatro; ver Brandherm, 2003, Tafels 49, no 802; 69, no 1113A; 70, no 1133 e no 1138) do Bronze Pleno da Península Ibérica. Na Península, as espadas com a impressão destes arcos duplos distribuem-se pela sua metade este, ocorrendo em três zonas: no sudeste (na área correspondente à Cultura de El Argar), no centro peninsular (região de Madrid, por exemplo) e no norte, na região cantábrica (ver Gómez Ramos, 2001, Fig. 3), encontrando-se ausentes em toda a área oeste com excepção da espada de bronze de Forcas (Orense), atribuível ao Bronze Final, e agora esta, a do Monte das Oliveiras. Também, os punhais com encabamento rebitado em três entalhes, tal como MO, parecem distribuir-se pelo sul e sudeste ibérico e os poucos exemplares no território português registam-se no sudoeste, designadamente na margem esquerda do Guadiana, como referido atrás. A exclusividade ibérica do tipo de encabamento que deixa a impressão em duplo arco em ferradura resultará, segundo diversos autores (ver, por exemplo, Almagro Gorbea, 1972, Gómez Ramos, 2001), duma origem argárica para o protótipo ou protótipos de todas estas armas. Também a espada do Monte das Oliveiras, bem como os punhais com três entalhes para o encabamento rebitado encontrados no concelho de Serpa, apontam para uma difusão desta tipologia de armas a partir do sudeste ibérico. Note-se, por exemplo, que o punhal TV12.01011.01, de tamanho muito pequeno, tem paralelos estreitos, pelas suas dimensões, em muitos destes artefactos registados em sepulturas de $\mathrm{El} \mathrm{Ar-}$ gar, designadamente na sepultura 275 , onde um pequeno punhal com 3 entalhes rebitados foi encontrado (Schubart e Ulreich, 1991, p. 94 e Tafel 19, 275). De igual modo, as dádivas de sepultura do hipogeu de Belmeque (Soares, 1994; Soares et al., 1996) e de alguns dos hipogeus de Torre Velha 3 (Alves et al., 2010) apontam para uma influência nessa direcção.

\section{CONSIDERAÇÕES FINAIS}

A espada do Monte das Oliveiras, até pela utilização de ouro na sua manufactura, foi certamente um item 
de prestígio e o seu possuidor deveria ter um elevado status social. Embora tenha sido encontrada descontextualizada, as composições elementares, quer do corpo da espada (cobre arsenical), quer da folha de ouro (liga natural de $\mathrm{Au}-\mathrm{Ag}$ ) que cobria os terminais dos rebites que a fixavam ao punho, quer ainda dos paralelos conhecidos, incluindo punhais com a mesma tipologia e composição elementar, permitem datá-la da $1^{1}$ metade ou até, arriscando ser mais preciso, do $2^{\circ}$ quartel do II Milénio a.C. O arco duplo em ferradura que ficou impresso na área de encabamento resultante do design do punho em material perecível, tornam-na no primeiro exemplar com esta tipologia encontrado em território português, estendendo para oeste da Península Ibérica a dispersão destas armas, com esta cronologia. Por outro lado, deverá notar-se que a técnica de douramento utilizada nos rebites da espada do Monte das Oliveiras tornam-na no exemplar de aplicação desta técnica mais antigo até hoje registado na Península Ibérica.

\section{AGRADECIMENTOS}

O nosso muito obrigado ao Senhor Joaquim Manuel Batarda Isqueiro, a pessoa que encontrou a espada e a tem preservado até hoje, e que muito amavelmente a disponibilizou em sua casa para procedermos ao seu estudo. A caracterização arqueometalúrgica foi efectuada no âmbito do Projecto UID/ Multi/04349/2019 financiado pela Fundação para a Ciência e a Tecnologia.

\section{REFERÊNCIAS BIBLIOGRÁFICAS}

ALMAGRO GORBEA, M. (1972) - La espada de Guadalajara y sus paralelos peninsulares. Trabajos de Prehistoria. 29, pp. $55-82$.

ALVES, C., COSTEIRA, C.; ESTRELA, S.; PORFÍRIO, E.; SERRA, M.; SOARES, A.M.M. e MORENO-GARCÍA, M. (2010) - Hipogeus funerários do Bronze Pleno da Torre Velha 3 (Serpa, Portugal). O Sudeste no Sudoeste?! Zephyrus. 66, pp. 133-153.

ARMBRUSTER, B. e PARREIRA, R. (Coords.) (1993) - Inventário do Museu Nacional de Arqueologia. Colecção de Ourivesaria. Do Calcolítico à Idade do Bronze. Vol. I. Lisboa: Instituto Português de Museus.

AUBET SEMMLER, M. E. (1981) - Sepulturas de la Edad del Bronce en La Mesa de Setefilla (Sevilla). Madrider Mitteilungen. 22, pp. 127-149.
AUBET SEMMLER, M.E.; SERNA, M. R.; ESCACENA, J.L. e RUIZ DELGADO, M. M. (1983) - La Mesa de Setefilla, Lora del Rio (Sevilla). Campaña de 1979. Excavaciones Arqueologicas en España. Madrid: Ministerio de Cultura.

BAPTISTA, L. e GOMES, S. (2012) - Cidade das Rosas 4 (S. Salvador, Serpa): breve notícia sobre os fragmentos cerâmicos com ornatos brunidos. Actas do VEncontro de Arqueologia do Sudoeste Peninsular (Almodôvar, 2010). pp. 605-614.

BLASCO, C.; LIESAU, C. e RÍOS, P. (2019) - El registro funerario campaniforme de la Región de Madrid, reflejo de una sociedad plural y compleja. In Un brindis por el príncipe! El vaso campaniforme en el interior de la Península Ibérica. Vol. I, pp. 247-277.

BRANDHERM, D. (1998) - Algunas consideraciones acerca de la espada de Guadalajara. Un excepcional depósito desarticulado del Bronce Medio de la Meseta? Trabajos de Prehistoria. 55(2), pp. 177-184.

BRANDHERM, D. (2003) - Die Dolche und Stabdolche der Steinkupfer und Iteren Bronzezeit auf der Iberischen Halbinsel. Frank Steiner Verlag, Stuttgart.

CAEIRO, J.O.S. (1978) - Observações sobre a cerâmica comum romana do século III proveniente da Cidade das Rosas, Serpa. Actas das III Jornadas Arqueológicas. Lisboa: Associação dos Arqueólogos Portugueses. Vol. 1, pp. 251-271.

CAEIRO, J.O.S. (1987) - A Cidade das Rosas. Arquivo de Beja. 2- Série, 4, pp. 111-125.

HARTMANN, A. (1982) - Prähistorische Goldfunde aus Europa. Studien zu den Anfängen der Metallurgie. 3:2. Berlin: Mann.

HITOS URBANO, M.A. (1991) - Espada inédita de la Edad del Bronce hallada en el término municipal de Priego de Córdoba. Antiquitas. 2, pp. 42-46.

MONTERO RUIZ, I.; LUGO ENRICH, L.B.; ÁLVAREZ GARCÍA, H.J.; GUTIÉRREZ-NEIRA, P.C.; MURILLO-BARROSO, M.; PALOMARES ZUMAJO, N.; MENCHÉN HERREROS, G.; MORALEDA SIERRA, J. e SALAZER-GARCÍA, D.C. (2014) - Copper for Dead. Archaeometric Study of Metal Objects from the Prehistoric Megalithic Monument Castillejo del Bonete (Terrinches, Ciudad Real). Zephyrus.73, pp.109-132.

PONTE, T.R.N.; SOARES, A.M.M.; ARAÚJO, M.F.; FRADE, J.C.; RIBEIRO, I.; RODRIGUES, Z.; SILVA, R.J.C. e VALÉRIO, P. (2012) - O Bronze Pleno do Sudoeste da Horta do Folgão (Serpa, Portugal). Os Hipogeus Funerários. O Arqueólogo Português. Série V, 2, pp. 265-295.

QUINTELA, A.C.; MASCARENHAS, J.M. e CARDOSO, J.L.S.C. (1986) - Barragens romanas do distrito de Beja. Actas do $1^{\circ}$ Encontro de Arqueologia da Região de Beja, (Beja, 17 1819 Janeiro 1986). Arquivo de Beja. 2aㅡ Série, 3, pp. 153-165. 
SCHUBART, H. e ULREICH, H. (1991) - Die Funde der Südostspanischen Bronzezeit aus der Sammlung Siret. Philipp von Zabern, Mainz.

SOARES, A.M.M. (1976/77) - Uma cista do Bronze do Sudoeste em Aldeia Nova de São Bento (Serpa). Setúbal Arqueológica. 2/3, pp. 273-279.

SOARES, A.M.M. (1994) - O Bronze do Sudoeste na Margem Esquerda do Guadiana. As Necrópoles do Concelho de Serpa. Actas das V Jornadas Arqueológicas. Lisboa, vol. II, pp. 179-197.

SOARES, A.M.M.; ARAÚJO, M.F. e ALVES, L.C. (2004) Análise química não-destrutiva de artefactos em ouro pré e proto-históricos: alguns exemplos. Revista Portuguesa de Arqueologia.7(2), pp. 125-138.

SOARES, A.M.M.; ARAÚJO, M.F.; ALVES, L. e FERRAZ, M.T. (1996) - Vestígios Metalúrgicos em Contextos do Calcolítico e da Idade do Bronze no Sul de Portugal. Miscellanea em Homenagem ao Professor Bairrão Oleiro. Edições Colibri, Lisboa, pp. 553-579.

VALERA, A.; PEREIRO, T. do; VALÉRIO, P. e SOARES, A.M.M. (este volume) - O recinto da Folha do Ouro 1 (Serpa) no contexto dos recintos de fossos calcolíticos alentejanos.

VALÉRIO, P.; SILVA, R.J.; SOARES, A.M.M.; ARAÚJO, M.F.; GONÇALVES, A.P. e SOARES, R.M. (2015) - Combining X-ray based methods to study the protohistoric bronze technology in Western Iberia. Nuclear Instruments and Methods in Physics Research B. 358, pp. 117-123.

VALÉRIO, P.; SOARES, A.M.M.; ARAÚJO, M.F. e CARVALHO, A.F. (2017) - Micro-EDXRF investigation of Chalcolithic gold ornaments from Portuguese Estremadura. X-Ray Spectrometry. 46, pp. 252-258.

VALÉRIO, P.; SOARES, A.M.M.; ARAÚJO, M.F.; SILVA, R.J. e BAPTISTA, L. (2016) - Middle Bronze Age arsenical copper alloys in Southern Portugal. Archaeometry. 58(6), pp. 1003-1023.

VALÉRIO, P.; SOARES, A.M.M.; ARAÚJO, M.F.; SILVA, R.J.; PORFÍRIO, E. e SERRA, M. (2014) - Arsenical copper and bronze in Middle Bronze Age burial sites of southern Portugal: the first bronzes in Southwestern Iberia. Journal of Archaeological Science. 42, pp. 68-8o.

VALÉRIO, P.; SOARES, A.M.M.; SILVA, R.J.; ARAÚJO, M.F.; REBELO, P.; NETO, N.; SANTOS, R. e FONTES, T. (2013) - Bronze production in Southwestern Iberian Peninsula: the Late Bronze Age metallurgical workshop from Entre Águas 5 (Portugal). Journal of Archaeological Science. 40, pp. 439-451. 


\begin{tabular}{llll}
\hline & $\mathrm{Cu}(\%)$ & $\mathrm{As}(\%)$ & \\
Lâmina & 94,4 & 5,5 & $\mathrm{Cu}(\%)$ \\
\hline Folha de Ouro & $\mathrm{Au}(\%)$ & $\mathrm{Ag}(\%)$ & \\
Rebite 1 & & & 0,30 \\
Rebite 2 & 89,6 & 10,1 & 0,37 \\
\hline
\end{tabular}

Tabela 1 - Análise por p-EDXRF dos elementos constituintes da espada do Monte das Oliveiras.

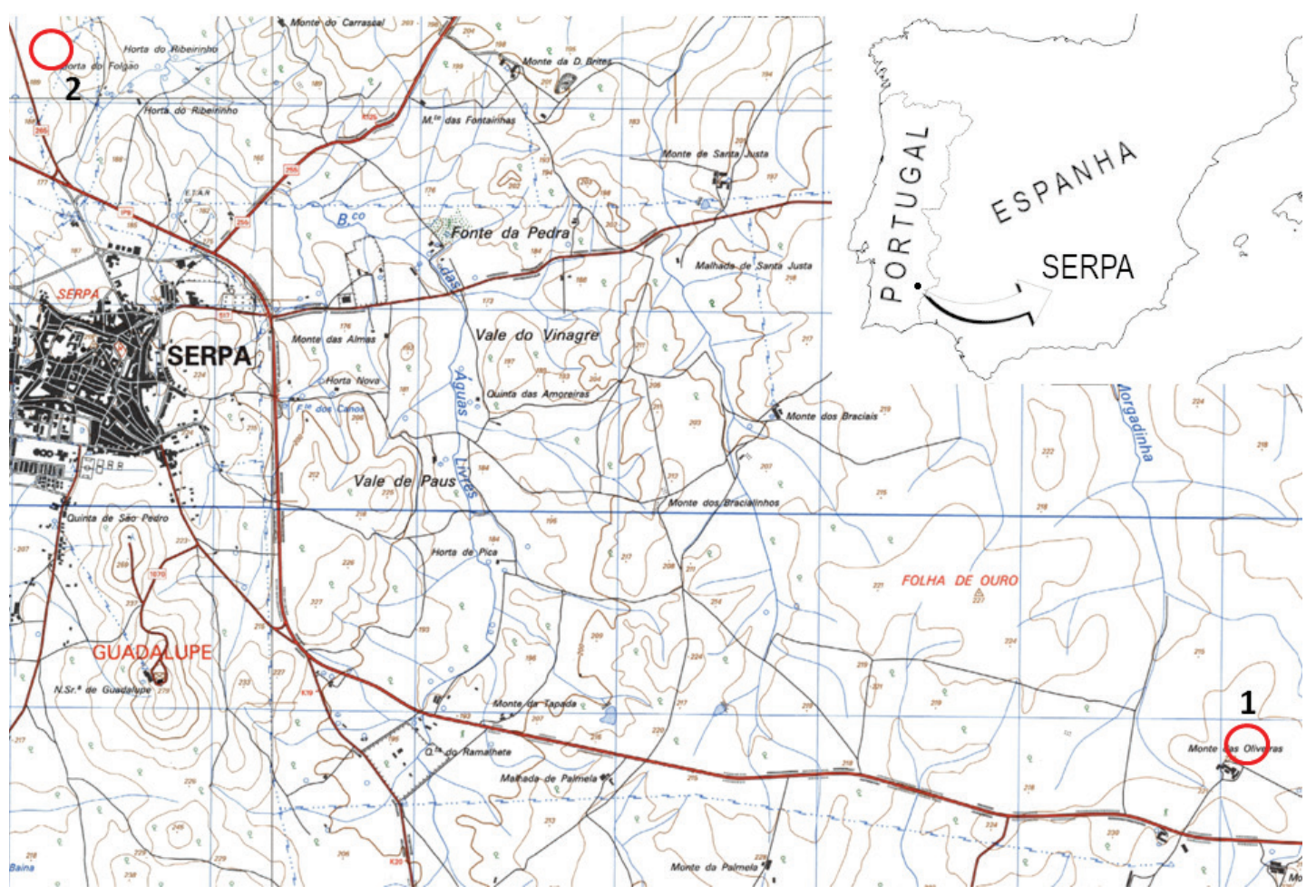

Figura 1 - Localização dos sítios Monte das Oliveiras (1) e Horta do Folgão (2) na Península Ibérica e na C.M.P., 1:250oo, fls. 522, 523, 532 e 533 . 


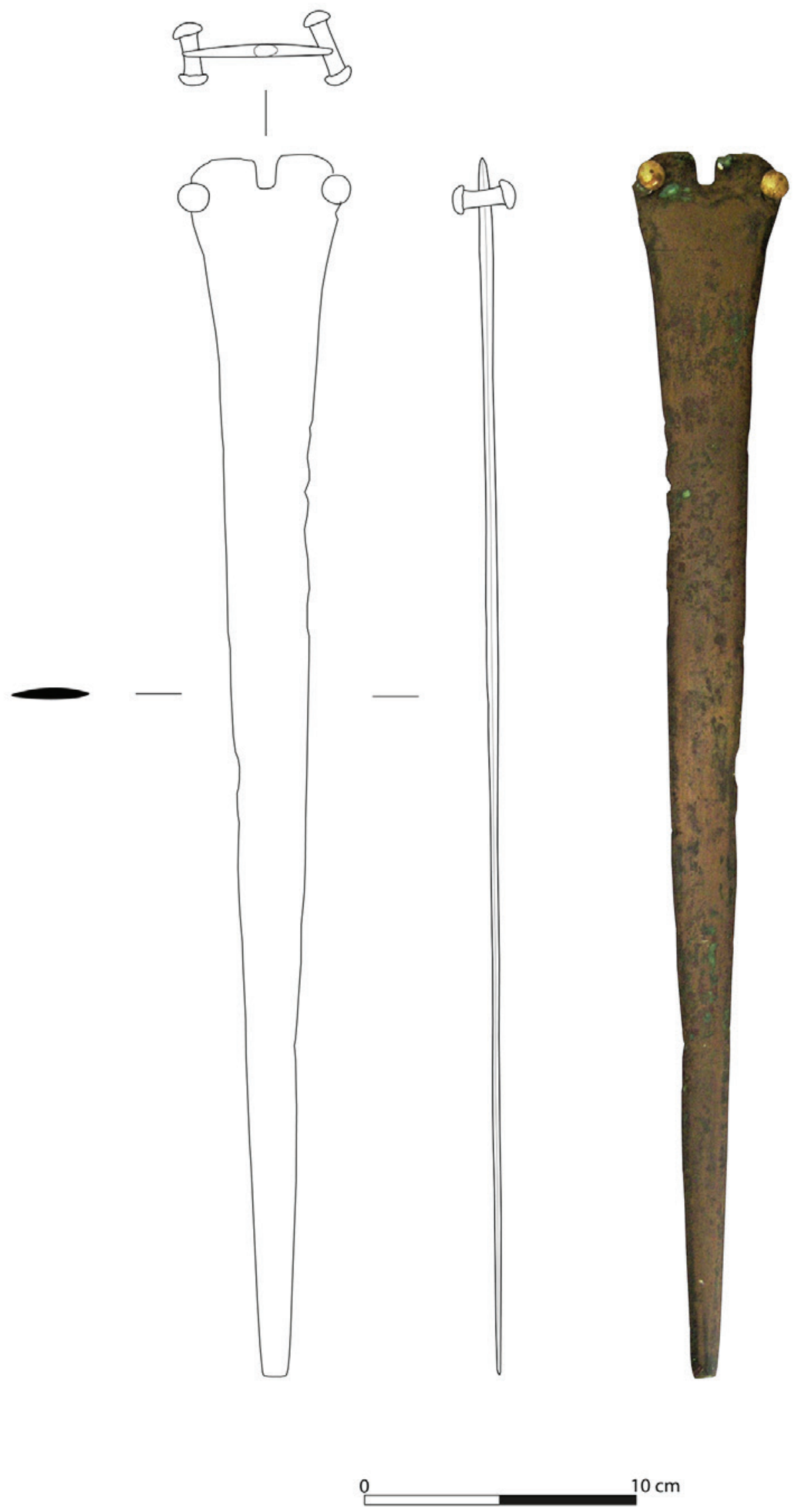

Figura 2 - A espada do Monte das Oliveiras. 

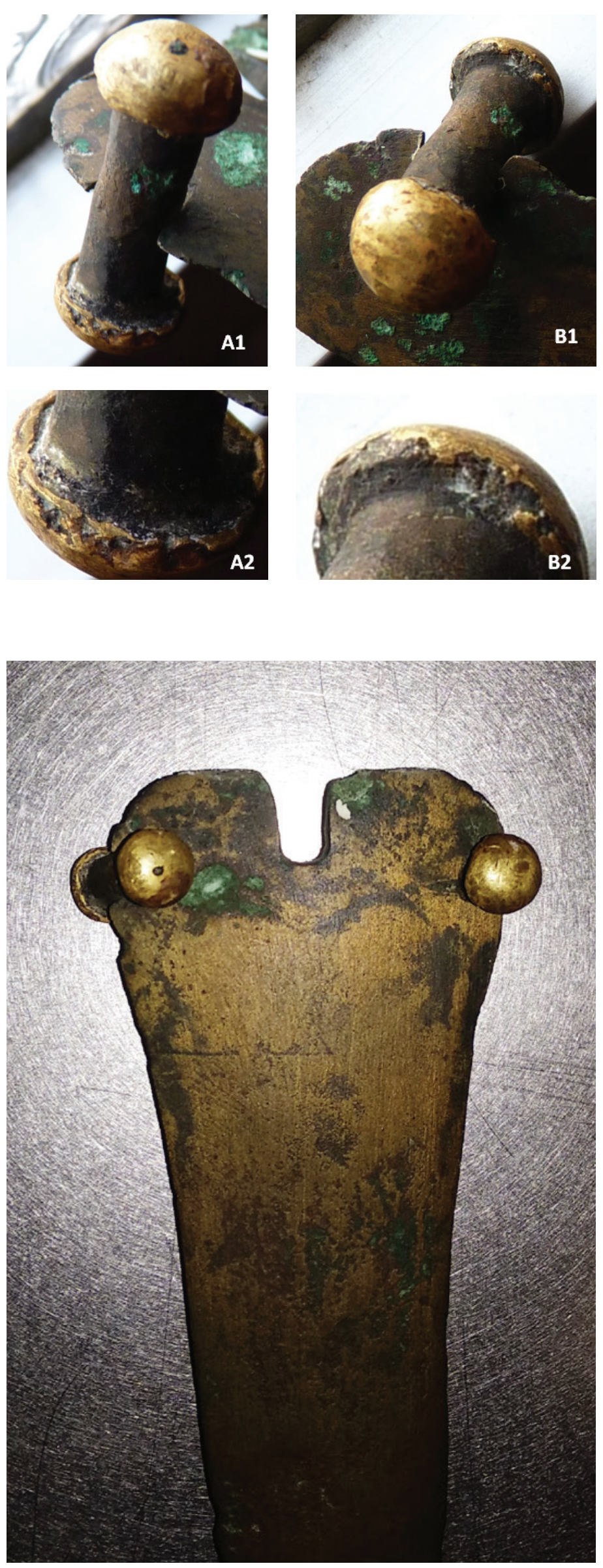

Figura 3 - Os dois rebites conservados da espada do Monte das Oliveiras com o anverso das cabeças coberto por uma folha de ouro. Notem-se as dobras das folhas de ouro no reverso das calotes esféricas, indiciando a técnica utilizada no douramento.
Figura 4-A zona de encabamento da espada do Monte das Oliveiras observando-se a impressão dos dois arcos em ferradura. 

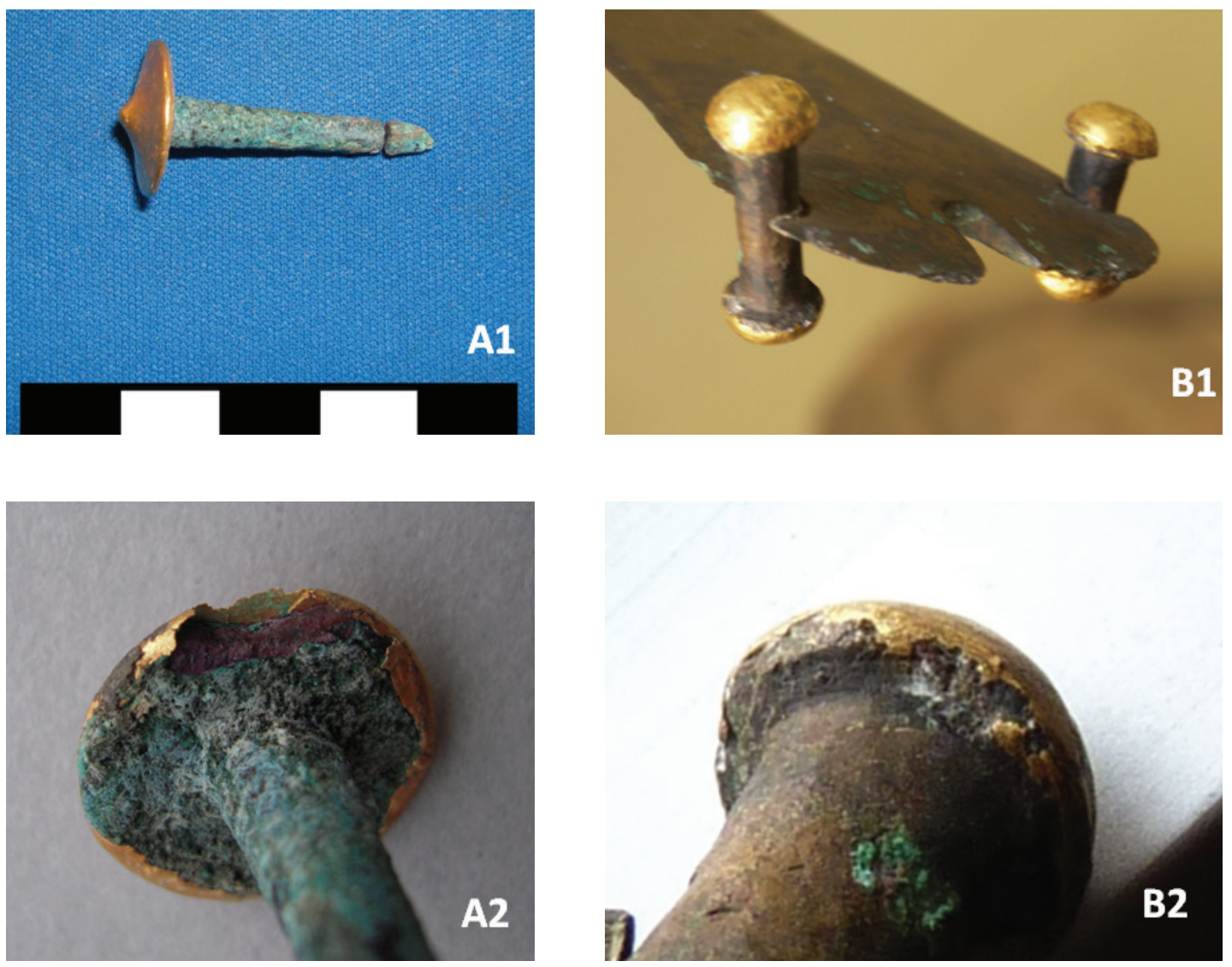

Figura 5 - Comparação entre a tacha de bronze de Entre Águas 5 (A), datável do Bronze Final, e os rebites de cobre arsenical da espada do Bronze Pleno do Monte das Oliveiras (B), todos eles revestidos a folha de ouro utilizando a mesma técnica de douramento. 


\title{
SÃO JULIÃO DA BRANCA \\ (ALBERGARIA-A-VELHA) \\ INVESTIGAÇÃO E VALORIZAÇÃO DE UM POVOADO DO BRONZE FINAL
}

\author{
António Manuel S. P. Silva ${ }^{1}$, Paulo A. P. Lemos ${ }^{2}$, Sara Almeida e Silva ${ }^{3}$, Edite Martins de Sá4
}

\begin{abstract}
RESUMO
O sítio arqueológico de São Julião é um povoado do Bronze Final, situado na plataforma litoral do Entre Douro e Vouga, que tem sido objeto de projetos de investigação sistemática desde 2014. As suas estruturas mais marcantes são a muralha pétrea que delimitava o recinto e um monumento megalítico, violado ou reutilizado em época moderna ou contemporânea. O espólio arqueológico integra um significativo conjunto cerâmico, objetos em pedra e metais, com destaque para um par de brincos em ouro, porventura relacionados com a evidência de metalurgia que se observa no local. Atualmente, está em curso um programa de conservação e valorização da estação arqueológica, com o apoio do Município.

Palavras-chave: Povoado, Idade do Bronze Final, Mamoa, Conservação e valorização, Albergaria-a-Velha.
\end{abstract}

\begin{abstract}
The archaeological site of São Julião is a Late Bronze Age settlement, located on the coastal platform between Douro and Vouga rivers, which has been the subject of systematic research projects since 2014. Its most striking structures are the stone wall that delimited the enclosure and a megalithic mound, violated or reused in modern or contemporary times. The archaeological collection includes a significant set of ceramics, objects in stone and metals, with emphasis on a pair of gold earrings, perhaps related to the evidence of metallurgy that is observed in the place. Currently, a site's archeological conservation and enhancement program is underway, with the support of the Municipality.
\end{abstract}

Keywords: Settlement, Late Bronze Age, Megalithic mound, Archaeological Conservation and enhancement, Albergaria-a-Velha.

\section{O SÍTIO E A SUA INVESTIGAÇÃO}

O povoado de São Julião (Branca, Albergaria-a-Velha) situa-se na primeira cordilheira de relevos significativos que marcam a transição entre as planícies litorais do Baixo Vouga e os contrafortes da
Serra do Arestal. Ocupa uma elevação de configuração ovalada, com cerca de dois hectares de superfície e à cota de 330 metros $^{5}$, com uma excelente visibilidade envolvente, sobretudo sobre a planície atlântica (Figura 1).

Desde há muito referenciado na historiografia re-

\footnotetext{
1. CITCEM - Centro de Investigação Transdisciplinar Cultura, Espaço, Memória (Univ. Porto); Centro de Arqueologia de Arouca. Coordenador do projeto VAL-JUL; amspsilva@hotmail.com.

2. Centro de Arqueologia de Arouca. Investigador do projeto VAL-JUL; paplemos@gmail.com.

3. Centro de Arqueologia de Arouca. Investigadora do projeto VAL-JUL; saralmeidasilva@gmail.com.

4. Centro de Arqueologia de Arouca. Investigadora do projeto VAL-JUL; editesa@gmail.com.

5. 40.770672 lat. N.; -8.470219 long. E.
} 
gional ${ }^{6}$, a natureza e cronologia do sítio só foram estabelecidas na década de 1990, através de uma intervenção arqueológica de emergência realizada na sequência de graves destruições provocadas pela florestação mecânica para o eucaliptal. São Julião foi então caracterizado como um povoado dos finais da Idade do Bronze, delimitado perimetralmente por uma estrutura composta por muro e talude de terra e pedras, propondo-se igualmente, atenta a homogeneidade do espólio cerâmico e a pouca possança dos depósitos arqueológicos, uma ocupação de relativamente curta duração (Silva \& Pereira da Silva, 1995; Silva, 1994; 2005).

Os trabalhos arqueológicos foram retomados em 2014, de forma programada, com o apoio do $\mathrm{Mu}-$ nicípio de Albergaria-a-Velha, ao abrigo de projetos de investigação desenvolvidos pelo Centro de Arqueologia de Arouca, o último dos quais - VAL-JUL $L^{19-21}$ - Estudo, conservação e valorização do sítio arqueológico de São Julião - visando também a valorização arqueológica, patrimonial e ambiental do sítio (Silva \& alii, 2016; 2019b).

Nesta linha, realizaram-se campanhas de escavação anuais, com uma duração de entre três a quatro semanas, envolvendo uma pequena equipa profissional e grupos de voluntários nacionais e estrangeiros, nos anos de 2014, 2015 (Silva $\mathbb{8}$ alii, 2015), 2016, 2017 (Silva \& alii, 2017b e 2019), estando prevista a sua continuidade em 2020. Ao mesmo tempo, têm sido levadas a cabo iniciativas de divulgação da estação arqueológica, quer à escala local (Silva, 2017; Silva \& alii, 2019b), quer promovendo a difusão e o debate junto da comunidade científica sobre aspetos particulares do sítio como as suas muralhas (Silva \& Pereira, 2020), a cerâmica recolhida nas escavações (Almeida e Silva \& alii, 2019) ou a memória oral sobre o arqueossítio (Silva \& alii, 2018-2019). De outros estudos em curso, que envolvem datações radiocarbónicas, análises de paleometalurgia, composição química de pastas cerâmicas, análises arqueobotânicas, prospeção geofísica, etc., aguardam-se desenvolvimentos e oportunidade para a sua discussão e publicação.

Os trabalhos arqueológicos têm incidido, de forma mais continuada, em duas áreas do povoado: a escavação de um troço da estrutura de delimitação do sítio, no talude poente; e a escavação de uma mamoa

6. Para não alongar o texto, vejam-se por exemplo, sobre este aspeto, Silva, 2014; Silva $\&$ alii., 2017b e 2019b. localizada no interior do recinto (Figura 2). Outras sondagens foram feitas na área mais central da parte preservada do sítio (sector $\mathrm{A})^{7}$, em busca de estruturas domésticas, para já sem grande sucesso; e também no prolongamento imediato da plataforma superior para norte (sector C), uma área que tem proporcionado espólio bastante interessante mas que se encontra arruinada, em termos de estratigrafia, devido ao plantio mecânico de eucalipto (Figura 2). Neste texto concentraremos a nossa análise, no que se refere às estruturas arqueológicas, no monumento megalítico e no troço da estrutura de delimitação do sítio.

\section{A MAMOA DE SÃO JULIÃO}

A designada "mamoa 1" de São Julião foi identificada no início da década de 1990, por um de nós (A.M.S.) e Fernando A. Pereira da Silva (1953-2010), no âmbito do reconhecimento da área do povoado proto-histórico. O montículo levantava então algumas dúvidas quanto ao seu contexto funerário, quer pela parca visibilidade da couraça, pela abundante vegetação e acumulação de sedimentos, quer por se encontrar imediatamente contígua a duas grandes crateras de exploração de pedra. Observações posteriores levaram Pereira da Silva a confirmar a identificação do monumento, que considerou de tradição megalítica, descrevendo-o como um tumulus com um diâmetro de pouco mais de 12 metros, coberto por couraça lítica e com dupla violação, propondo, pela morfologia mais ampla das violações, que a mamoa poderia ter encerrado "um dólmen de corredor curto" (Pereira da Silva, 1996, pp. 214-5).

No âmbito dos projetos de investigação que têm enquadrado a segunda fase de trabalhos arqueológicos, surgiu a possibilidade de avaliar e estudar este monumento megalítico, aferir o seu contexto crono-cultural e avaliar as suas características construtivas. A síntese dos resultados dessa pesquisa considera sequencialmente os dados relacionados com o tumulus, ou montículo funerário e, seguidamente, a área central do monumento (Figuras 3 e 4).

\footnotetext{
7. Uma ação de ripagem mecanizada do terreno, em 1992, destruiu por completo cerca de metade da plataforma onde está instalado o povoado, e, desde então, a quase totalidade dos terrenos circundantes, implicando, igualmente, parte da área arqueológica.
} 


\subsection{Tumulus}

As escavações permitiram identificar um tumulus de planta subcircular (ligeiramente ovalado segundo um eixo sudeste-noroeste), com um diâmetro máximo a rondar os $14 \mathrm{~m}$ (Figuras 3 e 4). Destaca-se também a sua pouca altura, que não ultrapassa, em média, os o.50 m, podendo admitir-se talvez um máximo de 0.70 ou $0.80 \mathrm{~m}$ para o topo do monumento, atendendo aos processos erosivos pós-deposicionais e outras ações que terá sofrido ao longo do tempo.

$\mathrm{O}$ monumento encontra-se totalmente revestido por uma couraça pétrea, com exceção das áreas perturbadas pela vegetação e outras ações modernas. A litologia predominante do montículo traduz-se por blocos de média e pequena dimensão de granito local, observando-se, no entanto, uma quantidade apreciável de calhaus de quartzo. Poderá verificar-se, eventualmente, a seleção intencional desta matéria-prima para a sua inserção em determinadas áreas do montículo, e consequente associação entre matérias visualmente contrastantes (Silva et alli, 2017a).

No sector es-nordeste do tumulus, para onde "abre" o incipiente "corredor" da zona da câmara, observa-se uma interrupção da couraça, aparentemente até ao exterior do montículo ${ }^{8}$; mas como a área possui abundantes raízes arbóreas, que perturbaram o subsolo, não é ainda possível interpretar com segurança esta descontinuidade como um "corredor" de acesso ou mera perturbação. Em certos pontos da couraça assinalam-se alguns blocos cuja morfologia e dimensões sugerem que poderiam ter sido esteios constituintes da câmara sepulcral, eventualmente deslocados da sua posição original, mas esta possibilidade requer ainda confirmação (Silva $\mathbb{\&}$ alli, 2018a; Silva \& alli, 2019a).

Os trabalhos mais recentes permitiram detetar um anel lítico periférico, composto por pedras de granito e ocasionais elementos em quartzo, com uma largura de cerca de dois metros. A sua implantação foi precedida pela colocação de um depósito de preparação e nivelamento, diretamente sobre a rocha de base, eventualmente nos locais onde a mesma não foi afeiçoada ou regularizada para o efeito, conferindo desta forma uma maior sustentabilidade estru-

8. Curiosamente, também F. A. Pereira da Silva - talvez induzido pela maior destruição ou abaixamento da couraça nessa parte do tumulus - sugeria que o pequeno corredor da sepultura megalítica poderia abrir para um "átrio" (1996, p. 214). tural a este elemento arquitetónico. Apesar de não ser possível apurar na íntegra, por ora, o processo de preparação do solo levado a cabo para receber a estrutura, os dados de que dispomos atestam um cuidado planeamento e faseamento construtivo, bem como a sua adaptação e articulação com as características morfológicas do terreno (Silva \& alli, 2019a).

\section{2. Área central do monumento}

A intervenção na área central da estrutura, onde se localizaria uma eventual câmara sepulcral, revelou surpresas e consideráveis desafios interpretativos, resultantes de grandes perturbações ocorridas em época moderna/contemporânea.

Após os trabalhos superficiais de limpeza e da decapagem de um nível de saibro granítico de aparente aspeto natural, observou-se uma vala preenchida por uma espécie de "anel lítico", composto por blocos de pedra de maiores dimensões que a pareciam delimitar. Ainda foi colocada a hipótese desse anel lítico, rebaixando um pouco a cota basal do monumento, ter tido funções de contrafortagem de uma câmara sepulcral megalítica ou submegalítica, entretanto desmantelada e removida, ou simplesmente de delimitação simbólica do espaço. Porém, sob estas estruturas, colmatadas (quase diríamos, pela aparência, "condenadas", na aceção simbólica que se dá a este termo nestes contextos pré-históricos) por inúmeros blocos de pedra de pequena e média dimensão, observou-se uma segunda fossa, também escavada no nível geológico natural, de configuração subquadrangular, com ângulos arredondados, medindo regularmente 1.80 x $1.80 \mathrm{~m}$ e com orientação OSO-ENE, a considerar-se este parâmetro (Figura 5).

A escavação desta fossa inferior, cujo topo estava também colmatado por blocos de pedra de pequena e média dimensão (aparentemente da litologia local, sem seleção evidente) viria a revelar que a fossa se encontrava seccionada transversalmente, sensivelmente pela metade, no sentido aproximado sudeste-noroeste, por um murete de três fiadas de pedras, sobrepostas sem qualquer ligante e que não atingiam o fundo da fossa, assentando ainda sobre sedimentos (Figura 5). Na sua metade es-nordeste, a fossa estava superiormente capeada por um pavimento em saibro pisado, relativamente compacto; a "metade" oposta da estrutura negativa achava-se preenchida por cinco depósitos de terra e pedras. Importa recordar, como se disse, que o "murete" septal não atin- 
gia a base da fossa, apoiando-se em três depósitos sedimentares linearmente sucedâneos (Silva $\mathbb{Z}$ alli, 2018a; Silva \& alli, 2019a).

A escavação destes depósitos, incluindo a desmontagem parcial do murete intermédio, forneceu escasso espólio arqueológico e, surpreendentemente, praticamente todo de cronologia moderna ou contemporânea, essencialmente fragmentos de material de construção (telha). Os níveis [113] a [115], subjacentes ao piso em saibro (UE o9o) não revelaram conteúdo artefactual; o murete [89] apenas um fragmento de telha e os seis depósitos subjacentes ao murete proporcionaram a recolha de 32 fragmentos de cerâmica moderna/contemporânea. Apenas foi registado um pequeno fragmento de cerâmica proto-histórica (afim da do povoado), no nível basal [125], mas coexistindo com seis fragmentos modernos; e no depósito [88] recolheu-se um geométrico em sílex, que todavia estava "acompanhado" por 14 fragmentos de telha e outra louça moderna (Silva \& alii, 2017a; 2018a; 2019b).

Ou seja, a avaliar pelo espólio recolhido nesta estranha fossa, temos de admitir duas interpretações possíveis: ou a fossa - e as ações construtivas correlatas - é de cronologia moderna/contemporânea (precisemos, entre os séculos XVIII e XX) e no mesmo intervalo cronológico foi abandonada e/ou colmatada; ou a fossa é de cronologia pré ou proto-histórica e foi, em tempos modernos, reutilizada - incluindo a construção do murete septal e o respetivo "meio-piso" superior - e posteriormente abandonada e atulhada com depósitos de aterro modernos/contemporâneos.

$\mathrm{Na}$ verdade, esta estranha súmula de ações antrópicas dificulta uma cabal interpretação dos dados, pelo que apenas nos é permitido, por ora, sustentar algumas hipóteses interpretativas para a compreensão deste ambiente e dos seus diferentes momentos construtivos, de eventual reformulação e, certamente, de violação/destruição/reutilização (?). Equaciona-se, assim, a possibilidade de ter sido ali erigida uma câmara submegalítica ou cistóide (atendendo à tipologia das lajes aparentemente deslocadas e presentes no montículo), ou alongada e sem corredor, ou com um corredor muito incipiente, o que em conjunto com as restantes características arquitetónicas do tumulus poderia corresponder a um monumento inserível cronologicamente no $3^{\circ}$ milénio ou no início do $2^{\circ}$ milénio (Calcolítico/Bronze Inicial) (Silva \& alli, 2018a; 2019a).
Ainda que esteja em aberto a hipótese da fossa subquadrangular ter integrado o conjunto sepulcral original, possibilidade que conta com alguns paralelos regionais (Jorge, 1985; Pereira da Silva, 1992; Carvalho, 2016), ou que a mesma estrutura possa, em alternativa ter resultado de uma reapropriação/reutilização coeva da ocupação do povoado no Bronze Final, não restam dúvidas - como atrás se explica - de que as ações patentes no seu enchimento evidenciam a sua violação/destruição/reutilização, ocorrida provavelmente entre os séculos XIX e XX, fosse no âmbito das explorações das pedreiras próximas ou da utilização do posto de telegrafia ótica que ali existiu9. Temos também de admitir, como terceira possibilidade, que a própria fossa subquadrangular seja de época histórica e que possa ter tido uma funcionalidade, que de todo nos escapa por enquanto, porventura associada a estes últimos eventos. Se assim foi, tal ação pode ter implicado o saque total dos esteios da presumível câmara ou cista e/ ou de uma eventual fossa/covacho associados, de menores dimensões, o que é já especulativo (Silva $\&$ alli, 2019a).

O espólio proveniente do monumento, considerando também a área do tumulus, acentua as dificuldades interpretativas, pois os materiais exumados são, na sua grande maioria, de cronologia moderna/contemporânea. A sua prevalência verifica-se quer nas áreas genéricas da mamoa, quer nos depósitos de enchimento da fossa central, como vimos. A escassez de espólio coevo do monumento ou mesmo da ocupação do povoado constitui, talvez, a problemática mais desafiadora, atendendo à sua percentagem diminuta e à evidência de grandes perturbações da estratigrafia original. A par das parcas cerâmicas que deverão integrar-se nos mesmos horizontes da ocupação do final da Idade do Bronze, destaca-se a ocorrência de algumas lâminas e lamelas em sílex, um bloco de quartzo com levantamentos e um geométrico (Silva \& alli, 2019a). Admite-se, com as devidas reservas, decorrentes dos factores referidos, que os artefactos em pedra talhada poderão ser os

\footnotetext{
9. De onde resulta o microtopónimo "Talégre» usado pela população local para referenciar o monte. O posto do "Alto da Branca" terá sido instalado no contexto da guerra civil liberal, e deverá ter funcionado pelo menos até meados do século XIX. Desconhece-se qual o sistema utilizado (telégrafo de persianas, de ponteiro ou outro) e que tipo de construção ou dispositivos de apoio implicou.
} 
únicos elementos artefactuais eventualmente integrantes no espólio votivo e na ambiência crono-cultural desta estrutura funerária pré-histórica - ou, pelo menos, da fruição mais remota da sua biografia (Figura 6).

\section{A ESTRUTURA DE DELIMITAÇÃO DO POVOADO}

A presença de muralhas em São Julião encontra-se registada desde, pelo menos, as Memórias Paroquiais de 1758 (Azevedo, 1896, p. 313), acompanhando também as primeiras interpretações de pendor arqueológico do sítio (Gomes, 1877, p. 69; Souto, 1942, p. 31; Almeida, 1946, p. 42) com textos descritivos e, por vezes, imagens, que evidenciavam que tal estrutura mostrava à época ainda alguma imponência (Silva et al. 2017b, p. 25). Reconhecida também nos trabalhos de 1993-1994 (Pereira da Silva \& Silva, 1993; 1994; Silva \& Pereira da Silva, 1995), a estrutura de delimitação do povoado, identificada em especial na encosta oeste, foi, durante os trabalhos dos projetos de investigação PROBA e PROBA ${ }^{+2}$, e, agora, VAL-JUL, alvo de novas intervenções.

Em 2014 procedeu-se à limpeza da área sondada nos trabalhos dos anos '9o e à abertura de uma nova sondagem, com o objetivo de caracterizar melhor a estrutura murária. Os trabalhos demonstraram a perturbação dos depósitos subjacentes à estrutura de delimitação, na sequência de ações de plantio recentes, verificando-se ainda que a mesma tinha sido reformulada em época moderna/contemporânea. Contudo, foi possível identificar dois depósitos relacionados com a construção da estrutura, tendo, de um desses depósitos, sido recolhida uma amostra de sedimentos que possibilitou a datação de um carvão de medronheiro. A data obtida (976-826 a.C.) aponta um terminus post quem para a edificação desta estrutura (Quadro 1). Em 2015, os trabalhos realizados permitiram a identificação, a Este, de um possível muro, bastante desmantelado, constituído por blocos de granito de médio calibre, relativamente aparelhados, sem qualquer ligante, ostentando cerca de dois metros de largura, com enchimento de terra e pedras de diferentes calibres. Entre 2016 e 2019 procedeu-se a diversos alargamentos da superfície escavada, afinando-se a compreensão do processo construtivo da estrutura de delimitação, exumada já numa extensão de $24 \mathrm{~m}$, numa superfície total de $176 \mathrm{~m}^{2}$.
Dos trabalhos realizados podemos afirmar que o povoado era dotado, aparentemente desde a sua origem, de uma estrutura de delimitação que, muito possivelmente, rodeava toda a plataforma superior do cabeço de São Julião, tal como sugerido pela bibliografia mais antiga. Infelizmente, em resultado da florestação e outras ações humanas, apenas é visível, atualmente, na encosta poente da plataforma. Podemos caracterizar a estrutura de delimitação como sendo composta por duas partes complementares. A primeira, um muro composto por pedra seca, integrando essencialmente blocos de granito de pequenas a grandes dimensões, com face externa relativamente alinhada e espessura de $3,5 \mathrm{~m}$. A "face interna" deste muro pétreo não é muito evidente, embora se note uma concentração de blocos de maior dimensão, que poderão ter funcionado como "fecho" da estrutura (Figuras. 6 e 7). Não temos elementos para estimar o seu alçado original, que temos reconstituído graficamente com uma altura a rondar os dois metros (Silva \& alii, 2016; 2016b; Silva $\&$ Pereira, 2020). A segunda, por sua vez, refere-se a uma estrutura interna, caracterizada por um talude constituído por terras e pedras em declive, adossado ao muro anterior, servindo quer de contraforte, quer de rampa de acesso ao topo do muro externo. A circunstância dos depósitos inferiores deste talude assentarem parcialmente sobre a estrutura basal do muro exterior sugere que ambos os elementos de delimitação, muro e talude, tenham feito parte do mesmo projeto construtivo, de que parece ter resultado, em síntese, uma espessa linha de delimitação, com cerca de quatro ou cinco metros de espessura total. O que, entretanto, podemos sublinhar é o grande interesse desta estrutura de contenção, como exemplo da diversidade dos dispositivos e arquiteturas que delimitavam os povoados desta época na região, considerando, por exemplo, os casos próximos dos sítios da Cividade ou do Senhor dos Aflitos, em Arouca (Silva \& Leite, 2010; Silva \& alii, 2018b; Silva \& Lemos, 2018; Silva \& Pereira, 2020), mas também os de outros povoados com menos documentação, situação que, aliás, se regista também à escala do norte do país (Bettencourt \& Sanches 1998; Bettencourt, 2000; Vieira, 2014).

\section{ESPÓLIO ARQUEOLÓGICO}

Ascendem já a cerca de 22 ooo objetos as recolhas de materiais resultantes das campanhas de 2014 a 
2019, sendo naturalmente mais volumoso o espólio cerâmico, que acusa uma assinalável homogeneidade, resultante talvez da relativamente curta diacronia de ocupação do sítio. Entre os outros itens destacam-se os artefactos líticos, em pedra talhada e polida e alguns objetos metálicos, com realce para um par de brincos áureos (Figura 8).

No que respeita à olaria (Almeida e Silva $\&$ alli, 2018-19; SILVA $\&$ alli, 2015, pp. 84-5; Silva $\&$ alli, 2017b, pp. 32-4), apesar do elevado grau de fragmentação do espólio, tem vindo a ser possível reconhecer algumas tipologias formais (Almeida e Silva $\mathbb{E}$ alli, 2018-19, pp. 28-31), sobretudo em virtude dos trabalhos realizados na zona C (Figura 2), onde a concentração de cerâmica proto-histórica é bastante superior, comparativamente a outras áreas do povoado. São sobretudo potes e potinhos, com diferentes tipos de bordo, aos quais se somam algumas taças carenadas (Figura 8-2), também de diferentes tipologias, e alguns recipientes de maiores dimensões destinados ao armazenamento, identificando-se também a presença de uma queijeira ou coador. O número residual de asas recolhido indica que não seriam muito abundantes as formas com elas (Figura $8-1$ ). Fora do reportório de uso alimentar está um conjunto de elementos relacionados com a metalurgia do bronze ${ }^{10}$, no qual se inserem cadinhos e moldes de fundição (Figura 8 - 5 a 7 ), o que sublinha a importância regional deste sítio do Bronze Final, bem como um cossoiro e um peso, talvez de rede.

A cerâmica de São Julião apresenta maioritariamente produção manual, cozedura mediana ou má, pastas arenosas ou areno-micáceas, sendo as primeiras pouco depuradas. As superfícies não apresentam tratamento cuidado, salvo raras exceções, não sendo também frequente a decoração (Almeida e Silva $\mathbb{8}$ alli, 2018-19, pp. 14-25), que surge maioritariamente sobre os lábios ou já na superfície interna, através de incisões ou impressão de dedadas (Figura 8-1 e 4), e sobre as panças, aí sob a forma maioritária de caneluras (Figura 8-14). Se em alguns casos parece evidente a intenção ornamental, outros há em que

10. Chegamos a considerar estes elementos, caracterizados por pastas de tonalidade bege-acinzentada, bastante depuradas, como possíveis peças de importação (Almeida e Silva et alli, 2018-19, p. 14). Apenas com o desenrolar dos trabalhos, e o surgimento de mais elementos, foi possível perceber que se tratava de moldes para fundição, não tendo sido ainda possível apurar a proveniência da argila utilizada na sua produção. ligeiras caneluras ou linhas incisas poderão resultar apenas do tratamento de superfície, por vezes aparentemente feito com escova. As linhas incisas são comuns, dispondo-se por vezes em aspa ou zig-zague e, mais raramente, em padrão geométrico ( $\mathrm{Fi}$ gura 8 - 10, 12). Verifica-se a existência de um fragmento com incisão pós-cozedura (Figura 8-11), e de outros decorados com pequenos puncionamentos $\mathrm{e}$ outros motivos impressos (dedadas, círculos, motivos subtriangulares, etc.) (Figura $8-13$ ). O brunido é bastante raro como acabamento, estando representado apenas por um exemplar, de alta qualidade (Figura 8-9).

São pouco mais de uma centena os objetos em pedra recolhidos no povoado (SILVA \& alli, 2015, p. 85; SILVA \& alli, 2017b, p. 34). Entre os elementos polidos surgem os relacionados com a moagem (dormentes e moventes de mós manuais), alguns amoladores, uma goiva, um machado e um conjunto significativo de pesos de rede, obtidos através de duplo entalhe paralelo sobre seixo de rio. Já entre os objetos produzidos através de talhe (Figura 9-1 a 10), sob quartzo ou sílex, destacam-se as lâminas (Figura $9-6$ a 8), algumas lamelas e lascas (Figura 9 - 1 a 5) e dois geométricos (Figura 9 - 9 e 10), ambos recolhidos na zona da mamoa.

Relativamente aos metais (SILVA \& alli, 2017b, p. 34) verifica-se a presença de seis objetos enquadráveis no Bronze Final ${ }^{11}$, sendo quatro em bronze e dois em ouro (Figura 9). Dois dos objetos em bronze são de dimensões diminutas, não sendo possível apurar a sua funcionalidade (Figura 9 - 13 e 14); um outro corresponde a um aro de uma possível bracelete ou objeto de adorno (Figura 9-12), e o restante a uma lâmina (Figura 9-11). Quanto às peças em ouro (Figura 9 - 15 e 16), um par de brincos, apresentam-se muito similares entre si, tendo sido produzidos através de fio de ouro maciço, dobrado em argola aberta, com secção ovalada e superfícies levemente facetadas, medindo cerca de $15 \mathrm{~mm}$ e pesando $6 \mathrm{~g}$. cada. Não é esta a ocasião discutir contextos, significados ou cronologias destas peças áureas, usualmente classificadas da $1^{\mathrm{a}}$ Idade do Ferro, ou seja, globalmente entre os séculos VIII-VII e V a.C., mas deverá anotar-se que são conhecidas apenas oito objetos similares em todo o País, todos provenientes da Estremadura: dois brincos da Boiça do Louro, Cadaval, outros

11. Havia sido recolhido, também, um ceitil de D. Afonso V (1438-1481). 
dois da Boiça, Alcobaça e finalmente quatro do Casal das Passadeiras, Torres Vedras, sendo que apenas o último achado tem contexto arqueológico, uma vez que apareceu em conjunto com outras peças áureas (Silva, A. R., 2014).

\section{A VALORIZAÇÃO DO SÍTIO ARQUEOLÓGICO}

O projeto de conservação e valorização, iniciado em 2020, em colaboração com o Município local, que tem financiado integralmente os trabalhos e procedeu à aquisição dos terrenos melhor conservados da estação arqueológica, visa assegurar a conservação e acessibilidade dos vestígios arqueológicos e a valorização das memórias da antropização do sítio em vários planos cronológicos, desde a pré-história (mamoa), passando pela Idade do Bronze até aos tempos modernos, marcados pela exploração artesanal de pedreiras ou pela instalação de um posto de telegrafia ótica no segundo quartel do século XIX, episódio que perpetuou a designação microtoponímica de "Alto do Talégre» aplicada ao local.

Em colaboração com uma associação da região, a BioLiving, pretende-se também intervir para a requalificação ambiental do sítio, que inclui a desflorestação das espécies exógenas de crescimento rápido e a promoção do coberto florestal e arbustivo autóctone. Desta forma, o programa de investigação arqueológica complementar-se-á com a «devolução" à comunidade, com valor acrescido, dos conhecimentos obtidos, preservando e requalificando o património cultural e potenciando novas áreas de saber e lazer (Silva \& alii, 2019b).

\section{NOTA FINAL}

Para além dos valores patrimoniais que, desde cedo, se anteviu que poderiam acrescer significado ao sítio no plano regional, a estação arqueológica de São Julião tem vindo a suscitar importantes questões no plano do conhecimento da proto-história do Centro e Norte de Portugal. Para tal concorrem, como elementos maiores, a sua muralha (ou de forma menos bélica, como preferimos dizer, "estrutura de delimitação"), que é já um referencial de investigação à escala regional; e a estranhíssima mamoa "acolhida" dentro do povoado. Estranha pela sua localização incomum, pelos diálogos de ritual e simbólica que certamente "entabulou" com os antigos residentes; estranha sobretudo pela insólita reutilização da sua área central, primordialmente sepulcral, se bem que disso não reste qualquer vestígio arquitetónico.

Mas não deixa, igualmente, de suscitar ricas questões ao historiador dos tempos sem escrita a natureza do "povoado" e dos seus lares e dispositivos do quotidiano. Da aldeia de cabanas singelas em que durante alguns séculos se multiplicaram famílias e alimentaram gerações, a invisibilidade estrutural é quase absoluta. Apenas por indícios indiretos se chega ao quotidiano e às gentes que habitaram aqueles altos: os restos de barro mal cozido que calafetavam as ramagens das cabanas ou pavimentavam o chão onde a família se aquecia à lareira, as mós onde grosseiramente se triturava o ralo pão, os utensílios de pedra lascada ou polida, reutilizados dos antepassados para novos usos e funções, um raro cossoiro a atestar a fiação de alguma fibra animal ou vegetal. Mas o "novo" e o excecional também ali tinham lugar - e porventura com uma expressão que ainda nem conseguimos antever: acumulam-se os objetos que testemunham a prática metalúrgica em São Julião, e o par de brincos áureos recorda-nos os signos de poder e hierarquia que o próprio trabalho dos metais já anuncia.

Enquanto se aguardam os resultados de novas datações por Carbono 14, interessa destacar a extraordinária homogeneidade daquelas já disponíveis (Quadro 1), uma relacionada com a construção da muralha (Sondagem 2), a segunda numa área bastante perturbada mas de onde procedem relevantes itens de espólio, ambas apontando para um horizonte de ocupação em pleno "Bronze Final Atlântico”, entre os séculos X e IX a.C.

\section{BIBLIOGRAFIA}

ALMEIDA, João de (1946) - Roteiro dos monumentos militares portugueses. II. Lisboa: Ed. A., pp. 40-2.

ALMEIDA E SILVA, Sara; SILVA, António Manuel S. P.; LEMOS, Paulo A. P.; PEREIRA, Gabriel R. (2018-2019) - Cerâmica proto-histórica do povoado de São Julião (Albergaria-a-Velha): estudo preliminar. Oppidum - Revista de Arqueologia, História e Património, 11, Lousada, pp. 9-36.

AZEVEDO, Pedro A. (1896) - Extractos archeologicos das Memórias Parochiais de 1758. O Archeólogo Portuguez. 2. Lisboa, pp. 305-18.

BETTENCOURT, Ana M. S. (200o) - Estações da Idade do Bronze e inícios da Idade do Ferro da Bacia do Cávado (Norte de Portugal). Braga: Universidade do Minho.

BETTENCOURT, Ana M. S.; SANCHES, Maria J. (1998) Algumas questões sobre a Idade do Bronze do Norte de Por- 
tugal. In FÁBREGAS, R. (ed.) - A Idade do Bronce en Galicia: novas perspectivas. A Coruña: Edicios do Castro: 13-45.

CARVALHO, Pedro M. S. (2016) - Taco a Taco: a história de dois monumentos. Albergaria-a-Velha: Câmara Municipal.

GOMES, João Marques (1877) - O Districto de Aveiro: Noticia geographica, estatistica, chorographica, heraldica, archeologica ... Coimbra: Imprensa da Universidade.

JORGE, Vítor O. (1985) - Les tumulus de Chã de Santinhos (ensemble mégalithique de Serra da Aboboreira, Nord du Portugal). Arqueologia, 12. Porto, pp. 96-128.

PEREIRA DA SILVA, Fernando A. (1992) - A Necrópole Megalítica do Taco (Albergaria-a-Velha). Trabalhos de Antropologia e Etnologia. 32, Porto, pp. 263-292

PEREIRA DA SILVA, Fernando A.; SILVA, António Manuel S. P. (1993) - Estação arqueológica de S. Julião (. . .). Relatório da $1^{\underline{a}}$. Campanha de Escavações (abril de 1993). Oliveira de Azeméis. Texto dactilografado

PEREIRA DA SILVA, Fernando A.; SILVA, António Manuel S. P. (1994) - Estação arqueológica de S.Julião (...). Relatório da $2^{\underline{a}}$. Campanha de Escavações. Oliveira de Azeméis. Texto datilografado.

PEREIRA DA SILVA, Fernando A. (1996) - Megalitismo a Sul do Douro: Bacias do Vouga e Alto Paiva. Práticas funerárias no Centro-Norte Litoral de Portugal durante a Pré-história Recente. 1.2 - Tumuli do Centro-Norte Litoral: Inventário. Tese de Doutoramento inédita, em preparação para apresentação na Universidade do Porto.

SILVA, Ana R. Vaz (2014) - Leituras sobre Ourivesaria Arcaica Portuguesa. Brincos, Contextos e Expressão Territorial. Coimbra. Dissertação de Mestrado em Arqueologia e Território apresentada à Faculdade de Letras da Universidade de Coimbra.

SILVA, António Manuel S. P. (1994) - Proto-história e Romanização no Entre Douro e Vouga Litoral. Elementos para uma avaliação crítica. Dissertação de Mestrado apresentada à Faculdade de Letras da Universidade do Porto.

SILVA, António Manuel S. P. (2005) - Povoamento proto-histórico no Entre Douro e Vouga Litoral: a estruturação do habitat. I - Arquitectura dos castros. In Castro, um lugar para habitar. Colóquio [Cadernos do Museu, 11]. Penafiel: Museu Municipal, pp. 167-188.

SILVA, António Manuel S. P (2014) - Dos vestígios do passado ao património arqueológico. Algumas reflexões sobre a Arqueologia de Albergaria-a-Velha. Albergue. História e Património do Concelho de Albergaria-a-Velha. 1. Albergaria-a-Velha, pp. 27-6o.

SILVA, António Manuel S. P. (2017) - O povoado proto-histórico de São Julião da Branca. In FERREIRA, Delfim B. (coord.) - 90o Anos. Albergaria-a-Velha. 1117-2017. Das origens a Osseloa. Exposição. Albergaria-a-Velha: Câmara Municipal, pp. 8-14 (não pag.).
SILVA, António Manuel S. P.; LEITE, Joana N. (2010) - The place of Cividade. An approach to Late Bronze/Iron Age transition in Arouca valley (NW Portugal). In BETTENCOURT, A. ; SANCHES, M.; ALVES, L.; FABREGAS VALCARCE, R. (eds.) - Conceptualizing space and place. On the role of agency, memory and identity in the construction of space from the Upper Paleolithic to the Iron Age in Europe. (Proc. of the $15^{\text {th }}$ Crongress of UISPP). Oxford: Archaeopress, pp. 153-6o.

SILVA, António Manuel S. P.; LEMOS, Paulo A. P. (2018) - Sondagem arqueológica no povoado da Idade do Bronze do Senhor dos Aflitos (Arouca, Centro-Norte de Portugal). In HERNÁNDEZ GUTIÉRREZ, N.; LARRAZABAL GALARZA, J.; PORTERO HERNÁNDEZ, R. (coord.) - Arqueologia en el valle del Duero: del Paleolítico a la Edad Media 6 - Actas de las VI Jornadas de Arqueología del valle del Duero. Valladolid: Glyphos, p. 191-203

SILVA, António Manuel S. P.; PEREIRA, Gabriel R. (2020) - Walls and Castros. Delimitation structures in the Protohistoric settlements of Entre Douro and Vouga region (Center-North of Portugal). In DELFINO, D.; COIMBRA, F. CARDOSO, D.; CRUZ, G. - Late Prehistoric Fortifications in Europe: Defensive, symbolic and territorial aspects from the Chalcolithic to the Iron Age. Oxford: Archaeopress, pp. 215-228.

SILVA, António Manuel S. P.; PEREIRA DA SILVA, Fernando A. (1995) - O Povoado de S. Julião (Branca, Albergaria-a-Velha, Aveiro). In SILVA, Isabel (coord.), A Idade do Bronze em Portugal. Discursos de poder. Lisboa: Instituto Português de Museus, p. 123.

SILVA, António Manuel S. P.; PEREIRA, Gabriel R.; LEMOS, Paulo A. P.; ALMEIDA e SILVA, Sara (2015) - Escavações arqueológicas em São Julião da Branca (Albergaria-a-Velha). Campanhas de 2014-2015. Albergue. História e Património do Concelho de Albergaria-a-Velha. 2. Albergaria-a-Velha, pp. 59-91.

SILVA, António Manuel S. P.; PEREIRA, Gabriel R.; TAVARES, João T.; LEMOS, Paulo A. P.; ALMEIDA E SILVA, Sara (2016) - Proto-história da Bacia do Antuã (2011-2015) - um projeto de investigação arqueológica em rede. Patrimónios de OAZ. № o. Oliveira de Azeméis: Câmara Municipal, pp. 77-96.

SILVA, António Manuel S. P.; PEREIRA, Gabriel R.; LEMOS, Paulo A. P.; ALMEIDA E SILVA, Sara (2017a) - Proto-história da Bacia do Antuã [Projeto de Investigação Arqueológica 2016-2017]. Povoado de São Julião | Albergaria-a-Velha. Aveiro. Relatório da 4 ${ }^{a}$ Campanha de Trabalhos Arqueológicos. Texto policopiado.

SILVA, António Manuel S. P.; PEREIRA, Gabriel R.; LEMOS, Paulo A. P.; ALMEIDA E SILVA, Sara (2017b) - São Julião da Branca e o povoamento do Entre Douro e Vouga na transição entre a Idade do Bronze e a Idade do Ferro. Albergue. História e Património do Concelho de Albergaria-a-Velha. 4. Albergaria-a-Velha, pp. 15-40. 
SILVA, António Manuel S. P.; PEREIRA, Gabriel R.; LEMOS, Paulo A. P.; ALMEIDA E SILVA, Sara (2018a) - Proto-história da bacia do Antuã (...). Povoado de São Julião, Albergaria-a-Velha, Aveiro. Relatório da 4 ${ }^{\underline{a}}$. campanha de trabalhos arqueológicos. Arouca: Centro de Arqueologia de Arouca. Texto policopiado.

SILVA, António Manuel S. P.; PEREIRA, Gabriel R.; LEMOS, Paulo A. P.; ALMEIDA E SILVA, Sara (2018b) - A Idade do Bronze na margem sul do Baixo Douro - sítios e pistas de investigação. In HERNÁNDEZ GUTIÉRREZ, N.; LARRAZABAL GALARZA, J.; PORTERO HERNÁNDEZ, R. (coord.) - Arqueologia en el valle del Duero: del Paleolítico a la Edad Media 6 - Actas de las VI Jornadas de Arqueología del valle del Duero. Valladolid: Glyphos, pp. 92-117.

SILVA, António Manuel S. P.; PEREIRA, Gabriel R.; LEMOS, Paulo A. P.; ALMEIDA E SILVA, Sara (2019a) - Proto-história da Bacia do Antuã. [Projeto de Investigação Arqueológica 2016-2018]. Povoado de São Julião| Albergaria-a-Velha. Aveiro. Relatório da $5^{\mathrm{a}}$ Campanha de Trabalhos Arqueológicos. Texto policopiado.
SILVA, António Manuel S. P.; SÁ, Edite M.; LEMOS, Paulo; ALMEIDA E SILVA, Sara (2019b) - Projeto de valorização do sítio do Alto do Talégre/São Julião (Branca, Albergaria-a-Velha). Investigar o Passado e (re)construir memórias. Albergue. História e Património do Concelho de Albergaria-a-Velha. 6. Albergaria-a-Velha, pp. 23-34.

SILVA, António Manuel S. P.; LEMOS, Paulo A. P.; ALMEIDA E SILVA, Sara; SÁ, Edite (2020) - Estudo, Conservação e Valorização do sítio arqueológico de São Julião. Branca, Albergaria-a-Velha, Aveiro. Relatório da 6‥ campanha de trabalhos arqueológicos. Arouca: Centro de Arqueologia de Arouca. Texto policopiado

SOUTO, Alberto (1942) - Romanização no Baixo Vouga. Novo "oppidum" na zona de Talábriga. Trabalhos de Antropologia e Etnologia, 9(4). Porto, pp. 283-328.

VIEIRA, Alexandra (2014) - Alguns dados para o estudo da Idade do Bronze do Norte de Portugal. In A Idade do Bronze em Portugal: os dados e os problemas. Tomar: Instituto Politécnico de Tomar: 52-101.

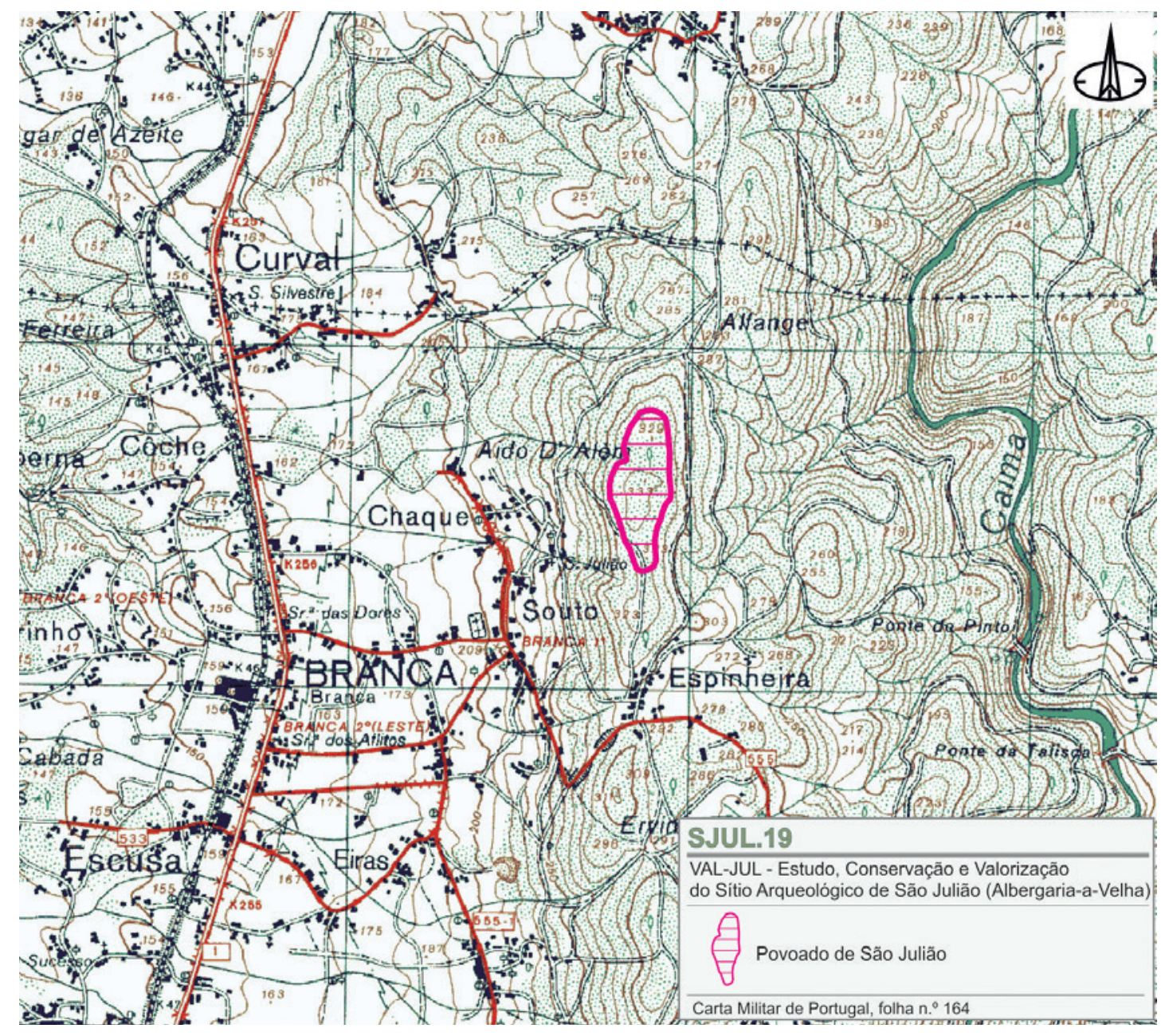

Figura 1 - Implantação do sítio arqueológico na Carta Militar de Portugal (Folha nํ164), à escala 1:2500o (reduzida), com demarcação da plataforma superior. 


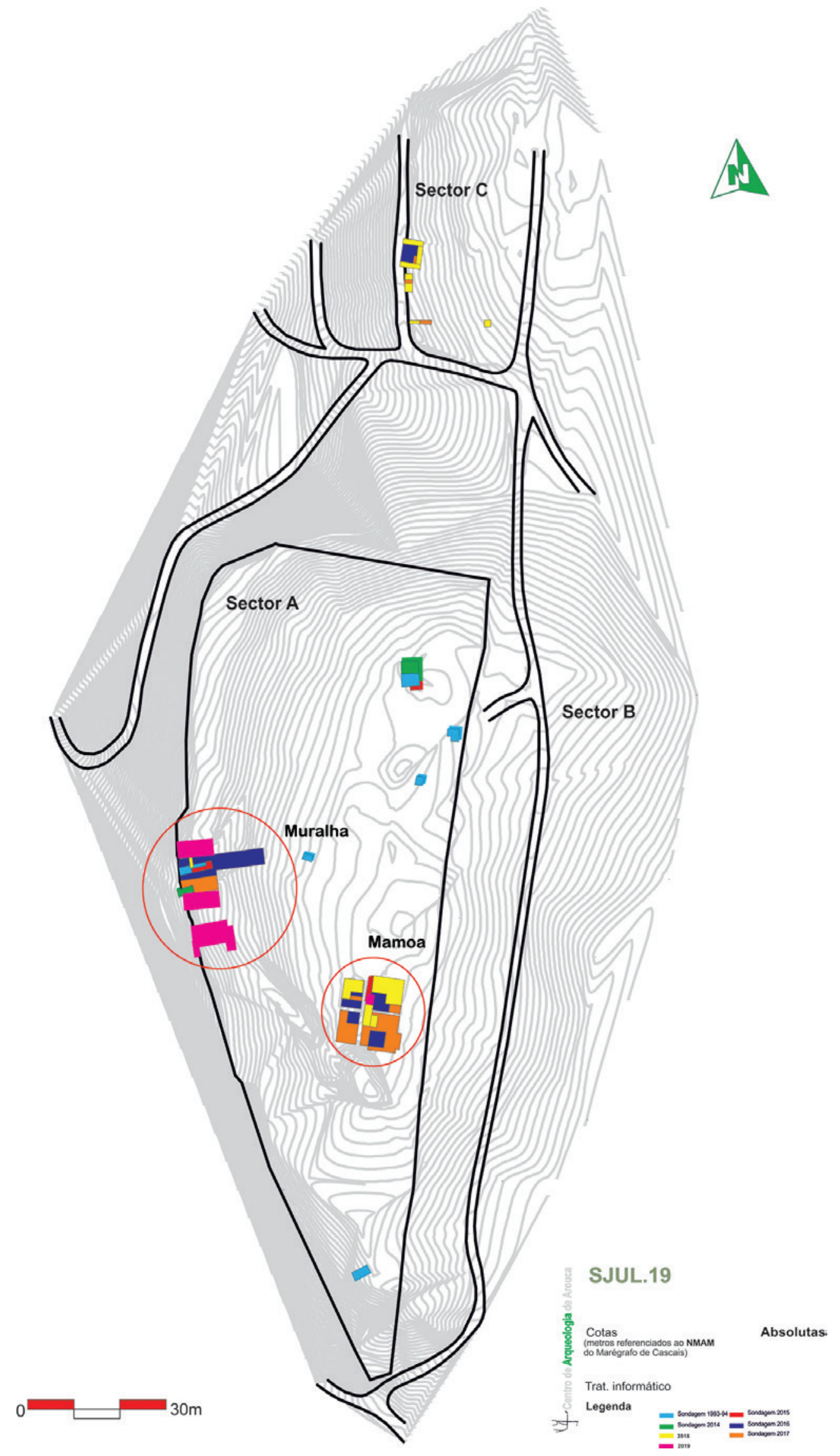

Figura 2 - Implantação das sondagens arqueológicas no sítio arqueológico (levantamento dos serviços de topografia da C. M. de Albergaria-a-Velha). 


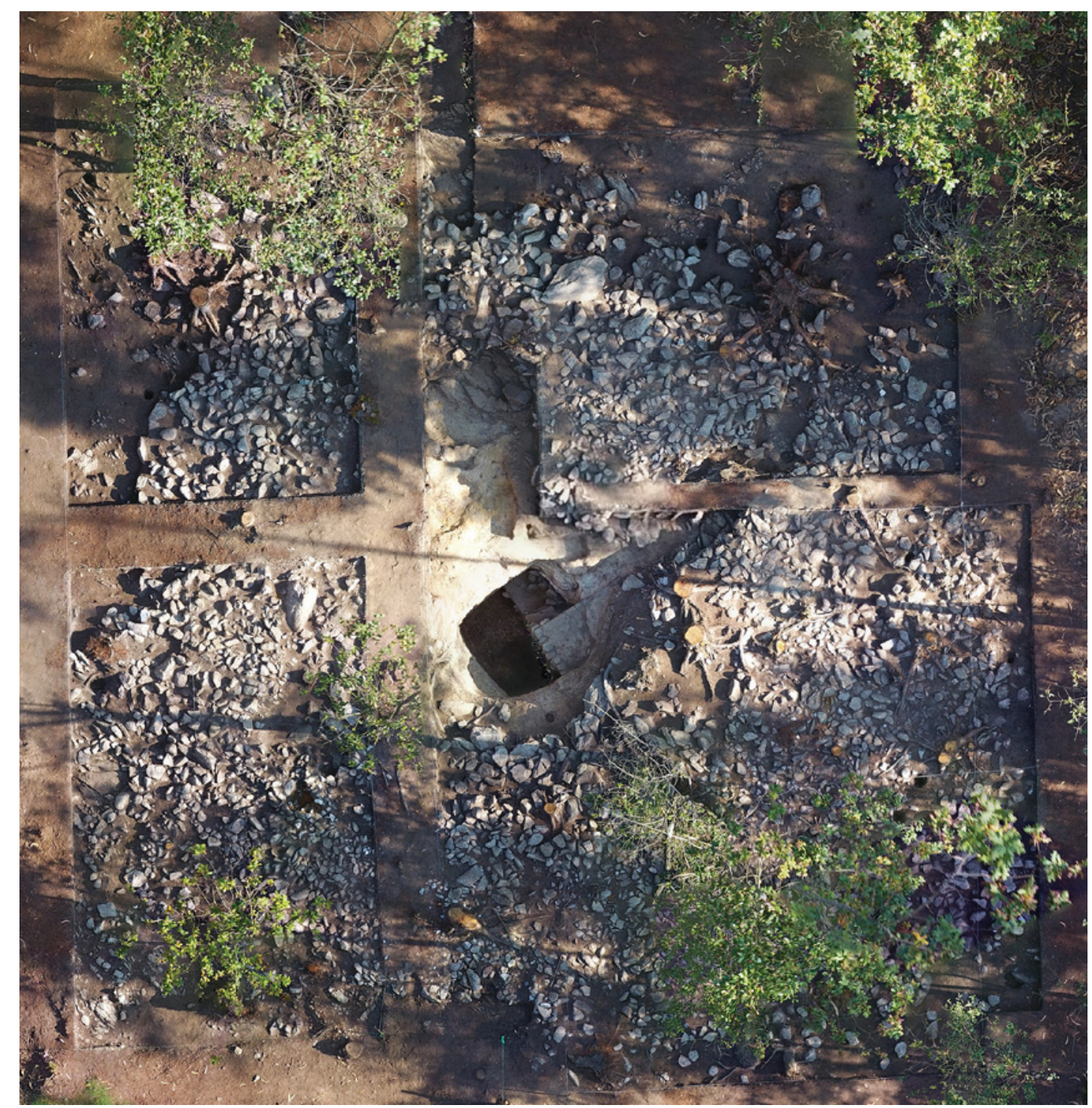

Figura 3 - Sector A. Mamoa de São Julião. Plano final 2019 (fotografia: Multimapa). 


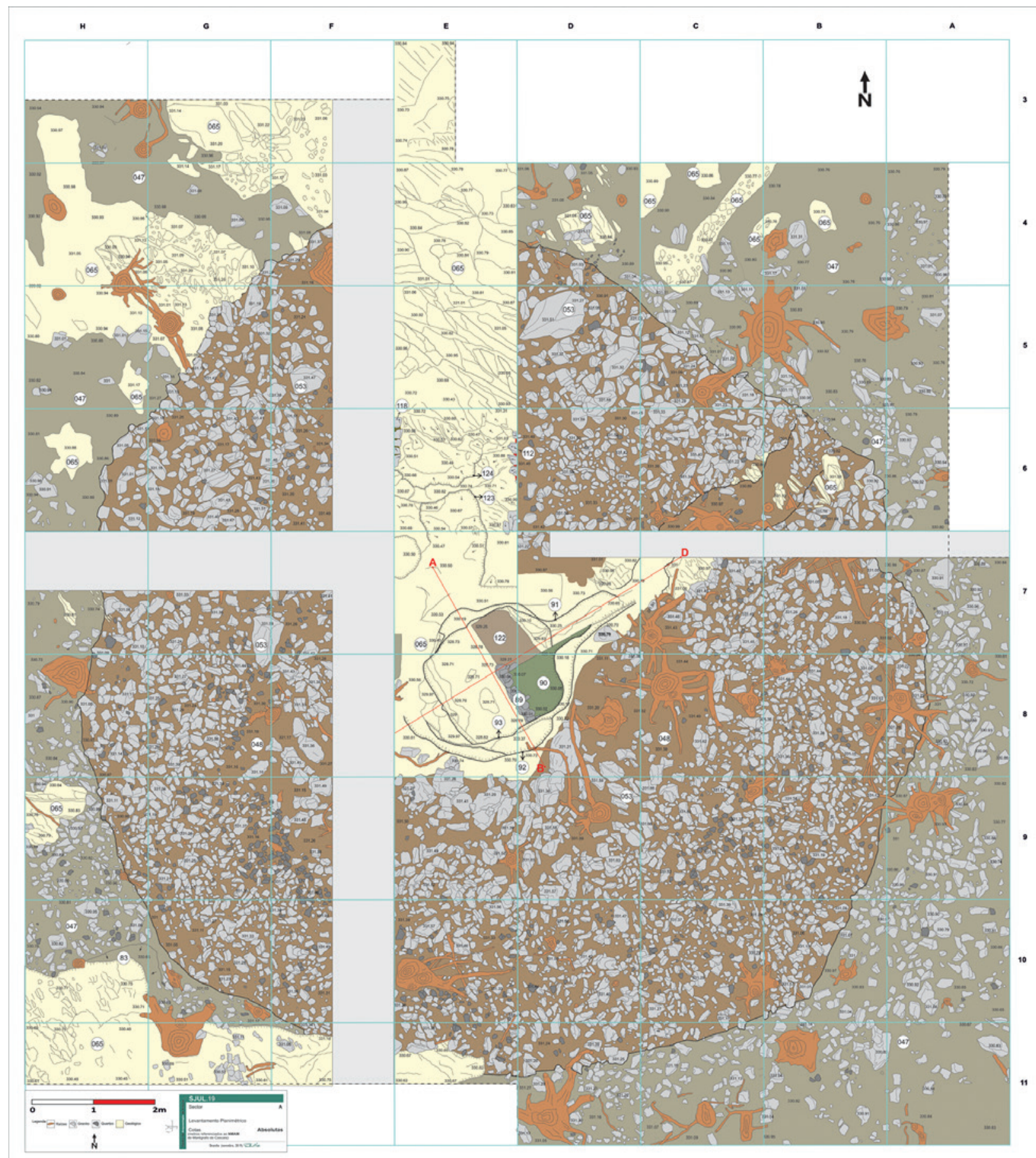

Figura 4 - Sector A. Mamoa de São Julião. Plano final 2019. 


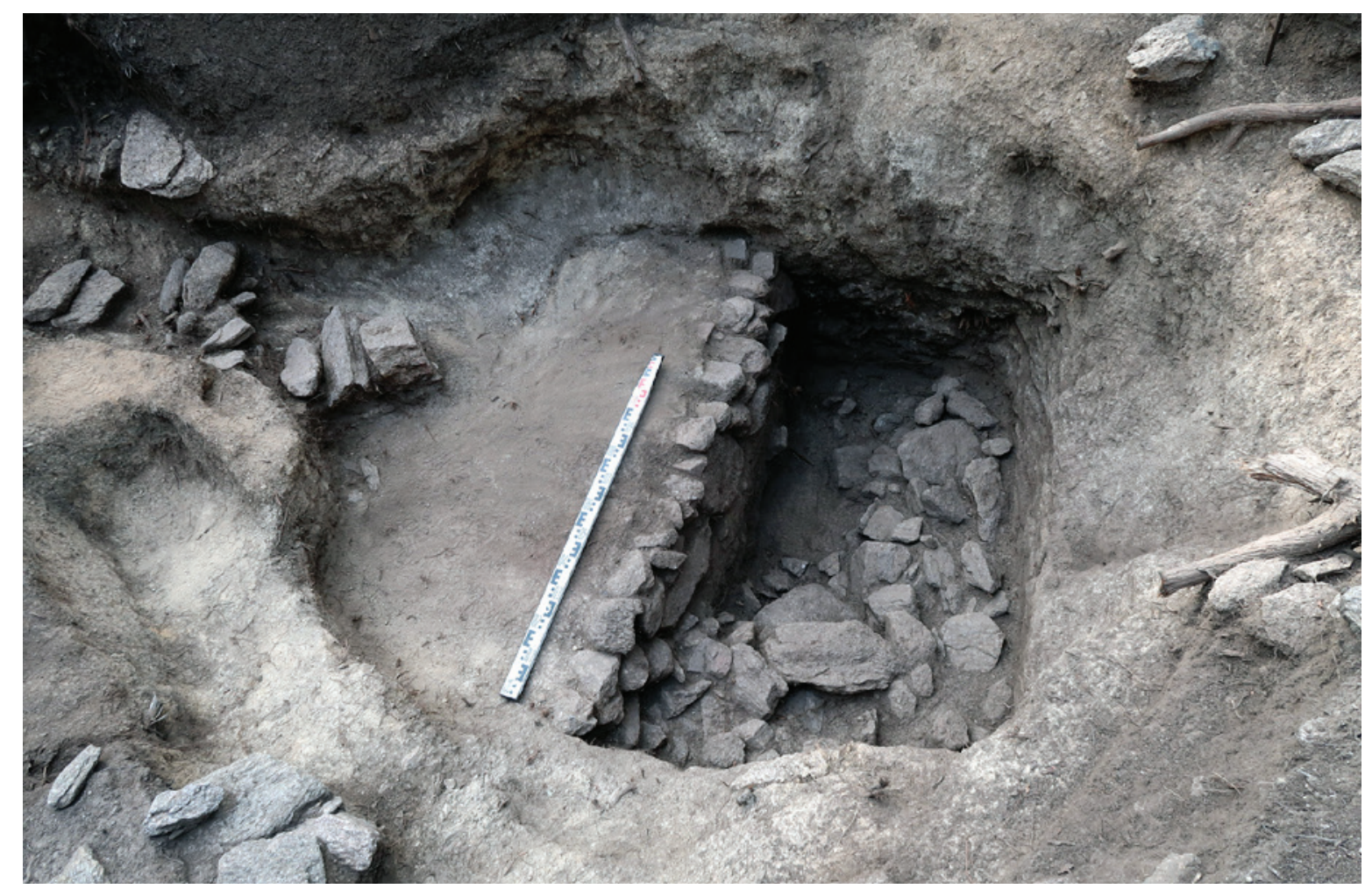

Figura 5-Sector A. Mamoa 1 de São Julião. Fossa central.

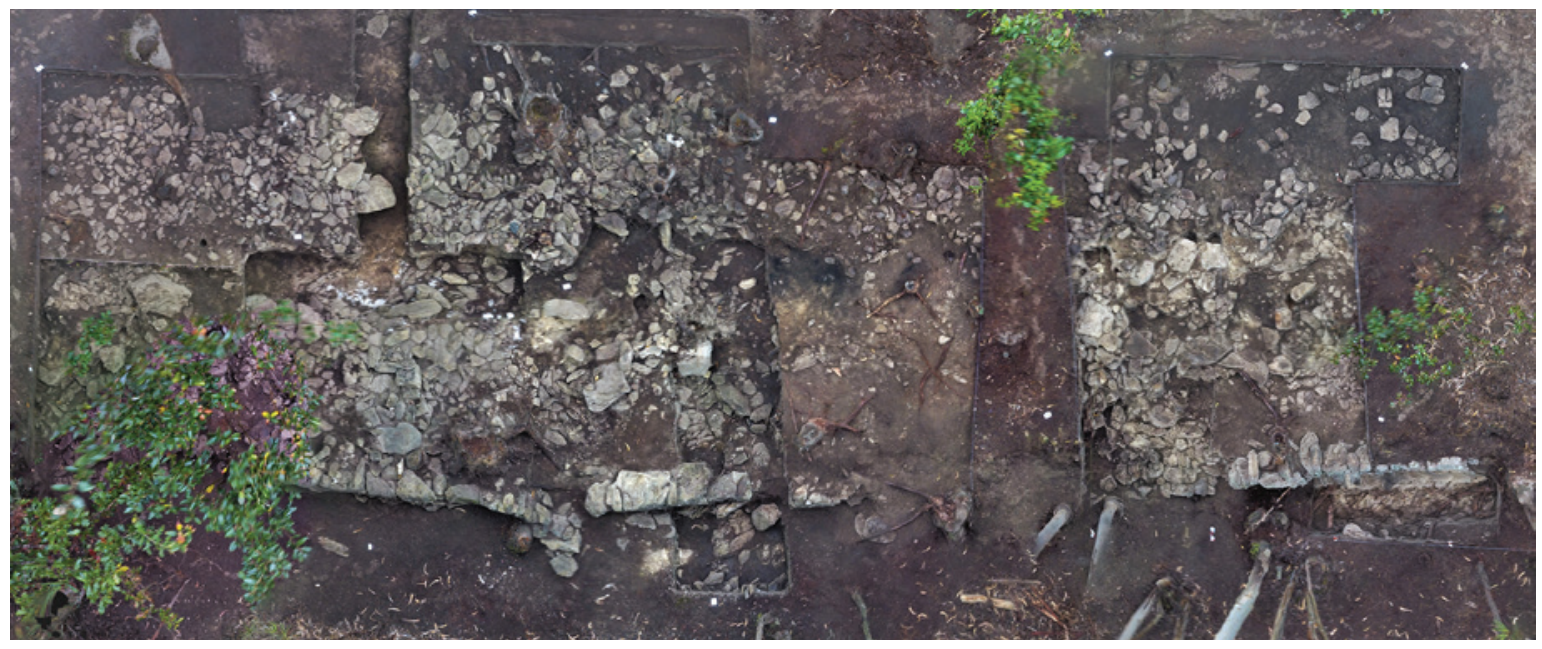

Figura 6 - Sector A. Estrutura de delimitação. Plano final 2019 (fotografia: Multimapa). 


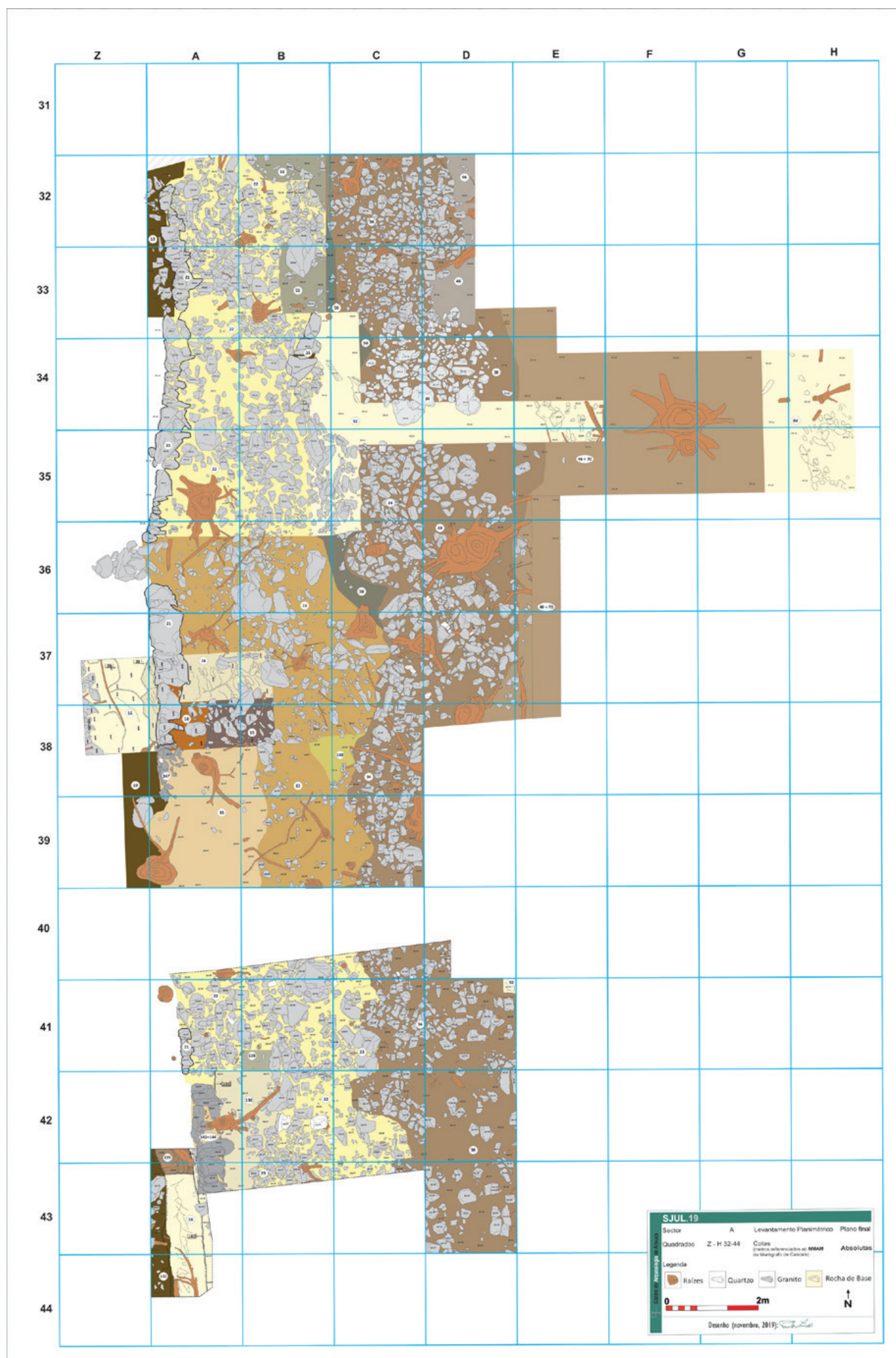

Figura 7 - Sector A. estrutura de delimitação. Plano final (2019). 

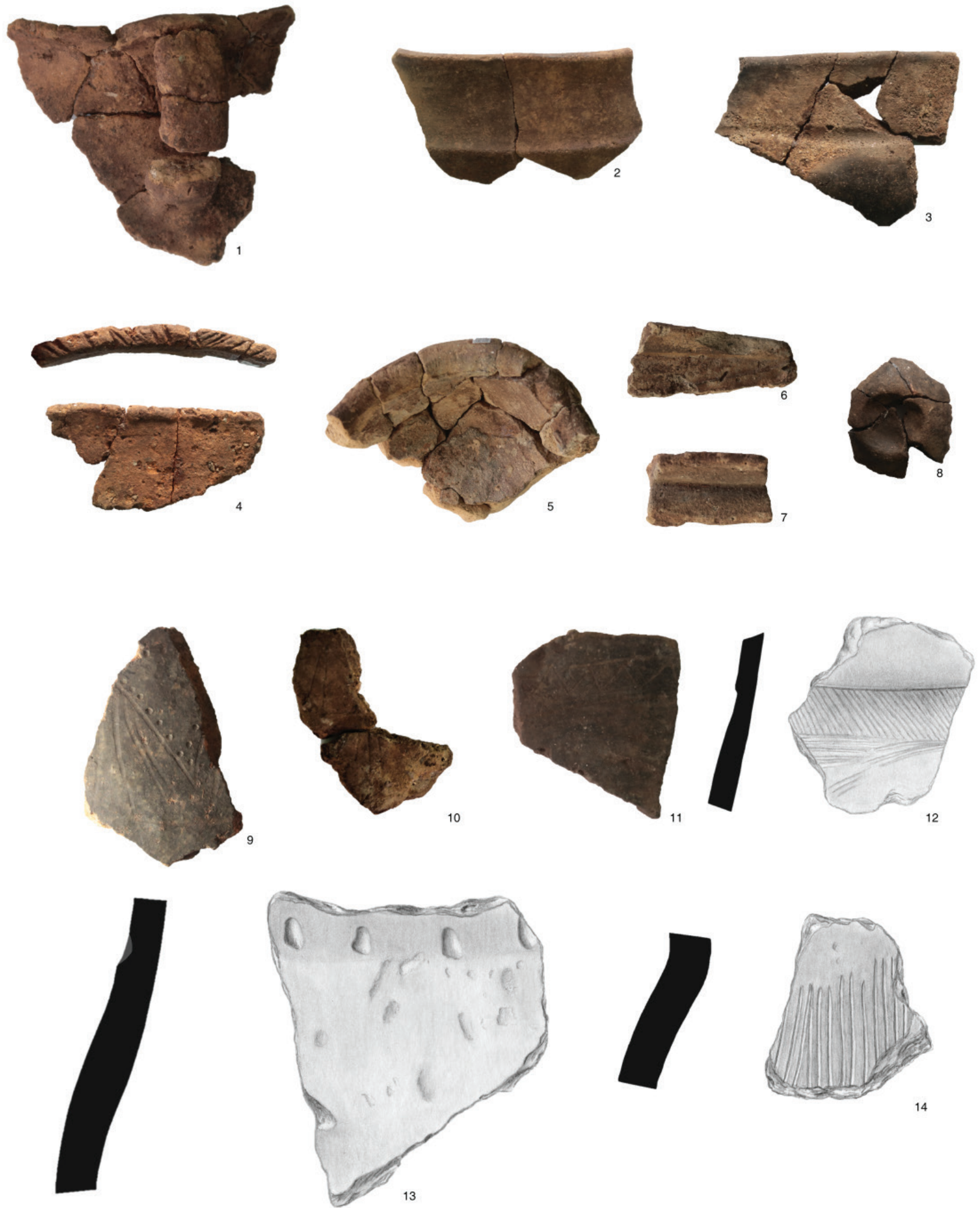

Figura 8 - Cerâmica de São Julião. (12 a 14 - desenhos: Amélia Marques/MDDS). 

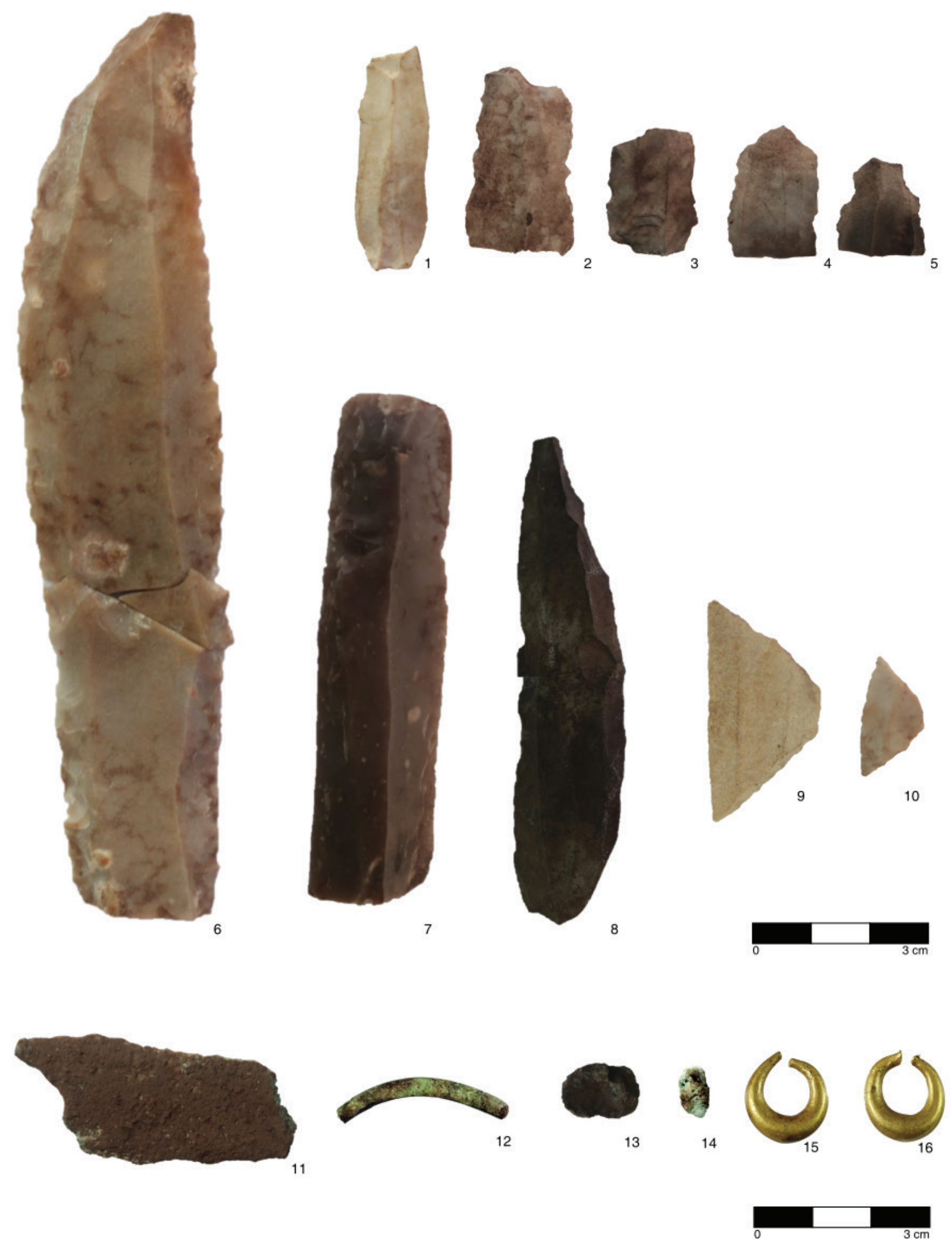

Figura 9 - Objetos líticos e metálicos de São Julião. (Fotos 12, 14, 15 e 16: M. Santos/MDDS). 


\begin{tabular}{|c|c|c|c|c|c|c|c|c|c|c|c|c|c|}
\hline \multirow{3}{*}{ № Lab } & \multirow{3}{*}{ Contexto } & \multirow{3}{*}{ Material } & \multirow{3}{*}{\begin{tabular}{|l|}
$\sigma(13 \mathrm{C})$ \\
per mil
\end{tabular}} & \multicolumn{2}{|c|}{$\begin{array}{c}\text { Fraction of } \\
\text { modern }\end{array}$} & \multirow{3}{*}{ BP } & \multirow{3}{*}{$\begin{array}{c}1 \\
\text { sigma }\end{array}$} & \multicolumn{2}{|c|}{ OxCAL $4.2[1]$} & \multicolumn{3}{|c|}{ Calib Rev 7.0.4 [2] } & \multirow{2}{*}{$\begin{array}{c}\text { CalPal_2007 } \\
\text { HULU [3] } \\
\text { Calendric Age } \\
\text { Cal BP }\end{array}$} \\
\hline & & & & \multirow{2}{*}{ pMC } & \multirow{2}{*}{$\begin{array}{l}1 \sigma \\
\text { error }\end{array}$} & & & 10 & $2 \sigma$ & $1 \sigma$ & $2 \sigma$ & \multirow{2}{*}{$\begin{array}{l}\text { Probab. } \\
\text { Mediana }\end{array}$} & \\
\hline & & & & & & & & $\begin{array}{c}68.2 \% \\
\text { probability }\end{array}$ & $\begin{array}{c}95.4 \% \\
\text { probability }\end{array}$ & $\begin{array}{c}68.3 \% \\
\text { probability }\end{array}$ & $\begin{array}{c}95.4 \% \\
\text { probability }\end{array}$ & & $68 \%$ \\
\hline \multirow{2}{*}{$\begin{array}{l}\text { D-AMS } \\
8883\end{array}$} & \multirow{2}{*}{$\begin{array}{c}\text { Sd } 2 \\
\text { UE } 026\end{array}$} & \multirow{2}{*}{$\begin{array}{c}\text { Carvão } \\
\text { arbutus } \\
\text { unedo }\end{array}$} & \multirow{2}{*}{-21.3} & \multirow{2}{*}{70.98} & \multirow{2}{*}{0.26} & \multirow{2}{*}{2753} & \multirow{2}{*}{29} & \multirow{2}{*}{$\begin{array}{c}920 \mathrm{BC} \\
(68.2 \%) \\
843 \mathrm{BC}\end{array}$} & \multirow{2}{*}{$\begin{array}{l}976 \mathrm{BC} \\
(95.4 \%) \\
826 \mathrm{BC}\end{array}$} & $\begin{array}{c}920 \mathrm{BC} \\
(46.3 \%) \\
887 \mathrm{BC}\end{array}$ & $\begin{array}{c}975 \mathrm{BC} \\
(07.1 \%) \\
951 \mathrm{BC}\end{array}$ & \multirow{2}{*}{-891} & \multirow{2}{*}{$893 \pm 35$} \\
\hline & & & & & & & & & & $\begin{array}{c}884 \mathrm{BC} \\
(53.7 \%) \\
844 \mathrm{BC}\end{array}$ & $\begin{array}{l}945 \mathrm{BC} \\
(92.9 \%) \\
827 \mathrm{BC}\end{array}$ & & \\
\hline \multirow{2}{*}{$\begin{array}{l}\text { D-AMS } \\
033464\end{array}$} & \multirow{2}{*}{$\begin{array}{l}\text { Sect. C } \\
\text { UE } 075\end{array}$} & \multirow{2}{*}{$\begin{array}{c}\text { Sementes } \\
\text { Triticum } \\
\text { sp. }\end{array}$} & \multirow{2}{*}{ n.i. } & \multirow{2}{*}{70.76} & \multirow{2}{*}{0.27} & \multirow{2}{*}{2778} & \multirow{2}{*}{31} & $\begin{array}{c}978 B C \\
(64.6 \%) \\
894 B C\end{array}$ & \multirow{2}{*}{$\begin{array}{c}1002 B C \\
(95.4 \%) \\
842 B C\end{array}$} & $\begin{array}{c}977 \mathrm{BC} \\
(95.1 \%) \\
895 \mathrm{BC}\end{array}$ & \multirow{2}{*}{$\begin{array}{c}1002 B C \\
(100 \%) \\
843 B C\end{array}$} & \multirow{2}{*}{-925} & \multirow{2}{*}{$930 \pm 44$} \\
\hline & & & & & & & & $\begin{array}{l}864 B C \\
(3.6 \%) \\
857 B C\end{array}$ & & $\begin{array}{l}864 \mathrm{BC} \\
(4.9 \%) \\
857 \mathrm{BC}\end{array}$ & & & \\
\hline
\end{tabular}

[1] OxCal v4.2.4 Bronk Ramsey (2013); r:5; IntCal13 atmospheric curve (Reimer et al 2013); OxCal v4.2.4 Bronk Ramsey (2013); r:5

[2] RADIOCARBON CALIBRATION PROGRAM*. CALIB REV7.1.0. Copyright 1986-2018 M Stuiver and PJ Reimer, *To be used in conjunction with: Stuiver, M., and Reimer, P.J., 1993,

Radiocarbon, 35, 215-230. Reimer PJ, Bard E, Bayliss A, Beck JW, Blackwell PG, Bronk Ramsey C, Buck CE, Cheng H, Edwards RL, Friedrich M, Grootes PM, Guilderson TP, Haflidason H, Hajdas

I, Hatté C, Heaton TJ, Hogg AG, Hughen KA, Kaiser KF, Kromer B, Manning SW, Niu M, Reimer RW, Richards DA, Scott EM, Southon JR, Turney CSM, van der Plicht J.

[3] quickcal2007 ver.1.5. Monrepos. Archäologisches Forschungszentrum und Museum für menschliche Verhaltensevolution. http://www.calpal-online.de

n.i. - não indicado

Quadro 1 - Datações absolutas, calibradas, do povoado de São Julião da Branca. 


\title{
DO CASTRO DE S. JOÃO AO MOSTEIRO DE SANTA CLARA: NOTÍCIA DE UMA INTERVENÇÃO ARQUEOLÓGICA, EM VILA DO CONDE
}

\author{
Rui Pinheiro'
}

\begin{abstract}
RESUMO
Este artigo tem como objectivo dar a conhecer os dados obtidos com a escavação arqueológica realizada no interior da cerca do convento de Santa Clara, em Vila do Conde, designadamente num dos seus socalcos localizado a nascente do edifício conventual. Após as sondagens de diagnóstico realizadas numa primeira fase e com os dados aferidos, foi realizada a escavação integral da área acima referida.

Palavras-chave: Arqueologia Preventiva, Arqueologia Moderna, Arqueologia Proto-Histórica.
\end{abstract}

\begin{abstract}
This article aims to make known the data obtained with the archaeological excavation carried out on the terrace located to the east of the Santa Clara conventual building, in Vila do Conde. After the diagnostic surveys carried out in the first phase and with the measured data, the full excavation of the above-mentioned area was carried out.
\end{abstract}

Keywords: Settlement, Late Bronze Age, Megalithic mound, Archaeological Conservation and enhancement, Albergaria-a-Velha.

\section{INTRODUÇÃO}

O Convento de Santa Clara, em Vila do Conde, está localizado no concelho epónimo, distrito do Porto, e tem as seguintes coordenadas:

- Lat: $42^{\circ} 21^{\prime} 08^{\prime \prime} \mathrm{N}$.

- Long: 8 44'20" W; Alt. $17 \mathrm{~m}$ (Fig. 1).

A intervenção arqueológica realizada no Mosteiro de Santa Clara, em Vila do Conde, foi realizada no âmbito de um projeto de reconversão do espaço conventual numa unidade hoteleira de 5 estrelas. Os trabalhos arqueológicos foram realizados pela ERA-Arqueologia S.A., e tiveram como arqueólogo responsável Rui Pinheiro, que dirigiu os trabalhos de campo.

Os trabalhos arqueológicos seguidamente descritos iniciaram-se em Outubro de 2019 e ficaram concluídos no início de Junho de 2020.

\section{ENQUADRAMENTO HISTÓRICO-ARQUEOLÓGICO}

No lugar onde hoje se localiza o Convento de Santa Clara existiu um castro da Idade do Ferro. Posteriormente, já em época medieval, séc. X, foi construída uma Igreja dedicada a São João, construção comprovada através de um documento datado do ano de 953 (Ferreira, 1923 e Freitas, 2001).

D. Afonso Sanches (1279-1329), filho bastardo de D. Dinis, adquiriu o senhorio de Vila do Conde e em conjunto com a sua mulher, D. Teresa Martins, fundou o mosteiro em 7 de maio de 1318 (Neves, 1982, p.15). O mosteiro foi dedicado a Santa Clara, com o intuito de ser entregue a freiras com votos de obediência, castidade e pobreza.

De referenciar, segundo Neves (1982, p.167), que pouco se sabe do primitivo mosteiro, do qual res-

1. ERA-Arqueologia, S.A.; ruipinheiro14@omniknos.pt. 
ta, além da igreja, parte do claustro e a casa do capítulo. Frei Fernando da soledade, na Memória dos Infantes, apenas afirma que o "edifício tinha grande material” (Neves, 1982, p.167). O dormitório e os outros espaços do mosteiro, incluindo a casa do capítulo, situavam-se em torno do claustro. Arquitetonicamente poderia ser semelhante ao mosteiro de Santa Clara de Coimbra (Coelho, 2014).

No século XVIII foi construído o aqueduto destinado a abastecer de água o Mosteiro. A concretização do aqueduto coube à abadessa D. Bárbara Micaela de Ataíde, com projeto do engenheiro Manuel Pinto de Vila Lobos de Viana do Castelo. Iniciado em 1705, foi inaugurado em 20 de outubro de 1714 (Miranda, 1998, p.43-44). É um dos mais extensos de Portugal com 999 arcos.

No séc. XVII, as freiras de Santa Clara começaram a pretender edificar um novo espaço conventual, porém a ampliação foi adiada por falta de recursos financeiros e só se concretizou no século seguinte. $\mathrm{O}$ novo mosteiro deve-se, no que se refere à sua construção, à iniciativa de D. Luísa Gertrudes de Luna e Azevedo, que foi abadessa entre 1777 a 1780. $\mathrm{O}$ projeto foi entregue ao arquiteto Henrique Ventura de Sousa Lobo, de Adaúfe, tendo ocorrido o lançamento da primeira pedra a 29 de junho de 1778 (Miranda, 1998, p.24).

Em 1788, as freiras começaram já a pernoitar no novo dormitório, apesar das obras ainda não estarem terminadas. Em 1801 foi inaugurado o novo refeitório, situado na ala ocidental (Diniz, 2009, p.158). Na porta do topo deste espaço do convento, existe uma inscrição comemorativa da conclusão da obra.

Outras construções que ainda subsistem devem ser igualmente do séc. XVIII, designadamente dois portais barrocos, ambos encimados por frontão, um situado no Largo D. Afonso Sanches e outro que foi deslocado para a cerca do convento, situada a Oriente (Rua Nuno Alvares Pereira).

No séc. XIX, o novo dormitório do convento, não chegou a ser concluído durante o período que esteve sob a alçada das Clarissas devido às Invasões Francesas, Guerra civil e extinção das ordens religiosas, em 1834. No entanto o convento continuou a ser habitado por freiras. Segundo Coelho (2014, p.52), desde 1825 que as obras foram interrompidas, ficando apenas concluída a ala sul. A fachada ocidental ficou com dois corpos terminados; a fachada oriental ficou com o corpo extremo, junto à frontaria, e três janelas em cada andar. Nessa época, segundo Coe- lho (2014, p.56), continuava de pé e a funcionar o velho dormitório.

Em 1886, na ala voltada a poente, onde havia algumas celas habitadas, uma tempestade causou o derrubamento de um dos fogarés que rompeu o telhado, destroçou os vigamentos e atravessou o andar superior (Neves, 1982, p.168).

No final do século XIX o convento era um edifício inacabado (a ala sul era a única terminada).

Em 19 de Abril de 1902, uma portaria colocou o edifício conventual à disposição do estado. O convento passou a dependência do Ministério da Justiça, para nele ser instalada a Casa de Detenção e Correção, inaugurada em dezembro de 1902. Em 1903, foi efetuado um projeto de adaptação que ficou a cargo da Direção das Obras Públicas do Porto.

Uma derrocada entre 1910 e 1915 fez ruir o primitivo dormitório. Segundo Coelho (2014, p.22), terá sido nessa altura que o claustro perdeu a forma, restando apenas de pé uma das alas laterais. Em 1915, houve um projeto de reparação e obras diversas que teve prossecução em 1922, consistindo essencialmente na demolição de anexos.

Com o restauro da igreja, pela DGEMN, em 1927, esta iria ficar definitivamente separada do Convento, que foi muito alterado na década de 30 do século passado. A proposta contida num ofício da Direção dos Edifícios Nacionais do Norte pretendia concluir a construção das alas poente e nascente de forma a que o reformatório tivesse uma planta em U (Diniz, 2009, p.170-171).

Entre 1936 e 1940 foram realizadas obras no convento, mas foi no interior que houve uma maior profundidade dos arranjos.

Comparável a outros edifícios e palácios da época, como o Palácio da Ajuda, o convento de Santa Clara destaca-se também por ter ficado inacabado (embora tenha sido terminado no século XX). Este edifício tem sido integrado no período do Neoclassicismo por razões de ordem cronológica e estilística.

\section{ESCAVAÇÃO EM ÁREA (SOCALCO NASCENTE)}

Após a abertura de 4 sondagens de diagnóstico arqueológico na primeira fase dos trabalhos num dos socalcos a nascente do edifício conventual, e tendo em consideração a identificação de várias realidades arqueológicas, ficou determinado em reunião realizada no local (dia 10 de outubro de 2019), onde 
estiveram presentes o promotor de obra, a tutela, empresa executante e Câmara Municipal de Vila do Conde, a necessidade de se intervencionar toda a plataforma em análise $(830 \mathrm{~m} 2)$ até a níveis estéreis do ponto de visto arqueológico.

Em termos gerais, e em primeiro lugar, verificou-se, após a retirada do nível de circulação em cimento da plataforma existente, um potente nível de entulhamento para a construção da respectiva plataforma (obras realizadas nos anos 30/40 do século XX). Nos trabalhos referenciados foi também possível colocar à vista, para além da vala de fundação da ala Este do actual edifício conventual, uma série de aterros/sedimentos que cobriam ou encostavam a várias estruturas.

Estes sedimentos com uma forte pendente NW-SE forneceram fragmentos de azulejos, faianças, cerâmica comum, vidrados de chumbo, entre outros, e que nos permite balizar estes aterros entre o século XVII e meados do século XVIII.

As estruturas identificadas (que se encontravam cobertas pelos aterros já mencionados), podem ser datadas entre os inícios da Idade Moderna e finais do século XVII/inícios do século XVIII.

Apesar de ainda não ter sido possível clarificar a devida funcionalidade das estruturas mencionadas, consideramos como hipótese que este conjunto de estruturas possam estar relacionadas ou terem feito parte de uma zona de lazer/meditação das freiras do convento.

As estruturas numeradas com as unidades [920] [921] [924] [923] e [922], piso em saibro compactado, correspondem à última fase de utilização deste espaço como zona de "recreio/lazer".

A unidade [921] corresponde a umas escadas que, por sua vez, estão inseridas num muro (unidades [920] e [923]). Este é constituído por um reaproveitamento de alguns elementos arquitectónicos e por silhares aparelhados, não tendo qualquer tipo de ligante. Esta estrutura com uma orientação S-N, aproximadamente, serviria como muro de "suporte" para um patamar constituído pela unidade [924], um nível de circulação constituído por um empedrado.

O piso em saibro compactado, identificado com a unidade [922] está localizado (encosta) ao primeiro degrau das escadas, ou seja, no lado exterior do espaço delimitado pela estrutura identificada com a unidade [920].

Após o desmonte destas estruturas e derrubes associados à ruína das mesmas, unidades [926] [930], foi possível percepcionar um espaço delimitado pelas estruturas/muros identificadas com as unidades [927] [929] e [1015]. Este espaço foi interpretado como um corredor, existindo no topo Norte do mesmo, vestígios de escadas de acesso a um patamar superior que existiria no lado Norte da estrutura [1015] (Figura 2).

A estrutura identificada com a unidade [929] é constituída por alvenaria de pedra aparelhada em aparelho insosso. Esta estrutura é de uma só face, isto é, só tem a face interna da estrutura bem definida.

O muro que delimita a Norte o corredor [1015] é um muro constituído quer por elementos arquitectónicos reaproveitados, quer por alvenaria de silhares aparelhados. O aparelho é insosso e muito provavelmente seria um muro de dupla face. Esta é apenas uma mera hipótese já que a face interna da estrutura estava já bastante destruída pela construção do muro de suporte/delimitação do patamar existente a Norte da área intervencionada.

No alçado e base deste muro temos ainda vestígios das escadas que permitiriam o acesso da área do corredor ao patamar superior.

Este espaço - corredor - estaria recoberto a azulejos, visto que, junto à estrutura/muro identificado com a unidade [927] (a estrutura cronologicamente mais antiga deste conjunto) detectou-se um derrube de azulejos de meados do século XVII.

A Sul da estrutura [927] foi possível também colocar a descoberto umas escadas [928] que ligariam o espaço delimitado pelo corredor a um patamar delimitado por esta mesma estrutura.

Em termos cronológicos, o corredor mencionado (embora esta cronologia careça de confirmação) poderá ser um espaço do século XVII.

A estrutura mais antiga que provisoriamente poderá datar da Baixa Idade Média, é constituída pelas unidades [927] e [1008]. Esta é a única estrutura argamassada e sem qualquer tipo de elemento arquitectónico reaproveitado.

Deste momento cronológico escavou-se uma sepultura em forma de caixa constituída por pedras avulsas. Esta sepultura tem uma orientação W-E e encosta ao muro identificado com a unidade [1008]. $\mathrm{O}$ contexto fúnebre mencionado encontrava-se vazio e não forneceu material arqueológico, mas pela sua posição estratigráfica e pela sua tipologia podemos datar o contexto em análise entre os finais do século XV e o século XVII.

Fora deste conjunto de estruturas, e sem qualquer 
ligação física às mesmas, foi também possível identificar - na zona Oeste da escavação - uma estrutura, interpretada como um muro de sustentação/ delimitação de um socalco (unidade [946]). Esta estrutura, de uma só face, é constituída por pedra aparelhada de média e grande dimensão; o seu interior/ miolo é constituído por terras mais escuras, saibros e pedra imbrincada. No que se refere à sua cronologia, ainda não nos foi possível com clareza aferir a seu espaço temporal.

Para permitir a construção das estruturas datáveis da Baixa Idade Média e, posteriormente, das estruturas mais recentes, toda a área Este da escavação com uma forte pendente topográfica - foi nivelada/ entulhada por uma camada de saibro de cor amarelada [977], sendo este entulhamento, em certas zonas, bastante espesso (nivelamento permitiu a regularização do terreno nesta zona).

Sob esta camada de nivelamento [977] foi possível averiguar um nível de terras mais "limpas", de coloração acinzentada [994], que cobrem estruturas/ derrubes da Proto-História, bem como o topo de enchimentos de estruturas negativas cronologicamente enquadráveis na Idade do Bronze Final e da Idade do Ferro.

Durante o processo de escavação foram identificadas 4 casas do período Proto-Histórico (casas redondas). Das quatro casas referenciadas foi possível ver a planta completa de três, porque uma das casas só está parcialmente escavada, já que se prolonga para lá do limite Sul da escavação.

A casa identificada com a unidade [1154], identificada nas sondagens prévias anteriormente realizadas, tem uma planta circular com um diâmetro exterior de $5,45 \mathrm{~m}$. O aparelho do muro é constituído por pedra aparelhada, sem marca de pico, de pequena e média dimensão sendo o seu interior preenchido por pedra miúda e saibros compactados. O aparelho é disposto/colocado de uma forma tendencialmente horizontal.

Desta casa não se detectou nenhum nível de circulação, estando o seu interior repleto de estruturas negativas, provavelmente anteriores à construção da casa.

A estrutura da casa acompanha a pendente do substrato geológico e o acesso ao seu interior, muito provavelmente estaria virada a SW onde existem umas pedras aparelhadas de média dimensão dispostas horizontalmente, o que nos poderá indiciar a existência de uns degraus ou uma “espécie” de soleira.
No lado NE constatou-se que o muro da casa, designadamente na sua base, possuía um espessamento elaborado provavelmente para compensar o desnível do terreno e dar mais solidez à parede da casa nesta zona (Figura 3).

No que se refere à segunda casa castreja, com a planta igualmente completa, localiza-se junto ao limite Sul da área intervencionada.

Esta casa, unidade [2063], tem um diâmetro exterior de 4,90 $\mathrm{m}$ e a espessura média da parede da casa é de $50 \mathrm{~cm}$.

O aparelho desta parede é constituído por pedras aparelhadas de pequena e média dimensão, dispostas em fiadas tendencialmente horizontais, não tendo as pedras qualquer marca de pico.

O interior da parede é constituído por pedras miúdas com saibros compactados.

Durante o processo de escavação da casa, no lado exterior e interior, foram recolhidos vários fragmentos/bocados de argamassa de cal o que nos poderá indiciar que quer o alçado exterior, bem como o interior da casa poderiam ter sido rebocados a cal. Todavia, nos alçados da casa não se observou qualquer vestígio de reboco. A casa em análise, tal como a anterior está mais bem conservada no seu lado NW.

No interior desta estrutura habitacional foi possível identificar 3 níveis de ocupação/pisos mais um conjunto de pedras dispostas horizontalmente [2061] que poderão fazer parte do 1. nível de ocupação (soleira referente à entrada da casa, ou estas serem um outro nível de ocupação do interior do espaço).

O $1 .^{\circ}$ piso identificado ( $3^{\circ}$ nível) no interior da casa [1296] é constituído por uma camada saibro compactado e encosta ao capeamento lateral da sepultura identificada no seu interior.

O 2.ํำ piso [2011] (2.. nível) identificado é constituído por uma mancha de argila cozida muito compacta, com inclusões de carvões.

O $3 .^{\circ}$ piso (1.ํ nível de ocupação) é constituído por saibros compactados. O nível de circulação é também cortado por uma sepultura identificada no seu interior.

Para a construção desta casa, as comunidades que habitaram o local terraplanaram a área com uma camada de saibro esbranquiçado que cobriu estruturas, em negativo, de cronologias mais antigas.

De referir ainda que no interior da casa identificada com a unidade [2063] foi identificado parte de um muro que poderá ser uma divisão interna do espaço doméstico [2067]. A largura da parede desta estru- 
tura é de $38 \mathrm{~cm}$ e o aparelho da construção é constituído por pedras aparelhadas de pequena e média dimensão em fiadas tendencialmente horizontais. O seu interior é constituído por pedra miúda compactada com terra (Figura 4).

A 3 . $^{\text {casa }}$ identificada na escavação arqueológica é igualmente de morfologia circular, unidade [2041]. Em termos construtivos é constituída por pedra aparelhada de pequena e média dimensão, disposta em fiadas tendencialmente horizontais sem argamassa entre elas. $O$ interior da parede é constituído por pedra miúda e saibro compactado. O seu diâmetro não foi possível de aferir já que esta se prolonga para lá dos limites da escavação (corte Sul).

A $4 .{ }^{\text {a }}$ casa deste período, caracterizada com a unidade [2126], encontra-se localizada a Este da casa anteriormente referida. Esta é de planta circular, tem 5,20 $\mathrm{m}$ de diâmetro exterior, um alçado máximo conservado de $1,25 \mathrm{~m}$, sendo a largura da sua parede de $50 \mathrm{~cm}$.

O aparelho desta parede, também, é constituído por pedras aparelhadas de pequena e média dimensão, dispostas em fiadas tendencialmente horizontais, não tendo as pedras qualquer marca de pico.

No interior desta casa temos uma situação análoga à 3. a casa, nomeadamente uma estrutura a dividir o seu espaço, contudo, nesta situação, a divisória é constituída por pedras afeiçoadas de alguma dimensão sem argamassa entre elas (Figura 5).

A cronologia proposta para as quatro casas circulares é a II Idade do Ferro.

Convém, no entanto, realçar que a cronologia mencionada carece ainda de confirmação, visto que só após o estudo do espólio exumado é que poderemos corroborar a hipótese agora levantada.

Facto importante, e de salientar, é a inexistência de vestígios de romanização do espaço, isto é, não foram identificados tégulas, imbrex, bem como muros ortogonais à maneira romana.

Dos inícios da Proto-História (Idade do Bronze Final e I Idade do Ferro), escavaram-se várias estruturas em negativo de morfologias e funcionalidades variadas.

A contabilização destas, à data da redacção deste artigo, não se encontra realizada, mas são efetivamente várias dezenas (Figura 6).

Das estruturas negativas identificas na escavação arqueológica, vamos destacar algumas pela sua singularidade:

A estrutura localizada junto à parede Este do Con- vento pela sua monumentalidade merece algum destaque. Esta tem uma orientação NE-SW (aproximadamente), as paredes ligeiramente oblíquas e o fundo é organizado em patamares/socalcos. No que se refere à sua dimensão, constatou-se que é bastante mais larga no seu extremo Sul do no extremo Norte. O espólio detetado no depósito de enchimento [949] remete-nos para uma cronologia da Idade do Ferro.

A funcionalidade desta estrutura não nos foi possível de aferir, mas esta, tem paralelos com estruturas do tipo "fosso".

- A estrutura identificada com a unidade [1141] é constituída por duas por câmaras, sendo que a entrada para o seu interior encontra-se localizada a Este. A zona interpretada como antecâmara (entrada) tem uma forma subquadrangular apesar da sua irregularidade. As paredes são ligeiramente oblíquas e na sua zona central tem uma estrutura tipo "fossa" para implantar um grande monólito fincado [1131].

A zona interpretada como câmara, tem uma forma subrectangular, paredes rectas e/ou ligeiramente oblíquas e fundo aplanado.

Quer na zona divisória, entre câmara e antecâmara, e entre esta e o exterior, existe um conjunto de pedras aparelhadas de pequena dimensão que nos parece ser o fecho destes espaços.

$\mathrm{O}$ pouco material recolhido desta estrutura remete-nos para uma cronologia do Bronze Final, e com todas as reservas, poderemos levantar a hipótese de esta estrutura ser um possível hipogeu.

- A estrutura identificada com a unidade [1277] foi interpretada como um hipogeu. Esta é constituída por duas câmaras ligadas por uma pequena passagem.

Esta estrutura negativa tem uma orientação S-N, aproximadamente. A câmara situada a Sul - a antecâmara -, tem uma forma subovalada, fundo côncavo, tendo na parede Sul umas pequenas "escadas" de acesso ao interior. A câmara situada a Norte - a câmara - tem uma forma, também, subovalada, paredes côncavas e ainda se conserva parte do tecto/cobertura desta. $\mathrm{Da}$ câmara exumou-se um crânio e da antecâmara uma omoplata direita e mais um conjunto de ossos humanos.

O material exumado remete-nos para uma cronologia entre o Bronze Final e Idade do Ferro, 
mas o hipogeu não estava selado, isto é, o que se escavou no seu interior corresponde a um momento posterior ou contemporâneo da sua ruína (Figura 8).

- Perto da estrutura anteriormente referida intervencionou-se igualmente uma estrutura negativa interpretada como sendo uma possível cabana.

Esta é constituída por uma câmara de forma subovalada, conservando parcialmente o seu tecto/cobertura. As suas paredes são côncavas e fundo rampeado para o seu interior.

A sua entrada é constituída por um acesso rampeado onde existe um buraco de poste.

O material exumado remete-nos para um período de transição entre o Bronze Final e I Idade do Ferro (Figura 9).

- Junto ao limite Sul da escavação escavou-se uma estrutura tipo "valado" com as paredes oblíquas fundo aplanado com uma pendente para Sul. O material recolhido do enchimento desta estrutura remete-nos para uma cronologia entre a Pré-história Recente e o Bronze Final.

Também datável do Bronze Final escavacou-se uma cabana constituída por uns buracos de poste e três negativos de forma alongada, que nos poderá indiciar o uso de uma pequena paliçada. Esta cabana está localizada no interior da casa identificada com a unidade [2063] e é anterior a esta.

De enaltecer igualmente a recolha de alguns fragmentos cerâmicos do tipo "Penha", bem como a identificação no interior de uma estrutura de combustão uma peça com uma forma globular que nos poderá indiciar o facto de que, pelo menos, algumas das estruturas negativas intervencionadas poderão ter uma cronologia mais antiga.

- No que se refere a outros contextos fúnebres foram escavadas, até ao momento, 6 sepulturas com inumações primárias, sendo que todos os indivíduos são do sexo masculino.

Apesar de ainda não podermos atribuir uma cronologia mais precisa existe a possibilidade (necessita de ser corroborada) de as sepulturas serem anteriores ao século XV.

Uma destas sepulturas [1294] quer pela sua localização (identificada no interior da casa redonda identificada com a unidade [2063]), quer pelas suas relações estratigráficas com os pisos da es- trutura habitacional merece um especial destaque pela sua singularidade e raridade (Figura 10).

\section{CONCLUSÃO}

Até à presente data, tendo em consideração os trabalhos arqueológicos já realizados num dos socalcos localizados a nascente (e no interior da cerca) do Convento de Santa Clara foi possível estabelecer 6 níveis crono estratigráficos relativos à ocupação do espaço:

- 1.․ nível. Esta fase de ocupação corresponde à construção dos socalcos e respectivo entulhamento/nivelamento dos mesmos nos anos $30 /$ 40 do século XX.

$-2 .^{\circ}$ nível. Esta fase corresponde à vala de fundação e construção do actual edifício conventual em 1778.

- 3.ํo nível. Este nível enquadra-se na Idade Moderna, bem como ao momento construtivo de uma série de estruturas associadas a um possível espaço ajardinado/lazer em patamares para vencer a pendente do terreno.

$-4 .^{\circ}$ nível. Esta fase corresponde às estruturas identificadas com as unidades [927] e [1008] (provavelmente um primeiro espaço de ajardinado/meditação enquadrável na Baixa Idade Média/inícios da Idade Moderna).

- 5. ${ }^{\circ}$ nível. Este nível enquadra-se na Proto-História (Idade do Ferro) e engloba derrubes e uma casas redondas.

- 6.ํำ nel. Esta fase está associada a uma série de estruturas escavadas no substrato geológico - estruturas negativas - inseridas cronologicamente na Idade do Bronze Final e na Idade do Ferro.

\section{BIBLIOGRAFIA}

ALMEIDA, Carlos Alberto Ferreira de (1974) - Necrópole galaicoromana de Vila do Conde. Revista da Faculdade de Letras. Porto. 45, pp. 209-222.

ALMEIDA, Carlos Alberto Brochado de (1995) - A romanização no concelho de Vila do Conde. Vila do Conde.

DINIZ, Sofia (2009) - O Convento de Santa Clara de Vila do Conde: Cento e Seis Anos de Memórias. In: AA VV - Arquitetura de Serviços Públicos em Portugal: os internatos na justiça de menores, 1871-1978. Direção Geral da Reinserção Social - Instituto da Habitação e da Reabilitação Urbana.

DINIS, António Pereira (1999) - Povoamento do Baixo Ave no 1 milénio A.C. Actas do $2^{\circ}$ Congresso de Arqueologia Pe- 
ninsular, Zamora, 1996. Zamora: Fundación Rei Afonso Henriques. Tomo III. p. 3748.

COELHO, Denise (2014) - (Re)Interpretar o Convento de Santa Clara de Vila do Conde, do Estudo à Representação. Tese de Mestrado. Escola de Arquitetura da Universidade do Minho.

FERREIRA, J. Augusto (1923) - Vila do Conde e seu Alfoz. Porto: Edições Marques Abreu.

FREITAS, Eugénio da Cunha (2001) - Vila do Conde. História e Património. 2. Vila do Conde.

MIRANDA, Marta (1998) - Vila do Conde. Lisboa: Editorial Presença.

NEVES, Joaquim (1982) - O Mosteiro de Santa Clara de Vila do Conde (Pequena crónica de um grande mosteiro). Gabinete de Cultura da Câmara Municipal de Vila do Conde.

PINTO, Paulo Costa (200o) - Vila do Conde Arqueológica. Almadan. Almada. 2aㅗ série: 9, p. 147150.

SEVERO, Ricardo, CARDOSO, Artur e SARMENTO, Francisco Martins (1886) - Notícias archeológicas sobre o Monte da Cividade. Revista de Guimarães. Guimarães. 3:3, p. 137145
SILVA, Armando Coelho Ferreira da (1986) - A Cultura Castreja no Noroeste de Portugal. Paços de Ferreira: Museu Arqueológico da Citânia de Sanfins e Câmara Municipal de Paços de Ferreira.

BARKER, P. (1989) - Techniques of archaeological excavation. 2 ed. [1 ${ }^{\underline{a}}$ Ed. 1977], London.

\section{CARTOGRAFIA}

Carta Militar de Portugal, Serviço Geográfico do Exército; Escala 1: 25 ooo; Folha nº96.

Carta Geológica de Portugal, folha 31-A, Escala 1/ 50 ooo, Direcção Geral de Minas e Serviços Geológicos, Serviços Geológicos.

\section{PÁGINAS DE INTERNET}

Portal do Arqueólogo: http://arqueologia.patrimoniocultural.pt

Atlas do Património Classificado e em Vias de Classificação: http://geo.patrimoniocultural.pt/

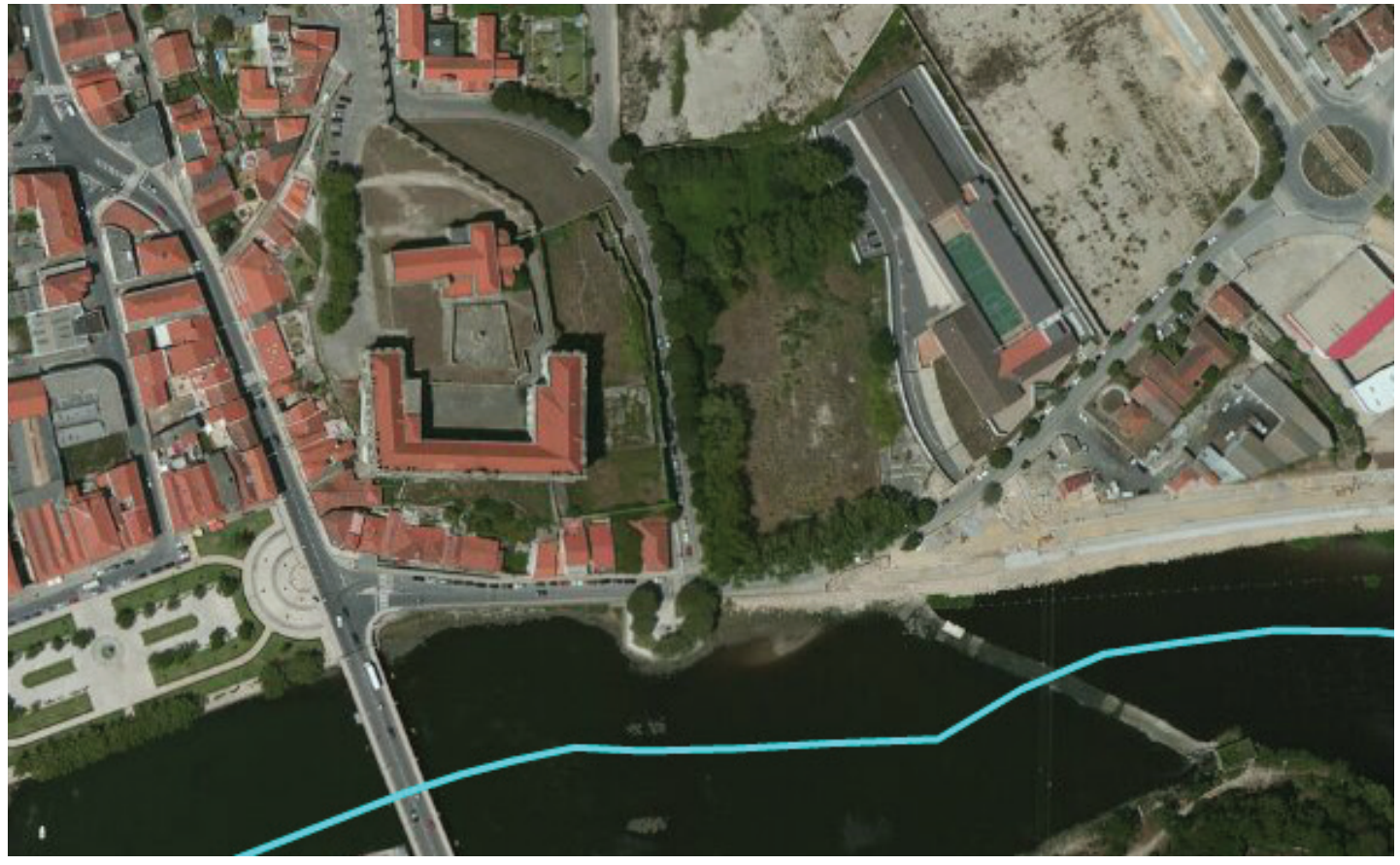

Figura 1 - Localização da área de intervenção - Convento Santa Clara, Vila do Conde. Fonte google earth. 


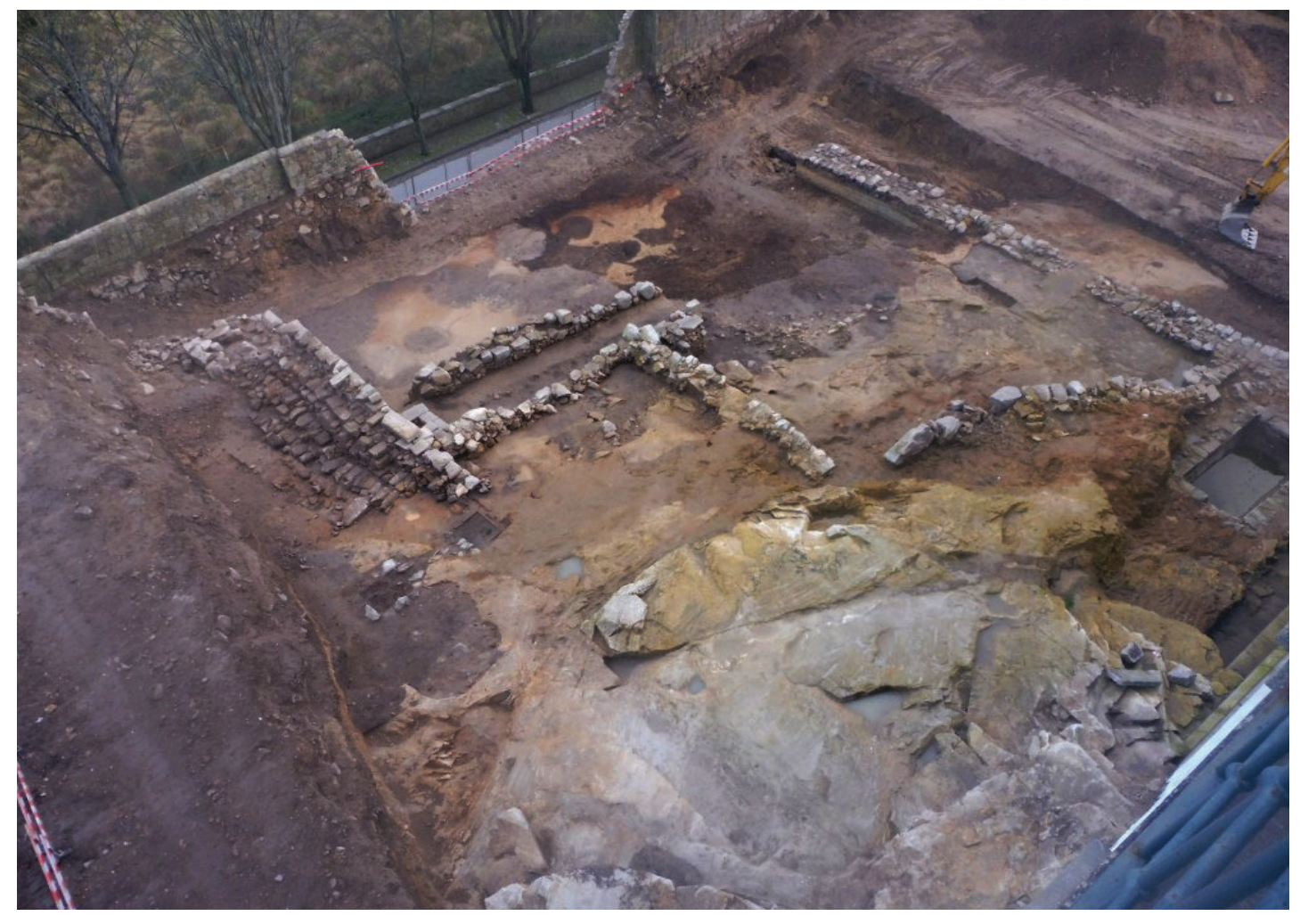

Figura 2 - Vista sobre as estruturas da Idade Moderna e Baixa Idade Média. Autor Rui Pinheiro.

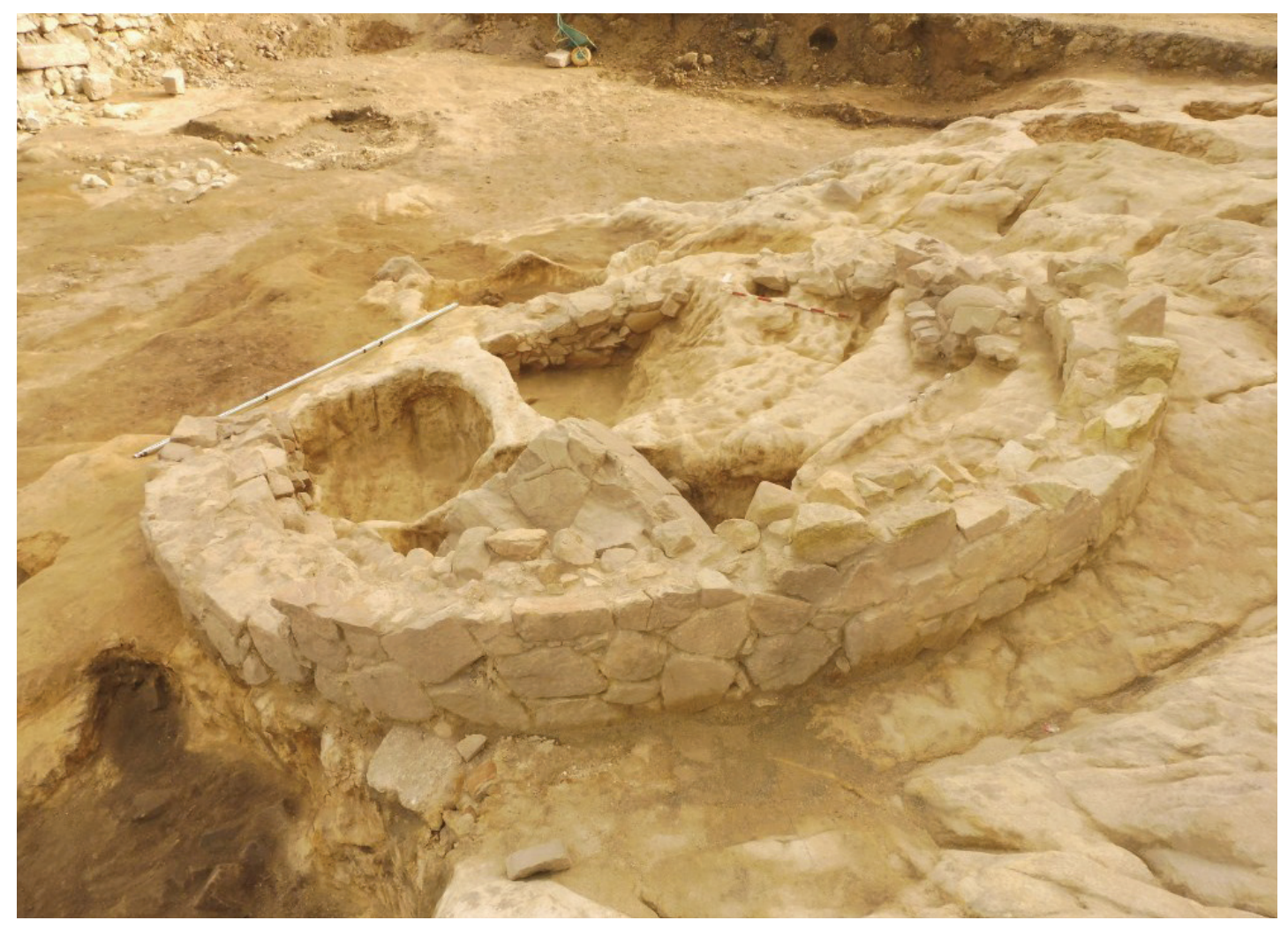

Figura 3 - Vista de NW sobre a casa redonda. [1154]. Autor Rui Pinheiro. 


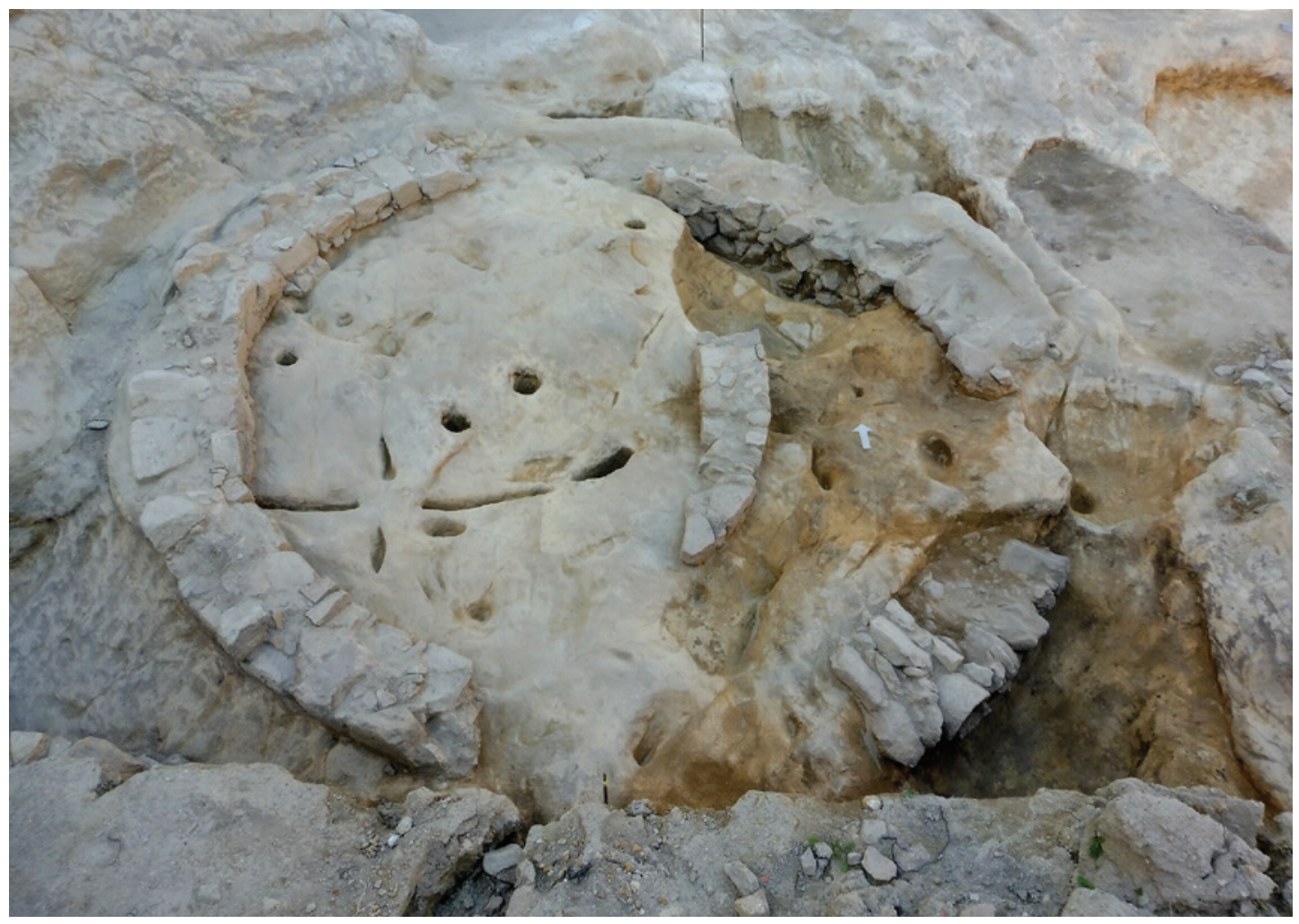

Figura 4 - Unidade [2063], onde se vê no interior da casa vestígios de uma cabana anterior a esta unidade. Perspectiva de Sul. Autor Rui Pinheiro.

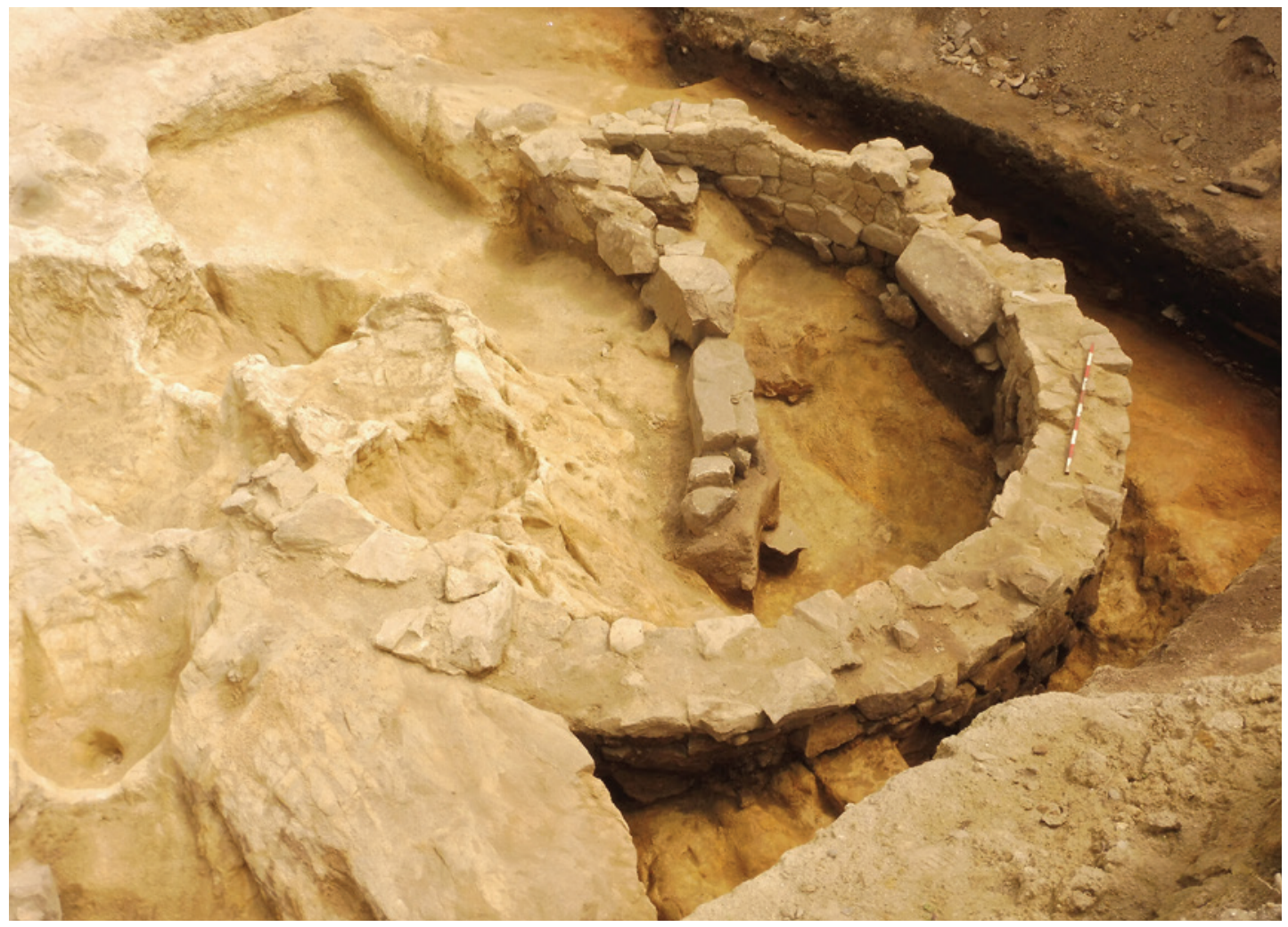

Figura 5-Vista de SW sobre a casa redonda identificada com a unidade [2126]. Autor Rui Pinheiro. 


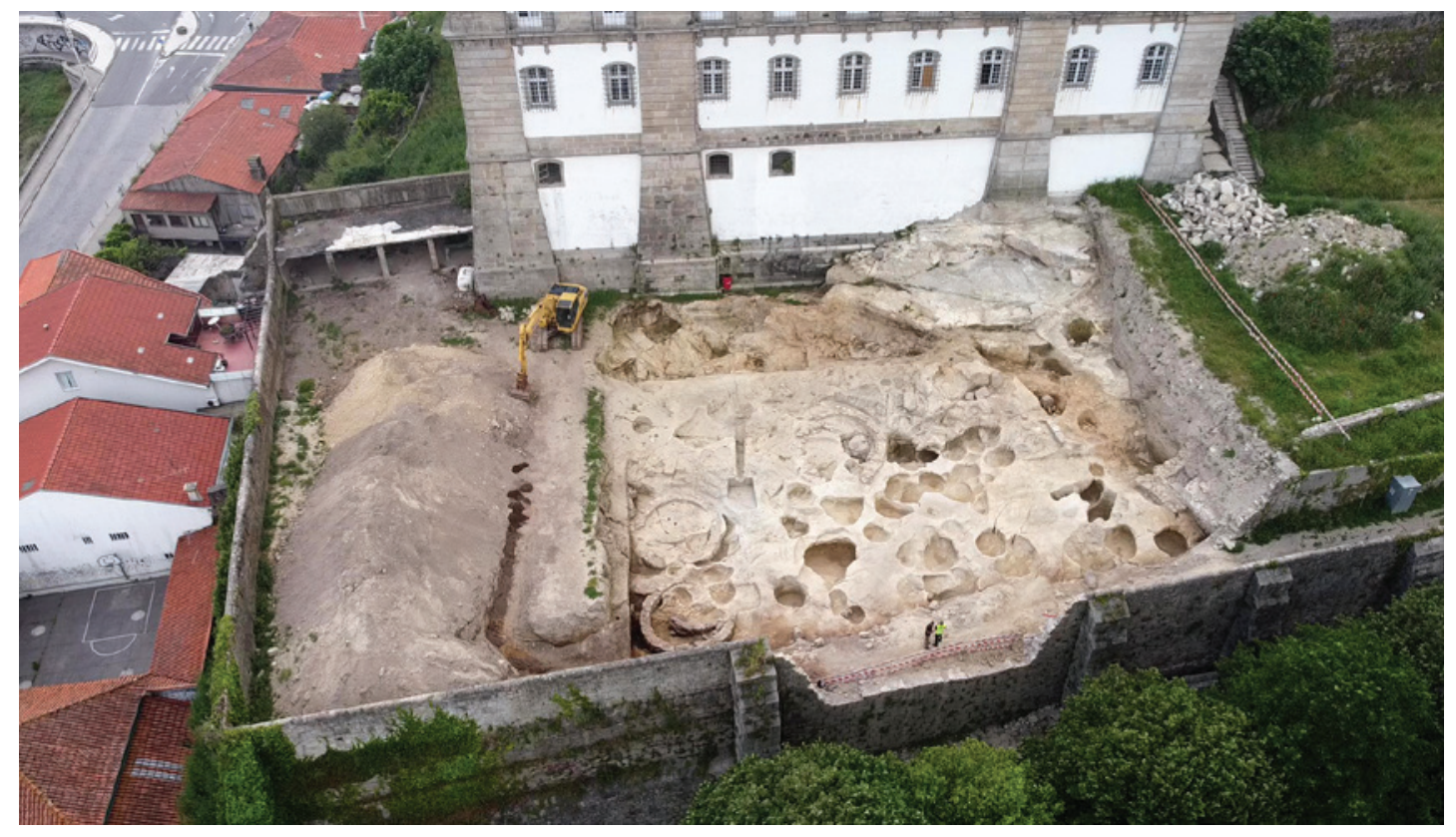

Figura 6 - Perspectiva final sobre a área intervencionada tirada com o drone. Estruturas negativas e casas redondas. Autor João Hipólito.

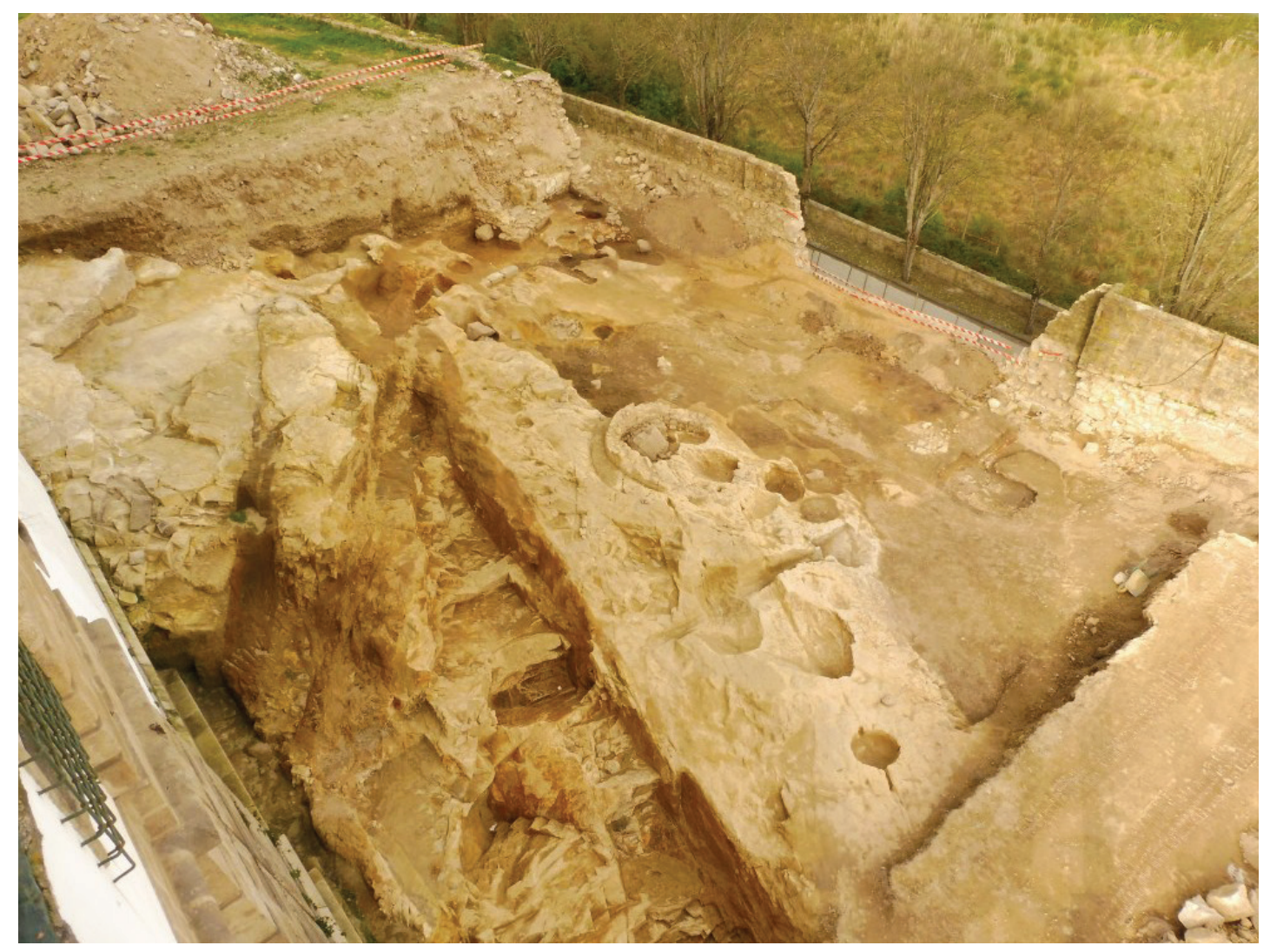

Figura 7 - Vista de SW sobre a estrutura tipo "fosso". Autor Rui Pinheiro. 


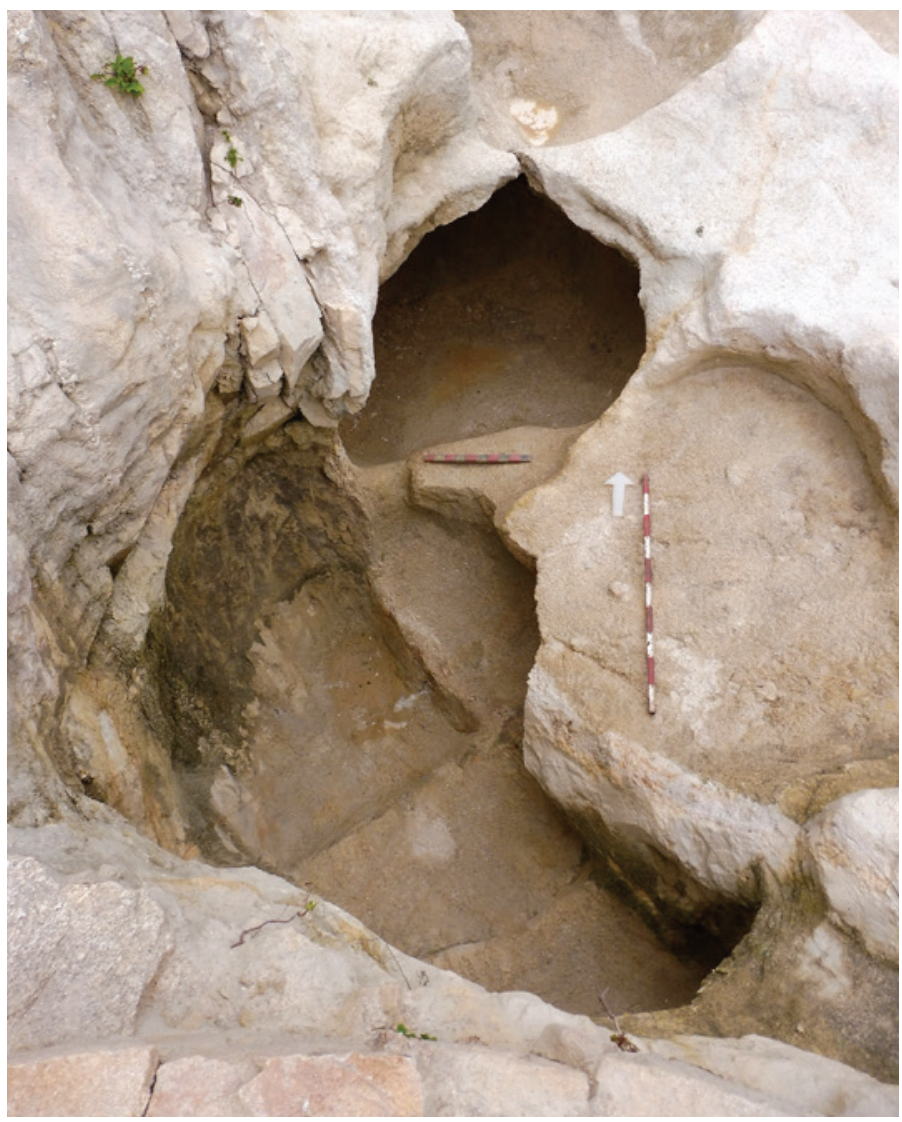

Figura 8 - Vista sobre a estrutura tipo "hipogeu" onde no $1^{\circ}$ plano se vê a antecâmara e em $2^{\circ}$ plano a câmara. Autor Rui Pinheiro.

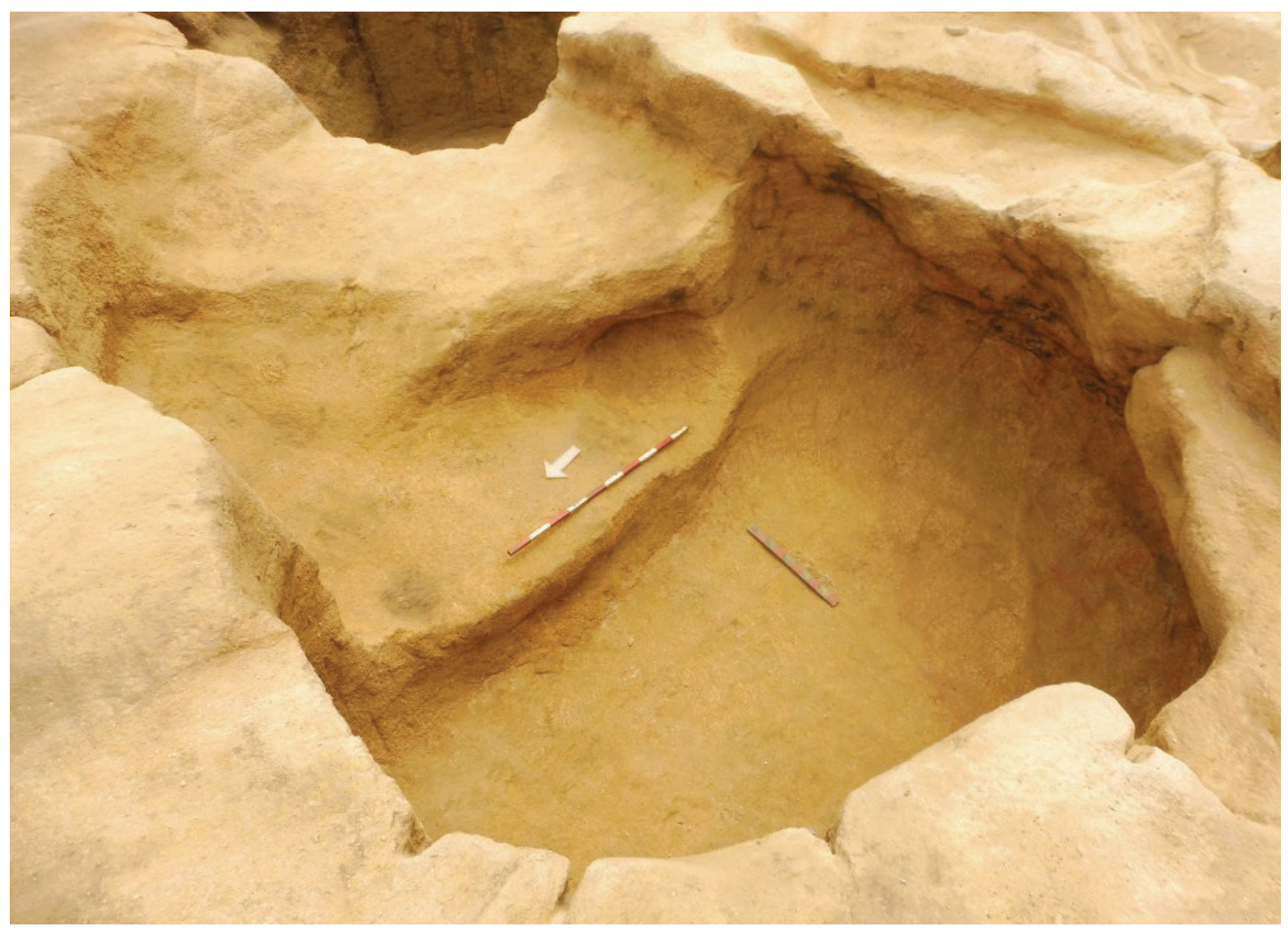

Figura 9 - Perspectiva de NW sobre a estrutura identificada como cabana. Autor Rui Pinheiro. 


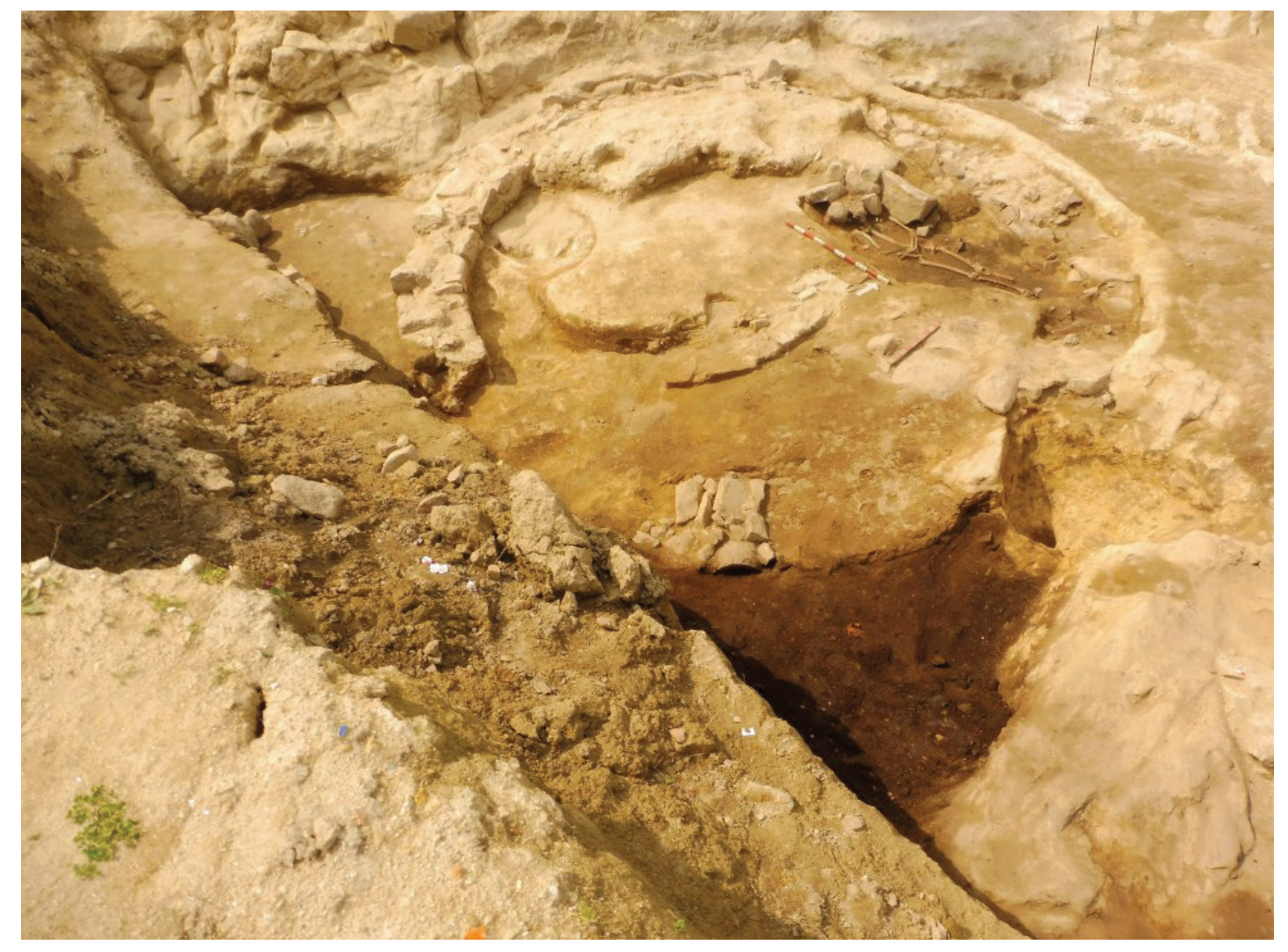

Figura 10 - Vista sobre a sepultura localizada no interior da casa redonda, identificada com a unidade [2063]. Autor Rui Pinheiro. 


\title{
O CASTRO DE OVIL (ESPINHO), UM QUARTO DE SÉCULO DE INVESTIGAÇÃO (RESULTADOS E QUESTÕES EM ABERTO)
}

Jorge Fernando Salvador ${ }^{1}$, António Manuel S. P. Silva ${ }^{2}$

\begin{abstract}
RESUMO
O castro de Ovil é um pequeno povoado da Idade do Ferro situado no cordão litoral, entre os rios Douro e Vouga. Após diversas fases de trabalhos arqueológicos, entre 1981 e 2006, o seu estudo foi recentemente retomado. O castro possui um sistema defensivo incomum, estruturado apenas por um profundo fosso, parcialmente duplicado, e apresenta uma arquitetura exclusivamente indígena, composta por construções circulares, com e sem vestíbulo, nuclearizadas pela sua orientação para pátios comuns. Os estudos arqueológicos, complementados já por duas datações de radiocarbono, apontam para três horizontes de ocupação deste povoado: a fase IA (séculos IV-III a.C.), a fase IB (sécs. III-II a.C.) e fase II (sécs. II-I a.C., com eventual abandono nos começos do século I).
\end{abstract}

Palavras-chave: Idade do Ferro, «Cultura Castreja», Entre-Douro-e-Vouga, Centro-Norte de Portugal.

\begin{abstract}
Castro of Ovil is a small Iron Age settlement located on the coastal cord between the rivers Douro and Vouga, center-north Portugal. After several campaigns of archaeological excavations, between 1981 and 2006, its study was recently restarted. The site has an uncommon defensive system, structured only by a deep ditch, partially duplicated, and presents an exclusively indigenous architecture, composed of circular constructions, with and without a vestibule, nuclearized by their orientation towards shared yards. Archaeological studies, complemented by two radiocarbon dating, point to three horizons of occupation in the settlement: Phase IA $\left(4^{\text {th }}-3^{\text {rd }}\right.$ centuries BC), Phase IB $\left(3^{\text {rd }}-2^{\text {nd }}\right.$ centuries BC) and Phase II $\left(2^{\text {nd }}-1^{\text {st }}\right.$ centuries BC, with eventual abandonment at the beginning of the first century).
\end{abstract}

Keywords: Iron Age, Castros' culture, Douro-Vouga rivers' region, Center-North Portugal.

\section{INTRODUÇÃO, LOCALIZAÇÃO E CARACTERIZAÇÃO GERAL}

O Castro de Ovil, situado na freguesia de Paramos, concelho de Espinho, distrito de Aveiro, assenta numa pequena colina, com 52,8 metros de cota máxima, encaixada sobre um meandro da ribeira de Riomaior ${ }^{3}$ (Figuras 1 e 2). Situado atualmente a 2 400 metros de distância do mar, o povoado integra o primeiro cordão orográfico que se sucede à planície litoral. Descoberto em 1981, foi objeto de trabalhos arqueológicos, de forma intermitente, entre $1981 \mathrm{e}$ 2006 (Ferreira \& Silva, 1984, 1985; Salvador \& Silva, 2000, 2010; Salvador, Silva \& Sárria, 2005a, 2005b; Silva \& Salvador, 2008). Na atualidade, o sítio integra o Plano de Investigação Plurianual Arqueologia da Idade do Ferro no Entre Douro e Vouga Atlântico (ARQ-EDOV), desenvolvido pelo Centro de Ar-

\footnotetext{
1. Arqueólogo. Câmara Municipal de Espinho; investigador do Projeto ARQ-EDOV; jfmdsal@gmail.com.

2. Arqueólogo. CITCEM - Centro de Investigação Transdisciplinar Cultura, Espaço e Memória (Universidade do Porto); Centro de Arqueologia de Arouca; Coordenador do Projeto ARQ-EDOV; amspsilva@hotmail.com.

3. As coordenadas geográficas de um ponto central são: $40^{\circ} 58^{\prime} 45^{\prime \prime} \mathrm{N} ; 8^{\circ} 37^{\prime} 15^{\prime \prime} \mathrm{W}$ (Carta Militar de Portugal, folha 143, Espinho, escala 1:25 00o).
} 
queologia de Arouca, em colaboração, para este local, com o Município de Espinho (Silva \& alii, 2019). No âmbito deste projeto, em 2019 foram retomadas as escavações arqueológicas no povoado.

Os trabalhos arqueológicos realizados em Ovil caracterizaram um pequeno povoado indígena da Idade do Ferro, composto por estruturas habitacionais circulares definidas por muros de aparelho irregular em xisto. As construções, ocupando uma superfície próxima dos dois hectares, distribuem-se por uma colina de configuração ovalada, em declive suave sobre o seu eixo maior ${ }^{4}$, na qual foram niveladas algumas plataformas para o assentamento proto-histórico. O castro terá as suas origens entre o final do século IV e o início do século III a.C., considerando os materiais recolhidos e uma datação por radiocarbono, e foi ocupado até às primeiras décadas da nossa era, não acusando, praticamente, a presença de materiais romanos, com exceção de algum vasilhame anfórico, a que adiante se fará menção.

A localização do Castro de Ovil, sobre uma área de xisto com alto grau de desagregação veio, talvez, condicionar a organização do seu sistema defensivo, para o qual constitui dispositivo fundamental a ribeira de Riomaior, que contorna as vertentes sul e oeste do sítio, sendo nestes sectores, pela profundidade do seu encaixe original e pela presença de afloramentos rochosos, elemento delimitador e defensivo exclusivo. A norte e a este do povoado, pelo contrário, o menor declive do terreno obrigou à construção de um sistema defensivo particular, constituído por um profundo fosso, com cerca de quinze metros de desnível e uma largura que ronda os oito metros, e que ocorre duplicado em parte da sua extensão.

Este sistema defensivo não parece ter sido complementado por qualquer estrutura de delimitação em pedra ou terra, sendo a este propósito um caso aparentemente singular na região do Entre Douro e Vouga litoral, já que uma parte significativa dos povoados desta época na região apresenta fossos associados a linhas de muralha, como sucede nos castros de Salreu (Estarreja), Ossela (Oliveira de Azeméis) ou nos de Sandim, Monte Murado e Castelo de Gaia, neste último concelho (Silva, 1994, 2005, 2020; Silva \& Pereira, 2010, 2020; Silva $\mathbb{E}$ alii, 2017).

4. De orientação Nordeste-Sudoeste, com cerca de 170 metros de extensão; o eixo Noroeste-Sudeste mede cerca de 114 metros.

\section{FASE IA - OCUPAÇÃO INICIAL DO POVOADO (SÉCULOS IV-III A.C.)}

A fundação do povoado não será anterior, como se disse, ao século IV, uma vez que não se registam quaisquer elementos, nomeadamente no conjunto artefactual exumado, para documentar ocupação anterior. Os primeiros trabalhos arqueológicos, realizados em 1982, junto à antiga Fábrica de Papel Castelo, sob responsabilidade de Carlos Jorge A. Ferreira e Maria Antónia Soares da Silva (Ferreira, Silva, 1982; 1985), não só deixaram a descoberto as primeiras estruturas habitacionais, como abriram caminho, com uma segunda fase de trabalhos entre 1995 e 1999, à caracterização, nesta área (Sector B), de um núcleo habitacional constituído por nove construções (Figuras 2 e 5), no qual, apesar de uma diacronia de ocupação relativamente curta, foi possível definir um esquema de periodização válido para todo o povoado.

Neste sector, o primeiro horizonte de ocupação evidencia-se num fundo de construção de plano subretangular, talhado no afloramento (Estrutura XIII) e em duas construções de planta circular (Est. IX e XI). A localização do povoado numa área de xisto determinou a matéria-prima, já que o xisto local é uma rocha branda e com alto grau de desagregação. As estruturas habitacionais circulares encontram-se definidas por muros de aparelho irregular, feitos com o xisto local, ligando-se com a terra argilosa igualmente local (Figura 5).

No sector F, situado a sudoeste do primeiro, corresponderá a esta fase de ocupação a estrutura circular XXV (Figuras 2 e 3). Os restos de madeira, carbonizada, da ombreira da porta desta construção foram datados por ${ }^{14} \mathrm{C}$, obtendo-se o intervalo de 390-180 calBC, apontando para o século IV a.C. ou, com menor probabilidade, para o séc. III a.C.5. Documentando também esta primeira fase, recolheram-se nas unidades estratigráficas mais antigas deste sector algumas cerâmicas e uma fíbula particularmente interessantes. No primeiro caso, trata-se de

\footnotetext{
5. A data convencional de radiocarbono $(2200 \pm 40)$ foi calibrada, fazendo uso da curva de calibração IntCalo4 (Reimer \& alii, 2004) e do programa OxCal v4.1.03 (Ramsey, 2001), por A. M. Monge Soares, do Instituto Tecnológico e Nuclear, entidade onde foram realizadas as datações e a quem agradecemos a amável e competente colaboração (Salvador \& Silva, 2010: 62-3).
} 
alguns fragmentos de ânfora, pertencentes à forma T-12.1.1.1. (Ramon Torres, 1995), um contentor piscícola, de produção gaditana de influência púnica ${ }^{6}$, cuja circulação pelo litoral atlântico tem vindo a ser enquadrada numa primeira fase de contactos com o noroeste peninsular, compreendidos entre o século IV a.C. e meados do século III a.C. (Ramon Torres, 1995: 233-9; Sáez Romero, 2008: 530-4; Mateo Corredor, 2016: 26). Já a fíbula em bronze, de tipo Sabroso/Ponte 22a, corresponde a uma peça de cronologia ampla, balizada entre a segunda metade do séc. VII e o séc. III a.C. (Ponte, 2006: 218-24), mas que, neste contexto, parece adequar-se bem a uma cronologia da fase inicial do castro.

\section{FASE IB - OCUPAÇÃO INTERMÉDIA (SÉCULOS III-II A.C.)}

A segunda fase de ocupação do castro de Ovil, atribuída aos séculos III e II a.C., foi identificada com clareza nos sectores B, E e F. Entre outros aspetos, parece corresponder, no plano arquitetónico, em diversos sectores, a um momento em que edificações circulares anteriores são dotadas de vestíbulos, podendo também interpretar-se como particularmente típica desta fase uma evidente nuclearização das construções em torno de pátios lajeados comuns.

No sector B, terá ocorrido uma dinâmica de expansão e crescimento do núcleo habitacional, traduzida pela ampliação, com vestíbulos, das estruturas IX e XI, e pela edificação das estruturas circulares X e XII, articuladas com um canal de escoamento de águas pluviais e um pavimento lajeado. Esta nova organização funcional dos conjuntos habitacionais parece privilegiar um modelo arquitetónico no qual a unidade doméstica, com vestíbulo e entrada marcada ao nível do pavimento de circulação, está estrategicamente voltada para uma estrutura circular simples com entrada sobrelevada. Estas associações, observadas no sector B e que poderão indiciar alguma diferenciação funcional de estruturas, configuram um modelo de organização que encontrámos repetido nos sectores $\mathrm{E}$ e $\mathrm{F}$.

No sector E, localizado em área de pendor relativa-

6. Agradecemos a A. M. Sáez Romero a classificação desta peça, por ocasião por workshop «Fenícios \& Púnicos: reflexos do diálogo mediterrâneo-atlântico na arqueologia do noroeste», realizado na Faculdade de Letras da Universidade do Porto em 10 e 13 de dezembro de 2018. mente suave da vertente oeste da plataforma (Figura 4), as intervenções arqueológicas realizadas em 2000 e 2001, vieram revelar um murete de contenção de terras, que define uma plataforma horizontalizada onde se desenvolve um núcleo residencial. Este murete de contenção de terras (Estrutura XVIII) tem por base o afloramento xistoso talhado segundo as linhas de clivagem naturais, resultando num interface vertical rematado por pedra de média e grande dimensão, disposta na horizontal e ligada por abundante argamassa argilosa. Este murete constitui, assim, um elemento estruturador da organização do povoado nesta vertente, definindo e regularizando uma plataforma onde foram detectadas as estruturas circulares XVII e XIX e as casas circulares com vestíbulo XVI, XX e XXI.

Ao nível do modelo de organização deste núcleo devemos registar que as estruturas com vestíbulo XVI e XXI estão estratégica e respetivamente voltadas para as estruturas circulares XIX e XVII, em torno de um pavimento lajeado comum. Estas estruturas circulares, assentes no afloramento previamente regularizado, apresentavam na parede interior um revestimento argiloso, tipo reboco, provavelmente com funções de impermeabilização. A escavação no interior de ambas as estruturas revelou a existência de pisos argilosos de circulação, cobertos por finas camadas de terra escura com pequenos carvões, o que interpretamos como resultado de um momento de incêndio e destruição, com responsabilidade na formação de um intenso derrube que incluía diversos fragmentos de barro, ligeiramente côncavos e espessos, provavelmente provenientes da cobertura das casas.

A estratigrafia observada neste ponto do povoado, a ausência dos materiais mais arcaicos identificados em outros sectores e a tipologia das construções apontam para a integração do núcleo habitacional do sector E na fase IB ocupação do povoado. Esta proposta cronológica surge ainda suportada pela identificação de fragmentos de ânfora que parecem integrar-se no conjunto das produções do séc. III-II a.C. da baía de Cádis7

No sector F, esta fase intermédia de ocupação evidencia as mesmas dinâmicas de crescimento e estra-

7. Agradecemos a J. García Fernández e A. Sáez Romero (Univ. de Sevilla) a classificação destas peças, por ocasião da reunião de trabalho do Proyecto Estrímnides no Museu do Mar (Vigo), em 16.06.2016. 
tégias de distribuição espacial observadas nos outros núcleos habitacionais intervencionados. Verificou-se que a estrutura XXV foi objeto de obras de ampliação, aproveitando parte do muro anterior, resultando numa ampliação da construção de 3,50 para 4,20 metros de diâmetro. Esta beneficiação foi acompanhada pela construção de um vestíbulo, num processo idêntico ao ocorrido no sector B. O processo de crescimento deste conjunto é ainda documentado pela edificação da estrutura circular XXIV, do pavimento lajeado e do muro de traçado retilíneo XXVI. A organização deste núcleo habitacional - estruturado pelo muro XXVI, articulado com o afloramento rochoso - repete os modelos de ocupação planimétrica observados nos outros sectores. A casa com vestíbulo XXV encontra-se voltada para a estrutura circular XXIV, em torno de um pátio lajeado. Este pavimento é formado por pedra de origem xistosa, de média e grande dimensão, disposta na horizontal, e incorporava elementos de dormente de mó giratória em contexto de utilização. $O$ pátio integrava ainda uma cavidade alongada, em tudo idêntica à observada no pavimento lajeado do sector B, que poderá ter servido para retenção de águas ou pia para serventia de animais. A escavação do interior da estrutura XXV permitiu também identificar um piso argiloso com decoração reticulada, feita provavelmente pela impressão de fio torcido, associado a uma lareira definida por uma pequena laje rectangular em xisto colocada na horizontal.

$\mathrm{Na}$ sequência estratigráfica observada no interior das estruturas XXIV e XXV registamos que os últimos níveis de ocupação estavam cobertos por uma fina camada de terra de cor escura, que incorporava numerosos fragmentos de madeira carbonizada, interpretada como estrato de destruição e incêndio. Fragmentos de madeira carbonizada recolhidos no interior da estrutura XXIV foram objeto de uma datação por radiocarbono que aponta para o séc. II a.C. ${ }^{8}$, relacionável, provavelmente, com o abandono deste núcleo habitacional, que não forneceu o material anfórico e as cerâmicas ligeiramente mais «evoluídas» que registamos no horizonte de ocupação da fase seguinte.

8. Ou, com menor probabilidade para a última metade do séc. III ou primeira metade do séc. I a.C. Calibração e comentário à data convencional de radiocarbono (Sac-202O $-2120 \pm 40$ ) por A. Monge Soares (Salvador \& Silva, 2010: $62-3)$.

\section{FASE II - OCUPAÇÃO FINAL (SÉCULOS II-I A.C.)}

A fase final de ocupação do povoado encontra-se muito bem caracterizada, no sector $B$, pela edificação das construções I, II, III, VII e do murete VIII. Mas, também, pelos últimos níveis de ocupação da estrutura XI, a utilização da soleira da estrutura X e, provavelmente, pela ocupação da estrutura XII.

A estrutura circular I está definida, em parte do seu perímetro, por um muro de aparelho irregular sobre um afloramento com acentuada inclinação. Para vencer o desnível e sustentar o muro, a estrutura apresenta, ao nível inferior, um contraforte de contenção de perfil retilíneo, formado por grandes pedras dispostas na horizontal e assentes em estratos anteriores.

A estrutura III revelou-se pelo afloramento xistoso talhado em semicírculo, criando um espaço provavelmente utilizado como habitação. Se a sul e sudeste não se conservaram vestígios de parede, já a oeste e noroeste o afloramento foi cortado, a cerca de o,6o $\mathrm{m}$ do nível do piso, em ângulo reto, formando uma bancada com a largura média de o,40 $\mathrm{m}$, terminando numa depressão semicircular (como um encaixe, que provavelmente sustentaria a parte superior da estrutura), a que se segue o afloramento não desbastado. No interior desta estrutura conservou-se uma lareira, em posição quase central, constituída por pedras definindo um espaço de planta subretangular, e restos de um piso argiloso, decorado por círculos impressos na argila ainda fresca (Ferreira \& Silva, 1982; Salvador \& Silva, 2004: 25).

A casa circular com vestíbulo II está delimitada por um muro relativamente bem cuidado, assente sobre o afloramento, com excepção do braço esquerdo do vestíbulo, que se encontrava apoiado no estrato de abandono e aterro da estrutura IX. No interior deste vestíbulo, adossado à parede da casa, foi também detetado um piso argiloso, de cor avermelhada, decorado por quatro círculos impressos na argila ainda fresca.

Ao nível artecfatual, este horizonte de ocupação do sector B forneceu material anfórico dos tipos Dressel 1, Oberaden 83 e Lusitana da época de Augusto $^{9}$, o que permite supor que o abandono deste núcleo habitacional, e do próprio povoado, terá

9. Classificação de Rui Morais (Universidade do Porto), a quem agradecemos a gentil colaboração. 
ocorrido entre o final do século I a.C. e o início da centúria seguinte.

\section{O ESPÓLIO ARQUEOLÓGICO}

Não se destacando propriamente pela singularidade ou pela presença de objectos exóticos ou valiosos, o espólio recolhido nas intervenções no Castro de Ovil - cujos traços gerais descrevemos na Tabela I - caracteriza-se, pelo contrário, por uma notória homogeneidade, que reflete essencialmente o artesanato e a ergonomia das comunidades autóctones do noroeste atlântico da segunda Idade do Ferro, sendo quantitativamente pouco representativos os materiais importados.

Como é comum em sítios desta natureza, a olaria é dominante entre os restos artefactuais recolhidos. A maior parte deste espólio é constituído por pequenos fragmentos cerâmicos muito rolados e fragmentados, de tonalidades irregulares, cozedura igualmente irregular efetuada geralmente em atmosfera oxidante, e pastas com abundantes elementos não plásticos de dimensão predominantemente média e grande. As peças são maioritariamente montadas ao torno, ainda que o inventário registe um significativo número de peças de fabrico manual.

A quantificação e seriação tipológica da olaria do castro mostra que no conjunto dos perto de 47000 fragmentos recolhidos em todas as campanhas, os morfotipos da fase inicial de ocupação identificados com alguma segurança ascendem a 70 vasilhas, 164 da fase intermédia e 92 da fase final de ocupação ${ }^{10}$, podendo distribuir-se por cinco grandes tipos, que adiante se descrevem.

O elenco formal, que espelha bem - pelos catálogos publicados (Silva, 1986; Martins, 1987; Almeida e Silva, Silva, no prelo) - o trem de cozinha, serviço, transporte e armazenamento das populações da Idade do Ferro, pode ver-se na Fig. 6, que todavia ilustra apenas as cinco formas mais comuns: panelas, potes, púcaros, talhas e vasos de suspensão com asa interior (Salvador \& Silva, 2010: 59-60; no prelo).

10. A distribuição morfológica do material cerâmico decorre da quantificação dos tipos após a sua reconstituição, correspondendo por isso, de um modo geral, ao "Número Mínimo de Indivíduos", embora haja um número superior de bordos, por exemplo, que não permitem decidir, pelas suas dimensões, se pertencem a potes ou a panelas, formas morfologicamente aparentadas ou, quando mais espessos, a potes ou a talhas.
Estas são também as formas que se encontram representadas no Gráfico I, resultante da quantificação dos tipos após a sua reconstituição, correspondendo por isso, de um modo geral, ao Número Mínimo de Indivíduos utilizado nas metodologias mais correntes de contabilização cerâmica (Orton, Tyers \& Vince, 1993: 172; Arcelin, Tuffreau-Libre, 1998).

\subsection{Panelas}

Esta é uma das formas melhor representadas no povoado, devendo corresponder a uma vasilha certamente destinada à cozedura de alimentos ou ao aquecimento de líquidos, o que os recorrentes vestígios de exposição ao fogo nas superfícies exteriores bem evidenciam. Nos contextos da Fase IA de ocupação, os exemplares identificados como panelas (24) apresentam habitualmente perfil em S mais ou menos acentuado e paredes finas, variando o diâmetro da boca entre os 120 e os $160 \mathrm{~mm}$. Na análise das bases observa-se a predominância de fundos rasos, em aresta, com diâmetros que vão dos 110 aos 140 $\mathrm{mm}$. Os exemplares desta forma documentados nas fases IB (45) e II (35) mostram uma clara continuidade formal com os anteriores, se bem que evidenciem uma ampla utilização do torno de oleiro (Figura 6 , números 5 a 10).

As pastas deste tipo de recipiente, de tonalidade exterior entre o castanho e o castanho avermelhado (mais raramente escuras), são arenosas, micáceas e, maioritariamente, de textura relativamente compacta e homogénea. As superfícies, regularizadas, apresentam traços de exposição ao fogo no exterior, como se observou. A qualidade da cozedura das peças, feita maioritariamente em ambiente oxidante, é irregular. A decoração é rara nas panelas, podendo por vezes observar-se uma singela linha incisa (Figura $6, n^{\circ} 6$ ) ou cordão plástico (Figura 6, ํํ8).

\subsection{Púcaros}

Utilizados certamente para o serviço de líquidos, os púcaros constituem um morfotipo algo especializado, cuja representatividade não atinge os $15 \%$ no conjunto total das formas reconhecidas, se bem que pelas suas dimensões e pouca espessura das paredes (originando maior fragmentação), esta forma possa estar algo subrepresentada nas contagens (Figura 6, números 1 a 4). Entre o conjunto olárico da fase IA foram identificados 10 púcaros, caracterizados essencialmente por possuírem perfil em $\mathrm{S}$ de colo alongado e paredes finas. O diâmetro dos bordos 
oscila entre os 90 e os $140 \mathrm{~mm}$. Cerca de um terço dos exemplares analisados são asas com arranque de bordo ou com ligação à parte superior da pança, o que indica a inserção do elemento de preensão no corpo da peça. Já as bases, em aresta ou em bolacha, são horizontais e apresentam diâmetros que variam entre os 65 e os $100 \mathrm{~mm}$. No que toca ao modo de fabrico, observam-se exemplares rodados e outros que indiciam fabrico manual.

Nas fases IB e II contabilizam-se, respetivamente, 19 e 11 púcaros, denotando maior variedade formal, pastas relativamente mais depuradas e acabamentos mais cuidados, servindo de base a diversas composições decorativas estampilhadas. No geral do conjunto, as pastas, de coloração similar à das panelas, são homogéneas, com presença regular de elementos não plásticos de calibre médio; as superfícies externas mostram-se regularizadas ou alisadas, sendo também melhor, por comparação com outros recipientes, a qualidade média de cocção.

\subsection{Potes}

Se bem que a sua morfologia os aproxime das panelas, sobretudo quando de menores dimensões, os recipientes que designamos como potes teriam, aparentemente função diversa, uma vez que não seriam usados para a cozinha, como peças de lume, mas para armazenamento, ou mesmo transporte, de alimentos sólidos e líquidos.

Os efetivos quantificados em cada uma das fases são de 12 potes nos contextos mais antigos, 24 no nível intermédio IB e 8 na fase final de ocupação. Esta forma apresenta geralmente perfil em $\mathrm{S}$ ou, mais raramente, corpo oval, com paredes relativamente finas. Os bordos, lançados para o exterior e por vezes com vestígios de aplanamento interno, exibem diâmetros que oscilam entre os 180 e os $260 \mathrm{~mm}$.

As pastas cerâmicas utilizadas para o fabrico destas vasilhas são de textura compacta e homogénea, geralmente com abundantes partículas de areia e mica. De tonalidade idêntica ao restante vasilhame do castro, as superfícies encontram-se maioritariamente regularizadas ou, menos frequentemente, alisadas. Identificamos exemplares rodados e outros de feitura manual. A decoração parece rara, se bem que para tal possa contribuir a grande fragmentação do conjunto ceramológico.

\subsection{Talhas}

Classificamos como talhas ${ }^{11}$ certos contentores de grandes dimensões, destinados certamente ao armazenamento de produtos alimentares sólidos ou líquidos. As pertencentes à fase IA (19 exemplares), apresentam geralmente bordos lançados para o exterior com superfície interna plana ou côncava e lábio boleado, com uma amplitude de diâmetros que oscilam entre os 260 e os $360 \mathrm{~mm}$. Os fundos, relativamente altos em aresta ou com alargamentos mais ou menos significativos, mostram correntemente diâmetros amplos, próximos de $260 \mathrm{~mm}$. Na fase IB ( 63 exemplares) e final (26) as talhas exibem maior diversidade de perfis, observando-se, nomeadamente, bordos em aba horizontal; variando também as suas dimensões, porventura a indiciar diversidade funcional (Figura 6, números 11 a 14).

As pastas argilosas, de aspeto mais regular ou grosseiro, incluem numerosos elementos arenosos e micáceos de média e grande dimensão. De tonalidade corrente, mostram amiúde variações cromáticas, denunciando a irregularidade da cocção. $\mathrm{O}$ aspeto das superfícies é por vezes rugoso no exterior. A ornamentação surge com alguma frequência. Nos contextos iniciais com recurso a diferentes técnicas e motivos - SS, triângulos rematados nos ângulos por círculos, triângulos internamente preenchidos por linhas paralelas incisas, linhas cruzadas em xadrez, punções circulares ao nível do bordo, etc.; nas fases IB e II, predominando decoração geométrica incisa.

\subsection{Vasos de Suspensão}

Estes vasos destinavam-se à cozinha e eram suspensos sobre a lareira, função confirmada pela sua morfologia e pela sistemática presença de sinais de exposição ao fogo no exterior das peças.

Nos horizontes de ocupação inicial foram exumadas cinco asas interiores de secção circular aplicadas na parte superior das paredes com os arranques em plano horizontal. Na fase IB temos 13 exemplares e na final 12 unidades, o que nos permitiu reconstituir graficamente recipientes de grande dimensão, largos e abertos (diâmetro do bordo entre os 400 e os $500 \mathrm{~mm}$.), com forma em tronco de cone relativamente baixo, de paredes direitas ou ligeiramente arqueadas, espessando para o bordo, e fundo raso.

11. Preferimos esta designação, tradicional no nosso país, à alternativa dolia, própria dos ambientes romanizados que não encontramos em Ovil. 
Na panóplia olárica de Ovil surgiu apenas um exemplar de um vaso de "asa em orelha», em contexto de derrube.

\subsection{Outros tipos cerâmicos}

Além das formas acima elencadas, registam-se outras, com representação bastante mais reduzida, que optámos por não descrever por economia de texto, o mesmo fazendo com as louças importadas, reduzidas, praticamente, aos materiais anfóricos que já foram mencionados. Devemos no entanto registar, no que respeita às produções indígenas, a presença de peças que identificámos como alguidares com vertedouro, cântaros e, em particular, uma forma muito específica que é uma assadeira retangular (Salvador, Silva, no prelo).

Passando aos itens cerâmicos não ligados à alimentação, devemos destacar, além de numerosos cossoiros discoidais e alguns pesos de tear, destinados respetivamente à fiação e à tecelagem, a identificação de um conjunto de pesos de maiores dimensões, feitos em barro, inicialmente interpretados como ligados à tecelagem mas que entretanto, em resultado de evidências mais claras, podemos, com maior segurança, classificar como pesos de fixação das coberturas das construções (Figura 7).

De facto, os níveis de derrube detetados no interior das estruturas XVII e XIX (sector E) continham uma grande quantidade de fragmentos de barro, ligeiramente côncavos e espessos, em tudo idênticos aos exumados no interior de algumas casas do sector B. Posteriormente, a escavação da estrutura XXV (sector F) revelou, numa espessa camada de abandono e derrube da construção, 16 destes pesos em barro, mais completos que os anteriores. Apresentam um formato ovalado, perfuração circular na extremidade e cerca de 3,3 kg. de peso, em média. Considerando que a cobertura das estruturas seria feita utilizando o colmo ou outro elemento vegetal, eventualmente reforçado por barro, tornava-se necessário, face à exposição aos fortes ventos marítimos, o recurso a elementos cujo peso assegurasse a integridade da cobertura, função desempenhada por estes pesos, amarrados com cordas e que ficariam suspensos, ou pousados, sobre a cobertura vegetal (Salvador \& Silva, 2010: 61).

A utilização de objetos classificáveis como pesos de cobertura ou "pedras de colmo", na maior parte dos casos feitos em pedra, está registada em muitos castros do Noroeste, se bem que não tenham merecido particular atenção dos investigadores portugueses, ao contrário da bibliografia galega (López-Cuevillas, 1988 [1953]: 119; Calo Lourido, 1993: 107-8; Arias Vilas \& Durán Fuentes, 1996: 69-70). Na região em que se insere o castro de Ovil documentam-se pesos de cobertura, feitos em pedra, pelo menos no Castro de Salreu, Estarreja (Silva \& alii, no prelo) e no Castro de Valinhas, Arouca, onde foram localizados, junto a uma casa redonda, sete exemplares, em xisto, com pesos que variam entre 2,4 e $7,0 \mathrm{~kg}$. (Salvador \& Silva, 2010: 61).

\subsection{Outros materiais}

Para além de alguns objetos metálicos, pouco frequentes, dos quais destacamos algumas fíbulas e duas pontas de lança em liga de ferro, exumaram-se no Castro de Ovil diversos materiais feitos em pedra. Trata-se, essencialmente, de mós, seixos talhados lateralmente para serem usados como pesos (presumivelmente de redes de pesca) e, em ocorrências mais raras, machados, lâminas, amoladores e outros. No que se refere às mós, localizaram-se quatro exemplares de rebolo ou vai-vém, em granito, e um número muito maior de fragmentos de dormentes e moventes de mós giratórias, merecendo nota a circunstância de alguns pavimentos lajeados, da fase intermédia de ocupação (IB), incorporarem, in situ, elementos dormentes em contexto de uso.

\section{NOTAS CONCLUSIVAS}

Contando já com uma significativa área escavada, o Castro de Ovil destaca-se no panorama regional, por ser um dos poucos que não acusa, ao nível arquitetónico, como no artefactual, evidência de "romanização»" ${ }^{12}$. Ou seja, observamos um povoado indígena com construções integralmente de plano curvilíneo ${ }^{13}$, sem a mínima evidência do uso de telha cerâmica e cuja ergologia, ao longo dos 350 ou 400 anos que estimamos para a sua ocupação, é também claramente autóctone, salvo talvez um par de fíbulas em bronze e, certamente, as contas de colar em pasta vítrea e os restos de material anfórico,

\footnotetext{
12. O mesmo sucede no vizinho Castro de Salreu (Almeida e Silva \& alii, neste volume), mas com menor área escavada e escassa documentação das estruturas domésticas.

13. Com a única exceção da Estrutura «rupestre» XIII, do sector $\mathrm{B}$, que pertence à fase inicial de ocupação.
} 
aliás, em pequena quantidade, que documentam contactos e trocas com ambientes forâneos.

Se bem que escassamente representadas em Ovil, estas articulações, comerciais e simbólicas, com horizontes culturais e económicos meridionais, primeiro de enquadramento púnico, e depois já na esfera das dinâmicas comerciais estimuladas por Roma, resultarão, primordialmente, da implantação litoral do povoado, e nomeadamente da sua proximidade à antiga Lagoa de Ovil (atual Barrinha de Paramos/ Esmoriz) aberta ao mar até aos séculos XII/XIII, formando uma enseada que permitia a atracagem de navios.

Mas, regressando à arquitetura e ao desenho «urbano" deste aglomerado, a leitura estratigráfica precisa proporcionada pelas escavações, permitiu afinar aspetos de grande interesse na arquitetura castreja, como a cronologia da tão disseminada "moda» da ampliação das construções com vestíbulos colaterais às entradas. Por outro lado, contrariando a imagem aparente, proporcionada por algumas plantas de castros, de uma ocupação do espaço intensa e cuja organicidade parece alheia a qualquer organização social ou funcional, as escavações de Ovil demonstraram um padrão de organização indígena, social ou vicinal, percebido já em outros castros mas que aqui se patenteia como típico da fase intermédia (séculos III-II a.C.). Referimo-nos à nuclearização funcional (que prescinde dos muros delimitadores das "casas familiares» alargadas que se observam nas grandes citânias como Sanfins ou Briteiros) que articula e orienta para um pátio lajeado comum construções com e sem vestíbulo; pátio assumido como elemento higienizador, vertebrador da circulação interna na aldeia e, certamente, convivial, não fossem as mós convenientemente inseridas nesse chão comum, a sugerir partilhas do trabalho e da vida.

Mais que as razões ou circunstâncias fundacionais do povoado, importam-nos em Ovil as condições e a cronologia do seu abandono, provavelmente pacífico, já discutidas em trabalho anterior (Salvador \& Silva, 2010: 63-4). Ao tempo do primeiro imperador, com a região pacificada e sob domínio das legiões, a comunidade fundadora e residente no castro Ovil (certamente menos de um milhar de almas) terá arrumado os pertences, esvaziado as casas e transportado alfaias e animais para nova morada. E não só os castellani de Ovil. Pela mesma época, mais década menos década, cremos que também os de Salreu, e provavelmente os de outros pequenos castros, tomaram, ou foram impelidos a tomar, a mesma decisão.

Se nestas movimentações de gentes e meios de produção há mão de Roma, ou simples fenómeno de sinecismo, motivado não já por necessidade de defesa congregada, mas por dinâmicas económicas e sociais que, porventura, atraíssem a certos povoados as populações dos vizinhos, é questão fulcral para a história da região e do noroeste castrejo-romano (Salvador \& Silva, idem, ibid.), que aqui não podemos discutir, mas para a qual a investigação sobre o pequeno castro de Ovil poderá dar um contributo não despiciendo.

\section{BIBLIOGRAFIA}

ALMEIDA e SILVA, Sara; SILVA, António Manuel S. P. [no prelo] - Breves considerações sobre a cerâmica da Idade do Ferro do Castro de Salreu (Estarreja, Aveiro). Atas do Congresso Internacional de Cultura Castreja. Santa Maria da Feira.

ARCELIN, Patrice; TUFFREAU-LIBRE, Marie, dir. (1998) - La quantification des céramiques. Conditions et protocole. Actes de la table-ronde (...) du Mont Beuvray. Glux-enGlenne: CAE (Bibracte, 2).

ARIAS VILA, Felipe ; DURÁN FUENTES, M. C. (1996) Museo del Castro de Viladonga - Castro de Rei, Lugo. S.l.: Xunta de Galicia.

CALO LOURIDO, Francisco (1993) - A Cultura Castrexa. Vigo: A nossa terra.

FERRER-ALBELDA, Eduardo; GARCÍA FERNÁNDEZ, Francisco; SÁEZ ROMERO, Antonio; RODRÍGUEZ-CORRAL, Javier; ALBUQUERQUE, Pedro (2019) - A Rota do Estanho: Gadir e o Comércio Fenício no Noroeste da Ibéria (Séculos IV - II a.C.). Revista Hélade, 5: 2. Rio de Janeiro, pp. 83-117. doi: 10.22409/rh.v5i2.42485

FERREIRA, Carlos J. A.; SILVA, Maria A. (1982) - Castro de Ovil, Paramos, Espinho. Relatório de trabalhos arqueológicos. Lisboa, relatório datilog.

FERREIRA, Carlos J. A.; SILVA, Maria A. (1984) - Distrito de Aveiro. Espinho. Castro de Ovil. Informação Arqueológica, 4 (1981). Lisboa, pp. 41-43.

FERREIRA, Carlos J. A.; SILVA, Maria A. (1985) - Espinho: Castro de Ovil. Informação Arqueológica, 5. (1982-83). Lisboa, pp. 38-39.

LÓPEZ CUEVILLAS, Florentino (1988) - La civilización céltica en Galicia. Madrid: Istmo [ed. orig. 1953].

MARTINS, Manuela (1987) - A cerâmica proto-histórica do Vale do Cávado: tentativa de sistematização. Cadernos de Arqueologia, série 2, nº 4. Braga, pp. 35-77.

MATEO CORREDOR, Daniel (2016) - Comercio anfórico y relaciones mercantiles en Hispania Ulterior (s. II a.C. - II d.C.). Barcelona: Universitat de Barcelona. 
ORTON, Clive; TYERS, Paul; VINCE, Alan (1993) - Pottery in archaeology. Cambridge: Cambridge Univ. Press

PONTE, Salete da (2006) - Corpus Signorum das Fíbulas Proto-Históricas e Romanas de Portugal. Coimbra: Caleidoscópio.

RAMON TORRES, Joan (1995) - Las ánforas fenicio-púnicas del Mediterráneao central y ocidental. Barcelona: Universitat de Barcelona.

RAMSEY, Christopher Bronk (2001) - Development of the Radiocarbon calibration program OxCal. Radiocarbon. 43 (2A). (Proceedings of the $17^{\text {th }}$ International Radiocarbon Conference). Cambridge, pp. 355-63. https://doi.org/1o. 1017/Soo33822200038212

REIMER, Paula J.[et. al.] (2004) - IntCalo4 Terrestrial Radiocarbon Age Calibration, o-26 cal Kyr BP. Radiocarbon. 46 (3), Tucson, pp. 1029-58. Disp. em https://journals.uair. arizona.edu/index.php/radiocarbon/article/view/4167

SÁEZ ROMERO, Antonio M. (2008) - La producción cerámica en Gadir en época tardopúnica (siglos -III/-I). Oxford: Archaeopress; Universidad de Cádiz.

SALVADOR, Jorge F.; SILVA, António Manuel S. P. (2000) - Da descoberta do Castro de Ovil à criação de um Gabinete de Arqueologia. Al-Madan. 2 Série, 9. Almada, pp. 169-73.

SALVADOR, Jorge F.; SILVA, António Manuel S. P. (2004)O Castro de Ovil e o povoamento da região de Espinho da proto-história à romanização (OVESP). Relatório Final de Trabalhos Arqueológicos. Espinho: Câmara Municipal, policop.

SALVADOR, Jorge F.; SILVA, António Manuel S. P. (2010) O Castro de Ovil (Espinho, um povoado da Idade do Ferro. In PINTO, Filipe M. S. (coord.) - Arqueologia da Terra de Santa Maria: balanços e perspectivas. Santa Maria da Feira: Liga dos Amigos da Feira: pp. 53-73.

SALVADOR, Jorge F.; SILVA, António Manuel S. P. (no prelo) - Cerâmica da Idade do Ferro do Castro de Ovil (Espinho, Aveiro). Atas do Congresso Internacional Cultura Castreja. Santa Maria da Feira.

SALVADOR, Jorge F.; SILVA, António Manuel S. P.; SÁRRIA, Carlos A. (2005a) - O Centro Interpretativo do Castro de Ovil (Espinho): a construção de um espaço de memória. In JORGE, V. O. (coord.) - Conservar Para Quê? 8. ${ }^{\underline{a}}$ Mesa-redonda de Primavera. Porto-Coimbra: Fac. de Letras da Universidade do Porto; CEAUCP, pp. 303-26.

SALVADOR, Jorge F.; SILVA, António Manuel S. P.; SÁRRIA, Carlos A. (2005b) - O Centro Interpretativo do Castro de Ovil (Espinho). In SILVA, António Manuel S. P. (coord.) - Cartas Arqueológicas: do inventário à salvaguarda e valorização do património. Actas das Jornadas realizadas em Arouca em 2004. Arouca: Câmara Municipal, pp. 61-68.

SILVA, António Manuel S. P. (1994) - Proto-história e Romanização no Entre Douro e Vouga Litoral. Elementos para uma avaliação crítica. Dissertação de Mestrado apresentada à Faculdade de Letras da Universidade do Porto.
SILVA, António Manuel S. P. (2005) - Povoamento proto-histórico no Entre Douro e Vouga Litoral: a estruturação do habitat. I - Arquitectura dos castros. In Castro, um lugar para habitar. Colóquio [Cadernos do Museu, 11]. Penafiel: Museu Municipal, pp. 167-188.

SILVA, António Manuel S. P. (2020) - O Castelo de Gaia, um sítio arqueológico excecional e um valor cultural a potenciar. In: Santa Casa da Misericórdia do Porto (coord.) Pessoa(s), Arte, Benemerência. IV Congresso de História da Santa Casa da Misericórdia do Porto. Porto: SCMP, p. 51936 , ilust. em extra-texto.

SILVA, António Manuel S. P.; PEREIRA, Gabriel R. (2010) - Povoamento proto-histórico na fachada atlântica do Entre Douro e Vouga. Paleoambientes e dinâmica cultural. In BETTENCOURT, A.; ALVES, M.; MONTEIRO-RODRIGUES, S. (eds.) - Variações paleoambientais e evolução antrópica no Quaternário do Ocidente Peninsular. S.l.: APEQ/ CITCEM, pp. 189-203.

SILVA, António Manuel S. P.; PEREIRA, Gabriel R. (2020) - Walls and Castros. Delimitation structures in the Proto-historic settlements of Entre Douro and Vouga region (Center-North of Portugal). In DELFINO, Davide; COIMBRA, Fernando; CARDOSO, Daniela; CRUZ, Gonçalo Late Prehistoric Fortifications in Europe: Defensive, symbolic and territorial aspects from the Chalcolithic to the Iron Age. Proceedings of the International Colloquium 'FortMetalAges', Guimarães, Portugal. Oxford: Archaeopress, pp. 215-28.

SILVA, António Manuel S. P.; PEREIRA, Gabriel R.; ALMEIDA E SILVA, Sara; LEMOS, Paulo (2017) - Uma aldeia de há dois mil anos. Um sítio arqueológico e a sua investigação. Terras de Antuã. Histórias e Memórias do Concelho de Estarreja. 11. Estarreja, pp. 15-29.

SILVA, António Manuel S. P.; PEREIRA, Gabriel; LEMOS, Paulo; ALMEIDA E SILVA, Sara (no prelo) - O Castro de Salreu (Estarreja): um povoado da Idade do Ferro nos limites meridionais da "cultura castreja". In Atas do I Ciclo de Conferências do Monte Padrão. Santo Tirso.

SILVA, António Manuel S. P.; SÁ, Edite M.; SALVADOR, Jorge F.; LEMOS, Paulo; ALMEIDA e SILVA, Sara (2019) - O castro de Salreu, um dos povoados proto-históricos atlânticos do Entre Douro e Vouga. Terras de Antuã. Histórias e Memórias do Concelho de Estarreja. 13. Estarreja, pp. 24-44.

SILVA, António Manuel S. P.; SALVADOR, Jorge F. (2008) - Castro de Ovil (Espinho, Aveiro). In VILAÇA, Raquel; CUNHA-RIBEIRO, João - Das primeiras ocupações humanas à chegada dos Romanos à Beira Litoral/From the first human occupations to the arrival of the Romans to Beira Litoral. Tomar: CEIPHAR, pp. 173-81.

SILVA, Armando C. F. (1986) - A Cultura Castreja no Noroeste de Portugal. Paços de Ferreira: Câmara Municipal; Museu Arqueológico da Citânia de Sanfins. 


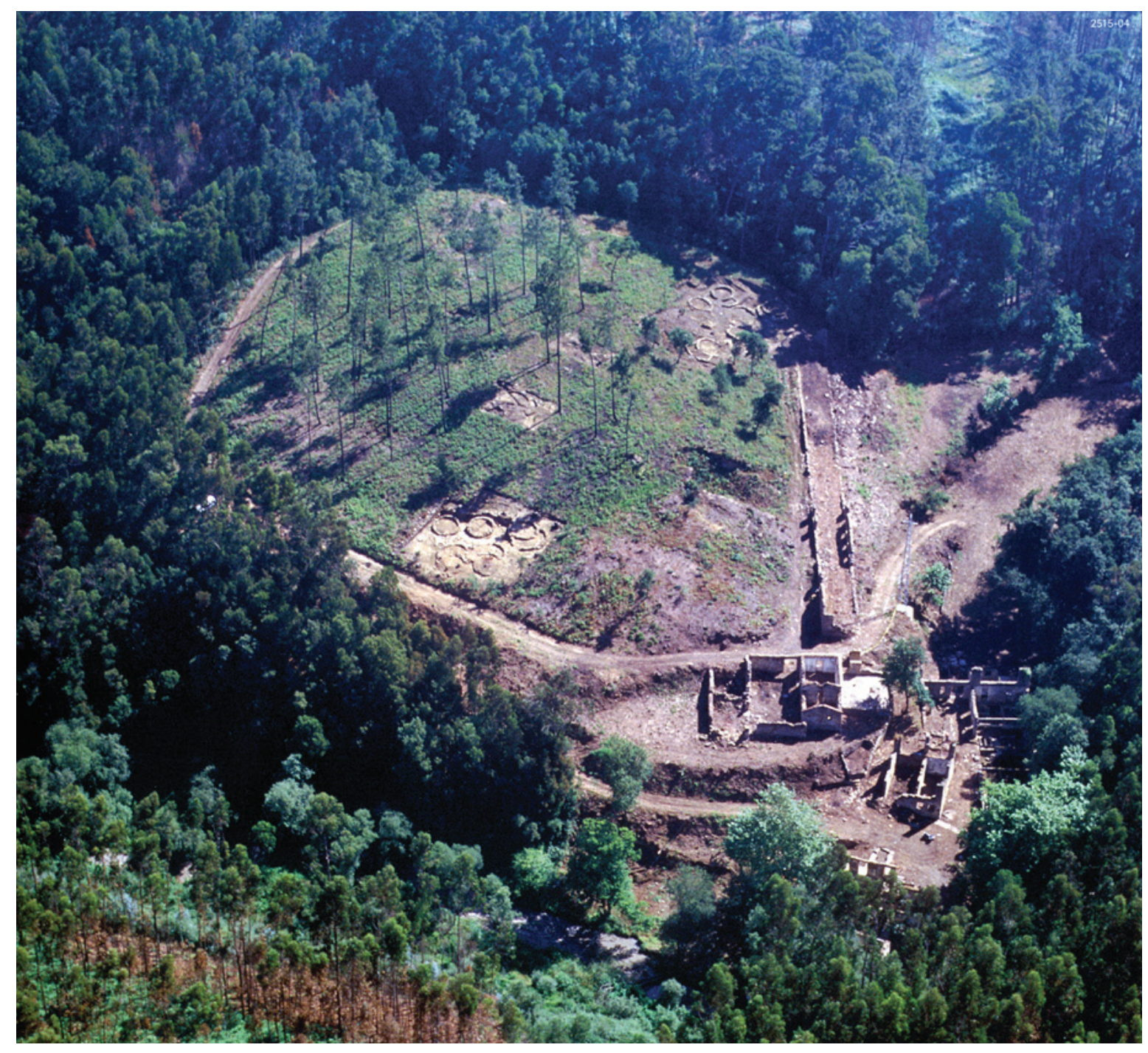

Figura 1 - Castro de Ovil, vista aérea. (Foto: J. Ferrand/C. M. Espinho) 


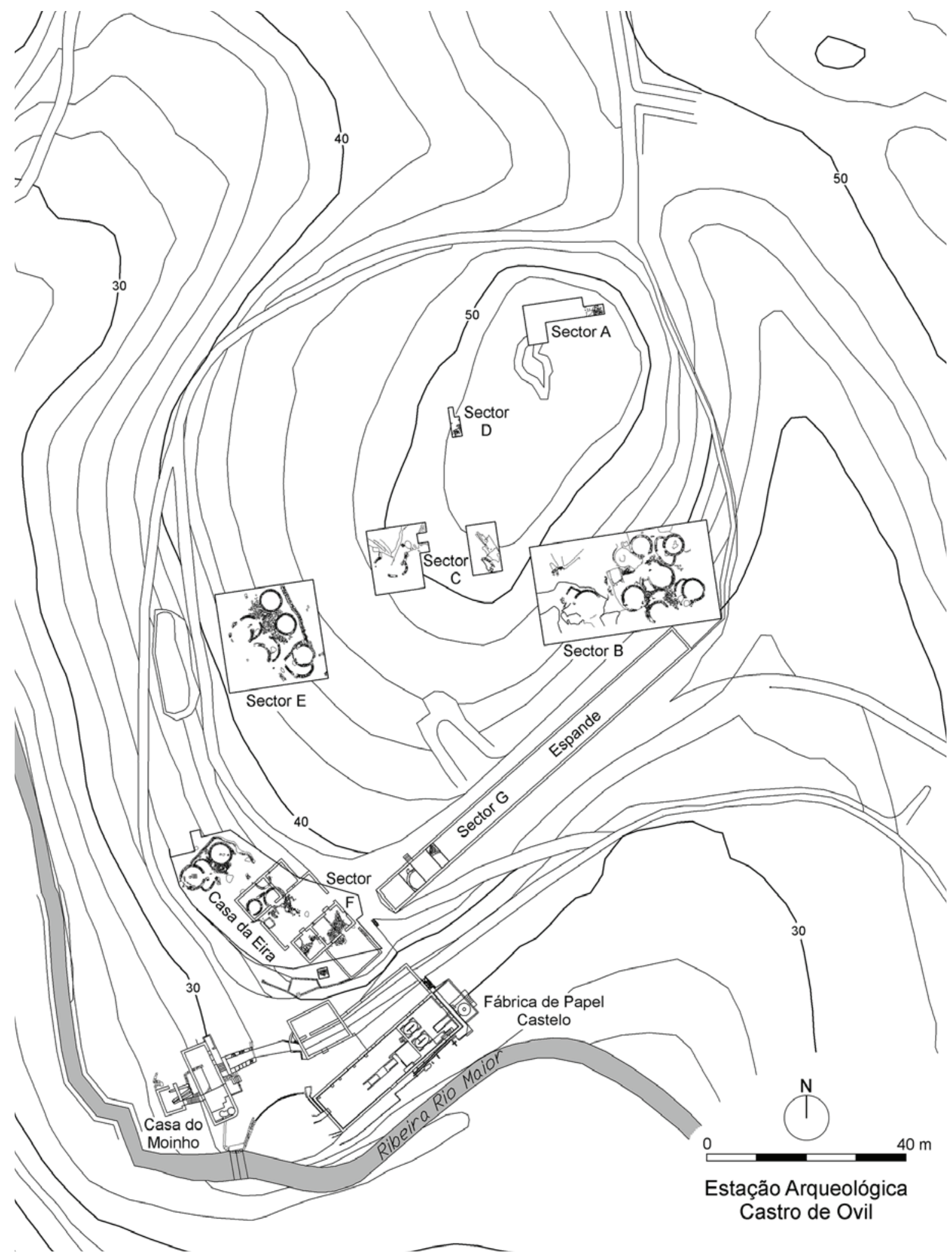

Figura 2 - Planta geral da estação arqueológica do Castro de Ovil (Serviço de Arqueologia/C. M. Espinho). 


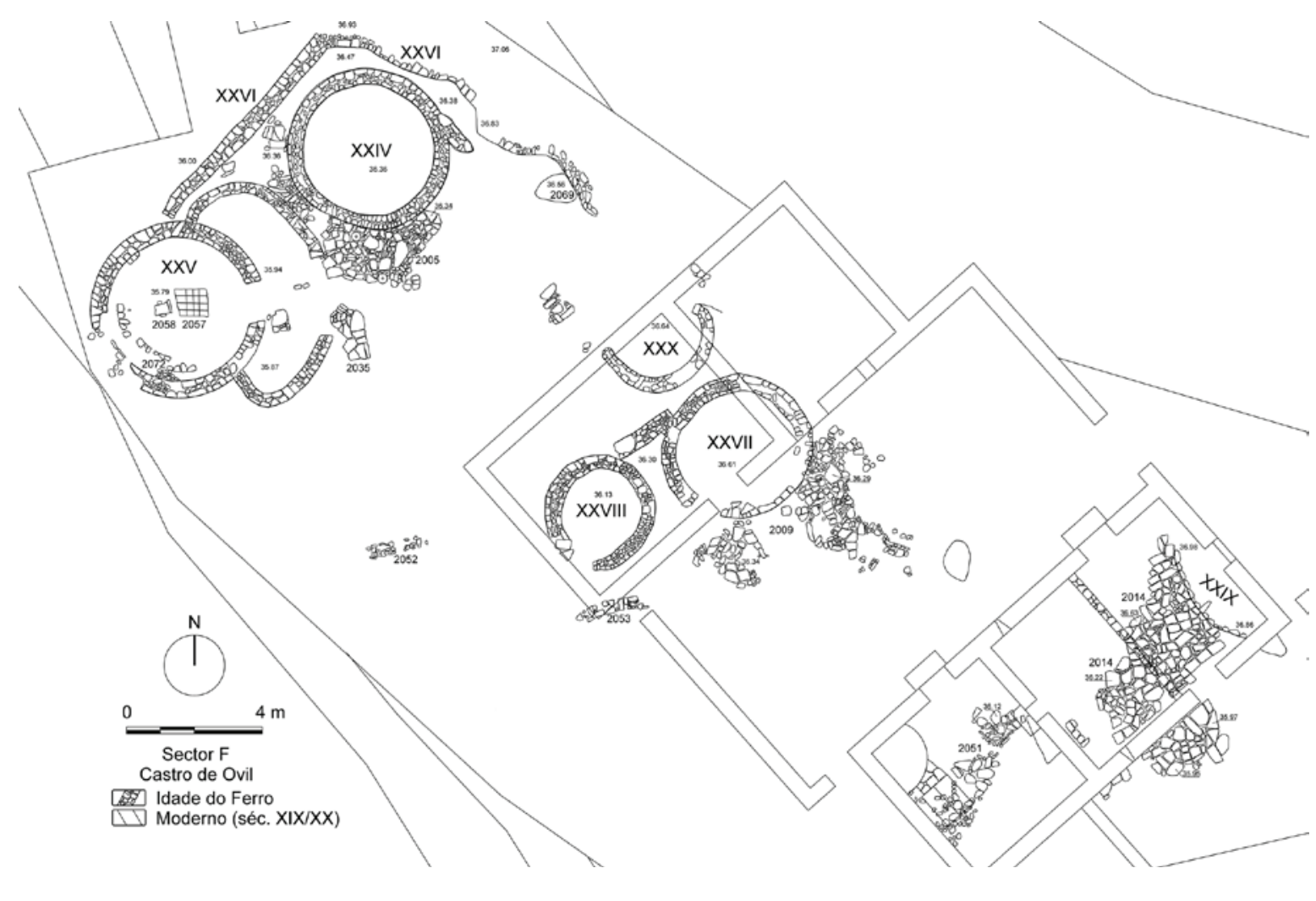

Figura 3 - Castro de Ovil. Planta do sector F (Serviço de Arqueologia/C. M. Espinho).

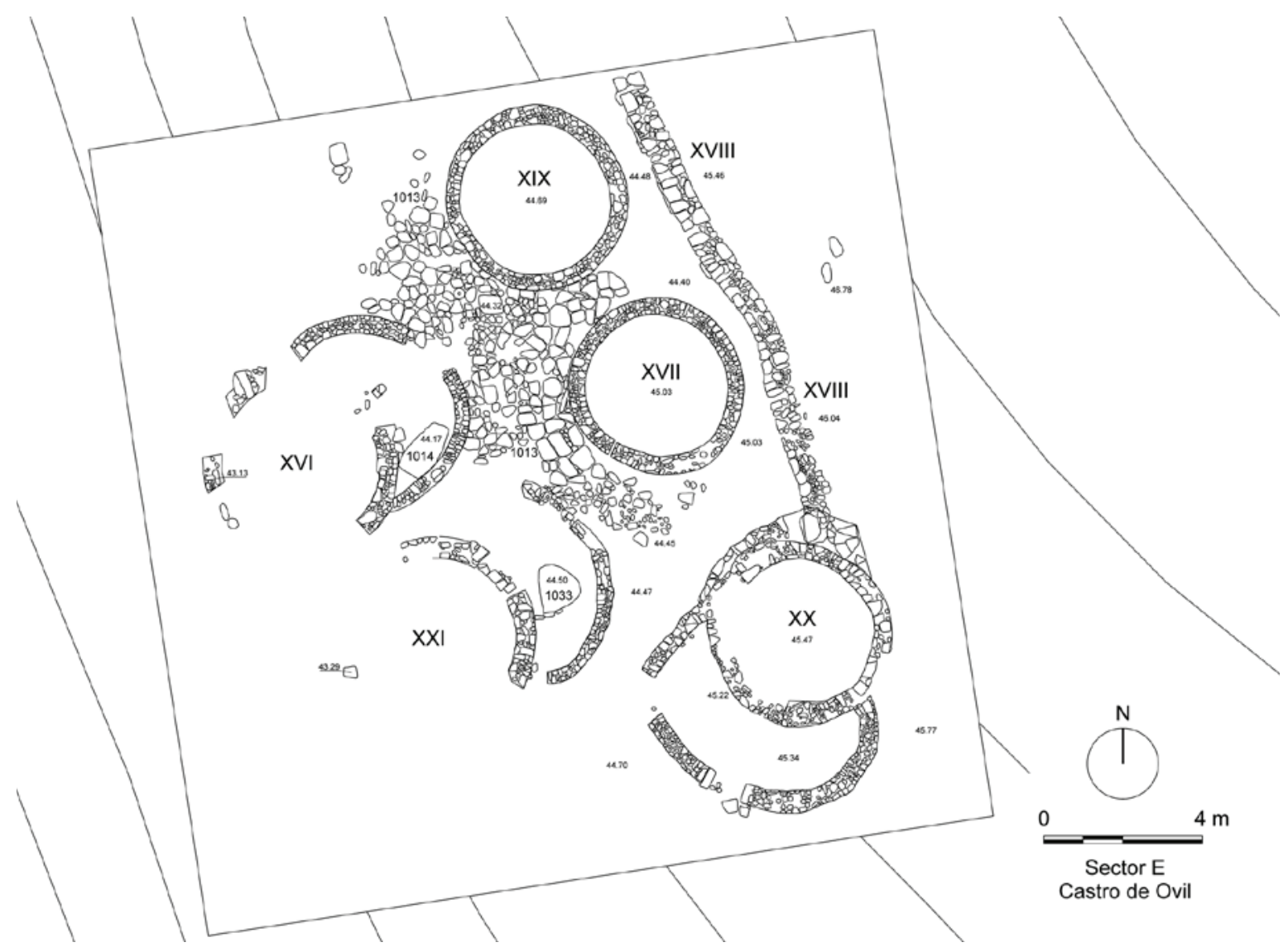

Figura 4 - Castro de Ovil. Planta do sector E (Serviço de Arqueologia/C. M. Espinho). 


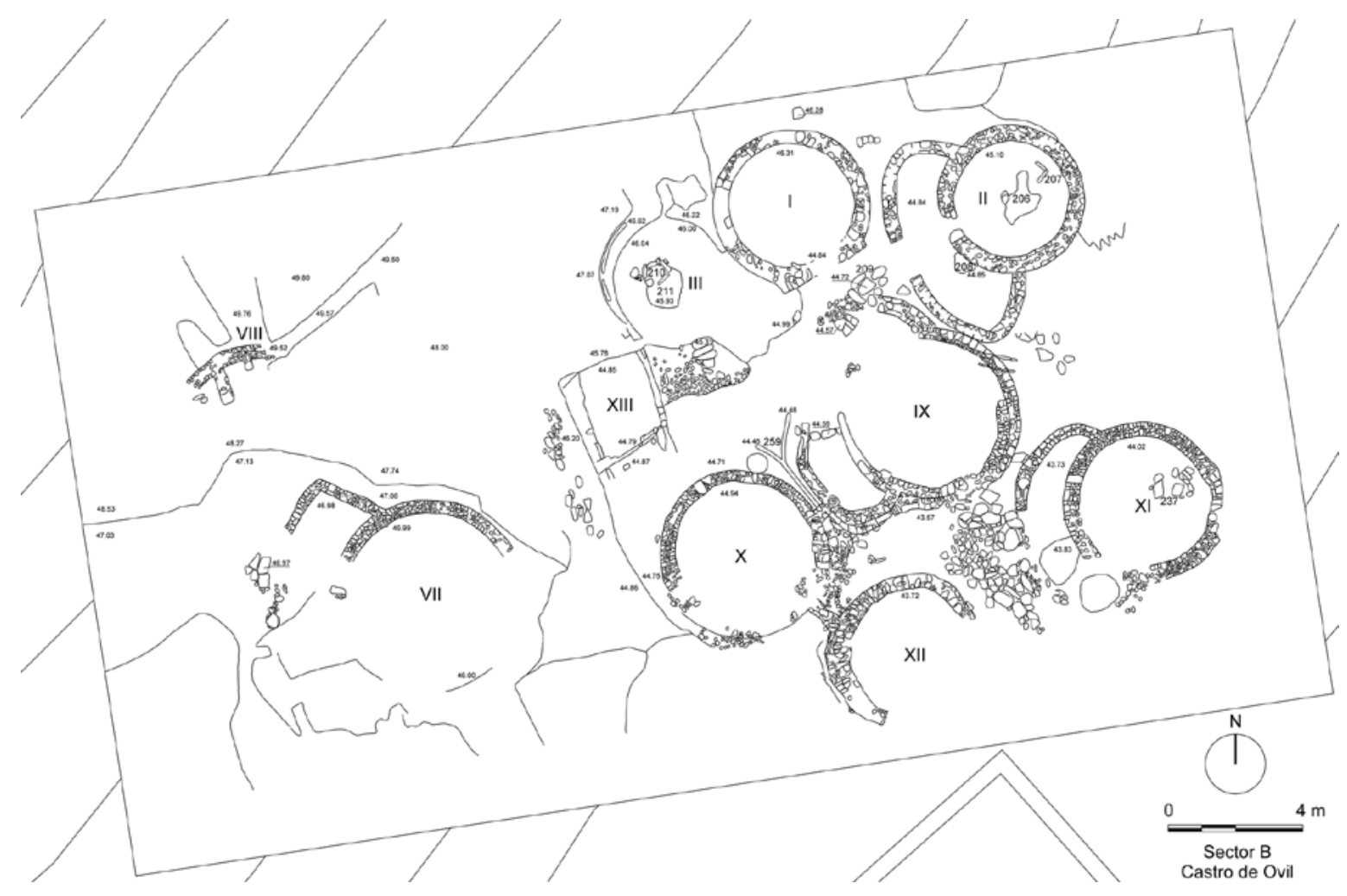

Figura 5- Castro de Ovil. Planta do sector B (Serviço de Arqueologia/C. M. Espinho).

\begin{tabular}{|c|c|c|c|c|}
\hline \multirow{2}{*}{ FASES } & \multicolumn{3}{|c|}{ CERÂMICA } & \multirow{2}{*}{ OUTROS MATERIAIS } \\
\hline & Modelação & Formas & Decoração & \\
\hline $\begin{array}{l}\text { Inicial (IA) } \\
\text { IV-III aC }\end{array}$ & $\begin{array}{c}\text { Cerâmica manual e } \\
\text { modelada a torno }\end{array}$ & $\begin{array}{l}\text { Homogeneidade do } \\
\text { elenco formal de panelas, } \\
\text { potes e vasos de } \\
\text { suspensão }\end{array}$ & $\begin{array}{l}\text { Homogeneidade nos } \\
\text { motivos }\end{array}$ & $\begin{array}{c}\text { Contas de colar } \\
\text { (pasta de vidro) } \\
\text { Fíbula tipo Sabroso } \\
\text { Ânfora gaditana de influência } \\
\text { púnica T-12.1.1.1. }\end{array}$ \\
\hline $\begin{array}{c}\text { Intermédia (IB) } \\
\qquad\|I-\| \mathrm{aC}\end{array}$ & $\begin{array}{l}\text { Mais cerâmica montada } \\
\text { a torno, ainda que se } \\
\text { registe cerâmica manual }\end{array}$ & \multirow{2}{*}{$\begin{array}{l}\text { Tendência para uma } \\
\text { variedade formal de } \\
\text { púcaros e talhas }\end{array}$} & \multirow{2}{*}{$\begin{array}{c}\text { Tendência para } \\
\text { alguma complexidade } \\
\text { na organização } \\
\text { decorativa. }\end{array}$} & $\begin{array}{l}\text { Contas de colar } \\
\text { (pasta de vidro) } \\
\text { Ânfora gaditana }\end{array}$ \\
\hline $\begin{array}{c}\text { Final (II) } \\
\text { II aC - inic. I dC }\end{array}$ & $\begin{array}{l}\text { Presença residual de } \\
\text { cerâmica manual }\end{array}$ & & & $\begin{array}{c}\text { Contas de colar } \\
\text { (pasta de vidro) } \\
\text { Ânforas - Dressel 1; Oberaden } \\
\text { 83; Lusitana (Augusto) }\end{array}$ \\
\hline
\end{tabular}

Tabela I - Quadro-síntese do espólio arqueológico do Castro de Ovil, por fases de ocupação. 


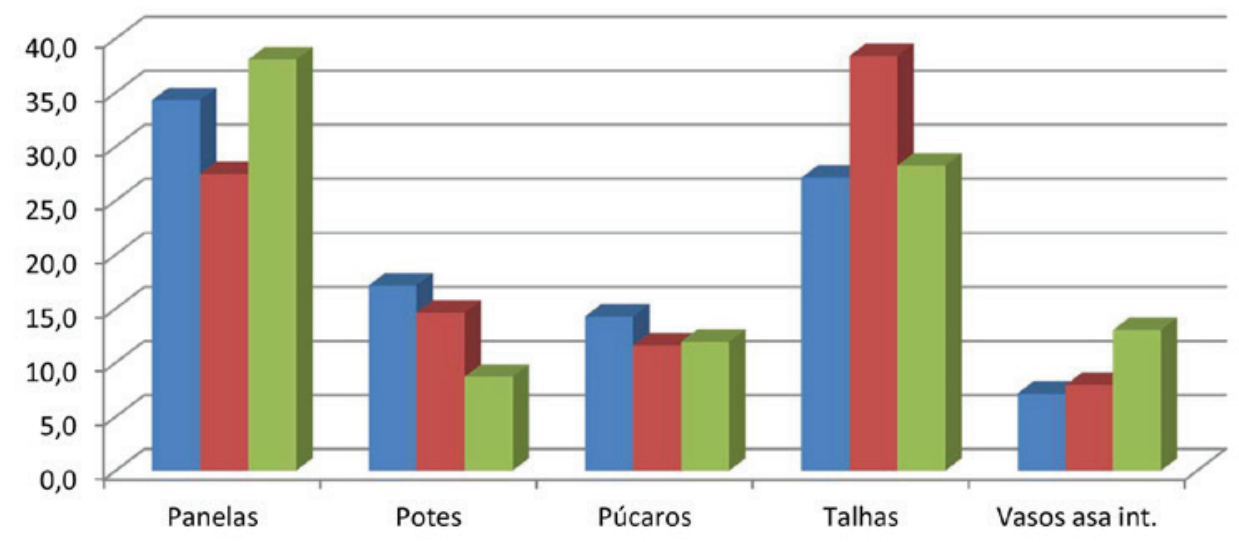

Fase IA

sécs. IV-III aC

- Fase IB

sécs. III-II aC

- Fase II

sécs. II-I aC

Gráfico I - Representação das principais formas por fases de ocupação (valores percentuais). 


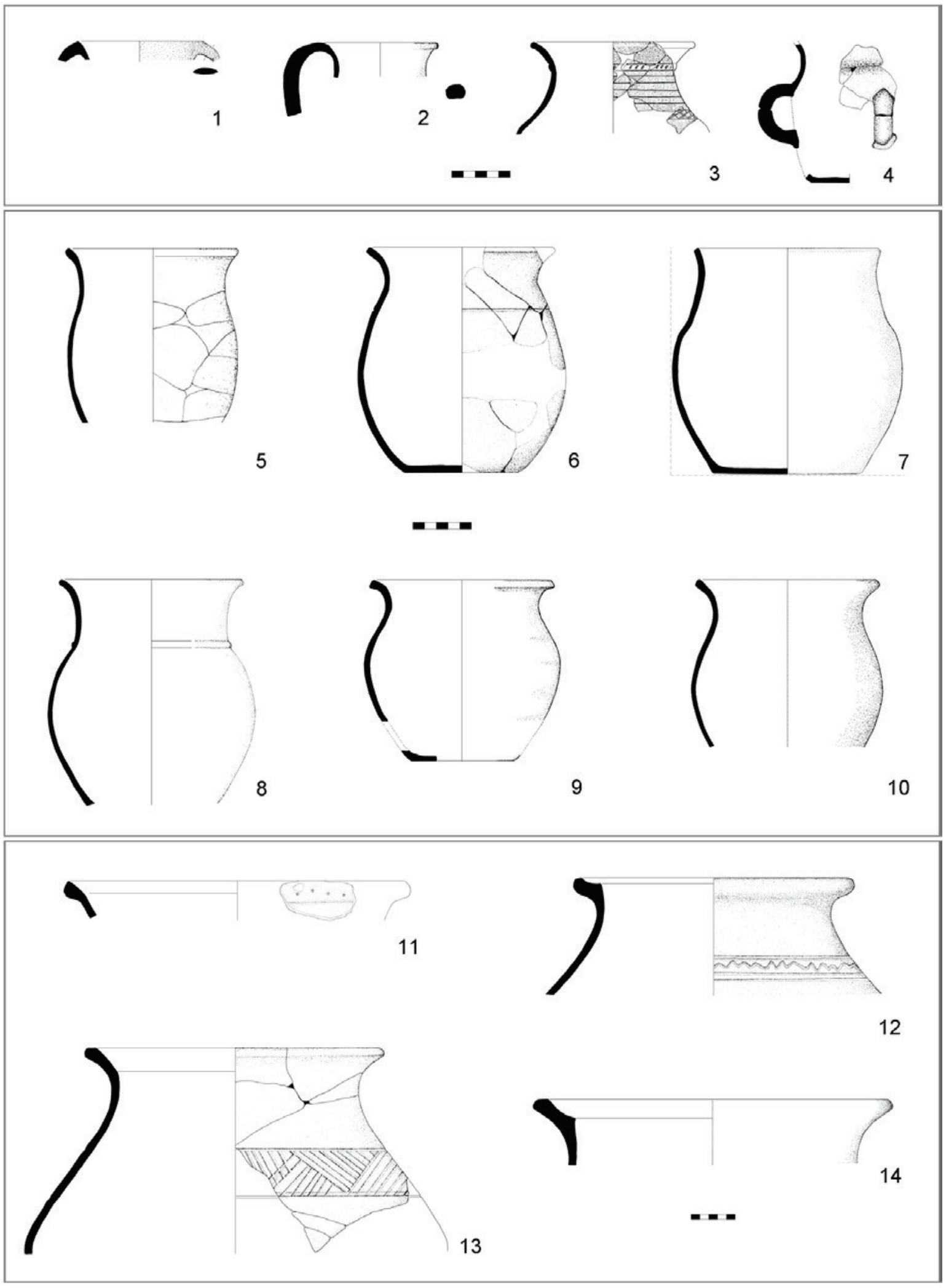

Figura 6 - Formas cerâmicas indígenas do Castro de Ovil, identificadas por grandes tipos, número de inventário e fases de ocupação. Púcaros: 1 - 2001 (IA); 2 -1523 (IB); 3-250 (II); 4-106 (II); Panelas: 5-2161 (IA); 6 - 422 (IA); 7-1562 (IB); 8 -420 (II); 9 - 257 (II); 10 - 2 (II); Talhas: 11 - 2169 (IA); $12-1564$ (IB); $13-374$ (IB); 14 - 57 (II). Desenho: Serviço de Arqueologia/C. M. Espinho. 


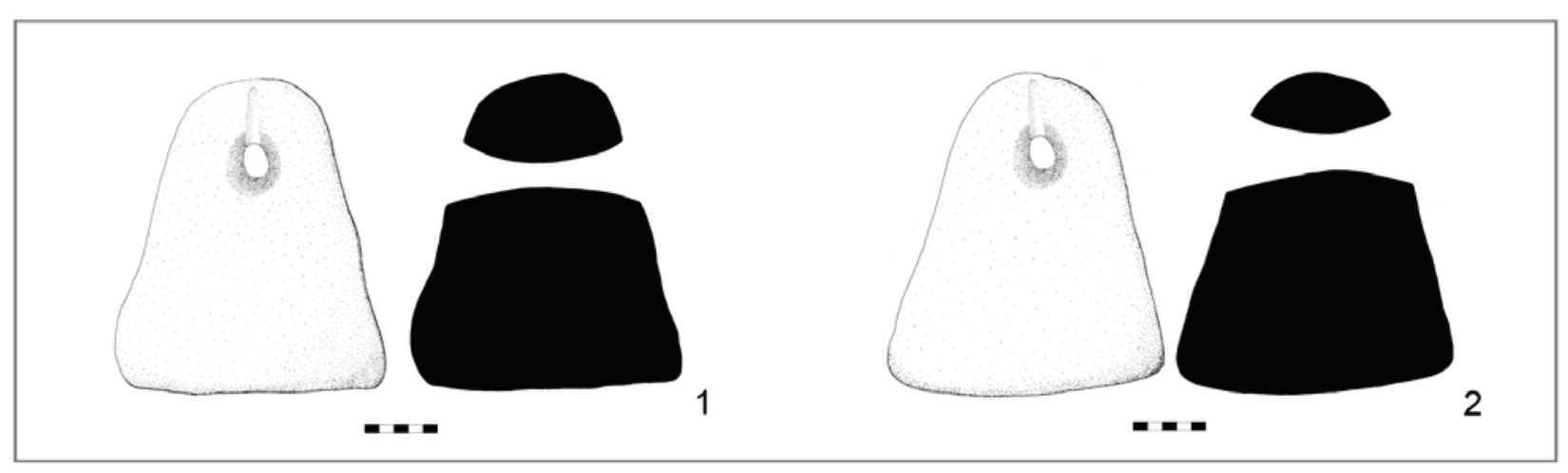

Figura 7 - Castro de Ovil. Pesos de cobertura em argila. 1 - 2058 (fase IB); 2 - 2056 (fase IB). Desenhos: Serviço de Arqueologia/ C. M. Espinho.

1110 


\title{
O CASTRO DE SALREU (ESTARREJA), UM POVOADO PROTO-HISTÓRICO NO LITORAL DO ENTRE DOURO E VOUGA
}

Sara Almeida E Silva ${ }^{1}$, António Manuel S. P. Silva ${ }^{2}$, Paulo A. P. Lemos ${ }^{3}$, Edite Martins de Sá ${ }^{4}$

\begin{abstract}
RESUMO
O Castro de Salreu, localizado no concelho de Estarreja (Aveiro, centro-norte de Portugal), é um dos povoados proto-históricos mais litorais do Entre Douro e Vouga, usufruindo de implantação privilegiada sobre um meandro do Antuã. O sítio tem vindo a ser alvo, nos últimos anos, de trabalhos arqueológicos que colocaram a descoberto estruturas em duas áreas principais, uma de cariz habitacional e, a outra, relacionada com a estrutura defensiva e delimitadora do espaço. As cinco campanhas realizadas permitiram a recolha de mais de 3500 fragmentos cerâmicos, alguns líticos, uma placa gravada, escassos metais e um conjunto de mais de duas dezenas de contas em pasta de vidro. Propõe-se que a sua ocupação tenha ocorrido entre os séculos IV/III a.C. e a mudança da Era.
\end{abstract}

Palavras-chave: Idade do Ferro, "Cultura castreja», Entre Douro e Vouga, Centro-Norte de Portugal.

\begin{abstract}
The Castro of Salreu, located in the municipality of Estarreja (Aveiro, center-north of Portugal), is one of the most coastal proto-historic settlements of the region between Douro and Vouga rivers, enjoying a privileged location on a meander of the river Antuã. The site has been the target, in recent years, of archaeological works that uncovered structures in two main areas, one of a housing nature and the other, corresponding to the defensive and delimiting structure of space. The five archaeological campaigns carried out allowed the collection of more than 35, ooo ceramic fragments, some lithic artifacts, an engraved plaque, few metal objects and a set of more than two dozen glass paste beads.

It is proposed that their occupation occurred between the $4^{\text {th }} / 3^{\text {rd }}$ centuries BC and the change of the Age. Keywords: Iron Age, Castros' Culture, Douro-Vouga region, Center-North of Portugal.
\end{abstract}

\section{INTRODUÇÃO}

Alvo de intervenção arqueológica pela primeira vez em 2011, o Castro de Salreu conta já com cinco campanhas de trabalhos, desenvolvidas no âmbito dos projetos deinvestigação PROBA (2011-2015) (SILVA, PEREIRA, LEMOS, 2012; SILVA $\&$ allii, 2016a) e PROBA ${ }^{+2}$ (2016-2018) (SILVA $\&$ alii, 2016b; SILVA $\&$ alii, 2017a; ALMEIDA E SILVA \& alii, 2018; SILVA $\&$ alii, no prelo), centrados no estudo da proto-história da bacia do rio Antuã, um afluente do
Vouga, e ARQ-EDOV (2019-2022) - Arqueologia da Idade do Ferro no Entre Douro e Vouga Atlântico (SILVA $\mathbb{Z}$ alii, 2019). Estes projetos de investigação são coordenados pelo Centro de Arqueologia de Arouca, sendo o financiamento assegurado pelas autarquias parceiras, neste caso pelo Município de Estarreja e Junta de Freguesia de Salreu.

O Castro de Salreu, um dos povoados proto-históricos litorais da região do Entre Douro e Vouga, constitui um exemplo da continuidade, nas regiões a sul do rio Douro, da tradicionalmente designada

\footnotetext{
1. saralmeidasilva@gmail.com; Centro de Arqueologia de Arouca

2. amspsilva@hotmail.com; Centro de Arqueologia de Arouca; Investigador do CITCEM

3.paplemos@gmail.com; Centro de Arqueologia de Arouca

4. editesa@gmail.com; Centro de Arqueologia de Arouca
} 
"cultura castreja" do noroeste ibérico. O presente texto sintetiza os resultados dos trabalhos efetuados e dá conta das principais problemáticas em investigação neste sítio arqueológico.

\section{LOCALIZAÇÃO, ENQUADRAMENTO E CARACTERIZAÇÃO GERAL DO POVOADO}

Localizado na freguesia de Salreu, concelho de Estarreja, distrito de Aveiro (Figura 1), o sítio apresenta uma implantação topográfica muito comum entre os povoados desta natureza, localizando-se sobre uma pequena colina, num meandro do rio Antuã, com escarpas declivosas por todos os sectores, exceto o voltando a nascente, através do qual se conecta ao pequeno lugar habitado que preserva ainda o topónimo Crasto. O castro apresenta uma altitude média de 54 metros, tendo como coordenadas do ponto central $40^{\circ} 45^{\prime} 42,50^{\prime \prime}$ N.; o 8 32 ' 57,64” O. (WGS84).

Hoje aparentemente mais distante do Atlântico, o Castro de Salreu estaria bem mais próximo do mar na Idade do Ferro, em virtude da evolução da linha costeira e das alterações significativas que a região sofreu relacionadas com a formação da laguna de Aveiro. Nessa época, o rio Antuã, com uma foz mais aberta queaatual, desaguaria diretamenteno Oceano e o povoado seria praticamente litoral, sendo certamente acessível a embarcações que ali chegassem por essa via (SILVA, PEREIRA, LEMOS, 2012: 49-50; SILVA \& alii, 2019: 27).

Do ponto de vista geológico, a estação implanta-se sobre xistos cloríticos, sericíticos e moscovíticos que se prolongam, no sentido NO.-SE., pela faixa litoral desde Espinho a Estarreja. Estas rochas sedimentares integram o tradicionalmente designado Complexo Xisto-Grauváquico ante-Ordovícico e séries metamórficas derivadas, demarcando-se no vale do Antuã pela presença frequente de lentículas de quartzo intercaladas, sendo, maioritariamente, coberto por depósitos de praia localizados na ordem dos 60 a $70 \mathrm{~m}$ de altitude, datáveis do Plio-Pleistocénico (TEIXEIRA, 1963: 10-1; REAL, 1987: 23).

O povoado ocupa uma área estimada de dois hectares e organiza-se, topograficamente, em três plataformas e respetivos taludes (Figura 2), encontrando-se a superior arrasada totalmente pelo plantio mecânico de eucaliptal. Nas restantes plataformas ocorreram também significativas movimentações de terra, na sequência de ações similares, o que prejudicou sobremaneira a preservação dos vestígios arqueológicos.

\section{A INVESTIGAÇÃO REALIZADA}

Ao longo do século XX, o "Castro de Salreu» foi mencionado quer por estudiosos locais, quer mesmo em inventários arqueológicos, com base, essencialmente, no microtopónimo sugestivo, sem que fosse apontada sequer a sua localização exata (SILVA, 1986: 105; SILVA, PEREIRA, LEMOS, 2012: 52-3). A sua correta identificação e primeira caracterização geral (SILVA, 1993; 1994: 53; 2002) abriram caminho ao estudo do povoado, que todavia só foi iniciado em 2011 (SILVA, PEREIRA, LEMOS, 2012). As primeiras sondagens, realizadas naquele ano, confirmaram a natureza e cronologia da estação arqueológica e evidenciaram a alteração profunda dos depósitos na plataforma superior, decorrente do plantio mecanizado. Já a intervenção efetuada no talude da plataforma intermédia propiciou a descoberta de ténues estruturas antigas,constituídas por restos de alinhamentos pétreos correspondentes a, pelo menos, duas fases distintas de construção e interpretados como muretes de delimitação e contenção da própria plataforma (SILVA, PEREIRA, LEMOS, 2012: 64-71).

Os trabalhos tiveram entretanto de ser interrompidos, por falta de financiamento, tendo sido retomados em 2016. Nessa segunda campanha privilegiou-se a escavação de uma área limítrofe à intervencionada em 2011, o designado sector A, o que viria a resultar na identificação de uma área habitacional, onde, com a continuidade dos trabalhos se pôs a descoberto o fundo de uma pequena cabana de planta ovalada.

Entre os anos de 2016 e 2018 foram feitas sondagens em outros pontos do povoado, nomeadamente na sua plataforma inferior, que forneceram bastante espólio arqueológico, não tendo revelado estruturas de realce (SILVA \& alii, 2016b; 2017a; 2019). Foi entretanto localizado um troço da estrutura de delimitação do povoado, que tem sido objeto de escavações desde 2017 (sector K) e à qual adiante se fará referência mais detalhada.

Um dos elementos que não pôde ainda contar com trabalhos específicos é o sistema de fossos, que complementavam a organização defensiva do povoado. De um, aberto em depressão natural resultante da presença de pequenas linhas de água tributárias do Antuã e muito assoreado, há vestígios na encosta a nordeste; na vertente sudeste, aparentemente delineado na continuidade do terceiro talude, vêem-se 
também traços de estrutura similar (SILVA, 1994: 53; 2002; SILVA, PEREIRA, LEMOS, 2012: 53).

\section{SECTOR A - UMA CABANA DA IDADE DO FERRO}

Localizado na segunda plataforma do povoado (Figura 2), este sector foi alvo de escavação em sucessivas campanhas, uma vez que os resultados obtidos iam ditando a necessidade de alargamentos da área escavada. Todavia, a zona de talude desta plataforma apresentava uma possança estratigráfica significativa, em consequência dos trabalhos de movimentações de terras ali ocorridos em épocas mais recentes. Se, por um lado, a grande profundidade dos vestígios, identificados a mais de dois metros de profundidade, poderá ter facilitado a sua preservação, por outro dificultou de forma notória o desenrolar dos trabalhos.

Neste sector foi identificada aquela que é, até à data, a única estrutura habitacional do povoado. Encontrava-se, pese embora a profundidade a que se achava, bastante mal preservada. Pôde determinar-se, porém, a planta de um espaço doméstico de contorno ovalado, que poderá medir, a admitirmos alguma regularidade, cerca de 4,30 $\mathrm{m}$ por 3,60 metros (Figuras 3 e 4). Esta cabana, se assim lhe podemos chamar, foi implantada no maciço rochoso natural, expressamente talhado para o efeito, tendo sido mesmo aberto um pequeno canal, provavelmente destinado ao escoamento de águas, junto ao limite sul da estrutura (SILVA \& alii, 2016b: 46-8; 2017a: 23-4; ALMEIDA E SILVA \& alii, 2018: 37-9).

A identificação dos negativos de assentamento das ombreiras da porta, orientada a poente, indicia que a dimensão média do muro da construção - de que resta apenas um pequeno tramo-rondaria os o,3om, o que configura um muro algo estreito, sendo talvez difícil que permitisse sustentar uma edificação exclusivamente em pedra, pelo que admitimos a possibilidade de um aparelho construtivo misto, fosse com materiais vegetais ou mesmo com algum tipo de adobe elementar, como recentemente se observou em ambientes desta cronologia no Castelo de Gaia (RAMOS, CARVALHO, 2020: 72-7) 5 .

No interior desta estrutura, presumivelmente habitacional, foi possível identificar dois níveis de piso,

5. O que talvez justifique a apreciável quantidade de «barro de construção» recolhido nas escavações de Salreu. sobrepostos, feitos com argila cozida pelo fogo. O mais recente exibia elementos ornamentais produzidos pela impressão de uma matriz circular, porventura com raios a ligar os círculos, elemento decorativo relativamente comum, tanto em pisos, como em bases de lareira de povoados castrejos do norte do país. Entre outros, podemos elencar os paralelos, muito semelhantes, encontrados no Castro de Ovil, no vizinho concelho de Espinho (SALVADOR, SILVA, 2010: 56); no Castro de Terroso, Póvoa de Varzim (GOMES, CARNEIRO, 1999: 47; 2005: 122) ou, recentemente, no Castelo de Gaia (RAMOS, CARVALHO, 202O: 74-5), sendo por isso admissível que pudesse igualmente ter correspondido à base de uma lareira, muito desmantelada, a evidência similar de Salreu. Na verdade, na mesma área localizou-se uma pequena zona de combustão, sob a qual existia um covacho escavado num depósito argiloso natural, de função indeterminada. No Castelo de Gaia, estas bases argilosas decoradas pertenciam indubitavelmente a lareiras, aliás de grandes dimensões (RAMOS, CARVALHO, 2020: 74-5), mas já em Terroso (GOMES, CARNEIRO, 2005: 122) e numa das duas ocorrências do Castro de Ovil (SALVADOR; SILVA, 2004: 25-7), estas estruturas não eram propriamente lares mas espaços adjacentes aos mesmos, parecendo ser atribuída a Terroso a cronologia mais antiga (GOMES, CARNEIRO, ibidem), em qualquer dos casos concordes com a ocupação de Salreu.

$\mathrm{Na}$ área exterior desta cabana foi também identificado um nível de circulação, caracterizado por um nível de argila compactada. Já no talude contíguo, a noroeste, numa sanja de escavação com dois metros de largura, descobriram-se na campanha de 2011, como dissemos, tramos de dois muretes sensivelmente paralelos, construídos em momentos distintos, eventualmente relacionados com uma estrutura de delimitação e, provavelmente, de suporte de terras da plataforma, nomeadamente da área habitacional que identificámos.

\section{SECTOR K - A ESTRUTURA DE DELIMITAÇÃO}

A intervenção neste sector (Figura 4) foi despoletada pela observação, no talude marginal de um caminho, de restos construtivos, em xisto, que viriam a revelar-se parte da estrutura de delimitação do segundo talude (SILVA \& alii, 2017a: 21; ALMEIDA 
E SILVA \& alii, 2018: 40-3; SILVA; PEREIRA 202O: 220, 222),

Esta estrutura tem uma espessura que ronda os quatro metros, e é composta por pedras e terra (Figuras 5 e 6), encontrando-se relativamente mal preservada, dada a natureza litológica dos seus constituintes, sobretudo pedras de xisto de médias e pequenas dimensões, sendo o seu ligante natural a terra argilosa local. Feito no rebordo da plataforma, este muro parece ter servido, quer como meio de nivelamento e contenção de terras, quer como elemento delimitador e defensivo do espaço habitado.

Os trabalhos mais recentes permitiram concluir que o muro principal que compõe a estrutura foi edificado em alvenaria seca de xisto, apresentando orientação NO.-SE., com face voltada a SO. É composto por calhaus de xisto de médio calibre, sem ligante, tendo sido identificado numa extensão de 5,30 m, com, aproximadamente, o,80 m de largura e o,70 m de altura máxima.

$\mathrm{Na}$ base deste alinhamento foram dispostos verticalmente, com ligeira pendente para o interior, blocos de xisto de médias e grandes dimensões, com a finalidade de suportar as pedras e terras dos diferentes aterros que integram a estrutura, conferindo-lhe assim maior reforço. A construção implicou a preparação do substrato rochoso natural, que foi rebaixado e ligeiramente nivelado a fim de facilitar a construção e lhe conferir maior estabilidade e eficácia.

A estrutura foi erguida com recurso à inclusão de um conjunto de sedimentos, bem compactados, resultando numa construção escalonada, diminuindo-se assim as dificuldades inerentes ao declive apresentado pelo terreno. Sobre a rocha natural foram colocados vários depósitos para nivelar o terreno e sustentar a construção. Estes depósitos integram sedimentos, por vezes compactados por ação térmica, e abundantes blocos e lascas de xisto, de pequenas e médias dimensões. Embora não seja ainda totalmente claro, o limite interno desta estrutura parece "diluir-se» na plataforma superior, assinalando-se apenas pela presença de alguns blocos de xisto de maiores dimensões.

A escavação foi alargada à zona situada imediatamente a Este deste muro de delimitação, visando documentar eventuais vestígios de ocupação doméstica junto ao seu limite interno, mas, não obstante o assinalável volume de espólio ali recolhido, apenas foi possível reconhecer algumas estruturas dispersas e de difícil interpretação, nomeadamente, uma estrutura de combustão, cuja instalação afetou ligeiramente o limite interno da cerca.

Esta área de combustão é constituída por um pequeno covacho, preenchido por sedimentos argilosos bastante compactos, que configuraram também a sua base, entre os quais se detetou um nível, pouco espesso, de cinzas e carvões. Nas imediações, foi recolhido um volume significativo (cerca de 120 fragmentos) de uma escória esverdeada, bastante leve, assim como de alguns materiais cerâmicos com o mesmo material incrustado, evidenciando a presença de uma zona oficinal e de transformação de matéria-prima ${ }^{6}$.

Na mesma plataforma, na área afetada pela abertura do caminho que permitiu a identificação da estrutura de delimitação, observou-se um pequeno tramo de piso em argila cozida, que se encontrava compreendido entre duas outras estruturas - o embasamento de um pequeno muro e uma estrutura composta por duas lajes de xisto fincadas. Como consequência das perturbações resultantes da abertura do caminho e da abundância de raízes de árvores, não foi possível esclarecer a natureza e relação destas construções, naturalmente mais recentes do que a edificação da muralha.

\section{ESPÓLIO ARQUEOLÓGICO}

São já mais de 34600 os fragmentos cerâmicos recolhidos no Castro de Salreu, sendo este género de espólio, naturalmente, o mais comum no povoado. À cerâmica, somam-se algumas centenas de objetos em pedra, escassos metais e mais de duas dezenas de contas em pasta de vidro. Entre as recolhas artefactuais, distinguem-se alguns materiais de cronologia moderna e contemporânea, relacionados com ocupações mais recentes do povoado, como uma moeda de três reais de D. João III, do século XVI (SILVA; PEREIRA; LEMOS 2012: 79).

No que respeita à cerâmica proto-histórica do Castro de Salreu (ALMEIDA E SILVA, SILVA no prelo; SILVA, PEREIRA, LEMOS, 2012: 76-9; SILVA \& alii, 2016b: 52-3; SILVA \& alii, 2017a: 23-4; 2017b: 29-30;

\footnotetext{
6. Apesar de termos avançado a possibilidade de se tratar de uma área relacionada com a fundição de metais (ALMEIDA E SILVA \& alii, 2018: 43), as análises químicas realizadas à escória não confirmaram esta hipótese, pelo que decorrem estudos complementares a fim de melhor se compreender a presença destes elementos.
} 
ALMEIDA E SILVA \& alii, 2018: 44-7), o seu estudo, ainda em desenvolvimento, é dificultado pelo elevado grau de fragmentação das vasilhas, que reduz consideravelmente as possibilidades de análise do repertório formal (Figura 7) e das composições decorativas das peças.

No entanto, reconhece-se, entre a olaria indígena deste povoado, a maioritária presença de potes ou panelas, seguindo-se recipientes de maiores dimensões destinados a armazenamento (Figura 7, 18-23). Foram ainda detetadas formas abertas, como os vasos de asa interior e uma ou duas assadeiras retangulares, e recipientes de menores dimensões, como púcaros ou pequenos copos, formas que por vezes se apresentam munidas de asa (Figura $7, \mathrm{n}^{\circ}{ }^{17}$ ).

Quanto aos motivos decorativos, é possível identificar uma grande diversidade, tendo sido feitos com recurso às técnicas de incisão e impressão, surgindo com menos frequência a decoração plástica. Entre os motivos impressos mais comuns destacam-se os círculos concêntricos, com alguma variabilidade em termos de tamanho e de composições. As decorações surgem sobretudo nos bojos dos recipientes, havendo raros casos de impressão (círculos concêntricos) e incisão (motivo em espinha) na superfície interna, junto ao bordo. Já a decoração plástica surge apenas ocasionalmente, através da aplicação de toros e altos ou baixo relevos, sendo por vezes complementada com outras técnicas ornamentais.

No que toca à matriz constituinte das pastas argilosas, observam-se, macroscopicamente, dois fabricos mais comuns, associados a pastas areno-micáceas e a pastas micáceas. Outras produções, de menor expressão, apresentam pastas mais arenosas (associadas a recipientes de maiores dimensões); reconhecendo-se ainda outras pastas, também arenosas mas de tonalidade acinzentada, e também um grupo de vasilhas feitas com argilas mais depuradas. Como forma de validar e aprofundar estas observações tecnológicas, têm vindo a ser realizadas análises da composição química das pastas por fluorescência de raios X e microscopia eletrónica de varrimento7. Os resultados estão ainda em estudo e requerem maior volume de amostras (nomeadamente associando matérias-primas locais aos produtos manufaturados), mas uma primeira hipótese de trabalho

7. Trabalhos feitos em parceria com a TecMinho (Universidade do Minho, Guimarães), sob a direção científica do Prof. Doutor Fernando Castro. parece apontar para uma significativa identidade elementar na composição de peças indígenas com um dos grupos, de pastas mais depuradas, que sugerimos poderem corresponder a importações, eventualmente de origem meridional (SILVA, PEREIRA, LEMOS, 2012: 76; SILVA \& alii, 2016a: 86; 2017b: 32). Como elemento residual, mas relevante enquanto indicador cronológico, deve assinalar-se a presença de um ou dois fragmentos cerâmicos de ânfora, muito rolados, identificando-se nomeadamente o tipo Dressel 1, de produção itálica, correspondendo por certo à fase de abandono do povoado, nas primeiras décadas do Império (SILVA \& alii, 2017b: 32 ). Os objetos metálicos não são muito frequentes, tendo sido recolhida escória e alguns utensílios em ferro, como uma lâmina de foice e dois objetos em bronze, de cronologia proto-histórica (Figura 8, n. ${ }^{\circ} \mathrm{s}$ 3 e 4). Destes últimos, um corresponde a um possível arco de fíbula, e o outro a um pequeno objeto, talvez de adorno, com orifício, decoração em pequenos losangos na superfície externa e dois pequenos ganchos na superfície interna (SILVA, PEREIRA, LEMOS, 2012: 79-80; SILVA \& alii, 2017a: 24; ALMEIDA E SILVA \& alii, 2018: 47).

Já as contas em pasta de vidro têm aparecido cada vez com mais frequência, cifrando-se num total de 21 exemplares (Figura 8, ํㅜ 1). Apresentam diâmetros, colorações e espessura variável, sendo dominantes as de tom azul. Duas delas, apresentam um pequeno orifício onde poderá ter sido incrustado um elemento doutra coloração, podendo talvez incluir-se no leque das contas oculadas (SILVA, PEREIRA, LEMOS, 2012:79-80; SILVA \& alii, 2017a: 24; ALMEIDA E SILVA \& alii, 2018: 47).

Por fim, os objetos em pedra correspondem sobretudo a pesos (de rede, tear e cobertura) e são maioritariamente em xisto, registando-se ocasionais elementos em granito, relacionados com a moagem. Um cossoiro, um machado polido e ainda um conjunto de xistos com pequenos entalhes ou perfurações, cuja finalidade ainda não foi possível esclarecer, completam o leque desta tipologia de recolhas. Foi também identificado um pequeno núcleo em sílex, sem que por ora se reconheçam outros utensílios na mesma matéria-prima (SILVA, PEREIRA, LEMOS 2012: 79; SILVA \& alii, 2016b: 54; SILVA \& alii, 2017a: 24).

Merece nota de destaque, todavia, a presença de uma placa de xisto gravada, com motivos abstratos (Figura 9). Esta laje, fragmentada e com espessura 
bastante reduzida, é proveniente de depósitos relacionados com o derrube da muralha, no sector $\mathrm{K}$. Tem as dimensões, aproximadas, de 30 por $17 \mathrm{~cm}$, apresentando-se gravada numa das faces, com alguns motivos bastante ténues e finos, aos quais acresce um signo ramiforme, aparentemente enquadrado por uma figura subtriangular (SILVA $\mathbb{\&}$ alii, 2019: 32). O paralelo mais evidente para este objeto "artístico" parece ser o vasto conjunto de placas gravadas do povoado da Idade do Ferro do Castelinho de Cilhades, Torre de Moncorvo (SANTOS \& alii, 2012; 2016; NEVES, FIGUEIREDO, 2015), constituindo assim, aparentemente, um dos primeiros exemplos de "arte móvel» da Idade do Ferro a sul do Douro.

\section{REFLEXÕES FINAIS}

O Castro de Salreu disfrutou de uma posição geográfica particular durante a proto-história sendo, a par do Castro de Ovil (Espinho), um dos povoados mais litorais do Entre Douro e Vouga. Essa posição terá facilitado contactos com o exterior, de que serão exemplo a aparente presença de algumas cerâmicas de importação mediterrânica, assim como as diversas contas de colar em pasta de vidro, evidenciando-se talvez dois momentos distintos de conexões culturais e comerciais, um primeiro relacionado com o comércio púnico, nos séculos IV-III a.C. (SILVA, PEREIRA, 2010; PEREIRA, 2011) e outro já no quadro das primeiras importações do mundo romanizado.

O povoado estava organizado em diferentes plataformas e taludes, estando identificada no registo arqueológico pelo menos uma estrutura linear de delimitação, no segundo talude, coincidindo com os sectores A e K, que foram alvo de maior investigação. Possivelmente, uma segunda estrutura marcaria o alinhamento do terceiro talude, que apresenta grande descontinuidade topográfica, hipótese esta que não foi possível corroborar ainda no registo arqueológico. Esta estrutura multifuncional, que, embora delimitando o espaço, talvez não o fizesse na totalidade da área habitada (tanto mais que estaria articulada com os fossos), serviria certamente como elemento de contenção das plataformas ocupadas e, também, como elemento defensivo e dissuasor do acesso ao povoado.

A fragilidade das construções em xisto, nas quais era utilizado apenas ligante natural - e porventura em adobe, como admitimos - dificulta bastante a preservação dos vestígios, circunstância que associada à forte afetação negativa da florestação mecânica das últimas décadas e às significativas movimentações de terras associadas, não tem facilitado a identificação de ambientes domésticos. Ainda assim, o testemunho de uma estrutura habitacional, de planta ovalada, com marcação clara de entrada, e um piso, ou lareira, em argila decorada, constitui um dado relevante, aliás com paralelos regionais, como se viu. Conjugando a observação do espólio recolhido com as três datações de radiocarbono já efetuadas (SILVA \& alii, 2016b: 44-5) (Quadro 1), cremos que a ocupação do povoado se estenderá, talvez, desde o século IV a.C. até à mudança da Era, ou pouco tempo depois. A datação de um depósito anterior à construção habitacional identificada no sector $\mathrm{A}$ forneceu o intervalo de $358-278 \mathrm{cal} \mathrm{BC}^{8}$, concedendo assim um terminus post quem para a construção na plataforma. Já a outra datação realizada nesse sector, a partir de vestígios orgânicos carbonizados recolhidos sobre o último nível de piso, forneceu uma datação - com maior probabilidade estatística - entre 196 e $39 \mathrm{cal}$ BC, balizando assim, por agora, a ocupação daquela área do povoado entre os séculos IV e I a.C., não sendo certo, todavia, que esta data corresponda ao último momento de utilização daquela cabana. No sector $\mathrm{K}$ foi também realizada uma datação, proveniente de um depósito posterior à construção da muralha, tendo uma semente de cevada proporcionado a data de 236-111 cal BC.

Deste modo, a investigação arqueológica que vem sendo desenvolvida neste povoado, enquadrada em diferentes projetos de investigação e abrangendo também outros povoados da região do Entre Douro e Vouga, tem trazido à luz do dia informações que consideramos bastante interessantes para a compreensão do habitat, da ergologia e do povoamento proto-histórico desta área geográfica, especialmente na sua franja mais atlântica, sublinhando o desenvolvimento endógeno das comunidades, num quadro de relações diferenciadas com o exterior.

8. Utilizámos os resultados com maior probabilidade a $2 \delta$ (Quadro I). 


\section{BIBLIOGRAFIA}

ALMEIDA E SILVA, Sara; SILVA, António Manuel S. P.; PEREIRA, Gabriel; LEMOS, Paulo (2018) - Trabalhos arqueológicos no Castro de Salreu. Breve crónica da intervenção de 2018. Terras de Antuã.12. Estarreja, p. 31-49.

ALMEIDA E SILVA, Sara; SILVA, António Manuel S. P. [no prelo] - Breves considerações sobre a cerâmica da Idade do Ferro do Castro de Salreu (Estarreja, Aveiro). Atas do Congresso Internacional de Cultura Castreja. Santa Maria da Feira.

GOMES, José Flores; CARNEIRO, Deolinda (1999) -Cividade de Terroso. Póvoa de Varzim: Câmara Municipal.

GOMES, José Flores; CARNEIRO, Deolinda (2005) - Subtus Montis Terroso. Património Arqueológico no Concelho da Póvoa de Varzim. Póvoa de Varzim: Câmara Municipal.

NEVES, Dário; FIGUEIREDO, Sofia S. (2015) - Quinhentas placas gravadas da Idade do Ferro do sítio fortificado do Castelinho (Nordeste Portugal): temas figurados e padrões de distribuição. In COLLADO GIRALDO, H.; GARCÍA ARRANZ, J. (eds.) - Symbols in the Landscape: Rock Art and its Context. Proceedings of the XIX International Rock Conference IFRAO 2015. Tomar: ITM - Instituto Terra e Memória, p. 1589-1605.

PEREIRA, Gabriel R. (2011) - Dinâmicas culturais e influências meridionais no NW Peninsular: intercâmbio púnico entre os séculos VI e III a.C. Dissertação de mestrado em Arqueologia apresentada à Faculdade de Letras da Universidade do Porto.

RAMOS, Rui; CARVALHO, José (2020) - O sítio do Rei Ramiro: contributo para o conhecimento das ocupações antigas no Monte do Castelo (Vila Nova de Gaia). Apontamentos de Arqueologia e Património, 14. Em linha: http:// www.nia-era.org/publicacoes

REAL, F. Sousa (1987) - Portugal. Atlas do Ambiente. Carta Geológica (Notícia Explicativa I.12). Lisboa: Secretaria do Estado do Ambiente e Recursos Naturais.

SALVADOR, Jorge F.; SILVA, António Manuel S. P. (2004) - O Castro de Ovil e o povoamento da região de Espinho da proto-história à romanização (OVESP). Relatório Final de Trabalhos Arqueológicos. Espinho: Câmara Municipal, policopiado.

SALVADOR, Jorge F.; SILVA, António Manuel S. P. (2010) O Castro de Ovil (Espinho), um povoado da Idade do Ferro. In PINTO, F. (coord.) - Arqueologia da Terra de Santa Maria: balanços e perspectivas. Santa Maria da Feira: Liga dos Amigos da Feira, 2010, p. 53-73.

SANTOS, Filipe; SASTRE, José; FIGUEIREDO, Sofia S.; ROCHA, Fábio; PINHEIRO, Eulália; DIAS, Rodrigo (2012)- El sitio fortificado del Castelinho (Felgar, Torre de Moncorvo, Portugal). Estudio preliminar de su diacronía y las plaquetas de piedra con grabados de la Edad del Hierro. Complutum, 23 (1). Madrid, p. 165-179. http://dx.doi. org/10.5209/rev_Cmpl.2012.v23.n1.39536.
SANTOS, Filipe; PINHEIRO, Eulália; ROCHA, Fábio; SASTRE, José (2016) - O sítio e a laje 1 do Castelinho (Cilhades, Felgar, Torre de Moncorvo). Contributos para o conhecimento da II Idade do Ferro em Trás-os-Montes oriental. Estudos Pré-históricos, 18. Viseu, p. 203-217.

SILVA, António Manuel S. P. (1993) - Ocupação proto-histórica e romana no Entre-Douro-e-Vouga Litoral: Breve balanço de uma investigação em curso. Trabalhos de Antropologia e Etnologia. 33 (3-4). Porto, p. 427-443.

SILVA, António Manuel S. P. (1994) - Proto-história e Romanização no Entre Douro e Vouga Litoral. Elementos para uma avaliação crítica. Dissertação de Mestrado apresentada à Faculdade de Letras da Universidade do Porto.

SILVA, António Manuel S. P. (2002) - O Castro de Salreu um povoado indígena da Idade do Ferro. Nota arqueológica à margem de uma polémica. O Jornal de Estarreja. 4150 (22-02-2002). Estarreja, p. 3-4.

SILVA, António Manuel S. P.; PEREIRA, Gabriel R. (2010) - Povoamento proto-histórico na fachada atlântica do Entre Douro e Vouga. Paleoambientes e dinâmica cultural. In BETTENCOURT, A. M.; ALVES, M.; MONTEIRO-RODRIGUES, S. (eds.) - Variações paleoambientais e evolução antrópica no Quaternário do Ocidente Peninsular. S.l.: APEQ/CITCEM, p. 189-203.

SILVA, António Manuel S. P.; PEREIRA, Gabriel R. (2020) - Walls and Castros. Delimitation structures in the Proto-historic settlements of Entre Douro and Vouga region (Center-North of Portugal). In DELFINO, D.; COIMBRA, F. CARDOSO, D.; CRUZ, G. - Late Prehistoric Fortifications in Europe: Defensive, symbolic and territorial aspects from the Chalcolithic to the Iron Age. Proc. of the International Colloquium 'FortMetalAges', Guimarães, Portugal. Oxford: Archaeopress, p. 215-228.

SILVA, António Manuel S. P.; PEREIRA, Gabriel R.; LEMOS, Paulo A. (2012) - O castro de Salreu (Estarreja): resultados da primeira campanha de escavações arqueológicas. Terras de Antuã. 6. Estarreja, p. 47-89.

SILVA, António Manuel S. P.; PEREIRA, Gabriel R.; TAVARES, João T.; LEMOS, Paulo A.; ALMEIDA E SILVA, Sara (2016a) - Proto-história da Bacia do Antuã (2011-2015) - um projeto de investigação arqueológica em rede. Patrimónios de OAZ. o. Oliveira de Azeméis, p.77-96.

SILVA, António Manuel S. P.; PEREIRA, Gabriel; LEMOS, Paulo; ALMEIDA E SILVA, Sara (2016b) - Trabalhos arqueológicos no Crasto de Salreu, Estarreja. Breve notícia. Terras de Antuã.10. Estarreja, p. 39-57.

SILVA, António Manuel S. P.; PEREIRA, Gabriel; ALMEIDA E SILVA, Sara; LEMOS, Paulo (2017a) - Uma Aldeia de há dois mil anos. Um sítio arqueológico e a sua investigação. Terras de Antuã. 11. Estarreja, p. 15-29.

SILVA, António Manuel S. P.; PEREIRA, Gabriel; LEMOS, Paulo; ALMEIDA E SILVA, Sara (2017b) - Uma Aldeia de há 
dois mil anos. Arqueologia no Castro de Salreu. Estarreja: Câmara Municipal.

SILVA, António Manuel S. P.; PEREIRA, Gabriel; LEMOS, Paulo; ALMEIDA E SILVA, Sara [no prelo] - O Castro de Salreu (Estarreja): um povoado da Idade do Ferro nos limites meridionais da "cultura castreja". Atas do I Ciclo de Conferências do Monte Padrão. Santo Tirso.

SILVA, António Manuel S. P.; SÁ, Edite Martins de; SALVADOR; Jorge Fernando; LEMOS, Paulo André P.; ALMEIDA E SILVA, Sara (2019) - O Castro de Salreu, um dos povoados proto-históricos atlânticos do Entre Douro e Vouga. Terras de Antuã. 13. Estarreja, p. 24-44.
SILVA, Armando C. F. (1986) - A Cultura Castreja no Noroeste de Portugal. Paços de Ferreira: Câmara Municipal; Museu Arqueológico da Citânia de Sanfins.

TEIXEIRA, Carlos (1963) - Carta Geológica de Portugal na escalade1/50.ooo.Notícia Explicativada Folha13-C(OVAR). Lisboa: Direcção-Geral de Minas e Serviços Geológicos de Portugal.

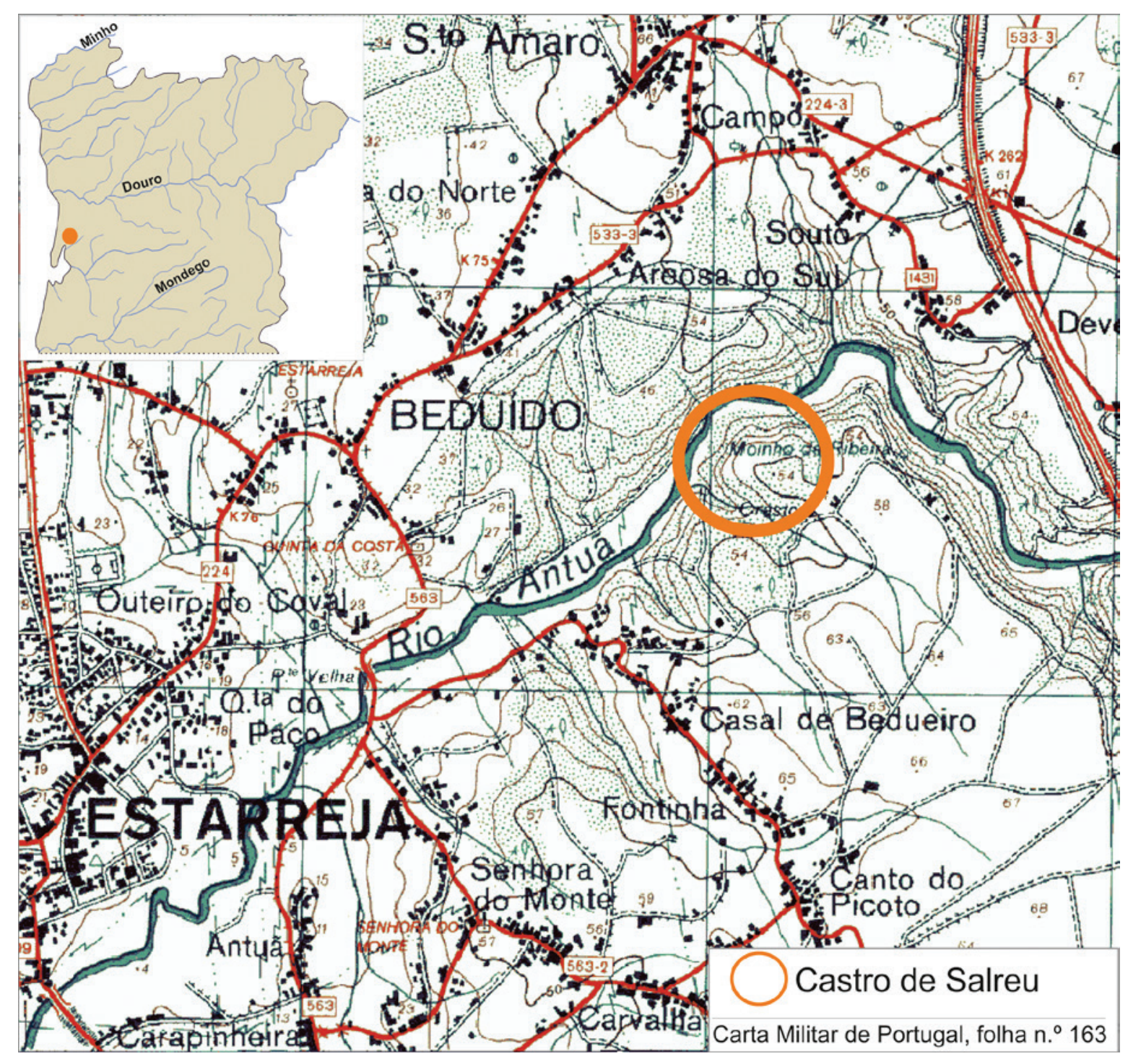

Figura 1 - Localização do Castro de Salreu. 


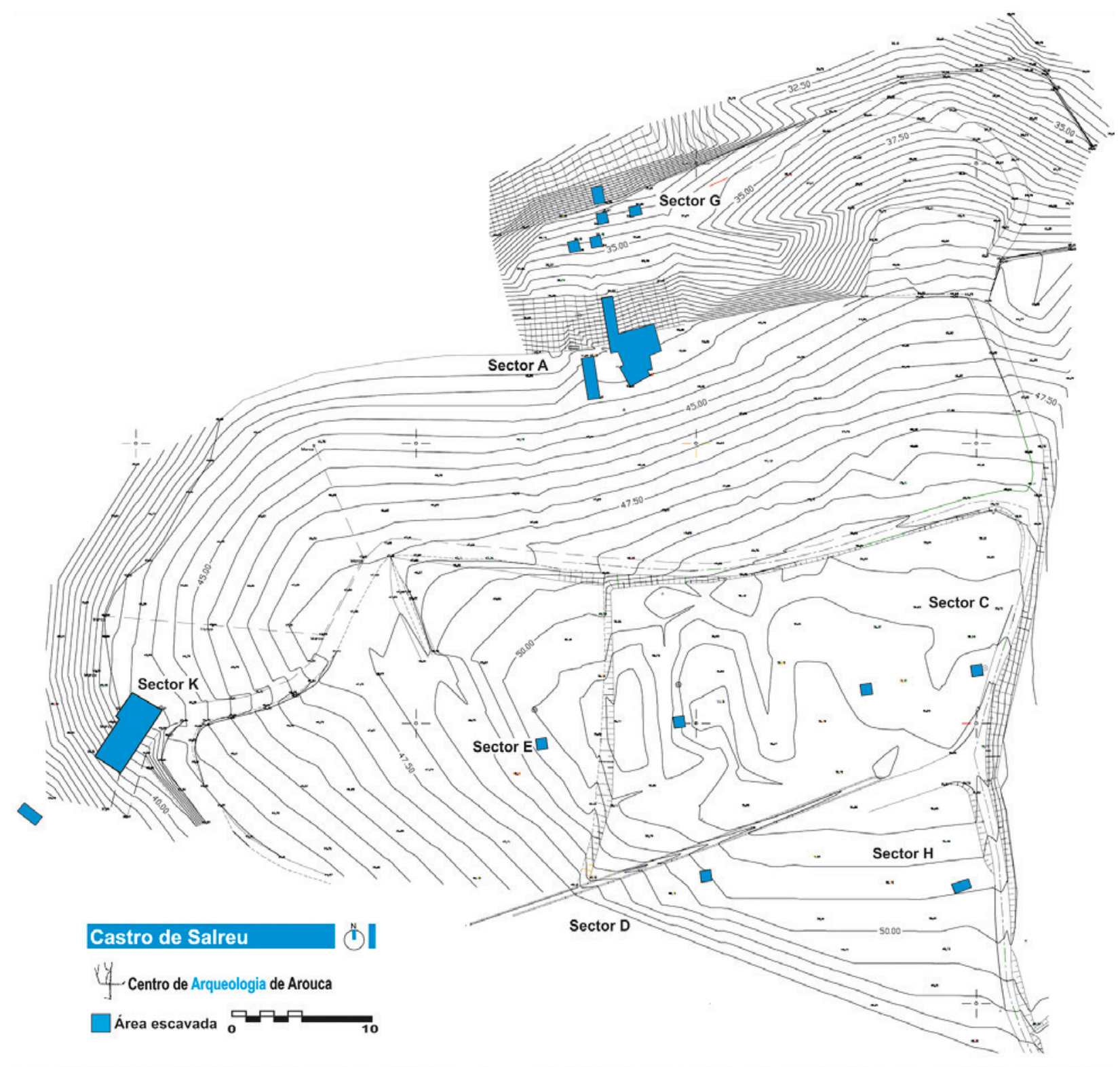

Figura 2 - Levantamento topográfico do Castro de Salreu, com implantação das áreas intervencionadas (C.M. Estarreja/Multimapa). 


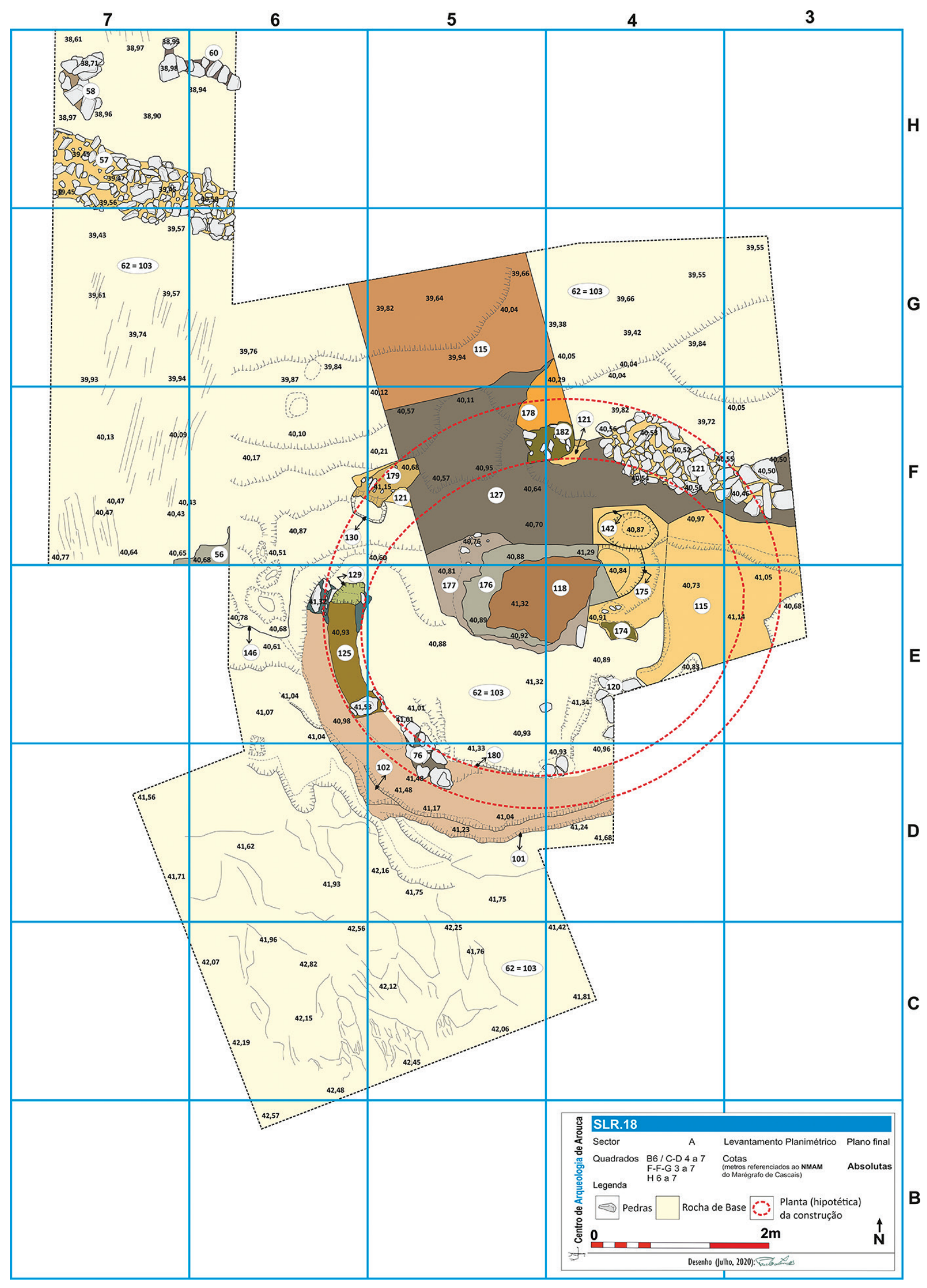

Figura 3 - Plano Final do Sector A, observando-se a base da estrutura doméstica. 


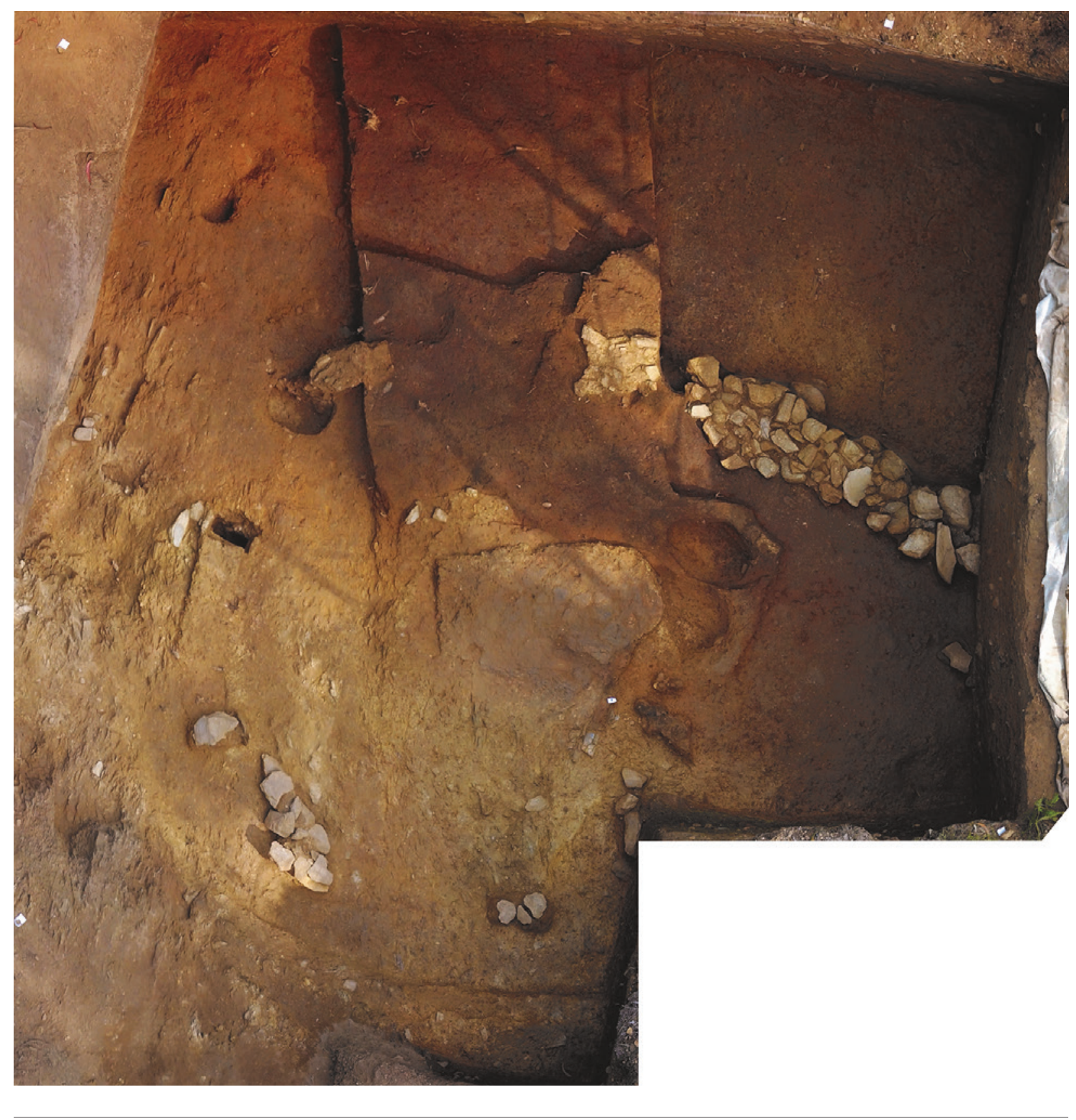

Figura 4 - Fotografia aérea do sector A (2018). Foto: Multimapa. 


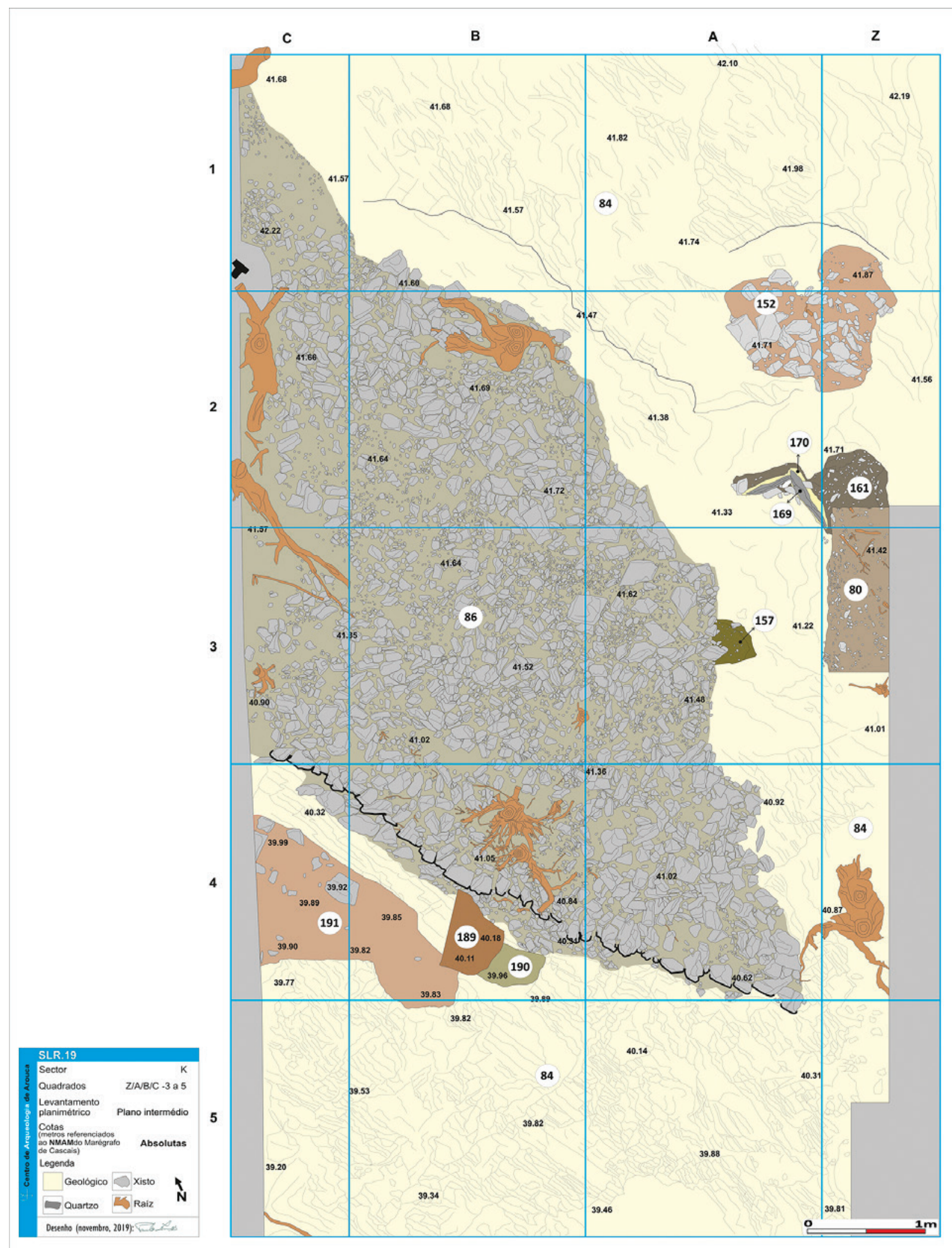

Figura 5 - Plano Final (2019) do Sector K, com o troço da estrutura de delimitação do povoado. 


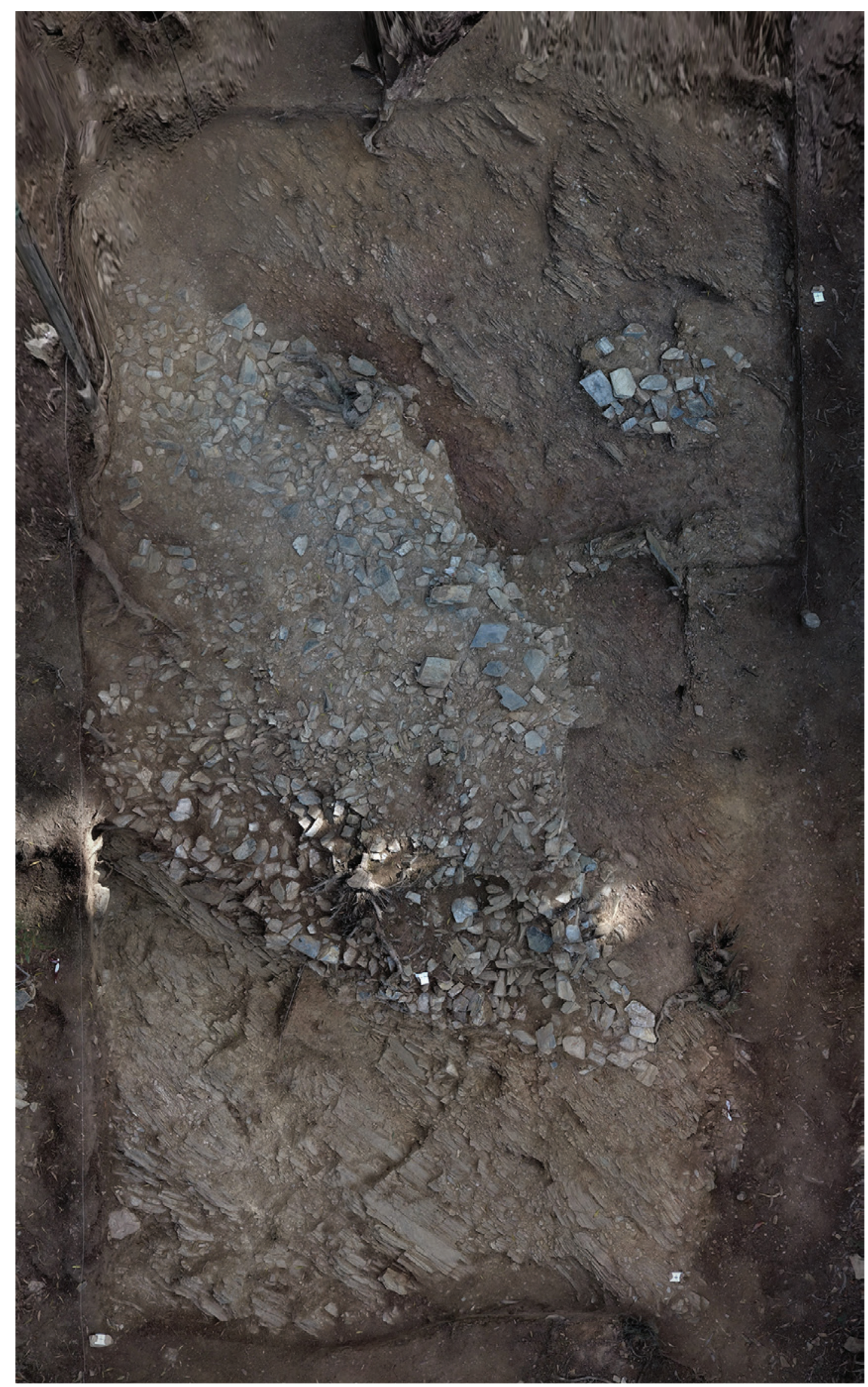

Figura 6 - Vista aérea do Sector K (2019). Foto: Multimapa. 


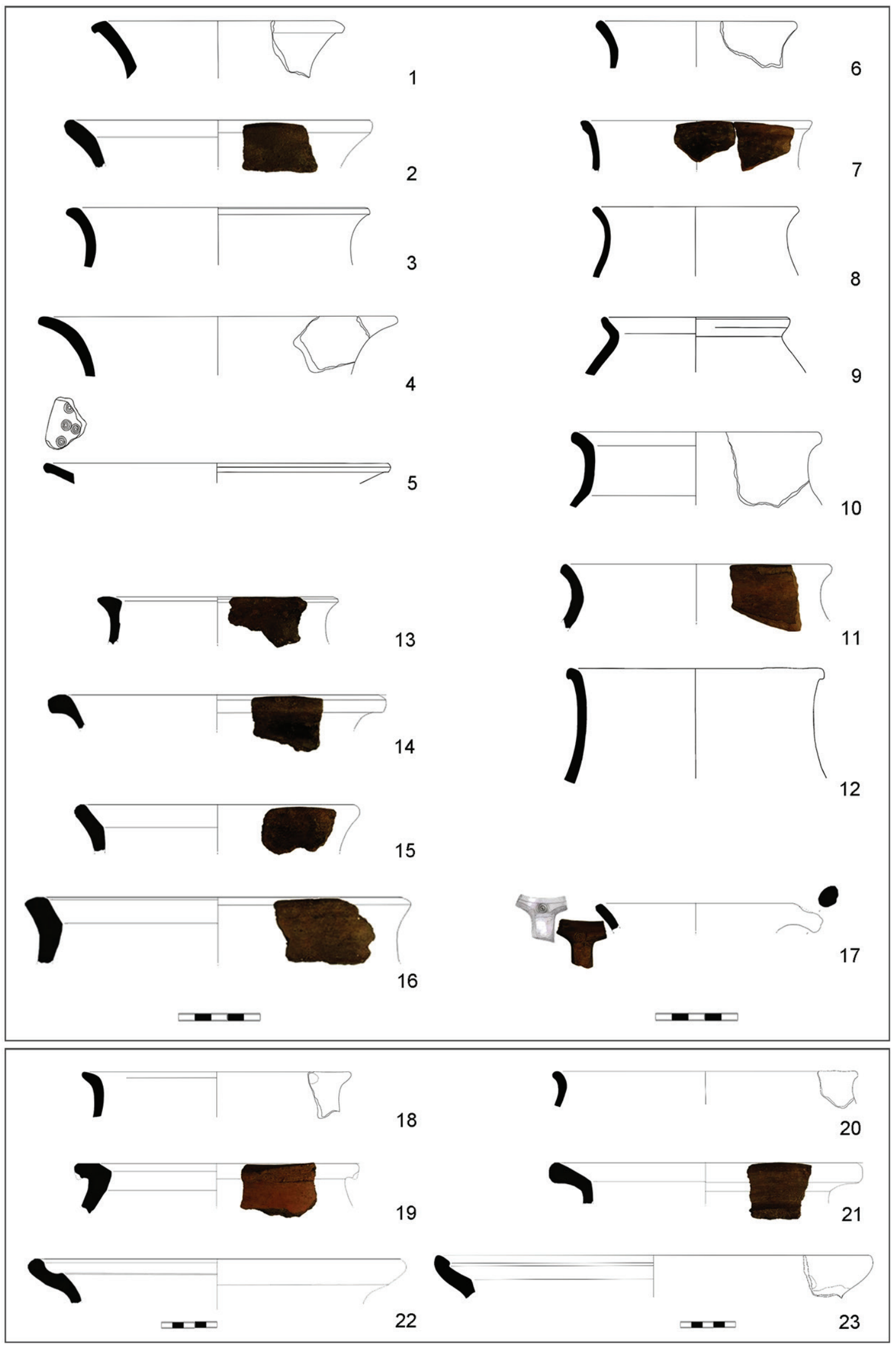

Figura 7 - Principais formas identificadas na cerâmica proto-histórica de Salreu. 


\section{O
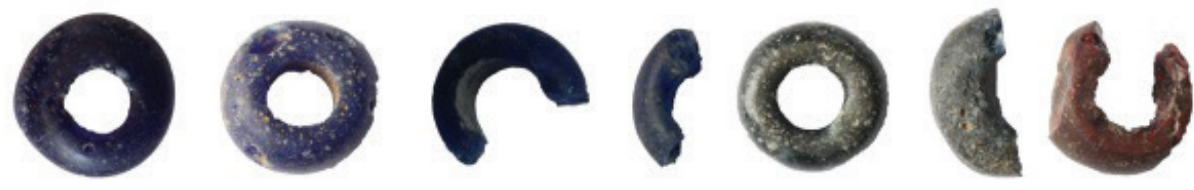 .

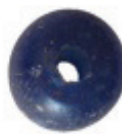 \\ ○ 0 \\ 000000

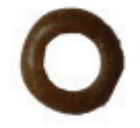

1
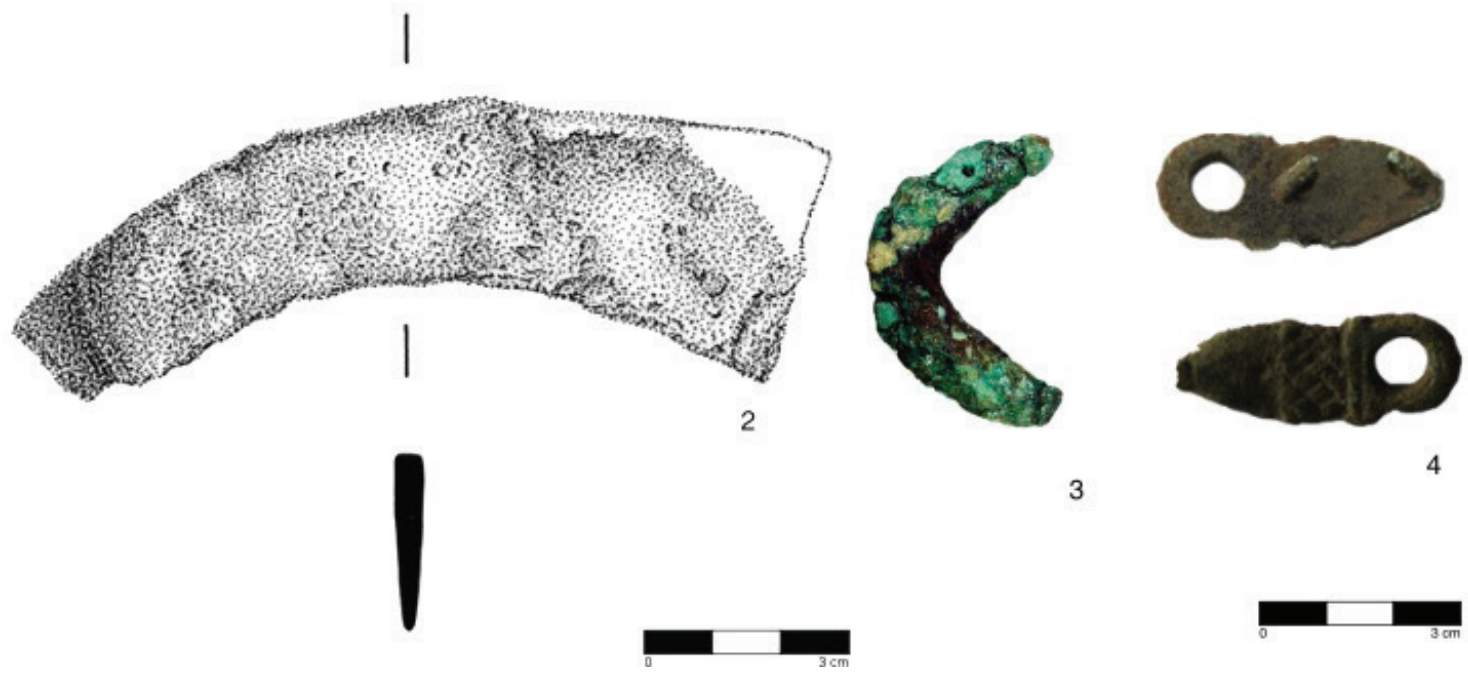

4

Figura 8 - Material não cerâmico do Castro de Salreu: Contas de colar em pasta de vidro e objetos metálicos (Desenho 2: Amélia Mendes/MDDS; Foto 3: Manuel Santos/MDDS).

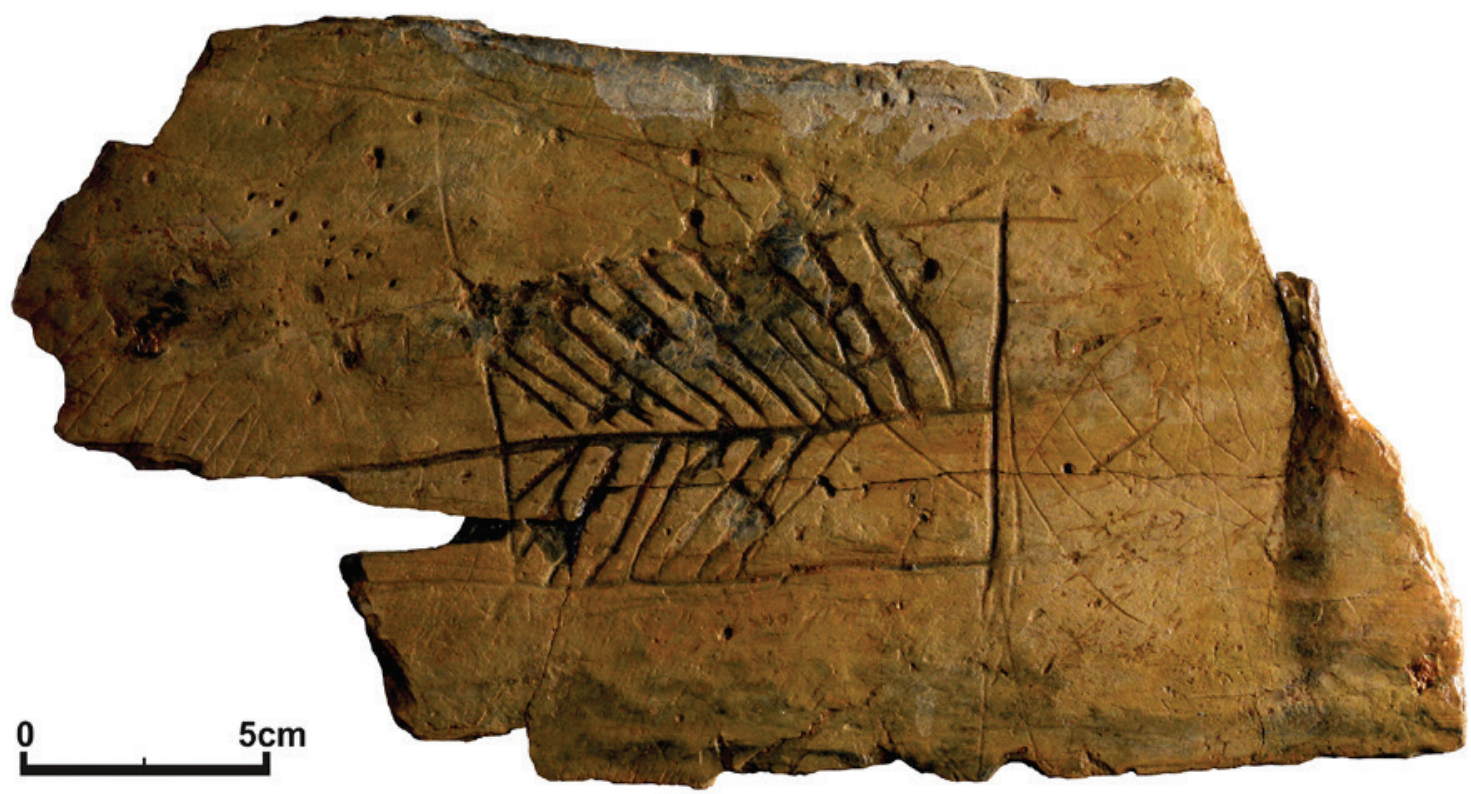

Figura 9 - Placa de xisto gravada. Fotografia: Manuel Santos/MDDS. 


\begin{tabular}{|c|c|c|c|c|c|c|c|c|c|c|c|c|c|}
\hline \multirow{3}{*}{ № Lab } & \multirow{3}{*}{ Contexto } & \multirow{3}{*}{ Material } & \multirow{3}{*}{\begin{tabular}{l|}
$o(13 \mathrm{C})$ \\
per mil
\end{tabular}} & \multicolumn{2}{|c|}{$\begin{array}{l}\text { Fraction of } \\
\text { modern }\end{array}$} & \multirow{3}{*}{ BP } & \multirow{3}{*}{1 sigma } & \multicolumn{2}{|c|}{ OXCAL $4.2[1]$} & \multicolumn{3}{|c|}{ Calib Rev 7.0.4 [2] } & \multirow{3}{*}{\begin{tabular}{|c}
$\begin{array}{c}\text { CalPal_2007_ } \\
\text { HULU [3] }\end{array}$ \\
$\begin{array}{c}\text { Calendric Age } \\
\text { Cal BP }\end{array}$ \\
$68 \%$
\end{tabular}} \\
\hline & & & & \multirow{2}{*}{ PMC } & \multirow{2}{*}{\begin{tabular}{|c|}
10 \\
error
\end{tabular}} & & & $1 \sigma$ & $2 \sigma$ & $1 \sigma$ & $2 \sigma$ & \multirow{2}{*}{$\begin{array}{l}\text { Probab. } \\
\text { Mediana }\end{array}$} & \\
\hline & & & & & & & & $68.2 \%$ probability & $95.4 \%$ probability & 68.3\% probability & $95.4 \%$ probabbility & & \\
\hline \multirow{3}{*}{$\begin{array}{l}\text { D-AMS } \\
8678\end{array}$} & \multirow{3}{*}{$\begin{array}{l}\text { Sect A- Sd } \\
1 \text { - UE 051 }\end{array}$} & \multirow{3}{*}{$\begin{array}{l}\text { Sementes } \\
\text { fovaceoee }\end{array}$} & \multirow{3}{*}{-25.1} & \multirow{3}{*}{76.22} & \multirow{3}{*}{0.22} & \multirow{3}{*}{2181} & \multirow{3}{*}{23} & $352 B C(50.7 \%) 2968 C$ & $358 \mathrm{BC}(57.5 \%) 278 \mathrm{BC}$ & $352 \mathrm{BC}(73.0 \%) 295 \mathrm{BC}$ & $358 B C(60.2 \%) 278 B C$ & \multirow{3}{*}{.300} & \multirow{3}{*}{$275 \pm 66$} \\
\hline & & & & & & & & $228 \mathrm{BC}(05.7 \%) 220 \mathrm{BC}$ & $259 \mathrm{BC}(37.99) 174 \mathrm{BC}$ & $229 B \mathrm{BC}(08.9 \%) 220 B C$ & 250051208001708 & & \\
\hline & & & & & & & & $2128 \mathrm{C}(11.8 \%) 198 \mathrm{BC}$ & & $2128 \mathrm{C}(18.1 \%) 1978 \mathrm{C}$ & & & \\
\hline \multirow{2}{*}{$\begin{array}{l}\text { D-AMS } \\
033461\end{array}$} & \multirow{2}{*}{$\begin{array}{l}\text { Sect. A } \\
\text { UE E118 } \\
\text { (piso) }\end{array}$} & \multirow{2}{*}{$\begin{array}{l}\text { Carvăo Erica } \\
\text { scoporia } \\
\text { /umbelloto }\end{array}$} & \multirow{2}{*}{ n.i. } & \multirow{2}{*}{77.13} & \multirow{2}{*}{0.30} & \multirow{2}{*}{2086} & \multirow{2}{*}{31} & $118 B C(95.4 \%) 408 C$ & \multirow{2}{*}{$196(95.4 \%) 40 B C$} & $118 B C(69.6 \%) 548 C$ & $196 \mathrm{BC}(99.9 \%) 39 \mathrm{BC}$ & \multirow{2}{*}{-109} & \multirow{2}{*}{$113 \pm 45$} \\
\hline & & & & & & & & $160 \mathrm{CC}(20.9 \%) 1318 \mathrm{C}$ & & $160 \mathrm{BC}(30.4 \%) 131 \mathrm{BC}$ & $78 C(0.1 \%) 5 B C$ & & \\
\hline \multirow{3}{*}{$\begin{array}{l}\text { D-AMS } \\
033463\end{array}$} & \multirow{3}{*}{$\begin{array}{l}\text { Sect. K } \\
\text { UE } 116\end{array}$} & \multirow{3}{*}{$\begin{array}{l}\text { Sementes } \\
\text { Hordeum } \\
\text { vulgare }\end{array}$} & & & & & & $350 \mathrm{BCC}(34.7 \%)$ 3038С & $236 \mathrm{BC}(51,5 \%) 111 \mathrm{BC}$ & $350 \mathrm{BC}(50.1 \%) 305 \mathrm{BC}$ & $235 \mathrm{BC}(48.5 \%)$ 1478C & & \\
\hline & & & n.i. & 76.41 & 0.26 & 2161 & 27 & & $358 \mathrm{BC}(42.2 \%) 281 \mathrm{BC}$ & & $3578 \mathrm{C}(44.3 \%) 282 \mathrm{BC}$ & .224 & $259 \pm 77$ \\
\hline & & & & & & & & $210 \mathrm{BC}$ (33.5\%) 1698C & $258 B C(01.6 \%) 2448 C$ & $209 \mathrm{BC}(49.9 \%)$ 170BC & $\frac{144 \mathrm{BC}(05.8 \%) 111 \mathrm{BC}}{257(01.4 \%) 245 \mathrm{BC}}$ & & \\
\hline
\end{tabular}

[1] OxCal v4.2.4 Bronk Ramsey (2013); r.5; IntCal13 atmospheric curve (Reimer et al 2013); OxCal v4.2.4 Bronk Ramsey (2013); r.5

[2] RADIOCARBON CALIBRATION PROGRAM". CALIB REV7.1.0. Copyright 1986-2018 M Stuiver and PJ Reimer, "To be used in conjunction with: Stuiver, M., and Reimer, PJ., 1993, Radiocarbon, 35, 215-230. Reimer PJ, Bard E, Bayliss A, Beck IW, Blackwell PG, Bronk Ramsey C, Buck CE, Cheng H, Edwards RL, Friedrich M, Grootes PM, Guilderson TP, Haflidason H, Hajdas I, Hatté C, Heaton TI, Hogg AG, Hughen Ka, Kaiser KF, Kromer B, Manning SW, Niu M, Reimer RW, Richards DA, Scott [3] quickcal2007 ver.1.5. Monrepos. Archäologisches forschungszentrum und Museum für menschliche Verhaltensevolution. http://www.calpal-online.de

n.i. - năo indicado

Quadro I - Datações radiocarbónicas do Castro de Salreu. 


\title{
CASTRO DE NOSSA SENHORA DAS NECESSIDADES (SERNANCELHE): UMA PRIMEIRA ANÁLISE ARTEFACTUAL
}

Telma Susana O. Ribeiro ${ }^{1}$

\begin{abstract}
RESUMO
O Castro de Nossa Senhora das Necessidades é, até à data, o único sítio arqueológico do concelho de Sernancelhe (distrito de Viseu) a ser discutido na bibliografia arqueológica. Referido como um castro do Bronze Final, o sítio tem vindo a ser destruído e conta apenas com recolhas superficiais que nunca foram estudadas de forma a dar a conhecer todas as suas ocupações. Assim, esta primeira análise, feita através de materiais cerâmicos, líticos e metálicos que resultam de prospecções ao cabeço, vem revelar outras cronologias para este sítio, procurando assim contribuir para a sua valorização e a compreensão da cultura material e povoamento da Beira Alta em alguns dos seus períodos pré-históricos e medievais.
\end{abstract}

Palavras-chave: Beira Alta, Pré-História Recente, Idade do Ferro, Medieval, Análise artefactual.

\begin{abstract}
The Nossa Senhora das Necessidades settlement is to date the only archaeological site in the county of Sernancelhe (Viseu district) to be discussed in the archaeological literature. Referred to as a settlement from the Late Bronze Age, the site has been continually destroyed and has only superficial findings that have never been studied so that we know all of its occupations. This first study, made through ceramic, lithic and metallic artefacts that result from prospections at the hill, aims to reveal the other chronologies of this site, seeking to contribute to the comprehension of the material culture and settlement network of the Beira Alta region in some of its prehistoric and medieval times.
\end{abstract}

Keywords: Beira Alta, Late Prehistory, Iron Age, Medieval, Artifactual study.

\section{O SÍTIO: LOCALIZAÇÃO E ENQUADRAMENTO}

O Castro de Nossa Senhora das Necessidades (CSN) localiza-se no topo de uma elevação conhecida como "Alto da Borralheira", na freguesia de Vila da Ponte, concelho de Sernancelhe, distrito de Viseu, com as coordenadas $40^{\circ} 54^{\prime} 46.4$ " $\mathrm{N}$ de Latitude e $7^{\circ} 31^{\prime} 25.9$ " W de Longitude na folha 159 da Carta Militar a 1/25000 (Figura 1).

A elevação, com altitude de cerca de $754 \mathrm{~m}$, está encaixada entre os vales da ribeira de Arados a Oeste e do rio Távora a Norte e Este, onde a paisagem foi alterada pela construção de uma barragem na década de 1960, formando agora uma albufeira (Figura 2). O sítio tem um grande domínio visual das serras da Lapa, Leomil e Estrela, dos seus vales e dos cas- telos de Sernancelhe e Caria. A região é constituída maioritariamente por granitos porfiróides de idade hercínia onde abundam os filões de quartzo branco. Estes solos ácidos são mais férteis nas margens do rio Távora que proporcionam a plantação de hortícolas, pomares, vinhas e soutos numa paisagem maioritariamente marcada por pinheiros, carvalhos, freixos, vimeiros e espécies arbustivas como as giestas e urzes. Ocupações antigas do sítio eram já apontadas pela lenda local da existência de habitações "mouriscas" que serviriam de vigia e comunicação aos castelos e cujas estruturas teriam sido reaproveitadas para a construção da primeira capela. O historiador Pinho Leal (1873, pp. 16o-161) refere o sítio como uma atalaia "construída pelos antigos lusitanos" e Vasco Moreira (1929, p. 253) acredita que a povoação de Vila da Ponte terá tido origem neste sítio. Por volta de 1400

1. UNIARQ; telmaribeiro@campus.ul.pt 
foi construída no topo deste monte uma pequena capela a St ${ }^{\mathrm{a}}$ Bárbara que foi em meados do séc. XVI ampliada para dedicação a Nossa Senhora das Necessidades, tendo-se construído ao longo do tempo todo um complexo religioso à sua volta que inclui outras capelas, a "casa do ermitão", altares exteriores, uma cerca, serviços de água canalizada, jardins, uma antena de comunicações e vários caminhos de acesso. Estas construções, suas consequentes obras de reparação e ainda a extracção de granito acabaram por destruir grande parte deste sítio arqueológico que contém também algumas grutas naturais que foram abrigo de romeiros e anacoretas.

\section{OS CONJUNTOS, SEUS CONTEXTOS DE RECOLHA E METODOLOGIA DE ESTUDO}

O presente estudo baseia-se em 3 conjuntos de materiais recolhidos à superfície no sítio, num total de 114 peças, das quais 98 são olaria, 14 são líticos e 2 são metais. O primeiro encontra-se sob a tutela da Uniarq e foi recolhido em 2001 em prospecções realizadas pela equipa do PEABMAM ${ }^{2}$. As recolhas foram na altura triadas e inventariadas tendo-se diferenciado os seus contextos de superfície designados por: abrigos, zona de convívio, subida, topo, vertente este e área geral. Procedemos a uma segunda triagem, resultando num conjunto de 59 peças classificáveis, das quais 9 são líticos, 2 são barro seco, 1 é escória, e os restantes são fragmentos cerâmicos. O segundo conjunto é o resultado das prospecções de 2005 realizadas pelo arqueológo António Costa do então Gabinete Técnico da Câmara Municipal de Sernancelhe no âmbito da realização da Carta Arqueológica de Sernancelhe, publicada em 2007. Este conjunto encontra-se nas instalações da mesma Câmara e apesar de já estar inventariado, não estava triado nem apresentava contextos, considerando-se também de uma área geral. Para evitar confusão, atribuímos novos números de inventário às peças, no seguimento da numeração do primeiro conjunto. Após a nossa triagem contamos com 27 fragmentos cerâmicos, 2 líticos e 1 escória, num total de 30 peças classificáveis. O terceiro conjunto foi recolhido pela signatária numa visita ao sítio na Primavera do presente ano. Recolheram-se e foram inventariados 25 fragmentos cerâmicos classificáveis e 3 líticos, todos

2. Programa de Estudo Arqueológico da Bacia do Médio e Alto Mondego provenientes da vertente Nordeste onde a abertura de um novo estradão deixou muito material à superfície e em iminente perigo de destruição.

Perante a constatação de pelo menos 3 períodos cronológicos no conjunto total de artefactos, procedeu-se ao seu estudo através da divisão das peças por grupos: as que remetem para o Calcolítico; as que remetem para o Bronze Final/Idade do Ferro; as medievais; as "indiferenciáveis", ou seja, aquelas sem período cronológico seguramente atribuível; e os líticos. Para cada um dos grupos foi criada uma matriz de dados, com a caracterização de todas as peças, que serve de base para a discussão de cada ocupação do sítio, procurando sempre paralelos próximos para poder compreendê-las no contexto da região e sua cultura material. No entanto, este processo esteve sempre truncado por diferenças metodológicas entre estudos e falta generalizada de investigações na região.

\section{UMA PRIMEIRA OCUPAÇÃO NO III ${ }^{\circ}$ MILÉNIO A.C.}

Até ao surgimento de novos dados, a primeira ocupação deste sítio deverá situar-se no período do Calcolítico. Tal é-nos comprovado por um total de 20 fragmentos cerâmicos decorados, dos quais 5 são bordos (Figura 3). É de referir que a maioria dos fragmentos apresentam um grande nível de erosão apesar de estarem pouco rolados. Ainda assim, verificamos que as pastas são todas compactas e xistosas, à excepção de duas únicas peças de textura granular, e a maioria com desengordurantes pequenos e pouco frequentes, compostos por quartzo, micas e feldspatos, apontando para uma produção local. As colorações das peças demonstram uma tendência por cozeduras oxidantes, embora a sua irregularidade resulte num número igual de cozeduras mistas. Verificam-se ainda casos de cozeduras com arrefecimentos opostos e duas únicas peças de cozedura totalmente redutora. Os acabamentos são preferencialmente por alisamento simples, mas 6 das peças apresentam polimento de pelo menos uma das faces, verificando-se ainda o espatulamento da face interior de uma delas. Confirma-se também a presença de aguadas ou engobes em 8 peças, com preferência para a face exterior. Estes fabricos vão, de modo geral, ao encontro do que já se conhece para a olaria calcolítica da região do Alto Mondego onde também predominam as pastas compactas, 
texturas xistosas, elementos não plásticos pequenos ou médios e relativamente frequentes, cozeduras oxidantes e acabamentos cuidados por alisamento ou polimento com recorrência a engobe (Valera, 1993; Valera, 2007).

Todos os bordos permitiram calcular os diâmetros, que caem entre os 11 e os $22 \mathrm{~cm}$. Apesar da grande fragmentação destes, podemos ainda assim perceber a sua morfologia, 3 dos quais remetem para formas fechadas, nomeadamente um vaso esférico (forma 5) e um vaso de colo troncocónico (forma 9). Os restantes aparentam pertencer a tigelas (forma 4), com a particularidade de uma delas remeter para a forma 4.6, de lábio exvertido (no 92). Tal remete às tabelas de formas calcolíticas construídas para os vários povoados da região da Beira Alta (Valera, 2007; Senna-Martinez, 1989) que são constituídas essencialmente por tigelas e formas fechadas de "fundo neo-calcolitíco" baseadas em esferas e elipses (Valera, 1993; Valera, 2007).

Relativamente às decorações, reinam os penteados ondulados, com alguns casos de penteados descontínuos (num exemplar com recurso a métopas polidas). No entanto, destaca-se um único exemplar com incisão pré-cozedura com uma faixa de reticulados em cruz sobre uma canelura ( $\mathrm{n}^{\circ} \mathrm{95}$ ). Enquanto os penteados são bem conhecidos pelo centro/norte do território actualmente português para as fases mais recentes do III- milénio, nomeadamente na Fraga da Pena, Quinta das Rosas (ambos em Fornos de Algodres), Murganho 1, Corujeira (ambos em Nelas), entre outros da região (Valera, 2007, pp. 370371), esta última decoração reticulada é mais rara, mas com paralelos, por exemplo, no sítio da Malhada (Fornos de Algodres) (Valera, 2007, p. 203).

Esta ocupação torna-se na primeira comprovada para o período calcolítico no concelho. Também não se conhecem necrópoles ou reutilizações da mesma cronologia nas imediações, algo que, no entanto, resultará apenas da falta de investigações. De facto, o que a área estudada do Alto Mondego (Valera, 2007) nos demonstra é que provavelmente existiria uma vasta rede de povoamento em torno do nosso sítio, marcada por povoados abertos, sazonais, juntos a cursos de água, em zonas mais aplanadas e sem domínio visual. Como paralelos próximos ao CSN surgem-nos a Fraga da Pena e, especialmente, o Castro de Santiago (Fornos de Algodres), povoados de altura com grande domínio visual e aproveitamento da geomorfologia do sítio para defesa natural, tendo este último sido fundado ainda na primeira metade do III ${ }^{\circ}$ milénio a.C. (Valera, 2007). No entanto, ao contrário do Castro de Santiago onde os penteados são raros, a abundância desta decoração no nosso sítio leva-nos a colocá-lo já em meados ou último quartel do IIIo milénio. Tanto a Fraga da Pena como o Castro de Santiago apresentam ainda estruturas defensivas, algo que poderá também ter existido no CSN. Conhecem-se ainda ocupações calcolíticas em abrigos, como é o caso do Buraco da Moura de S. Romão (Seia) (Valera, 1993) que, semelhante ao nosso sítio e seus respectivos abrigos, teve ocupação desde o Calcolítico, passando pelo Bronze Final, até ao período medieval. Apenas com prospecções não poderemos saber a estruturação de CSN neste período, nem dizer qual a sua extensão ou adiantar muito mais sobre a sua cultura material, mas os sítios escavados demonstram que os povoados seriam essencialmente áreas habitacionais de estruturas de cabana, muitas vezes aproveitando os afloramentos graníticos, construídas com ramagens revestidas a barro, com lareiras centrais e a presença de fossas (Valera, 2007). Além da cerâmica, costumam estar presentes pesos de tear, elementos de moagem e uma indústria lítica de resíduos de talhe e artefactos laminares em sílex (Valera, 2007).

\section{DA IDADE DO BRONZE À IDADE DO FERRO}

Como referido, este sítio é já identificado na bibliografia arqueológica como um castro do Bronze Final, isto devido ao aparecimento de uma ponta de lança em bronze. No entanto, estamos perante uma cronologia que apresenta várias problemáticas relativamente à sua transição para a Idade do Ferro nesta região. É apontado um "colapso" para as comunidades do Bronze Final da Beira Alta, verificando-se um repentino abandono da grande maioria dos povoados até finais do séc. VIII a.C., muitos só voltando a ser ocupados no período romano. No entanto, cremos que esta ideia de "hiato" resulta essencialmente de uma grande falha na investigação: uma maioria de sítios prospectados e não escavados e ainda o uso de diferentes conceitos e metodologias nos estudos. Existem sítios escavados, como o Castelo dos Mouros (Viseu), que nos demonstram uma clara continuidade para a Idade do Ferro, altura em que a sua ocupação se intensifica (Pedro, 1995, pp. 48-49; Almeida, 2005, p. 115). 
Também nos castros de Santa Luzia (Viseu) e Senhora da Guia de Baiões (S. Pedro do Sul) algumas estruturas e materiais recolhidos, nomeadamente cerâmicas estampilhadas, podem remeter para a Idade do Ferro (Vaz, 200o, p. 136). Muitos outros sítios só com recolhas superficiais apontam também para ocupações que se estendem a esse período (Pedro, 1995; Vaz, 200o). Assim, ainda que alguns sítios terão sido abandonados, outros terão sido reocupados durante uma $2^{\underline{a}}$ Idade do Ferro e, em alguns casos, poderemos mesmo verificar uma continuidade de ocupação que se poderá definir como um "período de transição" que alguns autores têm apoiado (Betterncourt, 2005; Silva, 2008; Ribeiro, 2017, p. 44). No fundo, não existem dados suficientes para poder definir nesta região uma $\mathbf{1}^{\mathbf{a}}$ Idade do Ferro que, até agora, parece ser uma extensão do Bronze Final, em termos de povoamento e cultura material, apenas com a introdução de pequenas novidades. Como aponta Senna-Martinez (2013, pp. 181-182), mesmo a $2^{\underline{a}}$ Idade do Ferro só é seguramente identificável com vestígios de uma "revolução urbana", em torno do séc. V a.C., ou até só com a romanização. Tudo isto serve para ilustrar como num sítio não escavado, como CSN, se torna muito complexo conseguir separar materiais do Bronze Final dos que remetem à Idade do Ferro. Assim, procedemos à divisão entre 3 subgrupos de materiais que identificámos como provenientes de entre estas balizas cronológicas: os que têm paralelos no Bronze Final; os que se conhecem da Idade do Ferro ou período de transição; e os que poderão facilmente pertencer a qualquer um dos períodos em causa.

Para o Bronze Final contamos com 2 carenas, 2 bojos decorados e uma base em omphalos (Figura 3), por serem fragmentos que seguem as características mais marcantes do "Mundo Baiões/Santa Luzia", grupo cultural que melhor define esse período na região. Assim, incluímos peças de pasta compacta, com textura xistosa e cozedura redutora (algumas mistas), com acabamentos muito polidos/brunidos sobre engobe interior e exterior. Quanto a morfologias, procurou-se que as peças remetessem para a tabela de Senna-Martinez (1989) para o Bronze Final da Beira Alta e, apesar da ausência de bordos neste subgrupo, foi possível corresponder os bojos a taças ou pequenos potes por se tratarem de cerâmicas de pequena espessura e bons acabamentos, com a típica decoração "tipo Baiões” de motivos triangulares. Quanto à base em omphalos ( $\mathrm{n}^{\circ} 52$ ), raras na Idade do Ferro, poderá remeter a taças de Forma 32 ou Forma 38, mas também a urnas de Forma 37, segundo os paralelos apontados na mesma tabela. Relativamente às carenas, o ângulo e acabamentos da $n^{\circ} 25$ aponta-nos para um possível prato de Forma 31. Já a carena $\mathrm{n}^{\circ} 77$, provavelmente da Forma 32.1, apesar de ser de cozedura mista onde sobressai a componente oxidante e de superfícies alisadas, apresenta reticulados por incisão pós-cozedura, com paralelos semelhantes em Canedotes (Vila Nova de Paiva) (Canha, 2002).

Como prováveis da Idade do Ferro incluímos 3 bordos a torno, 3 bordos manuais e 3 bojos decorados. Todos apresentam uma pasta compacta e com pouca frequência de desengordurantes, que apontam na sua maioria para produções regionais. Os fragmentos de mais evidente cronologia da $2^{\underline{a}}$ Idade do Ferro são os bojos decorados (Figura 4): as peças nำ 5 e 22 são decoradas com estampilhas, a primeira em círculos concêntricos e a segunda com triângulos concêntricos, caneluras e um padrão de pequenos quadrados, com paralelos muito próximos, por exemplo, no Morro da Sé de Viseu (Almeida, 2005). Já o fragmento $\mathrm{n}^{\mathrm{o}} 125$ é também estampilhado, mas com recurso a roleta, técnica também testemunhada na $2^{2}$ Idade do Ferro, nomeadamente em Aeminium (Almeida \& alii, 2011, p. 44). Quanto aos 3 bordos manuais (Figura 3), é essencialmente a sua forma que os coloca na Idade do Ferro ou, pelo menos, na fase de transição. As peças nํำ 102 e 103 são bordos espessos, com uma média de $23 \mathrm{~cm}$ de diâmetro e exvertidos, um com lábio horizontal e o outro oblíquo, ambos passíveis a serem cobertos por um testo. Estes tipos de bordos não são conhecidos de níveis anteriores à transição para a Idade do Ferro, mas estão bem representados nos médios/grandes potes de armazenagem da $2^{\underline{a}}$ Idade do Ferro, podendo as superfícies interiores polidas sobre engobe destes exemplares indicar a funcionalidade de armazenagem de líquidos. De facto, destaca-se ainda um testo ( $n$ o 61), de cozedura redutora e de frequentes e grandes desengordurantes, mas com um acabamento brunido sobre engobe na sua face superior. Os testos são conhecidos essencialmente a partir da Idade do Ferro e são a pasta e acabamento desta peça que nos levam a atribuir-lhe uma cronologia proto-histórica e não medieval. Já o bordo nํㅜㄴ, de $28 \mathrm{~cm}$ de diâmetro e espessura de quase $1 \mathrm{~cm}$, apresenta-nos paredes direitas, de forma troncocónica. O seu ângulo forma um bocal muito aberto e aparenta não desenhar um 
colo ou carena, pelo que nos sugere tratar-se de uma tigela (quase prato) que se aproxima da Forma 8B da tabela para o Castro de Tavarede (Figueira da Foz) (Neves, 2013, p. 36), onde ocorrem igualmente com acabamentos polidos, encontrando também paralelos em Sabugal Velho (Osório, 2009).

Relativamente aos 3 bordos a torno (Figura 3), dois deles apontam para influências exógenas, ou até mesmo importações. As peças no 89 e 127 são de cozedura redutora, com a típica coloração cinzenta esbranquiçada, com ambas as faces alisadas e sem engobes. Enquanto a primeira apresenta um bordo redondo e deverá corresponder a uma pequena taça, a segunda apresenta um raro bordo "cabeça de pato" com diâmetro de $14 \mathrm{~cm}$. Esta última aponta para contactos, directos ou indirectos, com a Meseta central já que encontramos paralelos para este tipo de bordo em ambientes de Cogotas II, mas também em sítios como o Morro da Sé de Viseu (Almeida, 2005, p.7980) e Sabugal Velho (Osório, 2009, p. 102), embora estejam na sua origem e nestes sítios referidos associados a potes de armazenagem. $\mathrm{O}$ terceiro bordo a torno ( $\mathrm{n}^{\circ} 70$ ), de $13 \mathrm{~cm}$ de diâmetro e apenas $0,5 \mathrm{~cm}$ de espessura, trata-se de um fabrico de tradição local, com cozedura muito redutora, superfícies polidas e engobe interno, muito na linha dos potes do Bronze Final. No entanto, é o facto de ser fabricado a torno e de ter as suas linhas de bordo e colo bem demarcadas que o coloca na Idade do Ferro, com inúmeros paralelos no Morro da Sé de Viseu (potinhos, Forma $2 \mathrm{C}$ ) (Almeida, 2005), Sabugal (Osório, 2009) e Castelo dos Mouros (Pedro, 1995), entre outros.

Resta-nos o grupo de fragmentos que pelo seu fabrico e acabamento apontam para uma cronologia de entre os finais da Idade do Bronze e Idade do Ferro, mas que carecem de características suficientes para poder especificar o seu período (Figura 4). Neste grupo contamos com 11 bordos, 2 bases, 1 asa de fita e 1 bojo com ressalto, todos com o mesmo problema: pastas e acabamentos cuidados e típicos da região para os períodos das Idades do Bronze e Ferro, mas uma fragmentação que nos impede de atribuir morfologias específicas. Os bordos remetem para formas abertas, de gargalo, e têm diâmetros que vão dos 9 aos $22 \mathrm{~cm}$ e espessuras que vão dos 0,4 aos $1,04 \mathrm{~cm}$, a maioria provavelmente de potes de armazenagem. Ainda assim, a maioria tem poucos desengordurantes visíveis e de pequeno calibre. As pastas são compactas, xistosas e a maioria de cozedura redutora. A grande maioria é também de acabamento polido, por vezes um brunido intenso, em ambas as faces, e em alguns casos sobre engobe. Três destes bordos apresentam decoração no lábio, um por digitação, outro por punção (n⿳o 101) e outro por incisão e ungulação (no 107 ), técnicas e motivos decorativos que são típicos ao longo dos dois períodos. Relativamente às bases, mais uma vez a sua pasta e acabamentos cuidados remetem para um fabrico típico das Idades do Bronze e Ferro, assim como a sua forma plana. No entanto, é pela mesma razão de manutenção de morfologias e fabricos de bases ao longo dos dois períodos que nos é impossível atribuí-las a um período específico. Nenhuma permite calcular diâmetro.

Como referido, a grande maioria dos povoados do Bronze Final/Idade do Ferro da Beira Alta nunca foram escavados, como acontece com CSN. Ainda assim, regista-se que a instalação da maioria dos povoados terá ocorrido entre os séculos XIV e XIII a.C., e verifica-se uma grande preferência por lugares de altura, em cabeços entre os 400 e $700 \mathrm{~m}$ de altitude (Senna-Martinez, 1989), o que faz do CSN um dos de maior altitude. Esta implantação prende-se com o grande domínio visual e condições naturais de defesa, de forma a controlar as redes de contactos e o território envolvente, neste caso do vale do Távora. Relaciona-se também com as riquezas naturais das zonas planálticas e montanhosas em minério, pastos e linhas de água, aspectos que ganham mais importância na Idade do Ferro (Almeida, 2005, p. 113). No geral são povoados de pequena dimensão que se complementariam com outros sítios ainda mais pequenos, "atalaias", em seu redor e em pontos estratégicos. O CSN poderia estar interrelacionado com o sítio do Castelo de Sernancelhe ${ }^{3}$, onde também se verifica uma ocupação do Bronze Final e Idade do Ferro, não sendo possível, no entanto, saber exactamente qual a relação entre os dois. Regista-se também que os povoados do Bronze Final seriam fundados de raiz, no entanto, a escavação do Outeiro do Castelo de Beijós (Carregal do Sal) (Senna-Martinez, 20ooa, p. 45) demonstrou que já existia uma ocupação desde os finais do Neolítico, vindo agora o CSN também refutar essa teoria. As habitações destes povoados seriam simples cabanas sub-circulares, construídas em materiais

3. Ainda sem publicação, o sítio foi escavado em sondagens no ano de 2019 com a signatária como interveniente, podendo assim testemunhar estas ocupações no sítio. 
perecíveis, por vezes com fundações em pedra, revestidas a barro, com lareiras interiores e exteriores. O uso da pedra ter-se-á intensificado com a Idade do Ferro, assim como a presença de muralhas, algumas em talude. No morro central do sítio vêem-se algumas pedras empilhadas que poderão corresponder a tal. Conhecem-se também áreas funcionais definidas dentro dos povoados, onde se praticavam diversas actividades necessárias à subsistência das comunidades, nomeadamente a armazenagem, moagem, tecelagem, metalurgia, olaria, entre outras. Viviam essencialmente da exploração agrícola de cereais e hortícolas, da pastorícia, da caça e da recolecção de frutos de Inverno, nomeadamente da bolota. Existem evidências de produção local, de cariz doméstico, de bronze em praticamente todos os sítios do Bronze Final da Beira Alta, testemunhadas por moldes, escórias, pingos de fundição e alguns fornos. Não temos ainda no CSN qualquer prova de produção metalúrgica embora a ponta de lança de alvado (Senna-Martinez $\&$ alii, 2004) possa ser um indicativo de tal. Este artefacto tem regionalmente paralelo no Castro de S. Romão (Seia), onde além de uma ponta de lança também foi achado o seu molde em cerâmica (Senna-Martinez, 20oob, pp. 140-141). Defende-se que neste mundo do Grupo Baiões/Santa Luzia as peças metálicas seriam símbolos de poder, podendo este artefacto ser testemunho da complexificação da comunidade de CSN. Já a presença de escórias de ferro poderá testemunhar a prática da metalurgia do ferro no sítio durante a Idade do Ferro.

Há ainda a referir que a grande maioria destes fragmentos foi recolhida na vertente Nordeste, podendo eventualmente indicar uma presença mais concentrada ou melhor preservada das comunidades destas cronologias naquela área.

\section{A OCUPAÇÃO MEDIEVAL}

São apenas 10 os fragmentos cerâmicos a torno, maioritariamente rápido, que nos testemunham uma ocupação medieval do sítio. Os fragmentos identificam-se pela sua pasta compacta e xistosa, na maioria de desengordurantes frequentes de pequeno e médio calibre, especialmente micas, e de acabamentos alisados. A cozedura é na maioria redutora, de tonalidades cinzentas, mas também se verificam algumas peças de cozedura mista e ainda um pequeno exemplar de oxidante. A bibliografia parece mostrar-nos uma divisão entre povoados da região com preferência por cozeduras redutoras e outros por oxidantes (Tente, Lantes \& Prieto, 2014, p. 122). Em todos os sítios, no entanto, se verifica que a olaria é maioritariamente de acabamentos alisados, pasta compacta, de desengordurantes frequentes de calibre médio e grande e de origem local (Tente, Lantes \& Prieto, 2014). Em termos morfológicos verifica-se em todos os sítios uma maioria de potes e panelas, seguida dos alguidares e jarros (Tente, Lantes \& Prieto, 2014). Predominam os bordos exvertidos de lábio redondo ou direito, os colos estrangulados e as bases planas angulosas (Tente, Lantes \& Prieto, 2014). No nosso conjunto não existem bases simples que possamos identificar seguramente como medievais, no entanto, existe um bordo aparentemente de orientação direita e com $28 \mathrm{~cm}$ de diâmetro (Figura 5, n⿳ำ 71), o que juntando aos ângulos dos vários bojos com cordão impresso (Figura 4), permite-nos perceber que estamos essencialmente perante fragmentos de talhas, jarros e, como prova a base em disco decorada a punção ( $\mathrm{n}^{\circ} 74$ ), principalmente de alguidares. Os nossos cordões são aparentemente repuxados e dividem-se entre impressão por digitação e por punção. Além da incisão, os cordões plásticos com digitações e punções são das decorações mais típicas desta cronologia e são mais frequentes em alguidares, talhas e em alguns jarros (Tente, Lantes \& Prieto, 2014, p. 133). São, no entanto, os alguidares que nos permitem tirar maiores conclusões sobre esta ocupação já que encontramos vários paralelos para o nosso alguidar em S. Gens (Tente \& alii, 2018a), Sé de Viseu (Rodrigues, 2014), Penedo dos Mouros (Tente, Carvalho \& Pereira, 2018) e Soida (Tente, Lantes \& Prieto, 2014). Os alguidares de fabrico mais fino seriam destinados a conter líquidos para lavagens ou para confecção e consumo alimentar enquanto os mais grosseiros seriam provavelmente para amassar pão (Rodrigues, 2014, p. 146). Por outro lado, Tente, Lantes \& Prieto (2014, p. 136) dizem-nos que os alguidares mais finos e escuros, como o nosso exemplar, seriam característicos dos séculos X a XI d.C. enquanto os mais grosseiros seriam mais típicos entre os séculos XII a XIV d.C..

É de notar que estes fragmentos foram recolhidos sem contexto definido (área geral) mas nenhum faz parte do conjunto recolhido na vertente Nordeste. Caso não se trate de uma simples casualidade, talvez esta vertente com ocupação pré e proto-histórica 
não tivesse sido escolhida como palco para actividades medievais. Tal como se verifica noutros sítios com ocupação contemporânea na região, também este se encontra num cabeço de grande altitude mas que não é o ponto local mais alto o que lhe confere a vantagem de ter boa visibilidade e ao mesmo tempo não ser facilmente identificado na paisagem. Como os outros sítios, também este poderia ter ainda uma muralha com uma só entrada, reforçando a sua defesa. A implantação próxima do rio Távora e suas margens férteis também vai ao encontro da estratégia de ocupação das comunidades alto-medievais que praticariam o cultivo e consumo de leguminosas e alguns cereais, assim como se dedicariam à pastorícia, caça e recolecção, nomeadamente da castanha (Tente $\&$ alii, 2018b, p. 291), fruto ainda hoje típico na região. Estas ocupações seriam possivelmente sazonais e de construções maioritariamente em materiais perecíveis. As escórias de ferro são bastante comuns nestas ocupações, assim como fundos de forja e vários artefactos como pregos e lâminas (Tente $\&$ alii, 2018b, p. 279), pelo que as escórias presentes no nosso conjunto serão mais provavelmente de cronologia medieval.

\section{CERÂMICA "INDIFERENCIÁVEL" E OUTRAS POSSÍVEIS OCUPAÇÕES}

Neste grupo, de 37 fragmentos cerâmicos, entram todos os restantes exemplares que por má conservação ou por grande longevidade de morfologia e fabrico não podem ser seguramente atribuídos a qualquer destes períodos de ocupação (Figura 5). Apenas uma peça é a torno. Todas, sem embargo, apresentam pastas compactas, de textura xistosa e com desengordurantes regionais, na maioria de pequeno calibre e pouco frequentes. A grande maioria apresenta superfícies interiores e exteriores alisadas, encontrando-se apenas 6 peças de superfícies polidas. Existem também 3 casos de engobe sobre alisamento e registam-se 3 exemplares com cepillo. Estamos, portanto, perante fabricos comuns e acabamentos variados. Deste grupo, 22 fragmentos são bordos, na sua grande maioria exvertidos, mas pequenos demais para poder aferir a sua forma e diâmetro. Outros remetem para formas "de fundo comum" que poderão pertencer a qualquer período. É ainda de referir que dois dos bordos demonstram a aplicação da técnica de colombino. Os diâmetros possíveis de calcular estão entre os 8 e os $27 \mathrm{~cm}$, com espessuras entre os 0,4 e 1,8cm o que mais uma vez lhes confere uma grande variedade de tamanhos e morfologias, mas aparentemente com maior incidência nos pequenos e médios potes de armazenagem. A maioria dos lábios são redondos ou direitos, mas também se verificam alguns biselados e espessados. É, no entanto, de destacar a peça no ${ }^{\circ} 8$, de contexto não especificado, que tem a particularidade de ter um bordo enrolado e que deverá pertencer a uma pequena taça a torno de cozedura oxidante, com faces alisadas e poucos desengordurantes. Não conseguimos encontrar-lhe paralelos, mas a sua pasta leva-nos a considerar tratar-se de um testemunho de visitas ao sítio em período romano tardio, mas não podemos, ainda assim, descartar a possibilidade de se tratar de uma intrusão recente.

Contam-se também 4 bases, todas aparentemente planas e provavelmente de recipientes pequenos, no entanto estão todas muito mal conservadas. Embora ainda raras em cronologias anteriores à Idade do Bronze, este tipo de base é conhecido já desde o Calcolítico e estende-se até ao período medieval. Relativamente a elementos de preensão, as asas são de fita, com várias cronologias possíveis. Os arranques apresentam diferentes técnicas de preensão: $\mathrm{o}$ arranque de asa que se encontra num bordo ( $\mathrm{n}^{\circ}$ 32), possivelmente de um pequeno pote, foi repuxado, enquanto o arranque de asa que encontramos solto ( $\mathrm{n}^{-}$31) demonstra que seria cravado. Aparentemente do mesmo recipiente que este último, surge-nos ainda um bojo com uma "perfuração" de grande diâmetro (nº 30) que poderá corresponder ao local de cravagem da asa, no entanto, muito mal conservado. Resta-nos também um bojo onde se verifica que teria algum tipo de elemento de preensão ali colado e que, entretanto, se descolou. Já quanto aos mamilos, que nos surgem com formas e em locais diferentes ( $n^{\circ} 23$ e 35), são bem conhecidos do Calcolítico e Bronze Final, mas a sua má conservação impede-nos, uma vez mais, a aferição de uma cronologia precisa. Inventariámos ainda uma carena, muito subtil e de pasta e acabamentos pouco depurados, pelo facto de apresentar pequenas incrustações nas duas faces daquilo que suspeitamos que seria tinta à base de ocre. Não nos sendo possível recorrer a análises microscópicas ou laboratoriais adequadas, podemos apenas apurar tratar-se de um pigmento de tom e brilho muito vermelho-acobreado. Neste grupo apenas 4 fragmentos são decorados, todos por incisão pré-cozedura e sempre 
na face externa. Os motivos são variados: temos linhas continuas e paralelas na horizontal ( $\left.\mathrm{n}^{\mathbf{0}} 45\right)$, bandas de linhas paralelas na vertical junto ao bordo ( $\mathrm{n}^{\circ}$ 18), pequenas linhas verticais em escada ascendente e descendente (no 8 ) e um reticulado de linhas paralelas e perpendiculares (no 6 ). Todos estes motivos são demasiados vagos e as peças demasiado fragmentadas para poder atribuir-lhes cronologia, sem que as pastas e acabamentos dêem qualquer pista.

Registam-se também, mais provavelmente para as cronologias pré/proto-históricas, dois pedaços de barro seco, com marcas de ramagens, provenientes de áreas diferentes do sítio, um da subida e outro do topo do monte, que reforçam a categorização do sítio como povoado provido de cabanas construídas com materiais perecíveis e revestidas a barro. Há ainda a referir um fragmento que testemunha ocupações mais recentes: uma carena de faiança azul $\left(n^{-} 57\right)$, provavelmente de produção portuguesa do século XVII d.C., ou seja, já dos inícios da dedicação do espaço a Nossa Senhora das Necessidades.

\section{PEQUENAS CONSIDERAÇÕES SOBRE O CONJUNTO LÍTICO}

Recolheram-se no sítio vários artefactos líticos que, apesar da impossibilidade de realizar uma análise detalhada, merecem a sua exposição. São 14 peças, a grande maioria em quartzo: 4 seixos rolados, 3 percutores, 2 lascas e 1 lamela. A estes juntam-se 2 exemplares em anfibolito, um percutor polido e um movente, e ainda uma lasca em sílex e um movente em granito. Como achados de superfície, pouco ou nada se poderá dizer sobre o seu contexto funcional e cronológico. É natural que a maioria destes artefactos seja em quartzo, visto este mineral ser abundante na região e fácil de talhar. Os seixos rolados provavelmente teriam origem no rio Távora ou outros cursos de água próximos, e as suas dimensões, formas e consequentes funções são variadas, desde os mais pequenos seixos com pouco mais de $2 \mathrm{~cm}$ de diâmetro, passando pelos mais ovalados e achatados que provavelmente serviriam de polidores, até aos mais toscos e de maior tamanho, usados para percutir. O movente em granito é também claro, sendo este mineral a base geológica da região e favorável na prática de moagem. Por outro lado, o movente em anfibolito é difícil de explicar, bem como o percutor: esta rocha é mais rara na região e pouco usada para estes fins. Talvez estes dois artefactos repre- sentem objectos de ostentação dentro destas comunidades. Da mesma forma, também o artefacto em sílex poderá ser visto como um objecto de excepção, já que a matéria-prima além de rara na região é também mais fácil de talhar e mais resistente de que o quartzo. Estes artefactos são comuns nos períodos pré/proto-históricos apontados, alguns até em períodos medievais, sendo assim impraticável atribuí-los a cronologias específicas.

\section{POSSÍVEIS CONCLUSÕES SOBRE O SÍTIO}

Apesar de todas as limitações inerentes a uma primeira análise artefactual a um sítio que nunca foi escavado, este estudo permite colocar o Castro de Nossa Senhora das Necessidades no mapa da arqueologia portuguesa para, pelo menos, três períodos cronológicos na região da Beira Alta, e não apenas como "mais um" castro do Bronze Final. Ficam, então, testemunhadas as ocupações durante o Calcolítico, Bronze Final/Idade do Ferro e período Alto-Medieval, ainda que pouco se possa aferir delas. É clara a necessidade de uma intervenção arqueológica neste sítio em destruição, mas que merece ser valorizado para que se possa conhecer e perceber melhor estas ocupações na forma como se inserem no seu enquadramento geográfico e cultural. A vertente Nordeste, em particular, parece-nos ter uma grande potência estratigráfica com uma grande quantidade de artefactos e, quem sabe, talvez até capaz de ainda conservar estruturas e a estratigrafia dos vários períodos, mas que está em iminente perigo com as constantes obras no local e a erosão natural da vertente. Será também necessário que se desenvolvam mais investigações no território circundante de forma a compreender o sítio e as redes de povoamento e contactos na região durante o período medieval, mas, particularmente, ao longo de toda a pré/proto-história.

\section{AGRADECIMENTOS}

Gostaríamos de agradecer à Câmara Municipal de Sernancelhe pelo seu demonstrado interesse nesta investigação e pela cedência dos materiais para a realização deste estudo. Agradecemos igualmente ao Professor Doutor Senna-Martinez (Uniarq) pela cedência do seu conjunto de materiais e por todo o apoio na análise deste. 


\section{BIBLIOGRAFIA}

ALMEIDA, Sara Oliveira (2005) - A Idade do Ferro no Planalto de Viseu: o caso do Morro da Sé. Dissertação de Mestrado apresentada à Faculdade de Letras da Universidade de Coimbra.

ALMEIDA, Sara Oliveira; NÓBREGA, José Ricardo; VILAÇA, Raquel; SILVA, Ricardo Costeira da (2011) - Cerâmica da II Idade do Ferro de Aeminium - R. Fernandes Tomás 72/74 (Coimbra, Portugal). Conimbriga. Coimbra: Faculdade de Letras da Universidade de Coimbra, Vol. 50, pp. 33-57.

BETTENCOURT, Ana Maria dos Santos (2005) - O que aconteceu às populações do Bronze Final do Noroeste de Portugal, no segundo quartel do I milénio AC, e quando começou, afinal, a Idade do Ferro?. In Actas do Colóquio Internacional: Castro, um lugar para habitar. Cadernos do Museu. Penafiel: Museu Municipal, 11, pp. 25-40.

CANHA, Alexandre (2002)-Canedotes: Povoado do Bronze Final do Alto Paiva. Dissertação de Mestrado apresentada à Faculdade de Letras da Universidade do Porto.

LEAL, Augusto Soares d'Azevedo Barbosa de Pinho (1873) Portugal antigo e moderno. Vol 7, Lisboa : Livraria Editora de Mattos Moreira \& Companhia.

MOREIRA, Ab. Vasco (1929) - Cernancelhe e seu Alfoz Terras da Beira. Porto: Officinas do Commercio do Porto.

NEVES, Sílvia Gonçalves (2013) - O Crasto de Tavarede (Figueira da Foz) no quadro das problemáticas da I Idade do Ferro no Baixo Mondego. Dissertação de Mestrado apresentada à Faculdade de Letras da Universidade de Coimbra.

OSÓRIO, Marcos (2009) - A Idade do Ferro no Alto Côa: os dados e as problemáticas. In Lusitanos y vettones. Los pueblos prerromanos en la actual demarcación Beira Baixa - Alto Alentejo - Cáceres. Museo de Cáceres. pp. 95-115.

PEDRO, Ivone (1995) - O povoamento proto-historico da região de Viseu. Dissertação de Mestrado apresentada à Faculdade de Letras da Universidade do Porto, policopiado.

RIBEIRO, Telma Susana (2017) - Cerâmica e áreas funcionais: O conjunto cerâmico do "Ambiente $\mathrm{AW}_{3}$ exterior" do Cabeço do Crasto de S. Romão (Seia). Dissertação de Mestrado apresentada à Faculdade de Letras da Universidade de Lisboa.

RODRIGUES, Patrícia (2014) - Cerâmicas medievais do Pátio do Museu Grão Vasco (Viseu): elementos para uma sistematização da cerâmica pleno medieval do espaço viseense. In Estudos de cerâmica medieval. O Norte e Centro de Portugal-séculos XI a XII. Lisboa: IEM - Instituto de Estudois Medievais (Colecçâo Estudos).

SENNA-MARTINEZ, João Carlos (1989) - Pré-História Recente da Bacia do Médio e Alto Mondego: algumas contribuições para um modelo sociocultural. Tese de Doutoramento em Pré-História e Arqueologia apresentada à Faculdade de Letras de Lisboa, 3 vols., policopiado.
SENNA-MARTINEZ, João Carlos (20ooa) - O problema dos primeiros ferros peninsulares em contextos do Bronze Final da Orla Atlântica: os dados do "Outeiro dos Castelos de Beijós" (Carregal do Sal). Trabalhos de Arqueologia da EAM. Lisboa: Colibri, Vol. 6, pp. 43-6o

SENNA-MARTINEZ, João Carlos (20oob) - O Cabeço do Crasto de São Romão (Seia). In Por Terras de Viriato: Arqueologia da Região de Viseu. Viseu: Governo Civil do Distrito de Viseu e Museu Nacional de Arqueologia, pp. 136-144.

SENNA-MARTINEZ, João Carlos.; ARAÚJO, Maria de Fátima; VALÉRIO, Pedro; PEIXOTO, Horácio (2004) - Estudos sobre a Arqueometalurgia do Grupo Baiões/Santa Luzia: (1) Uma Ponta de Lança do Castro da Senhora das Necessidades (Sernancelhe). O Arqueólogo Português. Lisboa. Série IV, 22, pp. 319-331.

SENNA-MARTINEZ, João Carlos (2013a) - Aspectos do Centro-Norte do Ocidente Peninsular no Final da Idade do Bronze: Povoamento, Metalurgia e Sociedade. Estudos Arqueológicos de Oeiras. Oeiras: Câmara Municipal, 20, pp. 173-19o.

SILVA, Ricardo Costeira (2008) - A passagem da Idade do Bronze para a Idade do Ferro na Beira Interior Centro - estado actual da investigação e enquadramento geral de problemáticas. In Actas das I Jornadas do Património (Belmonte - 21 e 22 de Abril de 2006). Câmara Municipal de Belmonte, pp. 67-82.

TENTE, Catarina; LANTES, Óscar; PRIETO, Pilar (2014) A produção cerâmica dos séculos IX a XI na região do Alto Mondego (Portugal). In Estudos de cerâmica medieval. O Norte e Centro de Portugal - séculos XI a XII. Lisboa: IEM Instituto de Estudos Medievais (Colecção Estudos).

TENTE, Catarina; CARVALHO, António Faustino; PEREIRA, Vera (2018) - O povoado do Penedo dos Mouros (Arcozelo, Gouveia) no contexto do século X no sector noroeste da Serra da Estrela. In Actas do congresso "Do Império ao Reino. Viseu e o território entre os séculos IV a XII”. Viseu. pp. 197-228.

TENTE, Catarina; BAPTISTA, Hugo; TERESO, João Pedro; CÉRCIO, Margarida; VELOSO, João Luís; OLIVEIRA, Cláudia; SEABRA, Luís; MEIRA, Catarina; SOUZA, Gabriel de; CORDERO RUIZ, Tomás; REAL, Manuel Luís (2018b) -Senhora do Barrocal (Sátão) na viragem do milénio. Primeira abordagem. In Actas do congresso "Do Império ao Reino. Viseu e o território entre os séculos IV a XII”. Viseu. pp. 197-228.

TENTE, Catarina; PRATA, Sara; CUESTA-GÓMEZ, Fabián; BROOKES, Stuart; MORENO-GARCÍA, Marta, SOUZA, Gabriel; TERESO, João Pedro; OLIVEIRA, Cláudia; JESUS, Ana (2018a) - Povoamento e modos de vida no limite oriental do território viseense durante o século $\mathrm{X}$ : O Povoado de S. Gens. In Actas do congresso "Do Império ao Reino. Viseu e o território entre os séculos IV a XII". Viseu. pp. 197-228. 
VALERA, António Carlos (1993) - A ocupação calcolítica da "sala 20" do Buraco da Moura de S. Romão. Trabalhos de Arqueologia da EAM. Lisboa: Colibri. Vol. 1, pp. 37-53.

VALERA, António Carlos (2007) - Dinâmicas locais de identidade: estruturação de um espaço de tradição no $3^{\circ}$ milénio AC (Fornos de Algodres, Guarda). Braga: Município de Fornos de Algodres / Terras de Algodres.
VAZ, João Luís Inês (200o) - O Castro de Santa Luzia (Viseu). In Por Terras de Viriato: Arqueologia da Região de Viseu. Viseu: Governo Civil do Distrito de Viseu e Museu Nacional de Arqueologia, pp. 135-136.

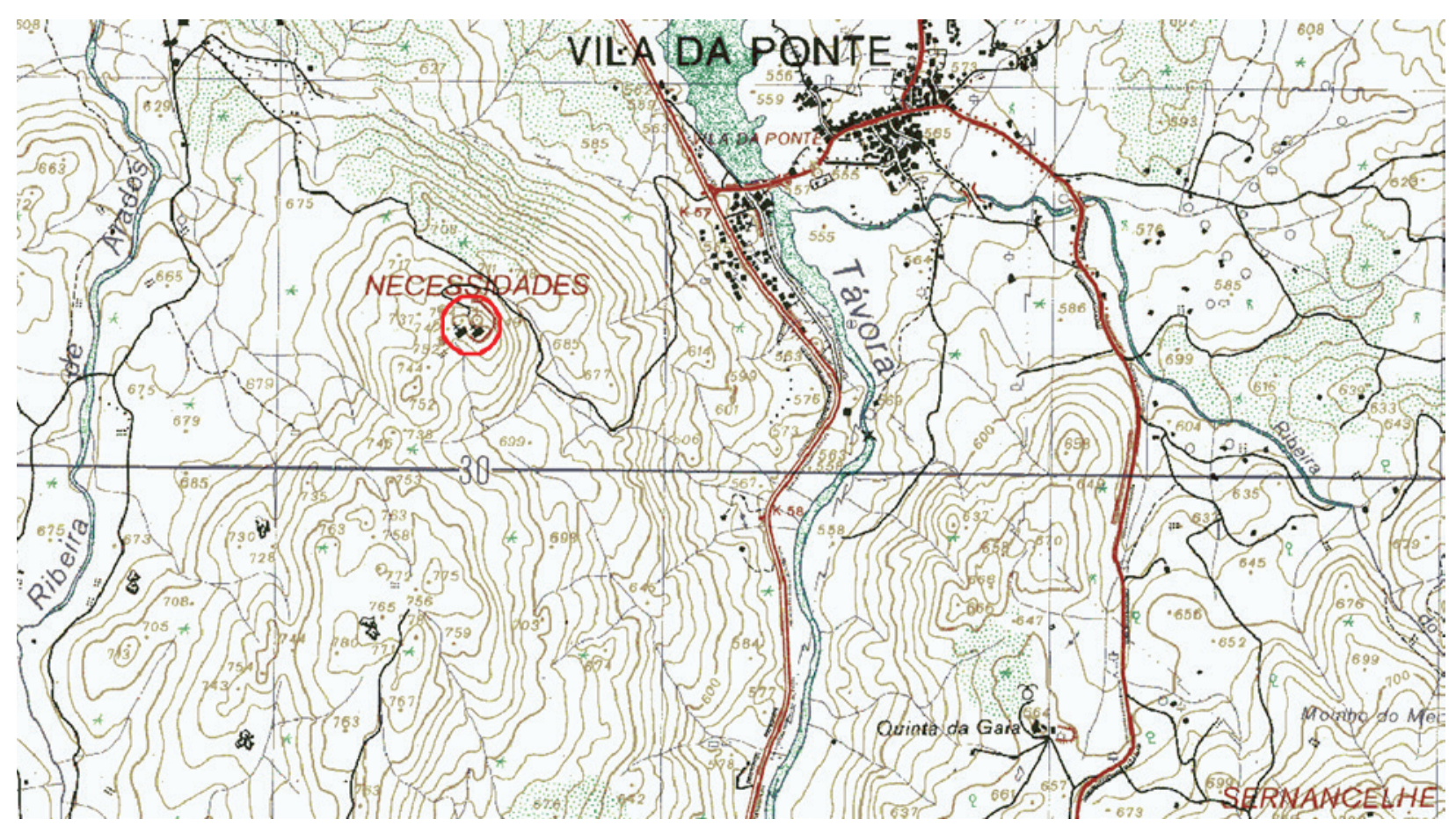

Figura 1 - Localização de CSN na Carta Militar Portuguesa, folha 159 (escala 1:250oo).

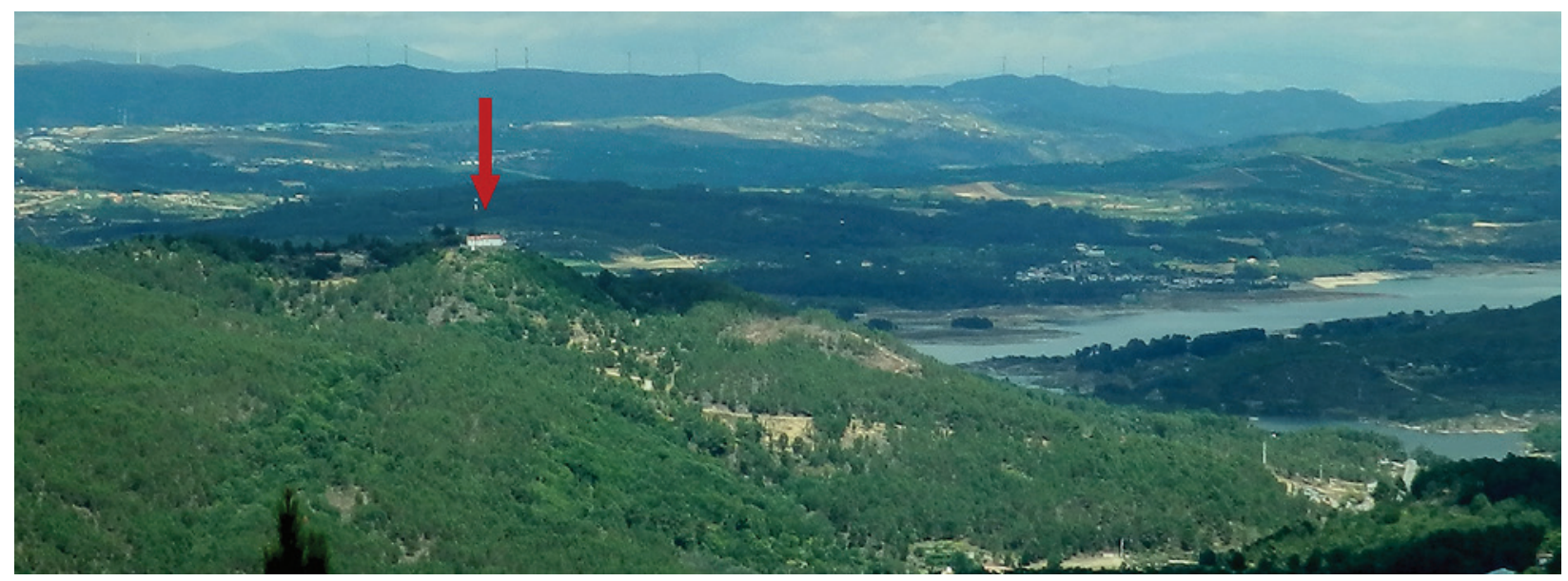

Figura 2 - Localização de CSN na paisagem, visto desde Sernancelhe. 


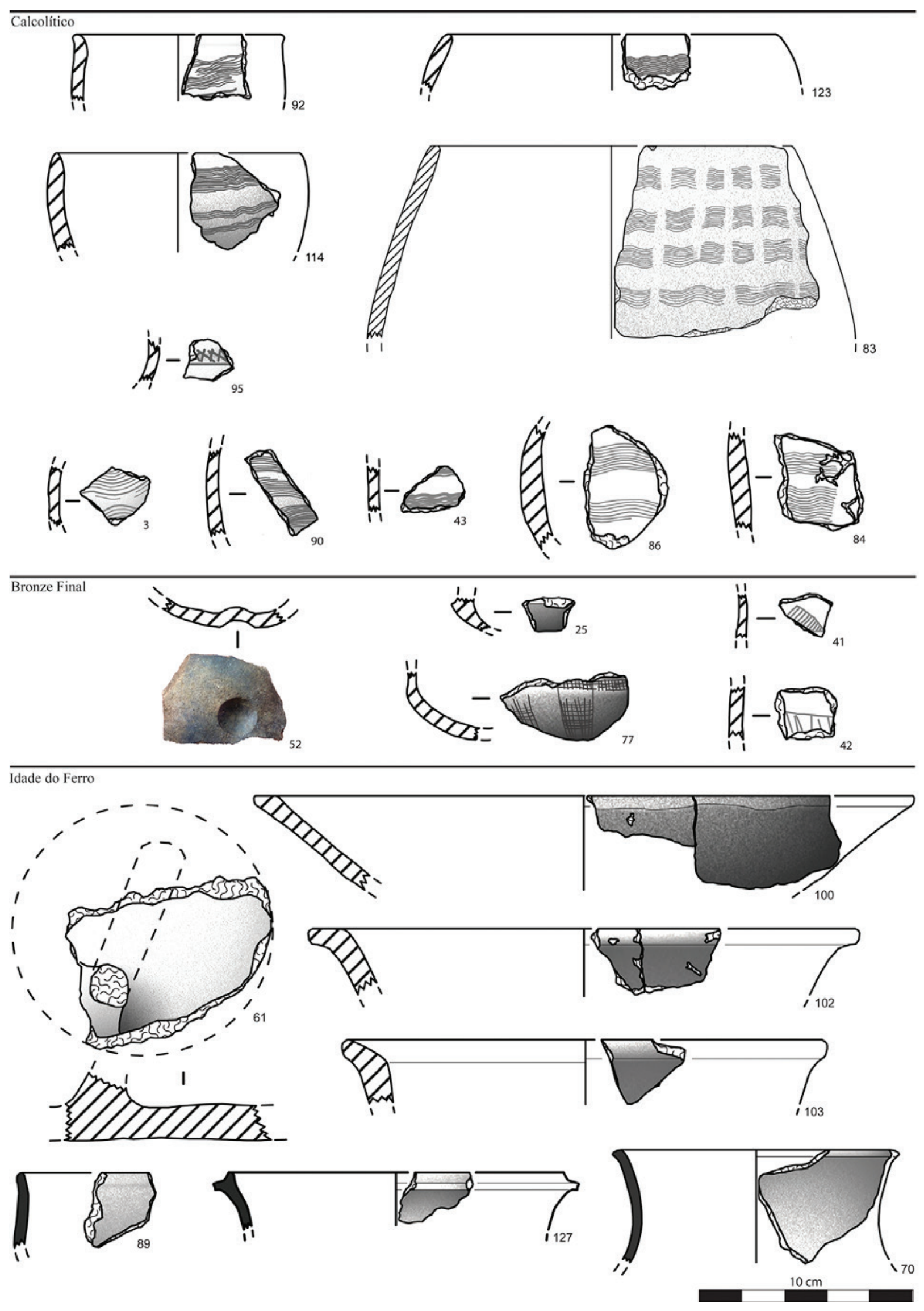

Figura 3 - Cerâmicas do Calcolítico, Bronze Final e Idade do Ferro. 

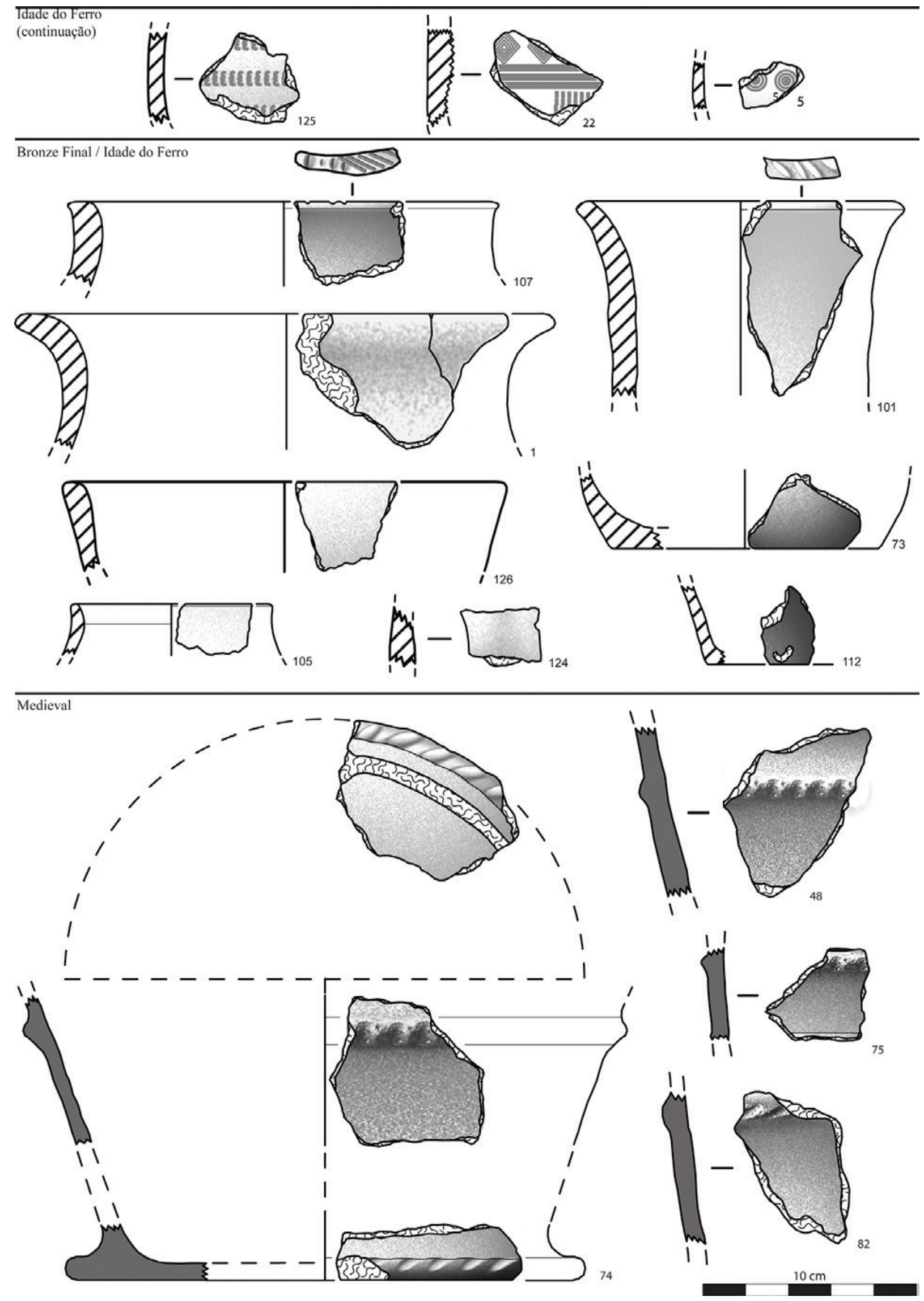

Figura 4 - Cerâmicas da Idade do Ferro (continuação), Bronze Final / Idade do Ferro e Medievais. 


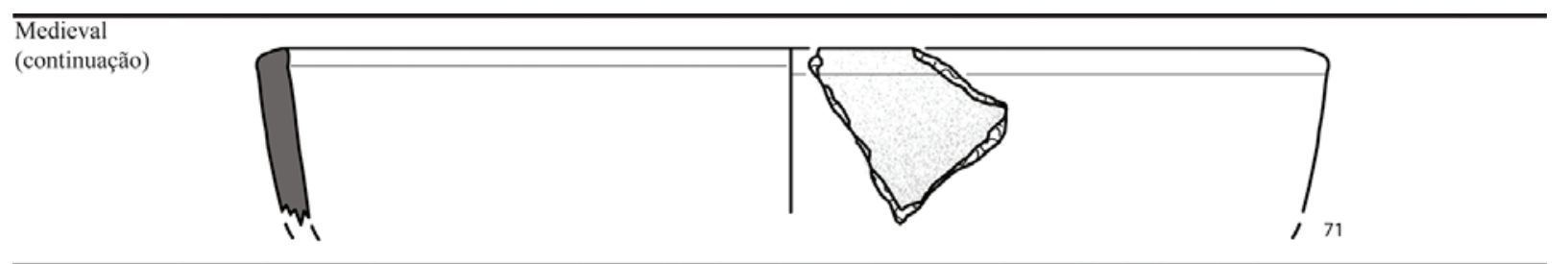

"Indiferenciáveis"
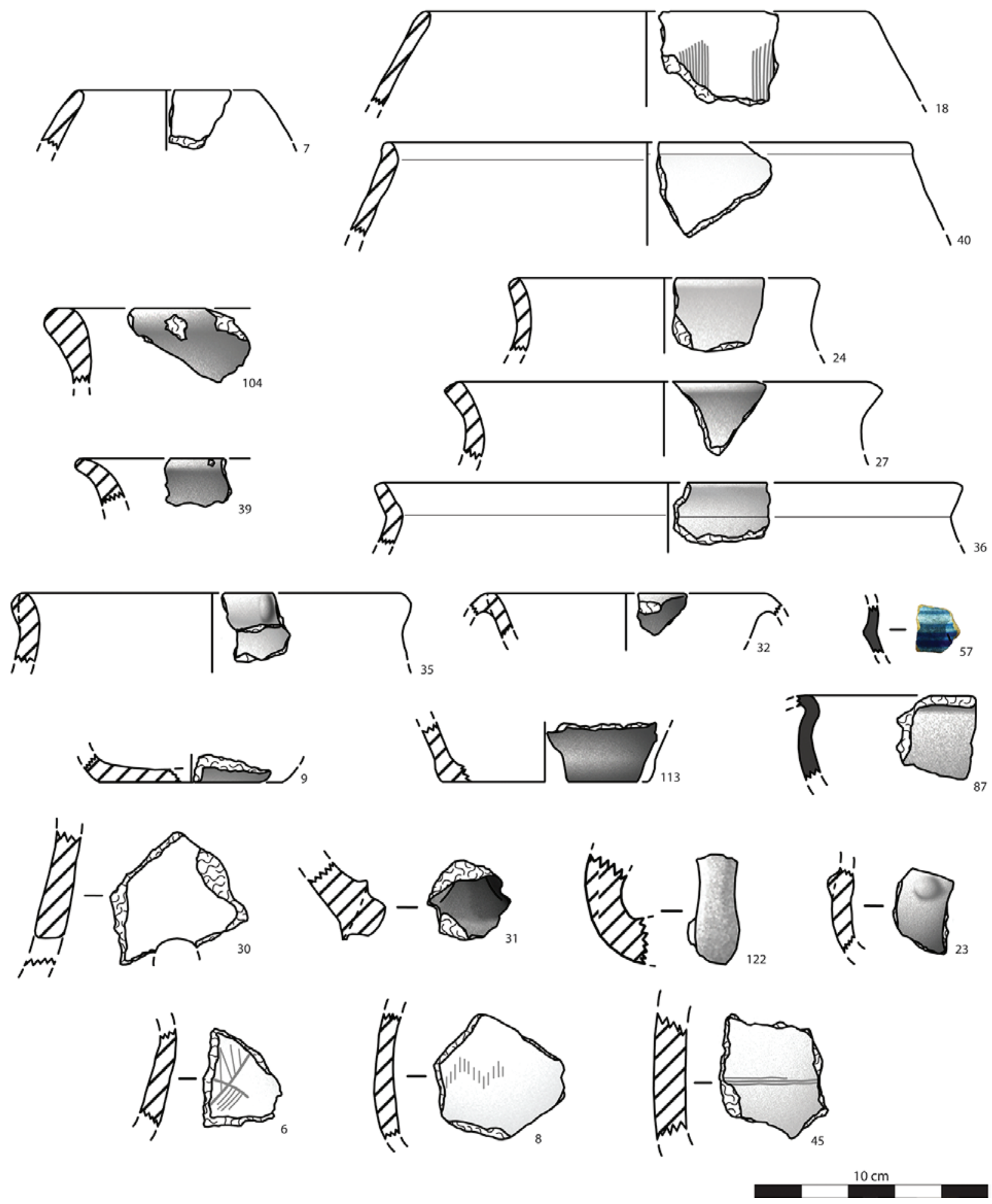

Figura 5-Cerâmicas medievais (continuação) e "indiferenciáveis". 


\title{
A CIVIDADE DE BAGUNTE. O ESTADO ATUAL DA INVESTIGAÇÃO
}

\author{
Pedro Brochado de Almeida ${ }^{1}$
}

\begin{abstract}
RESUMO
A Cividade de Bagunte é a mais divulgada estação arqueológica do concelho de Vila do Conde. Localizada num monte com ótima visibilidade para os territórios situados a norte e a sul do rio Ave, mereceu, já na ponta final do século XIX, o interesse de arqueólogos como Ricardo Severo e Martins Sarmento e na década de 40 da centúria seguinte de F. Russel Cortez. Sobretudo este realizou, ali, algumas campanhas de escavações que puseram a descoberto um misto de construções castrejas e romanas, distribuídas por espaços ortogonais que têm já a chancela da influência romana na região. Os trabalhos arqueológicos mais recentes permitem uma maior precisão quanto à sua evolução, embora subsistam muitas interrogações por decifrar.

Palavras-chave: Cividade, Cultura Castreja, Romanização.
\end{abstract}

\begin{abstract}
The Cividade of Bagunte is the most publicized archaeological site of the municipality of Vila do Conde. Located on a mound with great visibility over the territories to the north and south of the Ave River it called the attention and interest of various archaeologists such as Ricardo Severo and Martins Sarmento, in the end of the $19^{\text {th }}$ century, and F. Russell Cortez in the 40's of the next century. F. Russell Cortez organized digging campaigns at the site that uncovered a mixture Castrejo and Roman type buildings and structures, distributed by orthogonal spaces that already have the seal of a Roman influence in the region. The most recent archeological campaigns give us a higher precision to determine its evolution as a settlement, despite the many questions that remain unanswered.
\end{abstract}

Keywords: Cividade, Castrejo Culture, Roman period.

A Cividade de Bagunte localiza-se na freguesia com o mesmo nome, no concelho de Vila do Conde, num monte localmente conhecido por Cividade, Subidade, ou dos Sobreirinhos. Encontra-se classificada como Monumento Nacional desde 1910 (Decreto de 16-o6-1910, DG, n.. 136, de 23-o6-1910), sendo que atualmente a sua área classificada encontra-se em processo de ampliação (Anúncio n. $.^{\circ} 16 / 2016$, DR, 2..$^{\text {a }}$ série, $\mathrm{n} .{ }^{\circ} 12$, de 19-01-2016).

Trata-se de um povoado castrejo fortificado, central e romanizado que, tradicionalmente, tem sido enquadrado cronologicamente entre os séculos IV a.C. e IV d.C. (PINTO, 1997, 29; PINTO, 2003, 129), embora um estudo recente do espólio, depositado no Museu de História Natural e da Ciência da Universidade do Porto (a esta data ainda no prelo), permita afinar esta cronologia, como se verá mais adiante. Adicionalmente, escavações realizadas em conjunto pelo Gabinete de Arqueologia Municipal e pela University of Texas at Austin, determinou a existência de materiais cerâmicos e estruturas mais recentes, nomeadamente da Alta Idade Média.

Encontra-se implantado numa elevação com 206m de altura, num espaço geográfico que está delimitado pelo rio Este a norte, pelo rio Ave a sul e a oeste, embora um pouco mais distante, pelo oceano atlântico. O monte tem uma dimensão que se aproxima dos 5 oha, embora a zona arqueológica tenha uma área estimada seja inferior a essa cifra.

Em termos geológicos, a Cividade de Bagunte assenta sobre uma formação granítica que, a curta distância, faz fronteira com formações do complexo xisto-grauváquico, que se desenvolvem, no sentido noroeste-sudeste, desde a zona costeira de Esposende/Póvoa de Varzim até à região de Valongo/ Castelo de Paiva (TEIXEIRA, 1965).

1. Câmara Municipal de Vila do Conde - pedro.brochado@cm-viladoconde.pt 
Nas suas encostas nascem alguns fios de água que drenam para as bacias hidrográficas dos rios Este e Ave. Muitas destas linhas de água, de pequena relevância, mas importantes para um povoado fortificado da Idade Ferro Romanizado, foram artificialmente alteradas ao longos dos tempos mais recentes, nomeadamente pela construção de minas de água, das quais ainda se identificam alguns poços de ventilação/visita espalhados por todo o monte. Estas serviram, até há bem pouco tempo, para o regadio das extensas áreas agrícolas que se desenvolvem em seu redor, especialmente a este e a sul.

O monte apresenta uma configuração sub-arredondada,que assume um forte pendor nas vertentes voltadas a sul e oeste e uma inclinação suave na vertente norte e este. A noroeste e a sudeste existem dois esporões que, embora pouco evidentes, foram incluídos na área fortificada do povoado.

Um recente levantamento da biodiversidade ${ }^{2}$ constatou que, ao nível do coberto vegetal, o monte está densamente colonizado pelo eucaliptal, embora ainda subsistam algumas manchas de carvalhos, castanheiros e sobreiros. Com uma expressão maior encontram-se também os azevinhos, os sanguinhos-de-água e os salgueiros pretos. A presença destas duas espécies arbóreas é particularmente interessante por serem próprias de zonas húmidas. No que diz respeito às espécies arbustivas destaca-se a presença de várias espécies de ericas, de ulex, estevas, fetos, entre outras. Desde que, em 2015, o Município de Vila do Conde adquiriu 18ha da Cividade de Bagunte, tem sido possível regenerar as manchas de espécies autóctones, tendo com objetivo diminuir a presença do eucaliptal e controlar a outras espécies invasoras, nomeadamente de acácias.

A posição geográfica da Cividade de Bagunte permite-lhe ter um contacto visual com outros grandes povoados, como o Castro de Alvarelhos, a sul, ou a Cividade de Terroso, a norte. A sua posição também permite um controlo visual eficaz sobre um conjunto de povoados de menor dimensão que se erguiam nas suas imediações, nomeadamente o Castro Boi (Vairão), os castros de Casais e de Argifonso (situados em Arcos), de Retorta (Retorta), de S. Paio (Labruge), de Ferreiró (Ferreiró), de S. João (Vila do Conde).

Diversos autores identificaram-na como uma "povoação antiga”, pelo menos, desde o século XVIII,

2. Este levantamento foi realizado por técnicos do CMIA de Vila do Conde para a Câmara Municipal. quando foi mencionada por Jerónimo Contador de Argote, pelo Padre Carvalho da Costa, ou pelas Memórias Paroquiais, citadas por diversos estudiosos (PINTO, 2003, 126-127; ARGOTE, 1744; COSTA, 1868-1869).

A tentativa de a enquadrar cronologicamente começou, somente, no século XIX, quando entra na esfera de interesse de investigadores como Martins Sarmento (SARMENTO, 1999, 263-265; PINTO, 2003, 128). No entanto, foram Ricardo Severo e Fonseca Cardoso os primeiros a escavar na Cividade de Bagunte, em 1885 (SEVERO, 1886), tendo sido secundados por Mendes Correia, em 1915 (Arquivo da DGEMN - Cividade de Bagunte; ALMEIDA, 2015, 52). A intervenção arqueológica dirigida por Ricardo Severo e Artur Cardoso terá sido, inclusivamente, a responsável pela classificação da Cividade de Bagunte como Monumento Nacional, em 1910 (PINTO, 2003, 128).

A falta de um registo minucioso daquelas primeiras campanhas de escavação torna impossível localizar as áreas intervencionadas. Esta tarefa torna-se ainda mais difícil porque, na década de 40 do século XX, Fernando Russel Cortez empreendeu a maior campanha de escavação na Cividade de Bagunte (Arquivo da DGEMN - Cividade de Bagunte; ALMEIDA, 2015, 52-54).

É provável que os trabalhos da década de 40 do século XX tenham absorvido as zonas escavadas anteriormente. Todavia, a falta de uma publicação, ou registos detalhados dos trabalhos realizados por Russel Cortez torna impossível determinar quais as áreas escavadas por cada um dos investigadores (PINTO, 2003, 128-129). Tudo quanto Russel Cortez publicou sobre a Cividade de Bagunte reduz-se a um artigo datado de 1948 (CORTEZ, 1948, 269-281).

Estes trabalhos arqueológicos deixaram a descoberto parte do sistema defensivo, um misto de construções castrejas e romanas, distribuídas por espaços ortogonais, que já têm a chancela da influência romana na região. No total foi escavada uma área com $160 \mathrm{~m}$ de extensão (no sentido norte-sul) por cerca de $65 \mathrm{~m}$ de largura (no sentido este-oeste).

Seguiu-se um enorme desinteresse. No século XX nunca mais se escavou na Cividade de Bagunte. Este afastamento só foi sendo amenizado pela sua menção em alguns estudos científicos publicados durante os anos 8o e 9o do século passado (PINTO, 2003, 130-131; ALMEIDA, 1974; ROMERO MASIÁ, 1976; KALB, 1980; SILVA, 1986; CALO LOURIDO, 1994; 
QUEIROGA, 1996; DINIS, 1993; ALMEIDA, 1995; PINTO, 1998).

Esta tendência só foi quebrada com a criação do Gabinete de Arqueologia Municipal de Vila do Conde. Desde então foram realizados diversos esforços para resgatar as suas ruínas da floresta que, entretanto, cresceu em toda a área escavada. Foi também criado um primeiro documento que tinha por objetivo criar as bases do Parque Arqueológico da Cividade de Bagunte (PINTO, 2003, 125-159).

Adicionalmente foram feitos esforços para adquirir a sua propriedade, algo que se concretizou em 2015 e que incluiu toda a área com ruínas arqueológicas a descoberto.

Pouco antes foi possível, com o apoio de uma field-school anual da University of Texas at Austin, retomar as escavações arqueológicas, programa que dura até ao presente. Atualmente, o Gabinete de Arqueologia Municipal executa trabalhos arqueológicos, desde a escavação a trabalhos de conservação e manutenção anuais, com recursos a recursos humanos internos, mas também a o auxílio de alunos da Faculdade de Letras da Universidade do Porto.

As intervenções arqueológicas do século XXI concentraram-se na zona da acrópole da Cividade de Bagunte, área que foi divida em 8 Zonas artificiais que, por sua vez, foram divididos em quadrados.

Os trabalhos centram-se em quatro dessas zonas: 1 , 5,7 e 8 .

A grande maioria da área sondada foi dispersa por zonas que já haviam sido, de alguma forma, intervencionadas pelas campanhas do século XIX e XX (zonas 5,7 e 8). Os desafios desta decisão foram tomados de forma consciente, sabendo, à partida, que o registo estratigráfico poderia estar incompleto e perturbado. Contudo, também foi intervencionada uma área (zona 1), no âmbito da colaboração com a University of Texas at Austin, onde as garantias de preservação do registo estratigráfico eram superiores, por estar na periferia das intervenções arqueológicas mais antigas.

Tal como anteriormente referido, as propostas de datação para a Cividade de Bagunte enquadram a sua ocupação entre os séculos IV a.C. e IV d.C. (PINTO, 1997, 29; PINTO, 2003, 129), mas não tendo por base as escavações arqueológicas.

Um estudo recente, sobre os materiais da Cividade de Bagunte existentes no Museu de História Natural e da Ciência da Universidade do Porto, permite melhorar a sua cronologia, apontando para a exis- tência de materiais genericamente enquadráveis entre o período La Tène e o fim do Império (ALMEIDA, 2020) ${ }^{3}$.

Todavia, os resultados das escavações fornecem uma realidade diferente.

Contrariamente ao que acontece na Zona 1, onde o registo estratigráfico parece avançar até ao período Tardo-Romano, ou à Alta Idade Média, nas Zonas 5 , 7 e 8 o registo estratigráfico fica-se por uma cronologia que ronda o período dos Flávios (século I d.C.). Não avança para além desse período, mas também não recua. Se a escavação de Russel Cortez poderá explicar a falta de elementos arquitetónicos mais recentes, o mesmo não é viável para explicar a ausência dos mais antigos.

De acordo com os dados estratigráficos recolhidos nas campanhas arqueológicas realizadas recentemente, na Zona 1 aparecem estruturas Tardo-Romanas ou Alti-medievais. Estas caracterizam-se por muros onde a pedra é entremeada por tégula, disposta de forma pouco cuidada e onde se verifica a falta de alicerces assentes em terreno geológico. Nalgumas zonas preservaram lajeados que, à semelhança dos muros, denotam falta de empenho na construção de uma superfície regular. A forma como o edifício foi erguido denota uma clara falta de investimento, transmitindo a ideia de ser um refúgio transitório de alguém que recorreu à Cividade de Bagunte como local de habitação temporário, em tempos de incertezas.

Dado que as estruturas tardias encontradas na Zona 1 assentam sobre camadas de destruição das estruturas flavianas, parece ser seguro dizer-se que este movimento construtivo tardio corresponde a uma expansão/reocupação da Cividade de Bagunte. No entanto, os dados disponíveis não permitem, com segurança, afiançar se a Cividade de Bagunte, aquando daquela reocupação, estava totalmente abandonada, ou se este movimento correspondeu a uma nova fase de expansão.

É sabido que a instabilidade ganhou contornos conturbados na região aquando das invasões de Alanos, Suevos e Visigodos, sendo que muitas das populações locais hispano-romanas viram na orografia e nas muralhas dos castros uma forma eficaz de se manterem em segurança. Também são conhecidas as teses que defendem que muitos castros fo-

3. À data da redação deste artigo, o estudo ainda se encontrava no prelo. 
ram completamente abandonados, em detrimento do povoamento assente em núcleos urbanos e em villas, fomentado pelas políticas dos Flávios, mas que uma parte deles se manteve em funcionamento durante todo o período da Romanização (ALMEIDA, 2003, 272-285 e 395-406).

Neste momento, mercê da presença de cerâmica que cobre todas as cronologias associadas à Romanização, julgo que a Cividade de Bagunte se encaixa no modelo de uma ocupação contínua, embora com expansões e contrações urbanísticas significativas ao longo da sua existência, sendo esta a última fase da sua vida. Contudo, esta afirmação deve ser lida com cautela, pois os dados disponíveis para fazer uma afirmação tão concludente são ainda muito escassos e, em alguns casos, provenientes de contextos arqueológicos com registo pouco fiáveis.

Não faltam exemplos de povoados, com o Monte Mozinho, o Castro de São Lourenço e o Castro de Castelo de Neiva à cabeça, onde no século IV, se conhecem revitalizações da vida urbana, em muitos casos tornados prestadores de serviços daqueles que tinham optado por descer para a planície, quando os efeitos da romanização se começaram a fazer sentir na Gallaecia meridional.

Em termos urbanísticos, a Cividade de Bagunte apresenta um modelo claramente com influências da Romanização, baseado na ortogonalidade delineada por arruamentos, em bairros subdivididos em núcleos habitacionais, organizados em redor de pátios centrais e compostos por um misto de compartimentos redondos, quadrangulares/retangulares, com ângulos arredondados ou retos. Em suma, apresenta uma marca distintiva das alterações efetuadas por volta da segunda metade do século I, sob a influência da dinastia dos Flávios (ALMEIDA, 2015). As datações de $\mathrm{C}_{4} 4$ obtidas para estas estruturas parecem indiciar que o início destas alterações terá ocorrido um pouco mais cedo, logo após o câmbio da Era e ter-se-ão prolongado pela dinastia dos Flávios. Se assim é, então enquadram-se na fase III (A e B) proposta por Armando Coelho (SILVA, 1986, 66-67).

É comummente aceite pela historiografia da Cultura Castreja que o declínio da ocupação destas infraestruturas habitacionais começou com a integração do seu território na esfera político-administrativo-militar romana, que causou uma fragmentação das suas estruturas tradicionais. Esse movimento, embora possa ter iniciado antes, só se torna visível no século I, com a dinastia dos Flávios e acentuou-se no século II (ALMEIDA, 2003, 272-285).

As datações de C14 também permitiram perceber que nesta mesma área existem estratos arqueológicos que podem ser enquadrados numa cronologia um pouco mais antiga, mas que não recuam para além do II a.C., ou seja, enquadram-se na fase IIIA da periodização defendida por Armando Coelho (SILVA, 1986, 66-67).

Sobre a realidade imediatamente anterior à renovação empreendida entre o câmbio da Era e a dinastia dos Flávios, pouco ainda se sabe, em parte pela exiguidade da área escavada recentemente.

Esta exiguidade de dados é, no entanto, preenchida por uma inscrição revelada na intervenção de 2017. Esta foi descoberta no alicerce do muro de perímetro da unidade habitacional 3, com o campo epigrafado voltado para o arruamento, deposta em posição deitada e posicionada abaixo da cércea do pavimento. Portanto, não estava visível, indiciando uma deposição secundária. Na inscrição pode-se ler "VIRIVS FECIT". Se a inscrição comemorativa não está na sua deposição primária, deduz-se que "VIRIVS" mandou fazer algo distinto do edifício onde foi incorporado. Por outras palavras, terá de ser anterior às construções cuja datação medeia entre o câmbio da Era e o período dos Flávios, mas não pode ser anterior ao início da Romanização. A existir, essa ocupação corresponderá a um período intermédio da fase IIIA da periodização da Cultura Castreja proposta por Armando Coelho (SILVA, 1986, 66-67).

Quando a escavação ultrapassa as camadas relacionadas com o final do século II a.C., o que se encontra é uma realidade estratigráfica não antrópica. Essa camada será um solo vegetal anterior à ocupação humana daquela área. Esta realidade significa que, em todos os quadrados escavados no século XXI, sob a ocupação flaviana existem estratos datáveis do século II a.C., mas não se encontram dados mais antigos. Perante este quadro, pode-se pensar que as zonas escavadas no século XXI são área de expansão da Cividade de Bagunte, pois faltam as estruturas e os estratos arqueológicos que justifiquem a presença de espólio mais antigo, nomeadamente os fragmentos de tipo "Alpiarça" que se encontram no Museu de História Natural e da Ciência da Universidade do Porto. Estes foram encaixados numa faixa cronológica situadas entre os séculos VII e V a.C. (ALMEIDA, 2020) e que fazem pensar que o início da ocupação 
deste povoado possa ter acontecido durante a fase I da periodização proposta por Armando Coelho para a Cultura Castreja.

Mais recentemente, em 2018, recolheu-se uma fíbula em bronze do tipo Ponte 22a ou 22b. Esta terá uma cronologia que se situa entre o século VII a III a.C. (PONTE, 2004, Quadro 1b), corroborando a hipótese de estarmos numa área de expansão da Cividade de Bagunte.

Esse movimento ter-se-á iniciado no século no final do século II a.C. e prolongou-se até ao período dos Flávios.

Fica, no entanto, por responder onde se situa o núcleo mais ancestral da Cividade de Bagunte, o que justifica peças arqueológicas mais antigas. A resposta a esta questão talvez possa ser dada com o alargamento da área sondada, para outras áreas (Zona 2 e 3?) topograficamente mais elevadas e menos perturbadas por trabalhos arqueológicos anteriores.

Todas as áreas sondadas, desde o século XIX à atualidade, encontram-se no interior de, pelo menos, duas linhas de muralhas pétreas, aparentemente, concêntricas (há ainda um troço de muralha em terra, sobre a qual recaem mais dúvidas do que certezas, nomeadamente quanto à sua forma, dimensão e datação). Ainda não foi possível datar a construção das muralhas pétreas.

A muralha mais interior foi alvo de uma sondagem na atualidade, revelando que se encontrava muito destruída. Deu para perceber que era composta por duas faces opostas, distantes entre si em cerca de $1,4 \mathrm{~m}$, sendo que o espaço interior foi cheio com pedra não aparelhada e terra.

Esta muralha tem um pormenor interessante e que corresponde a uma caixa de escadas aberta na espessura do muro e que dava acesso ao topo da estrutura defensiva, pelo lado interior.

Durante as intervenções dos anos 40 do século XX, esta área deverá ter sido parcialmente escavada. Prova disso mesmo foi a recolha de uma conta de colar, de tom azul escuro, que depois de analisada, quanto à sua composição química, provou-se ser feita com vidro da Boémia. Por outras palavras, não poderia ser anterior ao século XIX e terá sido perdida por alguma das muitas trabalhadoras contratadas por Russel Cortez. Foi encontrado numa das unidades estratigráfica que, em algumas áreas, cobria o terreno geológico, sendo evidentes as reservas que pendem sobre os dados recolhidos nestas sondagens. Para procurar uma resposta para a datação das mu- ralhas da Cividade de Bagunte, num futuro próximo será aberta uma vala de sondagem que pretende, também do ponto de vista estratigráfico, determinar uma relação entre as estruturas habitacionais da acrópole e a primeira linha de muralha pétrea. Talvez nessa altura seja possível avançar com dados mais seguros.

Uma nota para futuras investigações prende-se com o acumular de um conjunto significativo de elementos que, devidamente trabalhados por outras ciências, poderão dar um quadro mais vasto e rico sobre a evolução da Cividade de Bagunte ao longo da sua "vida". Alguns destes trabalhos têm, potencialmente, a capacidade de criar sinergias interessantes. Neste rol incluem-se os trabalhos de antropologia física, de antracologia e carpologia e de cromatogramas.

Já foram ensaiados alguns esforços nesse sentido, mais numa perspetiva de comprovar que os dados estavam disponíveis, mas também para afinar estratégias futuras que permitam maximizar as recolhas de informação, algo que será aplicado em escavações futuras.

Assim sendo e apesar dos dados tratados não serem estatisticamente relevantes e de possuírem diversos problemas na sua recolha (entre outros, os dados resultam de recolhas não sistemáticas e de seleção aleatória), sabe-se que na Cividade de Bagunte estão presentes diversas espécies vegetais, onde predominam os "Quercus" de folha caducifólia, mas também das famílias das "Leguminosae", nomeadamente o "Cytisus scoparius" (giesteira das vassouras) e o "Ulex" (tojo). A amostra tratada possui, em número consideravelmente menor, um conjunto de espécies que usualmente são associadas a galerias ripícolas, como o "Salix" (salgueiro), o "Corylus avellana” (aveleira), a "Alnus” (amieiro) e a "Frangula sp.” (frângula). Uma outra espécie detetada foi a "Prumus Avium/Cerasus" (cerejeira brava/ginja) que, por norma, se posiciona nos limites de campos agrícolas. Também foram identificados carvões de "Erica" arbórea (Urze-branca) que etnograficamente está associada a atividades com necessidades caloríficas elevadas. Residualmente, aparecem carvões de "Quercus" de folha perenifólia, de "Rhamnus sp” (espinheiro) e de "Vitis Vinifera” (videira). Normalmente associados a contexto da antiguidade tardia, a "Castanea Sativa" (castanheiro) também marcou presença ${ }^{4}$.

4. A identificação destes elementos ficou a cargo de Catarina de Oliveira Magalhães, estudante de mestrado em Arqueociências, a quem agradeço a colaboração. 
Também estão a ser feitos estudos sobre os elementos carpológicos, mas os mesmos encontram-se numa fase mais atrasada, pelo que não é possível apresentar qualquer dado neste momento.

Numa abordagem complementar, foram realizados diversos estudos sobre os resíduos químicos absorvidos pela cerâmica, através da cromatografia. Uma vez mais, estes primeiros testes serviram para comprovar a existência de dados e afinar métodos de recolha, de manuseamento e armazenamento das peças a testar.

Os primeiros testes mostram que a cerâmica possui elementos químicos compatíveis com a sua utilização. Num dos casos, um dolium, foi possível determinar que o mesmo foi revestido interiormente por cera de abelha. Existem outros exemplos, nomeadamente ânforas, que atestam o uso de resina de pinheiros e ciprestes. Na cerâmica comum aparecem vestígios de óleos vegetais, com elevado grau de probabilidade de serem de azeite e gorduras animais. De entre os diversos problemas levantados por esta investigação, o que mais chamou à atenção é a falta de marcadores resultantes da queima de alimentos ${ }^{5}$. Também numa fase inicial está o estudo de material osteológico, provavelmente pertencente a fauna consumida, mas cujos ossos aparentar terem sido expostos a altas temperaturas. Este material foi encontrado numa entulheira, misturados com material diverso, que incluída escória metálica e vítrea, bem como uma grande quantidade de cinza.

Quando nos for possível a visão cruzada destes três trabalhos-haverá um conhecimento mais abrangente sobre o modo de vida neste povoado, devidamente enquadrado cronologicamente.

5. Estes testes, o tratamento da informação e a sua interpretação foram realizados por César Oliveira, Doutorado em Química pela Universidade do Porto e Post-Doc pela Universidade de Aveiro, a quem agradeço a colaboração.

\section{BIBLIOGRAFIA}

ALMEIDA, Carlos A. Ferreira de (1974) - Cerâmica Castreja, in Revista de Guimarães, Vol. LXXXIV (1-4), Guimarães, 1974.

ALMEIDA, Carlos Alberto Brochado de (1995) - A romanização no concelho de Vila do Conde, Guimarães.

ALMEIDA, Carlos A. Brochado de; ALMEIDA, Pedro Miguel D. Brochado de (2015) - Alguns Apontamentos sobre a Cividade de Bagunte - Vila do Conde, in Portugália, Nova Série, Vol. 36, Porto, DCTP-FLUP, pág. 49-62.

ALMEIDA, Carlos A. Brochado de; MORAIS, Rui, ALMEIDA, Pedro Brochado de, FILIPE, Ana Rita (202O) - Materiais arqueológicos da Cividade de Bagunte presentes no Museu de História Natural e da Ciência da Universidade do Porto (prelo a publicar na Revista Portugália).

ARGOTE, Jerónimo Contador de (1744) - Memórias para a História Eclesiástica do Arcebispado de Braga, tomo III, Braga.

CALO LOURIDO, Francisco (1994) - A Plástica da Cultura Castrexa Galego-Portuguesa, Vol. I, Museo de Pontevedra, Pontevedra.

CORTEZ, F. Russel (1948) - Actividade Arqueológica em Portugal durante 1947, in Archivo Español de Arqueologia, Vol. XXI (72), Madrid, 269-281.

COSTA, A. Carvalho da (1868-1869) - Corografia Portugueza e Descripçam Topografica do Reino de Portugal, Lisboa, 3. Vol, 2 $2^{\underline{a}}$ Edição, Braga,

DINIS, António Pereira (1993) - Ordenamento do Território do Baixo Ave no I Milénio a.C., Dissertação de Mestrado, Policopiado, FLUP, Porto.

KALB, Philine (1980) - Zur Atlantischen Bronzezeit in Portugal, Germania.

PINTO, Paulo Costa (1997) - Raízes de Vila do Conde, edição APPA-VC, Vila do Conde.

PINTO, Paulo Costa (1998) - Arqueologia e Administração Local, Actas dos Encontros O Archeólogo português. 100 anos de Arqueologia, edição APPA-VC, Vila do Conde.

PINTO, Paulo Costa (2003) - O Parque Arqueológico da Cividade de Bagunte. Projeto de Dinamização Cultural da área da Cividade de Bagunte, in Atas Encontros do Património de Vila do Conde, edição Câmara Municipal de Vila do Conde, 125-159.

PONTE, Salete da (2004) - Retrospetiva sobre Fíbulas proto-históricas e romanas de Portugal, in Revista Conimbriga, Volume XLIII, Faculdade de Letras da Universidade de Coimbra, Coimbra.

QUEIROGA, Francisco (1996) - As Sociedades do 1º Milénio a.C. do vale do Ave e as metalurgias do Bronze e Ferro, $I^{\circ}$ Colóquio "Mineração e Metalurgia do Ferro (da antiguidade aos nossos dias), Torre de Moncorvo. 
ROMERO MASIÁ, Ana (1976) - El Habitat Castreño. Asentamientos y Arquitectura de los Castros del N. O. Peninsular, Santiago de Compostela.

SARMENTO, Martins (1999) - Apontamentos de Arqueologia. Antiqua, edição Sociedade Martins Sarmento, Guimarães.

SEVERO, Ricardo, CARDOZO, Artur (1886) - Notícias archeologicas sobre o Monte da Cividade, Revista de Guimarães, III, Guimarães.
SILVA, Armando Coelho Ferreira da (1986) - A Cultura Castreja no Noroeste de Portugal, EDIÇÃO Câmara Municipal de Paços de Ferreira, Paços de Ferreira.

TEIXEIRA, C.; MEDEIROS, A. C. (1965) - Noticia explicativa da folha 9-A (Póvoa de Varzim) da Carta Geológica de Portugal à escala 1:50 ooo, Direcção Geral de Minas e Serviços Geológicos, Serviços Geológicos de Portugal, Lisboa.

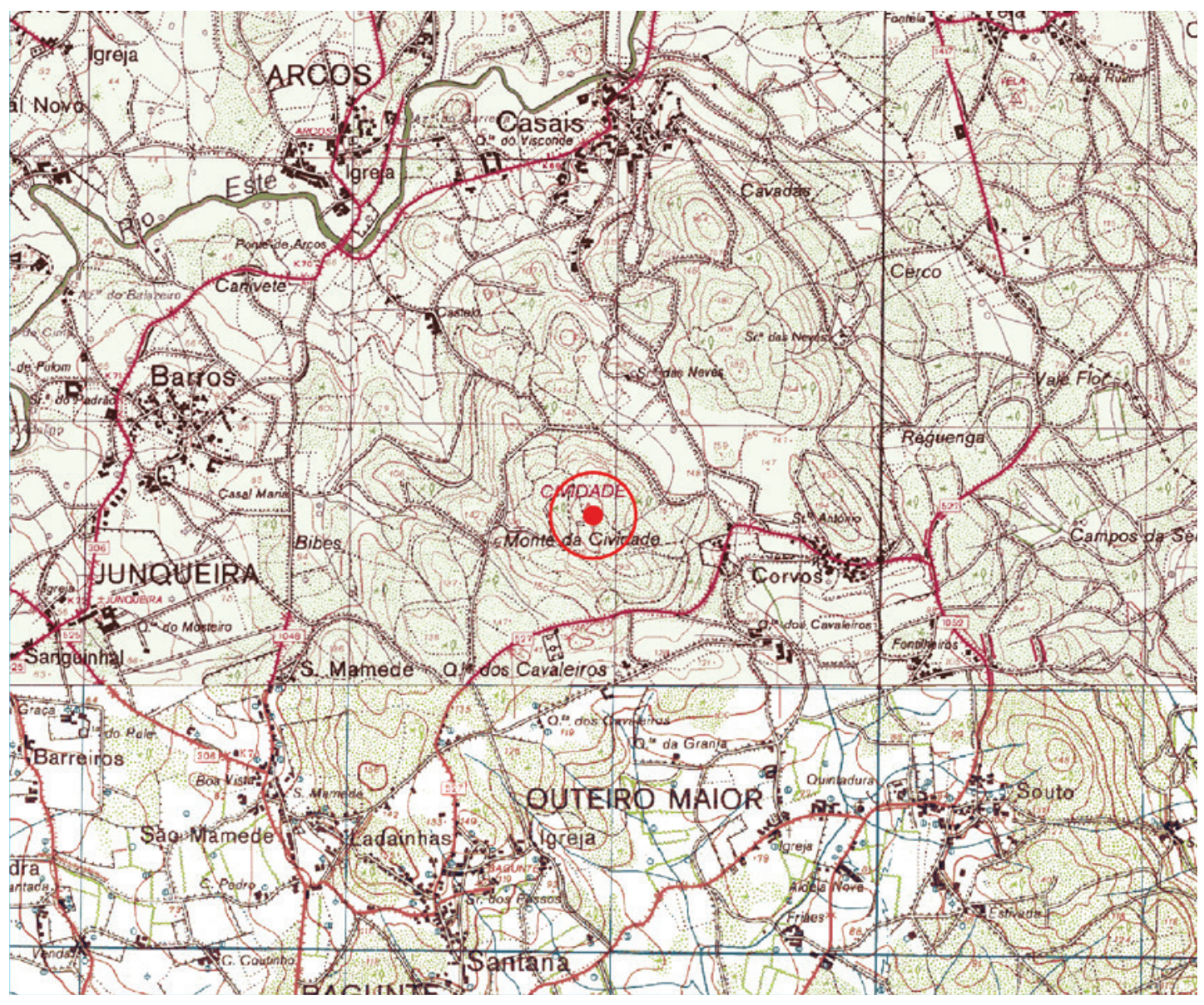

Figura 1 - Localização. 


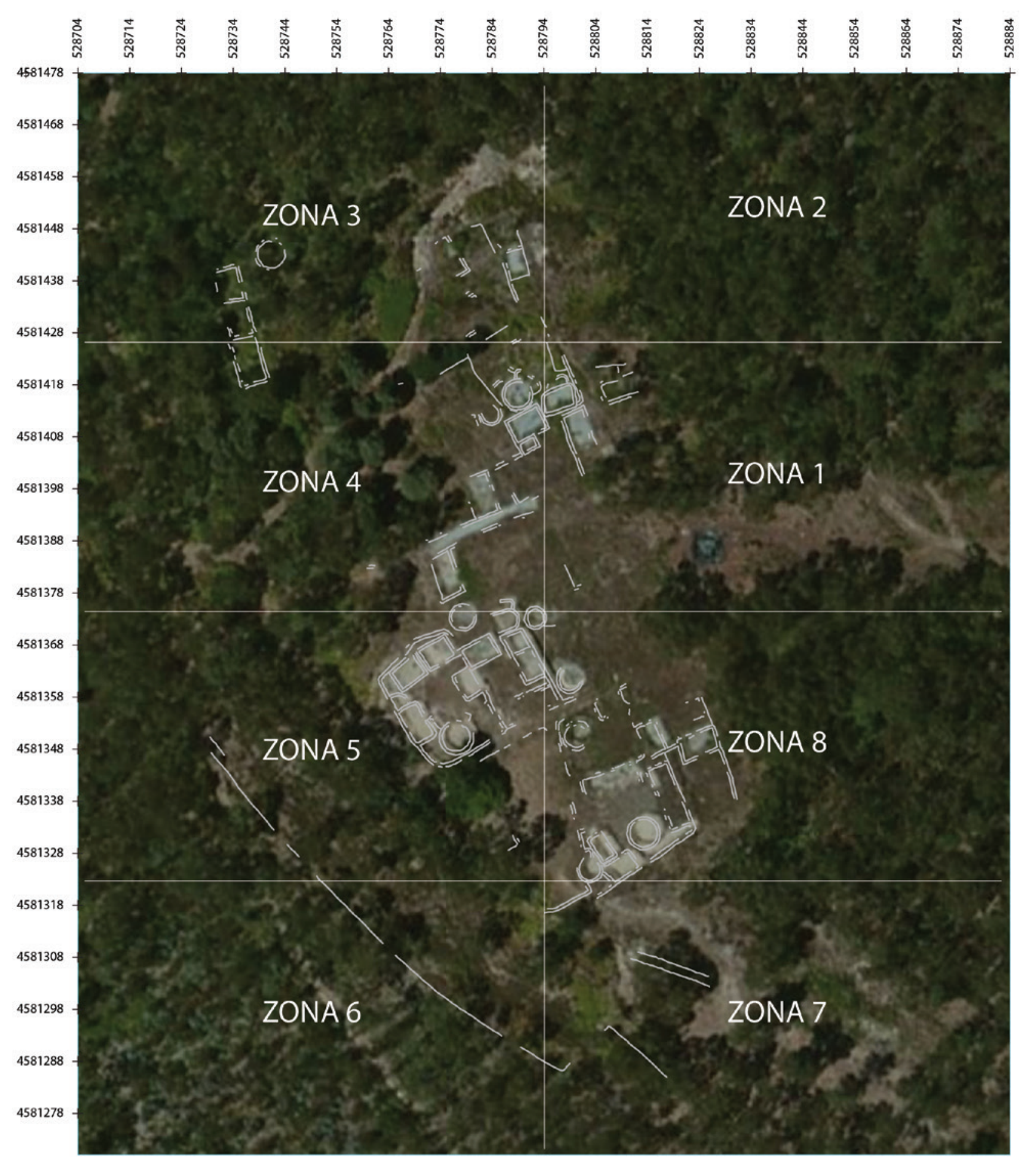

Figura 2 - Divisão da Cividade de Bagunte em zonas. 


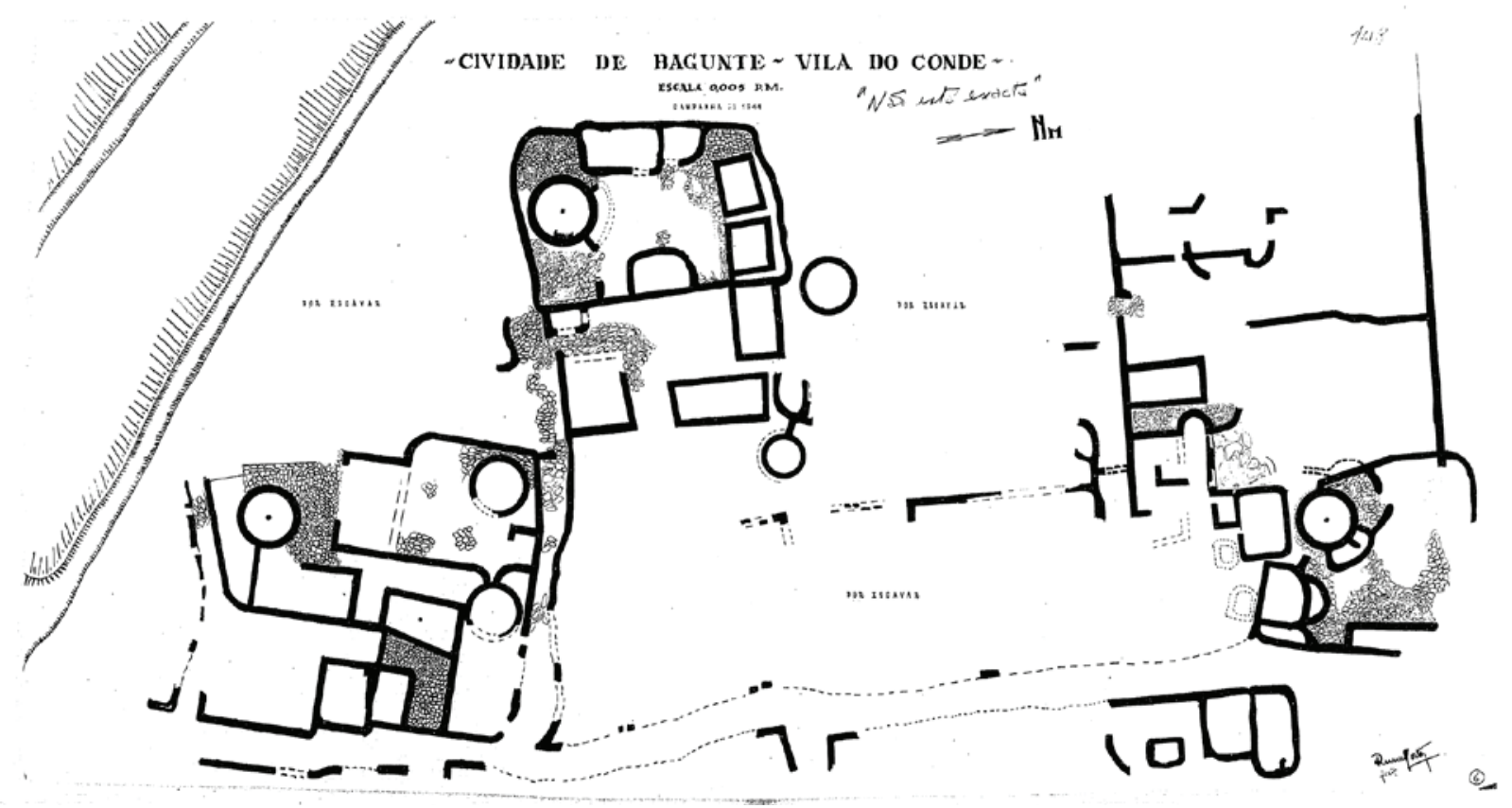

Figura 3 - Planta da Cividade de Bagunte feita por Russel Cortez (arquivo DGEMN).

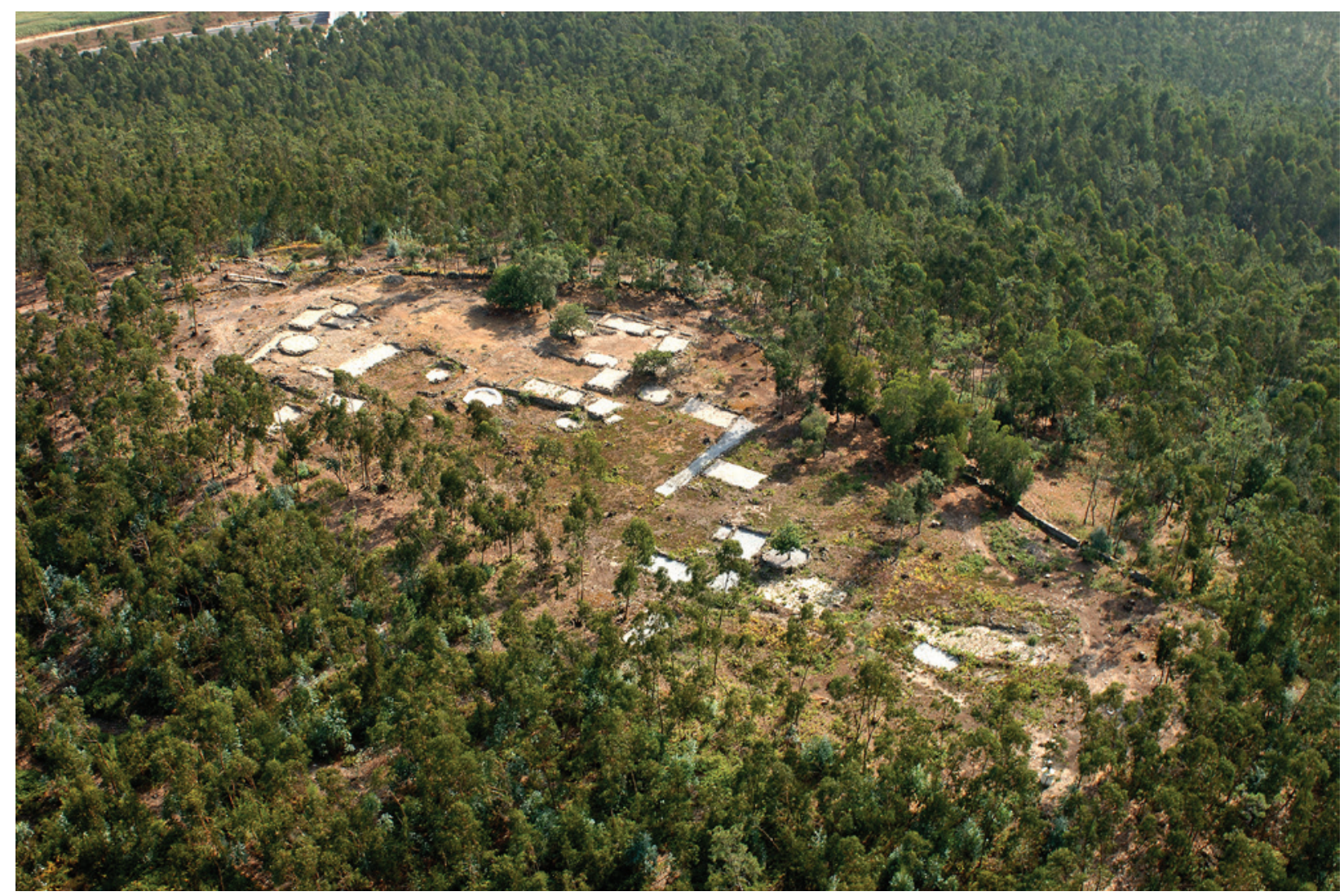

Figura 4 - Imagem aérea da acrópole da Cividade de Bagunte. 


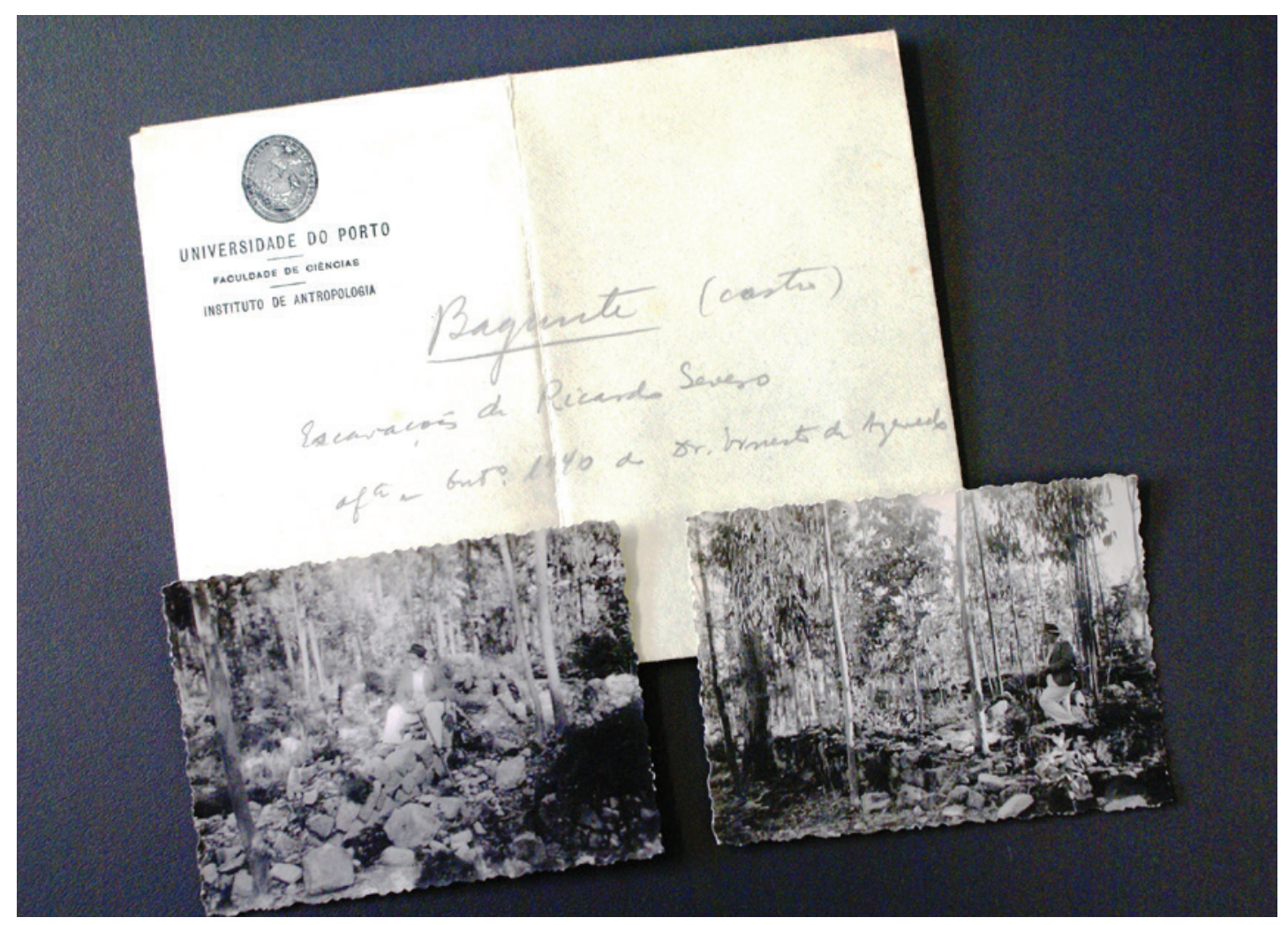

Figura 5 - Imagens da escavação de Ricardo Severo (Arquivo Museu de História Natural e da Ciência da Universidade do Porto).

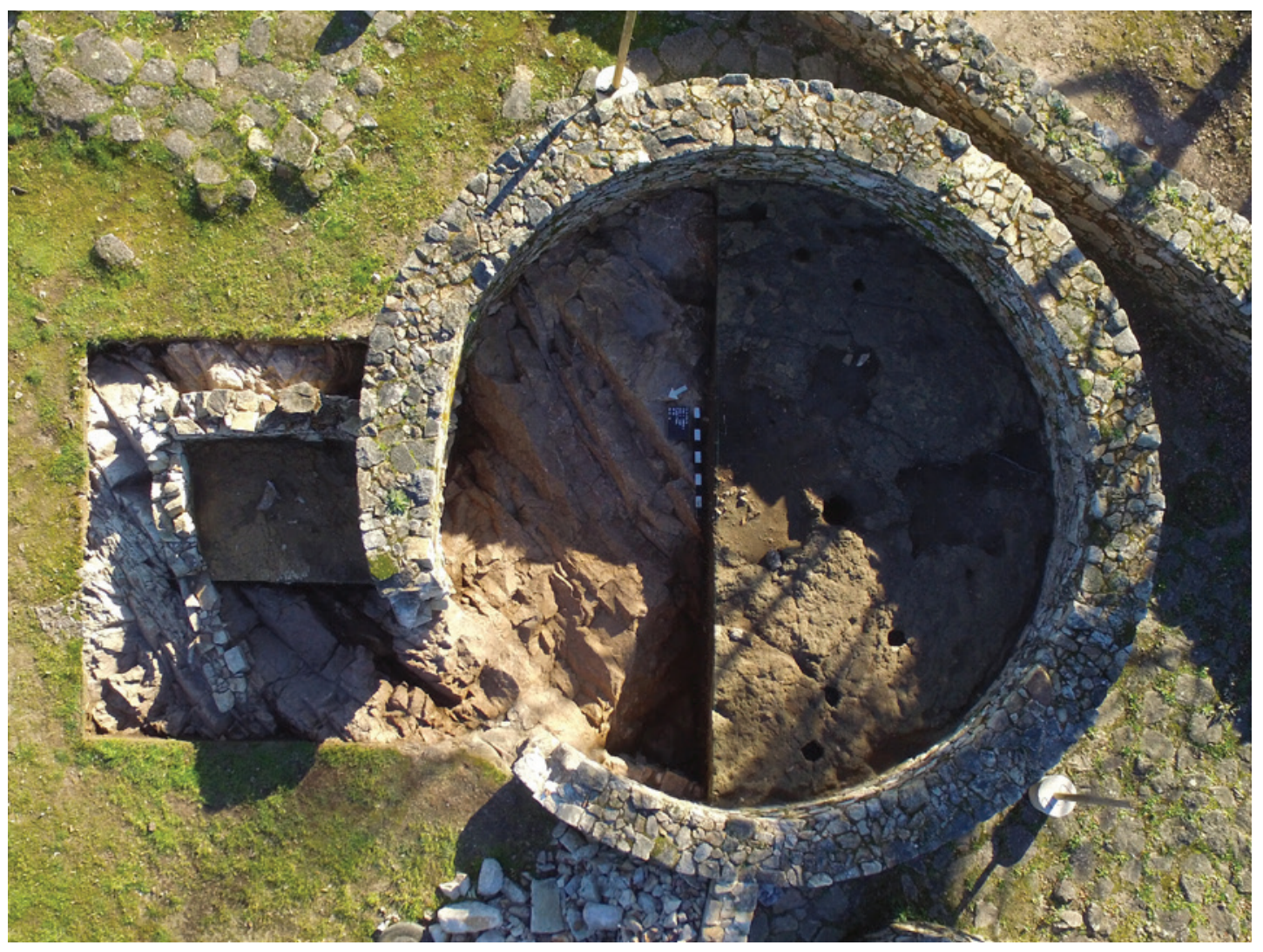

Figura 6 - Imagem escavação efetuada na zona 5. 


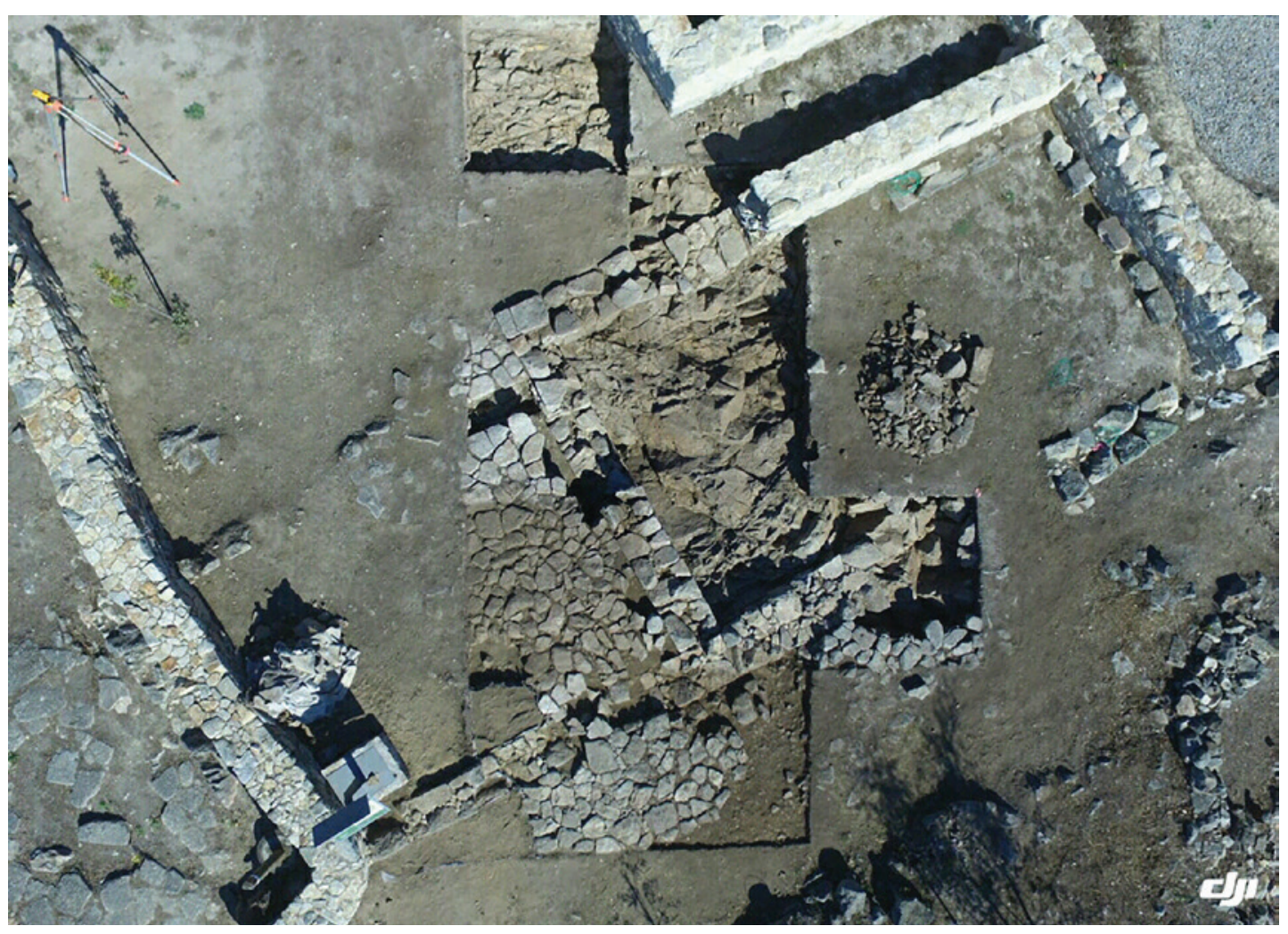

Figura 7- Imagem escavação efetuada nas zonas 5 e 8.

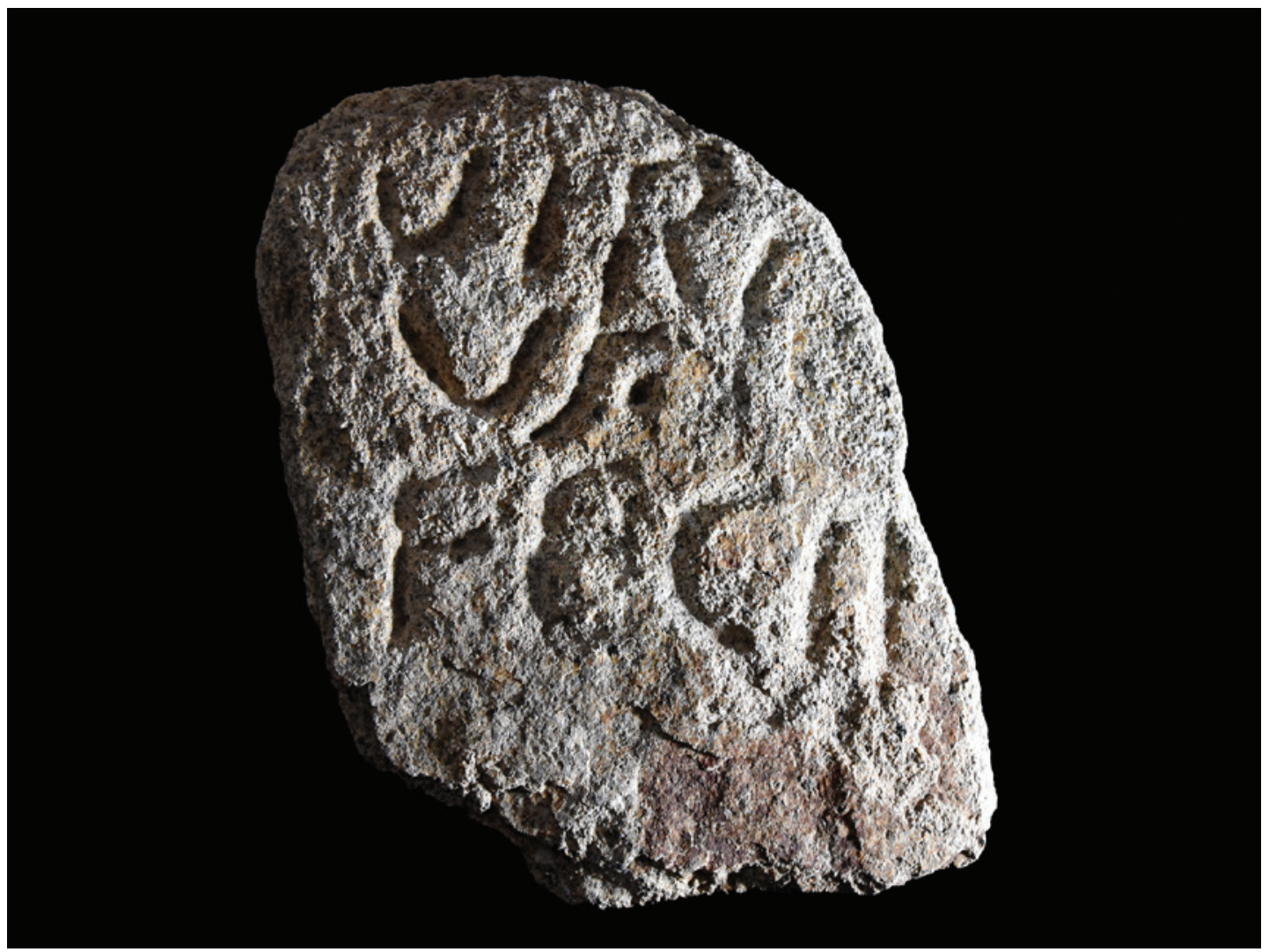

Figura 8 - Imagem escavação efetuada nas zonas 5 e 8. 


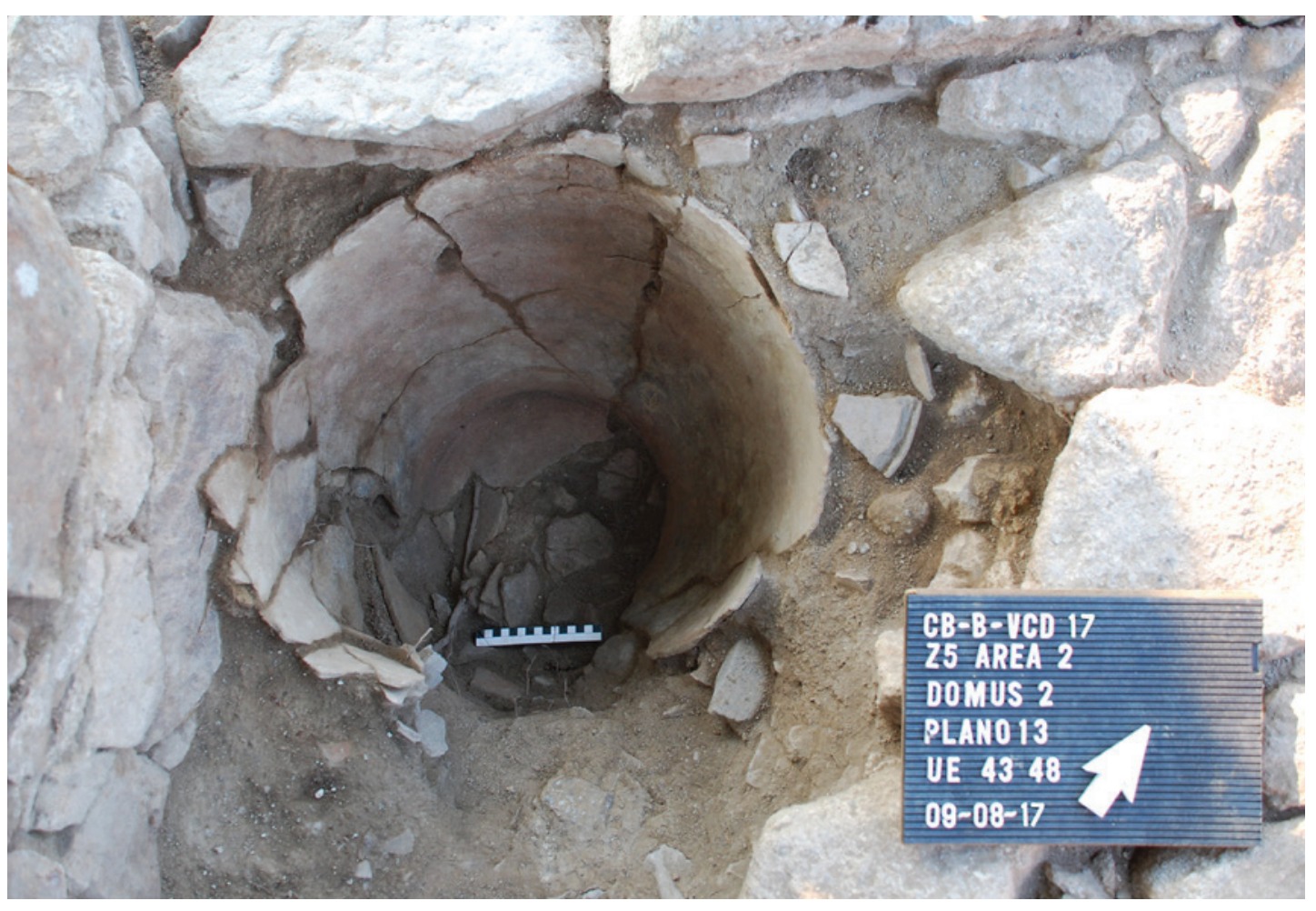

Figura 9 - Imagem de dolium encontrado na zona 5. 


\title{
ZOOMORFOS NA CERÂMICA DA IDADE DO FERRO NO NW PENINSULAR: INVEN- TÁRIO, CRONOLOGIAS E SIGNIFICADO
}

\author{
Nuno Oliveira ${ }^{1}$, Cristina Seoane ${ }^{2}$
}

\begin{abstract}
RESUMO
Nos estudos de cerâmica da Idade do Ferro no noroeste da Península Ibérica, destacam-se um determinado número de peças que apresentam decoração com motivos zoomórficos. Provavelmente sua relativa raridade neste período, onde predominam os motivos geométricos, se torne algo de especial interesse como instrumento social e ideológico para o estudo da sociedade.

O objetivo deste estudo foi o de realizar o primeiro inventário deste tipo de motivos associado ao seu contexto geográfico, à sua cronologia, funcionalidade, valor social e simbólico dessa representação na sociedade que a produziu. Após organização dos dados obtidos, esses elementos foram comparados com a decoração em metais e outros materiais.
\end{abstract}

Palavras-Chave: Coleção cerâmica, Motivos figurativos, Decoração estampada, Cronologia, Interpretação.

\begin{abstract}
In the Iron Age ceramics studies on the NW of Iberian Peninsula, had number of pieces that feature decoration with zoomorphic motifs stand out. Probably their relative rarity within the ceramics in this period, where geometric motifs dominate, become of special interest as a social and ideological instrument for the society. The aim of this study was to carry out the first inventory of this type of motifs associated with its geographical context and its chronology and the functionality, social and symbolic value of this representation in that society. After organizing the data obtained, these elements were compared with the decoration in metals and other fabrics.
\end{abstract}

Keywords: Ceramic collection, Figurative motifs, Stamped decoration, Chronology, Interpretation.

\section{INTRODUÇÃO}

Os estudos cerâmicos da Idade do Ferro do Noroeste Peninsular efetuados nos últimos 50 anos procuraram como principais abordagens a sistematização das características morfológicas e tecnológicas destes produtos artesanais, o que possibilitou a formulação de tipologias representativas desse período (SILVA, 1986; REY CASTIÑEIRA, 1991). Com base nesses estudos a investigação da cerâmica foi avançando ao longo do tempo, dando aos arqueólogos uma excelente de base de trabalho para as mais di- versas amplitudes territoriais. As combinações desses trabalhos com investigações mais recentes tornaram possível o estudo dos pormenores de todo o repertório cerâmico, incluído o que se procurou realizar neste artigo.

A decoração da cerâmica dos castros da Idade do Ferro conta com um amplo percurso desde diferentes perspetivas (CALO, 1999; REY CASTIÑEIRA, 1998), entre as quais se destaca o trabalho sobre cerâmica decorada por estampilha de E. Rodríguez Puentes (1986), estudo que teve muito peso no decorrer deste trabalho. Com efeito, a tese de doutoramento

\footnotetext{
1. Este trabalho foi realizado no decorrer da bolsa de doutoramento com a referência SFRH/BD/138105/2018, concedida pela Fundação da Ciência e Tecnologia. Instituição à qual agradecemos todo o apoio. Agradece-se ainda o apoio do Lab2PT, Universidade do Minho.;ntco_arque@sapo.pt.

2. Grupo de Estudo para Prehistoria do NO Ibérico - Arqueoloxía, Antigüidade e Territorio (GEPN-AAT);

crisseoanenovo@gmail.com.
} 
de G. Cabanillas de la Torre (2015) que engloba a estampagem em toda a Europa Atlântica, apresenta uma sistematização de alguns dos motivos decorativos que recolhemos neste artigo, o qual nos serviu de base para realizar a nossa base de dados.

Tomando como ponto de partida os trabalhos referenciados, além de muitos outros, associando o trabalho próprio e direto sobre as cerâmicas, levaram a observar a recorrente presença de motivos decorativos com formas zoomórficas por todo o NW Peninsular durante a Idade do Ferro.

Estes motivos contrastam com motivos geométricos que são abundantes desde da Idade do Bronze e durante toda a Idade do Ferro nesta área geográfica. Decerto, para os autores deste estudo é possível que a grande particularidade e escassez destes motivos zoomórficos seja também pelo facto de se ter dado pouco destaque estes motivos na literatura arqueológica até ao momento. Quer pela sua raridade nos espólios cerâmicos desta cronologia ou também pelas dificuldades dos estudos cerâmicos derivadas tanto à sua grande fragmentação, além de que em muitas ocasiões, estes não serem devidamente difundidos, nem são facilmente acessíveis aos investigadores por outras razões.

Aliás, este interesse por estas representações zoomórficas e a sua raridade talvez tenha várias razões de índole social e mesmo simbólicas que até agora não tinham sido consideradas.

Com efeito, os objetivos deste trabalho passaram desde logo por elaborar o primeiro inventário (o mais exaustivo e sistemático possível) deste tipo de motivos, associados com o seu contexto geográfico tanto à macro como à microescala. Mas a investigação requereu de seguida a observação das formas e/ ou tipologias cerâmicas previamente estabelecidas (MARTINS, 1987; REY CASTIÑEIRA, 1991; SILVA, 1986) em que estas decorações ocorrem, em que lugar do corpo dos recipientes se colocam, em que cronologias se inserem, quando foi possível, e finalmente, talvez o mais difícil, tentar compreender a sua funcionalidade, valor social e/ou simbólico que estas representações zoomórficas poderiam possuir e que só são entendidas seio de uma dada cultura e que neste momento nos escapa à nossa compreensão. Além destes objetivos foi ainda tido em conta a comparação com os materiais metálicos - quer em bronze (SILVA, 1986; FERNÁNDEZ, 2003; REY CASTIÑEIRA, 2005a), quer em ouro (BALSEIRO, 1994; PÉREZ, 1980) - e finalmente em último lugar apresentamos ainda exemplos de gravuras em lajes de pedra que formam parte dos espólios materiais de alguns castros do NW (FIGUEIREDO e NEVES, 2005; MEIJIDE, et al., 2009). Estes são elementos materiais que se empregam como apoio tanto a nível cronológico como simbólico e/ou cultural na hora de interpretar a importância que estes elementos guardam para as populações da Idade do Ferro no NW peninsular.

\section{METODOLOGIA}

No que diz respeito aos aspetos metodológicos que foram necessários para levar a cabo este trabalho, é de destacar que foi essencial elaborar um catálogo com todas as ocorrências de decoração de tipo zoomorfo na cerâmica. Para realizar esta compilação foi necessária tanto uma revisão bibliográfica extensa, como recorrer a alguns museus e profissionais da arqueologia na procura de fotografias ou mesmo desenhos de fragmentos que apresentassem estes motivos decorativos. Neste processo foram tidos em conta sobretudo os motivos decorativos que, sem sombra de dúvida, remetessem para ictiomorfos, ornitomorfos e quadrúpedes, que são os motivos decorativos que os autores vinham observando já algum tempo e que eram os que ocorriam em maior número. Em relação aos peixes, e sobretudo, às aves, optou-se por dividir estas representações em dois grupos: um primeiro mais próximo da realidade e com semelhanças evidentes com estes animais e um outro grupo mais abstrato, mas cuja forma remete para um tipo de animal em específico. Foram descartados aqueles motivos que, tradicionalmente, se vinham a identificar com aves como são as diferentes representações das séries de SSS estampadas, mas estas são descartadas deste trabalho por possuírem especificidades muito variadas e uma realidade complexa. De facto, este tipo de decoração merece um tratamento monográfico e específico para a sua sistematização e interpretação iconográfica.

Relativamente às fontes bibliográficas, consideraram-se as sínteses existentes para as bacias dos rios Minho (SILVA, 1986; REY CASTIÑEIRA, 1991, 1996, 2005b, 2014; SILVA, 2006),), do Lima (ALMEIDA, 1990), do Cávado (MARTINS, 1990; BETTENCOURT 1999, 2000), do Ave (DINIS, 1993); ou do Barbantiño (ÁLVAREZ GONZÁLEZ, 2019); estudos monográficos de sítios (AYÁN VILA, 2012a, 2012b; CONCHEIRO COELLO, 2008; DINIS, 2001; 
SILVA, 1997) e áreas concretas com a da Rías Baixas da Galiza (REY CASTIÑEIRA, 1990-1991).

Ainda foi necessário recorrer a de diferentes intervenções arqueológicas de sítios ainda inéditos ou cujas publicações apenas remetiam aos seus materiais.

Estas investigações foram muito importantes, posto que recolhem as primeiras compilações de alguns motivos zoomórficos, adicionando-os em mapas de distribuição de sítios que permaneciam inéditos. Todas estas e outras leituras venham a completar os dados aportados pelas mencionadas teses de licenciatura de E. Rodríguez Puentes (1986) e de doutoramento de G. Cabanillas de la Torre (2015) e J. Rey Castiñeira (1991), nas que as duas autoras e o autor fazem um percurso quer regional - no caso do primeiro e da terceira - quer suprarregional - no caso da segunda.

Além deste trabalho de recolha bibliográfica foi tido em conta o estudo direto e exaustivo, sempre que for possível, de novas coleções e contactos com museus ou colegas de profissão, que incidiram sobretudo, em povoados da bacia do rio Lima, ou das Rías Baixas, além das bacias dos rios Minho e Barbantiño na Galiza, além de outras localizações.

De todo este esforço de recompilação de informação por estes meios, conseguimos que fossem considerados 34 sítios com cerâmicas que apresentam motivos zoomórficos, repartidos em 16 assentamentos da Idade do Ferro para a área da Galiza, 4 para Astúrias e 1 em León e 12 para o norte de Portugal (Fig.1). Por último, em termos da metodologia de trabalho, os dados obtidos foram georreferenciados na plataforma IDEPatri (ABAD et al. 2011) o que possibilitou estabelecer a distribuição e dispersão geográfica dos materiais, diferenciados por motivos assim como comprovar as possíveis concorrências dos distintos motivos nos mesmos sítios e/ou se descrevem territórios ou se circunscrevem a uma área oleira das já definidas (REY CASTIÑEIRA, 1991, 1995, 2011) em particular. E também permite conhecer os limites que marcam este tipo de peças enquanto à sua distribuição.

No fim foi tentado, numa perspetiva mais global, compreender e relacionar a realidade existente nos metais dessa região onde são representados zoomorfos, procurando apresentar exemplos de peças e em que zonas dessas peças essa decoração por zoomorfos surge. Além dos metais foram consideradas as manifestações ao nível da arte rupestre inserível na proto-história da região. Procurou-se dessa forma as possíveis conotações sociais e simbólicas que teriam estes motivos zoomorfos partilhados: na cerâmica, nos metais e nas gravuras móveis.

\section{ZOOMORFOS NA CERÂMICA: AVES, PEIXES E CAVALOS}

O conjunto de dados analisados permitiu dividir os motivos zoomorfos em três grandes grupos: 1. os que representaram animais que voam; 2. os que evidenciam animais terrestres, como os equídeos e 3. os que reproduzem animais aquáticos, como os peixes. $\mathrm{Na}$ sua maioria, com a exceção dos motivos que apontam para animais terrestres, a decoração aqui em análise é produzida a partir de um estilete previamente produzido, em osso, madeira ou metal, o que tornaria os motivos a apresentar todos iguais mediante a preparação e aplicação desse selo com o desenho desejado. Esta pré-elaboração do motivo a criar e a imprimir sobre a peça requer uma considerável preparação tanto na conceção como na elaboração da peça final. No caso específico dos exemplares que apresentam quadrúpedes, a decoração é exclusivamente produzida através da impressão ou por incisão. Isto poderá ficar a dever-se ao facto de ir desenhando na peça este tipo de animal de modo manual, do que por produzir através de um estilete uma estampa de grande dimensão (Fig. 2).

Quanto a zoomorfos que se podem incluir os ornitomorfos e os ictiomorfos somam o maior número de exemplares registados neste trabalho e que, normalmente são acompanhados por caneluras incisas, por aplicações plásticas através de cordões lisos, ocorrendo inclusivamente com outras estampagens diferentes como combinações de círculos concêntricos, séries de SSS, etc.

Como podemos observar no mapa (Fig. 1), na atual Galiza os zoomorfos, sobretudo os peixes, concentram-se nas Rías Baixas, aparecendo fundamentalmente nos conhecidos tipos xerra -jarro- tipo "Toralla”, vasos de dimensões relativamente pequenas e pensadas para conter líquidos e com as paredes muito finas, e nas vasilhas de bordo engrossado tipo "Cíes", que são recipientes de grandes ou medianas dimensões destinadas provavelmente a armazenagem, bem de líquidos ou sólidos. São estas últimas as que se associam com as asas das formas conhecidas como crateriformes (REY CASTIÑEIRA, 2019) e que amossam decoração na cara exterior do lábio, 
em ocasiões com estas estampilhas zoomórficas, fundamentalmente peixes. Estas peças aparecem em castros coma o do Neixón Grande (Boiro, A Coruña), Illa de Toralla (Vigo, Pontevedra) ou o de Hortas/Cíes (Vigo, Pontevedra), entre outros vários. Também concorrem estas tipologias na região do noroeste de Portugal, como é o caso do Castro de Santo António (Oliveira e Bettencourt, 2020), onde foram registados zoomorfos aquáticos (peixes).

No caso das aves, concentram-se sobretudo na bacia do rio Minho e em parte da área Bracarense, em peças de perfil em S suave, é dizer, em vasos de bordo arredondado, colo alto e estrangulado, corpo curto, bojudo e esbelto e fundo plano de dimensões medias ou pequenas. Não obstante, para a região norte de Portugal nota-se uma preferência clara pelo uso de potinhos/púcaros para este género de decoração. É de destacar que são as aves mais esquemáticas as que se atopam na área mais oriental do NW como são Asturias ou Castilla y León. Em esta área a sua distribuição é em áreas de bacias de importantes cursos fluviais coma os rios Narcea, Nalón, Navia ou Eo, caso dos castros de Chao Samartín (Grandas de Salime, Asturias), Campa Torres (Gijón, Asturias) ou Llagú (Oviedo, Asturias), por exemplo.

No caso dos quadrúpedes, poucos são os motivos identificados neste estudo, somente dois possíveis casos na Galiza e outros dois em Portugal. Em todos os casos esta decoração foi efetuada por incisão e impressão. Estes motivos surgem em paredes que sugerem ser de formas com alguma dimensão, por exemplo de potes com mais de $20 \mathrm{~cm}$ de diâmetro e em vasilhas de tipo "Cíes". Em termos gerais, os quadrúpedes encontram-se dispersos, na área da ria de Vigo e na área entre as bacias dos rios Cávado e Ave. No caso dos motivos aquáticos, como são os, peixes, parece existir uma clara concentração na área mais próxima ao Atlântico, caso tanto da área das Rías Baixas (coma nos castros de Fozara ou Montealegre) como dos povoados no noroeste português (caso dos castros de S. Paio ou do Alto do Coto da Pena). Finalmente, os zoomorfos que apresentam aves encontram-se dispersos por todo o território em análise, contudo é necessário fazer uma ressalva: a quantidade e diversidade deste tipo de zoomorfo é bastante densa, o que em próximos trabalhos terá a devida atenção. Contudo, é necessário salvaguardar um aspeto importante: em muitos casos não foi possível identificar a tipologia de peça a que poderia pertencer. Isto porque variados motivos, ou a fon- te bibliográfica não é exaustiva a ponto de afirmar a tipologia, ou por outro lado o fragmento é de tal forma diminuto que não é possível saber a que tipo cerâmico se poderia aportar.

\section{ZOOMORFOS NOUTROS SUPORTES DA IDADE DO FERRO DO NW PENINSULAR}

A interpretação dos motivos representados foi tentada com base nas restantes materialidades existentes na Idade do Ferro do NW que apresentam motivos similares, bem gravados, tanto em relevo como em repuxados. Tal é o caso de alguns motivos na ourivesaria (diademas, torques, brincos, etc.) (BALSEIRO GARCÍA, 1994; LADRA FERNÁNDEZ, 2011; PÉREZ OUTEIRIÑO, 1980), em objetos metálicos de bronze (fíbulas, conteiras de bainha, etc.) (SILVA, 1986; FERNÁNDEZ CARBALLO, 2003; REY CASTIÑEIRA, 2005a) em elementos arquitetónicos (umbrais, lintéis, etc.) (ARIZAGA CASTRO et al., 2006) ou placas móveis com gravuras, quer na Galiza como no Norte de Portugal (SILVA, 1986; FERNÁNDEZ CARBALLO, 2003; REY CASTIÑEIRA, 2005a). Encontraram-se, ainda, equídeos gravados no NW, quer na sua área mais ocidental quer na mais oriental, assim como inúmeras placas móveis na área mais oriental com peixes também na oriental (MEIJIDE CAMASELLE et alli, 2009; NEVES, et al., 2015). Relativamente à ourivesaria, é necessário destacar, em primeiro lugar, o exemplar conhecido como Diadema de Moñes (GARCÍA VUELTA et al., 2001; SCHATTNER, 2012), uma peça singular da Idade do Ferro. Data de entre os séc. II a I a.C., e na qual está representada claramente uma cena ligada a uma celebração, onde se observam vários caldeirões, provavelmente sítulas (SEOANE, 2018), vários antropomorfos a cavalo e a pé e na que estão representadas três famílias distintas de animais: peixes, aves e cavalos. Desta peça note-se um aspeto curioso, posto que um dos fragmentos regista aves a alimentar-se de peixe e que alguns dos antropomorfos contam com uma cabeça de ave.

No que diz respeito à representação de quadrúpedes que aparecem fundamentalmente nos conhecidos como bronzes com motivos de sacrifício (ARMADA PITA, GARCÍA VUELTA, 2003). Em estes machados de bronze concorrem habitualmente os protomos dos machados - habitualmente um bovino ou ovicaprino - encabeçando uma procissão de animais quadrúpedes tanto selvagens - caso do javali - como 
domésticos - com a dos suínos ou os ovicaprinos e inclusivamente algum antropomorfo (ARMADA PITA, GARCÍA VUELTA, 2003).

Além destes exemplares é necessário fazer menção ao carro votivo de Vilela (Paredes) (SILVA, 1986) no qual surge uma espécie de procissão com vários antropomorfos apeados e nos dois extremos da peça temos uma parelha de bois.

Quanto a animais presentes em elementos arquitetónicos destaca-se o exemplar da pedra talhada e decorada procedente de um castro e que na atualidade está reutilizada na capela de Formigueiro (Chaos de Amoeiro, Ourense) neste caso temos apenas animal representado. Este alto-relevo contem uma narração na que participam un únicoantropomorfo montado num cavalo, e que aparece acompanhado aparentemente por outros quatro cavalos não montados junto com outros motivos decorativos mui próprios do NW (ARIZAGA CASTRO, et alli, 2006).

No que diz respeito a gravuras em rocha há a registar vários exemplares em vários locais. Destacamos desde logo as placas móveis com animais gravados do sítio do Castelinho (Felgar, Torre de Moncorvo), na qual se encontram placas gravadas com animais selvagens e domésticos, como os javalis, ou o cavalo, que pode aparecer com um antropomorfo montado (numa única placa, podendo representar uma cena de caça), numa outra placa surge um antropomorfo com uma lança, a apontar para aquilo que poderá ser um javali, e ainda um antropomorfo armado com uma espécie de espada embainhada e com uma lança em posição de tiro (Laje 1 do Castelinho). O Castelinho é um local com uma cronologia datável de forma geral e impressa durante a Idade do Ferro (NEVES, et al., 2015) além deste sítio aludimos a um outro que é o caso do Castro de Formigueiros (Samos, Lugo) onde foram detetadas, in situ, várias placas gravadas, no chão, com cavalos e peixes. Neste caso a datação do povoado será por volta do séc. III - II a.C. (MEJIDE CAMESELLE et alli, 2009), da qual deverá datar, provavelmente, a produção destas gravuras, em tudo semelhantes aquelas imagens produzidas sobre a cerâmica. Por último, estão as gravuras em placas do castro do Chao Samartín (Grandas de Salime, Asturias), lugar no que se localizam gravuras unicamente de cavalos (VILLA VALDEÉS, 2010-2012). E também as gravuras localizadas no Castelón de Coaña (Coaña, Asturias), nas que se representam o que parecem ser cervos (VILLA VALDEÉS, 2010-2012).

\section{ICONOGRAFIA ZOOMORFA: ALGUMAS CONSIDERAÇÕES FINAIS}

Estas peças profusamente decoradas que estiveram sob análise são produzidas para serem vistas, posto que estes desenhos são realizados nas partes mais visíveis dos vasos. Estas decorações encontram-se na área externa do lábio, passando pelo ombro, e chegando a toda a pança. Além disso, nota-se que as peças decoradas com zoomorfos são acompanhadas de outro tipo de motivos elaborados mediante diferentes técnicas como a incisão, a impressão, a aplicação plástica ou até outros elementos estampados, tornado as peças esteticamente muito apelativas.

Com efeito, no nosso entender não seria apenas o gosto estético o que estaria na origem da produção destas peças, senão talvez a representação de animais importantes para estas comunidades devido a razões de carácter social, simbólico e/o cultural.

Os diferentes contextos e matérias onde estes motivos ocorrem indiciam o seu carácter e poder comunicacional dentro duma comunidade, a sua capacidade para narrar uma outra história. Assim como possibilitam colocar a hipótese de que os recipientes decorados com estes motivos de carácter excecional, é possível que fossem usados em contextos de exceção e em ações de grande valor social e simbólico, ou simplesmente estão feitos para serem vistos.

Acreditamos, pois, que cada imagem gravada, que seria compreensível para uma comunidade e uma entidade cultural determinada, e que fora de aí poderia não ser entendida. Além disso, o trabalho que é necessário para elaborar uma peça tão preenchida com decoração e na que há que talhar um selo previamente, é muito possível que isto não seria apenas por motivos estéticos, mas também por motivos sociais, simbólicos e/ou culturais. A questão encontra-se em tentar perceber o porquê desta relação com o mundo animal e a várias espécies sobretudo no caso das aves e dos peixes.

Ora, a preocupação figurativa destas peças, poderá ser um produto da forma de olhar, imaginar, e representar muito específicos. Estas imagens zoomorfas não seriam produtos estáticos, não têm apenas um significado, mas provavelmente muitos significados que seriam negociados a para e passo na vivência social. Isto aplicado à realidade Vaccea, mas que nos serve aqui também. Assim, estas imagens na cerâmica poderiam ser uma espécie de mensagem que transportaria consigo uma dada informação que 
todos no seio daquela sociedade percecionavam recreavam e representaria parte da sua cosmovisão. É de salientar que, na sua esmagadora maioria são retratados animais selvagens e não animais domesticados pelas comunidades da Proto-história.

Nenhum trabalho no capítulo do estudo de materiais é feito sem que existam algumas dificuldades. Ora, por muitas ocasiões um dos aspetos mais complexos de se estudar a cerâmica decorada é o facto de que em muitos casos esta se encontra muito fragmentada, o que está muito vinculado à sua completa localização em ambientes habitacionais. Esta alta fragmentação é que não permitiu, por variadas vezes, compreender a que tipologia de peça previamente estabelecida pertenceria.

Além disso, muitas vezes o motivo é tão diminuto ou se encontra tão degradado que não é tão percetível, por isso condiciona a seleção de material para este trabalho, pelo que apenas foram escolhidos aqueles que indubitavelmente fizessem lembrar a algum animal, deixando fora os mais abstratos e complexos de tratar.

Finalmente, tendo em conta o inventário realizado, a conclusão mais clara é que, na sua grande maioria, as decorações por zoomorfos encontram-se em recipientes para conter líquidos, ou seja, potes e potinhos, Xerras tipo "Toralla” e vasilhas de armazenagem como as tipo "Cíes".

A posição das decorações não é muito diversa, posto que os animais estão praticamente sempre de perfil, podendo ser mais ou menos realistas ou estilizadas, sobretudo no diz respeito às decorações com ictiomorfos e ornitomorfos. Contudo, parece não existir no NW uma tendência quer de esquematização, quer de realismo dos motivos zoomorfos ao longo da Idade do Ferro.

$\mathrm{Na}$ sua esmagadora maioria os motivos zoomorfos são elaborados por estampagem e impressão a partir de um estilete previamente idealizado pela pessoa ou pessoas incumbidas e tecnicamente capazes que estampavam sobre a peça o motivo, repetindo-o a espaços regulares por todo o diâmetro do vaso. Esse trabalho teria de ser efetuado por pessoas já bastante experientes na técnica de olaria.

Sendo mais próximos, ou não do realismo, o facto é que noutros suporte quer em gravação em pedra quer a ourivesaria pelo repuxado, ou pela cera perdida, o realismo dos animais é bastante mais notório do que na cerâmica.

\section{BIBLIOGRAFIA}

ABAD VIDAL, Emilio; REY CASTIÑEIRA, Josefa; ÁLVAREZ CASTRO, Gabriel; VARELA PET, José (2011) - Diseño y desarrollo de un modelo de datos para una IDE arqueológica de la Edad de Hierro en Galicia. En II Jornadas Ibéricas de Infraestructuras de Datos Espaciales. Barcelona 9, 10, 11 de novembro.

ALFAYÉ VILLA, Silvia (2010) - Iconografia Vaccea; una aproximación a las imágenes del território vacceo. De La región Vaccea A la Arqueología Vaccea. ROMERO.

ALMEIDA, Carlos Alberto Brochado de (1990) - Proto-História e Romanização da Bacia Inferior do Lima. Estudos Regionais, Número Especial, nº.7-8, Centro de Estudos Regionais, Viana do Castelo.

ARIZAGA CASTRO, Álvaro R.; FÁBREGA ÁLVAREZ, Pastor; AYÁN VILA, Xurxo M.; RODRÍGUEZ PAZ, Anxo (2006) - "A Apropiación Simbólica da Cultura Material Castrexa na Paisaxe Cultural dos Chaos de Amoeiro (Ourense, Galicia)". Cuadernos de Estudios Gallegos, LIII N.ำ119, pp. 87-129.

ARMADA, Xosé Lois, GARCÍA-VUELTA, Óscar (2015) "O machado figurativo de bronce da praia da Basteira (Cariño): novos datos para unha revisión.” Terras de Ortegal, 2, pp. 152-172.

AYÁN VILA, Xurxo M. (2012a) - Escavación arqueolóxica no Castro Grande de Neixón (Boiro, A Coruña). Campaña de 2005. Memoria Técnica. Laboratorio de Arqueoloxía da Paisaxe, Instituto de Estudos Galegos Padre Sarmiento. Santiago de Compostela.

AYÁN VILA, Xurxo M. (2012b) - Escavación arqueolóxica no Castro Grande de Neixón (Boiro, A Coruña). Campaña de 2007. Memoria Técnica. Laboratorio de Arqueoloxía da Paisaxe, Instituto de Estudos Galegos Padre Sarmiento, Consejo Superior de Investigaciones Científicas. Santiago de Compostela. Inédita.

BALSEIRO GARCÍA, Aurelia. (1994) - El oro en la provincia de Lugo. Servicio de Publicacións da Deputación Provincial de Lugo, Museo Provincial de Lugo. Lugo.

BETTENCOURT, Ana Maria dos Santos (1999) - A Paisagem e o Homem na bacia do Cávado durante o II e o I milénios AC, 5 vols. Braga, Universidade do Minho (Tese de Doutoramento - Policopiada).

BETTENCOURT, Ana Maria dos Santos (2000) - Estações da Idade do Bronze e Inícios da Idade do Ferro da Bacia do Cávado (Norte de Portugal). Cadernos de Arqueologia Monografias 11. Unidade de Arqueologia da Universidade do Minho, Braga.

CABANILLAS DE LA TORRE, Gadea (2015) - Arts et sociétés celtiques du Second Âge du Fer en Europe Occidentale: la céramique à décor estampé. Université de Paris I Panthéon - Sorbonne, Universidad Autónoma de Madrid. París - Madrid. 
CALO RAMOS, Nuria (1999) - Introducción ao estudio da decoración da cerâmica castreña. Un caso puntual: Borneiro. Trabalho de investigação de Doutoramento (1997-1999). Universidade de Santiago de Compostela. Santiago de Compostela. Inédito.

CONCHEIRO COELLO, Ángel (2008) - Castro do Achadizo. Cultura material, economía de subsistencia na Idade do Ferro. Memoria das escavacións 1991-1994. Caderno Cultural 11, Concello de Boiro. Boiro.

DINIS, António Pereira (1993) - Ordenamento do Território do Baixo Ave no I Milénio A.C. Tese de Mestrado apresentada à Faculdade de Letras da Universidade do Porto.

DINIS, António Pereira (2001) - O Povoado da Idade do Ferro do Crastoeiro (Mondim de Basto, Norte de Portugal). Cadernos de Arqueologia - Monografias 13. Unidade de Arqueologia da Universidade do Minho, Braga.

FERNÁNDEZ CARBALLO, Laureano (2003) - "Achega ó estudo dos ornitomorfos acuáticos da cultura castrexa galaica: anaco de fíbula indíxena ornado cun pato cullerete (Anas Clypeata). Gallaecia, 22, p. 143-155.

FIGUEIREDO, Sofia; NEVES, Dário (2015) - Quinhentas placas gravadas da Idade do Ferro do sítio fortificado do Castelinho (Nordeste Portugal): temas figurados e padrões de distribuição." Actas de Conferência: Congresso Internacional da IFRAO 2015, ARKEOS 37, (eds.) Collado Giraldo, H., García Arranz, J. J., pp. 1589-1605.

GARCÍA VUELTA, Óscar; PEREA CAVEDA, Alicia (2001) - "Las diademas-cinturón castreñas: el conjunto con decoración figurada de Moñes (Villamayor, Piloña, Asturias)". Archivo Español de Arqueología, 74, pp. 3-23.

LUENGO Y MARTINEZ, José María (1964) - "Machadinha votiva de Cariño, La Coruña." Revista de Guimarães, 74 (1-2), pp. 149-157.

MARTINS, Manuela (1987) - A cerâmica proto-histórica do Vale do Cávado: tentativa de sistematização. Cadernos de Arqueologia, Série II, 4, p. 35-77.

MARTINS, Manuela (1988) - O Povoado fortificado do Lago, Amares. Cadernos de Arqueologia, Monografias, 1, Braga.

MARTINS, Manuela (1990) - O Povoamento Proto-Histórico e a Romanização da Bacia do Médio Curso do Cávado. Cadernos de Arqueologia, Monografias, 5, Braga.

MARTINS, Manuela (1991) - O Povoado de Santo Ovídio (Fafe). Resultados dos trabalhos realizados entre 1980.1984. Cadernos de Arqueologia. Monografias, 6, Braga.

MEIJIDE CAMASELLE, Gonzalo, VILASECO VÁZQUEZ, Xosé Ignacio, BLASZCZYK, Jazek. (2009) - "Lousas decoradas con círculos, cabalos e peixes do Castro de Formigueiros (Samos, Lugo)." Gallaecia, 28, p. 113-130.

OLIVEIRA, Nuno Tiago Correia; BETTENCOURT, Ana Maria dos Santos (2020) - O povoado proto-histórico de
Santo António (Afife, Viana do Castelo): dados e reflexões sobre as suas materialidades. In CENTENO, Rui, MORAIS, Rui, SOEIRO, Teresa, FERREIRA, D. (Eds.), Cultura Castreja: Identidade e Transições. Vol. I. Santa Maria da Feira: Museu Convento dos Lóios / Câmara Municipal de Santa Maria da Feira.

PÉREZ OUTEIRIÑO, Bieito (1980) - Os ornitomorfos acuáticos no conxunto dos motivos decorativos da orfebrería castrexa. Boletín Auriense, 10, pp. 9-24.

Prehistoria. Arte Castrexa. Arte da Romanización. A Nosa Terra, Vigo, pp. 224-240.

REY CASTIÑEIRA, Josefa (2005a) - A metalurxia castrexa. In HIDALGO CUÑARRO, J. M. coord. Arte e Cultura de Galicia e Norte de Portugal. Arqueoloxía. Tomo II. Nova Galicia. Vigo, pp. 56-83.

REY CASTIÑEIRA, Josefa (1991) - Yacimientos castreños de la Vertiente Atlántica. Análisis de la cerámica indígena. Tese de Doutoramento. Universidade de Santiago de Compostela. Santiago de Compostela.

REY CASTIÑEIRA, Josefa (1995) - Cuestións de tipo territorial na Cultura Castrexa." In HIDALGO CUÑARRO, José Manuel; RODRÍGUEZ SOBRAL, José Manuel; DOMÍNGUEZ PÉREZ, M. eds. Actas del XXII Congreso Nacional de Arqueología. Vigo, 1993. Volumen II, Comunicacións de tema libre. Sección Xeralidades e Prehistoria (Continuación del Volumen I). Vigo, pp. 165-171.

REY CASTIÑEIRA, Josefa (1996) - Referencias de tempo na cultura material dos castros galegos." In HIDALGO CUÑARRO, José Manuel (coord.) (1996). A Cultura Castrexa galega a debate. Instituto de Estudios Tudenses. Tui, pp. 157-206.

REY CASTIÑEIRA, Josefa. (1998) - "Cerámica castrexa decorada.” In FÁBREGAS VALCARCE, Ramón; CARBALLO ARCEO, L. Xulio; ACUÑA CASTROVIEJO, Fernando (coords.).

REY CASTIÑNIRA, Josefa (2005b) - A cerámica castrexa. In HIDALGO CUÑARRO, J. M. coord. Arte e Cultura de Galicia e Norte de Portugal. Arqueoloxía. Tomo II. Nova Galicia. Vigo, pp. 84-108.

RODRÍGUEZ MARTÍNEZ, Rafael M. (2008) - Análise do material cerámico recuperado. In AYÁN VILA, Xurxo M. coord. Os Castros de Neixón (Boiro, A Coruña) II: de espazo natural a paisaxe cultural. Serie Keltia, Toxosoutos. Noia, pp. 150-229.

RODRIGUEZ PUENTES, Eugenio (1986) - La cerâmica estampillada castreña. (Aportácion a su estúdio). Tese para obtenção do grau de licenciado, apresentada à Universidade de Santiago de Compostela (policopiado).

RODRÍGUEZ PUENTES, Eugenio; TOMÁS BOTELLA, Víctor; ABAD GALLEGO, J. C. (1990-1991) - «Prospección y excavación arqueológica en Val Miñor: poblados fortificados». Castrelos, 3-4, p. 165-19o. 
SILVA, António Baptista (2006) - Proto-História e Romanização. O Baixo Minho. (Dissertação de Doutoramento em Arqueologia apresentada à Universidade do Porto).

SILVA, Armando Coelho Ferreira (1986) - A Cultura Castreja no Noroeste de Portugal. Museu Arqueológico da Citânia de Sanfins. Paços de Ferreira.
SILVA, Maria Antónia Dias (1997) - A Cerâmica Castreja da Citânia de Briteiros. Edição Sociedade Martins Sarmento, Guimarães.

SILVA, Maria Fátima Matos (2006) - O Povoamento Proto-Histórico e a Romanização da Bacia Superior do Rio Coura: Estudo, Musealização e Divulgação. Apresentada à Universidade de Granada (Tese de Doutoramento).

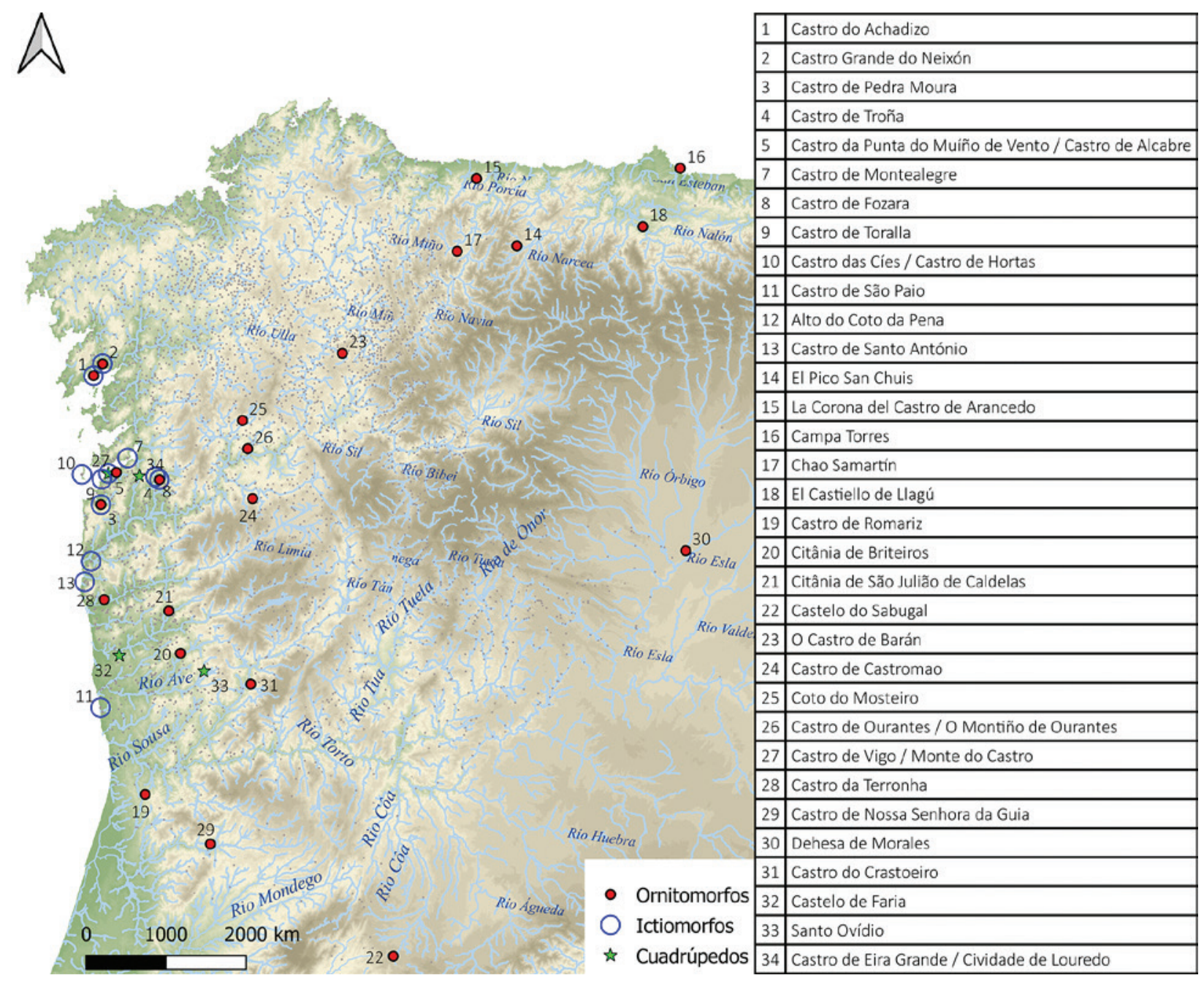

Figura 1 - Sítios arqueológicos considerados neste estudo. 

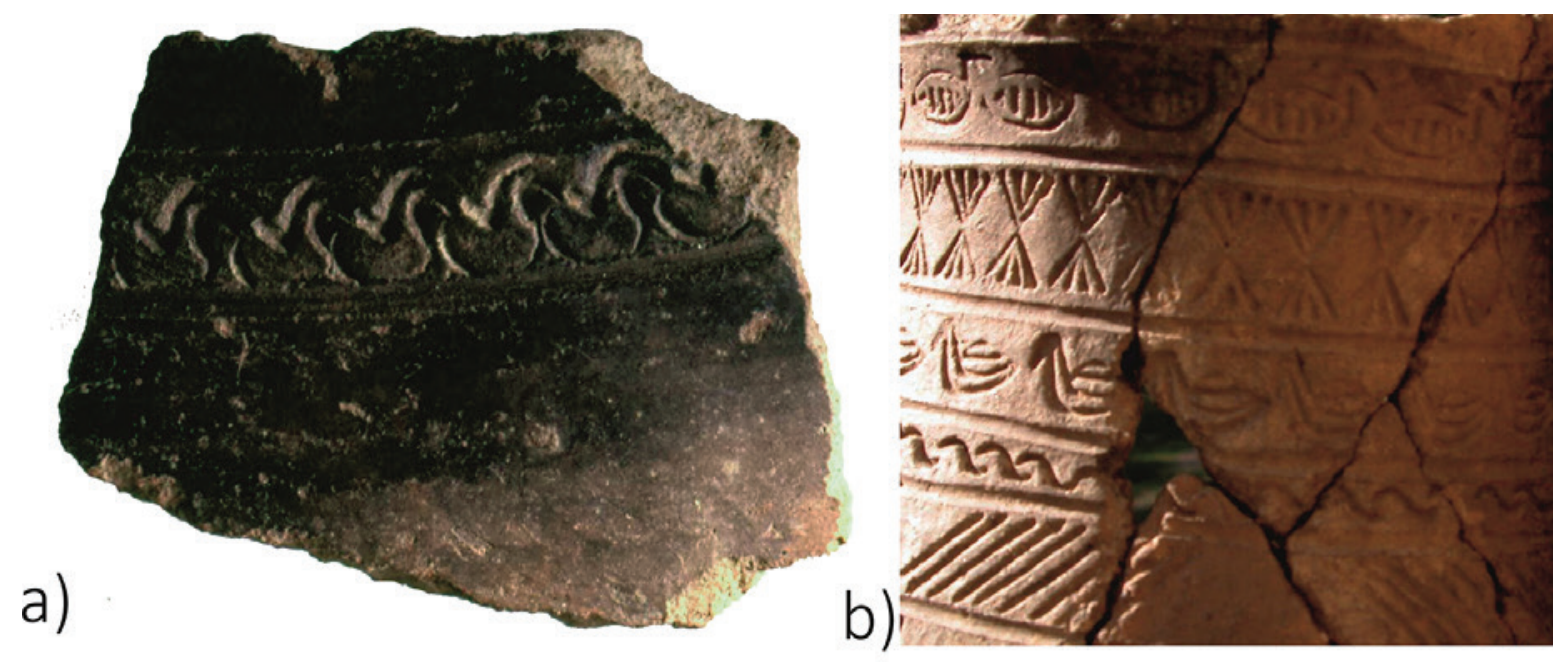

c)

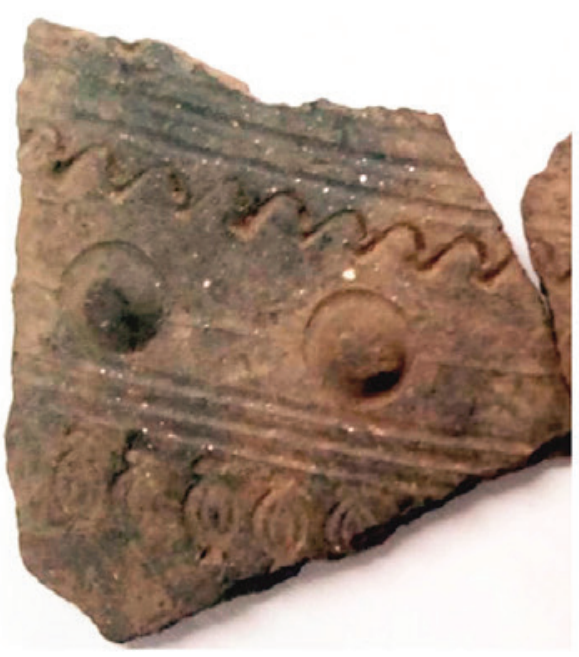

d)

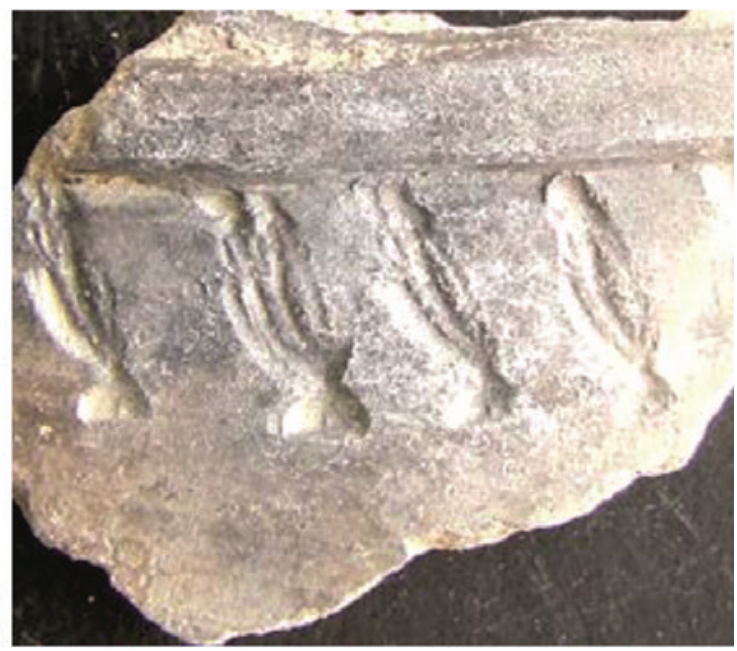

d)
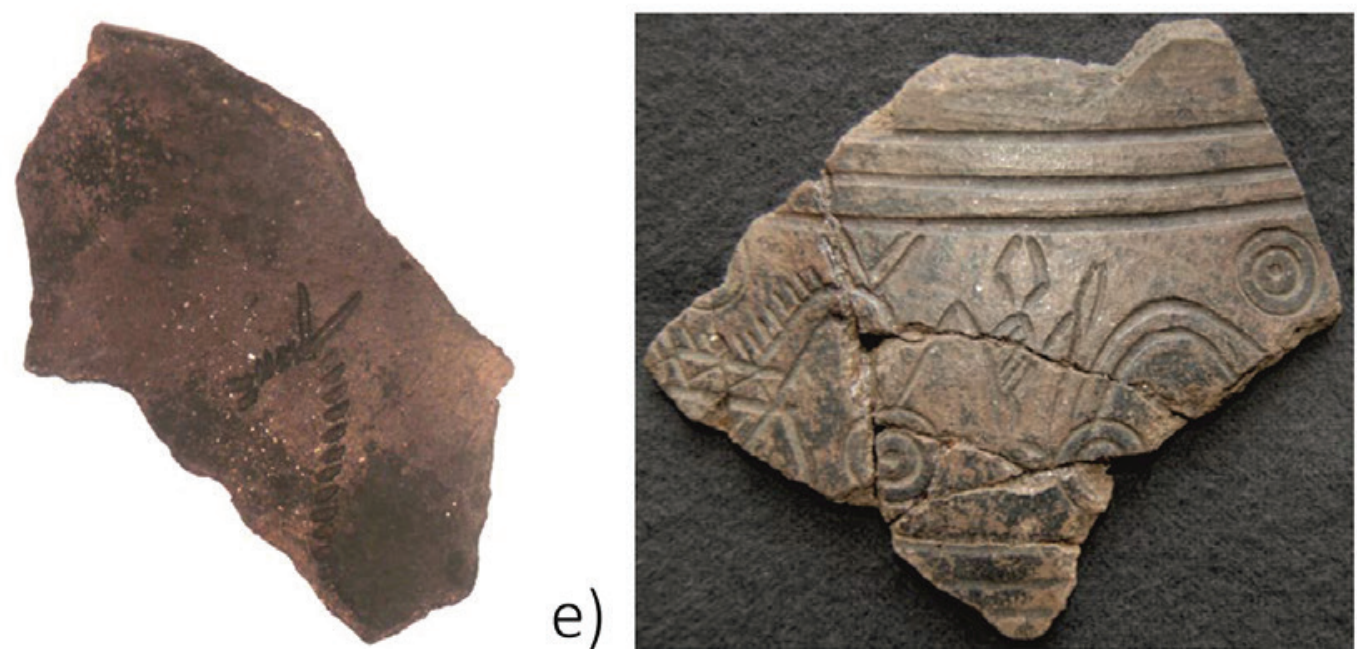

Figura 2 - Cerâmica com ornitomorfos: a) Castro de Vigo/Monte do Castro (Vigo, Pontevedra) (Foto: http://vigoarqueologico.blogspot.com/, modificada); b) Xerra tipo “Toralla” procedente do Castro Grande do Neixón (Boiro, A Coruña) (Foto: http://neixon.blogspot.com/, modificada). Cerâmicas com ictiomorfos: c) Castro do Achadizo (Boiro, A Coruña) (Foto: C. Seoane); d) Castro de Toralla (Vigo, Pontevedra) (Foto: P. Rey). Cerâmica com quadrúpedes: d) Castro de Santo Ovídio (Fafe, Braga) (Foto: X. Carballo); e) Castelo de Faria (Barcelos, Braga) (Foto: P. Rey). 


\title{
VASOS GREGOS EM PORTUGAL: DIFERENTES MANEIRAS DE CONTAR A HISTÓRIA DO INTERCÂMBIO CULTURAL NA IDADE DO FERRO
}

\author{
Daniela Ferreira ${ }^{1}$
}

RESUMO

Neste artigo procuramos dar a conhecer o conjunto de dados históricos e arqueológicos disponíveis para o estudo das cerâmicas gregas e das relações comerciais estabelecidas entre o Mediterrâneo Oriental e o atual território português, entre os séculos VII-IV a.C.

Palavras-chave: Vasos Gregos, Idade do Ferro, Relações Comerciais, Aculturação, Identidade Cultural.

\begin{abstract}
This paper aimed to describe and interpret the archaeological data available associated to the Greek pottery and commercial relations concerning the Eastern Mediterranean and the current Portuguese territory, between the $7^{\text {th }}$ and the $4^{\text {th }}$ centuries b.C.
\end{abstract}

Keywords: Greek Vase, Iron Age, Commerce, Cultural Exchanges, Cultural identity.

\section{AS TRAMAS E AS TEIAS DA HISTÓRIA DA ARQUEOLOGIA GREGA NA PENÍNSULA IBÉRICA}

\author{
"Ali as taças de ambrósia \\ foram misturadas; \\ e Hermes pegou no jarro e serviu vinho aos deuses. \\ Todos eles \\ seguraram as taças \\ e ofereceram libações e desejaram coisas boas \\ ao noivo.»
}

(Safo, fr.141 PLF)

A arqueologia grega na Península Ibérica acompanhou de perto os contextos de investigação e de desenvolvimento do pensamento científico aplicado aos estudos históricos. Do fenómeno de colecionismo resultante do movimento neoclássico que marca o despontar do interesse estético e histórico por estas peças, à iniciativa de eruditos e historiadores que, ainda no século $\mathrm{XV}$, procuram estabelecer a conexão entre os materiais e os locais de ocupação grega, passando pelo desenvolvimento da arqueolo- gia filológica, que paulatinamente se descredibiliza dando lugar à valorização das evidências materiais apoiadas em estudos classificatórios e taxonómicos com base em estratigrafia.

O grande impulso nos estudos da arqueologia grega peninsular ocorre, no entanto, nas primeiras décadas do século XX, com a discussão dos fenómenos históricos através da leitura e interpretação dos textos clássicos. É neste contexto, que Adolfo Schülten, nas suas investigações sobre Tartessos (1922), introduz o tema da colonização grega em Espanha, adotando uma abordagem empírica, de base filológica, marcada pelo pressuposto da veracidade absoluta das fontes e pelo entendimento da arqueologia como veículo de confirmação das notícias textuais. A visão representativa do idealismo histórico perfilhada por Schülten foi acompanhada do entendimento da superioridade civilizacional grega e da desvalorização pelo pequeno objeto cerâmico entre as várias expressões de arte e cultura. Idêntico critério metodológico é igualmente seguido por Bosch Gimpera, em «Problemi della colonizzazione greca in Spagna» (1929), onde o investigador apresenta a

1. CITCEM -Centro de Investigação Transdisciplinar "Cultura, Espaço e Memória»; danielafilipaferreira@gmail.com. 
leitura críticas das fontes antigas e a sua confrontação com os dados obtidos por via da arqueologia, como base do discurso histórico da colonização grega de Espanha.

O questionamento da veracidade das fontes escritas e a consciência das suas limitações acompanhou desde cedo o movimento filológico, testemunhando-se, ainda que de forma muito incipiente, logo em 1925, com a publicação da obra "The Greeks in Spain»" de Rhys Carpenter, através da qual o investigador procura fazer corresponder os acidentes naturais da paisagem do Levante espanhol a locais de ocupação grega, fundamentando-se em raciocínios de âmbito geográfico. O início das escavações sistemáticas da cidade grega de Emporion, em 1908, com Josep Puig i Cadafalch, e a publicação dos achados das campanhas sucessivamente realizadas contribuíram, de igual forma, para a criação de uma base sólida de conhecimento arqueológico para a caracterização da presença grega da Península Ibérica.

A descoberta do capacete grego na Ría de Huelva², assim como a realização das primeiras escavações sistemáticas nos povoados e necrópoles ibéricas, vieram dar um novo impulso para o conhecimento desta área, verificando-se, sobretudo no decorrer dos anos 40 e 50, a proliferação dos estudos sobre a presença grega em Espanha. Novas orientações metodológicas e teóricas são assumidas, destacando-se ainda na década de 40, o papel de António García y Bellido, como a figura maior da investigação sobre a presença grega neste território e impulsionador da adoção de critérios modernos de investigação. A obra que publica em 1948, "Hispania Graeca", contribuiu não só a integração da Península Ibérica nos estudos de âmbito mediterrâneo, como possibilitou, através da sua visão global dos testemunhos arqueológicos identificados até à data, abrir novas linhas de investigação (Cabrera Bonet \& Olmos, 2017, pp. 31-41). Também Martín Almagro Basch, enquanto diretor das escavações de Ampúrias, contribui para a valorização do testemunho arqueológico como via preferencial para o desenvolvimento dos estudos sobre esta temática. No grande trabalho sobre as necrópoles que publica nos inícios dos anos 50 (Almagro Basch, 1953, 1955) e nos estudos seguintes, recorre ao estabelecimento de tipologias e à ordenação dos materiais de acordo com as aná-

2. Sumariamente publicado, em 1931, no Boletín de la Academia de la Historia por Hugo Obermaier. lises estratigráficas, afastando-se dos critérios esteticistas e da ditadura das fontes clássicas enquanto elemento primordial para a definição da presença grega na Península Ibérica. Esta corrente metodológica e conceptual, inspirada na arqueologia pré-histórica - que desde o início do século XX desenvolve a descrição empírica dos pequenos objetos, classificando-os evolutivamente e integrando-os em esquemas taxonómicos -, enfrentará continuados movimentos de resistência que perdurarão pelas décadas seguintes e que derivam, em boa parte, da escassez de testemunhos arqueológicos conhecidos à época.

A perceção de que os materiais gregos chegavam por intermédio do comércio púnico-fenício desponta apenas na década seguinte (Pellicer Catalán, 1964; Trías, 1967-1968), na mesma altura em que se confirma a antiguidade da fundação de Ampúrias, com a publicação do resultado das campanhas de escavação de 1962 e 1963 realizadas em Palaiapolis (Almagro Basch, 1964). Igualmente nesta altura, Maria Helena da Rocha Pereira publica o estudo pioneiro "Greek Vases in Portugal» (1962), dando a conhecer importantes testemunhos do colecionismo de vasos gregos em território português, a par do estudo dos escassos exemplares áticos provenientes de contextos arqueológicos, designadamente, seis vasos identificados na Necrópole do Senhor do Olival dos Mártires de Alcácer do Sal. Descobertos os primeiros exemplares em 1874, e ainda que tenham sido prontamente classificados como vasos etruscos, o interesse destas peças impulsionou a realização de escavações sistemáticas na necrópole de Alcácer, conduzidas apenas em 1925 sob a direção de Vergílio Correia (1930), abrindo caminho para a definitiva integração do atual território português nos estudos sobre a presença grega no Ocidente.

Os novos dados obtidos com a intensificação dos trabalhos em Ampúrias, a par dos desenvolvimentos arqueológicos em Ullastret e da descoberta de feitorias fenícias no Sul da Península Ibérica, lançaram novos debates sobre as rotas e frequências do comércio de produtos gregos e sobre as características dos materiais importados, obrigando a repensar Tartessos à luz da colonização fenícia. Estes assuntos são desde logo tratados por Glòria Trías Rubiés (1967-1968) que, adotando uma visão conciliadora dos textos clássicos e dos elementos arqueológicos, publica um catálogo documental do conjunto de materiais gregos identificados até à data na Pe- 
nínsula Ibérica. Ao modo generalista da Hispania Graeca de García y Bellido, em "Cerámicas griegas de la Peninsula Ibérica», Trías desenvolve uma síntese das problemáticas ligadas ao mundo grego, tendo como ponto de partida os testemunhos materiais cerâmicos, apresentados de forma geográfica e cronologicamente ordenada. O esforço de compilação e sistematização presente na sua obra, ainda que com importantes limitações ${ }^{3}$, constitui referência válida para os ensaios tipológicos e estilísticos relativos à presença grega na Península Ibérica até aos dias de hoje. Simultaneamente, a sua ordenação dos testemunhos cerâmicos de acordo com áreas geográficas, permitiu criar as bases necessárias para relançar a discussão sobre a distribuição espacial dos achados e repensar as rotas de comércio destes materiais.

Logo em 1970, Lepore procura definir com maior precisão a atividade comercial, analisando os materiais identificados nos emporia, e defendendo que o estabelecimento de relações comerciais, sobretudo as inaugurais, foi instituído com a aristocracia indígena. Este assunto é retomado no ano seguinte, no "Simposio Internacional de Colonizaciones", onde se discutem as limitações da perspetiva tradicional para abordar os problemas da colonização (Morel, 1972), um termo que deixa de ser utilizado de forma generalizada ainda no decorrer da década de 70. Outras terminologias, como a "cerâmica proto-campaniense» estabelecida por Lamboglia, tornam-se igualmente obsoletas, não obstante o sistema classificatório instituído pelo investigador continuar a ser utilizado por várias décadas, por via da sua articulação com a escola emporitana de Almagro.

Nos anos que se seguiram, com a publicação dos conjuntos materiais entretanto identificados ${ }^{4}$,abrem-se novas perspetivas sobre os circuitos de distribuição e integração destes objetos exógenos no quadro das estruturas sociais e ideológicas indígenas, reconhecendo-se a penetração de influências culturais orientalizantes até regiões mais interiores. Para o avanço no conhecimento do comércio estabelecido em áreas costeiras, contribuíram ainda a primeira publicação sistemática dos materiais de Ullastret pela mão

3. Destacando-se a não inclusão de determinados conjuntos de cerâmica não figurada e a desvalorização das problemáticas da receção e uso dos materiais gregos em contextos funerários indígenas.

4. Como, por exemplo, os vasos de Medellín (Olmos, 1977b). de Marina Picazo (1977) e o desenvolvimento dos estudos emporitanos (Jully, 1976), possibilitando uma melhor definição dos horizontes de importação de materiais gregos, em particular no atual território da Catalunha. É igualmente neste momento que surgem as primeiras notícias sobre o naufrágio de El Sec (Pallarés Salvador, 1974), não obstante a publicação final do conjunto exumado ocorrer apenas em finais dos anos 8o (Arribas \& alii., 1987).

Com o aumento do volume de materialidades conhecidas, desenvolve-se a tradição dos estudos de conjuntos cerâmicos homogéneos, destacando-se a importante análise dos vasos sobrepintados e de estilo Saint-Valentin (Picazo \& Rouillard, 1976), das taças áticas da Andaluzia e da cerâmica proveniente da Grécia de Este (e.g. Rouillard, 1978). Estas análises são acompanhadas de diversos trabalhos de síntese (Olmos \& Picazo, 1979, entre muitos outros) e da realização de encontros científicos com vista à discussão e apresentação de novos dados, tendo em comum, uns e outros, o reconhecimento da influência orientalizante sobre as comunidades autóctones que recebem estes produtos.

Para o atual território português, surgem as primeiras notícias sobre testemunhos de vasos gregos no Norte de Portugal, provenientes do Castelo de Castro de Faria (Almeida, 1973-1974, p. 201, nota de rodapé $\mathrm{n}^{\circ} 15$, e Rouillard, 1975, p. 42, nota de rodapé $\mathrm{n}^{\mathrm{o}} 31$ ), um achado verdadeiramente valorizado apenas aquando da descoberta de cerâmica grega em contextos estratigráficos conservados, datados da Idade do Ferro do povoado de Santo Estevão da Facha.

Nos anos 8o, multiplicam-se as campanhas de escavação em contextos sidéricos com presença de materiais importados, iniciando-se ou consolidando-se os trabalhos desenvolvidos na Andaluzia Ocidental e na região do Levante Peninsular, à medida que prosseguem as campanhas de escavação na Catalunha, com a intervenção na colónia focea sob a direção de E. Sanmartí (e.g. Sanmartí Grego \& alii., 1986) e o início dos trabalhos em Neápolis. As escavações conduzidas em Huelva (e.g. Fernández Jurado \& Cabrera Bonet, 1987), Málaga (Gran Aymerich, 1987), Toscanos (Niemeyer, 1985), Guadalhorce (Cabrera Bonet, 1994b), Cástulo (Sánchez Fernández, 1987) e Torre de Doña Blanca (Cabrera Bonet, 1995) confirmam a presença das importações de época arcaica e clássica, lançando novos dados sobre a intensidade e dinâmica do comércio estabelecido e possibilitando novas interpretações para a reconstrução deste 
processo histórico (e.g. Cabrera Bonet \& Olmos, 1985). A discussão dos velhos debates e das novas descobertas ocorre em 1983, em Ampúrias, na Mesa Redonda "Cerámicas griegas y helenísticas en la Península Ibérica», destacando-se a problemática das imitações de cerâmicas gregas (e.g. Page Del Pozo, 1984, entre muitos outros). A discussão foi retomada na Mesa Redonda decorrida em Bordéus, em 1986, organizada por Pierre Rouillard e Marie Christine Villanueva-Puig, com o título "Griegos e Iberos en el siglo IV a.C. Comércio e iconografia», abordando-se, uma vez mais, questões ligadas à receção dos vasos gregos. Efetivamente, o tema da relação entre as sociedades indígenas o mundo grego ganha, nesta altura, um novo impulso com a consolidação do conceito de aculturação e a abertura a novas propostas de interpretação histórica.

Novos estudos são conduzidos, dando uma visão de conjunto da presença grega neste território (e.g. García Cano, 1989), e indo ao encontro da especificidade exigida por determinados temas, como o são os aspetos ligados à presença de produtos massaliotas na P.I. (e.g. Miró, 1989). A par da constatação da puridade de problemáticas ligadas à presença grega neste território, verifica-se, neste momento, o alargamento da discussão a novas áreas geográficas, fruto do desenvolvimento de inúmeras campanhas de escavação e da frequente descoberta de novos testemunhos dos intercâmbios estabelecidos. Destacam-se as campanhas arqueológicas realizadas em áreas do interior da Península, particularmente na Extremadura, na zona Sul da Meseta e na Alta Andaluzia, permitindo aprofundar o estudo das redes de comércio e da redistribuição de produtos a partir de povoados litorais.

A publicação das atas da Mesa Redonda «La presencia de material etrusco en la Península Ibérica» (1991), dos congressos "Marsella griega» e "Marsella y la Galian, no terceiro volume dos Études Massaliètes (1992), e a realização da mesa redonda "Griegos e Iberos: lecturas desde la diversidad" celebrada em 1991, em Ampúrias, permitiram abordar o processo comercial de produtos gregos numa perspetiva (cronológica e geográfica) mais ampla e integradora de várias disciplinas, como a epigrafia e numismática.

Em 1991, Pierre Rouillard publica "Les grecs à la Peninsule Ibérique du VIIIe au IVe siècle avant Jésus-Christ», apresentando um exaustivo catálogo dos materiais gregos identificados até então, incluindo treze arqueossítios localizados no atual território português. Tal como Glorias Trías, na sua obra de 1967, também Rouillard se socorre das fontes literárias, em confrontação com os dados arqueológicos para abordar a fisiografia do comércio grego na Península Ibérica. As considerações tecidas pelo autor, em particular as que dizem respeito às dinâmicas de aculturação das culturas indígenas recuperam discursos elitistas, rapidamente suplantados pela emergente consciência de que terão sido as estruturas sociais e políticas indígenas que originaram a demanda de importações gregas por oposição à ideia de que foi o estabelecimento de relações comerciais com o mundo orientalizante a determinar as mudanças nas culturas autóctones. A este propósito, logo no ano seguinte, Carmen Sanchéz (1992) publica o resultado dos trabalhos que desenvolveu sobre o comércio de produtos gregos na Andaluzia Oriental, valorizando a preferência da clientela autóctone por determinados vasos, utilizados com propósitos distintos daqueles que serviram de base à sua produção, correspondendo à interpretação local dada a estas peças. Para a reivindicação do papel de protagonista das sociedades autóctones contribuiu ainda a publicação do resultado das escavações de Palaiapolis (Aquilué, 1999), confirmando a existência de um povoado indígena prévio à chegada dos primeiros comerciantes gregos de Emporion, assim como a publicação de P. Cabrera Bonet e M. Santos, "Cerámicas jonias de época arcaica. Centros de producción y comercialización en el Mediterráneo Occidental», onde se aborda uma vez mais a problemática da interação entre indígenas e gregos.

Pela parte portuguesa, a década de go é marcada pela publicação do conjunto de cerâmica de filiação grega de Castelo de Castro Marim, pela mão de Ana Margarida Arruda. A continuação das intervenções neste arqueossítio permitiu não só aumentar o número de peças gregas identificadas em território português, como clarificar o panorama conhecido para a chegada destas produções ao Sul de Portugal. Os novos achados foram sendo paulatinamente publicados, em diversos trabalhos, realizando-se a publicação da totalidade do conjunto em 2019 (Arruda, Ferreira \& Sousa, 2020).

Em 2007, realiza-se no Museu Nacional de Arqueologia de Portugal a exposição «Vasos Gregos em Portugal: Aquém das colunas de Hércules", que vem dar seguimento, pela parte portuguesa, à exposição "Los griegos en España: tras las huellas de Heracles», 
apresentada no Museu Arqueológico Nacional de Espanha, sete anos antes. O catálogo dela resultante permitiu sintetizar os conhecimentos até então adquiridos sobre esta temática, e simultaneamente divulgar novos achados das campanhas conduzidas ao longo da década de 90.

Mais recentemente, no decorrer das duas primeiras décadas do século XXI, verifica-se a publicação da monografia da colónia de Rode (Girona) por Anna Puig e Aurora Martín, assim como a análise dos conjuntos de cerâmica grega da Extremadura (Jiménez Ávila, 2004), do importante complexo ibérico de Coimbra del Barranco Ancho (García Cano \& Gil González, 2009), dos arqueossítios de Mas Castellar de Pontós (e.g. Pons, 2002), Cancho Roano (Gracia Alonso, 2003, pp. 23-46, 2005, entre outros), Calle Zacatín-Granada (Rouillard \& De la Torre, 2014, pp. 1-14, entre outros), e dos materiais recuperados no barco grego de Cala de San Vicenç-Mallorca (Nieto \& Santos, 2008), entre vários outros locais onde foram recolhidos um número mais reduzido de exemplares cerâmicos gregos. Os novos dados obtidos, em conjunto com a análise dos conjuntos homogéneos ${ }^{5}$, e as tentativas de síntese conduzidas por Adolfo Domínguez e Carmen Sánchez (2001), Ricardo Olmos ${ }^{6}$, entre muito outros, mantiveram até aos dias de hoje o dinamismo que caracteriza a arqueologia grega em Espanha desde os inícios do século XX.

Também as inúmeras publicações de Ana Margarida Arruda (2008, 2009 2019, entre muitas outras) procuraram integrar os dados arqueológicos recolhidos em Portugal em estudos mais abrangentes, de âmbito ibérico e mediterrâneo. O número crescente de exemplares de cerâmica grega identificados e as evidentes disparidades de conhecimento sobre a presença grega entre o Norte e o Sul do actual território português justificaram, no entanto, a elaboração de uma tese de doutoramento da autoria da signatária do presente artigo (Ferreira, 2019). Este trabalho de síntese, defendido em novembro de 2019, deu a conhecer novas peças, até então inéditas, procurando contribuir para o esclarecimento de problemáticas

5. E.g. Maite Miró, «La cerámica ática de figures roges de la ciutat grega d'Emporion" (2006), onde se compila todos os fragmentos de vasos de figuras vermelhas identificados em Ampúrias desde o início das escavações até à data da publicação.

6. Destacando-se os trabalhos sobre a imagética autóctone e os sistemas iconográficos mediterrâneos. discutidas ao longo de mais de um século de estudos sobre a presença grega na Península Ibérica.

\section{OS DADOS DA ARQUEOLOGIA: A CERÂMICA GREGA NO ACTUAL TERRITÓRIO PORTUGUÊS}

No decorrer da última centúria foram identificados, um pouco por todo o território português, produtos cerâmicos gregos que testemunham uma importante vertente do intercâmbio cultural estabelecido e que nos permitem caracterizar a fisionomia e as várias fases cronológicas do comércio destes bens. O número de exemplares identificados é, também ele, bastante considerável, registando-se 922 exemplares de origem grega, encontrados em 42 arqueossítios localizados entre o litoral Algarvio e o Norte de Portugal. Com exceção de onze fragmentos de ânfora de distintas proveniências e três fragmentos de origem coríntia, a cerâmica grega corresponde a produções áticas de figuras negras, de figuras vermelhas e de verniz negro (Figura 1).

As cerâmicas gregas de época arcaica, dos finais do século VII a inícios do V a.C., estão pouco representadas, contabilizando-se apenas três fragmentos do período coríntio médio e um fragmento ático de figuras negras. Formam parte deste conjunto, dois fragmentos de vasos vertedouros procedentes de Castelo de Castro Marim e da Quinta do Almaraz e um arýballos identificado igualmente neste último local (Arruda, 2019; Ferreira, 2019). Os dados disponíveis sugerem que estes dois vasos coríntios terão chegado ao ocidente peninsular num contexto de abastecimento de produtos orientalizantes às colónias fenícias do Sul da Península Ibérica, cuja presença está já arqueologicamente bem documentada. Além destes, regista-se a aquisição de uma taça de faixas da Necrópole do Olival do Senhor dos Mártires, em Alcácer do Sal, datável entre finais do século VI e inícios do $\mathrm{V}$ a.C., que testemunha o início da importação das formas abertas, uma clara preferência registada no território em estudo.

Após um hiato de aproximadamente um século, entre a $2^{2}$ metade do século $V$ a.C. e a centúria seguinte, começam a difundir-se as cerâmicas áticas de figuras vermelhas representadas por uma dezena de formas distintas, destacando-se as taças e os kratêres. É apenas na transição dos finais do século $\mathrm{V}$ e inícios do IV a.C. que ocorre um considerável aumento das cerâmicas áticas de verniz negro. Estas produções 
com cerca de duas dezenas de formas identificadas (contando as suas variantes), são maioritariamente representadas por taças de pé baixo, em particular as de bordo convexo, e por tigelas de bordo esvasado e reentrante, com testemunhos abundantes em vários contextos (Figura 2).

A cerâmica de figuras vermelhas é, genericamente, menos abundante quando comparada com as produções revestidas de verniz negro, com exceção de dois contextos funerários. Referimo-nos à necrópole do Olival do Senhor dos Mártires, em Alcácer do Sal, que regista uma presença maioritária de exemplares decorados de figuras vermelhas, e ao arqueossítio de Cerro Furado, com a presença exclusiva de cerâmica com esta técnica decorativa.

Como observámos na figura 1 , no que refere à dispersão geográfica, encontramos cerâmica grega em todo o actual território português. São, no entanto, maioritárias as cerâmicas encontradas nas áreas litorais e nas zonas de influência de grandes rios, tirando partido do acesso facilitado a esses territórios através dos cursos fluviais. Esta distribuição sugere um abastecimento e difusão costeira, por via marítima e fluvial, complementado por curtos trajetos terrestres que permitiam o acesso a áreas mais interiores.

Os arqueossítios que mais precocemente são abastecidos por cerâmica grega correspondem a Almaraz, Castro Marim e Alcácer do Sal, revelando a existência de rotas fragmentadas que não obedeciam a um percurso natural e espectável de navegação (no sentido norte/sul e este/oeste), mas antes ao contacto com áreas estratégicas deste território7 (Figura 3). A partir da transição do século $V$ a.C. dá-se um aumento exponencial dos arqueossítios com a presença de cerâmica grega, aumentando igualmente o número de fragmentos. Neste âmbito, o Sul destaca-se como o grande consumidor deste tipo de produtos, com um número muito avultado desta cerâmica, quando comparado com o restante território português. A disseminação da influência orientalizante em toda a fachada atlântica sugere uma dinâmica de comércio distinta da anteriormente enunciada. A fundação de novos povoados que registam cerâmica grega nos estratos arqueológicos mais antigos terá certamente a sua origem num quadro de prosperidade económica, percetível através do grande

7. Esta problemática foi largamente abordada por Ana Margarida Arruda (2017, p. 126), sublinhando a referida investigadora diversas possibilidades interpretativas. número de produtos exógenos que chegam a este território, a par do aumento demográfico. Sendo o século IV a.C., o momento de maior intensidade no comércio de bens orientalizantes, verifica-se um aumento no número de locais geograficamente vocacionados para participar e tirar partido das redes comerciais já estabelecidas, como é o caso de alguns dos arqueossítios situados ao longo das vias marítimas e fluviais, em áreas favoráveis ao controlo da navegação.

Em locais previamente povoados, como Castro Marim e Tavira, ocorre neste período uma profunda reestruturação urbanística que traduz um fenómeno de crescimento (económico e de outras índoles) deste espaço, verificado através da intensa chegada de importações. Aos bens tradicionalmente conhecidos acrescentam-se novos produtos, quer na forma de bens manufaturados, quer na qualidade de produtos alimentares, estes últimos transportados através do recurso a ânforas (Arruda, 2005).

No que concerne às estratégias de povoamento das populações deste território, destaca-se a aparente uniformidade verificada entre os núcleos urbanos da Idade do Ferro. Regra geral, os povoados sidéricos que importam materialidades exógenas obedecem a uma tipologia concreta, assente na implantação na orla costeira, em pequenas elevações que proporcionam o domínio visual da paisagem e o controlo das vias marítimas e dos acessos a áreas localizadas em territórios mais interiores. Não obstante esta tipologia de implantação acarretar vantagens defensivas e, em alguns casos, a exploração de variados recursos (piscícolas, agrícolas, etc.), deverá levar-se em conta a vantagem que garantem ao desenvolvimento de atividades comerciais, permitindo controlar a realização de trocas comerciais, quer entre regiões próximas, quer com territórios distantes. Como já referimos, estes povoados localizam-se igualmente em locais favoráveis ao controlo das vias aquíferas e em rotas de penetração para áreas interiores, semelhantes aos modelos de implantação territorial fenícios situados na costa de Málaga e na Andaluzia Ocidental (Aubet, 2009, pp. 311-316).

Com poucas excepções, a cerâmica grega até à data encontrada no actual território português apresenta-se muito fragmentada. Esta situação condiciona grandemente a sua classificação e dificulta a determinação da sua forma e cronologia. Esta frágil condição resulta do facto dos fragmentos serem, regra geral, encontrados em contextos de habitat, onde são 
usados de forma intensiva, no quotidiano, em ambientes domésticos, como loiça de mesa. A exceção a esta tendência verifica-se nos contextos funerários e votivos. A necrópole do Senhor dos Mártires, em Alcácer do Sal, a necrópole do Cerro Furado, em Beja e o santuário da Azougada, em Moura, são disso exemplo. É destes locais que provêm os conjuntos de cerâmica grega melhor conservados, incluindo peças inteiras.

Os vasos importados, com um reportório formal reduzido, apresentam pastas e vernizes de qualidade inferior, espelhando uma tendência já verificada em território espanhol (Cabrera Bonet \& Perdigones, 1996), relacionada com o abastecimento de produtos de características particulares destinadas exclusivamente aos mercados periféricos. A decoração presente nos exemplares de figuras vermelhas, pouco cuidada, pouco variada e restrita às obras de não mais do que seis pintores ou Grupos de Pintores, concorrem igualmente para esta tese. $\mathrm{O}$ conjunto apresenta-se assim bastante homogéneo, predominando os recipientes concebidos para serem utilizados à mesa, para beber e comer. Além destes, regista-se um número considerável de kratêres, particularmente recorrentes no Noroeste Peninsular, traduzindo assim a preferência destas comunidades por peças mais elaboradas, de maiores dimensões e profusamente decoradas.

Ainda no respeitante aos recetores destes produtos exógenos, é "relevante» sublinhar que são, eles próprios, também agentes de comércio, que recebem bens em troca de outros, estabelecendo, com um maior ou menor peso, as condições e as mais-valias destas transações. Esta participação indicia a existência de indivíduos, dentro dos grupos sociais, que conduzem o desenrolar desta atividade económica beneficiando financeiramente dela. Se considerarmos que este desenvolvimento das trocas comerciais poderá ter potenciado a criação de riqueza e restruturado socialmente estas povoações, contribuindo para o apuro da divisão de trabalhos e incentivando uma possível hierarquização de estatuto social e riqueza de um destes grupos, poderemos atribuir a esta atividade comercial um fenómeno de progressiva complexidade e hierarquização social (Arruda, 2003, p. 55). Este processo, com início no século VII a.C. e desencadeado pela presença de comerciantes de origem fenícia e/ou grega no atual território português, ganha dimensão nos séculos seguintes, acompanhando o crescimento das re- lações comerciais e do volume de trocas realizado. Estamos assim perante um possível fenómeno de reorganização económica.

O contacto com produtos importados, veículos de cultura, contribuiu para a introdução e assimilação de hábitos exógenos. Naturalmente que, quanto mais facilitado é o acesso a estes bens (pela proximidade geográfica a centros redistribuidores e capacidade de aquisição), maior o seu impacto na alteração de hábitos dos seus compradores (Arruda, 1997; Blech, 2001). Veja-se o caso de um fragmento de um possível ponderal proveniente de Castro Marim. A verificar-se esta classificação, estaríamos possivelmente perante um sistema métrico de influência oriental, implementado neste local em finais do Século VII a.C. (Vilaça, 2003, p. 272).

As transformações geopolíticas verificadas no decurso do século IV a.C., tiveram como consequência direta uma quebra na chegada dos produtos cerâmicos áticos. A diminuição da oferta, traduziu-se na proliferação, em outras áreas do Mediterrâneo, de centros oleiros dedicados à produção de cerâmicas que obedecem à estética helenística. É neste particular contexto que devemos explicar o início da comercialização e a proliferação da cerâmica de tipo Kuass que surge em grandes quantidades no Círculo do Estreito de Gibraltar, a partir de finais do século IV a.C. De engobes acinzentados, acastanhados e avermelhados, imitam os protótipos formais da cerâmica ática de verniz negro, sendo por isso, plenamente integradas nos circuitos comerciais do mundo mediterrâneo ocidental.

Ainda que tradicionalmente se associe a presença de vasos gregos maioritariamente a contextos de habitat (VGP, 2007), excepção feita às necrópoles de Alcácer do Sal, Quinta da Queimada, Cerro Furado, e ao santuário de Cabeço da Azougada, o estudo das condições de achamento destes materiais testemunha uma realidade distinta. Não obstante, uma percentagem considerável de exemplares gregos provir de contextos de revolvimento, deposição secundárias ou de intervenções arqueológicas espacialmente limitadas que não permitem a determinação da natureza dos espaços escavados, verifica-se um número crescente de vasos gregos identificados recintos com funcionalidades religiosas. Registamos esta associação de forma evidente, por exemplo, no complexo arqueológico de Castro Verde, em Corvo I e Neves I e II, e no depósito votivo de Garvão. A referida associação dos vasos gregos a contextos 
de natureza votiva testemunha não só a ligação orgânica entre as áreas de áreas de habitat e de culto entre as comunidades sidéricas da fachada atlântica da Península Ibérica, como acentua o cariz de excepção e de estatuto associado à utilização dos vasos gregos. Ainda que em determinados arqueossítios onde os conjuntos de cerâmica grega são mais abundantes, seja admissível a sua utilização como loiça de mesa, estarão seguramente ligados a rituais de comensalidade, associados a celebrações e ritos, como veículo de reafirmação religiosa e social.

\section{ABREVIATURAS}

PLF - LOBEL, Edgar; PAGE, Denis (1955) - Poetarum Lesbiorum Fragmenta. Oxford. Tradução de Fraderico Lourenço (2006) - Poesia grega de Álcman a Teócrito. Lisboa: Livros Cotovia.

VGP-ROCHA-PEREIRA, Maria Helena, ed. (2007) - Vasos gregos em Portugal: Aquém das colunas de Hércules. Lisboa: Museu Nacional de Arqueologia, Instituto Português de Museus.

\section{BIBLIOGRAFIA}

ALMAGRO BASCH, Martín (1953) - Las necrópolis de Ampurias. Monografías Ampuritanas III. Barcelona. Volume I.

ALMAGRO BASCH, Martín (1955) - Las necrópolis de Ampurias. Monografias Ampuritanas III. Barcelona. Volume II.

ALMAGRO BASCH, Martín (1964) - Excavaciones en la Palaiápolis de Ampurias, Excavaciones arqueológicas en España. Madrid. Volume 27.

ALMEIDA, Carlos (1973-1974) - Influências meridionais na cultura castreja. Revista da Faculdade de Letras. Porto. Série I, vol. 04/o5, p. 201.

AQUILUÉ, Xavier, ed. (1999) - Intervencions arqueològiques a Sant Martí d'Empúries (1994-1996), Monografies Emporitanes - De l'assentament precolonial a l'Empúries actual. Girona. Número 9.

ARRIBAS, António; TRÍAS DE ARRIBAS, Gloria; CERDÁ, Damián.; DE HOZ ARRIBAS, Javier (1987) - El barco de El Sec (costa de Calvià, Mallorca): Estudio de los materiales. Mallorca: Ayuntamiento de Calvià, Universitat de les Illes Balears.

ARRUDA, Ana Margarida (1997) - As cerâmicas áticas do Castelo de Castro Marim no quadro das exportações gregas para a Península Ibérica. Lisboa: Ed. Colibrí.

ARRUDA, Ana Margarida (2003) - A Idade do Ferro no Castelo de Castro Marim através das importações cerâmicas. Xelb, Actas do $1^{\circ}$ Congresso de Arqueologia do Algarve. Silves: Câmara Municipal de Silves. Volume 4, pp. 70-88.
ARRUDA, Ana Margarida (2005) - O 1o Milénio a.n.e. no Centro e no Sul de Portugal: leituras possíveis no início de um novo século. O Arqueólogo Português. Lisboa. Série 4, 23, pp. 9-156.

ARRUDA, Ana Margarida (2008). Fenícios e púnicos em Portugal: problemas e perspectivas. In VITA, Juan-Pablo; ZAMORA, José Ángel, eds. - Nuevas perspectivas II: la arqueología fenicia y púnica en la Península Ibérica. Barcelona: Universidad Pompeu Fabra, pp. 13-23.

ARRUDA, Ana Margarida (2009). Phoenician colonization on the Atlantic coast of the Iberian. In DIETLER, Michael; LÓPEZ RUIZ, Carolina, eds - Colonial Encounters in Ancient Iberia. Chicago: University Press.

ARRUDA, Ana Margarida (2019) - A cerâmica grega de época arcaica do território actualmente português. [Archaic Greek pottery from Portugal]. Archivo Español de Arqueología. 92, pp. 19-25.

ARRUDA, Ana Margarida; FERREIRA, Daniela; SOUSA, Elisa (2020) - A cerâmica grega de Castelo de Castro Marim. Lisboa: Centro de Arqueologia da Universidade de Lisboa (Colecção Estudos \& Memórias, número 13).

AUBET, Maria (2009) - Tiro y las colonias fenicias de Occidente. Barcelona: Bellaterra.

BLECH, Michael (2001) - Tartessos. In Hispania Antiqua. Mainz: Denkmäler der Frühzeit, pp. 305-348.

CABRERA BONET, Paloma (1995) - Cerámicas griegas en Tartessos: su significado en la costa meridional de la Península Ibérica desde Málaga a Tartessos 25 años después. In Actas del Congreso conmemorativo del V Symposium Internacional de Prehistoria Peninsular. Jerez de la Frontera, pp. 387-399.

CABRERA BONET, Paloma; OLMOS, Ricardo (1985) - Die Griechen in Huelva, Zum Stand der Diskussion. Madrider Mitteilungen. Mainz. 26, pp. 61-74.

CABRERA BONET, Paloma, \& OLMOS, Ricardo (2017) - Cerámicas griegas en la Península Ibérica, un hito en la historia de la arqueología española. In AQUILUÉ, Xavier; CABRERA BONET, Paloma; ORFILA, Margarita, eds. Homenaje a Glòria Trias Rubiés. Cerámicas griegas de la Península Ibérica: cincuenta años después 1967-2017. Barcelona, pp. 31-43.

CABRERA BONET, Paloma e SANTOS, Marta, eds. (200o) - Ceramiques jonies dépoca arcaica: centres de producció $i$ comercializació al Mediterrani Occidental. Actes de la Taula Rodona. (Empúries, 26-28 maig de 1999). Monografies Emporitanes. Barcelona.

CABRERA BONET, Paloma; PERDIGONES, Lorenzo (1996) - Importaciones áticas del siglo V a.C. del Cerro del Prado (Algeciras, Cádiz), Trabajos de Prehistoria. Madrid. 53:2, pp. 157-165. 
CORREIA, Vergílio (1930) - Alcácer do Sal. Esboço de uma monografia. Biblos, Coimbra. 1:7, p. 40-59.

DOMÍNGUEZ MONEDERO, Adolfo; SÁNCHEZ, Carmen (2001) - Greek Pottery from the Iberian Peninsula: archaic and classical Periods. Brill.

FERNÁNDEZ JURADO, Jesús; CABRERA BONET, Paloma (1987) - Comercio griego en Huelva a fines del siglo V a. C. In ROUILLARD, Pierre; VILLANUEVA-PUIG, Maria, eds. - Revue des Études Anciennes. Grecs et Ibères au IVe siècle avant Jésus-Christ. Paris: Centre National de la Recherche Scientifique. 89:3-4, pp. 149-159.

FERREIRA, Daniela (2019) - A cerámica grega na Fachada Atlântica da Península Ibérica. Tese de Doutoramento apresentada à Universidade Complutense de Madrid.

GRACIA ALONSO, Francisco (2003) - Las cerámicas áticas del palacio-santuario de Cancho Roano. In CELESTINO PÉREZ, Sebastián, ed. - Cancho Roano VIII. Los materiales Arqueológicos. Mérida: Instituto Arqueológico de Mérida. Volume I, pp. 23-194.

GARCÍA CANO, José (1989) - Kantharos de la clase Saint Valentin en Murcia: Contribución a su estudio en la Península Ibérica. In XIX Congreso Nacional de Arqueología, Castelló 1987. Zaragoza, pp. 527-537.

GARCÍA CANO, José; Gil, Francisco. (2009) - La cerámica ática de figuras rojas: talleres y comercio (siglo IV a.C): El caso de Coimbra del Barranco Ancho (Jumilla, Murcia). Murcia.

GRAN AYMERICH, Jean (1987) - Céramiques grecques du Ve et IVe s. av. J. C. de Málaga (Campagnes de fouilles 19801986). In Grecs et ibères au IV e siècle avant Jésus-Christ, Commerce et iconographie, (Table Ronde Bordeaux 16-18 de decembre de 1986), Revue des Études Anciennes. Bordeaux. Volume LXXXIX: 3-4, pp. 69-177.

GARCÍA Y BELLIDO, Antonio (1948) - Hispania Graeca. Barcelona: Instituto Español de Estudios Mediterráneos.

JIMÉNEZ ÁVILA, Javier (2004) - La necrópolis de El Jardal (Herrera del Duque, Badajoz): Elementos para una revisión Cronológica de las Necrópolis de la $1^{\underline{a}}$ Edad del Hierro del Sur de Portugal, In Actas do II Encontro de Arqueologia do Sudoeste. Faro. pp. 106-114.

JULLY, Jean Jacques (1976) - Les importations attiques dans la Neapolis d'Ampurias du VIe s. au IVe s., Revue Belge de Philologie et d'Histoire. Bruxelles. LIV:1, pp. 25-51.

LEPORE, E. (1970) - Strutture della colonizzazione focea in Occidente. Parola del Passado, 130, 19-54.

MIRÓ, Jordi (1989) - Ánforas arcaicas en el litoral catalán: un estudio acerca de las primeras importaciones de vino en Catalunya, Archivo Español de Arqueología. Madrid. 62, pp. 21-70.

MIRÓ, Jordi (2006) - La ceràmica àtica de figures roges de la ciutat grega d'Empòrion. Barcelona: Museu d'Arqueologia de Catalunya-Empúries (Monografies Emporitanes 14).
MOREL, Jean-Paul (1972) - La céramique archaïche de Velia et quelques problémes connexes. In SANMARTÍ I GREGO, Enric; RIPOLL PERELLÓ, Eduardo, eds. - Simposio internacional de colonizaciones. Barcelona, pp. 139-158.

NIEMEYER, Hans Georg (1985) - Cerámica griega en factorías fenicias. Un análisis de los materiales de la campaña de1967 en Toscanos (Málaga). In PICAZO, Marina; SANMARTÍ, Enric, eds. - Ceràmiques Gregues $i$ Helenístiques a la Península Ibèrica. Taula Rodona amb motiu del $75 e ̀$ Aniversari de les Excavacions d'Empuries. Monografies Emporitanes. Barcelona: Diputació de Barcelona, Institut de Prehistòria i Arqueologia. VII, pp. 27-36.

NIETO, Xavier; SANTOS, Marta (2008) - El vaixell grec arcaic de Cala Sant Vicenç. Girona.

OLMOS, Ricardo; PICAZO, Marina (1979) - Zum Handel mit griechische Vasen und Bronzen auf der Iberischen Halbinsel. Madrider Mitteilungen. Madrid. 2O, pp. 184-201.

PAGE DEL POZO, Virginia (1984) - Imitaciones de influjo griego en la cerámica ibérica de Valencia, Alicante y Murcia. Iberia Graeca, Serie arqueológica. Madrid. Volume 1.

PALLARÉS SALVADOR, Francisca (1974) - El pecio del Sec y su significación histórica. In SANMARTÍ GREGO, Enric; RIPOLL PERELLÓ, Eduardo, eds. - Simposio internacional de colonizaciones. Barcelona, pp. 211-217.

PELLICER CATALÁN, Manuel (1964) - Excavaciones en la necrópolis púnica Laurita del Cerro de San Cristobal (Almuñecar, Granada). Excavaciones Arqueológicas de España. Madrid: Dirección General de Bellas Artes, Servicio Nacional de Excavaciones Arqueológicas. Volume 17.

PICAZO, Marina (1977) - La cerámica ática de Ullastret. Barcelona.

PICAZO, Manina; ROUILLARD, Pierre (1976) - Les skyphos attiques à decor reservé et surpeint de Catalogne et du Languedoc, Mélanges de la Casa de Velázquez, XII, pp.7-25.

PONS, Enriqueta, ed. (2002) - Mas Castellar de Pontós (Alt Empordà): un complex arqueològic d'època ibèrica (excavacions 1990-1998). Girona (Sèrie Monogràfica del Museu d'Arqueologia de Catalunya-Girona 21)

PUIG, Anna; MARTÍN, Aurora (2006) - La colonia grega de Rhode (Roses, Alt Empordà). Girona: Museu d'Arqueologia de Catalunya-Girona (Sèrie Monogràfica 23).

ROCHA-PEREIRA, Maria Helena (1962) - Greek Vases in Portugal. Coimbra: Imprensa da Universidade de Coimbra; Centro de Estudos Clássicos e Humanísticos.

ROUILLARD, Pierre (1975) - Les coupes attiques à Figures Rouges du IV s. en Andalusie. Paris: Melanges de la Casa de Velazquez.

ROUILLARD, Pierre (1978) - Les céramiques peintes de la Grèce de 1'Est et leurs imitations dans la Péninsule Ibérique: Recherches preliminaires. In Les Céramiques de la 
Gréce de l'Est et leur Diffusion en Occident. Paris-Nápoles, pp. 274-286.

ROUILLARD, Pierre (1991) - Les grecs et la Péninsule Ibérique du VIII au IV aoècle avant Jésus-Christ. Paris: Diffusion de Boccard.

ROUILLARD, Pierre; DE LA TORRE CASTELLANO, Inmaculada (2014) - Les coupes à tige attiques de Zacatin (Grenade); premières réflexions sur un lot de vases du IV e.s. av. J.-C), Bastetania. Baza-Granada. Volume 2, pp. 1-15.

SANCHÉZ, Carmen (1992) - Imágenes de Atenas en el mundo ibérico. Análisis iconográfico de la cerâmica ática del siglo IV a.C. hallada en Andalucía oriental, AnArte 4, 23-33.

SÁNCHEZ FERNÁNDEZ, Carmen (1987) - Algunas observaciones sobre la cerámica atica de Ibiza. In PICAZO, Marina \& SANMARTI, GREGO, Enric - Ceràmiques Gregues $i$ Helenístiques a la Península Ibérica. Taula rodona amb

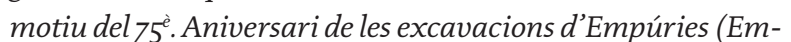
púries, 18-20 de març 1983), Monografies Emporitanes. Barcelona, VII, pp. 83-85.
SANMARTÍ GREGO, Enric; BARBERÀ, Josep; CASTANYER I MASOLIVER, Pere; TREMOLEDA I TRILLA, Joaquim (1986) - Las estructuras griegas de los siglos VI y IV a. de J. C., halladas en el sector sur de la Neápolis de Ampurias (campaña de excavaciones del año 1986). Barcelona: Generalitat de Catalunya.

SCHULTEN, Adolf (1922) - Tartessos. Ein Beitrag zur ältesten Geschichte des Westens (Hamburg, 1922; Spanish tr. Madrid, 1924, 2nd ed. 1945).

TRÍAS DE ARRIBAS, Glória (1967-1968) - Cerámicas griegas de la Península Ibérica. Valencia: William L. Bryant Foudation.

VILAÇA, Raquel (2003) - Acerca da existência de ponderaisem contextos do Bronze Final / Ferro Inicial noterritório português. O Arqueólogo Português. Lisboa. Série IV, XXI, pp. $245-288$.

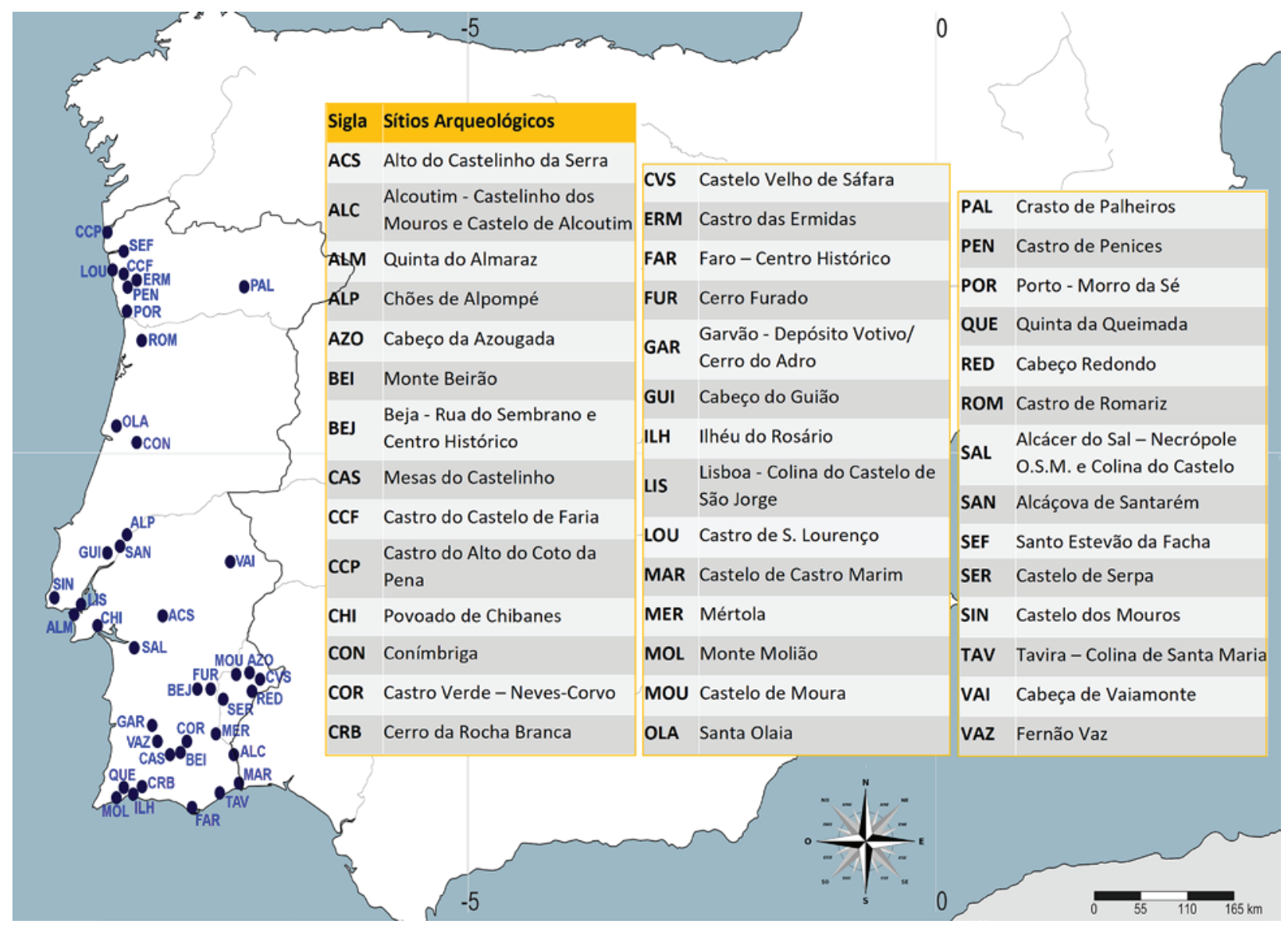

Figura 1 - Mapa com distribuição dos sítios arqueológicos onde foram identificados exemplares de cerâmica grega. 

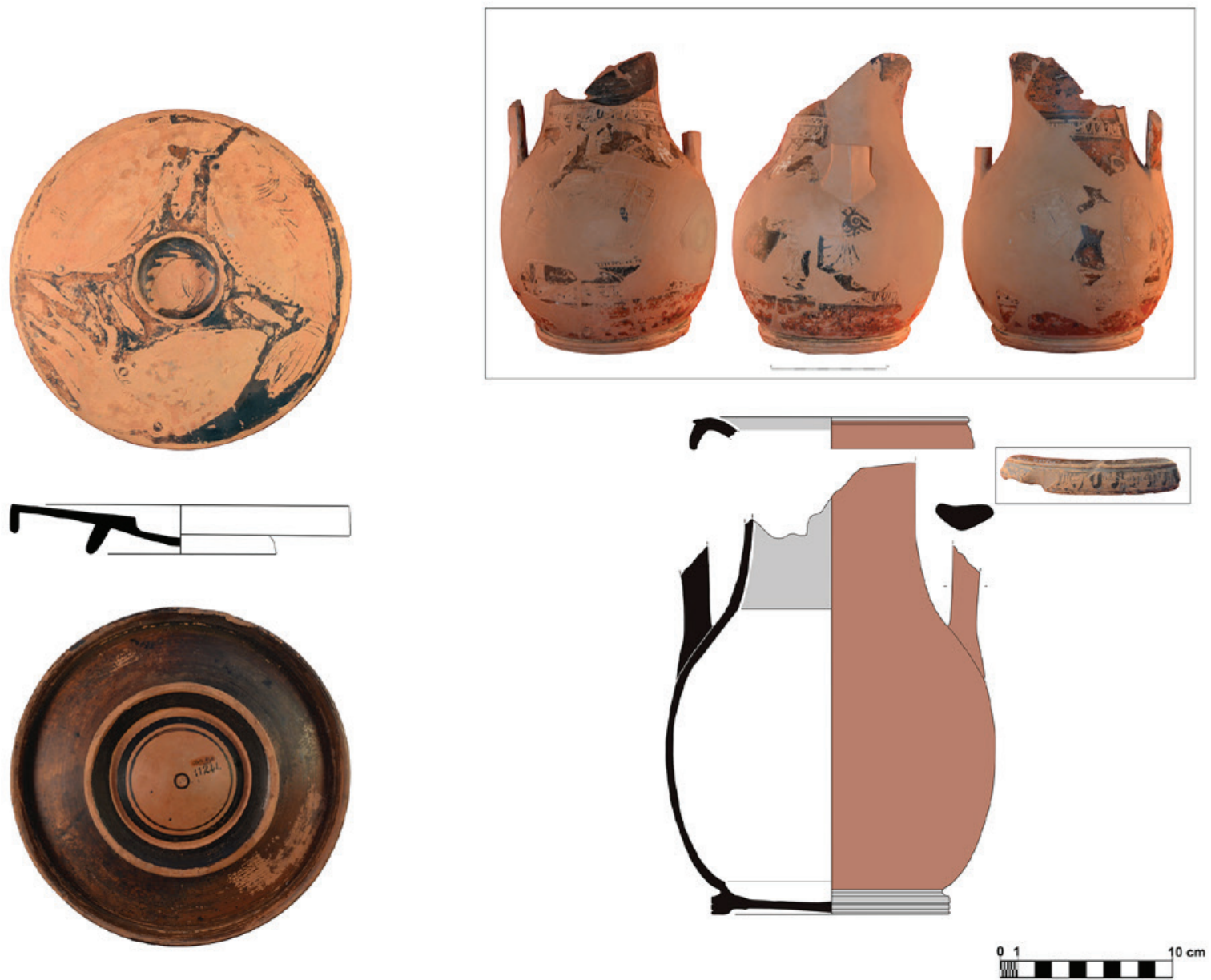

Figura 2 - Prato de peixes e pelike de figuras vermelhas provenientes da Necrópole do Olival dos Mártires, Alcácer do Sal.

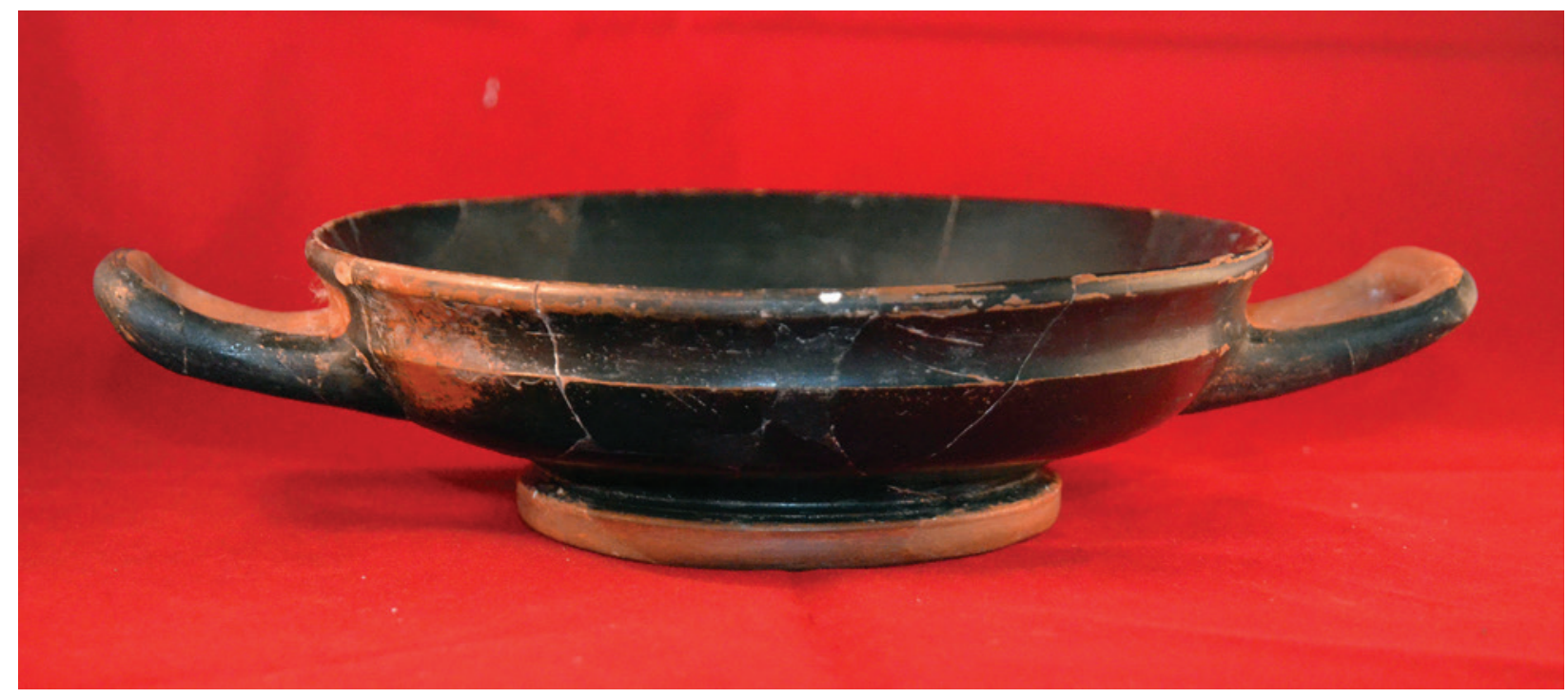

Figura 3 - Taça de Bordo convexo de verniz negro proveniente do arqueossítio de Cabeço da Azougada (AZO). 


\title{
OS EXOTICA DA NECRÓPOLE DA IDADE DO FERRO DO OLIVAL DO SENHOR DOS MÁRTIRES (ALCÁCER DO SAL) NO SEU CONTEXTO REGIONAL
}

\author{
Francisco B. Gomes ${ }^{1}$
}

\begin{abstract}
RESUMO
Ao largo da sua longa existência (meados do século VII a meados do II a.n.e.), a necrópole da Idade do Ferro do Olival do Senhor dos Mártires (Alcácer do Sal) manteve uma estreita afinidade cultural com o Sul peninsular e o Mediterrâneo, expressa, entre muitos outros aspectos, pela presença de um conjunto de exotica (vidro, cornalina, amuletos de tipo egípcio e púnico, marfim/osso e ovo de avestruz) plausivelmente correspondentes a importações mediterrâneas ou de tipo mediterrâneo. Na presente contribuição analisa-se a posição destes elementos na sequência da necrópole, contextualizando-os no repertório de elementos importados durante a Idade do Ferro regional.

Palavras-chave: Olival do Senhor dos Mártires (Alcácer do Sal), Idade do Ferro, Exotica, Comércio mediterrâneo, Consumo.
\end{abstract}

\begin{abstract}

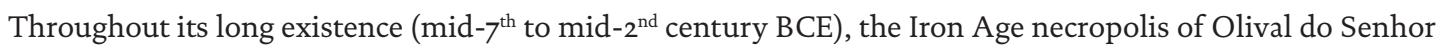
dos Mártires (Alcácer do Sal) shows a close cultural affinity with the southern Iberian Peninsula and the Mediterranean, which can be gauged, among many other aspects, by the presence of a small assemblage of exotica (glass, carnelian, Egyptian and Punic type amulets, ivory/bone and ostrich egg shell) which likely correspond to Mediterranean or Mediterranean-type imports. In this contribution these elements are set against the backdrop of the necropolis's sequence and analysed in light of the repertoire of imported elements known for the regional Iron Age.

Keywords: Olival do Senhor dos Mártires (Alcácer do Sal), Iron Age, Exotica, Mediterranean trade, Consumption.
\end{abstract}

\section{O ENQUADRAMENTO: A SEQUÊNCIA DE UTILIZAÇÃO DA NECRÓPOLE DO OLIVAL DO SENHOR DOS MÁRTIRES DURANTE A IDADE DO FERRO}

Conhecida desde finais do século XIX, a necrópole do Olival do Senhor dos Mártires (Alcácer do Sal) ${ }^{2}$ (Figura 1) constitui provavelmente o conjunto funerário da Idade do Ferro mais longa e intensamente estudado do Sul do actual território português. A complexa história da investigação sobre o sítio, que pode aferir-se pela extensa bibliografia dedicada ao mesmo (para uma síntese, ver Gomes, 2016: 72-
80), foi já exposta em detalhe em várias ocasiões (Paixão, 1970: 25-42; Rouillard et al., 1988-1989: 46-50; Fabião, 1998: 350-351; Gomes, 2016: 72-80), não parecendo pertinente neste contexto repetir essa narrativa.

Pelo contrário, e como forma de contextualizar os materiais analisados na presente contribuição, parece imprescindível recordar, em traços gerais, a sequência de utilização do OSM como área funerária por excelência da comunidade instalada na área dos actuais castelo e centro histórico de Alcácer do Sal (Silva et al., 1980-1981; Gomes, 2008; Arruda, 2014: 520-524).

1. UNIARQ - Centro de Arqueologia da Universidade de Lisboa; Faculdade de Letras da Universidade de Lisboa; Fundação para a Ciência e Tecnologia - franciscojbgomes@gmail.com.

2. De aqui em diante abreviada como OSM. 
Apesar do carácter muitas vezes lacunar da informação disponível, os dados veiculados por Vergílio Correia (1972a [1925]; 1972b [1927]) e António Cavaleiro Paixão $(1970$; 1983) relativos aos conjuntos funerários por si identificados e escavados, somados ao estudo exaustivo dos materiais recolhidos na necrópole (Gomes, 2016), permitem hoje reconhecer a sua longa diacronia de uso, desde os inícios da Idade do Ferro regional em meados do século VII a.n.e. até ao período romano republicano, bem como estabelecer com alguma segurança o seu faseamento interno (idem).

Assim, o primeiro momento de utilização do OSM como espaço funerário corresponde, grosso modo, à I Idade do Ferro regional (meados do século VII - segundo quartel / meados do $\mathrm{V}$ a.n.e.); dentro desse período podem contudo distinguir-se duas etapas diferenciadas. Assim, entre c. 650 e 575/550 a.n.e., assiste-se a uma primeira etapa, caracterizada pela diversidade de soluções funerárias (cremações in situ em fossas de perfil escalonado e em busta simples convivendo com cremações com deposição secundária dos restos em urnas "Cruz del Negro") e pela presença de espólios funerários ricos e, nalguns casos, aparatosos (Gomes, 2016: 345-346).

No segundo quartel do século VI a.n.e. parece contudo verificar-se uma homogeneização das práticas funerárias. A cremação in situ em busta simples converte-se na solução funerária predominante, senão mesmo exclusiva, desaparecendo dos espólios documentados nas sepulturas alguns dos elementos de aparato mais destacados (Gomes, 2016: 346-347). Esta etapa poderia corresponder a uma fase de consolidação das instituições urbanas de *Beuipo/Alcácer do Sal, que roubariam protagonismo à arena funerária como palcos de representação do estatuto e do poder.

A segunda grande etapa de utilização do espaço funerário do OSM corresponde genericamente à II Idade do Ferro regional, que caberia balizar entre os meados do século $V$ a.n.e. e os meados ou o terceiro quartel do II a.n.e. (Gomes, 2016: 347-350; 2018a). Os momentos iniciais desta nova etapa (c. 450-40o a.n.e.) encontram-se ainda mal caracterizados, embora as evidências disponíveis sugiram que é neste período que se generalizam os enterramentos em urna, que apresentam características notavelmente alinhadas com os da Baixa Andaluzia e, até certo ponto, do Sudeste e do Levante ibérico (v. Gomes, 2018a, com bibliografia).

$\mathrm{O}$ apogeu desta segunda etapa parece contudo cor- responder já à primeira metade do século IV a.n.e., em que se documenta a presença de ricos conjuntos funerários (ibidem) integrando panóplias armamentárias complexas, elementos de indumentária destacados e um rico repertório cerâmico que engloba um significativo conjunto de vasos gregos (Rouillard et al., 1988-1989; Gomes, 2017).

Após a quebra no abastecimento da cerâmica grega, a escassez de bons fósseis-directores para o período que medeia entre os meados do século IV e os meados / terceiro quartel do II a.n.e. dificultou o reconhecimento das fases mais tardias da necrópole. Ainda assim, em trabalhos recentes foi possível reconhecer um conjunto de materiais que podem distribuir-se por esse intervalo cronológico (Gomes, 2018a: 128-130), confirmando a continuidade do uso deste espaço funerário.

Em todo o caso, parece importante recordar que ao longo de toda esta plurissecular sequência de utilização, tanto os rituais e arquitecturas funerárias como a própria cultura material exumada no OSM revelam uma contínua afinidade cultural com o Sul peninsular e, através deste, com o Mediterrâneo.

Com efeito, numa primeira etapa, as pautas culturais documentadas nesta necrópole parecem estreitamente alinhadas com as do mundo "orientalizante" do Sudoeste peninsular, revelando por outro lado a influência da presença colonial fenícia no Baixo Sado (Arruda, 1999-2000: 63-100; Mayet \& Silva, 2000; Silva, 2005). Numa segunda etapa, e contrariamente ao defendido por alguns autores (Beirão, Gomes \& Monteiro, 1979), a necrópole do OSM revela a continuidade das estreitas relações da comunidade local com a Baixa Andaluzia "turdetana”, bem como o estabelecimento de novos laços com a área "ibérica" do Sudeste e do Levante (v. Gomes, 2018a). Os aspectos da cultura material móvel e imóvel do OSM que denunciam essa afinidade preferencial com a área meridional e com o Mediterrâneo são numerosos e diversos (v. Gomes, 2016; 2018a). Entre eles, destaca-se contudo a presença de um pequeno mas expressivo conjunto de elementos que, pela sua natureza, devem em princípio considerar-se como importações mediterrâneas ou, pelo menos, de tipo mediterrâneo.

Além de um certo número de recipientes cerâmicos, já estudados (v. Gomes, 2016, com bibliografia), esse conjunto engloba diversos elementos de adorno e/ou apotropaicos em matérias-primas exóticas que, apesar de em muitos casos terem já sido estu- 
dados de forma isolada (v. infra), não foram ainda objecto de uma apreciação de conjunto. O presente contributo pretende precisamente valorizar estes últimos elementos, analisando a sua distribuição ao longo da sequência da necrópole do OSM e contextualizando-os no panorama regional actualmente conhecido.

\section{OS EXOTICA DA NECRÓPOLE DE ALCÁCER DO SAL}

\subsection{O vidro e a faiança}

O vidro ocupa um lugar destacado no inventário dos elementos importados mediterrâneos, ou de tipo mediterrâneo, da Idade do Ferro do Sudoeste peninsular. Os elementos de colar produzidos nesta matéria-prima são com efeito uma presença habitual nos contextos deste período, particularmente durante os séculos VI e V a.n.e..

Em face deste panorama, e especialmente da profusão de elementos vítreos noutros conjuntos funerários sidéricos do território meridional português, o conjunto de elementos de adorno de vidro do OSM surpreende pela sua pequena dimensão. Com efeito, entre o extenso conjunto de materiais recolhidos no sítio contabilizam-se apenas três contas de colar de vidro (Figura 2, nn. 1-3).

Todas estas contas correspondem a peças de morfologia esférica achatada de matriz azul turquesa com decorações oculadas estratificadas a branco e azul ultramarino. Em duas delas as oculações são simples, distribuindo-se ao longo do eixo transversal da peça; o terceiro exemplar, em contrapartida, apresenta oculações simples alternadas com oculações geminadas, formando um padrão decorativo invulgar neste tipo de contas. Estas peças apresentam dimensões homogéneas, com diâmetros de $1 \mathrm{~cm}$ e alturas entre 0,65 e $0,8 \mathrm{~cm}$.

As contas deste tipo são presença habitual na maioria dos conjuntos da Idade do Ferro do Sudoeste peninsular. Assim, e num entorno regional alargado, caberia mencionar a presença de contas similares às do OSM nas necrópoles da Herdade do Gaio (Sines) (Costa, 1967; 1972), do Galeado (Vila Nova de Milfontes) (Beirão \& Gomes, 1983: 226; Fig. 16), da Nora Velha (Aljustrel) (Soares \& Martins, 2013: Fig. 5), da Mealha Nova (Ourique) (Dias, Beirão \& Coelho, 1970: 219) e da Fonte Santa (Ourique) (Beirão, 1986; 71-74), bem como, possivelmente, no conjunto funerário de Corte Margarida (Aljustrel)
(Deus \& Correia, 2005). Em contextos não funerários haveria a assinalar os exemplares do povoado de Fernão Vaz (Ourique) (Beirão \& Gomes, 1986: Fig. 2), do santuário de Corvo I (Castro Verde) (Maia \& Maia, 1986) e do povoado das Mesas do Castelinho (Almodôvar) (Estrela, 2019: 205-206).

Mais a Norte, as contas deste tipo estão documentadas nos conjuntos das necrópoles da Vinha das Caliças 4 (Beja) (Arruda et al., 2017: Fig. 18), do Monte do Bolor 1-2 (Beja) (Soares et al., 2017: 284-285) e talvez também de Palhais (Beja) (Santos et al., 2017: 238), bem como, já no Alentejo Central, na necrópole da Tera (Mora) (Mataloto, 2010-2011: 92) e, no Alto Alentejo, no povoado da Cabeça de Vaiamonte (Monforte) (Fabião, 2001: 204).

Quanto ao território algarvio, podem identificar-se contas muito similares às que aqui nos ocupam na necrópole da Fonte Velha de Bensafrim (Lagos) (Veiga, 2005 [1891]: Est. XXVIII), na da Hortinha (Lagos) ${ }^{3}$ e na de Cômoros da Portela (Veiga, 2005 [1891]: 259; Est. XXVIII, n. 8).

Já no âmbito da Estremadura e do Baixo Tejo estão documentadas contas similares na gruta-santuário da Lapa da Cova (Sesimbra) (Calado et al., 2017: 535536; Fig. 3) e no povoado da Quinta do Almaraz (Almada) (Filardi, 2011: Fig. 1.6.1), bem como em Freiria (Cascais), no Moinho da Atalaia (Amadora), no Porto do Sabugueiro (Salvaterra de Magos), na Alcáçova de Santarém e no sítio de Moinhos Velhos (Torres Vedras) (Arruda et al., 2016, com bibliografia). Poderiam ainda citar-se muitos outros paralelos mais distantes, reveladores da origem mediterrânea deste tipo de peças (Ruano Ruiz 200o: 63-64; 111-112). Como se podeapreciar pelos paralelos anteriormente enunciados, este tipo de contas é relativamente corrente no Sudoeste, mas também no âmbito mediterrâneo, com destaque para as áreas mais directamente tocadas pela influência fenícia e púnica. Devido à sua transversalidade, torna-se difícil situar estes elementos de colar, infelizmente sem contexto preciso, na sequência da necrópole. Ainda assim, a ponderação da cronologia dos paralelos disponíveis, somada ao que actualmente conhecemos sobre os ritmos de importação e consumo das contas de vidro, permite sugerir que as três peças do OSM procederão de sepulturas enquadráveis nos séculos VI e V a.n.e., podendo talvez integrar-se na segunda etapa da I Idade do Ferro anteriormente comentada.

3. Materiais em depósito no MNA, actualmente em estudo. 
Uma outra conta, anteriormente identificada como de vidro, parece na realidade corresponder a um exemplar de faiança, esférico, de tonalidade azul esverdeada e dotado de ranhuras longitudinais irregulares que lhe conferem um aspecto galonado (Figura 2, n. 4). Corresponde a uma peça de pequenas dimensões, com um diâmetro de $1,4 \mathrm{~cm}$ e uma altura de $1,25 \mathrm{~cm}$.

Ao contrário das contas galonadas de vidro, relativamente bem conhecidas no Sul de Portugal (Fabião, 2001: 203; Filardi, 2011: Fig. 1.6.1; Arruda et al., 2016: Fig. 5; Estrela, 2019: 204; v. tb. Ruano Ruiz 2000: 124), as contas de faiança deste tipo estão escassamente documentadas na região, excepção feita aos exemplares do possível enterramento da II Idade do Ferro de Fronteira (Vila do Bispo) (Viana, Formosinho \& Ferreira, 1953: 12 e Lám. I, n. 13). Tal facto poderá dever-se ao facto de as contas deste material não terem sido devidamente individualizadas regionalmente até datas relativamente recentes, graças sobretudo ao achado de grandes quantidades de exemplares discoides nas necrópoles da área de Beja (Santos et al. 2017: Fig. 7; Arruda et al. 2017: 212). Em face da presença de elementos deste tipo noutros contextos (Viana, Formosinho \& Ferreira, 1953: $12 \mathrm{e}$ Lám. I, n. 13; v. tb. Verdú Parra 2015: Fig. 3.447), caberia esperar que no futuro se venham a identificar novos exemplos que permitam definir melhor a cronologia da peça do OSM, que de momento caberia situar genericamente na II Idade do Ferro.

A estes escassos elementos de adorno haveria a acrescentar um fragmento de vidro polícromo (Figura 2, n. 5), ostentando uma matriz azul ultramarina e uma decoração de linhas paralelas (possivelmente em espiral) amarelas e brancas. Apresenta ainda um pequeno elemento cilíndrico, azul de cádmio, aplicado sobre a superfície, possivelmente correspondente aos restos deformados de uma pequena asa.

Apesar das suas pequenas dimensões e do seu mau estado de conservação, resultado da sua exposição ao fogo, este fragmento pertencerá muito provavelmente a um recipiente moldado sobre núcleo friável, cuja tipologia infelizmente não é possível precisar. Ainda assim, o esquema cromático e decorativo que se entrevê no fragmento preservado permite pensar que a peça em apreço se integraria no chamado Grupo Mediterrâneo I (Harden, 1981: 59-93; Grose, 1989: 110-115).

Quanto ao seu contexto, a informação patente no inventário do Museu Nacional de Arqueologia indi- ca que esta peça procede da Sepultura 6 de Vergílio Correia, contexto que contudo oferece significativos problemas de leitura, na medida em que se atribuem ao mesmo materiais com cronologias algo discrepantes (Gomes, 2016: Anexo III). Ainda assim, os materiais que lhe são atribuídos distribuem-se por um intervalo entre o século VI e o IV a.n.e., consistente com a atribuição do recipiente em análise ao Grupo Mediterrâneo 1.

Com efeito, estes recipientes, de provável produção grega,parecemter-seproduzidoedifundidopeloMediterrâneo entre os meados do século VI e os inícios do IV a.n.e. (Harden, 1981: 58; Grose, 1989: 110-111). Menos comuns do que as contas de vidro, os recipientes deste grupo estão também bem documentados no Extremo Ocidente peninsular (Feugère, 1989; Jiménez Ávila, 1999: Mapa 1; 2003: Fig. 4; Fabião, 2001: Fig. 14). Parece ocioso repetir, neste contexto, o panorama já esboçado nas várias sínteses disponíveis, embora deva chamar-se a atenção para a presença de um outro fragmento de vidro polícromo atribuível a um recipiente deste grupo procedente do povoado de Alcácer do Sal, concretamente dos contextos do século $\mathrm{V}$ a.n.e. documentados na área do Castelo (Silva et al., 1980-1981: Fig. 18, n. 224).

Podem por outro lado citar-se os achados mais recentes da Malhada das Taliscas (Alandroal) (Calado, Mataloto \& Rocha, 2007: 156), do Monte da Tera (Mataloto, 2010-2011: Fig. 8) ou, já na Estremadura/ Baixo Tejo, os de Castelo dos Mouros (Sintra) (Silva \& Sousa, 2016) e de Cabeço Guião (Arruda et al., 2017: Fig. 29) ${ }^{4}$, que vieram incrementar a densidade da malha de dispersão deste tipo de recipientes anteriormente conhecida (Jiménez Ávila, 1999: Mapa 1; 2003: Fig. 4; Fabião, 2001: Fig. 14). A estes achados vem agora somar-se o exemplar do OSM, reforçando o peso destes pequenos contentores de perfumes ou unguentos nas economias de prestígio regionais do período em apreço.

\subsection{A cornalina}

Embora bastante menos frequente do que o vidro, a cornalina constitui também uma presença relativamente frequente no repertório dos elementos de adorno da Idade do Ferro (cf. Gomes 2018b).

\footnotetext{
4. A integração deste último exemplar no Grupo Mediterrâneo 1 não é segura, podendo também pertencer já ao Grupo Mediterrâneo 2, mais raro - mas não desconhecido - no Extremo Ocidente peninsular.
} 
No OSM, contudo, esta matéria-prima de origem exótica, muito provavelmente egípcia (Martín de la Cruz, 2004; Martín de la Cruz et al., 2005; Gomes, 2018b), encontra-se possivelmente representada por uma única conta de colar (Figura 2, n. 6), de morfologia esférica, com 1,1 cm de diâmetro e 1,1cm de altura. A identificação da matéria-prima desta conta levanta contudo certas reservas, não podendo excluir-se igualmente que corresponda a um elemento de âmbar.

Em todo o caso, caberia recordar que no panorama actualmente conhecido as contas de cornalina esféricas são menos comuns do que as bitroncocónicas (Gomes, 2018b: 63-64); ainda assim, e no âmbito regional mais próximo, caberia citar a presença de contas desta morfologia no depósito votivo de Garvão (Ourique) (Beirão et al., 1985: 92 e Fig. 35, nn. 99-101), pertencentes portanto a uma cronologia tardia, do final do século III ou mesmo dos inícios do II a.n.e.. No entanto, nos contextos fenícios e púnicos do Levante e do Sul peninsular não faltam exemplares de contas de cornalina esféricas mais antigas, distribuídas entre os finais do século VIII/ inícios do VII e o século IV a.n.e. (Gomes 2018b: 64, com bibliografia).

Infelizmente, a peça do OSM não dispõe de coordenadas contextuais, pelo que, dada a larga diacronia abarcada pelos paralelos disponíveis, não parece possível determinar a que momento concreto dentro da sequência da necrópole pertence. Ainda assim, caberia notar que o período de máxima difusão dos adornos de cornalina no Sul de Portugal corresponde aos séculos VI e V a.n.e., podendo como hipótese pensar-se que a conta do OSM se enquadrará também nesse horizonte cronológico.

\subsection{Os aegyptiaca}

Entre os exotica recolhidos durante as intervenções realizadas no OSM, os escaravelhos de tipo egípcio foram sem dúvida os que mereceram maior atenção, tendo sido publicados pelos seus descobridores (Correia, 1972C [1925]; Paixão, 1971; 1983; Gamer-Wallert \& Paixão, 1983) e posteriormente analisados em diversos trabalhos de síntese, quer sobre os aegyptiaca peninsulares (Gamer-Wallert, 1978: 104-107; García Martínez, 2001: 169-175), quer especificamente sobre os escaravelhos e escarabóides do Sul de Portugal (Almagro-Gorbea \& Torres Ortiz, 2009: 528-534).

Os cinco escaravelhos de tipo egípcio do OSM (Fi- gura 2, nn. 7-11) foram objecto de análise muito aprofundada em data recente por parte de Martín Almagro-Gorbea e Mariano Torres Ortiz (2009: 528-534), pelo que parece redundante insistir neste contexto nas suas características específicas, que se sintetizam no quadro da Figura 3. Deve, no entanto, recordar-se que os exemplares alcacerenses se integram num panorama mais vasto. Com efeito, os escaravelhos e escarabóides egípcios e/ou de tipo egípcio constituem uma ocorrência relativamente frequente no Sul do actual território nacional, particularmente em contextos funerários, podendo citar-se, além dos exemplares já resenhados pelos autores citados (idem), os achados mais recentes da Vinha das Caliças 4 (Arruda et al., 2017), do Monte do Bolor 1-2 (Soares et al., 2017) e de Palhais (Santos et al., 2017), que vieram enriquecer de forma significativa o repertório regional deste tipo de elementos.

Atéao momento, os exemplares do OSM encontram-se relativamente isolados no seu âmbito regional mais próximo, o do Baixo Sado, marcando contudo uma das possíveis rotas de difusão deste tipo de elementos para o interior alentejano, onde são comparativamente abundantes. Não deve no entanto esquecer-se que os aegyptiaca estão igualmente representados no povoado de Alcácer do Sal, concretamente por uma placa-amuleto de faiança procedente da área do Convento de Aracoeli (Gomes, 2008: 21), pertencente ao conhecido tipo vaca/udjat (López Grande \& Velázquez Brieva, 2011-2012), que confirma o papel de centro de consumo e, eventualmente, de redistribuição de aegyptiaca do polo sadino.

\subsection{Os amuletos "púnicos"}

Aparte dos objectos apotropaicos de tipo egípcio anteriormente comentados, na necrópole do OSM recolheram-se também três outras peças que poderiam enquadrar-se no vasto universo dos chamados amuletos "púnicos". Estas três peças, de faiança de tonalidade azul esverdeada, foram recentemente estudadas com alguma profundidade (Gomes, no prelo; v. tb. Gomes, 2016: 318-320), pelo que neste contexto se oferecerá apenas um resumo das suas características principais.

O primeiro e mais representativo destes amuletos corresponde a uma figuração itifálica do deus Bes (Figura 4, n. 12), de pequenas dimensões ( $3 \mathrm{~cm}$ de comprimento por $1,7 \mathrm{~cm}$ de largura). Os amuletos figurando esta divindade de origem egípcia são muito comuns no Mediterrâneo púnico, alcançando o Me- 
diterrâneo Ocidental e a Península Ibérica (Gómez Peña \& Rodríguez Mellado, 2014: Tabla 1).

Infelizmente, desconhece-se actualmente o contexto exacto em que se recolheu o amuleto do OSM, não sendo por isso possível situá-lo com segurança na sequência de uso da necrópole. Ainda assim, deve assinalar-se que a documentação peninsular, recentemente compilada (Gómez Peña \& Rodríguez Mellado, 2014), parece sugerir que a maioria dos amuletos com figurações de Bes do Ocidente se concentram num período centrado entre os séculos VI e o V/IV a.n.e. (idem: 109-111), cronologia que os exemplares de Ibiza não desmentem (López-Grande et al., 2014: 169-170).

O segundo amuleto "púnico" do OSM (Figura 4, n. 13) oferece maiores dificuldades do ponto de vista da sua interpretação iconográfica. A priori, esta peça, com $2,3 \mathrm{~cm}$ de comprimento e $0,3 \mathrm{~cm}$ de largura máxima, poderia interpretar-se como um amuleto fálico (Gomes, 2016: 319), embora alguns detalhes, como as estrias longitudinais, pareçam algo deslocadas numa figuração dessa natureza. Por outro lado, peças similares (mas desprovidas de sulcos) procedentes de contextos púnicos da Sardenha foram interpretados como representações de seios (Acquaro, 1977: nn. 22-23), leitura que tão-pouco se adequa de forma clara ao exemplar alcacerense.

Independentemente destas dúvidas quanto à sua interpretação iconográfica, caberia salientar que os paralelos exactos para este amuleto são raros. Pode contudo recordar-se que Horace Beck, no seu clássico estudo sobre as contas de colar, classifica este tipo de objectos no seu Grupo XXIII, e concretamente no Tipo B.3.a, ilustrado por um exemplar egípcio da Baixa Época (Beck, 1928: Fig. 21). No âmbito peninsular parece documentar-se um único exemplar análogo ao do OSM, procedente da necrópole de La Albufereta (Alicante), infelizmente sem contexto seguro (Verdú Parra, 2015: 398 y Fig. 3447). A peça alicantina não será contudo anterior ao século $\mathrm{V}$ a.n.e., pelo que o exemplar do OSM, infelizmente também ele desprovido de coordenadas contextuais, poderá tentativamente atribuir-se ao horizonte da II Idade do Ferro da necrópole.

Finalmente, o terceiro amuleto recolhido no conjunto funerário sadino, também ele de pequenas dimensões (1,9cm de comprimento por $1 \mathrm{~cm}$ de largura), parece corresponder a uma representação realista dos genitais masculinos e da correspondente área púbica (Figura 4, n. 14). Este motivo encontra-se bem re- presentado nos amuletos egípcios, atribuindo-se as representações do mesmo em faiança já ao período Ptolemaico (Müller-Winckler, 1987: 193); no Mediterrâneo Central e Ocidental, pelo contrário, não se conhecem amuletos deste tipo realizados em faiança, ainda que o motivo seja frequente entre os amuletos púnicos de osso de Ibiza (Fernández et al., 2009: Tipo 4.1.1).

Em face do exposto, caberia pensar que, tal como o exemplar putativamente fálico antes descrito, este amuleto se terá depositado nalgum enterramento integrável nos horizontes mais tardios do OSM, sem que possa igualmente excluir-se que se trate de uma peça já de cronologia republicana.

\subsection{O marfim/osso}

A presença de marfim ou osso trabalhado no OSM é francamente vestigial, resumindo-se na prática a uma placa circular que ostenta decoração gravada numa das faces, concretamente a representação de uma roseta de 16 pétalas enquadrada por uma moldura formada por dois círculos concêntricos (Figura 4, n. 15) (Gomes, 2016: Est. CXLII, n.1166). Esta peça conta com um paralelo exacto entre os materiais do santuário ribeirinho da Rua do Rato, em Alcácer do Sal, datado do século VI a.n.e. (Arruda, 2014: Fig. 17). Na ausência de dados contextuais específicos, o exemplar do OSM deverá considerar-se contemporâneo desta outra placa procedente do povoado.

A esta peça poderia apenas acrescentar-se o uso do marfim/ osso como complemento decorativo de elementos metálicos, nomeadamente nos cabos de facas afalcatadas (Gomes, 2016: Est. LXVIII, nn. 765766; Est. LXIX, n. 773) e, num caso, como remate de uma dobradiça pertencente a um elemento de mobiliário, possivelmente uma banqueta funerária de tipo diphros (idem: Est. CXX, n. 1018). Os paralelos disponíveis para o tipo de objectos que serviu de suporte a estes elementos de eborária permite sugerir que os mesmos se concentrarão fundamentalmente no século VI a.n.e. (Gomes, 2016: 276 e 302-303).

\subsection{O ovo de avestruz}

A lista dos exotica do OSM aqui analisados encerra-se com um recipiente sobre ovo de avestruz (Figura 4, n. 16), infelizmente sem contexto preciso (Arruda, 2014: Figura 6; Gomes, 2016: 320-322). Esta peça integra-se na Forma II definida por María del Pilar San Nicolás para os recipientes de ovo de avestruz fenícios e púnicos peninsulares, corres- 
pondente a recipientes fechados obtidos mediante a extracção do quinto superior do ovo (San Nicolás 1975: 79). O bordo do recipiente assim obtido apresenta uma aresta contínua, o que permite aproximar o exemplar alcacerense da variante II-A definida por aquela mesma autora (idem: Lám. II). Quanto às suas dimensões, a peça do OSM apresenta um diâmetro máximo de $13,4 \mathrm{~cm}$, um diâmetro de bordo de $9 \mathrm{~cm}$ e uma altura total de $12,2 \mathrm{~cm}$.

Como é habitual nas peças da Forma II, a superfície do recipiente do OSM apresentar-se-ia decorada com motivos gravados e pintados, infelizmente hoje praticamente perdidos. Actualmente apenas se aprecia a presença de barras verticais que dividem o campo decorativo em métopas e de barras horizontais repartindo cada métopa em dois registos. O esquema composicional destas barras, de certa complexidade, não conta com paralelos exactos no repertório dos recipientes de ovo de avestruz peninsular, embora possa aproximar-se tentativamente dos Motivos $6 \mathrm{e}$ 8 de María del Pilar San Nicolás (1975: Lám. V).

Embora estejam muito bem representados no Mediterrâneo Ocidental (Savio 2004, com bibliografia), os recipientes de ovo de avestruz praticamente não alcançaram o actual território português, onde aparte do exemplar do OSM apenas haveria a citar os fragmentos exumados nas escavações do Palácio da Galeria, em Tavira (Maia, 2003: 68). No resto do Sudoeste peninsular o panorama não é muito mais rico, resumindo-se aos escassos exemplares de La Joya (Huelva), de El Carambolo (Camas) e das necrópole dos Alcores de Carmona (Cruz del Negro, El Acebuchal e Santa Lucía) (Savio, 2004: 71-72, com bibliografia).

Infelizmente, não dispomos de dados sobre o contexto original da peça em apreço, o que dificulta a correcta aferição da sua posição na sequência global da necrópole, sobretudo quando o mau estado de conservação da decoração impede qualquer comparação estilística aprofundada. Por outro lado, a produção e uso de recipientes de ovo de avestruz no âmbito fenício-púnico abarca uma longa diacronia, que se estende pelo menos do século VII ao século III ou mesmo ao II a.n.e., o que não ajuda a dilucidar a questão. Note-se no entanto que os poucos exemplares documentados no Sudoeste Peninsular procedem de contextos tendencialmente antigos, dos séculos VII e VI a.n.e., pelo que parece verosímil que o recipiente do OSM pertença também aos horizontes mais antigos da necrópole alcacerense.

\section{AS IMPORTAÇÕES MEDITERRÂNEAS DO OLIVAL DO SENHOR DOS MÁRTIRES NO SEU CONTEXTO REGIONAL}

Como se pode apreciar pelo panorama traçado nas páginas anteriores, os exotica do OSM, apesar de não muito numerosos, são diversificados e apresentam simultaneamente características que aproximam a necrópole sadina dos demais contextos funerários do Sul português e outros que a individualizam dentro do seu âmbito regional.

Desde logo, a presença de elementos de adorno de vidro e cornalina constitui um rasgo partilhado entre a necrópole sadina e muitas das suas congéneres alentejanas e algarvias. No entanto, em comparação com estas, o volume de materiais deste tipo no OSM parece algo surpreendente. Naturalmente esse facto pode dever-se a questões de conservação - a prática da cremação no OSM poderá ter obliterado muitos outros objectos, especialmente de vidro, que tenham originalmente existido -, mas também a factores culturais.

Com efeito, este tipo de elementos parece ser muito valorizado em contextos de povoamento eminentemente rural, sobretudo durante os séculos VI e V a.n.e., sendo contudo raros em ambientes de natureza (proto-)urbana, como bem demonstram os casos de Medellín (Almagro-Gorbea 2008a) ou de La Angorrilla (Alcalá del Río) (Fernández Flores et al. 2014), com os quais a comunidade de Alcácer do Sal pareceterpartilhadoum regimedevalordiferenciado do das comunidades rurais de outras áreas.

Quanto aos amuletos, destaca-se a riqueza do conjunto de escaravelhos de tipo egípcio, que bem poderia evidenciar o papel do pólo do Baixo Sado como centro redistribuidor, ajudando assim a compreender a abundante presença deste tipo de amuletos no interior alentejano. Pelo contrário, a presença dos amuletos de tipo "púnico" constitui uma especificidade do sítio sadino, que evidencia a sua proximidade com os núcleos de origem fenícia do Sul peninsular, com destaque naturalmente para Cádiz, onde este tipo de amuletos é também bem conhecido (cf. Perdigones, Muñóz \& Pisano 1990).

Quanto à eborária, o panorama do OSM é francamente modesto, faltando aqui por completo os produtos mais característicos da chamada eborária hispano-fenícia, tão frequentes nos ambientes funerários orientalizantes do vizinho território espanhol (Almagro-Gorbea 2008b, com bibliografia). Pelo 
contrário, a presença do recipiente de ovo de avestruz permite integrar o conjunto funerário alcacerense na lista restrita e exclusiva dos sítios do Sudoeste peninsular em que se identificaram elementos deste tipo (Savio 2004), destacando uma vez mais a estreita relação da comunidade alcacerense com o Sul peninsular e a sua capacidade de aceder às rotas comerciais que o conectavam com o Mediterrâneo.

Em face destas considerações, pode afirmar-se que o conjunto de exotica do OSM constitui simultaneamente um reflexo modesto mas fiel do repertório de importações mediterrâneas presentes na Idade do Ferro do Sul de Portugal, e, nalguns aspectos, uma excepção no quadro desse mesmo repertório, facto que reflecte a marcada personalidade própria do processo histórico da comunidade local, que nos últimos anos se tem vindo a evidenciar de forma cada vez mais clara (Gomes 2016; 2018).

\section{BIBLIOGRAFIA}

ACQUARO, Enrico (1977) - Amuleti egiziani ed egittizzanti del Museo nazionale di Cagliari. Roma: CNR.

ALMAGRO-GORBEA, Martín, dir. (2008a) - La necrópolis de Medellín. II. Estudios de los hallazgos. Madrid: Real Academia de la Historia.

ALMAGRO-GORBEA, Martín (2008b) - Objetos de marfil y hueso. In ALMAGRO-GORBEA, Martín, dir. - La necrópolis de Medellín. II. Estudios de los hallazgos. Madrid: Real Academia de la Historia, p. 401-512.

ALMAGRO-GORBEA, Martín; TORRES ORTIZ, Mariano (2009) - Los escarabeos fenicios de Portugal. Un estado de la cuestión. Estudos Arqueológicos de Oeiras. Oeiras. 17, pp. 521-554.

ARRUDA, Ana Margarida (1999-200o) - Los Fenicios en Portugal. Fenicios y mundo indígena en el centro y sur de Portugal (siglos VIII-VI a.C.). Barcelona: Universitat Pompeu Fabra.

ARRUDA, Ana Margarida (2014) - A Oeste tudo de novo. Novos dados e outros modelos interpretativos para a orientalização do território português. In ARRUDA, Ana Margarida, ed. - Fenícios e Púnicos, por Terra e Mar (2). Actas do VI Congresso Internacional de Estudos Fenícios e Púnicos. Lisboa: UNIARQ, p. 513-535.

ARRUDA, Ana Margarida; BARBOSA, Rui; GOMES, Francisco B.; SOUSA, Elisa de (2017) - A necrópole da Vinha das Caliças (Beja, Portugal). In JIMÉNEZ ÁVILA, Javier, ed. - Sidereum Ana III. El Río Guadiana y Tartessos. Mérida: Consorcio Ciudad de Mérida, p. 187-225.

ARRUDA, Ana Margarida; PEREIRA, Carlos; PIMENTA, João; SOUSA, Elisa de; MENDES, Henrique; SOARES, Rui
(2016) - As contas de vidro do Porto do Sabugueiro (Muge, Salvaterra de Magos, Portugal). CUPAUAM. Madrid. 42, pp. 79-101.

ARRUDA, Ana Margarida; SOUSA, Elisa de; BARRADAS, Elisabete; BATATA, Carlos; DETRY, Cleia; SOARES, Rui Monge (2017) - O Cabeço Guião (Cartaxo - Portugal): um sítio da Idade do Ferro do Vale do Tejo. In CELESTINO PÉREZ, Sebastián; RODRÍGUEZ GONZÁLEZ, Esther, eds. Territorios comparados: los valles del Guadalquivir, el Guadiana y el Tajo en época tartésica. Madrid: CSIC, p. 319-361.

BECK, Horace C. (1928) - Classification and nomenclature of beads and pendants. Archaeologia. Londres. 77, pp. 1-76.

BEIRÃO, Caetano de Mello (1986) - Une Civilisation Protohistorique du Sud du Portugal (Ier Âge du Fer). Paris: Éditions du Boccard.

BEIRÃO, Caetano de Mello; GOMES, Mário Varela (1983) - A necrópole da Idade do Ferro do Galeado (Vila Nova de Milfontes). O Arqueólogo Português. Lisboa. Série IV. 1, pp. 207-266.

BEIRÃO, Caetano de Mello; GOMES, Mário Varela (1986) - Grafitos da Idade do Ferro do Centro e Sul de Portugal. In de HOZ BRAZO, Javier, ed. - Actas del III Coloquio sobre Lenguas y Culturas Paleohispánicas. Salamanca: Universidad de Salamanca, p. 465-502.

BEIRÃO, Caetano de Mello; GOMES, Mário Varela; MONTEIRO, Jorge Pinho (1979) - As Estelas Epigrafadas da I Idade do Ferro do Sul de Portugal. Setúbal: MAEDS.

BEIRÃO, Caetano de Mello; SILVA, Carlos Tavares da; SOARES, Joaquina; GOMES, Mário Varela; GOMES, Rosa Varela (1985) - Depósito votivo da II Idade do Ferro de Garvão. Notícia da primeira campanha de escavações. O Arqueólogo Português. Série IV. 3, pp. 45-135.

CORREIA, Vergílio (1972a [1925]) - Uma conferência sobre a Necrópole de Alcácer do Sal. In Obras. Volume IV, Estudos Arqueológicos. Coimbra: Universidade de Coimbra, p. 151-168.

CORREIA, Vergílio (1972b [1928]) - Escavações realizadas

na Necrópole Pré-Romana de Alcácer do Sal em 1926 e 1927. In Obras. Volume IV, Estudos Arqueológicos. Coimbra: Universidade de Coimbra, p. 169-179.

CORREIA, Vergílio (1972c [1925]) - Um amuleto egípcio da Necrópole de Alcácer do Sal. In Obras. Volume IV, Estudos Arqueológicos. Coimbra: Universidade de Coimbra, p. 195-201.

CALADO, Manuel; GONÇALVES, Luís; MATALOTO, Rui; JIMÉNEZ ÁVILA, Javier (2017) - Lapa da Cova: un santuario costero en los acantilados de Sesimbra (Portugal). In MARTÍNEZ ALCALDE, María Martínez; GARCÍA CANO, José Miguel; BLÁNQUEZ PÉREZ, Juan; INIESTA SANMARTÍN, Ángel, eds. - Mazarrón II. Contexto, viabilidady perspectivas del barco B-2 de la bahía de Mazarrón. En homenaje a Julio Mas García. Madrid: Universidad Autónoma de Madrid: 525-545. 
CALADO, Manuel; MATALOTO, Rui; ROCHA, Artur (2007)-Povoamento Proto-Histórico na Margem Direita do Regolfo do Alqueva (Alentejo, Portugal). In RODRÍGUEZ DÍAZ, Alonso; PAVÓN SOLDEVILA, Ignacio, eds. - Arqueología de la Tierra. Paisajes rurales de la protohistoria peninsular. Cáceres: Universidad de Extremadura, p. 129-179.

COSTA, José Miguel da (1967) - O tesouro Fenício ou Cartaginês do Gaio (Sines). Ethnos. Lisboa. 5, pp. 529-537.

COSTA, José Miguel da (1972). O tesouro púnico-tartéssico do Gaio. In Actas das II Jornadas da Associação dos Arqueólogos Portugueses. Lisboa: Associação dos Arqueólogos Portugueses, p. 97-120

DEUS, Manuela de; CORREIA, José (2005) - Corte Margarida. Mais uma necrópole orientalizante no Baixo Alentejo. In CELESTINO PÉREZ, Sebastián; JIMÉNEZ ÁVILA, Javier, eds. - El Período Orientalizante. Madrid: CSIC, p. 615-618.

DIAS, Maria Manuela Alves; BEIRÃO, Caetano de Mello; COELHO, Luís (1971) - Duas necrópoles da Idade do Ferro no Baixo-Alentejo: Ourique. (Notícia preliminar). O Arqueólogo Português. Lisboa. Série III. 4, pp. 175-219.

ESTRELA, Susana (2019) - Adornos, espaço e tempo: as contas de colar em Mesas do Castelinho (Santa Clara-a-Nova, Almodôvar). Setúbal Arqueológica. Setúbal. 18, pp. 193-214.

FABIÃO, Carlos (1998) - O Mundo Indígena e a sua Romanização na Área Céltica do actual território português. Tese de Doutoramento. Universidade de Lisboa. Inédita.

FABIÃO, Carlos (2001) - Importações de origem mediterrânea no interior do sudoeste peninsular na segunda metade do I Milénio a.C.: materiais da Cabeça de Vaiamonte, Monforte. In Os Púnicos no Extremo Ocidente. Lisboa: FCSH-UNL, p. 197-228.

FERNÁNDEZ, Jordi H.; LÓPEZ-GRANDE, María José; MEZQUIDA, Ana; VELÁZQUEZ, Francisca (2009) - Amuletos púnicos de hueso hallados en Ibiza. Ibiza: Museo Arqueológico de Ibiza y Formentera.

FERNÁNDEZ FLORES, Álvaro; RODRÍGUEZ AZOGUE, Araceli; CASADO ARIZA, Manuel; PRADOS PÉREZ, Eduardo, coords. (2014) - La necrópolis de época tartésica de la Angorrilla (Alcalá del Río, Sevilla). Sevilha: Universidade de Sevilha.

FEUGÈRE, Michel (1989) - Les vases en verre sur noyau d'argile en Mediterranée nord-occidentale. In FEUGÈRE, Michel, ed. - Le verre préromain en Europe occidentale. Montpellier: Éditions Monique Mergoil, p. 29-62.

FILARDI, Vivian H (2011) - Caracterização química de contas de vidro arqueológicas do século VII a.C. provenientes da Quinta do Almaraz, Cacilhas. Tese de Mestrado. Universidade Nova de Lisboa. Inédita.

GAMER-WALLERT, Ingrid (1978) - Ägyptische und ägyptisierende Funde von der Iberischen Halbinsel. Wiesbaden: Reichert Verlag.
GAMER-WALLERT, Ingrid; PAIXÃO, António Cavaleiro (1983) - A inscrição do escaravelho de Psamético I, da necrópole do Olival do Senhor dos Mártires: novos elementos para a sua interpretação. O Arqueólogo Português. Lisboa. Série IV. 1, pp. 267-272.

GARCÍA MARTÍNEZ, María Antónia (2002) - Documentos prerromanos de tipo egipcio de la vertiente atlántica hispano-mauritana. Montpellier: Université Paul Valéry.

GOMES, Esmeralda (2008) - Os ex-votos proto-históricos do Castelo de Alcácer do Sal. Tese de Mestrado. Universidade de Lisboa. Inédita.

GOMES, Francisco B. (2014) - Importações mediterrâneas em contextos «Pós-Orientalizantes» do Sul de Portugal (séculos VI-IV a.n.e.). Onoba. Huelva. 2, pp. 27-44.

GOMES, Francisco B. (2016) - Contactos culturais e discursos identitários na I Idade do Ferro do Sul de Portugal (séculos VIII a V a.n.e.): leituras a partir do registo funerário. Tese de Doutoramento. Universidade de Lisboa. Inédita.

GOMES, Francisco B. (2017) - Un conjunto de cerámicas áticas inéditas de la necrópolis de Olival do Senhor dos Mártires (Alcácer do Sal, Portugal). Onoba. Huelva. 5, pp. 45-58.

GOMES, Francisco B. (2018a) - The Olival do Senhor dos Mártires necropolis (Alcácer do Sal, Portugal) during the Late Iron Age: new social, political and cultural insights. Zephyrus. Salamanca. LXXXI, pp. 117-139.

GOMES, Francisco B. (2018b) - La Cornalina en el Bronce Final y la Edad del Hierro del Sur de Portugal. Lucentum. Alicante. XXXVII, pp. 55-74.

GOMES, Francisco B. (no prelo) - Tres amuletos 'púnicos' inéditos de la necrópolis de Olival do Senhor dos Mártires (Alcácer do Sal, Portugal). In NIVEAU, Ana María, ed. Mare Sacrum. Religión, cultos y rituales fenicios en el Mediterráneo. Actas del X Coloquio Internacional del CEFYP. Cádiz: Universidad de Cádiz / CEFYP.

GÓMEZ PEÑA, Álvaro; RODRÍGUEZ MELLADO, Jesús (2014) - A propósito de dos nuevos amuletos de Bes procedentes de Chipiona y Rota (Cádiz). SPAL. Sevilha. 23, pp. 147-165.

GROSE, David F. (1989) - Early Ancient Glass. Toledo: Toledo Museum of Art.

HARDEN, Donald (1981) - Catalogue of Greek and Roman Glass in the British Museum. Volume 1, Core- and rodformed vessels and pendants and Mycenaean cast objects. Londres: British Museum.

LÓPEZ GRANDE, María José; VELÁZQUEZ BRIEVA, Francisca (2011-2012) - Amuletos-placa de iconografía egipcia: el modelo vaca/udjat en el ámbito fenicio-púnico. CuPAUAM. Madrid. 37-38, pp. 509-523.

LÓPEZ-GRANDE, María José; VELÁZQUEZ, Francisca; FERNÁNDEZ, Jordi H.; MEZQUIDA, Ana (2014) - Amu- 
letos de Iconografía Egipcia procedentes de Ibiza. Ibiza: Museo Arqueológico de Ibiza y Formentera.

MAIA, Maria; MAIA, Manuel (1986) - Arqueologia da área mineira de Neves Corvo. Trabalhos realizados no triénio 1982-84. Castro Verde: Somincor.

MARTÍN de la CRUZ, José Clemente (Coord.) (2004) Colgantes y cuentas de cornalina procedentes de Andalucía Occidental. Revista de Prehistoria. Córdova. 3, pp.7-47.

MARTÍN de la CRUZ, José Clemente; VERA RODRÍGUEZ, Juan Carlos; GAVILÁN CEVALLOS, Beatriz; PERLINES BENITO, María (2005) - Un colgante de cornalina de manufactura oriental procedente de la provincia de Córdoba. In CELESTINO PÉREZ, Sebastián; JIMÉNEZ ÁVILA, Javier (Eds.). El Período Orientalizante. Madrid: CSIC, p. 503-509.

MATALOTO, Rui (2010-2011) - Os Senhores da Terra: necrópoles e comunidades rurais do território alto alentejano nos sécs. VI-V aC. Arqueologia\&História. Lisboa. 62-63, pp. 77-100.

MÜLLER-WINKLER, Claudia (1987) - Die Ägyptischen Objekt-Amulette. Friburgo: Universidade de Friburgo.

PERDIGONES, Lorenzo; MUÑOZ, Ángel \& PISANO, Giovanna (1990). La necrópolis fenicio-púnica de Cádiz. Roma: Universitá degli Studi di Roma.

MAYET, Françoise \& SILVA, Carlos Tavares da (2000) L'établissement phénicien d'Abul. Portugal. Paris: Diffusion du Boccard.

PAIXÃO, António Cavaleiro (1970) - A necrópole do Senhor dos Mártires, Alcácer do Sal. Novos elementos para o seu estudo. Tese de Licenciatura. Universidade de Lisboa. Inédita.

PAIXÃO, António Cavaleiro (1971) - O recente achado de três escaravelhos na necrópole do Senhor dos Mártires em Alcácer do Sal. In: Actas do $11^{\circ}$ Congresso Nacional de Arqueologia. Coimbra: Universidade de Coimbra, p. 309-315.

PAIXÃO, António Cavaleiro (1983) - Uma nova sepultura com escaravelho da necrópole proto-histórica do Senhor dos Mártires, Alcácer do Sal. O Arqueólogo Português. Lisboa. Série IV. 1, pp. 273-286.

ROUILLARD, Pierre; PAIXÃO, António Cavaleiro; VILLANUEVA-PUIG, Marie-Christine; DURAND, Jean-Louis (1988-1989) - Les vases grecques d'Alcácer do Sal. O Arqueólogo Português. Lisboa. Série IV. 6-7, pp. 43-108.

RUANO RUIZ, Encarnación (200o) - Las cuentas de vidrio halladas en España desde la Edad del Bronce hasta el Mundo Romano. Madrid: Stock Cero.

SAN NICOLÁS, María del Pilar (1975) - Las cáscaras de huevo de avestruz fenicio-púnico en la Península Ibérica y Baleares. CuPAUAM. Madrid. 2, pp. 75-10o.
SANTOS, Filipe; ANTUNES, Ana Sofia; DEUS, Maria de; GRILO, Carolina (2017) - A necrópole de Palhais (Beringel, Beja). In JIMÉNEZ ÁVILA, Javier, ed. - Sidereum Ana III. El Río Guadiana y Tartessos. Mérida: Consórcio Ciudad de Mérida, p. 227-261.

SAVIO, Gigliola (2004) - Le uova di struzzo dipinte nella cultura punica. Madrid: Real Academia de la Historia.

SILVA, Carlos Tavares da (2005) - A presença fenícia e o processo de Orientalização nos Estuários do Tejo e do Sado. In: CELESTINO PÉREZ, Sebastián; JIMÉNEZ ÁVILA, Javier, eds. - El Período Orientalizante. Madrid: CSIC, p. 749-766.

SILVA, Carlos Tavares da; SOARES, Joaquina; BEIRÃO, Caetano de Mello; DIAS, Luísa Ferrer; COELHO-SOARES, Antónia (1980-1981) - Escavações arqueológicas no Castelo de Alcácer do Sal (campanha de 1979). Setúbal Arqueológica. Setúbal. 6-7, pp. 149-218.

SILVA, Rodrigo Banha da; SOUSA, Maria João (2016) - O Castelo dos Mouros nos Primeiros Séculos do I Milénio a.C.. Al-madan. Almada. 2O, pp. 22-26.

SOARES, Rui Monge; BAPTISTA, Lídia; PINHEIRO, Rui; OLIVEIRA, Lurdes; RODRIGUES, Zélia; VALE, Nélson (2017) - A necrópole da I Idade do Ferro do Monte do Bolor 1-2 (São Brissos, Beja). In JIMÉNEZ ÁVILA, Javier, ed. - Sidereum Ana III. El Río Guadiana y Tartessos. Mérida: Consorcio Ciudad de Mérida, p. 263-302.

SOARES, Rui Monge; MARTINS, A. (2013) - A necrópole da Nora Velha 2 (Ourique). Novos dados e interpretações 20 anos após a sua escavação. In ARNAUD, José Morais; MARTINS, Andrea; NEVES, César, coords., Arqueologia em Portugal. 150 Anos. Lisboa: Associação dos Arqueólogos Portugueses, p. 661-669.

VIANA, Abel; FORMOSINHO, J.; FERREIRA, Octávio da Veiga (1953) - De lo prerromano a lo arabe en el Museo Regional de Lagos. Archivo Español de Arqueología. Madrid. 26 , p. $113-138$.

VEIGA, Sebastião Estácio da (2005 [1891]) - Antiguidades Monumentaes do Algarve, Volume 4. Faro: Universidade do Algarve.

VERDÚ PARRA, Enric (2015) - La Necrópolis Ibérica de L'Albufereta (Alacant). Ritos y usos funerarios en un contexto de interacción cultural. Alicante: MARQ. 


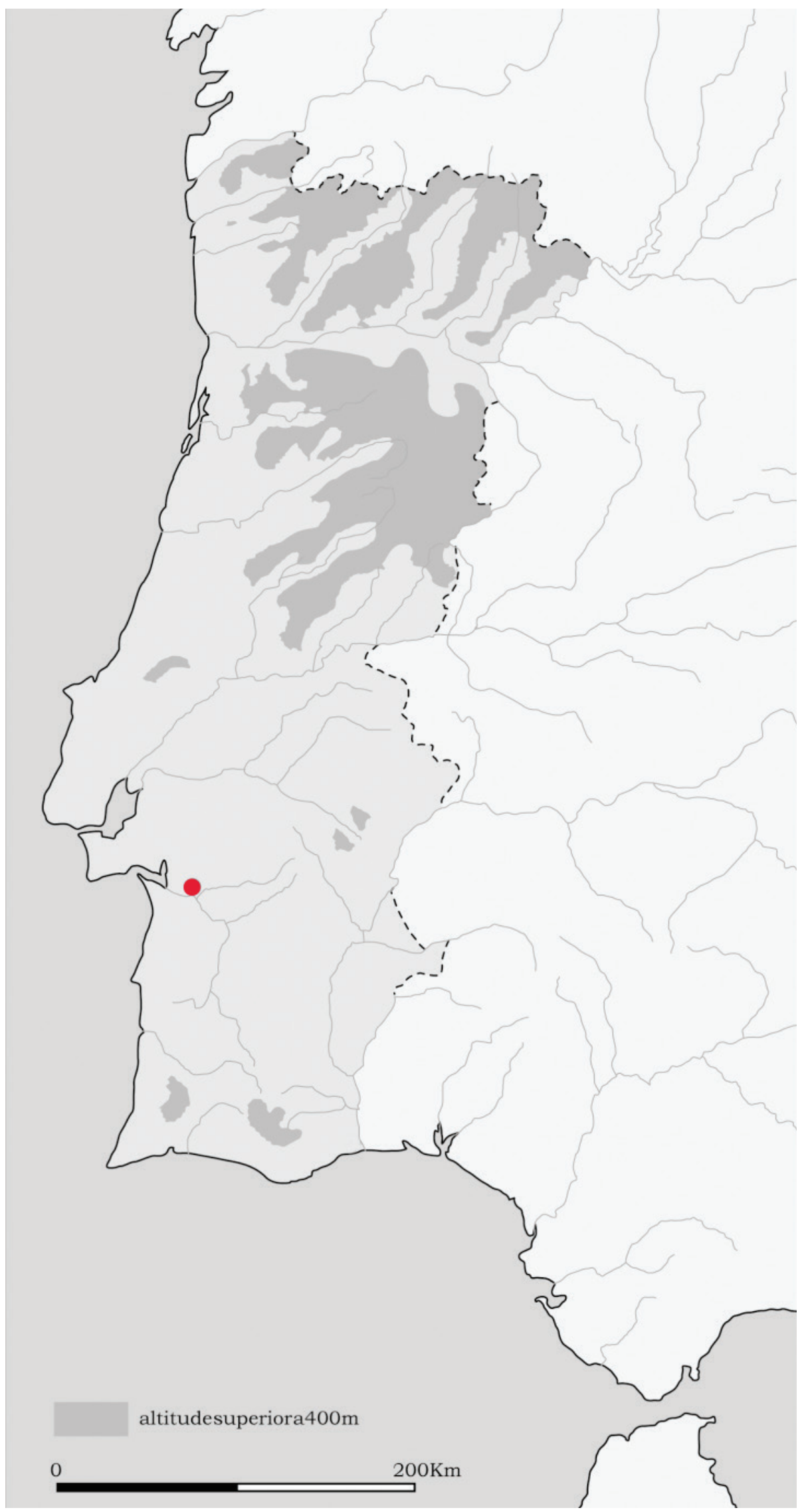

Figura 1 - Localização da necrópole do Olival do Senhor dos Mártires (base cartográfica: Victor S. Gonçalves). 


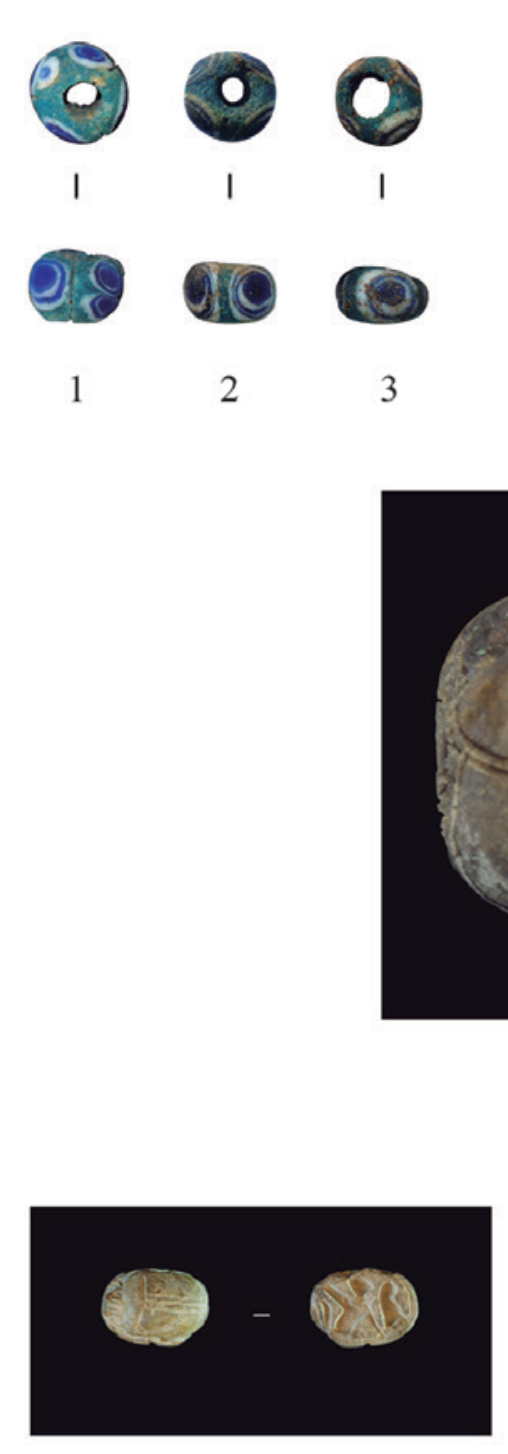

8

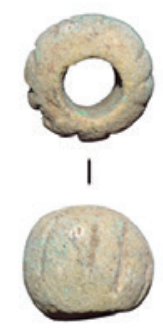

4

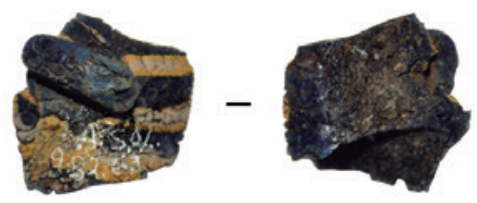

5

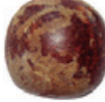

6

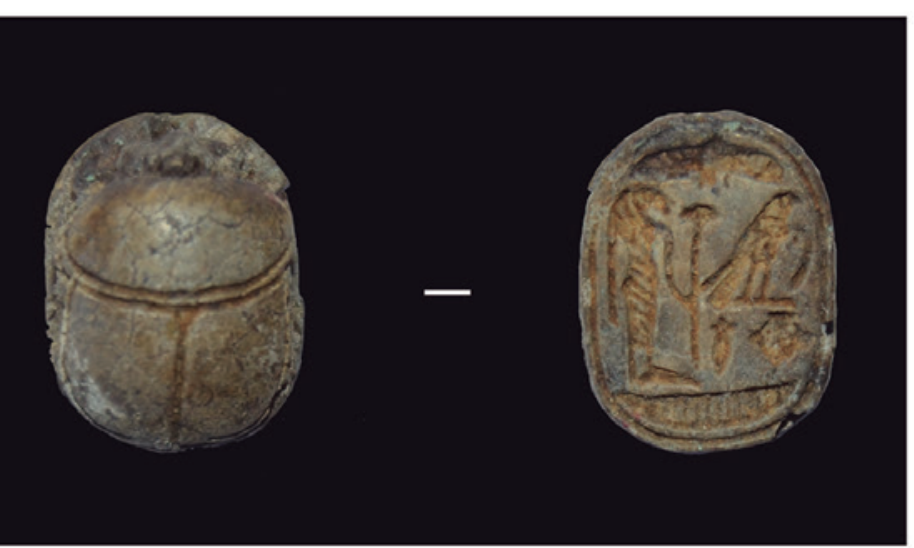

7

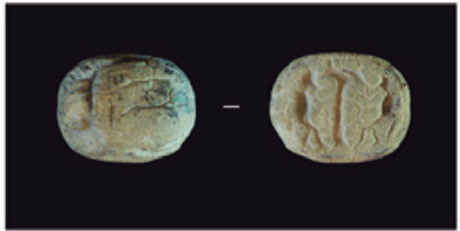

9

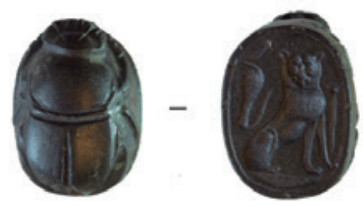

10

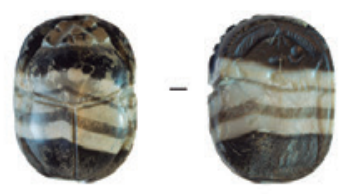

11

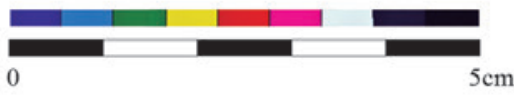

Figura 2 - Exotica do Olival do Senhor dos Mártires (1): 1-3 - contas de colar de vidro; 4 - conta de colar de faiança; 5 - fragmento de recipiente de vidro; 6 - conta de colar de cornalina (?); 7-11 - escaravelhos egípcios / de tipo egípcio. 


\begin{tabular}{|c|c|c|c|c|c|c|c|}
\hline & 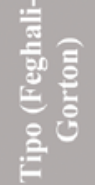 & 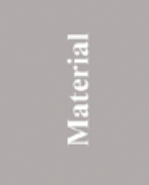 & 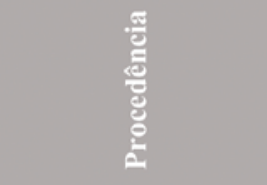 & 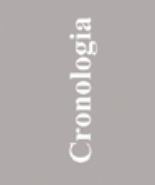 & 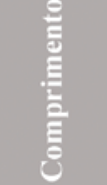 & 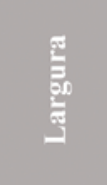 & 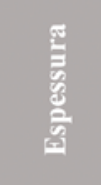 \\
\hline 7 & XIVB & $\begin{array}{c}\text { Pasta } \\
\text { vítrea (?) }\end{array}$ & Naucrátis? & $\begin{array}{c}2^{\mathrm{a}} \mathrm{m} . \mathrm{VII}- \\
\text { i. VI }\end{array}$ & $3,7 \mathrm{~cm}$ & $3,4 \mathrm{~cm}$ & $0,7 \mathrm{~cm}$ \\
\hline 8 & XVI & Espinela & Naucrátis? & VI & $1,15 \mathrm{~cm}$ & $0,82 \mathrm{~cm}$ & $0,6 \mathrm{~cm}$ \\
\hline 9 & $\begin{array}{l}\mathrm{XXC} \\
(\text { simil) }\end{array}$ & $\begin{array}{l}\text { Esteatite } \\
\text { vidrada (?) }\end{array}$ & $\begin{array}{l}\text { Chipre (ou imitação } \\
\text { ocidental)? }\end{array}$ & VII - VI & $1,5 \mathrm{~cm}$ & $1,2 \mathrm{~cm}$ & $0,89 \mathrm{~cm}$ \\
\hline 10 & - & $\begin{array}{l}\text { Quartzo } \\
\text { negro (?) }\end{array}$ & Sardenha (Tharros?) & $\mathrm{V}-\mathrm{IV}$ & $1,9 \mathrm{~cm}$ & $1,4 \mathrm{~cm}$ & $1,1 \mathrm{~cm}$ \\
\hline 11 & - & Ágata & Desconhecida & $\mathrm{V}$ ? & $1,8 \mathrm{~cm}$ & $1,32 \mathrm{~cm}$ & $1 \mathrm{~cm}$ \\
\hline
\end{tabular}

Figura 3-Escaravelhos egípcios / de tipo egípcio do Olival do Senhor dos Mártires: principais características (seg. Almagro-Gorbea \& Torres Ortiz, 2009).

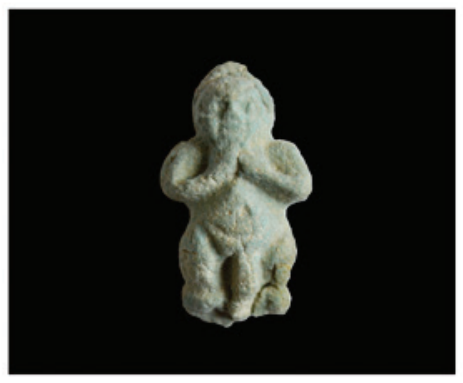

12

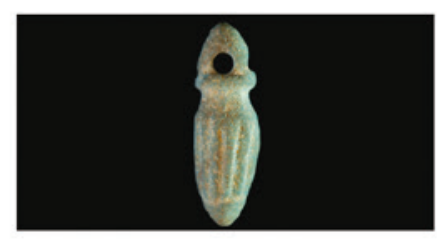

13

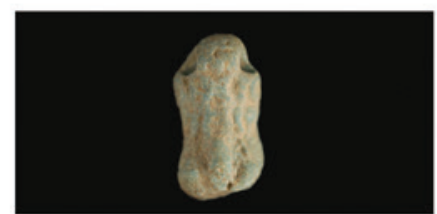

14

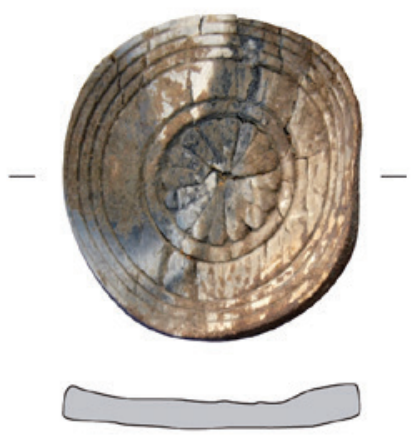

15
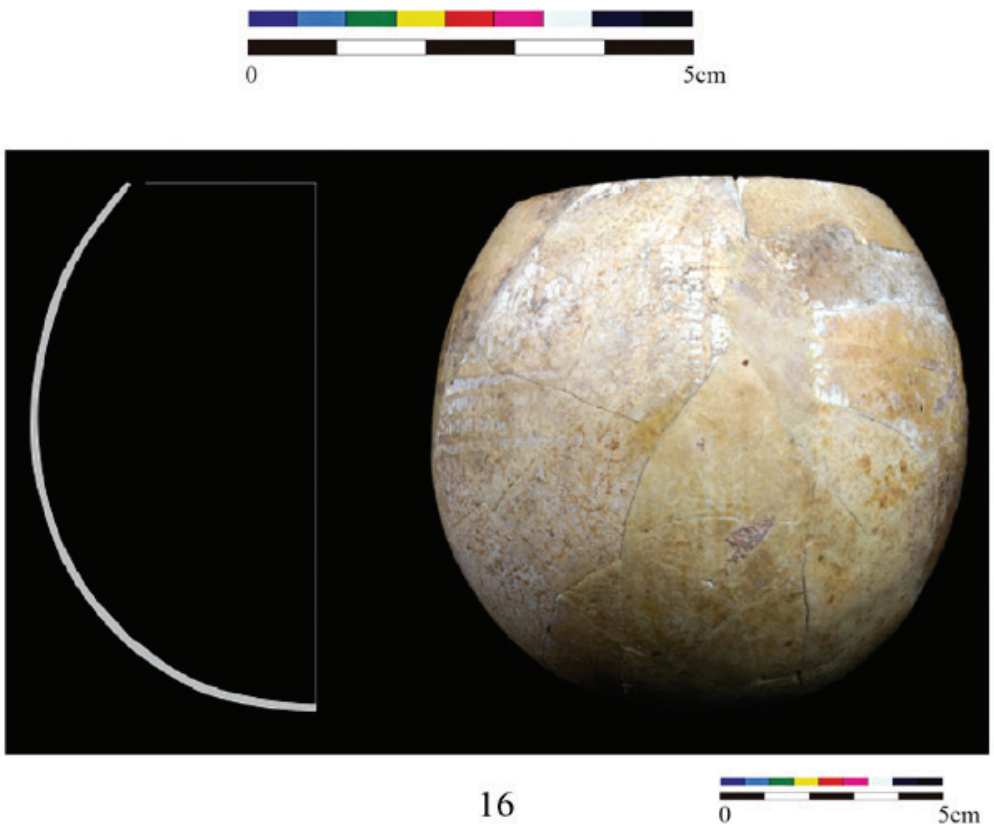

Figura 4 - Exotica do Olival do Senhor dos Mártires (2): 12-14 - amuletos "púnicos”; 15 - roseta de marfim ou osso trabalhado; 16 - recipiente de ovo de avestruz. 
7
Antiguidade
Clássica e Tardia

7
Antiguidade
Clássica e Tardia

7
Antiguidade
Clássica e Tardia

\section{Antiguidade
Clássica e Tardia \\ -}

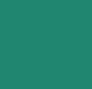

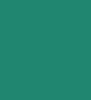

r

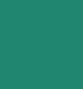




\section{O USO DE MADEIRA COMO COMBUSTÍVEL NO SÍTIO DA QUINTA DE CRESTELOS (BAIXO SABOR): DA IDADE DO FERRO Ä ROMANIZAÇÃO}

Filipe Vaz ${ }^{1}$, João Tereso ${ }^{1,2,3}$, Sérgio Simões Pereira ${ }^{4}$, José Sastre ${ }^{4}$, Javier Larrazabal Galarza ${ }^{5}$, Susana Cosme ${ }^{6}$, José António Pereira ${ }^{7}$, Israel Espi ${ }^{4}$

\section{RESUMO}

No sítio da Quinta de Crestelos (Mogadouro) foi recolhido um extenso conjunto de amostras arqueobotânicas, cujas análises têm vindo a ser publicadas nos últimos anos. Neste artigo abordar-se-ão os dados antracológicos ainda inéditos referentes a dois sectores deste sítio. O primeiro, identificado na plataforma inferior, refere-se a contextos de habitat enquadradas entre os séc. IV a II a.C. O segundo diz respeito a uma área funcional com três fornos de tipologia diferenciada, enquadráveis nos sécs. I e II d.C.

Este estudo relevou conjunto diversificado de táxones, com destaque para os carvalhos (folha perene e caduca), estevas, pinheiros e freixos. Estes dados permitiram avaliar padrões de utilização dos recursos vegetais, nomeadamente relacionados com a função e tipo de cada estrutura.

Palavras-chave: Quinta de Crestelos, Baixo Sabor, Arqueobotânica, Idade do Ferro, Romanização.

\section{ABSTRACT}

A large set of archaeobotanical samples were recovered during the excavation of Quinta de Crestelos (Mogadouro), several of which have already been published.

This paper focusses on the charcoal analysis still unpublished from two sectors of this site. The first, located in the lower platform, relates to a habitation area comprised of huts and fireplaces from the $4^{\text {th }}$ to the $2^{\text {nd }}$ centuries BC. The second is a functional area with three ovens of different typologies dating to the $1^{\text {st }}-2^{\text {nd }}$ centuries AD. Results revealed a diverse set of taxa, dominated by evergreen and deciduous oak, heath, pine and ash. This data allowed to access uses of wood in the site, namely their relation to the function and type of structures where they have been found.

Keywords: Quinta de Crestelos, Lower Sabor, Archaeobotany, Iron Age, Romanization.

\footnotetext{
1. CIBIO-InBio - Centro de Investigação em Biodiversidade e Recursos Genéticos, Universidade do Porto.

2. UNIARQ - Centro de Arqueologia da Universidade de Lisboa, Faculdade de Letras.

3. Museu de História Natural e da Ciência da Universidade do Porto.

4. Arqueólogo(a) Independente.

5. Lab2PT - Laboratório de Paisagens, Património e Território, Universidade do Minho.

6. CITCEM-FLUP - Centro de Investigação Transdisciplinar Cultura, Espaço e Memória, Faculdade de Letras da Universidade do Porto.

7. Novarqueologia. Lda.
} 


\section{INTRODUÇÃO: O SÍTIO DA QUINTA DE CRESTELOS}

O sítio da Quinta de Crestelos (Meirinhos, Mogadouro) (Figura 1) implantava-se numa plataforma limitada a norte por uma pequena crista sobranceira ao Rio Sabor, numa das poucas áreas amplas do seu curso (Figura 2). Se o sítio em termos defensivos parece questionável, é bem mais interessante pela diversidade de recursos que poderia oferecer, como a disponibilidade de terrenos amplos com potencial agrícola, encostas mais suaves (em contraste com o perfil encaixado do vale do Sabor), provável local de passagem entre planaltos e de transposição do rio, grandes áreas florestais, assim como a abundância em água.

Descoberto em 1997, durante trabalhos de prospeção arqueológica (Rodrigues \& Teixeira, 1997), só foi parcialmente escavado 14 anos depois, entre 2011 e 2015, no âmbito do Plano de Salvaguarda Patrimonial integrado na construção do Aproveitamento Hidroelétrico do Baixo Sabor ${ }^{8}$ (AHBS). A escavação abrangeu uma área total de $10800 \mathrm{~m}^{2}$, envolvendo diversas empresas de arqueologia e uma vasta equipa técnica - arqueólogos, antropólogos, técnicos de arqueologia e trabalhadores indiferenciados (Pereira et al. 2015).

Registou-se uma intensa ocupação no sítio, desde o terceiro milénio a.C. até finais do séc. XX, quando a quinta agrícola foi abandonada. Os dados sobre as fases mais antigas, referentes aos contextos do Calcolítico e Idade do Bronze, não foram ainda analisados e as evidências arqueológicas não são suficientemente conclusivas para formular uma interpretação coerente do sítio (Pereira \& alli, 2015; Martín-Seijo $\&$ alli, 2017). O mesmo não se passou com os últimos séculos da Idade do Ferro e Romanização, que concentram a maior parte das estruturas identificadas no sítio.

Entre o séc. IV e II a.C., na parte superior da crista existiram vários fossos de grandes dimensões (Figura 3), cuja escavação providenciou a pedra extraída usada para a construção de vários níveis muralhados, protegendo plataformas onde vários contextos domésticos foram identificados, não obstante a sua má preservação decorrente de ocupações posterio-

8. Promovido pela EDP Produção e executado pelo Baixo Sabor ACE - consórcio integrando as empresas de construção Odebrecht/Bento Pedroso S.A. e Lena Construções Lda. res. Na fase seguinte, o fosso é reutilizado através da construção de cerca de 30 fornos/lareiras de pequena dimensão, com base de argila e xisto utilizadas de forma aparentemente simultânea (Vaz \& ${ }^{8}$ alli, 2017). Na base da elevação verifica-se a construção de várias cabanas circulares, com base em xisto e paredes em materiais perecíveis como argila e madeira (Larrazabal, 2017), juntamente com estruturas de combustão de tipologia semelhante às observadas no fosso da crista (vide infra). Mais tarde, novas plataformas e vários celeiros (tipo horrea) são construídos na crista (Sastre, 2014, (Pereira $\mathbb{\&}$ alli, 2015; Tereso $\mathbb{\&}$ alli, 2018a).

Desde meados do séc. I a.C., a ocupação da crista é progressivamente preterida em função da plataforma inferior, onde a maior parte das evidências romanas no sítio foram identificadas e que incluem uma necrópole, um edifício de grande dimensão equipado com cella vinaria, lagar e horrea de grande capacidade (Cosme, 2014; Pereira \& alli, 2015). Ligeiramente a sul, foi identificada uma uma área funcional com três fornos de diferentes tipologias (vide infra). A eventual pars urbana desta unidade agrícola não terá sido identificada podendo encontrar-se sob os casebres da quinta do séc. XVII, contígua a esta área. Esta ocupação estaria integrada numa rede de pequenos sítios identificados ao longo do vale do Sabor no âmbito de escavações motivadas pelo AHBS, cuja extensão e organização se encontra ainda por compreender (Pereira \& alli, 2014; Bodí \& Pereira, 2014). Durante a Antiguidade Tardia e Alta Idade Média, verifica-se uma retração na ocupação do sítio, com a adaptação de estruturas do período anterior e com a construção de anexos de menor investimento. A identificação de uma pequena necrópole, balizada entre o final do séc. IX e os inícios do séc. XIII, comprova a ocupação do sítio nesse período (Amorim et alli. no prelo). Até à Modernidade, e não obstante a provável existência de hiatos de ocupação, o sítio continua a ser frequentado, eventualmente como casal agrícola. Apesar do numeramento de D. João III referir a presença de cinco moradores neste sítio, os vestígios arqueológicos nesta fase são escassos. No séc. XVII, o local sofre uma nova reconfiguração com a construção dos primeiros edifícios da referida quinta, implantados parcialmente sobre as estruturas romanas e medievais (Tereso $\&$ alli, 2018b). Depois do seu abandono no final do séc. XX e das escavações arqueológicas aqui sintetizadas, o sítio da Quinta de Crestelos, encontra-se atualmente 
submerso pelo reservatório principal da Barragem do Baixo Sabor.

No decorrer das intervenções na Quinta de Crestelos foi implementado um ambicioso programa de recolha de sedimentos com vista à realização de estudos arqueobotânicos, resultando na análise de mais de 1500 amostras, abarcando quase toda a diacronia de ocupação. Em função do seu grande número e diversidade, os resultados destes estudos têm vindo a ser publicados nos últimos anos, nomeadamente os referentes aos níveis da Idade do Bronze (Martín-Seijo $\&$ alli,. 2017), os fornos da Idade do Ferro do fosso 1 da crista (Vaz \& alli, 2017a), os horrea da transição da era também da crista (Tereso $\&$ alli, 2018a), e os níveis da Antiguidade tardia e Época Medieval da plataforma inferior (Tereso $\&$ alli, 2018b). Existem, no entanto, outros contextos cujos resultados não se encontravam ainda devidamente divulgados, entre os quais, os contextos habitacionais do séc. IV a II a.C. da plataforma inferior e o conjunto de fornos do séc. I e II d.C. no limite sul da zona escavada, que serão tratados neste artigo.

\section{MATERIAIS E MÉTODOS}

Como referido, este estudo irá incidir sobre duas áreas da plataforma inferior da Quinta de Crestelos, com ocupações de cronologias bem distintas.

2.1. Unidades habitacionais dos séculos IV-II a.C. Imediatamente no sopé da elevação da crista, foram recolhidas amostras num conjunto de unidades domésticas dos séculos IV-II a.C. (Tabela 1). As estruturas habitacionais apresentavam uma planta circular, com diâmetro máximo de $5 \mathrm{~m}$ e tipologias construtivas variadas.

A mais frequente corresponde a cabanas circulares erigidas usando materiais perecíveis (argila compactada para o piso e uma estrutura de madeira coberta com argila para paredes, com a cobertura em ramos). Muitas das cabanas apresentavam uma estrutura de combustão ao centro (Figura 4). Pese embora encontrar-se em mau estado de preservação, uma destas estruturas apresentava elementos que permitiram associá-la a atividades metalúrgicas (Mateos \& alli, 2014).

Foram amostradas 41 unidades estratigráficas (u.e.) (Tabela 1) associadas a oito cabanas, assim como a diferentes estruturas dispersas pela área, salientando-se um conjunto de fossas. O volume recolhido por u.e. varia entre os $0,4 \mathrm{~L}$ e os $29 \mathrm{~L}$, cifrando-se o seu valor médio nos 3,8 L.

\subsection{Fornos dos séc. I-II d.C.}

Na mesma plataforma inferior, mas mais a sul, na área onde se concentram abundantes vestígios de época romana e medieval, foi intervencionada uma área funcional com três fornos dos séc. I-II d.C. (Cosme, 2014).

O forno 1, do tipo "forno pote" (Figura 5), estaria associado a atividades metalúrgicas de bronze, atendendo aos atendendo à sua dimensão, escórias e outros vestígios metálicos feitos nesta liga encontrados na sua área envolvente (Cosme, 2014). Consistia num pequeno covacho com uma grelha e vasilha forno, onde o metal seria fundido.

O forno 2 (Figura 6), foi identificado a cerca de $3 \mathrm{~m}$ do forno 1 e foi interpretado como estando relacionado com a confeção de alimentos. No entanto, por se encontrar no limite da área intervencionada, não foi possível obter a dimensão e configuração total da estrutura. Era constituído por uma única câmara que cumpria funções de fornalha e câmara de cozedura, boca orientada a norte, paredes de argila vermelha e abóbada também de argila com a inclusão de elementos de xisto (Cosme, 2014).

Posicionado cerca de $2 \mathrm{~m}$ a sul do forno 1 , o forno 3 (Figura 7), de maior dimensão que os anteriores, corresponde tipologicamente a um forno de cerâmica. Era constituído por duas câmaras sobrepostas, uma de combustão e outra de cozedura, mediadas por uma grelha de argila sustentada por um pilar central e arcos de ligação à parede exterior (Cosme, 2014). Verificaram-se ainda vestígios do arranque da abóbada, também de argila e pedra de xisto, cobrindo a câmara de cozedura.

Foram amostradas 19 u.e. (Tabela 2), totalizando 288 L de sedimento ( 15 L em média), em unidades diretamente associadas aos fornos (níveis internos das câmaras, níveis de cinzas, u.e. de abandono e destruição), incluindo o enchimento de uma grande fossa localizada entre as bocas dos fornos 1 e 3 . Em três u.e. desta estrutura negativa foram recolhidos $25 \mathrm{~L}$ de sedimento. Considerando a grande dimensão do forno 3, foi aí investido um maior esforço de amostragem, totalizando cerca de $172 \mathrm{~L}$ de sedimento em 8 u.e.

\subsection{Métodos laboratoriais}

As amostras foram flutuadas manualmente no estaleiro do Baixo Sabor ACE, pela equipa de arqueo- 
logia, recorrendo a malhas mínimas de o,5 mm. As análises laboratoriais foram realizadas no laboratório do Departamento de Biologia da Faculdade de Ciências da Universidade do Porto.

Carvões com dimensões superiores a $2 \mathrm{~mm}$ foram seccionados manualmente de forma a obter as três secções de diagnóstico (transversal, tangencial e radial). Estas foram observadas com recurso a lupa binocular e microscópio de luz refletida e comparadas com as descrições patentes em atlas anatómicos (e.g. Schweingruber, 1990) com vista à sua identificação. Para além dos elementos anatómicos necessários para a identificação dos táxones, foram também registadas outras características dendrológicas capazes de fornecer importantes informações sobre a utilização e gestão de recursos lenhosos (Carrión, 2007; Marguerie \& Hunot, 2007; Théry-Parisot \& Henry, 2012) tais como a identificação da parte da planta utilizada, presença de casca/medula, curvatura anelar, número de anéis, presença de vitrificação e fissuras radiais ou degradação biológica.

Um mínimo de 150 carvões foi estudado por amostra. No entanto, e como seguidamente se verá, muitos foram os casos de contextos em que a análise deste número de elementos carbonizados não foi sequer possível em virtude da escassez de material identificável.

\section{RESULTADOS}

3.1. Contextos do séc. IV a.C. ao séc. II a.C.

No caso dos contextos habitacionais datados do séc. IV a.C. ao séc. II a.C. do sopé da crista, não só as amostras de 8 das 41 unidades estratigráficas analisadas se revelaram estéreis no que concerne à componente antracológica como ainda uma parte das restantes não providenciou um número significativo de carvões com detalhe taxonómico suficientemente detalhado para puderem ser tidas em conta a nível interpretativo (Tabela 3).

No total foram analisados 2421 fragmentos de carvão provenientes desta área, revelando um conjunto relativamente diverso de táxones. No entanto, mais de um terço dos carvões - 40,5\% (n=981) - encontravam-se em mau estado de preservação e apresentava dimensões muito reduzidas, resultando em identificações com pouco detalhe taxonómico, nomeadamente ao nível da classe (Dicotiledóneas). Dentro do conjunto detêm especial prevalência o Cistus sp. e Pinus pinaster mas são também de as- sinalar as presenças de Quercus de folha perene e caduca, Arbutus unedo, Fraxinus sp., Juniperus sp., Fabaceae e Erica australis/arborea. Os restantes táxones surgem em número residuais.

No que diz respeito à análise individualizada por contexto, ressaltam alguns casos de particular interesse. $\mathrm{Na}$ estrutura de combustão $9 / 17$ (u.e. 1859o) da sondagem 18 , terá sido principalmente usada madeira de Pinus pinaster e Arbutus unedo, não obstante a presença residual de outras espécies. Por seu turno, na outra lareira identificada desta cronologia (u.e. 3192 e 3197) o conjunto antracológico é substancialmente diferente, sendo maioritários os carvões de Erica australis/arborea depois da exclusão dos carvões classificados como Dicotiledóneas. Duas u.e. de ocupação/abandono (u.e. 36393 e 36394) foram amostradas na Cabana 1 da sondagem 36 , cada uma apresentando um conjunto antracológico substancialmente diferente, não obstante ambos serem dominados, quase em exclusivo, por apenas um táxon. No primeiro caso foram identificados 23 fragmentos de Juniperus sp., enquanto no segundo 48 fragmentos de Fraxinus sp. O mesmo se poderá dizer do conjunto identificado na Canalização 1, dominada por carvalhos de folha caduca.

No que se refere às seis u.e. de ocupação/abandono e construção da cabana 4 da sondagem 18 , verificam-se igualmente algumas diferenças entre si. A u.e. 18181 apresenta 39 carvões de Pinus pinaster, quando nas restantes este táxon ou não foi identificado ou foi-o apenas em casos singulares.

O conjunto de fossas amostradas e adscritas a esta cronologia, várias das quais com múltiplos níveis de enchimento amostrados, revelaram um conjunto antracológico substancial, com especial preponderância para a Fossa 5. Este contexto reúne a maioria dos carvões identificados como Cistus sp. desta cronologia. Por seu turno, a fossa 19 (u.e. 1405) apresenta as únicas ocorrências de Acer sp. em todo a área. O caso das fossas 8 e 9, fruto da existência de várias unidades amostradas, permite a comparação de contextos intra-fossa.

Em ambos os casos, as unidades estratigráficas referentes ao enchimento da base (u.e. 1130 e 1150, respetivamente) providenciaram um reduzido número de carvões e de táxones quando comparados com enchimentos posteriores. Paradoxalmente, o enchimento do topo da fossa 8 (u.e. 1147) que a terá colmatado, foi inclusivamente o contexto que maior diversidade de táxones proporcionou em todo o es- 
tudo. O enchimento intermédio da mesma fossa (u.e. 1138) apresenta sensivelmente os mesmos táxones, mas em muito menor quantidade. O segundo enchimento da Fossa 9 (u.e. 1143) providenciou igualmente um número elevado de táxones (13) e carvões (107) quando comparado com a u.e. de base da mesma fossa - a já referida u.e. 1150 .

\subsection{Fornos do séc. I a II d.C.}

Tratando-se de contextos onde o uso de madeira como combustível terá sido profuso e uma constante, as amostras provenientes da área funcional dos três fornos providenciaram um número assinalável de carvões (Tabela 4), especialmente quando comparados com outros contextos primários do sítio (Vaz \& alli, 2017a).

Do Forno 1, como vimos, interpretado tipologicamente como estando associado à fundição metalúrgica, foram analisados 514 carvões provenientes de quatro u.e. Quercus sp. perenifólio foi o táxon mais frequentemente identificado nesta estrutura, contando com 27,4\% do conjunto. A alguma distância, surgem, com 13,6\% e 13,4\%, respetivamente, Quercus sp. caducifólia e Cistus sp, sendo que os restantes 21 táxones identificados atingem percentagens inferiores a 3\%, apenas com exceção de Quercus sp. (7\%) e Fraxinus sp. (4,7\%). Os carvões registados como Dicotiledóneas em função do seu estado de preservação, cifram-se nos $18.7 \%$.

Por seu turno, o Forno 2, eventualmente associado à preparação de alimentos, forneceu um conjunto antracológico mais vasto e diverso, contando 945 fragmentos analisados de 22 táxones, provenientes de 5 unidades estratigráficas. Dois táxones, Cistus sp. e Fabaceae, dominam esta estrutura, com. Respetivamente, $26,5 \%$ e $18,7 \%$ do total observado. Quercus sp. perenifólia surge com $9 \%$, Pinus pinaster com $4,5 \%$ e Arbutus unedo com 4,2\%. Os restantes táxones surgem em percentagens inferiores a $3 \%$. À semelhança do Forno 1, o número de Dicotiledóneas foi também elevado, constituindo 19,8\% do total. Tipologicamente afeto à produção cerâmica, o Forno 3 foi a estrutura que contemplou o maior esforço de amostragem desta área, o que se traduziu no maior conjunto analisado de carvões (1639). Neste forno registou-se um conjunto igualmente diversificado de táxones, não obstante Quercus sp. perenifólio ter sido novamente o mais comum, com $18.5 \%$ do total analisado. No entanto, surgiram num segundo plano um grupo de cinco táxones com al- gum relevo percentual, entre os 10\% e os 5\%: Quercus suber (9,7\%), Alnus sp. (9.3\%), Cistus sp. (7,1\%), Erica australis/arborea (6,5\%), Fraxinus sp. (5,5\%). Entre os táxones com menor relevo, destacam-se Buxus sempervirens, Juniperus sp. por se encontrem ausentes dos outros dois fornos. Os restantes casos cifram-se abaixo dos $2 \%$.

Os vários parâmetros de características dendrológicas aferidos foram registados em escassos fragmentos e sem qualquer padrão discernível.

\section{DISCUSSÃO}

A análise conjunta do uso de madeira como combustível no sítio da Quinta de Crestelos, durante a Idade do Ferro e Romanização, requer a comparação e interpretação dos contextos já publicados, com os que se disponibilizam pela primeira vez neste artigo. Assim, far-se-á seguidamente uma discussão integrada das evidências desta prática nos vários contextos de combustão presentes no sítio.

Os contextos mais antigos com evidências do uso de madeira como combustível verificaram-se no fosso 1 que delimita o lado noroeste da crista onde se implantou parte da ocupação da Idade do Ferro do sítio. Referem-se a um grande conjunto de cerca de 30 pequenas lareiras e/ou fornos, feitos de argila e cujos dados disponíveis apontam para que tenham sido utilizados sincronicamente.

Os resultados antracológicos obtidos e já publicados (Vaz \& alli, 2017a), apesar de escassos, demonstraram que o principal combustível lenhoso queimado nestas estruturas proveio de Arbutus unedo (medronheiro), Cistus sp. (esteva), Fraxinus sp. (freixo), Juniperus sp. (zimbro) e Quercus (carvalho) tipo perenifólio, não obstante uma grande diversidade de táxones ter sido também nelas usada (Vaz $\mathbb{\&}$ alli, 2017a). A eventual escolha da madeira a utilizar nestas estruturas estaria limitada fisicamente às reduzidas dimensões das estruturas, levando a que peças de maior dimensão, provenientes de espécies arbóreas como os referidos carvalhos, freixos e zimbros, fossem eventualmente alvo de corte antes de serem queimados, podendo, igualmente, terem sido escolhidos pequenos ramos. A madeira de espécies arbustivas (medronheiro e estevas) não exigiriam este passo. No entanto, foram raros os fragmentos que possibilitaram o registo das curvaturas anelares, não permitindo, assim, esclarecer este ponto. Em termos objetivos, este padrão de utilização, com- 
binando espécies de grande e pequeno porte, foi já verificado quer em exemplos etnográficos (e.g. Carvalho, 2005) quer noutros sítios arqueológicos no norte de Portugal (e.g. Vaz \& alli, 2017b). A madeira de espécies arbustivas de menor dimensão e com elevado potencial calorífico, poderia ter sido usada como iniciadora da combustão, enquanto fragmentos de madeira de espécies como o carvalho e o freixo, manteriam por maiores períodos de tempo uma temperatura estável dentro da câmara.

Da mesma cronologia, mas no sopé da crista, os contextos habitacionais aqui apresentados, demonstraram um conjunto antracológico escasso, não obstante o esforço de amostragem realizado. Este facto limitou fortemente a interpretação arqueobotânica destes contextos. Acresce ainda o facto de que os contextos de ocupação/abandono associados às cabanas serem de difícil interpretação arqueobotânica em função da incógnita da proveniência daqueles carvões. Efetivamente, à exceção das estruturas de combustão em causa, e considerando a inexistência de evidências que corroborassem a presença de um incêndio que terá destruído o local, todos os restantes contextos se classificam como deposições secundárias. O material carbonizado neles identificado poderá provir de uma miríade de processos antrópicos ou naturais, dificilmente identificáveis, complexificando a natureza da relação entre os carvões e os contextos onde foram recolhidos. Atendendo ao posicionamento deste sector, no sopé da vertente encimada pela crista (zona alvo de uma intensa ocupação, como vimos), é possível que muito sedimento tenha sido transportado, depositando-se neste local. Tal é confirmado pelo espesso horizonte sedimentar sob o qual os contextos da plataforma inferior foram identificados.

Não obstante esta condicionante, os resultados das lareiras analisadas permitem, em alguns casos, tecer considerações relativamente ao seu conteúdo antracológico. A estrutura de combustão 9/17 (u.e. 1859o) revelou ser o contexto de toda a cronologia com maior concentração de madeira de Pinus pinaster (pinheiro-bravo), devendo corresponder à combustão de um tronco desta espécie, atendendo à similitude de características identificadas entre os carvões. Por seu turno, a estrutura de combustão identificada no sector 3 (u.e. 3192 e 3197) revelou diferenças substanciais face às demais, materializadas na predominância de madeira de Erica sp., podendo estar relacionadas ao eventual cariz metalúrgico deste segundo contexto. Efetivamente, a madeira de urze-branca (Erica arborea), e em especial as formações tumorais ou hipertróficas dos tecidos vegetais das suas raízes ou caules subterrâneos (designadas como cecídios), foi especialmente apreciada como combustível em fornos de função metalúrgica face à sua capacidade calorífica, tal como sugerem estudos de cariz etnográfico (Tsoumis $\&$ alli, 1988). Tal se poderá dever ao facto de a estrutura anatómica destas formações apresentar características distintas do seu tronco, que a tornam particularmente propícias para combustões em estruturas metalúrgicas, mais exigentes do ponto de vista de temperatura. Os cecídios destas urzes são anatomicamente distintos das partes aéreas, tornando difícil a sua identificação usando as descrições disponíveis nos atlas anatómicos (Schweingruber, 1990) e no estudo específico dirigido a este grupo de plantas (Queiroz \& van der Burgh, 1989). Em amostras onde as urzes são maioritárias e se verifiquem percentagens elevadas de madeiras de Dicotiledóneas, é provável que vários destes fragmentos também sejam de urzes, como acontece nos contextos referidos. Acresce ainda que algumas das características das formações tumorais destes caules subterrâneos, nomeadamente a irregularidade das estruturas anatómicas, são também identificadas nestes carvões.

O outro conjunto de contextos analisado, referente a três fornos do séc. I e II d.C. da plataforma inferior de Crestelos, revelaram também interessantes resultados no que respeita ao uso de madeira como combustível.

Cerca de $43 \%$ do conjunto de carvões analisado proveniente do Forno 1 diz respeito a Quercus, em especial do tipo perenifólio, sendo que o segundo táxon mais frequente, Cistus sp., se cifra nos 13,4\% (Tabela 4). Dos três fornos, este foi também o que menor diversidade de táxones proporcionou, podendo não ser alheio ao facto de contar com menos unidades estratigráficas amostradas e menor número de carvões disponíveis para análise: 514, face aos 945 do Forno 2 e 1639 do Forno 3. Não obstante tratar-se de uma estrutura associada a práticas metalúrgicas, não se verificou, ao contrário do pequeno forno da fase anterior relacionado com a mesma atividade, a utilização de madeira de urze (vide supra). No entanto, o padrão de consumo de madeira neste forno, com a utilização de dois conjuntos diferentes de tipos de madeira (troncos de espécies de maior dimensão como carvalho e freixo, complementa- 
dos com madeiras de arbustivas como Fabaceae ou Cistus sp.) assemelha-se aos verificados em outros fornos da Quinta de Crestelos (vide supra).

Por seu turno, o conteúdo do Forno 2, possivelmente destinado à confeção alimentar, é maioritariamente composto por espécies arbustivas como Cistus sp. $(26,5 \%)$ e Fabaceae $(18,7 \%)$, sendo a única das três estruturas que apresenta percentagens substanciais desta família. Os carvalhos, maioritários no Forno 1, e também no Forno 3 (vide infra), contam com cerca de $11 \%$ do total analisado. Efetivamente, este padrão coaduna-se com uma utilização doméstica deste forno, considerando as próprias características da estrutura (com boca estreita e reduzida dimensão da câmara), e a não necessidade de temperaturas elevadas durante um longo período de tempo.

Já no que concerne ao conteúdo antracológico do Forno 3, de produção cerâmica, verificou-se a maior diversidade dos três analisados, com 23 táxones, sendo igualmente o contexto onde foi recolhido maior volume de sedimento. Desta vez, os táxones maioritários foram os Quercus perenifólios (incluindo Quercus suber) com $28 \%$ do total, mas com um grupo mais vasto de táxones a atingirem percentagens relevantes (Tabela 4 - vide supra). Em comparação com os restantes fornos, foi identificado no Forno 3 uma percentagem elevada de Alnus sp. (9,2\%), ausentes nos anteriores, e duas a três vezes mais Erica australis/arborea e, em contraste, valores residuais de Quercus caducifólia (1,5\%). Estes dados são ainda mais consubstanciados quando foi neste forno de grande dimensão e complexidade arquitetónica que mais amostras e carvões foram recolhidos. A necessidade de alimentar a sua grande câmara de combustão com um elevado volume de madeira durante as várias horas necessárias à cozedura da fornada de peças, deverá ter levado a uma diversificação do tipo e local de recoleção de madeiras, assim como a uma prevalência de lenha essencialmente proveniente de espécies de porte arbóreo. Os táxones associados a espécies arbustivas refletem apenas $15 \%$ do total, contrastando de sobremaneira com o padrão de consumo de madeira verificado no Forno 2 onde atingem os $51 \%$.

Convém também referir que o conteúdo carpológico identificado nestas amostras foi extremamente escasso (Vaz \& alli, 2017; Tereso \& alli, 2018a). A presença destes vestígios nos fornos e lareiras poderá estar relacionado com o descarte de resíduos do processamento de cultivos.
A análise antracológica dos conteúdos associados a estruturas de combustão ainda inéditos destes dois sectores do sítio da Quinta de Crestelos, revelou assim padrões de utilização de combustível diferentes entre si. Mais relevante, verifica-se um critério de escolha da madeira, manifestado pela adequação das características do combustível ao fim a que se destina. Não obstante as suas limitações, inerentes à má preservação de vestígios botânicos que se verificou, este estudo demonstra uma vez mais o potencial da arqueobotânica, e da antracologia em particular, no esclarecimento de questões relacionadas entre o uso de recursos vegetais no quotidiano das comunidades do passado.

\section{AGRADECIMENTOS}

Os dados antracológicos aqui apresentados fazem parte da tese de doutoramento de Filipe Vaz, a decorrer na Faculdade de Letras da Universidade do Porto, intitulada "O uso e gestão de recursos lenhosos no norte de Portugal no final da Idade do Ferro e Época Romana: uma abordagem arqueológica e antracológica". Os dados arqueológicos referentes aos contextos da Idade do Ferro e Romanização do sítio da Quinta de Crestelos são o foco da tese de doutoramento de Javier Larrazabal Galarza, a decorrer na Universidade do Minho, intitulada "Territory and Society: The Baixo Sabor Valley in the Iron Age and at the beginning of its integration into the Roman world".

José Sastre (Idade do Ferro) e Sérgio Pereira (Romano) foram os coordenadores dos estudos arqueológicos do AHBS, ao serviço do Baixo Sabor ACE. Susana Cosme, Israel Espí, Javier Larrazabal, Rosa Mateos, César Neves, João Nisa e José Pereira coordenaram os trabalhos arqueológicos no sítio da Quinta de Crestelos.

João Tereso coordenou os estudos arqueobotânicos, suportado inicialmente pela Faculdade de Ciências da Universidade do Porto (FCUP) e depois pela Fundação para a Ciência e Tecnologia (FCT). Filipe Vaz realizou parte do processo de identificação e interpretação dos estudos arqueobotânicos, suportados pela FCUP e pela FCT através de uma bolsa de doutoramento com a referência SFRH/BD/99930/2014. Os seguintes investigadores colaboraram também no trabalho laboratorial de antracologia: Ana Luísa Ramos, Cláudia Oliveira, Ginevra Coradeschi, Leonardo da Fonte, Maria Martín-Seijo e Valentina Bellavia. O presente artigo foi concebido e escrito por Filipe 
Vaz sob a supervisão de João Tereso, tendo os restantes autores providenciado os dados de campo e revisto a sua versão final.

\section{BIBLIOGRAFIA}

AMORIM A, RORIZ A, PEREIRA S, RODRIGUES Z (no prelo). O mundo dos mortos na Quinta de Crestelos: paradigma das sepulturas escavadas na rocha da necrópole Este. In: Sepulturas escavadas na rocha na Fachada Atlântica da Península Ibérica. FLUP.

CARRIÓN Yolanda (2007) - Woodland in the middle Ebro valley (Spain). Dendrological analysis of archaeological timber from Bell Baker and Iron Age periods. ArcheoSciences Revue d'archéométrie 31:151-161.

CARVALHO Ana Maria (2005) - Etnobotânica do Parque Natural de Montesinho. Plantas, tradição e saber popular num território do nordeste português. Tese de Doutoramento apresentada à Universidad Autónoma de Madrid.

COSME Susana (2014) - Estudo sobre a Romanização no Vale do Sabor, EP189 (Quinta de Crestelos). Relatório Final.

LARRAZABAL Javier (2017) - Tierra, madera y piedra. Arquitecturas, mobiliario y diacronías de la II Edad del Hierro en Trás-os-Montes Oriental: Quinta de Crestelos (Mogadouro). Estudos do Quaternário/Quaternary Studies. 16:31-40.

MARGUERIE Dominique, HUNOT Jean-Yves (2007) Charcoal analysis and dendrology: data from archaeological sites in north-western France. Journal of Archaeological Science. 34:1417-1433 doi:10.1016/j.jas.2006.10.032.

MARTÍN-SEIJO Maria, TERESO João, VAZ Filipe, GASPAR Rita, RODRÍGUEZ RELLÁN Carlos (2017) - EarlyMiddle Bronze Age communities and wood resources management in northeast Portugal: the Sabor valley. Quaternary International. 458:28-43 doi: 10.1016/j.quaint.2017.04.032.

MATEOS Rosa, LARRAZABAL Javier, PEREIRA José António (2014) - Estudo sobre a romanização no vale do sabor EPı89 (Quinta de Crestelos): Relatório final.

PEREIRA Sérgio, SASTRE José, GASPAR Rita, ESPÍ Israel, PEREIRA António, MATEOS Rosa, LARRAZABAL Javier (2015) - O Povoado da Quinta de Crestelos (Mogadouro, Portugal): Fortificação e controlo de um território. In: Fortificaciones en la edad del hierro: Control de los recursos y el territorio. Zamora, p. 13.

QUEIROZ Paula, van der BURGH Chris (1989) - Wood anatomy of Iberian Ericales. Revista de Biologia 14:95-134.

RODRIGUES Miguel, TEIXEIRA Ricardo (1997) - Estudo de Impacto Ambiental do Empreendimento Hidroeléctrico do Baixo Sabor. Relatório Final.

SASTRE José (2014) - Da Idade do Ferro à Romanização da área de Crestelos. In: Actas do I Encontro de Arqueologia do Mogadouro. Mogadouro, 79-94.
SCHWEINGRUBER Fritz (1990) - Anatomy of European Woods. Paul Haupt, Berna.

TERESO João, VAZ Filipe, SEABRA Luís, COSME Susana, PEREIRA Sérgio (2018b) - Os níveis medievais do sítio de Quinta de Crestelos (Mogadouro): Agricultura e Paisagem. Arqueologia Medieval. Mértola. 14:75-91.

TERESO João, VAZ Filipe, JESUS Ana, PEREIRA Sérgio, ESPÍ Israel, SASTRE José (2018a) - Os horrea na Quinta de Crestelos (Mogadouro) na Idade do Ferro e Romanização: dados arqueobotânicos sobre armazenagem e construção. Cadernos do GEEvH.7:95-137.

TSOUMIS Georgios, KEZOS N, FANARIOTOU I, VOULGARIDIS E, PASSIALIS C (1988) - Characteristics of briarwood. International Journal of the Biology, Chemistry, Physics and Technology of Wood. 42:71-77.

VAZ Filipe, TERESO João, de CARVALHO Teresa Pires (2017) - Selection of firewood in Monte Mozinho (NW Iberia) in the Late Antiquity: A question of function and availability Quaternary International. 431, Part A:103-115.

VAZ Filipe, TERESO João, MARTÍN-SEIJO Maria, PEREIRA Sérgio, GASPAR Rita, SEABRA Luís, SASTRE José (2017) Iron Age ovens and hearths from the hilltop of Quinta de Crestelos, Sabor Valley (NE Portugal): An archaeobotanical approach on typology, functionality and firewood use. Quaternary International. 458:75-93. 


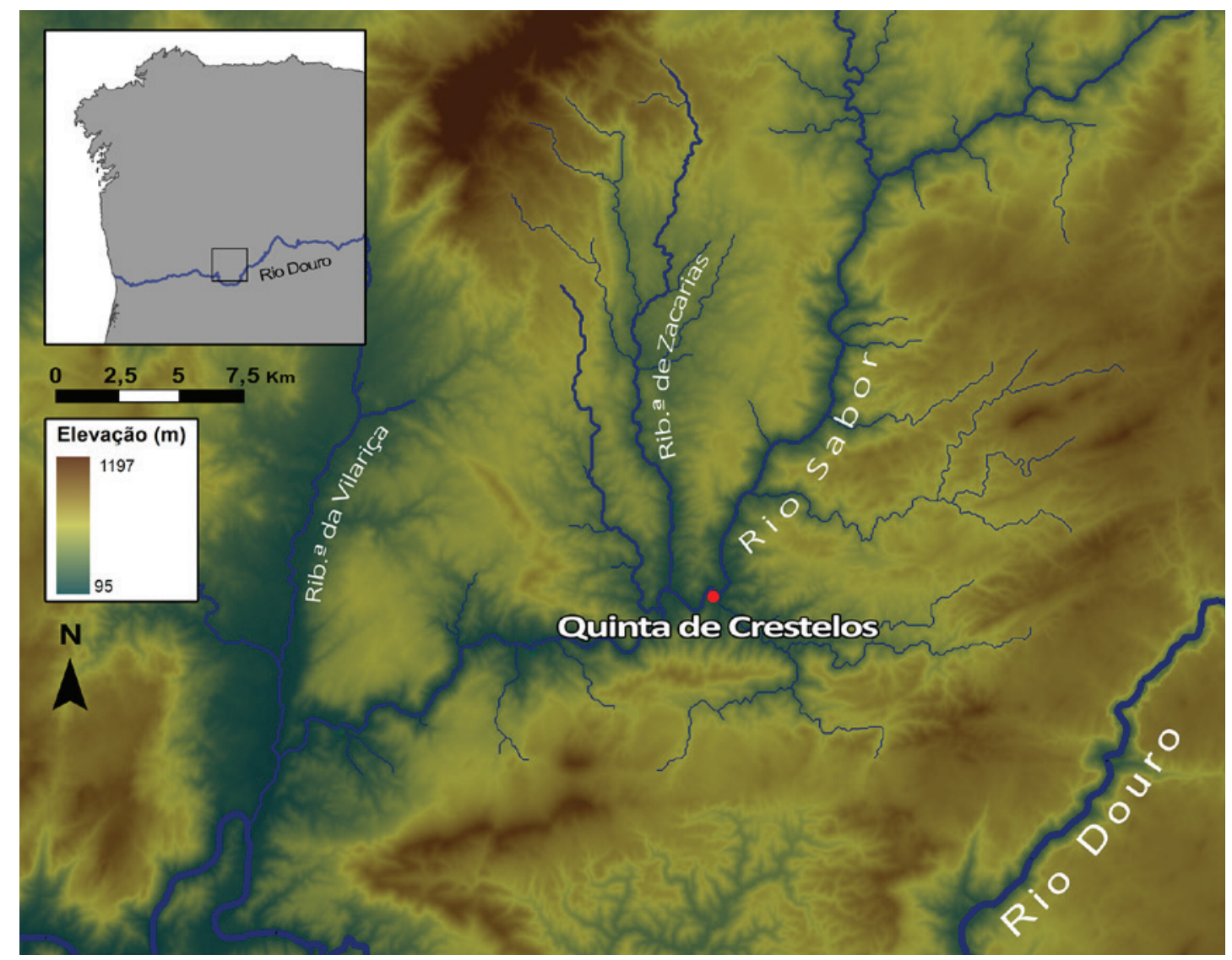

Figura 1 - Localização do sítio da Quinta de Crestelos no curso final do Rio Sabor e no Noroeste Peninsular.

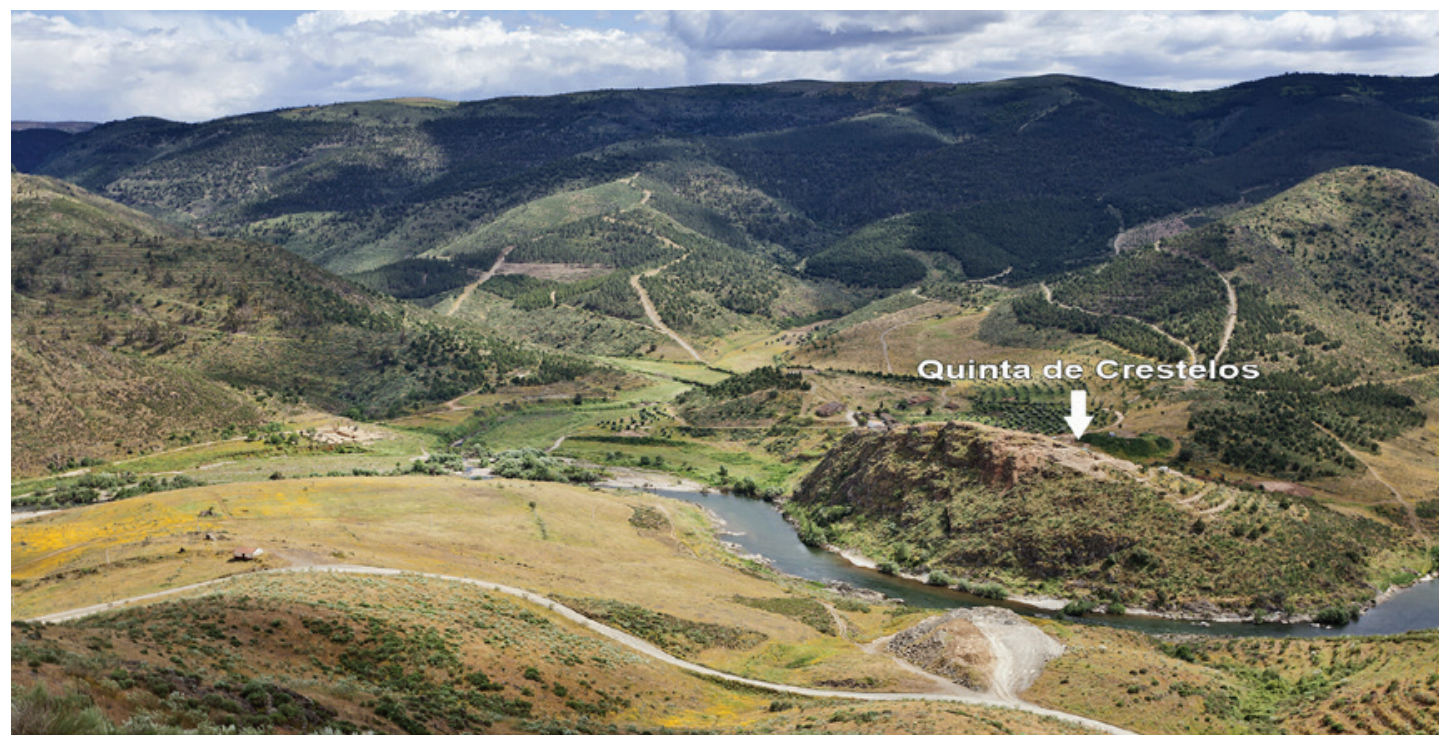

Figura 2 - Vista geral do vale do Sabor e zona de implantação do sítio da Quinta de Crestelos. Autor: Adriano Ferreira Borges (adaptado). 


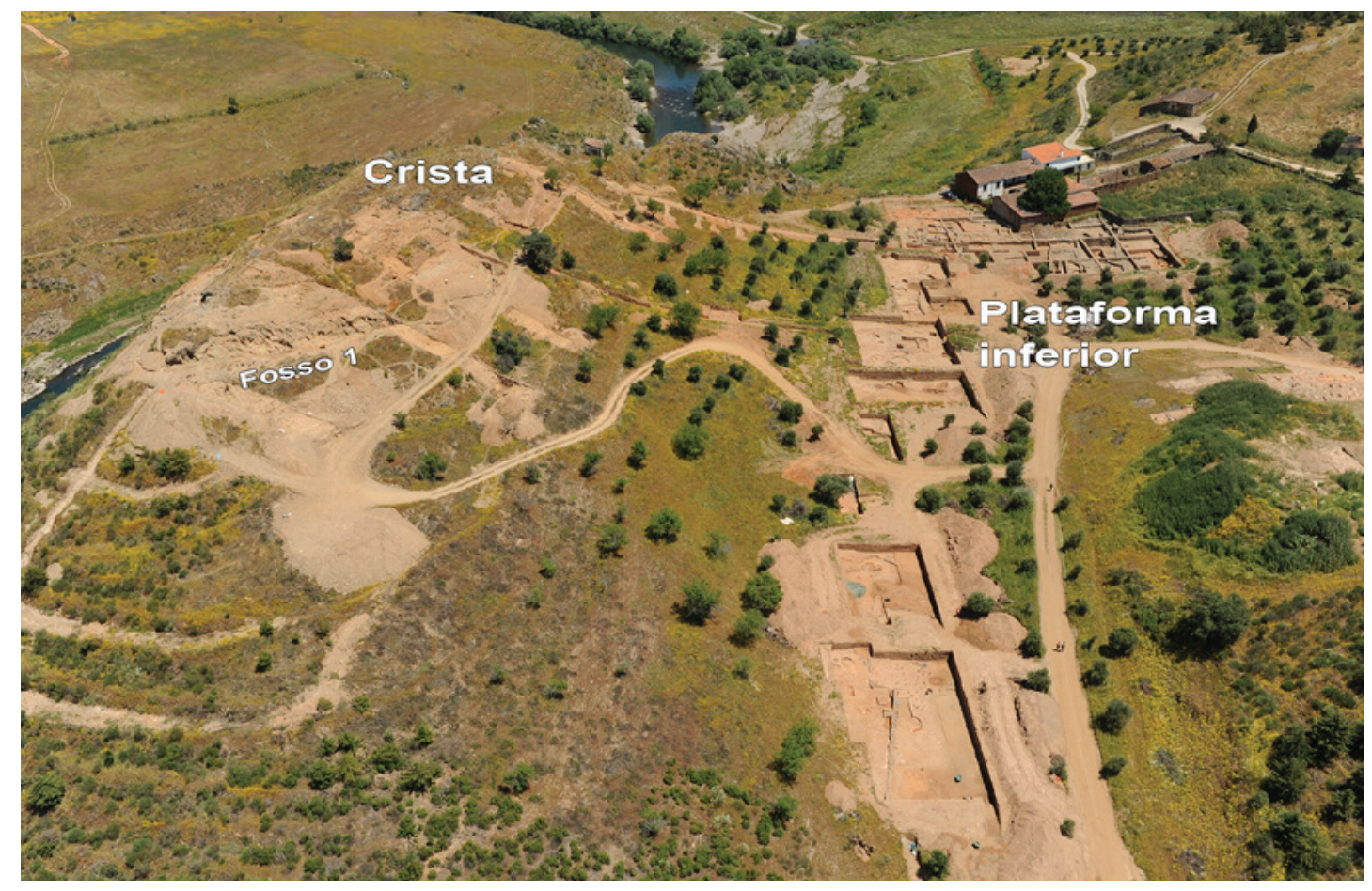

Figura 3 - Vista aérea do sítio da Quinta de Crestelos e das suas principais áreas. Autor: Arte Fotográfica Lda (adaptado).

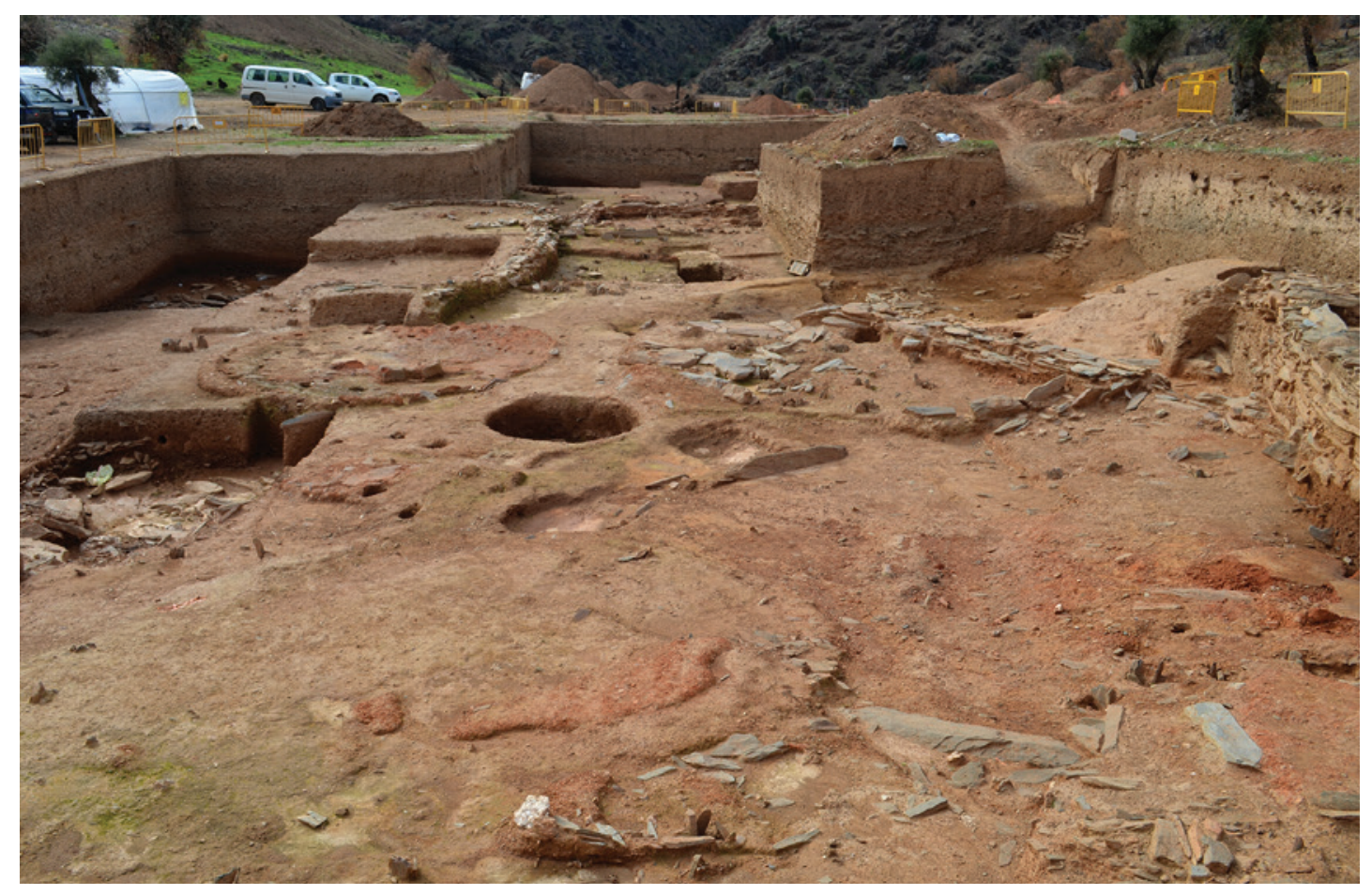

Figura 4 - Vista geral, virada a oeste, da área da Plataforma Inferior da Quinta de Crestelos. 

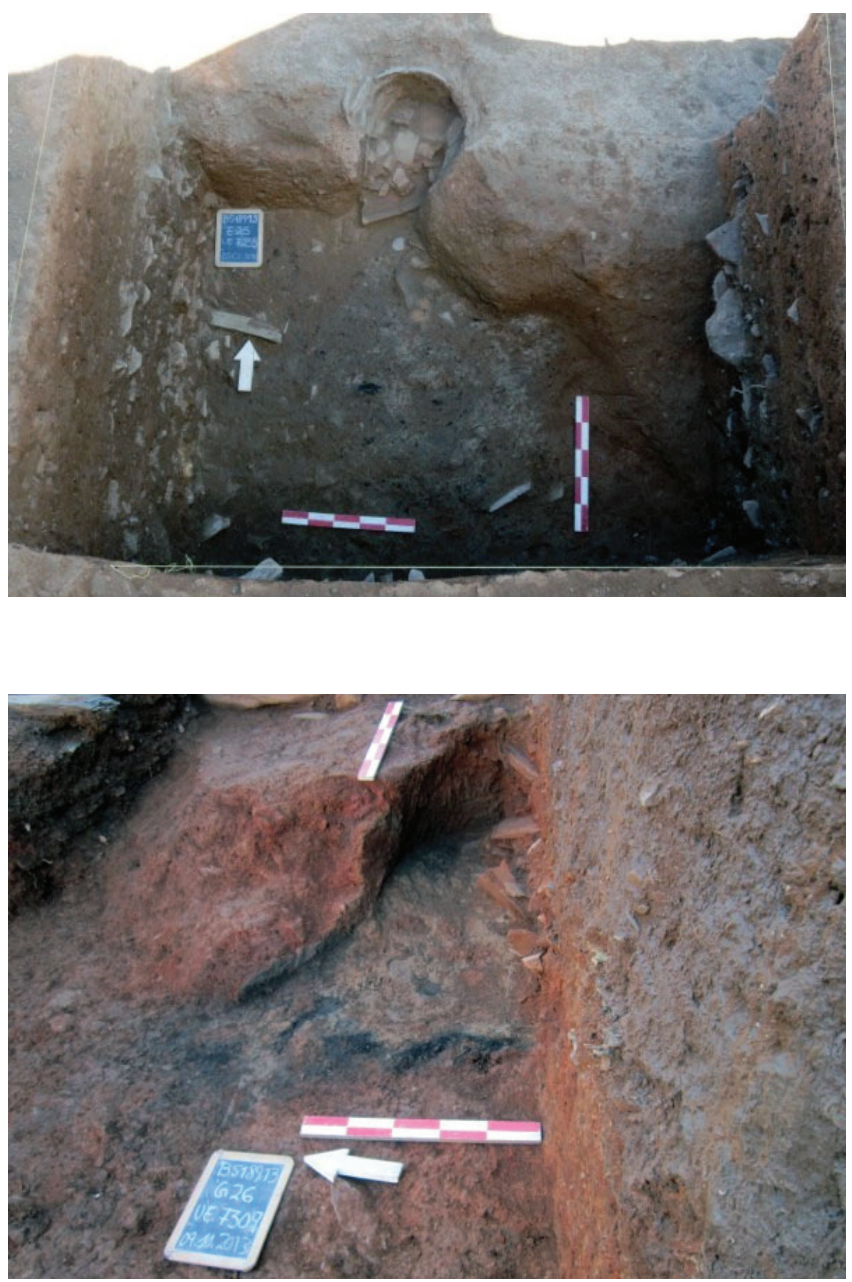

Figura 5-Forno 1, tipo pote, identificado na plataforma inferior da Quinta de Crestelos.

Figura 6 - Forno 2, na plataforma inferior da Quinta de Crestelos.

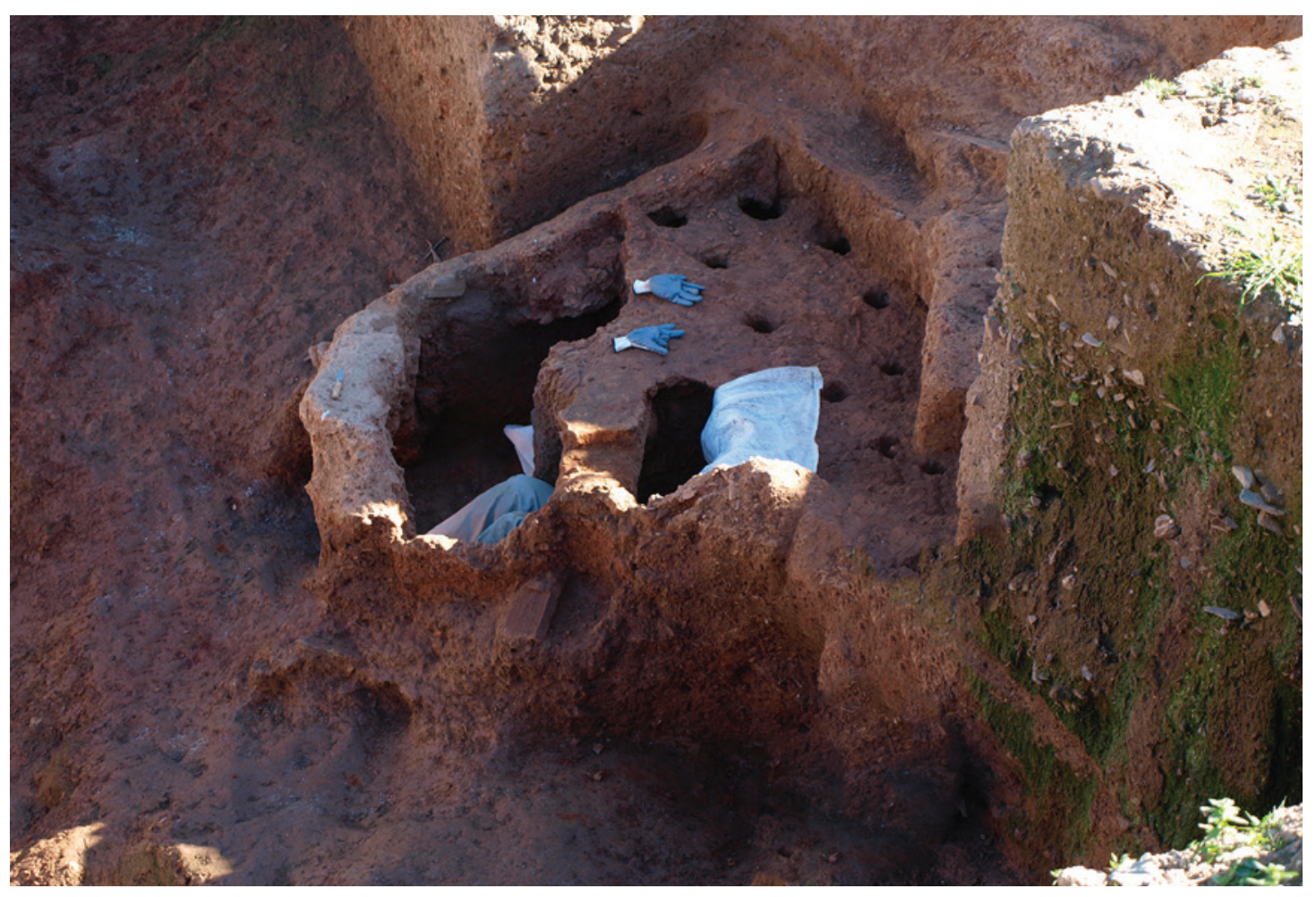

Figura 7 - Forno 3 em processo de escavação. 


\begin{tabular}{|c|c|c|c|}
\hline Contexto & Contexto detalhado & UE & Volume (L) \\
\hline \multirow{3}{*}{ Cabana 3 -Sond. 18} & Piso em argila & 18515 & 1,6 \\
\hline & \multirow{2}{*}{ Lareira 18573} & 18514 & 29 \\
\hline & & 18573 & 2,9 \\
\hline \multirow{3}{*}{ Cabana 5-Sond. 18} & Piso em argila & 18571 & 1,2 \\
\hline & Lareira 18572 & 18572 & 0,4 \\
\hline & Piso em argila & 18586 & 2,2 \\
\hline Cabana 6 - Sond. 18 & Lareira 18307 & 18308 & 2 \\
\hline Fossa 5-Sond. 18 & Fossa & 18243 & 0,4 \\
\hline Estrutura combustão 9/17 & Lareira 18590 & 18590 & 9,7 \\
\hline \multirow{3}{*}{ Cabana 3 - Sond. 36} & Piso em argila & 36273 & 2 \\
\hline & Lareira 36274 & 36274 & 2,8 \\
\hline & Disperso & 36052 & 2,5 \\
\hline Fossa 5-Sond. 36 & Fossa & 36037 & 2 \\
\hline Cabana 4 -Sond. 36 & Ocupação/abandono & 36284 & 1,3 \\
\hline \multirow{2}{*}{ Cabana 1 -Sond. 36} & Ocupação/abandono & 36393 & 1,2 \\
\hline & Ocupação/abandono & 36394 & 0,4 \\
\hline Área funcional - Sond. 36 & Estrutura 36016 & 36016 & 2,7 \\
\hline Canalização 1 - Sond. 18 & Ocupação/abandono & 18245 & 2,4 \\
\hline \multirow{7}{*}{ Cabana 4-Sond. 18} & Ocupação/abandono & 18543 & 3,1 \\
\hline & Ocupação/abandono & 18548 & 1,7 \\
\hline & Estrutura combustão & 18546 & 0,9 \\
\hline & Ocupação/abandono & 18843 & 1,4 \\
\hline & Construção & 18545 & 2,1 \\
\hline & Ocupação/abandono & 18842 & 2,1 \\
\hline & Ocupação/abandono & 18181 & 13,6 \\
\hline \multirow{10}{*}{ Concentração de fossas } & Fossa 3 & 1046 & 3,5 \\
\hline & Fossa 4 & 1049 & 3,5 \\
\hline & Fossa 8 (nível de base) & 1130 & 4,7 \\
\hline & Fossa 8 nível médio) & 1138 & 5,2 \\
\hline & Fossa 8 (nível de topo) & 1147 & 9,5 \\
\hline & Fossa 9 (nível de topo) & 1143 & 4,6 \\
\hline & Fossa 9 (nível de base) & 1150 & \multirow{2}{*}{ Recolhas manuais } \\
\hline & Fossa 12 & 1155 & \\
\hline & Fossa 19 & 1405 & 0,4 \\
\hline & Fossa 21 & 1383 & 2,3 \\
\hline Fossa $17 \mathrm{~b}$ - Sond. 18 & Fossa & 1290 & 1,5 \\
\hline \multirow{2}{*}{ Estrutura de combustão } & Limpeza & 3192 & 7,6 \\
\hline & Estrutura combustão (metalurgia) & 3197 & 6 \\
\hline \multirow{3}{*}{ Cabana metalúrgica } & Construção & 5209 & 2 \\
\hline & Ocupação/abandono & 5198 & 3,5 \\
\hline & Ocupação/abandono & 5200 & 2,6 \\
\hline
\end{tabular}

Tabela 1 - Inventário dos contextos amostrados na Plataforma Inferior da Quinta de Crestelos, entre o séc. IV e II a.C. 


\begin{tabular}{|c|c|c|c|}
\hline Contexto & Contexto detalhado & UE & Volume (L) \\
\hline \multirow{4}{*}{ Forno i Metalurgia } & \multirow{4}{*}{ Conteúdo interior forno } & 7204 & 5,2 \\
\hline & & 7209 & 7,1 \\
\hline & & 7254 & 5,4 \\
\hline & & 7255 & 8,8 \\
\hline \multirow{4}{*}{ Forno 2 Alimentar } & Câmara & 7306 & 5 \\
\hline & Nível amarelo interior & 7307 & 18 \\
\hline & Nível cinzas interior & 7308 & 7,1 \\
\hline & Limpeza da fornalha (exterior) & 7314 & 33,6 \\
\hline \multirow{8}{*}{ Forno 3 Cerâmica } & Destruição da abóbada & 7316 & 21,7 \\
\hline & Abandono & $7322(=7327)$ & 2,8 \\
\hline & Interior forno & 7335 & 46,4 \\
\hline & \multirow{5}{*}{ Abandono e destruição } & $7317(=7347)$ & 66,1 \\
\hline & & 7328 & 13,6 \\
\hline & & 7331 & 7,3 \\
\hline & & 7332 & 12,1 \\
\hline & & 7334 & 2,8 \\
\hline \multirow{3}{*}{ Fossa entre fornos } & \multirow{3}{*}{$\begin{array}{c}\text { Colmatação de fossa entre forno } \\
\text { metalurgico e cerâmica }\end{array}$} & 7298 & 16 \\
\hline & & 7303 & 3,5 \\
\hline & & 7304 & 5,5 \\
\hline
\end{tabular}

Tabela 2 - Inventário dos fornos amostrados na Plataforma Inferior da Quinta de Crestelos, balizados entre o séc. II a.C. e II d.C. 


\begin{tabular}{|c|c|c|c|c|c|c|c|c|c|c|c|c|c|c|c|c|c|}
\hline Cronologia & & \multicolumn{16}{|c|}{ IV-III a.C. } \\
\hline $\begin{array}{l}\text { Sondagem/ } \\
\text { Sector }\end{array}$ & & \multicolumn{6}{|c|}{ Sond. 18} & \multicolumn{6}{|c|}{ Sond. 36} & \multicolumn{4}{|c|}{ Setor 1} \\
\hline Contexto & & \multicolumn{2}{|c|}{ Cabana 3} & Cabana & Cabana & Fossa & Estr. & \multicolumn{2}{|c|}{ Cabana 1} & \multicolumn{2}{|c|}{ Cabana 3} & \multirow{3}{*}{\begin{tabular}{|c|}
$\begin{array}{c}\text { Fossa } \\
5\end{array}$ \\
36037
\end{tabular}} & \multirow{3}{*}{$\begin{array}{l}\text { Estrut. } \\
\text { Comb. } \\
36016\end{array}$} & \multirow{3}{*}{\begin{tabular}{|c} 
Fossa \\
3 \\
\\
1046 \\
\end{tabular}} & \multicolumn{3}{|c|}{ Fossa 8} \\
\hline $\begin{array}{l}\text { Contexto } \\
\text { detalhado }\end{array}$ & & Estr. C. & Ocup & /Aban. & Estr. C. & & $9 / 17$ & Ocupa & ão / Ab & andono & Disp. & & & & & & \\
\hline Táxone & Total & 18514 & 18515 & 18586 & 18308 & 18243 & 18590 & 36393 & 36394 & 36274 & 36052 & & & & 1130 & 1138 & 1147 \\
\hline Acer sp. & 18 & & & & & & & & & & & & & & & & \\
\hline Alnus sp. & 18 & 2 & & & & & & & & & & & & 1 & & & \\
\hline Alnus/Corylus & 9 & 1 & & & & & 2 & & & & & & & 4 & 1 & & \\
\hline Arbutus unedo & 71 & & & & & & 62 & & & & & & 1 & & & & 1 \\
\hline Cistus sp. & 254 & 18 & 3 & & & 3 & 6 & 1 & & & & 85 & & 5 & & 16 & 57 \\
\hline $\begin{array}{r}\text { Erica australis/ } \\
\text { arborea }\end{array}$ & 91 & 8 & & & & & 4 & 1 & & & & 1 & 2 & 2 & & 1 & \\
\hline Fabaceae & 41 & 2 & & & & 1 & 2 & & & & & 9 & & 1 & 1 & 1 & 6 \\
\hline Fraxinus sp. & 118 & & & & & & & & 48 & & & 3 & & 5 & & & 13 \\
\hline Juniperus sp. & 34 & & & & & & 1 & 23 & & & & & & & & 1 & 6 \\
\hline Olea europaea & 2 & & & & & & & & & & & & & & & & \\
\hline Pinus pinaster & 199 & 3 & & 1 & 6 & & 99 & & 3 & & & & & 10 & 3 & 1 & 10 \\
\hline $\begin{array}{r}\text { Pinus pinea/ } \\
\text { pinaster }\end{array}$ & 28 & & & & & & & & & & 1 & & & & & 2 & 15 \\
\hline Pinus sp. & 41 & & & & & & 41 & & & & & & & & & & \\
\hline Prunus sp. & 36 & & & & & & 2 & & 1 & & & & & & & & 12 \\
\hline Quercus suber & 57 & 2 & & & & & & & & & & 5 & & 6 & & 2 & 13 \\
\hline $\begin{array}{c}\text { Quercussp. } \\
\text { - caducifólia }\end{array}$ & 101 & & & & & & & & & & & & & 7 & & & 22 \\
\hline $\begin{array}{c}\text { Quercussp. } \\
\text { - perenifólia }\end{array}$ & 129 & 4 & & & & & 4 & 4 & 1 & & & 3 & 1 & 1 & 1 & 10 & 11 \\
\hline Quercussp. & 148 & & & & & & 2 & & & & & 19 & & 8 & & 17 & 34 \\
\hline $\begin{array}{r}\text { Rosaceae } \\
\text { Maloideae }\end{array}$ & 1 & & & & & & & & & & & & & & & & \\
\hline Salix sp. & 3 & & & & & & & & 3 & & & & & & & & \\
\hline Dicotiledónea & 981 & 262 & & 4 & & & 87 & 1 & 3 & 4 & & 75 & 3 & 13 & 7 & 10 & 65 \\
\hline Gimnospérmica & 39 & 1 & & & 9 & & 15 & & & & & & & & 2 & & 1 \\
\hline Total & 2421 & 303 & 3 & 5 & 15 & 4 & 327 & 30 & 59 & 4 & 1 & 200 & 7 & 63 & 15 & 61 & 266 \\
\hline
\end{tabular}

Tabela 3 - Resultados antracológicos dos contextos habitacionais na plataforma inferior da Quinta de Crestelos, relativos aos séc. IV a II a.C. 


\begin{tabular}{|c|c|c|c|c|c|c|c|c|c|c|c|c|c|c|c|c|}
\hline & & & & & \multicolumn{12}{|c|}{ IV-II a.C. } \\
\hline \multicolumn{5}{|c|}{ Setor 1} & \multicolumn{7}{|c|}{ Sond. 18} & \multirow{3}{*}{\multicolumn{2}{|c|}{$\begin{array}{c}\text { Setor } 3 \\
\text { Estrutura } \\
\text { Combustão }\end{array}$}} & \multirow{2}{*}{\multicolumn{3}{|c|}{$\begin{array}{c}\text { Setor } 5 \\
\text { Cabana metal. }\end{array}$}} \\
\hline \multirow{2}{*}{\multicolumn{2}{|c|}{ Fossa 9}} & \multirow{3}{*}{$\begin{array}{c}\begin{array}{c}\text { Fossa } \\
19\end{array} \\
1405 \\
\end{array}$} & \multirow{3}{*}{$\begin{array}{c}\text { Fossa } \\
21 \\
1383 \\
\end{array}$} & \multirow{3}{*}{$\begin{array}{c}\text { Fossa } \\
17 \mathrm{~b} \\
1290 \\
\end{array}$} & Canal. & \multicolumn{6}{|c|}{ Cabana 4} & & & & & \\
\hline & & & & & \multicolumn{4}{|c|}{ Ocupação / Abandono } & \multirow{2}{*}{$\begin{array}{l}\text { Const. } \\
18545\end{array}$} & \multicolumn{2}{|c|}{ Ocup./Aban. } & & & \multirow{2}{*}{$\begin{array}{l}\text { Const. } \\
5209 \\
\end{array}$} & \multicolumn{2}{|c|}{ Ocup./Aban. } \\
\hline 1150 & 1143 & & & & 18245 & 18543 & 18548 & 18843 & & 18842 & 18181 & 3192 & 3197 & & 5198 & 5200 \\
\hline & & 18 & & & & & & & & & & & & & & \\
\hline & 1 & 10 & & & & & & & 3 & & 1 & & & & & \\
\hline & & & & & & & & & 1 & & & & & & & \\
\hline & & & & & 1 & & & & 4 & 1 & 1 & & & & & \\
\hline 4 & 5 & & & 1 & 2 & 1 & 1 & 3 & 18 & 4 & 7 & 8 & 2 & 2 & 1 & 1 \\
\hline \multirow[t]{5}{*}{2} & 12 & 4 & & & 1 & & & 1 & 1 & & 2 & 38 & 12 & & & \\
\hline & 5 & & & & & & & & 12 & & 1 & & & & & \\
\hline & 4 & 32 & & & 1 & 1 & & & 6 & 1 & & 4 & & & & \\
\hline & & & & & & & & & & & 3 & & & & & \\
\hline & & & & & 2 & & & & & & & & & & & \\
\hline \multirow[t]{4}{*}{1} & 6 & & & & 2 & & & & 2 & 1 & 39 & & 1 & & 2 & 9 \\
\hline & & & 1 & & 6 & & & & & & 3 & & & & & \\
\hline & 14 & & & 1 & 1 & & & & & & & 6 & & & & \\
\hline & 20 & & & 1 & & & & & 8 & & & & & & & \\
\hline 1 & 1 & 19 & & & 43 & 4 & 2 & & 1 & & & 1 & & & & \\
\hline \multirow[t]{3}{*}{2} & 2 & 18 & & 1 & 12 & 1 & 2 & 13 & 10 & 7 & 5 & 8 & 4 & & 4 & \\
\hline & 6 & 21 & & 3 & & 2 & 1 & 2 & 16 & 1 & 1 & & 15 & & & \\
\hline & 1 & & & & & & & & & & & & & & & \\
\hline \multirow[t]{2}{*}{10} & 30 & 51 & 2 & 34 & 21 & 9 & 9 & & 32 & 4 & 38 & 137 & 40 & 6 & 16 & 8 \\
\hline & & & & & 2 & & 1 & & & 2 & 6 & & & & & \\
\hline 20 & 107 & 173 & 3 & 41 & 94 & 18 & 16 & 19 & 114 & 21 & 107 & 202 & 74 & 8 & 23 & 18 \\
\hline
\end{tabular}

Tabela 3 (continuação) - Resultados antracológicos dos contextos habitacionais na plataforma inferior da Quinta de Crestelos, relativos aos séc. IV a II a.C. 


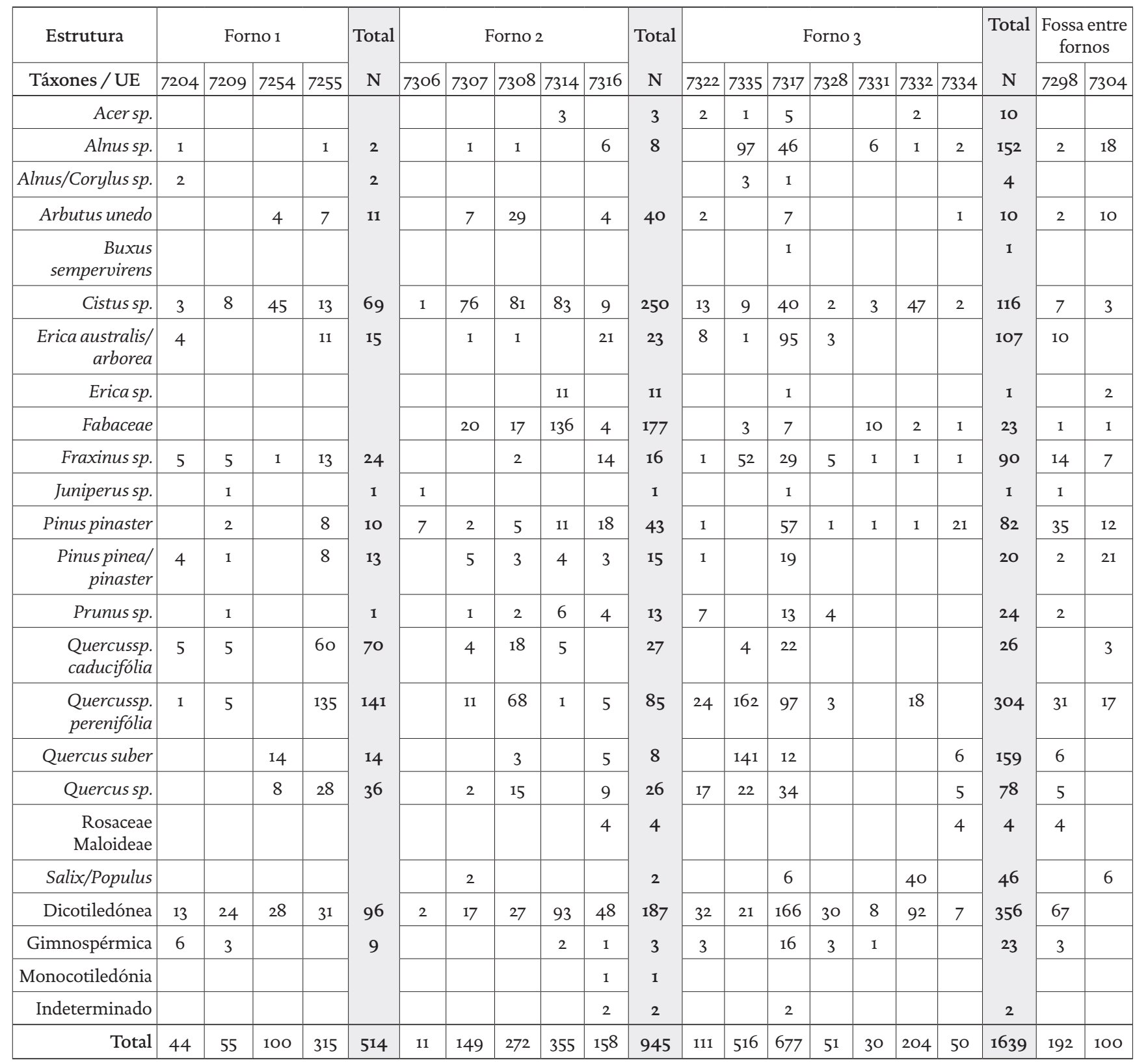

Tabela 4 - Resultados antracológicos dos fornos do séc. II a.C. a II d.C. da plataforma inferior da Quinta de Crestelos. 


\title{
CULTIVOS DE ÉPOCA ROMANA NO BAIXO SABOR: CONTINUIDADE EM TEMPOS DE MUDANÇA?
}

\author{
João Pedro Tereso ${ }^{1}$, Sérgio Simões Pereira ${ }^{2}$, Filipe Santos ${ }^{3}$, Luís Seabra ${ }^{4}$, Filipe Vaz ${ }^{5}$
}

\begin{abstract}
RESUMO
Na sequência de intervenções em oito jazidas romanas no Baixo Sabor foram efetuados estudos carpológicos que permitiram obter informações acerca dos cultivos consumidos e da forma como seriam armazenados. O trigo de grão nu terá sido o principal cultivo em época romana, mas a cevada e o milho-miúdo também terão sido importantes. A presença de uvas está documentada, enquanto leguminosas domésticas e plantas silvestres edíveis são raras.

Este cenário contrasta com outras regiões do Noroeste Peninsular onde, tanto em época romana como na Idade do Ferro, os trigos de grão vestido detinham especial relevância. Com os dados atuais, é difícil entender a peculiaridade do vale do Sabor a este nível, mas alguns fatores ambientais e culturais são aqui adiantados.

Palavras-chave: Agricultura, Romanização, Trás-os-Montes, Arqueobotânica.
\end{abstract}

\begin{abstract}
During the excavation of eight roman sites in the Lower Sabor valley, sediment samples were recovered and carpological analyses were carried out in order to obtain data regarding agriculture and storage.

Naked wheat was the most frequent crop during the Roman period, but barley and millet were also relevant. The presence of grapes is documented while pulses and other wild edible plants were scarce. These results contrast with those found in other regions of Northwest Iberia, both in Roman Times and the Iron Age, where hulled wheats were particularly relevant. Current available data does not allow us to know the reason behind the specificities of the Sabor valley's sites, although some environmental and cultural aspects may provide suitable explanations.
\end{abstract}

Keywords: Agriculture, Romanization, NE Portugal, Archaeobotany.

\section{INTRODUÇÃO}

O conhecimento que temos acerca da agricultura de Época Romana na Península Ibérica advém de uma combinação de dados arqueológicos de diferentes naturezas. Entre estes, os estudos arqueobotânicos assumem particular relevância. Apesar de os dados existentes permitirem já efetuar algumas sínteses (Tereso, Ramil-Rego \& Almeida-da-Silva, 2013; Peña-Chocarro \& alii, 2019) é evidente a escassez de estudos carpológicos em algumas regiões. No Norte de Portugal foram realizados estudos em diversas

\footnotetext{
1. InBIO (Rede de Investigação em Biodiversidade e Biologia Evolutiva, Lab. Associado /CIBIO (Centro de Investigação em Biodiversidade e Recursos Genéticos, Univ.do Porto); UNIARQ - Centro de Arqueologia da Universidade de Lisboa; MHNC-UP - Museu de História Natural e da Ciência da Universidade do Porto; jptereso@gmail.com

2. Arqueólogo Independente; sergiomspereira71@gmail.com

3. Arqueólogo Independente; santos.philipe@gmail.com

4. InBIO (Rede de Investigação em Biodiversidade e Biologia Evolutiva, Lab. Associado /CIBIO (Centro de Investigação em Biodiversidade e Recursos Genéticos, Univ.do Porto); lc_pacos@hotmail.com
}

5. InBIO (Rede de Investigação em Biodiversidade e Biologia Evolutiva, Lab. Associado /CIBIO (Centro de Investigação em Biodiversidade e Recursos Genéticos, Univ.do Porto); filipe.mcvaz@gmail.com 
jazidas, mas, até recentemente, eram quase inexistentes os estudos deste período no nordeste transmontano, sendo as análises da Terronha de Pinhovelo (Tereso, 2009) uma exceção.

Este cenário alterou-se recentemente, quando, entre os anos 2011 e 2014 diversos sítios de cronologia romana foram escavados no Baixo Sabor, incluindo pequenas quintas, casais agrícolas, assim como locais de maior dimensão com evidências estruturais perenes. Estes trabalhos decorreram da minimização dos impactes da implementação do Aproveitamento Hidroelétrico do Baixo Sabor, no âmbito da qual foi estruturado um Plano de Salvaguarda Patrimonial. Este previa a realização de estudos arqueobotânicos, para os quais foram efetuadas amplas recolhas de amostras sedimentares, obtendo-se um vasto corpo de dados que tem vindo a ser publicado. O estudo destas jazidas, concentradas numa área geográfica circunscrita, constitui uma oportunidade para obter dados sem paralelos na região, sobre a diversidade de povoamento e de estratégias económicas, assim como do impacte paisagístico, entre outros, da romanização no nordeste português.

Neste trabalho apresenta-se a síntese dos resultados das análises carpológicas realizadas em jazidas de cronologia romana, com especial enfoque naquelas que permaneciam inéditas. Pretende-se não só identificar os principais cultivos consumidos no vale neste período e tentar obter informações acerca dos seus modos de produção e armazenamento, mas também interpretar estes dados à luz das dinâmicas de povoamento do vale. Embora abordagens socioeconómicas à agricultura e povoamento romano no nordeste trasmontano tenham já sido ensaiadas em estudos anteriores (Lemos, 1993), nunca tiveram em conta dados arqueobotânicos, até recentemente inexistentes para a região. Esta situação é, na verdade, comum a quase todo o ocidente peninsular no que respeita ao período romano, pelo que este estudo assume particular importância.

\section{METODOLOGIA}

Este estudo incide sobre oito sítios arqueológicos (Figura 1), com cronologias entre a viragem da Era e o século $\mathrm{V}$ d.C., intervencionados no Baixo Sabor. Dada a diversidade tipológica das jazidas, verificam-se grandes discrepâncias na dimensão das áreas de intervenção e, consequentemente, no nível de compreensão das dinâmicas de ocupação de cada uma (vide infra). De igual modo, as amostragens com vista aos estudos de arqueobotânica seguiram estratégias distintas em cada sítio, o que se traduz em grandes diferenças entre jazidas, no que se refere ao número de amostras e contextos analisados.

As amostras de sedimento foram flutuadas manualmente com recurso a malhas de $0,5 \mathrm{~mm}$. As flutuações decorreram nos estaleiros do Baixo Sabor ACE e foram da responsabilidade da equipa de escavação. As análises laboratoriais foram realizadas na Faculdade de Ciências da Universidade do Porto.

A fração leve das amostras foi triada com recurso a uma lupa binocular e os frutos e sementes foram identificados por comparação com material atual das coleções de referência do CIBIO e do Herbário da Universidade do Porto e com o auxílio de atlas morfológicos (e.g. Berggren, 1981).

Os resultados podem ser consultados nas tabelas $1 \mathrm{e}$ 2. No texto, os sítios são apresentados seguindo uma ordem geográfica, de Norte para Sul. Alguns contextos estruturais encontravam-se representados por diversas u.e. mas quando estas apresentaram escassos vestígios e cuja diferenciação estratigráfica não foi considerada relevante, os dados foram apresentados ao nível do contexto e não da u.e., de forma a ajustar a dimensão das tabelas a esta publicação.

\section{SÍTIOS ANALISADOS: CARACTERIZA- ÇÃO, AMOSTRAGEM E RESULTADOS}

\subsection{Cabeço da Grincha (Mogadouro)}

O Cabeço da Grincha é uma jazida de cronologia romana com um edifício de pequena dimensão implantado na segunda metade do séc. I d.C., posteriormente remodelado, equipado com um lagar e interpretado como um casal agrícola, que controlaria uma área de passagem do rio Sabor (Pereira \& alii, 2014).

Foram recolhidas 35 amostras em 19 u.e. da segunda fase de ocupação, em especial em depósitos relacionados com o abandono e destruição das estruturas. O único vestígio carpológico identificável é um grão de centeio (Secale cereale), encontrado no derrube da cúpula (u.e. 1078) de um pequeno forno doméstico.

\subsection{Foz da Ribeira do Poio (Mogadouro)}

Localizado junto de um afluente da margem esquerda do rio Sabor, o sítio da Foz da Ribeira do Poio compreende um edifício de $16 \mathrm{~m}$ por $15,3 \mathrm{~m}$, com 12 divisões internas, correspondendo a uma quinta ou 
casal, eventualmente integrado numa unidade fundiária mais abrangente. A jazida parece ter tido, pelo menos, duas fases de ocupação: a implantação de um lagar ou torcularium, durante um período curto entre finais do séc. I d.C. e II d. C (Pereira \& alii, 2014) e, mais tarde, um momento de remodelação em que foi desmontada a unidade de transformação. Após o desmonte dos tanques ou laci, foram criados novos compartimentos e o edifício adaptado a um espaço habitacional, talvez sazonal, ou com outra função não determinada.

As análises antracológicas e carpológicas foram já publicadas (Tereso \& alii, 2018b), pelo que na Tabela 2 é apresentado um somatório dos dados.

Foram recolhidas 63 amostras, num total de $126,7 \mathrm{~L}$ de sedimento, de 36 u.e., principalmente em níveis de abandono e derrubes de telhados. Os frutos e sementes advêm de 19 u.e., uma do exterior do edifício, de um depósito natural (u.e. 1067) anterior à implantação da construção e as restantes de sete compartimentos, integrando: níveis de abandono, sobre pisos de circulação (u.e. 1011, 1028, 1044, 1117), derrubes (1052, 1056, 1058, 1061, 1062, 1089, 1112), depósitos de cobertura de derrubes ou depósitos dispersos sem conexão direta com níveis de ocupação (1004, 1008, 1003), enchimentos de tanques (1097, 1065, 1106) e a vala de fundação de um muro (1038).

Os cereais são raros, contando-se um grão de cevada de grão vestido (Hordeum vulgare subsp. vulgare) e um grão identificado ao nível da tribo (Triticeae). Foram recuperadas, porém, 7 grainhas de uva inteiras (Vitis vinifera), além de alguns fragmentos, assim como um fragmento de caroço de azeitona (Olea europaea). Acrescentam-se ainda escassas sementes de espécies ruderais/daninhas.

\subsection{Vale da Bouça (Mogadouro)}

A intervenção permitiu identificar um edifício relacionado com a produção de vinho ou azeite, ocupado entre o final do séc. II d.C. e o séc. V d.C., segundo a análise de fragmentos de TSH e TSHT. Foram identificadas duas plataformas de prensagem e dois tanques, assim como uma possível cella vinaria pertencentes a um lagar (Pereira \& alii, 2014).

Foram analisadas 10 amostras de 8 u.e., num total de 28,6 L de sedimento, associadas ao abandono de 2 tanques, uma estrutura negativa e dois níveis de circulação. As únicas que forneceram vestígios carpológicos provêm da u.e. 1023, no interior do tanque 1, onde foram encontrados fragmentos de recipientes de armazenagem, selados por um nível de derrube de telha. Neste contexto foi encontrado um grão de Triticeae, assim como nove aquénios de silva/framboesa (Rubus sp.).

\subsection{Chã (Alfândega da Fé)}

Sítio localizado junto à Ribeira de Zacarias, afluente do rio Sabor, com ocupações da Idade do Ferro e de Época Romana. A ocupação do final da Idade do Ferro (séc. IV-I. a.C.) caracterizava-se pela presença de estruturas negativas. Em época romana (séc. I-II d.C.), as estruturas anteriores terão sido colmatadas, implementando-se um pequeno edifício, que embora se encontrasse muito destruído aquando da escavação, deveria pertencer a um pequeno casal rural. Um conjunto de aterros modelou o espaço para a ocupação alto-imperial, sobre a qual ainda se construiu uma estrutura mais grosseira, num momento mais tardio.

Os estudos arqueobotânicos incidiram sobre 43 amostras de 18 u.e. correspondendo principalmente $a$ aterros e enchimentos de fossas. Foram encontradas sementes/frutos identificáveis em três depósitos da fase romana: o enchimento de uma fossa (u.e. 821), o enchimento de um muro (u.e. 813) e um depósito relacionado com o abandono do local (u.e. 802). Os resultados dos estudos arqueobotânicos encontram-se já publicados (Vaz \& alii, 2016) pelo que aqui apresenta-se o somatório desta fase (Tabela 2).

Os frutos e sementes são escassos, tendo sido recolhidas cinco grainhas de uva inteiras e cinco fragmentos, assim como escassas ruderais ou daninhas. Ao contrário das amostras do final da Idade do Ferro deste mesmo sítio, não foram identificados cereais ou leguminosas, o que, considerando o pequeno número de contextos analisados, não deve ser sobrevalorizado.

\subsection{Quinta de Crestelos (Mogadouro)}

Sítio com grande diacronia de ocupação, desde a Pré-história recente até à atualidade, implementado junto à margem esquerda do rio Sabor. Amplamente escavado (10.80o $\left.\mathrm{m}^{2}\right)$, apresenta uma plataforma aplanada e uma crista sobrelevada e alongada, com áreas de declive acentuado entre ambas e uma grande escarpa em direção ao rio. Terá sido um importante povoado durante a $2^{\underline{a}}$ Idade do Ferro, tendo sido definidas diversas cabanas, fossos e muralhas/taludes (Pereira \& alii, 2014). Entre o final da Idade do Ferro e o período alto-imperial (séc. II a.C. a II d.C.), a 
crista terá sido usada principalmente como área de armazenagem, identificando-se aí diversos horrea, tanto circulares como retangulares. Estes apresentavam uma base pétrea, constituída por muretes paralelos, de xisto, um tabulatum em xisto, com paredes de materiais perecíveis revestidos com argila.

Na plataforma inferior, no séc. I d.C. foi construído um grande edifício que terá funcionado como lagar e armazém. Este contava com uma cave rebaixada, um grande horreum e ainda outros compartimentos anexos de funcionalidade indeterminada.

Durante a Antiguidade Tardia verifica-se uma retração da área ocupada, surgem novas construções, ao mesmo tempo que as estruturas anteriores são adaptadas. Ainda que o sítio mantenha a sua função agrícola, o povoado transforma-se numa quinta.

Foram já publicados estudos arqueobotânicos focando os níveis da Idade do Bronze (Martín-Seijo \& alii, 2017), um amplo conjunto de fornos da Idade do Ferro (Vaz \& alii, 2017), os horrea e contextos envolventes do topo da crista (Tereso \& alii, 2018a) (Tabela 2) e os níveis da Antiguidade Tardia e Idade Média (Tereso \& alii, 2018c).

De entre o material já publicado, importa referir, de cronologia romana (séc. I-II d.C), os sedimentos associados a estruturas de armazenagem no topo da crista, nomeadamente os horrea 4, 6, 7 e 8 e o depósito [1348], um nível de escorrência datado por radiocarbono do séc. I ou início de II d.C. e localizado sob os horrea 7 e 8. Para questões cronológicas e para ver os dados pormenorizados das várias u.e. associadas a cada estrutura, conferir Tereso \& alii (2018a). As datações e a estratigrafia do sítio colocam alguns horrea no final da Idade do Ferro, séc. II a I a.C., nomeadamente os horrea 1 e 2. Outros apresentam uma cronologia indeterminada, entre os séc. II a.C e II d.C. Os dados de todos estes contextos encontram-se já publicados (Tereso \& alii, 2018a). Permanecem inéditos e serão aqui apresentados, materiais romanos da plataforma inferior, nomeadamente, o conteúdo de uma fossa, constituída por cinco u.e. (u.e. 1012, 1013, 1018, 1105, 1117), genericamente datadas entre o séc. I a.C. e o séc. I d.C., e um conjunto de três fornos no limite sul da área de escavação, onde foram recolhidos $288 \mathrm{~L}$ de sedimentos, em 19 u.e., algumas delas sem qualquer semente/fruto:

- Um forno de metalurgia (Forno 1), nomeadamente a u.e. 7255 no seu interior.

- Um forno muito destruído aparentemente des- tinado à confeção de alimentos (Forno 2), tendo sido recolhidos macrorrestos nas u.e. $7307 \mathrm{e}$ 7308, no seu interior, e na u.e. 7314 , numa área exterior associada à limpeza da estrutura.

- Um forno de cerâmica (Forno 3), tendo sido recolhidos carporrestos num sedimento no seu interior (u.e. 7335), assim como em níveis de destruição (u.e. 7317, 7328, 7331, 7332), incluindo o depósito [7316], associado à destruição da abóbada.

- Foram ainda recolhidos macrorrestos em dois depósitos (u.e. 7298 e 7304) no interior de uma depressão que se encontrava entre os fornos de cerâmica e de metalurgia.

A Quinta de Crestelos é o sítio romano com o maior conjunto carpológico do Baixo Sabor. Nos sedimentos associados aos horrea alto-imperiais da crista recuperaram-se cerca de 10 mil grãos de cereais, em especial de trigo de grão nu - trigo-mole ou trigo-duro (Triticum aestivum/durum) - e milho-miúdo (Panicum miliaceum). A cevada surge em números muito menores, enquanto os caroços de azeitona (8), as grainhas de uva (5) e as favas (Vicia faba) (3) são ainda mais raros. Sementes e frutos de espécies silvestres não são abundantes, mas são diversos (Tabela 1).

Na plataforma inferior, no interior de uma grande fossa com vários enchimentos e com material da viragem da Era, foram identificados dois grãos de trigo-mole/duro, fragmentos de cereais indeterminados, escassas silvestres - Malva sp. - e aristas de Poaceae, que podem ser domésticas ou silvestres.

Nos níveis associados aos fornos do séc. II d.C., os vestígios carpológicos também não são muito abundantes. No nível de destruição da abóbada do forno de cerâmica foi encontrada a única unidade de centeio (Secale cereale) e na fossa em frente a este forno recuperaram-se dois outros fragmentos de grãos da mesma espécie. De resto, além de três grãos de trigo neste mesmo forno, surgem escassos fragmentos de cereais (Triticeae) em mau estado de preservação nos três fornos. Escassas sementes/frutos de silvestres ruderais ou daninhas foram recolhidos nos três fornos, devendo representar no mínimo 11 espécies diferentes. As Malva sp. são as que surgem num maior número de contextos, seguidas dos Rumex sp. e das gramíneas (Poaceae). O forno de metalurgia é aquele que apresenta maior quantidade de silvestres, devido à presença de 63 sementes de Hyoscyamus niger e 33 mericarpos de Malva nicaeensis. 
A presença de mericarpos possibilitou a identificação das malvas ao nível da espécie, o que torna esta amostra importante pois as sementes de Malva sp. são comuns noutras amostras.

\subsection{Olival da Santa (Alfândega da Fé)}

A escavação neste sítio revelou um edifício complexo, composto por vários compartimentos, incluindo um lagar associado à produção de vinho, cella vinaria e um tanque, assim como cerâmicas de armazenagem. A construção foi alvo de reformulações, associadas a dois momentos sequenciais de ocupação, balizados entre a segunda metade do séc. I d.C. e o período baixo imperial.

Foram analisadas 51 amostras de cronologias que vão desde o Alto Império até à Alta Idade Média. Só em 4 não foi registado o volume de sedimento, as restantes somavam $261 \mathrm{~L}$. Do período aqui analisado, foram recuperados vestígios carpológicos em 18 amostras de 15 u.e.:

- Fase Alto Imperial - um depósito (u.e. 165) associado a diferentes muros; três depósitos associados a níveis de circulação ou ao abandono dos mesmos (102, 103, 109); um nível de abandono (110) sobre os anteriormente mencionados; dois níveis de derrube $(152,1008)$, um piso (1023) e três níveis, sobrepostos entre si, do enchimento de uma fossa de um dolium (do topo para a base: 1041, 1043, 1045).

- Fase Baixo Imperial - dois depósitos associados ao abandono do local $(171,130)$, o preenchimento de uma vala de fundação de um muro desta fase (188) e o enchimento de uma fossa (149).

Foram recuperados 12 grãos de trigo-mole/duro e escassos fragmentos de cereais em mau estado nos níveis das duas fases, enquanto o depósito [165] da fase mais antiga forneceu o único grão de cevada desta jazida. De resto, em u.e. de ambas as fases foram recuperadas escassas sementes/frutos de espécies silvestres.

\subsection{Cemitério dos Mouros (Torre de Moncorvo)}

No Cemitério dos Mouros, na proximidade do sítio do Castelinho, foi identificado um conjunto de estruturas negativas (fossas e buracos de poste) e alinhamentos pétreos possivelmente relacionados com um edifício do séc. I d.C., que terá sido destruído durante as ocupações posteriores do sítio.

Foram estudadas 23 amostras de sedimento, mas só em sete, recolhidas em seis u.e. - num total de 52,5
$\mathrm{L}$ - foram recolhidos vestígios carpológicos. Cinco contextos apresentam uma cronologia Alto-Imperial (séc. I-III d.C.) um outro advém já de níveis dos séc. IV-V d.C. A u.e. 3046 corresponde ao enchimento de uma estrutura em caixa de época alto-imperial, enquanto as restantes cinco são enchimentos de igual número de fossas.

Os vestígios carpológicos são escassos. Foram encontrados raros grãos de trigo e cevada em mau estado de preservação (Tabela 2). As espécies silvestres são igualmente raras e devem corresponder a ervas daninhas.

\subsection{Olival do Poço da Barca (Torre de Moncorvo)} Os contextos arqueológicos verificados neste sítio do séc. I ou II d.C. estavam associados a uma unidade de produção de cerâmica - barreiro, área de preparação, lixeira e o forno. Além do forno, foram encontradas áreas de despejo de peças inutilizadas e detritos resultantes da sua utilização.

Em cinco u.e. foram recolhidas 6 pequenas amostras de sedimento, num total de 9,9 L. Os raros vestígios carpológicos advêm de uma amostra da u.e. 220 (nível de abandono com inclusões esporádicas de cerâmica de cobertura) e outra da u.e. 229 (depósito na base do forno e que se prolonga para o praefurnium). No total, foram encontradas três sementes identificáveis, de espécies silvestres (Tabela 2).

\section{CULTIVOS DE ÉPOCA ROMANA NO BAIXO SABOR: ENQUADRAMENTO REGIONAL}

Os vestígios carpológicos são quase sempre raros nos sítios estudados. A única exceção é a Quinta de Crestelos e, mesmo aí, só nos depósitos dos séc. I-II d.C. associados aos horrea encontramos grande quantidade de frutos e sementes. Aqui o trigo-mole/duro e o milho-miúdo são abundantes, encontrando-se igualmente cevada em diversos contextos. As azeitonas, uvas e favas são muito raras. As três favas deste sítio são as únicas leguminosas identificada em todo o vale, em sítios de época romana.

Nos restantes sítios surgem os mesmos cultivos com exceção da fava - mas em quantidades muito pequenas. Somente no Olival da Santa foram encontradas todas as espécies de cereais encontradas na Quinta de Crestelos o que poderá resultar do maior esforço de amostragem verificado neste sítio. Em alguns sítios, a escassez de dados não deverá ser 
alheia à natureza dos contextos analisados -e.g. no Olival do Poço da Barca só foi escavado um forno cerâmico - ou à pequena quantidade de amostras recolhidas. Ainda assim, a existência de várias quintas ou casais agrícolas fazia esperar uma presença mais visível de frutos/sementes de espécies domésticas. Não foi possível detetar qualquer padrão cronológico claro, dada a raridade dos frutos e sementes e o predomínio de contextos dos dois primeiros séculos após a viragem da Era. A generalidade dos cultivos foi encontrada em jazidas de cronologias anteriores no vale, como os horrea do final da Idade do Ferro do Castelinho (Seabra \& alii, 2020) e da Quinta de Crestelos (Tereso \& alii, 2018a) e as fossas da Idade do Bronze do Terraço das Laranjeiras (Jesus, Tereso \& Gaspar, 2020). O trigo-mole/ duro, o milho-miúdo e a cevada encontram-se no noroeste peninsular desde a Pré-história, mas a presença de centeio, mesmo em contextos romanos é rara. Como vimos, no Baixo Sabor surge em duas jazidas: um grão e dois fragmentos associados aos fornos dos séc. I-II d.C. da Quinta de Crestelos e um grão no derrube da abóbada de um forno do séc. II d.C. no Cabeço da Grincha. Ainda que tenham sido datados grãos de centeio do séc. I a.C. no Crastoeiro (Mondim de Basto) (Seabra \& alii, 2018), este cereal parece ter-se tornado mais frequente na agricultura da região noroeste a partir do Baixo-Império. $\mathrm{Na}$ Quinta de Crestelos, surgem em níveis do séc. V d.C. e posteriores (Tereso \& alii, 2018c), exatamente no mesmo sector dos fornos aqui analisados, pelo que não se pode excluir a existência de perturbações. Só datações de radiocarbono poderão esclarecer a cronologia dos raros grãos descobertos nestes dois sítios, em níveis aparentemente alto-imperiais. As sementes de plantas silvestres, várias delas daninhas de cultivos, são também escassas e não fornecem dados relevantes acerca das estratégias agrícolas. A presença de milho-miúdo atesta a existência de cultivos de Primavera; os restantes cereais, ainda que sendo normalmente cultivos de Inverno, podem ser adaptados a ciclos de vida curtos de Primavera-Verão. Salienta-se a ausência de inflorescências de cereais em quase todos os sítios, o que, juntamente com a escassez de daninhas, pode indicar que os cereais entravam nos locais já processados, o que não é surpreendente considerando o amplo predomínio de trigos de grão nu. Considerando diversos exemplos etnográficos (e.g. Hillman, 1985), o processamento destes produz facilmente grão limpo e poderia ocorrer em eiras afastadas dos locais de habitação. Problemas de amostragem não podem, porém, ser excluídos. Escassos fragmentos de aristas e ráquis foram encontrados na Quinta de Crestelos, mas se isto resulta do maior esforço de amostragem neste sítio ou numa diferença de outro tipo é difícil de avaliar (ver discussão abaixo).

No que respeita às uvas e azeitonas, os vestígios são raros. Foram encontradas grainhas na Foz da Ribeira do Poio (7) e em Chã (5), assim como na Quinta de Crestelos (5). Caroços de azeitona foram recuperados na Quinta de Crestelos (8) e Foz da Ribeira do Poio (1 frag.). Enquanto os vestígios de azeitonas são raros no noroeste peninsular, as grainhas surgem em diversos sítios da Idade do Ferro e Época Romana, sempre em pequenas quantidades (Tereso, 2012; Tereso, Ramil-Rego \& Almeida-da-Silva, 2013), incluindo no sítio do Castelinho (séc. II-I a.C.) (Seabra \& alii, 2020) e Terraço das Laranjeiras (Bronze médio) (Jesus, Tereso \& Gaspar, 2020) no Baixo Sabor. A principal diferença dos resultados obtidos no Baixo Sabor face ao registo arqueobotânico conhecido para o noroeste peninsular encontra-se na ausência de trigos de grão vestido - Triticum aestivum subsp. spelta e Triticum turgidum subsp. dicoccum - comuns em jazidas romanas e da Idade do Ferro de outras áreas, especialmente mais a Oeste (Tereso, 2012; Tereso \& alii, 2013; Seabra \& alii, 2018; Teira-Brión, 2019). Esta ausência havia já sido notada nas jazidas de períodos anteriores, tais como o Castelinho, Quinta de Crestelos e Terraço das Laranjeiras, onde os vestígios carpológicos são abundantes. Neste sentido, as preferências das comunidades que habitaram o Baixo Sabor em Época Romana, a nível cerealífero, demonstram, até à introdução do centeio, uma continuidade desde a Idade do Bronze. As razões das diferenças face à área castreja, a Oeste, não são claras. Por um lado, a parte terminal do vale do Sabor insere-se numa área biogeográfica de fácies mediterrânica, enquanto a maior parte da área castreja encontra-se no limite sul da área Eurosiberiana, de clima atlântico e perfil acidentado, particularmente propícia ao cultivo de trigos vestidos, em especial de espelta, adequado para ambientes húmidos de montanha. Os trigos mole e duro preferem solos mais férteis e terrenos soalheiros. Por outro lado, o Baixo Sabor insere-se numa área cultural distinta, território dos Banienses (Lemos, 1993; Garibo Bodí \& Pereira, 2014), onde se verificam influências evidentes da atual Meseta espanhola. Embora haja 
poucos dados carpológicos que sirvam de comparação, em especial nas áreas próximas ao atual território português, os trigos de grão nu parecem ser dominantes nas áreas do médio e alto Douro - território de Vaceus - desde tempos pré-romanos (Delibes de Castro \& alii, 1995).

Deste modo, questões de âmbito ambiental ou cultural de amplo espectro cronológico poderão justificar a ausência de trigos de grão vestido e o predomínio de trigo-mole/duro. Ainda assim, o predomínio de trigo espelta noutros sítios da região tornam a situação complexa, ainda que não inviabilizem as interpretações acima apresentadas: nos níveis do final da Idade do Ferro/ início de Época Romana do Crasto de Palheiros (Murça) (Figueiral, Sanches \& Cardoso, 2017; Leite, Tereso \& Sanches, 2018), c. 40 $\mathrm{km}$ a oeste, no território de um grupo étnico com nome desconhecido (Garibo Bodí \& Pereira, 2014); nos níveis baixo-imperiais da Terronha de Pinhovelo (Macedo de Cavaleiros) (Tereso, 2009), c. $33 \mathrm{~km} \mathrm{a}$ norte, na transição para a Terra Fria Transmontana, em território dos Zoelae. Seja como for, os dados são ainda escassos para estabelecer uma relação entre o espaço de um grupo humano específico e determinadas escolhas a nível agrícola. Na verdade, a hipótese de o registo carpológico do Baixo Sabor traduzir uma situação meramente local, ainda que diacrónica, adaptada aos solos e ambiente do fundo deste vale, não pode ser excluída. Só a realização de estudos arqueobotânicos em sítios coetâneos, nas áreas de planalto limítrofes ao Sabor, no vale da Vilariça e outras áreas, poderá ajudar a esclarecer esta questão.

\section{AGRICULTURA E POVOAMENTO NO BAIXO SABOR EM ÉPOCA ROMANA}

Os sítios de época romana amostrados no Baixo Sabor apresentam diferentes características (vide supra) e diferentes implantações. A parte terminal do vale do Sabor apresenta um perfil tendencialmente declivoso alternado por poucas áreas mais amplas, onde se concentram abundantes vestígios de ocupação humana, com diacronias por vezes alargadas, desde a Pré-história até à atualidade. É aqui que encontramos a Quinta de Crestelos e, noutra destas áreas, o Cemitério dos Mouros e o Olival do Poço da Barca que forneceram poucos dados carpológicos. A Quinta de Crestelos destaca-se pelos horrea dos séc. I-II d.C., que dão continuidade a estruturas semelhantes dos séc. II-I a.C., associados a abun- dantes cereais. Também em Chã e no Cemitério dos Mouros se verificam pré-existências da Idade do Ferro, porém, difíceis de interpretar devido à fraca preservação das suas estruturas. No último caso, admite-se uma relação com o próximo sítio do Castelinho, onde, à semelhança da Quinta de Crestelos, se destacam os abundantes horrea do final da Idade do Ferro, protegidos por uma imponente fortificação (Santos, 2015).

Por outro lado, contamos com um conjunto de pequenos estabelecimentos rurais romanos - quintas ou casais agrícolas - sem pré-existências e sem paralelos conhecidos no povoamento da Idade do Ferro da região. Alguns destes sítios parecem ter sido ocupados por períodos de tempo relativamente curtos, de 100 a 200 anos (Pereira \& alii, 2014), sendo possível até que alguns se tenham sucedido no tempoa Foz da Ribeira do Poio e o Vale da Bouça situam-se em margens opostas, mas próximos um do outro, sendo o primeiro ocupado entre a segunda metade do séc. I d.C. e o séc. II d.C., enquanto o segundo terá sido ocupado a partir do séc. II d.C..

A presença de tanques e/ou lagares, assim como dolia, sugere que a produção de vinho e/ou azeite teria alguma importância nestes sítios. Ao contrário da Quinta de Crestelos, nestas jazidas, os vestígios de cereais são sempre escassos. Em alguns casos, como vimos, não é possível compreender se esta escassez ou ausência se deve a problemas de amostragem ou se nestes sítios a produção de cereais teria pouco ou nenhum peso económico. Isto não equivale a dizer que os cereais não teriam peso na alimentação das pessoas que habitavam os locais. Mas, devemos ter em conta a premissa segundo a qual a presença de cereais (grãos e inflorescências) em depósitos dispersos nos sítios arqueológicos se deve à reutilização, como combustível, de resíduos de processamento pós-colheita (Hillman, 1981; van der Veen, 2007). Neste sentido, onde os cereais não eram processados ou eram processados em menor quantidade, é menos provável encontrar estes resíduos. Este cenário corrobora a interpretação destes pequenos estabelecimentos como locais especializados na produção de azeite e/ou vinho, sendo provavelmente estes os seus principais cultivos. Foram recuperados vestígios carpológicos de uvas e azeitonas em algumas destas jazidas, nomeadamente Foz da Ribeira do Poio e Chã, mas em pequena quantidade. Por outro lado, não podemos excluir a existência de problemas de preservação, i.e., de sobrevivência à combustão, 
no caso das grainhas, podendo conduzir à sua eventual sub-representação. A preservação em época romana e recuperação em escavação só pode ocorrer se estes resíduos tiverem sido submetidos ao fogo na área intervencionada, usualmente áreas residenciais ou com vestígios estruturais visíveis. Se os resíduos fossem descartados ou reutilizados em outros locais (e.g. adubando terrenos agrícolas), a sua recolha em escavação arqueológica seria improvável. Algum comportamento diferencial face a distintos resíduos - de cereais e de uvas - induziria interpretações erradas da nossa parte. Porém, não temos dados que possam avaliar esta possibilidade.

Quando comparamos os dados destes sítios com a Quinta de Crestelos, as diferenças são evidentes. Neste último sítio, os cereais e a sua armazenagem são elementos cruciais, contando o sítio com diversos horrea, alguns de grande dimensão, e abundantes grãos, em especial de trigo-mole/duro e milho-miúdo. Além disto, localiza-se junto a uma das poucas áreas onde o vale apresenta um perfil mais aberto, potenciando maior produção cerealífera e não só. Neste sítio, também foram encontradas estruturas e cerâmicas relacionadas com a produção e armazenagem de vinho ou azeite. Desta forma, a Quinta de Crestelos, pelo menos nos séc. I-II d.C., distinguir-se-ia da generalidade dos sítios por se tratar de um povoado, não uma quinta, e pela sua maior dimensão e complexidade estrutural. Do ponto de vista carpológico, apresenta diversas e abundantes produções agrícolas. Conta com grande capacidade de armazenagem de cereais e não só, traduzindo eventualmente uma maior escala de produção, ou um papel local relacionado com a armazenagem e distribuição ou comercialização dos bens, distinto do das pequenas quintas. Estas últimas poderiam ter uma produção mais especializada no vinho e/ ou azeite, para comércio local, contrabalançada com pequenas produções cerealíferas ou hortícolas para consumo próprio.

Ainda assim, mais uma vez salientamos as limitações de alguns dados. A grande área de escavação da Quinta de Crestelos contrasta com as intervenções mais localizadas de alguns dos pequenos sítios, ainda que estas últimas tenham sido dimensionadas aos vestígios encontrados à superfície. É possível que tenham restado por descobrir outros elementos estruturais nestes casais agrícolas, tal como é possível que nestes últimos se tenha optado por estratégias de armazenagem e processamento de cereais distintas das da Quinta de Crestelos, não potenciando a sua preservação até hoje. Por fim, a perspetiva que temos do povoamento local está condicionada pelo facto de as intervenções terem sido centradas nas áreas a afetar pela construção das barragens, restando por estudar grande parte das áreas acima da cota de inundação.

\section{CONCLUSÕES}

No Baixo Sabor, passamos de um povoamento concentrado, na $2^{\underline{a}}$ Idade do Ferro, para um povoamento disperso em pequenas quintas e casais, em especial na segunda metade do séc. I d.C. Seriam locais interligados entre si e alguns dos sítios pequenos não terão durado mais de dois séculos (Garibo Bodí \& Pereira, 2014; Pereira \& alii, 2014). Neste período, terá existido no Baixo Sabor uma agricultura diversificada, mas com principal incidência na produção de cereais - em especial trigo-mole e/ou trigo-duro e o milho-miúdo - e de vinho e/ou azeite. Embora a produção cerealífera esteja bem atestada no registo carpológico, principalmente da Quinta de Crestelos, o cultivo de oliveiras ou vinha deixou poucas evidências botânicas, restando, porém, tanques e lagares em diversas pequenas quintas ou casais.

Encontramos um padrão diacrónico no vale, desde a Pré-história recente ao Período Romano, nomeadamente o predomínio de trigos de grão nu face aos trigos de grão vestido, muitos abundantes nos sítios do noroeste peninsular, sendo possível que este padrão resulte de especificidades ambientais e/ou culturais. Infelizmente, a escassez de dados nas regiões limítrofes torna difícil um enquadramento mais amplo dos dados arqueobotânicos do Baixo Sabor. Por outro lado, são necessárias outras perspetivas, mais integradoras do registo arqueológico nesta área de estudo, que cruzem os dados carpológicos com a componente artefactual e mesmo com as dinâmicas estruturais dos sítios analisados. Só assim, as dinâmicas locais ao nível agrícola poderão vir a ser melhor compreendidas.

\section{AGRADECIMENTOS}

Filipe Santos coordenou os trabalhos realizados em Cilhades, Sérgio Pereira coordenou nos restantes sítios romanizados, ambos ao serviço do Baixo Sabor, ACE.

João Tereso coordenou os estudos arqueobotânicos, 
suportado inicialmente pela Faculdade de Ciências da Universidade do Porto (FCUP) e depois pela Fundação para a Ciência e Tecnologia. Filipe Vaz e Luís Seabra realizaram parte dos estudos arqueobotânicos, suportados pela FCUP.

Os seguintes investigadores colaboraram no trabalho laboratorial de carpologia: Ana Jesus, Ginevra Coradeschi, Inês Oliveira Martins, Joana Leite (triagem e identificação), Ana Cláudia Oliveira, Ana Paula Senra Portela, Cristiana Maia Alves (triagem). António Carvalho, Joan Garibo e Helder Carvalho foram responsáveis pelas flutuações das amostras recolhidas em sítios romanizados, ao serviço do Baixo Sabor, ACE.

Agradecemos ainda aos arqueólogos que coordenaram as intervenções em cada um dos sítios referidos, nas campanhas/áreas referidas neste texto: Bruno Silva e José Pereira (C. da Grincha); Rosa Mateos e Hugo Gomes (F. Rib. do Poio); Rosa Mateos e Pedro Costa (V. da Bouça); José Pereira (Chã); Susana Cosme, João Nisa, Javier Larrazabal, José Pereira, Rosa Mateos, Israel Espi e César Neves (Q. de Crestelos); Filipe Pinto e Gabriel Pereira (O. da Santa); Sandra dos Santos (C. dos Mouros); José Pereira (O. do P. da Barca).

\section{BIBLIOGRAFIA}

BERGGREN, Greta (1981) - Atlas of seeds and small fruits of Northwest European plant species with morphological descriptions 3-Salicaceae-Cruciferae. Stockholm: Swedish Museum of Natural History.

DELIBES DE CASTRO, Germán; ROMERO CARNICERO, Fernando; ESCUDERO NAVARRO, Zoa; SANZ MÍNGUEZ, Carlos; SAN MIGUEL MATÉ, Luis Carlos; MARISCAL ÁLVAREZ, Blanca; CUBERO CORPAS, Carmen; UZQUIANO OLLERO, Paloma; MORALES MUÑIZ, Arturo; LIESAU VON LETTOW-VORBECK, Corina, CALONGE CANO, GUILLERMO (1995) - El medio ambiente durante el primer milenio a.C. en el valle medio del Duero. Consideraciones finales. In DELIBES DE CASTRO, Germán; ROMERO CARNICERO, Fernando; MORALES MUNIIZ, Arturo, eds. - Arqueología y Medio ambiente: el primer milenio a. C. en el Duero medio. Valladolid: Junta de Castilla y León, Consejería de Cultura y Turismo, pp. 543-582.

FIGUEIRAL, Isabel; SANCHES, Maria de Jesus; CARDOSO, João (2017) - Crasto de Palheiros (Murça, NE Portugal, $3^{\text {rd }}-1^{\text {st }}$ millennium BC): from archaeological remains to ordinary life. Estudos do Quaternário. Braga. 17, pp. 13-28.

GARIBO BODÍ, Joan; PEREIRA, Sérgio Simões (2014) - A civitas dos banienses: em torno da sua implantação e territorium, In MARTÍNEZ CABALLERO, Santiago; CABAÑERO
MARTÍN, Victor Manuel; MERINO BELLIDO, Carlos, eds. - Arqueologia en el Valle del Duero, del Paleolítico a la Edad Media: Actas de las IV jornadas de jóvenes investigadores del valle del Duero, Segovia, 2O,21 y 22 de noviembre de 2014. Valladolid: Glyphos Publicaciones, pp. 532-557.

HILLMAN, Gordon (1981) - Reconstructing crops husbandry practices from charred remains of crops. In MERCER, Robert, ed. - Farming practice in British Prehistory. Edinburgh: Edinburgh University Press, pp. 123-162.

HILLMAN, Gordon (1985) - Traditional husbandry and processing of archaic cereals in recent times: the operations, products and equipment that might feature in Sumerian texts. Part II: the free-threshing cereals. Bulletin of Sumerian Agriculture. Cambridge. 2, pp. 1-32.

JESUS, Ana; TERESO, João Pedro; GASPAR, Rita (2020) - Interpretative trajectories towards the understanding of negative features using Terraço das Laranjeiras Bronze Age site as a case study. Journal of Archaeological Science: Reports. 30:102222.

LEITE, Margarida Leite; TERESO, João Pedro; SANCHES, Maria de Jesus (2018) - Cultivos da Idade do Ferro no Crasto de Palheiros: novos dados carpológicos da Plataforma Inferior Leste. Cadernos do GEEvH. 7:2, pp. 40-68.

LEMOS, Francisco de Sande (1993) - O Povoamento Romano de Trás-os-Montes Oriental. Braga: Tese de doutoramento apresentada à Universidade do Minho.

MARTÍN-SEIJO, María; TERESO, João Pedro; VAZ, Filipe Costa; GASPAR, Rita; RODRÍGUEZ RELLÁN, Carlos (2017) - Early-Middle Bronze Age communities and wood resources management in northeast Portugal: The Sabor valley. Quaternary International. 458, pp. 28-43.

PEÑA-CHOCARRO, Leonor; PÉREZ-JORDÀ, Guillem; ALONSO, Natàlia; ANTOLÍN, Ferran; TEIRA-BRIÓN, Andrés; TERESO, João Pedro; MONTES MOYA, Eva María; LÓPEZ REYES, Daniel (2019) - Roman and medieval crops in the Iberian Peninsula: A first overview of seeds and fruits from archaeological sites. Quaternary International. 499: Part A, pp. 49-66.

PEREIRA, Sérgio Simões; SILVA, Bruno; LARRAZABAL, Javier; GARIBO, Joan; NISA, João; PEREIRA, José António; MATEOS, Rosa; COSME, Susana (2014) - A romanização no vale do Sabor: de Meirinhos a Remondes (Mogadouro). In DINIS, António Pereira, ed. - I Encontro de Arqueologia de Mogadouro. Mogadouro: Município de Mogadouro, pp. 95-143.

SANTOS, Filipe (2015) - Arquitecturas da II Idade do Ferro. A evolução do sistema defensivo do sítio fortificado do Castelinho (Cilhades, Felgar, Portugal). In RODRÍGUEZ MONTERRUBIO, Óscar; PORTILLA CASADO, Raquel; SASTRE-BLANCO, José; FUENTES MELGAR, Patrícia, eds. - Fortificaciones de la Edad del Hierro: control de los recursos y el territorio. Valladolid: Glyphos Publicaciones, pp. 242-276. 
SEABRA, Luís; SANTOS, Filipe; VAZ, Filipe Costa; LEITE, Joana; TERESO, João Pedro (2020) - Crops behind closed walls: Fortified storage at Castelinho in the Late Iron Age of NW Iberia. Journal of Archaeological Science: Reports. 30:102200.

SEABRA, Luís; TERESO, João Pedro; BETTENCOURT, Ana M.S.; DINIS, António (2018) - Crop diversity and storage structures in the settlement of Crastoeiro (Northwest Iberia): new approaches. Trabajos de Prehistoria. 75:2, pp. 361-378.

TEIRA-BRIÓN, Andrés (2019) - Cambio e resiliencia na agricultura exestión de recursos vexetais no NW da Península Ibérica (10oo a.n.e.-40o d.n.e.). Santiago de Compostela: Tese de doutoramento apresentada à Faculdade de Xeografía e Historia da Universidade de Santiago de Compostela.

TERESO, João Pedro (2009) - Plant macrofossils from the Roman settlement of Terronha de Pinhovelo, northwest Iberia. Vegetation History and Archaeobotany. 18, pp.489-501.

TERESO, João Pedro (2012) - Environmental Change, Agricultural Development and social trends in NW Iberia from the Late Prehistory To The Late Antiquity. Porto: Tese de doutoramento apresentada à Faculdade de Ciências da Universidade do Porto.

TERESO, João Pedro; RAMIL-REGO, Pablo; ALMEIDA-DA-SILVA, Rubim (2013) - Roman agriculture in the conventus Bracaraugustanus (NW Iberia). Journal of Archaeological Science. 4 O, pp. 2848-2858.

TERESO, João Pedro; RAMIL-REGO, Pablo; ÁlVAREZ GONZÁLEZ, Yolanda, LÓPEZ GONZÁlEZ, Luis, ALMEIDA-DA-SILVA, Rubim (2013) - Massive storage in As Laias/O Castelo (Ourense, NW Spain) from the Late Bronze Age/Iron Age transition to the Roman period: a palaeoethnobotanical approach. Journal of Archaeological Science. 40, 3865-3877.

TERESO, João Pedro; VAZ, Filipe Costa; JESUS, Ana; PEREIRA, Sérgio; ESPÍ, Israel; SASTRE-BLANCO, José (2018a) - Os horrea na Quinta de Crestelos (Mogadouro) na Idade do Ferro e Romanização: dados arqueobotânicos sobre armazenagem e construção. Cadernos do GEEvH. 7:2, pp. 95-137.

TERESO, João Pedro; VAZ, Filipe Costa; PEREIRA, Sérgio; MATEOS, Rosa; PEREIRA, José António (2018b) - Recursos vegetais num sítio rural: dados arqueobotânicos no sítio Romano da Foz da Ribeira do Poio (Mogadouro, Nordeste de Portugal). In ROQUE, Ana; MELO, Cristina; AMORIM, Inês; FREITAS, Joana; TORRÃO, Maria, eds. - Alterações Ambientais em Perspetiva Histórica. Porto: CITCEM, pp. 149-179.

TERESO, João Pedro; VAZ, Filipe Costa; SEABRA, Luís; COSME, Susana; PEREIRA, Sérgio Simões (2018c) - Os níveis medievais do sitio de Quinta de Crestelos (Mogadouro): agricultura e paisagem. Arqueologia Medieval. Porto. 14, pp. 75-91.
VAN DER VEEN, Marijke (2007) - Formation processes of desiccated and carbonized plant remains e the identification of routine practice. Journal of Archaeological Science. 34, pp. 968-99o.

VAZ, Filipe Costa, TERESO, João Pedro; MARTÍN-SEIJO, María; PEREIRA, Sérgio Simões; GASPAR, Rita, SEABRA, Luís; SASTRE-BLANCO, José (2017) - Iron Age ovens and hearths from the hilltop of Quinta de Crestelos, Sabor Valley (NE Portugal): An archaeobotanical approach on typology, functionality and firewood use. Quaternary International. 458 , pp. $75-93$.

VAZ, Filipe Costa; TERESO, João Pedro; PEREIRA, José António; PEREIRA, Sérgio Simões (2016) - O potencial interpretativo de contextos secundários e terciários: o caso do estudo arqueobotânico de Chã (Alfândega da Fé). Cadernos do GEEvH. 5:1, pp. 7-28. 


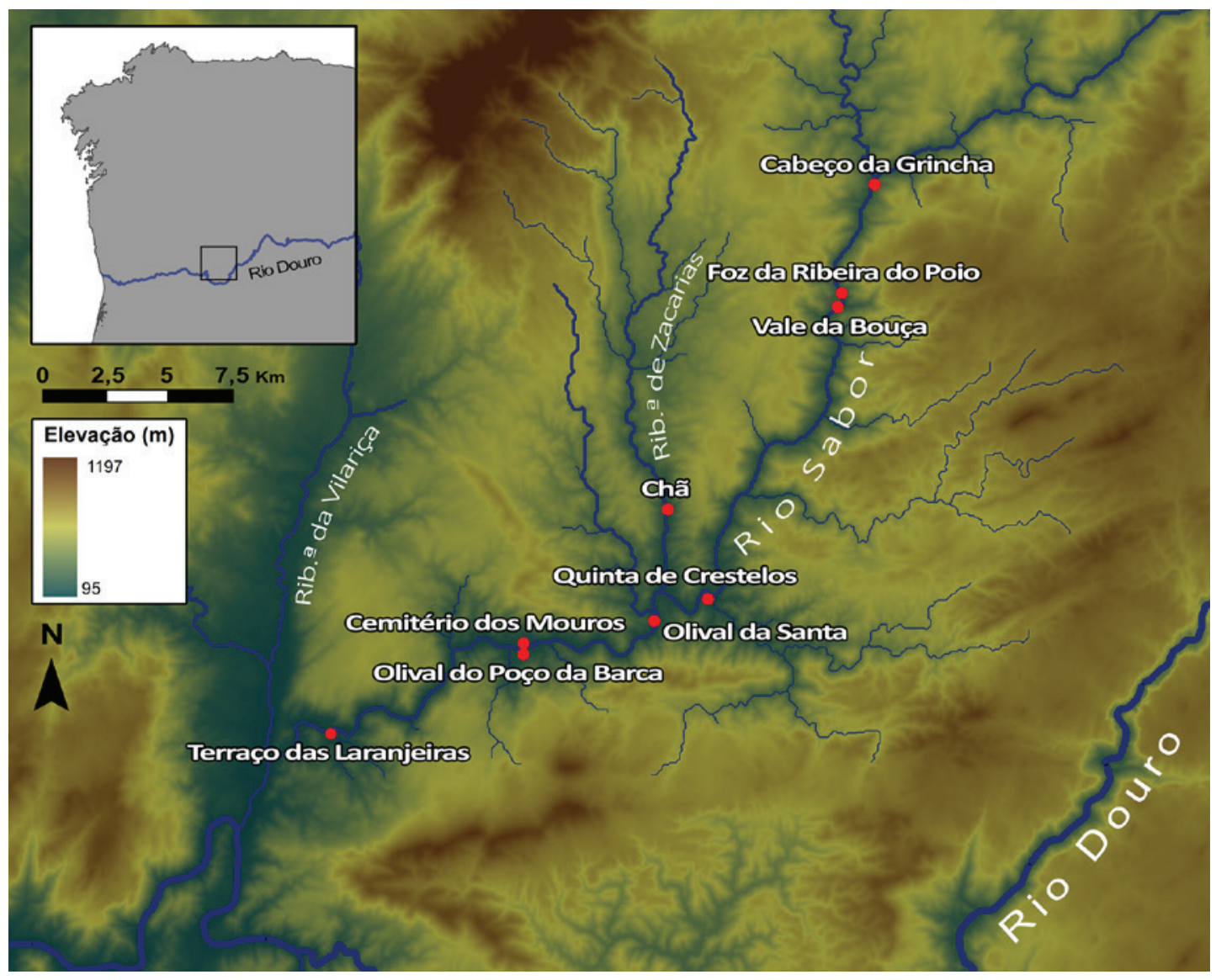

Figura 1 - Localização dos sítios analisados. 


\begin{tabular}{|c|c|c|c|c|c|c|c|c|c|c|c|c|c|c|}
\hline & \multicolumn{8}{|c|}{ Plataforma inferior } & \multirow{2}{*}{\multicolumn{5}{|c|}{$\begin{array}{c}\text { Crista } \\
\text { I - II d.C }\end{array}$}} & \\
\hline & \begin{tabular}{|l|} 
I a.C.- \\
I d.C.
\end{tabular} & \multicolumn{7}{|c|}{ I - II d.C. } & & & & & & \\
\hline & \multirow{2}{*}{$\begin{array}{c}\text { Fossa } \\
\mathbf{1}\end{array}$} & \multirow{2}{*}{$\begin{array}{c}\text { Forno } \\
1\end{array}$} & \multicolumn{2}{|c|}{ Forno 2} & \multicolumn{3}{|c|}{ Forno 3} & \multirow{2}{*}{ Fossa } & \multicolumn{4}{|c|}{ Horrea } & \multirow{2}{*}{ U.E. 1348} & \\
\hline & & & Int. & Ext. & Int. & Abóbada & Aband. & & 4 & 6 & 7 & 8 & & Total \\
\hline \multicolumn{15}{|l|}{ Cereais (grão) } \\
\hline Hordeum vulgare & & & & & & & & & 1 & $/ 1$ & $22 / 9$ & & $33 / 39$ & $56 / 49$ \\
\hline Panicum miliaceum & & & & & & & & & & $2 / 1$ & $10 / 5$ & 5 & $4710 / 2460$ & $4727 / 2466$ \\
\hline Panicoideae & & & & & & & 1 & & & & & 1 & 111 & 113 \\
\hline Secale cereale & & & & & & 1 & & $/ 2$ & & & & & & $1 / 2$ \\
\hline $\begin{array}{l}\text { Triticum aestivum/ } \\
\text { durum }\end{array}$ & 2 & & & & & & $3 / 1$ & & $4 / 3$ & $182 / 29$ & $663 / 135$ & $\begin{array}{l}28 \\
/ 9\end{array}$ & $3843 / 255$ & $4725 / 432$ \\
\hline $\begin{array}{l}\text { T. aestivum/durum } \\
\text { (frag. longitudinal) }\end{array}$ & & & & & & & & & 3 & 87 & 290 & 13 & 513 & 906 \\
\hline Triticum sp. & & & & & & & 1 & 1 & & & & & & 2 \\
\hline Triticeae & & & & & & & $3 / 19$ & $1 / 5$ & $1 / 11$ & $23 / 271$ & $58 / 1121$ & $3 / 28$ & $477 / 1039$ & $566 / 2520$ \\
\hline $\begin{array}{l}\text { Triticeae (escutelo / } \\
\text { embrião) }\end{array}$ & & & & & & & 1 & & & 15 & 36 & & $223 / 4$ & $275 / 4$ \\
\hline \multicolumn{15}{|l|}{ Outros cultivos } \\
\hline $\begin{array}{l}\text { Olea europaea } \\
\text { (endocarpo) }\end{array}$ & & & & & & & & & & $/ 1$ & $8 / 4$ & & & $8 / 5$ \\
\hline Vicia faba (semente) & & & & & & & & & & $2 / 8$ & & & 1 & $3 / 8$ \\
\hline Vitis vinifera (semente) & & & & & & & & & & & 5 & & & 5 \\
\hline \multicolumn{15}{|l|}{ Silvestres } \\
\hline Allium sp. (semente) & & & & & & & & & & & $4 / 2$ & & & $4 / 2$ \\
\hline Asteraceae (aquénio) & & & & & & & & & & & $7 / 4$ & & & $7 / 4$ \\
\hline $\begin{array}{l}\text { Asterolinon linum- } \\
\text { stellatum (semente) }\end{array}$ & & & & & & & & & & 1 & & & & 1 \\
\hline Briófita & & & & & & 1 & & & & & & & & 1 \\
\hline $\begin{array}{l}\text { Caryophyllaceae } \\
\text { (semente) }\end{array}$ & & & & & & & 1 & & & & & & 9 & 10 \\
\hline $\begin{array}{l}\text { Chenopodiaceae } \\
\text { (semente) }\end{array}$ & & & & $/ 3$ & & & & & & & & & & $/ 3$ \\
\hline $\begin{array}{l}\text { Chenopodium } \\
\text { sp.(semente) }\end{array}$ & & 2 & & 1 & 1 & & & & & & & & & 4 \\
\hline Cistus ladanifer (cápsula) & & $/ 2$ & & & & & & & & & $/ 26$ & & & $/ 28$ \\
\hline Fabaceae (semente) & & & & & & & 1 & & 1 & & & & & 2 \\
\hline $\begin{array}{l}\text { Hyoscyamus niger } \\
\text { (semente) }\end{array}$ & & $63 / 46$ & & & & & & & & & & & & $63 / 46$ \\
\hline Lolium/Festuca (grão) & & & & & & & & & & 2 & $3 / 1$ & & $/ 4$ & $5 / 4$ \\
\hline $\begin{array}{l}\text { Malva nicaeensis } \\
\text { (mericarpo) }\end{array}$ & & 33 & & & & & & & & & & & & 33 \\
\hline Malva sp. (semente) & $1 / 1$ & $3 / 6$ & $2 / 1$ & 1 & 2 & $6 / 2$ & $7 / 1$ & & & 1 & $/ 1$ & & & $23 / 12$ \\
\hline $\begin{array}{l}\text { Medicago tipo } \\
\text { polymorpha (semente) }\end{array}$ & & & & & & 1 & & & & & & & & 1 \\
\hline $\begin{array}{l}\text { Ornithopus sp. (seg. } \\
\text { lomento) }\end{array}$ & & & & & & & & & & & 1 & & 1 & 2 \\
\hline Poaceae (frag. caule) & & & & & 1 & & & & & & & & & 1 \\
\hline Poaceae (frag. arista) & 4 & & & & 1 & & 2 & & & 1 & 2 & & & 10 \\
\hline Poaceae (grão) & & 1 & & & & 1 & $5 / 3$ & & & $3 / 1$ & $2 / 3$ & & $30 / 13$ & $42 / 21$ \\
\hline Poaceae (frag. ráquis) & & & & & & & 2 & & & & & & & 2 \\
\hline $\begin{array}{l}\text { Portulaca oleraceae } \\
\text { (semente) }\end{array}$ & & & & & & 1 & & & & & & & & 1 \\
\hline $\begin{array}{l}\text { Potentilla/Fragaria } \\
\text { (aquénio) }\end{array}$ & & & & 1 & & & & & & & & & & 1 \\
\hline Rumexsp. (aquénio) & & & & 1 & & 1 & 2 & & & & & & & 4 \\
\hline $\begin{array}{l}\text { Rumexcrispus/ } \\
\text { obtusifolius (aquénio) }\end{array}$ & & & 4 & & & 2 & & & & & & & & 6 \\
\hline $\begin{array}{l}\text { Sherardia arvensis } \\
\text { (mericarpo) }\end{array}$ & & & & & & & & & & & 1 & & & 1 \\
\hline Vicia/Lathyrus (semente) & & 1 & & & & & & & & & 2 & & & 3 \\
\hline Indeterminado & 37 & 149 & 4 & 20 & 3 & 10 & 32 & 36 & 30 & $1 / 1129$ & 4465 & 95 & $17 / 19987$ & $18 / 25997$ \\
\hline
\end{tabular}

Tabela 1 - Quinta de Crestelos: síntese de dados carpológicos (unidades / fragmentos) 


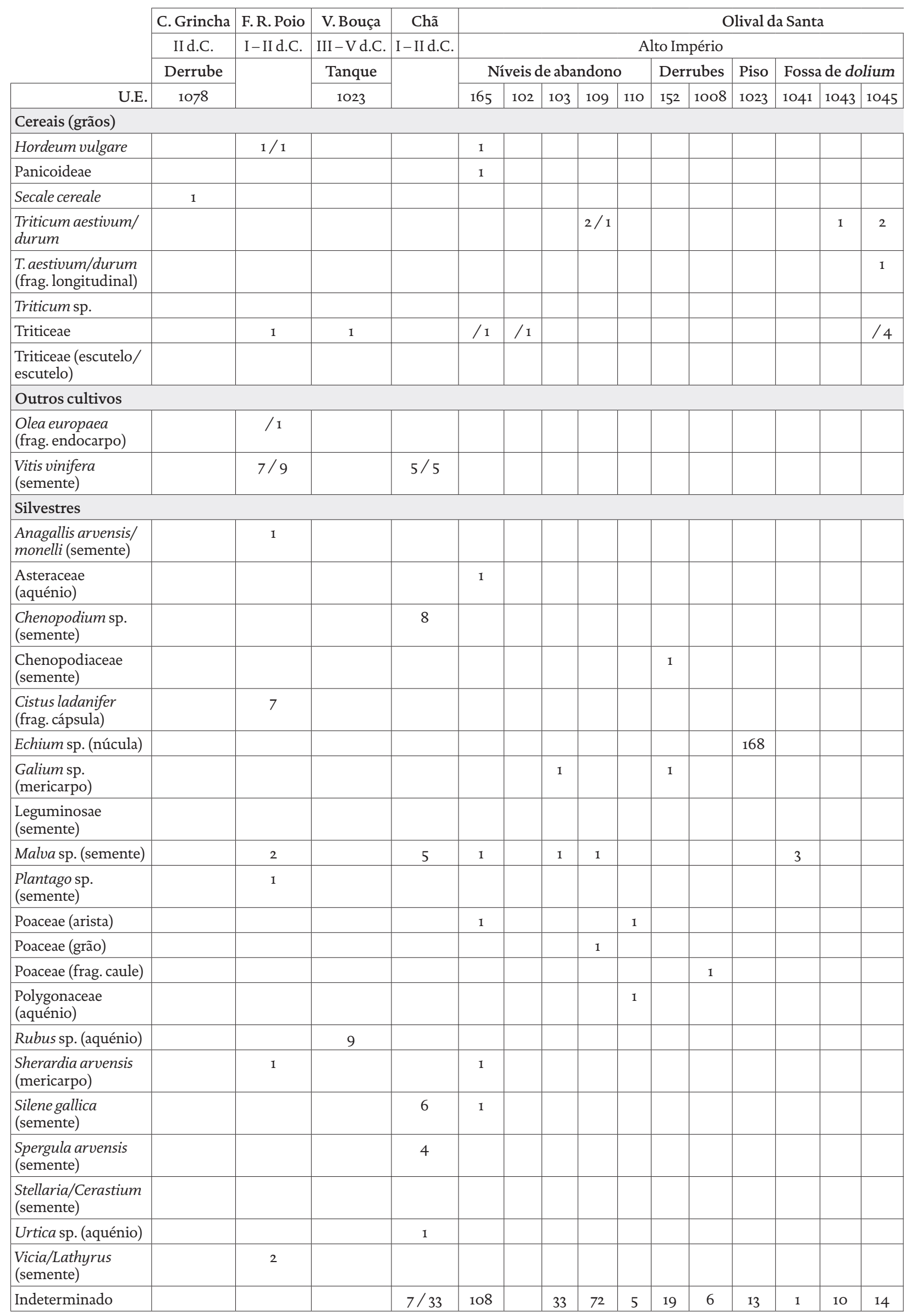

Tabela 2 - Dados carpológicos dos sítios romanos (unidades / fragmentos). 


\begin{tabular}{|c|c|c|c|c|c|c|c|c|c|c|c|c|c|}
\hline \multirow[b]{4}{*}{ U.E. } & \multirow{2}{*}{\multicolumn{4}{|c|}{$\begin{array}{c}\text { Olival da Santa } \\
\text { Baixo Império } \\
\end{array}$}} & \multicolumn{7}{|c|}{ Cemitério dos Mouros } & \multirow{4}{*}{$\begin{array}{c}\text { O.P. Barca } \\
\text { I- II d.C. } \\
\text { Abandono } \\
\end{array}$} & \multirow[b]{4}{*}{ Total } \\
\hline & & & & & \multicolumn{5}{|c|}{ I-III d.C. } & \multirow{2}{*}{\multicolumn{2}{|c|}{ IV-V }} & & \\
\hline & \multicolumn{2}{|c|}{ Abandono } & \multirow{2}{*}{$\begin{array}{l}\text { Vala } \\
188 \\
\end{array}$} & \multirow{2}{*}{\begin{tabular}{|c|} 
Fossa \\
149 \\
\end{tabular}} & \multirow{2}{*}{$\begin{array}{l}\text { Cista } \\
3046 \\
\end{array}$} & \multicolumn{4}{|c|}{ Fossas } & & & & \\
\hline & 130 & 171 & & & & 2043 & 2047 & 4041 & 2034 & 3045 & 3045 & & \\
\hline \multicolumn{14}{|l|}{ Cereais (grãos) } \\
\hline Hordeum vulgare & & & & & & & $/ 1$ & & & & $/ 1$ & & $2 / 3$ \\
\hline Panicoideae & & & & & & & & & & & & & 1 \\
\hline Secale cereale & & & & & & & & & & & & & 1 \\
\hline $\begin{array}{l}\text { Triticum aestivum/ } \\
\text { durum }\end{array}$ & & 1 & 6 & $/ 2$ & & & & & & & & & $12 / 3$ \\
\hline $\begin{array}{l}\text { T. aestivum/durum } \\
\text { (frag. longitudinal) }\end{array}$ & & & & & & & & & & & & & 1 \\
\hline Triticum sp. & & & & & & & & 1 & & & & & 1 \\
\hline Triticeae & & $/ 2$ & $2 / 1$ & $/ 5$ & 1 & & $/ 1$ & $/ 2$ & & & 2 & & $7 / 20$ \\
\hline $\begin{array}{l}\text { Triticeae (escutelo/ } \\
\text { escutelo) }\end{array}$ & & 1 & $/ 1$ & & & & & & & & & & $1 / 1$ \\
\hline \multicolumn{14}{|l|}{ Outros cultivos } \\
\hline $\begin{array}{l}\text { Olea europaea } \\
\text { (frag. endocarpo) }\end{array}$ & & & & & & & & & & & & & 1 \\
\hline $\begin{array}{l}\text { Vitis vinifera } \\
\text { (semente) }\end{array}$ & & & & & & & & & & & & & $12 / 14$ \\
\hline \multicolumn{14}{|l|}{ Silvestres } \\
\hline $\begin{array}{l}\text { Anagallis arvensis/ } \\
\text { monelli (semente) }\end{array}$ & & & & & & & & & & & & & 1 \\
\hline $\begin{array}{l}\text { Asteraceae } \\
\text { (aquénio) }\end{array}$ & & & & & & & & & & & & & 1 \\
\hline $\begin{array}{l}\text { Chenopodium sp. } \\
\text { (semente) }\end{array}$ & & & & & & & & & & & & & 8 \\
\hline $\begin{array}{l}\text { Chenopodiaceae } \\
\text { (semente) }\end{array}$ & & & & & & & & & & & & & 1 \\
\hline $\begin{array}{l}\text { Cistus ladanifer } \\
\text { (frag. cápsula) }\end{array}$ & & & & & & & & & & & & & 7 \\
\hline Echium sp. (núcula) & & & & & & & & & & & & & 168 \\
\hline $\begin{array}{l}\text { Galium sp. } \\
\text { (mericarpo) }\end{array}$ & & & & & & & & & & 1 & & & 3 \\
\hline $\begin{array}{l}\text { Leguminosae } \\
\text { (semente) }\end{array}$ & & & & & & & & 1 & 1 & 1 & & & 3 \\
\hline Malva sp. (semente) & & 1 & 1 & 1 & & & & & & & & & 16 \\
\hline $\begin{array}{l}\text { Plantago sp. } \\
\text { (semente) }\end{array}$ & & & & & & & & & & & & & 1 \\
\hline Poaceae (arista) & 4 & & & & & 1 & & & & & & & 7 \\
\hline Poaceae (grão) & & & & & & & & 1 & & & & & 2 \\
\hline Poaceae (frag. caule) & & & & & & & & & & & & & 1 \\
\hline $\begin{array}{l}\text { Polygonaceae } \\
\text { (aquénio) }\end{array}$ & & & & 1 & & & & & & & & & 2 \\
\hline Rubus sp. (aquénio) & & & & & & & & & & & & & 9 \\
\hline $\begin{array}{l}\text { Sherardia arvensis } \\
\text { (mericarpo) }\end{array}$ & & & & & & & & & & & & 1 & 3 \\
\hline $\begin{array}{l}\text { Silene gallica } \\
\text { (semente) }\end{array}$ & & & & & & & & & & & & & 7 \\
\hline $\begin{array}{l}\text { Spergula arvensis } \\
\text { (semente) }\end{array}$ & & & & & & & & & & & & & 4 \\
\hline $\begin{array}{l}\text { Stellaria/Cerastium } \\
\text { (semente) }\end{array}$ & & & & & & & & 1 & & & & & 1 \\
\hline Urtica sp. (aquénio) & & & & & & & & & & & & & 1 \\
\hline $\begin{array}{l}\text { Vicia/Lathyrus } \\
\text { (semente) }\end{array}$ & & & & & & & & & & & & 2 & 4 \\
\hline Indeterminado & 3 & 16 & 34 & 104 & 1 & 1 & & & & & $1 / 2$ & 8 & $8 / 483$ \\
\hline
\end{tabular}

Tabela 2 (continuação) - Dados carpológicos dos sítios romanos (unidades / fragmentos). 


\title{
A CASA ROMANA NA HISPÂNIA: APLICAÇÃO DOS MODELOS ITÁLICOS NAS PROVÍNCIAS IBÉRICAS
}

\author{
Fernanda Magalhães ${ }^{1}$, Diego Machado², Manuela Martins ${ }^{3}$
}

\begin{abstract}
RESUMO
O modelo de casa itálica foi difundido desde os finais do século II a.C., a partir do Levante ibérico, expandindo-se progressivamente para os territórios do interior da Península Ibérica, acabando por se generalizar no contexto das novas fundações urbanas que terão lugar após o fim das guerras cantábricas. Assim, é possível constatar que, a partir de Augusto, as diferentes regiões da Hispânia vão conhecer um amplo processo de estandardização cultural das habitações urbanas de elite, em que se reconhece a disseminação de uma linguagem arquitetónica, bastante flexível, que tira partido de um léxico de formas, originariamente desenvolvido em Itália, ainda que alguns dos seus traços remontem às tradições helenísticas do Oriente. Inicia-se um processo sem precedentes de ampla estandardização cultural.
\end{abstract}

Palavras-chave: Hispânia, Arquitetura privada, Domus, Vida quotidiana.

\begin{abstract}
The model of the italic house was spread since the end of the 2 st century BC, from the Iberian Levant, gradually expanding into the territories of the interior of the Iberian Peninsula, eventually becoming generalized in the context of the new urban foundations that will take place after the end of the Cantabrian wars. Thus, it is possible to verify that, from Augustus, the different regions of Hispania will know a broad process of cultural standardization of elite urban dwellings, in which the dissemination of an architectural language, quite flexible, is recognized, which takes advantage of a lexicon of forms, originally developed in Italy, although some of its traits go back to the Hellenistic traditions of the East. An unprecedented process of broad cultural standardization begins.
\end{abstract}

Keywords: Hispania, Private architecture, Domus, Daily life.

\section{INTRODUÇÃO}

A partir de finais do século II a.C dissemina-se o modelo de casa itálica, iniciando-se o processo no Levante ibérico, ampliando-se progressivamente para os territórios do interior da Península Ibérica, acabando por se generalizar no contexto das novas fundações urbanas que terão lugar após o fim das guerras cantábricas. A partir de Augusto, as diferentes regiões da Hispânia vão experimentar um largo processo de estandardização cultural das habitações urbanas de elite, em que se reconhece a dissemina- ção de uma linguagem arquitetónica bastante flexível, que tira partido de um léxico de formas originariamente desenvolvido em Itália, ainda que alguns dos seus traços remontem às tradições helenísticas do Oriente. Inicia-se um processo sem precedentes de ampla estandardização cultural, assente na criação de uma linguagem franca, adaptável e sedutora, capaz de atrair as elites locais. Essa linguagem passa pelo urbanismo e pela arquitetura, atingindo os bens consumíveis, desde os alimentos a uma gama variada de produtos.

A disseminação alargada da linguagem arquitetó-

\footnotetext{
1. Unidade de Arqueologia da Universidade do Minho, Lab2PT, UMinho; fmagalhaes@uaum.uminho.pt

2. Unidade de Arqueologia da Universidade do Minho, Lab2PT, UMinho; diegosfmachado@gmail.com

3. Professora Catedrática da UMinho e investigadora do Lab2PT; mmmartins@uaum.uminho.pt
} 
nica itálica, aplicada às casas, quer nos contextos das novas fundações urbanas, de que são exemplo Bracara Augusta e Complutum, na Tarraconense, ou Augusta Emerita, na Lusitânia, quer em núcleos urbanos que se desenvolvem a partir de povoados indígenas, como acontece com Conimbriga, cidade da Lusitânia, contribuiu para consolidar os espaços urbanos, mas também a sociedade provincial, na qual emerge uma nova elite hispano-romana, que reelabora os aspetos essenciais das funções sociais associadas aos espaços da casa de prestígio. Nelas se incluem os átrios e os vestíbulos, destinados a impressionar a clientela, ou os jardins porticados, envolvidos por salões de receção, os quais se tornam espaços que transmitem a identidade dos elementos de elite de qualquer cidade, fossem eles originários da Itália, ou descendentes de indígenas.

As domus passam então a estruturar-se em função de um conjunto de espaços que se organizam em torno de áreas abertas (atria), ou ajardinadas (peristyla), independentemente da sua dimensão e configuração, aspetos que resultavam da sua adequação à topografia das cidades e da riqueza dos seus proprietários ou das suas atividades quotidianas. Usando um conjunto de exemplos de casas de várias cidades procuraremos demonstrar como as domus, para além de servirem às necessidades de residência da família, representam, na verdade, um conjunto de espaços arquitetónicos interrelacionáveis que transmitem a identidade de quem neles residia.

\section{AS PRIMEIRAS CASAS DE INSPIRAÇÃO ITÁLICA}

O início do processo de conquista romana da Hispania esteve intimamente inserido no contexto da Segunda Guerra Púnica, desencadeada pelo avanço de Roma sobre a fronteira previamente estabelecida com Cartago, na região definida pelo rio Ebro. A defesa da cidade de Sagunto acabaria por resultar num conflito que se arrastaria por dois séculos e que só terminaria em 19 a.C., encerrando o ciclo das guerras cantábricas, com a vitória romana e subsequente anexação da Península Ibérica ao Império romano (Eckstein, 2006, pp. 170-176).

A influência de Roma sobre as cidades do sul da Península, bem como sobre as populações hispânicas, situadas a norte e sul do Ebro, começou a partir dos inícios do século III a.C. Nos séculos subsequentes, o interior peninsular foi conquistado pelos generais romanos e a Hispania foi incluída no orbis romanorum, o que conduziu a uma reorganização administrativa de toda a Península Ibérica, através da configuração de três províncias, a Lusitania, no sudoeste ibérico, onde hoje estão situados os territórios portugueses a sul do Douro, a Estremadura espanhola e parte da província de Salamanca, a Baetica, localizada no extremo sul peninsular, ocupando, sensivelmente, a atual Andaluzia e, por fim, a Tarraconense, que integrava as demais regiões peninsulares.

O ritmo do avanço romano no território da Hispânia também se manifesta na influência dos modelos arquitetónicos itálicos nas casas dos aglomerados habitacionais peninsulares, maioritariamente de fundação indígena. Com efeito, o contacto com os militares e mercadores romanos nas regiões levantinas e meridionais foi bastante precoce desencadeando uma romanização mais antiga, cuja expressão, a nível da arquitetura doméstica, se encontra bem documentada nas cidades dispostas ao longo da costa mediterrânica e nas margens do rio Ebro. Nesses locais é possível perceber a gradativa adaptação das plantas e dos espaços das habitações, com clara incorporação da linguagem arquitetónica de origem itálica, cujos resultados compositivos assinalam a versatilidade dos modelos construtivos locais, que representam um inevitável resultado de processos de forte interação cultural entre indígenas, Fenícios, Gregos e Púnicos. A gramática itálica nos espaços das domus é reconhecida com a disposição dos compartimentos em redor de um atrium, cuja implantação, nalguns casos, parece estar relacionada com a evolução de um pátio, utilizado para captação de água, bem como com o recurso ao uso do opus signinum e do opus tessellatum no revestimento dos pavimentos de algumas salas.

Em Ampurias identificaram-se um conjunto de habitações que retratam bem a progressiva incorporação de elementos itálicos nas plantas das casas desde de meados do século II a.C.. Nessa cidade as unidades domésticas mais antigas estão representadas por construções muito simples, designados por tabernae, com planta retangular, internamente divididas em dois compartimentos. O desenvolvimento desse tipo de habitação acontece com a implantação de um terceiro compartimento, formalizando-se uma planta em 'L', cujos vestígios arqueológicos permitem sugerir a existência de pátios (Mar \& Ruiz de Arbulo, 1993, pp. 349-360). Todavia, esses pátios viriam a dar origem aos atria itálicos, os quais se 
assumem como o elemento ordenador dos compartimentos que se desenvolvem em seu redor. Por outro lado, atesta-se igualmente uma rica variedade de plantas associadas a esse espaço, que tanto podia ocupar numa posição central como lateral, enquadrando-se em diferentes tipologias, das quais são exemplos os atria toscanos, os tetrástilos, os coríntios e testudinados, o que expressa bem a variedade de linguagens arquitetónicas, cuja gramática foi estimulada pelos ricos colonos que habitavam a cidade de Ampúrias em época tardo-republicana (Mar \& Ruiz de Arbulo, 1993, pp. 361-380).

Das cidades articuladas com grandes vales de rios salientamos Celsa, colónia romana fundada no baixo vale do Ebro, em meados do século I a.C,. por Marcus Emilius Lepidus, destinada a albergar veteranos das legiões. Nesta cidade, os exemplares de casas configuram diferentes tipologias de espaços centrais abertos, assinalando claras influências itálicas, como as casas de atrium toscano, testudinado e as casas de pátio, alguns dos quais porticados, que, para além de reproduzirem na Hispania esse tipo de espaços, proveniente dos modelos habitacionais difundidos na Península Itálica, apresentam também outros compartimentos relacionados com as atividades diárias próprias de uma casa de elite, como seria o caso do fauces, destinado à prática da salutatio, ou o tablinum, onde o paterfamilias geria os seus negócios (Beltrán Lloris, 1991, pp. 135-151).

Em termos gerais, podemos constatar que a arquitetura doméstica das cidades tardo-republicanas do sul da Península Ibérica revela uma marcada preferência pelos modelos utilizados nas cidades da Itália. Inicialmente, os espaços das casas que assumiram funções de ordenação e distribuição das demais áreas do interior das residências foram os pátios, alguns dos quais com funções de captação de água, exibindo caraterísticas e dimensões bastante variadas. Parte desses pátios foram transformados em atria, com tipologias que reproduzem a grande variedade de soluções observadas em Itália, desde os átrios toscanos, ou testudinados, até aos mais elaborados, que recorriam a colunatas tetrástilas, ou hexástilas, estes também chamados coríntios. Ainda que com expressão mais modesta, cabe referir que, no período tardo-republicano, o peristylium também se foi afirmando como um elemento de cariz itálico, introduzido nas arquiteturas domésticas hispânicas.

\section{A DIFUSÃO DA LINGUAGEM ARQUITETÓNICA ITÁLICA NOS CONTEXTOS INDÍGENAS}

Nas cidades da Península Ibérica a linguagem arquitetónica itálica foi aplicada em crescente escala ao longo do período tardo-republicano, em contextos habitacionais das cidades de Ampurias, Badalona, Tarraco, ou Celsa, sendo os proprietários das habitações presumíveis cidadãos romanos, ou libertos destacados para esses locais, como parece acontecer com a 'Casa C', na Ínsula I, de Celsa, cujo dono terá sido um L. Licinius At(ico), talvez um liberto de $L$. Licinius Sura, um magistrado monetário daquela cidade (Beltrán Lloris, 1991, pp. 148-149).

A difusão da linguagem arquitetónica itálica foi identicamente observada noutros aglomerados de origem diversa, mas que acolheram populações de origem romana, os quais acabaram por influenciar o modo de vida e os gostos das comunidades indígenas. Esse foi o caso dos povoados de origem pré-romana, onde habitavam populações locais, cuja relação com Roma durante a República nem sempre foi pacífica, quer na área ibérica da Península, quer na chamada área céltica. Trata-se de duas regiões culturais que apresentam identidades diferenciadas e comportamentos distintos na sua relação com Roma. Logo, na área ibérica incluem-se alguns povos com um longo historial de comunicação com o litoral mediterrânico, enquanto a zona céltica do interior da Península, ou da área litoral norte atlântica e cantábrica se caracteriza pela sua tardia relação com Roma, em grande medida apenas conseguida após as campanhas de Brutus, em 137 a.C. e, nalguns casos, após as Guerras Cantábricas, depois de 19 a.C., que assinalou o fim do longo ciclo da conquista da Hispânia.

A influência mediterrânica sobre as comunidades do sul e do sudeste da Península Ibérica acabaria por ajudar a produzir a grande família de sociedades ibéricas, enquanto as influências continentais, que penetraram no interior da Península e se difundiram ao longo das regiões atlânticas, viriam a dar origem a uma outra região, onde se reconhecem traços culturais comuns aos territórios centro europeus. Em resultado dessas duas influências constitui-se um mosaico de etnias e grupos culturais, que apresentam diferentes graus de complexidade, tendo cada grupo desenvolvido uma relação particular com Roma, por vezes através de enfrentamentos militares e, noutros casos, por via de pactos de paz. O grau de inte- 
gração de cada grupo no grande sistema económico e sociopolítico romano determinou uma maior aceitação dos modelos culturais importados da Itália. Neste sentido, a casa constitui, um precioso indicador cultural que nos mostra o modo como atuaram as elites dos diferentes povos indígenas e as condições socioculturais e económicas que acompanharam a sua progressiva integração no sistema romano.

Desde os primeiros momentos da conquista romana as populações locais exerceram um papel deveras importante no próprio domínio romano da Hispânia, seja pela sua aceitação inicial, ou após conflitos bélicos, desse domínio, ou pela associação das suas elites a Roma, tornando-se aliadas e com claros interesses em conseguir manter as suas posições de destaque, através da ocupação de cargos políticos, administrativos, económicos e religiosos, enquadrados nas novas lógicas sociais que se foram impondo com a presença romana. Este processo fez-se acompanhar de um gradativo processo de alteração das habitações, que adotaram os modelos itálicos com a consequente reprodução do léxico arquitetónico das casas de elite tardo-republicanas (Gros, 2006).

Em conjunto com o desenvolvimento das soluções locais de habitações dos povoados da Idade do Ferro da Península Ibérica, observam-se mudanças no modo de construir e organizar as casas, que adotam os modelos produzidos em Itália, oferecendo paralelos e exemplos nas cidades romanas de toda a Hispania.

O povoado de 'La Caridad', em Caminreal, Teruel, constitui um bom exemplo do processo assinalado, fornecendo importantes dados sobre a assimilação dos modelos itálicos pelas populações locais. Implantado nas proximidades do rio Jiloca, ocupa uma plataforma pouco elevada, delimitada por acidentes naturais, o que permitia a aplicação de modelos urbanísticos de tipo ortogonal sem grandes problemas, para além de possuir uma localização privilegiada para o escoamento da produção, que era feito pelo leito da via fluvial que desaguava no rio Jalón, um afluente do Ebro (Herce San Miguel \& alii, 1991, p. 82). Destacamos em 'La Caridad' a chamada 'Casa de Likine', uma habitação com cerca de $915 \mathrm{~m}^{2}$ que se estruturava em torno de um pátio central porticado de grandes dimensões, ocupando cerca de $1 / 4$ do tamanho total do lote, a partir do qual se tinha acesso a todos os demais compartimentos (Herce San Miguel \& alii, 1989).

Em Azaila, também na região de Teruel, existe um outro povoado ibérico que sofreu influência direta dos modelos itálicos nas suas habitações, logo após a sua conquista. Povoado fundado no século VII a.C., situado nas proximidades do rio Ebro, que terá uma vitalidade pujante até ao século I a.C. (Beltrán Lloris, 1976). Do conjunto das suas residências, destacamos a que é designada por $2 \mathrm{D}$, que corresponde à maior habitação identificada no povoado, estruturada em função de um amplo pátio central, que era acedido a partir de um uestibulum, cujo pavimento foi preservado na sua totalidade e apresenta um lajeado formado por placas de arenito (Beltrán Lloris, 1991, pp. 132-133).

Por sua vez, o NO peninsular que foi tardiamente integrado no Império, em 19 a.C., o que poderá ter contribuído para que nessa região a Idade do Ferro tenha perdurado até aos finais do I século a.C., situação que claramente proporcionou diferentes realidades sociais, políticas, económicas e urbanísticas, as quais podem ser agrupadas grosso modo na chamada 'Cultura Castreja' (Silva, 1986), com as devidas e necessárias ressalvas à aplicação desse termo, conforme vem sendo sugerido por vários autores (Martins, 1990; González Ruibal, 2006-2007; Cruz, 2018).

A Arqueologia demonstrou a existência de grandes assimetrias culturais entre estes grupos, destacando-se claramente um maior desenvolvimento da região meridional, correspondente à Gallaecia bracarense, onde no último século antes da nossa era se desenvolveram grandes povoados, tipo oppida, que funcionavam como lugares centrais e controlavam povoados mais pequenos, muitos dos quais ligados à exploração agropecuária intensiva dos vales (Martins, 1990). Logo, pode considerar-se que as assimetrias regionais do NO peninsular se aprofundam com a expedição de Decimus Iunius Brutus ao território situado entre o rio Minho e o Douro, que colocou a região sob controlo romano, embora sem ocupação militar, facilitando a relação desses territórios com as populações mais romanizadas do sul da Península Ibérica. Essas ligações terão potenciado o original desenvolvimento da fachada ocidental dessa região, ao longo do século I a.C., caracterizado pela emergência de um povoamento encabeçado por oppida, com sistemas defensivos complexos e uma forte concentração populacional, os quais possuíam sempre uma ampla visibilidade sobre o território envolvente, no qual pontuavam outros povoados dependentes. Internamente esses grandes povoados organizavam-se segundo uma estrutura viária 
ortogonal, que dividia o espaço em quarteirões, dentro dos quais se erguiam vários complexos residenciais, compostos por conjuntos de construções, unidas através de pátios lajeados (Silva, 1986). Estes grandes povoados, que chegavam a atingir vários hectares, possuíam equipamentos públicos, entre os quais se destacam as casas do conselho (Lemos, 2009; Cruz, 2015) e os balneários rituais (Gonzalez Ruibal, 2004; Silva \& Machado, 2007).

No noroeste peninsular os povoados fortificados mais antigos tiveram origem no Bronze Final e surgem na região meridional, precisamente aquela que será sempre mais influenciada pelos impulsos civilizacionais e tecnológicos do Mediterrâneo. No entanto, poucos são os povoados extensamente escavados, suscetíveis de revelar boas sequências de ocupação e os que foram muito escavados, foram-no, quase sempre, sem grandes preocupações metodológicas. Assim acontece com um dos mais conhecidos povoados fortificados do NO peninsular, a Citânia de Briteiros, em Guimarães, que começou a ser escavada no século XIX (Cruz, 2018). Trata-se de um povoado cuja origem remonta à Idade do Bronze Final, ou seja, aos inícios do Io milénio a.C., localizando-se no coração daquela que presumivelmente foi a área de domínio dos Bracari, tendo perdurado ocupado até pelo menos o século II. Neste verdadeiro oppidum da Idade do Ferro, sensivelmente a partir do século II a.C., ter-se-á configurado um verdadeiro centro urbano, onde se verifica uma alteração no modo de habitar, pois as áreas e construções residenciais passam a agregar-se em pequenos conjuntos delimitados por muros, formalizando unidades domésticas, que integravam casa, celeiro e outras construções destinadas a outras atividades domésticas mais especializadas, todas unificadas por pátios lajeados (Cruz, 2018, pp. 76-83).

$\mathrm{Na}$ Citânia de Briteiros, a influência mediterrânica e itálica faz-se sentir, sobretudo, no modo de organização do espaço dos povoados e de distribuição das suas habitações, pois os povoados tipo oppida são cruzados por um rudimentar sistema de eixos viários ortogonais, sistema que justificou uma reiterada discussão quanto à sua suposta datação romana. No entanto, sabemos hoje, com base nas recentes escavações de Gonçalo Cruz, que essa organização é anterior às Guerras Cantábricas e à fundação de Bracara Augusta, precedendo em várias décadas a integração da região dos Bracari no Império romano, pelo que o contexto em que o povoado se organizou, num modelo ortogonal, é perfeitamente indígena, ainda que influenciado por outras realidades peninsulares, quer do sul, quer da Meseta (Cruz, 2015).

No entanto, foi possível identificar duas casas, cuja configuração é completamente distinta da típica casa redonda castreja e que apresentam influências itálicas bem marcadas. Trata-se de duas casas de pátio central, uma localizada na área interior da primeira linha de muralhas e a outra situada entre esta fortificação e a segunda linha defensiva, cujos compartimentos são acedidos a partir dos pátios. Apesar de possuírem plantas bastante peculiares, com formas pouco regulares, sobretudo nos limites dos lotes, os compartimentos conformam retângulos com vértices bem marcados, sendo as suas funcionalidades de difícil interpretação. Destacamos a presença de uma espécie de uestibulum na casa localizada na parte mais alta do povoado, ainda que o mesmo apresente uma forma trapezoidal e não se encontre centrado com o pátio (Cruz, 2018).

O Castro do Monte Padrão, em Santo Tirso é outro povoado da Idade do Ferro do NO português, que regista uma grande longevidade, cuja implantação remonta aos inícios do Io milénio a.C., datando da Idade do Bronze Final (Martins, 1985), tendo sido abandonado em meados do século III. Este povoado situava-se na área de influência da Citânia de Sanfins, um oppidum também extensamente escavado, tal como a Citânia de Briteiros, que exerceria o controlo da área entre os rios Ave, a norte e Leça, a sul (Moreira, 2009, pp. 76-77). A uma fase avançada da ocupação do povoado, posterior à integração da região no Império romano, pertencerão duas construções de planta ortogonal, que foram construídas no topo do povoado, uma das quais seguramente correspondente a uma casa de modelo itálico, com pátio central. Anexo a essa habitação existia uma outra construção retangular. Trata-se de edifícios de grandes dimensões, com cerca de $77 \mathrm{om}^{2}$ e $8 \mathrm{oom}^{2}$, com espaços cuja funcionalidade, nalguns casos, é de difícil interpretação (Moreira, 2005).

A racionalização das formas construtivas e de reprodução da linguagem arquitetónica de matriz itálica por parte das elites indígenas da Península Ibérica, desde os inícios do processo de conquista da Hispania, ratifica a capacidade romana de atrair as populações locais e de integrá-las nos novos modelos económicos e sociais que se instauram com a conquista romana. É importante não esquecer que o conceito de romanização deve ser matizado pois, 
se é certo que existe uma receção e aceitação de modelos itálicos, ela faz-se acompanhar pelo aparecimento de uma nova base social formada por uma mistura de indígenas e de distintas categorias de pessoas que se fixam na Península Ibérica, atraídas pelas oportunidades do novo contexto sociopolítico de um vasto território, que passou a estar controlado integralmente por Roma. À medida que a conquista foi avançando e que os territórios foram sendo colocados sob controlo romano, soldados desmobilizados, populações itálicas e comerciantes foram engrossando a população das áreas integradas, contribuindo para a sua evolução e mudança cultural e para a adoção de novos hábitos que se difundiram num contexto de novas oportunidades para as populações de origem indígena negociarem novas identidades, designadamente através do uso de expressões arquitetónicas itálicas.

A ideia de 'casa' chegou de modo natural com emigrantes de Roma e da Itália, cuja expetativa seria a de conseguirem uma casa de prestígio na Hispânia romana, como expressão de reconhecimento de um estatuto social que não conseguiam alcançar nas suas terras de origem. Na verdade, nas cidades republicanas da costa mediterrânica, ou do vale do Bétis, tal como nas bem mais tardias cidades fundadas por Augusto no NO da Península Ibérica, confluíam os elementos que iriam formar uma nova elite de origem romano-itálica, que se viriam a misturar com os descendentes das antigas elites indígenas dos territórios que foram sendo progressivamente integrados. Assim, as casas romanas de elite das cidades do NO da Península Ibérica oferecem particularidades na interpretação dos modelos que chegam do âmbito mediterrânico, fundamentais para se compreender, de modo flexível, a adoção do peristilo porticado que se adapta às condições de cada casa e à natureza e protagonismo socioeconómico dos seus proprietários. Para melhor compreendermos esta realidade vamos tentar perceber o contexto de desenvolvimento das casas romanas no âmbito do urbanismo planificado, que se desenvolve a partir de Augusto, no quadro das cidades peninsulares de nova fundação.

\section{A CASA DA HISPÂNIA NO TEMPO DE AUGUSTO}

A linguagem arquitetónica criada em Itália destacava-se, sobretudo, pela imensa variedade de soluções que fornecia, o que resultou do facto do léxico for- mal que a compunha ter sido adaptado e reproduzido na Península Itálica durante séculos, pelo menos desde os finais do século IV a.C., o que possibilitou a formulação de diferentes soluções e o crescimento da gramática arquitetónica.

A casa latina mais antiga que se conhece corresponde às pequenas cabanas circulares, com teto de palha, no centro das quais havia uma abertura que permitia a saída do fumo proveniente da lareira, construções que eram características dos pagi, que compunham as ciuitates da Itália proto-histórica. Essas primeiras habitações já assinalavam aquilo que será fundamental no desenvolvimento das unidades domésticas itálicas e que se traduziu na diversidade de soluções para garantir a relação entre os espaços abertos e os fechados, as quais foram ganhando cada vez mais sofisticação (Gros, 2006; Pesando, 1997), resultando em casas que cresceram longitudinalmente, em redor de um espaço aberto, que viria a constituir-se com os átrios, onde o espaço aberto, o impluuium, assumia as funções de organizar os demais compartimentos e de armazenar água, através dos compluuia (Mar \& Ruiz de Arbulo, 1993, p. 361).

$\mathrm{Na}$ verdade, a capacidade que Roma revelou em adotar os modelos provenientes das cidades conquistadas, ao longo do período republicano, resultou na criação de um sistema identitário bastante diversificado, que lhe permitiu usar aquilo que lhe interessava e ignorar o que não queria, processo que deu origem a um léxico artístico e arquitetónico variado e adaptável (Zanker, 1998; Hölscher, 200o), bastante percetível quando olhamos especificamente para os espaços domésticos. De facto, a anexação da Magna Grécia nos inícios do século III a.C., bem como da Grécia e do Oriente helenístico em meados da centúria seguinte, forneceram um conjunto de modelos de espaços que atraíam os interesses das elites romanas por salas de representação cada vez mais sumptuosas, com a capacidade de impressionar e afirmar a relevância dos seus papéis sociais. As linguagens arquitetónicas oferecidas pelos territórios helenísticos e helenizados respondiam a esses interesses das elites romanas, estando os triclinia e os oeci incluídos no grande reportório de formas e soluções que podiam ser usados pelos membros destacados da aristocracia romana no momento da elaboração dos projetos das suas domus e da escolha de seus programas decorativos (Wallace-Hadrill, 2015, p. 183).

Atualmente, sabemos que as casas romanas eram distintas umas das outras, principalmente por con- 
ta das escolhas e dos gostos dos proprietários, existiam também alguns fatores externos, de natureza urbanística, que condicionavam os projetos, na hora de conceber os espaços do interior das habitações. Referimo-nos sobretudo a cidades em que o plano fundacional previa a implantação de quarteirões com pórticos na sua envolvente, as quais se encontram bem representadas na Hispania, constituindo um dos traços mais característicos da implantação romana de novas cidades. Trata-se de cidades com urbanismo ortogonal, com ruas porticadas, previstas logo desde a sua origem, de que são exemplo Augusta Emerita, Complutum e Bracara Augusta, onde a presença contínua do porticado condicionou o perímetro dos quarteirões, a regularidade da distribuição dos lotes, bem como a forma das casas. Porém, nas três cidades referidas verifica-se que os particulares chegaram a apropriar-se dos pórticos em momentos em que as casas necessitavam de mais área construída, como aconteceu em Bracara nos finais do século III/inícios do IV, quando, devido à promoção da cidade a capital da nova província da Galécia, as domus foram praticamente todas remodeladas (Martins $\mathbb{\&}$ alii, 2016). Esta apropriação é um sinal do desenvolvimento da vida urbana e do incremento das atividades no centro das cidades, cada vez mais densificado, que é característico de fases avançadas de ocupação. Naturalmente que, nas vias principais, nem sempre se regista esse processo de ocupação, criando-se deste modo uma hierarquia no sistema viário, com clara diferenciação entre as vias principais, que atravessavam as cidades, o que não acontecia com as vias secundárias e as ruas sem saída, que experimentaram um processo de privatização, ou a sua conversão num caminho de acesso a um grupo de propriedades privadas, geridas quase como uma via privada, sobre a qual se podia chegar a construir.

Na cidade de Conimbriga é possível observar o modo como as vias principais que conduziam ao foro, templos, ou ao exterior da cidade, foram monumentalizadas com a construção de pórticos e monumentos urbanos, algo que resulta da circunstância de corresponderem a eixos de circulação que canalizavam ou atraíam as atividades de natureza simbólica, como as procissões religiosas ou políticas, os cortejos, as festas e os sacrifícios. Estas vias atraíam também os fluxos comerciais e as atividades associadas com mercados, possuindo, normalmente, maior concentração de tabernae e locais comerciais e produtivos, que ocupavam a frente das casas, por onde se realizava o acesso aos locais de produção.

A colonia Augusta Emerita, capital da província da Lusitania, foi fundada em 25 a.C., nas margens do rio Anas, hoje chamado rio Guadiana, tendo sido povoada pelos soldados veteranos das legiões $\mathrm{V}$ Alaudae e X Gemina, ambas combatentes nas Guerras Cantábricas, sendo possível que um pequeno contingente de licenciados da legião XX tenha também participado na fundação da colónia (Faria, 1998). Os investimentos imperiais na construção dos edifícios públicos da cidade, dos quais destacamos o grande forum administrativo e alguns edifícios de espetáculo, como o teatro e o anfiteatro, ainda que construídos mais tarde, demonstram o grande interesse da casa imperial em garantir que a cidade prosperasse, o que parece estar associado com o controlo dos povos indígenas que habitavam aquela região, que define uma fronteira entre as tribos lusitanas e a Baetica, cuja produção oleica e piscícola era de grande importância para a economia romana. Outro motivo que parece ter sido estratégico para a implantação desta cidade relaciona-se com o controlo do rio Guadiana, uma importante via de comunicação, transporte e comércio entre o interior ibérico e o Atlântico, cuja foz se situava nas proximidades da costa dos centros exportadores da Baetica e não muito longe das Colunas de Hércules, atual Estreito de Gibraltar, que assinala o limite entre o oceano e o Mediterrâneo (Mateos Cruz, 2011, pp. 127-128).

Graças ao estudo dos vestígios provenientes das sucessivas décadas de escavações que se realizaram um pouco por toda a atual Mérida, sabemos que a cidade possuía um traçado ortogonal. Trata-se de uma malha com cardines e decumani retilíneos que conformam quarteirões quadrados e retangulares, denotando uma certa hierarquia dos espaços, a qual teve reflexo nas diferentes dimensões dos lotes das habitações que neles foram sendo implantados. Por outro lado, a colónia também apresenta alguns espaços que rompem com a matriz regular e ortogonal dos quarteirões, nos quais se instalaram grandes edifícios públicos, designadamente o forum e dois edifícios de espetáculos, que se apresentam contíguos: o teatro e o anfiteatro (Mateos Cruz, 1994-95, pp. 233-237).

Nas várias regiones de Augusta Emerita foram construídas habitações que apresentam variadíssimas plantas que documentam a utilização do amplo léxico arquitetónico de matriz itálica que já havia 
sido testado antes da fundação da cidade, noutros aglomerados urbanos do levante ibérico e da costa mediterrânica. Logo, foram reconhecidas casas que ostentavam espaços de distribuição e outras em que estes não existiam. Por outro lado, no que toca à tipologia desses espaços, foram individualizados tanto átrios como peristilos (Corrales Álvarez, 2014, pp. 193-202).

Em Augusta Emerita observa-se a uma adaptação dos modelos itálicos à forma das parcelas em que foram implantadas as casas. Assim acontece com a 'Casa 6 da Mouraria', localizada na regio III, a qual apresenta uma planta com forma quase quadrada, ocupando uma área de cerca de $100 \mathrm{om}^{2}$, metade da qual foi reservada a tabernae abertas ao cardo que corria a nascente da casa. Tendo em conta o espaço reduzido onde esta habitação foi implantada, parece aceitável admitir que possuía um segundo piso. Cabe também destacar a adequação dos espaços internos da casa em relação à forma dos lotes. Esses espaços seriam tendencialmente quadrados, como acontece com o peristilo, que possui três colunas em cada lado do jardim, o que lhe confere uma grande regularidade também reproduzida no ambulacrum. Nas reformas posteriores, a habitação avançou sobre o pórtico adjacente ao decumanus, localizado a norte, o que permitiu a ampliação do espaço interno da casa e a instalação de um balneário (Corrales Álvarez, 2014, pp. 837-840). O avanço das casas sobre os pórticos, resultando na privatização de um espaço que anteriormente era público, está patente em diversas casas da colonia, estando sobretudo bem documentado na área da Mouraria, onde algumas das habitações avançaram além dos passeios cobertos, tendo ocupado parte das vias ou mesmo encerrando-as (Sánchez Barrero, 2007).

A "Casa do Mitreo" foi implantada na regio VIII, ficando localizada extramuros, fora da malha urbana ortogonal, o que justifica que a sua planta seja bastante distinta das demais conhecidas, possuindo dimensões e uma morfologia que fogem por completo ao modelo urbano emeritense. Atualmente, não se conhecem os limites da casa, embora saiba-se que ela ocupava bem mais de $1500 \mathrm{~m}^{2}$ e que estaria organizada pelo menos em três espaços de distribuição, sendo um deles representado por um atrium e os outros por dois peristilos. O uso da área disponível para a construção denota a capacidade do proprietário investir em salas de receção e numa rica decoração, composta por pavimentos com mosaicos e paredes decoradas com pinturas, bem como na engenhosa articulação desses espaços de representação com as entradas e os espaços abertos (Corrales Álvarez, 2014, pp. 1349-1353).

Por sua vez, Complutum, um municipium romano implantado na zona de confluência dos rios Henares e Camarmilla, cuja fundação terá ocorrido na época de Augusto, conheceu o primeiro projeto de urbanização ao longo do período júlio-cláudio. Os dados disponíveis sobre o plano fundacional complutense permitem evidenciar a estruturação de uma malha urbana ortogonal que conformava quarteirões regulares, sendo aqueles incluídos nas regiones I e IV, os mais próximos à confluência dos rios, com formato retangular, enquanto os demais apresentam forma quadrada, com 1 actus de lado (120 pedes) (Rascón Marqués \& Sánchez Montes, 2014, pp. 309-312).

Os quarteirões das regiones das partes nascente e poente da cidade apresentam ligeiras diferenças formais e dimensionais, no entanto, é possível reconhecer um projeto urbanístico que previa a construção de pórticos ao longo das vias, os quais estariam associados com a proteção contra as intempéries climatéricas do centro peninsular (Rascón Marqués \& Sánchez Montes, 2017, p. 129), mas que também serviu para dar uma unidade paisagística à cidade.

Atualmente, são reconhecidas oito casas em Complutum, as quais documentam uma grande variedade dimensional, ocupando um, dois ou quatro lotes, os quais são definidos por quartos dos quarteirões. A variedade tipológica das casas é igualmente significativa, existindo domus de átrio, de peristilo e de pátio.

O local onde foram construídas as habitações parece ter tido grande influência na disposição do elemento distribuidor, como se verifica nas chamadas "Casa de los Grifos" e na "Casa de Baco", que ocupavam a totalidade dos quarteirões em que se implantaram. Trata-se de domus de peristilo centrado, cujos espaços adjacentes aos pórticos foram utilizados para a instalação de tabernae, ou para instalar grandes salas de representação, aproveitando-se assim os eixos das colunatas dos jardins e as perspetivas de simetria e axialidade que eles criavam (Sánchez Montes, 2011, pp. 174-176). Por outro lado, ao analisarmos a "Casa del Átrio" e a "Casa de la Lucerna de la Máscara Trágica”, verificamos que os espaços organizadores das habitações não são centrados, mas sim traseiros, facto a que não será alheia a circuns- 
tância dessas casas ocuparem, respetivamente, um quarto e meio de quarteirão, o que reduziu significativamente a área disponível para implantar os seus compartimentos, pelo que foi necessário recuar o espaço aberto e sacrificar parte de seu ambulacrum, mas mantendo a sua função ordenadora (Sánchez Montes, 2011, p. 178).

Quando analisamos as cidades do NO da Hispania, observamos processos idênticos aos registados no urbanismo e arquitetura de Augusta Emerita e Complutum nas cidades de Lucus Augusti, Asturica Augusta e de Bracara Augusta.

Bracara Augusta foi fundada entre 16/15 a.C., tendo conhecido a primeira fase de urbanização entre Augusto e o período júlio-cláudio. No entanto, as primeiras casas de elite parecem ter sido construídas a partir de meados do século I, intensificando-se a sua construção na época flávia. Trata-se de uma cidade cujo plano fundacional estabelecia uma malha ortogonal, na qual os eixos viários principais apresentam uma largura de 24 pedes $(7.24 \mathrm{~m})$, enquanto os demais apresentam metade desse valor. Os quarteirões, exclusivamente quadrados, possuem cerca de 144 pés $(42.76 \mathrm{~m})$ de lado e apresentam-se envolvidos por pórticos com cerca de 12 pedes (3.12m) de profundidade, o que conformava um espaço construível no interior dos quarteirões de cerca de 1 actus quadrado (120x120 pedes ou $35.52 \times 35.52 \mathrm{~m}$ ) (Martins \& alii, 2017a).

Em Bracara Augusta, o parcelamento dos quarteirões parece ter dado origem a lotes retangulares que ocupavam meio quarteirão, que corresponde ao valor mais pequeno que podemos atribuir às unidades domésticas conhecidas, pois não foi possível reconhecer lotes de menores dimensões, o que não significa que não possam ter existido, à semelhança do que acontece em Complutum. Assim, podemos concluir da diversidade formal e dimensional das domus de Bracara Augusta, que ou ocupavam a totalidade dos quarteirões, como aconteceu com as domus das Carvalheiras, do ex Albergue Distrital e das Cavalariças, ou meio quarteirão, conforme se encontra demonstrado nas zonas arqueológicas da Escola Velha da Sé/rua Frei Caetano Brandão nos 166-168 e da rua Afonso Henriques nos 42-56 (Magalhães, 2019).

Na cidade de Bracara Augusta é possível perceber uma relação harmoniosa entre as entradas e o ritmo dos pórticos que rodeavam os quarteirões, verificando-se uma axialidade associada aos espaços internos das casas, formalizada pelo alinhamento do uestibulum com os espaços abertos das casas, sejam átrios ou peristilos, mas também com salas de receção/ representação, por vezes implantadas no sentido oposto ao das entradas, situação que surge bem documentada na domus do ex-Albergue Distrital, cuja entrada foi alvo de monumentalização através da implantação de duas colunas que definem um pequeno pórtico, exterior à porta, de modo a que visualmente o ritmo de colunatas do quarteirão era reproduzido na entrada e no peristilo (Magalhães, 2019).

\section{ALGUMAS CONSIDERAÇÕES SOBRE A APLICAÇÃO DOS MODELOS ITÁLICOS NAS CASAS ROMANAS DA HISPÂNIA}

Os exemplares de arquitetura doméstica encontrados por toda a Hispania documentam uma forte influência da gramática arquitetónica produzida e desenvolvida na Itália e uma grande diversidade de usos desse léxico, aplicado em diferentes soluções compositivas. De facto, mais do que reproduzidos ou imitados, os modelos itálicos foram constantemente emulados e reinterpretados, de acordo com as especificidades, quer materiais e topográficas das cidades, quer relativas ao nível social e económico dos seus proprietários.

Uma vez que os proprietários das habitações participavam na elaboração dos projetos arquitetónicos e decorativos que deram origem às grandes domus implantadas nas cidades do Império, podemos associar a incorporação de elementos que compunham o cenário urbano no interior das habitações, como a projeção do externo/público ao interno/privado, através da qual os proprietários procuravam projetar as suas posições de controlo da vida cívica das cidades, a sua riqueza, oriunda da terra, mas também do comércio, e o seu estatuto, o qual resultaria dos cargos que ocupavam na administração local, conventual ou provincial. Na verdade, o continuum causado pela centralidade das entradas das habitações em relação ao intercolúnio das colunatas dos pórticos induzem a participação dos proprietários nas atividades públicas da cidade, sendo o prolongamento do exterior para o interior (e vice-versa) reiterado pelos uestibula alinhados com os peristilos ou átrios porticados, espaços que também recorriam às colunatas e, desta forma, também reproduziam o ritmo das paisagens urbanas (Wallace-Hadrill, 2015).

De facto, a necessidade de projeção pública das 
elites das cidades romanas, sobretudo em épocas fundamentais para a manutenção do poder dessas personagens, como nos períodos eleitorais, criavam fortes motivações para o investimento em espaços e soluções arquitetónicas sempre mais elaboradas e sumptuosas, tendo em vista impressionar e convencer os habitantes das cidades, sobretudo aqueles que possuíam cidadania latina ou romana e, portanto, direito ao voto.

A leitura atenta ao tratado De Architectura de Vitrúvio permite assinalar o variado léxico arquitetónico à disposição dos proprietários para conseguir o efeito desejado, o qual passava por uestibula regalia alta, atria et peristylia amplissima, siluae ambulationesque laxiores ad decorem maiestatis perfectae, tornando-se assim o interior da habitação acessível à altura de alguém qui honores magistratusque gerundo praestare debent officia ciuibus (VI.V.2). A obra assinala também a relação com o espaço externo que encontramos nas cidades com pórtico da Hispania romana (Vitr. De arch. VI.V.3). Esse recurso permitia reforçar o conceito de rus in urbe, próprio dos uiridaria dos peristilos, sem perder o caráter de natura capta. Com efeito, ao contemplar o jardim a partir dos ambulacra do peristilo tinha-se certamente a perceção de um espaço selvagem, mas controlado, sensação bem assinalada pelos elementos decorativos espalhados por esses espaços, como fontes e tanques, mas também pelas colunatas que os encerravam, que evocavam, um sentido bem próximo daquele que regia a delimitação dos pomoeria das cidades, momento em que o espaço urbano, ordenado, se separava do caótico ager (Wallace-Hadrill, 2015).

Depreende-se da leitura proposta que a casa romana não pode ser entendida como o resultado, nem da repetição de um modelo repetitivo e único de um esquema de organização da casa, com base num sistema axial de organização dos compartimentos, presente na casa pompeiana, nem da aplicação de um tipologia rígida, que definia os critérios de uma casa de átrio, de uma casa de peristilo, ou uma casa de átrio e peristilo. Será mais correto entender a casa romana como uma linguagem, necessariamente variável em termos morfológicos, mas também como um léxico, composto por unidades gramaticais que exprimem várias possibilidades semânticas, harmoniosamente resolvidas na solução arquitetónica que configura a sintaxe da habitação, a qual é necessariamente fruto de diversos fatores, mas sobretu- do um claro reflexo das atividades do proprietário e da sua família e das necessidades decorrentes de exibição pública do seu estatuto no quadro do corpo cívico das cidades. Na verdade, a casa romana era o espelho da classe e riqueza dos seus ocupantes, refletindo nas suas características arquitetónicas o seu estatuto social, pelo que a casa funcionava como uma poderosa linguagem que, numa sociedade pouco letrada, transmitia lógicas de poder, hierarquias e valores. Desta forma, as domus eram o cenário principal da vida política e social dos seus proprietários, estabelecendo a exibição física do seu poder económico, operando como estrutura de representação e controlo social.

\section{FONTES IMPRESSAS}

VITRUVIUS. On Architecture VI-X. Frank Granger (trad.) (1934) - Loeb Classical Library 280, Harvard University Press.

\section{BIBLIOGRAFIA}

BELTRÁN LLORIS, Miguel (1976) - Arqueología e Historia de las Ciudades Antiguas del Cabezo de Alcalá de Azaila. Zaragoza: Teruel.

BELTRÁN LLORIS, Miguel (1991) - La colonia Celsa. In La casa urbana hispanorromana: ponencias y comunicaciones. Zaragoza: Institución Fernando El Católico, Zaragoza, pp. 131-164.

CORRALES ÁlVAREZ, Álvaro (2014) - La arquitectura doméstica de Augusta Emerita. Cáceres: Universidade da Extremadura (Tese de Doutoramento).

CRUZ, Gonçalo (2015) - O surgimento do espaço urbano no Noroeste da Ibéria. Um reflexão sobre os oppida pré-romanos. In MARTÍNEZ PEÑIN, Raquel; CAVERO DOMÍNGUEZ, Gregória (Eds) - Evolución de los espacios urbanos y sus territorios en el Noroeste de la Península Ibérica. León/ Braga: Instituto de Estudios Medievales da la Unviversidad de León e Unidade de Arqueologia da Universidade do Minho, pp. 403-424.

CRUZ, Gonçalo (2018) - Northern Portugal in the transition of Era: from the hillforts, through the oppida, till the roman integration, In FONTES, Luís; CRUZ, Gonçalo; ALVES, Mafalda (eds.) - Actas do Simpósio Internacional: Interações Culturais e Paisagens em Mudança na Europa (séc. $2^{\circ}$ a.C. / séc. $2^{\circ}$ d.C.). Braga: Unidade de Arqueologia da Universidade do Minho, pp. 73-89.

ECKSTEIN, Arthur (2006) - Mediterranean anarchy, interstate war, and the rise of Rome. Los Angeles/London: University of California Press.

GONZÁLEZ RUIBAL, Alfredo (2004) - Material Culture and artistic expression in Celtic Gallaecia. In ARNOLD, 
Bettina; ALBERRO, Manuel (eds.) - The Celts in the Iberian Peninsula. Milwaukee: University of Wisconsin (E-Keltoi; 6), pp. 113-67.

GONZÁLEZ RUIBAL, Alfredo (2006/2007) - Galaicos. Poder y comunidade $n$ el Noroeste de la Península Ibérica (120o a.C. - 50 d.C.). A Coruña: Museo Arqueolóxico e Histórico da Coruña (Brigantium; 18).

FARIA, António (1998) - Algumas questões em torno da fundação de Augusta Emerita. Revista Portuguesa de Arquelogia. 1:1, pp. 161-167.

GROS, Pierre (2006) - L’Architecture romaine. Du début du IIIe siècle av. J.-C.à la fin du Haut Empire: Maisons, palais, villas et tombeaux. Paris: Editions A\&J Picard (v. 2).

HERCE SAN MIGUEL, Ana; PUNTER GÓMEZ, María; VICENTE REDÓN, Jaime; ESCRICHE JAIME, Carmen; MARTÍN RODRIGO, Jesús (1989) - Un pavimento de Opus Signinum com epígrafe ibérico. In Mosaicos romanos: Actas de la I Mesa Redonda Hispano-Francesa sobre Mosaicos Romanos (Madrid, 1985). Madrid, pp. 11-42.

HERCE SAN MIGUEL, Ana; PUNTER GÓMEZ, María; VICENTE REDÓN, Jaime; ESCRICHE JAIME, Carmen (1991) - La Caridad (Caminreal, Teruel). In La casa urbana hispanorromana: ponencias y comunicaciones: Congreso sobre la Casa- Urbana Hispanorromana (Zaragoza, Espanha, 1988). Zaragoza; Institución Fernando el Católico, pp. 8-13o.

LEMOS, Francisco (2009) - A cultura castreja no Minho. Espaço nuclear dos grandes povoados proto-históricos do Noroeste peninsular. In Pereira, Paulo (coord) - Minho. Traços de Identidade. Braga: Conselho Cultural da Universidade do Minho, pp. 122-213.

MAGALHÃES, Fernanda (2019) - A domus Romana no Noroeste Peninsular: Construção, Arquitetura e Sociabilidades. Braga: Universidade do Minho (Tese de Doutoramento).

MAR, Ricardo; RUIZ DE ARBULO, Joaquín (1993) - Ampurias romana. História, arquitectura y arqueología. Sabadell: Ed. Ausa.

MARTINS, Manuela (1985) - Sondagens Arqueológicas no Castro do Monte do Padrão, em Santo Tirso. Cadernos de Arqueologia. Série II. 2, pp. 217-230.

MARTINS, Manuela (1990) - O povoamento proto-histórico e a romanização da bacia do curso médio do Cávado. Cadernos de Arqueologia. Braga (Monografias; 5).

MARTINS, Manuela; MAGALHÃES, Fernanda; MARTÍNEZ PEÑÍN, Raquel; RIBEIRO, Jorge (2016) - The housing evolution of braga between Late Antiquity and the Early Middle Ages. Arqueologia Medieval. Lérida. VIII, pp. 35-52.

MARTINS, Manuela; RIBEIRO, Maria; RIBEIRO, Jorge; MAR, Ricardo (2017a) - Topografia e urbanismo fundacional de Bracara Augusta. In DOPICO CAÍNZOS, María; VILLANUEVA ACUÑA, Manuel, eds. - In Roma nata, per Italiam fusa, in provincias manat. A cidade romana no noroeste: no- vas perspectivas. Lugo: Servizo de Publicacións da Deputación de Lugo (Philtáte. Studia et acta antiquae Callaeciae; Vol. 2), pp. 203-226.

MATEOS CRUZ, Pedro (1994-95) - Reflexiones sobre la trama urbana de Augusta Emerita. Anas. Mérida. 7-8, pp. $233-247$.

MATEOS CRUZ, Pedro (2011) - Topografía y urbanismo de Augusta Emerita. In Actas Congreso Internacional 19102010: El Yacimiento Emeritense. Mérida: Consorcio Ciudad Monumental Histórico-Artística y Arqueológica de Mérida, pp. 127-144.

MOREIRA, Álvaro (2005) - Estação arqueológica do Monte do Padrão: o Castro do Monte do Padrão: Do Bronze Final ao fim da Idade Média. Santo Tirso: Câmara Municipal de Santo Tirso.

MOREIRA, Álvaro (2009) - "Castellum Madiae" formação e desenvolvimento de um "aglomerado urbano secundário" no ordenamento do povoamento romano entre Leça e Ave. Santiago de Compostela: Universidade de Santiago de Compostela (Tese de Doutoramento).

PESANDO, Fabrizio (1997) - Domus. Edilizia privata e società pompeiana fra III e I secolo a.C.. Roma.

RASCÓN MARQUÉS, Sebástian; SÁNCHEZ MONTES, Ana (2014) - "Complutum” de la ciudad clásica a la deconstruida a través de 700 años de historia. In VAQUERIZO GIL, Desiderio; Garriguet Mata, José; León Muñoz, Alberto (coord.) - Ciudad y territorio: transformaciones materiales e ideológicas entre la época clásica y el Altomedioevo. Córdoba: Universidad de Córdoba, Servicio de Publicaciones (Monografias de arqueología cordobesa; 20), pp. 309-324.

RASCÓN MARQUÉS, Sebástian; SÁNCHEZ MONTES, Ana (2017) - La ciudad romana de Complutum nuevos datos, nuevas interpretaciones. Vides monumenta veterum: Madrid y su entorno en época romana. Comunidad de Madrid: Museo Arqueológico Regional, Alcalá de Henares (Zona arqueológica; №. 20; 1,), pp. 127-143.

SÁNCHEZ BARRERO, Pedro (2007) - Nuevos datos sobre el trazado viario urbano de Augusta Emerita en el cerro del Calvario. Memoria. 10, pp. 113-119.

SÁNCHEZ MONTES, Ana (2011) - Aportaciones al conocimiento de la casa privada romana en España: La domus en la ciudad de Complutum. In Actas de las octavas jornadas de Patrimonio Arqueológico en la Comunidad de Madrid. Madrid: Consejería de Cultura y Deportes. Dirección General de Patrimonio Histórico, pp. 171-182.

SILVA, Armando (1986) - A Cultura Castreja no Noroeste de Portugal. Paços de Ferreira: Museu Arqueológico da Citânia de Sanfins.

SILVA, Armando; MACHADO, José (2007) - Banhos Castrejos do Norte de Portugal. In Pedra Formosa - Arqueologia Experimental. Vila Nova de Famalicão: Câmara Municipal de 
Vila Nova de Famalicão/Museu Nacional de Arqueologia, pp. 20-6o.

WALLACE-HADRILL, Andrew (2015) - What makes a Roman House a "Roman House"? in TUORI, Kaius; NISSIN, Laura (eds.) - Public and Private in the Roman House and Society. Rhode Island, Portsmouth (Journal of Roman Archaeology Supplementary Series 102), pp. 177-186.
ZANKER, Paul (1988) - The Power of Images in the Age of Augustus. Ann Arbor: The University of Michigan Press.

ZANKER, Paul (1998) - Pompeii, Public and Private Life. London: Harvard University Press.

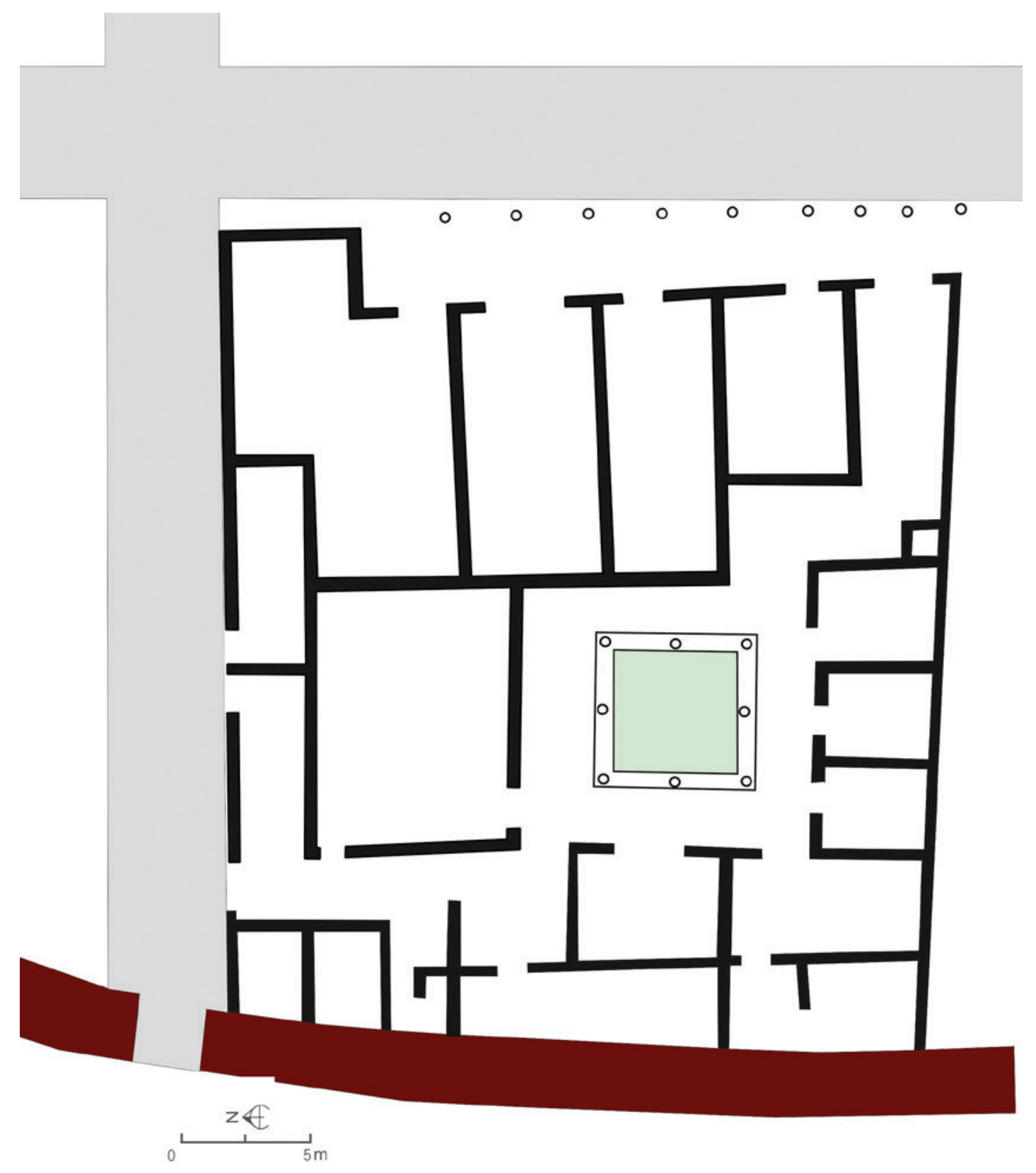

Figura 1 - Planta da 'Casa da 6’ Mouraria (Magalhães, 2019). 


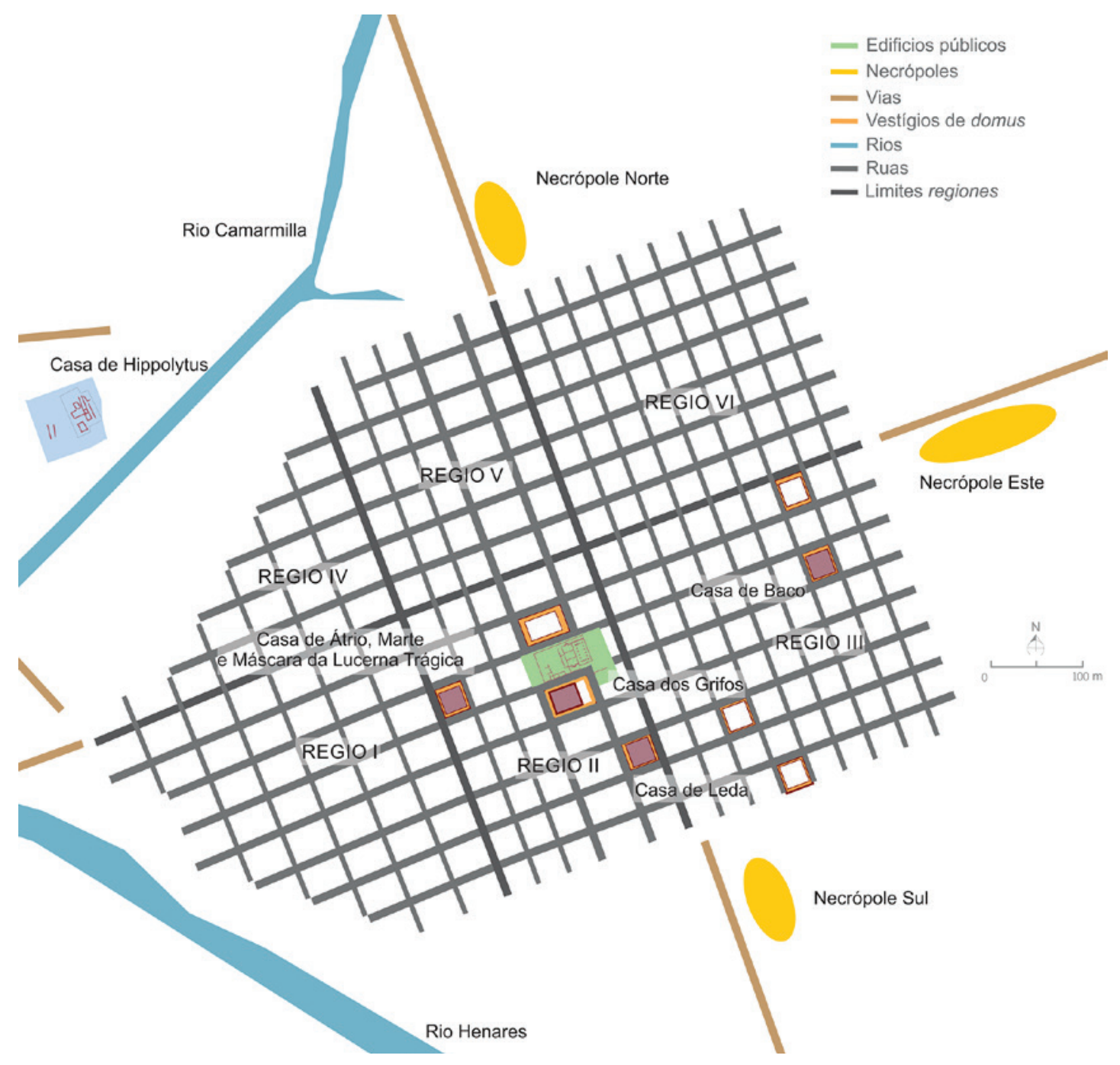

Figura 2 - Planta da cidade de Complutum com a identificação das domus (Magalhães, 2019).
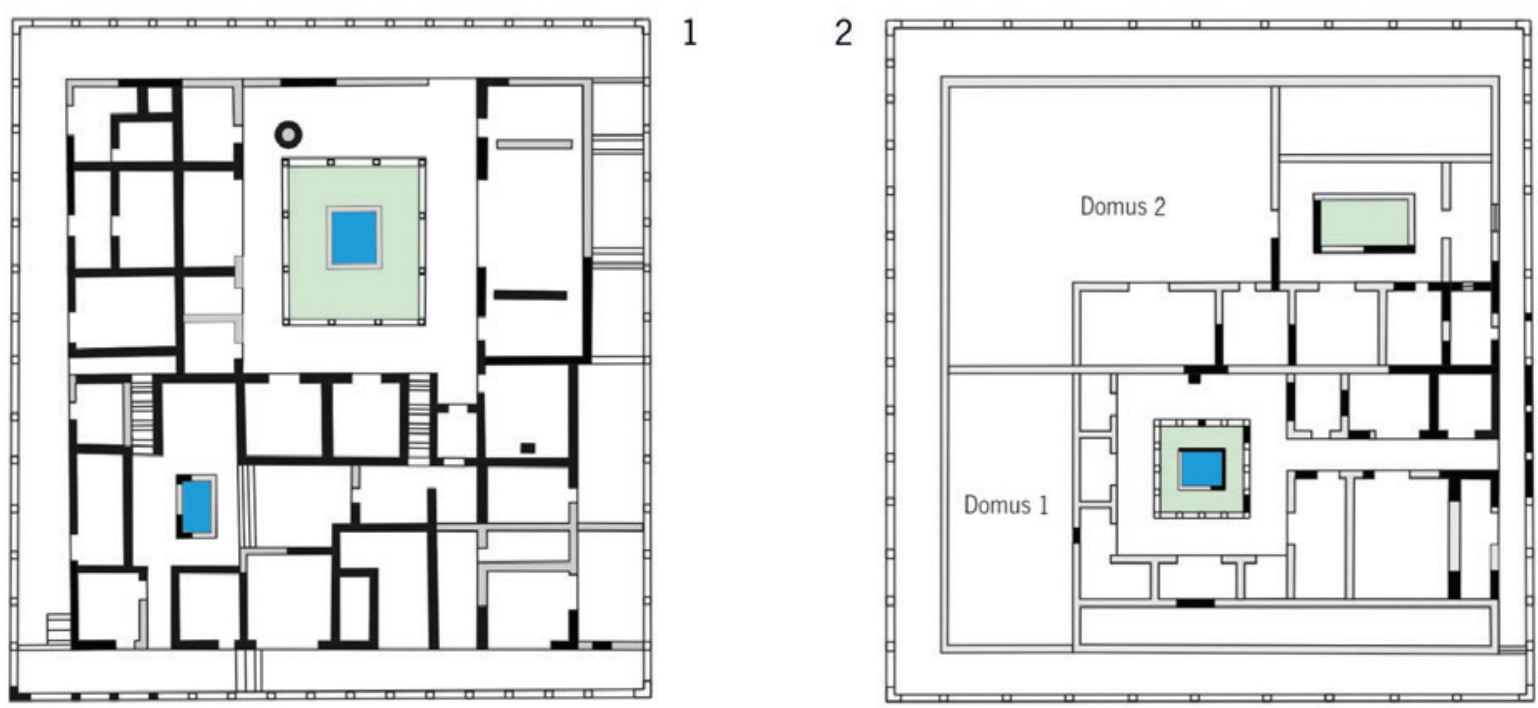

Figura 3 - Modelos das domus identificadas em Bracara Augusta.1. Domus das Carvalheiras; 2. Domus Escola Velha da Sé/rua Frei Caetano Brandão nºs 166-168. 


\title{
AS PINTURAS MURAIS ROMANAS DA RUA GENERAL SOUSA MACHADO, N. ${ }^{\circ} 51$, CHAVES
}

José Carvalho ${ }^{1}$

\begin{abstract}
RESUMO
No diagnóstico arqueológico realizado na Rua General Sousa Machado, n. ${ }^{\circ} 51$, em Chaves, no âmbito de uma obra relacionada com a reabilitação de um imóvel, foi identificado um conjunto de estruturas romanas pertencentes a um edifício habitacional da Época Romana. Em dois dos muros pertencentes ao edifício referenciado foram detetados vestígios de dois painéis pintados a fresco (pinturas murais). Foi realizado um plano de conservação e restauro das pinturas tendo em vista a sua preservação. Os contextos murais em análise eram totalmente desconhecidos no atual território transmontano.
\end{abstract}

Palavras-chave: Aquae Faviae, Domus, Termas, Criptopórtico, Pintura mural.

\begin{abstract}
In the archaeological diagnosis carried out in the pre-construction phase, at Rua General Sousa Machado, 51, in Chaves, as part of a work related to the rehabilitation of a property, the archeology team identified Roman structures belonging to a residential building. In two of the walls belonging to the referenced building, were detected two freshly painted panels (mural paintings). A plan for the conservation and restoration of the paintings was carried out to allow their preservation. The mural contexts under analysis were totally unknown in the current territory of Trás-os-Montes.
\end{abstract}

Keywords: Aquae Faviae, Domus, Mural painting, Roman baths, Underground vaults.

\section{DADOS INTRODUTÓRIOS}

Os trabalhos arqueológicos desenvolvidos pela ERA-Arqueologia, S.A. decorreram de forma faseada entre janeiro de 2017 e outubro de 2018. Consistiram na realização de diagnóstico prévio e o subsequente acompanhamento arqueológico (fase de obra) no âmbito do plano de minimização de impactes patrimoniais de uma empreitada de requalificação de um edifício, sito na Rua General Sousa Machado, n.ํำ 51 Rua Luís Viacos, em pleno centro histórico da cidade de Chaves, em área de grande proximidade com outras estruturas arqueológicas de cronologia romana, bem como da muralha medieval (Amaral, 1993; Carneiro, 2003).

As medidas de minimização preconizadas no plano de trabalhos passaram, numa primeira fase, pela realização de 3 sondagens manuais de $2 \mathrm{mx} 2 \mathrm{~m}\left(12 \mathrm{~m}^{2}\right)$ implantadas sobre as superfícies da propriedade onde se efetuariam maiores afetações ao nível do solo. No âmbito do diagnóstico arqueológico realizado em fase prévia à obra (fevereiro de 2017), a equipa de arqueologia identificou um conjunto de estruturas romanas pertencentes a um edifício habitacional de cronologia romana. Dos contextos mencionados sobressaíram evidências claras da presença de vestígios inéditos da cidade de Aqua Flaviae, designadamente frescos/pinturas murais associados aos muros detetados na intervenção arqueológica prévia à obra.

Face ao elevado estado de degradação do edifício alvo de reabilitação, e na sequência de várias reuniões entre o dono de obra, DRCN, equipa de arqueologia e serviços de arqueologia da Câmara Municipal de Chaves, ficou acordado entre os intervenientes (em maio de 2017) a necessidade de se reforçar estruturalmente o edifício para posteriormente a equipa de

1. Omniknos, Lda; josecarvalho@omniknos.pt 
arqueologia realizar, com as devidas condições de segurança, o alargamento da sondagem onde foram detetados os muros romanos com vestígios de pinturas murais.

Neste seguimento, as medidas de minimização passaram pela selagem das sondagens n...2 e n..${ }^{3}$, a realização de uma laje térrea com uma profundidade máxima de $45 \mathrm{~cm}$ (evitando-se a elaboração de sapatas até ao substrato geológico) e, no caso da sondagem onde foram identificados os vestígios de pintura mural, foi elaborado pelo empreiteiro uma reentrância na laje de betão (no piso térreo) para tornar possível, após o reforço estrutural do edifício, a caracterização e registo dos contextos arqueológicos identificados. Com efeito, o presente trabalho não pretende fazer qualquer revisão ou reinterpretação dos resultados da escavação arqueológica, mas, sim, realizar uma apresentação e contextualização das inéditas pinturas murais romanas.

A metodologia de que nos servimos, para além de uma explicação genérica dos contextos arqueológicos, compreendeu uma descrição das características das pinturas murais e um breve panorama da sua distribuição no atual território português (Figura 1).

\section{BREVE DESCRIÇÃO DOS CONTEXTOS ARQUEOLÓGICOS IDENTIFICADOS}

As estruturas identificadas nas sondagens realizadas na Rua General Sousa Machado, 51, fazem parte de uma domus da cidade romana de Aquae Flaviae. No ambiente 1, sondagem 4, foi detetada uma estrutura subterrânea (muito fragmentada), cuja particularidade construtiva/arquitetónica apresenta paralelismos com as designadas estruturas fixas de aquecimento-hypocaustum.

A suspensurae, que inclui o pavimento de circulação, tal como em muitos outros locais, não se conservou. É constituído por grandes tijolos quadrangulares, do tipo bipedale, apresentando uma largura suficiente para recobrir solidamente as 5 fiadas de $\operatorname{arcos}$ (Figura 2).

Por cima da estrutura subterrânea destaca-se o piso em opus signinum que foi cortado e destruído por uma derrocada (ou derrube) que ocorreu no local. A base da estrutura anteriormente mencionada, onde pousavam ou arcos que suportavam a suspensurae, é em opus signinum, o que não constitui uma particularidade, visto que são conhecidos pavimentos de estruturas de aquecimento subterrâneas em tijolo, opus signinum, sendo, por vezes, utilizada a própria rocha regularizada para o efeito, que assumia o papel de area, tal como acontece nas termas do Alto da Cividade, em Braga, pelos menos nas fases de utilização mais tardias (fases III e IV) (Martins, 2005: 46-64).

No âmbito da escavação não foram identificados tubuli, bem como elementos de carvão associados às fornalhas de aquecimento. No caso da ausência de carvões deverá ter-se em consideração que a escavação em níveis de lama (devido ao escoamento de águas pluviais para a área da escavação condicionou a obtenção desses dados). Desta forma, apesar de considerarmos que o compartimento em análise estava associado a um balnea de uma domus romana, torna-se difícil aferir, com toda a certeza, se a estrutura subterrânea identificada constituía, de facto, uma estrutura de aquecimento de uma sala quente do complexo termal da habitação.

De facto, o pavimento romano suspenso em pequenos arcos de tijolo cerâmico poderia igualmente constituir um princípio construtivo de laje elevada, não para possibilitar o seu aquecimento inferior, mas para o isolar das águas que ainda hoje continuam a nascer no local. Para corroborar esta hipótese não se pode negligenciar a presença de opus signinum utilizado como revestimento parietal e do solo (na base do criptopórtico) para provavelmente permitir o isolamento do mesmo da humidade e da água (Figura 3).

De uma forma geral, a análise ao escasso espólio cerâmico recolhido por ambientes na sondagem n. ${ }^{\circ} 4$, não permite uma leitura cronológica clara devido à falta (ou quase ausência) de materiais com cronologias específicas de produção (por exemplo cerâmica fina e de luxo), todavia, a presença de raros fragmentos sigillata sudgálica indicia uma provável primeira ocupação do espaço no séc. I d.C.

A presença de um fragmento de terra sigillata hispânica tardia na sondagem 3, poderá também demonstrar que a ocupação do espaço prolongou-se pelo Baixo Império.

Por outro lado, não se pode descurar a presença de vários fragmentos de cerâmica com decorações plásticas associadas a um depósito de um nível de violação (que corta várias realidades arqueológicas romanas dos ambientes 1,2 e 3 ) e que evidencia também que o sítio foi reocupado ou reutilizado no decurso da Idade Média. 


\section{AS PINTURAS MURAIS ROMANAS (SONDAGEM 4)}

Os painéis pintados a fresco (já muito deteriorados) localizam-se em dois muros que delimitam um compartimento do edifício romano identificado nos trabalhos de diagnóstico arqueológico (Figura 4).

Em termos gerais, as pinturas encontravam-se já muito deterioradas, mas preservaram-se as camadas de preparação em argamassa, assim como parte dos revestimentos pintados, no entanto, já parcialmente destruídos, sendo difícil restituir os painéis originais (Figura 5).

Os painéis identificados são policromáticos, ou seja, apresentam várias tonalidades como o vermelho, o preto, o cinzento, o azul, o castanho e o branco. Os motivos pintados são difíceis de identificar, visualizando-se, no entanto, fundos com temas vegetalistas e geométricos (Figura 6).

No atual território português os exemplos fragmentários de pintura mural romana, in situ, atualmente conhecidos permitem situar este tipo de produções entre o séc. I e o séc. IV d. C.

Em Bracara Augusta, salienta-se a presença de pintura mural em vários edifícios romanos, quer públicos, quer privados. Como exemplo, poderíamos referir as argamassas que revestiam a fronspulpiti do teatro que receberam painéis pintados, pontualmente identificados nas escavações.

Também a domus identificada na Rua Frei Caetano Brandão / Santo António das Travessas, datada do século I d.C., apresenta, em vários dos seus muros, vestígios de argamassas arenosas, que constituíam revestimentos preparatórios destinados a receber painéis pintados (Ribeiro, 2010, p.394) (Figura 7). O mesmo acontece nos corredores da parte da domus escavada na Escola Velha da Sé (Braga), onde se encontraram argamassas de revestimento das paredes, facto que indicia que as mesmas deveriam ter sido pintadas, pelo menos na fase tardia de ocupação da casa.

No restante território português as pinturas murais, segundo Pedroso (2005, p.321) aglomeram-se, sobretudo, nas áreas mais romanizadas dos conventus pacencis e scalabitanus (Figura 8).

\section{CONCLUSÃO}

O elevado valor arqueológico das estruturas identificadas nas sondagens efetuadas, permite-nos per- ceber que estamos perante achados arqueológicos únicos e importantes para o conhecimento da evolução da cidade de Chaves.

A identificação de pinturas murais de cronologia romana na sondagem n. .4 (onde se executou um plano de conservação e restauro das mesmas tendo em vista a sua preservação, incluindo a estrutura em forma de criptopórtico identificada no ambiente 2), revelam a raridade e importância dos achados (no atual território transmontano os vestígios de pintura mural romanas eram totalmente desconhecidos).

Perante as dificuldades encontradas para a musealização dos vestígios, por aí se verificar um constante aparecimento de água como nascente, ficou acordado entre os intervenientes que a zona escavada deveria ser novamente preenchida e selada, para possibilitar a preservação in situ das realidades arqueológicas, evitar futuros abatimentos dos alicerces do edifício e também para evitar que a humidade e evaporação daí provenientes não permitam tornar os compartimentos habitáveis.

\section{BIBLIOGRAFIA}

AMARAL, Paulo (1993) - O Povoamento Romano no Vale Superior do Tâmega - Permanência e mutações na Humanização de uma Paisagem. Dissertação de Mestrado em Arqueologia apresentada à Faculdade de Letras da Universidade do Porto. Porto.

CARNEIRO, Sérgio (2005) - Intervenções arqueológicas de emergência no centro histórico de Chaves (1999-2000), Revista Aquae Flaviae, ํㅜ3ㄹ, Chaves.

PEDROSO, Rui (2005) - Pintura Mural Luso-Romana. O Arqueólogo Português. Série IV. 23. 2005, p.321-366 (Disponível em http://www.patrimoniocultural.gov.pt/static/ data/publicacoes/o_arqueologo_portugues/serie_4/volume_23/pintura.pdf).

RIBEIRO, João (2010) - O Tecido Urbano Flaviense De Aquae Flaviae a Chaves Medieval. Dissertação de Mestrado em Arqueologia apresentada à Universidade do Minho. Braga. (Disponível em http://repositorium.sdum.uminho.pt/ handle/1822/13805).

RIBEIRO, Jorge (2010) - Arquitetura Romana em Bracara Augusta. Uma análise das técnicas edilícias. Vol.I. Tese de doutoramento apresentada à Universidade do Minho. Braga (Disponível em http://repositorium.sdum.uminho.pt/ handle/1822/12232).

TEIXEIRA, Ricardo (1996) - De Aquae Flaviae a Chaves. Povoamento e organização do território entre a Antiguidade e a Idade Média. Dissertação de Mestrado em Arqueologia apresentada à Faculdade de Letras da Universidade do Porto. Porto. 


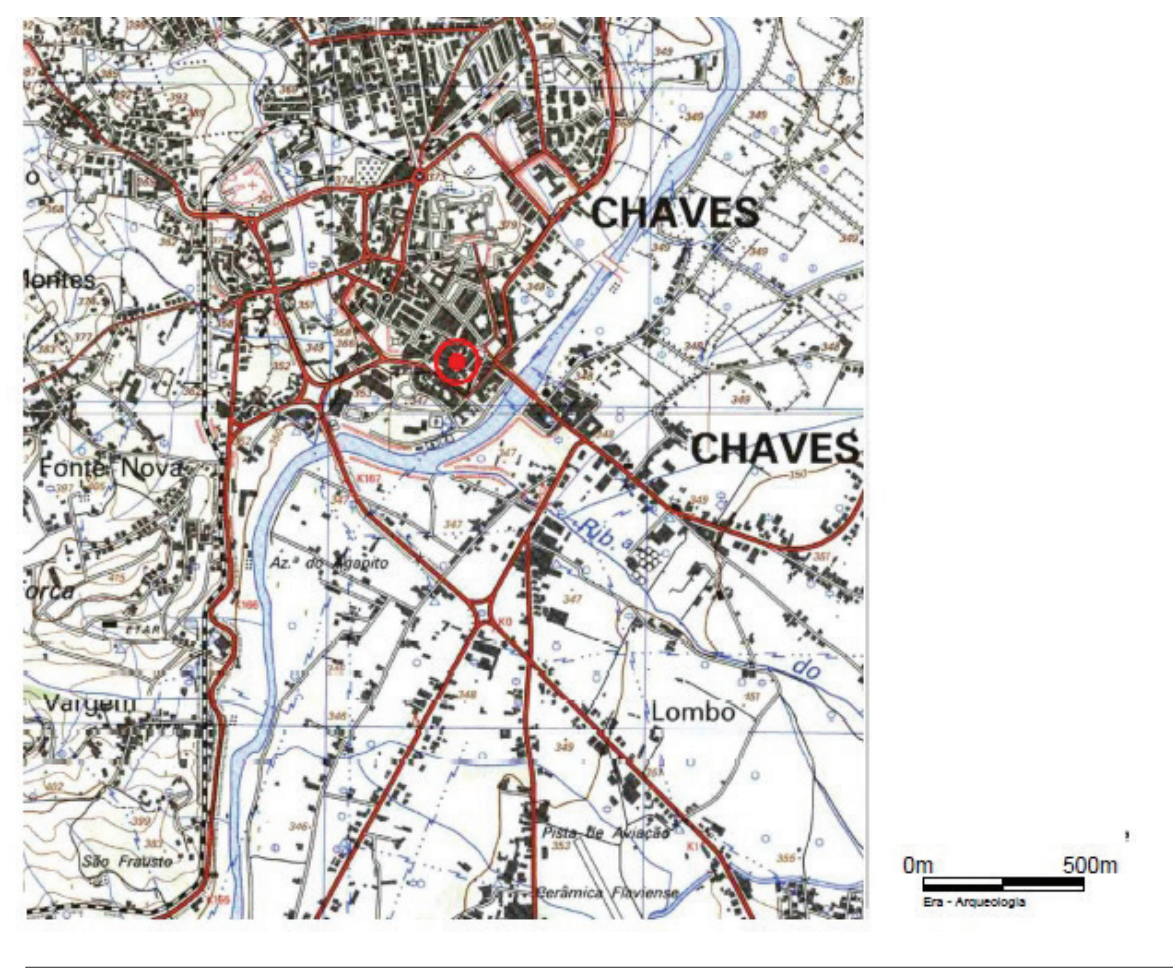

Figura 1 - Localização do sítio num excerto da Carta Militar de Portugal 1/25 ooo, folha 34.

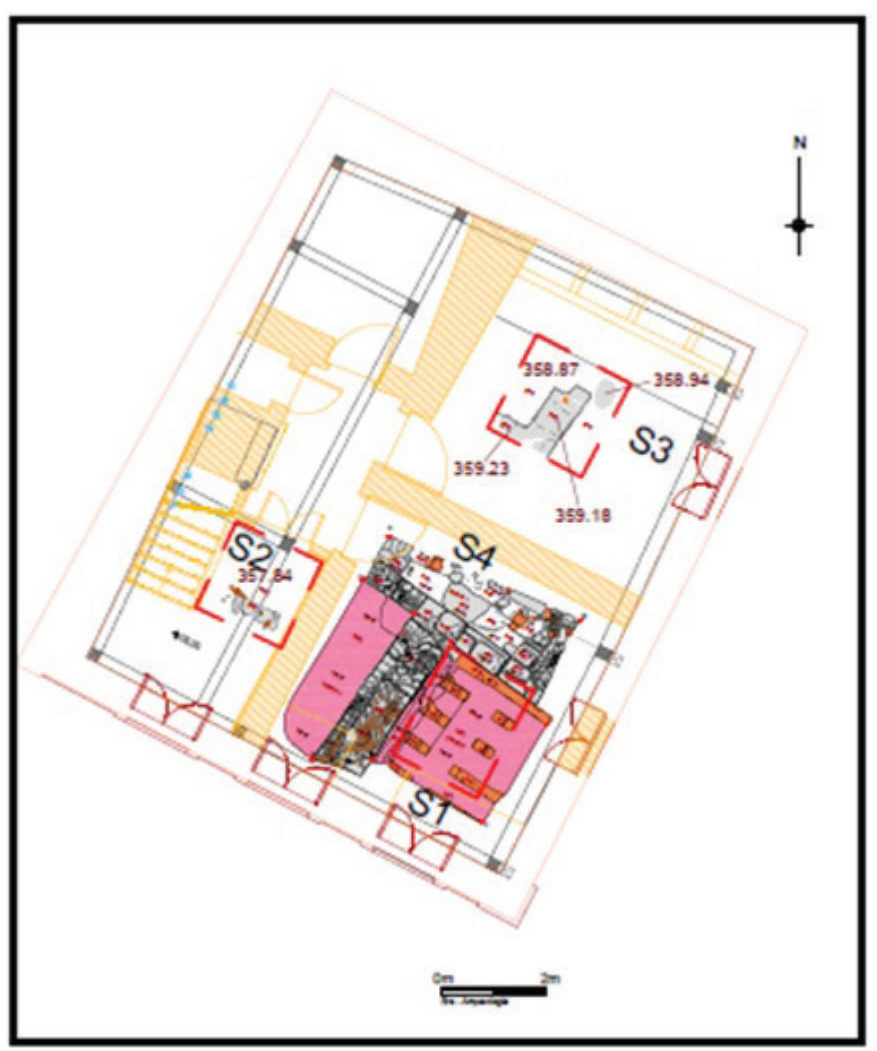

Figura 2 - Localização das sondagens arqueológicas e dos vestígios identificados na rua General Sousa Machado, 51 (piso o), Chaves. 


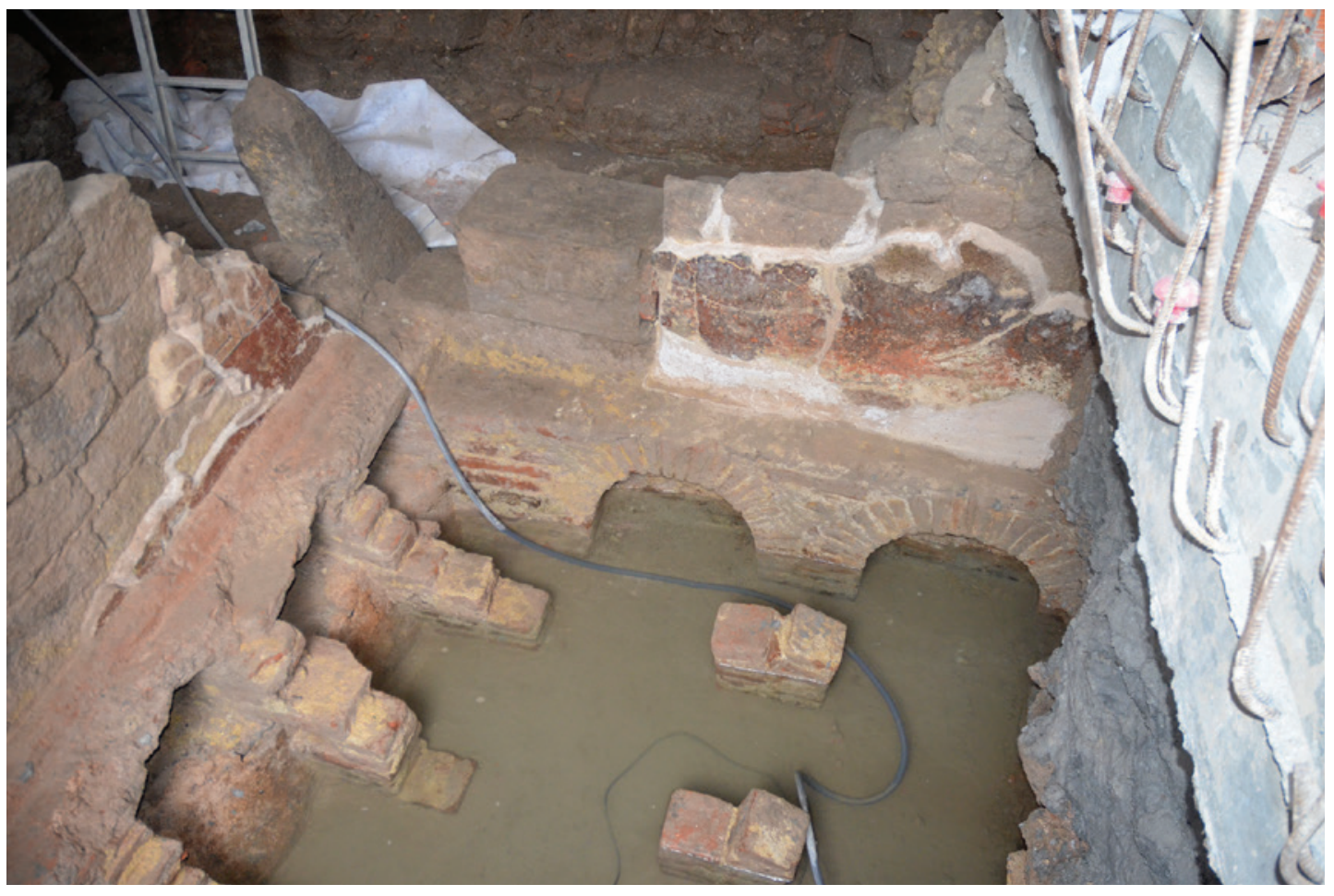

Figura 3 -Localização dos dois painéis com pinturas murais e pormenor da estrutura subterrânea.

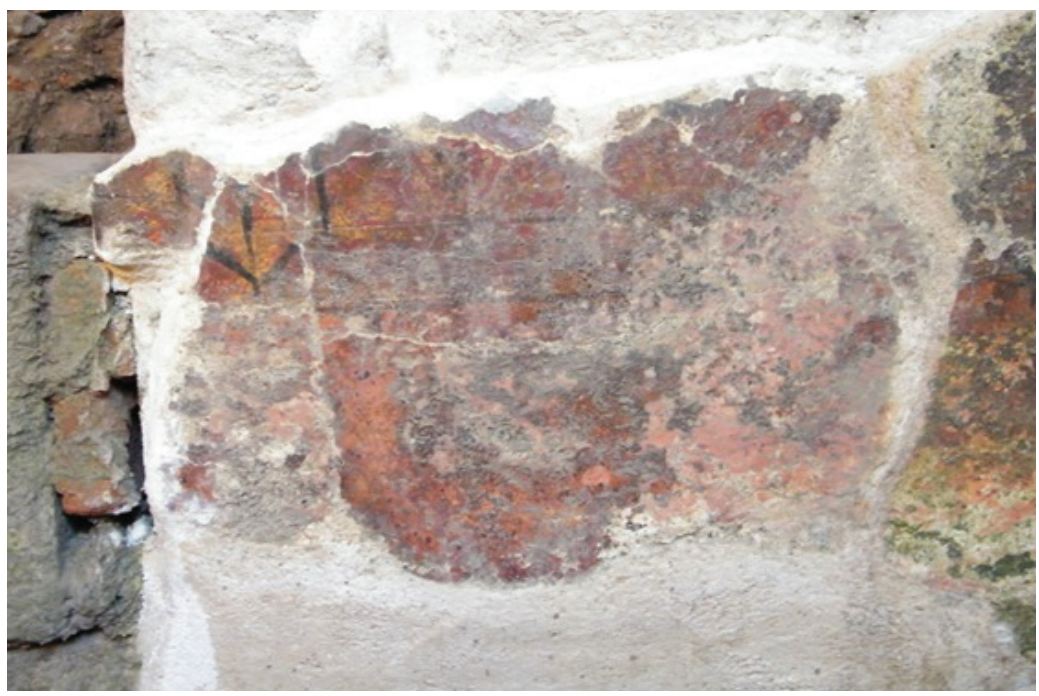

Figura 4 - Pormenor do painel 1 com vestígios de pintura mural. 


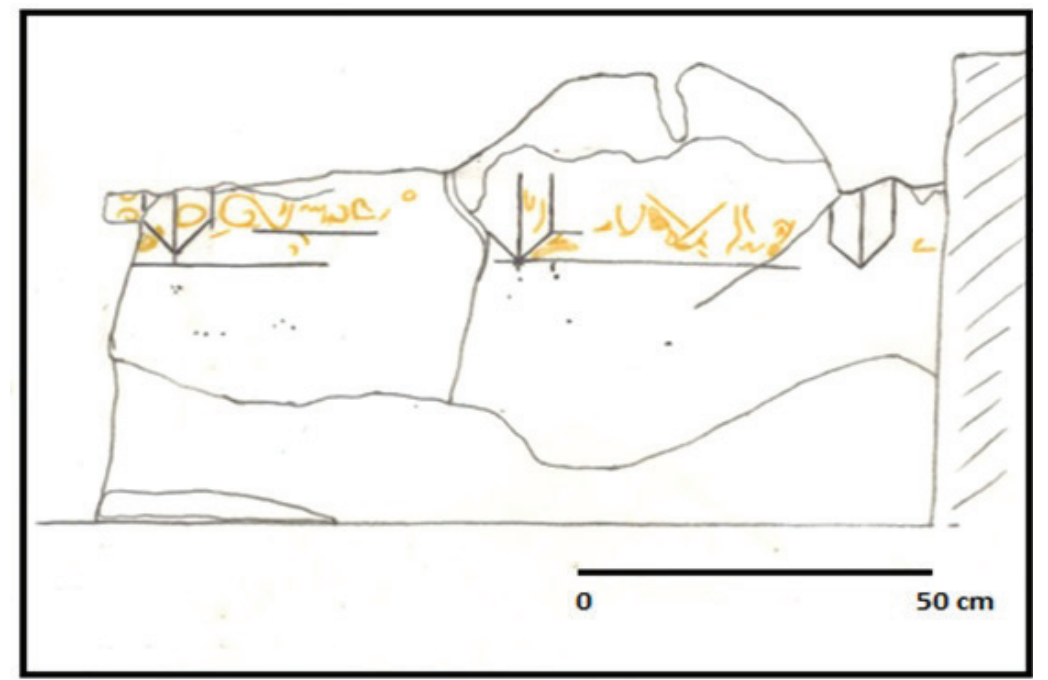

Figura 5-Desenho com a representação dos motivos decorativos associados ao revestimento do painel n. ${ }^{\circ}$.

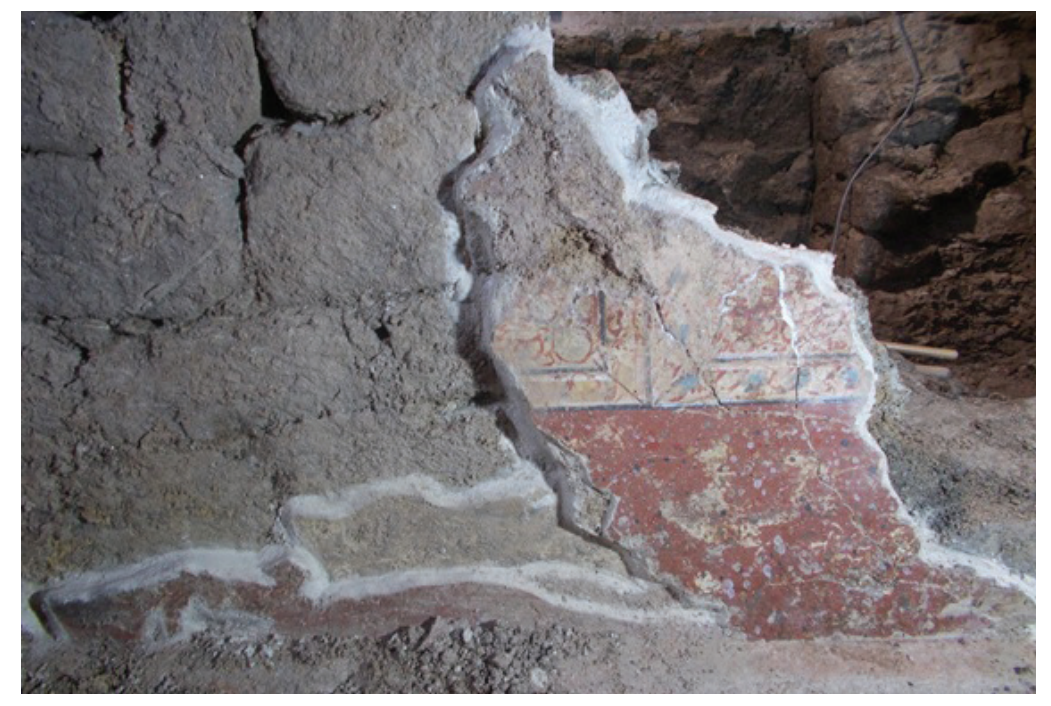

Figura 6 - Fotografia pormenorizada com os motivos decorativos associados ao painel n. ${ }^{\circ}$ 


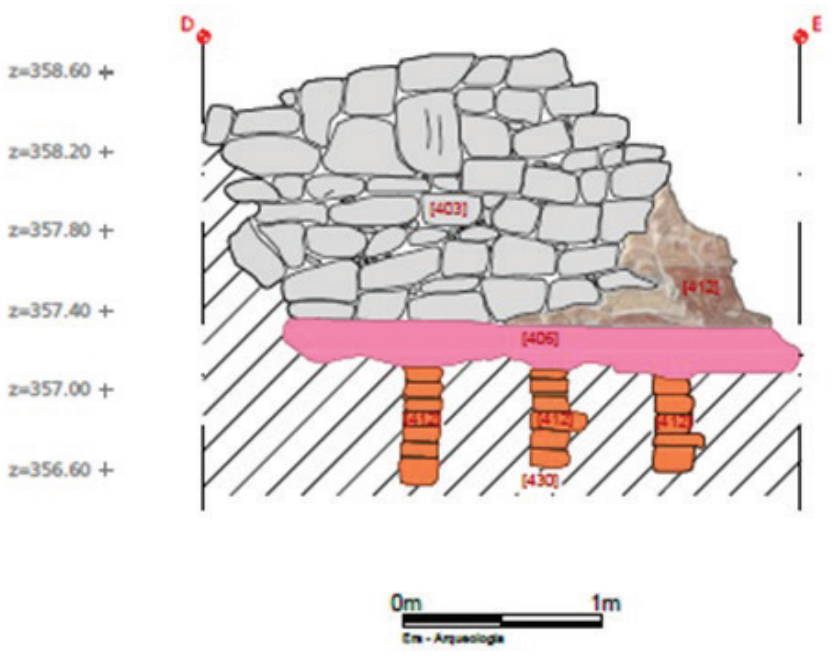

Figura 7- Perfil estratigráfico do limite Oeste do compartimento onde se identificaram os vestígios de pintura mural (Rua General Sousa Machado, 52, Chaves).

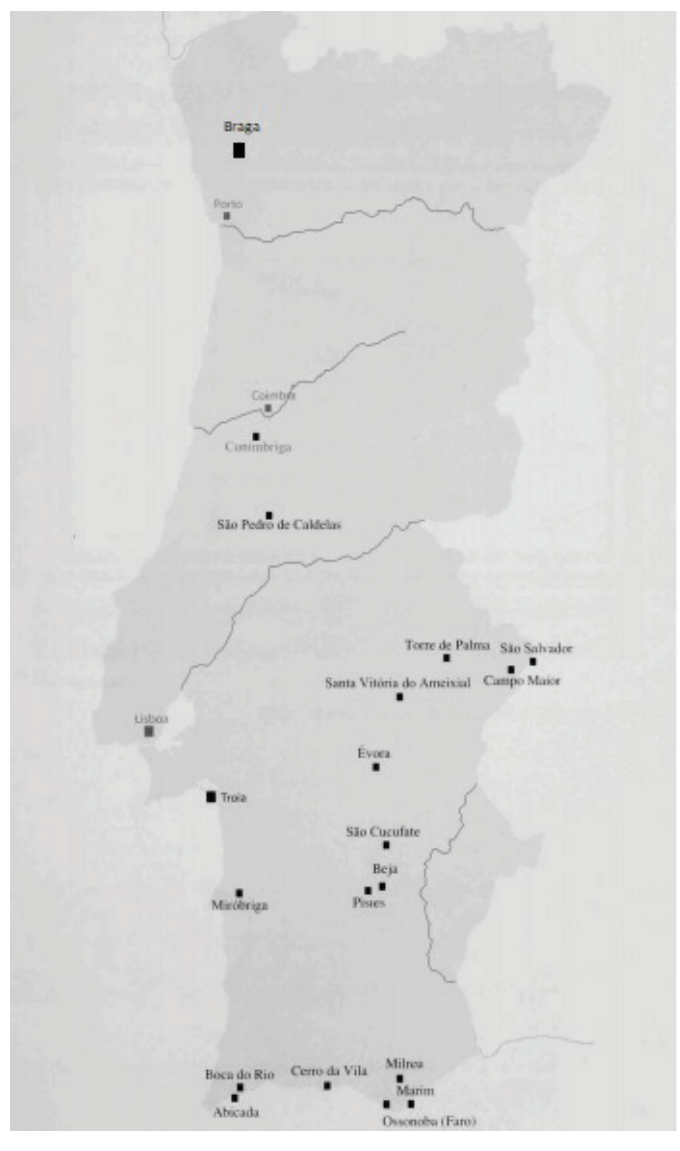

Figura 8 - Localização dos vestígios de pintura mural romana identificados no atual território português, adaptado de Pedroso (2005, p.363). 


\title{
TRÁS DO CASTELO (VALE DE MIR, PEGARINHOS, ALIJÓ) - UMA EXPLORAÇÃO AGRÍCOLA ROMANA DO DOURO
}

Tony Silvino ${ }^{1}$, Pedro Pereira ${ }^{2}$

Este texto é dedicado, in memoriam, ao nosso amigo, o jornalista Carlos Magalhães de Vale de Mir

\begin{abstract}
RESUMO
O Vale do Douro é um dos territórios com maior potencial arqueológico por estudar no Noroeste Peninsular. Embora tenham sido realizados estudos mais aprofundados em algumas zonas, a maioria da informação que possuímos nos dias de hoje provém de intervenções antigas ou da historiografia tradicional. A presença romana no território do Vale do Douro é geralmente aceite, pela historiografia tradicional, para o período a partir do século II da nossa Era, ainda que se aceite cada vez mais a presença de "ruídos de fundo", de dados que permitem mencionar instalações romanas anteriores. O sítio de Trás do Castelo, implantado a meia encosta de um pequeno castro da Idade do Ferro, é o reflexo do início de uma transformação da paisagem, iniciada com a chegada de Roma ao território do Douro e que virá a moldar esta zona montanhosa no Vale do Douro nos “jardins suspensos” de Miguel Torga.
\end{abstract}

Palavras-chave: Romanização, Agropecuária, Vale do Douro.

\begin{abstract}
The Douro Valley is one of the least studied, though with the most archaeological potencial areas in Norwestern Portugal. Even though some areas have been extensivelly researched, the information that we have for most of the territory comes from older excavations or traditional historiography. The roman presence in the Douro Valley is generally accepted for the period since the II century AD, even though it is more and more accepted the presence of backgound noises, data that allow for older roman instalations. The site, located on the hillside of a small Iron Age castro, is the reflexion of a landscape change, that started with the advent of Rome in the territory, and that will forever change the Douro Valley unto the suspended garden of Miguel Torga.

Keywords: Romanization, Farming, Douro Valley.
\end{abstract}

\section{TRÁS DO CASTELO E O SEU ENQUADRAMENTO}

O lugar de Vale de Mir (freguesia de Pegarinhos, concelho de Alijó) localiza-se numa extremidade de um planalto granítico, próximo da estrada municipal que liga a aldeia de Pegarinhos à Estrada Nacional e ao recente Itinerário Complementar 5. O "castelo" situa-se a Oeste do núcleo habitado atual. Situa-se numa pequena elevação que se destaca bem da área envolvente, com um altitude relativa de $782 \mathrm{~m}$. As primeiras referências a este sítio remontam ao tra-

1. EVEHA, UMR 5138 ArAr e CITCEM; tony.silvino@eveha.fr

2.CITCEM; pedro.abrunhosa.pereira@gmail.com balho do padre Henrique Botelho, que fornece as primeiras referências sistemáticas sobre os castros do concelho de Alijó (Botelho 1986: 266). A segunda referência é de Pedro de Azevedo, que realiza uma recolecção dos dados patentes nas memórias paroquiais de 1758 (Azevedo 1901: 106). A partir destas recolhas, o sítio é apenas mencionado em estudos mais amplos, contexto regional ou macro-regional (Silva 1986; Lemos 1993; Almeida et al. 1997). Actualmente, o sítio encontra-se coberto de pinheiros e gestias na zona mais alta e de campos de cultivo nas zonas baixas, na sua maioria abandonados. Estes tra- 
balhos de agricultura terão, infelizmente, destruído parte dos vestígios edificados, pelo menos na zona da muralha exterior. Trata-se de um habitat de pequenas dimensões, protegido por duas linhas defensivas, onde podemos ainda observar pequenos troços de aparelho constructivo de opus incertum em granito. O "castro" ou "castelo" encontra-se numa posição dominante, sobre o Vale do Souto e o rio Tinhela (Figura 1).

\section{O PROJECTO DE INVESTIGAÇÃO SOBRE A OCUPAÇÃO HUMANA EM TORNO DA ALDEIA DE PEGARINHOS, ALIJÓ}

Em 2012 foi aprovado o Projecto de Investigação sobre a Ocupação Humana em torno da aldeia de Pegarinhos, Alijó (PIOHP) 3 . O objectivo inicial era o de realizar uma série de sondagens tanto na encosta do Castelo de Vale de Mir como no Castro de Castorigo. No entanto, após a primeira campanha de escavação, foi decidido concentrar esforços no local de Trás do Castelo, tanto pelas questões que levantava como pelo aparente potencial. O PIOHP duraria um total de cinco campanhas de intervenção no terreno, contando com dezenas de voluntários, sobretudo alunos de Arqueologia da Universidade do Porto e arqueólogos. Durante esta primeira intervenção, foi possível descobrir uma série de estruturas, com duas fases principais de ocupação e abandono, relacionadas com um estabelecimento agrícola, com uma série de cadeias de produção e transformação de matérias primas. A fase de ocupação mais antiga, datável do Alto Império, foi datada durante a intervenção, apenas através dos materiais descobertos em níveis selados, sendo o caso mais paradigmático o denário de Vespasiano, em flor de cunho, descoberto na argamassa do lagar, datando efectivamente a sua construção para o final do século I d.C. Uma segunda fase, que aparenta ser de re-ocupação dos espaços anteriores, decorre no século IV d.C.

3. Este projecto, que duraria até 2016, teve o apoio de estruturas administrativas locais, como a Junta de Freguesia de Pegarinhos e a Câmara Municipal de Alijó, mas também de outras estruturas, como o Regimento de Infantaria 13, de Vila Real. Foi suportado quase totalmente pela Porto Gran Cruz, pelo Centro de Investigação Transdisciplinar Cultura, Espaço e Memória (CITCEM) e pela EVEHA. No entanto, devemos ainda mencionar o apoio da população local, sobretudo de Pegarinhos e Vale de Mir, que nos acolheram e auxiliaram sempre que lhes foi possível.
A ocupação do Alto Império expande-se em vários conjuntos arquitectónicos (A, B e C). Devido à sua planta, o conjuto A (espaços 1 a 4) pode corresponder a uma unidade habitacional, com o seu acesso a Sul, através de um grande terraço. No entanto, poderemos estar perante um espaço utilizado para albergar animais, como equídeos, não destinados à alimentação mas sim para dar resposta às necessidades agrárias, como transporte ou trabalho de campo. No entanto, estas divisões podem também ter sido utilizadas como alojamentos temporários para trabalhadores. O conjunto B, situado a Norte do sítio, articula-se em torno de um pátio central (espaço 9) que, por sua vez, dá acesso a três divisões, a Sul (espaços 5 a 7). A função destes últimos poderia ser diversa, desde o alojamento estival de trabalhadores, arrumação de ferramentas ou armazenamento de materiais. A Oeste, o pátio dá acesso ao espaço 8 que, pelo menos na fase final de ocupação, poderá ter estado ligado à produção têxtil, de origem animal (lã) ou vegetal (linho). A Norte do pátio existem dois espaços, 10 e 12, onde funcionava uma instalação de produção e armazenamento de vinho. O último conjunto, C, localizado a Nordeste, possui dois espaços cuja planta total ainda é desconhecida. Embora o primeiro espaço, 14, possa ser interpretado como um corredor, o espaço 11, pelas suas dimensões, poderá ter sido utilizado como um estábulo ou redil (Figura 2).

O sítio de Trás do Castelo terá muito provavelmente constituído, num primeiro momento, numa pars rustica de uma exploração agrícola. A descoberta de estruturas ligadas à produção de vinho, com o lagar mais antigo conhecido no Vale do Douro (Silvino et al., 2018a), ao tratamento e armazenamento de cereais e à pastorícia, tal como a ausência de uma zona verdadeiramente residencial, dão força a este argumento. Todavia, no final do projecto existiam ainda muitas questões em aberto, tal como a localização e organização da adega ou cella vinaria, a função do espaço 8, no qual, em 2015, haviam sido descobertas uma série de estruturas pouco usuais e uma grande quantidade de pesos de tear e esclarecer a funcionalidade do grande espaço aberto, designado como 14 na planta (Figura 3).

Assim, após a aquisição do terreno vizinho pela Câmara Municipal de Alijó ${ }^{4}$, foi decidido realizar uma

\footnotetext{
4. Devemos agradecer aqui o apoio que temos recebido da Câmara Municipal de Alijó, sobretudo na pessoa do seu autarca, José Paredes.
} 
nova intervenção, no sentido de tentar esclarecer algumas das questões deixadas em aberto pelo PIOHP relativas ao sítio de Trás do Castelo.

\section{O PROJECTO CVTC (2019)}

O objectivo primário do projecto Cella Vinaria de Trás do Castelo (CVTC) foi o de identificar e estudar a cave ou cella vinaria que teria impreterivelmente de estar associada ao lagar descoberto em $2015 \mathrm{em}$ Trás do Castelo. A campanha de 2019 com uma duração limitada a duas semanas, permitiu esclarecer a maioria das questões colocadas. A intervenção centrou-se em torno do espaço identificado como lagar e do grande pátio localizado imediatamente a Este do mesmo. Numa primeira fase, foi terminada a escavação do espaço 8, o que permitiu constatar que existia um elemento complexo, que era já parcialmente visível na campanha de 2016, no centro do espaço. Anteriormente, haviamos evocado a hipótese de podermos estar perante um espaço ligado à produção têxtil, sobretudo devido à quantidade de pesos de fiação, num total de 14 elementos, descobertos aí (Silvino e Pereira, 2018) (Figura 4).

Foram descobertos dois tipos de pesos, oito em cerâmica e seis em xisto. No estudo dos artefactos realizado pelo colega Yannick Tessonneyre, os pesos em cerâmica remetem para uma utilização de fios mais finos, algo comum no mundo romano, com diâmetros inferiores a $0,5 \mathrm{~mm}$. No entanto, a utilização de pesos em pedra levanta algumas interrogações. Embora o tema dos pesos em pedra seja relativamente pouco estudado, esta utilização está documentada até há muito pouco tempo no território português ${ }^{5}$. As várias volumetrias e pesos distintos descobertos na mesma zona levam a que possamos considerar a presença de pelo menos três teares diferentes, tendo em conta que normalmente todos os pesos do mesmo tear têm volumes similares: um com pesos entre os 400 e $800 \mathrm{~g}$, outro com pesos de cerca de $1500 \mathrm{~g}$ e, finalmente, um tear com pesos de 4000 g. Os pesos superiores contrastam muito com a realidade conhecida no Mediterrâneo durante a romanização, com costuras mais ligeiras e pesos de tear normalmente pouco pesados. Pelo contrário, no caso de Trás do Castelo, os pesos recordam as costu-

5. Durante a década de 1950, era comum a utilização de pesos de tear em pedra (Cheval, 2009: 47). ras gaulesas referidas por Estrabão ${ }^{6}$, sobretudo lãs, mais pesadas e preparadas para climas mais agrestes. Os exemplares de pesos mais pesados descobertos em Trás do Castelo sugerem que a sua utilização centrou-se em fibras vegetais, mais pobres, normalmente linho, que implicam maior força de tracção do que as fibras animais (Cheval, 2009: 57).

Relativamente às estruturas descobertas no espaço 8 , a primeira, dois blocos de granito retangulares, pousados na vertical e cada um com uma perfuração (UE 144), poderia ter um eixo móvel em madeira, equipado de uma manivela, que não deixaram vestígios. Esta estrutura poderia também ter sido equipada com uma pedra para servir de amolador, em xisto ou grés, com uma manivela lateral. Embora tenha sido encontrada uma mó em contexto de re-utilização no espaço, o seu peso e forma de encaixe não são enquadráveis nesta tipologia. Paralelamente, seria também necessária a presença de água para um dispositivo deste género, sendo que a segunda estrutura descoberta foi uma "pia"', em granito, circular (UE 145), que poderia ter sido utilizada para receber água para esse fim, sendo que este tipo de estrutura é relativamente comum em contextos arqueológicos, como é notório no caso de Terlamonte I (Teixoso, Covilhã), em que uma pia similar era utilizada para metalurgia (Carvalho, 2007: 2016) (Figura 5).

Embora a hipótese que referimos anteriormente seja possível, devemos ter em conta algumas questões importantes. A primeira prende-se com a relativa raridade deste tipo de estrutura de amolar no mundo romano, sendo que em Trás do Castelo foram descobertas cerca de trinta de pedras de amolar manuais. Paralelamente, a pia descoberta em Trás do Castelo é mais similar a um almofariz do que a um recipiente de água, tendo sido descoberto no seu interior um seixo, provávelmente utilizado para moagem. A primeira estrutura que descrevemos tem uma explicação mais viável, a de ter recebido um enrolador, para auxiliar à criação de novelos de lã ou linho. O linho é a fibra vegetal mais comum e das mais antigas a serem utilizadas na Europa Ocidental (Plínio, H.N., XIX, 1-25). É semeado durante o Inverno e a sua plantação e apanha não têm instrumentos específicos. Após um primeiro tratamento, as fibras são

\section{Geographia, IV, 7, 3.}

7. Devemos assinalar o roubo desta peça, antes do início da campanha de 2019. Foi remetida uma queixa contra desconhecidos junto das autoridades. 
fiadas com o auxílio de um instrumento movido por uma manivela manual. Infelizmente este tipo de engenho é conhecido sobretudo a partir da iconografia para o período antigo, embora tenham chegado até nós exemplares mais recentes. A pedra de moagem, descoberta no interior da "pia", foi alvo de análises analíticas por parte do laboratório Nicolas Garnier, que demonstrou a existência de traços de gordura de um animal não ruminante, possívelmente porco, aquecida, e um derivado de uva não fermentado, vinho ou vinagre.

Finalmente, falta referir a estrutura em blocos de granito (UE 142) e o espaço de aquecimento (UE 154 e 159). Estas duas estruturas poderiam funcionar em conjunto devido à sua proximidade. Relativamente à funcionalidade destas estruturas, embora o espaço de aquecimeo pudesse ser apenas isso mesmo, um ponto de calor utilizado durante o Inverno e servir para cozinhar alimentos, poderá, da mesma forma, ter servido para actividades artesanais, muito provávelmente para o trabalho de fibras têxteis. Paralelamente, a função da estrutura UE 142 continua a ser difícil de discernir. Podemos, no entanto, encontrar algumas hipóteses funcionais, sobretudo a partir da documentação etnográfica do Ocidente Europeu (Figura 6).

O trabalho do linho necessita de uma fase de lavagem, durante a qual as fibras são colocadas num balde ou tina em madeira com água quente. A esta eram adicionados elementos de lavagem, como cinzas e sabão, sendo estas técnicas ainda utilizadas em algumas zonas de Portugal. A estrutura UE 142 recorda os suportes em madeira que são visíveis em documentação etnográfica em França. Uma tina em madeira seria instalada em cima de um suporte, dentro da qual eram colocadas as fibras, os carvões e sabão. No fundo da tina, existia um buraco para permitir a passagem da água, através de um tubo, para um caldeirão, colocado numa zona de aquecimento ou lareira. A água era aquecida e, com o auxílio de uma estrutura de canalização, era re-transferida para a tina, passando pelas fibras e pelas substâncias de limpeza, e escoando novamente para a estrutura de aquecimento. As fibras, lavadas e com uma cor mais esbranquiçada, seriam depois secas. Finalmente, a fibra seria torcida e fiada numa zona da casa preparada para esse efeito, normalmente sombrias e húmidas, num engenho de fiação.

Relativamente ao tratamento do linho, sobretudo após a colheita, a curtimenta da planta, seca, era fei- ta normalmente em ribeiras. Era utilizada uma zona com pelo menos meio metro de profundidade, com pouca corrente, sítio normalmente apelidado de pequena lagoa ou laga. Esta etapa, que necessitaria de água corrente em abundância, poderia ser realizada na estrutura descoberta na campanha de 2012. Trata-se de um tanque hidráulico, de formato rectangular $(7,20 \times 2,50 \mathrm{~m})$ situado a cerca de 50 metros a Sul do conjunto de estruturas do sítio. Embora a parte oriental tenha desaparecido, a escavação deste espaço permitiu descobrir um tanque construído com recurso a muros em blocos de granito e revestido a opus signinum. A análise das estruturas que compõem o tanque e a sua localização permitem elaborar alguma reflexão sobre a sua funcionalidade. $\mathrm{O}$ tanque seria alimentado por água que descia da plataforma imediatamente acima do mesmo, sendo ainda visível os restos de uma mina nesta zona. A água passaria pela conduta a Oeste do tanque. A fossa retangular a Oeste aparenta ter feito parte de um sistema de comportas, permitindo controlar a passagem da água. Finalmente, um canal permitia a passagem das águas para fora do tanque. É ainda visível um degrau de acesso no ângulo Sudoeste do tanque. Embora esta seja apenas mais uma hipótese funcional, uma vez que este tanque poderia ter sido utilizado para ouros fins, como bebedouro de animais ou para lavagem de minerais, o conhecimento técnico aplicado na construção e a sua articulação com as restantes estruturas descobertas leva-nos a colocar a hipótese de o tanque ter sido utilizado para curtimenta de linho.

Finalmente, no ângulo sudoeste da estrutura, encontramos uma caixa de escadas (UE 16o) que permitiria o acesso a uma abertura do lado do espaço 5 ou mesmo a um andar superior. Foi ainda encontrada uma base de coluna, ao contrário, que aparenta estar num contexto de re-utilização e poderá ter servido de simples assento?

As estruturas descobertas nas divisões 1o e 12 são provavelmente orientadas para a produção de vinho. A estrutura UE 120, localizada no ângulo Sudeste do espaço 10, aparenta constituir uma area de prensagem. É-nos difícil elaborar sobre as características precisas deste lagar, mas a presença de muros utilizando argamassa de cal neste local demonstra a necessidade de conter uma pressão importante, o que vai ao encontro das características necessárias para a utilização de uma prensa. Foram realizadas análises analíticas pelo laboratório Nicolas Garnier 
a dois framentos de opus signinum, que permitiram atestar a presença de vinho. Os dois fragmentos de opus que foram analisados possuem impregnações orgânicas de constituição química muito similar. Os marcadores presentes permitiram identificar très elementos principais : uva tinta fermentada, o que demonstra que o espaço foi utilizado para produção de vinho através de maceração e fermentação de uva ; gorduras animais, que poderão corresponder a micro-organismos presentes no solo, podendo ser explicadas por poluições das amostras posteriores ao abandono da estrutura ; gorduras vegetais, ricas em lípidos, que não possuem marcadores de azeitona (Figura 7).

Este lagar funcionava directamente com o tanque (lacus) (UE 128), situado numa cota inferior, a Sudoeste da divisão 12. Este tanque, embora não fosse revestido a argamassa, deveria acolher uma peça de tipo dolium. O mesmo tipo de sistema foi encontrado em outros sítios na região, como no Alto da Fonte de Milho (Peso da Régua) (Brun, 2004: 94) ou na zona de Freixo de Numão, como em Rumansil I ou Zimbro II (Silvino et al. no prelo; Coixão, 2018: 130). Tendo em conta este cenário, vários tipos de vinhos poderiam ser armazenados em dolia.

Relativamente à localização da cella vinaria, os espaços 9 e 12 não aparentam ter sido utilizados para acolher recipientes associados à vinificação. A localização desta divisão seria, certamente, o espaço 18. A intervenção dos níveis de abandono permitiu descobrir uma grande quantidade de fragmentos de dolia, embora a remodelação do terreno para receber terraços contemporâneos tenha revolvido muito o terreno. A escavação do solo em terra batida não permitiu identificar estruturas negativas de recipientes, como foi possível observar em sítios como no Alto da Fonte do Milho. No entanto, como sucedia em Rumansil I, os mesmos podiam estar acima do nivel de solo, sobretudo tendo em conta a tipologia dos mesmos, de dimensões mais modestas, com uma capacidade média de cerca de 50 litros. Tendo em conta o espaço e articulações necessárias, poderia existir um máximo de 25 dolia, se tivermos em conta a dimensão média destes recipientes quando utilizados sobre o solo. Deveria ainda existir, certamente, uma passagem entre os diferentes espaços que compreendem a cella vinaria e as estruturas de prensagem, a entrada principal estaria localizada a Este, onde existe uma padieira onde assentaria uma porta de grandes dimensões.
Embora os espaços 11 e 14 não tenham sido alvo de uma escavação integral, os dados recolhidos foram suficientes para propor um quadro hipotético para a funcionalidade de cada divisão. Situado numa cota inferior aos restantes edifícios, este conjunto é constituído, a Norte por um grande espaço (14) que, num primeiro momento, foi interpretado como um grande pátio. Na campanha de 2019 foram descobertas duas bases de granito, alinhadas, no centro do espaço, demonstrando a presença de pilares centrais de um sistema de cobertura. Embora não tenha sido possível descobrir outros elementos de apoios intermediários entre as duas bases, foram descoberto traços de pelo menos um apoio em negativo no solo, podendo o mesmo ter sido reutilizado numa ocupação posterior. Teríamos assim um alinhamento de três pilares, equidistantes de $4 \mathrm{~m}$. Uma futura intervenção na zona oriental do espaço 4 poderá permitir a descoberta de uma quarta base.Se for esse o caso, estaríamos perante um grande espaço fechado, com quatro pilares, um tipo de estrutura bem documentado na região do Douro e mesmo na Península Ibérica. Poderia assim tratar-se de um edifício de armazenamento, com uma superfície ampla de cerca de $105 \mathrm{~m}^{2}$ ( $15 \times 7 \mathrm{~m}$ ). Este tipo de planta normalmente está associada a lagares de vinho. Podemos citar, entre outros, os exemplos das villae do Prazo (Freixo de Numão) ou de Vale do Mouro (Coriscada) (Coixão, 2018: 379 e 447). No entanto, é necessário observar que estas estruturas têm normalmente uma largura menos ampla e estão sempre associadas às estruturas das prensas. A utilização do espaço 14 para armazenamento de vinho é assim difícil de assimilar. Esta planta encontra um paralelo mais próximo a uma estrutura descoberta na pars rustica da villa do Vale do Mouro, com duas filas de três pilares (Coixão, 2018: 447). Neste caso, a função da estrutura poderia estar ligada a armazenamento de materiais diversos devido à vocação agro pastoril da zona (alimentos para os animais, materiais agrícolas ou mesmo carruagens). Mas a possibilidade do espaço ter sido utilizado para animais não deve ser posta de parte, sobretudo tendo em conta o facto da estrutura estar localizada no andar térreo. Podemos aqui citar o exemplo de um edifício similar descoberto em Ca’Tron, em Itália (Busana et al., 2011). Um edifício com dois pilares centrais que, no rés-do-chão recebia instrumentos agrícolas e onde era feito armazenamento de cereais no andar imediatamente acima. Embora as análises analíticas realiza- 
das aos sedimentos (com o objetivo de determinar a taxa de fosfatos derivados de matérias orgânicas, como urina ou excrementos) do interior do edifício de Trás do Castelo não nos tenham fornecido dados concretos, ao contrário dos resultados de outros espaços do sítio, não podemos excluir a possível utilização do espaço para animais. Um outro exemplo similar foi identificado em Près-Bas, Loupian, França. Neste caso, tratava-se de uma cella vinaria que é readaptada para celeiro durante o século II da nossa Era (Pellecuer, 2000: 123-124).

A funcionalidade do espaço 11, a Sul do espaço 14, é também difícil a discernir. Embora a zona oriental nos seja desconhecida, sabemos que se trata de um espaço longo e estreito, com pelo menos $13 \times 3$ $\mathrm{m}$, ou $39 \mathrm{~m}^{2}$. Infelizmente não subsitiu nenhum traço de um nível de solo, sendo que os níveis de demolição do edifício estavam directamente acima dos níveis associados à construção do espaço e do substrato natural, que foi escavado nesta zona em forma cupiforme em toda a extensão da divisão. A localização da entrada deste espaço, a uma cota alta, aparenta demonstrar a utilização de uma escada para aceder ao interior do espaço. Propusemos anteriormente que este espaço possa ter sido utilizado para armazenamento ou como abrigo para animais. Segundo alguns agrónomos, os solos dos edifícios que albergam caprideos não devem receber nenhum tipo de pavimento nem escoamento para esgotos, uma vez que estes sedimentos podem ser re-aproveitados como estrume e, no caso das ovelhas, o mesmo deve estar saturado em urina (Dufour 2012: 65). Nos nossos dias, as únicas estruturas de tipo redil ou curral de grandes dimensões de época romana conhecidas encontram-se no Sul da Gália, mais especificamente em Crau, com cerca de 50 x 10 metros. A todo o comprimento, a estrutura estava fechada por um alinhamento de barrotes de madeira espaçados e, numa superfície de $250 \mathrm{~m}^{2}$, estes espaços poderiam abrigar 700 a 900 ovelhas (Badan et al., 1995). Podemos citar outros exemplos de estruturas deste género, ainda que de menores dimensões, na Gália. La Coupe III - Saint-Hippolyte, em Narbonne (Aude), uma construção com $175 \mathrm{~m}^{2}$ possui, como em Crau, um pequeno espaço de habitação e um vasto espaço no qual, a partir de amostragens micro-morfológicas, foi possível identificar esferolitos (Mayoud, 2010). Podemos ainda citar sítios como Cenel à La Cavalerie e La Cordenade à Salles-la-Source em Aveyron (Raynaud et al., 2009), que possuem vários pontos comuns com o espaço 14 de Trás do Castelo.

\section{CONCLUSÕES E PERSPETIVAS}

Finalmente, o estabelecimento rural acolhe, manifestamente, unidades de transformação de recursos naturais: uvas, cereais, animais e têxtil. Poucos espaços parecem ter sido utilizados enquanto habitat permanente. E mesmo nesses casos, trata-se de ocupações aparentemente frustres. Os elementos presentes, associados à qualidade e nível técnico necessários para as construções no terreno acidentado demonstram, sem dúvida, um certo nível de riqueza da parte do proprietário. As estruturas descobertas terão feito, sem dúvida, parte de um complexo mais importante, difícil ainda de discernir. Poderá o sítio de Trás do Castelo ter feito parte da pars rustica de uma villa? Ou mesmo ter feito parte de uma pequena aglomeração rural secundária, um vicus, um tipo de estrutura bem documentada no mundo rural romano?

No entanto, quer estejamos perante uma villa ou um vicus, ainda não foi possível identificar a zona residencial., possivelmente localizada sob a actual aldeia de Vale de Mir. Ao longo do processo de escavação foi possível descobrir uma grande quantidade de elementos arquitetónico em granito, em condição de re-utilização, desde o século III da nossa Era, elementos que poderão ter pertencido a uma domus. A Sul de Trás do Castelo, a uma altitude mais baixa, é possível ainda hoje observar uma grande quantidade de material clássico. Uma futura campanha poderá permitir compreender como se desenvolveria o resto do estabelecimento.

Finalmente, o estudo do sítio de Trás do Castelo permite enriquecer os conhecimentos sobre a ocupação romana nesta região, frequentemente esquecida pela investigação arqueológica. Este projeto de investigação permitiu desvendar uma faceta do habitat antigo do Vale do Douro que era, até ao momento, pouco conhecido, ajudando a compreender como é que se processava a exploração de recursos naturais entre o final do século Io da nossa Era até ao final do período de domínio romano. 


\section{BIBLIOGRAFIA}

ALARCÃO, Jorge de (2003) - As estátuas de guerreiros galaicos como representações de príncipes no contexto da organização político-administrativa do Noroeste pré-flaviano. In: Madrider Mitteilungen, 44, pp. 116-126.

ALARCÃO, Jorge de (2004) - Notas de arqueologia, epigrafia e toponímia: II. In: Revista Portuguesa de Arqueologia, vol. $7, \mathrm{n}^{\circ}$ 2, pp. 193-216.

ALARCÃO, Jorge de (2008) - Notas de arqueologia, epigrafia e toponímia: V. In: Revista Portuguesa de Arqueologia, vol. 11, n. ${ }^{\circ}$ 1, pp. $103-121$.

ALARCÃO, Jorge de (2018) - A Lusitânia e a Galécia do séc. II A. C. ao séc. VI D. C., Coimbra.

ARIÑO, Enrique (2013) - El Habitat rural en la peninsula iberica entre finales del siglo IV y principios del VIII: un ensayo interpretativo. In: AnTard, 21, pp. 93-123.

AZEVEDO, Pedro A. de (1901) - Extractos archeológicos das Memórias Parochiais de 1758. In O Archeologo Portugues. $1^{\text {a }}$ série. Volume VI, pp. 103-121.

BADAN, Otello, BRUN, Jean-Pierre e CONGÈS, Gaetan (1995) - Les bergeries romaines de la Crau d'Arles. Les origines de la transhumance en Provence. In: Gallia, 52, pp. 263-310.

BLIN, Olivier, MÉDARD, Fabienne e PUYBARET, MariePierre (2003) - Fils et pesons: éléments pour une approche des techniques de tissage en Gaule romaine du Nord. In: Revue archéologique de Picardie, $\mathrm{n}^{\circ}$ 1-2. LEPETZ, Sébastien e MATTERNE, Véronique (coord.) - Cultivateurs, éleveurs et artisans dans les campagnes de Gaule romaine, p. 157-176.

BROGIOLO, Gian Pietro e CHAVARRIA ARNAU, Alexandra (2008) - El final de las villas y las transformaciones del territorio rural en Occidente (siglos V-VIII). In FERNANDEZ OCHOA, Carmen, GARCIA-ENTERO, Virginia e GIL SENDINO, Fernando (eds.) - Las villae tardoromanas en el occidente del Imperio. Arquitectura y funcion, IV Coloquio Internacional de Arqueologia en Gijon, Ediciones Trea, pp. 193-213.

BRUN, Jean-Pierre (2004) - Archéologie du vin et de l'huile dans l'Empire romain, Errance, Paris.

BUSANA, Maria Stella, BON, Mauro, CERATO, Ivana, GARAVELlO, Silvia, GHIOTTO; Andrea Raffaele, MIGLIAVACCA, Mara, NARDI, Serenella, PIZZEGHELLO, Diego e ZAMPERI, Silvia (2011) - Agricoltura e allevamento nell'agro orientale di Altinvm: il caso di Ca' Tron. In: BUSANA, Maria Stella e BASSO, Piero (coord) La lana nella Cisalpina romana, Economia e Società, studiinonoredi Stefania Pesaventomattioli atti del convegno, pp. 127-169.

CARVALHO, Pedro (2017) - Época romana. In: CARVALHO, Pedro, GOMES, Luís Filipe Coutinho e MARQUES, João Nuno (coord.) - Estudo histórico e etnológico do vale do Tua (Concelhos de Alijó, Carrazeda de Ansiães, Mirandela, Murça e Vila Flor), EDP/Edições Afrontamento, pp. 241-383.
COIXÃO, António Nascimento de Sá (2018) - A romanização no baixo Côa, Dissertação de doutaremento. Ed. da Câmara Municipal de Vila Nova de Foz Côa.

DIAS; Lino Tavares (1997) - Tongobriga, Lisboa.

FONTE, João (2008) - Sistemas defensivos proto-históricos de Trás-os-montes ocidental (norte de Portugal). In: Cuadernos de Estudios Gallegos, № 121, Enero-Diciembre, 2008, pp. 9-29.

FONTE, João, LEMOS, Francisco Sande, CRUZ, Gonçalo e CARVALHO, Carla (2008) - Segunda idade do Ferro em Trás-os-montes ocidental. In: Férvedes, 5, pp. 309-317.

LARRAZABAL GALARZA, Javier (2015) - Las murallas protohistoricas de la villa romana del Alto da fonte do Milho (Peso da Régua, Portugal). In Fortificationes en la edad del Hierro: control de los recursos y el territorio, Glyphos Publicaciones pp. 324-337.

MAYOUD, Stephane (2010) - Narbonne, La coupe III Saint-Hippolyte In: Bilan scientifique régional 2008, DRAC Languedoc-Roussillon, SRA, Montpellier, pp. 38-39.

LEMOS, Francisco Sande (1993) - Povoamento Romano em Trás-os-Montes Oriental, Tese de doutoramento na especialidade de Pré-História e História da Antiguidade, apresentada à Universidade do Minho. Policopiada.

PELLECUER, Christophe (200o) - La villa des Prés-Bas (Loupian, Hérault) dans son environnement: contribution à l'étude des villae et de l'économie domaniale en Narbonnaise, I-II, thèse de doctorat, Université d'Aix-Marseille 1. Policopiado.

PEREIRA, Pedro (2012) - Materiais esquecidos - o espólio cerâmico de armazenamento (dolia) do Alto da Fonte do Milho, Peso da Régua. In: Almadan. 17. Tomo 1. Almada.

PEREIRA, Pedro (2013a) - Uma história de dolia - uma primeira análise aos recipientes cerâmicos de armazenagem de Vale do Mouro (Coriscada, Meda). In: CEM, 3, CITCEM, Porto.

PEREIRA, Pedro (2013b) - De vino ac vineas - viticultura romana no Vale do Douro. In: Actas das ıas Conferências do Museu de Lamego. CITCEM/Museu de Lamego. Lamego. pp. 141-149.

PEREIRA, Pedro (2017) - O Vinho na Lusitânia. Ed. Afrontamento/CITCEM.

PEREIRA; Pedro (2018) - O mundo agrícola romano no Vale do Douro. In: DIAS, Lino Tavares e ALARCÃO, Pedro (coord.) - Construir, Navegar, (Re)usar o Douro da Antiguidade. CITCEM. pp. 195-210.

PEREIRA; Sérgio, GOMES, Hugo, COSTA; Pedro e BARBOSA, TERESA (2013) - Estudo da romanização no vale do rio Sabor. Noticia preliminar, in SASTRE BLANCO, José Carlos, CATALAN RAMOS, Raul e FUENTES MELGAR; PATRICIA (coord.) - Arqueologia en el valle del Duero. Del Neolitico a la Antigüedad Tardia: nuevas perspectivas. 
Arqueología en el valle del Duero: del Neolítico a la Antigüedad Tardía : nuevas perspectivas: actas de las primeras Jornadas de Jóvenes Investigadores del Valle del Duero. Ediciones de la Ergástula.

RAYNAUD, Claude, com a colaboração de POMARÈDES, Hervé e MANNIEZ, Yves (2009) - Fermes gallo-romaines de la province de Narbonnaise. In : LEVEAU, Phillipe, RAYNAUD, Claude, SABLAYROLLES, Robert e TRÉMENT, Fréderic (Eds.) Les formes de l'habitat rural gallo-romain. Terminologies et typologies à l'épreuve des réalités archéologiques, Actes du VIIIe colloque AGER, Toulouse, Aquitania Suppl. 17, Bordeaux, pp. 141-165.

REDENTOR, Armando, ANDRÉ, Clara, CARVALHO, Pedro e TERESO, Sofia (2018) - Torre Velha de: Castro de Avelãs (Bragança). Resultados arqueologicos e novidades epigraficas", in SOARES, Carmen, BRANDÃO, José Luís e CARVALHO, Pedro (coord.) - Historia Antiga : relações interdisciplinares. Paisagens Urbanas, Rurais e Sociais, Universidade de Coimbra, pp. 321-344.

RIBEIRO, Jorge Manuel Pinto (2011) - Arquitectura romana em Bracara Augusta. Uma analise das tecnicas edilicias, CITCEM.

SALIDO DOMINGUEZ, Javier (2017) - Arquitectura rural romana: graneros y almacenes en el occidente del imperio, Autun, Ed. Mergoil.

SILVA, Armando Coelho (2007) - A Cultura Castreja no Noroeste de Portugal. Câmara Municipal de Paços de Ferreira.

SILVINO, Tony e PEREIRA, Pedro (2017) - O projecto de investigação sobre a ocupação humana em torno da aldeia de Pegarinhos (Alijó) - em busca das origens da Romanização do Douro. Actas do $2^{\circ}$ Congresso da Associação dos Arqueológos Portugueses. 2017. pp. 1085-1095.

SILVINO, Tony, PEREIRA; Pedro e BRITO, Joana, com a colaboração de TEIXEIRA, Rita (2018) - A cerâmica romana de Trás do Castelo (Vale de Mir, Alijó) -rupturas e continuidades de uma exploração agrícola roma-na no Vale do Douro.In Actas das VI Jornadas de Arqueologíado Vale do Douro. Ed. Glyphos.

SILVINO, Tony e PEREIRA; Pedro (2018) - O Projecto de Investigação sobre a Ocupação Humana em torno da aldeia de Pegarinhos (Alijó) - em busca das origens da romanização do douro. Relatório das escavações entre 2012-2016, Porto.

SILVINO, Tony, COIXÃO, António Nascimento de Sá e PEREIRA; Pedro (2020) - Rumansil I (Murça-do-Douro): um complexo artesanal antigo no vale do Douro. In: Conimbriga, no prelo.

TRANOY, Alain (1995-1996) - La route, image et instrument du pouvoir impérial dans le nord-ouest ibérique. In: Cadernos de Arqueologia, 12-13, pp. 31-37.

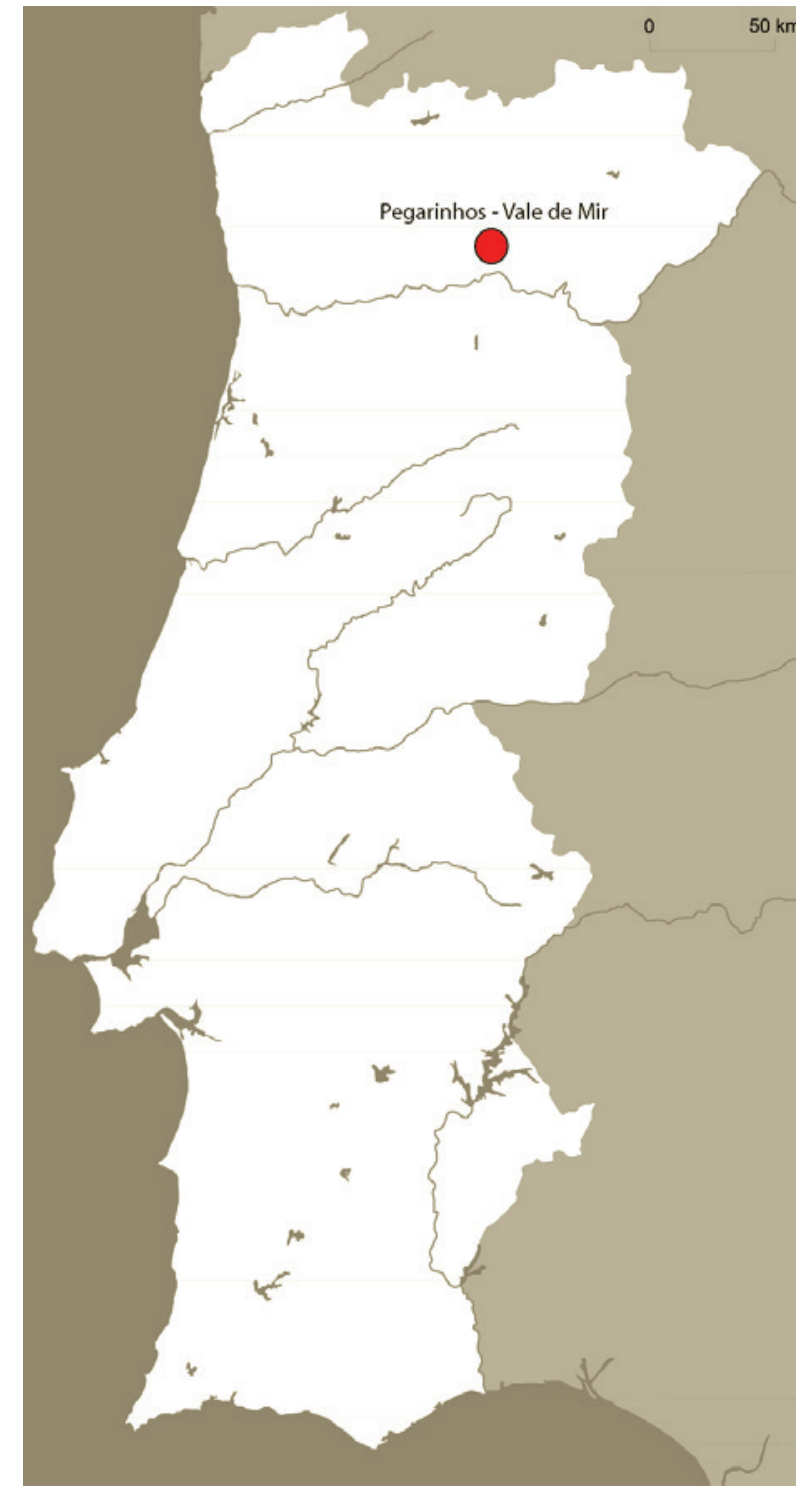

Figura 1 - Localização de Trás do Castelo (Vale de Mir, Pegarinhos). 


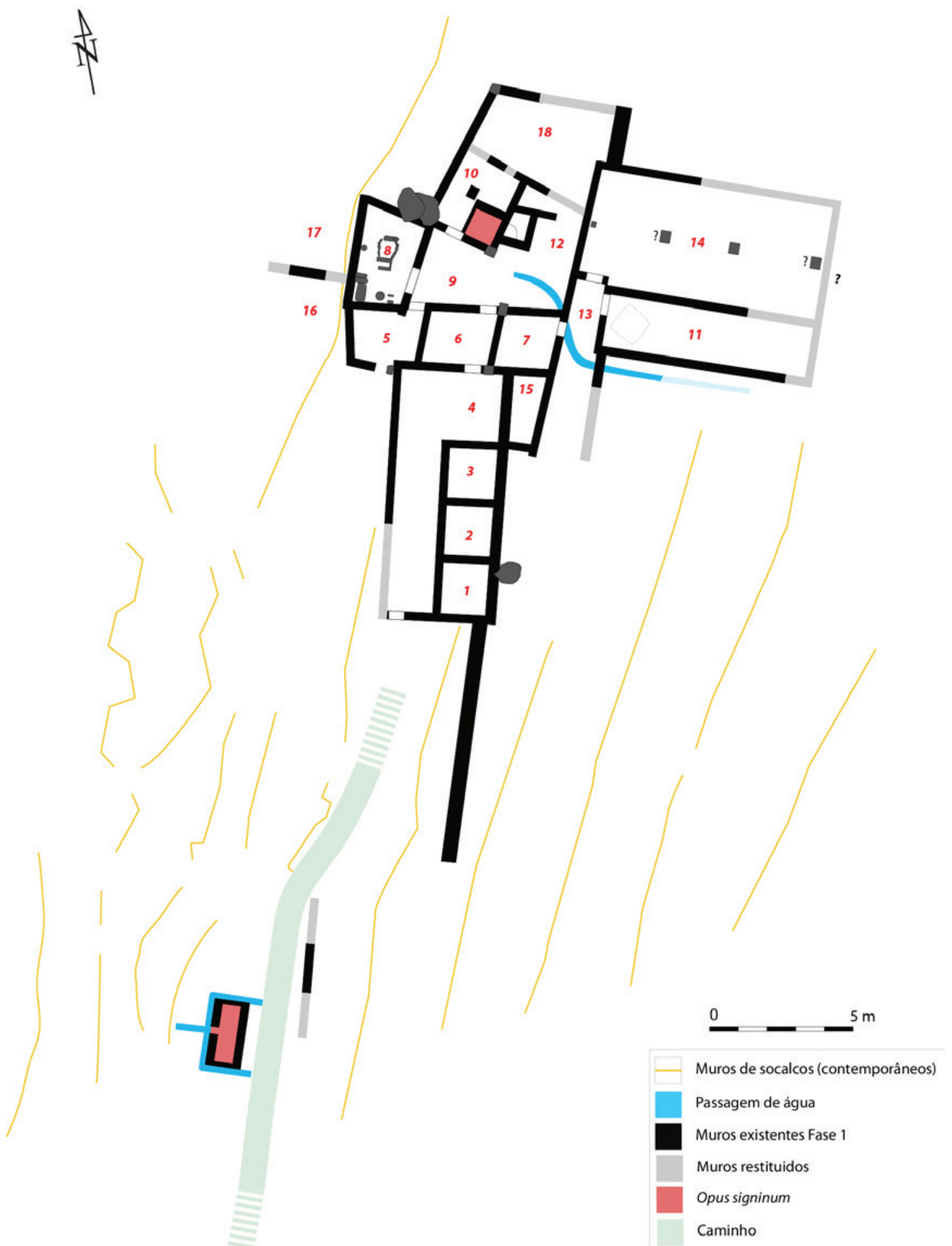

Figura 2 - Planta de Trás do Castelo, 2020. 


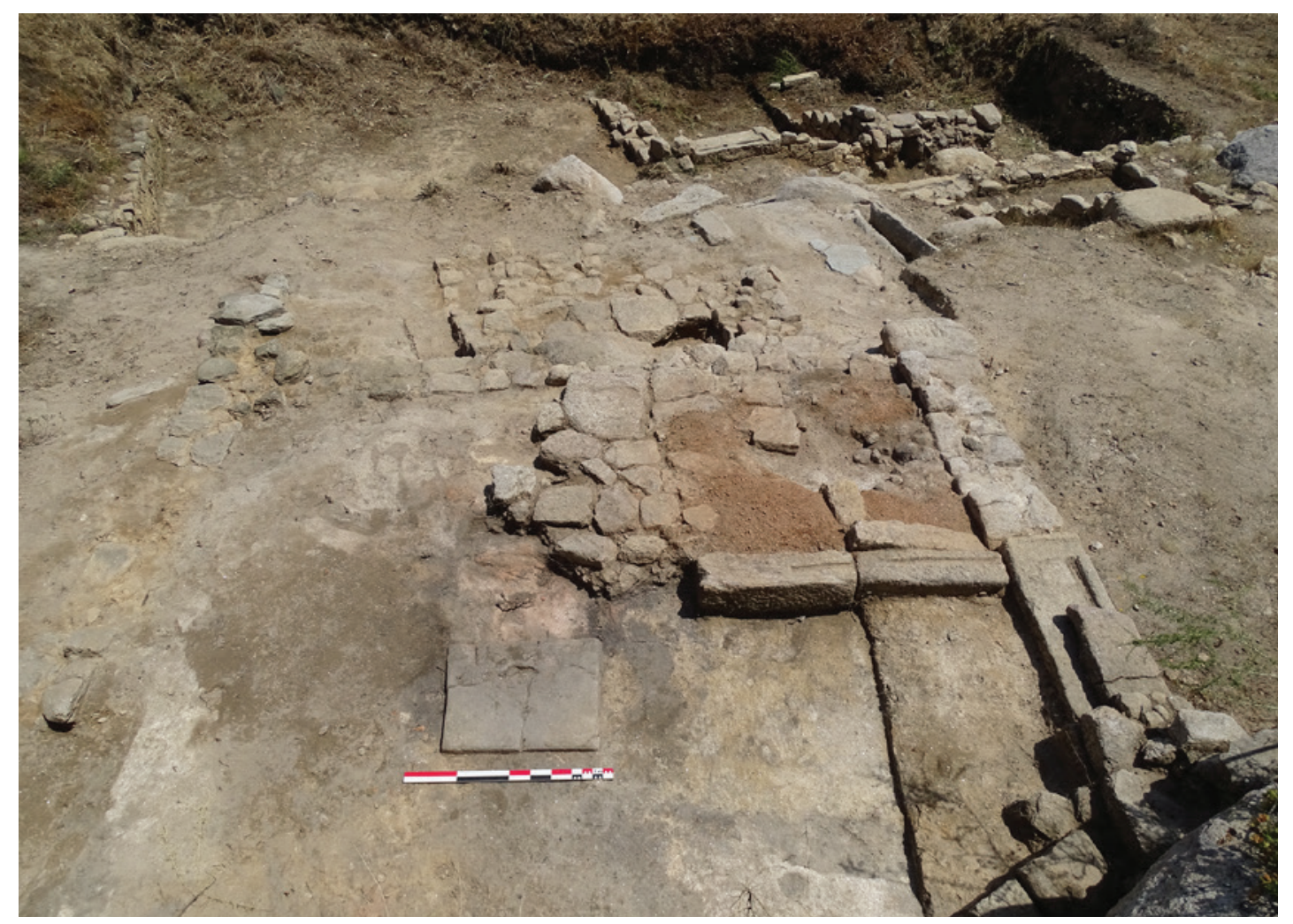

Figura 3 - Lagar de Trás do Castelo e zona envolvente, 2020.
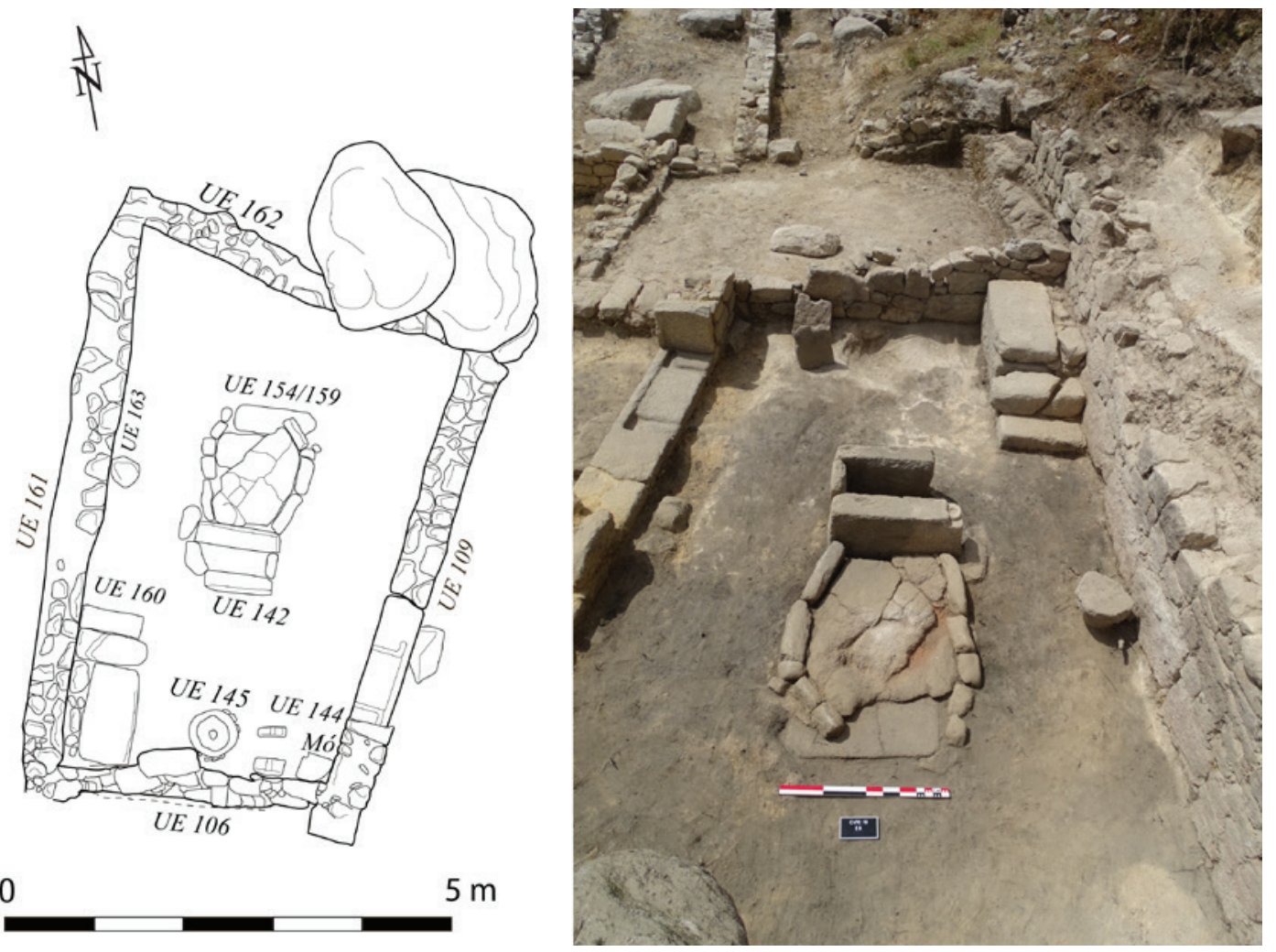

Figura 4 - Planta e vista a Norte do espaço 8, 2019. 


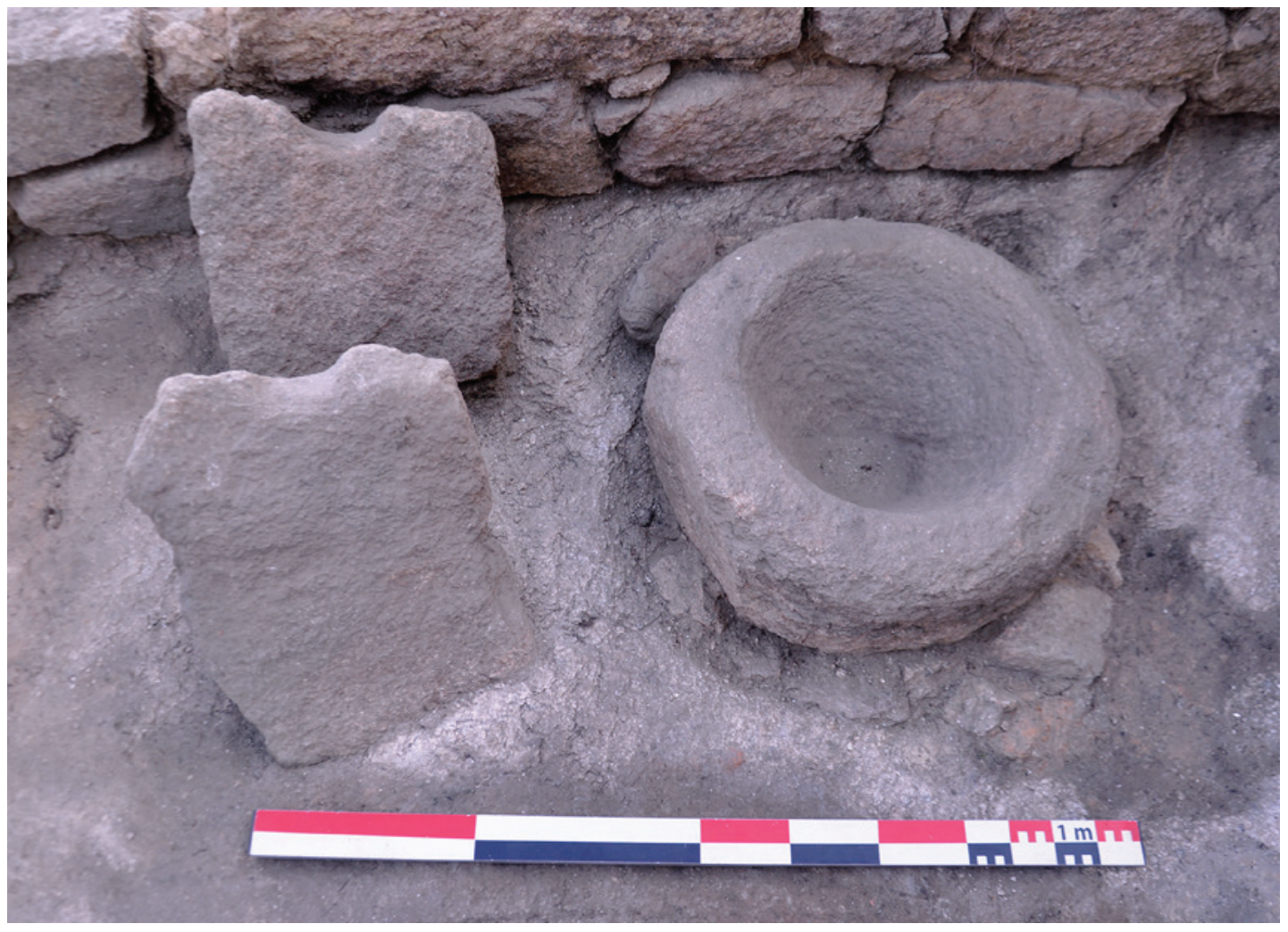

Figura 5 - Estruturas UE 144 e UE 145, descobertas em 2016, mas furtadas em 2019.

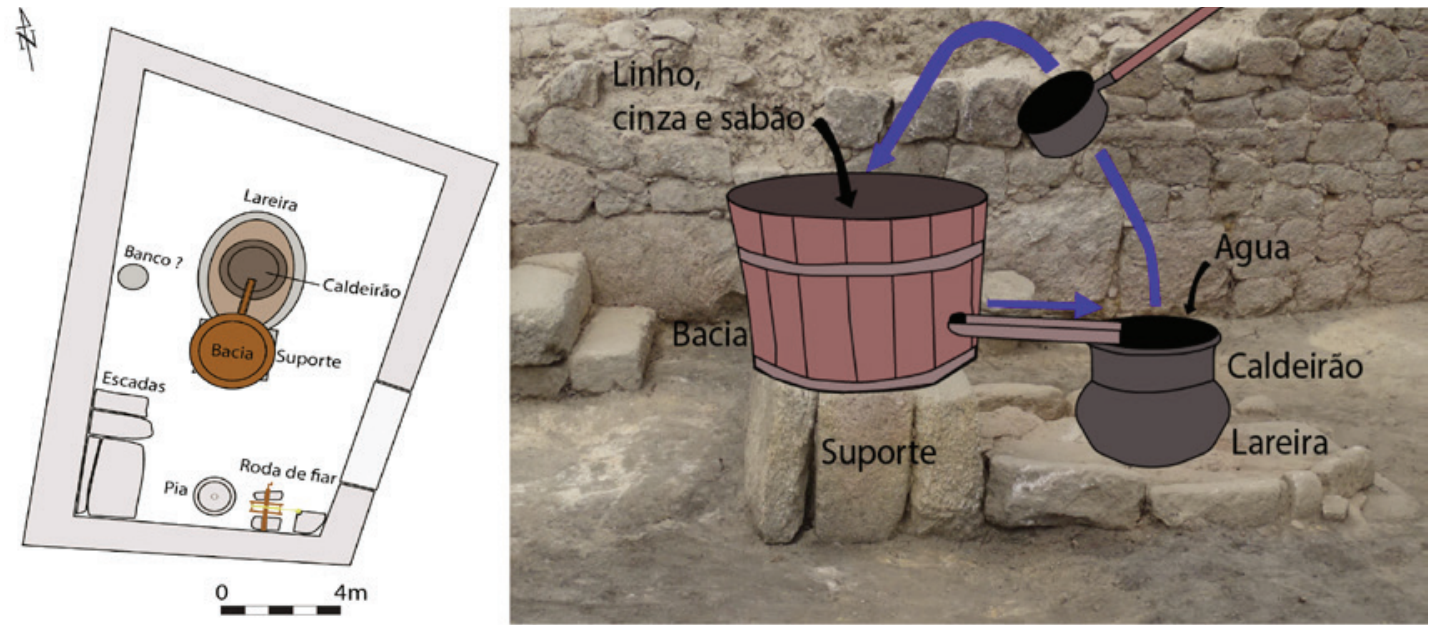

Figura 6 - Proposta funcional da estrutura composta pelas [142], [154] e [159]. 


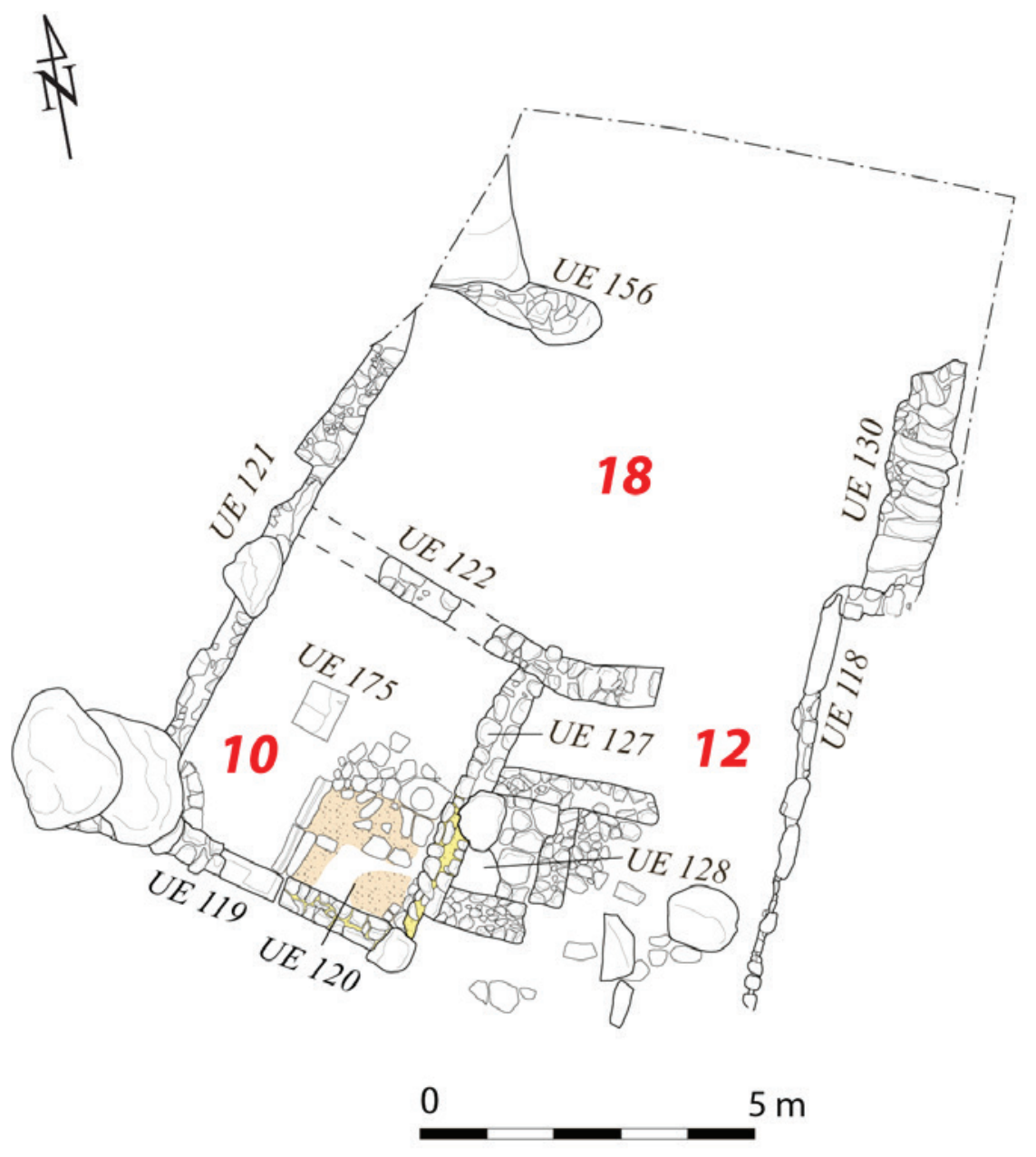

Opus signinum

Argamassa

Figura 7 - Planta do lagar e cella vinaria de Trás do Castelo. 


\title{
A SEQUÊNCIA DE OCUPAÇÃO NO QUADRANTE SUDESTE DE BRACARA AUGUSTA: AS TRANSFORMAÇÕES DE UMA UNIDADE DOMÉSTICA
}

\author{
Lara Fernandes ${ }^{1}$, Manuela Martins ${ }^{2}$
}

\begin{abstract}
RESUMO
Os trabalhos de escavação realizados nos terrenos da Santa Casa de Misericórdia de Braga, entre 1999 e 200o, permitiram colocar a descoberto um conjunto de estruturas que se viriam a revelar importantes para o estudo do urbanismo e da arquitetura doméstica da época romana, uma vez que se situam num setor da cidade com grande potencial arqueológico e reduzida sobreposição construtiva, em terrenos abandonados posteriormente à Antiguidade Tardia. Neste artigo pretende-se dar a conhecer algumas das estruturas escavadas que formalizam uma unidade doméstica inserida num quarteirão da cidade romana de Bracara Augusta, construída no Alto Império e remodelada no período tetrárquico. Para tal, serão valorizados os vestígios identificados na intervenção no Tabuleiro A dos Terrenos da Santa Casa de Misericórdia de Braga.
\end{abstract}

Palavras-chave: Bracara Augusta, Urbanismo romano, Domus.

\begin{abstract}
The excavation work carried out on the ground of the Santa Casa da Misericórdia in Braga between 1999 and 200o, helped to uncover a set of structures that would prove to be important for the study of the urbanism and the domestic architecture of the Roman era, as it is located in a sector of the city with a great archeological potential and little constructive overlap, in territories abandoned after the Late Antiquity, In this article we inted to make know some of the excaveted stuctures that formalize a domestic unit inserted in a block of the Roman city of Bracara Augusta, built in the High Empire and remodeled in the tetrarchic period. To this end, the traces identified in the intervention in Tabuleiro A of the ground of the Santa Casa da Misericórdia in Braga will be assessed.
\end{abstract}

Keywords: Bracara Augusta, Roman urbanism, Domus.

\section{INTRODUÇÃO}

O estudo de Bracara Augusta é devedor do projeto iniciado em 1977 pela Unidade de Arqueologia da Universidade do Minho, no âmbito do qual se têm vindo a realizar trabalhos arqueológicos sistemáticos na cidade de Braga ao longo das últimas quatro décadas. Apesar dos constrangimentos naturalmente associados à arqueologia urbana, designadamente os que decorrem do facto do avanço das escavações serem determinadas, em grande medi- da, pela atividade construtiva, a cidade romana, que deu origem à Braga moderna, vem sendo objeto de consideráveis avanços no conhecimento relativo ao urbanismo, arquitetura e economia.

Com efeito, a partir de uma análise do conjunto de vestígios de ruas, pórticos e edificados foi possível restituir, com bastante segurança, o traçado da malha urbana fundacional da cidade, globalmente composta por eixos viários que replicam paralelamente o cardo e o decumano máximos, as artérias principais da cidade, que formalizou uma morfo-

1. Bolseira de Investigação da Unidade de Arqueologia da Universidade do Minho; lararitafernandes@gmail.com

2. Professora Catedrática da UMinho e investigadora do Lab2PT; mmmartins@uaum.uminho.pt 
logia urbana ortogonal, na origem de quarteirões regulares e homogéneos, de forma quadrada e a dimensão de 1 actus de lado (Martins $\&$ alii, 2017).

Se o estudo da malha urbana tem a capacidade de conjugar dados provenientes de intervenções realizadas em lotes dispersos, pontuais e, por vezes, distantes, mais difícil se afigura, contudo, a valorização de aspetos arquitetónicos dos edifícios que compunham os equipamentos públicos e o parque habitacional bracaraugustano. Com efeito, o resultado das intervenções arqueológicas, que muitas vezes se resumem a pequenas sondagens dispersas, um pouco por toda a cidade, é um conhecimento ainda parcelar de estruturas que permitem sugerir a restituição parcial das planimetrias dos edifícios (Magalhães, 2010). Contudo, e através do estudo sistemático dos vestígios que vão sendo exumados na cidade, alguns dos edifícios públicos são já conhecidos, de que é exemplo o teatro, cuja planta apresenta uma caraterística simetria que permitiu a sua restituição (Martins \& alii, 2013). Também o exaustivo estudo de amplas áreas escavadas, como acontece com a domus das Carvalheiras, ou de estruturas de várias intervenções, ou dispostas em áreas contíguas, de que é exemplo a domus da Escola Velha da Sé/rua Frei Caetano Brandão, têm permitido restituir a planta de alguns quarteirões romanos e respetivas unidades domésticas (Magalhães, 2019).

Porém, se os estudos sobre a cidade e os seus edifícios conheceram avanços, ora lentos ora significativos, ao sabor da atividade construtiva de Braga, há um setor de Bracara Augusta que é deveras deficitário de trabalhos arqueológicos. Com efeito, uma vez que a Santa Casa da Misericórdia de Braga é detentora de vastos terrenos que compunham o quadrante sudeste da cidade romana, os conhecimentos sobre esta área são consideravelmente menores do que os que possuímos sobre os demais setores de Bracara Augusta. Neste sentido, propomos com este trabalho valorizar os dados provenientes de uma das poucas intervenções realizadas nos terrenos da Santa Casa de Misericórdia, com o intuito de melhor divulgar a arquitetura doméstica da cidade romana.

\section{ENQUADRAMENTO DA ZONA ARQUEOLÓGICA}

A zona arqueológica da Santa Casa de Misericórdia localiza-se na União de Freguesias de S. José de São Lázaro e S. João do Souto, em Braga, e foi dividida em duas plataformas, designadas por tabuleiros superior (A) e inferior (B). No primeiro, situado a oeste do antigo Hospital Distrital de São Marcos (Figura 1), foram realizados trabalhos arqueológicos pela Unidade de Arqueologia da Universidade do Minho (UAUM), entre maio de 1999 e março de 2000 , tendo em vista a instalação de um pavilhão com fins educativos.

A intervenção neste local exigiu a realização de seis sondagens de $4 \times 4 \mathrm{~m}$, abertas em momentos diferentes. Inicialmente, procedeu-se à abertura de três sondagens ( $\mathrm{S}_{25}, \mathrm{P}_{25}$ e M26), as quais revelaram algumas estruturas de interesse arqueológico, optando-se de seguida pela abertura de mais três (Q26, $\mathrm{O}_{25}$ e N25) com o propósito de compreender a continuidade dos dados exumados.

A importância e o potencial arqueológico destes terrenos já tinham sido confirmados no ano de 1977/78 pelas sondagens geofísicas de Garchy, trabalhos de prospeção por resistividade elétrica (Alves, 2016), que se realizaram em diferentes pontos da cidade de Braga, confirmando onde era previsível a existência de ruínas (Delgado, Martins \& Lemos, 1989). Tendo sido o Tabuleiro A dos Terrenos da Misericórdia abarcados pela prospeção levada a cabo foi possível verificar a existência de estruturas que se viriam a revelar importantes para compreender o urbanismo romano de Braga.

Trata-se de um terreno que se integra no quadrante sudeste da cidade romana, organizada em quarteirões, tendo a escavação aí realizada permitido identificar vestígios de uma habitação romana, possibilitando localizar o limite sul de um dos quarteirões e validar a localização de um dos pórticos que ladeava a casa e, consequentemente, confirmar a orientação da ruas que delimitavam o quarteirão, apoiando mais uma vez a malha rigorosamente ortogonal da cidade romana, defendida desde inícios da década de 90 do século XX (Martins, 1995; 2004; 2009; 2014; Martins \& Delgado, 1989-9o) (Figura 2).

\section{A PRIMEIRA FASE DE OCUPAÇÃO}

A análise destes contextos possibilitou identificar um conjunto de vestígios compostos por muros e fundações, de tipologia e cronologia romanas, o que nos permitiu estabelecer uma longa ocupação deste local, balizada entre o século I e a época moderna, no que consideramos ser passível de dividir em três fases. Os vestígios identificados aquando da escavação desta zona arqueológica encontram-se no inte- 
rior de um quarteirão delimitado pelos decumanos D8 e D9 e pelos cardos $\mathrm{K}_{4}$ e $\mathrm{K}_{5}$, tendo em conta a numeração que foi recentemente proposta (Martins $\&$ alii, 2017) (Figura 3 ).

Como nota prévia, é de destacar que não foram identificados os característicos silhares do período augustano, delimitadoras dos quarteirões, o que pode ser justificado tendo em conta que a área escavada não abarcou as esquinas da insula. Desta forma, podemos considerar a primeira fase de ocupação no Tabuleiro $\mathrm{A}$, datável do século $\mathrm{I}$, à qual correspondem grandes valas abertas no substrato rochoso para a implantação de muros, pertencentes a uma construção de cariz habitacional. Admite-se que estaremos perante uma domus de peristilo, que se desenvolvia na área a norte do pórtico que ladeava o decumano 9. Os pórticos na cidade de Bracara Augusta são característicos da construção doméstica do Alto Império (Martins $\&$ alii, 2017), sendo possível identificar a sua presença em todas as estruturas de cariz habitacional escavadas até hoje, de que são exemplos as Zonas Arqueológicas das Carvalheiras, Escola Velha da Sé/rua Frei Caetano Brandão nºs166-168, Frei Caetano Brandão nos 183-185/Santo António das Travessas nos 20-26, Ex Albergue Distrital, rua Afonso Henriques nºs 42-56 e Antigas Cavalariças (Magalhães, 2019).

A casa identificada nos terrenos do Tabuleiro A apresenta vestígios que confirmam esta característica do urbanismo bracaraugustano, sendo possível verificar o desenvolvimento de um pórtico a sul da habitação, que se encontrava no alinhamento do cardo 4 e encerrava esse eixo viário a norte. A partir do eixo pedonal abria-se a entrada para a habitação, formalizada por uma porta que era ladeada por dois silhares, individualizados com as UEso73 e 085 , que deveriam suportar duas colunas, que certamente funcionariam como um elemento decorativo de prestígio, assinalando talvez o estatuto do proprietário. Associado a um dos silhares UE073, surge um troço de um muro (UEo84), a uma distância de aproximadamente $3,6 \mathrm{~m}$ do limite sul do quarteirão. Trata-se de elementos cuja projeção sobre a malha urbana proposta para Bracara Augusta sugerem que definiam a área do pórtico que se desenvolveria na fachada sul da habitação, cuja profundidade colhe paralelos com os demais quarteirões da cidade nos quais os eixos pedonais apresentam sensivelmente a largura de 12 pés (Martins $\&$ alii, 2017).

Uma vez analisadas as áreas externas da domus, pas- samos agora a analisar as estruturas alusivas ao interior da habitação. Constituem-se como elementos construídos associados ao primeiro compartimento acedido através da entrada sul uma área interna delimitada por três muros UEo82 (a sul), UE104 (a oeste) e UEo18 (a norte) e que apresenta silhares (UE043, 102 e 111), facto que indica corresponder a uma área porticada, pelo que julgamos poder ser atribuída ao peristilo da habitação. Com efeito, logo a norte dos silhares que materializam a porta da casa (UE073 e UE085), encontramos um muro de orientação E/O (UEo82), o qual apresenta no seu alinhamento um silhar (UE1O2) que parece formar o limite sul da área aberta. Por sua vez, adossado ao referido silhar, encontra-se um outro muro, com orientação N/S (UE104), registado numa extensão de aproximadamente $12 \mathrm{~m}$, certamente o limite oeste do peristilo, perpendicular a um outro muro com orientação E/O (UEo18), que delimitava aquele espaço aberto a norte.

Além dos elementos de delimitação referidos foi possível identificar ainda alguns dos silhares que sustentavam a colunata do jardim, de que são exemplo aquele individualizado com a UE104, localizado a $8 \mathrm{~m}$ do início do muro UE104, bem como o bloco UE111, que corresponderia ao limite nordeste. Não obstante, é possível observar a presença de alguns negativos referentes ao saque destes elementos arquitetónicos (UEo28 e UEo29), atividade certamente associada à procura por blocos graníticos de qualidade. O cálculo da distância entre estes elementos indica que neste local existiria um intercolúnio de $2 \mathrm{~m}$ para o limite oeste desta área, o que nos leva a crer que o mesmo ocorreria no lado este, tendo em consideração a simetria que se verifica nestes espaços. Por outro lado, no limite sul, é possível estimar um intercolúnio de $3 \mathrm{~m}$, que nos é indicado pelos embasamentos dos dois silhares a nascente (UEo73 e 085). Desta forma podemos então considerar que a área porticada do interior da domus em análise, apresenta uma planta retangular, com $108 \mathrm{~m}^{2}$ ( $\left.9 \times 12 \mathrm{~m}\right)$, que possuiria um total de 18 colunas, sendo que o limite sul e norte possuiriam quatro colunas cada, separadas entre si $3 \mathrm{~m}$ e os limites este e oeste cinco colunas cada, separadas $2 \mathrm{~m}$ entre si (Figura 4).

Podemos ainda calcular a área de ambulacrum que envolveria o jardim colunado, tendo em conta a distância entre o limite sul do peristilo (UEo82) e a fachada sul da habitação (UEo84), que apresenta uma largura de $2,5 \mathrm{~m}$. Considerando agora todos 
os dados apresentados acreditamos poder concluir que existiria uma área ajardinada, rodeada por um ambulacrum com $14 \mathrm{~m}$ de largura e $17 \mathrm{~m}$ de comprimento perfazendo uma área total de $238 \mathrm{~m}^{2}$, à volta da qual se distribuiriam vários compartimentos, os quais não foram possíveis de identificar aquando da escavação deste local (Figura 5).

A utilização de peristilos para distribuir os compartimentos das habitações é um recurso recorrente em Bracara Augusta, identificado na generalidade das domus. Com efeito, a implantação de jardins porticados parece ter por objetivo a emulação da paisagem urbana bracarense, largamente caraterizada pelo ritmo das colunas dos pórticos que se desenvolviam ao longo dos eixos viários e que permitiam intuir um aspeto de continuidade do espaço externo com o interior das habitações, reforçando o caráter de importância pública que os proprietários das casas pretendiam associar à sua importância política, económica e social (Magalhães, 2019). Apesar da domus do Tabuleiro A das Misericórdia não apresentar um corredor de entrada ou um vestíbulo a separarem a porta do jardim, é notável a implantação das colunas que ladeiam a porta e dialogam tanto com os elementos do porticado externo como interno.

\section{A SEGUNDA FASE DE OCUPAÇÃO}

Na segunda fase de ocupação, balizada entre os finais do século III e os inícios do IV, registamos uma reforma na habitação que alterou significativamente a área interna de peristilo, caracterizada pela implantação de novos muros, que, juntamente com os pré-existentes, passaram a compartimentar a área ajardinada.

O muro que define o limite oeste do peristilo (UE104) articula-se agora com um novo muro perpendicular (UE112) que fecha a área oeste do ambulacrum do peristilo, conformando novos compartimentos, cuja morfologia foi impossível restituir. $\mathrm{Na}$ área interior do peristilo foi registado o reaproveitamento de um muro (UEo18) que limitava o jardim a norte, que apresenta na parte superior um novo aparelho (UEoo2). Este muro, em conjunto com a implantação de outros dois (UEs11o e 108), forma agora um novo compartimento, que se desenvolve a norte do peristilo. Este novo espaço está limitado a sul pelo muro correspondente à UE1o8 e a norte por um novo muro (UE055) que reaproveita uma estrutura já existente (UEo82). A norte, e ocupando parte do que foi ambulacrum que envolvia o peristilo, na fase alto imperial, encontra-se agora um novo muro (UE136) que delimita a poente um outro compartimento, cujo pavimento era revestido em opus signinum (UE135) (Figura 6).

Assim, durante a segunda fase de ocupação deste local observa-se a subdivisão da área interna de peristilo em dois espaços. O mais meridional apresenta uma área aproximada de $42 \mathrm{~m}^{2}(7 \times 6 \mathrm{~m})$ delimitado por três muros conhecidos (UEo82, a sul, UE055, a oeste e UE108, a norte), representando este último, o limite sul de um outro espaço (UEı1o, a oeste e UEııg, a norte), com uma área de aproximadamente $28 \mathrm{~m}^{2}$ (4x7m). A área do antigo ambulacrum é, por sua vez, fechada a oeste e norte por dois novos compartimentos. A norte, dispõe-se um muro (UE136), que limita a oeste uma área pavimentada com opus signinum (UE135), verificando-se a oeste o fecho da construção representado na UE112. Uma vez implantados os dois muros (UEo55 e UE11o), que fecham a área ajardinada, podemos sugerir que se tenha criado um novo corredor de circulação no interior da habitação, correspondente ao espaço formalizado entre estes muros e o outro já existente (UE104).

Embora não seja possível realizar grandes ilações acerca das alterações que a casa sofreu nesse período, uma vez que os limites da intervenção impossibilitam a restituição da planimetria completa do edifício, certamente as reformas realizadas na época tetrárquica alteraram significativamente o seu interior. Com efeito, o sacrifício do peristilo para a implantação de dois espaços leva-nos a supor que outro espaço ajardinado possa ter sido criado noutro setor da habitação, podendo ter-se formalizado uma domus com dois espaços abertos aquando de sua fundação, à semelhança da domus das Carvalheiras, na primeira fase, ou da domus da Escolha Velha da Sé/rua Frei Caetano Brandão, em cujo quarteirão havia duas habitações no período alto imperial, cada um com o seu peristilo, mas que, no século $\mathrm{IV}$, foi ocupado por uma única casa e teve um dos espaços abertos transformado num oecus e numas termas (Magalhães, 2019). Por outro lado, não é possível descartar a possibilidade da reforma da casa ter sido ainda maior e que um novo peristilo tenha sido construído noutro espaço da casa, ou que a habitação tenha recorrido a outros elementos de organização e distribuição dos compartimentos fechados. 


\section{CONSIDERAÇÕES FINAIS}

Podemos atestar que os vestígios identificados no Tabuleiro A dos Terrenos da Santa Casa da Misericórdia de Braga revelam-se deveras importantes para a compreensão da sequência de ocupação do quadrante sudeste da cidade romana de Bracara Augusta. A sua análise permitiu ampliar os conhecimentos sobre a arquitetura doméstica na cidade romana, quer em período alto imperial, quer em período tetrárquico, bem como compreender a articulação desse edifício privado com o espaço urbano.

Comparativamente a outras áreas da cidade melhor estudadas, verificamos que este quadrante apresenta o mesmo tipo de construções de carácter habitacional e um crescimento urbanístico semelhante, no qual se verifica a ocupação dos quarteirões residenciais a partir da segunda metade do século I. Nos finais do século III/inícios do IV, com a elevação da cidade a capital da nova província da Gallaecia, observam-se reformas nas domus, globalmente representadas pela ampliação dos programas decorativos e pela implantação de espaços balneares.

Deste modo, apesar das limitações encontradas, uma vez que nesta área não foi possível realizar um estudo arqueológico muito aprofundado, consideramos os vestígios desta intervenção deveras importantes para o continuado estudo da cidade de Bracara $\mathrm{Au}$ gusta, pelo seu carácter mais periférico relativamente aos equipamentos públicos conhecidos que se concentram as áreas a norte e poente do forum.

\section{BIBLIOGRAFIA}

ALVES, Mafalda (2016) - Da utilização e análise de dados de Geofisica em contextos arqueológicos: o Castro de Sapelos (Boticas) e o Seminário Conciliar de São Pedro e São Paulo (Braga). Braga: Universidade do Minho (Dissertação de Mestrado).

DELGADO, Manuela; MARTINS, Manuela; LEMOS, Francisco (1989) - Salvamento de Bracara Augusta. Forum. Braga. 6 , pp. 3-40.

FERNANDES, Lara (2018) - Urbanismo e arquitetura do quadrante sudeste da cidade romana de Bracara Augusta entre a época fundacional e a Antiguidade Tardia. Braga: Universidade do Minho (Dissertação de Mestrado).

MAGALHÃES, Fernanda (2010) - Arquitectura doméstica em Bracara Augusta. Braga: Universidade do Minho (Dissertação de Mestrado).
MAGALHÃES, Fernanda (2019) - A domus Romana no Noroeste Peninsular: Construção, Arquitetura e Sociabilidades. Braga: Universidade do Minho (Tese de Doutoramento).

MARTINS, Manuela (1995) - Bracara Augusta, uma cidade na periferia do Império. In Actas do Colóquio Internacional de Arqueologia "Los finisterres atlanticos en la antiguedad" (época préromana e romana). Gijon, pp. 121-128.

MARTINS, Manuela (2004) - Urbanismo e arquitectura em Bracara Augusta. Balanço dos contributos da Arqueologia Urbana. In Simulacra Romae. Roma y las capitales provinciales del Occidente Europeo: Estúdios arqueológicos. Tarragona, pp. 149-174.

MARTINS, Manuela (2009) - Bracara Augusta. Panorama e estado da questão sobre o seu urbanismo. In DOPICO CAINZOS, María; RODRÍGUEZ ALVAREZ, Patrícia; VILLANUEVA ACUÑA, Manuel, eds. - Do Castro à Cidade. A Romanización na Gallaecia e na Hispania indoeuropeia, Actas do Curso de Actualización sobre a romanizacion de Galiza. Lugo, pp. 167-198.

MARTINS, Manuela (2014) - Projeto de Bracara Augusta. 38 anos de descoberta e estudo de uma cidade romana. Revista da faculdade de letras. Ciências e técnicas do património. Porto. Vol. XIII, pp. 165-175.

MARTINS, Manuela; DELGADO, Manuela (1989-9o)-História e arqueologia de uma cidade em devir: Bracara Augusta. Cadernos de Arqueologia. Braga. Série II. 6/7, pp. 11-39.

MARTINS, Manuela; RIBEIRO, Maria; RIBEIRO, Jorge; MAR, Ricardo (2017) - Topografia e urbanismo fundacional de Bracara Augusta. In DOPICO CAÍNZOS, María; VILLANUEVA ACUÑA, Manuel, eds. - In Roma nata, per Italiam fusa, in provincias manat. A cidade romana no noroeste: novas perspectivas. Lugo: Servizo de Publicacións da Deputación de Lugo (Philtáte. Studia et acta antiquae Callaeciae; Vol. 2), pp. 203-226. 


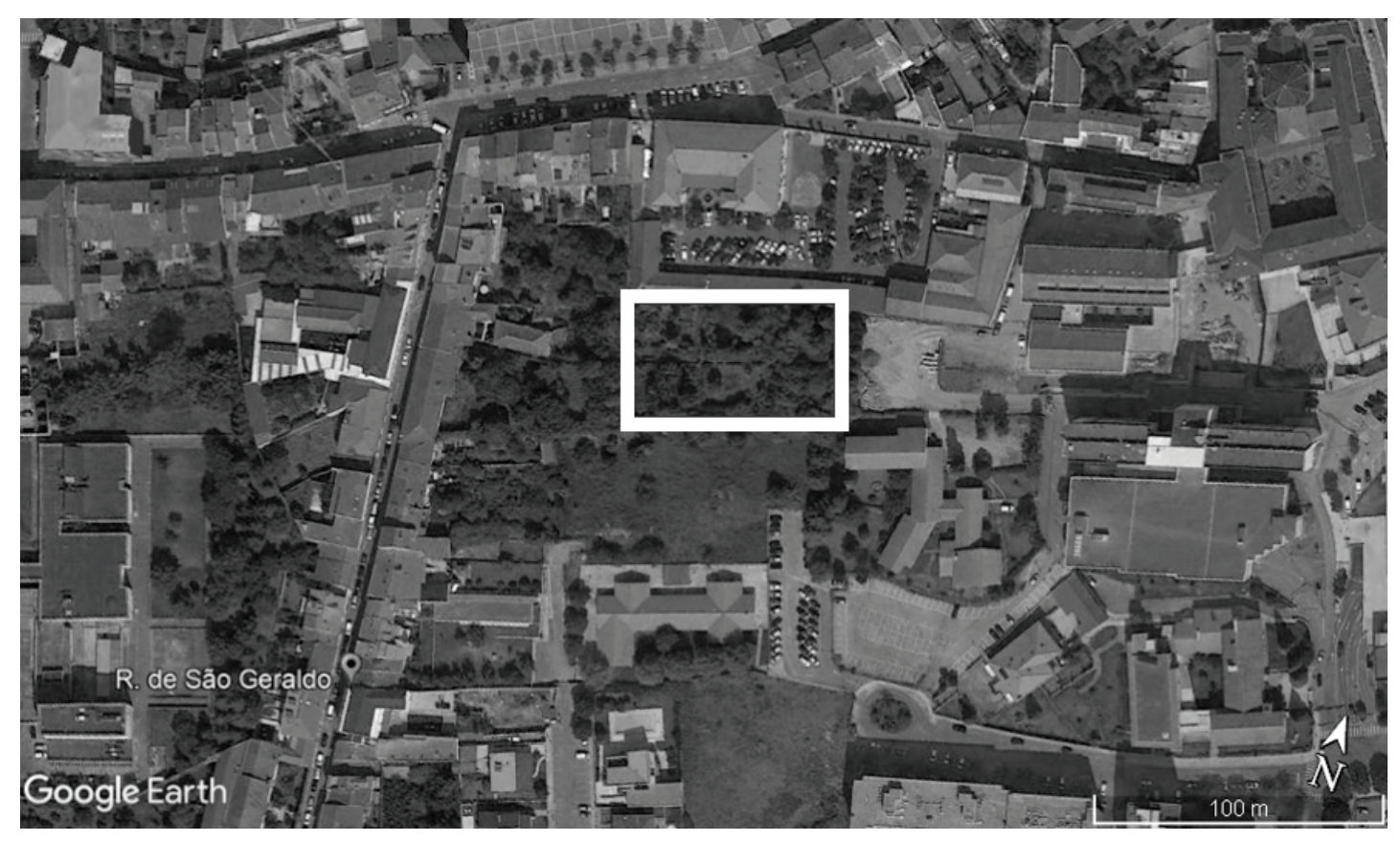

Figura 1 - Localização do Tabuleiro A dos Terrenos da Santa Casa da Misericórdia de Braga (@ Google Earth).

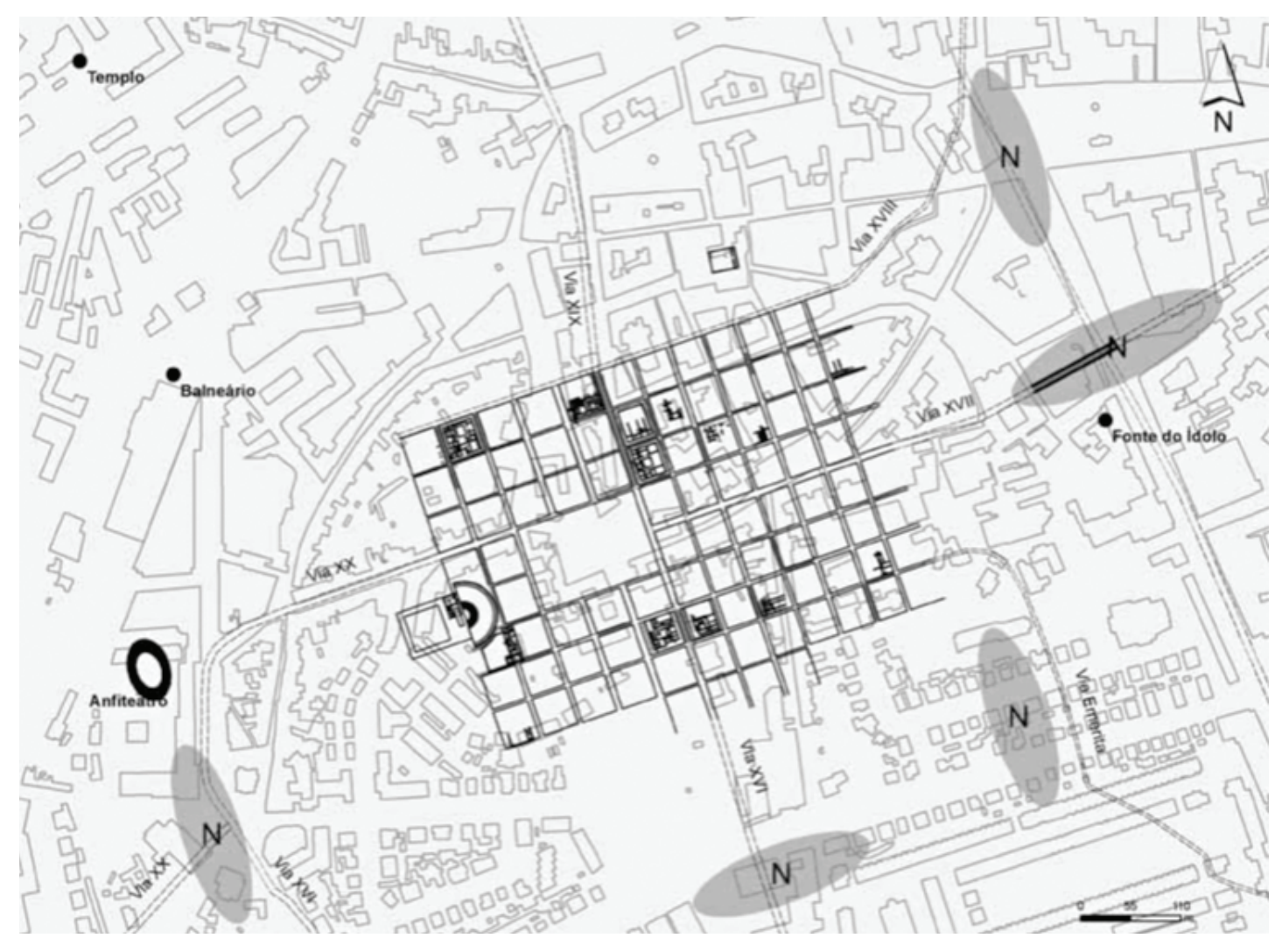

Figura 2 - Malha urbana de Bracara Augusta (Martins \& alii., 2017). 


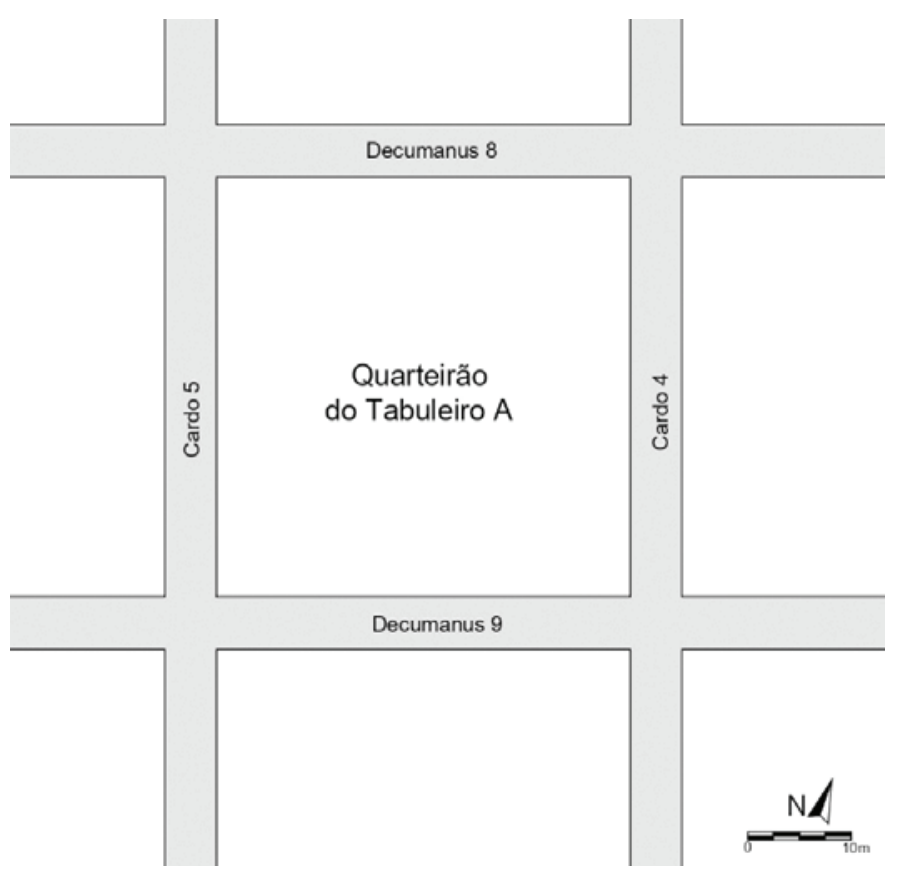

Figura 3- Quarteirão da zona arqueológica do Tabuleiro A inserido na malha urbana de Bracara Augusta (Fernandes, 2018).

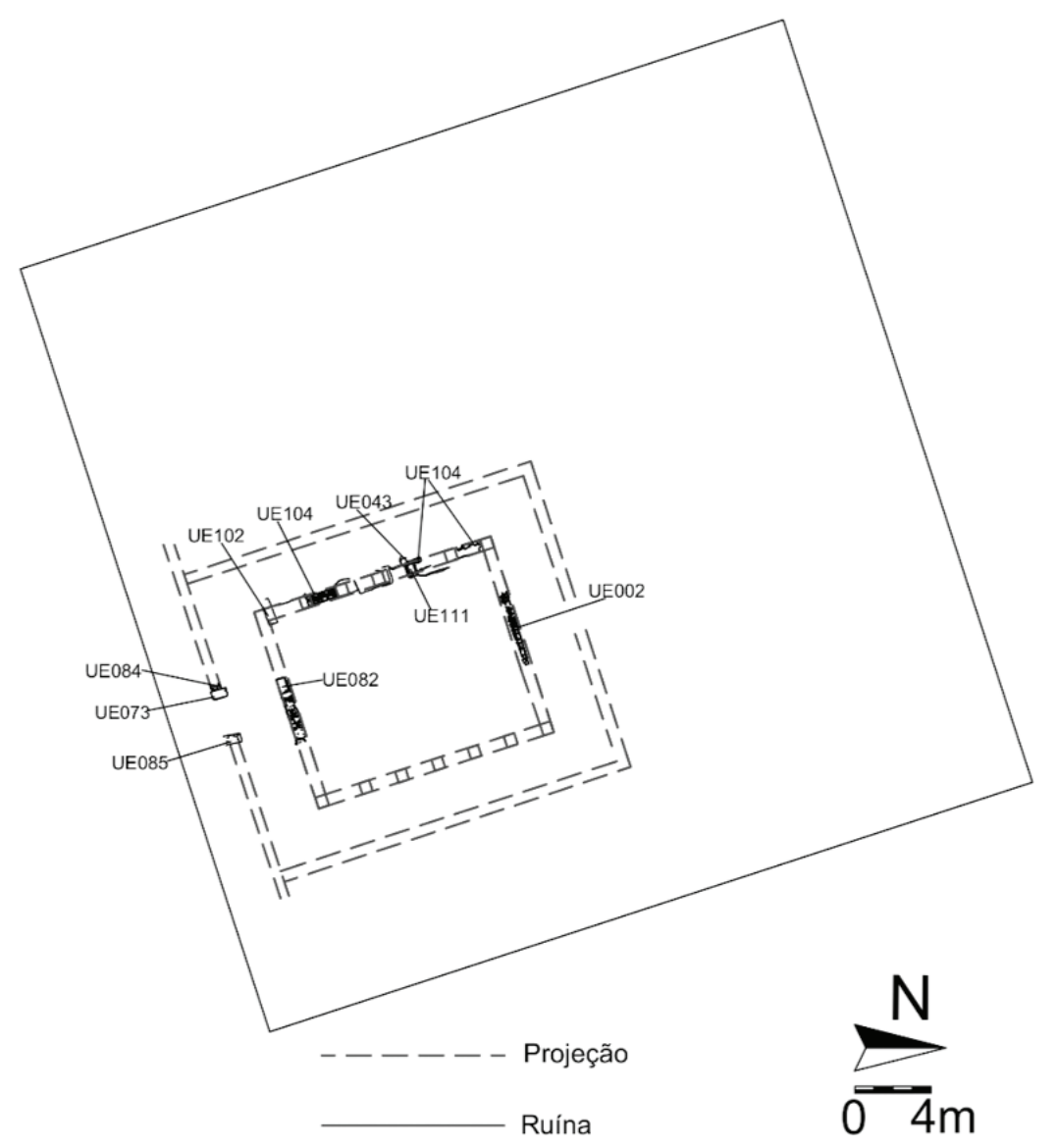

Figura 4 - Fase 1 do Tabuleiro A sobre a malha urbana (Fernandes, 2018). 


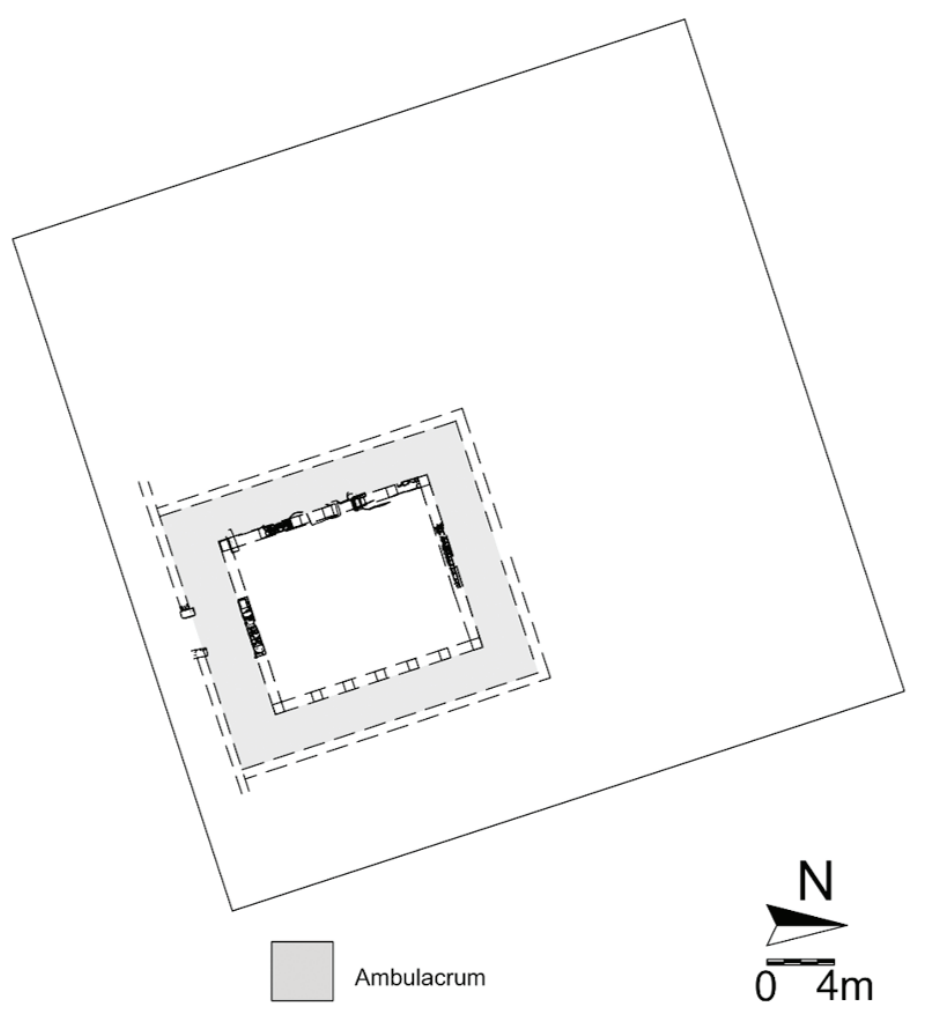

Figura 5 - Área do ambulacrum do peristilo da $1^{\underline{a}}$ fase de ocupação do Tabuleiro A (Fernandes, 2018).

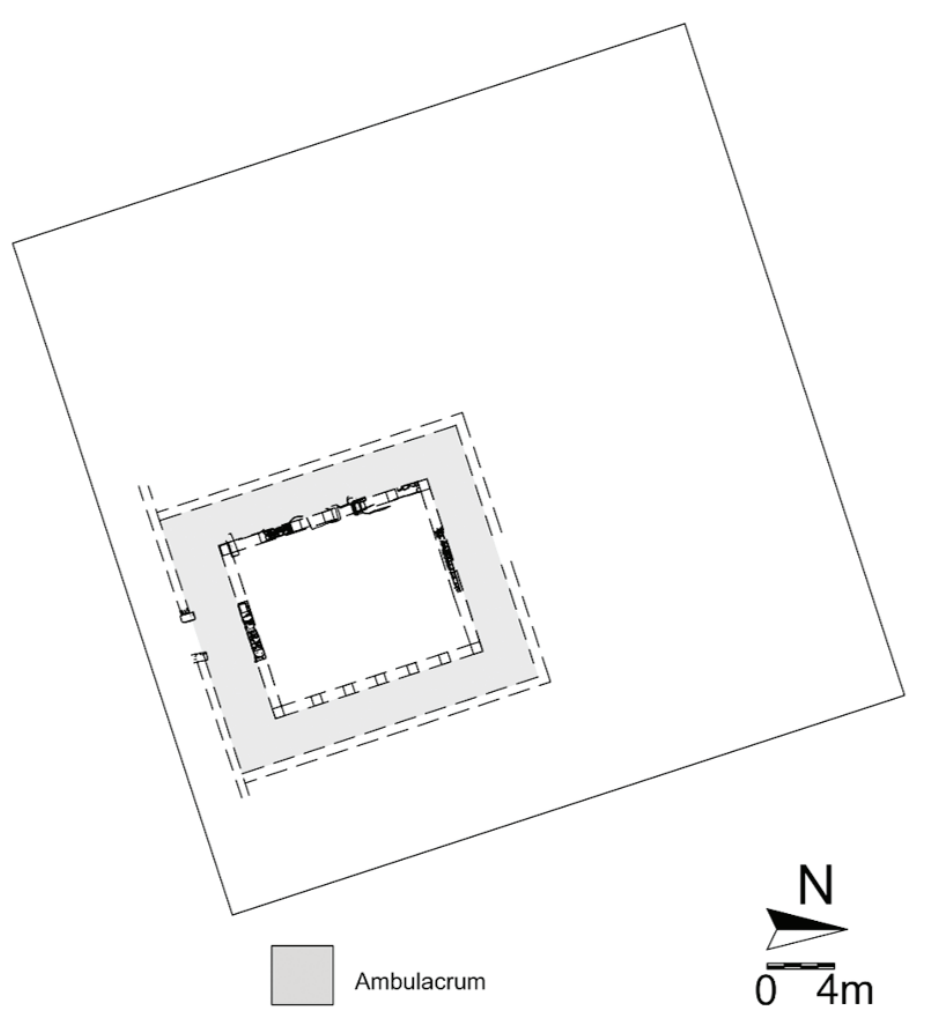

Figura 6 - Fase 2 do Tabuleiro A sobre a malha urbana (Fernandes, 2018). 


\title{
OS MOSAICOS COM DECORAÇÃO GEOMÉTRICA E GEOMETRICO-VEGETALISTA DOS SÍTIOS ARQUEOLÓGICOS DA ÁREA DO CONUENTUS BRACARAUGUSTANUS. NOVAS ABORDAGENS QUANTO À CONSERVAÇÃO, RESTAURO, DECORAÇÃO E DATAÇÃO
}

\author{
Maria de Fátima Abraços, Licínia Wrench
}

\begin{abstract}
RESUMO
O presente estudo permite revisitar alguns dos mosaicos já apresentados no Corpus dos Mosaicos Romanos do Conuentus Bracaraugustanus (Hispania) publicado em Junho de 2019, pelo Centro de Estudos Históricos da Universidade NOVA de Lisboa, quanto à decoração e estado de conservação. Indicar-se-ão vários exemplos das decisões tomadas durante as intervenções arqueológicas quanto ao levantamento mosaístico e consequente diversificação de abordagens na apresentação e/ou documentação dos mosaicos em apreço, que na sua maioria se justificam devido a informações adicionais que resultaram do prosseguimento da nossa pesquisa e das que nos foram proporcionadas já depois da publicação do Corpus.

Palavras-chave: Conuentus Bracaraugustanus, Mosaicos romanos, Conservação, Restauro, Decoração.
\end{abstract}

\begin{abstract}
The present study allows us to revisit some of the mosaics already studied in the Corpus of Roman Mosaics of Conuentus Bracaraugustanus published in June 2019, by the Centro de Estudos Históricos da Universidade NOVA of Lisbon, regarding decoration and state of conservation. Examples of the decisions taken during archaeological interventions regarding the mosaic survey and the consequent diversification of approaches in the presentation and/or documentation of the mosaics under study will be indicated, which are mostly justified due to additional information that was known and was provided to us after the publication of the Corpus. Keywords: Conuentus Bracaraugustanus, Roman mosaics, Conservation, Restoration, Decoration.
\end{abstract}

\section{INTRODUÇÃO}

Os mosaicos descobertos nos diferentes sítios arqueológicos requerem medidas de conservação de modo a poderem subsistir aos diferentes ambientes a que vão ficar expostos ou acondicionados. $\mathrm{O}$ conhecimento antecipado dos factores de deterioração permite estabelecer planos direccionados para atenuar os seus efeitos, no sentido de proporcionar a salvaguarda destes bens. Assim os arqueólogos e técnicos de restauro tomam as suas decisões depois de um estudo prévio e podem decidir se os mosaicos ficam in situ, se são musealizados, se são reenterrados, e onde ficam acondicionados: nas reservas dos museus, nos depósitos de materiais arqueológicos ou outros. Tendo em conta esta metodologia, passamos a apresentar o modo como foram tratados neste artigo os mosaicos deste Conuentus. Para cada mosaico apresentamos as intervenções de conservação, restauro, musealização seguida da descrição dos elementos decorativos relevantes e datação.

Da totalidade dos noventa e três mosaicos pertencentes a trinta e sete sítios arqueológicos estudados no "Corpus dos Mosaicos Romanos do Conuentus 
Bracaraugustanus", seleccionámos alguns exemplos para os quais se manteve a numeração dos mosaicos analisados no Corpus, o número das páginas que o seu estudo ocupa e os sítios arqueológicos de onde provêm. Essa selecção foi efectuada consoante as informações adicionais que resultaram do prosseguimento da nossa pesquisa e das que nos foram proporcionadas já depois da publicação do Corpus. A grande maioria dos mosaicos provenientes do Conuentus Bracaraugustanus apresenta decoração geométrica e geometrico-vegetalista. Os poucos exemplares conhecidos com decoração figurativa, fauna aquática e vasos, provêm da cidade de Braga, mas foi também registado um mosaico com a representação de peixes no sítio arqueológico de Fonte do Milho, em Canelas (Peso da Régua), e a representação de um cantharus em uma tampa sepulcral encontrada no Lugar do Castelo, Frende, Baião (Marco de Canaveses). Seleccionaram-se os mosaicos cuja decoração e aspectos técnicos se consideraram significativos para a datação que lhes foi proposta, em diálogo com o contexto arqueológico em que se integravam. Em muitos casos, a datação resultante da análise estilístico-comparativa vai de encontro à datação proposta para os respectivos sítios arqueológicos, mas existem outros casos em que prevaleceram, ou os critérios estratigráficos, ou os estilísticos.

\section{MOSAICOS CONSERVADOS IN SITU MUSEALIZADOS}

\section{A - Mosaico da Domus da cripta do MDDS, Bra- cara Augusta/Eixo Interior}

Em 1991, durante a construção do edifício do Museu D. Diogo de Sousa, foram descobertas estruturas de uma domus que apresentava duas salas revestidas com mosaicos decorados com tabuleiro de xadrez e quadrícula de linhas de ampulhetas. (CMRCB, mosaico 1, pp. 47-54 - salas 1 e 2). Foi feito um isolamento especial desta área e foi também decidido que seria construído um novo edifício para albergar as novas estruturas. Tendo em conta as sucessivas inundações que ocorriam na área onde se encontravam os mosaicos situados ao nível friático, foi necessário e urgente proteger e enterrar novamente as estruturas, para que se realizasse com segurança a cobertura, que iria albergar os alicerces da domus. Em 1997, depois da construção do Bloco A, que alberga o espaço, onde se encontram os mosaicos, procedeu-se à remoção de todos os materiais de protecção usados quando do seu enterramento. Nesta altura, decidiu-se deixar ainda a camada de areia fina que cobria os mosaicos. Efectuou-se também a consolidação e reconstituição de algumas estruturas com uma argamassa à base de cal hidráulica e saibro. Foi aplicado um biocida (Dipcid da CIN) nas áreas mais elevadas que já não estavam protegidas e apresentavam microorganismos (AMDDS). Ainda durante o ano de 1997 começaram os preparativos do espaço dos mosaicos para ser musealizado. Durante o Inverno e quase diariamente, verificava-se a existência de inundações e infiltrações, a partir do tecto e junto às paredes do piso. Em 2003/2004, foi construída uma galeria para resolver esta situação e drenar o espaço envolvente ao mosaico, mas não ficou bem executada.

Desde 1998, que se verificam infestações, que se desenvolvem devido à entrada de luz pela clarabóia e pela humidade geral existente nas paredes e sob a área do mosaico. De 1999 a 2004 foram efectuadas várias limpezas com vapor de água e esponja e aplicado o biocida "Dipcid" da Tintas CIN em toda a área de ruínas, que não estavam protegidas da entrada de luz, para tentar eliminar microrganismos. Concluiu-se que este processo de limpeza e o biocida aplicado não estavam a resolver a eliminação das áreas verdes. Verificou-se ainda que a entrada de luz pelas clarabóias, conjuntamente com a humidade existente, tornava muito difícil o combate aos musgos (Figura 1).

No sentido de procurar diminuir as entradas de luz natural, e assim reduzir o aparecimento de fungos e algas, foi pedida a aquisição de uma película de raios ultravioletas ao Instituto Português de Museus. Como a resposta tardou e numa tentativa de evitar a propagação de microrganismos nas áreas limpas, colocou-se manga plástica preta. Como não se conseguia eliminar a infestação de microorganismos com o "Dipcid”, especialmente nas áreas mais próximas da entrada de luz (clarabóia), decidiu-se aplicar outro biocida, o "25X" e finalmente foi feita uma aplicação do biocida Preventol R8o, mas todas as diligências efectuadas até agora não resultaram (Figura 2).

Perante as situações apresentadas, podemos apontar algumas soluções: procurar diminuir a entrada de luz natural, proceder à drenagem das estruturas e aplicar biocidas adequados para eliminação dos fungos. Mas serão necessárias verbas para proceder a mais estudos microbiológicos e resolver de vez a drenagem desta área com a construção de uma nova galeria que 
envolva toda a caixa, onde está inserida esta Domus. Mas nesta época de escassos recursos, com um orçamento mínimo para a Cultura, constitui um grande desafio encontrar financiamento, que permita a realização destes empreendimentos, que só poderão avançar através de patrocínios ou de intercâmbios entre universidades, ou no âmbito de mestrados e doutoramentos. Entretanto, pode ser feito um ensaio, utilizando lâmpadas ultravioletas, que poderão ficar activas durante a noite, para minimizar o crescimento de fungos neste ambiente húmido.

A estes mosaicos, decorados com temas que se verificam desde época recuada a época tardia, foi atribuída uma datação alto-imperial tendo em conta a análise das estruturas da casa a que pertenciam, a perfeição da canalização em granito que passa sob os painéis, o rigor da execução dos temas decorativos e a dimensão e densidade das tesselas. Tendo Bracara Augusta sido objecto de um programa construtivo realizado entre o último quartel do século I e os inícios do século II d. C., os mosaicos poderão corresponder a estruturas dessa época.

B - Os mosaicos da Domus da Sé Velha - Rua D. Afonso Henriques, № 1, Bracara Augusta/Eixo Interior

Em 1998, devido a uma proposta de remodelação do edifício da antiga "Escola Velha da Sé", procedeu-se a uma intervenção arqueológica que foi realizada pelo Gabinete de Arqueologia da Câmara Municipal de Braga, dirigida pelo Dr. Armandino Cunha, cujos trabalhos decorreram, em diferentes fases, até 2003 (Figura 3).

A área intervencionada, na cave do edifício da Escola Velha da Sé, ocupa uma superfície total de 720 $\mathrm{m}^{2}$, onde foi reconhecida a parte sul de uma habitação romana, na qual se destacam os vestígios de um hipocausto e de pavimentos revestidos com material laterício e mosaicos. Parte do mosaico encontra-se in situ, onde tem sido consolidado (CMRCB, mosaico 15, pp. 84-88). Em Março de 200o, cinco fragmentos muito frágeis foram levantados e consolidados com Plexigum N8o e aplicação de tela. Estes fragmentos deram entrada na reserva do MDDS. Foram individualizadas três fases construtivas para esta habitação, tendo por base a estratigrafia e os materiais arqueológicos analisados. A primeira fase pode ser datada do século I. A segunda fase corresponde a uma remodelação significativa da habitação, que pode ser datada de entre os finais do século III e os inícios do século IV, tendo em conta o contexto arqueológico e a análise estilística dos mosaicos. A remodelação da domus que define esta segunda fase de ocupação caracterizou-se pela construção de um balneário, na área sudoeste do edifício. A edificação do complexo de banhos sacrificou a zona da casa anteriormente ocupada por um possível peristylium. Relacionado com esta reforma está um pavimento em mosaico que recobria um extenso corredor e que permitia aceder à nova área da habitação, possibilitando a articulação do espaço de banhos com outros compartimentos da casa (Magalhães, 2010, pp. 50-51).

Este mosaico de tesselas bicromas (calcário branco e preto) apresenta um padrão ortogonal de círculos e quadrados no vértice determinando bobinas. Para o esquema decorativo deste mosaico de pavimento, encontraram-se paralelos em mosaicos da Hispania, incluindo a Gallaecia, e do Norte de África, datados dos séculos II-III, III, III-IV e século IV. Quanto à decoração realizada no interior dos círculos, ela parece ser uma adaptação de ressaltos desiguais ao espaço circular ou de ressaltos arredondados. Nos mosaicos do Conuentus Bracaraugustanus, muitas das figuras geométricas de vários esquemas compositivos são decoradas interiormente com ressaltos desiguais, mesmo no interior de um círculo, como se verifica num mosaico da Villa de Tralhariz (CMR$C B$, mosaico 93) que poderá ser um pouco posterior ao desta domus de Braga. A utilização de ressaltos ao jeito de "corola" pode dever-se à inabilidade do artífice mosaísta na cópia de modelos, mas também pode revelar certa capacidade criativa ao realizar este motivo para o qual não se encontraram paralelos.

Para além deste mosaico foram identificados nas salas limítrofes outros pequenos fragmentos com tesselas de várias cores, mas devido à sua fragmentação não foi possível caracterizá-los. (Magalhães, 2010, pp. 57). Na parte Oeste do edifício, no prolongamento do espaço musealizado, foi aberto um restaurante com entrada pelo Campo das Carvalheiras, no ${ }_{13}$, mas que mantem uma porta que dá acesso ao espaço musealizado. Muitas vezes durante o período das refeições esta porta é aberta e os utentes do restaurante podem circular livremente pelo espaço musealizado pondo em risco as estruturas das habitações romanas.

C - Mosaico da Domus de Sendim, Felgueiras, Porto /Eixo Interior

$\mathrm{Na}$ estação arqueológica de Sendim, Felgueiras, Por- 
to, os trabalhos de escavação dirigidos por Marcelo Mendes Pinto puseram a descoberto algumas das estruturas da pars urbana de uma Villa, com pavimentos musivos. Um dos mosaicos que subsiste, muito deteriorado, corresponde ao pavimento de um cubiculum, tendo sido datado de entre finais do século III e finais do século IV. Esta datação teve por base o contexto arqueológico que aponta para uma significativa renovação da pars urbana desta Villa em finais do século III, bem como a análise estilístico-comparativa dos temas decorativos usados. $\mathrm{O}$ tapete principal e maior apresenta uma composição centrada por um octógono com uma estrela de 8 losangos, que encontra paralelos em mosaicos do território português como nos das Villae de Cerro da Vila e Milreu e de Conímbriga ("Casa dos esqueletos”), todos datados dos séculos III-IV, e do Norte de África, salientando-se um mosaico de Thysdrus, das primeiras décadas do século III. O motivo da "estrela de 8 losangos" em diferentes composições de superfície é muito frequente na arte do mosaico do mundo romano.

A faixa de ligação ao tapete menor que corresponde à zona do lectus, elevada por um pequeno degrau, apresenta duas fiadas de moinhos de peltas à volta de nó-de-Salomão, decoração também ocorrente em outros mosaicos tardios hispânicos, nomeadamente do território português, igualmente datados dos séculos III-IV. (CMRCBA, mosaico 72, pp.183-193).

O mosaico mantém-se in situ e apresenta-se muito danificado. Foi construída sobre toda a área da estação arqueológica uma cobertura de madeira, que protege todas as estruturas.

\section{D - O mosaico da casa do Infante, Porto/ Eixo do Douro}

No decurso da intervenção arqueológica realizada na Casa do Infante, na zona ribeirinha da cidade do Porto, identificaram-se dois pavimentos de mosaico. Os trabalhos arqueológicos foram motivados pelo projecto de remodelação e ampliação do edifício onde se encontra instalado o Arquivo Histórico Municipal cuja matriz surge definida no século XIV com a construção da Alfândega régia e da Casa da Moeda. Subjacente a estas construções foi escavada uma sequência de ocupação alto-medieval e tardo-romana na qual se integram os dois pavimentos de mosaico, correspondentes a dois compartimentos da habitação tardo-romana. Para a decoração que apresentam foram encontrados paralelos em mosai- cos hispânicos, sobretudo do território português, enquadráveis nos séculos III e IV (CMRCB, Mosai$\cos 82$ e 83, pp. 209-220).

O tipo de solo caracterizado por um elevado teor de humidade e $\mathrm{pH}$ ácido condicionou a preservação dos dois pavimentos de mosaico que apresentavam um avançado estado de degradação física e química com perda da maioria das tesselas.

Dado o acentuado estado de degradação dos pavimentos o projecto de exposição optou por fazer substituir a sua exibição directa por uma réplica.

\subsection{MOSAICOS CONSERVADOS IN SITU NÃO MUSEALIZADOS.}

A - Pavimento misto, em opus sectile e opus tessellatum, Bracara Augusta/Eixo Interior

Na área do actual jardim do Museu D. Diogo de Sousa (BA-Cavalariças/BRA88CVL, zona X126Y173-sond. 079), foram descobertas estruturas que apresentavam um pavimento misto, em opus sectile e opus tessellatum, que depois de estudado, desenhado e fotografado, permaneceu in situ, coberto com tela sintética e areia. (CMRCB, mosaico 2, pp.55-58). Foram retiradas algumas lajes de granito que se encontram na reserva do MDDS.

Este tipo de pavimento em que se usam os dois opera constitui um unicum no conjunto dos mosaicos do Conuentus Bracaraugustanus. As lajes, hexagonais e quadradas, dispor-se-iam regularmente ao longo da superfície do pavimento, sendo cada quadrado rodeado por quatro hexágonos. As tesselas, policromas, que subsistiram entre as lajes, desenhariam uma trança de dois cordões (Abraços, 2016, p. 320, Figs. 5 e 8), o que leva a supor o seu envolvimento por este tema, produzindo o conjunto um belo efeito decorativo. Atendendo a que este pavimento foi encontrado a uma cota superior relativamente à domus da cripta do MDDS, numa área da cidade que não terá sido abandonada, embora tenha visto alterado o seu protagonismo no século $\mathrm{V}$, em detrimento do novo centro urbano deslocado para nordeste, e sabendo-se que os pavimentos mistos foram muito usados em época bizantina, considerou-se possível atribuir-lhe uma datação, ainda que interrogada, nos séculos V-VI.

\section{B - Mosaico da Casa da Roda}

Na Rua de S. João, em Braga (BRAgo/92 CRO) foi realizada uma escavação, onde foi descoberto um 
mosaico com suporte original (CMRCB, mosaico 34, pp.112-123). Após consolidação, in situ, pela equipa técnica do MDDS, o mosaico foi tapado com tela sintética e areia. O mosaico in situ encontra-se enterrado sem que exista, no referido edifício, qualquer referência ao local preciso do achado, ou alguma fotografia ilustrativa daquele que será um dos mais ricos mosaicos que até ao presente nos chegou, provenientes da capital da Gallaecia (Figura 4):

É um mosaico policromo de tesselas em calcário branco, preto, vermelho e amarelo que, no limitado espaço posto a descoberto (cerca de 2,30 $\mathrm{m} \mathrm{x} \mathrm{1,50} \mathrm{m),}$ se organizam em quatro diferentes temas decorativos: linha descontínua de florzinhas em cruz; linha de peltas alternadamente invertidas com folhas cordiformes no vértice mediano; onda policroma e linha de sólidos. Ainda que todos os temas encontrem paralelos em mosaicos hispânicos, norte-africanos e do Oriente mediterrânico, no que respeita à linha de sólidos será de salientar que este tema está pouco documentado nos mosaicos do actual território português, conforme referimos no $C M R C B$ (pp. 118-119). A análise estilistico-comparativa dos diferentes temas ocorrentes no mosaico da Casa da Roda e as informações sobre a arqueologia de Bracara Augusta que sofreu um significativo desenvolvimento construtivo após a sua passagem a capital da Gallaecia levaram a datar este mosaico de entre os séculos III e IV.

\section{C - Mosaicos de Vizela/ Eixo Interior \\ (CMRCB, mosaico 71 A e B, pp. 180-182)}

$\mathrm{Na}$ actual Praça da República, foram referenciadas desde o século XIX, evidências de estruturas termais romanas, onde terá sido posto a descoberto um mosaico romano do qual ficaram desenhos no Museu da Sociedade Martins Sarmento (CMRCB, mosaico $71 \mathrm{~A}$ ), bem assim como outros vestígios dispersos pelo complexo balnear.

Em 1898, e por ocasião de novas obras, foi encontrado um outro mosaico integrado numa estrutura de banhos, a qual posteriormente se enterrou. Durante uma intervenção de emergência realizada pelo arqueólogo Francisco Queiroga (Queiroga 2013, pp. 181-201), em 1996/97 foi descoberto junto ao tanque termal um outro mosaico (CMRCB, mosaico 7 B). Todo este legado se encontra ainda in situ e coberto.

Os mosaicos provenientes do complexo termal apresentam decoração geométrica que se enquadra nas características estilísticas de outros mosaicos do
Conuentus Bracaraugustanus e de outras regiões administrativas romanas, nomeadamente da Gallaecia. (Figura 5)

Um dos mosaicos é composto por quadrados e losangos adjacentes, encaixados, todos delineados no interior por filetes denticulados, sendo os losangos ainda sublinhados interiormente por ressaltos desiguais. Os quadrados levam ao centro nó de Salomão (um deles de voltas rectilíneas), moinho de velas e florzinha com borlas. A composição de superfície que no território português aparece, por exemplo, em um mosaico de Conímbriga da "Casa da cruz suástica”, datado da $2^{\mathrm{a}}$ metade do século III (Correia, 2003, p. 25; Oliveira, 2005, p. 40, mosaico 24.1), é um tipo de composição geométrica que surge também em Lugo e La Cigarrosa (Orense), na Gallaecia (Torres Carro, 2015ª, p. 215). No mosaico de Lugo, no Museu Provincial desta cidade, o esquema compositivo é usado em uma larga faixa que enquadra as figurações de Dédalo e Pasífae (Regueras Grande, 2015, p. 283; Irastorza \& Carnero Vásquez, 2015, p. 255, Fig. 5). O outro mosaico aparenta uma composição em quadrados, sendo visível em um deles o mesmo tipo de filete denticulado no seu interior. Por comparações estilísticas com outros mosaicos, os mosaicos de Vizela poderão datar do século IV.

\section{D - Freixo, Marco de Canaveses/Eixo do Douro} Em Marco de Canaveses, a Igreja de Santa Maria do Freixo foi objecto de escavação arqueológica, iniciada em 2001. No subsolo da actual igreja foi detectada uma construção de consideráveis dimensões com pavimentos revestidos a mosaico (CMRCB, mosaico 86, pp. 222-230). Segundo António Manuel de Carvalho Lima este mosaico apresenta uma datação não anterior a meados do V e em uso ainda no VI. Os mosaicos mantêm-se in situ, excepto um pequeno fragmento que foi removido e exposto no Centro Interpretativo de Tongobriga. Actualmente nada se encontra visível. Os mosaicos que revestiam os compartimentos A e B preservam-se sob o soalho da igreja paroquial.

\subsection{MOSAICOS LEVANTADOS E CONSERVADOS NAS RESERVAS DOS MUSEUS}

\author{
A - Rua 25 Abril, Quinta do Fujacal \\ Em 2001, na estação Arqueológica da Rua 25 Abril, \\ Quinta do Fujacal (escavação: BRA20oıBMIS, zona
}


B20, n.․ complexo 9, n.. campo 1/Unidade estratigráfica 031 - Enchimento da vala de saque UE 030). Fragmento de mosaico com suporte original, sobreposto a outro fragmento de mosaico (CMRCB, mosaico 7, pp.66-67). Deu entrada em 20.02.2001, no MDDS para tratamento de conservação.

O fragmento de mosaico bicromo (branco e preto), de tesselas calcárias, no qual se desenha um triângulo de base côncava, centrado por uma cruzeta de quatro tesselas, foi encontrado num contexto arqueológico datável do século I, época Flaviana. A perfeição de execução do tessellatum, a densidade das tesselas, 145/ dm2, e o contexto arqueológico do achado levaram a atribuir a sua realização à época Flaviana.

B - Estruturas de tanques revestidos a mosaico/ Cardoso da Saudade, Largo de S. Paulo, Bracara Augusta/Eixo Interior

$\mathrm{Na}$ estação Arqueológica Cardoso da Saudade, no Largo de S. Paulo, foram postas a descoberto estruturas de três tanques (CMRCB, Mosaicos 11 a 13, pp. 73-80). Um foi escavado em 1968, mas apenas se conservava o fundo, revestido a mosaico já muito danificado, e duas paredes. Este, em data desconhecida, terá sido incorporado noutro tanque de maiores dimensões. Esta remodelação pode ter estado na origem dos maiores danos do mosaico. Actualmente existem apenas fragmentos com suporte original no MDDS e outros continuam in situ. Ainda no mesmo ano foi posto a descoberto outro tanque de onde foi retirado um fragmento decorado com cabeça incompleta de um peixe, pertença da colecção do MDDS. Em 1993, foram descobertos grandes fragmentos de mosaico que revestiam as paredes e o fundo de um tanque com degraus, decorados com florzinhas em cruz de tesselas pretas sobre fundo de tesselas brancas. O mosaico está em desagregação e encontra-se muito fragmentado. Quando do levantamento do mosaico procedeu-se à limpeza da sua superfície e foi feita a sua consolidação com Plextol B500; colagem de gaze sobre todo o mosaico utilizando Plextol B50o; colagem de uma tela de pano-cru sobre a gaze; construção de contramoldes em poliuretano expandido. Encontra-se em completa desagregação.

\section{C-Mosaicos da Rua D. Afonso Henriques núme- ros 20-28, Bracara Augusta/Eixo Interior}

(CMRCB, mosaicos 17 a 30, pp. 91-106)

Outro conjunto de mosaicos foi descoberto nas sondagens arqueológicas que tiveram lugar no edifício da Rua D. Afonso Henriques números 20-28, que depois das escavações foi restaurado e reconvertido em Hotel, em 2017. Nesta escavação foram recolhidos mais de quatrocentos fragmentos, depositados como entulhos de remodelações, como provam as dez fases construtivas apresentadas no relatório de escavação (Trabalhos Arqueológicos da U.A.U.M./ Memórias, 25, 2012).

Alguns dos fragmentos apresentam medalhões circulares, na sua maioria delimitados por faixas de tesselas brancas e trança de dois cordões e, no interior, florões e vasos desenhados sobre fundo de tesselas pretas. Estes fragmentos, com idêntica técnica de execução, semelhante densidade das tesselas e o mesmo tipo de argamassas do tardoz, parecem fazer parte de um mesmo pavimento musivo que poderia apresentar uma composição de superfície de círculos tangentes, determinando quadrados côncavos, sendo visível, em um dos fragmentos, um segmento de círculo determinando um dos lados do quadrado. O tipo de florão representado encontra paralelos em florões com folhas fuseladas e estames, só com estames, ou com a junção de vários tipos de folhas, em mosaicos de território português como em Conímbriga ("Casa da cruz suástica" e "Casa dos esqueletos”), Torres Novas (Villa Cardílio), Pisões, Cerro da Vila, Abicada e, particularmente, no mosaico do Oceano de Faro (Wrench, 2005, pp. 33-48, Est. 1-5), podendo todos eles ser integrados nos séculos III e IV. Em mosaicos norte-africanos, datados dos séculos III-IV, o estilo de florões aproxima-se ao dos ocorrentes no Mosaico do Oceano de Faro, sendo o florão XIIb aí desenhado bastante semelhante aos do mosaico de Braga. Relativamente aos círculos, emoldurados por faixas brancas e trança de dois cordões, foram encontradas semelhanças com os desenhados em pavimentos da Domus Oceani de Lugo (sala que antecede o oecus e uma das alas do pátio porticado), aparecendo o círculo com trança de dois cordões bastante documentado na musivária tardia hispânica da zona centro (González Fernández, 2005, Figs. 58, 65, 96 e p. 91). O conjunto dos mosaicos desta casa situa-se cronologicamente entre finais do século III e princípios do século IV (González Fernández, 2015, p. 225). Tanto os mosaicos da sala que antecede o oecus como o do oecus terão sido realizados por oficina de Lugo que usou procedimentos de execução idênticos aos usados por oficinas norte-africanas, concretamente de Cherchel, Thuburbo Majus e Timgad (Torres Carro, 2015 b p. 336). Refira- 
-se também que no repertório compositivo dos mosaicos galegos, se emprega com frequência a figura do quadrado e do círculo em diversas combinações (Torres Carro, 2015' , p. 214).

Quanto aos vasos esquemáticos e bastante atípicos, de onde saem grossas volutas brancas, poder-se-á supor para eles uma realização mais tardia do que a dos florões. A análise estilística, as técnicas de execução e o contexto arqueológico levaram a propor os séculos III-IV para a realização deste mosaico que terá sido todo fragmentado.

\section{D-Mosaicos da Rua D. Afonso Henriques nos 42- 56, Bracara Augusta/Eixo Interior}

Outro grupo de fragmentos de mosaico foi descoberto na Rua D. Afonso Henriques n⿳s ${ }^{0} 2-56$. Os trabalhos arqueológicos foram executados nos anos de 1998 e 2002. A campanha de 1998 decorreu entre 18 de Maio e 10 de Novembro, tendo então sido abertas seis sondagens de $4 \times 4 \mathrm{~m}$, tendo em vista proceder a uma avaliação preliminar do potencial estratigráfico e patrimonial do logradouro. Tendo-se verificado que as estruturas romanas se encontravam a cerca de $2,5 \mathrm{~m}$ da superfície do solo atual e dada a dificuldade de remoção de terras do interior do quarteirão, os trabalhos arqueológicos foram interrompidos em Novembro de 1998 e retomados em 2002. Esta segunda fase dos trabalhos compreendeu a realização de uma escavação em área, com cerca de $307 \mathrm{~m}^{2}$. (Trabalhos Arqueológicos da U.A.U.M. / MEMÓRIAS, 48, 2014, 10-12). Foram descobertos fragmentos de mosaico, que fariam parte de um balneário que teve uma remodelação num período que os arqueólogos admitem situar-se entre finais do século III/ inícios do IV, quando se registaram importantes transformações no balneário, que modificaram a funcionalidade de alguns espaços. Um dos aspetos mais marcantes da remodelação operada nesse período associa-se ao aumento dos espaços frios do balneário e a uma diminuição de áreas quentes (Trabalhos Arqueológicos da U.A.U.M. / MEMÓRIAS, 48, 2014, 78). Sobre os níveis de enchimento do hipocausto foi assente um solo de opus signinum, que revelou decoração com mosaico, infelizmente muito destruído, cuja cota tinha 192,20m. A poente da nova sala fria deveria existir um outro espaço frio, que recebeu um pavimento de opus signinum, decorado com mosaico, registado numa área muito circunscrita das sondagens (Trabalhos Arqueológicos da U.A.U.M./ MEMÓRIAS, 48, 2014,
79). Admitindo que esta sala teria funcionado no período anterior como tepidarium, presume-se que o seu hipocausto tenha sido entulhado para permitir o assentamento do pavimento com decoração musiva (CMRCB, mosaicos 31 a 33, pp.107-111).

Todo o espólio deu entrada no MDDS foi lavado, marcado, inventariado e devidamente acondicionado, tendo o seu tratamento sido realizado por alunos de Mestrado de Arqueologia da Universidade do Minho, no ano académico de 2011-2012 (Trabalhos Arqueológicos da U.A.U.M. / MEMÓRIAS, 48, 2014) em colaboração com o pessoal do referido Museu. Os fragmentos de mosaico apresentam suporte original, mas em desagregação, foram removidos limpos e consolidados com plexigum N8o e acetona. Os fragmentos de mosaico nos 31 e 32 encontram-se na reserva do MDDS. O mosaico 33 continua in situ. Foi consolidado com Plextol B500 e água e depois coberto.

\section{E-Mosaicos provenientes do quintal de Fernando Castiço, Braga/ Eixo Interior}

O Museu Arqueológico da Sociedade Martins Sarmento (MASMS) guarda um conjunto de vinte e dois fragmentos de mosaicos, provenientes de Braga. Os fragmentos, todos em opus tessellatum e com suporte original, não apresentam restauros antigos, constituindo um material significativo quanto às temáticas decorativas, técnica de execução e de assentamento (CMRCB, mosaicos 40 a 6o, pp. 131-161). Em 2014, quando visitámos o Museu para fotografar os mosaicos, estes já tinham sido inventariados, limpos e consolidados.

\section{F-Mosaicos de Dume, Braga/Eixo Interior (CMRCB, mosaicos 61 a 68, pp.16o-177)}

Em 1987, foram realizadas escavações de emergência, em Dume, junto à Igreja Paroquial e na Capela de Nossa Senhora do Rosário, onde se pôs a descoberto as estruturas da antiga Igreja e Mosteiro de Dume, datáveis do séc. VI d.C. (SMD87, zona A72, n.. campo 75, fase II). Os mosaicos encontrados no espaço da basílica paleocristã e na necrópole alto-medieval foram todos reaproveitados em épocas posteriores e podem ter estado associados, quer ao edifício balnear datável dos séculos III-IV, anexo à Villa romana, quer à basílica paleocristã. A decoração que apresentam tem paralelos em outros mosaicos, cujo espectro cronológico igualmente varia entre os séculos III e VI. Dois destes fragmentos (Mosaicos 
61 e 62) apareceram num degrau de acesso exterior à abside sul da cabeceira trilobada, orientada, da basílica do século VI, acesso correspondente a uma remodelação no século X.

Um dos fragmentos (Mosaico 62) é constituído por tesselas de calcário preto, branco e rosa e por tesselas cor de tijolo, com a densidade de 110/dm2. É decorado por círculos concêntricos e um meandro fraccionado (?), levando o círculo central uma florzinha em cruz, marcada por tesselas pretas, envolvida por uma corola policroma. O motivo aparenta uma flor de 4 pétalas bilobadas, organizadas nos quadrantes definidos pela cruzeta de tesselas pretas. Este tipo de flor é semelhante ao ocorrente em mosaicos da Villa de Almoçageme, Sintra, nomeadamente em um dos painéis do triclinium, datado da segunda metade do século III (Caetano, 2012, pp. 877-881 e p.887, Fig. 5), ou ao que ocorre na abside de uma sala da parte sul da Villa de Santiago da Guarda, Ansião, Leiria, datável dos séculos IV-V. Trata-se de um motivo que surge em alguns mosaicos africanos desde o século II, adquirindo grande popularidade na musivária da zona oriental do Império, especialmente a partir do século $\mathrm{V}$, tanto em contextos religiosos cristãos como domésticos.

Os mosaicos provenientes dos sítios arqueológicos de Dume foram tratados pelos técnicos de restauro do MDDS, encontrando-se actualmente no espaço musealizado da Basílica paleocristã.

\section{G-Mosaicos da Villa de Granjinha, Chaves/Eixo Interior \\ (CMRCB, mosaico 75, pp. 197-20o)}

Os fragmentos de mosaico, provenientes desta $V i$ lla, encontram-se expostos no Museu da Região Flaviense, na cidade de Chaves. Os cinco pequenos fragmentos são constituídos por tesselas de calcário branco, preto e vermelho, apresentando um deles tesselas de cor verde-água. Junto à zona onde haviam sido encontradas tessellae, foi detectado um impluuium e recolhido um espólio que não incluía tesselas, mas outros materiais datáveis de entre os séculos II e III. Tanto a técnica de execução como o espólio arqueológico recolhido na área levaram a atribuir a estes fragmentos uma datação enquadrada nos séculos II-III.

H - Fontão de Antela, Lavra, Matosinhos/Eixo Atlântico

(CMRCB, Mosaicos 76 a 81, pp. 201-204)
Esta estação de Fontão de Antela não foi ainda objecto de escavações sistemáticas, mas têm aparecido pontualmente diversos elementos que nos indicam ter existido aqui uma estação arqueológica relativamente importante, nomeadamente fragmentos de mosaicos. Estas estruturas parecem datar duma época tardia da romanização (séculos III-IV) (Figura 6).

I - Quinta da Ribeira, Tralhariz, Carrazeda de Ansiães/Eixo do Douro

(CMRCB, mosaico 93, pp. 240-242).

Este arqueossítio ficou particularmente famoso devido ao aparecimento de mosaicos policromos com decoração geométrica. Com esta proveniência existe um pequeno fragmento de mosaico incaracterístico no Museu Nacional de Arqueologia (MNA 16761); outros continuam in situ; outros desapareceram. Segundo os relatos da época, mais tarde compilados por Fernando Russel Cortez (Cortez, 1946, pp. 3045 ), os mosaicos surgiram em quatro compartimentos rectangulares que estruturavam um edifício. - (Portal do Arqueólogo, DGPC-CNS.2188). Aquando do achado, o pavimento melhor conservado perdera o emblema central. Pelo desenho que lhe corresponderá, o quadro central estaria inserido numa composição de meandros de suásticas em trança de dois cordões e 4 quadrados angulares. O emblema central é enquadrado por uma faixa decorada por guilhoché e o quadrado angular é demarcado exteriormente por trança de dois cordões. Um dos quadrados nele encaixado é demarcado por ressaltos desiguais. Exteriormente a esta composição, é visível uma larga faixa decorada por uma linha de círculos e quadrados sobre o vértice, decoração que é geralmente usada em composições de superfície e nas quais os círculos e os quadrados determinam rectângulos de lados curvos ou bobinas. O círculo visível é decorado interiormente por uma faixa de ressaltos desiguais e os quadrados por meandro fraccionado. A composição em que se inseria o emblema central encontra paralelos no "mosaico dos cavalos" de Torre de Palma, datado de finais do século III, inícios do século IV, em mosaicos de Quintana del Marco (León) e de Camarzana de Tera (Zamora), datáveis dos séculos IV-V. A decoração da faixa exterior de quadrados e círculos assemelha-se à do "mosaico de Hilas e as Ninfas” de Quintana del Marco (León) e surge, como composição de superfície, em vários mosaicos tardios do território português, como no mosaico da Coriscada, Meda, Foz Côa, a sul de Tra- 
lhariz, ou no mosaico de Braga da Rua D. Afonso Henriques, ํㅡ 1 (Mosaico 15). Atendendo às suas características estilísticas, o mosaico de Tralhariz foi datado dos séculos IV-V.

\section{CONSIDERAÇÕES FINAIS}

Os mosaicos deste Conuentus foram descobertos a partir do final do século XIX e encontrados, quase na sua totalidade, em estruturas arquitectónicas. $\mathrm{Na}$ área de Bracara Augusta o conhecimento dos sítios arqueológicos deve-se ao trabalho desenvolvido desde a década de setenta, quando foi criado o Campo Arqueológico de Braga, encarregado de proceder a salvamentos na área urbana e de verificar a extensão da cidade romana. Excluindo as intervenções arqueológicas de salvamento de emergência, tem sido prática das diferentes equipas conservar in situ as estruturas e os mosaicos descobertos durante as escavações. Quando não estão reunidas as condições para a sua manutenção in situ, os mosaicos são levantados, limpos e consolidados e ingressam nas reservas dos museus.

Relativamente às cronologias propostas para os mosaicos deste Conuentus, a sua maioria localiza-se nos séculos III-IV, época em que Bracara Augusta adquirira o estatuto de capital provincial, tendo sido criada a Gallaecia e acrescentada às demais Províncias romanas da Hispania.

Quanto à decoração dos mosaicos aqui apresentados, verifica-se que ela diz respeito a um repertório generalizado na arte do mosaico romano, desde época recuada a época tardia, com paralelos encontrados em mosaicos da área do próprio Conuentus, mas também de outras áreas administrativas romanas, tanto do território português como do espanhol, das províncias romanas do Ocidente, incluindo o Norte de África, e do Oriente mediterrânico.

Será de atentar que em alguns dos motivos decorativos dos mosaicos do Conuentus Bracaraugustanus são evidentes imperfeições na execução dos mesmos, o que aponta para o trabalho de artífices locais ou regionais. Alguns dos desvios aos modelos podem ser também considerados como certa capacidade criativa da parte desses artífices. Outro aspecto regional destes mosaicos estará patente na pouca variedade da paleta cromática das tesselas calcárias, material pouco abundante numa região por excelência granítica, preferindo-se para o vermelho a cerâmica cor de tijolo, usando-se os calcários pre- to, branco e cinzento e, pontualmente, o vermelho, rosa, amarelo e verde-água. Os exemplos de Braga referentes aos pavimentos de uma domus, expostos na cripta do MDDS, nos quais se usaram tesselas de granito róseo e ao pavimento tardio da mesma cidade, em opus tessellatum e opus sectile, composto por lajes de granito, revelam como deste material se tirou partido, numa região em que ele é abundante.

\section{BIBLIOGRAFIA}

ABRAÇOS, Maria de Fátima (coordenação de) (2019), LIMA, António; MOURÃO, Cátia; ABRAÇOS, Fátima; LIMÃO, Filomena; WRENCH, Licínia; PINTO, Marcelo Mendes; GOMES, Paulo Dórdio; LOPES, Rui, O Corpus dos Mosaicos Romanos do Conuentus Bracaraugustanus. Centro de Estudos Históricos, Universidade NOVA de Lisboa.

ABRAÇOS, Maria de Fátima (2016) - Os Mosaicos Romanos de Bracara Augusta. Novos Achados. In NEIRA JIMÉNEZ, Luz, ed. Estudios sobre mosaicos antiguos y medievales, Actas del XIII Congreso AIEMA Madrid, 14-18 septiembre de 2015. Roma: «L'ERMA» di Bretschneider, pp. 315-322.

CAETANO, Maria Teresa (2012) - Mosaicos da Finisterra Ocidental - a Villa de Santo André de Almoçageme. In X Colóquio do Mosaico Greco-Romano. O Mosaico Romano nos Centros e nas Periferias. Originalidades, influências e identidades. Conímbriga: (2005) 2012, pp. 873-887.

CORREIA, Virgílio Hipólito (2003) - Conimbriga. Guia das Ruínas. Instituto Português de Museus.

GONZÁLEZ FERNÁNDEZ, Enrique (2005) - DOMVS OCEANI. Aproximación á arquitectura doméstica de Lucus Augusti. Traballos de Arqueoloxía 2, Concello de Lugo, Servizo de Arqueoloxía - Concellería de Urbanismo.

GONZÁLEZ FERNÁNDEZ, Enrique (2015) - Los Mosaicos de la Domus Oceani (Lugo). In PESSOA, Miguel Coord. Actas do Encontro Portugal - Galiza. Mosaicos Romanos Fragmentos de Cultura nas Proximidades do Atlântico (6 e 7 de Julho de 2013), Rabaçal, Braga e Lugo. APECMA/AIEMA, pp. 225-247.

IRASTORZA, Enrique; CARNERO VÁZQUEZ, Ofelia (2015) - Mostras Musivarias Romanas no Museo Provincial de Lugo. Algunhas Observacións ao Mosaico de Dédalo e Pasifae e Xeométrico. In Pessoa, Miguel Coord. - Actas do Encontro Portugal-Galiza. Mosaicos Romanos-Fragmentos de Cultura nas Proximidades do Atlântico (6 e7 de Julho de 2013), Rabaçal, Braga e Lugo. APECMA/AIEMA, pp. 248-265.

MAGAlHÃES, Fernanda Eugénia Puga (2010) - Arquitectura doméstica em Bracara Augusta. Tese de Mestrado de Arqueologia. Universidade do Minho, Instituto de Ciências Sociais.

OLIVEIRA, Cristina (2005) - Mosaicos de Conímbriga. X Colóquio Internacional AIEMA. Conímbriga: Instituto Português de Museus-Museu Monográfico de Conímbriga. 
REGUERAS GRANDE, Fernando (2015) - Mosaicos Romanos del Conventus Asturum. Estado de la Cuestion y Encrucijada Patrimonial. In PESSOA, Miguel, Coord. - Actas do Encontro Portugal - Galiza. Mosaicos Romanos - Fragmentos de Cultura nas Proximidades do Atlântico (6 e 7 de Julho de 2013), Rabaçal, Braga e Lugo. APECMA/AIEMA, pp. 279-304.

TORRES CARRO, Mercedes (2015a) - Mosaicos Romanos da Galicia. In PESSOA, Miguel, Coord. - Actas do Encontro Portugal - Galiza. Mosaicos Romanos - Fragmentos de Cultura nas Proximidades do Atlântico (6 e 7 de Julho de 2013), Rabaçal, Braga e Lugo. APECMA/AIEMA, pp. 196-224.

TORRES CARRO, Mercedes (2015b) - A propósito del análises de la estrutura geométrica de la decoracion del mosaico de la antesala del Oecus de la "Domus Oceani” de Lugo. In PESSOA, Miguel, Coord. - Actas do Encontro Portugal - Galiza. Mosaicos Romanos - Fragmentos de Cultura nas Proximidades do Atlântico (6 e 7 de Julho de 2013), Rabaçal, Braga e Lugo. APECMA/AIEMA, pp. 336-338.

WRENCH, Licínia N. C. (2005) - Decoração vegetalista nos mosaicos portugueses Lisboa: Ed. Colibri/IHA.

\section{ABREVIATURAS}

AMDDS - Arquivo do Museu D. Diogo de Sousa.

APECMA - Associação Portuguesa para o Estudo da Conservação do Mosaico Antigo.

CMRCB - O Corpus dos Mosaicos Romanos do Conuentus Bracaraugustanus.

MDDS - Museu D. Diogo de Sousa.

MASMS - Museu Arqueológico da Sociedade Martins Sarmento.

UAUM - Unidade de Arqueologia da Universidade do Minho

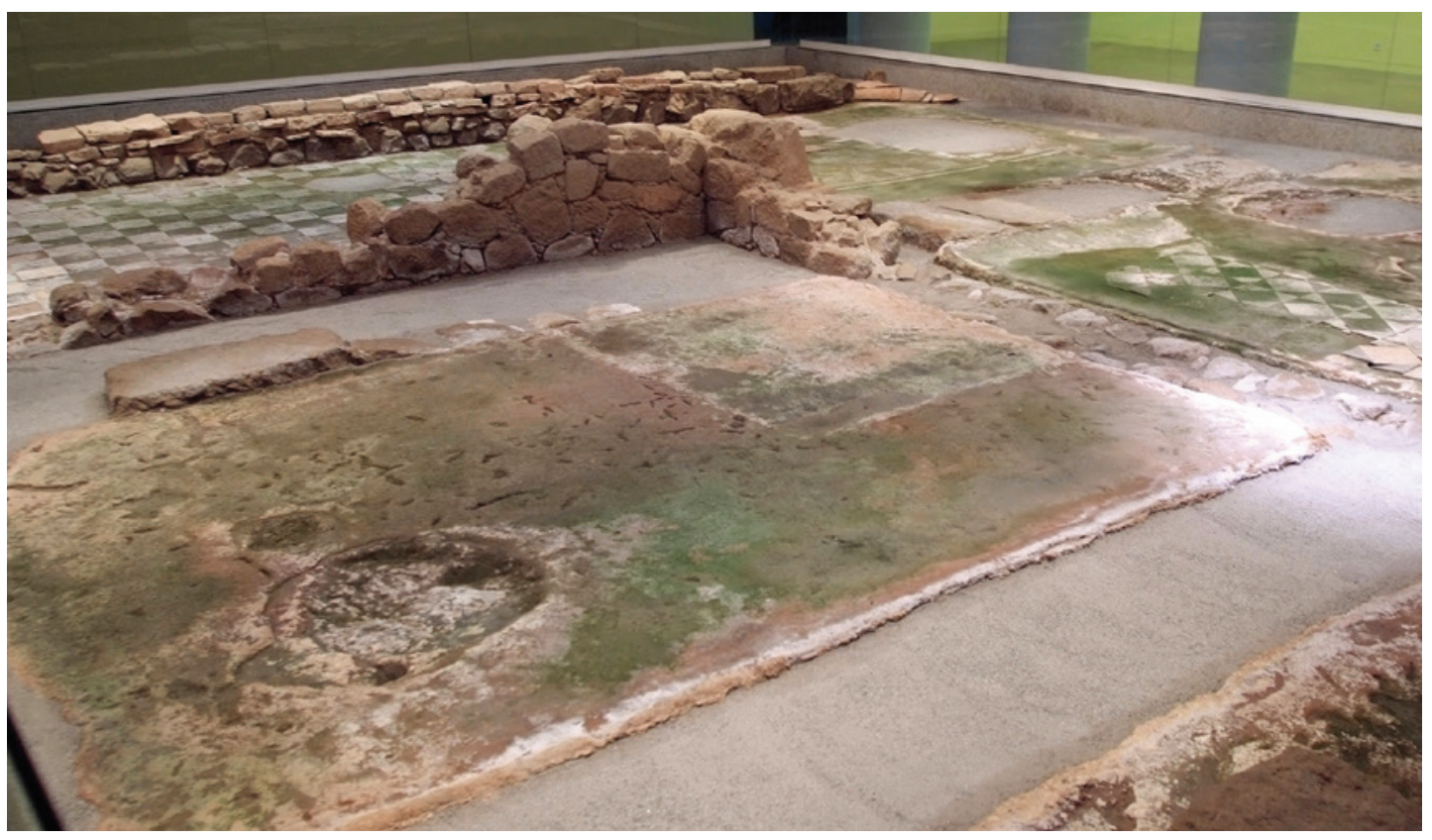

Figura 1 - Aspecto do mosaico com fungos, em 17/10/2003. (C) Fotos de Manuel Santos (AMDDS). 


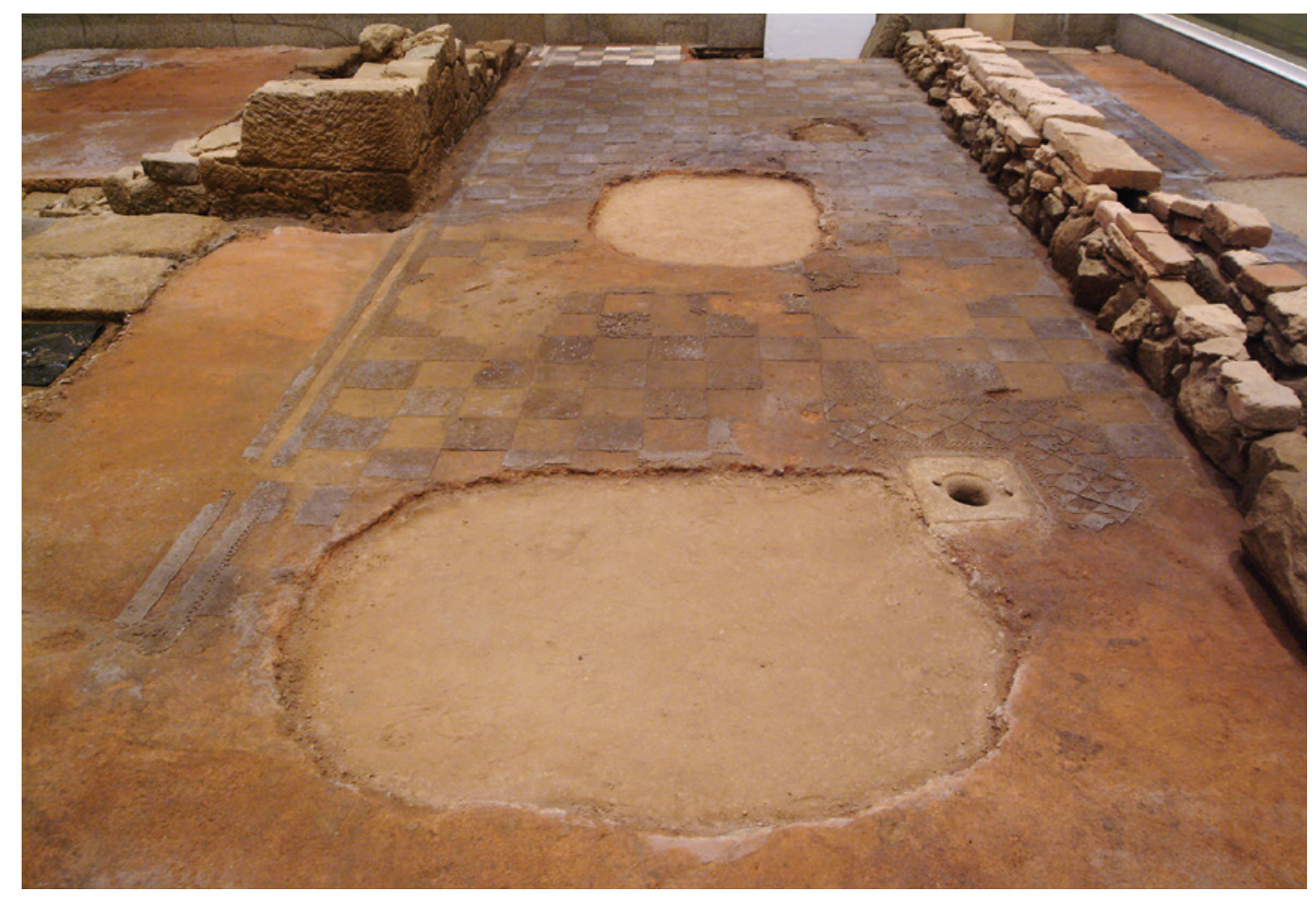

Figura 2 - Aspecto do mosaico depois de limpo para apresentação no espaço da cripta do Museu. (C) Foto de Manuel Santos (AMDDS)

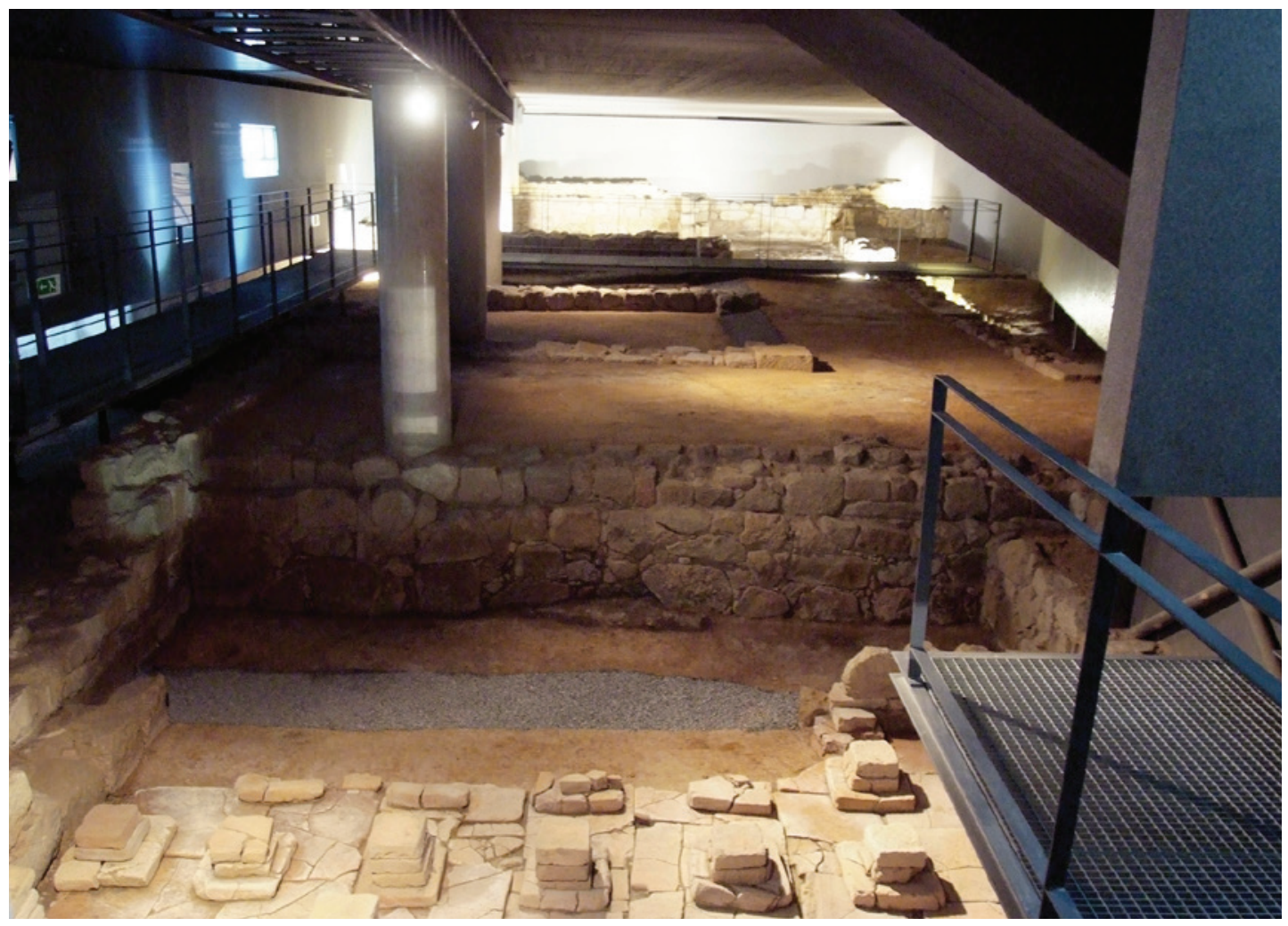

Figura 3 - Musealização dos vestígios arqueológicos na cave do edifício da Escola Velha da Sé. (C) AMDDS 


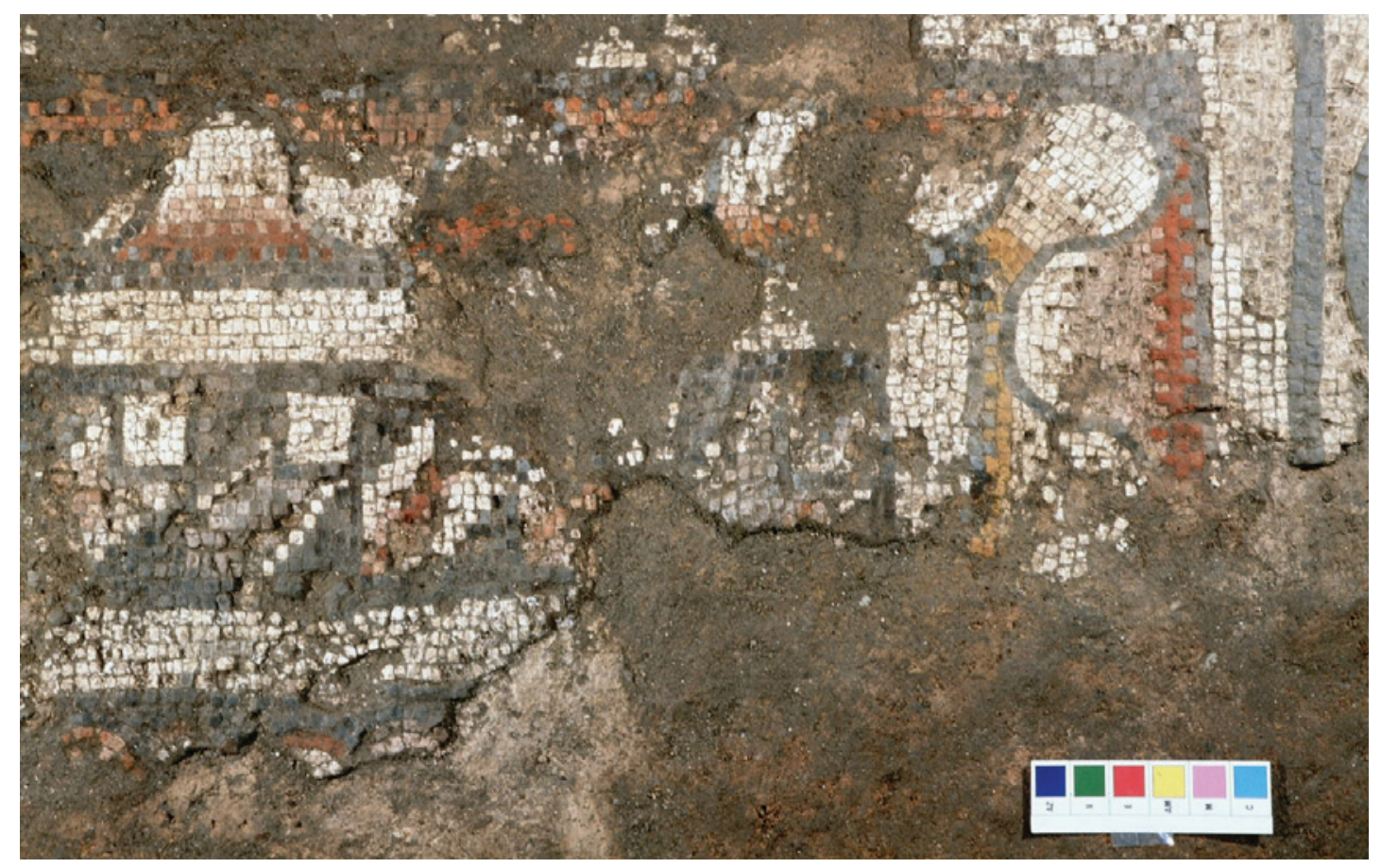

Figura 4 - Aspecto do mosaico da Casa da Roda. (c) AMDDS.

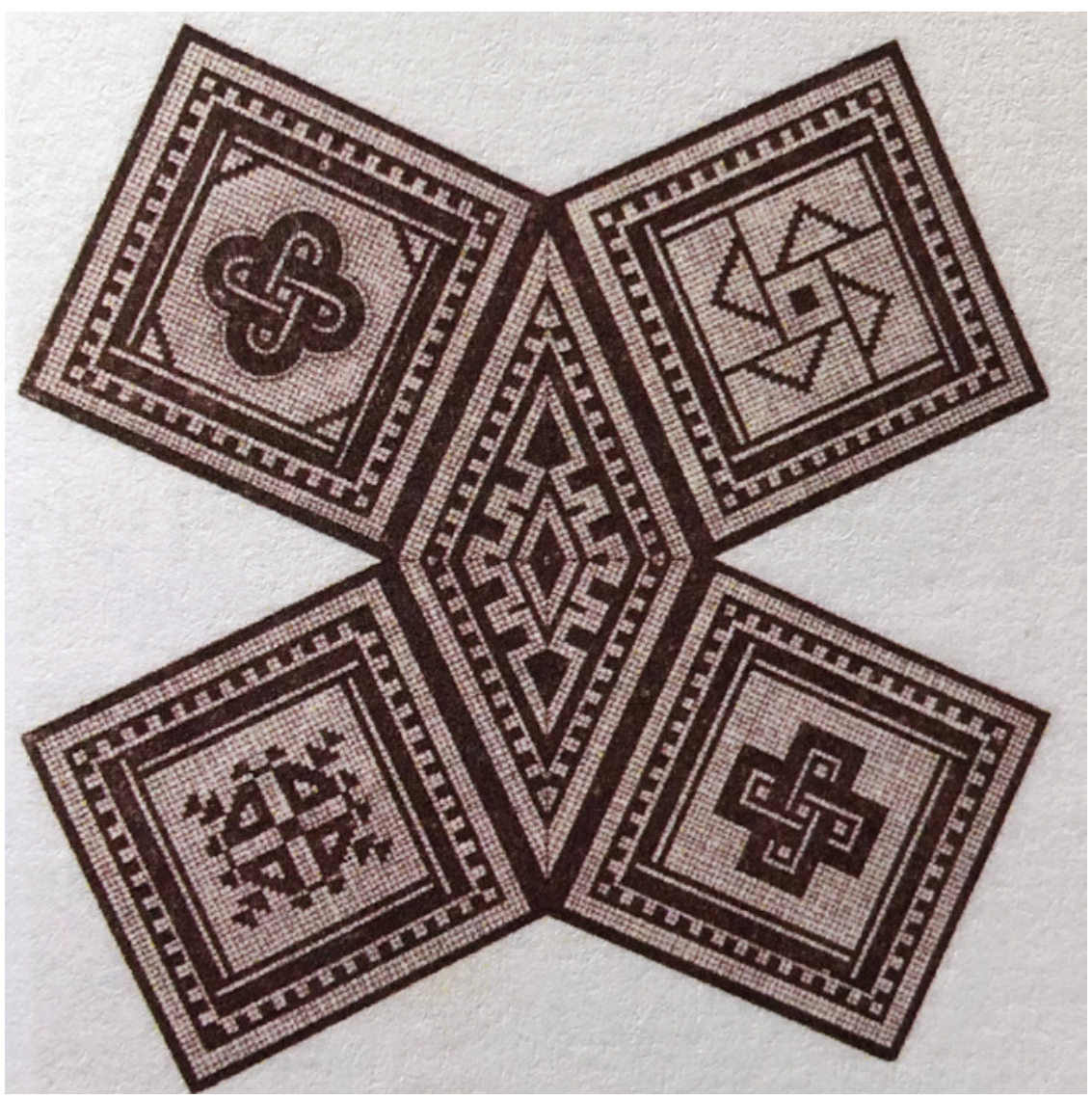

Figura 5 - Organização decorativa do mosaico de Vizela. Regueras Grande 2015, p. 283, Lam. 3a. 


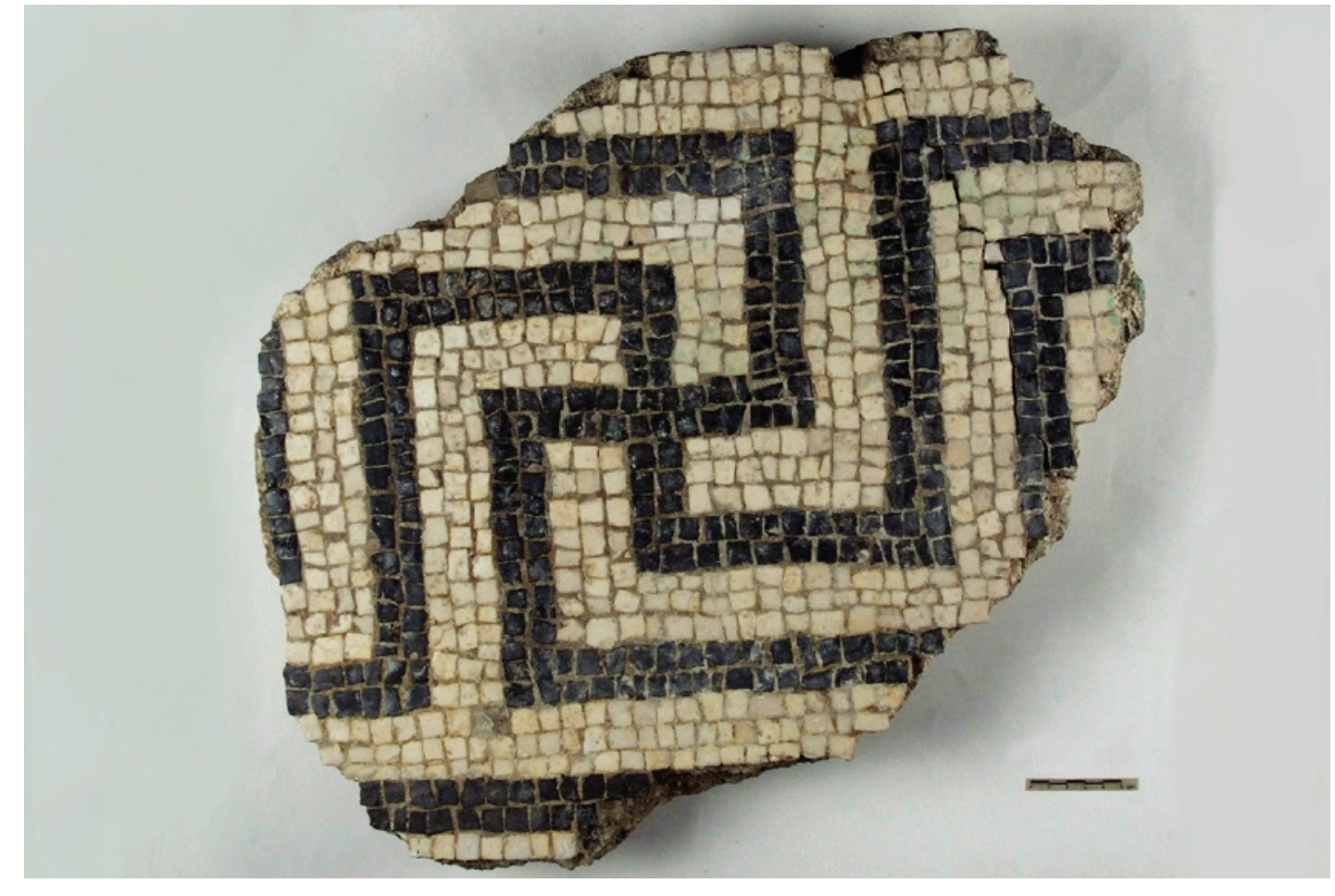

Figura 6 - Mosaico de Fontão de Antela, Lavra, Matosinhos. (c) AMDDS. 


\title{
"CASA ROMANA" DO CASTRO DE SÃO DOMINGOS (CRISTELOS, LOUSADA): ESCAVAÇÃO, ESTUDO E MUSEALIZAÇÃO
}

Paulo André de P. Lemos ${ }^{1}$

\begin{abstract}
RESUMO
No presente artigo dão-se a conhecer os resultados dos trabalhos arqueológicos efetuados no assentamento romano na meia encosta do monte de São Domingos, no âmbito do projeto de investigação "Escavação, estudo e musealização da "Casa Romana" do Castro de São Domingos”. Este projeto, que surgiu da vontade expressa da autarquia de Lousada em levar a cabo um estudo clarificador e de valorização do espaço arqueológico, sob a coordenação científica do signatário, ainda que aberto à participação de outros colaboradores/investigadores. Palavras-chave: Época Romana, Idade do Ferro, Fossas, Sepulturas.
\end{abstract}

\begin{abstract}
In this article we present the results of archaeological work carried out in the Roman settlement on the halfslope of the hill of São Domingos, included in the research project "Excavation, study and musealization of the "Casa Romana" (Roman House) of the Hillfort of São Domingos". This project arises from the expressed intention of the local authority of Lousada to carry out a clarifying and valorization study of the mentioned archaeological place, under the scientific coordination of the signatory, although opened to the participation of other collaborators/investigators.
\end{abstract}

Keywords: Roman period, Iron Age, Dug pits, Graves.

\section{RESUMO DO PROJETO}

O desenvolvimento dos trabalhos arqueológicos (concretamente as intervenções levadas a cabo por José Marcelo Sanches Mendes-Pinto) e a progressiva revelação da importância científica e patrimonial do Castro de São Domingos (o povoado fortificado encontra-se em vias de classificação) levaram a autarquia de Lousada a desenvolver, entre 2009-2011, o projeto de investigação “A 'Casa Romana' do Castro de São Domingos: intervenção arqueológica e valorização patrimonial”, que tinha como premissa a conservação e salvaguarda de toda a informação correlacionada com o assentamento romano na meia encosta do monte de São Domingos. O mencionado projeto foi estruturado em quatro fases: 1) ações de escavação arqueológica; 2) realização de estudos sedimentológicos, arqueométricos, antracológicos, geológicos, palinológicos e datações por radiocarbono; 3) ações de estudo e tratamento de materiais provenientes das anteriores intervenções realizadas no Castro de São Domingos, na década de 1990;4) ações de conservação, restauro e valorização.

A primeira etapa foi efetuada numa superfície superior a $500 \mathrm{~m}^{2}$, numa tentativa de definição do potencial arqueológico do espaço, esclarecendo a situação do assentamento romano na meia encosta do monte de São Domingos, apurando o seu estado de conservação e caracterizando novos elementos arqueológicos. No que concerne à segunda fase, graças a um protocolo com o Laboratório do Porto da Direção-Geral de Energia e Geologia, foi realizado um conjunto de estudos de cariz geológico, com vista à clarificação das hipóteses aventadas para uma das funcionalidades das fossas identificadas no povoado, nomeadamente a sua utilização na atividade

1. Arqueólogo coordenador do Projeto de Investigação Escavação, Estudo e Musealização da "Casa Romana” do Castro de São Domingos; paplemos@gmail.com 
extrativa de material argiloso para utilização nas estruturas murais das diversas construções da designada "Casa Romana" (Nunes et al., 2011, pp. 72-82; Novais et al., 2014, pp. 213-215).

Contudo, refira-se que o supramencionado projeto de investigação não foi, por imperativos financeiros, concluído. Com o intuito de terminar a intervenção arqueológica e a respetiva valorização patrimonial do sítio, o atual projeto de investigação, denominado de "Escavação, estudo e musealização da 'Casa Romana' do Castro de São Domingos”, foi delineado para os anos de 2017 a 2020, sob a coordenação científica do signatário, contando com a colaboração de António Manuel dos Santos Pinto da Silva, como consultor científico. Deste modo, e com o desígnio de alcançar os resultados propostos, foram delineados vários objetivos, necessariamente apoiados em metodologias adequadas e condições de financiamento estáveis, asseguradas pela autarquia de Lousada, estruturadas em três fases: a) escavação arqueológica (numa superfície de $1500 \mathrm{~m}^{2}$ ); b) estudos sedimentológicos, arqueométricos, antracológicos, geológicos, palinológicos e datações por radiocarbono; e, finalmente, c) conservação, restauro e valorização do sítio. Mediante os resultados previstos dos trabalhos planeados, pretende-se, na conclusão do projeto, uma clarificação e valorização do espaço arqueológico do assentamento romano na meia encosta do monte de São Domingos.

\section{CASTRO DE SÃO DOMINGOS}

2.1. Antecedentes. Descoberta do sítio arqueológico e trabalhos realizados

A primeira referência documental ao Castro de São Domingos regista-se nas Inquirições de D. Afonso II de 1258 (Academia das Ciências de Lisboa, 18881897, fl. 547), onde se refere que "Item quod habetur ibi unum castrum et fuit populatum: et dixit quod omnes qui morantur in ipsa villa partierunt illud se et laborant illud".

Mais tarde, nos primórdios do século XVIII, o padre Carvalho da Costa, refere-se ao povoado nos seguintes termos: "Aqui está o Monte de Crasto de S. Domingos, que tomou este nome de huma Capella que teve deste Santo: tem sinais de fortificação, que pelo nome suppomos ser dos Romanos" (Costa, 1706, p. 400). Em 188o Francisco Martins Sarmento, “em visita ao local tece as primeiras considerações científicas sobre o povoado. Nessa visita [...] descreve-o como tendo sido um povoado fortificado onde ainda eram visíveis várias linhas de muralha. Refere ainda o achado de diversos fragmentos cerâmicos que considerou de cronologia romana" (Nunes, Sousa e Gonçalves, 2008, p. 106).

Já no século XX (1957), D. Domingos de Pinho Brandão foi o primeiro autor a divulgar e a recolher materiais de superfície do castro (Mendes-Pinto, 2008, p. 51). Ao longo do século XX, outros autores se debruçaram sobre este povoado e/ou o espólio dele proveniente, designadamente: Vieira (1887, p. 355), Alarcão (1958, pp. 249-315), Lanhas (1971, pp.574575), Silva (1986), Dias (1997) (Nunes, et al. 2008, p 106) e, finalmente, Mendes-Pinto (Nunes, Sousa e Gonçalves, 2007, pp. 1-4, 2008, p. 106; Mendes-Pinto, 2008, pp. 51-52) tendo aqui realizado campanhas arqueológicas na década de 1990.

\subsection{Descrição do sítio arqueológico}

$\mathrm{O}$ castro de São Domingos $\left(41^{\circ} 16^{\prime} 31.50^{\prime \prime} \mathrm{N}\right.$; $08^{\circ} 17^{\prime} 45.96^{\prime \prime}$ ), localizado na União de freguesias de Cristelos, Boim e Ordem, concelho de Lousada e distrito do Porto, retira o nome de uma antiga capela que terá existido no topo do monte, dedicada a São Domingos, e que, à semelhança de muitos outros locais, tinha como finalidade a cristianização do sítio (Sarmento, 188o apud Guimarães, 1989, pp. 26-27; Mendes-Pinto, 2008, p. 51). (Figura 1)

Constituindo o maior e mais bem preservado povoado proto-histórico identificado ao longo da bacia do Mezio, território que atualmente se insere, na sua quase totalidade, no concelho de Lousada, o povoado, apesar de uma intensa humanização da paisagem envolvente (florestação, rede viária e construção civil), conserva importantes vestígios associados ao povoamento da Idade do Ferro, correspondentes às denominadas Fase IIA e IIB (século VI a.C. à segunda metade do século III a.C.) e Fase IIIA e IIIB (século II a.C. à segunda metade do século I a.C.) da "cultura dos castros" (Nunes, et. al., 2007, p. 1). Atingiu, segundo Martins (1990, p. 206), por volta do século II a.C. e sensivelmente até à segunda metade do século I, portanto já no quadro da romanização, o seu período optimum (Nunes, et. al., 2007, p. 1).

O Castro de São Domingos apresenta-se como "um povoado fortificado de médias dimensões, implantado num outeiro cónico isolado que domina visualmente todo o vale do rio Mezio e apresenta ótimas condições naturais de defesa" (Mendes-Pinto 
1995, p. 273), claramente percetível na paisagem e em notória dominância e centralidade relativamente aos demais povoados implantados na bordadura montanhosa que ladeia o vale do Mezio (Nunes, et al., 2007, p. 2), onde, e de acordo com a tese defendida por Ferreira da Silva (1980, p. 88), a distribuição destes povoados, longe de ser anárquica, poderia obedecer a uma certa hierarquização, cabendo, com alguma certeza, ao povoado de São Domingos um certo grau de preponderância, que, no entanto, ainda não nos é inteiramente percetível (Nunes, et al., 2007, p. 2) (Figura 2).

O povoado de São Domingos, "possui três linhas de muralhas, correspondentes a cada uma das três grandes plataformas aí visíveis, separadas por fortes declives, onde se terão inscrito preferentemente as estruturas habitacionais" (Mendes-Pinto 1995, p. 273). As escavações aqui realizadas permitiram constatar duas realidades distintas: uma primeira, nas cotas acima dos $300 \mathrm{~m}$, onde persiste uma área onde os vestígios se encontram relativamente bem preservados, e uma segunda, situada abaixo da cota dos $300 \mathrm{~m}$, onde a realidade arqueológica foi sendo alvo de perturbações, mais ou menos evidentes.

A conquista, e consequente destruição do povoado, provavelmente no decurso das Guerras Cantábricas (26-19 a.C.), é apontada por Mendes-Pinto como ponto de partida para uma "reorganização espacial do povoado, com o reordenamento interno dos núcleos familiares, que passam a ser compostos por unidades circulares e unidades sub-retangulares ou quadrangulares cercadas por um muro e dando para um grande pátio lajeado, onde se processavam algumas das principais atividades domésticas, notando-se desde logo a adaptação à cultura romana e a influência mediterrânica da casa-pátio. [...] Talvez pelos finais da primeira metade do século I, ou inícios da sua segunda metade, vemos a coroa do monte ser paulatinamente abandonada em favor das plataformas da meia-encosta, quando se começam a construir casas já tipicamente romanas" (Mendes-Pinto, 2008, p. 6o). “[É] no decurso deste processo de reordenamento defendido por [Mendes-Pinto] que se verificou a construção de um pólo habitacional romano (século I a $\mathrm{V}$ d.C.), implantado na encosta virada a Sudeste" (Nunes, et al., 2008, p. 107). Do espólio proveniente do monte de São Domingos "destaca-se a presença de cerâmica de importação, nomeadamente ânforas vinárias Alterne 70 e Dressel 20 (século I-II d.C.), e ainda várias sigillatas, entre as quais um fragmento de fundo de sigillata hispânica, possível forma Drag.27, com marca de oleiro, de ângulos curvos onde se pode ler OFVAPA, isto é, proveniente da oficina do oleiro Valerius Paternus, de Tritium Magallum (atual Tricio, Espanha)" (Nunes, et. al., 2007, p. 4). A ocupação do monte de São Domingos "perdurará pelo menos até aos inícios do século $\mathrm{V}$, época da chegada dos bárbaros, quando terá sido destruída a habitação [romana a meia-encosta] por meio de novo incêndio" (Mendes-Pinto, 2008, p. 6o).

\subsection{Descrição do assentamento romano na meia encosta do monte de São Domingos}

$\mathrm{O}$ assentamento romano na meia encosta do monte de São Domingos corresponde a uma área implantada na sua vertente sudeste e na qual se insere a faixa de terreno intervencionada em 1996 pelo arqueólogo Mendes-Pinto, designada de "Casa Romana".

$\mathrm{Na}$ mencionada vertente foram detetados "restos de muros e abundantes fragmentos de tegula e cerâmica comum romana a indiciarem a presença de importantes vestígios arqueológicos" (Mendes-Pinto, 2008, p. 55). De acordo com o mencionado autor (2008, p. 55), estes indícios de ocupação romana do espaço foram percetíveis graças aos trabalhos das máquinas de um empreiteiro que realizou trabalhos de terraplenagem, com o objetivo de proceder à construção de um prédio habitacional. As escavações levadas a cabo por Mendes-Pinto (2008, pp. 55-56) revelaram os restos de uma casa romana, que apropriou um pátio lajeado e uma antiga habitação circular. Foram escavados dois compartimentos: o primeiro, no extremo nordeste, de planta quadrangular, com cerca de $4,5 \mathrm{~m}$ de lado, possui porta virada a sudeste, pela qual comunicava com uma sala (da qual apenas subsiste $\mathrm{o}$ arranque de uma das paredes e vestígios de um piso em terra batida); o segundo compartimento encontra-se incompleto, mas apresentaria planta retangular, com largura mínima de $4 \times 6 \mathrm{~m}$, ao qual Mendes-Pinto atribui uma cronologia provável do século I. No exterior da casa, no seu lado sudoeste, encontrou-se um lajeado de um pátio pertencente a uma habitação de planta circular. A casa romana sofreu um incêndio, sendo, posteriormente, alvo de uma remodelação, que lhe reduziu o espaço anexo (provavelmente na segunda metade do século III). O nível de circulação foi alteado em cerca de $0,80 \mathrm{~m}$, reaproveitando-se para esse fim parte dos derrubes da anterior construção. Des- 
sa edificação mais antiga apenas chegaram até nós os vestígios inferiores dos seus muros e dos seus pisos em terra batida e compactada. Sobre estes, um derrube de tegulae e imbrex comprova o desmoronamento do telhado, originado, uma vez mais, por um incêndio, presumivelmente em meados do século $\mathrm{V}$, aquando da invasão Visigoda (Mendes-Pinto, 2008, p. 56).

\section{RESULTADOS PRELIMINARES DA INTERVENÇÃO}

As ações desenvolvidas no âmbito do atual projeto de investigação na vertente SE do castro, numa superfície de $988 \mathrm{~m}^{2}$, possibilitaram a perceção da dinâmica ocupacional do espaço, revelando uma considerável potência e complexidade estratigráfica, tendo sido identificadas uma multiplicidade de níveis ocupacionais de diferentes cronologias.

$\mathrm{Na}$ parte central da área intervencionada foi, primeiramente, identificado o muro [388], de Época Contemporânea/Moderna, composto por pedras de corneana, com ocasionais de granito, de médias a grandes dimensões, equivalendo a reaproveitamentos de anteriores estruturas, sendo percetíveis, por exemplo, fragmentos de mós de vaivém. Ostenta apenas uma face, com os interstícios preenchidos por pedras de pequenas dimensões e terra pouco compacta. Este muro, conjuntamente com os muros [389] e [409] da Idade do Ferro, delimita o espaço concernente a um antigo caminho que serpenteia o terreno no sentido SO.-NE., com largura média de 1,10 m, sendo percetível numa extensão de $13 \mathrm{~m}$, associado a um nível de circulação, que fazia a ligação entre a zona do vale do rio Mezio e o topo do monte de São Domingos, de acesso a uma antiga capela que terá existido no topo do monte, dedicada a São Domingos (Figura 3 ).

No limite SO. da área escavada foi identificada uma estrutura de delimitação do espaço, de Época Medieval, percetível numa extensão superior a $12 \mathrm{~m}$, com 1,70 $\mathrm{m}$ de largura média e uma altura máxima de $0,50 \mathrm{~m}$. Equivale a um amontoado de pedras estruturadas, mas não argamassadas, com ocasionais fragmentos de tegulae, envoltas por terras, originando uma espécie de "muralha" edificada no sentido N.-S (Figura 4 e 5).

Em direta associação a esta estrutura foram identificadas seis sepulturas que atestam a utilização cemiterial do espaço. A totalidade dos sepulcros apresen- tam orientação SO-NE., de forma semiretangulares, encontrando-se abertos no geológico natural. A té ao momento foram escavados três sepulcros (Sepulturas 1, 2 e 3) uma vez que as restantes não foram, ainda, delimitadas na sua totalidade. De entre as sepulturas identificadas a Sepultura 2 revelou ser a mais recente sendo as restantes, aparentemente, coevas, achando-se compostas por pedras de corneana e granito de médias dimensões. A Sepultura 1, composta por pedras de corneana e granito de médias dimensões, apresenta 1,70 $\mathrm{m}$ de comprimento, 0,40 $\mathrm{m}$ de largura na cabeceira e $0,30 \mathrm{~m}$ de largura nos pés (dimensões internas). Não revelou quaisquer vestígios de inumação, apresentando somente uma unidade deposicional formada por terras homogéneas, soltas, de cor castanho-escura, de grão médio a fino, com escasso espólio cerâmico repartido entre cerâmica de uso doméstico da Idade do Ferro (n=10) e de pequenos fragmentos de tegula $(n=3)$, além de um fragmento de escória metálica.

A Sepultura 2, formada por pedras de corneana e granito de médias dimensões, ostenta $1,74 \mathrm{~m}$ de comprimento, o, $42 \mathrm{~m}$ de largura na cabeceira e o,20 $\mathrm{m}$ de largura nos pés (dimensões internas). Não revelou vestígios de inumação, apresentando parte das lajes da tampa de cobertura. Revelou estar preenchida por dois depósitos. O primeiro formado por terras homogéneas, soltas, de cor castanho-escura e de grão médio a fino, patenteando apenas 2 diminutos fragmentos de tegula. A unidade subsequente revelou possança inferior a $5 \mathrm{~cm}$, sendo composta por terras heterogéneas, desagregadas, argilosas de grão fino, cor castanho-escura, com frequentes bolsas saibrentas de cor bege/laranja (Figura 6).

A Sepultura 3, constituída por pedras de corneana e granito de médias dimensões, revelou 1,74 $\mathrm{m}$ de comprimento, $0,40 \mathrm{~m}$ de largura na cabeceira e 0,32 $\mathrm{m}$ de largura nos pés (dimensões internas). Não revelou vestígios de inumação, apresentando somente dois depósitos. O primeiro correspondia a um nível de terras homogéneas, medianamente compactas, cor castanho claro, grão fino a médio, com frequente espólio cerâmico repartido por fragmentos cerâmicos da Idade do Ferro ( $\mathrm{n}=31)$ e fragmentos de Época Romana (tegula) $(\mathrm{n}=5)$. A última unidade identificada equivalia a um depósito de terras homogéneas, soltas, de cor castanho-escuro e grão médio a fino, com ocasionais fragmentos cerâmicos $(n=19)$ da Idade do Ferro.

A Sepultura 4 foi percetível em cerca de metade, 
prolongando-se para a área não intervencionada. Constituída por pedras de corneana de médias a pequenas dimensões, com o,7o $\mathrm{m}$ de comprimento (não totalmente delimitada) por o,42 $\mathrm{m}$ de largura (dimensões internas), não ostentando lajes da tampa de cobertura, o que indicia que a mesma tenha sido aberta e violada em altura indeterminada.

A Sepultura 5 foi parcialmente delimitada, uma vez que a mesma se prolonga para além da área intervencionada, sendo apenas visível duas pedras de granito de grandes dimensões e uma de corneana de pequenas dimensões. Está em mau estado de conservação tendo sido truncada aquando dos trabalhos abertura da Travessa Nossa Senhora Conceição.

Finalmente, a Sepultura 6 é constituída por pedras de corneana e granito de médias dimensões, não estando totalmente delimitada, apresentando $1,80 \mathrm{~m}$ de comprimento por $0,38 \mathrm{~m}$ de largura (dimensões internas).

As ações desenvolvidas revelaram igualmente a presença de níveis ocupacionais correlacionados com a ocupação de Época Romana, ainda que em mau estado de conservação. Desta cronologia foram identificadas duas estruturas habitacionais.

A primeira [187], localizada nos quadrados H/I18-19, apresenta 5,70 m (SO.-NE.) x 1.80 m (NO.-SE.), perfazendo um espaço interno mínimo de $10 \mathrm{~m}^{2} \mathrm{com}-$ posto por pedras de granito e ocasionais de corneana. A segunda estrutura [399]/[505]/[550]/[566], ostenta forma quadrangular $(4,80 \times 4,80 \mathrm{~m}) \mathrm{com}$ uma área interna de $23 \mathrm{~m}^{2}$, porta voltada a SO., com 1,10 m de largura, e paredes constituídas, essencialmente, por pedras de granito de médias dimensões, com interstícios preenchidos por pedras de granito de pequenas dimensões, fragmentos de tegula e terras argilosas. As paredes [399] e [566] apresentam-se em toda a sua extensão, ainda que esta última esteja ligeiramente danificada na sua parte interna. As paredes [505] e [550] estão destruídas nos seus limites, concretamente no lado sul da habitação. Destas edificações apenas chegaram até nós os vestígios inferiores dos seus muros não tendo sido identificados os seus pisos. A correlação destas duas estruturas, aparentemente coevas, com a designada "Casa Romana" identificada e intervencionada por Mendes-Pinto (ver ponto 2.3.) é de difícil análise, sendo, contudo, de admitir a possibilidade de fazerem parte de uma mesma orgânica habitacional, cujos limites/ funções se nos afiguram de difícil perceção.

Relacionada com a ocupação da Idade do Ferro fo- ram identificadas mais de uma dezena de estruturas habitacionais, de três fases ocupacionais distintas. Estas revelaram, na sua generalidade, por contraponto com as estruturas habitacionais de Época Romana, serem compostas por pedras de corneana de pequeno a médio porte, com interstícios preenchidos por terras saibrentas compactas. Associadas a estas estruturas foram identificados pisos de circulação compostos por saibro compacto, ou por terras barrentas, argilosas de tonalidade laranja, cozidas in situ, com indícios de combustão. Ainda em associação a esta realidade foram identificados, em quatro situações, a remanescência de pátios abertos e lajeados, circunscritos por muros.

A ocupação corelacionada com a Idade do Ferro baliza-se entre o século IV a I a.C. encontra-se separada dos níveis de Época Romana por uma sequência de depósitos com inclusão de material cerâmico de produção local e cerâmica importada. Estas unidades comprovam uma dinâmica ocupacional muito intensa, com uma sobreposição de espaços habitacionais e áreas funcionais, cuja sincronia se afigura, por vezes, de difícil perceção (Figura 7).

De entre as estruturas conotadas com esta época temos a evidenciar, dada a sua particularidade, a presença da estrutura habitacional [672] (Quadrados $\mathrm{L} / \mathrm{M} / \mathrm{N}$ io a 12) em que o uso de argila foi primordial na sua edificação, sendo contemporânea de edifícios em alvenaria de pedra mais tradicionais dentro do que se conhece da arquitetura deste período no território em que o povoado se localiza. Corresponde a uma casa de planta circular com 4,80 m de diâmetro que seria constituída por uma parede composta por terras saibrentas-argilosas de grão fino a médio, cor laranja, com inclusão de pedras de corneana de pequenas dimensões, com o,50 m de largura, circunscrevendo uma área interna com 3,90 m de diâmetro, perfazendo uma área útil de $12,25 \mathrm{~m}^{2}$. A entrada, com 1,55 m de largura estava orientada a este. $O$ seu piso de circulação [67o] está nivelado, sendo composto por saibro muito compacto, de grão médio a grosso, de cor bege/amarelo com zonas de tonalidade laranja. Na parte central desta estrutura habitacional foi identificado um bloco de corneana de forma trapezoidal, com o topo plano, relacionado com o apoio do respetivo teto, não tendo, contudo, sido identificadas estruturas de combustão. $\mathrm{Na}$ área exterior, na envolvente à casa, foi colocado um lajeado composto por pedras de corneana e ocasionais de granito, de médias a grandes dimensões, de entre as 
quais se destacam a incorporação de fragmentos de mós de vaivém e de moinhos manuais rotativos. As lajes apresentam indícios de desgaste e correspondem a um nível de circulação relacionado com a utilização da casa e com o espaço envolvente (Figura 8). Anterior a toda esta realidade foram identificadas 63 fossas escavadas no geológico natural, ocupando o espaço de forma aparentemente aleatória. De morfologia variável apresentam perfil, ora arredondado, ora ovalado ou mesmo irregular, ainda que os seus contornos não sejam, na sua maioria, completamente regularizados. A diversidade de formas e dimensões poderá relacionar-se, entre outros fatores, com questões de funcionalidade, com características específicas dos produtos a armazenar, ou acesso aos mesmos. Assim, sendo provável, ou pelo menos admissível, a utilização dos materiais inertes retirados das fossas para a obtenção de argamassas, não resulta claro se esta extração se realizou per si nem, tampouco, as razões que levaram a uma extração "cuidada", atribuindo às fossas formas arredondadas, mais próprias de silos que de "barreiros" ou "saibreiras" onde a extração segue filões de matéria-prima sem preocupações arquitetónicas (Figura 9). Por outro lado, a avaliar pelos indícios detetados na Fossa 19, nitidamente isolada com argamassa de saibro na zona de contacto com a Fossa 18, é aceitável a hipótese de estarmos, pelo menos em algumas das fossas, perante uma situação de dupla funcionalidade. Isto é, a abertura de estruturas tipo silo, no geológico seria feita provavelmente com o intuito de armazenagem de alimentos, e num momento subsequente, far-se-ia o aproveitamento dos materiais argilosos disponibilizados durante o processo de escavação. Sendo de presumir que a ordem dos eventos seja esta, não é de descartar uma relação causal distinta. Com efeito, a situação inversa - a abertura de cavidades para a extração de materiais argilosos e o seu posterior afeiçoamento para servir como estrutura de armazenamento - não tendo suporte arqueológico evidente, possui suporte geológico, já que os materiais extraídos foram utilizados na produção de argamassas para as estruturas habitacionais da Idade do Ferro (Nunes, et. al., 2018, pp.426-227) (Figura 10).

A nível temporal e cronológico, foi possível definir distintos momentos que presidiram à abertura das fossas, dado que se entrecruzam com alguma frequência, ainda que muito provavelmente essas fases construtivas se efetivem num tempo muito próximo entre si. Em termos latos, esse momento construtivo cristaliza-se numa fase anterior às estruturas habitacionais presentes na designada "Casa Romana". Embora seja crível que a época construtiva das fossas possa recuar aos primórdios da ocupação do povoado, não podemos ignorar que a abertura de fossas é uma constante entre as comunidades da Idade do Bronze, pelo que a pervivência destas estruturas na Idade do Ferro reforça a ideia de uma certa continuidade entre o Bronze Final e a Idade do Ferro.

\section{CONCLUSÕES}

As ações desenvolvidas no âmbito do atual projeto de investigação, entre os anos de 2017 e 2019, na vertente SE. do Castro de São Domingos, numa superfície de $988 \mathrm{~m}^{2}$, permitiram a perceção da dinâmica ocupacional do espaço, revelando uma considerável potência e complexidade estratigráfica, ainda que o terreno tenha sido afetado pelos trabalhos de terraplenagem efetuados na década de 1990, aquando da preparação do terreno para a edificação das residências familiares.

No que concerne às três sepulturas intervencionadas as mesmas foram, infelizmente, abertas e violadas em altura indeterminada e o conteúdo que outrora poderão ter encerrado foi perdido, tendo sido apenas recuperado escasso espólio da Idade do Ferro e de época Romana. No verão de 2020 a área de escavação será alargada às sepulturas 4, 5 e 6 e focar-se-á na procura do templo religioso a que a necrópole deverá ter estado associada, assim como no melhor enquadramento da sua cronologia que, por comparação com os poucos contextos ibéricos idênticos, não poderá, para já, ser mais específica dentro da Época Medieval. Apesar do contexto do sítio parecer indicar que assumiu importância na região, apenas se suspeita que na zona mais elevada do povoado terá, em tempos, existido uma ermida evocativa do santo que deu nome ao monte.

As rochas das estruturas associadas ao assentamento romano na meia encosta do monte de São Domingos podem ser agrupadas em dois conjuntos distintos, relacionáveis com a idade dos vestígios em estudo. As estruturas da Idade do Ferro apresentam quase exclusivamente corneanas, que se encontram em afloramento na envolvente ao local do edificado. As estruturas de época romana, contêm corneanas e granito de Lousada. Os locais que constituem fonte provável das rochas são o Monte de São Domingos 
para as corneanas e um contato com o granito de Lousada nas imediações do mesmo topónimo. Consequentemente, a evolução de uma cultura da Idade do Ferro para uma de influência romana é acompanhada de uma descida na altitude da extração da rocha, bem como numa movimentação do processo extrativo em direção a este, possivelmente a partir do século I d.C.

As fossas são as estruturas mais numerosas desta estação arqueológica, contudo, são aquelas que postam mais problemas do ponto de vista interpretativo. Tendo em conta a sua morfologia diversa, a sua estrutura geológica, o seu contexto arqueológico e, ainda, alguns paralelos regionais, como o povoado fortificado do Lago (Amares) ou do povoado do Crastoeiro (Mondim de Basto), foram aventadas diversas interpretações relativas à(s) sua(s) funcionalidade(s). Parcas na informação, facultando apenas um vislumbre da sua arquitetura ou, as mais das vezes, o momento da sua inutilização enquanto estruturas, a maioria das fossas desempenhou, pelo menos na fase final da sua vida útil, uma função detrítica, tendo sido intencionalmente entulhadas, indicando, assim, um terminus ante quem para as estruturas que se lhe sobrepõem. Conquanto a função detrítica prevaleça sobre as demais no registo arqueológico, é de crer que a função primordial fosse outra. Os paralelos com outras fossas detetadas em habitats da Idade do Bronze Final, no contexto regional, são evidentes, e permitem considerar a hipótese de algumas destas estruturas terem sido utilizadas como fossas de aprovisionamento, vulgarmente denominados "silos", destinadas à armazenagem de bens alimentares.

\section{BIBLIOGRAFIA}

ALARCÃO, A. M. (1958) - Sigillata hispânica em museus do Norte de Portugal. In Revista Guimarães: 68 (3-4), pp. 249-315.

LANHAS, F. (1971) - Lousada: Arqueologia. Enciclopédia Luso-Brasileira da Cultura, Volume 12. Lisboa: Editorial Verbo, pp.574-575.

MARTINS, M. (1990) - O Povoamento Proto-histórico e a Romanização da bacia do Curso Médio do Cavado. In Cadernos de Arqueologia. Monografias. Braga.

MENDES-PINTO, J.M.S. (1995) - O Povoamento da bacia superior do Rio Sousa: da Proto-História à Romanização. Trabalhos de Antropologia e Etnologia. In Atas do $1^{\circ}$ Congresso de Arqueologia Peninsular. Vol. V. Porto: Sociedade Portuguesa de Antropologia e Etnologia, pp. 265-283.
MENDES-PINTO,J.M.S.(2008)-Do castro deS.Domingos a Meinedo: Proto-história e Romanização na bacia superior do rio Sousa. In Oppidum - Revista de Arqueologia, História e Património, número especial, Câmara Municipal de Lousada, pp. 45-63.

NOVAIS, H., LEMOS, P., LEITE, J., NUNES, M. (2014) - As rochas do edificado da "Casa Romana" (Cristelos - Lousada). Variação cronológica da sua tipologia e origem. In $O p$ pidum. N.ำ 7 . Lousada: CML, pp. 211-216.

NUNES, M.; SOUSA, L. e GONÇALVES, C. (2007) - O Castro de S. Domingos (Cristelos - Lousada): algumas notas sobre a sua ocupação durante a Idade do Ferro e Época Romana. In Revista Municipal, ano 8, 3. ․ㅗ' Série, n. ${ }^{4}$ 45, setembro, Suplemento de Arqueologia, Município de Lousada, pp. 1-4.

NUNES, M., SOUSA, L. e GONÇALVES, C. (2008) - Carta Arqueológica do concelho de Lousada, Gabinete de Arqueologia, Câmara Municipal de Lousada, pp. 41-46/106-107.

NUNES, M.; LEMOS, P.; LEITE, J.; NOVAIS, H.; OLIVEIRA, A. (2011) - Estruturas negativas da "Casa Romana" do Castro de São Domingos (Lousada): as fossas escavadas no saibro. In Oppidum - Revista de Arqueologia, História e Património, N.ำ 5 , Câmara Municipal de Lousada, pp. 61-84.

NUNES, M.; LEMOS, P.; LEITE, J.; NOVAIS, H. (2018) - Estruturas negativas no sítio arqueológico da "Casa Romana" do Castro de São Domingos (Lousada): as fossas escavadas no saibro. In GUTIÉRREZ, Noelia H.; GALARZA, Javier L.; HERNÁNDEZ, Rodrigo P (coord.) Investigaciones arqueológicas en el valle del Duero: del Paleolítico a la Edad Media 6 - Actas de las VI Jornadas de Arqueología del valle del Duero (Oporto, 2016). Espanha: Zamoraprotohistorica, pp. 419-427.

SARMENTO, F. M. (1880) - Antiqua. Manuscritos inéditos de Francisco Martins Sarmento (Informes, reconhecimentos e prospeções). Guimarães: Sociedade Martins Sarmento, [Anotados por F.J. Salgado Guimarães], pp. 26-27.

SILVA, Armando Coelho Ferreira da (1980) - Organizações Gentilícias entre Leça e Ave. Portugália. Nova Série, vol. I. Porto, pp. 79-9o.

SILVA, Armando Coelho Ferreira da (1986) - A Cultura Castreja no Noroeste de Portugal, Dissertação de Doutoramento em Pré-História e Arqueologia, Apresentada à Faculdade de Letras da Universidade do Porto, Câmara Municipal de Paços de Ferreira, Museu Arqueológico da Citânia de Sanfins. 


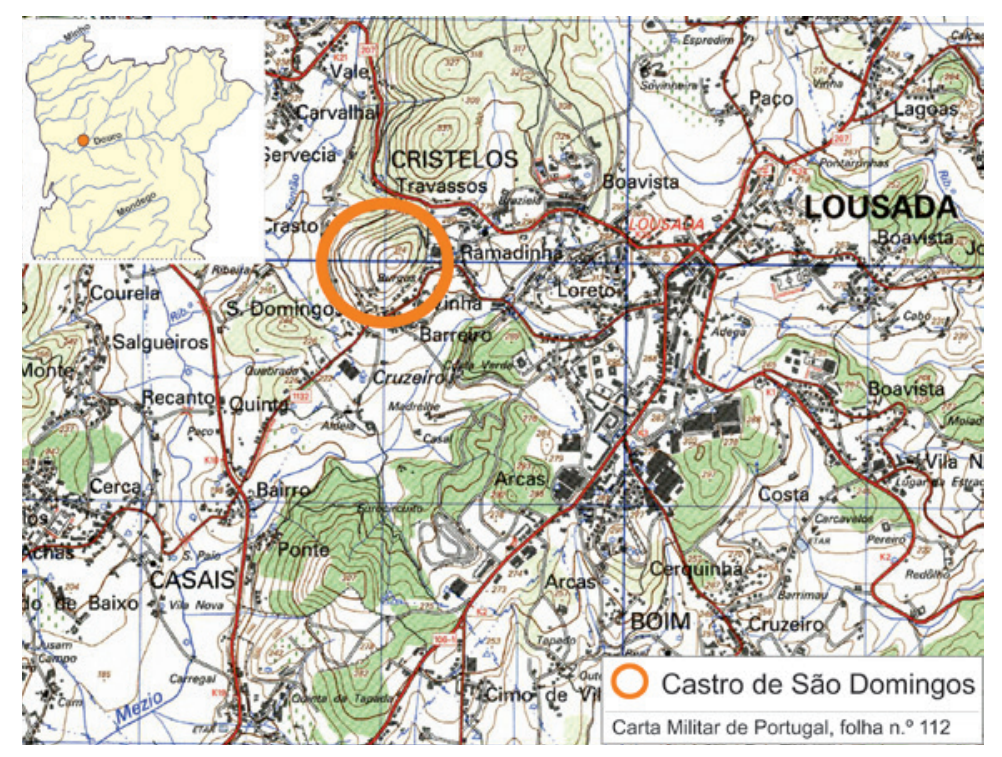

Figura 1 - Localização do Castro de São Domingos (Cristelos, Lousada) (IGeoE, 1998).

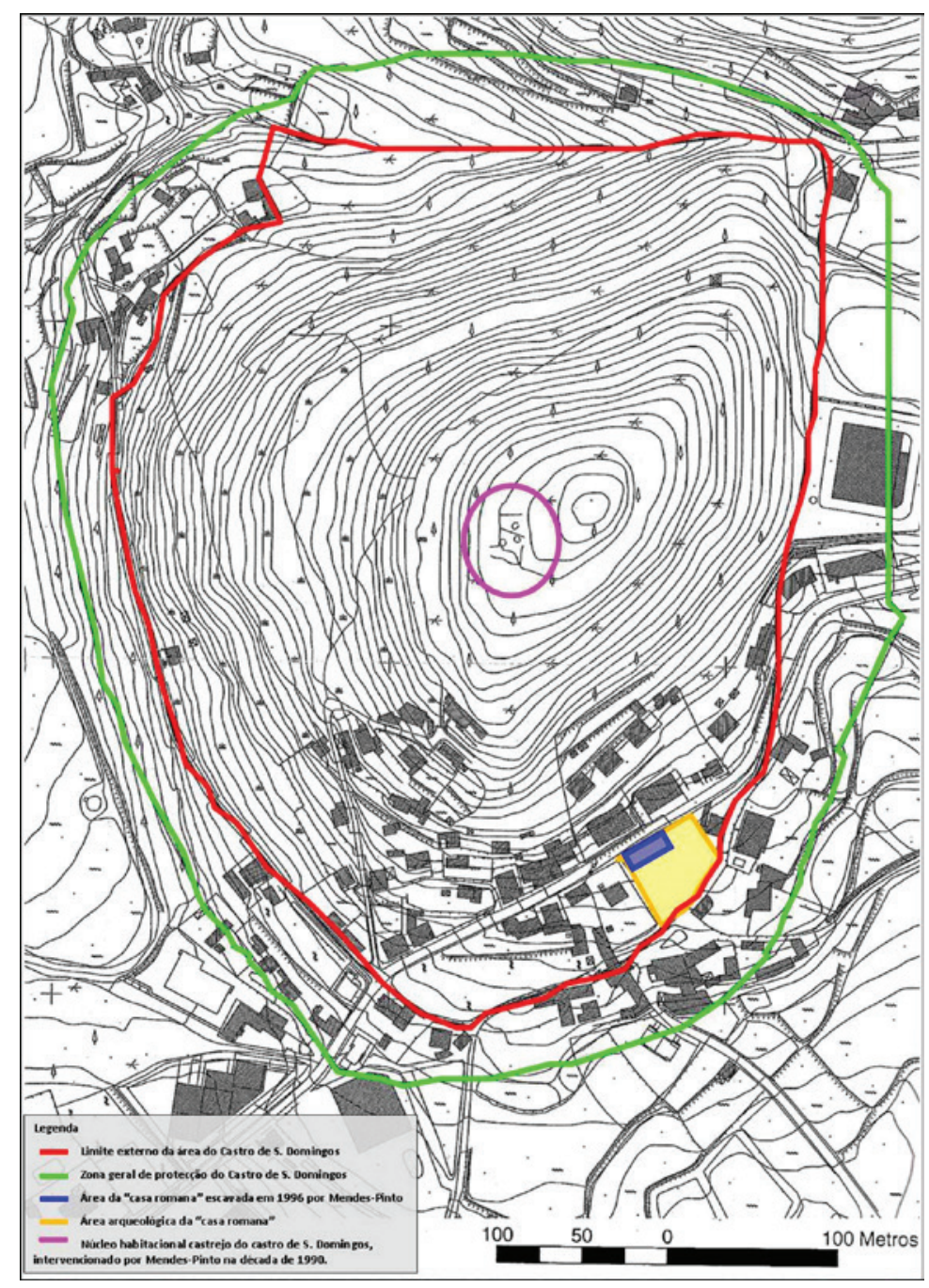

Figura 2 - Planta topográfica do Castro de São Domingos. (Fonte: Câmara Municipal Lousada). 


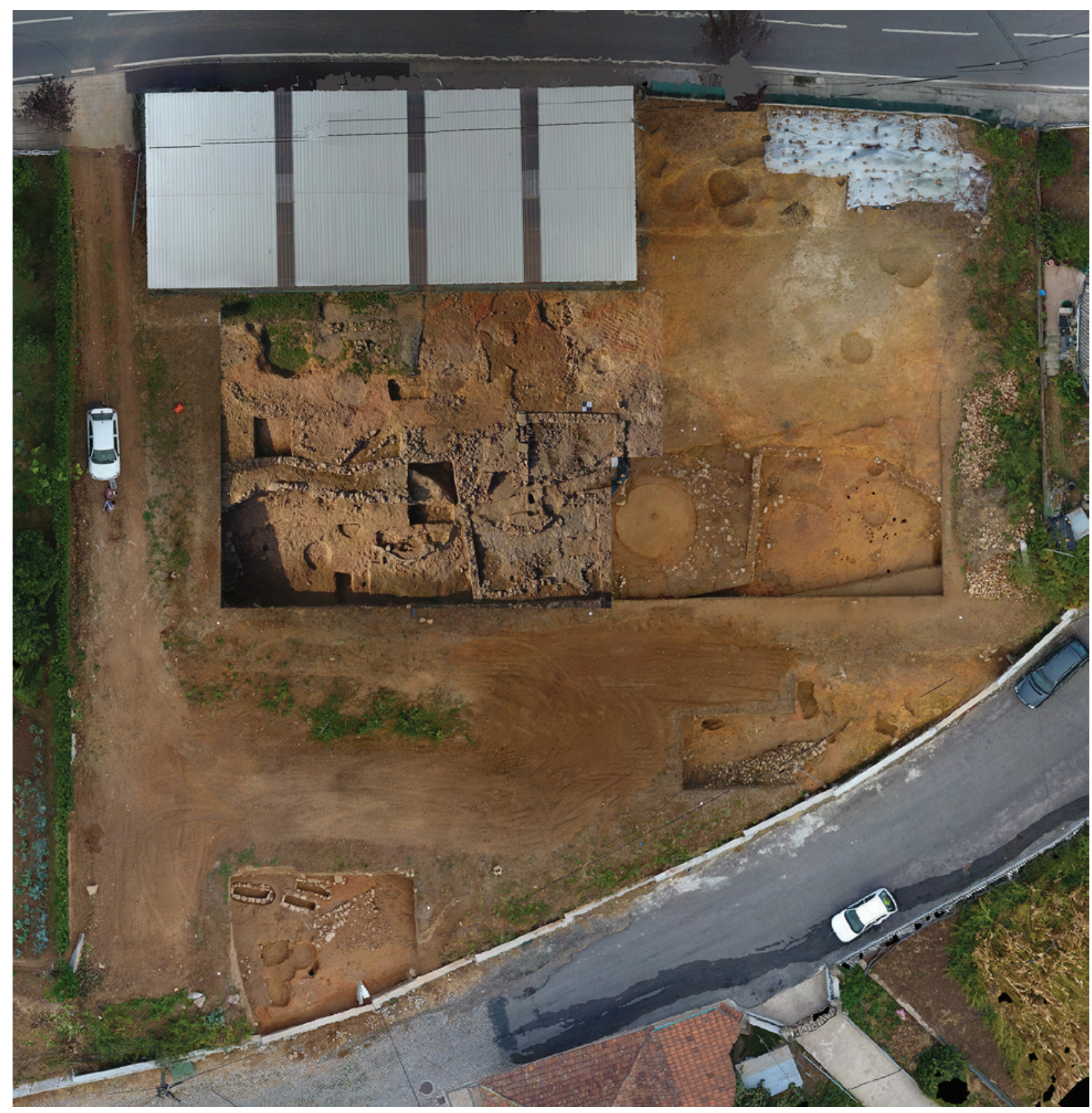

Figura 3 - Fotografia aérea da designada “Casa Romana” do Castro de São Domingos (António Alfredo da Silva da Mota Leitão). 


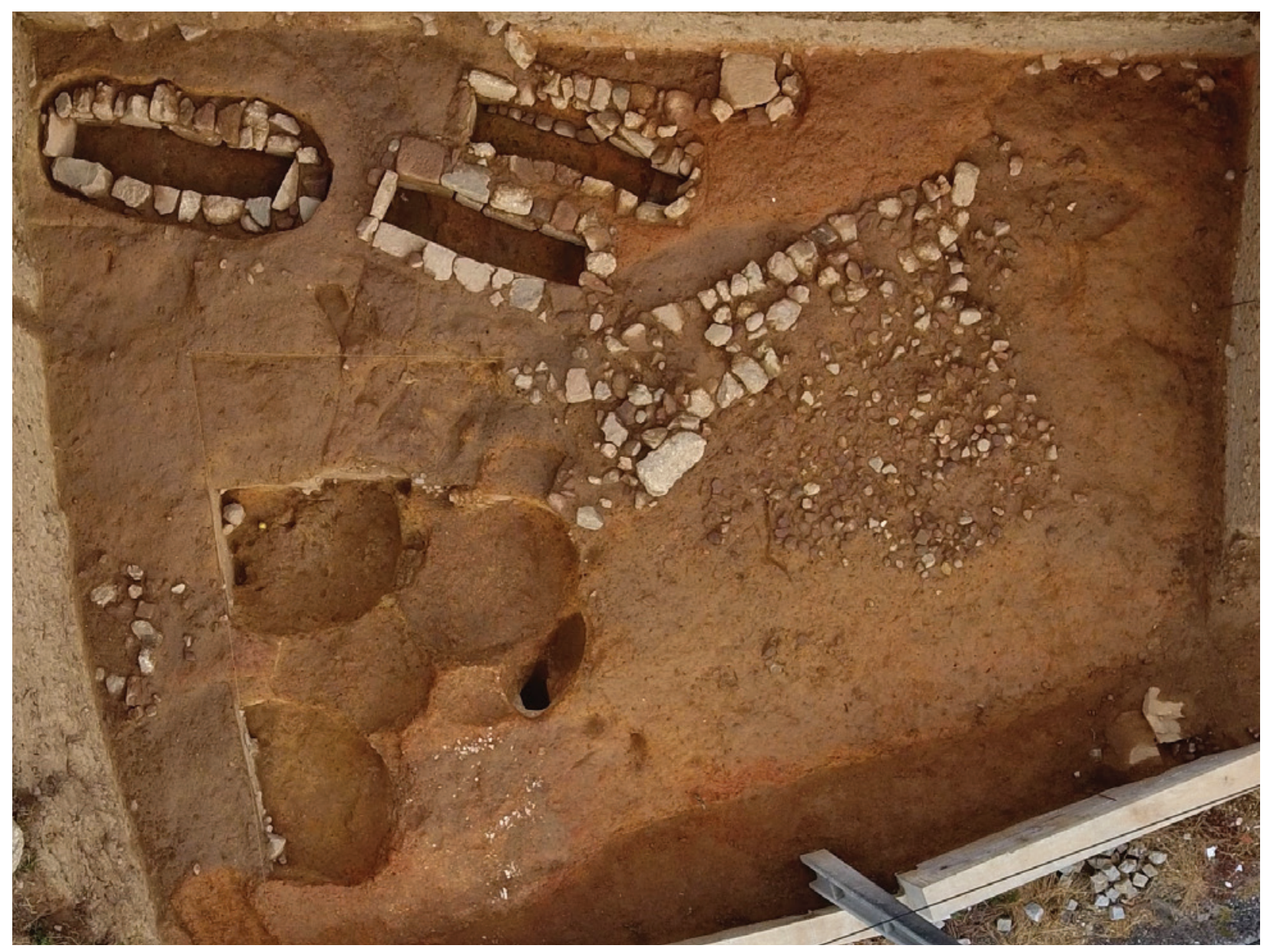

Figura 4 - Fotografia aérea da estrutura de delimitação e das sepulturas (António Alfredo da Silva da Mota Leitão). 


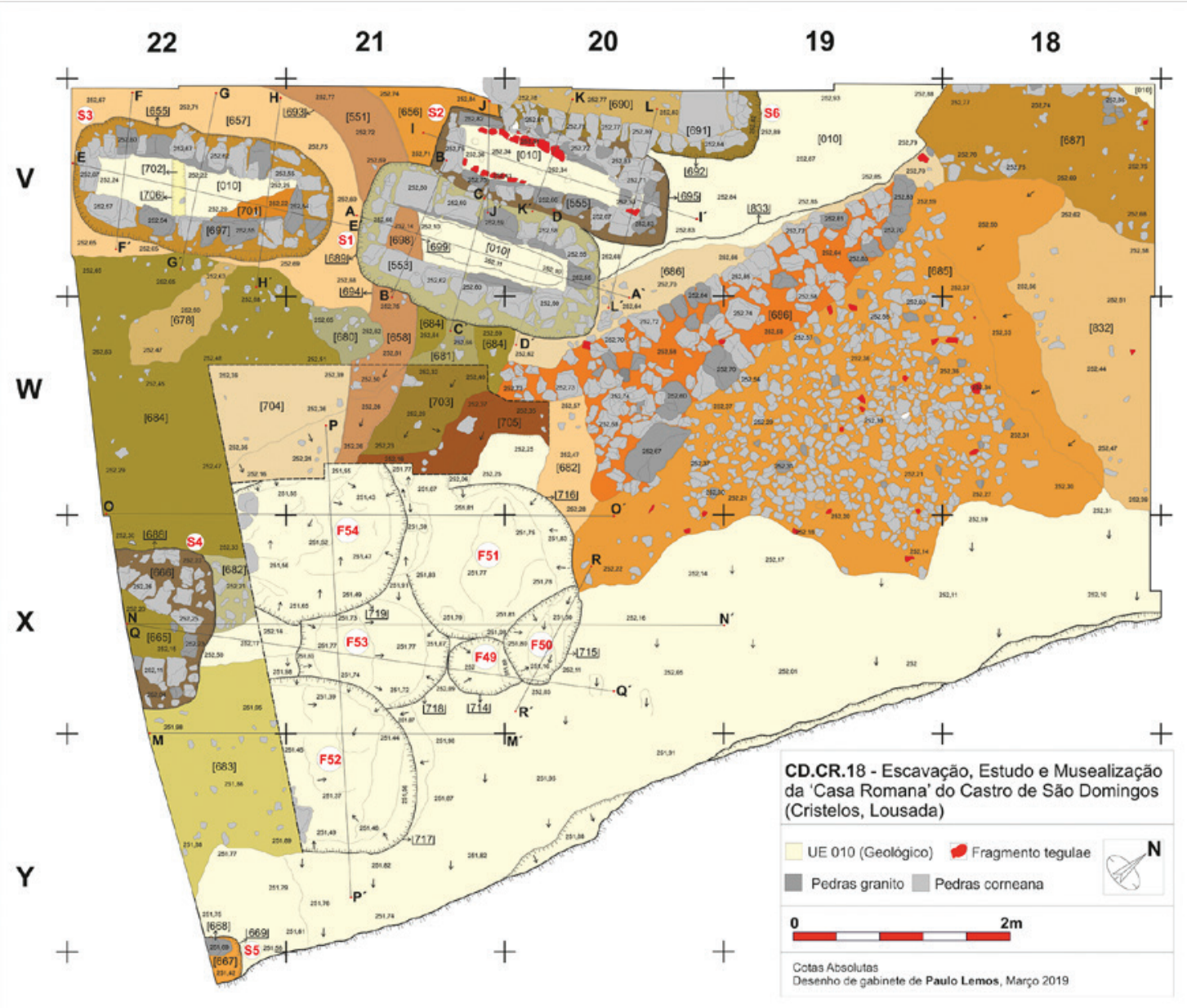

Figura 5 - Pormenor da estrutura de delimitação e das sepulturas.

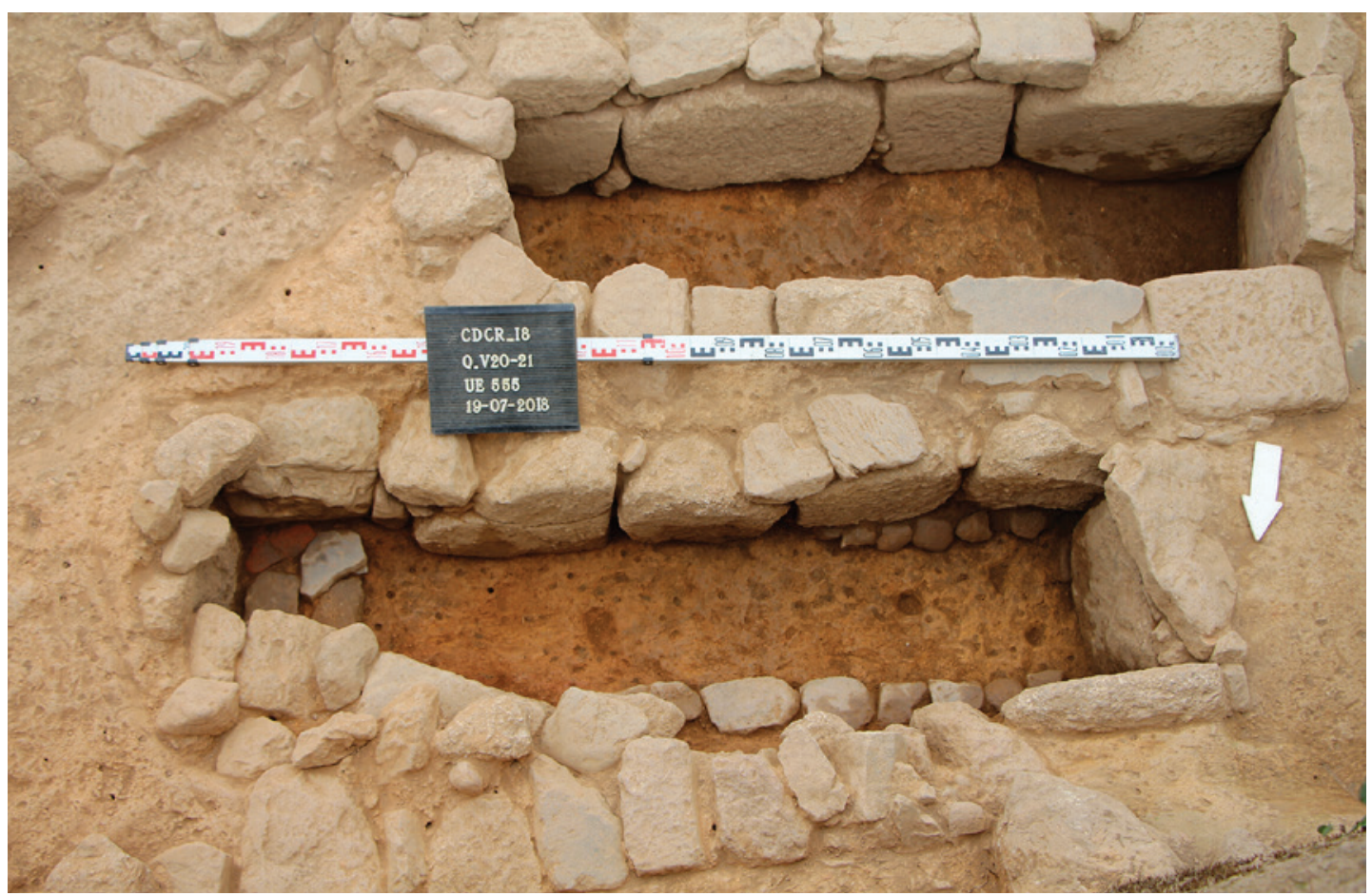

Figura 6 - Pormenor das sepulturas 1 e 2. 


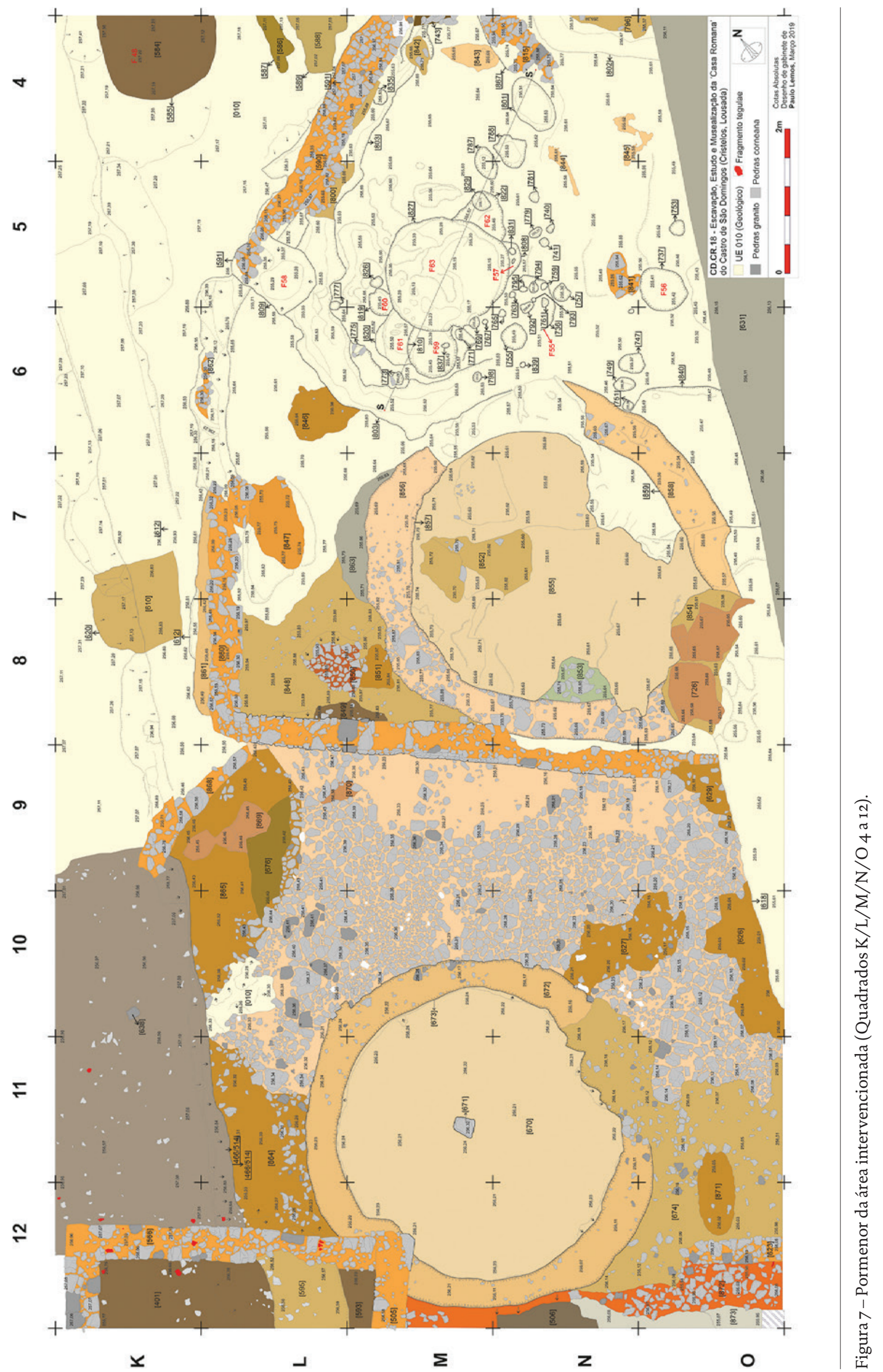




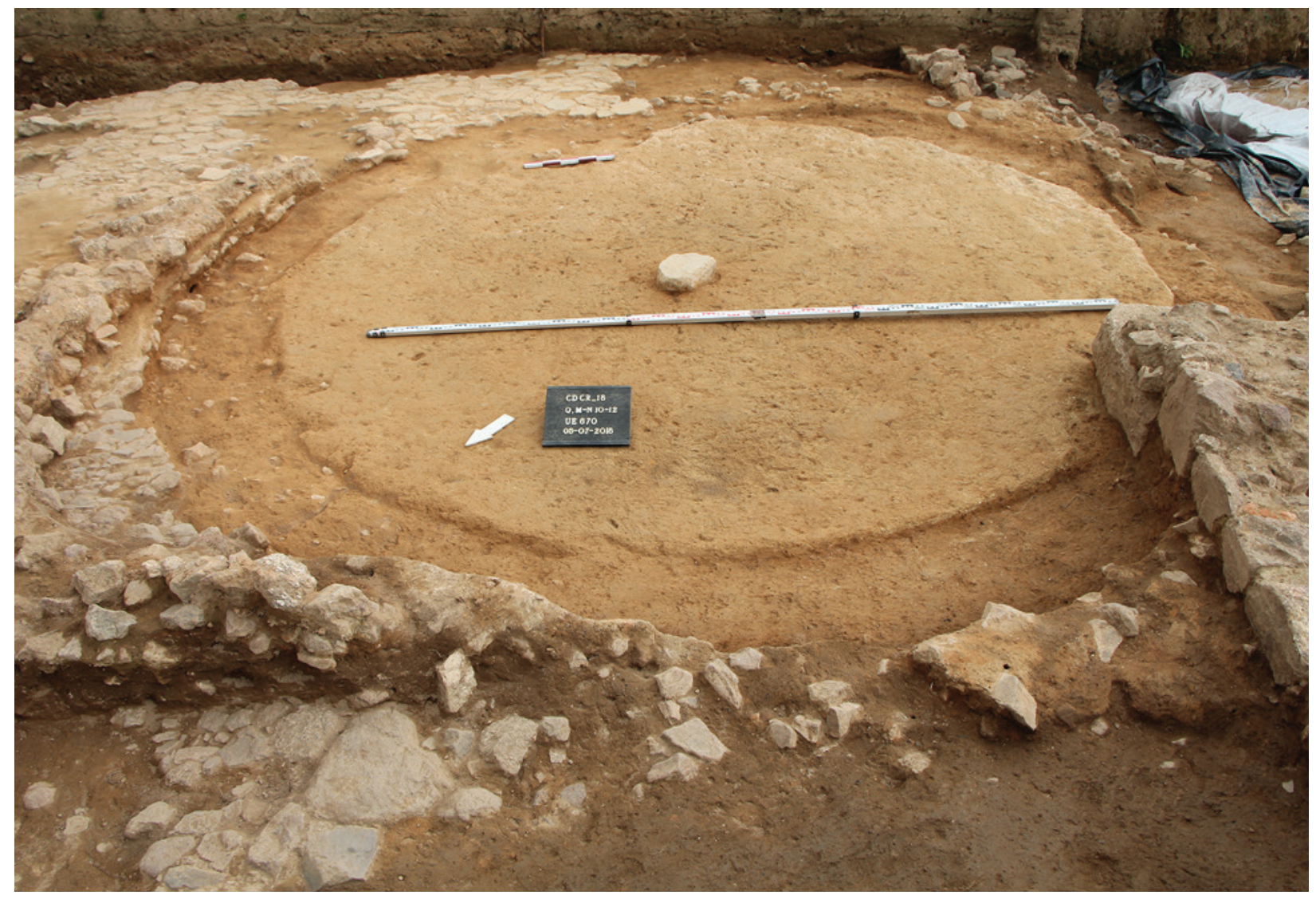

Figura 8 - Pormenor da estrutura habitacional [672].

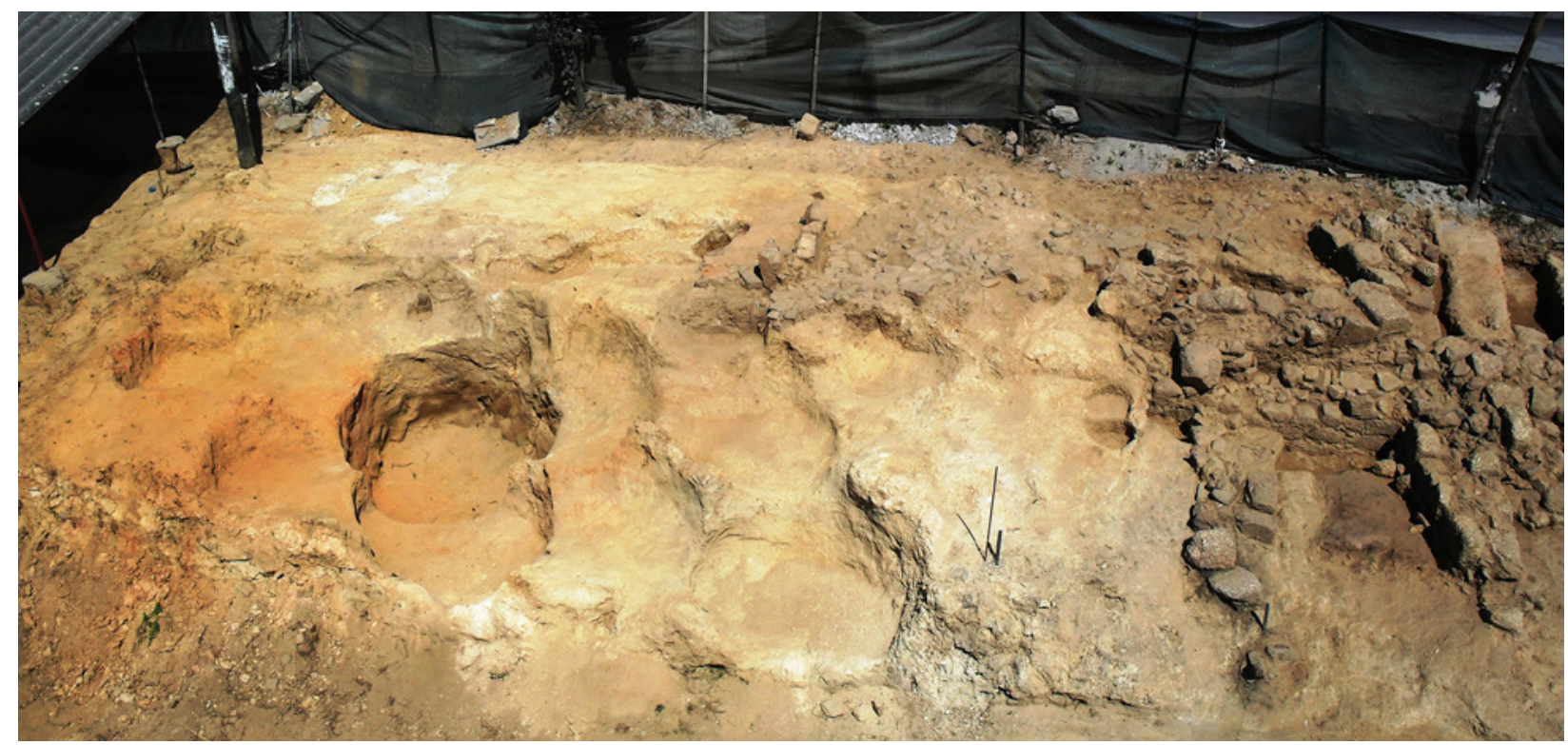

Figura 9 - Fotografia aérea do limite NO da designada “Casa Romana” do Castro de São Domingos (Manuel da Mota Nunes). 


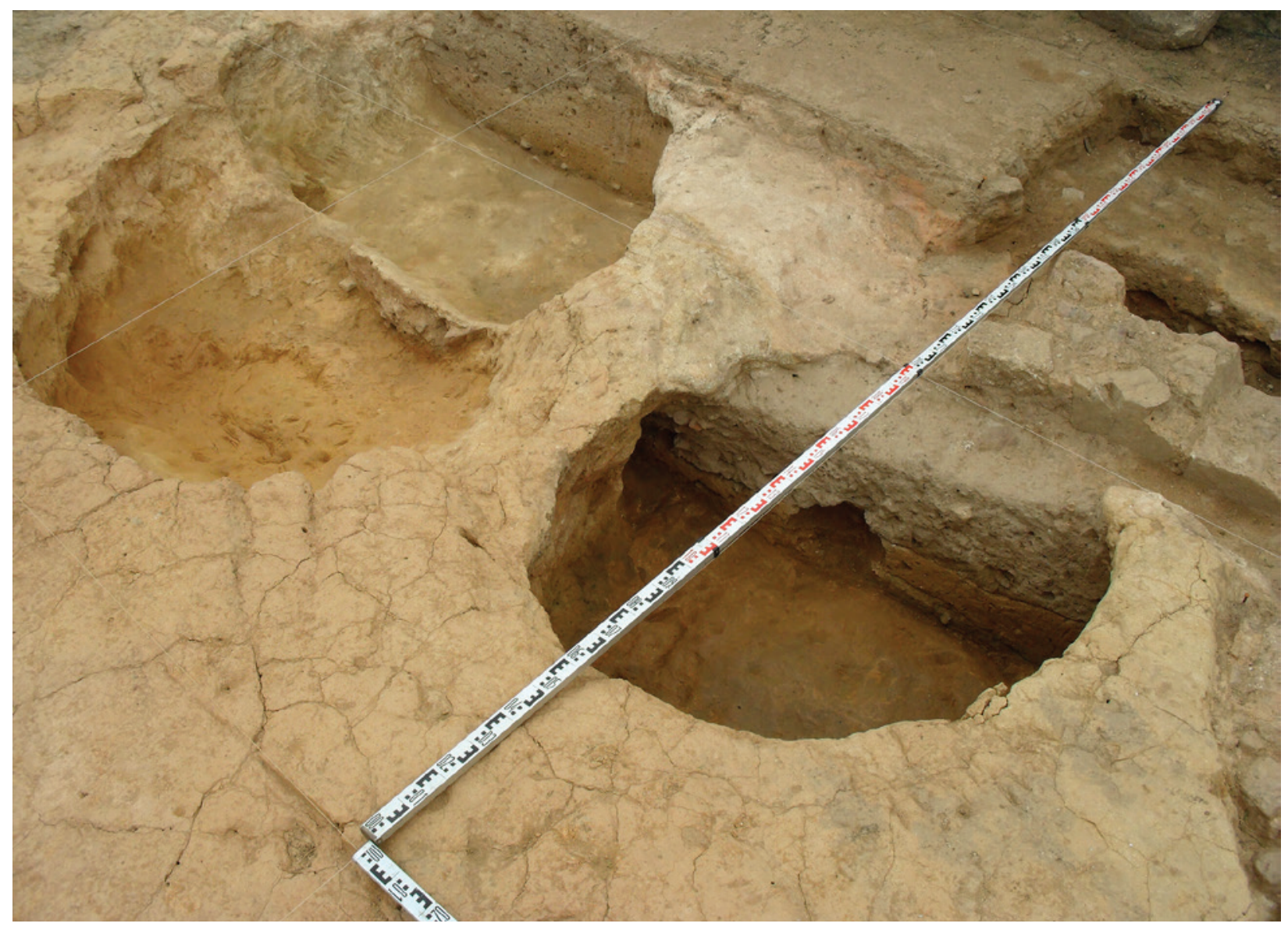

Figura 10 - Aspeto final dos trabalhos realizados nas Fossas 17 a 20. 


\title{
A ARQUEOBOTÂNICA NO CASTRO DE GUIFÕES (MATOSINHOS, NOROESTE DE PORTUGAL): O PRIMEIRO ESTUDO CARPOLÓGICO
}

\author{
Luís Seabra ${ }^{1}$, Andreia Arezes ${ }^{2}$, Catarina Magalhães ${ }^{3}$, José Varela ${ }^{4}$, João Pedro Tereso ${ }^{5}$
}

\begin{abstract}
RESUMO
O Castro de Guifões (Matosinhos, Noroeste de Portugal), estrategicamente implantado junto ao Rio Leça, tem sido alvo de estudo por vários arqueólogos, desde os finais do século XIX. Em 2016, tiveram início novas escavações arqueológicas que levaram à recolha de amostras sedimentares para análises arqueobotânicas. Neste trabalho serão divulgados os resultados do estudo carpológico (frutos e sementes), de amostras provenientes de quatro campanhas. Este estudo cobre uma ampla diacronia, que se estende entre a Idade do Ferro e a Antiguidade Tardia, bem como um conjunto diverso de contextos arqueológicos. Os resultados revelaram um predomínio de cereais, principalmente de milho-miúdo e de trigo de grão nu. O centeio e, sobretudo, o milho-painço e a cevada, surgiram em número mais reduzido.
\end{abstract}

Palavras-chave: Castro de Guifões, Carpologia, Idade do Ferro, Período Augustano, Antiguidade Tardia.

\begin{abstract}
The Castro de Guifões (Matosinhos, Noroeste de Portugal), strategically settled nearby the river Leça, has been studied by several archaeologists, since the end of the XIX century. In 2016, new archaeological excavations led to the recovery of sediment samples for archaeobotanical analyses. This work presents the carpological results (fruits and seeds) of samples from four campaigns, covering a large time-span, between the Iron Age and the Late Antiquity, as well as a diverse set of archaeological contexts. The results showed a predominance of cereals, mainly broomcorn millet and naked wheat. Rye, and above all foxtail millet and barley appeared in smaller amounts.
\end{abstract}

Keywords: Castro de Guifões, Carpology, Iron Age, Age of Augustus, Late Antiquity.

\footnotetext{
1. InBIO - Rede de Investigação em Biodiversidade e Biologia Evolutiva, Lab. Associado; CIBIO - Centro de Investigação em Biodiversidade e Recursos Genéticos, Universidade do Porto; lc_pacos@hotmail.com

2. CITCEM - Centro de Investigação Transdisciplinar "Cultura, Espaço e Memória”; Departamento de Ciências e Técnicas do Património da Faculdade de Letras da Universidade do Porto; aarezes@letras.up.pt

3. FLUP - Aluna no Mestrado em Arqueologia da Faculdade de Letras da Universidade do Porto; omcatarina@gmail.com

4. CMM - Câmara Municipal de Matosinhos; jose.varela@cm-matosinhos.pt

5. InBIO - Rede de Investigação em Biodiversidade e Biologia Evolutiva, Lab. Associado; CIBIO - Centro de Investigação em Biodiversidade e Recursos Genéticos, Universidade do Porto; UNIARQ - Centro de Arqueologia da Universidade de Lisboa; Faculdade de Letras da Universidade de Lisboa; MHNC-UP-Museu de História Natural e Ciência da Universidade do Porto; jptereso@gmail.com
} 


\section{INTRODUÇÃO}

Nos últimos anos, tem-se assistido a um incremento de estudos carpológicos no Norte de Portugal, particularmente em sítios arqueológicos ocupados entre a Idade do Ferro e o Período Romano (e.g. Tereso, 2012; Leite, Tereso \& Sanches, 2018; Seabra \& alii, 2018), tendo estes estudos incidido, quase exclusivamente, sobre áreas não costeiras.

A faixa costeira do norte português encontra-se sub-representada, sendo as análises carpológicas desenvolvidas no Castro de São de Lourenço uma exceção. Neste sítio foi recuperado um pequeno conjunto de macrorrestos vegetais, em níveis do século IV d.C. (Tereso, 2012). Por outro lado, na costa da Galiza, nomeadamente nas Rias Baixas, observa-se um maior incremento de estudos e conjuntos carpológicos, principalmente em sítios habitados durante a Idade do Ferro e a viragem da era (Teira-Brión, 2019).

A implementação de habitats na faixa costeira atlântica, assume particular relevância, sobretudo pelo elevado potencial económico possibilitado pelo eventual papel destes sítios nas rotas comerciais entre o litoral e o interior. Entre estes, encontra-se o Castro de Guifões (Matosinhos), localizado junto ao antigo estuário do Rio Leça, sendo que na Antiguidade, o rio seria navegável até ao sopé do Castro.

O novo projeto de investigação recentemente iniciado no Castro de Guifões, incidiu sobre uma área de cota baixa, junto ao rio, conhecida como "Campo da Ponte” (Figura 1). Os trabalhos aqui desenvolvidos, incorporaram desde cedo uma vertente multidisciplinar, através da recolha de amostras sedimentares, para o desenvolvimento de estudos arqueobotânicos (Arezes \& Varela, 2017). Aqui, serão divulgados os resultados da análise carpológica. Esta tem como objetivos principais contribuir para compreensão do sítio e dos respetivos depósitos arqueológicos, bem como produzir informação sobre práticas agrícolas e o ambiente ruderal, durante um intervalo de ocupação do Castro de Guifões, e, consequentemente, a sua integração nas dinâmicas socioeconómicas e de ocupação da faixa costeira do Noroeste Peninsular, entre a Idade do Ferro e a Antiguidade Tardia.

\section{SÍTIO ARQUEOLÓGICO}

O Castro de Guifões, também chamado de Monte Castêlo, inscreve-se administrativamente na União de Freguesias de Custóias, Leça do Balio e Guifões, concelho de Matosinhos, na margem esquerda do Rio Leça. O Castro implanta-se precisamente junto ao rio, no local onde deixa de correr num meandro mais apertado entre escarpas rochosas e se começa a abrir num largo estuário em direção ao Atlântico, do qual dista apenas cerca de três quilómetros. A importância arqueológica do sítio decorre da relação próxima que estabelece com o mar e o rio (Arezes, 2019) estando documentada a navegabilidade do troço final do Leça, pelo menos, até ao século XVI (Varela, 2013). Ocupando uma área de cerca de nove hectares, surge rodeado por espaços aplanados que albergam solos de boa potencialidade agrícola.

Os dados conhecidos sobre este sítio apontam para uma ocupação contínua, que recuará ao Bronze Final, passando pela Idade do Ferro, até à Antiguidade Tardia (Varela, 2011). E, na verdade, há muito que os achados de materiais neste local chamam a atenção para a sua importância arqueológica, captando a atenção de investigadores como Francisco Martins Sarmento, José Leite Vasconcelos ou Rocha Peixoto, entre outros (Cleto \& Varela, 1999).

Já em meados do século XX Joaquim Neves dos Santos dedica uma parte significativa do seu tempo e dos seus bens a estudar este Castro, procedendo a diversas escavações, quase sempre como forma de minimização de impactos causados pela abertura de caminhos ou pela exploração agrícola dos terrenos a ele afetos. Entre 1961 e 1962 promove uma intervenção na base do Monte Castêlo, muito perto da margem do Rio Leça, numa zona a que chamavam de "Campo da Ponte" (Santos, 1963). Trata-se de uma área de cerca de $800 \mathrm{~m}^{2}$, constituída principalmente por depósitos aluvionares aqui assentados pela ação das cheias cíclicas do Rio Leça.

Os trabalhos ali desencadeados tinham como objetivo concretizar o registo arqueológico dos vestígios ali patentes antes da destruição a que o arroteamento inevitavelmente conduziria. Estes colocaram à vista um conjunto dotado de vários compartimentos (Santos, 1995/96), associados à presença de um acervo muito significativo de materiais cerâmicos, predominantemente enquadráveis no Baixo Império e Antiguidade Tardia. Entre estes materiais destacam-se a Sigillata Africana Clara D e C, os pratos de Sigillata Bracarense Tardia, ou ainda os almofarizes com vidrado interior (Almeida \& Santos, 1975; Fernández \& Morais, 2012; Arezes \& Varela, 2017).

Em 2016 arrancou o Projecto de Investigação Plurianual em Arqueologia designado "GUIFARQ - 
Projeto de Investigação Arqueológica de Guifões" (presentemente, na sua II edição), apoiado numa parceria estabelecida entre a Câmara Municipal de Matosinhos e a Faculdade de Letras da Universidade do Porto. Uma das vertentes do referido projeto prendia-se especificamente com a escavação arqueológica de uma parcela do terreno do já mencionado "Campo da Ponte" (Figura 1): concretamente, uma parcela contígua àquela onde, entre 1961 e 1962, Joaquim Neves dos Santos promovera trabalhos (Arezes \& Varela, 2017).

Após a concretização das primeiras quatro campanhas de escavação anuais no âmbito do Projeto GUIFARQ, começam a avolumar-se os dados recolhidos, ainda que a dimensão das interrogações suscitadas pelas modalidades específicas de ocupação do sítio se mantenha ampla. Todavia, algumas das evidências, sobretudo as relativas à perturbação desta zona aplanada, são sintomáticas desde 2016 (Arezes \& Varela, 2017). Com efeito, num universo de nove quadrículas já intervencionadas (cada uma das quais com $16 \mathrm{~m}^{2}$ de área) há um denominador comum a apontar e que se prende com o facto de vários níveis (naturalmente, com destaque para os superficiais) demonstrarem a ocorrência de revolvimentos; a tal acresce ainda a deposição de aterros que terão sido deslocados, no sentido de nivelar e, eventualmente, melhorar a capacidade agrícola do "Campo da Ponte". Na verdade, as lavras do terreno surgem plenamente comprovadas, não apenas em documentação fotográfica, mas também na presença de alguns negativos que parecem coadunar-se com a passagem recorrente de arados ou mecanismos equivalentes. É, pois, na combinação de tais circunstâncias, que radica a mescla de inclusões materiais atestada: uma mescla que, em algumas unidades estratigráficas, compreende artefactos integráveis num universo temporal que se estende desde a Idade do Ferro até à época Contemporânea (Arezes \& Varela, 2017).

Em contrapartida, o aprofundamento da escavação permitiu a exumação de um complexo conjunto de construções, representativos de diferentes momentos de ocupação deste espaço. Até ao momento, as mais antigas estruturas identificadas, [133] e [170], constam, respetivamente, de uma lareira de argila pisoteada, dotada de círculos impressos, e de uma outra, contígua, mas isenta de decoração (Arezes \& Varela, 2018; Arezes, 2019). Estas lareiras integrariam o espaço interior de uma antiga cabana da Idade do Ferro, entretanto cortada, e à qual se so- brepôs posteriormente um dos alinhamentos, [20], pertencentes a uma construção de planta tendencialmente ortogonal (Compartimento 2). Em posição sensivelmente simétrica, mas a poente da área de intervenção, foi parcialmente desvelado [63], um dispositivo constituído por blocos de médio porte, e dotado de cunhal muito bem esquadriado (Arezes \& Varela, 2018). Aliás, o lanço que arranca a partir do cunhal e se prolonga no sentido sudoeste/nordeste poderá ter sido utilizado como base de apoio para a construção ou reformulação tardia deste Compartimento. Com efeito, o alinhamento [15], que integrava, juntamente com [35], um único dispositivo de aparelho menos conseguido e atualmente truncado, segue a orientação de [63], sobrepondo-se a este. No interior do Compartimento 2, foram já diversos os estratos detetados, mas destacamos [19], caracterizado pela significativa presença de dolia, e de alguns exemplares de sigillatas africanas Clara D (Arezes \& Varela, 2017).

Sensivelmente a norte da referida construção, foi possível detetar um outro dispositivo (Compartimento 1), que apresentava a particularidade de exibir cantos arredondados e abarcava, a somar a vários outros depósitos, um consideravelmente enegrecido pela presença abundante de cinzas e carvões, [25]. Face ao exposto, comprova-se que o "Campo da Ponte", situado na periferia do Castro e muito próximo da margem do Rio Leça, foi efetivamente pautado por sucessivos momentos de construção, arrasamento e reconstrução, sem nunca quebrar a relação primordial que manteve com o curso fluvial.

\section{MATERIAIS E MÉTODOS}

\subsection{Amostragem e descrição dos contextos ar- queológicos}

Entre as campanhas de 2016 e 2019, foram recolhidas 191 amostras para análises arqueobotânicas. 67 correspondem a amostras sedimentares, perfazendo um total de 393,6 L de sedimento. Destas, apenas uma amostra foi crivada. As restantes foram processadas através de flutuação manual, com recurso a uma malha de o,5 mm. 124 amostras refletem recolhas manuais, recuperadas de forma selecionada pela equipa de campo.

Para este artigo foram consideradas apenas as U.E. que providenciaram elementos carpológicos quantificáveis (ver metodologia laboratorial). Deste modo, contabilizam-se 111 amostras, oriundas de 28 U.E., 
identificadas em oito quadrículas (Tabela 1), sendo que 60 amostras constituem $383,7 \mathrm{~L}$ de sedimento. As remanescentes 51 amostras constituem recolhas manuais.

Os depósitos em estudo representam um conjunto heterogéneo de contextos arqueológicos, provenientes de diferentes áreas do "Campo da Ponte", designadamente, do interior de dois compartimentos, da área que medeia entre ambos e respetivos espaços limítrofes (Tabela 1, Figura 1). Abrangem uma diacronia de ocupação ampla, entre a Idade do Ferro e a Antiguidade Tardia. Em várias ocasiões, não foi possível restringir a um único momento de ocupação e, por esse motivo, foi necessário atribuir um faseamento mais abrangente (e.g. Idade do Ferro/ Período Romano, Período Romano/Antiguidade Tardia). Não obstante, foi possível distinguir três fases principais: $1^{\circ}$ ) Idade do Ferro, $2^{\circ}$ ) Período Augustano e $3^{\circ}$ ) Antiguidade Tardia (Tabela 1 ).

$\left.\mathbf{I}^{\circ}\right)$ As U.E. [65], [159] e [163] representam momentos antigos de ocupação, correlacionáveis com a Idade do Ferro. Nestas camadas, não foi percetível a presença de espólio arqueológico de qualquer outra cronologia. Correspondem a depósitos dispersos, recolhidos na zona este do sítio arqueológico, em zonas exteriores ao compartimento 2, provavelmente construído ou reformulado na Antiguidade Tardia (Tabela 1, Figura 1). Foi recolhido um total de $16 \mathrm{~L}$ de sedimento, em que 14 destes provêm da U.E. [65], uma camada que cobria duas lareiras, U.E. [133] e [177], da Idade do Ferro (Arezes \& Varela, 2018; Arezes, 2019).

$\left.2^{\circ}\right)$ A segunda fase retrata um momento circunscrito da ocupação alto-imperial no "Campo da Ponte", no Período Augustano. Presente em cinco U.E.: [26], [38], [43], [47] e [93], com características distintas (Pisos/Pavimentos, depósito disperso, enchimentos). Provenientes do interior do compartimento 2 e de espaços próximos a este (Tabela 1, Figura 1). Destas camadas foram recolhidos $84 \mathrm{~L}$ de sedimento. Estes depósitos integravam conjuntos artefactuais compatíveis com o período de transição compreendido entre o século I a.C. e I d.C., com destaque para as cerâmicas micáceas de produção local e para materiais caracteristicamente romanos.

$\left.3^{\circ}\right)$ Nove U.E.: [11], [17], [21], [23], [25], [41], [49], [184], [185] encontram-se associadas à Antiguidade Tardia. Trata-se da fase com maior repre- sentação e esforço de amostragem (156,5 L). Estas unidades são oriundas do interior dos dois compartimentos identificados e de zonas próximas (Tabela 1, Figura 1). A maior parte destas camadas corresponde a depósitos dispersos. Algumas (e.g. [11], [25], [184]), incluem materiais de outros períodos cronológicos, sendo de admitir a ocorrência de revolvimentos. Contudo, as relações estratigráficas entre os depósitos, bem como a globalidade do acervo, indicam estarmos perante níveis da Antiguidade Tardia. Relativamente às restantes camadas, tanto o espólio como o contexto arqueológico não permitiram, de uma forma clara, a associação a um único momento de ocupação. Foram estabelecidas outras categorias cronológicas, que englobam duas ou até mesmo três fases (Tabela 1). Independentemente das dificuldades de interpretação cronológica que estes depósitos podem suscitar, os resultados obtidos serão incluídos neste estudo carpológico.

\subsection{Metodologia laboratorial}

A triagem das frações leves foi realizada com o auxílio de uma lupa binocular. Para a caracterização e identificação dos vestígios carpológicos utilizou-se bibliografia especializada, sobretudo atlas morfológicos (e.g. Hillman \& alii, 1996; Jacomet, 2006; Neef, Cappers \& Bekker, 2012). Para o diagnóstico taxonómico, recorreu-se igualmente à comparação com espécimes atuais, através da coleção de referência presente no Herbário da Universidade do Porto (PO), localizado nas instalações do Museu de História Natural e Ciência da Universidade do Porto (MHNC-UP) e do CIBIO.

Devido ao seu elevado peso e volume, e para tornar o trabalho laboratorial exequível, foi necessário subamostrar 31 amostras (Tabela 2). A fração leve de cada amostra foi divida por dimensão, através de uma coluna de crivos, com malhas de $2 \mathrm{~mm}, 1 \mathrm{~mm}$ e $0,5 \mathrm{~mm}$. Em relação à malha de $2 \mathrm{~mm}$, foi realizada uma triagem integral em todas as amostras. No caso das malhas de $1 \mathrm{~mm}$ e $0,5 \mathrm{~mm}$, foi necessário aplicar, de um modo regular, a subamostragem. Na realização deste procedimento, procurámos obter valores consistentes. Assim, sobre a malha de crivos de 1 $\mathrm{mm}$ foi analisado em média 5,8 gramas, enquanto sobre a malha de $0,5 \mathrm{~mm} \mathrm{2,3}$ gramas.

$\mathrm{Na}$ generalidade, tanto as amostras realizadas na íntegra como as subamostradas, mostraram poucos elementos carpológicos (ver Resultados). Assim, 
estimar o número de sementes/frutos existentes na totalidade da amostra extrapolando a partir dos resultados obtidos, tendo em conta a percentagem analisada da amostra, poderia sobrestimar a presença de alguns táxones, pelo que se optou por não efetuar qualquer extrapolação. Deste modo, os resultados apresentados na Tabela 3 refletem unicamente valores efetivos, identificados nas subamostras.

Neste estudo foram quantificados elementos carpológicos unitários, fragmentos com escutelo/hilo e escutelos individuais. Excetua-se apenas alguns carporrestos, que por fornecerem algum nível de detalhe taxonómico (género ou espécie) e pelo facto de terem aparecido apenas fragmentados, foram incluídos nos resultados (Tabela 3).

Para efeitos contabilísticos, no grupo dos cereais, dois fragmentos longitudinais foram quantificados como uma unidade (grão). Um procedimento similar foi aplicado às leguminosas, tendo dois cotilédones (metades) sido determinados como uma semente. Relativamente às inflorescências, foram contabilizados segmentos e fragmentos de ráquis de centeio, nós de ráquis de trigo nu e bases de lema de cevada.

\section{RESULTADOS}

O estudo carpológico realizado no "Campo da Ponte", revelou um conjunto de pequena dimensão (625 carporrestos), caracterizado na sua maioria pela presença de grãos de cereais (Tabela 3 ). Em termos quantitativos, verifica-se um predomínio de milho-miúdo (Panicum miliaceum), seguido do trigo de grão nu (Triticum aestivum/durum), centeio (Secale cereale), milho-painço (Setaria italica) e cevada (Hordeum vulgare), este último em números esporádicos.

Foi recuperada uma quantidade considerável de grãos de milho, identificados como Panicum/Setaria (52). Apesar de não ter sido possível uma diferenciação, este número reforça a presença dos milhos no registo carpológico. No entanto, esta maior representação dos milhos, designadamente do milho-miúdo, não deve ser sobrevalorizada. Os grãos de milho apresentam dimensões mais reduzidas do que os restantes cereais aqui identificados, sendo que, em termos de volume, este predomínio deixa-se de verificar, principalmente em comparação com o trigo nu.

Para além dos grãos, foram recolhidas inflorescências de cereal. É de realçar um registo significativo de nós de ráquis de trigo nu (6o), inclusive, maior do que os grãos (51). Em número mais reduzido, foram recolhidos 15 segmentos e cinco fragmentos de ráquis de centeio, bem como duas bases de lema de cevada. Este estudo demonstrou a presença de uma única espécie de leguminosa cultivada. No "Campo da Ponte", foram recuperadas cinco favas (Vicia faba). Não podemos descartar que, considerando a dimensão das sementes, as leguminosas identificadas como Vicia/Lathyrus correspondam a cultivos, contudo o seu estado de conservação não permitiu uma interpretação mais sólida.

Salienta-se o registo de grãos de aveia (Avena sp.). Identificados ao nível do género devido à ausência das inflorescências, não foi possível compreender se estamos perante elementos cultivados ou silvestres. A presença das inflorescências é crucial para esta clarificação (Ruas \& Pradat, 2001; Jacomet, 2006). Apesar de estarmos perante um conjunto carpológico de baixa dimensão, os resultados demonstraram alguma diversidade. Além de cereais e leguminosas, foram recuperados alguns vestígios de frutos. Em especial, dois fragmentos de caroço de pêssego (Prunus persica) e fragmentos de castanha (Castanea sativa), que deverão corresponder a elementos cultivados. Em relação aos dois aquénios de amo$\mathrm{ra} /$ framboesa (Rubus sp.), estes podem tratar-se de vestígios silvestres e/ou cultivados. Já o único fragmento de cotilédone de bolota (Quercus sp.) identificado trata-se de um carporresto silvestre.

Os restantes vestígios carpológicos correspondem, da mesma maneira, a elementos silvestres. Foram recolhidas algumas gramíneas (e.g. Poaceae, Festuca/Lolium) e leguminosas (e.g. Ornithopus sp., Fabaceae) silvestres. Destaca-se a presença frequente de camarinha (Corema album), sendo este o macrorresto silvestre em maior número (28). Morrião (Anagallis arvenses), saramago (Raphanus raphanistrum), verbena (Verbena officinalis) ou beldroega (Portulaca oleracea) são outros exemplos de carporrestos silvestres identificados no "Campo da Ponte". Tal como mencionado previamente, este estudo demonstrou um conjunto carpológico de pequena extensão. Cada unidade estratigráfica apresentou sempre um conteúdo inferior a 100 carporrestos. 13 U.E. revelaram, individualmente, menos de dez elementos (Tabela 3). Os vestígios carpológicos são oriundos de depósitos significativamente heterogéneos entre si e estes abarcam uma larga diacronia, desde a Idade do Ferro até à Antiguidade Tardia. Como tal, 
a análise da distribuição e interpretação dos macrorrestos pelo sítio, bem como o respetivo faseamento exige cautelas. Apesar disto, e tendo em contas as fases de ocupação estabelecidas (ver Amostragem e descrição dos contextos arqueológicos) é possível tecer algumas considerações:

A fase mais antiga, da Idade do Ferro, é representada por 28 elementos carpológicos. Este pequeno conjunto é coincidente com o baixo volume de sedimento recolhido (16 L). A maioria dos macrorrestos provém da U.E. [65], a camada alvo do maior esforço de amostragem (14 L). Refere-se a presença de seis grãos de milho-miúdo e um grão de milho-painço, e um nó de ráquis de trigo nu. Dentro do grupo das plantas silvestres, evidencia-se o registo de nove sementes de camarinha.

Um total de 111 carporrestos foi identificado em depósitos adscritos ao Período de Augusto. No entanto, tendo em conta o volume recolhido (84 L), trata-se de uma baixa quantidade de vestígios carpológicos. Há um predomínio dos cereais, nomeadamente de 24 grãos de milho-miúdo, seguidos de 21 nós de ráquis e oito grãos de trigo nu. Num plano menos substancial, confere-se o registo de cinco grãos de milho-painço, uma base de lema e um grão de cevada, tal como um segmento de ráquis de centeio. O remanescente é composto por outras gramíneas (e.g. aveia, Panicoideae), leguminosas (e.g. Ornithopus sp., Vicia/Lathyrus) e por plantas silvestres (e.g. camarinha, saramago, Asteraceae tipo Chrysanthemum). Estes vestígios encontram-se, do mesmo modo, representados em quantidades pouco relevantes.

O terceiro momento de ocupação (Antiguidade Tardia), revelou um conjunto carpológico um pouco mais expressivo e diverso, mas sem transcender de forma muito óbvia. Em nove U.E., que configuram 156,5 L de sedimento, foram recuperados 285 vestígios carpológicos. Tal como na fase anterior, assiste-se a um domínio dos cereais. O milho-miúdo é predominante (86 grãos), seguido de uma quantidade considerável de grãos (28), segmentos (14) e fragmentos de ráquis (quatro) de centeio, bem como de grãos (14) e nós de ráquis (11) de trigo nu. Em segundo plano, surgem o milho-painço (oito grãos) e a cevada (quatro grãos). Sobre os restantes carporrestos, em comparação com as fases anteriores, salienta-se algumas diferenças: a identificação de duas favas, assim como o registo de outros frutos, designadamente um fragmento de caroço de pêssego, fragmentos de castanha e um fragmento de cotilédone de bolota.
Em relação aos conjuntos carpológicos provenientes de camadas associadas a mais do que um momento de ocupação (Idade do Ferro/Período Romano, Período Romano/Antiguidade Tardia, Idade do Ferro/Período Romano/Antiguidade Tardia), no geral, observa-se um panorama semelhante ao já referido (Tabela 3), sendo as diferenças pouco significativas para serem aqui detalhadas.

\section{DISCUSSÃO}

\subsection{O contexto arqueológico}

Muitos dos vestígios carpológicos recolhidos no "Campo da Ponte" provêm de depósitos arqueológicos de difícil caracterização e interpretação, essencialmente deposições secundárias ou depósitos formados após o abandono do local (Tabela 1). O seu enquadramento cronológico é igualmente complexo, visto que das 28 U.E. em estudo, 11 dispõem de um faseamento dúbio, entre dois ou três momentos de ocupação. Para além disto, apesar da atribuição de uma única fase às restantes camadas, algumas revelaram evidências de intrusões e/ou revolvimentos (e.g. [11], [17], [21], [25], [43], [184]).

O milho-miúdo, o milho-painço e o trigo nu foram identificados nas três fases principais de ocupação do sítio. A cevada não foi recuperada, unicamente, na $1^{\circ}$ fase de ocupação. No entanto, esta é representada por um volume reduzido de sedimento. Além disto, foram recuperados grãos de cevada na fase Idade do Ferro/Período Romano, não sendo assim de excluir, a hipótese da cevada ter sido consumida no local durante a Idade do Ferro, à semelhança do que tem sido identificado em outros sítios da região.

O aparecimento do centeio aparenta ser a exceção mais relevante. Os registos mais antigos (U.E. [26] e [46], apontam para a sua ocorrência entre o final da Idade do Ferro e o Período Augustano, no "Campo da Ponte". Contudo, trata-se de um registo muito esporádico. No piso/pavimento [26], atribuído ao período de Augusto, foi identificado um segmento de ráquis. No caso da U.E. [46], um dos enchimentos da fossa [42], que integrava material cerâmico do final da Idade do Ferro / arranque da ocupação Romana, foi encontrado um fragmento de ráquis de centeio. Sendo o centeio (grãos e ráquis) mais frequente nos níveis da Antiguidade Tardia, os exíguos vestígios dos níveis antigos, poderão resultar de intrusões.

Algo semelhante poderá ser apontado à presença do pêssego, também identificado na U.E. [46]. Este 
depósito, incluía o maior número (78) e diversidade de elementos carpológicos (22 táxones). Trata-se de um de dois depósitos de enchimento de uma fossa (interface [42]) que deverão resultar do uso desta estrutura como lixeira. O depósito inferior (U.E. 46), aqui referido, tem materiais da Idade do Ferro / Período Romano, enquanto que o depósito superior da mesma estrutura (U.E. 41) apresenta materiais da Antiguidade Tardia. Como tal, não podemos excluir a possibilidade de intrusões entre os sedimentos desta estrutura. Um outro fragmento de caroço de pêssego foi detetado num depósito da Antiguidade Tardia (U.E. [25]).

Em relação aos restantes elementos carpológicos, estes aparentam enquadrar-se no padrão geral. Independentemente da fase ou do contexto de proveniência, estes são parcos em número. Destaca-se apenas que alguns táxones (e.g. aveia, camarinha), estão presentes em número considerável e em todos os momentos de ocupação identificados no "Campo da Ponte".

\subsection{Cultivos}

Tal como referido anteriormente, a dificuldade em atribuir um enquadramento cronológico seguro aos depósitos arqueológicos, obriga a cautelas na interpretação dos vestígios carpológicos. Em suma, os resultados revelam uma diversidade de cultivos, principalmente de cereais, tendo sido registados em proporções não muito divergentes, independentemente da fase de ocupação e do contexto em análise. Algo que impõe cuidados na realização de leituras diacrónicas, bem como na respetiva integração do Castro de Guifões nas dinâmicas socioeconómicas da faixa costeira do Noroeste Peninsular.

O milho-miúdo e o trigo nu, aparentam ter tido uma maior relevância para as comunidades que habitaram o Castro de Guifões, sendo as suas presenças significativas e transversais a todas as fases de ocupação. Por um lado, o milho-miúdo é, a nível quantitativo, o cultivo dominante, mas por outro, se tivermos em conta o volume (ver Resultados), o trigo nu é predominante. O centeio, e principalmente o milho-painço e a cevada surgem em menor expressão no registo carpológico. A maior parte destes cereais é presença recorrente na faixa costeira do Noroeste Peninsular, nos períodos em análise. Observam-se algumas diferenças, tanto para com o Castro de São Lourenço como para os sítios nas Rias Baixas, mas realçam-se dois dados importantes: a ausência de trigos de grão vestido (Triticum dicoccum e Triticum spelta) no Castro de Guifões e a inexistência de centeio nos restantes sítios mencionados.

No Castro de Guifões, os registos mais antigos de centeio apontam para o final da Idade do Ferro e o período de Augusto. Algo que não é totalmente surpreendente, pois a datação mais antiga na Península Ibérica deste cereal, remonta a meados do século I a.C. e ao povoado do Crastoeiro (Mondim de Basto) (Seabra \& alii, 2018). Contudo, o "Campo da Ponte" revelou um conjunto reduzido nestes níveis, estando grãos e ráquis presentes de forma consistente, somente na fase da Antiguidade Tardia.

A possibilidade de uma cronologia tardo-antiga para o centeio no Castro de Guifões, poderá ser fulcral para compreender estas diferenças para com o resto da faixa costeira do Noroeste Peninsular. A maioria dos sítios nas Rias Baixas com estudos carpológicos apresentam principalmente ocupações dentro da Idade do Ferro e da viragem do milénio, tal como materialidades arqueológicas muito específicas da região (Teira-Brión, 2019). Além do mais, os dados disponíveis para o resto da Península Ibérica, apontam para uma presença frequente do centeio, somente em fases mais avançadas do Período Romano (Alonso, 2005; Tereso, 2012). Neste caso, para destrinçar esta questão, de forma inequívoca, será necessário a obtenção de datações por radiocarbono sobre os vestígios de centeio do "Campo da Ponte". A presença de leguminosas foi rara. Observou-se apenas a presença da fava, em número muito baixo. Apesar desta leguminosa ser bastante comum no registo carpológico e nos mais diversos períodos cronológicos, a sua pequena expressão em comparação com os cereais é bastante comum no Noroeste Peninsular (Tereso, 2012).

Neste estudo foram observados dois frutos (pêssego e castanha), que deverão corresponder a cultivos. Em relação ao pêssego, a possibilidade de atribuir uma cronologia tardo-antiga no Castro de Guifões, é também admissível. Outras evidências de pêssego no Noroeste Peninsular, nomeadamente no sítio costeiro do Areal (Vigo) e nas termas romanas de Aquae Flaviae, atestam, do mesmo modo, o registo deste fruto em níveis da Antiguidade Tardia (Vaz \& alii, 2016; Teira-Brión, 2019). Contudo, numa necrópole romana de Bracara Augusta, foram encontrados caroços de pêssego em níveis mais antigos, nomeadamente em contextos dos séculos I e II d.C. (Vaz \& alii, aceite). Por outro lado, a presença da cas- 
tanha durante a Antiguidade Tardia no "Campo da Ponte", vai totalmente ao encontro da informação disponível para o Noroeste Peninsular. No sítio de Monte Mozinho (Penafiel) e no sítio do Areal, foram identificados frutos de castanha em níveis igualmente adscritos à Antiguidade Tardia (Vaz \& alii, 2017; Teira-Brión, 2019).

Os restantes elementos carpológicos, correspondem a vestígios silvestres. A sua interpretação é dificultada pelo número reduzido encontrado. Verifica-se alguma diversidade de táxones, sendo que muitos destes deverão corresponder a acompanhantes dos cultivos e a plantas ruderais, comuns em ambientes antropizados. Dentro deste grupo, evidencia-se a presença considerável de sementes de camarinha. Este registo permite atestar a relevância desta planta na costa atlântica, sendo cada vez mais claro que a sua distribuição na Antiguidade seria bem mais extensa do que a que se verifica na atualidade, mercê da pressão antrópica recente sobre os ambientes costeiros. Não é claro se a sua presença está diretamente relacionada com o seu consumo, mas é algo plausível, visto que as suas bagas são comestíveis (López-Dóriga, 2018).

\section{CONCLUSÃO}

Os resultados do primeiro estudo arqueobotânico realizado no Castro de Guifões demonstraram um conjunto diminuto de elementos carpológicos, caracterizado pelo predomínio dos grãos de cereais, principalmente de milho-miúdo e trigo de grão nu. O centeio, e sobretudo o milho-painço e a cevada foram registados em menor número. Para além dos grãos, foram identificadas quantidades significativas de inflorescências de cereais, designadamente nós de ráquis de trigo nu, e num plano secundário, segmentos e fragmentos de ráquis de centeio e bases de lema de cevada. O restante conjunto carpológico, revelou-se pouco frutífero, sendo de realçar o registo da fava e de alguns frutos, nomeadamente o pêssego e a castanha. Foi ainda recolhida alguma diversidade de elementos silvestres.

Estes elementos carpológicos provêm de depósitos recolhidos por todo o sítio arqueológico, refletindo uma ampla diacronia, entre a Idade do Ferro e a Antiguidade Tardia, sendo que muito destes revelaram-se de difícil contextualização e interpretação. A análise das diferentes fases de ocupação e contextos de proveniência revelou resultados pou- co heterogéneos entre si, seja a nível da diversidade como da quantidade de carporrestos encontrados. A maior parte dos cereais recolhidos no "Campo da Ponte" foram identificados, de modo simultâneo, nos três momentos principais de ocupação.

O centeio representa a exceção mais notável. Apesar de ter sido recolhido em contextos associados ao final da Idade do Ferro e ao Período Augustano, a sua presença deverá remeter-se apenas à Antiguidade Tardia. De modo similar, para os fragmentos de pêssego e de castanha admite-se uma cronologia tardo-antiga, no Castro de Guifões. O registo do centeio e ausência de trigos vestidos são as principais diferenças detetadas, em comparação com os restantes sítios costeiros do Noroeste Peninsular. Algo justificado sobretudo pela diacronia de ocupação da maior parte destes sítios, dentro da Idade do Ferro e da viragem da era, sendo o centeio frequente em momentos mais avançados do Período Romano (Alonso, 2005; Tereso, 2012; Teira-Bríon, 2019).

Este estudo representa um avanço para o conhecimento de uma área (faixa costeira), em que os estudos arqueobotânicos são ainda escassos, principalmente no Norte de Portugal. No entanto, tendo em conta a complexidade dos contextos arqueológicos analisados no "Campo da Ponte", assim como a inerente dificuldade de interpretação dos vestígios carpológicos, é crucial a continuação dos estudos arqueobotânicos. Novas análises assumem-se como fundamentais para uma melhor compreensão do uso dos recursos vegetais durante a ocupação do Castro de Guifões e para um apropriado enquadramento na faixa costeira do Noroeste Peninsular.

\section{BIBLIOGRAFIA}

ALMEIDA, Carlos Alberto Ferreira de; SANTOS, Joaquim Neves dos (1975) - Cerâmica Romana, Tardia, de Guifões. Archaeologica Opuscula. Porto. 1, pp. 49-56.

ALONSO, Natàlia (2005) - Agriculture and food from the Roman to the Islamic Period in the North-East of the Iberian peninsula: archaeobotanical studies in the city of Lleida (Catalonia, Spain). Vegetation History and Archaeobotany. 14:4, pp. 341-361.

AREZES, Andreia; VARELA, José (2017) - Castro de Guifões (Matosinhos) - das primeiras notícias aos resultados preliminares de um Projecto de Investigação. In ARNAUD, J. Morais; MARTINS, Andrea, eds. - Arqueologia em Portugal. 2017 - O Estado da questão. Lisboa: Associação dos Arqueólogos Portugueses, pp. 125-136. 
AREZES, Andreia; VARELA, José (2018) - GUIFARQ - Projecto de Investigação Arqueológica de Guifões: Relatório Final, Porto - 14 de Dezembro. Porto: texto policopiado ( $\mathrm{n}^{\circ} \mathrm{de}$ páginas: 111).

AREZES, Andreia (2019) - Castro de Guifões (Matosinhos): evidências de uma ocupação diacrónica. Revista Portuguesa de Arqueologia. Lisboa. 22, pp. 183-191.

CLETO, Joel; VARELA, José Manuel (1999) - O Castro de Guifões (Matosinhos): dos estudos de Martins Sarmento às investigações da actualidade. Revista de Guimarães. Guimarães. Volume Especial 2, pp. 467-479.

FERNÁNDEZ FERNÁNDEZ, Adolfo; MORAIS, Rui (2012) - Terra Sigillata Bracarense Tardía (Tsbt). O Grupo II das Cerâmicas de engobe vermelho não vitrificavel (Delgado 1993-94). Cerâmicas de Engobe Vermelho. Grupo II (Delgado y Morais, 2009). In BERNAL CASASOLA, Darío; RIBERA I LACOMBA, Albert, eds. - Cerámicas hispanorromanas II: producciones regionales. Cádiz: Universidad de Cádiz, pp. 131-174.

HILLMAN, Gordon; MASON, Sarah; DE MOULINS, Dominique; NESBITT, Mark (1996) - Identification of archaeological remains of wheat: the 1992 London workshop. Circaea. 12:2, pp. 195-210.

JACOMET, Stephanie (2006) - Identification of cereal remains from archaeological sites: Archaeobotany Lab. Basel: IPAS, Basel University.

LEITE, Margarida Leite; TERESO, João Pedro; SANCHES, Maria de Jesus (2018) - Cultivos da Idade do Ferro no Crasto de Palheiros: novos dados carpológicos da Plataforma Inferior Leste. Cadernos do GEEvH. 7:2, pp. 40-68.

LÓPEZ-DORIGA, Inés (2018) - The Archaeobotany and Ethnobotany of Portuguese or White Crowberry (Corema album (L.) D. Don). Ethnobiology Letters. 9:2, pp. 19-32.

NEEF, Reinder; CAPPERS, René; BEKKER, Renée (2012) Digital Atlas of Economic Plants in Archaeology. Groningen Archaeological Studies Volume 17. Groningen: Barkhuis \& Groningen University Library.

RUAS, Marie-Pierre; PRADAT, Bénédicte (2001) - Les semences découvertes: plantes attestées et origine des déchets. In Les habitats carolingiens de Montours et La Chapelle Saint-Aubert (Ille-et-Vilaine). Paris: Maison des Sciences de l'Homme (Documents d'archéologiefrançaise; 89), pp. 65-79 $+219-221$.

SANTOS, J. Neves dos (1963) - Serpentes geminadas em suástica e figurações serpentiformes do Castro de Guifões. Lucerna. Porto. 3, pp. 136-156.

SANTOS, J. Neves dos (1995/1996) - Sobre uma sítula do Castro de Guifões. Matesinus. Matosinhos. 1/2, pp. 20-22.

SEABRA, Luís; TERESO, João Pedro; BETTENCOURT, Ana M.S.; DINIS, António (2018) - Crop diversity and storage structures in the settlement of Crastoeiro (Northwest
Iberia): new approaches. Trabajos de Prehistoria. 75:2, pp. 361-378.

TEIRA-BRIÓN, Andrés (2019) - Cambio e resiliencia na agricultura e xestión de recursos vexetais no NW da Península Ibérica (10oo a.n.e.-40o d.n.e.). Santiago de Compostela: Tese de doutoramento apresentada à Faculdade de Xeografía e Historia da Universidade de Santiago de Compostela.

TERESO, João Pedro (2012) - Environmental Change, Agricultural Development and social trends in NW Iberia from the Late Prehistory To The Late Antiquity. Porto: Tese de doutoramento apresentada à Faculdade de Ciências da Universidade do Porto.

VARELA, José Manuel (2011) - Monte Castêlo (Guifões, Matosinhos). In O Rio da Memória: Arqueologia no Território do Leça, Matosinhos. Matosinhos: Câmara Municipal de Matosinhos, pp. 108-110 e 142-145.

VARELA, José Manuel (2013) - O Sítio do Monte Castêlo (Guifões, Matosinhos), o Rio Leça e as Navegações na Antiguidade. al-Madan. Almada. Série II. 18, pp.75-81.

VAZ, Filipe Costa; BRAGA, Cristina; TERESO, João Pedro; OLIVEIRA, Cláudia; GONZALEZ CARRETERO, Lara; DETRY, Cleia; MARCOS, Bruno; FONTES, Luís; MARTINS, Manuela (aceite) - Food for the dead, fuel for the pyre: symbolism and function of plant remains in provincial Roman cremation rituals in the necropolis of Bracara Augusta (NW Iberia). Quaternary Internacional.

VAZ, Filipe Costa; MARTÍN-SEIJO, María; CARNEIRO, Sérgio; TERESO, João Pedro (2016) - Waterlogged plant remains from the Roman healing spa of Aquae Flaviae (Chaves, Portugal): Utilitarian objects, timber, fruits and seeds. Quaternary International. Part A, pp. 86-103.

VAZ, Filipe Costa; SEABRA, Luís; TERESO, João Pedro; CARVALHO, Teresa Pires de (2017) - Combustível para um forno: dinâmicas de ocupação de um espaço em Monte Mozinho (Penafiel) a partir de novos dados arqueobotânicos. In ARNAUD, J. Morais; MARTINS, Andrea, eds. - Arqueologia em Portugal. 2017 - O Estado da questão. Lisboa: Associação dos Arqueólogos Portugueses, pp. 1331-1345. 


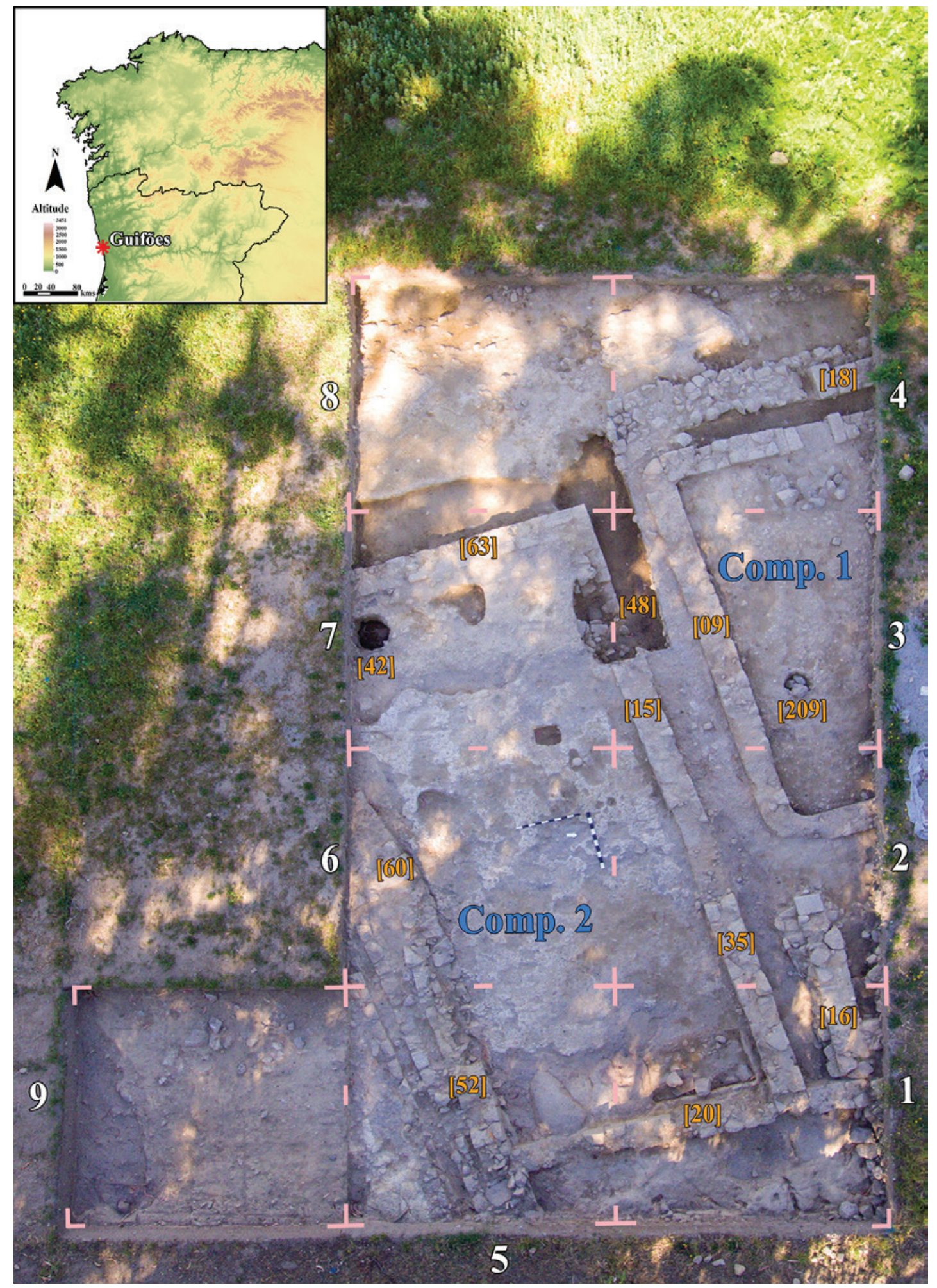

Figura 1 - Guifões no Noroeste Peninsular (parte superior esquerda) e vista aérea das intervenções no "Campo da Ponte” (campanha de 2019). Fotografia da autoria de César Guedes e adaptada de Arezes (2019). 


\begin{tabular}{|c|c|c|c|c|c|c|c|}
\hline Fase & U.E. & Quad. & $\begin{array}{c}\text { № } \\
\text { Amostras }\end{array}$ & Processamento & Volume & Contexto & Contexto Amostrado \\
\hline \multirow{5}{*}{$\begin{array}{l}\text { Idade } \\
\text { do Ferro }\end{array}$} & \multirow{2}{*}{65} & \multirow{2}{*}{1} & 1 & Flutuação & 14 & \multirow{2}{*}{$\begin{array}{l}\text { Junto a alinhamentos pétreos } \\
\text { [20] e [35] }\end{array}$} & \multirow{2}{*}{ Depósito disperso } \\
\hline & & & 5 & Manual & $\mathrm{N} / \mathrm{A}$ & & \\
\hline & \multirow{2}{*}{159} & \multirow{2}{*}{$5 / 6$} & 1 & Flutuação & 2 & \multirow{2}{*}{$\begin{array}{c}\text { Entre o alinhamento pétreo } \\
\text { [20] e o corte este }\end{array}$} & \multirow{2}{*}{ Depósito disperso } \\
\hline & & & 1 & Manual & $\mathrm{N} / \mathrm{A}$ & & \\
\hline & 163 & 5 & 1 & Manual & $\mathrm{N} / \mathrm{A}$ & $\begin{array}{l}\text { Delimitado por alinhamentos } \\
\text { pétreos [20] e [52] }\end{array}$ & Depósito disperso \\
\hline \multirow{8}{*}{$\begin{array}{l}\text { Período } \\
\text { Augustano }\end{array}$} & \multirow[b]{2}{*}{93} & \multirow[b]{2}{*}{$7 / 8$} & 2 & Flutuação & 16 & \multirow[b]{2}{*}{ Compartimento 2} & \multirow{2}{*}{$\begin{array}{c}\text { Enchimento da vala de } \\
\text { fundação do alinhamento } \\
\text { pétreo [63] }\end{array}$} \\
\hline & & & 7 & Manual & $\mathrm{N} / \mathrm{A}$ & & \\
\hline & \multirow[b]{2}{*}{43} & \multirow{2}{*}{$6 / 7$} & 2 & Flutuação & 26 & \multirow{2}{*}{$\begin{array}{l}\text { Compartimento 2. Junto a } \\
\text { alinhamento pétreo [6o] }\end{array}$} & \multirow{2}{*}{ Piso/Pavimento } \\
\hline & & & 4 & Manual & $\mathrm{N} / \mathrm{A}$ & & \\
\hline & 26 & $1 / 2$ & 4 & Flutuação & 18 & $\begin{array}{l}\text { Entre alinhamentos pétreos } \\
\text { [16] e [35] }\end{array}$ & Piso/Pavimento \\
\hline & 38 & 5 & 4 & Flutuação & 13 & $\begin{array}{c}\text { Junto a alinhamento pétreo } \\
{[52]}\end{array}$ & Depósito disperso \\
\hline & \multirow{2}{*}{47} & \multirow{2}{*}{$3 / 7$} & 2 & Flutuação & 11 & \multirow{2}{*}{$\begin{array}{l}\text { Interrupção alinhamento } \\
\text { pétreo [15] }\end{array}$} & \multirow{2}{*}{$\begin{array}{c}\text { Enchimento de } \\
\text { Interface/Vala [48] }\end{array}$} \\
\hline & & & 2 & Manual & $\mathrm{N} / \mathrm{A}$ & & \\
\hline $\begin{array}{l}\text { Final Id. } \\
\text { Ferro / Período } \\
\text { Romano } \\
\end{array}$ & 46 & 7 & 3 & Flutuação & 19,1 & Compartimento 2 & Enchimento da Fossa [42] \\
\hline \multirow{11}{*}{$\begin{array}{l}\text { Idade do } \\
\text { Ferro / Período } \\
\text { Romano }\end{array}$} & \multirow{2}{*}{56} & & 2 & Flutuação & 16,5 & $\begin{array}{l}\text { Compartimento 2. Delimitado } \\
\text { por alinhamentos pétreos }[20]\end{array}$ & Piso/Pavimento \\
\hline & & $1 / 2 / 5 / 6$ & 3 & Manual & $\mathrm{N} / \mathrm{A}$ & $\begin{array}{c}\text { por allnnamentos petreos [20] } \\
\text { e [35] }\end{array}$ & \\
\hline & 57 & 6 & 1 & Flutuação & 8 & Compartimento 2 & Depósito disperso \\
\hline & 57 & 0 & 1 & Manual & $\mathrm{N} / \mathrm{A}$ & & \\
\hline & 157 & $2 / 3$ & 1 & Flutuação & 11 & Entre alinhamento pétreo [og] & Depósito disperso \\
\hline & & & 2 & Manual & $\mathrm{N} / \mathrm{A}$ & e alinhamento pétreo [15] & \\
\hline & 188 & $3 / 4$ & 1 & Flutuação & 3 & $\begin{array}{c}\text { Retificação do } \\
\text { desmoronamento da vala [48] }\end{array}$ & Depósito disperso \\
\hline & 198 & $3 / 4$ & 2 & Flutuação & 16 & $\begin{array}{c}\text { Retificação do } \\
\text { desmoronamento da vala [48] }\end{array}$ & Depósito disperso \\
\hline & 36 & 1 & 3 & Flutuação & 12,1 & $\begin{array}{l}\text { Junto a corte este. Paralelo a } \\
\text { alinhamento pétreo [20] }\end{array}$ & Piso/Pavimento \\
\hline & & & 1 & Flutuação & 7 & Junto a corte norte e & Doń́citodianoro \\
\hline & 143 & 4 & 3 & Manual & $\mathrm{N} / \mathrm{A}$ & alinhamento pétreo [18] & Deposito disperso \\
\hline & 23 & 3 & 2 & Flutuação & 12 & Compartimento 1 & Lareira [32] \\
\hline & 11 & $2 / 4$ & 6 & Flutuação & 46,1 & Compartimento 1 & Denósito disnerso \\
\hline & 11 & $3 / 4$ & 6 & Manual & $\mathrm{N} / \mathrm{A}$ & Compartimento 1 & Deposito aisperso \\
\hline & 25 & $2 / 3$ & 4 & Flutuação & 46 & & \\
\hline & & & 3 & Manual & $\mathrm{N} / \mathrm{A}$ & Compartimento 1 & Deposito disperso \\
\hline & 184 & $1 / 3$ & 1 & Flutuação & 7 & Compartimento 1 & Depósito disperso \\
\hline Antiguidade & 41 & 7 & 4 & Flutuação & 6,2 & Compartimento 2 & $\begin{array}{c}\text { Enchimento da Fossa } \\
{[42]}\end{array}$ \\
\hline Tardia & 185 & 1 & 2 & Flutuação & 18 & $\begin{array}{l}\text { Compartimento 2. Delimitado } \\
\text { por alinhamentos pétreos [20] } \\
\text { e [35] }\end{array}$ & Depósito circunscrito \\
\hline & & ז/7 & 1 & Flutuação & 0,1 & Junto ao alinhamento pétreo & Denósito disnerce \\
\hline & 17 & $1 / 5$ & 2 & Manual & $\mathrm{N} / \mathrm{A}$ & {$[16]$} & Deposito disperso \\
\hline & 21 & 1 & 3 & Flutuação & 16,1 & $\begin{array}{c}\text { Junto ao alinhamento pétreo } \\
{[20]}\end{array}$ & Depósito disperso \\
\hline & 49 & 5 & 1 & Flutuação & 5 & $\begin{array}{l}\text { Entre alinhamento pétreo [20] } \\
\text { e corte este }\end{array}$ & \begin{tabular}{|c} 
Enchimento de Interface \\
{$[53]$}
\end{tabular} \\
\hline & 202 & 3 & 1 & Flutuação & 2 & Compartimento 1 & Lareira [209] \\
\hline $\begin{array}{l}\text { Romano / Ant. } \\
\text { Tardia }\end{array}$ & 51 & 8 & 1 & Flutuação & 6 & $\begin{array}{l}\text { Pequeno nível carbonizado } \\
\text { na parte central/centro-sul da } \\
\text { quadrícula } 8\end{array}$ & Depósito circunscrito \\
\hline $\begin{array}{l}\text { Id. Ferro / } \\
\text { Período }\end{array}$ & & & 4 & Flutuação & 26,5 & Compartimento 2. Junto a & \\
\hline $\begin{array}{c}\text { Romano / Ant. } \\
\text { Tardia }\end{array}$ & 176 & $1 / 2 / 5 / 6 / 7$ & 11 & Manual & $\mathrm{N} / \mathrm{A}$ & $\begin{array}{l}\text { alinhamentos pétreos }[52] \mathrm{e} \\
{[6 \mathrm{o}]}\end{array}$ & Depósito disperso \\
\hline
\end{tabular}

Tabela 1 - Inventário: Proveniência das amostras e contextualização das U.E. em análise. 


\begin{tabular}{|c|c|c|c|c|c|}
\hline \multirow{2}{*}{ № Amostra } & \multirow{2}{*}{$\begin{array}{c}\text { Malha } \\
\text { U.E. }\end{array}$} & \multicolumn{2}{|c|}{$1 \mathrm{~mm}$} & \multicolumn{2}{|c|}{$0,5 \mathrm{~mm}$} \\
\hline & & Peso inicial (g) & Triado (g) & Peso inicial (g) & Triado (g) \\
\hline 1 & 11 & 22,04 & 5,49 & 18,34 & 2,5 \\
\hline 2 & 11 & 7,86 & 7,86 & 13,36 & 1,64 \\
\hline 3 & 11 & 5,76 & 5,76 & 9,88 & 2,75 \\
\hline 4 & 21 & 10,96 & 4,81 & 10,37 & 2,46 \\
\hline 5 & 23 & 55,13 & 6,29 & 66,57 & 2,17 \\
\hline 6 & 23 & 20,98 & 5,18 & 24,32 & 1,79 \\
\hline 7 & 11 & 26,51 & 6,27 & 30,5 & 1,77 \\
\hline 8 & 21 & 14,62 & 7,89 & 12,44 & 1,63 \\
\hline 9 & 11 & 11,56 & 6,34 & 14,9 & 1,69 \\
\hline 37 & 49 & 57,98 & 9,71 & 47,65 & 2,43 \\
\hline 39 & 36 & 22,22 & 5,32 & 23,18 & 2,81 \\
\hline 49 & 65 & 35,96 & 6,77 & 50,62 & 3,18 \\
\hline 50 & 25 & 41,06 & 4,74 & 67,41 & 1,76 \\
\hline 51 & 185 & 11,28 & 4,81 & 32,58 & 3,78 \\
\hline 52 & 25 & 25,04 & 6,11 & 37,06 & 2,38 \\
\hline 53 & 57 & 14,03 & 7,15 & 23,45 & 2,82 \\
\hline 55 & 25 & 49,31 & 5,51 & 59,87 & 1,75 \\
\hline 59 & 43 & 5,09 & 5,09 & 15,68 & 1,97 \\
\hline 60 & 93 & 3,75 & 3,75 & 4,69 & 2,18 \\
\hline 61 & 157 & 8,02 & 8,02 & 17,07 & 2,06 \\
\hline 62 & 93 & 24,78 & 5,59 & 28,23 & 3,21 \\
\hline 63 & 185 & 13,09 & 5,56 & 25,55 & 3,3 \\
\hline 65 & 188 & 32,2 & 3,73 & 36,6 & 2,29 \\
\hline 66 & 176 & 6,98 & 6,98 & 9,41 & 2,25 \\
\hline 69 & 25 & 45,04 & 5,23 & 74,2 & 2,19 \\
\hline 70 & 56 & 7,34 & 7,34 & 15,53 & 2,08 \\
\hline 71 & 198 & 17,38 & 4,18 & 17,11 & 2,21 \\
\hline 72 & 198 & 20,51 & 5,06 & 20,07 & 2,18 \\
\hline 73 & 149 & 42,21 & 5,03 & 60,31 & 1,57 \\
\hline 74 & 143 & 7,09 & 7,09 & 16,24 & 2,1 \\
\hline 191 & 202 & 1,75 & 1,75 & 2,99 & 1,53 \\
\hline
\end{tabular}

Tabela 2 - Subamostragens realizadas. 


\begin{tabular}{|c|c|c|c|c|c|c|c|c|c|c|c|c|c|c|c|c|}
\hline \multirow{2}{*}{$\begin{array}{l}\text { Fase } \\
\text { U.E. } \\
\end{array}$} & \multicolumn{3}{|c|}{$\mathrm{F}$} & \multicolumn{5}{|c|}{ AUG } & \multicolumn{8}{|c|}{$\mathrm{F} / \mathrm{R}$} \\
\hline & 65 & 159 & 163 & 93 & 43 & 26 & 38 & 47 & 46 & 56 & 57 & 157 & 188 & 198 & 36 & 143 \\
\hline Volume (Litros) & 14 & 2 & $\mathrm{O}$ & 16 & 26 & 18 & 13 & 11 & 19,1 & 16,5 & 8 & 11 & 3 & 16 & 12,1 & 7 \\
\hline \multicolumn{17}{|l|}{ Cereais (grãos) } \\
\hline Hordeum vulgare & & & & & 1 & & & & & 1 & & & & & & \\
\hline Panicum miliaceum & 6 & & & 5 & 2 & 10 & 7 & & 17 & 1 & 1 & 2 & & 5 & 3 & 2 \\
\hline Setariaitalica & 1 & & & 1 & 3 & & & 1 & 3 & & & & & & & \\
\hline Panicum/Setaria & & & & 1 & 1 & 2 & & & 6 & & & & 1 & 1 & 4 & 1 \\
\hline \multicolumn{17}{|l|}{ Secale cereale } \\
\hline Triticum aestivum/durum & & & & 4 & & 4 & & & 12 & & & & & 4 & 5 & \\
\hline Triticum sp. & 1 & & & 1 & & & & & & & & & & 2 & & 1 \\
\hline Triticeae & 1 & & & & 1 & & 1 & & 4 & & & & & 2 & & \\
\hline \multicolumn{17}{|l|}{ Cereais (inflorescências) } \\
\hline Hordeum vulgare (base lema) & & & & & & & 1 & & 1 & & & & & & & \\
\hline Secale cereale (segmento de ráquis c/ 1 nó) & & & & & & 1 & & & & & & & & & & \\
\hline Secale cereale (ráquis frag.) & & & & & & & & & 1 & & & & & & & \\
\hline Triticum aestivum/durum (nó ráquis) & & 1 & & 4 & & 15 & 2 & & 11 & & & 2 & & 2 & 1 & \\
\hline \multicolumn{17}{|l|}{ Fabaceae } \\
\hline Ornithopus sp. (semente) & & & & & & & & & 1 & & & 1 & & & & \\
\hline Ornithopus sp. (síliqua) & & & & & & 1 & & & & & & & & 2 & & \\
\hline Vicia faba (semente) & & & & & & & & & 1 & & & & & 1 & 1 & \\
\hline Vicia/Lathyrus (semente) & & & 1 & & & 2 & & & & & & 1 & & & & \\
\hline Fabaceae tipo Genista (semente) & & & & & & & & & 1 & & & & & 2 & & \\
\hline Fabaceae (semente) & & & & 2 & 1 & & & & & 2 & & & & 1 & & \\
\hline \multicolumn{17}{|l|}{ Outras Poaceae (grãos) } \\
\hline Avena sp. & & 1 & & 1 & 3 & 1 & & 1 & 4 & & & & & 2 & & \\
\hline Festuca/Lolium & & & & & & 1 & & & & & & & & & & \\
\hline Poa sp. & & 1 & & & 1 & & & & & & & & & & & \\
\hline Setaria sp. & & & & & 1 & & & & & & & & & & & \\
\hline Panicoideae & & 2 & & 1 & & 1 & & 1 & & & & & & 1 & 1 & \\
\hline Poaceae & 1 & & & & 1 & 1 & & & 1 & & & 2 & & & & \\
\hline \multicolumn{17}{|l|}{ Poaceae (espigueta c/grão) } \\
\hline Frutos & & & & & & & & & & & & & & & & \\
\hline Castanea sativa (fruto frag.) & & & & & & & & & & & & & & & & \\
\hline Prunus persica (caroço frag.) & & & & & & & & & 1 & & & & & & & \\
\hline Quercus sp. (cotilédone frag.) & & & & & & & & & & & & & & & & \\
\hline Rubus sp. (aquénio) & & & & & 1 & & & & 1 & & & & & & & \\
\hline Outros & & & & & & & & & & & & & & & & \\
\hline Anagallis arvensis (semente) & & & & & & & & & & & & & 1 & & & \\
\hline Asteraceae tipo Chrysanthemum (aquénio) & & & & 1 & & 2 & 1 & 1 & & & & & & & & \\
\hline Asteraceae (aquénio) & & & & 1 & & & & & 3 & & & & & & & \\
\hline Caryophyllaceae (semente) & & & & & & 1 & 2 & & 2 & & & & & & & \\
\hline Corema album (semente) & 8 & 1 & & 2 & & 2 & & 1 & 3 & & & & & 1 & & 1 \\
\hline Galium sp. (mericarpo frag.) & 1 & & & & & & & & & & & & & & & \\
\hline Malva sp. (semente) & & & & & & & & & & & & & & & & \\
\hline Plantago sp. (semente) & & & & & 1 & & & & & & & & & & & \\
\hline Polygonum lapathifolium (aquénio) & & & & & & 1 & & & & & & & & & & \\
\hline Polygonum sp. (aquénio) & & & & & & & & & & & 1 & & & & & \\
\hline Polygonaceae (aquénio) & & & & & & & & & & & & & & & & \\
\hline Portulaca oleracea (semente) & & & & & & & & & 1 & & & & & & & \\
\hline Raphanus raphanistrum (síliqua) & & & & & & 1 & & & 1 & & & & & & & \\
\hline Rumex bucephalophorus (aquénio) & & & & & & & & & & & & & & & & \\
\hline Rumex sp. (aquénio) & & & & & & & & & & & & & & & & \\
\hline Sambucus sp. (caroço) & & & & & & & & & 1 & & & & & & & \\
\hline Solanaceae (semente) & & & & & & & & & 1 & & & & & & & \\
\hline Spergula arvensis (semente) & & & & & & & & & & & & & & & & \\
\hline Urtica sp. (aquénio) & & & & & & & & & & & & & & & & \\
\hline Verbena officinalis (mericarpo) & & & & & 1 & & & & & & & & & & & \\
\hline Viola sp. (semente) & & & & & & & & & & & & & & & & \\
\hline Indeterminado unidade & 2 & & & 1 & 1 & 1 & 1 & & 1 & & & & & & 2 & \\
\hline Total & 21 & 6 & $\mathbf{I}$ & 25 & 19 & 47 & 15 & 5 & 78 & 4 & 2 & 8 & 2 & 26 & 17 & 5 \\
\hline
\end{tabular}

Tabela 3 - Resultado do estudo carpológico. Legenda: F - Ferro; AUG - Período de Augusto; R - Período Romano; AT Antiguidade Tardia. 


\begin{tabular}{|c|c|c|c|c|c|c|c|c|c|c|c|c|}
\hline \multirow{2}{*}{$\begin{array}{c}\text { Fase } \\
\text { U.E. } \\
\end{array}$} & \multicolumn{9}{|c|}{ AT } & \multicolumn{2}{|c|}{$\mathrm{R} / \mathrm{AT}$} & \multirow{2}{*}{$\frac{\mathrm{F} / \mathrm{R} / \mathrm{AT}}{176}$} \\
\hline & 23 & 11 & 25 & 184 & 41 & 185 & 17 & 21 & 49 & 202 & 51 & \\
\hline Volume (Litros) & 12 & 46,1 & 46 & 7 & 6,2 & 18 & 0,1 & 16,1 & 5 & 2 & 6 & 26,5 \\
\hline \multicolumn{13}{|l|}{ Cereais (grãos) } \\
\hline Hordeum vulgare & 1 & 1 & 1 & & & & & 1 & & & & 1 \\
\hline Panicum miliaceum & 30 & 36 & 11 & & 1 & 2 & & 5 & 1 & & & 12 \\
\hline Setaria italica & 3 & & 3 & & 2 & & & & & 1 & & 1 \\
\hline Panicum/Setaria & 8 & 11 & 3 & & 6 & & & 3 & & 1 & & 3 \\
\hline Secale cereale & 4 & 1 & 14 & & & 3 & & 5 & 1 & & & \\
\hline Triticum aestivum/durum & & 1 & 8 & & & & & 5 & & & & 8 \\
\hline Triticum sp. & & & & & & 1 & & & & & & 1 \\
\hline Triticeae & 1 & 1 & & & & & & 4 & 2 & & & 1 \\
\hline \multicolumn{13}{|l|}{ Cereais (inflorescências) } \\
\hline \multicolumn{13}{|l|}{ Hordeum vulgare (base lema) } \\
\hline Secale cereale (segmento de ráquis c/ 1 nó) & 8 & 1 & 5 & & & & & & & & & \\
\hline Secale cereale (ráquis frag.) & 4 & & & & & & & & & & & \\
\hline Triticum aestivum/durum (nó ráquis) & & & & & 1 & 1 & & 9 & & & & 11 \\
\hline \multicolumn{13}{|l|}{ Fabaceae } \\
\hline Ornithopus sp. (semente) & 1 & & & & & 1 & 1 & & & & & 1 \\
\hline Ornithopus sp. (síliqua) & & & & & 1 & & & & & & & 1 \\
\hline Vicia faba (semente) & & & 2 & & & & & & & & & \\
\hline Vicia/Lathyrus (semente) & 2 & & & & & & & & & & & 1 \\
\hline Fabaceae tipo Genista (semente) & & & & & & & & & & & 1 & \\
\hline Fabaceae (semente) & 5 & & 2 & & & 2 & & 1 & & & & 1 \\
\hline \multicolumn{13}{|l|}{ Outras Poaceae (grãos) } \\
\hline Avena sp. & & & 1 & & & & & 2 & & & & 1 \\
\hline \multicolumn{13}{|l|}{ Festuca/Lolium } \\
\hline Poa sp. & & & 1 & & & & & & & & & \\
\hline Setaria sp. & & & 2 & & & & & & & & & \\
\hline Panicoideae & 1 & 1 & 2 & 1 & & 1 & & 1 & & 2 & & 2 \\
\hline Poaceae & 3 & & 3 & & & & & 1 & & & & 1 \\
\hline Poaceae (espigueta c/grão) & & 1 & & & & & & & & & & \\
\hline \multicolumn{13}{|l|}{ Frutos } \\
\hline Castanea sativa (fruto frag.) & & 11 & & & & & & & & & & \\
\hline Prunus persica (caroço frag.) & & & 1 & & & & & & & & & \\
\hline Quercus sp. (cotilédone frag.) & & & 1 & & & & & & & & & \\
\hline \multicolumn{13}{|l|}{ Rubus sp. (aquénio) } \\
\hline Outros & & & & & & & & & & & & \\
\hline Anagallis arvensis (semente) & & & & & & & & & & & & \\
\hline Asteraceae tipo Chrysanthemum (aquénio) & 1 & & & & & & & 1 & & & & 1 \\
\hline Asteraceae (aquénio) & & & & & & & & & & & & 3 \\
\hline Caryophyllaceae (semente) & & & & & & & & & & & & \\
\hline Corema album (semente) & & 1 & & & & & 1 & 6 & & & & 1 \\
\hline Galium sp. (mericarpo frag.) & & & & & & & & & & & & \\
\hline Malva sp. (semente) & & & & & 1 & & & & & & & 1 \\
\hline Plantago sp. (semente) & & & & & & & & & & & & \\
\hline Polygonum lapathifolium (aquénio) & & & & & & & & & & 1 & & \\
\hline Polygonum sp. (aquénio) & & & & & & & & & & & & \\
\hline Polygonaceae (aquénio) & & & & & & & & 1 & & & & \\
\hline Portulaca oleracea (semente) & & & & & & & & & & & & \\
\hline Raphanus raphanistrum (síliqua) & & 1 & & & & & & & & & & \\
\hline Rumex bucephalophorus (aquénio) & & & & & & & & 1 & & & & \\
\hline Rumexsp. (aquénio) & & 1 & & & & & & & & & & 1 \\
\hline Sambucus sp. (caroço) & & & & & & & & & & & & \\
\hline Solanaceae (semente) & & & & & & & & & & & & \\
\hline Spergula arvensis (semente) & 1 & & & & & & & & & & & \\
\hline Urtica sp. (aquénio) & & 1 & & & & & & & & & & \\
\hline Verbena officinalis (mericarpo) & & & & & & & & & & & & \\
\hline Viola sp. (semente) & & & & & & & & 1 & & & & \\
\hline Indeterminado unidade & & & 1 & 1 & & & & 4 & & & & \\
\hline Total & 73 & 69 & 61 & 2 & 12 & 11 & 2 & 51 & 4 & 5 & 1 & 53 \\
\hline
\end{tabular}

Tabela 3 (continuação) - Resultado do estudo carpológico. Legenda: F - Ferro; AUG - Período de Augusto; R - Período Romano; AT - Antiguidade Tardia. 


\title{
UM HORREUM AUGUSTANO NA FOZ DO DOURO (MONTE DO CASTELO DE GAIA, VILA NOVA DE GAIA)
}

Rui Ramos ${ }^{1}$

\begin{abstract}
RESUMO
A escavação arqueológica realizada entre Fevereiro de 2016 e Novembro de 2018 pela Era Arqueologia S.A. na vertente Nordeste do Monte do Castelo de Gaia, pôs em evidência uma lata sequência ocupacional cuja génese remonta ao século IV a.C. e que se prolongou - entre hiatos mais ou menos prolongados - até ao século XX. Das ocupações mais relevantes dentro desta ampla diacronia (idade do ferro, romana e medieval), optamos ora por nos debruçar sobre a que nos parece mais significativa, porquanto inédita neste âmbito geográfico: um grande edifício de planta rectangular com aproximadamente 300 metros quadrados, datado de entre 30 a 15 a.C. que interpretamos como um Horreum, que poderá ter sido construído no âmbito das campanhas relacionadas com a pacificação da Hispânia Setentrional empreendidas por Augusto.

Palavras-chave: Douro, Castelo de Gaia, Horreum, Romano, Augusto.
\end{abstract}

\begin{abstract}
The archaeological excavation carried out between February 2016 and November 2018 by Era Arqueologia S.A. in the Northeast side of Monte do Castelo de Gaia, highlighted a wide occupational sequence whose genesis dates back to the $4^{\text {th }}$ century $\mathrm{BC}$. and that it extended until the $2 \mathrm{O}^{\text {th }}$ century. Of the most relevant occupations within this wide diachrony (iron age, roman and medieval), we have now chosen to focus on the one that seems most significant to us, since it is unprecedented in this geographical scope: a large rectangular building with approximately 300 square meters, dated from 30 to 15 BC that we interpret as a Horreum, which may have been built in the context of the campaigns related to the pacification of Northern Hispania undertaken by Augustus.
\end{abstract}

Keywords: Douro, Castelo de Gaia hill, Horreum, Roman, Augustus.

\section{CONTEXTUALIZAÇÃO}

O Monte do Castelo de Gaia localiza-se na margem esquerda do Douro, a cerca de 4 quilómetros da sua foz e constitui um marco proeminente na paisagem ribeirinha do curso final do rio. (Figura 1 e Figura 2). Esta colina domina a montante um fundeadouro natural, junto ao qual foram construídos a maior parte dos - hoje célebres - armazéns de Vila Nova de Gaia e constituiria um importante ponto de passagem entre as duas margens até à construção das primeiras travessias fixas desta parte do rio.

Desde a hipotética localização neste local do Portus ou da Cale do Itinerário de Antonino até à existência da fortificação medieva que perdurou na memória e na toponímia da cidade, o Monte do Castelo tem cativado o interesse de cronistas e historiadores ao longos dos séculos e ainda que a arqueologia tenha tardado a entrar em cena, as diversas intervenções realizadas em vários pontos deste monte desde os anos 80 do século XX, (Silva,2020) ainda que não tenham conseguido resgatar ao oblívio o nome antigo do lugar, vieram confirmar um sítio arqueológico de excepcional valor e um importante manancial de informação para o estudo das rotas comerciais costeiras que ligavam o Sul e o Norte da Península desde a antiguidade.

A escavação arqueológica, realizada no âmbito do

1. Era Arqueologia, S.A.; ruiramos@omniknos.pt 
plano de minimizações prévias a um projecto de construção, localiza-se na vertente Nordeste do monte, fronteira a Miragaia na margem oposta e a escassos metros do rio. A área intervencionada ocupa um socalco de planta rectangular à cota de 21 metros no logradouro de um antigo armazém, onde entre 1998 e 2006 funcionou o Hard Club.

Os níveis ocupacionais postos em evidência, intercalados por depósitos coluvionares mais ou menos espessos, abrangem uma longa diacronia balizada entre os séculos IV a.C. e o século XX, (Ramos; Carvalho, 2020) com particular destaque para um habitat da II idade do ferro composto por casas e cabanas de planta circular e um grande edifício de planta rectangular, do tipo horreum, construído em finais do século I a.c. e que sendo o mote da nossa comunicação, passaremos a descrever nos parágrafos seguintes.

As condicionantes impostas pela necessidade de garantir a estabilidade do socalco, cujo muro de contenção ruiu parcialmente em Abril de 2016 e obrigou à interrupção dos trabalhos durante alguns meses, levou a que parte do edifício não fosse intervencionado nesta fase dos trabalhos, nomeadamente a área localizada a Este, junto a um segmento do muro de contenção que apresenta problemas de estabilidade e a área Sul, na confluência com um caminho público.

Uma vez que que a planta do edifício extravasa os limites da área intervencionada, as medidas aqui apresentadas são uma tentativa de padronização das medidas observáveis nos muros postos em evidência no decurso da escavação, com vista a uma aproximação à reconstituição da sua planta original. Assim, foi intervencionada uma área de aproximadamente 140 metros quadrados correspondentes ao espaço interior e muro perimetral do edifício embora as evidências apontem para que o edifício terá pelo menos o dobro desta área.

\section{DESCRIÇÃO DO EDIFÍCIO}

A génese da ocupação romana deste espaço corresponde a um grande edifício de planta rectangular, construído e utilizado entre os anos 30 e 15 a.C. ainda que nos depósitos coluvionares sobre os quais foi fundado tenhamos registado a presença de ânforas itálicas produzidas a partir da segunda metade do século II a.C. , o que denuncia a gradual aproximação desta finisterra à órbita romana. (Figura 3)

O edifício é composto por um único volume, com o embasamento construído em alvenaria de pedra, sem evidências que possam indiciar mais de uma fase construtiva ou remodelações posteriores à sua génese. Durante o período em que o edifício se encontrava funcional ou pouco depois do seu abandono, a fachada Este - virada ao rio - foi obliterada por uma derrocada, pelo que não identificamos qualquer indício da mesma.

O eixo maior do edifício, com orientação Norte-Sul, apresenta um comprimento de pelo menos 33,20 metros. Apesar de não termos identificado indícios da fachada Este, pressupomos que teria a mesma espessura da fachada Oeste - cerca de 80 centímetros - e tendo em consideração que um dos muros internos perpendiculares ao eixo maior apresenta 7,60 metros de comprimento, o edifício teria pelo menos 9,20 metros de largura. Assim, a 33,20 metros de comprimento e 9,20 metros de largura, corresponde uma área de implantação de 305,44 metros quadrados. (Figura 4)

$O$ edifício encontrava-se dividido em 6 cellae às quais atribuímos a designação de Ambiente 1, Ambiente 2, Ambiente 3, Ambiente 4, Ambiente $5 \mathrm{e}$ ambiente 6 . Em todas as cellae existiam 3 muretes longitudinais, 2 adossados aos muros divisórios internos e um murete axial, que teriam como função suportar um tabuado. Estas 6 cellae, de planta rectangular, apresentavam 4,90 metros de largura. A ruína da fachada Este não nos permite aferir o comprimento original dos mesmos, mas o maior segmento conservado de um dos muretes internos, identificado no Ambiente 2, tinha 7,6o metros de comprimento, o que nos permite extrapolar que todos os compartimentos teriam no mínimo esta dimensão. Considerando estas medidas, cada compartimento teria pelo menos uma área de 37,24 metros quadrados, o que corresponde a uma área útil total de 223,44 metros quadrados. (Figura 5)

Em relação à altura do edifício, não nos foi possível identificar qualquer elemento que nos fornecesse informação, já que os muros conservados não excediam os 170 centímetros de altura, sendo que destes, 70 a 80 centímetros correspondem ao alicerce.

Os alicerces distinguem-se do aparelho dos muros pela inclusão de blocos de granito irregulares de maiores dimensões, sendo que em alguns dos alicerces foi colocada uma camada de argila sobre a última fiada de pedra, com o intuito de a regularizar para assentar a primeira fiada de pedra do aparelho do muro. Os muretes longitudinais, talvez por não 
se constituírem como elementos estruturais, não tinham alicerce.

O muro perimetral que constitui a fachada Oeste e a Norte é construído em alvenaria de granito, de dupla face, com 80 centímetros de espessura. O aparelho é composto por blocos poligonais de granito de pequena e média dimensão que formam duas faces regulares e bem aparelhadas e o miolo é composto por blocos toscos de pequena dimensão ligados com argila.

Os 5 muros internos, paralelos ao eixo menor do edifício, delimitavam os 6 compartimentos identificados e eram compostos por alvenaria de granito de dupla face, com 50 centímetros de espessura. Os paramentos destes muros são constituídos por blocos poligonais de pequena e média dimensão bem aparelhados, ligados com argila e argamassa de saibro. O miolo é composto por blocos toscos de granito de pequena e média dimensão e argila. Apenas os muros divisórios entre o Ambiente 3 e o Ambiente $4 \mathrm{e}$ o Ambiente 4 e o Ambiente 5 estão imbricados na fachada Oeste, estando os restantes muros encostados à fachada sem qualquer travamento.

No aparelho de um dos muros internos melhor conservados, entre o Ambiente 2 e o Ambiente 3 identificamos uma fiada horizontal de lajes de granito de pequena e dimensão que parecem indiciar uma transição de aparelho ou de técnica construtiva, mas não identificamos quaisquer indícios preservados do tipo de construção que se desenvolveria acima desta cota.

Os muretes longitudinais identificados apresentam dupla face, com 30 centímetros de espessura e são constituídos por blocos poligonais de granito de pequena dimensão assentes a seco. Estes muretes apresentam entre 30 e 40 centímetros de altura nos Ambientes 6, 1, 2 e 3 e cerca de 60 e 70 centímetros de altura nos Ambientes 4 e 5 .

Não identificamos cerâmica de construção, reutilizada ou não, nos paramentos e no miolo dos muros e dos muretes, sendo que o único material que parece ter sido reutilizada foram fragmentos de mós rotatórias inclusas em alguns dos muros divisórios e muretes e um bloco de uma rocha sedimentar exógena a esta região.

\section{DESCRIÇÃO DA ESTRATIGRAFIA}

Ao contrário de tantos outros sítios de cronologia afins, não identificamos níveis pétreo relacionados com a ruída das paredes ou níveis de telha relacionados com a ruína do tecto, no interior ou no exterior do edifício, A sequência estratigráfica identificada no interior é composta por um depósito areno-argiloso de coloração alaranjada, com 50 a 70 centímetros de espessura provavelmente relacionado com a ruína das paredes, que cobre um depósito arenoso de coloração cinzenta com inclusão de carvões, com 10 a 20 centímetros de espessura e que parece corresponder a um nível de abandono do edifício.

No Ambiente 3 e no Ambiente 4, sob o nível de abandono, identificamos um depósito muito compacto de composição argilosa e coloração laranja com cerca de 5 a 10 centímetros de espessura que se desenvolve em praticamente toda a superfície do compartimento que parece corresponder a um nível coetâneo com a construção ou utilização do edifício, porquanto os muretes longitudinais terem sido construídos por cima dele.

No exterior do edifício, os únicos indícios coevos com a sua construção e utilização são um nível de circulação em saibro, contíguo à fachada Oeste do edifício, um depósito pétreo bastante concentrado que parece resultar do descarte intencional de pedra relacionado com a construção do edifício e uma pequena lareira constituída por fragmentos de ânforas.

\section{INTERPRETAÇÃO}

Os 3 muretes longitudinais identificados em cada uma das 6 cellae escavadas parecem corresponder a apoios para um tabuado que constituiria o nível de circulação do edifício, com paralelos documentados em horrea construídos na Hispânia durante o período Republicano (Domínguez, 2009). Este tipo de estrutura enquadra-se na descrição de Varrão e Columela dos Tabulatum/a, isto é, pavimentos sobre-elevados construídos em madeira que se destinavam a armazenar grão e mantê-lo isolado da humidade e dos roedores. (Domínguez, 2003-2004). O material arqueológico associado aos depósitos coetâneos com a construção e uso do horreum é muito residual, sendo composto maioritariamente por cerâmica de tradição indígena e material anfórico, este de suma importância para o enquadramento temporal do edifício. No interior do Ambiente 4 identificamos vários fragmentos de ânforas da Bética Costeira, 2 fundos de ovóides lusitanas, 2 fragmentos de ânforas Itálicas produzidas no Lácio/ Campânia e 1 fragmento de uma ânfora ovóide gadi- 
tana, produzida entre os primeiros anos do segundo quartel do século I a.C. até ao início do Século I d.C. $\mathrm{Na}$ pequena lareira enquadrável temporalmente na fase de construção ou utilização do grande edifício identificamos fragmentos de ânforas produzidas na Bética Costeira e no Vale do Guadalquivir, onde está presente a forma Haltern 70 , produzida entre 50 a.C. e o reinado de Augusto e uma Dressel i Bética Costeira Ulterior produzida entre 140/130 a.C. e 30 a 25 a.C. e 1 fragmento de produção Lusitana de tipologia indeterminada.

O espólio datável leva-nos a enquadrar a construção e a utilização deste edifício entre 30 e 15 a.C., intervalo de tempo que abrange a última campanha de pacificação da Hispânia, empreendida por Augusto entre 29 e 19 a.C. contra Cântabros e Astures. $\mathrm{O}$ vasto teatro de operações, para onde foram mobilizadas 6 legiões, abrangeu todo o Noroeste Peninsular, sendo que o Douro, na retaguarda dos avanços e afastado das principais bases do exército romano (González, 1998) terá sido pouco mais do que um ponto de passagem nas rotas que se dirigiam ao Norte, através das quais se abasteciam as legiões que lutavam na frente com o grão proveniente do Sul da Hispânia (Echegaray, 1999). Aventamos a possibilidade do horreum que ora apresentamos se possa ter constituído como um dos entrepostos de apoio à circulação de mantimentos até às frentes de combate, construído nas margens de um rio caudaloso e tantas vezes de difícil travessia nos meses de invernagem, mas ainda assim navegável por 140 quilómetros. O único testemunho da presença de militares no Monte do Castelo de Gaia é atestada pela existência de um cipo funerário identificado a 100 metros do sítio, nas Escadas da Boa Passagem, de L. Lavius Tuscus, natural de Olissipo, militar da $\mathrm{X}$ Gemina, uma das legiões que Augusto deslocou para a Hispânia no decurso da campanha Cantábrica (Cérdan, 2017) e que foi datado de entre Augusto a Tibério por Vasco Mantas (Mantas, 2013).

Os dados recolhidos no decurso da escavação levam-nos a considerar que o embasamento pétreo posto em evidência constituiria a base de um edifício parcialmente construído em madeira ou em argila, materiais que permitiam levantar estruturas de maneira rápida e eficiente ao mesmo tempo que garantiam um bom isolamento dos elementos (Domínguez, 2015), obedecendo assim aos critérios de outras construções erguidas durante campanhas militares. Sendo as construções em argila mais comuns em regiões secas, não é despicienda a ocorrência de construções em terra neste sítio já que pelo menos uma das casas do habitat da Idade do Ferro seria construída com tijolos de adobe, o que demonstra que esta técnica não era estranha à comunidade local.

A homogeneidade do material arqueológico identificado nos depósitos relacionados com o edifício, leva-nos a considerar também que este terá sido utilizado durante poucos anos, não sendo possível distinguir a sua construção da sua utilização, o que poderia significar que foi abandonado após o fim da guerra, depois de deixar de ser útil.

\section{BIBLIOGRAFIA}

CÉRDAN, Angél Morrillo (2017) - El periodo de la "Paz Armada” en el norte de Hispania (19/15 a.C.-15/20 d.C.): ¿la creación de un sistema de defensa sin frontera? In Gérion, Vol. 35, pp. 191-223

DOMÍNGUEZ, Javier S. (2003-2004) - La Documentación Literaria Aplicada al Registro Arqueológico: Las Técnicas de Construcción de lo Graneros Romanos Rurales, in Espacio, Tiempo y Forma, Serie I, Prehistoria y Arqueologia, 16-17.

DOMÍNGUEZ, Javier S. (2008) - La investigación sobre los horrea de época romana: Balance historiográfico y perspectivas de futuro in CuPAUAM, 34, pp. 105-124.

DOMÍNGUEZ, Javier S. (2009) - Los Graneros Romanos Militares de Hispania, in Gladius, Anejos 13. Madrid, Ediciones Polifemo, pp. 679-692.

DOMÍNGUEZ, Javier S. (2015) - Los Granero Sobreelevados en la Hispania Romana: Materiales y Técnicas Contructivas, in Arqueología de la Arquitectura, 12. Madrid/Vitória.

ECHEGARAY, Joaquín G. (1999) - Las Guerras Cântabras en las Fuentes in Guerras Cântabras. Santander. Real Academia de La Historia - Fundacíon Marcelino Botín.

GONZÁLEZ, Julio R. (1998) - As Legiões Romanas no Vale do Douro na Época de Augusto e da Dinastia Júlio-Cláudia (31 A.C. -68 D.C.), in Douro, Estudos e Documentos, Volume III (5), pp. 29-48.

MANTAS, Vasco G. (2013) - População e Mobilidade na Cidades Romanas de Portugal, in I Congresso Histórico Internacional. As Cidades na História - População. Vol. 2. Guimarães, pp. 99-125.

RAMOS, Rui, CARVALHO, José (2020) - Contributo para o Conhecimento das Ocupações Antigas no Monte do Castelo (Vila Nova de Gaia), in Apontamentos de Arqueologia e Património, N.14, Era Arqueolgia.

SILVA, António. M. S. P. (2020) - O Castelo de Gaia, Um Sítio Arqueológico Excepcional e um Valor Cultural a Po- 
tenciar in Actas do IV Congresso de História da Santa Casa da Misericórdia do Porto, Porto, pp. 529-547.

SILVA, António. M. S. P. (2018) - Cale Callaeocorum Locus? Notas Arqueológicas Sobre a Ocupação Indígena e Romana

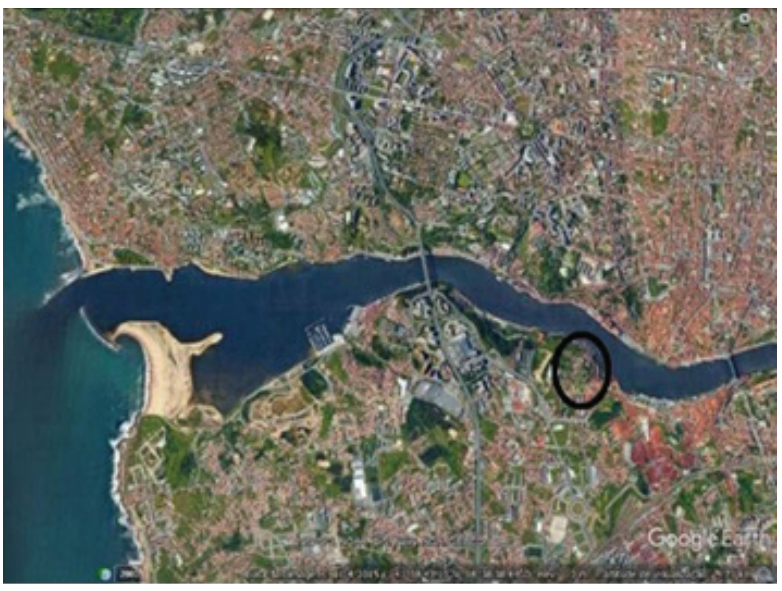

Figura 1

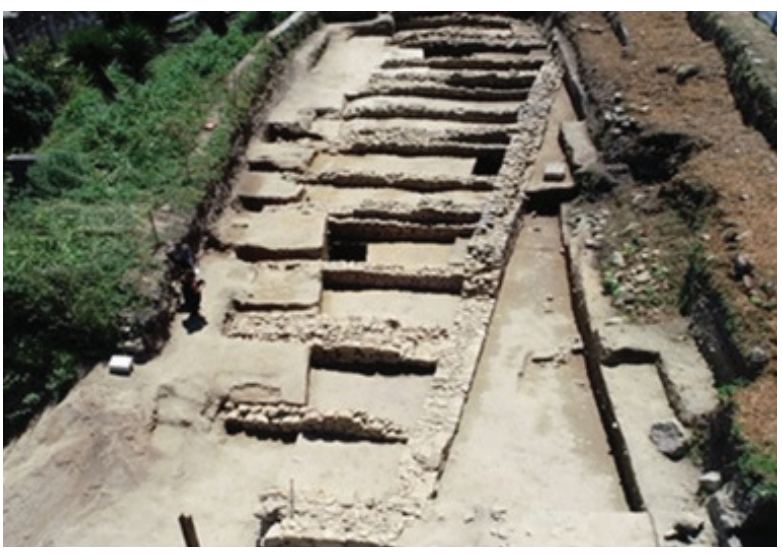

Figura 3

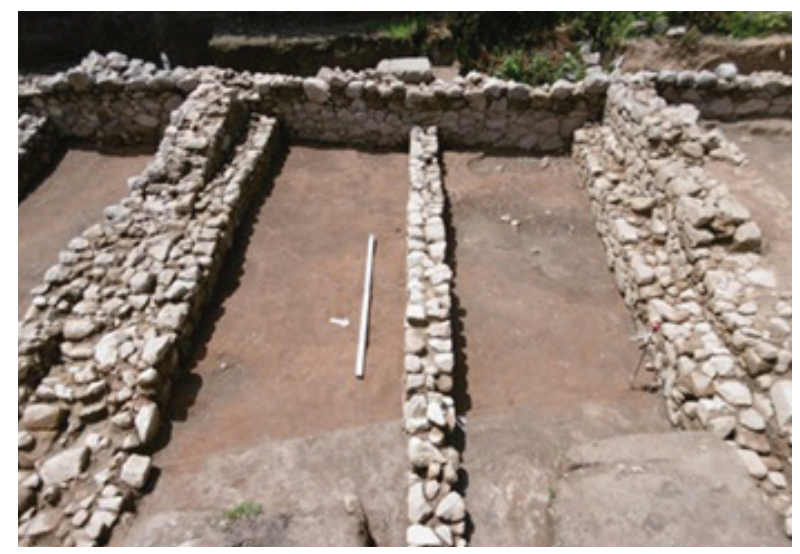

Figura 5 da Foz do Douro, in Actas do Congresso Construir, Navegar, Re(usar) o Douro da Antiguidade, Porto, CICTEM, pp. 45-67.

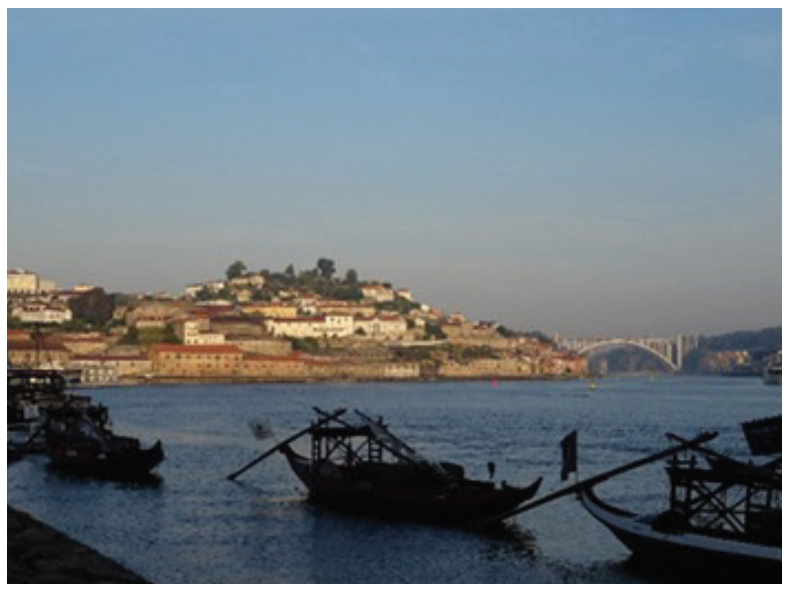

Figura 2

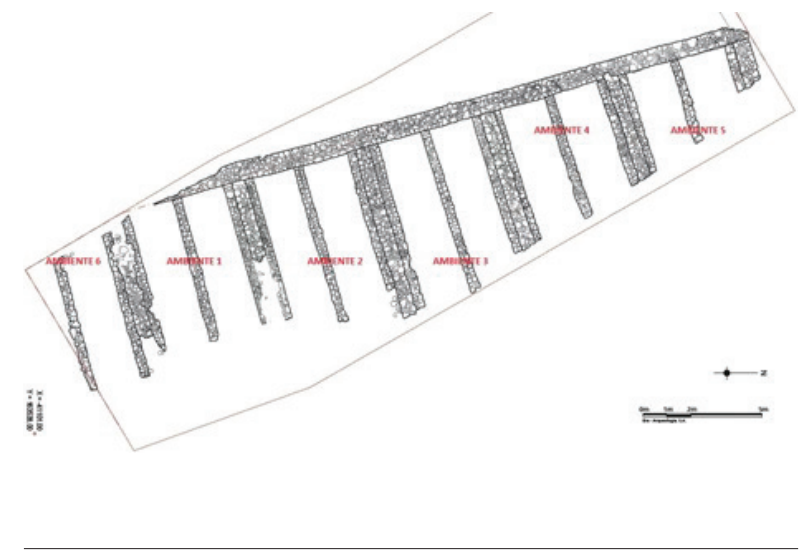

Figura 4 


\title{
PONDERAIS ROMANOS NA LUSITÂNIA: PADRÕES, FORMAS, MATERIAIS E CONTEXTOS DE UTILIZAÇÃO
}

\author{
Diego Barrios Rodríguez
}

\begin{abstract}
RESUMO
Os sistemas de peso e os testemunhos ponderais constituem uma das marcas mais evidentes dos grupos culturais. No entanto, esses tipos de materiais foram pouco valorizados pelos investigadores devido ao seu baixo atração material e formal. A compilação desses objetos encontrados no território da Lusitânia permitiu observar dados de interesse para documentar os sistemas romanos de implantação. As descobertas, tanto em contextos militares como na oppida indígena, são reveladores muito sobre a coexistência e posterior substituição de padrões locais pelos romanos. Precisamente por esse motivo, concentramos nossa atenção no exame dos materiais com os quais essas peças são fabricadas, suas formas, valores e o seu contexto de descoberta.

Palavras-chave: Lusitânia, Metrología, Exército romano, Oppida indígenas, Cidades romanas.
\end{abstract}

\begin{abstract}
The weight systems and their testimonies are one of the most evident signs to identify of cultural groups. However, this type of material has received very little attention among historians and archaeologists due to its low material and formal attractive. The compilation of finds in the Lusitanian area has allowed to observe interesting details about the Roman implantation system. The finds in military settlement and indigenous oppida contexts are very revealing the coexistence and, later, the substitution of local patterns for the Roman. For precisely this reason, we have focused our interest on examining the materials these pieces are made of, their shapes, their values and their finding context.
\end{abstract}

Keywords: Lusitania, Metrology, Roman Army, Local oppida, Roman towns.

\section{INTRODUÇAO ${ }^{2}$}

A criação de um sistema de medição constituiu um processo fundamental na evolução das sociedades pré-industriais. Por tras da invenção de um padrão metrológico encontra-se um processo de desenvolvimento cognitivo do ser humano, que começa com a observação de uma mesma propriedade: tempo, duração etc. e sua comparação a partir de diferentes objetos (Morley \& Renfrew, 2010: pp. 1-4). Através dessas equações, identificaram-se valores específicos que foram concebidos como "unidade" e atribuídos diferentemente em cada comunidade condicionados por umas características comerciais, políticas, geográficas e ambientais específicas de cada local (Kula, 1972: pp. 485-486).

Todo esse processo foi organizado por uma autoridade central capaz de outorgar o valor da lei a medidas socialmente concordadas; por exemplo, a elite de um oppida lusitano ou, mais tarde, o Estado romano. Dessa forma, as medidas converteram-se um símbolo representativo de poder (Kula, 1972: p. 490; Rahmstorf, 2010: p. 101), facilitando com o estabelecimento de padrões metrológicos a distribuição da

\footnotetext{
1. Universidad de Salamanca; diebr@usal.es

2. Este trabalho foi realizado no âmbito do Projeto de Investigaçao de Excelência: Paisaje y territorio militarizado en la Hispania romana: movilidad y transferencia cultural (ss. II a. C.-IV d. C.) Ref.: HAR2017-85929-P, cujos II. PP. são Dres. C. Blázquez Cerrato e A. Morillo Cerdán, financiado pelo Ministerio de Economía, Industria y Competitividad de Espanha, no Programa Estatal de Fomento de la Investigación Científica y Técnica de Excelencia. Apreciamos a revisão da tradução portuguesa do texto que foi realizada por Maria Encarnación Mancebo Rodríguez.
} 
terra, a alocação de valor aos objetos, a cobrança de impostos, etc. (Morley \& Renfrew, 2010: pp. 1-4).

Assim, juntamente com o valor prático, os padrões metrológicos também têm um significado simbólico, algo que se reflete na documentação arqueológica através dos testemunhos metrológicos que participam ou registam os processos de medição e pesagem (Morley \& Renfrew, 2010: pp. 1-4). Essa informação nos fornece dados sobre mentalidade, hierarquia de grupos, estabelecimento de novos contingentes da populaçao, vicissitudes políticas e contatos culturais das comunidades que os utilizam.

Para o proceso de pesagem dos productos para troca foram utilizados instrumentos que variaram de acordo com as circunstâncias e também passagem dos séculos. Assim, por exemplo, entre as balanças usadas na Antiguidade, é preciso diferenciar entre as balanças de dois pratos ou libra e as de braços assimétricos ou statera, geralmente conhecidas como romanas. A diferença mais importante entre as duas é o uso de um ponderais ou contrapeso. Ambas são peças, geralmente de metal, cujo peso é determinado por um valor metrológico. No entanto, no caso de ponderais, seu peso é sempre igual ao de um valor oficialmente reconhecido. O caso de contrapesos ou aequipondia é diferente, pois eles não necessariamente precisam corresponder a um valor de padrão de peso, pois é condicionado pelo comprimento do outro braço, onde está localizado o objeto cujo peso deve ser verificado (Cebrián \& Hortelano, 2017: p. 205).

Com base nessa diferenciação, ambos tipos de balança têm uma forma diferente. Por um lado, as librae possuem uma barra, normalmente cilíndrica, disposta em uma posição horizontal chamada scapus; em seu ponto médio está o iugum que, em posição vertical, forma os braços de dimensões iguais, dos quais nas extremidades ficam pendurados os pratos (Chaves \& Pliego, 2007: p. 240). O funcionamento da statera está fundamentada no fato de que o prolongamento de um dos braços permite que o mesmo efeito seja alcançado usando força menor (Cebrián \& Hortelano, 2017: p. 202).

Em suma, sistemas e testemunhos metrológicos contribuem com muita informação sobre os grupos culturais que criaram e usaram esses padrões de medição. De facto, no caso específico dos pesos, é possível verificar que, por surgirem em contextos sociais específicos, eles determinam suas características físicas que se refletem nas diferentes formas, materiais e até na configuração dos valores: unidades, múltiplos e fracções.

\section{ESTADO ATUAL DAS INVESTIGAÇÕES}

Embora a informação que pode ser extraída dos objetos ponderais seja muito abundante, a historiografia arqueológica peninsular não dedicou um grande número de páginas a essas peças. O material de fabricação ou morfologia que eles geralmente apresentam não os tornou atraentes para os investigadores. Além disso, a grande maioria das publicações concentrou seus estudos no período anterior à conquista romana e, na maioria dos casos, deixou de lado aspectos sociais ou simbólicos em favor de estudos quase exclusivamente metrológicos ou morfológicos.

Para o território que estudamos aqui, os pesos do período pré-romano foram analisados em detalhes por Vilaça (2011), que examinou especialmente materiais datados do final da Idade do Bronze e durante a Idade do Ferro. Esta investigadora observou a existência de dois sistemas de pesagem adquiridos através de contatos com comerciantes do Mediterrâneo oriental. No entanto, para o período romano ainda não se realizaram estudos da mesma entidade, senão que unicamente foram analizados os testemunhos metrológicos do um mesmo local: Conimbriga (Salete, 1979) ou Chões de Alpompé (Fabiâo, Pereira \& Pimenta, 2015). Da mesma forma, não devemos esquecer os achados desse tipo de objetos feitos nas campanhas arqueológicas e publicados em sua revisão destas, como é o caso de um exemplar de Chões de Alpompé (Arruda \& alii, 2018).

No nível peninsular, a situação é idêntica, destacando apenas o estudo conjunto de Chaves e Pliego (2007), que, de maneira muito sintética, tentaram compilar os achados na Península Ibérica.

\section{ANÁLISE DOS PONDERAIS DOCUMENTADOS NA LUSITÂNIA}

Os ponderais são objetos cuja elaboração e uso deriva da existência de alguns fatores sociais que determinam sua forma, tamanho, composição e utilização. Por esse motivo, sua análise no âmbito da Lusitânia (Figura 1) nos permite abordar o processo de adoção do sistema de pesos romanos e as variações dessas peças, morfologicamente, funcionalmente ou cronologicamente. 


\subsection{Contextos}

A procedência dos achados nos permite identificar a funcionalidade de um peso, mas, para isso, é necessário conhecer a origem de cada peça da maneira mais precisa possível. No entanto, para a maioria dos exemplares, não sabemos exatamente onde foram encontrados. Mesmo assim, decidimos fazer uma primeira tentativa da organização e apresentação dos pesos com base em sua proveniência, para nos aproximar do uso desses objetos. No caso da Lusitânia, diferenciamos dois tipos de contextos: estabelecimentos militares e habitats.

Nos estabelecimentos militares incluímos todos os lugares onde o exército romano se estabeleceu durante o processo de conquista e o subsequente processo de pacificação e controle do território: acampamento, casamatas, torres de vigia etc. Desta tipologia, um total de 5 locais foram documentados na Lusitânia: Cáceres el Viejo, Castillo del Puerto, Monte dos Castelinhos, Chões de Alpompé e Castelo da Lousa.

Em primeiro lugar, Cáceres el Viejo é o acampamento localizado ao norte da atual cidade de Cáceres. Este enclave foi identificado como Castra Caecilia e, portanto, datado da guerra sertoriana, mas as investigações posteriois revelaram uma ocupação mais longa entre 95 e 78 a.C. (Ulbert, 1984). Dentro deste grupo, incluímos também os complexois do Monte dos Castelinhos (Vila Franca de Xira, Lisboa) e Chões de Alpompé (Santarém), uma vez que também é atestada a presença de soldados romanos ali nos séculos II-I a.C. (Pimenta, 2013; Fabiâo, Pereira \& Pimenta, 2015). No entanto, o estado atual das investigações em cada enclave não permite identificar se é um acampamento, um fortin ou uma cidade indígena onde está estabelecida essa população de origem romana (Pimenta, 2013: p. 69).

Por outro lado, já datado de meados do século I a.C. são documentadas as casamatas, cuja função era controlar o território e as rotas comerciais. Nas proximidades deste Cáceres el Viejo está localizado o Castillo de Puerto (Cáceres), local onde é controlada a estrada que liga o rio Tejo ao rio Guadiana através da cidade de Metellinum, o que também permite relacioná áreas com o distrito de mineração Plasenzuela-Tamuja (Heras, 2018: pp. 149-151). Por seu lado, Castelo de Lousã (Mourão, Évora) pode responder a esse mesmo objetivo, mas nas proximidades do rio Guadiana. No entanto, outros autores advogam identificá-lo como um edifício civil forti- ficado dedicado ao comércio com os oppida próximos. Esta hipótese está relacionada à implementação de uma nova política no território pelo estado romano. Todos esses enclaves militares, que aceitam o estabelecimento de tropas neste último, mostram o uso pelo exército de ponderais para controle e participação em rotas comerciais.

Na outra topologia, como nos estabelecimentos militares, há uma dinâmica temporal, sendo encontrados pesos em habitats indígenas na era republicana e em enclaves romanizados ou fundações ex novo no período imperial. No primeiro caso, deve ser feita uma distinção entre as que aparecem na atual Estremadura e as que aparecem no território atualmente português.

O Castro de Villasviejas del Tamuja (Botija, Cáceres) é identificado com o oppidum pré-romano de Tamusia devido ao grande número de achados numismáticos desta ceca (Blázquez, 1995: 243-258). Por outro lado, a Fornacis de Ptolomeu está localizada no Cerro de Hornachuelos (Ribera del Fresno, Badajoz) devido à toponímia do local e à aparência de um lingote com uma inscrição (Heras, 2018: pp. 267-268). Ambos os enclaves são cidades indígenas, mas durante o século II a.C. ocorre o período de maior desenvolvimento do habitat, incluido importantes modificações no enclave: mudanças em parte das muralhas, novas contruçoes no topo das muralhas, restos de novos materiais, como cerâmica campaniense, fíbulas militares, como as de “ômega”, etc. (Heras, 2018: pp. 153-166, 259-268). A causa dessas mudanças é o início da exploração por Roma das minas localizadas nas proximidades das duas oppidas.

Por esse motivo, os ponderais documentados nesses locais devem responder ao controle da produção mineira, como evidenciado pela descoberta de uma fábrica metalúrgica na colina em frente a Hornachuelos (Heras, 2018: pp. 257-259). No entanto, os dados atuais nos impedem de conhecer com precisão total o local onde foram encontrados podendo ser utilizados com outras funcionalidades, como cobrança de impostos ou validação das trocas.

Quanto aos habitats portugueses, Cabeça do Vaiamonte (Monforte, Portoalegre) e Castelho Velho de Veiros (Estremoz, Évora) estão localizados nas proximidades da estrada que liga subsequentemente Olisipo a Augusta Emerita. Na era republicana, esse caminho une o estuário do Tejo e a área em torno de Scallabis, onde são encontrados enclaves como 
Chões de Alpompé e Monte dos Castelinhos, com o rio Guadiana (Mataloto \& Roque, 2012: p. 670).

Em ambos lugares, é possível o estabelecimento de contingentes militares, pois foram documentados restos materiais relacionados a armas e vestimenta militar romanas, especialmente em Cabeça de Vaiamonte (Mataloto \& Roque, 2012: p. 678). Essa hipótese foi identificada em outras regiões e em outros momentos, como ocorre no Chao de Samartin (Grandas de Salime, Astúrias) após as guerras cantabras (Villa, 2009). Como no caso das cidades da Extremadura, não sabemos o local exato da descoberta dos ponderais, até o exemplar de Castelo Velho de Veiros provém de uma coleção superficial (Arnaud, 1968: p. 72). Nesse caso, a funcionalidade deve estar relacionada ao controle comercial e produtivo, mas um uso específico não pode ser reconhecido.

Mesmo assim, os quatro habitats mostram a importância do exército e a exploração do território por Roma na adoção do padrão romano pela população local. Esse processo é lento porque a metrologia faz parte da cultura de um grupo. O melhor exemplo é Cabeça de Vaiamonte, onde os pesos são documentados ao mesmo tempo siguindo um padrão de peso pré-romano e o sistema romano (Pereira, 2016: pp. 178-193).

Já na época imperial, o padrão romano é usado por toda a população, pois não são documentados exemplares pré-romanos no momento. Da mesma forma, os contextos de descoberta agora estão localizados em cidades altamente romanizadas, como Conimbriga. No entanto, muitos dos ponderales desta cidade são encontrados em escavações antigas (Ponte, 1979: pp. 131-132), fato que nos impede de conhecer o local e com que materiais eles apareceram. Entre os que se conhecem, destacam-se os 6 espécimes do fórum, que, sendo de bronze, como explicaremos infra, podem responder a medidas oficiais (Alarçao \& Étienne, 1979: p. 177). Também no fórum foram documentados os pesos que permitiram identificar a officina ponderaria da Arucci (Aroche, Huelva) (Bermejo \& Campos, 2009). O peso restante provém de uma insula, provavelmente relacionada à possível existência de uma sala comercial no piso térreo deste edifício (Alarçao \& Étienne, 1979: p. 177).

$\mathrm{O}$ uso de ponderais para controlar a produção e o comércio é evidente em Caetobriga (Setúbal), pois, neste caso, provém da grande fábrica de salga localizada na península de Troia, um complexo de produção com capacidade superior a de Olisipo ou Gadir
(Soares \& Tavares, 2018: p. 26-30). É uma descoberta antiga, portanto, não se sabe se é proveniente da própria fábrica ou da área residencial próxima, onde foram documentados edifícios de dois andares e vários mosaicos (Soares \& Tavares, 2018: p. 26-30).

Uma situação semelhante quanto à impossibilidade de identificação precisa do contexto da descoberta se repete com as atividades arqueológicas de Estácio da Veiga, na costa sul de Portugal. No caso de Baesuri (Castro Marim, Faro), não sabemos onde foram encontrados os ponderales. Encontramos o mesmo problema em Myrtilis (Mértola, Beja), embora tenhamos verificado o achado de uma balança completa no Barranco do Azeite, onde estaría localizada uma exploração agrícola (Cardoso, 2007: pp. 302 e 321). Não sabemos, no entanto, se essa balança foi acompanhada pelos pesos.

Por outro lado, os exemplares de Balsa (Torre d'Ares, Faro) também foram encontrados nas escavações realizadas pela Estácio da Veiga na necrópole do norte da cidade. A ausência de uma metodologia rigorosa impede o reconhecimento de pertencer aos bens funerários, a uma descoberta superficial, etc. (Pereira, 2014: pp. 75-76; 188). Mesmo assim, o aparecimento de ponderais nas áreas funerárias deve estar relacionado ao simbolismo que acompanha essas peças. Nesse caso, poderia interessar-se em mostrar que o falecido exercia uma profissão de comerciante, artesão ou cargo público vinculado a atividades econômicas.

Finalmente, a presença de ponderales se estende a habitats rurais e villae com produção agrícola. Ali sua funcionalidade pode estar ligada ao controle das trocas, mas, novamente, esses são achados superficiais (Vasconcelos, 1896: pp. 142-143; 1917: p. 145; Pereira, 1909: p. 173; Haba, 1998: pp. 302-303; 308-309). No caso de Vinha de Moruços (Rominha, Leiria), uma grande villa com um alfar em operação durante o Alto Império foi documentada (Peixe, 2018: 58-59). Também em Aranhas (Penamacor, Castelo Branco), estudos sobre a área identificaram a existência de uma grande villa agrícola, onde também apareceram restos de escória (Carvalho, Cardoso e Mascarenhas, 1995: 87). Enquanto Los Ventosos (Medellín, Badajoz) e Vegas del Ortigas (Medellín, Badajoz) são vilas rurais localizadas no ambiente Metellinum. (Haba, 1998: 302-303; 308-309).

\subsection{Metrología}

Os padrões de peso, como comentamos anterior- 
mente, nascem como consequência de um contexto cultural, social e político e se tornam o símbolo de uma comunidade. A substituição de um sistema de pesos por outro é um processo lento e um expoente da existência de alterações dentro de um grupo. As investigações realizadas por Vilaça (2011) documentaram o uso de padrões de origem mediterrâneo desde o final do primeiro milênio a.C. na costa atlântica portuguesa, eles se espalharam para o interior graças a rotas comerciais como a Via da Prata. Durante esse período, os ponderais seriam usados para garantir o pagamento em metais de alto valor, como ouro e prata. Portanto, os valores utilizados são de pequenas dimensões, não excedendo $100 \mathrm{~g}$ de peso em nenhum caso.

Esta situação continua após a chegada do exército romano neste território, como mostra os pesos documentados em Cabeça de Vaiamonte, parte dos quais ainda segue um sistema pré-romano. Da mesma forma, os exemplares de Castelo Velho (Pereira, 2016: pp. 178-193) de Veiros (Arnaud, 1968: p. 72) e Hornachuelos (Jiménez Ávila, 1989-199o: p. 130133) mostram que nesses enclaves ainda é mantido o uso de valores reduzidos de peso: semiuncia, quadrans e semis.

Como vimos supra, a introdução do padrão romano está ligada à presença de contingentes militares na era tardorrepublicana neste território. Eles usam ponderais para o comércio dentro do assentamento e com habitats próximos. Por isso, os valores são variados, sendo um claro exemplo o complexo de Chões de Alpompé, onde é documentado desde uma semiuncia até 2,5 librae. No entanto, o peso de grandes quantidades estaria reduzido a certos enclaves, uma vez que múltiplos da libra estão documentados os dois exemplares de Chões de Alpompé (Fabio, Pereira \& Pimenta, 2015: p. 137) e 13 em Cáceres el Viejo, que atingem até 49 librae (Ülbert, 1984: p. 101).

Após a conquista e o controle do território, a cultura romana foi adotada pela população local. A partir deste momento, os pesos que seguem um sistema pré-romano desaparecem e a amplitude de valores é reduzida, documentando apenas divisores da $l i-$ bra e, inclusive, do uncia, exceto um exemplar de 3,5 librae de Conimbriga (Ponte, 1979: p. 132). Esses valores estão documentados em possíveis áreas comerciais, como o peso proveniente da área da fábrica de salga em Caetobriga e também em prédios públicos urbanos, como no fórum de Conimbriga. Da mesma forma, em habitats rurais, os pesos re- conhecidos também são divisores da libra, como sextans (2 unidades) ou deunx (11 unidades). Isso indicaria que nos tempos imperiais neste território a funcionalidade dos ponderais está relacionada à pesagem de pequenas quantidades.

\subsection{Forma}

$\mathrm{O}$ aspecto formal desse tipo de peça as torna em objetos reconhecíveis para os usuários, que as identificam para um uso e um valor predeterminados. Pode-se dizer que o modelo apresentado por esses exemplares depende da função a ser realizada, mas também do grupo socioeconômico no qual o fabricante e o usuário estão integrados. Nesse sentido, as diferentes morfologias utilizadas pela população local antes da chegada da população romana, bitroncocônica, discoidal, cônica e paralelepipédica (Vilaça, 2011: p. 156), ainda são reconhecíveis durante o período republicano em habitats indígenas. Já na era imperial, o número de exemplares dessas tipologias é reduzido, mas elas ainda o mantêm em uso.

Por outro lado, o uso do padrão romano traz consigo novas morfologias, como as formas troncopiramidal, cônica e ânfora ou bolota. Entre estes, os mais proeminentes são os esféricos e os cilíndricos, especialmente o último na era imperial, uma vez que foram encontrados 7 espécimes em comparação a apenas 1 no período republicano. Digno de nota é o uso da forma cúbica para grandes pesos; até agora, esa morfologia foi documentada apenas nos ponderais do mais valor e peso mais alto de Cáceres el Viejo (49, 29, 22 e 2 librae, juntamente com 8 unciae e 1 quincux) (Ulbert, 1984: p. 101). No entanto, com base nos contextos de descoberta e na cronologia, ainda não é possível especificar mais sobre sua funcionalidade específica ou seu uso durante uma determinada cronologia.

\subsection{Materiais}

A maioria dos pesos documentados, tanto na Lusitânia como no resto da Hispânia, são feitos de bronze ou chumbo, uma situação que também é constatada nos tempos pré-romanos. A escolha de um ou outro material está relacionada à funcionalidade que esses objetos executaram. Assim, o bronze, no período pré-romano, está associado à população indígena e, nesses habitats, há pontos de controle (Vilaça, 2011: p. 164). Isso se deve à dureza, ao melhor acabamento e à difícil modificação subsequente. Após a chegada de Roma à Lusitânia, essa idéia é mantida 
como evidenciado pelos pesos de Cabeça de Vaiamonte, onde, em comparação com 26 exemplares de bronze, existem apenas 9 de chumbo. Além disso, o bronze também é considerado um material de prestígio, como mostra o peso encontrado na necrópole do norte da cidade de Balsa, na Torre d'Ares, Faro (Pereira, 2014: p. 188).

O chumbo, devido à sua maior maleabilidade e sua fácil transformação para adaptá-lo a um novo peso, foi utilizado nos locais em que sua funcionalidade prática predomina sobre o valor simbólico, como pontos de troca ou oficinas metalúrgicas. Essa dualidade funcional e material é observada nos exemplares de Conimbriga, onde todos os pesos para os quais conhecemos seu contexto são feitos de bronze, enquanto aqueles que desconhecemos são quase todos de chumbo. Além disso, alguns desses pesos vêm do fórum, onde podem responder a algum sistema de medidas oficiais, como as documentadas no officina ponderaria da Arucci (Aroche, Huelva) (Bermejo \& Campos, 2009). Nos estabelecimentos militares, devido à sua funcionalidade eminentemente prática, o chumbo é o material mais utilizado para esses objetos.

No caso da Lusitania, também devemos ter em consideração o acesso a esses recursos metáliferos. Nesse sentido, habitats indígenas, como Villasviejas del Tamuja (Botija, Cáceres) e Hornachuelos (Ribera del Fresno, Badajoz), são encontrados em distritos de mineração dedicados à obtenção de chumbo e prata, mas não de cobre e zinco, necessários para a obtenção de bronze. Pelo contrário, as cidades localizadas ao redor da desembocadura do rio Guadiana têm fácil acesso a esses minerais. Por esse motivo, em Balsa (Torre d'Ares, Faro), Baesuri (Castro Marim, Faro) e Myrtilis (Mértola, Beja), todos os exemplares documentados são de bronze, uma questão que pode responder ao fácil acesso que eles devem ter para adquirir esse material.

Finalmente, também são utilizados outros materiais como ferro, arenito ou pedra serpentina. Todos eles foram documentados em outras partes da Hispânia (Chaves \& Pliego, 2007), mas como na Lusitânia, é uma quantidade menor em comparação ao bronze e ao chumbo.

\section{CONCLUSÕES}

A revisão dos achados de ponderais romanos na Lusitânia nos permitiu abordar, sob outro ponto de vista, o processo de conquista e aculturação liderado por Roma neste território. Os primeiros contingentes da população romana a chegar são os militares, que carregam com eles esses pesos, que usam no comércio. A presença dos militares não se reduz apenas a estabelecimentos militares, mas também a oppida indígenas. Por esse motivo, é o exército que introduziu o uso do padrão romano na vida dos habitantes do território, criando uma dualidade cronológica. Assim, são documentadas uma fase de adaptação que ocorre na República, enquanto no Império o sistema romano é o único existente.

Essa dualidade não se reflete exclusivamente no aspecto metrológico, mas afeta todas as características formais dos ponderais e seus contextos de origem. Nas datas republicanas, eles são documentados em estabelecimentos militares e em cidades indígenas, enquanto nos tempos imperiais só foram encontrados em grandes centros de intercâmbio e também em areas funerais. Esses últimos achados podem significar que a população já aceitou os testemunhos de peso como um símbolo de sua própria cultura. Por sua vez, as formas herdadas da tradição pré-romana predominam durante a República, sendo parcialmente substituídas por novas formas como a esférica ou cilíndrica.

Nesta primeira abordagem, também pudemos ver outros aspectos, como a manutenção da dualidade do material, ou seja, o bronze está associado o poder e à oficialidade, enquanto o chumbo está associado a funções práticas, como a produção metalúrgica. Este sistema duplo já está identificado nos ponderais pré-romanos em toda a Península Ibérica. Como também aconteceu nos pré-romanos, a tendência de pesar pequenas quantidades também permanece, uma vez que os valores documentados são na maioria fracionários, tanto republicanos quanto imperiais.

Em suma, a chegada da população romana foi o ponto de partida para o uso do padrão romano pelos povos indígenas. No entanto, é um processo lento que se desenvolve durante, pelo menos, os dois últimos séculos do primeiro milênio a.C. Com a mudança de época e o estabelecimento do Império, o sistema romano já é aceito por grande parte dos lusitanos. Mesmo assim, certas características presentes nos pesos imperiais continuam sendo herdadas da tradição anterior à chegada do estado romano. 


\section{BIBLIOGRAFIA}

ALARCÃO, Jorge de; ÉTIENNE, Robert (1979) - Fouilles de Conimbriga, vol. VII: Trouvailles diverses, Conclusions générales. Paris: Diffusion De Boccard.

ARNAUD, José Morais. (1968) - Castelo Velho de Vieiros, Estremoz. Notícia da sua identificação. Revista de Guimarães, 78: 1-2, pp. 61-76.

ARRUDA, Ana Margarida; PEREIRA, Carlos; SOUSA, Elisa de; PIMENTA, João; DETRY, Cleia; GOMES, João (2018) - Chões de Alpompé (Valle de Figueira, Santarém): Lendas e Narrativas. Spal, 27.2, pp. 201-227.

BERMEJO MELÉNDEZ, Javier; CAMPOS CARRASCO, Juan Manuel (2009) - La sala de los Ediles de Arucci/Turobriga, Officina Ponderaria Aruccitana. Saguntum, 41, pp. 187-198.

BLÁZQUEZ CERRATO. Cruces (1995) - Sobre las cecas celtibéricas de Sekaisa y Tamusia y su relación Extremadura. Archivo Español de Arqueología, 68, pp. 243-258.

CARDOSO, João Luís (2007) - Estácio da Veiga e a Arqueologia: um percurso científico no Portugal oitocentista. Estudos Arqueológicos de Oeiras, 14, pp. 293-520.

CARVALHO QUINTELA, Antonio de; CARDOSO, João Luís; MASCARENHAS, José Manuel (1995) - Barragens romanas do distrito de Castelo Branco e Barragem de Alferrarede. Conimbriga, XXXIV, pp. 75-127.

CEBRIÁN FERNÁNDEZ, Rosario; HORTELANO UCEDA, Ignacio (2017) - Librae, Staterae y Aequipondia de Segobriga. Instrumentos de pesar hallados en la ciudad y su entorno. Lucentum, 36, pp. 201-219.

CHAVES TRISTÁN, Francisca; PLIEGO VÁZQUEZ, Ruth (2007) - Instrumentos de medida de pesos en la Hispania antigua. Sautuola, 12, pp. 237-250.

DOMERGUE, Claude (2002) - Les objects en metal. In BLÁZQUEZ MARTÍNEZ, José María; DOMERGUE, Claude; SILLIÈRES, Pierre, eds. - La Loba (Fuenteobejuna, Cordoue, Espagne). La Mine et le village minier antiques. Bordeaux: Ausonius Memories 7, pp. 333-369.

FABIAO, Carlos; PEREIRA, Teresa Rita; PIMENTA, João (2015) - Coleção de metais do sítio arqueológico dos Chões de Alpompé (Santarem). Cira Arqueologia, IV, pp. 110-150.

HABA QUIRÓS, Salvadora (1998) - Medellín romano. La colonia Metellinensis y su territorio. Badajoz: Diputación de Badajoz.

HERAS MORA, Francisco Javier (2018) - La implantación militar romana en el suroeste hispano (siglos II-I a.n.e.). Madrid: Ediciones Polifemo, Anejos de Glaudius, 18.

JIMÉNEZ ÁVILA, Javier (1989-9o) - Notas sobre la minería romano-republicana bajoextremeña: las explotaciones de plomo de la Sierra de Hornachos (Badajoz). Anas, 2-3, pp. 123-134.
KULA, Witold. (1972) - Problemas metodológicos y métodos de la historia económica. Barcelona: Edic. Península.

MATALOTO, Rui; ROQUE, Conceição (2012) - Un regresso, de pessagem, ao Castelo Velho de Veiros. In DEUS, Manuela de, ed. - Actas do VEncontro de Arqueologia do Sudoeste Peninsular, Almodôvar: Municipio de Almodôvar, pp. 669-685.

MORLEY, Iain; RENFREW, Colin, eds. (2010) - The Archaeology of Measured: Comprehending Heaven, Earth and Time in Ancient Societies. Cambridge.

PEIXE, Alexandre Roberto (2018) - Abordagem espacial preliminar do sitio Algar da Água, Alvaiázere, Distrito de Leiria, Portugal. Dissertaçao de Mestrado, Tomar: Instituto Politécnico de Tomar.

PEREIRA, Carlos (2014) - As necrópoles romanas do Algarve. Acerca dos espaços do norte no extremo sul da Lusitânia. Tese de doutoramento, Lisboa: Faculdade de Letras da Universidade de Lisboa, 2 vols.

PEREIRA, Felix Alves (1909) - Ruinas de ruinas ou Estudos Igeditanos. O Arqueólogo Português, 14, pp. 169-197.

PEREIRA, Teresa Rita (2016) - O papel do exército no processo de romanização: a Cabeça de Vaiamonte (Monforte) como estudo de caso. Tese de doutoramento, Lisboa: Faculdade de Letras da Universidade de Lisboa.

PIMENTA, João (2013) - Catálogo da exposição "Monte dos Castelinhos (Castanheira do Ribatejo). Vila Franca de Xira e a conquista romana do Vale do Tejo". Vila Franca de Xira.

PONTE, Salete da (1979) - Balanças e pesos de Conimbriga. Conimbriga, vol. XVIII, pp. 121-132.

RAHMSTORF, Lorenz (2010) - The concept of weighing during the Bronze Age in the Aegean, The Near East and Europe. In MORLEY, Iain; RENFREW, Colin, eds. - The archeology of Measured: Comprehending Heaven, Earth and Time in Ancient Societies. Cambridge, pp. 88-105.

SOARES, Joaquina; TAVARES DA SILVA, Carlos (2018) Introdução. Caetobriga: uma cidade fabril e polinucleada na foz do Sado. Setúbal Arqueológica, 17, pp. 11-42.

ULBERT, Günter (1984) - Cáceres el Viejo, Ein spätrepublikanisches Legionslager in Spanisch-Extremadura. Mainz am Rhein: Verlag Philipp von Zabern.

VASCONCELOS, Jose Leite de (1896) - Acquisições do Museu Ethnographico Português. O Arqueólogo Português, Serie I, 2, pp. 142-143.

VASCONCELOS, Jose Leite de (1917) - Coisas Velhas. O Arqueólogo Português, Serie I, 23, pp. 107-169.

VILLA VALDÉS, Ángel (2009) - ¿De aldea fortificada a Caput civitatis? Tradición y ruptura en una comunidad castreña del siglo I d.C.: El poblado de Chao de Samartin (Grandas de Salime, Asturias). Cuadernos de Prehistoria y Arqueología de la Universidad Autónoma de Madrid, 35, pp.7-26. 
VILAÇA, Raquel (2011) - Ponderais do Bronze final-Ferro Inicial do occidente peninsular In GARCÍA-BELLIDO, M..$^{\mathrm{a}}$ Paz; CALLEGARIN, Leandre; JIMÉNEZ, Alicia, eds. - Barter, money and coinage in ancient Mediterranean $\left(10^{\text {th }}-1^{\text {st }}\right.$ centuries). Madrid, pp. 139-167.

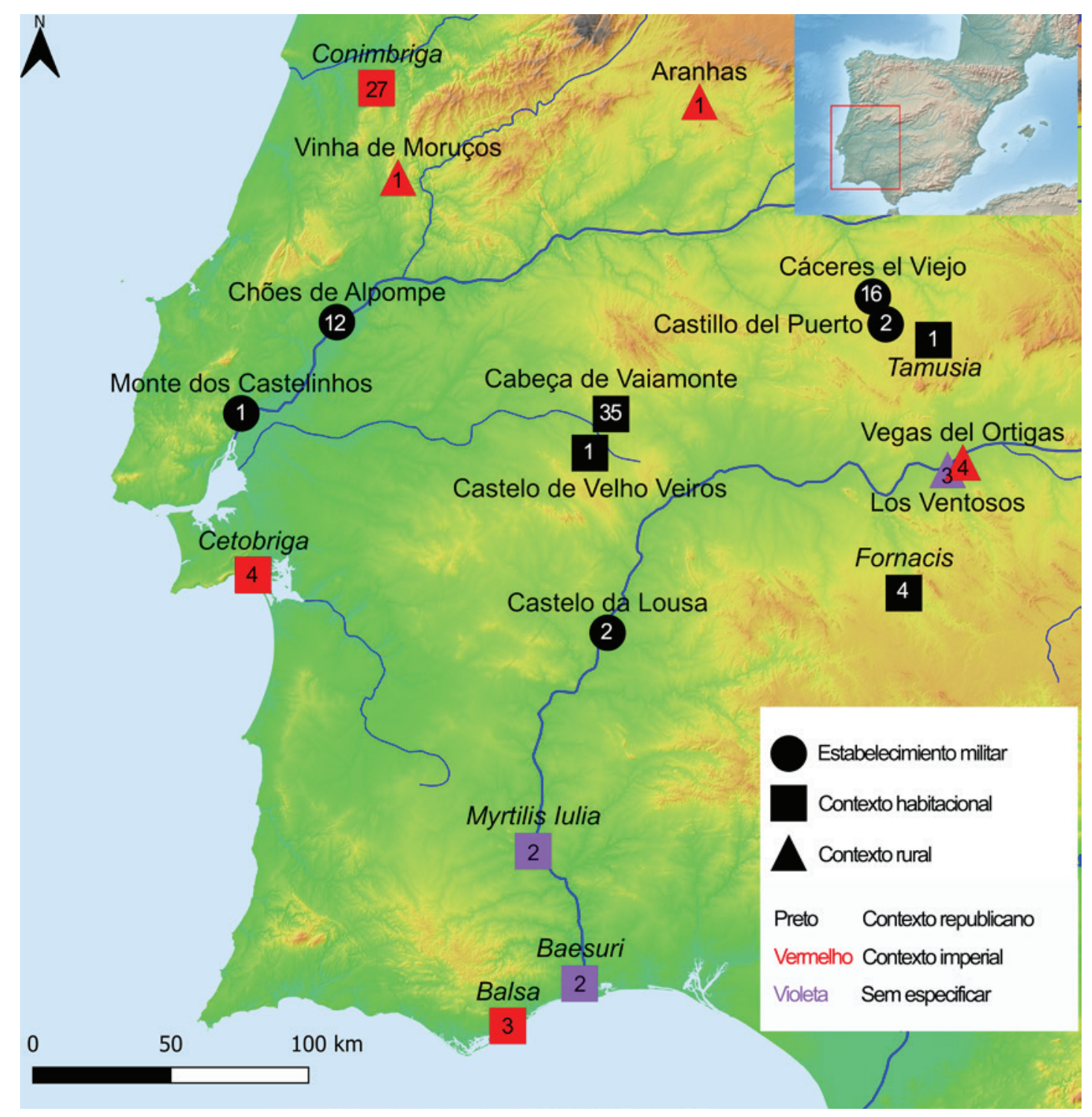

Figura 1 - Achados de ponderais no território lusitano; a variedade de símbolos detalha a cronologia das peças e o tipo de contextos de onde elas vêm; a figura dentro de cada símbolo refere-se ao número de pesos encontrados; Detalhes formais e metrológicos são coletados na tabela na fig. 2. As denominações dos sítios estão em itálico quando o nome antigo é conhecido e em redondo quando o topónimo é actual. 


\begin{tabular}{|c|c|c|c|c|c|c|}
\hline Local & $\begin{array}{c}\text { N. }{ }^{\circ} \text { de } \\
\text { ponderais }\end{array}$ & Materiais & Formas & Valores & Cronologia & Tipo do contexto \\
\hline $\begin{array}{c}\text { Balsa (Torre d'Ares, } \\
\text { Faro) }\end{array}$ & 3 & $\mathrm{Ae}$ & $\begin{array}{c}\text { esférica (2) } \\
\text { retangular (1) }\end{array}$ & sem especificar & séculos I-III d.C. & funerário \\
\hline $\begin{array}{c}\text { Baesuri (Castro } \\
\text { Marim, Faro) }\end{array}$ & 2 & $\mathrm{Ae}$ & discoidal & sem especificar & $\begin{array}{l}\text { séculos II a.C. } \\
\text { - V d.C. }\end{array}$ & indeterminado \\
\hline $\begin{array}{l}\text { Myrtilis Iulia } \\
\text { (Mertola, Beja) }\end{array}$ & 2 & $\mathrm{Ae}$ & $\begin{array}{l}\text { esférica } \\
\text { cilíndrica }\end{array}$ & sem especificar & $\begin{array}{l}\text { séculos I a.C. } \\
\text { - V d.C. }\end{array}$ & indeterminado \\
\hline $\begin{array}{c}\text { Caetobriga (Troia, } \\
\text { Setuball) }\end{array}$ & 1 & $\mathrm{Ae}$ & cilíndrica & sem especificar & séculos I-V d.C. & indeterminado \\
\hline $\begin{array}{c}\text { Monte dos } \\
\text { Castelinhos } \\
\text { (Vila Franca de Xira, } \\
\text { Lisboa) }\end{array}$ & 1 & $\mathrm{~Pb}$ & troncopiramidal & 1 libra & $\begin{array}{l}\text { segunda mitade } \\
\text { del século I a.C. }\end{array}$ & $\begin{array}{l}\text { estabelecimiento } \\
\text { militar }\end{array}$ \\
\hline \multirow{4}{*}{$\begin{array}{l}\text { Chões de Alpompé } \\
\text { (Santarém) }\end{array}$} & \multirow{4}{*}{12} & \multirow{4}{*}{$\mathrm{Pb}$} & discoidal (2) & sextans e semiuncia & \multirow{4}{*}{$\begin{array}{l}\text { primeiro quarto } \\
\text { del século I a.C. }\end{array}$} & \multirow{4}{*}{$\begin{array}{l}\text { estabelecimiento } \\
\text { militar }\end{array}$} \\
\hline & & & paralelepipédica (6) & $\begin{array}{c}2,5 ; 1,5 \text { librae, } \\
\text { deunx, semis, } \\
\text { quadrans y uncia }\end{array}$ & & \\
\hline & & & forma do ánfora (1) & Dextans & & \\
\hline & & & prismática (3) & $\begin{array}{c}\text { Septunx, quincuxe } \\
\text { triens }\end{array}$ & & \\
\hline $\begin{array}{l}\text { Vinha de Moruços } \\
\text { (Rominha, Leiria) }\end{array}$ & 1 & $\mathrm{~Pb}$ & cilíndrica & sem especificar & $\begin{array}{l}\text { século I a. C. } \\
\text { - inicios século } \\
\text { II d.C. }\end{array}$ & villa romana \\
\hline $\begin{array}{l}\text { Castelo da Lousa } \\
\text { (Mourão, Évora) }\end{array}$ & 2 & $\mathrm{~Pb}$ & $\begin{array}{l}\text { troncopiramidal } \\
\text { paralelepipédica }\end{array}$ & sem especificar & $\begin{array}{c}\text { mediados del } \\
\text { século I a.C. } \\
\text { — inicios del século } \\
\text { I d.C. }\end{array}$ & $\begin{array}{l}\text { estabelecimento } \\
\text { militar }\end{array}$ \\
\hline \multirow{6}{*}{$\begin{array}{c}\text { Conimbriga } \\
\text { (Condeixa-a-Velha, } \\
\text { Coimbra) }\end{array}$} & \multirow{6}{*}{27} & $\operatorname{Ae}(7)$ & $\begin{array}{l}\text { cilíndrica (1) } \\
\text { discoidal (1) } \\
\text { retangular (4) } \\
\text { esférica (1) }\end{array}$ & $\begin{array}{c}\text { semiuncia } \\
\text { uncia } \\
\text { semis, triens, } \\
\text { quadrans e sextans } \\
\text { deunx }\end{array}$ & \multirow{6}{*}{$\begin{array}{l}\text { séculos I a.C. } \\
\text { - V d.C. }\end{array}$} & \multirow{4}{*}{$\begin{array}{l}\text { cidade romana, } \\
\text { indeterminado }\end{array}$} \\
\hline & & $\mathrm{Pb}(11)$ & $\begin{array}{c}\text { troncopiramidal (3) } \\
\text { esférica (2) } \\
\text { cilíndrica (2) } \\
\text { cônica (3) } \\
\text { discoidal (1) }\end{array}$ & $\begin{array}{c}\text { quadrans e } \\
\text { semiuncia }(2) \\
3,5 \text { librae }(1) \\
\text { quadrans e sextans } \\
\text { deunx e sextans (2) } \\
8 \text { unciae }\end{array}$ & & \\
\hline & & $\mathrm{Fe}(1)$ & forma do bolota (1) & sem especificar & & \\
\hline & & Pedra (1) & esférica (1) & 1 libra & & \\
\hline & & \multirow[t]{2}{*}{ Ae (1) } & bitroncocônica & quadrans & & \\
\hline & & & $\begin{array}{l}\text { bitroncocónica (2) } \\
\text { forma de bolota (1) } \\
\text { esférica (2) } \\
\text { cilíndrica (1) }\end{array}$ & $\begin{array}{c}\text { duella e uncia } \\
\text { sextans } \\
\text { sextans e semiuncia } \\
\text { semiuncia }\end{array}$ & & $\begin{array}{l}\text { cidade romana, } \\
\text { espaço público }\end{array}$ \\
\hline $\begin{array}{c}\text { Aranhas } \\
\text { (Penamacor, Castelo } \\
\text { Branco) }\end{array}$ & 1 & $\mathrm{Ae}$ & bitroncocônica & sem especificar & séculos I-V d.C. & villae romana \\
\hline \multirow{2}{*}{$\begin{array}{c}\text { Cabeça de Vaimonte } \\
\text { (Monforte, } \\
\text { Portoalegre) }\end{array}$} & \multirow{2}{*}{35} & $\operatorname{Ae}(26)$ & $\begin{array}{c}\text { discoidal (3) } \\
\text { bitroncocônica (8) } \\
\text { troncocônica (5) } \\
\text { esférica (9) } \\
\text { paralelepipédica (1) }\end{array}$ & \multirow{2}{*}{$\begin{array}{l}\text { sistemas do peso } \\
\text { prerromano e } \\
\text { romano }\end{array}$} & \multirow[t]{2}{*}{ séculos II-I a.C. } & \multirow[t]{2}{*}{ hábitat indígena } \\
\hline & & $\mathrm{Pb}(9)$ & $\begin{array}{c}\text { discoidal (6) } \\
\text { cilíndrica (1) } \\
\text { troncocônica (1) } \\
\text { paralelepipédica (1) }\end{array}$ & & & \\
\hline $\begin{array}{l}\text { Castelo Velho de } \\
\text { Veiros (Estremoz, } \\
\text { Évora) }\end{array}$ & 1 & $\mathrm{Ae}$ & esférica & semiuncia & séculos II-I a.C. & hábitat indígena \\
\hline
\end{tabular}

Figura 2 - Características materiais dos ponderais romanos encontrados na Lusitânia. 


\begin{tabular}{|c|c|c|c|c|c|c|}
\hline Local & $\begin{array}{c}\mathrm{N} . \stackrel{\mathrm{o}}{\mathrm{de}} \\
\text { ponderais }\end{array}$ & Materiais & Formas & Valores & Cronologia & Tipo do contexto \\
\hline \multirow[t]{4}{*}{$\begin{array}{l}\text { Cáceres el Viejo } \\
\text { (Cáceres) }\end{array}$} & \multirow[t]{4}{*}{16} & $\mathrm{~Pb}(9)$ & $\begin{array}{c}\text { troncocônica (1) } \\
\text { discoidal (3) } \\
\text { paralelepípeda (1) } \\
\text { cúbica (3) } \\
\text { piramidal truncada } \\
\text { (1) }\end{array}$ & $\begin{array}{c}2 \text { librae } \\
5 \text { librae (2) } \\
\text { e quincux } \\
\text { 10 librae } \\
2 \text { librae, } 8 \text { unciae } \\
\text { e quincux } \\
\text { 7,5 librae }\end{array}$ & \multirow[t]{4}{*}{ 95-78 a.C. } & \multirow[t]{4}{*}{$\begin{array}{l}\text { estabelecimiento } \\
\text { militar }\end{array}$} \\
\hline & & $\begin{array}{l}\text { Serpentina } \\
\text { (4) }\end{array}$ & $\begin{array}{c}\text { cúbica (3) } \\
\text { esférica truncada (1) }\end{array}$ & $\begin{array}{l}\text { 49, } 29 \text { e } 22 \text { librae } \\
\text { 10 librae }\end{array}$ & & \\
\hline & & Argila (2) & esférica truncada (2) & 26 e 22 librae & & \\
\hline & & Pedra (2) & cilíndrica (1) & 1 libra & & \\
\hline $\begin{array}{l}\text { Castillo del Puerto } \\
\text { (Cáceres) }\end{array}$ & 2 & $\mathrm{~Pb}$ & sem especificar & sem especificar & $\begin{array}{l}\text { mediados del } \\
\text { século I a.C. } \\
\text { - mediados } \\
\text { século I d.C. }\end{array}$ & $\begin{array}{l}\text { estabelecimiento } \\
\text { militar }\end{array}$ \\
\hline $\begin{array}{c}\text { Tamusia- } \\
\text { Villasviejas del } \\
\text { Tamuja (Botija, } \\
\text { Cáceres) }\end{array}$ & 1 & $\mathrm{~Pb}$ & troncopiramidal & sem especificar & século II-I a.C. & $\begin{array}{l}\text { hábitat indígena, } \\
\text { exploração } \\
\text { mineira }\end{array}$ \\
\hline $\begin{array}{c}\text { Los Ventosos } \\
\text { (Medellín, Badajoz) }\end{array}$ & 3 & $\mathrm{~Pb}$ & $\begin{array}{c}\text { discoidal } \\
\text { troncopiramidal } \\
\text { paralelepípedo }\end{array}$ & $\begin{array}{c}\text { sextans } \\
\text { deunx } \\
\text { sem especificar }\end{array}$ & indeterminada & villae romana \\
\hline \multirow{2}{*}{$\begin{array}{l}\text { Vegas del Ortigas } \\
\text { (Medellín, Badajoz) }\end{array}$} & \multirow[b]{2}{*}{4} & $\mathrm{~Pb}(\mathrm{I})$ & discoidal (1) & 9 unciae & \multirow[b]{2}{*}{ séculos I-III d.C. } & \multirow[b]{2}{*}{ villae romana } \\
\hline & & $\operatorname{Ae}(3)$ & $\begin{array}{l}\text { cilíndrica (1) } \\
\text { discoidal (2) }\end{array}$ & $\begin{array}{l}\text { sem especificar } \\
\text { triens (1) }\end{array}$ & & \\
\hline $\begin{array}{c}\text { Fornacis } \\
\text { - Hornachuelos } \\
\text { (Ribera del Fresno, } \\
\text { Badajoz) }\end{array}$ & 4 & $\mathrm{~Pb}$ & $\begin{array}{l}\text { discoidal (3) } \\
\text { cilíndrica (1) }\end{array}$ & $\begin{array}{c}\text { semis e quadrans } \\
\text { (2) } \\
\text { uncia }\end{array}$ & $\begin{array}{c}\text { finales século } \\
\text { III a.C. - século } \\
\text { I d.C. }\end{array}$ & $\begin{array}{l}\text { hábitat indígena, } \\
\text { exploração } \\
\text { mineira }\end{array}$ \\
\hline
\end{tabular}

Figura 2 (continuação) - Características materiais dos ponderais romanos encontrados na Lusitânia. 


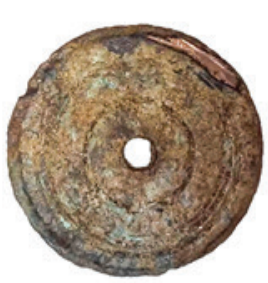

1

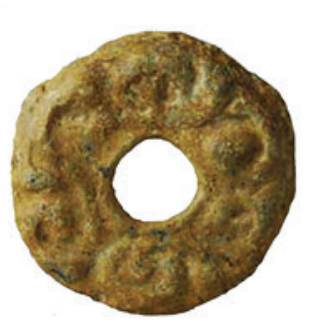

2

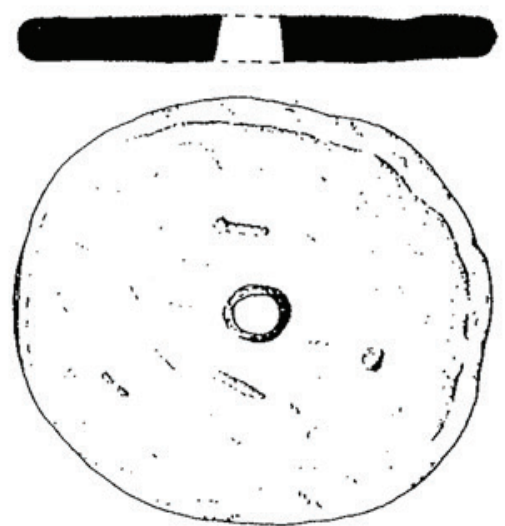

3

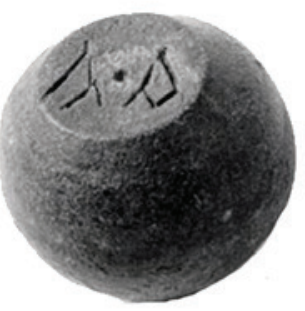

7

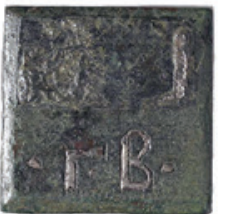

11

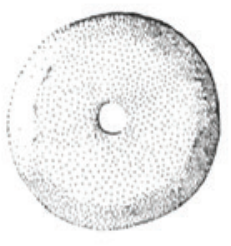

6

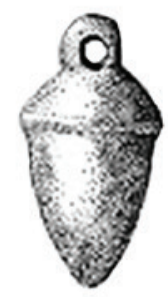

9
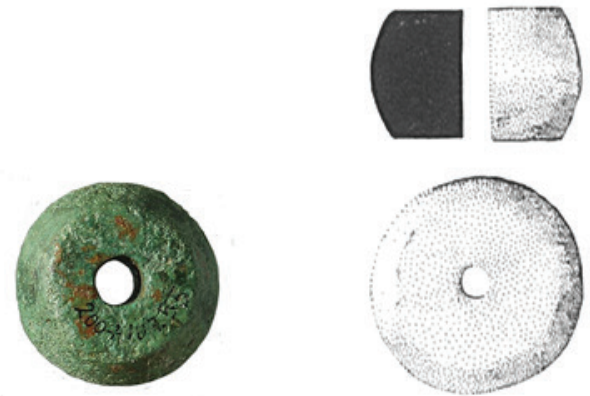

5

.

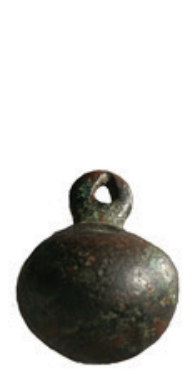

10

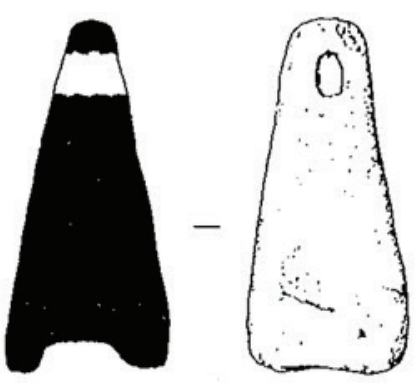

4

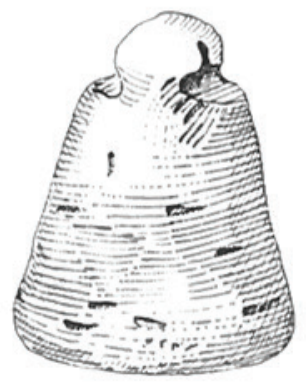

8

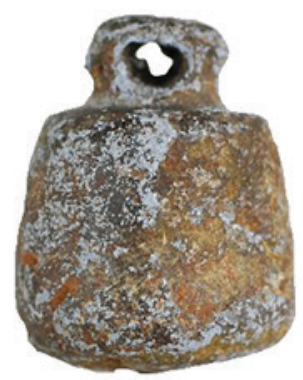

12

0

$3 \mathrm{~cm}$

Figura 3 - Alguns ponderais achados na Lusitânia, com indicação de peso (g) e diâmetro (mm): 1) Chões de Alpompé (Arruda \& alii, 2018: p. 221) =10 g/33 mm; 2) Chões de Alpompé (Fabiâo \& alii, 2015: p. 136) = 52,58 g/37 mm; 3) Hornachuelos (Jiménez Ávila, 1989-1990: p.132)=160,97g;4) Hornachuelos (Jiménez Ávila,1989-199o: p.132) =sem dimensões; 5) Cabeça de Vaiamonte (http://www.matriznet.dgpc.pt/MatrizNet/Objectos/ObjectosConsultar.aspx?IdReg=1029178) = 26,5 mm; 6) Conimbriga (Alarçao \& Étienne, 1979: lam. XLVIII) = 80,96 g/ 28 mm; 7) Conimbriga (Ponte, 1979: p. 132) = 305 g/38 mm; 8) Conimbriga (Ponte, 1979: p. 132) = 26o g/ 35 mm; 9) Conimbriga (Alarçao \& Étienne, 1979: lam. XLVIII) = 56,9 g; 10) Balsa (http://www. matriznet.dgpc.pt/MatrizNet/Objectos/ObjectosConsultar.aspx?IdReg=144858) = 18,5 mm; 11) Balsa (http://www.matriznet.dgpc.pt/MatrizNet/Objectos/ObjectosConsultar.aspx?IdReg=144962); alt. 8,8 mm, larg. 27 mm, anc. 27,6 mm; 12) Vinha de Morouços (http://www.matriznet.dgpc.pt/MatrizNet/Objectos/ObjectosConsultar.aspx?IdReg=1116o75) =36,6 mm. 


\title{
UM ALMOFARIZ CENTRO-ITÁLICO NA FOZ DO MONDEGO
}

\author{
Marco Penajoia ${ }^{1}$
}

\begin{abstract}
RESUMO
O Museu Municipal Santos Rocha realizou uma Exposição e Colóquio intitulada: "Santos Rocha, Arqueologia e Territórios da Figueira da Foz”. Este evento visou a sensibilização para a arqueologia e para o património arqueológico local, através da exposição de alguns espólios museológicos, nunca antes expostos e inéditos, entre os quais um fragmento de almofariz romano. Pretendemos com este artigo divulgar e desenvolver o estudo deste artefacto. Trata-se de um mortarium de fabrico centro-itálico e de tipologia Dramont $\mathrm{D}_{2}$ identificado na zona denominada de Igreja Velha do Negrote-Alqueidão. Este tipo de artefacto, atendendo à sua especificidade, vem apoiar a investigação no que concerne ao grau de romanização na foz do Mondego. Uma posição geográfica com elevada dinâmica flúvio-marítima.
\end{abstract}

Palavras-chave: Almofariz, Dramont D2, Foz do Mondego, Navegação, Museu Municipal Santos Rocha.

\begin{abstract}
The Santos Rocha Municipal Museum held an Exhibition and Colloquium entitled: "Santos Rocha, Archaeology and Territories of Figueira da Foz". This event is aimed at raising awareness for archaeology and the local archaeological heritage, through the exhibition of some museum exhibits never before exposed and unpublished, including a fragment of a Roman mortar. With this article, we intend to disseminate and develop the study of this artefact. It is a centre-italic mortarium and Dramont D2 typology identified in the area called Igreja Velha do Negrote-Alqueidão. This type of artefact, given its specificity, supports the investigation regarding the degree of romanization at the mouth of the Mondego river. A geographical position with high fluvial-maritime dynamics.
\end{abstract}

Keywords: Mortar, Dramont D2, Mouth of Mondego, Navigation, Santos Rocha Municipal Museum.

\section{TERRITÓRIO - VALORES TOPONÍMICOS}

Esta zona de estudo (Figura 1 e 2) integra registos toponímicos ${ }^{2}$ a considerar: Alqueidão, de etimologia árabe, pode advir de <ár.alqtun, ou seja «acampamento" (Fernandes, 1999, p. 38-39), ou derivar de al-qaddân, "o calcário", "o cascalho", e de al-gaytân, "os campos», "os jardins", "as hortas" (Alves, 2013, p. 195). Já o Paião pode enquadrar-se numa problemática relacionada com a administração dos territórios romanos. Veja-se pagus, que se refere ao marco fixado na terra e, consequentemente, ao território delimitado por esses marcos. $\mathrm{Na}$ área urbana do
Paião existe o microtopónimo - Marco, este volta a registar-se a $9 \mathrm{~km}$ Oeste, já em território de Soure e a 850 m do sítio romano da Madanela ${ }^{3}$. Neste âmbito é possível problematizar o território do Paião no contexto de pagus. Esta designação, no mundo romano, poderá expressar uma certa extensão do território rural, uma subdivisão rural da civitas. Aos pagi romanos e suevo-visogodos vieram suceder as "terras» e os "territórios» da administração condal dos séculos IX e seguintes (Dias, 1980). Jorge de Alarcão descreve as paróquias e pagi como "aglomerados urbanos já existentes e importantes na época romana, aglomerados que terão conservado,

\footnotetext{
1. Município da Figueira da Foz - Museu Municipal Santos Rocha; Centro de História da Sociedade e da Cultura - Universidade de Coimbra; arqueologia.museu@cm-figfoz.pt / penajoia@fl.uc.pt
}

2. A análise da distribuição dos antigos povoamentos deve ter em conta a avaliação toponímica e espacial (Ruiz Zapatero, 1988, p. 43).

3. De Man e Ruivo, 2009. 
na época suévica, os seus primitivos nomes, eventualmente já com alguma alteração fonética ou ortográfica" (Alarcão, 2001, p. 31).

Com a Reconquista e com as mudanças de povoamento da Península, os pagi passaram muitas vezes a ser designados paenas pelo onomástico. Noutros casos mantiveram a totalidade do nome, geralmente adulterado. Assim deve ter acontecido com as terras denominadas Paio, ou Pai. Embora nenhum estudo nos prove que Paio vem do termo Pagus, julgamos que gramaticalmente e filologicamente isso é possível. Num documento do século XI Pajo aparece já a significar "terra». Assim, os autores listaram cartograficamente dois sítios na Figueira da Foz com este valor toponímico - Paião e Pai Penela, em Quiaios (Dias, 1980).

Outros valores toponímicos em torno desta zona alertam-nos para potenciais indicadores arqueológicos, alguns já confirmados: Bizorreiro de Castela, Cabaço, Casal Verde, Facho, Lagoinha, Portela e Telhada. Em frente a esta zona, e na margem direita do Mondego, temos as posições geostratégicas de Lares, Outeiro de Mosquitos, Monte do Cavalo ${ }^{4}$ e Monte da Amoreira ${ }^{5}$, estes últimos com vestígios de ocupação romana.

\section{ENQUADRAMENTO GEOMORFOLÓGICO}

Os rios são, efetivamente, os grandes eixos de desenvolvimento de um território, pelo que nunca estarão imunes a uma mutação antrópica constante. O sítio da Igreja Velha do Negrote apresenta uma posição geoestratégica na margem esquerda do paleoestuário do Mondego, próximo do estrangulamento natural entre o Alqueidão e a posição de Moinho do Almoxarife/Pena ${ }^{6}$, a montante. Salienta-se a comunicação náutica com a entrada do Rio Pranto e a zona do vale do Alqueidão. Assim, define-se como um sítio com condições naturais de excelência para a ocupação antrópica e de apoio ao controlo náutico, portuário e defensivo do passado. Nessa perspetiva, Vasco Mantas realça as alterações ocorridas na linha de costa, no final do período romano. Estas terão sido causadas por questões geomorfo-

\footnotetext{
4. Alarcão, 1988.

5. Ferreira e Pinto, 2017; Penajoia, no prelo.

6. Recentemente identificou-se uma possível lasca de descorticamento (Penajoia, 2014-2015).
}

lógicas, que se manifestaram em "colmatagem de reentrâncias, progressão de cabedelos, alterações de lagunas, assoreamento da parte vestibular de rios" (Mantas, 1999, p. 137-138). É perante esta realidade, com escassez de investigação relativamente ao povoamento antigo, que antigos portos romanos e medievais deixaram de ser alcançados (Idem, 1999). A dinâmica geomorfológica demonstra que os vales confluentes a esta zona estariam no passado preenchidos por pequenas rias e esteiros, que desaguavam para a linha de água atual. Em algumas margens ainda é possível verificar alguns cortes com cascalheira de um terraço fluvial7.

Analisando de uma forma preliminar a planimetria em torno do Negrote, verificamos parcelários que se orientam maioritariamente para o paleoestuário e com parcelas a rondar, em média, os $1200 \mathrm{~m}^{2}$. Apresenta um desenvolvimento urbano, que se enquadra no sistema de tipo "aldeia-rua". Esta zona apesar de defendida a Este por uma encosta em socalcos, que atinge no seu topo cerca de $35 \mathrm{~m}$ de altitude, evidencia mais a norte, no Alqueidão, um elemento morfogenético - tipo interflúvio onde hoje se processa a Rua da Fonte Velha.

\section{VIAS DE COMUNICAÇÃO - NAVEGAÇÃO}

Dada a especificidade deste território, uma análise arqueológica deverá saber conjugar a Arqueologia do povoamento com a Arqueologia de meio-aquático. Esta última não se restringe às zonas submersas, incluindo também todos os locais cujas condições físicas tenham permitido, ou permitam, a implantação de estruturas de apoio associadas à prática náutica. Quanto à ocorrência de vestígios arqueológicos romanos no estuário do Mondego, para o período romano, salientamos o achado de Maiorca, que nos remete para um possível naufrágio de uma embarcação romano-republicana (Imperial, 2017). Junto ao Porto de Sanfins, define-se um estreitamento natural com povoamento romano, que envolve na margem direita os cabeços do Mosquito, Cavalo ${ }^{8} \mathrm{e}$

\footnotetext{
7. Para o Baixo Mondego são distinguidos vários níveis de terraços do Quaternário. Alguns investigadores apontam para níveis entre os 50, 30 e $15 \mathrm{~m}$; outros para os 70-9o m, 40-6o m, 20-35 m, 5-15 m; sendo o de 25-40 m o que tem maior expressão cartográfica (Ribeiro e Patrício, 1942 e Soares, 1966, apud Vilaça, 1988, p. 11).

8. Alarcão, 1988.
} 
Amoreira, e na margem esquerda o monte de Reveles, com estreita ligação ao sítio de Sevelha (Penajoia, 2011; 2012; 2013). As redes de um barco na sua faina trouxeram à tona recipientes de dolia $\mathrm{e}$ anforae, que se crê serem provenientes também de um naufrágio de uma nave romana ${ }^{9}$. Estes achados permitem comprovar que o Mondego teria uma excelente dinâmica náutica neste período, aliás já comprovada pela longa diacronia do complexo portuário de Santa Olaia, sobretudo na Idade do Ferro. Por outro lado, não podemos esquecer que este rio era a via principal para o escoamento da produção de sal e indústrias associadas (produzidas na sua foz). Nos parcelários fósseis, que ainda se detetam junto aos campos de arroz, é possível verificar que estariam associados a antigas salinas.

Assim, é pertinente focar as questões relacionadas com a construção naval e as explorações salineiras. Aqui existia uma população dispersa de pescadores e salineiros, que sempre caracterizaram a foz do rio, e que estão incipientemente estudadas/os. Sabemos que existiam marinhas e que o Mosteiro de Santa Cruz estaria interessado na sua aquisição para a exploração do sal e do pescado, neste caso na margem direita (Alarcão, 2004, p. 103). Não esquecendo também a complementaridade da produção oleira, que seria essencial nesta atividade. A esse respeito, Santos Rocha identificou vários vestígios de fornos para produção cerâmica romana na área circundante (Rocha, 1897; Penajoia, no prelo). Trata-se realmente de uma posição geográfica sugestiva para complexos de olaria, incluindo materiais anfóricos que dinamizariam uma economia de povoados costeiros, onde a indústria da salga de peixe e de preparados piscícolas seriam determinantes (Blot, 2003). Neste campo, Carlos Fabião assinala as dificuldades que uma investigação pode sentir no objetivo de detetar centros de exploração de recursos marinhos e de olarias, que estariam localizadas em áreas litorais (seja na costa, fundos de estuário, ou zonas lagunares). Neste contexto, segundo o investigador, enquadra-se o território a norte do complexo portuário da Estremadura - o Mondego. Este vasto estuário estabelece-se numa importante tradição histórica de recursos marinhos, inserido numa costa onde escasseiam fundeadouros, e onde se deverá projetar investigações norteadas para a identificação de vestígios da Lusitânia Romana, tendo sempre a

9. Cortez, 1957, p. 120-122. noção das antigas geografias e não o presente quadro paisagístico (Fabião, 2004, p. 383-384).

As próprias vias terrestres apontam para o contexto económico e cultural existente nesta zona da foz. Algumas rotas e caminhos tiveram desde sempre um foco relevante na circulação de pessoas e animais sendo perpetuados, por exemplo, até à área da Serra da Lousã/Açor/Sobral de São Miguel e Casegas (Covilhã) conhecidas por: "A Rota do Sal ou Estrada Real" até ao século XX (Ribeiro; Joaquinito e Pereira, 2010, p. 204).

No período romano, pode apontar-se a existência de uma reciprocidade no relacionamento entre núcleo urbano e núcleo rural. Esse relacionamento não era, porém, igualitário, mas essencial para permitir o controlo imperial sobre o território colonial, sendo reflexo da influência política/militar, e condicionado pela distribuição e hierarquização dos povoamentos.

Quanto à distribuição destes, verificamos, na área de estudo, uma relação muito próxima com o sistema hídrico Mondego/Pranto, ao longo do qual se implantaram os sítios de ocupação romana. Os povoados estabelecem-se normalmente em encostas suaves e voltadas a SE, tendo em vista a acessibilidade fluvial e a sua adaptação à atracagem das embarcações.

Nesta perspetiva efetuámos uma análise espacial referente a sítios de ocupação romana no paleoestuário do Mondego e seus afluentes. É possível observar que as distâncias entre eles em linha reta rondam, em média, os $6 \mathrm{~km}$.

Finalmente, apercebemo-nos também que o território é limitado, na zona mais baixa, pelo traçado ferroviário, sendo uma via de comunicação de especial interesse para o estudo dos indicadores arqueológicos, visto que a sua implantação veio substituir muitos dos ancoradouros e portos fluviais existentes no passado.

\section{O SÍTIO ARQUEOLÓGICO DA IGREJA VELHA DO NEGROTE E O ALMOFARIZ}

Esta zona do Alqueidão/Paião/Negrote, ainda que pouco documentada na época, foi de alguma forma caracterizada por Santos Rocha aquando da sua incursão no vizinho castro de Bizorreiro de Castela. "O outeiro é muito ingreme de todos os lados, e só facilmente acessível pela encosta de Oeste. Do cimo descobre-se um soberbo panorama. Ao Sul ergue-se 
a Serra do Paião. A Este, Nordeste e Norte os campos e o Mondego: toda a margem direita, com os seus relevos e povoações até Ferrestelo; e na margem esquerda, Abrunheira, Revelles” (Rocha, 1909, p. 245). Do Paião temos algumas notícias de materiais romanos, nomeadamente as coligidas por Belchior da Cruz, que dá conta da entrada de quatro fragmentos de dolium no museu (Cruz, 1899-19oo, p. 180).

O sítio da Igreja Velha do Negrote enquadra-se no âmbito legal da Carta Arqueológica da Figueira da Foz e respetivas salvaguardas, integradas no PDM. O sítio está protegido por uma zona arqueológica - ZA14 - e classificado como Valor Arqueológico n. VA66. Daqui são provenientes os fragmentos de uma ânfora de tipologia Haltern 7o, datável dos meados do século I a.C. aos meados/finais do I d.C. (Figura 3), e de um almofariz (mortarium), que se conservam na reserva de arqueologia do Museu Municipal. Analisando o almofariz, verificámos que a entrada desta peça no acervo do Museu está registada no Catálogo Geral com o n.ำ4374 e com a designação de "fragmento de um vaso" (Rocha, 1905, p. 140). Trata-se de um almofariz de tipologia Dramont D2, de fabrico centro-itálico e sem marca de oleiro conservada (Figura 4 e 5). Esta tipologia está relacionada com a abundante representatividade destes almofarizes no naufrágio, com o mesmo nome, sucedido na costa francesa (Joncheray, 1972). Esta forma itálica, primeira área de produção, está também representada na Tarraconense e foi igualmente elaborada na Gália (Quaresma, 2006, p. 151).

Para além de Lisboa e seu território, identificam-se exemplares, nomeadamente em Conimbriga (Alarcão \& alii, 1976, p. 75, desenho n.ํ137), Santarém (Arruda e Viegas, 2004) e Braga (Morais, 2004). A escassez de mais resultados referentes a esta tipologia parece agora começar a ser invertida e a ganhar alguma representatividade, pois a falta de estudos publicados será certamente uma causa a assinalar (Mota \& alii, 2016-2017, p. 180). A presença desta tipologia em meio rural também se aproxima da questão náutica, visto que são identificados, algumas vezes, próximo da linha de costa, não só em Portugal, mas também na vizinha Espanha (Moscardó Sabater, 2008; Trelis Martí, 2012).

A análise deste exemplar leva-nos a enquadrá-lo na época Flaviana conforme, análise do bordo tipo 3 de Aguarod Otal (1991, p. 141), e nas semelhanças com um exemplar de Caeseraugusta (Idem, 1991, fig. 34-3).
Atualmente o estudo de almofarizes romanos começa a integrar uma especialidade dentro da ceramologia romana. Para além da cozinha, poderiam estar relacionados com "outras funções como as ligadas à obtenção de produtos medicinais ou de beleza (por exemplo, a preparação de cremes e pinturas com fins de aplicação cosmética), ou com a maceração de vísceras de peixes destinada à preparação de molhos do tipo garum ou de liquamen" (Sepúlveda $\mathbb{E}$ alii, 2007, p. 256). O estudo destes almofarizes permite analisar a dimensão económica romana, apoiar a sua definição cronológica, bem como avaliar a dinâmica de aquisição de hábitos culturais itálicos (Silva, 2015, p. 1).

Ao nível da descrição morfológica do almofariz em estudo, trata-se de um fragmento de bordo largo desenvolvido externamente e espessado, de secção amendoada. É dotado de paredes espessas de tendência hemisférica. Amplo vertedor, com canal de drenagem de forma troncopiramidal e flanqueado por dois sulcos oblíquos. Apresenta as seguintes dimensões: altura máxima - 6,2 cm; largura máxima conservada $-7,0 \mathrm{~cm}$; espessura da parede $-1,8 \mathrm{~cm}$; diâmetro $-44 \mathrm{~cm}$, aproximadamente.

Quanto às características das pastas, estas apresentam uma origem vulcânica, ricas em minerais ferro-magnesianos, com tons amarelo e rosa claros (Aguarod Otal, 1991, p. 141).

A tipologia D2 difere do D1, também pelo seu maior peso e profundidade (Luezas Pascual, 2001, p. 77).

No Laboratório de Petrologia ${ }^{10}$ foi efetuada uma análise petrográfica ao almofariz (Figura 6). No que concerne à pasta, esta é globalmente de granulometria fina com coloração interior e exterior tendencialmente bege/rosada 5 YR $8 / 4^{11}$. Já no que diz respeito aos elementos não plásticos (ENPS) observam-se minerais geralmente não angulosos e de calibre pequeno: micas, biotites, moscovite, quartzos, piroxenas alongadas e chamota. A zona de superfície aparenta um acabamento de engobe e parece apresentar alguns alisamentos para a definição da morfologia da peça. Evidencia, nas zonas laterais do vertedor e no reverso, uma pasta bastante granulosa com matriz de quartzo e alguns nódulos de cal. Trata-se possivelmente de argamassa. Esta observação levanta

10. DCT - Departamento de Ciências da Terra - Universidade de Coimbra. Utilizámos o microscópio estereográfico Nikon SMZ 8oo.

11. Munsell Colour Chart. 
uma problemática em torno do segundo momento funcional desta peça. Estaria adaptada e consolidada numa estrutura, ou simplesmente reaproveitada num qualquer aparelho construtivo local?

Afigura-se promissora a metodologia de prospeção sistemática desta área. Recentemente desencadeámos uma batida ao local, com paragem num outro sítio próximo e de interesse, designado de Barra. Aqui, a $200 \mathrm{~m}$ de uma capela seiscentista e junto a uma quinta voltada a SE, identificámos vários fragmentos de cerâmica comum de pasta alaranjada e de construção - tégula. A cerca de $1500 \mathrm{~m}$ NE do sítio do Negrote, na zona baixa do Alqueidão, existe um troço de calçada e uma ponte já referenciados como valores patrimoniais em PDM.

Na subida para o Negrote/Alqueidão, acompanhados por alguns residentes, parámos junto à escola primária, onde os mesmos nos "localizaram" o sítio da "Igreja Velha”. Aqui identificámos uma estrutura em muito mau estado de conservação. Esta ruína está voltada para Oeste, ou seja, para o Atlântico. Apresenta-se alinhada por antigos socalcos de vinhas com uma orientação de $30^{\circ} \mathrm{NE}$, a $500 \mathrm{~m} \mathrm{NE}$ da Escola.

Este sítio levanta-nos alguns problemas na sua identificação exacta, desde logo pela ambiguidade da posição da dita igreja. Em segundo lugar, porque a maior parte dos terrenos que vão desde a escola à igreja restaurada estão registados no livro de matrizes prediais do concelho como de Igreja Velha. Ou seja, numa distância aproximada de $300 \mathrm{~m}$ em linha reta. Apesar de nos faltar comprovar o núcleo central do sítio, conseguimos verificar, a partir das ruínas, alguma dispersão de materiais cerâmicos de feição romana, e que nos levaram até ao talude da estrada principal no sentido Negrote-Alqueidão. Neste talude é possível verificar pontualmente na sua estratigrafia, uma linha de argamassa e alguns materiais cerâmicos muito rolados.

Muito próximo do Negrote, a cerca de $2 \mathrm{~km}$ Oeste e na margem oposta ao rio Pranto, encontram-se águas termais exploradas certamente no período romano. Helena Frade e José Beleza (1992, p. 517) dão conta da estância termal n. ${ }^{\circ} 38$ - Nossa Senhora do Pranto, atualmente, Termas da Azenha.

Trata-se, de facto, de uma zona que certamente terá sido explorada pela sua posição de grande domínio visual, quer para o Atlântico, Mondego/Pranto, quer para antigos povoados da margem direita e esquerda. Esta situação também conferiu uma apetência náu- tica, devido à sua proximidade com o paleoestuário, bem como a utilização de matérias-primas locais (pedra calcária), que lhes forneceriam um papel de fixação e dinamismo. Assim, não é de estranhar a presença de materiais importados neste território, como é o exemplo deste almofariz.

\section{AGRADECIMENTOS}

Agradecemos à Dr. - Margarida Perrolas e à Dr..$^{\underline{a}}$ Ana Ferreira o apoio incondicional a esta investigação, bem como à equipa técnica da Divisão de Cultura do Município da Figueira da Foz.

À Doutora Carmen Aguarod Otal, Ao Prof. Doutor Carlos Fabião e à Prof. ․ Doutora Lídia Catarino, o nosso agradecimento pelos esclarecimentos que nos prestaram relativamente ao almofariz.

\section{BIBLIOGRAFIA}

AGUAROD OTAL, Carmen - (1991) Cerámica común romana de cocina en la Tarraconense. Zaragoza: Institución "Fernando el Católico".

AGUAROD OTAL, Carmen (2017) - Cerámica común de mesa y de cocina en el valle del Ebro y producciones periféricas. In FERNÁNDEZ OCHOA, Carmen; MORILLO, Ángel; ZARZALEJOS, Mar, eds. - Manual de cerámica romana II: cerámicas romanas de época altoimperial en Hispania : importación y producción. Alcalá de Henares: Museo Arqueológico Regional, pp. 15-95.

ALARCÃO, Jorge de; DELGADO, Manuela; MAYET, Françoise; ALARCÃO, Adília Moutinho e PONTE, Salete da, (1976) - Fouilles de Conimbriga VI, Céramiques diverses et verres. Paris, De Boccard.

ALARCÃO, Jorge de (1988) - Roman Portugal, Coimbra, England: Aris \& Phillips Ltd. Vol.II, fasc.2.

ALARCÃO, Jorge de (2001) - As paróquias suévicas do território actualmente português. In F. VILLARe M.P.FERNÁNDEZ ÁLVAREZ (eds.), Religión, lengua y cultura prerromanas de Hispania. Salamanca: Universidad de Salamanca, pp. 29-59.

ALARCÃO, Jorge de (2004) - In territorio colimbrie: lugares velhos (e alguns deles deslembrados) do Mondego. Lisboa: IPA (Trabalhos de Arqueologia, 38).

ALVES, Adalberto (2013) - Dicionário de Arabismos da Língua Portuguesa. Lisboa: Imprensa Nacional-Casa da Moeda.

ARRUDA, A. Margarida.; VIEGAS, Catarina. (2004) - Les mortiers de l'Alcáçova de Santarém (Portugal). In Société Française d'Étude de la Céramique Antique en Gaule: actes du Congrès de Vallauris, 2O-23 mai 2004. Marseille: Société Française d’Étude de la Céramique Antique en Gaule, pp.341-349. 
BLOT, M. Luísa Pinheiro (2003) - Os portos na origem dos centros urbanos: contributo para a arqueologia das cidades marítimas e flúvio-marítimas em Portugal, IPA, Lisboa.

DE MAN, Adriaan; RUIVO, José (2009) - Primeiros dados sobre a villa da Madanela (Coles de Samuel, Soure). Revista Portuguesa de Arqueologia. Lisboa. 12:1, pp. 201-210.

CORTEZ, Fernando Russel (1957) - Pesquizas arqueológicas submarinas no Atlântico. Viriatis - Arte, Arqueologia, Museologia: boletim do Museu de Grão Vasco. Viseu. 1:2, pp. 120-122.

CRUZ, Belchior da (1899-19oo) - Museu Municipal da Figueira da Foz - 1: Acquisições em 1898. O Archeologo Português. Lisboa. Vol. V, pp. 177-184.

DIAS, Alverinho (2004) - A história da evolução do litoral português nos últimos vinte milénios. In TAVARES, A.A.; TAVARES, M.J.F; CARDOSO, J.L. - Evolução geohistórica do litoral português e fenómenos correlativos: Geologia, História, Arqueologia e Climatologia. Lisboa: Universidade Aberta, pp. 157-170.

DIAS, J. Alves (1980) - Do "Pagus" ao Paio (Notas sobre a administração Romana em Portugal). Bracara Augusta. Braga. 34, pp. 659-672. Em colaboração com A. H. de Oliveira Marques.

FABIÃO, Carlos (1998) - O vinho na Lusitânia: reflexões em torno de um problema arqueológico. Revista Portuguesa de Arqueologia. Lisboa. 1:1, pp. 169-198.

FABIÃO, Carlos (2004) - Centros oleiros da Lusitania: balanço dos conhecimentos e perspectivas de investigação. In BERNAL, D.; LAGOSTENA, L., eds. - Figlinae Baeticae: talleres alfareros y producciones cerâmicas en la Bética romana. (ss. II a.C. - VII d.C.): actas del Congreso Internacional (Universidad de Cádiz, 12-14 de Noviembre de 2003). Oxford: Archaeopress, pp. 379-410. (BAR Internacional Series; 266)

FERNANDES, A. de Almeida (1999) - Toponímia portuguesa (exame a um dicionário). Arouca: Associação para a defesa da Cultura Arouquense.

FERREIRA, Ana; PINTO, Sónia (2017) - Análise e Diagnóstico Património Classificado e Referenciado - Documento final. Secção 2 Carta municipal de arqueologia. Divisão de Urbanismo - subunidade de planeamento; Divisão de Cultura. Câmara Municipal da Figueira da Foz. Acessível na Biblioteca do Museu Municipal Santos Rocha.

FRADE, Helena; MOREIRA, J. Beleza (1992) - A arquitectura das termas romanas de S. Pedro do Sul. Espacio, Tiempo y Forma, Serie II, Historia Antigua № 5 . UNED: Facultad de Geografia e Historia, pp. 515-544.

FUENTES SÁNCHEZ, J. Luis (2017) - Nuevo ejemplo de mortero Dramont Di, hallado en Laminium (Alhambra, Ciudad Real). Alebus. Elda. 10-12, pp. 155-192. N.- dedicado a: Investigaciones ibéricas, romanas y medievales 2000-2015.
HEVIA GONZÁlEZ, Susana; MONTES LÓPEZ, Ruben (2009) - Cerámica común del siglo I d.C. en el castro del Chao Samartín (Grandas de Salime, Asturias): notas sobre el repertorio en un ambiente militarizado. In: MORILLO, A.; HANEL, N.; MARTÍN, E., ed. - Limes XX: estudios sobre la frontera romana. Madrid: Consejo Superior de Investigaciones Cientificas. Vol. 2, pp. 639-654 (Anejos de Gladius; 13)

IMPERIAL, Flávio (2017) - O Sítio arqueológico de Maiorca no contexto da conquista romana do ocidente peninsular. Lisboa: Universidade de Lisboa, Faculdade de Letras.

JONCHERAY, J.P. (1972) - Contribution a l'étude de l'Epave Dramont D, dite "des pelvis». Cahiers d'Archeologie Subaquatique. Antibes. I, pp. 11-34.

LUEZAS PASCUAL, R. Aurora (2001) - Cerámicas comunes de importación de época romana en el Municipium Calagurris Ivlia (Calahorra, La Rioja). Kalakorikos. Calahorra. 6, pp. 71-10o.

MANTAS, Vasco (1999) - As villae marítimas e o problema do povoamento do litoral português na época romana. In GORGES, Jean-Gérard; RODRÍGUEZ MARTIN, F. Germán, ed. - Économie et Territoire en Lusitanie romaine: actes et travaux. Madrid: Casa de Velázquez, pp. 135-156 (Casa de Velázquez; 65).

MORAIS, Rui (2004) - Os almofarizes béticos em Bracara Augusta. In BERNAL, D.; LAGOSTENA, L., ed. - Figlinae Baeticae: talleres alfareros y producciones cerâmicas en la Bética romana. Oxford: Archaeopress. Vol. II, pp. 567-570 (BAR Internacional Series; 266)

MOSCARDÓ SABATER, Emili (2008) - El poblamiento rural romano en el território Norte de Dianium. La comarca de La Safor-Valldigna (Valencia). Saguntum, 4O, pp. 177-192.

MOTA, Nuno; GRILO, Carolina; ALMEIDA, Rui de; FILIPE, Victor (2016-2017) - Apontamento crono-estratigráfico para a topografia histórica de Olisipo. A intervenção arqueológica na rua de São Mamede (Via Pública - 19), Santa Maria Maior, Lisboa. CIRA Arqueologia 5, Câmara Municipal de Vila Franca de Xira, pp. 149-206.

PENAJOIA, Marco (no prelo) - Elementos para o Estudo da Ocupação Romana na Foz do Mondego. Colóquio Santos Rocha Arqueologia e Territórios da Figueira da Foz. Câmara Municipal da Figueira da Foz/Instituto de Arqueologia - FLUC.

PENAJOIA, Marco (2012) - A Questão portuária em torno de Montemor-o-Velho: Estudo de Arqueologia. Colecção Memória e Identidade, Câmara Municipal, Montemor-o-Velho.

PENAJOIA, Marco (2013) - Introdução ao estudo das planimetrias antigas: foto interpretação dos sítios arqueológicos de Sevelha e Vinha Velha. Monte Mayor - a terra e a gente. Montemor-o-Velho. 8:14, pp.149-151. 
PENAJOIA, Marco (2014-2015) - Território de Abrunheira, Verride e Vila Nova da Barca: bases para o seu estudo arqueológico e patrimonial: relatório técnico. Verride: União das Freguesias de Abrunheira, Verride e Vila Nova da Barca.

QUARESMA, J. Carlos (2006) - Almofarizes béticos e lusitanos: revisão crono- morfológica de alguns tipos. Revista Portuguesa de Arqueologia. Lisboa. 9:1, pp. 149-166.

RIBEIRO, Nuno; JOAQUINITO, Anabela.; PEREIRA, Sérgio (2010) - O Podomorfismo na Arte Rupestre da Fachada Atlântica, que significado?, Actas do VEncontro de Arqueologia do Sudoeste Peninsular, 18-20 Novembro de 2010, Almodôvar. Câmara Municipal de Almodôvar.

ROCHA, A. dos Santos (1897) - Fornos luso-romanos da freguesia de Brenha. In Memórias sobre a Antiguidade, Figueira da Foz: Imprensa Lusitana, pp. 259-264.

ROCHA, A. dos Santos (1905) - O Museu Municipal da Figueira da Foz: Catálogo Geral. Figueira da Foz: Imprensa Lusitana.

ROCHA, A. dos Santos (1909) - O castro do Bizorreiro de Castella. Boletim da Sociedade Arqueológica Santos Rocha.

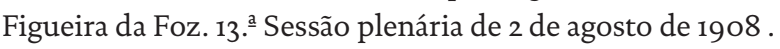
N.o 9 , pp. $245^{-246}$.

ROCHA, Artur (2016) - Peça do mês: almofariz. Museu do dinheiro, o1/24. Banco de Portugal. Lisboa.

RUIZ ZAPATERO, Gonzalo (1988) - La prospección arqueológica en España: passado, presente y futuro. Arqueologia Espacial. Lisboa, Tomar. 12, pp. 33-48.

SEPÚLDEVA, Eurico; SANTOS, Patrícia A.; FARIA, J. Carlos; FERREIRA, Marisol (2007) - Cerâmicas romanas do lado ocidental do castelo de Alcácer do Sal, 5: almofarizes de produção bética, pesos e cossoiros. Revista de Arqueologia. Lisboa. 10:2, pp. 255-284.

SILVA, R. Banha da (2015) - Um almofariz itálico com "marca de oleiro" de M. COMINIVS SATVRNINVS, de Lisboa. Lisboa: R.B. Silva (Estudos e relatórios de Arqueologia Tagana; 4).

TRELIS MARTÍ, Julio (2012) - La Canyada Joana (Crevillent-Alicante): una villa romana del ager ilicitanus. Anales de Prehistoria y Arqueología. Murcia. N. 27-28 (2011-2012). N.․e especial: NOGUERA CELDRÁN, J. M.; ANTOLINOS MARÍN, J. A., coord. - De vino et oleo Hispaniae. Áreas de producción y procesos tecnológicos del vino y el aceite en la Hispania romana. Coloquio Internacional, Universidad de Murcia, pp. 293-303

VILAÇA, Raquel (1988) - Subsídios para o estudo da Pré-História recente do Baixo Mondego. Trabalhos de Arqueologia 05. IPPC, Lisboa.

\section{CARTOGRAFIA}

PORTUGAL. Direção dos Trabalhos Geodésicos, Corográficos e Hidrográficos do Reino (1858) - [Planta Provisória dos Campos Inundados pelas Máximas Cheias do Mondego, seus afluentes e valas desde Coimbra à sua Foz na Vila da Figueira]. 1 planta para servir de base às disposições do $\$$ 2..$^{\circ}$ do artigo 3. . da Lei de 12 de agosto 1856 , levantada sob a direção do Conselheiro F. Folque, Brig. Grad. Dir. dos Trab. Geod. Corog. e Hidrog. do Reino, pelo Chefe da Secção Hidrogr. e Cap. Ten. da Armada F. M. P. da Silva e mais oficiais que o coadjuvaram.

PORTUGAL. Direção Geral dos Trabalhos Geológicos e Topográficos (1917) - [Carta de Portugal]. Escala 1:50.00o. 1 carta. Folha N.ำ 12-C. Ampliada e retificada na Direção Geral dos Trabalhos Geológicos e Topográficos no ano de 1901. Acessível no Arquivo Histórico do Museu Municipal Santos Rocha. Figueira da Foz

PORTUGAL. Instituto Geográfico (1866) - [Carta corográfica do reino de Portugal]. Escala 1:100.00o. 1 carta. Folha n. ${ }^{\circ}$ 13. Redigida e gravada no instituto Geográfico, sob a direção do Conselheiro F. Folque. Acessível no Arquivo Histórico do Museu Municipal Santos Rocha. Figueira da Foz. 


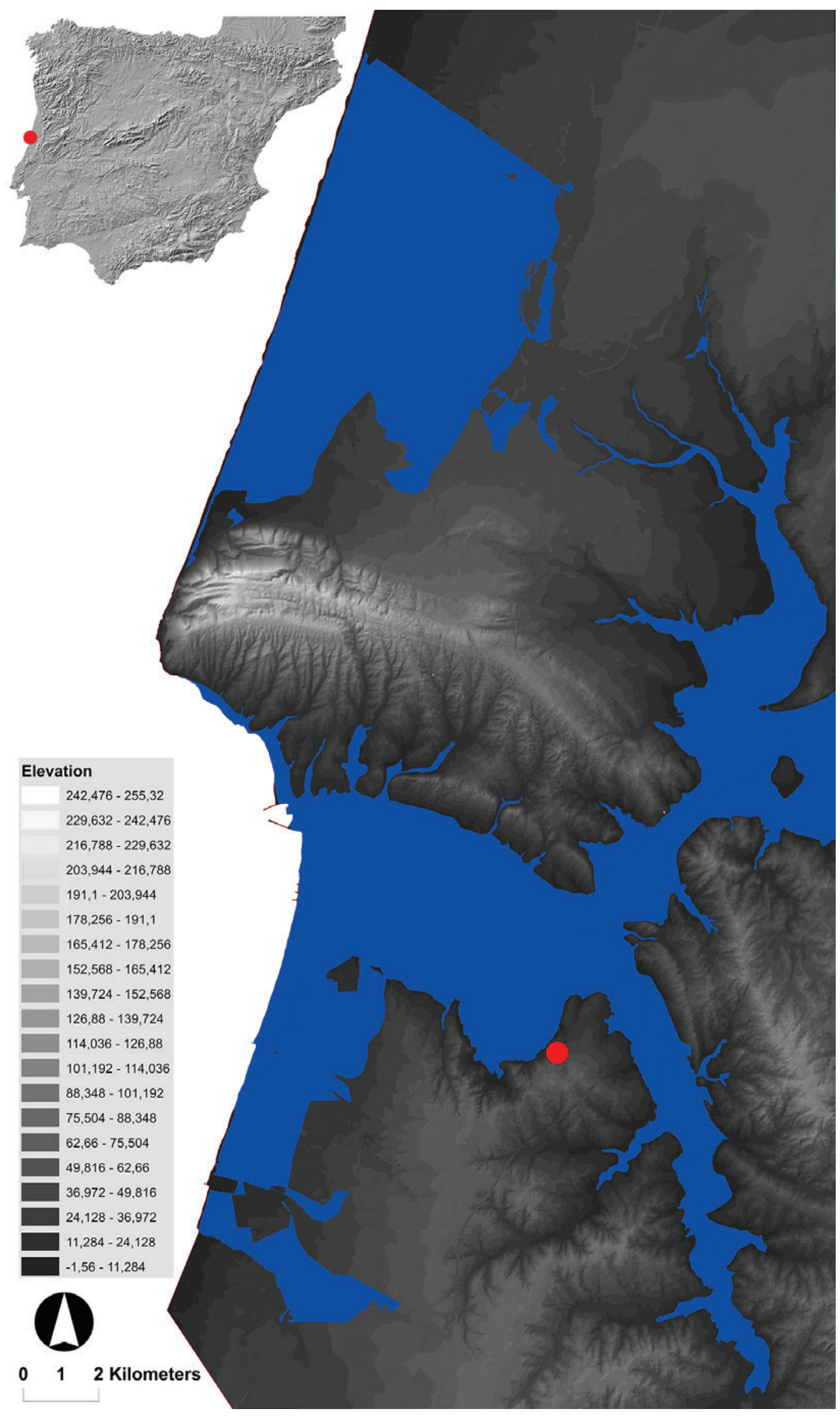

Figura 1 - Localização da Igreja Velha do Negrote. 


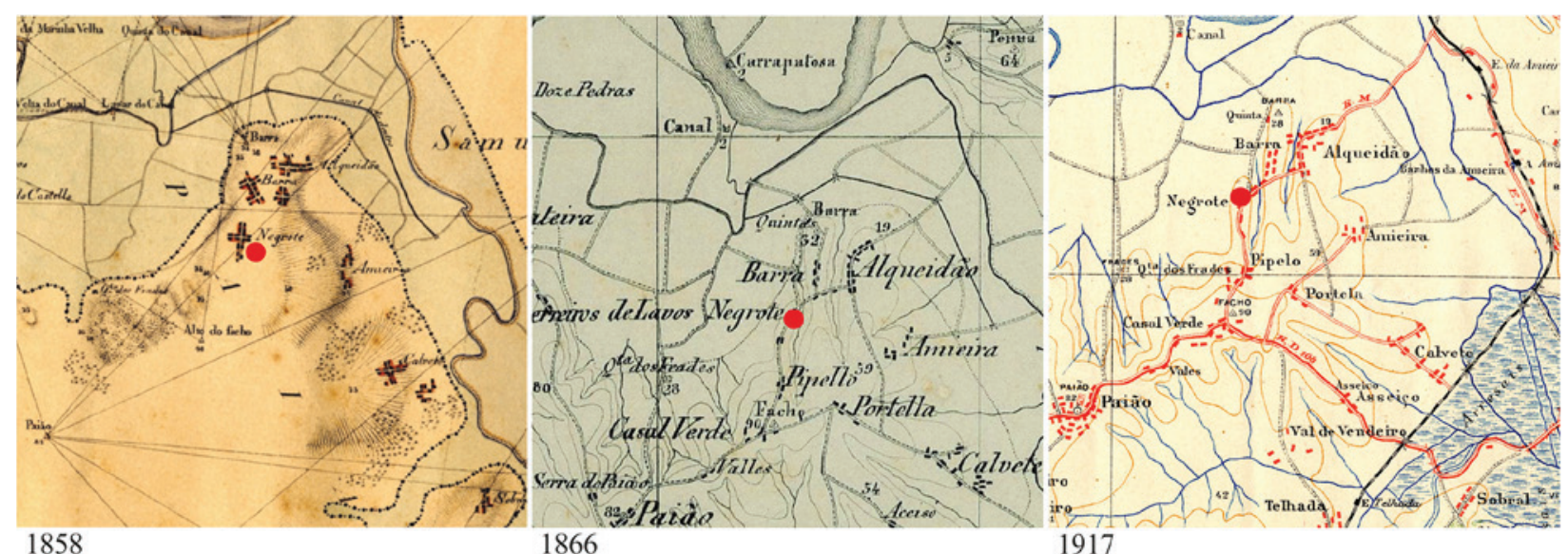

Figura 2 - Localização da Igreja Velha do Negrote a partir de cartografia histórica. Excertos adaptados de: Direção dos trabalhos geodésicos, corográficos e hidrográficos do Reino (1858); Instituto Geográfico (1866); Direção Geral dos Trabalhos Geológicos e Topográficos (1917).

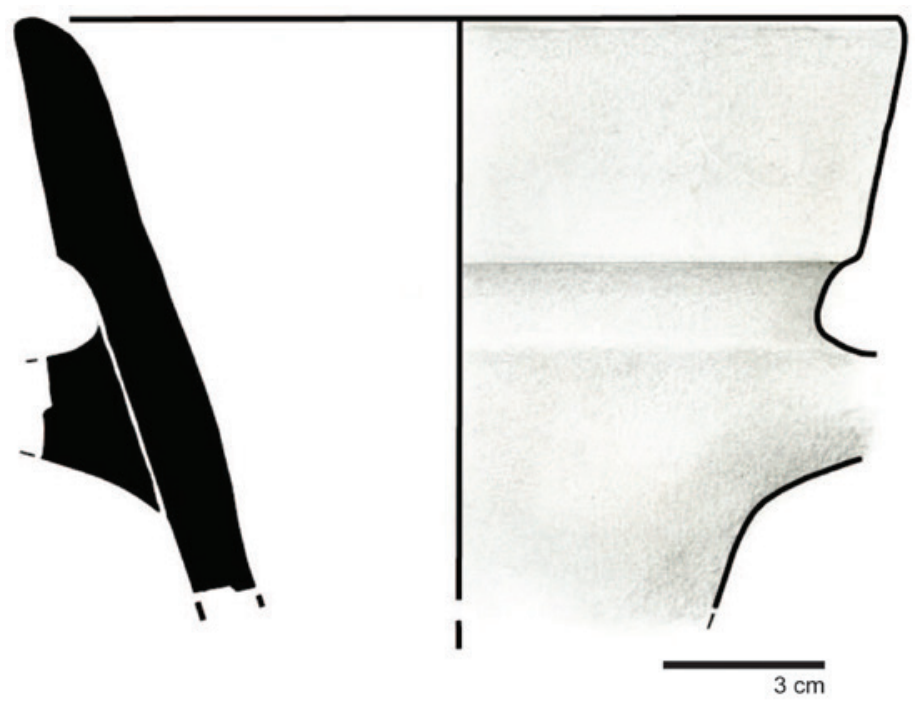

Figura 3 - Ânfora Haltern 7o. Escala $3 \mathrm{~cm}$. 

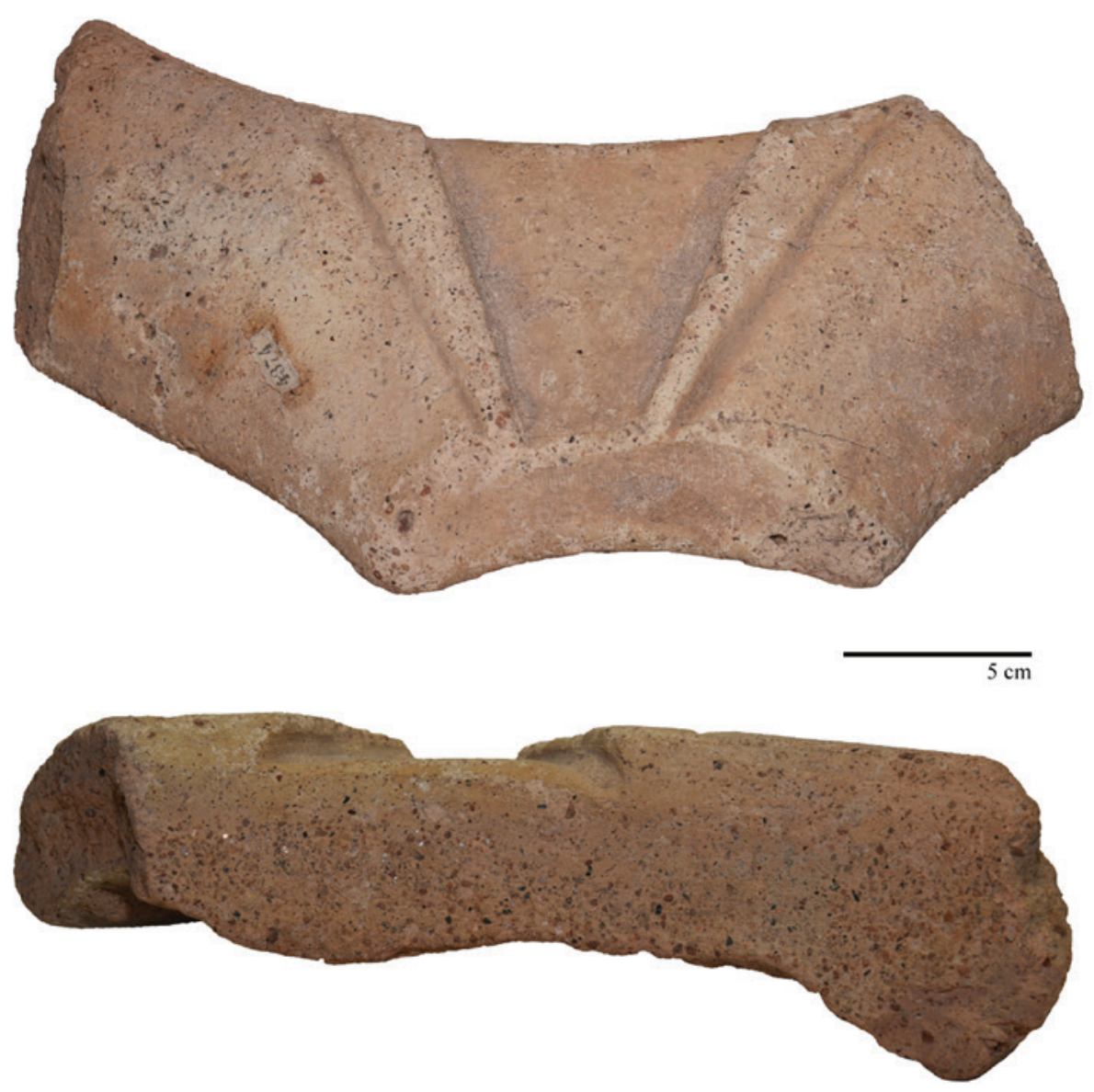

Figura 4 - Registo fotográfico do fragmento de almofariz. Escala $5 \mathrm{~cm}$.

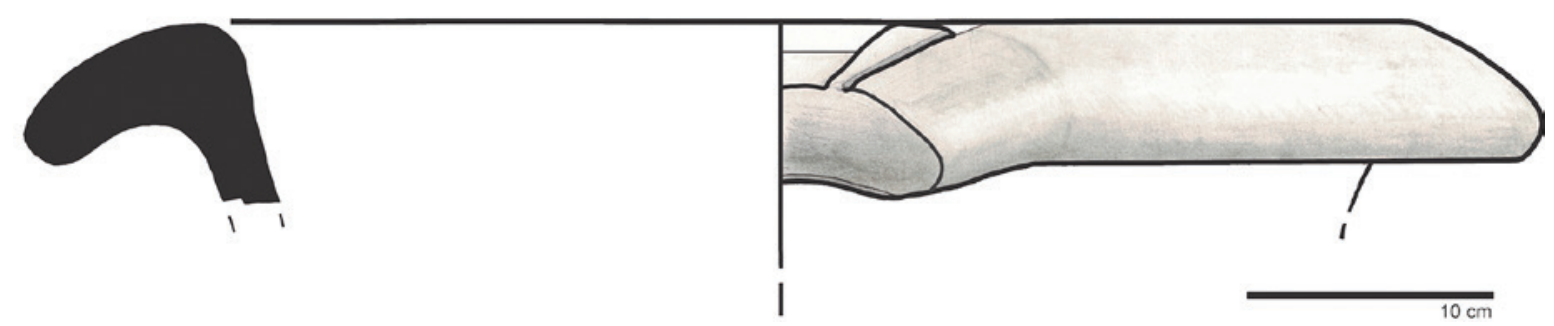

Figura 5-Almofariz Dramont D2. Escala $10 \mathrm{~cm}$. 


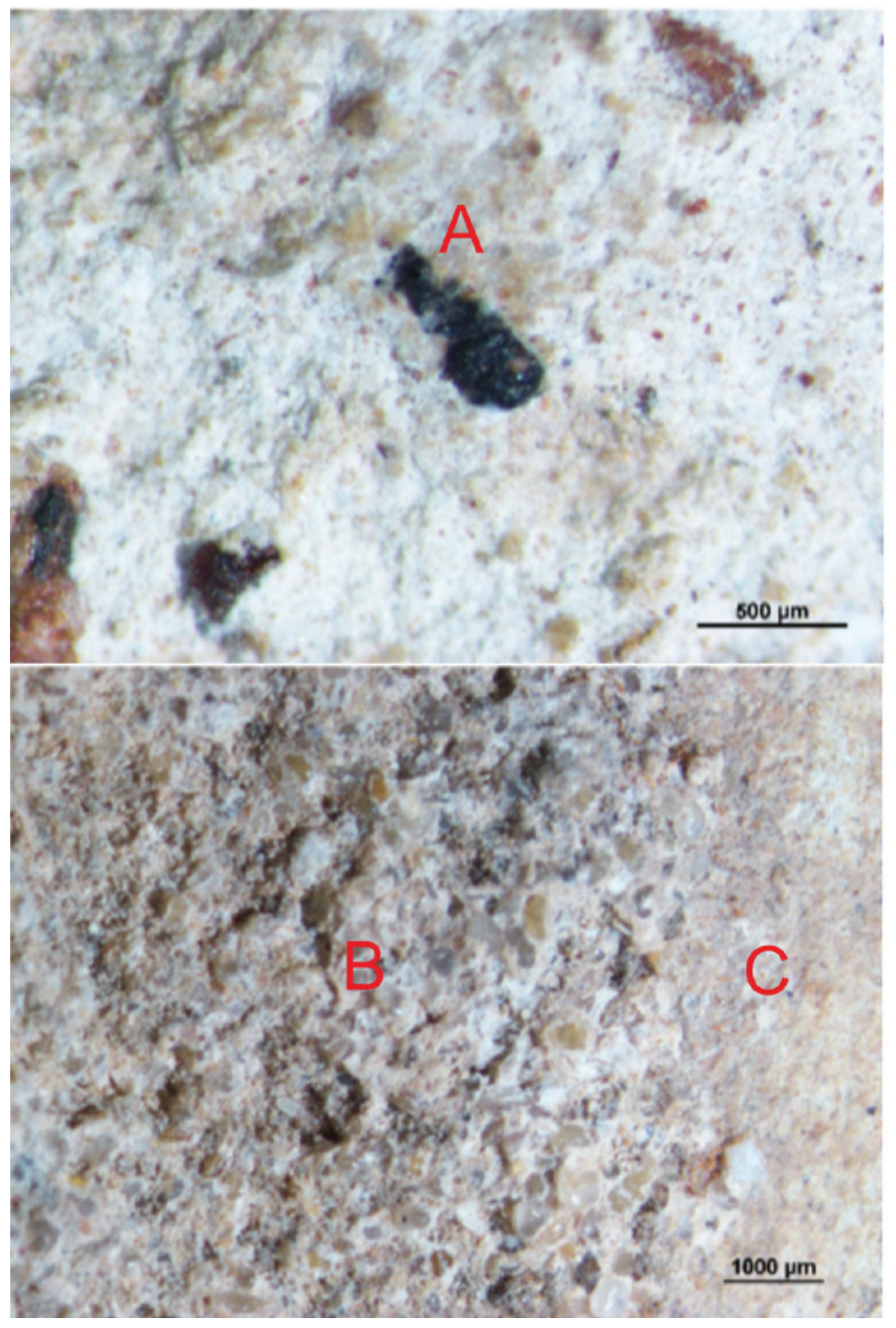

Figura 6 - Fotomicrografia executada à pasta do almofariz. A - presença de piroxenas; $\mathrm{B}$ - argamassa incrustada junto ao sulco do vertedor; $\mathrm{C}$ - pasta original. Laboratório de petrologia (DCT-UC). 


\title{
ESTRUTURAS ROMANAS DE CARNIDE - LISBOA
}

\author{
Luísa Batalha ${ }^{1}$, Mário Monteiro² ${ }^{2}$ Guilherme Cardoso ${ }^{3}$
}

\begin{abstract}
RESUMO
Os trabalhos arqueológicos realizados no Palácio Sant'Anna, Carnide (Lisboa) revelaram a presença romana através de restos de um piso em opus signinum, possivelmente de um tanque e um poço escavado no geológico, com boca circular de alvenaria seca, colmatado com terra, pedras e materiais daquele período. Entre os materiais de época romana recolhidos, destacam-se: fragmentos de recipientes de terra sigillata, ânforas Lusitanas e Béticas, cerâmica comum, assim como um dormente de mó em arenito, elementos que apontam para uma ocupação do sítio entre os séculos I-III d.C.

Palavras-chave: Carnide, Período Romano, Poço, Cerâmica Romana.
\end{abstract}

\begin{abstract}
The archeological excavations carried out at Sant'Anna Palace, Carnide (Lisbon) revealed Roman occupation documented by the remains of an opus signinum coated pavement. Possibly a tank or a well dug in bed rock, circle shaped built with dry stone masonry. It was deactivated and filled with dirt, stones and other archeological materials. Standing out among the collected Roman materials we can find: terra sigillata ceramic fragments, Lusitana and Bética type amphoras, common ceramic, as well as static part of a sandstone millstone, which lead us to the conclusion that this place was occupied between the $1^{\text {st }}$ and $3^{\text {rd }}$ centuries A. C.
\end{abstract}

Keywords: Carnide, Roman Period, Well, Roman Pottery.

\section{ENQUADRAMENTO GEOGRÁFICO E GEOLÓGICO}

A intervenção arqueológica foi realizada na Rua da Fonte, n. ${ }^{\circ}$ 41-51, em Carnide, concelho de Lisboa, à cota dos 104/105 metros.

Esta área da cidade de Lisboa encontra-se sobre unidades geológicas do Complexo Miocénico do Burdigaliano, (Pais et al., 2006). Localiza-se sobre uma unidade dos "Calcários de Entre Campos" também designados por "Banco Real”, que são atribuídos à sequência deposicional Bı (Pais et al., 2006).

Constituída por biocalcalcarenitos, com componente detrítica e por acumulação de conchas e moldes, ligados por cimento carbonatado, incluem ainda calcarenitos finos, margosos e arenitos micáceos pouco carbonatados. No topo, evolui para areias muito finas e siltitos argilosos de cor acinzenta. Passando progressivamente á formação superior, observam-se as "Argilas do Forno do Tijolo", atingindo espessuras da ordem dos 12 a 17m (Cotter, 1956).

\section{RESUMO HISTÓRICO}

A zona de Carnide, Lisboa, é um local onde uma longa diacronia temporal se encontra preservada no subsolo, bem como no património construído, presente na sua zona histórica. Ainda que dos vestígios pré-históricos e romanos apenas existam vagas notícias e alguns achados, a ocupação do período Medieval Islâmico carece de elementos significativos, indicadores das vivências desta época, como consequência de neste local ter funcionado um espaço de enterramento, cujas características de inumação o identificaram e dataram de época islâmica. Entre as referências da existência de quintas senhoriais des-

\footnotetext{
1. Associação Cultural de Cascais

2. EMERITA, Lda.

3. CAL, (Centro de Arqueologia de Lisboa) e Associação Cultural de Cascais
} 
de meados do século XIV, encontra-se o paço real de Carnide (em 1313, era Carnide uma aldeia com seu rocio). Após o terramoto de 1755, que muito terá afetado a zona, dá-se um incremento construtivo, tendo o mesmo, em grande parte, permanecido conservado até à atualidade.

Os trabalhos arqueológicos realizados pela EMERITA no Palácio Sant'Anna - também designado por Palácio da Praça ou Quinta da Praça - revelaram, que a última ocupação do palácio ocorreu já nos finais do século $\mathrm{XX}$, mais propriamente entre as décadas de 70-80, data em que, por motivo de um incêndio, se verificou em definitivo o seu abandono. No solo, um considerável espólio arqueológico atestou a ocupação do espaço desde a Pré-História recente, mas, também as construções de outras eras ficaram ocultadas e preservadas, pelas que se lhe foram sobrepondo, e, consequentemente, alteando a cota do palácio.

\section{OS VESTÍGIOS ROMANOS}

Não era de todo desconhecida a presença romana em Carnide, sendo esta apoiada através de alguns vestígios, tais como as duas tampas cupiformes que surgiram há alguns anos, uma na esquina da Travessa do Pregoeiro com a Rua Neves Costa e outra oriunda do Largo da Praça, n⿳⺈ 7, com a Travessa do Pregoeiro (Cardoso \& Gonzalez, 2008, p. 6).

Durante uma escavação realizada no edifício entre o Largo da Praça, n.. 7 e a Travessa do Pregoeiro, n.. 2, foi recolhido no interior de uma bolsa, um pequeno fragmento de opus signinum, junto a materiais pré-históricos e contemporâneos (Monteiro \& Cardoso, 2016, p. 48, 62).

No edifício nº 84/86 da Rua Neves Costa, durante o acompanhamento de reabilitação, foi recolhido um fragmento de uma ara votiva, reaproveitada no aparelho construtivo das paredes do século XIX, bem como fragmentos de um possível friso romano, encontrando-se estes reutilizados ornamentalmente, no pátio interior do no 82 da mesma rua (Cuesta-Gómez \& Prata, 2017, 601).

Localiza-se Carnide entre as quatro e as cinco milhas romanas de Olisipo, junto a uma das antigas vias que ligava a zona Oeste do ager olisiponesis. Partia do Rossio através da Rua das Portas de Santo Antão, ligando a Carnide e dali seguia para a villa romana da Bolacha, Amadora, de onde bifurcava para Oeste, através do território dos actuais concelhos de Oeiras e Cascais até ao Guincho, enquanto um segundo ramal seguia para o concelho de Sintra até São João das Lampas, passando nas cercanias de Faião e Odrinhas.

\subsection{As Estruturas Romanas}

Durante as escavações arqueológicas efetuadas no interior do antigo palácio de Sant'Anna, para além de materiais romanos recolhidos em unidades estratigráficas sob os pisos de época Contemporânea, identificou-se no canto Sudeste, junto à fachada do edifício que dá para a rua da Fonte, a cerca de $20 \mathrm{~cm}$ de profundidade, o que restava de um pedaço de piso de opus signinum. Devido ao seu tamanho, encontrando-se muito danificado e não apresentando qualquer limite lateral da superfície a que pertencia, tornou-se impossível relacioná-lo com algum tipo de estrutura, desconhecendo-se se fazia parte de um tanque ou de um piso de uma habitação. No entanto, somos tentados a pensar que seria efectivamente um tanque, implantado junto à antiga via, que certamente por ali passaria, e que hoje é a rua da Fonte. Sob o arco Sul da cozinha de época Contemporânea, a sete metros de distância para Noroeste do referido piso de opus signinum, identificou-se uma estrutura negativa, correspondendo a um poço circular, aberto no subsolo dos "calcários de Entrecampos", com 1,5 m de diâmetro ao nível da boca e 1,2 m de diâmetro no seu interior, tendo sido colmatado em época romana.

A escavação atingiu a profundidade de 4,2 $\mathrm{m}$, não sendo possível dar continuidade aos trabalhos, devido ao perigo de desabamento da estrutura, bem como, ter sido ultrapassada a cota de afetação da obra. Na área da boca deste poço, ainda existiam vestígios de um muro de pedra solta de dupla fiada.

$\mathrm{Na}$ parede interna observaram-se diversos orifícios, localizados a cotas distintas e desalinhados, depreendendo-se que foram utilizados para facilitar a escalada, em caso de necessidade de limpeza.

No seu interior identificaram-se três UEs: a primeira camada correspondia à última fase de enchimento [C18a]. Continha algumas pedras provenientes do derrube da guarda do poço, nódulos de argamassa rosada, cerâmica comum e de construção; a segunda camada de enchimento [C18b], encontrava-se encostada à parede Norte do poço e incluía igualmente nódulos de argamassa rosada, e tal como na camada anterior, cerâmica comum e de construção; a terceira unidade estratigráfica [C18c,] encontrava-se entre $1,5 \mathrm{~m}$ até aos $4,2 \mathrm{~m}$ de profundidade. Nesta, no meio 
da terra do enchimento, havia uma concentração de pedras de grande dimensão, como consequência do derrube ocorrido na metade Sul da estrutura. Incluía nódulos de argamassa rosada, um dormente de mó, fragmentos de terra sigillata, ânforas, cerâmica comum e cerâmica de construção.

\subsection{Os Materiais}

Terra sigillata

No compartimento da cozinha, UE [Cog], recolheram-se três fragmentos de parede em terra sigillata itálica, correspondendo a duas peças diferentes de forma indeterminada.

$\mathrm{Na}$ UE [C18e] foi recolhido um fragmento de terra sigillata hispânica, provavelmente de Trício, do tipo Drag. 27, datável entre 40-200 d.C. (Fonseca, 2004, p. 427).

De terra sigillata sudgálica, foram exumados do interior do poço, UE [C18b], um fragmento de parede indeterminada e na UE [C18c] um fragmento de bordo de prato, de tipo igualmente indeterminado (n. ${ }^{2}$ ).

Foi também recolhido, na UE [C18c], um fragmento de bordo de taça de terra sigillata africana A, tipo Hayes 14/15 III (n.ํㅜ), datável entre os finais do séc. II a inícios do séc. III (Cardoso, 2018, p. 272) e das lamas provenientes da UE [C18], um fragmento de pé de terra sigillata africana $\mathrm{A} / \mathrm{D}$, de forma indeterminada (n. $\left.{ }^{-} 4\right)$.

\section{Ânforas}

$\mathrm{Na}$ antiga adega, localizada no canto Noroeste do edifício, a mais de vinte metros do poço, na UE [Ao4], recolheu-se um fragmento de boca de ânfora Dressel 7/11, (n. ${ }^{\circ}$ 5), apresentando cor cinzento claro amarelada (Munsell 2.5Y8/2). Um segundo fragmento do mesmo tipo (Figura 6) foi exumado na zona da cozinha UE [Co9], apresentando pasta cor bege claro (Munsell 2.5Y7/2), ambas produzidas na Bética, sendo possível data-las entre 15 a.C. e inícios do século II d.C. (Cardoso, 2018, pp. 301 e 302), utilizadas no transporte de derivados piscícolas.

Do interior do poço, UE [C18c], foram recuperados vários fragmentos de ânforas do tipo Lusitana 3 ou Almagro 51c, dos quais apresentamos dois bordos e duas asas (n.. ${ }^{\circ}$ 7-10), com lábios em fita ligeiramente curvos, apresentando uma ou duas caneluras e ressalto em barbela na ligação ao colo. As pastas são de cor vermelha (Munsell 2.5Y6/8) ou vermelho acastanhado (Munsell 2.5Y5/6), características das figlinae do Tejo/Sado. Eram ânforas que serviam fundamentalmente para o transporte de vinho. Apresentam cronologia dos inícios do século II d. C. a meados do século III d. C. (Cardoso, 2018, p. 307), com especial relevância para as que se encontram apoiadas nas cronologias de um conjunto de exemplares recolhidos em Sevilha, no Patio de Banderas e que foram datados dos finais do século II d. C. inícios do século III d. C. (Garcia Vargas, 2016, p. 411). De entre as ânforas provenientes do poço, UE [C18c], registamos mais dois fragmentos de ânforas do tipo Almagro 50, lusitana (nº 11 e 12), também elas produzidas com as características pastas avermelhadas do Tejo/Sado (Munsell 2.5Y6/8). O início da produção deste tipo de ânfora dá-se na figlina de Porto dos Cacos, em finais do século II d. C. ao primeiro terço do século III d. C., e na figlina da Quinta do Rouxinol em finais do século II, sendo ali produzida até ao primeiro quartel do século $\mathrm{V}$ (Raposo \& Almeida, 2016).

Durante a escavação de blocos delimitativos foi retirada uma asa de ânfora de forma indeterminada (n.. 13). A pasta, de cor bege (Munsell 7.5YR6/4) é característica da região da Bética.

\section{Cerâmica Comum}

Entre os materiais recuperados mais antigos, em cerâmica comum, temos um conjunto de fragmentos de cerâmica castanha e cinzenta, característica das produções regionais, indígenas, como são os casos da boca de jarro (n.. 14 ) de pasta castanha escura, fina (Munsell 5 YR4/6), bem como da asa de secção circular (n. ${ }^{17}$ ) de pasta cinzenta escura (Munsell ${ }_{5} \mathrm{YR}_{3} / 1$ ), ambas provenientes da zona da cozinha UE [Cog], semelhantes a exemplares recolhidos em Freiria, num contexto de uma antiga pedreira da Idade do Ferro, em MZ' e que foi datado entre o século III a.C. e o I a.C. (Cardoso \& Encarnação, 2013, p. 160). Uma taça de perfil completo (n. ${ }^{-}$15) de pasta cinzenta, brunida internamente (Munsell 5YR6/1), proveniente da sala 5, UE [505], e um pequeno fragmento (n.. 16 ) de pasta cinzenta, brunida internamente (Munsell 5YR6/1), proveniente da cozinha, UE [Cog], são nitidamente produções regionais, influenciadas pelo gosto romano dos finais do século II - I a.C. a finais do século I a. C. (Cardoso, 2018, p. 325 , fig. 250 e 251).

Proveniente do poço, UE [C18c] existe um bordo provável de garrafa (n.. $\left.{ }^{18}\right)$, apresentando pasta castanha avermelhada (Munsell $5 \mathrm{YR}_{5} / 6$ ), semelhante no lábio a uma garrafa de Reguengos, datável de 
meados do século II d. C. (Nolen, 1985, 50, fig. 80). Também da mesma UE foram exumados fragmentos de bilhas de boca larga, como é o caso da boca vertical, com lábio triangular (n.ำ19), pasta rosada (Munsell 5YR7/6) ou um outro, de boca ligeiramente exvasada e lábio rectangular (n.․ 20), pasta castanha (Munsell 5YR5/3) com paralelos em Freiria, datado dos séculos I d.C. ao IV d.C. (Cardoso, 2018, p. 332, fig. 256 , n. - 44 e 5). Do mesmo contexto, foi recolhido um fundo de bilha globular (n. ${ }^{-21}$ ), de pasta alaranjada (Munsell 5YR6/8), muito semelhante a um exemplar proveniente de uma das necrópoles do alto Alentejo, publicada por Jeannette Nolen, datando-o dos finais do século I d.C. a inícios do II d.C. (1985, p. 45, fig. 65).

Do interior do poço, UE [C18c], foi retirado um fragmento de asa de bilha (n.. 22), de pasta alaranjada (Munsell 5YR6/8) e na área da cozinha, UE [Cog], uma outra asa, também de bilha (n.․ 23), de pasta rosa pálido (Munsell 5 YR8/3).

Bilhas de boca larga, apresentando bojo mais ou menos periforme, temos dois exemplares. Um, recolhido no interior do poço, UE [C18c], (n.. 24), de pasta laranja (Munsell 2.5YR6/8) e outro na parte superior (n.․ 25), de pasta laranja escura (Munsell 2.5 $\mathrm{YR}_{5} / 8$ ), UE [C18b], datados dos finais do século I d.C. aos finais do século II d.C.

Ainda da parte superior do poço, UE [C18b], registou-se um grande fragmento de tigela (n.. 26), de pasta laranja (Munsell 2.5YR6/8), semelhante a um exemplar proveniente de uma necrópole do Alto Alentejo, com cronologia atribuível entre o século I d.C. e os inícios do século III (Nolen, 1985, p. 100, fig. 372).

Um fragmento de bordo de prato com inflexão interna (n.. 27 ), de pasta laranja (Munsell 2.5YR6/8), foi retirado do interior da estrutura, UE [C18c]. Trata-se de uma forma, com datação lata, da $2^{\underline{a}}$ metade do século I d.C. aos inícios do século IV d.C. (Nolen, 1985, p. 85 , fig. 258).

O interior do poço, UE [C18c], ofereceu também um pote de bojo brunido e bordo plano, exvasado (n.․ 28), de pasta castanha alaranjada (Munsell 2.5YR5/6). No mesmo estrato foi recolhido um fragmento de panela, de bordo em aba (n.․ 29), com pasta castanha alaranjada (Munsell 2.5 $\mathrm{YR}_{5} / 6$ ), encontrando-se um paralelo para este no Castelo de Alcácer do Sal, datado da segunda metade do século I d.C. aos inícios do século II d. C. (Silva et alii, 198081, p. 201, fig. 24, 303).
Da zona da cozinha, UE [Cog], foi recolhido um fragmento de boca de pote, forma em S (n.. 30 ), de pasta laranja acastanhado (Munsell ${ }_{5} \mathrm{YR}_{5} / 8$ ). Existem paralelos para este modelo em Conimbriga, datado entre o principado de Cláudio e o de Tibério (Alarcão, 1974, p. 83 e 158, n.․ 409).

Esta estrutura ofereceu ainda, na UE [C18c], um bordo de pote, em aba (n.․ 31 ), de pasta laranja escura (Munsell 2.5YR5/8), sendo que, em Conimbriga, este tipo foi recolhido em estratos que vão de $\mathrm{Au}$ gusto a Trajano (Alarcão, 1974, p. 53 e 150, n.o 81B). Da UE [C18c], são provenientes os quatro fragmentos de fundos de potes: o (n. ${ }^{\circ}$ 32) com pasta laranja (Munsell 2.5YR6/8); o (n.. 33), também de pasta laranja (Munsell 5YR6/6); o (n.․ㅜ 34), apresentando pasta cinzenta acastanhada (Munsell 1oYR5/2) e no fundo interno, vestígios de uma camada negra. Finalmente, o (n.. 35), que apresenta pasta alaranjada (Munsell 5YR6/8).

\subsection{Mó}

Durante a escavação do poço, UE [C18c], foi recolhido um dormente de mó, cónico, de arenito de grão grosso, com um diâmetro de $35,8 \mathrm{~cm}$. Encontrava-se a cerca de $2,5 \mathrm{~m}$ de profundidade, o que pressupõe, ter sido ali lançado como entulho após o seu abandono (Figura 9 e 10).

\section{A MODO DE CONCLUSÃO}

Através dos trabalhos arqueológicos efectuados no Palácio de Sant'Anna, ficou finalmente comprovada a ocupação romana em Carnide na antiguidade, entre o século I d.C. e os inícios do século III d.C. Contudo, devido aos vestígios materiais serem pouco significativos ao nível das estruturas, apresentando unicamente um poço escavado no subsolo, conjuntamente com um piso de opus signinum, num sítio que teve ocupação pelo menos dois séculos, não nos é permitido, de momento, avançar com outras considerações.

Pelo tipo de peças encontradas, mó, cerâmicas finas e cerâmica comum, podemos deduzir tratar-se da uma ocupação de um espaço rural de pequena dimensão, ainda que os moradores possuíssem algum poder económico para importarem cerâmica em terra sigillata itálica, sudgálica, hispânica e africana. Consumiam conservas de derivados piscícolas produzidos na Bética e na Lusitânia e vinho, também em ânforas lusitanas. 
A recolha de uma ara e duas cupas nas proximidades do palácio de Sant'Anna indicia a existência de uma necrópole da mesma época, colocando-se a hipótese de estarmos nas imediações de uma villa romana, da qual ainda não se encontrou o núcleo principal.

\section{BIBLIOGRAFIA}

ALARCÃO, Jorge de (1974) - Cerâmica comum local e regional de Conimbriga. Suplemento de Biblos, 8, Coimbra.

ALMEIDA, F. M. (1986) - Carta Geológica do Concelho de Lisboa, Folha 1, na Escala 1:10 ooo. Lisboa. Serviços Geológicos de Portugal.

BERKELLY-COTTER, J. C. (1956) - O Miocénico Marinho de Lisboa. Comunicações dos Serviços Geológicos de Portugal, Suplemento do Tomo XXXVI, Lisboa.

CARDOSO, Guilherme (2018) - Villa Romana de Freiria, Estudo Arqueológico. Câmara Municipal de Cascais. Cascais.

CARDOSO, Guilherme \& ENCARNAÇÃO, José d' (2013) - O povoamento pré-romano de Freiria - Cascais. Cira Arqueologia, 2, Vila Franca de Xira, pp. 133-18o.

CARDOSO, Guilherme \& GONZALEZ, António (2008) - Duas cupas romanas em Carnide (Lisboa). Al-madan, II série, n. ․ 16, Almada, p. 6.

CUESTA-GÓMEZ, J. Fabian \& PRATA, Sara (2017) - Uma ara romana recuperada em Carnide, Lisboa (Conventus Scallabitanus). Ficheiro Epigráfico, 148, ํㅜㅇㅣ.

FONSECA, Cristóvão Pimentel (2004) - Revista Portuguesa de Arqueologia, Vol. 7, ํํ⒈ Lisboa, pp. 421-449.

GARCIA VARGAS, Enrique (2016) - Ánforas vinarias de los contextos severianos del Patio de Banderas de Sevilla. In Aguilera Aragón, Isidro.; BELTRÁN LLORIS, Francisco; DUEÑAS JIMÉNEZ, María J.; LOMBA SERRANO, Concepción; PAZ PERALTA, Juan Á., eds. - De las Ánforas al Museo. Estudios dedicados a Miguel Beltrán, Zaragoza, 2015, pp. 395-412.

MONTEIRO, Mário \& CARDOSO, Guilherme (2016) Vestígios arqueológicos identificados no Largo da Praça (Carnide, Lisboa). Emerita - Estudos de Arqueologia e Património Cultural, n.. 2, Oeiras, pp. 46-62.

NOLEN, Jeannette U. S. (1985) - Cerâmica comum de necrópoles do Alto Alentejo. Fundação da Casa de Bragança, Lisboa.

NOLEN, Jeannette U. S. (1985) - A villa romana do Alto do Cidreira (Alcabideche - Cascais). Conimbriga, XXVII, Coimbra, pp. 61-140.

PAIS, J.; Moniz C.; CABRAL, J.; CARDOSO, J. L.; LEGOINHA, P.; MACHADO, S.; MORAIS, M. A.; LOURENÇO, C.; RIBEIRO, M. L.; HENRIQUES, P.; FALÉ, P. (2006) - Notícia Explicativa Folha $34-D$, da Carta Geológica de Lisboa, na Escala 1:50 ooo. Lisboa. Instituto Nacional de Engenharia, Tecnologia e Inovação, Departamento de Geologia.

RAPOSO, Jorge M. C. \& ALMEIDA, Rui R. (2016)-Almagro 50 (Western Lusitania). Amphorae ex Hispania. Landscapes of production and consumption. (http://amphorae.icac.cat/ amphora/almagro-5o-western-lusitania), 8 July, 2016.

SANTOS, Cézer R.; RAPOSO, Jorge; QUARESMA, José C. (2015) - Análise crono-estratigráfica da Olaria Romana da Quinta do Rouxinol (Corroios, Seixal). In QUARESMA, José Carlos \& MARQUES, João António, coords. - Contextos Estratigráficos na Lusitânia (do Alto Império à Antiguidade Tardia). Lisboa: Associação Arqueólogos Portugueses, pp. 117-148 (Monografias, 1 - Actas do Colóquio Contextos Estratigráficos Romanos na Lusitania: da República à Antiguidade Tardia, Lisboa, 2012).

SILVA, Carlos T. SOARES, Joaquina; BEIRÃO, Caetano M.; DIAS, Luísa F.; COELHO-SOARES, Antónia (1980-81) - Escavações arqueológicas no Castelo de Alcácer do Sal (Campanha de 1979). Setúbal Arqueológica, VI-VII, Setúbal, pp. 149-218. 


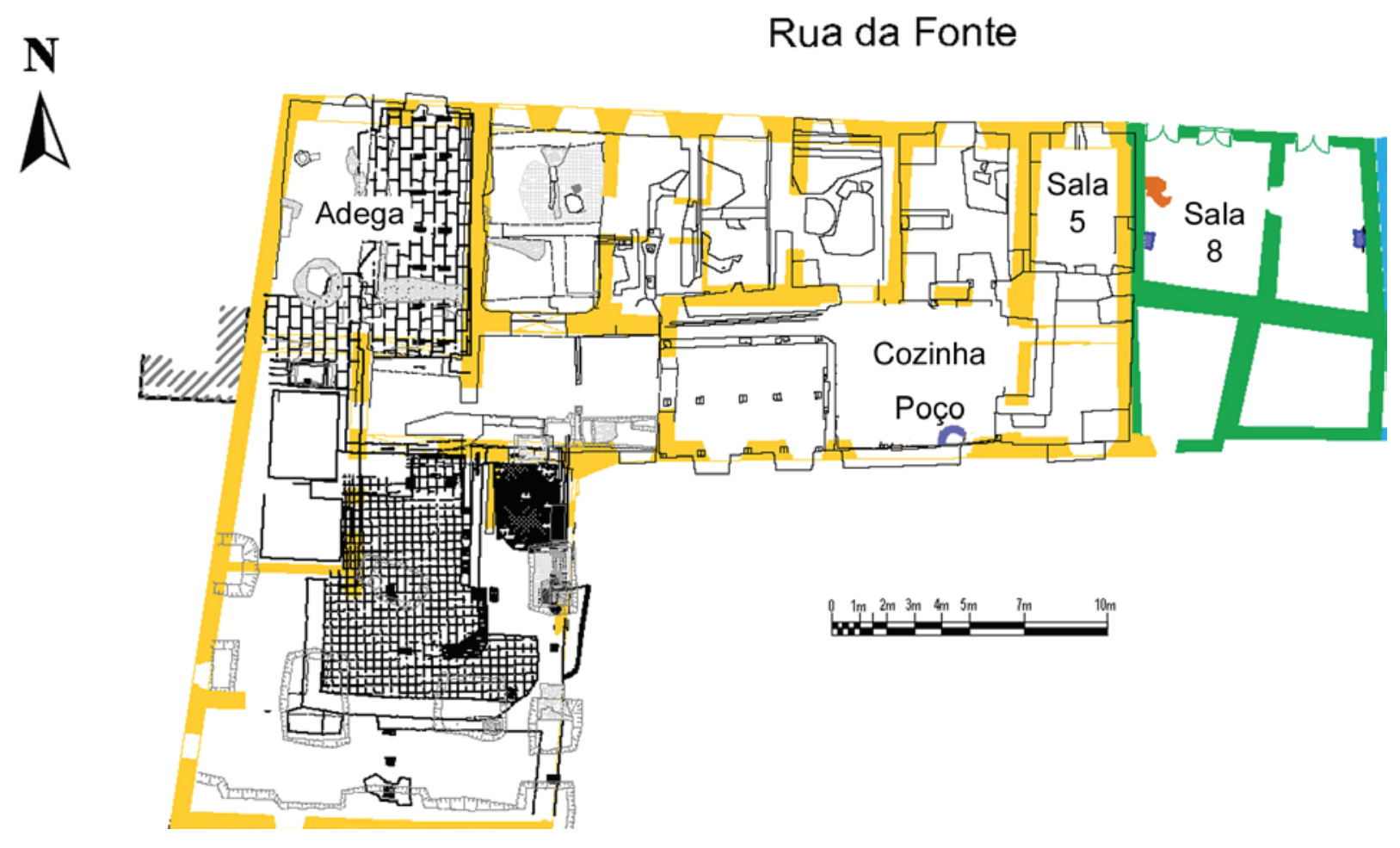

Figura 1 - Planta da área do Palácio.
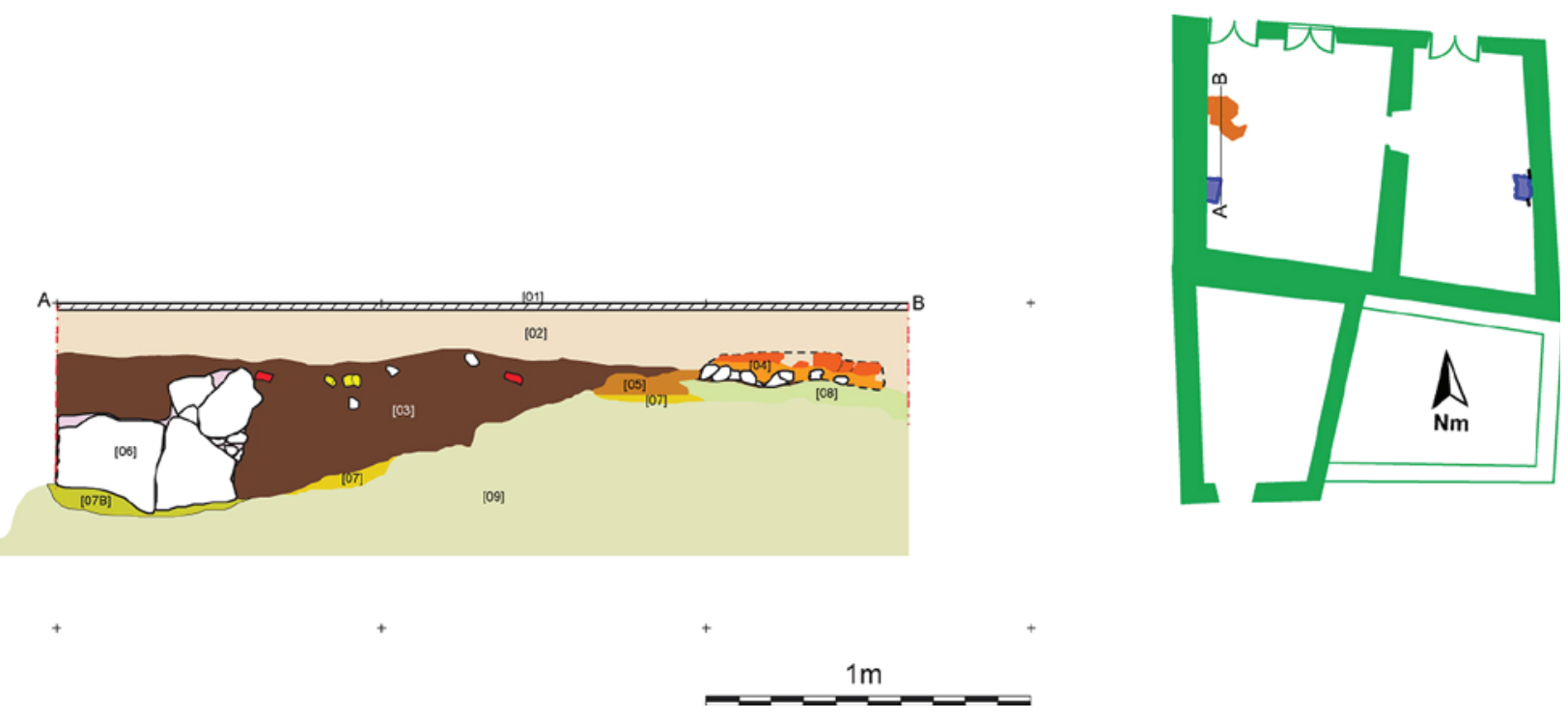

Figura 2-Sala 8, corte A-B do piso romano. 


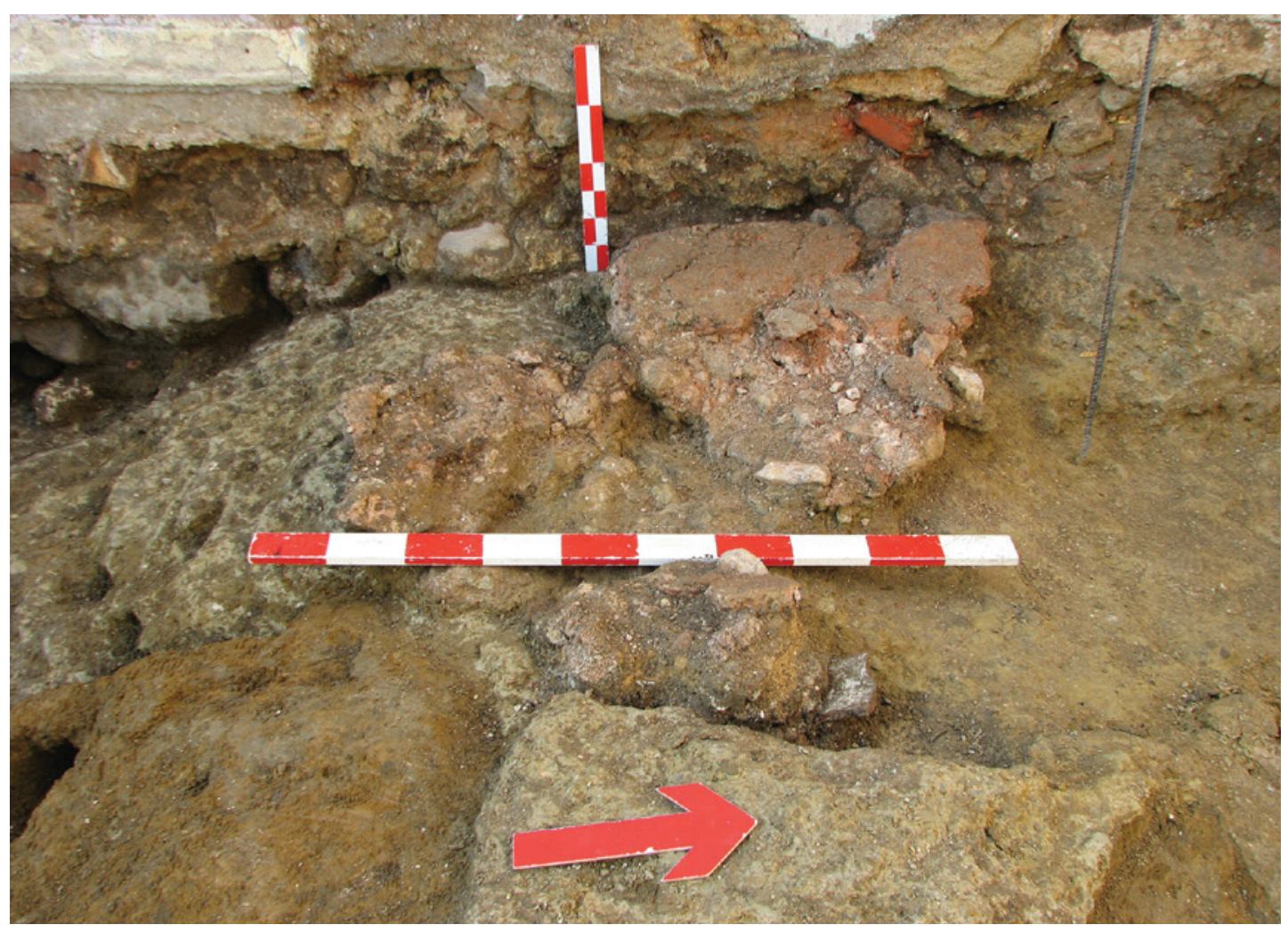

Figura 3 - Sala 8, vestígios de opus signinum.

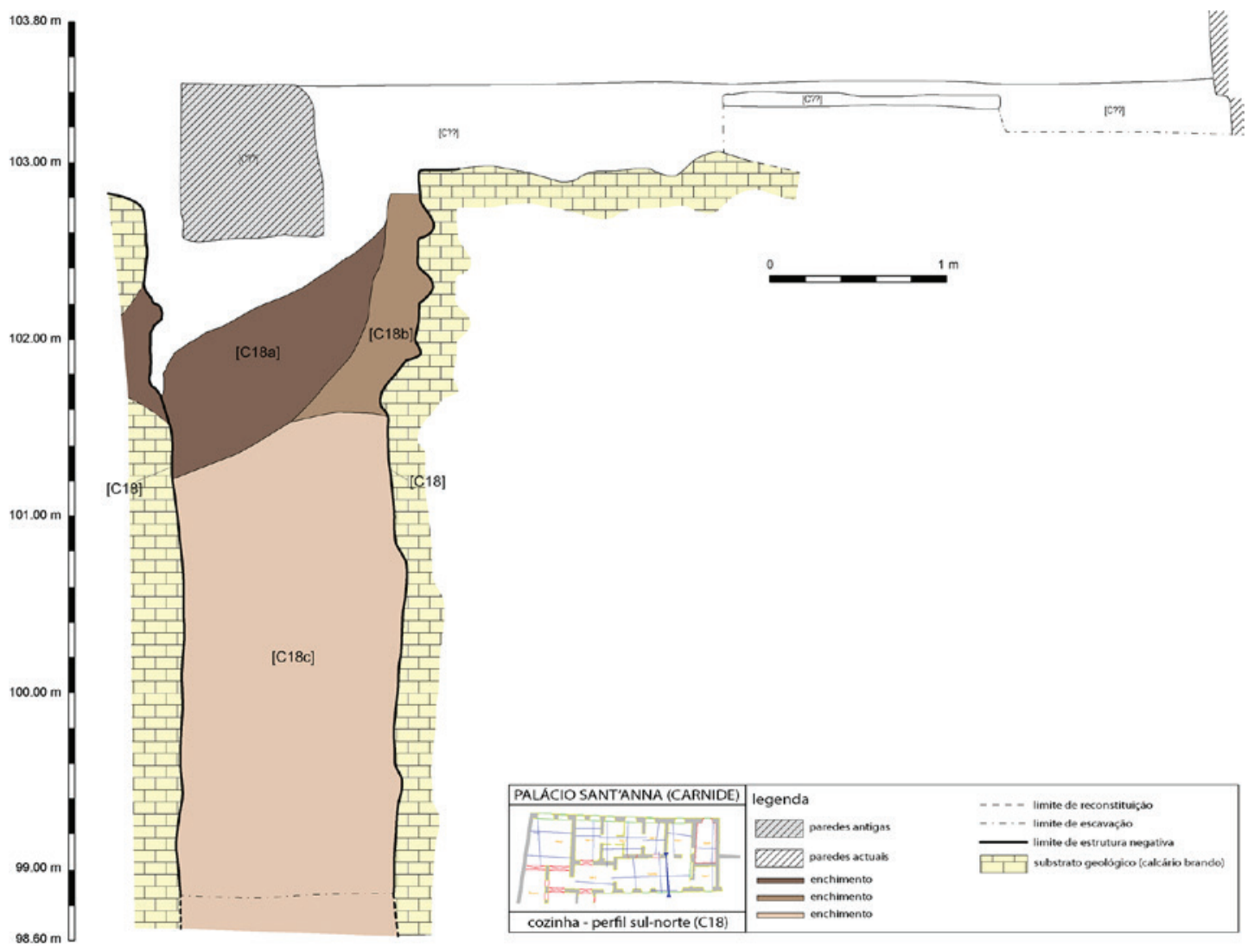

Figura 4-Corte do poço romano. 


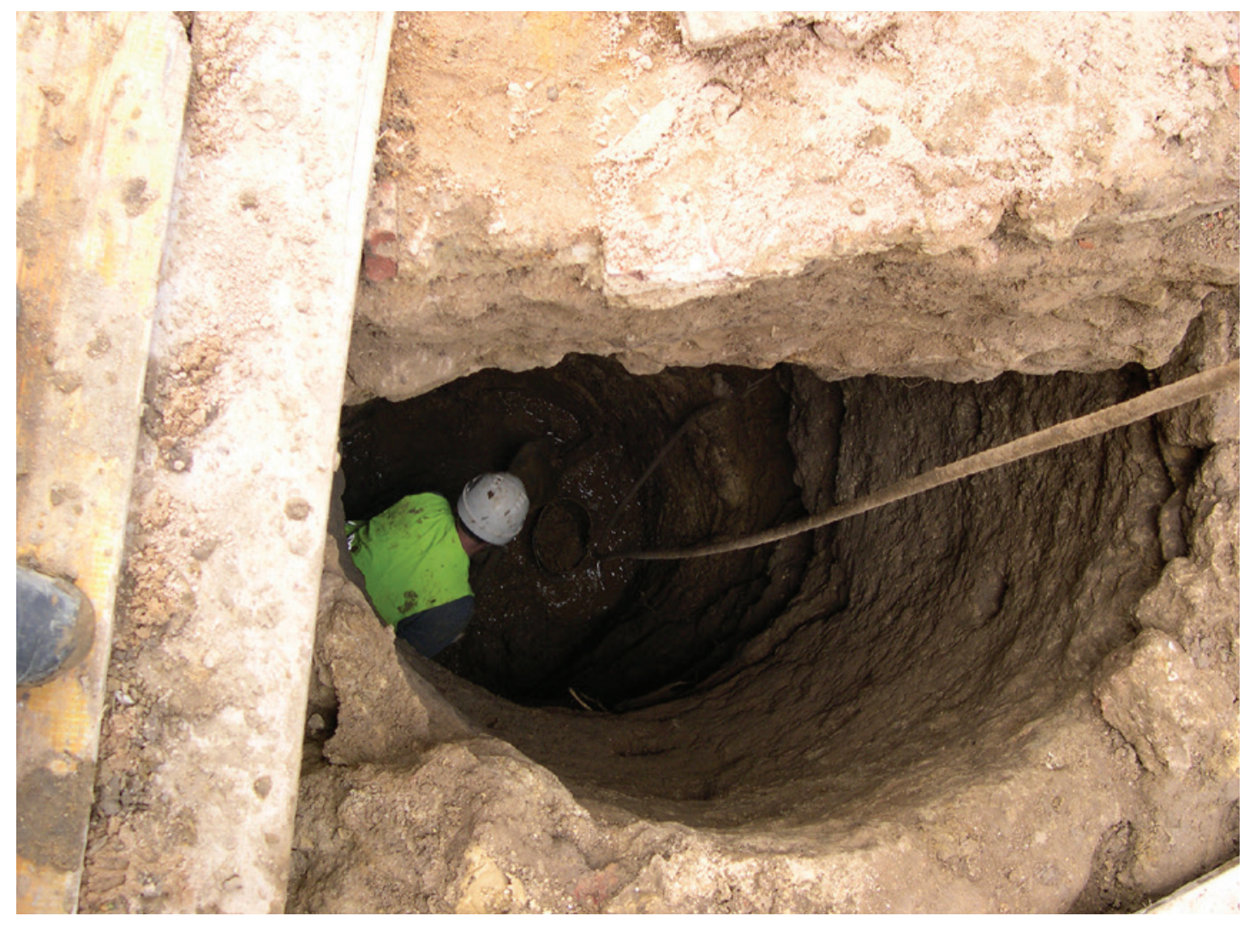

Figura 5- Poço romano.

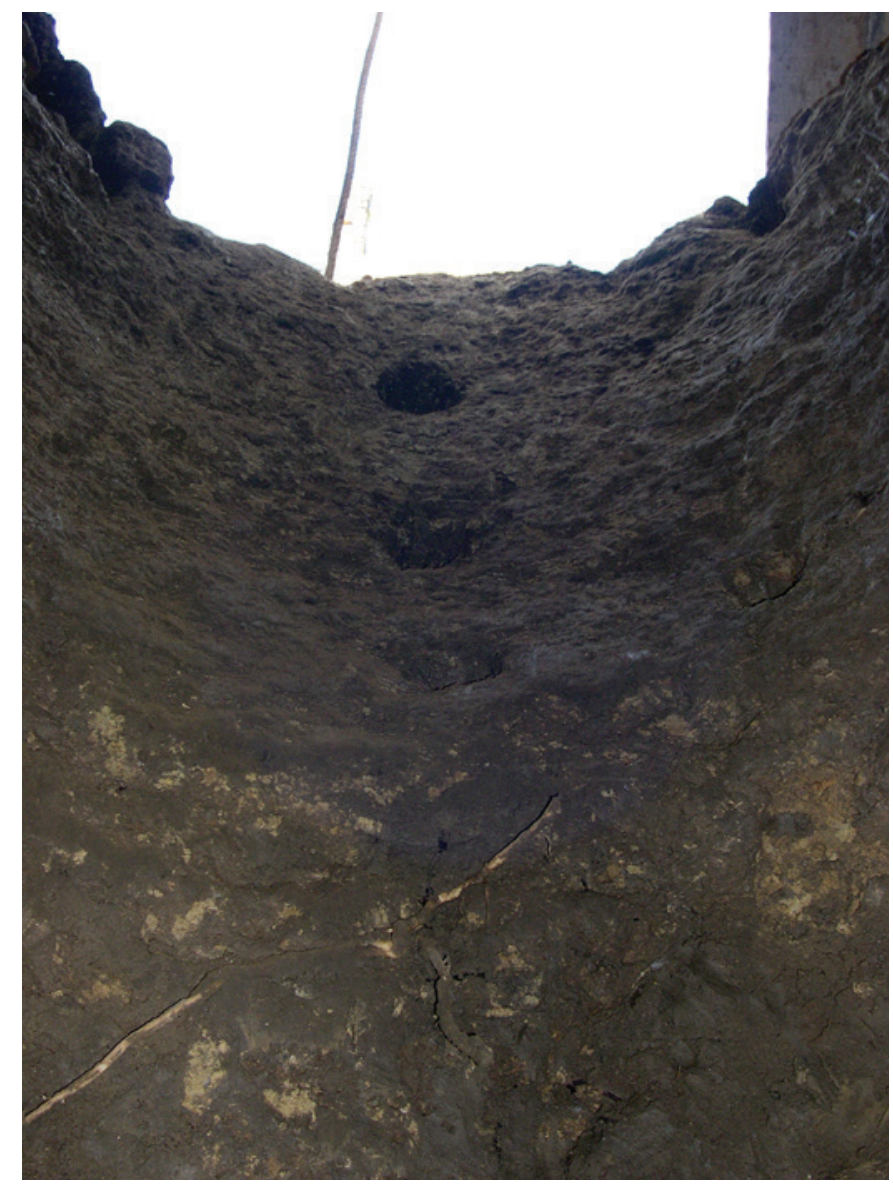

Figura 6 - Parede nascente do poço onde se vêm os buracos abertos na rocha. 


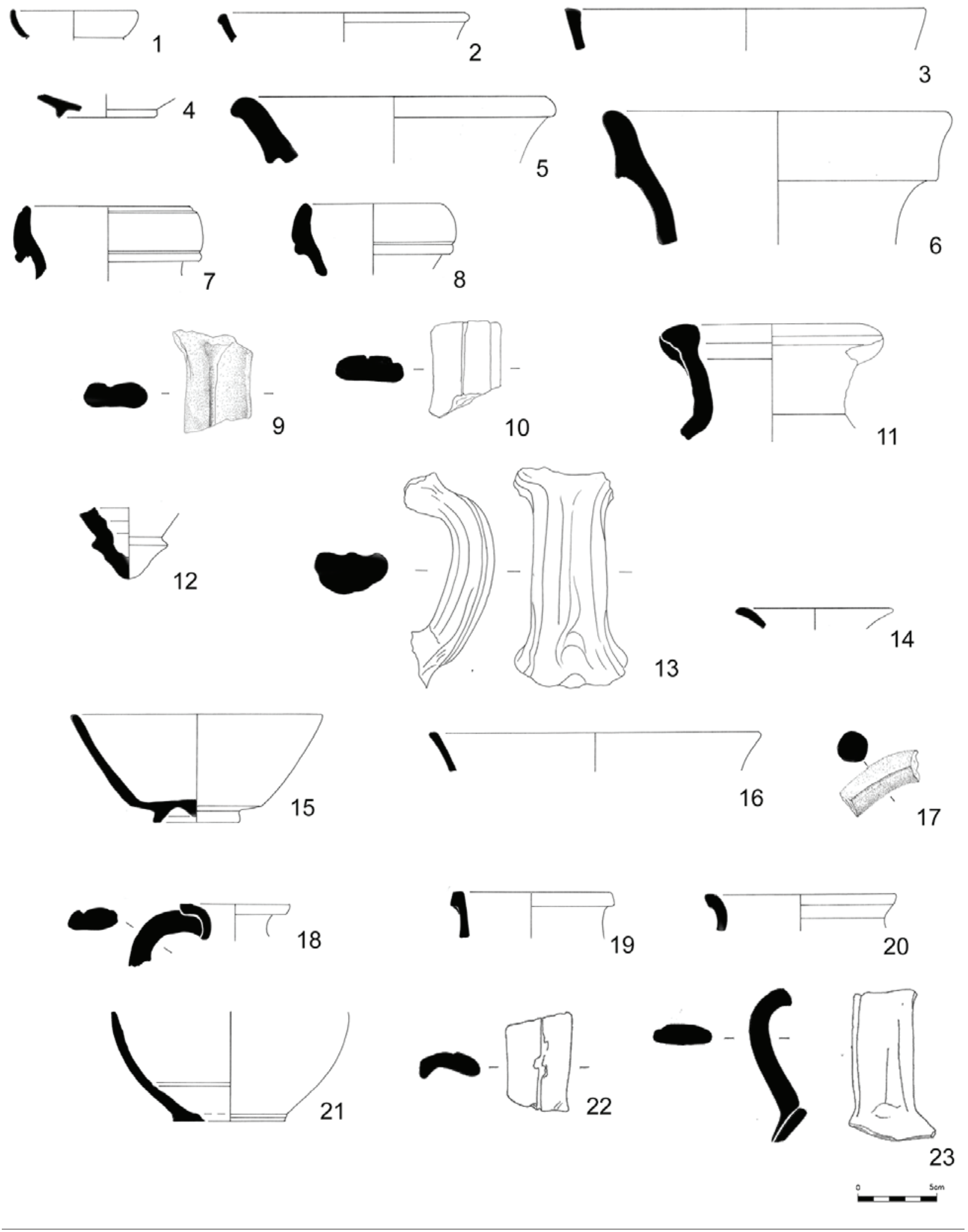

Figura 7-Desenhos de materiais 1 a 23. 

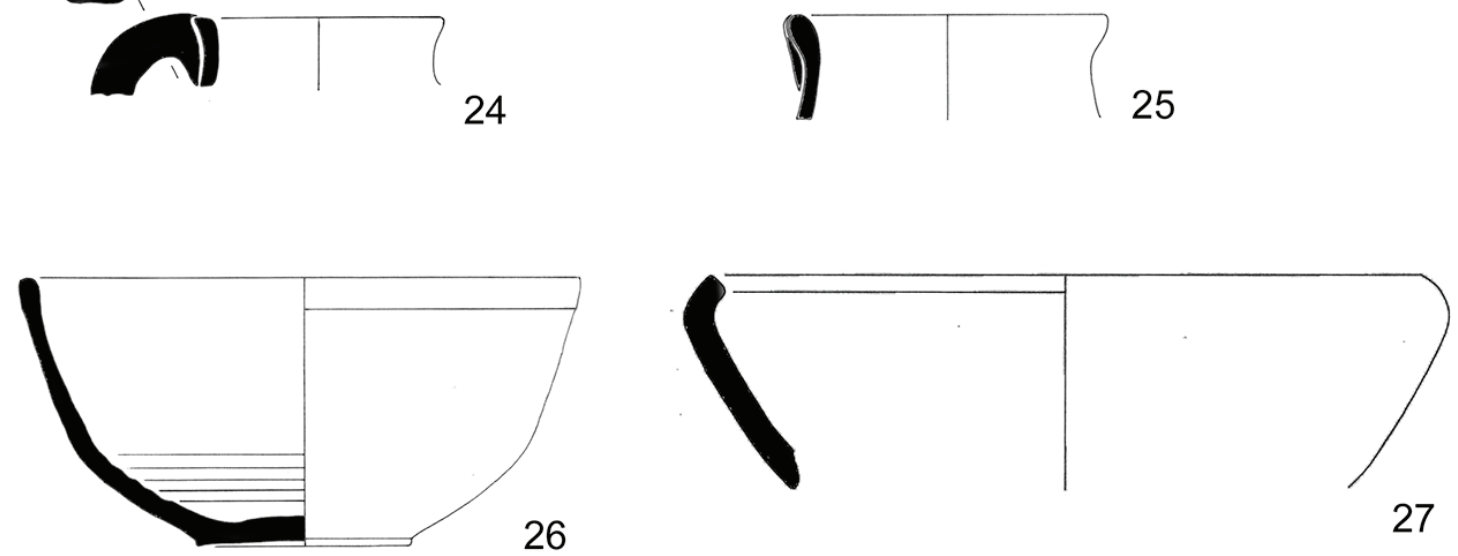

26
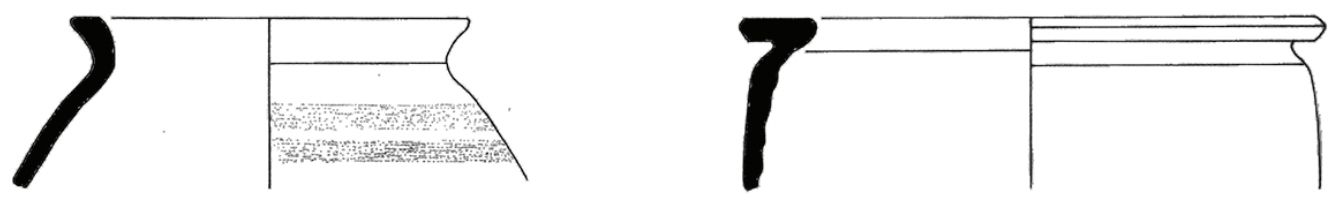

28
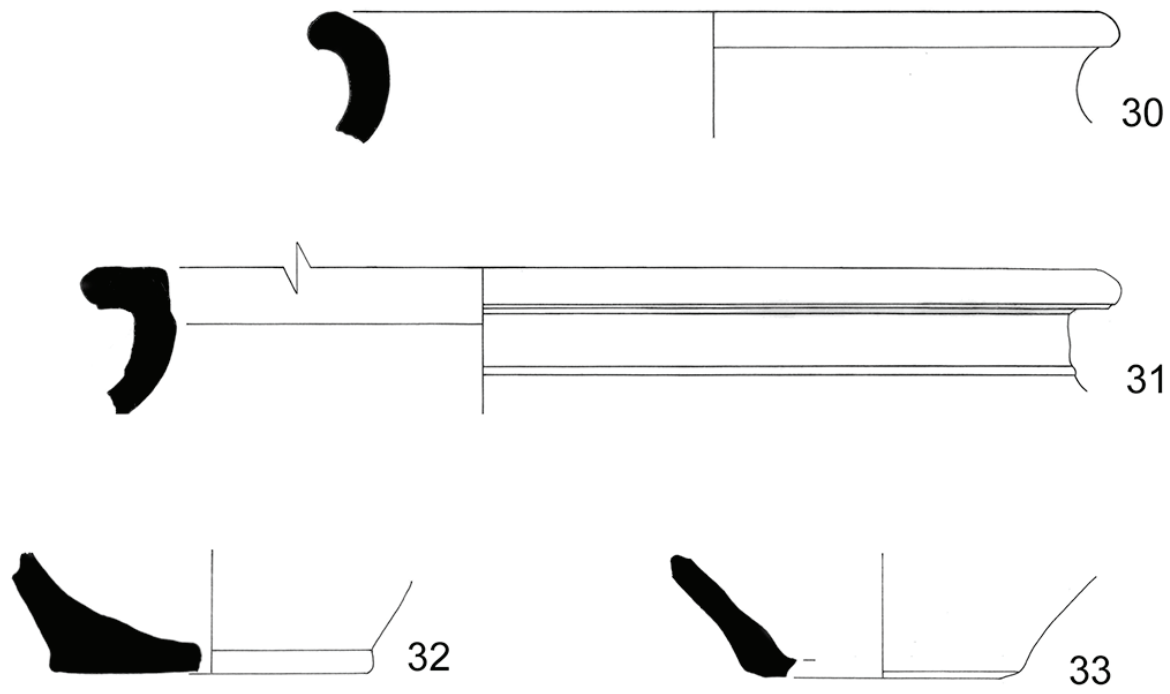

34
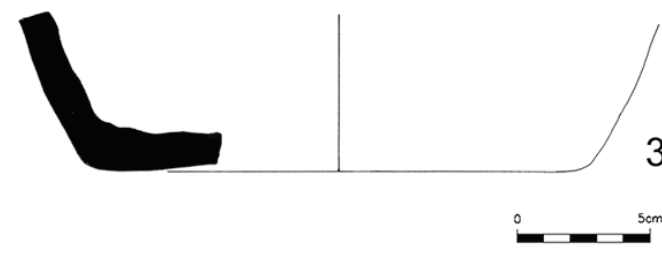

Figura 8-Desenhos de materiais 24 a 35 . 


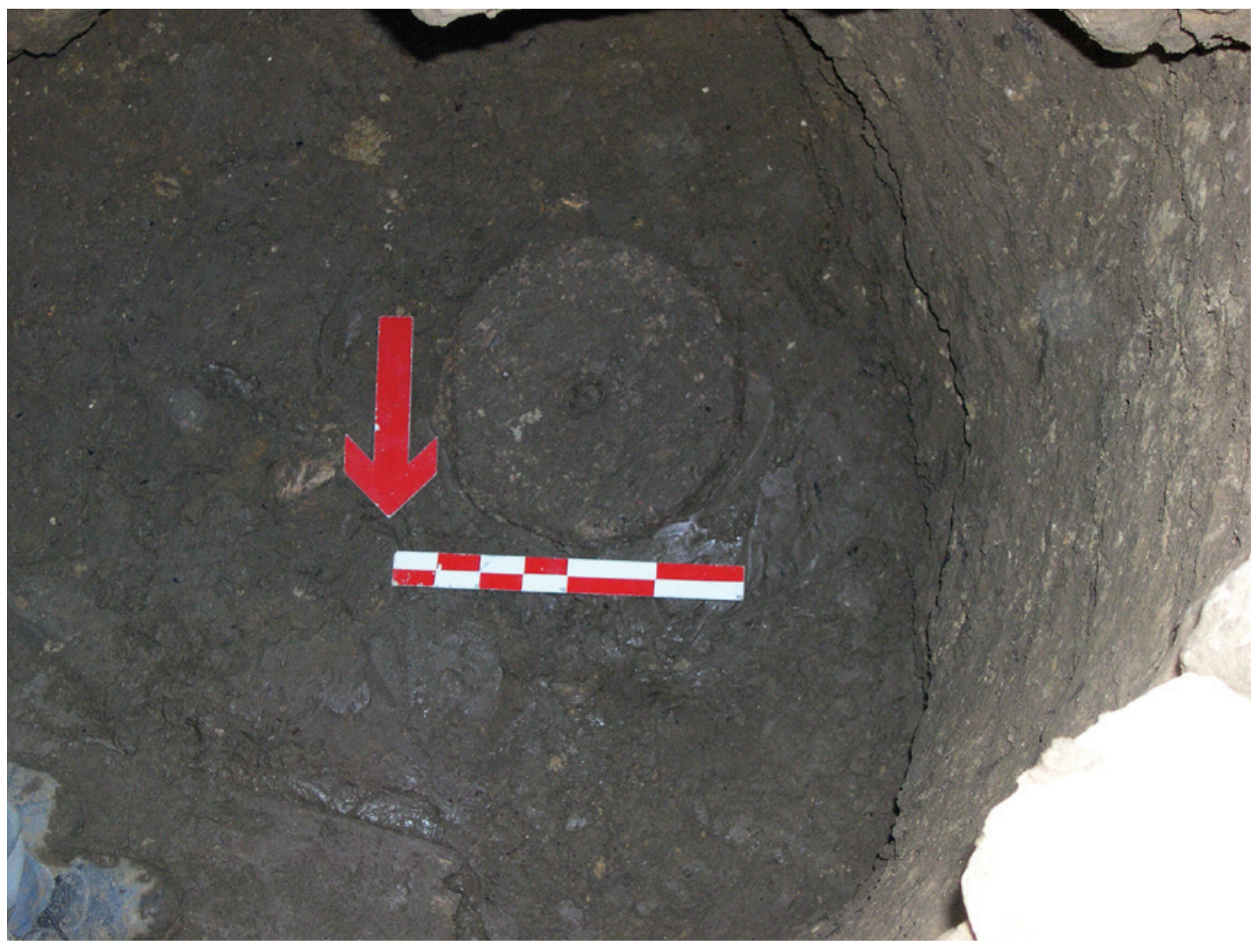

Figura 9- Fotografia do dormente de mó in situ no interior do poço.

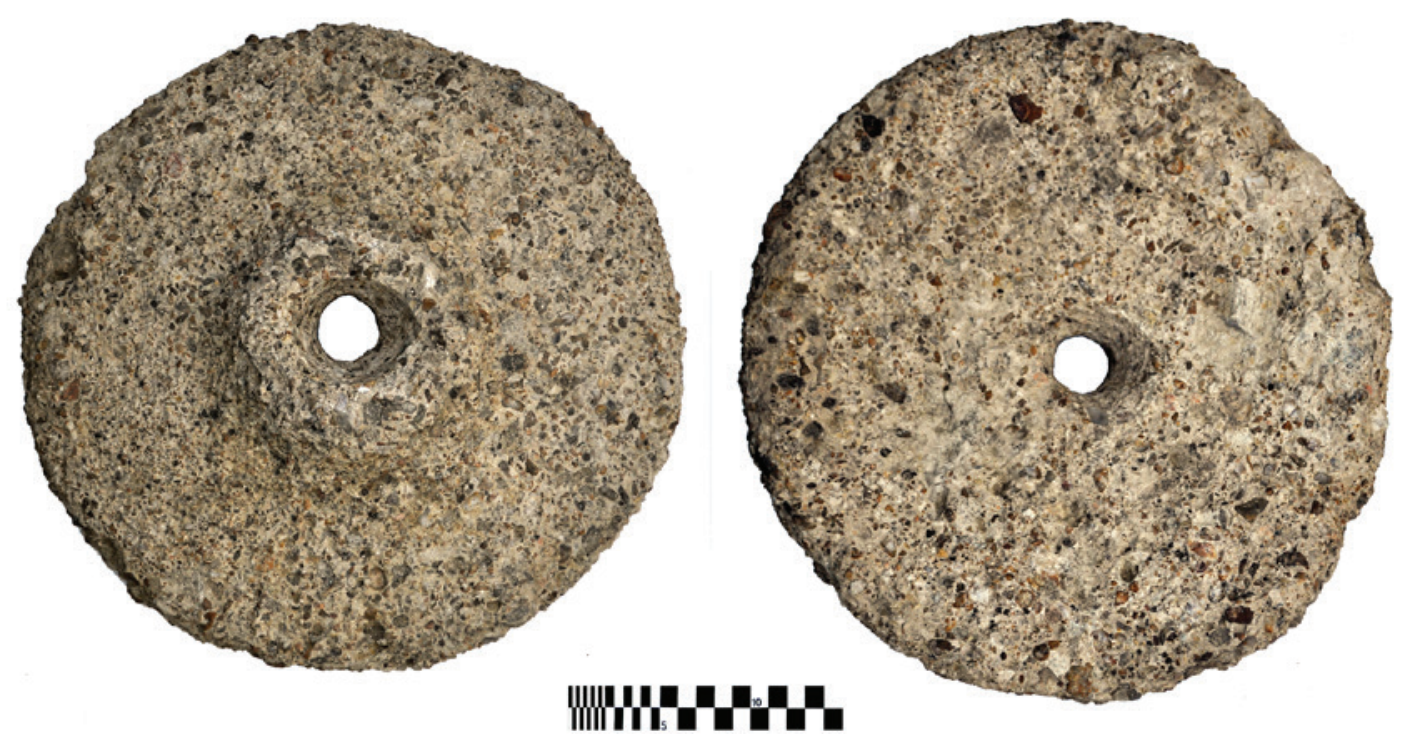

Figura 10 - Fotografia de dormente de mó recolhida no interior do poço. 


\title{
O CONTEXTO FUNERÁRIO DO SECTOR DA “NECRÓPOLE NO"DA RUA DAS PORTAS DE S. ANTÃO (LISBOA): O ESPAÇO, OS ARTEFACTOS, OS INDIVÍDUOS E A SUA INTERCONECTIVIDADE NA INTERPRETAÇÃO DO PASSADO
}

\author{
Sílvia Loja ${ }^{1}$, José Carlos Quaresma ${ }^{2}$, Nelson Cabaço ${ }^{3}$, Marina Lourenço ${ }^{4}$, Sílvia Casimiro ${ }^{5}$, \\ Rodrigo Banha da Silva ${ }^{6}$, Francisca Alves-Cardoso ${ }^{7}$
}

\begin{abstract}
RESUMO
A intervenção arqueológica da Rua das Portas de Santo Antão, em Lisboa, revelou uma extensa diacronia, com vestígios situados cronologicamente entre a Idade do Bronze Final e a Época Contemporânea, destacando-se as evidências associadas ao uso do espaço enquanto local funerário durante a Época Romana Imperial. A área, tirando proveito de uma antiga e pequena plataforma natural situada no sopé da Encosta de Sant 'Ana, encontrava-se decerto próxima ao trajecto da "Via Norte" de Olisipo, o principal eixo das comunicações terrestres da cidade, integrando por este motivo a designada "Necrópole NO". O presente trabalho procede ao estudo do contexto funerário, expondo-se em articulação os dados contextuais, os estudos artefactual e bioantropológico, visando uma interpretação compreensiva do núcleo funerário.

Palavras-chave: Arqueologia Romana, Arqueologia Funerária Romana, Sigillata Clara Africana, Vidro, Cerâmica Romana.
\end{abstract}

\section{ABSTRACT}

The archaeological intervention of Rua das Portas de Santo Antão, in Lisbon, revealed an extensive diachrony, with archaeological findings dating chronologically between the Late Bronze Age and the Contemporary Period. The findings associated with the use of the space as a funerary site, during the Roman Imperial Period deserve special attention. The area, taking advantage of an old and small natural platform located in the foothills of the Encosta de Sant 'Ana, was certainly close to Olisipo's “Via Norte”, the main axis of the city's land communications, integrating for this reason the so-called "Necropolis NO". This paper presents the funerary context, articulating the contextual, artefactual and bioanthropological data, aiming at a comprehensive interpretation of this burial ground.

Keywords: Roman Archaeology, Roman funerary archaeology, Bioanthropology, Roman Glass, Roman Pottery.

1. NOVA FCSH; Mestranda em Arqueologia; Laboratório de Antropologia Biológica e Osteologia Humana, Centro em Rede de Investigação em Antropologia (LABOH-CRIA); silvialoja@hotmail.com

2. Departamento de História NOVA FCSH. Instituto de Estudos Medievais, IEM NOVA FCSH; josecarlosquaresma@gmail.com

3. Era-Arqueologia.nelsoncabaco@era-arqueologia.pt

4. Era-Arqueologia.marinalourenco@era-arqueologia.pt

5. Instituto de Estudos Medievais, IEM NOVA FCSH, Laboratório de Antropologia Biológica e Osteologia Humana, Centro em Rede de Investigação em Antropologia (LABOH-CRIA), NOVA FCSH; scasimiro@fcsh.unl.pt

6. CAL/DPC/CML. Departamento de História NOVA FCSH; Centro de humanidades, CHAM NOVA FCSH; rbds@fcsh.unl.pt 7. Laboratório de Antropologia Biológica e Osteologia Humana, Centro em Rede de Investigação em Antropologia (LABOH-CRIA), NOVA FCSH; Cranfield Defense \& Security, Cranfield University, Reino Unido; francicard@fcsh.unl.pt 


\section{INTRODUÇÃO}

O núcleo funerário romano escavado no prédio com os n. ㅇs 84-9o da Rua das Portas de Santo Antão, em Lisboa, foi primeiro apresentado no II Congresso da Associação dos Arqueólogos Portugueses (Cabaço \& alii, 2017a) tendo-se, entretanto, também divulgado um compasso com aquela cronologia (Cabaço \& alii, 2019). Conforme foi descrito antes, remetendo-se o leitor para a bibliografia aí cotejada, o espaço equivale a um núcleo da Necrópole NO da cidade (Cabaço \& alii, 2017a; 2019), designação cunhada por um dos autores, inspirada em modelos de estudo urbanístico de cidades romanas peninsulares (Silva, 2005).

\section{OS DADOS DO NÚCLEO DAS PORTAS DE SANTO ANTÃO}

Conforme já antes notado, assinala-se no núcleo de "Portas de Santo Antão, uma homogeneidade mais do que relativa nas práticas funerárias documentadas, onde o ritual de inumação era exclusivo, e o uso do esquife recorrente" (Cabaço \& alii, 2017a, p. 1248). A relativa sincronia das práticas documentadas no local, atestada pelas cronologias dos elementos da cultura material associados e que nos colocam as acções fúnebres dentro do séc. III d.C., é também sugerida pela própria gestão do espaço: não se verificaram sobreposições/afectações das sepulturas por outras posteriores, havendo uma relativa "organização" das dinâmicas, patente na orientação dos vários episódios fúnebres, o que implica que por diversas formas se assinalou a visibilidade da existência dos sepultamentos, nalguns casos ainda preservada no momento da escavação arqueológica. Articulam-se aqui os dados contextuais, artefactuais e bioantropológicos, visando uma interpretação compreensiva do núcleo no seu todo, destacando os aspectos mais relevantes evidenciados até ao momento pelos estudos ainda em curso.

\section{ABORDAGEM METODOLÓGICA DA ANÁLISE DOS DADOS}

A abordagem combina a informação presente na documentação da intervenção, a análise do mobiliário funerário, de modo a afinar a informação crono-tipológica, e a análise bioantropológica obtida em laboratório. Esta incidiu na determinação do perfil biológico dos indivíduos, e.g. diagnose sexual e a es- timativa da idade à morte, e outros indicadores morfológicos quando possível. A diagnose sexual foi aferida apenas nos indivíduos adultos, uma vez que estimativa do sexo em indivíduos cuja maturidade é incipiente incorre em significativos erros interpretativos (Cardoso \& Saunders, 2008). Para aferir a diagnose sexual, foram empregues vários métodos que evidenciam o dimorfismo sexual, com base na análise morfológica e métrica do material ósseo (Bruzek, 2002; Buikstra \& Ubelaker, 1994; Ferembach, Schwidetzky \& Stloukal, 1980; Lovejoy \& alii, 1985; Walker, 2005, 2008; Wasterlain, 200o), sendo os vários indivíduos classificados de feminino, masculino, ou de sexo indeterminado com base nos resultados das análises. Para a estimativa da idade à morte foi considerado o critério da fusão das epífises utilizando-se diversos métodos de acordo com os elementos ósseos a avaliar (Buikstra \& Ubelaker, 1994; MacLaughlin, 1990; White \& Folkens, 2005). Com base na análise desenvolvida os indivíduos foram classificados de adultos (provavelmente com $>30$ anos) e adulto jovem (provavelmente com $>18$ anos mas $<30$ anos), sobretudo com base no estágio de maturação epifisária da extremidade esternal da clavícula (MacLaughlin, 1990). Alguns indivíduos foram ainda identificados como não adultos, atribuindo-se um intervalo etário mais específico como complemento da estimativa qualitativa. Para cada sepultura são apresentados os dados relativos às características construtivas, dados da bioantropologia, características e cronologias do mobiliário funerário e sua disposição (Figura 1).

Sepultura 1 - Sepultura com deposição de ataúde documentado por pregos em ferro- (Cabaço $\mathbb{\&}$ alii, 2017a: fig.3) no interior de coval. Cobertura exterior não passível de identificação dadas as afectações posteriores.

Bioantropologia: esqueleto em mau estado de conservação, inumado em decúbito dorsal com os membros superiores e inferiores em extensão. Estimou tratar-se de um indivíduo adulto, do sexo masculino (Buikstra \& Ubelaker, 1994; Bruzek, 2002; Walker, 2005), com mais de 30 anos com base no estágio de fusão epifisária da extremidade esternal da clavícula (MacLaughlin, 1990).

"Mobiliário funerário": Para além do numisma no 172, um antoninianus inclassificável, a sep. 1 apresenta um espólio de terra sigillata, lucerna, vidro e cerâmica comum. O no 174 é um prato em T.S.Cl.Afr. 
C, do tipo Hayes 50A/B, com proximidade grande à variante $5 \mathrm{OB}$ (quase $5 \mathrm{~mm}$ de espessura, parede esvasada e bordo de topo arredondado - Hayes 1972). $\mathrm{O}$ vidro $\mathrm{n}^{\mathbf{0}} \mathbf{1 7 0}$ pode integrar-se, como basicamente todos os vidros presentes neste conjunto de sepulturas, no tipo AR 6o, com pé-de-anel denteado, datável a partir de 250 d.C. (Rütti, 1991). A lucerna no 171, sobremoldada, de grande porte (diâmetro de $108 \mathrm{~mm}$ ), poderá integrar-se no universo das lucernas de disco, embora apresente um canal que a relaciona com as Firmalampen, coevas das primeiras, entre os sécs. I e III d.C. (Quaresma, no prelo). Com um disco e ombro planos, apresenta uma Victoria frontal com disco na mão direita (Rodríguez Martín, 2002). Por fim, o no 173 é uma pequena bilha de cerâmica comum em pasta branca de matriz calcária, com colo estreito e canelura larga, à altura do arranque da asa. Não tem paralelo no centro produtor da Quinta do Rouxinol, onde este fabrico está diagnosticado (Santos, 2011), nem em São Cucufate (Pinto, 2003), mas exemplares semelhantes surgem nas necrópoles do Alto-Alentejo (Nolen, 1985, p. 42, 43, no 39: pasta $\mathrm{H}_{2}$ - pasta branca-ocre) e em Conimbriga, em depósito de Trajano (Alarcão, 1975, ํㅜ5 586).

Sepultura 2 - Deposição de ataúde no interior de coval, denunciado pela presença de elementos da pregaria.

Bioantropologia: o esqueleto encontrava-se muito frágil, em mau estado de conservação, e a sua metade superior muito afectada. Depositado em decúbito dorsal com os membros superiores ligeiramente flectidos sobre o abdómen, as mãos sobre a zona pélvica e os membros inferiores em extensão. Trata-se de um indivíduo do sexo feminino (Wasterlain, 2000; Bruzek, 2002; Walker, 2005). A avaliar pela morfologia da superfície auricular, parece tratar-se de um adulto ainda jovem (Lovejoy $\&$ alii, 1985).

"Mobiliário funerário": A sepultura 2 apresenta um anel, uma lucerna, dois vidros e cerâmica comum. O anel de prata no 196 mostra simulação de pedra de sinete feita no mesmo material, e é equivalente ao tipo IVc de Aquincum, morfologia ali do séc. III d.C. e que sobreviveria ao longo do séc. IV d.C. (Facsády \& Verebes, 2009: 994, fig.1; 997). Voltamos a registar vidros na gama do tipo AR 6o, mas evidenciando a sua diversidade morfológica e a necessidade de uma melhor especificação deste tipo em vários. Assim, o no 197 apresenta as depressões oblongas verticais, mas fundo agora onfalado, enquanto $o$ no 196 apresenta a parede lisa, mas o fundo maciço. Este último apresenta-se agora mais próximo do descritório de copos de paredes finas e base maciça, relacionados também com a Isings 34, datáveis entre os séc.s II e IV (Cruz, 2009, p. 91). A lucerna no 196 também se inclui na morfologia do séc. III, referida supra para a família de lucernas de disco, com moldura larga, ombro oblíquo curvo e disco curvo também (Quaresma, 2018). Na cerâmica comum, o no 200 é um jarro de bordo extrovertido, curto e não-trilobado, de fabrico quartzo-micáceo, castanho-claro-laranja, com parede curva, lisa e ligeira semelhança com o tipo XI-A de São Cucufate, em fabrico calcário bético, mais esguio e estreito do que o de Olisipo. No centro produtor sadino do Pinheiro, surge uma morfologia semelhante, em camada da segunda metade do séc. IV (Pinto, 2003, p. 425). O no 199 é uma taça de fundo maciço, em pasta quartzo-micácea avermelhada, cuja fisionomia da parede e bordo em aba a inclui nas inspirações da Hayes 3 de terra sigillata africana A, datável nos séc.s II e III d.C. (Hayes, 1972). Por fim, o no 201 é um pote baixo de bordo curto exvertido e pasta laranja, quartzo-micácea. Como referimos supra, os potes do Norte Alentejano são sempre gráceis, mas com semelhanças formais (Nolen, 1985, p. 118).

Sepultura 3-Deposição em coval de secção rectangular. Assinalando a visibilidade do sepultamento foi composta uma cobertura primária de 4 lateres recobertos por elementos pétreos e laterícios fragmentários de pequena dimensão, unidos com uma argamassa pobre, dispostos de forma aleatória e concentrados longitudinalmente no lado esquerdo do indivíduo inumado. Completavam esta estrutura dois lateres oblíquos na zona da cabeceira formando uma cobertura de duas águas.

Bioantropologia: apesar do mau estado de conservação dos vários elementos ósseos, o esqueleto apresenta uma boa representatividade óssea. $\mathrm{O}$ indivíduo encontrava-se em decúbito dorsal, com membro superior esquerdo fletido sobre o abdómen e a mão sobre o ilíaco direito, e o membro superior direito, bem como os membros inferiores, em extensão. A análise do perfil biológico revelou tratar-se de um indivíduo do sexo feminino (Ferembach, Schwidetzky \& Stloukal, 1980, 1980, Wasterlain, 2000, Bruzek, 2002; Walker, 2008). Com base na morfologia da superfície auricular (Lovejoy $\&$ alii, 1985), na observação da linha de fusão da cabeça do fémur direito 
(Buikstra \& Ubelaker, 1994), e na ausência de fusão da extremidade esternal da clavícula (MacLaughlin, 1990), estamos perante um adulto ainda jovem.

"Mobiliário funerário": o numisma n. ${ }^{-180}$ ligeiramente descentrado, mas não cerceado, equivale a um antoninianus cunhado sob Galieno (253268 d.C.), das séries Providentia ou Providentia Aug(usta), emitidas em Roma entre $260-268$ d.C. ( RIC V-1.270; 276). O anel em prata n. ${ }^{\circ} 181$ repete o tipo IVc de Aquincum (vide Sep. 2, acima). O artefacto em osso n. ${ }^{\mathbf{1}} \mathbf{1 8 2}$ corresponde a um alfinete de cabelo (acus crinalis), impedindo-nos a ausência da extremidade superior de o precisar tipo-cronologicamente. O compasso n. $^{\mathbf{0}} \mathbf{1 8} 3$ foi já objecto de publicação (Cabaço \& alii, 2019), e embora não encerre especial significado crono-tipológico, destaca-se pela sua assimilação ao trabalho artesanal de pormenor (joalharia? bijuteria? trabalho em osso?), sugerida pelos contornos funcionais de um contexto bordalês (Raux, 2016: 42). O recipiente em vidro n.․ 187 , de tonalidade verde-gelo, translúcida, revela afinidades com alguns exemplares de Augst do tipo AR 6o, que revelam semelhanças morfológicas (Rütti, 1991, nºs 1298, 1333). Com uma decoração de dois círculos concêntricos relevados produzidos a buril, com aquele interior opaco, alternados com métopas de traço vertical simples e os topos com outros pequenos ligeiramente oblíquos, obtidos da mesma forma. Tem paralelo exacto num exemplar divulgado por Deus como colectado em 1798 numa sepultura do aro mirobrigense céltico, em Herdade do Raco (Santiago do Cacém), ofertado a Fr. Manuel do Cenáculo, estando hoje em exposição no Museu de Évora (Deus, 2016, p. 64 e 70). A lucerna, no 179 , lacriforme, com disco raiado, é datável para o séc. II e III (?) em Ampúrias (Casas i Genover; Solé i Fusté, 2006). Na cerâmica comum, em pasta quartzo-micácea vermelha, o nํㅜ $\mathbf{1 8 8}$, com pé-de-anel, volta a revelar inspiração no tipo Hayes 3 de terra sigillata africana (ver supra, n⿳ำ 199 , com corpo mais baixo e largo, mais próximo do protótipo africano coevo. Hayes, 1972). Os nos 189 e 190, potinhos de fabrico quartzo-micáceo, laranja e laranja-castanho respectivamente, rico em moscovite, têm paralelos no Norte Alentejano (Nolen, 1985, p. 71, nºs 172-175: referidos em contextos da segunda metade do séc. I e do II d.C.). No centro da Quinta do Rouxinol (225/250-425+ d.C.), o tipo 2.3.4.2 possui curva e contracurva enquanto os $n^{\circ} \mathbf{S}$ 189 e 190 possuem apenas a carena suave (voltaremos infra a esta fisionomia com o $\mathbf{n}^{\mathbf{0}} \mathbf{2 3 0}$ ).
Sepultura 4 - Deposição em coval rectangular, com as paredes laterais interiores revestidas a reboco branco. A presença da sepultura foi sinalizada com lateres dispostos horizontalmente, recobertos por amálgama de pedras calcárias de pequena e média dimensão.

Bioantropologia: A metade esquerda do esqueleto foi destruída, e o antebraço direito afectado. $\mathrm{O}$ indivíduo encontrava-se em decúbito dorsal com o membro superior direito ligeiramente flectido com a mão sobre o ilíaco direito, e os membros inferiores estendidos. Trata-se de um indivíduo adulto feminino (Wasterlain, 200o; Bruzek, 2002; Walker 2008), com uma idade à morte superior a 30 anos, a avaliar pelo estágio de fusão epifisária da extremidade esternal da clavícula (MacLaughlin, 1990).

"Mobiliário funerário": Na sepultura 4 recorre-se a vidro, terra sigillata, lucerna e cerâmica comum. O gobelet $\mathrm{n}$ 을 210 não tem paralelo aproximado. Com pé maciço muito baixo tem corpo troncocónico e colo cilíndrico altos. A parede tem decoração plástica com cordões de vidro que desenham formas oblongas verticais (com segmento simétrico aposto à base) separadas por bastões lineares verticais. $\mathrm{O}$ n을 212, com marcas de polimento forte na parede, volta a integrar-se na forma genérica da AR 6o, com semelhanças evidentes ao no 196 (supra), apesar do corpo agora mais verticalizado. Neste sentido, aproxima-se igualmente do tipo $\mathrm{AR} 38$, que termina no terceiro quartel do séc. III (Rütti, 1991), bem como do copo de paredes finas e base maciça, datado em Bracara Augusta entre os séc.s II e IV (Cruz, 2009). O no 213 é um exemplar completo de terra sigillata africana A, tipo Hayes 16/Hayes 15, ou seja, fundindo as duas morfologias, com o corpo baixo da primeira e o bordo biselado da segunda, que a data a partir de 250 d.C. (Bonifay, 2004). O no 214 integra-se novamente na fase final de desenvolvimento das lucernas de disco no séc. III (Quaresma, 2018), com moldura larga a separar orla e disco curvos, planos (ver supra nos 224 e 198). Em cerâmica comum, o no 202 é um pote alto de bordo curto exvertido, com pasta castanho-vermelha, quartzo-micácea. Segundo Cézer Santos (2011, p. 81-82: tipo 2.2.4.1), é uma forma muito comum, com paralelos em São Cucufate e na Península de Lisboa. Todos os exemplares da Quinta do Rouxinol (225/250-425+ d.C.) são do fabrico C (matriz quartzo-micácea, de tom vermelho-laranja). 
Sepultura 5 - Deposição de ataúde - numerosos pregos assinalados (Cabaço \& alii, 2017b, p.35) no interior de coval sub-rectangular.

Bioantropologia: Não obstante o mau estado de conservação dos vários elementos ósseos, e a fraca representatividade óssea, os pequenos fragmentos recuperados de crânio, da escápula direita, de costelas e dos membros inferiores, sugerem tratar-se de um indivíduo não-adulto. Por forma a obter um intervalo etário mais específico, e dada a natureza fragmentaria deste individuo, procedeu-se a uma comparação com os não adultos identificados na Praça da Figueira em 1999-2001, de idêntica cronologia (Casimiro, Silva \& Alves-Cardoso, no prelo). Os resultados obtidos a partir desta comparação apontam para um individuo com menos de 12 meses de vida. O nível de fragmentação e afectação deste enterramento, impossibilitou a observação no que respeita à deposição do individuo.

"Mobiliário funerário": A sepultura 5 apresenta uma menor variedade de tipologias que a anterior. Para além de um numisma no 221, um "bronze" exausto, regista-se novamente um vidro, $\mathrm{n}$ - 223, do tipo AR 6o (250+ d.C.: Rütti 1991), mas com pé-de-anel simples e depressões verticais oblongas na parede. A sua fisionomia é próxima igualmente do tipo AR 53, datado a partir de final do séc. II d.C. (Rütti, 1991), enquanto que em Bracara Augusta se apontam algumas relações de copos de base maciça com o tipo Isings 34 e as produções do séc. II, III e IV d.C. (Cruz, 2009). Na Gallia, alguns fundos em disco de gobelets assim decorados, estão datados do séc. III (Foy, 2010, p. 361, nos 668-670). A lucerna no 224 inclui-se novamente na família das lucernas de disco, com ombro e disco lisos e moldura larga a separar ambos, uma característica que marca a fase final das lucernas de disco, no séc. III d.C., como acontece em sepulturas de c. 250 d.C. de Almoínhas (Quaresma, 2018). Na cerâmica comum, o no 226 é um potinho de fabrico calcário, com paralelos formais e de fabrico no centro produtor da Quinta do Rouxinol, entre 225-25o e $425+$ d.C.. O tipo 2.3.4.2 possui, contudo, curva e contracurva, enquanto o no 226 possui apenas a carena suave com canelura larga. O fabrico D3a (matriz calcária, branca-creme) é, porém, secundário neste tipo, fabricado sobretudo em matriz quartzo-micácea de pasta vermelha e alaranjada (Santos, 2011, p. 85 e est. XXV). O no 225 é um pote de bordo curto exvertido, com pasta castanho-clara, quartzo-micácea. Com altura de 18omm conforma versão grande dos potes gráceis do Norte Alentejano (Nolen, 1985, p.118).

Sepultura 6 - Deposição de ataúde (alguns pregos) no interior de coval sub-rectangular, extenso. Parte superior não preservada.

Bioantropologia: Apenas foram recuperados fragmentos dos membros inferiores. A posição destes elementos ósseos sugere que o individuo foi depositado em decúbito dorsal, com os membros inferiores em extensão, ligeiramente inclinados para o lado direito. A observação da maturação óssea sugere tratar-se de um indivíduo adulto, muito provavelmente do sexo feminino (Ferembach, Schwidetzky \& Stloukal, 1980, 1980; Wasterlain, 2000).

"Mobiliário funerário": A sepultura 6 é o contexto com o maior número de exemplares, incluindo dois numismas, anel, lucerna e um leque abrangente de cerâmica comum. Os numismas no 229 A e 229 B equivalem, respectivamente, a um bronze com efígie radiada muito gasto e um antoninianus de Galieno (253-2698 d.C.). O anel s/no de [661] é de novo do tipo Aquincum IVc (vide supra, sepulturas 2 e 3 ). A lucerna no $\mathbf{2 2 8}$ revela alguns pormenores novos de transição final para a futura Dressel 28, mas ainda com orla lisa. Para além da moldura larga a separar orla e disco, o bico já é cordiforme, como será na forma mais tardia referida (Bussière, 200o). No disco, sobremoldado (como acontece em todas as lucernas deste artigo), Helios com Diana Hecate, parecendo tratar-se de uma reprodução de um modelo itálico campano (Catalano, 1953, p. 4, fig.1).

$\mathrm{Na}$ cerâmica comum de fabrico, o fabrico calcário está representado pelo no $\mathbf{2 3 0}$, com carena suave e canelura larga. A morfologia e o fabrico, como se disse supra, tem paralelos no centro produtor da Quinta do Rouxinol - 225/250-425+ d.C. (Santos, 2011, p. 85 e est. XXV - o tipo 2.3.4.2 que possui curva e contracurva, tem fabrico minoritário de matriz calcária). No Norte Alentejano, alguns contextos da segunda metade do séc. I e do II d.C. apresentam exemplares similares (Nolen, 1985, p. 71, nºs 161-177). O no 227 é um potinho de fabrico calcário, creme-rosa, com parede curva, lisa (não tem bordo nem colo conservados), com relativas semelhanças ao $\mathrm{n}$ - $\mathbf{2 1 6}$ (ver supra), mas de parede mais curva. No fabrico de matriz quartzo-micácea, o no 233 é uma terceira imitação, algo distante morfologicamente (parede muito rectilínea e, novamente, ausência de pé-de-anel) da Hayes 3 de T.S. Clara africana (ver 
supra). O no 234 é um potinho de fabrico quartzo-micáceo, laranja, rico em moscovite, semelhante ao no 230, mas agora com a curva e contracurva conhecida no Norte Alentejano (Nolen, 1985, p. 71, nos 172-175: em contextos da segunda metade do séc. I e II d.C.) e no Porto dos Cacos (Santos, 2011). O no 231 está muito próximo do $n^{\circ}$ 234, também com canelura acima ma meia-pança. Exibe, porém, decoração espatulada de linhas oblíquas paralelas em série, frequente nestas gamas de cerâmica comum na Península de Lisboa e no Norte alentejano. Esta mes-

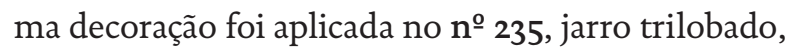
com canelura larga acima da carena suave e espatulado oblíquo entre a canelura e o colo, em fabrico quartzo-micáceo, castanho-claro. Neste caso, sem paralelos na Quinta do Rouxinol, mas com alguma semelhança formal, embora de bordo mais comprido e sem espatulado, no Norte Alentejano (séc. I e inícios do II: Nolen, 1985, p. 6o, nํ130: fabrico G: laranja, fino), e em Conimbriga, de pastas finas e com espatulado (Alarcão, 1975, nº 504 e 579). O no 232 é uma bilha pequena, sem bordo conservado.

Sepultura 7 - Sepultura em caixa estruturada por fundo argamassado, paredes em argamassa com elementos pétreos e cerâmica e um dos topos com later argamassado. Cobertura visível, de lateres e imbrex dispostos em telhado de duas águas na zona da cabeceira e o restante por um later horizontal travando uma imbrex, argamassados lateralmente.

Bioantropologia: o esqueleto encontrava-se em muito mau estado de conservação, sendo apenas recuperados fragmentos do crânio, costelas e vértebras. Com base na morfologia óssea foi possível estimar tratar-se de um indivíduo não adulto. Tal como aconteceu no caso da sep.5, por forma a obter um intervalo etário mais específico, procedeu-se a uma comparação com os indivíduos não adultos identificados na Praça da Figueira em 1999-2001, recorrendo a fragmentos de costelas e de vertebras. Os resultados obtidos a partir desta comparação apontam para um individuo com menos de 6 meses de vida. "Mobiliário funerário": Sem mobiliário funerário.

Sepultura 8 - Coval com cobertura em telhado laterício de duas águas, travado no topo por fragmento de later em cutelo (preservada apenas a parte correspondente à cabeceira). O contexto foi profundamente afectado por uma construção contemporânea.
Bioantropologia: não foram identificados vestígios ósseos no interior da sepultura.

"Mobiliário funerário": Identificou-se apenas um pote biansado no topo, não se apurando a sua relação com a disposição do inumado. Com o n⿳o 216, será um potinho em pasta quartzo-micácea semelhante aos nํㅗ 226 (supra), 190, 230 e 227 (infra).

Sepultura 9 - Coval ovalado, no interior do qual se depositou um ataúde (pregarias). Cobertura não preservada.

Bioantropologia: devido ao grau de afectação desta sepultura, apenas foi possível recuperar fragmentos dos membros inferiores. Terá sido depositado em decúbito dorsal, a avaliar pela posição dos elementos ósseos identificados. A observação da maturação óssea revela tratar-se de um indivíduo adulto, muito provavelmente do sexo masculino (Wasterlain, 200o).

"Mobiliário funerário": não identificado dada a afectação da sepultura.

Sepultura? 1o - Trata-se de um revestimento parietal e do fundo de coval com laterício, muito marginalmente preservado sob as estruturas do prédio, e que, a despeito de não se terem encontrado evidencias funerárias categóricas, deverá corresponder a uma sepultura muito destruída.

Sepultura? 11 - Coval sub-rectangular, em tudo idêntico aos seguramente funerários documentados no local. O depósito de preenchimento do seu fundo nada revelou de evidências funerárias. Cobria-o um depósito de pedra de pequena dimensão, que revelou escassos fragmentos cerâmicos, alguns de cronologia medieval/moderna. Pode, todavia, corresponder a uma sepultura violada.

\section{DISCUSSÃO}

O núcleo funerário das Portas de Santo Antão apresenta algumas características singulares, nomeadamente a boa gestão do espaço, dado não se verificarem cerceamentos ou sobreposições de acções sepulcrais, a sincronia, aqui refinada para o último terço do séc. III d.C. (possivelmente centrada nas décadas de 260 a 280 d.C.), bem como evidentes afinidades constatadas nos "mobiliários funerários", elementos que no seu conjunto se destacaram desde a primeira hora e que levaram alguns dos autores a 
propor preliminarmente "sugerirem-se explicações de índole cultural e/ou de parentesco dos inumados, que só outro tipo de análises poderia sustentar" (Cabaço \& alii, 2017a, p. 1249).

De outro modo, e sintomaticamente, o espaço utilizado no período em causa não revelou quaisquer indícios de práticas fúnebres anteriores, ao contrário do que fora antes constatado nos núcleos da Praça da Figueira (Silva, 2005) e Encosta de Santana (Muralha, Calado \& Costa, 2002), sujeitos a um faseamento mais rico e complexo. Este aspecto assume relevância, por implicitamente acarretar outro tipo de usos anteriores do terreno, podendo significar, em sentido inverso, um fenómeno de expansão fúnebre, já documentado nos outros núcleos mencionados da Necrópole Noroeste de Olisipo, da Praça da Figueira, Encosta de Sant 'Ana (Muralha, Calado \& Costa, 2002) e, eventualmente, da Calçada do Lavra. Atentando à representatividade do perfil biológico presente no núcleo, e a despeito das óbvias limitações que impõem a exiguidade da amostra e o seu mau estado de preservação, a análise comprovou a heterogeneidade desta, visto ser composta por indivíduos de ambos os sexos e de diferentes grupos etários. Não deverá ser valorizada aqui a relação de sexo (4 femininos / 2 masculinos). Todavia, a presença dos dois infantes deve ser aqui destacada pela discrepância entre ambos: no indivíduo classificado como "com menos de 6 meses" é evidente a ausência de "mobiliário associado" (Sep. 7), por contraste com aquele classificado como "com menos de 12 meses" (Sep. 5), onde a existência de ataúde e a composição do "mobiliário funerário" em nada o distinguem dos restantes indivíduos adultos.

O "mobiliário funerário", conjugado com os dados do perfil biológico dos indivíduos, não revelou diferenças significativas entre estes, antes similitude. Assinala-se neles a assídua presença de numismas, lucernas, objectos destinados ao consumo alimentar e à sua conservação (líquidos e sólidos; predominantemente depostos após a colocação do ataúde, no exterior deste, com maior incidência numa zona reservada do coval junto aos pés, mas não só- Seps.1 e 2), com dois casos em que a olla foi usada para conter a lucerna. Destacam-se somente destas observações os elementos de adorno pessoal (anéis de prata tipo Aquincum IVc e acus crinalis), invariavelmente associados a indivíduos adultos femininos.

Sendo admissível no núcleo das Portas de Santo Antão a utilização de um mesmo espaço funerário por parte de um grupo humano de relativa homogeneidade (cultural, social, ...), só ulteriores análises poderão eventualmente vir a esclarecer de forma categórica a natureza das suas afinidades, constituindo, de qualquer das formas, um relevante repositório das práticas funerárias a uso num espaço de tempo confinado do último terço do séc. III d.C.

\section{BIBLIOGRAFIA}

ALARCÃO, Jorge de (1975) - Fouilles de Conimbriga. V (La Céramique Commune Locale et Régionale). Paris: Difusion E. de Boccard.

BONIFAY, Michel (2004) -Études sur la céramique romaine tardive d'Afrique. Oxford: Archaeopress (Col. British Archaeological Reports, International Series. 1301).

BRUZEK, Jaroslav (2002) - A method for visual determination of sex, using the human hip boné. American Journal of Physical Anthropology. pp. 157-168.

BUIKSTRA, Jane E.; UBELAKER, Douglas H. (1994) Standards for data collection from human skeletal remains: proceedings of a seminar at the Field Museum of Natural History. Fayettevile, Arkansas, Arkansas Archeological Survey.

BUSSIÈRE, Jean (200o) - Lampes antiques d'Algérie. (Monographies Instrumentum; 16). Éditions Monique Mergoil.

CABAÇO, Nelson; SARRAZOLA, Alexandre; SILVA, Rodrigo Banha da; CARVALHO, Liliana Matias; LOURENÇO, Marina (2017a) - O espaço de necrópole Romana das Portas de Santo Antão, Lisboa. In Arqueologia 2017. Estado da Questão. Lisboa: Associação dos Arqueólogos Portugueses, pp. 1243-1254.

CABAÇO, Nelson; SARRAZOLA, Alexandre.; REIS, Helena; LOURENÇO, Marina (2017b) - Relatório Final de Trabalhos Arqueológicos, Projeto de Requalificação Urbana Intervenção Arqueológica Rua das Portas de Santo Antão 84/9o Lisboa. Cruz Quebrada, ERA Arqueologia.

CABAÇO, Nelson; LOURENÇO, Marina; SILVA, Rodrigo Banha da (2019) - O compasso do espaço de necrópole romana das Portas de Santo Antão, Lisboa. In Revista Apontamentos de Arqueologia e Património, $\mathrm{n}^{\circ}{ }^{13}$. Lisboa: NIA, Era-Arqueologia S.A., pp. 47-54.

CARDODO, Hugo; SAUNDERS, Shelley (2008) - Two arc criteria of the ilium for sex determination of immature skeletal remains: a test of their accuracy and an assessment of intra an inter observer error. Forensic Science International,178, pp. 24-29.

CASAS i GENOVER, J.; SOLE i FUSTÉ, V. (2006) - Llànties romanes d'Empúries. Materiales augustals i alto-imperials. Girona: Museu d' Árqueologia de Catalunya (Monografies Emporitanes; 13). 
CASIMIRO, Silvia; SILVA, Rodrigo Banha da; ALVES-CARDOSO, Francisca (no prelo) - 'et sepultus est'. A multiplicidade da morte na Necrópole Noroeste de Olisipo (séc. I a IV d.C.). In A Morte em Lisboa: novos dados, novas problemáticas. Comissão de Estudos Olisiponenses, Museu Arqueológico do Carmo. Lisboa.

CATALANO, Virgilio (1953) - La lucerna di Civitá. In Samnium, Napoli: Instituto della Stampa, 35, pp. 3-8.

CRUZ, Mário da (2009) - O Vidro Romano no Noroeste Peninsular: um olhar a partir de Bracara Augusta. Tese de doutoramento. Braga: Universidade de Minho.

DEUS, Manuela de (2016) - Quando o objecto desafia a curiosidade: A actividade arqueológica de Cenáculo e seus colaboradores em Santiago do Cacém. In Dom Frei Manuel do Cenáculo Itinerários por Santiago do Cacém. Santiago do Cacém: União das Freguesias de Santiago do Cacém, Santa Cruz e São Bartolomeu da Serra, pp. 165-183.

FACSÁDY, Annamária R.; VEREBES, Anett (2009) - Analysis of Roman Bronze Finger Rings from Aquincum. In Materials and Manufacturing Processes, 24:9. London: Taylor \& Francis Group LLC, pp. 993-998.

FEREMBACH, D.; SCHWIDETZKY, I.; STLOUKAL, M. (1980) - Recommendations for age and sex diagnoses of skeletons. Journal of Human Evolution, 9. pp. 517-549.

FOY, Danièle (2010) - Les verres antiques d'Arles: La collection du Musée Dépertemantal. Arles Antique. Paris: Éditions Errance.

HAYES, John W. (1972) - Late Roman Pottery. Londres: British School at Rome.

ISINGS, Clasina (1959) - Roman glass from dated finds. Groningen e Jacarta: Academiae Rheno - Traiectinae Instituto Archaeologico (colArchaeologia Traiectina, II).

LOVEJOY, C. Owen; MEINDL, Richard; PRYZBECK, Thomas; MENSFORTH, Robert (1985) - Chronological metamorphosis of the auricular surface of ilium: new method for the determination of adult skeletal age at death. American Journal of Physical Anthropology, 68. pp. 15-28.

MACLAUGHLIN, S. M. (1990) - Epiphyseal Fusion at The Sternal End of the Clavicle in a Modern Portuguese Skeletal Sample. Antropologia Portuguesa, 8. pp. 59-68.

MURALHA, João; COSTA, Cláudia, CALADO, Marco (2002) - Intervenções Arqueológicas na Encosta de Sant'Ana (Martin Moniz, Lisboa) in Al-Madan. Almada 2ª série $\mathrm{n}^{0}$ 11, pp. 245-246.

NOLEN, J. S. (1985) - Cerâmica comum de necrópoles do Alto Alentejo. Lisboa: Fundação da Casa de Bragança.

PINTO, I. Vaz (2003) - A cerâmica comum das villae romanas de São Cucufate (Beja). Lisboa: Universidade Lusíada Editora. (Colecção Teses).
QUARESMA, José Carlos (2018) - Transição estratigráfica em Almoínhas (Loures, Portugal): evolução das importações finas na Lusitania entre c.10o e c.32O d.C.. CIRA Arqueologia. 6, p. 199-230.

QUARESMA, José Carlos (no prelo) - The $3^{\text {rd }}$ century AD in motion: new proposals on morphologic-and-chronological lamps evolution (Disc-type, Dressel 28, Dressel 27, Dressel 30 and Disc-type derived). Terracota lamps in Archaic, Classical, Hellenistic, Roman and Early Byzantine Anatolia: production, use, typology and distribution. An international symposium. May 16-17, 2019, Izmir, Turkey.

RAUX, Stéphanie (2016) - Jambes de compas du Haut-Empire portant des graduations de mesure : un exemplaire sur le site de l'Auditorium à Bordeaux (F, Gironde). In Bulletin Instrumentum, 43. S/1, Association Instrumentum, p.42.

RICVa= MATTINGLY, Harold; SYDENHAM, Edward Allen; WEBB, Percy H. (1927) - Roman Imperial Coinage, vol. 5, Part.1, Valerian to Florian (253-276). London: Spink.

RODRÍGUEZ MARTÍN, F. G. (2002) - Lucernas romanas del Museo Nacional de Arte Romano (Mérida). Madrid: Ministerio de Educación, Cultura y Deporte (Monografías Emeritenses; 7).

RÜTTI, Beat (1991) - Die Römischen Gläser aus Augst und Kaiseraugst, vol. II, Katalog und Tafeln. Augst: Museen und Archäologie des Kantons Basel- Landschaft (col. Forschungen in Augst, 13).

SANTOS, Cézer Renato (2011) - As cerâmicas de produção local do centro oleiro romano da Quinta do Rouxinol (Setúbal, Portugal) (Dissertação de Mestrado em Arqueologia). Lisboa: Faculdade de Letras da Universidade de Lisboa (policopiado).

SILVA, Rodrigo Banha da (2005) - As "marcas de oleiro" em terra sigillata da Praça da Figueira (Lisboa): uma contribuição para o conhecimento da economia de Olisipo (séc. I a.C.séc. II d.C.) (Dissertação de Mestrado). Braga: Universidade do Minho, Instituto de Ciências Sociais (policopiado).

WALKER, Phillip L. (2005) - Greater sciatic notch morphology: sex, age, and population differences. American Journal of Physical Anthroplogy, 127(4). pp. 385-391.

WALKER, Phillip L. (2008) - Sexing skulls using discriminant function analysis of visually assessed traits. American Journal of Physical Anthroplogy, 136(1). pp. 39-50.

WASTERLAIN, Rosa Sofia (200o) - Morphé: análise das proporções entre os membros, dimorfismo sexual e estatura de uma amostra da colecção de esqueletos identificados do Museu de Antropologia da Universidade de Coimbra. Dissertação de mestrado em Evolução Humana. Departamento de Antropologia. Coimbra: Universidade de Coimbra.

WHITE, Tim., FOLKENS, Peter (2005) - The human bone manual. Amsterdam: Academic Press. 

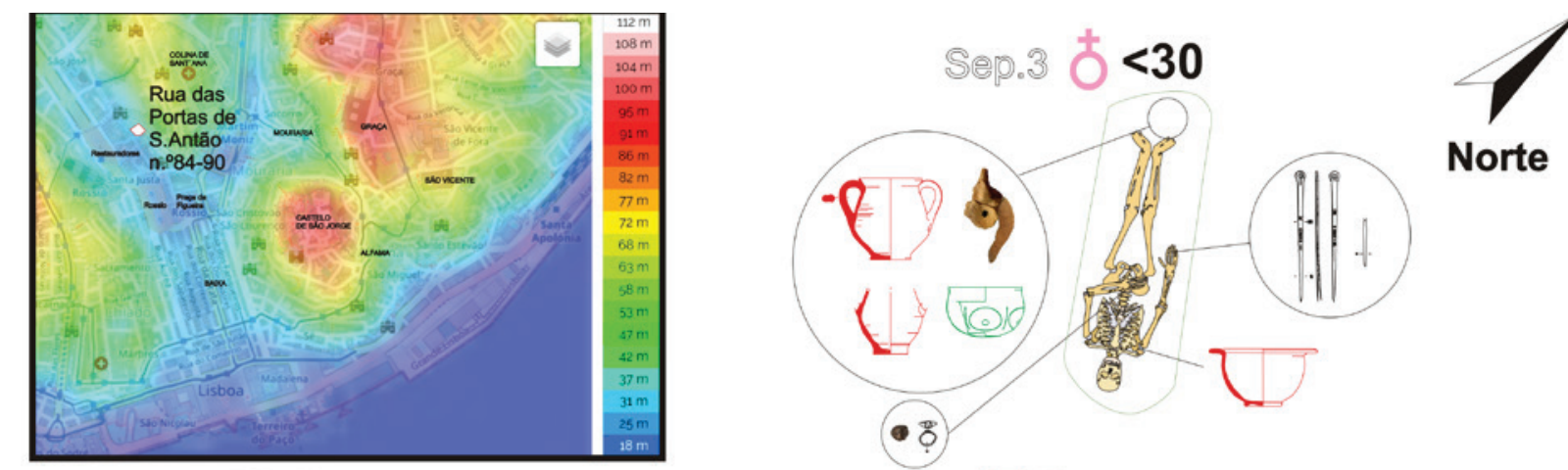

Norte

Sep.80?
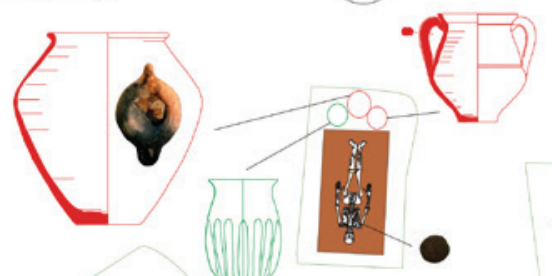

Sep.7 $0<6 \mathrm{~m}$

Sep.5

( $<<12 \mathrm{~m}$

11 ?

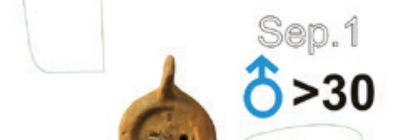

(5)
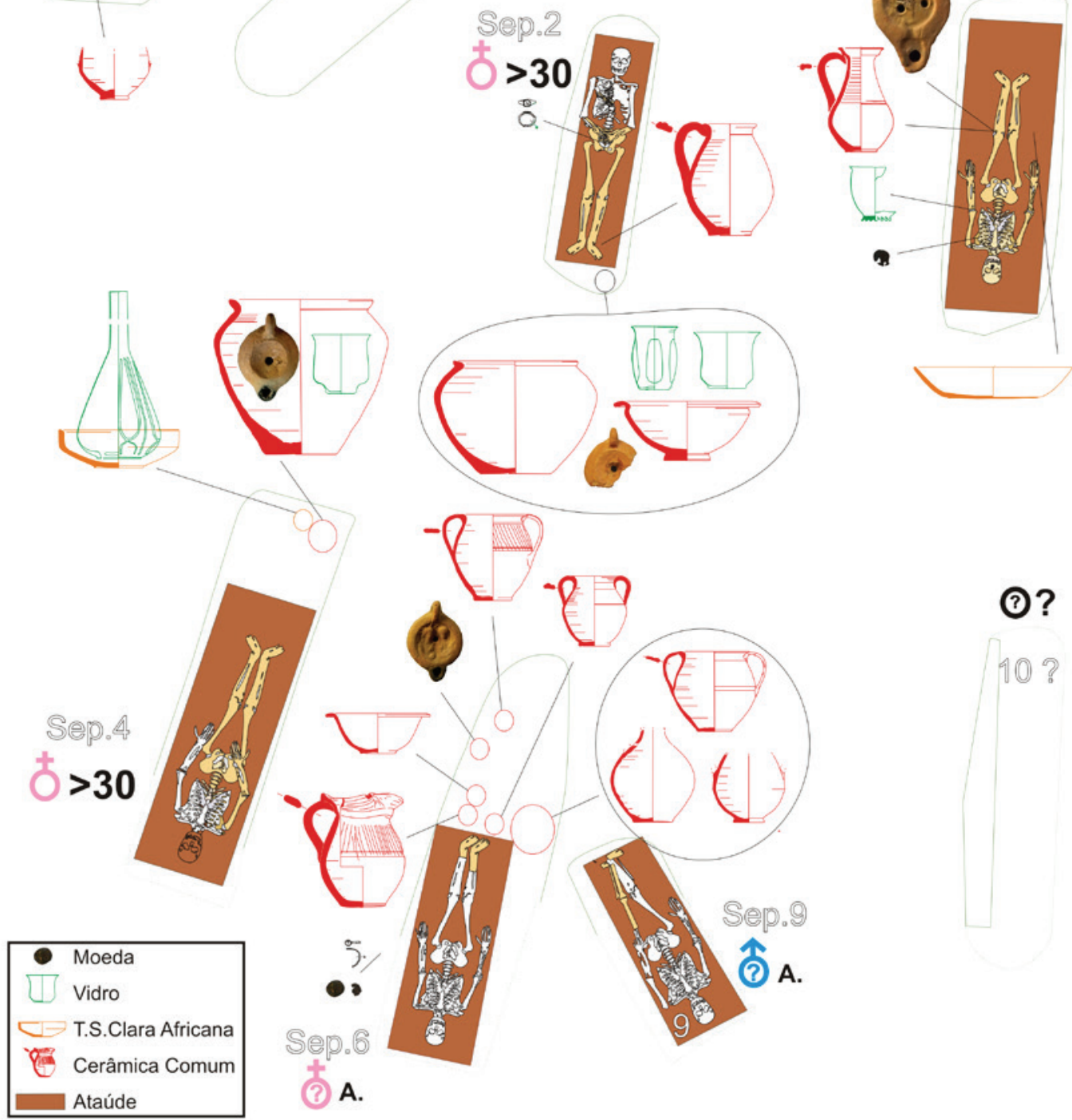

ㅇ? 


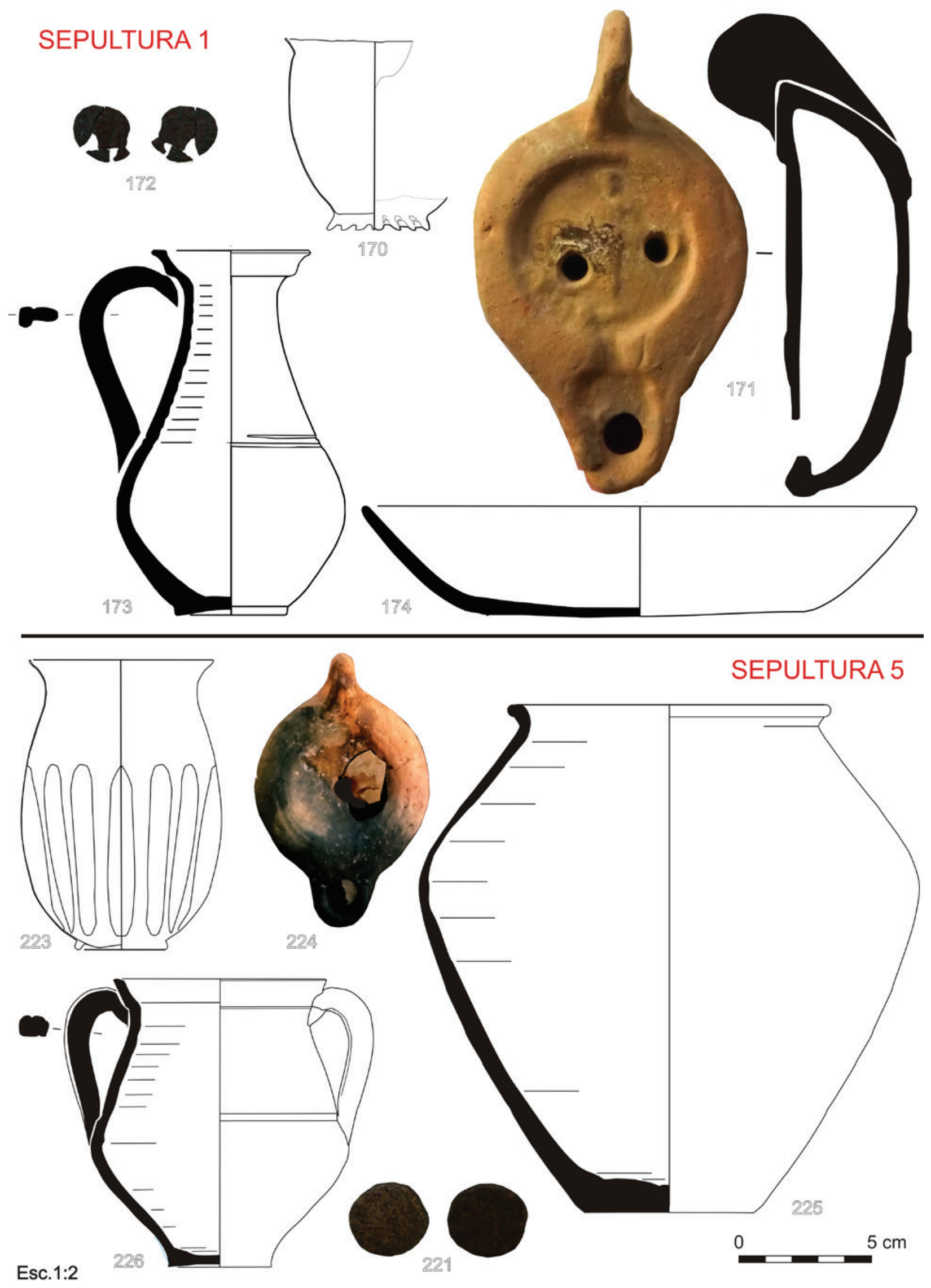

Figura 2 


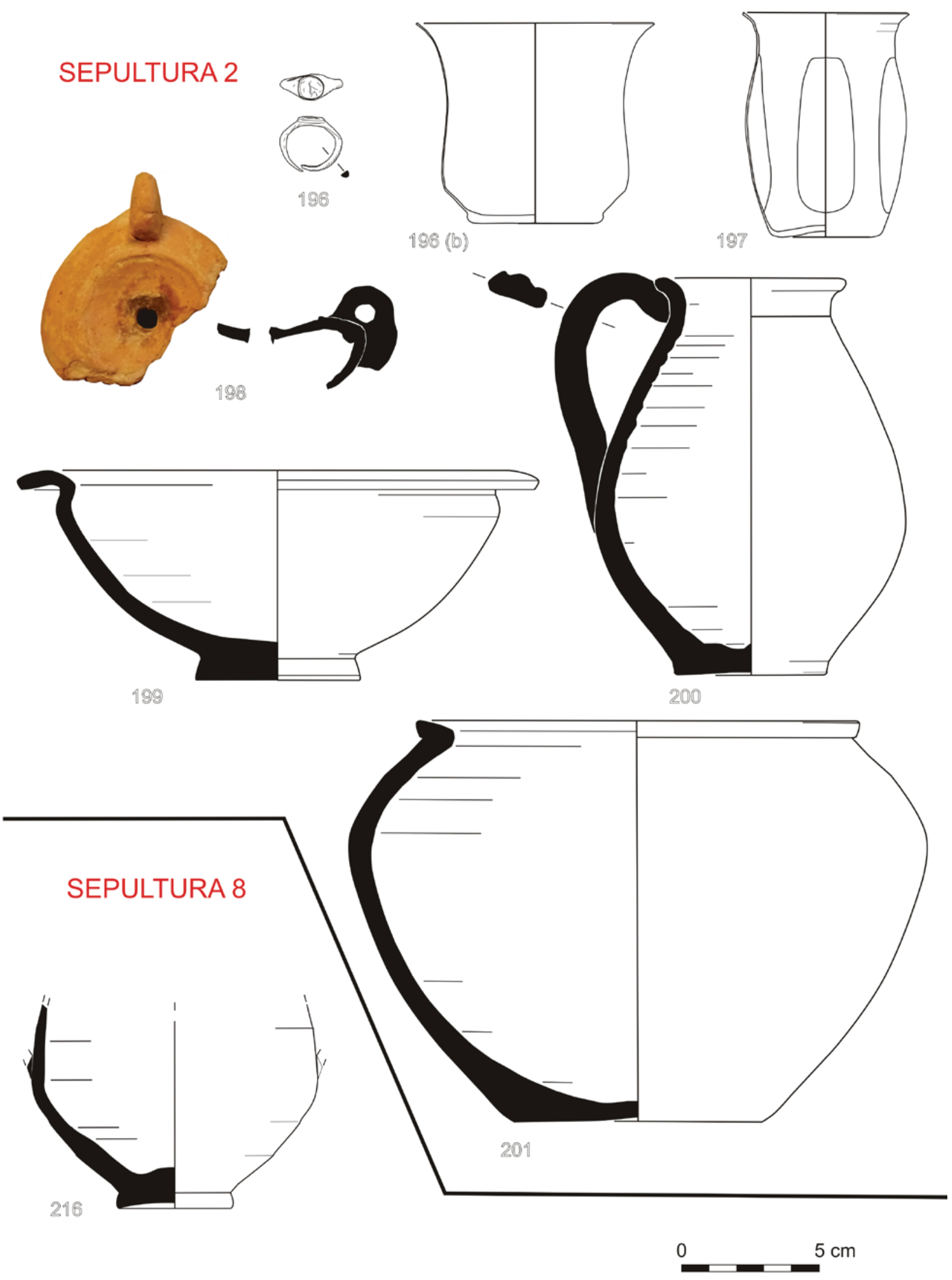

Esc.1:2

Figura 3 


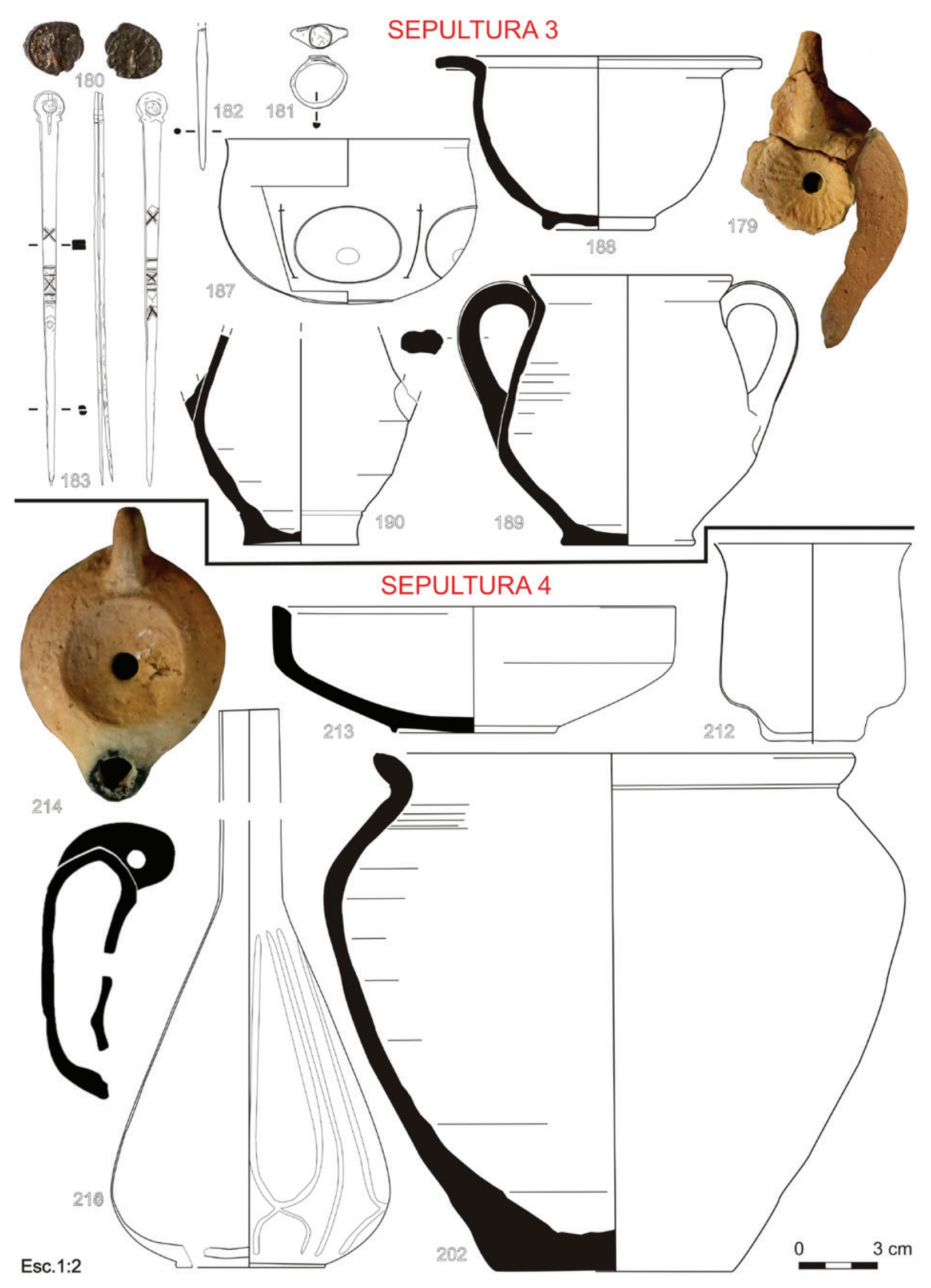

Figura 4 


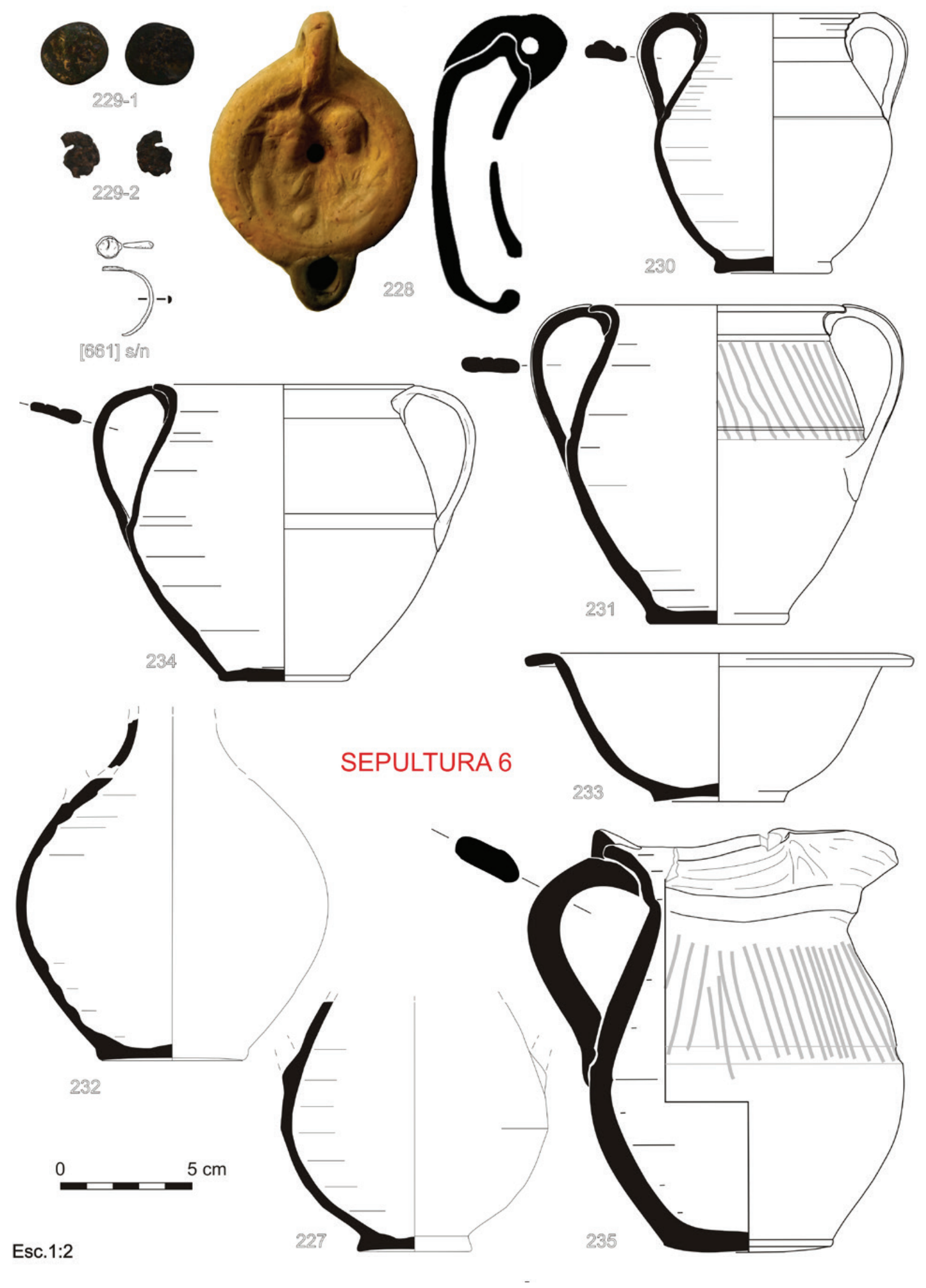

Figura 5 


\title{
POVOAMENTO EM ÉPOCA ROMANA NA AMADORA - RESULTADOS DE UM PROJETO PLURIDISCIPLINAR
}

\author{
Gisela Encarnação ${ }^{1}$, Vanessa Dias ${ }^{1}$
}

\begin{abstract}
RESUMO
O projeto de investigação "PERA - Povoamento em Época Romana na Amadora” teve o seu início em 2017, completando o ciclo plurianual no início de 2021. Os objetivos definidos para o mesmo compreenderam sempre uma necessária abordagem pluridisciplinar aos dados recolhidos nas escavações arqueológicas levadas a cabo nos sítios de época romana identificados no concelho.

O profícuo encontro da arqueologia e outras ciências, como a antropologia, a arqueobotânica, a química, a geofísica e a ilustração científica, permitiu um conhecimento complexo acerca das balizas cronológicas de ocupação, das populações, dos seus hábitos de consumo e quotidiano durante a antiguidade no ager de Olisipo.

Neste Congresso, apresentam-se os resultados alcançados até ao momento, tendo por base os objetivos inicialmente propostos, reforçando a importância das abordagens interdisciplinares.
\end{abstract}

Palavras-chave: Época Romana, Amadora, Pluridisciplinaridade.

\begin{abstract}
The research project "PERA - Settlement in the Roman Period in Amadora" started in 2017, completing the multi-annual cycle in early 2021. The objectives defined for it always included a necessary multidisciplinary approach to the data collected in the archaeological excavations carried out in Roman sites identified in the municipality.

The fruitful encounter of archeology and other sciences, such as anthropology, archeobotany, chemistry, geophysics and scientific illustration, allowed a complex knowledge about the chronological marks of occupation, of the populations, of their consumption and daily habits during antiquity in Olisipo ager.

In this congress the authors present the results achieved so far based on the objectives initially proposed, reinforcing the importance of interdisciplinary approaches.
\end{abstract}

Keywords: Roman Period, Amadora, Pluridisciplinarity.

\section{INTRODUÇÃO}

Os vestígios arqueológicos da presença romana na atual cidade da Amadora são conhecidos desde finais da década de 70 , através dos trabalhos de prospeção realizados pelos membros do Centro Cultural Roque Gameiro, responsáveis pela identificação da maioria dos sítios de época romana e pelas primeiras intervenções no Aqueduto Romano de Olisipo e na villa romana da Quinta da Bolacha (Encarnação, 2003; Encarnação e Dias, 2015; 2017; no prelo; Encarnação et alli, 2016; 2019; Miranda e Encarna- ção, 1998; Miranda et alli, 1999; Viegas e Gonzalez, 1994; 1996).

No final da década de 90 e início de 200o, as intervenções realizadas na villa romana, e mais recentemente, os trabalhos arqueológicos no Moinho do Castelinho e a descoberta de sítios como a Necrópole de Casal de São Brás, a Serra de Carnaxide - via F e a Quinta da Lage/Quinta do Estado, contribuíram para a perceção da importância deste território na romanidade, e sobretudo a sua diacronia de ocupação (Almeida, Encarnação e Dias, no prelo; Dias e Encarnação, no prelo; Encarnação, 2003; Encarna-

1. Câmara Municipal da Amadora / Departamento de Educação e Desenvolvimento Social/ Divisão de Intervenção Cultural/ Museu Municipal de Arqueologia; museu.arqueologia@cm-amadora.pt 
ção e Dias, 2015; 2017; no prelo; Encarnação et alli, 2016; 2017; 2019; Miranda e Encarnação, 1998; Miranda et alli, 1999; Viegas e Gonzalez, 1994; 1996). Assim o projeto plurianual de investigação "PERA Povoamento em Época Romana na Amadora”, submetido à DGPC em 2016, surge da necessidade de saber mais sobre as formas de ocupação e exploração no ager Olisiponensis, cujos objetivos foram apresentados pelas autoras em 2017, no II Congresso da Associação dos Arqueólogos Portugueses (Encarnação e Dias, 2017). Durante 2020, constrangimentos vários impediram a obtenção de resultados a tempo da sua divulgação neste congresso.

\section{ACERCA DO ESTUDO DO POVOAMENTO EM ÉPOCA ROMANA NA AMADORA}

Desde a sua conceção, existiu sempre a pretensão de criar um projeto pluri e interdisciplinar, cujas valências de diferentes ciências, investigadores e instituições pudessem fornecer uma maior riqueza de dados e resultados abrangentes e complementares. Nesse sentido, ao longo de quase quatro anos e a meses de concluir o primeiro ciclo deste projeto de investigação, pudemos analisar múltiplos aspetos que revestiram o povoamento romano da Amadora, à luz da arqueologia, da antropologia biológica, da arquebotânica, da zooarqueologia, da física e da química, envolvendo ainda as novas tecnologias de virtualização e reconstrução digital.

Toda essa informação foi ainda de encontro ao esforço empreendido na promoção, divulgação e sensibilização do património arqueológico do Concelho e de todas as atividades desenvolvidas no âmbito deste projeto, com a comunidade científica e sobretudo com a população, através da promoção de exposições, palestras, visitas orientadas, atividades de mediação para diferentes públicos, comunicação nos meios digitais, integração em projetos nacionais, participação em encontros de especialidade e publicação de artigos e monografias.

\subsection{Trabalhos arqueológicos realizados pelo $\mathrm{Mu}$ -} seu Municipal de Arqueologia

A partir de 2017 foram realizadas anualmente intervenções arqueológicas no sítio do Moinho do Castelinho, e a partir de 2019 na villa romana da Quinta da Bolacha, ao abrigo do projeto referido.

Estes são os sítios que melhor conservam os vestígios da presença romana, e onde até então, apenas tinham decorrido trabalhos de emergência, justificados por perigo de exposição ou destruição eminente dos vestígios, ou para efeitos de classificação patrimonial (Encarnação, 2003; Encarnação et alli, 2016; 2019; Miranda e Encarnação, 1994), revelando sempre contextos com bastante potencial informativo e de grande importância.

Na villa romana da Quinta da Bolacha foram realizadas intervenções em 2019 e 202O. Estas centraram-se no setor III, onde, ao contrário do setor I, se localiza um conjunto de estruturas cuja funcionalidade levanta várias questões, sobretudo devido ao estado de conservação precário das mesmas. Os trabalhos mais recentes permitiram compreender a continuidade dessas estruturas e a existência de um tanque opus signinum e caementicium, bem como a conservação de contextos de abandono em algumas áreas do setor (Figura 1 ).

A complexidade diacrónica do Moinho do Castelinho proporcionou a realização de quatro campanhas de escavação igualmente profícuas, entre 2017 e 2020. Os trabalhos possibilitaram a aferição da existência de contextos de época romano republicana conservados, nomeadamente a existência de um pequeno edifício, a escavação de várias estruturas funerárias, e a recuperação de espólio relevante no interior das sepulturas e nos contextos habitacionais (Figura 2).

2.2. A interdisciplinaridade no estudo dos contextos de ocupação e das populações de época romana A partir dos dados e espólios resultantes, não só dos trabalhos mais recentes, mas também das campanhas de escavação antigas, foram realizados múltiplos estudos e análises, com o objetivo de um conhecimento exaustivo da ocupação do território pelas populações em época romana, recorrendo sempre que possível a meios tecnológicos avançados.

A prospeção geofísica surge como meio complementar da escavação. Alguns dos sítios com cronologia romana possuem uma área de dispersão de vestígios ampla, tornando a escavação arqueológica num processo moroso, destrutivo, e nem sempre obtendo os resultados esperados. Nesse sentido, no âmbito do presente projeto, através da contratação de serviços da empresa Arrow 4D, foi programada a recolha de dados através de métodos de prospeção geofísica em dois sítios arqueológicos de características bastante diferentes: em julho de 2020, na villa romana da Quinta da Bolacha, onde efetivamente existem ves- 
tígios estruturais relevantes da presença romana, sobretudo entre os setores I e III, que deixam adivinhar a possibilidade da existência de mais elementos pertencentes a esta villa no subsolo, ao longo dos mais de $3000 \mathrm{~m}^{2}$ de área de dispersão dos vestígios; e em 2021, no sítio arqueológico da Quinta da Laje, identificado em 2013, levantando dúvidas, uma vez que a intervenção realizada foi de emergência, tendo-se escavado uma área pequena, onde se identificou uma estrutura de funcionalidade desconhecida e cujos materiais surgiam em pouca quantidade e demonstrando uma diacronia de ocupação balizada entre os séculos I a.C. e IV d.C., abrangendo a cronologia de ocupação do Moinho do Castelinho e da Quinta da Bolacha (Figura 3).

Através do CIBIO - Centro de Investigação em Biodiversidade e Recursos Genéticos da Universidade do Porto, foram realizadas análises antracológicas e carpológicas a 11 amostras sedimentares, recolhidas num contexto de utilização no interior da villa romana da Quinta da Bolacha, durante a campanha de 2000/2001. Com as respetivas ressalvas e tendo em consideração as limitações das amostras, este estudo teve como principal objetivo perceber que frutos, sementes e espécies vegetais se conservavam no registo arqueológico e que por ali existiriam e seriam consumidas e utilizadas pelas populações romanas (Figura 4).

Outro dos estudos desenvolvidos recaiu sobre as faunas dos contextos romano republicanos do sítio do Moinho do Castelinho. Realizado por Nelson J. Almeida, teve como principal objetivo o conhecimento aprofundado do registo faunístico existente nos contextos do final do século I a.C., permitindo, inclusive, a realização de análises por $\mathrm{C}_{4} 4$ (Almeida, Encarnação e Dias, no prelo).

Em colaboração com o Departamento de Ciências e Técnicas do Património, da Faculdade de Letras da Universidade do Porto, entre 2019 e 202O, foram desenvolvidas análises referentes à presença de resíduos orgânicos em seis peças recuperadas nas sepulturas intervencionadas no Moinho do Castelinho, de forma a aferir conteúdos e modos de utilização (Figura 5).

Ainda no âmbito do estudo dos espólios, Noé Conejo Delgado realizou um estudo intensivo de todos os elementos de numismática, recuperados nos sítios arqueológicos do Moinho do Castelinho, na villa romana da Quinta da Bolacha e na Serra de Carnaxide - via F. Todos os contextos são bastantes diferentes, tratando-se de espaços habitacionais e funerários, e os resultados serão publicados em dois artigos realizados do âmbito da participação no projeto Lisboa Romana, que referiremos no próximo capítulo.

O presente projeto de investigação plurianual possibilitou ainda um olhar mais cuidado sobre os contextos de antropologia biológica. Deu-se continuidade à escavação dos contextos funerários identificados no Moinho do Castelinho, com a colaboração de vários antrológos, totalizando atualmente 41 sepulturas.

Além da cuidada escavação dos vestígios osteológicos e do minucioso registo, foram realizadas em campo recolhas das amostras de sedimento para análises de paleoparasitologia. Estas são efetuadas em colaboração com o Departamento de Ciências da Vida da Universidade de Coimbra (Figura 6).

De forma a obter uma caracterização concreta das necrópoles identificadas e escavadas no atual território a Amadora, realizaram-se várias datações por radiocarbono, utilizando amostras de fragmentos ósseos dos indivíduos escavados nos sítios da Serra de Carnaxide - Via F, Casal de São Brás e Moinho do Castelinho.

Entre 2019 e 2020 iniciámos o projeto "Dar Rosto à Villa", com o objetivo de ensaiar uma aproximação facial de cariz científico a partir de um crânio de um indivíduo cuja sepultura foi identificada no Moinho do Castelinho, a cargo do ilustrador Filipe Franco. Para tal, foi realizado um relatório antropológico e a digitalização virtual do crânio e mandibula, e por fim, uma análise de ADN, em colaboração com Ron Pinhasi, investigador do Departamento de Antropologia da Universidade de Viena, cujos resultados aguardamos este ano (Figura 7 ).

\section{DAR A CONHECER A OCUPAÇÃO ROMANA NA AMADORA}

A par das atividades de investigação em torno dos sítios e dos espólios arqueológicos, foram realizadas diversas iniciativas que pretenderam a divulgação pública e o envolvimento de várias entidades e pessoas, promovendo ações através do Museu Municipal de Arqueologia da Câmara Municipal da Amadora, nalguns casos em colaboração com a ARQA - Associação de Arqueologia e Defesa do Património da Amadora.

No início de 2018 foi realizada a reformulação da exposição permanente de arqueologia do Núcleo Mu- 
seográfico do Casal da Falagueira, intitulada "Antes da Amadora”. Nela se incluíram novas peças recuperadas nas intervenções mais recentes, e uma reconstituição de uma cozinha romana, remetendo para os vestígios existentes na villa romana da Quinta da Bolacha. Em 2019, com o objetivos de dar a conhecer os objetos encontrados no interior das sepulturas durante as campanhas de 2017 e 2018 no Moinho do Castelinho, e um conjunto de imagens que ilustram os trabalhos de campo, foi concebida a exposição temporária "Reflexos da vida e da Morte no Moinho do Castelinho", patente no mesmo núcleo (Figura 8).

Desde 2018, a Amadora faz parte da lista de municípios da rede metropolitana que integram o projeto Lisboa Romana | Felicitas Iulia Olisipo, criado e gerido pelo Centro de Arqueologia de Lisboa (CAL) e através do qual será feita a divulgação dos os sítios romanos existentes no concelho, integrando circuitos turísticos, participando nos eventos do projeto, e tendo várias contribuições nos volumes da série monográfica homónima.

A promoção de palestras, workshops e a participação em encontros e congressos de especialidade, nacionais e internacionais, foi sempre uma constante, contabilizando-se, sete comunicações e três posters. Até ao final de 2021 terão sido publicados cerca de 20 títulos, entre artigos, monografias e catálogos. Foram realizadas com regularidade visitas orientadas aos sítios arqueológicos, bem como, no decorrer dos trabalhos de campo, possibilitando ao visitante o contacto mais direto com esta realidade.

O protocolo "Campo Escola de Arqueologia" existente entre a Autarquia e a Faculdade de Ciências Sociais e Humanas da Universidade Nova de Lisboa possibilitou a integração de dezenas de alunos da licenciatura e do mestrado de arqueologia nas intervenções arqueológicas. Os programas de voluntariado e "Férias na Cidade - 16+" permitiram que inúmeros jovens e curiosos pela atividade arqueológica integrassem as equipas e ajudassem na realização dos trabalhos de campo e laboratório.

Durante 2019, foi iniciada uma estreita colaboração entre o Museu Municipal de Arqueologia e as turmas do projeto PIEF - Programa Integrado de Educação e Formação da Escola EB 2/3 do Agrupamento Mães de Água, que integra sobretudo jovens residentes nos bairros de proximidade, desenvolvendo um currículo alternativo, através da criação dos "Patrulheiros da Villa". Este grupo de jovens, acompanhado pelos professores, desenvolveu ações de monitorização do estado de conservação do espaço visitável da villa romana da Quinta da Bolacha, tentando-se a criação de uma ligação com o património cultural de que são "vizinhos", uma vez que este sítio se insere no "espaço da escola".

Por fim, procurou-se sempre uma conciliação com os meios tecnológicos mais recentes, através da realização de reconstruções $3 \mathrm{D}$ de espólio e do sítio arqueológico do Moinho do Castelinho e da disponibilização de QRcodes nos núcleos expositivos; e uma ampla divulgação nos meios de comunicação e nas redes sociais, com a realização de diversas reportagens e publicações constantes no site, Youtube e Facebook da autarquia e dos parceiros (Figura 9).

\section{AÇÕES DE VALORIZAÇÃO DOS SÍTIOS ARQUEOLÓGICOS}

Uma das preocupações durante o desenvolvimento deste PIPA foi sempre a conservação e valorização dos sítios arqueológicos intervencionados, nomeadamente da villa romana da Quinta da Bolacha e do Moinho do Castelinho, integrando a equipa um técnico de conservação e restauro do Museu Municipal de Arqueologia.

Nesse sentido, em ambos os sítios, de forma a combater a vegetação infestante, procedeu-se, em 202O, à aplicação de um biocida e foram realizadas ações pontuais de conservação e restauro nalgumas estruturas que se encontravam fragilizadas. Elaborou-se um plano para a conservação e restauro da área visitável da villa romana, que compreendeu ações de limpeza, manutenção, consolidação de estruturas e colocação de manta geotêxtil e gravilha.

No Moinho do Castelinho, dada a fragilidade da rocha de base, todas as sepulturas após a intervenção, são cobertas com manta geotêxtil, colmatadas com sedimento "limpo", e as lajes recolocadas de forma a travar a degradação da estrutura negativa.

Em laboratório existe um trabalho contínuo de conservação sobre o espólio existente em reserva e recuperado nas intervenções mais recentes.

\section{CONSIDERAÇÕES FINAIS}

O projeto de investigação plurianual em arqueologia "Povoamento em Época Romana na Amadora" possibilitou um estudo exaustivo sobre a presença romana na Amadora, através do desenvolvimento 
de trabalhos de campo e da análise dos dados recolhidos em campanhas anteriores.

Pareceu-nos natural a integração de vários profissionais de outras áreas de estudo na leitura que pretendemos fazer. Só com uma visão pluridisciplinar conseguimos retirar toda a informação dos dados recolhidos em campo e dar a conhecer as populações que habitaram a Amadora há quase dois mil anos.

\section{AGRADECIMENTOS}

O nosso agradecimento a todos os investigadores e amigos que ao longo de quatro anos (alguns antes disso) colaboraram na nossa investigação e ajudaram-nos no conhecimento e divulgação do património arqueológico da Amadora:

ARQA, Ana Luísa Santos, António Gonzalez, Carlos Carpetudo, César Oliveira, Elisa de Sousa, Filipe Franco, Graça Cravinho, João Marques, João Tereso, José Carlos Quaresma, Liliana M. Carvalho, Yuliet Quintino Arias, Nelson J. Almeida, Noé Conejo Delgado, Samuel Neves, Raquel Granja, Ron Pinhasi.

\section{BIBLIOGRAFIA}

ALMEIDA, Nelson J.; ENCARNAÇÃO, Gisela; DIAS, Vanessa (no prelo) - Moinho do Castelinho e a época romano-republicana na Amadora: estruturas, materiais e subsistência. In Lisboa Romana | Felicitas Iulia Olisipo. O Ager Olisiponensis e as estruturas de povoamento. Lisboa: Caleidoscópio.

CRAVINHO, G.; ENCARNAÇÃO, Gisela; DIAS, Vanessa (2017) - Uma Peça Glíptica proveniente do Sítio Arqueológico do Moinho do Castelinho, (Amadora). Almadan Online. II série, $\mathrm{n}^{\mathrm{o}}$ 21, tomo II. Almada: Centro de Arqueologia de Almada. pp. 28-32.

DIAS, Vanessa; ENCARNAÇÃO, Gisela (no prelo) - A Necrópole Romana do Moinho do Castelinho, Amadora (Portugal). In Actas da Reunión de Arqueología Madrileña. Madrid: Colégio de Arqueólogos de Madrid.

ENCARNAÇÃO, Gisela (2003) - A villa romana da Quinta da Bolacha. Um caso de Arqueologia Urbana, in Actas do Quarto Encontro de Arqueologia Urbana, Amadora, Câmara Municipal da Amadora/ARQA - Associação de Arqueologia da Amadora.

ENCARNAÇÃO, Gisela; DIAS, Vanessa (2015) - Moinho do Castelinho. Um sítio a descobrir. Catálogo de exposição. Amadora: Câmara Municipal da Amadora.

ENCARNAÇÃO, Gisela; DIAS, Vanessa (2017) - Estado atual do conhecimento acerca do povoamento em época romana na amadora. in Arnaud, J. M.; Martins, A. (coords.) (2017) - Arqueologia em Portugal. 2017 - Estado da Questão. Lisboa: Associação dos Arqueólogos Portugueses. pp. 171-183.
ENCARNAÇÃO, Gisela; GRANJA, Raquel; BARBOSA, R.; DIAS, Vanessa; (2016) - Moinho do Castelinho. Trabalhos arqueológicos realizados entre 2011 e 2015. Relatórios 9. Amadora: ARQA - Associação de Arqueologia da Amadora.

ENCARNAÇÃO, G.; BRITO, S.; GRANJA, R.; DIAS, V.; (2017) - Serra de Carnaxide - via F. Trabalhos arqueológicos de emergência realizados em 2009. Relatórios 11. Amadora: ARQA - Associação de Arqueologia da Amadora.

ENCARNAÇÃO, G.; MIRANDA, J.; DIAS, V.; DUARTE, V.; DUARTE, C.; (2019) - Villa Romana da Quinta da Bolacha. Trabalhos arqueológicos realizados entre 1998 e 2015. Relatórios 12. Amadora: ARQA - Associação de Arqueologia da Amadora.

ENCARNAÇÃO, Gisela; DIAS, Vanessa (no prelo) - Aqueduto romano de Olisipo na Amadora - a história de um monumento em vias de classificação. In Lisboa Romana | Felicitas Iulia Olisipo. O Ager Olisiponensis e as estruturas de povoamento. Lisboa: Caleidoscópio.

MIRANDA, J.; ENCARNAÇÃO, G. (1998) - Villa romana da Quinta da Bolacha. Campanha de Abril/Maio de 1997. Relatórios 4. Amadora: Gabinete de Arqueologia Urbana/ Associação de Arqueologia da Amadora.

MIRANDA, J.; ENCARNAÇÃO, G.; VIEGAS, J.C.; ROCHA, E.; GONZALEZ, A. (1999) - Carta Arqueológica da Amadora: do Paleolítico ao Romano. Amadora: Câmara Municipal da Amadora.

VIEGAS, João Carlos e GONZALEZ, António (1994) Aqueduto romano da Amadora. In Almadan. 2ª Série:3. Almada: Centro de Arqueologia de Almada. pp. 29-35.

VIEGAS, João Carlos e GONZALEZ, António (1996) Aqueduto Romano da Amadora. Relatórios 2. Amadora: ARQA - Associação de Arqueologia da Amadora. 


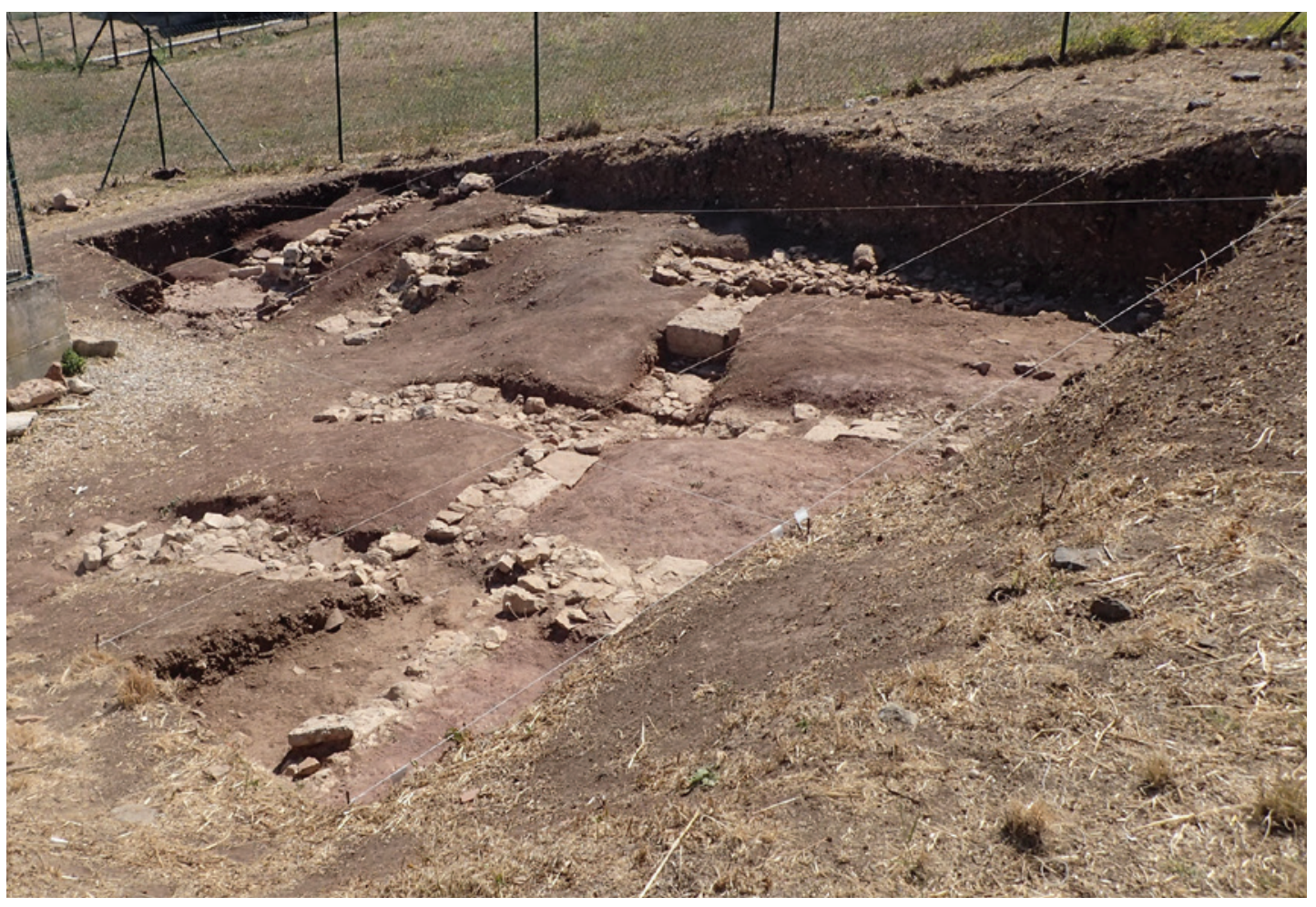

Figura 1 - Vista geral do setor III da villa romana da Quinta da Bolacha no final das escavações de 2020. Autoria: Museu Municipal de Arqueologia/Câmara Municipal da Amadora.

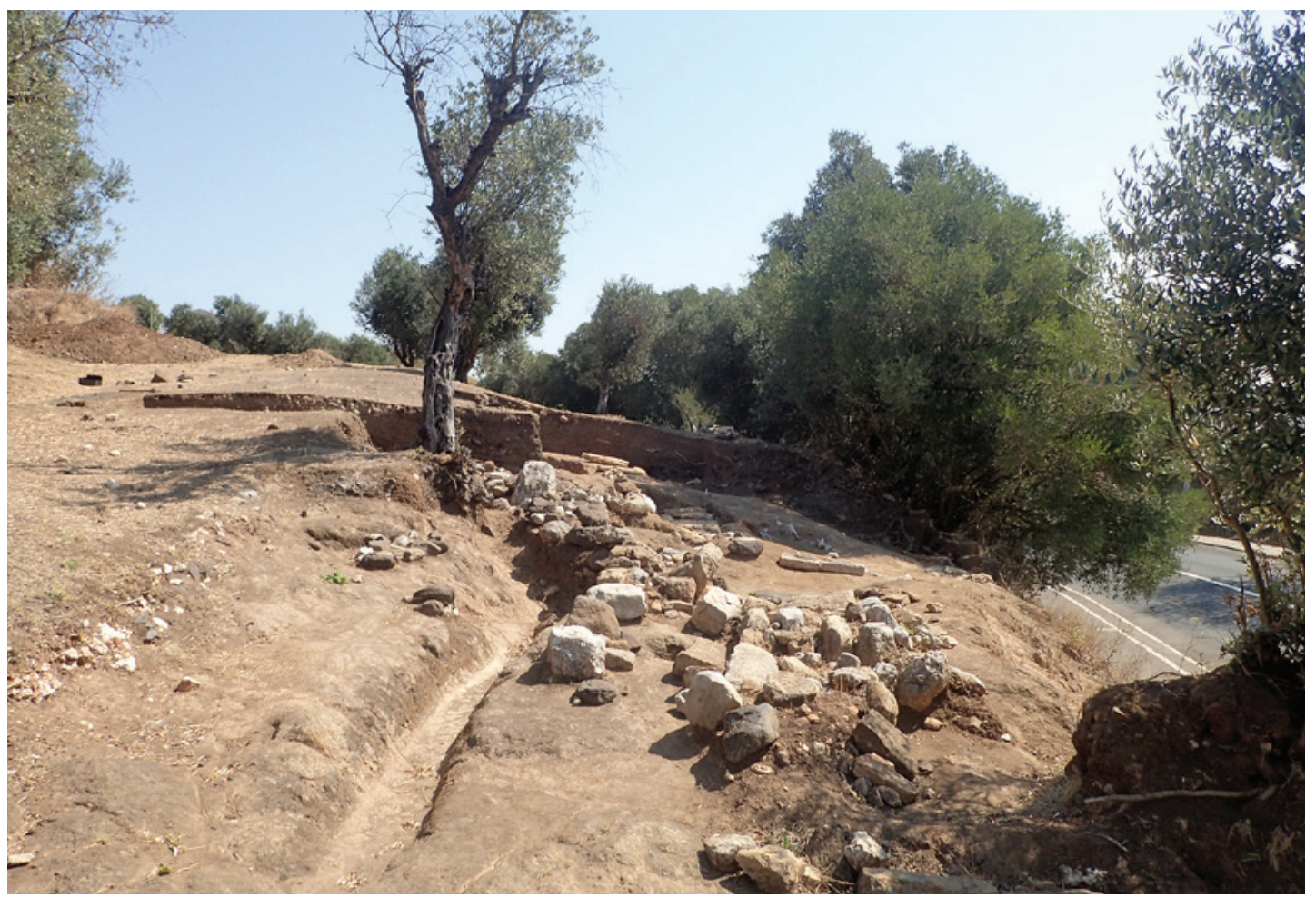

Figura 2 - Vista geral do setor II do sítio arqueológico do Moinho do Castelinho. Autoria: Museu Municipal de Arqueologia/Câmara Municipal da Amadora. 

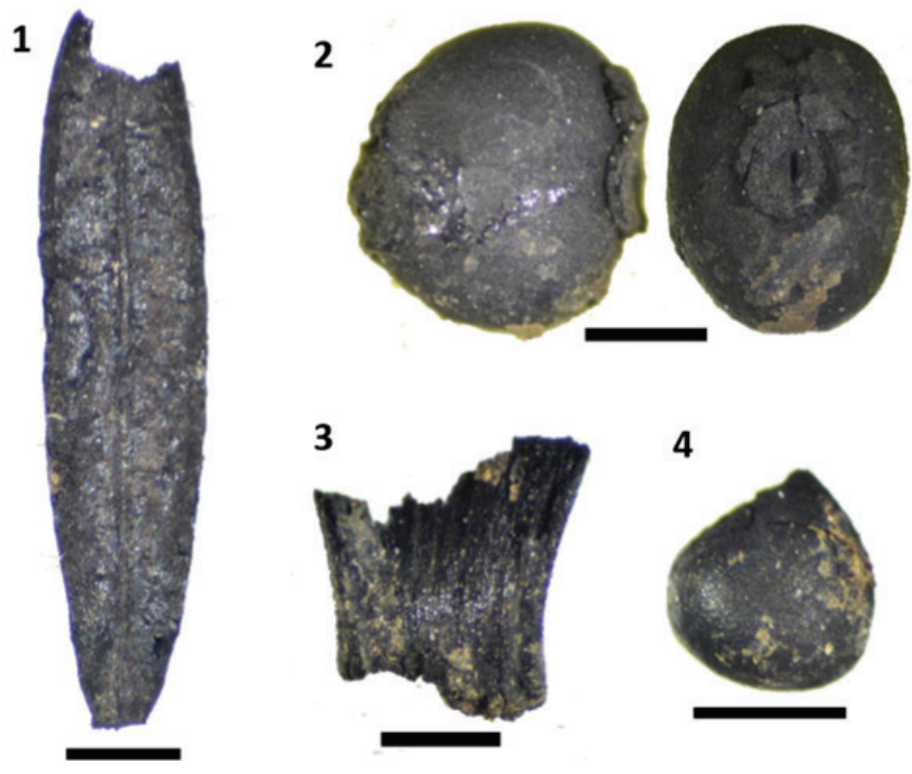

Figura 3 - Amostras carpológicas: cariopse de Bromus sp. (1), semente de Fabaceae tipo Retama (2), fragmento de ráquis de Triticum aestivum/durum (3), semente de Ficus carica (4). (escala $1 \mathrm{~mm}$ ). Autoria: João Tereso (CIBIO).
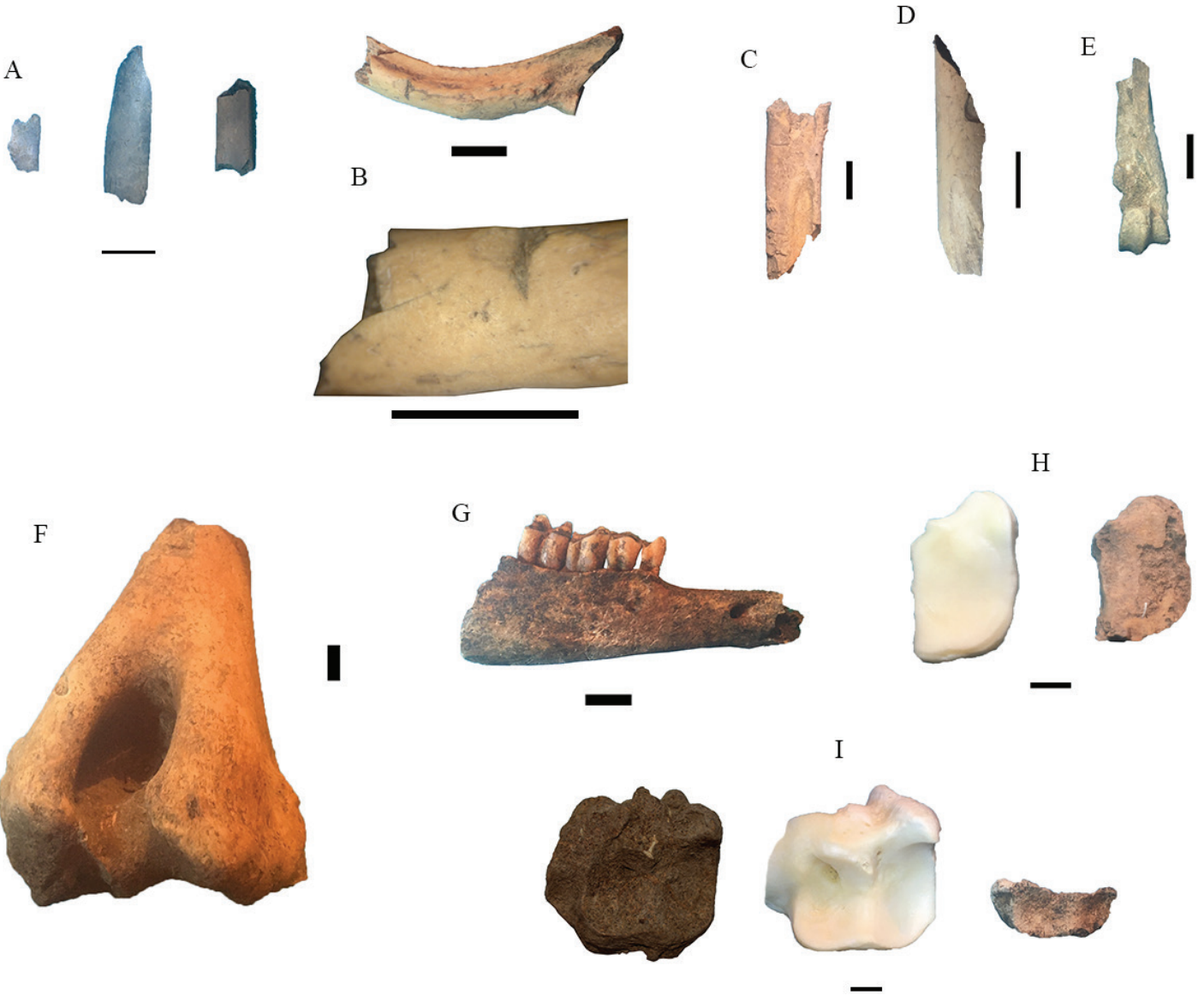

Figura 4 - Exemplares arqueofaunísticos recuperados nos contextos romano republicanos do Moinho do Castelinho. Autoria: Nelson J. Almeida. 


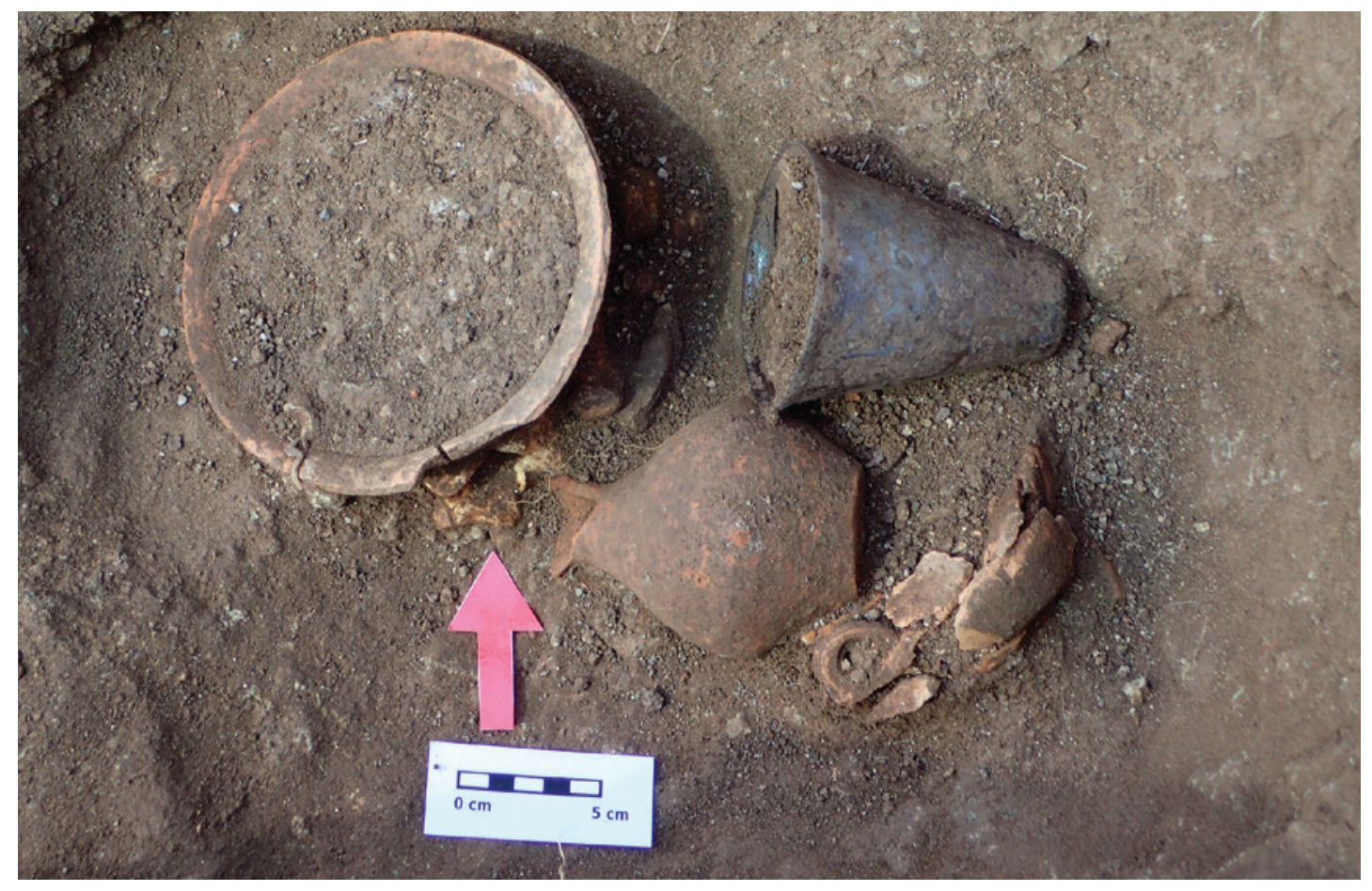

Figura 5-Fotografia de pormenor de espólio recuperado no interior de uma sepultura da necrópole do Moinho do Castelinho. A candeia em vidro foi uns dos objetos de estudo da análise de resíduos orgânicos. Autoria: Museu Municipal de Arqueologia/Câmara Municipal da Amadora

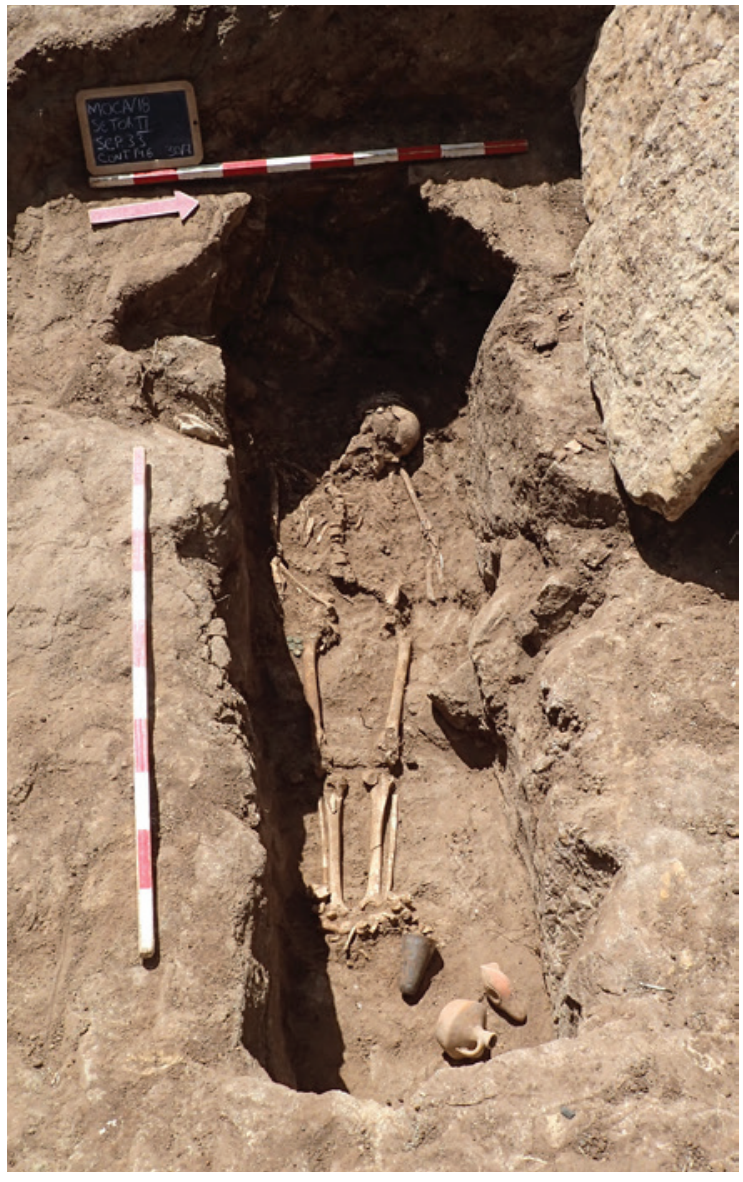

Figura 6 - Sepultura com deposição de indivíduo da necrópole do Moinho do Castelinho. Autoria: Museu Municipal de Arqueologia/Câmara Municipal da Amadora. 


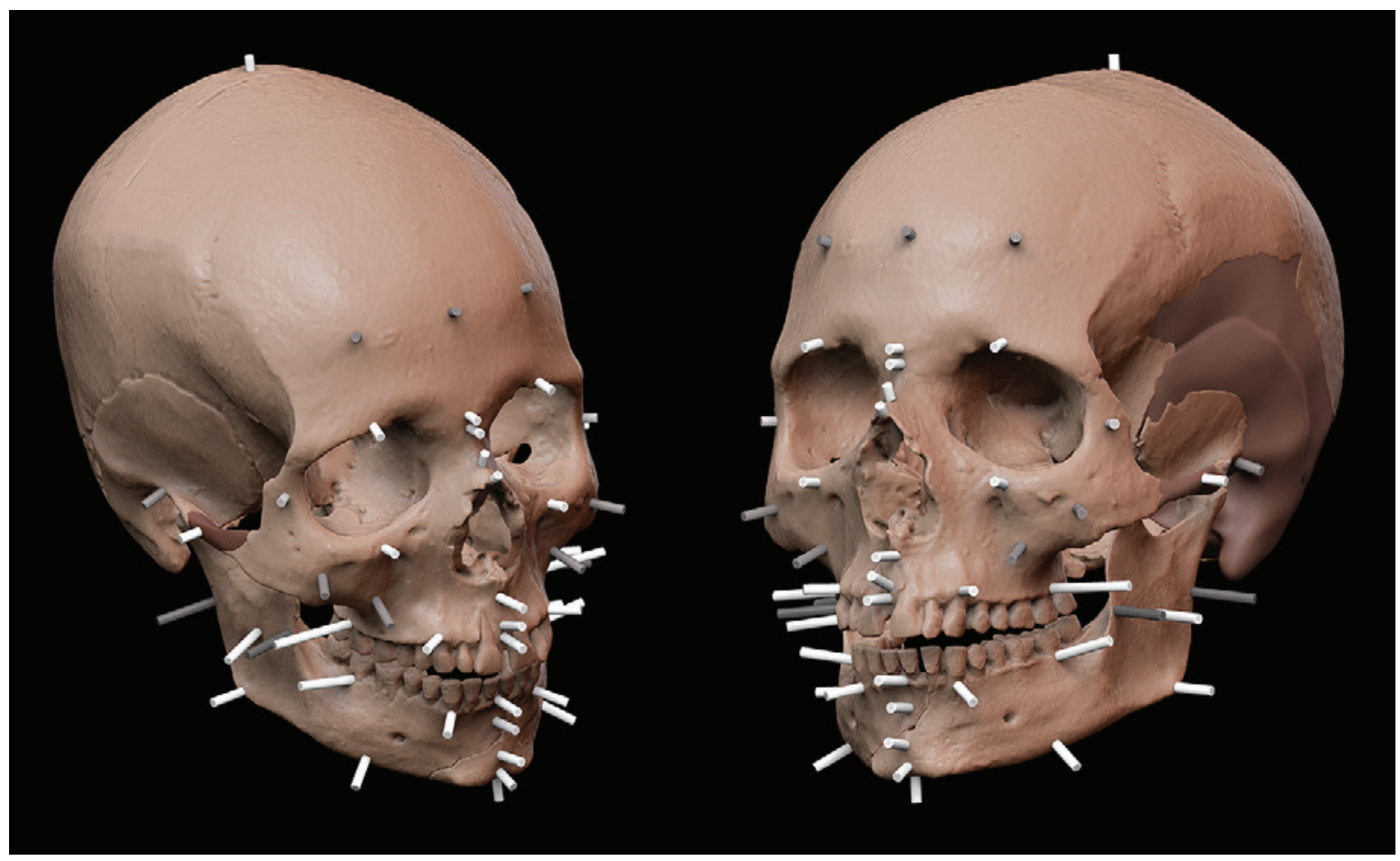

Figura 7 - Crânio do projeto "Dar Rosto à Villa” durante o processo de modelação. Autoria: Filipe Franco a partir da digitalização 3D realizada por Yuliet Quintino Arias.

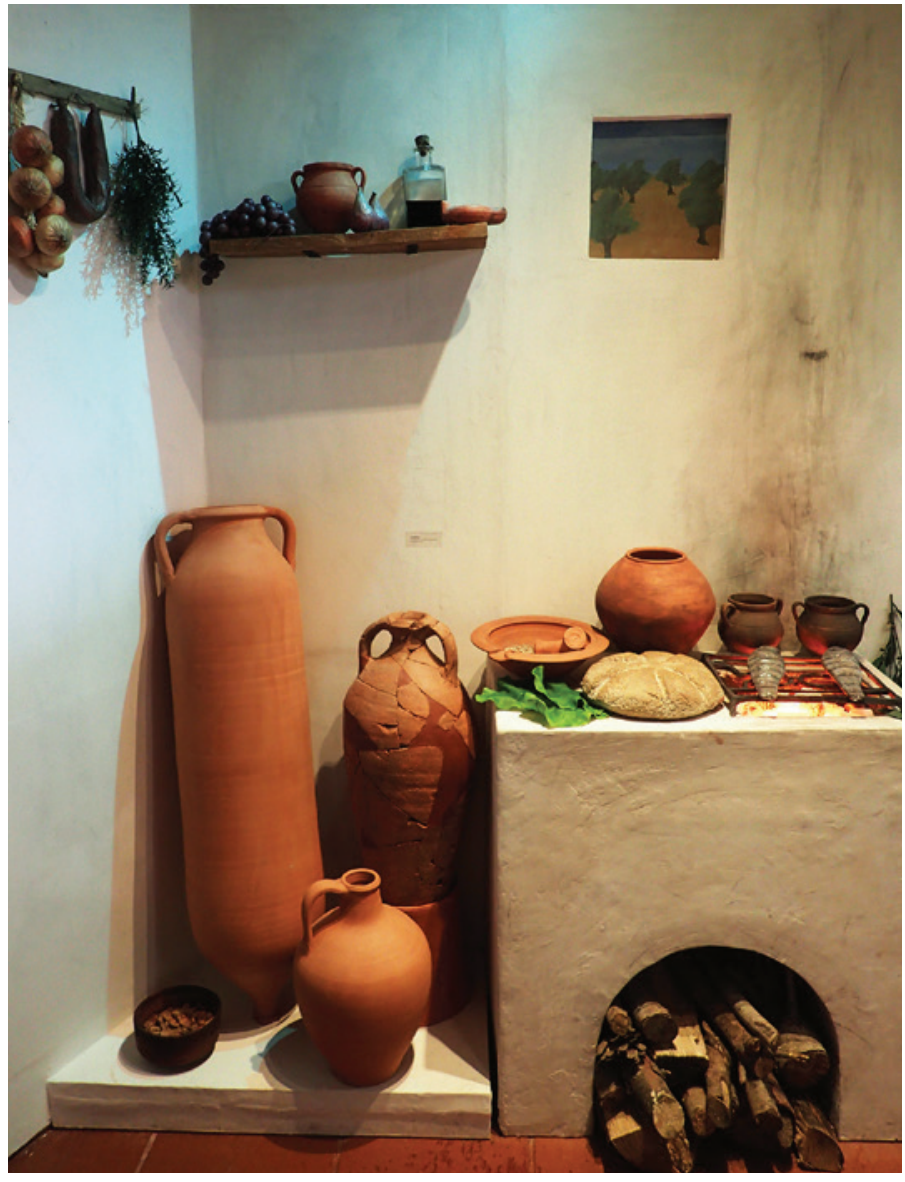

Figura 9 - Reconstituição de cozinha romana da exposição permanente "Antes da Amadora” patente no Núcleo Museográfico do Casal da Falagueira. Autoria: Museu Municipal de Arqueologia/Câmara Municipal da Amadora. 


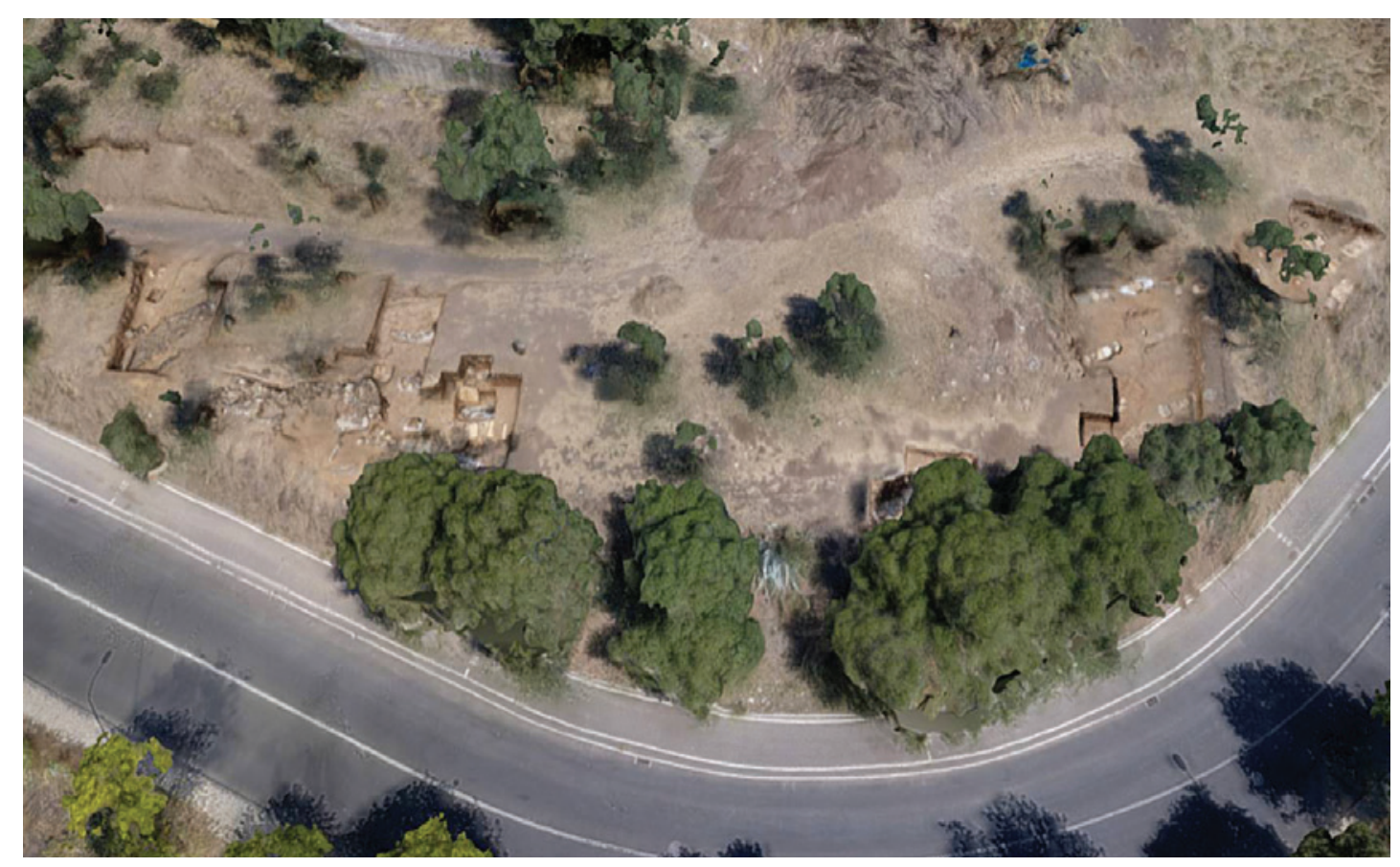

Figura 9 - Modelo 3D do Moinho do Castelinho efetuado através de levantamento por drone. Autoria: João Marques (Geodrone). 


\title{
A ARQUITECTURA RESIDENCIAL EM MIROBRIGA (SANTIAGO DO CACÉM): CONTRIBUTO A PARTIR DE UM ESTUDO DE CASO
}

\author{
Filipe Sousa ${ }^{1}$, Catarina Felício ${ }^{2}$
}

\begin{abstract}
RESUMO
O estudo de um edifício habitacional situado na cidade romana de Mirobriga (Santiago do Cacém) permitiu a sua identificação como uma casa de peristilo de planimetria axializada. O edifício incluía ainda um espaço comercial anexo que, numa fase mais tardia, poderá, pela presença de estruturas hidráulicas, ser associado ao tratamento de têxteis.

O cruzamento do estudo dos contextos estratigráficos, da arquitectura e dos faseamentos construtivos forneceu dados acerca da sequência de construção, reformas, abandonos e reocupações do edifício ao longo dos séculos I a IV d.C., contribuindo para a compreensão da evolução urbana da cidade.

Palavras-chave: Arquitectura Romana, Domus, Taberna, Época Flávia, Século III d.C.
\end{abstract}

\begin{abstract}
The study of a residential building in the roman city of Mirobriga (Santiago do Cacém, Portugal) led to the its identification as an axis orientated peristyle house. The building had commercial or productive facility as well, attached to the residential block, that possibly worked, in a later phase, on a textile related activity.

The cross study of stratigraphic contexts, architecture and construction phases provided information regarding the building's sequence of construction, reform, abandonment and reoccupation throughout the $1^{\text {st }}$ to $4^{\text {th }}$ centuries, allowing for a better understanding of this city's urban development.
\end{abstract}

Keywords: Roman Architecture, Domus, Taberna, Flavian Period, $3^{\text {rd }}$ century A.D.

\section{INTRODUÇÃO}

O estudo que aqui se apresenta teve por base uma casa de peristilo situada na cidade romana de Mirobriga. Este estudo englobou uma análise estratigráfica completa, tendo em vista o conhecimento da sua diacronia, assim como um estudo fundamentado aos compartimentos identificados. A abordagem às técnicas construtivas, apesar de ter constituído um objectivo de base, excede o alcance deste artigo, pelo que será alvo de uma publicação independente.

$\mathrm{O}$ edifício em questão, inicialmente designado como "Casa da Calçada" (Barata 1996) e posteriormente referido como "construção de átrio" (Barata
1999) e "Construção 3" (Quaresma 2012), foi escavado parcialmente nos anos de 1995 e 1996 por Filomena Barata, tratando-se de uma escavação de diagnóstico com vista à identificação de um local adequado à implantação do Centro Interpretativo (Barata 1996:3).

Embora parcial, a escavação revelou um edifício de planta centralizada por um pátio porticado, encontrando-se bastante mal conservado a todos os níveis, com excepção do muro limite situado a oeste (Barata 1996: 7), com uma altura conservada de cerca de 1,60 m, ao qual se adossa uma escadaria que também se conserva parcialmente e que terá contribuído para a conservação do muro.

\footnotetext{
1. (FCSH-UNL); filipe.alb.sousa@gmail.com

2. (FCSH-UNL); catarina.m.felicio@gmail.com
} 
A análise estratigráfica revelou cinco momentos na vida do edifício assim como quatro fases construtivas das quais apenas a primeira e a última dizem respeito ao corpo principal do edifício, sendo as restantes fases adscritas ao corpo oeste, um pequeno espaço comercial ou oficinal que, para a primeira fase, carece de elementos de caracterização. Foi ainda identificada uma última fase de utilização do espaço, numa época em que a casa já estaria em avançado estado de ruína, nomeadamente uma possível oficina de transformação metalúrgica (Sousa 2018: 107-108).

\section{A EVOLUÇÃO ARQUITECTÓNICA DA CASA}

\subsection{A $1^{\underline{a}}$ fase: $80-110$ d.C}

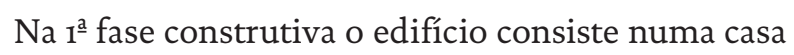
de peristilo onde foram identificados 12 ambientes, tendo como anexo, do lado oeste, um pequeno compartimento, o ambiente 1 , que pelas dimensões do vão de acesso e respectiva soleira, foi-lhe atribuída uma funcionalidade comercial ou oficinal (Figura 2). A conformação inicial do edifício é assim constituída por um corpo principal de função residencial e um segundo corpo, substancialmente menor, de função comercial ou oficinal (Sousa 2018: 86 e 23).

\subsubsection{A casa e o seu enquadramento tipológico}

A casa apresenta uma planta de tendência axializada, estando o triclinium encostado ao alçado Oeste, descentrado do enquadramento cénico proporcionado pelas colunas do peristilo. O vestibulum situa-se à direita desse eixo, também descentrado, quer relativamente ao enquadramento das colunas do peristilo quer relativamente ao vão de acesso ao triclinium.

Embora não totalmente conseguida, eventualmente devido a limitações do projecto, a sua planimetria encontra paralelo nos modelos de planta perfeitamente axializada, tais como a Casa de los Pájaros, em Italica (Garcia y Bellido 1960: fig.8 apud Beltrán 2003: 36), a Casa del Cuadrante, em Baelo (Silliéres 1991: fig.2 apud Beltrán 2003: 33), a Casa dos Repuxos ou a Casa de Cantaber, em Conimbriga (Correia 2013: 107 e 92) e que vem a ser característica a partir dos inícios do século I d.C., pela presença do eixo vestibulum/peristylum/triclinium, encontrando-se as dependências privadas, os cubicula, situadas em redor do peristilo (Beltrán 2003: 33-34; Farrar 2011: 16-17).

A atribuição tipológica de Casa de peristylum em vez de Casa de atrium é motivada pela identificação dos compartimentos que compõem este eixo. Por outro lado, a designação de átrio acarreta implicações e conotações de cariz sociocultural que não se adequam a espaços criados nesta cronologia.

Até ao Principado as habitações apresentam a disposição tradicional fauces-atrium-tablinum, sendo o ritual da salutatio realizado no atrium. Com o advento do Principado e consequentes transformações sociais, que ditaram a diversificação dos papéis sociais dos diferentes ambientes da casa (Beltrán 2003: 25) este modelo de habitação cai em desuso. O tablinum é substituído pelo triclinium enquanto sala de representação e aparato que preside ao peristilo. $\mathrm{O}$ atrium cai em desuso e, segundo alguns autores, é, aparentemente, substituído pelo vestibulum enquanto sala de recepção e distribuidora de circulação existindo, por vezes, bancos destinados aos que aguardavam ser recebidos (Beltrán 2003: 31; Farrar 2011: 17 e 19). O tablinum é lateralizado, ou colocado numa área da casa mais privada, sendo possível a sua identificação com a exedra, como é o caso da Casa dos Repuxos, da Casa do Medianum Absidado e da Casa de Cantaber, em Conimbriga (Beltrán, 2003, p.29; Correia, 2013, p.182) e da Casa del Mitreo, em Emerita Augusta, sendo que neste último caso o autor propõe a designação de tablinum (Corralez Álvares, 2013, p.211 e 212).

\subsubsection{Os compartimentos e estruturação interna}

\subsubsection{O vestibulum}

$\mathrm{O}$ acesso à habitação a partir da via seria efectuado pelo ambiente 3, o vestibulum. A sua leitura enquanto vestibulum (Ginouvès 1998: 157) prende-se, por um lado, pelas suas proporções de $12 \times 12$ pés $(352 \mathrm{cmx} 351 \mathrm{~cm})$ e pela sua posição quase centralizada na fachada da casa que comunica com a via. $O$ vão de acesso ao peristilo é duplo, centralizado por um pilar de planta quadrangular, segundo a morfologia do alicerce que ainda se conserva, estruturando duas passagens independentes (Sousa 2018: 79), à semelhança dos vestibula da Casa dos Repuxos (Correia 2013: 105-107) e da Casa de Cantaber, em Conimbriga (Correia 2013: 92-93), embora de dimensões mais modestas.

Tal como proposto por vários autores, este espaço poderá ter funcionado como o local onde visitantes e clientes aguardariam ser recebidos pelo seu patronus, podendo também ser o local da salutatio (Correia 2010: 196; Farrar 2011: 17 e 19). 


\subsubsection{O peristylum}

A identificação de dois quadrantes de coluna caídos na zona norte do ambiente 6 , associada à morfologia planimétrica do espaço, permite a sua identificação com uma área porticada.

Apesar de não ser evidente qual o número de colunas que terão existido, a necessidade de suportar a cobertura pressupõe a existência de pelo menos quatro, uma em cada canto, embora seja expectável a existência de mais colunas no lado mais comprido do muro estilóbato, presumivelmente 3 , pela necessidade de transpor uma maior distância de cobertura. Esta quantidade e disposição de colunas $3 \times 2$ é também sugerida no peristilo da Casa Periquito, igualmente situada em Mirobriga, verificando-se o interface de assentamento das colunas centrais, em falta à época da sua escavação (Kopf 2018: fig.68).

A divisão entre o ambulatorium e a área sem cobertura é efectuada por um muro estilóbato ou pluteus (com uma altura estimada de cerca de $85 \mathrm{~cm}$ ), sobre o qual foram construídas as colunas. Este elemento é característico das casas de peristilo tendo surgido, inicialmente, como uma cerca, colocada entre as colunas, dando mais tarde lugar a um muro, também construído entre as colunas, cuja principal função seria, possivelmente, a de impedir as águas pluviais de alcançar o ambulatorium e os compartimentos anexos (Farrar 2011: 30).

Quer o ambulatorium quer a área sem cobertura seriam pavimentadas a opus siginum colocado directamente sobre o nível rochoso, conservando-se ainda o nível de preparação no ambulatorium. A pavimentação do espaço descoberto repercute-se na maioria dos peristilos escavados em Mirobriga. Esta solução construtiva poderá ter sido motivada pela a inexistência de níveis de solo que possibilitassem o crescimento de plantas, inviabilizado a existência de um jardim na área exterior.

Em todo o caso, existe a possibilidade, embora ainda não comprovada arqueológicamente, de estes espaços pavimentados terem possuído vasos com plantas de forma a embelezar o espaço (Farrar 2013: 20). O pavimento impermeável facilitaria a recolha das águas pluviais e sua condução para o exterior do edifício, tendo sido identificado, na base do muro estilóbato, UEM 20, o ponto de recolha da canalização $\mathrm{C}$ 17, que seguia para norte e desaguava numa outra canalização, a C18, situada no exterior da casa e que encaminhava a água para sul (Sousa 2018: 48 , 49 e 89).

\subsubsection{O triclinium}

$\mathrm{Na}$ Casa da Calçada as dimensões $(6,57 \mathrm{~m} \mathrm{x} \mathrm{8,37} \mathrm{m)}$ e morfologia do ambiente 7 , assim como a sua localização axializada na casa, permitem a sua identificação como triclinium (Sousa 2018: 90-92).

A localização destes espaços no eixo central da casa e com vão aberto para o peristilo, bem como a sua morfologia e dimensões podem ser utilizados como elementos para a identificação destes como triclinia, por vezes auxiliada pela presença de mosaicos (Dunbabin 2003: 41-42; Uribe Agudo 2009: 155). Em condições ideais, os triclinia podem ser identificados pela estruturação da sua decoração parietal ou dos pavimentos que teria como função demarcar a área na qual se desenrolaria o banquete da área de entrada ou recepção (Guiral Pelagrín e Mostalac Carrillo: 1993; Uribe Agudo 2009: 55; Correia 2019: 187-188). Aproximandamente $2 / 3$ do espaço era dedicado à colocação dos lecti triclinares, sendo o restante 1/3 destinado à área de entrada ou recepção (Uribe Agudo 2009: 155). Esta repartição é notória ao nível dos pavimentos musivos destinados a estes espaços, com reflexo num padrão $T+U$, sendo o " $U$ " reservado à colocação dos lecti em redor de um tapete central (Dunbabin 2003: 41-42; Uribe Agudo 2009: 156-158; Correia 2010: 187-188).

$\mathrm{Na}$ ausência destes elementos arquitectónicos e/ou decorativos, podemos apenas, por meio de comparação com exemplares mais completos e que apresentam as mesmas proporções, inferir que os mesmos princípios de ocupação e utilização do espaço se terão verificado.

\subsubsection{Os cubicula}

Este tipo de compartimentos distingue-se normalmente pela divisão do espaço interno em duas partes: uma destinada ao lectus, correspondendo a $1 / 3$ do espaço e outra constituindo uma antecâmara correspondendo a 2/3 do espaço (Guiral Pelegrín 2018: 621 ). Esta hierarquização dos espaços pode ser marcada quer pela estruturação dos pavimentos, tectos ou pinturas murais cujos esquemas decorativos procuram demarcar esta divisão, quer pela existência de pilastras a demarcar ambos os espaços (Guiral Pelegrín 2018: 621). A forma mais comum de identificação de cubicula prende-se pela demarcação, em pavimentos de mosaico, daquela que seria a posição do mobiliário, no caso o lectus (Correia 2013: 191192; Corralez Álvares 2016: 212-213).

No caso em estudo, foram interpretados como $\mathrm{cu}$ - 
bicula os ambientes 2, 8 e 16, que apresentam dimensões semelhantes entre si, $3,55 \mathrm{~m} \times 3,26 \mathrm{~m}$, com excepção do ambiente 2 que apresenta uma largura menor $(2,96 \mathrm{~m})$, correspondendo a uma planimetria de tendência quadrangular. Apesar de não existirem soleiras conservadas ou qualquer outro indício da localização dos vãos de acesso, este deveria efectuar-se por um vão aberto para o peristilo, como é a norma nas casas de peristilo (Sousa 2018: 92).

Apesar de neste caso não se conservarem os elementos arquitectónicos ou decorativos que normalmente atribuídos aos cubicula, a sua localização na casa e dimensões encontram paralelo em vários compartimentos identificados como cubicula em casas de planimetria similar, como é o caso da Casa de los Marmoles, em Augusta Emerita, cujos compartimentos apresentam planta tendencialmente quadrangular com medidas de $3,6 \mathrm{om}$ de comprimento por $3,80 \mathrm{~m}$ de largura, sendo o seu acesso realizado por um vão aberto para o peristilo; da designada Casa V/A, na mesma cidade, onde foram identificados compartimentos com metrologia análoga, também interpretados como cubicula (Corrales Álvarez 2016: 224) ou a Casa dos Repuxos, nomeadamente os compartimentos, ํo 26 e ํㅜ 27 , identificados como cubicula devido à estrutura evidenciada pela decoração dos pavimentos musivos (Correia 2013: 109 e 218) e que apresentam medidas de cerca de $4,56 \mathrm{~m}$ de comprimento por $3,8 \mathrm{om}$ de largura.

Neste último exemplo salienta-se ainda que a localização dos cubicula, relativamente ao pseudo-peristylum do ninfeu, é bastante semelhante à verificada na Casa da Calçada.

\subsubsection{Outros compartimentos}

No sector nordeste do edifício existem dois compartimentos cuja identificação não é inequívoca. $\mathrm{O}$ ambiente 9, de configuração rectangular e estreita, poderá tratar-se de uma culina pela sua localização anexa ao triclinium. A identificação de compartimentos anexos a triclinia como culinae encontra paralelo em outros exemplares hispanos, como é o caso da Casa del Pretorio, em Arcobriga (Uribe Agudo 2008: 56), da Domus 2, de Bilbilis (Idem: 109 e 112), da Casa de los Delfines, em Celsa (Idem: 206 e 210), da Casa de Likine, em La Caridad (Idem: 365 e 371), da Casa Villanueva, de Emporiae (Balil Illana 1972: 95 apud Uribe Agudo 2008: 237 e 244).

Em Mirobriga, a culina da Casa 7, compartimento R7.1.4, evidenciada pela existência de um balcão em alvenaria que terá funcionado como estrutura de combustão (Oberhofer 2018b: 110 e 113), apesar de apresentar uma morfologia distinta, encontra-se numa localização análoga à do ambiente 9 .

O ambiente 10 poderia tratar-se de uma cella penaria, acumulando simultaneamente a função de aposentos servis. A proposta de interpretação deste ambiente, se bem que por enquanto especulativa, prende-se com a sua localização na casa, numa zona recuada e oculta, que poderíamos associar a uma área de trabalho ou armazenamento, correspondendo a uma zona de serviço da habitação.

O sector sudeste apresenta também identificação problemática. Os dois ambientes aí identificados, 4 e 17, resultam da reconstituição da planimetria do edifício, não sendo clara a forma como ambos se articulariam. O primeiro poderia tratar-se de uma antecâmara para o segundo no caso de este se aceder pelo interior. Outra hipótese é a de o ambiente 4 se tratar de um outro espaço comercial ou oficinal sendo acedido pela via. $\mathrm{O}$ ambiente 17 apresenta dimensões algo reduzidas para ser interpretado como cubiculum 7 x 12 pés $(2,12 \mathrm{~m} \times 3,57 \mathrm{~m})$ e, embora se localize numa área central da casa, estão ausentes outros elementos que permitam caracterizar a sua funcionalidade.

\subsubsection{Os elementos de datação}

A cronologia proposta para construção da $1^{\underline{a}}$ fase provém do contexto 1, localizado no peristilo. Este contexto corresponde ao interface de destruição ou remoção do pavimento em opus signinum aí existente. A remoção do pavimento, assunto que abordaremos mais aprofundadamente abaixo, resultou num interface que deixou exposto o nível de preparação do referido pavimento, composto por cerâmica britada envolta em argamassa de cal e areia e colocada directamente no afloramento geológico. O conjunto dos materiais recolhidos deste interface sugere uma cronologia de construção situada entre 8o d.C e 100 d.C., podendo alcançar a primeira década do século II d.C. (Figura 7 - Contexto 1) (Sousa 2018: 28-29).

\subsection{A $2^{2}$ fase: $120-150$ d.C.}

A $2^{2}$ fase consistiu numa ampliação do ambiente 1 para norte e na criação de um piso superior. A análise estratigráfica murária permitiu detectar um corte efectuado no cunhal formado pelo muros norte e oeste da $1^{\underline{a}}$ fase, de forma a permitir a inserção do novo muro de fachada oeste no espaço anteriormen- 
te ocupado pelo cunhal. Por sua vez, o muro norte, UEM5, terá sido apenas parcialmente demolido, mantendo-se em utilização na $2^{\underline{a}}$ fase, sendo ainda visível o seu interface de adossamento no muro oeste, UEM23. Contudo, nela terá sido aberto um vão para permitir a passagem para o espaço recém-construído. Nesta reformulação o espaço comercial ou oficinal ficou constituído por 2 ambientes, Ar.1 e A1.2, uma vez que o muro tardoz do espaço anterior, UEM5, continuou em utilização nesta fase (Sousa 2018: 53) (Figura 3).

$\mathrm{O}$ acesso ao piso superior era efectuado por uma escadaria exterior, adossada a oeste ao edifício recém-construído. A restituição da funcionalidade dos ambientes criados nesta fase apresenta-se problemática. Apesar de ser fácil manter a atribuição de uma função comercial ou oficinal aos ambientes 1.2 e 1.2 nesta nova fase, não existem quaisquer dados para a sua caracterização.

Quanto ao piso superior pode colocar-se a hipótese de uma funcionalidade habitacional. A ser o caso, a criação deste novo corpo residencial poderia ser reflexo de alterações na estrutura familiar dos proprietários, por exemplo relativamente aos elementos servis, que poderiam explorar o espaço comercial e habitar no piso superior; ou então a hipótese da criação de um espaço habitacional com vista à sua rentabilização.

\subsubsection{Os elementos de datação}

O principal elemento que permite a atribuição de uma cronologia à $2^{\underline{a}}$ fase consiste num depósito votivo de cariz fundacional identificado no ambiente 1.2. (Sousa 2018: 29-30). O depósito consiste num recipiente tipo tigela ou prato-tampa, dentro do qual foram colocados os ossos de uma ave (Barata 1999: 56). O recipiente, correspondente à forma III-A, da variante 1, com uma cronologia situável entre os meados do século I d.C. e os meados do século II d.C. (Pinto 2003: 220 - 225), encontrava-se depositado em posição invertida funcionando como "tampa” de uma pequena cova escavada no afloramento (Barata 1999: 56-57). De uma outra depressão escavada no afloramento, com cerca de $20 \mathrm{~cm}$ de diâmetro, foi também recolhido um bronze de Adriano (117 - 138 d.C.) (Mir-568-oor), pelo que, considerando a cronologia de construção da primeira fase, a construção da $2^{\circ}$ fase terá tido lugar na $1^{\circ}$ metade do século II d.C. (Figura 7 - Contexto 2).

\subsection{A $3^{\mathrm{a}}$ fase: $150-250$ d.C.?}

Também nesta fase apenas se verificam transformações no corpo comercial do edifício. Estas consistiram no aumento do edifício novamente para norte, em ambos os pisos, sendo que nesta fase o espaço comercial é dotado de estruturas hidráulicas destinadas ao funcionamento de uma actividade produtiva (Sousa 2018: 86-87).

Destas estruturas conservam-se apenas duas concavidades escavadas no afloramento, uma de grandes dimensões, encostada ao muro UEM26, e outra mais pequena situada a sudeste da anterior. Ambas as concavidades eram escoadas por duas canalizações independentes, as $\mathrm{C}_{4} 4$ e C16, que desaguavam numa outra, C15, que despejava o conteúdo das anteriores directamente na via (Sousa 2018: 58-59) (Figura 4).

\subsubsection{Compartimentos e estruturação interna}

O espaço comercial encontra-se dividido em, pelo menos, duas áreas que constituiriam áreas de trabalho distintas. A área junto à entrada corresponde ao antigo compartimento da $\mathrm{I}^{\mathrm{a}}$ fase e não regista nenhuma característica que possa levar à sua funcionalidade. Para lá deste compartimento funcionavam as estruturas hidráulicas. $O$ seu estado de conservação não permite, todavia, uma interpretação segura da sua funcionalidade, embora se coloque a possibilidade de uma funcionalidade associada ao tratamento de têxteis (Sousa 2018: 86-88).

\subsubsection{Elementos de datação}

Não existem dados cronológicos absolutos para esta fase. A sua construção ter-se-á efectuado num período incerto após os meados do século II d.C. e anterior aos meados do século III d.C., intervalo cronológico apontado de forma relativa pelas datações da fase anterior e posterior.

\subsection{A $4^{\mathrm{a}}$ fase: 275 ? -325 ? d.C.}

A esta fase correspondem algumas transformações visíveis em toda a área do edifício que consistem, na maioria dos casos identificados, em subdivisões de compartimentos já existentes e eliminação de alguns vãos de passagem. Esta reformulação terá sido efectuada após um período de abandono do edifício, situado algures na $2^{\underline{a}}$ metade do século III d.C., possivelmente de algumas décadas, período após o qual o edifício é reocupado ainda na $2^{\underline{a}}$ metade deste século. As razões que motivam a hipótese de ter exis- 
tido um período de abandono, anterior a esta fase, prendem-se não só com a aparente distância "cultural" e tecnológica que parece verificar-se nesta reformulação, relativamente à ocupação do edifício, que rompe com a configuração da construção anterior; mas também o facto de os dados disponíveis apontarem para que o ambiente 7 se encontrasse já em ruína numa época anterior à a $1^{\mathrm{a}}$ metade do século IV d.C. o que poderá ter motivado o fecho do vão de acesso ao triclinium de forma a excluir esta área da casa do espaço agora ocupado. Os novos ocupantes não terão procurado manter o status quo do edifício nem a funcionalidade da compartimentação original. Estas reformulações aparentam aproveitar o edificado pré-existente como elemento de apoio.

A subdivisão mais marcante é a efectuada no peristilo, na qual este espaço é dividido em duas partes desiguais pela construção de um muro, UEM $31+32$, que o atravessa no sentido este/oeste. No ambulatorium sul identificaram-se 4 possíveis buracos de poste (Barata 1996: 10), em aparente associação ao muro, 3 dispostos paralelamente a este a uma distância de 2,71 metros (buraco 1) e 2,60 metros (bura$\cos 2$ e 3), distando entre si 2,70 metros (buraco 1 e 2) e 1,38 metros (buraco 2 e 3 ), e um no ambulatorium oeste, o $\mathrm{n}^{\circ} 4$. Este último encontra-se alinhado com o nํำ, alinhamento que se salienta pela existência de um sulco que aparenta conectar ambos os buracos (Figura 5 e 6). A distância entre o muro UEM $31+32$ e o alinhamento de buracos ( 1,2 e 3 ) é a mesma que entre o referido muro e a UEM19, o que parece indicar alguma racionalidade nesta transformação, embora o seu propósito não seja claro. Estes não parecem ser consistentes com buracos de andaime colocados aquando da construção da casa, uma vez que teriam sido identificados mais buracos semelhantes em todos os corredores do peristilo distribuídos num padrão similar.

A análise à distribuição dos buracos sugere que estes poderão corresponder ao local de implantação de postes de auxílio ao suporte do travejamento do peristilo (Barata 1999: 56) (localização estimada do travejamento), num período em que a estrutura apresentaria sinais de ruína (Figura 5). Esta solução não discorda do carácter rudimentar das restantes reformulações desta fase, pelo que poderá estar associada. A existência de um sulco que aparenta conectar os buracos 1 e 4, poderia, por outro lado, apontar o local de implantação de uma subdivisão efectuada por meio de um taipal de madeira, embo- ra não tenha sido identificado nenhum outro sulco a conectar os restantes buracos. Observa-se, também, que o posicionamento do buraco 4, a corresponder a um travejamento superior, apresenta a mesma distribuição no espaço que o muro $\mathrm{UEM}_{31+32}$, sendo ambos equidistantes das UEMig e 21, o que parece reforçar a hipótese distributiva dos travejamentos e localização dos buracos enquanto local de postes de suporte, admitindo-se ainda a hipótese de terem acumulado outras funcionalidades como elementos de apoio a divisórias de madeira.

Outra das subdivisões desta fase é a realizada nos ambientes 1.1 e 2. Esta consiste na construção de um muro, UEM29, perpendicular à soleira do vão de acesso ao ambiente 1.1, criando uma divisão este-oeste, originando em dois novos ambientes $1.5 \mathrm{e}$ 1.6. Este muro divisor articulava-se com o muro de entaipamento desse vão, visível na documentação das escavações, mas, entretanto, desmontado. Este entaipamento foi documentado apenas do lado oeste da porta, sendo uma reformulação comum em edifícios comerciais desta cidade. Presumivelmente, o acesso ao ambiente 1 terá continuado a existir a partir da via, tendo de ser efectuado pelo local onde passa a canalização da $3^{\underline{a}}$ fase, à direita do entaipamento. Uma terceira subdivisão foi criada a este da anterior originado no ambiente 1.6. Para tal, foi realizada a demolição parcial da UEM9, presumivelmente até ao interface de ligação com a UEM8, tendo posteriormente sido construído um outro troço de muro, cerca de $30 \mathrm{~cm}$ a este, a $\mathrm{UEM}_{3} \mathrm{O}$, roubando espaço ao ambiente 2. Esta reformulação terá permitido a comunicação entre o ambiente $1.5 \mathrm{e} o$ peristilo, que nesta fase continuaria a existir, passando pelo ambiente 2 .

Uma outra subdivisão, detectada no ambiente 1.4, foi realizada mediante a construção de um troço de muro, UEM 33 , do qual apenas restam dois elementos pétreos colocados lado-a-lado. Estes sobrepõem-se a uma pequena vala de implantação com cerca de $4 \mathrm{~cm}$ de profundidade, prolongando-se esta por cerca de 1,40m e curvando ligeiramente para este. Esta nova unidade adossa-se perpendicularmente à UEM27, a uma distância de 1,9om da UEM9, dando origem a um pequeno compartimento a Este, $\mathrm{o}$ ambiente 1.7, cuja configuração não pode ser indubitavelmente restituída.

O outro entaipamento, a UEM28, foi documentado no vão de acesso ao ambiente 7 . Esta reformulação destaca-se das anteriores do ponto de vista constru- 
tivo uma vez que é composto por pedaços de opus signinum reaproveitados. Ocupa toda a largura do vão e impediu o acesso ao ambiente 7 a partir do peristilo. Com efeito, há indícios de que este compartimento deveria estar já em ruína na época em foram efectuadas estas reformulações, conforme se verá de seguida, razão que terá motivado o seu isolamento da área agora em utilização.

\subsubsection{Compartimentos e estruturação interna}

É desconhecida a funcionalidade destas novas compartimentações, embora se encontrem exemplos semelhantes onde as subdivisões são efectuadas com vista à obtenção de várias unidades de habitação destinadas a várias famílias (Ellis 1988: 568 ), sendo que noutros caso a sua função é apenas referida como tendo cariz habitacional (Perich Roca 2014: 141-142; Olesti Vila et alii 2014: 140 e 212). Seja como for, a fragilidade não só das estruturas de subdivisão, mas também a do edificado original, pelo seu estado ruinoso, não permitiu a sua existência de forma continuada no tempo, verificando-se o seu abandono e ruína possivelmente nas primeiras décadas do século IV d.C. (Sousa 2018: 40).

\section{3. ÚLTIMA UTILIZAÇÃO DO ESPAÇO}

A interpretação para a última utilização do espaço é sugerida por dados algo frágeis que não permitem uma leitura inequívoca do seu significado. Neste último momento a maior parte da área sul do edifício aparenta ter sido arrasada para a implementação de uma área de trabalho metalúrgico. Este dado é sugerido pela ausência de derrubes de telhado e de alvenaria na área sul da casa. Esta constatação poderá dever-se por um lado, à acção de nivelamento de forma a acomodar o novo espaço que removeu as paredes eventualmente ainda existentes, assim como os derrubes de alvenaria e telhado da casa, que poderá ter sido conciliada com actividades de espoliação. A essas actividades acrescentam-se eventuais processos pós-deposicionais que também não facilitaram a conservação de grande parte das estruturas de alvenaria na área sudeste da casa, verificando-se os únicos contextos de derrube de telhado indubitavelmente associáveis ao edificado original na zona norte do edifício (triclinium e ambulatorium norte). Tendo em conta os dados referidos, é possível aventar a hipótese de uma outra fase de abandono, época em que terá ocorrido o colapso de algumas áreas do edifício e na qual se parece verificar o arrasamento do edificado anterior, nomeadamente na área sul do edifício.

Alguns dos materiais presentes nessa área consistiam em carvões e pingos de metal em liga de cobre recolhidos de uma concavidade no afloramento, bem como uma grande concentração de escória metálica, contexto sugestivo da existência de uma actividade de transformação metalúrgica (Barata 1999: 56; Sousa 2018: 107-108), assim como um pondus recolhido de outra concavidade próxima (Barata 1996: 11), cuja associação ao contexto não é comprovável .

Com excepção da área sul, todas as restantes áreas constituiriam agora a envolvente da possível oficina, tendo estas sido alvo de despejos de lixos diversos, nomeadamente os ambientes 1 (contextos 3 e 4 ), 5 e 6 norte (contextos 5, 8 e 9) e 7 (contexto 6) (Figura 7), tendo sido aí recuperados fragmentos de escória estratigraficamente associados a materiais da $1^{\mathfrak{a}}$ metade do século IV d.C., sugerindo que terá sido neste período que a oficina terá laborado, depositando os resíduos nas áreas envolventes. Não foram recuperados materiais posteriores aos meados do século IV d.C. sugerindo o fim da utilização do espaço e o seu completo abandono (Sousa 2018: 30 - 42).

\section{CONSIDERAÇÕES FINAIS}

As características arquitectónicas e planimétricas diagnosticáveis na Casa da Calçada afiguram-se como elementos identitários de uma cultura construtiva transversal às casas de peristilo da cidade de Mirobriga, observável na organização interna dos edifícios, bem como na proporção dos peristyla e triclinia, sugerindo a existência de modelos arquitectónicos padronizados nas habitações.

Estas semelhanças poderão prender-se com o facto de todos os edifícios datados até ao momento terem sido construídos numa mesma cronologia, no caso, Flávia (Sousa 2018; Oberhofer 2018a e b; Kopf 2018a e b), sugerindo a existência de uma corrente/escola arquitectónica comum na cidade ou mesmo um programa construtivo residencial.

Por sua vez, a identificação de um dos ambientes como espaço comercial/oficinal de consideráveis dimensões afigura-se como uma novidade numa zona da cidade antes genericamente designada como habitacional, atestando a convivência de distintas funções num mesmo edifício.

A análise da sequência estratigráfica da Casa da Cal- 
çada e respectivos processos de formação, permitiu a identificação de cinco grandes momentos na vida deste edifício: $\mathrm{O}$ primeiro corresponde à sua construção e utilização enquanto domus, englobando as fases 1,2 e 3, num período situável entre a plena Época Flávia e, possivelmente, meados do século III d.C., período no qual se inclui a utilização e respectivas reformulações da taberna. O segundo momento consiste num período de abandono situado nos meados ou na $2^{\underline{a}}$ metade do século III d.C., que poderá ter durado algumas décadas. Ainda na $2^{\underline{a}}$ metade desse século o edifício é reocupado, configurando o terceiro momento, no qual foram efectuadas as reformulações correspondentes à $4^{a}$ fase, seguindo-se, aparentemente, um segundo período de abandono, época em que terá ocorrido o colapso de algumas áreas do edifício e na qual se parece verificar o arrasamento e/ou espoliação de parte do edificado.

No decorrer, ou pouco após a formação destes contextos de abandono, na $1^{\underline{a}}$ metade do século IV d.C, esta zona, agora completamente em ruínas, é aparentemente reocupada enquanto possível espaço de produção metalúrgica.

Posteriormente a esta fase, não se detectaram momentos de ocupação. O abandono total desta área, onde se situara a Casa da Calçada, pode ser datado da $1^{\underline{a}}$ metade do século VI d.C., de acordo com a presença de uma terra sigillata foceense tardia da forma Hayes $3 \mathrm{H}$ numa unidade coluvionar de superfície na zona do ambiente 7 , demonstrando a sua posterioridade ao colapso da estrutura e aos níveis de abandono que se encontram em associação às actividades metalúrgicas (Sousa 2018: 107-108).

Os momentos finais da Casa da Calçada, situáveis a partir dos meados do século III d.C., são pautados por uma descaracterização funcional e arquitectónica, intermitente com períodos de abandono (Sousa 2018: 102-107), que se associa ao fenómeno de crise urbana das cidades clássicas com lugar a partir dos finais do século II d.C. (Gurt Esparraguera 2002). Esta situação é também evidenciada pelo estudo de outros edifícios de Mirobriga. O abandono dos edifícios balneários ter-se à verificado a partir da $2^{\underline{a}}$ metade do século III d.C., estando ausentes materiais posteriores ao início do século IV d.C. (Biers 1988: 108 a 112). Outros edifícios, Construção 1 e 2 (Quaresma 2012), de interpretação mais problemática (Felício 2019: 30-37) também apresentam transformações datadas do século III d.C. (Quaresma 2012: 38 e 55) que, no caso da Construção 1, constituiu a desactiva- ção de um conjunto de canalizações e a criação de um novo nível de circulação em terra (Quaresma 2012: 55). Os restantes edifícios habitacionais estudados possuem cronologias de abandono que se situam no século III d.C. como são o caso da Casa 7 (Oberhofer2018a: 121-123; Peña Cervantes et al 2018: 206-207), da Casa 8, também com algumas reformulações análogas ao caso aqui apresentado (Oberhofer 2018b: 128 e 145; Peña Cervantes et al 2018: 208-209) e, possivelmente, da Casa Periquito (Felício 2019: 49). A estes dados, somam-se os indícios cronológicos para o abandono/sedimentação se algumas vias, também enquadráveis nos meados do século III d.C. (Arthur 1983: 61-72; Oberhofer 2018b: 128 e 145; Peña Cervantes et al 2018: 208-209; Felício 2019: 26-27).

A perspectiva veiculada pela informação arqueológica aponta para um fenómeno algo generalizado na Hispania, embora ainda mal compreendido, caracterizado pelo abandono e desmantelamento de edifícios públicos bem como o abandono de grande parte das áreas habitadas (Gurt Esparraguera 2002: 451). Fortemente vinculado à designada Crise do Século III d.C. pela tradição historiográfica (Járrega 2008: 106 a 109), o fenómeno tem início ainda no final do século II d.C., como nos casos de Cartago Nova (Ramallo Asensio e Quevedo Sánchez, 2015, p.164) ou Iulia Livica (Olesti Vila et alii, 2014, p.84), prolongando-se pelo século III d.C. em inúmeras outras cidades como Barcino (Olesti Vila et alii, 2014, p.140), Baelo Claudia (Olesti Vila et alii, p.212) ou Tarraco (Gurt Esparraguera 2002: 445).

Face aos dados existentes, a Casa da Calçada afigura-se como um microcosmo da evolução urbana da cidade. Construída na Época Flávia, no que aparenta ter sido período de grande prosperidade ao nível da arquitectura doméstica mirobriguese, as ampliações e transformações do seu espaço comercial ao longo do Alto-Império poderão ser o reflexo de uma época de vitalidade. Por outro lado, as etapas de abandono e reocupação verificadas a partir de cerca dos meados do século III d.C. espelham os dados que têm vindo a ser identificados noutros pontos da cidade, repercutindo um fenómeno de transformação urbana vasto e complexo.

\section{AGRADECIMENTOS}

Os autores gostariam de agradecer à equipa do Centro Interpretativo de Mirobriga, a Manuela de Deus e a Filomena Barata. 


\section{BIBLIOGRAFIA}

BALIL ILLANA, A. (1972) - Casa y urbanismo en la España antigua, BSAA, 38 , pp. 55-131.

BARATA, Filomena (1996) - Escavações 1995/95 - Continuação dos relatórios preliminares entregues ao IPPAR em Março de 1996 (Informação nº 240/DA/96) e Outubro de 1996 (Inf. №20/FB/96).

BARATA, Maria Filomena (1999) - As habitações de Miróbriga e os ritos domésticos romanos, Revista Portuguesa de Arqueologia, Lisboa, Volume 2, № 2.

BELTRÁN, Miguel (2003) - La casa hispanorromana. Modelos, in Bolskan, № 20, pp. 13-63.

CORRALES ÁlVAREZ, Álvaro (2016) - La Arquitectura Doméstica de Augusta Emerita, Anejos de AEspa LXXVI, Archivo Español de Arqueologia, CSIC.

CORREIA, Virgílio Nuno Hipólito (2010) - A Arquitectura Doméstica de Conimbriga e as Estruturas Económicas e Sociais da Cidade Romana, Tese de Doutoramento em História, Especialidade em Arqueologia apresentada à Faculdade de Letras da Universidade de Coimbra sob a orientação do Prof. Doutor Jorge de Alarcão, Coimbra.

DUNBABIN, Katherine (2003) - The Roman Banquet - Images of Conviviality, Cambridge University Press.

ELLIS, Simon P. (1988) - The End of the Roman House, in American Journal of Archaeology, Vol.92, № 4, pp. 565-576.

FARRAR, Linda (2013) - Ancient Roman Gardens, The History Press.

FELÍCIO, Catarina (2019) - Gestão de resíduos em Mirobriga - O sistema de sneamento (Séculos I - IV d.C.), Dissertação de Mestrado em Arqueologia apresentada à Faculdade de Ciências Sociais e Humanas da Universidade Nova de Lisboa.

GARCÍA Y BELliDO, A. (1960) - Colonia Ælia Augusta Itálica. Madrid.

GINOUVÉS, R., (1988) - Dictionnaire méthodique de l'architecture grecque et romaine vol. III (Paris, CEFR no ${ }^{84}$ ).

GUIRAL PELEGRÍN, Carmen (2018) - Cubicula y triclinia pintados en Hispania: articulación del espacio, sistemas decorativos e iconografía, in PICTORES PER PROVINCIAS II - STATUS QUAESTIONIS, Actes du $13^{\mathrm{e}}$ Colloque de l'Association Internationale pour la Peinture Murale Antique (AIPMA), Colloque international organisé par Yves Dubois, Michel E.Fuchs et Alexandra Spühler à l'Université de Lausanne, Anthropole, du 12 au 16 septembre 2016.

GUIRAL PELEGRÍN, C.; MOSTALAC CARRILLO, A. (1993) - Influencias itálicas em los programas decorativos de cubicula y triclinia de época republicana e alto-imperial em España, Algunos ejemplos representativos, Espacio, Tiempo y Forma, Série I, 6, pp. 365-392.
GURT ESPARRAGUERA, J. M., (2002) - Transformaciones en el tejido de las ciudades hispanas durante la Antigüedad tardía: dinámicas urbanas, Zephyrus, lin-liv, 20oo2001, pp. 443-471.

JÁRREGA, Ramon (2008) - La crisis del segle III a l'àrea compresa entre Tarraco i Saguntum: aproximació a partir de les dades arqueològiques, In El camp al segle III. De Septimi Sever a la Tetrarquia, ESTUDIS SOBRE EL MÓN RURAL D'ÈPOCA ROMANA - 3, Institut de Recerca Històrica. Universitat de Girona Grup de Recerca Arqueològica del Pla de l'Estany, pp. 105-139.

KOPF, Julia (2018) - Archäologische und stratigraphisce untersuchungen zu Haus 5, in Teicnher, Felix (Ed.), Mirobriga, Eine Stadt im fernen Westen des Imperium Romanum, Kleine Schriften aus dem Vorgeschichtlichen Seminar Marburg, Heft 62, Philipps - Universitat Marburg, pp. 58-91.

OBERHOFER, Karl (2018a) - Archäologische und stratigraphisce untersuchungen zu Haus 7, in Teicnher, Felix (Ed.), Mirobriga, Eine Stadt im fernen Westen des Imperium Romanum, Kleine Schriften aus dem Vorgeschichtlichen Seminar Marburg, Heft 62, Philipps - Universitat Marburg, pp. 109-127.

OBERHOFER, Karl (2018b) - Archäologische und stratigraphisce untersuchungen zu Haus 8, in Teicnher, Felix (Ed.), Mirobriga, Eine Stadt im fernen Westen des Imperium Romanum, Kleine Schriften aus dem Vorgeschichtlichen Seminar Marburg, Heft 62, Philipps - Universitat Marburg, pp. 128-147.

OLESTI VILA, Oriol; GUÀRDIA FELIP, Jordi; MERCADAL FERNÁNDEZ, Oriol (2014) - El fin del sueño urbano en Iulia Llivica (Llivia, Cerdaña), in Las Ciudades de la Tarraconense Oriental entre los s. II-IV d.C. - Evolución urbanistica y contextos materiales, editores S. F. Ramallo Asensio e A. Quevedo Sánchez, Universidad de Murcia, Servicio de Publicaciones, pp. 61-88.

PEÑA CERVANTES, Yolanda; JANKOWIAK, Anna; TEICHNER, Felix (2018) - Keramisches fundmaterial haus Mirobriga in Teicnher, Felix (Ed.), Mirobriga, Eine Stadt im fernen Westen des Imperium Romanum, Kleine Schriften aus dem Vorgeschichtlichen Seminar Marburg, Heft 62, Philipps - Universitat Marburg, pp. 199-210.

PERICH ROCA, Arnau (2014) - Las transformaciones urbanas en Tarraco. El ámbito doméstico a finales del alto-imperio, in Las Ciudades de la Tarraconense Oriental entre los s. II-IV d.C. - Evolución urbanistica y contextos materiales, editores S. F. Ramallo Asensio e A. Quevedo Sánchez, Universidad de Murcia, Servicio de Publicaciones, pp. 119-147.

PINTO, Inês Vaz (2003) - A cerâmica comum das villae romanas de São Cucufate (Beja), Universidade Lusíada Editora, Lisboa.

QUARESMA, José Carlos (2012) - Economia antiga a partir de um centro de consumo lusitano. Terra sigillata e cerâmica 
africana de cozinha em Chãos Salgados (Mirobriga?), Estudos e Memórias 4, UNIARQ, Centro de Arqueologia da Universidade de Lisboa.

QUEVEDO SÁNCHEZ A.; RAMALLO ASENSIO S. F. (2015) - Urbanisme Civique en Temps de Crise - Les Espaces Publiques D'Hispanie et de L'Occident Romain entre le II et le III siècle, Collection de la Casa de Velazquez, Vol. 149.

SILLIÉRES, P. (1991) - La maison romaine a Belo Claudia, Essai de revision des donnes anciennes, Actas de la casa urbana hispanoromana, Zaragoza, pp. 321-328.
SOUSA, Filipe (2018) - A Casa da Calçada - Mirobriga: Diacronia de um edifício habitacional de Época Romana, Dissertação de Mestrado apresentada à Faculdade de Ciências Sociais e Humanas da Universidade Nova de Lisboa.

URIBE AGUDO, P., (2008) - La edilicia doméstica urbana romana en el cuadrante Nordeste de la Península Ibérica (ss. I a.C. - III d.C.), Universidad de Zaragoza (Ciencias de la Antigüedad), <http://zaguan.unizar.es/record/189o> (tesis doctoral inédita).

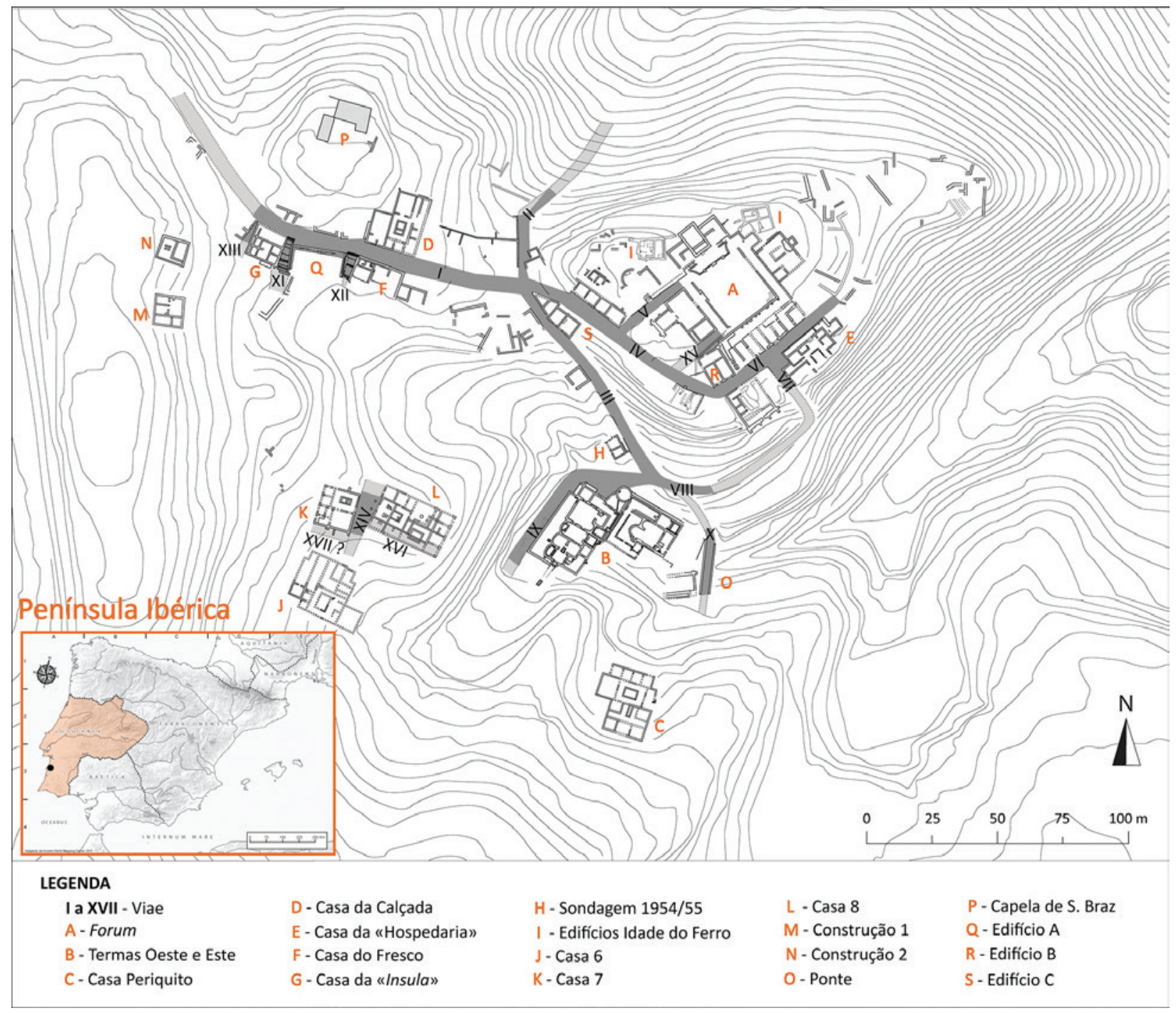

Figura 1 - Planta geral de Mirobriga e localização da Casa da Calçada. 


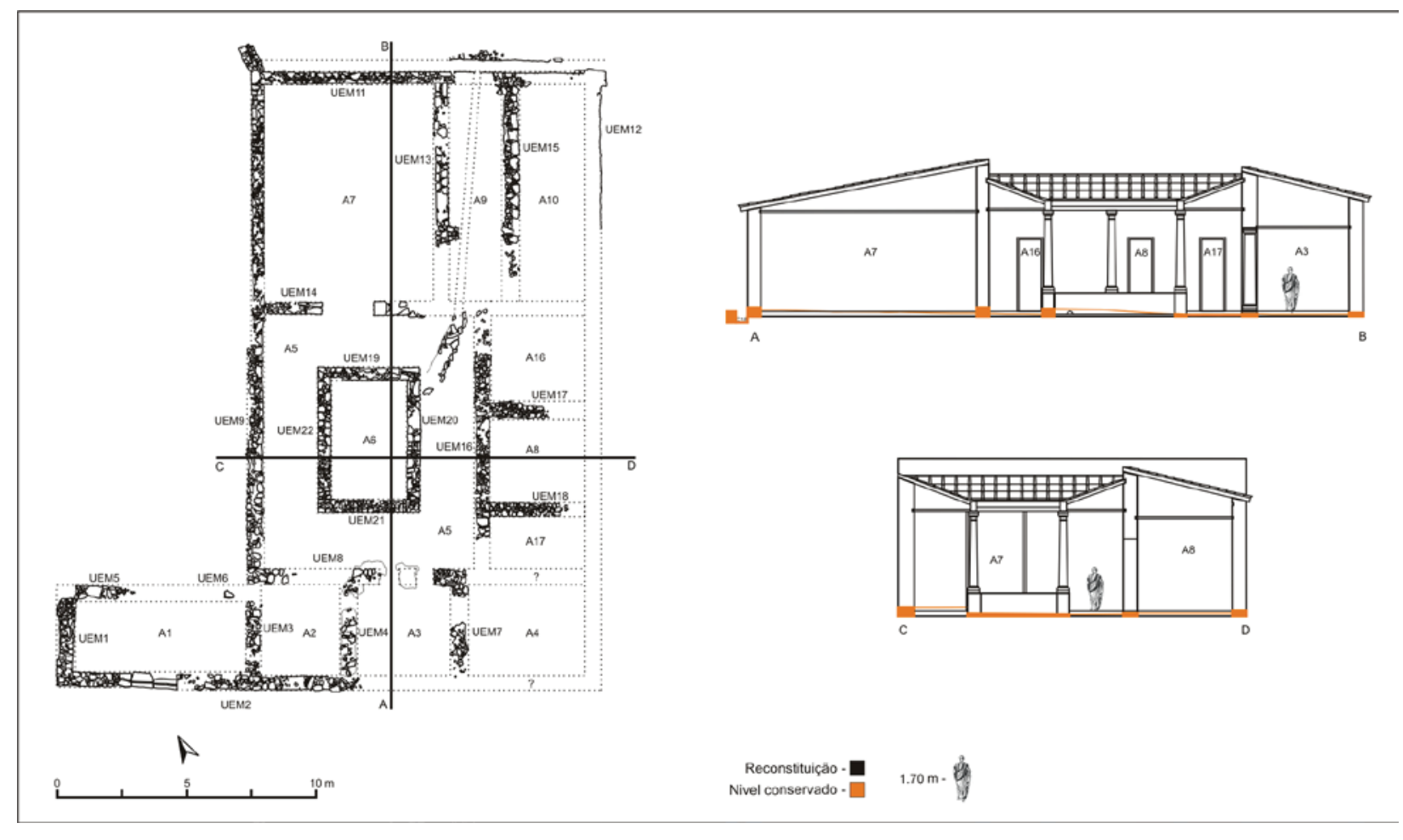

Figura 2 - A: Planimetria da 1ํำ fase; B: Reconstituição em Corte, Norte - Sul (adaptado de Sousa 2018).

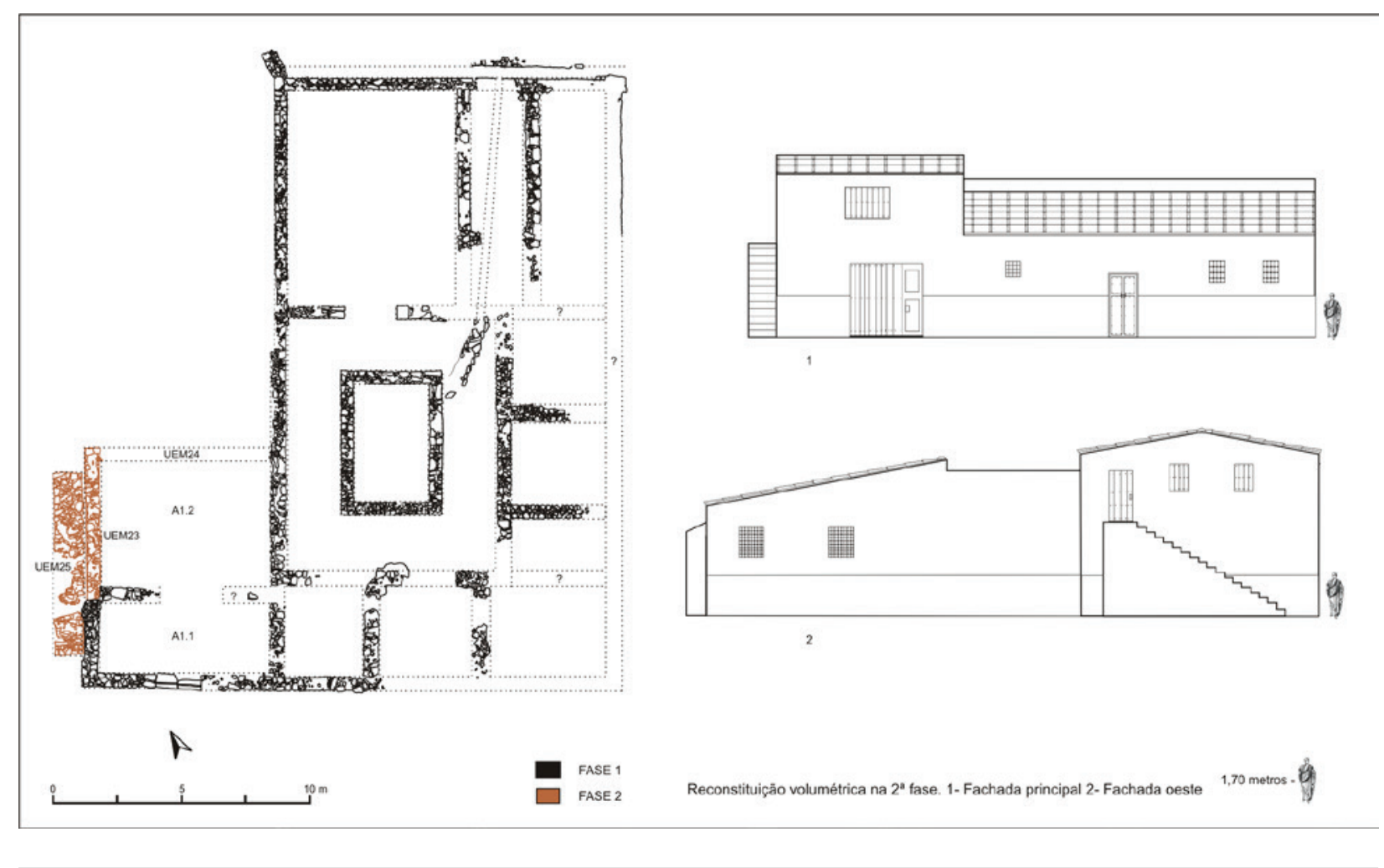

Figura 3 - Planimetria da $2^{\underline{a}}$ fase. Hipótese reconstrutiva das fachadas sul e oeste. 


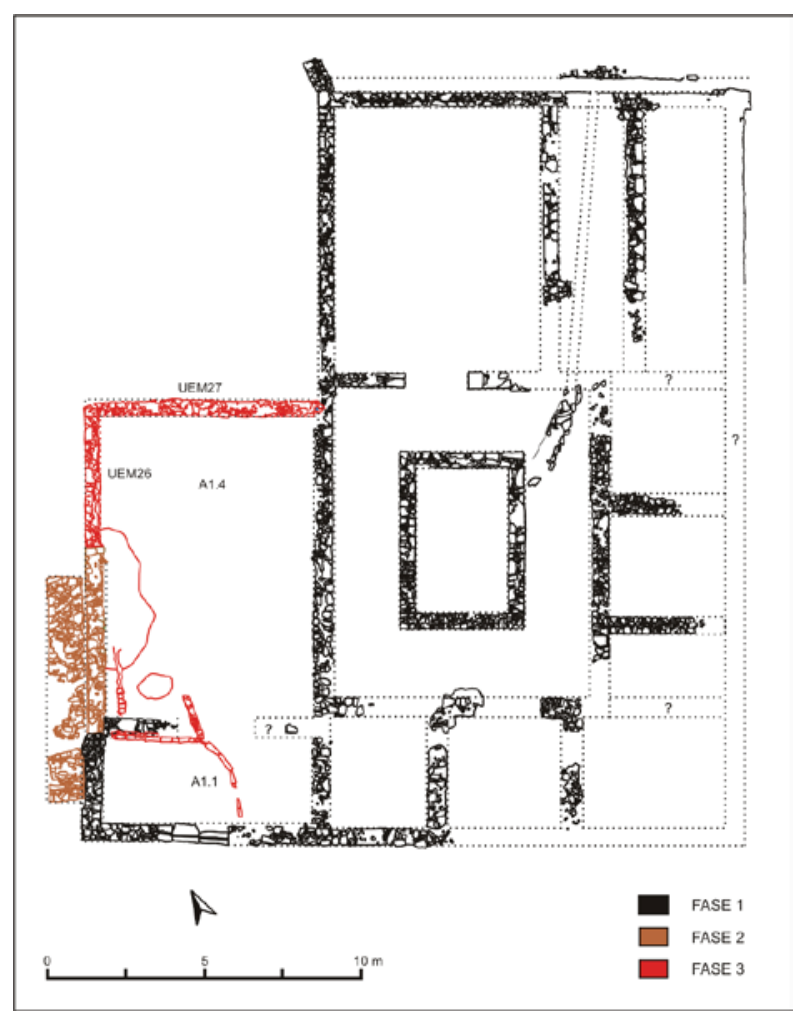

Figura 4 - Planimetria da $3^{\underline{a}}$ fase.

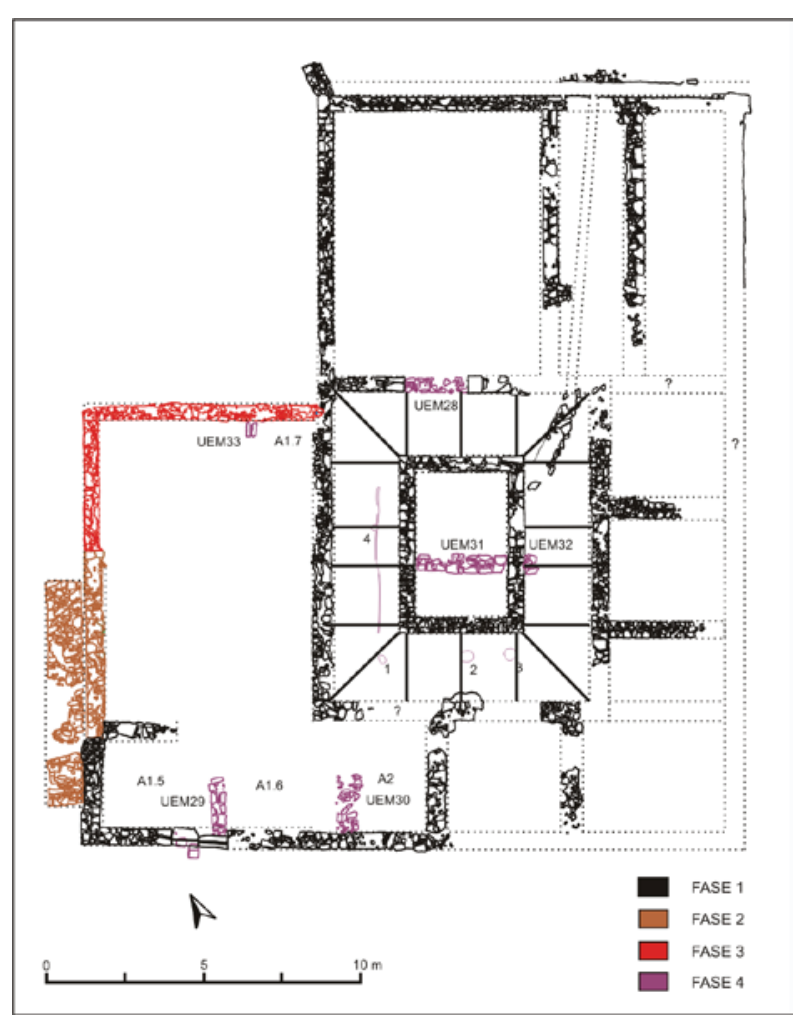

Figura 5 - Planimetria da $4^{\underline{a}}$ fase.

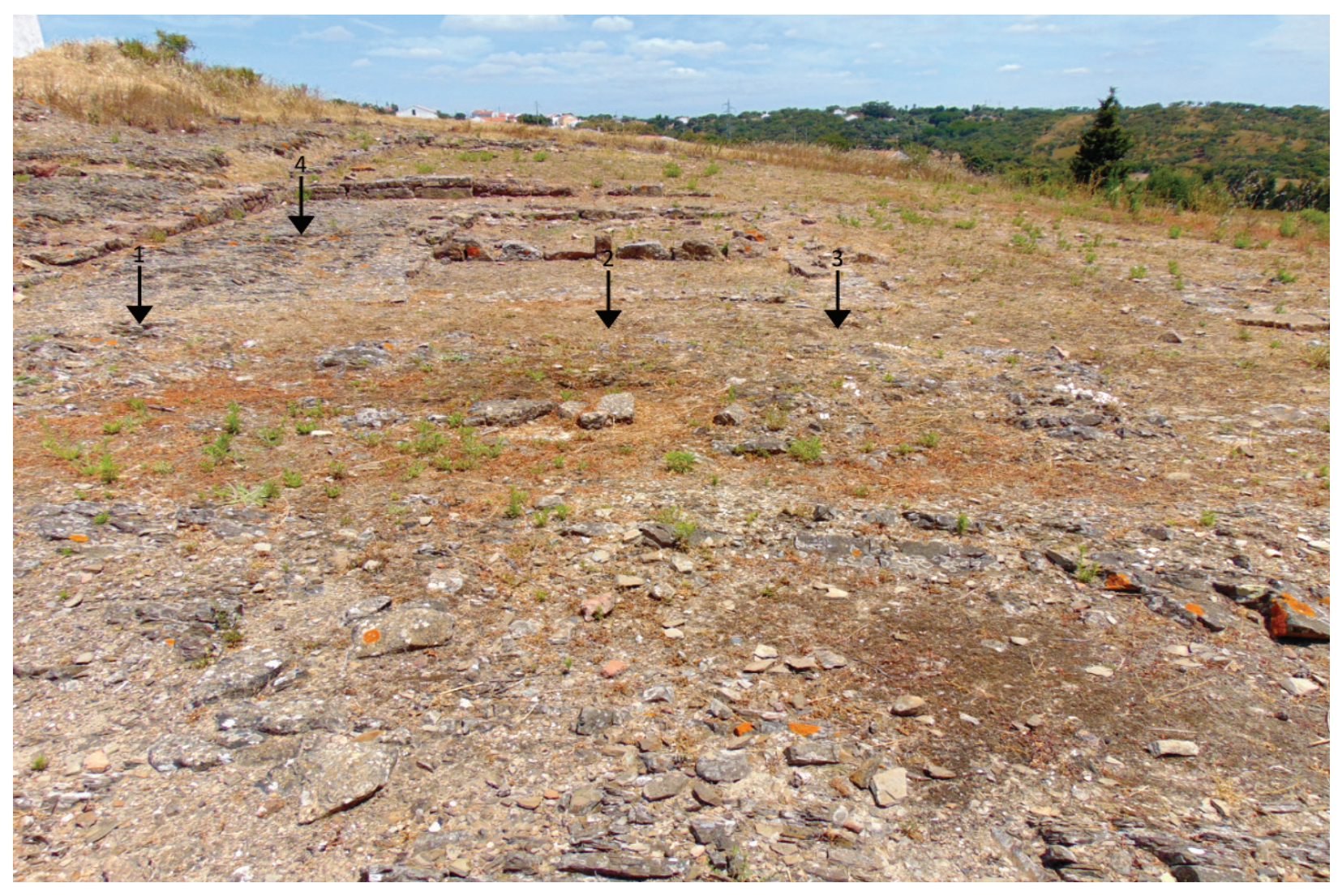

Figura 6 - Área sul da casa, sendo visíveis os buracos de poste e o sulco no ambulatorium este. 


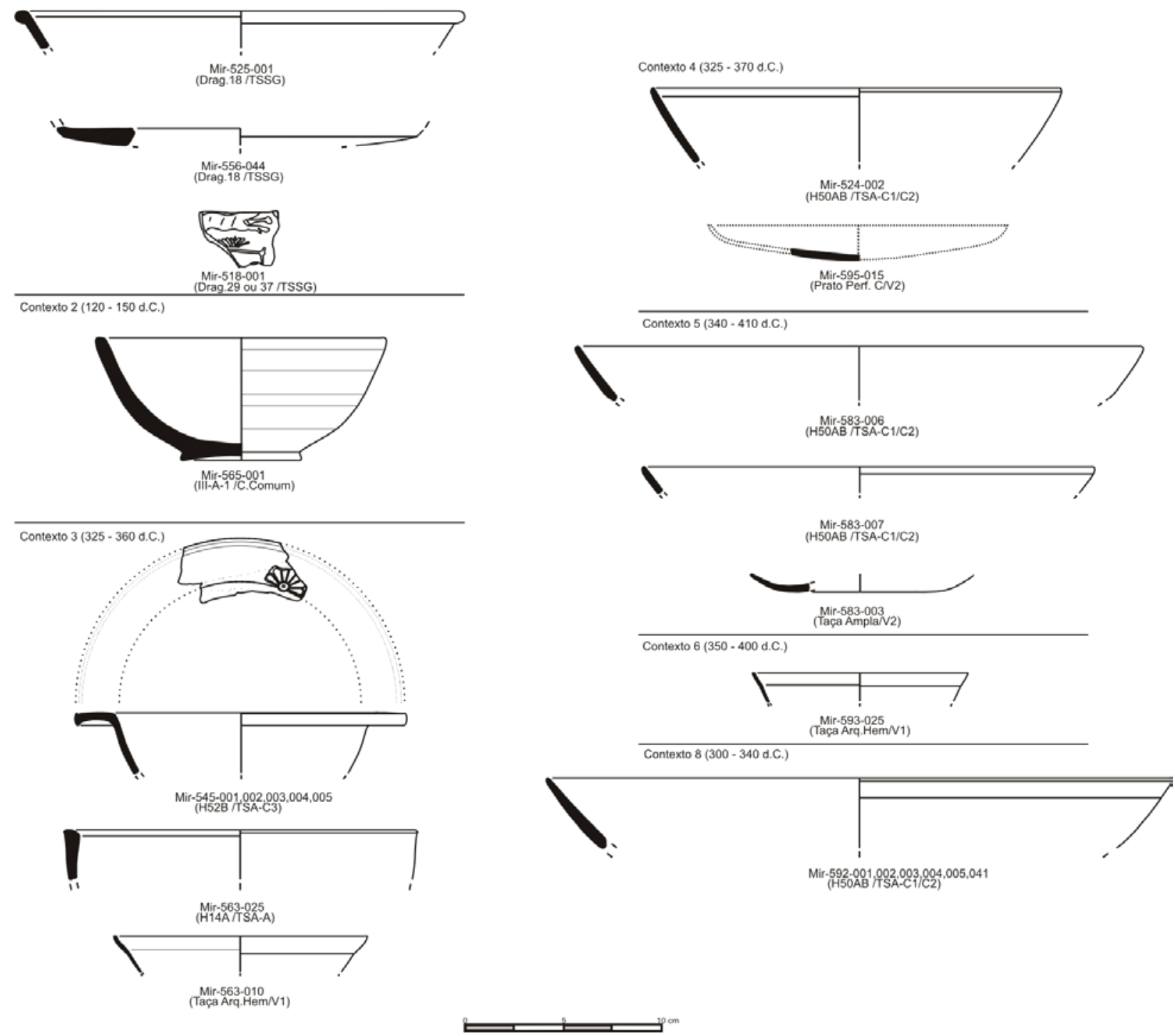

Figura 7 - Materiais datantes dos contextos estratigráficos da Casa da Calçada. 


\title{
O FIM DO CICLO. SANEAMENTO E GESTÃO DE RESÍDUOS NOS EDIFÍCIOS TERMAIS DE MIROBRIGA (SANTIAGO DO CACÉM)
}

\author{
Catarina Felício ${ }^{1}$, Filipe Sousa ${ }^{2}$
}

\begin{abstract}
RESUMO
Os edifícios termais de Mirobriga encontram-se localizados no seu ponto mais baixo, num vale conformado pelas colinas onde se desenvolvia o núcleo urbano. O seu bom estado de conservação permitiu a análise detalhada de um dos sistemas fundamentais no funcionamento de um edifício termal: o sistema de escoamento. Dedicados à limpeza e cuidado do corpo, os edifícios termais são, paradoxalmente, grandes focos de poluição, gerando vastas quantidades de efluentes.

O estudo do sistema de escoamento e resíduos gerados permitiu colocar esta questão em evidência, contribuindo para uma imagem mais clara da atmosfera e salubridade em torno e no interior destes espaços de lazer e socialização.
\end{abstract}

Palavras-chave: Gestão de resíduos, Poluição urbana, Balnea, Cloaca, Latrina.

\begin{abstract}
The bath buildings identified in Mirobriga were built a low area, surrounded by several hills. Both are well preserved allowing for a detailed analysis of a fundamental part of its functioning: the sewage system.

Despite being dedicated to bathing and body care, bath buildings are, none the less, responsible for a great amount of pollution, due to the vast volume of wastewater generated.

The analysis of the drainage/sewage system and of the overall waste produced within these buildings has brought some light to the subject as well as giving a clearer picture of what could have been overall atmosphere and salubrity in and around these places of leisure and socialization.

Keywords: Waste management, Urban pollution, Balnea, Cloaca, Latrine.
\end{abstract}

\section{INTRODUÇÃO}

Embora a identificação de uma cidade romana no Castelo Velho de Santiago do Cacém remonte ao século XVI, suscitando interesse de diversas personalidades ao longo dos séculos que se seguiram (Barata e Vale 2010, p. 12-15), seria a descoberta de um caldarium no fundo de um pequeno vale a marcar o início da sua escavação sistemática (por exemplo Silva 1944).

O local seria alvo de escavação extensiva em vários momentos das décadas de 1940 a 1970, sendo o primeiro edifício identificado apelidado de Termas Oeste, após a descoberta de um segundo edifício termal (Termas Este) situado paredes-meias (Silva 1944; Almeida 1964).

O primeiro estudo completo dos edifícios seria publicado em 1988 (Biers), sendo estes posteriormente incluídos no trabalho dedicado aos diversos edifícios termais urbanos da Lusitania (Reis 2014), bem como no estudo do sistema de saneamento da cidade de Mirobriga (Felício 2019), trabalho de um

\footnotetext{
1. (FCSH-UNL); catarina.m.felicio@gmail.com

2. (FCSH-UNL); filipe.alb.sousa@gmail.com
} 
dos signatários que serve de base para o presente artigo, que actualiza e aprofunda o estudo anteriormente efectuado.

As designações aqui utilizadas para os diferentes elementos do sistema de escoamento dos edifícios termais de Mirobriga, aqui apresentados de forma sintética, correspondem ao inventário efectuado para esse estudo, onde são apresentadas as características e dimensões de cada um de forma mais pormenorizada.

\section{O CICLO DA ÁGUA NOS EDIFÍCIOS TERMAIS DE ÉPOCA ROMANA}

De entre os diversos edifícios e recintos de lazer, os edifícios afectos a actividades balneares destacam-se não só pela «modernidade» que o conceito a elas subjacente pode suscitar, mas, sobretudo pela forma como o seu correcto funcionamento pressupõe a existência de dois complexos sistemas funcionais que se interligam: o sistema de calefacção e o sistema hídrico. Sendo o último o mais complexo e aquele que mais condicionantes impõe aquando da escolha de um local para a construção de um novo edifício termal, não fosse a água o «elemento que dá sentido à arquitectura termal» (Acero 2018b).

A escolha de uma localização para um edifício balnear, teria como condicionante a disponibilidade e aprovisionamento de água, existindo, para esse efeito, várias possibilidades: construção de cisternas para colecção e armazenamento de águas pluviais; existência de nascentes no local ou construção de poços ou minas de água; utilização das águas de rios ou outros cursos de água; ou construção de aquedutos para o transporte de água a partir de fontes geograficamente distantes (Manderscheid $2000 \mathrm{p}$. 484). A escolha de uma ou várias das opções estaria intimamente relacionada com os meios financeiros, técnicos e humanos disponíveis para cada projecto. Com excepção dos complexos de águas provenientes de nascentes termais, a grande maioria dos restantes edifícios balneares possuía reservatórios, que permitiriam não só a regulação e manutenção da pressão de água necessária ao fornecimento de água às diversas valências dos edifícios, mas também a sua manutenção em funcionamento em momento de menor disponibilidade de água, ainda que apenas por breves períodos. Dependendo das características de cada um, os usos dados a esta água podiam variar, sendo esta distribuída, por meio de um sistema de condução interna, pelos tanques e fontaná- rios de água fria, ou encaminhadas para os circuitos de calefacção. (Manderscheid 2000, p. 490-501).

A cada ciclo de renovação da água correspondia um avultado fluxo de efluentes a ser eliminado, sendo, todavia, comum a reutilização destas águas, a par das águas pluviais depositadas no interior dos edifícios, para tarefas de limpeza dos próprios espaços ou evacuação de resíduos fisiológicos e de outros detritos acumulados nos sistemas de escoamento internos do edifício (Manderscheid 2000, p. 503505). Esta última etapa do ciclo da água, à semelhança da primeira, colocava condicionantes à escolha de uma localização para o edifício, devido à necessidade de precaver o destino a dar a estes resíduos, em virtude da topografia e densidade urbanística envolvente bem como os recursos financeiros, técnicos e humanos disponíveis.

Apesar de fundamentais ao funcionamento de um edifício termal, os elementos hidráulicos responsáveis pelo escoamento das águas têm recebido uma atenção francamente menor do que os sistemas de adução, resultando em lacunas no seu conhecimento (Acero 2018a, p.38-39).

\section{OS EDIFÍCIOS TERMAIS DE MIROBRIGA - CAPTAÇÃO E UTILIZAÇÃO DE ÁGUA}

A construção do primeiro edifício termal público, as Termas Este, remontará aos finais do século I d.C / 120 d.C. (Biers 1988, p. 108-115). A sua implantação num fundo de um vale ao redor do qual têm vindo a ser identificadas algumas nascentes (Biers 1988, p.8), parece ter sido a única localização, no perímetro conhecido da cidade, que permitia a captação de água em volume suficiente. Aquando da construção das Termas Oeste, possivelmente algumas décadas mais tarde (Biers 1988, p. 108-115), aplicar-se-iam as mesmas condicionantes, pelo que o novo edifício foi justaposto ao já existente, utilizando águas das mesmas fontes (Felício 2019, p.18). (Figura 2)

Até ao momento, não obstante a menção, no século XVI, da existência de um aqueduto (Barata e Vale 2010, p. 12-13), não foi encontrado qualquer vestígio de um conduto para captação e transporte de águas desde longas distâncias, pelo que esta referência poderá, ou ser fruto de uma interpretação errada de uma estrutura parcialmente visível à data (Felício 2019, p.17), ou ser relativa a um aqueduto de menor dimensão, hoje desaparecido, que fizesse a ligação entre as fontes locais e os edifícios termais. 
Com efeito, associado às Termas Este, foi identificado um reservatório em alvenaria, revestido a opus signinum, situado a imediatamente a sul do edifício termal e apenas parcialmente escavado, que seria responsável pela manutenção do caudal e pressão pretendidos (Reis 2014, p. 213-215). A sua volumetria não é conhecida, uma vez que a sua escavação não foi concluída. No entanto, em 1998 (Barata 1999) e 2004 (Quaresma 2014), foram detectadas diversas canalizações de adução de água, pelo que este aprovisionaria água de diversas fontes. Esta hipótese é compatível com a dimensão relativamente pequena das nascentes identificadas até ao momento na área. Para além desta estrutura, foi ainda proposta a existência de um segundo reservatório na área (Felício 2019, p. 19) que, pela localização, deverá pertencer ao sistema de abastecimento das Termas Oeste. A ligação entre estas estruturas e o sistema de adução de água de cada um dos edifícios não está, ainda, totalmente esclarecida. Contudo, é expectável que esta consistisse numa canalização com alguma envergadura, possivelmente um pequeno aqueduto, tal como a existência de uma torre em alvenaria, localizada entre o possível segundo reservatório e os praefurnia das Termas Oeste, parece sugerir.

O volume de água necessário para o funcionamento das Termas Este foi calculado em aproximadamente $33,15 \mathrm{~m}^{3}$ de água, excluindo o volume do tanque localizado no tepidarium, cujo estado de conservação não permitiu o cálculo volumétrico. Para as Termas Oeste o volume calculado foi de aproximadamente $39,97 \mathrm{~m}^{3}$ (Reis 2014, p. 213), valores correspondentes a cada ciclo de renovação das águas, cuja regularidade desconhecemos.

A cada ciclo de renovação seria aproximadamente este o volume necessário e ao qual o sistema de captação e armazenamento de água teria de dar resposta. Contudo, uma vez que a escavação dos reservatórios não se encontra concluída, não é possível compreender se o sistema estaria bem dimensionado ou qual a sua eficiência.

\section{O SISTEMA DE ESCOAMENTO E SUA EVOLUÇÃO}

A implantação dos edifícios e concepção do seu sistema de escoamento aproveitou a existência de uma ribeira sazonal no vale, consistindo, assim, uma solução simples e de baixo custo para o escoamento dos efluentes procedentes dos diversos tanques, bem como os resíduos fisiológicos provenientes das latrinas, uma vez que o seu leito actuaria como canal de transporte para fora do perímetro urbanizado, mesmo em períodos em que a ribeira estivesse seca. (Figura 2)

A origem dessa linha de água encontra-se na própria topografia da cidade de Mirobriga, que favorece o escoamento de águas pluviais ao longo das encostas e vales das suas diversas colinas, criando três grandes zonas de confluência de águas, duas das quais se unem, acabando por formar uma ribeira sazonal em períodos de maior pluviosidade.

Esta dinâmica, apesar de favorecer o escoamento dos efluentes produzidos pelos edifícios termais, expunha-os a uma enorme pressão hídrica, proveniente das encostas, durante os períodos de pluviosidade intensa, desvantagem que desconhecemos se terá sido equacionada aquando da projecção do primeiro edifício.

\subsection{Termas Este}

O edifício encontra-se construído no sopé da vertente sul da colina do forum, a norte do leito da ribeira. Ao longo da sua vida útil, que, com base nos dados actualmente disponíveis, terá abarcado o período desde os finais do século I d.C. / 120 d.C. até meados do século III d.C. (Biers 1988, p. 108-115 e Apendix C p. 180-182), sofreu diversas reformulações, fruto não só de novas necessidades ao nível do circuito balnear, mas também das claras dificuldades ao nível da gestão dos caudais de águas pluviais que se concentravam no entorno do edifício.

\subsubsection{Primeira fase}

Na sua fase original, o edifício seria composto apenas pelas Salas 13 a 17 e pela zona de serviço. Nesta fase, as Salas 15 e 16, tepidarium e caldarium, respectivamente, teriam menores dimensões. Sondagens efectuadas na Sala 12 revelaram que esta era resultado de uma ampliação, e que anteriormente o porticus se prolongava para esta área (Biers 1988, p. 289). Na altura, devido à relação estratigráfica entre o muro estilóbato identificado e o corpo principal do edifício, não foi excluída a hipótese de o pátio porticado ser também uma adição ao edifício, sendo a sua construção designada como Fase $1 \mathrm{~b}$ (Biers 1988, p. 108-115). Assim, os dados cronológicos recolhidos, referentes à construção do muro estilóbato, permitem apenas datar o porticus.

Aquando da construção do edifício, a ribeira sazo- 
nal foi parcialmente canalizada passando a correr sob o mesmo, através da cloaca designada por $\mathrm{C}_{35}$, uma estrutura abobadada construída em alvenaria de pedra calcária com aproximadamente im de largura (Felício 2019, p.70). Esta canalização actuaria como elemento base do sistema de escoamento do edifício termal aproveitando o caudal natural da ribeira para conduzir estes resíduos para longe da área urbanizada. (Figura 2-A)

A localização do tanque original do caldarium é-nos dada por aquela que seria a sua canalização de escoamento, na parede sul da Sala 16, que escoaria para a cloaca C35. (Felício 2019, p. 70). Já o tanque do frigidarium aparenta escoar directamente para o leito da ribeira, por meio de um sistema de canalizações de média dimensão identificadas a este do edifício (Barata e Tiago 2003), não utilizando a $\mathrm{C}_{35}$. As fotografias da intervenção de 2003 sugerem ainda a existência de uma canalização proveniente da zona dos praefurnia, não tendo, porém, a sua existência sido apontada no relatório. A confirmar-se a sua existência, devemos estar perante uma estrutura análoga ao conjunto identificado nos praefurnia das Termas Oeste, possivelmente relacionado com a limpeza dos hypocausta. (Figura 3)

Aos efluentes gerados no edifício somar-se-iam as águas pluviais que se acumulavam no porticus e que, embora não subsistam vestígios, poderiam ter sido escoados por meio de um sumidouro para a cloaca $\mathrm{C}_{35}$.

Nesta fase, a zona a oeste do edifício termal, a montante da ribeira, poderia estar consolidada por diques ou muros de contenção/desvio de águas, de forma a facilitar a sua condução para o interior da cloaca (Felício 2019, p. 70-71). No entanto, a terem existido, estas estruturas terão sido destruídas aquando da construção das Termas Oeste.

Em 1988 foi proposto que a $\mathrm{C}_{35}$ teria tido originalmente uma extensão maior, ligando-se à C25, e que a construção deste edifício termal teria cortado essa canalização original, unindo os dois troços sobrantes com o seu próprio sistema de escoamento (Biers 1988, p.75-79). Contudo, esta hipótese não dispõe, a nosso ver, de indícios suficientes, uma vez que a entrada da $\mathrm{C}_{35}$ não apresenta indícios evidentes de corte, além disso, a relação entre a C25 e as Termas Oeste aponta para que esta seja, pelo menos, contemporânea à construção deste edifício.
4.1.2. Fases intermédias sem cronologia atribuída A construção da Sala 10, uma latrina, foi anteriormente considerada como Fase $2 \mathrm{c}$ (Biers 1988, p.289) com base na análise da sobreposição de unidades murárias, que indicam que esta não faria parte da fase primordial do edifício. A escavação do interior da sala apenas revelou dados relativos ao seu abandono, não sendo impossível que a sala tenha sido construída antes da datação atribuída à $2^{\underline{a}}$ fase, pelo que se optou por designá-la como Fase ic (Felício 2019, 71-72) A escolha do local para a sua construção ter-se-á prendido pela proximidade do caldarium, reutilizando as águas como descarga para a latrina, adaptando a canalização de escoamento do caldarium para o efeito; e pela proximidade da cloaca $\mathrm{C}_{35}$, que passa directamente sob a Sala 1o. Este espaço, com capacidade para 9 utilizadores em simultâneo (Felício 2019, p. 118-121), apresentava, assim, um funcionamento híbrido combinando, com base nos atributos definidos por Alain Bouet (2009 p. 41-44 e 47-49), características das latrinas de esgoto sob dois lados e das latrinas em poço/avaloir (Felício 2019, p 93-94).

Nesta fase as águas pluviais acumuladas no porticus seriam escoadas para o canal principal da latrina através de uma canalização localizada no paramento oeste da Sala 1o, actualmente bastante degradada.

Num momento indeterminado foi também construída uma canalização, na Sala 14, ao longo da borda do tanque, com origem no paramento este da Sala 13, junto ao pavimento, e que se unia ao sistema de escoamento do frigidarium. A adição desta estrutura foi interpretada como uma resposta a necessidades de limpeza que, presumivelmente, não haviam sido precavidas. Neste ambiente, a entrada e saída no tanque, mais ou menos frequente, aliada à circulação dos utentes para o interior ou exterior da sala, facilmente deixaria o pavimento bastante sujo, pelo que a existência de um ponto de escoamento facilitaria a eliminação das águas utilizadas na limpeza e lavagem do pavimento.

\subsubsection{Segunda Fase}

Esta fase caracteriza-se pela construção da Sala 12, interpretada como apodyterium. Esta fase data de, pelo menos, $155 / 158$ d.C., tendo sido encontrado um numisma de Antoninus Pius na preparação para a colocação do piso em opus signinum da sala (Biers 1988, p. 86 e 111 e Apendix C p. 183). Aqui poderá ter sido igualmente adicionada a Sala 8 , anteriormente 
inscrita numa Fase $2 b$ (Biers 1988, p.289). Consideramos que ambos espaços pertençam a uma mesma reformulação uma vez que a construção de uma canalização com origem na Sala 8 acarretaria um corte no pavimento da Sala 12, do qual não existem evidências; e que o seu ponto de escoamento desta canalização, localizado na parede sul da Sala 12, aparenta ser contemporâneo da construção deste paramento. A existência deste elemento de escoamento, associável às necessidades de limpeza do espaço, autoriza a interpretação da Sala 8 como possível unctorium/destrictarium, onde actividades relacionadas com a aplicação de óleos e sua remoção, por meio de strigil $^{-}$es, implicaria uma limpeza frequente do pavimento (Felício 2019, p 72-73). A localização desta sala no lado oposto ao elemento central de escoamento do edifício não tornava fácil a construção de uma ligação directa à cloaca $\mathrm{C}_{35}$, acabando os efluentes por ser escoados para o pavimento do pátio, e posteriormente encaminhados por gravidade, do mesmo modo que as águas pluviais, para o canal principal da latrina.

A esta fase foi também associada a construção da estrutura $\mathrm{C}_{3} 8$, localizada ao longo do lado norte do edifício termal, e que se adossa à Sala 8. Esta consiste numa segunda parede, paralela ao limite da Sala 12, distanciada em média o,6om desta. No espaço entre ambas, e à cota de conservação do muro interior, foi identificado um revestimento em opus signinum, dotado de meia-cana, acompanhado todo o comprimento do lado norte do edifício, adossando-se, no seu topo norte, à parede da Sala 8.

As características da estrutura e respectiva localização levam-nos a crer que se trate de uma estrutura de impermeabilização, podendo ter-se tratado de uma estrutura de deflexão de águas pluviais, depositando-as no lado este do edifício, permitindo que se encaminhassem para o leito da ribeira; ou então de uma estrutura de paredes duplas, uma solução com vista a criar um espaço oco e diminuir a percolação de água e humidade para o seu interior (Felício 2019, p. 115-118), comummente adoptada em edifícios construídos contra pendentes e em ambientes de elevada humidade (Vitr. VII, 4,1; Giuliani 2006, p. 158, fig. 12).

Além desta estrutura, também a $\mathrm{C}_{5} \mathrm{O}$, adossada à Sala 8, poderá ser incluída nesta segunda fase. Esta estrutura consiste num embasamento em alvenaria, cujo topo em declive, revestido a opus signinum, deflecte a água e protege a base do muro, contra o qual foi construído, de infiltrações.
A adição destas estruturas, apesar de não consistirem em elementos do sistema de escoamento, revela-nos que o edifício seria atingindo por um caudal considerável de águas pluviais que, devido a um escoamento pouco eficiente, provocaria problemas de infiltração de águas ou humidade. Estes problemas poderão não ter sido equacionados à data da construção do edifício ou terem sido agravados devido a alguma transformação da sua envolvente, da qual pouco se conhece.

\subsubsection{Terceira Fase}

Esta fase caracteriza-se pela construção das absides actualmente existentes nas Salas 15 e 16, distinguíveis como uma nova fase, relativamente à construção da Sala 12, devido aos os seus níveis de fundação se situarem a uma cota mais baixa que os dessa sala, à qual a abside da Sala 15 se adossa (Biers 1988, p. 105). Esta reformulação anulou tanque original do caldarium e respectiva canalização de escoamento, criando dois novos que passaram a escoar directamente para o pavimento do pátio porticado, hipótese já apresentada por outros autores (Biers 1988, p.102; Reis 2014, p.199). Os efluentes dos tanques, à semelhança das águas pluviais e efluentes da Sala 8, fluiriam pelo pavimento até ao canal principal da latrina. Nesta fase foi também adicionado um tanque na Sala 15, tepidarium (Biers 1988, p. 105), não sendo o seu escoamento fácil de determinar, uma vez que a quase totalidade do nível de circulação da Sala 15 colapsou para o interior do hypocaustum. Foi proposto anteriormente que o espaço para a passagem de uma canalização, conformado por dois imbrices colocados um sobre o outro, localizado no exterior da parede desta abside, fosse a localização da sua canalização de escoamento (Reis 2014, p. 199). Contudo, a existência de uma estrutura idêntica na abside mais pequena do caldarium, localizada a uma cota superior à do escoamento do tanque e apontada como o provável ponto de adução de água ao mesmo, sugere que estrutura identificada na abside do tepidarium, por analogia, se destinasse igualmente à adução de água ao espaço (Felício 2019, p. 76). Com efeito, a identificação de uma canalização localizada no hypocaustum da Sala 15 imediatamente sob a localização do tanque, (Biers 1988, p. 98-99), leva-nos a crer que esta canalização estará relacionada com o escoamento do mesmo.

A existência de canalizações de escoamento no interior de hypocausta não é incomum, sendo, con- 
tudo, mais frequente nos praefurnia quando o escoamento dos tanques é feito através de testudines (Maréchal, 2017). Neste caso, uma vez que não conhecemos o percurso total desta canalização e não podemos garantir que fosse realmente a estrutura de escoamento do tanque da Sala 15, é difícil formular uma hipótese acerca do motivo pelo qual o escoamento deste tanque seria distinto dos restantes. Em todo o caso, a existência desta estrutura, no interior do hypocaustum, contribui a favor da existência de uma canalização proveniente da área de serviço, anteriormente mencionada.

Para além das alterações no circuito balnear, foi associada a esta fase a construção de uma barreira em tijolo, revestido de opus signinum, localizada junto da entrada do edifício termal $\left(\mathrm{C}_{3} 6\right)$, que teria a função de impedir a escorrência de águas pluviais para a entrada do edifício, desviando o fluxo para o interior do sistema de escoamento das Termas Oeste. Esta barreira consistiria, assim, numa protecção adicional, revelando a sua posterioridade em relação às reformas anteriores que não terão sido suficientes. Embora não possuamos quaisquer dados cronológicos precisos para a sua construção, esta terá, necessariamente, ocorrido após a construção das Termas Oeste.

A construção deste sistema de desvio de águas pluviais levanta ainda questões relativas à propriedade dos dois edifícios termais, uma vez que uma estrutura pertencente a um edifício atravessa tão contundentemente outro, sugerindo um proprietário comum, situação que é também sugerida pelo facto de a canalização basilar do sistema de escoamento das Termas Oeste escoar para a $\mathrm{C}_{35}$.

\subsubsection{Encerramento e abandono}

Apesar de a quase totalidade do edifício termal ter sido escavado num momento recuado, não havendo registo dos contextos que existiriam, foram identificados três contextos preservados, dois dos quais permitiram datar a obstrução da canalização da Sala 8 e do canal principal da latrina (Biers 1988, Apendix C p. 180-182). Estes apontam para a obstrução destas canalizações a partir de meados do século III d.C., não existindo materiais posteriores ao início do século IV d.C., sugerindo que o encerramento do edifício termal terá ocorrido um pouco antes, talvez na primeira metade do século III d.C., levando ao assoreamento do seu sistema de escoamento e saneamento. No caso do tanque do frigidarium, o con- texto aí identificado, apesar de não conter material datante significativo preservado (Biers 1988, Apendix C p. 192-195), sugere que o espaço, que à data já se deveria encontrar parcialmente em ruína, tenha sido utilizado como lixeira (Felício 2019, p. 78-79).

\subsection{Termas Oeste}

As sondagens efectuadas nos anos 1980 foram inconclusivas, permitindo apenas fixar a construção do edifício algures na primeira metade do século II d.C., não devendo a sua construção distar da das Termas Este mais do que algumas décadas (Biers 1988, p. 108-115). O seu aspecto actual é também resultado de algumas remodelações ao longo do tempo, embora os dados actualmente não permitam distinguir se todas terão ocorrido numa mesma altura e qual a sua cronologia. A este respeito, devemos referir que para o presente artigo apenas foram tidos em conta os elementos directamente relacionados com o sistema de escoamento do edifício.

\subsubsection{Fase original}

O edifício encontra-se justaposto ao muro ocidental das Termas Este, alçado partilhando por ambos os edifícios, e evidencia uma concepção, ao nível da gestão e escoamento de efluentes e águas pluviais, muito mais completa, quando comparada com a do edifício vizinho, demonstrando uma maturação no conhecimento do terreno e suas problemáticas no período que discorreu entre a construção dos dois edifícios termais. (Figura 2-C)

O seu sistema de escoamento tem por base uma cloaca que contorna o edifício ( $\mathrm{C}_{56}$ ), para a qual confluem todos os resíduos gerados no edifício. Esta situa-se sob um recinto impermeabilizado (Pátio Nordeste e um possível segundo pátio a este do edifício) que permite a recolha de águas pluviais e sua condução, por meio de diversos sumidouros, para o interior da cloaca C56 (Felício 2019, p.8o-87), criando um perímetro que afasta o edifício das vertentes do vale. (Figura 4)

Para além desta canalização foi criada uma outra, C25, com 0.85m de largura e uma altura de 1,40m, que provavelmente replicaria o traçado da antiga ribeira, agora soterrada pela urbanização do vale. O propósito deste elemento aparenta estar unicamente relacionado com a captação de águas pluviais de escorrência superficial que se acumulariam na base do pequeno vale a sul das Termas Oeste e que corresponde a uma das zonas naturais de confluên- 
cia de águas identificadas. Nesta fase é possível que estas águas fossem encaminhadas para o pátio que contorna o edifício termal, sendo depois escoadas para a cloaca $\mathrm{C}_{5} 6$.

O sistema que protegia o edifício da pressão provocada pelas águas pluviais contemplava ainda duas estruturas de impermeabilização por deflexão de águas $\left(\mathrm{C}_{51}\right.$ e $\left.\mathrm{C}_{52}\right)$ localizadas no canto norte, no exterior da Sala 3, entre as quais se situava um sumidouro. Este sistema, localizado precisamente na base de outra das zonas de confluência de águas, aliado à morfologia da própria via a Oeste do edifício, que apresentava uma nervura central, conduzindo as águas pluviais na direcção do sumidouro, captava a maioria destas águas, encaminhando-as para o sistema de escoamento.

Quanto aos elementos de escoamento em si, embora a totalidade do percurso da cloaca $\mathrm{C}_{5} 6$ não seja, actualmente, transitável, existindo troços não escavados e uma zona onde esta colapsou, é possível reconstituir o seu percurso em torno do edifício. Esta tem início no topo norte do edifício, junto à Sala 3, contornando o edifício pelo sul e desembocando no canal principal de uma latrina simples de esgoto sob dois lados localizada na Sala 9, onde foi estimada uma capacidade de 12 utilizadores em simultâneo (Felício 2019, p. 118-121). O canal da latrina escoa, por sua vez, para a cloaca $\mathrm{C}_{35}$, pertencente às Termas Este, seguindo posteriormente para o leito da ribeira, a jusante do complexo termal.

A C56 apresenta paredes em alvenaria de pedra, apresentando uma cobertura em abóbada, sendo o seu pavimento em tijolo. Percorre os lados Oeste, Sul e Este do edifício termal e apresenta uma altura de entre $0.80 \mathrm{~m}$ e $0.90 \mathrm{~m}$ e uma largura de $0.6 \mathrm{om}$ nos troços Este e Sul, e de $0.70 \mathrm{~m}$ no troço Oeste. As dimensões da cloaca permitem a circulação de um adulto no seu interior, rastejando, sendo assim possível proceder à sua manutenção, tendo sido identificados dois pontos de acesso ao sistema subterrâneo: $O$ primeiro (C33) localizado no corredor de acesso à latrina, que consiste numa abertura de $1.10 \mathrm{~m}$ por $1.12 \mathrm{~m}$; e um segundo localizado no Pátio Noroeste (C23) estrutura já anteriormente apontada como entrada para manutenção, devido à sua dimensão (o.6oxo.7om), (Biers 1988, p. 74). Ambos os pontos de entrada estariam cobertos, apresentando o do pátio uma moldura de meia-cana em opus signinum, que impediria a entrada de águas pluviais naquele ponto.

$\mathrm{Na}$ sua fase original, o edifício contaria apenas com dois tanques, um no caldarium e outro no frigidarium, sendo que o primeiro escoava para a $\mathrm{C}_{5} 6$, por meio de uma fistula, controlada por uma possível torneira localizada no Pátio Nordeste; e o segundo para o canal principal da latrina, por meio de uma canalização conformada em tijolo, embutida na alvenaria da parede e possivelmente vedada por uma tampa ou rolha.

Para além dos tanques e das águas pluviais, o sistema de escoamento original das Termas Oeste contemplava ainda canalizações associadas à limpeza e manutenção do espaço. Destas, duas estavam ligadas ao percurso balnear e três à área de serviço aos praefurnia.

As primeiras, localizadas nas Salas 1 e 4, encontram-se contruídas em alvenaria de tijolo, e foram associadas à limpeza dos pavimentos, sendo possível observar, em cada uma das salas, um declive que pende na direcção de cada uma destas canalizações: Uma localizada no localizada na base do canto este da Sala 4 (frigidarium) e que escoaria os efluentes resultantes da limpeza do pavimento para o canal principal da latrina; e outra localizada na Sala 1, interpretada como uma possível palestra interior, onde, a par da actividade física seriam realizadas actividades de unção e limpeza do corpo, pelo que a presença de um ponto de escoamento facilitaria a limpeza do espaço (Felício 2019, p. 82), Esta proposta encontra paralelo em edifícios como a chamada "Palestra dei Iuvenes", regio VIII.2.23, um espaço associado ao Complexo Termal do Sarno, em Pompeii, cujo pavimento está igualmente dotado de escoamento.

Já na sala de serviço aos praefurnia foram identificadas três canalizações, uma construída em tijolo, cuja cobertura seria, possivelmente em lajes de pedra e duas de menor dimensão escavadas directamente no substrato geológico (xisto) (Biers 1988, p. 116). Com base nos dados disponíveis, foi proposto que as três canalizações fizessem parte de um possível sistema de limpeza dos hypocausta, escoando águas e cinzas resultantes da sua lavagem (Felício 2019, p. 83). Estas estruturas encontram paralelo no edifício termal de Eburobrittium, tendo-se sugerido que pudessem ser responsáveis pelo escoamento de tanques (Reis 2014, p. 305-306)

\subsubsection{Remodelações}

Apesar de o edifício não ter sofrido reestruturações de vulto, existem algumas estruturas hidráulicas que terão sido adicionadas ao longo do seu período 
de funcionamento, muito embora não possamos, de momento, localizar ou ordenar cronologicamente algumas delas. Com efeito, a única estrutura para a qual possuímos um indicador cronológico relativo é a canalização localizada no corredor de acesso à latrina, que foi construída em simultâneo com a barreira $\mathrm{C}_{3} 6$, enquadrada na terceira fase das Termas Este. Inicialmente pensou-se que ambos os tanques da caldarium pertencessem ao projecto original (Biers 1988, p. 75-78), no entanto, as observações efectuadas no interior da cloaca $\mathrm{C}_{5} 6$ revelaram que esta foi cortada para construção do hypocaustum do tanque de menor dimensão, existindo também indícios de ter existido uma janela no paramento onde o tanque se situa actualmente (Felício 2019, p. 88). Na Sala 6, caldarium, foi adicionado um segundo tanque, de menor dimensão, $\mathrm{O}$ escoamento deste novo tanque seria feito por meio de uma fistula (Biers 1988, p. 69), que se encontra actualmente incessível devido ao colapso de parte da cloaca $\mathrm{C}_{56}$. A construção desta nova abside obrigou a uma reformulação no traçado desta cloaca, no interior da qual foi identificado o corte para a implantação do hypocaustum do novo tanque, bem como a abertura, a sul, de um novo troço que contorna a nova abside. Este troço apresenta uma cobertura de lintéis calcários, ao contrário da restante $\mathrm{C}_{5} 6$, que possui uma abóbada de canhão construída em placas de xisto. Infelizmente este troço encontra-se obstruído pelo colapso quer da sua cobertura, quer de parte do paramento da abside do caldarium. Esta adição provocou constrangimentos também na C25, cujo escoamento, possivelmente para o pavimento do pátio, se faria precisamente neste local, levando à necessidade de criar uma ligação entre esta e novo troço da $\mathrm{C}_{5} 6$.

A adição de um novo tanque no caldarium, levanta a possibilidade de o tanque mais pequeno do frigidarium ser também resultado desta reformulação do edifício, que teria, assim, recebido um incremento de capacidade com a adição de mais um tanque em cada uma das salas de banho (Felício 2019, p. 89). Esta hipótese que carece ainda de confirmação, uma vez que a $\mathrm{C}_{5} 6$ se encontra obstruída nesta zona, podendo o terminar da sua escavação vir a clarificar a relação estratigráfica entre a canalização de escoamento deste tanque e as estruturas que sabemos serem originais do edifício.

\subsubsection{Encerramento e abandono}

A falta de dados relativos à sua escavação, somada ao facto de as sondagens efectuadas no troço da $\mathrm{C}_{5} 6$ sob o Pátio Noroeste não terem encontrado qualquer material, datante ou não, no seu interior (Biers 1988, p. 73-75), não permitiram chegar a uma conclusão acerca do encerramento do edifício. No entanto, uma vez que o sistema de escoamento das Termas Oeste dependia da manutenção da $C_{35}$, pertencente às Termas Este, o edifício não teria meio de subsistir caso esta canalização se encontrasse obstruída, o que poderá ter acontecido a partir do encerramento desse edifício termal (Felício 2019, p. 89-90). É, todavia, possível que a manutenção da cloaca possa ter continuado a ser realizada pelos responsáveis pelas Termas Oeste após o encerrar do edifício vizinho, uma vez que o ponto de acesso para manutenção localizado junto à latrina permite também o acesso à C35. Contudo, os dados recolhidos nas Termas Este e na envolvente (Arthur 1983, p.81-83; Biers 1988, Apendix C p. 180-182 e 192-195; Felício 2019, p. 26-27), não obstante um possível restauro localizado do pavimento da ponte nessa cronologia (Quaresma 2014, p. 127) são consistentes com um cenário de degradação e abandono ou, pelo menos, negligência desta zona da cidade a partir de meados do século III d.C., sendo plausível que nesta cronologia, as Termas Oeste não se encontrassem igualmente em funcionamento. Com efeito, a recolha, em 1955, de elementos pétreos no Amb.2 do designado Edifício $\mathrm{C}$, num contexto enquadrável na primeira década do século IV d.C. (Arthur 1983, p. 83 e 99-102; Felício e Sousa 2019, p. 138-139), identificados à data, como possivelmente pertencentes às Termas Oeste (Arthur 1983, 96-97), aponta uma possível cronologia para a espoliação de elementos decorativos dos edifício, consistindo, assim, num terminus ante quem para o seu encerramento.

\section{MANUTENÇÃO, SANEAMENTO E PAISAGEM URBANA}

A contaminação ambiental provocada pelas cidades antigas não é novidade, sendo já merecedora da crítica de algumas das personalidades da época, que se queixavam da sujidade e odores fétidos que algumas cidades, em particular as de maior dimensão, apresentavam, (Acero 2018a, p. 70-76).

Se, por um lado, estes efeitos seriam particularmente notórios nas grandes metrópoles, devemos, por outro, salientar que por menor que um aglomerado urbano possa ter sido, algumas das actividades 
e valências inerentes a estes núcleos populacionais, como sejam a convivência próxima de pessoas, a laboração de oficinas manufactureiras, mercados de animais ou, no que ao presente artigo se refere, os edifícios termais, teriam, sem dúvida, um importante papel enquanto focos de poluição.

Contudo, se actividades tidas como poluentes ou perigosas como as figlinae, oficinas, metalúrgicas, vidreiras e de preparados piscícolas ou mesmo os espaços dedicados aos fora boaria eram, geralmente, relegados aos espaços extra-urbanos (Acero Pérez 2018, p.85), os espaços termais encontravam-se, de uma forma geral, nas zonas centrais das mesmas. Para além das questões relacionadas com gestão florestal, suscitadas pelo consumo de lenha para alimentar os sistemas de calefacção dos edifícios termais, e que extravasam o âmbito do presente artigo, o dia-a-dia de um edifício termal tinha diversas implicações ambientais, nomeadamente ao nível do fumo proveniente dos praefurnia e dos efluentes gerados.

No seu interior, factores como a humidade e temperatura elevadas; a realização de actividades físicas, motivando a transpiração; seguida da utilização de óleos e sua deposição no pavimento; a entrada e saída de várias pessoas nos tanques e circulação entre vários os ambientes; bem como a preparação e consumo de alimentos nos estabelecimentos concorriam para a criação de uma atmosfera pouco limpa. Os testemunhos que nos chegaram acerca destes espaços, apesar de enaltecerem os benefícios e comodidades desta actividade de lazer, transmitem também a volatilidade com que os mesmo se degradariam, levando, por exemplo, ao surgimento de baratas (Plinius apud Jansen 2011, p. 159). À dinâmica do circuito balnear, somar-se-ia o funcionamento das latrinas, quase omnipresentes nestes complexos, onde a utilização comunitária do espaço, aliada a uma acumulação de resíduos fisiológicos nos canais sob os assentos, que muitas vezes apenas seriam escoados aquando de um ciclo de renovação de água nos tanques do complexo, criaria um ambiente muito pouco higiénico, pelo menos na acepção moderna do termo (Jansen 2011, p. 159-161).

Seria comum a gestão e exploração de um edifício termal estar concessionada a um Conductor Balnei, por meio de um contrato, após o terminus do qual o edifício e todo o equipamento a ele pertencente deveria ser entregue em bom estado. Durante a sua exploração, o conductor deveria manter o edifício a funcionar correctamente e proceder à limpeza regular das caldeiras, sendo-lhe cobrada uma indeminização por períodos de não funcionamento. (Encarnação 1984, p. 204-211).

Embora não sejam especificados os motivos pelos quais este não funcionaria correctamente e qual o equipamento a ser entregue em boas condições, o sistema de escoamento, sendo um dos aspectos fulcrais, constaria, certamente, na lista. O mesmo se aplicaria ao hypocaustum, sendo possível que a manutenção regular das caldeiras englobasse a totalidade do sistema de calefacção, podendo as estruturas de escoamento identificadas nos praefurnia de ambos os edifícios consistir um testemunho da limpeza ou lavagem dos resíduos de combustão.

A limpeza das diversas salas, embora não seja explicitamente mencionada, provavelmente estaria implícita na referência à conservação das condições de funcionamento do edifício, que supomos terem em consideração uma utilização minimamente agradável do espaço. Com efeito, a existência de estruturas de escoamento em ambientes associados à prática de actividade física e ao ritual de aplicação e remoção de óleos relacionado com esta, denuncia a realização de uma limpeza profusa do espaço (Felício 2019, p. 135-136), constituindo os únicos vestígios tangíveis de alguma regularidade na limpeza, sem a qual a qualidade do ambiente se degradaria rapidamente. Os efluentes gerados pelas actividades de limpeza e mudanças de água dos tanques teriam, numa boa parte dos casos, como destino a rede de cloacas das cidades, longe da vista e do olfacto, da maioria dos seus habitantes. Todavia, o mesmo não se terá passado em Mirobriga, onde, como vimos, a totalidade dos efluentes de ambos os edifícios termais era depositada no leito da ribeira sazonal, numa localização relativamente central da cidade, e imediatamente a montante de uma das vias acesso à mesma, o que terá, certamente, criado um ambiente algo desagradável, influenciando a paisagem urbana e sua vivência.

\section{CONSIDERAÇÕES FINAIS}

A localização da cidade, herdada de um antigo povoado indígena, é caracterizada pela existência diversas colinas, levando a que alguns dos edifícios fossem construídos a meia encosta ou mesmo no fundo de vales. Muitos dos eixos viários aproveitaram o declive natural das vertentes, tendo tomado o lugar de um sistema subterrâneo de escoamento, 
que nunca viria a ser construído, uma vez que consistiam numa forma simples de escoar as águas pluviais, e outros resíduos, dos vários pontos da cidade (Felício 2019, p. 20-27)

A construção dos edifícios termais na única localização conhecida que permitia a captação e adução de água necessária para o seu funcionamento, tirou também partido desta dinâmica natural de escoamento, tornando a ribeira sazonal e respectivo leito num dos principais agentes para o transporte das águas residuais daí provenientes.

Contudo, se em momentos de pluviosidade intensa, o caudal gerado era suficiente não só para transportar os resíduos, mas também para trazer problemas aos edifícios devido ao excesso de água e humidade; o mesmo poderia não ser o caso em períodos estivos. A escassez de chuva, e consequente diminuição dos caudais das nascentes, poderia causar disrupções no aprovisionamento de água aos edifícios; mas os seus efeitos far-se-iam sentir sobretudo ao nível do escoamento dos resíduos fisiológicos gerados nas latrinas, que em períodos de pouca ou nenhuma pluviosidade dependeriam apenas da renovação de água nos tanques para o seu transporte, o que poderá ter provocado a acumulação de resíduos no interior do próprio sistema de escoamento e no leito da ribeira. Não será demais destacar o impacto negativo que períodos de temperatura elevada aliados a uma acumulação de resíduos fisiológicos e outros efluentes teria na qualidade ambiental da zona, atravessada por uma importante via que ligaria a cidade ao circus e nas proximidades da qual existe, pelo menos, um edifício habitacional (Casa Periquito).

Dada a importância que este pequeno curso de água tinha para o bom funcionamento dos edifícios termais, é possível que nestes períodos algum tipo de acção de manutenção suplementar tenha ocorrido, sendo espectável que este fosse alvo de limpeza com alguma regularidade, nomeadamente da vegetação que aí crescia, mas também ao nível dos detritos acumulados, numa lógica talvez semelhante à da actuação dos foricarii ou stercorarii (Acero 2018, p. 74-75). Apesar das condicionantes impostas pelo terreno, os edifícios termais de Mirobriga procuraram, desde a concepção das Termas Este, adaptar-se e tirar partido das mesmas. Contudo, é notória uma evolução no conhecimento da forma como a topografia influenciava a dinâmica hídrica do local, materializada no planeamento cuidado do sistema de escoamento das Termas Oeste.
Esta evolução, que desconhecemos se se deveu a uma aprendizagem empírica ou à contratação de equipas mais especializadas aquando da construção do segundo edifício termal e reformulação do primeiro, legou-nos uma série de estruturas que nos permitem compreender quais as preocupações que a manutenção com a limpeza e salubridade mas também estabilidade destes edifícios acarretava, contribuindo para o conhecimento e para uma aproximação mais tangível àquele que seria o ambiente, vivência $\mathrm{e}$ realidade cultural destes espaços de lazer.

\section{BIBLIOGRAFIA}

ACERO PÉREZ, J. (2018a) - La gestión de los resíduos en Augusta Emerita (Mérida, España) Siglos I a.C. - VII d.C.Anejos del Archivo Español de Arqueología. LXXXII. CSIC - Instituto de Arqueología de Mérida. Mérida.

ACERO PÉREZ, J. (2018b) - Agua para el baño. Abastecimiento, uso y evacuación hídrica en las termas públicas de Hispania. In NOGUERA CELDRÁN, J.M.; GARCÍA-ENTERO, V. e PAVÍA PAGE, M. (eds.) Pre-Actas del Congreso internacional Termas públicas de Hispania (Murcia-Cartagena, 19-21 de abril de 2018). p.27-29.

ALMEIDA, F. (1964) - Ruínas de Miróbriga dos Célticos (Santiago do Cacém), Setúbal: Junta Distrital de Setúbal.

ARTHUR, M. L. C. (1983) - Merobriga. Santiago do Cacém (Portugal). In Caesaraugusta. 57-8, pp. 51-109.

BARATA, M. F. (1999) - Trabalhos arqueológicos na ponte romana de Miróbriga. Vipasca, 8. Aljustrel, pp. 67-72.

BARATA, M. F.; TIAGO, J. R. (2003) - Intervenção Arqueológica - exterior do muro limite das Termas Este. Relatório de escavação entregue à DGPC.

BARATA, M. F.; VALE, F. (2010) - Mirobriga o Tempo ao longo do Tempo. Catálogo da exposição decorrida no Museu Municipal de Santiago do Cacém, Museu de Arqueologia e Etnologia do Distrito de Setúbal e no Centro Interpretativo de Mirobriga. Câmara Municipal de Santiago do Cacém.

BIERS, W. R. (Ed.) (1988) - Mirobriga. Investigations at an Iron Age and Roman site in southern Portugal by the University of Missouri-Columbia, 1981-1986. BAR - International Series 451. Oxford.

BOUET, A. (2009) - Les Latrines dans les Provinces Gauloises, Germaniques et Alpines. Supplément à GALLIA 59. CNRS Éditions, Paris.

ENCARNAÇÃO, J. D' (1984) - Inscrições romanas do Conventus Pacensis. Coimbra: Faculdade de Letras de Coimbra. Instituto de Arqueologia.

FELÍCIO, C. (2019) - Gestão de Resíduos em Mirobriga - O Sistema de Saneamento (séculos I-IV d.C.). Dissertação de Mestrado em Arqueologia apresentada à Faculdade de Ciências Sociais e Humanas da Universidade Nova de Lisboa. 
FELÍCIO, C.; SOUSA, F. (2019) - Dois amuletos em osso de Mirobriga - Evidências do culto de Magna Mater? In OPHIUSSA $\mathrm{n}^{\circ}$ 3. UNIARQ. Faculdade de Letras da Universidade de Lisboa. pp. 133-143.

GIULIANI, C. F. (2006)-L'edilizia nell'antichità 2 $2^{\underline{a}}$ Edizione. Collana Manuali Universitari. Carocci.

JANSEN, G. C. M. (2011) - Toilets and Health. In JANSEN, G. C.M.; KOLOSKI-OSTROW, A. O.; MOORMAN, E. M. (Ed.) - Roman Toilets: Their Archaeology and Cultural History. BABESCH Annual Papers on Mediterranean Archaeology Supplement 19. pp. 157-164.

MANDERSCHEID, H. (200o) - The Water Management of Greek and Roman Baths. In Handbook of Ancient Water Technology. Brill. Leidein. pp. 467-535.

MARÉCHAL, S. (2017) - A note on the drainage of pools in Roman baths. In BABESCH - Annual Papers on Mediterranean Archaeology 92. pp. 179-186.
QUARESMA, J. C. (2014) - Escavações de 2004 e 2005 na área da ponte de Chãos Salgados (Mirobriga?): estratigrafia, arquitectura e materiais de um sector público da cidade romana. In Musa, nº 4. pp. 125-156.

REIS, M. P. (2014) - DE LVSITANIAE VRBIVM BALNEIS. Estudo sobre as termas e balneários das cidades da Lusitânia. Tese de Doutoramento apresentada à Faculdade de Letras da Universidade de Coimbra.

SILVA, J. G. C. (1944) - Apontamentos e considerações sobre as pesquisas arqueológicas realizadas desde 1922 nos concelhos de S. Tiago-de-Cacém, Sines e Odemira. In Arquivo de Beja nº̄1, pp. 226-31.

TEICHNER, Félix (2018) - Einleitende Bemerkungen zur Fundstelle. In Félix Teichner (Ed.). Mirobriga. Eine Stadt im fernen Westen des Imperium Romanum. Marburg. pp. 9-18.

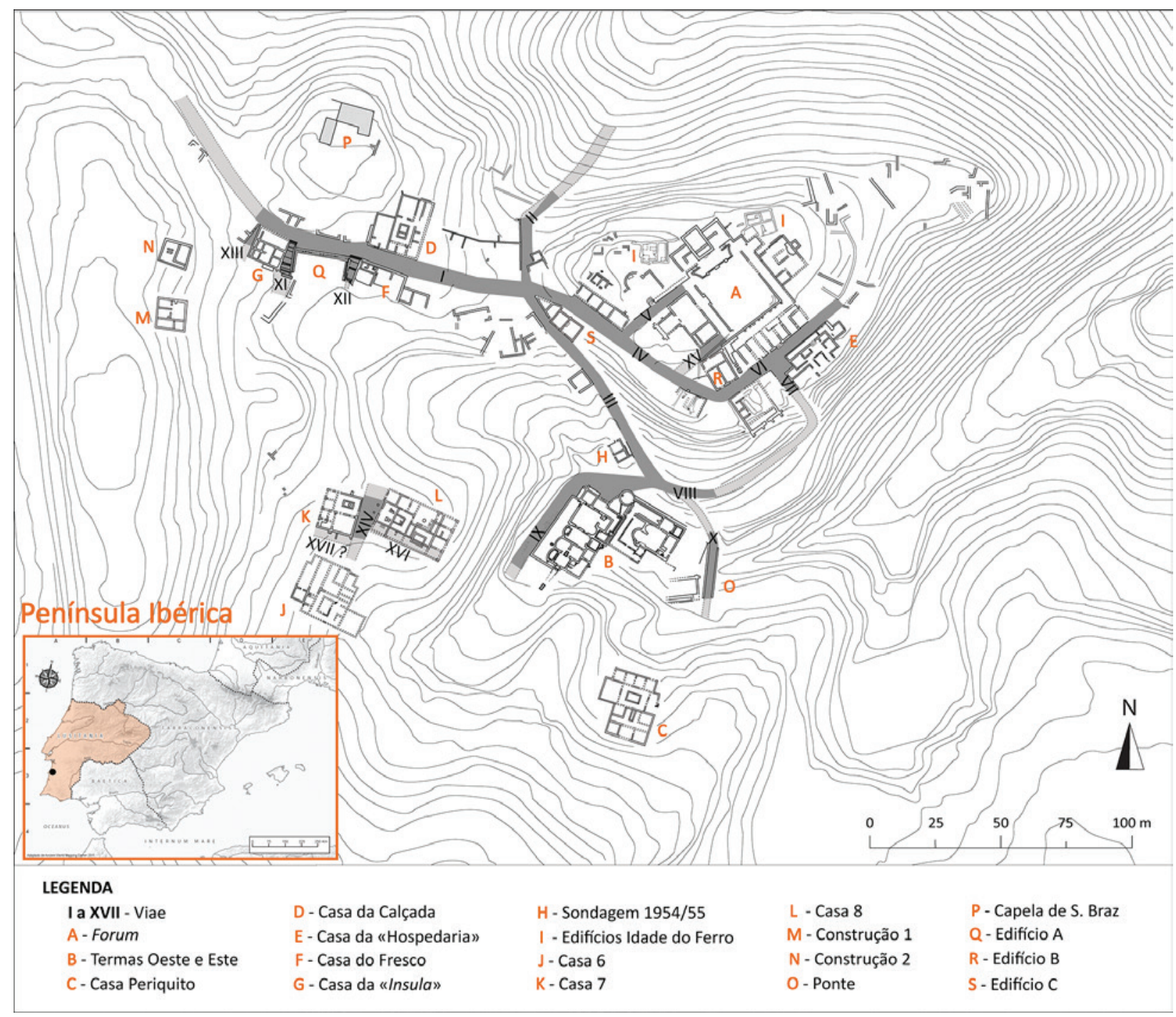

Figura 1 - Área urbana conhecida em Mirobriga. 

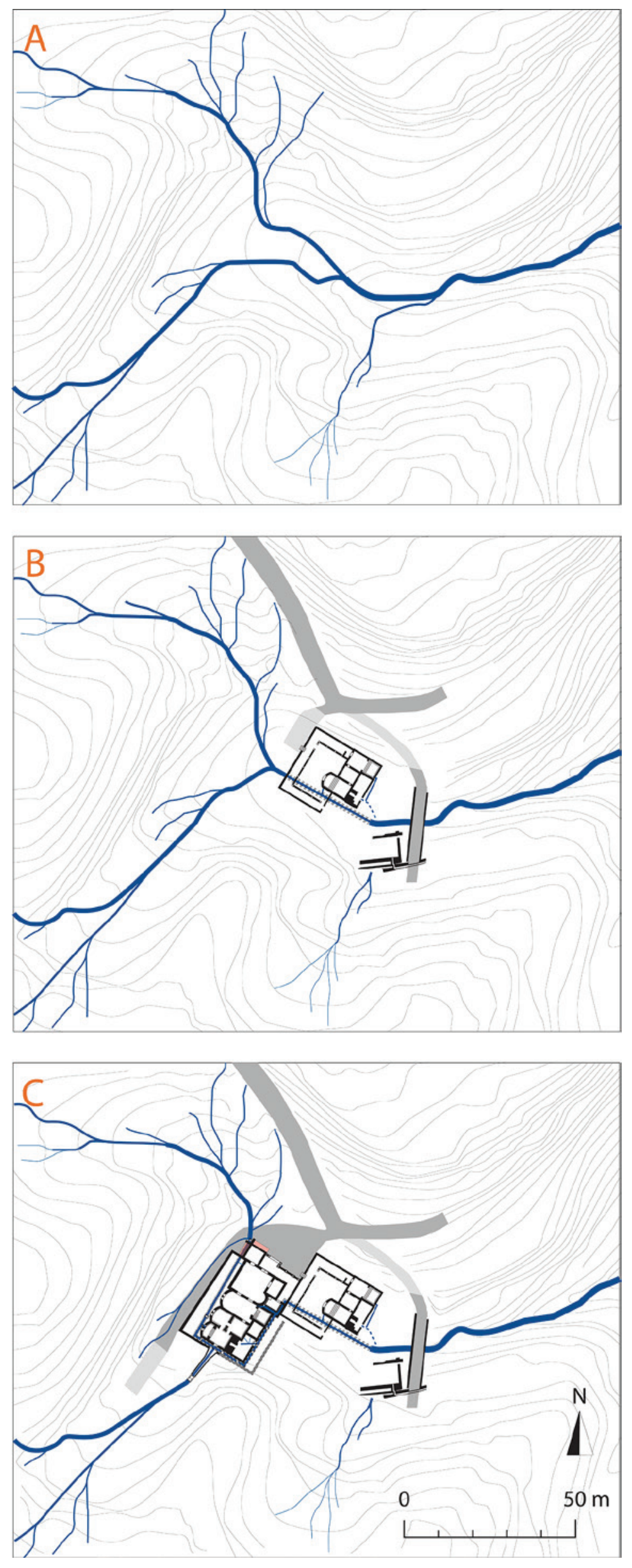

Figura 2 - Implantação dos edifícios termais e evolução das zonas de confluência de águas. (Linhas de água adaptadas de Teichner 2018, p.11) 

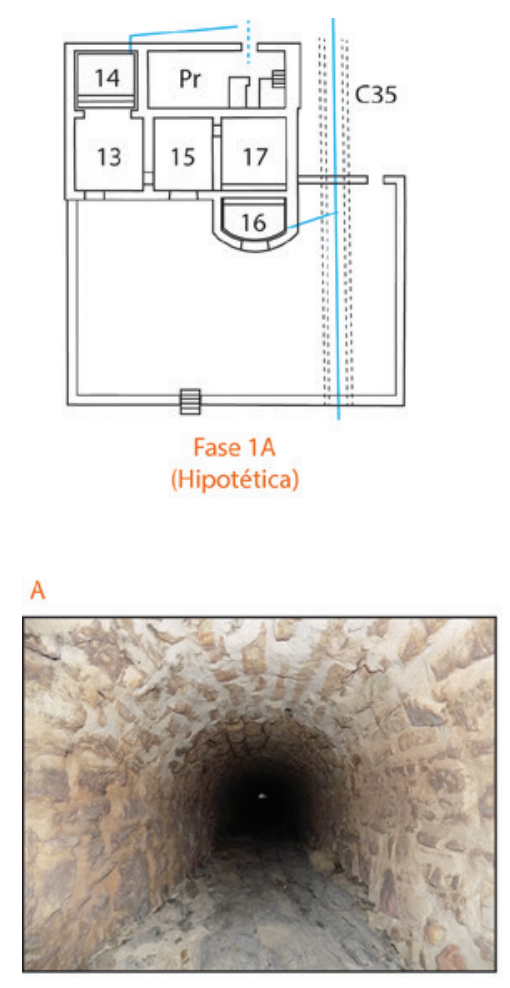

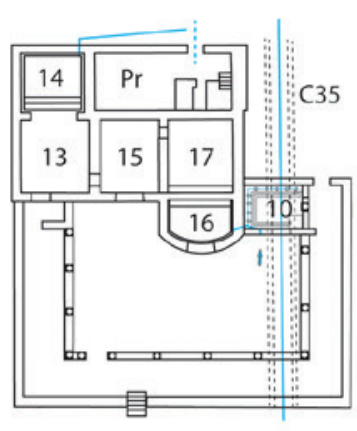

Fase $1 \mathrm{C}$

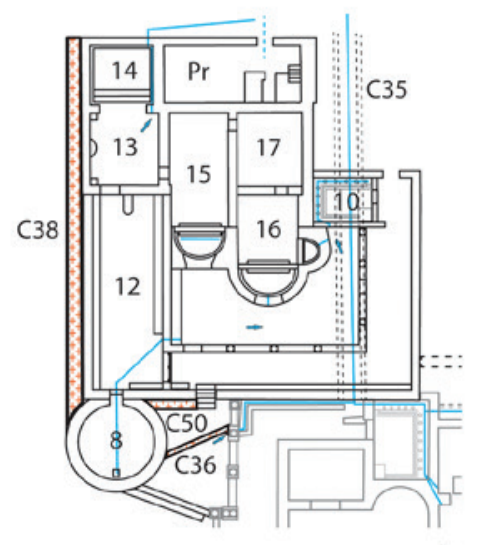

Fase 3

Figura 3 - Evolução do sistema de escoamento das Termas Este. A: Interior da cloaca C35.
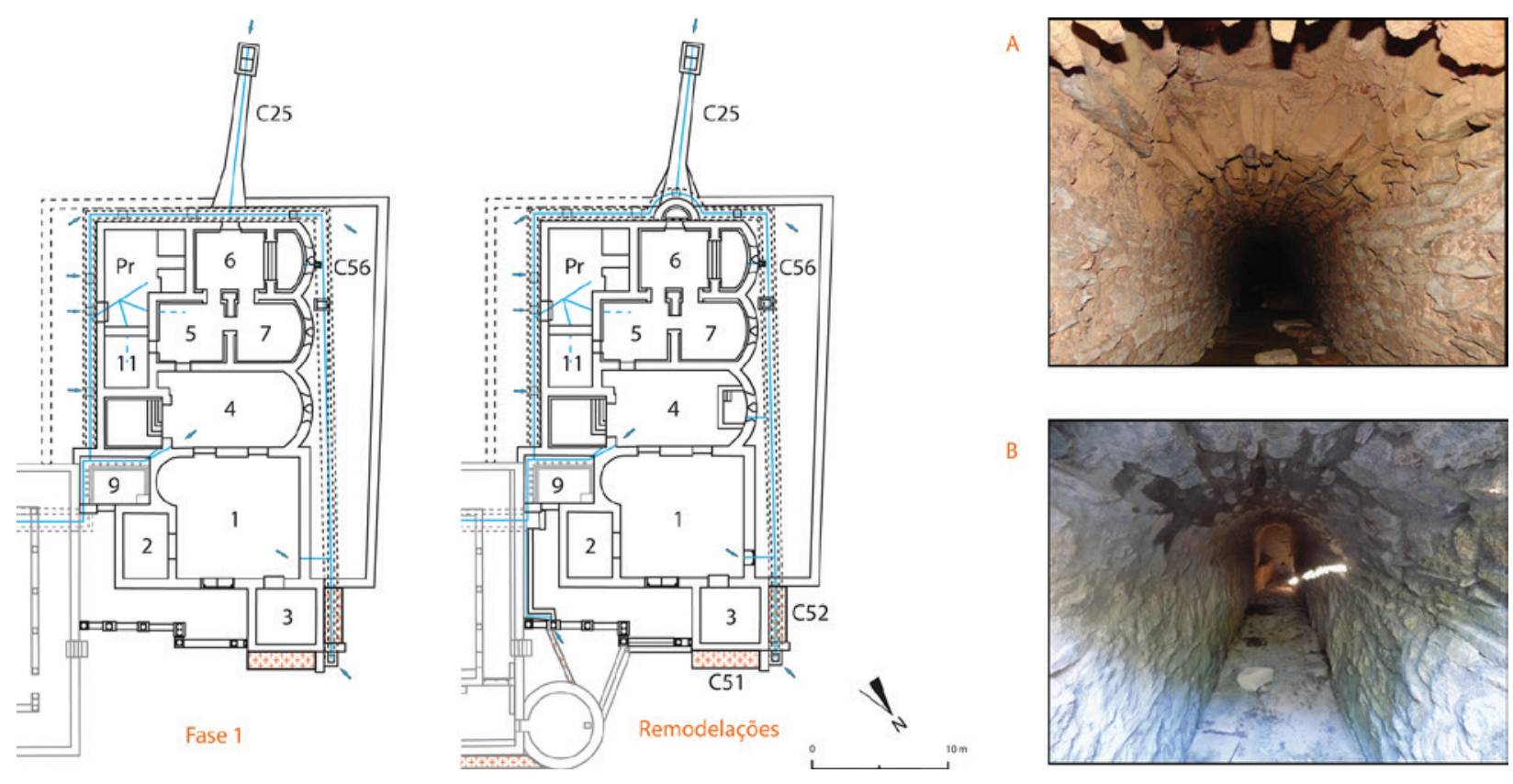

Figura 4 - Evolução do sistema de escoamento das Termas Oeste. A: interior do troço este da cloaca C56. B: Interior da cloaca C25. 


\title{
BALSA, TOPOGRAFIA E URBANISMO DE UMA CIDADE PORTUÁRIA
}

\author{
Vítor Silva Dias ${ }^{1}$, João Pedro Bernardes² ${ }^{2}$ Celso Candeias ${ }^{3}$, Cristina Tété Garcia ${ }^{4}$
}

\begin{abstract}
RESUMO
Prospeções geofísicas, sondagens e escavações arqueológicas recentemente levadas a cabo e ainda em curso no âmbito do projeto Balsa, searching the origins of Algarve, têm permitido compilar novos dados científicos sobre a antiga urbe, nomeadamente aferindo o que ainda se preserva e/ou o que já terá sido destruído, a extensão da cidade, algumas das suas realidades urbanísticas e topográficas ou, simplesmente, afastando definitivamente hipóteses de realidades arqueológicas que, comprovadamente, nunca existiram. Assente numa metodologia multivariada e recorrendo a diferentes tecnologias e especialistas, os resultados dos trabalhos já efetuados permitiram atestar que a urbe é mais pequena do que se supunha, estendendo-se por uma estreita faixa ao longo da ria Formosa; permitiram ainda conhecer a orientação da malha urbana, a localização e extensão da sua principal necrópole, a localização do fórum e, provavelmente, do “porto", bem como alguns aspetos da forma como a cidade evoluiu.
\end{abstract}

De uma forma necessariamente muito sintética, dá-se a conhecer o percurso metodológico dos trabalhos realizados, os resultados já obtidos, bem como as expetativas para os trabalhos futuros.

Palavras-chave: Métodos geofísicos, Cidade romana portuária, Sul da Lusitânia, Algarve romano.

\begin{abstract}
Geophysical surveys, field walking prospections and archaeological excavations recently carried out and still ongoing under the project, "Balsa, searching the origins of Algarve", have allowed us to know more about this ancient city, namely by assessing what is still preserved and / or what it will have been destroyed, the extension of the city, some of its urban and topographic realities or, definitively eliminating hypotheses of archaeological realities that, evidently, never existed. Based on a multivariate methodology and using different technologies and specialists, the results of the work already carried out allowed us to attest that the city is smaller than was supposed, extending along a narrow strip along the Ria Formosa; they also allowed to know the orientation of the urban plan, the location and extent of its main necropolis, the location of the forum, as well as some aspects of the way the city has evolved.
\end{abstract}

Keywords: Geophysical methods, Roman town, South Lusitania, Atlantic and Mediterranean, Roman Port City.

\section{O PROJETO DE INVESTIGAÇÃO: «BALSA - EM BUSCA DAS ORIGENS DO ALGARVE»}

Os resultados apresentados enquadram-se no âmbito do projeto: «BALSA - Em Busca das Origens do Algarve» ${ }^{5}$. Avaliado e aprovado pela Fundação da Ciência e Tecnologia e financiado pelo programa operacional do Algarve CRESC 2020, será desenvolvido entre 2019 e 2022, prevendo um conjunto de prospeções geofísicas e sondagens arqueológicas com vista a avaliar o potencial remanescente das ruínas do antigo burgo romano, bem como a sua atual

\footnotetext{
1. CIDEHUS.

2. Universidade do Algarve - CEAACP.

3. C. M. Tavira.

4. DRC Algarve-CEAACP.

5. Sobre o projeto veja-se a respetiva página Web em https://balsa.cvtavira.pt.
} 
real extensão, estando também prevista a realização de ações de divulgação de resultados. Desenvolvido pela Universidade do Algarve e o Centro de Ciência Viva de Tavira, a que se associam o Município de Tavira e a Direção Regional de Cultura do Algarve, surge na sequência das investigações realizadas em 2016-17 no âmbito da minimização de impactes (Dias, Bernardes, Mantas et alii, 2018, fig. 1, p.180) e da Resolução da Assembleia da República no 2007/2017 de 19 de junho (publicado no D.R., $1^{\mathrm{a}}$ série, $\mathrm{n}^{\circ}$ 155/2017 de 11 de agosto), que recomenda ao Governo a preservação das ruínas da antiga cidade romana de Balsa.

O plano de investigação visa, a partir da compilação de toda a informação dispersa e de uma abordagem transdisciplinar (arqueologia, história, geofísica, turismo), estudar a cidade romana de Balsa, clarificando a coexistência milenar das populações no extremo sudoeste da Península Ibérica com comunidades de marítimos que continuamente chegavam a este território. Com recurso a abordagens metodológicas interdisciplinares, procura ainda, especificamente, reconhecer os limites da cidade, bem como as infraestruturas que ainda se preservam, inferindo a importância da cidade e do seu porto. O objetivo principal é, pois, conhecer o que ainda subsiste da cidade romana, os seus limites reais e, finalmente, obter informação concreta que nos permita determinar a importância efetiva desta cidade no contexto das cidades marítimas do sul da Lusitânia.

Procurando comprometer a comunidade local aumentando o impacto social e territorial deste projeto de arqueologia, a componente científica cruza-se, nesta medida, com a formação da comunidade, num exercício de plena ciência cidadã. Através da realização de trabalhos arqueológicos, exposições, formação de operadores turísticos e ações de informação abertas à comunidade, levados a cabo pelo Centro de Estudos em Arqueologia, Artes e Ciências do Património (CEAACP) da Universidade do Algarve, em articulação com o Centro de Ciência Viva de Tavira, a Direção Regional de Cultura do Algarve e o Município de Tavira, espera-se não só recuperar muito da memória perdida desta cidade e das origens do Algarve como, de forma sustentável e integrada, lançar as raízes para a preservação de uma cidade costeira romana articulada na paisagem da Ria Formosa e, com isso, contribuir para a qualificação cultural e identitária da região, onde a natureza, o Património Cultural, a agricultura e a tradição concorrem de for- ma holística para a qualificação inteligente do território e para a sua capacidade atrativa (Figura 1).

Situada no extremo Sudoeste da Península Ibérica, a cidade romana de Balsa é um dos sítios arqueológicos mais importantes e emblemáticos do sul de Portugal ${ }^{6}$. Este sítio preserva ainda testemunhos e elementos de uma longa tradição decorrente de influências mediterrânicas e atlânticas, essenciais para se entender e definir a identidade da região do Algarve. A identificação de algumas estruturas da cidade de Balsa paredes meias com a ria Formosa, como sejam estruturas em opus caementicium e alguns tanques relacionados com atividades produtivas de processamento de peixe situados ao longo da sua margem, bem como um variado espólio com distintas origens e que aqui chega via marítima, vem acentuar a íntima relação que sempre existiu entre o mar, a ria Formosa e as ocupações urbanas do litoral algarvio, numa simbiose entre o elemento natural e cultural que, se excetuarmos raros exemplos (Garcia, 2008) não tem sido devidamente explorado na região (Figura 2) .

\section{OS TRABALHOS DE CAMPO: 2019}

Os trabalhos de escavação/sondagens arqueológicas, no âmbito deste projeto, tiveram o seu início durante o mês de agosto e conclusão em setembro de 2019, tendo sido previamente realizado levantamento fotogramétrico por drone e correspondente modelo digital de terreno (MDT), e modelo de elevação digital, incluindo curvas de nível, posteriormente integrados em plataforma SIG. Graças às sinergias conseguidas com a articulação do projeto internacional "ATLANTIR: del Atlantico al Tirreno", os trabalhos de campo tiveram o contributo de um conjunto de especialistas nacionais e estrangeiros, com destaque para a equipa espanhola de sedimentólogos, petrólogos, paleontólogos e geólogos das Universidades de Huelva, Sevilha e Barcelona. Privilegiou-se a continuidade da validação dos dados geofísicos obtidos anteriormente no âmbito

\footnotetext{
6. Este importante sítio arqueológico foi classificado como Imóvel de Interesse Público pelo Decreto nํㅡㄴ 6 -A/92 de 1 de junho, com Zona Especial de Proteção publicada na Portaria $n^{\circ} 516 / 2011$ de 27 de abril, com atualização recente da classificação para SIP-Sítio de Interesse Público - e aumento da área da ZEP em 9 de maio de 2017, através do Anúncio

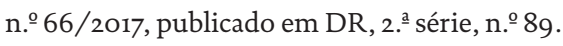


dos estudos de impacte dos trabalhos agrícolas no património arqueológico realizados em 2016/2017 (Figura 3 e 4).

Deste modo, foram continuadas as investigações, que, em 2017, nortearam a implantação da sondagem 4 (S4) e cujos resultados se mostraram inconclusivos quanto à origem (estruturas portuárias? ou outras?) das anomalias ali assinaladas (Dias, Bernardes, Mantas et alii, 2018, p.191-192), efetuando agora sondagens mecânicas (SM1-SM8, ver Figura 2). Por motivos idênticos foi alargada a sondagem 1 (S1, Figura 3 e 4) que revelou o cunhal de um edifício cuja natureza não tinha sido esclarecida (Dias, Bernardes, Mantas et alii, 2018, p. 187-189). Foi ainda aberta uma sondagem sobre a anomalia que a geofísica indiciara como uma estrutura absidada (S6), situada a três dezenas de metros a noroeste da anterior (Dias, Bernardes, Mantas et alii, 2018, fig. 6, p.186), de forma a validá-la como tal, conhecer o seu potencial e definir qual o grau de precisão deste tipo de dados obtidos por métodos não invasivos e correspondente interpretação. Se os resultados da prospeção geofísica em redor da sondagem 1 já tinham sido validados em 2017, tornava-se agora imperioso melhor aferir as relações entre as unidades estratigráficas e determinar as dimensões e orientação destas unidades entre elas e a geomorfologia do sítio. Os resultados de 2019 (Figura 5) revelam com clareza dois momentos construtivos de cronologia distinta nas estruturas murais. Um momento fundacional Alto Imperial [111], com silhares de volumetria generosa e outro, posterior, de cronologia Baixo Imperial [121], edificado em cima do primeiro, com matéria-prima reaproveitada (tégulas e ladrilhos/lateres) em posição visivelmente secundária. Este segundo momento construtivo aproveitando as bases fundacionais do Alto Império está associado a uma fase de pré-abandono da cidade onde os habitantes se apropriaram de espaço público. O exemplo das canalizações tardias [108] e [118], construídas em imbrices a uma cota superior sobre a via [112] já colmatada, demonstram que a transitabilidade do espaço público e correspondente fruição já não existia. Estas canalizações, muito frustres e já parcialmente destruídas pela ação mecânica dos trabalhos agrícolas, corriam, aparentemente, para a ria (Figura 5).

Esta área da cidade indicia, pois, ter tido pelo menos duas fases claramente distintas de ocupação do espaço urbano. Para além das canalizações, também a estrutura mural [117], localizada a norte da via alto- -imperial, a exemplo do que sucede a sul da mesma, na estrutura [121], são erigidas reaproveitando as bases murais alto-imperiais [119] e [111], respetivamente. A estrutura mural [121] e as canalizações [108] e [118] documentam muito bem o reaproveitamento de materiais construtivos, processo típico de maior parte das construções da Antiguidade Tardia, alterando a funcionalidade original dos imbrices para canalizações e a das tégulas para elementos murais. Curiosamente a aplicação das tégulas em cima dos silhares do Alto Império, documenta o momento do arranque da construção tardia, cuja verticalidade poderá ter sido em determinado momento desenvolvida em taipa. Indicia esta possibilidade a orientação/posição e composição da unidade [115]. De qualquer modo, esta interpretação, bem como a identificação da vala fundacional de [111] poderão ser clarificadas nas campanhas vindouras.

Já no limite norte da propriedade, junto à estrada em terra batida que ali passa foi implantada a sondagem 5. Esta resultou da necessidade de esclarecer se os elementos pétreos identificados em fase de acompanhamento arqueológico aquando dos trabalhos agrícolas de 2018 correspondiam a alguma evidência arqueológica, tentando assim caracterizar a sua eventual tipologia. A ausência de georreferenciação dos locais escavados por Estácio da Veiga ${ }^{7}$, aconselhou cautelas metodológicas acrescidas para este sítio. Assim a proximidade com o local da necrópole escavada por Estácio da Veiga recomendou a realização de uma sondagem/limpeza manual no ponto onde apareciam aquelas pedras. Os resultados desta sondagem $\left(\mathrm{S}_{5}\right)$ confirmaram que os elementos pétreos, apesar de sugestivos, não se encontravam in situ nem tinham continuidade em profundidade tendo, aparentemente, sido movidos por meios mecânicos e apresentando-se completamente desconexos e soltos. De qualquer forma a sua natureza e extensão bem como os parcos fragmentos cerâmicos detetados coadunam-se com a existência de uma qualquer estrutura funerária, indiciando que a necrópole escavada pelo pioneiro da arqueologia algarvia se estenderia até aqui (Figura 6).

\footnotetext{
7. No relatório técnico desta intervenção exercitamos a georreferenciação das coordenadas das intervenções de Estácio da Veiga segundo proposta de Carlos Pereira, (Pereira, 2018). De acordo com estes dados o distanciamento desta proposta para a sondagem no 5 regista $175 \mathrm{~m}$ (Bernardes, Dias e Candeias, 2019).
} 
A sondagem 6 (S6, Figura 6) pretendeu validar os anteriores dados da geofísica, cujo local correspondia a uma dupla abside. Tal como o alargamento da sondagem 1 , revelou-se determinante para paulatinamente conhecer com maior rigor a zona ribeirinha situada mais a nascente da Quinta de Torre D'Aires. Demonstrou ser igualmente crucial para aferir o grau de afetação mecânica e de fiabilidade entre as anomalias registadas inicialmente com metodologia geofísica e a natureza das estruturas arqueológicas ainda existentes no subsolo.

A estratigrafia do sítio documenta escasso potencial antrópico, revelando uma unidade estratigráfica superficial de terreno arável sujeita a intensas lavras [6oo] e uma unidade intermédia de sedimento ainda arável [6or], com cerca de $30 / 40 \mathrm{~cm}$, antes de identificados sulcos mecânicos regularizados de considerável dimensão [603] e respetivo enchimento [604]. Os sulcos mecânicos cortam de forma profunda o substrato geológico [612], sendo esclarecedora a exígua verticalidade dos estratos antrópicos e a elevada afetação mecânica de toda a área (cfr. Figura 7,8 e 9 ).

Apesar de muito afetada a estrutura em alvenaria calcária identificada como [605], aparenta corresponder à base de fundação da estrutura mural com morfologia planimétrica em abside identificada nos trabalhos de geofísica. A sua localização, orientação e dimensão coincidem com a interpretação feita durante aqueles trabalhos por Cornelius Meyer (Dias, Bernardes, Mantas et alii, 2018, fig. 6, p.186).

O elevado índice de afetação da estrutura e dos sedimentos que se lhe sobrepunham pressupõe o uso continuado de maquinaria pesada no local. Restando no registo arqueológico praticamente apenas a base fundacional de [605] e um pequeno fragmento dum provável pavimento [6o6], o interesse espacial e estratigráfico do local foi fortemente abalado, tornando no futuro mais pertinente explorar a resposta de outras questões porventura mais reveladoras e coerentes com o estado embrionário da investigação da cidade de Balsa, nomeadamente o profundo grau de afetação e/ou destruição do registo arqueológico em toda a vertente a norte desta sondagem, onde a potência de terras antrópicas é muito reduzida.

Com efeito, a sondagem 6 apesar de certificar a interpretação geofísica e espacial de 2017, atesta igualmente o elevado índice de afetação mecânica de toda esta área. Associando esta informação estratigráfica com os mesmos elementos informativos da sonda- gem 1, tudo indica que por ação mecânica as terras das cotas mais altas tenham sido mecanicamente arroteadas e transportadas seguindo a pendente natural e consequente desnível até à Ria Formosa. O grau de afetação por ação mecânica também está presente no elevado índice de fragmentação no pequeno mas coerente conjunto de materiais recolhidos, onde se destacam pequenos fragmentos de paredes finas e de terra sigillata sudgálica e hispânica que apontam para uma datação alto imperial deste contexto.

Verificando-se uma mobilização de terras pelo uso continuado de meios mecânicos ao longo de décadas na vertente que corre para a ria Formosa onde se localizam as sondagens 1 e 6 (Figura 1), os níveis superficiais de revolvimento identificados na Si terão sido mecanicamente transportados das cotas imediatamente acima, fazendo antever que o índice de preservação das estruturas arqueológicas aumente nas cotas altimétricas mais próximas da Ria Formosa.

Distando as sondagens ( $\mathrm{S}_{1}$ e S6) cerca de $33 \mathrm{~m}$ no sentido SE-NW o espaço que medeia entre elas parece indicar o intervalo a partir do qual aumenta consideravelmente a verticalidade das estruturas preservadas, graças à diminuição de afetação mecânica.

No que se refere às sondagens mecânicas (SM) realizadas na parte ocidental da propriedade, em todas elas é inexistente a presença de ocorrências arqueológicas. A perspetiva do conjunto de todas as intervenções devidamente cartografadas e fotografadas, apresenta uma noção integrada da caracterização estratigráfica da área poente da propriedade (cfr. Figura 2). A ausência de dados arqueológicos não confere com a interpretação da prospeção geofísica e condiciona diretamente a interpretação sobre a extensão da cidade de Balsa, encurtando a sua dimensão para W e provavelmente no sentido W-E se considerarmos o carácter genericamente ortogonal e simétrico que registam as cidades romanas.

A sondagem mecânica $1(\mathrm{SM}$ ), corresponde às imediações da localização da sondagem manual no 4 realizada em 2017, e materializou o tão desejado alargamento dessa sondagem com o objetivo de verificar possíveis lapsos de implantação de coordenadas e definitivamente atestar a presença ou inexistência de estruturas arqueológicas.

A ausência de quaisquer estruturas arqueológicas foi comprovada mecanicamente em extensão (c. de $12 \mathrm{~m}$ no sentido W-E e profundidade de 1,9o $\mathrm{m}$ ) e, apesar das anomalias decorrentes da interpretação dos dados geofísicos, não se confirmou qualquer estrutura 
ou ocorrência de natureza arqueológica e/ou contemporânea. Recorda-se que os dados obtidos por Geo-radar indicavam estruturas a cerca de 6o/8o cm (Dias e Freire, 2017, mapa 12A e 12B, p. 64-65). A realidade sedimentar registou sequência e características estratigráficas idênticas às já identificadas na sondagem manual realizada em 2017 (Figura 10). Confirmou-se, deste modo, que a hipótese de trabalho colocada anteriormente, de possível desfasamento de coordenadas na implantação da sondagem manual n4 4 , não se verifica e que no local não existem quaisquer ocorrências arqueológicas sugeridas pela interpretação geofísica.

Distando da SM1 apenas 4 metros, a SM2 pretendeu igualmente aferir a validade da estrutura circular interpretada pelos dados da geofísica. Também neste caso os resultados estratigráficos confirmam a ausência de dados arqueológicos contradizendo a interpretação da geofísica. O solo regista até esta latitude características dunares e marítimas.

As $\mathrm{SM}_{3}$ e $\mathrm{SM}_{4}$ registaram dados semelhantes, apresentando características sedimentares que denotam uma clara transição para ambiente mais terreste e menos marítimo.

A localização da sondagem mecânica (SM9), distante de qualquer sondagem realizada, pretendeu averiguar as possíveis estruturas ortogonais identificadas em 2017 na fotografia aérea (Dias e Freire, 2017, mapa 1, p. 49). Tal como as restantes sondagens mecânicas apenas foram identificadas unidades sedimentares sem inclusões arqueológicas ou patrimoniais. Afasta-se, assim, a possibilidade de em toda esta área próxima da ribeira da Luz terem existido quaisquer estruturas portuárias, desconhecendo-se, no caso da Balsa, por enquanto, quaisquer dados sobre estruturas portuárias romanas ou sobre elementos de sinalização de apoio à navegação, tão frequentes na costa portuguesa (Fabião, 2014, 102-103).

\section{INTERPRETAÇÃO DOS RESULTADOS}

Considerando os resultados alcançados e apesar da fase embrionária da investigação sugerir, naturalmente, mais questões do que respostas, teve a presente campanha dois principais objetivos. O primeiro visava verificar a existência de estruturas arqueológicas no limite poente da propriedade; o segundo, aferir os índices de afetação na sua parte nascente.

Relativamente ao primeiro objetivo, impôs-se como imperioso averiguar a existência, ou não, de estru- turas portuárias na parte mais ocidental da quinta, junto à ribeira da Luz, onde alguns indicadores (fotografia aérea e métodos de deteção remota, não invasivos) e vária bibliografia sugeria poder situar-se o porto da cidade (Silva, 2007, pp. 68, 98, 100; Mantas, 2016, pp. 40-41) ${ }^{8}$. Foram realizadas 9 extensas sondagens mecânicas, perfazendo um total de c. 120 $\mathrm{m}^{2}$, com recurso a retroescavadora que, durante mais de um dia, sondaram os terrenos onde se situavam os indícios (geofísicos) de estruturas. Sondagem após sondagem, foi-se descartando a possibilidade de existência de qualquer estrutura portuária ou de outra tipologia, bem como de materiais arqueológicos. Os raros fragmentos cerâmicos de origem romana que surgiram, confirmaram-se muito rolados, denotando, claramente, terem sido transportados da sua posição primária. Registo arqueológico contrastante, por exemplo, com a importante área industrial de preparados de peixe associada a fragmentos anfóricos nos lodos da zona ribeirinha de Ossonoba (Viegas, 2011; Bernardes, 2012; Bernardes, 2017b), cuja densidade de fragmentos identificados mais se parece assemelhar à zona escavada por Manuel e Maria Maia (Maia \& Maia, 1978), apesar das intensas afetações mecânicas ainda documentada nas prospeções de 2016 e 2017 (Dias, Bernardes, Mantas et alii, 2018, fig.3, p. 183).

A realidade sedimentar e a ausência de estruturas portuárias a poente, claramente contradiz a interpretação dos dados da prospeção geofísica (Dias e Freire, 2017, mapas 12A, 12B, 12C, p. 64-66). O registo estratigráfico permitiu traçar um padrão coerente entre as sondagens sendo possível definir espacialmente quais são as sondagens com matriz sedimentar marítima (SM1; SM5; SM6; SM7) e quais as sondagens com matriz terreste ( $\mathrm{SM}_{2} ; \mathrm{SM}_{3} ; \mathrm{SM}_{4}$; $\left.\mathrm{SM} 8\right)$. Os perfis estratigráficos são genericamente associados a unidades de cariz geológico com cronologia recente como os depósitos dunares eólicos e as rochas sedimentares (margas) correspondentes a antigos depósitos marinhos e lacustres de material clástico. O carácter excecional que o porto de Balsa poderia significar na estratégia portuária da costa da Lusitânia onde essencialmente se privilegiariam as condições naturais e não a construção estruturada e artificial de apoios à atracagem ou ancoradouro (Mantas,

8. Sobre a sequência dos trabalhos arqueológicos e geofísicos, bem como as expetativas sobre o potencial deste sítio vide também Dias, Bernardes, Mantas et alii, 2018, 191. 
2017, p. 185) também não se confirmou. A abertura das sondagens permitiu reconhecer os limites da antiga ria através dos fundos lodosos que apareceram, cuja natureza e extensão impossibilitavam a existência de qualquer porto no local, conforme foi confirmado pela equipa de geólogos e sedimentólogos de várias universidades espanholas que se deslocaram ao local.

Face a estes dados, fica completamente descartada a possibilidade da cidade romana de Balsa se estender até junto da ribeira da Luz, devendo o seu limite mais ocidental situar-se no fim do declive da colina que cai para o vale daquela linha de água. A identificação de algumas sepulturas tardias nesta área, em 2017 (Dias, Bernardes, Mantas et alii, 2018, fig. 12, pp.19o-191), reforça a ideia de que os limites ocidentais da cidade se situariam por esta longitude. A presença desta necrópole, distando cerca de 275 $\mathrm{m}$ do local da sondagem 4 (e da SMi), onde a geofísica interpretava a presença de fundações estruturais, que se pensavam com provável funcionalidade portuária, reforça a possibilidade da cidade ser mais curta para $\mathrm{W}$ do que inicialmente se pensou depois da interpretação dos resultados geofísicos. Quanto às anomalias detetadas remotamente e algumas também visíveis em fotografia aérea, é plausível explicá-las através de alterações no solo provocadas por intensos revolvimentos mecânicos, eventualmente associados à implantação de sistemas de rega nas últimas décadas aliás bem identificados em uma das sondagens (SM 6) e pontualmente visíveis à superfície entre SM4 e SM8.

$\mathrm{Na}$ ausência de novos dados, e pressupondo que a necrópole a que correspondem as sepulturas identificadas em 2017 poderá significar o limite $\mathrm{W}$ da cidade de Balsa, as estruturas portuárias certamente que se localizaram noutro local que não o interpretado/ sugerido pelos dados da geofísica e que não foram atestados, quer pela sondagem manual 4 de 2017 , quer pelo alargamento mecânico da mesma sondagem em 2019: SM1, SM 2, SM 3 e SM 7.

Descartada a presença de estruturas arqueológicas na parte mais ocidental da propriedade, sugere-se que o porto de eleição da cidade se situasse na proximidade do fórum, onde dados geomorfológicos e fontes orais documentam a presença de um cais. De resto, e por uma questão prática, é bem conhecida a tendência dos fora das cidades marítimas se situarem próximo dos locais de acesso a partir do mar, como é o caso da vizinha cidade de Ossonoba (Bernardes 2017b).
Para a credibilização desta hipótese contribuem a proximidade das cetárias escavadas por Manuel Maia e Maria Maia (Maia \& Maia, 1978), bem como o registo de maior presença de recipientes de armazenamento em toda esta zona aquando dos trabalhos de prospeção sistemática de superfície (Dias, Bernardes, Mantas et alii, 2018, fig. 3, p.183). A importância económica, da pesca, do sal e da produção dos preparados de peixe nas cidades ribeirinhas da Lusitânia com boas condições portuárias, ocupou papel de grande destaque nestas comunidades (Fabião 20oo; 2006), influenciando diretamente não só a dinâmica exportadora, como a dieta alimentar e o urbanismo (Bernardes, 2015). As dificuldades na identificação do local de implantação do porto de Balsa esbarram quer na obtenção de novos dados preferencialmente com metodologia multidisciplinar, quer na variada tipologia de soluções "naturais" aplicada na seleção dos "portos” romanos (Mantas, 2016).

Em relação ao outro grande objetivo destas intervenções, avaliar o grau de destruição e, consequentemente, aferir a existência, ou não, de ruínas pertencentes à antiga cidade, verificou-se, de forma clara, o nível e a profundidade de afetação das estruturas romanas provocada pelas práticas agrícolas.

Nas duas sondagens abertas na parte oriental da Quinta (Si e S6), observou-se que o terreno foi rompido e ripado por escarificador de máquina de rastos até $70 / 80 \mathrm{cms}$ de profundidade. Assim, todas as estruturas soterradas a profundidades inferiores foram destruídas ou seriamente afetadas (cfr. figuras $6,7,8,9)$. É o caso do grande edifício com dupla abside revelado pela prospeção geofísica e parcialmente detetado na sondagem 6 , que poderia ter pertencido a um complexo termal ou edifício de grandes dimensões, cujos alicerces, a pouca profundidade, foram parcialmente arrancados pela ripagem do terreno, vendo-se bem as marcas dos dentes mecânicos (rippers) no solo e camada geológica (S6).

Estas mesmas marcas estão igualmente bem documentadas no registo estratigráfico e sedimentar de S1, com cerca de $35 \mathrm{~m}^{2}$ e situada na vertente mais perto da ria. No entanto, como a potência de terras aqui é muito maior, praticamente o processo de arroteamento afetou apenas o topo das estruturas arqueológicas que se conservaram até ao século XX (cfr. fig. 3).

Nesta sondagem (SI), a partir dos $70 \mathrm{~cm}$ de profundidade, deteta-se ainda uma canalização e restos de muros romanos tardios (datáveis a partir dos sécs. 
III/IV) que assentam em estruturas murais de época anterior, de boa construção, que definem um entroncamento de ruas. A altura conservada destes muros é variável, podendo atingir cerca de $80 \mathrm{~cm}$. $\mathrm{O}$ conjunto destas estruturas correspondem a uma fachada alinhada do lado sul de uma rua, que corre no sentido Este/Oeste, e o que parece ser o entroncamento de uma segunda rua perpendicular à primeira, vendo-se uma esquina da mesma e o seu entaipamento por estruturas tardias.

Como a intervenção neste primeiro ano foi meramente exploratória, ficou por investigar o interior dos edifícios daquela fachada sul ou as edificações relacionadas com a outra rua. De qualquer forma, parece claro que a partir de cerca de 50 metros para norte da ria, onde a potência estratigráfica de terra antrópica é relativamente diminuta, as estruturas romanas estão muito afetadas ou simplesmente já não existem. Em contrapartida, na faixa junto à ria Formosa mantém-se ainda um forte potencial arqueológico que tencionamos continuar a conhecer nas próximas campanhas.

Importante também nos anos vindouros seria melhor perceber o que ainda existe nos terrenos a nascente da atual propriedade da Quinta da Torre d'Aires, por onde a malha urbana se estendia. A proposta de intervenção para os próximos anos nestes terrenos por métodos não invasivos e/ou de escavação está necessariamente dependente da autorização dos proprietários e dos arrendatários da(s) propriedade(s).

Quer seja pelas dificuldades inerentes à preservação do registo arqueológico, pelo ritmo dos estudos, ou mesmo por um maior interesse "orientalizante" do tráfego marítimo em detrimento do atlântico, a investigação na região (Bernardes, 2017a) seguiu um rumo que resultou numa secundarização da importância dos ritmos comerciais atlânticos (Fabião 2014; Mantas, 2016; Mantas, 2017). Representa a costa algarvia, onde está localizada a cidade portuária de Balsa, não só, o "pré-Mediterrâneo” de Orlando Ribeiro, ou o prolongamento da Andaluzia Ocidental (Fabião, 2009), mas também, algo aparentemente contraditório cuja dinâmica marítimo-económica e cultural se materializa numa região singular, que funciona ora como fronteira geográfico-administrativa, ora como elo, entre os dois mundos.

Um particular prolongamento do Mare Nostrum até à costa ocidental atlântica (cabo de São Vicente), ou uma marcada gaditanização da costa algarvia (Sousa \& Arruda, 2010), têm sido amplamente debatidos como características regionais, destacando diversos autores o papel de Cádis e a estreita relação deste importante porto com a costa algarvia (Fabião, 200o; Bernardes, 2017b; Mantas, 2017; Sousa \& Arruda, 2010). Fará todo o sentido pormenorizar, no futuro, o papel de cidades portuárias como Balsa, na dinâmica comercial marítima entre Bética, Lusitânia e Mauritânia Tingitana (Mantas, 1998), documentada já em fase pré-romana tanto na costa algarvia (Arruda, 2001), como nos contatos atlânticos (Fabião, $2014,100)$ e fortemente indiciada pela epigrafia (IRCP). Somente multiplicando os casos de estudo semelhantes ao de Balsa, será possível, por exemplo, melhor compreender aquelas dinâmicas comerciais. Não sendo necessário, por razões históricas resgatar a importância do mar na tradição algarvia ou lusitana, não será, por motivos idênticos, necessário relembrar a importância regional e simbólica, tal como o intrigante e complexo tema das continuidades e descontinuidades da ocupação humana (Fabião, 2009, 559) associado à costa algarvia, à cidade de Balsa e seu porto. Não faltarão por isso, boas razões, nem motivos, para continuar a investigar o urbanismo de Balsa e a sua natural vocação marítima com metodologia arqueológica e abordagens interdisciplinares.

\section{BIBLIOGRAFIA}

ARRUDA, A. M. (2001) - Importações 'púnicas' no Algarve: cronologia e significado, in A. Tavares, M. J. Ferro e J. L. Cardoso (orgs.), Os Púnicos no Extremo Ocidente. Lisboa, pp. 69-98.

BERNARDES, J. P. (2012) - A cidade de Ossónoba e o seu território, Anais do Município de Faro, XXXVII, pp.11-26.

BERNARDES, J. P. (2015) - Consumo e transformação de peixe entre o mundo romano e o islâmico, in S. Gomez Martinez (Coord.), Memória dos Sabores do Mediterrâneo, Campo Arqueológico de Mértola/ Centro de Estudos Arqueológicos das Universidades de Coimbra e Porto. pp. 55-68.

BERNARDES, J. P. (2017a) - O Sul da Lusitânia Romana nos últimos 25 anos: avanços e novas perspetivas de investigação, in T. Nogales Basarrate (ed.), Atas IX Mesa Redonda Internacional de Lusitania Romana: del passado al presente de la investigación / EMuseu Nacional de Arte Romano 29-30 septiembre 2016. Mérida. pp. 275-292.

BERNARDES, J. P. (2017b) - O sistema portuário de Ossonoba, In Juan M. Campos Carrasco, Javier Bermejo Meléndez (eds), Los puertos atlánticos béticos y lusitanos y su relación comercial con el Mediterráneo /. Huelva. Universidad de Huelva. Hispania Antigua, Serie Arqueológica, 7 , pp. 379-398. 
BERNARDES, J.P., DIAS V.S. e CANDEIAS, C. (2019)-Balsa em busca das origens do Algarve (saict-alg/39581/2018). Estação Arqueológica Romana da Luz - Balsa (C.N.S.: 6o). (Dactilografado, disponível na DGPC).

DIAS, V. S.; FREIRE, J. (2017) - Relatório Final. Prospeção sistemática, prospeção geofisica e sondagens arqueológicas na Quinta de Torre d'Aires. Estação arqueológica romana da Luz-Balsa (CNS: 6o). Archaeofactory. Faro (Disponível na DGPC).

DIAS, V.S. e BERNARDES, J. P., MANTAS, V., FREIRE, J. e DORES, T. (2018) - A cidade romana de Balsa: novos dados e algumas problemáticas da prospeção geofísica em meios muito humanizados, in J. P. Bernardes et. alii., Arqueologia Urbana em Centros Históricos, Faro: Universidade do Algarve, pp. 178-195.

FABIAO, C. (200o) - O sul da Lusitania (Algarve Portugues) e a Baetica: concorrencia ou complementaridade?, in Ex Baetica Amphorae, Actas do Congresso Internacional "Conservas, aceite y vino de la Betica en el Imperio Romano. Ecija: 717-730.

FABIÃO, C. (2006) - A exploração de recursos marinhos na Lusitania romana: balanço dos conhecimentos e perspectivas da investigação, in Historia de la pesca en el ámbito del estrecho. I Conferencia internacional, (Puerto de Santa María Cádiz, Junho de 2004), Cádis, pp. 489-529.

FABIÃO, C. (2009) - Cetárias, ânforas e sal, Estudos Arqueológicos de Oeiras. Oeiras: Câmara Municipal de Oeiras, pp. 555-594.

FABIÃO, C. (2014) - Uma história resgatada ao mar. Vestígios de rotas marítimas romanas nas costas portuguesas, in A. Silveira (coord.), O Tempo Resgatado ao Mar. Lisboa: 99-104.

GARCIA, C. (2008) - Cacela, Terra de Levante. Memórias da Paisagem Algarvia, C. M. de Vila Real de Santo António/ Campo Arqueológico de Mértola.

MAIA, M. G. P.; MAIA, M. (1978) - Relatório da Campanha de escavações realizada em Torre de Ares (Tavira) entre 24 de Outubro e 25 de Novembro de 1977 (Datilografado, disponível na DGPC).

MANTAS, V. G. (1998) - Navegação, economia e relações interprovinciais. Lusitânia e Bética, Humanitas, 50: 199-239.

MANTAS, V. G. (2016) - Navegação e Portos no Algarve Romano, AlUlya, XVI, Loulé, pp. 2551.

MANTAS, V. G. (2017) - Navegação, centros urbanos e espaços portuários na Lusitania, in T. Nogales Basarrate (ed.) Atas IX Mesa Redonda Internacional de Lusitania Romana: del passado al presente de la investigación, (Museu Nacional de Arte Romano 29-30 septiembre 2016), Mérida. pp. 179-208.
PEREIRA, C. S. P. (2018) - As Necrópoles Romanas do Algarve: acerca dos espaços da morte no extremo sul da Lusitânia, (Suplemento 9 do O Arqueólogo Português), Lisboa: Museu Nacional de Arqueologia / Imprensa Nacional.

SILVA, L. F. da (2007) - Balsa, Cidade Perdida, Tavira: Campo Arqueológico de Tavira / Câmara Municipal de Tavira.

SOUSA, E. \& ARRUDA, A. M. (2010) - A Gaditanização do Algarve, Mainake, XXXII (II), 951-974. Málaga: Universidad de Málaga.

VIEGAS, C. (2011) - A ocupação romana do Algarve. Estudo do povoamento e economia do Algarve central e oriental no período romano (Estudos e Memórias, 3), Lisboa. 


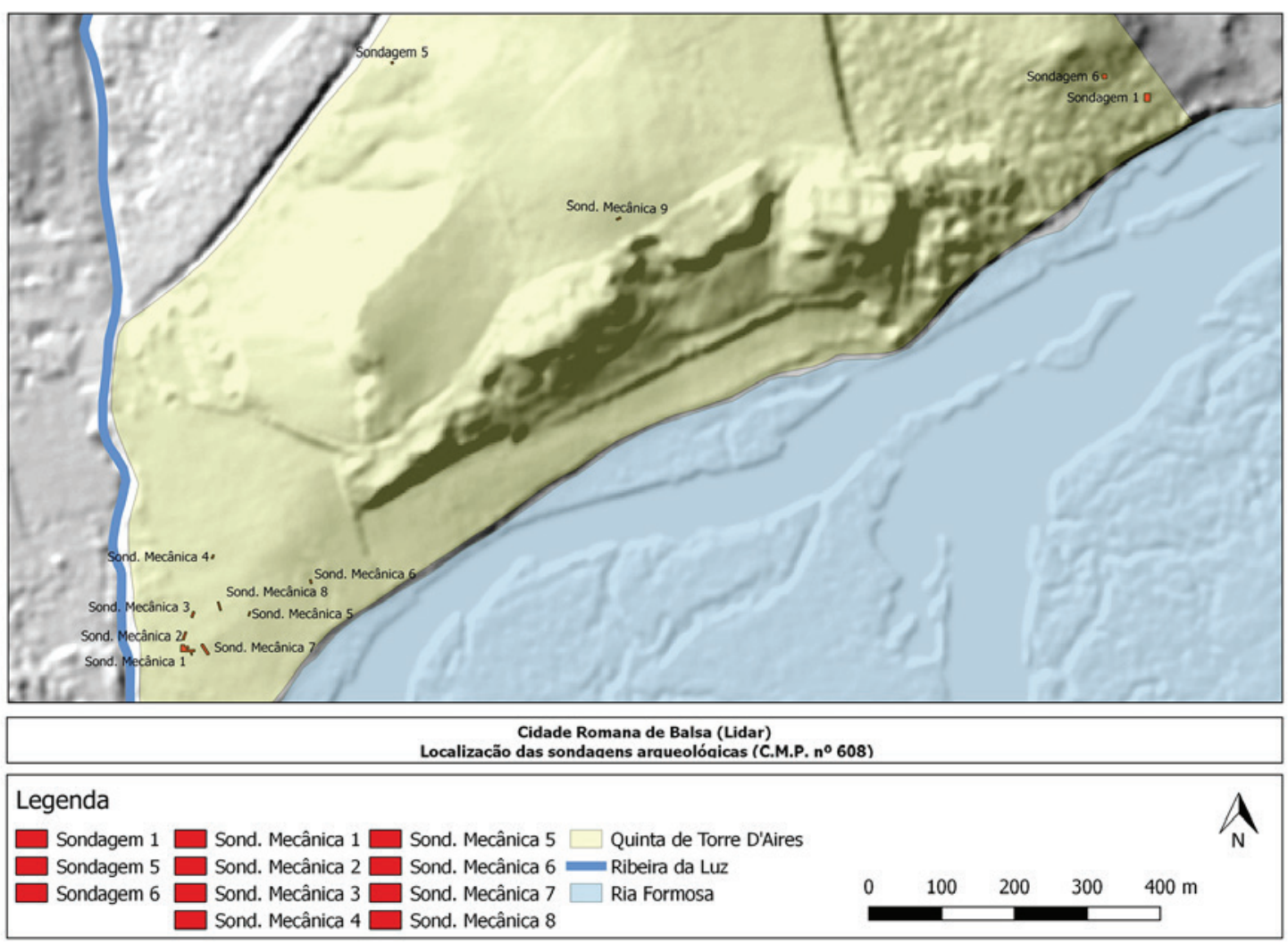

Figura 1 - Localização das sondagens manuais (S) e das sondagens mecânicas (SM).

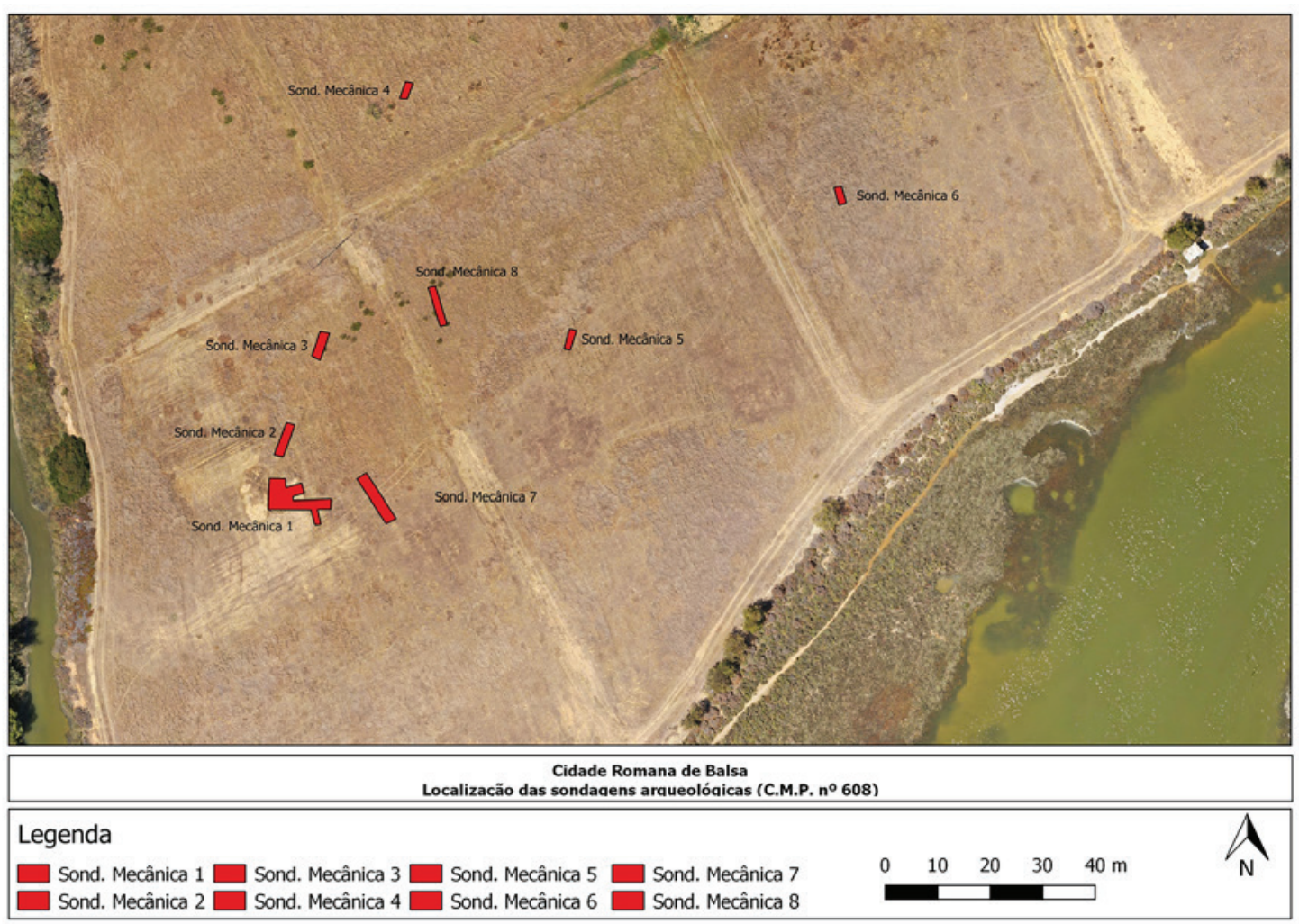

Figura 2 - Localização das mecânicas (SM1 - SM8). 


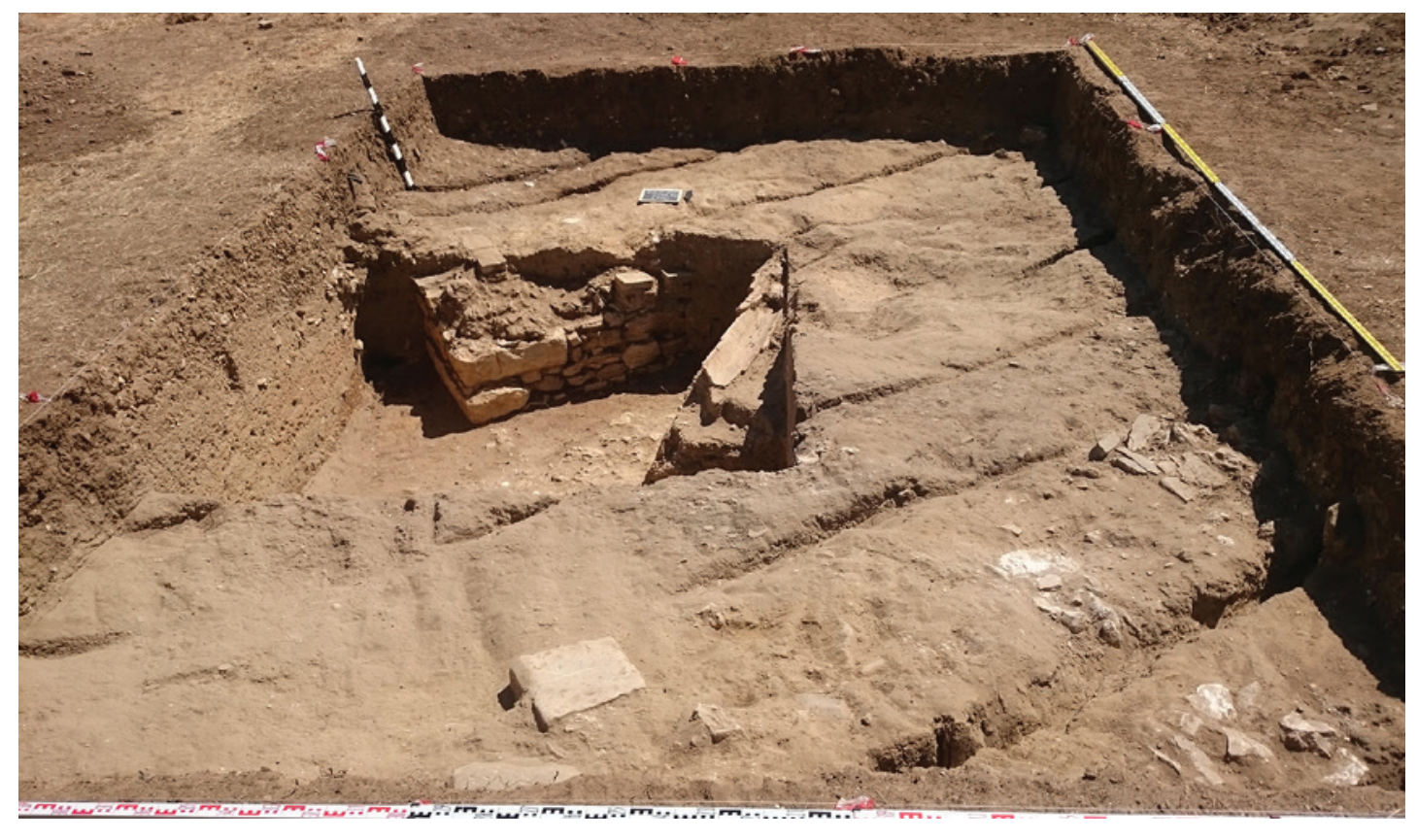

Figura 3 - Alargamento da Sondagem 1.

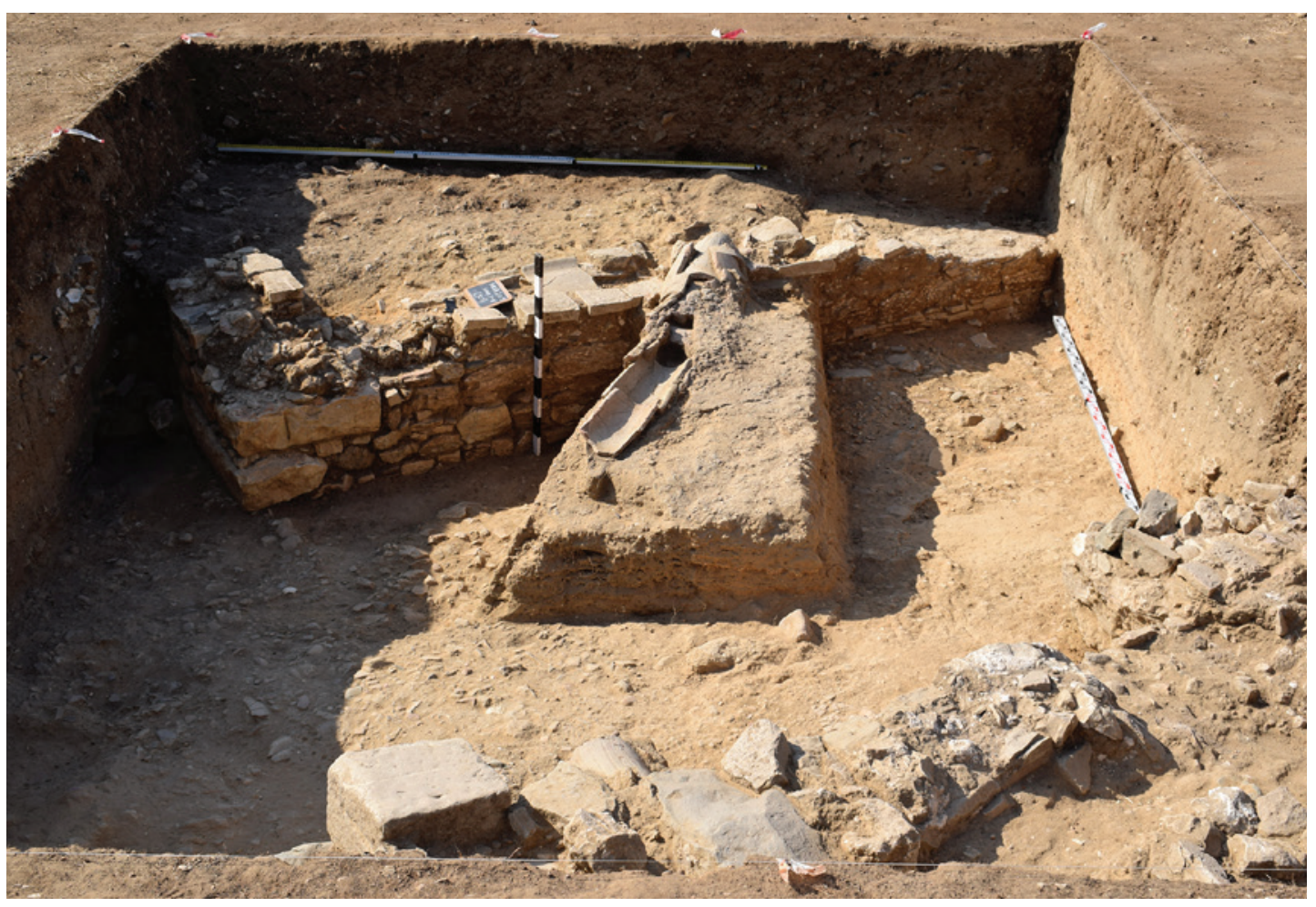

Figura 4 - Figura 6 plano final da sondagem 1. 

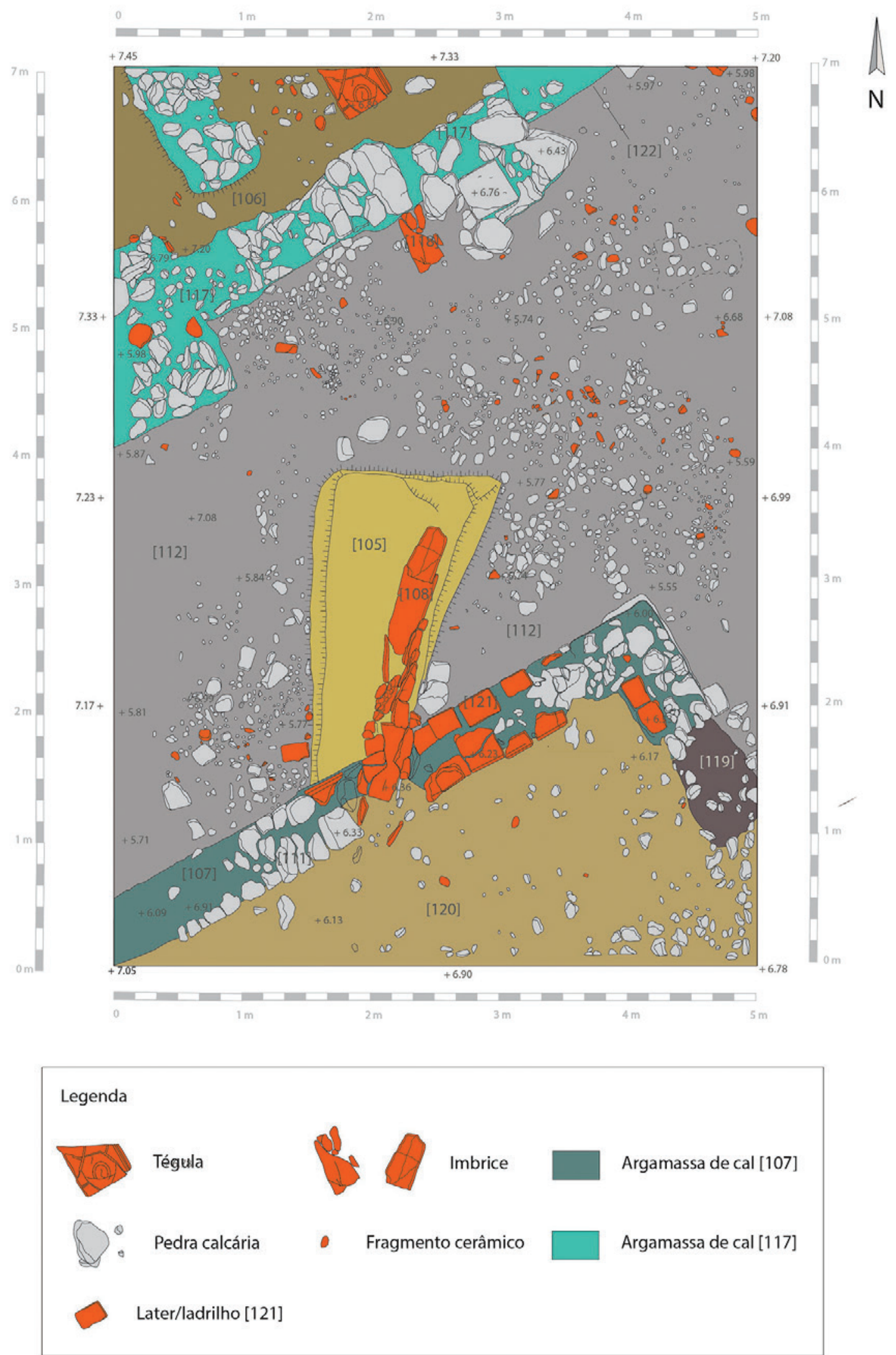

Figura 5- Plano final da sondagem 1. 


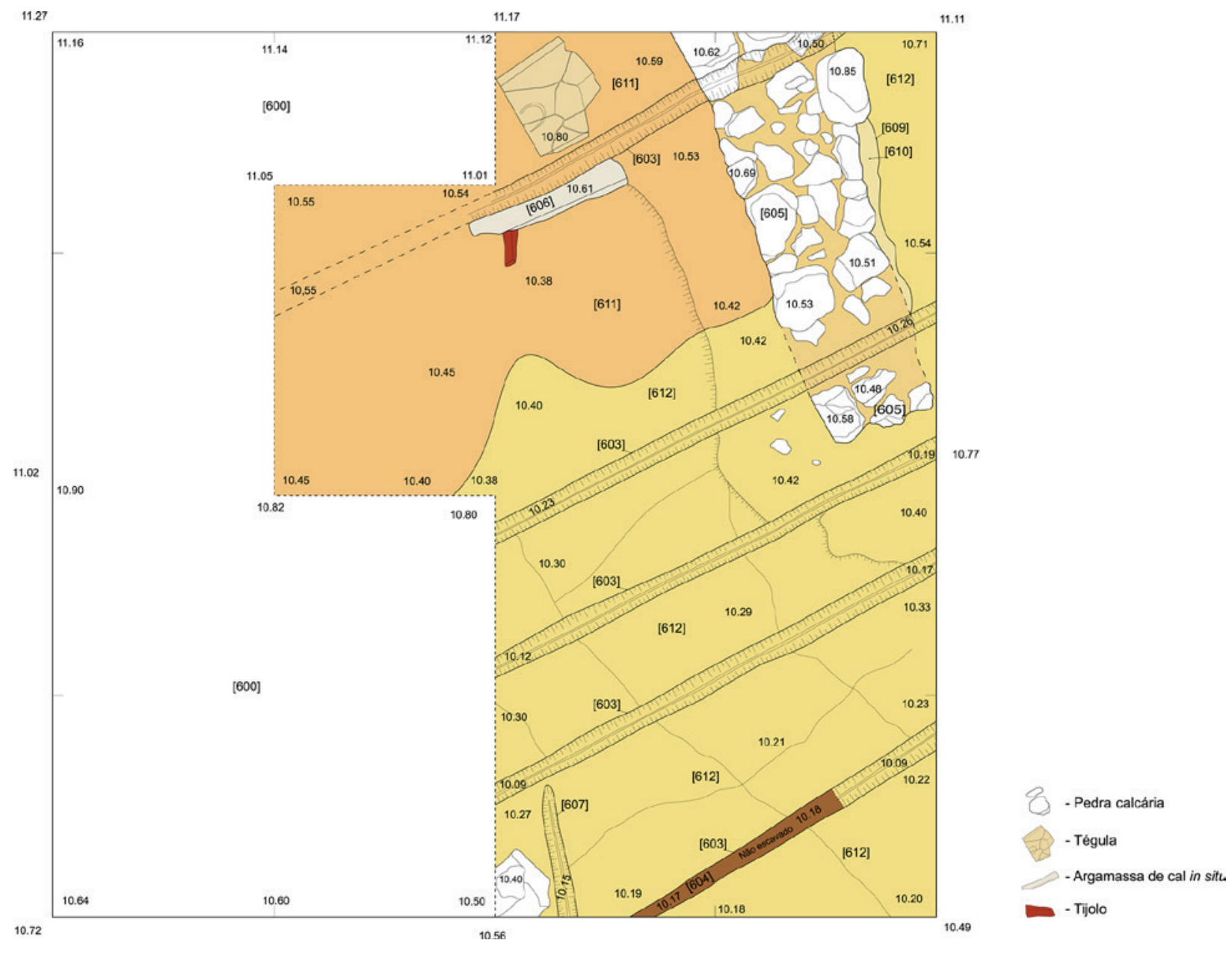

Figura 6 - Plano final da sondagem 6.
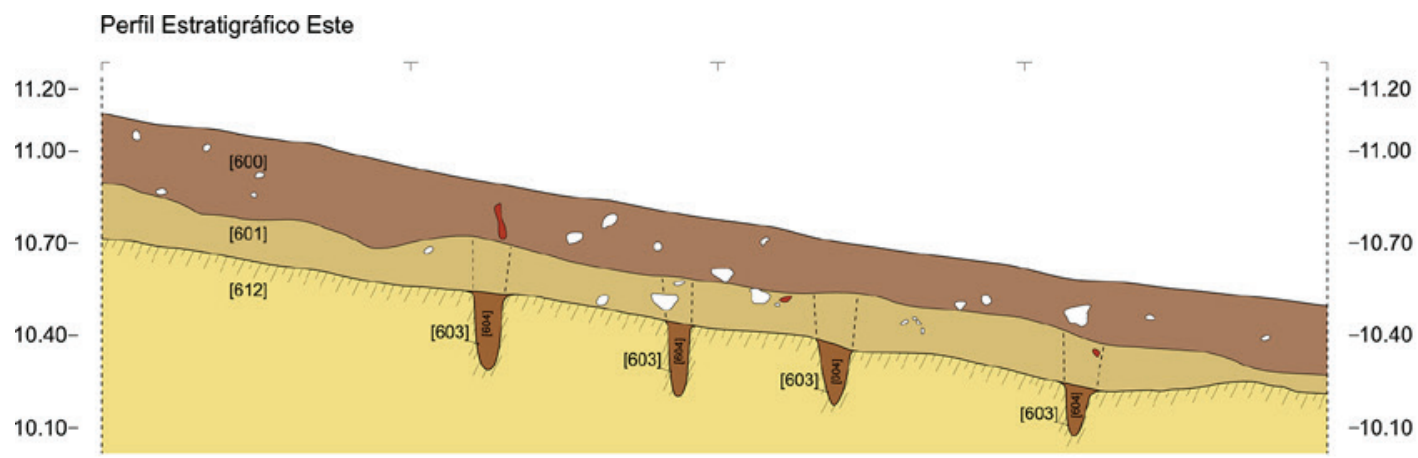

30. Pedra calcárie
2 - Cerămica

$-10.10$

Figura 7 - Perfil estratigráfico Este da sondagem 6. 


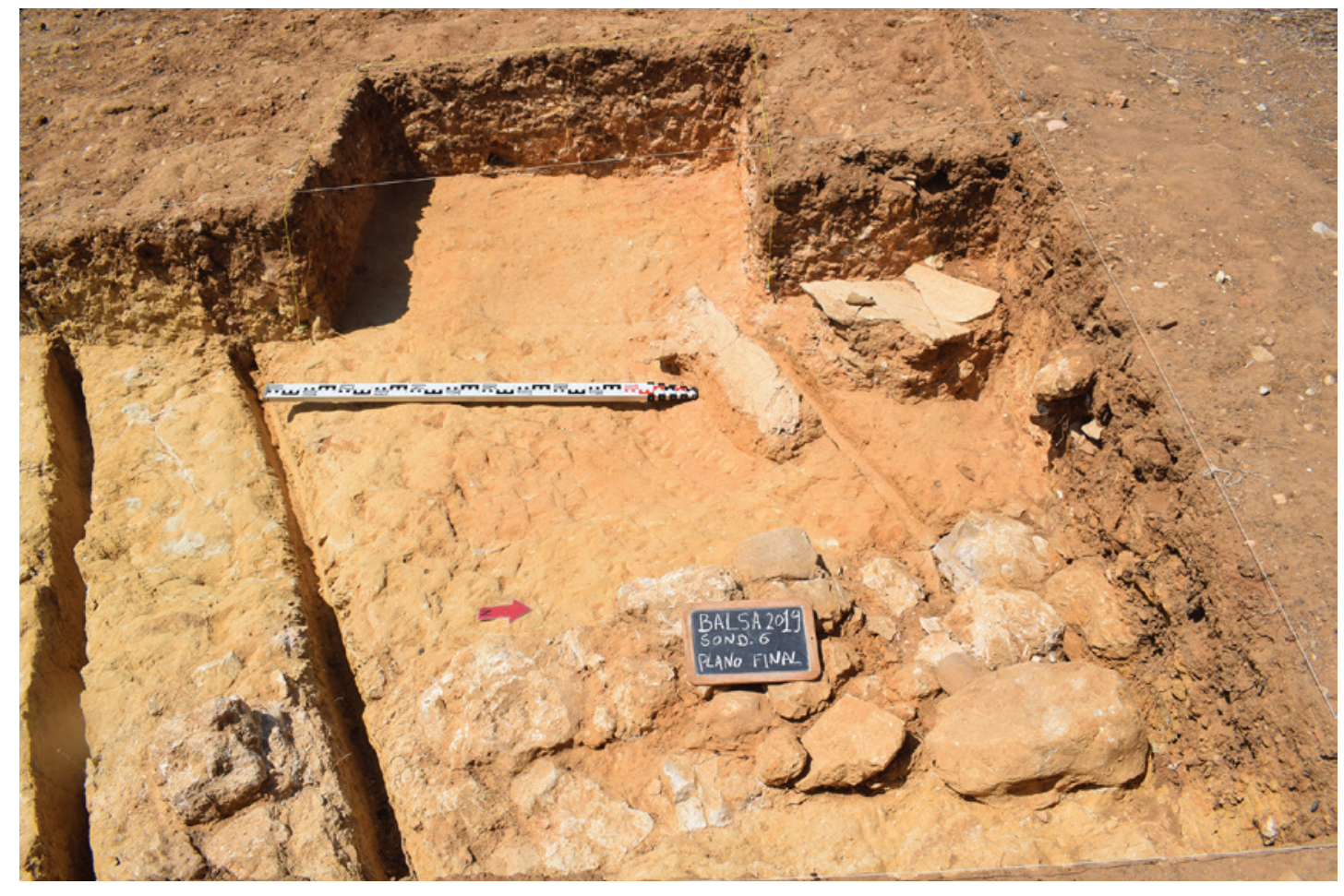

Figura 8 - Pormenor dos sulcos de ripper da sondagem 6 (plano final).

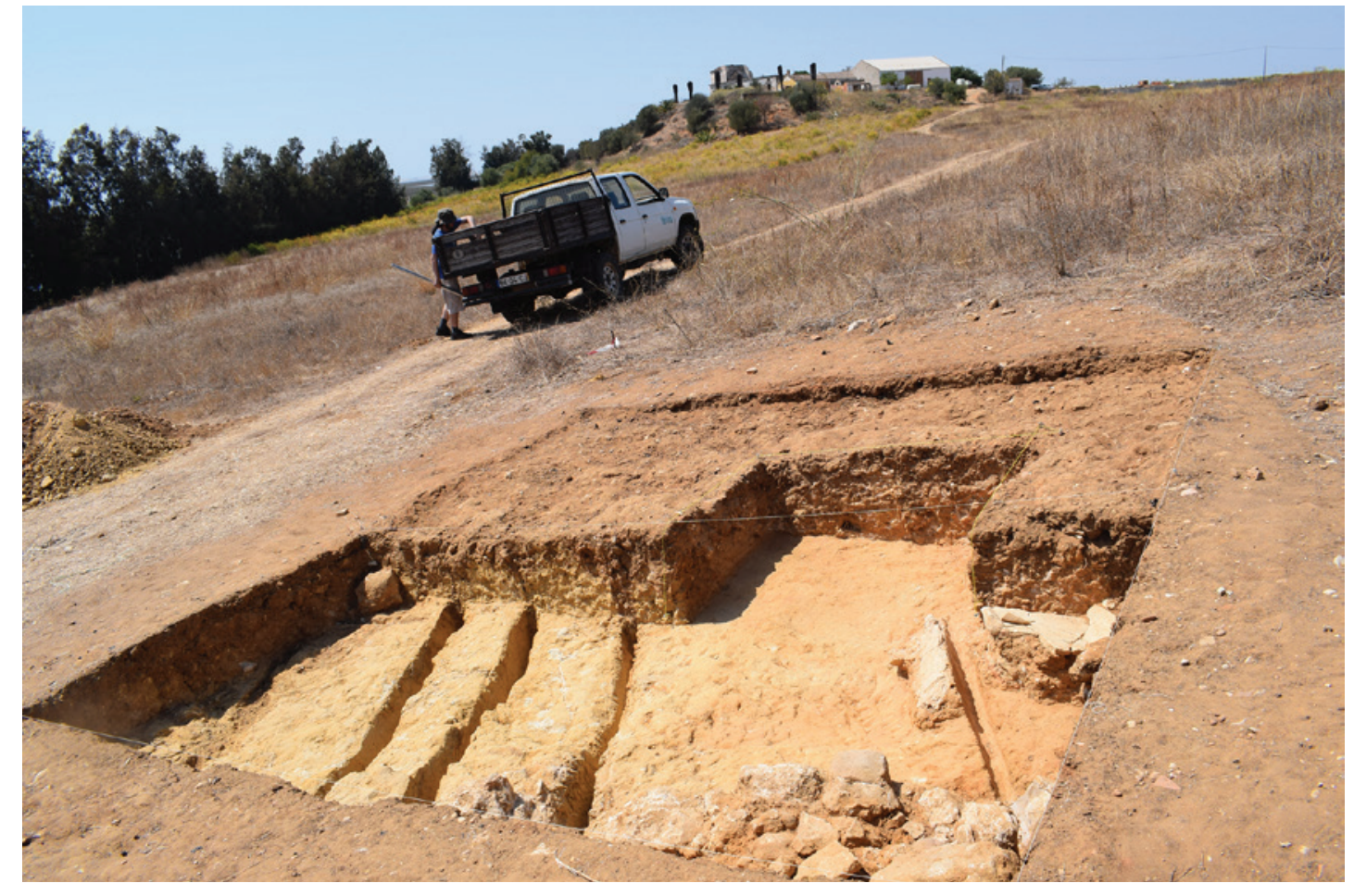

Figura 9 - Enquadramento geral da sondagem 6. 


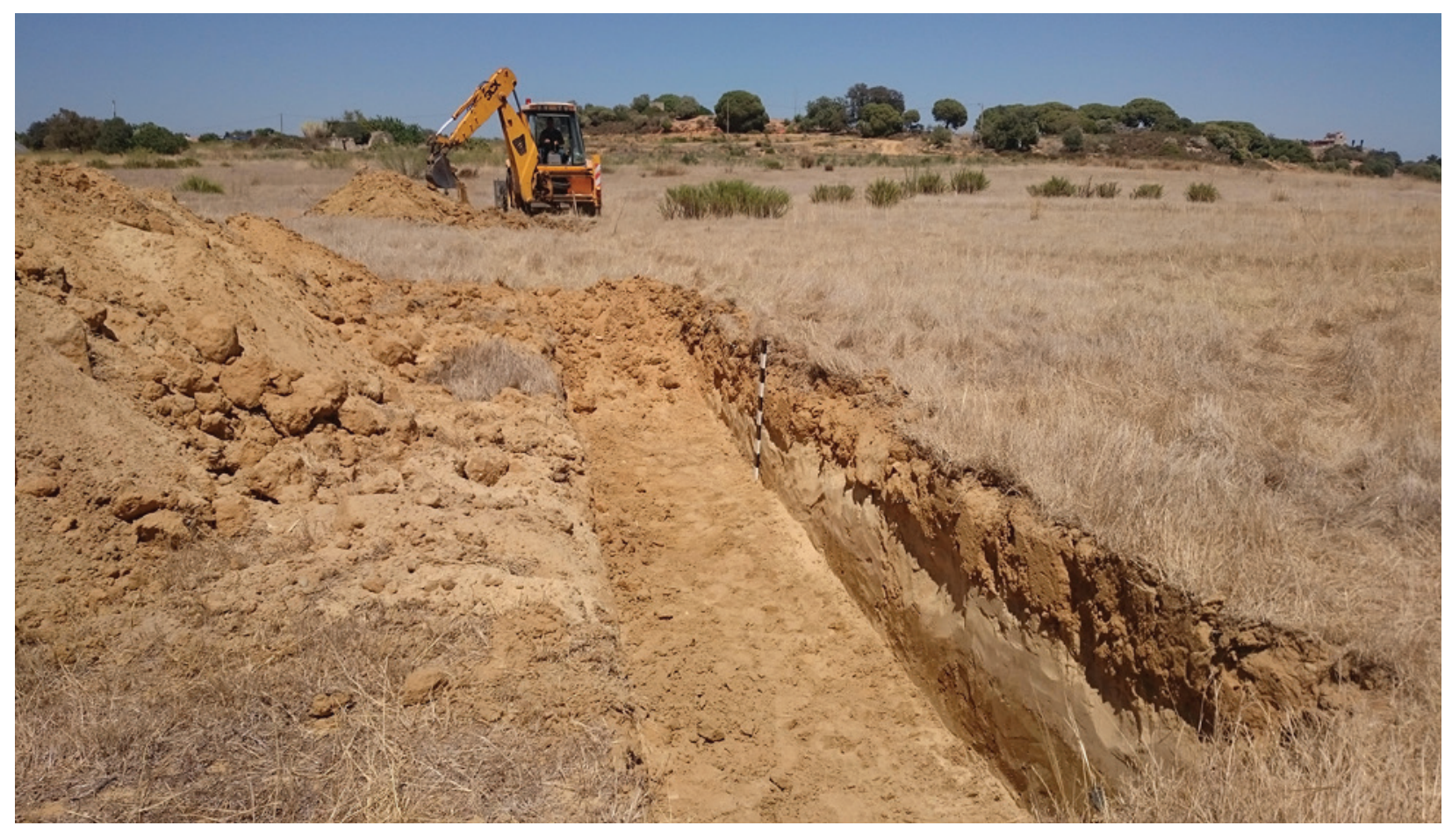

Figura 10 - Sondagens mecânicas (SM): abertura da SM 2. 


\title{
NO LARGO DAS MOURAS VELHAS \\ EM FARO (2017): NOVAS EVIDÊNCIAS DA NECROPOLE NORTE DE OSSONOBA E DA SUA OCUPAÇÃO MEDIEVAL
}

\author{
Ricardo Costeira da Silva ${ }^{1}$, Paulo Botelho ${ }^{2}$, Fernando Santos $^{3}$, Liliana Nunes ${ }^{4}$
}

\begin{abstract}
RESUMO
No decorrer da intervenção arqueológica de minimização de impacte do projecto de arranjo urbanístico do Largo das Mouras Velhas e ruas adjacentes em Faro (2017), foram identificadas novas sepulturas de inumação pertencentes à necrópole norte de Ossonoba. Apresenta-se o contexto estratigráfico, a tipologia e arquitectura das sepulturas e o respectivo mobiliário funerário recuperado, procurando-se integrar estes novos achados no panorama global dos espaços sepulcrais ossonobenses já conhecidos.

Nesta intervenção foram ainda identificados, pela primeira vez nesta zona noroeste da cidade, vestígios de época medieval islâmica. Este contexto testemunhado por uma simples fossa detrítica colmatada entre os séculos XII/XIII permite relançar a discussão acerca da estratégia de ocupação periurbana de Ocsonoba.

Palavras-chave: Ossonoba (Faro), Necrópole romana, Sepulturas, Mobiliário funerário.
\end{abstract}

\begin{abstract}
During the archeological intervention survey to mitigate the impact of Largo das Mouras Velhas and surrouding streets urban project in Faro (2017), a few new burial graves belonging to the northern necropolis of Ossonoba were identified. It is presented the stratigraphic context, the typology and architecture of the graves and the related funerary furniture retrieved, as it is sought to integrate these new findings in the overall picture of the Ossonoba's burial spaces already known.

In this intervention it was also identified, for the first time in this northwest part of the city, traces of Medieval Islamic times. This context, witnessed by a simple detritic pit sealed between the 12th and 13th centuries, allows us to relaunch the discussion about Ocsonoba's peri-urban occupation strategy.
\end{abstract}

Keywords: Ossonoba (Faro), Roman necropolis, Graves, Funerary furniture.

\section{ENQUADRAMENTO - A NECRÓPOLE NORTE DE OSSONOBA}

Passados mais de 140 anos da primeira referência à necrópole norte de Ossonoba continuam, episodicamente, a surgir novos vestígios do principal espaço funerário daquela cidade portuária do sul da Lusitânia romana. Os resultados agora apresentados não são tão exuberantes face aos que Estácio da Vei- ga outrora pôs a descoberto (Santos, 1971: 188-192), ou mesmo a outros que se sucederam. Insistimos, porém, na divulgação dos resultados deste tipo de intervenções de natureza preventiva. Não pela eloquência dos resultados, mas pela importância de manter actualizado o atlas do subsolo de determinada cidade. Muito embora reproduzindo aspectos já atestados no perfil desta necrópole pública, os novos testemunhos proporcionam uma, sempre opor-

\footnotetext{
1. Faculdade de Letras da Universidade de Coimbra; rcosteiradasilva@gmail.com

2. Engobe - Arqueologia e Património Lda.; paulo.botelho@engobe.pt

3. Engobe - Arqueologia e Património Lda.; fernando.santos@engobe.pt

4. Engobe - Arqueologia e Património Lda.; liliana.nunes@engobe.pt
} 
tuna, actualização da base documental referente à paisagem funerária de Ossonoba.

Inscrita no espaço suburbano setentrional da cidade, esta necrópole dispunha-se em torno das duas principais vias que partiam para Norte, em direcção a Pax Iulia, e para Noroeste, em direcção a Balsa. Abarcando o espaço compreendido entre o actual Largo das Mouras Velhas, Rua João de Castro, Largo 25 de Abril, Rua Dr. João Lúcio e Rua das Alcaçarias (Bernardes, 2005: 30; Teichner \& alii., 2007: 161, fig. 1), ocuparia uma extensão aproximada de cerca de 4 hectares (Pereira, 2014: 295).

A identificação desta necrópole e respectiva "exploração" em 1878 por Estácio da Veiga, na qual começa por registar 38 sepulturas entre o Largo das Mouras Velhas e ao longo da fachada principal do Teatro Lethes (Santos, 1971: 188-192) marca, simultaneamente, o início da praxis arqueológica no meio urbano de Faro. Ao longo dos anos, este espaço cemiterial continua a agregar o fervor da acção arqueológica na cidade, sendo alvo de intervenções pontuais por diversos investigadores, incluindo alguns de igual nomeada, como Abel Viana (1951) ou Teresa Gamito (1992). Já na presente centúria, toda esta área tem sido alvo de sistemáticas intervenções arqueológicas avulsas de salvaguarda, no âmbito de obras públicas e privadas, como é o caso dos resultados agora apresentados. Entre estas destaca-se a escavação realizada em 2004 no Largo 25 de Abril (só em parte publicada), pelo elevado número de sepulcros detectado, por atestar a coexistência dos ritos de incineração e inumação, revelar novas tipologias funerárias e permitir estimar uma longa cronologia de ocupação/ utilização entre o séc. I e o séc. IV/VI d.C. (Teichner \& alii, 2007: 169). Dispensa-se, no entanto, elencar e aprofundar os detalhes de todas estas intervenções e enquadrá-las no contexto arqueológico de Faro uma vez que esse compêndio já se encontra realizado (Viegas, 2011: 79-98) somando-se, inclusivamente, várias sínteses referentes aos contextos funerários conhecidos de Ossonoba (eg. Bernardes, 2005; Teichner \& aii., 2007; Pereira, 2014: 277-295).

\section{NO LARGO DAS MOURAS VELHAS EM 2017}

A intervenção arqueológica que aqui se apresenta decorreu no âmbito da implementação de medidas de minimização referentes ao Projecto do Arranjo Urbanístico do Largo das Mouras Velhas e das ruas ad- jacentes, promovido pelo Município de Faro em 2017 e dirigida por dois dos autores deste texto (PB e FS). Neste contexto, previa-se a abertura de valas para instalação de diversas redes de infra-estruturas. No total, realizaram-se 43 valas, algumas atingindo os $2,30 \mathrm{~m}$ de profundidade. No curso dos trabalhos de acompanhamento arqueológico foram identificadas cinco ocorrências de interesse arqueológico situadas em torno do Largo das Mouras Velhas. Estas correspondem, essencialmente, a vestígios da necrópole norte de Ossonoba, ampliando-se o número total de sepulturas confirmadas e que aqui ultrapassava já a centena e meia de exemplares (Pereira, 2014: 293). Pela primeira vez, foi também aqui identificado um nível de ocupação de época medieval islâmica que conjuntamente se dá à estampa.

\subsection{Vestígios da Necrópole Norte de Ossonoba}

As ocorrências relacionadas com a necrópole romana surgiram junto ao limite sul do Largo das Mouras Velhas. No decurso da abertura de uma vala foram identificadas e registadas sete novas estruturas funerárias (Figura 1, n.ำ 5) que correspondem a inumações primárias individuais, todas com orientação NO-SE (Figura 2 e 3). De acordo com as características observadas, distinguem-se três tipos de sepulturas (Figura 3 e 4 ) que pouco diferem das tipologias conhecidas nesta necrópole e que, basicamente, representam as formas mais comuns de inumação presentes na Hispânia romana (Teichner $\mathbb{E}^{\circ}$ alii, 2007: 163). O tipo mais reiterado é constituído por quatro exemplares (u.e. 512, 520, 524 e 528 - Figura 3 ) e reporta-nos para enterramentos em fossa simples com cobertura de tegulae formando um telhado de duas águas rematado por tegula vertical em cada topo. Corresponde ao tipo B de Estácio da Veiga (Santos, 1971: planta n.․26) ou subtipo 2c de Sánchez Ramos (2005: 172, fig. 2) já referido, para este local, como sendo o mais frequente (Santos, 1971: 189).

O espólio arqueológico associado é escasso ou mesmo nulo. Numa sepultura (u.e. 524) recolheu-se um fragmento de bordo e arranque de gargalo de peça em vidro transparente, azul gelo (Figura $5, \mathrm{n}$. . 1). Não resulta fácil classificar esta peça pois os bordos tubulares ocorrem numa grande diversidade de formas. Pelas características do bordo (virado para o exterior e dobrado sobre si) e tendo em conta o gargalo alto e cilíndrico, poderá corresponder a um unguentário de colo largo de tipo "candelabro", possivelmente do tipo Isings $82 \mathrm{~A} 2$ de cronologia ampla 
mas limitada entre os finais do séc. I e o séc. III d.C. (Isings, 1957: 97-98). Noutra sepultura (u.e. 539) exumou-se uma pequena taça com carena baixa em cerâmica comum de pasta alaranjada fina mas com algumas inclusões de médio calibre (Figura $5-$ n. ${ }^{\circ}$ ). Duas outras sepulturas (u.e. 531 e 540 - Figura 3) apresentam fossa simples com cobertura plana de tegulae. Correspondem ao tipo $2 \mathrm{~b}$ de Sánchez Ramos (2005: fig. 2), também já documentado nesta necrópole (Viana, 1951). Neste caso, apenas uma sepultura (u.e. 531) forneceu mobiliário funerário. Trata-se de uma lucerna de volutas que podemos incluir no tipo Loeschcke IV/Dressel 11 (Figura 5, n.- 3). Este tipo formal apresenta volutas salientes no bico redondo, corpo circular sem asa e secção troncocónica e orla estreita, plana e lisa. A transição para o disco faz-se por uma moldura que define duas caneluras concêntricas. O disco é côncavo, com orifício de alimentação ligeiramente descentrado e está decorado com auriga sobre biga voltada à direita. Os dois cavalos a galope puxam o carro (com roda de cinco raios). Colhe paralelo muito próximo com vários exemplares conhecidos, destacando-se, pela sua maior proximidade, a lucerna n. .295 proveniente do depósito votivo de Santa Bárbara em Castro Verde (Maia e Maia, 1997: 92). Apesar de nos depararmos com autores que atribuem a esta forma diferentes cronologias para o início de produção, é consensual que o auge da mesma terá ocorrido em meados do século I d.C., assim como parece seguro que o seu termo se fixe entre o final do mesmo século e inícios do seguinte. Bailey (1980), por exemplo, estabelece para a produção do tipo IV Loeschcke em Itália, um período que se prolonga desde o início do principado de Augusto ao primeiro terço do segundo século II d.C.

Finalmente, uma última sepultura (u.e. 516) em fossa simples encontrava-se estruturada e coberta por grandes fragmentos pertencentes a um dollium e restos de imbrex. O contentor de armazenamento reutilizado apresenta bordo reentrante em forma de rim, munido de duas asas verticais com canelura central, adivinhando-se o corpo de perfil ovóide (Figura 6 - n.․․ 2). A reutilização de material cerâmico como parte integrante na construção de uma sepultura parece também não ser novidade nesta necrópole (Teichner $\mathbb{Z}$ alii, 2007: 166).

Um dos aspectos mais intrigante e patente nas sepulturas enunciadas prende-se com a ausência de vestígios osteológicos associados aos respectivos sedimentos de enchimento. Para esta situação, certificada pela antropóloga responsável (Sónia Ferro) que acompanhou a intervenção, não se apresenta qualquer justificação plenamente satisfatória ${ }^{5}$. Este facto poderá estar relacionado com processos pós-deposicionais, aparentemente associados á lixiviação do material osteológico causado pela exposição a terrenos com elevado teor de metais ferrosos e em frequente contacto com água. Situações semelhantes foram reportadas noutros locais tais como a necrópole romana do Porto dos Cacos em Alcochete (Sabrosa, 1996: 287; Monteiro, 2012: 72), onde se verificou uma deficiente selagem das sepulturas (de semelhante tipologia) que condicionou a conservação das ossadas humanas. Apesar de esta fundamentação suscitar alguma perplexidade, uma vez que noutros pontos da necrópole não se constata esta situação, importa mencionar o facto de neste preciso ponto a vala se sobrepor a uma antiga linha de água, provável braço da ribeira das Lavadeiras. Fica, porém, a certeza de se estar perante estratos em deposição primária. O topo das sepulturas encontra-se cerca de 1,50m de profundidade em relação à cota do pavimento actual e o,40m abaixo de um primeiro estrato (u.e. 510), datado de época romana, que sela os níveis da necrópole. Nesta camada, que cobre as sepulturas, foram recuperados alguns fragmentos de tegulae, imbrices e bojos de ânforas. Destaca-se, contudo, no espaço limítrofe (Figura 1, n.ํㅜ 4) e na continuidade deste estrato (composto por sedimento silto-arenoso, medianamente compacto de tonalidade castanho acinzentado - u.e. 406) a recolha de uma ânfora de perfil quase completo, encontrada fracturada in situ (Figura 6, n.․ 1). Trata-se de uma produção lusitana, local/regional, do tipo Almagro ${ }_{51 C}$ que corresponde, durante o Baixo-império (séc. III-V), à ânfora melhor representada e que conheceu maior volume de produção na Lusitania (Viegas, 2011: 237), sendo mesmo o modelo mais frequente em Faro (idem: 239, tabela 27). O exemplar identificado apresenta corpo fusiforme com $63 \mathrm{~cm}$ de perfil conservado (poderia atingir os $67 / 68 \mathrm{~cm}$ de altura), bordo de secção arredondada de onde arranca asa em fita que assenta no ombro (Figura $6,{ }^{\circ} .^{\circ} 1$ ), encai-

\footnotetext{
5. Tanto mais que, noutro ponto mais a ocidente deste local (vala 2 - Fig. 1, n. ${ }^{\circ}$ 2) foi possível verificar, no corte da respectiva vala, a existência de membros inferiores preservados (u.e. 209) com a mesma orientação que as restantes sepulturas identificadas.
} 
xando perfeitamente nos modelos produzidos nos vários centros oleiros conhecidos na região algarvia como a Quinta do Lago (Loulé) (Arruda e Fabião, 1990: fig. 6o-61), Manta Rota (Viegas, 2006: 177196), S. Bartolomeu de Castro Marim (Vasconcellos, 1898: 329-336; Alves, Diogo e Reiner, 1990: fig. 56) e Martinhal (Sagres) (Silva, Soares e Correia, 1990: 225-246).

Salta assim em evidência que, nesta área sul do Largo, não existe ao nível do registo estratigráfico qualquer vestígio entre o período romano e as camadas datadas do final de época moderna/contemporânea que se sobrepõem, fazendo supor que, em fase recente, alguma acção terá truncado e criado um hiato na estratigrafia. Esse fenómeno não se estende a todo o Largo das Mouras Velhas. Como adiante se apresenta, noutros pontos (zona poente, vala 3) foi ainda possível recuperar informação de cronologias intermédias.

Regista-se, por fim, o reconhecimento de mais uma estrutura, possivelmente funerária, durante a execução da vala 2, localizada no limite Oeste do Largo das Mouras Velhas (Figura 1, n.ำ1). No perfil exposto observa-se apenas a presença de tegulae dispostas em cutelo (u.e. 207 - Figura 4 - A), aparentemente com uma orientação semelhante às anteriores (NO-SE). O desenvolvimento destes vestígios para lá do limite da área afectada impossibilitou que se pudesse aferir com maior rigor o seu desenho e natureza. Parece, no entanto, tratar-se de um sepulcro de tipo C da classificação de Estácio da Veiga (Santos, 1971: planta n. ${ }^{26}$ ) composto por uma caixa construída com tegulae colocadas ao alto e cobertas com o mesmo material disposto horizontalmente (tipo 3 a de Sánchez Ramos (2005: fig. 2). A comprovar-se, este será o vestígio material que, por agora, marca o limite ocidental desta necrópole.

\subsection{As evidências medievais no Largo das Mou- ras Velhas}

Uma das novidades desta intervenção foi a identificação, pela primeira vez nesta zona noroeste da cidade, de um contexto de época medieval islâmica. Este foi localizado no limite ocidental do Largo das Mouras Velhas (vala 3 - Figura 1 - n.. 3 ) e circunscreve-se a uma simples fossa detrítica de planta sub-circular escavada no substrato geológico (Figura 7), numa área onde este se encontra a uma cota mais elevada. Esta encontrava-se colmatada por dois estratos (u.e.s 308 e 309) de onde foi possível recolher um conjunto singelo mas relevante de louça doméstica medieval a par de fauna (malacológica e mamalógica), cerâmica de construção (telha de meia cana) e restos residuais de cerâmica romana (ânfora e fundo de taça em terra sigillata).

Para além da louça doméstica de superfícies foscas, reduzida maioritariamente a fragmentos informes, distingue-se a presença de cerâmica vidrada e dois candis. Estes contentores de fogo para iluminação, fabricados em pasta creme bem depurada, não apresentam qualquer decoração ou tratamento superficial. Não foi possível restituir nenhum perfil completo. Um encontra-se reservado ao depósito discóide carenado e ao colo alto (troncocónico invertido) com bordo simples ligeiramente extrovertido e lábio boleado (Figura 8, n.․․ 2). O outro, acrescenta ainda, uma asa de laço/vertical de secção em " $D$ " e o arranque do bico (Figura 8, n.ำ 1). Candis tipologicamente semelhantes são comuns nestes contextos islâmicos do sul peninsular a partir do reino de taifas, atingindo grande difusão no período almorávida - entre o séc. XI-XII (Catarino, 2017: 531).

Com o mesmo fabrico (pasta esbranquiçada e compacta), regista-se uma base com pé que poderá pertencer a um recipiente com três (trípode) ou quatro pequenos apoios (Figura 9, n.․ 6). Em termos morfológicos colhe o melhor paralelo na Alcáçova do Castelo de Mértola, assemelhando-se a pequeno alguidar proveniente de níveis datados do séc. XII (Torres, 1987: n.. 34 ).

Não obstante, neste contexto destacam-se quantitativamente as formas abertas que podemos associar aos serviços de mesa. De superfícies vidradas, surgem em peças com pastas de boa qualidade, claras e esbranquiçadas, devendo corresponder, muito provavelmente, a grandes tigelas ou malgas. Dois exemplares, um fundo e um bordo, apresentam superfície monocroma a verde e marcas de decoração impressa/estampilhada (Figura 9, n. ${ }^{\circ} 1$ e 2). Os restantes (11 fragmentos) ostentam superfícies meladas, maioritariamente ( 7 ) com motivos a óxido de manganés (Figura 9, n.ํㅜ 3-5). Estas peças encontram-se resumidas ao fundo, impossibilitando a obtenção de paralelos formais. Os dados disponíveis para o território Algarvio permitem, porém, afirmar que as peças vidradas (monocromas estampilhadas e com pintura a óxido de manganês) se disseminam durante a fase almorávida e almóada, predominando os vidrados melados (com ou sem motivos a manganés) sobre os de outra coloração (Gómez Martínez \& alii, 2015: 
42-44). Por outro lado, o facto destas peças apresentarem, como característica dominante, fundos espessos com pés anelares bem salientes (Figura 9, n. 1 1 e 3-5), poderá adscrevê-las ao período almóada (Catarino, 1997-98: 827). Por estes motivos, aponta-se para que a colmatação desta fossa possa ter ocorrido entre o séc. XII-XIII.

\section{SÍNTESE}

A necrópole romana Norte de Ossonoba tem vindo a ser documentada através de sucessivas intervenções arqueológicas preventivas e de salvaguarda numa área que se estende entre o Largo das Mouras Velhas até à rua D. João de Castro (Bernardes, 2005: 30). Além da sua extensão e circunscrição espacial, os contextos analisados permitem comprovar a sua ampla cronologia de utilização entre o séc. I/II e o séc. VI (Teichner $\&$ alii, 2007). Os dados agora expostos embora não forneçam, efectivamente, novidades de vulto, contribuem, modestamente, para actualizar os números e informação concernente a este espaço cemiterial. Na verdade, surgem num local já identificado com a necrópole (apesar de poderem marcar o limite máximo ocidental) e registam tipologias de enterramento já conhecidas em Ossonoba, nomeadamente a sepultura com telhado de duas águas formado por tegulae (tipo B de Estácio da Veiga). É igualmente escasso o mobiliário funerário recuperado. Não obstante, conta-se a presença de alguns objectos que participaram no processo de inumação e nos fornecem pistas de âmbito cronológico que se integram no período alto-imperial. Para além do fragmento em vidro do que parece tratar-se de um unguentário do tipo Isings $82 \mathrm{~A} 2$ (finais do séc. I - séc. III d.C.), destaca-se uma lucerna Loeschcke IV/Dressel 11 com cronologia mais refinada entre meados e finais do séc. I d.C. (Deneauve, 1969: 126), embora podendo estender-se aos inícios da centúria seguinte.

O dado mais original reside, como referido, na identificação, inédita na zona noroeste da cidade já afastada do núcleo primitivo que tem por base a Vila-a-Dentro, de um contexto de época medieval islâmica. Os testemunhos identificados circunscrevem-se a uma fossa detrítica colmatada entre os séculos XII/XIII e são insuficientes para que sobre eles se possam tecer considerações mais desenvolvidas sobre a natureza do sítio que integravam. Devem, no entanto, relançar a discussão sobre a es- tratégia de ocupação do espaço peri-urbano de Santa Maria de Ocsonoba. Os vestígios poderiam integrar uma estrutura habitacional nos arrabaldes da cidade, não sendo também de descartar a possibilidade do cemitério islâmico decalcar, até certo ponto, o espaço da necrópole romana.

Dentro do que são as virtualidades da arqueologia de salvaguarda em meio urbano, a actual intervenção vem contribuir para o adensar de questões que se enredam neste complexo e interessante desvendar das cidades sobrepostas. Neste processo de construção do mapa do subsolo urbano juntam-se, assim, mais alguns fragmentos. Uns apoiam a leitura de elementos já conhecidos embora de contornos ainda em aberto, outros apontam para problemáticas emergentes e por emergir.

\section{BIBLIOGRAFIA}

ALVES, Francisco; DIOGO, António Dias; REINER, Francisco (1990) - A propósito dos fornos de cerâmica lusitano-romanos de S. Bartolomeu do Mar. In ALARCÃO, Adília; MAYET, Françoise, eds. - Ânforas Lusitanas. Tipologia, produção, comércio (Actas das Jornadas de estudo. Conimbriga, 1988). Coimbra / Paris, pp. 193-198.

ARRUDA, Ana M.; FABIÃO, Carlos (1990) - Ânforas da Quinta do Lago (Loulé). In ALARCÃO, Adília; MAYET, Françoise, eds. - Ânforas Lusitanas. Tipologia, produção, comércio (Actas das Jornadas de estudo. Conimbriga, 1988). Coimbra / Paris, pp. 199-213.

BAILEY, Donald M. (1980) - A Catalogue of the Lamps in the British Museum, II. Roman Lamps made in Italy. Londres.

BERNARDES, João P. (2005) - As necrópoles de Ossonoba. Morrer em Faro há 2000 anos. Caminhos do Algarve Romano, Catálogo da Exposição. Faro, pp. 26-34.

CATARINO, Helena (1997-1998) - O Algarve Oriental durante a ocupação islâmica: povoamento rural e recintos fortificados. "Al’Ulyã”, n. 6, 3 vols., Loulé: Arquivo Histórico Municipal.

CATARINO, Helena (2017) - Fichas de catálogo. Núcleo VI. Época islâmica do Gharb ao Algarve: cinco séculos de Islão. Loulé, Territórios, Memórias, Identidades. Catálogo da Exposição. Museu Nacional de Arqueologia - Museu Municipal de Loulé, Imprensa Nacional, pp. 504-540; 542-570.

DENEAUVE, Jean (1969) - Lampes de Carthage. Paris: Centre de la Recherche Scientifique.

GAMITO, Teresa J. (1992) - Cemitério romano do século II/III - Faro, Rua das Alcaçarias. Conimbriga. 31, pp. 99-118.

GÓMEZ MARTÍNEZ, Susana; GONÇALVES, Maria J.; INÁCIO, Isabel ; SANTOS, Constança; COELHO, Catarina; LIBERATO, Marco; GOMES, Ana S.; BUGALHÃO, Jacin- 
ta; CATARINO, Helena; CAVACO, Sandra; COVANEIRO, Jaquelina; FERNANDES, Isabel C. (2015) - A cidade e o seu território no Gharb al-Andalus através da cerâmica. Actas $X$ Congresso Internacional a Cerâmica Medieval no Mediterrâneo / Proceedings of $10^{\text {th }}$ International Congress on Medieval Pottery in the Mediterranean. Silves: Câmara Municipal de Silves / Campo Arqueológico de Mértola. T. 1, pp. 19-50.

ISINGS, Clasina (1957) - Roman Glass from Dated Finds. Gröningen: D. B. Wolters.

MAIA, Maria; MAIA, Manuel (1997) - Lucernas de Santa Bárbara. Castro Verde: Cortiçol.

MONTEIRO, José L. (2012) - Necrópole Romana do Porto dos Cacos (Alcochete, Portugal). Dissertação de Mestrado em Arqueologia apresentada à Faculdade de Letras da Universidade de Lisboa.

PEREIRA, Carlos (2014) - As necrópoles romanas do Algarve: acerca dos espaços da morte no extremo sul da Lusitânia. Tese de doutoramento em História (Arqueologia) apresentada Faculdade de Letras da Universidade de Lisboa. Policopiado.

SABROSA, Armando (1996) - Necrópole Romana do Porto dos Cacos (Alcochete). In FILIPE, Graça; RAPOSO, Jorge, eds. - Ocupação Romana dos Estuários do Tejo e do Sado. Lisboa: Câmara Municipal do Seixal, pp. 283-30o.

SÁNCHEZ RAMOS, Isabel (2005) - Las necrópolis de Corduba durante la Antigüedad tardia. AnMurcia. Múrcia. 21, pp. 165-177.

SANTOS, Maria L. E. da V. A. dos (1971) - Arqueologia Romana do Algarve. Associação dos Arqueólogos Portugueses, 1. Lisboa.

SILVA, Carlos T.; SOARES, Antónia; CORREIA, Virgílio H. (1990)- "Produção de ânforas romanas no Martinhal (Sagres)”, In ALARCÃO, Adília; MAYET, Françoise, eds. Ânforas Lusitanas. Tipologia, produção, comércio (Actas das Jornadas de estudo. Conimbriga, 1988). Coimbra / Paris, pp. $225-246$.

TEICHNER, Felix; SCHIERL, Thomas; GONÇALVES, Ana; TAVARES, Paula (2007) - Sebastião Philipes Martins Estácio da Veiga e as necrópoles romanas de Ossonoba (Faro). Xelb. Silves. 7, pp. 159-178.

TORRES, Cláudio (1987) - Cerâmica Islâmica Portuguesa. Catálogo. Lisboa: Fundação Calouste Gulbenkian.

VASCONCELLOS, José L. (1898) - Olaria luso-romana em S. Bartolomeu de Castro Marim. O Arqueólogo Português, 4, pp. 329-336.

VIANA, A. (1951) - O cemitério luso-romano do Bairro Letes (Faro). Separata da revista, Brotéria, Lisboa. 53: 2/3, pp. 1-23.
VIEGAS, C. (2006) - O Forno romano da Manta Rota (Algarve). Setúbal Arqueológica (Simpósio Internacional Produção e Comércio de Preparados Piscícolas durante a Proto-História e a Época Romana no Ocidente da Península Ibérica, Homenagem a Françoise Mayet). 13, pp. 177-196.

VIEGAS, C. (2011) - A ocupação romana do Algarve: estudo do povoamento e economia do Algarve central e oriental no período romano. Universidade de Lisboa, Lisboa: UNIARQ. 

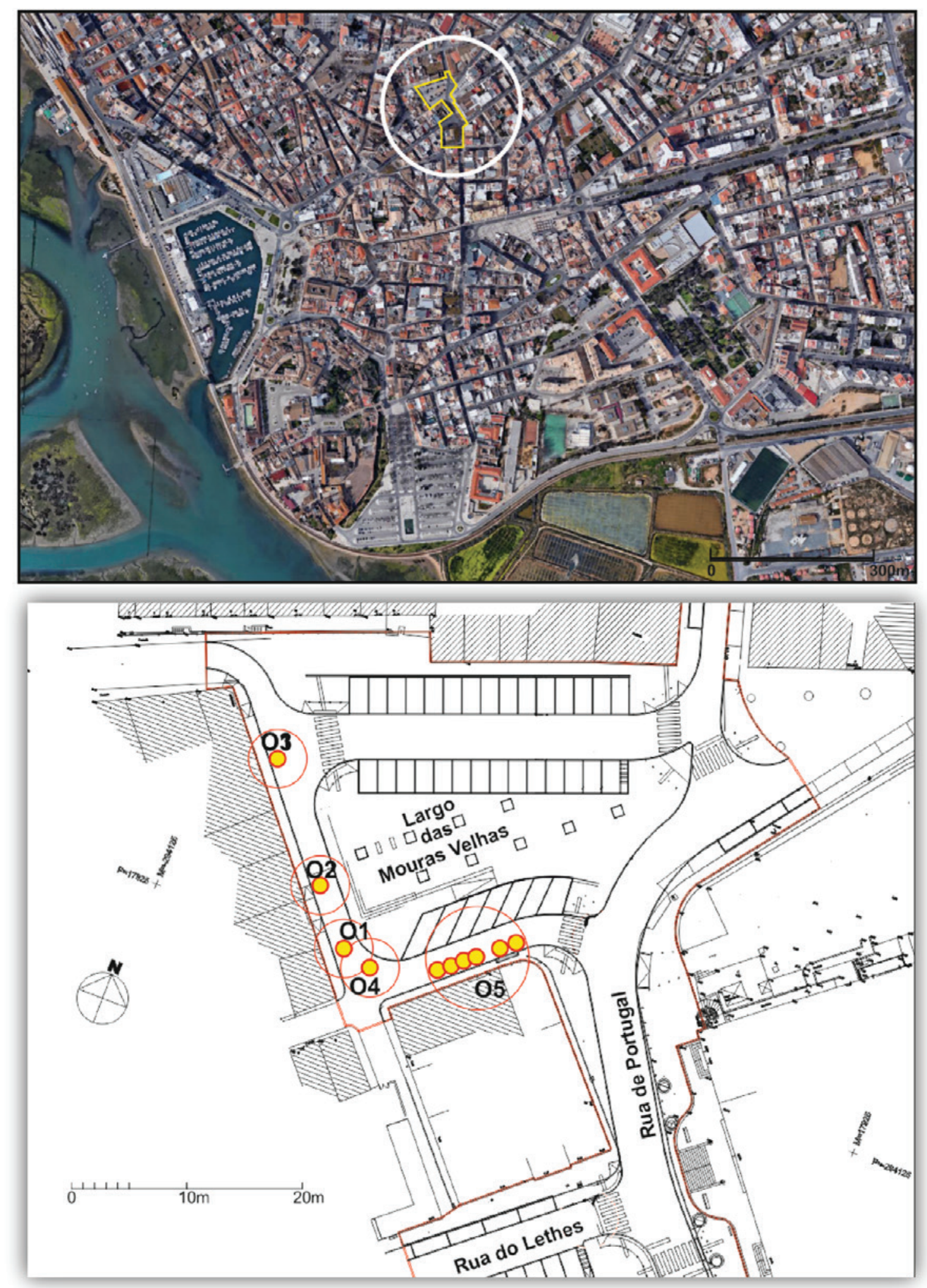

Figura 1-Em cima, localização da intervenção na malha urbana da actual cidade de Faro (base do Google Earth). Em baixo, localização das ocorrências arqueológicas na planta de pormenor do Largo das Mouras Velhas. 


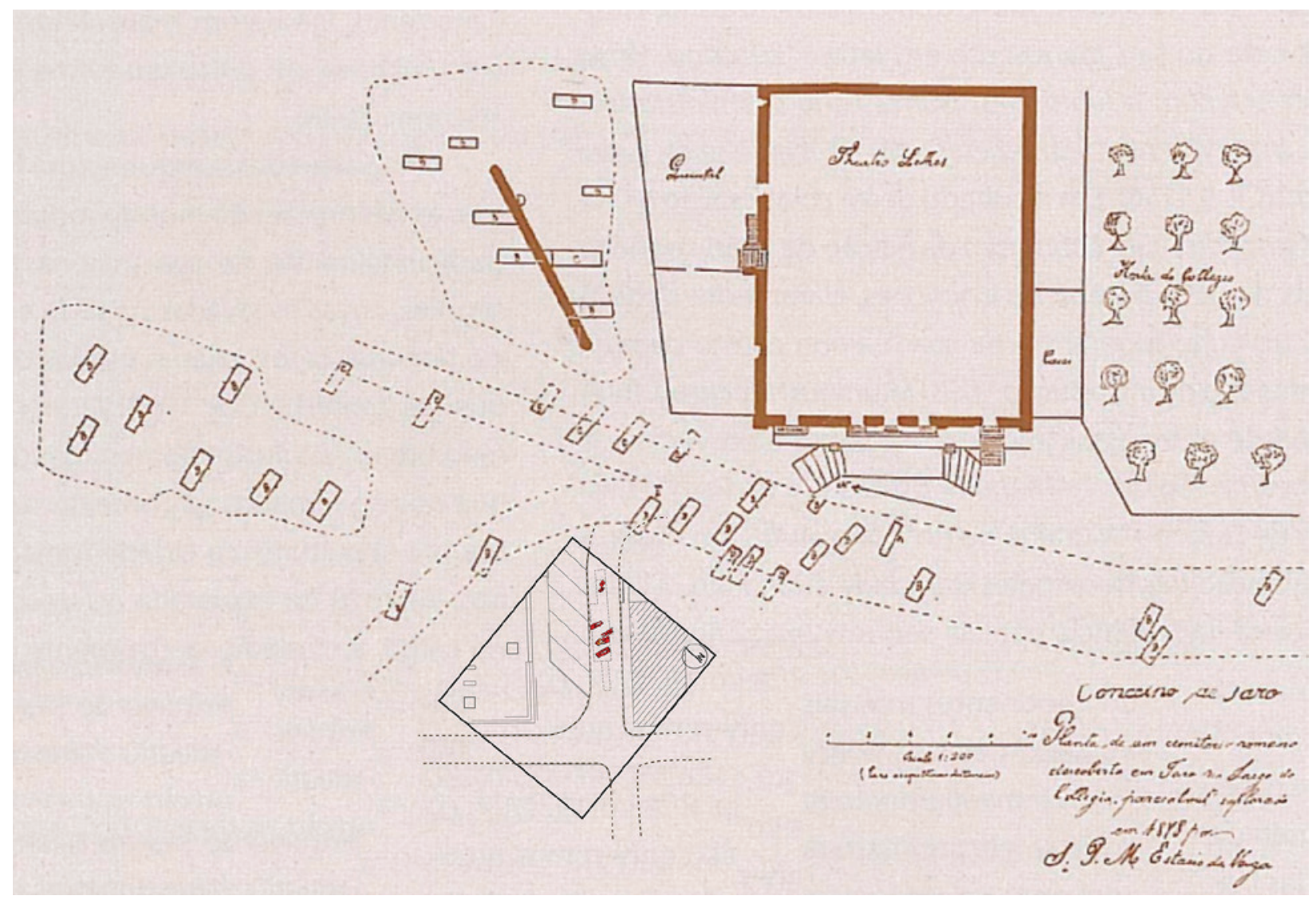

Figura 2 - Implantação das novas sepulturas na planta elaborada por Estácio da Veiga em 1878 (base retirada de Santos, 1971: planta n. ${ }^{2}$ ). 

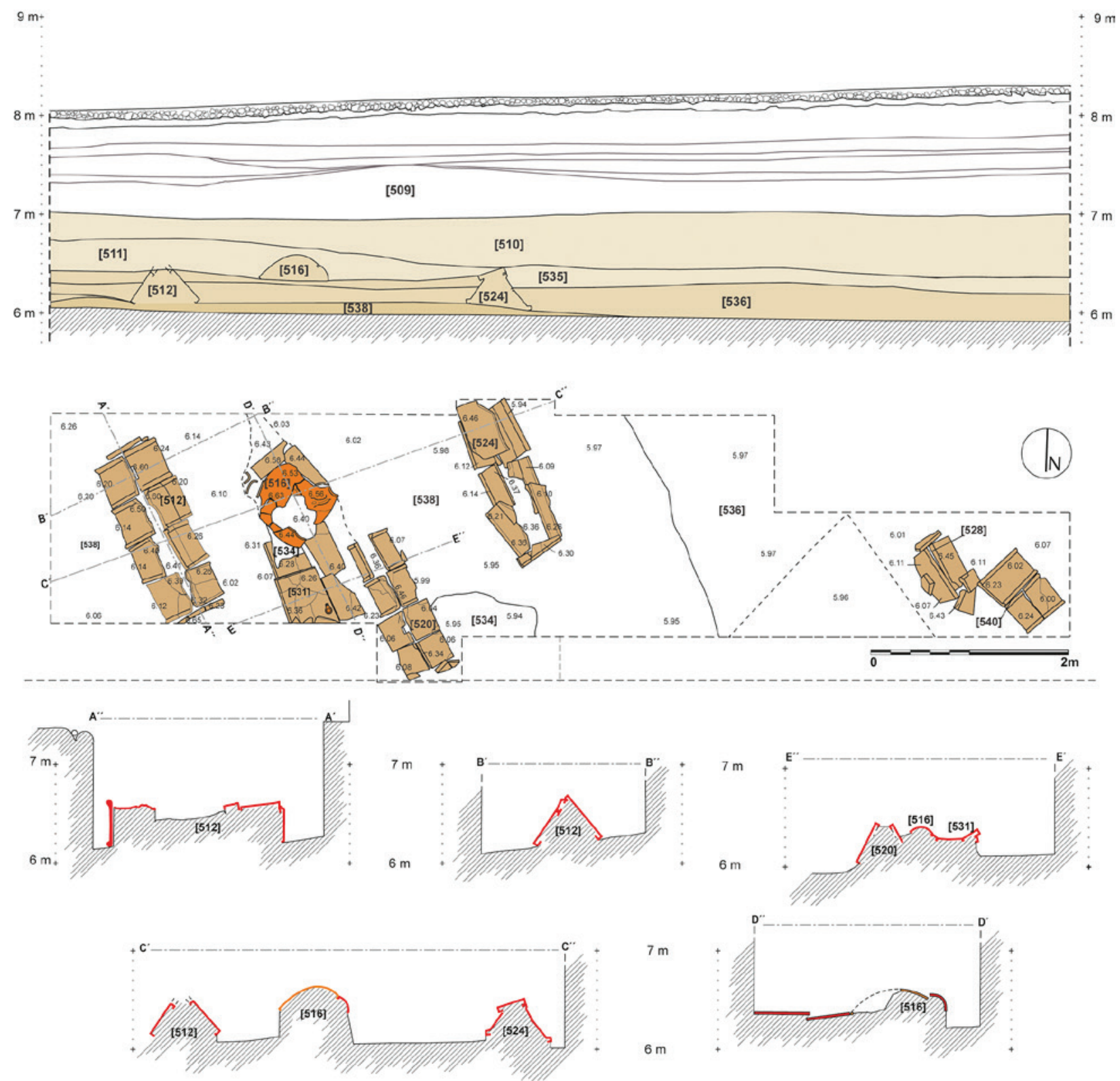

Figura 3 - Plano final e corte das sepulturas identificadas (ocorrência 5) e perfil da vala 5 

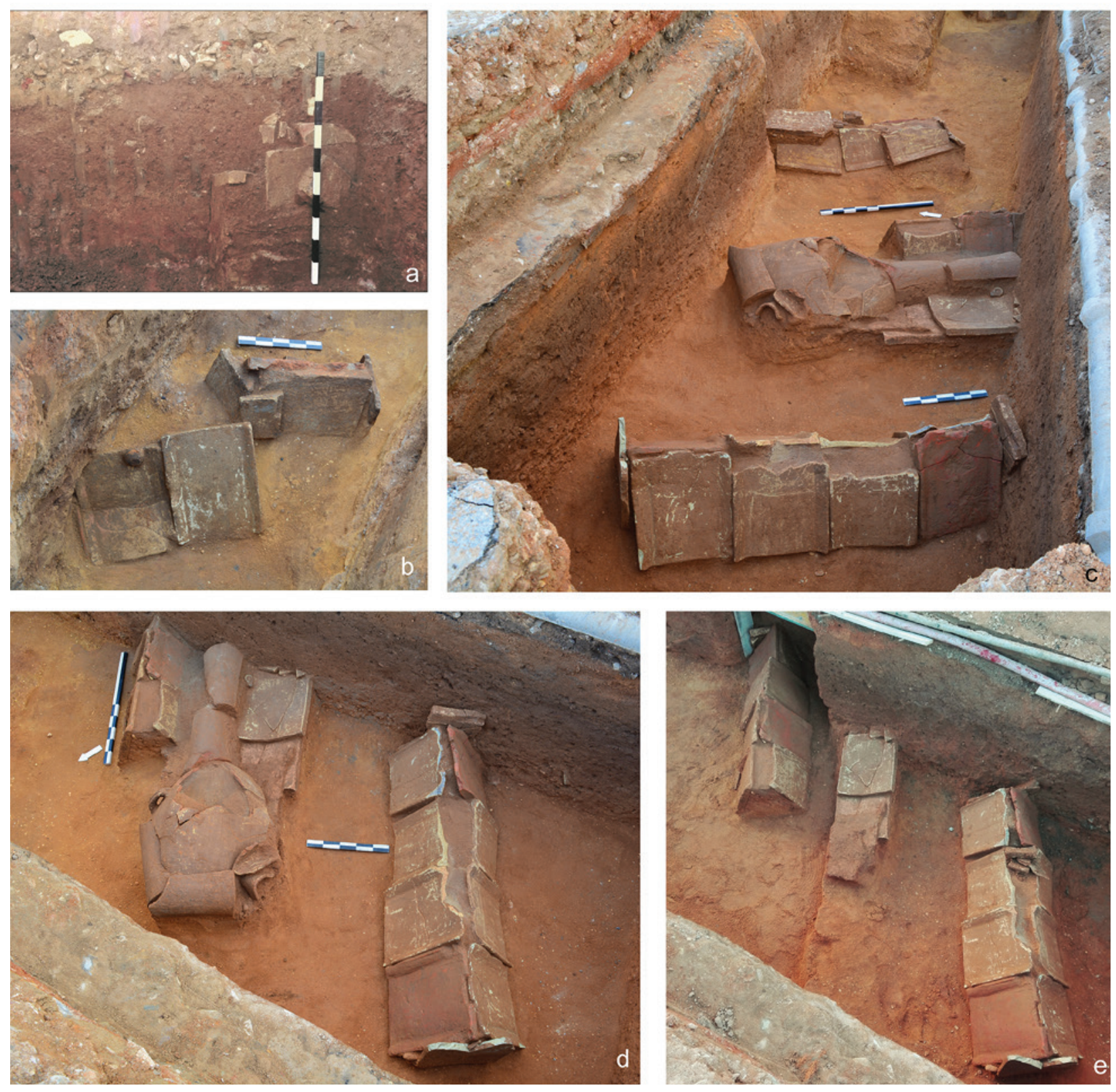

Figura 4 - Vista geral e de pormenor das várias sepulturas identificadas. 

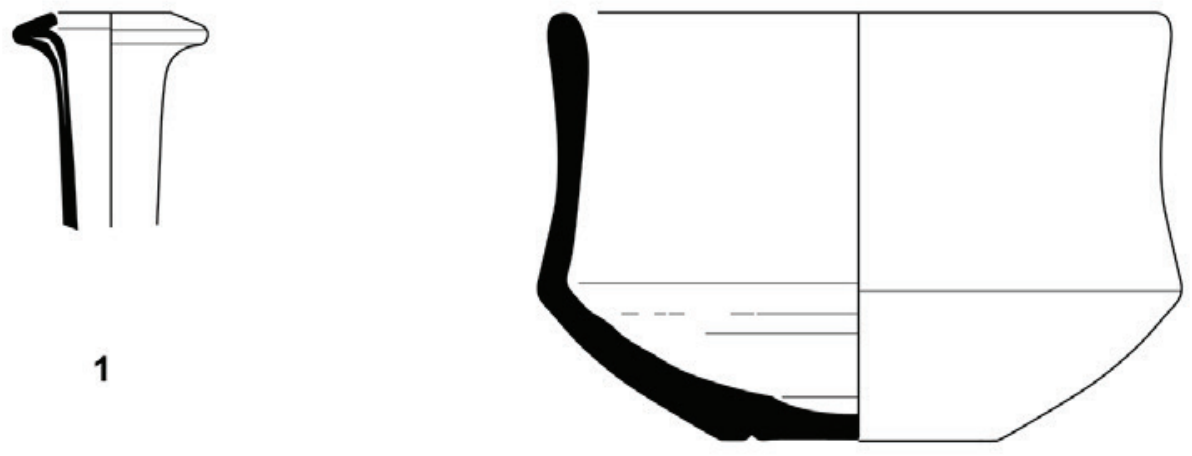

2
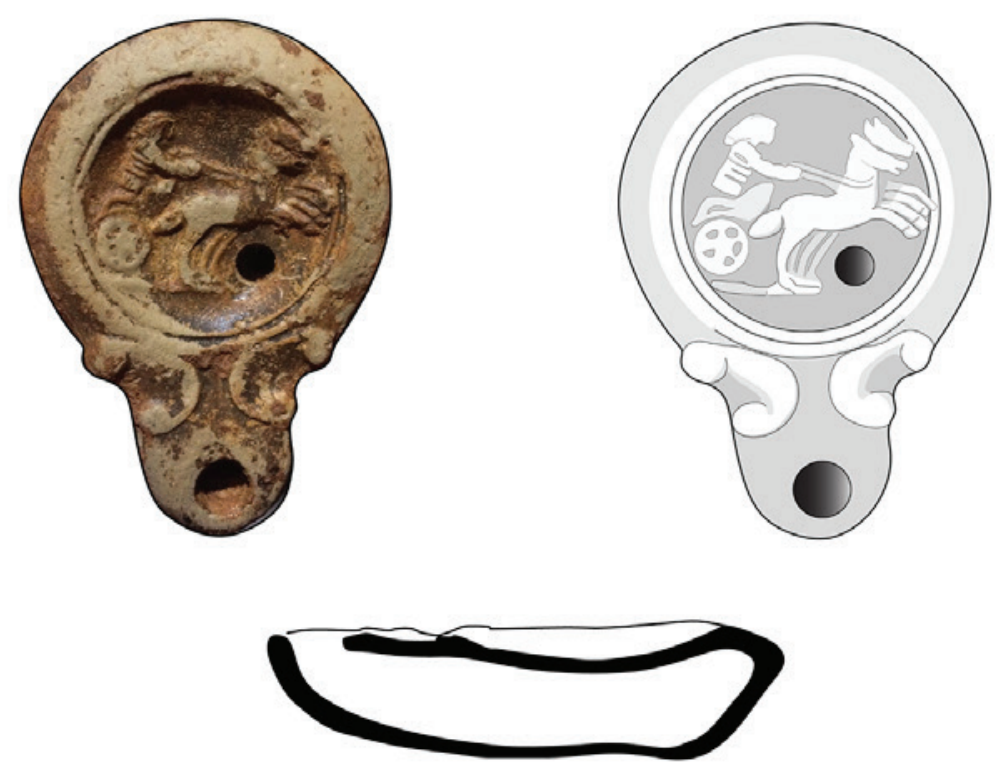

3

$5 \mathrm{~cm}$

Figura 5-Mobiliário funerário recuperado. 

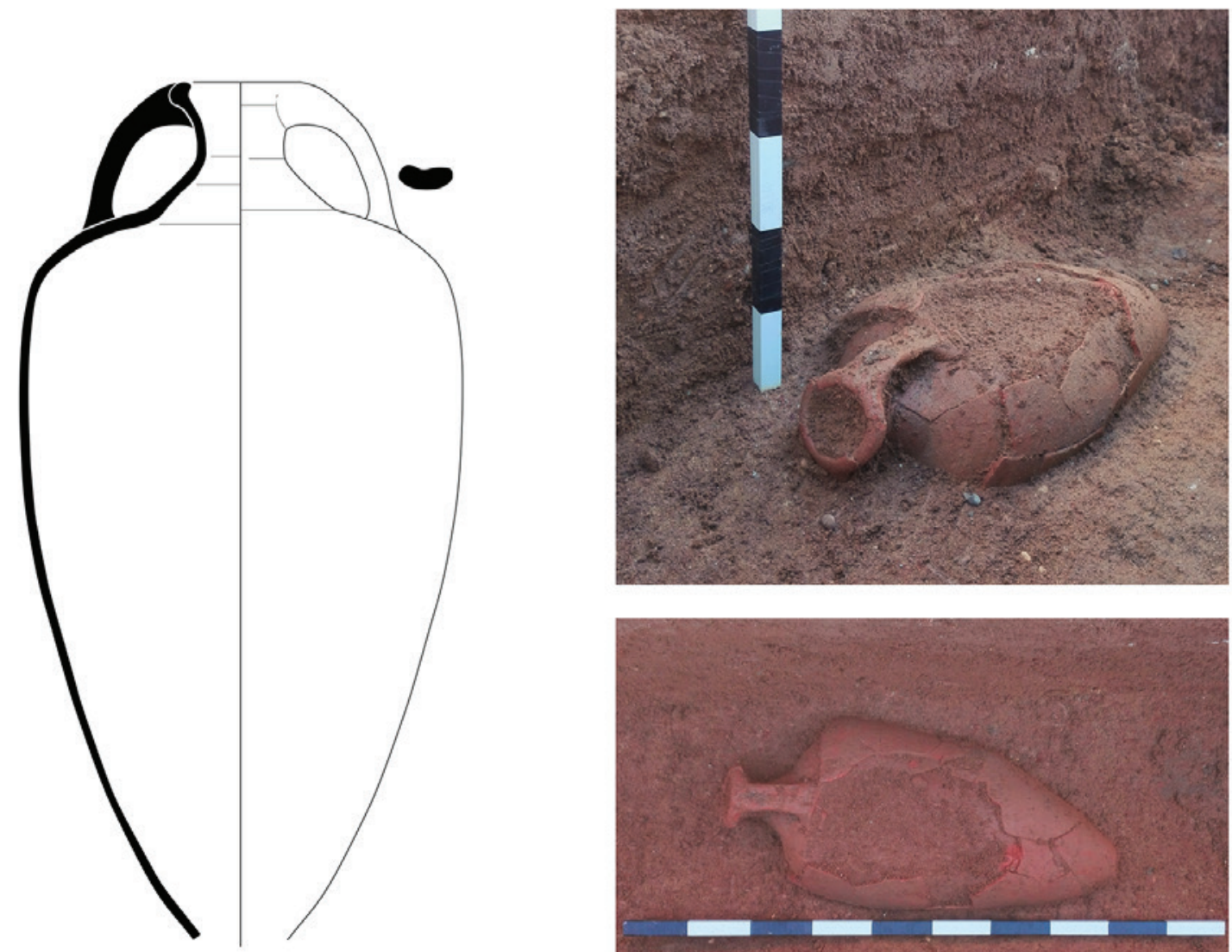

1

$15 \mathrm{~cm}$
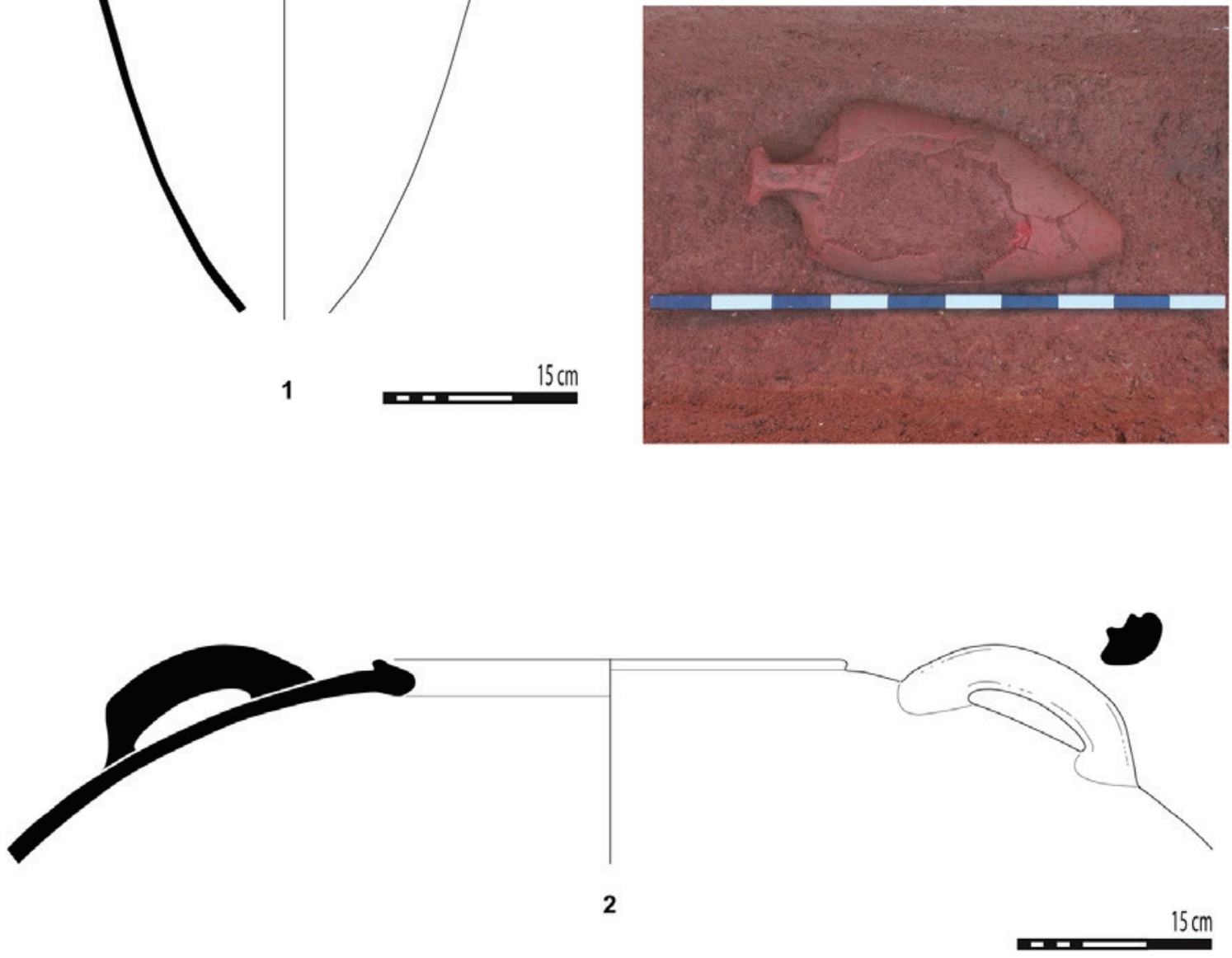

Figura 6 - Em cima, ânfora (ocorrência n.ํ4). Em baixo, dollium que compunha sepultura - u.e. 516. 

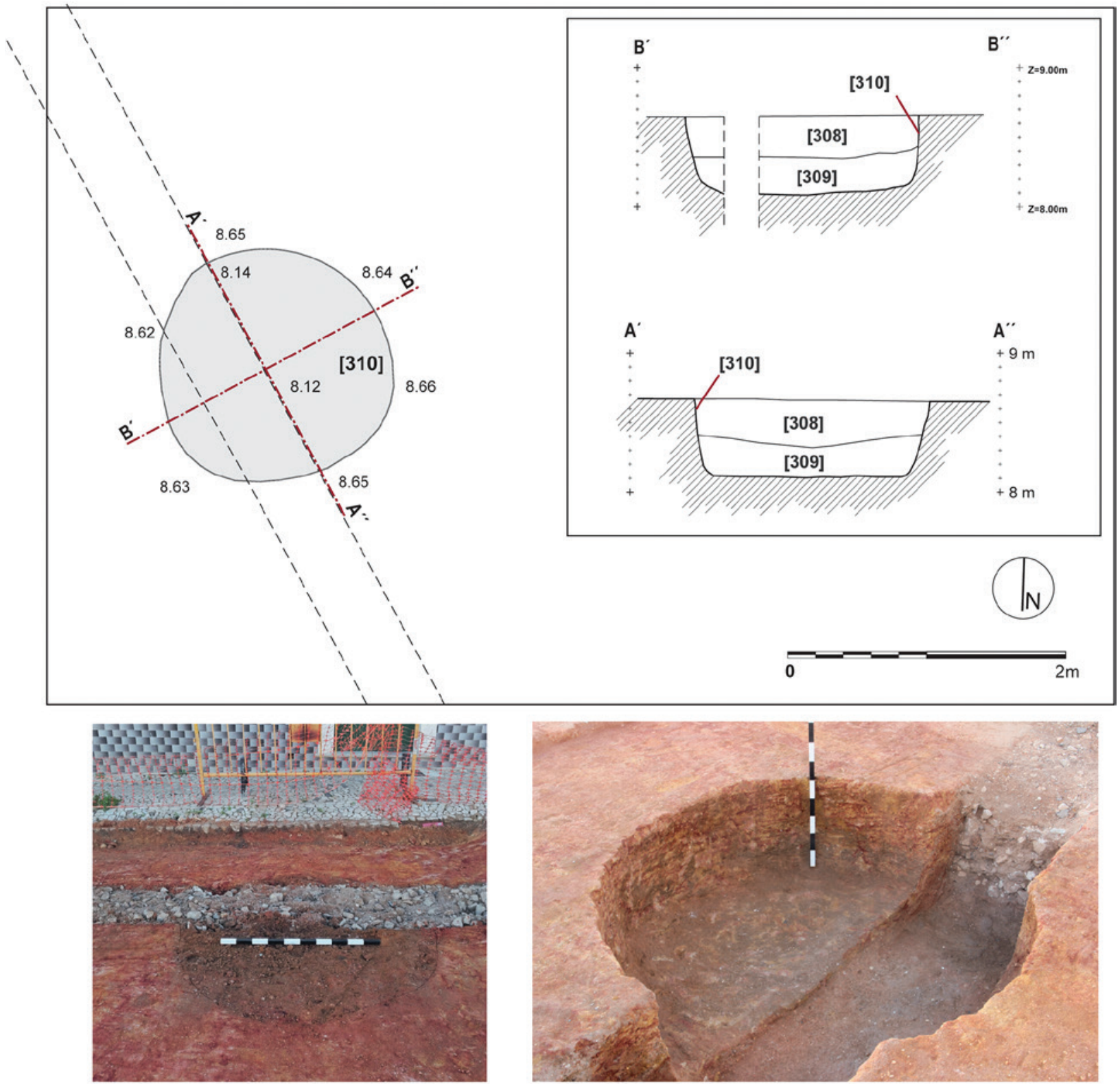

Figura 7 - Planta, perfil e vista geral de fossa medieval (vala 3). 

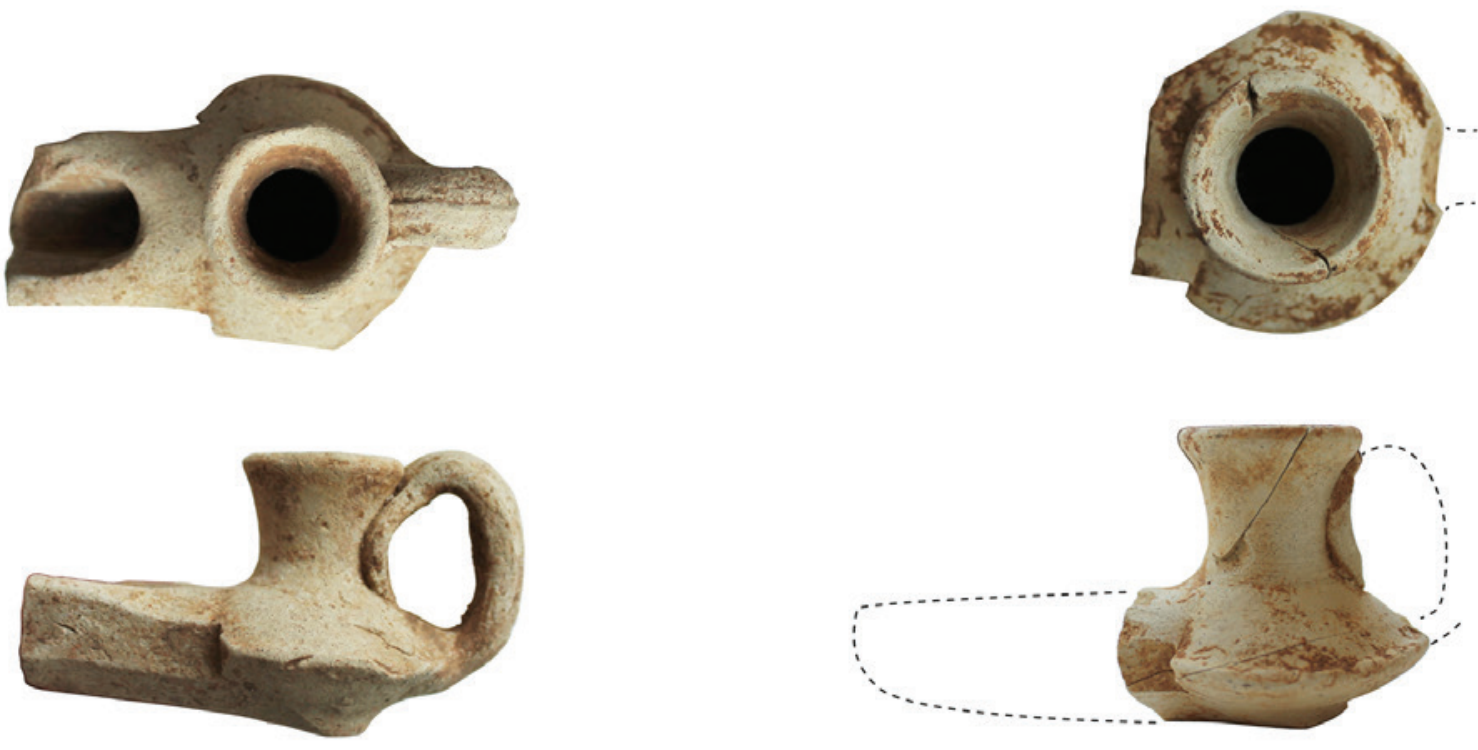

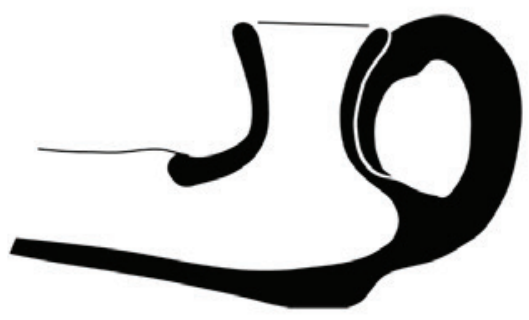

1

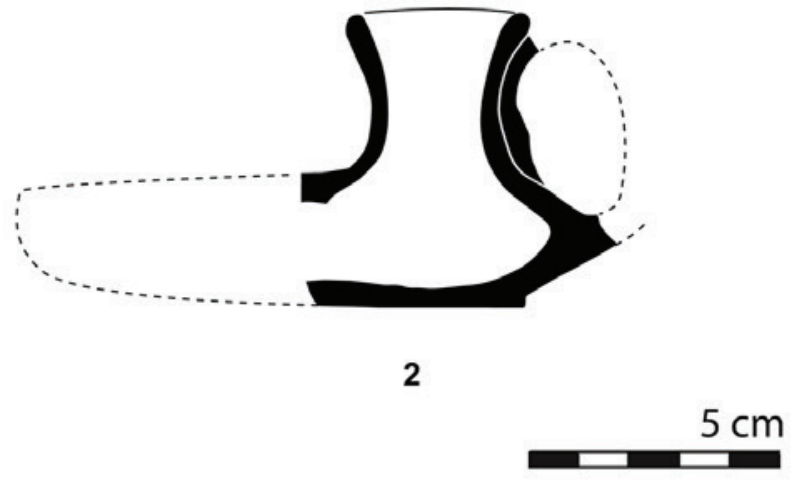

Figura 8-Candis. 

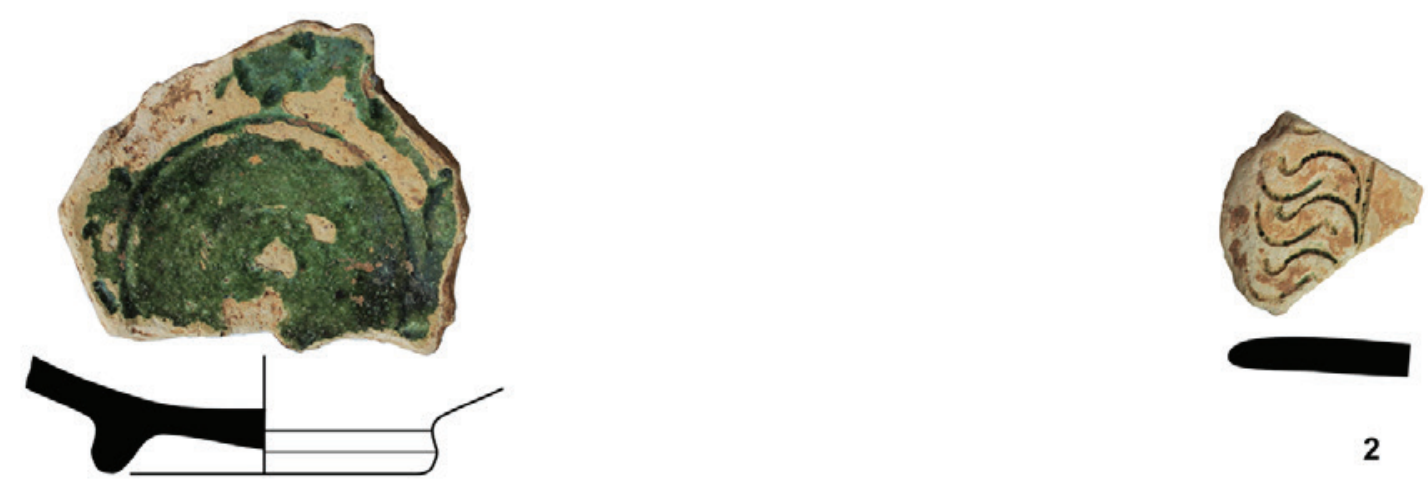

2

1
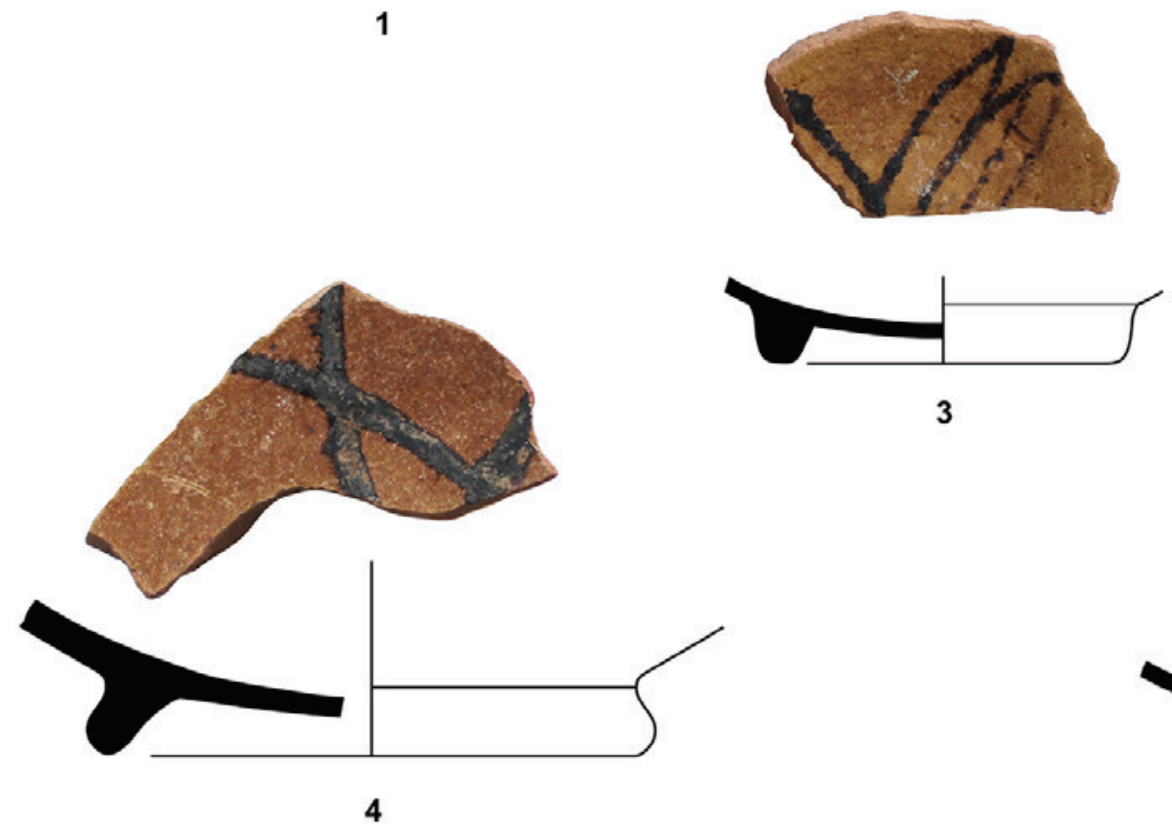

3
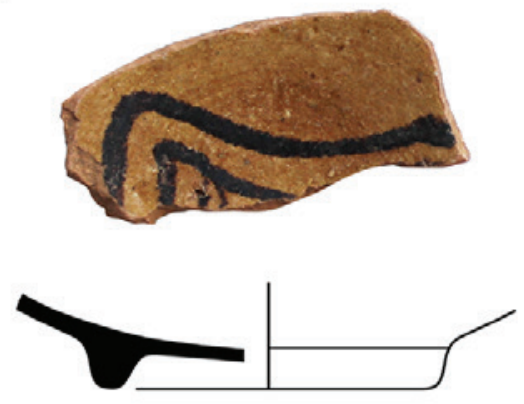

5
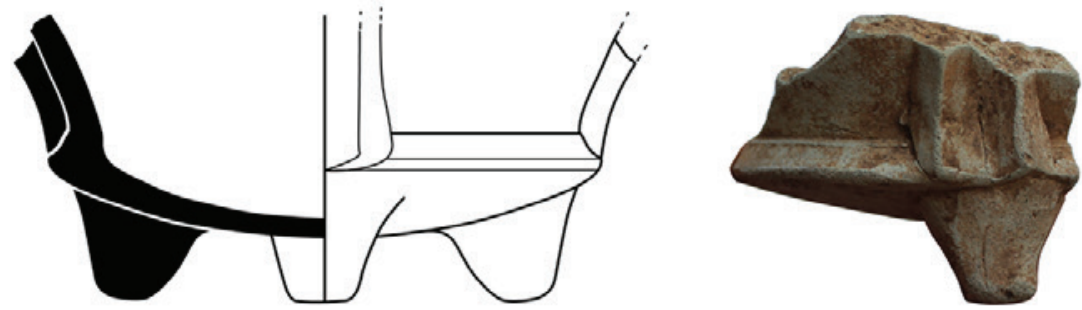

$5 \mathrm{~cm}$

6

Figura 9 - Conjunto cerâmico recuperado nos níveis de colmatação da fossa medieval. 


\title{
INSTRUMENTOS DE PESCA RECUPERADOS NUMA FÁBRICA DE SALGA EM OSSONOBA (FARO)
}

Inês Rasteiro ${ }^{1}$, Ricardo Costeira da Silva ${ }^{2}$, Paulo Botelho ${ }^{3}$

\begin{abstract}
RESUMO
O presente texto apresenta o estudo dos instrumentos de pesca recuperados num novo complexo de produção de preparados piscícolas identificado na zona ribeirinha de Faro (em 2017) durante uma intervenção arqueológica preventiva. À semelhança de outros espólios da mesma categoria provenientes deste tipo de officinae, a colecção é composta por anzóis, agulhas e um peso de rede.

Tendo em conta o interesse histórico e arqueológico das peças inventariadas pretendeu-se, para além da sua catalogação, realizar o estudo morfo-tipológico detalhado dos artefactos e analisar as técnicas pesqueiras utilizadas neste período cronológico, sistematizando e confrontando esta informação com a disponibilizada noutros trabalhos similares efectuados na região.

Palavras-chave: Ossonoba (Faro), Instrumentos de pesca, Anzóis, Agulhas de rede, Peso de rede em cerâmica.
\end{abstract}

\begin{abstract}
This paper addresses a group of fishing tools gathered in 2017 at an archaeological survey in a new fish production complex identified on the riverside of Faro. Like similar sets found on identical officinae, this collection is composed by hooks, needles and a clay net weight. Regarding the historic and archaeological significance of the instruments, it was intended, in addition to their catalogue and morpho-typological description, a mention of the fishing techniques used in this chronological period, confronting with the information provided by similar researches in the region.
\end{abstract}

Keywords: Ossonoba (Faro), Fishing tools, Hooks, Needles, Clay net weight.

\section{INTRODUÇÃO}

Em 2017, uma intervenção de arqueologia preventiva realizada na área ribeirinha de Faro (Portugal) permitiu identificar uma nova unidade de preparados de peixe (Figura 1 e 2), integrada numa zona de cariz industrial da antiga cidade romana de Ossonoba, da qual se conheciam escassas referências. A actividade pesqueira seria absolutamente fundamental ao funcionamento destes complexos de preparados piscícolas, recolhendo-se frequentemente neste tipo de sítios uma panóplia de materiais associados à pesca. Nesta etapa preliminar da investigação relativa ao sítio, em que se dá primazia ao estudo e divulgação da cultura material, apresenta-se a colecção de instrumentos de pesca identificada neste local composta, à semelhança de outras officinae análogas, por anzóis, agulhas e um peso de rede.

Ao contrário do que se tem vindo a observar para a vizinha província da Bética, a temática da pesca na Antiguidade e dos artefactos a ela associados não tem merecido particular atenção no actual território português. A cadência, mais ou menos regular, com que vão surgindo notícias de descoberta de novas unidades fabris conserveiras de época romana, não é acompanhada pelo acréscimo de novos estudos dedicados a este tipo de artefactos que surgem, incondicionalmente e especialmente, nesta categoria

\footnotetext{
1. Mestranda em Arqueologia. Faculdade de Letras da Universidade de Coimbra; ines.rasteiro@hotmail.com

2. Faculdade de Letras da Universidade de Coimbra; rcosteiradasilva@gmail.com

3. Engobe - Arqueologia e Património Lda.; paulo.o.botelho@gmail.com
} 
de sítios. Estes objectos só raramente são mencionados nos relatórios das intervenções e apenas excepcionalmente proporcionam estudos descritivos e tipológicos mais detalhados. Este é o caso do estudo sobre as evidências do instrumental pesqueiro de Loulé (Vargas Girón, 2017) e de dois trabalhos académicos desenvolvidos a partir do espólio recolhido no castelo de Castro Marim (Pereira, 2008) e no Monte Molião em Lagos (Lourenço, 2010). Não deixa de ser sintomático a afiliação desta temática com a região algarvia, de resto já notada nas referências bibliográficas mais antigas (Figueiredo, 1898; Ferreira, 1968; Santos, 1971-1972).

Tendo em conta a relevância das actividades piscícolas no litoral algarvio (pelo menos) desde os primeiros séculos da nossa era, interessa estudar a panóplia artefactual associada a esta actividade económica. Neste caso, as evidências expostas, sem serem excepcionais, contribuem para um melhor conhecimento das artes da pesca na Antiguidade. É neste contexto que se enquadra a singela contribuição apresentada.

\section{O CONTEXTO: A FÁBRICA DE SALGA DA R. FRANCISCO BARRETO EM FARO}

Ossonoba, localizada sob a actual capital do Algarve - Faro, terá sido uma das cidades portuárias mais importantes do sul da antiga província romana da Lusitânia. Situada na extremidade ocidental do chamado golfo de Cádis, terá desempenhado papel de relevo no tráfego mercantil entre o Mediterrâneo e o Atlântico.

Apesar do fulgor dos trabalhos de arqueologia preventiva e de emergência que nas últimas décadas se têm realizado um pouco por toda a área urbana da cidade (Viegas, 2011: 81-98) são ainda muitas as indefinições relativas ao seu traçado urbanístico e arquitectónico. Ainda assim, paulatinamente, cruzando toda a informação que vai brotando do subsolo desta urbe, é possível avançar com uma proposta de reconstituição parcial da topografia de Ossonoba (e.g. Viegas, 2011: 98, fig. 26; Bernardes, 2014: 357, lám. 2; Mantas, 2016: 41, fig. 8). A área monumental da cidade, onde se encontraria instalado o fórum (actual Largo da Sé) como centro político administrativo da capital de civitas, estaria cerzida à colina que se encontra definida pela cortina amuralhada medieval. A expansão da cidade para além dos limites do seu núcleo genético terá tido início logo na primeira metade do séc. I d.C., muito embora a consolidação e definição do seu tecido urbano tenha ocorrido apenas na segunda metade desta centúria ou já no início do séc. II (Bernardes, 2011: 13-14). Será nesta fase que a cidade ocupa a zona poente, junto à frente ribeirinha, onde irá proliferar uma intensa actividade artesanal e industrial essencialmente votada à exploração e transformação de recursos piscícolas (Bernardes, 2011: 19-20; Bernardes, 2014: 357). É neste contexto que se enquadram os vestígios postos a descoberto em 2017, na rua Francisco Barreto (Figura 1), durante intervenção arqueológica preventiva no âmbito da construção de um hotel.

A escavação, que se estendeu por cerca de $400 \mathrm{~m}^{2}$ de área, permitiu identificar duas etapas de ocupação diferenciadas. A fase de ocupação mais recente corresponde a uma unidade de preparados de peixe composta por, pelo menos, oito tanques de salga que se organizam em torno de um pátio central (Figura 2). Deste conjunto fabril, só parcialmente escavado, fazem ainda parte outros pequenos compartimentos (alguns com pavimentos em opus signinum) articulados entre si e uma área de combustão onde funcionou uma forja destinada ao trabalho do vidro. A análise preliminar do conjunto de baixela fina importada exumado nos níveis de colmatação das cetárias e de amortização da oficina permitem estimar o final da produção e consequente abandono do sítio nos finais do séc. VI (Silva \& alii, no prelo).

Todos os instrumentos de pesca recuperados e aqui dados à estampa são provenientes destes níveis, sobretudo da colmatação dos tanques de salga. Podendo eventualmente corresponder nalguns casos a material residual mais antigo, tudo indica que a generalidade da colecção se enquadre no momento precedente ao abandono do sítio.

\section{OS INSTRUMENTOS DE PESCA}

A amostra artefactual apresentada é constituída por três agulhas e dez anzóis em bronze e ainda um peso de rede em cerâmica. Neste caso, distinguem-se duas categorias de instrumentos pesqueiros: os directamente utilizados na pesca como os anzóis e o peso de rede e os que são usados complementarmente no apoio desta actividade como as agulhas. De qualquer modo, uns e outros revestem-se de igual interesse histórico e arqueológico ao atestar a prática pesqueira - uma das bases económicas desta região durante a época romana. 


\subsection{Agulhas de rede}

Entre as agulhas identificadas (Tabela 1) distinguem-se duas tipologias de acordo com a sua morfologia e função - a confecção ou a reparação de redes.

Referente à confecção das redes de pesca regista-se um exemplar completo do que vulgarmente se designa por lançadeira (Figura 3) ou agulha de "naveta” (Lourenço, 2010: 40). No fabrico da rede, a agulha passava alternadamente sob a malha, da direita para a esquerda e vice-versa (cit. por Martínez Maganto, 1992: 230). Por esse motivo, este tipo de agulhas apresenta uma morfologia e tamanho singular, assinalando-se duas partes essenciais na sua constituição, a haste e as forquilhas (Gracia Alonso, 1981-82: 324) que, por sua vez, se caracterizam por possuir diferente orientação. O exemplar, recuperado em bom estado de conservação, apresenta-se com 21,5 cm de comprimento, uma haste de secção circular com $0,35 \mathrm{~cm}$ de espessura e duas forquilhas completas (Cf. Tabela 1). Na região contam-se alguns exemplares desta tipologia, nomeadamente em Monte Molião (Lourenço, 2010: 40), Loulé Velho e Cerro da Vila (Quarteira) (Vargas Girón, 2017: 19), que exibem, no entanto, comprimento inferior $(\mathrm{c} .16 \mathrm{~cm})$ face à peça de Faro.

As restantes duas agulhas identificadas destinavam-se à reparação de redes de pesca (Cf. Tabela 1). Do ponto de vista morfológico, estes objectos são constituídos por uma haste e por uma cabeça. Um dos exemplares encontra-se bem conservado em termos de corrosão superficial embora fracturado na zona da cabeça, pelo orifício onde seria colocada a linha (Figura 4, n.․ 2). A outra agulha é mais delgada ( $0,2 \mathrm{~cm}$ de espessura) e está completa embora se encontre dobrada e com o orifício obstruído por concreções (Figura 4, n.ำ 1). Estas juntam-se a outras duas agulhas de coser já referenciadas em Faro (Santos, 1971: 196-199) e a outras peças semelhantes identificadas na região, designadamente, e uma vez mais, em Loulé Velho, Cerro da Vila (Vargas Girón, 2017:18) e Monte Molião (Lourenço, 2010: 40-41).

\subsection{Anzóis}

Os anzóis destacam-se entre os instrumentos de pesca mais comuns e facilmente identificáveis em contextos associados à actividade pesqueira. A existência de anzóis em metal é conhecida e documentada desde os alvores da metalurgia (Idade do Cobre - Calcolítico) (Ferreira, 1968: 115). Apesar disso, a sua morfologia geral não sofreu grandes alterações ao longo dos tempos. Ainda assim, uma análise tipológica mais detalhada terá de ter em conta as características das suas partes constituintes: o olhal (extremidade da haste onde se coloca a linha); a haste (que liga o olhal à curvatura do anzol); e a farpa (a extremidade afiada). Tendo em conta estes elementos pode-se ainda determinar a abertura e a garganta do anzol. A abertura corresponde à distância entre a haste e a farpa e a garganta condiz com a medida entre o extremo da abertura e a curvatura (Lourenço, 2010: 32, fig. 18).

Por suscitarem bastante interesse aquando do estabelecimento de sistemas de classificação, vários foram os investigadores que objectivaram a criação de diferentes tipologias. Neste âmbito pode mencionar-se a proposta de classificação de Déchelette (1910) que tinha por base a distinção das diferentes morfologias da extremidade distal da haste; a de Galliazzo (1979) com tipologia sustentada pela mesma variável ou, ainda, o sistema de classificação de F. Gracia Alonso (1981-1982) baseado nas variadas combinações que poderiam existir entre as diferentes partes constituintes do anzol. Em território português e ao nível do estudo morfológico e detalhado dos anzóis, deverá igualmente mencionar-se o contributo de Margarida Ribeiro (1973). Mais recentemente e no âmbito do projecto SAGENA apresenta-se uma proposta de classificação mais elaborada para os anzóis identificados no Círculo do Estreito (Bernal Casasola, 2010). A análise realizada aos dez anzóis da colecção em estudo contemplou os critérios utilizados naquele projecto, nomeadamente a morfologia, o tamanho e o sistema de fixação da linha ao anzol (Vargas Girón, 2011: 211). Os anzóis analisados são, quanto a estes preceitos, muito semelhantes, não apresentado grandes diferenças ao nível dos aspectos morfológicos ou mesmo das dimensões apresentadas (Cf. Tabela 2). Pelo que é possível observar, todos os exemplares se integram no grupo dos anzóis simples, com a extremidade da haste martelada e sem qualquer tipo de marcas ou ranhuras horizontais (Figura 5). De acordo com o estudo citado, a classificação da dimensão deste tipo de objectos baseia-se no comprimento total da haste. Também a este nível o conjunto apresenta valores muito semelhantes, integrando-se genericamente no grupo dos anzóis pequenos registando um comprimento de haste entre os 2,5 e $4 \mathrm{~cm}$.

A preponderância deste tipo de anzóis havia já sido notada nos sítios em torno do Círculo do Estreito 
(Vargas Girón, 2011: 214), sendo associados à pesca típica com cana e linha, usualmente praticada na linha de costa ou em pequenas embarcações. Apenas um exemplar da amostra (Figura 5, n..$^{-}$) apresenta um comprimento de $4,2 \mathrm{~cm}$, na fronteira que distingue os anzóis pequenos e médios. Em última análise, esta conformidade nos padrões dos anzóis poderá testemunhar uma ligação à captura das mesmas espécies piscícolas.

\subsection{Peso de rede}

Por último, refere-se a presença de uma peça de classificação controversa, mas que se optou por incluir na categoria dos pesos de rede em cerâmica. Apresenta uma forma cilíndrica e oca com estrangulamento na extremidade superior (Figura 6). Não se identificou nenhum paralelo formal absoluto. Todavia, a sua morfologia e dimensão assemelha-se aos denominados "pesos fusiformes" (Bernal Casasola, 2008: 197) identificados nalguns sítios costeiros da antiga província Mauritânia Tingitana como as fábricas de processamento de peixe em Tahaddart (na província de Tânger) (Ponsich, 1988: 149-150, fig. 32-4) ou em Septem Frates (Península de Almina, Ceuta) (Bernal Casasola, 2010: 101 e fig. 9 - CIV). A sua cronologia é para já difícil de determinar face a ausência de exemplares provenientes de contextos estratigráficos bem datados.

Caso se confirme, esta classificação acresce de interesse pois, até ao momento, a distribuição deste tipo de pesos relacionados com redes de médio ou grande porte encontrava-se limitada aos contextos pesqueiros de época imperial do litoral Tingitano, que se dispõem ao longo do Magrebe (Bernal Casasola, 2008: 197).

\section{CONSIDERAÇÕES FINAIS}

A grande densidade de vestígios de instalações conserveiras com cetárias que tem vindo continuamente a ser exposta nos sítios romanos do litoral sul da Lusitania, nomeadamente Algarve e estuários do Sado e Tejo, testemunham a vinculação dessa população ao mar e à indústria de preparados piscícolas. Neste contexto, tal como a extracção de sal, a actividade piscatória seria essencial para garantir a preparação de molhos e salgas, muito apreciados e difundidos por todo o Império Romano.

A notória evolução e diversificação das práticas pesqueiras na Antiguidade ficam a dever-se, essen- cialmente, ao desenvolvimento de um conjunto de instrumentos que tornaram a pesca uma actividade generalizada e rentável. No campo da investigação arqueológica, o estudo destes testemunhos materiais encontra-se ainda pouco desenvolvido, revelando algumas lacunas ao nível da sua perfeita contextualização e caracterização. $\mathrm{O}$ recorrente aparecimento de instrumental pesqueiro em sítios arqueológicos costeiros testemunha a ampla difusão e prática generalizada das diferentes técnicas de pesca.

Os artefactos que integram a amostra analisada remetem para o uso complementar de duas técnicas pesqueiras em particular: a pesca à linha e anzol e a utilização de redes que proporcionam capturas mais numerosas. Porém, a análise destes materiais terá de ser necessariamente correlacionada com os vestígios ictiológicos que começam, finalmente, a ser também contemplados nalguns projectos interdisciplinares. Apesar da fauna marinha surgir bem representada na iconografia (e.g. mosaicos e moedas) e referida na literatura, existem ainda algumas falhas de conhecimento relativamente às espécies capturadas e ao tipo de pesca praticada na Antiguidade. Será, provavelmente, na complementaridade entre estes dois ramos, ictiologia e o estudo do instrumental pesqueiro, que residirá a chave para o esclarecimento de algumas questões pendentes acerca desta actividade económica que seria de vital relevância para as populações costeiras, já nos primeiros séculos da nossa era.

\section{BIBLIOGRAFIA}

BERNAL CASASOLA, Darío (2008) - Arqueología de las redes de pesca. Un tema crucial de la economia marítima hispanorromana. Mainake. Málaga. XXX, pp. 181-215.

BERNAL CASASOLA, Darío (2010) - Fishing tackle in Hispania: reflections, proposals and first results. In BEKKERNIELSEN, Tonnes, BERNAL CASASOLA, Darío, eds. - Ancient nets and fishing gear: proceedings of the International Workshop on Nets and Fishing Gear in Classical Antiquity: a first approach. Cádiz, pp. 83-138.

BERNARDES, João P. (2011) - A cidade de Ossonoba e o seu território. Anais do Municipio de Faro, 37, pp.11-26.

BERNARDES, João P. (2014) - Ossonoba e o seu território: as transformações de uma cidade portuária do sul da Lusitânia. In VAQUERIZO GIL, Desiderio, GARRIGUET MATA, José A.; LEÓN MUÑOZ, Alberto, eds. - Ciudad y territorio: transformaciones materiales e ideológicas entre la época clásica y el Altomedievo, Monografías de Arqueología Cordobesa. Córdoba. 2o, pp. 355-366. 
DÉCHELETTE, Joseph (1910) - Manuale d'archéologie Prehistorique, Celtique et Gallo-Romaine, Paris.

FERREIRA, O. Veiga (1968) - Algumas notas sobre a pesca na Antiguidade. O Arqueólogo Português. Lisboa. Série III. 3, pp. 113-134.

FIGUEIREDO, António Mesquita (1898) - Contribuições para o estudo da história da pesca, em Portugal, na epocha luso-romana. O Arqueólogo Português. Lisboa. Série I. 4, pp. 53-58.

GALLIAZO, Vittorio (1979) - Bronzi romani del Museo Civico di Treviso, Roma.

GRACIA ALONSO, Francisco (1981-1982) - Ordenación tipológica del instrumental de pesca en bronce ibero-romano. Pyrenae. Barcelona. 17-18, pp. 315-328.

LOURENÇO, Pedro R. (2010) - A pesca na Antiguidade: o caso de Monte Molião (Lagos). Tese de Mestrado em Arqueologia apresentada à Faculdade de Letras da Universidade de Lisboa (disponível em http://repositorio.ul.pt/handle/ 10451/3731).

MANTAS, Vasco G. (2016) - Navegação e Portos no Algarve Romano. Al - Úlyá - Revista do Arquivo Municipal de Loulé, 16 , pp. 25-51.

MARTÍNEZ MAGANTO, Julio (1992) - Las técnicas de pesca en la Antigüedad y suimplicación económica en el abastecimiento de las industrias de salazón. Cuadernos de Prehistoria y Arqueologia de la Universidad Autónoma de Madrid. 19, pp. 219-244.

PEREIRA, Teresa R. (2008) - Os artefactos metálicos do Castelo de Castro Marim na Idade do Ferro e em época Romana - Metalurgia em transição: a amostra numa análise de conjunto. Tese de Mestrado em Arqueologia apresentada à Faculdade de Letras da Universidade de Lisboa (disponível em http://repositorio.ul.pt/handle/10451/393).

PONSICH, Michel (1988) - Aceite de oliva y salazones de pescado. Factores geo-económicos de Betica y Tingitania. Madrid: Universidad Complutense de Madrid.

RIBEIRO, Margarida (1973) - Anzóis de Tróia. Subsídios para o estudo da pesca no período lusitano-romano. O Arqueólogo Português. Lisboa. Série III. 4, pp. 221-236.

SANTOS, Maria L. E. V. (1971/1972) - Arqueologia romana do Algarve (volumes I/II). Lisboa: Associação dos Arqueólogos Portugueses.

SILVA, Ricardo C.; FERNÁNDEZ, Adolfo; SANTOS, F.; BOTELHO, P. (no prelo) - Vajillas finas importadas tardoantiguas de los niveles de abandono de la factoría de salazones de la calle Francisco barreto en Faro (Portugal). Proceedings of the $7^{\text {th }}$ International Conference on Late Roman Coarse Wares Cooking. Roman and Late Antique Mediterranean Pottery. Archaeopress: Oxford.
VARGAS GIRÓN, José M. (2011) - La pesca com caña y sedal en el Círculo del Estrecho. In BERNAL CASASOLA, Darío, ed. - Pescar con Arte. Fenícios y romanos en el origen de los aparejos andaluces. Catálogo de la exposición (Baelo Claudia, Diciembre 2011- Julio 2012). Cádiz. pp. 199-230 (Monografías del Proyecto Sagena 3).

VARGAS GIRÓN, José M. (2017) - Evidencias de instrumental pesquero en Loulé. Recientes resultados de un estudio de materiales realizado en el marco de la exposición Loulé - territórios, memórias e identidades. Al - Úlyá - Revista do Arquivo Municipal de Loulé, 18, pp. 9-24.

VIEGAS, Catarina (2011) - A ocupação romana do Algarve. Estudo do povoamento e economia do Algarve central e oriental no período romano. UNIARQ (Estudos e Memórias, 3), Lisboa. 


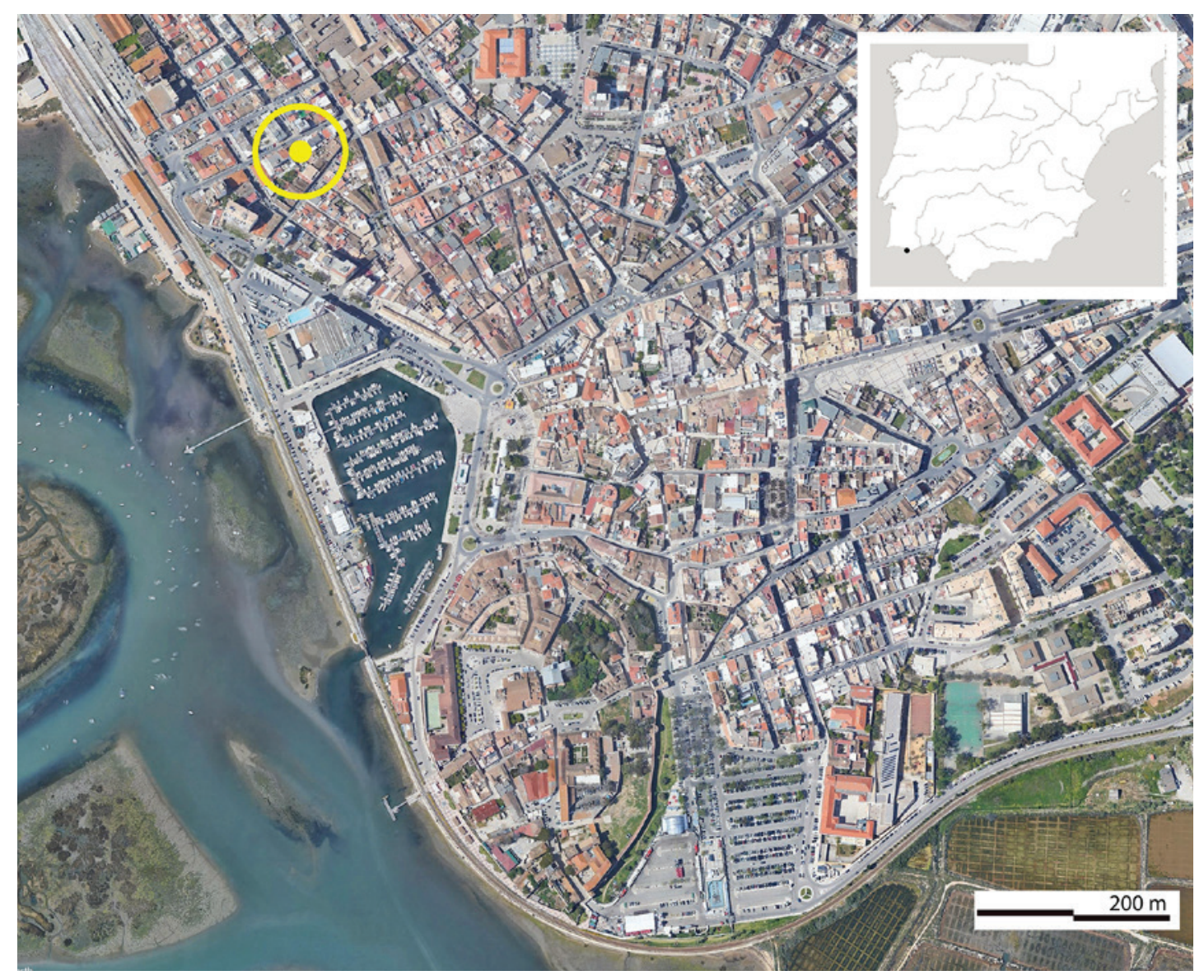

Figura 1 - Localização da intervenção na malha urbana da actual cidade de Faro (base do Google Earth).

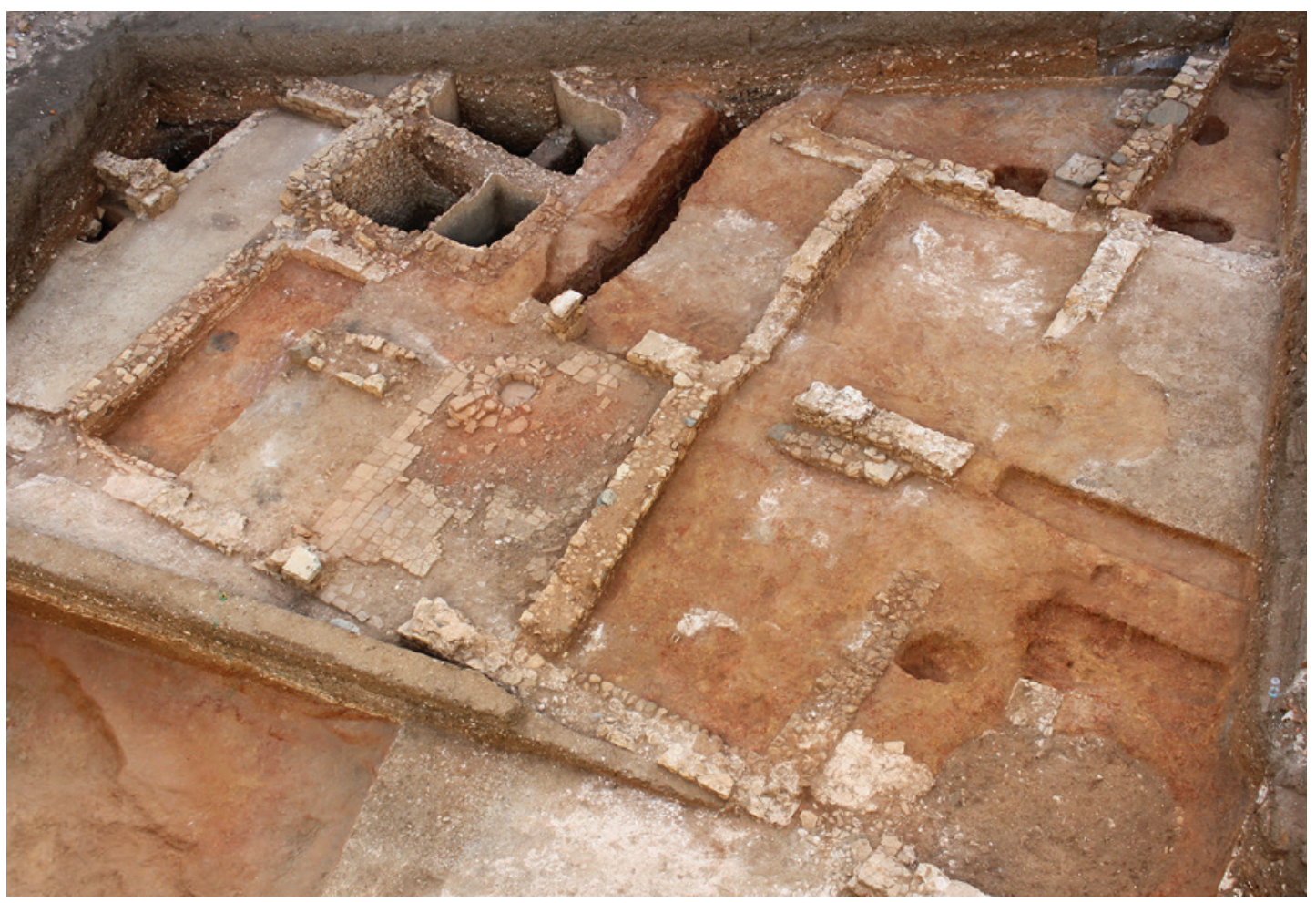

Figura 2 - Vista geral da área de intervenção. 


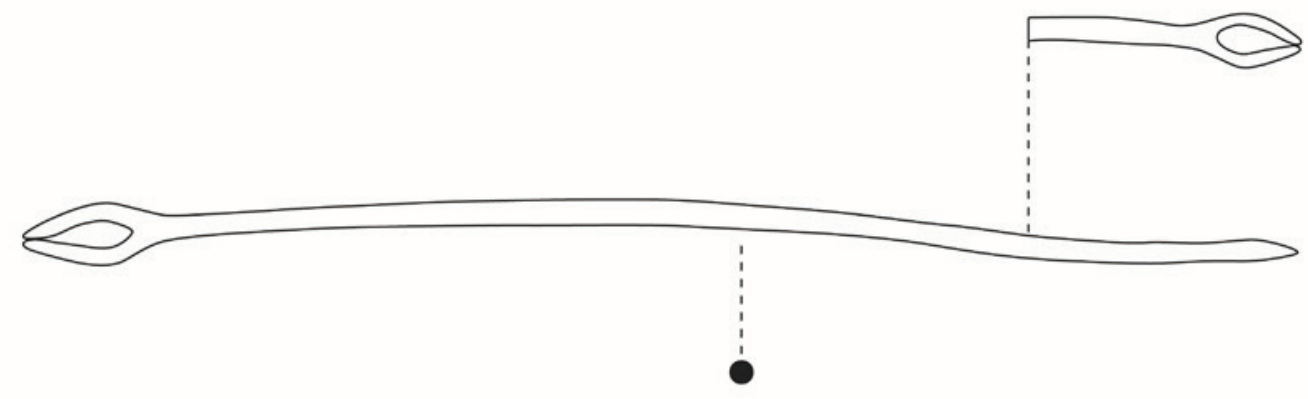

$5 \mathrm{~cm}$

Figura 3-Lançadeira.
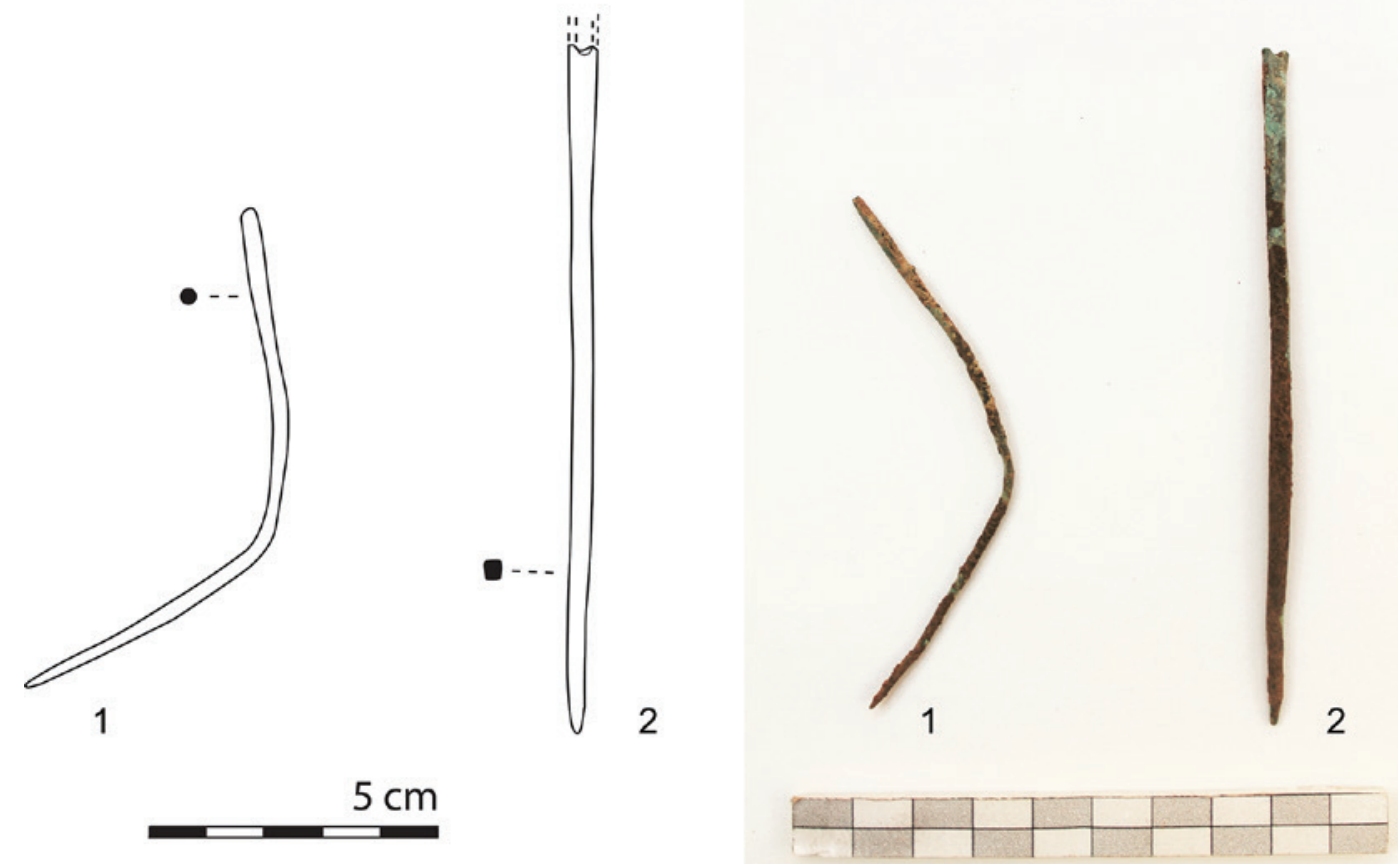

Figura 4-Agulhas. 

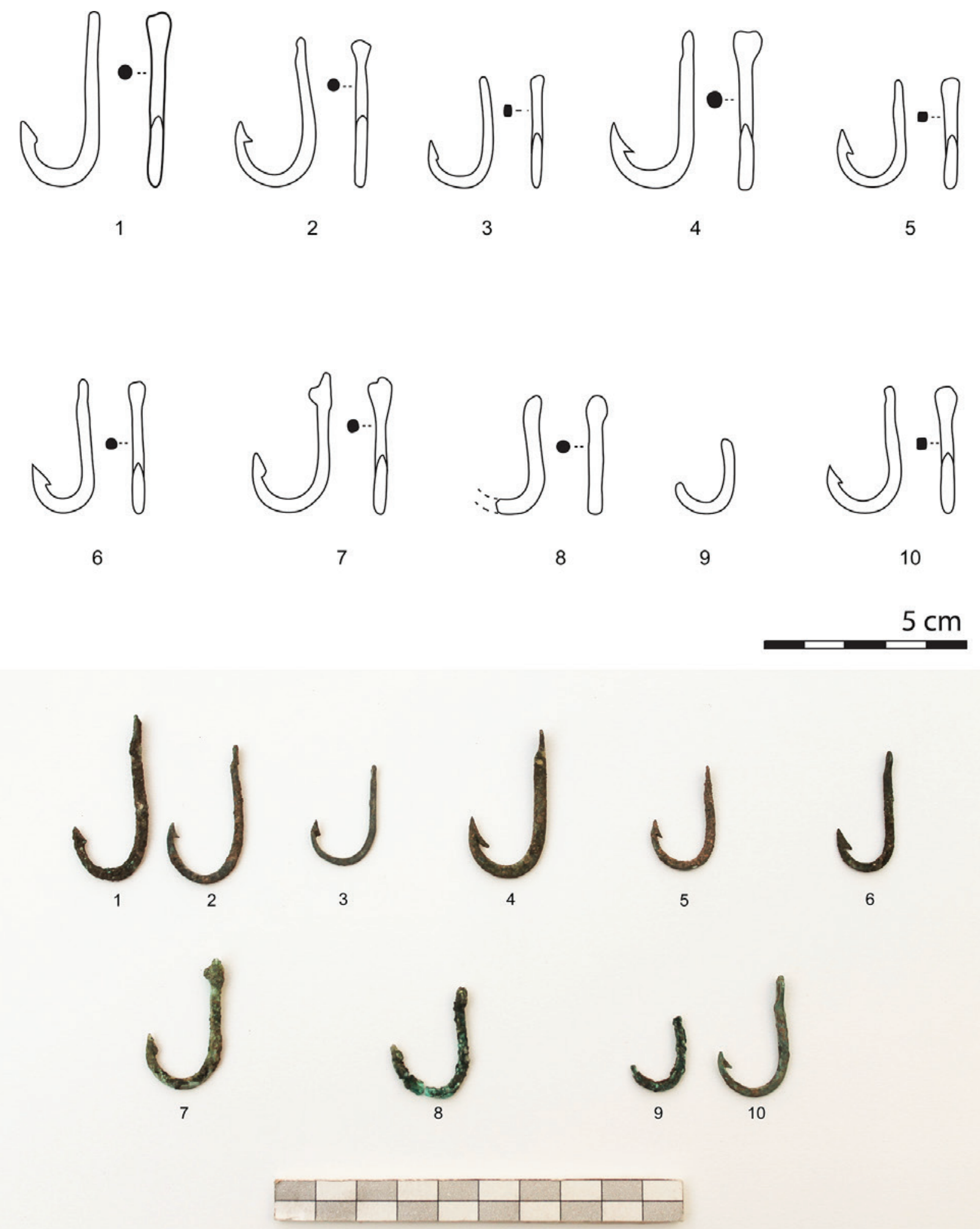

Figura 5-Anzóis. 

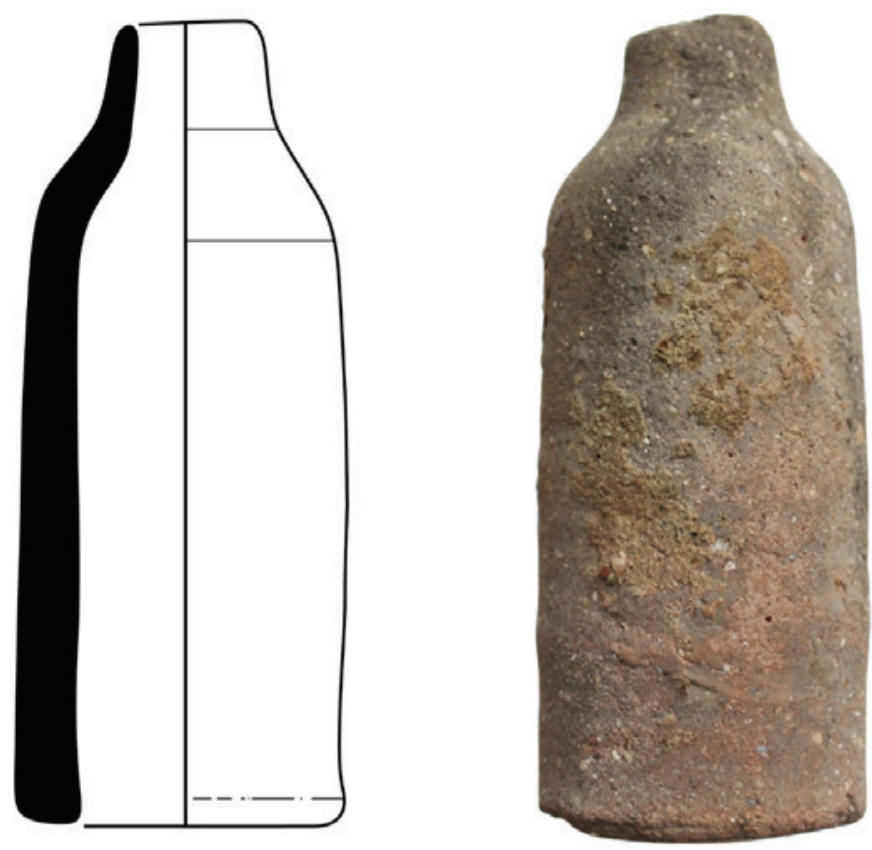

$5 \mathrm{~cm}$
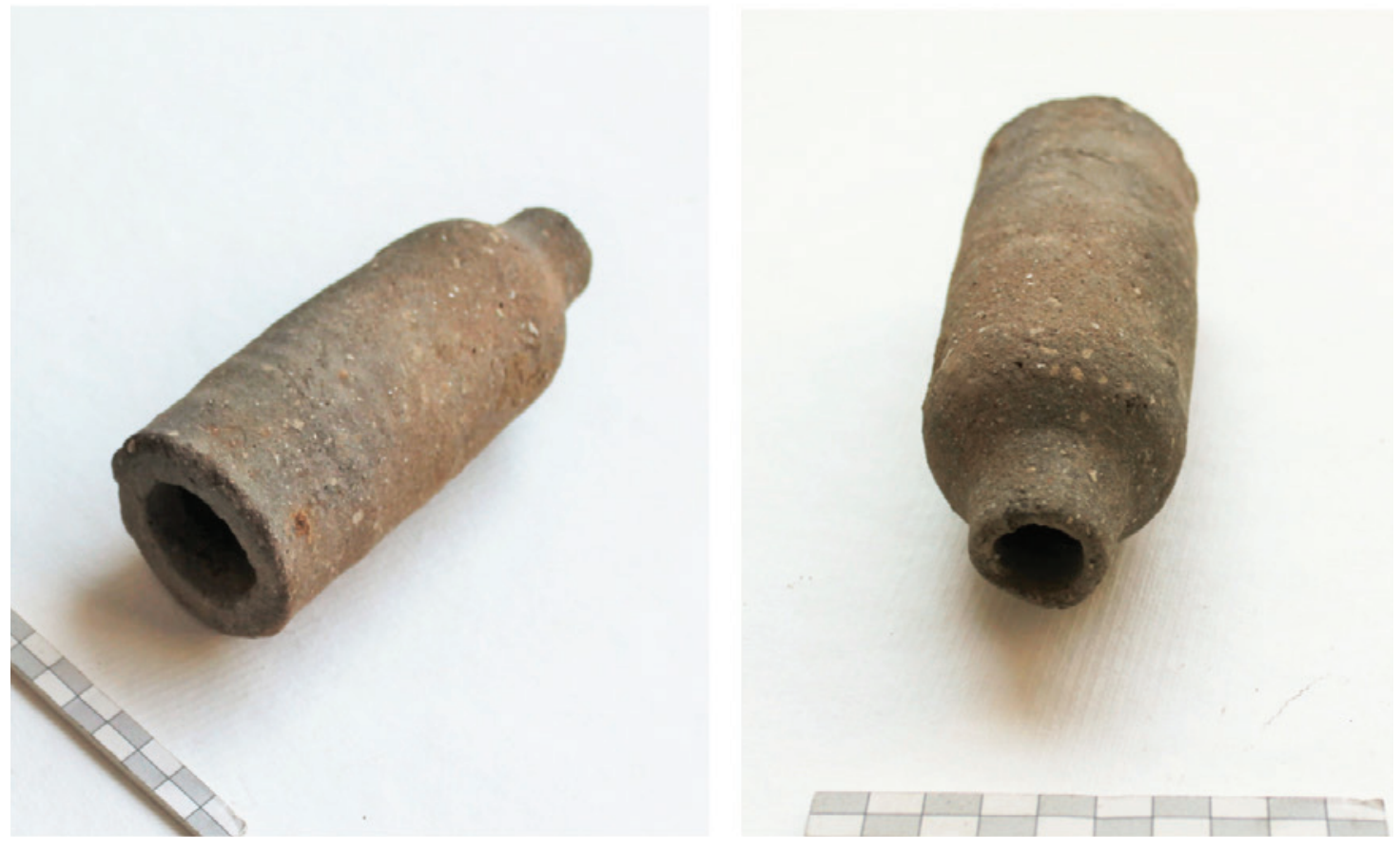

Figura 6 - Peso de rede em cerâmica. 


\begin{tabular}{|l|l|l|l|l|l|}
\hline Designação & Área e U.E. & Comprimento & Espessura & Estado de Conservação & Outras informações \\
\hline Lançadeira & Área F [707] & $21,5 \mathrm{~cm}$ & $0,35 \mathrm{~cm}$ & Completa & $\begin{array}{l}\text { Duas forquilhas, uma em } \\
\text { cada extremidade da haste; } \\
\text { Amplitude da abertura: } \\
\text { o,5x1,5cm e } 0,4 \times 1,2 \mathrm{~cm}\end{array}$ \\
\hline Agulha & Área A [719] & $11,6 \mathrm{~cm}$ & $0,5 \mathrm{~cm}$ & Incompleta & \\
\hline Agulha & Comp. V [860] & $10,2 \mathrm{~cm}$ & $0,2 \mathrm{~cm}$ & Completa, mas dobrada & \\
\hline
\end{tabular}

Tabela 1 - Agulhas - Quadro recapitulativo.

\begin{tabular}{|c|c|c|c|c|c|c|c|c|}
\hline Anzol & $\begin{array}{l}\text { Área } \\
\text { e U.E. }\end{array}$ & Comprimento & Abertura & Garganta & $\begin{array}{l}\text { Espessura } \\
\text { da haste }\end{array}$ & Farpa & $\begin{array}{l}\text { Extremidade } \\
\text { da haste }\end{array}$ & $\begin{array}{l}\text { Estado de } \\
\text { Conservação }\end{array}$ \\
\hline 1 & $\begin{array}{l}\text { Área F } \\
{[707]}\end{array}$ & $4,2 \mathrm{~cm}$ & $1,5 \mathrm{~cm}$ & $1,2 \mathrm{~cm}$ & $0,3 \mathrm{~cm}$ & Presente & Martelada & Completo \\
\hline 2 & $\begin{array}{l}\text { Área F } \\
\text { [707] }\end{array}$ & $3,6 \mathrm{~cm}$ & $1,5 \mathrm{~cm}$ & $1,4 \mathrm{~cm}$ & $0,2 \mathrm{~cm}$ & Presente & Martelada & Completo \\
\hline 3 & $\begin{array}{l}\text { Área F } \\
\text { [708] }\end{array}$ & $2,7 \mathrm{~cm}$ & $1,3 \mathrm{~cm}$ & $0,7 \mathrm{~cm}$ & $0,15 \mathrm{~cm}$ & Presente & $\begin{array}{l}\text { Subtilmente } \\
\text { martelada }\end{array}$ & Completo \\
\hline 4 & $\begin{array}{l}\text { Área A } \\
\text { [719] }\end{array}$ & $3,8 \mathrm{~cm}$ & $1,5 \mathrm{~cm}$ & $1,15 \mathrm{~cm}$ & $0,3 \mathrm{~cm}$ & Presente & Martelada & Completo \\
\hline 5 & $\begin{array}{l}\text { Área L } \\
{[865]}\end{array}$ & $2,6 \mathrm{~cm}$ & $1,3 \mathrm{~cm}$ & $1,15 \mathrm{~cm}$ & $0,2 \mathrm{~cm}$ & Presente & Martelada & Completo \\
\hline 6 & $\begin{array}{l}\text { Área D } \\
{[894]}\end{array}$ & $3,2 \mathrm{~cm}$ & $1,2 \mathrm{~cm}$ & $0,85 \mathrm{~cm}$ & $0,2 \mathrm{~cm}$ & Presente & Martelada & Completo \\
\hline 7 & $\begin{array}{l}\text { Área H } \\
\text { (Comp. } \\
\text { VIII) } \\
\text { [940] }\end{array}$ & $3,35 \mathrm{~cm}$ & $1,4 \mathrm{~cm}$ & $1,1 \mathrm{~cm}$ & $0,25 \mathrm{~cm}$ & Presente & Martelada & Completo \\
\hline 8 & $\begin{array}{l}\text { Área H } \\
\text { (Comp. } \\
\text { VIII) } \\
{[942]}\end{array}$ & $2,9 \mathrm{~cm}$ & $1,35 \mathrm{~cm}$ & $0,85 \mathrm{~cm}$ & $0,25 \mathrm{~cm}$ & $\begin{array}{l}\text { Presente } \\
\text { fragmentada }\end{array}$ & Indeterminada & Fragmentado \\
\hline 9 & $\begin{array}{l}\text { Área J } \\
\text { [967] }\end{array}$ & $1,8 \mathrm{~cm}$ & - & - & $0,25 \mathrm{~cm}$ & Ausente & Ausente & Incompleto \\
\hline 10 & $\begin{array}{l}\text { Área J } \\
\text { [967] }\end{array}$ & $3 \mathrm{~cm}$ & $1,4 \mathrm{~cm}$ & $0,85 \mathrm{~cm}$ & $0,25 \mathrm{~cm}$ & Presente & Martelada & Completo \\
\hline
\end{tabular}

Tabela 2 - Anzóis - Quadro recapitulativo. 


\title{
A NECRÓPOLE ROMANA DO EIRÔ, DUAS IGREJAS (PENAFIEL): INTERVENÇÃO ARQUEOLÓGICA DE 2016
}

\author{
Laura Sousa $^{\mathrm{I}}$, Teresa Soeiro $^{2}$
}

\begin{abstract}
RESUMO
Em 2016, a construção do Centro Paroquial de Duas Igrejas (Penafiel) proporcionou a (re)escavação, pelo Museu Municipal de Penafiel, de uma das necrópoles romanas conhecidas na freguesia, lugar do Eirô. Abílio Miranda publicou a primeira notícia em 1941, reportando-se ao achamento ocasional de enterramentos, num terreno entre a igreja e o cemitério. Continham cerâmica comum romana e um anel decorado, materiais que, sem destrinça, deram entrada no Museu. Com a presente intervenção, recuperaram-se as estruturas tumulares remanescentes daquela ocorrência e escavaram-se, integral ou parcialmente, mais seis sepulturas de inumação preservadas, contendo cerâmica, pregadura de calçado com vestígios de tecido e numismas, permitindo uma nova leitura do sítio e a datação destes enterramentos, atribuídos ao terceiro quartel do século IV d.C.

Palavras-chave: Necrópole romana, Sepulturas de inumação, Século IV, Duas Igrejas/Penafiel, Museu Municipal de Penafiel.
\end{abstract}

\begin{abstract}
The (re)excavation, in 2016, by Penafiel's Municipal Museum, of one of the known parish's Roman necropolis at Eirô hamlet, was facilitated by the construction of the Duas Igrejas Parish Centre. In 1941, Abílio Miranda published the first news referring the casual finding of archeological burials in a ground between the church and the graveyard. Roman coarse wares and an ornamented ring were found there. These materials entered the Museum unrecorded. In this intervention the remaining grave structures of that occurrence were uncovered. Six more preserved inhumation tombs were partially or fully excavated that contained pottery, hobnails with fabric remains, and coins. It allowed for a new interpretation of the site and these burials datation, attributed to the $4^{\text {th }}$ century A.D.
\end{abstract}

Keywords: Roman necropolis, Inhumation tombs, $4^{\text {th }}$ century, Duas Igrejas/Penafiel, Municipal Museum of Penafiel.

\section{O SÍTIO ARQUEOLÓGICO}

Abílio Miranda (1893-1962), estudioso do património local e director da Biblioteca-Museu Municipal de Penafiel, noticiou, no início dos anos Quarenta, o achado de duas necrópoles romanas na freguesia de Duas Igrejas (Penafiel). No primeiro artigo, publicado em 1941 (Miranda, 1941), referiu-se à descoberta casual, que lhe fora de imediato comunicada pelo pároco, resultante de obras em curso junto da Igreja. Assim, teve ensejo de se deslocar ao lugar do
Eirô, visionar a intervenção e recolher algum espólio para o futuro Museu, nomeadamente vasos cerâmicos e um anel de azeviche (MMPNF/4655). A outra ocorrência sucedera em 1933, ao abrir os alicerces para a Escola Primária, no lugar de Antas, $300 \mathrm{~m}$ a SO da Igreja, tendo sido avisado pelo mesmo sacerdote, ainda a tempo de observar "uma ou duas cavidades de sepulturas" (Miranda, 1942, p. 65). Dele recebeu, para acervo museológico, cerâmicas romanas e um anel em bronze (MMPNF/4656), cuja mesa ostenta o conhecido tema clássico do

\footnotetext{
1. CITCEM - Centro de Investigação Transdisciplinar «Cultura, Espaço e Memória»; laura_sousa@hotmail.com

2. CITCEM - Centro de Investigação Transdisciplinar «Cultura, Espaço e Memória»; teresasoeiro@sapo.pt
} 
"casal afrontado» (Cravinho, 2014, p. 363). Provirão também desta necrópole as 41 moedas do século IV (MMPNF/2949-2950, 2952-2989 e 4334) estudadas por Isabel Pereira (1975) e um estilete de bronze (MMPNF/4687) referido por Pinho Brandão (1961, p. 30). O enquadramento do sítio e a publicação dos materiais cerâmicos (MMPNF/2906-2920; 2922-2933 e 5311), que integram a colecção apenas com indicação da freguesia (não especificando qual dos cemitérios e conjunto funerário), bem como dos anéis e estilete, foi realizada pela segunda autora desta comunicação, em 1984 (Soeiro, 1984, pp. 89-95).

Estando a área sob vigilância desde então, a construção do novo Centro Paroquial de Duas Igrejas motivou a realização de sondagens arqueológicas, em 2015, a cargo do Museu e dirigidas pela primeira autora (DRCN-DSBC/2015/495). Foi confirmado o interesse patrimonial do espaço, procedendo-se, em 2016, ao alargamento da escavação em área, na plataforma superior, coincidente com as descrições de Abílio Miranda. Aqui, para além do reconhecimento de algumas das estruturas exumadas em 1941, identificaram-se novos enterramentos, preservados, possibilitando a (re)interpretação da necrópole e datação de pelo menos um período de utilização, o que permite o cotejo com outras congéneres, estudadas na área de Penafiel e região envolvente ${ }^{3}$ (Figura 1).

\section{O LUGAR}

A necrópole do Eirô (41.185625-8.269802) está localizada numa área aplanada do centro da freguesia de Duas Igrejas, que pouco ultrapassa os $400 \mathrm{~m}$ de altitude, na mancha de "granitos monzoníticos, porfiróides de duas micas, essencialmente biotíticos" (CGP - Folha 9-D). Contornam esta rechã os altos de Marecos (449m), a Poente, e os da Brenha (477m) e Chocal (589m) a NE-E, tendo a Sul o planalto de Luzim $(556 \mathrm{~m})$. Elevações inabitadas, foram até ao passado século áreas de pastoreio e recolha de lenha, e delas descem águas que alimentam córregos e nascentes, fundamentais ao assentamento e cultivo do solo em altitude intermédia. A sede da paróquia de Santo Adrião de Canas, instalada, na Idade Média,

3. Agradecemos a Rui Centeno a classificação das moedas, apesar da dificuldade decorrente de ainda não terem sido objecto de qualquer tratamento, bem como as sugestões de interpretação, a Rui Oliveira a realização das estampas e a Eduardo Cunha a fotografia de artefactos. entre campos agrícolas, num local mais baixo, a Sul, foi transferida, por 1564, para o lugar do Eirô (Santos, 1973, pp. 540-541; R., 1973), desafogado e bem conectado, onde existia a ermida de Santa Maria e, antes dela, a necrópole romana e, provavelmente, o respectivo povoado aberto/aldeia, com o qual também se relacionará o espaço funerário de Antas. Quase contígua à nova igreja foi erguida, antes dos meados do século XVIII, a residência paroquial, com campo do passal e horta (Cardoso, 1751, p. 403), que interferiram com os enterramentos romanos, pois um dos escavados (S. 8) está coberto pelo alicerce desta parede. Também o muro periférico do actual cemitério, datado de 1886 e implantado a Este do passal, cortou o sítio, sendo comum surgirem materiais arqueológicos dispersos ao preparar os funerais. Em Duas Igrejas cruzam-se caminhos naturais de passagem, quer os que ligam as terras baixas das margens do Sousa e Cavalum (W) ao vale do Tâmega (E), à altura da ponte romana de Canaveses, quer o que da Portela de Santa Marta (N) se dirige a S, pelos altos de Luzim até às passagens do Tâmega e Douro, ou por Rans e o vale da ribeira da Camba, em cota baixa, até Entre-os-Rios. Em qualquer destes percursos se encontram sítios arqueológicos de época romana, muitos coetâneos da necrópole em estudo (Soeiro, 1984 e 2018; PDM - Carta do Património).

\section{O ACHADO DE 1941 E A INTERVENÇÃO DE 2016}

Abílio Miranda (1941) descreve o sítio como "uma vasta necrópole mixta de sepulturas circulares, rectangulares e uma antropomórfica aberta na rocha». Parco e por vezes desconcertante nos detalhes, individualizou seis destas sepulturas: uma antropomórfica aberta na rocha, quatro rectangulares "abertas em terra, mas aparelhadas à volta com pedra», que «mediam aproximadamente dois metros de comprido por sessenta centímetros de largo" e "eram tôdas forradas, pela parte interior, de tabuões de madeira", e uma "de menores dimensões, que serviu a uma criança». Deixamos de lado as covas circulares, que diz vazias, e as demais cavidades irregulares do saibro, possível resultado da plantação de árvores e colocação de estruturas efémeras no campo do passal. Pelo contrário, valorizamos a sua referência ao facto de uma sepultura ser aberta na rocha e simultaneamente conter espólio (romano), condições que se repetiram nas S. 4 e S. 5, de 2016, contribuindo 
assim para esclarecer o equívoco gerado por aquela notícia e exacerbado em notas posteriores, com larga repercussão na historiografia das sepulturas (antropomórficas) abertas na rocha, medievais (Barroca, 2010-2011, p. 135).

A intervenção de 2016 estendeu-se pela plataforma sensivelmente horizontal entre a igreja e o muro do cemitério (c. $\left.325 \mathrm{~m}^{2}\right)$, à face da rua da Liberdade, e permitiu identificar: cinco sepulturas romanas preservadas (S. 1 a S. 5), das quais uma não escavada na totalidade por estar sob o passeio da via pública (S. 3); uma sepultura (S. 8) perturbada pela construção da antiga Casa Paroquial, cujo alicerce integrava também parte de uma mó giratória em granito de moinho manual romano (MMPNF/14483) e, na vala de fundação, uma moeda de Constâncio II (MMPNF/14424); cinco das seis sepulturas referidas por Abílio Miranda, agora renumeradas (S. 6, 7 e 9 a 11) (Figura 2).

\section{A NECRÓPOLE E AS SEPULTURAS}

A necrópole do Eirô ficou delimitada em escavação apenas no sentido Sudeste, pela confirmação da não existência de elementos cemiteriais numa faixa de $\pm 12 \mathrm{~m}$ antes do declive do terreno. No sentido oposto, sabemos que avança para a via pública (veja-se $S$. 3); em direção SO-NE, foi cortada tanto pelo adro e casa paroquial (S. 8), como pelo atual cemitério (zona escavada em 1941). Estava instalada numa área aplanada, certamente com pouca potência de terra sobre o substrato, constituído sobretudo por alterite de granito, fácil de escavar com instrumentos de ferro mas suficientemente estável para as covas não necessitarem de estrutura de contenção. As marcas de corte e desbaste indiciam a morfologia da lâmina e a direcção dos golpes dos instrumentos utilizados para as abrir. Porém, em alguns pontos este saibro muito alterado dá lugar a outro, duro, com grânulos de quartzo e feldspato de maior dimensão, mais difícil de aprofundar. A gradação prossegue até às sepulturas abertas na própria rocha, situação provavelmente não desejada e mesmo evitada quando o afloramento ficava visível, que resultou em sepulcros pouco profundos (S. $4=0,4 \mathrm{Om} \mathrm{e} \mathrm{S.} 5=0,25 \mathrm{~m}$ escavados) e com os limites verticais e o fundo irregulares e toscos (Figura 3).

Apesar destas contingências, dez dos enterramentos reconhecidos, com diferente tipologia construtiva, estão organizados sensivelmente na mesma orientação, NE-SO, sem sobreposições e com interceções tangenciais (nas S. 2 e 3, pela abertura da S. 10, e na S. 5, pela S. 8). Nenhum dos escavados em 2016, covas simples distribuídas pela área com pouca potência de solo arável, conservava a cobertura, se existiu. Pelo contrário, os descobertos em 1941, de construção pétrea e implantados numa zona mais funda do terreno (S. 6,7 e 11), estariam capeados com "cascões de pedra» granítica, como registou Abílio Miranda. Contudo, as cotas superiores de uns e outros são idênticas, pelo que também estas coberturas poderiam não ter impacto à superfície, colocando-se mais uma vez a questão do reconhecimento externo, que evitasse violações inadvertidas e facilitasse a identificação do defunto para a aproximação dos familiares à campa em momento de celebração.

Faremos, de seguida, a caracterização sumária dos enterramentos. Para cada um são indicadas as dimensões (compr. x larg.) à superfície do natural e na base da cova (sup./base), seguidas da profundidade medida a partir do natural, embora, à época, este estivesse certamente recoberto por terra, o que ampliaria este valor, em alguns casos manifestamente insuficiente para se realizar qualquer deposição de um corpo. Como é normal no Noroeste, não foram encontrados vestígios osteológicos.

S. 1 - Cova sub-retangular aberta no saibro $(1,66 /$ $1,32 \mathrm{~m} \times 0,90 / 0,80 \mathrm{~m} \times 0,56 \mathrm{~m}$ ), com paredes irregulares e ângulos arredondados, fundo horizontalizado. O espólio cerâmico está quase todo agrupado a $\mathrm{SO}$, com dois pratos pousados no fundo, encaixados, e sobre eles o copo, ladeado pelos outros dois pratos e o jarro; a meio da linha central encontra-se a bilha; as 8 moedas agrupam-se a N, sobre o lado. Os vasos fechados foram propositadamente deitados (todos no mesmo sentido), para sobre eles ser depositado o corpo, simplesmente ou numa padiola à qual atribuir as ferragens em L e prego. Esta distribuição sugere que a cabeça ficaria a NE e as moedas ao lado (?) do defunto. Na terra de enchimento, a cota superficial, havia fragmentos de pelo menos outros três vasos (jarro, bilha e copo, 14391-14393), bastante incompletos, quiçá peças partidas e abandonadas em 1941, arrastadas pelas movimentações de terra posteriores (Figura $4 \mathrm{e} 9$ ).

S. 2 - Cova sub-retangular aberta no saibro $(1,84 /$ 1,72m x 0,92/o,70m x 0,52m), com paredes rectas e fundo aplanado. Defunto com a cabeça a SO, espólio depositado sobre o fundo, à esquerda da linha longitudinal, começando pelas moedas, a ladear o ombro (?), seguidas de um púcaro, três pratos e 
novo púcaro, distribuindo-se o restante vasilhame, tombado, em redor dos pés, documentados a NE pela presença de 63 tachas de calçado com cabeça em calote esférica, amontoadas, com vestígios de tecido (da mortalha?), que envolveria o corpo, certamente também vestido (Figura 5 e 10).

S. 3 - Cova sub-retangular aberta no saibro, parcialmente escavada ( $1,55 / 1,50 \mathrm{~m}$ x ? x o,57m), com paredes algo encurvadas e fundo aplanado com concavidades junto dos dois ângulos expostos, distando entre si cerca de 1,20m. Deposição orientada com a cabeça a NE (?). Espólio depositado no fundo, moeda e um grupo de 18 tachas de calçado com vestígios de tecido a SO (11 em outros dois grupos); uma bilha, deitada, ao centro, e os restantes vasos na outra metade da sepultura (sob a cabeça e o dorso?), alguns intencionalmente sobrepostos. As cavidades nos ângulos e a mortalha apontam para o uso de padiola/ leito (ou caixão com pés de apoio) (Figura 11).

S.4-Cova sub-retangular/trapezoidal aberta na rocha, mais estreita a SO (1,70/1,44m x $\pm 1,10 / 0,70 \mathrm{~m}$ x o,40m). Espólio depositado no fundo aplanado, próximo da linha média longitudinal, com os dois vasos fechados deitados para ficarem sensivelmente à altura dos pratos, facilitando a sobreposição do cadáver, para a orientação do qual não temos argumento a não ser a maior largura dos ombros, a $\mathrm{NE}$ (Figura 12).

S. 5 - Cova sub-retangular irregular aberta na rocha $(1,92 / 1,72 \mathrm{~m} \times 0,80 / 0,72 \mathrm{~m} \times 0,25 \mathrm{~m})$, cabeceira a NE, com concavidades junto dos ângulos, na proximidade das quais foi recolhida a moeda. Espólio depositado no fundo aplanado, a maioria na linha média da metade inferior, com os vasos fechados deitados, a que se segue uma mancha com 83 tachas, muitas patenteando marcas de tecido bem visíveis (Figura 6). Um jarro, muito incompleto, e 8 tachas estão próximo da parede NO (Figura 13).

S. 8 - Cova sub-retangular aberta no saibro, com um topo destruído pela parede da antiga Casa Paroquial (? x c.1,05/1,12 x c.0,48m). Poderia ser estruturada com lajes graníticas na vertical, adossadas ao saibro, reduzindo a largura, o que a aproxima às de 1941. Recolheram-se 32 tachas, muitas com vestígios de tecido, e um copo incompleto.

Das sepulturas noticiadas por Abílio Miranda, em 1941, foram analisadas as seguintes estruturas, concentradas a Norte, no ângulo formado pela rua e o muro do cemitério.

S. 6 - Sepultura retangular com caixa pétrea $(1,90 /$

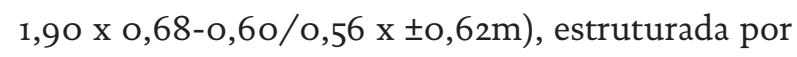
seis lajes de granito, com pedra miúda e saibro nos interstícios, usa o saibro como fundo. O lado SO está encostado ao afloramento, cortado para receber a laje. Estas são pouco trabalhadas e poderiam obter-se neste local, mesmo à superfície: trata-se dos cascões de pedra com que os trabalhadores de 1941 se depararam (Figura 7).

S. 7 - Sepultura retangular com caixa pétrea $(1,63 /$ $1,58 \times 0,58 / 0,62 \times \pm 0,52 \mathrm{~m}$ ), estruturada com sete lajes de granito e duas pedras que nivelam o topo NE, onde encosta ao afloramento, podendo assim receber mais facilmente a cobertura. Saibro do fundo demasiado aprofundado em 1941, abaixo do limite das lajes (Figura 8).

S. 9 - Sepultura retangular escavada na rocha $(1,70 /$ 1,64 x o,63/o,6o x 0,04 a NE e o,24m a S). Corresponderá à sepultura "antropomórfica escavada na rocha».

S. 10 - Sepultura (?) quadrangular escavada no saibro ( $1,60 \times 1,20 \times 0,40 m)$. Cortou marginalmente a S. 2 e S. 3, e será a «de menores dimensões, que serviu a uma criança».

S. 11 - Sepultura retangular muito destruída (aprox. 1,80 x 0,74-0,80 x 0,6om), identificável pelos cortes no saibro onde encostariam as lajes da caixa, como nas 6 e 7 .

S. 12 - Interfaces na área escavada em 1941, junto do muro do Cemitério, poderão corresponder a esta sepultura (retangular e de caixa com lajes?).

\section{OS MATERIAIS DEPOSITADOS}

Abílio Miranda diz-nos que nas sepulturas estruturadas com lajes havia louça. Mas, apenas destaca o espólio de duas outras: na chamada antropomórfica, foi recolhido um anel de azeviche e, junto dos membros inferiores, "uma anforeta de uma asa e uma ampula" (púcaro e bilha), existindo ainda pregos e «bastante carda grossa, que pertencia ao calçado do cadáver»; a de criança conteria objectos cerâmicos "de uma interessante miniatura", entre os quais um jarro com bocal trilobado (Miranda, 1941, p. 28-29). No Museu, apenas o anel de azeviche pode ser isolado. Datável do Baixo Império, tem aro de decoração torsa, a alargar para a mesa, saliente, onde se abriu, a picotado, um motivo semi-circular preenchido com linhas radiais (Soeiro, 1984, p. 90-91). Fabrico provincial, terá origem nas oficinas de Bracara Augusta (Cravinho, 2014, p. 599). 
Todos os enterramentos escavados (2016) apresentavam materiais cerâmicos, por vezes acompanhados de moedas. Trata-se de olaria de fabrico local/ regional, com uma panóplia de formas limitada: jarro trilobado (bico unido, asa sem dedeira), bilha (bocal estreito, asa com dedeira, pança elíptica ou cortada), púcaro de perfil em $\mathrm{S}$ (vários tamanhos, decoração de caneluras finas a marcar o colo), copo de perfil em S e prato/prato de lume. São conjuntos vulgares nas necrópoles baixo-imperiais de Penafiel (Soeiro, 1984, 2009-2010, 2015; Pinto, 1998) e por toda a bracarense (Tabela 1 ).

Nos jarros trilobados e pratos, as pastas apresentam texturas fortemente arenosas, com grãos brancos muito visíveis, e superfícies ásperas ou pouco alisadas, em tons de castanho, do claro ao enegrecido pelo uso ao lume. A S. 5 é um expoente deste fabrico grosseiro e mau acabamento do jarro e pratos, mesmo do copo, cujo alisamento exterior não encobre as irregularidades da parede. Grande semelhança entre si mostram os pequenos pratos da S. 1 (Figura 9: 4) e S. 4 (Figura 12: 3 e 4), pouco ou nada usados, em tom bege acastanhado, alisados, que seguramente saíram das mãos do mesmo artífice. Outros, com fortes marcas de terem estado ao lume, apesar de deformados na cozedura, serviram em vida e, por fim, seguiram para a cova (Figura 10: 8 e 12: 5).

De entre a olaria usada ao fogo sobressai uma peça da S. 1 (Figura 9: 5), com parede reta esvasada e lábio boleado com ligeiro espessamento, facetado. Somos levados a colocá-la como tampa por o disco central (como que fundo) apresentar externamente, ao centro, dois arranques de uma asa de fita. Outras particularidades são a argila babada na mal conseguida união "fundo"/parede, a diferente coloração das partes, o perfil irregular e a fuligem interior. Partida a asa, podia ter sido depositada na sepultura como prato.

Um outro grupo, de vasos para líquidos - bilhas, púcaros e copos -, apresenta-se geralmente sem fuligem, fabricado numa pasta arenosa de calibre menos grosseiro, por vezes com desengordurante cerâmico, bem cozida. Tem perfis regulares, tom castanho/alaranjado e superfícies cuidadas no exterior, incluindo dos fundos, e interior do bordo. Os púcaros médios da S. 2 e S. 3 (Figuraio: 4 e 11: 3) mostram fuligem exterior, concentrada no lado oposto à asa, como é típico dos jarros, encostados ao lume para aquecer o conteúdo. Pelo menos num caso, o copo da S. 3 (Figura 11: 4), verificou-se que o bojo apresenta um orifício subcircular aberto intencionalmente, após a cozedura, talvez aquando do depósito, prática recorrente nas necrópoles escavadas em Penafiel.

Apesar de sensivelmente sincrónico, o espólio da S. 3 (Figura 11), suscitou, desde o momento do achado, o reconhecimento de diferença por uma maior delicadeza na feitura e aparência de algumas vasilhas: a bilha era de tamanho pequeno, morfologia cuidada, pasta comparativamente depurada e bom alisamento; havia também um pratel e uma tacinha (a formar serviço?) de superfícies castanho/alaranjadas, bem alisadas e, no caso da segunda, cobertas por espessa aguada do mesmo tom em todo o interior e numa faixa exterior a partir do lábio. Teria sido, talvez, outro conjunto assim que levou Abílio Miranda a identificar uma das sepulturas (S. 10, ao lado desta?) como de criança, situação que lembra a da escavação da sepultura 4 (1974) do Castro de Monte Mozinho, pequena inumação de meados ou 2. a $^{\text {a }}$ made do século IV, com formas cerâmicas de tamanho bastante reduzido e fabrico relativamente apurado, que levou Carlos Alberto Ferreira de Almeida a sugerir parecer-lhe infantil (Almeida, 1974, p. 44-45).

Na S. 5, além da cerâmica e moeda, havia um fragmento mínimo de vaso de vidro incolor com leve curvatura e espessura inferior a 1mm. Já a S. 4 continha um pequeno fragmento indeterminado de bronze, recto e com secção circular.

As moedas, treze depositadas em quatro das sepulturas e duas recolhidas nas UE envolventes, apresentam uma cronologia bastante homogénea, sendo

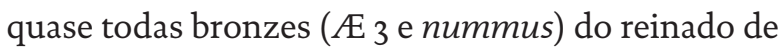
Constâncio II, com sinais de alguma circulação, o que aponta para a datação dos enterramentos no $3 .^{.}$ quartel do século IV. Na S. 1, surgiram oito, amontoadas, na metade da sepultura onde não havia outro espólio, ao lado da cabeça/peito do defunto, muito juntas, talvez contidas em bolsa. São cunhagens de $335-340$ a $357-361$. A S. 2 forneceu três, sendo as duas legíveis também de Constâncio II (355-357), assim como a da S. 5; a da S. 3, colocada junto das tachas, muito deteriorada, foi atribuída ao século IV. Os dois exemplares recolhidos na estratigrafia envolvente pertencem ao mesmo reinado. $\mathrm{Na}$ anterior escavação (1941), não ficou notícia do aparecimento de numismas. Já na necrópole do lugar de Antas havia moedas nos enterramentos, as quais deram entrada no Museu, juntamente com a cerâmica e o anel. São 41 exemplares, sem indicação dos conjun- 
tos funerários. Inventariadas por Isabel Pereira (Pereira, 1975), a sua cronologia coincide com a anterior, prolongando-se, porém, até ao final do século IV (394-395), com possível circulação no seguinte.

Em síntese, estaremos perante uma das necrópoles desta aldeia estabelecida em área aberta, na interface do monte com as melhores terras agrícolas, em local de passagem. A existência da área funerária de Antas, a 3oom, sugere uma localização do povoado no espaço intermédio, desde a época moderna centrado na igreja paroquial. As sepulturas escavadas, do $3 .^{\circ}$ quartel do século IV, são inumações em cova retangular, onde o falecido, amortalhado (sobre o calçado) seria depositado em decúbito dorsal (?), maioritariamente com a cabeça a NE, sobre uma padiola/leito ou caixão (suportes a pousar nas concavidades dos ângulos), ou directamente por cima das vasilhas, com o remanescente do banquete fúnebre, distribuídas no fundo, por vezes empilhadas e com os vasos fechados deitados para nivelamento. Não havia objectos de adorno da pessoa e vestuário (excepto o de S. 4 ?), sendo os conjuntos bastante uniformes e bem mais pobres do que os dos níveis sincrónicos das necrópoles penafidelenses de Montes Novos e Monteiras, com as quais tem paralelos e para cuja discussão remetemos (Pinto, 1998; Soeiro, 2009-2010, 2015). Em Bracara Augusta, por esta época, já escassos artefactos se depositavam nas inumações (Braga, 2018, p. 417). As sepulturas de 1941, com caixa de lajes pétreas, diferenciam-se destas (Arezes, 2017, p. 195), ainda que sigam o alinhamento e contivessem cerâmica comum, não sendo possível precisar a datação, que poderá chegar ao século V, como as da área de Antas, momento em que a ocupação disseminada pelo território continuava densa e variada (Soeiro, 2018).

\section{BIBLIOGRAFIA}

ALMEIDA, Carlos Alberto Ferreira de (1974) - Escavações no Monte Mozinho (19749. Penafiel: Centro Cultural Penafidelis.

AREZES, Andreia (2017) - O mundo funerário na antiguidade tardia em Portugal: as necrópoles dos séculos V a VIII. Porto: CITCEM/Edições Afrontamento.

BARROCA, Mário Jorge (2010-2011) - Sepulturas escavadas na rocha de Entre Douro e Minho. Portvgalia. Porto. Nova Série. 31-32, pp. 115-182.

BRAGA, Cristina Maria Vilas Boas (2018) - Morte, memória e identidade. Uma análise das práticas funerárias de
Bracara Augusta. Braga: Universidade do Minho (tese de doutoramento).

BRANDÃO, D. de Pinho (1961) - Atramentarium e stilus do Museu de Penafiel. Lucerna. Porto, 1:1, pp. 29-34.

CARDOSO, Luiz (1751) - Canas de Duas Igrejas. In Diccionario geografico. Lisboa: Na Regia Officina Sylviana, e da Academia Real. Tomo 2, p. 403.

CRAVINHO, Graça Maria Pombo (2014) - Glíptica romana em Portugal. Santiago de Compostela: USC-Faculdad de Xeografia e Historia (tese de doutoramento).

MIRANDA, Abílio (1941) - Sepulturas abertas na rocha. Douro Litoral. Porto. 1. érie, 3, pp. 27-29.

MIRANDA, Abílio (1942) - Anel de Casados. Douro Litoral. Porto. 1. érie, 5, pp. 65-66.

PEREIRA, Isabel (1975) - Moedas tardo-romanas da necrópole das Duas Igrejas (concelho de Penafiel). Conimbriga. Coimbra. 14, pp. 185-197.

PINTO, Gilda Correia (1998) - A necrópole romana de Montes Novos/Croca, Penafiel. Cadernos do Museu. Penafiel: Museu Municipal, vol. 2, pp. 187-240.

R, A. M. (1973) - Comenda de Duas Igrejas. Penafiel. Boletim de Cultura da Câmara Municipal. Penafiel. 2, pp.6o-67.

SANTOS, Cândido Augusto Dias dos (1973) - Censual da Mitra do Porto. Subsídios para o estudo da diocese nas vésperas do Concílio de Trento. Porto: Câmara Municipal do Porto.

SOEIRO, Teresa (1984) - Monte Mozinho. Apontamentos sobre a ocupação entre Sousa e Tâmega em época romana.

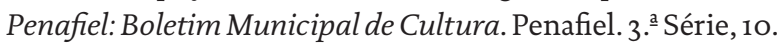

SOEIRO, Teresa (2009-2010) - Necrópole romana de Monteiras (Bustelo-Penafiel). Cadernos do Museu. Penafiel: Museu Municipal, vol.12/13, pp. 5-221.

SOEIRO, Teresa (2015) - A preferência pela inumação nas necrópoles romanas dos sécs. III-IV d.C. do Município de Penafiel (Norte de Portugal). Actas do II Congresso Internacional sobre Arqueologia de Transição. Évora: UE/CHAIA, pp. 159-174.

SOEIRO, Teresa (2018) - O Castro de Monte Mozinho (Penafiel, Porto) e o seu aro em época tardo-romana e tardo-antiga, In LÓPEZ QUIROGA, Jorge (coord.) - In tempore sueborum. Ourense: Deputación Provincial de Ourense, pp. 211-216. 


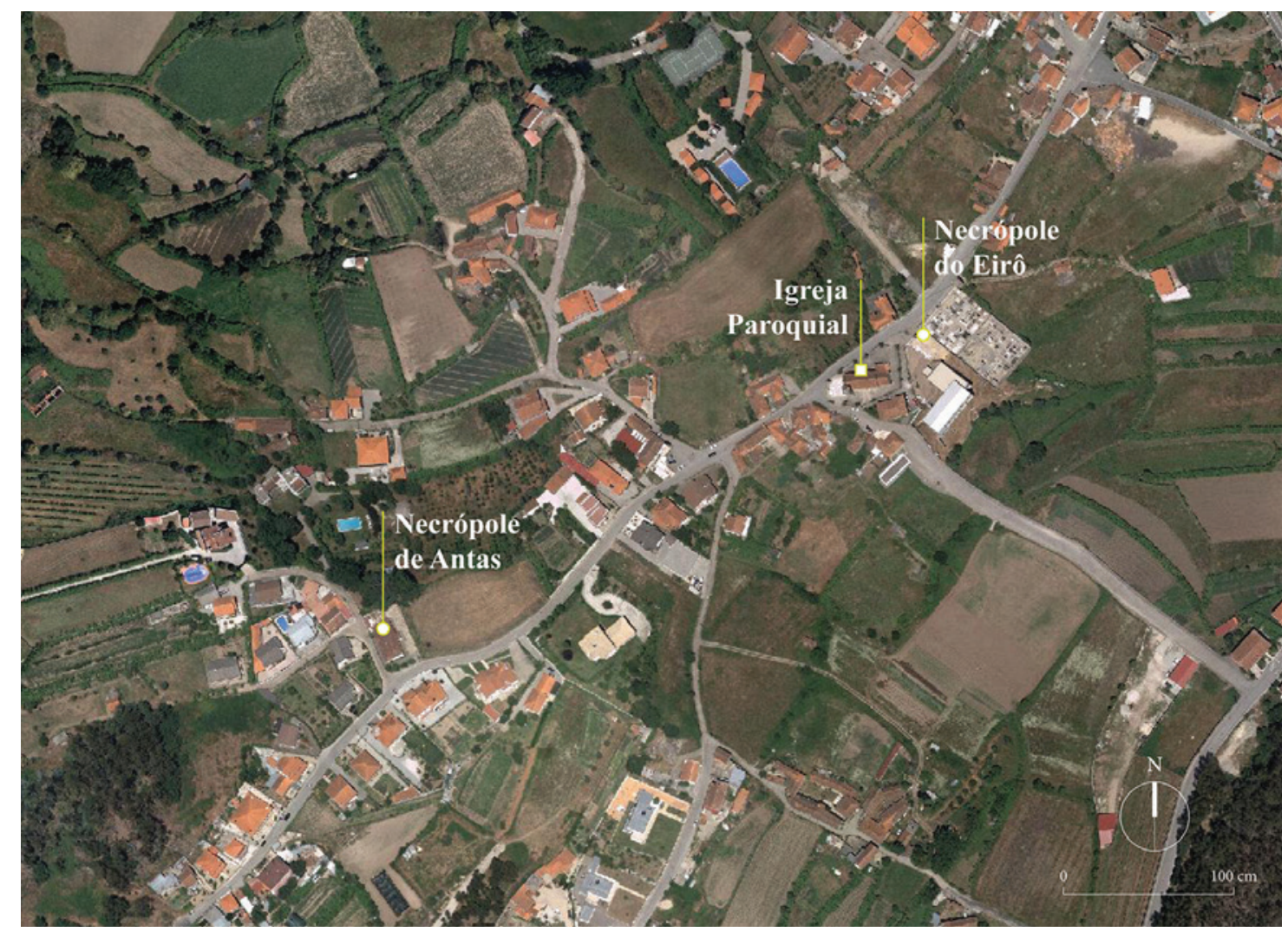

Figura 1 - Necrópoles romanas do Eirô e de Antas (Duas Igrejas): levantamento aerofotogramétrico (CMPNF).

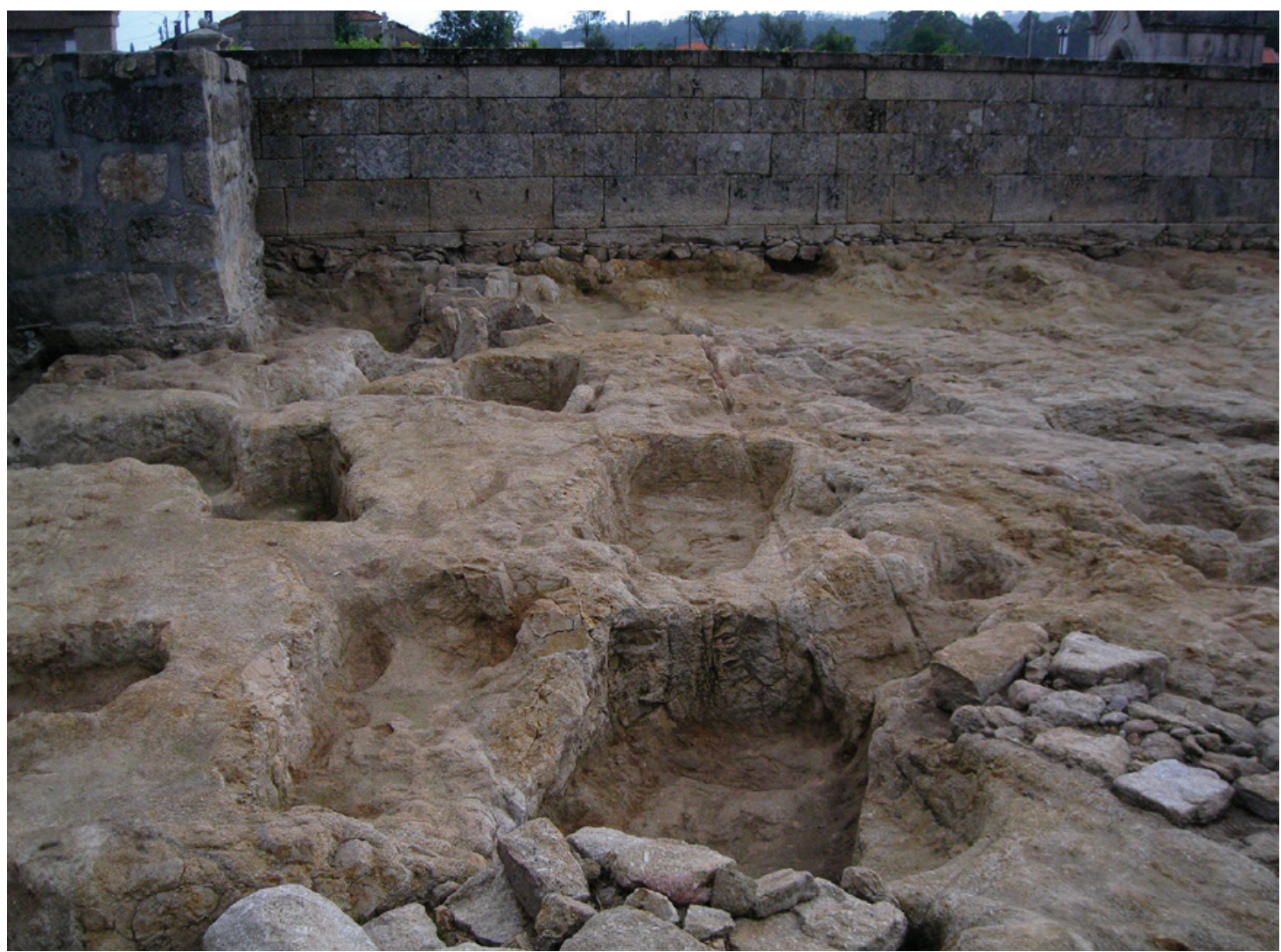

Figura 2 - Vista geral da intervenção na necrópole romana do Eirô (2016). 


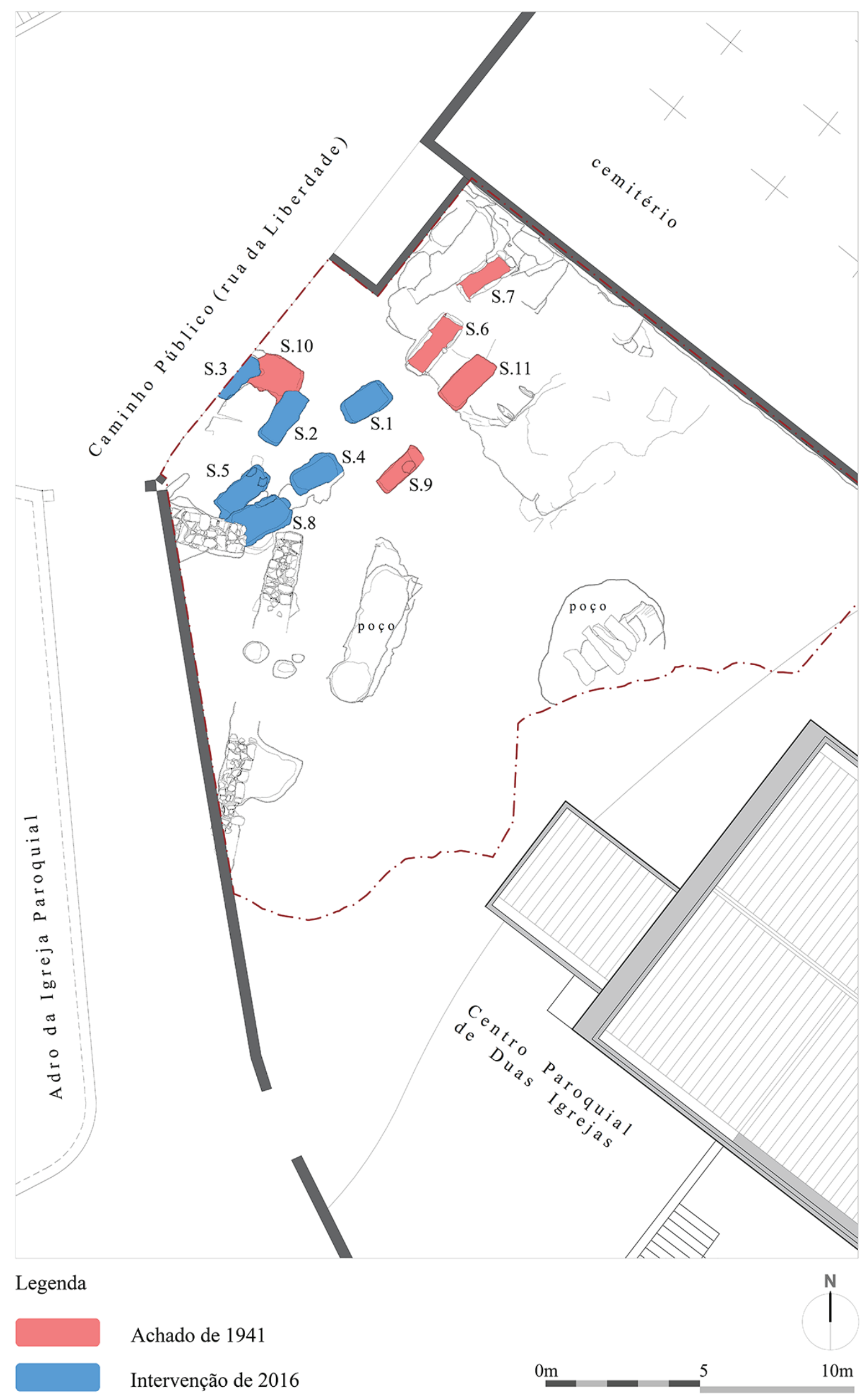

Figura 3 - Plano final da necrópole romana do Eirô (2016). 


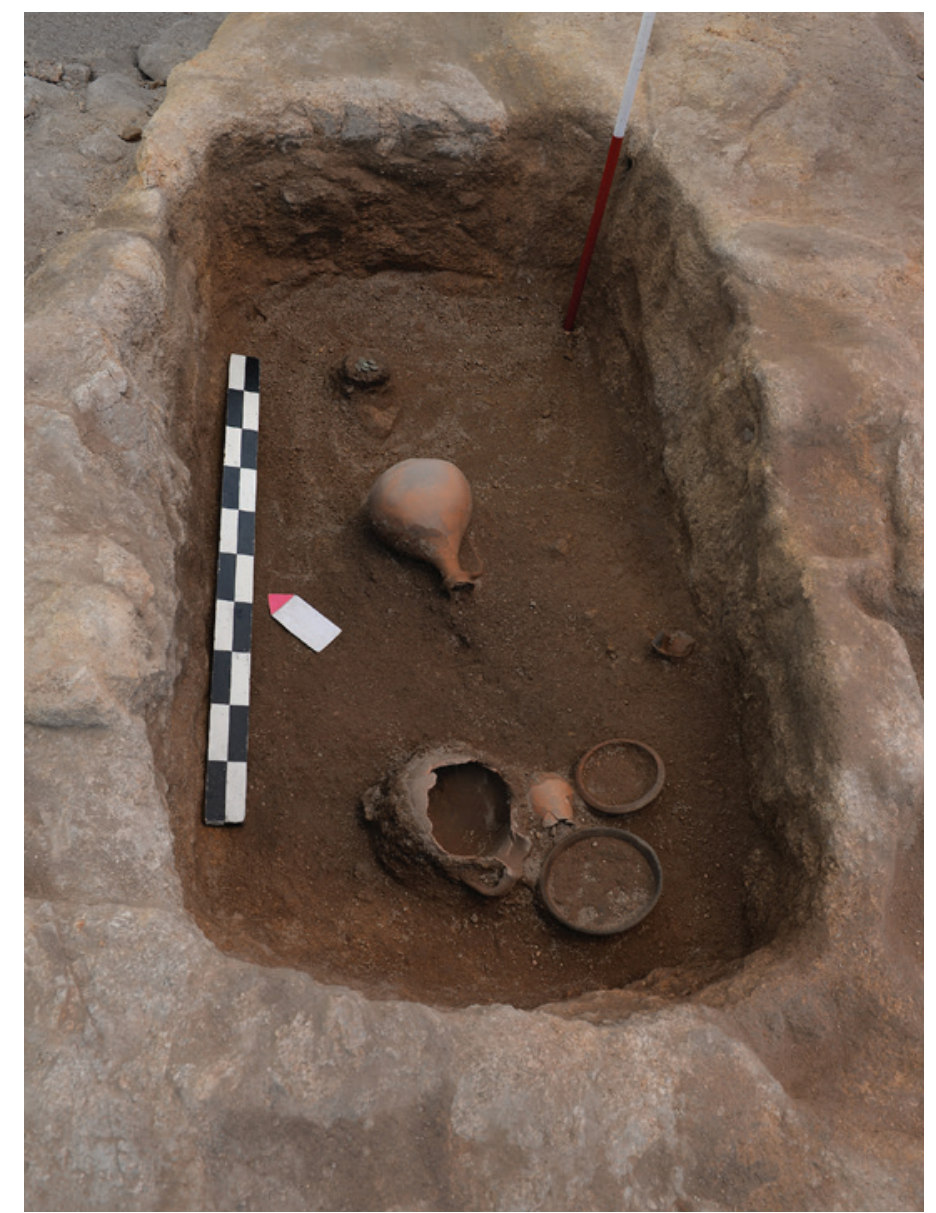

Figura 4 - Necrópole romana do Eirô: sepultura de inumação S. 1, com o respetivo mobiliário funerário.

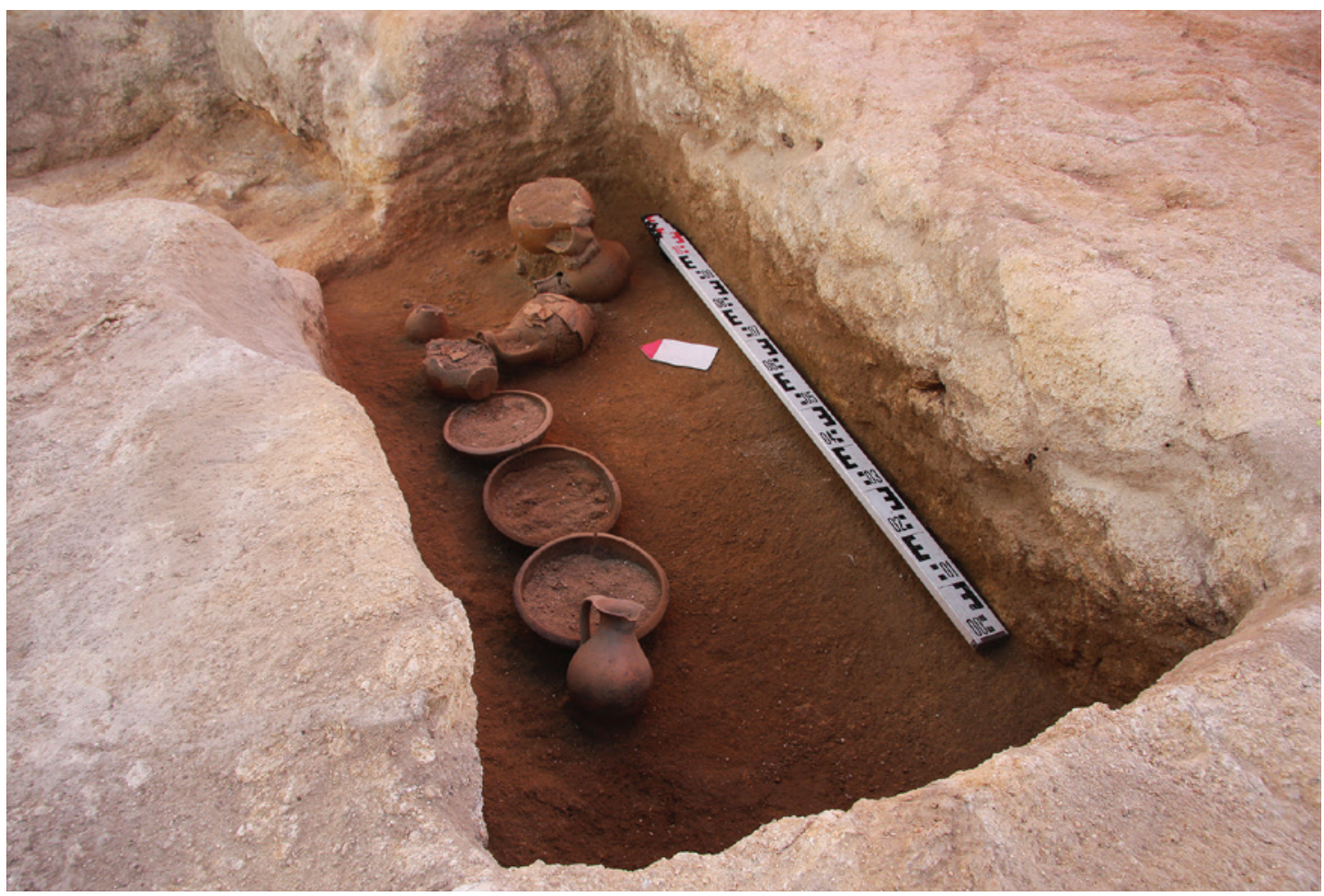

Figura 5-Necrópole romana do Eirô: sepultura de inumação S. 2, com o respetivo mobiliário funerário. 


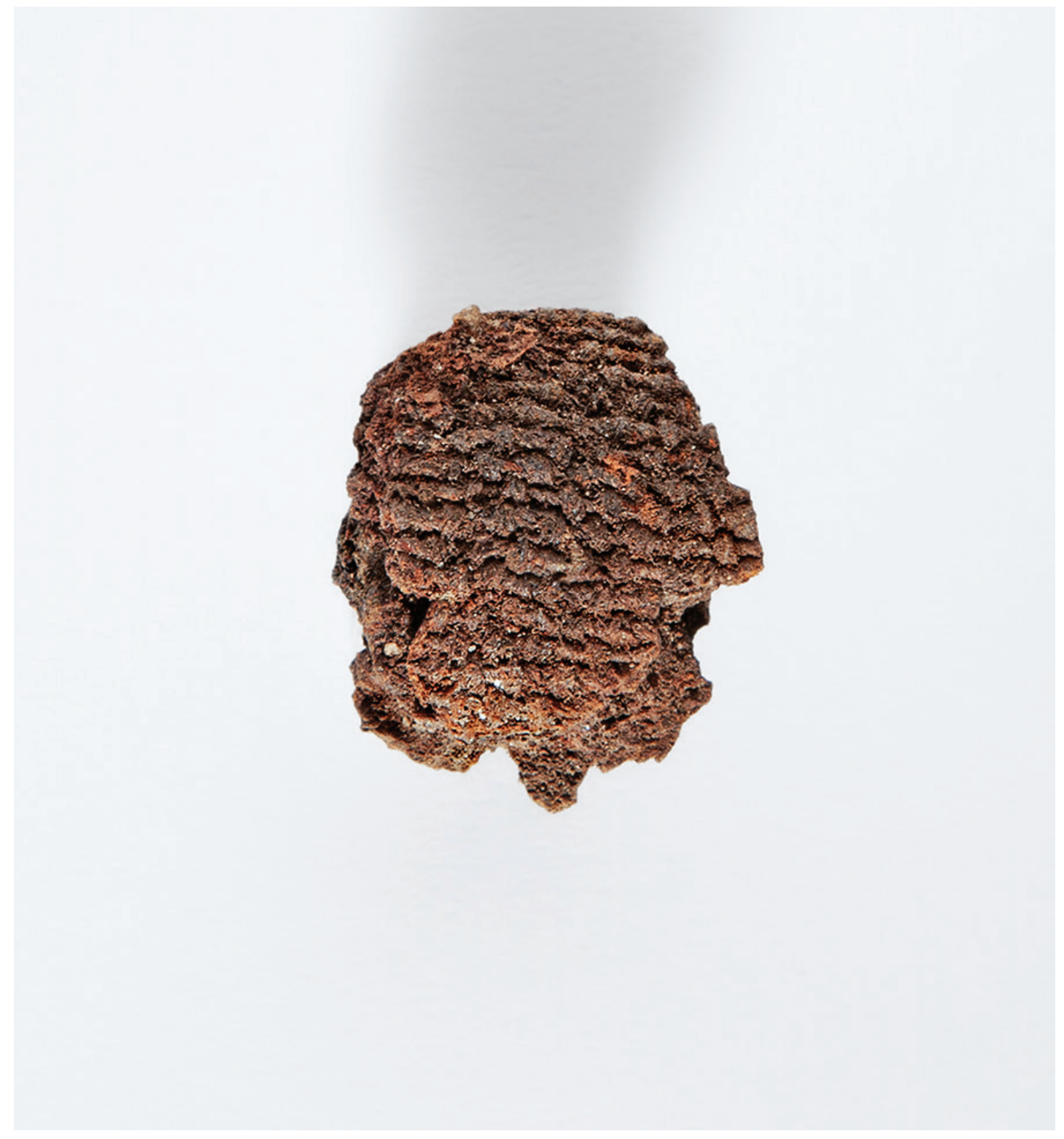

Figura 6 - Pormenor de tacha de calçado com vestígios de tecido, da S. 5 (fot. Eduardo Cunha). 


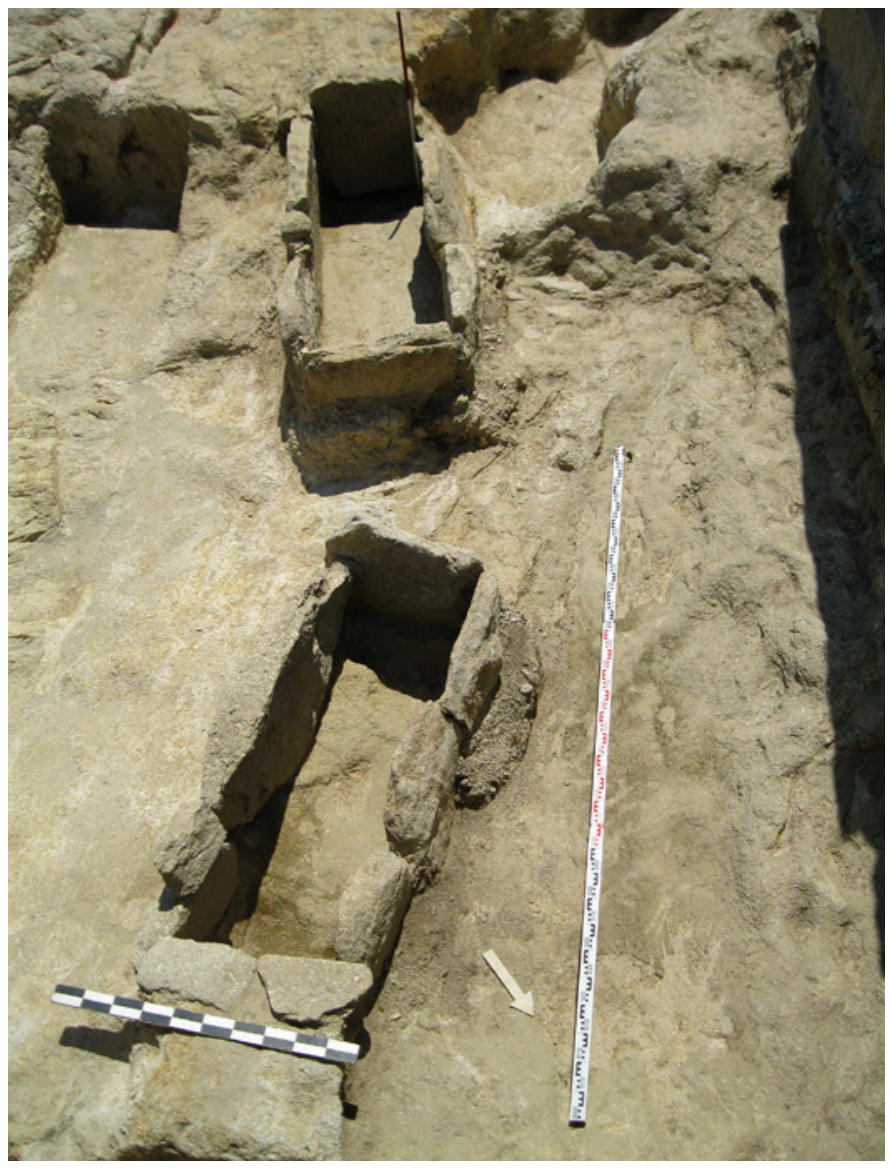

Figura 7-Sepulturas estruturadas com lajes, descobertas em 1941 (S. 6 e S. 7).

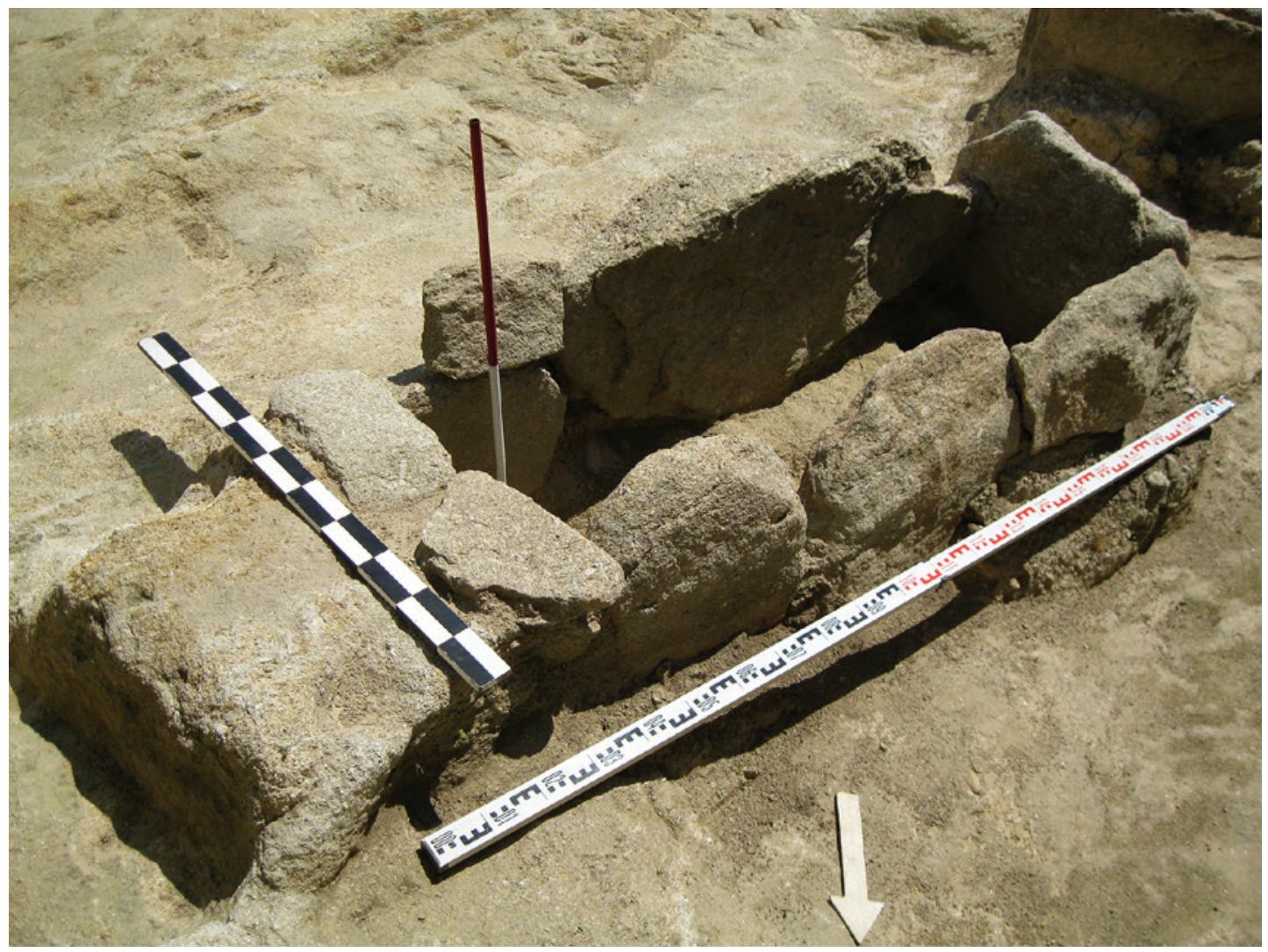

Figura 8 - Sepultura S. 7, evidenciando o sistema construtivo. 

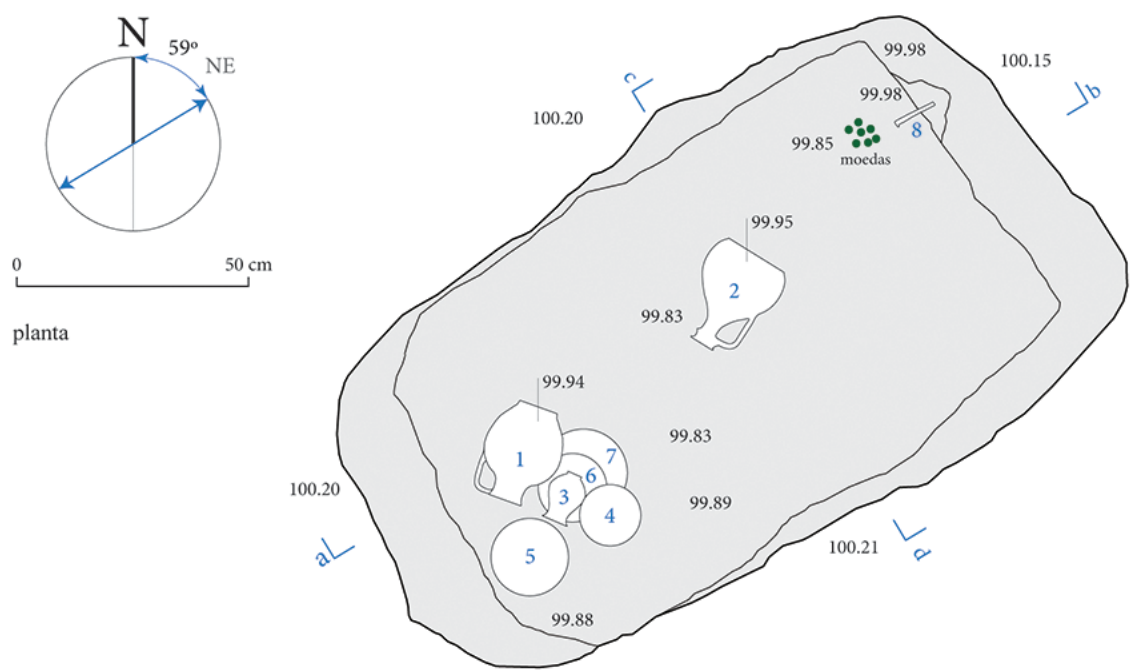

Sepultura 1

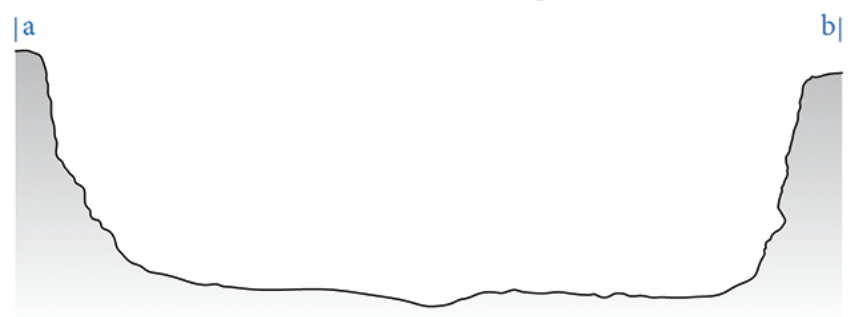

perfil longitudinal

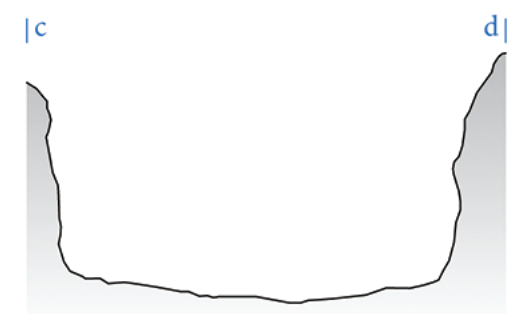

perfil transversal
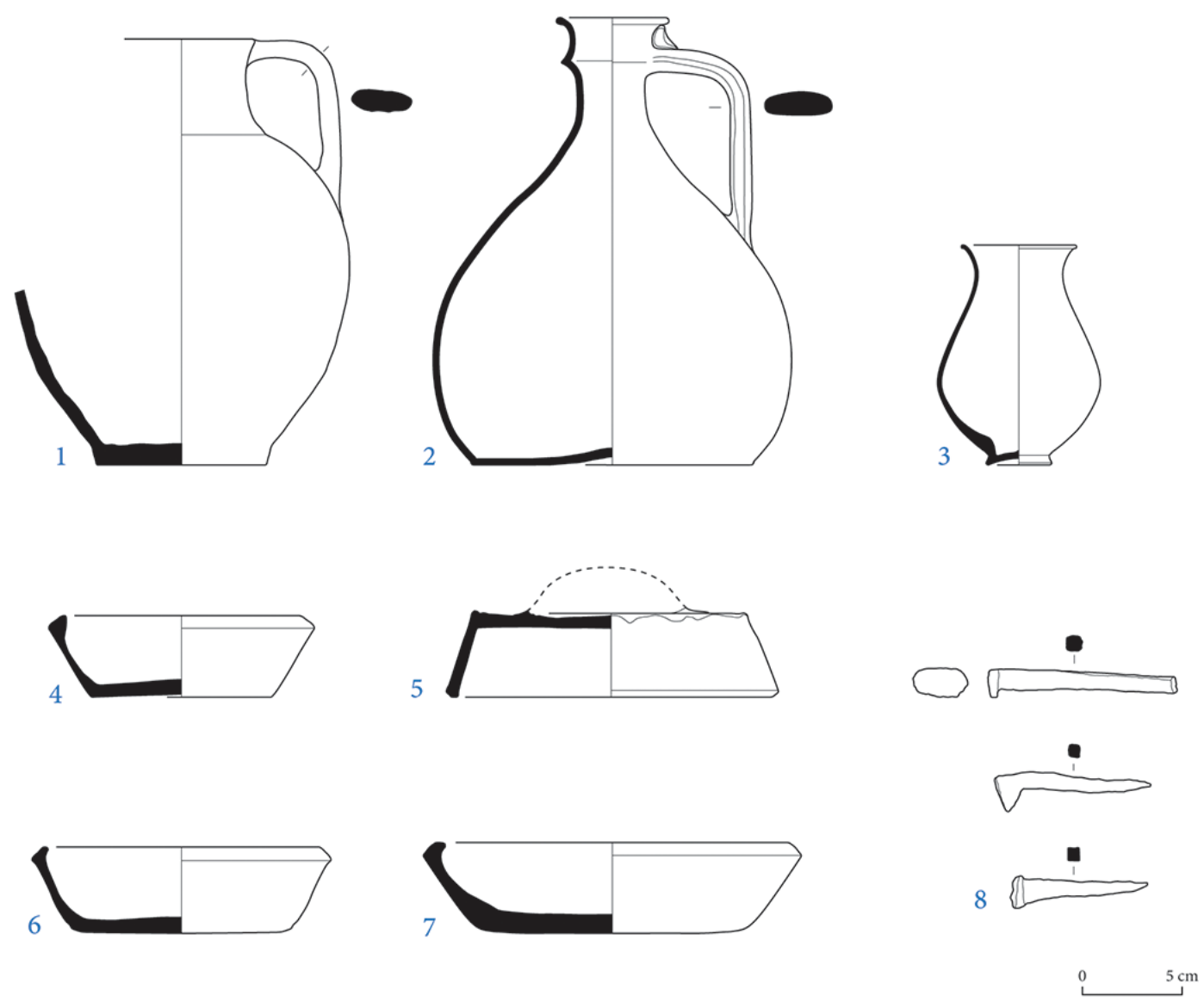

Figura 9 - Sepultura 1: plano, cortes e respetivo espólio. 

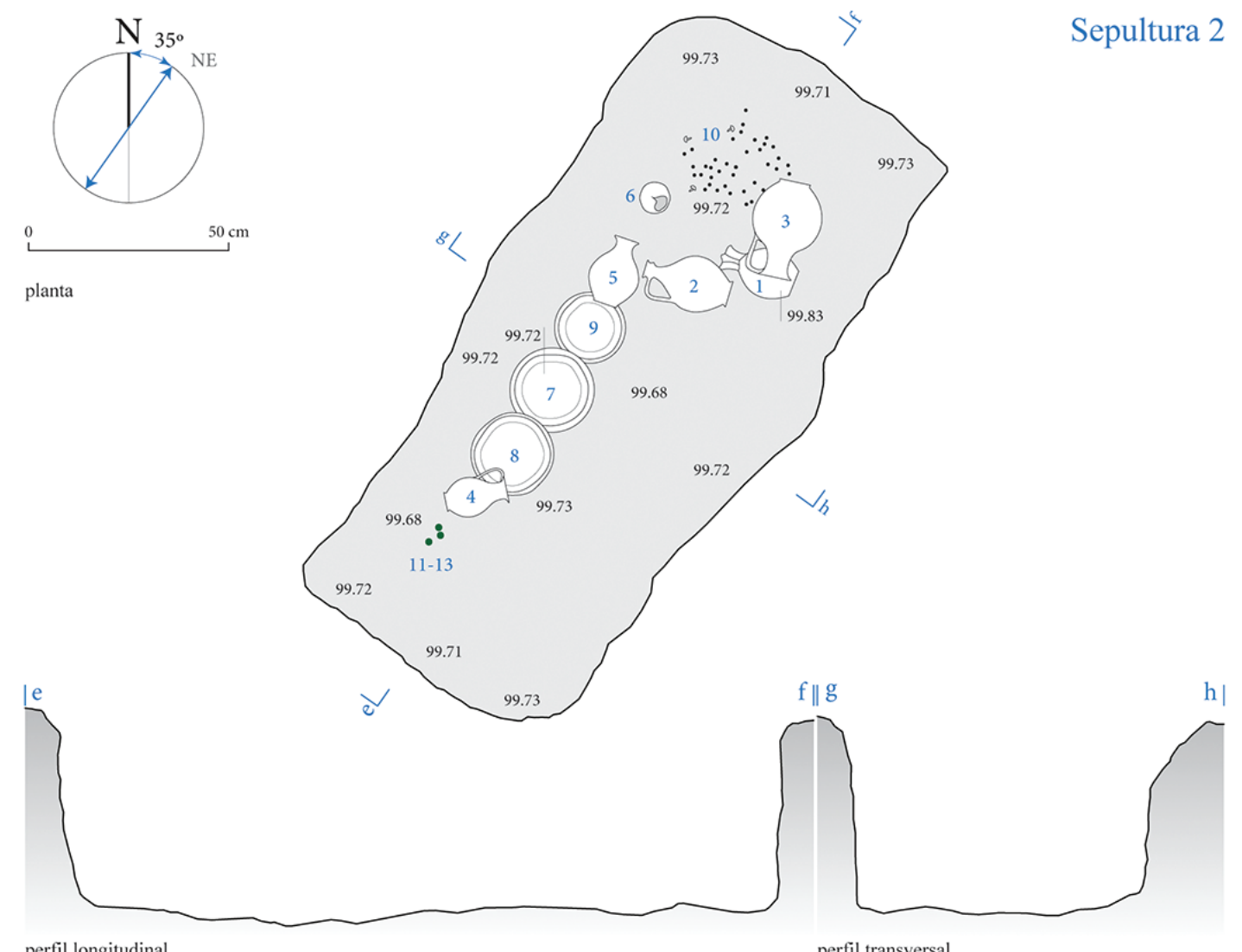

perfil transversal
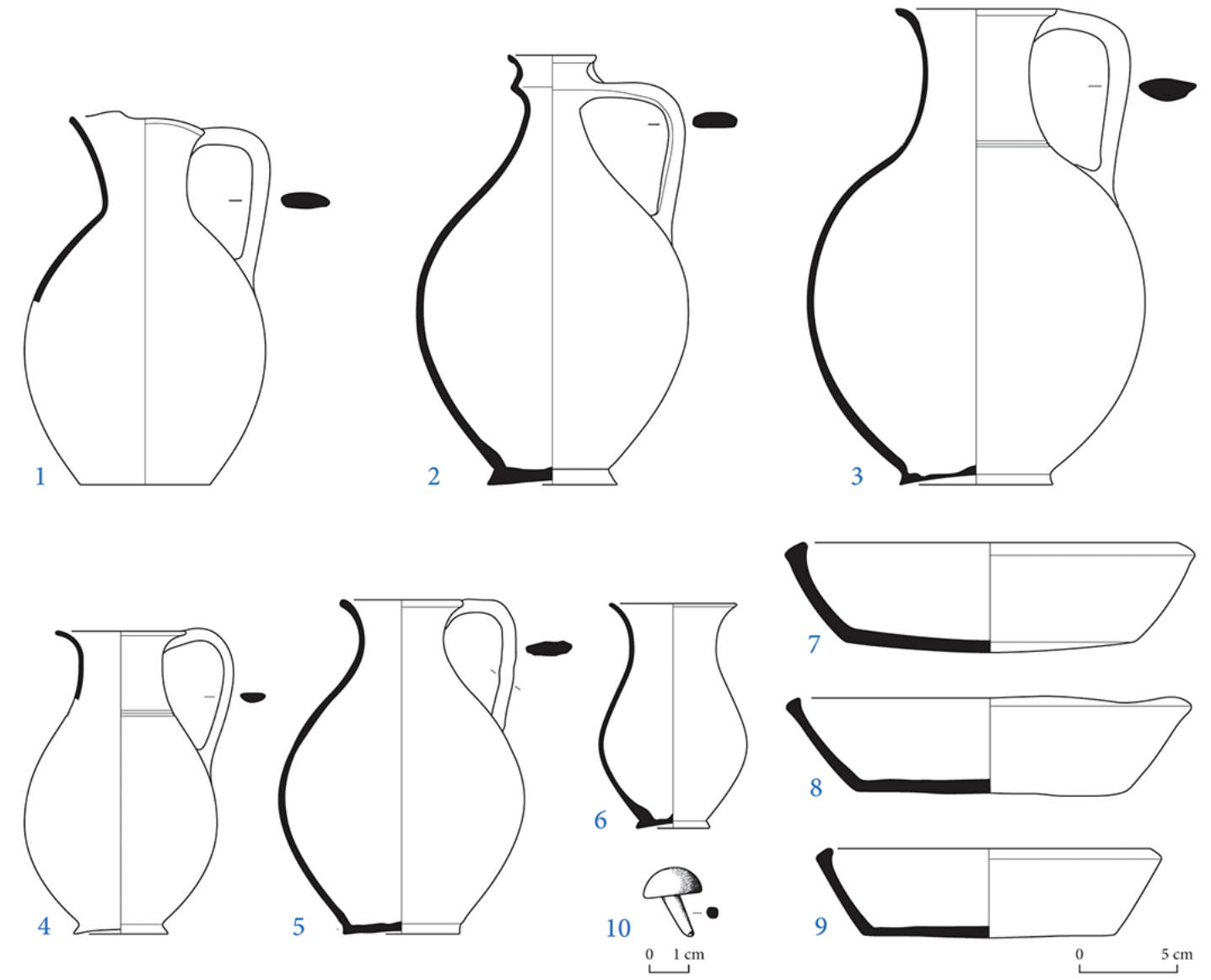

Figura 10 - Sepultura 2: plano, cortes e respetivo espólio. 

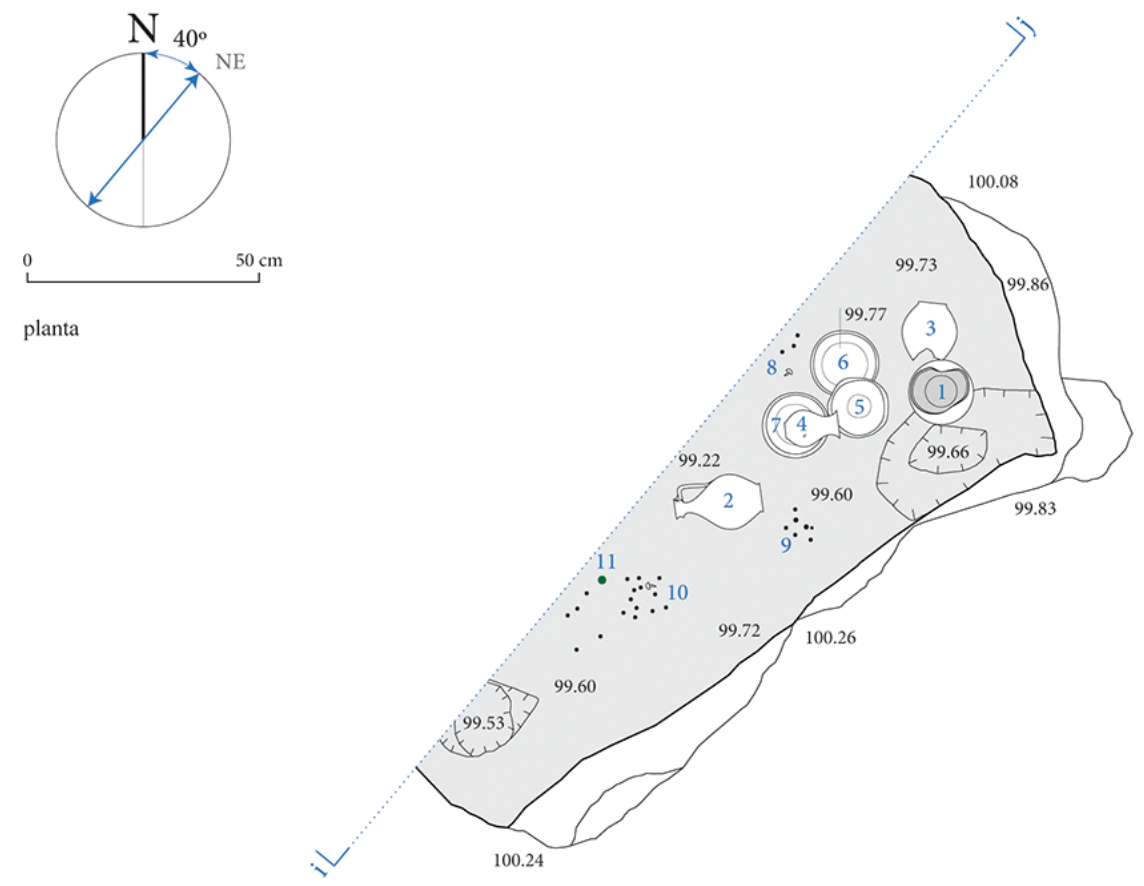

Sepultura 3

planta
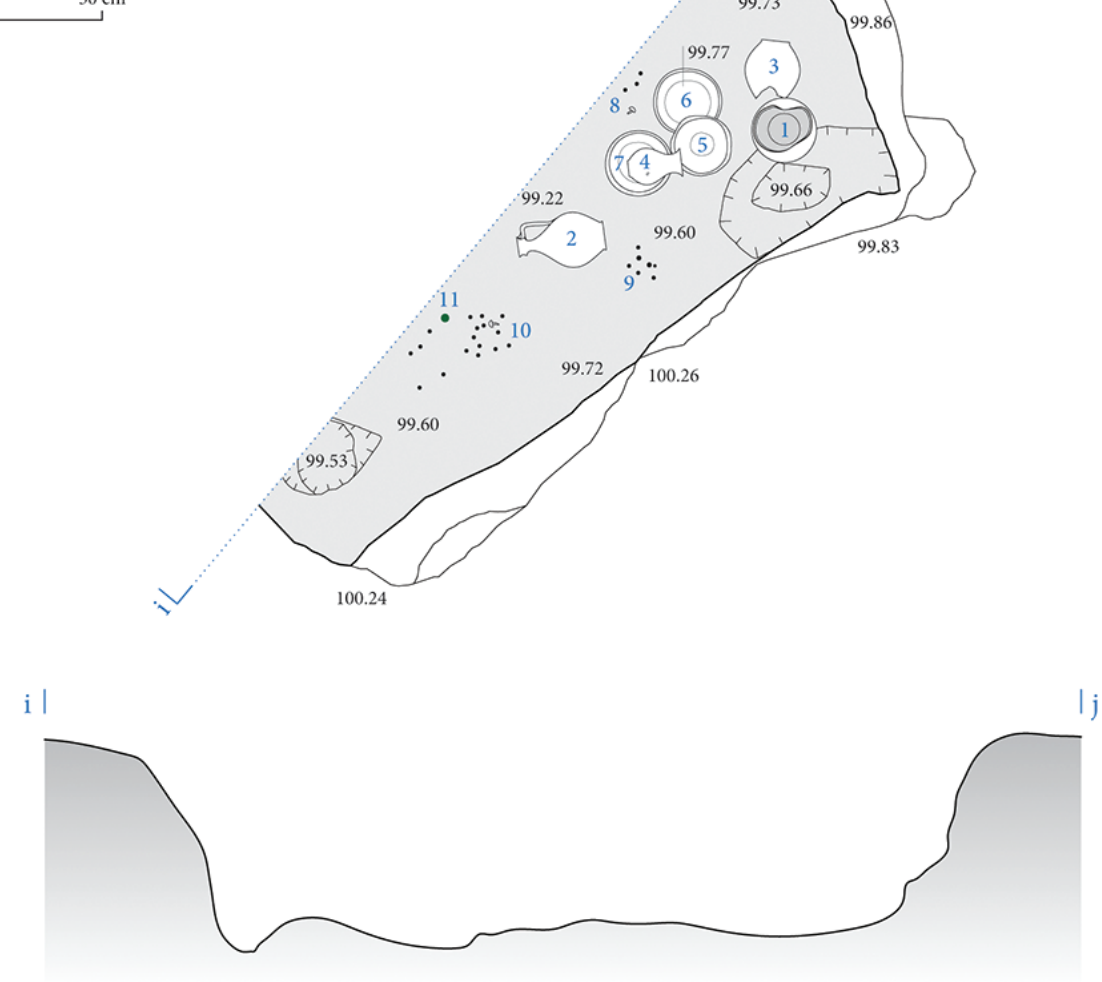

perfil longitudinal
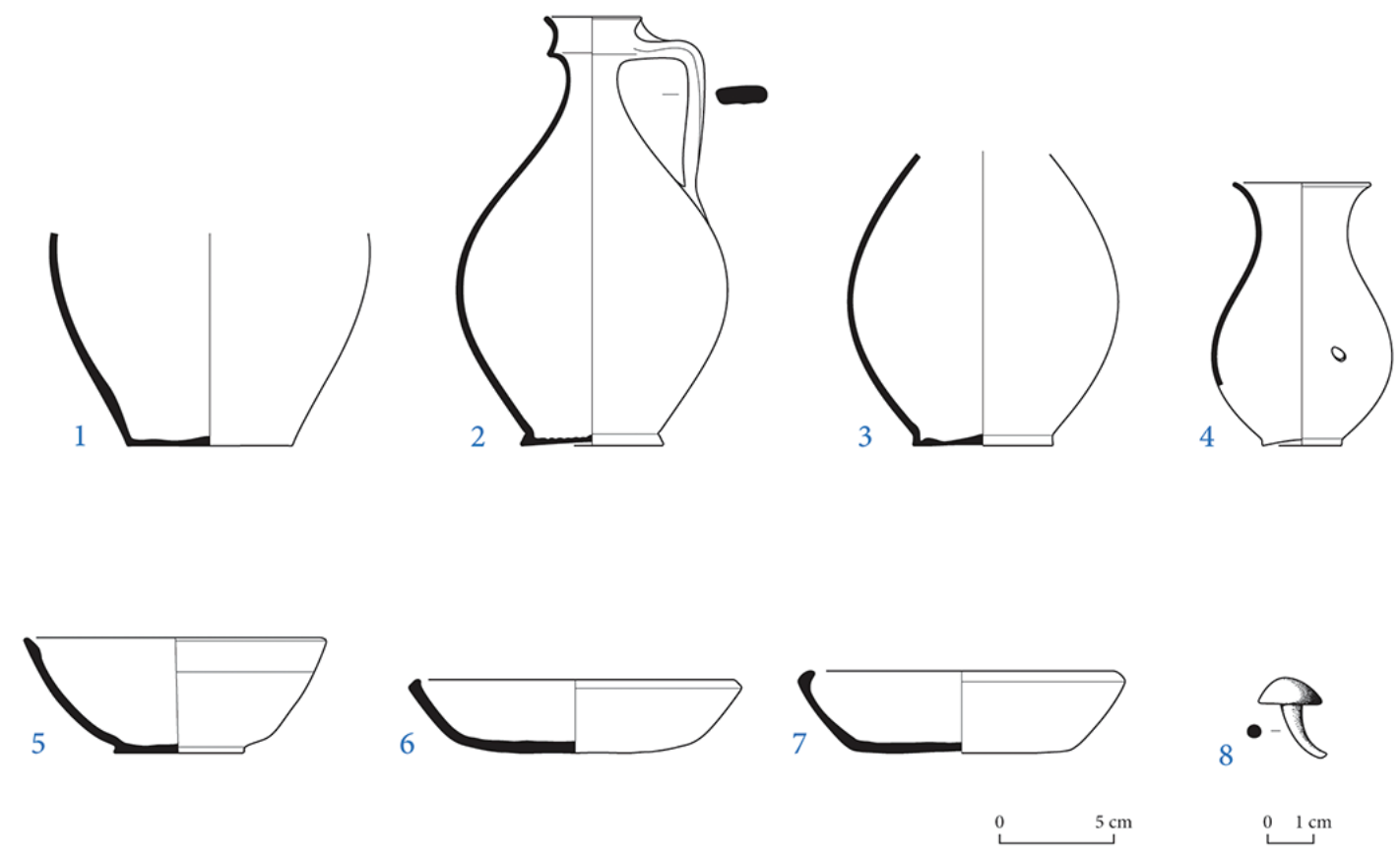

Figura 11 - Sepultura 3: plano, cortes e respetivo espólio. 


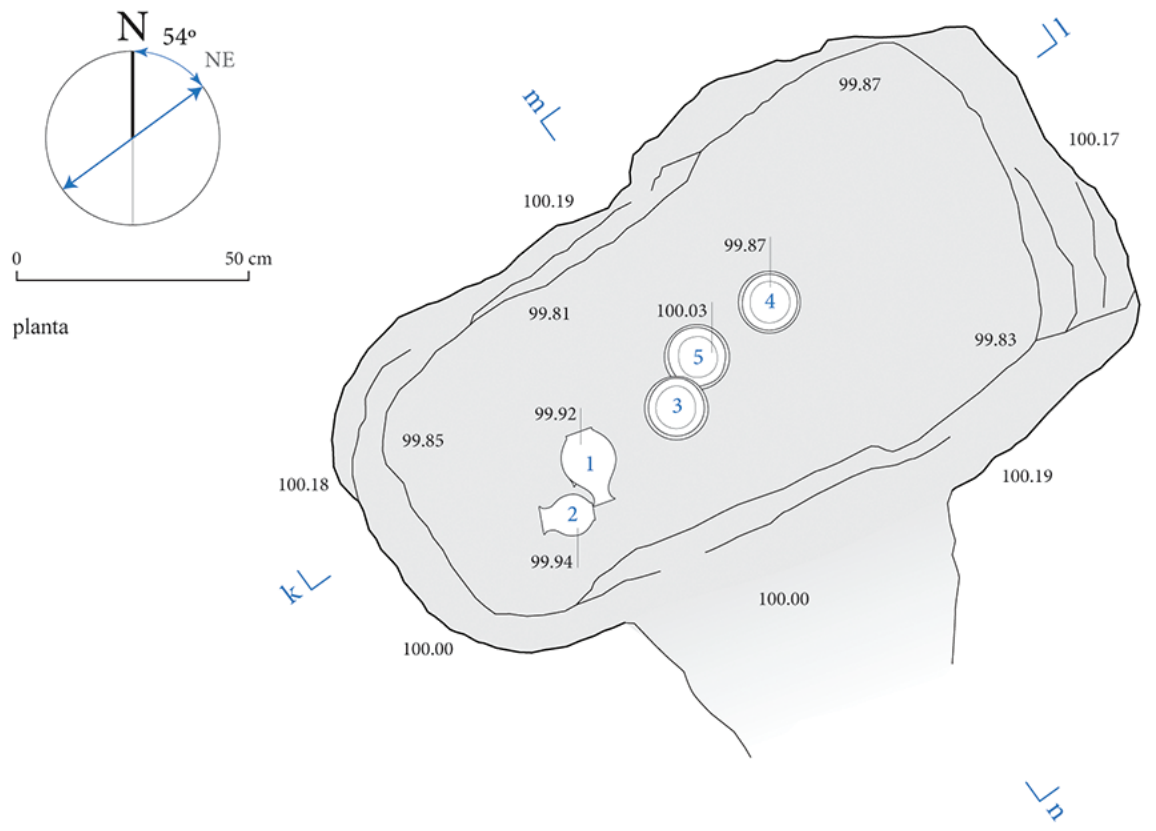

Sepultura 4

$\mathrm{k} \mid$

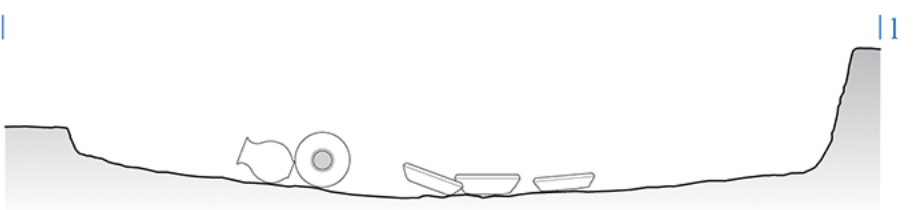

perfil longitudinal
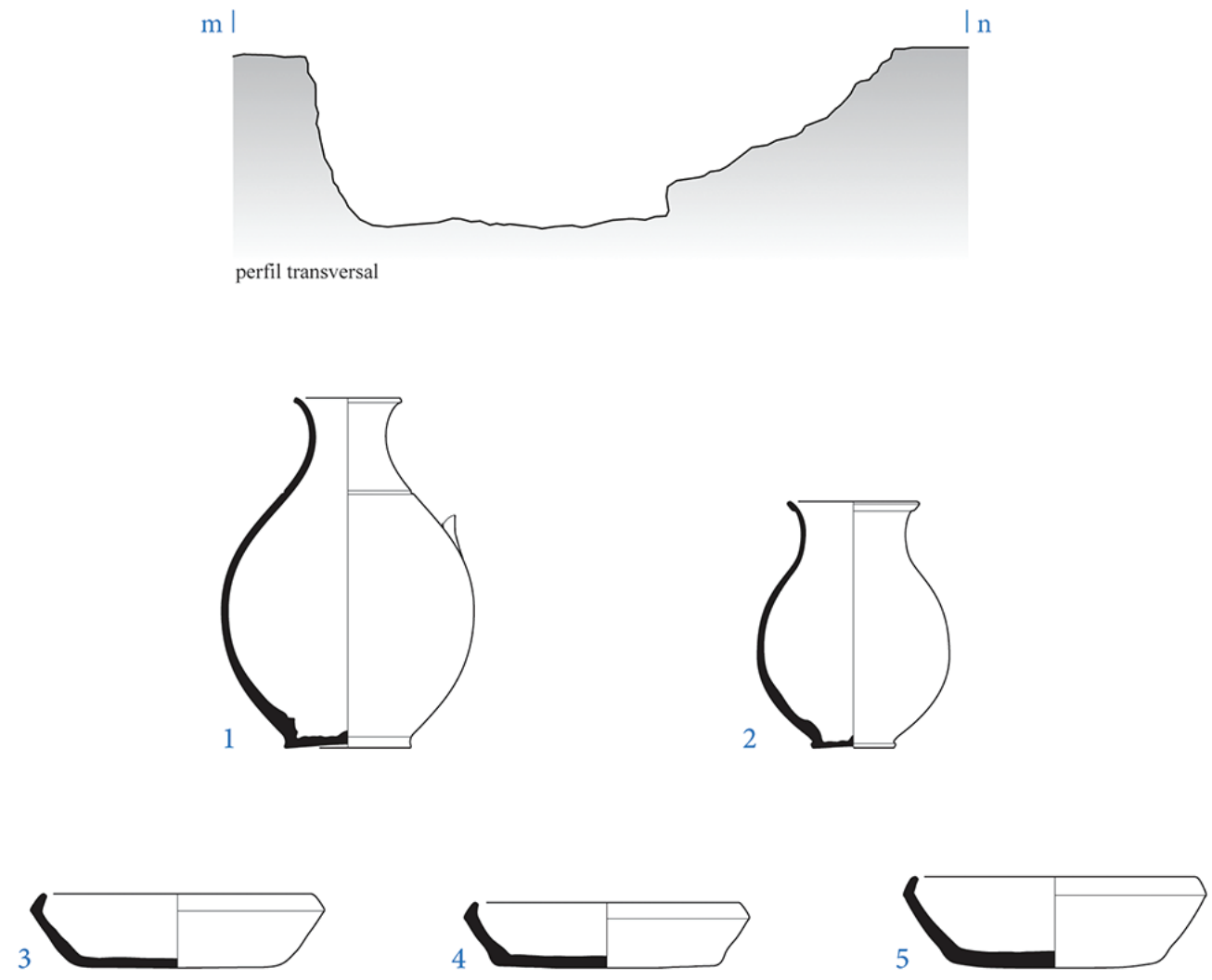

$\stackrel{0}{2}$

Figura 12 - Sepultura 4: plano, cortes e respetivo espólio. 


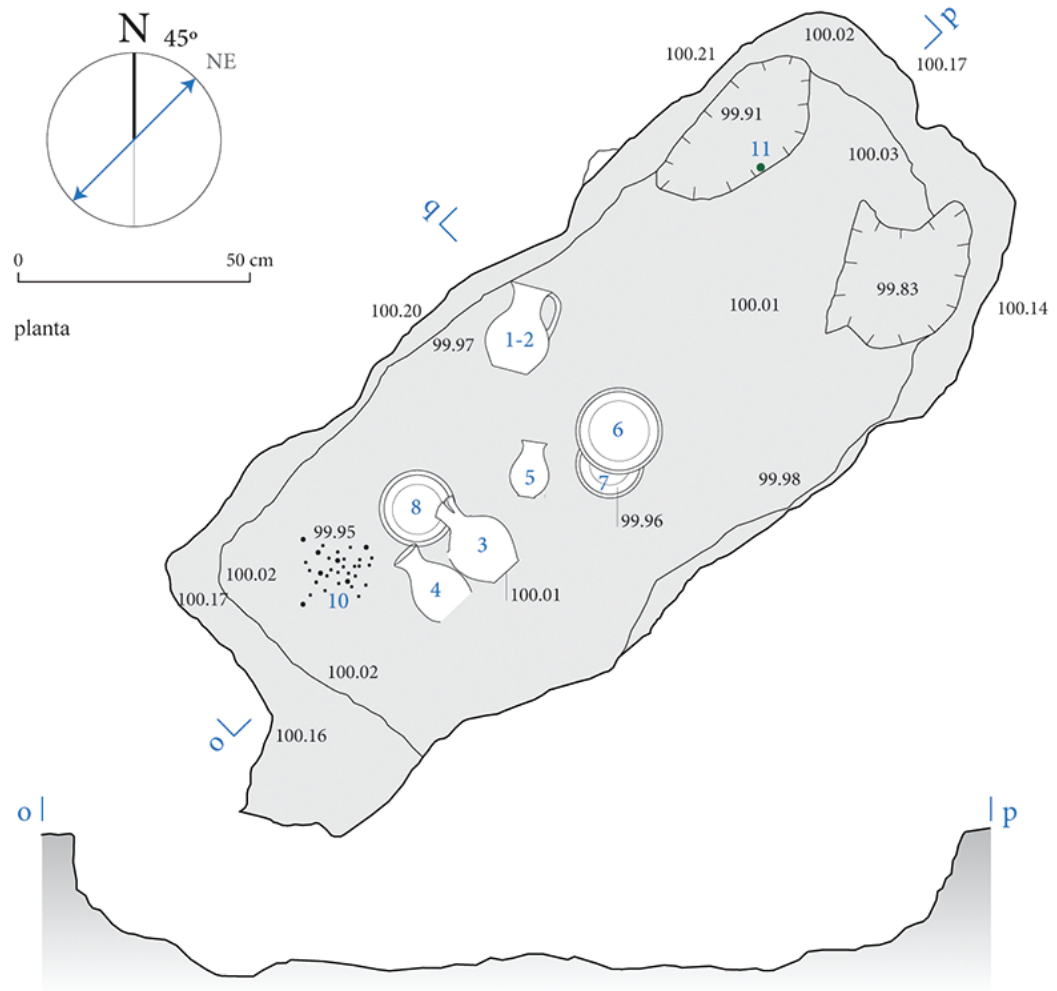

Sepultura 5

perfil longitudinal

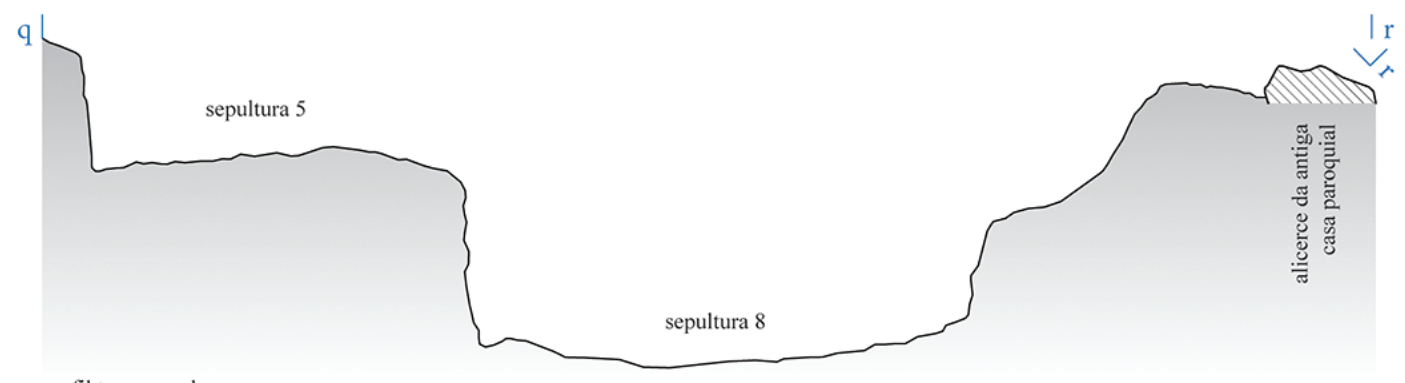

perfil transversal

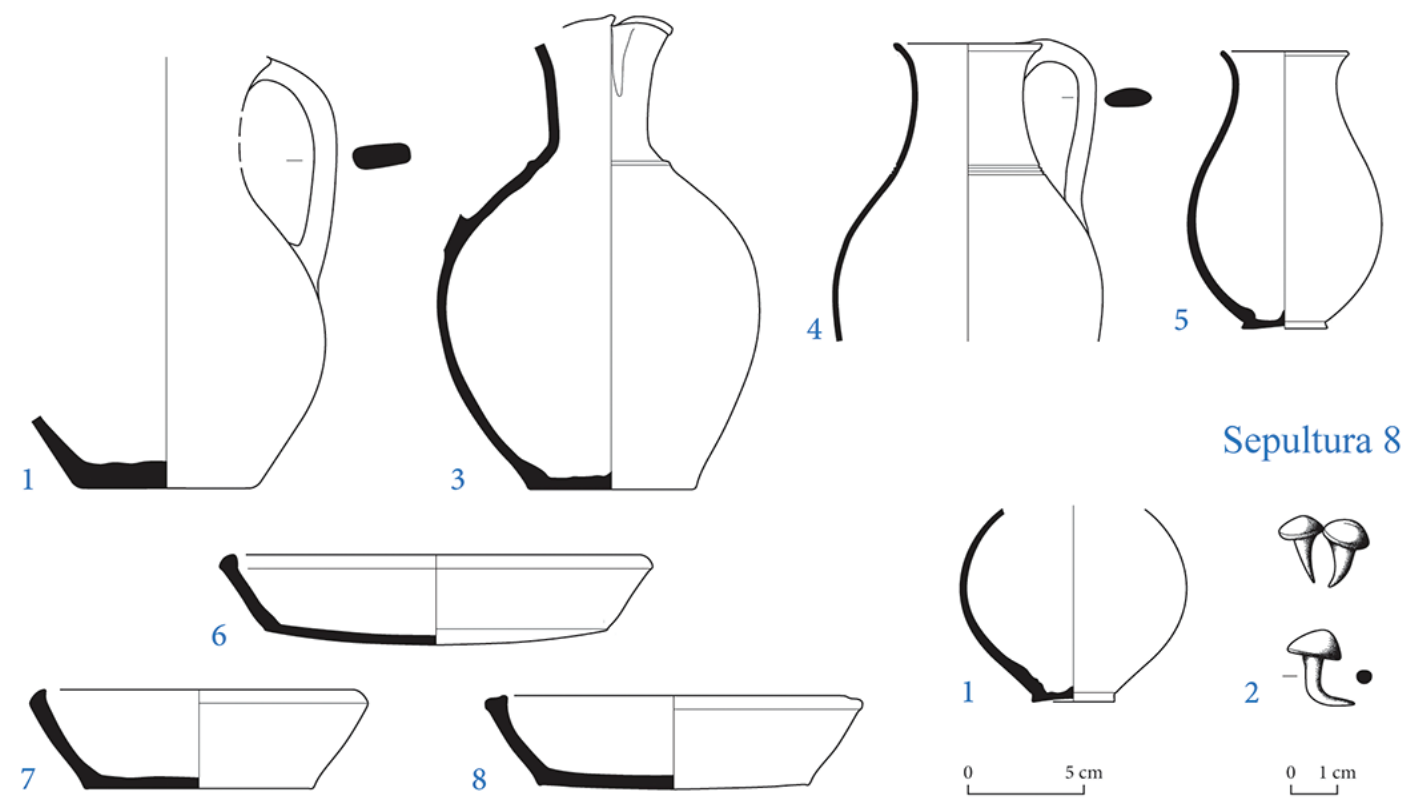

Figura 13 - Sepulturas 5 e 8: plano, cortes e respetivos espólios. 


\begin{tabular}{|c|c|}
\hline \multicolumn{2}{|r|}{ S. 1} \\
\hline Inv. & Objeto \\
\hline 14375 & $\begin{array}{l}\text { 1. Jarro - trilobado (?), p. arenosa, sup. alisada, } \\
\text { castanha; aparência nova }\end{array}$ \\
\hline 14376 & $\begin{array}{l}\text { 2. Bilha }- \text { p. arenosa, sup. } \pm \text { alisada, alaranjada, } \\
\text { bem cozida }\end{array}$ \\
\hline 14377 & $\begin{array}{l}\text { 3. Copo - p. arenosa fina, sup. alisada, bege, bem } \\
\text { cozida }\end{array}$ \\
\hline 14378 & $\begin{array}{l}\text { 4. Prato }- \text { p. arenosa, sup. } \pm \text { alisada, bege- } \\
\text { acastanhada }\end{array}$ \\
\hline 14379 & $\begin{array}{l}\text { 5. Tampa/Prato - perfil irregular, p. arenosa, sup. } \\
\text { pouco alisada, acastanhada, alguma fuligem no } \\
\text { int.; asa partida }\end{array}$ \\
\hline 14380 & $\begin{array}{l}\text { 6. Prato }- \text { p. arenosa, sup. } \pm \text { alisada, acastanhada, } \\
\text { fuligem no int. e ext. }\end{array}$ \\
\hline 14381 & $\begin{array}{l}\text { 7. Prato }- \text { p. arenosa, sup. } \pm \text { alisada, castanha- } \\
\text { alaranjada, fuligem no int. e ext. }\end{array}$ \\
\hline 14382 & 8. Objetos em ferro - pregos e ferragens \\
\hline 14383 & $\begin{array}{l}\text { 9. Nummus, Divus Constantinus I, C. M. ilegível, } \\
337-40 \\
\text { Rev.) Constantino em quadriga à direita }\end{array}$ \\
\hline 14384 & $\begin{array}{l}\text { 10. Nummus, Constantinus I, Constantinus II, } \\
\text { Constatius II ou Constans, C. M. ilegível, 335-40 } \\
\text { Rev.) Gloria Exercitus (1 estandarte) }\end{array}$ \\
\hline 14385 & $\begin{array}{l}\text { 11. } \text { \& 3, Constantius II, C. M. ilegível, 357-361 } \\
\text { Rev.) Spes Reipublice }\end{array}$ \\
\hline 14386 & $\begin{array}{l}\text { 12. Æ 3, Constantius II, C. M. ilegível, 355-357 } \\
\text { Rev.) Fel Temp. Reparatio (FH3) }\end{array}$ \\
\hline 14387 & $\begin{array}{l}\text { 13. Nummus, Constantius II, Antioquia, } 347-348 \text {, } \\
\text { RIC VIII, } 113 \text {. } \\
\text { Rev.) VOT/XX/MVLT/XXX dentro de coroa de } \\
\text { louros }\end{array}$ \\
\hline 14388 & $\begin{array}{l}\text { 14. Æ 3, Constantius II, C. M. ilegível, 355-357 } \\
\text { Rev.) Fel Temp. Reparatio (FH3) }\end{array}$ \\
\hline 14389 & $\begin{array}{l}\text { 15. Æ 3, Constantius II, C. M. ilegível, 355-357 } \\
\text { Rev.) Fel Temp. Reparatio (FH3) }\end{array}$ \\
\hline 14390 & $\begin{array}{l}\text { 16. Nummus, Constantius II, C. M. Ocidental, } \\
347-348 \\
\text { Rev.) Victoriae DD Augg Q NN }\end{array}$ \\
\hline \multicolumn{2}{|r|}{ S. 2} \\
\hline Inv. & Objeto \\
\hline 14394 & $\begin{array}{l}1 \text { Jarro - trilobado, bico unido, p. arenosa, sup. } \pm \\
\text { alisada, castanha, fuligem exceto na zona da asa }\end{array}$ \\
\hline 14395 & $\begin{array}{l}\text { 2. Bilha }- \text { p. arenosa fina, sup. } \pm \text { alisada, bege- } \\
\text { alaranjada, bem cozida }\end{array}$ \\
\hline 14396 & $\begin{array}{l}\text { 3. Púcaro - grande, p. arenosa com grãos } \\
\text { vermelhos, sup. alisada, bege com manchas de } \\
\text { tom alaranjado }\end{array}$ \\
\hline 14397 & $\begin{array}{l}\text { 4. Púcaro - p. arenosa fina, sup. alisada, castanha } \\
\text { com manchas de tom alaranjado, fuligem do lado } \\
\text { oposto à asa }\end{array}$ \\
\hline 14398 & $\begin{array}{l}\text { 5. Púcaro - p. arenosa fina, sup. alisada, castanha- } \\
\text { alaranjada }\end{array}$ \\
\hline 14399 & 6. Copo - p. arenosa fina, sup. alisada, bege \\
\hline 14400 & $\begin{array}{l}\text { 7. Prato - perfil irregular, p. arenosa, sup. } \pm \\
\text { alisada, castanha, fuligem no int. e ext. }\end{array}$ \\
\hline 14401 & $\begin{array}{l}\text { 8. Prato de lume }- \text { p. arenosa, sup. } \pm \text { alisada, } \\
\text { castanha, fuligem no int. e ext. }\end{array}$ \\
\hline 14402 & $\begin{array}{l}\text { 9. Prato de lume }- \text { p. arenosa, sup. } \pm \text { alisada, } \\
\text { acastanhada, fuligem no ext. }\end{array}$ \\
\hline 14403 & $\begin{array}{l}\text { 10. Tachas - } 63 \text {, de tamanho pequeno e médio, } \\
\text { com sinais do tecido, pouco percetível }\end{array}$ \\
\hline 14404 & $\begin{array}{l}\text { 11. } \text { E 3, Constantius II, C. M. ilegível, 355-357 } \\
\text { Rev.) Fel Temp. Reparatio (FH3) }\end{array}$ \\
\hline 14405 & $\begin{array}{l}\text { 12. } Æ \text { 3, Constantius II, C. M. ilegível, 355-357 } \\
\text { Rev.) Fel Temp. Reparatio (FH3) }\end{array}$ \\
\hline 14406 & $\begin{array}{l}\text { 13. } Æ \text { 3, fragmentada, ilegível, séc. IV (post. } \\
330 \text { ?) }\end{array}$ \\
\hline
\end{tabular}

\begin{tabular}{|c|c|}
\hline \multicolumn{2}{|r|}{ S. 3} \\
\hline Inv. & Objeto \\
\hline 14407 & $\begin{array}{l}\text { 1. Jarro - p. arenosa, sup. } \pm \text { alisada, castanha, } \\
\text { fuligem exceto na zona da asa (?) }\end{array}$ \\
\hline 14408 & $\begin{array}{l}\text { 2. Bilha - p. fina com desengordurante cerâmico, } \\
\text { sup. bem alisada, bege-alaranjada }\end{array}$ \\
\hline 14409 & $\begin{array}{l}\text { 3. Púcaro (?) - p. arenosa fina, sup. alisada, bege- } \\
\text { alaranjada, fuligem no lado oposta à asa }\end{array}$ \\
\hline 14410 & $\begin{array}{l}\text { 4. Copo - p. arenosa fina, sup. alisada, bege- } \\
\text { alaranjada, orifício aberto na pança depois da } \\
\text { cozedura }\end{array}$ \\
\hline 14411 & $\begin{array}{l}\text { 5. Tacinha - pasta arenosa } \pm \text { fina, sup. bem } \\
\text { alisada, bege-alaranjada, forte aguada castanho- } \\
\text { alaranjado no int. e ext. do lábio }\end{array}$ \\
\hline 14412 & $\begin{array}{l}\text { 6. Pratel - pasta arenosa } \pm \text { fina, sup. bem alisada, } \\
\text { bege-alaranjada }\end{array}$ \\
\hline 14413 & $\begin{array}{l}\text { 7. Prato - p. arenosa, sup. alisada, castanha, } \\
\text { fuligem no int. e ext. }\end{array}$ \\
\hline 14414 & $\begin{array}{l}\text { 8. Tachas - } 4 \text { médias, com marcas ténues de } \\
\text { tecido }\end{array}$ \\
\hline 14415 & $\begin{array}{l}\text { 9. Tachas }-7 \text { pequenas e médias, com marcas } \\
\text { ténues de tecido }\end{array}$ \\
\hline 14416 & $\begin{array}{l}\text { 10. Tachas - } 18 \text { pequenas, algumas com marcas } \\
\text { de tecido }\end{array}$ \\
\hline 14417 & $\begin{array}{l}\text { 11. Nummus ou } Æ \mathbf{~} \mathbf{3} \mathbf{4} \text { (?), fragmentado, século } \\
\text { IV (post. 330?) }\end{array}$ \\
\hline \multicolumn{2}{|r|}{ S. 4} \\
\hline Inv. & Objeto \\
\hline 14418 & 1. Púcaro - p. arenosa fina, sup. alisada, bege \\
\hline 14419 & 2. Copo - p. arenosa fina, sup. alisada, bege \\
\hline 14420 & $\begin{array}{l}\text { 3. Prato - p. arenosa, sup. } \pm \text { alisada, bege- } \\
\text { acastanhada }\end{array}$ \\
\hline 14421 & $\begin{array}{l}\text { 4. Prato }- \text { p. arenosa, sup. } \pm \text { alisada, bege- } \\
\text { acastanhada }\end{array}$ \\
\hline 14422 & $\begin{array}{l}\text { 5. Prato - perfil irregular, p. com grãos de } \\
\text { quartzo, ext. alisado, acastanhado, fuligem no int. } \\
\text { e ext. }\end{array}$ \\
\hline 14423 & $\begin{array}{l}\text { 6. Objeto de bronze - fragmento reto de secção } \\
\text { circular, com revestimento de natureza orgânica }\end{array}$ \\
\hline \multicolumn{2}{|r|}{ S. 5} \\
\hline Inv. & Objeto \\
\hline 14470 & $\begin{array}{l}\text { 1. Jarro - trilobado(?), p. arenosa, sup. alisada, } \\
\text { castanha-alaranjada, bem cozida, com fuligem }\end{array}$ \\
\hline 14471 & $\begin{array}{l}\text { 2. Tachas }-8 \text {, idênticas às outras, mas sem (?) } \\
\text { marcas de tecido }\end{array}$ \\
\hline 14472 & $\begin{array}{l}\text { 3. Jarro - trilobado, p. arenosa, sup. alisada, } \\
\text { castanha, fuligem no ext. }\end{array}$ \\
\hline 14473 & $\begin{array}{l}\text { 4. Púcaro - p. arenosa fina, sup. alisada, castanha- } \\
\text { avermelhada, bem cozida }\end{array}$ \\
\hline 14474 & $\begin{array}{l}\text { 5. Copo }- \text { p. arenosa } \pm \text { fina, sup. alisada, } \\
\text { acastanhada }\end{array}$ \\
\hline 14475 & $\begin{array}{l}\text { 6. Prato }- \text { p. arenosa, sup. } \pm \text { alisada, castanha- } \\
\text { alaranjada }\end{array}$ \\
\hline 14476 & $\begin{array}{l}\text { 7. Prato }- \text { p. arenosa, sup. } \pm \text { alisada, acastanhada, } \\
\text { fuligem no int. e ext. }\end{array}$ \\
\hline 14477 & 8. Prato - p. arenosa, sup. áspera, castanha \\
\hline 14478 & $\begin{array}{l}\text { 9. Vaso de vidro - fragmento mínimo de vidro } \\
\text { incolor, curvo, espessura }>1 \mathrm{~mm}\end{array}$ \\
\hline 14479 & $\begin{array}{l}\text { 10. Tachas }-83, \text { muitas com marcas de tecido } \\
\text { bem visíveis }\end{array}$ \\
\hline 14480 & $\begin{array}{l}\text { 11. Æ 3, Constantius II, Roma, 355-357, RIC VIII } \\
\text { 316. Rev.) Fel Temp. Reparatio (FH3) R. M. [?] }\end{array}$ \\
\hline \multicolumn{2}{|r|}{ S. 8} \\
\hline Inv. & Objeto \\
\hline 14481 & $\begin{array}{l}\text { 1. Púcaro (?) - p. arenosa fina, sup. alisada, bege, } \\
\text { bem cozida }\end{array}$ \\
\hline 14482 & $\begin{array}{l}\text { 2. Tachas }-32 \text {, de tamanho pequeno e médio, } \\
\text { com sinais do tecido }\end{array}$ \\
\hline
\end{tabular}

Tabela 1 - Necrópole Romana do Eirô (Duas Igrejas, Penafiel, 2016): síntese dos artefactos pertencentes a cada enterramento. 


\title{
RITUAL, DESCARTE OU AFETIVIDADE?
}

\section{A PRESENÇA DE CANIS LUPUS FAMILIARIS NA NECROPOLE NOROESTE DE OLISIPO (LISBOA)}

\author{
Beatriz Calapez Santos ${ }^{1}$, Sofia Simões Pereira ${ }^{2}$, Rodrigo Banha da Silva ${ }^{3}$, Sílvia Casimiro ${ }^{4}$, Cleia Detry $^{5}$, \\ Francisca Alves Cardoso ${ }^{6}$
}

\begin{abstract}
RESUMO
Os contextos funerários onde se regista a presença de Canis lupus familiaris são diversos, compreendendo enterramentos individuais (com ou sem espólio associado), inclusão em sepulturas de humanos, ou descarte de cadáveres, sugerindo por consequência um leque diversificado de significados, aferíveis em função da natureza do contexto arqueológico. O estudo aqui apresentado corresponde à análise contextual e, em especial, zooarqueológica, de quatro canídeos identificados na Necrópole Noroeste de Olisipo. A análise osteológica incidiu na identificação anatómica, estimativa da idade à morte, diagnose sexual e identificação de eventuais alterações ósseas de origem tafonómica e patológica. Deste modo foi possível determinar a presença de três indivíduos jovens adultos do sexo masculino e um não adulto, indeterminado.

Palavras-chave:Zooarqueologia, Rituais Romanos, Tafonomia, Arqueologia Funerária, Época Romana Imperial.
\end{abstract}

\begin{abstract}
The funerary contexts in which the presence of Canis lupus familiaris are identified are diverse, comprehending individual burials (with or without artifacts), inclusion in human graves, or disposal of corpses, thus suggesting a diverse range of meanings, measurable in function of the nature of the archaeological context. This study reports to the contextual and, especially, zooarchaeological analysis, of four canids (Canis lupus familiaris) identified in the Necrópole Noroeste de Olisipo. The osteological analysis aimed the anatomical identification, estimation of age at death, sexual diagnosis and the identification of eventual taphonomical and pathological bone changes. The methodology employed allowed to determine the presence of three adult male individuals and one non-adult.
\end{abstract}

Keywords: Zooarchaeology, Roman Rituals, Taphonomy, Funerary Archeology, Imperial Roman Period.

\footnotetext{
1. Mestranda em Arqueologia, Departamento de História, NOVA FCSH; Laboratório de Antropologia Biológica e Osteologia Humana, LABOH-CRIA, NOVA FCSH; beatrizcalapez@hotmail.com

2. Mestranda em Arqueologia, Departamento de História, NOVA FCSH; Laboratório de Antropologia Biológica e Osteologia Humana, LABOH-CRIA, NOVA FCSH; sofia.simoeso3.97@gmail.com

3. Departamento de História NOVA FCSH; CHAM-FCSH/NOVA e UAç; CAL/DPC-CML; rodrigobanhadasilva@gmail.com

4. Instituto de Estudos Medievais, IEM, NOVA FCSH; Laboratório de Antropologia Biológica e Osteologia Humana, LABOH-CRIA, NOVA FCSH; scasimiro@fcsh.unl.pt

5. UNIARQ, Centro de Arqueologia da Universidade de Lisboa, Faculdade de Letras da Universidade de Lisboa; cdetry@letras. ulisboa.pt

6. Laboratório de Antropologia Biológica e Osteologia Humana, LABOH-CRIA, NOVA FCSH; Cranfield Defense \& Security, Cranfield University, Reino Unido; francicard@fcsh.unl.pt
} 


\section{INTRODUÇÃO}

A presença de Canis lupus familiaris, cujo processo de domesticação foi iniciado há cerca de 14000 anos, é significante em contextos arqueológicos. Uma vez que desde cedo se desenvolveu uma ligação especial entre esta espécie e o ser humano, os enterramentos de C. l. familiaris verificam-se tão antigos quanto a sua domesticação, tendo sido praticados e arqueologicamente atestados em muitas regiões, culturas e sociedades. Também em necrópoles romanas a sua presença é algo comum, sendo que alguns estudos interpretam estes contextos como resultado de gestos afetivos ou práticas rituais (Davis \& Valla, 1978, p. 6o8; De Grossi Mazzorin \& Tagliacozzo,1997, p. 438; Vuković-Bogdanović \& Jovičić, 2012, pp. 687-699).

Na Antiguidade Clássica acreditava-se que os cães tinham poderes especiais e que eram capazes de transportar espíritos humanos para o Além. Os textos greco-latinos mencionam a existência da prática de deposições funerárias de canídeos, e fazem referência às capacidades "sobrenaturais" detidas por este animal. Plínio, o Jovem, por exemplo, referiu que as crianças eram por vezes enterradas com os seus animais de estimação, descrevendo a esse respeito as qualidades especiais dos cães malteses (Vuković-Bogdanović \& Jovičić, 2012, pp. 687-699). Demonstram ainda a existência de várias raças, às quais chegam mesmo a reconhecer diferenciadas aptidões para certas funções, tais como a caça, guarda, pastoreio, tração e estimação (MacKinnon, 2010, p. 291). As fontes escritas parecem ser suportadas pela iconografia romana, que através da arte (pinturas, esculturas, mosaicos) atestam a existência de uma diversidade de morfologias e cores de pelagem ${ }^{7}$ (Pires et alii, 2017, p. 2). As análises dos elementos osteológicos destes animais também vão de encontro ao referido anteriormente, já que se observam grandes diferenças de tamanho e forma a nível do crânio, o que indica a existência de fenótipos com características bem definidas e diferenciadas (De Grossi Mazzorin \& Tagliacozzo, 1997, p. 439; Bennet \& Timm, 2015, pp. 101-102).

A presença de C. l. familiaris foi identificada em va-

7. Na cidade romana de Conímbriga (Portugal), na Casa dos Repuxos, foram identificados mosaicos, com representações de C. 1. familiaris, onde é possível comprovar a diversidade morfológica desta sub-espécie (Pires et alii, 2017, p. 2). riados contextos funerários, desde enterramentos individuais (com ou sem espólio associado), inclusão em sepultura humanas, ou descartes, o que sugere uma diversidade de significados: do ritual, integrando uma amplitude de práticas de purificação, de dedicação aos deuses do submundo, ou de mera afetividade, no sentido de prolongar a ligação para além da vida ou, ainda, podem tratar-se de uma simples ocultação que, por si, pode corresponder a múltiplas atitudes em relação ao animal, aferíveis em função da natureza do contexto arqueológico (De Grossi Mazzorin \& Tagliacozzo, 1997, pp. 438-439; De Grossi Mazzorin \& Minniti, 2002, p. 62; VukovićBogdanović \& Jovičić, 2012, pp. 687-699). Não existem, contudo, evidências claras do consumo de cão em período romano (Mazzorin \& Tagliacozzo, 1997, p. 439; Bennet \& Timm, 2015, p. 93).

O objetivo deste estudo zooarqueológico é analisar o material osteológico identificado como pertencente a C. l. familiaris, intentando definir o perfil contextual arqueológico dos quatro indivíduos objecto de análise, a fim de produzir uma leitura sustentada do significado da sua presença no espaço. Realça-se o contributo que esta análise terá no estudo do contexto arqueológico da Necrópole Noroeste de Olisipo, e ainda em estudos zooarqueológicos de C. l. familiaris, uma vez que, este resultou na criação de uma base de dados (em formato Excel) que será disponibilizada a outros investigadores no sentido de promover o crescimento da mesma, por forma a reunir dados para futuras análises comparativas focando, principalmente, os parâmetros biológicos, mas não descurando os comportamentais (no âmbito da relação entre seres humanos e não humanos).

\section{ENQUADRAMENTO ARQUEOLÓGICO}

A Necrópole Noroeste de Olisipo corresponde a uma designação criada em 2005 para se referir a um conjunto urbanisticamente coerente de utilizações funerárias dos espaços na periferia da cidade romana (Silva, 2005), inspirando-se a designação noutros exemplos hispânicos (Vaquerizo, 2002). Conhecem-se hoje núcleos funerários romanos na Calçada do Garcia, identificado antes de 1870 (Silva, 2002), no Largo de São Domingos, cerca de 1898 (Vasconcelos, 1900), Praça da Figueira, em 1961-62 e 2000-2001 (Branco, 1961; Ferreira, 1962; Moita, 1968; Silva, 2005, 2012), Encosta de Santana, em 2002 e 2004 (Muralha, Costa \& Calado, 2002), a que se vieram so- 
mar em datas mais recentes outro na Rua das Portas de Santo Antão (Cabaço et alii., 2017; Cabaço, Lourenço \& Silva, 2019) e em 2018 e 2019 na Calçada do Lavra/Largo de Santa Bárbara. No seu conjunto, os espaços da necrópole dispõe-se preferencialmente na proximidade da grande "via norte" Olisipo-Scallabis (Silva, 2018), para já espraiando-se ao longo de cerca de $600 \mathrm{~m}$ no sentido N-S, mas acompanhando também para oriente o divertículo viário que a partir da via principal se dirigia para o Vale de Arroios, casos dos núcleos da Calçada do Garcia e Encosta de Santana, não existindo para já uma definição categórica dos seus limites mais meridionais e setentrionais.

Os contextos agora apresentados foram reconhecidos na campanha de escavações de 2000-2001 na Praça da Figueira, da responsabilidade do extinto Serviço de Arqueologia do Museu da Cidade, resultantes da construção de um parque de estacionamento subterrâneo naquele local. Estes contextos enquadram-se no faseamento definido para o local correspondente às Fases III a V (Figura 1) (Silva, 2005), equivalendo o uso privilegiado do espaço como local funerário às fases III - "monumentalizada" e datada de meados do séc. I d.C. aos finais do séc. III d.C., traduzindo o "fenómeno de transformação da ritualidade da morte que ocorre em cidades hispanas a partir dos finais da República e, sobretudo, na época dos Júlio-Cláudios, que se manifesta na adopção de uma estruturação urbana para os espaços e edificações funerárias" (Silva, 2005: 43) - e IV - "desmonumentalizada" mas coerente, datável de finais do séc. III d.C. a meados do séc. IV d.C. (Silva, 2012), registando-se ainda sepultamentos dispersos e maioritariamente infantis inseríveis na Fase $\mathrm{V}$, em que a zona perde o carácter urbano e privilegiadamente funerário, situável genericamente entre os meados-finais do séc. IV e o V (VI ?) d.C. (Silva, 2005; Casimiro, Silva \& Alves Cardoso, no prelo). No quadro da Necrópole NO de Olisipo estava já referenciada a presença de animais associada direta ou indiretamente a práticas e rituais funerários romanos, quer no núcleo da Praça da Figueira escavado em 1962 por Bandeira Ferreira, no caso o esqueleto parcial de um equídeo (Ferreira, 1962 apud Costa, Duarte \& Muralha, 2006, p. 111), encontrado depositado nas traseiras do "Monumento SE" (Ferreira, 1962 apud Silva, 2005, p. 45, fig. 5, n.. 12 ), quer no caso do "Sector A" da Encosta de Sant'Ana, onde se assinalou também a presença de restos de equídeos (Costa, Duarte \& Muralha, 2006).
Assim, a presença comprovada de C.l.familiaris vem somar-se às espécies já conhecidas para o espaço da Necrópole NO de Olisipo, sendo aqui apresentados quatro casos que, todavia, equivalem a contextos arqueológicos funcionalmente muito distintos.

\section{MATERIAL E METODOLOGIA}

A metodologia aplicada no estudo do contexto funerário e do material ósseo desenvolve-se em várias fases, que resultam da aplicação de vários métodos utilizados para a identificação anatómica, estimativa da idade, diagnose sexual, osteometria, análise tafonómica e patológica (Habermehl, 1975; Davis, 1987, p. 46; Moreno-García, Davis \& Pimenta, 2003, pp. 191229; Vuković-Bogdanović \& Jovičić, 2012, p. 695). Neste sentido, primeiramente procedeu-se à análise de cada indivíduo, visando: 1) a identificação das peças anatómicas presentes recorrendo ao diagrama de Helmer, com base nas obras Comparative Skeletal Anatomy (Adams \& Grabtree, 2008, pp. 153-175) e Anatomy of the Dog (Budras et alii., 2007) registando, a par, a presença de alterações ósseas; 2) estimar a idade à morte através da análise dos estágios da fusão epifisária de vários elementos ósseos, preferencialmente dos ossos longos, e através da avaliação do desenvolvimento dentário (i.e. erupção dentária), e 3) realização da diagnose sexual, neste caso, desenvolvida através da identificação do baculum, osso peniano presente na espécie C. l.familiaris.

Seguidamente, o material foi revisto, a fim de explorar as alterações ósseas observadas, distinguindo-as entre as de natureza patológica daquelas que resultam de processos tafonómicos, passo fundamental para a identificar processos que afetaram o indivíduo ante e pos-mortem (Moreno-García, Davis \& Pimenta, 2003, pp. 206-222). Salienta-se, no entanto, que o objetivo deste estudo não é o desenvolvimento de um diagnóstico paleopatológico. A paleopatologia explora a origem e evolução de certas doenças, por forma a traçar perfis individuais e/ou populacionais (Alves Cardoso, 2018, p. 1). Constituindo-se como uma componente mais complexa, será explorada num futuro próximo. Por fim, realizou-se a análise osteométrica, com base no método de von den Driesch (1976), registando os resultados obtidos em formato de tabela, organizada por indivíduo e por parte anatómica. Conforme referido anteriormente, procedeu-se também à análise conjunta das características contextuais arqueológicas, 
no sentido de identificar os gestos que resultaram na deposição dos quatro canídeos.

\section{RESULTADOS E DISCUSSÃO}

\section{a) Indivíduo [3691]}

O indivíduo [3691] (Figura 2) foi identificado na quadrícula D7 sepultado sob estrutura pétrea [3931] construída deliberadamente para o efeito (Figura 3). Foi edificada sem auxílio de argamassa e com raro fragmento laterício, e seria visível na sua totalidade acima do solo durante o funcionamento da necrópole na sua Fase III, e na base possuía um oco de secção quadrangular, transversal ao muro, com eventual significado ritual. A estrutura funerária pétrea e o sepultamento do canídeo correspondente estavam localizados ligeiramente afastados e por detrás de um conjunto de edificações e práticas de sepultamentos de inumação e incineração de humanos, junto ao limite oeste da via Olisipo-Scallabis e c. $5 \mathrm{~m}$ a norte do muro de limite da área da via secundária que conduzia ao circus.

Não se tendo identificado nenhum "material datante" associado, a posição estratigráfica de [3931] denuncia-lhe uma cronologia provavelmente situada para lá dos finais do séc. I d.C., dada a sua posteridade à fossa [9033] e ao ustrinum [3878], e com anterioridade ao depósito [9005], gerado pelas primeiras acções de "desmonumentalização" que estarão situadas no último terço do século III d.C. (Silva, 2005, pp. 53-56).

Relativamente à análise osteológica, verificando-se a completa fusão das epífises com as diáfises dos ossos longos, e segundo o método de Habermehl (1975) trata-se de um indivíduo adulto com, pelo menos, dois anos de vida (Vuković-Bogdanović \& Jovičić, 2012, p. 695). Relativamente à diagnose sexual, a presença do baculum indica tratar-se de um macho. Não foram observadas alterações ósseas.

\section{b) Indivíduo [9114]}

O indivíduo [9114] (Figura 4) foi identificado na quadrícula L3. Trata-se de uma deposição praticada no interior de uma fossa pouco profunda e de configuração ovalada, posteriormente seccionada pela inumação humana [9115], também praticada no interior de fossa pouco profunda, e com características atípicas relacionadas com a deposição do indivíduo (Casimiro $\&$ alii., 2017). Os enterramentos - humano e canídeo - aparentam uma óbvia relação espa- cial, podendo ter sido realizados no mesmo período de tempo, dadas as escassas evidências de obliteração de enterramentos por outros, dentro da mesma fase. As evidências de seccionamento da deposição do animal pela inumação humana, comprovam a sua anterioridade.

A deposição foi praticada na proximidade do ângulo SE de um amplo recinto funerário edificado, muito provavelmente, no período de Cláudio-Flávios e cuja utilização se prolongou atéà obliteração completa do mesmo no último terço do séc. III d.C. Assinale-se que ambos os contextos se enquadram na Fase III da Necrópole NO, mas as relações estratigráficas específicas do setor escavado com [9114] apontam para uma datação pós-flávia e necessariamente anterior aos meados do séc. III d.C. em função do mobiliário funerário associado à inumação humana [9115].

A análise osteológica revelou um indivíduo adulto, uma vez que apresenta a fusão completa das epífises com as diáfises dos ossos longos, tendo certamente mais de dois anos, segundo o método de Habermehl (1975) (Vuković-Bogdanović \& Jovičić, 2012, p. 695). A diagnose sexual foi aferida tendo em conta a presença do baculum, indicando tratar-se de um macho. Verificam-se algumas alterações ósseas principalmente na extremidade distal das tíbias, associado a maior rugosidade e crescimento ósseo, provavelmente resultantes de um processo inflamatório de causa desconhecida.

\section{c) Indivíduo [8288]}

$\mathrm{O}$ indivíduo assinalado em $\mathrm{H} 8 / 9$ na unidade estratigráfica [8288], equivale a uma ocorrência inclusa num depósito integrante de um ambiente de aterro e preparação de um piso de renovação da Via Olisipo-Scallabis, seguramente datado de época posterior aos Flávios em função, podendo aventar-se uma data ainda incerta dentro do séc. II d.C. ou do primeiro terço do séc. III d.C.. A forma como a deposição se verificou, de permeio com outro material, indica tratar-se de um descarte.

Trata-se de um indivíduo não adulto, a avaliar pela ausência de fusão das epífises associadas às diáfises dos ossos longos. Não foi possível desenvolver a diagnose sexual, uma vez que os elementos anatómicos do coxal não estão fundidos, e porque a ausência de baculum, por si só, não é suficiente para aferir o sexo. Foram identificadas alterações ósseas de natureza patológica, bilateralmente, nos coxais, úmeros e ulnas, mas também, no rádio e no fémur 
esquerdos, na mandíbula, maxilar e costelas. Estas alterações manifestam-se, essencialmente, em forma de micro porosidade e, como foi já referido, serão exploradas futuramente. As alterações ósseas de origem tafonómica, que afetaram particularmente os ossos longos, estão relacionadas com a humidade do solo e a exposição ao sol.

\section{d) Indivíduo [5306]}

$\mathrm{O}$ indivíduo foi exumado na quadrícula $\mathrm{O}_{7}$ na unidade estratigráfica [5306], um depósito lodoso, negro, de colmatação de um poço [5302]. Esta estrutura hidráulica estava afastada cerca de $27 \mathrm{~m}$ do limite oriental da via Olisipo-Scallabis, e estava associada a um pequeno número de outras estruturas muito mal conservadas, à exceção de um pátio quadrangular de acesso [5283] ao poço, com o piso forrado a opus signinum. Trata-se, portanto, de um conjunto de edificações isoladas e distantes $15 \mathrm{~m}$ dos limites dos recintos funerários mais próximos a oeste, podendo aventar tratar-se de restos de construções associadas a usos agrícolas do espaço.

A estrutura conservada do poço preservava c. 4,20 $m$ de profundidade, sendo preenchido pela sequência [5292=5300], uma unidade da Fase V que noutro setor da escavação se comprovou datar do séc. V-VI d.C. Sobrepunha-se este depósito de coloração verde claro, argiloso e muito compacto (sugerindo uma deposição lenta) a uma outra sequência ([5304] a [5308]) negra e lodosa, que equivale a um outro segmento de colmatação temporalmente mais recuado. A associação a este último de cerâmicas datadas dos séc. III-IV d.C. fixa, por conseguinte, a cronologia do indivíduo de [5306] que aqui se trata. As características da deposição sugerem com muita probabilidade uma ação de descarte do canídeo.

Trata-se de um indivíduo adulto, uma vez que apresenta a fusão completa das epífises com as diáfises dos ossos longos, tendo certamente mais de dois anos (Vuković-Bogdanović \& Jovičić, 2012, p. 695; Habermehl, 1975). A diagnose sexual foi, mais uma vez, aferida tendo em conta a presença do baculum, tratando-se de um macho. Verifica-se ainda a existência de desgaste dentário atípico, especialmente no Mi esquerdo, que poderá indiciar um desequilíbrio da mandíbula - algo a explorar futuramente com o recurso a Raio X.

Procedeu-se também a uma análise comparativa (Figura 5) das medidas do primeiro molar inferior dos canídeos da Praça da Figueira, de lobo actual (Detry
\& Cardoso, 2010) e de canídeos de um contexto ritual da Calle Almendralejo em Mérida (Espanha) datado do Séc. I d.C. (Detry et alii., 2018). As medições seguiram os critérios de Angela von den Driesch (1976). Podemos verificar que os casos da Praça da Figueira se destacam das medidas do lobo ibérico, e se enquadram perfeitamente dentro da amplitude de medidas obtidas para os cães de Mérida do período Romano. Confirmando assim, que os esqueletos encontrados no centro de Lisboa pertencem com grande probabilidade a animais domesticados.

\section{CONSIDERAÇÕES FINAIS}

A metodologia de análise aplicada permitiu aferir alguns resultados importantes para a caracterização osteológica e determinação do perfil biológico dos indivíduos em análise. A amostra é composta por três indivíduos adultos do sexo masculino ([3691], [9114] e [5306]) e um não-adulto de sexo indeterminado ([8288]). Foi ainda possível observar a presença de alterações ósseas, tanto de origem tafonómica como patológica. Relativamente ao contexto funerário, e no sentido de compreender a relação entre estes enterramentos, e os enterramentos humanos, os dados não permitiram chegar a uma conclusão. Por exemplo, foi possível inferir que no caso dos indivíduos [3691] e [9114] estamos perante enterramentos intencionais, no entanto não nos é possível aferir se a intencionalidade seria de cariz ritual ou afetivo, e específica a estes animais. Nos restantes casos - [5306] e [8288] - atendendo ao contexto arqueológico em que foram identificados (poço e aterro) estamos, provavelmente, perante situações de descarte ou abandono de cadáver. No entanto, e uma vez mais, esta é a interpretação possível de momento com os dados que possuímos. De futuro este material será reanalisado, em conjunto com a análise de outros materiais associados, com objetivo de possibilitar interpretações mais conclusivas. Numa primeira fase, a implementar, os dados da análise osteométrica serão disponibilizados numa base de dados, com a possibilidade de ser complementada por outros investigadores, no sentido de promover futuras análises comparativas que incidam, não só nos parâmetros biológicos, mas também nos arqueológicos e etnozoológicos. 


\section{BIBLIOGRAFIA}

ADAMS, Bradley J.; CRABTREE, Pamela J. (2008) - Comparative Skeletal Anatomy: A Photographic Atlas for Medical, Examiners, Croners, Forensic Anthropologists and Archaeologists. Humana Press, pp. 153-175.

ALVES CARDOSO, Francisca (2018) - Paleopathology. In The Encyclopedia of Archaological Science. John Wiley \& Sons, Inc. pp. 1-4.

BICHO, Nuno, ed. (2004) - Animais na Pré-História e Arqueologia da Península Ibérica. Actas do IV Congresso de Arqueologia Peninsular. Faro: Universidade do Algarve, pp. 105-116.

BRANCO, Fernando Castelo (1961) - Problemas da Lisboa Romana: Vestígios de um cais ou de uma necrópole? Revista Municipal. Lisboa: Câmara Municipal de Lisboa. 91, pp. 61-75.

BUDRAS, Klaus-Dieter; BENNET, Deb; TIMM, Robert M. (2016) - The dogs of Roman Vindolanda, Part II: Timestratigraphic occurrence, ethnographic comparisons, and biotype reconstruction. Archaeofauna. 26, pp. 93-122.

CABAÇO, Nelson; LOURENÇO, Marina; SILVA, Rodrigo Banha da (2019) - O compasso do espaço de Necrópole Romana das Portas de Santos Antão, Lisboa. In Apontamentos de Arqueologia e Património. 13, pp. 47-54

CABAÇO, Nelson; SARRAZOLA, Alexandre; SILVA, Rodrigo Banha da; CARVALHO, Liliana Matias de; LOURENÇO, Marina (2017) - O espaço de Necrópole Romana das Portas de Santo Antão, Lisboa. In Arqueologia em Portugal 2017. Estado da Questão. Lisboa: Associação dos Arqueólogos Portugueses, pp. 1243-1254

CASIMIRO, Ślvia; ALVES CARDOSO, Francisca; SILVA, Rodrigo Banha da; ASSIS, Sandra (2017) - Requiscat in pace. Abordagem transdisciplinar a possíveis casos de enterramentos atípicos identificados na necrópole noroeste de Olisipo. In Arqueologia em Portugal 2017. Estado da Questão. Lisboa: Associação dos Arqueólogos Portugueses, pp. 1215-1227.

CASIMIRO, Sílvia; SILVA, Rodrigo Banha da; ALVES CARDOSO, Francisca (no prelo) - 'et sepultus est'. A multiplicidade da morte na Necrópole Noroeste de Olisipo, In A Morte em Lisboa: novos dados, novas problemáticas, Lisboa: Comissão de Estudos Olisiponenses.

COSTA, Cláudia; DUARTE, Cidália; MURALHA, João (2006) - Associações de Equus asinus ao estudo de necrópole romana da Encosta de Sant 'Ana (Martim Moniz, Lisboa), p. 111 .

DAVIS, Simon J. M. (1987) - The Archaeology of Animals. Londres: Routledge, pp. 23-46.

DAVIS, Simon; VALLA, François R. (1978) - Evidence for domestication of the dog 12000 years ago in the Natufian of Israel. Nature. 276, pp. 6o8-610.
DE GROSSI MAZZORIN, Jacopo; MINNITI, Claudia

(2002) - Dog Sacrifice in the Ancient World: A Ritual Passage? In Proceedings of the $9^{\text {th }}$ Conference of the International Council of Archaeozoology, SNYDER, Lynn M.; MOORE, Elizabeth A. - Dogs and People in Social, Working, Economic or Symbolic Interaction. Durham, pp. 62-66.

DE GROSSI MAZZORIN, Jacopo; TAGLIACOZZO, Antonio (1997) - Dog remains in Italy from the Neolithic to the Roman Period. Anthropozoologica. 25-26, pp.430-439.

DETRY, Cleia; CARDOSO, João Luís (2010) - On some remains of dog (Canis familiaris) from the Mesolithic shellmiddens of Muge, Portugal. Journal of Archaeological Science. 37:11, pp. 2762-2774.

DETRY, Cleia; CARDOSO, João Luís; MORA, Javier Heras; BUSTAMANTE-ÁLVAREZ, Macarena; SILVA, Ana Maria; PIMENTA, João; FERNANDES, Isabel; FERNANDES, Carlos (2018) - Did the Romans introduce the Egyptian mongoose (Herpestes ichneumon) into the Iberian Peninsula? The Science of Nature. 105:11-12, p. 63.

DRIESCH, Angela von den (1976) - A guide to the measurement of animal bones from archaeological sites. Peabody Museum of Archaeology and Ethnology. Harvard University, pp. 1-136.

FERREIRA, Fernando A. B. (1962) - Diário das Escavações Sistemáticas na Praça da Figueira em Lisboa. Lisboa: Junta Nacional da Educação, (manuscrito - exemplar policopiado a partir de microfilme).

HABERMEHL, Karl-Heinz (1975) - Die Altersbestimmung bei Haus- und Labortieren. Berlin / Hamburg.

MACKINNON, Michael (2010) - 'Sick as a dog': zooarchaeological evidence for pet dog health and welfare in the Roman world. World Archaeology. 42:2, pp. 290-309.

MCCARTHY, Patrick H.; FRICKE, Wolfgang; RICHTER, Renate; HOROWITZ, Aaron; BERG, Rolf (2007) - Anatomy of the Dog. Hannover: Schlütersche Verlagsgesellschaft mbH \& Co., pp. 1-26.

MOITA, Irisalva (1968) - Achados de época romana no sub-solo de Lisboa. Revista Municipal. Lisboa. Ano 19. 116:11, pp. 33-71.

MORENO-GARCÍA, Marta; DAVIS, Simon J. M.; PIMENTA, Carlos M. (2003) - Arqueozoologia: estudo da fauna no passado. In MATEUS, José E.; MORENO-GARCÍA, Marta., eds. - Paleoecologia Humana e Arqueociências - um programa multidisciplinar para a arqueologia sob a tutela da cultura. Trabalhos de Arqueologia 29, Lisboa: Instituto Português de Arqueologia, pp. 191-234.

MURALHA, João; COSTA, Cláudia CALADO, Manuel (2002) - Intervenções Arqueológicas na Encosta de Sant'Ana (Martim Moniz, Lisboa). Al-Madan. Almada. 2ª̣ série. 11, pp. 245-246. 
PIRES, Ana Elisabete; DETRY, Cleia; FERNANDEZ-RODRIGUEZ, Carlos; VALENZUELA-LAMAS, Silvia; ARRUDA, Ana Margarida; DE GROSSI MAZZORIN, Jacopo; OLLIVIER, Morgane; HANNI, Catherine; SIMÕES, Fernanda; GINJA, Catarina (2017) - Roman dogs from the Iberian Peninsula and the Maghreb - A glimpse into their morphology and genetics. Quaternay Intenational, pp. 1-15.

SILVA, Rodrigo Banha (2002) - As sepulturas da Calçada do Garcia e o urbanismo de Olisipo. Actas do $3^{\circ}$ Encontro Nacional de Arqueologia Urbana (Almada, 20 a 23 de Fevereiro de 1997). Almada: Câmara Municipal de Almada (col. Monografias Arqueologia), pp. 193-205.

SILVA, Rodrigo Banha (2005) - As "marcas de oleiro" em terra sigillata da Praça da Figueira (Lisboa): uma contribuição para o conhecimento da economia de Olisipo (séc. I a.C. - séc. II d.C.) (Dissertação para a obtenção do grau de Mestre em Arqueologia, especialização em Arqueologia Urbana) Braga: Universidade do Minho, Instituto de Ciências Sociais (policopiado), pp.53-56.
SILVA, Rodrigo Banha (2012) - As "marcas de oleiro» na terra sigillata e a circulação dos vasos na Península de Lisboa (Dissertação de Doutoramento em História, especialidade de Arqueologia). Lisboa: Faculdade de Ciências Sociais e Humanas da Universidade Nova de Lisboa (policopiado).

SILVA, Rodrigo Banha (2018) - A «Via Norte» de Olisipo: a arqueologia na Praça da Figueira (Lisboa). A caracterização dos troços viais e a dinâmica da paisagem suburbana envolvente. In Fragmentos de Arqueologia de Lisboa 2 - Meios, vias e trajectos. . . entrar e sair de Lisboa. Lisboa: Câmara Municipal, pp. 73-86.

VUKOVIĆ-BOGDANOVIĆ,Sonja;JOVIČIĆ,Mladen(2012) - Dog Burials from the Cemeteries of the Roman City of Viminacium (Moesia Superior, Kostolac, Serbia). In Proceedings of the $22^{\text {nd }}$ International Congress of Roman Frontier Studies, Ruse, Bulgaria, pp. 687-702.

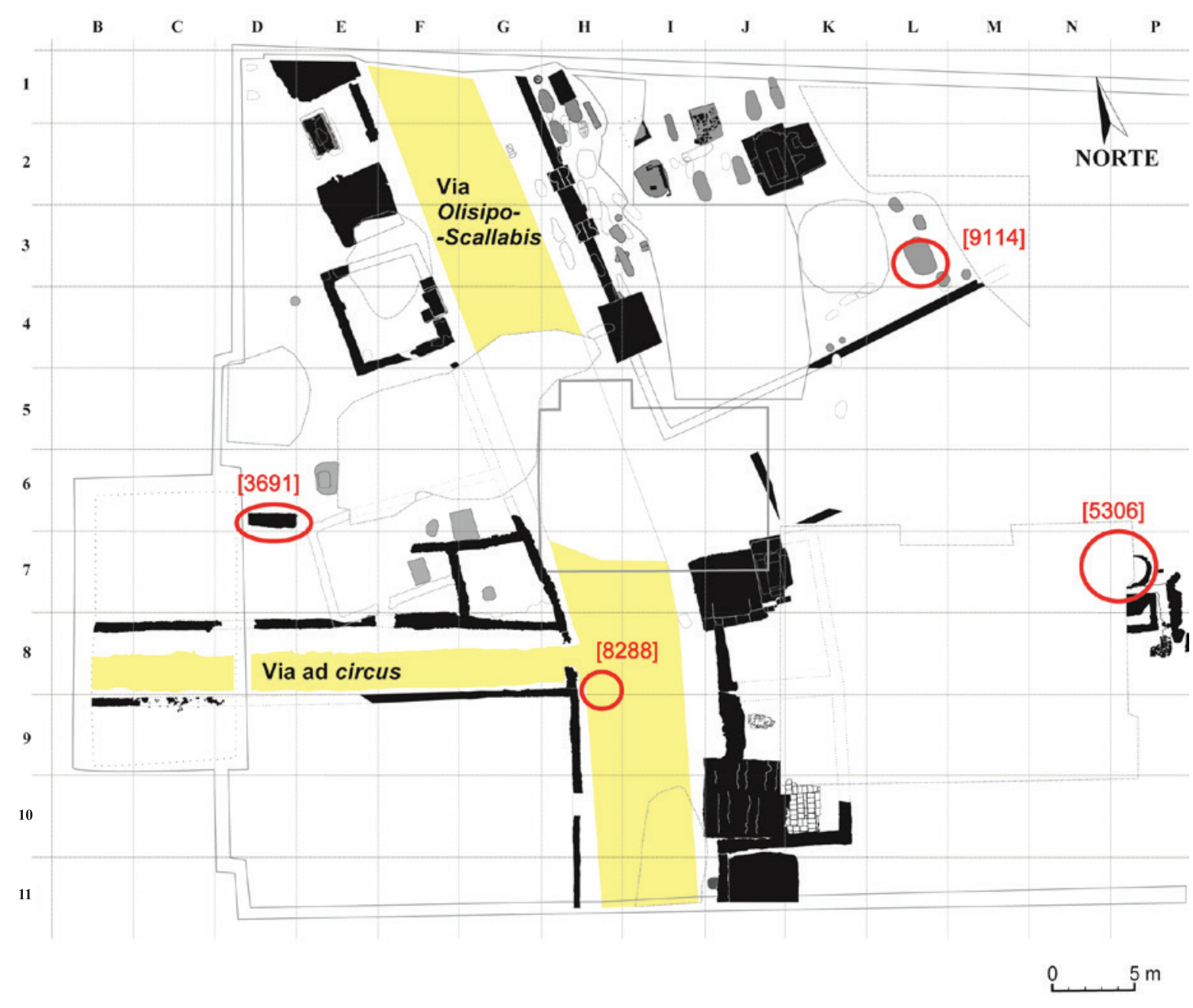

Figura 1 - Planta da Fase III da intervenção arqueológica na Praça da Figueira (200o/2001), com a localização dos indivíduos; seg. Silva, 2005, adaptado. 


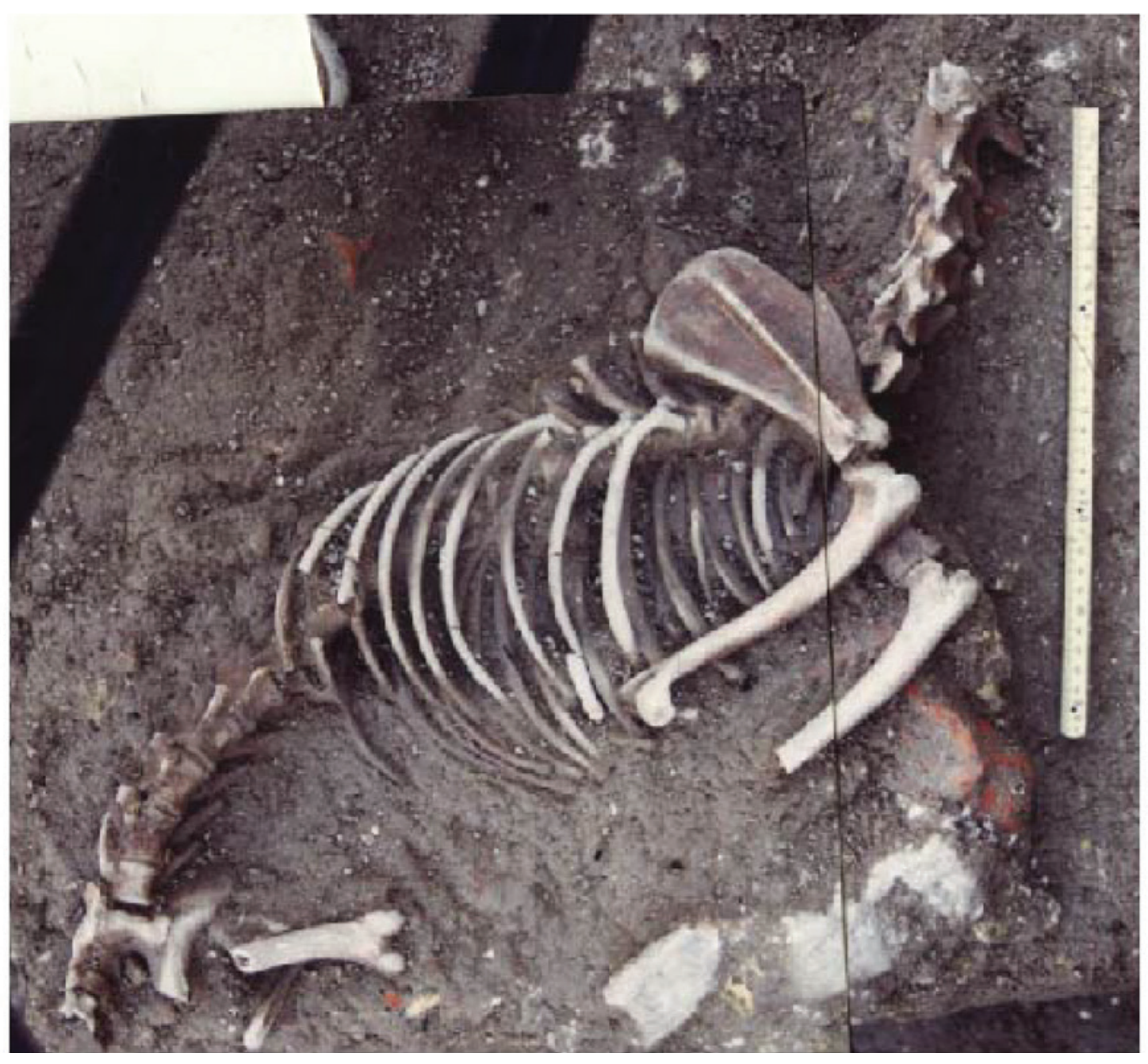

Figura 2 - Deposição do indivíduo [3691] in situ. Centro de Arqueologia de Lisboa, 2000. 


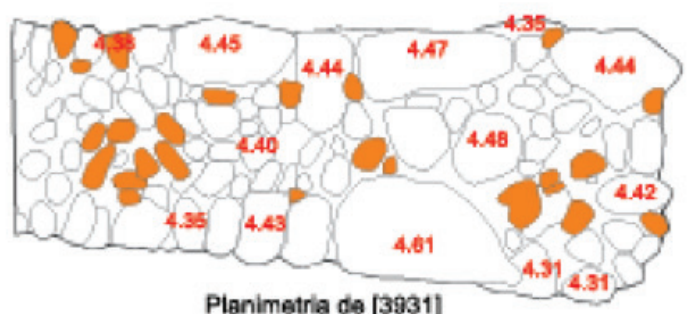

Planimetrla de [3931]

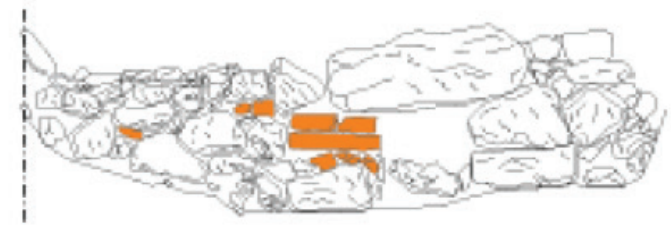

Alpado sul de [3931]

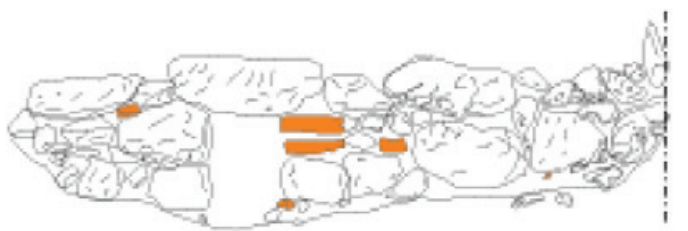

Algado norte de [3931]

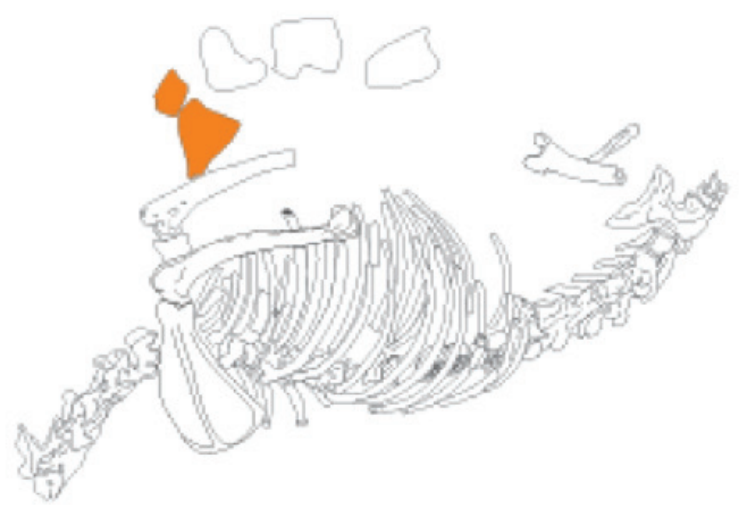

Figura 3 - Deposição do indivíduo [9114] sob estrutura pétrea [3931]; seg. Silva, 2005, adaptado. 


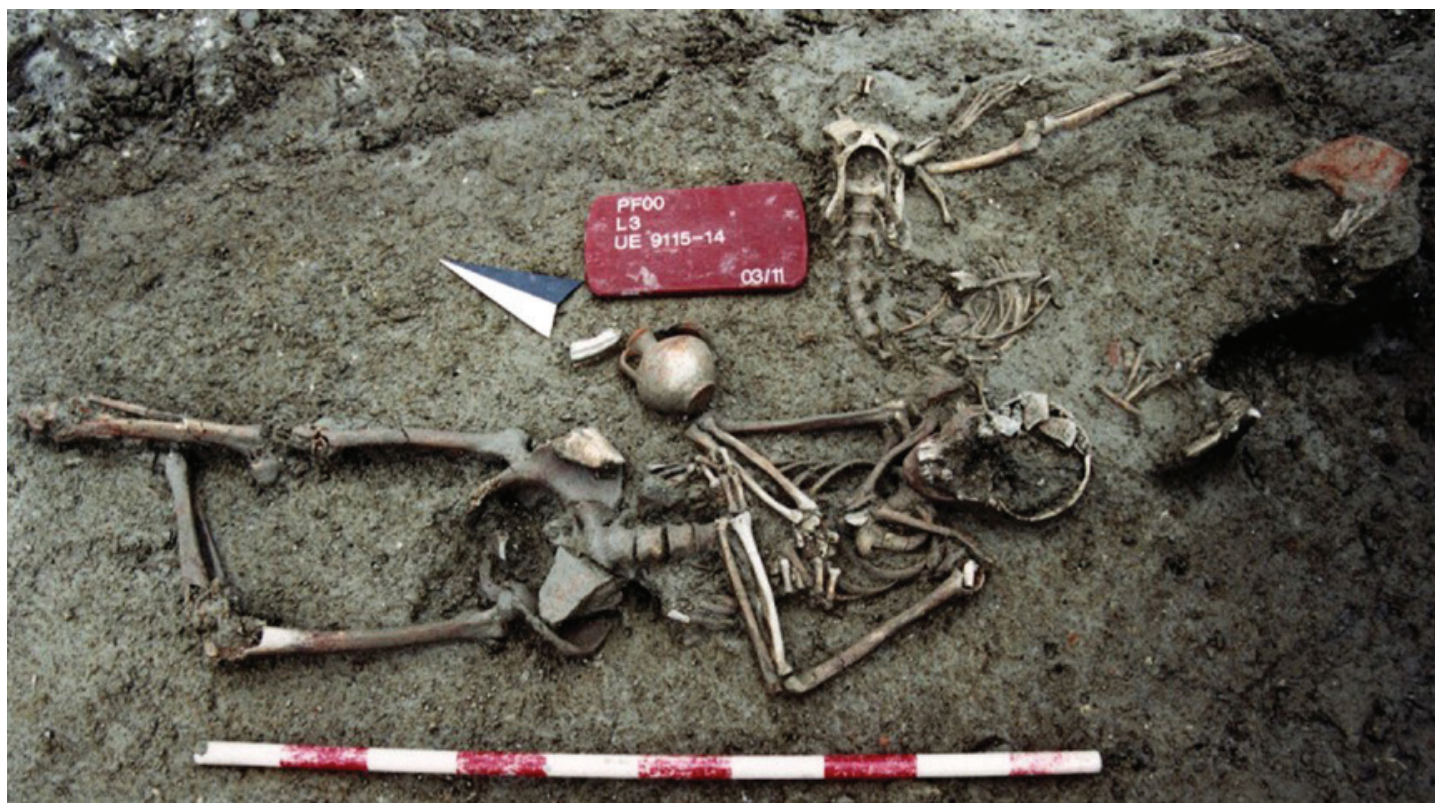

Figura 4 - Deposição do indivíduo [9114] seccionada pela inumação humana [9115]; Centro de Arqueologia de Lisboa, 2000.

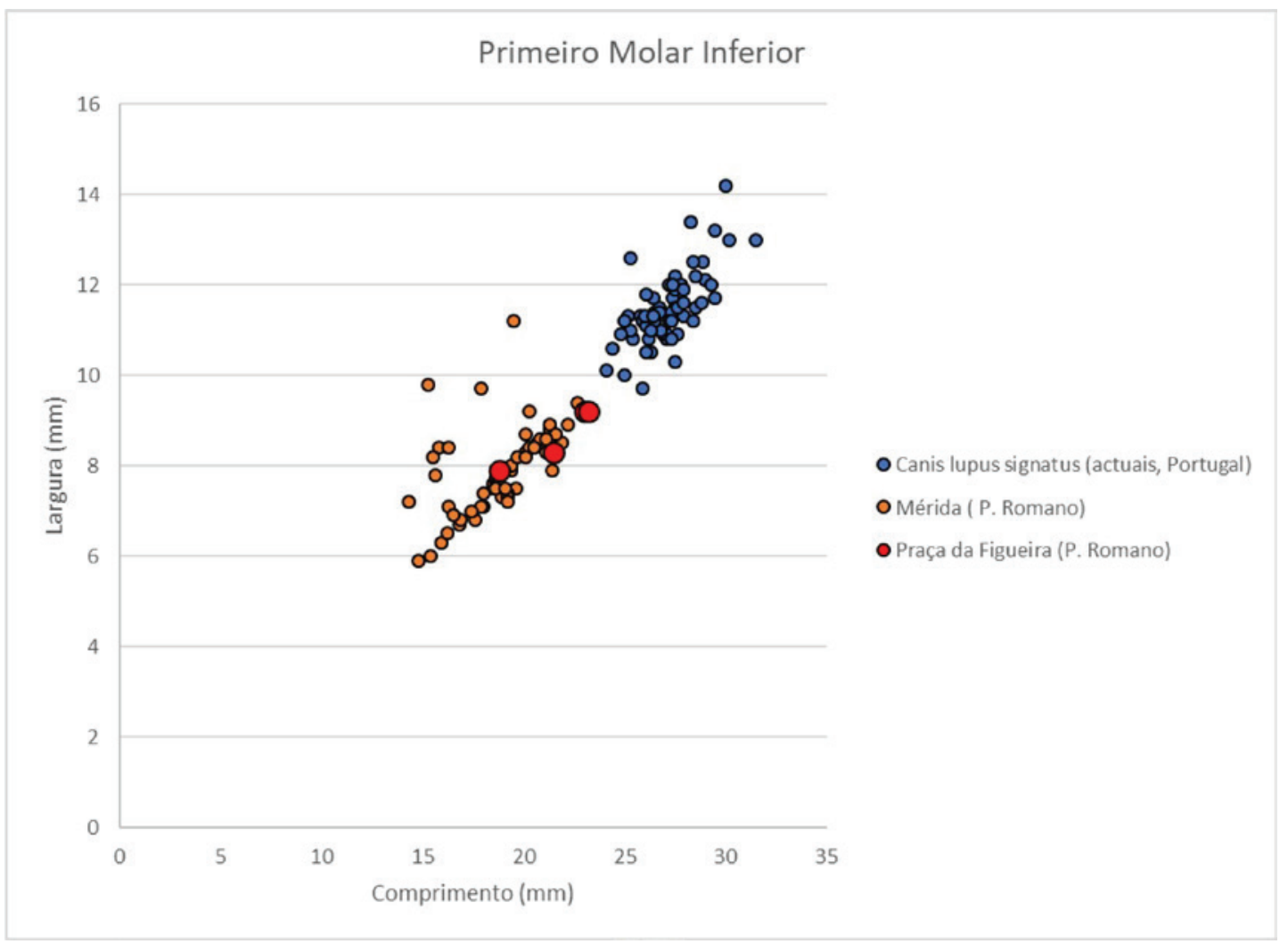

Figura 5 - Gráfico de dispersão comparativo com as medidas de comprimento e largura do primeiro molar inferior, segundo os critérios de Angela von den Driesch (1976), entre lobo actual (Detry \& Cardoso, 2010), cão de um contexto ritual da Calle Almendralejo em Mérida (Espanha) datado do Séc. I d.C. (Detry et alii. 2018) e os canídeos identificados na Praça da Figueira. 


\title{
DINÂMICAS ECONÓMICAS EM BRACARA NA ANTIGUIDADE TARDIA
}

\author{
Diego Machado ${ }^{1}$, Manuela Martins ${ }^{2}$, Fernanda Magalhães ${ }^{3}$, Natália Botica ${ }^{4}$
}

\begin{abstract}
RESUMO
O estudo do período histórico que sucedeu ao Império Romano no Ocidente evidenciou profundas transformações sociais e económicas que tiveram grande expressão no tecido urbano das cidades. Neste sentido, propomos uma síntese sobre as dinâmicas económicas de Bracara na Antiguidade Tardia, período profundamente marcado, por um lado, pela afirmação de novas realidades urbanísticas, sociais, políticas e religiosas, e por outro, pelo gradativo abandono de condicionantes e imperativos que marcaram a cidade alto-imperial. Para tal, vamos recorrer aos dados provenientes das intervenções arqueológicas realizadas em Braga, que documentam as transformações ocorridas entre os séculos III e VIII, período balizado pela elevação da cidade à capital da Gallaecia e pelas invasões muçulmanas, que marcam o fim do comércio a nível mediterrânico.
\end{abstract}

Palavras-chave: Bracara, Antiguidade Tardia, Economia, Sociedade.

\begin{abstract}
The study of the historical period that followed the Western Roman Empire evidenced social and economic transformations that had great expression in the urban fabric of cities. In this sense, we propose a synthesis of the economic dynamics of Bracara in Late Antiquity, a period marked by the affirmation of new urban, social, political and religious realities, as well as by the gradual abandonment of constraints and imperatives that marked the previous city. For that, we will use data from archaeological interventions carried out in Braga, which document how transformations occurred between $3^{\text {rd }}-8^{\text {th }}$ centuries, a period delimited by the elevation of the city to capital of Gallaecia and Muslim invasions, which mark the end of trade at Mediterranean level.

Keywords: Bracara, Late Antiquity, Economy, Society.
\end{abstract}

\section{INTRODUÇÃO}

Após um período de grande desenvolvimento económico e cultural que conformou um pujante Império desde Augustus até a dinastia Nerva-Antonina, com a morte de Commodus, em 193, foi iniciado um período de bastante instabilidade política que apenas se viu apaziguada no final daquele ano com a ascensão de Septimius Seuerus. Contudo, os quarenta e três anos que a dinastia dos Severos esteve com o comando de Roma foram marcados por constantes entraves bélicos nos limites do Império que, apesar de terem garantido o controlo sobre os vastos territórios, terminaram por agravar a instabilidade que antecedeu aos Seuerii e resultou num período de grande crise política e económica, marcado por sucessivas usurpações do poder imperial e uma profunda desvalorização da moeda romana, que só vai ser recuperado com a ascensão de Diocletianus, em 284 (De Blois, 2019).

Porém, a crise do século III afetou, de facto, a Península Itálica, com particular destaque para Roma e as cidades cuja economia estava centrada na produção monocultural voltada ao abastecimento da capital do Império, levando a um quadro de diminuição do índice de importação, em comparação com aquele que havia nos séculos anteriores. Na Hispânia, e em especial no noroeste da Península Ibérica, esta crise

\footnotetext{
1. Unidade de Arqueologia da Universidade do Minho, Lab2PT, UMinho; diegosfmachado@gmail.com.

2. Unidade de Arqueologia da Universidade do Minho, Lab2PT, UMinho; mmmartins@uaum.uminho.pt.

3. Unidade de Arqueologia da Universidade do Minho, Lab2PT, UMinho; fmagalhaes@uaum.uminho.pt.

4. Unidade de Arqueologia da Universidade do Minho, Lab2PT, UMinho; nb@uaum.uminho.pt.
} 
não parece ter sido tão significativa, uma vez que os vestígios arqueológicos documentam um período marcado, sobretudo, por um quadro de continuidade a nível das estruturas e dos materiais, apesar da rarefação do numerário em circulação, sobretudo aquele constituído por moedas de maior qualidade (Ripollès Alegre, 2002; Ruivo, 2008; Vila Franco, 2012). Em Bracara, por sua vez, a promoção da cidade a capital da província da Gallaecia, criada por Diocletianus, nos finais do século III, intensificou a competição pelos altos cargos na administração provincial e proporcionou a emergência de uma sociedade ainda mais hierarquizada e economicamente dinâmica.

Entretanto, a desarticulação política e administrativa romana nas antigas províncias ocidentais, que na Hispania aconteceu logo nos inícios do século V, deu origem a novos poderes e relações, associados com a instalação dos povos germânicos, sem que isso, contudo, significasse a total dissolução das tradicionais rotas de intercâmbio, que permaneceram em funcionamento até à invasão muçulmana, nos finais do século VII, no norte da África, importante parceiro comercial do Ocidente europeu, e nos inícios do século VIII na Hispânia (Pirenne, 1925). No plano social, por sua vez, as relações globais que o Império proporcionava não sobreviveram ao colapso da estrutura administrativa nas províncias ocidentais, ainda que as estruturas organizativas não tenham sofrido alterações significativas, apesar da transferência do poder que antes vinha do Imperador em Roma e que passou a ser detido pelo bispo na basílica (Brown, 1971).

Assim, realizaremos uma síntese das dinâmicas económicas de Bracara durante a Antiguidade Tardia, de modo a melhor evidenciar os processos que incidiram sobre a cidade com o fim do Principado até ao século VIII. Esta abordagem irá privilegiar a análise dos dados arqueológicos de Braga, com enfoque na atividade construtiva, na produção oleira e vítrea, na circulação monetária e nas importações.

\section{A ATIVIDADE CONSTRUTIVA}

Bracara é herdeira do processo evolutivo que Bracara Augusta teve desde a sua fundação, em finais do século I a.C., até à consolidação dos processos construtivos que conformaram uma cidade de significativas dimensões e detentora de um alargado conjunto de equipamentos públicos, urbanísticos e habitacionais. Com efeito, as primeiras décadas que sucederam à fundação da cidade foram marcadas pela implantação de estruturas públicas fundamentais ao funcionamento do centro urbano, representadas pelo forum, onde se teriam construído os edifícios religiosos e judiciais, mas também pelos equipamentos urbanos viários e pelas infraestruturas de abastecimento de água e drenagem de resíduos, dando origem a uma malha urbana bastante homogénea, formada por quarteirões quadrados com dimensão de 1 actus e uma área total de cerca de zoha (Martins \&alii, 2017a).

Uma vez que a estrutura urbana estava criada, foi iniciada a ocupação do parque habitacional da cidade, em época flávia, que estava representado por domus que preenchiam a metade ou a totalidade dos quarteirões rodeados por eixos pedonais porticados e reproduziam com grande qualidade o léxico arquitetónico itálico nas plantas e na escolha dos materiais (Magalhães, 2019). Durante a dinastia nerva-antonina foram implantados equipamentos públicos ligados ao ócio e entretenimento, como as termas públicas do Alto da Cividade e da rua Afonso Henriques, um teatro e um anfiteatro (Morais, 2001; Martins et al., 2015; 2017b).

Por sua vez, nos dois últimos séculos da administração romana em Bracara, e a partir dos finais do século III com a promoção da cidade a capital da província da Gallaecia, os investimentos construtivos passam a tomar outros rumos. Embora ainda tenham sido mantidas atividades construtivas públicas, como a reforma nas termas públicas do Alto da Cividade, cujo abandono aconteceu somente nos inícios do século V (Martins, 2005), e, especialmente, a construção de uma muralha que cercou uma área de 48 ha, mais ampla que a cidade planificada (Lemos, Leite \& Cunha, 2007), é a nível do contexto doméstico que as maiores transformações desse período foram documentadas.

Com efeito, os investimentos realizados nas domus da cidade entre os séculos III e IV foram deveras significativos e refletem a busca pela ascensão política e social das elites bracarenses face às novas possibilidades de cargos na administração pública provincial (Figura 1).

Algumas antigas habitações que ocupavam metade de quarteirões foram expandidas para o lote contíguo através da compra do mesmo pelo proprietário, como está documentado na domus da Rua Frei Caetano Brandão/Escola Velha da Sé, o que permitiu a reprodução de salas de representação para a receção 
de conuiuas, atividades expectáveis de qualquer $p a-$ terfamilias que busca ampliar as suas relações com os demais membros da elite urbana. Assim como, e de maneira bastante generalizada pelas habitações da cidade, os programas decorativos dos espaços domésticos com uso público passaram por reformas que incluíam o uso de mosaicos para cobrir os pavimentos e de pinturas para as paredes e o mármore, utilizado em capitéis e outros elementos arquitetónicos. Este processo está bem documentado na domus das Antigas Cavalariças de Braga, onde foram recuperados restos de tesselae desses mosaicos e identificado um ninfeu com pavimento em opus alexandrino, bem como a construção de espaços termais destinados ora ao uso privado e ora ao público, como da domus da Escola Velha da Sé e Frei Caetano Brandão e da domus das Carvalheiras (Ribeiro, 2010; Magalhães, 2010; 2019).

Por outro lado, foi identificado um fenómeno de apropriação do espaço público pelos proprietários de algumas habitações de modo a ampliarem as suas residências através da ocupação dos antigos eixos pedonais porticados. Essa alteração deu-se através do avanço do espaço doméstico sobre as tabernae que se dispunham ao longo das fachadas das casas, abertas ao pórtico que delimitava o quarteirão, e essas lojas, por sua vez, sobre o eixo porticado, resultando na completa alteração da paisagem urbana que definia Bracara Augusta, bem marcada pelo ritmo das colunas ao redor das insulae (Magalhães, 2019). Da mesma forma, outro fenómeno identificado na cidade a partir do século IV, e que também rompe com a forma urbis da cidade planificada augustana, é a orientação de novas construções em relação à muralha e não à malha urbana, observando-se ainda o avanço de edifícios sobre algumas ruas que perderam a importância que tinham no período anterior (Pereira, 2018).

Se, por um lado, as reformas registadas nas domus bracarenses assinalam um período de grande investimento no património privado dos seus proprietários, por outro lado, os espaços públicos de entretenimento são abandonados e desmantelados. Com a desafetação do teatro de Bracara Augusta, entre os séculos III-IV, as suas estruturas foram, gradativamente, reutilizadas para a criação de novos contextos construtivos residenciais e artesanais. Com efeito, a área a norte do parascaenium foi remodelada e nela implantada uma unidade habitacional, enquanto o muro perimetral, na plataforma superior, foi reutilizado como parede de uma construção de carácter artesanal, bem marcada pela identificação de um forno destinado ao derretimento do bronze e ainda, num espaço um pouco mais a norte, foi construída uma outra estrutura, que reutilizou a parte da parede do aqueduto que cruza aquela área, com um ramal que assegurava o abastecimento das termas. Ao nível das técnicas construtivas dessas novas habitações é importante salientar que abandonam completamente o utilizado na restante da cidade, onde o uso do granito é generalizado. Essas estruturas utilizam placas de xisto na base dos muros, alçados em madeira e os pavimentos eram em terra batida (Martins \& alii, 2015).

Com o fim da administração romana e a instalação dos suevos na Gallaecia assistimos a um processo de profundas modificações nos contextos privados bracarenses. Se os últimos séculos da ocupação romana foram marcados pelo aprofundamento do léxico arquitetónico itálico nas habitações com a ampliação dos espaços de representação e dos programas decorativos, os séculos V-VII são marcados pelo colapso das grandes casas de elite unifamiliares através do desmembramento dos antigos compartimentos para criação de novas realidades habitacionais mais pequenas que recortam as plantas das domus. Esse fenómeno, ainda que mal conhecido devido ao caráter fragmentário das escavações em Braga e da má preservação dos vestígios, encontra-se reconhecido em alguns zonas arqueológicas da cidade, como a do Ex-Albergue Distrital e das Cavalariças (Martins $\&$ alii, 2016).

\section{PRODUÇÃO OLEIRA E VÍTREA}

Desde as primeiras décadas a cidade fabricou recipientes cerâmicos e vítreos cujas diferentes produções atendiam à diversificada população que nela habitava. Com efeito, no que toca às atividades oleiras, ao longo do século I foram manufaturados objetos que apresentavam uma continuidade formal e tecnológica em relação às produções da Idade do Ferro, as chamadas cerâmicas de tradição indígena, bem como outras que assinalam variações a nível das pastas, mas que ainda são enquadrados como produtos comuns, sem grande acabamento ou decoração, que seria destinado ao uso de cozinha ou que compunham as mesas das classes menos afortunadas. Por outro lado, também foram produzidos recipientes em que se observa um maior cuidado no 
que toca ao alisamento das paredes ou à aplicação de pinturas, com fim decorativo, ou engobes, para revestimento das superfícies. Neste grupo estão representadas as cerâmicas comum fina, fina pintada, cinzenta fina polida e engobe vermelho (Delgado \& Morais, 2009).

Não obstante, outras produções locais dos primeiros séculos da cidade especializaram-se na reprodução de formas exógenas em recipientes de alta qualidade, certamente destinados a uma camada da população com melhores condições financeiras e ao mercado regional, identificadas tanto no conuentus bracaraugustano como no lucense. Estão representados nesse grupo os fabricos de cerâmica bracarense, que imita as terrae sigillatae hispânicas, as paredes finas, cujo paralelo são as produções de mesmo nome originárias da Bética, bem como alguns objetos em manufaturas já mencionadas como as finas pintadas e os engobes vermelhos (Leite, 1997; Gomes, 2000; Delgado \& Morais, 2009).

Por sua vez, o início da Antiguidade Tardia marcou uma clara evolução no seio da produção oleira bracarense. Com efeito, as produções comuns finas e pintadas assumem formas específicas a partir do século IV, em que se destaca a imitação de Hisp. 56 entre as primeiras e o uso das cores branco e vermelho nas decorações das outras. Por sua vez, as cerâmicas de engobe vermelho assumem caraterísticas tecnológicas bastante distintas, principalmente a nível da tonalidade do acabamento e começam a imitar peças originalmente em terra sigillata africana e hispânica tardia, sobretudo no que toca aos pratos e cassarolas (Delgado, 1993-94; Delgado \& Morais, 2009).

Da mesma forma, outros fabricos começam a ser produzidos nesse período, designadamente as cerâmicas de engobe branco, cinzentas tardias e as vidradas (Figura 2). As primeiras possuem como caraterística principal o acabamento que recebem com um engobe cuja manufatura foi iniciada nos finais do século III mas conheceu maior presença em contextos do século $\mathrm{V}$ em formas como os jarros e os potes, por vezes com decorações vegetalistas ou geométricas (Delgado \& Morais, 2009).

As chamadas cinzentas tardias são dividas em duas categorias, comuns e de imitação. O primeiro grupo é caraterizado pelo fabrico de recipientes entre os finais do século IV e o VII que não apresentam grande cuidado a nível dos acabamentos, bem como pelas paredes espessas e formas tradicionalmente associadas a um uso na cozinha, como potes, tige- las e bilhas, embora algumas estejam vinculadas a funções de mesa e despensa. Por outro lado, as cerâmicas cinzentas tardias de imitação, presentes em contextos dos séculos V e VI, reproduzem uma ampla gama de objetos originalmente em terra sigillata africana, focense e gálica e apresentam um significativo esforço técnico no que toca à depuração das pastas e ao tratamento das superfícies, sempre bastante polidas (Gaspar, 2000).

Por fim, outra produção bastante particular do período tardio bracarense está representada pelos fabricos de almofarizes em cerâmica comum grosseira que recebem no interior um caraterístico vidrado plumbífero (Figura 3), estando presente em contextos de finais do século IV e a sétima centúria (Delgado \& Morais, 2009; Martínez Peñín \& alii, 2018).

No que toca à produção vítrea, reconhece-se que a mesma tenha sido iniciada ainda no século I, tendo sido identificado na zona arqueológica do quarteirão dos CTT vestígios de uma fábrica que teria funcionado entre a primeira e a segunda centúria (Cruz, 2009, pp. 217-219; Martins \& alii, 2009). Nesse período, as formas presentes no registo arqueológico são aquelas que, de certo modo, atestam uma homogeneidade do Império Romano, bem marcado pelas taças caneladas e garrafas quadrangulares em vidro verde azulado, taças helenísticas e vidro de mosaico policromático, do século I, e o vidro incolor na centúria seguinte (Cruz, 2009, pp. 136-139).

Contudo, estão melhor estudados os locais de produção vítrea de época tardia, bem como os fabricos dessa época que assumem um caráter mais local ou regional. Com efeito, a já referida fábrica do quarteirão dos CTT apresenta uma segunda fase, cujo abandono aconteceu no século $\mathrm{V}$, onde foi possível registar um forno circular que apresenta a incorporação da tecnologia de fusão do vidro em cadinho e não em cuba, como acontecia com o forno da fase anterior (Figura 3) (Cruz, 2009, pp. 217-223).

Outro local de produção de vidro reconhecido em Bracara é aquele localizado na zona arqueológica da Quinta do Fujacal. Nesta parte da cidade foi identificada uma significativa concentração de restos de produção vidreira o que sugere a existência de uma verdadeira zona artesanal que congregaria várias oficinas, cujo funcionamento não teria ultrapassado o século VI (Cruz, 2009, p. 236).

No referente às produções tardias, é possível destacar três que, por um lado, são reconhecidamente bracarenses e, por outro, apresentam grande expres- 
são no registo arqueológico. A primeira trata-se das taças paleocristãs, bastante frequentes em contextos dos séculos IV e V, em cuja base recebem um símbolo cristão, seja a cruz ou o anagrama formado pelas letras gregas chi e ro.

Já a taça campanulada é aquela que mais abunda em Bracara no período tardio, sendo uma produção caraterizada pelo bordo em "cabeça de fósforo", perfil em forma de sino ou campânula e base reentrante com marca de pontel, cujas variantes vão dos recipientes amplos e baixos aos fundos. É uma produção que recorre sistematicamente à reciclagem de vidro e que apresenta grandes impurezas associadas às oficinas, apresentando-se numa variação cromática que vai do castanho amarelado ao verde amarelado (Cruz, 2009, pp. 74-77; 2011, pp. 87-88).

Por fim, temos uma produção de adornos em vidro negro opaco fabricados entre os séculos IV e V com uma variabilidade formal representada por braceletes, anéis, alfinetes, contas de colar, amuletos e falsas gemas, especialmente imitações de nicolos, uma variedade de ágata. Trata-se de uma produção realizada na zona artesanal do Fujacal onde foi identificado um amplo conjunto de restos de produção e cadinhos com vidro negro agarrado ao fundo (Cruz, 2008).

A produção oleira e vítrea bracarense tardia conhece uma expressão comercial deveras significativa. Além do abastecimento da cidade de Bracara, essas produções também estavam presentes no território do conuentus bracaraugustano e na área meridional do lucense, posteriormente reino Suevo, encontrando grande expressão entre os materiais importados no porto de Vigo e nas uillae da região, como a de Toralla (Fernández Fernández, 2013).

Dos objetos produzidos localmente e que abasteciam o mercado regional da zona ocidental do noroeste ibérico destacamos os recipientes em cerâmica vidrada, de engobe branco e de engobe vermelho, cuja forte expressão no registo arqueológico do Entre Douro e Minho e sul da Galiza, bem como em locais mais distantes como Conimbriga ou Troia, na Lusitannia, conduz alguns investigadores a classificar a segunda produção como Terra Sigillata Bracarense Tardia, sob a sigla TSBT. Estes materiais conheceram dois períodos de um forte intercâmbio durante os séculos IV e V, tendo o auge do primeiro ocorrido na segunda metade da primeira centúria e do segundo nos finais da última (Morais \& alii, 2014; Fernández Fernández; 2017; \& alii, 2019).

Por sua vez, a produção vítrea tardia bracarense também alcança grande expressão nos mercados regionais do noroeste da Península Ibérica. A dinâmica comercial desta região entre os séculos IV e V garantiu que os objetos produzidos em Bracara fossem difundidos pelo conuentus bracaraugustanus e mesmo fora dele, como documenta a identificação de taças paleocristãs em Coruxo (Pontevedra), Lugo e Clúnia, bem como uma conta e um pendente em vidro negro opaco proveniente da uilla de Toralla, Vigo (Cruz, 2009, pp. 274-276; Fernández Fernández, 2013).

\section{CIRCULAÇÃO MONETÁRIA}

Dentre os aspetos das dinâmicas económicas, talvez a circulação monetária seja o menos conhecido. Por um lado, isso deve-se ao menor número de estudos sobre os numismas encontrados em Bracara no período tardio, e por outro, ao baixo número de moedas identificadas na cidade cujo contexto encontra-se documentado, com exceção daquelas em bronze produzidas até a primeira metade do século $\mathrm{V}$.

Com efeito, existem até ao momento alguns estudos que tentaram compreender esses objetos no seio da sociedade bracarense desse período, e que, necessariamente, incidiram sobre conjuntos monetários constituídos pelos numerosos bronzes tardios exumados na cidade.

Desta feita, sabemos que o século III conheceu uma diminuição na massa monetária em circulação em Bracara, ainda que as suas cunhagens apresentassem um maior valor, expresso pela maior qualidade das ligas utilizadas (Zabaleta Estévez, 1999, pp. 82-83). Dada a instabilidade na provisão de moedas, recorrentemente foram utilizados numismas por períodos bastante extensos, como parece ter sido o caso das emissões antoninas, em uso ao longo da primeira metade do século III, e aqueles produzidos sob os signa dos imperadores Claudius II e Galienus (260-270) que se mantiveram em circulação até pelo menos 335 quando o abastecimento parece ter sido regularizado (Amaral, 2007).

O aprovisionamento de moedas para Bracara, e de toda a Península Ibérica, cujo objetivo incidia no pagamento de funcionários da administração conventual e provincial, era realizado com base nas casas de cunhagem localizadas em Roma, Lugdunum e Arelate (atuais Lyon e Arles, em França, respetivamente). A isso deve-se o elevado número de numismas identificados que foram produzidos em offici- 
nae proveniente destas cidades, cuja percentagem em comparação com o total de objetos ultrapassa os $50 \%$, bem como a significativa quantidade de ocultamentos monetários identificados em contextos habitacionais em cuja composição figuram moedas produzidas desde os finais do século III até à primeira metade do quinto (Figura 4) (Amaral, 2007; Machado, 2017).

Apesar do fim da administração romana no noroeste da Península Ibérica nos inícios do século V, a cidade continuou a ter moedas cunhadas sob os signa dos Augustos de Roma e Constantinopla ao longo da primeira metade desta centúria, embora em número bastante reduzido. De facto, objetos que ostentam as efígies de Honorius, Valentinianus III e mesmo Arcadius foram identificadas em ocultamentos monetários, cujas emissões mais recentes contemplam a primeira metade da quinta centúria (Machado, 2017).

Por outro lado, no que toca ao período de ocupação sueva, sobretudo, mas também visigótica, a investigação sobre a natureza e os processos monetários e financeiros encontram maiores obstáculos, o que resulta em um reduzido número de trabalhos realizados. Com efeito, dentre todos os períodos históricos, o reino Suevo é dos mais difíceis de se analisar, e as moedas cunhadas ao longo dos quase dois séculos em que ocupou o noroeste da Península Ibérica são um tema ainda mais complicado. A isso deve-se, em primeiro lugar, ao baixo número de exemplares identificados até ao momento, que somam quase duas centenas, e por outro lado, a ausência de contexto estratigráfico da maioria destes objetos (Cabral \& Metcalf, 1997).

Atéao momento, não foi identificada nenhuma moeda desse período em escavações realizadas em Braga, apesar de Bracara ter sido uma das principais cidades a cunhá-las, facto que nos impossibilita de conhecer a circulação monetária bracarense nesses séculos.

Contudo, se a nível económico os entraves são significativos, o mesmo não se dá a nível social. Uma vez que Braga foi a capital do reino Suevo, as emissões realizadas nesse período refletem diretamente os interesses comunicativos de sua corte ao veicularem signa, visuais e escritos, que afirmam identitariamente aquele povo ao passo que incorpora mensagens bastante claras aos demais reinos germânicos e ao imperador em Roma. Neste sentido, é notável que as primeiras emissões em prata (Figura 5), as siliquae de Requiário (448-456), ostentam no anver- so o busto do imperador Honorius (394-423) com a fórmula $D$ N HONORIVS P F AVG, enquanto no reverso temos representado uma cruz envolta em uma coroa e a expressão IVSSV RICHIARI REGES (Pliego, 2017).

Apesar de Honório ter falecido vinte e cinco anos antes do início do reinado de Requiário, este entende necessário vincular o seu nome à imagem deste imperador, sendo este, ainda, outro fenómeno bastante significativo. Com efeito, o rei suevo (rex) não tem representado o seu busto na moeda, mas sim o imperador, numa composição imagética deveras aproximada, seja nas imagens centradas, seja na disposição das fórmulas epigráficas que as envolvem. Neste processo de justaposição orientado pela rotação do objeto, os nomes próprios (HONORIVS e RICHIA$R I$ ) aparecem no mesmo lugar, o mesmo acontecendo com as evocações Pius, Felix e Augustus do romano com o Rex do bracarense (López Sánchez, 2010).

\section{IMPORTAÇÕES}

Enquanto a cidade mantinha as atividades produtivas e económicas a nível regional com uma dinâmica bastante intensa ao longo do período tardio, as rotas comerciais a nível peninsular e mediterrânico também se mantiveram ativas.

Em relação às importações peninsulares destacamos as terrae sigillatae hispânicas tardias e contentores anfóricos da Bética e de San Martiño de Bueu (Pontevedra, Galiza), cujas principais formas também foram alvo de imitações em produções locais de cerâmica de engobe vermelho e cinzenta tardia, estando representadas por pratos (Drag. 15/17, Hisp. 83B, Hayes 42 e 76), tigelas (Ritt. 8, Hayes 61B) e taças (Drag. 37, Hayes 12/102), cujas cronologias vão desde os finais do século III até aos finais do VI, com o auge das importações tendo ocorrido entre meados da quarta centúria até os inícios da sexta. Contudo, assume-se que, no caso das imitações desses objetos, é possível que tenham ocorrido em um tempo mais lato, avançando para o século VII (Ribeiro \& alii, 2014; Fernández Fernández \& Morais, 2017; Martínez Peñín \& alii, 2018).

Por outro lado, também são identificados objetos cujo centro de produção é externo à Península Ibérica, de que são exemplo os recipientes em terrae sigillatae gálica e africana tardias e LRC, cuja representação numérica na cidade não é tão substancial como as hispânicas, com exceção das africanas. Inseridos 
nessas rotas comerciais mediterrânicas também estão presentes os géneros alimentares, patentes na presença de contentores anfóricos provenientes do norte da África, Gália e de províncias orientais, para além das LRC (Martínez Peñín, Magalhães \& Martins, 2014; Martínez Peñín \& alii, 2018).

Se as importações de recipientes cerâmicos, sejam finos para usos de mesa ou anfóricos, atestam a permanência das rotas comerciais atlânticas ao longo da Antiguidade Tardia, o mesmo também é documentado a nível do material vítreo. Com efeito, foram identificados fragmentos de vidro bruto, cujas tonalidades incluem o negro opaco, castanho amarelado, verde amarelado e azul escuro, cuja presença na cidade de Bracara, sobretudo no século V, reiteram o abastecimento da cidade com essa matéria prima proveniente da costa Sírio-Palestina e do Egipto, cujo declínio apenas acontece no século VI, quando a produção secundária bracarense conhece um aumento da reciclagem para manter o seu fabrico (Cruz, 2009).

\section{CONSIDERAÇÕES FINAIS}

A divisão do tempo através de períodos cronológicos que condensem, com algum princípio de homogeneidade, os processos históricos contribuem, por um lado, para uma leitura didática e temporal dos factos, embora, por outro, inviabilizem a análise de outros fenómenos (Finley, 1989).

Isto é particularmente verdade quando observamos o fim da administração romana nas províncias da Ocidente europeu, como um todo, e a cidade de Braga, em particular. Se colocarmos como pressuposto orientador da análise a perspetiva política o ponto de viragem será a ocupação sueva da região que põe fim ao domínio do Augustus em Roma e passa a ser governada pelo rex sueborum em Bracara, refletindo-se, assim, no fim do Baixo Império Romano e iniciando-se a Alta Idade Média (Gibbon, 2014).

Por outro lado, quando a perspetiva de análise é alterada, torna-se imperativo que se discuta ou mesmo reposicione os marcos temporais que assinalam o início e o fim de períodos cronológicos. Em relação ao mesmo fenómeno, a passagem da sociedade clássica para a medieval no Ocidente europeu, uma vez que se toma para o foco da análise os processos económicos (Pirenne, 1925), as lutas sociais (Jones, 1964) ou as práticas culturais (Brown, 1971), vemos uma mudança significativa nas balizas facto-temporais.
Com este trabalho procuramos sintetizar as dinâmicas económicas de Bracara entre os séculos III e VII explorar os processos que ocorreram na cidade neste período de modo a melhor enquadrá-lo no quadro geral das discussões sobre a passagem da cidade clássica à alto-medieval. Através da análise das quatro atividades destacadas: construção, produção oleira e vítrea, circulação monetária e importações, percebemos que diversos fenómenos iniciados após o século III, ou seja, em pleno domínio romano, vão perdurar para além da ocupação sueva, nos inícios do século $\mathrm{V}$.

Nos finais do século I a.C., quando a cidade foi fundada e planificada, as ruas e quarteirões obedeciam a um rígido traçado ortogonal que exigia formas e dimensões bastante definidas, apesar do mesmo ter sido rompido pontualmente, nos inícios da segunda centúria, com a implantação do teatro, que ocupou um espaço superior a uma insula e que resultou no fechamento de três vias (Martins $\mathbb{\&}$ alii, 2013). Contudo, a partir dos finais do século III, intensificando-se no quarto e generalizando-se no quinto, vemos o progressivo avanço de unidades habitacionais sobre o espaço público, inicialmente os pórticos e depois as ruas. Se a exceção à regra dada pelo ordo decurionum para a construção do teatro teve como base o interesse pro populum, duas centúrias depois vemos a apropriação sendo realizada por paterfamiliae para o ganho privado.

Da mesma forma, as produções cerâmicas e vítreas que têm o início de seu fabrico entre os séculos III e IV, e que correspondem, necessariamente, a mudanças a nível do gosto e do interesse da população, vão conhecer uma continuidade que irrompeu, ou mesmo ignorou, o fim da administração romana, e que perdurou pelos séculos subsequentes à instalação sueva. Este fenómeno também está presente no que toca às importações, em que são documentados produtos vindos de novas regiões, como as terrae sigillatae africanas, ou de produtos oriundos de centros que já comerciavam com a Bracara Augusta do Principado, como as olarias de terra sigillatae hispânicas e gálicas, mas cujos objetos são significativamente distintos dos seus percursores, sobretudo a nível do acabamento, patente nas alterações cromáticas das superfícies das TSHT, ou como o vidro bruto importado da costa Sírio-Palestina e do Egipto, que assumem tons mais escuros como o amarelo acastanhado ou mesmo o negro.

Por fim, concluímos que esse cenário, marcado por 
uma frequente continuidade de processos que se iniciaram nos séculos III e IV e que perduraram até $o$ VI e VII, produziu uma sociedade em Bracara que se apresenta bastante homogénea no recorte proposto para a Antiguidade Tardia e que difere, em distintos níveis, daquela que foi constituída durante o Principado e mesmo a medieval que a sucedeu. Apesar de pouco conhecida, seja pela falta de estudos sobre o período, que se intensifica após a instalação do reino suevo na região, seja pela ausência de fontes documentais escritas ou a descontextualização de grande parte de seus vestígios arqueológicos, a Antiguidade Tardia em Bracara assume-se como um período bastante rico social e economicamente e basilar para a constituição do medievo bracarense e a afirmação do arcebispado de Braga.

\section{BIBLIOGRAFIA}

AMARAL, Luís (2007) - As moedas das Carvalheiras. Contributo para o estudo da circulação monetária em Bracara Augusta. Braga: UAUM/Narq (Bracara Augusta: Escavações Arqueológicas; 3 ).

BROWN, Peter (1971) - The World of Late Antiquity. London: Thames and Hudson.

CABRAL, João; METCALF, David (1997) - A moeda sueva: Suevic coinage. Porto: Sociedade Portuguesa de Numismática (Nummus Anexos; 4).

CRUZ, Mário (2008) - Black glass jewellery from Bracara Augusta. In Analles du iłe congrès de l'AIHV. Antuérpia: AIHV, pp. 96-102.

CRUZ, Mário (2009) - O Vidro Romano no Noroeste Peninsular. Um olhar a partir de Bracara Augusta. Braga: Universidade do Minho (Tese de Doutoramento).

CRUZ, Mário (2011) - Fragmentos de vidro, fragmentos da memória. Aproximação à actividade vidreira em Bracara Augusta. Cultura, Espaço \& Memória. Porto. 2, pp. 83-94

DE BLOIS, Lukas (2019) - Image and Reality of Roman Imperial Power in the Third Century AD: The Impact of War. London and New York: Routledge Taylor \& Francis Group.

DELGADO, Manuela (1993-94) - Noticia sobre cerâmica de engobe vermelho não vitricável encontradas em Braga. Cadernos de Arqueologia. Braga. № 10-11, pp. 113-152.

DELGADO, Manuela; MORAIS, Rui (2009) - Guia das cerâmicas de produção local de Bracara Augusta. Braga: CITCEM.

FERNÁNDEZ FERNÁNDEZ, Adolfo (2013) - O comercio tardoantigo no Noroeste Peninsular. Unha análise da gallaecia sueva e visigoda a través do rexistro arqueolóxico. Galícia: Editorial Toxosoutos (Trivium; 48).
FERNÁNDEZ FERNÁNDEZ, Adolfo (2017) - El comercio en el noroeste peninsular en época tardoantigua (siglos IV al VII). In LÓPEZ QUIROGA, Jorge, coord. - In tempore sueborum: El tiempo de los suevos en la Gallaecia (411-585). El primer reino medieval de occidente: Volumen de estudios. Ourense: Deputación Provincial de Ourense, pp. 317-330.

FERNÁNDEZ FERNÁNDEZ, Adolfo; BARTOLOMÉ ABRAIRA, Roberto; FOLGUEIRA CASTRO, Adrián; ALCORTA IRASTORZA, Enrique (2019) - Horizontes cerámicos tardoantiguos en Punta Atalaia (Cervo-Lugo): Una revisión del comercio cantábrico entre los siglos IV al VI. Anejos de Nailos. Oviedo. 5, pp. 551-6o2.

FERNÁNDEZ FERNÁNDEZ, Adolfo; MORAIS, Rui (2017) - Las ánforas tardoantiguas de San Martiño de Bueu (MR 7): el primer centro de producción de ánforas del noroeste de Hispania, In DIXNEUF, Delphine, ed. - La céramique commune, la céramique culinaire et les amphores de l'Antiquité tardive en Méditerranée: Archéologie et archéométrie. Alexandria: Centre d'Études Alexandrines, pp. 117-129.

FINLEY, Moses. (1989) - Uso e Abuso da História. São Paulo: Martins Fontes.

GASPAR, Alexandra (200o) - Contribuição para o estudo das Cerâmicas Cinzentas dos séculos V-VI d. C. de Braga. Braga: Universidade do Minho (Dissertação de Mestrado).

GIBBON, Edward (2014) - Declínio e Queda do Império Romano. Lisboa: Letras Itinerantes.

GOMES, Ana (200o) - Cerâmicas pintadas de época romana: tecnologia, morfologia e cronologia. Braga: Universidade do Minho (Dissertação de Mestrado).

JONES, Arnold (1964) - The Later Roman Empire.284-6o2. Cambridge: Cambridge University Press.

LEITE, Felisbela (1997) - Contribuição para o estudo da cerâmica fina de Braga: a cerâmica 'dita Bracarense'. Braga: Universidade do Minho (Dissertação de Mestrado).

LEMOS, Francisco;LEITE,José;CUNHA,Armandino(2007) - A muralha romana (Baixo Império) de Bracara Augusta, In RODRÍGUEZ COLMENERO, Antonio; RODÁ DE LLANZA, Isabel, eds. - Actas del Congreso Internacional Murallas de ciudades romanas en el Occidente del Imperio: Lucus Augusti como paradigma. Lugo: Museo Provincial de Lugo \& Deputación de Lugo, pp. 129-341.

LÓPEZ SÁNCHEZ, Fernando (2010) - Suevic coins and Suevic kings (418-456): the Visigothic connection. In CURTA, Florin ed. - Neglected Barbarians. Turnhout: Brepols Publishers (Studies in the Early Middle Ages; 32), pp. 503-536.

MACHADO, Diego (2017) - Tesouros numismáticos baixo-imperiais de contextos domésticos de Bracara Augusta. Braga: Universidade do Minho (Dissertação de Mestrado).

MAGALHÃES, Fernanda (2010) - Arquitectura doméstica em Bracara Augusta. Braga: Universidade do Minho (Dissertação de Mestrado). 
MAGALHÃES, Fernanda (2019) - A domus Romana no Noroeste Peninsular: Construção, Arquitetura e Sociabilidades. Braga: Universidade do Minho (Tese de Doutoramento).

MARTÍNEZ PEÑÍN, Raquel; MAGALHÃES, Fernanda; MARTINS, Manuela (2014) - Contribución de las producciones de cerâmica tardoantiguas para el estúdio de la ciudad de Braga. Oppidum. Porto. 7, pp. 11-28.

MARTÍNEZ PEÑÍN, Raquel; MARTINS, Manuela (2016) Characterization of late antique and Early Medieval pottery production of the city of Braga and its territory. In SABATÉ, Flocel; BRUFAL, Jesús, dirs. - Arqueologia Medieval. Hàbitats Medievals. Lleida: Pagès editors, pp. 53-67.

MARTÍNEZ PENIÍN, Raquel; MARTINS, Manuela; MAGALHÃES, Fernanda; RIBEIRO, Jorge; BRAGA, Cristina (2018) - Estudio preliminar de las producciones cerámicas tardías localizadas en el teatro romano de Braga (Portugal). In MARTÍN VISO, Iñaki; FUENTES MELGAR, Patricia; SASTRE BLANCO, José; CATALÁN RAMOS, Raúl, coords. - Cerámicas altomedievales en Hispania y su entorno (siglos V-VIII d.C.). Espanha, Glyphos, pp. 189-209.

MARTINS, Manuela (2005) - As termas romanas do Alto da Cividade: Um exemplo de arquitectura pública em Bracara Augusta, Braga: UAUM/Narq (Bracara Augusta: Escavações Arqueológicas; 1).

MARTINS, Manuela; MAGALHÃES, Fernanda; BOTICA, Natália (2018) - O urbanismo fundacional de Bracara Augusta e Lucus Augusti. In DOPICO CAÍNZOS, María; VILLANUEVA ACUÑA, Manuela, eds. - Sine iniura in pacer vivatur: A constución do Imperio durante os xulio-claudios. Lugo: Servizo de Publicacións da Deputación de Lugo (Philtáte. Studia et acta antiquae Callaeciae; Vol. 3), pp. 345-373.

MARTINS, Manuela; FONTES, Luís; BRAGA, Cristina; BRAGA, José; MAGALHÃES, Fernanda; SENDAS, José (2009) - Relatório final dos trabalhos arqueológicos realizados no Quarteirão dos CTT - Avenida da Liberdade. Braga: UAUM (Memórias 1).

MARTINS, Manuela; MAGALHÃES, Fernanda; MARTÍNEZ PEÑÍN, Raquel; RIBEIRO, Jorge (2016) - The housing evolution of Braga between Late Antiquity and the Early Middle Ages. Arqueología Medieval. Lleida. VIII, pp. 35-52.

MARTINS, Manuela; MAR, Ricardo; RIBEIRO, Jorge; MAGALHÃES, Fernanda (2013) - A construção do teatro romano de Bracara Augusta. In MELO, Arnaldo; RIBEIRO, Maria, orgs. - História da Construção. Arquiteturas e Técnicas Construtivas. Braga: CITCEM, pp. 41-74.

MARTINS, Manuela; RIBEIRO, Jorge; MAGALHÃES, Fernanda; BRAGA, Cristina; RIBEIRO, Maria (2017b) - O espaço construído de Bracara Augusta no Alto Império. In DOPICO CAÍNZOS, María; VILLANUEVA ACUÑA, Manuel, eds. - In Roma nata, per Italiam fusa, in provincias manat. A cidade romana no noroeste: novas perspectivas. Lugo: Servizo de Publicacións da Deputación de Lugo (Philtáte. Studia et acta antiquae Callaeciae; Vol. 2), pp. 251-276.
MARTINS Manuela; RIBEIRO Jorge; MAGALHÃES Fernanda; MARTÍNEZ PEÑÍN, Raquel (2015) - Urban changes in Braga in Late Antiquity: the area of the Roman Theater. In MARTÍNEZ PENIÍN, Raquel, org. - Braga and its territory between the fifth and the fifteenth centuries. Lleida/Braga: UAUM \& Universitat de Lleida (Espai/temps; 67), pp. 11-28.

MARTINS, Manuela; RIBEIRO, Maria; RIBEIRO, Jorge; MAR, Ricardo (2017a) - Topografia e urbanismo fundacional de Bracara Augusta. In DOPICO CAÍNZOS, María; VILLANUEVA ACUÑA, Manuel, eds. - In Roma nata, per Italiam fusa, in provincias manat. A cidade romana no noroeste: novas perspectivas. Lugo: Servizo de Publicacións da Deputación de Lugo (Philtáte. Studia et acta antiquae Callaeciae; Vol. 2), pp. 203-226.

MORAIS, Rui (2001) - Breve ensaio sobre o anfiteatro de Bracara Augusta. Forum. Braga. 30, pp. 55-76.

MORAIS, Rui; SOEIRO, Teresa; FERNÁNDEZ FERNÁNDEZ, Adolfo; SOUSA, Maria (2014) - As cerâmicas de engobe branco de época imperial no Noroeste Peninsular. In MORAIS, Rui; FERNÁNDEZ FERNÁNDEZ, Adolfo; SOUSA, Maria, eds. - As produções cerâmicas de imitação na Hispania. Porto: FLUP (Monografias Ex Officina Hispana; II), pp. 361-368.

PEREIRA, Felipe (2018) - A Zona Arqueológica do Fujacal e os impactos urbanísticos e topográficos da construção da muralha romana de Bracara Augusta. Braga: Universidade do Minho (Dissertação de Mestrado).

PIRENNE, Henri (1925) - Medieval Cities: their origins and the revival of trade. Princeton: Princeton University Press.

PLIEGO, Ruth (2017) - La moneda de época sueva: Un destello fugaz en la historia monetaria de Gallaecia. In LÓPEZ QUIROGA, Jorge, coord. - In tempore sueborum: El tiempo de los suevos en la Gallaecia (411-585). El primer reino medieval de occidente: Volumen de estudios. Ourense: Deputación Provincial de Ourense, pp. 145-156.

RIBEIRO, Jorge (2010) - A Arquitectura romana de Bracara Augusta. Uma análise das técnicas edilícia. Braga: Universidade do Minho (Tese de Doutoramento).

RIBEIRO, Jorge; FERNÁNDEZ FERNÁNDEZ, Adolfo; CUNHA, Armandino; MARTINS, Manuela; MAGALHÃES, Fernanda; BRAGA, Cristina (2014) - A cerâmica romana do balneário da rua D. Afonso Henriques: estudo preliminar da sequenciação cronológica e ocupacional do edifício (Braga, Portugal). In MORAIS, Rui; FERNÁNDEZ FERNÁNDEZ, Adolfo; SOUSA, Maria, eds. - As produções cerâmicas de imitação na Hispania. Porto: FLUP (Monografias Ex Officina Hispana; II), pp. 361-368.

RIBEIRO, Maria; MARTINS, Manuela (2018) - A cidade nas encruzilhadas da história. Evolução urbana de uma cidade com 2000 mil anos: Braga (Noroeste de Portugal). Dimensões. Espírito Santo. V. 4O, pp. 11-38. 
RIPOLLÈS ALEGRE, Pere (2002) - La moneda romana imperial y su circulación en Hispania. AespA. Madrid. 75, pp. 195-214.

RUIVO, José (2008) - Circulação monetária na Lusitania do século III. Porto: Universidade do Porto (Tese de Doutoramento).

VILA FRANCO, María (2012) - La monetización del noroeste de la Península Ibérica a través de la red viaria terrestre en época romana. Santiago de Compostela: Universidade de Santiago de Compostela (Tese de Doutoramento).

ZABALETA ESTEVÉZ, María (1999) - Breve síntese sobre os estudos das moedas de Bracara Augusta - as moedas das termas do Alto da Cividade. Forum. Braga. 26, pp. 8o-85.

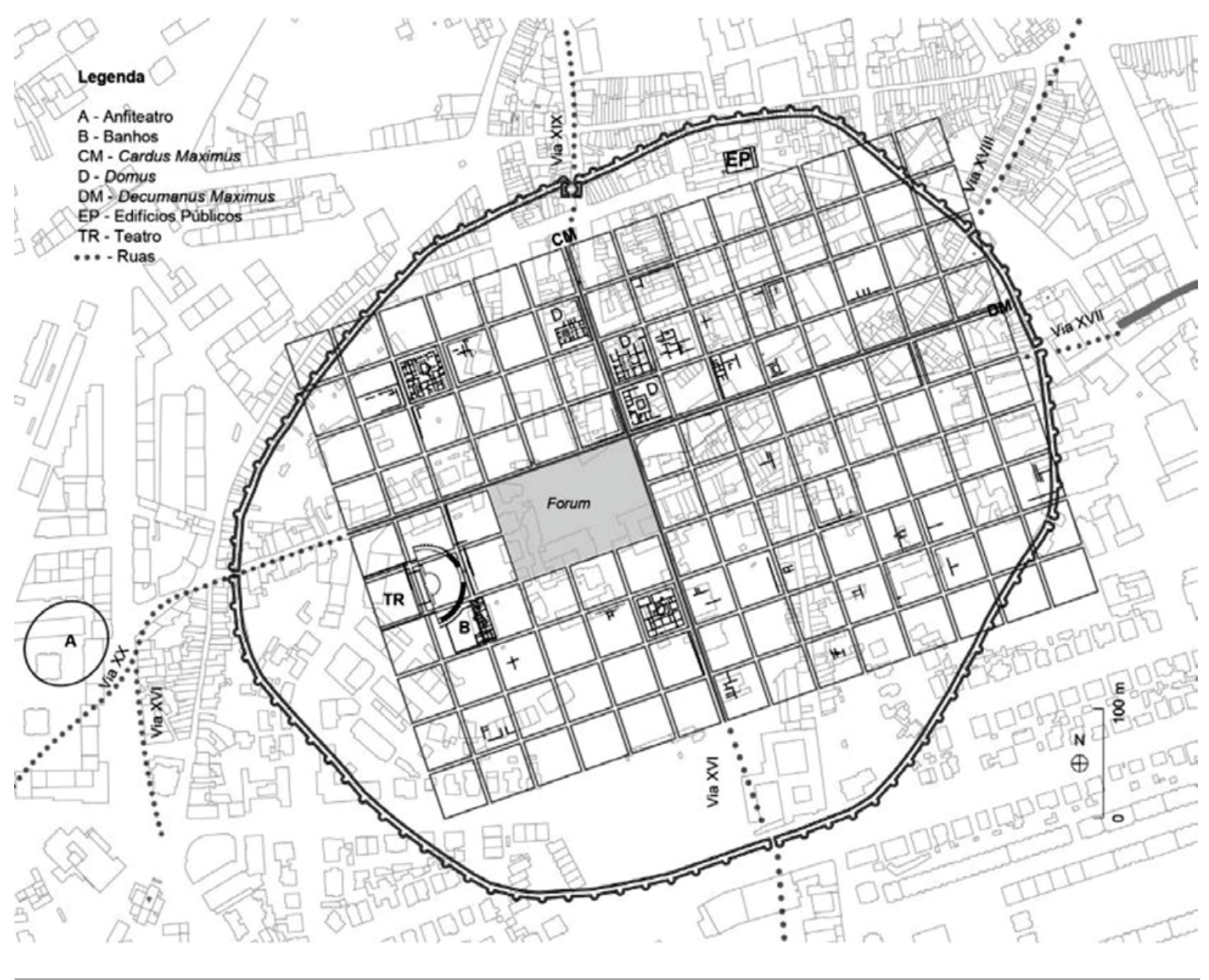

Figura 1 - Planta de Bracara Augusta no século IV (Ribeiro \& Martins, 2018). 

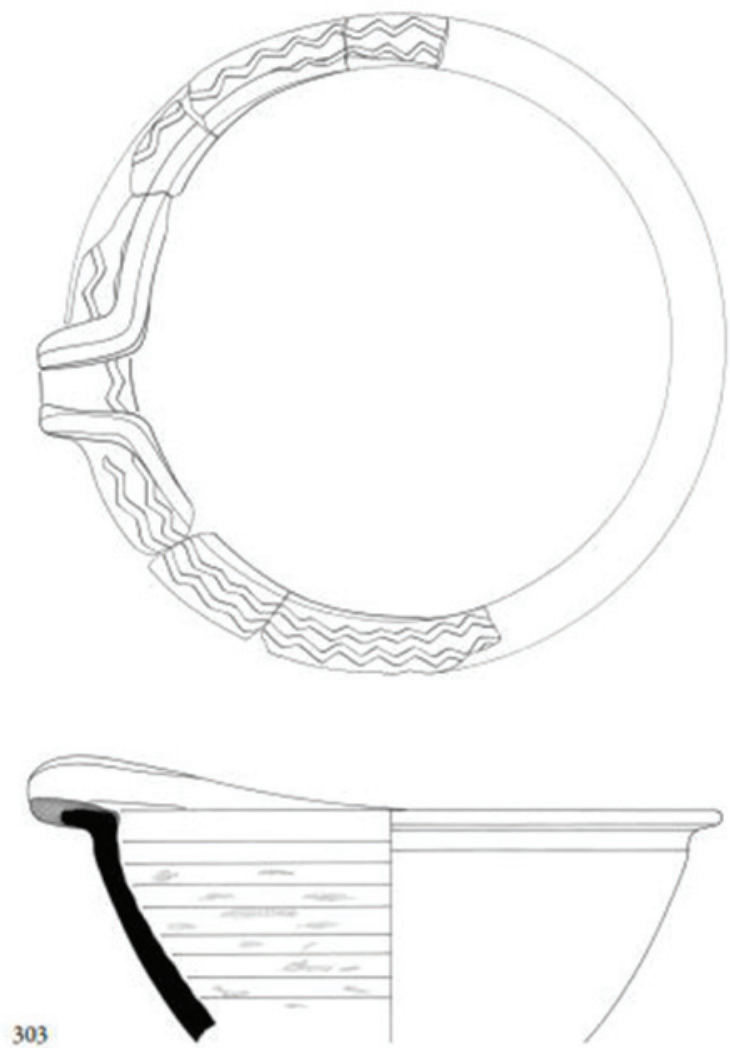

Figura 2-Almofariz vidrado tardio de Bracara (Delgado \& Morais, 2009).

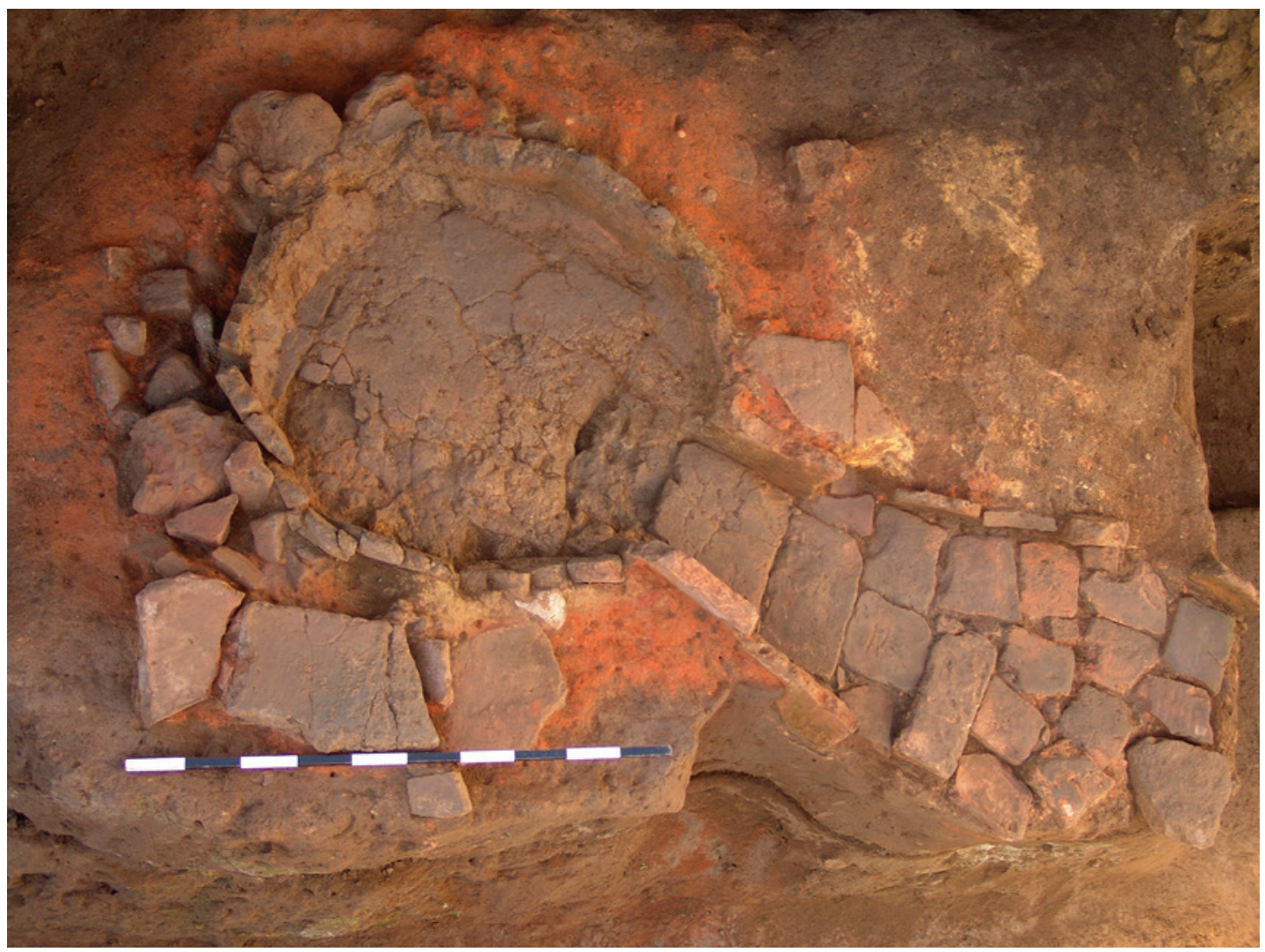

Figura 3 - Forno de produção vítrea dos CTT (C UAUM). 


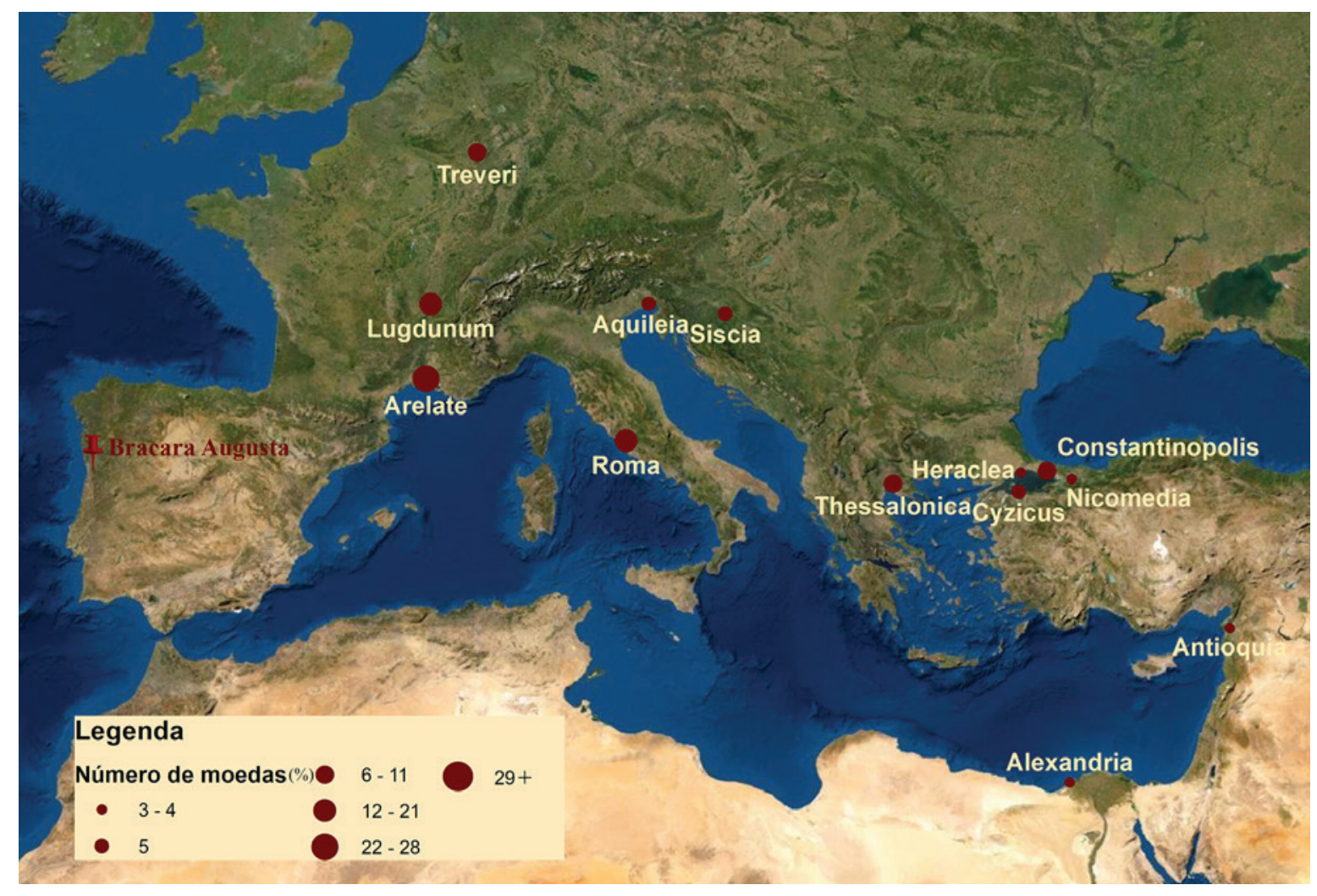

Figura 4 - Mapa com a distribuição das casas de cunhagem que compõem o tesouro da domus de Santiago (C UAUM).
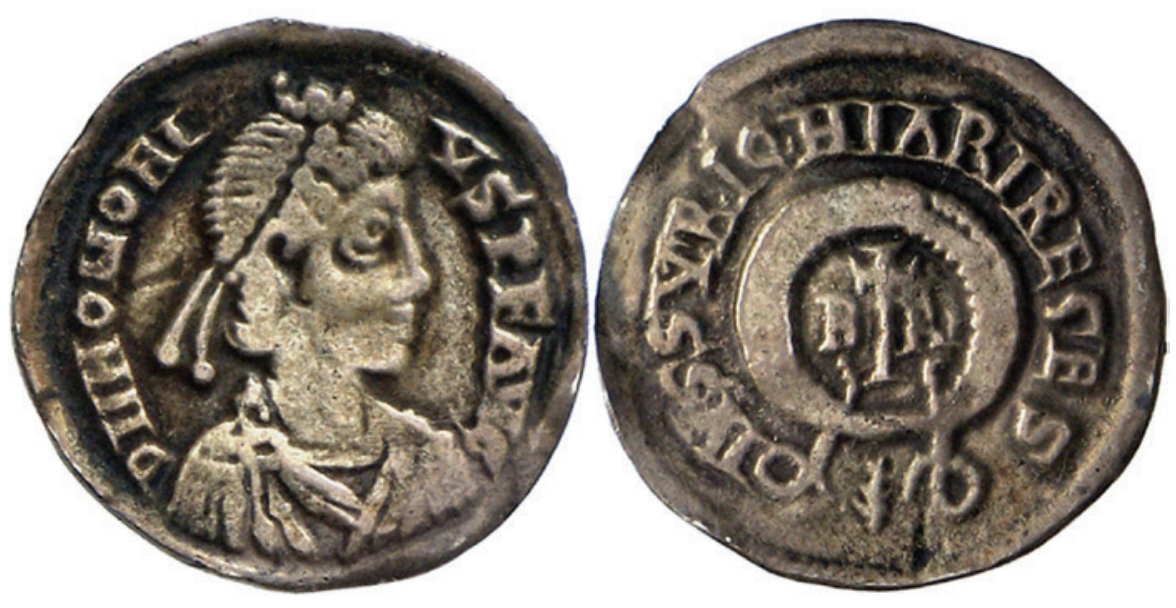

Figura 5-Siliqua de Requiário ( Münzkabinett, Staatliche Museen zu Berlin). 


\title{
CERÂMICAS E VIDROS DA ANTIGUIDADE TARDIA DO EDIFÍCIO SOB A IGREJA DO BOM JESUS (VILA NOVA DE GAIA)
}

\author{
Joaquim Filipe Ramos
}

\begin{abstract}
RESUMO
Nos finais do séc. XX, as escavações arqueológicas realizadas na Igreja do Bom Jesus de Gaia fizeram surgir mais um ponto de história no município de Vila Nova de Gaia, com o levantamento de um amplo espólio arqueológico, datável desde o séc. V/VI até à época moderna. Até à data, o material recolhido só tinha sido parcialmente estudado, de forma a dar a conhecer os resultados das escavações. Como tal, era necessário um estudo, um pouco mais detalhado, sobre os materiais encontrados nestas intervenções.

Nesse sentido é aqui apresentado um estudo, desenvolvido em contexto de estágio académico, sobre os fabricos de sigillata, africana, hispânica e focense, e cerâmica cinzenta tardia, ou seja, os fabricos de cerâmica utilitária tardia, provenientes da igreja do Bom Jesus de Gaia, anexando ainda o estudo do vidro tardio, um material de igual versatilidade e ainda assim pouco estudado.

Palavras-chave: Bom Jesus de Gaia, Sigillata, Vidro tardio, Vila Nova de Gaia.
\end{abstract}

\begin{abstract}
At the end of the XX century, the archaeological survey carried out at the Bom Jesus de Gaia church, gave rise to another point of history in the city of Vila Nova de Gaia, with the survey of a wide archaeological collection dating back since the V/VI century, to the modern times.

Until now, the collected materials were only superficially studied, just to provide the first results of the excavations. As such a study a little more in depth was needed. In that sense we present here a study on the late roman pottery, the late grey ceramics, that is, the manufactures of late utilitarian ceramics from the church of Bom Jesus de Gaia, also enclosing the study of late glass, an equally versatile material and still a lot less studied. Keywords: Bom Jesus de Gaia, Late Roman Pottery, Late Grey Pottery, Late glass.
\end{abstract}

\section{LOCALIZAÇÃO E DESCRIÇÃO DO SÍTIO}

O edifício conhecido como igreja do Bom Jesus de Gaia ou igreja de Gaia ${ }^{1}$, atualmente designada por capela da Nossa Sra. da Bonança / capela do Bom Jesus de Gaia, foi escavada nos anos 1988/89 e 1992. Situa-se na interceção da rua Viterbo de Campos, para a qual está virada a sua fachada principal, com a rua do Prior, uma pequena ruela pedonal que dá acesso à fachada lateral da capela, orientada a Sul. $\mathrm{Na}$ fachada lateral que se encontra a Norte existe uma pequena viela apertada entre muros, de pedra e escadeada, que se encontra atualmente entaipada (GUIMARÃES, 1995).
O edifício religioso está assente num socalco artificial, que permite um melhor nivelamento do terreno. Tem 17,5 metros de comprimento máximo e 7,75 metros de largura no corpo principal do templo. A área de implantação é de 576 metros quadrados considerando o pequeno adro no lado norte e o largo do Prior a Sul (GUIMARÃES, 1995, pp.124 e segs.). É composta por dois corpos simples e justapostos, o da capela-mor e o corpo principal, ao qual estão adoçados a sacristia a sul e a torre sineira no lado norte. A torre está alinhada com a fachada principal e com uma pequena escada de acesso exterior acessível a partir do adro norte. Foi um edifício que ao longo dos tempos sofreu bastantes obras de amplia-

1. Designação considerada por GUIMARÃES, Gonçalves, Escavações Arqueológicas na Igreja de Gaia, Barcelona, 1995. 
ção e várias tentativas de melhoramento, mas que acabaram por o descaracterizar. Neste momento apresenta o aspeto de uma pequena igreja com uma frontaria da segunda metade do século XVII com uma torre sineira datável do século XVIII (GUIMARÃES, 1995, pp.124-130).

\section{RESULTADOS DAS ESCAVAÇÕES: ESTRUTURAS, ESTRATIGRAFIA E ESPÓLIO}

Estas escavações foram desenvolvidas durante campanhas realizadas pelo Gabinete de História e Arqueologia de Vila Nova de Gaia nos anos de 1988, 1989 e 1992, em seguimento da solicitação feita à Câmara Municipal de Vila Nova de Gaia, em 1987, para a realização de obras nesta igreja integrada no Centro Histórico (GUIMARÃES, 1995).

As escavações realizadas nos anos 1988 e 1989 permitiram perceber as sucessivas fases de construção, reconstrução e alteamento efetuadas no local (GUIMARÃES, 1988). A campanha de 1992 permitiu obter mais dados e tecer algumas considerações sobre as mais antigas fases de ocupação, paleocristãs e alti-medievais².

Sobre o afloramento granítico, a uma cota negativa de -2,50 metros do ponto o (que era o nível do soalho existente antes das intervenções), foram descobertas as ruínas daquele que teria sido um edifício paleocristão, violentamente destruído no século VI. Sobre este encontravam-se vestígios de um edifício alti-medieval, também violentamente destruído e incendiado. Por fim, no nível superior, coincidente com parte da igreja atual, foram identificados alguns segmentos de parede da Baixa Idade Média, sucessivamente alteados e reforçados ao longo das épocas moderna e contemporânea.

Nas ruínas paleocristãs encontra-se, nos já referidos 2,50 metros abaixo do alicerce da fachada atual, um muro com orientação NNE/SSO para o qual foi atribuída a designação $\mathrm{Mi}^{3}$ (ver Figura 1). Este travaria um socalco de saibro onde estão abertas sepulturas

2. Estes resultados estão bem descritos na obra de GUIMARÃES, Gonçalves 1995, Gaia e Vila Nova na Idade Média - Arqueologia de uma área ribeirinha Porto, Universidade Portucalense, o cerne de grande parte da informação para este trabalho.

3. Estas designações atribuídas estão presentes e assinaladas na Estampa XI - "Planta da Igreja de Gaia: área escavada” (GUIMARÃES, 1995) de uma época já posterior ao muro. Neste mesmo socalco de saibro está inserida uma escadaria de granito com cerca de 1,5 metros de largura, da qual se encontravam preservados quatro degraus. As escavações permitiram perceber que a escadaria terminaria a uma cota mais elevada pois existiam ainda vestígios do seu alinhamento. Os degraus que faltam teriam sido destruídos pela abertura das tais sepulturas anteriormente mencionadas, ou ainda para alinhar a grelha sepulcral de Época Moderna (GUIMARÃES, 1989). O muro estava bastante derrubado no lado SSO, devido ao rolamento de enormes blocos de granito, aos quais se atribui a causa da destruição violenta do edifício tardo-romano. A NNE o muro está melhor conservado, com mais de um metro de altura e de aparelho regular. Deste mesmo lado partia outro muro, designado $\mathrm{M}$, perpendicular ao Mi e que no sentido ONO/ESSE, prosseguia ultrapassando a sapata do arco triunfal terminando em ângulo reto já na área da capela-mor, com um total de 9 metros de comprimento. Desse ângulo arranca outro muro o $\mathrm{M}_{3}$ direcionado a NE que, ao contrário dos anteriores referidos formados por duas faces de parede aparelhada com enchimento interior, este era constituído por grandes lajes graníticas bem esquadriadas e aparelhadas interpretado como parte de parede de fachada ou pedestal de uma colunata, dado que foi encontrado neste lado da escavação, no entulhamento, um fuste partido. Neste canto, existe ainda um outro muro, M4, também constituído por grandes blocos graníticos aparelhados, paralelo ao muro $\mathrm{M}_{2}$, e que seria parte de uma parede interior (GUIMARÃES, 1995, p. 133) (Figura 1).

Cronologicamente estas ruínas estavam relacionadas com um extenso nível de tégula que cobriria toda a área disponível, sobre a qual se posicionava uma camada de entulhamento, formada por pedras do derrube da estrutura, mas também por grandes blocos graníticos que não faziam parte da construção existente. No estrato $03^{4}$, sob a tégula e tijoleiras, encontrou-se um vasto número de fragmentos de cerâmica importada e vidro datados do séc. VI (GUIMARÃES, 1995, p. 135).

O estudo da escavação e dos dados de cultura material, e neste caso particular da cerâmica e do vidro, permitiu constatar que os vestígios mais antigos

\footnotetext{
4. Designação atribuída a uma das camadas descritas na Estampa XII "Cortes longitudinal e transversal da área escavada da igreja de Gaia"
} 
correspondem a um edifício paleocristão, que terá sido destruído no último quartel do séc.VI, mas que teria sido construído ainda em período de ocupação romana (GUIMARÃES, 1995, p.135).

Foram recuperados cerca de 15000 fragmentos de cerâmica de todas épocas (GUIMARÃES, 1995, p. 135), dentro dos quais 842 correspondem sigillatas tardias de origem africana, foceense e hispânica, e a cinzenta tardia ${ }^{5}$, com 650 fragmentos. Deste conjunto, convém destacar duas peças ${ }^{6}$ expostas no Núcleo de Arqueologia do Solar Condes de Resende. Trata-se de dois pratos, um de produção focense (GUIMARÃES, 1998, p. 556) e outro de produção africana (GUIMARÃES, 1995, p. 303), com motivos decorativos com clara conotação cristã.

\section{AS CERÂMICAS FINAS TARDIAS DO BOM JESUS DE GAIA}

Como referimos, o nosso estudo, realizado em contexto de estágio no Solar Condes de Resende, consistiu na análise de um conjunto de fragmentos de cerâmica de produções finas tardias, correspondentes a sigillatas de origem africana, focense e hispânica cerâmicas cinzentas tardias de fabrico regional (GUIMARÃES, 1995). Para as produções de sigillata foram contabilizados um total de 193 fragmentos (ver Histograma 1). O fabrico foceense é o mais presente, com o correspondente a $41 \%$ dos fragmentos de Sigillata.

Como se observa no Histograma 1 as produções hispânicas estão pouco representadas, o que poderá estar associado à cronologia de ocupação do local, pois aponta-se que o edifício tenha sido destruído em finais do séc.VI coincidente com o final desta produção (GUIMARÃES, 1995). Também a localização geográfica, junto à foz do rio Douro, poderá explicar a maior presença de produções orientais que chegaram por via marítima.

Além das produções de sigillata, existe ainda um

5. Este grupo de cerâmicas cinzentas carece ainda de um estudo mais aprofundado das suas formas comuns, neste estudo apenas nos focamos em algumas formas e fragmentos decorados, dando maior destaque às imitações de DSP.

6. Estas duas peças estão já publicadas e podem ser vistas nas Estampas XXII e XXIII (GUIMARÃES, 1995, pp. 302 e 303) e no catálogo da exposição In Tempore Sueborum. El Tiempo de los Suevos en la Gllaecia (441-585). El primer reino Medieval de Occidente (GUIMARÃES, 2018, pp. 209-2012). conjunto de 650 fragmentos de Cerâmica Cinzenta, composta maioritariamente por formas comuns e um conjunto mais modesto de imitações de cerâmica fina de mesa de época tardia.

A partir dos dados compilados, apresentamos a catalogação dos fragmentos mais relevantes de cada uma das produções e respetivas formas.

\section{TERRA SIGILLATA AFRICANA TARDIA}

Esta cerâmica fina de mesa, teve um período de produção consideravelmente vasto. Começa em meados do séc. II e termina por volta do séc. VI. Os seus centros produtores situam-se na província da África Proconsular, um território atualmente abrangido pelo norte da Tunísia (BELTRÁN LLORIS,199o).

Neste estudo apenas documentamos as produções tardias, dos fabricos C e D (HAYES, 1972). O fabrico C está representado pelo tipo Hayes 56 da segunda fase de produção (finais séc. IV/1 $1^{\underline{a}}$ metade do séc. V) e pelos tipos 83 e $85 \mathrm{~B}$ da terceira fase de produção (c. 430 a inícios do séc. VI).

O fabrico D está representado pelos tipos Hayes 91A, 93 B, 97 e 104A, todos de uma segunda fase produtiva na sua versão mais comum, datadas dos séculos VI a VII. Apresentam uma pasta de cor laranja/ avermelhada de textura grosseira. $\mathrm{O}$ engobe, semi-lustroso, é muito polido e macio. A superfície externa, não engobada, é ligeiramente rugosa.

A decoração estampada é a mais utilizada, geralmente impressa no fundo interno; os motivos decorativos variam: cruzes, pequenos animais e figuras antropomórficas. Exemplo disto, é o prato do tipo Hayes 104A onde figura uma cruz latina filigranada, com três cordeiros a circundá-la (GUIMARÃES, 1998, p. 551).

Foram ainda identificados fragmentos de lucerna do fabrico D de forma indeterminável (Figura 2).

\section{TERRA SIGILLATA FOCENSE}

A Terra Sigillata Foceense tem, como o próprio nome indica, a sua origem na Foça, uma pequena região do oeste da atual Turquia, situada entre Esmirna e Pérgamo. Foi amplamente difundida no Mediterrâneo Oriental, entre inícios do séc. V até meados do séc. VII, mas também nas costas mais ocidentais do império (DELGADO, 1988, p. 38).

Trata-se de uma cerâmica com fabrico uniforme, com pastas de grãos finos, com partículas brancas 
de calcite. Estas pastas possuem cores bastante homogéneas, variando entre o vermelho, vermelho-alaranjado, vermelho escuro ou acastanhado, oxidantes que podiam chegar aos $1000^{\circ} \mathrm{C}$ (HAYES, 1972, p.324). O engobe cobre toda a superfície da peça, conferindo-lhe um tom mate, por vezes com brilhos levemente metalizados.

Conhecem-se dois tipos de fabrico. Numa primeira fase são peças menos cozidas, consequentemente mais brandas, o que lhe confere cores mais alaranjadas e engobe menos aderente. Na segunda fase, as peças são cozidas a altas temperaturas, ficando a pasta mais dura, com cores vermelhas acastanhadas, a vermelho púrpura.

O reportório de formas é modesto, apenas se conhecem 10 formas (HAYES, 1972), das quais a mais comum é a forma 3. Esta segunda fase de produção caracteriza-se por possuir os bordos enegrecidos, conferindo-lhes uma cor exterior sépia ou mesmo acinzentada (DELGADO, 1992). Na Igreja do Bom Jesus esta foi a forma recuperada tendo-se identificado distintas variantes: $3 \mathrm{~A},{ }_{3} \mathrm{C},{ }_{3} \mathrm{E}, 3 \mathrm{~F}$ e $3 \mathrm{G}$, sendo que a mais comum é a forma ${ }_{3} \mathrm{~F}$ (DELGADO, 1988 , p. 38$)$.

No que toca à decoração destaca-se o uso de guilloché 7 aplicado na superfície, o tipo de decoração mais utilizado, mais concretamente na superfície externa dos bordos da forma 3 (DELGADO, 1988, p. 38 ). Foram também recuperados alguns fundos desta forma com decoração estampada, nomeadamente cruzes e monogramas como é o caso de um conjunto de fragmentos de sigillata foceense expostos no Núcleo Museológico de Arqueologia (GUIMARÃES, 1998, p. 552) (Figura 3).

\section{TERRA SIGILLATA HISPÂNICA TARDIA}

A Terra Sigillata Hispânica Tardia fabricada nos vales do Ebro e Douro, difundiu-se amplamente por toda a Península Ibérica, especialmente no norte peninsular, (BÉLTRAN LLORIS, 1990, p. 111).

Como referimos, nas escavações realizadas na igreja do Bom Jesus Gaia foram encontrados alguns fragmentos de Sigillata Hispânica Tardia, ainda que notoriamente em menor número em comparação com

7. É um motivo decorativo que é obtido através de um instrumento com duas, três ou quatro series de entalhes, capazes de produzir uma larga banda de decoração de uma só vez (HAYES, 1972, p. 329). outras cerâmicas finas, tendo-se apenas identificado as formas Hisp. 27 e Hisp. 68. Estas formas possuem um fabrico típico do Vale do Ebro. Caracterizam-se por possuir um engobe muito poroso e fino, com pastas de cores alaranjadas e avermelhadas, abandonando as pastas calcárias, com baixa percentagem de cálcio (BÉLTRAN LLORIS, 1990, p. 118). Não tendo sido identificados produções do Vale do Douro.

Na parte decorativa, os motivos iam de encontro aos produzidos até então pelos fabricos anteriores, com motivos florais, figuras antropomórficas e zoomórficas, estando presentes nos fragmentos da igreja do Bom Jesus de Gaia, apenas motivos decorativos obtidos por incisões (Figura 4).

\section{CERÂMICA CINZENTA TARDIA}

Nestas escavações foram recuperados 649 fragmentos de Cerâmica Cinzenta, que numa pequena parte imitam ou se inspiram em outros tipos de produção tardios, em sua maioria nas DSP (Derivadas de Sigillata Paleocristã), de origem gálica. Cronologicamente estas produções datam dos finais do séc. $\mathrm{V}$ a inícios do séc. VI, prolongando-se até épocas alti-medievais (DELGADO; MORAIS, 2009, p. 61).

Caracterizam-se por possuir pastas de cores cinza, com presença abundante de desengordurantes; as superfícies são alisadas e, por vezes, polidas. Estas foram fabricadas em ambiente redutor e sujeitas a altas temperaturas, que podem variar entre $900^{\circ} \mathrm{e}$ 1100으 (RIGOIR, 1968, pp. 195-196).

O espectro de formas identificadas é pouco diversificado, correspondendo a imitações de Terra Sigillata Africana, (forma Hayes 59B), e imitações de DSP, (formas Rigoir 3A e 29). São, todavia, mais abundantes as formas de cerâmica comum.

Quanto à decoração, predominam as decorações estampadas, utilizando como motivos decorativos as rosetas e os padrões reticulados. (RIGOIR, 1960, pp. 36-39) (Figura 5).

\section{O VIDRO TARDO ANTIGO}

Na igreja de Bom Jesus de Gaia a presença de fragmentos de vidro é vasta com um total de 1549 fragmentos recolhidos de vários tipos de vidro desta intervenção. No entanto, na nossa análise, apesar de nos estratos superiores ser possível classificar alguns fragmentos como vidro tardio, iremos focar-nos apenas nos fragmentos retirados do estrato 03 , 
objetivamente por dois motivos, o primeiro por ser aquele com maior número de fragmentos, e segundo por estarem diretamente associados com as sigillatas, ou seja, relacionados com o nível paleocristão da intervenção.

Exatamente como a cerâmica tardia, a maior quantidade de vidro antigo foi retirada de uma zona compreendida entre os muros $\mathrm{M}_{1}$ e M2 das ruínas paleocristãs. Gonçalves Guimarães sugere que esta zona seria uma zona de banquete ou copa, ou seja, uma área doméstica do edifício, atentando ao tipo de materiais ali presentes (GUIMARÃES, 1995, p. 136). Estaria coberta por um telhado abatido, anteriormente mencionado, que separava o estrato 02 do estrato 03. Porém, alguns fragmentos de vidro deformados demonstram que foram submetidos a altas temperaturas, podendo concluir-se que houve destruição física do edifício seguida de incêndio, ainda que parcelar. $\mathrm{O}$ que fez cair o telhado foram os batólitos que derrubaram o edifício, o incêndio terá vindo a seguir (Figura 6).

Neste estrato 03, foram recolhidos 519 fragmentos de vidro de duas colorações distintas (ver histograma 3), para as quais atribuimos as denominações Verde azulado e Amarelo acastanhado. Quanto a atribuição destas terminologias seguimos a tabela de cores apresentada por Mário Cruz (CRUZ, 2009, p. 93), que por sua vez é uma interpretação das terminologias atribuidas até então seguindo um quadro de apróximação cromática de código de cor Pantone.

Não sendo possível a análise quimica dos fragmentos, as distinções foram feitas maioritáriamente por apróximação da cor e das formas destes mesmos fragmentos.

Objetivamente, o número minimo de peças apróximar-se-à do número de fundos encontrados neste estrato, cerca de 20. Os fundos encontram-se num estado menos fragmentado, na sua maioria, não apresentando colagens uns com os outros e por esse motivo se singularizam em relação aos outros fragmentos, que apesar de estarem em número muito superior o seu estado de fragmentação impede-os de serem viáveis neste tipo de contagem.

Quanto ao aspeto formológico, foram detetadas semelhanças com as formas do catálogo de Isings, 41A, 97A, 111 e a forma 112, sendo que esta última é a forma já tinha sido anteriormente identificada por Gonçalves Guimarães.

A forma Isings 41A caracteriza-se como sendo uma tigela de paredes retas, bastante similar à forma 22 do mesmo catálogo. Tem uma base recortada e um bordo grosso e dobrado (ISINGS, 1957 p. 57).

O prato Isings $97 \mathrm{~A}$, um prato circular baixo de base sólida, é um tipo de peça atribuida ao séc. II inicios do séc. III, no entanto pela sua versatilidade manteve-se em utilização até tempos muito mais recentes (ISINGS, 1957 pp. 116-117).

Um dos fragmentos de bordo aproxima-se da forma Isings 111, um cálice de caule, com algumas variantes, um tipo de forma que se manteve em uso por toda a Europa e Próximo Oriente até tempos medievais (ISINGS, 1957 pp. 139-140).

Destacamos ainda a taça com asas, designada como Taça nํำ (GUIMARÃES, 1995, p.316), com uma asa, de bordo espesso e base tubular, que apesar de incompleta, apresenta semelhanças com a forma Isings 112 .

Finalizando, ao contrário dos fabricos cerâmicos, nos fragmentos de vidro analisados não foram identificados quaisquer motivos decorativos (Figura 7).

\section{CONCLUSÃO}

As escavações feitas na igreja do Bom Jesus de Gaia trouxeram um conjunto de informações importantes sobre a povoação que ocupava aquele local no séc.VI através do espólio paleocristão levantado. É assim de realçar a importância do estudo das produções utilitárias de cerâmica e vidro tardias aqui encontradas. Neste estudo pudemos corroborar a cronologia proposta para a destruição do edifício paleocristão, por volta de 580 (GUIMARÃES, 1995, p. 135). A quantidade de cerâmica importada é notável, com destaque para as produções foceenses, revelando a importância económica da região do curso terminal do Rio Douro. Assim o documentam as produções finas de cerâmica tardia, as sigillatas de origem africana, focense e hispânica a par das cerâmicas cinzentas tardias, cronologicamente enquadrados nos séc. V/VI d.C.

Também a análise de forma do vidro permitiu identificar semelhanças com formas utilizadas em séculos anteriores ao séc. VI, como também ser evidência fisica da destruição violenta do edificio paleocristão. As intervenções arqueológicas que se têm vindo a realizar no municipio, de uma maneira ou de outra, ajudam numa construção do passado da região, neste caso o estudo de um conjunto particular de materiais utilitários como uma mais valia nessa construção. Em suma procuramos ter contribuído para o conhe- 
cimento da antiguidade tardia no território gaiense e dar a conhecer as produções de vidro e cerâmicas tardias da igreja do Bom Jesus de Gaia.

\section{BIBLIOGRAFIA}

BERNAL CASSOLA, Dario; RIBERA I LACOMBA, Albert (2008) - Cerámicas hispanorromanas. Un estado de la cuestión. Vol I e II, Universidad de Cádiz, Cadíz.

BELTRAN LLORIS, Miguel (1997) - Guia de las cerámicas romanas., Libros Pórtico, Zaragoza.

CRUZ, Mário da (2009) - O vidro no Noroeste Peninsular, Vol. 1-2, Tese de Doutoramento apresentada na Universidade do Minho, Braga.

DELGADO, Manuela (1988) - Contribuição para o estudo das cerâmicas romanas tardias do Médio Oriente, Cadernos de Arqueologia, série II, 5, pp. 35-49.

DELGADO, Manuela (1992) - Cerâmicas Romanas Tardias de Mértola Originarias do Médio Oriente, Arqueologia Medieval, nำ1, Edições Afrontamento, Porto.

DELGADO, Manuela; MORAIS, Rui (20o9) - Guia das cerâmicas de produção local de Bracara Augusta, CITCEM, Braga.

FOY, Danièle (1995) - Le verre de l'antiquité tardive et du haut moyen age: typologie, chronologie, diffusion, Musée Archéologique Departmental du Val d'Oise.

GASPAR, Alexandra (20oo) - Contribuição para o estudo das cerâmicas dos séculos V/VI de Braga. Tese de Mestrado apresentada na Universidade do Minho, Braga.

GUIMARÃES, J. A. Gonçalves (1989) - Escavações Arqueológicas na Igreja do Bom Jesus de Gaia, Boletim da Associação Cultural Amigos de Gaia, ํํ 28, dezembro, Vila Nova de Gaia.

GUIMARÃES, J. A. Gonçalves (1992) - Museologia Arqueológica em Vila Nova de Gaia. Boletim da Associação Cultural Amigos de Gaia, junho, Vila Nova de Gaia, pp. 3-7.

GUIMARÃES, J. A. Gonçalves (1995) - A Colecção Marciano Azuaga e a sua bibliografia. Prefácio a PEREIRA, António Sérgio dos Santos-Mundurukús, Carajás e outros índios do Brasil na Colecção Marciano Azuaga. Câmara Municipal de Vila Nova de Gaia - Casa Municipal de Cultura/ Solar Condes de Resende, Vila Nova de Gaia, pp. 5-14.

GUIMARÃES, J. A. Gonçalves (1995) - Gaia e Vila Nova Na Idade Média - Arqueologia de uma Área Ribeirinha. Universidade Portucalense, Porto.

GUIMARÃES, J. A. Gonçalves (200o) - Um século de Arqueologia em Vila Nova de Gaia, Almadam, II Série, no 9. outubro, pp. 155-168.
GUIMARÃES, J. A. Gonçalves (2010) - Os Romanos em Gaia, Boletim da Associação Cultural Amigos de Gaia, ํํㄱㅇ, junho, Vila Nova de Gaia.

GUIMARÃES, J. A. Gonçalves (2018) - O edificio de tradição roamana sob a igreja do Bom Jesus de Gaia (Vila Nova de Gaia - Portugal) destruído nos últimos dias do reino dos Suevos, LÓPEZ QUIROGA, coord. (2018) - In Tempore Sueborum. El Tiempo de los Suevos en la Gllaecia (441-585). El primer reino Medieval de Occidente, Volumen de Estudios. Ourense: Deputacion Provincial, pp. 209-212.

GUIMARÃES, J. A. Gonçalves (2019) - O edificio de tradição roamana sob a igreja do Bom Jesus de Gaia destruído nos últimos dias do reino dos Suevos, Revista de Portugal, ํํ⒗ Novembro, pp. 16-24.

HAYES, J.W. (1972), Late Roman Pottery - A Catalogue of Roman Fine Wares, The British School at Rome, London.

HAYES, J.W. (1980) - Suplement to Late Roman Pottery, The British School at Rome, London.

ISINGS, Classina. (1957) - Roman Glass from dated Finds, Archaeologica Traiectina, Jacarta.

MAYET, François (1975) - Les céramique à paroi fines dans la Péninsule Ibérique. Diffusion E. de Boccard, Paris.

MEZQUIRIZ, Maria Angeles (1985) - Terra sigillata hispánica, In Atlante delle Forme Ceramiche (Ceramica Fine Romana Nel Bacino Mediterraneo. Enciclopédia Dell'arte Antica Clássica), vol. II, Roma, pp. 97-174.

MOREIRA, Álvaro de Brito (1997) - Vidros Romanos do Noroeste Português. Estudos Monográficos de Tomgobriga e Alvarelhos, Estudos Monográficos de Tomgobriga e Alvarelhos, $1,2^{\underline{a}}$ série, Museu Municipal Abade Pedrosa, Santo Tirso; 13-82.

RAMOS, Joaquim Filipe (2017) - Estágio Solar Condes de Resende. Contributo para os estudo das cerâmicas finas tardias da igreja do Bom Jesus de Gaia. Relatório de Estágio para obtenção de Mestrado apresentado na FLUP, Porto.

RIGOIR, Jacqueline (1960) - La Céramique Paleochrétiene Sigillée Grise, In Provence Historique, tome X, fasc. 42, La Pensée Universitaire, Aix-en-Provence, pp. 1-93.

RIGOIR, Jacqueline (1968) - Les Sigillées Paléochrétiennes grises et orangées, Gallia, XXVI, fasc. 1, Paris, p. 177-244.

SILVA, António Manuel S. P.; CARVALHO, Teresa P. (2014) - Originalidade e tradição clássica na cerâmica local e regional tardo-antiga do castelo de Crestuma (V. N. Gaia, Portugal), in MORAIS, R.; FERNANDÉZ, A.; SOUSA, M. J. (eds.) - As produçôes cerâmicas de imitação na Hispania. S.1. [Porto-Madrid]: Faculdade de Letras da Universidade do Porto - Ex Officina Hispana II, pp. 381-396. 


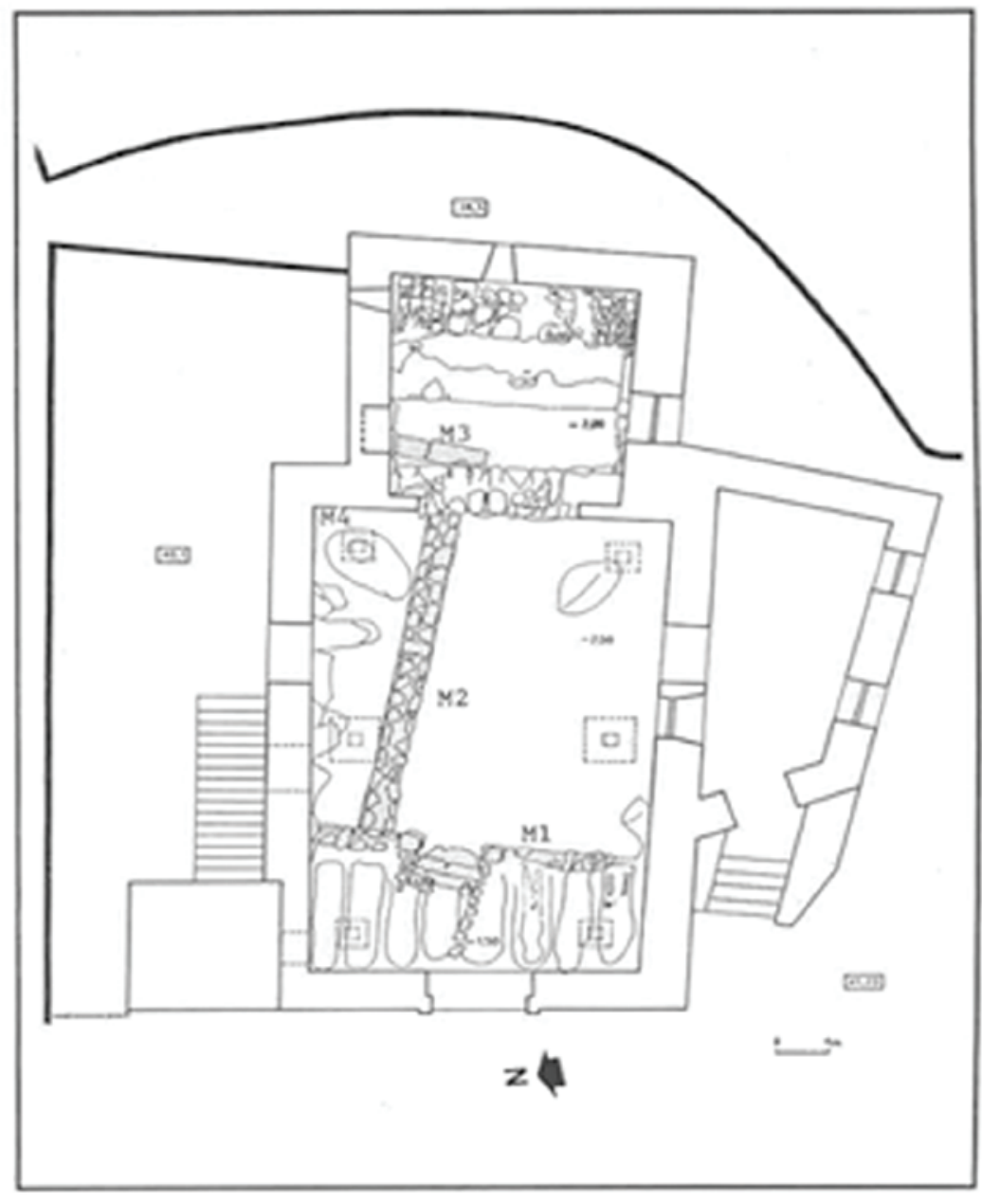

Figura 1 - Planta da igreja de Gaia: área escavada. Fonte: Estampa XI (GUIMARÃES, 1995, p. 291) 


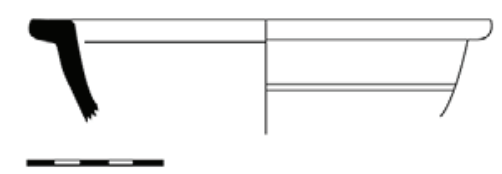

1

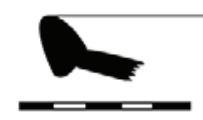

3

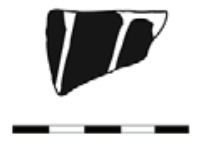

5

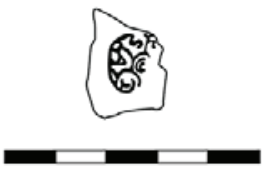

9

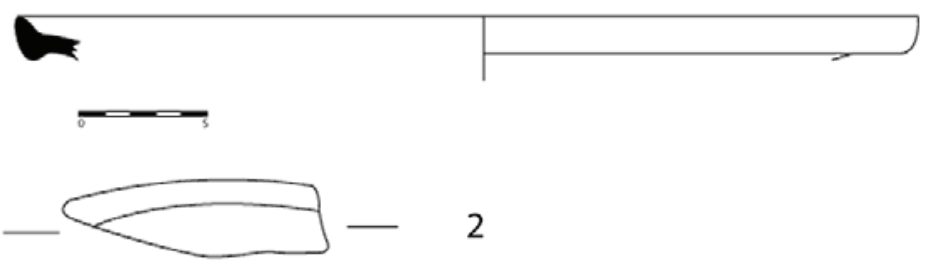

4
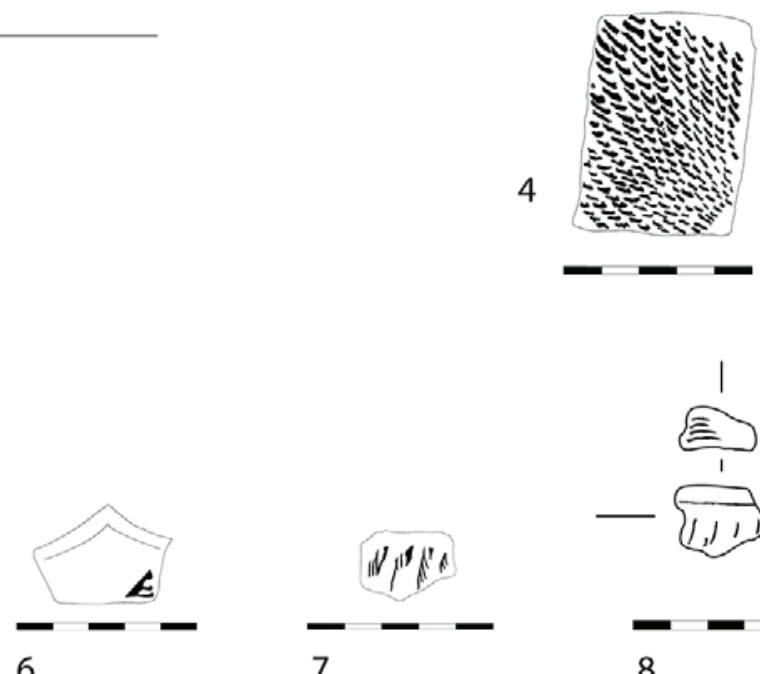

7

8

Figura 2 - Conjunto de Sigillatas Africanas Tardias: 1 - fragmento de bordo de tigela, forma Hayes 93B, 450-530 d.C.; 2 - fragmento de bordo de prato, forma Hayes 104A, 530-580 d.C; 3 - fragmento de bordo de prato, forma Hayes 104A, 530-580 d.C; 4-fragmento de fundo tigela, forma Hayes 91A, 450-530 d.C.; 5-fragmento de prato, forma Hayes 56, de cronologia indeterminada; 6 - fragmento de bordo de tigela, forma Hayes 97, decorada na parte interior do bordo, 490-540 d.C.; 7 - fragmento de tigela, forma Hayes 83A, datada dos inícios do séc.V d.C.; 8 - fragmento de bordo de tigela, forma Hayes85B, datável da segunda metade do séc.V d.C.; 9 - fragmento de lucerna de fabrico D, datavél do séc.V, de forma indeterminada; 10 - fragmento de lucerna de fabrico D, datavél do séc.V, de forma indeterminada. Escalas apresentadas de $5 \mathrm{~cm}$. 


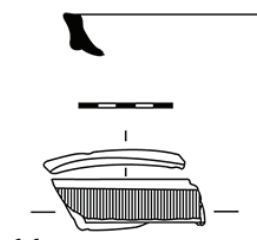

11
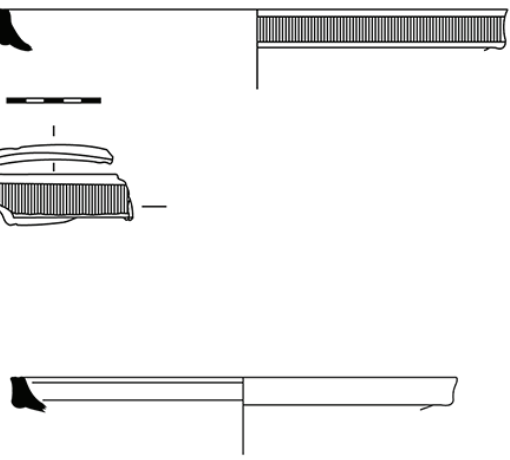

13
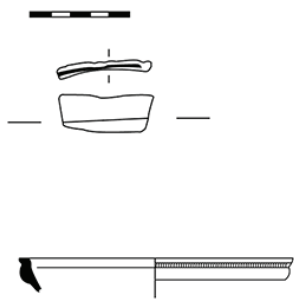

15

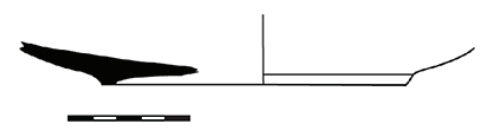

18
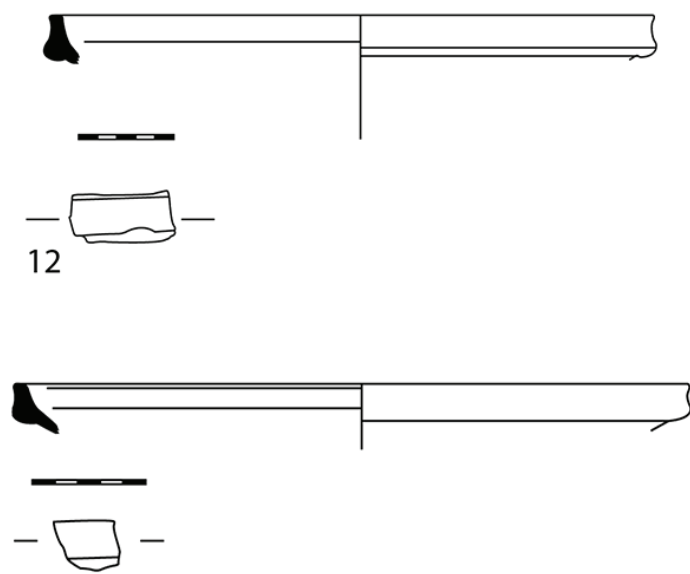

14
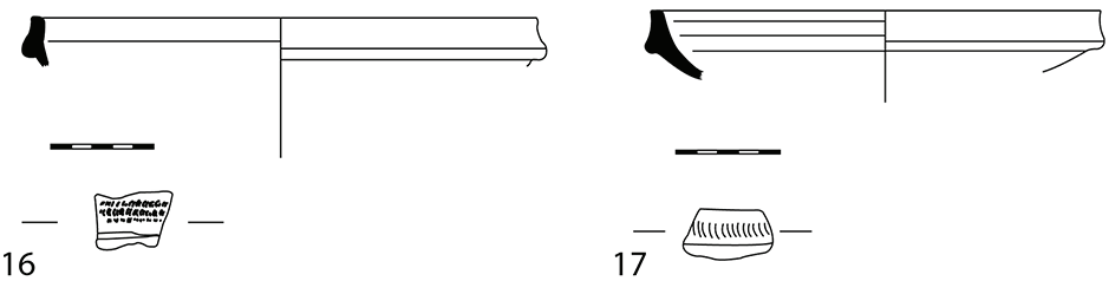

17
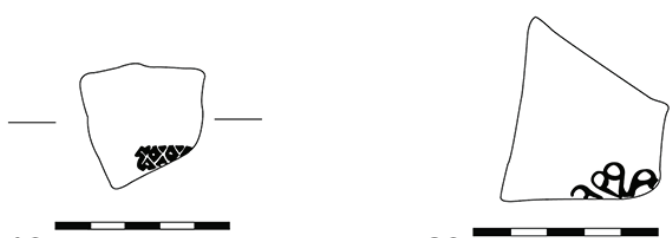

19

20

Figura 3 - Conjunto de Sigillatas Focenses Tardias: 11 - fragmento de bordo de prato/taça, forma Hayes 3A, com decoração de Guilhóche, datado de inícios do séc. V d.C.; 12 - fragmento de bordo de prato/taça, forma Hayes 3 G, segundo quartel do séc. VI d.C.; 13 - fragmento de bordo de prato/taça, forma Hayes 3F, inícios do séc. VI d.C.; 14 - fragmento de bordo de prato/taça, forma Hayes 3 F, inícios do séc. VI d.C.; 15 fragmento de bordo de prato/taça, forma Hayes ${ }_{3} C$, meados do séc. V d.C.; 16 - fragmento de bordo de prato/taça, forma Hayes 3F, com decoração de Guilhóche, inícios do séc. VI d.C.; 17 - fragmento de bordo de prato/taça, forma Hayes ${ }_{3} \mathrm{C}$, meados do séc. V d.C.; 18 - fragmento de pé de prato/taça, forma Hayes $3 \mathrm{~A}$, inícios do séc. V d.C.; 19 - fragmento de bordo de prato/taça, forma Hayes 3F, com decoração estampada (Carimbo de lozangulos com circulos no centro decoração Late Roman) inícios do séc. VI d.C.; 20 - fragmento de fundo de prato/taça, com decoração estampada, forma Indeterminada. Escalas apresentadas de $5 \mathrm{~cm}$. 


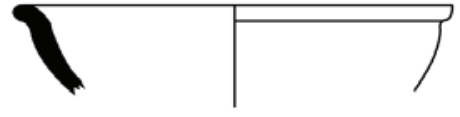

21

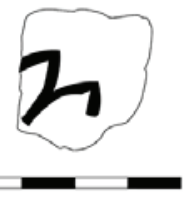

23
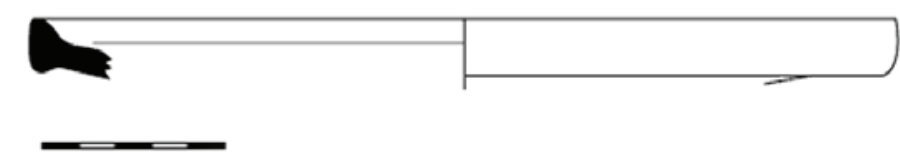

22

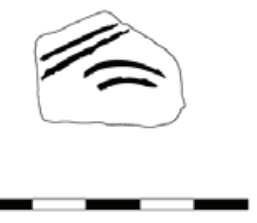

24

Figura 4 - Conjunto de Sigillatas Hispânicas Tardias: 21 - fragmento de bordo de taça, forma Hisp. 27, finais séc. V d.C.; 22 fragmento de bordo de prato, forma Hisp. 68, finais do séc. V d.C.; 23 - fragmento decorado com motivos florais, forma indeterminada; 24 - fragmento decorado com incisões, forma indeterminada. Escalas apresentadas de $5 \mathrm{~cm}$. 

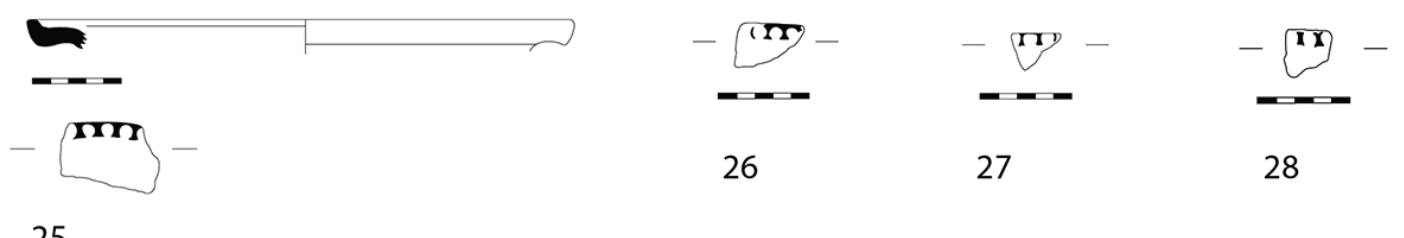

25

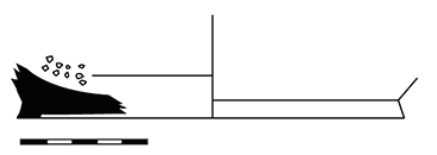

29
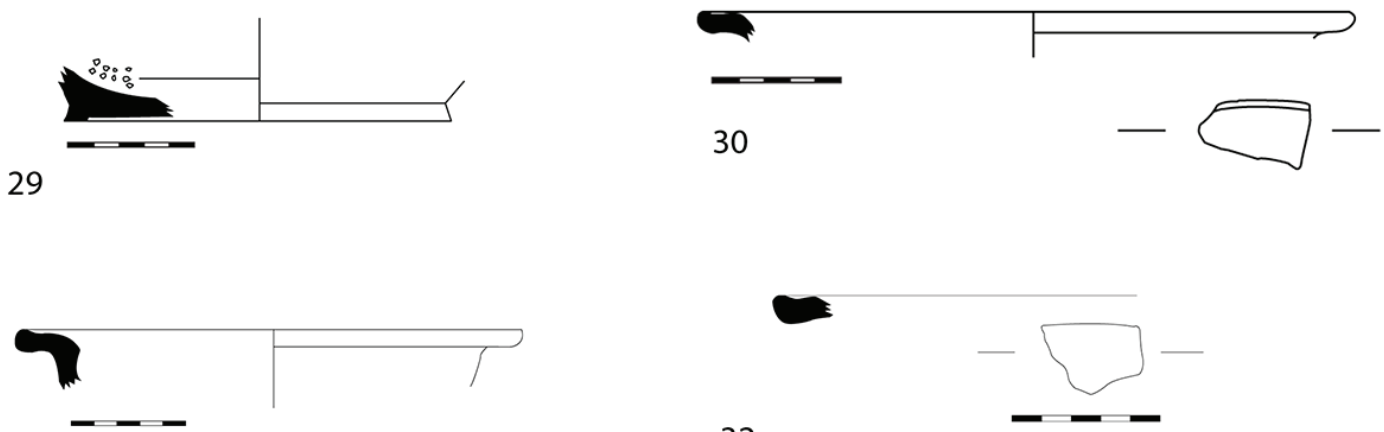

31
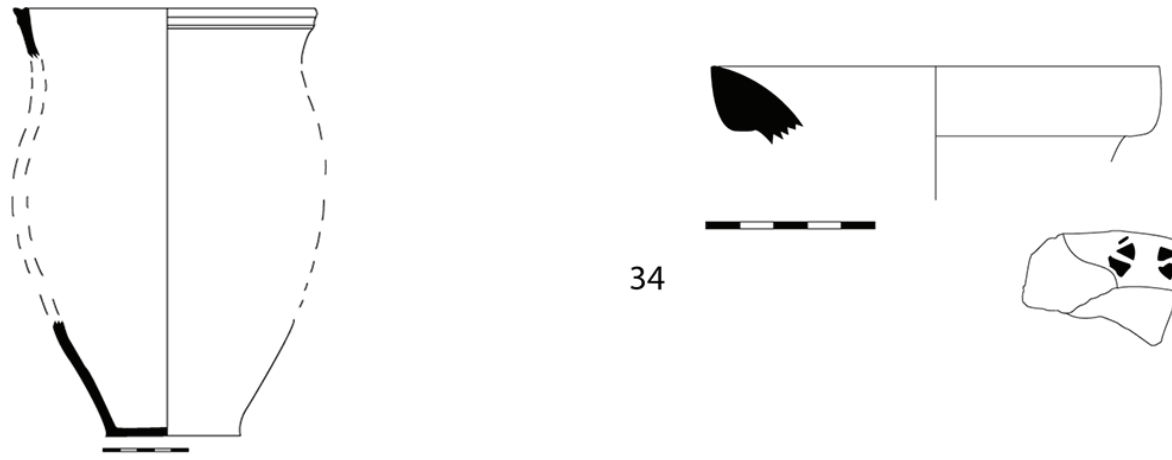

34

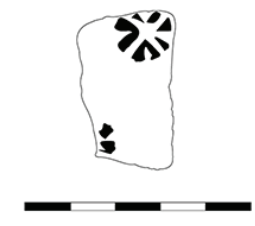

36

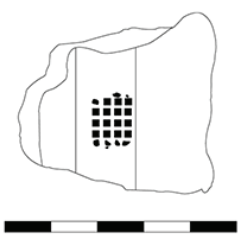

37

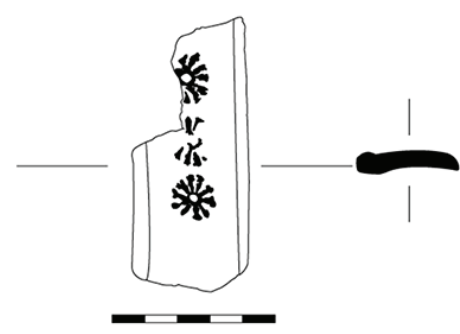

38

Figura 5 - Conjunto de Cerâmicas Cinzentas Tardias: 25 - fragmento de bordo de tigela, imitação de forma Rigoir 3A, 450530 d.C.; 26 - fragmento de bordo de tigela, imitação de forma Rigoir 3A, 450-530 d.C.; 27 - fragmento de bordo de tigela, imitação de forma Rigoir 3A, 450-530 d.C.; 28 - fragmento de bordo de tigela, imitação de forma Rigoir 3A, 450-530 d.C.; 29 - fragmento de pé/fundo, imitação forma Rigoir 29, séc. V/VI; 30 - fragmento de bordo de tigela imitação de forma Hayes 59B, séc. V/VI; 31 - fragmento de bordo de tigela imitação de forma Hayes 59B, séc. V/VI; 32 - fragmento de bordo de tigela imitação de forma Hayes 59B, séc. V/VI; 33 - Pote de forma comum de cerâmica cinzenta tardia; 34 - fragmento de bordo de forma comum, decorado com rosetas na face exterior do bordo; 35 - fragmento de fundo de forma indeterminada, decorado com rosetas estampadas e duas linhas de entalhe a circundar, sendo uma linha curvilinea e a outra serpenteada; 36 - fragmento de forma indeterminada, decorado com rosetas estampadas; 37 - fragmento de forma indeterminada, com grelha reticulada estampada, similar à decoração Hayes 67A; 38 - fragmento de asa de forma indeterminada, com decoração estampada, rosetas na face exterior da asa. Escalas apresentadas de $5 \mathrm{~cm}$. 


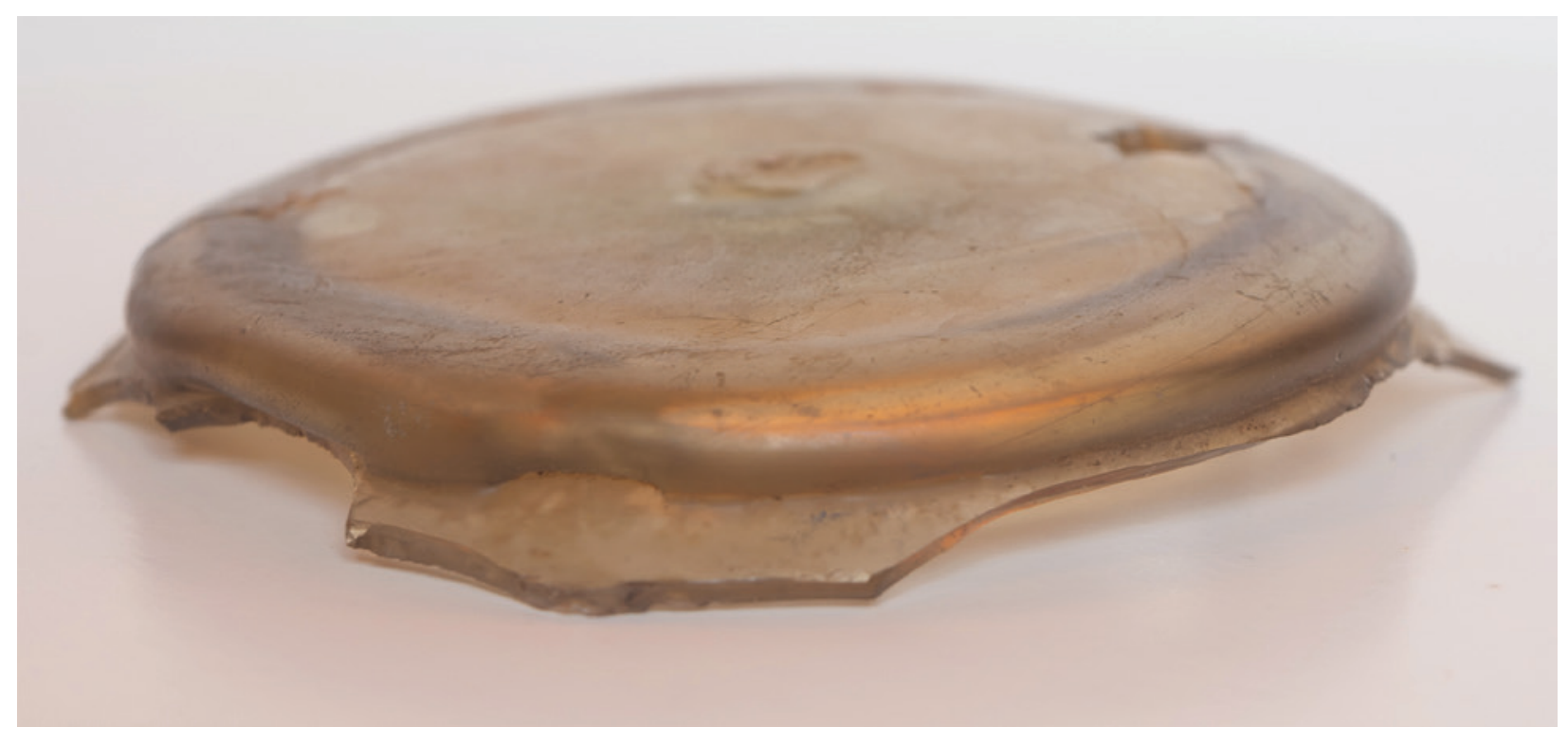

Figura 6 - Fragmento de fundo deformado forma Isings 47A, com cerca de $10 \mathrm{~cm}$ diâmetro de base.

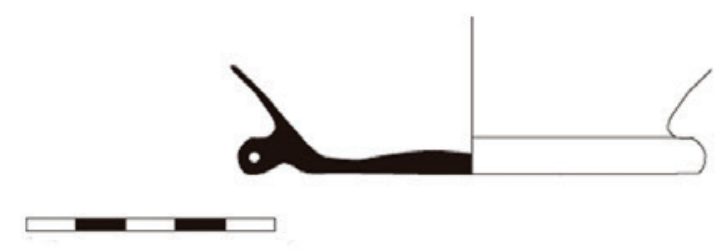

39

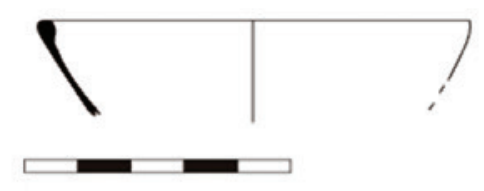

40

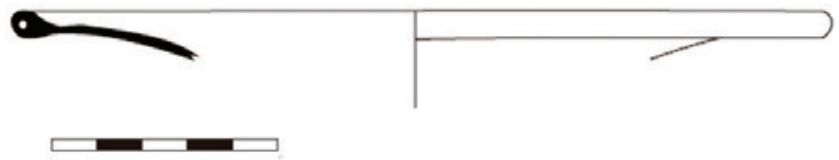

41

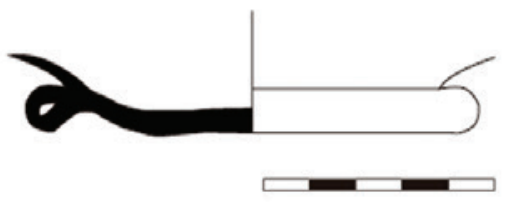

42

Figura 7 - Conjunto de Vidro tardo antigo: 39 - fragmento de fundo de tigela, forma Isings 41A; 40 - fragmento de bordo de taça, forma Isings 111; 41 - fragmento de bordo de prato, forma Isings 97A; 42 - fragmento de fundo de prato, forma Isings $97 \mathrm{~A}$. 


\section{SIGILLATAS TARDIAS DO BOM JESUS DE GAIA}

Bordos Pés/Fundos @ Outros

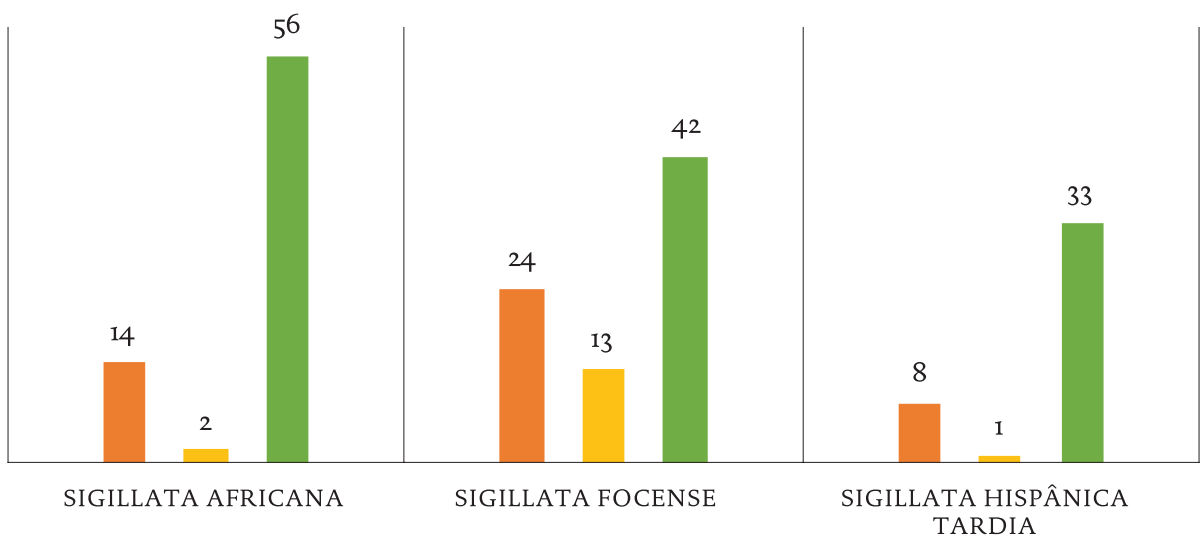

Histograma 1 - Número de fragmentos de sigillata por fabrico.

IGREJA DO BOM JESUS DE BRAGA

Variantes da Forma 3 Hayes

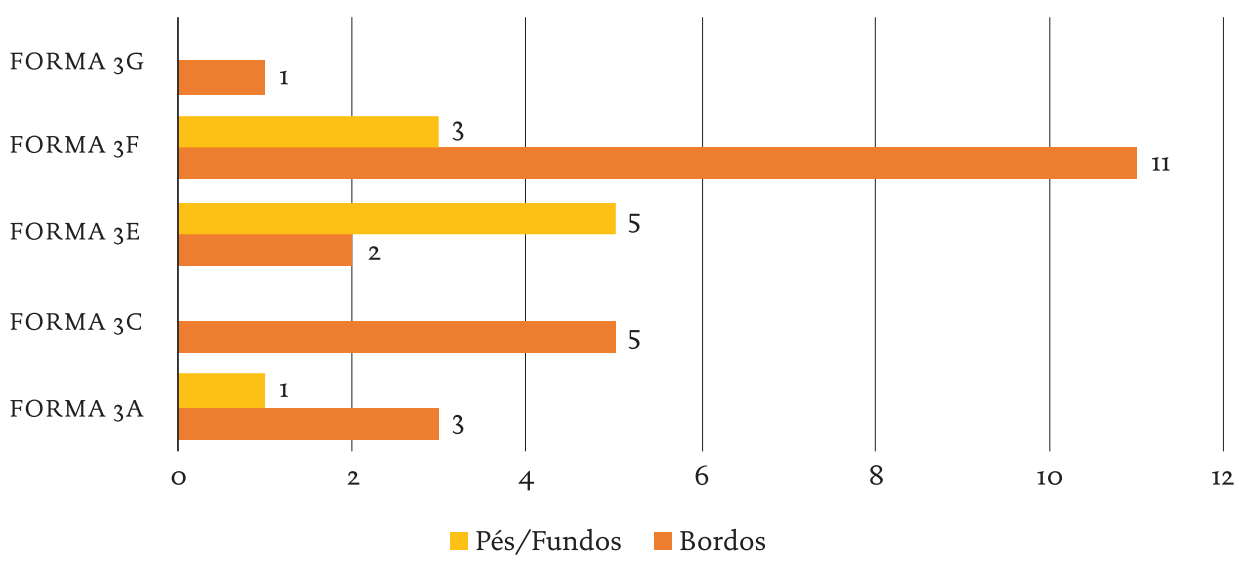

Histograma 2 - Número de fragmentos das variantes de Sigillata Foceense forma 3 de Hayes.

FRAGMENTOS DE VIDRO DO ESTRATO O3 IBJG

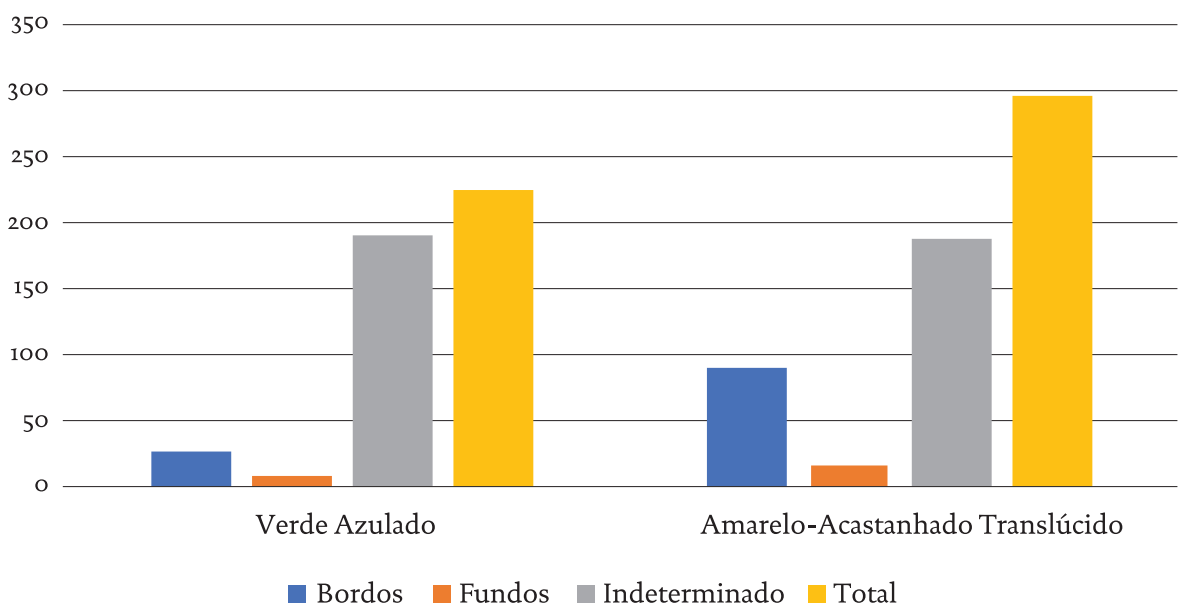

Histograma 3 - Fragmentos de vidro paleocristão do estrato o3 da igreja do Bom Jesus de Gaia. 


\title{
NOVOS CONTRIBUTOS PARA A TOPOGRAFIA HISTÓRICA DE MÉRTOLA NO PERÍODO ROMANO E NA ANTIGUIDADE TARDIA
}

\author{
Virgílio Lopes ${ }^{1}$
}

\begin{abstract}
RESUMO
No presente trabalho pretende-se fazer uma abordagem às novidades arqueológicas ocorridas nos últimos anos em Mértola, dando a conhecer os resultados obtidos e o seu contributo para o conhecimento da cultura material e da topografia histórica da cidade de no Período Romano e na Antiguidade Tardia. Palavras-chave: Estatuária romana, Fora, Complexo religioso, Criptopórtico, Torre do Rio.
\end{abstract}

\begin{abstract}
This paper is intended to show the archaeological discoveries made in the last years in Mértola, in order to show the results and its' contributions to the knowledge of the material culture and historical topography of the city of Myrtilis in the Roman Ages and Late Antiquity.

Keywords: Roman statuary, Fora, Religious complex, Cryptoportic, River Tower.
\end{abstract}

\section{INTRODUÇÃO}

O casco histórico da vila de Mértola tem a nascente o rio Guadiana e a poente a ribeira de Oeiras. O rio Guadiana foi a grande via fluvial que ligava Mértola ao litoral algarvio e, consequentemente, ao Atlântico e ao Mediterrâneo. O facto das marés se fazerem sentir até Mértola, o que provoca uma oscilação diária do nível do rio de cerca de dois metros junto à vila, favorecia a navegação de vários tipos de barcos até ao "porto fluvial mais a norte da grande estrada que era o Guadiana" (Torres, 1992, p. 190; Boiça, 1993, p. 47). Ao analisarmos as gravuras quinhentistas de Duarte D’ Armas é possível observar nesta linha de água, barcos com três mastros, o que indica boas possibilidades de navegação para embarcações de alguma dimensão e capacidade de transporte de mercadorias (Almeida, 1943, p. 31-37). A ligação ao porto era feita, em período romano, pela Porta da Ribeira. Esta, como é visível nas gravuras, era constituída por uma porta em cotovelo encimada por um torreão cuja demolição só aconteceria em meados do século XIX (Boiça, 1993, p. 59). Esta lógica funcional só é alterada em meados do século, quando se procedeu à construção do cais atual e se abriu uma estrada de acesso. Com esta remodelação urbanística, também o local de travessia do rio se alterou, e assim a construção do cais levou a que, nas suas imediações, se instalasse a "ponte barca", que substituiu a velha travessia do Guadiana que anteriormente se fazia junto à Torre do Rio (Figura 1).

\section{A CIDADE NO PERÍODO ROMANO}

A muralha atual tem um perímetro de cerca de 1.291 metros e abarca uma área de cerca de $50.000 \mathrm{~m}^{2}$, ou seja, aproximadamente 5 hectares. Neste recinto são identificáveis quatro acessos, a porta da Acrópole, a porta de Beja, a porta da Ribeira, a porta do Buraco, que devem corresponder às portas existentes desde os tempos romanos (Lopes, 2012, p. 26).

Um dos possíveis fora de Myrtilis localizava-se na plataforma artificial situada na extremidade noroeste da cidade. Nesta zona foram identificados, até ao

1. Campo Arqueológico de Mértola, Centro de Estudos em Arqueologia Artes e Ciências do Património, Bolseiro Pós-Doutoramento da Fundação para a Ciência e a Tecnologia. 
momento, vestígios de uma basílica (localizada na parte noroeste), um possível templo nas proximidades da atual igreja cristã e ainda o criptopórtico (Torres \& Oliveira, 1987, pp. 618-626). Esta plataforma era delimitada pelas seguintes estruturas: a poente, por duas muralhas paralelas; no limite norte, pelo criptopórtico e por uma muralha onde se insere uma porta monumental.

$\mathrm{Na}$ parte virada a nascente, os trabalhos arqueológicos trouxeram à luz uma possível porta de acesso ao forum e ainda um conjunto de seis "arcossólios", cuja técnica construtiva se assemelha à alvenaria do criptopórtico, delimitavam esta praça, ou seriam o elemento estruturante de uma plataforma capaz de vencer a forte inclinação da topografia original.

A porta situada a norte do forum e que a este dava acesso, apesar de incompleta e parcialmente escavada, demonstra bem a monumentalidade da construção. Apresenta uma largura de quatro metros e meio e descreve um arco de pleno centro cujas aduelas são constituídas por tijolos de grandes dimensões ${ }^{2}$. A porta foi posteriormente adaptada e introduzido um novo sistema de fecho em cataratae. O interior desta estrutura utiliza um aparelho de técnica mista onde o xisto é também utilizado com abundância. A muralha onde esta porta se inscreve possui aproximadamente três metros de largura. A porta inevitavelmente conduziria a uma rua, o que criava duas plataformas com cotas diferentes (Figura 2).

No que concerne aos edifícios públicos, destaca-se a possível basílica localizada na parte poente da plataforma. Composta por um corpo retangular e delimitado a oeste por uma ábside semicircular, apresenta na sua parte conservada 21 metros de comprimento e 7 metros de largura. A parede sul eleva-se a cerca de cinco metros. No pavimento que foi revestido de mosaicos, ainda é visível, num dos ângulos da abside, uma base de coluna em mármore. São vários os elementos arquitetónicos, dispersos ou reutilizados, que apontam para a existência de um templo romano localizado no mesmo local onde se ergueu a mesquita e onde hoje se encontra a igreja matriz.

A nível da arquitetura doméstica de Myrtilis, os dados disponíveis resumem-se apenas a uma "casa romana”, escavada na década de oitenta do século XX no subsolo da Câmara Municipal (onde hoje está

2. Comprimento $43 \mathrm{~cm}$, largura $30 \mathrm{~cm}$, espessura $6 \mathrm{~cm}$, dispostos em fiadas que alternam com fiadas de alvenaria de pedra e argamassa. instalado o núcleo museológico correspondente) e, entre 1994 e 2004, na intervenção arqueológica realizada no edifício contíguo a poente, na chamada "Casa do Lanternim». A escavação arqueológica não permitiu esclarecer muitas questões, dada a impossibilidade de prosseguir sob as construções vizinhas e a rua que as separa, no entanto, conseguimos determinar que esta casa teve dois níveis distintos de ocupação: um mais antigo, possivelmente de época imperial, e um outro, posterior ao século III d.C. O certo é que no extremo da "casa romana" se deteta a existência de um impluvium mais antigo que foi completamente recoberto por um opus signinum compacto, ainda hoje visível, com o objetivo de o adaptar a tanque ou lago interior. Esse impluvium certamente ocuparia também a rua que hoje separa essa casa da do Lanternim (Lopes, 2012).

\section{OS NOVOS DADOS DA ARQUEOLOGIA}

Entre 2017 e 2018 foram levadas a cabo as escavações na chamada Casa Cor de Rosa, um imóvel construído nos finais do século XIX e inícios do seguinte. Este edifício situa-se na Rua 5 de Outubro (com os números $7,7 \mathrm{~A}$ e $7 \mathrm{~B}$ ), é uma das maiores casas do centro histórico da vila de Mértola, e inclui, para além da zona coberta, um quintal, anexos e uma cisterna que ocupam uma área total $742 \mathrm{~m}^{2}$. Mandada edificar por Manuel Francisco Gomes, um grande comerciante local, com barcos próprios a circular no rio Guadiana, tinha no piso térreo da sua habitação um grande armazém onde se guardavam consideráveis quantidades de cereais.

A escavação arqueológica começou na zona do quintal onde foi identificada e escavada uma fossa séptica utilizada como depósito do lixo hospitalar do então consultório médico do Dr. Francisco Gomes, médico no concelho de Mértola entre 1927 e 1970. Seguiram-se trabalhos de escavação no piso térreo onde foi possível uma intervenção numa área $193 \mathrm{~m}^{2}$ e com níveis variáveis tendo, em alguns casos, ultrapassado os 4 metros de profundidade.

A intensa ocupação humana do casco urbano de Mértola gerou uma complexa e rica estratigrafia arqueológica. Contudo, dada a imprevisibilidade deste tipo de intervenções em contexto urbano, constatou-se, mais uma vez, que as estruturas encontradas se prolongam em várias direções, pelas construções e ruas adjacentes, fazendo com que, na maioria dos casos, as interrogações persistam; noutros permite-nos a 
articulação com informação já existente, proveniente de trabalhos arqueológicos realizados anteriormente em edifícios situados nas imediações, e a colocação de novas hipóteses de leitura diacrónica do espaço.

Nos níveis mais profundos foram identificadas construções monumentais do período romano, sendo possível observar três momentos construtivos. Um primeiro, do qual resta parte de um tanque de canto arredondado, constituído por uma espessa camada de opus signinum (geralmente associado a estruturas hidráulicas), no qual estavam agregados muros de alvenaria de lajes de xisto dispostas na horizontal, ligadas por terra e muito bem facetadas. Este tanque foi cortado pela construção posterior, possivelmente um templo, com paredes cuja largura ronda os dois metros, e que está associado ao conjunto escultórico do século I. d.C., o que quer dizer que terá uma cronologia anterior.

Do segundo momento construtivo foi identificada uma edificação de forma retangular, com 12 metros no seu lado maior e 10,75 metros no lado menor, com muros com uma espessura entre os 1,5 e os 3 metros, não sendo possível determinar toda a extensão do edifício, já que este se prolonga para as construções vizinhas. Parte dessa construção romana, situada na sala correspondente ao número $7 \mathrm{~B}$, apresenta, em dois pontos distintos, uma destruição motivada pelo facto do seu principal material construtivo - a pedra - ter sido retirada para ser utilizada em construções posteriores.

Numa terceira fase, foi acrescentada aos muros laterais uma outra estrutura de alvenaria argamassada, com 50 centímetros de largura. Estes muros são constituídos por pedra de xisto aparelhada e ligada por uma forte argamassa, sendo pontualmente utilizados silhares de granito e blocos de arenito. Na parede nordeste conservam-se restos da argamassa de revestimento com vestígios de pintura com cores distintas (vermelho, creme e preto). A composição é formada por painéis retangulares onde apenas são percetíveis as molduras lineares (vermelho e preto) e as barras verticais de vermelho "pompeiano". No canto nordeste da Casa Cor de Rosa, a cerca de 4 metros de profundidade, numa cova propositadamente aberta para o efeito, foi descoberto um conjunto escultórico, constituído por uma estátua masculina, incompleta, de grandes proporções, que enverga trajes militares, de tipo Thoracata e por três estátuas femininas, tendo uma delas proporções idênticas (Figura 3). Junto à estrutura absidada, foram encontrados uma cabeça feminina e um fragmento de braço envolto na toga, a par de vários fragmentos escultóricos, disformes e de reduzidas dimensões. A qualidade escultórica em termos estéticos, técnicos e dos materiais constituintes - mármore branco - podem enquadrar estas esculturas na primeira metade do século I d.C. Os dados planimétricos obtidos apontam para uma estrutura monumental, de caráter público, possivelmente um templo. A razão que sustenta esta hipótese está relacionada com a dimensão das construções identificadas capazes de comportar edificações de grande envergadura e volumetria. Por outro lado, em 2007 e 2008, no decurso da obra de recuperação da Casa Fagulha ${ }^{3}$, localizada nas proximidades, foram detetadas estruturas que parecem ter correspondência e situar-se no mesmo alinhamento destas, e que podem, eventualmente, constituir o prolongamento deste edifício.

Uma constatação interessante é a existência de uma camada espessa de terra exógena, que serviu para o nivelamento da topografia pré-existente e sobre a qual se edificaram as distintas construções. A existência desta terra alaranjada com pequenos módulos petrificados parece-nos provir de zonas exteriores ao território de Mértola, podendo ser originária da zona costeira. Este tipo de terra foi encontrado nos níveis mais antigos da escavação da casa cor de rosa e nas intervenções levadas a cabo nas casas da Rua Professor Batista da Graça, nas imediações da igreja da Misericórdia, na parte baixa do casco histórico.

A monumentalidade das estruturas arqueológicas identificadas, a que acresce este fabuloso conjunto escultórico, permite-nos deduzir que podemos estar na presença de um templo integrado num conjunto monumental do tipo forum. Esta ideia é reforçada pelo achado, nos finais do século do XIX, aquando da construção da mesma Casa Cor de Rosa, de uma outra estátua de togado, que se encontra em exposição no núcleo museológico Casa Romana, situado no edifício dos Paços do Concelho na Praça Luís de Camões. De referir ainda a importante localização topográfica, na proximidade da porta de ligação de Mértola ao rio Guadiana e à antiga zona portuária (Figura 4).

Duas estruturas da Antiguidade Tardia foram localizadas no canto norte do mesmo edifício. São constituídas por muros de alvenaria de pedra vã, sendo

3. Obra de requalificação a cargo do Município de Mértola com a intervenção arqueológica de Jorge Feio. 
num deles visíveis elementos arquitetónicos e fragmentos de estatuária romana, em mármore. Uma vez desmontada a primeira, foram removidas duas bases de estátua, um elemento de friso marmóreo de grandes dimensões e alguns fragmentos de estatuária, nomeadamente a parte inferior de uma estátua e vários fragmentos correspondentes a restos de panejamentos.

A segunda estrutura situada nesse sítio, apresenta uma planta absidada, que envolve uma outra, que forma um canto perfeitamente retilíneo. Estas estruturas correspondem a muros bem construídos, em blocos de xisto bem facetados, ligados com terra. No embasamento desta estrutura foi reutilizado um grande bloco de mármore, possivelmente um elemento de friso e, por debaixo deste, identificado aquando do desmonte, um numisma de Graciano, cunhado em Aquileia e datado entre $379-383^{4}$. Este achado fornece uma datação importante para o desmantelamento do complexo monumental do período romano e a ocultação das estátuas, mas também o momento da construção das estruturas da Antiguidade Tardia.

Dos novos achados escultóricos, ocultados numa fossa, fazem parte: a parte superior das pernas e o dorso duma estátua masculina, de tipo Thoracata, partida em duas partes; um fragmento do pé esquerdo, descalço, sobre a base e ainda um grande fragmento com restos do braço esquerdo de onde pendem os panejamentos; três estátuas femininas, uma de grandes proporções (cerca de $152 \mathrm{~cm}$ conservados) apresenta apenas a parte inferior, bacia, pernas e pés assentes numa base, outra que parece ser de uma jovem (assente numa base incompleta e com $139 \mathrm{~cm}$ de altura), apresenta parte do pescoço, do que se depreende que seria uma estátua inteira e não como a maior parte dos casos conhecidos, que estavam preparadas para a colocação de diferentes cabeças; a terceira estátua feminina, incompleta, (tem altura conservada de $120 \mathrm{~cm}$ ), apresenta vestuário ricamente adornado e uma fíbula no ombro direito, podendo a base ser um fragmento encontra-

4. AE2. D N GRATIA-NVS P F AVG, diadema de pérola, drapeado, com o busto virado para o lado direito / REPARATIO REIPVB, Graciano em pé na frente, cabeça para a esquerda, oferecendo a mão direita à mulher ajoelhada, na mão esquerda segura uma Victoria com um globo. http://www.wildwinds.com/coins/ric/gratian/_siscia_ RIC_O26a_mm4.jpg http://www.wildwinds.com/coins/ ric/gratian/t.html (consultado em 10. 1.2019) do nas imediações, em que estão esculpidos os restos de vestes (Figura 5).

Noutro local da mesma Casa, próximo do anterior, apareceu uma cabeça feminina (com cerca de $43 \mathrm{~cm}$ de altura), de mármore branco de excelente qualidade e tratamento escultórico, que se encontra danificada na zona do nariz. Nas proximidades desta peça encontrou-se um fragmento de braço que segura um panejamento. É de considerar a hipótese de se tratar da cabeça de Lívia, esposa de Augusto a sua métrica é enquadrável na peça feminina de maiores proporções (Lopes, 2018b, pp. 34-41).

À monumental estátua thoracata poderá ter pertencido a cabeça de Augusto, descoberta em Mértola, em data incerta e que hoje se encontra no Museu Nacional de Arqueologia ${ }^{5}$, em Lisboa. Contudo, a observação desta peça permite perceber que foi desbastada, na zona do pescoço, e encaixada no togado proveniente de Mértola. Esta composição forçada esteve em exposição nos anos sessenta do século XX no referido museu e está documentada fotograficamente num artigo de Garcia e Bellido, num texto publicado no Arquivo de Beja. O togado está encimado com a cabeça de Augusto e na estátua feminina de orante foi colocada a cabeça de Cibele, interpretada erradamente como sendo Lívia (Garcia y Bellido, 1966, p. 28o-282, figs. 1 e 2).

Tendo em conta a métrica da estátua e da cabeça e o facto do pescoço de Augusto terminar num espigão arredondado e o thoracata ter um recetáculo côncavo, podemos supor que as duas peças pertenceriam a uma só. A verificar-se esta hipótese de trabalho, teríamos em Mértola um templo do culto imperial criado por Augusto.

Nesta estátua envergando traje militar, de pé e numa atitude solene, destaca-se a decoração da sua armadura, constituída na parte superior por um relevo representando a Medusa, a que se segue o peitoral decorado com duas vitórias aladas defrontadas, uma que segura e outra que alimenta um queimador. Na parte inferior, os pterigia estão dispostos em três fileiras, sendo a sua decoração constituída por figuras e bustos humanos, figuras mitológicas, motivos vegetais e animais como águias e cabeças de lince. Este animal também possui representações em estátuas da mesma tipologia na Guarda, Mérida,

5. http://www.matriznet.dgpc.pt/MatrizNet/Objectos/ ObjectosConsultar.aspx?IdReg=110213 (consultado em 10. 12.2017) 
Baeza e Verona. Na parte inferior do corpo ainda são visíveis restos de panejamento e da perna esquerda, e dela poderão também fazer parte os restos de um pé descalço de grandes dimensões o que, a pertencer a esta peça, nos indica que esta se encontraria no interior do templo.

Ainda relacionadas com estes exemplares escultóricos estão as duas bases de mármore reutilizadas numa estrutura murária, a par de vários fragmentos escultóricos. Poderia tratar-se de plintos que serviram de elementos de suporte para as estátuas.

\section{A CIDADE NA ANTIGUIDADE TARDIA O CRIPTOPÓRTICO - CISTERNA}

Na plataforma artificial, onde o desnível era compensado pelo pano de muralha construída com silharia, foi implantada uma construção subterrânea designada por criptopórtico-cisterna, que inicialmente era um sítio de passagem. A descoberta desta construção foi feita no início do século XVI, por Duarte D’Armas que anota no seu "Livro das Fortalezas" o seguinte: aqui esta huã abobada atopida muyto booa (Branco, 1997, p. 6). Três séculos mais tarde Estácio da Veiga faz a seguinte descrição da parede exterior do criptopórtico: começam a manifestar-se no revestimento externo varias pedras, incluindo belos mármores, que bem significam haver pertencido a nobres edificios. Quasi toda a cortina adherente ao baluarte fronteiro à ermida da Senhora das Neves é abundante d' esta mescla, incluindo espaçosas pedras rectangulares de granito, que necessariamente vieram de grande distancia e não para construcção das muralhas (Veiga, 1983, p. 78).

Os trabalhos de escavação levados a cabo pelo Campo Arqueológico de Mértola (CAM), em finais dos anos setenta do século XX, no interior desta estrutura, que "foi minuciosamente desentulhada durante cinco anos" (Torres \& Silva, 1989, p. 31), revelaram uma galeria com um papel essencialmente estrutural, de contenção e suporte da plataforma de implantação do forum. Assim, no lado norte, para suportar maiores pressões numa amplitude mais vasta, o desnível era compensado por um criptopórtico de $32 \mathrm{~m}$ de comprimento, com largura e altura médias de, respetivamente, 2,70 e 5,80 m (Torres \& Oliveira: 1987, 618).

A feição assumidamente militar do conjunto galeriacriptopórtico e muro-exterior, não parece suscitar dúvidas. Para isso aponta a sua localização, a solidez da construção e ainda as quatro aberturas na muralha (estando uma ainda entaipada) que poderão ter funcionado como seteiras, podendo o criptopórtico ser uma espécie de "casamata" no caso da cidade ser sujeita a assédio militar.

Por esclarecer está ainda a ligação do criptopórtico à porta de acesso do forum, na parte nordeste da plataforma, pois só novos trabalhos arqueológicos nessa área a poderão revelar. No entanto, pela abertura existente no topo este do criptopórtico, é possível inferir que este se prolongaria nessa direção. Tão pouco está completamente esclarecida a contribuição que as remodelações dos torreões medievais podem ter dado para a destruição do criptopórtico nos seus dois topos.

Mais tarde o criptopórtico foi redimensionado e sofreu um programa de obras que lhe modificou as funções. Refira-se que são notórios dois momentos distintos desta construção: um primeiro, em que são erguidas as paredes do criptopórtico e, outro posterior, em que ambos os topos são fechados. No topo leste é visível essa diferença. Depois de redimensionado esse espaço, o pavimento e a parte inferior das paredes, até uma altura entre 1,50 e 1,70 m, foram revestidos por uma sólida argamassa impermeável tipo opus signinum e as quatro "seteiras" entaipadas com o evidente objetivo de adaptar o espaço a cisterna. Este entaipamento poderá ser enquadrável, cronologicamente, nos finais do século IV ou inícios do $\mathrm{V}$, em data não muito distante da sua construção inicial (Macias, 1996, p. 53).

A cisterna tinha uma capacidade para armazenamento de $138 \mathrm{~m}^{3}$ de água (Macias, 1996, p. 53). O encerramento dos topos da galeria foi feito com paredes de alvenaria e pela análise da técnica construtiva destes entaipamentos, é notório que se trata de intervenções posteriores, pois as pedras que formam os cantos apenas encostam às paredes do criptopórtico, não havendo qualquer espécie de travamento entre elas. Por um orifício existente na parte superior da parede é possível observar que a abóbada se prolongava para além do entaipamento. Questões de segurança impedem-nos, porém, de prosseguir com trabalhos de escavação que permitissem investigar a existência dessa estrutura subterrânea. O entaipamento das quatro seteiras teve certamente como objetivo proteger as águas, evitando a entrada de aves e outros animais.

De uma das seteiras entaipadas foi removido um capitel de grandes dimensões, finamente decorado 
com motivo liriforme. Este elemento arquitetónico é possivelmente originário de um edifício público do forum da cidade, e é enquadrável cronologicamente no século II - III (Lopes, 2012, p. 83).

A hipótese que coloco situa a adaptação do criptopórtico a cisterna como coetânea da construção do complexo baptismal. A cisterna aproveitava a água das chuvas provenientes dos edifícios situados na plataforma superior. A sustenta esta hipótese está o facto de, no muro sul da galeria porticada, em ambas as extremidades, existirem duas aberturas rasgadas nos muros e que deveriam ser o remate de um sistema de algerozes que recolhiam dos telhados a água das chuvas e a conduzia para esses pontos. O facto destas aberturas terem sido escavadas nos muros e perfurarem a abóbada do criptopórtico, sugerem tratar-se de um momento posterior de adaptação do espaço a cisterna (Figura 6).

\section{O COMPLEXO RELIGIOSO}

Durante os séculos V - VI d.C. na zona da antiga acrópole, as construções do possível forum foram remodeladas e adaptadas às novas necessidades criadas com a introdução do Cristianismo. Na parte oeste da plataforma foi erguido um complexo de edifícios para albergar dois monumentais batistérios. Para além das piscinas batismais, chegaram até aos nossos dias vestígios de pavimentos adornados com painéis de mosaicos, onde não faltava a policromia das tesselas ou dos frescos de que restam vestígios. O complexo religioso era constituído pela sala do batistério, um compartimento anexo situado a norte, uma passagem em cotovelo e um espaço que ladeava a ábside; a sul e a norte é delimitado, respetivamente, por um compartimento de planta basilical e uma galeria porticada (Figura 7).

A parte do complexo religioso da Alcáçova, onde ainda hoje se podem admirar belos mosaicos paleocristãos, assenta sobre uma construção subterrânea designada por criptopórtico/cisterna. Esta edificação é referida por Duarte de Armas, no início do século XVI, que anota: aqui esta huã abobada atopida muyto boa (Almeida, 1943). Trata-se duma galeria com um papel essencialmente estrutural, de contenção e suporte da plataforma de implantação do forum (Torres \& Oiveira:1987, p. 618; Torres \& Silva, 1989, p.31). O pavimento da galeria porticada e o deambulatório estavam cobertos por um significativo conjunto musivo, do qual realçamos, no deambu- latório, Belerofonte cavalgando o Pégaso para matar a Quimera e, no longo corredor porticado, dois leões afrontados e várias cenas de caça com um cavaleiro empunhando um falcão (Lopes, 2003). Se a falta de paralelos bem datados inviabiliza uma cronologia segura, leituras estratigráficas e traços estilísticos permitem atribuir esta obra à primeira metade do século VI d.C.

O edifício de planta retangular continha no seu interior um batistério octogonal, implantado no centro de um tanque ou piscina e rodeado por um deambulatório, no qual se abria a leste uma ábside de planta em arco ultrapassado. A pia batismal, de desenho octogonal, onde se recortam, pelo exterior, oito pequenos absidíolos, é constituída, no seu interior, por uma pequena piscina, também oitavada, onde um ressalto em degrau serviria de assento ${ }^{6}$. O sistema hidráulico de abastecimento do batistério, supomos que se efetuaria com recurso a tubagens inseridas numa canalização em alvenaria ${ }^{7}$. De seguida a água era conduzida para uma pequena pia quadrangular existente no fundo, no lado sul, com as dimensões interiores de $30 \mathrm{~cm}$ de lado. Posteriormente a água seguiria por uma tubagem até ao pináculo perfurado, localizado no centro da piscina batismal, por onde jorraria (Figura 8).

Como todo este conjunto arquitetónico se encontra numa cota inferior, por ação da gravidade a água, trazida por uma conduta, da qual só resta o negativo do seu assentamento, penetrava no interior da pia, onde poderia jorrar através de um pequeno pináculo fixado no fundo; sendo que as águas utilizadas escorriam para uma fossa estreita com 2,80 $\mathrm{m}$ de profundidade. No fundo são visíveis restos de reboco de argamassa em opus signinum e as paredes laterais são de alvenaria de xisto, onde se notam, encastrados, alguns fragmentos de uma imposta e de um fuste de coluna em mármore.

Com os trabalhos arqueológicos do verão de 2013, um pouco mais acima, na encosta do Castelo de Mértola, surgiu parte de um novo edifício de cabeceira tripartida e planta retangular. Este edifício

\footnotetext{
6. A altura máxima desta pia batismal era 1,07 metros, a largura interior varia entre 1,12 metros na base e 1,50 no topo. No exterior as medidas no eixo norte-sul são 3,50 e este-oeste 4,46 metros.

7. Possui uma altura situada em torno dos $27 \mathrm{~cm}$ e uma largura de $22 \mathrm{~cm}$ e entrava na piscina por um orifício de $15 \mathrm{x}$ $15 \mathrm{~cm}$.
} 
envolvia uma monumental estrutura batismal de forma octogonal, cujo interior apresenta quatro degraus revestidos com placas de mármores ${ }^{8}$. No lado norte da piscina foi aberta, numa fase posterior, um pequeno tanque quadrado, rematado exteriormente por um pequeno absidíolo e por uma cancela vazada para o interior. Do lado oposto deveria haver outra cancela, mas só restam alguns fragmentos de ferro que eventualmente serviriam para a sustentar. Este pequeno tanque absidíolo tanto poderia ser o local para a colocação de um membro do clero que auxiliasse o neófito na imersão batismal como poderia estar relacionado com o batismo de crianças. Esta última possibilidade pode justificar a existência do pequeno tanque que se encontra ao lado (Figura 9). No lado ocidental, o tanque octogonal possui um orifício de escoamento na placa de mármore colocada na vertical. Neste ponto apenas resta o negativo da tubagem metálica, entretanto desaparecida. A canalização, constituída por imbrices, segue depois para norte, por debaixo das lajes do pavimento, na direção da canalização maior, no entanto a ligação foi destruída pelas ocupações posteriores (Lopes, 2018a, pp. 34-41).

No que concerne a circulação da água neste tipo de espaços, são conhecidas duas modalidades: batistérios com orifícios de entrada e de escoamento, como ocorre no batistério I de Mértola e em Aix, Nantes II, Lyon e Port-bail; e batistérios com apenas um orifício de esvaziamento, como neste batistério II e em Fréjus, Rescamone e Figari (Guyon, 1991, p. 82). Já tem sido abordada a incongruência que se verifica entre o princípio do batismo por imersão e as medidas das piscinas batismais (com diâmetros entre os $1,30 \mathrm{~m}$ e os $1,60 \mathrm{~m}$ e a profundidade a rondar $1 \mathrm{~m}$ ) o que não invalida a sua função. Parece provável que a imersão fosse apenas simbólica e que o celebrante, ou os que o assistiam, lançassem água sobre o que estava a ser batizado. Em todo o caso, o catecúmeno poder-se-ia ajoelhar ou acocorar dentro da piscina, até que a água o cobrisse (Godoy Fernández, 1989, p. 607-635). No entender desta autora não se podem extrair conclusões litúrgicas da profundidade

8. Neste caso o tanque tinha uma largura exterior máxima de 4,80 metros, sendo a largura média exterior nas restantes paredes de 4,63 metros $\mathrm{O}$ interior apresenta uma largura média de 3,25 metros, a profundidade máxima é de 1,52 metros e a profundidade até ao orifício do desaguo é de 1,16 metros. das piscinas pois, caso ela não permitisse a imersão completa, praticava-se uma fórmula mista de "infusión-inmersión" que em nada afetaria a validade da cerimónia (Godoy Fernández, 1989, p. 613). A água sempre teve um papel importante no ato batismal. As primitivas comunidades cristãs manifestavam predileção pela imersão completa do catecúmeno que, nos primeiros tempos, se realizava em fontes de água viva (rio ou mar), imitando o Batismo de Jesus Cristo no Rio Jordão. Segundo se depreende das palavras utilizadas pelos autores antigos para designar as fontes batismais, a forma mais frequente de conferir o sacramento era a imersão. Os termos mais empregues no ocidente são: fons, lavacrum, piscina $y$ tinctorium e as referências à ação sacramental: mergere, mergitare, in aquas mittere, intinguere, para designar tanto a imersão total como a parcial (Godoy Fernández, 1989, p. 613).

\section{A TORRE DO RIO}

$\mathrm{Na}$ área ribeirinha as estruturas monumentais inscrevem-se na Antiguidade Tardia e são testemunho da importância que a zona portuária possuía nessa época. De todo o conjunto monumental de muralhas existentes, a chamada Torre do Rio (também conhecida por Torre Couraça) é paradigmática das técnicas construtivas do período tardo-romano. A Torre do Rio foi declarada Monumento Nacional em 1910 sendo, na linguagem popular, o monumento designado por "ponte romana”. Um exemplo desta designação encontra-se no foral outorgado a Mértola em 1254 pelo Mestre da Ordem de Santiago, D. Paio Peres Correia, no qual se pode ler Della ponte a suso quem ahy quizer pescar auenhaseis com o comendador do lugar (Veiga, 1983, pp. 177-178). Esta referência à "ponte" mantem-se na documentação produzida pelas visitações da Ordem de Santiago servindo, por exemplo, para determinar o dízimo a pagar pela pesca no rio (Barros, Boiça e Gabriel, 1996, p. 27). Contudo, esta designação carece de qualquer confirmação arqueológica. Abel Viana, que chegou mesmo a efetuar ali trabalhos arqueológicos, informou Fernando de Almeida, que "não encontrara absolutamente nada nas escavações que para tal fim ali fizera" (Almeida, 1976, p. 265). De facto não se trata de uma ponte, mas de um passadiço constituído por seis pilares e outros tantos arcos (dos quais apenas se conserva a zona do arranque), que se situava entre a Porta da Ribeira e o rio e que permitia ligar o espaço 
intramuros ao Guadiana. A sua extensão total ronda os 47,8 m; no entanto, se considerarmos a ligação, inevitável, à muralha, a dimensão do monumento chega aos 51,3 m (Figura 10).

No nível superior dos pilares é percetível o arranque dos arcos que ligariam todo o conjunto, existindo nos pilares dois, três, quatro e seis arcos menores, hoje parcialmente destruídos, que teriam como função aliviar a pressão exercida sobre a estrutura, deixando passar parte das águas vindas de montante e diminuindo o impacto da força da corrente. Esses sumidouros possuem uma largura regular que se situa em 1,3 m, com exceção do pilar 6 cujo arco apresenta 1,5 m de largura. Esta técnica construtiva é adotada na maior parte das pontes construídas durante o período romano. Numa imagem fotográfica de Mértola do ano 1875, um ano antes da grande cheia, ainda é visível a união, por um arco, entre o terceiro e o quarto pilar (Custódio, 2013, p. 21).

No que se refere à técnica construtiva, esta é claramente idêntica à que foi adotada na edificação do criptopórtico. Temos, assim, um terminus ante quem para a construção do criptopórtico proporcionado pela pavimentação dos espaços com mosaicos, para os quais os paralelos existentes se situam maioritariamente no século VI d C. A Torre do Rio em si insere-se num espectro cronológico entre os finais do século III, data posterior à da ara votiva aqui encontrada, e o século VI, limite cronológico atribuído à aplicação dos pavimentos musivos existentes sobre o criptopórtico do complexo religioso de Mértola. Mais tarde, durante a permanência islâmica, não terá perdido a função de defesa do porto mas também poderia ter tido a funcionalidade de abastecer a vila de água através de uma zona protegida. No desenho de Duarte D’Armas, de 1509/10, é descrita: pegões de poonte começados em tempo de mouros (Almeida, 1943), possivelmente remetendo para a última utilização desta edificação. Estácio da Veiga e Pavón Maldonado coincidem na opinião de que esta mantinha em época islâmica uma função de torre couraça para aprovisionar a água à população (Pavón Maldonado, 1993, p. 38).

\section{ALGUMAS CONCLUSÕES E QUESTÕES EM ABERTO}

As escavações arqueológicas levadas a cabo na Casa Cor-de-Rosa abrem novas perspetivas para a compreensão do urbanismo romano, pondo a descober- to uma estrutura monumental, de caráter público, possivelmente um templo. Estruturas encontradas em 2006 e 2007, no acompanhamento da obra de recuperação da Casa Fagulha, relativamente próxima, parecem situar-se no mesmo alinhamento destas, pelo que poderão constituir, eventualmente, o prolongamento deste edifício até esse outro imóvel. Estas estruturas monumentais estariam, possivelmente, integradas numa praça do tipo forum, constituído por plataformas e coroado por um templo. Com ela se relacionaria a descoberta do século XVI no torreão que deu lugar à Igreja da Misericórdia, de seis ou oito estátuas às quais viriam a juntar-se, no final de 2017, mais quatro exemplares exumados no âmbito dos trabalhos arqueológicos realizados (Lopes, 2018).

Dada a monumentalidade das estruturas e a concentração da estatuária encontrada nesta parte da vila, é perfeitamente admissível que nesta zona existisse um forum que se desenvolveria em plataformas e que possivelmente teria um rico programa iconográfico estatuário de forte impacto visual. Quem chegava a Myrtilis, subindo o rio Guadiana, deparava-se com um cenário monumental constituído por imponentes templos ricamente ornamentados.

A concentração de estruturas e achados escultóricos e de elementos de arquitetura decorativa de grandes dimensões na parte baixa da vila de Mértola vem reacender o debate em torno da topografia antiga de Myrtilis e colocar a possibilidade da existência de dois fora, um na parte alta da cidade e, um outro, na parte baixa ligado aos prováveis templos de Augusto e de Cibele possivelmente localizados nas imediações da zona portuária (Figura 10).

Se excetuarmos o togado que se encontra no Museu Nacional de Arqueologia, que apresenta a parte de trás lisa, para encostar a uma parede, todos os outros elementos escultóricos estão trabalhados em todos os lados, deveriam ser vistos em todos os seus ângulos.

Os elementos escultóricos encontrados em Mértola demonstram a prática da Damnatio memoriae, bem visível nas cabeças e em concreto nas faces, com a destruição dos queixos e dos narizes. Esta prática está também documentada no caso das estátuas ocultadas na vala. A Damnatio memoriae das peças escultóricas, ou seja, a destruição parcial e a ocultação propositada, num contexto arqueológico bem datado, atesta um processo de cristianização em que uma religião politeísta foi substituída por uma religião monoteísta - o cristianismo. Terá sido um mo- 
vimento semelhante, conduzido pelos cristãos vitoriosos após 312, que levou à mutilação, destruição e enterramento das estátuas da Antiguidade romana. Se ela foi objeto de um motim de fúria popular como esses, mais ou menos espontâneo, ou se de um ritual oficial de dessacralização ('maledictio' ou 'damnatio') oficial. Temos assim documentado arqueologicamente um episódio de conflito e da intolerância entre religiões nos inícios da Antiguidade Tardia, e de como os acontecimentos religiosos marcaram o tecido urbano da antiga cidade de Mértola.

Estas novas descobertas reafirmam a importância histórica desta cidade portuária e o seu forte grau de romanização. No período subsequente Mértola mantem a dinâmica e a importância que se materializam no Complexo religioso, nas basílicas do Rossio do Carmo e do Cineteatro Marques Duque e no mausoléu (Lopes, 2019).

Mértola, julho de 2020

\section{BIBLIOGRAFIA}

ALMEIDA, Fernando (1976) - A ruínas da Chamada Ponte Romana de Mértola (Portugal). In Madrider Mitteilungen, 17, pp. 295-300.

ALMEIDA, JOÃO de (1943) - Livro das Fortalezas de Duarte De Armas, Lisboa.

BARROS, Maria, BOIÇA, Joaquim \& GABRIEL, Celeste (1996) - As comendas de Mértola e Alcaria Ruiva - As Visitações e os Tombos da Ordem de Santiago 1482-1607, Mértola.

BOIÇA Joaquim e BARROS Maria de Fátima R. (2013) - O castelo de Mértola, Mértola.

BOIÇA, Joaquim (1993) - Topografia Histórica de Mértola. Arqueologia Medieval, 3, pp. 47-59.

BARROS, Maria, BOIÇA, Joaquim \& GABRIEL, Celeste (1996) - As comendas de Mértola e Alcaria Ruiva - As Visitações e os Tombos da Ordem de Santiago 1482-1607, Mértola.

BOURGUET, Pierre (1965) - La peinture paléo-chrétienne, Port Royal, 3, Suiça.

BRANCO, Manuel da S. C. (1997) - Duarte de Armas Livro das Fortalezas, Edição fac-similado MS 159 da Casa Forte do Arquivo Nacional da Torre do Tombo ( $2^{\mathrm{a}}$ ed.). Lisboa.

COSTA, Miguel R. (2015): - Mértola A arquitetura da vila e do termo, Mértola.

CUSTÓDIO, Jorge (2013) - Mina de S. Domingos, território, história e património mineiro. Lisboa: Socius - ISEG, Universidade de Lisboa.
DIAS, M. M. Alves, GASPAR, Catarina (2006) - Catálogo das Inscrições Paleocristãs do Território Português, Centro de Estudos Clássicos, Universidade de Lisboa.

DIAS, M. M. Alves, GASPAR, Catarina e LOPES, Virgílio, (2013) - Mértola en la Antigüedad Tardía: Nuevos datos arqueológicos y epigráficos. HABIS, 44, 247-267.

GARCIA y BELLIDO, (1966-67) - Retratos Romanos Imperiales de Portugal, Arquivo de Beja, Volume XXIII-XXIV, Beja, pp. 280-291.

GODOY FERNÁNDEZ, Cristina (1989) - Baptistérios hispánicos (siglos IV aI VIII): arqueología y liturgia. In Actes du XI Congrès international d'archéologie chrétienne vol. 1, Rome, pp. 607-635.

GUYON Jean, (1991) - Le baptême et ses monuments. In Naissance des arts chrétiens: atlas des monuments paléochrétiens de la France, Paris, pp. 70-87.

LOPES, Virgílio (2003) - Mértola na Antiguidade Tardia. Mértola.

LOPES, Virgílio (2012) - Casa romana: Museu de Mértola. Mértola.

LOPES, Virgílio (2014) - Mértola e o seu território na antiguidade tardia (séculos IV-VIII). Huelva: Universidade de Huelva. Dissertação de Doutoramento, 2014. Disponível em http://rabida.uhu.es/dspace/ handle/10272/8053

LOPES, Virgílio, (2018a) - O complexo religioso de Mértola. Monumentos, nº 36, Direção Geral do Património Cultural, Lisboa, pp. 54-61.

LOPES, Virgílio, (2018b) - Recentes descobertas arqueológicas em Mértola: a intervenção na Casa Cor-de-Rosa, Monumentos, no 36, Direção Geral do Património Cultural, Lisboa, ISBN 0872-8747, pp. 34-41.

LOPES, Virgílio, (2019) - Mértola e o seu território na Antiguidade Tardia. In Tarraco bienal ACTES 4 t Congrés Internacional d'Arqueologia i Món Antic VII Reunió d'Arqueologia Cristiana Hispànica El cristianisme en l'Antiguitat Tardana Noves perspectives, Tarragona, 21-24 de novembre de 2018, Edició a cura de Jordi López Vilar, Tarragona, 2019, pp. 377-384.

MACIAS, Santiago (1993) - Um espaço funerário. In Museu de Mértola: basílica paleocristã, Mértola, pp. 30-62.

MACIAS, Santiago (1996) - Mértola islâmica: estudo histórico do Bairro da Alcáçova (séculos XII-XIII), Mértola.

NICOLAI, Vincenzo. F., BISCONTI, Fabrizio. \& MAZZOLENI, Danilo, (200o) - Les catacombes chrétiennes de Rome. Turnhout: Brepols Publishers.

TORRES, Cláudio e OLIVEIRA, José C. (1987) - O criptopórtico-cisterna da Alcáçova de Mértola. In II Congreso de Arqueología Medieval Española, Madrid, 1987. (T. II, pp. 617-626). Madrid: [Comunidad de Madrid]. 
TORRES, Cláudio e SILVA, Luís, (1989) - Mértola Vila Museu, Mértola.

TORRES, Cláudio (1992) - Povoamento antigo no Baixo Alentejo: alguns problemas de topografia histórica. Arqueologia Medieval, n. 1, pp. 197-198.
VEIGA, Estácio da (1983) - Memórias das Antiguidades de Mértola, (ed. fac-similada de 1880). Lisboa: Imprensa Nacional, Mértola.

PAVÓN MALDONADO, B. (1993) - Ciudades y fortalezas lusomusulmanas: crónicas de viajes por el sur de Portugal. Madrid: Instituto de Cooperación con el Mundo Arabe.

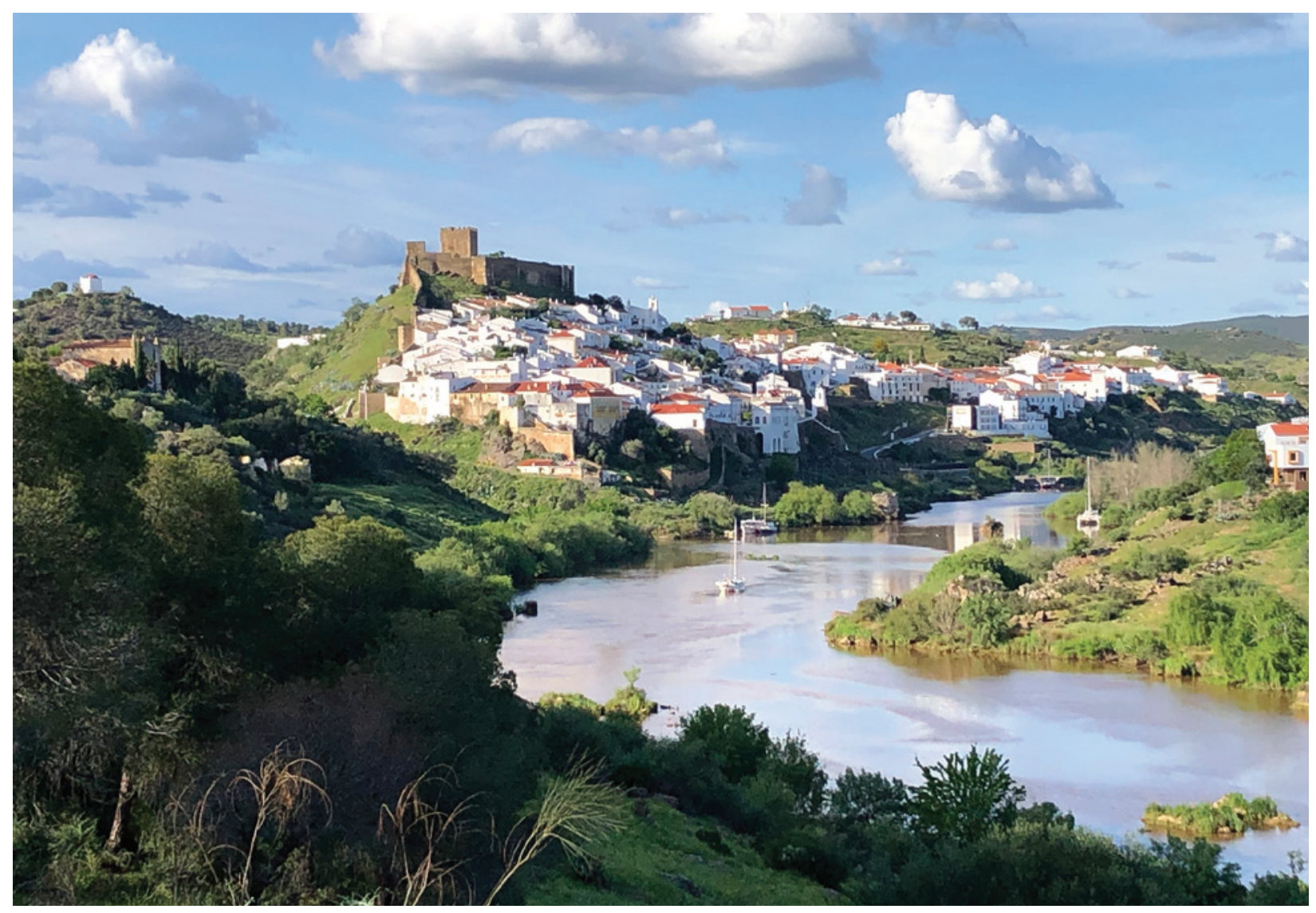

Figura 1 - O rio Guadiana e Mértola.

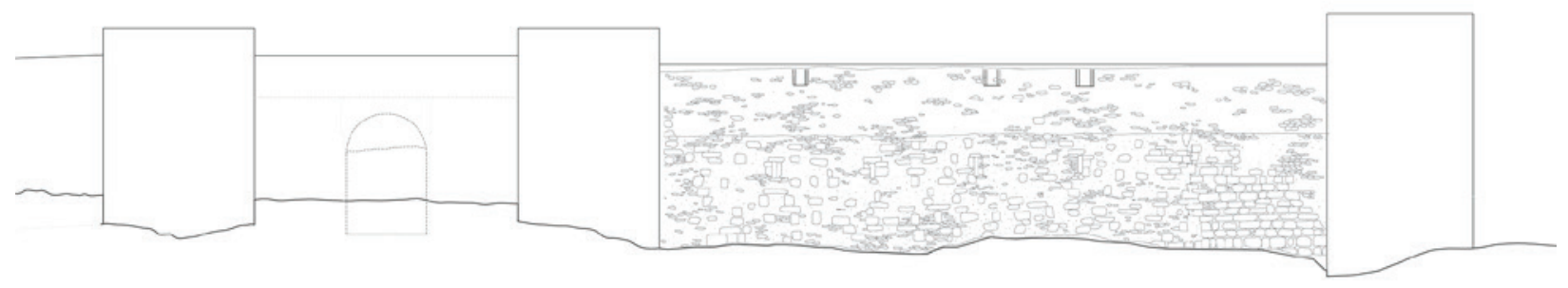

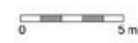

Figura 2 - A muralha exterior do criptopórtico e a porta (desenho Carlos Alves). 


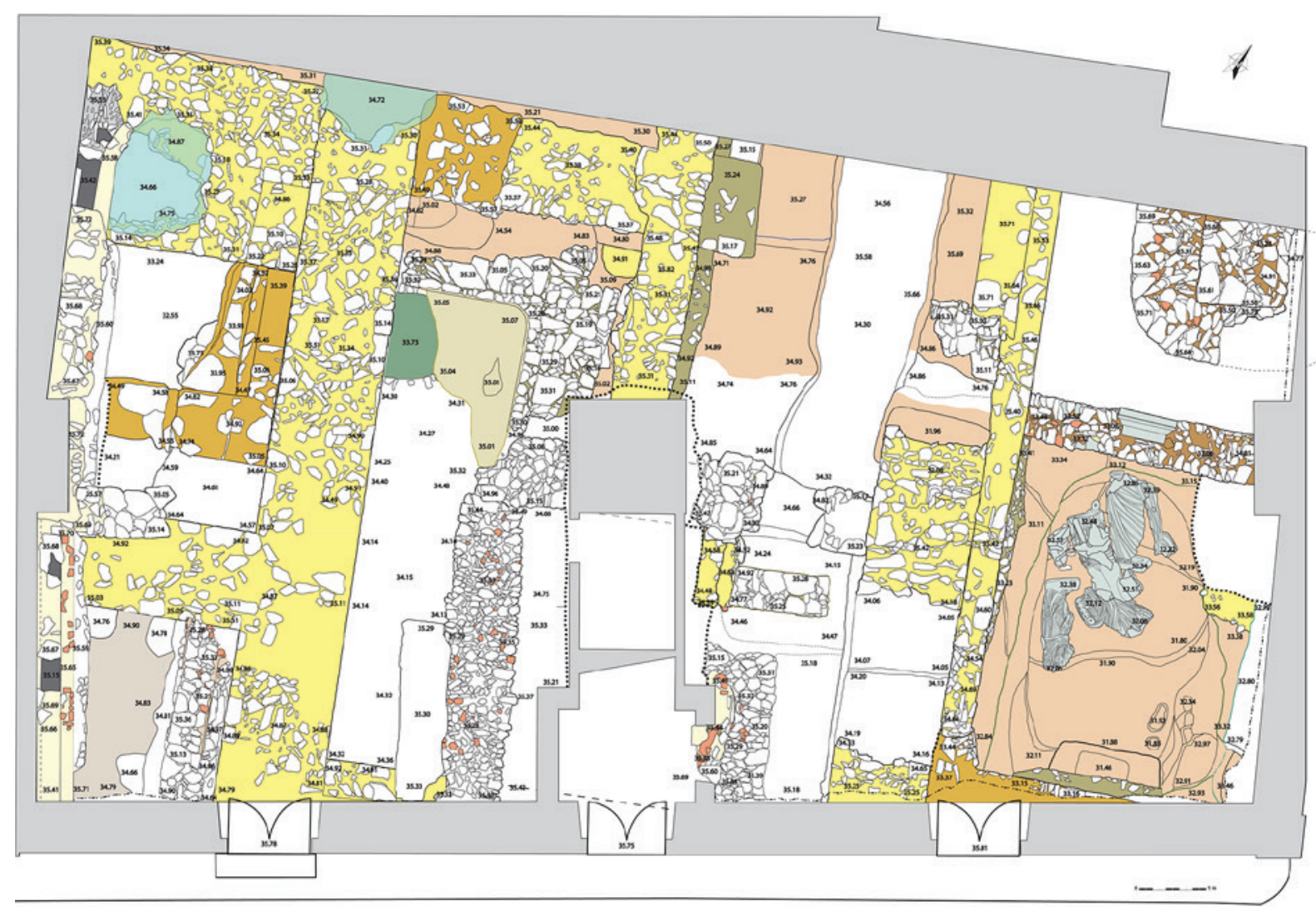

Figura 3 - Planta Casa cor de Rosa (desenho Nélia Romba e Marco Fernandes).

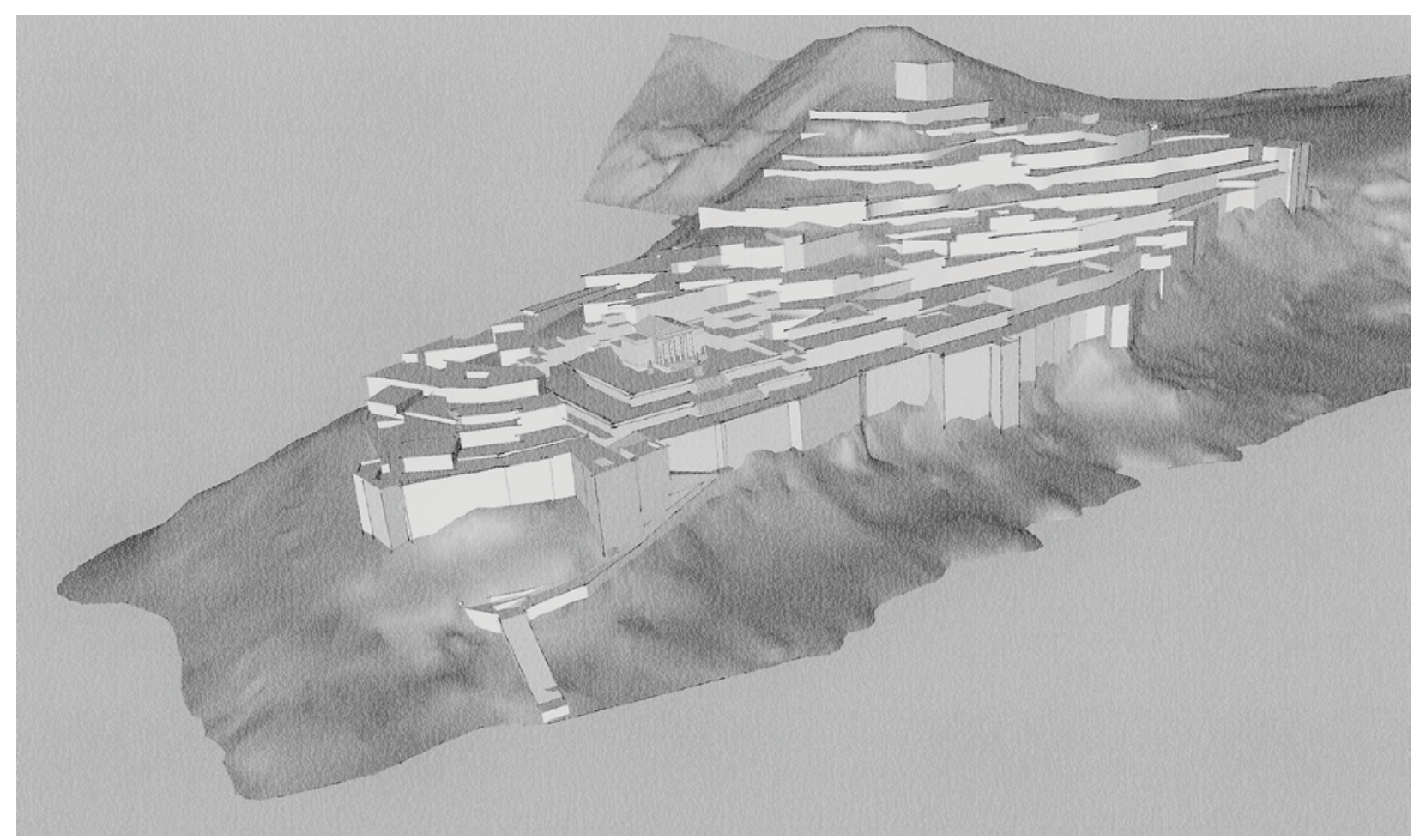

Figura 3 - Proposta de reconstituição volumétrica da parte baixa de Myrtilis (desenho Carlos Alves). 


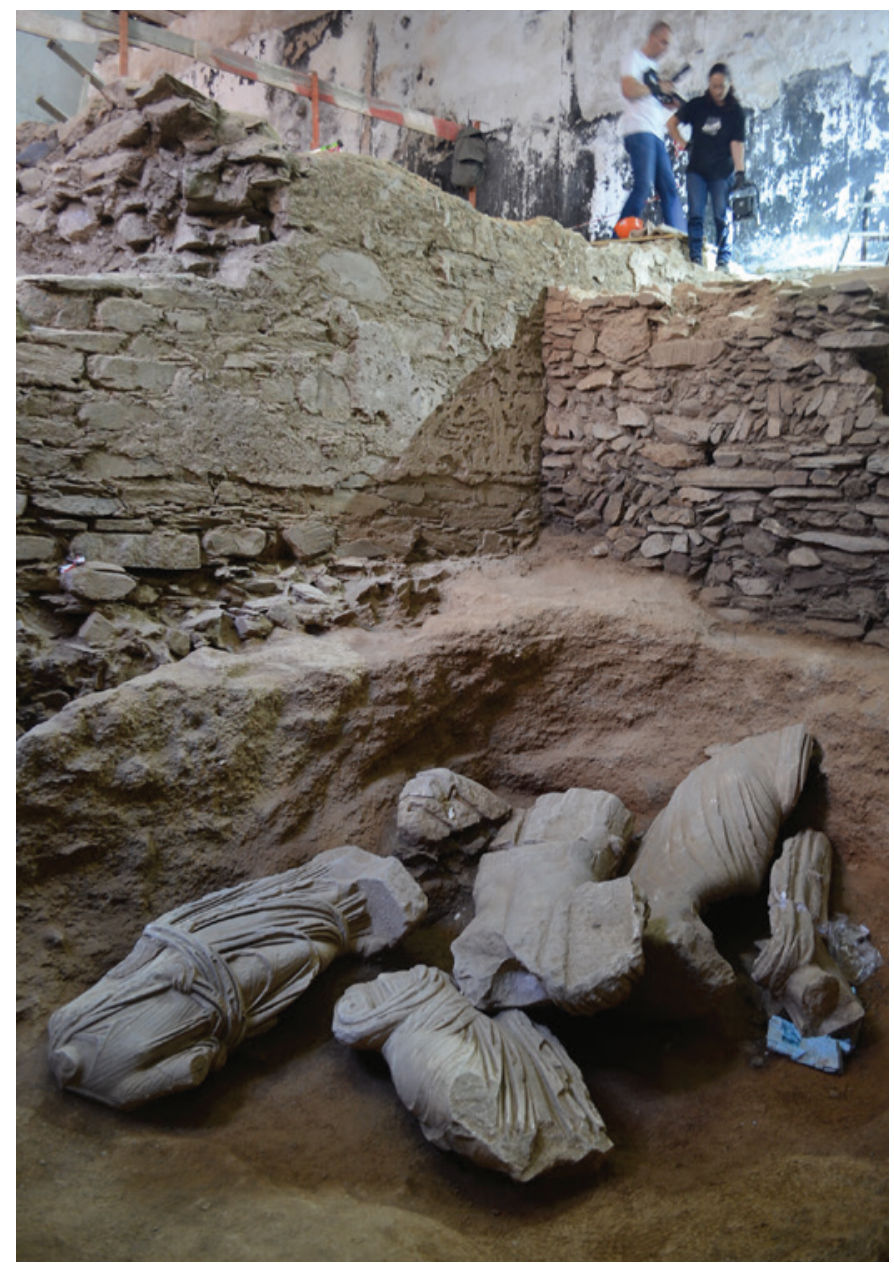

Figura 5 - Escavação do grupo escultórico na Casa Cor de Rosa.
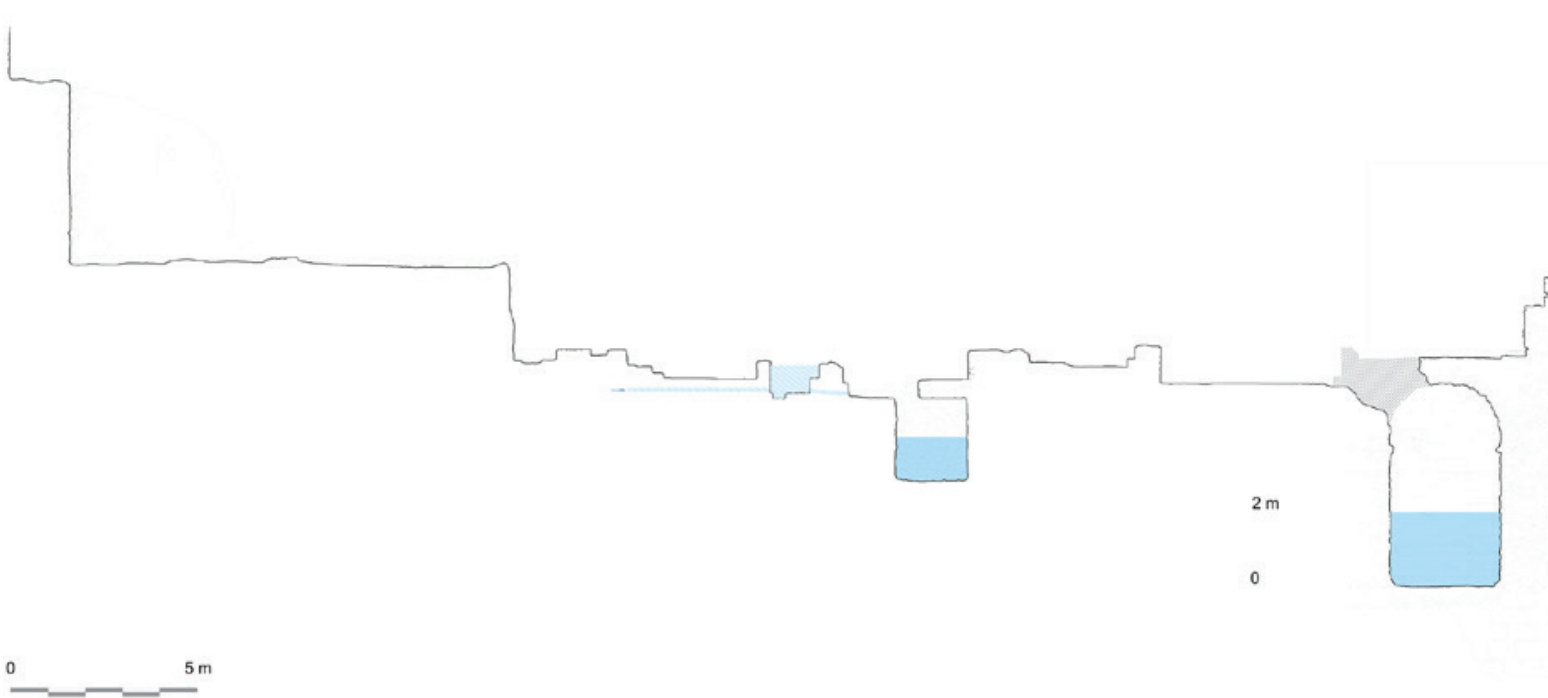
m

Figura 6 - Corte da zona batismal e do criptopórtico (desenho Carlos Alves). 


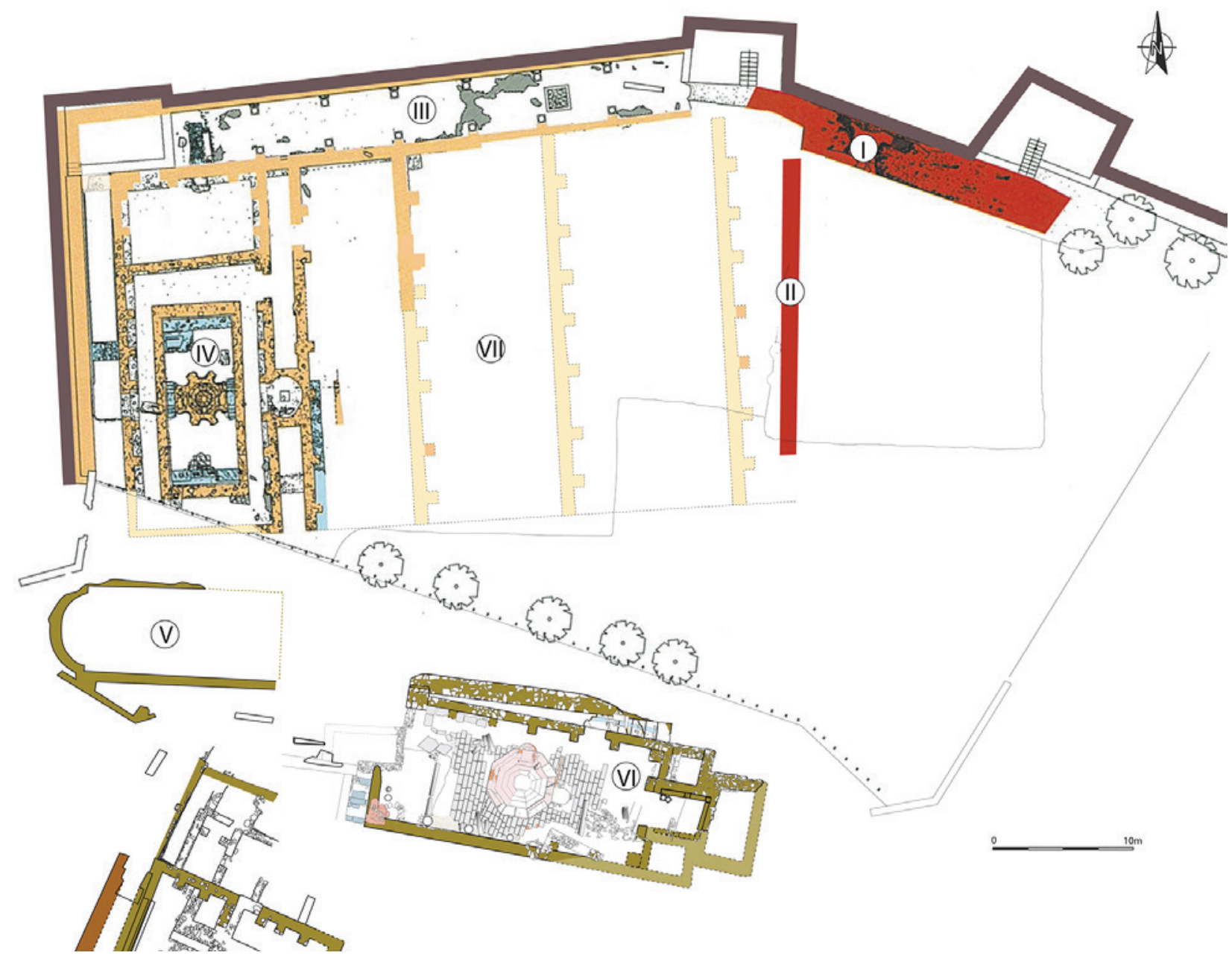

Figura 7 - Planta geral do complexo religioso. Planta do complexo religioso: I - Porta do forum, II Arcossólios, III Pórtico, IV Batistério I, V Compartimento absidado, VI Batistério II (desenho de Nélia Romba). 


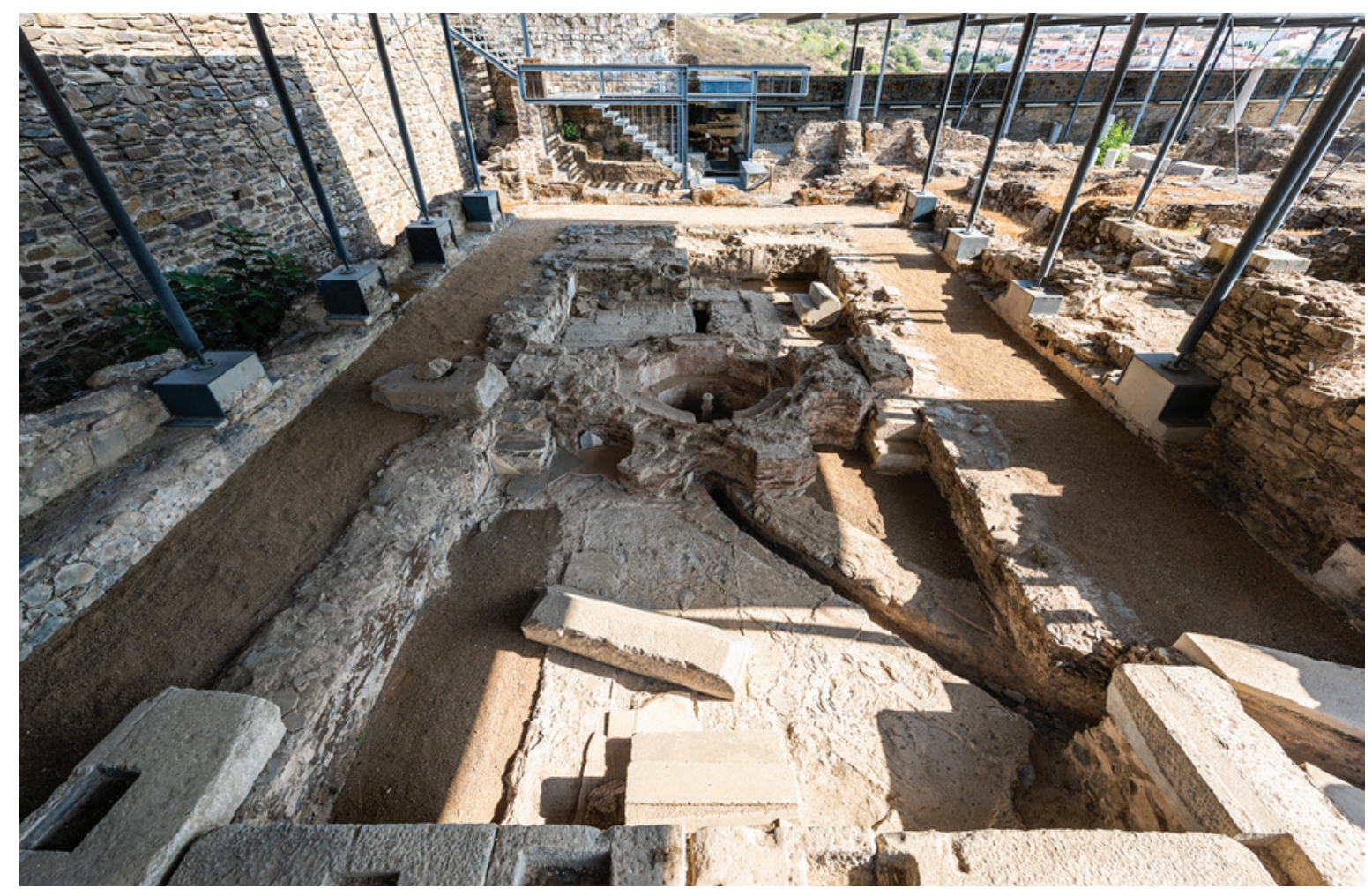

Figura 8 - Batistério I (Jorge Branco CMMértola).

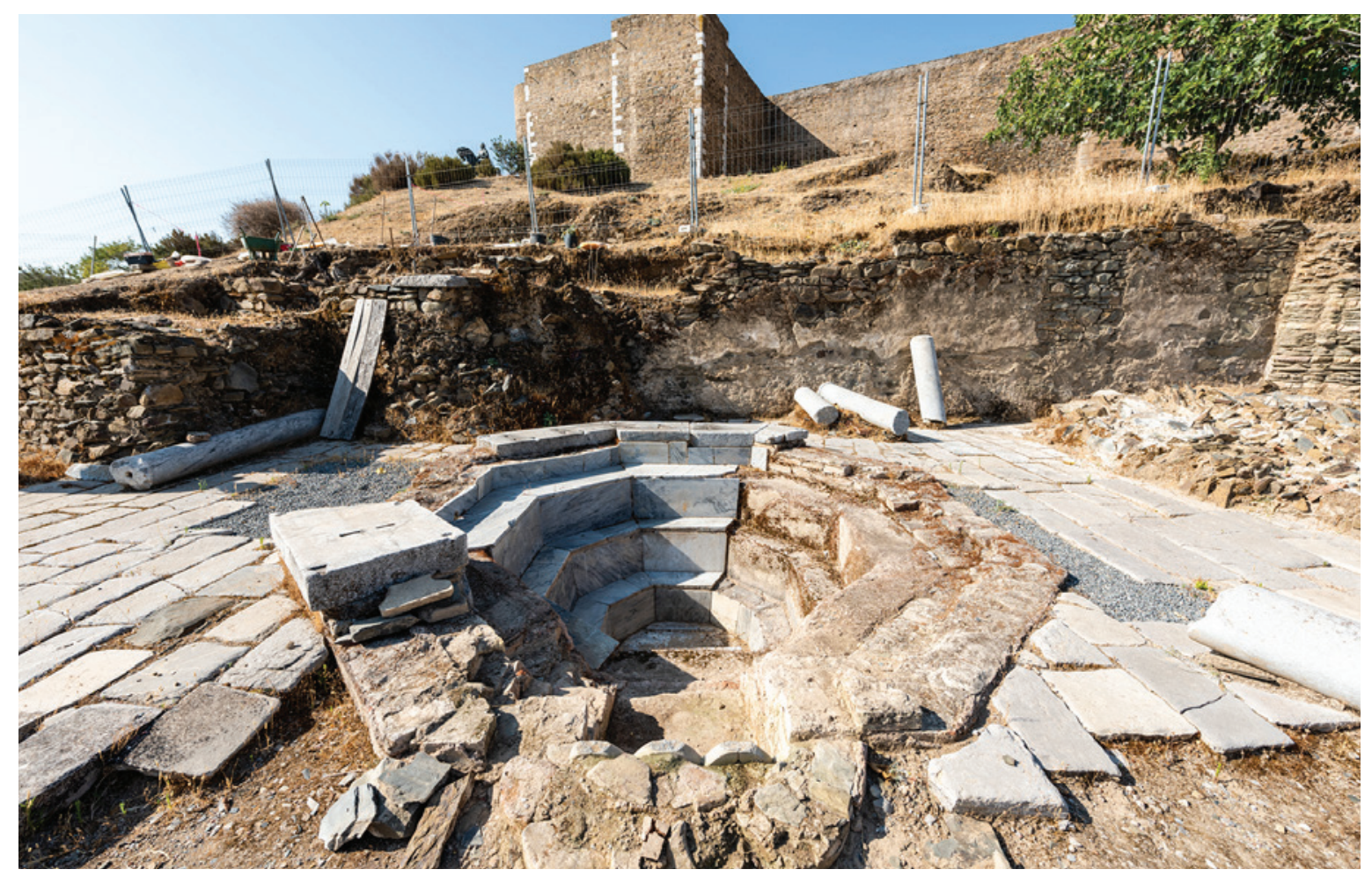

Figura 9 - Batistério II (Jorge Branco CMMértola). 

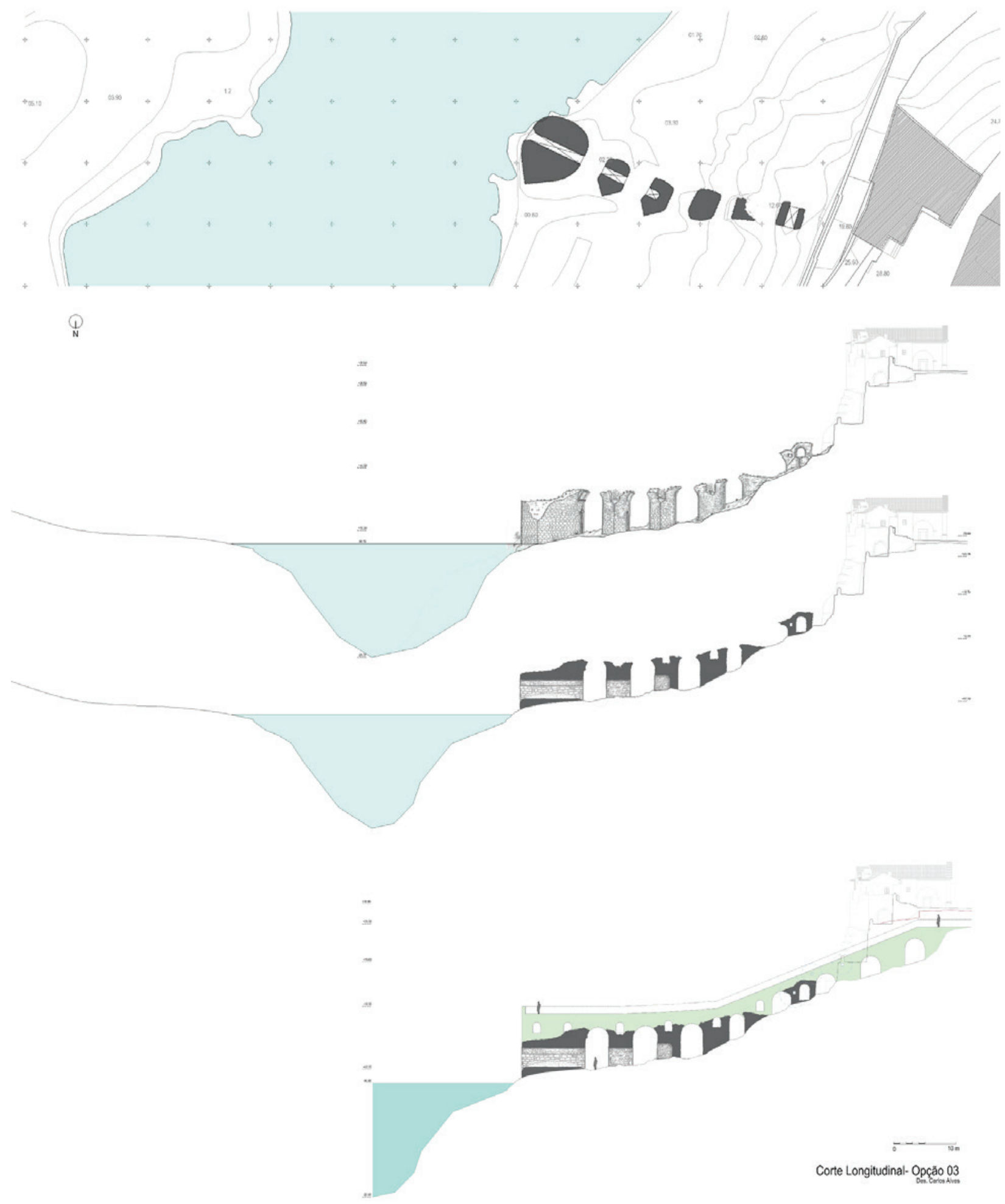

Figura 1o - Torre do Rio (desenho Carlos Alves). 


\section{8
Época Medieval \\ 8

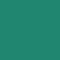

(n)

(

$\varepsilon$

(ृ)

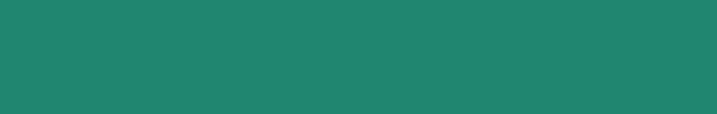

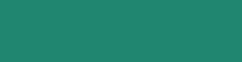

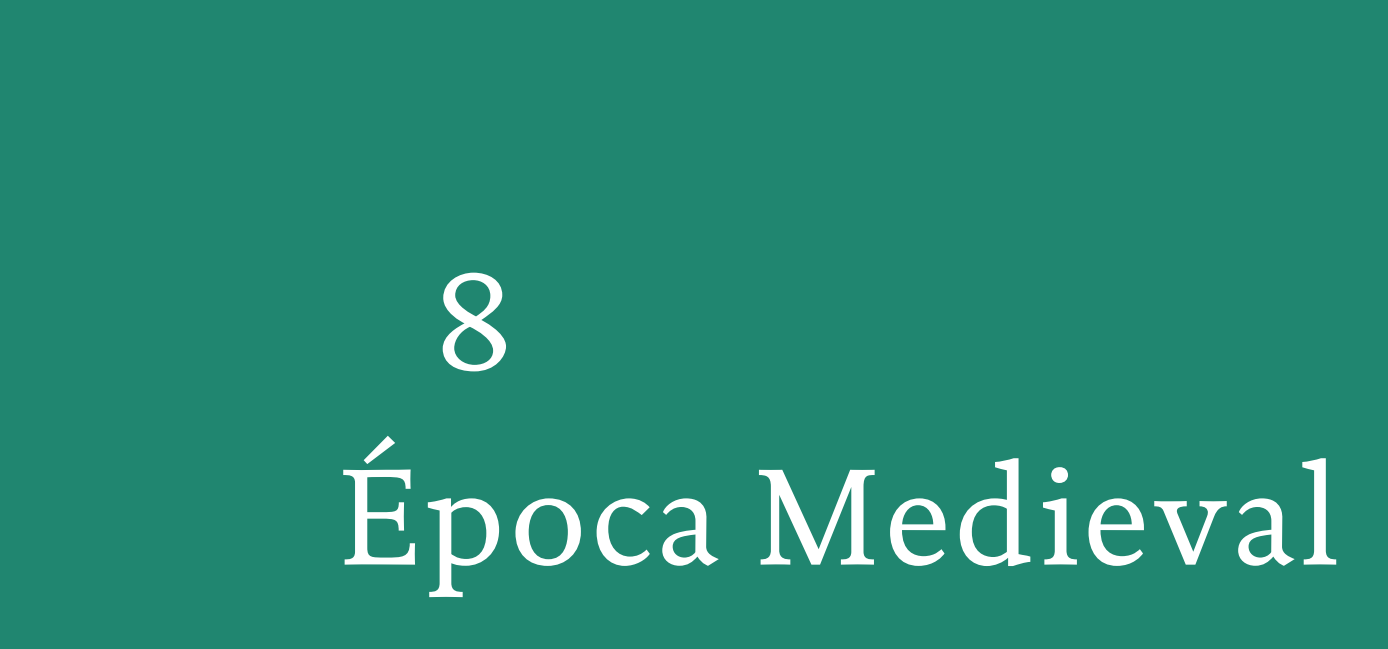




\title{
CERÂMICAS ISLÂMICAS NO GARB SETENTRIONAL "PORTUGUÊS": ALGUMAS EVIDÊNCIAS E INCÓGNITAS
}

Constança dos Santos ${ }^{1}$, Helena Catarino ${ }^{2}$, Susana Gómez ${ }^{3}$, Maria José Gonçalves ${ }^{4}$, Isabel Inácio ${ }^{5}$, Gonçalo Lopes ${ }^{6}$, Jacinta Bugalhão $^{7}$, Sandra Cavaco ${ }^{8}$, Jaquelina Covaneiro ${ }^{9}$, Isabel Cristina Fernandes ${ }^{10}$, Ana Sofia Gomes ${ }^{11}$

\begin{abstract}
RESUMO
O presente artigo apresenta uma primeira síntese da presença de cerâmicas islâmicas no território setentrional do Garb “português” partindo da pesquisa bibliográfica, com o objectivo de expor e discutir as presenças / ausências de cerâmicas correlacionáveis com protótipos islâmicos entre os séculos VIII e XII, comparando as realidades conhecidas a norte e a sul do Douro. A partir do seu mapeamento tentar-se-á definir e caracterizar realidades geográficas e de povoamento, com particularidades relativas à sua maior ou menor relação com o mundo islâmico, contribuindo assim para a definição de um limite territorial do Garb al-Andalus a partir dos dados arqueológicos.
\end{abstract}

Palavras-chave: Cerâmica islâmica, Marca Inferior, Distribuição, Fronteira.

ABSTRACT

This paper presents a first synthesis about the presence of Islamic ceramics in the northern territory of the "Portuguese" Garb, based on bibliographic research, with the aim to expose and discuss the material presence / absence of Islamic prototypes between the $8^{\text {th }}$ and $12^{\text {th }}$ centuries, comparing the realities known in the north and south of the Douro River. From its mapping, an attempt will be made to define and characterize geographic and population realities, with particularities related to their greater or lesser relation with the Islamic word, thus contributing to the definition of a territorial limit of Garb al-Andalus from archaeological data.

Keywords: Islamic Ceramics, Lower March, Distribution, Frontier.

\footnotetext{
1. CIGA*; constancavs@gmail.com

2. CIGA* / Universidade de Coimbra; hcatarino@fl.uc.pt

3. CIGA* / Universidade de Évora / Campo Arqueológico de Mértola; susanagomez@sapo.pt

4. CIGA* / Município de Silves; maria.goncalves@cm-silves.pt

5. CIGA* / Direcção-Geral do Património Cultural; isabelminacio@gmail.com

6. CIGA*; g.simoeslopes@gmail.com

7. CIGA* / Direcção-Geral do Património Cultural; jacintabugalhao@gmail.com

8. CIGA* / Câmara Municipal de Tavira; scavaco@cm-tavira.pt

9. CIGA* / Câmara Municipal de Tavira; jaquelinacovaneiro@hotmail.com

10. CIGA* / Museu Municipal de Palmela; isacrisff@gmail.com

11. CIGA* / Direcção-Geral do Património Cultural; agomes@dgpc.pt

* Grupo de Estudo sobre Cerâmica Islâmica do Garb al-Andalus. ciga.portugal@gmail.com. Centro de Estudos em Arqueologia, Artes e Ciências do Património.
} 


\section{INTRODUÇÃO}

Quando pensamos em cerâmica islâmica no Garb setentrional português deparamo-nos com um quase vazio de evidências para um território de enormes dimensões, integrado na Marca Inferior. Procurar essas evidências, nomeadamente na bibliografia, continua a ser uma tarefa difícil. Por um lado, pelas próprias características intrínsecas de um território de fronteira, como espaço de coexistências, onde a presença de comunidades muçulmanas seria diminuta e descontínua; por outro lado, porque quando se estuda a Alta Idade Média é, sobretudo, para realçar a "reconquista" e a importância, a partir do século IX, do repovoamento asturo-leonês, permanecendo um défice de conhecimento sobre o século VIII e a maior parte dos seguintes. Deve salientar-se que a presença de cerâmicas islâmicas não é sinónimo directo de domínio islâmico ou presença de comunidades muçulmanas, sendo múltiplas as explicações possíveis para a presença de cerâmicas oriundas do Sul ou produzidas sob influência cultural do Sul nestes territórios de fronteira.

Com este trabalho pretendemos, assim, apresentar uma síntese das cerâmicas que conseguimos rastrear, eventual ou seguramente correlacionáveis com a cultura material islâmica e, principalmente, reconhecer o muito que há ainda por pesquisar. Se é certo que, no Entre-Minho-e-Douro, a presença de vestígios arqueológicos islâmicos é quase nula, sendo também escassas as referências nas fontes documentais, para o Vale do Douro, a toponímia pode ajudar-nos a colmatar ausências de testemunhos arqueológicos. Ainda assim, mesmo sendo esporádicas e pouco explícitas, as referências bibliográficas aludem a alguns materiais que pretendemos indagar. Para sul do Douro, começa a entender-se melhor a presença de cerâmicas islâmicas que convivem com produções locais/regionais de matriz moçárabe. Contudo, salvo o caso de Coimbra e, pontualmente, de outros casos do Centro português, as evidências materiais publicadas continuam a ser muito desiguais e nem sempre seguramente indexáveis às produções cerâmicas inequivocamente islâmicas ou de influência islâmica.

Partindo do exposto, apresentamos uma primeira aproximação às presenças/ausências de cerâmicas correlacionáveis com protótipos islâmicos entre os séculos VIII e XII, no território em análise, comparando as realidades conhecidas a norte e a sul do Dou- ro. A partir do seu mapeamento tentaremos definir e caracterizar realidades geográficas e de povoamento, com particularidades relativas à presença islâmica.

\section{O GARB SETENTRIONAL OU TAGR-AL-ADNÀ}

O Garb Setentrional ou Tagr-al-Adnà (a Marca Inferior) define-se, essencialmente, pela sua condição de território de fronteira, encerrando todas as vicissitudes e dinâmicas que a circunstância implica. Esta vasta área, que num primeiro momento tinha como limite sul o vale do Tejo e a norte chegava à bacia do Douro, actuou como território limítrofe entre o al-Andalus e o mundo cristão. Podemos entender esta zona de fronteira, que separava os espaços geopolíticos do Sul islâmico dos do Norte cristão, como uma área de limites difusos, encontrando-se marcada pelos avanços e retrocessos dos reinos cristãos do Norte e do poder do Sul islâmico, aliados a um controlo territorial por vezes igualmente difuso. Deste modo, temos um território dinâmico, muito permeável, onde as fronteiras políticas não se encontram bem delimitadas, alterando-se em função dos equilíbrios de forças de cada soberano e dos poderes locais.

A escassez de fontes e de estudos arqueológicos que encontramos para a região em causa, não nos permite um conhecimento consistente da sua organização territorial. No entanto, sabemos que, a norte do Tejo, a conquista islâmica fez-se, maioritariamente, através de pactos de capitulação e as principais cidades entregaram-se sem luta. Deste modo, é lógico pensar que o novo domínio muçulmano, estabelecido a partir da conquista de 711, não pressupôs mudanças bruscas no ordenamento territorial, social e económico desta vasta área de fronteira, mantendo-se as unidades administrativas existentes. As antigas dioceses visigodas correspondem agora, grosso modo, às novas províncias administrativas, onde os centros urbanos, herdeiros da cidade visigótica, exercem um poder central mais ou menos activo. Contudo, mesmo dentro da sua fragilidade, estes serão essenciais como polos organizadores do território, segundo as directrizes emanadas do poder de Córdova, assentando a ocupação desta vasta área de fronteira, maioritariamente, num povoamento de carácter rural, disperso e de fraca intensidade. Organizando-se em grupos de vizinhos: villa / "aldeia" / alcaria e em pequenos casais agrícolas, o mundo rural estrutura-se 
em enclaves fortificados (castrum / hisn e talaiya), que eram vigilantes das "paisagens" que defendiam. Os husun tornam-se centros de novos distritos rurais islâmicos, fixando sobre o terreno o controlo e a delimitação destes. Estas comunidades rurais mantêm-se semi-autónomas relativamente ao poder central, assimilando de forma mais ou menos intensa a cultura islâmica, mas mantendo-se essencialmente cristãs. Há ainda a considerar, igualmente, a presença de muladís e de grupos de berberes. Verificamos, assim, uma pluralidade social e cultural que caracteriza esta extensa área fronteiriça, onde os poderes cristãos e islâmicos nem sempre gozaram de um controlo efectivo, num espaço de coexistências sociais e culturais, plasmadas nas suas materialidades, de caracterização complexa.

\section{TERRITÓRIO E CARTA ARQUEOLÓGICA}

O extenso território que constituía a Marca Inferior, ou Tagr-al-Adnà, como já referimos, estendia-se, num primeiro momento, desde o vale do Tejo até à bacia do Douro, chegando mesmo a alcançar áreas a norte deste rio. Contudo, em meados do século IX, o limite norte vai abandonar a região do Douro localizando-se, agora, no sistema central (Serra da Gata - Malcata -Estrela). A sul, no vale do Tejo, a estrutura política islâmica é mais estável e os dados arqueológicos são mais abundantes e melhor reconhecíveis no terreno. Partindo destas diferenças mais marcantes em termos arqueológicos, uma vez que um tão extenso território contém, necessariamente, inúmeras realidades e diversidades, considerámos os seguintes limites territoriais: a norte a bacia do Douro (em ambas as margens), a leste, e apenas por questões práticas, a actual fronteira com Espanha, e a sul a Serra de Aires e Candeeiros. Considerando a parca informação que encontramos nas fontes escritas, quer cristãs quer muçulmanas, relativamente a este território, torna-se necessário procurar os traços dessa presença noutros marcadores, diferentes das fontes tradicionais. Para tal são essenciais os dados que a arqueologia nos pode fornecer, sendo nestes que o presente estudo se baseia. Contudo, tendo presente as características já referidas destes territórios de fronteira, surgem muitas questões quanto aos indícios materiais da frequência e/ou permanência de grupos muçulmanos e quanto à interpretação de cerâmicas eventualmente originárias de territórios islâmicos ou produzidas sob influência destas. A actividade arqueológica (prospecção e escavação) tem fornecido apenas pontualmente dados relativamente a sítios com vestígios materiais eventualmente correlacionáveis com a ocupação islâmica, ou onde se exumaram cerâmicas que reflectem uma filiação nos contactos culturais e comerciais com o al-Andalus. O presente estudo organiza-se de norte para sul, partindo da bacia do Douro (no seu lado norte) até, como já referido, à Serra de Aires e Candeeiros, a sul, tendo como base a análise exaustiva da bibliografia arqueológica.

\subsection{Território a norte do Douro}

Relativamente ao território a norte do Douro, é notória a escassez de vestígios relacionáveis com a presença islâmica, que não chegou a ser efectiva, embora se encontrem evidentes marcas na toponímia da região e as fontes refiram o estabelecimento de grupos berberes Masmuda na zona do Porto e em Trás-os-Montes (Figura 1 e Figura 2).

Neste contexto, na última fase de ocupação da Quinta do Paço Velho (Ponte de Lima, Viana do Castelo), dos séculos VII/VIII, foi identificada cerâmica cujas características as integram entre exemplares islâmicos de época emiral (Brochado, 2004, fig. 42, 끌), nomeadamente púcaros de bordo direito arredondado e colo recto ou levemente curvo, e um jarro de colo alto, com moldura em carena a meio deste, encontrando-se exemplares idênticos em contextos meridionais, como Mérida, Cáceres e Málaga.

$\mathrm{Na}$ margem direita do rio Sabor, no Cemitério dos Mouros (Cilhades, Felgar, Torre de Moncorvo), foi identificado um importante conjunto de materiais cerâmicos datáveis entre os séculos VIII e XI, que indicia marcado cariz islâmico emiral/califal, convivendo com outros materiais que podemos adscrever ao mundo cristão (Rosselló et alii, 2016). Neste conjunto verifica-se a quase exclusividade da cerâmica comum, tendo sido identificado apenas um fragmento vidrado, informe, cujas características da pasta e do próprio vidrado sugerem horizontes cronológicos emirais. Prevalecem os fabricos a torno, embora se afiram algumas produções manuais/ torno lento. Entre as peças decoradas é de salientar a presença de pintura a branco, negro ou vermelho (Figura 3). Refira-se um fragmento que associa cordão digitado com pintura branca, numa solução decorativa de síntese, conjugando elementos de cariz islâmico com elementos decorativos comuns ao mundo cristão (Rosselló et alii, 2016, p. 59). 
Destaca-se, também, o candil proveniente de Pedrantil (Croca, Penafiel) (Barroca e Santos, 2005), cujas características apontam para cronologia califal. Tratando-se de uma peça isolada e sem contexto arqueológico conhecido, poderá remeter para os contactos comerciais e civilizacionais entre estas populações de fronteira.

Por último, no Castelo de Aguiar de Sousa, o célebre hisn Aquilar sobre o Douro, conquistado por Almançor, cuja tipologia se afasta dos castelos roqueiros cristãos (Silva, 2008), a par das cerâmicas de adscrição cristã, encontramos alguns exemplares que podem remeter para o mundo islâmico, nomeadamente uma peça de pasta clara e moldura no colo (Fonseca, 2014, p. 51, fig. 145).

\subsection{Território a sul do Douro}

A sul do Douro a escassez de dados arqueológicos é semelhante à encontrada a norte, pois, salvo alguns casos, como Coimbra, é muito pouca a informação disponível. As fontes da época são parcas em informação, não existe investigação arqueológica dedicada a estas problemáticas e são raros os estudos centrados no intervalo cronológico relativo às realidades históricas aqui analisadas (Figura 1 e Figura 2).

Assim, no distrito de Aveiro, no Castelo de Santa Maria da Feira foi identificado um conjunto de cerâmica comum, alguma ostentando pintura a branco ou a vermelho, e ainda um bico de candil (Figura 3), datável de finais do século IX ou primeira metade do $\mathrm{X}$, convivendo com cerâmica caracteristicamente cristã, nomeadamente panelas de pastas cinzentas, cozeduras redutoras e asas puncionadas (Teixeira e Fonseca, 2002/2003).

Verificamos realidade idêntica no Castro de Valinhas/Castelo de Arouca, de onde é proveniente um conjunto de materiais com características islâmicas, nomeadamente alguns fragmentos com pintura e outros com vidrados verdes e verde-melados sobre pintura a manganés (Silva e Ribeiro, 2015, p. 316; Silva e Ribeiro, 2014; Silva. 2011, p. 8), a par de outros de cariz cristão.

Em Viseu, cidade que se rendeu por pacto de capitulação, destaca-se um conjunto de cerâmica com cronologia dos séculos X/XI-XII, de aparentes características islâmicas, proveniente do Pátio do Museu Grão Vasco (Rodrigues, 2014). Trata-se de cerâmica de fabrico a torno rápido e cozedura oxidante. A nível decorativo temos os púcaros de colo alto e cilíndrico com caneluras, a pintura a branco e a aplicação de engobe vermelho ou cinzento sobre superfícies vermelhas.

Em meio rural, mas ainda dentro do actual distrito de Viseu, são de referir dois povoados fortificados. O Castro de Mogueira/São Martinho de Mouros (Resende), onde, para além de um dedal mitriforme de bronze com paralelos no mundo islâmico, foi recolhida cerâmica decorada com incisões, cordões plásticos e alguns fragmentos com vidrado melado (Santos, 2012, p. 468). Seguindo a mesma dinâmica de convivência entre o mundo cristão e o mundo islâmico, assinalamos o sítio de Nossa Senhora do Barrocal (Sátão), onde foi identificado um conjunto de peças oriundas do mundo islâmico, nomeadamente os vidrados (verde e manganés, melado, melado e manganés e vidrado a verde plúmbeo) e ainda alguns fragmentos de pequena dimensão de peças pintadas a negro e a branco (Tente et alii, 2018, p. 278). Segundo os autores, estes materiais “( ...) revelam, sem sombra para dúvidas, ligações entre as populações da região viseense com o Sul islamizado. As mesmas podem ainda traduzir materialmente a capacidade de aquisição de peças em mercados onde produtos fabricados no mundo islâmico eram vendidos" (Tente et alii, 2018, p. 279).

No Castelo de Trancoso, sobretudo em torno da Torre de Menagem, foi identificado um importante conjunto de peças filiadas em produções islâmicas, nomeadamente cerâmica pintada a branco e vidrados melados com ou sem traços de manganés (Figura 3 ). Associado a estes materiais, encontra-se, igualmente, um vasto acervo cerâmico de cariz cristão (Ferreira et alii, 2012, p. 18). Neste conjunto, datável entre os séculos VIII e o século XII, predominam os fabricos manuais ou a torno lento e a torno incerto, maioritariamente de cozedura oxidante. Os tratamentos de superfície vão do simples alisamento ao brunido em espatulado, podendo apresentar motivos incisos, cordões plásticos, caneluras e ainda traços pintados a branco (Ferreira et alii, 2012, p. 18).

Na cidade da Guarda, surge um conjunto de cerâmicas, cujos elementos decorativos, tecnológicos e morfológicos apontam para os séculos X-XI. Pontuam panelas de bordos extrovertidos e colos estreitos, cântaros de asas de fita decoradas, com pastas grosseiras de cor acastanhada, creme e alaranjadas. Entre estas, foi identificada uma asa de pasta creme-alaranjada, decorada com traços de engobe branco, que permite especular sobre a presença islâmica na Guarda (Osório, 2004, p. 10). 
Por fim, assinalamos um conjunto de pequenos aglomerados, predominantemente fortificados, situados na região do Alto Mondego (Tente, 2010). Destes povoados, salientamos Soida (Guarda e Celorico da Beira), S. Gens (Celorico da Beira), Castro de Santiago (Fornos de Algodres), Penedo dos Mouros (Gouveia) e Monte Aljão (Gouveia). Na Soida, cujo topónimo de origem muçulmana remete para um local elevado, foi identificada cerâmica medieval maioritariamente oxidante: pastas laranjas, avermelhadas, castanhas-avermelhadas e rosadas, com cronologia entre o século IX e o X. S. Gens apresenta um conjunto cerâmico com algumas peças que remetem para o mundo mais meridional, como, por exemplo, o jarro/púcaro de colo canelado (Souza, 2013, p. 75, fig. 23). No Monte Aljão surge cerâmica com pintura branca, nomeadamente um fragmento de gargalo com arranque de asa, fabrico a torno rápido e cozedura oxidante (Tente, 2010, p. 73 e 109, fig. IV.1.33, n.os 4 e 20). A ocupação medieval do Castro de Santiago (Tente, 2010, p. 330) forneceu uma peça com pintura vermelha na asa, atribuída a época tardo-romana (Tente, 2010, p. 333). Não havendo qualquer outro indício de ocupação romana neste sítio, poderá tratar-se de uma peça islâmica, onde este tipo de produção se encontra difundido a partir do século IX. Por fim, no Penedo dos Mouros, foi identificado um conjunto de peças, entre as quais panelas com cordões plásticos e incisões, jarros com bico "pinçado", alguns fragmentos de cerâmica pintada e uma peça de pasta distinta das restantes e caneluras no colo (Tente, 2010, p. 151 e 198, fig. IV.4.29, n. .66$)$. Os dados recolhidos indicam que alguns destes sítios do Alto Mondego foram abandonados na segunda metade do século $\mathrm{X}$.

No eixo Serra da Estrela/Cova da Beira e seguindo para sul, no distrito de Castelo Branco, temos como referência fundamental a cidade de Laydâniyya (Idanha-a-Velha). Após a conquista islâmica esta cidade terá mantido o seu papel político-administrativo.É identificada nas fontes durante o emirato como uma kura, com, pelo menos, quatro distritos ou iqlim, podendo intuir-se que os seus termos territoriais terão sofrido poucas alterações, pelo menos até finais do século IX, momento em que Córdova perde a vinculação política com os territórios a norte do Tejo. Não há qualquer referência a esta região durante o califado. Sabemos que à região da Egitânia chegaram diferentes grupos de origem berbere, como os Miknasa e os Mas.muda dos Banu Tayit, e que esta zona se viu envolvida em numerosas revoltas, destacando-se as de Ibn Marwan, muladí emeritense, que convulsionaram todo o território durante um período considerável. São factores que marcaram a região, em cuja população se incluíam, à semelhança de praticamente toda a Marca Inferior, elementos de algumas tribos berberes, muladís e moçárabes.

Relativamente aos dados arqueológicos, foi recolhido em Idanha-a-Velha um significativo conjunto de materiais hispano-muçulmanos (Sánchez Hidalgo et alii, 2018). Trata-se de um variado grupo de cerâmicas, destinadas a diferentes usos, como a preparação de alimentos, armazenamento, iluminação, transporte. A maioria das peças possui decorações comuns no mundo islâmico, isto é, pintura (branca, negra ou vermelha), aplicações plásticas, incisa e vidrada, por vezes combinadas. Em síntese, o conjunto cerâmico revela características habituais no mundo islâmico, concretamente entre os séculos $\mathrm{X}$ e XI (Sánchez Hidalgo et alii, 2018, p. 744).

Um pouco mais a norte, integrando o vasto espaço do agora território da kura Laydâniyya, encontra-se a Capela de São Pedro da Capinha (Fundão), onde foram exumados compartimentos habitacionais e um silo, sendo proveniente deste contexto um conjunto de material cerâmico datado de período emiral (Santos e Albuquerque, 2015). Trata-se exclusivamente de cerâmica comum de reduzida variedade formal, destacando-se os grandes contentores que se dividem em dois grupos coexistentes: aqueles que podemos considerar como herdeiros dos dolia, possuindo bordo introvertido praticamente indiferenciado da pança, e as talhas ou grandes potes, de bordo moldurado, por vezes ainda ligeiramente introvertido. Os fabricos são maioritariamente a torno lento, predominando as cozeduras oxidantes. No que respeita à decoração, as caneluras constituem a principal técnica decorativa relativamente à cerâmica de menores dimensões, sendo a decoração incisa, nomeadamente a pente, impressa e aplicada, exclusiva dos grandes contentores, alguns dos quais se apresentam profusamente decorados, por vezes conjugando diferentes técnicas (Figura 3). Pode tratar-se de um conjunto cerâmico de transição entre o mundo visigótico e o emiral, onde se identificam as influências e perdurações típicas do reportório formal romano-visigótico convivendo com peças claramente inovadoras (Santos e Albuquerque, 2015, p. 921).

A norte de Laydâniyya, no Castelo de Belmonte, 
foram reconhecidas cinco fases de ocupação, correspondendo a primeira fase a um momento anterior ao actual edifício do século XIII. Deste período mais antigo foram descobertos restos de estruturas habitacionais, quatro silos e alguns materiais cerâmicos, entre os quais destacamos uma bilha decorada com caneluras na parte superior do bojo e pintura a branco, cuja cronologia foi atribuída aos séculos XII/XIII (Marques, 2000, p. 266 e fig. 17).

$\mathrm{Na}$ Casa da Torre (Caria, Belmonte), foi recolhido abundante espólio, salientando-se um conjunto de cerâmica medieval com características possivelmente islâmicas, como alguns melados com ou sem traços de manganés e o fragmento de um possível jarro, de pasta creme, bem depurada, com esmalte de cor verde (Robalo, 2008, p. 194). Estes materiais coexistem com outros que podemos adscrever ao mundo cristão, nomeadamente recipientes com asas puncionadas. A cronologia indicada situa-se entre o século XII e o XIII, contudo, alguns paralelos apontados podem recuar a cronologia de algumas destas peças ao século XI.

Em Castelo Novo (Fundão) foi recolhido um conjunto significativo de materiais cerâmicos enquadráveis nos séculos XIII e XIV, referindo-se a existência de exemplares vidrados de cor verde, alguns dos quais com decoração estampilhada. Destaca-se um fragmento de parede com arranque de asa que mostra pequeno botão, compatível com produções islâmicas datáveis dos séculos XII/XIII (Silvério e Barros, 2005, p. 59).

Do Castelo de Penamacor, cujo topónimo parece ter fossilizado o nome de Ibn Nakur, um dos rebeldes da fitna de finais do século IX (Catarino e Santos, 2012: 11), é proveniente o fragmento de uma taça decorada a corda seca total, com motivo do cordão da felicidade, ou da eternidade, tema que embora nos remeta para uma filiação islâmica dos séculos XII/ XIII, poderá ser, segundo os autores, "compatível com os modelos mudéjares” (Silvério et alii, 2004, p. 488 , fig. $16, \mathrm{n}^{\circ} 39$ ).

A sul de Laydâniyya, entre o rio Zêzere e a Ribeira da Isna, situa-se o enclave do hisn da Sertã, onde foram identificadas várias fases de ocupação (Batata, 1998; Batata 200o, p. 435-437), salientando-se uma fundição de ferro e cerâmica com cronologias do século X/XI de características islâmicas. Trata-se de cerâmica comum, de pastas e superfícies castanhas e avermelhadas, algumas decoradas com motivos pintados a branco, nas tradicionais formas de pane- las de bordo triangular e púcaros de colo canelado (Batata, 2000, Est. IV).

No Castro de S. Miguel da Amêndoa (Vila de Rei/ Mação), identificaram-se estruturas habitacionais, às quais se encontrava associado um conjunto de materiais cerâmicos, cujas características podem remeter para o período islâmico, embora na época tenham sido datadas do século II a.C. (Bubner e Bubner, 1993, p. 37-40). Trata-se de peças de cor alaranjada, fabrico a torno, normalmente sem decoração, embora, por vezes, apresentem caneluras, incisões e cordões plásticos (Figura 3). Estas peças aproximam-se formalmente, entre outros, de exemplares de Coimbra e Santa Olaia (Montemor-o-Velho), aqui em contextos dos séculos X/XII.

Por fim, da cidade de Castelo Branco, temos notícia de algumas peças de cariz islâmico, nomeadamente um bico de candil, cuja forma larga e curta denuncia a sua cronologia tardia, apontando para meados do seculo XII (Boavida, 2013, p. 962 e 965, fig. 4). Do castelo são provenientes materiais medievais, entre os quais alguns fragmentos de cerâmica com pintura branca (Boavida, 2015, p. 910).

Na região do Baixo Mondego, a cidade de Coimbra, uma das principais cidades da Marca Inferior, cujas fontes árabes indicam que capitulou a Abd al-Aziz em 714/715, terá, possivelmente, correspondido a uma cidade-território, centro de um 'amal não militarizado. Agora designada como Madinat Qulumriyya, terá sido o centro de um vasto território herdado da anterior diocese (Catarino, 2008, p. 135). Embora a população fosse maioritariamente moçárabe, também se instalaram no território de Coimbra grupos de berberes, como os Masmuda e os Sadfura, sobre os quais nos informam as mesmas fontes (Catarino, 2008, p. 137). Desde a capitulação até 1064, altura em que cai definitivamente em administração do poder cristão, a história do governo das terras de Coimbra vai ser pontuada, como em todo o território de fronteira, por uma alternância de poderes entre cristãos e muçulmanos, reflectida na cultura material que parece evidenciar coexistência de cerâmicas do "mundo cristão" e do "mundo islâmico". São conhecidos importantes vestígios da ocupação da cidade em período islâmico no Museu Machado de Castro e zonas adjacentes (Silva 2014; Silva 2015), e nos espaços da Universidade de Coimbra, particularmente no Pátio das Escolas da Universidade de Coimbra, no Colégio da Trindade e no Largo D. Dinis (Catarino et alii, 2009). A cerâmica recolhida 
atesta uma ocupação centrada na época califal / taifas (séculos X/XI) prolongando-se algumas formas e decorações até ao século XII (Figura 3). Sendo notório o predomínio da cerâmica comum de cozedura oxidante, podem ostentar pintura a negro, vermelho ou branco. A presença de cerâmica vidrada é assinalável, relacionando-se com importações de diversas regiões do al-Andalus. Estão representados os melados, os melados com traços de manganés, o verde e manganés, a corda seca parcial e a corda seca total, sendo ainda de referir a presença de dois fragmentos de louça dourada (Catarino et alii, 2009, p. 353).

Em Conimbriga (Condeixa), antiga diocese visigótica, além da recolha de moedas e dos enterramentos muçulmanos, há também a referir a cerâmica, nomeadamente, entre outras, as cerâmicas pintadas a branco e os púcaros de colo canelado (De Man et alii, 2014), indício da presença islâmica nessa antiga cidade.

Ainda em Condeixa, no Paço da Ega (Condeixa) foi exumado um conjunto cerâmico de características islâmicas, que reportam a horizontes cronológicos dos séculos X-XI. Constitui-se como um conjunto muito homogéneo, de pouca variedade formal e predomínio das formas fechadas. Relativamente aos modelos decorativos, denota-se a utilização da pintura a branco como técnica dominante (Revez, 2012, p. 52). Em Montemor-o-Velho, o período muçulmano está comprovado pelos vestígios arqueológicos, nomeadamente cerâmica com pintura branca, um capitel e estuques trabalhados (Barroca, 2005, p. 115), com paralelos califais/taifas, lápides moçárabes e uma inscrição árabe (Penajoia, 2014, p. 246-247).

O outeiro de Santa Olaia (Figueira da Foz) forneceu um conjunto de cerâmicas de cariz cristão coexistentes com cerâmicas de pastas oxidantes, com superfícies polidas, engobadas e pintadas em bandas a branco (Figura 3), possivelmente importadas do Sul do Garb al-Andalus, que se enquadram nas épocas emiral/califal e reinos de taifas. É ainda de referir a presença de peças que conjugam particularidades de filiação cristã e islâmica (Nazaré, 2013, p. 86-87).

Já no distrito de Leiria, há a referir um conjunto de candis e pesos de tear, ainda por publicar, alguns com indícios de vidrado (Figura 3), datável dos séculos $\mathrm{X} / \mathrm{XII}$, provenientes de Ansião (Pombal) ${ }^{12}$. Trata-se de peças sem contexto arqueológico, mas importantes enquanto reveladoras dos contactos existentes.

12. Colecção Padre José Eduardo Coutinho.
No Castelo de Leiria foram realizados trabalhos arqueológicos na Torre de Menagem, daí resultando alguns testemunhos eventualmente islâmicos, nomeadamente escassos fragmentos de cântaros e púcaros, destacando-se os motivos decorativos em caneluras e os pintados a branco, com cronologia de "inícios do Califado, ou mesmo ainda do Emiral" (séculos IX/X) (Lopes, 2001, p. 33). Nos estratos seguintes assinalou-se igualmente a presença de cerâmica com formas e decorações próprias dos modelos que acompanham a reconquista cristã. $\mathrm{Na}$ envolvente do castelo, nomeadamente no interior da primeira linha de muralha, foram exumados alguns fragmentos cerâmicos possivelmente atribuíveis a produção islâmica. O conjunto merece alguma cautela, pois se alguns materiais poderão ser classificados de época emiral/califal, outros apenas poderão ser genericamente considerados islâmicos. Após 1135 o Castelo esteve efectivamente ocupado por tropas muçulmanas em dois períodos muito próximos no tempo, até à sua conquista pelos cristãos por volta de 1140/1142. Os vestígios referidos podem relacionar-se com estas ocupações (Carvalho e Inácio, 2013, p. 162).

O sítio Quinta da Granja I (Maiorga, Alcobaça) forneceu recipientes de cariz utilitário sobretudo para cozinhar e também para transportar/servir alimentos à mesa e armazenagem. A maioria dos fragmentos cerâmicos de cariz islâmico pertence a formas fechadas, principalmente panelas ou potes, jarros, jarrinhas, cântaros e talhas (Figura 3). Globalmente, o espólio pode integrar-se na Alta Idade Média, entre os séculos VII e IX, parecendo reunir influências visigóticas e emirais (Gonzalez, 2013, p. 916).

Já no distrito de Santarém, no limite geográfico aqui em estudo, há a referir Tomar e Torres Novas. Tomar possui evidências de ocupação nos séculos IX-X e no forum de Sellium/Tomar, foi encontrada uma moeda coetânea da conquista islâmica. Relativamente às cerâmicas, não foram ainda recuperados exemplares correlacionáveis claramente com produções islâmicas.

Em Torres Novas foram identificadas estruturas habitacionais, silos e lixeiras de época islâmica, das quais são provenientes materiais cerâmicos que podemos colocar em dois momentos cronológicos: um conjunto, tipológica e cronologicamente homogéneo, sem grande diversidade formal, que poderá ser enquadrado nos séculos $\mathrm{X} / \mathrm{XI}$; e outro conjunto com cronologia dos séculos XII/XIII. É de referir a 
presença de um cantil de pasta bege e decoração pintada a vermelho, de produção exógena à região (Lopes, 2007, p. 322).

\section{A SÍNTESE POSSÍVEL}

Neste trabalho procurámos sistematizar os objectos e conjuntos cerâmicos identificados no território hoje português da Marca Inferior, com cronologia entre os séculos VIII e XII, cujas características, de forma mais ou menos evidente, se podem relacionar com as produções cerâmicas islâmicas do Garb al-Andalus, distinguindo-se das comuns e conhecidas naqueles território e cronologia. A realidade observada é ainda bastante difusa em grande parte do território analisado, principalmente na zona mais setentrional. A filiação islâmica das cerâmicas aqui analisadas é evidente nalguns casos e, mais frequentemente, apenas hipotética. A título de exemplo, refira-se a dificuldade na distinção entre cerâmicas alto-medievais visigóticas e emirais; e entre cerâmicas medievais islâmicas e algumas produções tardo medievais cristãs de tradição mudéjar (séculos XIII e XIV). Mais complexa ainda é a interpretação de achados isolados e conjuntos, uma vez que não é fácil relacionar estes materiais com a presença de populações islâmicas ou de cultura islâmica e menos ainda com um domínio islâmico territorial efectivo. Os contactos e as trocas, de natureza diversa, entre cristãos e muçulmanos, neste território, ocorreram decerto durante todo o período em que aqui conviveram, negociaram, viajaram e se confrontaram.

A norte do Douro, embora se identifiquem cerâmicas de cozedura redutora, mais presentes nas áreas de "fronteira" do al-Andalus, verifica-se, igualmente, em pequena escala, o aparecimento de novidades formais e ornamentais. Aliando a diminuta presença muçulmana nestas terras a norte do Douro à ausência de estudos vocacionados para os séculos VIII/IX, bem como ao débil conhecimento dos materiais que caracterizam o período islâmico inicial, deparamo-nos com uma escassez de informação arqueológica superior àquela que as fontes indicam. Deste modo, além de ser imprescindível incrementar as intervenções e os estudos, tendo como objectivo reconhecer a presença islâmica e de materiais islâmicos nestas regiões mais nortenhas da Marca Inferior, é também fundamental a revisão de algumas cerâmicas atribuídas genericamente à Antiguidade Tardia.
A sul do Douro, o "inventário" dos sítios com indícios de presença islâmica ou de contactos com o mundo islâmico denota, tal como acontece para a região mais a norte, as lacunas da investigação, sugerindo uma certa relutância em aceitar a influência islâmica para as áreas setentrionais da "fronteira". Continuam a ignorar-se as evidências toponímicas, que, embora impere a onomástica cristã arabizada, indica a existência de grupos árabes-berberes. Regista-se, igualmente, o desconhecimento do povoamento rural, nomeadamente dos sítios rurais de transição (séc. VII/VIII e séc. VIII/IX). Num território de população predominantemente cristã (pese embora os grupos de berberes que aqui se estabeleceram), em que a conquista se fez sobretudo por pactos de capitulação, e onde os sucessivos movimentos de conquistas e reconquistas impediram uma ocupação islâmica continuada, torna-se muito difícil distinguir no terreno os vestígios que nos deixaram as populações que o habitaram entre os séculos VIII e XII. De qualquer forma, deve referir-se alguma convergência na distribuição dos vestígios arqueológicos e nas referências documentais, essencialmente na fase califal/taifa (Figura 2). Se bem que beneficiando de estudos importantes no que toca à componente moçárabe da população e de abordagens com recurso à toponímia, a caracterização do processo de islamização nestes territórios, particularmente no que concerne aos abandonos e continuidades entre os períodos visigótico e emiral, carece de aprofundamento.

\section{BIBLIOGRAFIA}

BATATA, Carlos (1998) - Carta arqueológica do concelho da Sertã. Sertã: Câmara Municipal da Sertã.

BATATA, Carlos (200o) - Presença árabe no Castelo da Sertã (Centro de Portugal). In Actas do 3. . Congresso de Arqueologia Peninsular, vol. VII - Arqueologia da Idade Média da península Ibérica. Porto: ADECAP, pp. 435-437.

BARROCA, Mário Jorge (2005) - O castelo de Montemor-o-Velho nos séculos X a XIII. In Muçulmanos e Cristãos entre o Tejo e o Douro (Sécs. VIII a XIII). Palmela: Câmara Municipal de Palmela/Faculdade de Letras da Universidade do Porto. Palmela, pp. 111-126.

BARROCA, Mário Jorge (2008-2009) - De Miranda do Douro ao Sabugal - Arquitectura Militar e Testemunhos Arqueológicos Medievais num Espaço de Fronteira. Portugália. Porto. Nova Série, XXIX-XXX, pp. 193-252.

BARROCA, Mário Jorge (2016) - Muçulmanos e Cristãos no Douro português (séc. VIII-XI). In Atas das $4 \cdot{ }^{a s}$ Confe- 
rências do Museu de Lamego. Porto: CITCEM/FLUP. Disponível em: www.museudelamego.pt.

BARROCA, Mário Jorge; SANTOS, Maria José Ferreira dos (2006) - O candil califal de Pedrantil (Croca, Penafiel). In Al-Ândalus espaço de mudança. Balanço de 25 anos de história e arqueologia medievais, Seminário de Homenagem a Juan Zozaya Stabel-Hansen (Mértola 2005). Mértola: Campo Arqueológico de Mértola, pp. 310-317.

BOAVIDA, Carlos (2013) - Castelo de Castelo Branco achados fortuitos nas colecções do Museu Francisco Tavares Proença Júnior. In Arqueologia em Portugal 150 anos. Lisboa: Associação dos Arqueólogos Portugueses, pp. 961-967.

BOAVIDA, Carlos (2015) - Medieval pottery from the Castle of Castelo Branco. In X Congresso Internacional a Cerâmica Medieval no Mediterrâneo (Silves/Mértola, 2012). Silves: Câmara Municipal de Silves / Campo Arqueológico de Mértola, pp. 906-911.

BROCHADO, Cláudio Roberto Laranjeira (2004) - Povoamento tardo-romano e altomedieval na bacia terminal do Rio Lima (séculos IV-XI). Dissertação de Mestrado em Arqueologia apresentada à Faculdade de Letras da Universidade do Porto. Disponível em: https://hdl.handle.net/ $10216 / 15264$.

BUBNER, Maria Amélia Horta Pereira; BUBNER, Thomas (1993) - Castro de São Miguel de Amêndoa. Relatório dos trabalhos 88-89. Arquivo da Arqueologia Portuguesa, DGPC, processo $\mathrm{S}-852$ (documento policopiado).

BUBNER, Maria Amélia Horta Pereira; BUBNER, Thomas (1993a) - O Castro de S. Miguel de Amêndoa (Mação) - Noticia Preliminar das escavações efectuadas. Arquivo da Arqueologia Portuguesa, DGPC, processo S-852 (documento policopiado).

CARVALHO, Vânia; INÁCIO, Isabel (2013) - O Projeto de Investigação Arqueológica do Núcleo do Castelo de Leiria: enquadramento, objetivos e resultados. In Arqueologia em Portugal 150 anos. Lisboa: Associação dos Arqueólogos Portugueses, pp. 157-164.

CATARINO, Helena (2008) - A Marca Inferior em Portugal na época de Almansor: hipóteses de trabalho e os exemplos de Viseu e Coimbra. In La Península Ibérica al Filo del Año 10oo. Congreso Internacional Almanzor y su época (Córdoba, 14 a 18 de octubre de 2002). Córdova: Fundación Prasa, pp. 123-146.

CATARINO, Helena; FILIPE, Sónia; SANTOS, Constança (2009) - Coimbra islâmica: uma aproximação aos materiais cerâmicos. In Actas do 6ํㅡㄹ Encontro de Arqueologia do Algarve. O Gharb no al-Andalus; síntese e perspectivas de estudo. Homenagem a José Luís de Matos (Silves, 2008) (Xelb, 9). Silves: Museu Municipal de Arqueologia/Câmara Municipal de Silves, pp. 333-376.

CATARINO, Helena; SANTOS, Constança dos (2012) - A cerâmica Islâmica da Marca Inferior em território português. Arqueologia Medieval. Porto. 12, pp.7-14.
DE MAN, Adriaan; CORREIA, Virgílio H.; LOVEGROVE, Sofia; ANDRADE, Francisco (2014) - Cerâmica medieval de Conímbriga. In DE MAN, Adriaan; TENTE, Catarina, coord. - Estudos de Cerâmica Medieval - o Norte e Centro de Portugal, séculos IX a XII. Lisboa: Instituto de Estudos Medievais/Faculdade de Ciências Sociais e Humanas/Universidade Nova de Lisboa, pp. 57-68.

FONSECA, Jorge Manuel Vieira (2014) - Relatório Final. Estudo para a Definição da área arqueológica da Torre do castelo de Aguiar de Sousa. Arquivo da Arqueologia Portuguesa, DGPC, processo S - 30326 (documento policopiado).

GONZALEZ, Cristina (2013) - Quinta da Granja I (Maiorga, Alcobaça): novos dados sobre o povoamento da Estremadura na Alta Idade Média. In Arqueologia em Portugal 150 anos. Lisboa: Associação dos Arqueólogos Portugueses, pp. 913-921.

LOPES, Gonçalo (2002) - Cerâmicas medievais da Torre de Menagem do Castelo de Leiria. In Torre de Menagem do Castelo de Leiria. Leiria: Câmara Municipal de Leiria, pp. 32-37.

LOPES, Gonçalo (2007) - Um cantil almóada em Torres Novas. Nova Augusta, Revista de Cultura. Torres Novas. 19, pp. 319-330.

MARQUES, António Augusto da Cunha (2000) - Escavações arqueológicas no castelo de Belmonte (1992-1995). In Actas. Beira Interior Historia e Património. Guarda: Câmara Municipal da Guarda, pp. 253-286.

NAZARÉ, M. J. V. (2013) - Cerâmicas medievais de Santa Olaia (Figueira da Foz) depositadas no Museu Municipal Dr. Santos Rocha. Relatório de Estágio 2 Ciclo/ Mestrado em Arqueologia e Território. DHAA / FLUC. Disponível em: http://hdl.handle.net/10316/23836.

OSÓRIO, Marcos (2004) - Novos contributos para o estudo dos Castelos Velhos (Guarda). Praça Velha. Guarda. 15, pp. 5-15.

PENAJOIA, Marco (2014) - Grafitos, inscrições árabes e outras marcas históricas identificadas no castelo de Montemor-o-Velho. Revista de História da Sociedade e da Cultura. Coimbra. 14, pp. 231-252. Disponível em: http://hdl.handle.net/10316.2/39367.

REVEZ, Ana Lima (2012) - Trabalhos arqueológicos no projecto de recuperação do Paço da Ega (2007-2009). Arqueologia Medieval. Porto. 12, pp. 41-57.

ROBALO, Elisabete Martins (2008) - Escavações arqueológicas na Casa da Torre (Caria - Belmonte). Resultados preliminares. In Actas das I Jornadas de Belmonte. Belmonte: Câmara Municipal de Belmonte, pp. 188-215.

RODRIGUES, Patrícia (2014) - Cerâmicas medievais do Pátio do Museu Grão Vasco (Viseu): elementos para uma sistematização da cerâmica pleno medieval do espaço viseense. In DE MAN, Adriaan; TENTE, Catarina, coord. - Estudos de Cerâmica Medieval - o Norte e Centro de Portugal, séculos IX a XII. Lisboa: Instituto de Estudos Medievais/Faculdade 
de Ciências Sociais e Humanas/Universidade Nova de Lisboa, pp. 141-16o.

ROSSELLÓ, Miquel; SANTOS, Constança; CARVALHO, Liliana; SANTOS, Filipe (2016) - Contributo para o conhecimento das ocupações tardo-antiga e alto-medieval do Vale do Sabor. O caso de Cilhades (Felgar, Torre de Moncorvo), à luz do estudo da sua componente cerâmica. Arqueologia Medieval. Porto. 13, pp. 35-63.

SÁNCHEZ HIDALGO, Fernando; SANABRIA MURILLO, Diego; MORÍN DE PABLOS, Jorge; SÁNCHEZ RAMOS, Isabel María (2018) - La cerámica andalusí de Idanha-a-Velha (Portugal). In VIII Encontro de Arqueologia do Sudoeste Peninsular. Encuentro de Arqueología del Suroeste Peninsular (Serpa/Aroche, 2014). Serpa: Câmara Municipal de Serpa, pp. 741-748.

SANTOS, Maria Constança; ALBUQUERQUE, Elisa (2015) - A Capela de São Pedro da Capinha através dos materiais: a cerâmica medieval. In X Congresso Internacional a Cerâmica Medieval no Mediterrâneo (Silves/Mértola, 2012). Silves: Camara Municipal de Silves / Campo Arqueológico de Mértola, pp. 917-923.

SANTOS, Maria João Correia dos (2012) - La arqueologia, lo imaginario y lo real. El santuario rupestre de Mogueira (São Martinho de Mouros, Portugal). Madrider Mitteilungen. Madrid. 53, pp. 455-496.

SILVA, António Manuel (2011) - No tempo dos Mouros. Castelos de Arouca numa terra de fronteira (séculos IX-XI). Arouca: Câmara Municipal de Arouca.

SILVA, António Manuel S. P.; RIBEIRO, Manuela C. S. (2014) - Cerâmicas do período da reconquista no Vale do Arda: Castelo de Arouca e Casal da Malafaia. In DE MAN, Adriaan; TENTE, Catarina, coord. - Estudos de Cerâmica Medieval -o Norte e Centro de Portugal, séculos IX a XII. Lisboa: Instituto de Estudos Medievais/Faculdade de Ciências Sociais e Humanas/Universidade Nova de Lisboa, pp. 161-182.

SILVA, António Manuel S. P.; RIBEIRO, Manuela C. S. (2015) - Cerâmicas medievais (séc.s IX-XII) do Castelo de Arouca (N. Portugal). In X Congresso Internacional a Cerâmica Medieval no Mediterrâneo (Silves/Mértola, 2012). Silves: Camara Municipal de Silves / Campo Arqueológico de Mértola, pp. 310-317.

SILVA, Maria Antónia (2008) - Torre do Castelo de Aguiar de Sousa: resultados preliminares de uma sondagem arqueológica. Oppidum. Lousada. Número especial, pp. 117-130.

SILVA, Ricardo Costeira da (2014) - A cerâmica dos níveis alto-medievais do fórum de Aeminium (MNMC, Coimbra). In DE MAN, Adriaan; TENTE, Catarina, coord. - Estudos de Cerâmica Medieval - o Norte e Centro de Portugal, séculos IX a XII. Lisboa: Instituto de Estudos Medievais / Faculdade de Ciências Sociais e Humanas / Universidade Nova de Lisboa, pp. 79-98.
SILVA, Ricardo Costeira da (2015) - Medieval pottery from the Forum of Aeminium (Coimbra, Portugal): a proposal of chrono-typological evolution. In X Congresso Internacional a Cerâmica Medieval no Mediterrâneo (Silves/Mértola, 2012). Silves: Camara Municipal de Silves / Campo Arqueológico de Mértola, pp. 739-749.

SILVÉRIO, Silvina; BARROS, Luís de; TEIXEIRA, André (2004) - Escavações arqueológicas no castelo de Penamacor/Cimo da Vila: resultados da primeira campanha (2003). Revista Portuguesa de Arqueologia. Lisboa. 7:2, pp. 497-540.

SILVÉRIO, Silvina; BARROS, Luís de (2005) - Arqueologia no Castelo da Aldeia Histórica de Castelo Novo (20022004) Resultados Preliminares. Fundão: Câmara Municipal do Fundão.

SOUZA, Gabriel Manzoni Venturini (2017) - O sítio alto-medieval de S. Gens (Celorico da Beira). Contributo para o estudo da produção cerâmica identificada nas campanhas realizadas 2011-2013. Dissertação de Mestrado apresentada à Faculdade de Ciências Sociais e Humanas da Universidade Nova de Lisboa. Disponível em: http://hdl.handle. net/10362/20270.

TEIXEIRA, Ricardo; FONSECA, Victor (2002/2003) - Relatório Intervenção Arqueológica. Castelo de Santa maria da Feira. 2002/2003. Arquivo da Arqueologia Portuguesa, DGPC, processo S - 6371 (documento policopiado).

TENTE, Catarina (2010) - Arqueologia Medieval Cristã no Alto Mondego. Ocupação e exploração do território nos séculos V a XI. Dissertação de Doutoramento apresentada Faculdade de Ciências Sociais e Humanas da Universidade Nova de Lisboa. Disponível em: https://run.unl.pt/ handle/10362/4804.

TENTE, Catarina; BAPTISTA, Hugo; TERESO, João Pedro; CÉRCIO, Margarida; VELOSO, João Luís; OLIVEIRA, Cláudia; SEABRA, Luís; MEIRA, Catarina; SOUZA, Gabriel de; CORDERO RUIZ, Tomás; REAL, Manuel Luís (2018) - Senhora do Barrocal (Sátão) na viragem do milénio. Primeira abordagem. In Do Império ao reino. Viseu e o território entre os séculos IV a XII. Viseu: Câmara Municipal de Viseu, pp. 195-263.

VIGUERA MOLINS, Maria-Jesus (1998) - En Torno a Riba Coa y Al-Andalus. In O Tratado de Alcanices e a Importância História das Terras de Riba Côa. Actas do Congresso Histórico Luso-Espanhol (1997). Lisboa: Universidade Católica Editora, pp. 131-152. 


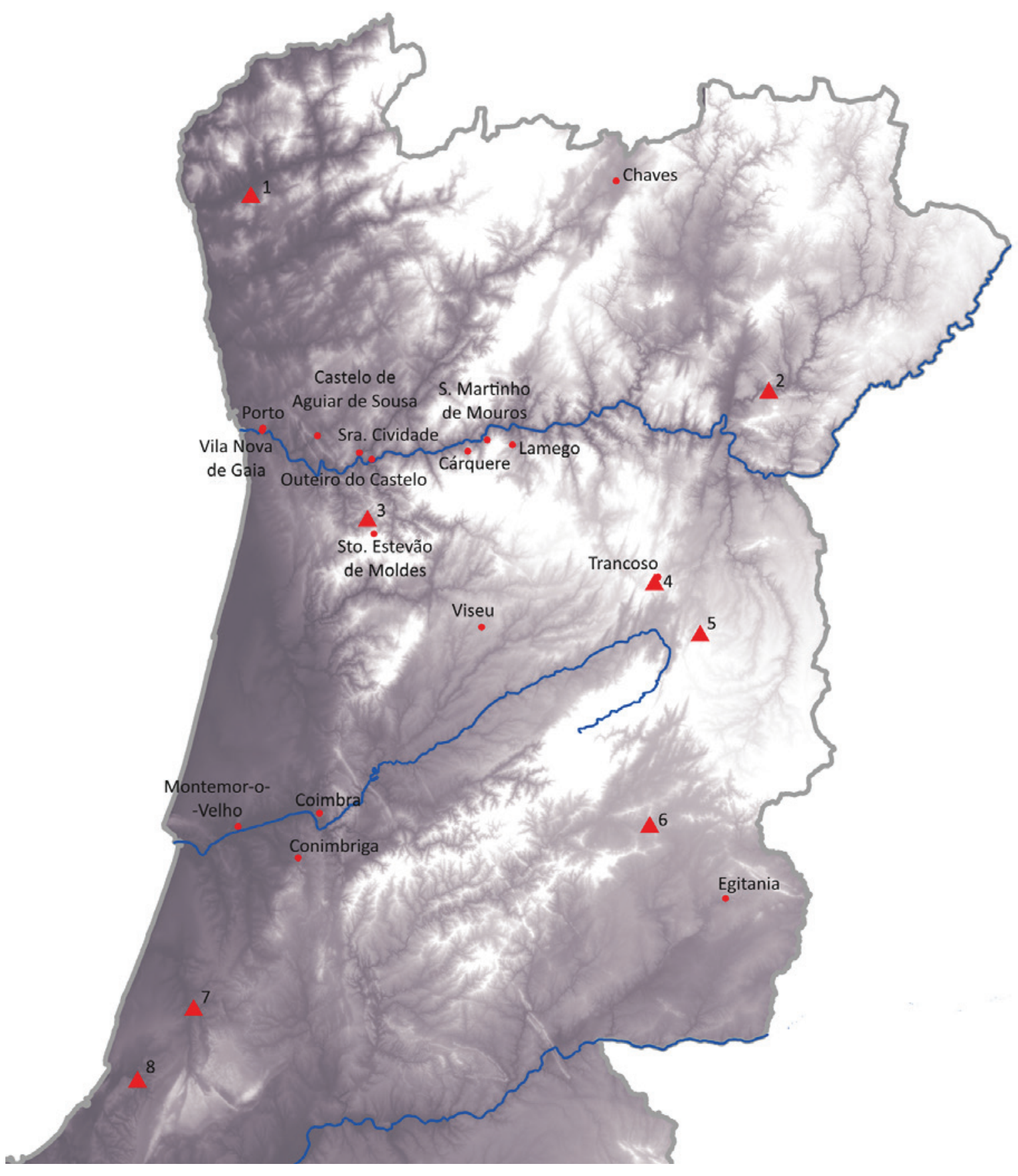

Figura 1 - Distribuição dos sítios arqueológicos com cronologia Emiral, com indicação dos locais referidos na documentação (Barroca, 2008-2009 e 2016; Viguera Molins, 1998).

Sítios que forneceram conjuntos cerâmicos: 1: Quinta do Paço Velho (Ponte de Lima); 2: Cilhades (Torre de Moncorvo); 3: Castro do Monte Valinhas (Arouca); 4: Trancoso (Trancoso); 5: Torre do Codesseiro (Guarda); 6: São Pedro de Capinha (Fundão); 7: Castelo de Leiria (Leiria); 8: Quinta da Granja (Alcobaça). 


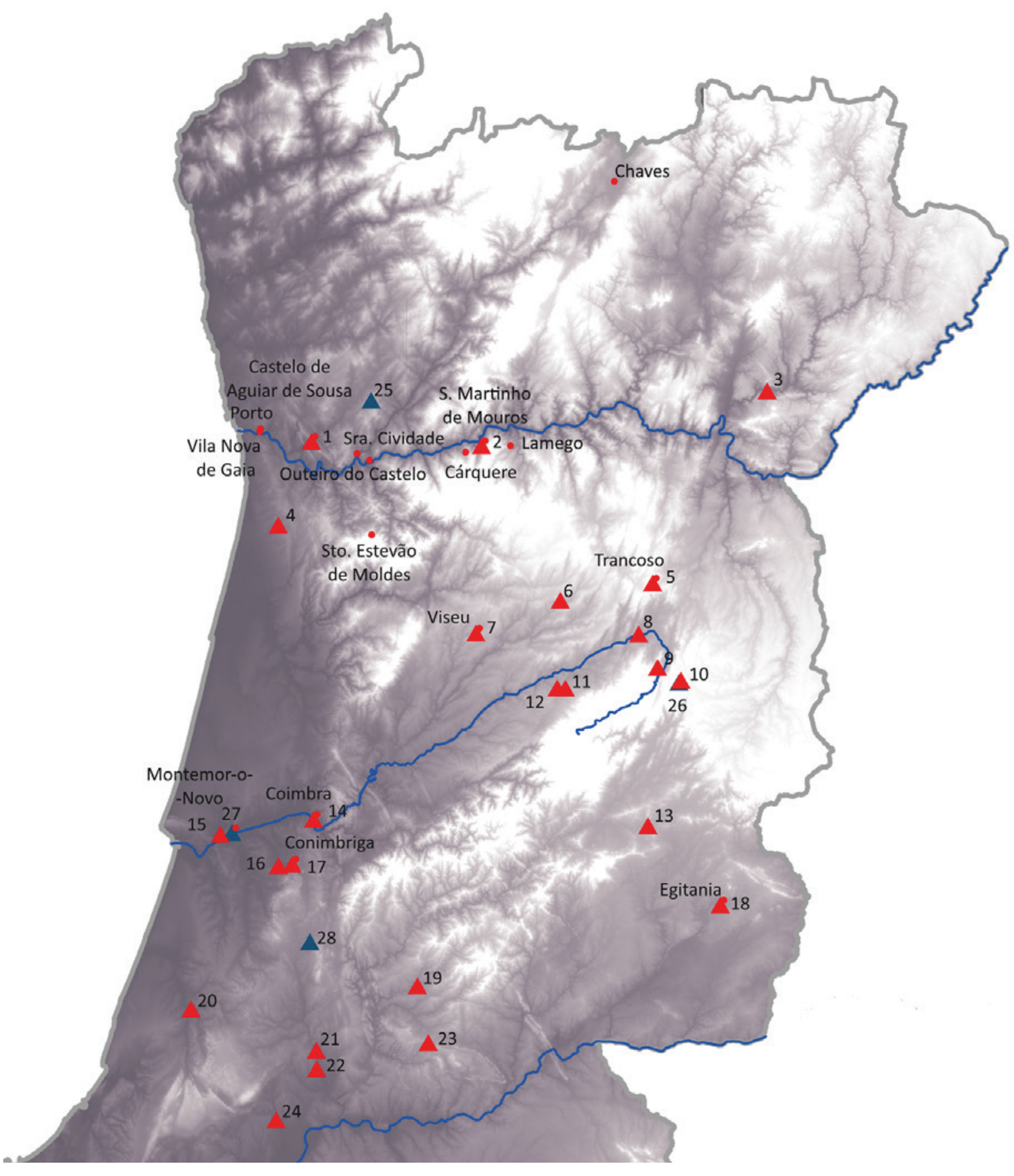

Figura 2 - Distribuição dos sítios arqueológicos com cronologia Califal-Taifas, com indicação dos locais referidos na documentação (Barroca, 2008-2009 e 2016; Viguera Molins, 1998).

Sítios que forneceram conjuntos cerâmicos: 1: Castelo de Aguiar de Sousa (Paredes); 2: Castro da Mogueira/São Martinho de Mouros (Resende); 3: Cilhades (Torre de Moncorvo); 4: Castelo da Feira (Santa Maria da Feira); 5: Trancoso (Trancoso); 6: Senhora do Barrocal II (Satão); 7: Viseu (Viseu); 8: São Gens (Celorico da Beira); 9: Soida (Guarda); 10: Castelos Velhos (Guarda); 11: Penedo dos Mouros (Gouveia); 12: Monte Aljão (Gouveia); 13: São Pedro da Capinha (Fundão); 14: Coimbra (Coimbra); 15: Santa Olaia (Figueira da Foz); 16: Paço da Ega (Condeixa-a-Nova); 17: Conimbriga (Condeixa-a-Nova); 18: Egitania/Idanha-a-Velha (Idanha-a-Nova); 19: Sertã (Sertã); 20: Castelo de Leiria (Leiria); 21: Gruta do Caldeirão (Tomar); 22: Tomar (Tomar); 23: Castro de São Miguel da Amêndoa (Vila de Rei/Mação); 24: Torres Novas (Torres Novas).

Achados isolados: 25: Croca (Penafiel); 26; Guarda (Guarda); 27: Montemor-o-Velho (Montemor-o-Velho); 28: Ansião (Ansião). 


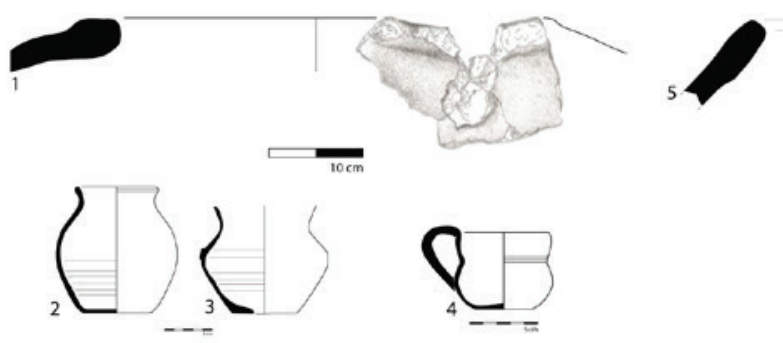

Quinta da Granja (Alcobaça)
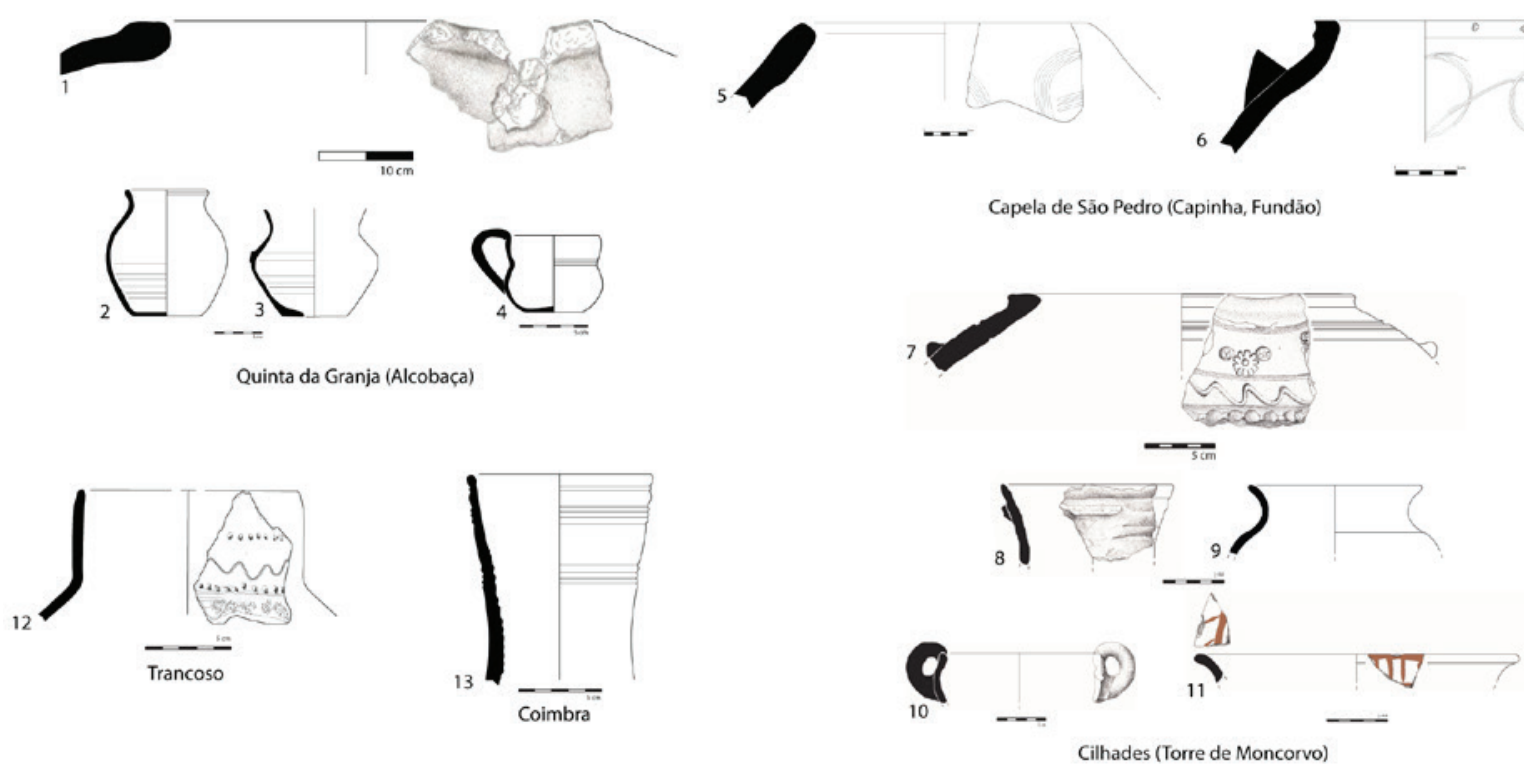

Período Califal-Taifas (século X/XI)

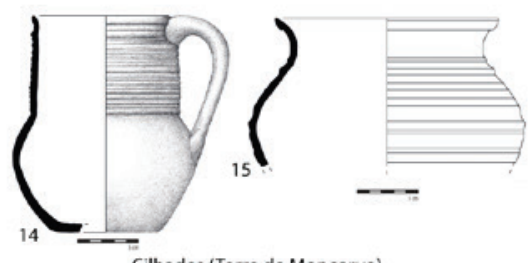

Cilhades (Torre de Moncorvo)
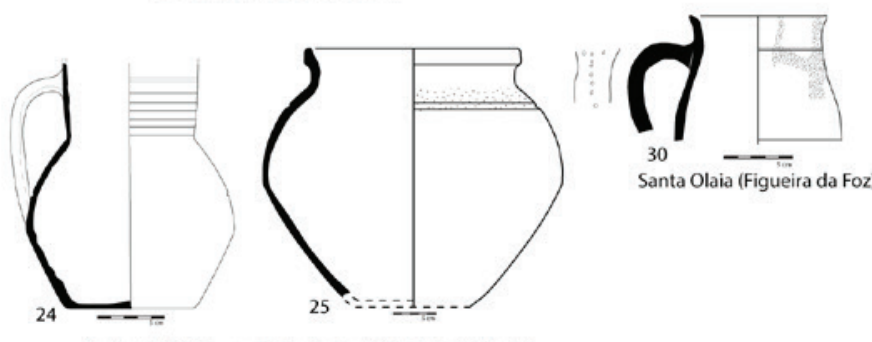

$--$
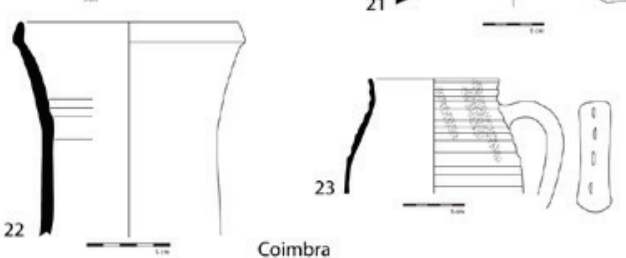

Castro de S. Migues da Amêndoa (Vila de Rei / Maçăo)

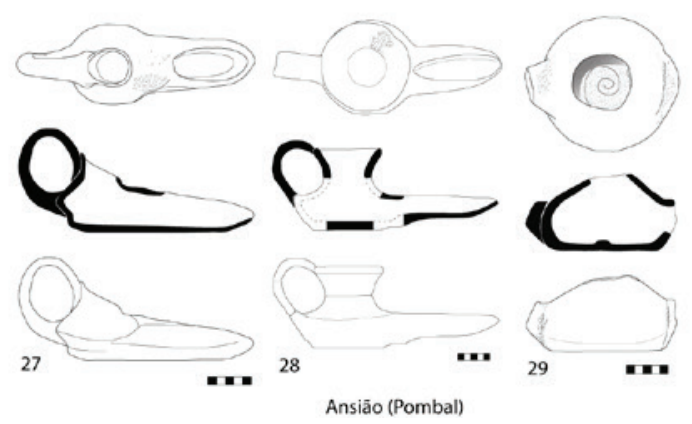

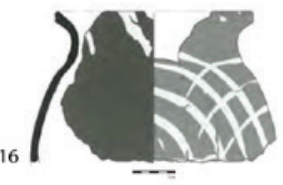

Santa Maria da Feira

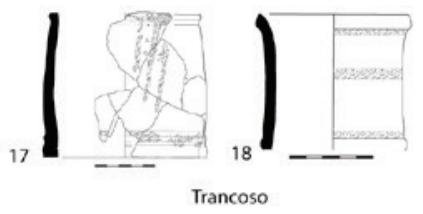

Figura 3 - Cerâmicas islâmicas do Garb setentrional “português”. (1-4) Quinta da Granja, Maiorga, Alcobaça (Gonzalez, 2013); (5 e 6) Capela de São Pedro, Capinha, Fundão (Santos e Albuquerque, 2015); ( 7 a 11, 14 e 15) Cilhades, Felgar, Torre de Moncorvo (Rosselló et alii, 2016); (12, 17 e 18) Castelo de Trancoso, Trancoso (Ferreira et alii, 2012); (13, 19 e 22) Pátio das Escolas da Universidade de Coimbra, Coimbra (Catarino et alii, 2009); (16) Castelo de Santa Maria da Feira, Santa Maria da Feira (Teixeira e Fonseca, 2002/2003); (20, 21 e 23) Beco das Condeixeiras, Coimbra (Silva, 2014); (24 e 25) Castro de S. Miguel da Amêndoa, Vila de Rei / Mação (Bubner e Bubner, 1993 e 1993a); (27-29) Ansião, Pombal (colecção Padre José Eduardo Coutinho); (3o) Santa Olaia, Figueira da Foz (Nazaré, 2013). 


\title{
CONTRIBUTO PARA O CONHECIMENTO DA COSMÉTICA ISLÂMICA, EM SILVES, DURANTE A IDADE MÉDIA
}

\author{
Rosa Varela Gomes ${ }^{1}$
}

\begin{abstract}
RESUMO
As numerosas escavações que temos dirigido de contextos islâmicos no sul de Portugal, designadamente em Silves, ofereceram, entre muito outro espólio, conjunto artefactual tipologicamente diversificado, que podemos relacionar com a cosmética. Entendemos esta como actividade que usa objectos e produtos destinados não só ao embelezamento, como à conservação e protecção do corpo, nomeadamente no caso dos humanos, da pele, cabelo, olhos, dentes, etc. . A cosmética tem existência próxima da medicina e, sobretudo, da farmácia. Palavras-chave: Silves, Cosmética, Aplicador de kohl, Pente, Pinça.
\end{abstract}

\begin{abstract}
The numerous excavations that we have conducted from Islamic contexts in the south of Portugal, particularly in Silves, offered, among many other items, a typologically diversified artefact set, which we can relate to cosmetics. We understand this as an activity that uses objects and products intended not only for beautifier, but also for the conservation and protection of the body, namely in the case of humans, skin, hair, eyes, teeth, etc. Cosmetics has a close existence to medicine and, especially, to the pharmacy.
\end{abstract}

Keywords: Silves, Cosmetics, Kohl pencils, Comb, Tweezers.

\section{INTRODUÇÃO}

O cuidado com o corpo, relacionado tanto com rituais religiosos (purificação dos crentes), como higiénicos e profilácticos, encontra-se presente em todo o mundo muçulmano medieval constando, também, na informação literária, dado constituir exigência tanto pessoal como colectiva, ligada à cidadania, religião e espiritualidade. Valorizava-se então a saúde e o bem-estar físico, conforme nos é transmitido, entre outros, pelo médico cirurgião Abū Merwān 'Abdal-Malik ibn Zuhr, mais conhecido por Avenzoar, que escreveu, no século XII, o primeiro livro sobre cosmética (Kitāb al-Iqtisād), com o objectivo de conservar, restaurar e, em particular, fazer ressaltar a beleza e perfeição criada por Deus; praticá-la é colaborar com o Criador (Brabant, 1974: 434; 1996: 298). Este aspecto que, de certo modo, questiona a exclusividade da criação Divina, poderá justificar a crítica dos teólogos almorávidas à obra daquele tratadista e a sua subsequente prisão. $\mathrm{O}$ mesmo texto refere tratamentos de embelezamento (tahsin) propondo, para tal, pomadas e unguentos, ou contra determinadas infecções da pele, pós para os dentes, colírios para os olhos e tintas para o cabelo ou a barba, além de produtos para dissimular cicatrizes, fortalecer o cabelo e as unhas, depilatórios, desodorizantes, perfumes e fumigações, recomendando mesmo a cirurgia estética, para corrigir a forma do nariz ou dos lábios (Brabant, 1974: 435; 1996: 289). Ibn Halsūn também se debruça, na centúria seguinte, sobre cosmética (tarīq al-zìna) no Livro dos Alimentos, encarando-a na perspectiva da farmacopeia (Gigandet, 1996).

Muito embora nas obras mencionadas tenhamos conhecimento de tratamentos para a conservação e protecção do corpo, existem poucas referências aos recipientes onde aqueles produtos eram guardados. Não obstante, sabe-se que as mulheres do al-Andalus conservavam o kohl, pigmento de cor negra para contornar os olhos, em frascos, que podiam ser de cerâmica, vidro ou metal, estes mais raros, e em pe-

1. Instituto de Arqueologia e Paleociências da Universidade Nova de Lisboa F.C.S.H.; rv.gomes@fcsh.unl.pt 
quenos estojos, enquanto as essências e óleos eram colocados e transportados em pequenos recipientes de vidro ou cristal (Arié, 1987: 300; Lévi-Provençal e Torres Balbás, 1982: 279).

Nas escavações arqueológicas que temos vindo a dirigir em Silves, há mais de três décadas, recolhemos conjunto artefactual que podemos relacionar com a cosmética. Este, encontrou-se, maioritariamente, na área palatina daquela cidade, onde residiria boa parte da sua elite e, sobretudo, nas zonas correspondentes aos complexos de banhos, do século XII ou dos inícios da centúria seguinte, tanto do palácio principal, como do localizado no lado nascente daquela Alcáçova (Gomes, 2003: 49-111, 188, 211; Gomes, 2015; Gomes e Gomes, 2001: 74-76). Também detectámos, exemplares descartados no interior de silos, usados como lixeiras, ou em fossa detrítica.

\section{ARTEFACTOS DE OSSO}

- Aplicador de kohl (Cast. Silv. Q32/C2-2). Fragmento que apresenta corpo de forma bitroncocónica alongada, possuindo a extremidade proximal arredondada, e a distal mostra elemento para encaixe em peça que teria orifício circular. Oferece decoração constituída por finas incisões, paralelas e perpendiculares ao seu eixo maior, organizadas em oito grupos. Mede o, 070 $\mathrm{m}$ de comprimento e o,oog $\mathrm{m}$ de maior diâmetro. Foi encontrado no pátio do complexo de banhos (hamman) do palácio principal, que terá pertencido ao governador da cidade (Gomes, 2003: 87, 187, 188) (Figura 1).

- Aplicador de kohl (Cast. Silv. Q537/C2-2). Fragmento que mostra corpo de forma bitroncocónica alongada, com a extremidade proximal piramidal, apresentando a distal elemento para encaixe em peça com orifício circular. A superfície exterior oferece decoração constituída por finas incisões, paralelas e perpendiculares ao seu eixo maior, organizadas em seis grupos. Mede o,043 $\mathrm{m}$ de comprimento e o,o1o $\mathrm{m}$ de maior diâmetro. Foi exumado no interior de uma das casas identificadas no sector noroeste do Castelo de Silves.

- Aplicador de kohl (Cast. Silv. Q301/Fos. 2-1). Fragmento que oferece corpo de forma bitroncocónica alongada, com a extremidade proximal piramidal, e a distal com elemento para encaixe em peça com orifício circular. A superfície exterior apresenta decoração constituída por finas incisões, paralelas e perpendiculares ao seu eixo maior, organizadas em seis grupos. Mede o,045 $\mathrm{m}$ de comprimento e o,006 $\mathrm{m}$ de maior diâmetro. Provém de fossa detrítica, reconhecida junto ao interior do pano de muralha do lado sudeste do Castelo de Silves.

- Pente (Cast. Silv. Q77/C2-1). Encontra-se reduzido a fragmento possuindo, apenas, quatro dentes e parte do corpo. Mede o,059 $\mathrm{m}$ de altu$\mathrm{ra}, \mathrm{o,010} \mathrm{m}$ de largura e 0,004 $\mathrm{m}$ de espessura máxima. Foi identificado em compartimento de casa localizada entre o pano de muralha do lado nascente e o palácio principal do Castelo de Silves (Gomes, 2003: 109, 188, 189).

- Pente duplo (Silv.4). Apresenta forma rectangular e possuía duas filas de dentes, uma contando actualmente, apenas, com seis dentes, espaçados, e, no lado oposto, vinte e três dentes, que seriam mais finos e juntos, mas agora reduzidos aos seus arranques. $O$ espaço entre as duas fiadas de dentes, é liso, mostrando apenas duas incisões junto aos dentes maiores. Mede o,053 $\mathrm{m}$ de altura, o,048 $\mathrm{m}$ de comprimento e o,oo6 m de espessura máxima. Foi achado na encosta situada no lado nascente do Castelo de Silves, juntamente com outro espólio islâmico proveniente, possivelmente, do interior daquele espaço (Gomes, 2003: 355; Gomes e Gomes, 2001: 74).

\section{ARTEFACTOS DE METAL}

- Pinça (Cast. Silv. Q108/C2-3). Produzida em liga de cobre, apresenta hastes de forma rectangular, contendo cada uma delas três linhas incisas na zona proximal. Mede o,046 m de comprimento e 0,004 $\mathrm{m}$ de largura. Foi exumada no complexo de banhos, junto a uma das tinas, do palácio principal da Alcáçova (Gomes, 2003: $87,188,190)$.

- Pinça (Cast. Silv. Q334/C2-1). Fabricada em liga de cobre, possui hastes de forma trapezoidal, oferecendo ambas, linhas incisas na zona distal. Mede 0,047 $\mathrm{m}$ de comprimento e o,008 $\mathrm{m}$ de largura máxima. Foi descoberta junto a uma das casas existentes no sector noroeste do Castelo de Silves. 


\section{ARTEFACTOS DE VIDRO}

- Taça (Cast. Silv. Q74/C2-8). Quase completa, mostra corpo troncocónico, bordo oblíquo, possuindo lábio de secção semicircular e assenta em fundo côncavo. Foi fabricada com vidro, translúcido, de cor azul. Mede o,064 $\mathrm{m}$ de diâmetro no bordo, o,032 $\mathrm{m}$ de diâmetro no fundo, 0,030 $\mathrm{m}$ de altura e a espessura média das paredes é de $\mathrm{0}, 002 \mathrm{~m}$. Foi recolhida junto de frasco, no interior de canalização situada a norte do complexo de banhos do palácio principal da Alcáçova de Silves (Cast. Silv. Q74/C2-7) (Gomes, 2003: 104, 208, 211; Gomes, 2015:442; Gomese Gomes, 2001: 75).

- Taça hemisférica achatada (Cast. Silv. Q20/C2-7). Fragmento contendo porção do bordo e do corpo. Mostrava corpo de forma hemisférica achatada, com bordo vertical, espessado no exterior, com lábio de secção semicircular. Foi fabricada com vidro, opaco, de cor verde água. Media o,080 m de diâmetro no bordo e a espessura média das paredes é de o,002 $\mathrm{m}$. Provém do pátio anexo ao complexo de banhos do palácio principal (Gomes, 2003: 94, 208, 211; Gomes, 2015: 442).

- Frasco (Cast. Silv. Q74/C2-7). Conserva-se inteiro. Mostra corpo de forma esférica, algo achatada e gargalo alto, troncocónico. O bordo, ligeiramente espessado, apresenta lábio de secção semicircular. O fundo contém ônfalo. O corpo oferece decoração, constituída por pequenos motivos ovais em relevo. Foi fabricado com vidro, translúcido, de cor castanha esverdeada. Mede $0,130 \mathrm{~m}$ de altura, 0,026 $\mathrm{m}$ de diâmetro no bordo, o, $028 \mathrm{~m}$ de diâmetro na base e a espessura média das paredes é de $0,002 \mathrm{~m}$. Este raro exemplar deve ter sido utilizado para conter perfume. Foi recuperado, com outras peças sumptuárias, no interior de canalização situada a norte do complexo de banhos do palácio principal, ali escondido aquando do fim da administração muçulmana (Gomes, 2003: 104, 209, 211; Gomes, 2015: 442; Gomes e Gomes, 2001: 76).

- Frasco (Cast. Silv.Q35/C2-7). Mostrava corpo de forma esférica achatada, possuía gargalo alto, troncocónico. Conserva-se fragmento contendo porção do bordo, gargalo, com o arranque de duas asas e parte do corpo. O bordo é vertical, afilado e apresentava lábio de secção semicircular. Possivelmente, assentava em fundo com pé anelar, dados os paralelos com outras peças. As extremidades superiores das asas estavam fixadas a meio do gargalo e as inferiores repousavam a meio do volume do corpo. Foi fabricado com vidro, opaco, de cor castanha avermelhada. Mede o,046 m de diâmetro no bordo, o,070 m de diâmetro no corpo e a espessura média das paredes é de $0,002 \mathrm{~m}$. Encontrava-se sobre o pavimento de corredor de acesso a instalação sanitária, de apoio ao complexo de banhos do palácio principal (Gomes, 2003: 91, 209, 211; Gomes, 2015: 442).

- Frasco (Cast. Silv. Silo 4 - 94). Fragmentos correspondentes ao bordo, ao corpo e ao fundo. $\mathrm{O}$ corpo possuía forma ovoide e assentava em pé baixo e anelar. O bordo era ligeiramente espessado e algo extrovertido, com lábio em bisel. Foi fabricado com vidro, translúcido, de cor verde. Oferece, no corpo, decoração moldada, com motivos ovais e circulares, em relevo, junto ao fundo. Mede o,094 $\mathrm{m}$ de diâmetro no bordo, 0,029 $m$ de diâmetro no fundo e a espessura média das paredes é de $0,002 \mathrm{~m}$. O silo que o continha situa-se na zona norte da Alcáçova de Silves.

- Frasco (Cast. Silv. Silo 4 - 96). Fragmentos correspondendo a parte do gargalo e do fundo. Apresenta corpo de forma troncocónica, assente em fundo côncavo. O gargalo troncocónico era alto e largo. O bordo, ligeiramente introvertido, possuía lábio de secção semicircular. Foi fabricado com vidro, translúcido, de cor verde. Mede 0,054 m de diâmetro no bordo, 0,045 m de diâmetro no fundo e a espessura média das paredes é de o,002 m. Foi encontrado próximo da peça anteriormente descrita.

- Pequenos frascos (alabastra) (Cast. Silv. Q282/ C2-2; Cast. Silv. Q.282/C2-1; Cast. Silv. 284/C21). Quase completos, mostram corpo fusiforme, gargalo alto e troncocónico, com anel na ligação com o corpo. O bordo, espessado e extrovertido, apresenta lábio de secção semicircular. Os fundos são planos. Possuíam pequenas tampas, também de vidro, que encaixavam em estrangulamento do bordo. Foram produzidos com vidro marmoreado, opaco, de cor vermelha vinhosa e oferecem decoração de reflexos metálicos dourados. Medem entre $0,079 \mathrm{~m}$ e $0,082 \mathrm{~m}$ de altura, o,016 $\mathrm{m}$ a 0,019 $\mathrm{m}$ de diâmetro no bordo e o,008 $\mathrm{m}$ a o,010 $\mathrm{m}$ de diâmetro no fundo. Foram recolhidos, com muitos outros fragmentos 
de recipientes congéneres, no interior de compartimento anexo ao complexo de banhos do palácio, que se desenvolvia paralelamente ao pano interior da muralha nascente do Castelo de Silves (Gomes, 2015:442, 444; Gomes, 2016: 23; Gomes e Gomes, 2001: 75).

\section{ARTEFACTOS DE CERÂMICA}

- Pote (Cast. Silv. Q144/C2-1). Quase completo, dado apenas faltarem-lhe alguns fragmentos do corpo e as asas. Mostra corpo de forma ovoide, bordo baixo algo introvertido, possuindo lábio de secção recta. Assenta em pé anelar destacado e teria duas pequenas asas, opostas, de que subsistem os arranques. Foi fabricado com pasta, homogénea e compacta, de cor cinzenta clara $\left(5 \mathrm{Y}_{7} / 1\right)^{2}$ contendo elementos, não plásticos, de grão finíssimo a fino. A superfície interior mostra cor semelhante à do núcleo, enquanto a exterior apresenta esmalte, aderente mas sem brilho, de cor verde. Esta oferece várias linhas, incisas, dispostas horizontalmente. Mede o,077 m de altura, o,037 m de diâmetro no bordo, o,040 m de diâmetro no pé e a espessura média das paredes é de $0,005 \mathrm{~m}$. A forma do bordo indica que teria tampa. Foi recolhido no pátio do palácio principal do Castelo de Silves (Gomes, 2003: 240, 241) (Figura 2).

- Frasco (balsamário) (Cast. Silv. Q268/C2-1). Fragmento correspondendo ao corpo, com forma ovoide, ao gargalo e ao bordo. O gargalo é estreito e o bordo ligeiramente extrovertido, mostrando lábio com secção semicircular. Foi fabricado com pasta, homogénea e compacta, de cor branca (10 YR 8/2), contendo elementos, não plásticos, de grão finíssimo a fino. Ambas superfícies apresentam cor semelhante à do núcleo, oferecendo a exterior, na zona mesial, decoração constituída por caneluras horizontais. Conserva parte da tampa, de chumbo, no interior do bordo, presa por arame de cobre. Mede 0,020 $\mathrm{m}$ de diâmetro no bordo e a espessura média das paredes é de o,002 $\mathrm{m}$. Foi recolhido no depósito de água que abastecia complexo de banhos do palácio, que se desenvolvia paralelamente ao pano interior da muralha nascente do

2. Os códigos cromáticos correspondem às Munsell Soil Color Charts e, por isso, devem considerar-se como aproximados.
Castelo de Silves (Gomes, 2003: 75, 293, 297; Gomes e Gomes, 2001: 92).

- Frasco (balsamário) (Cast. Silv. Q51/C3-1). Quase completo, mostra corpo globular, gargalo estreito, com bordo vertical, possuindo lábio de secção semicircular. Assenta em fundo destacado, mas plano. Foi fabricado com pasta, homogénea e compacta, de cor branca (10 YR 8/2), contendo elementos, não plásticos, de grão fino. Ambas superfícies possuem cor igual à da pasta. A superfície exterior oferece decoração, formada por caneluras horizontais que preenchem a sua zona mesial. Mede $0,074 \mathrm{~m}$ de altura, 0,008 $\mathrm{m}$ de diâmetro no bordo, 0,034 $\mathrm{m}$ de diâmetro no fundo e a espessura média das paredes é de o,003 $\mathrm{m}$. Foi recolhido sob o pavimento do compartimento 1 da casa B, do Castelo de Silves (Gomes e Gomes, 2001: 61; Gomes, 2003: 109, $346,383,384)$.

- Frasco (balsamário) (Cast. Silv. Silo 6-8). Fragmento correspondendo ao gargalo, ao corpo, de forma ovoide alongada, e ao fundo. O gargalo é cilíndrico e baixo, possuindo bordo introvertido com lábio em bisel. O fundo era ligeiramente convexo. Foi fabricado com pasta, homogénea e compacta, cor-de-laranja (5 YR 6/8), contendo elementos, não plásticos, de grão fino a médio. Ambas superfícies apresentam cor semelhante à da pasta. Observa-se, na superfície exterior, decoração constituída por várias caneluras paralelas que preenchem a superfície mesial. Mede o,176 m de altura, o,o26 $\mathrm{m}$ de diâmetro no bordo, o,024 $\mathrm{m}$ de diâmetro no fundo e a espessura média das paredes é de o,004 m. O silo de onde provém situa-se na zona norte da Alcáçova de Silves.

- Frasco (balsamário) (AR. Q1/E3/C1-3o). Quase completo. Apresenta corpo de forma globular, assentando em pé, destacado e em bolacha. Mostra gargalo baixo, com bordo provido de lábio de secção semicircular. Foi fabricado com pasta, homogénea e compacta, de cor rosada (5 YR 7/4), contendo elementos, não plásticos, de grão finíssimo e, alguns, de grão médio. A superfície interior oferece cor algo mais escura que a da pasta, enquanto à exterior foi aplicada aguada de cor branca. Possui, na superfície do volume mesial, decoração constituída por várias caneluras horizontais. Mede $0,113 \mathrm{~m}$ de altura, 0,026 $\mathrm{m}$ de diâmetro no bordo, o,047 m 
de diâmetro no pé e a espessura média das paredes é de o,o03 $\mathrm{m}$. Provém do interior de silo, da designada Zona da Arrochela, na área urbana de Silves (Gomes, 2011: 92, 104, 124, 125).

\section{COMENTÁRIO}

Entre os artefactos de osso inventariados, os aplicadores de kohl ou "kohl pencils" apresentam a extremidade proximal mais espessa e de forma bitroncocónica, indicando a pega. A todos falta a extremidade distal, ao que parece móvel. Exemplares completos, com as mesmas funções, produziram-se em distintas matérias-primas como metal, vidro, madeira, marfim, osso e pedra, possuindo a maioria cerca de o,10 m de comprimento. A descoberta de aplicadores de kohl, fabricados em vidro, durante os trabalhos arqueológicos que, nos últimos anos, temos vindo a realizar na antiga fortaleza de Quelba/Khor Kalba, no Emirado de Sharjah (EAU), conduziu-nos a obter mais informação sobre aqueles artefactos de cosmética, tanto a partir dos exemplares patentes em Museus, como em colecções particulares ou na bibliografia arqueológica e etnográfica (Gomes, 2019: 132, 133).

O kohl (marwad/mirwed), fabricado com sulfitos de antimónio e de chumbo, pulverizados, ou negro de fumo, de girassóis e essências vegetais queimadas, reduzidas a pó, podia ser misturado com óleos $(\mathrm{ka}-$ jal), sendo usado desde o III milénio A.C., e ainda hoje, por mulheres, homens e crianças em todo o mundo islâmico, de Marrocos à Índia, no contorno dos olhos, sobre as pálpebras e até nas sobrancelhas. Ele tem funções estéticas e sobretudo profiláticas, protegendo a vista de infecções, provocadas pela poeira, ou dos raios solares, mas, igualmente, apotropaicas em particular contra o mau olhado. No al-Andalus as mulheres utilizaram $k o h l$, tanto nas sobrancelhas como nas pestanas (Arié, 1987: 300). Este produto, nos finais dos anos sessenta do século passado, era vendido nos souks marroquinos, em pequenos frascos de vidro de uso farmacêutico, ainda com as tampas originais de borracha, associando-o de certo modo, aos medicamentos. O aplicador de kohl, vendido separadamente, oferecia duas extremidades, rematadas por pontas arredondadas, sendo uma, a distal, de menor dimensão que a oposta, permitindo realizar traço mais fino (Figura 3A). No Museu de Arqueologia do Emirado da Fujairah (EAU), observa-se exemplar semelhante, atribuído aos inícios do século passado (Figura 3 B). Na Península Arábica as elites guardavam o kohl em recipientes de vidro e sobretudo de prata, cujo aplicador, no mesmo material, se encontrava preso àquele por pequena corrente, conforme se observa em peças, do século XIX, iemenitas, possuindo corpo cilíndrico ou fusiforme (Figura 4).

Os pequenos recipientes fusiformes de vidro, dos quais descrevemos três exemplares, encontrados quase completos, mas de que exumámos abundantes fragmentos, correspondendo a gargalos e fundos, foram utilizados para conter perfumes ou mais provavelmente kohl, pois muitos dos fragmentos ainda conservavam restos daquele cosmético de cor negra. Confirma a nossa interpretação, a identificação em escavações arqueológicas, realizadas em Israel, nos sítios de Khirbet el-Minyeh, Tel Erani e al-Tūr, de pequenos frascos de perfumes e de outros de forma idêntica aos de Silves, contendo ainda kohl, com cronologias situadas entre os séculos VIII e o XV (Brosh, 1993: 290-292). Naquele último arqueossítio, importante porto e centro produtor de vidro, foi encontrado pequeno recipiente e respectivo aplicador de kohl, produzido em cobre (Shindo, 1993: 303, 304). Ao longo da costa do Mar Vermelho têm sido descobertos frascos de vidro para kohl, com decoração marmoreada, atribuídos a período compreendido entre os séculos VII-VIII e XIII (Shindo, 1993: 303).

Pequenos contentores para kohl, de vidro, figuram em diversas colecções, entre outras, nas do Museu do Louvre, em Paris, ou no Corning Museum of Glass de Nova York (Pasquier, 2007: 42, 83).

Os pentes, de osso, oferecem forma rectangular, podendo ter uma ou duas fiadas de dentes. Estes possuem dentes mais espaçados e de maiores dimensões em um dos lados, enquanto do oposto aqueles são menores e mais numerosos. Eram utilizados, tal como hoje, no tratamento do cabelo, ordenando-o ou penteando-o, e na sua higiene, dado poderem remover parasitas, embora, não raro, constituíssem adornos, interpretados como itens de riqueza, quando produzidos em matérias primas raras ou preciosas, como o marfim, prata ou ouro, e possuíssem decorações de dimensão simbólica. No mundo islâmico os pentes, "com numerosos dentes" eram usados para desembaraçar o cabelo e, em particular, ajudar a alterar a sua cor, aplicando henna, preferencialmente no hamman, usando o compartimento correspondente aos banhos temperados (bayt al-sajun) mas, apenas, 
uma vez por estação (Aguirre de Cárcer, 1995: 229; Gigandet, 1996: 51, 82).

A henna, embora fosse utilizada na cosmética, possui, segundo Ibn Halsūn, maravilhosas propriedades, sendo indicada para prevenir aftas, fortalecer o cabelo e as unhas, embelezando-as e, misturada com outros ingredientes, para fazer sabão (Gigandet, 1996: 53, 58, 65). No al-Andalus as mulheres alisavam o cabelo com pentes de osso ou marfim e decoravam as unhas com henna (Arié, 1987: 300). Presentemente, as mulheres muçulmanas, tanto do Norte de África como do Próximo e Médio Oriente, utilizam-na para decorar as mãos e os pés, prática que quiçá se deve a influência indiana, existindo especialistas na sua aplicação, que executam elaborados e esteticamente apelativos motivos decorativos. A henna era considerada uma planta abençoada, com grande baraka que, segundo parece, o Profeta tinha-a em conta como "A rainha de todas as flores", cujo perfume se associa ao Paraíso (Chebel, 2001: 197). A utilização da henna teria, por isso, carácter profiláctico e apotropaico.

Muito embora o cabelo devesse estar bem tratado, na mitologia muçulmana é considerado como sendo a ligação entre as forças do bem e as do mal devendo, por isso, ser protegido, conforme fazem as mulheres escondendo-o sobre lenços ou os homens ao cobrirem a cabeça com cafias sobre toucas de algodão (Chebel, 2001: 95). Deste modo, ambos se protegem não só de encantamentos como de, possíveis, forças demoníacas.

Pequenas pinças, de liga de cobre, seriam, de igual modo, utilizadas, por ambos géneros na depilação facial ou corporal. Esta podia ocorrer no ambiente doméstico, conforme indicam as duas pinças anteriormente referidas, ou no hamman, onde além de depiladoras profissionais existiam massagistas e cabeleireiras, que vendiam unguentos, perfumes e saquinhos de pós aromáticos para os vestidos (Lévi-Provençal e Torres Balbás, 1982: 279; Marín, 200o: 234, 235). O género de tais profissionais dependia do dos utilizadores daquele espaço. No seu desempenho as cabeleireiras e massagistas também se deslocavam a casa de mulheres com elevado estatuto social (Marín, 2000: 287, 297).

Os frascos, de vidro, apresentam corpo de forma esférica, esférica achatada, por vezes com altos gargalos, ovoide ou fusiforme, constituindo pequenos contentores de perfumes ('athan) ou de unguentos. As taças conteriam pomadas e outros preparados cosméticos. Teriam as mesmas funções exemplares de cerâmica, pequenos potes e frascos, que oferecem corpo de forma globular ou ovoide.

A maior parte das peças, de vidro ou de cerâmica, que exumámos na Alcáçova de Silves foi encontrada, conforme mencionámos anteriormente, junto ou próximo aos complexos de banhos.

Perfumes e unguentos eram, em todo o mundo islâmico, muito apreciados, relacionando-se com a socialização e a saúde. Produtos de cosmética, como os óleos, de amêndoas doces ou de rosas, eram então usados depois dos banhos, não só para hidratar a pele como para perfumar o corpo. Recomendava-se, entre outros, o óleo de jasmim para tornar a pele do rosto macia, enquanto, no corpo o óleo a aplicar dependia da estação do ano (Gigandet, 1996: 65, 66). A utilização de essências e unguentos estava interdita, segundo interpretação do Corão, durante a Peregrinação a Meca (Alcorão, Cap. 2, Ver. 157).

Os perfumes, considerados substâncias benignas, eram usados tanto na liturgia como no quotidiano, através de fumigações ou da cosmética, sendo os de melhor qualidade fabricados no Omã e no Iémen, onde se produzia o incenso e a mirra, sendo comercializados, através do Egipto ou do Golfo Arábico, para diferentes destinos (Chebel, 2001: 326, 327). A venda destas essências constituía importante actividade que terá estado associada ao nome de uma das portas situada no arrabalde ocidental de Córdova, designada por Bāb Al-'Attārīn, a porta dos vendedores de perfumes, sendo muito frequentada, em particular, por público feminino (Alesa, 2007: 225; Marín, 200o: 235, 304).

As essências eram produzidas com várias matérias-primas, dispendiosas como a algalia, e outras substâncias que incluem o âmbar cinzento, sândalo, açafrão, noz de moscada, canela, gordura de camelo, óleos vegetais e estratos florais ou cítricos, entre outros (Brabant, 1996: 297). A importância das essências conduziu a que, conforme relatámos, se tivesse escondido frascos de vidro, cujo conteúdo seria considerado precioso, numa canalização do Castelo de Silves.

Os vidros produzidos tanto no Sharq al-Andalus como no Próximo Oriente seriam peças dispendiosas, mas a cujo valor se associava o do seu conteúdo, as essências raras e os perfumes exóticos, vindos de longe. Eles confirmam o relacionamento comercial a longa distância e indicam a presença, no Castelo de Silves, de estrato social com usos e costumes orien- 
tais, poder económico e gosto requintado para utilizar, no seu quotidiano, peças e produtos raros, exógenos e dispendiosos. O comércio mediterrânico de recipientes de vidro e dos seus conteúdos, encontra-se documentado, em Silves, através dos exemplares descritos e de muitos outros, que eram vendidos em diferentes destinos, conforme bem documenta barco afundado no porto de Bodrum, em Seçe Limani (Turquia), com vidros fatímidas (Pasquier, 2007: 43). De facto, a circulação de pessoas, bens e ideias, durante a Idade Média (séculos VIII-XIII), entre o Ocidente Peninsular e o Mediterrâneo Oriental, em viagens de carácter religioso ou comercial, encontra-se assinalada em distinta informação literária e é, também, confirmada através dos espólios que temos vindo a encontrar nas escavações arqueológicas de Silves (cerâmicas, vidros, metais, elementos arquitectónicos, jóias...), ao longo de diferentes ocupações, nomeadamente da sua Alcáçova, abrangendo período compreendido entre 713 e 1248.

\section{BIBLIOGRAFIA}

ALCORÃO (2002) - Complexo do Rei Fahd, Medina, Arábia Saudita, Mem Martins: Sporpress.

AGUIRRE DE CÁRCER, Luisa Fernanda, (1995) - Ibn Wāfid (m.46o/1067), Kitāb Al-Adwiya Al-Mufrada (Libro de los Medicamentos Simples), vol. I. Madrid: Consejo Superior de Investigaciones Científicas / Agencia Española de Cooperatión Internacional.

ALESA, Muhammad Sayyah Mesned (2007) - El Estatus de la Mujer en la Sociedad Árabo-Islámica Medieval Entre Oriente y Ocidente. Granada: Universidad de Granada.

ARIÉ, Rachel (1987) - España Musulmana (Siglos VIII-XV), Barcelona: Edición Labor.

BRABANT, Rosa Kühne (1974) - Avenzoar y la cosmética, Orientalia Hispanica, vol. I, pp. 428-437.

BRABANT, Rosa Kühne (1996) - Zīna e Islāh. Reflexiones para entender la medicina estética del joven Abū Marwān b. Zuhr (ob. 1161/2), Al-Andalus-Magreb, ํํ4, pp. 281-298.

BROSH, Na'ama (1993) - Kohl bottles from Islamic periods excavated in Israel, Annales du $12^{e}$ Congrès de l'Association Internationale pour L'Histoire du Verre, pp. 289-295. Amsterdam: Association Internationale pour L'Histoire du Verre.

CHEBEL, Malek (2001) - Dictionnaire des Symboles Musulmans. Paris: Éditions Albin Michel.

GOMES, Mário Varela (2019) - Aplicador de kohl / Kohl applicator / Appliqueur de kohl, Identidade e Cultura. Património Arqueológico de Sharjah (EAU), pp. 132, 133. Lisboa: Museu Nacional de Arqueologia / Sharjah Archaeological
Autority / Instituto de Arqueologia e Paleociências da Universidade NOVA de Lisboa.

GOMES, Rosa Varela (2003) - Silves (Xelb) - Uma Cidade do Gharb al-Andalus. A Alcáçova. Trabalhos de Arqueologia, $\mathrm{n}^{\circ}$ 35. Lisboa: Instituto Português de Arqueologia.

GOMES, Rosa Varela (2011) - Silves (Xelb) - Uma Cidade do Gharb al-Andalus. A Zona da Arrochela. O Espaço e o Quotidiano. Trabalhos de Arqueologia, $\mathrm{n}^{\circ}$ 53. Lisboa: Instituto de Gestão do Património Arquitectónico e Arqueológico.

GOMES, Rosa Varela (2015) - Islamic Glass from Silves' Castle (Portugal), Annales du $19^{e}$ Congrès de l'Association Internationale pour l'Histoire du Verre (Piran, 2012), pp. 438-445. Koper: Association Internationale pour l'Histoire du Verre.

GOMES, Rosa Varela (2016) - Antecedentes da construção naval em Portugal, A Gestão dos Recursos Florestais Portugueses na Construção Naval da Idade Moderna: História e Arqueologia, pp. 23-32. Lisboa: Instituto de Arqueologia e Paleociências da Universidade Nova de Lisboa.

GOMES, Rosa Varela; GOMES, Mário Varela (2001) - Palácio Almoada da Alcáçova de Silves. Lisboa: Museu Nacional de Arqueologia.

LÉVI-PROVENÇAL, Évariste; TORRES BALBÁS, Leopoldo (1982)-España Musulmana (711-1031), Instituciones, sociedad, cultura, História de España, tomo V. Madrid: Espasa-Calpe.

GIGANDET, Suzanne (1996) - Ibn Halsūn, Le Livre des Aliments (KITĀB Al-AǴDIYA), Santé et diététique chez les Arabes au XIII siècle. Damas: Institut Français de Damas.

MARÍN, Manuela (200o) - Mujeres en Al-Ándalus. Madrid: Consejo Superior de Investigaciones Científicas.

PASQUIER, Jacqueline du (2007) - Histoire du Verre les Chefs-D’Oeuvre de L'Islam. Paris: Massin Éditeur.

SHINDO, Yoko (1993) - Islamic marvered glass from al-Tūr, South Sinai, Annales du $12^{e}$ Congrès de l'Association Internationale pour L'Histoire du Verre, pp. 297-305. Amsterdam: Association Internationale pour L'Histoire du Verre. 

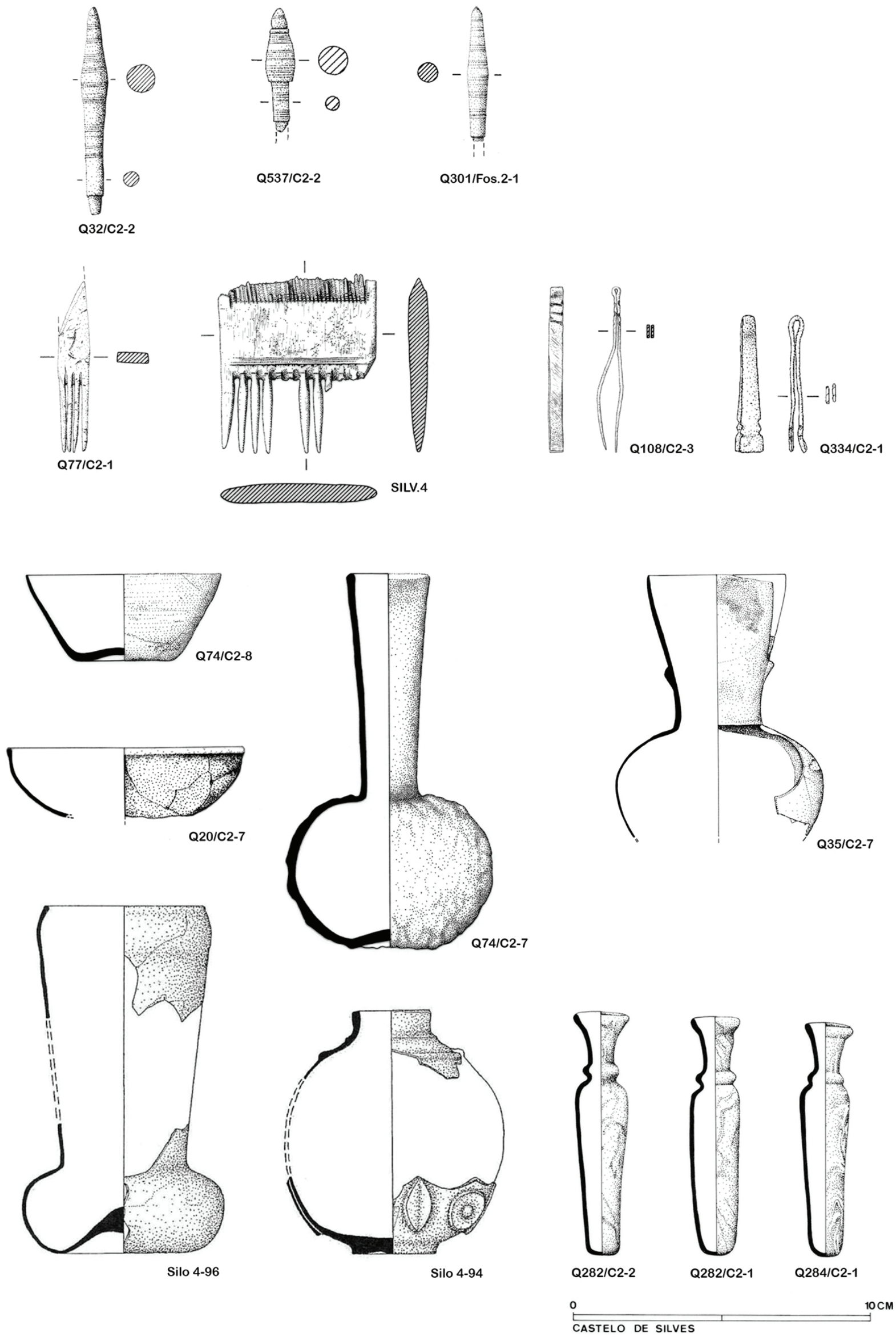

Figura 1 - Artefactos de cosmética, de osso, metal ou vidro. Silves (des. A. Machado; J. Gonçalves; S. Costa). 

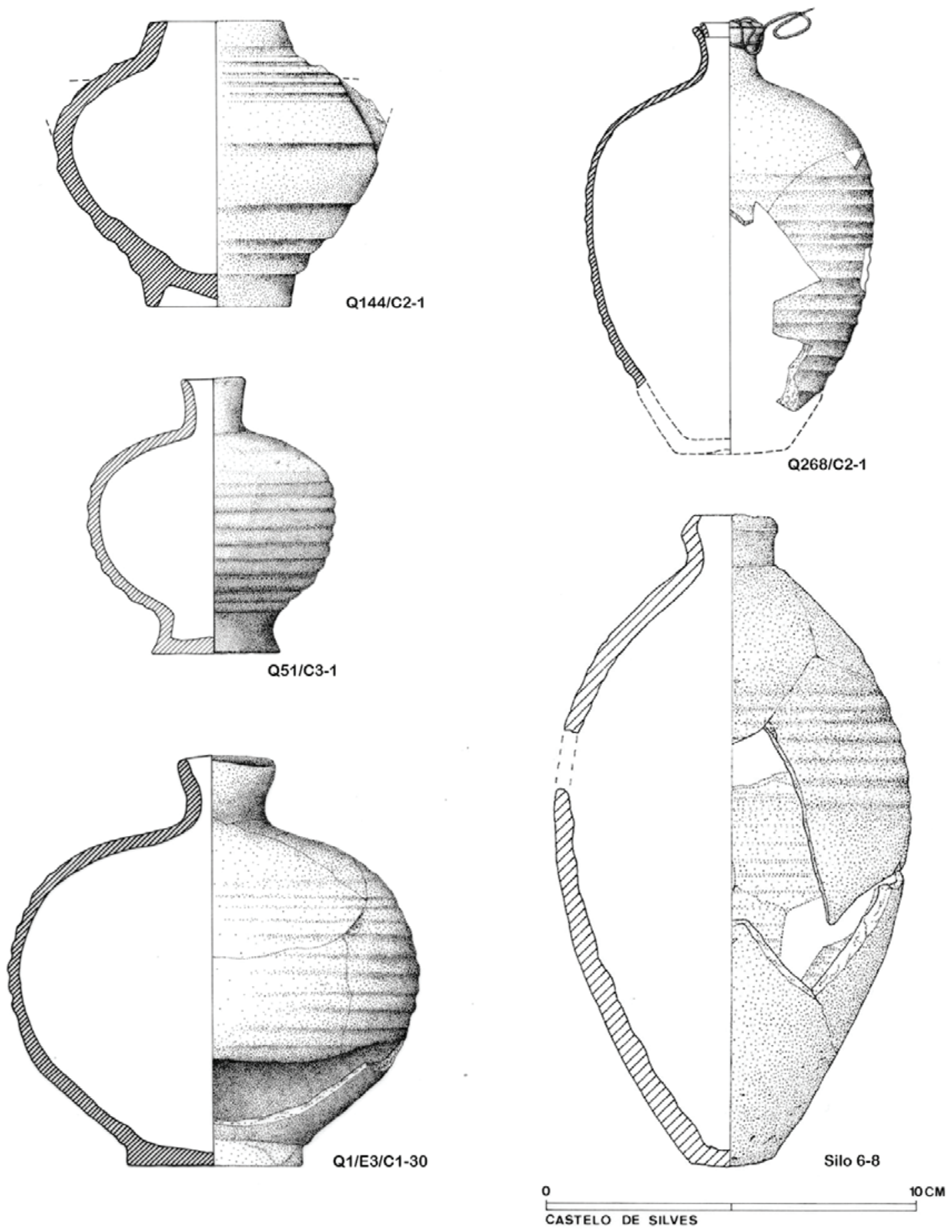

Figura 2 - Artefactos, de cerâmica, ligados à cosmética. Silves (des. A. Machado; C. Gaspar; S. Costa). 

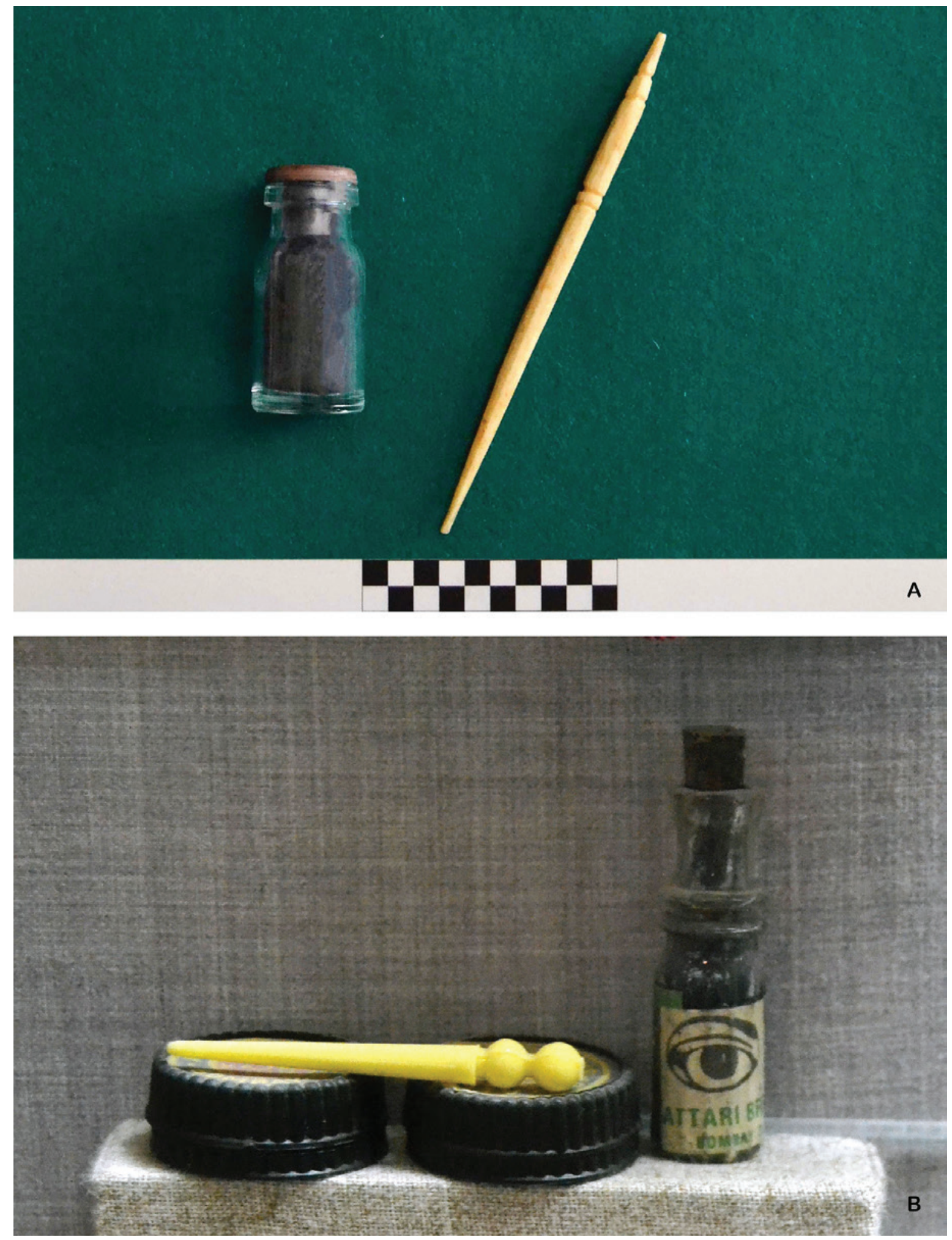

Figura 3 - A - Frasco de vidro, com tampa de borracha, contendo kohl, e aplicador de osso. Marrocos, finais dos anos sessenta da passada centúria (col. R. e M. Varela Gomes). B - Frasco de vidro contendo kohl e aplicador, em exibição no Museu de Arqueologia do Emirado da Fujairah (EAU) (fotos Rita Varela Gomes). 


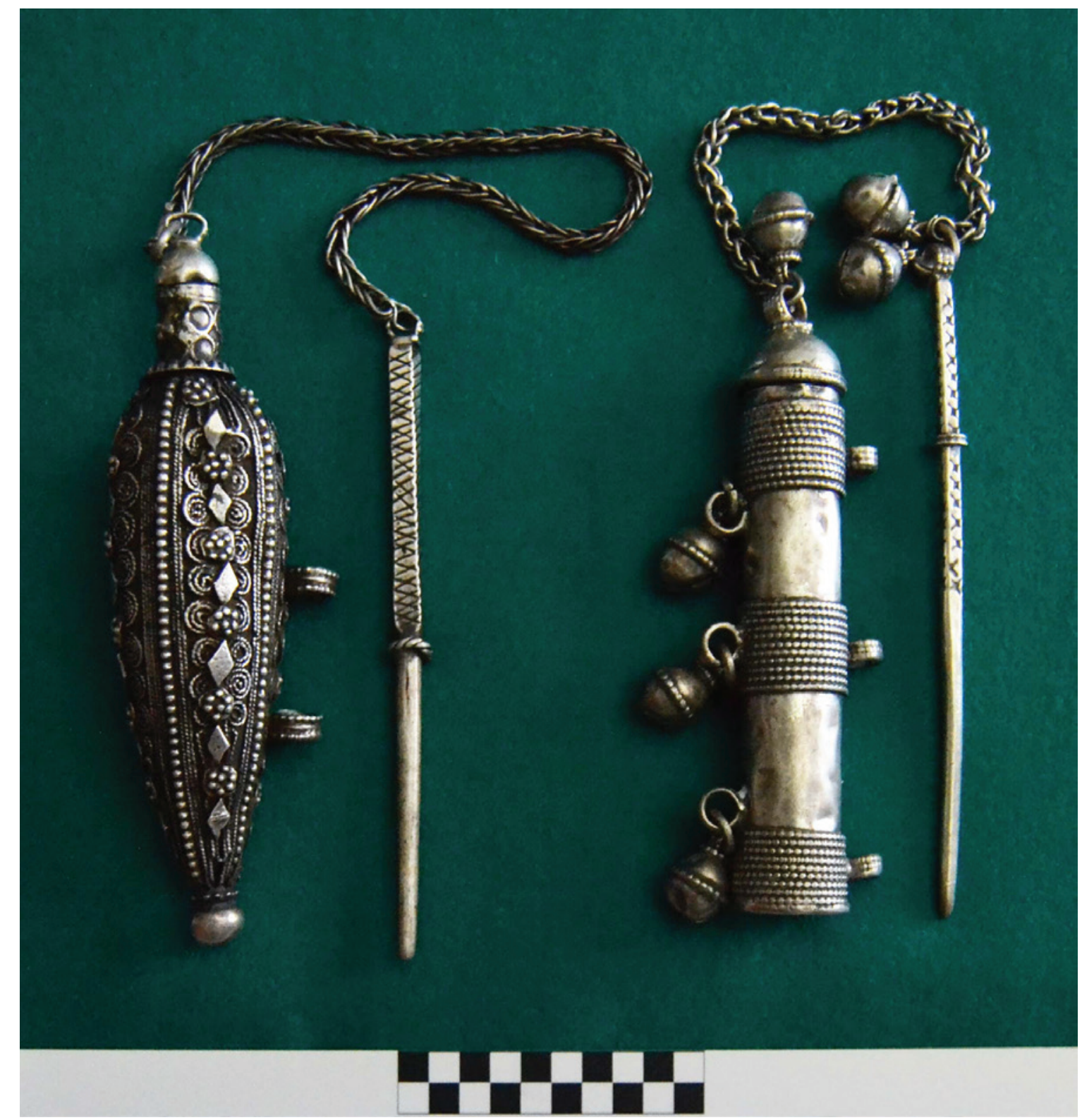

Figura 4 - Recipientes iemenitas para kohl e respectivos aplicadores, de prata, do século XIX (col. R. e M. Varela Gomes) (foto Rita Varela Gomes). 


\title{
YÁBURA E O SEU TERRITÓRIO - UMA ANÁLISE HISTÓRICO-ARQUEOLÓGICA DE ÉVORA ENTRE OS SÉCULOS VIII-XII
}

José Rui Santos ${ }^{1}$

\begin{abstract}
RESUMO
O ataque efetuado a Évora pela mão do cavaleiro cristão Ordonho II em 912 foi um acontecimento decisivo para a mudança de paradigma e evolução da cidade. Esta vulnerabilidade dos territórios do Garb, levou a que Évora fosse reconstruída e repovoada, tornando-se uma cidade relevante para a Taifa de Badajoz no século $\mathrm{XI}$, trazendo até este território um paradigma cultural maioritariamente islamizado, assumindo-se, a partir daqui, como um ponto essencial na relação entre as rotas terrestes que atravessavam a marcas media e inferior de al-Andalus.

Palavras-chave: Évora, Época islâmica, História e arqueologia, Análise cartográfica.
\end{abstract}

\begin{abstract}
The attack carried out on Évora by the hand of the Christian knight Ordonho II in 912 was a decisive event for the change of paradigm and evolution of the city. This vulnerability of the Garb's territories led to Évora being rebuilt and repopulated, becoming a relevant city for the Taifa of Badajoz in the $11^{\text {th }}$ century, bringing to this territory a culturally mostly Islamized paradigm, assuming, from here, as an essential point in the relationship between the land routes that crossed the middle and lower marks of al-Andalus.

Keywords: Évora, Ceramics, Al-Andalus, History and archeology, Cartographic analysis.
\end{abstract}

\section{INTRODUÇÃO}

Os estudos da ocupação islâmica em Portugal sofreram um percurso peculiar ao longo das primeiras décadas do século XX, este período histórico foi considerado "menor" comparativamente com a "glorioso" época romana e com o "grandioso" reino de Portugal.É uma corrente de pensamento que tem origem no processo de conquista cristã, e se enraizou na sociedade mediante a prevalência cristã sobre o islão (Macias, 2010: 162). O estado da investigação em Évora é marcado por uma relativa escassez de estudos analíticos que se foquem no período medieval-islâmico, tendo em linha de conta a pobreza de fontes literárias conhecidas, os vestígios materiais tornam-se assim fundamentais para descortinar informações desta camada histórica da cidade.

\section{UMA ÉPOCA DE INDEFINIÇÃO}

Durante o período romano, Évora manteve relações comerciais com outros centros urbanos, não se sabendo ao certo se este contacto comercial se mantém durante o período visigótico, tudo indica que depois de florescer durante os séculos V e VI, a cidade encontra declínio no século VII, tanto do ponto de vista social como económico (Mattoso, 1997: 34). Este antigo municipium encontrava-se já desde os tempos de Roma sob a alçada da cidade do convento pacense (Alarcão, 1974: 54), ligação que será retomada durante os séculos VIII e IX (Picard, 200o: 197). O espaço geográfico que confina o Garb é pautado pela continuidade territorial através da manutenção das antigas divisões administrativas (Macias, 2005: 31). É na Kūra de Beja ${ }^{2}$ que Évora encontra circuns-

1. Câmara Municipal de Évora; jr.ribeiro.santos@gmail.com

2. A obra de al-Rasi trata a geografia do al-Andalus no século X, com destaque para as sedes de Kūra, Évora encontra-se na obra integrada administrativamente e militarmente na órbita de Beja. 
crição militar e administrativa e política nos tempos emirais (Coelho, 1989: 36; Rei, 2005: 24).

O desconhecimento acerca dos primeiros tempos da ocupação islâmica de Évora encontra justificação em diferentes pontos. Em primeiro lugar a ausência relativa de informação estratigráfica do período emiral, que se alastra a todo o Garb al-Andalus, a ruralização progressiva que se assiste na alta idade média deve ter conduzido ao colapso das produções romanas tardias, dando lugar a criações menos especializadas (Gómez Martínez, 2007: 99), os meios tecnológicos apresentavam-se pouco desenvolvidos e com mercados urbanos demasiado restritos para permitir aos oleiros investir numa longa aprendizagem técnica. As produções cerâmicas misturam produções manuais com fabrico a torno bastante grosseiros e rudimentares, com pastas mal depuradas e abundantes elementos não plásticos de tamanhos elevados, assim como cozedura redutora com morfologias muito próprias, ainda de tradição tardo-romana (Gómez Martínez, 2007: 99).

Foi um processo simbiótico lento, que encontra origem na islamização demorada das populações do Garb, que lentamente foram assimilando a nova religião e o novo sistema socioeconómico, e na falta de recursos e de técnicas de produção (Torres, 1992: 417). Apenas no século X é feita uma referência nas fontes escritas muçulmanas à cidade de Évora ${ }^{3}$, a qual aparece designada como uma vila (Marques, 1993: $64,104)$ cuja antiguidade e prévio topónimo importa ter em conta, revelando elementos de continuidade urbana com o passado clássico e uma sobreposição dos estabelecimentos humanos.

É certo que no início da administração islâmica na cidade as populações autóctones mantem-se em maior número do que os "recém-chegados", assistindo-se a uma assimilação lenta dos novos paradigmas sociais. Podemos retirar uma leitura sobre este fenómeno centrífugo através de uma análise aos espólios cerâmicos de produção autóctone dos finais do século IX e X, estas formas encontram paralelos em diferentes pontos da Península no período homónimo.

Aos poucos assimilar-se-ão as correntes estilísticas, técnicas, iconográficas, etc. que vigoram no mundo islâmico (Coelho, 2010: 125). Esta primeira fase de assimilação pauta-se não só pelas influências do ex-

3. Ahmad al-Rasi refere, “[...] jaz uma vila a que os antigos chamavam Elbris e ora é chamada de Yábura com os seus termos" (PICARD, 200o, p. 23). terior, mas também pela modelação de influências locais antigas. Facto que resultará numa realidade material própria que vai absorver influências não só ao mundo islâmico, mas também no clássico, romano e visigótico, originando na criação de uma cultura material própria do Garb e com reminiscências locais como se pode constatar nas cerâmicas de uso comum enquadráveis cronologicamente no século IX e X, sendo um dos períodos históricos no qual se registou o maior salto qualitativo na evolução da cerâmica nos territórios que atualmente constituem Portugal (Gómez Martínez, 2007: 100) (Figura 1).

Em Évora, do ponto de vista administrativo e político, os tempos emirais foram bastante conturbados, nestes séculos além de se assistir à construção de uma identidade cultural, verifica-se também o clarear das ligações administrativas e políticas. A continuidade da importância das elites locais, motivou em Beja todo um ciclo de revoltas contra o poder central que justifica a atenção dos cronistas, negligenciando nas suas crónicas as demais cidades. As fontes documentais ao primarem pela abstenção informativa em relação a Évora poderão quer evidenciar convulsões político-sociais na cidade de Beja.

\section{O SÉCULO X E A MUDANÇA DE PARADIGMA}

No texto de Isa ar-Rázi, presente na obra al-Muqtabis $\mathrm{V}$, relativamente ao saque da cidade de Évora pelo galego Ordonho II ocorrido em 912 e à sua nova fundação, assume-se como ponto de observação privilegiado, não só dos acontecimentos que influenciaram os destinos da cidade nos séculos X e XI (Figura 2).

A primeira constatação é a clara decadência a que a se tinha votado a cidade pela altura do referido saque. Isa ar-Rázi relata que quando as tropas de Ordonho II analisavam as muralhas no momento que antecedeu o ataque verificaram que eram baixas e não tinha no topo parapeito nem ameias. Havia numa zona do perímetro exterior um elevado monte de lixo, os habitantes costumavam atirá-lo para ali a partir do interior da muralha (Sidarus, 1988: 22), verificando-se assim o claro descuido a que a cidade se tinha votado, o facto da muralha não ter sido alvo de recuperação ou robustecimento por parte dos habitantes da cidade é sinonimo de falta de recursos.

Um ano após ter sido destruída, Yábura foi reconstruída e repovoada pelo muladí Úd Ibn Sa 'dún as-Shurumbaqi, a mando de Ibn Marwan ficando sob 
a alçada de Badajoz, o que será a força motriz para assegurar o seu renascimento económico e cultural. Se durante os séculos VIII e IX em Évora o reportório de materiais arqueológicos é bastante reduzido, os dados em análise parecem confirmar que a partir da segunda metade do séc. X se verificou um aumento significativo, tanto a nível de produções locais como no volume de importações.

Apesar da reconstrução e repovoamento da cidade se ter iniciado em período emiral, é sob a alçada do califa 'Abd al-Rahmān III que se concretiza. O saque veio demonstrar alguma vulnerabilidade dos territórios do Garb e justificar a posição levada a cabo por 'Abd al-Rahmān III, o qual alastrou a todas as regiões do al-Andalus a centralização do seu poder governativo a partir de Córdova. Irá submeter todos os territórios dissidentes, unificando-os e controlando os novos ímpetos regionalistas através da nomeação de governadores da sua confiança para a administração das cidades (Torres, 1992: 420). Assume estrategicamente a autoria da reconstrução de Évora em 914, apropriando-se deste acontecimento fundacional para ocultar a obra dos seus inimigos demonstrando a sua hegemonia e ligando-o ideologicamente à sua ação (Filipe, 2012: 54).

A partir do ano de $929^{4}$ um enorme florescimento cultural e económico prospera a partir de Córdova, criaram-se as condições para que o comércio leve a todos os territórios do al-Andalus inovações culturais diversificadas. Sob o signo da "pacificação" califal chegam aos territórios ocidentais do Garb pessoas, mercadorias e inovações tecnológicas de produção, vindas de todo o mundo islâmico, com destaque para os produtos que proveem da região de Córdova, que se assume como principal centro produtor e dispersor cultural deste período, facto que só foi possível devido à estabilidade política imposta pelo governo Califal que transformou e integrou o Ocidente Ibérico na grande síntese islâmica (Gómez Martínez, 2007: 100).

Foi neste momento que Évora se incluiu na próspera rede comercial que caracterizou o período omíada. O momento do renascimento da cidade juntamente com a progressiva incorporação da cidade na orla de Badajoz, fazem com que comecem a chegar a Évora peças exógenas com enorme requinte, simbolismo, propaganda ideológica e com um índice de raridade

4. Data do inicio formal do Califado Omíada na Península Ibérica. bastante acentuado, em alguns casos únicas, vindas de diferentes pontos do al-Andalus.

A simbologia religiosa do Islão está presente no quotidiano destas populações, sinónimo claro da presença de uma elite islâmica, que se fixa em Évora na segunda metade do século $X$, na sequência do renascer da cidade, a partir de 914, detentora de algum poder económico e com uma clara abertura aos gostos culturais da época. São indícios claros de uma revitalização urbana e do fortalecimento de um comércio estreito entre Évora, Badajoz e a região de Córdova, como se comprova pelo elevado número de paralelos com peças destas regiões 5 .

Ao nível das produções locais encontramos peças que exprimem grande diversidade de formas e uma tecnologia de fabrico bastante especializada, com técnicas de cozedura predominantemente oxidantes e um nível de depuração bastante avançado. A introdução de expressões artísticas características deste período é sinónima de um progresso social consentâneo com a ordem vigente. A morfologia do espólio traduz hábitos alimentares e tradicionais, claramente pertencentes a um contexto cultural mediterrânico, denotando evolução nas formas e entrando em rotura com as de tradição visigótica e emiral, o que representa novas tradições gastronómicas e numa cultura material característica de uma sociedade plenamente islamizada.

O fenómeno cultural ligado ao ressurgimento socioeconómico da cidade no quadro do al-Andalus deveu-se à decadência de Beja e Mérida no século X e a uma elevação político-administrativa de Badajoz.

\section{A ASCENSÃO DE YÁBURA}

A taifa de Badajoz é fundada em 1013 por Sābūr al-Saklabī, mas será a dinastia Banū al-Aftas, que ligará o seu nome a uma das taifas mais poderosas do século XI (Franco Moreno, 2008: 69), o reino Aftácida, que compreendia o distrito militar noroeste, estendendo-se a sua autoridade pelas cidades de Coimbra, Santarém, Lisboa, Sintra, Évora, Alcácer do Sal e Beja. O crescimento económico de Évora prende-se com a sua localização geográfica, preeminente para os objetivos comerciais, militares e políticos de Badajoz, posicionando-se como o ponto central da via comercial mais importante para o rei-

5. Registado bibliográfico extenso, a título de exemplo: (Fernández Valdés, 1998: 393). 
no aftácida em direção às duas cidades portuárias: Lisboa e Alcácer do Sal.

A alteração do estatuto político e jurídico da cidade e da região de Évora no século XI para segunda cidade em termos de importância da Taifa de Badajoz, apoiada possivelmente numa elite culta e inovadora, permitiu a experiência governativa sobre um espaço económico, no qual a cidade de Alcácer do Sal era sua dependente. Lembremos, que Muhammad b.' Abd Allāh, al-Muzaffar “(...) colocou nela o seu filho al-Mansûr” (Rei, 2005: 24), escolhendo-o para a administração desta de entre todas as cidades que existem no seu reino.

A partir deste periodo Évora teve uma singular importância como ponto-chave de diversas rotas comerciais, dos territórios centrais do eixo longitudinal do Garb, era encruzilhada das rotas terrestres que comunicavam com os reinos de Toledo e Badajoz, e por outro lado, os territórios do interior do actual Alentejo com os portos do comércio mediterrâneo. Está posição importante trou-se até Évora um conjunto material heterogeneo e vasto, neste decifram-se tradições culturais pré-islâmicas embebidas em correntes artísticas com características próprias nascidas desta diversidade de culturas inerentes a este período. Destaca-se um profundo compromisso com o que são princípios doutrinais do Profeta e da cultura muçulmana, que se deixa influenciar por uma corrente oriental, particularmente a bizantina e a sassânida (Fernandes, 1999: 94). O mundo omíado absorveu muito dessas culturas, mas criando mesmo os seus novos modelos com originalidade concordante com o vasto império islâmico (Fernandes, 1999: 94).

Não existe na cultura tradicional muçulmana uma base doutrinal direcionada para as artes, mas sim atitudes, algumas desenvolvidas ou copiadas a partir das regiões dominadas (Oleg Grabar, 1996: 28). $\mathrm{O}$ autor André Bazzana defende a função inegável dos princípios corânicos que norteiam o dia-a-dia dos crentes nas conceções artísticas, realçando o papel afetivo da unidade num mesmo credo, que se traduz numa sensibilidade comum (André Bazzana, 1991: 352). A iconografia da cerâmica é indissociável do contexto político-religioso do Islão peninsular, enquadrando-se na singularidade do reino omíada independente que se desenvolveu em Córdova, então um dos focos principais de irradiação cultural do mundo islâmico.

Destaca-se um conjunto de peças fabricadas com recurso à técnica comumente designada como "verde e magnanês", com representações antropomórficas, que segundo Isabel Fernandes, peças com este tipo de ornamentação chega a converter-se em oferendas do soberano, a título de recompensa ou de afabilidade. Expressão de um poder centralizado que divulga uma imagem de opulência e de ostentação (Fernandes, 1999: 95). Possivelmente são fruto de um trabalho artesanal de encomenda para uma clientela urbana, plausivelmente culta e de um "status" social elevado, que aprecia decorações de qualidade, mesmo em artigos utilitários como estes. "Ao gosto do comprador atraem as alusões ao sagrado e ao poder, através de um desenho invulgar, evocador de antigas tradições orientais e do efeito estético do "verde e manganés", a moda palaciana de grande ostentação" (Fernandes, 1999: 95). É tentador associar estas peças aos acontecimentos ocorridos em Évora nos anos que sucederam o saque da cidade, atendendo à cronologia e proveniência das peças, não é descabido que se trate de uma relação entre estes líderes "mecenas" (Figura 3).

\section{A EVOLUÇÃO URBANA}

Durante os primeiros séculos a cidade manteve as estruturas herdadas da antiguidade com poucas alterações, é notório que a zona do fórum romano sofreu uma ocupação polifásica, os silos, escavados no pavimento romano, são prova da reutilização das estruturas antigas pelas populações do período islâmico e a cronologia dos entulhos recuperados apresenta uma datação post quem emiral e ante quem do período almóada, traduzindo uma ocupação incessante do espaço durante a época islâmica (Figura 4). É bastante provável que o templo romano tenha sido transformado numa estrutura defensiva neste período $^{6}$, é natural que se tenham fixado habitações junto a este forte, que se prolongará geograficamen-

6. Veja-se (SIDARUS, 1988: 196) - “[...]de acordo com o relato da peleja, estas torres "pareciam não ter ligação estratégica com a muralha”. Isto é estranho do ponto de vista da arquitectura militar e da própria situação dos refugiados: divididos por vários edifícios e todos eles tão impenetráveis? A verdade é que o problema pode prender com a terminologia e o documento pode-se referir a um único edifício (mabnā) poderia ser o antigo edifício do Templo Romano, com certeza, já emparelhado e transformado em torre inexpugnável. Terá funcionado antes, como igreja, na sequência do fim do paganismo em Évora?”. 
te até à zona da "mesquita", ligando-se fisicamente a esta, como comprovam os dados analisados por Vanessa Filipe no que toca à estratigrafia registada nas escavações do Museu Frei Manuel do Cenáculo. Existe um reaproveitamento de estruturas de períodos anteriores, com estruturas que se enquadram nas normas construtivas descritas por Ibn 'Abdun. São habitações que dão conta de um bairro de grandes dimensões que terá sido abandonado após conquista cristã da cidade em 1165 (Filipe, 2012: 148150), consentâneo com o términus ocupacional das estruturas junto ao templo romano (Figura 5).

Os vestígios materiais e estratigráficos encontrados no edifício do Colégio dos Meninos do Coro da Sé de Évora, traduzem de igual forma a presença de um conjunto habitacional. Existe claramente uma continuidade da zona áulica romana, na qual se insere o templo e a mesquita (Fernandes, 2001: 5), habitada por uma elite urbana durante todo o período islâmico. É notório que estejamos perante uma continuação um espaço que se advinha intenso em torno da Mesquita, estendendo-se para a zona sul/sudoeste (S-SW) da mesma, em direção à Porta de Moura.

$\mathrm{Na}$ encosta Este (E) da cidade, foi encontrada uma casa de grandes dimensões associada ao período islâmico, o que sugere um edifício palatino, justificando os moldes de ocupação do espaço como alcáçova. Junto à muralha, no quadrante Oeste $(\mathrm{O})$, na zona da atual Casa de Burgos e Rua Vasco da Gama encontramos, de igual forma, vestígios de habitações, materializados em espólios do quotidiano. Um dado que parece certo é que a cidade se foi construindo em torno das estruturas romanas já existentes, e logicamente do centro para a periferia. Apesar de surgirem materiais emirais nas escavações da natatio das termas romanas, fato que leva a ponderar a reutilização das termas (ou pelo menos da natatio) como vazadouro de lixos domésticos, provavelmente uma lixeira urbana (Figura 6).

Os vestígios osteológicos funcionam como fator delimitador da cidade nos diferentes períodos, assim sendo existem duas primeiras necrópoles na zona da Praça do Geraldo e Portas de Moura, em zonas junto às muralhas. Será, portanto, factual que até aos finais do século $\mathrm{X}$ a cidade se mantém com a geografia mais ou menos definida pela muralha tardo-romana. O período de desenvolvimento califal é consentâneo com a reconstrução da cidade pós-saque, a par- tir deste momento surge o crescimento urbano, aliado logicamente ao aumento financeiro e comercial, tanto da cidade como de todo o al-Andalus. Surgem então os primeiros arrabaldes e, já no século XII, em pleno domínio almorávida, a cidade toma nova forma, sendo potenciada por um crescimento habitacional elevado.

A comprovar estão fatos arqueológicos como a presença de necrópoles bastante mais afastadas da muralha antiga (zona do Antigo Convento de S. Domingos) e uma quantidade relevante de novos vestígios em que os materiais apontam para uma cronologia exclusiva do século XII, ao contrário dos sítios centrais em que os vestígios abarcam todas as fases do período islâmico. São testemunhos que sugerem um vincado crescimento urbano no século XII. E visto que a ameaça cristã paira sobre a cidade ${ }^{8}$, não é desapropriada a hipótese de ter existido uma segunda linha de muralha na cidade construída em finais do século XI e inícios do XII.

As muralhas de Évora neste período teriam as características poliorcéticas que agora se desconhecem? Não é impossível. Segundo a cronica do eborense Christovão Rodrigues Acenheiro9 ${ }^{9}$ D. Fernando de Portugal terá mandado destruir grande parte da "cerca velha", aquando da obra da muralha medieval (Correia, 2012: 664-665) ${ }^{1 \mathrm{O}}$.

Esta conjetura parece bastante plausível, no entanto esta hipotética segunda cerca muçulmana pode em alguns troços ter coincidido com as linhas Fernandinas, no entanto parece um pouco exagerado que tivesse tais dimensões (Figura 7).

\section{CONCLUSÕES}

A investigação arqueológica em Évora tem vindo a proporcionar um apreciável conjunto de dados acerca da cidade durante a época muçulmana. Apesar de uma leitura fragmentada da realidade e de uma abordagem necessariamente esquemática, denotamos a ausência de vestígios que confirmem uma

8. Veja-se o impacto que o saque de Évora por Ordonho II teve no seio do poder muçulmano, exemplo disso é a forma injuriosa como Ibn- hayan se refere ao príncipe galego no texto al-Muqtabis.

9. "E despoys, era de mil e quatrocemtos e dezoito, maódou este Rei derribar a cerca velha d 'Evora, que era a mylhor couza d'espanha" (Acenheiro, 1824: 146).

10. 
chegada abrupta ou violenta das tropas muçulmanas, nem uma doutrina ou política imposta à força, mas sim uma realidade que se molda lentamente ao sabor de ruturas com tradições passadas, numa simbiose cultural que lentamente aceita os novos costumes e religião, a muçulmana.

\section{BIBLIOGRAFIA}

ALARCÃO, Jorge (1974) - Portugal Romano, ed. Verbo, Lisboa.

BAZZANA, André (1991) - La Céramique Verde y Morado Califale à Valence: Problèmas Morphologiques et Stylistiques, A Cerâmica Medieval no Mediterrâneo Ocidental, Campo Arqueológico de Mértola, Mértola.

BEIRANTE, Maria Ângela (1995) - Évora na Idade Média, Ed: Fundação Calouste Gulbenkian, Lisboa.

BILOU, Francisco (2010) - A Refundação do Aqueduto da Água de Prata, em Évora 1533-1537, ed. Colibri, Lisboa.

COELHO, António Borges (2010) - Donde Viemos, História de Portugal, volume I, Editorial Caminho.

COELHO, António Borges (2008) - Portugal na Espanha Árabe, ed. Caminho, $3^{\circ}$ ed., Lisboa.

CORREIA, Fernando Branco (2010) - Fortificação, Guerra e Poderes no Garb al-Andalus, Tese de Doutoramento, policopiada;

CHRISTOVÃO, Rodrigues Acenheiro (1824) - Chronicas dos Senhores Reis de Portugal, in: Collecção de Inéditos de História Portugueza, tomo V, Lisboa, Real Academia das Sciencias.

FARIA, António Marques de (2001) - Pax Iulia, Felicitas Iulia; Liberalitas Iulia, Revista Portuguesa de Arqueologia, Vol. 4-2, IPA, Lisboa.

FERNANDES, Hermenegildo (1991) - Organização do espaço e sistema social no Alentejo medievo. Ocaso de Beja, Dissertação de Mestrado, FCSH, Lisboa.

FERNANDES, Hermenegildo; VILAR, Hermínia (2007) O Urbanismo de Évora no Período Medieval, Revista Monumentos $\mathrm{n}^{\circ} 26$.

FERNANDES, Isabel (1999) - Uma taça islâmica com decoração antropomórfica proveniente do castelo de Palmela, Arqueologia Medível 6, ed. Afrontamento, Lisboa.

FERNÁNDEZ, Valdés Fernando, et all (1998) - La Ceramica Andalusí de la Ciudad de Badajoz.primer período (siglos IX-XII), según los trabajos en el antíguo hospital militar y en el área del aparcamento de la c/ de Montesinos. Sítios Islâmicos do Sul Peninsular, ed. Ajuntamento de Extremadura.

FILIPE, Vanessa (2012) - Contributo para o Conhecimento da Presença Islâmica em Yabura, Dissertação de Mestrado em Arqueologia, Universidade Nova de Lisboa, Lisboa.
GÓMEZ MARTÍNEZ, Susana (2004) - La Cerámica Islámica de Mértola: Producción e Comercio, Tesis Doctoral, Universidad Complutense de Madrid, Madrid.

GÓMEZ MARTÍNEZ, Susana (1998) - Cerâmica Islâmica do Garb al-Ândalus, Portugal islâmico, os últimos sinais do Mediterrâneo, Lisboa.

GÓMEZ MARTÍNEZ, Susana (2007) - Cerâmica Islâmica do Gharb al-Ândalus, Campo Arqueológico de Mértola, in. Seminário - "A produção de cerâmica em Portugal: histórias com futuro, Mértola.

GRABAR, Oleg. (200o) - La Formación del Arte Islámico. 8를. Cátedra, Madrid, p. 216.

MACIAS, Santiago (2010) - Islamic Archeology in Portugal, in: The Historiography of Medieval Portugal (c.1950-2010), Direcção de José Mattoso, ed. Centro de Estudos de História Religiosa e 10 outras instituições, Lisboa.

MACIAS, Santiago (1996) - Mértola Islâmica, Estudo Histórico-Arqueológico do Bairro da Alcáçova, (Séculos XII-XIII), Mértola.

MATTOSO, José (1997) - A época sueva e visigótica, História de Portugal, Dir. José Mattoso, vol. I - Antes de Portugal, ed. Estampa, Lisboa.

PICARD, Christophe (200o) - Le Portugal Musulman (VIII - XIII siècle), L'Occident d'al-Andalus sous domination islamique, Maisonneuve \& Larose, Paris.

REI, António (2005) - O Gharb al-Andalus em dois geógrafos árabes do século VII/XII: Yāqūt al-Hamāwī e Ibn Sa '̄id al-Maghribī, Medievalista, $\mathrm{n}^{\mathrm{o}} \mathrm{I}$ (online).

SALINAS PLEGUEZUELO, Mํㅡㄹ Elena (2012) - La cerâmica Islâmica De Madinat Qurtuba, de 1031 a 1236: Cronotipología y Centros de Producción, Tesis Doctoral, Universidad de Córdoba, Córdoba.

SIDARUS, Adel (1988) - Um Texto Árabe do Século X Relativo à Nova Fundação de Évora e aos Movimentos Muladi e Berbere no Ocidente Andaluz, A Cidade de Évora, nº 71-76, Ed. Gráfica Eborense, Évora.

TEICHNER, Felix (1998) - A ocupação do centro da cidade de Évora da época romana à contemporânea. Primeiros resultados da intervenção do Instituto Arqueológico Alemão (Lisboa), Actas das II Jornadas de Cerâmica Medieval e Pós-Medieval, Câmara Municipal de Tondela, Tondela

TEICHNER, Felix (1986-1992) - Évora, Vorbericht über die Ausgrabungen am Römischen Tempel, Madrider Mitteilungen, Mainz, Verlag Philipp Von Zabern.

TORRES, Cláudio (2008) - Camponeses e Mercadores no Mediterrâneo, Arqueologia Medieval 1o, ed. Afrontamento, Porto.

TORRES, Cláudio (1992) - O Garb al-Andaluz, História de Portugal de José Mattoso, Vol. I, ed. Circulo de Leitores, Lisboa. 
VALDÉS FERNANDO, et all (1998) - La Ceramica Andalusí de la Ciudad de Badajoz.primer período (siglos IX-XII), según los trabajos en el antíguo hospital militar y en el área del aparcamento de la c/ de Montesinos. Sítios Islâmicos do Sul Peninsular, ed. Ajuntamento de Extremadura.

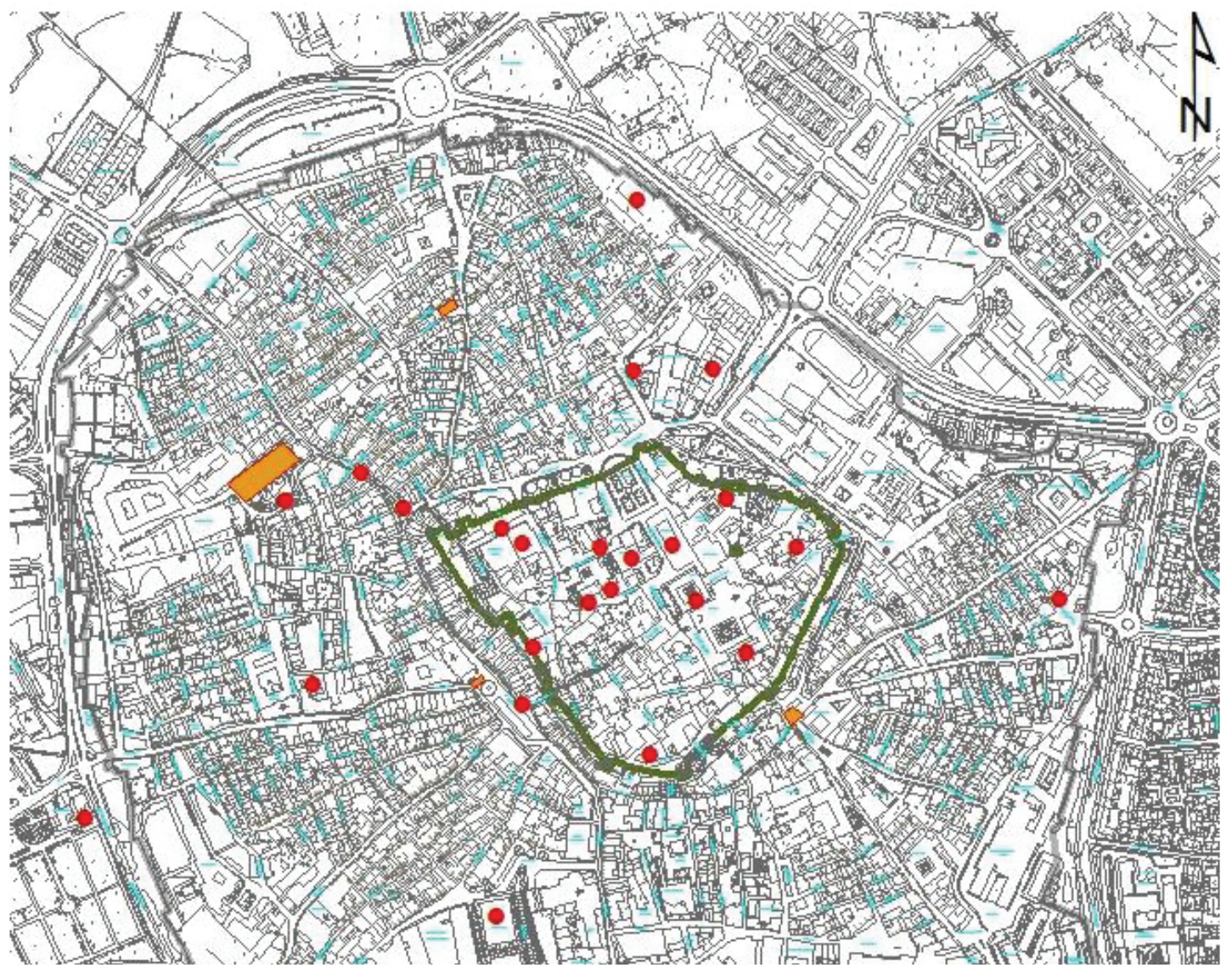

Figura 1 - Georreferenciação dos achados do período islâmico, com necrópoles (a amarelo) e zonas habitacionais (a vermelho). 


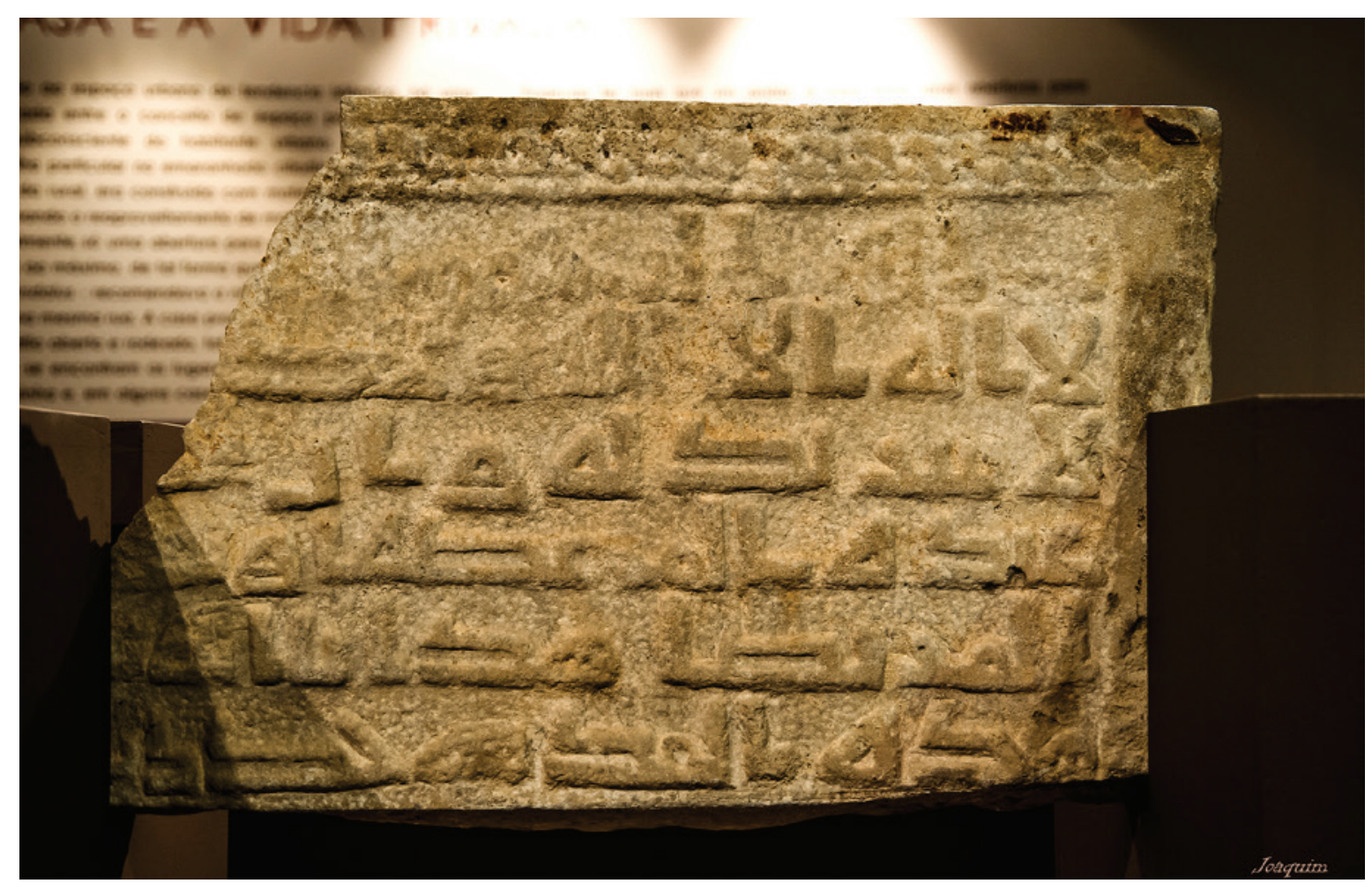

Figura 2 - Lado 1 da lapide duplamente epigrafada. Corresponderá à reconstrução de Évora, após o ataque de Ordonho II e destruição das suas torres e muralhas por Ibn al-Jilliqi (século X-914/915 d.C.-3O2 H.) - "Em nome de Deus, o Clemente, o Misericordioso. [Dou testemunho que] não há outro Deus, senão Deus, Ele só, [que] não tem associado e que Muhammad é o seu servo eleito e o seu profeta, merecedor de toda a Sua complacência - Que Deus nos guie através Dele pelo bom caminho. Esta cidade foi reconstruída [...]”. Fotografia de Joaquim Carrapato - Exposição Yábura - Uma Cidade do al-Andalus.

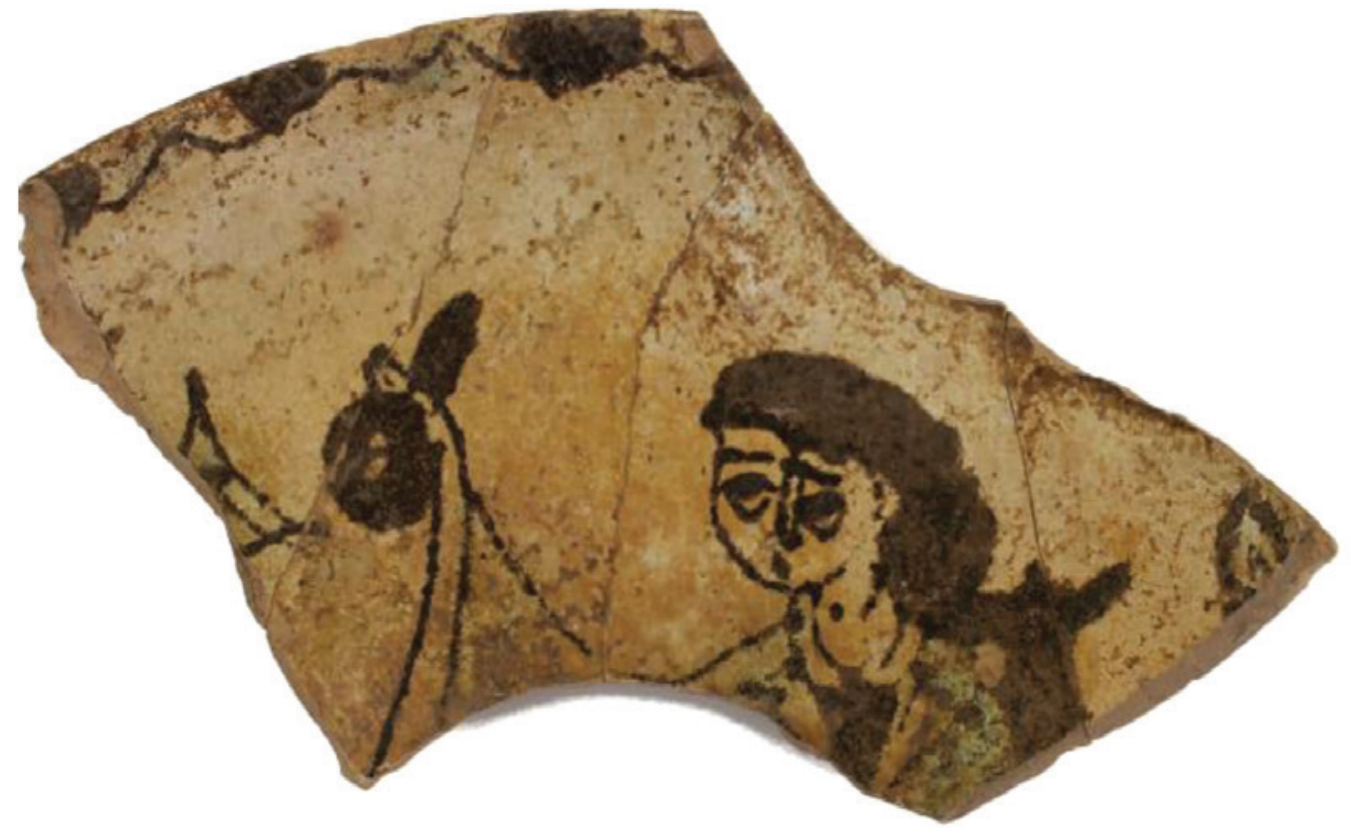

Figura 3 - Cerâmica com ornamentação a "verde e manganês” com motivo antropomórfico encontrada em Évora. 


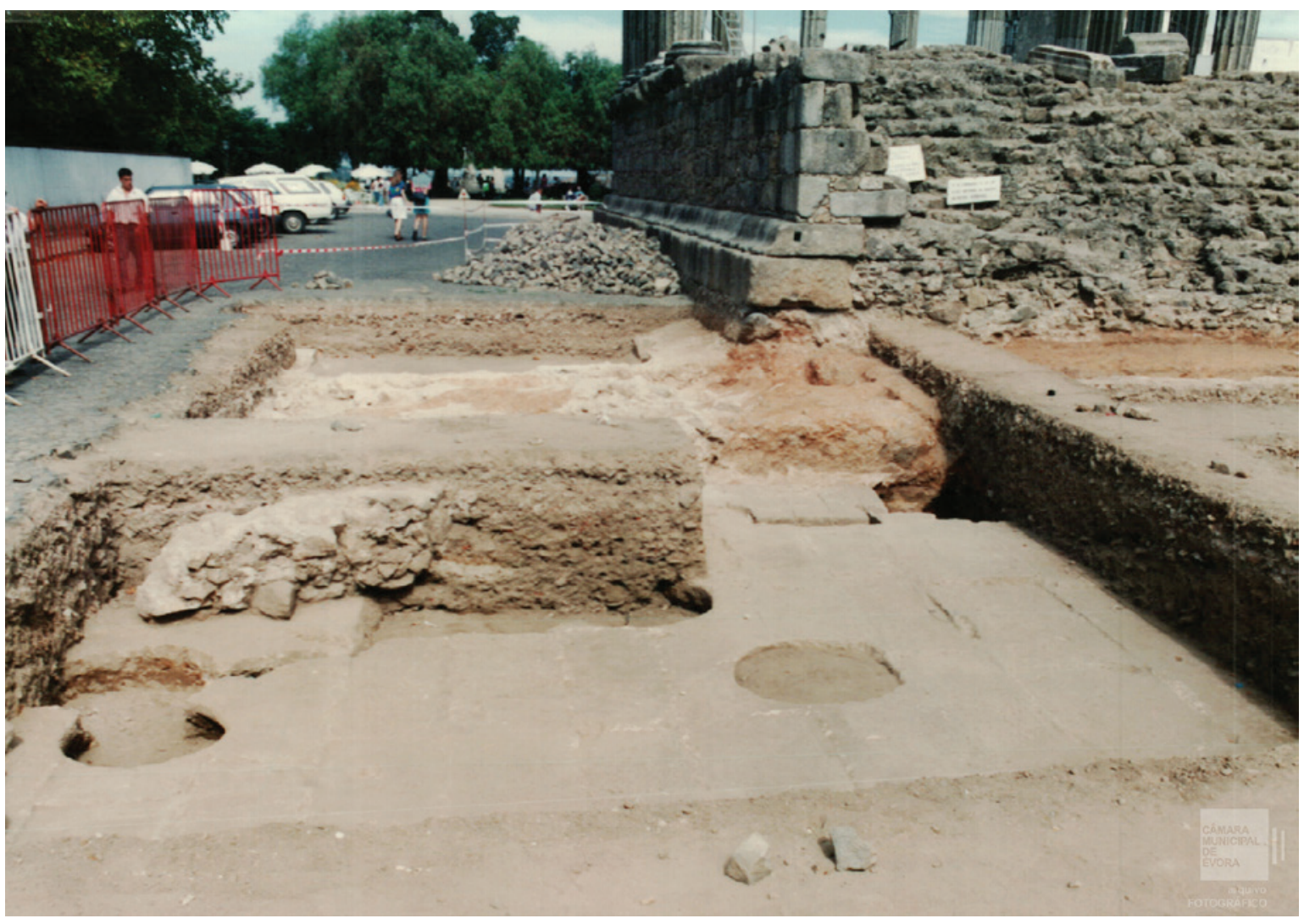

Figura 4 - Pormenor da intervenção arqueológica junto ao templo romano por Theodor Hauschild em 1991. São percetíveis vários silos do período islâmico escavado diretamente no pavimento do fórum romano.

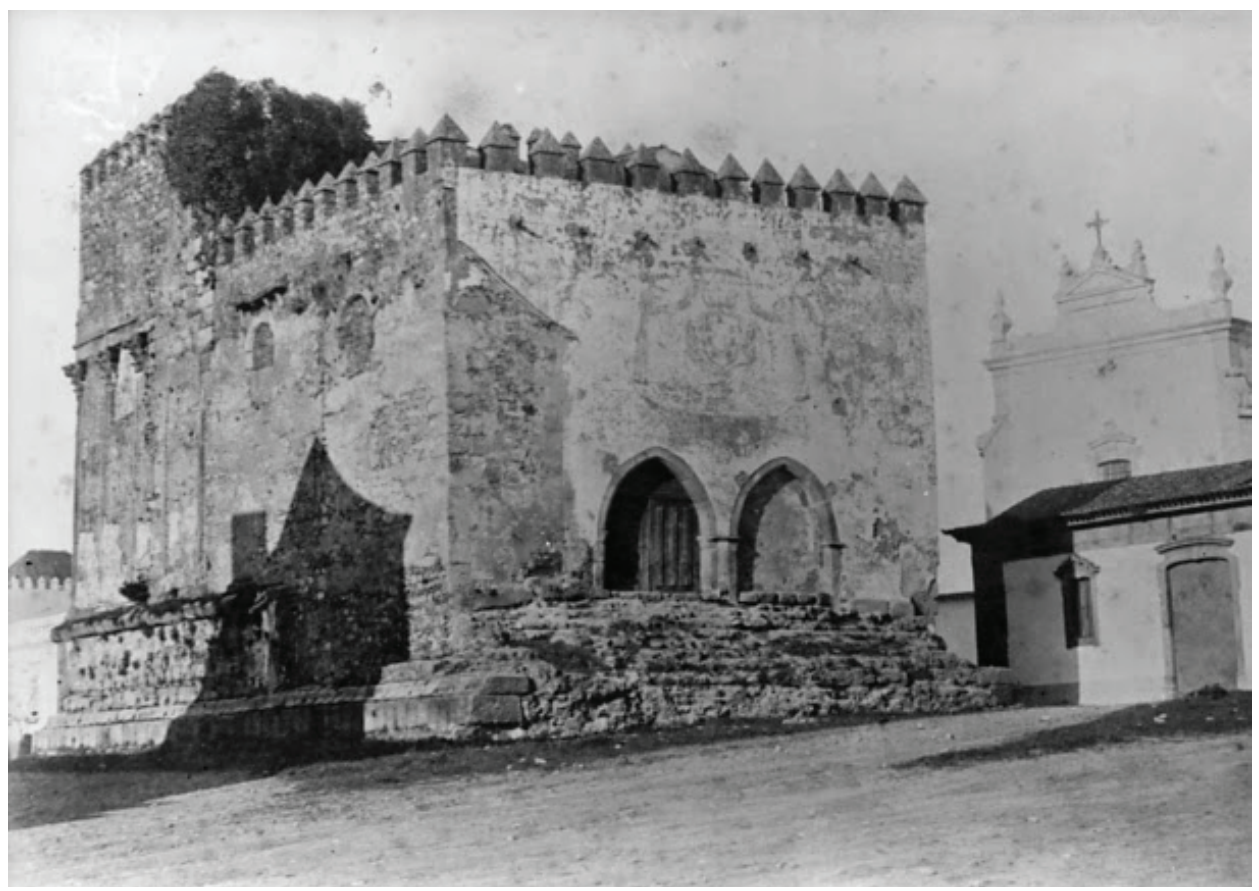

Figura 5-Fotografia do templo romano com edificações medievais - Arquivo CME. 

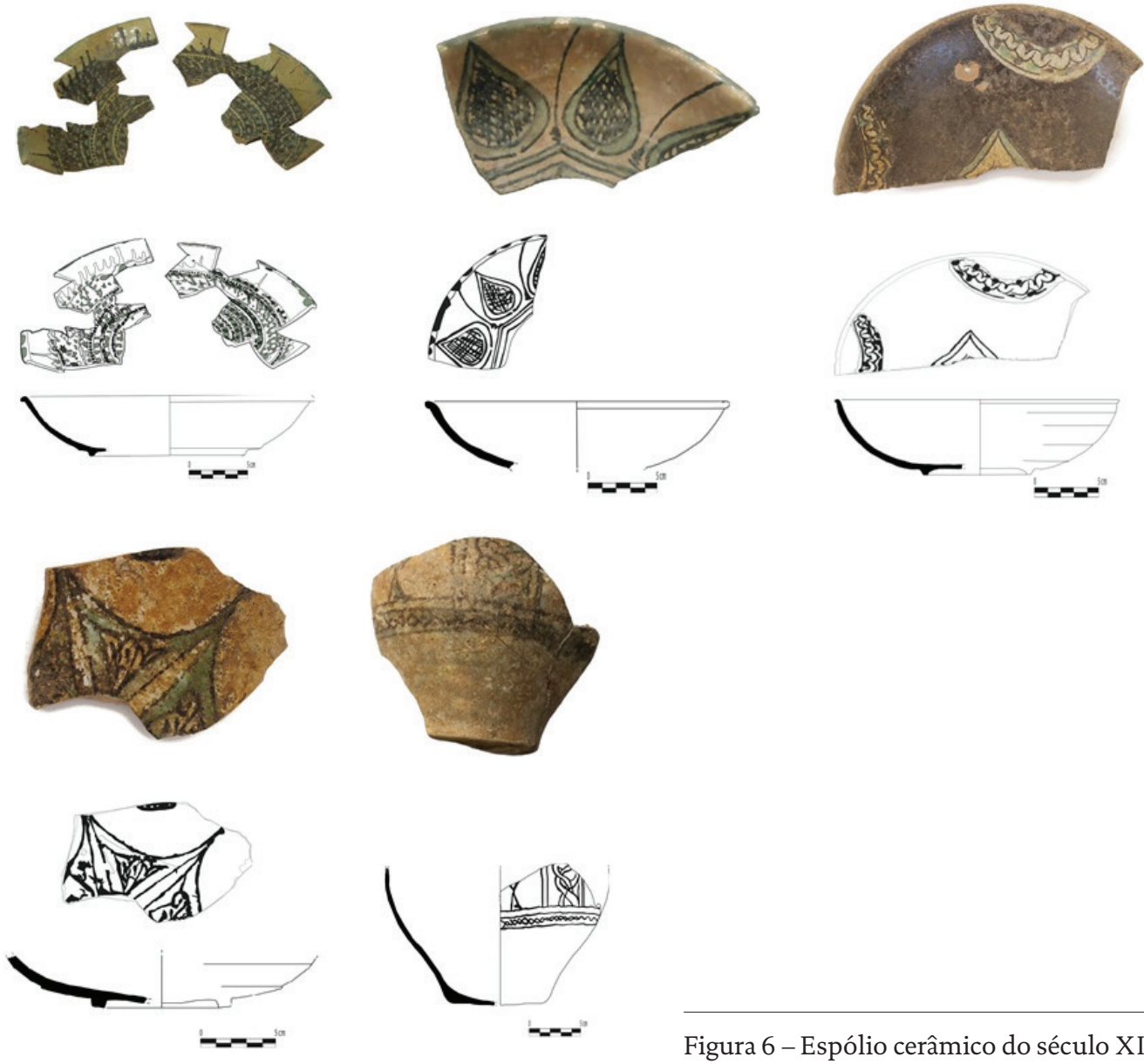

Figura 6 - Espólio cerâmico do século XI.

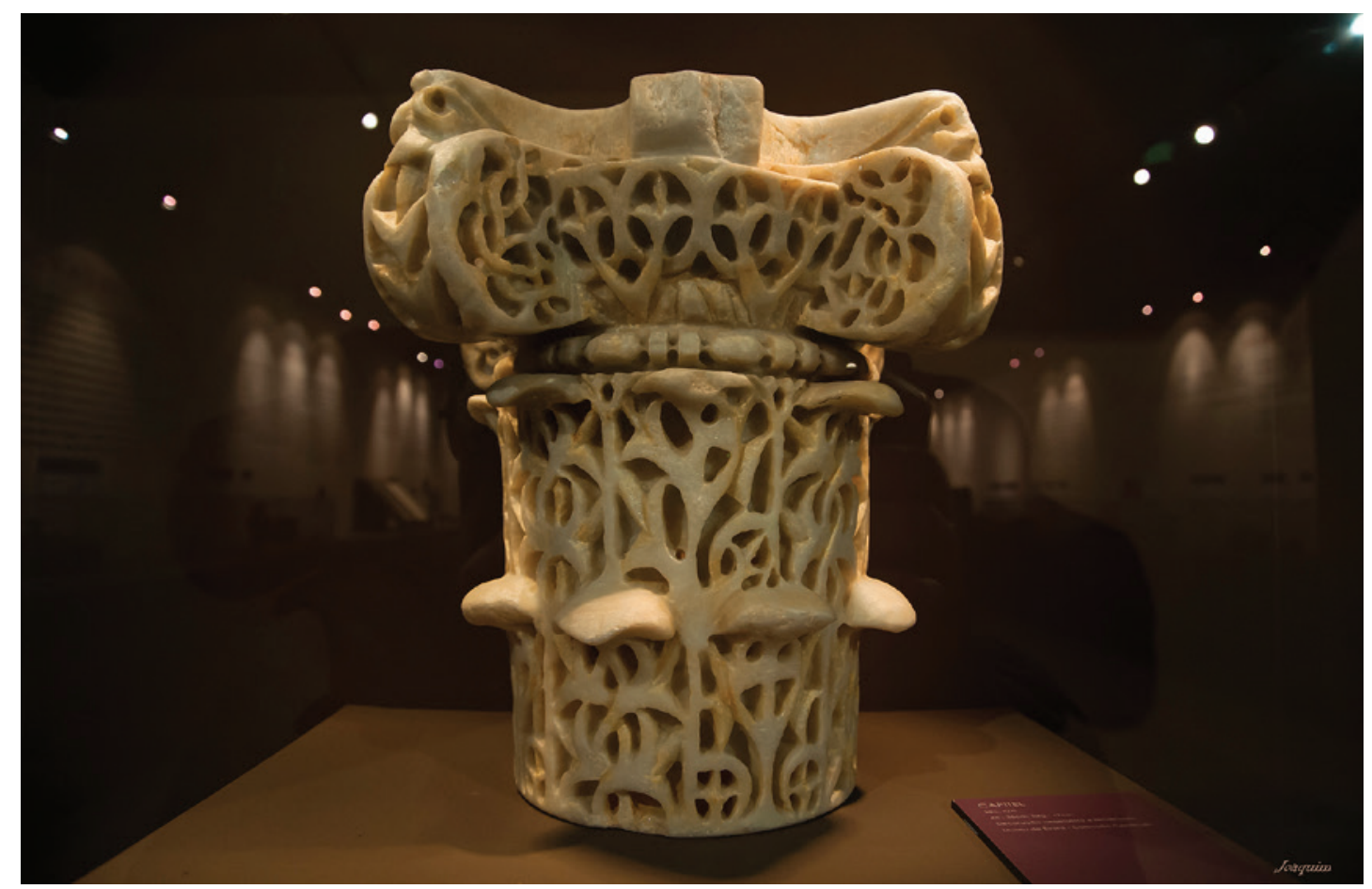

Figura 7 - Capitel de estilo acolmeado. Fotografia de Joaquim Carrapato - Exposição Yábura - Uma Cidade do al-Andalus. 


\title{
A ENCOSTA SUL DO CASTELO DE PALMELA - RESULTADOS PRELIMINARES DA ESCAVAÇÃO ARQUEOLÓGICA
}

Luís Filipe Pereira ${ }^{1}$, Michelle Teixeira Santos ${ }^{2}$

\author{
RESUMO \\ Apresentação dos resultados preliminares da escavação arqueológica realizada na Encosta Sul do Castelo \\ de Palmela. \\ Palavras-chave: Castelo de Palmela, Islâmico, Silos, Encosta sul.
}

\begin{abstract}
Presentation of the preliminary results of the archaeological excavation in the South hillside of the Castle of Palmela.
\end{abstract}

Keywords: Castle of Palmela, Islamic, Silo, South hillside.

\section{INTRODUÇÃO}

O presente trabalho apresenta os resultados preliminares dos trabalhos arqueológicos realizados no âmbito do projecto de obra «Intervenção de Natureza Estrutural para Evitar Derrocadas na Encosta Sul do Castelo de Palmela» que decorreram entre novembro de 2018 e junho de 2019.

A intervenção arqueológica teve como director científico o arqueólogo Luís Filipe Pereira (Arqueohoje, Lda.), signatário do presente artigo, contando com a colaboração das arqueólogas Marina Évora (Arqueohoje, Lda.) e Michelle Teixeira Santos (Museu Municipal de Palmela), também signatária deste artigo, e a antropóloga Fátima Almeida. O tratamento das peças cerâmicas foi realizado com o apoio de Cláudia Sofia Oliveira (Museu Municipal de Palmela). As cerâmicas foram desenhadas por Maria Santos Constança, Marina Évora e Miguel Correia (Museu Municipal de Palmela). Os trabalhos de escavação contaram ainda com o auxílio de uma equipa de trabalhadores indiferenciados.

Este artigo, complementar ao poster científico, demonstra uma primeira abordagem sobre a leitura e interpretação dos resultados obtidos nos trabalhos de campo, a análise preliminar de uma selecção do espólio recolhido no interior de um silo de grandes dimensões, o silo 6 (U.E. [217/218]), cuja cronologia de utilização e encerramento remete para a última ocupação islâmica e a primeira ocupação cristã do castelo, com datação enquadrada entre os finais do século XII e o início do XIII.

\section{LOCALIZAÇÃO}

O Castelo de Palmela localiza-se no concelho de Palmela, pertencente ao distrito de Setúbal, e ocupa o topo de um cerro, com cerca de $252 \mathrm{~m}$ de altitude, e com as seguintes coordenadas geográficas (Sistema WGS84): Latitude $=38^{\circ} 33^{\prime} 56,73$ e Longitude $=$ $8^{\circ} 53^{\prime} 59,54$ (Figura 1).

A sua implantação beneficia estrategicamente de um amplo domínio visual sobre a paisagem circundante, podendo avistar a sul a cidade de Setúbal, o estuário do rio Sado e a costa atlântica até Sines, a poente os vales e o conjunto montanhoso da serra da Arrábida, a nascente a ampla planície do Ribatejo, e a norte o estuário do Rio Tejo.

\footnotetext{
1. Arqueohoje Lda. - Conservação e Restauro do Património Monumental, Lda; lpereira@arqueohoje.com

2. Museu Municipal de Palmela; mtsantos@cm-palmela.pt
} 


\section{CONTEXTOS E OBJECTIVOS}

O projecto de "Intervenção de natureza estrutural para evitar derrocadas nas encostas do Castelo de Palmela" contemplou a realização de trabalhos de natureza diversa, compreendendo trabalhos de engenharia estrutural que visava a estabilização da encosta sul, nascente e sudoeste do castelo.

Os trabalhos arqueológicos foram efectuados no âmbito das medidas preventivas para a minimização de impactos no solo e no subsolo para a execução do projecto, tendo em conta a sensibilidade e o potencial arqueológico do castelo, e com o objectivo de diagnosticar, caracterizar e registar a existência de vestígios arqueológicos preservados nesta área, e avaliar eventuais impactos negativos decorrentes da construção da antiga piscina da Pousada, nos finais dos anos 70 do século XX.

A investigação arqueológica do Castelo de Palmela inicia-se nos anos 9o do século passado sob a direcção da arqueóloga Isabel Cristina F. Fernandes. Os trabalhos realizados incidiram sobretudo na praça de armas, muralha norte e nascente, e permitiram identificar um conjunto habitacional da fase Omíada (século VIII), bem como uma sucessiva e continuada ocupação entre os séculos IX-X até à conquista definitiva do castelo pelos exércitos cristãos, no século XII (Fernandes, 2004). É nesta fase que a ordem de Santiago se instala e cria sede no castelo, onde mantém um comendador-cavaleiro e uma pequena guarnição de freires-cavaleiros.

\section{A INTERVENÇÃO ARQUEOLÓGICA}

\subsection{Metodologia}

A realização da avaliação patrimonial do subsolo afecto à área de implantação do projecto de execução, nomeadamente através da determinação da dimensão da área arqueológica e da sua caracterização científica/patrimonial; do registo das sequências estratigráficas contribuíram para a salvaguarda das estruturas arqueológicas in loco e para o consolidar do conhecimento sobre a ocupação da fortificação.

A escavação das sondagens prévias fez-se pela decapagem sucessiva dos diferentes sedimentos identificados até ao substrato geológico, estéril em vestígios arqueológicos, ultrapassando a cota de afectação da obra prevista para interior do recinto do baluarte Sul. As diferentes fases dos trabalhos foram devidamente registadas através do preenchimento indi- vidualizado de uma ficha de unidade estratigráfica, para cada estrato/depósito/estrutura; de fotografia digital, em suporte gráfico (à escala 1:20) e topográfico, abrangendo todos os planos (inicial, intermédios e final), dos perfis dos cortes e as estruturas arqueológicas postas a descoberto. Para cada uma das quatro sondagens foram atribuídas unidades estratigráficas distintas a partir do [0o], [100], [200] e [300], respectivamente.

\subsection{A Escavação}

A escavação arqueológica focou-se na encosta sul do castelo, onde foram implantadas quatro sondagens no interior do recinto abaluartado e junto da muralha medieval (alçado sul) como o objectivo de intervencionar uma área total de $80 \mathrm{~m}^{2}$. As sondagens, com diferentes dimensões, foram distribuídas desde a parte central do Baluarte Sul até à área mais a poente deste recinto, privilegiando uma área que à partida não teve impacto negativo com a construção da piscina da Pousada do Castelo situada na parte mais a nascente do baluarte.

Implantou-se a sondagem 1 junto à base da Torre do Telegrafista tendo sido intervencionado um total de $26,7 \mathrm{~m}^{2}$. O afloramento rochoso surge a cerca de o,40 $\mathrm{m}$ de profundidade, e encontra-se também por baixo da base da torre do Telegrafista servindo de base de assentamento das primeiras fiadas de pedra do aparelho da torre, solução construtiva observada noutras partes do pano de muralha medieval (Islâmico e Cristão) do castelo. Nesta sondagem identificaram-se vestígios de cronologia medieval islâmica, caracterizado por dois silos, restos osteológicos humanos e a fundação de um muro em alvenaria, e vestígios de cronologia moderna e contemporânea, na qual se destaca um piso de argamassa.

A sondagem 2 foi implantada na zona mais a poente da plataforma do Baluarte Sul, junto da Torre 8 (do Miradouro), tendo sido intervencionado 7,5 $\mathrm{m}^{2}$ de área. A estratigrafia identificada era constituída por várias camadas de aterro, que regularizavam a plataforma do recinto do baluarte. O substrato geológico (arenito compacto), com declive acentuado para Sul, surge a cerca de 2,5 $\mathrm{m}$ de profundidade. Identificou-se um piso de argamassa, que apresentava características idênticas ao piso registado na sondagem 1, de cronologia moderna, e um silo de cronologia medieval cristão.

A sondagem 3 estava localizada entre as sondagens 1 e 2, e corresponde à maior área de escavação, com 
um total de $35,3 \mathrm{~m}^{2}$ intervencionados. Procurou-se aproximar esta sondagem do pano de muralha medieval, alçado sul, compreendido entre as torres do Telegrafista e a Torre 8. Só foi possível encostar a sondagem à muralha na área central da intervenção, em cerca de $3 \mathrm{~m}$ de comprimento, salvaguardando assim o coberto arbustivo e arbóreo existente. O substrato geológico surge a cerca de 1,10 $\mathrm{m}$ de profundidade, e o terreno apresenta-se aplanado/ regularizado. Foi neste estrato que foram escavados durante a ocupação islâmica do castelo, os nove silos de diferentes tamanhos, a vala de fundação de um muro (de construção e alinhamento semelhante ao registado na sondagem 1 ), bem como outras estruturas negativas associadas, eventualmente, a sistemas de drenagem de águas pluviais (U.E.'s [222] e [223]). A sondagem 4 foi implantada na parte mais central do baluarte e mais próxima à antiga piscina da Pousada do Castelo, tendo sido intervencionada uma área com 10,5 $\mathrm{m}^{2}$ e até à cota de afectação da obra, aos $4 \mathrm{~m}$ de profundidade. A estratigrafia revelou tratar-se de unidades de aterro utilizadas para regularizar o solo, e que contém inúmeros artefactos de ampla cronologia, sensivelmente desde o século $\mathrm{XIV} / \mathrm{XV}$ até ao século XX. A rocha base calcoarenítica apresenta-se em plataformas que intercalam com níveis mais arenoso muito compacto, e com declive abrupto para Sul. Desta sondagem apenas se destacam um resto de um muro (U.E. [309]), de função indeterminada, e o piso de argamassa (U.E. [305]) registado nas restantes sondagens. Também se identificaram alguns contextos resultantes das obras de restauro realizadas nas décadas de 30/40 do século passado pela DGEMN (Direcção Geral de Edifícios e Monumentos Nacionais), das adaptações resultantes da ocupação/utilização do castelo pelo Exército Português Transmissões Militares) e das obras de relacionadas com a construção da antiga piscina da Pousada do Castelo. A leitura da estratigrafia permitiu clarificar o comportamento do terreno natural e a influência da topografia na construção do baluarte sul. $\mathrm{O}$ afloramento rochoso surge aos $0,40 \mathrm{~m}$ de profundidade, observável no perfil norte, e surge em escamas até aos cerca dos $4 \mathrm{~m}$ de profundidade, sempre com acentuado declive para sul. Os sedimentos que compõem o enchimento do interior do baluarte correspondem a sucessivas camadas de aterro depositadas desde a rocha base, onde a muralha adossa e se sobrepõe, até ao nível mais regularizado existente no topo do baluarte.
De um modo geral, a estratigrafia do terreno é bastante homogénea, estendendo-se na horizontal em quase toda a área intervencionada, com excepção na sondagem 4 que se apresenta mais revolvida e alterada devido à proximidade com a antiga piscina, e associada à presença militar em especial na Torre dos Telegrafistas. As camadas que caracterizam os diferentes estratos são sedimentos de natureza arenosa, medianamente compactos, por vezes revolvidos, e apresentam uma coloração em tons castanhos, cinzentos e amarelos. A cultura material recolhida parece indicar que toda esta área foi sujeita a melhoramentos sobretudo no que respeita a nivelamento do solo, para a construção do baluarte sul no século XVII e centúrias seguintes.

\subsection{Resultados}

No total foram identificadas 38 estruturas, de funções por vezes distintas, que se inserem cronologicamente, desde o período medieval islâmico (silos, muro e valas) ao período contemporâneo (valas de infra-estruturas de saneamento e electricidade).

As estruturas arqueológicas melhor preservadas são de cronologia medieval e encontravam-se ao nível do subsolo, sensivelmente à cota do substrato geológico (Figura 2). Destes vestígios evidenciam-se os doze silos de cronologia medieval (11 islâmicos e 1 cristão), escavados integralmente, com excepção dos silos 1 e 7 que ficaram salvaguardados no perfil sul, além do silo io junto ao perfil oeste. Estas estruturas destinadas ao armazenamento de bens alimentares terão sido eventualmente, construídas entre os séculos IX-X e utilizadas até à sua desactivação, durante a primeira metade do século XIII, momento em que todos os silos foram devidamente atulhados e selados, na sequência da conquista definitiva do Castelo de Palmela pelos exércitos cristãos, no final do século XII e, da ocorrência de profundas transformações da fortificação medieval, após a sua conquista (Fernandes, 2004), ficando assim localizados extramuros da muralha medieval cristã. Os silos escavados na rocha base e apresentam formato ovalado, com diferentes dimensões, variando entre os $0,90 \mathrm{~m}$ de diâmetro e os $3,45 \mathrm{~m}$, e com profundidades oscilando entre os $0,40 \mathrm{~m}$ e os $3,20 \mathrm{~m}$. A maioria destas estruturas negativas tinha pouca capacidade de armazenamento, com excepção do silo de grandes dimensões (Silo 6 - U.E. [217/218]). Nenhum dos silos tinha o bocal estruturado, pelo menos preservado, e alguns encontravam-se sela- 
dos com blocos pétreos de tamanho médio e grande, por vezes argamassados.

A área onde se localizam os silos islâmicos, que corresponde às sondagens 1 e 3 (Fotos 1 e 2), estava delimitada a sul por um muro em alvenaria (Muro 1 -U.E. [22] - sondagem 1 e U.E. [230] - sondagem 3), que se estendia no sentido nascente-poente e que poderia corresponder, a uma estrutura de apoio, de âmbito residencial ou defensivo do tipo barbacã.

Sobre esta última hipótese temos algumas reservas, na sua classificação, como parte de um sistema defensivo tendo em consideração as características que apresentava, um vez que não se tratava de uma sólida construção, tendo apenas $0,57 \mathrm{~m}$ de largura máxima registada na sondagem 1 . No entanto, a sua implantação no limite desta plataforma com acentuada vertente a sul, confere-lhe boas condições defesa não justificando uma construção robusta, razão pela qual não podemos excluir esta interpretação. A vala de fundação do Muro 1 (U.E. [22b] e [31]) na sondagem 1 foi escavada integralmente (lados norte e sul), e permitiu perceber que foi aberta no substrato geológico, prolongando-se para a sondagem 3. Nesta sondagem a vala de fundação (U.E. [229]) do Muro I (U.E. [230]) cortava e aproveitava estruturas pré-existentes, nomeadamente os silos 9, 11 e 12 (U.E.'s [224], [233] e [234], respectivamente). Admitimos que a cronologia da construção do muro 1 possa balizar-se entre os séculos XI e os inícios do XII, sendo eventualmente, posterior à construção de grande parte dos silos. Não foi possível clarificar a planta da estrutura que delimitava os silos medievais devido ao mau estado de preservação em que se encontrava, e também por não se ter identificado a sua continuidade, nas vertentes poente e nascente, da área intervencionada. A presença de uma vala (U.E. [231]) no limite poente da sondagem 3 corta, aparentemente, o Muro 1 no sentido sudoeste - nordeste, o que poderá indicar um hipotético cunhal desta estrutura que já não se preservava, ou até corresponder ao vestígio da destruição deste muro em séculos posteriores, talvez resultado da construção do recinto abaluartado na época moderna ou da transformação do sistema defensivo medieval. Para nascente, na sondagem 1 , o afloramento surge praticamente à superfície, não se conseguindo observar a continuidade do muro, ainda que o seu negativo desenhado na rocha base, ligeiramente afeiçoada nos sugira a sua presença. O piso de argamassa de cronologia moderna encontrava-se à mesma cota do afloramento rochoso, este que se apresentava regularizado para aproveitamento como piso de circulação, facto que terá apagado os vestígios do muro medieval.

Na sondagem 1 identificaram-se restos osteológicos humanos (U.E. [25]) que se encontravam depositados sobre o afloramento geológico e junto à vala de fundação do muro 1, no lado norte. Este conjunto era constituído por três fragmentos de ossos, nomeadamente pela tíbia direita, o fémur direito e a fíbula direita pertencentes a dois indivíduos adultos do sexo feminino. Trata-se de um depósito secundário segundo a análise antropológica realizada in situ, e a sua origem levanta muitas dúvidas, enquadrando-se num dos momentos mais conturbados da história do castelo, na segunda do século XII.

Observou-se, na sondagem 3 que a base da muralha sul assentava sobre uma estrutura pré-existente (U.E. [206]), cuja funcionalidade não podemos determinar, e que se caracterizava por um aparelho irregular, constituído por blocos pétreos de calcoarenito local, de calibre médio e grande, unidas por argamassa. Possuía visível, $3 \mathrm{~m}$ de comprimento, por aproximadamente $0,40 \mathrm{~m}$ de altura, por $0,20 \mathrm{~m}$ de largura, e assenta directamente no substrato geológico.

A existência em todas as sondagens de um piso de argamassa está associada ao nível de circulação do recinto abaluartado, ou até a um melhoramento do solo no decorrer do século XVIII. Esta estrutura demarcava bem a diferenciação cronológica dos artefactos identificados e recolhidos, contribuindo para a preservação das estruturas medievais precedentes. Os vestígios de ocupação humana mais antiga são pouco expressivos no registo e são testemunhados por artefactos cerâmicos e líticos, enquadrados no 2./. 1.ำ milénios a.n.e. Era já referida a presença de cerâmicas campaniforme com decoração linear-pontilhada associada à incisa do Grupo Palmela, datada do último quartel do 3. ․ milénio a.n.e. e também, alguns exemplares da Idade do Bronze (Fernandes e Carvalho, 1993:10; Fernandes, 2004: 235 e Fernandes e Santos, 2008:73). Presentemente, a intervenção realizada na encosta sul revelou que o cerro do castelo foi efectivamente, ocupado no final do $3 .^{\circ} \mathrm{e}$ durante 0 2.. / $1 .$. milénios a.n.e., como nos comprovam os vestígios materiais aqui recolhidos e outros dados, provenientes das restantes áreas escavadas no castelo. No caso, individualizamos nas unidades estratigráficas mais antigas e, que revestem o afloramento rochoso desta plataforma ou no enchimento dos silos, alguma indústria lítica maioritariamente 
em sílex e quartzito, alguns recipientes de cerâmica manual, por vezes decorada, e na sua maioria, brunidas. Destacamos, a presença de cerâmica decorada por traços brunidos, ainda que não tenhamos conseguido individualizar os contextos preservados, desta ocupação do Bronze Final / I. . Idade do Ferro, nem de períodos cronológicos anteriores, consequência das sucessivas reocupações e utilizações da fortificação promovidas por muçulmanos e cristãos. No conjunto da informação exumada, outros materiais remetem-nos para os contextos de uma ocupação romana, sobretudo tardia, prévia à construção da fortificação Omíada e igualmente, individualizada nas intervenções realizadas na alcáçova e junto à muralha norte-nascente. Documentamos na área de intervenção formas abertas de Terra Sigillata Clara e um numisma (materiais em estudo). A presença de contextos e materiais das ocupações pré-islâmicas foi igualmente, registada nas intervenções coordenadas por I. C. Fernandes, através do reaproveitamento de elementos arquitectónicos em mármore branco, nas muralhas e habitações Omíadas nomeadamente, os dois capitéis decorados com volutas, os dois fustes de coluna integrados num sistema de escoamento da muralha islâmica e um fragmento de friso (?), reutilizado como tabuleiro de jogo do 'Alquerque dos 9'. Estas evidências, a par dos vestígios materiais recolhidos na Encosta sul do Castelo, reforçam a possibilidade de existir uma anterior edificação da Antiguidade Tardia, ocupada até finais do século VIII e inícios do IX, posteriormente destruída/desmantelada pelos muçulmanos (Fernandes, 2004: 221).

Os artefactos de cronologias mais recuadas foram recolhidos em diferentes estratos sedimentares, que antecedem a formação rochosa de base - plataforma sul - ou no enchimento de alguns silos desprovidos dos seus contextos originais.

\subsubsection{O silo 6 - U.E. [217/218]}

A atribuição de unidades distintas, a este silo, deve-se à observação inicial, de duas manchas com coloração mais escura no substrato geológico, facto que parecia indicar a presença de duas estruturas negativas diferentes. Porém, durante a escavação em simultâneo destas U.E.'s determinou-se que se tratava de um silo de grande dimensão e cuja realidade estratigráfica era igual (Foto 3). A superfície do substrato geológico, em especial na área onde se registou a U.E. [217] mostrava sinais de abatimento da cobertura do silo, realidade testemunhada no seu enchimento, observando-se no perfil, o deslizamento dos sedimentos, resultante de um fenómeno natural, eventualmente fruto de algum terramoto, ocorrido após a desactivação do silo e posterior, à primeira metade do século XIII.

Escavado no substrato geológico (U.E. [214]), apresentava uma secção oval, com cerca de 3,20 m de profundidade, por 3,45 $\mathrm{m}$ de largura e tinha um bocal com cerca de $2 \mathrm{~m}$ de diâmetro. Estava selado com fragmentos de telha de canudo, alguns com decoração pintada e blocos pétreos, de médio e grande calibre. Compreendia quatro depósitos camadas no seu enchimento (U.E.'s [218A], [218B], [218C] e [218D]), associados a carvões e cinza, juntamente com restos faunísticos, objectos metálicos (fragmentos de peças de armamento, moedas e outros objectos indeterminados), ecofactos (algumas sementes carbonizadas e coprólitos), fragmentos de mós, e inúmeros fragmentos de cerâmica (doméstica, armazenamento e de construção). A estratigrafia do seu enchimento forneceu a seguinte leitura (Figura 3 ):

U.E. [218A]: Sedimento arenoso, pouco compacto, granulometria média, e cor castanha. Contém inúmeros fragmentos de telha, blocos pétreos de médio e grande calibre, fragmentos de cerâmica, metais, carvões e fauna.

UE [218B]: Sedimento arenoso, pouco compacto, granulometria média e cor cinzenta. Presença de recipientes cerâmicos, elementos metálicos, carvões, ecofactos e fauna.

UE [218C]: Sedimento pouco compacto com textura arenosa granulometria mediana e cor castanho-acinzentada. Contém espólio cerâmico (doméstico e de armazenamento), carvões, metais, ecofactos e fauna.

UE [218D]: Sedimento arenoso, com pouca resistência e de grão médio, apresenta cor castanho-acinzentada. Recolheram-se fragmentos cerâmicos, elementos metálicos-carvões e fauna.

\subsection{Espólio}

O espólio resultante desta intervenção contabiliza mais de 20000 exemplares, incorporando recipientes cerâmicos de funcionalidade e tipologia distintas, artefactos e elementos metálicos, ecofactos, vestígios osteológicos de origem humana, restos faunísticos, fragmentos de vidro e materiais líticos (pedra lascada e polida). A cronologia das diferentes materialidades recolhidas vai desde a pré-história até ao período contemporâneo. 
O que aqui apresentamos sumariamente pertence ao silo 6 (U.E. [217/218]) e corresponde a uma primeira selecção dos materiais, privilegiando os artefactos cerâmicos de cronologia atribuível, entre a segunda metade do século XII e a primeira metade do século XIII. O estudo ainda preliminar dos artefactos permitiu concluir que o grupo das cerâmicas é predominante no registo e que as recolhidas neste contexto ocupacional são maioritariamente de uso doméstico, destacando-se as formas de cozinha (panelas e testos), de armazenamento e transporte (cântaros, talhas, potes), os recipientes de servir à mesa (tigelas, pratos, jarras, púcaros, copos), os recipientes de iluminação (queimador; candil), de uso doméstico (mealheiro) e lúdico (malhas de jogo). São também numerosos os artefactos e elementos metálicos, em especial numismas e associados ao armamento (pontas de virote, pontas de seta, fragmentos de lâminas ou de lanças e esporas) e líticos (projecteis de catapultas), e ecofactos, em especial coprólitos.

As cerâmicas apresentam pastas bem depuradas e calibradas na generalidade, com presença de grãos de sílica; abundante mica, quartzo e quartzitos, algumas partículas de cerâmica moída e calcário. A dimensão dos elementos não plásticos (E.N.P.) é na maioria pequena, por vezes, e sobretudo nas pastas claras, muito fina (inferior a $2 \mathrm{~mm}$ ) denunciando uma depuração cuidada das pastas. Registam-se sobretudo em exemplares de armazenamento e transporte ou de cozinha, mas em número pouco expressivo, a presença de grãos de média dimensão (entre 3 a $5 \mathrm{~mm}$ ). Nas tipologias cerâmicas (Figura 4) há um predomínio da Panela - globulares, ovóides e bitroncocónicas -, seguindo-se as tampas, jarras/jarros e cântaros; os púcaros e copos; as tigelas, caçoilas, pratos e alguidares. Verifica-se que muitos recipientes tinham função mista, não sendo fácil fazer corresponder tipo e funcionalidade (Ex. panela/pote; tigela/caçoila). Uma determinada peça poderia ser usada como recipiente de cozinha, mas também como louça de mesa ou mesmo, para armazenar bens/produtos alimentares. As cerâmicas foram produzidas em ambientes irregulares, revelando as superfícies externas e internas oscilação de tonalidades relativamente ao núcleo da pasta, entre os cinzentos e castanhos, os vermelhos e laranjas, os beges, brancos e rosados. Os tratamentos das superfícies são diversificados estando presentes embora em menor percentagem, as peças que não sofreram qualquer acabamento, as revestidas por engobe incluindo também o grupo das vidradas, e as alisadas e brunidas. Os exemplares de cerâmica comum e pintada a branco são os predominantes, tratando-se de recipientes de uso quotidiano para confecção, consumo e armazenamento de produtos e alimentos. Porém são igualmente expressivos os exemplares de pastas claras, com pintura a vermelho, castanho e negro, correspondendo a formas de ir à mesa, de armazenamento e consumo e de iluminação (ex. jarras, cântaros, copos, púcaros, bules, candis). Também presentes no interior dos silos e associadas às unidades estratigráficas dos séculos X-XI, mas em menor abundância, surgem as peças vidradas - os vidrados a verde, amarelo melado, e as verde e manganês. Também a técnica da incisão, se encontra bem documentada e mais esporádicas temos as impressões digitadas, os cordões plásticos, as estampilhas.

As tipologias que estudamos aproximam-se das formas conhecidas na cidade de Lisboa (Bugalhão \& Folgado, 2001), Loulé (Catarino, 1997/98), Mértola (Gómez-Martinez, 2004), Palmela (Fernandes, 2004), Santarém (Viegas \& Arruda 1999), Sintra (Sousa, 2015) e Silves (Gomes \& Gomes, 1991).

Ainda na categoria das cerâmicas, destacamos as de produção manual, que nos parecem enquadráveis e representativas dos contextos das comunidades precedentes que ocuparam o cerro do castelo de Palmela, durante o 2.. /1.$^{\circ}$ milénios a.n.e. No reportório individualizaram-se as formas abertas e fechadas, de uso doméstico e armazenamento de bens alimentares. Tipologicamente, registaram-se alguns fundos planos provavelmente de potes e vasos, um bordo com lábio boleado (U.E. [22C] - Sondagem 1) e um fragmento de parede com carena de uma taça (Sondagem 3, silo 6). Na sua maioria os fragmentos apresentam pastas bem depuradas e calibradas, com abundantes elementos não plásticos compostos por mica, quartzo, quartzitos e distintos minerais que não conseguimos caracterizar, com uma simples observação a olho. De um modo geral, os grãos são muito finos a finos ( $\leq 2 \mathrm{~mm})$, observam-se por vezes, elementos de grande calibre ( $\geq 5 \mathrm{~mm})$, associados a pastas mais rudimentares e grosseiras. Nas tonalidades das pastas e das superfícies prevalecem, as cores negro e castanho, denunciando ambientes de cozedura redutores ou em alguns casos, ambientes mais instáveis, com cozeduras irregulares.

A maioria das peças apresenta revestimento com engobe espesso e aderente, embora as superfícies muito erodidas, preservem ainda visível, o brunido e po- 
limento aplicado no exterior e interior do fragmento. No interior do silo 6, na U.E. [218C] recolheram-se fragmentos de cerâmica manual, com decoração brunida em traços nomeadamente, o fragmento decorado com os "ornatos brunidos» (vaso?) estilo "Lapa do Fumo». A decoração incide apenas na superfície externa.

$\mathrm{Na}$ indústria lítica estão presentes os materiais em pedra lascada e em pedra polida (percurtor?), surgindo alguns núcleos prismáticos esgotados em sílex, lamelas, lâminas e lascas em sílex, quartzo e matéria siliciosa e abundantes restos de talhe.

No conjunto dos metais, os numismas contabilizam um total de 251 exemplares, sendo que 182 foram retiradas do silo 6 - U.E. [217/218], um das quais é de cronologia romana (em estudo), e as restantes pertencentes aos reinados de D. Sancho I e D. Afonso II, séculos XII-XIII).

Os objectos em osso são representados por diversos botões (em osso, pasta vítrea e madrepérola), escova e pentes de cronologia moderna (séculos XVII/ XVIII), dois dados, um elemento de roca e uma peça de adorno decorada de cronologia atribuível ao século XII.

Os ecofactos estão testemunhados pela presença de algumas sementes, caroços e coprólitos recolhidos nos silos islâmicos, principalmente no silo 6 e no silo 10.

\section{CONSIDERAÇÕES PRELIMINARES}

Os trabalhos permitiram determinar que a ocupação na fase islâmica se estendia por toda a plataforma superior do castelo até ao lado sul, testemunhado pela existência de 11 silos de diferentes tamanhos e de um de grandes dimensões, delimitados a sul, por um muro em alvenaria. Esta área teve como principal função o armazenamento de alimentos, eventualmente destinada à guarnição do castelo, ou ao abastecimento da população que habitava às portas do castelo durante os séculos X/XI e XII. O uso pleno destas estruturas deverá ter sido prolongado, até aos meados ou finais do século XII, quando ocorrem as primeiras conquistas cristãs. $\mathrm{O}$ abandono e encerramento definitivo destas estruturas ocorre justamente, após a última conquista do castelo, em 1196, permanecendo subterradas/seladas e extramuros do castelo, aquando a reformulação da sua estrutura defensiva ao longo do século XIII.

A proposta da evolução da fortificação desde a sua fundação, no século VIII/IX, defendida por I. C. Fernandes (2004), aponta para no início da ocupação islâmica o castelo, desenhar um recinto de planta rectangular de menores dimensões, que se vai expandindo e transformando nas fases seguintes, admitindo-se que na restante área da plataforma superior - alcáçova -, e ao longo da encosta sul, se pudessem concentrar estruturas habitacionais e outras dedicadas ao aprovisionamento da população, como nos parecem sugerir as realidades agora escavadas. A insegurança vivida neste território originada pelas investidas e pelo avanço dos exércitos cristãos nos territórios a Sul do rio Tejo, bem como pelos ataques viquingues que assolaram a costa portuguesa anteriormente, no século $\mathrm{X}$, podem justificar a necessária proximidade da população à fortificação, como refúgio de defesa. São também conhecidos historicamente algumas destruições no castelo, em especial com a violenta incursão almóada, obrigando a algumas reparações e alterações já sob gestão cristã. Terá sido numa destas alturas de maior instabilidade na fronteira entre o cristianismo e o islamismo, que o muro (U.E. [22] / [230]) terá sido erguido, aproveitando os silos (U.E.'s [333] e [334]) como fundação. A identificação da fundação da muralha sul sobre uma estrutura pré-existente (U.E. [306]) parece um claro indicador da evolução da fortificação, a partir do século XIII, com reforço da cerca e de construção de novas torres, nomeadamente da Torre 8 (Fernandes, 2004: 244).

O contexto cronológico dos artefactos cerâmicos existentes no interior do silo 6 baliza-se entre o final do século XI e a primeira metade do século XII, do período Almorávida. A construção dos silos e a ocupação habitacional ou militar desta área poderá remontar ao século IX-X, com utilização destas estruturas, pelo menos ao até aos meados do século XII. O encerramento e a selagem dos silos terão acontecido num curto espaço de tempo, durante o avanço dos exércitos cristãos, no decorrer da segunda metade do século XII. Será entre os finais do século XII e o início do século XIII que toda esta área é abandonada, tendo por base os achados numismáticos recolhidos do silo 6 .

No final dos trabalhos arqueológicos todas as estruturas identificadas nas sondagens foram devidamente acondicionadas e aterradas, salvaguardadas novamente, por baixo de um piso argamassado, conforme solução prevista no projecto de execução.

Para terminar, sublinhamos a ocorrência de vestí- 
gios de várias cronologias que revelaram uma ampla diacronia de ocupação do cerro do castelo, com materialidades que vão desde a Pré-história recente até ao período Contemporâneo. Embora a leitura e interpretação segura sobre as primitivas ocupações, não sejam ainda possíveis podemos, agora, afirmar que previamente à construção do castelo, outras comunidades e culturas estiveram presentes neste lugar, destacado na paisagem e com uma implantação geográfica de absoluto domínio visual para a foz do Sado e um vasto território, a que afluíam diferentes pessoas, produtos, culturas, se não antes, pelo menos desde fins do $3 .{ }^{\circ}$ milénio a.n.e.

\section{BIBLIOGRAFIA}

BUGALHÃO, Jacinta e FOLGADO, Deolinda (2001) - O arrabalde ocidental da Lisboa islâmica: urbanismo e produção oleira in Arqueologia Medieval, n.. 7. Porto. Edições Afrontamento. pp. 111-145.

CATARINO, Helena (1997/98) - O Algarve Oriental durante a ocupação islâmica. Povoamento rural e recintos fortificados. Al-Ulyâ, Revista do Arquivo Histórico Municipal de Loulé, nำ6, Vols. I, II e III, Loulé.

FERNANDES, Isabel Cristina F. (2004) - O Castelo de Palmela do islâmico ao cristão. Palmela: Edições Colibri e Câmara Municipal de Palmela.

FERNANDES, Isabel Cristina F. e CARVALHO, A. Rafael (1993) - Arqueologia em Palmela, 1988-92. Catálogo da Exposição no Castelo de Palmela, 28 de Agosto a 19 de Dezembro de 1993. Palmela: Câmara Municipal de Palmela, pp. 10.

FERNANDES, Isabel Cristina F. e SANTOS, Michelle Teixeira (2008) - Palmela Arqueológica. Espaços. Vivências. Poderes. Catálogo da Exposição na Igreja de Santiago - Castelo de Palmela, 17 de Maio de 2008 a 18 de Maio de 2009. Palmela: Câmara Municipal de Palmela / Museu Municipal pp. 73.

GOMES, Mário Varela e GOMES, Rosa Varela (1991) - Cerâmicas Almoadas do Castelo de Silves in Actas do Congresso A Cerâmica Medieval no Mediterrâneo Ocidental, Campo Arqueológico de Mértola. Pp. 387-403.

GÓMEZ-MARTÍNEZ, Susana (2004) - Cerámica Islámica de Mértola: producción y comercio. [Recurso electrónico] Madrid: Servicio de Publicaciones dela Universidad Complutense de Madrid, ISBN: 84-669-2568-6.

PEREIRA, Luís Filipe (2019) - Intervenção Arqueológica no Castelo de Palmela - Resultados Preliminares in + Museu, Boletim do Museu Municipal de Palmela, n. . 20. Câmara Municipal de Palmela.

SOUSA, Maria João de (2015) - Uma habitação do Século XI/XII sob a muralha do Castelo dos Mouros de Sintra Evidências arqueológicas de um contexto doméstico, GON-
ÇALVES, M. J. e GÓMEZ-MARTINÉZ, S. Eds., Actas do X Congresso Internacional - A Cerâmica no Mediterrâneo, Vol. 1, Silves, C.M. Silves/Campo Arqueológico de Mértola, pp. 262-265.

VIEGAS, Catarina e ARRUDA, Ana Margarida (1999) - Cerâmicas islâmicas da alcáçova de Santarém. Revista Portuguesa de Arqueologia, Vol. 2, número 2, Lisboa, pp. 105-186. 


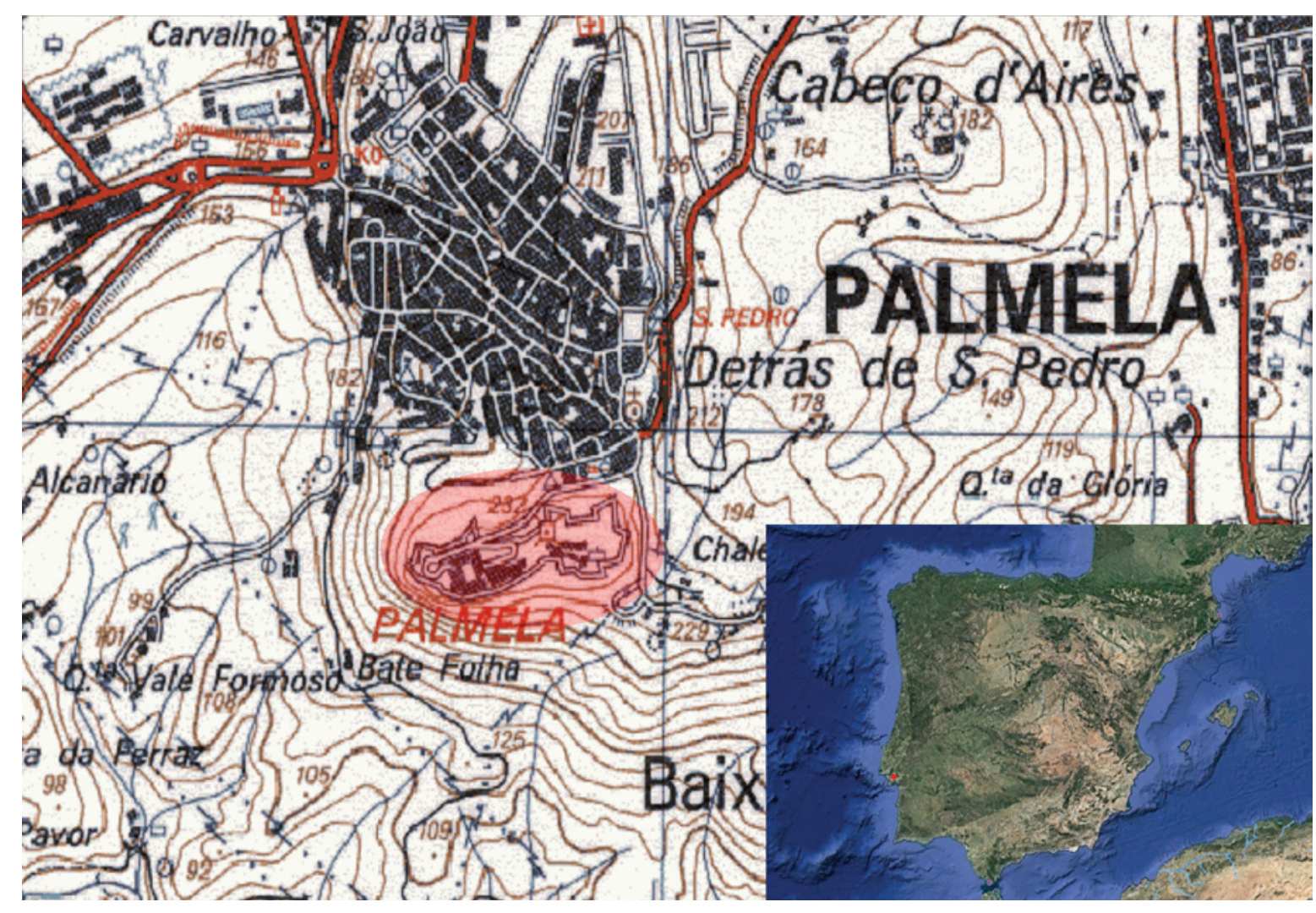

Figura 1 - Localização do Castelo de Palmela na Carta Militar de Portugal, n. ํ454, esc. 1:250oo.

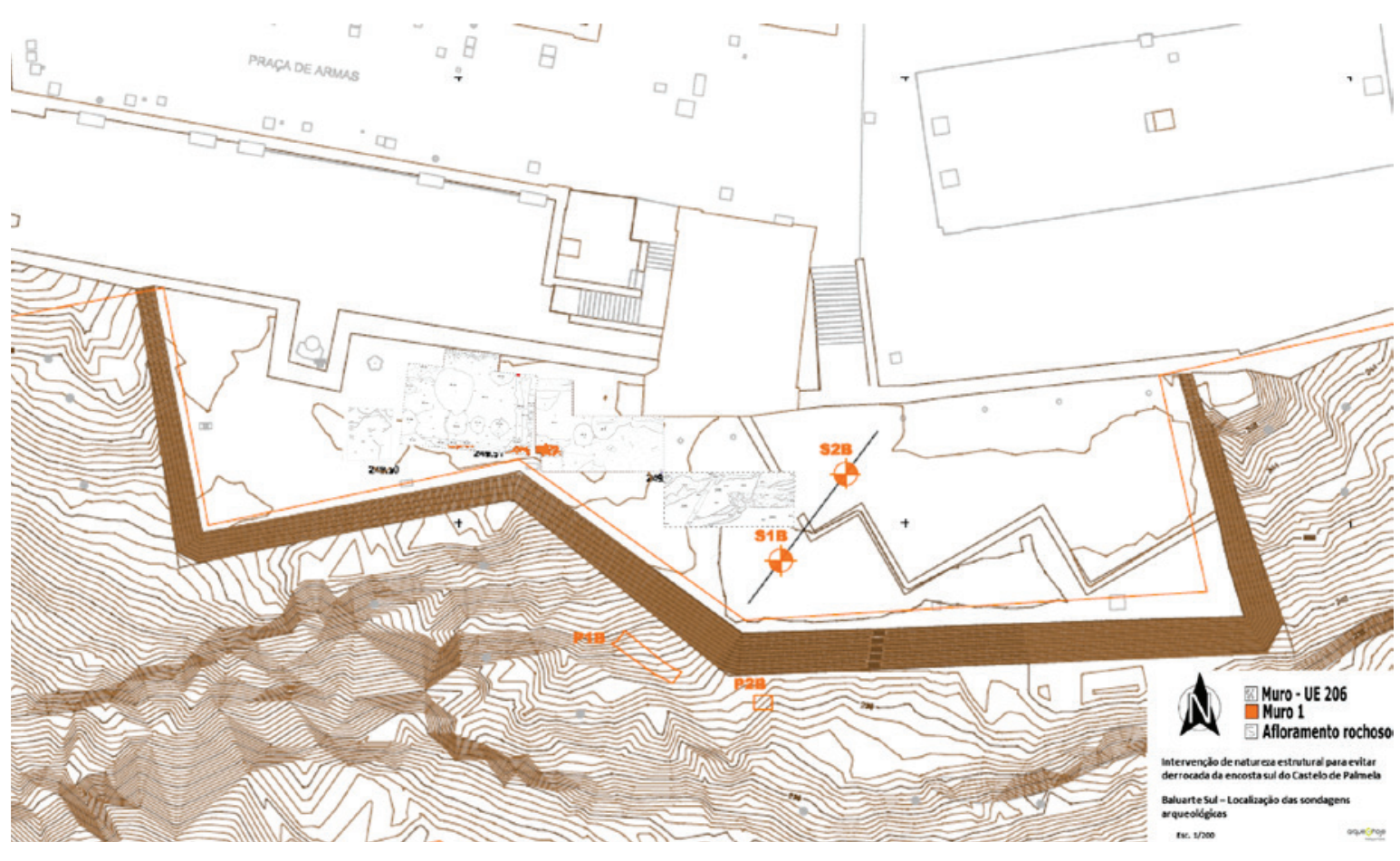

Figura 2- Localização das sondagens na planta do Castelo de Palmela - Baluarte Sul. Escala 1:20o. 


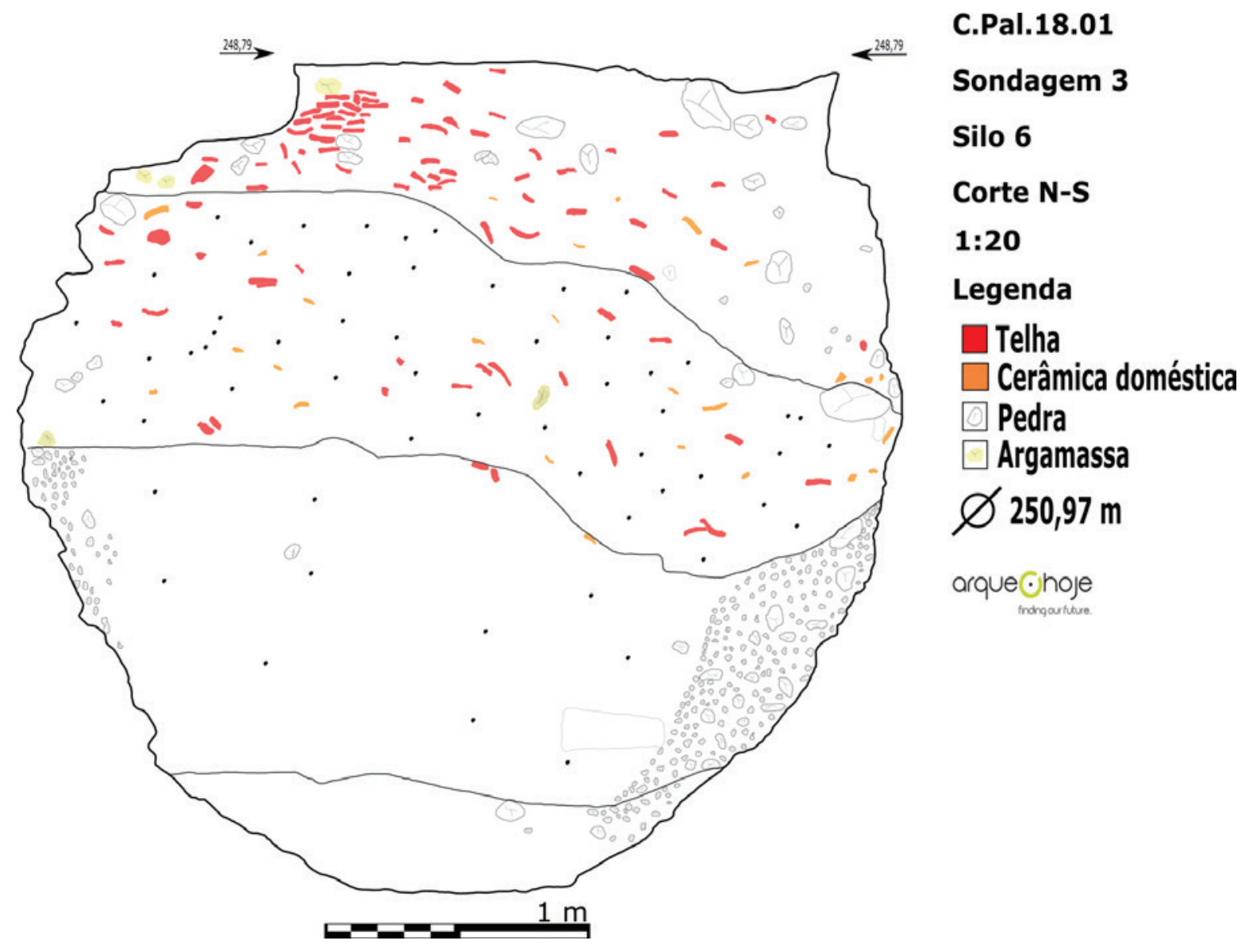

Figura 3 - Perfil do enchimento do Silo 6.

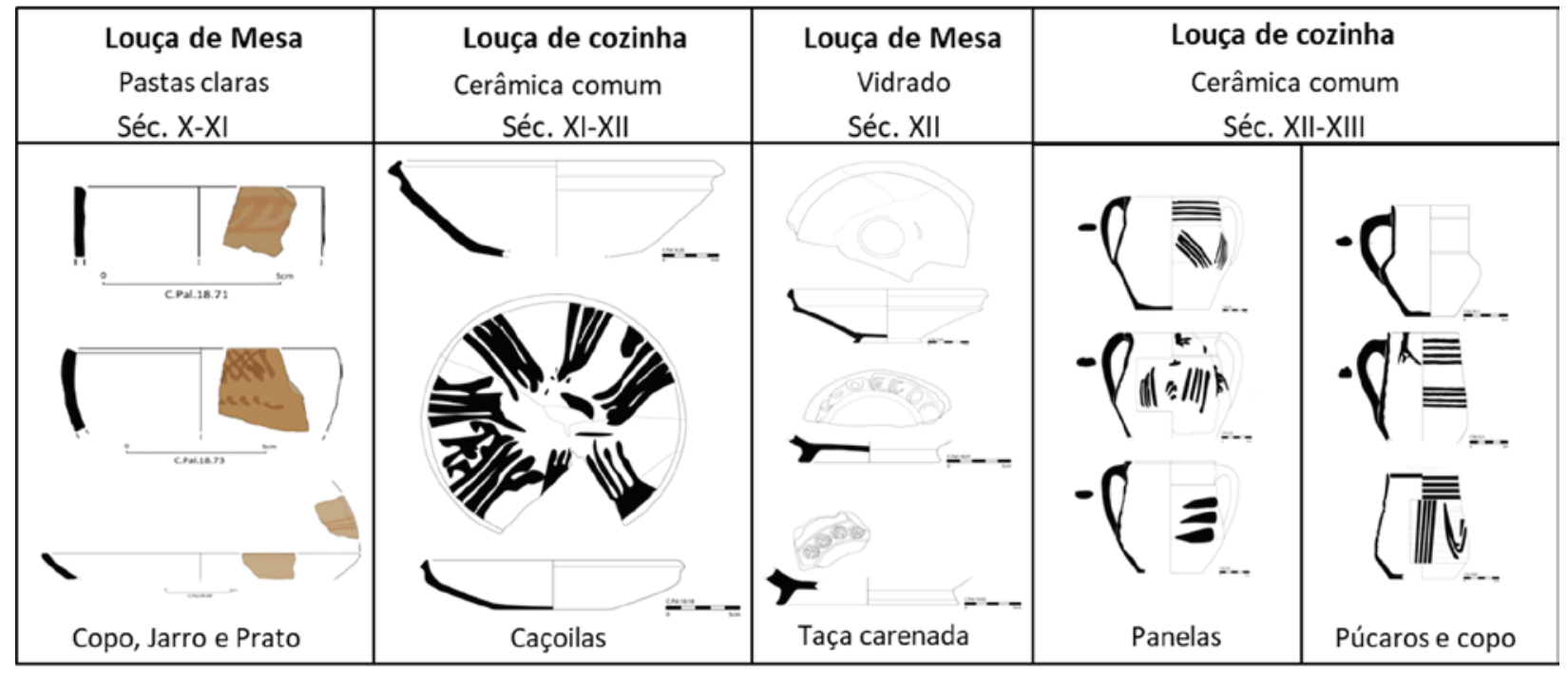

Figura 4-Tabela das diferentes tipologias de cerâmicas recolhidas no Silo 6. 


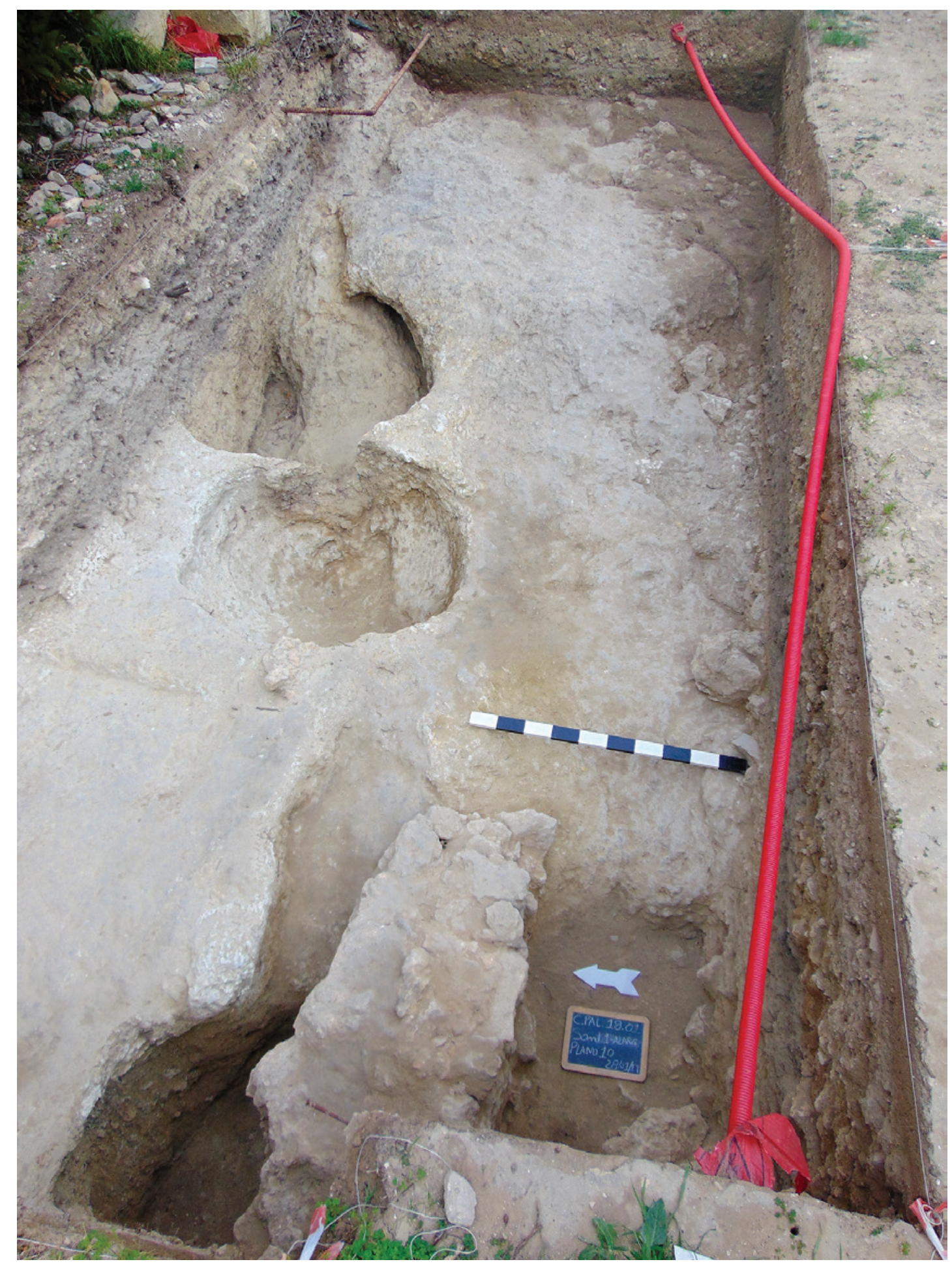

Foto 1 - Plano final da sondagem 1. Vista de Oeste. 


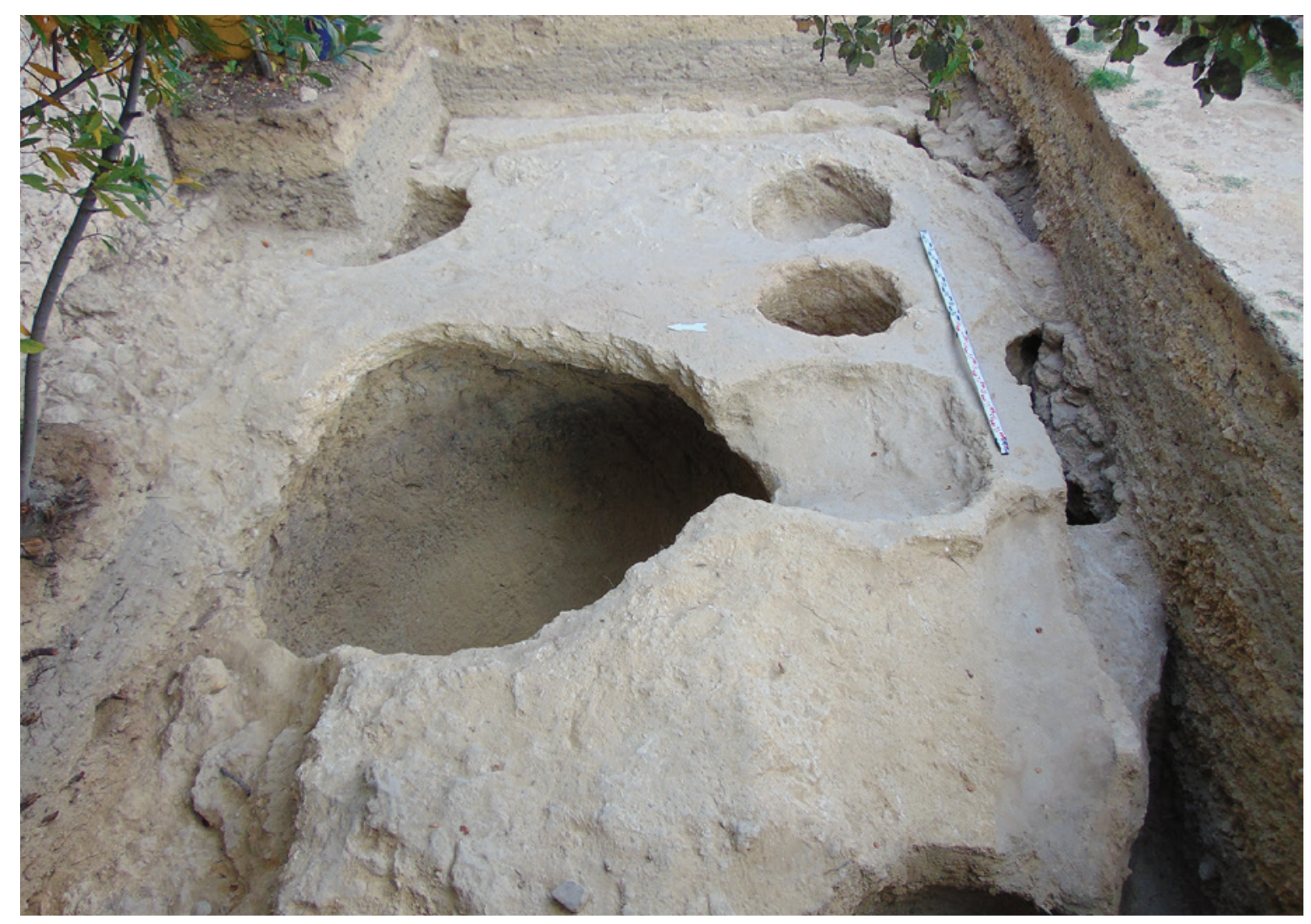

Foto 2- Plano final da Sondagem 3. Vista de Oeste.

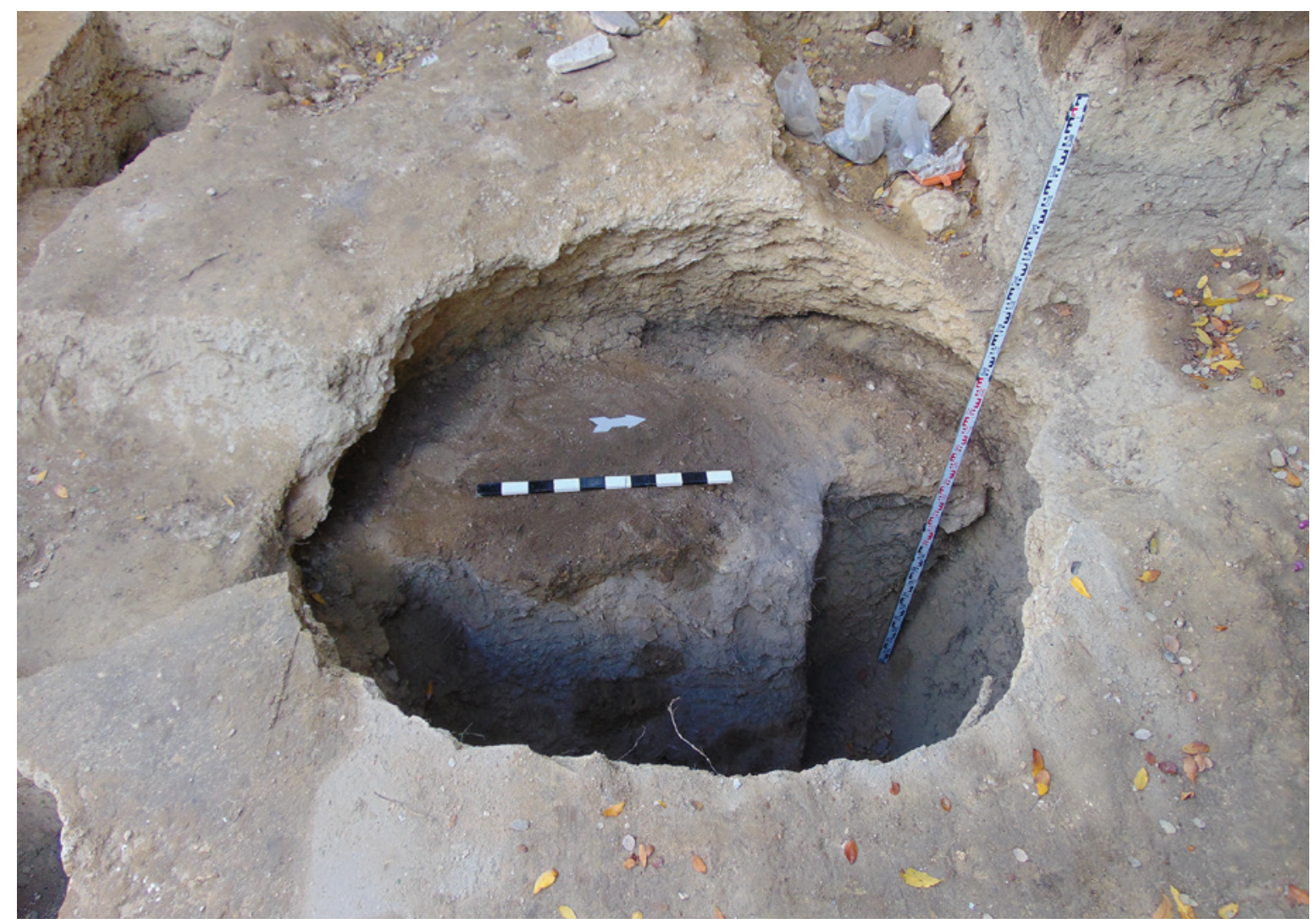

Foto 3 - Aspecto geral do Silo 6 durante a escavação do seu enchimento. 


\title{
A IGREJA DE SÃO LOURENÇO (MOURARIA, LISBOA): UM CONJUNTO DE SILOS E DE CERÂMICA MEDIEVAL ISLÂMICA
}

Andreia Filipa Moreira Rodrigues ${ }^{1}$

\begin{abstract}
RESUMO
A realidade arqueológica colocada a descoberto, em 1992 e 1993, na igreja de São Lourenço, situada Mouraria, em Lisboa, revelou uma ampla diacronia de ocupação, que se traduz numa sequência de enterramentos atribuíveis à idade média e moderna, associados ao espaço de culto; mas também, num conjunto de quinze silos que, de acordo com o espólio exumado do seu interior, se enquadram no período medieval islâmico, sendo anteriores à edificação da igreja.

Desta feita, pretende-se dar a conhecer a componente artefactual cerâmica que foi exumada do interior das estruturas de armazenamento, o seu significado e que relação possui este contexto com a realidade associada ao espaço de culto religioso, que se lhe sobrepõe.
\end{abstract}

Palavras-chave: Arqueologia, Lisboa, Silos, Cerâmica medieval islâmica.

\begin{abstract}
The archaeological context uncovered, in 1992 and 1993, in the church of São Lourenço, located in Mouraria, in Lisbon, revealed a wide diachrony of occupation, which translates into a sequence of burials attributable to the middle and modern age, related to the church; but also, in a set of fifteen silos that, according to the exhumed materials of its interior, fit into the medieval islamic period, being prior to the building of the church.

This time, it is intended to make known the ceramic artefactual component that was exhumed from the interior of the storage structures, its meaning and what relationship this context has with the reality associated with the religious cult space, which overlaps it.
\end{abstract}

Keywords: Archaeology, Lisboa, Silos, Medieval islamic ceramics.

\section{LOCALIZAÇÃO GEOGRÁFICA E CONTEXTUALIZAÇÃO HISTÓRICA}

A igreja de São Lourenço está localizada na junção entre a Rua do Marquês de Ponte de Lima, situada a Oeste, e o Largo da Rosa, que está a Sul; a Norte e Oeste está delimitada pelo Palácio da Rosa. Administrativamente, a igreja de São Lourenço começou por estar enquadrada da freguesia de São Lourenço, que seria substituída em 1886 pela freguesia de São Cristóvão e São Lourenço, para actualmente integrar a freguesia de Santa Maria Maior (SILVA, 1968, p. 186, 205, 240).

Os contextos colocados a descoberto com a intervenção arqueológica remetem para a Lisboa islâmica, sendo possível verificar a existência de duas reali- dades definidas pela muralha. De facto, no interior do perímetro muralhado desenvolveu-se a Medina, marcada pela Alcáçova, que surgia no ponto mais elevado. Fora de portas, surgiram os Arrabaldes Oriental e Ocidental, sendo neste último que se enquadra o sítio arqueológico da igreja de São Lourenço, mais concretamente no extremo Noroeste (SILVA, 1987a, p. 64, 183; SILVA, 2008, p. 79, 80, 85; BUGALHÃO, 2009, p. 384, 385, 388; SILVA, 2017, p. 234, 272; RODRIGUES, 2019, p. 6).

A conquista da cidade em 1147 provocou uma alteração de poderes e agentes políticos, que deixaram a sua marca ao restabelecerem a diocese, sacralizarem o espaço de culto e nomearem um novo bispo, Gilberto de Hastings. É ainda nesta altura que é fundado o espaço monástico de São Vicente de Fora

1. Arqueóloga; andreia93rodrigues@hotmail.com 
(BRANCO, 1996, p. 124, 125, 129; BRANCO, 1998, p. 57; RODRIGUES, 2019, p. 6). A par de todas estas transformações dá-se o movimento muito rápido de criação de freguesias associadas a espaços de culto cristão, que com o desenrolar do tempo vai perdendo força. De facto, é sabido que até 1191 eram 23 as igrejas paroquiais e que esta realidade não vai sofrer alterações até bem próximo da segunda metade do século XVI, que é quando se cria uma nova paróquia (SILVA, 1968, p. 189, 190; SILVA, 2012, p. 13; RODRIGUES, 2019, p. 7).

É, pois neste movimento que pode ser inserida a igreja de São Lourenço, ainda que existam algumas dúvidas acerca da sua data de fundação entre os investigadores (ARAÚJO, s.d., p. 64; ANDRADE, 1950, p. 181, 182; CASTRO, 1763, p. 329; MATOS, PORTUGAL, 1974, p. 145; GONÇALVES, SEGURADO, 1984, p. 37; SILVA, 1968; p. 186; BARROCA, 2000, p. 970; BOISSELLIER, 2002, p. 100; SILVA, 2008, p. 68, 253; RODRIGUES, 2019, p. 8).

Recentemente, surgiu uma hipótese que defende que quer a igreja, quer a freguesia, tenham sido criadas no ocaso do século XII, previamente a 1191 (FARELO, 2008, p. 249; SILVA, 2012, p. 13, 16). Esta datação alicerça-se numa fonte documental de 1346 , que mais não é do que uma cópia de um documento na qual se define "a divisão das igrejas da diocese entre o bispo e o Cabido de Lisboa em 1191, surgindo aí menção à igreja de São Lourenço já consagrada ao culto” (RODRIGUES, 2019, p. 8).

A igreja de São Lourenço teria tido um primeiro edifício do qual não se preservaram vestígios. Sabe-se de igual modo que foram sendo feitas modificações estruturais, que se traduziram na construção de 5 capelas góticas, fortemente afectadas durante os sismos de 1531 e 1755 (COELHO, 1998, p. 38; GONÇALVES, SEGURADO, 1984, p. 41-44; SILVA, 1995, p. 3).

Os danos provocados pelo sismo de 1531 foram de tal ordem que foi necessário instituir um imposto por forma a custear a reconstrução da igreja, que viria a ser reconstruída apenas no século seguinte. A par da reconstrução da igreja foi ainda construído o Palácio da Rosa que foi edificado no local onde outrora existiram as capelas góticas e ainda parte do local por onde passava a cerca Nova, que foi destruída. O terramoto de 1775 deixou também a sua marca e é referido inclusivamente a "queda de metade do tecto e de todo o coro” (GONÇALVES, SEGURADO, 1984, p.41-44; COELHO, 1998, p.38; AMARO, 2000, p. 2, 9; SILVA, 1995, p. 3; RODRIGUES, 2019, p. 9).
O dealbar do século XX traz consigo alterações no que ao urbanismo é referente, constatando-se, junto à igreja de São Lourenço, a abertura da Rua do Marquês de Ponte de Lima. Por fim, nos anos 70 da passada centúria os sinais de degradação da igreja e do palácio eram claros e tal facto levou a que a edilidade lisboeta se tornasse proprietária de ambos os edifícios (AMARO, 200o, p. 2; SILVA \& alli, 2014, p. 8; RODRIGUES, 2019, p. 9).

\section{A ESCAVAÇÃO ARQUEOLÓGICA}

A intervenção arqueológica realizada na igreja de São Lourenço enquadrava-se no âmbito de um projecto de requalificação do monumento, cujo intuito era consolidar a estrutura do edifício, desentulhar uma das capelas góticas e ainda alvitrar e efectuar o registo dos diversos enterramentos que existiam na igreja (AMARO, 20ooa, p. 2).

Deste modo, definiram-se doze sondagens das quais apenas se escavaram oito. As áreas intervencionadas foram distribuídas pelas várias zonas da igreja, tendo sido implantadas sondagens na nave central (sondagens 1 e 2), na primeira capela gótica (sondagens 3 a 6), num compartimento anexo à igreja (sondagem 7) e na segunda capela gótica (sondagem 8) (Figura 1) (AMARO, 200oa, p. 4-9; AMARO, 200ob, p. 1; RODRIGUES, 2019, p.10).

A estratigrafia detectada na Sondagem 1 corresponde a níveis de entulho e enterramentos. Esta realidade associada aos materiais recolhidos, como as moedas, e às estruturas colocadas a descoberto, como os muretes e o pavimento, permitiu antever a existência de várias fases da necrópole, cronologicamente balizada entre a idade moderna e a contemporaneidade (COELHO \& alii, 1999, p. 4, 5; AMARO, 200oa, p. 5-10; AMARO, 20oob, p. 2-6; Informações de Tiago Curado; RODRIGUES, 2019, p. 11, 12).

A escavação da Sondagem 2 revelou uma sequência de inumações, cronologicamente enquadrados entre a idade média e a idade contemporânea. Para além disso, colocaram-se a descoberto, estruturas como muretes de compartimentação da necrópole, um nível de pavimento e um conjunto de silos, os silos 1 a 4. Nos níveis de ocupação mais recentes foram recolhidas moedas. Relativamente aos silos, na sua grande maioria, os materiais exumados do seu interior remetem para o período medieval islâmico, excepção feita a uma destas estruturas onde para além de espólio desta cronologia surgiram igualmente ma- 
teriais atribuíveis aos séculos XV e XVI (AMARO, 200oa, p. 5-7; AMARO, 20oob, p. 2-6, 10; COELHO \& alii, 1999, p. 2, 11, 12; Informações de Tiago Curado; RODRIGUES, 2019, p. 12-15).

Nas Sondagens 3, 4 e 5 a estratigrafia observada é semelhante, tendo sido escavados níveis de entulho ulteriores ao terramoto de 1755 , que cobriam uma camada cronologicamente enquadrada entre a idade média e a modernidade. Nesta última camada, nas Sondagens 3 e 5 , as realidades mais recentes correspondem a enterramentos, de época moderna, e as mais antigas a silos, que integram o período medieval islâmico, de acordo com o espólio exumado. $\mathrm{Na}$ Sondagem 4 , a realidade mais recente desta segunda camada é referente a um nível de entulho enquanto a baliza cronológica mais recuada é atribuída a um conjunto de silos (COELHO \& alii, 1999, p. 13, 14; AMARO, 200oa, p. 7, 8; AMARO, 200ob, 7-11; Informação de Tiago Curado; RODRIGUES, 2019, p. 15-18). Quanto à Sondagem 6, a primeira camada detectada é referente a níveis de entulho resultantes do terramoto de 1755, conforme atestam os azulejos e moedas recolhidos. Num segundo momento colocaram-se a descoberto um ossário e enterramentos que são datados como sendo posteriores à segunda metade do século XVIII. Cronologicamente mais antigo, e atribuível à necrópole da idade média surge uma outra inumação feita no substrato rochoso (AMARO, 200oa, p. 7; AMARO, 200ob, 7, 8; Informação de Tiago Curado; RODRIGUES, 2019, p. 18).

Os trabalhos realizados na Sondagem 7 revelaram uma estratigrafia composta por uma camada de entulho posterior ao terramoto de 1755 , um conjunto de enterramentos associados a muretes de compartimentação da necrópole, cuja cronologia remonta à idade média, e quatro silos. Nos níveis mais recentes o espólio recolhido é composto por azulejos, moedas, faiança espanhola, parte de um pente em osso, medalhas em bronze ou um tubo de cachimbo. Já o enchimento dos silos forneceu materiais que podem ser enquadrados no período medieval islâmico (COELHO \& alii, 1999, p. 17-19; AMARO, 200oa, p. 8, 9; AMARO, 20oob, 13-16; Informação de Tiago Curado; RODRIGUES, 2019, p. 18-19).

A escavação encetada na Sondagem 8 forneceu poucas informações, sabendo-se apenas da existência de uma inumação, que foi escavada em parte, e de um silo cujo enchimento continha espólio atribuível ao período medieval islâmico (AMARO, 20ooa, p. 9; AMARO, 200ob, p. 16; RODRIGUES, 2019, p. 21).

\section{AS CERÂMICAS MEDIEVAIS ISLÂMICAS}

O estudo da componente artefactual exumada foi feito através da análise macroscópica dos materiais e das suas características que permitiram efectuar uma descrição pormenorizada, e posteriormente definir tipologias, 19 grupos de fabrico distintos e ainda identificar proveniências (RODRIGUES, 2019, p. 22).

O estabelecimento de uma tipologia e das formas que a integram teve em conta os diversos contributos que diversos autores aportaram ao longo dos anos (ROSSELLÓ-BORDOY, 1991; CATARINO, 1997/ 1998; GOMES, 2002; TORRES \& alii, 2003; GÓMEZ MARTINEZ, 2014; BUGALHÃO \& alii, 2010). Neste sentido, a tipologia definida é constituída pelos grupos da louça de mesa; louça de cozinha; vasilhames de armazenamento e transporte; materiais de construção; objectos lúdicos; contentores de fogo ou objectos de iluminação e os utensílios artesanais e agrícolas (Figura 2) (RODRIGUES, 2019, p. 28).

No grupo da louça de mesa cuja finalidade é a de servir alimentos para serem consumidos posteriormente, identificaram-se taças hemisféricas e carenadas, bilhas, jarras ou jarrinhas e jarros ou jarrinhos. De entre todas as formas detectadas as que têm maior expressão percentual são as jarras ou jarrinhas e as taças hemisféricas, por oposição às taças carenadas, aos jarros ou às bilhas que não são tão frequentes (RODRIGUES, 2019, p. 75, 76).

A aferição de paralelos nem sempre foi possível de ser efetuada para a totalidade do espólio exumado. As jarras provenientes da igreja de São Lourenço encontram paralelos em contextos de Lisboa, Santarém, Tavira ou Silves, e podem ser balizadas cronologicamente entre os séculos XI/XII e em alguns casos são idênticos a exemplares do século XIII (RODRIGUES, 2019, p. 41, 42, 63).

Para as taças hemisféricas existem semelhanças com peças de Lisboa, Santarém ou Palmela que podem ser enquadradas entre os séculos XI e XIII (RODRIGUES, 2019, p. 35-37, 63, 65, 68).

Já as taças carenadas encontram similitudes em contextos de Lisboa de cronologia compreendida entre os séculos XI e XII (RODRIGUES, 2019, p. 37-40, $63,65,67,68)$.

Para os jarros e as bilhas não foi possível proceder à sua integração cultural (RODRIGUES, 2019, p. 46). Dentro dos utensílios da louça de cozinha, que se destinam a confecionar os alimentos é possível 
encontrar panelas, tampas e alguidares. Neste conjunto é a panela a forma que está mais representa$\mathrm{da}$, contrastando com as tampas e os alguidares que estão presentes de forma menos significativa (RODRIGUES, 2019, p. 31, 75).

Algumas das panelas que foram exumadas dos silos da igreja de São Lourenço são em tudo idênticas a outros exemplares provenientes de Lisboa, Santarém, Palmela, Almada, Mértola ou Alcoutim e são atribuíveis cronologicamente aos séculos XI/XII, e XII/XIII (RODRIGUES, 2019, p. 32, 33).

Nos alguidares uma das peças recolhidas é semelhante a um exemplar oriundo do Núcleo Arqueológico da Rua dos Correeiros, cuja datação corresponde à segunda metade do século XII. Tal facto contrasta com outra das peças deste grupo que se insere num espectro cronológico mais lato compreendido entre os séculos VIII e XII (RODRIGUES, 2019, p. 32, 33, 63, 66, 68).

No caso das tampas não foram detectados paralelos formais ou cronológicos (RODRIGUES, 2019, p. 23 , $24,26,33)$.

Em termos de espólio exumado que pode ser enquadrado na categoria dos vasilhames de armazenamento e transporte apenas se identificaram formas como os cântaros e as talhas, cujo intuito é o transporte e o armazenamento quer de líquidos, quer de sólidos (RODRIGUES, 2019, p. 29-31,75).

Os cântaros são a forma que ocorre mais no registo arqueológico por oposição às talhas. Relativamente à existência de paralelos apenas os cântaros permitiram efectuar uma integração cultural. De facto, foi possível encontrar cântaros muito parecidos a algumas das peças da igreja de São Lourenço no Núcleo Arqueológico da Rua dos Correeiros inseridos do ponto de vista cronológico no século XI (RODRIGUES, 2019, p. 30, 31, 75).

Nos materiais de construção é possível englobar formas que têm como intuito a sua utilização no processo construtivo. Para os materiais da igreja de São Lourenço apenas se percepcionou a existência de telhas, que na ausência de elementos que as diferenciassem, não permitiu aferir cronologias (RODRIGUES, 2019, p. 46, 75).

Os utensílios que se enquadram na categoria dos contentores de fogo têm como objectivo a contenção do fogo, por forma a permitir a iluminação e ou o aquecimento. Dentro do contexto arqueológico estudado apenas se detectaram formas como o fogareiro ou o candil, não sendo possível estabelecer datações ou cronologias (RODRIGUES, 2019, p. 23 , $46,47,75)$.

Na série de objectos lúdicos surgem utensílios utilizados em actividades lúdicas ou rituais que no caso dos materiais estudados encontram repercussão em formas como as peças de jogo ou o tambor (RODRIGUES, 2019, p. 51, 52, 75).

Da totalidade das peças de jogo apenas duas forneceram algumas pistas em termos de datação, estando inseridas de uma forma genérica no século XI. De facto, estas formas resultam de reaproveitamentos de outras peças, que deixaram de desempenhar a sua função principal, e como se tratam de reutilizações afigurou-se difícil encontrar exemplares semelhantes (RODRIGUES, 2019, p. 52).

Quanto ao tambor não foi possível estabelecer cronologias ou até mesmo encontrar peças idênticas, devido as características do fragmento recolhido (RODRIGUES, 2019, p. 52).

Dentro da categoria dos utensílios ou instrumentos artesanais e agrícolas podem ser englobados objectos que servem para serem utilizados em trabalhos de cariz agrícola ou artesanal, tendo repercussão em formas como o cossoiro ou o bocal de poço (RODRIGUES: 2019, p. 48-51, 75, 76).

O cossoiro identificado é idêntico a um outro encontrado em Tavira que pode ser atribuído cronologicamente aos séculos XI e XII (RODRIGUES, 2019, p. 49).

O bocal de poço da igreja de São Lourenço encontra similitudes com uma peça proveniente de Beja, que tem uma gramática decorativa mais vasta. Para além disso, possui uma decoração que se repercute em fragmentos de talhas exumados em Tavira. Tendo em conta tudo isto, é possível defender que a cronologia desta peça se enquadra entre a segunda metade do século XII e a centúria seguinte (RODRIGUES, 2019, p. 51, 63).

De uma forma genérica o conjunto referente à louça de mesa é o que possui maior expressividade (58\%), por oposição ao grupo dos instrumentos artesanais ou agrícolas que é o menos representado (o,2\%) (Figura 3) (RODRIGUES, 2019, p. 71, 72).

Atentando na questão dos grupos de fabrico, foi possível dividir os fabricos em três grandes grupos: os fabricos 1, 10 e 6; os fabricos 2, 3, 4, 5, 7, 8, 9 e 11 a 13 e os fabricos 14 a 19 (RODRIGUES (2019, p. 22-25, 58). No primeiro conjunto, a dissonância reside essencialmente no ambiente de cozedura das peças. De facto, no fabrico 1 surgem peças onde é visível uma 
cozedura oxidante, no fabrico 10 uma cozedura redutora-oxidante e no fabrico 6 onde se evidencia um ambiente redutor. A aproximá-los estão aspectos como a presença de inclusões (reduzida a elevada), as pastas duras, que podem ser compactas a muito compactas, medianamente a muito homogéneas, a textura esponjosa e fractura irregular para além do torno rápido (RODRIGUES (2019, p. 22-25, 58).

O grupo composto pelos fabricos 2, 3, 4, 5, 7, 8, 9 e 11 a 13 apenas tem em comum as características da pasta que varia entre o pouco a muito homogéneo, pode ser compacta a muito compacta e tem inclusões de tamanho variável. Como factor diferenciador existe o ambiente de cozedura das peças que pode ser oxidante (fabrico 2 a 5), redutor, (fabricos 7 e 8), redutor-oxidante (fabricos 11 a 13), ou oxidante-redutor (fabrico 9). O torno e a dureza das pastas também diferem verificando-se a associação torno rápido e pastas duras (fabricos 2, 9 e 11); torno rápido e pastas brandas (fabricos 3,8 e 12), torno lento e pastas brandas (fabrico 4) e torno lento e pastas duras (fabrico 5,7 e 13). Para além de tudo isto a maior parte dos fabricos (fabricos 3, 4, 5, 7 a 9 e 12) possui uma textura esponjosa e fractura irregular contrastando com os casos em que isso não se verifica (fabrico 2, 11 e 13) (RODRIGUES (2019, p. 22-25, 58).

$\mathrm{O}$ último grupo assume algumas especificidades. Os fabricos 14 a 16 e 19 têm como principal traço marcante o facto de serem constituídos por peças feitas a torno rápido em que as pastas são duras, medianamente a muito homogéneas, medianamente a muito compactas, de textura esponjosa e fractura irregular, com grandes quantidades de elementos não plásticos e cozeduras oxidantes. Os fabricos $17 \mathrm{e}$ 18 são diferentes dos anteriores em termos dos ambientes de cozedura das peças e da homogeneidade das pastas. Assim, existem peças com cozedura redutora-oxidante e pastas muito homogéneas, contrastando com peças de cozedura redutora e pastas medianamente homogéneas (RODRIGUES (2019, p. 22-25, 58).

Em termos de proveniências foi possível constatar a presença de dois grandes grupos, as produções locais ou regionais, conjunto mais expressivo (96\%), e produções exógenas ou forâneas (4\%). Considerando os grupos de fabrico definidos e cruzando estes dados com as proveniências, foi possível alvitrar que as produções de cariz local ou regional se distribuem de uma forma esmagadora pelos grupos 1 , 10 e $6(76 \%)$, por oposição aos grupos 2, 3, 4, 5, 7, 8 ,
9 e 11 a 13, onde a sua presença não é tão significativa (20\%) (RODRIGUES, 2019, p. 22-25, 58).

Nas produções de carácter local e regional identificaram-se formas como a bilha, o cossoiro, o cântaro, o jarro, a jarra, a panela, a taça carenada, a taça hemisférica, a tampa, a peça de jogo, o alguidar, as talhas ou as telhas. No que concerne à gramática decorativa, este conjunto de peças pode ostentar pintura a branco, que é a mais representativa (conjuntos de 3 ou 4 riscas), a pintura a preto, ou ser desprovida de qualquer pintura. Para além da pintura verifica-se a aplicação de vidrados, de incisões e excisões, ou da digitação. Relativamente ao acabamento pode existir a aplicação de brunido (RODRIGUES, 2019, p. 58).

Para as as produções exógenas é possível enquadrar peças como o bocal de poço, uma peça de jogo, tampas e jarras, para além das panelas, que correspondem aos fabricos 14 a 19. Neste conjunto de peças apenas o bocal de poço, a peça de jogo e as taças carenadas e hemisféricas apresentam decoração. No bocal de poço está presente a combinação do vidrado e estampilhado, na peça de jogo é possível perscrutar a aplicação da corda seca, ao passo que nas taças hemisféricas e carenadas, que têm pastas de tonalidade laranja, foram pintados motivos a vermelho. As restantes formas identificadas não têm decoração, contudo fazem parte integrante deste grupo devido às suas pastas. Assim, tampas e as jarras possuem pastas de cor creme ao passo que as panelas têm pastas alaranjadas (RODRIGUES, 2019, p. $25,26,28,58,59)$.

\section{OS SILOS EM AL-UXBUNA}

Um silo é por definição uma estrutura de armazenamento, construída em profundidade e coberta por uma pedra, onde poderiam ser guardados alimentos secos que seriam posteriormente consumidos (RAMALHO \& alii, 2001, p. 150, 151; MALALANA UREÑA, MORÍN DE PABLOS; BARROSO CABRERA, 2013, p. 341).

Partindo deste prossuposto e tendo em conta informações, os relatórios referentes aos trabalhos arqueológicos desenvolvidos e ainda artigos de síntese acerca da prática arqueológica em Lisboa, onde para além de contextos de época islâmica se identificaram silos, foi possível aferir a existência de 116 silos, distribuídos por 26 locais. De facto, constata-se a presença de estruturas de armazenamento no 
espaço intra-muros, mas também no seu exterior (Figura 4) (BUGALHÃO, 2009, p. 388).

Dentro do perímetro muralhado foram detectados 5 conjuntos de silos na Medina e 6 na Alcáçova, perfazendo um total de 11. De todas as evidências identificadas na Medina apenas se contabilizaram este tipo de estruturas negativas em 2 locais, na Rua da Saudade (PRATA, 2014, p. 30) e no Teatro Romano (FERNANDES, 2013, p. 767).

Já para a Alcáçova o número de silos, 63, corresponde a todos os registos existentes. Morfologicamente, este tipo de estruturas podem apresentar forma piriforme (GOMES, GASPAR, 2000, p. 10, foto 10 e 11; (GASPAR, GOMES; 2001, p. 4-16; GASPAR, GOMES, 2013, p. 6-22, fig. 8; MIRANDA, 2013, p. 20, des. 5); ou sub-circular (SOUTA, LIMA, SARRAZOLA, 2012, p. 44, 50). Os dados existentes permitiram perceber que os silos sub-circulares coexistem no mesmo local onde também foram encontrados silos piriformes (GOMES, GASPAR, 2000, p. 10, foto 10 e 11; GASPAR; GOMES, 2001, p. 6-22; GASPAR, GOMES, 2013, p. 6-22, fig. 8; MIRANDA, 2013, p. 20) ou troncocónicos (FILIPE, 2011, p.14-16). Ainda na alcáçova existiram silos para os quais não foi possível saber a morfologia (GASPAR, GOMES, 1997, p. 23; GASPAR, GOMES, 2001, p.4-16).

No exterior do perímetro muralhado colocaram-se a descoberto 15 sítios com um total de 51 estruturas de armazenamento negativas. Destas, 5 estão situadas na parte ocidental da cidade e $5 \mathrm{em}$ Alfama.

No que é referente à forma, para além de estruturas de armazenamento sub-circulares (PEREIRA, 1924, p. 172, 173; RAMOS, JORDÃO, 1996/1997, fig. 32; SILVA, VALONGO, 2016/2017, p. 121), piriformes (AMARO, 200oa, p. 7; RODRIGUES FERREIRA, 2001, p. 51-53) e troncocónicos (AMARO, 200oa, p. 8, 9; RODRIGUES FERREIRA, 2001, p. 50), detectaram-se ainda silos bitroncónicos (AMARO, 200oa, p. 8, 9). Nestas três últimas morfologias é possível enquadrar os silos escavados na igreja de São Lourenço (AMARO, 200oa, p. 8, 9).

Ainda assim, importa mencionar os 37 silos para os quais a informação é escassa e que se distribuem pela alcáçova (GOMES, GASPAR, 2001, p. 8), medina (FERNANDES, 2013, p. 767; PRATA, 2014, p. 30); e arrabaldes (CALADO, LEITÃO, 2005, p. 462; RIBEIRO, 2012, p. 8; FERNANDES, 2009, p. 200; SILVA, 2014, p. 181; GOMES, SEQUEIRA, 2001, p. 105; RAMOS, JORDÃO, 1996/1997, p. 110-113; SALOMÉ, CALADO, 2012, p. 25).
Ainda nos arrabaldes existem sítios para os quais se sabe que existem silos mas não se sabe a sua quantidades, informação oral de Rodrigo Banha da Silva, a quem se agradece).

As diversas ocorrências de silos apuradas permitem perceber a sua dispersão quer dentro, quer fora do perímetro muralhado, sendo muito semelhante quer o número de núcleos de silos (11 zona intra-muros e 15 zona extra-muros), quer a quantidade de estruturas negativas identificadas ( 65 dentro do espaço muralhado e 51 no exterior da muralha).

De facto, a diferença reside quando se observa a alcáçova, a medina e os arrabaldes individualmente. No caso da alcáçova para um espaço relativamente diminuto existem uma grande quantidade de silos, cujo objectivo era o de garantir a sobrevivência das elites que estavam estabelecidas na Alcáçova.

Este aspecto contrasta de sobremaneira com o que se verifica na medina, em que dos 5 locais com silos apenas foram contabilizadas duas destas estruturas, algo que não se coaduna com a dimensão deste espaço e o número de pessoas que aqui residiam.

Fora de portas detectaram-se 15 sítios com um total de 51 silos. Destes, 36 estão disseminados por 6 locais no arrabalde ocidental, 11 pelo arrabalde oriental, correspondendo a 3 sítios, e apartado dos arrabaldes foram colocados a descoberto mais quatro silos. Tal como acontece na medina também nos arrabaldes existiram casos em que não se afigurou possível aferir o número de silos (2 no arrabalde oriental e 3 no arrabalde ocidental).

A cultura material exumada do interior dos silos deixa antever a presença de formas que podem ser encontradas em contextos habitacionais, como panelas, tampas, e alguidares, usados para a confecção de alimentos; taças hemisféricas e carenadas, bilhas, jarras ou jarrinhas e os jarros ou jarrinhos, nos quais eram consumidos os alimentos previamente preparados; para além dos cântaros e das talhas, usados para armazenamento e transporte. Acresce a toda esta panóplia formal a presença, ainda que menos expressiva, de candis e fogareiros, que serviam para iluminação e para cozinhar; de cossoiros, destinados às actividades de tecelagem; de tambores ou peças de jogo e do bocal de poço (RODRIGUES, 2019, p. 84,85$)$.

A alusão a silos, à sua existência, implantação, capacidade e funcionalidade, enquanto estruturas de armazenamento de alimentos para consumo da população, feita em fontes históricas, como a Cróni- 
ca da conquista de Lisboa aos Mouros, de Osberno (OLIVEIRA, SILVA, 1936, p. 81, 108) é enfatizada e reforçada com os vestígios arqueológicos colocados descobertos. Considerando a descrição presente nesta fonte, é possível fazer corresponder um dos locais e o conjunto de silos ao sítio onde foi construída a igreja de São Lourenço: “Encontraram-se depois no arrabalde, do nosso lado, e em cavernas abertas na encosta do monte, perto de cem mil cargas de trigo, cevada, milho e legumes, mantimentos da maior parte da cidade, porque ao sopé dos muros tinham grande extensão de espaço e a dureza da rocha forma para guardarem grande quantidade de objectos domésticos, ao passo que em baixo, no vale, a abundância das águas não lhes permitia abrir fossos" (OLIVEIRA, SILVA, 1936, p. 81).

Primordialmente estas estruturas destinavam-se a armazenar alimentos, mas quando deixaram de cumprir a sua função foram desactivadas e entulhadas com materiais e terra. Em Lisboa, através dos vestígios arqueológicos e nos casos em que foi possível perceber cronologias, verificou-se que a desactivação dos silos ocorreu paulatinamente, existindo estruturas de armazenamento que foram colmatadas mais tarde do que outras.

De facto, a primeira desactivação de silos ocorreu por volta dos séculos IX/X na Encosta de Sant'Anna (CALADO, LEITÃO, 2005, p. 468) seguindo-se os silos que foram detectados no Mosteiro de São Vicente de Fora que foram entulhados durante os X e XI (RODRIGUES FERREIRA, 2001, p. 49). Posteriormente no século XI dá-se a colmatação das estruturas presentes Fundação Ricardo Espírito Santo Silva (RAMOS, JORDÃO, 1996/1997, p. 110-112), tendo acontecido o mesmo no Largo das Portas do Sol (GOMES, SEQUEIRA, 2001, p. 105; SILVA, 2014, p. 181) e na Encosta de Sant'Anna (CALADO, LEITÃO, 2005, p. 468) em meados deste século.

Com a chegada do século XII mais um silo na Encosta de Sant'Anna deixa de armazenar alimentos (CALADO, LEITÃO, 2005, p. 468), tal como os silos descobertos na igreja de São Lourenço (RODRIGUES, 2019, p. 96) e no Palácio dos Condes de Penafiel, sítios inéditos, informação oral de Rodrigo Banha da Silva, a quem se agradece). Nas centúrias seguintes é no Palácio das Cozinhas do Castelo de S. Jorge, que são desactivados silos, 1, nos séculos XIII e XIV e mais 3 no século XV (FILIPE, 2011, p. 14-16). Por vezes, nem sempre é possível ter tanta clareza no estabelecimento das cronologias de desactivação dos silos conforme é patente numa das estruturas de armazenamento do castelejo do castelo de S. Jorge, em que apenas é mencionada uma datação posterior ao século XI (GOMES, GASPAR, 2001, p. 10); em 3 silos existentes na Encosta de Sant'Anna, colmatados em data anterior à edificação da Cerca Fernandina (CALADO, LEITÃO, 2005, p. 462); e num silo no Palácio das Cozinhas que terá sido entulhado entre o período islâmico e até ao século XV. No Beco do Forno, lote 40, foi possível detectar silos que foram cheios em dois momentos diferentes, século XI e séculos XV e XVI (GOMES \& alii, 2009, p. 957).

\section{CONCLUSÃO}

O sítio arqueológico da igreja de São Lourenço apresenta uma longa diacronia que vai desde o período medieval islâmico até à contemporaneidade. O espólio exumado do interior das estruturas de armazenamento permitiu aferir uma datação para a construção da igreja que se situa entre a segunda metade do século XI e a centúria seguinte, no máximo até pouco antes de 1191 .

Relativamente aos silos são estruturas que ocorrem em diversas urbes do al-Ândalus e a sua desactivação é um fenómeno paulatino que ocorre quando este tipo de estruturas deixa de servir o seu propósito inicial.

\section{BIBLIOGRAFIA}

ANDRADE, Ferreira de (1950) - A Mouraria: o Palácio da Rosa e os templos de S. Lourenço e do Coleginho [conclusão]. Olisipo. Revista do Grupo Amigos de Lisboa. Lisboa: 52, pp. 178-192.

AMARO, Clementino (20ooa) - Palácio Rosa - Igreja de São Lourenço (Mouraria - Lisboa). Relatório dos trabalhos arqueológicos. Relatório apresentado ao Instituto de Gestão do Património Arquitectónico e Arqueológico (IGESPAR).

AMARO, Clementino (20oob) - Caderno de Campo da Igreja de S. Lourenço. Relatório dos trabalhos arqueológicos. Relatório apresentado ao Instituto de Gestão do Património Arquitectónico e Arqueológico (IGESPAR).

ARAÚJO, Norberto (s.d.) - Peregrinações em Lisboa. Lisboa: s.e., vol. III.

BARROCA, Mário (200o) - Epigrafia Medieval Portuguesa (862-1422). Lisboa: Fundação Calouste Gulbenkian, 3 vols..

BOISSELLIER, Stéphane (2002) - Registres fiscaux et administratifs de bénéfices ecclésiastiques du royaume portugais XIII $-\mathrm{XIV}^{\mathrm{e}}$ siècles (Édition et présentation). Cotribution à l'étude du phénomène admnistratif. Memória inédita de 
habilitação para dirigir projectos de Investigação, Université Paris I-Sorbonne.

BRANCO, Maria João (1996) - A Conquista de Lisboa revisitada: estratégias de ocupação do espaço político, físico e simbólico. In $2^{\circ}$ Congresso Histórico de Guimarães: actas [Guimarães]. Guimarães: Câmara Municipal de Guimarães; Universidade do Minho, vol. 2, pp. 119-137.

BRANCO, Maria João (1998) - Reis, Bispos e Cabidos: A diocese de Lisboa durante o primeiro século da sua restauração. Lusitânia Sacra. Lisboa: 2ª série, tomo 10, pp. 55-94.

BUGALHÃO, Jacinta (2009) - Lisboa Islâmica: uma realidade em construção. Xelb. Silves: 9, pp. 379-393.

BUGALHÃO, Jacinta; CATARINO, Helena; CAVACO, Sandra; COVANEIRO, Jaquelina; FERNANDES, Isabel Cristina; GOMES, Ana; GÓMEZ MARTINEZ, Susana; GONÇALVES, Maria José; GRANGÉ, Mathieu; INÁCIO, Isabel; LOPES, Gonçalo; SANTOS, Constança (2010) - CIGA: Projecto de sistematização para a cerâmica islâmica do Gharb al-Andalus. Xelb. Silves, 10, pp. 455-476.

CALADO, Marco; SALOMÉ, Rita (2012) - Um Pequeno Conjunto Cerâmico de Época Medieval da rua de São Mamede (Lisboa). Al-Mandan. Almada: II, 1, pp. 23-30.

CALADO, Marco; LEITÃO, Vasco (2005) - A ocupação islâmica na Encosta de Sant'Ana (Lisboa). Revista Portuguesa de Arqueologia. Lisboa: 8,2, pp. 459-470.

CATARINO, Helena (1997/1998) - O Algarve Oriental Durante a Ocupação Islâmica - Povoamento rural e recintos fortificados. Al-'Ulyã, Revista do Arquivo Municipal de Loulé. Loulé, 6, 3vols.

COELHO, Teresa Campos (1998) - Trabalhos de Recuperação da Igreja de São Lourenço de Lisboa. Pedra \& Cal. Lisboa, 1, pp. 38-41.

COELHO, Teresa Campos; SILVA, José Custódio Vieira da; AMARO, Clementino; SABROSA, Armando; MONTEIRO, José Luís (1999) - Trabalhos de Recuperação da igreja de S. Lourenço de Lisboa-Conjunto de vestígios do período islâmico ao século XV. Comunicação apresentada no II Colóquio Temático Estudos de Lisboa - Séculos VIII - XV, Lisboa (trabalho inédito policopiado, consultado no Centro de Arqueologia de Lisboa).

FARELO, Mário (2008) - A Oligarquia Camarária de Lisboa (1325-1433). Lisboa. Tese de Doutoramento em História Medieval apresentada à Faculdade Letras da Universidade de Lisboa.

FERNANDES, Lídia (2013) - Teatro romano de Olisipo: a marca do novo poder romano. In ARNAUD, José; MARTINS, Andrea e NEVES, César, coord. - Arqueologia em Portugal. 150 Anos. Lisboa: Associação dos Arqueólogos Portugueses, pp. 765-773.

FERNANDES, Lídia (2009) - Capitel das Thermae Cassiorum de Olisipo (Rua das Pedras Negras, Lisboa). Revista Portuguesa de Arqueologia. Lisboa: 12, 2, pp. 191-207.
FILIPE, Victor (2011) - Projecto de ampliação e alterações para a Rua do Espírito Santo nº 31 - 35-ampliação da albergaria do Castelo de S. Jorge, Lisboa. Relatório apresentado à Direcção Geral do Património Cultural (DGPC).

GASPAR, Alexandra; GOMES, Ana; MENDES, Henrique Calé; PINTO, Paula; GUERRA, Sandra; RIBEIRO, Suzana; PIMENTA, João; VALONGO, António (2009) - Cerâmicas medievais provenientes do Beco do Forno - Castelo de S. Jorge. In ZOZAYA, Juan; RETUERCE, Manuel; HERVÁS, Miguel Ángel; JUAN, Antonio de (eds.), Actas del VIII Congreso Internacional de Cerámica Medieval en el Mediterráneo. Ciudad Real - Almagro del 27 de febrero al 3 de marzo de 2006, Tomo II, Ciudad Real, Asociación Española de Arqueología Medieval, pp. 955-962.

GOMES, Ana.; GASPAR, Alexandra.; Guerra, S.; VALONGO, António.; PIMENTA, João.; Pinto, P.; MENDES, Henrique.; Ribeiro, S. (2009) - A cerâmica vidrada da Alcáçova do Castelo de S. Jorge. In: ZOZAYA, Juan.; RETUERCE, Manuel.; HERVÁS, Miguel Ángel; JUAN, Antonio de (eds.), Actas del VIII Congreso Internacional de Cerámica Medieval en el Mediteráneo. Cuidad Real - Almagro del 27 de febrero al 3 de marzo de 2006, Tomo 1, Asociación Española de Arqueología Medieval, pp. 399-404.

GOMES, Ana; SEQUEIRA, Maria José (2001) - Continuidades e descontinuidades na arquitectura doméstica do período islâmico e após a conquista da cidade de Lisboa: Escavações Arqueológicas na Fundação Ricardo Espírito Santo Silva. Arqueologia Medieval. Porto, 7, pp. 103-110.

GOMES, Rosa Varela (2002a) - Silves (Xelb), Uma cidade do Gharb Al-Andalus: território e cultura. Lisboa: Instituto Português de Arqueologia (Trabalhos de Arqueologia, 23).

GOMES, Ana; GASPAR Alexandra; PIMENTA, João; VALONGO, António; PINTO, Paula; MENDES, Henrique; RIBEIRO, Susana; GUERRA, Sandra (2001) - A cerâmica pintada de época medieval da Alcáçova do Castelo de S. Jorge. In Garb. Sítios Islâmicos do Sul Peninsular (Sítios Islámicos del Sur Peninsular). Lisboa: Ministério da Cultura, Instituto Português do Património Arquitectónico Departamento de Estudos (IPPAR/DE), Junta de Extremadura - Consejaría de Cultura, pp. 119-163.

GÓMEZ MARTINEZ, Susana (2014) - Cerâmica Islâmica de Mértola. Museu de Mértola. Mértola: Campo Arqueológico de Mértola.

GONÇALVES, António Manuel, SEGURADO, Jorge (1984) - O Largo da Rosa e do Nobre Sítio de São Lourenço. Lisboa: Academia Portuguesa da História.

MALALANA UREÑA, Antonio; MORÍN DE PABLOS, Jorge; BARROSO CABRERA,Rafael (2013) - Acerca de la funcionalidad de los denominados "silos-basureros": una propuesta metodológica para el estudio de la agricultura andalusí en época califal y taifa. Archeologia Medievale. Firenze, XL, pp. 337-352. 
MIRANDA, Pedro (2013) - Intervenção arqueológica no Beco do Forno do Castelo nº $14-20$ - Muro (BFCM) Lisboa. Relatório apresentado à Direcção Geral do Património Cultural (DGPC).

OLIVEIRA, José Augusto de; SILVA, Augusto Vieira da (1936) - Conquista de Lisboa aos Mouros (1147). Lisboa: Serviços Industriais da Câmara Municipal de Lisboa.

PEREIRA, Félix Alves (1924) - Antiqvitvs: XXIII - Quatro "silos» ou celeiros encontrados no Chiado - Olaria portuguesa antiga - Covas dos mouros: sua antiguidade - A cêrca do Carmo. O Arqueólogo Português. Lisboa: $1^{\underline{a}}$ série, vol. XXVI, pp. 171-178.

PRATA, Sara (2014) - Relatório Final: Acompanhamento arqueológico - Recuperação de um edificio na Rua da Saudade, $n^{o}$ 2, 2 a e $2 b$ (Lisboa) - Relatório apresentado à Direcção Geral do Património Cultural (DGPC).

RAMALHO, Maria; LOPES, Carla; CUSTÓDIO, Jorge; VALENTE, Maria João (2001) - Vestígios da Santarém islâmica - Um silo no Convento de S. Francisco. Arqueologia Medieval. Porto: 7, pp. 147-168.

RAMOS, Rita; JORDÃO, Patrícia (1996/1997) - Relatório dos trabalhos arqueológicos realizados na Fundação Ricardo Espírito Santo - Lisboa (Campanhas de 1996 e 1997). Relatório apresentado ao Instituto Português de Arqueologia (IPA).

RIBEIRO, Nuno (2012) - Relatório Final, Beco da Cardosa - Ramais 33 e 35. Projecto de implantação de Gás Natural. Relatório apresentado à Direcção Geral do Património Cultural (DGPC).

RODRIGUES FERREIRA, F. E. (2001) - Os silos medievais de S. Vicente de Fora. Arqueologia e História, 53 (Estudos de Lisboa - séculos VIII-XV - II Colóquio Temático), Lisboa, Associação dos Arqueólogos Portugueses, Edições Colibri, pp. 49-66.

RODRIGUES, Andreia (2019) - Nos arrabaldes de al-Uxbuna: a ocupação islâmica no sítio arqueológico da igreja de São Lourenço (Mouraria, Lisboa). Dissertação de Mestrado em Arqueologia apresentada à Faculdade de Ciencias Sociais e Humanas da Universidade Nova de Lisboa.

ROSSELLÓ-BORDOY, Guillem (1991) - El Nombre de las Cosas en Al-Andalus, Una Propuesta de Terminología Cerámica. Palma de Mallorca: Museo de Mallorca.

SOUTA, Ana Rita; LIMA, Joana; SARRAZOLA, Alexandre (2012) - Relatório Final dos Trabalhos Arqueológicos. Sondagens de Diagnóstico Arqueológico Rua do Recolhimento 35 / Beco do Leão, Lisboa. Relatório apresentado à Direcção Geral do Património Cultural (DGPC).

SILVA, Augusto Vieira da (1968) - Dispersos. Lisboa: Câmara Municipal de Lisboa.

SILVA, Augusto Vieira da (1987a) - A Cerca Moura de Lisboa. Estudo Histórico Descritivo. Lisboa: Câmara Municipal de Lisboa.
SILVA, Augusto Vieira da (1987b) - A Cerca Fernandina de Lisboa. Lisboa: Câmara Municipal de Lisboa.

SILVA, Vítor (1995) - Igreja de S. Lourenço, na Mouraria Consolidação da estrutura. Jornal Arquitectos, no 147, pp. 54-55.

SILVA, Carlos Guardado da (2008) - Lisboa Medieval. A organização e a estruturação do espaço urbano. Lisboa: Colibri.

SILVA, Gonçalo (2017) - Ennoblecimiento, Saber y Poder: Las bibliotecas de las capillas de los Nogueira (1296-1464). In A. Suárez González (Ed.), Escritura y sociedad: La Noble$z a$. Santiago de Compostela, Instituto de Estudos Medievais (IEM), pp. 367-382).

SILVA, Gonçalo (2012) - Espiritualidade e Poder na Lisboa dos Finais da Idade Média: a Colegiada de São Lourenço e os seus Patronos (1298-1515). Lisboa. Tese de Mestrado em História - Área de Especialização em História Medieval apresentada à Faculdade de Ciências Sociais e Humanas da Universidade Nova de Lisboa (Policopiada).

SILVA, Manuel (2017) - Mutação Urbana na Lisboa Medieval. Das Taifas a D. Dinis. Tese de Doutoramento em História - Área de especialização em História Medieval apresentada à Faculdade de Letras da Universidade de Lisboa.

SILVA, Rodrigo Banha da, VALONGO, António (2016/2017) - A Urbanística do Subúrbio Ocidental de Felicias Iulia Olisipo (Lisboa): Um Contributo da I.A.U. da Rua do Ouro n.os 133-145. Cira Arqueologia. Vila Franca de Xira: 5, pp.116-148.

SILVA, Rodrigo Banha da (2014) - Intervenção arqueológica urbana de 1993 na Fundação Ricardo Espírito Santo Silva/ Largo das Portas do Sol (Lisboa): as evidências do período romano. Cira Arqueologia. Vila Franca de Xira: 4, pp. 178-199.

TORRES, Cláudio; GOMÉZ MARTINEZ Susana; FERREIRA, Manuela B. (2003) - Os Nomes da Cerâmica Medieval. Inventário de Termos. In III Jornadas de Cerâmica Medieval e Pós- Medieval - Métodos e Resultados para o seu Estudo (Tondela, 1997). Porto: Câmara Municipal de Tondela, pp. 125-134. 
Igreja de S. Lourenço

Bairro da Mouraria - Lisboa

Planta Geral

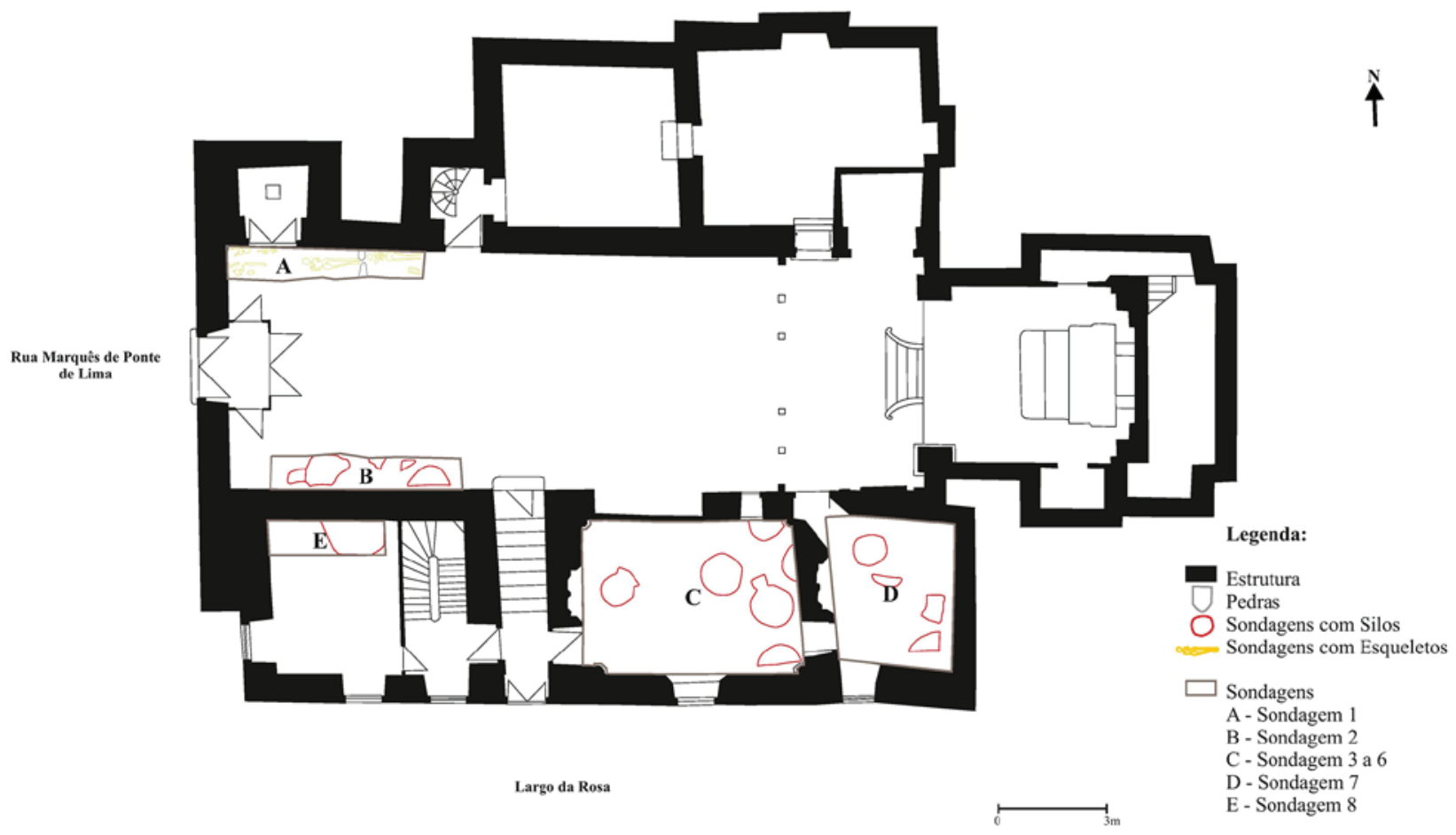

Figura 1 - Planta Geral da Igreja de S. Lourenço (AMARO, 200o, Figura 3, adaptado).

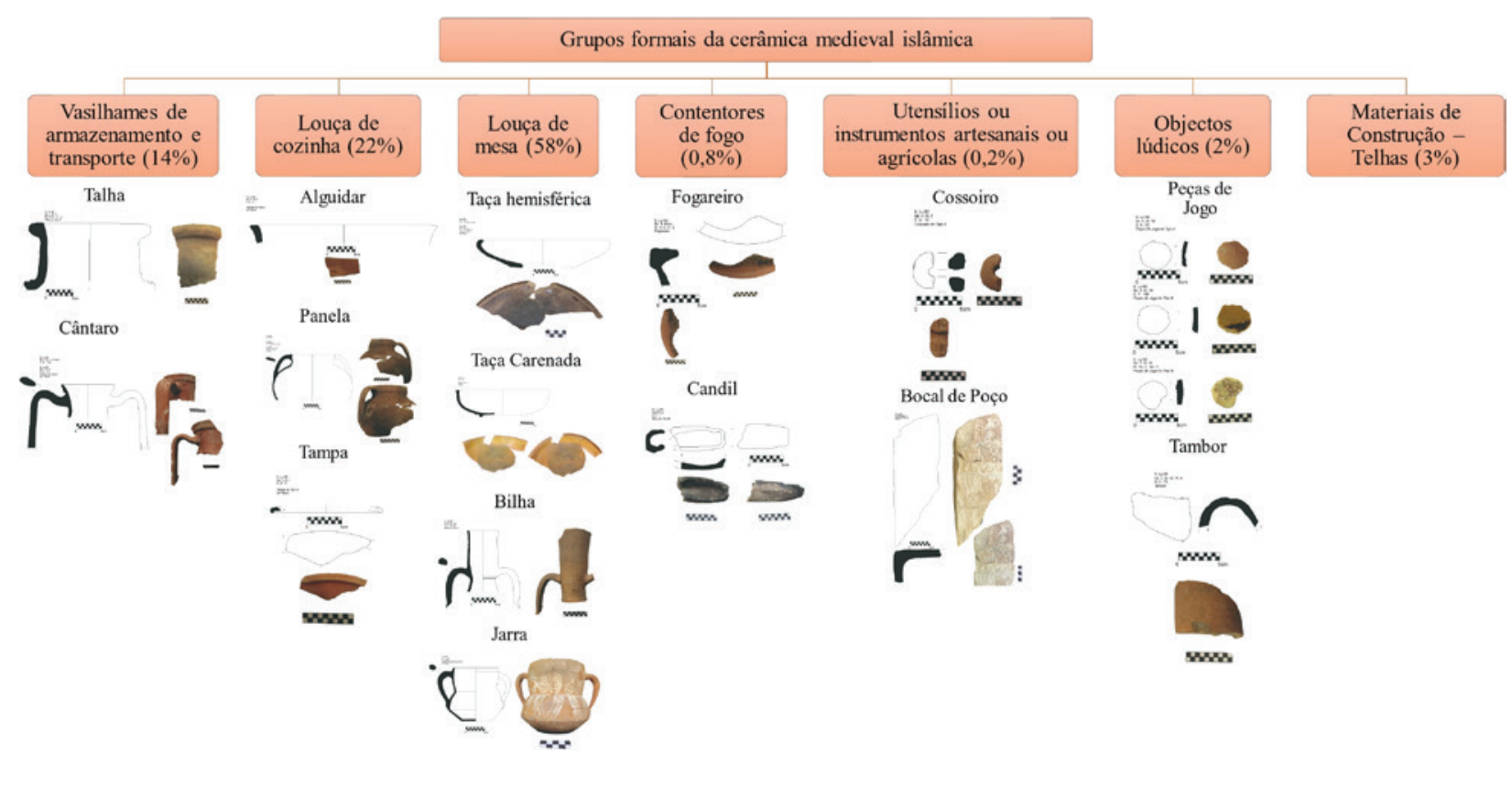

Figura 2 - Grupos formais da cerâmica medieval islâmica e a sua representatividade. 


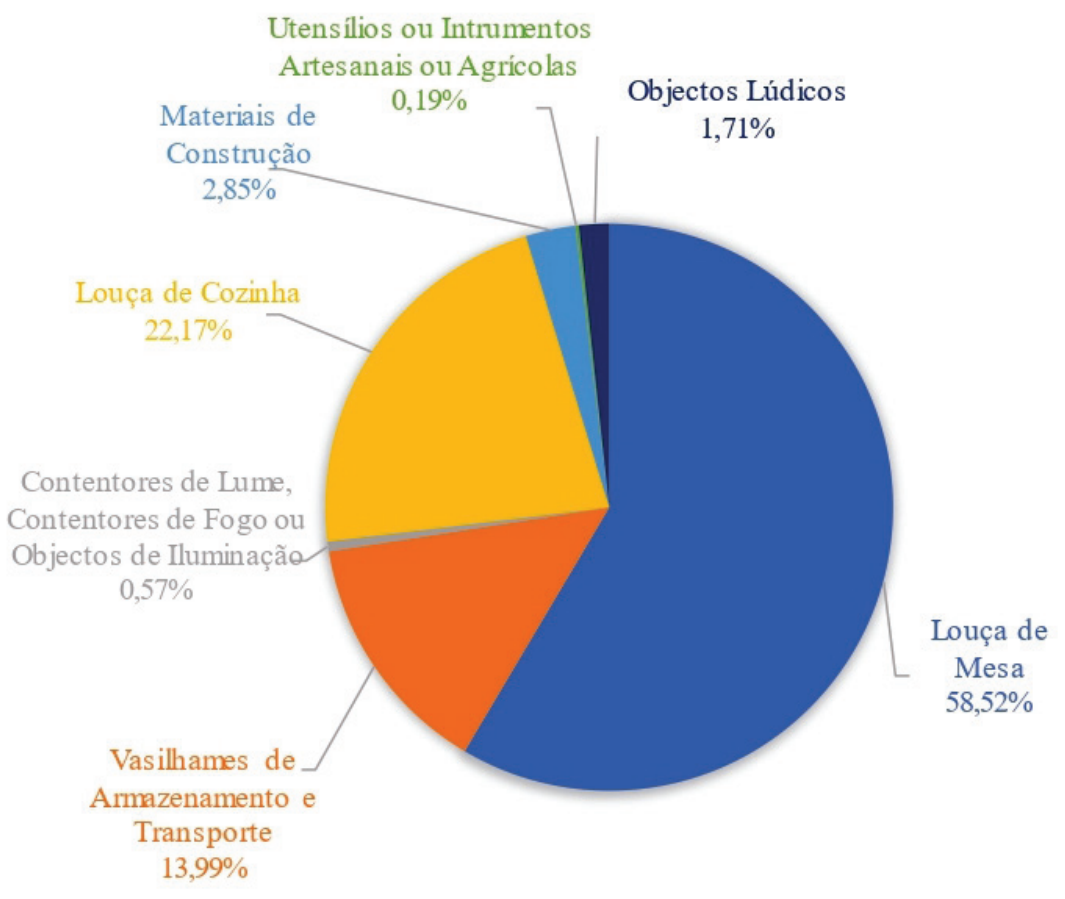

Figura 3 - Categorias tipológicas e respetivos percentuais.

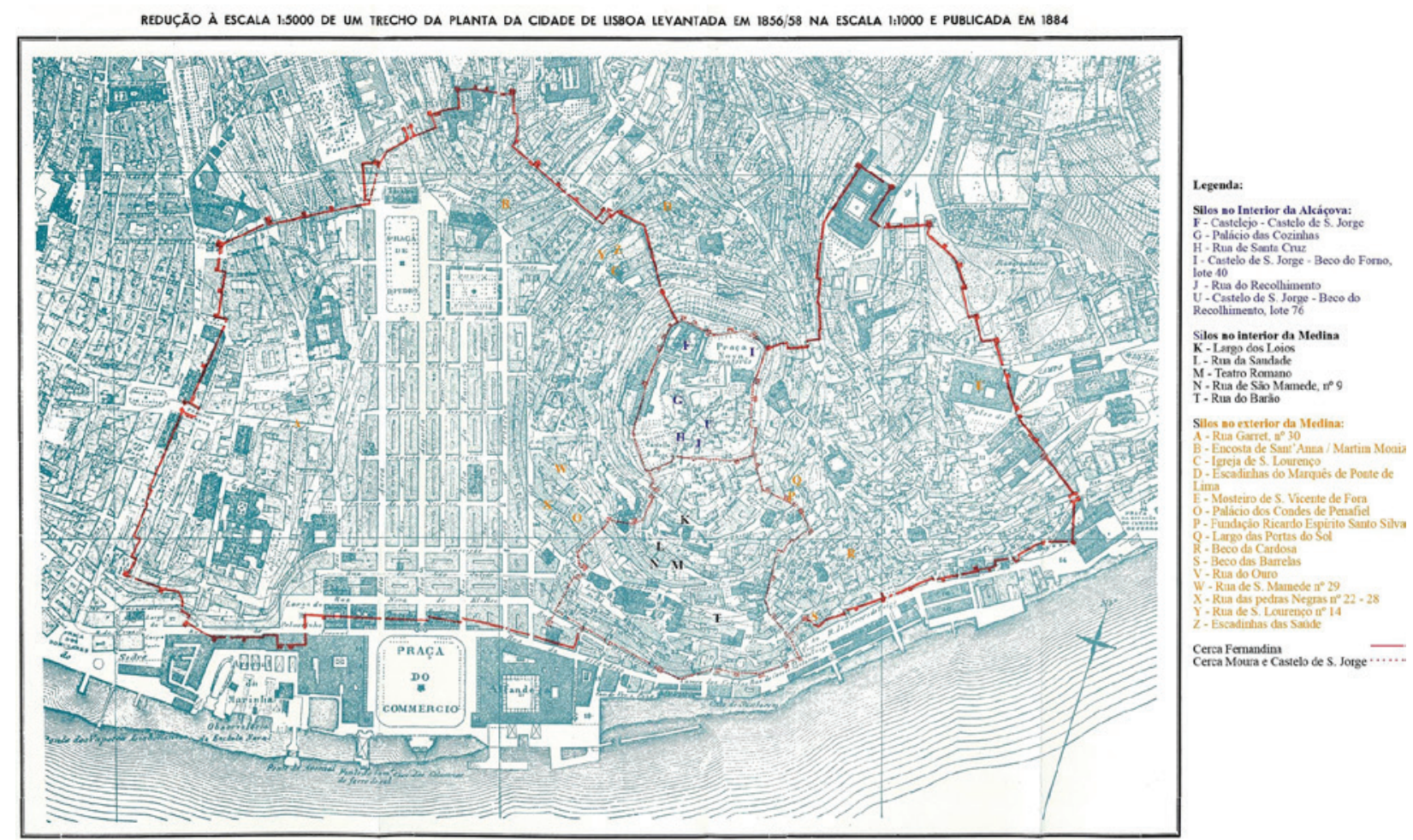

Figura 4 - Planta da cidade de Lisboa publicada em 1884 (SILVA, 1987b, adaptado) sobre a qual foram assinalados os locais que registaram a ocorrência de silos. (SILVA, 1987b, adaptado). 


\title{
O REGISTO MATERIAL DE
}

MOVIMENTAÇÕES POPULACIONAIS

NO MÉDIO TEJO, DURANTE OS SÉCULOS

XII-XIII. DOIS CASOS DE "SUNKEN

FEATURED BUILDINGS”, NOS CONCELHOS

DE CARTAXO E TORRES NOVAS

\author{
Marco Liberato $^{1}$, Helena Santos ${ }^{2}$, Nuno Santos $^{3}$
}

\begin{abstract}
RESUMO
Apresentam-se dois casos na bacia do Tejo em que estruturas negativas terão sido utilizadas como espaços domésticos. Os conjuntos artefactuais revelam uma cronologia em torno dos séculos XII-XIII e os perfis cerâmicos são claramente dissonantes das produções tipificadas para o período islâmico. Correspondem antes a soluções que evoluíram sem contacto com influências meridionais, características do Centro e Norte da Península. A tipologia dessas estruturas, conjuntamente com a hipotética origem geográfica dos seus construtores, torna razoável equacionar que estejamos perante habitats provisórios de populações recém-chegadas a estas latitudes. Assim, conclui-se que correspondem ao registo material do elemento humano que escorou a progressiva implementação nesta região de uma formação social diversa, após a conquista cristã, dinamizando novas fórmulas de exploração e controlo territorial.

Palavras-chave: Habitats temporários, Movimentos populacionais, Séculos XII-XIII.
\end{abstract}

\begin{abstract}
This paper presents and discusses two cases of sunken featured buildings in Tagus Valley region. The pottery recovered in association with the structures is similar to the productions of central e northern provinces of the Iberian Peninsula, where Islamic influences were tenuous or even non-existent. Both the typology of these contexts and the likely origin of their builders, allows us to equate their correspondence with temporary habitats of newcomers ready to settle after the Christian conquest of the area, in the XII ${ }^{\text {th }}$ century.

In conclusion, we are probably dealing with the material record of the human element that supported the progressive implementation in this region of a different social formation, promoting new formulas of territorial control. Keywords: Temporary habitats, Migrations, XII ${ }^{\text {th }}-\mathrm{XIII}^{\text {th }}$ centuries.
\end{abstract}

\section{OS CONTEXTOS ARQUEOLÓGICOS}

\section{a. Quinta da Aramenha III, Cartaxo}

O primeiro sítio considerado, localizado no concelho do Cartaxo, implanta-se no topo de uma pequena elevação $(36 \mathrm{~m})$ sobranceira às várzeas aluvionais do
Tejo (4-5m), distando cerca de quatro quilómetros do leito atual do rio. Tendo sido identificado no decurso da exploração de inertes para a empreitada de alargamento da autoestrada A1, foi nomeado como Quinta da Aramenha e intervencionado por várias vezes, entre 2004 e 2006. Foi a reativação dessa ati-

\footnotetext{
1. Centro de Estudos em Arqueologia, Artes e Ciências do Património, marcoliberato@hotmail.com

2.lenamps@hotmail.com

3.nuno.arh.santos@gmail.com
} 
vidade de extração, já no âmbito da requalificação da ferrovia que lhe passa próxima, que determinou a intervenção de maiores dimensões. Foi então estipulada, como medida de minimização, a escavação de 400 metros quadrados, registada com o topónimo Quinta da Aramenha III (Borges, 2007, p. 3) (Foto 1). Os materiais recolhidos demonstram atividade antrópica numa ampla diacronia, iniciada com a abertura de estruturas negativas tipo fossa/silo em período proto-histórico. É indubitável também algum tipo de ocupação em época romana, atestada pela recolha de um fundo de ânfora e pela presença generalizada de telhas bastante espessas, mas muito fragmentadas, por toda a área. Ocorrem ainda, nas camadas superficiais, testos com barbela e fundos em "bolacha", sinalizando um horizonte baixo-medieval que ficou pouco definido na intervenção. Mas que poderá relacionar-se com a abertura de novas estruturas negativas, de planta muito regular, tendencialmente quadrangulares e que foram interpretadas como ações com vista ao plantio de árvores.

No entanto, a ocupação mais consistente corresponde ao período pleno-medieval. A mesma encontra-se representada por três contextos, cujas características apontam para soluções de habitat pouco documentadas para estas cronologias, organizadas a partir de estruturas negativas.

É o caso da estrutura [35], uma depressão no substrato geológico com pelo menos seis metros de comprimento por cerca de dois de largura ${ }^{4}$. Não conseguimos determinar a sua profundidade, mas rondaria os $50 \mathrm{~cm}$, a julgar pelo registo gráfico de algumas realidades associadas (Borges, 2007a, p.9) (Foto 2).

Os dois "alvéolos" semi-circulares que apresenta no alçado Este, serão estruturas negativas tipo fossa que intercetaram posteriormente a estratigrafia original, na medida em que a sua abertura parece ter desmantelado parcialmente a realidade [24]. Esta foi descrita como um «lar de argila cozida, muito regular, com uma pequena fornalha central de paredes sobreelevadas» (Borges,2007, p.7). Estará diretamente relacionada com a utilização primária da estrutura negativa, na medida em que se posicionava, estratigraficamente, entre os depósitos [9] e [8]. O primeiro sedimento, que cobria a base da realidade [35], apresentava uma tonalidade escura que

4. O relatório refere que não foi escavada na integra, mas ficou delimitada a "maior parte do seu traçado» (BORGES, 2007, p. 8). denuncia um maior contributo de matéria orgânica na sua formação e testemunhará, com maior segurança, o período de utilização desse ambiente, pelo que só consideramos os seus materiais nesta abordagem ao sítio.

Assinale-se que não se verifica qualquer derrube de revestimentos cerâmicos do telhado, que teria neste contexto as condições ideais para se ter preservado. Assim, consideramos altamente provável que, a ter existido um esquema de cobertura, se tenha recorrido a materiais orgânicos na sua edificação.

A Este deste contexto, outra realidade presente na escavação replica várias das suas características, ainda que com formatos diferentes. Trata-se da estrutura negativa [34], que apresentaria uma planta para-circular, com cerca de 3 metros de diâmetro. É bastante menos profunda que a anterior, mas a sua associação com uma estrutura tipo forno, ainda que localizada no exterior, parece demonstrar, de facto, a mesma lógica funcional ${ }^{5}$ (Foto 3 ).

Um terceiro contexto é ainda de mais difícil interpretação. Trata-se da sobreposição entre os sedimentos [46] e [47]. O primeiro foi definido como um "estrato" associado a "uma grande quantidade de cerâmica no que se supõe ser um espaço doméstico» enquanto o segundo, "com sedimentação igual à [46]", cobriria uma depressão no substrato geológico de "contornos quadrangulares" (Borges, 2007, p. 13). Esta interface, que não recebeu número de unidade $^{6}$, é muito pouco percetível nas fotos, pelo que teria pouca profundidade (BORGES, 2007, foto 19). Nesse mesmo registo podem ser observadas algumas depressões que poderão corresponder a buracos de poste, mas esse tipo de estruturas nunca foi individualizado pelos responsáveis da intervenção (BORGES, 2007, foto 19) ${ }^{7}$.

5. (BORGES, 2007, foto 17). Nesta foto é visível uma outra estrutura negativa, mais profunda. Corresponderá à realidade [67] colmatada pelo depósito [66], que estaria «coberta pela [33] (Idem, p. 14), constituindo certamente uma pré-existência.

6. No relatório assinala-se que o depósito [47] «enche a [48]» (BORGES; 2007, p. 13). No entanto, regista-se nesse mesmo local, que essa unidade estratigráfica preenche a estrutura negativa [49] e surge representada no registo fotográfico no quadrado J4 (BORGES, 2007a, foto 11). Assim, a primeira referência trata-se certamente de um lapso.

7. Assim se constata pela sua visibilidade no caso das estruturas negativas [64] (BORGES, 2007a, foto 18) e [13] (BORGES, 2007, foto 10), sem que exista menção à sua ocorrência. 


\section{b. Prédio Alvarenga, Torres Novas}

O outro caso de sunken featured buildings foi identificado num contexto totalmente distinto, no interior da malha urbana da cidade de Torres Novas, permitindo assim uma contextualização mais documentada à sua ocorrência.

Muito embora as tradições locais insistam numa ocupação islâmica do sítio, não se conhece nenhum dado empírico que a sustente. A primeira menção conhecida a Turribus Novis data de 1179, quando D. Afonso Henriques atribuiu uma verba aos pobres locais no seu legado testamental, uma informação que tem sido interpretada como significante de um tecido social pouco coeso, que teria na recente fundação da vila uma explicação plausível (Coelho, 1992, p. 61). Em 119o, uma incursão almóada, que não conseguiu dominar Santarém, saqueia a fortaleza da povoação, chamando-lhe castelo de Torres (hisn Torrech), dirigindo-se depois a Tomar (Conde, 200o, p. 77), certamente deslocando-se sobre as estradas romanas da região. Terá sido esse acontecimento a motivar a atribuição de foral à vila, nesse mesmo ano, com o objetivo de fomentar o seu povoamento e operacionalizar, com maior sucesso, as valências militares da sua posição, no corredor de circulação Santarém-Coimbra. Iniciativa que será coroada de sucesso uma vez que, na década de 20 do século XIII, encontravam-se já construídas pelo menos quatro igrejas, correspondendo às paroquiais que se mantiveram organizadas até ao século passado (Boissellier, 2012, p. 102) ${ }^{8}$.

Os dados arqueológicos apontam também para a inexistência de um povoado islâmico. A recente identificação de marcas de canteiro em várias torres do castelo, comprova definitivamente que a fortaleza, pelo menos no formato que atingiu o século XX, corresponde a uma edificação cristã. De facto, os melhores paralelos estilísticos e formais para essas gravações encontram-se em construções relacionadas com a expansão portucalense e que se julga terem sido erigidas entre os séculos XII e XIII, como S. João de Alporão em Santarém ou o Mosteiro da Batalha (Liberato, et al., 2017).

As associações cerâmicas pleno-medievais recuperadas na cidade convergem no mesmo sentido. Não

8. São referidas mais duas igrejas, Sancta Maria de extra villam que poderá corresponder à actual S. Maria do Vale, o que reforçaria ainda mais a imagem de "explosão" demográfica da vila e a Ecclesia de Ortis, que não conseguimos fazer corresponder com nenhum templo conhecido. ocorrem elementos que possam comprovar uma ocupação anterior ao século XII, não se detetando produções relacionáveis com ambientes culturalmente islamizados. Pelo contrário, verifica-se que os seus melhores paralelos são soluções tipicamente setentrionais, onde os influxos mediterrânicos nunca foram suficientemente fortes para determinar a evolução das tradições oleiras. A frequência de alguidares de fundo em disco ou a raridade de pintura a branco são elementos comprovativos desta interpretação (Liberato e Santos, 2017) (Liberato e Santos, 2018) (Costa, et al., 2007). A identificação de um cantil pintado a vermelho, classificado como almóa$\mathrm{da}$, acaba por reforçar essa imagem, pelo evidente contraste técnico, ornamental e formal com a restante cerâmica conhecida na cidade (Lopes, 2007). Em 2019, a reabilitação de um imóvel denominado Prédio Alvarenga, implicou uma escavação em área de cerca de $150 \mathrm{~m}^{2}$. Localizada a cerca de cem metros do castelo, partilha a mesma implantação topográfica, no topo de um planalto sobranceiro ao rio Almonda. Encontra-se, assim, naquela que seria a direção natural da expansão da malha urbana medieval. Que se terá constituído como arrabalde exterior à fortificação, entre os finais do século XII e inícios do século XIII, a julgar pela menção às igrejas de S. Maria e S. Salvador circa 1220, como já avançamos. Viria depois a ser cintado no âmbito das Guerras Fernandinas e a partir daí denominado como Cerca nas fontes documentais (Conde, 2000, p. 355) (Foto 4).

O contexto identificado nessa escavação e que agora analisamos, corresponde a um dos primeiros testemunhos de atividade antrópica detetada. Consiste numa estrutura negativa de planta tendencialmente retangular, escavada no substrato geológico, registada como [743], com pelo menos $4 \mathrm{~m}$ de comprimento, uma vez que se prolongava para fora da área intervencionada. A largura apresentava um valor médio em torno dos $2,5 \mathrm{~m}$ enquanto a profundidade máxima rondava os $20 \mathrm{~cm}$. Toda a área limítrofe, a sul, encontra-se polvilhada de buracos de poste, não tendo sido possível determinar se existiu uma relação funcional, muito embora a inexistência destas realidades a Norte possa indiciar uma resposta negativa. Por fim, à semelhança do verificado no Quinta da Aramenha III, destaque-se a ausência de cerâmica de construção no seu enchimento (Foto 5). Para além das coincidências ao nível arquitetónico, também parecem ocorrer semelhanças funcionais 
com os contextos do Cartaxo, dada a identificação de pequenos fornos construídos com barro cozido. No caso de Torres Novas, não temos provas incontestáveis da sincronia dessa solução com a utilização da estrutura [743]. Mas a ocorrência de inúmeros fragmentos de barro cozido no seu enchimento/ abandono (registado como depósitos [734] e [740]), a par da frequência de ossos de animal carbonizados, tornam-na bastante provável.

Indiscutível é a construção/utilização de pelo menos duas dessas estruturas de combustão já sobre essa colmatação. Assim, ligeiramente desfasado de um primeiro forno, nomeado [732] e sobrepondo-se-lhe parcialmente, foi registada a estrutura [710]. Que constituiria uma unidade funcional com uma depressão de planta retangular, preenchida quase exclusivamente por material lenhoso carbonizado e designada como [712]. As características desse enchimento tornam provável que estejamos perante uma solução que, a partir da contenção de brasas, mantivesse a temperatura de alimentos já cozinhados (Foto 6).

Parece-nos, assim, plausível que a confeção de alimentos com recurso a fornos construídos com argila tenha ocorrido quer durante a utilização da estrutura negativa [743], quer após a sua condenação, mantendo-se a área adstrita ao mesmo tipo de atividades durante um período de tempo razoável.

\section{MATERIAIS E CRONOLOGIA}

A cultura material recuperada também contribui para a imagem de semelhança funcional entre as duas realidades, acrescentando ainda, à listagem de coincidências, uma cronologia aparentemente idêntica. Em ambos os sítios surgem fragmentos de uma forma cerâmica específica, modelada manualmente. As pastas utilizadas para o seu fabrico constituem outro caractere individualizador, apresentando sempre muitos desengordurantes inorgânicos, alguns de grande dimensão. Assinala-se ainda uma grande descontinuidade nas suas superfícies, que apresentam "falhas" de dimensões e formas diversas, mas que correspondem indubitavelmente a impressões de matéria vegetal, entretanto desaparecida.

A adição de grandes quantidades deste desengordurante ao barro terá certamente uma conexão direta com a função a que se destinava. Muito embora não a consigamos por agora descortinar, julgamos tratar-se de um elemento de louça de cozinha rela- cionada com a confeção de um alimento específico, cujo consumo seria ocasional, na medida em que raramente surge nos conjuntos artefactuais. Concorrem a favor desta hipótese, desde logo, as marcas de forte exposição ao fogo que os fragmentos geralmente apresentam. Bem como a fragilidade do recipiente, que não deveria ter um tempo de vida longo, na medida em que se esboroa facilmente, sendo de equacionar um uso tendencialmente "descartável" dessa forma, inutilizada após poucas utilizações.

Estas características determinam que, geralmente, surja muito fragmentado, em pedaços informes, dificultando a sua identificação. Por vezes, devido à modelação manual, é mesmo confundido com a forma vulgarmente denominada de tabaq, como aconteceu em dois conjuntos de Torres Novas (Lopes, 2007) (Lourenço, 2002). No entanto, consideramos que não representa uma adesão a valores culturais meridionais/islâmicos, mas exatamente o seu contrário. Pelos contextos que conhecemos, constituem, a par das asas puncionadas e dos alguidares de fundo em disco, um elemento tipicamente setentrional.

Não espanta, assim, que o exemplar com o perfil mais completo que conhecemos, proveniente de Conimbriga, tenha surgido contextualmente associado com esses perfis. Foi o contacto com essa peça que nos levou a designar a forma como alguidar modelado manualmente, na falta de informações que permitam concretizar a sua função e definir uma nomenclatura mais adequada (Foto 7 ).

Assim, no enchimento da estrutura [743] do Prédio Alvarenga foram recolhidos mais de 250 fragmentos de cerâmica manual associáveis a esta forma, demonstrando um intensivo recurso ao(s) preparado(s) alimentar(es) que assegurava. (Fig 1) Surgem também nos depósitos [727] e [728], realidades sedimentares que anulavam o forno [732], mas estratigraficamente anteriores à estrutura de combustão mais recente, registada como [710].

Comparecem ainda no depósito [664], cuja sobreposição ao substrato geológico, a par da elevada percentagem de cinzas e carvões que embala, parece indiciar uma contemporaneidade ou posteridade imediata à utilização desses fornos, correspondendo eventualmente a uma área de despejo dos detritos originados pelo seu funcionamento. Significativamente, é sobre esta realidade que ocorrem os primeiros muros em pedra, atestando a definitiva reconversão funcional do espaço. 
No caso da Quinta da Aramenha III, surgem também no enchimento da estrutura negativa [34]. Esta estava colmatada com o sedimento [33], que embalava muitos fragmentos de barro cozido, em geral informes, com a típica ocorrência de negativos provocados pelo desaparecimento de matéria orgânica aquando da sua exposição a altas temperaturas. Outros, mais regulares, parecem tratar-se de bases. Mas no depósito que se lhe sobrepunha no quadrado D8, registado como [2], foi recuperado um bordo que permite associar definitivamente esses vestígios à manipulação de alguidares modelados manualmente (Figura 1).

A restante componente artefactual recuperada nos dois sítios é bastante escassa. Assim, proveniente do depósito [9], que corresponderá à utilização da estrutura negativa [35] da Quinta da Aramenha III, destaca-se um jarro com bordo trilobado (Fig. 2:[9] - 320). Muito embora, por vezes, esta solução seja associada, acriticamente, ao mundo islâmico, verifica-se que se encontra praticamente ausente, por exemplo, do sítio emiral da Quinta da Granja (González, 2013) ou dos abundantes conjuntos materiais tardo-islâmicos da Alcáçova de Santarém (VIEGAS e ARRUDA, 1999).

Pelo contrário, é possível detetar a sua ocorrência diacrónica em ambientes onde as influências meridionais nunca foram determinantes. Vejam-se os exemplos do século $\mathrm{X}$ do Castelo de Arouca (Silva e Ribeiro, 2014, p. 177), enquanto que em quatro povoados da Serra da Estrela de cronologia idêntica surge em quatro dos dezoito jarros identificados (Tente, Lantes e Prieto, 2014, p. 130). Demonstrando a sua grande divulgação e estabelecendo uma lógica evolutiva directa com as realidades alto-medievais, sendo exemplo o conjunto dos séculos VI-VIII do Casal do Acipreste, Tomar (Barradas e Batata, 2012). Comprova-se, assim, que constitui um traço de arcaísmo, que terá persistido nos ambientes ruralizados do Centro e Norte da Península, para surgir exuberantemente nos conjuntos pleno-medievais, como nos anunciam as produções de grés de Conimbriga (Alarcão, 1975, prancha XLV) ou os contextos do século XII de Coimbra (Silva, 2015, p. 67). As reduzidas dimensões do outro jarro identificado neste contexto (Fig. 2: [9] - 336) e a ampla distribuição das panelas de bordo triangular de colo estrangulado (Fig. 2: [9] - 353), bem como a sua longa diacronia, impedem datações finas, apontando para um período genérico, entre os séculos XII a XIV.
Os materiais provenientes do depósito [33], que colmatava a estrutura negativa [34], também não permitem maior detalhe, na medida em que se resumem a fragmentos diminutos de panelas de bordo triangular (Fig. 2: [9]-355, 365).

Como se observou acima, as condições de deposição do sedimento [47] permitem algumas dúvidas sobre a homogeneidade crono-cultural do seu espólio, na medida em que se encontrava muito exposto a movimentações de terras superficiais. No entanto, dada a presença de percentagens razoáveis de perfis de algumas peças, nomeadamente uma panela praticamente completa, pelo menos alguma da cerâmica encontrava-se indubitavelmente em deposição primária.

As cerâmicas que embalava apresentam uma dissonância ainda mais marcada com as produções da Bacia do Tejo. Desde logo pela prevalência de cozeduras muito irregulares e pela percentagem razoável de cerâmica de modelação manual, que se cifra em $14 \%$. Poderíamos mesmo equacionar uma ocupação cíclica deste espaço, acompanhando uma qualquer actividade económica sazonal. No entanto, como não possuímos informações que possam escorar essa hipótese e se verifica uma identidade tipológica ao nível contextual, admitimos antes a sua sincronia com as restantes estruturas negativas.

O pote que apresenta perfil completo sublima essa diferença, pela ausência de asas (Foto 8; Fig. 2: [47] - 1603). Adicionalmente, a simplicidade do seu remate - que recorda as produções alto-medievais - também não encontra paralelo nas morfologias conhecidas até ao momento em contextos islamizados. Uma vez mais, é necessário recorrer a realidades setentrionais para contactar com semelhanças evidentes. É o caso dos conjuntos de Viseu, com uma cronologia proposta em torno do século XIII (RODRIGUES, 2014, p. 154) ou Conimbriga, onde comparecem no lote da denominada fase III, que abarca as produções entre os séculos X e XII (MAN, 2006, p. 172) (Figura 2).

Outro exemplar (Fig. 2: [47] - 1604) morfologicamente muito semelhante, diferencia-se essencialmente pela maior espessura das paredes, diretamente relacionada com a sua modelação, que decorreu sem recurso a torno rápido. Interpretamos esta ocorrência tecnológica, por agora única nos materiais pleno medievais da região, como uma solução de recurso por parte de uma comunidade ainda marginal à estrutura produtiva instalada. Por alguma 
razão, por agora indescortinável, esteve pelo menos temporariamente afastada do mercado cerâmico e recorreu a este tipo de fabrico, numa lógica de autoabastecimento.

Pelo contrário, duas peças, uma escudela (Fig. 9: [47] -959] e um alguidar (Fig. 9: [47] - 070), apresentam morfologias "meridionais", bastante comuns nos contextos baixo-medievais da bacia do Tejo. Poderão corresponder a uma intrusão de materiais do horizonte de ocupação mais tardio que já mencionamos. Em alternativa, poderiam sinalizar uma progressiva integração nos intercâmbios da região por populações alógenas, chegadas em cronologias mais recentes, já em torno do século XIV. De facto, existe pelo menos um contexto em Santarém que parece sinalizar a continuação de movimentos migratórios, séculos depois da integração da cidade nos domínios portugueses (Liberato, 2012, p. 97).

No que diz respeito aos materiais torrejanos, os enchimentos da estrutura negativa [743] ofereceram um lote reduzido de cerâmicas, mas muito coerente formal e culturalmente. Assim, a par de morfologias mais divulgadas e por isso pouco precisas cronologicamente, como o jarro com bico vertedor (Fig. 9: [740] - 2971) e a panela de bordo triangular (Fig. 9: [734] - 2931), comparece um alguidar com o bordo espessado para o interior (Fig. 9: [734] - 2933), aproximando-se das soluções típicas do Mondego, em época pleno-medieval (Man, 2014, p. 64).

Já o perfil e a decoração "arcaizante" de uma panela (Fig. 9: [734] - 2932), apresentando remate simplificado e lábio proto-bífido, a par de incisões desenquadradas de moldura, convocam semelhanças com cerâmicas alto-medievais da Bacia do Tejo, que foram substituídas por tradições de origem meridional a partir do século IX. Mas que continuariam a comparecer em latitudes setentrionais, como na Trancoso do século X-XI (Ferreira, Lobão e Catarino, 2012) ou em Coimbra, na fase final desse âmbito cronológico (Silva, 2015, p. 163). Pela associação de caracteres formais presentes neste conjunto, propõe-se assim uma datação centrada no século XII para o seu depósito.

\section{CONSIDERAÇÕES FINAIS}

De acordo com os dados recolhidos, estes sítios estão irmanados por três características comuns. A primeira consiste na definição de espaços domésticos e/ou habitacionais, a partir de estruturas negativas.
Depois, estas parecem estar sempre associadas a atividades gastronómicas, que decorreram em estruturas de combustão de fácil construção, com pouco investimento de recursos e tempo, mas aparentemente muito precárias. Por fim, reforçando uma imagem de recurso generalizado a soluções circunstanciais, com intervalo de vida curto, observa-se a sistemática presença de alguidares modelados manualmente, cuja estrutura física, muito quebrável, implicaria um elevado índice de descartabilidade.

Com base nestas constatações e por analogia com contextos alto-medievais (Quirós e Bengoetxea, 2010, p. 178), pensamos estar perante soluções de habitat provisórios que, à falta de melhor definição, designamos como acampamentos. Pela cerâmica associada, parecem corresponder ao assentamento de gentes com pouco ou nenhum contacto com o âmbito cultural islâmico, habilitando a hipótese de se tratarem de elementos com origem no Centro ou Norte da Península, recém-chegados às novas possessões cristãs, mas com precária integração na exploração económica do território e, portanto, num estado de pré-sedentarização.

Nalguns casos, chegariam enquadrados pela monarquia ou por outro senhor, com o objetivo concreto de dinamizarem, a prazo, centros urbanos providos de fortaleza, o elemento estruturante da expansão da formação social de tipo feudal. Parece ser esse o caso de Torres Novas, onde a sua superioridade demográfica (ou mesmo exclusividade) determinaram o surgimento de um novo foco de tradições cerâmicas com origem setentrional.

Movimentos populacionais que certamente também demandaram o mundo rural, procurando aproveitar a prodigalidade da bacia do Tejo, assegurando um nível de rentabilidade do trabalho agrícola inatingível nos seus locais de origem. Seria esse o caso da Quinta da Aramenha III, que não parece ter originado nenhum núcleo de povoamento mais estável e poderia ser apenas uma "estação" no processo de adaptação à nova realidade. De resto, terá sido um processo comum e a identificação, à superfície, de um alguidar de fundo em disco no sítio da Ponte do Celeiro (Matias, 2018), a escassos $5 \mathrm{~km}$ de Santarém, será um indício de que mesmo áreas onde o domínio por parte dos poderes islâmicos tinha sido mais efetivo, também acolheram esses movimentos colonizadores.

A própria fortaleza do Tejo recebeu novos habitantes, como nos demonstram os achados episódicos de asas puncionadas, alguidares de fundo em disco 
e jarros trilobados com cozedura redutora e brunimento exterior (Liberato, 2012). A discrição com que surgem no registo arqueológico, sendo absolutamente residuais, relacionar-se-á certamente com a realidade com que se depararam. Santarém era uma cidade plenamente islamizada, com um nível de especialização produtiva excecional face aos ambientes ruralizados do Norte e os conquistadores rapidamente terão abandonado as suas tradições oleiras, de qualidade e diversidade inferiores, em favor de uma estrutura de oferta e consumo que já encontrava definida.

A continuação de estudos contextuais que permitam identificar cerâmicas de tradição setentrional e o seu peso relativo no conjunto da cultura material de cada povoação, parece-nos uma interessante linha de investigação. Em especial em áreas, como a Bacia do Tejo, onde a influência da historiografia eventual na prática arqueológica ainda apresenta uma anacrónica resiliência. Promovendo uma leitura "continuísta" da conjuntura dos séculos XI-XII que teria correspondido, essencialmente, a uma substituição de poderes na malha de povoamento pré-existente, de origem islâmica.

Pelo contrário, os dados disponíveis apontam, cada vez mais, para que a integração nos domínios cristãos do espaço entre Tejo e Mondego e a consequente afirmação dos valores e estratégias da formação social de tipo feudal tenha determinado alterações estruturais. Afirmando o trinómio fortaleza / sede de concelho / termo como uma inédita forma de articulação territorial e exploração de recursos. E que a captação de contingentes populacionais, oriundos do Centro e Norte peninsular, terá sido a condição determinante para o sucesso da sua implantação.

\section{BIBLIOGRAFIA}

ALARCÃO, Jorge (1975) - Fouilles de Conimbriga - V - La céramique commune locale et régionale, Paris: Mission Archéologique Francaise au Portugal / Musée Monographique de Conimbriga.

BARRADAS, Elisabete, BATATA, Carlos (2012) - Casal do Acipreste (Tomar) - um habitat tardo-romano/visigótico. Poster apresentado no $1^{\circ}$ Congresso Internacional sobre Arqueologia de Transição realizado na Universidade de Évora -3 a 5 de Maio de 2012, Documento eletrónico [Consultado em 26-11-2019] https://www.academia.edu/1563985/O_ Casal_do_Acipreste_Tomar_-_um_habitat_tardo-romano_visigótico
BORGES, Nelson (2007) - Relatório final da escavação arqueológica na Quinta da Aramenha III (saibreira), Cartaxo, relatório policopiado.

BORGES, Nelson (2007a) - Relatório final da escavação arqueológica na Quinta da Aramenha III (saibreira), Cartaxo. Elementos em falta, relatório policopiado.

BOISSELLIER, Stéphane (2012) - La construction administrative d'un royaume. Registres de bénéfices ecclésiastiques portugais (XIII-XIVe siècles). Lisboa: Centro de Estudos de História Religiosa/Universidade Católica Portuguesa.

COELHO, Maria Helena da Cruz (1992) - O concelho de Torres Novas em tempo de crescimento e consolidação do reino. Nova Augusta. 6, pp. 55-67.

CONDE, Manuel Sílvio Alves (200o) - Uma paisagem humanizada. O Médio Tejo nos finais da Idade Média. Cascais: Patrimonia Histórica. 1.

COSTA, Cláudia, RODRIGUES, Filipa, COSTA, Teresa, LOPES, Gonçalo (2007) - A intervenção arqueológica no nํㅜ 121 da Rua Carlos Reis (Torres Novas). Primeiros Resultados. Nova Augusta. 19, pp. 287-318.

FERREIRA, Maria do Céu; LOBÃO, João Carlos, CATARINO, Helena (2012) - Cerâmicas altomedievais do Castelo de Trancoso - uma primeira abordagem. Arqueologia Medieval. 12, pp. 15-32.

GONZÁLEZ, Cristina (2013) - Quinta da Granja I (Maiorga, Alcobaça): novos dados sobre o povoamento da Estremadura na Alta Idade Média). in Arqueologia em Portugal - 150 Anos. Lisboa: Associação dos Arqueólogos Portugueses, pp. 913-921.

LIBERATO, Marco (2012) - Cerâmica Pintada a Branco na Santarém Medieval. Séculos XI-XVI. Dissertação de mestrado apresentada à Faculdade de Letras da Universidade de Lisboa.

LIBERATO, Marco; RAMOS, Romão; SANTOS, Helena; MAURÍCIO, Fernando (2017) - Marcas de canteiro em Torres Novas: novos dados sobre a evolução da malha urbana medieval. Nova Augusta. 29, pp. 151-164.

LIBERATO, Marco; SANTOS, Helena (2017) - O registo arqueológico de um centro urbano periférico do Médio Tejo: Torres Novas, séculos XII-XIV. In O papel das pequenas cidades na construção da Europa Medieval. Lisboa: Instituto de Estudos Medievais / Câmara Municipal de Castelo de Vide, pp. 197-212.

LIBERATO, Marco; SANTOS Helena (2018) - Between two worlds: cultural and technological characteristics of medieval pottery from Torres Novas (Santarém district, Portugal) in Actas do $\mathrm{XI}^{\text {th }}$ Congress AIECM3 on Medieval and Modern Period Mediterranean Ceramics. Antalya: Association Internationale pour l'Etude des Céramiques Médiévales et Modernes en Méditerranée / Koç University, pp. 255-258. 
LOPES, Gonçalo (2007) - Um cantil almóada em Torres Novas. Nova Augusta. 19, pp. 319-325.

LOURENÇO, Sandra (2002) - A ocupação medieval da Rua Tenente Valadim, n. ․ㅗ 1 e 3, Torres Novas. Nova Augusta. 14: pp. 109-156.

MAN, Adriaan de (2006) - Conimbriga. Do Baixo Império à Idade Média, Lisboa:Edições Ś́labo.

MAN, Adriaan; CORREIA, Virgílio Hipólito; LOVEGROVE, Sofia; ANDRADE, Francisco (2014) - A Cerâmica Medieval de Conimbriga. In Estudos de Cerâmica Medieval. O Norte e Centro de Portugal - séculos XI a XII. Lisboa: Instituto de Estudos Medievais, pp. 57-68.

MATIAS, António (coord.) (2018) - Santarém. Carta Arqueológica Municipal. Santarém: Município de Santarém.

QUIRÓS CASTILLO, Juan Antonio, BENGOETXEA REMENTERIA, Belen (2010) - Arqueología III: Arqueología medieval y posmedieval. Madrid: Universidad Nacional de Educación a Distancia.
SILVA, António Manuel S. P.; RIBEIRO, Manuela C. S. (2014) - Cerâmicas do período da reconquista no Vale do Arda: castelo de Arouca e Casal da Malafaia. In Estudos de Cerâmica Medieval. O Norte e Centro de Portugal - séculos XI a XII. Lisboa: Instituto de Estudos Medievais, pp. 161-181.

SILVA, Ricardo (2015) - O Museu Nacional de Machado de Castro - um ensaio de arqueologia urbana em Coimbra: do fórum augustano ao paço episcopal de Afonso de Castelo Branco. dissertação de doutoramento em Arqueologia. Coimbra: Faculdade de Letras - Universidade de Coimbra.

TENTE, Catarina; LANTES, Óscar; PRIETO, Pilar (2014) A produção cerâmica dos séculos IX a XI na região do Alto Mondego (Portugal). In Estudos de Cerâmica Medieval. O Norte e Centro de Portugal - séculos XI a XII. Lisboa: Instituto de Estudos Medievais, pp.110-139.

VIEGAS, Catarina; ARRUDA, Ana Margarida (1999) - Cerâmicas islâmicas da Alcáçova de Santarém». Revista Portuguesa de Arqueologia. 2:2, pp. 105-186.

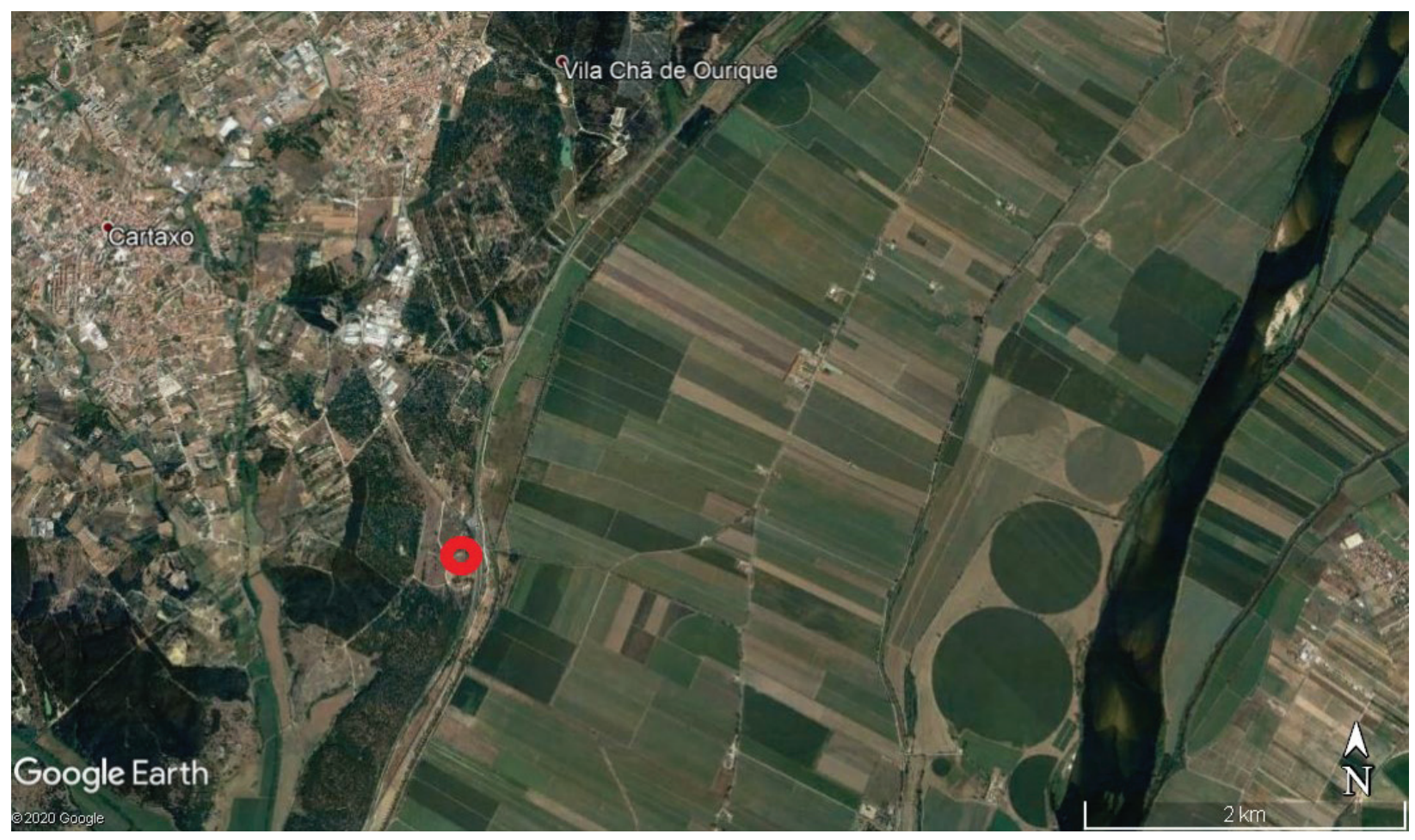

Foto 1 - Localização (a vermelho) do sítio Quinta da Aramenha III. 


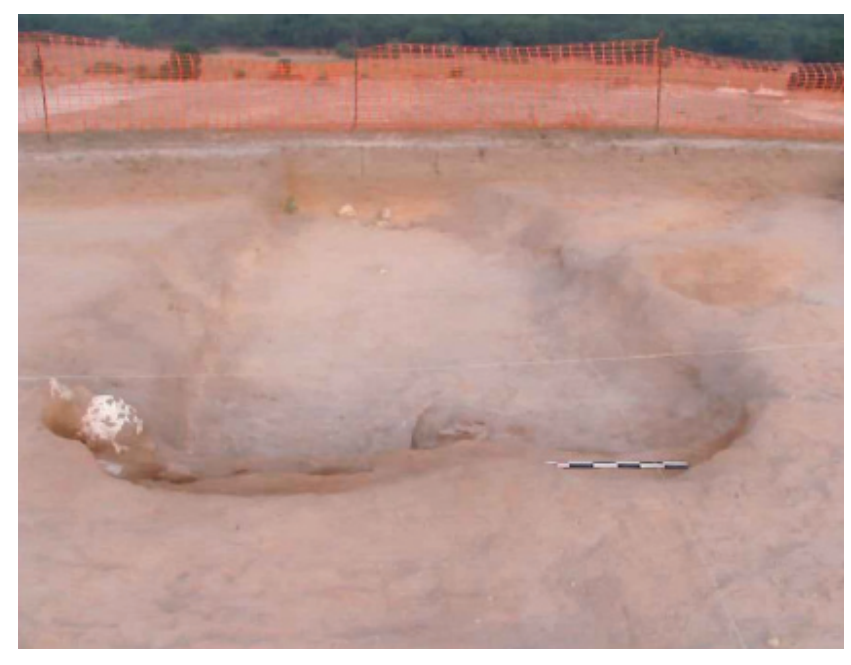

Foto 2 - Estrutura negativa [35] da Quinta da Aramenha III (Borges, 2007).

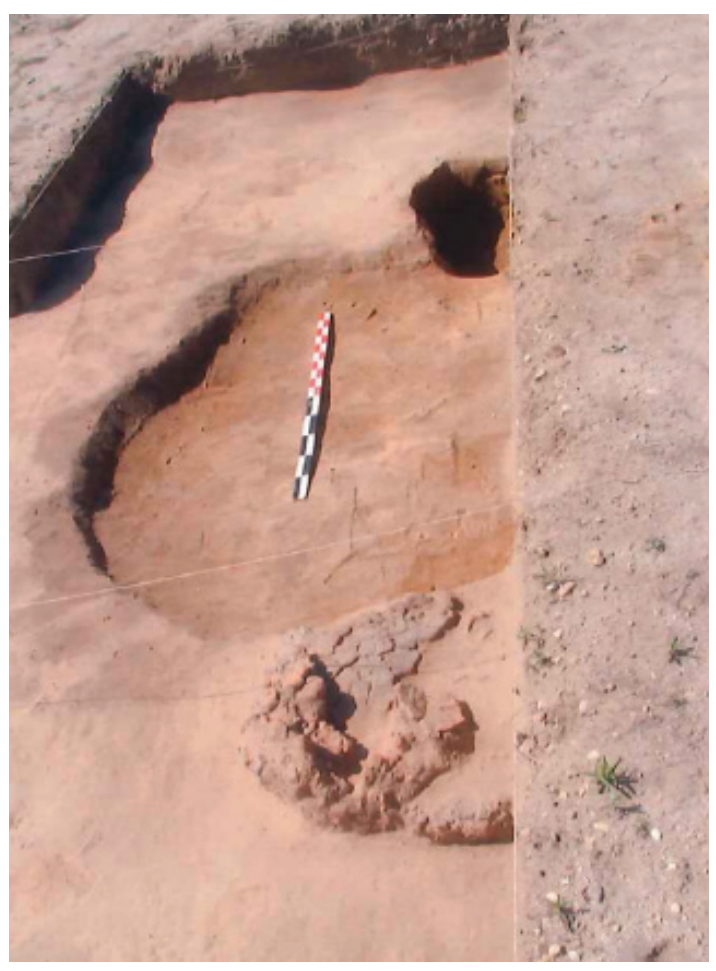

Foto 3 - Estrutura negativa [34] da Quinta da Aramenha III (Borges, 2007).

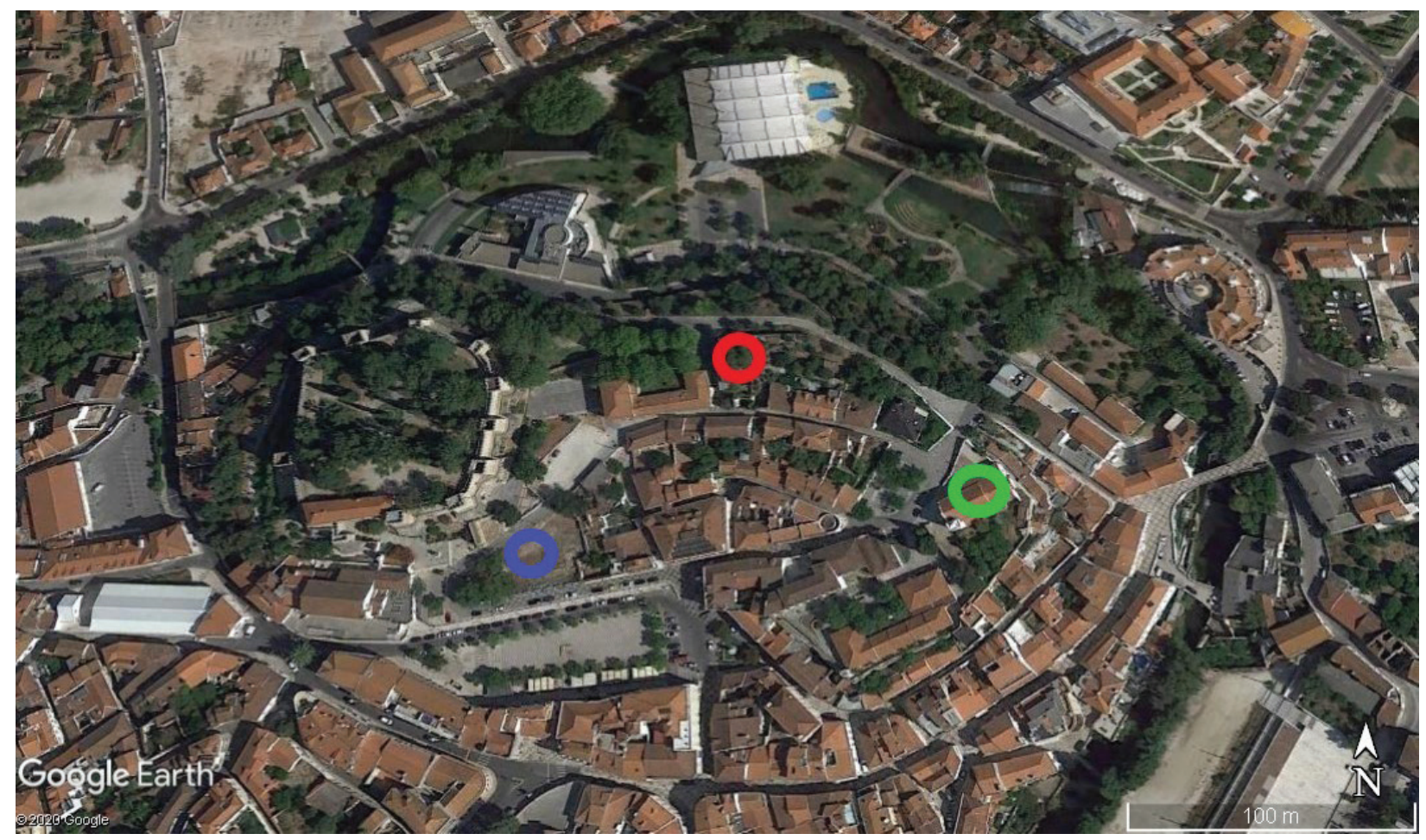

Foto 4 - Localização do Prédio Alvarenga (vermelho) e das igrejas de Santa Maria (azul) e de S. Salvador (verde), na malha urbana de Torres Novas. 


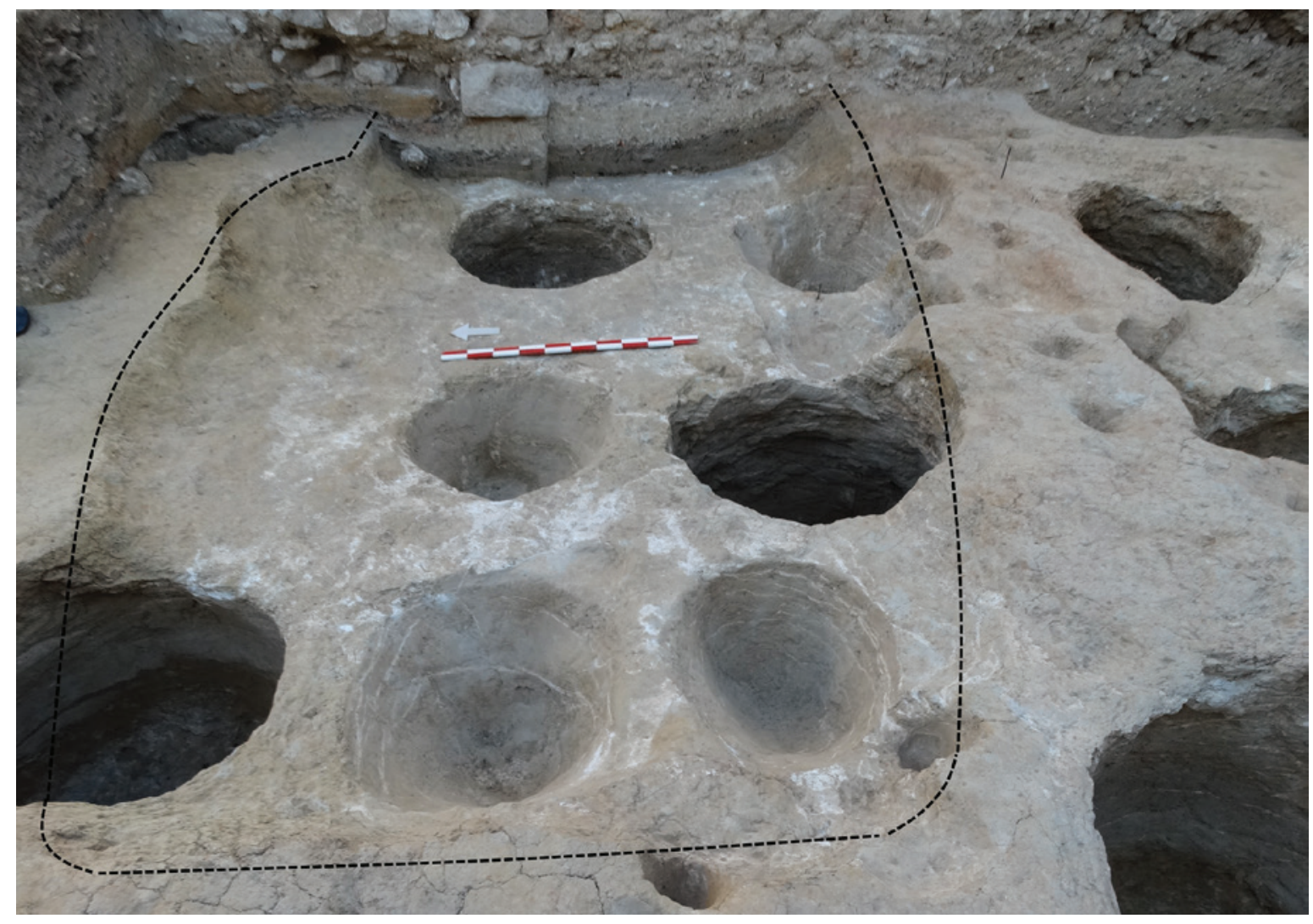

Foto 5 - Estrutura negativa [743] do Prédio Alvarenga. As interfaces circulares que a intercetam correspondem a silos escavados posteriormente ao abandono da mesma.

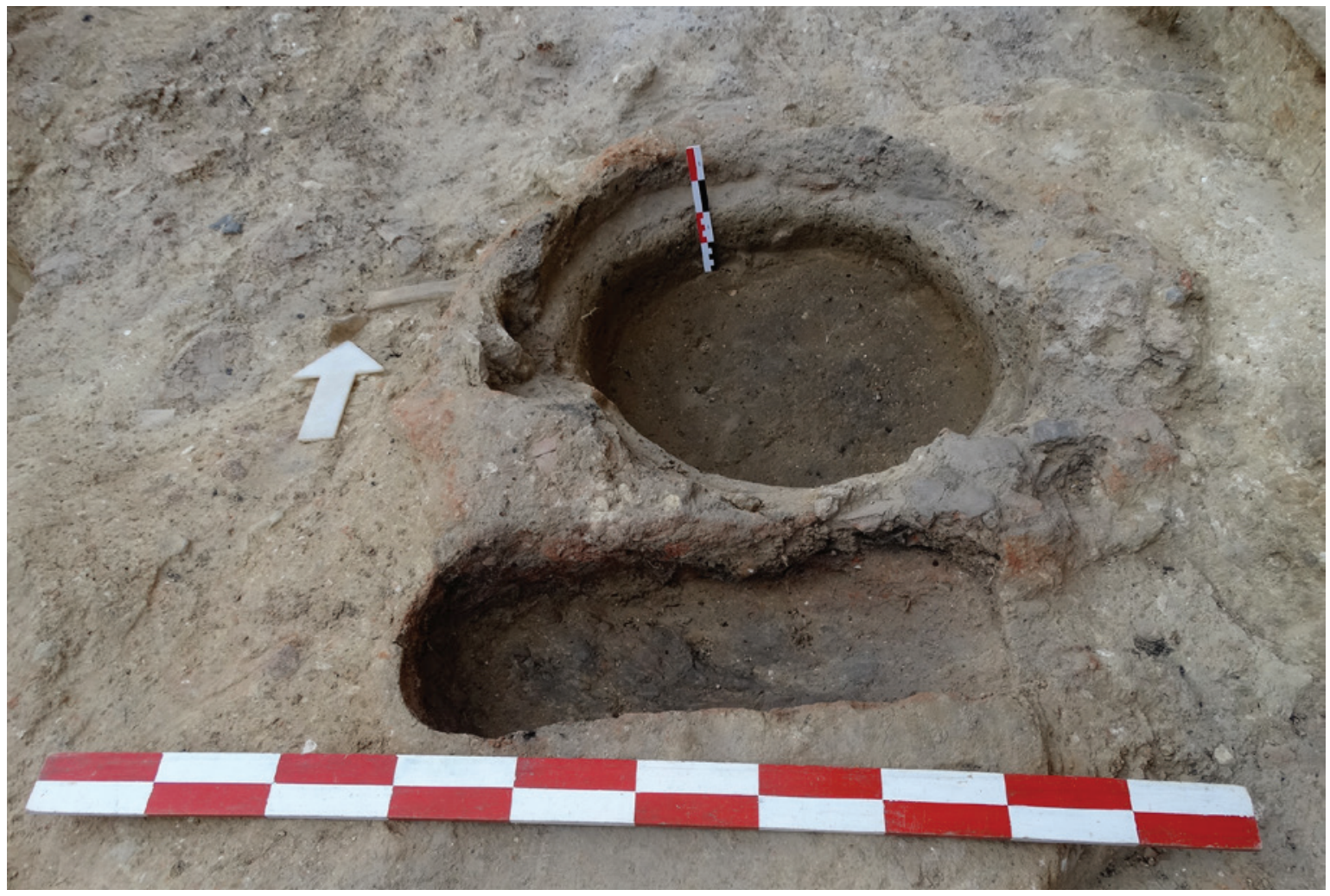

Foto 6 - Unidade funcional forno [710] / "braseiro” [712]. Prédio Alvarenga. 


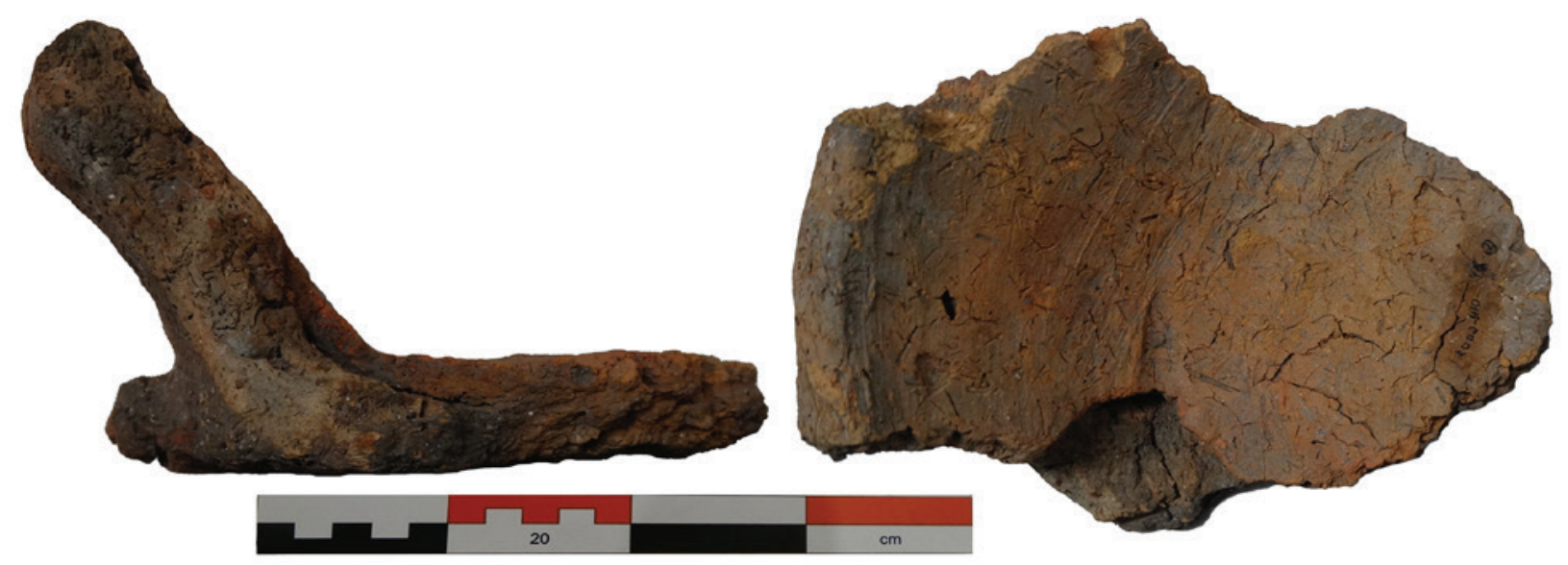

Foto 7-Alguidar modelado manualmente proveniente dos níveis pleno-medievais da casa do Mediano Absidiado, Conímbriga.
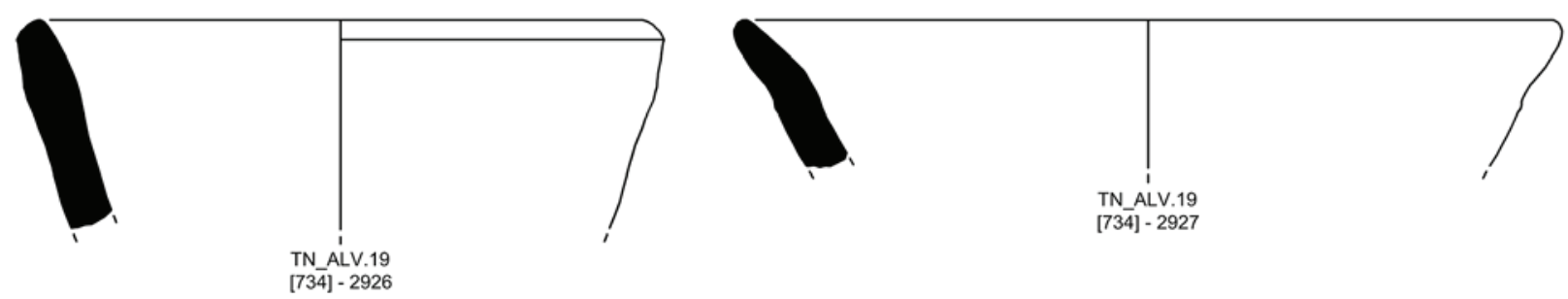

TN_ALV.19
$[734]-2927$

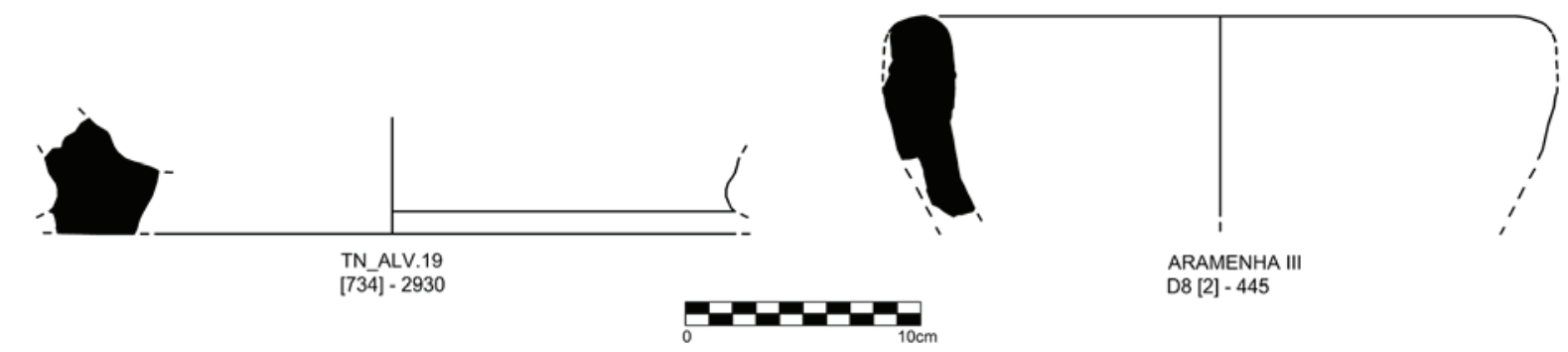

Figura 1 - Alguidares modelados manualmente do Prédio Alvarenga e do Quinta da Aramenha III. 


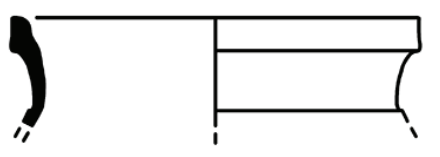

ARAMENHA III

[9] - 353

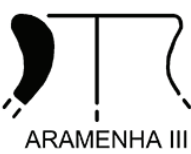

[9] . 336

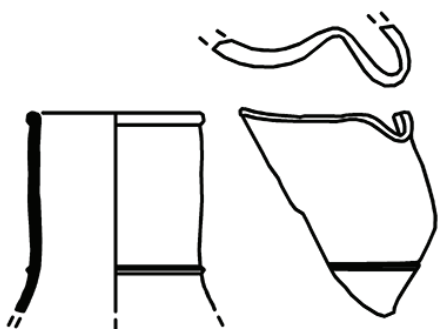

ARAMENHA III

[9] -320

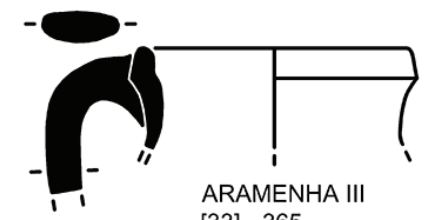

[33] - 365

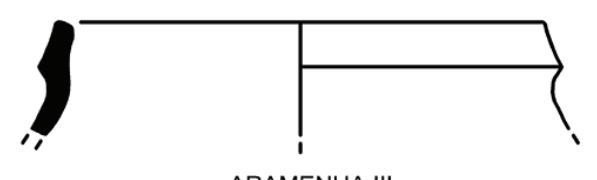

ARAMENHA III

[33] - 355
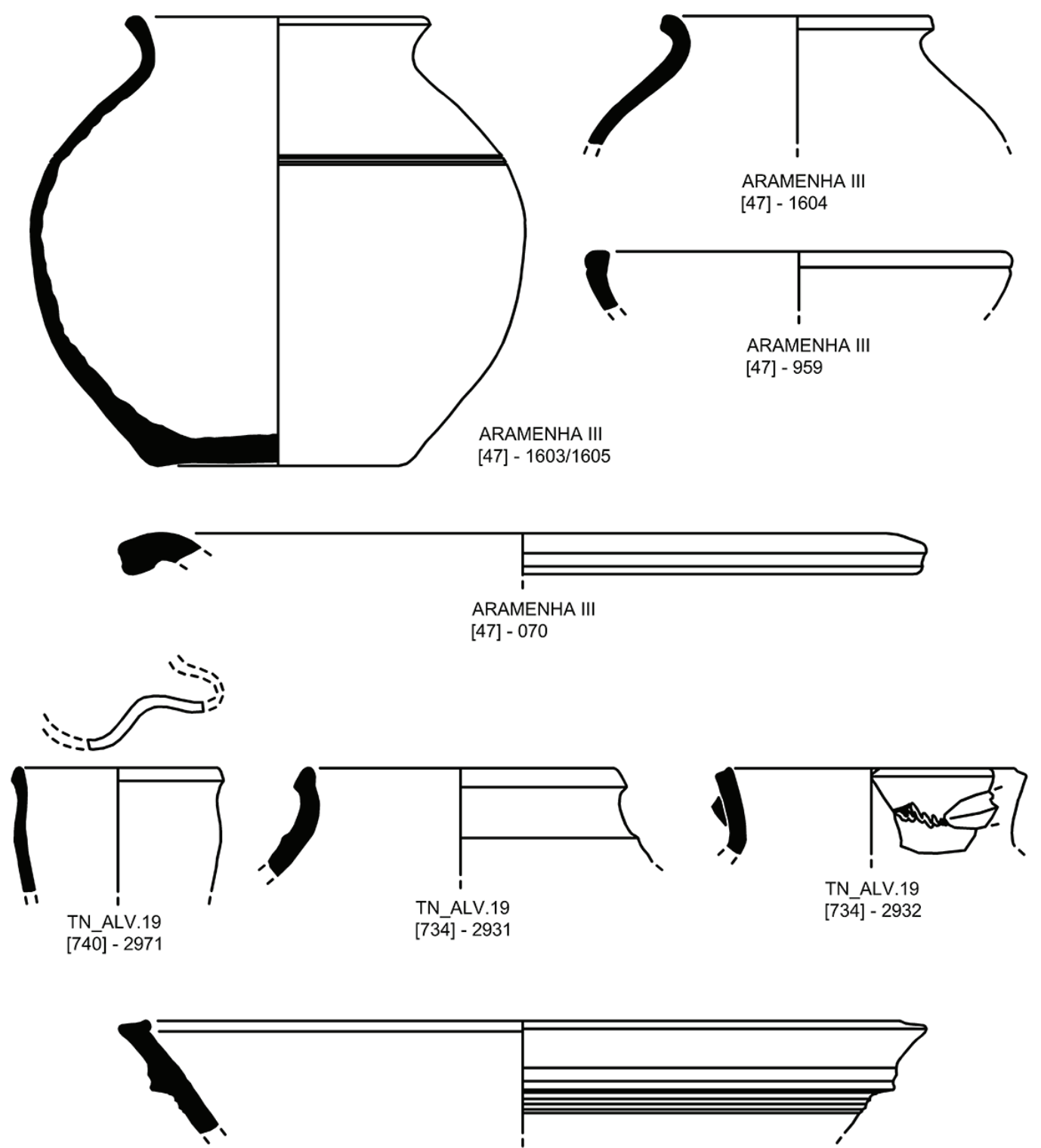

TN_ALV.19

[734] - 2933

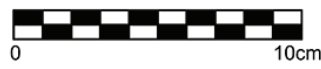

Figura 2 - Conjuntos cerâmicos dos sítios analisados. 

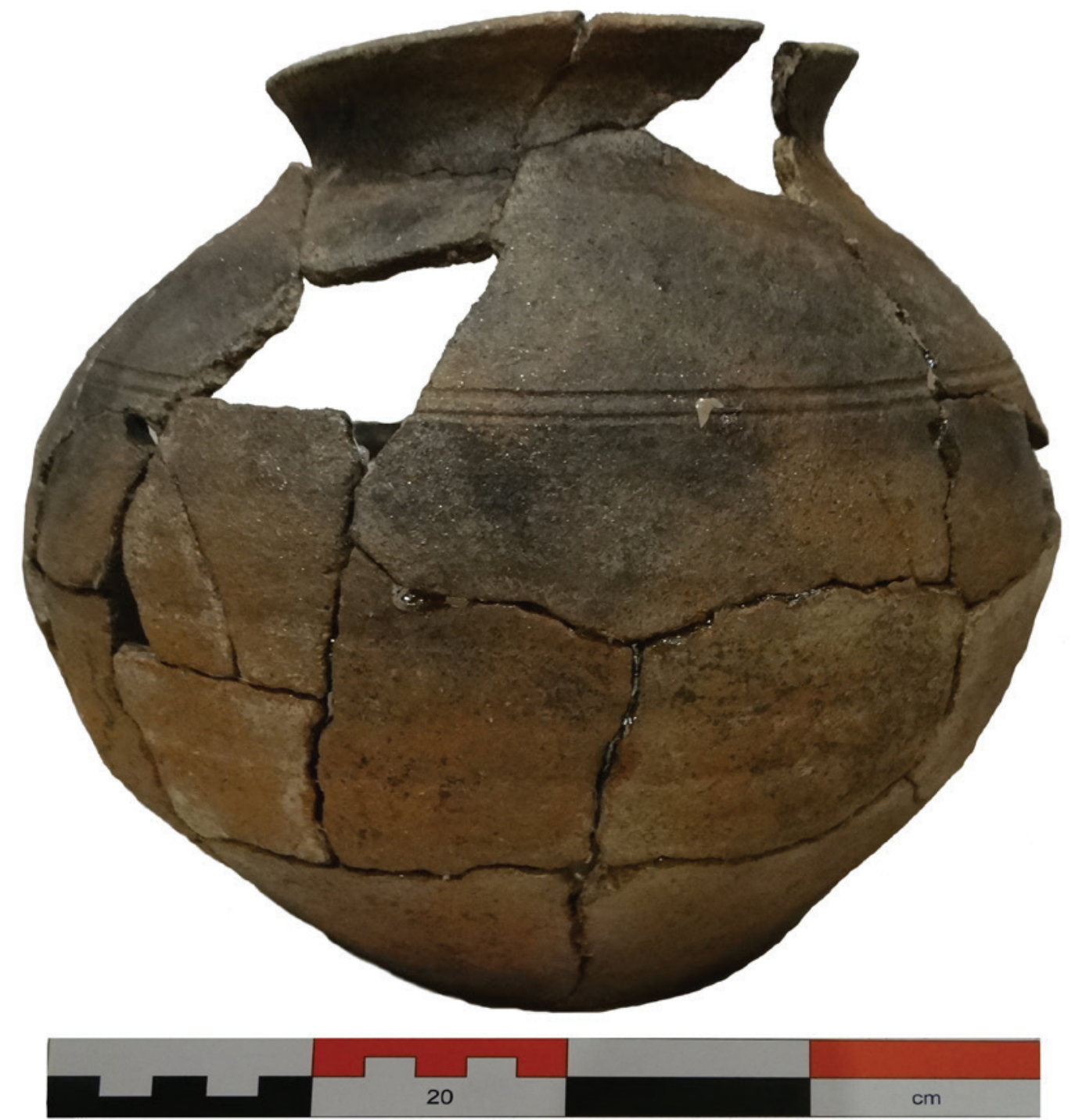

Foto 8 - Pote recuperado no depósito [47] do Quinta da Aramenha III. 


\title{
O NORDESTE TRANSMONTANO NOS ALVORES DA IDADE MÉDIA. NOTAS PARA REFLEXÃO
}

\author{
Ana Maria da Costa Oliveira ${ }^{1}$
}

\begin{abstract}
RESUMO
Compreender a fronteira do nordeste transmontano, a sua defesa e dinâmica no contexto da formação do reino de Portugal, requer uma apreensão da ocupação territorial cuja génese mergulha em períodos ancestrais. As estratégias e opções de fixação de comunidades ao longo dos séculos, obedecendo a diferentes condicionalismos e oportunidades, desenharam um cenário que viria a enquadrar, com todas as suas dificuldades e vicissitudes, uma política de autonomia em relação ao território leonês/castelhano.

O desequilíbrio patente no conhecimento que tem sido produzido sobre estes períodos ancestrais, suscita questões inevitáveis sobretudo sobre a ausência de materialidades para o período alto medieval nesta região. Foi este silêncio que suscitou uma análise crítica dos dados conhecidos, propondo abordagens diversificadas que podem trazer alguma objetividade.

Palavras-chave: Trás-os-Montes, Alta Idade Média, Povoamento, Revisão.
\end{abstract}

\begin{abstract}
To understand the border of the northeastern region of Trás-os-Montes, it's defense system and dynamics in the context of the Portuguese Kingdom formation, requires a knwoledge of the territorial ocupation whose genisis dive in ancestral periods.

The strategies and settlement options of the population over the centuries, obeyed different conditions and opportunities and draw a scenario that would come to frame, with all its difficulties and vicissitudes, the autonomic policy in relation to the Leonese / Castilian territory.

The imbalance in the knowledge that has been produced about these ancestral periods, namely the absence of information about the early medieval period in this region, raised some questions and gave rise to a critical analysis of the known data, leading to the proposal of diversified approaches and new perspecives.
\end{abstract}

Keywords: Trás-os-Montes, High Medieval Age, Settlement, Data review.

\section{INTRODUÇÃO}

No âmbito do nosso projeto de Doutoramento em Estudos do Património - Arqueologia, intitulado "Os castelos e a fronteira entre Vinhais e Miranda do Douro (séculos XI-XVI): estratégias e diálogos na raia transmontana", que estamos a desenvolver na Faculdade de Letras da Universidade do Porto, temos vindo a estudar a região nordeste transmontana, entre os concelhos de Vinhais e Miranda do Douro, área que, efetivamente, se tornou de fronteira a partir do tratado de Alcañices, datado de 1297.
A nossa atenção, neste texto, centrar-se-á num período anterior a esse momento, mais concretamente, no espaço histórico que sucede a "desarticulação" da organização romana e inicia uma reorganização muçulmana, com início em 711 . Interessa perceber a evolução de um território que acabará por entrar na esfera da monarquia asturo-leonesa, identificando as diferentes soluções que formaram as estruturas de povoamento. Estas comunidades vão ser o suporte dessa monarquia que, com o apoio de uma nobreza em ascensão, enquadrará um território em expansão. Da conjugação deste processo político e

1. Arqueóloga, Bolseira de Doutoramento da FCT SFRH/BD/129436/2017, investigadora do CITCEM; anamcostaoliveira@gmail.com 
militar e desta rede de povoamento resultará, mais tarde, o desenho de novas fronteiras.

Desta época alto-mediévica, nomeadamente nesta faixa transmontana, pouco se sabe. As fontes documentais são praticamente inexistentes e os trabalhos arqueológicos realizados são insuficientes, fornecendo uma leitura parcelar e incaracterística da realidade. Este silêncio e desconhecimento, compromete em parte a compreensão das fases cronológicas posteriores que levaram à formação da fronteira transmontana. Desta forma, sentimos a necessidade de dedicar parte da nossa análise e reflexão aos possíveis modelos de ocupação territorial dos alvores da idade média.

O que propomos são, pois, reflexões e possibilidades, ainda em desenvolvimento, que dão conta de uma realidade diversificada, muito dependente das características territoriais de cada região, constituindo possíveis soluções diferenciadas de ocupação, exploração e circulação.

Os dados recolhidos configuram uma amostragem generalista que pretende, num primeiro momento, lançar o debate e suscitar na comunidade científica o interesse na realização de estudos mais aprofundados, complementados com planos de trabalhos arqueológicos, que permitam lançar alguma luz sobre as mudanças ocorridas durante a alta idade média.

\section{METODOLOGIA}

A análise do povoamento alto medieval que se propõe abrange três dos quatro concelhos estudados no âmbito do doutoramento: Bragança, Vimioso e Miranda do Douro. O concelho de Vinhais, que completa o território da fronteira nordeste de Trás-os-Montes, não integra esta análise porque à data da redação deste texto, o trabalho de pesquisa não se encontra concluído.

O trabalho realizado teve como base os dados recolhidos na bibliografia. Para a região transmontana contam-se algumas monografias ${ }^{2}$ que, variando na sua abrangência e pertinência, têm servido de suporte a investigações e trabalhos mais recentes. Tendo em conta a limitação de espaço de publica-

2. De entre os diversos títulos, não podemos deixar de realçar o incontornável Abade de Baçal e as suas Memórias Arqueológico-Históricas do Distrito de Bragança. Edição da Câmara Municipal de Bragança / Instituto Português de Museus - Museu do Abade de Baçal. Tomo I - XII. ção, limitar-nos-emos a referir duas fontes obrigatórias: o Portal do Arqueólogo 3 (PA) e o estudo de Francisco Sande Lemos (1993), que serve de base ao portal do património arqueológico e a outros estudos posteriores ${ }^{4}$.

Selecionados os sítios e ocorrências que julgamos pertinentes, passamos ao trabalho de contextualização e caracterização dos dados, através de visitas e representação cartográfica. A análise e cruzamento destes resultados, com os raros trabalhos de escavação arqueológica que se têm realizado em sítios de ocupação tardo-antiga na região e em outras regiões periféricas, nomeadamente no país vizinho, suscitaram um conjunto de reflexões e possibilidades que pensamos dever ser consideradas em pesquisas posteriores.

\section{TERRITÓRIO}

Como base de trabalho optamos pelo território organizado segundo as atuais divisões administrativas por não se conhecerem, a nível regional, outras divisões para as épocas em estudo.

Os três concelhos estudados, somam um território de cerca de $2.116 \mathrm{~km}^{2}$ sendo Bragança o mais vasto. Em termos geográficos, cabe realçar que uma parte substancial do território é ocupado por elevações, das quais se destacam as serras da Nogueira e de Montesinho, ambas no concelho de Bragança. Para além das serras, importa realçar os planaltos - pontuados por cabeços cuja altitude máxima oscila entre os $600-800 \mathrm{~m}$, estendendo-se de norte para sul, ocupando sobretudo a região inferior do território. Entre estes planaltos cabe destacar o de Izeda, que se prolonga para Macedo de Cavaleiros; o de Milhão-Argozelo; e o extenso planalto de Miranda do Douro. A norte destaca-se a depressão de Bragança e o vale que, vindo de oeste, dá acesso à cidade. Nesta faixa foi aberto o IP4 e, posteriormente, a autoestrada $\mathrm{A}_{4}$.

Em regra, os planaltos têm a delimitá-los linhas de água que, grosso modo, correm de norte para sul.

\footnotetext{
3. Disponível em: https://arqueologia.patrimoniocultural.pt.

4. O mais recente é a monografia coordenada por Fernando de Sousa, com o título "Bragança. Das origens à Revolução Liberal de 1820", editada pela Câmara Municipal de Bragança e o CEPESE - Centro de Estudos da População, Economia e Sociedade, em 2019.
} 
Assim, o planalto de Izeda é cortado e delimitado a leste pelo rio Sabor; o rio Maçãs delimita a leste o planalto de Milhão-Argozelo, definindo parcialmente a linha de fronteira entre Portugal e Espanha; e o planalto de Miranda do Douro é delimitado a oeste pelo rio Angueira e a leste pelo rio Douro, marcador de fronteira internacional. Mais a norte, destaca-se ainda o rio Fervença, que atravessa a cidade de Bragança e é tributário do Sabor e o rio Rabaçal que corre na extremidade oeste de Bragança e é tributário do rio Tuela. É neste vasto e complexo território que tentaremos inferir a génese da ocupação medieval.

\section{DADOS}

Durante a nossa investigação identificamos 193 ocorrências passiveis de análise e reflexão (Mapa 1). Este conjunto, muito pouco homogéneo e preciso, distribui-se no território da seguinte forma: 44 ocorrências no território atual de Miranda do Douro, 26 no de Vimioso e 123 no de Bragança. (Gráfico 1) Com base nas propostas cronológicas apontadas pelas fontes bibliográficas, verificamos que os vestígios da ocupação da Idade do Ferro (Mapa 2) e de Época Romana (Mapa 3) são bem mais expressivos. Verifica-se uma quebra bastante acentuada para os indícios da Alta Idade Média (Mapa 4) e um tímido crescimento para o longo período da Idade Média. Claro que estes dados não traduzem "a realidade", são antes o resultado dos trabalhos realizados até aos dias de hoje. Paralelamente, dizem respeito a um período cronológico muito longo, cujo conhecimento das materialidades não se traduz de forma igual e equitativa. Correspondem, portanto, a diferentes realidades que se traduziram em diferentes soluções, havendo, como é evidente, pontos de contato na transição entre cada uma delas, dificultando assim uma leitura objetiva.

Contudo, e mesmo considerando todas as reservas, não deixa de ser curiosa a discrepância de ocorrências para os períodos alto-medievais. O que significará esta constatação?

\section{ANÁLISE}

As 193 ocorrências foram divididas por tipologias de sítio, podendo o mesmo sítio ter mais do que uma ocorrência - por exemplo, um povoado poderá incluir as estruturas de habitação, uma igreja e ne- crópole. Cada uma destas estruturas pode ou não ser contemporâneas. Nestes casos, e para a atual análise, apenas consideramos a ocorrência que nos parece poder revelar uma ocupação da Alta Idade Média, deixando a análise do conjunto para outra altura. Temos consciência que a tipificação e enquadramento cronológico de determinados sítios, fundamentados em dados exclusivamente de superfície, é uma opção limitadora, logo discutível, dificilmente reveladora de uma realidade completa. Mesmo assim, aceitamos o risco apenas como ponto de partida.

Convém ainda esclarecer que, quando não nos foi possível acrescentar novos dados sobre determinado sítio, para além daqueles que colhemos na bibliografia conhecida, optamos por atribuir a tipologia e cronologia sugerida pelas fontes consultadas. Contudo, quando analisamos o sítio, estudamos a sua morfologia e o contextualizamos no território, consideramos, se for o caso, outras possibilidades para a sua ocupação/utilização, por vezes, enquadráveis no período cronológico sobre o qual nos detemos aqui.

Centremos agora a nossa atenção nos locais de assentamento, claramente maioritários, nomeadamente, nos povoados fortificados, povoações - abertas ou em altura e sem muralhas - e nos pequenos habitats. Estes sítios totalizam 126 estações, o equivalente a $65,2 \%$ do total dos assentamentos. Deste total, o grupo mais numeroso é o dos povoados fortificados, com 70 sítios; seguem-se as povoações com 39 ocorrências; e os habitats com 17 estações.

\subsection{Povoados fortificados}

Do total dos 70 povoados fortificados identificados, 39 foram classificados com cronologias exclusivamente da Idade do Ferro, o que corresponde a 55,7\% do total. Se considerarmos os povoados cuja cronologia inicia nesta época e que têm uma ocupação posterior, o número sobe para 59. Assim, podemos inferir que, dos 70 povoados fortificados datados da Idade do Ferro, 20 tiveram uma ocupação diacrónica, sendo que, apenas três, têm uma possível ocupação durante a Alta Idade Média: Castelo Velho, em Campo de Víboras (Vimioso); Cabeço da Cocolha, Angueira (Vimioso); e São João das Arribas (Miranda do Douro).

Objetivamente, apenas no povoado fortificado de São João das Arribas está confirmada uma ocupação alto-medieval, graças às campanhas arqueológicas 
que têm vindo a ser desenvolvidas nos últimos anos. Aliás, os resultados têm demonstrado ténues indícios da Idade do Ferro, sendo mais evidentes os vestígios romanos e, sobretudo, da Alta Idade Média. Análises radiocarbónicas apresentaram uma cronologia para estratos do interior do castro datáveis dos séculos VI e VII. Nos terraços das imediações foram identificadas datações entre os séculos IV e XVII. Apesar de ser considerado na bibliografia como um povoado da Idade do Ferro (Sande Lemos e PA, entre outros), os trabalhos arqueológicos têm aclarado uma outra realidade. São os próprios responsáveis pelas escavações arqueológicas que sugerem "colocar em debate a existência de um castro nos termos em que a historiografia tradicional defende desde cedo." Acrescentam que, apesar de terem encontrado "materiais mais antigos do que o Baixo Império", não registaram "vestígios estruturais organizados" da mesma época. Significativo é "o material cerâmico de importação" que revela "um vigor comercial aparentemente extraordinário para esta zona do Douro. Ao longo das últimas campanhas foram descobertos fragmentos de sigillata clara $\mathrm{D}$, oriundas do Norte de África, materiais do Vale do Ebro e da Rioja e mesmo importações regionais, oriundas de Bracara Augusta e de Conímbriga." Paralelamente aos vestígios romanos foram registados nos promontórios junto ao castro "manchas de materiais, aparentemente da Alta Idade Média, que revelam uma ocupação mais extensa do que a que a historiografia tradicional sugere.” (Pereira \& Salgado, 2018, pp. 131-132).

Para além dos povoados fortificados com origem pré-histórica, registam-se dois com possível fundação romana: o povoado da Senhora da Hera, Espinhosela (Bragança), que também tem confirmada ocupação medieval, e o povoado do Castrolouço, Atenor (Miranda do Douro). Sobre este último, Sande Lemos diz que a muralha poderia ser tardia, da Alta Idade Média, apesar de o considerar romano (1993, pp. 211-213).

Notamos ainda que se registam sete povoados com cronologia indeterminada o que aumenta o campo das possibilidades para outras ocupações alto-medievais. Na verdade, pensamos que alguns dos povoados considerados apenas da Idade do Ferro merecem uma revisão cuidada, pois as suas características morfológicas e posicionamento estratégico, sugerem o uso do espaço nesta época conturbada, quer por razões de defesa, de controlo territorial ou de vigia 5 .

\subsection{Povoados abertos}

Este grupo contabiliza 39 povoados, sendo os de cronologia romana e medieval em número de nove. Os povoados com possível cronologia da Alta Idade Média são sete e, à exceção de um, todos têm ocupação a iniciar em Época Romana e apenas quatro continuam ocupados na Idade Média.

Atentando nos povoados com ocupação da Alta Idade Média, comecemos pelo que tem como cronologia mais recuada a Idade do Ferro. Trata-se do povoado de Castelar ou Castro de Picote (Miranda do Douro), considerado pelo PA como povoado fortificado, mas que não apresenta um sistema defensivo evidente ${ }^{6}$. A última intervenção arqueológica neste sítio ocorreu em 2013, no âmbito do Projeto de Investigação: História do Povoamento de Picote, promovido pela Frauga - Associação para o Desenvolvimento Integrado de Picote e pelo Departamento de Ciências e Técnicas do Património da Faculdade de Letras da Universidade do Porto. Os trabalhos não foram de todo conclusivos, mas confirmaram materiais arqueológicos com uma larga diacronia Bronze Final até Época Medieval - e estruturas pétreas que formavam um sistema de socalcos, cuja funcionalidade não foi aferida.

Os povoados cuja cronologia inicia em Época Romana, e que segundo a bibliografia terão tido ocupação alto medieval, são dois: Castro de Coelhoso e Trás do Souto, ambos em Bragança. A estes, propomos que se junte o povoado das Faceiras da Granja, em Duas Igrejas (Miranda do Douro), que a bibliografia diz ser romano, mas onde foram identificados materiais tardo-antigos. Nas proximidades, registaram-

\footnotetext{
5. Dentro desta possibilidade consideramos os seguintes povoados: Cabeço do Cercado; Crasto; Cabecinho dos Mouros; Sumidago; Castanheiro do Senhor; Picoto; Fragas do Castro; Castragosa; Castro da Sapeira; Fragas do Castro; Cercas; Alto do Castro e Castelo das Olgas.

6. Sande Lemos admite que a fundação deste sítio é problemática, desvalorizando o registo de alguma cerâmica manual. Considera que este povoado não é um povoado fortificado e que terá sido fundado por volta do século I d.C. (1993, pp. 236-237). O PA considera este sítio como um povoado fortificado, com base num muro que forma um patamar agrícola, colocando como hipótese o desmantelamento da muralha.
} 
-se dois núcleos sepulcrais. O da Fonte do Amador será, segundo Sande Lemos, de cronologia alto medieval, com reaproveitamento de estelas funerárias romanas (1993, pp. 218-219). Cremos que a probabilidade de existir aqui, ou nas imediações, um povoado da Alta Idade Média é considerável. Todos estes povoados se situariam próximos de zonas de cultivo. Na zona do Castro de Coelhoso está identificada exploração mineira e a cerca de $3 \mathrm{~km}$ a nascente das Faceiras da Granja, em Miranda do Douro, passava a via designada de Carril Mourisco.

Ainda como povoados abertos, apesar de serem considerados fortificados, e com ocupação que medeia entre Época Romana e a Idade Média, contam-se três. Para os povoados da Coroa (Miranda do Douro) e para o de São Martinho, em Algoso (Vimioso), não são concretizadas cronologias alto medievais, contudo, e à semelhança do caso das Faceiras da Granja, os indícios, nomeadamente terra sigillata tardia e sepulturas estruturadas com lajes, atribuídas a cronologias medievais, nomeadamente em São Martinho (Lemos, 1993, p. 411), leva-nos a propor uma continuidade de ocupação entre Época Romana e plena Idade Média.

Com cronologias da Alta Idade Média e comprovadas por análises radiocarbónicas, regista-se o povoado de Torre Velha de Castro de Avelãs (Bragança). O PA designa este sítio como povoado fortificado. Contudo coloca interrogações, pois não se detetou nenhuma estrutura defensiva, facto que corroboramos depois de uma visita ao local. Nos anos de 2012 e 2013 desenvolveu-se um projeto arqueológico conjunto entre a Câmara Municipal de Bragança e a Universidade de Coimbra. A "Intervenção arqueológica no sítio da Torre Velha, Terras de S. Sebastião, Bragança”, foi da responsabilidade da arqueóloga Maria Clara Machaqueiro André (Câmara Municipal de Bragança) e de Pedro Jorge Cardoso de Carvalho (Universidade de Coimbra) e contou com a colaboração de Miguel Cipriano Esteves Costa e Sofia Catarina Gabriel Tereso. Os resultados revelaram "uma importante ocupação romana (século I-V d.C.)" e "vestígios do período suevo-visigótico", bem como, dos séculos "que antecederam a formação do reino de Portugal.” (PA).

\subsection{Habitats}

Em número de 17 são os designados habitats, que correspondem a pequenas quintas, casais, etc.. Nes- te grupo, destacam-se as ocorrências de Época Romana, contando-se apenas o sítio de São Martinho de Carrazedo com cronologia provável da Alta Idade Média. Segundo Sande Lemos, existiriam neste sítio as ruínas de "um edifício que terá sido uma capela de evocação a S. Martinho” (1993, p. 6o). Embora não tenhamos visitado o local, coberto por densa vegetação, há notícias de telhas e outros materiais de construção.

Ainda no que concerne aos habitats, devemos notar que existem duas ocorrências de cronologia indeterminada, nomeadamente o Lombo da Igreja, em Rebordaínhos, e Izei, Nogueira, ambos em Bragança. Atentemos no sítio do Lombo da Igreja, que poderá ter correspondido, no nosso entender, a um povoado em altura e não a uma pequena quinta. Aquando da nossa visita, constatamos materiais arqueológicos, não só neste local, mas espalhados por uma área mais extensa. O sítio ocupa um lombo aplanado com altitudes superiores a $1000 \mathrm{~m}$, com solos agrícolas, atualmente ocupados com soutos, e com um excelente domínio territorial. Apesar de não termos detetado estruturas, observamos que nos terrenos lavrados existe alguma pedra, podendo indiciar antigas construções e buracos de poste, nas zonas onde o penedo aflora. Segundo o PA, a tradição local diz "que aqui teria sido a primitiva igreja e povoação de Rebordainhos, antes de se mudar para baixo."

Dentro dos materiais observados, contam-se telha de meia cana, cerâmica comum e metais, cujas cronologias poderão enquadrar-se em período medieval. Para além do habitat, detetamos ainda num cabeço granítico que ocupa, sensivelmente, o centro do lombeiro, grande número de buracos de poste e entalhes que sugerem uma possível estrutura que julgamos poder ter correspondido a uma atalaia ou torre de vigia.

\subsection{Necrópoles}

Das 24 necrópoles registadas, apenas uma éindicada com possível cronologia da Alta Idade Média: Fonte Amador (Miranda do Douro). Contudo, cabe destacar a necrópole do povoado de Torre Velha de Castro de Avelãs, objeto de intervenções arqueológicas e de análises radiocarbónicas, como já referimos acima. Segundo os responsáveis pelos trabalhos arqueológicos, foram registadas 43 sepulturas, e escavadas 34. Exumaram-se 21 indivíduos não havendo registo de espólio associado (Tereso \& alii, 2015, p. 149). 
As datações revelaram uma fase mais antiga de enterramentos, com cronologias dos séculos VI-VIII, e uma outra fase com cronologias dos séculos X-XII. Destacamos ainda a necrópole de São João, localizada na cidade de Bragança, a menos de $200 \mathrm{~m}$ das muralhas da cidadela, associada à desaparecida igreja paroquial de São João, referida nas inquirições de 1258. A sua escavação arqueológica, realizada no âmbito dos trabalhos de requalificação da Polis, em 2003, revelou alguns elementos de interesse sobre os quais importa refletir. Na Travessa de São João, foi escavada "uma sepultura de inumação infantil, escavada na rocha, com lajes de xisto à cabeceira, parte torácica e abdominal." Por baixo desta sepultura foi registado "um buraco circular, escavado também na rocha em xisto, onde se detectaram cinco peças cerâmicas características da época baixo-medieval (séculos XIII e XIV) com enchimento de vários tipos de sedimentos: carvões, cinzas e ossos de animais." (Capela \& alii, 2004, p. 62).

$\mathrm{Na}$ restante necrópole foram ainda recolhidos "um anel e um par de brincos de prata." O conjunto total dos materiais permitiram aos investigadores sugerir que "a necrópole poderá datar da fundação da Igreja de S. João, no séc. XIII e prolonga-se até ao séc. XVIII." (Capela \& alii, 2004, pp. 62-63). Uma ampla diacronia, portanto.

Resumindo, os autores sintetizam que nesta Travessa foram identificadas "duas fases sepulcrais: uma moderna caracterizada pelas sepulturas em fossa simples escavadas num nível sedimentar e outra de época medieval com lajes de xisto e escavadas parcialmente na rocha de base." (Capela \& alii, 2004, p. 62).

Estas evidências merecem um apontamento, nomeadamente sobre as cronologias apresentadas. Ao que tudo indica não foram realizadas análise para determinar datações para as diferentes fases de enterramento. A proposta avançada pelos investigadores é sustentada na altura provável da construção da igreja de São João (séc. XIII), na tipologia dos sepulcros, nas relações estratigráficas e nos materiais recolhidos, realçando-se os objetos de adorno pessoal, encontrados em duas sepulturas distintas, e no conjunto cerâmico da fossa subcircular. Ora estes indícios, por si só, parecem-nos insuficientes e, de certa forma, equívocos, pois seria importante esclarecer a tipologia dos adornos encontrados e apresentar os paralelos para o conjunto cerâmico da fossa.

\section{REFLEXÃO}

Apresentados alguns dos dados recolhidos, torna-se necessário questionar a escassez de vestígios de uma ocupação alto-medieval na região nordeste transmontana. A insuficiência de trabalhos arqueológicos não justifica, por si só, esta realidade, pois a mesma falta é sintomática para ocupações de outras cronologias. Mesmo admitindo um recuo demográfico em época alto-medieval, causa-nos estranheza a acentuada ausência de vestígios, quando, nos sítios intervencionados, se verifica uma certa vitalidade cultural para este período, como no caso de Torre Velha de Castro de Avelãs e de São João das Arribas. Por outro lado, não podemos deixar de notar que os trabalhos de prospeção que antecederam as escavações nestes últimos dois sítios, conferiram-lhes cronologias essencialmente da Idade do Ferro, facto de certa forma contrariado pelos trabalhos de escavação e pelas datações radiocarbónicas. Ora, esta recontextualização de determinados assentamentos humanos alerta para uma necessária revisão de critérios de análise e interpretação dos sítios de povoamento alto-medievais. Parece evidente que os resultados de prospeções "básicas", focadas apenas, e só, nos vestígios materiais identificáveis à superfície e na bibliografia existente, resultam em leituras ambíguas que não permitem "constituir uma narrativa histórica, com características concretas e com propostas crono-temporais seguras." (Bohigas Roldán, 1999, p. 93). A arqueologia medieval, especialmente a que se dedica a cronologias mais antigas, tem sido prejudicada por determinados condicionalismos. Por um lado, pela prevalência de uma "arqueologia preventiva ou de gestão" que impede, frequentemente, um trabalho e uma investigação aprofundados; por outro lado, o desinvestimento na formação "ligadas a este período cronológico", que resulta na falta de investigadores experientes e capazes de identificarem "vestígios importantes para a compreensão do povoamento e do território medieval." (Bohigas Roldán, 1999, p. 8o-81).

Felizmente, e para a região transmontana, têm-se desenvolvidos alguns trabalhos de monta, nomeadamente os realizados no âmbito da construção das barragens de Foz Tua ou a do Sistema Hidroelétrico do Baixo Sabor, que contaram com importantes escavações arqueológicas, algumas com datações radiocarbónicas. Contudo, estamos longe de um corpus de trabalhos, cujos dados possibilitem uma 
sistematização e caracterização da ocupação humana medieval em Trás-os-Montes. Falta um planeamento teórico e conceptual para a arqueologia medieval, que tenha por base projetos de investigação integrados, permitindo leituras globais que incorporem os diferentes elementos estruturadores do território. Passar de uma leitura iminentemente descritiva, para uma análise interpretativa e procurar resultados mais objetivos e menos tipológicos ${ }^{7}$.

$\mathrm{Na}$ verdade, e ao longo deste estudo, verificamos que houve uma variedade considerável de opções de assentamento que, adaptando realidades já existentes ou criando novas soluções, desenharam um quadro de povoamento que não se resume a uma única solução. Esta variabilidade é comum para outras regiões estudadas, quer em Trás-os-Montes, quer no país vizinho, nomeadamente na região de Zamora ${ }^{8}$. Durante a Alta Idade Média, e no que se refere à região do nordeste transmontano, as populações não terão ocupado unicamente povoados fortificados, como São João das Arribas, em Miranda do Douro, ou povoados "abertos" em altura, como Torre Velha de Castro de Avelãs, em Bragança. Cremos existirem indícios de pequenas comunidades rurais, implantadas em locais abrigados, longe o suficiente das principais vias de comunicação, herdadas da romanização, e próximas das zonas de cultivo, que tanto poderiam ocupar terraços, como na Capela de São Paulo, em Miranda do Douro, como parcelas agrícolas antigas que se estenderiam pelos rebordos dos planaltos, muitas vezes, junto a desaparecidas ocupações romanas, como em Faceiras da Granja,

7. Seguindo esta linha de investigação, foram dados importantes passos, nomeadamente através do projeto "As sepulturas escavadas na rocha do norte de Portugal e Vale do Douro (SER-NPVD)", da responsabilidade científica do Prof. Doutor Mário Jorge Barroca e promovido pelo CITCEM - Centro de Investigação Transdisciplinar «Cultura, Espaço e Memória» e Faculdade de Letras do Porto. Este projeto, no qual colaboramos, procura reunir e sistematizar toda a informação disponível sobre sepulturas escavadas na rocha no norte de Portugal, relacionando-as com as diferentes estruturas territoriais. Foi criada uma base de dados, disponível online, que pretende contributos vários, garantindo uma constante atualização dos dados. A apresentação do projeto disponível em: https://www.citcem. org/projeto/36.

8. Para o território português e no que concerne à zona transmontana ver Tente, Catarina, 2017, pp. 4-57. Para o território zamorano ver Gutiérrez González, 2017, pp. 1985 ou Martín Viso, 2001, pp. 75-122. em Duas Igrejas (Miranda do Douro). Também parece terem existido comunidades pastoris implantadas em vales ou nas faldas das montanhas, junto a cursos de águas secundários, com lameiros para a criação de gado bovino, como em São Martinho, Carrazedo (Bragança).

A tradição conserva ainda uma memória toponímica de lugares onde terão existido antigas comunidades, muitas vezes associadas a igrejas e a sepulturas, estas quase sempre estruturadas por lajes, e, por vezes, próximas de locais fortificados: como São Martinho, em Algoso, onde Sande Lemos diz poder existir uma fortificação da Alta Idade Média no Cabeço da Forca (1993, pp. 411-412).

Igualmente importantes, e pouco conhecidos nesta região, são os centros militares e de poder que, apesar da desestruturação que se seguiu ao período romano, terão tido alguma espécie de materialização, indispensável para uma certa estruturação territorial, que, mais tarde servirão os propósitos dos avanços da monarquia asturo-leonêsa dos inícios da Idade Média. Estes sítios, habitados ou não, privilegiariam critérios estratégicos de controlo e vigia territorial. Apoiados em comunidades fortes e de importância relevante, como poderia ser o caso de Torre Velha de Castro de Avelãs, ou talvez de Bragança ${ }^{9}$, existiria uma rede de estruturas militares e administrativas necessárias à manutenção da paz ou defesa das populações. Estas estruturas, num território imenso e parco de população, poderão ter-se materializado em antigos povoados fortificados, cuja evidente importância geoestratégica não teria sido ignorada: seria o caso do Castelo de Pinela, em Bragança. Este sítio, para o qual a bibliografia não refere especificamente uma cronologia alto medieval, ergue-se no planalto de Parada, controlando grande parte do território bragançano. Tem um domínio abrangente sobre o vale que acede à cidade de Bragança, vindo de sudoeste, e comunica visualmente com grande parte dos locais fortificados das imediações. Pela sua dimensão e pelos materiais espalhados à superfície, foi claramente habitado em diferentes épocas

9. Notamos que no Paroquial Suevo é mencionado o pagus Brigantia e apesar de se desconhecer o sítio exato desta paróquia, não se poderá descartar a hipótese de ela corresponder à zona onde se ergue hoje a cidade de Bragança. Mais tarde, em 1194, D. Sancho I irá adquirir, talvez no mesmo sítio, a herdade de Benquerença e em 1188, deixa uma quantia de dinheiro para fortificar a cidade (DS, p. 118-119, Doc. 76 e DS, p. 49-51, Doc. 31). 
cronológicas, sendo ainda referido na documentação do século XIII ${ }^{10}$. É provável, portanto, que o Castelo de Pinela tenha tido um importante papel como centro estruturador do território em épocas alto medievais, podendo mesmo ter continuando "como cabeça da "terra" de Bragança", antes da vila, com o mesmo nome, ter assumido esse papel (Gomes, 2003, p. 11).

Num território acidentado e com um coberto florestal certamente diferente, onde os eixos de circulação mais importantes não seriam propriamente numerosos, a circulação pelos vales dos rios ou pelos planaltos seriam pontos de necessário controlo e vigilância. Ao percorrer o território apercebemo-nos que os antigos povoados edificados em cabeços, na zona planáltica, ou junto a pequenos cursos de água, ou erguidos em esporões e meandros dos rios Sabor, Angueira, Maçãs, etc., eram locais privilegiados para vigiar a circulação de pessoas e bens.

Esta rede de estruturas parece obedecer a diferentes níveis de controlo territorial: o local, formado através de estruturas fortificadas, por vezes reaproveitadas de construções pré-existentes, que vigiariam as produções agrícolas, de pastoreio, ou de mineração, como poderia ser o caso de Castrilhão de Coelhoso ${ }^{11}$, Bragança; o regional, que controlaria as zonas de passagem, por exemplo, vales agrícolas e de pastoreio, utilizando pontos estratégicos de médio alcance, como esporões ou meandros, que possibilitam uma visualização parcelar de um curso de água, ou de passagens a vau de rios e ribeiras, como no caso de Penedo, Grijó de Parada, ou Fragas do Castro, em São Julião de Palácios, ambos em Bragança - o primeiro sobre o rio Sabor e o segundo sobre o

10. Nas inquirições de 1258, o castelo de Pinela, também conhecido por Alfenim e Alvelina é mencionado no Julgado de Lamas de Orelhão, na paróquia de Santo Estevão de Fresulfe, afirmando as testemunhas que a vila de Parada foi regalenga e que D. Sancho I a doou a "Donno Galeco", pai de "Munio Pelagij milite de Trasbaceiro", pelo castelo de "Aluelia" que "Donno Galeco" construiu. É referido ainda, nas inquirições no Julgado de Bragança, na paróquia de Santa Maria de Serapicos, afirmando-se que os homens da vila de "Paradias" entregavam o foro aos homens do rei que estavam em "Alueliam” (PMH - Inq. 1258).

11. O PA aponta para este sítio uma ocupação da Idade do Ferro. Já Sande Lemos diz que o Castrilhão terá sido romanizado (1993, pp. 70-71). Pensamos que, pela sua posição geoestratégica, de controlo de uma região mineira, poderá também ter sido utilizado como estrutura defensiva/vigia durante períodos alto-medievais e medievais. rio Maçãas ${ }^{12}$; e os pontos de controlo suprarregionais, articulados com outros pontos regionais, privilegiando um controlo geoestratégico mais vasto, vigiando as grandes movimentações e quase sempre em articulação com centros estruturadores de poder como seria o Castelo de Pinela. Neste grupo, deverá destacar-se o sítio da Senhora da Conceição, Carocedo, Faílde, e a Fraga do Cavaleiro, também em Faílde, ambos no rebordo sudeste do vale que conduz a Bragança, tratando-se de povoados fortificados com origens anteriores à Alta Idade Média; no rebordo oposto, e comunicando visualmente com os sítios anteriores, podemos destacar o Castelo ${ }^{13}$, em Quintela de Lampaças, a possível atalaia do Lombo da Igreja, em Rebordaínhos, e o Castelo de Rebordãos ${ }^{14}$. Todos estes sítios ocupam as faldas da serra da Nogueira. O Castelo seria um povoado fortificado, com uma forte implantação territorial, e de cronologias indeterminadas. O Lombo da Igreja, um povoado "aberto" em altura, onde se destaca um cabeço rochoso com buracos de poste, sugerindo a existência de uma possível construção perecível, talvez uma torre ou plataforma elevada, com claro domínio sobre o vale. Sobre a cronologia do povoado nada é adiantado pela bibliografia. Ao Castelo de Rebordãos apontam-se ocupações pré-históricas. Contudo, as estruturas que hoje conserva são claramente medievais.

Para além dos núcleos de povoamento e das estruturas defensivas/vigia, podemos identificar outras duas importantes evidências da organização social

12. Para estes sítios a bibliografia aponta cronologias da idade do ferro e romanas (PA). No nosso entender estas estruturas fortificadas poderão ter sido utilizadas em épocas alto medievais e talvez medievais. Mais uma vez, a classificação cronológica atribuída pelo PA tem como base dados pouco concretos, pois apenas encontraram "alguns fragmentos cerâmicos da Idade do Ferro" no sítio do Penedo (PA).

13. O sítio do Castelo, como também é designado na carta militar, é referido num documento de 1303, em que Rui Martins, alcaide de Bragança e procurador do rei, doa a 15 moradores carta de foro do vilar de Pombares, que então se chamava "Pinhel", que ficava sob Teixedo (povoação atualmente abandonada, pertencente a Pombares) para ser povoado. Na definição dos termos de Pombares, é referido o castelo sobre Veigas, que julgamos corresponder ao sítio do Castelo (Santana, 2008, pp. 91-93).

14. O Castelo de Rebordãos é referido, pela primeira vez na documentação, em 1208, no foral que lhe é atribuído por D. Sancho I. É designado por castelo de “Taurones", pertença de cavaleiros (DS, p. 271-272, Doc. 179). 
do espaço alto-medieval transmontano: as necrópoles, já mencionadas, e as vias de comunicação.

Relativamente às vias, importa referir dois importantes eixos: a incontornável via XVII do Itinerário de Antonino, que atravessa o território de Bragança no sentido este-oeste, e o Carril Mourisco, que atravessa o planalto de Miranda, no sentido norte-sul. O primeiro de origem romana e o segundo identificado como medieval, mas também como romano. Independentemente da sua origem, cremos que tanto um como outro foram percorridos ao longo dos tempos, numa região onde os grandes eixos são raros e o relevo determinante.

A via XVII, e segundo estudos anteriores (André, 2008, pp. 48-49), teria duas variantes na região de Bragança, encontrando-se numa só em Castro de Avelãs. O traçado da variante norte, passava pelas atuais aldeias ou nas suas imediações, muitas vezes, decalcado pelas estradas recentes. Se relacionarmos o seu percurso com o povoamento mais antigo, verificamos, por exemplo, que em Castrelos a via atravessaria o rio Baceiro, talvez no mesmo sítio da ponte de Castrelos, sob o controlo vigilante do Cabeço de São João, povoado fortificado, com uma ocupação de longa diacronia. Neste sítio, para além da referência a uma igreja de São João, terão sido descobertas duas sepulturas estruturadas com lajes, entretanto destruídas.

Já a variante sul, poderia passar sob o controlo do povoado fortificado do Picoto, quem sabe reutilizando antigos itinerários da Idade do Ferro. O Picoto é descrito como um povoado da Idade do Ferro, contudo não foram detetados quaisquer materiais.

Em Castro de Avelãs, a via passaria nas imediações do povoado da Torre Velha, seguindo em itinerário único para leste, passando em Bragança, a norte do castelo, e talvez na zona da ponte das Carvas, dirigindo-se para Gimonde, onde teria uma outra travessia do rio. Aqui o controlo era feito pelo Castro de Gimonde, este com vestígios romanos. Em Babe ergue-se o Castro da Sapeira, mais um povoado da Idade do Ferro, datado pela sua tipologia e por um único fragmento de cerâmica de superfície (PA). O local é um excelente ponto de controlo geoestratégico, que não terá sido ignorado em períodos posteriores. Na zona de São Julião de Palácios, a bibliografia, mais uma vez, não aponta nenhum sítio com cronologias medievais. Contudo, os povoados das Cercas ou o do Caracuto do Castro, poderiam ter um papel de vigia da via.
Do itinerário XVII partiriam vias secundárias que fariam a ligação a pontos estruturantes da economia romana, nomeadamente aos locais de extração mineira. Assim, da zona de Babe, partiria uma via em direção a sul, percorrendo o planalto de Milhão-Argozelo, região onde os vestígios de mineração são relevantes. Entre Babe e Milhão cremos que esta via passaria nas imediações dos povoados de Castragosa e Cativelo, seguindo para Milhão. Em Argozelo, existiriam caminhos de ligação a Coelhoso, atravessando o Sabor, talvez controlados pelo sítio de São Bartolomeu. Também haveria ligação a Pinelo, atravessando no sítio da Ponte Velha, controlado pelo povoado do Serro Grande de Argozelo.

O Carril Mourisco, que consideramos também estruturante, embora diferente da via XVII, atravessava o planalto de Miranda do Douro. Descendo para sul, a via passaria a ribeira da Matança, controlada pelo povoado fortificado de São Martinho de Angueira, com vestígios de romanização e seguiria até à zona de Sendim. Esta via não atravessa as atuais povoações, distando delas cerca de $2 \mathrm{kms}$.

Entre o Carril Mourisco e o rio Douro, no rebordo do planalto, haveria um outro eixo de circulação norte-sul. Entre estes dois eixos, distribuem-se grande parte dos sítios de cronologia romana e possíveis habitats de época alto medievais.

Nas arribas do Douro imperam os povoados ou estruturas fortificadas, controlando o rio, e uma rede de caminhos que os ligam, passando pelos terraços agricultados que aproveitam os pequenos cursos de água que caem no Douro. Aqui, como já vimos, também houve ocupação alto medieval.

\section{CONCLUSÃO}

Não é novidade que a paisagem medieval foi construída sob um legado tardo-antigo, adaptando realidades e operando importantes mudanças. A falta de documentos escritos e de trabalhos arqueológicos, aconselham a uma reinterpretação dos dados existentes, propondo leituras diversificadas. O povoamento alto medieval não obedeceria a uma única fórmula, adaptando-se à realidade geográfica e sociopolítica da região e do tempo. Assim, é natural uma continuidade de ocupação junto aos cursos dos rios mais importantes, eixos estruturadores e orientadores dos grandes territórios. É também natural o aproveitamento de certos espaços de exploração agrícola da Antiguidade Tardia, dos seus arrotea- 
mentos e emparcelamentos, das suas estruturas de rega e de transformação. Mas também não se deverá estranhar que tenha havido uma reocupação e/ ou reutilização de estruturas mais antigas, como os povoados fortificados, ditos "da Idade do Ferro", beneficiando da sua aparente proteção e domínio estratégico. Enfim, terão sido criados novos núcleos comunitários, muito provavelmente sob o amparo de um pequeno templo e da sua necrópole, que na alvorada de uma nova era se tornaram demasiado pequenos para uma população crescente, obrigando a transformações.

O ritmo da "modernização atual" exige uma resposta mais célere e atenta do conhecimento, sob pena de se perderem os vestígios e a memória de um passado ainda pouco explorado.

\section{BIBLIOGRAFIA}

ANDRÉ, Clara (2008) - Projecto VIAS AVGVSTAS e traçado da Via XVII do itinerário de Antonino. In Bragança um olhar sobre a História II. Bragança: Câmara Municipal de Bragança, pp. 47-55.

ANDRÉ, Clara; CARVALHO, Pedro C. (2015) - Arqueologia funerária alto medieval da Torre Velha (Castro de Avelãs, Bragança). In Identidad y Etnicidad en Hispania: Propuestas teóricas y cultura material en los siglos V-VIII. Documentos de Arqueología Medieval 8. Euskal Herriko Unibertsitatea. Universidad del País Vasco, pp. 145-16o.

BOLÓS, Jordi (2015) - Paisatges i transicions: canvis i continuitats al llarg de la història. In El paisatge en èpoques de transició al llarg dels darrers dos mil anys. Territori i Societat: el paisatge històric. Universitat de Lleida. (Història, Arqueologia, Documentació. VII), pp. 59-126.

CAPELA, Mafalda; GARCIA, Maria; LOPES, Lídia; MENÉNDEZ, Jorge; SALGADO, Mónica (2004) - Trabalhos Arqueológicos no âmbito da Sociedade Bragança Polis. In Bragança um olhar sobre a História. Bragança: Câmara Municipal de Bragança, pp. 31-94.

DS Documentos de D. Sancho I (1174-1211). Rui de Azevedo; P. Avelino de Jesus da Costa; Marcelino Rodrigues Pereira (Edição). Coimbra: Universidade de Coimbra. 1979. Vol. I, p. 49-51 - Doc. 31; p. 118-119, Doc. 76; p. 271-272 - Doc. 179.

GOMES, Rita Costa (2003) - Castelos da Raia: Trás-os-Montes. Lisboa: Ministério da Cultura. Instituto Português do Património Arquitectónico. Vol. II. (Colecção Arte e Património).

GTT As Gavetas da Torre do Tombo. A. da Silva Rego (Edição). Lisboa: Centro de Estudos Históricos Ultramarinos. Vol. II. Gav. III-XII. 1962, p. 657 - Doc. 1824.
GUTIÉRREZ GONZÁLEZ, J. Avelino (2017) - Processos de formación de ciudades altomedievales en el norte peninsular. In O papel das pequenas cidades na construção da Europa Medieval. Estudos 17. IEM - Instituto de Estudos Medievais / Câmara Municipal de Castelo de Vide, pp. 19-85.

LEMOS, Francisco de Sande (1993) - Povoamento Romano de Trás-os-Montes Oriental. Braga: Universidade do Minho (Dissertação de Doutoramento na especialidade de Pré-História e História da Antiguidade).

MARTÍN VISO, Iñaki (2001) - La articulación des poder en la cuenca del duero: el ejemplo del espacio zamorano (siglos VI-X). In Anuario de Estudios Medievales. 31: 1, pp. 75-122. (Disponível em https://doi.org/10.3989/aem.2001.v31.i1).

PA Portal do Arqueólogo disponível em: https://arqueologia.patrimoniocultural.pt.

PMH-Inq. Portugaliae Monumenta Historica - Inquisitiones. Inquirições Gerais de D. Afonso III 1258. Lisboa: Academia das Ciências. Vol. I. Pars II. Fascículo VIII. Quarta Alçada. 1961, pp. 1280-1345.

SANTANA, Maria Olinda Rodrigues (2008) - Documentação foraleira dionisina de Trás-os-Montes: breve estudo e edição interpretativa. Lisboa: Edições Colibri, pp. 91-93.

TENTE, Catarina (2017) - Alta Idade Média no Vale do Tua: continuidades e mudanças entre o fim do Império Romano e o início da nacionalidade. In Estudo Histórico e Etnográfico do Vale do Tua (Concelhos de Alijó, Carrazeda de Ansiães, Mirandela, Murça e Vila Flor). Aproveitamento Hidroelétrico de Foz Tua. EDP. Porto. Vol. II, pp. 4-57.

TERESO, Sofia; BRITO, André; UMBELINO, Cláudia; CIPRIANO, Miguel; AMDRÉ, Clara; CARVALHO, Pedro C. (2015) - Arqueologia funerária alto medieval da Torre Velha (Castro de Avelãs, Bragança). In Identidad y Etnicidad en Hispania: Propuestas teóricas y cultura material en los siglos V-VIII. Documentos de Arqueología Medieval 8. Euskal Herriko Unibertsitatea. Universidad del País Vasco, pp. 145-16o. 


\section{ANEXOS}

(pontos que estão nos 4 mapas)

MIRANDA DOURO: 1-Faceiras da Granja; 2-Fonte Amador; 3-Senhora Monte; 4-Urreta da Malhada; 5-Vinha do Padre; 6-Castro do Cércio; 7-Santa Maria de Cércio; 8-Santo André; 9-Via Romana; 10-Via RomanaII; 11-Castro Vale de Águia; 12-Raio; 13-São João das Arribas; 14-Coroa; 15-Via Romana; 16-Santos; 17-Capela de São Paulo; 18-Trampas Carreiras; 19-Navalhos; 20-Castrolouço; 21-Nossa Senhora da Assunção; 22-Toural; 23-Penhal do Castro; 24-Picão do Diabo; 25-Picão da Penha Alva; 26-Castelar; 27-Necrópole Igreja de Picote; 28-Via Romana; 29-Via Romana; 30-Cigadonha; 31-Castrilhouço da Braceosa; 32-Castralheiras; 33-Casicas; 34-Capela de Santo Albino; 35-Necrópole Igreja Vila Chã Braciosa; 36-Abadia; 37-Santo Eustáquio; 38-Touro; 39-Castrilhouço; 40-Penha da Torre; 41-Senhora da Luz; 42-São Martinho de Angueira; 43-Via Romana; 44-Via Romana. VIMIOSO:45-Via Romana; 46-Castelo dos Mouros; 47-Castelo de Algoso; 48-Penenciada; 49-Cabeço da Forca; 5o-São Martinho; 51-Castelo Velho; 52-Terronha; 53-Castro dos Mouros; 54-Batoqueira; 55-Castelo; 56-São Mamede; 57-Penedo da Abrunheira; 58-Pedras Altas; 59-Rebolo; 60-Caminho Romano; 61-Gago; 62-Cabeço da Cocolha; 63-São Miguel; 64-Santa Marinha; 65-Picoto; 66-Lagoaço; 67-Canto da Serra; 68-Castro do Serro Grande; 69-Terronha; 70-São Bartolomeu. BRAGANÇA: 71-Castelo; 72-Santa Eulália; 73-Castelo dos Mouros; 74-Povoado do Castelo dos Mouros; 75-São Justo; 76-Castelo do Sanguinho; 77-Mata Mouros; 78-Castro do Serro de Coelhoso; 79-Castrilhão de Coelhoso; 8o-Castro de Coelhoso; 81-Cabeço da Terronha; 82-Castro de Vila Boa; 83-Senhora do Aviso; 84-Trás do Souto; 85-São Julião; 86-Terronha; 87-Castelo; 88-São Miguel; 89-Pombares; 90-Cabeço do Cercado; 91-Lombo da Igreja; 92-Eiró de Sortes; 93-Castro Mau; 94-Castro de Ciragata; 95-Castelinho; 96-Muradelhas; 97-Lameiro da Anta; 98-Senhora da Conceição; 99-Ferradoza; 10o-Fonte de À Mó; 101-Cabeço da Mêda; 102-Fraga do Cavaleiro; 103-Estrepelgo; 104-Castelo de Alfenim; 105-Cortinha do Castelo; 106-Souto da Capela; 107-Penedo; 108-Cabeço das Freiras; 109-Castelinho; 110-Torre de Medorro; 111-Castro Mouro; 112-Barrocal; 113-Crasto; 114-Castelo dos Mouros; 115-Cativelo; 116-Buraco da Moura; 117-Igreja São Lourenço de Milhão; 118-Cabecinho dos Mouros; 119-Senhora da Veiga; 120-Sumidago; 121-Castanheiro do Senhor; 122-Monte dos Xistos; 123-Quinta de São Lourenço; 124-Alto do Martim Cansado; 125-Castelo de Rebordãos; 126-Ferradal; 127-Vale das Pereiras; 128-Cigadonha; 129-Sampaio; 130-Izei; 131-Senhora da Serra; 132-Castelinho; 133-Castro da Seara/; 134-Picoto; 135-Castelo de Alimonde; 136-Terronha de Alimonde; 137-São Martinho de Carrazedo; 138-Canada de Alimonde; 139-Santo Amaro de Alimonde; 140-Escalões de Alimonde; 141-Cabeço de São João; 142-Igreja Velha de Conlelas; 143-Fragas do Castelo; 144-São Cláudio; 145-Torre Velha Castro Avelãs; 146-Via XVII; 147-São Martinho; 148-Devesa; 149-Sagrado; 150-Quinta de Britelo; 151-São Tiago de Lagomar; 152-São Salvador; 153-São Bartolomeu; 154-Igreja de Santa Maria; 155-Necrópole da Igreja de São Vicente; 156-Necrópole da Igreja de São João; 157-Necrópole Convento São Francisco; 158-Mata de São Sebastião; 159-Castro de Gimonde; 16o-Castro de Baçal; 161-Castro Sacóias; 162-Castro de Sacóias/Senhora da Assunção; 163-Castragosa; 164-Castro da Sapeira; 165-Monte Cercado; 166-São Pedro; 167-São Sebastião; 168-Fragas do Castro; 169-Cercas; 17o-Caracuto do Castro; 171-Caminho das Doñas; 172-Castro; 173-Cabeço dos Mouros; 174-Fragas do Cabril 1; 175-Vale de Igrejas/; 176-Alto do Castro; 177-Torre; 178-Chaira; 179-Lombeiro Branco; 180-Torre do Castro; 181-Sagrado; 182-Lombeiro dos Maquieiros; 183-Vinha do Santo; 184-São Salvador de Oleiros; 185-Castelo dos Mouros; 186-Alto dos Currais; 187-Ruínas Senhora da Hera; 188-Santo Amaro; 189-Santo André Velho; 190-São Tomé; 191-Alto da Torre; 192-Castro de Zeive; 193-Castelo das Olgas/Urreta Formosa. 


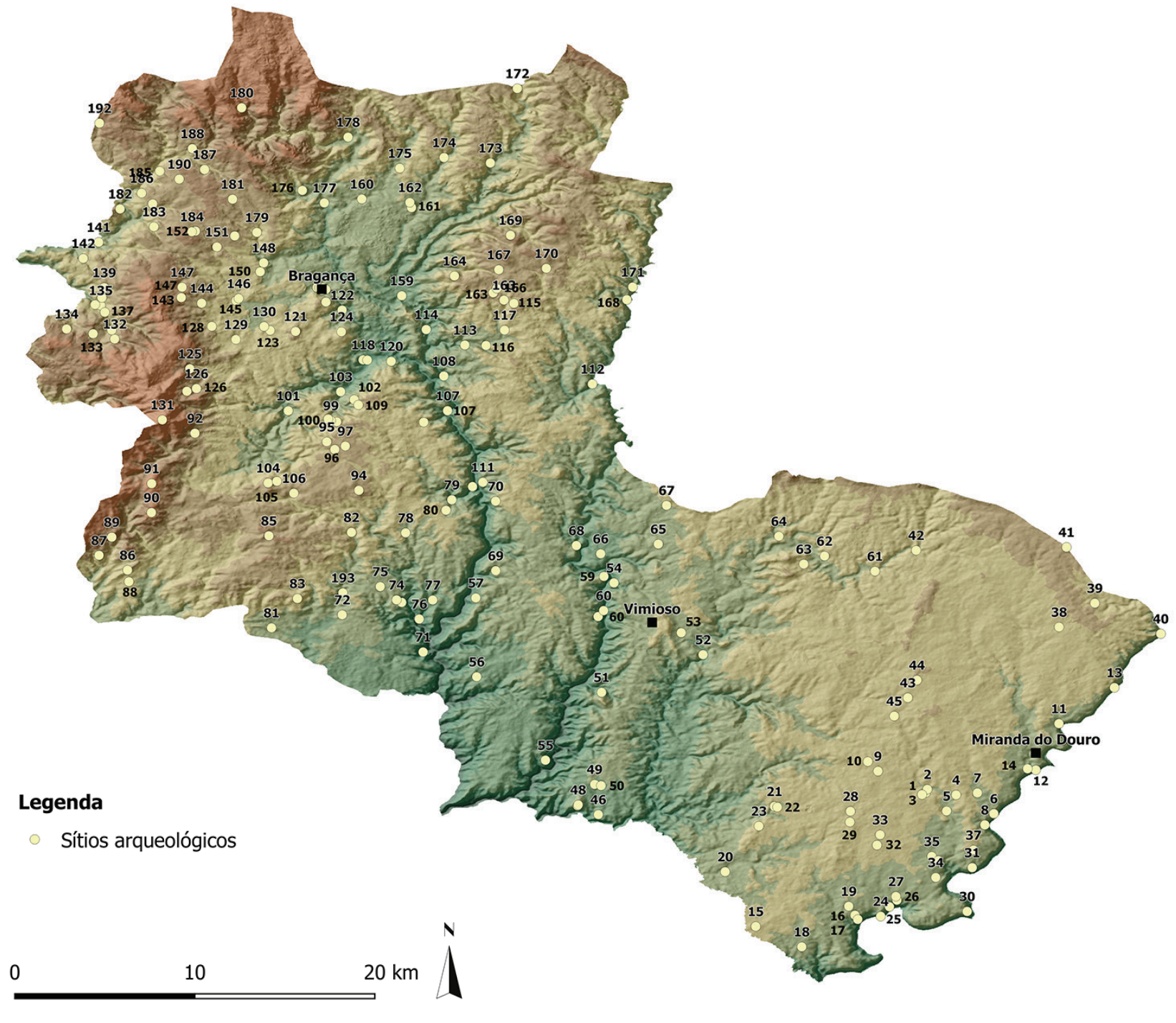

Mapa 1 - Sítios arqueológicos. Autor: César Guedes. 


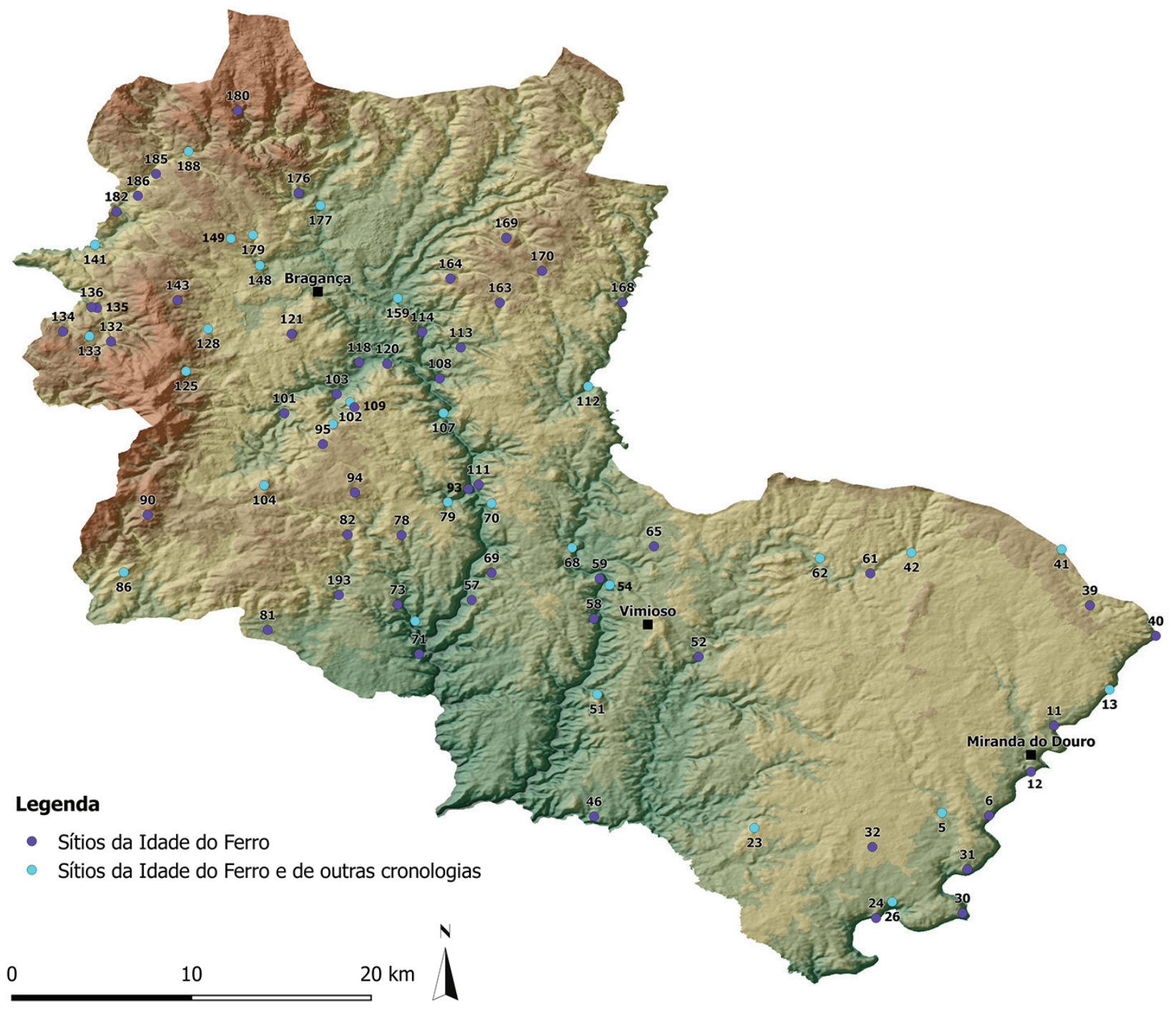

Mapa 2 - Sítios de cronologias da Idade do Ferro. Autor: César Guedes 


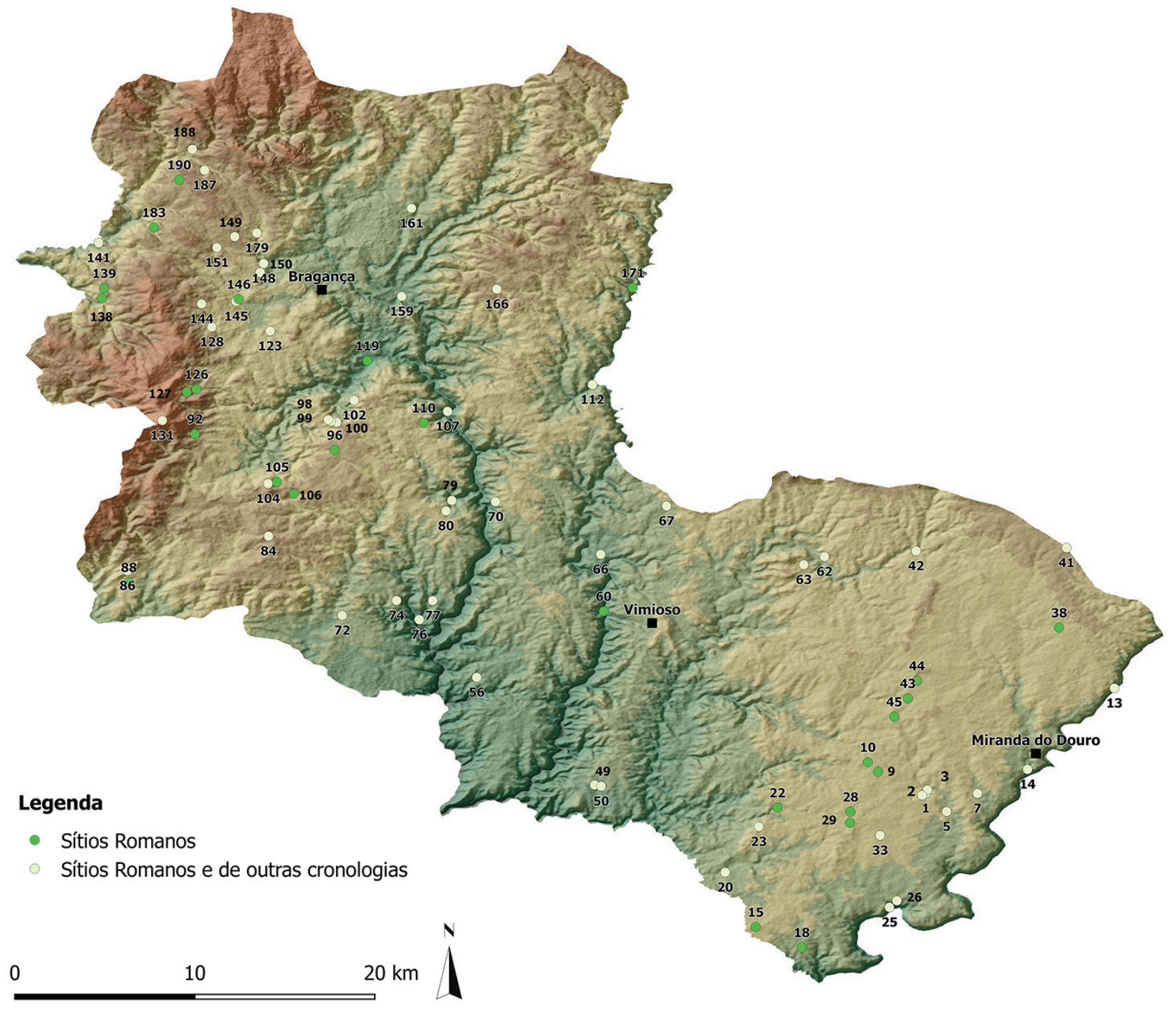

Mapa 3 - Sítios de cronologias Romanas. Autor: César Guedes. 


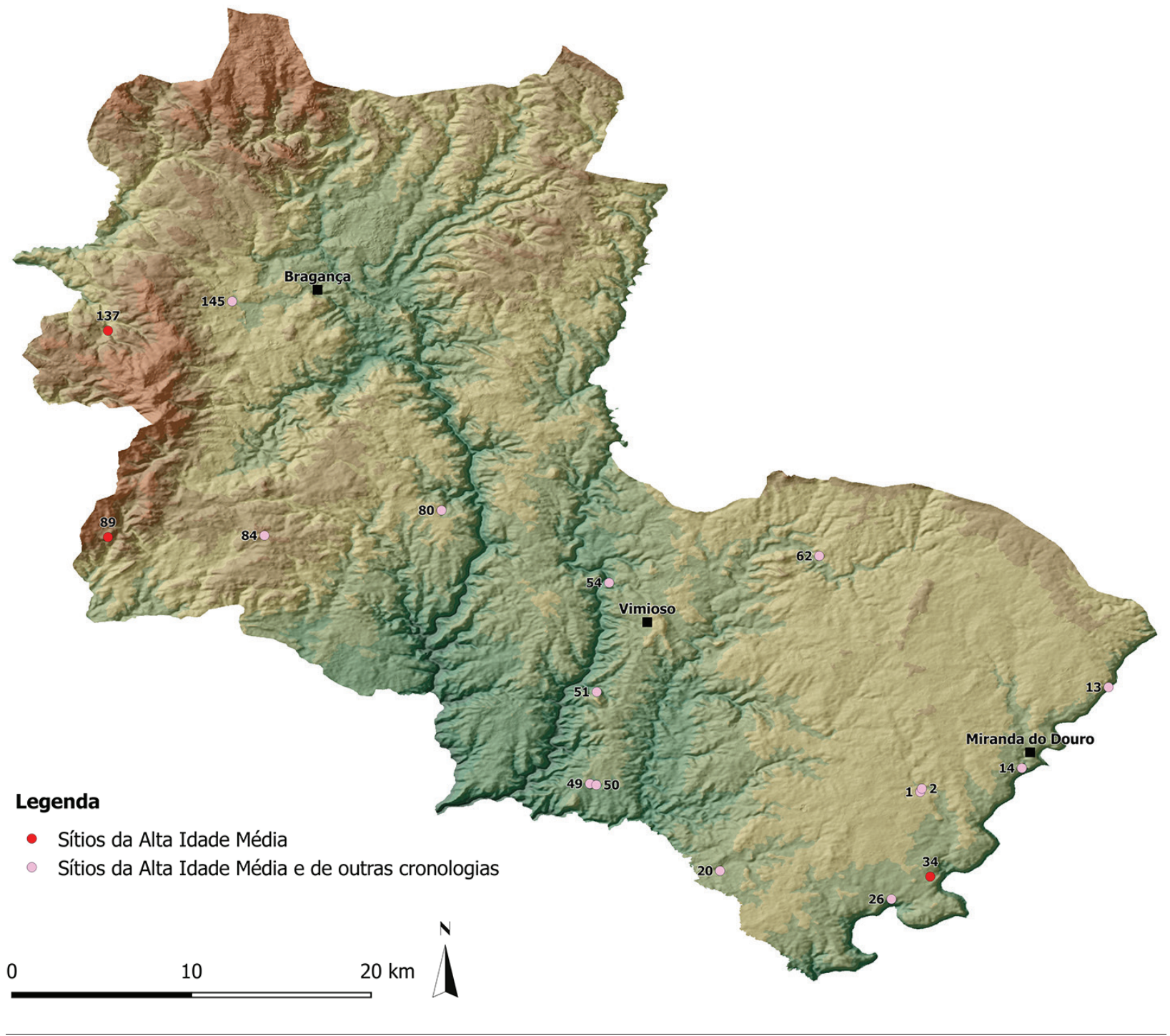

Mapa 4 - Sítios de cronologias da Alta Idade Média. Autor: César Guedes. 


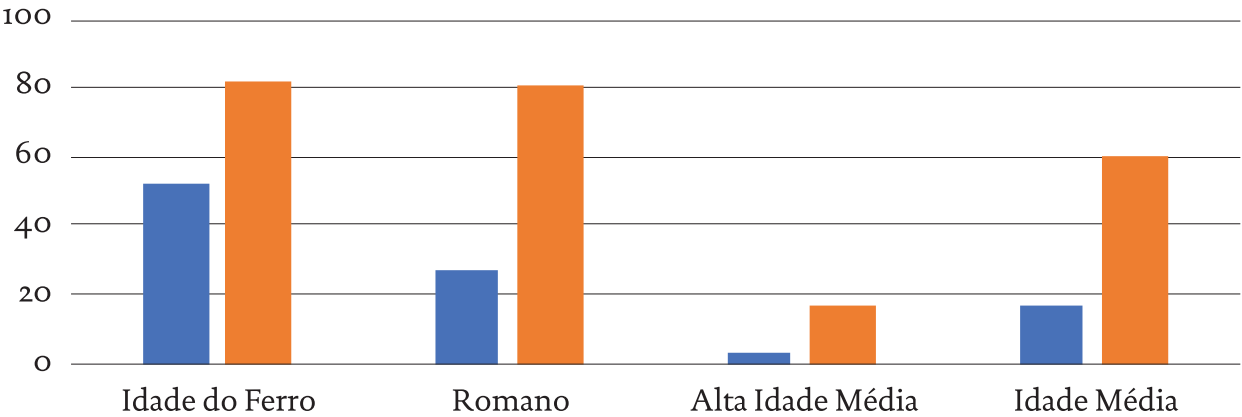

- Ocorrências com cronologia exclusiva

Total com as ocorrências com cronologias diacrónicas

Gráfico 1 


\title{
SEPULTURAS ESCAVADAS NA ROCHA DO NORTE DE PORTUGAL E DO VALE DO DOURO: PRIMEIROS RESULTADOS DO PROJECTO SER-NPVD
}

\author{
Mário Jorge Barroca ${ }^{1}$, César Guedes ${ }^{2}$, Andreia Arezes ${ }^{3}$, Ana Maria Oliveira ${ }^{4}$
}

\begin{abstract}
RESUMO
Apresentam-se os resultados preliminares do projecto «Sepulturas escavadas na rocha do Norte de Portugal e do Vale do Douro" (SER-NPVD)", que se propôs sistematizar a informação sobre as sepulturas rupestres do Norte de Portugal, abarcando as duas margens do vale do Douro e todo o espaço a norte deste rio. Esboça-se uma primeira caracterização das estações identificadas e das sepulturas que as constituem, sendo abordadas as suas principais características e o tipo de espaço funerário em que se inserem. Procura-se também apresentar uma primeira leitura da integração paisagística destes monumentos e da sua relação com alguns dos elementos estruturadores do povoamento.
\end{abstract}

Palavras-chave: Sepulturas escavadas na rocha, Norte de Portugal, Idade Média.

\begin{abstract}
In this text, we present the preliminary results of the project "Rock-cut graves from Northern Portugal and the Douro Valley (SER-NPVD)", a project that intends to systematize the information about the rock graves in the North of Portugal, covering both banks of the Douro valley and the entire territory located north of this river. We also present an outline of the identified sites and correlated graves, approaching their main features and the type of funerary space in which they are inserted. Furthermore, we propose a first insight focused both on the integration of these monuments in the landscape, and on their relation with some of the structuring patterns of settlement.
\end{abstract}

Keywords: Rock Cut graves, Northen Portugal, Middle Ages.

\section{APRESENTAÇÃO 5}

O projecto "Sepulturas Escavadas na Rocha do Norte de Portugal e do Vale do Douro" (SER-NPVD) surgiu em 2018, na sequência da realização do Congresso Internacional «Sepulturas Escavadas na Rocha da Fachada Atlântica da Península Ibérica», uma co-organização da FLUP e do CITCEM (Centro de Investigação Transdisciplinar "Cultura, Espaço e Memória»), que decorreu na Faculdade de Letras da
Universidade do Porto, entre os dias 19 e 20 de outubro de 2017. Por essa altura, os signatários deste texto entenderam que não se devia deixar esmorecer a dinâmica que se tinha gerado e que se podia - e devia - avançar para uma plataforma de trabalho distinta. Nesse sentido, no âmbito do Grupo de Investigação "Territórios e Paisagens» do CITCEM, apresentaram a este Centro de Investigação uma proposta para desenvolver uma plataforma, a ser disponibilizada on line, que fornecesse aos arqueólogos portu-

\footnotetext{
1. FLUP/CITCEM; mbarroca@letras.up.pt

2. CITCEM; cesarlguedes@gmail.com

3. FLUP/CITCEM; aarezes@letras.up.pt

4. CITCEM/FCT; anamcostaoliveira@gmail.com

5. Os autores não seguem o Acordo Ortográfico.
} 
gueses uma sistematização de todas as informações relativas a sepulturas escavadas na rocha do Norte de Portugal. Este projecto de investigação, que recebeu o acrónimo "SER-NPVD", mereceu, desde a primeira hora, o acolhimento e apoio da direcção do CITCEM, o que nos apraz registar aqui, deixando o nosso testemunho público de reconhecimento pela disponibilização dos meios materiais e logísticos que permitiram levar a cabo esta iniciativa ${ }^{6}$.

\section{O PROJECTO E A ÁREA DE ESTUDO}

A proposta formulada foi, portanto, a de sistematizar, em ficha padronizada, todos os dados disponíveis para sepulturas escavadas na rocha do norte de Portugal.

O âmbito geográfico do projecto abrangeu todos os concelhos localizados a Norte do rio Douro, repartidos pelos distritos de Viana do Castelo, Braga, Porto, Vila Real e Bragança, num total de 68 municípios. Mas, porque se entendeu que o vale do rio Douro constituía uma unidade geográfica e histórica, sendo as suas margens indissociáveis, a opção foi a de englobar, igualmente, todos os concelhos que confinam com a margem sul deste rio. Estes concelhos, que se repartem pelos distritos de Aveiro, Viseu e Guarda, foram considerados em toda a sua área, com uma única excepção - o concelho de Santa Maria da Feira, que foi apenas considerado na zona mais a norte, nomeadamente a freguesia de Canedo. Procurou-se, desta forma, obter uma mancha geográfica que fosse coesa e coerente, abrangendo as duas margens do rio Douro e todo o espaço a norte deste rio. A área inventariada corresponde, ao todo, a perto de $20.400 \mathrm{~km}^{2}$ (Quadro 1).

O projecto SER-NPVD incide, assim, sobre um território que, do ponto de vista administrativo, abarca oito distritos, 78 concelhos e 1.928 freguesias. Neste âmbito, o rio Douro apresenta-se como o elemento geomorfológico, dotado de inequívoca espessura histórica, que norteia a constituição desta "unidade" de estudo. Com efeito, ela compreende as áreas concelhias que se espraiam a norte do seu curso, estendendo-se até à actual linha de fronteira política com Espanha e, a sul, as que com ele confinam de modo directo.
Não se trata, pois, de um território homogéneo, mas antes de um espaço marcado por especificidades várias, notórias ao nível da grande variabilidade hipsométrica e da própria constituição geológica, o que se reflecte, necessariamente, na organização da paisagem e da ocupação humana, apenas para sinalizar alguns vectores mais impactantes. Se considerarmos, por exemplo, o relevo e, consequentemente, as altitudes atingidas em diversos pontos do espaço em análise, constatamos não apenas a existência de evidentes variáveis naturais como, em paralelo, a vigência de padrões diferenciados de implantação das sepulturas, ou mesmo a tendência para uma articulação mais reiterada de certas tipologias de estruturas com determinadas áreas geográficas. Por seu turno, a constituição geológica, ao definir o substrato rochoso predominante, teve uma evidente implicação nas diferentes modalidades de enterramentos adoptadas pelas comunidades humanas e ajuda a compreender melhor a distribuição espacial dos sepulcros.

A opção tomada teve, ainda, em atenção a área estudada por um projecto semelhante, coordenado por Catarina Tente, na Faculdade de Ciências Sociais e Humanas da Universidade Nova de Lisboa, e que estudou a região do Centro de Portugal7 7 . Desta forma, procurou-se evitar sobreposições geográficas desnecessárias. Graças a estas duas bases de dados, Portugal ficou dotado de instrumentos de pesquisa que cobrem uma parte significativa do seu espaço territorial. Esta é, julgamos nós, uma situação inédita em termos peninsulares.

Os dados obtidos pelo Projecto SER-NPVD estão disponibilizados on-line, através do link: http:// web2.letras.up.pt/citcem/sepulturas/home.

Importa sublinhar que esta plataforma de pesquisa não é encarada como um projecto encerrado. Pelo contrário, assumimos que um projecto desta natureza estará sempre em construção. Neste sentido, será assegurada a manutenção e actualização de dados na plataforma, pelo que todos os contributos serão bem-vindos. Na página do projecto encontra-se o endereço para o qual podem ser enviados novos dados, que, depois de validados, serão contemplados em actualizações futuras.

\footnotetext{
7. Cf. Pereira, 2015; Tente, 2015; Tente, 2017.
}

6. A apresentação do Projecto encontra-se em https:// www.citcem.org/projeto/36. 


\section{AS SEPULTURAS ESCAVADAS NA ROCHA DO NORTE DE PORTUGAL E DO VALE DO DOURO}

Feita a apresentação do projecto SER-NPVD e da área de estudo, procuraremos de seguida apresentar as primeiras, e ainda muito preliminares, leituras sobre as sepulturas escavadas na rocha do Norte de Portugal e do Vale do Douro. Porém, antes de avançarmos para a análise dos dados propriamente ditos, referiremos apenas algumas das opções metodológicas utilizadas na construção da base de dados que serve de suporte a estas leituras.

A base de dados é constituída por duas fichas de registo interrelacionáveis. Uma ficha é dedicada às estações arqueológicas com presença de sepulturas escavadas na rocha e a outra debruça-se especificamente sobre as características individuais de cada sepulcro. A primeira, que designámos «Ficha de $\mathrm{Ne}-$ crópole», corresponde, portanto, a uma "Ficha de Sítio» e é uma ficha única. A segunda, que chamámos "Ficha de Sepultura», corresponde a uma "Ficha de Monumento» e existem tantas quanto o número de sepulcros que integram uma determinada estação arqueológica.

A «Ficha de Necrópole» reúne as informações sobre as estações arqueológicas, procurando sistematizar os dados relativos à sua localização, ao número de sepulturas que a constituem e se são compostas apenas por sepulturas escavadas na rocha, ou se estas se associam a outras tipologias de enterramento. Para além destas características, procura também, sempre que possível, registar a tipologia de espaço funerário de cada estação e as suas relações com os elementos estruturadores do povoamento, isto é, se se relacionam directamente com locais de habitat, templos, povoados fortificados, castelos ou vias de comunicação. A sistematização dos dados relativos às estações, sobretudo a definição da tipologia de espaço funerário, seguiu o modelo preconizado por Inãki Martin Viso e que tem vindo a ser aplicado nos estudos realizados na região da Beira Alta por Catarina Tente ${ }^{8}$ e outros investigadores. Esta opção metodológica possibilitará, no futuro, a realização de leituras integradas dos espaços funerários existentes tanto a Norte, como a Sul do rio Douro, numa

8. Sobre a definição das tipologias de espaços funerários, cf. Martin Viso, 2012a, pp. 170-173. Vd. tb. Martin Viso, 2012b e Martin Viso, 2016. vasta área que se prolonga até aos contrafortes da Serra da Estrela.

A «Ficha de Sepultura», por seu turno, regista os dados arqueográficos de cada sepulcro, contendo campos destinados à recolha de informações sobre o estado de conservação, as características morfo-tipológicas, a orientação ou alinhamento geográfico e, claro, as suas dimensões.

A recolha de informação foi realizada essencialmente a partir de trabalhos académicos, cartas arqueológicas, monografias locais e relatórios arqueológicos. Recorremos também a alguns recursos on-line, como o Portal do Arqueólogo ou as Cartas Patrimoniais integrantes dos PDM's, frequentemente disponíveis para consulta nos sítios de internet dos municípios. No final de cada "Ficha de Necrópole», no campo Bibliografia, são referidos os trabalhos que serviram de base ao preenchimento dos dados. Este campo não pretende elencar toda a produção bibliográfica sobre cada estação arqueológica, às vezes muito extensa, mas apenas referir as obras utilizadas na constituição da base de dados, a partir das quais se retiraram os dados. Salvaguardou-se, assim, também a autoria científica dos elementos arrolados.

Passando para a análise breve das informações recolhidas, o levantamento bibliográfico realizado permitiu, até ao momento, identificar um conjunto de 386 estações, constituídas por 1.170 sepulcros (Mapa 1).

No que respeita ao estado de conservação, a maioria destas sepulturas preserva-se inteira, mas sem tampa (532 sepulcros, ou seja $45,5 \%$ ), enquanto que apenas 35 sepulturas conservam a respectiva tampa $(3 \%)$. As sepulturas inacabadas ascendem a 28 casos $(2,4 \%)$, fornecendo dados sobre a técnica de execução das sepulturas rupestres, ao mesmo tempo que suscitam uma rica problemática, subjacente aos motivos por que foi abandonada a sua execução. As sepulturas que foram totalmente destruídas ascendem a 91 casos ( $7,8 \%)$, as parcialmente destruídas a 180 ca$\operatorname{sos}(15,4 \%)$, enquanto que não foram localizadas 140 sepulturas $(11,9 \%)$ e 164 não eram visíveis $(14,0 \%)$. Entre as sepulturas que chegaram até nós, a grande maioria foi escavada no substrato geológico granítico, correspondendo a 294 estações $(76,2 \%)$. Este valor não deve causar admiração, porque, como se sabe, o substrato granítico é o predominante na zona estudada. A segunda mancha geológica mais significativa corresponde aos xistos. As sepulturas abertas nesta rocha metamórfica compreendem 48 
locais e constituem apenas $12,4 \%$ do total. Para a discrepância entre estes dois grupos concorre o facto de as manchas xistosas corresponderem a uma área significativamente menor do que as áreas graníticas. Por outro lado, os substratos xistosos originam terrenos mais pobres e menos produtivos que os terrenos graníticos, que, porque têm lençóis freáticos mais superficiais, dão origem a solos mais ricos e produtivos. Isto explica que as manchas xistosas sejam, sistematicamente, áreas com menor densidade populacional e, logo, menos testemunhos arqueológicos, nomeadamente funerários. Isso transparece, até, na dimensão geográfica das paróquias de uma e outra mancha geológica. Mas devemos ainda registar os problemas de conservação diferencial. Com efeito, o xisto é um suporte mais frágil e sujeito a uma maior e mais rápida erosão, o que pode ter contribuído para acentuar a desproporção percentual que se verifica entre as sepulturas abertas no granito e as escavadas no xisto, que poderia, na origem, não ser tão pronunciada. No Norte de Portugal encontramos, ainda, pequenas áreas de quartzitos e de arenitos, mas não conhecemos referências a sepulcros criados nestas rochas. De resto, saindo fora da hegemonia dos granitos e dos xistos, apenas se regista uma sepultura aberta noutro suporte - o saibro, que é, no fundo, um produto resultante da alteração do granito 9 . Registemos, por fim, a ausência de sepulcros abertos no calcário, substrato rochoso ausente no espaço considerado pelo projecto SER-NPVD, dominado pelos granitos e, em menor proporção, pelos xistos, o que contrasta, desde já, com a área do Centro de Portugal. A bibliografia consultada revelou-se omissa quanto ao suporte geológico de 44 locais onde foram abertas as restantes sepulturas (11,4\%).

As estações registadas são, na sua grande maioria, constituídas exclusivamente por sepulturas escavadas na rocha (Mapa 2). A este tipo correspondem 315 sítios (ou seja, 81,6\% do total). Todavia, em alguns casos verifica-se a convivência entre este tipo de sepulcros e outras formas de enterramento medievais, como as sepulturas delimitadas por lajes, registada em 21 sítios (5,4\%), ou os sarcófagos, como ocorre em sete estações $(1,8 \%)$, ou então com ambas as tipologias, verificando-se esta situação apenas em seis locais $(1,6 \%)$. Nos casos em que a bibliografia refere a

9. Trata-se de uma sepultura da Igreja do Bom Jesus de Gaia (CNS5832 do Portal do Arqueólogo). existência de outros tipos de enterramentos associados às sepulturas escavadas na rocha, mas que não é explícita quanto à sua tipologia, optamos por incluir estas estações no grupo "Necrópole Indeterminada". Estas situações totalizam 9,6\% das estações (37 sítios). A seu tempo estas situações poderão ser aclaradas, diminuindo-se o peso percentual destes casos. Os espaços funerários são maioritariamente constituídos por sepulturas escavadas na rocha isoladas ou integradas em núcleos de 2 a 5 sepulturas, totalizando $63,7 \%$ dos sítios (Mapa 3). No caso das sepulturas isoladas contabilizamos 121 sítios $(31,3 \%)$ e os núcleos de 2 a 5 sepulturas são 125 (32,4\%). Ou seja, confirma-se plenamente a ideia de que, no Norte de Portugal, a maioria das sepulturas escavadas na rocha aparecem isoladas ou associadas em conjuntos muito limitados, que dificilmente podem corresponder a "necrópoles" de povoados. As necrópoles constituídas por 6 a 10 monumentos correspondem a $8 \%$ do total, verificando-se a existência de 31 estações deste tipo. As necrópoles desordenadas, para usar a expressão de Iñaki Martin Viso, i.e. as que são compostas por mais de dez monumentos, em que as sepulturas se distribuem pelo espaço de uma forma aparentemente aleatória, sem estarem polarizadas em torno de edifícios de culto, implantando-se isoladas ou em pequenos núcleos, correspondem somente a $3,1 \%$ das estações (12 locais) ${ }^{10}$. No que concerne aos espaços cemiteriais associados a igrejas, verificamos que apenas $8 \%$ dos sítios inventariados se enquadram nesta tipologia (31 sítios). As situações em que não foi possível aferir claramente a tipologia de espaço funerário em que os monumentos se inserem totalizam 17,1\% e dizem respeito a 66 espaços de enterramento.

Como referimos anteriormente, as 386 estações identificadas são constituídas por 1.170 sepulcros. A grande maioria das sepulturas (730) destinava-se a receber indivíduos adultos. Contudo existem 50 sepulturas que, pelas suas dimensões, terão provavelmente sido criadas para receber inumações subadultas. Em 373 casos, o estado de conservação dos sepulcros ou a ausência de informação na bibliografia impediu aferir se os monumentos se destinavam a adultos ou a inumações subadultas.

Entre as diferentes tipologias de sepultura, as de configuração antropomórfica são as mais numerosas, contando com 525 exemplares e corresponden-

10. Cf. Martin Viso, 2012a, p. 171. 
do a $44,9 \%$ do total. As mais representativas são as que apresentam cabeceira rectangular, com 110 sepulturas $(20,9 \%)$, logo seguidas pelas de arco peraltado, com 63 exemplares (12,0\%), pelas de arco de volta perfeita, com 51 monumentos $(9,7 \%)$, e de arco ultrapassado, com 39 monumentos $(7,4 \%)$. As soluções menos frequentes são as que apresentam cabeceiras angulosas ou trapezoidais, com somente nove exemplares $(1,7 \%)$, e as cabeceiras assimétricas, apenas representadas por seis sepulcros (1,1\%). Infelizmente, o conjunto mais numeroso refere-se aos sepulcros em que não foi possível aferir de forma rigorosa a tipologia da sua cabeceira, correspondendo a 247 monumentos e a $47 \%$ do total de monumentos de contornos antropomórficos. Esperamos que, futuros desenvolvimentos desta plataforma permitam, também aqui, reduzir o peso percentual deste grupo de indefinição. Em todo o caso, afigura-se interessante constatar que os túmulos com cabeceira de arco ultrapassado surjam em quarto lugar no conjunto dos monumentos com tipologia de cabeceira definida. Registemos, ainda, um pequeno, mas significativo, grupo de túmulos antropomórficos com desnível entre a cabeceira e o corpo, criando um apoio para o occipital. Este tipo, que aparentemente corresponde ao século XI, regista-se em 48 sepulcros $(4,1 \%)$, enquanto que 325 sepulturas não apresentam qualquer desnível (27,8\%).

As sepulturas de configuração não antropomórfica representam 32,5\% do total de monumentos identificados, correspondendo a 380 sepulturas. Ou seja, grosso modo um terço dos sepulcros rupestres do Norte de Portugal corresponde a tipologias não antropomórficas. A maioria opta pelos contornos ovalados, como se observa em 139 exemplares $(36,6 \%)$, mas as sepulturas rectangulares e trapezoidais não se afastam muito destes valores, contando-se 115 exemplares das primeiras (30,3\%) e 82 das segundas $(21,6 \%)$. As sepulturas não antropomórficas cujos contornos são indeterminados totalizam 44 (11,6\%). Os sepulcros de configuração indeterminada são 265 , o que corresponde a $22,7 \%$ do conjunto das tumulações sem antropomorfismo.

A análise da distribuição das diferentes configurações das sepulturas pela tipologia de espaços funerários revela-nos que as sepulturas antropomórficas são sempre mais numerosas do que os sepulcros não antropomórficos, mantendo, porém, um certo equilíbrio representativo nos núcleos de sepulturas isoladas, nos núcleos de 2 a 5 e de 6 a 10 sepul- turas. As únicas situações em que se observa uma clara predominância de uma tipologia de sepultura sobre a outra, verifica-se nas necrópoles desordenadas e nas necrópoles associadas a templos, onde os monumentos de configuração antropomórfica predominam sobre as sepulturas que negam o antropomorfismo, sendo aproximadamente duas vezes mais numerosos (Gráfico 1). Aceitando que a polarização dos monumentos funerários em torno de templos é um acontecimento mais tardio, estes dados parecem confirmar que as tipologias não antropomórficas têm cronologias um pouco mais recuadas, embora continuem a ser utilizadas ao longo de todo o período cronológico em que se criaram sepulturas rupestres. Antes de entrarmos na análise da relação entre as estações com sepulturas escavadas na rocha e os elementos estruturadores do povoamento, como os locais de habitat, templos, fortificações ou vias de comunicação, devemos ressalvar que a bibliografia, na maioria das vezes, é omissa, não referindo directamente estas relações. Esta situação resulta do facto de, em demasiados casos, os estudos se contentarem com o estudo, de per se, das sepulturas, ignorando outros testemunhos ocupacionais, sobretudo se resumidos a vestígios arqueológicos (quer sejam cronologicamente coevos dos sepulcros, quer se situem, simplesmente, na sua proximidade física). Deste modo, e tendo em consideração que a sistematização realizada se alicerçou sobretudo em dados bibliográficos, as leituras que realizaremos de seguida deverão ser encaradas como provisórias, pois a realização de trabalhos de campo e de levantamentos arqueológicos mais sistemáticos certamente acrescentarão outras informações aos dados compilados (Quadro 2 e Mapa 4).

Feitas as devidas ressalvas, verificamos que 196 estações se encontram localizadas nas imediações de vestígios arqueológicos de habitat e/ou de templos, sendo esta associação mais frequente com os núcleos de 2 a 5 sepulcros e com sepulturas isoladas. Apesar de corresponder a apenas a pouco mais de metade das estações identificadas, o número de sepulturas que as integra é bastante elevado, sendo composto por 746 sepulcros. Mas não deixa de ser significativo, e tema para reflexão, o facto de esta associação ser tão representativa nestes grupos que correspondem a núcleos relativamente pequenos. Já vários estudos tinham sublinhado a articulação entre sepulcros isolados ou conjuntos de pequena dimensão e a matriz de povoamento, nomeadamen- 
te o cadastro de propriedades. Corresponderiam a uma fase em que os espaços de enterramento não estavam, ainda, polarizados em torno dos templos, sendo deixada às populações uma ampla margem de opção relativamente à eleição do local de sepultura.

A proximidade entre os espaços funerários e templos, áreas de habitat com templos ou a fortificações e templos corresponde a um total de 122 estações, cerca de $32 \%$, e a um conjunto de 477 sepulturas. Entre estas, as mais numerosas são as que se enquadram nas "Necrópoles associadas a templos", que correspondem a 31 estações e a 223 sepulturas e que Inãki Martin Viso relaciona com uma paisagem hierarquizada em que há uma memória comunitária gerida por uma instância de poder ${ }^{11}$.

A relação entre os sepulcros e as estruturas de cariz militar ou defensivo, como os povoados fortificados ou os castelos, tem uma representação muito pouco expressiva, resumindo-se apenas a 16 estações, constituídas no total por 6 o sepulturas. Igualmente residual é o número de locais associados exclusivamente a vias de comunicação. A implantação junto a caminhos e vias apenas se regista em 16 locais. A maioria destes espaços de enterramento é constituída por sepulturas isoladas (nove), por núcleos de 2 a 5 sepulturas (quatro casos), por núcleos de 6 a 10 sepulturas (dois casos) e por uma única necrópole desordenada. Mas, no seu conjunto totalizam apenas 55 sepulturas.

\section{PRIMEIROS RESULTADOS: LEITURAS PRELIMINARES}

Os dados apresentados sintetizam, de forma expressiva, um trabalho de prospeção e registo de uma área considerável do Norte de Portugal e do vale do Douro. Esta área geográfica, caracterizada por diferentes realidades geomorfológicas e de ocupação humana, corresponde a cerca de $23 \%$ da superfície de Portugal Continental. Nos dias de hoje, verifica-se uma maior densidade populacional na faixa atlântica, nomeadamente na região do Entre-Douro-e-Minho e um acentuado declínio demográfico nas terras do interior do país. A mesma assimetria verificar-se-ia também no decurso da Idade Média, sendo abundantes, na documentação medieval, os exemplos de atribuição de cartas de foral, de povoamento ou de privilégios a quem se fixasse no hinterland português.

11. Cf. Martin Viso, 2012, p. 172.
No total, falamos de um território com $20.388 \mathrm{~km}^{2}$, que apresenta um conjunto de 386 estações constituídas por 1.170 sepulturas escavadas na rocha. Isto equivale a um índice de 0,06 s.e.r. $/ \mathrm{km}^{2}$.

Em termos comparativos, Stuart Brookes, Catarina Tente e Sara Prata registaram no território de Viseu, e numa área de cerca de $6.150 \mathrm{~km}^{2}$, a existência de 522 estações com 1.726 sepulturas escavadas na rocha ${ }^{12}$. Corresponde a um índice de 0,28 s.e.r. $/ \mathrm{km}^{2}$, um valor bastante superior ao da região norte.

Ora, esta contabilidade coloca algumas perguntas sobre as quais importa reflectir. Desde logo, e olhando para a cartografia apresentada, notamos espaços vazios. Destes destacamos dois, procurando fundamentar essa realidade.

O primeiro é a zona costeira do território analisado, nomeadamente a região entre os rios Cávado e Ave, prolongando-se até às portas da cidade do Porto e estendendo-se para sul, para Vila Nova de Gaia, onde as estações com sepulcros rupestres são em reduzido número ou praticamente inexistentes. Na verdade, esta rarefacção ou ausência não se pode explicar por uma falta de pesquisas nesta região pois, desde cedo, ela tem merecido a atenção e o trabalho de diferentes investigadores ${ }^{13}$. Uma das causas poderá estar relacionada com a pressão urbana, bastante intensa nesta região, talvez responsável pela destruição de muitos vestígios, mesmo que nas últimas décadas, as políticas patrimoniais, enquadradas na arqueologia preventiva, tenham permitido salvaguardar muita informação. Contudo, não poderemos deixar de parte uma outra via de reflexão que explique a ausência de sepulturas escavadas na rocha em determinadas áreas, nomeadamente a opção por diferentes formas de inumação. Com efeito, a mancha geográfica das planícies do Minho, onde as sepulturas escavadas na rocha estão quase ausentes, corresponde a uma das áreas de maior densidade de sarcófagos não antropomórficos, lisos ou decorados com cruzes gregas páteas em relevo (na cabeceira e/ou nos pés), ou com os laterais apresentando decorações com arcaturas ou arquitecturas, alguns cobertos com tampas em estola, tudo materiais que correspondem ao período cronológico que se estende entre os séculos IX e XI/ XII. Neste sentido, a clara complementaridade entre a cartografia das sepulturas rupestres e a de estes sar-

12. Cf. Brookes, Tente \& Prata, 2017, p. 215.

13. Cf., por exemplo, Barroca, 1987, pp. 103-175; reeditado e actualizado em Barroca, 2010-11, pp. 115-182. 
cófagos, já realçada por um de nós, torna-se muito eloquente, revelando que, afinal, numa mesma época conviviam diferentes modalidades de enterramento, sujeitas a variabilidades de ordem geográfica e social ${ }^{14}$.

O segundo vazio evidente observa-se na região transmontana, particularmente na zona central onde, a par do relevo acidentado, sobressai o vale do rio Tua e os planaltos de Bragança e Miranda do Douro. Sobre esta extensa região faltam ainda trabalhos de investigação aprofundada, que analisem os dados existentes e acrescentem novos registos, permitindo propostas interpretativas devidamente fundamentadas. Mas parece evidente o contraste com a zona da falha tectónica Régua-Verín (que passa por Vila Real, Vila Pouca de Aguiar e Chaves), ou com o vale do Douro, a montante e a jusante do Marão ${ }^{15}$. Na região de Bragança e de Miranda os esforços têm recaído em trabalhos de levantamento, muitas vezes no âmbito da elaboração dos descritores dos planos directores municipais, integrando cartas arqueológicas onde as sepulturas escavadas na rocha são apenas mais um elemento patrimonial sumariamente mencionado e descontextualizado ${ }^{16}$. No entanto, não será apenas a escassez de trabalhos de investigação a justificar a inexistência de sepulturas escavadas na rocha. Lembramos que nesta região os solos são maioritariamente xistosos ou quartzíticos, materiais de fácil erosão, uns, ou de talhe difícil, outros, que podem ter levado as populações a procurar outras formas de enterramento. Por outro lado, as transformações económicas das últimas décadas alteraram de forma profunda a paisagem transmontana, povoando-a de extensas áreas de cultura intensiva de oliveira, castanheiros e vinha. Sabemos, por exemplo, que na região de Bragança a limpeza de largas extensões de terrenos tem destruído e danificado algum património arqueológico, onde se incluem necrópoles de variadas tipologias. Esta realidade, à qual não se poderá escapar, merece uma atenção urgente por parte das autoridades competentes e dos investigadores, de forma a ser assegurado o registo do património existente.

\footnotetext{
14. Barroca, 1987, pp. 177-251.

15. Para as sepulturas rupestres implantadas na zona da falha tectónica Régua-Verín vd. Almeida, 2009; Barroca \& Morais, 1983 e 1985-86; Teixeira, 1996; para o vale do Douro vd., entre outros, Lopes, 2002; Santos, 2005; e Guedes, 2015.

16. Para esta região vd. o estudo de Oliveira, 2020 (no prelo).
}

Uma segunda questão, que a aparente baixa densidade de sepulturas escavadas na rocha nesta região suscita, é se as comunidades terão, conscientemente, dado primazia a outras formas de enterramento, talvez mais "práticas" e económicas, como a inumação em fossas simples ou em sepulturas estruturadas com lajes ou pedras. Esta seria uma explicação válida para a falta de registos em zonas xistosas, independentemente de se registarem exemplos expressivos da sua existência, como acontece no caso da necrópole do Adro da Igreja de Mós (Torre de Moncorvo) com 39 sepulturas, das quais 21 são escavadas na rocha xistosa ${ }^{17}$, ou a necrópole da Igreja de Vila de Sinos (Mogadouro) intervencionada por Francisco Sande Lemos e Domingos dos Santos Marcos, que identificaram 69 sepulcros, tendo escavado 24 sepulturas das quais apenas oito eram escavadas exclusivamente no substrato rochoso ${ }^{18}$. Notamos que o distrito de Bragança, onde se regista um número reduzido de sepulturas escavadas na rocha, ocupa uma área de $6.608 \mathrm{~km}^{2}$, equivalente a $32 \%$ do total do território estudado e, mesmo contando com uma baixa taxa demográfica, continua a ser difícil explicar a falta de necrópoles rupestres em Trás-os-Montes. Observação idêntica poderá ser feita para a região litoral, que totaliza cerca de $7.500 \mathrm{~km}^{2}$, representado $37 \%$ do território analisado. Como já vimos, aqui o número de sepulcros rupestre é evidentemente baixo se considerarmos a densidade demográfica da região.

Voltando a analisar a cartografia, verificamos que a zona central do território estudado, correspondendo, grosso modo, ao distrito de Vila Real e Viseu, na margem sul do Douro, apresenta uma maior densidade de sepulturas escavadas na rocha, mesmo contando que se trata de uma região bastante acidentada, mas sobretudo granítica. Na verdade, se considerarmos a totalidade das estações, constatamos que cerca de $51 \%$ das sepulturas se implantam entre os 400 e os $800 \mathrm{~m}$ de altitude (Quadro 3), destacando-se as regiões de Montalegre, Vila Pouca de Aguiar e Lamego, onde existem estações a altitudes que rondam os $1.000 \mathrm{~m}$. Se os estudos conseguissem associar estas necrópoles aos elementos estruturadores do povoamento, como os locais de habitat, templos, fortificações ou vias de comunicação, poderíamos ter respostas para possíveis modelos de

17. Perpétuo, 2010.

18. Lemos e Marcos, 1985, pp. 142-143. 
assentamento, podendo, ao mesmo tempo, aferir de forma mais precisa cronologias para estes monumentos funerários.

Paralelamente a esta zona central, o vale do Douro, especialmente a margem direita, correspondente grosso modo aos concelhos de Penafiel, Marco de Canaveses, Amarante e Baião, agrupa um número considerável de sepulturas escavadas na rocha, existindo uma concentração bastante expressiva no curso final do rio Tâmega. Aqui as cotas de implantação das necrópoles são mais baixas e terão privilegiado zonas junto a possíveis áreas de exploração agrícola.

Efectivamente, a representação cartográfica demonstra que as necrópoles de sepulturas escavadas na rocha foram construídas preferencialmente ao longo das bacias hidrográficas, sobretudo ao longo dos cursos de água mais significativos, como os já referidos Douro e Tâmega, mas também dos rios Lima, Corgo, Tua e Sabor. A distribuição destes núcleos sepulcrais não obedece, aparentemente, a um padrão específico, pois nos rios Lima, Tâmega e Sabor existe uma maior concertação na zona terminal dos rios, enquanto que nos rios Douro e Corgo há uma "distribuição" ao longo das suas bacias, parecendo evitar-se as zonas da foz. O que parece claro é o facto de as linhas de água serem eixos estruturantes do território medieval, essenciais para a fixação de comunidades, mas também guias de orientação territoriais, onde o Douro tinha um papel primordial.

Finalmente, e porque o espaço de publicação nos obriga a ser sintéticos, importa atentar nas características gerais dos núcleos sepulcrais rupestres e questionarmo-nos sobre a sua relação com as estruturas de povoamento.

Os registos actuais dizem-nos que os espaços funerários são maioritariamente constituídos por sepulturas escavadas na rocha isoladas ou integradas em núcleos de 2 a 5 sepulturas, totalizando $63,7 \%$ dos sítios. No caso das sepulturas isoladas contabilizamos 121 sítios (31,3\%) e os núcleos de 2 a 5 sepulturas são $125(32,4 \%)$. As necrópoles constituídas por 6 a 1o monumentos correspondem a $8 \%$ do total, verificando-se a existência de 31 estações deste tipo. Estes são os dados. Se os pensarmos relacionados com o povoamento, e independentemente da sua distribuição geográfica e da sua cronologia, ocorrem-nos determinadas interrogações que o avanço da investigação pode aclarar.

Vejamos, por exemplo, as sepulturas isoladas e os pequenos grupos de 2 a 5 sepulturas, conjunto até agora maioritário. Que tipo de povoamento definem? Isolado, próprio de comunidades com alguns recursos económicos, que vivem da exploração agrícola, em zonas profundamente parceladas e trabalhadas por dependentes? Ou concentrado, em pequenas comunidades familiares (ou não), talvez "independentes", mas ligadas entre si por fortes laços de solidariedade, que garantiam a sobrevivência do grupo? E como se articularia cada uma destas comunidades com os locais de culto? Teriam "igreja própria" ou estavam agregadas em paróquias mais amplas que, pela sua extensão territorial, permitiam a existência de vários espaços de enterramento no interior do seu âmbito geográfico? Sendo assim, a escolha de local de sepultura, próximo dos seus, seria uma opção preferível? Para os pequenos proprietários, seria uma forma de legitimação de direitos fundiários? Temos vários indícios, ao longo da plena Idade Média, de que a presença de sepulcros de antepassados foi encarada como forma de sancionar direitos hereditários...

As inumações junto a templos são facilmente compreensíveis para comunidades, talvez mais numerosas, multifamiliares, concentradas em povoações que exploram determinado território sob orientação de um poder. Este tipo de assentamento deu origem a núcleos sepulcrais mais extensos. Mas eles são relativamente raros na zona que estudámos. Esta observação tem evidente implicação cronológica. Significa que a implantação do modelo paroquial resultante da reforma gregoriana - que impôs que, dentro do espaço de uma paróquia, existisse um único templo apto a ministrar os sacramentos de passagem (baptismo, casamento, funeral), que existisse um único ministro da Igreja apto para os ministrar (o pároco), que existisse um único templo com pia baptismal e que existisse um único espaço de enterramento (o adro da igreja) - surgiu numa fase em que a "moda" das sepulturas escavadas na rocha estava a entrar em declínio. Por isso, os exemplos de necrópoles rupestres estruturadas em torno de adros de templos paroquiais parece ser uma opção residual. E, pelo contrário, as sepulturas estruturadas com lajes, são muito mais comuns. A menos que, futuras intervenções arqueológicas venham aduzir novos dados para esta problemática...

Outro aspecto interessante relaciona-se com a personalização, ou não, dos enterramentos. Já muitos autores sublinharam o anonimato das sepulturas rupestres, para as quais não se conhece qualquer 
exemplo de epitáfio ${ }^{19}$. Esta aparente ausência de preocupação em registar a identidade do defunto poderá estar relacionada com o facto de, nessa altura, ainda não se ter difundido o conceito que atribuía às orações o poder de intercessão no destino das almas no Além. Isso implica aceitar que, durante uma boa parte do período em que se criaram sepulturas rupestres, ainda não haveria comemorações obituárias por alma do defunto, e portanto, como não se tinha de ir sobre a sua sepultura, esta apresentava-se despida de elementos identificadores. Mas existe um pequeno conjunto de sepulcros que começam a denunciar a preocupação de o individualizar. Referimo-nos às sepulturas escavadas na rocha que apresentam encaixes para estelas discoides. Na zona que estudámos isso ocorre em 10 casos (nove com encaixe para uma estela, na zona da cabeceira; um com duplo encaixe, na cabeceira e pés). O seu valor percentual é insignificante ( $0,9 \%)$, mas a sua importância é grande.

Um último, e necessariamente breve, apontamento para analisar a problemática em torno da orientação dos sepulcros. Este é um tema complexo, que não podemos explorar integralmente neste traba1ho. O quadro que apresentamos de seguida (Quadro 4) sistematiza os principais dados alcançados, subdividindo-os por quadrantes de orientação dos sepulcros. Subdividimos os $360^{\circ} \mathrm{em}$ oito categorias - os quatro pontos cardiais e os seus pontos intermédios - obtendo, assim, grupos com $45^{\circ}$ de amplitude. Subdividimos cada grupo pelo ponto médio com o precedente e o seguinte. Ou seja, consideramos como quadrante Norte todos os valores obtidos entre os $337,6^{\circ}$ e os $22,5^{\circ}$, tendo como valor médio os $\mathrm{O}^{\circ}$ equivalentes a Norte. $\mathrm{E}$ assim sucessivamente. Esta sistematização - que não impede que os dados precisos, sempre que eles existam, estejam arrolados na Base de Dados - permitiu definir grandes categorias, tornando-as comparáveis. Como se pode verificar, a maioria das sepulturas escavadas na rocha encontra-se orientada com cabeceira voltada para Oeste (244 exemplos, 21\%). Há um conjunto, igualmente significativo, de sepulcros com a cabeceira orientada para o quadrante de Noroeste (111 sepulcros, 10\%). O que significa que, se tivermos em consideração a oscilação do curso solar ao longo do ano, entre os dois solstícios, teremos mais de um terço das sepulturas cultualmente orientadas. Este dado é interessante porque, como se sabe, a Igreja só muito tardiamente justificou a orientação do sepulcro cristão. O que quer dizer que este hábito se afirmou independentemente das directrizes da hierarquia da Igreja. Mas é igualmente muito expressivo o grupo de sepulcros que tem uma orientação diametralmente oposta, ou seja, que apresenta a cabeceira orientada para Leste (são 159 sepulturas, equivalentes a 14\%). É mesmo o segundo alinhamento mais comum no Norte de Portugal e Vale do Douro. Esta orientação sepulcral inversa pode ter implicações religiosas e/ou sociais. Já vários autores sugeriram que ela seria um sintoma de práticas sociais marginais, condenadas pela sociedade e pela Igreja. As mesmas que levariam à inumação em decubito prono, em vez da prática, esmagadoramente predominante, do enterramento em decubito supino. Mas não temos dados seguros para defender esse tipo de interpretações, que mais não passam de hipóteses. Poderiam ser, quiçá, o resultado de alguma confusão no conceito da orientação cultual do enterramento, optando-se por colocar a cabeça voltada para Leste, para Jerusalém. O que merece ser sublinhado é que as orientações pelo curso solar - seja com a cabeceira voltada para Oeste, seja com a cabeceira virada para Leste - são claramente predominantes. E que as orientações diametralmente opostas - viradas para Norte ou para Sul - parecem corresponder a uma franja marginal, quase inexpressiva (com 5 e $3 \%$, respectivamente). Vale a pena, igualmente, cruzar os dados da orientação dos sepulcros com os indicadores tipológicos. Aqui, encontramos um persistente equilíbrio: $52,9 \%$ das sepulturas orientadas para Oeste são antropomórficas, e 35,7\% são não antropomórficas; $57,2 \%$ das sepulturas orientada para Leste são antropomórficas, e 33,3\% são não antropomórficas. Confessamos que a nossa impressão era que o conjunto de sepulturas não antropomórficas seria mais receptivo a ter orientações não cultuais, e o que estes dados nos revelam é que o comportamento é sensivelmente equivalente. Por fim, registemos que estes dados ajudam a sublinhar a necessidade de se registar, com rigor, a orientação axial de todos os sepulcros, não apenas numa orientação genérica, por quadrante, mas em graus, com recurso a bússola. Só esses dados permitem tratamento mais fino.

19. Barroca, 2010, p. 437. 


\section{CONCLUSÃO}

Com a implementação do projecto "Sepulturas Escavadas na Rocha do Norte de Portugal e do Vale do Douro" começou a ser construído um novo instrumento de pesquisa que, conforme previamente explicitado, se articula com um outro, em curso, para o Centro do território português. Focados, pois, em áreas geográficas distintas, assumem-se, a este nível, como complementares, mas simultaneamente, como potenciadores de leituras não necessariamente coincidentes ou unívocas.

Com efeito, a própria mancha de ocorrências inventariadas e cartografadas denota variáveis expressivas em termos quantitativos, circunstância que é em si mesma ilustrativa da ausência de um padrão único de implementação e, eventualmente, até da existência de graus distintos de adesão a este tipo singular de prática funerária.

Todavia, também os dados recolhidos no âmbito do projecto SER-NPVD, e que sumariamente se apresentam e discutem nos pontos 3 e 4 deste texto, evidenciam a vigência de assimetrias no próprio interior do território em análise. Assimetrias que, como demonstrado, poderão estar correlacionadas com múltiplos factores, naturais e humanos, em si mesmos igualmente indissociáveis. Consideremos, por exemplo, as especificidades do substrato geológico, do relevo, a proximidade de cursos fluviais ou de vias, ou a articulação das áreas de habitat com um eventual templo agregador da comunidade. Vectores que, necessariamente, se impõe examinar e articular não apenas com as particularidades morfológicas dos enterramentos, mas também com a prevalência das ocorrências documentadas: isoladas, em núcleos de 2 a 5 sepulturas ou integradas em efectivas necrópoles.

A compilação dos dados que têm vindo a ser recolhidos não é isenta de constrangimentos. De facto, e apenas para retomar um dos pontos já evocados, a bibliografia disponível e sistematicamente consultada espelha uma ampla diversidade de inquéritos e métodos de abordagem ao terreno, os quais, inevitavelmente, condicionam a própria profundidade e pormenor das informações veiculadas. De igual modo, a existência de programas de investigação direccionados para unidades geográficas específicas é susceptível de permitir um arrolamento rigoroso das sepulturas rupestres conservadas, potenciando um mapeamento numericamente significativo.
Em contrapartida, os "vazios" detectados poderão, ou não, reflectir uma efectiva ausência ou escassez deste tipo de testemunho material. Não obstante, e sendo certo que a construção das bases de dados do projecto SER-NPVD configura um desafio a vários níveis, inclusivamente também devido à extensão do território por ele abarcado, não temos dúvidas de que representa também um veículo determinante para a abertura de possibilidades de análise, questionamento e interpretação de um fenómeno ainda insuficientemente compreendido e que, neste sentido, continua a interpelar os investigadores.

\section{BIBLIOGRAFIA}

ALMEIDA, Joana Filipa Tuna de (2009) - Sepulturas escavadas nas rochas no Concelho de Vila Real. In Tellus. Vila Real. 50, pp. 39-68.

AREZES, Andreia (2020) - Sepulturas escavadas na rocha no curso inferior da bacia do rio Lima. O concelho de Viana do Castelo em perspectiva. In M. J. Barroca (Coord.), Congresso Internacional Sepulturas escavadas na rocha na Fachada Atlântica da Península Ibérica. Porto. CITCEM (no prelo).

BARROCA, Mário Jorge; MORAIS, António J. C. (1983) Sepulturas Medievais na Terra de Aguiar da Pena (Vila Pouca de Aguiar). In Arqueologia. 8, pp. 92-102.

BARROCA, Mário Jorge; MORAIS, António J. C. (1985-86) - A Terra e o Castelo. Uma experiência arqueológica em Aguiar da Pena. In Portvgalia. Porto. 6-7, pp. 35-88.

BARROCA, Mário Jorge (1987) - Necrópoles e Sepulturas Medievais de Entre-Douro-e-Minho (Séculos V a XV). Porto: Faculdade de Letras da Universidade do Porto.

BARROCA, Mário Jorge (2010) - Memórias. In J. Mattoso (Dir. de) e B. V. Sousa (Coord. de), História da Vida Privada em Portugal. vol. 1. Lisboa, Círculo de Leitores, pp.418-456.

BARROCA, Mário Jorge (2010-2011) - Sepulturas escavadas na rocha de Entre Douro e Minho. In Portvgalia. Porto. 31-32, pp. 115-182.

BARROCA, Mário Jorge (2020) - Os estudos sobre sepulturas escavadas na rocha em Portugal, trinta anos depois. In M. J. Barroca (Coord.), Congresso Internacional Sepulturas escavadas na rocha na Fachada Atlântica da Península Ibérica. Porto. CITCEM (no prelo).

BROOKES, Stuart; TENTE, Catarina; PRATA, Sara (2017) - Interpreting Rock-Cut Grave Cemeteries: The Early Medieval Necropolis and Enclosure of São Gens, Portugal. In Medieval Archaeology. 61:2, pp. 215-238. DOI: 10.108o/oo766 097.2017.1374093.

GUEDES, César (2015) - A sul do Douro: percurso pelas sepulturas escavadas na rocha entre os rios Távora e Cabrum. Porto: Faculdade de Letras da Universidade do Porto, Porto. Tese de Mestrado. 
GUEDES, César (2020) - As sepulturas escavadas na rocha entre os rios Távora e Cabrum. Tipologias, implantação e as leituras possíveis do território. In M. J. Barroca (Coord.), Congresso Internacional Sepulturas escavadas na rocha na Fachada Atlântica da Península Ibérica. Porto. CITCEM (no prelo).

LEMOS, Francisco Sande (1993) - Povoamento Romano de Trás-os-Montes Oriental. Braga: Universidade do Minho. Tese de Doutoramento.

LEMOS, Francisco Sande e MARCOS, Domingos dos Santos (1985) - A necrópole medieval de Vila dos Sinos - Mogadouro Segunda Campanha de Escavações, 1982. In Cadernos de Arqueologia. Braga: Unidade de Arqueologia da Universidade do Minho - Museu D. Diogo de Sousa. Série II, Vol. 2. pp. 127-156.

LOPES, Isabel Alexandra Resende Justo (2002) - Contextos Materiais da Morte durante a Idade Média: as Necrópoles do Douro Superior. Porto: Faculdade de Letras da Universidade do Porto. Tese de Mestrado.

MARTIN VISO, Iñaki (2012a) - Enterramientos, memoria social y paisaje en la alta edad media: propuestas para un análisis de las tumbas excavadas en roca en el centro oeste de la Península Ibérica. In Zephyrus. LXIX, pp. 165-187.

MARTIN VISO, Iñaki (2012b) - Paisajes sagrados, paisajes eclesiásticos: de la necrópolis a la parroquia en el Centro de la Península Ibérica. In Reti Medievali Rivista. 13(2). Firenze, pp. 2-45 (disponível em http://rivista.retimedievali.it).

MARTIN VISO, Iñaki (2016) - Comunidades locales, lugares centrales y espácios funerários en la Extremadura del Duero medieval: Las necrópolis de tumbas excavadas en la roca alienadas. In Anuário de Estudios Medievales. Barcelona. 46(2). pp. 859-897.
OLIVEIRA, Ana Maria (2020) - Sepulturas escavadas na rocha da região de Bragança: contributo para o estudo do povoamento medieval. In M. J. Barroca (Coord.), Congresso Internacional Sepulturas escavadas na rocha na Fachada Atlântica da Península Ibérica. Porto. CITCEM (no prelo).

PEREIRA, Sofia (2015) - Inventário e Georreferenciação do mundo funerário rupestre no Centro de Portugal. Lisboa, UNL-FCSH. Relatório de Estágio.

PERPÉTUO, João Miguel André (2010) - Adro da Igreja de Mós - Escavação Arqueológica, Preservação e Acondicionamento (Mós-Torre de Moncorvo). Viseu: Arqueohoje Lda. Relatório policopiado.

SANTOS, Maria José Ferreira dos (2005) - A Terra de Penafiel na Idade Média. Estratégias de Ocupação do Território (875-1308). In Cadernos do Museu. Penafiel: Museu Municipal de Penafiel. 10.

TENTE, Catarina (2015) - Tumbas rupestres en el Alto Mondego (Guarda, Portugal). Patrones de distribución, significados y construcción del paisaje rural altomedieval. In Munibe Antropologia-Arkeologia. Bilbao. 66, pp. 271-29o.

TENTE, Catarina (2017) - Rock-cut graves and cemeteries in the medieval rural landscape of the Viseu region (central Portugal). In C. Theune-Vogt e C. Bis-Worch (Eds.), Religious places, cult and rituals in medieval rural environment, Leiden. pp. 215-226.

TEIXEIRA, Ricardo (1996) - De Aquae Flaviae a Chaves. Povoamento e organização do território entre a Antiguidade e a Idade Média. Porto: Faculdade de Letras da Universidade do Porto. Tese de Mestrado. 


\begin{tabular}{|c|c|c|c|}
\hline Distrito & Municípios & Freguesias ${ }^{*}$ & Área \\
\hline Viana do Castelo & $\begin{array}{l}\text { 1o (Arcos de Valdevez; Caminha; Melgaço; Monção; Paredes } \\
\text { de Coura; Ponte da Barca; Ponte de Lima; Valença do Minho; } \\
\text { Viana do Castelo; Vila Nova de Cerveira) }\end{array}$ & 290 & $2.255 \mathrm{~km}^{2}$ \\
\hline Braga & $\begin{array}{l}14 \text { (Amares; Barcelos; Braga; Cabeceiras de Basto; Celorico de Basto; } \\
\text { Esposende; Fafe; Guimarães; Póvoa de Lanhoso; Terras de Bouro; } \\
\text { Vieira do Minho; Vila Nova de Famalicão; Vila Verde; Vizela) }\end{array}$ & 519 & $2.706 \mathrm{~km}^{2}$ \\
\hline Porto & $\begin{array}{l}18 \text { (Amarante; Baião; Felgueiras; Gondomar; Lousada; Maia; Marco } \\
\text { de Canaveses; Matosinhos; Paços de Ferreira; Paredes; Penafiel; Porto; } \\
\text { Póvoa de Varzim; Santo Tirso; Trofa; Valongo; Vila do Conde; Vila } \\
\text { Nova de Gaia) }\end{array}$ & 393 & $2.395 \mathrm{~km}^{2}$ \\
\hline Vila Real & $\begin{array}{l}14 \text { (Alijó; Boticas; Chaves; Mesão Frio; Mondim de Basto; Montalegre; } \\
\text { Murça; Peso da Régua; Ribeira de Pena; Sabrosa; Santa Marta de } \\
\text { Penaguião; Valpaços; Vila Pouca de Aguiar; Vila Real) }\end{array}$ & 268 & $4.328 \mathrm{~km}^{2}$ \\
\hline Bragança & $\begin{array}{l}12 \text { (Alfândega da Fé; Bragança; Carrazeda de Ansiães; Freixo de } \\
\text { Espada à Cinta; Macedo de Cavaleiros; Miranda do Douro; Mirandela; } \\
\text { Mogadouro; Torre de Moncorvo; Vila Flor; Vimioso; Vinhais) }\end{array}$ & 299 & $6.608 \mathrm{~km}^{2}$ \\
\hline Aveiro & 2 (Castelo de Paiva e, de Santa Maria da Feira, apenas a freg. de Canedo) & 10 & $144 \mathrm{~km}^{2}$ \\
\hline Viseu & 6 (Armamar; Cinfães; Lamego; Resende; S. João da Pesqueira; Tabuaço) & 115 & $1.045 \mathrm{~km}^{2}$ \\
\hline Guarda & 2 (Figueira de Castelo Rodrigo; Vila Nova de Foz Côa) & 34 & $907 \mathrm{~km}^{2}$ \\
\hline TOTAIS & 78 & 1.928 & $20.388 \mathrm{~km}^{2}$ \\
\hline
\end{tabular}

Quadro 1

* Para o SER-NPVD consideramos a organização administrativa anterior à reforma de 2013, pelo facto de ela se aproximar mais da organização paroquial medieval. Por isso, o número de freguesias apresenta-se mais elevado do que o actualmente em vigor.

\begin{tabular}{|c|c|c|c|c|c|c|c|c|c|c|c|}
\hline \multirow[b]{2}{*}{ Espaço Funerário } & \multicolumn{11}{|c|}{ Articulação com a paisagem } \\
\hline & 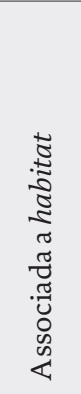 & 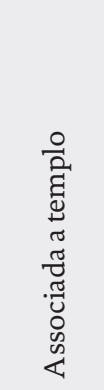 & 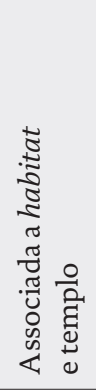 & 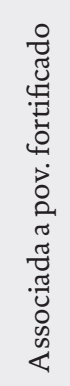 & 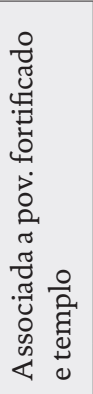 & 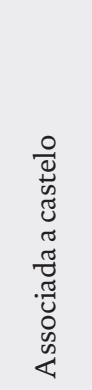 & 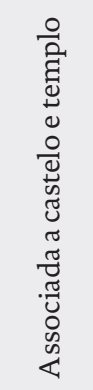 & 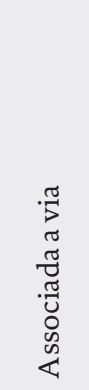 & 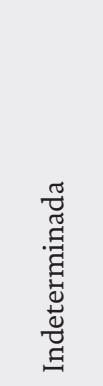 & Total & $\%$ \\
\hline Sepultura isolada & 19 & 19 & 6 & 1 & 2 & $\mathrm{o}$ & 1 & 9 & 64 & 121 & $31,3 \%$ \\
\hline N. de 2 a 5 sepulturas & 44 & 17 & 10 & o & 2 & o & 2 & 4 & 46 & 125 & $32,4 \%$ \\
\hline N. de 6 a 10 sepulturas & 14 & 4 & 2 & 1 & o & 1 & $\mathrm{o}$ & 2 & 7 & 31 & $8 \%$ \\
\hline Nec. Desordenada & 2 & 3 & 1 & o & o & $\mathrm{o}$ & 1 & 1 & 4 & 12 & $3,1 \%$ \\
\hline Nec. associada a templo & - & 27 & 3 & o & o & o & 1 & o & o & 31 & $8 \%$ \\
\hline Indeterminado & 6 & 12 & 7 & 2 & 1 & o & 1 & o & 37 & 66 & $17,1 \%$ \\
\hline Total & 85 & 82 & 29 & 4 & 5 & 1 & 6 & 16 & 158 & 386 & $100 \%$ \\
\hline$\%$ & $22 \%$ & $21,2 \%$ & $7,5 \%$ & $1 \%$ & $1,3 \%$ & $0,3 \%$ & $1,6 \%$ & $4,1 \%$ & $40,9 \%$ & $100 \%$ & \\
\hline
\end{tabular}

Quadro 2 


\begin{tabular}{|l|c|c|}
\hline Altitude & N.. de Estações & Percentagem \\
\hline o-99 m & 22 & $5,7 \%$ \\
\hline $100-199 \mathrm{~m}$ & 33 & $8,5 \%$ \\
\hline $200-299 \mathrm{~m}$ & 34 & $8,8 \%$ \\
\hline $300-399 \mathrm{~m}$ & 35 & $9,1 \%$ \\
\hline $400-499 \mathrm{~m}$ & 27 & $7,0 \%$ \\
\hline $500-599 \mathrm{~m}$ & 45 & $11,7 \%$ \\
\hline $600-699 \mathrm{~m}$ & 74 & $19,2 \%$ \\
\hline $700-799 \mathrm{~m}$ & 50 & $13,0 \%$ \\
\hline $800-899 \mathrm{~m}$ & 24 & $6,2 \%$ \\
\hline $900-999 \mathrm{~m}$ & 12 & $3,1 \%$ \\
\hline$>1000 \mathrm{~m}$ & 6 & $1,6 \%$ \\
\hline Ind. & 24 & $6,2 \%$ \\
\hline Total & 386 & $100,0 \%$ \\
\hline
\end{tabular}

Quadro 3

\begin{tabular}{|l|c|c|c|c|c|}
\hline Orientação & Antropomórficas & Não Antropomórficas & Indeterminadas & Total & $\%$ \\
\hline $\mathrm{N}\left(337,6^{\circ}-22,5^{\circ}\right)$ & 28 & 24 & 1 & 53 & $5 \%$ \\
\hline $\mathrm{NE}\left(22,6^{\circ}-67,5^{\circ}\right)$ & 11 & 37 & 2 & 50 & $4 \%$ \\
\hline $\mathrm{E}\left(67,5^{\circ}-112,5^{\circ}\right)$ & 91 & 53 & 15 & 159 & $14 \%$ \\
\hline $\mathrm{SE}\left(112,6^{\circ}-157,5^{\circ}\right)$ & 7 & 16 & 0 & 23 & $2 \%$ \\
\hline $\mathrm{S}\left(157,6^{\circ}-202,5^{\circ}\right)$ & 17 & 14 & 3 & 34 & $3 \%$ \\
\hline $\mathrm{SW}\left(202,6^{\circ}-247,5^{\circ}\right)$ & 41 & 27 & 28 & 72 & $6 \%$ \\
\hline $\mathrm{W}\left(247,6^{\circ}-292,5^{\circ}\right)$ & 129 & 87 & 1 & 244 & $21 \%$ \\
\hline $\mathrm{NW}\left(292,6^{\circ}-337,5^{\circ}\right)$ & 62 & 48 & 211 & 411 & $10 \%$ \\
\hline Indeterminada & 139 & 74 & 265 & 1170 & $100 \%$ \\
\hline Total & 525 & 380 & & & $36 \%$ \\
\hline
\end{tabular}

Quadro 4

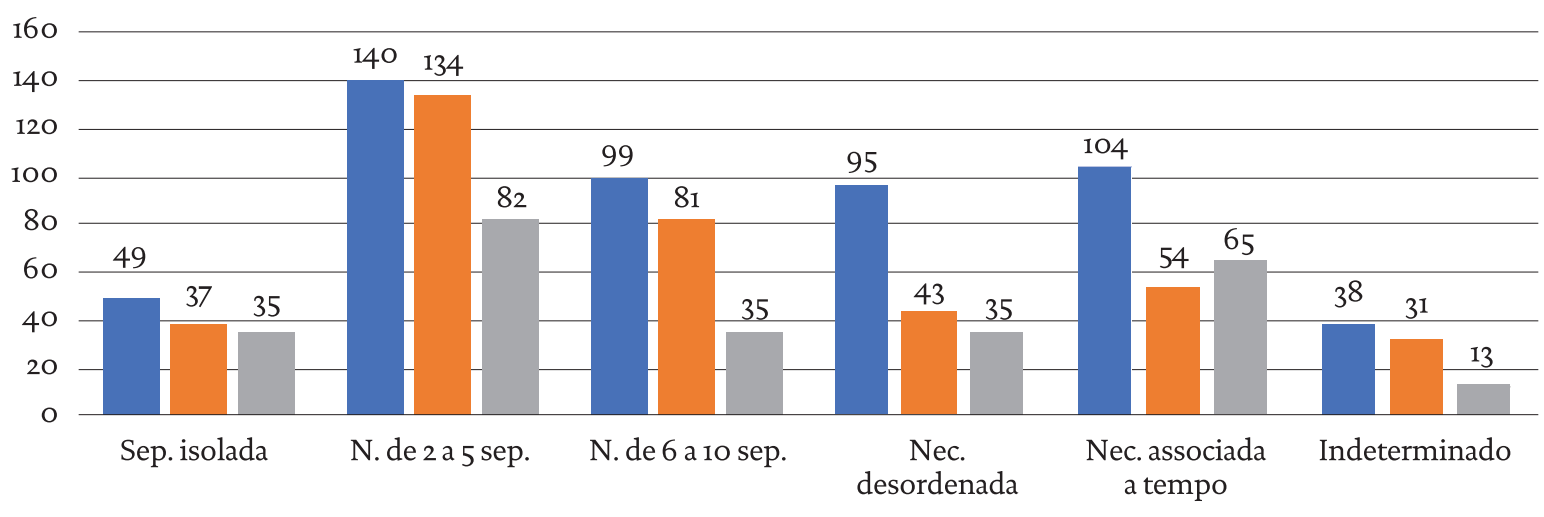

antropomórfica $\quad$ Não antropomórfica $\quad$ Indeterminada

Gráfico 1 - Distribuição das diferentes tipologias de sepultura pelos espaços funerários. 


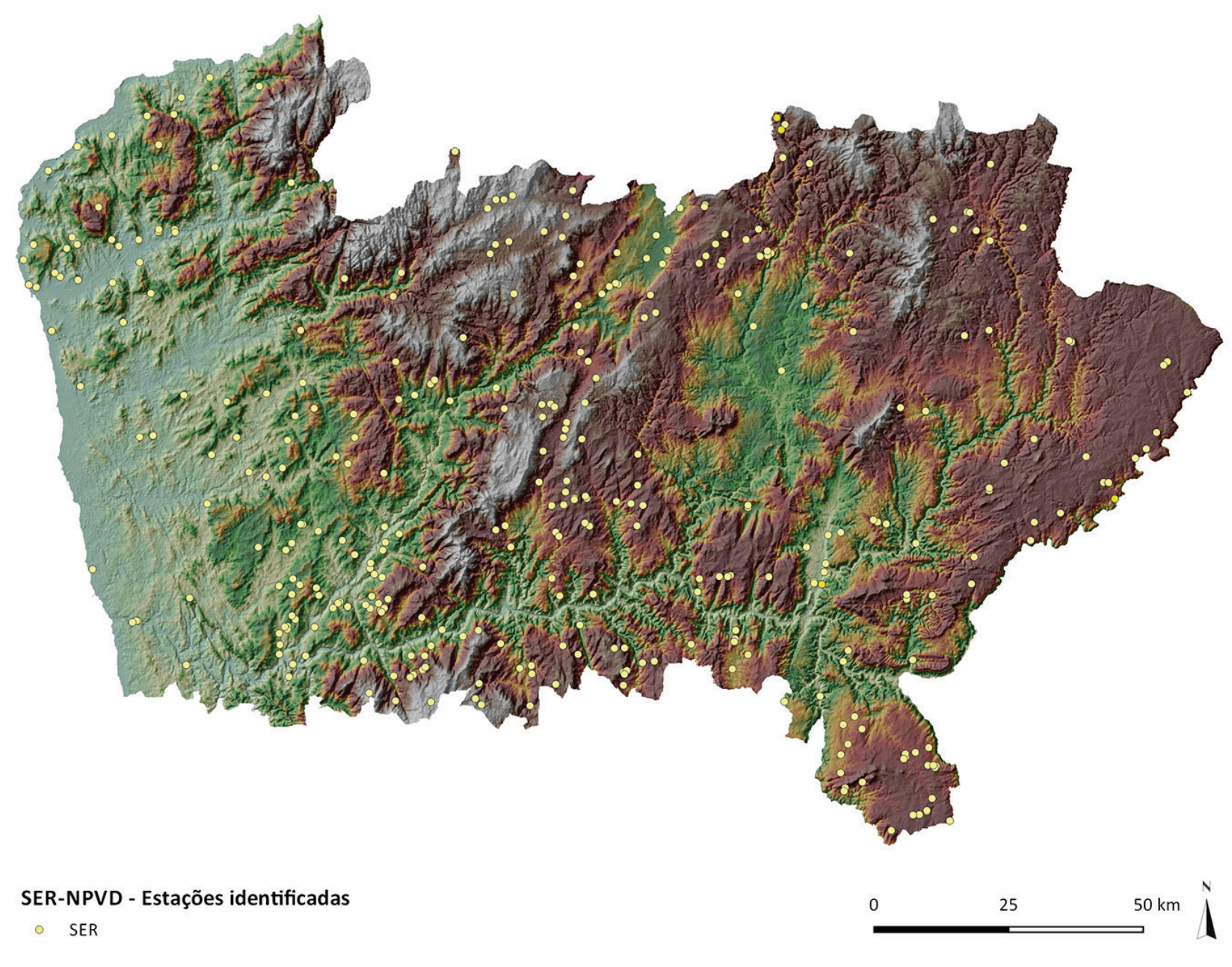

Mapa 1 - Área de estudo e distribuição das estações identificadas no âmbito do SER-NPVD. Autor: César Guedes. 


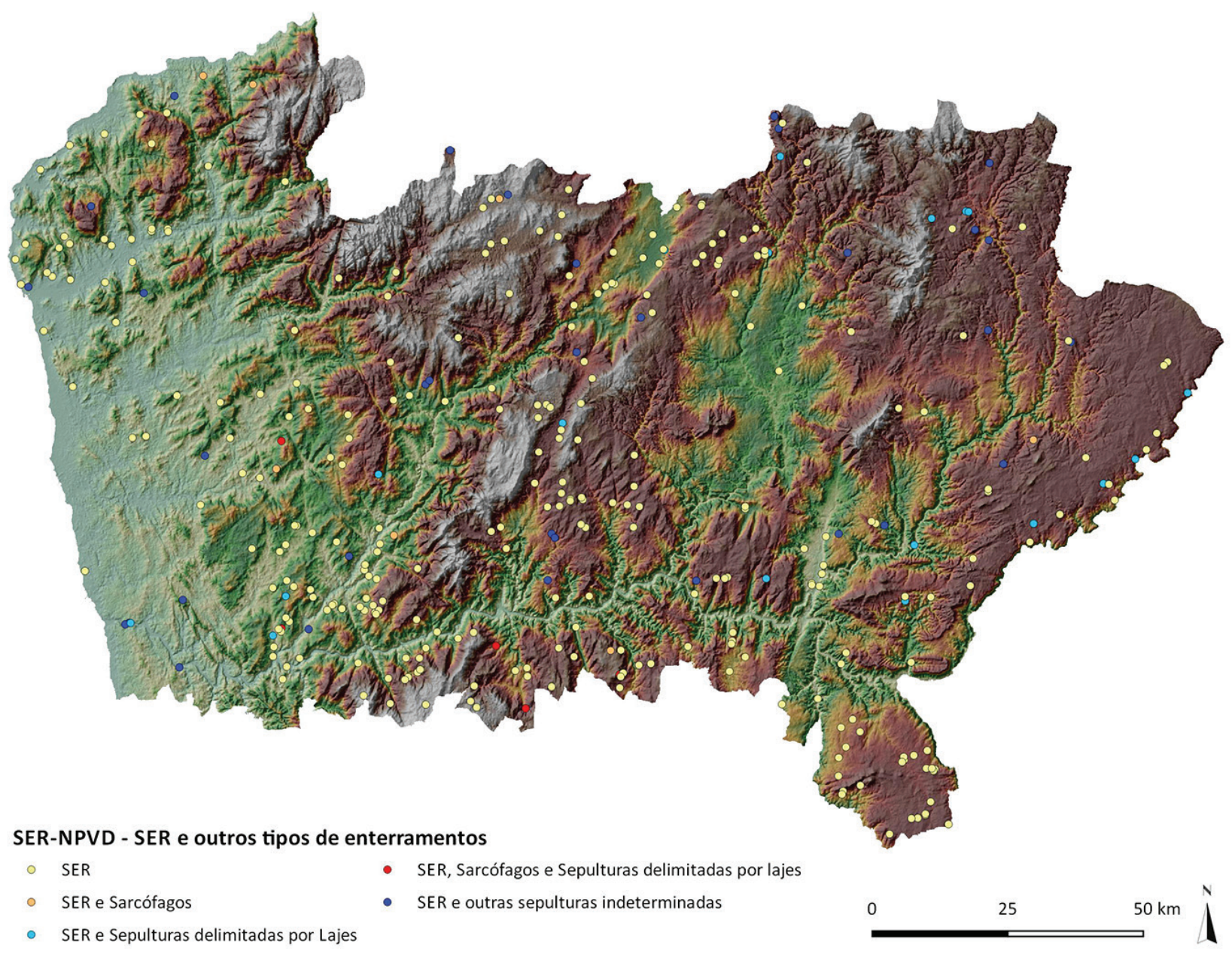

Mapa 2 - Distribuição das estações com sepulturas escavadas na rocha e outros tipos de enterramentos. Autor: César Guedes. 


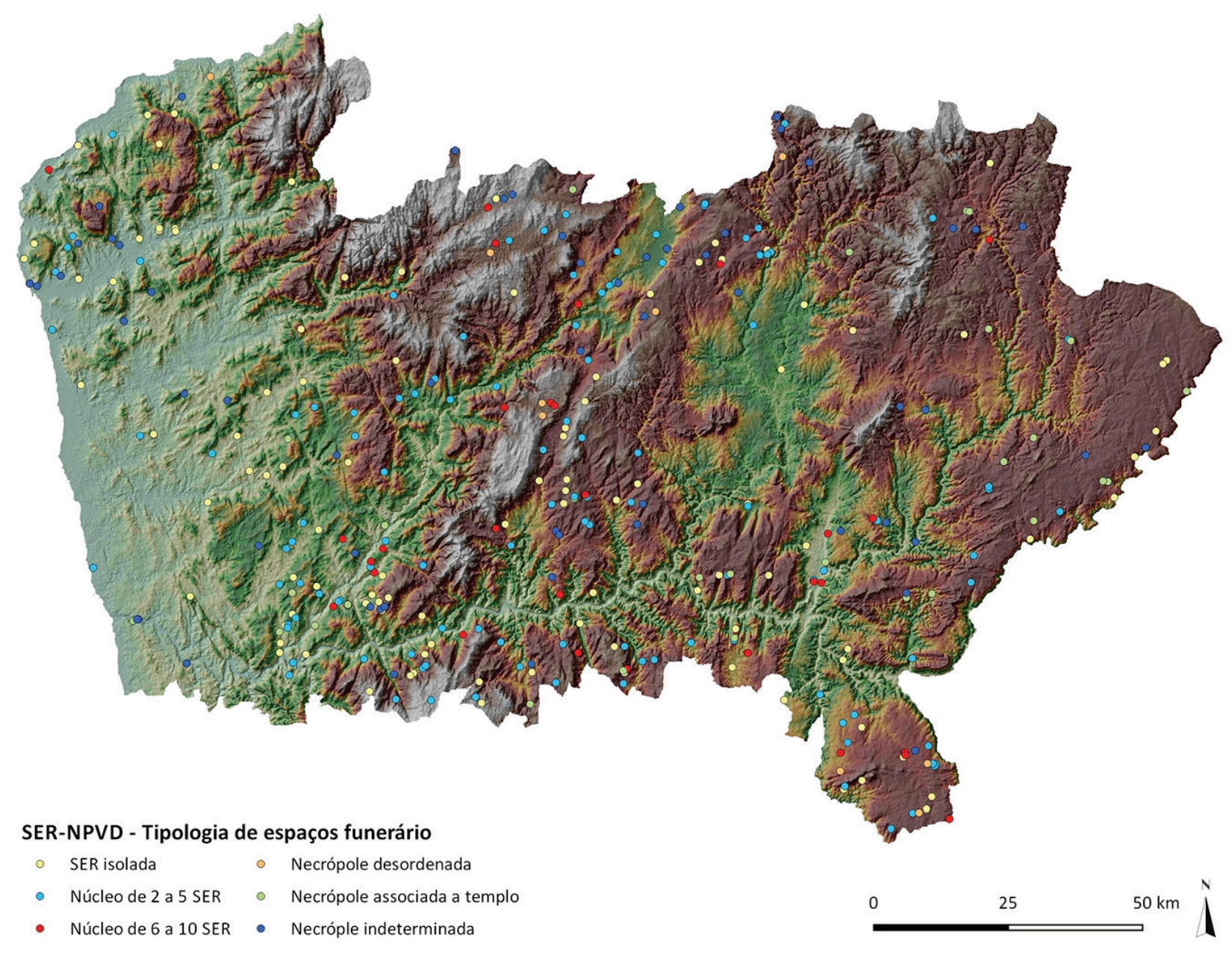

Mapa 3 - Tipologia dos espaços funerários. Autor: César Guedes. 


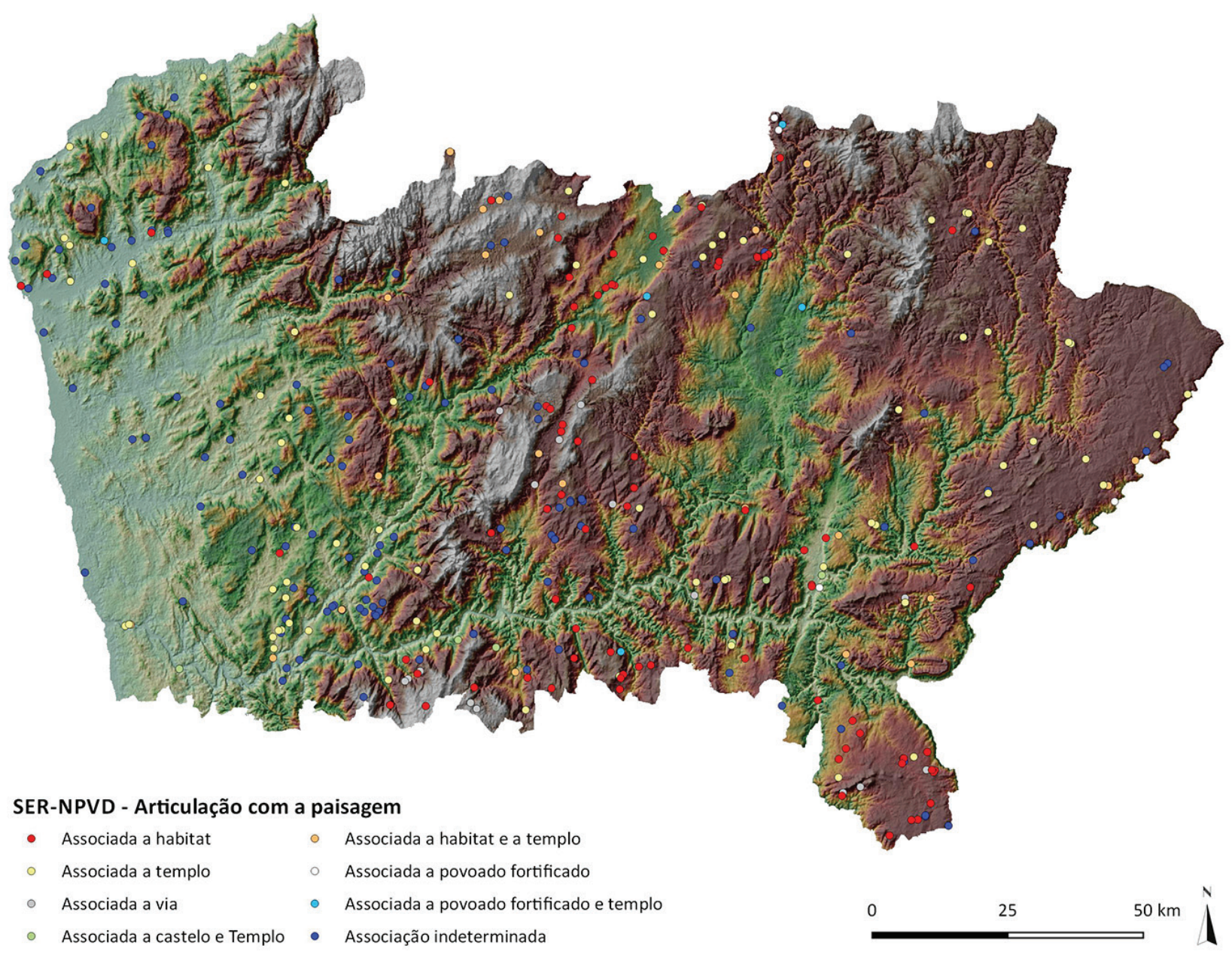

Mapa 4 - Articulação entre as estações com sepulturas escavadas na rocha e a paisagem. Autor: César Guedes. 


\title{
"PORTUCALEM CASTRUM NOVUM" ENTRE O MEDITERRÂNEO E O ATLÂNTICO: O ESTUDO DOS MATERIAIS CERÂMICOS ALTO-MEDIEVAIS DO ARQUEOSSÍTIO DA RUA DE D. HUGO, $N^{\circ} \cdot 5$ (PORTO)
}

João Luís Veloso ${ }^{1}$

\begin{abstract}
RESUMO
Apresentamos neste artigo objetivos, metodologia e alguns resultados preliminares do trabalho que, desde 2019, temos vindo a desenvolver no âmbito da nossa tese de Mestrado. Concretamente, fazemos um resumo da primeira fase do estudo, que incidiu na classificação da coleção de cerâmica comum proveniente dos níveis ocupacionais alto-medievais do arqueossítio da rua de D. Hugo, $\mathrm{n}^{\circ} 5$, localizado em pleno centro histórico da cidade do Porto.
\end{abstract}

Palavras-chave: Arqueologia Urbana, Noroeste Peninsular, Período Suevo-Visigótico, Cerâmica Comum.

\begin{abstract}
In the following article, we present the objectives, methodology, and preliminary results of the work that, since 2019, we have been developing in the context of our Master's thesis. Concretely, we summarize the first phase of this work, which focused on the classification of the coarse ware assemblage collected from the Early Medieval strata of the "Rua de D. Hugo, No. 5" archaeological site, located in the historic centre of the city of Porto.
\end{abstract}

Keywords: Urban Archaeology, Northwest Iberia, Suebi-Visigothic Period, Coarse Ware.

\section{INTRODUÇÃO}

O conhecimento do passado suevo-visigótico da cidade do Porto é ainda condicionado por uma série de incógnitas que urge solucionar. Ainda que as fontes documentais sejam algo tácitas, comprovam, nos séculos imediatamente ulteriores ao ocaso do domínio romano da Península Ibérica, acontecimentos na cidade que não podemos descurar. Refira-se a menção na Divisio Theodemiri - ou "Paroquial Suevo" a este núcleo urbano, que é descrito como "Portugalensem in castro novo", em oposição ao "Portucale castrum antiquum" localizado na margem sul do Douro (Real \& Silva, 2018, p. 205). Ainda que não seja pertinente que aqui nos alonguemos sobre a antiga problemática da localização do povoado origi- nal de Cale, não deixa de ser significativa a oposição entre um núcleo "antigo", em oposição ao "novo". Com efeito, foi esta designação o que levou vários autores, como Pierre David, a defender a existência de uma fundação (ou, mais provavelmente, refundação) sueva do atual centro histórico (Ibidem).

De resto, a importância da cidade do Porto para as elites suevas está patente na Crónica de Idácio de Chaves, que refere que, após ter sido derrotado às mãos de Teodorico nas margens do rio Órbigo, o rei Requiário se terá refugiado no castrum do Porto, onde viria a ser capturado (Mattoso, 1992, p. 308). Também no Porto seria assassinado o seu sucessor Agiulfo, quando um novo potentado, Maldras, Portucale castrum idem invadit (Silva, 1994, p. 99). O conhecimento do passado alto-medieval da cida-

1. Instituto de Estudos Medievais, NOVA-FCSH; joaolveloso.arch@outlook.pt 
de viria a ser revigorado, porém, com as escavações do Morro da Sé, entre 1984 e 1986, que, pela primeira vez, puseram à superfície o núcleo populacional primitivo da cidade, ocupado durante uma longa sequência estratigráfica desde a Proto-História à Contemporaneidade (Real \& alii, 1985/86; Silva, 200o, p. 136).

Um dos arqueossítios intervencionados nessa escavação foi o domicílio sediado na Rua de D. Hugo, no․ 5, nas traseiras da Sé Catedral, debruçando-se sobre a atual avenida Vímara Peres. Ainda que neste sítio não se tenham encontrado estruturas do período suevo-visigótico, foi identificada uma camada de incêndio, caracterizada por uma abundância de fragmentos de telha, pedra miúda e cinzas, decorrentes do abatimento de um telhado. Pela sua posição relativa e facies cerâmico - "não se tratando de cerâmica de fabrico romano e distanciando-se largamente das cerâmicas da Reconquista ou posteriores" - esta camada estratigráfica foi datada pelos responsáveis pela escavação como correspondendo ao período suevo-visigótico (Real \& alii, 1985/86, p. 31).

Em 2019, ano em que se assinalava o $35^{\circ}$ aniversário das escavações do Morro da Sé, propusemo-nos a retomar o estudo dos materiais exumados desta escavação, até então depositados nos Serviços de Arqueologia da Câmara Municipal do Porto, no âmbito da nossa tese de Mestrado ${ }^{2}$, trabalho que continua em curso. O nosso objetivo era reinterpretar esta coleção à luz do conhecimento que se produziu nas últimas três décadas e meia acerca dos ritmos de produção, consumos e comércio do Noroeste Peninsular durante a Alta Idade Média. Nas páginas seguintes elencamos alguns dos resultados preliminares da primeira fase deste trabalho.

\section{O CONJUNTO CERÂMICO}

A cerâmica é a matéria-prima mais abundante entre os materiais da Rua de D. Hugo, $\mathrm{n}^{\circ} .5$, constituindo $99,6 \%$ do conjunto total. O conjunto de começámos por estudar divide-se em cerâmica comum $(96,4 \%)$, terra sigillata variada $(0,8 \%)$, fragmentos de ânfora $(2,6 \%)$ e cerâmica cinzenta fina (o, $2 \%)$. Neste artigo apresentamos as formas, técnicas de fabrico e carac-

2. Veloso, J. L. (em curso). Ocupação e consumos no Porto através do arqueossítio da Rua de D. Hugo, $n^{\circ} .5$ (séculos V-VIII). Dissertação de Mestrado. Faculdade de Ciências Sociais e Humanas da Universidade Nova de Lisboa. terísticas da cerâmica comum, uma vez que, devido à sua incomparável quantidade, foi por ela que principiámos o estudo.

Ao abrir os contentores dos materiais e separar as diversas Unidades de Depósito, a primeira conclusão que pudemos tirar foi que a coleção estava altamente fragmentada. De facto, embora dispuséssemos de 6874 fragmentos de cerâmica comum, apenas 22 se verificaram elegíveis para constituir o Número Mínimo de Indivíduos (NMI). Adotámos os preceitos utilizados por Tente, Lantes e Prieto para o estudo da cerâmica alto-medieval da região do Alto Mondego (2014, pp. 110-113) contando como indivíduos apenas fragmentos cerâmicos em que se conservassem pelo menos $5 \mathrm{~cm}$ do bordo. Este número é naturalmente deflacionado, mas evidencia bem o fraco estado de conservação das peças, que se manifestam em fragmentos muito pequenos, frequentemente com menos de $35 \mathrm{~mm}$.

Para colmatar esta escassez de peças individualizadas, acrescentámos ao NMI um conjunto secundário, a que chamámos Número Mínimo Alargado (NMA). Para este último, tivemos em conta todos os fundos que se conservavam, assim como os bordos cujas dimensões não permitiam integrar o NMI. Assim, ficámos com um número total de 285 bordos (NMI+NMA) e 84 fundos. Identificámos igualmente 23 fragmentos de asas, assim como 8 bojos em que se conservava o arranque das mesmas. Extremamente raros são perfis completos - apenas dois, que constituem $0,03 \%$ do conjunto de cerâmica comum (Figura 1).

Como nos interessava sobretudo o período suevo-visigótico para este trabalho, começámos por nos restringir ao já referido nível de incêndio, a denominada camada 6 . Todavia, para que melhor pudéssemos entender a diacronia do sítio, estudámos também as duas camadas que lhe eram imediatamente adjacentes: a camada 5 (e a sua subcamada $5 a$ ) e a camada 7 (assim como as $7 \mathrm{a}, 7 \mathrm{~b}$ e $7 \mathrm{c}$ ).

Concluímos imediatamente que estas camadas, embora bem definidas, eram altamente permeáveis, tendo-se inclusivamente identificado fragmentos da mesma peça em camadas distintas. Tanto na camada 6 como na 7, que a cerâmica fina data como baixo-imperial, encontrámos inclusivamente fragmentos de produções castrejas, de pastas muito micáceas e cozedura redutora, que, desavisadamente, poderiam ser confundidas com produções mais tardias.

Não obstante esse pormenor, conseguimos separar 
os diversos fragmentos por camada, como sistematizamos na Figura 2.

No que diz respeito a tipologias formais, verificamos, em todas as camadas, a coexistência de formas abertas (pratos, taças, alguidares) e fechadas (potes-panelas e jarros) (Figura 3).

Os pratos caracterizam-se por serem formas quase planas, de bordos redondos. Têm entre 10 e $22 \mathrm{~cm}$ de diâmetro máximo, e não apresentam decoração. São a segunda forma mais frequente, contando com um total de 12 indivíduos, e surgem nas três camadas estratigráficas principais.

As taças são peças de dimensões reduzidas, de perfil oblíquo, que apresentam bordos redondos ou biselados. Têm entre 11 e $20 \mathrm{~cm}$ de diâmetro máximo. Contam apenas com 5 indivíduos, divididos pelas camadas 6 e 7 .

Os alguidares são formas particulares, que se reconhecem pelas paredes espessas, retas e oblíquas. Têm bordos redondos ou espessados. Uma vez que não se conservam os seus perfis inteiros, foram identificados pela espessura dos bordos e diâmetro máximo, compreendido entre os 20 e os 36 $\mathrm{cm}$. Dada a dificuldade de identificação que o grau de fragmentação comporta, talvez o número que propomos, 4 indivíduos, esteja aquém do total real. Estão presentes nas camadas 5, 6 e 7 .

Contamos apenas com um exemplar de jarro ( $\mathrm{n}^{\circ}$ 2011), que foi classificado como tal devido ao seu característico bordo, dotado de bico vertedor. A partir de um só fragmento de bordo não nos é fácil reconstituir o seu perfil, mas acreditamos que fosse uma forma estreita, eventualmente dotada de uma asa. Finalmente, a forma mais frequente é o pote-panela, representando 59\% das morfologias cerâmicas identificadas. Utilizamos este termo para a designar pois o que distingue um pote de uma panela é a sua finalidade. Como apenas contamos com bordos, não podemos tirar conclusões acerca de se as peças eram levadas ao lume (panelas) ou eram meramente contentores para armazenamento (potes). Pela mesma razão não podemos inferir muito acerca do desenho do seu perfil. Concluímos, todavia, que são peças estranguladas, sendo que por vezes se conserva ainda um perfil em S. Têm bordos extrovertidos, geralmente redondos, com diâmetro máximo entre 9 e $18 \mathrm{~cm}$. Contamos com 33 indivíduos, que estão dispersos pelas camadas 5, 5a, 6, 7 e 7c.

\section{AMBIENTES DE COZEDURA}

O segundo critério de análise a que nos propusemos nesta primeira fase de trabalho diz respeito às técnicas de fabrico da cerâmica. Concretamente, quisemos perceber se havia diferenças entre os ambientes de cozedura das cerâmicas de umas e outras camadas. Tal como se pode verificar na Figura 4, há uma alteração considerável da proporção entre cerâmicas cozidas em ambientes oxidantes e redutores. Após um período de relativo equilíbrio entre as duas técnicas, expresso nas camadas 7 (40,9\% vs. $34 \%), 6$ $(35,1 \%$ vs. $36,2 \%)$ e $5 a(39,2 \%$ vs. $37,3 \%)$, comprova-se um aumento considerável das colorações redutoras, que na camada 5 se assumem como preponderantes (56,9\%).

A estes dois tipos de cozedura, acrescentam-se ainda as peças executadas em ambiente oxidante-redutor e redutor-oxidante. É de salientar, todavia, que não raramente nos deparámos, nas camadas 5 , 5 a e 6, com peças de cozeduras "mistas" que talvez tenham adquirido esta coloração não por desígnio do oleiro, mas devido a um mau controlo das condições de cozedura dos fornos. Com efeito, estas peças revelam verdadeiras "manchas" mais escuras ou claras, que não nos parecem intencionais, devido à sua irregularidade.

\section{DECORAÇÃO}

Embora não sejam muito visíveis nas peças do NMI e do NMA, existem na coleção diversas formas de decoração, que se identificaram em todas as camadas, à exceção da 7a e da 7 b. Por essa razão, alargámos o universo de estudo a todos os fragmentos cerâmicos com marcas de decoração, num total de 113 itens (Figura 5).

A forma de decoração mais predominante é a incisão, presente em quantidade e em todas as camadas estratigráficas. Esta assume geralmente a forma de bandas horizontais, paralelas ao bordo, em grupos de duas ou três linhas.

A segunda técnica mais frequente é a canelura, obtida através da moldagem de bandas em relevo, transversais ao eixo de simetria da peça. Verificamos uma grande representação deste tipo decorativo nas camadas baixo-imperiais ( 7 e 7 c), onde é o modelo decorativo proeminente.

Na camada 6, contudo, surgem pela primeira vez os cordões plásticos, que estão igualmente presen- 
tes nas camadas subsequentes. Ao invés de serem moldados a partir do barro originário da peça, estes são aplicados posteriormente à sua rodagem na superfície do bojo, e são frequentemente decorados com digitações. Este parece-nos o motivo decorativo alto-medieval por excelência, que parece multiplicar-se ao longo deste período: constitui 11,6\% das formas decorativas da camada $6,28,5 \%$ da camada $5 a$, e $33,3 \%$ da camada 5 . O número reduzido de fragmentos decorados patentes nestas últimas duas camadas, todavia, leva-nos a olhar para estas percentagens com cautela.

A camada 6 constitui também o último testemunho de cerâmica pintada, que surge de igual forma nas camadas 7 e 7 c. A pintura manifesta-se em listas irregulares, em tons de ocre e branco, aplicados sobre pastas beges, de cozedura oxidante.

O último motivo decorativo que identificámos é a punção. Dada a sua baixa quantidade - 2 fragmentos - e uma vez que surgem em duas camadas díspares que, à partida, nada têm em comum, é difícil tirar conclusões acerca da evolução deste motivo decorativo.

Tendo em conta que todos os motivos decorativos acima enumerados surgem em bojos isolados, muito fragmentados, não nos foi possível fazer corresponder diferentes formas de decoração a variadas morfologias de peças.

\section{CONSIDERAÇÕES FINAIS}

Em jeito de conclusão, gostaríamos de fazer duas advertências e assinalar perspetivas para o futuro. Em primeiro lugar, lembramos que os dados aqui expostos são resultado de uma fase ainda inicial do estudo da coleção, representando somente uma parte, ainda que numerosa, da mesma. Para uma completa e rigorosa interpretação do sítio arqueológico, será, portanto, necessário acrescentar à sua leitura os dados que o estudo da cerâmica fina e de transporte nos fornecerão. Aliás, esses materiais têm a mais-valia de nos fornecerem informações que a cerâmica dita comum não consegue fornecer. A título de exemplo, refiram-se a possibilidade de afinar cronologias, através da classificação morfotipológica da terra sigillata, e a identificação da proveniência de importações, patente nas formas das ânforas.

Em segundo lugar, gostaríamos de relembrar que o arqueossítio da rua de D. Hugo, no. . 5, apesar da sua já comprovada importância, é apenas um vislumbre do passado arqueológico da cidade. Com efeito, estamos a falar de um espaço com pouco mais de 100 $\mathrm{m}^{2}$ de área, o que, naturalmente, condiciona a leitura do registo arqueológico.

Talvez por isso se comprove a necessidade de desenvolver mais estudos deste género, que tenham como objetivo, em primeiro lugar, estudar em profundidade os conjuntos de materiais de sítios arqueológicos portuenses, frequentemente votados ao esquecimento. Para além disso, achamos necessário dotar a arqueologia alto-medieval do Porto de um fio condutor coeso, que interrelacione os diversos contextos de modo a que se possa obter uma visão de todo do passado da cidade.

\section{BIBLIOGRAFIA}

MATTOSO, José, ed. (1992) - História de Portugal: Primeiro Volume. Lisboa: Círculo de Leitores.

ORTON, Clive; HUGHES, Michael (2013) - Pottery in Archaeology: Second Edition. Cambridge: Cambridge University Press.

REAL, Manuel Luís; TÁVORA, Maria José; OSÓRIO, Maria Isabel Pinto; TEIXEIRA, Filipe Fernando (1985/86) - Escavações Arqueológicas no Morro da Sé. Separata do Boletim Cultural da Câmara Municipal do Porto. Porto. Série II. 3/4.

REAL, Manuel Luís; SILVA, António Manuel (2018) - Porumcalem Castrum Novum na época sueva. In LÓPEZ QUIROGA, Jorge, ed. - In Tempore Sueborum: El tiempo de los Suevos en la Gallaecia (411-585). Ourense: Armonía Universal, pp. 205-210.

SILVA, António Manuel (200o) - Rua D. Hugo, 5: um arqueossítio fundador. Almadan. Almada. Série II. 9, pp. 136-137.

SILVA, Armando Coelho da (1994) - Origens do Porto. In RAMOS, Luís de Oliveira, ed. - História do Porto. Porto: Porto Editora, pp. 45-117.

TENTE, Catarina; LANTES, Óscar; PRIETO, Pilar (2014) A produção cerâmica dos séculos IX a XI na região do Alto Mondego (Portugal). In DE MAN, Adriaan; TENTE, Catarina, eds. - Estudos de Cerâmica Medieval: O Norte e Centro de Portugal, séculos IX a XII. Lisboa: IEM - Instituto de Estudos Medievais, pp. 109-140. 


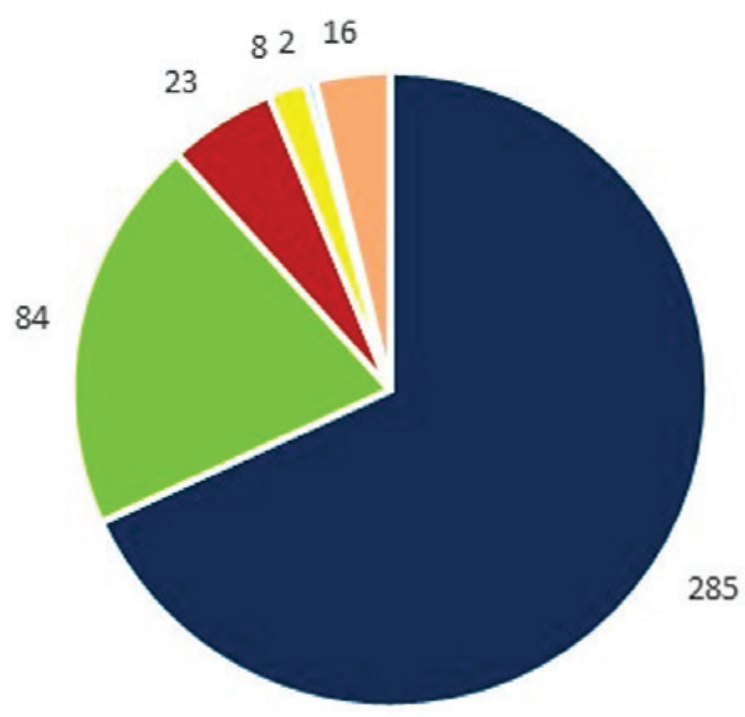

- Bordos "Fundos - Asas "Arranques de asa "Perfis Completos "Ind.

Figura 1 - Contabilização da cerâmica comum.

\section{Tipos de fragmentos por camadas}

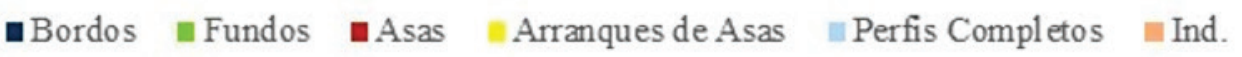

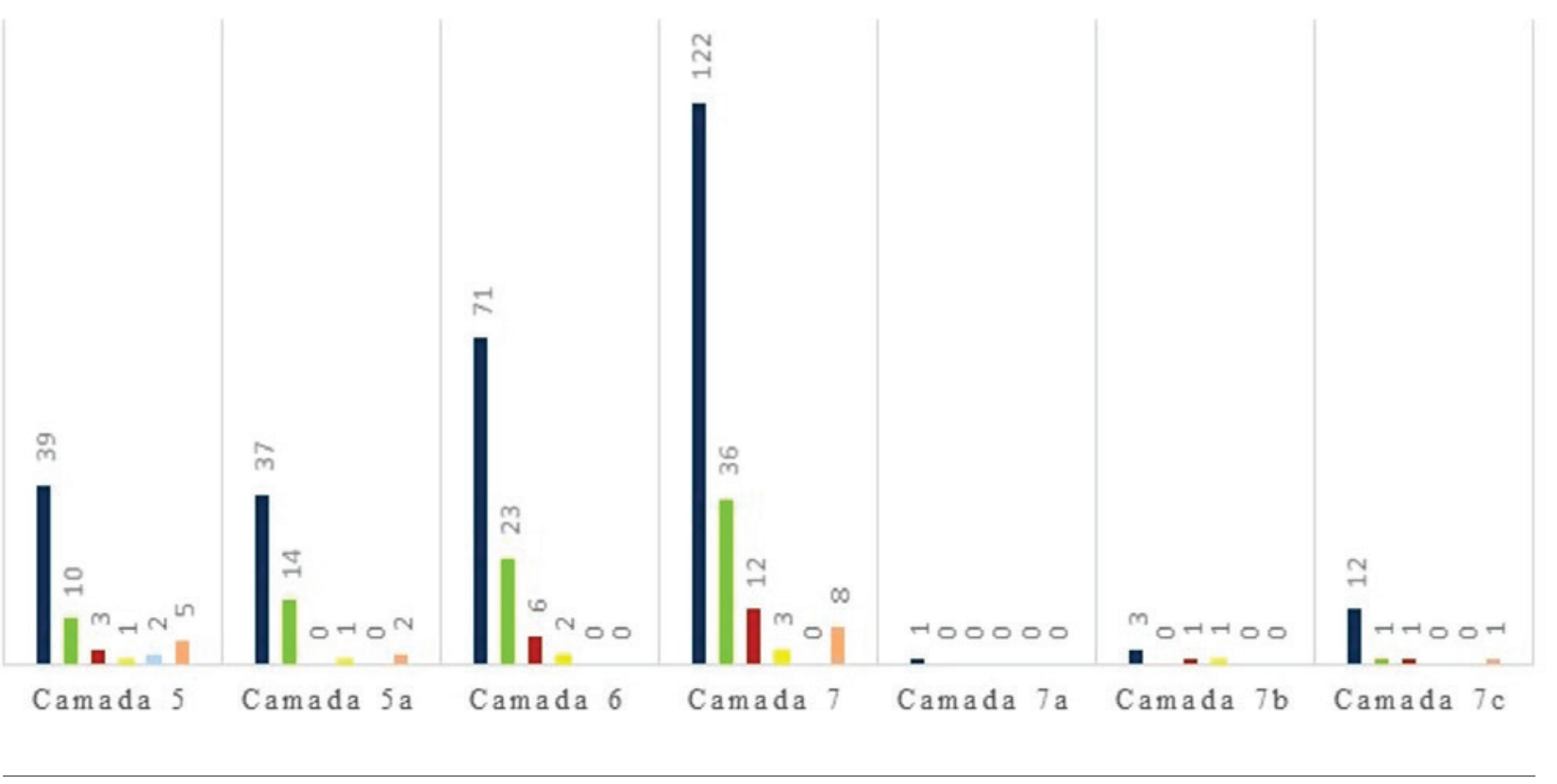

Figura 2 - Contabilização de tipos de fragmentos por camadas estratigráficas. 


\section{Classificação morfológica}

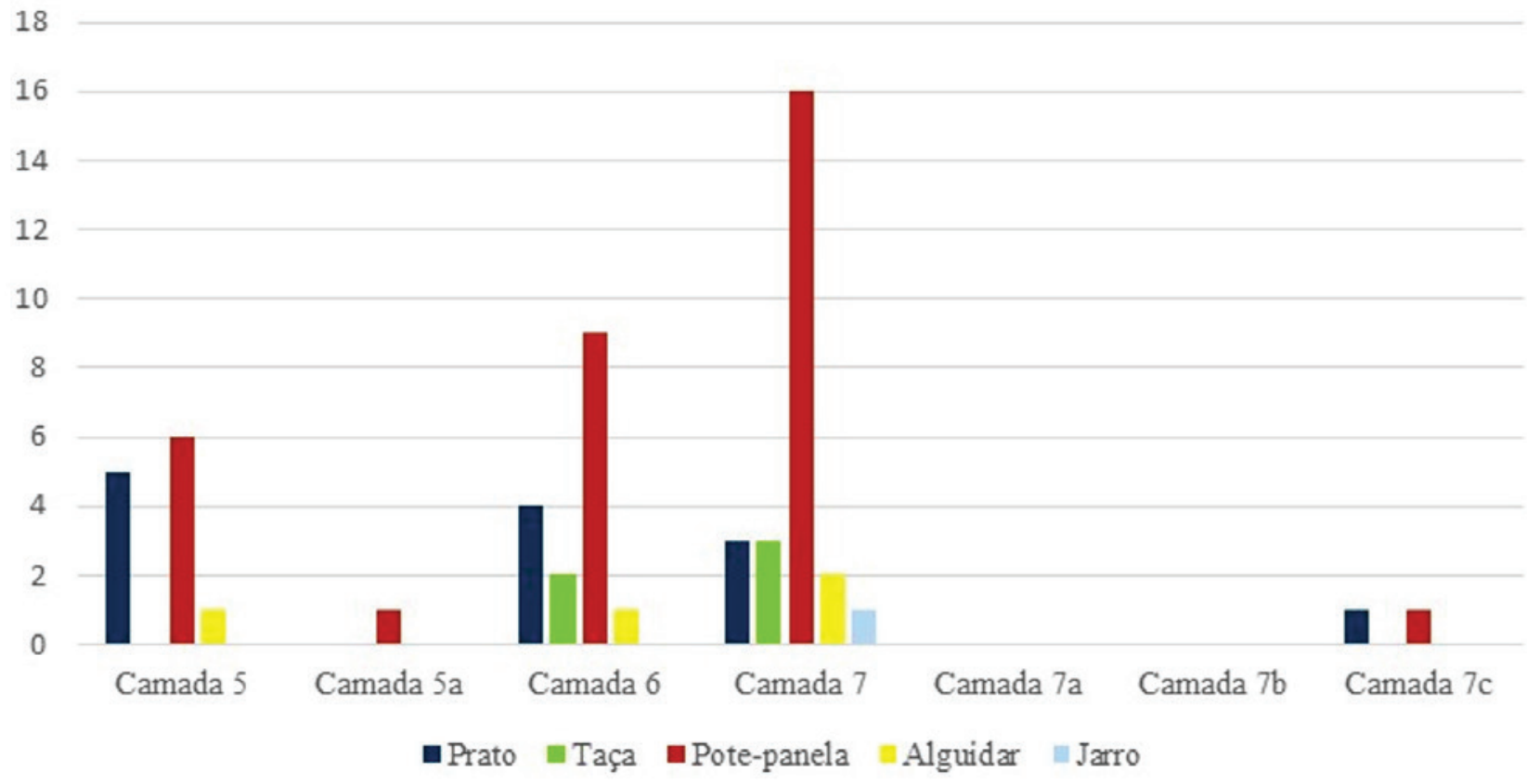

Figura 3-Classificação morfológica.

\section{Tipos de cozedura}

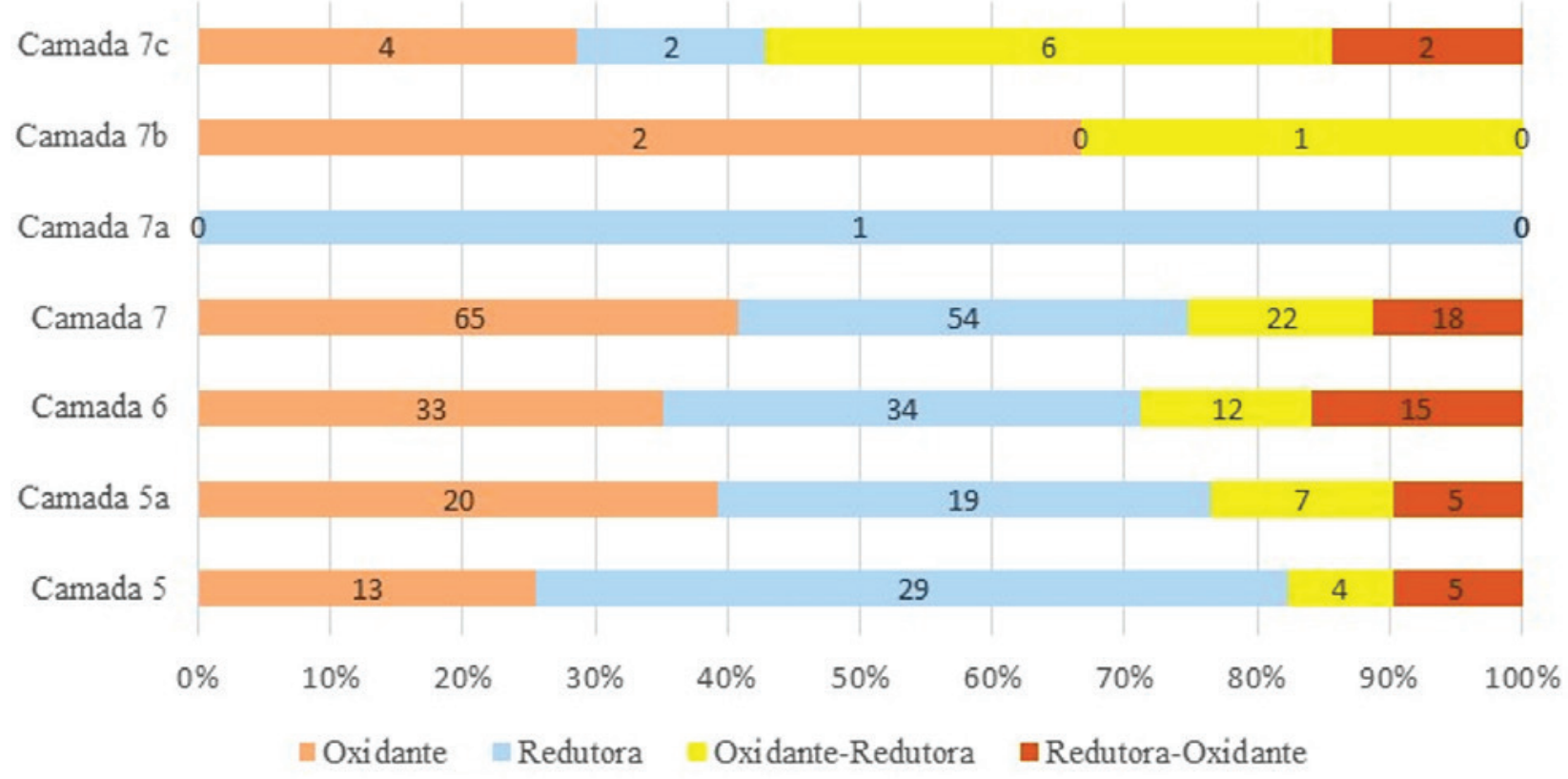

Figura 4-Tipos de cozedura. 


\section{Decoração da superfície}

25

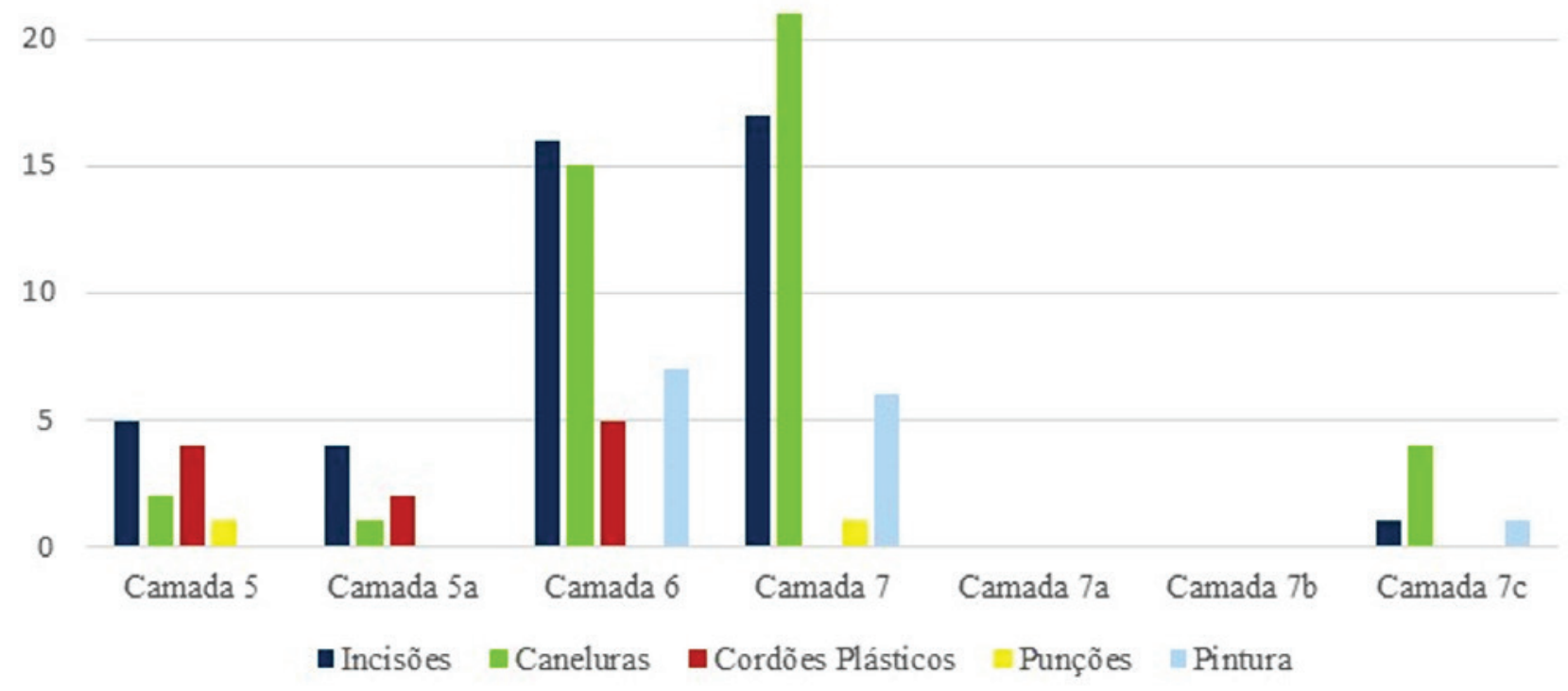

Figura 5-Decoração da superfície. 


\title{
A ALTA IDADE MÉDIA NA FRONTEIRA DE LAFÕES: NOTAS PRELIMINARES SOBRE A ARQUEOLOGIA NO CONCELHO DE VOUZELA
}

\author{
Manuel Luís Real ${ }^{1}$, Catarina Tente ${ }^{2}$
}

\begin{abstract}
RESUMO
Desde a proto-história que o território de Lafões foi submetido a uma intensa ocupação humana, com o intuito de explorar as suas riquezas minerais. Durante a Alta Idade Média foi uma zona chave na região centro de Portugal. Aqui encontramos indícios (escritos e arqueológicos) para a presença de populações locais cristãs, às quais se vieram juntar membros da nobreza galaico-asturiana, por eventual acordo estabelecido entre os sécs. IX e X. Após quase uma centúria de domínio político cristão, a região de Lafões ficou temporariamente na posse muçulmana, para ser finalmente resgatada quando se deu a reconquista de Viseu (1058) e de Coimbra (1064). Nessa altura, a fortificação da Senhora do Castelo (Vouzela), conhecida na documentação, mas só agora revelada arqueologicamente, já desempenharia funções estratégicas de relevância.
\end{abstract}

Palavras-chave: Lafões, Vouzela, Ocupação de montanha, Territórios medievais.

\begin{abstract}
The Lafões territory was subjected to an intense human occupation since Protohistoric times, focused on the exploitatian of its mineral wealth. In the Early Middle Ages it was a kea-area where written and archaeological evidence shows its importance for local Christian populations and to recently-established Galician-Asturian lords. After almost a century of Christian rule, the Lafões region was temporarily back in Muslim hands, only to be finally regained when Viseu and Coimbra were reconquered (in 1058 and 1064, respectively). At that time, the fort that has now been revealed archaeologically on Monte da Senhora do Castelo (Mount of Our Lady of the Castle) in Vouzela would have already a relevant strategic functions.
\end{abstract}

Keywords: Vouzela, Lafões, Mountain occupations, Medieval territories.

\section{INTRODUÇÃO}

Nos últimos quatro anos foram realizados vários trabalhos de inventário, prospeção e escavação arqueológica na região de Lafões-Vouzela. Esta investigação decorreu no âmbito do PIPA (2016-2019) Estudo do Património Histórico-Arqueológico de Vouzela (LAFÕES), que visava a sistematização da informação histórico-arqueológica e a obtenção de novos dados sobre o património arqueológico existente no território do atual concelho de Vouzela. Este conhecimento foi bastante ampliado, em particular após os incêndios de outubro de 2017, momento que determinou um investimento sem precedentes na intensidade da prospeção sistemática das áreas ardidas. $\mathrm{O}$ projeto contou com o apoio logístico e financeiro da autarquia, a qual disponibilizou igualmente alguns dos seus colaboradores, para reforçar a equipa de investigação.

No plano metodológico, a investigação orientou-se em quatro direções: 1 - Levantamento documental e toponímico; 2 - Prospeção arqueológica e análise espacial; 3 - Estudo de espólios das escavações antigas; 4 - Escavações arqueológicas. Merece especial

1. CITCEM-UP; IEM - NOVA FCSH; manuelluisreal@gmail.com

2. IEM - NOVA FCSH, Av. de Berna, 26C, 1069-o61 Lisboa; catarina.tente@gmail.com 
referência o registo sistemático da microtoponímia, a partir do cadastro de propriedades da Repartição das Finanças. Esta tarefa, que ficou a cargo de um investigador do Município3 ${ }^{3}$, veio a ampliar largamente as pistas para localização de novos sítios arqueológicos. O intensivo trabalho de prospeção levado a efeito permitiu assim identificar muitos locais até então desconhecidos e reconhecer melhor outros que estavam já referenciados na bibliografia sobre o património concelhio ${ }^{4}$.

Os dados obtidos ao longo do projeto permitem muitas abordagens à ocupação daquele território. O que nos ocupa neste artigo são algumas considerações que podem já ser avançadas no que se refere à ocupação alto medieval. Como já largamente abordado, a região de Lafões foi na Alta Idade Média um território relevante e protagonista de alguns episódios relacionados com avanços e recuos da fronteira entre cristãos e muçulmanos. Mas também foi palco de estratégias sociopolíticas de elites locais e supralocais. Sabemo-lo devido à documentação escrita que se conservou até aos dias de hoje.

Embora, como se referiu, o projeto tivesse objetivos mais abrangentes, pode considerar-se que, no que concerne ao período medieval, logrou atingir avanços significativos para o conhecimento da região de Lafões entre os séculos VIII e XI5.

\section{O PERÍODO DAS MONARQUIAS SUEVA E VISIGODA}

São inúmeros os locais com indícios de romanização, embora deles estejam sistematicamente ausentes os objetos de luxo ou de importação, bem como ocupações rurais mais suntuosas. Não há dúvida

\footnotetext{
3. A pesquisa ficou a cargo de Daniel de Melo Branco, que nas tradicionais 12 freguesias do concelho registou cerca de 17.850 ocorrências. Alguns topónimos aparecem repetidas vezes, até sob designação variável, mas a riqueza informativa coligida foi preciosa para as tarefas de prospeção.

4. Entre a bibliografia publicada são de salientar o trabalho pioneiro de A. Amorim Girão, sobre as Antiguidades Pre-históricas de Lafões, assim como a Carta Arqueológica do Concelho de Vouzela, da autoria de Jorge Adolfo de M. Marques.

5. Para conhecimento mais detalhado sobre os temas aqui tratados poderão consultar-se as comunicações às I Jornadas de Arqueologia de Vouzela-Lafões, que se realizaram a 14-16 de Novembro de 2019 e cujas atas estão em vias de publicação.
}

que o território foi submetido a uma intensa ocupação romana, indubitavelmente com o intuito da exploração das riquezas mineiras da região. Aliás, estas haviam também sido responsáveis pela intensa ocupação pré-romana da região, que tão eloquentemente se expressa nos diversos castros de grande dimensão ali existentes e nas inúmeras e densas necrópoles de cistas que aqui se identificaram nos últimos anos (Carvalho, Carvalho, 2018). Os recursos minerais foram o motor para ocupação intensiva deste território desde a Idade do Bronze e terão sido estes mesmos recursos que suportaram a construção das emblemáticas termas de São Pedro do Sul. Os principais vestígios romanos e tardo-romanos estão fundamentalmente relacionados com a exploração dos recursos mineiros. São disso exemplo o sítio de Carvalhal do Estanho, onde também se reconheceu uma necrópole tardia, ou o lugar de Fataunços, situado junto a uma das principais vias de comunicação e na periferia de outra importante zona mineira, na vertente ocidental do monte da Senhora do Castelo (Figura 1). A exploração dos recursos e a posição de fronteira deste território terá sido responsável pela construção de inúmeras vias (muitas delas calçadas) que ligariam o litoral ao interior, desde Talabriga a Vissaium, quer através do vale do Vouga, quer atravessando a Serra do Caramulo. O controle romano da região deve ter-se centrado junto às vizinhas Termas Romanas (situadas no limite do atual concelho de S. Pedro do Sul), onde estanciaria a elite militar e administrativa.

Para o período do fim do Império na região, pouco se pode adiantar. É provável que se tenha continuado a ocupar espaços já anteriormente habitados, tal como ocorreu em Fataunços e no Carvalhal do Estanho. Em ambos os sítios estão documentadas necrópoles de inumação que usaram materiais de tradição romana, como tegulae. Na zona do Areal/ Corgo (Fataunços), foram igualmente reconhecidas sepulturas escavadas na rocha (Marques, 1999), cuja cronologia poderá recuar até ao século VI.

Apesar dos parcos indícios materiais, certamente que a região não terá sido despovoada após o século V. Assim o faz pensar a proximidade de Viseu, que assume protagonismo político na época, ao elevar-se a sede episcopal durante a sexta centúria. Apesar do controle que os bispos exerceriam nos territórios rurais ser assimétrico e depender, muitas das vezes, dos laços que conseguiam estabelecer com as elites locais (Tente, 2016), a proximidade geográfica de La- 
fões a Viseu e a presença das termas (que certamente não terão cessado de funcionar e continuariam a ser um pólo de atração importante para a aristocracia da época) devem ter colocado Lafões no mapa de interesses diretos das próprias elites viseenses. Não será de descartar a hipótese da continuidade de ocupação dos antigos castros romanizados, nomeadamente os de Ribamá (Queirã) e da Senhora do Castelo (Vouzela), onde se identificaram sepulturas escavadas na rocha, que podem ter tido origem no período das monarquias suevo-visigoda. Muito poderíamos discutir sobre a cronologia das sepulturas escavadas na rocha, cuja janela temporal para a sua utilização é demasiado alargada (século VI - XII). Todavia, Lafões constitui-se como um caso interessante, pois são muito escassas as sepulturas aqui identificadas, o que contrasta com a restante região da Beira Alta. Efetivamente, de Viseu à Guarda, passando por regiões de vale e zonas serranas, é muito comum este tipo de vestígios e, quando associados a outros dados arqueológicos, eles remetem-nos para cronologias balizadas entre o século IX e o XI. Ocorre que em Vouzela/Lafões, tal como se irá expor, é neste período que se ergue uma série de templos cristãos, circunstância que parece ser responsável pela ausência destas soluções funerárias rupestres, que resultam em larga maioria de opções de cariz familiar (Tente, 2017). É possível, ainda que não comprovável, que algumas das escassas sepulturas escavadas na rocha de Vouzela possam ter sido construídas num momento anterior ao século IX, quando as elites locais controlariam já as comunidades e os seus hábitos religioso/funerários.

\section{DO SÉCULO VIII AO SÉCULO XII}

Com a invasão islâmica, este território passou a apresentar características muito peculiares, por se situar num espaço que não seria controlado efetivamente, nem pelo norte cristão-asturiano, nem pelo sul islâmico. É possível que em algum momento, durante o século VIII, as elites locais tenham estabelecido um pacto de submissão com o poder muçulmano. Nestes pactos os cristãos mantinham a liberdade de culto e era-lhes conferido o direito de propriedade, devendo, em contrapartida, respeitar o Islão e pagar imposto próprio. Esta circunstância pode eventualmente explicar o desenvolvimento de uma comunidade moçárabe em Lafões, da qual, inclusive, nos chegou testemunho através de fonte árabe, relativa a certa investida do cadi de Sevilha, por volta de 1026-1030 (Aillet, 2005).

É significativo notar que o topónimo “Loumão”, povoação atual designada como Noumam nas Inquirições de 1258 , tem uma origem árabe, o que pode remeter para esta comunidade arabizada que habitaria na região de Vouzela. O lugar de Loumão fica, precisamente, junto ao núcleo mineiro mais rico do concelho, e aí identificou-se a ruína de uma torre, cuja construção deverá situar-se entre os séculos. IX-X (Figura 2), se a compararmos com o aparelho ostentado na coeva capela de S. Martinho, integrada no complexo das termas de S. Pedro do Sul.

A documentação e alguns achados arqueológicos mostram uma intensa ocupação, que se expressa no número de edifícios religiosos que terão sido erguidos, nomeadamente a partir do século X. Esta invulgar densidade de templos contrasta com a generalidade da região situada entre o Douro e o Mondego. Dos primeiros templos temos aparentemente vestígios na fase mais antiga da capela de S. Martinho de Alcofra (Fig. 9, fase I), que então poderia ter sido apenas um diminuto oratório. Talvez mais importante e também muito antigo seria o templo original de Carvalhal de Estanho, igualmente dedicado a S. Martinho. A igreja atual é de construção moderna, mas situa-se junto ao núcleo romano das minas da Bejanca e estava rodeada pela maior necrópole conhecida, até ao momento, no concelho de Vouzela. $\mathrm{O}$ orago tem fortes possibilidades de ser muito arcaico e, segundo testemunhos recolhidos, tal cemitério continha campas em tegulae, de presumível tipologia romana, sarcófagos em granito e sepulturas abertas na rocha.

Tendo em conta um arco cronológico mais amplo, sensivelmente entre a época tardo-romana e o século XI, só na área concelhia de Vouzela - correspondente a uns exíguos $194 \mathrm{Km}^{2}$ - por informação documental ou através de vestígios materiais, identificaram-se com segurança cerca de uma dúzia de templos e há indícios de mais alguns (Figura. 3). Do ponto de vista arqueológico, encontraram-se testemunhos concretos em S. Martinho de Alcofra (na capela mor e primeira fase de construção da nave - Figura 9), em S $\mathbf{a}$ Maria de Figueiredo das Donas (fustes de coluna, pedras almofadadas, fragmento de ara e inscrição alto medieval - Figura 8), em S $\mathrm{S}^{\underline{a}}$ Marinha de Paços de Vilharigues (distante da atual sede paroquial, mas com o mesmo orago - existindo fragmento de muro original, silhares com desbaste dos antigos 
almofadados, cruz gravada e restos de tegulae nas imediações), em S. Miguel de Felgosa (no Passal, em Fataúnços - fig. 10, tendo-se identificado um cunhal com pedras almofadadas, o saimel de arco em ferradura, estelas sepulcrais e fragmentos de telha curva, antiga e moderna) e em S. Miguel de Queirã (elementos de coluna, medidos pelo palmo craveiro e atribuíveis à primitiva igreja).

Tal como já abordado, há uma percentagem bastante reduzida de sepulturas escavadas na rocha: para além dos casos já citados, apenas se documentam o par de sepulturas em Lamas (Paços de Vilharigues), a sepultura antropomórfica do Lameirão de S. Domingos (Ventosa) e a campa rupestre do Castro da Ribamá (Figura 4). Como atrás se expôs, é possível que estas sepulturas tenham sido construídas entre os séculos VI e VIII, pelo que não se relacionam com a nova realidade, quando se terá intensificado a construção de edifícios religiosos na região. Efetivamente, após o século IX tudo indica que o território passou a estar enquadrado por uma densa malha de templos. A relativamente rápida cobertura religiosa, mediante a criação vários centros de acolhimento e serviço eclesiástico, fez com que os fiéis neles procurassem, muito precocemente, um lugar para enterrar os seus mortos. A maior parte destes lugares estão por investigar arqueologicamente, mas conhece-se o aparecimento de campas e/ou estelas sepulcrais - neste caso, um pouco mais tardias - na matriz de Vouzela e em algumas outras sedes de freguesia (Alcofra, Campia, Passal/Fataúnços). Quanto às sepulturas antropomórficas da Senhora do Castelo, encostadas à cerca do povoado alto medieval, no seu lado exterior ${ }^{6}$, elas poderiam ter justificação lógica pela sua proximidade ao aldeamento relacionado com o castelo ali existente, mas é igualmente provável que possam ser anteriores à construção do castelo. Seriam assim mais antigas e integrar-se-iam na cronologia avançada para as demais sepulturas escavadas na rocha identificadas neste concelho, isto é, entre o século VI e o IX. Teriam sido erguidas junto a um local que já anteriormente estava ocupado (desde a Idade do Bronze) numa situação muito semelhante à que se detetou no castro de Ribamá e que aqui já foi referido. A capela da Senhora

6. Tal cerca desapareceu neste local, mas o seu alinhamento pode reconstituir-se tendo em conta o traçado geral do circuito, percetível através da topografia do terreno e por trechos do próprio muro. do Castelo, refeita várias vezes, foi erguida no cimo do monte apenas quando a torre castrense deixou de desempenhar funções militares, pelo que, na hipótese de haver um anterior templo dedicado a Santa Maria, este deveria ter sido erguido nas imediações das sepulturas.

O exemplo da Senhora do Castelo remete-nos para um outro problema, muito debatido em estudos sobre o povoamento na Alta Idade Média. Costuma dar-se especial ênfase ao encastelamento, cuja origem se prolonga no tempo, mas teve particular expressão ao longo do século XI. A prospeção arqueológica revelou que no monte da Senhora do Castelo, em Vouzela, surgiu um importante castro da Idade do Bronze, o qual veio a ser abandonado na época romana, provavelmente quando aí se intensificaram os trabalhos de mineração. Na Alta Idade Média o cimo do monte voltou a ter ocupação. Recentemente foi identificado um dos muros da torre medieva, em torno da qual se parece estender um pequeno povoado. No atual estado de conhecimentos não podemos aferir se a origem de tal povoado é anterior à torre ou lhe sucedeu. Só escavações arqueológicas poderão, eventualmente, permitir chegar a uma conclusão mais segura a esse respeito. Todavia, daquilo que se sabe sobre o processo histórico da região, emerge uma interessante problemática a respeito do paulatino desenvolvimento do sistema de governança e defesa deste território.

\section{LAFÕES NO QUADRO DA EXPANSÃO TERRITORIAL ASTURIANA NO OCIDENTE PENINSULAR}

É hoje praticamente adquirido que no vale do Vouga, em finais do século IX, se veio a refugiar o príncipe asturiano Bermudo Ordonhes, na sequência de uma frustrada revolta contra seu irmão, o rei Afonso Magno. A região de Viseu pode ter-se transformado, nesta época, em zona de abrigo de alguns nobres descontentes e insubmissos frente à corte de Oviedo, como Diogo Fernandes, alguns descendentes dos presores de Tude e de Portucale e, supostamente (embora isso seja menos seguro) o conde Odoário, outro irmão do monarca, que foi presor de Flavias e poderá ter dominado em Viseum. Ora, a instalação de gente tão insigne vinda do norte galaico-asturiano, para ser pacífica, não pode deixar de ter sido precedida de contactos prévios e uma negociação com elites locais (Real, 2013: 209-211). Na verdade, nos 
territórios de fronteira vivia-se com relativa autonomia, o que terá favorecido a emergência de uma multiplicidade de pequenos poderes. Para as vizinhanças do atual concelho de Vouzela há indícios de alguns centros de poder secundários, esporadicamente referidos em documentação posterior, mas que devem assentar numa tradição mais antiga. É o caso do chamado "territorio Centum Cortes" (DC 61 e 660) e do "territorio Sancte Cruce" (DC 672), o primeiro documentado logo no século X e o segundo um pouco mais tardiamente, mas ambos absorvidos entretanto pela undecentista Terra de Lafões. É bem possível que a fortificação conhecida como "mons Aguto" ou "mons Castro Alafoei", tenha sido erguida para controlar o território, mostrar e representar o poder das gentes que o dominavam e defende-lo das ameaças externas a que ele estava sujeito. A primeira referência documental ao castelo de Lafões data do ano 1019, numa carta de venda a Fromarigo Viegas, da villa de Ferreiros, junto à margem direita do Vouga e mesmo defronte a Vouzela ("castro alahoueines” - DC 243) $)^{7}$. Embora não saibamos, ao certo, quando o monte foi reocupado militarmente, é possível que tal possa ter sucedido quando os habitantes locais começaram a sentir necessidade de reforçar a sua segurança ou, em alternativa, a partir do momento em que aceitaram que o citado grupo de dissidentes galaico-asturianos se instalasse nesta região. Como veremos a seguir, a importância estratégica da fortificação terá aumentado durante o reinado de Afonso V de Leon, quando a região de Viseu começou a ser, de novo, assediada por forças cristãs. E só assim se explica que, em dois documentos de 1030, apareça já uma referência ao "territorium alahoueines" ou "territorium alahobeines" (DC $268 \mathrm{e}$ AUC, Pergaminhos, IV-3 $3^{\mathrm{a}}$, Gav. 29, no 1$)^{8}$. Todavia, é possível que só se tenha transformado em cabeça de Terra na segunda metade do século XI, a partir da reconquista das cidades de Viseu e Coimbra por Fernando Magno. Este monarca rapidamente perce-

7. Tem sido também invocado o DC 19o, supostamente datado do ano 1002, porque fala do "territorio alaphoen”, um corónimo que supõe já a existência do castelo do mesmo nome. Todavia a data foi corrigida para 1102, na recente edição do Livro Preto da Sé de Coimbra (LP 495).

8. Agradecemos ao Dr. Daniel Melo o conhecimento da existência deste último documento e, ao Arquivo da Universidade de Coimbra (AUC), as facilidades que nos deu para a consulta do mesmo. beu que, para controlar as áreas conquistadas, tinha de afastar a alta aristocracia tradicional do exercício do poder político-militar. É neste contexto que o governo do território entre Coimbra e Arouca é entregue a um $d u x$ de confiança régia, ao qual ficavam submetidos os chefes militares ou funcionários encarregados da tenência das Terras.

Com o decorrer do tempo, como se viu, a área geográfica dominada por este castelo passou a ser conhecida por "territorio alahueines", expressão com algumas variantes formais. É consensual que este designativo deriva de al-`ahwân, nome que em árabe se referia ao castelo dos "dois irmãos", assim denominado pelo par de outeiros que coroam o monte da Senhora do Castelo. Esta designação tem paralelismo em outros topónimos castrenses de raiz latina, mas com o mesmo significado: por exemplo, nos castelos beirãos de Germanelo e Jarmelo.

A fortificação vouzelense seria de planta quase quadrangular e estava assente numa amplo tor granítico. Durante a vigência deste projeto foi posto a descoberto um muro em cuja base se perceciona ainda uma estrutura arruinada que remonta à fase mais antiga do castelo medieval. Esta base, posteriormente, deu lugar à radical reconstrução da própria torre do castelo (Figura 5). É possível que a ruína da primeira fortificação se possa ter devido a confrontos decorrentes da desestabilização regional que ocorreu no contexto das campanhas militares de Almançor ou, mais provavelmente, na já referida investida do cadi de Sevilha e quando a região foi assolada por várias incursões das forças em contenda. $\mathrm{O}$ ataque sevilhano ao castelo de Lafões, com o cativeiro de cerca de 300 cavaleiros, poderá ter ocorrido entre 1026-1030 (Aillet, 2010: 300). Este episódio, relatado por fonte muçulmana, tem dado origem a várias interpretações sobre a respetiva data e quanto à origem de uma parte de população cristã, que falava correntemente o árabe. Assim, o debate tem incidido mais sobre aspetos concretos de tal acontecimento, do que acerca da sua relevância no contexto do plano leonês para recuperar as cidades fronteiriças de Viseu e Coimbra. As condições para desencadear uma operação militar de tão ampla envergadura, por parte do rei Afonso V, só se começaram a proporcionar a partir de 1016-1023, ou seja, depois de afastados alguns perigos internos para a monarquia e interrompidas as ameaças vindas do exterior, em consequência da desintegração política do califado (Real, 2018: 326-327). A base territo- 
rial da estratégia leonesa, neste momento, passou a ser a Terra de Santa Maria e o vale do Vouga, de conflito com partidários do poder califal, mas que sempre mantivera uma forte presença cristã e cuja jurisdição, por delegação do rei leonês, passou a estar a cargo do conde Mendo Lucídes (Mattoso, 1981: 110). Daí terão partido os principais ataques ${ }^{9}$, dando origem a um período de grande instabilidade regional, expressa na documentação coeva, que fala do resgate de cativos, da fuga do abade da Vacariça para o mosteiro de Leça, a norte do Douro, e do conflito contra os próprios conterrâneos que, no passado, se tinham aliado a Almançor e agora ocupavam posições de destaque. Nesta primeira fase, a frente mais avançada terá ficado a cargo de dois irmãos da casa de Marnel, linhagem descendente do conde Ero Fernandes e cujo castelo senhorial ocupava uma posição estratégica primordial no baixo Vouga, controlando a antiga estrada romana que ligava Portucale a Emínio e a via secundária que daí seguia para Viseu. Tais irmãos eram filhos de Egas Eris Iala e atuariam, decerto também por delegação régia, sob a autoridade do referido conde Mendo Lucídes ${ }^{10}$. Ao primogénito, Gonçalo Viegas, coube governar Montemor, cujo castelo fora tomado cerca de 1017, como etapa preliminar para o assalto a Coimbra (In era $M^{\underline{\underline{a}}} L^{\underline{\underline{a}}} V^{\underline{\underline{u}}}$ si ganaui domno iben gundisaluo iben egas... in diebus domno adefonso rex quando sedia in monte maiore de manu ille rex - DC 549). Embora as fontes documentais não sejam tão explícitas, terá cabido a seu irmão, Fromarigo Viegas, uma iniciativa

9. É possível que também tenha havido um envolvimento de Viseu a partir do sul, tal como parece comprovar-se pela existência de uma epígrafe cristã do ano 1018, em Vila Maior (Sabugal), onde aparece o nome de Osorio Teles, primo do conde Mendo Lucídes, e tal como este, neto de Alvito Nunes e Múnia Dias. Encontram-se ambos ligados ao clã de Lafões, donde alguns dos seus membros partiram para colonizar o vale superior do Mondego (Real, 2018: 325 e fig. 11).

10. O conde Mendo Lucídes deve ser filho de Lucídio Alvites, segundo José Mattoso, sendo assim descendente em $4^{\circ}$ grau do presor de Portucale, Vímara Peres. Ele está já ao lado de Afonso V em 1014 (DC 223) e num documento de 1019 fala-se da conquista da praça de Montemor, que anteriormente se encontrava a cargo do governador nomeado pelos muçulmanos, Froila Gonçalves, "sed superualiauit eum menendus lucidi” (LP 134). O conde Mendo Lucídes deve ser entendido, aqui, apenas como o representante do rei, já que o castelo havia sido tomado dois anos antes por Gonçalo Viegas de Marnel, que era quem exerceria funções militares no terreno. paralela sobre o castelo de Lafões ${ }^{11}$. Dois anos mais tarde, ele estava já a adquirir uma propriedade em Vouzela, no sopé do monte da Senhora do Castelo $(D C 243)^{12}$ e reaparecerá em dois documentos de 1030, num deles com funções de tenência territorial (DC 268) e noutro a receber incomuniação de uma herdade no vizinho lugar de Iben Ordonis ${ }^{13}$. Neste intervalo de tempo é que decorreu o fatídico cerco à cidade de Viseu (1028), na sequência do qual o rei Afonso $\mathrm{V}$ viria a falecer, atingido por uma seta. E em data incerta, mas seguramente numa missão de auxílio à quase isolada guarnição militar de Viseu, dá-se o assalto ao ameaçador castelo de Lafões, por tropas sevilhanas comandadas pelo cadi Abû al-Qâsim, de acordo com alguns analistas, ou pelo segundo rei da taifa, al-Mu'tadid, no dizer de fonte árabe. É bem possível que a morte do monarca e, sobretudo, esta celebrada vitória muçulmana em Vouzela tenham conseguido suster, por algumas décadas, a queda de Viseu. A reconquista da cidade só sucederá no tempo de Fernando Magno, através de um envolvimento militar de algum modo inspirado na estratégia montada, já nos anos 20 , por Afonso $\mathrm{V}$ de Leon. Sendo certo que Viseu conseguiu resistir, a região de Lafões poderá ter continuado como linha avançada das forças cristãs, cada vez mais pressionantes, tal como sucedeu em Montemor relativamente a Coimbra ${ }^{14}$.

Como é óbvio, o controlo de um território não se podia restringir a apenas um ponto fortificado. Tem

\footnotetext{
11. Deve-se a A. de Almeida Fernandes a chamada de atenção para a quase simultaneidade das ações militares sobre os castelos de Montemor e Lafões, que confirmamos terem sido dirigidas separadamente
}

por dois membros da casa de Marnel, irmãos entre si (Fernandes, 1972: 201-205).

12. Em Ferreiros, junto à quinta de Valgode e na margem direita do Vouga, onde brotam também águas termais.

13. Trata-se de Bordonhos, uma villa aristocrata em que terá vivido exilado o príncipe asturiano Bermudo Ordonhes, irmão de Afonso Magno (AUC, Pergaminhos, IV-3 $3^{\underline{a}}$, Gav. $29, \mathrm{n}^{\circ}{ }^{1}$ ).

14. Montemor será reconquistada em 1034 por Gonçalo Trastamires, da Maia. Não deve ser por acaso que se repete novo paralelismo histórico com a tenência do castelo de Lafões, cuja liderança virá a ser entregue a outro prócere da Maia, Piniolo Garcia. A mudança política pode ter-se iniciado com a crise instaurada nos anos finais do reinado de Bermudo III e a subida ao trono de Fernando Magno, após a batalha de Tamarón. 
vindo a ser detetada uma complexa rede defensiva que incluía outros castelos, com função mais restrita, e uma série de atalaias e fachos de comunicação. Uma boa parte do sistema extravasa, naturalmente, para fora da área do município de Vouzela. Mesmo assim, dentro do território concelhio existe uma variedade tipológica de postos miltares, que é bastante representativa das múltiplas funções e dos distintos níveis de atuação no âmbito do sistema: Castêlo (castelo roqueiro que defendia o vale de Alcofra e controlava itinerários alternativos que, a partir de Viseu e de Besteiros, se dirigiam para Vouzela ou para o litoral - Figura 6; dado a conhecer em Marques, 1999: 39); Pena da Penoita ou Outeiro dos Mouros (elevação roqueira com importante posição estratégica, pela sua ampla visibilidade regional, superior à Senhora do Castelo); Atalaia (posto de controlo da antiga calçada romana, junto à Ponte Pedrinha); Esculca (ponto de vigilância, ao serviço de uma pequena instalação rural de altitude, nos Lameiros Tapados); Candeeira (possíveis lugares onde se produziam sinais luminosos). Todavia, para a maior parte dos locais não possuímos dados arqueológicos para a sua cronologia. O povoamento do território concelhio deveria, então, apresentar já uma notável diversidade. Quase todas as sedes de freguesia estão referenciadas documentalmente desde cedo, mas raramente fornecem vestígios materiais de ocupação antiga, fruto do sucessivo desgaste causado pelo uso permanente do espaço. Uma das características mais interessantes deste território e que, uma vez mais, contrasta com a restante região beirã, é o facto da rede de aldeias (muitas delas sobreviventes até hoje) ter sido definida num momento muito recuado da Idade Média. Não é possível precisar a cronologia para o início da constituição desta rede de povoamento, precisamente porque os vestígios jazem sob as atuais povoações. Identificaram-se também vários povoados abandonados, como o do Pobral (Ventosa), de origem seguramente remota, mas cuja amplidão, estado ruinoso e densidade florestal dificultam o respetivo estudo. O projeto permitiu ainda a identificação de um conjunto de sítios rurais bastante promissores para a investigação arqueológica altomedieval. O primeiro a ser arqueologicamente intervencionado situa-se nos Lameiros Tapados, no limite de Ventosa com Paços de Vilharigues (Figura 7). Trata-se de um sítio de montanha, mas que ocupa uma rechã protegida por um tor granítico dominante e onde há facilidade de acesso a uma fonte de água. O sítio foi reconhecido na sequência dos incêndios de 2017. Apesar de não se identificarem materiais arqueológicos à superfície, eram visíveis uns alinhamentos de muros de duplo paramento, os quais levaram a que a intervenção fosse ali efetuada. A primeira campanha de escavações revelou cerca de uma meia dúzia de construções pétreas de planta alongada (sub-retangulares), que apresentam apenas uma entrada, um espaço de fogueira no seu interior e áreas de trabalho (aqui foram identificados diversos elementos de dormentes de vai-vem, assim como moventes em granito). É possível que se tratem de construções de carácter sazonal, erguidas e em uso entre os séculos X/XI, que podem ter sido utilizadas por várias famílias durante o Verão, para o aproveitamento dos pastos de altitude. A investigação ainda está no início, pelo que é prematuro avançar com mais interpretações.

A existência de elites terratenentes parece ser, desde muito cedo, uma das marcas caracterizadoras da região de Lafões. O mais significativo indício disto é a migração de um príncipe asturiano - Bermudo Ordonhes - que se veio a instalar na villa Iben Ordonis (Bordonhos - c. São Pedro do Sul), quer dizer, na herdade do filho do [rei] Ordonho. Muito possivelmente foi ele o fundador da capela de S. Martinho, anexa ao Banho de Lafões. E na outra margem do Vouga encontrava-se a villa ou paço de Moçâmedes (c. Vouzela), pertencente a Diogo Fernandes e Onega. Aí nasceu a futura condessa Mumadona e foi criado, na infância, o célebre rei Ramiro, seu irmão de leite (Real, 2013: 211-215). Em redor desta casa senhorial gravitaram também dois descendentes do conde Afonso Betotes e um neto de Vímara Peres, os quais vieram a casar com as filhas de Diogo e Onega. Mas haveria mais gente nobilitada, como parece poder concluir-se do precoce surgimento do topónimo $\mathrm{Pa}$ ços (de Vilharigues), cujo dono - hoje desconhecido - deve ter sido o patrono da vizinha igreja pré-românica de $S^{a}$ Marinha, já desaparecida, mas da qual ainda restam vestígios no local, como se referiu acima. Após a conquista de Almançor e com as lutas pela recuperação cristã do território, no tempo de Fernando Magno, as linhagens tradicionais viram-se ultrapassadas por algumas famílias de infanções que souberam aproveitar o momento para se guindarem socialmente, aproximando-se da corte e enriquecendo o seu património. A sua origem encontra-se pouco esclarecida, por vezes, mas provavelmente elas emergem de desconhecidas elites da região ou pertencem a ramos bastante colaterais da antiga 
nobreza terratenente. Estão neste caso, bem documentados em Lafões, homens como Cid David, Cid Aires ou João Gosendes (Ventura, 1985). Mas existirão outros, cuja memória quase se perdeu, como aquele Auriasu Crescones, que uma epígrafe datável do século XI, encontrada durante no âmbito do atual Projeto, nos ensina que fecit a igreja de $\mathrm{S}^{\underline{a}}$ Maria de Figueiredo das Donas (Figura 8). Os dois primeiros estão ligados à fundação das cavalarias vilãs de Vouzela e de Alcofra, estruturas paramilitares criadas a par dos progressos da conquista, com o intuito de reforçar os meios de defesa fronteiriça e de auxiliar o rei quando este ia em fossado sobre terras inimigas. Os chefes de tais elites irão tornar-se patronos de novos mosteiros, fundados pela respetiva linhagem, como aconteceu nos de Santa Maria de Vouzela ou de São Pedro do Sul. A Cid Aires poderá ser atribuída também a fase proto-românica da igreja de S. Martinho de Alcofra (Figura 9, fase II). Esta última, tal como os mosteiros acima referidos, a igreja de $\mathrm{S}$. Miguel de Folgosa, sobranceira à villa de Fataúnços (Figura 10), e outras casas religiosas cedo nomeadas na documentação, virão a ser protagonistas no precoce processo de paroquialização da Terra de Lafões. Abre-se assim um novo ciclo na gestão do território, que acompanha a reorganização de poderes, coeva da instauração da Monarquia por iniciativa do rei D. Afonso Henriques, que colocará homens da sua confiança à frente da Terra de Lafões e nela facilitará a implantação do mosteiro de $S^{a}$ Cruz de Coimbra.

Uma das características mais notórias deste território é a intensa exploração mineira, que foi amiúde responsável, não só pela acentuada densidade ocupacional da região, mas também pelo revolvimento de solos que alterou os contextos arqueológicos, quando não mesmo os destruiu. Não se conseguiu ainda comprovar arqueologicamente a continuidade das explorações de estanho e ouro, que desde a Proto-História caracterizaram a vida económica da região. Todavia, a circunstância de ter existido uma torre senhorial em Noumam (Loumão), situada em plena zona mineira e propriedade de um potente, pode indiciar que então ainda pudessem estar em exploração recursos mineiros. Tal hipótese não é de descurar, mesmo que seja admitida a perda de importância da extração de minério nesta época. Não podendo ser ainda comprovada esta atividade no período Alto Medieval, fica a certeza de a mesma ter sobrevivido em Lafões em épocas mais tardias, numa clara continuidade de aproveitamento dos recursos que o território dispunha para oferecer aos seus habitantes.

\section{FONTES UTILIZADAS}

DC - Portugaliae Monumenta Historica: Diplomatae et Chartae. Lisboa: Academia das Ciências, 1867 e ss.

LP - Livro Preto: Cartulário da Sé de Coimbra. Coimbra: Arquivo da Universidade de C., 1999

\section{BIBLIOGRAFIA}

AILLET, C. (2005) - Aux marges de l'Islam: le châteaux des deux frères et le dernier des Ghassanides. In DESWARTE, T; SÈNAC, P., dirs. - Guerre, pouvoirs et idéologies dans l'Espagne chrétienne aux alentours de l'an mil. Turnhout: Brepols, p. 25-35.

AILLET, C. (2010) - Les Mozarabes. Christianisme, islamisation et arabisation en Péninsule Ibérique (IX-XII siècles). Madrid: Casa de Velázquez.

CARVAlHO, P. S., CARVALHO, A. F. (2018) - Para uma recuperação do megalitismo de Lafões (Viseu-Portugal). O concelho de Vouzela enquanto case-study. In SENNA-MARTINEZ, J. C., DINIZ, M., CARVALO, A. F. (Eds.) - De Gibraltar aos Pirenéus. Megalistismo, vida e morte na fachada atlântica peninsular. Nelas: Fundação Lapa do Lobo, pp. 37-50.

FERNANDES, A. de A. (1972) - Território e política portugalenses (séculos VI-XII). S.l. (sep. de "O Tripeiro", 4ª série, anos 10-12).

GIRÃO, A. A. (1921) - Antiguidades pré-históricas de Lafões: Contribuição para o estudo da arqueologia portuguesa. Coimbra: Imprensa da Universidade.

MARQUES, J. A. M (1999) - Carta Arqueológica do Concelho de Vouzela. Câmara Municipal de Vouzela.

MATTOSO, J. (1981) - A nobreza medieval portuguesa. Lisboa: Editorial Estampa.

REAL, M. L. (2013) - O Castro de Baiões terá servido de atalaia ou castelo, na Alta Idade Média? Sua provável relação com o refúgio de Bermudo Ordonhes na Terra de Lafões. Revista da Faculdade de Letras: Ciências e Técnicas do Património. 12, pp. 203-230.

REAL, M. L. (2018) - O papel das elites na definição progressiva do território: sua presença na senhorialização da "Fronteira Beirã" (séculos IX-XII). In TENTE, C. (Coord.) - Do Império ao Reino: Viseu e o território entre os séculos IV a XII. Viseu: Câmara Municipal de V., pp. 297-340.

TENTE, C. (2016) - A geografia diocesana entre os séculos VI a 1147. In PAIVA, J. P. (Coord.) - História da Diocese de Viseu, Vol. I - Século VI a 1505, Viseu: Diocese de Viseu, pp. 23-42.

TENTE, C. (2017) - Rock-cut graves and cemeteries in the medieval rural landscape of the Viseu region (central Portugal). In THEUNE-VOGT, C., BIS-WORCH, C. (Eds.) - Ruralia XI Conference: Religious places, cult and rituals in medieval rural environment, Leiden: Sidestone press, pp. 215-226.

VENTURA, L. (1985) - O cavaleiro João Gosendes: sua trajectória político-social e económica (1083-1116). Revista de História-Económica e Social, 1, Lisboa, pp. 31-69. 


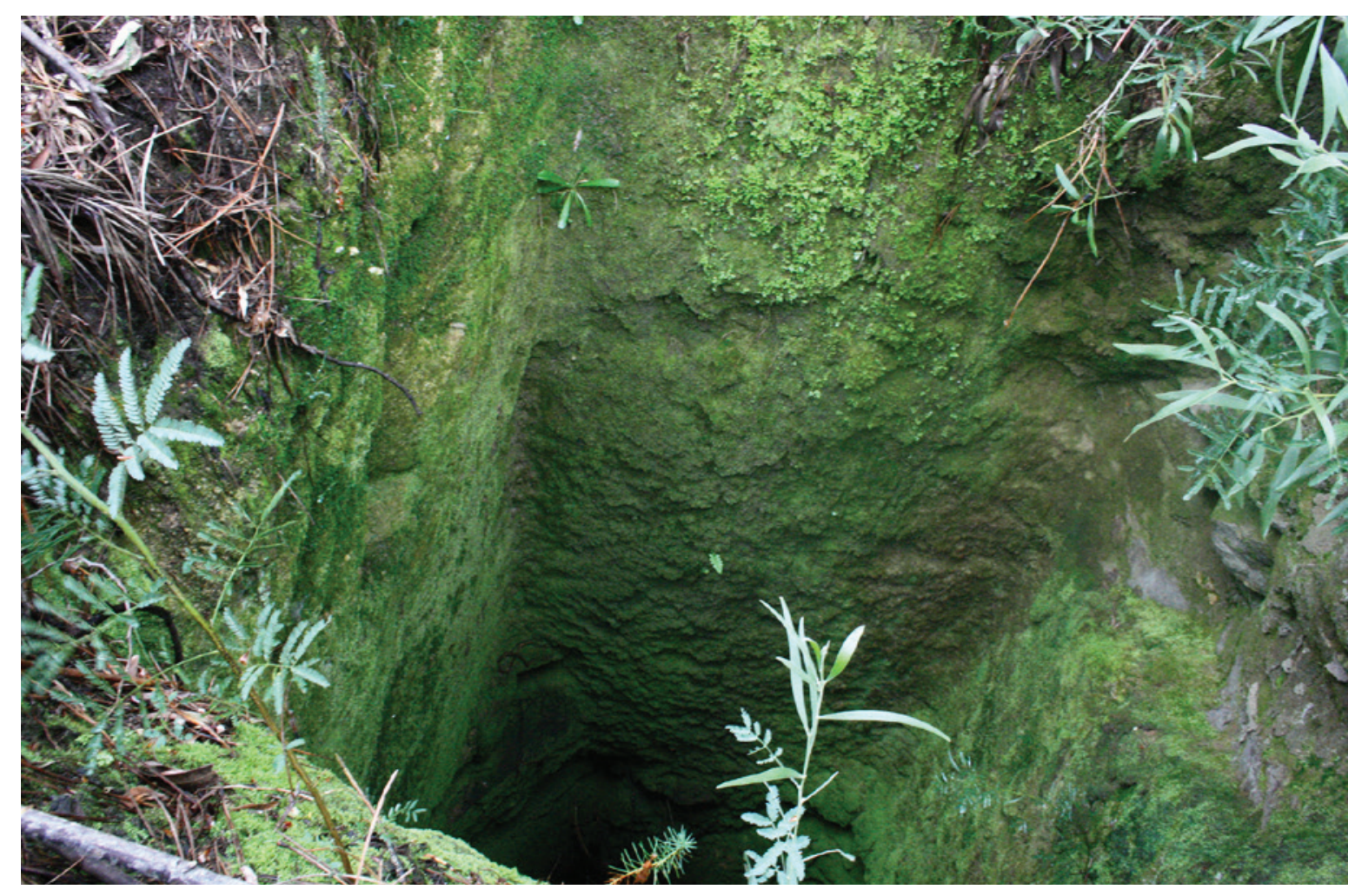

Figura 1 - Poço de mina na Senhora do Castelo, em Vouzela (cl. M. L. Real).

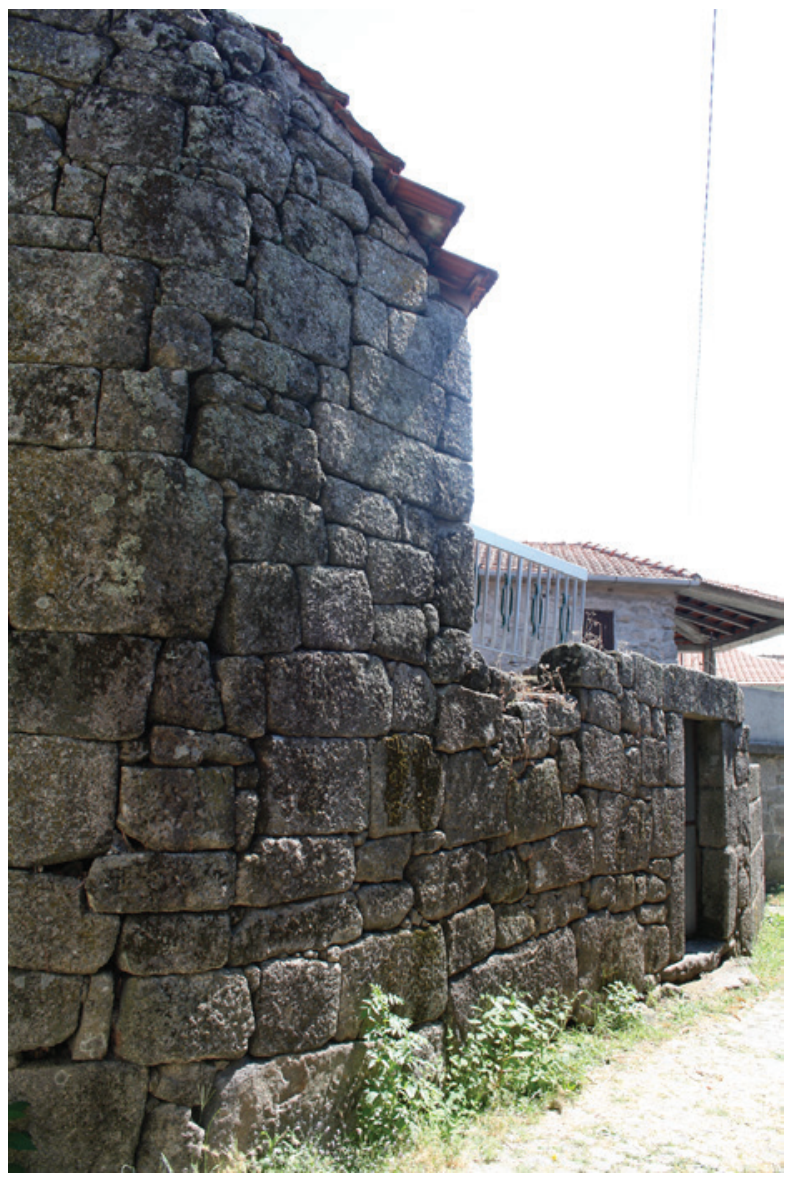

Figura 2 - Muro arruinado da torre pre-românica de Loumão, em Queirã (cl. M. L. Real). 
ESTUDO DO PATRIMÓNIO HISTOORICO-ARQUEOLOGICO DE VOUZELA TEMPLOS ANTERIORES AO SÉC. XII

$\downarrow$ Registo Documental

Vestigios Arqueológicos

ठndicios e Hagiotopónimo

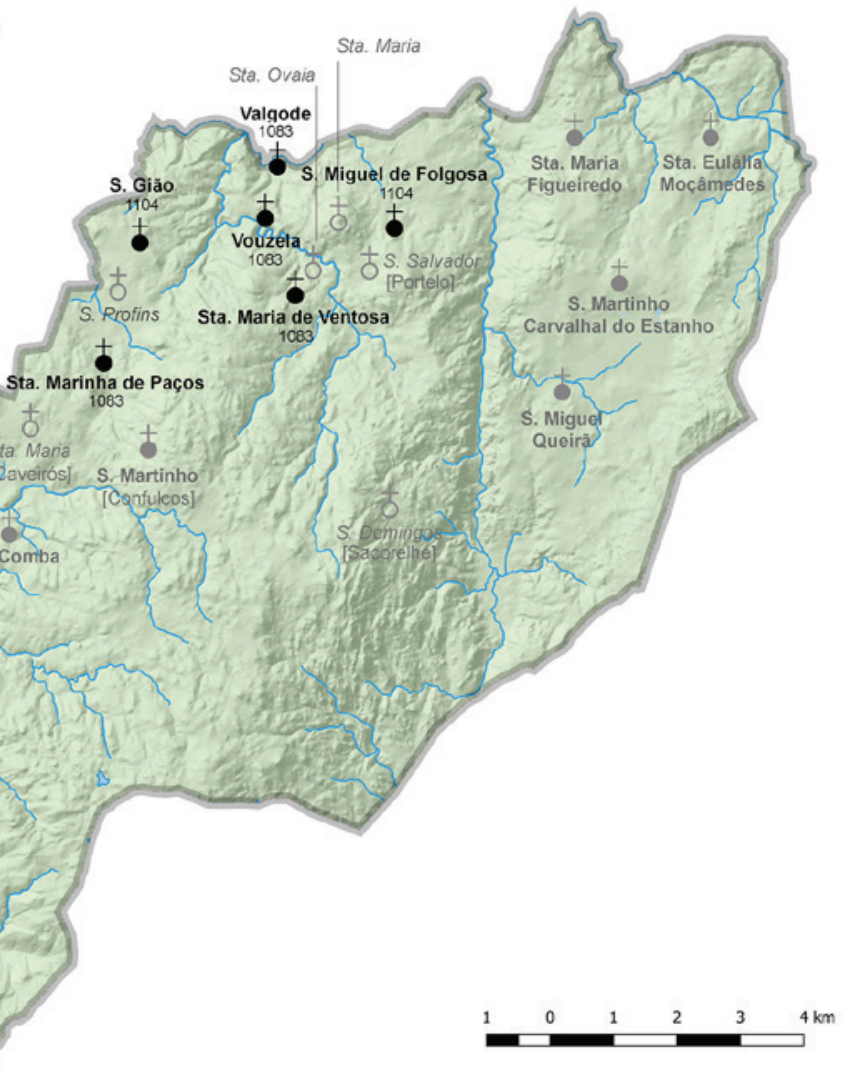

Figura 3-Templos anteriores ao séc. XII (des. Daniel de Melo Branco).

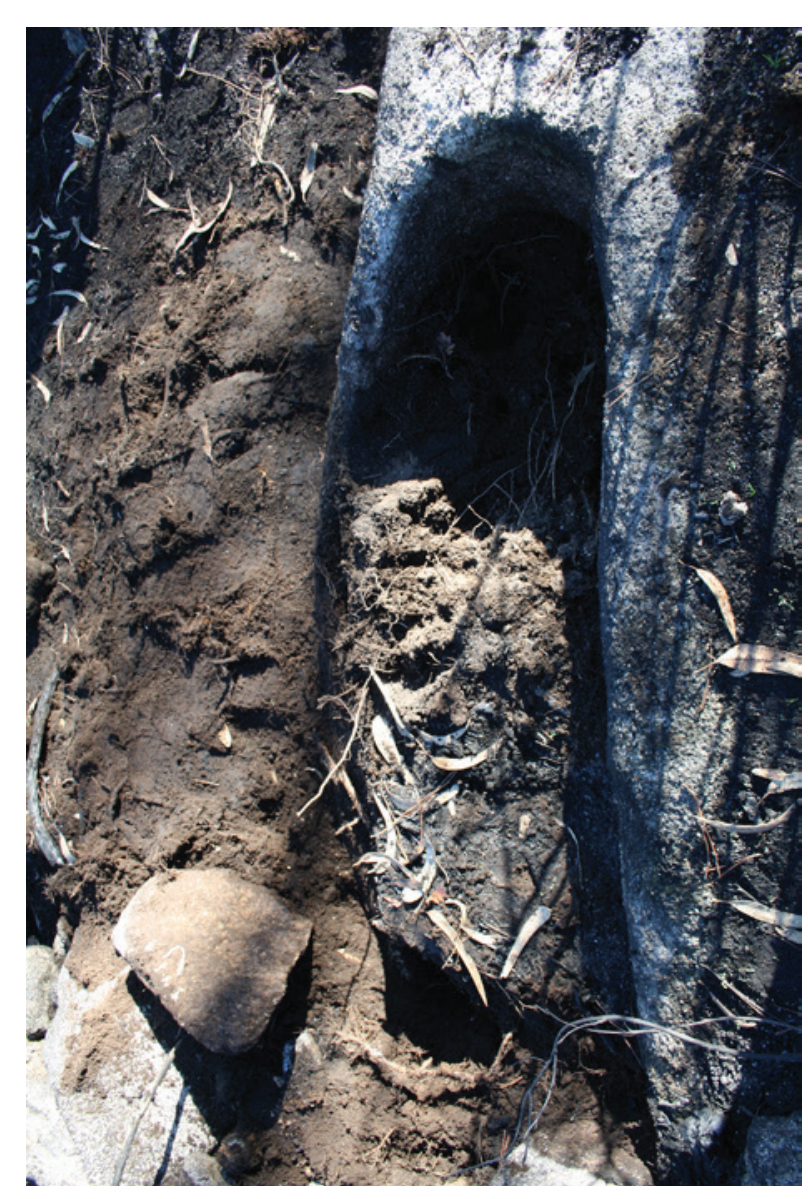

Figura 4 - Sepultura aberta na rocha, no castro da Ribamá, em Queirã (cl. M. L. Real). 


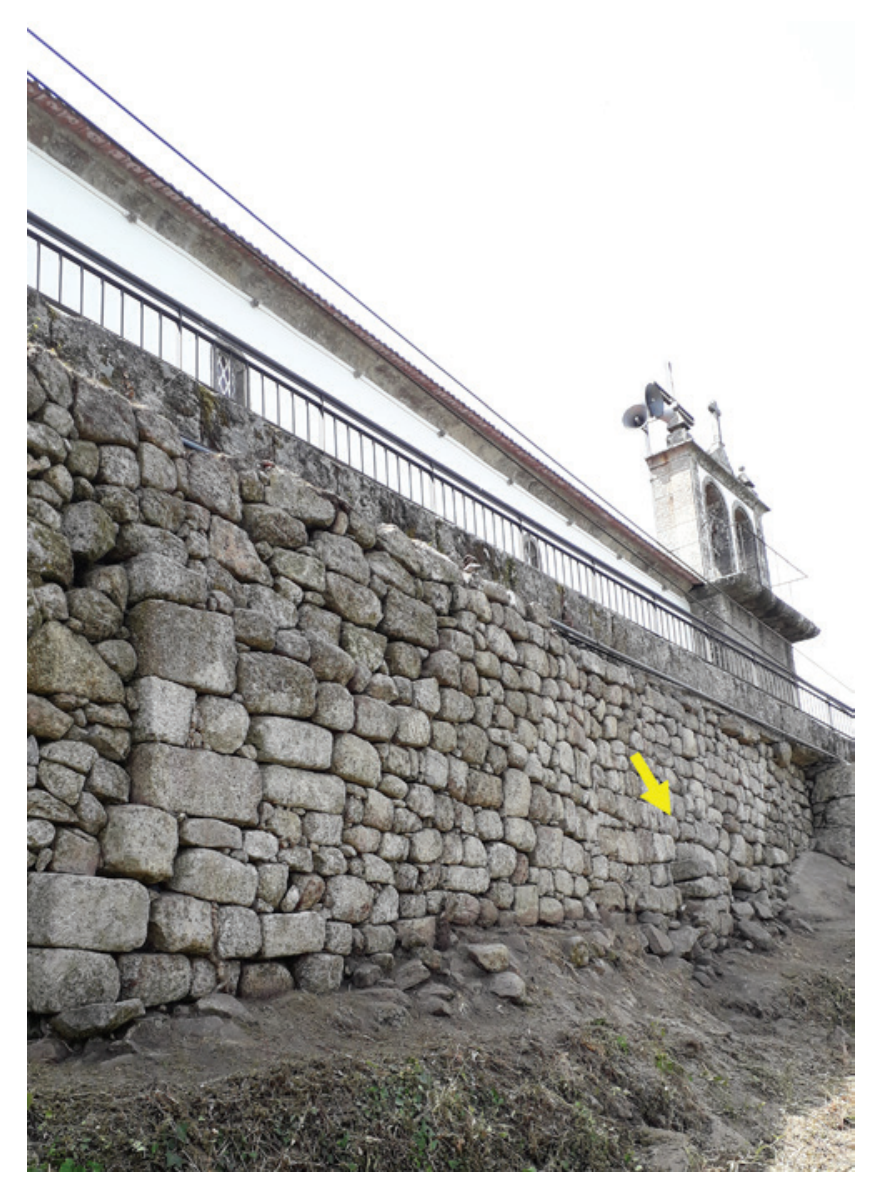

Figura 5 - Muro do castelo de Lafões. A seta aponta para o aproveitamento parcial da ruína de uma fase anterior da fortificação (cl. Luís André Pereira; trat. imag. Paulo Cruz).

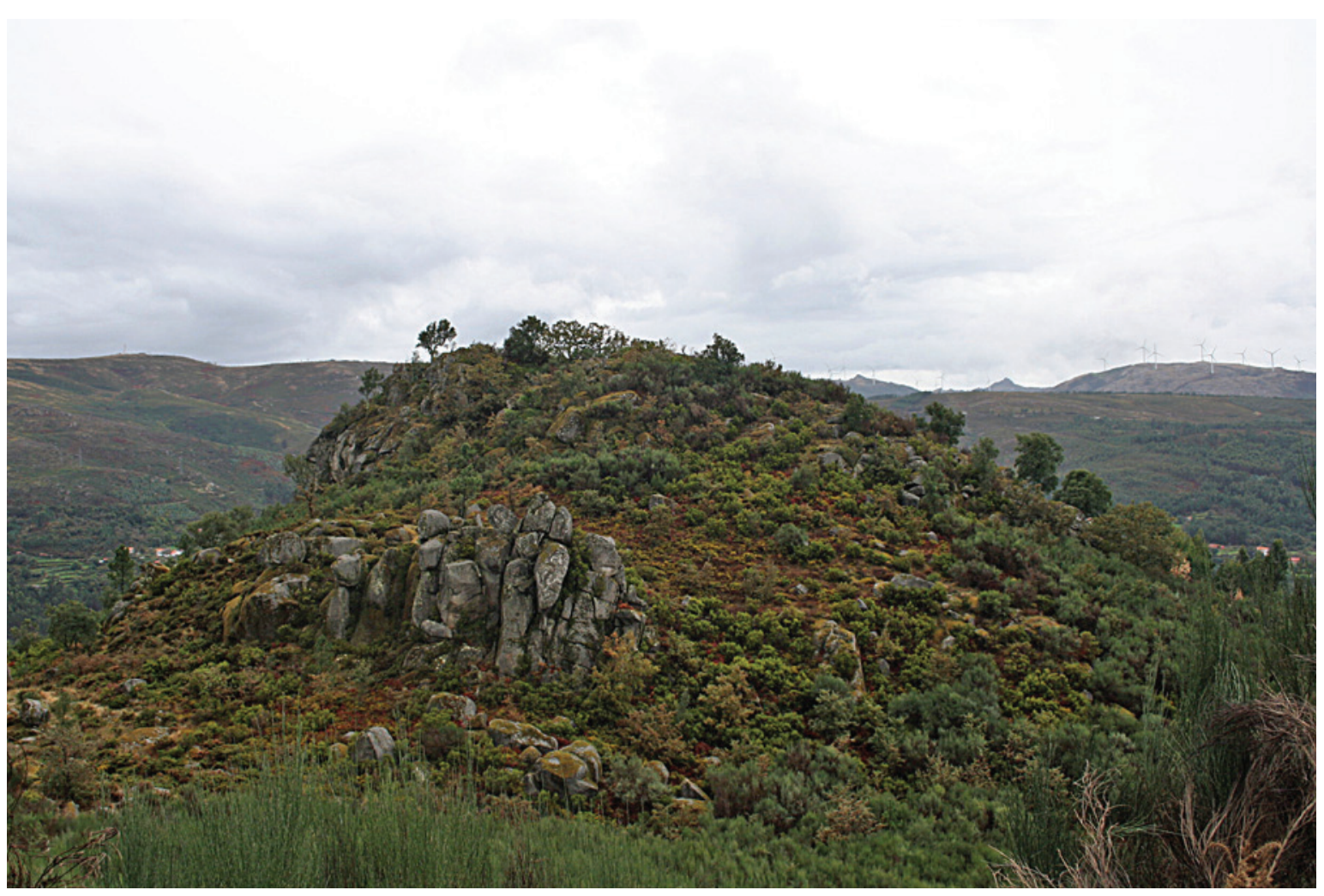

Figura 6 - O Castêlo de Alcofra, antes do incêndio de 2017 (cl. M. L. Real). 


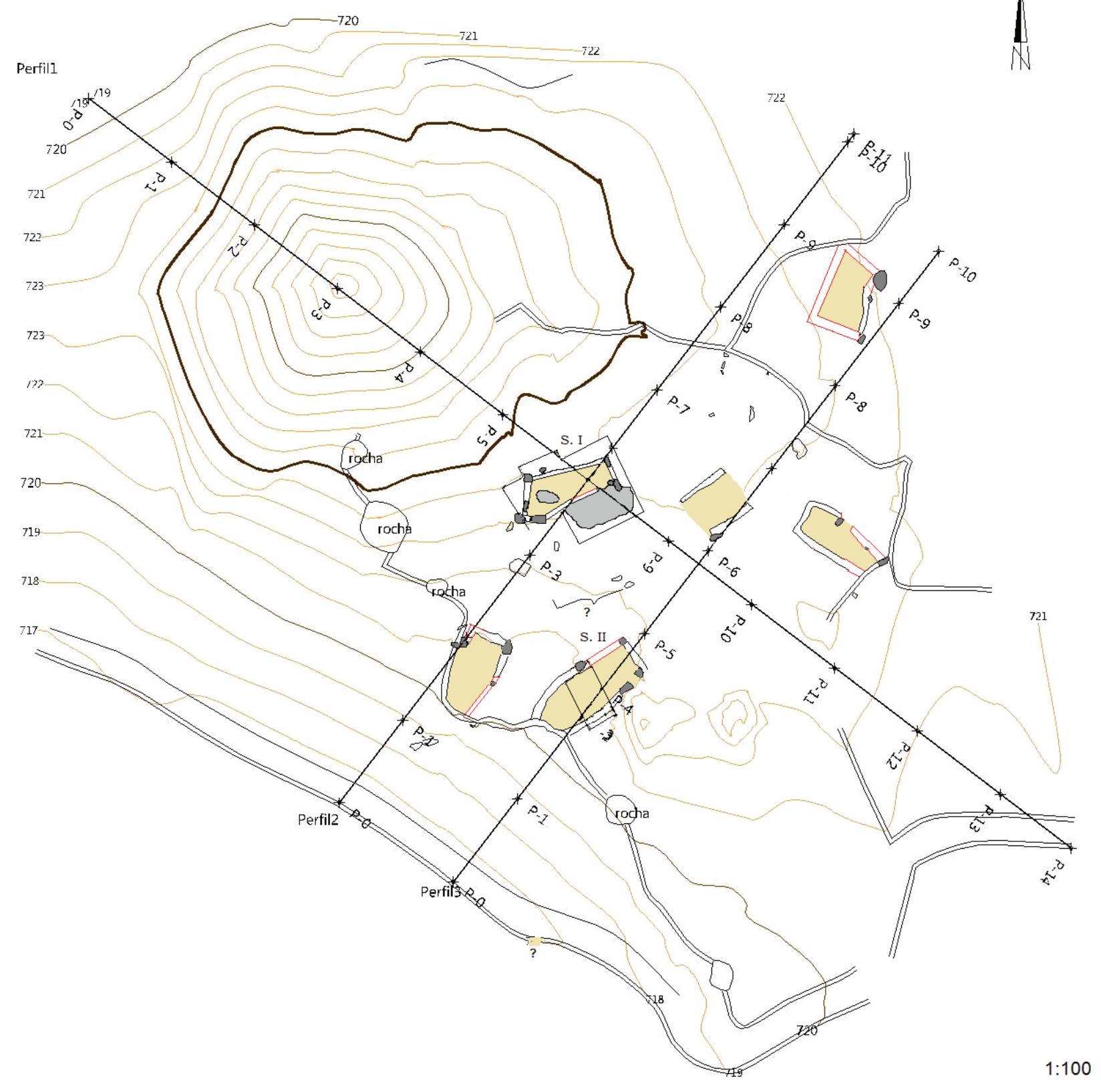

Figura 7 - Planta do habitat dos Lameiros Tapados, em Ventosa (topogr. José António Tomás; interpr. Catarina Tente). 


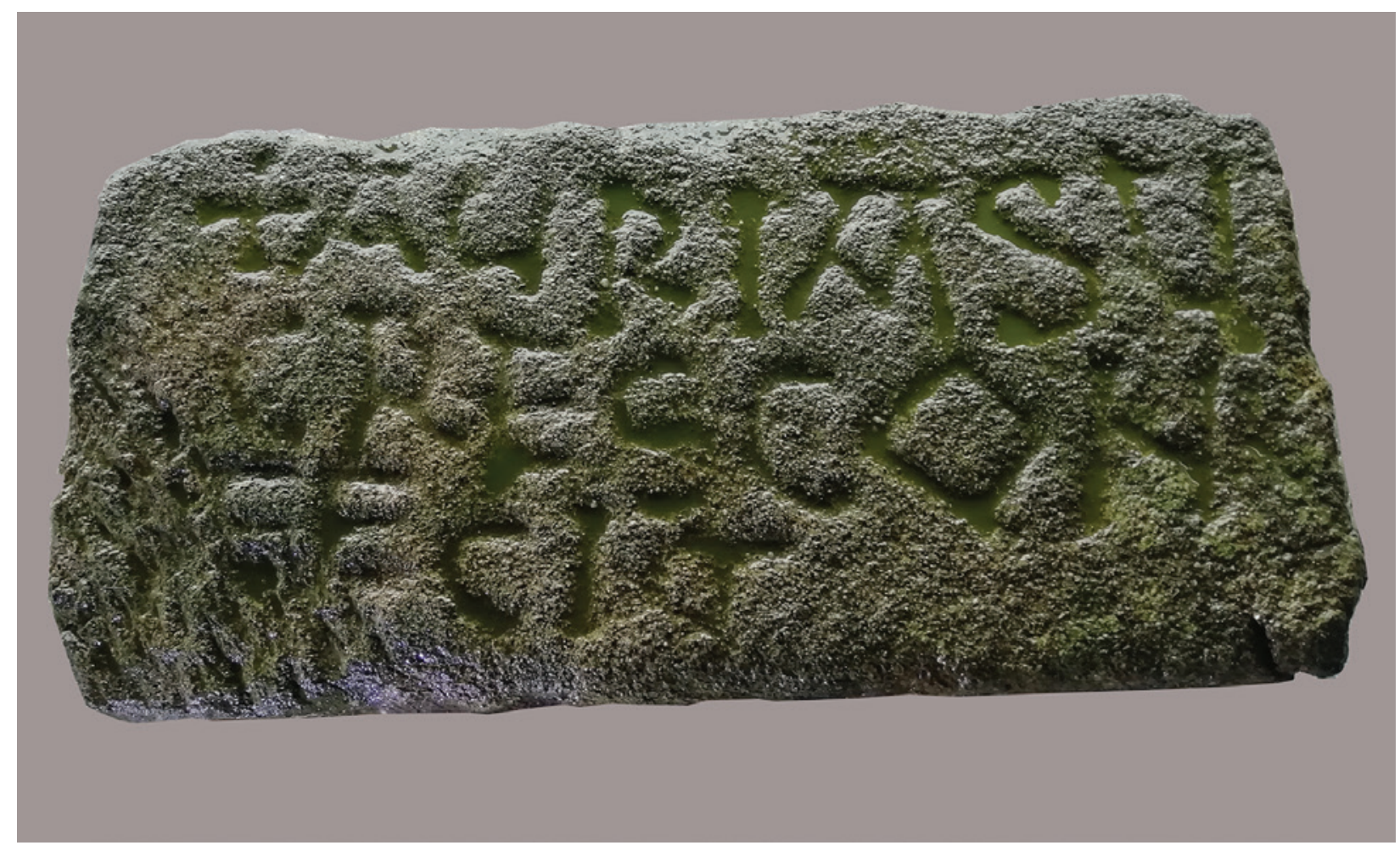

Figura 8 - Inscrição de Ṣa Maria de Figueiredo (das Donas), datável do séc. XI (cl. Luís André Pereira; trat. imag. Paulo Cruz).
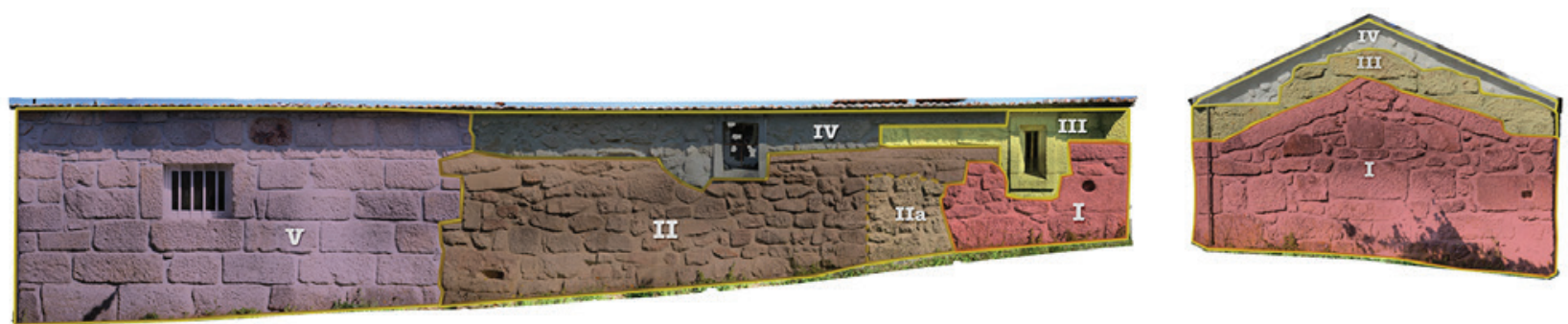

Figura 9 - Alçados Sul e Este da capela de S. Martinho de Alcofra: I - séculos V-VII ou VIII-X; II - século XI-XII; III - 1652; IV - 1960: V - 2008 (cl. Arqueologia e Património; trat. imag. Cláudio Almeida). 


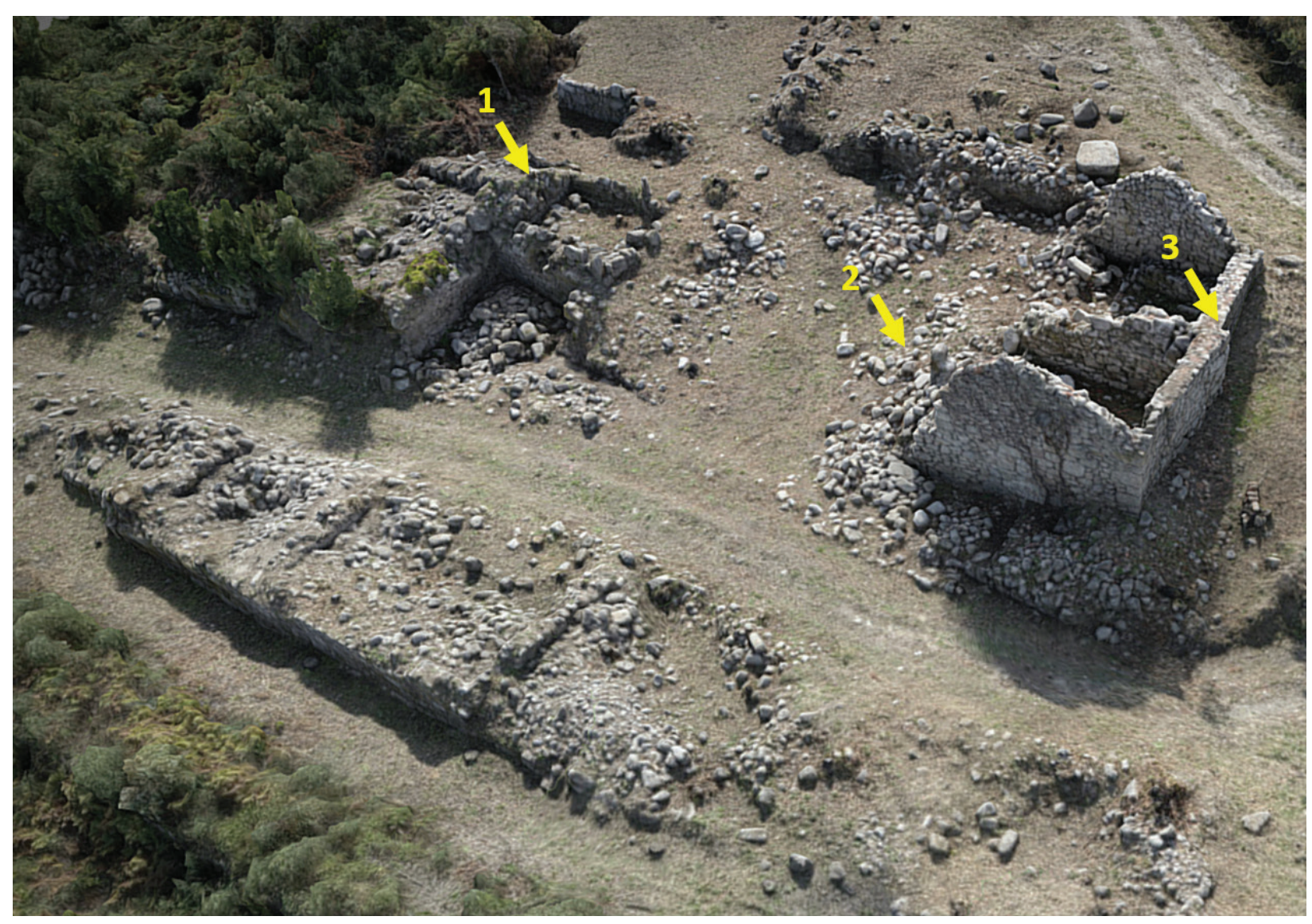

Figura 10 - Ruínas do Passal e igreja de S. Miguel de Folgosa, em Fataúnços. As setas assinalam: 1 - Presumível capela-mor do templo baixo-medieval; 2 - Provável localização da cabeceira pre-românica; 3 - Cunhal com pedras almofadadas, da igreja primitiva (cl. Arqueologia e Património; trat. imag. Paulo Cruz). 


\title{
UM CONJUNTO CERÂMICO MEDIEVAL FORA DE PORTAS: UM BREVE TESTEMUNHO AVEIRENSE
}

\author{
Susana Temudo ${ }^{1}$
}

\begin{abstract}
RESUMO
A realização de uma intervenção arqueológica de diagnóstico e de salvaguarda patrimonial, na avenida de Santa Joana, Aveiro, no biénio de 2017-18, permitiu a constituição de um acervo cerâmico até ao momento sem paralelos conhecidos na cidade.

Proveniente de depósitos de aterro antrópicos e de estruturas em negativo, o conjunto cerâmico insere-se numa linha temporal estremada entre o século IX e o séc. XIII, constituído por vasilhames de caráter doméstico como panelas, alguidares, jarros, bilhas, potes e caçoilas. Fragmentos com pastas resultantes de diferentes fabricos e gramáticas decorativas plásticas em cordão, puncionadas ou incisas.
\end{abstract}

Palavras-chave: Aveiro, Cerâmica, Medieval, Séc. IX-XIII.

\begin{abstract}
The realization of an archaeological intervention of diagnosis and heritage safeguard, in Santa Joana avenue, Aveiro, in the biennium of 2017-18, allowed the establishment of a ceramic collection so far without known parallels in the city.

From anthropic landfill deposits and negative structures, the ceramic collection is part of a storm line between the 9 th and the 13th century. It consists of domestic pottery such as pans, pots, bowls and jars. Fragments with pastes resulting from different manufactures and plastic decorative grammars like punched and structed motifs. Keywords: Aveiro, Pottery, Medieval, IX-XIII Century.
\end{abstract}

\section{BREVE ENQUADRAMENTO}

Os trabalhos arqueológicos desenrolaram-se no âmbito da construção de um empreendimento privado, na avenida de Santa Joana - Aveiro, num lote, à data dos trabalhos, sem qualquer tipo de edificação visível, justificando-se a intervenção pela sua inscrição na Zona de Proteção do Monumento de Interesse Público - Edifício Testa \& Amadores.

Pertencente a atual união de freguesias da Glória e Vera Cruz, a área assume-se de grande sensibilidade arqueológica, pelo que foi objetivo a deteção de vestígios arqueológicos, com a consequente minimização de impactos e salvaguarda dos elementos patrimoniais/arqueológicos pelo registo. Nesse sentido a escavação teve em consideração a sua área de implantação conjugada pela sua proximidade para com antiga linha de muralha, ainda que do lado exterior a esta mas no enfiamento da antiga porta da vila que permitia o acesso ao quarteirão do bairro dos oleiros e ao núcleo populacional em torno da antiga igreja do Espírito Santo, sede freguesia em 1572, demolida entre 1858 e 1875 (Curado, 2019, p. 9o). Não esquecendo o atual Museu da Princesa Santa Joana, também conhecido como o antigo mosteiro de Jesus.

Da intervenção resultou a constatação de uma ocupação do espaço desde o período medieval até aos nossos dias, com especial incidência nas centúrias seiscentista e setecentistas, apesar das interferências dos revolvimentos ocorridos na contemporaneidade. Assinalaram-se várias estruturas correlacionáveis com os níveis modernos e cadastráveis com a cartografia existente, os quais se sobrepuseram direta ou indiretamente sob os depósitos medievais e cuja temporalidade se posiciona entre os inícios do séc. XIV, recuando até ao séc. IX-X. Uni-

1. susanathemudo@gmail.com. 
dades estratigráficas assentes sobre o solo geológico em forma de aterro, por vezes cortadas por fossas detríticas, maioritariamente atribuíveis aos níveis de ocupação moderna ou então assinaláveis em estruturas em negativo como as fossas concheiro ${ }^{2}$ ou covachos de perfil côncavo (Figura 1). Desses estratos exumou-se um conjunto considerável de materiais composto por cerâmicas, numismas, líticos e fragmentos de tégula, assim como fauna mamalógica e malacológica.

\section{AVEIRO MEDIEVAL: APONTAMENTOS HISTÓRICOS VS DISCURSO ARQUEOLÓGICO}

A freguesia de Vera Cruz foi fundada a ro de Julho de 1572 pelo Bispo João Soares, atendendo ao crescimento populacional que se fez sentir nessa parte da cidade e atestado pelo livro de óbitos da freguesia de S. Miguel ${ }^{3}$ (Gonçalves, 1986, p.107). Justifica Jorge Arroteia (1999, p. 36) que a população ter-se-á expandido durante essa centúria face ao crescimento económico do burgo: "a população foi augmentando, chegando a transpor os limites que a apertavam, e dilatando-se para norte e para sul, formou arrabaldes cheios de boa casaria, que não tardaram a constituírem-se em novos bairros da vila" (Costa, 1930, p. 36).

O lote localiza-se exatamente na parte sul da cidade e fora da antiga zona de intramuros da cerca muralhada, nas imediações do atual largo da Fonte das 5 Bicas, local de implantação da igreja do Espírito Santo e na saída da porta de muralha que ligava à rua Direita, hoje rua dos Combatentes da Grande Guerra, portanto, junto de um dos principais eixos da rede urbana, no quarteirão fronteiro ao bairro das olarias (Figura 2).

Da análise da cartografia sabemos que o espaço onde se recolheu o espólio apresenta edifícios deduzíveis na cartografia de 1696 e evidenciadas com maior rigor na de 178o-81. Porém, a ocupação dos quarteirões em torno da igreja do Espírito Santo, de acordo com as parcas fontes históricas, as edificações serão

\footnotetext{
2. Estruturas em negativo de planta circular ou subcircular e de perfil concavo, escavadas no solo geológico ou cortando outros depósitos arqueológicos; preenchidas por conchas de bivalves (ameijoa, ostra, mexilhão ou berbigão).

3. Atualmente pertencente à união de freguesias da Glória-Vera Cruz.
}

anteriores, ainda que os trabalhos arqueológicos já executados apenas tenham registado ocupações de época moderna4. Segundo Rangel Quadros (2009, p. 137), apesar de não existir nenhuma documentação que ateste a fundação da igreja, sabe-se que D. Dinis terá mandado erguer vários templos sob esta invocação, descrevendo a de Aveiro onde "o arquitecto havido tido as suas pretensões a dar-lhe um estilo romano-bisantino (...) teria muito semelhança com os templos de S. Tiago e de S. Cristóvão da Cidade de Coimbra"; referindo mais adiante que no seu frontispício ostentava uma varanda sob o arco da entrada principal "e sobre esse arco havia um pequeno oculo redondo, envidraçado que dava luz ao interior da capela" (Idem, p. 138). Indícios que permitem aventurar uma edificação para o período balizado pelo estilo românico e consequentemente, contemporâneo à fundação da nacionalidade. As comparações com as supostas homólogas de Coimbra apontam para uma edificação no séc. XII. A igreja de S. Tiago, segundo Nogueira Gonçalves (1938, p.121), terá sido edificada no ano de 1183 . $\mathrm{O}$ que posiciona a data da sua fundação durante $o$ reinado de Fernando, o Magno, e consequentemente, a integra no arcebispado de Santiago de Compostela, ao qual pertenceu até 1183 (Viqueira, 1957, p.77). Com o crescimento urbano do arrabalde coimbrense, torna-se igreja paroquial e, por certo, terá sido por essa altura em que ocorre a primeira grande transformação arquitetónica, com a construção da matriz românica. Consta que terá sido erguida antes de 1206 - data da sua consagração (Borges, 1987, p. 88; Dias,1995, p. 56; Sacarrão,1999, p.4), uma vez que em 1119 tinha sido destruída pelo cerco de Ali Ibn Jusuf, e novamente afetada pelos ataques de 1139 e 1142, implicando, pois, a sua reconstrução em 1183 (Pereira, 1995, p. 254-55). A sua conterrânea, a de S. Cristovão ${ }^{5}$, apesar de ainda não haver consenso sobre a data de fundação, pelas características des-

\footnotetext{
4. Relembre-se que grande parte das intervenções arqueológicas ocorrem na figura do acompanhamento arqueológico. Ação que tem como intuito a observação e registo dos vestígios revelados pelas ações da obra e as quais nem sempre permitem visualizar a totalidade dos contextos arqueológicos, uma vez que os arqueólogos ficam sempre limitados à "cota de obra".

5. Igualmente demolida no séc. XIX para dar lugar a um teatro, reformulado posteriormente, resultando no atual teatro Sousa Bastos, sito no encontro da rua Joaquim António Aguiar com a rua das Esteirinhas.
} 
critas nas fontes documentais e iluminuras conhecidas, sabe-se que se insere dentro do estilo românico e que durante o tempo do Conde D. Henrique (1099-1108) já existia (Alarcão, 2008, p. 93).

A cidade de Aveiro é referida pela primeira vez num documento datado de 959, indicada pelo nome de "Alavarium in territorio Colimbrie (...) terras in alavarium et salinas(...)" (Oliveiros, 1984, p. 17), surgindo posteriormente em 1050 já com o nome de vila de Alaveiro, no inventário dos bens de Gonçalo Ibn Egas e de sua mulher D. Flâmula: "in illa marina costa sala tertia de Alaveiro" (Idem, p. 18), referindo António Gaspar que a zona central do burgo se posicionaria junto da antiga igreja de S. Miguel, demolida em 1840 para dar lugar ao largo municipal, delimitado a sudeste pelo edifícios dos Paços de Concelho (Cruz, 2005, p. 19). Igreja que se posicionava ao fundo da antiga rua Direita. Ora, sabendo da existência de um pequeno aglomerado no séc. $\mathrm{X}$ no eixo central da vila, com ligação a outro espaço religioso, a igreja do Espírito Santo, acredita-se que os vestígios arqueológicos encontrados possam estar relacionados com a presença de uma pequena mancha urbana posicionada numa área correlacionável com o núcleo populacional existente nas imediações da igreja do Espírito Santo e que com a construção da muralha no séc. XIV, ficou fora de "muros". Um elemento arquitetónico que somente veio assumir com maior premência a importância da cidade no contexto económico nacional, quebrando assim o caracter senhorial que ostentava desde os tempos da reconquista, apesar de ligeiramente atenuado com a elevação a vila por D. Dinis, responsável pela primeira cerca, após a sua recuperação para a coroa em 1306 (Silva, 1991, p. 13). Refira-se que terá sido no âmbito desta elevação que a igreja do Espírito Santo terá sofrido reformulações a julgar pela presença do seu escudo real no arco cruzeiro (Quadros, 2009, p. 138). Indício da importância que este templo teria no núcleo urbano da cidade.

$\mathrm{O}$ registo arqueológico aponta para um assentamento contemporâneo do burgo inicial, ainda que não se tenham encontrado estruturas habitacionais. Uma população provavelmente ligada à exploração do sal e às atividades piscatórias. Entre o espolio assinalou-se alguns pesos de pesca em cerâmica de pasta cinza e outros objetos líticos que poderão estar relacionados com este ofício, o que permite assegurar que se trata de uma povoação autóctone ou com residência sazonal. Possibilidade que poderá justifi- car a ausência de estruturas fixas e indiciando a utilização de elementos construtivos de pouca durabilidade, os quais poderão explicar a presença das valas, buracos de poste e os covachos (Figura 3). Contudo, também poderão corresponder a áreas de descarte, nomeadamente as fossas e covachos (deixando em aberto a interpretação das valas), posicionando-se os espaços da habitação na zona contígua à parcela, sita a sudeste e assim orientados para o largo das 5 Bicas, local que se crê central deste núcleo.

A questão relativa aos materiais de construção é referida na documentação, sendo os mais viáveis e de fácil acesso, segundo a autora Maria Violante Silva (1997), a madeira, utilizada na armação dos telhados e na edificação das próprias casas - talvez nos ditos "pardieiros"; a pedra, com predomínio do calcário, oriundo do Eixo; o barro e o seixo/calhau rolado, material em abundância na zona, procedentes do mar. Para além destes, há menção ao tijolo seco ao sol e depois cozido no forno. Um material muito utilizado em toda a cidade, havendo inclusive menção que o mesmo era utilizado em construções notáveis, como no Mosteiro de Jesus.

Dos elementos elencados pela autora, o registo arqueológico identificou a presença de seixos conjuntamente com pedra granítica. Aliás refira-se que a presença do granito está associada aos níveis de ocupação medieval, apesar dessa pedra também ter surgido igualmente nas edificações do período moderno, conjugadas com outras em calcário e arenitos, tendo-se interpretado como reaproveitamentos das estruturas preexistentes, pois refira-se que a presença desta pedra nas construções modernas na cidade não é comum. Por norma os aparelhos construtivos modernos caracterizam-se pela presença dos arenitos vermelhos, seixos rolados de grande calibre, xisto, tijolos, alguns da tipologia rabo de andorinha, telha e fragmentos de cerâmica vermelha, nomeadamente as formas de açúcar; envoltos em argamassas pobres em cal e de cor castanha ou amarelada. Acrescente-se ainda que se registou a presença de fragmentos de tégula de pasta laranja em alguns contextos. Indicador da presença de construções. Daí acreditar-se que o espaço habitacional situar-se-ia nas imediações da área escavada ou então, terem sido desmontadas e a reaproveitadas. 


\section{O CONJUNTO DAS CERÂMICAS} DE PASTA CINZENTA DE AVEIRO...

Apesar da oportunidade em observar um conjunto de fragmentos extenso, permitindo uma sucessão cronológica de ocupação e de destruição/abandono definido pela estratigrafia do sítio, é consciência de que o estudo deste acervo em particular, ainda não se encontra concluído, uma vez que falta completa-lo com outros elementos e realizar um estudo comparativo e contextual mais aprofundado. No entanto, acredita-se que é importante dar a conhecer algumas dessas peças, lançando Aveiro para a discussão que até ao momento tem sido mantida à parte nas cronologias medievais mais recuadas. A presença deste conjunto permite repensar a ocupação da cidade e pela primeira vez, o testemunho arqueológico parece confirmar o referido pelas fontes históricas.

Os materiais surgem em contextos com pouca expressividade estratigráfica quando comparados com os das cronologias anteriores, associados a níveis de depósito antrópico maioritariamente de aterro, existindo, porém, alguns de níveis selados como as fossas concheiro e as valas. Os objetos aqui apresentados compõem uma amostra selecionada desses estratos, em concreto das camadas [204], [506] e dos concheiros [504], [518], [547] e [557]; encontrando-se este último selado por uma unidade datada por um dinheiro de D. Dinis. Portanto atribuível ao séc. XII-XIII.

Deste conjunto constatou-se a presença de artefactos de carácter doméstico, pertencentes a diferentes universos. Identificaram-se fragmentos de louça associada ao armazenamento e transporte: potes; louça de cozinha: alguidares e panelas; e louça de mesa: bilhas e taças. Fragmentos que pressupõem a ocupação deste espaço. Curiosamente os fragmentos não se encontram rolados ou com indícios de desgaste, denunciando, pelo contrário, um bom estado de conservação e dimensões consideráveis, permitindo várias colagens. Outro aspeto interessante é o facto de alguns deles apresentarem vestígios de combustão, atribuindo às suas superfícies externas uma imagem ainda mais enegrecida (Figura 5).

\subsection{Características do fabrico}

As pastas das cerâmicas foram observadas superficialmente e havendo a consciência de que a análise ainda se encontra por concluir, é certo que se destacam dois grandes grupos dentro das pastas cinzentas. Uma diferença que poder-se-á justificar por pertencerem a sítios produtivos e/ou ambientes temporais diferentes dentro da medievalidade.

Os fragmentos foram feitos a torno e denunciam uma cozedura redutora.

\section{Tipo 1}

O primeiro grupo correspondente ao de pastas mais claras, homogéneas, de superfícies alisadas e bastantes micáceas, provendo uma imagem metálica provocada pelo reflexo das micas. Estas estão presentes nos fragmentos que se julgam ser mais recentes, ou seja, atribuíveis aos níveis do séc. XII/XIII, como é o caso do alguidar carenado presente na estampa 4, pertencente à u.e. [557]; e as asas de bilha decoradas constantes na Figura 4.

\section{Tipo 2}

Grupo com maior representatividade e composto pelos fragmentos de cor cinza acastanhada; pastas não tão compactas como o primeiro, homogéneas, pouco alisadas e com desengordurantes bem destacados, como quartzos e micas, entre outros; contendo alguns fragmentos, sobretudo os alguidares de base em disco alargado, mica dourada. Curiosamente, são estes que surgem nos contextos cronológicos mais recuados - séc. IX-X, e que no caso aqui apresentado corresponde aos alguidares com decoração plástica em cordão da estampa 4, contemporâneos dos potes da estampa 1 .

\subsection{As formas}

Para a sua nomenclatura foi seguida a terminologia da cerâmica medieval sugerida por Torres et alli (1997). As formas identificadas encontram-se documentadas na região norte e centro, apresentando os exemplares de Santa Joana paralelos em Conimbriga, Coimbra, Santa Olaia (Figueira da Foz), Casal da Malafaia e Castelo de Arouca, Viseu e Crestuma (Vila Nova de Gaia) (Mann; Tente, 2012; Nazaré, 2012). Os potes mostram quase sempre a mesma morfologia, mas variedade quanto ao tamanho, com oscilações entre os $14 \mathrm{~cm}$ e os $16 \mathrm{~cm}$ de diâmetro; bordos boleados ou ligeiramente extrovertidos e de lábios com um leve ressalto (Estampa 1). Não se conseguiu assinalar nenhum perfil completo, mas pela dimensão e orientação das paredes é percetível que seriam pouco espessas, perfazendo corpos ovoides estrangulados no colo e base plana.

As panelas presentes na estampa 2 inserem-se plenamente nos contextos domésticos do séc. X-XI. Re- 
presentam as formas com maior expressividade no conjunto com bordos extrovertidos, lábios arredondados, colos côncavos e corpos globulares de base plana com asas de perfil oval ou plano, com ou sem decoração puncionada. Dentro das panelas de pasta cinza, inseríveis no grupo 2, existem também exemplares de asa em rolo e paredes côncavas com caneluras.

Deste grupo destacou-se ainda a presença da panela de bordo reto e paredes com caneluras paralelas (Estampa 2, Figura 5). Uma forma que surge no mesmo contexto que um dos potes da estampa 1.

Os alguidares, a forma mais comum nos acervos cerâmicos pela sua multifuncionalidade, apresentam quase sempre a mesma tipologia. Formas troncocónicas, de paredes retas e oblíquas, com ou sem decoração em cordão digitado, tal como no lábio; de base em disco alargado e igualmente com ou sem decoração (Estampa 4).

As taças surgem como formas abertas de grande dimensão, com vários diâmetros, com variações entre os $15 \mathrm{~cm}$ e os $18 \mathrm{~cm}$. Corpos de paredes côncavas e bordos de diferentes tipologias (Estampa 3).

Por último, as bilhas (Figura 4), representadas pelas suas asas planas ou ligeiramete ovais, com uma decoração golpeada ou puncionada. Infelizmente desta forma não se obteve nenhum perfil completo, havendo, no entanto, a possibilidade de algumas colagens.

\section{CONSIDERAÇÕES FINAIS}

Das formas encontradas nesta intervenção e pela amostragem aqui exposta, conclui-se que não existe uma variedade muito grande quanto ao tipo de vasilhame. No entanto, assumem-se como um primeiro contributo para o estudo da cerâmica medieval de Aveiro, até ao momento desconhecida. Acredita-se que estas cerâmicas poderão ser fruto de uma produção local, talvez feitas no bairro dos oleiros e com as argilas de Aveiro. As denominadas margas cinzentas e que poderão corresponder às pastas pertencentes ao primeiro grupo. Porém, admite-se a igual possibilidade de haver peças de outros locais, como Coimbra, nomeadamente o grupo das pastas acastanhadas, apesar dos alguidares de micas douradas poderem ser fragmentos fruto de produções mais a norte. Atualmente os dados ainda são muito escassos e parcelares, não permitindo uma visão global sobre a sua distribuição na região, pelo que o que se apresenta deverá ser considerado como um ponto de partida de um estudo que ainda se quer mais aprofundado.

\section{BIBLIOGRAFIA}

AMORIM, Inês (1996) - Aveiro e sua provedoria no séc. XVIII (169o-1814): Estudo económico de um espaço histórico; Dissertação de Doutoramento apresentada à Faculdade de Letras da Universidade do Porto; Coimbra: Ed. Comissão de Coordenação da Região Centro.

ARROTEIA, Jorge Carvalho (1999) - Aveiro: aspectos Geográficos e do Desenvolvimento Urbano; Aveiro: Universidade de Aveiro.

BARREIRA, Manuel (2001) - As Muralhas da Vila de Aveiro em 1692 - Segundo o Tombo da Casa de Aveiro, Patrimónios n. ${ }^{1} 12001$, Abril 2001, ano XXII, 2ª série.

COSTA, A. B (1930) - Diccionário Chronográphico de Portugal continental e insular; XII vols; Vila do Conde: Typographia Privativa do Diccionário Chronográphico.

GASPAR, João Gonçalves (1988) - Porquê "Vera-Cruz" na cidade de Aveiro in Boletim Municipal de Aveiro, Ano XVIII, n.. 36, pág. 95-109.

GASPAR, Mons. João Gonçalves (1997) - Aveiro na História, Aveiro.

GONÇALVES, António Nogueira (1986) - Inventário Artístico de Portugal: Distrito de Aveiro, Lisboa.

GONÇALVES, A. Nogueira (1938) - Novas hipóteses acerca dos canteiros medievais de Coimbra, Coimbra: Gráfica de Coimbra Almedina.

MANN, Adrian; TENTE, Catarina (2012) - Estudos de cerâmica medieval: o norte e centro de Portugal - séculos XI e XII; Lisboa: Instituto de Estudos Medievais.

NAZARÉ, Maria João (2012) - Cerâmicas Medievais de Santa Olaia (Figueira da Foz) depositadas no Museu Municipal Dr. Santos Rocha; Dissertação de Mestrado em Arqueologia e Território; Coimbra: Faculdade de Letras.

NEVES, Amaro; FERREIRA, Delfim dos Santos Bismarck Álvares (2009) - História de Aveiro: sínteses e perspectivas, Aveiro.

PEREIRA, Paulo (dir.) (1995) - História da Arte em Portuguesa, vol I, $1^{\mathrm{a}}$ edição, Lisboa.

OLIVEIROS, Albertina Valentim (1984) - Aveiro no séc. XV in Boletim Municipal de Aveiro, n. $\stackrel{\circ}{4}$, Ano II, Aveiro: Câmara Municipal de Aveiro.

OUDINOT, José Rangel (2009) - Quadros - Aveiro. apontamentos históricos; CMA, Aveiro.

SACARRÃO, Carolina; PIMENTA, Olga; MESQUITA, Paula(1999) - A Igreja de S. Tiago de Coimbra, trabalho apresentado na disciplina de História da Arquitectura Clássica e Medieval, Lic. Arquitectura, Universidade de Coimbra, Coimbra.

SILVA, Cristina (1999) - Aveiro: território e cidade, Arqueo- logia de uma forma urbana; Dissertação de seminário da 
Licenciatura em Arqueologia; Faculdade de Ciências e Tecnologia da Universidade de Coimbra, Coimbra.

SILVA, Maria J. (1997) - Aveiro Medieval; Aveiro: Câmara Municipal de Aveiro.

VIQUEIRA, José M. (1957) - Coimbra: impressiones y notas de un itinerário, Coimbra Editora Limitada, Coimbra.

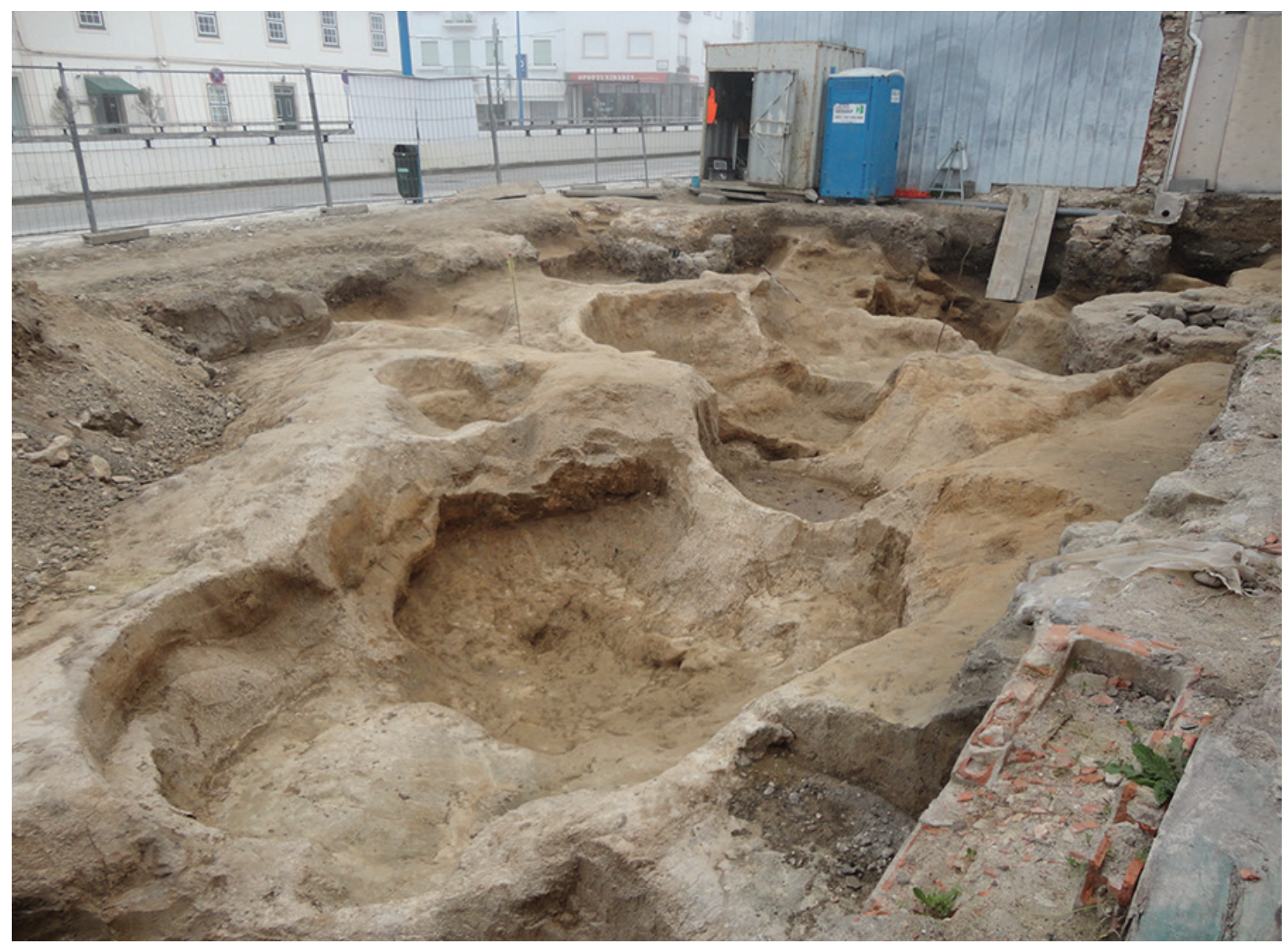

Figura 1 - Vista geral da área da escavação: plano final. 


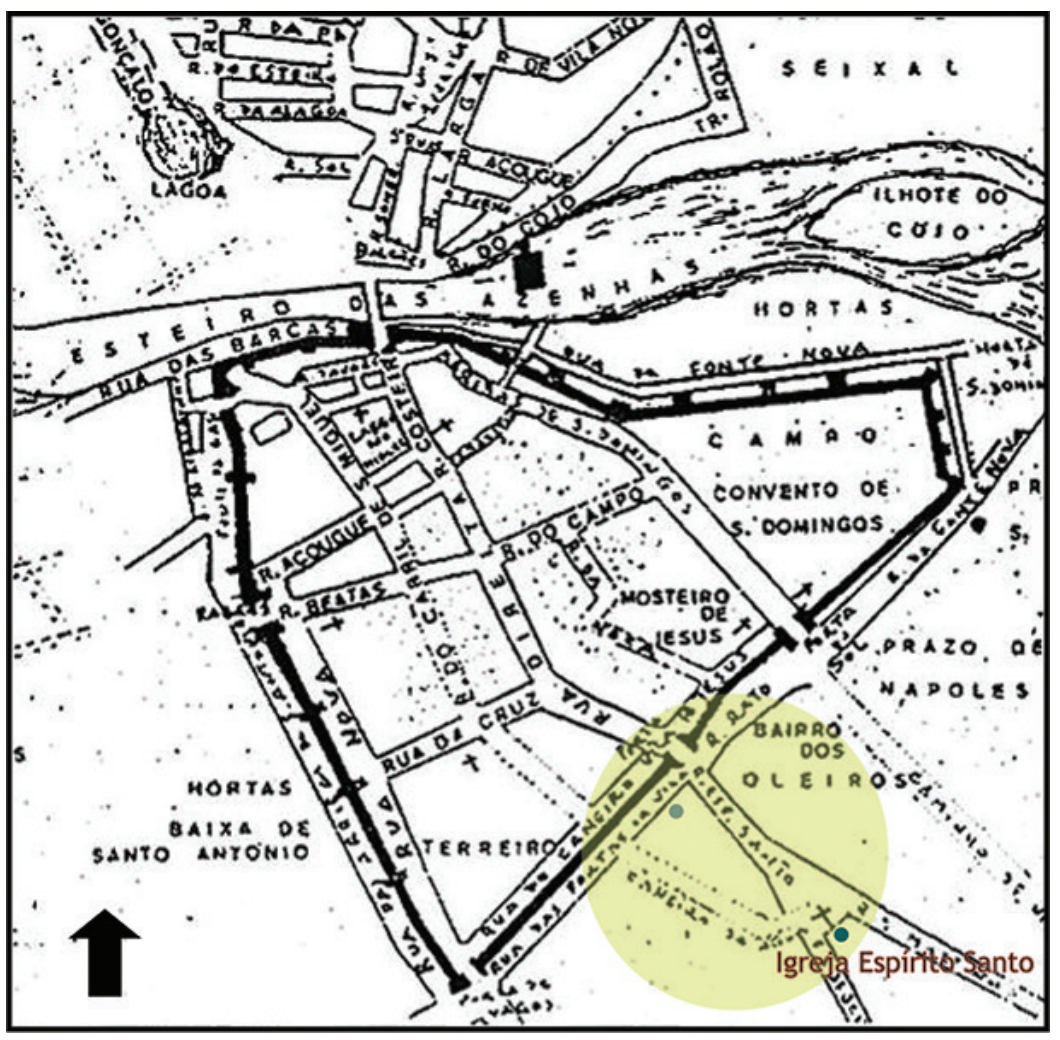

Figura 2 - Excerto do mapa da cidade datado de 1696 com a localização da intervenção e da Igreja do Espírito Santo.

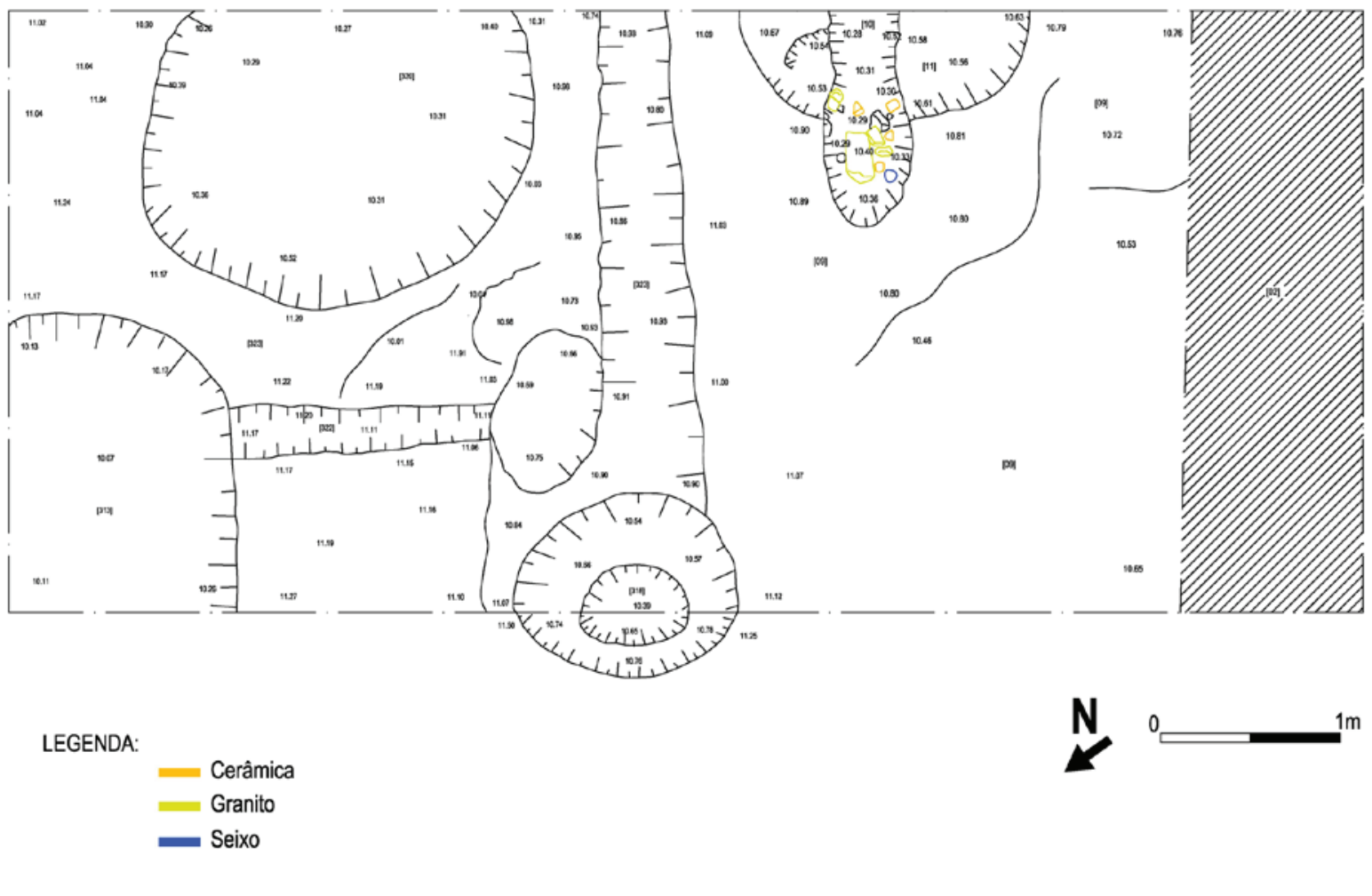

Figura 3 - Planta das fossas e valas. 


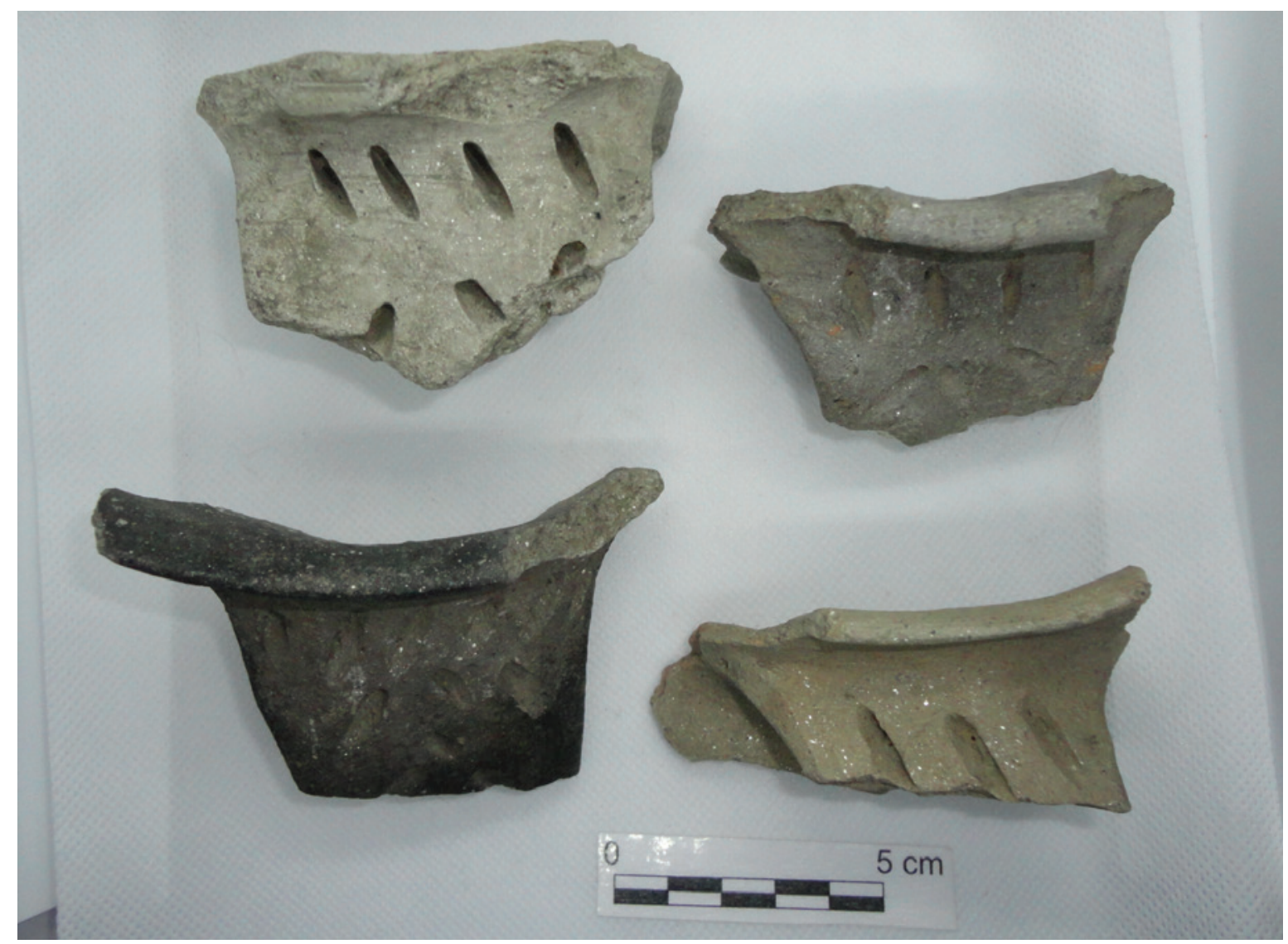

Figura 4-Asas de bilhas com decoração.

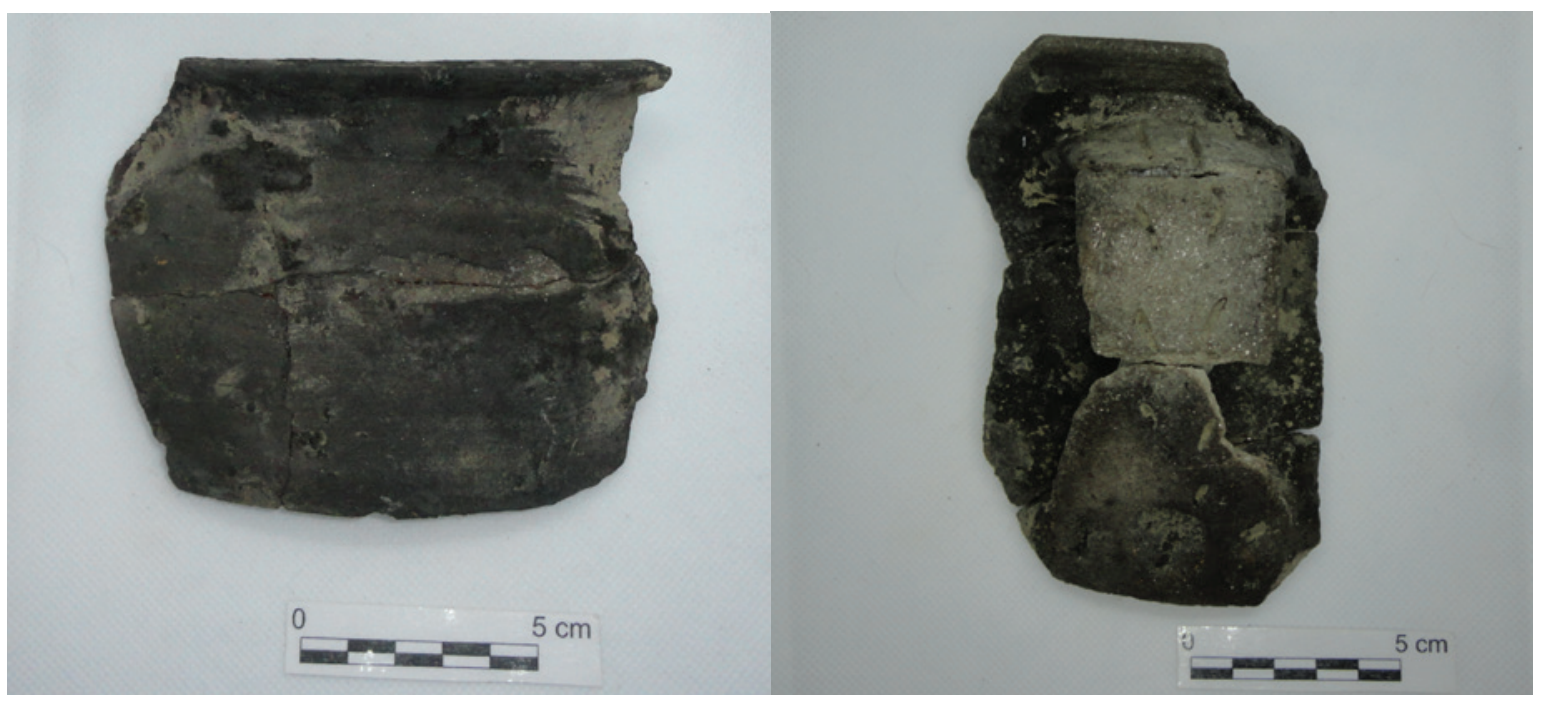

Figura 5-Panelas. 

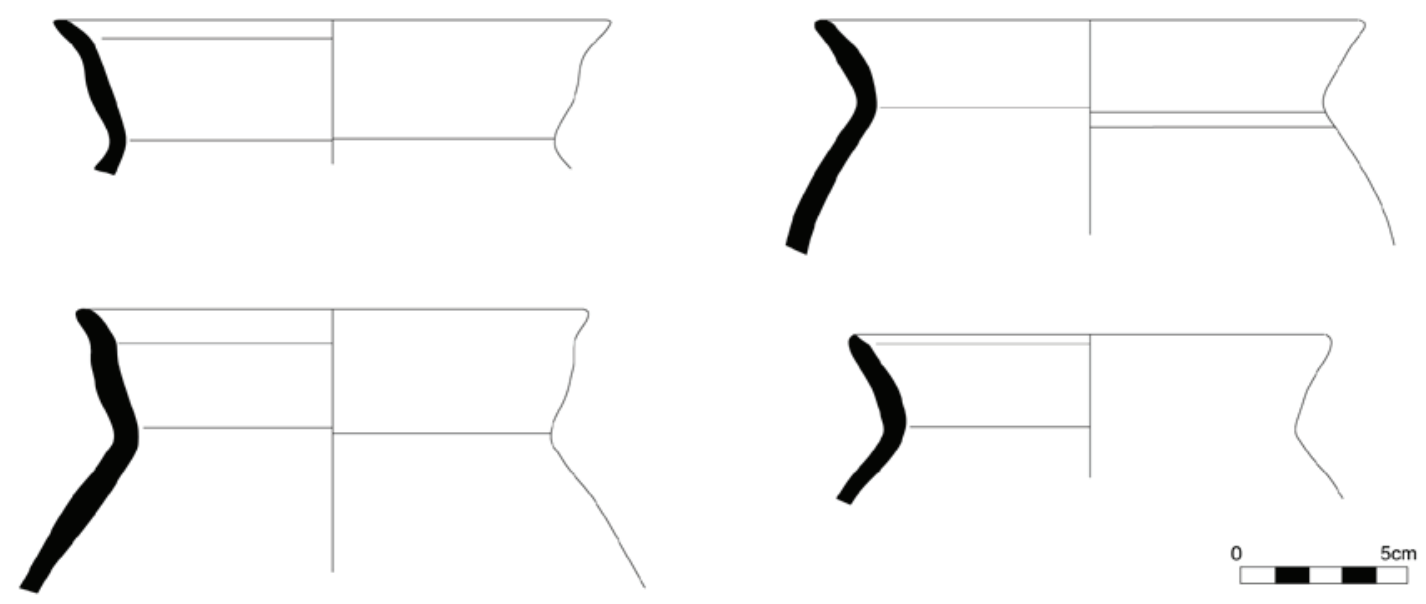

Estampa 1 - Potes.
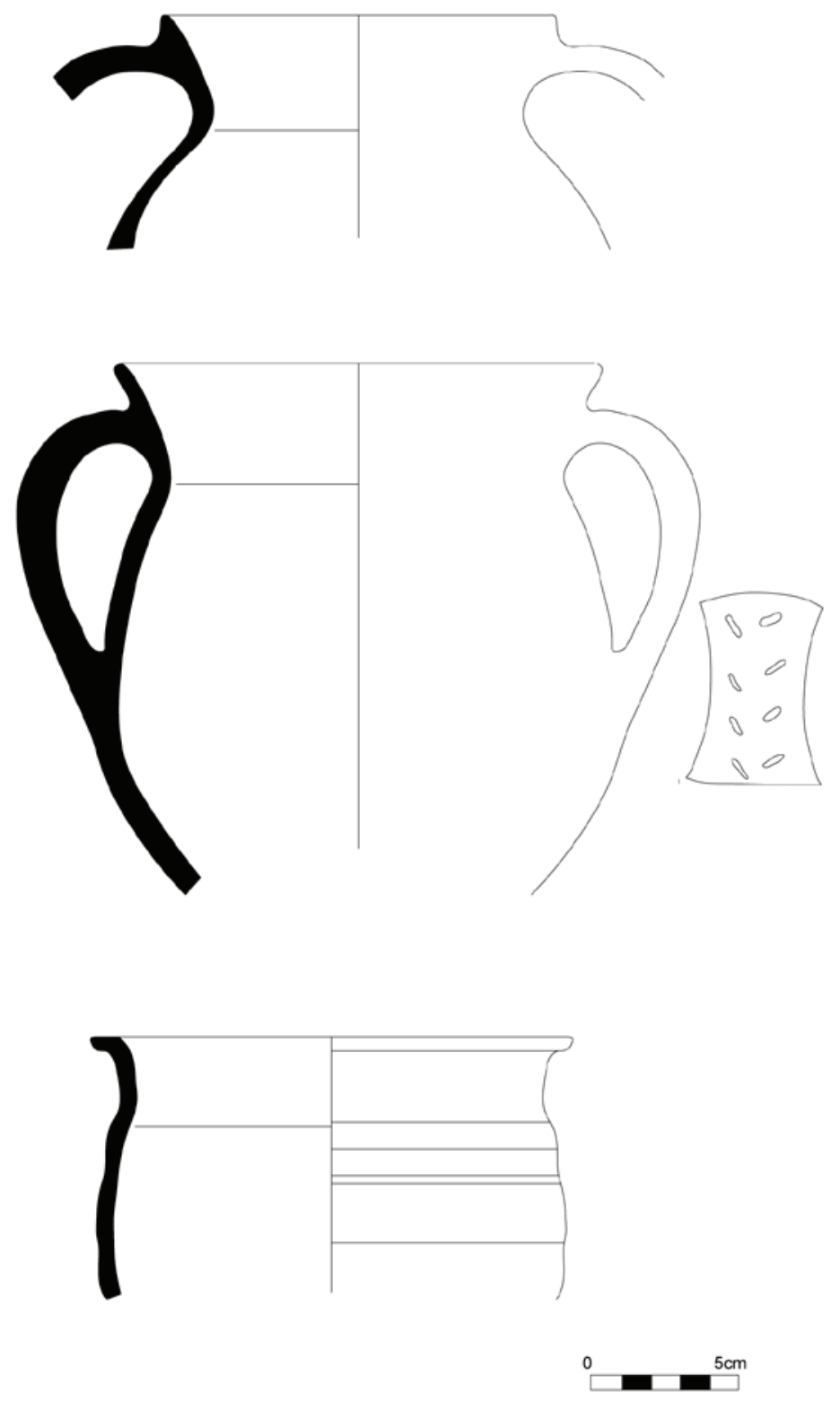

Estampa 2 - Panelas.

1649 Arqueologia em Portugal / 2020 - Estado da Questão 


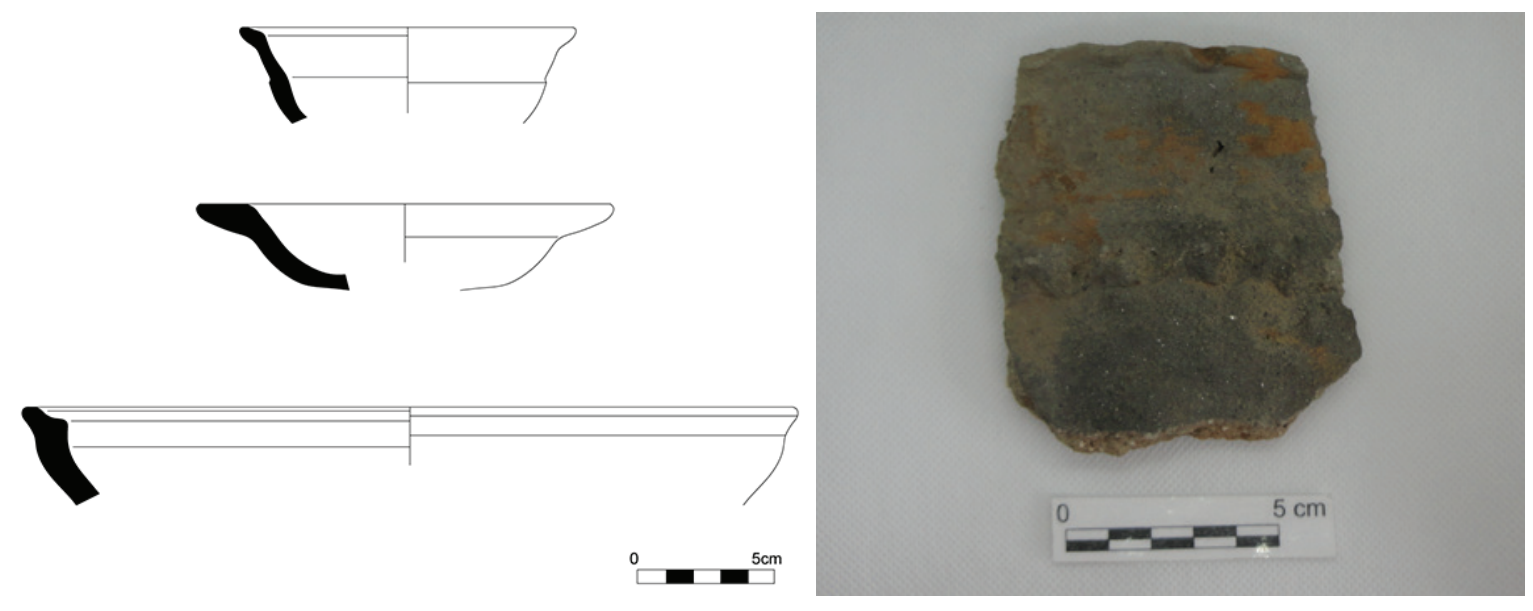

Estampa 3 - Taças. A fotografia é de um alguidar.
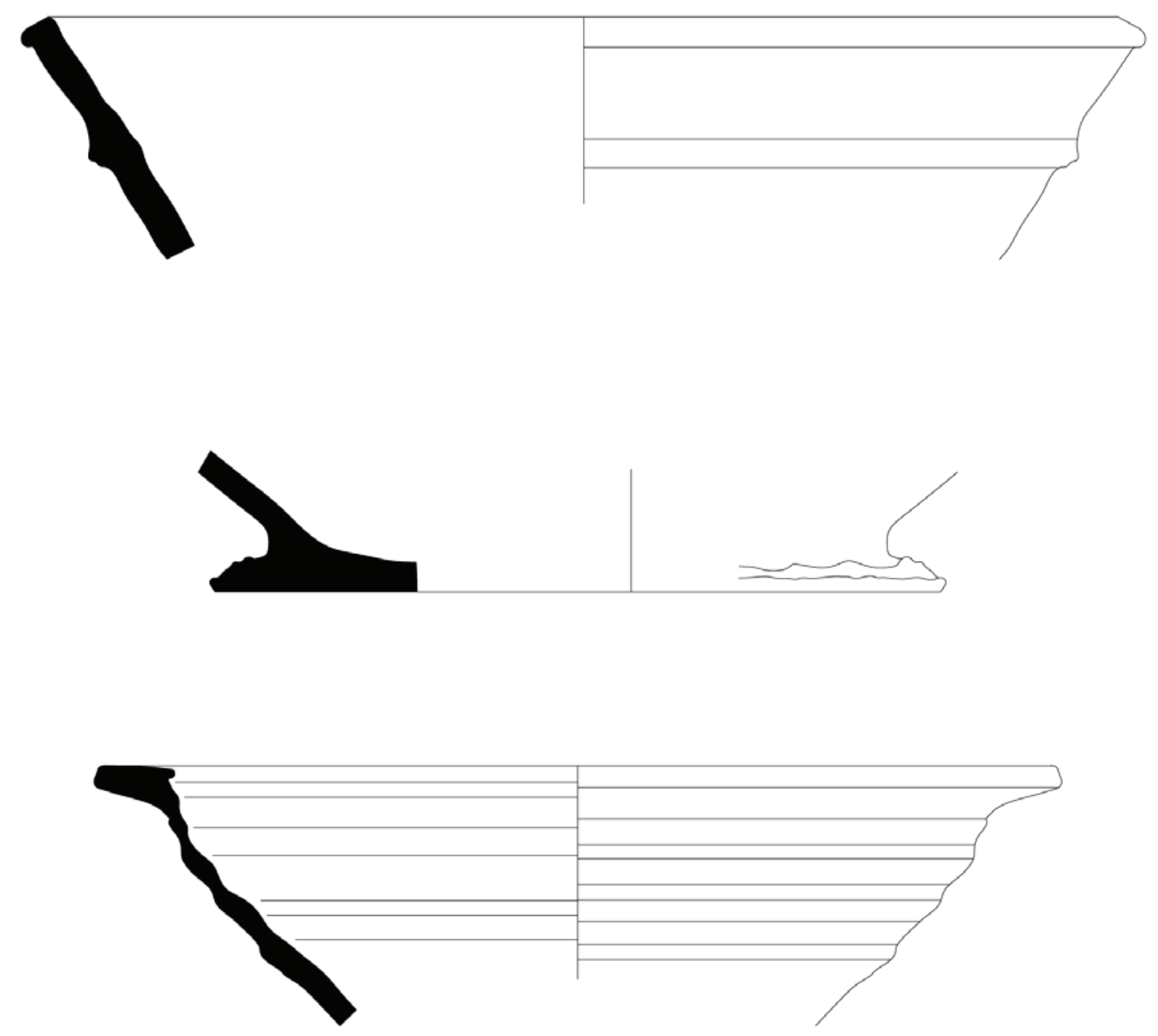

\begin{tabular}{ll}
$0 \quad 5 \mathrm{~cm}$ \\
\hline$\square$ & \\
\hline
\end{tabular} 


\title{
OS LÓIOS DO PORTO: UMA PERSPETIVA INTEGRADA NO PANORAMA FUNERÁRIO DA BAIXA IDADE MÉDIA À ÉPOCA MODERNA EM MEIOS URBANOS EM PORTUGAL
}

\author{
Ana Lema Seabra ${ }^{1}$
}

\begin{abstract}
RESUMO
Os indivíduos exumados do Convento do Lóios do Porto, intervencionado em contexto de arqueologia de salvaguarda prévio à construção do Hotel Intercontinental e à requalificação do Quarteirão das Cardosas, foram estudados parcialmente no âmbito de uma tese de mestrado. São apresentados num contexto mais abrangente das práticas funerárias da Baixa Idade Média a Época Moderna, sendo utilizados como ponto de partida para explorar a importância das fontes históricas aliadas ao estudo dos dados bioarqueológicos para reconstruir as práticas mortuárias para o período em análise. O estudo dos indivíduos exumados revela diversas semelhanças com indivíduos exumados de outros sítios arqueológicos contemporâneos, assim como levanta questões relativas à preservação de informação histórica e bioarqueológica relativa aos contextos funerários. Palavras-chave: Práticas Funerárias, Bioarqueologia, Análise de Dados, Centros Urbanos.
\end{abstract}

\begin{abstract}
The individuals exhumed from the Convent of Loios from Porto, which was object to intervention by rescue archaeology prior to the construction of the Intercontinental Hotel and the requalification of the Cardosas block, were partially studied in a master dissertation. They are presented within a wider context of funerary practices from the Lower Middle Ages to Modern Period, serving as a starting point to explore the importance of historical records combined with bioarchaeological data in order to reconstruct mortuary behaviour for the aforementioned timeline. The study of the individuals exhumed show some similarities with individuals exhumed from contemporaneous sites, as well as raising questions pertaining data preservation of historical and bioarchaeological information pertaining to funerary contexts.
\end{abstract}

Keywords: Funerary Practices, Bioarchaeology, Data Analysis, Urban Centers.

\section{INTRODUÇÃO}

As práticas funerárias podem ser entendidas como produto da relação entre o corpo/cadáver e a comunidade enlutada (Carr, 1995), transferindo o indivíduo na sua perceção biossocial do "mundo dos vivos" para o "mundo dos mortos" (Knudson e Stojanowiski, 2008; Geller, 2009). É neste sentido que traduzem no campo material e ideológico os valores fundamentais dominantes na sociedade e, consequentemente, variações e desvios da norma pode- rão refletir mudanças de mentalidades (Ariés, 1988; Rebay-Salisbury, 2012), crenças, preceitos religiosos e/ou sociais.

Devido ao exposto, nas populações do passado, as atitudes perante a morte têm sido alvo de estudos, ao nível documental e material, na Filosofia, História, História de Arte, Antropologia e Arqueologia, e os restos mortais pela Antropologia Biológica, fazendo-se sentir a ausência de uma perspetiva integradora desses contributos relativamente insulares (Cruz, 2012; Crangle, 2015).

1. CIAS; asbr73@gmail.com. 
Em 2009, no âmbito de uma escavação de emergência para a construção do Hotel Intercontinental e dois parques de estacionamento no Quarteirão das Cardosas no Porto, foi identificada parte do Convento e Igreja dos Lóios, também conhecido como Convento de Santa Maria da Consolação. Foi exumado todo o material osteológico humano presente nas 21 sepulturas do claustro e de uma cripta possivelmente associada a uma das capelas da Igreja. No total, foram exumadas 31 inumações primárias e diversos ossos em deposição secundária correspondentes a reduções e ossários. A exumação foi levada a cabo pela presente autora e pela Antropóloga Inês Elias, responsável pelos trabalhos antropológicos de campo. A escavação esteve a cargo da Empresa Logiark Lda. sob direção científica de Paulo Barbosa e Roger Prieto. Dada a quantidade do material osteológico recolhido, foi selecionada uma amostra para estudo com vista à realização de uma tese de mestrado em Evolução e Biologia Humanas (Seabra, 2012). Optou-se pelo estudo integral dos restos humanos provenientes da cripta e das sepulturas $1,2,3,13$ e 21 , correspondendo a um NMI de 65-15 indivíduos em deposição primária e aproximadamente 50 em deposição secundária. De notar que a sepultura 4 do claustro já havia sido escavada (Silva, 20o8) onde foi identificado o único caso na população inumada deste convento de um enterramento com evidências de autópsia. Salientamos que para efeitos da presente comunicação nos vamos referir a "indivíduos" no sentido de esqueletos encontrados em inumação primária, salvo indicação em contrário.

O estudo realizado para a dissertação consistiu na observação de práticas funerárias, no estudo do perfil biológico com identificação de possíveis patologias e a comparação com estudos de amostras provenientes de outros dois conventos pertencentes à mesma ordem de Santo Elói, nomeadamente Vilar de Frades (Tavares, 2001; Assis, 2002) e Arraiolos (Tavares, 2003; Ventura, 2004).

No que concerne às inumações primárias observou-se a presença de 19 indivíduos adultos e 12 não adultos (Figura 1) maioritariamente neonatos e na primeira infância, com os restantes na segunda infância. No que concerne os 19 indivíduos adultos, observou-se (Figura 2), a presença de uma maioria de indivíduos masculinos, com parca presença de femininos, não tendo sido o sexo observável em parte da amostra devido a constrangimentos tafonómicos e de preservação.
Sumariamente, do ponto de vista das práticas funerárias, podemos observar a prevalência de reutilização dos espaços sepulcrais no Convento de Santo Elói no Porto, com 13 reduções junto à inumação, com a maioria $(12 / 13)$ dispostos dos lados em torno da inumação, e um exemplo em que a redução se encontrava em cima do individuo $(1 / 13)$, bem como a utilização pontual de cal circunscrita aos quatro indivíduos inumados dentro da cripta com um único possível exemplo no claustro - enterramento 20 da sepultura 21 correspondente a um individuo adulto maduro do masculino. Neste último, apesar da distribuição do granulado branco que se considerou como cal ser compatível com a deposição de cal, observa-se uma grande diferença na quantidade quando comparada com os indivíduos da cripta, os quais se encontravam completamente cobertos.

No que concerne a presença de espólio, 24/31 inumações apresentavam algum tipo de espólio, 15 evidenciavam a presença de caixão e apenas 3 evidenciavam a presença direta de sudário.

Atualmente, estando a prosseguir doutoramento com foco nas práticas funerárias da Baixa Idade Média à Época Moderna em meios urbanos em Portugal Continental, propomo-nos nesta comunicação expor em linhas gerais a nossa estratégia de investigação, partindo do estudo da amostra do Convento dos Lóios do Porto. A investigação pretende aliar dados de fontes históricas com a informação bioarqueológica recolhida em campo durante os trabalhos de escavação, a qual consta nos relatórios de campo entregues à Tutela, depositados na Biblioteca Nacional de Arqueologia, para formular hipóteses relativamente à realidade observada, e em última análise, embora sendo o ato de escavação indiscutivelmente um ato destrutivo, analisar a possibilidade de reutilização de dados presentes nos relatórios de escavação para responder e reformular questões relativas ao passado funerário. No presente trabalho focamos apenas as inumações consideradas cristãs ou possivelmente cristãs.

\section{OS LÓIOS DO PORTO, REFLEXO DE UMA REALIDADE GENERALIZADA?}

Tratando-se de um trabalho em curso, comparamos os dados recolhidos do Convento de Santo Elói com os da amostra de 632 indivíduos onde estão agora integrados os 31 indivíduos exumados desse Convento. Os indivíduos da amostra são provenientes 
de 14 sítios arqueológicos cristãos e/ou possivelmente cristãos (tabela 1). Observamos que a recolha da amostra foi possível graças ao Archaeology of Portugal Fellowship Award 2018/2019 que nos foi atribuída pelo Archaeological institute of AmericaAIA, sendo que pretendemos de futuro expandir a amostra para um mínimo de 1000 indivíduos.

Em termos de classificação, observa-se que 4/14 dos sítios apresentados correspondem a espaços funerários de ordens regrantes, das quais apenas o Convento de Santo Elói pertenceu aos Lóios, 3/14 correspondem a cemitérios, 2/14 a Misericórdias; 1/14 que podemos considerar como atípico, encontrando-se classificado no Portal do Arqueólogo como sepultura coletiva. Os restantes espaços corresponderam possivelmente a espaços sepulcrais sob égide do clero secular.

No que concerne aos locais relacionados com ordens religiosas, se bem que algumas já existiam em território português antes do Concílio de Trento, como por exemplo as ordens de S. Domingos e do Carmo (Castro Pina, Andrade e Santos, 2016), as quais são alvo de reforma durante o séc. XVI, apenas os Lóios se iniciam já depois do Concílio com um caracter marcadamente reformista (Castro Pina Andrade e Santos 2016).

De momento a nossa amostra de 632 indivíduos encontra-se balizada cronologicamente entre o final da Alta Idade Média e o século XIX, ressalvando-se o recurso maioritariamente a datação relativa, nomeadamente datas de fundação, presença de numismas ou outro tipo de espólio, e um caso no qual se obteve datação absoluta por Ci4. Se observarmos do ponto de vista da data de fundação ou início de ocupação de cariz funerário, 13 dos sítios estudados têm referência explícita ao início de utilização, destes 7 sítios tem início durante ou após o séc. XIV, correspondendo a 400 indivíduos, 5 sítios iniciaram-se na Plena a Baixa Idade Média, séc. XII e XIII, correspondendo a 131 indivíduos, e apenas um local se inicia ainda durante a Alta Idade Média, correspondendo a 45 indivíduos. Apenas 8 sítios, correspondentes a 307 indivíduos, se reportam a espaços em que foi possível determinar uma data de término de utilização da função funerária dos espaços, observando-se que 3 sítios correspondentes a 106 indivíduos tem o término no séc. XIV a XVI, e 5 sítios têm o seu término de utilização durante ou após o séc. XVIII, correspondentes a 201 indivíduos. Podemos assim considerar que estamos perante uma amostra cro- nologicamente Baixo-Medieval a Moderna, com um maior pendor para a Época Moderna.

No que concerne a distribuição geográfica, temos de momento uma ligeira prevalência do Centro, Ribatejo e Algarve, como é possível ver no Gráfico 1 (Figura 3).

Em termos demográficos, a restante amostra registou 433 indivíduos adultos (433/601) e 197 não adultos (197/601), com 2 indeterminados. Na seguinte figura é possível observar a distribuição por faixa etária nos casos em que esta foi determinada.

No que concerne a estimativa de sexo dos indivíduos adultos, 135 foram identificados como masculinos, 123 como femininos, 3 como indeterminados e 174 indivíduos foram considerados como não observáveis. No que diz respeito ao posicionamento dos indivíduos, salientam-se as diferenças na orientação e posição dos membros superiores. Importante referir que o Convento dos Lóios tem um exemplo de decúbito ventral, 1/31, e no total da restante amostra foram observados 8/6o1 casos de indivíduos em decúbito ventral que dizem respeito no total a 5 adultos ( 3 do sexo feminino e 2 indeterminados) e 4 não adultos, sendo que do Convento dos Lóios apenas se identificou um indivíduo adulto feminino localizado na cripta.

No que concerne o recurso à utilização de cal, observaram-se 41/632 no total da amostra, dos quais 4 correspondem a indivíduos sepultados no Convento de Santo Éloi (4/31). Até ao momento, a nossa análise parece apontar para que a utilização de cal tem relação com o espaço funerário, sendo utilizada no interior ou em grande proximidade com uma igreja ou capela. Não se observaram diferenças significativas, quer entre adultos e não adultos, quer em termos de sexo biológico. Notamos que a sepultura, considerada como coletiva da Rua dos Barcos, não evidenciou o uso de cal, ao contrário do esperado dado o tipo de enterramento.

A presença de caixão e sudário na amostra foi de $51 / 632$ e $20 / 632$.

Relativamente à presença de espólio, apenas se encontrou presente algum tipo de espólio $128 / 632 \mathrm{ca}$ sos e apenas $46 / 128$ apresentavam mais do que um tipo de espólio. No que concerne o tipo de espólio, o mais frequente foi a presença de numismas assim como de espólio dito religioso, especialmente o relacionado com terços ou rosários. Em relação a evidências de roupa, apenas se encontra em indivíduos adultos de ambos os sexos (19/433) e, até 
ao momento, apenas os sapatos estão exclusivamente associados a indivíduos masculinos 6/135. Salientamos o peso que os processos tafonómicos e o próprio tipo de material obviamente têm para a sua identificação em campo, recolha e, em última análise, representatividade nas amostras. Desta forma, por exemplo, torna-se mais fácil a identificação da presença de numismas do que a identificação de escapulários, dado estes últimos serem geralmente feitos em tecido - por exemplo no total da nossa amostra apenas se identificaram 6/632 exemplos de tecido sem função atribuída, ou seja, tecido que não foi atribuído a sudário, forro de caixão ou roupa.

\section{O CONTRIBUTO DAS FONTES HISTÓRICAS}

No caso particular do Convento de Santo Elói no Porto sabemos que existem cerca de 90 tomos muitos dos quais em latim - relativos a este convento no Arquivo do Porto, o que por si só são um trabalho de investigação para filtrar informação potencialmente relevante. Contudo, três trabalhos foram de especial utilidade para compreender e contextualizar o convento, nomeadamente os trabalhos de Freitas, (1947), Tavares (2001) e de Falcão (2009) sobre o Convento dos Lóios e os seus patronos. Ambos os trabalhos permitiram traçar o perfil arquitetónico geral e por isso a disposição das capelas no interior da igreja, permitindo inferir que a área correspondente à cripta pertenceria a uma de 3 capelas da Igreja, a capela do Senhor Atado à Coluna, para a qual não se encontrou documentação, ou possivelmente de Nossa Senhora do Amparo - pertencente a Domingos de Araújo e depois aos Lóios, ou de Nossa Senhora dos Anjos - pertencente a Martim Ferraz de Almeida, devido ao posicionamento destas no interior da igreja e a proximidade com uma porta, que foi identificada em campo (Seabra, 2012). O trabalho de Freitas permite ainda não só confirmar a existência de um livro de sepulturas (Freitas,1947, p.58) mantido na sacristia, como também o facto de já na altura do seu trabalho, em 1947, não ter sido possível localizar o mesmo. Não obstante, o trabalho de Freitas manteve-se de grande valor dado que consegue descrever os enterramentos realizados no corpo da igreja (os quais não foram localizados em campo) e refere a ausência de informação sobre as sepulturas do claustro (as quais foram identificadas em campo), exceto parcas referências ao sepulta- mento no claustro, que não são possíveis de localizar, referentes a uma sepultura particular de Susana Cardosa, e 3 sepulturas pertencentes à Confraria do Espírito Santo (Freitas,1947, p. 74). De salientar que menciona ainda a presença de 4 espaços de enterramento adquiridos por cristãos-novos, todos dentro do corpo da igreja, um dos quais é perdido pelo seu adquirente num processo inquisitorial por práticas judaizantes (Freitas,1947, p. 45).

No que concerne as práticas funerárias, informa não só sobre a existência de duas capelas com "carneiro", assim como a presença de diversos elementos relacionados com o planeamento do rito funerário da época, entre os quais o pedido de missas por alma, com ênfase na sexta-feira, bem como a presença de lamparinas acesas junto à sepultura, prática documentada por diversos testamentos para a época (Barbosa, 1995; Castro Pina, 1995) característicos da Devoção Moderna, que vai ganhando crescente aceitação na Época Moderna (Carvalho, 2016).

\section{CONSIDERAÇÕES FINAIS}

O convento do Lóios parece estar em linha com outros espaços funerários e práticas funerárias da época, que pretendemos caracterizar com a futura expansão do nosso estudo durante a prossecução do nosso trabalho de doutoramento. Esperamos ter demonstrado, através do exemplo do Convento dos Lóios, no Porto, a importância da junção da informação histórica aos dados bioarqueológicos, mesmo que, como no caso dos Lóios, a informação histórica complemente os dados sem se sobrepor. Houve informação que não foi possível cruzar entre fontes históricas e dados bioarqueológicos por dificuldades várias, entre as quais a dificuldade de acesso à informação escrita ou a impossibilidade de localizar a informação no espaço físico dos sítios arqueológicos. Apesar destes constrangimentos, acreditamos que a existência de documentação histórica sobre a cronologia escolhida, aliada à grande quantidade de informação de antropologia de campo disponíveis para estudo são fundamentais para a construção de uma visão integrada biossocial da morte nas populações Medievais e Modernas em Portugal e consequentemente contribuir para a reconstrução das cosmogonias vigentes. 


\section{AGRADECIMENTOS}

A Autora agradece ao Americal Institute of Archaeology (AIA) pelo apoio dado através da atribuição do Archaeology of Portugal Fellowship Award 2018/2019.

À Biblioteca Nacional de Arqueologia e à Direção Geral Património Arqueológico (DGPC) pelo bom acolhimento e apoio ao longo deste trabalho.

Às empresas de Arqueologia: Empatia Arqueologia; Dryas Octopetália; Logiark e ERA Arqueologia pela disponibilização de relatórios de campo.

\section{BIBLIOGRAFIA}

ARIÉS, Philippe (1988) - Sobre a história da morte no ocidente desde a Idade Média. Lisboa, Teorema.

ASSIS, Sandra. (2002) - Vilar de Frades - reminiscência do passado: estudo paleodemográfico e paleopatológico de uma amostra antropológica proveniente do Convento de Vilar de Frades. Dissertação de Mestrado. Coimbra: Faculdade de Ciências e Tecnologia da Universidade de Coimbra.

BARBOSA, Albertina (1995) - Capelas e Aniversários do Mosteiro de S. Domingos do Porto no séc. XV. Dissertação de Mestrado. Porto: Faculdade de Letras Universidade do Porto.

CARR, Christopher (1995) - Mortuary practices: their social, philosophical-religious, circumstantial and physical determinants in Journal of Archaeological Method Theory 2:2, pp. 105-200.

CARVALHO, José (2016) - Antes de Lutero: A Igreja e as Reformas Religiosas em Portugal no século XV. Anseios e limites. Porto: Afrontamento.

CASTRO PINA, Isabel (1995). - Ritos e imaginário da morte em testamentos dos séculos XIV e XV. In José Mattoso (ed.) O Reino dos Mortos na Idade Média Peninsular. Lisboa: Edições João Sá da Costa, pp. 125-164.

CASTRO PINA, Isabel; ANDRADE, Maria Filomena; SANTOS, Maria Leonor; SOUSA, Bernardo (2016) - Ordens Religiosas em Portugal: Das Origens a Trento - Guia Histórico. Lisboa: Coleção Horizonte Histórico, Livros Horizonte.

CRANGLE, Jennifer (2015) - A Study of Post-Depositional Funerary Pratices in Medieval England. Tese de Doutoramento. Sheffield: University of Sheffield.

CRUZ, Cristina (2012) - Viver a Morte em Portugal. Tese de Doutoramento. Coimbra: Faculdade de Ciências e Tecnologia da Universidade de Coimbra.

FALCÃO, Nuno. (2008) - Os azuis no Porto: o convento Lóio de Nossa Senhora da Consolação: 149o-1640. Dissertação de Mestrado. Porto: Faculdade de Letras da Universidade do Porto.
FREITAS, Eugénio (1947) - O Convento Novo de Santa Ma- ria da Consolação (Padres Lóios). Documentos e Memórias para a História do Porto. Porto: Publicações da Câmara Municipal do Porto, Gabinete de História da Cidade.

GELLER, Pamela (2009) - Bodyscapes, biology and heteronormativity. In American Anthropologist. 3:4, pp. 504-516.

KNUDSON, Kelly e STOJANOWISKI, Christopher (2008) - New Directions in Bioarchaeology: Recent Contributions to the Study of Human Social Identities. In Journal of Archaeological Research. 16:4, pp. 397-432.

REBAY-SALISBURY, Katharina (2012) - Inhumation and cremation: how burial practices are linked to beliefs. In S $\varnothing$ RENSEN, Marie Louise; REBAY-SALISBURY, Katharina, eds. Embodied Knowledge: Historical Perspectives on Technology and Belief. Oxford: Oxbow Books, pp. 15-26.

SEABRA, Ana. (2012) - Os Lóios do Porto: De Convento a Palácio. Dissertação de Mestrado. Coimbra: Faculdade de Ciências e Tecnologia da Universidade de Coimbra.

SILVA, Ana Maria (2008) - A sepultura 4 das Cardosas (antigo convento dos Lóios) Porto: Análise Antropológica do esqueleto encontrado in situ e dos ossos dispersos associados. In BARBOSA, João. Quarteirão das Cardosas, sondagem de avaliação prévia [Relatório Final]. Unidade de Intervenção do Quarteirão das Cardosas. Porto.

TAVARES, Pedro (2001) - Legislação capitular da Congregação de S. João Evangelista: (séculos XV-XVI). Estudos em homenagem a João Francisco Marques. Porto: Faculdade de Letras da Universidade do Porto. Vol. II: pp. 455-472.

TAVARES, Paula. (2003) - Convento dos Lóios: estudo paleoantropológico das sepulturas das alas norte e oeste do claustro do antigo Convento dos Lóios de Arraiolos (Alto Alentejo). Dissertação de Mestrado. Coimbra: Faculdade de Ciências e Tecnologia da Universidade de Coimbra.

VENTURA, António. (2004) - Estudo paleodemográfico e paleopatológico de uma amostra antropológica proveniente da ala Este do claustro do Convento dos Lóios em Arraiolos. Dissertação de Mestrado. Coimbra: Faculdade de Ciências e Tecnologia da Universidade de Coimbra. 


\begin{tabular}{|l|l|}
\hline Sítio Arqueológico & N Indivíduos \\
\hline Alto de Santa Ana & 25 \\
\hline Antigo Cemitério da Igreja de S. Pedro de Óbidos & 35 \\
\hline Campo Sá da Bandeira & 15 \\
\hline Castelo dos Mouros & 26 \\
\hline Cemitério Sousa Bastos & 45 \\
\hline Convento Corpus Christi & 37 \\
\hline Convento e Igreja do Carmo & 42 \\
\hline Ermida de São Francisco & 28 \\
\hline Igreja da Misericórdia de Almada & 27 \\
\hline Igreja de Santa Maria do Castelo & 28 \\
\hline Largo da Igreja da N. S. da Assunção- Igreja Matriz & 69 \\
\hline Convento dos Lóios (Quarteirão das Cardosas) & 31 \\
\hline Rua dos Barcos & 144 \\
\hline Santa Casa Misericórdia de Faro (Hosp.T. Santos) & 80 \\
\hline TT de sítios N14 & TT 632 \\
\hline
\end{tabular}

Tabela 1 - Inumações primárias por sítio arqueológico consultado.

\begin{tabular}{|l|l|l|}
\hline \multicolumn{2}{|l|}{ Posição de inumação mais frequente } \\
\hline & Convento dos Loíos n31 & Amostra Geral n6o1 \\
\hline orientação & E-O $\mid 16$ & O-E $\left.\right|_{368}$ \\
\hline decúbito & dorsal $\left.\right|_{30}$ & dorsal| 559 \\
\hline crânio & centrado $\mid 11$ & centrado| 131 \\
\hline m.sup.esq & fletido abdómen $\mid 7$ & fletido torax $\mid 91$ \\
\hline m.sup.dto & fletido abdómen $\mid 6$ & fletido torax|96 \\
\hline m.inf.esq & est. paralelo c/pés paralelos $\mid 20$ & est. paralelo c/pés paralelos | 264 \\
\hline m.inf.dto & est. paralelo c/pés paralelos| 20 & est. paralelo c/pés paralelos| 268 \\
\hline
\end{tabular}

Tabela 2 - Posição de inumação mais frequente comparação do Convento de Santo Elói com a restante amostra. De salientar as diferenças na orientação cardeal e na posição dos membros superiores. 


\section{Distribuição por faixa etária}

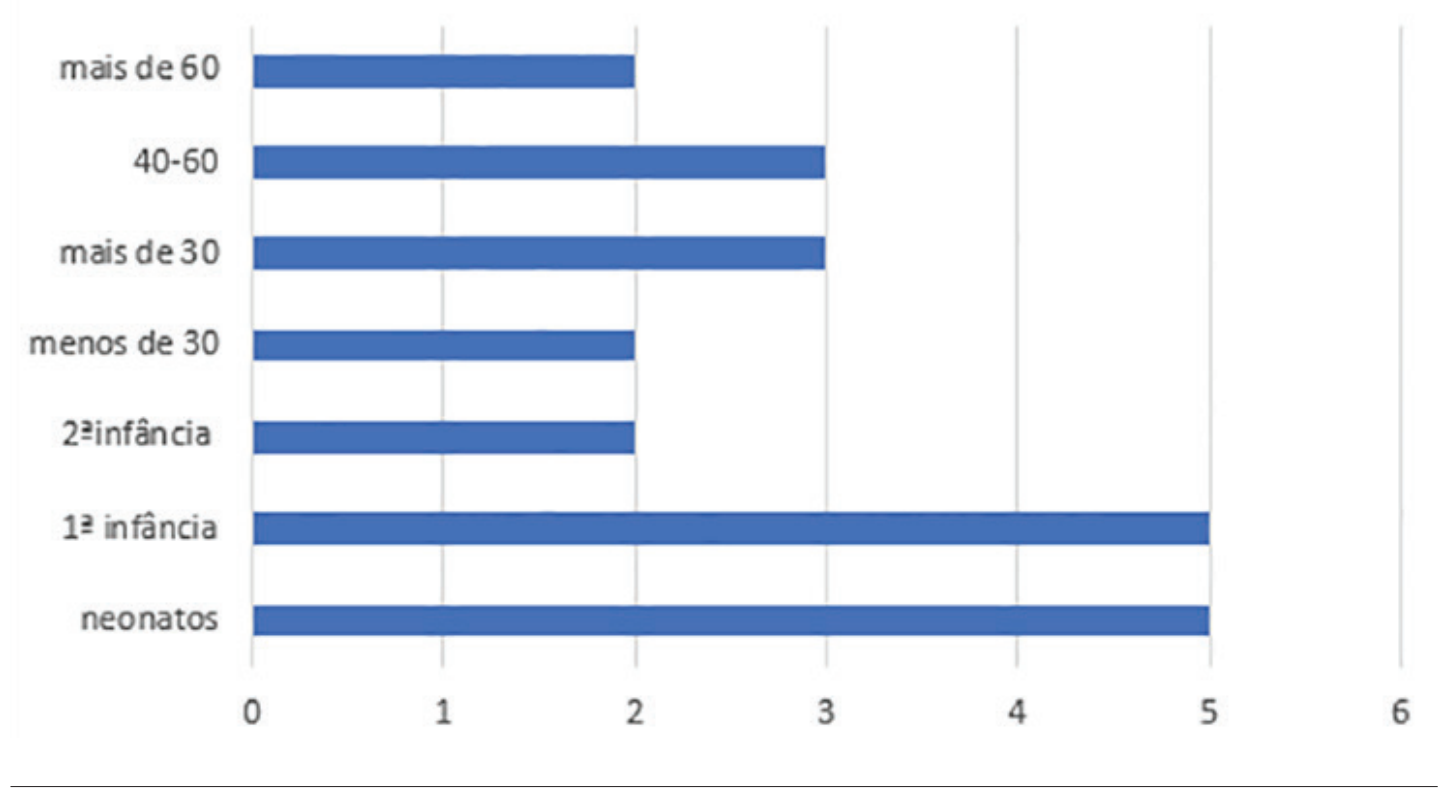

Figura 1 - Distribuição da amostra do Convento dos Lóios, por faixa etária.

\section{Demografia no Convento dos Lóios adultos por sexo}

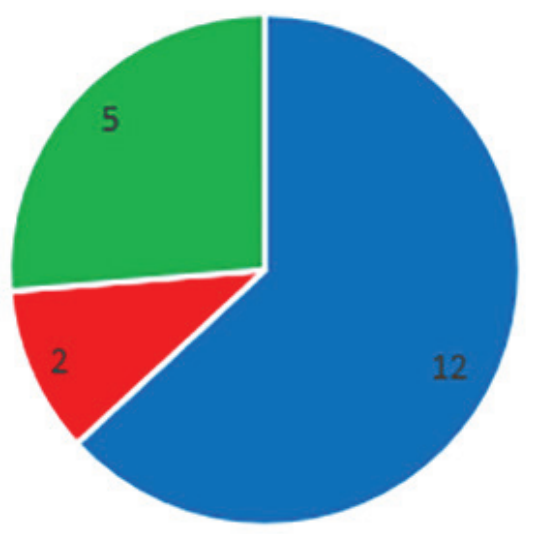

- masculino $\quad$ feminino $=$ indeterminado

Figura 2 - Distribuição da amostra do Convento dos Loios indivíduos adultos por sexo. 


\section{Por Zona Geográfica}

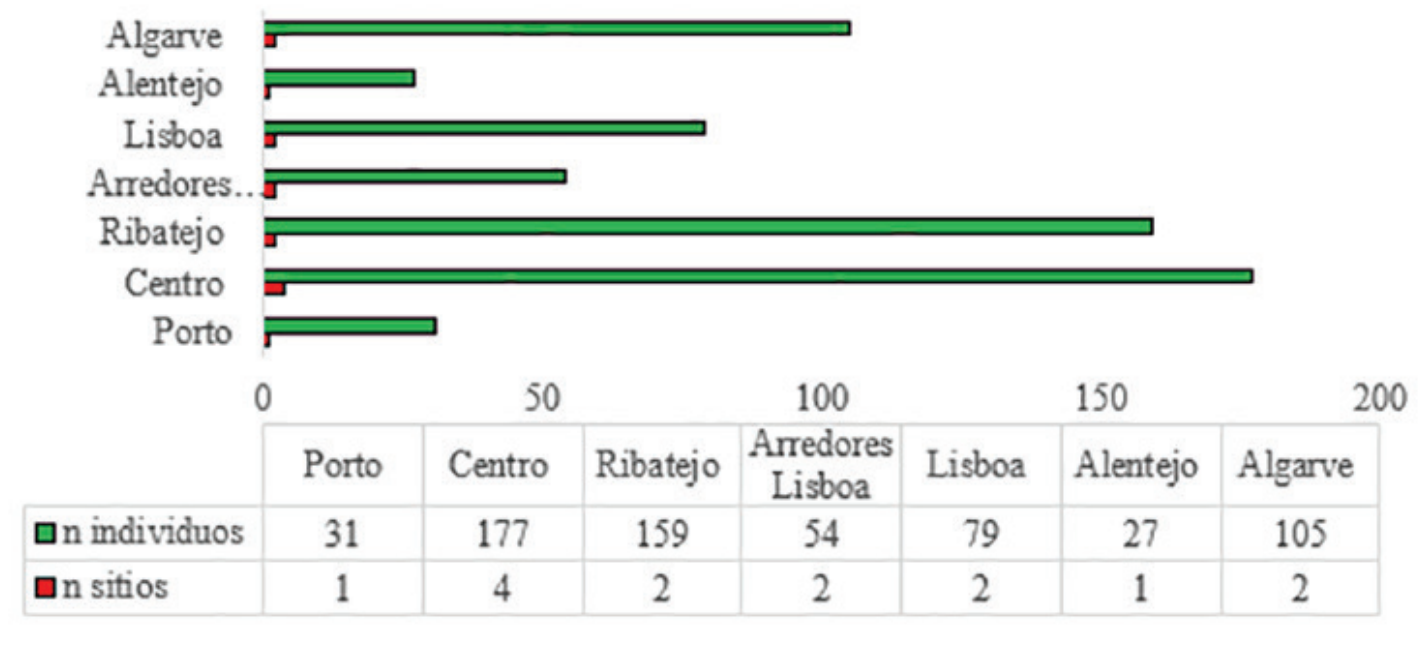

口n individuos $\square \mathrm{n}$ sitios

Figura 3 - Gráfico de sítios arqueológicos e número de inumações primárias por zona geográfica de Portugal Continental.

\section{Por Faixa Etária}

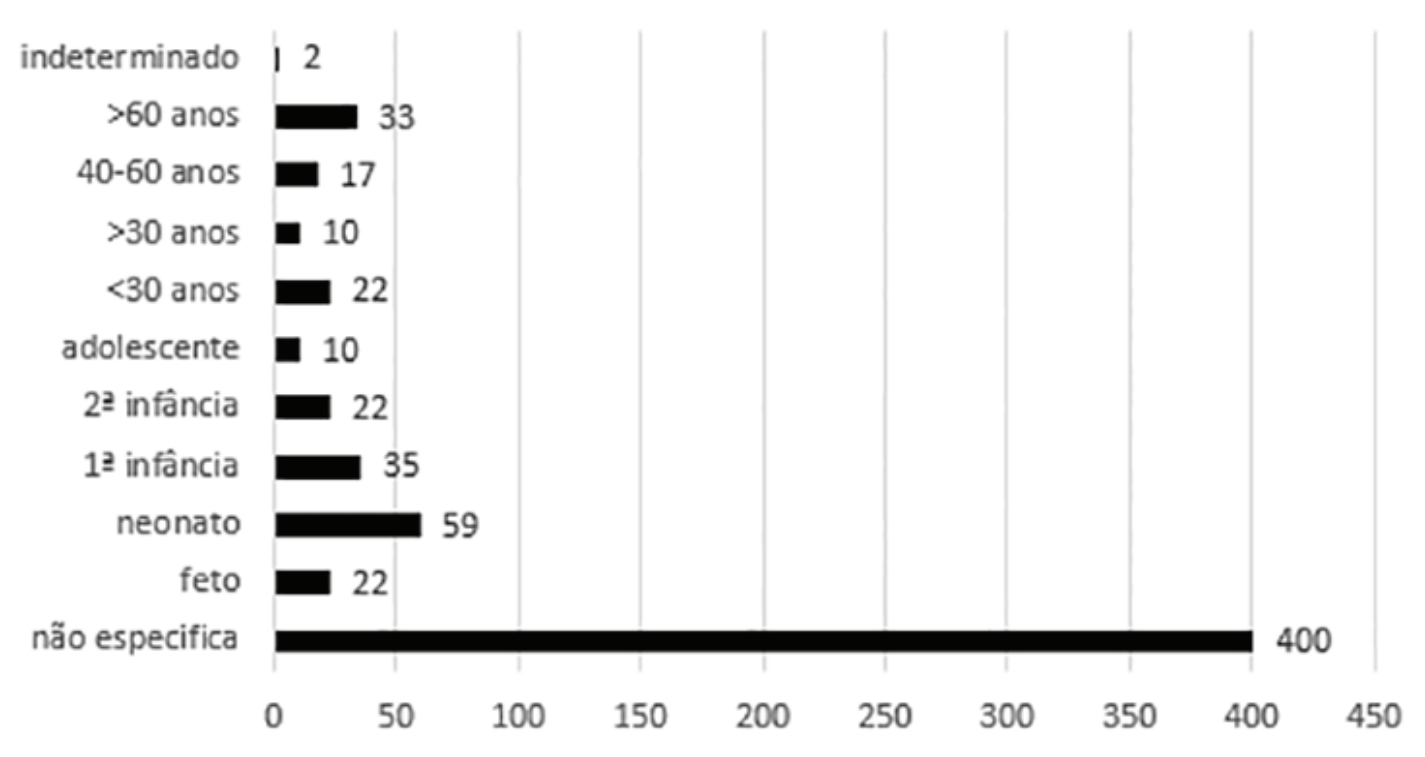

Figura 4 - Número total de indivíduos por faixa etária presentes na amostra. Note-se a mesma tendência que se observou para os Lóios portuenses nos casos em que foi especificado um intervalo etário para os indivíduos. 


\title{
O CAMINHO PORTUGUÊS INTERIOR DE SANTIACO COMO EIXO VIÁRIO NA IDADE MÉDIA
}

\author{
Pedro Azevedo ${ }^{1}$
}

\begin{abstract}
RESUMO
As peregrinações a Santiago de Compostela possuem origens seculares. Em Portugal, um dos Caminhos de peregrinação mais antigos é o Caminho Português Interior de Santiago (CPIS), cujo itinerário assenta em antigas vias romanas e medievais.

O objetivo deste trabalho pretende identificar as estruturas pré-existentes como calçadas e pontes, tendo por base a realização de trabalho de campo in situ. Estas estruturas são importantes em termos arqueológicos e porque desempenharam um papel fundamental na passagem dos peregrinos e das comunidades locais, acabando mesmo por chegar aos nossos dias.

As evidências históricas e arqueológicas permitem comprovar que o CPIS (Viseu - Vila Real - Chaves - Verín Ourense - Santiago de Compostela) desempenhou um eixo viário principal desde a Idade Média.

Palavras-chave: Caminho Português Interior de Santiago, Eixo viário, Idade Média, Calçadas, Pontes.
\end{abstract}

\begin{abstract}
Pilgrimages to Santiago de Compostela have secular origins. In Portugal, one of the oldest pilgrimage paths is the Portuguese Inner Way to Santiago de Compostela (PIWSC), whose itinerary is based on ancient Roman and medieval routes.

The objective of this work is to identify pre-existing structures such as sidewalks and bridges, based on the realization of field work in situ. These structures are important in archaeological terms and because they played a fundamental role in the passage of pilgrims and local communities, even reaching the present day.

Historical and archaeological evidence shows PIWSC (Viseu - Vila Real - Chaves - Verín - Ourense - Santiago de Compostela) has played a major road since the Middle Ages.

Keywords: Portuguese Inner Way to Santiago de Compostela, Road axis, Middle Ages, Sidewalks, Bridges.
\end{abstract}

\section{INTRODUÇÃO}

O objetivo principal deste estudo consiste em demonstrar a importância que o Caminho Português Interior de Santiago desempenhou ao longo da Idade Média como eixo viário principal (Almeida, 1968), demonstrando a existência de inúmeras estruturas como pontes e calçadas, onde algumas assentam em construções pré-existentes do período romano. Além do mais, estas estruturas permitiram moldar a paisagem e o próprio itinerário, bem como permitiram a transposição de rios e montanhas. Os seus inúmeros troços demonstram adaptações estruturais resultantes da passagem não só dos peregrinos, mas também das comunidades - ou seja, é um caminho que resulta da prosápia do quotidiano.

Esta via de peregrinação assistiu à multiplicação de caminhos e de pontes em consequência do aumento populacional, da dispersão dos povoamentos e principalmente da intensificação das peregrinações a Santiago de Compostela. Ao mesmo tempo, evidenciar-se-ão algumas diferenças existentes nas calçadas e pontes medievais em relação às estruturas edificadas durante a época romana.

1. Este trabalho é realizado no âmbito da bolsa de investigação com a referência SFRH/BD/136459/2018 atribuída pela FCT - Fundação para a Ciência e a Tecnologia, Portugal; O Centro de Estudos Transdisciplinares para o Desenvolvimento (CETRAD) é financiado através de fundos nacionais inscritos no orçamento da FCT I.P., no âmbito do projeto UIDB/04011/202O; pedrodosrc@gmail.com 


\section{CAMINHO PORTUGUÊS INTERIOR DE SANTIAGO}

O Caminho de Santiago é uma rota seguida por milhares de peregrinos desde que foi descoberto o túmulo de Santiago no início do século IX. No território português, as antigas vias romanas foram usadas, ao longo da Idade Média e da Idade Moderna, pelos peregrinos rumo a Santiago de Compostela (Almeida e Almeida, 2011, p. 15). As marcas da devoção ao culto de Santiago enraizadas no Norte de Portugal são muito antigas, tal como defende José Marques, apresentando-se muito anteriores ao processo de independência de Portugal (1992, p. 100).

O Caminho Português de Interior de Santiago consiste num itinerário de origem medieval, sendo um dos caminhos de peregrinação mais antigos de Portugal e constitui um eixo viário estruturante (Almeida, 1973). Como refere Vítor Adrião, "de Portugal ia-se a Santiago de Compostela por duas vias-principais: a de Lisboa-Porto-Tui, e de Lamego-Chaves-Ourense" (2011, p. 224). Existia um ritmo intenso de passagem de peregrinos pelas terras de Trás-os-Montes (Moreno, 1986, p. 79).

Possui uma extensão de 205 quilómetros em território português e tem início em Viseu, prosseguindo pelos concelhos de Castro Daire, Lamego, Peso da Régua, Santa Marta de Penaguião, Vila Real, Vila Pouca de Aguiar e Chaves, onde ultrapassa a fronteira para a Galiza. Ao longo deste eixo situavam-se alguns importantes núcleos urbanos como Viseu, Lamego que constituía uma importante encruzilhada viária, e Chaves.

As primeiras obras de melhoramento desta via romano-medieval ocorreram apenas durante a dinastia filipina e consistiram na (re)edificação de pontes que permitiu essencialmente encurtar distâncias.

\section{O CPIS COMO ESTRUTURA VIÁRIA ROMANA E MEDIEVAL: EVOLUÇÃO E CARATERÍSTICAS}

O Caminho Português Interior de Santiago assenta numa importante via romana e que foi amplamente utilizada e mantida ao longo da Idade Média, conforme é demonstrado nas figuras 1 e 2 .

As estruturas viárias existentes ao longo do percurso, do ponto de vista construtivo e de inovação, apresentaram uma diminuta progressão em relação às estruturas romanas.
Vários estudos documentam o modo como as vias de origem romana se perpetuaram nomeadamente no espaço urbano (Ribeiro e Martins, 2016). Em termos construtivos, as estradas romanas eram mais complexas: apresentavam um pavimento construído e uma estrutura por camadas. As estradas medievais eram mais simples, onde "na maioria dos casos, ficava confinada a uma superfície da terra, e os materiais existentes no local ou nas proximidades eram usados sem muita preparação. A técnica de construção utilizada limitou-se apenas a aplanar o leito da estrada (...)" (Monteiro, 2012: 22). Excecionalmente, a pavimentação de estradas poderia ocorrer na entrada das cidades, no acesso a pontes ou em locais estratégicos.

Outros aspetos que importam ser mencionados prendem-se com o facto de as estradas romanas excluírem as curvas acentuadas, ou seja, em regra, as calçadas são retilíneas; e apresentam um perfil arcado e curvo, com o objetivo de drenar a água da chuva para as bermas, sendo exemplo desta situação a calçada romana de Pousa Maria, em Almargem, Viseu (Figura 3). Esta calçada apresenta blocos de grandes dimensões e constitui uma das calçadas mais antigas de Portugal e que apresenta um excelente nível de conservação.

O sistema viário romano foi projetado para servir e unir um império coeso, enquanto os interesses das autoridades medievais resumiam-se a preocupações de natureza mais local. A tendência das estradas medievais desvalorizava a edificação de obras de engenharia para apostar na criação de meros direitos de passagem.

A via romana seguia para Aqua Flavia (Chaves), seguindo a margem direita do rio Corgo, passando por Vila Pouca de Aguiar (Balsa, 2017: 46). A ponte de Trajano sobre o Tâmega, na figura 4, foi edificada entre os séculos I e II e integrava o itinerário XVII de Antonino, que ligava Bracara Avgusta a Asturica Avgusta.

As pontes medievais existentes ao longo do itinerário, como a ponte de Relvas, em Vila Real, evidenciam a relevância estruturante que era atribuída às redes viárias e demonstram a aplicação de técnicas construtivas especializadas. Em termos arquitetónicos, as pontes medievais caraterizam-se por elevarem arcos de grande amplitude; apresentarem geralmente uma configuração do tabuleiro em cavalete, como é o caso da ponte das Caldas em Chaves; por serem mais estreitas que as pontes romanas e 
não possuírem passeios. O seu tabuleiro é ligeiramente em cavalete, isto é, com piso em dupla rampa (Almeida, 2001: 149). Esta situação é exemplificada pela ponte das Caldas, na figura 5 .

Algumas das pontes conservam as cavidades para o encaixe dos vigamentos que suportavam a cofragem de madeira, o denominado cimbre.

Entre Viseu e Lamego, o Caminho passaria, entre outros lugares, pelas pontes de Almargem, de Reconcos e de Pretarouca/Magueija. Ambas são estruturas viárias de origem romana que evidenciam a passagem das comunidades e dos peregrinos por estes locais.

Relativamente às calçadas medievais, dos quais ainda restam alguns vestígios com os seus troços lajeados, verificam-se algumas diferenças em relação às calçadas romanas: nas pontes e nas povoações, as vias medievais não possuíam passeios. Ao contrário das calçadas romanas, pavimentadas com lajes poligonais, as calçadas medievais possuíam grandes blocos com um formato geralmente retangular e que eram assentes diretamente no solo.

Importa referir que a toponímia é um indicador fundamental da existência secular desta via de peregrinação no território, como é exemplo a rua Caminho de Santiago em Oura (Chaves) e a Calçada Romana em Chaves.

\section{CONCLUSÃO}

Os vestígios do passado como calçadas, pontes, a toponímia bem como outras estruturas permitem comprovar que o Caminho Português Interior de Santiago constituiu um eixo viário fundamental ao longo do período romano, da Idade Média e da Idade Moderna, chegando aos nossos dias e preservando importantes vestígios arqueológicos.

\section{BIBLIOGRAFIA}

ADRIÃO, Vitor M. (2011) - Santiago de Compostela: Mistérios da Rota Portuguesa. Lisboa: Dinapress.

ALMEIDA, Carlos A. F. (1968) - Vias Medievais de Entre Douro e Minho, tese de licenciatura apresentada à Faculdade de Letras da Universidade do Porto.

ALMEIDA, Carlos A. F. (1973) - Os caminhos e a assistência no norte de Portugal. A pobreza e a assistência aos pobres na Península Ibérica durante a Idade Média: Actas das 1.as Jornadas Luso-espanholas de História Medieval. Tomo I (pp.39-58). Lisboa: Instituto de Alta Cultura - Centro de Estudos Históricos.
ALMEIDA, Carlos A. F. (2001) - História da Arte em Portugal - O românico. História da Arte em Portugal. Lisboa: Editorial Presença.

BALSA, Carlos (2017) - Via do Marão - Contributos para a identificação do traçado do antigo caminho do Marão. $O p$ pidum, vol. X, 41-62.

BROCHADO DE ALMEIDA, C. A.; BROCHADO DE ALMEIDA, P. M. (2011) - Caminhos Portugueses de Peregrinação. O Caminho do Litoral para Santiago. Maia: ISMAICEDTUR-CETRAD.

CPIS (2020). Disponível em: https://cpis. utad.pt/mapasdo-cpis-via-da-prata-sig/

Junta de Freguesia de Lordosa (2020). Disponível em: http: //www.flordosa.pt/lugares

MARQUES, José (1992) - O culto de S. Tiago no Norte de Portugal. Lusitania Sacra, 2. ㄹ série, 4, 99-148.

MONTEIRO, Helena (2012) - A Estrada da Beira: Reconstituição de um Traçado Medieval. Lisboa: Universidade Nova de Lisboa.

MORENO, Humberto B. (1986) - Vias portugueses de peregrinação a Santiago de Compostela na Idade Média. História-Revista da Faculdade de Letras, (3), 77-89.

RIBEIRO, Maria D. C. F.; MARTINS, Manuela (2016) - O papel das vias romanas na formação e desenvolvimento periférico da cidade de Braga, desde a época romana até à atualidade. In Atas da $5^{\underline{a}}$ Conferência Internacional da Rede Lusófona de Morfologia Urbana (pp. 27-38). Guimarães: Universidade do Minho. 

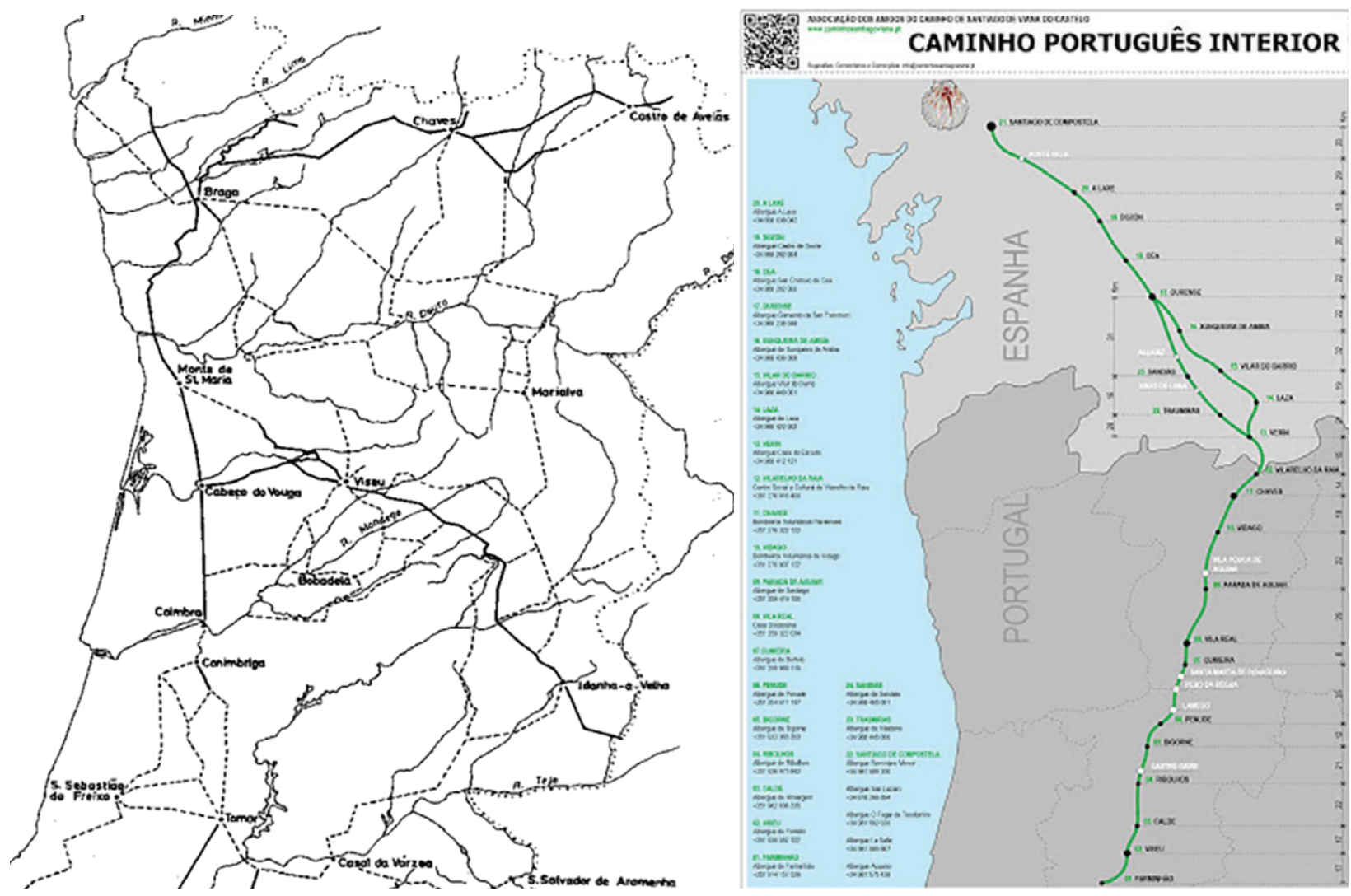

Figuras 1 e 2 - Vias romanas no norte de Portugal e traçado do Caminho Português Interior de Santiago. Fonte: https://cpis. utad.pt/mapas-do-cpis-via-da-prata-sig/ (acedido em: 10 de julho de 2020).

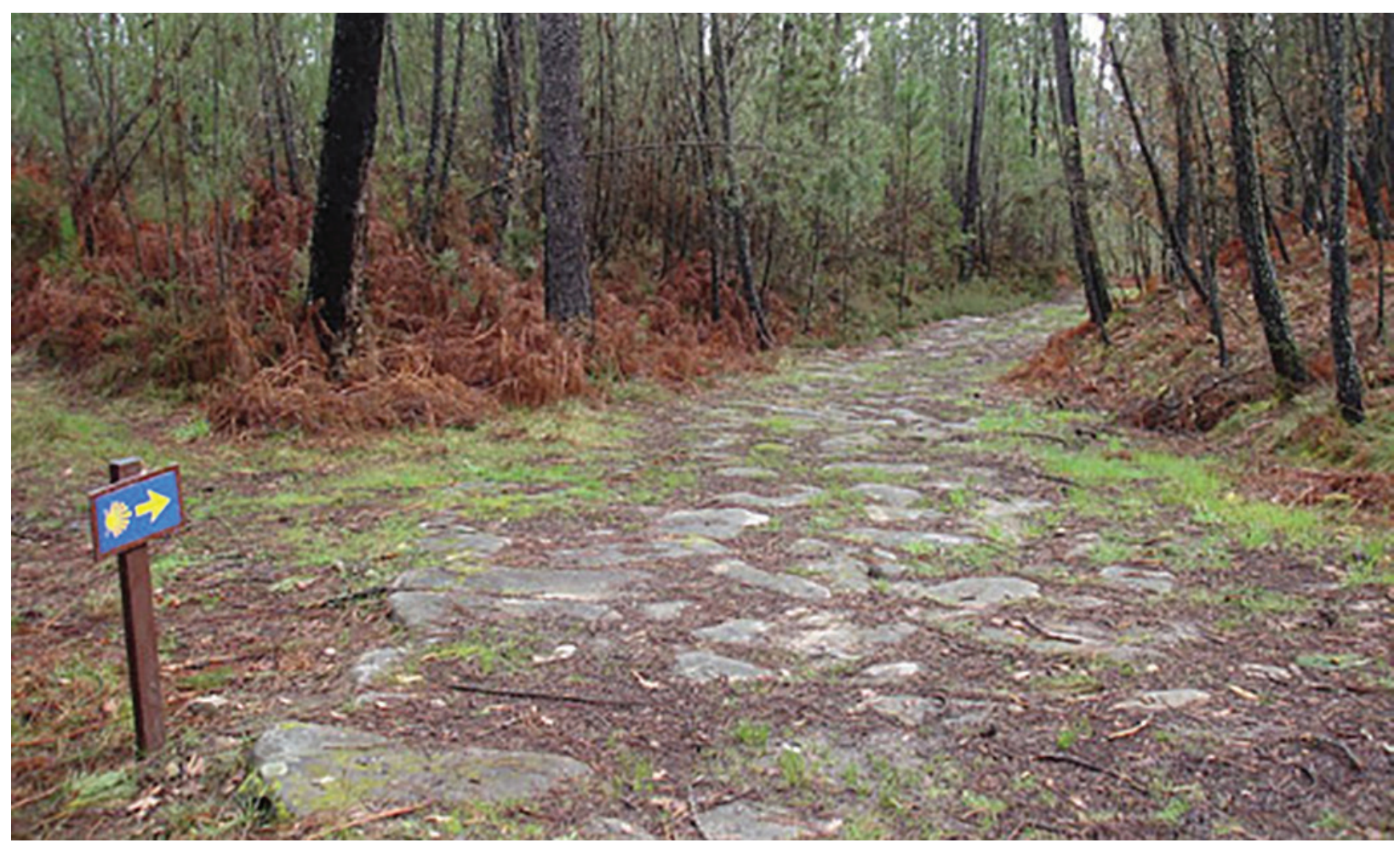

Figura 3 - calçada romana de Pousa Maria em Almargem, Viseu. Fonte: http://www.flordosa.pt/lugares (Acedido a 12 de julho de 2020). 


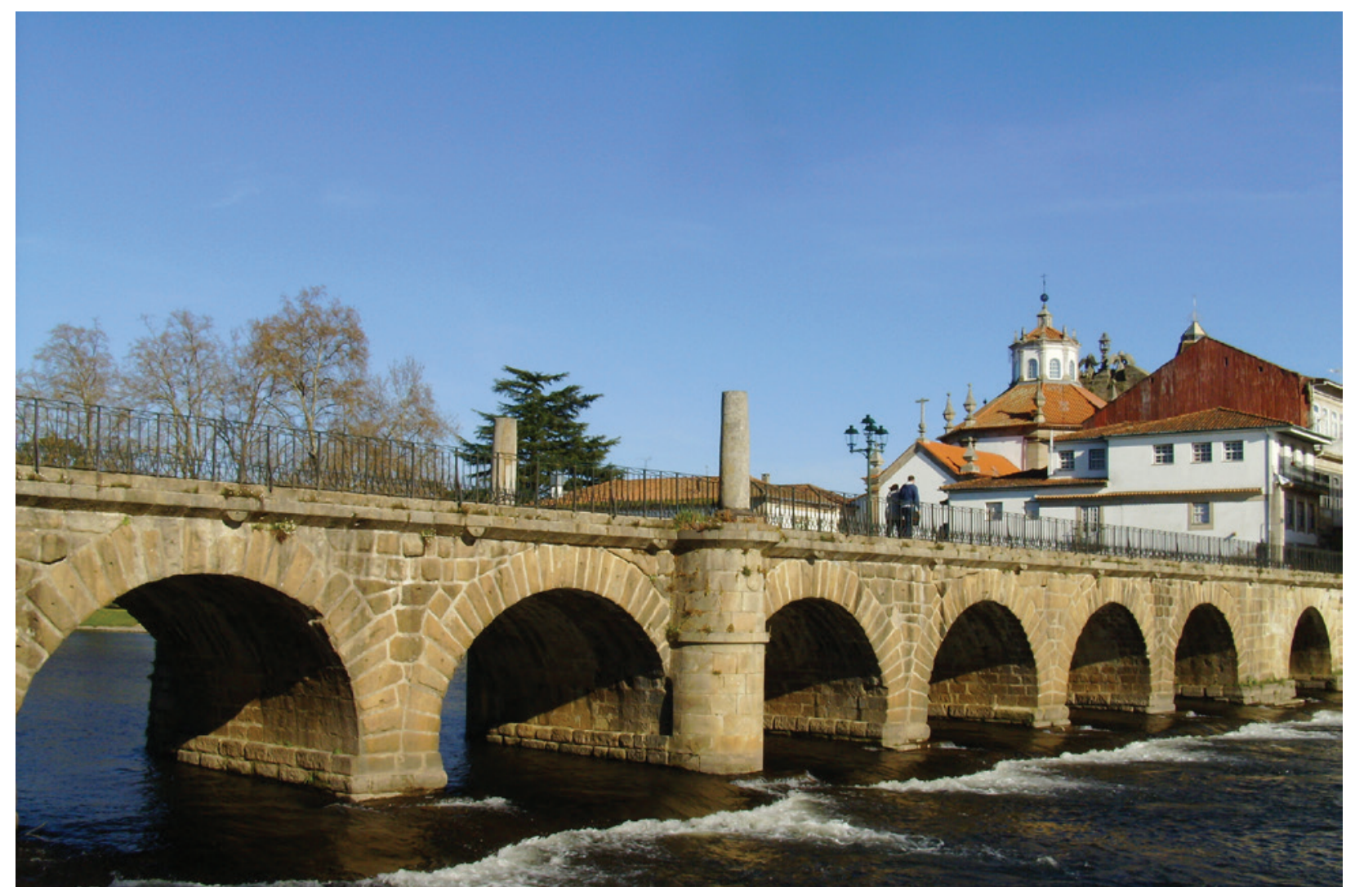

Figura 4 - Ponte de Trajano, Chaves. Fonte: do próprio autor.

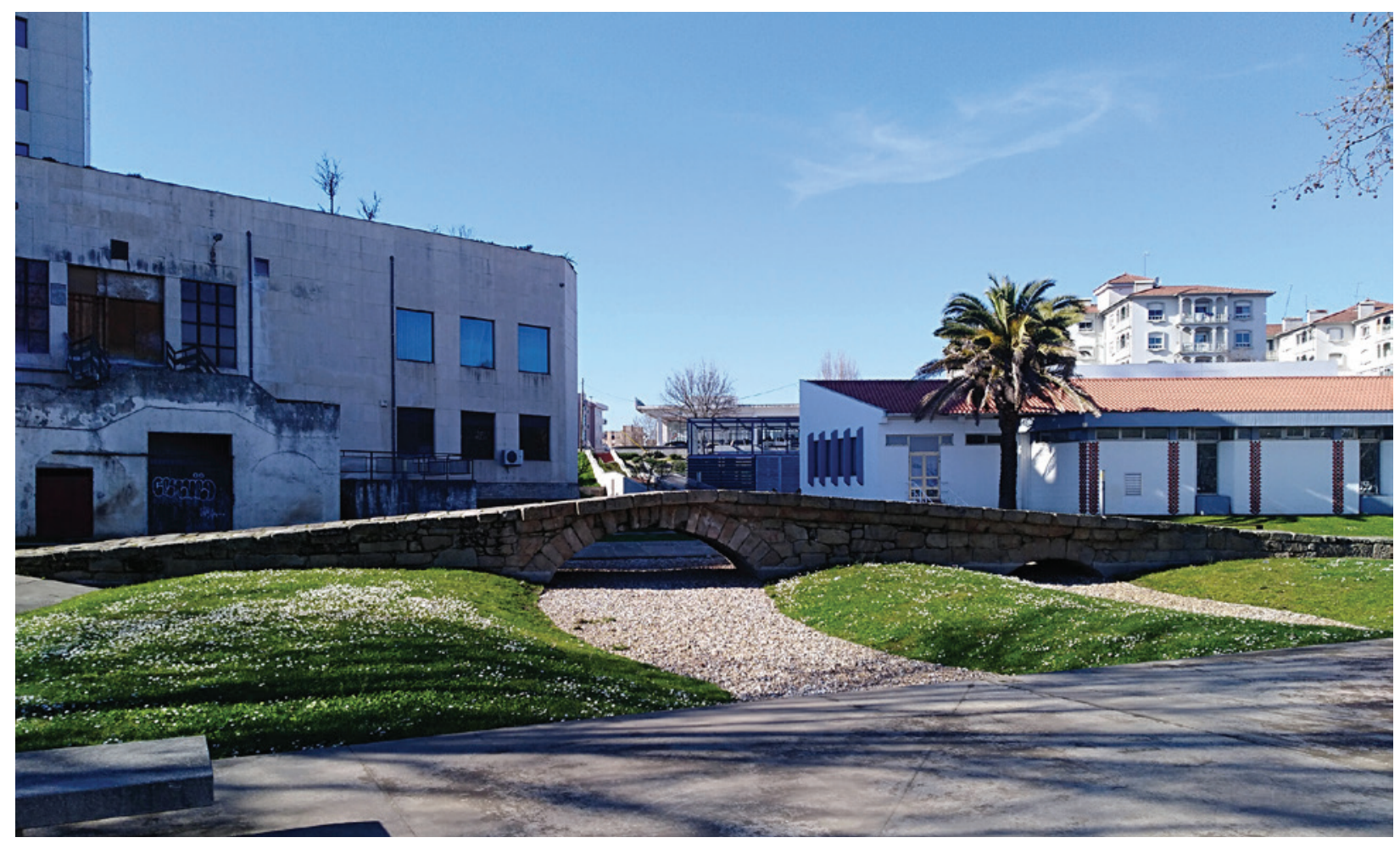

Figura 5 - Ponte das Caldas, Chaves. Fonte: do próprio autor. 


\title{
MORFOLOGIA URBANA: UM EXERCÍCIO EM TORNO DO CASTELO DE OURÉM
}

\author{
André Donas-Botto ${ }^{1}$, Jaqueline Pereira ${ }^{2}$
}

\begin{abstract}
RESUMO
O estudo da fotografia aérea através da fotointerpretação e da fotointerpretação da morfologia urbana não é novidade na Arqueologia, ainda que cada vez mais se recorra a ela para tirar conclusões do foro arqueológico. Para além da identificação de possíveis sítios arqueológicos, a fotografia aérea é também um recurso para a leitura de morfologias urbanas. Aliás, é bastante útil na percepção da evolução do traçado da malha urbana.

Ao observarmos uma paisagem - urbana ou não - devemos sempre ter em atenção o seu dinamismo. Assim, através da detecção de transmissões Isotópicas, Isoaxiais e Isoclinas, propomo-nos desenvolver uma proposta de evolução morfológica do Núcleo Medieval de Ourém ao longo dos tempos e cruzar essa análise com a realidade arqueológica já conhecida.

Palavras-chave: Ourém, Arqueogeografia, Heranças, Geomorfologia, Transmissões.
\end{abstract}

\begin{abstract}
The study of aerial photography through photointerpretation and photointerpretation of urban morphology is not new in Archaeology, although it is increasingly used to draw conclusions within this field. In addition to identifying possible archaeological sites, aerial photography is also a resource for reading urban morphologies. In fact, it is very useful for the perception of the evolution of the layout of an urban network. When observing a landscape - urban or not - we must always pay attention to its dynamism. Thus, through the detection of Isotopic, Isoaxial and Isocline transmissions, we propose to develop a proposal for the morphological evolution of the Medieval Nucleus of Ourém over time and cross this analysis with what is already known within archaeological reality.
\end{abstract}

Keywords: Ourém, Archeogeography, Inheritances, Geomorphology, Transmissions.

Os trabalhos de arqueologia preventiva promovidos desde 2002, no topo do monte onde se conhece o castelo medieval e as vertentes, até às cotas onde figura a Colegiada, revelaram ocupações pré-históricas e proto-históricas.

A presença humana no território de Ourém fica mais pi menos clara para todos os períodos, ainda que por vezes apenas a topografia faça presente aqueles vestígios nunca encontrados.

A natureza cársica do território, a presença de rios e ribeiras e a linha de água subterrânea que alimenta a nascente que emerge no interior do Castelo, a proximidade do mar, a localização central, entre o norte e o centro peninsular, e a boa visibilidade proporcionada pela elevação, trouxeram sempre boas condições ao povoamento, nomeadamente desde o Calcolítico.
O território de Ourém abarca as bacias hidrográficas do rio Lis e do Rio Nação e, naturalmente foi sempre um excelente espaço de circulação, em direcção a qualquer um dos pontos cardiais.

Partimos deste local tão marcante na paisagem oureense e propomos uma análise morfológica da área atendendo aos mecanismos da Arqueogeografia.

Será possível reconhecer na Arqueogeografia o desenvolvimento da Arqueologia da Paisagem de tradição francesa nas últimas décadas, tendo para isso contribuído, na década de 1990, a multiplicação de escavações arqueológicas, especialmente de parcelários, no âmbito da Arqueologia Preventiva, que permitiram conhecer a transmissão das formas da paisagem no espaço e no tempo. Por conseguinte, expuseram a "crise", já perceptível, no estudo do

1. Arqueólogo, Divisão de arqueologia da Ediestreido, Lda.; adonasbotto@gmail.com.

2. Arqueóloga, Divisão de arqueologia da Ediestreido, Lda.; agape@sapo.pt 
espaço das sociedades do passado, visível no desgaste das disciplinas, como a Geografia Histórica, a Geohistória, a Geografia Agrária e a Arqueologia da Paisagem, e dos objectos, maioritariamente planimétricos, de investigação tradicional (FREITAS, 2017, p. 82).

Rober Fossier será o autor da mais antiga ocorrência do termo Arqueogeografia. Porém, a formalização da disciplina só ocorrerá a partir de 2000 com o projecto Traité d'archéogéographie. A Arqueogeografia, como disciplina, debruça-se sobre a geografia e as dinâmicas históricas dos espaços e dos meios das sociedades do passado. É uma disciplina da memória e da transmissão das formas. Com a Arqueogeografia, é possível esclarecer os contributos obtidos através dos métodos de teledetecção e dos métodos de análise das formas para o conhecimento das múltiplas heranças que se manifestam, nas formas mais recentes (DONAS-BOTTO, 2012, p. 48). "A forma é a totalidade da unidade complexa organizada que se manifesta fenomenicamente enquanto todo no tempo e no espaço" (MORIN apud COSTA, 2010, p. 43). As formas apresentam-se de diversos modos, não obedecendo a um tempo cíclico, são um testemunho daquilo que já foi. Revelam-se como fósseis do passado na paisagem rural e urbana (DONAS-BOTTO, 2012, p. 48)!

Gérard Chouquer (2007, p. 39), afirma que são três as categorias principais do discurso arqueogeográfico: o espaço geográfico, o tempo histórico e os objectos territoriais identitários.

Do ponto de vista do Espaço Geográfico a composição que a Arqueogeografia visa alcançar é a leitura do "écoumène" (ibid. 2003, pp. 13-21). Valorizando-se a dimensão geográfica do ser humano, algo que o geógrafo Augustin Berque apelidou de "géographicité" (CHOUQUER, 2007, p.55). Para este autor, a Arqueogeografia propõe-se a restaurar esta relação integrando principalmente as formas e cartas dos geógrafos. O conceito de "médiance", dá-nos a conhecer esta relação (isto é, a dimensão geográfica), sendo enriquecida pelas dinâmicas espaço-tempo. Assim, surge a ideia que entre os seres humanos e as "coisas geográficas" nascem contornos que aparentam, pelo menos aos nossos olhos, serem imóveis na cartografia e/ou na fotografia aérea (FREITAS, 2015, p. 42).

Por outras palavras, este conceito de "médiance" subentende as relações que se estabelecem entre o material e o imaterial; entre o subjectivo e o ob- jectivo; entre o passado, o presente e o futuro. Este processo dinâmico, que observamos nas fotografias aéreas, requer transformação para que haja transmissão, proporcionando ao conceito de "médiance" a dimensão espaço-tempo que lhe faltava. Demonstra, assim, a ligação entre o histórico e o geográfico, revelando o erro dos que opunham à dinâmica dos factos históricos a imobilidade das coisas dos espaços geográficos (Ibid).

Já no que respeita ao tempo histórico, a Arqueogeografia constata que o espaço não comporta apenas traços históricos associados às diferentes intervenções que os homens aí desenvolveram, mas também, e sobretudo, uma memória (ibid.: 39). Perante esta evidência arqueogeográfica devemos substituir as origens, prática comum e instaurada pela História, pelas heranças (CHOUQUER, 2007, p. 39). Os historiadores foram sempre confrontados com a dificuldade de determinar as cronologias das planimetrias e dos objectos geográficos, isto porque não reconhecem a complexa natureza das temporalidades. Acresce a esta dificuldade, os elementos de datação propostos, os quais visam permanecer na periodização e cujas referências são originárias da História. Consequentemente, estes objectos geográficos são sempre interpretados como "marcas" das instituições e das políticas, excluindo-lhes uma história diferente da dos documentos escritos (FREITAS, 2015, p. 43).

Em face destes conhecimentos, Gérard Chouquer estabelece uma orientação arqueogeográfica para o estudo das planimetrias assente num conhecimento profundo e melhorado das planificações, assim como das suas condições de realização e cronologias (CHOUQUER, 2007, p.63). É igualmente importante ter em mente que nunca conheceremos o que as planificações foram no seu momento inicial, mas sim no que elas se transformaram (FREITAS, 2015, p. 43).

$\mathrm{Na}$ última das três principais categorias do discurso arqueogeográfico entramos, explicitamente, no Naturalismo. Em Arqueogeografia, a ligação entre o Naturalismo, como base filosófica de compreensão do mundo, e a Modernidade, como tempo de emergência e consolidação desta ontologia, é imediata. A percepção desta ligação é crucial, já que dela nascem as três principais metodologias: Naturalismo, $\mathrm{Na}-$ cionalismo e Historicismo metodológico (CHOUQUER, 2007, p. 114). Podemos interpretá-las, respectivamente, como os efeitos da separação entre a 
Natureza e a Cultura; do Nacionalismo na concepção dos objectos antigos, medievais e modernos; das periodizações dos historiadores na compreensão das diversas dinâmicas (WATTEAUX, 2014).

Os objectos territoriais identitários corresponderão aos objectos geográficos, carregados de heranças, que foram recuperados, ou manipulados, pelo $\mathrm{Na}$ cionalismo na formação da sua identidade. Esta crise dos objectos, acontece, por duas razões principais: uma, os historiadores e arqueólogos construíram o passado tendo em mente o nascimento, seguido da consolidação, dos Estados-nação; outra, os investigadores procuraram nos diferentes passados as razões que permitissem justificar as suas actuais escolhas. Poderemos utilizar a Geografia Histórica como exemplo desta abordagem. Tradicionalmente, a Geografia Histórica instaura objectos periodizados e estáticos, já que pouco ou nada evoluem nos respectivos períodos. Contudo, paradoxalmente, relacionam-se explicitamente entre eles, surgindo frequentemente associados (a diocese em relação à cidade da Antiguidade, a aldeia em relação à paróquia medieval, etc). Através destas filiações pretendem-se utilizar os feitos e objectos emblemáticos de forte valor identitário e histórico (territórios, paisagens, sítios, monumentos, etc.) para justificar o que é, e como é, o actual território nacional (FREITAS, 2015, p. 44/5).

Tal como temos vindo a desenvolver, para além das fontes escritas bem como vestígios arqueológicos deveremos abordar outras fontes de estudo. Nesta vertente da investigação científica deveremos começar a considerar um maior número de documentação existente como fontes para a mesma (CHOUQUER, 2007, p. 217). Devemos então acrescentar aqui também a documentação das fotografias aéreas como fonte para este nosso exercício.

O estudo da fotografia aérea através da fotointerpretação e da fotointerpretação da morfologia urbana não é novidade na Arqueologia, ainda que cada vez mais se recorra a ela para tirar conclusões do foro arqueológico. Para além da identificação de possíveis sítios arqueológicos, a fotografia aérea é também um recurso para a leitura de morfologias urbanas. - Aliás, é bastante útil na percepção da evolução do traçado da malha urbana. A forma como a cidade cresce e se organiza está estritamente relacionada com o seu passado, deixando marcas possíveis de visualizar através das suas cartas e fotografias.

Ao observarmos uma paisagem - urbana ou não - devemos sempre ter em atenção o seu dinamismo. Não podemos adoptar uma postura coerente com um modelo palimpsesto (DONAS-BOTTO, 2012, p. 50); a paisagem, na realidade, não é composta por diversas camadas que se sobrepõem do mais recente para o mais antigo (COSTA, 2010, p. 43). Estas camadas de facto existem, mas não são opacas, e, se olharmos com atenção, é-nos possível ver a sua interligação (DONAS-BOTTO, 2012, p. 50). Conseguiremos assim, desta forma, assimilar as heranças existentes na planimetria urbana.

É nesta perspetiva que abordaremos o centro histórico de Ourém, nomeadamente o seu Castelo e envolvência urbana, socorrendo-nos dos dados de recentes escavações arqueológicas ${ }^{3}$, para tentar validar as interpretações por técnicas de observação remota. Assim, através da detecção de transmissões Isotópicas (transmissões feitas directamente sobre uma antiga estrutura, ou antiga orientação), Isoaxiais (não estando localizadas directamente sobre antigos traçados, mas que seguem as direcções anteriores) e Isoclinas (transmissões que não se encontram directamente ligadas com as formas antigas, mas cuja orientação toma como estas o seu ponto de partida) (Ibid, p. 52). Propomo-nos desenvolver uma proposta de evolução morfológica do núcleo medieval de Ourém ao longo dos tempos e cruzar essa análise com a realidade arqueológica já por nós conhecida. Este exercício, acaba por revelar a dinâmica no crescimento contra a estática da localização. Na realidade, existe um elemento estático nesta situação, a localização da vila naquele local, a fixação de gente naquele sítio específico, em contrapartida a dinâmica da sua evolução deita por terra o modelo do palimpsesto, o passado não foi totalmente apagado e

\footnotetext{
3.-Nomeadamente a intervenção arqueológica no morro do Castelo que ocorreu em 2003, na Rua Beato Simão Lopes e no Largo da Sé Colegiada. A segunda, a cerca de 150 $\mathrm{m}$ a SE da primeira, ocorreu em 2004, num terreno marginado pela rua Gonçalo Hermingues. No âmbito destes trabalhos recolheu-se um razoável conjunto de cerâmica fina cinzenta da Idade do Ferro, bem como outros variados indícios, nomeadamente do Período Medieval e Moderno. Em 2005, no âmbito de um projecto de recuperação e salvaguarda do castelo, promoveu-se a abertura de diferentes sondagens no seu interior, em redor da cisterna existente. Em 2008 procedeu-se aí a uma escavação em área pretendendo clarificar-se a estratigrafia deste sítio, ocupado desde o Calcolítico. Em 2009 efectuaram-se sondagens a norte do Castelo que nos remetem para o período Moderno. Em 1017 e 18 intervencionaram-se contextos similares.
} 
ficou vincado na morfologia adoptada pelas ruas e sua disposição.

"Cada núcleo urbano assemelha-se a um organismo vivo" (SÁ, 2001, p. 31), o crescimento da povoação a evolução cronológica do sítio adapta-se à situação. Com a desnecessidade da existência de muralha para efeitos defensivos, e sobretudo com o seu abandono definitivo após os danos do terramoto de 1755, muita da sua pedra acabou por ser reaproveitada para a reconstrução do casario da vila medieval bem como utilizada em novas construções. Muitas destas construções acabaram por assumir a mesma orientação dos antigos níveis de muralha. Desta for$\mathrm{ma}$, as novas ruas que surgiram adotaram o traçado da mesma, sendo clara esta herança na morfologia observável na fotografia aérea de Ourém. Para além desta delimitação clara de traçados de muralha conseguimos observar também uma formação rádio-concêntrica de onde irradiam traçados viários e praticamente toda a planimetria do burgo. Em termos grosseiros, podemos intuir que as redes viárias que emanam a partir destes centros são muito antigas, tão antigas como os vestígios arqueológicos mais antigos aí presentes (COSTA, 2010, p. 63).

Num primeiro ponto podemos assinalar uma área a verde que corresponderá à herança mais antiga e marcante de todo o morro. Esta área corresponderá inicialmente a uma ocupação proto-histórica e posteriormente será a "semente" de onde irá germinar o burgo medieval (Figura 1).

Confirmou-se, durante os trabalhos de 2008, a ocupação do Calcolítico (240o e 2200 a.C) escavando-se duas estruturas negativas, de tipo fossa, preenchidas por restos faunísticos artefactos dessa época (PEREIRA, 2011, 154)

As técnicas e motivos decorativos são diversificados, sendo que se denota um cruzamento de influências do Calcolítico Beirão (o caco com penteados) e Estremenho (o caco decorado com folha de acácia), incluídas no Calcolítico Pleno (CARVALHO, 2010/2011). No ano de 2003, junto à Colegiada de Ourém, sob a muralha e no lado N, verificou-se um nível do Bronze Final e I Idade do Ferro (até cerca de 450 a. C.), nomeadamente as chamadas cerâmicas cinzentas (tratadas por meio de alisamento ou polimento) e outras de pasta clara, pintadas a cores vermelhas e alaranjadas. Mesmo que a ocupação do local tenha sofrido alguma interrupção, no final do Calcolitico, o fato é que também na escavação de 2008 (no interior do castelo) se detectaram algumas cerâmicas cinzentas. A não detecção de material de períodos posteriores à Idade do Ferro sob a muralha, recuando até ao século VII a.C., faz-nos colocar a hipótese de que o solo poderia ter sido terraplanado para a implantação da muralha. Até porque as cerâmicas da Idade do Ferro que apareceram quer nas sondagens de 2004, junto à rua Gonçalo Hermingues, na encosta oriental abaixo do cemitério (Pereira et all, 2017, p. 27) e noutros pontos do morro conduzem-nos a crer numa profunda alteração da morfologia do monte e sequente destruição de anteriores níveis e ocupação. A terraplanagem que ocorreu no interior do Castelo, permanecendo apenas os níveis mais antigos, nomeadamente do lado oeste (PEREIRA, 2011, 156). Uma operação de terraplanagem pode, por exemplo e também, justificar o desconhecimento de vestígios de ocupação muçulmana. Quando o investigador Doutor Saúl António Gomes refere a expressão "castellus de nouo" como indicativo que se construiu um castelo de raiz, cremos que não invalida a existência de uma torre de cisterna e antigas estruturas inerentes ao castro. De facto, aquela a construção de um castelo de raiz pode vir a ser reforçada com a presença do muro sob a parede leste do actual recinto triangular e sobre os níveis Pré-históricos. No entanto não se percebe ainda que muro será aquele, bem como não se coloca de lado que outros níveis tenham sido decapados à época da construção do edificado, podendo a estrutura ser medieval. Por outro lado, algumas das disposições detectadas em 2005 e o facto de a torre sul da edificação actual apresentar um aparelho em blocos de grandes dimensões, silhares com marcas de fórceps, característica típica dos séculos VIII E IX12, levam-nos a acredita na possível existência de uma dita primeira edificação - a torre da cisterna (?). (PEREIRA, 2011, 159).

Após um período de fortalecimento da zona fronteiriça, assiste-se no século XII, a um retorno à estratégia de conquista. $\mathrm{O}$ espaço, em que se insere o concelho de Ourém, não era desconhecido quer por mouros quer por cristãos, mas com certeza foi durante algum tempo uma terra que não pertenceria a nenhum dos quadrantes político militares.

As invasões de Almorávidas e Almóadas, vindas dos confins de Marrocos, pesaram duramente na maneira de viver dos cristãos, a quem não respeitavam nem a fé nem os usos. Assolados pela guerra, muitos lugares devem ter vivido, pelo espaço de algumas gerações, na insegurança das pessoas e dos 
bens: arruinadas as povoações, foragida a escassa população rural, constituíram-se alguns espaços ermos, sem cultura e sem dono. Nesta "terra de ninguém”, sem se embaraçarem com divisões de propriedades ou contestações de posse, os primeiros reis fizeram enormes doações de território às ordens militares, bens aos mosteiros e latifúndios a grandes senhores e na maioria das vezes os quadros da administração e os limites das propriedades precediam a ocupação efectiva do solo ou, pelo menos, a organização da vida rural.

Conquista por D. Afonso Henriques por volta de 1136, Abdegas não terá sido um território com ermamento total durante o período da pré-reconquista, mas também não haveria aí, até à segunda metade de XII, povoações dignas de serem referidas pelos documentos da época. À época a sua ocupação integra-se numa política de ocupação de espaço, levada a cabo por D. Afonso Henriques que, em 1135, tinha já ordenado a construção do castelo de Leiria.

É após a Reconquista do local e a construção da igreja de S.ta Maria de Ourém que D. Afonso Henriques doa ao Mosteiro de S.ta Cruz, os reguengos e a vila de Ourém são entregues a sua filha D. Teresa, em 1158, fazendo assim desta vila um investimento régio, deixando ali um delegado da sua autoridade, demonstrando a preocupação para com as ameaças vindas de sul. Desde o início da monarquia portuguesa que o castelo de Ourém é caracterizado pela presença de iniciativa régia e pela participação dos habitantes na sua defesa e manutenção, como se conclui de um diploma régio de 1178 .

É provável que já existisse um castelo em Ourém, apenas refúgio, sem carácter habitacional permanente, com dispositivos para armazenar água e alimentos onde se refugiavam as gentes dos vales de Aurem. Em torno desta área. E com o normal crescimento do burgo ter-se-á alargado a muralha dando lugar a uma cerca vilã para albergar toda a população dentro da proteção da estrutura militar. Neste momento, a área delimitada a verde terá assumido uma posição de cidadela continuando a marcar fortemente a morfologia da área (Figura 2).

Este alargamento terá certamente sofrido intervenção nos reinados de D. Fernando ou muito mais provavelmente no reinado de D. João I. Aquando da doação do condado de Ourém a D. Nuno Álvares Pereira este empreendeu algumas intervenções na área do castelo e acessos ao burgo. Em 1384, D. João I concede a Vila e o território, bem como o tí- tulo de Conde de Ourém, ao Condestável do Reino, D. Nuno Álvares Pereira (3.. Conde de Ourém). Nessa altura Nuno Álvares Pereira manda edificar a Fonte dos Cavalos. E, já no século XV, é com o neto do dito Condestável, D. Afonso Conde de Ourém e Marquês de Valença, que o território condal conheceu um período bastante dinâmico. É nessa altura que as muralhas do primitivo castelo são rasgadas para edificação do conhecido Paço do Conde, sito a sul do castelo.

Deste período temos um elemento morfológico muito marcante estando assinalado a azul na Figu-ra 2. Esta transmissão acaba por se revelar como uma transmissão Isotópicas nas áreas das ruas de São João e São José bem como na rua D. Afonso Quarto Conde de Ourém. Esta transmissão é feita directamente sobre o que acreditamos ser o alinhamento da antiga estrutura de uma primeira cerca vilã, ou pelo menos a sua antiga orientação). $\mathrm{O}$ casario que se desenvolve em torno destes eixos e na parte interior dos mesmos acabam por se revelar transmissões Isoaxiais, isto é, não estando localizadas directamente sobre antigos traçados, mas que seguem as direcções anteriores formando assim parcelários e elementos morfogenéticos. A Rua da Saudade e Calçada de Gonçalo Hermingues acabam por também assumir uma morfologia testemunho de transmissão Isoaxial (Figura 3 e 4).

Na vertente mais a este desta calçada podemos testemunhar uma transmissão Isoclina, ou seja, as transmissões não se encontram directamente ligadas com as formas antigas, mas a sua orientação toma estas como o seu ponto de partida. É neste ponto que observamos o elemento morfogenético mais marcante. Queremos com isto dizer que o parcelário antigo transmitiu a sua orientação em parte ao actual apesar das alterações que a área sofreu ao longo dos tempos bom como da sua ocupação funcional. Esta área está assinalada na Figura 5 com um polígono laranja.

Por fim poderemos observar os últimos momentos responsáveis pela morfologia urbana do Núcleo Medieval de Ourém. Na figura 5 podemos observar assinalado a vermelho o alargamento da cerca vilã com as intervenções de D. Afonso IV Conde de Ourém. A par desta observação podemos constatar os mortórios ou espaços vazios sem casario certamente consequência do terramoto de 1755 bem como das incursões militares aquando das invasões francesas. $\mathrm{O}$ terreno intervencionado, em 2009, situa-se a N 
do Castelo e toma a forma prismática e em arco, no sentido norte-sul; fica situado entre a Rua da Saudade que, vindo da porta de Santarém, leva ao cemitério (situado a sudeste), e a rua de S. João, que segue da porta de Santarém para o centro do aglomerado urbano (...). O contexto arqueológico apresentou-se similar àquele do ano de 2004, grande número de fragmentos cerâmicos, designadamente faiança portuguesa - XVII a XIX. (PEREIRA, 2011, 154)

Todas estas reformas deixaram uma marca bem patente na morfologia do burgo, se por um lado a Sé Colegiada acaba por ganhar uma posição de destaque na plataforma limítrofe norte da vila murada, o eixo concêntrico da rede viária urbana não se perde, bem como a influencia e herança primordial da área do castelo na formação de uma planimetria concêntrica e de um parcelário que vai seguindo tanto as novas como as formas mais antigas. O próprio alargamento da cerca vila acaba por se revelar uma transmissão Isoaxial assumindo agora o casario o lugar da transmissão isotópica das partes da muralha já desaparecida (Figura 6 a 8).

Tal como foi possível observar nas duas figuras anteriores o castelo mantém-se ainda hoje como ponto fulcral tanto nos parcelários urbanos como nos sentidos de fluxo da rede viária do burgo. Desta forma não deveremos assumir o castelo em si apenas como uma herança medieval, mas sim como um marco de toda a ocupação do morro, sendo esta estrutura e este ponto uma manifestação no terreno do ecohumano, de todas as formas como o ser humano moldou este morro, mas como aquele ponto manteve inalterada a sua centralidade e influencia na definição morfológica do povoado.

Concluindo, foi possível atestar as ocupações apresentadas a partir do exercício de análise das imagens de satélite da área do castelo de Ourém. Este exercício de Arqueogeografia é ainda muito preliminar, mas foi já suficiente para retirar algumas conclusões como a centralidade do castelo e da área assinalada a verde na Figura 1, a existência de pelo menos três parcelários urbanos que vão acompanhando o desenvolvimento do burgo e vão sendo reflexo da evolução do mesmo. As cercas medievais e sucessivas intervenções na área - sobretudo com a construção do paço condal - vão sendo reflexo de transmissões Isotópicas e Isoaxiais chegando a existir áreas onde os diferentes traçados se sobrepõem tal como poderemos ver nos dois esquemas finais deste artigo representados nas figuras 9 e 10. Estas cercas chegam- -nos hoje até nós não só pelos elementos que ainda hoje são visíveis dos mesmos mas também pela observação da morfologia das ruas e casario como desenvolvemos nas linhas anteriores!

Estas diferentes transmissões e parcelários correspondentes aos diferentes períodos de desenvolvimento marcados na paisagem acabam por revelar três fases evolutivas que ficaram marcadamente presentes na morfologia urbana da área (Figura 9 e 10).

\section{BIBLIOGRAFIA}

FREITAS, Bruno Bairrão de (2015) - Paisagens do Baixo Mondego: Por um debate acerca de Ega, Arrifana e PicotaDissertação, Dissertação de mestrado apresentada à Faculdade de Letras da Universidade de Coimbra, Coimbra.

FREITAS, Bruno Bairrão de (2017) - "Anatomia" de um Mito Medieval: a aldeia e a forma rádio-concêntrica. Al-Madan Online [Em linha]. II Série. N.ㅇ 21. Tomo 2 pp. 81-91.

CARVALHO, A. Faustino; NUNES, Ana; GONÇALVES, Ana; PEREIRA, Jaqueline (2010/2011) - A ocupação calcolítica do Castelo de Ourém: contextos, cultura material, zooarqueologia, cronologia absoluta e integração regional. Estudos Arqueológicos de Oeiras, 18, Oeiras, Câmara Municipal, pp. 407-418.

CHOUQUER, Gérard (2007) - Quels scénarios pour l'histoire du paysage? - Orientations de recherche pour l'archéogeographie - Centro de Estudos Arqueológicos das Universidades deCoimbra e Porto, Coimbra.

COSTA, Miguel Cipriano (2010) - Redes viárias de Alenquer e suas dinâmicas. Um estudo de arqueogeografia - Tese de Mestrado em Arqueologia e Território, Faculdade de Letras da Universidade de Coimbra, Coimbra.

DONAS-BOTTO, André (2012) - São João da Pesqueira: Subsídios para o estudo do território medieval - Dissertação de mestrado apresentada à faculdade de Letras da Universidade de Coimbra, Coimbra.

PEREIRA, Jaqueline \& GONÇALVES, Alexandre (2006) Carta Arqueológica do Concelho de Ourém, Ed. Câmara Municipal de Ourém, Ourem.

PEREIRA, Jaqueline e FERREIRA, Sofia (2011) - OURÉM: De povoado a Vila Velha, I Congresso de História e Património da Alta Estremadura, pp. 149-165.

SÁ, Alberto (2001) - Sinais da Guimarães Urbana em 1498 Dissertação de Mestrado em História e Cultura Medievais, Instituto de Ciencias Sociais, Universidade do Minho, Braga.

WATTEAUX, Magali (2014) - La terre en héritage. Espaces Temps.net. 


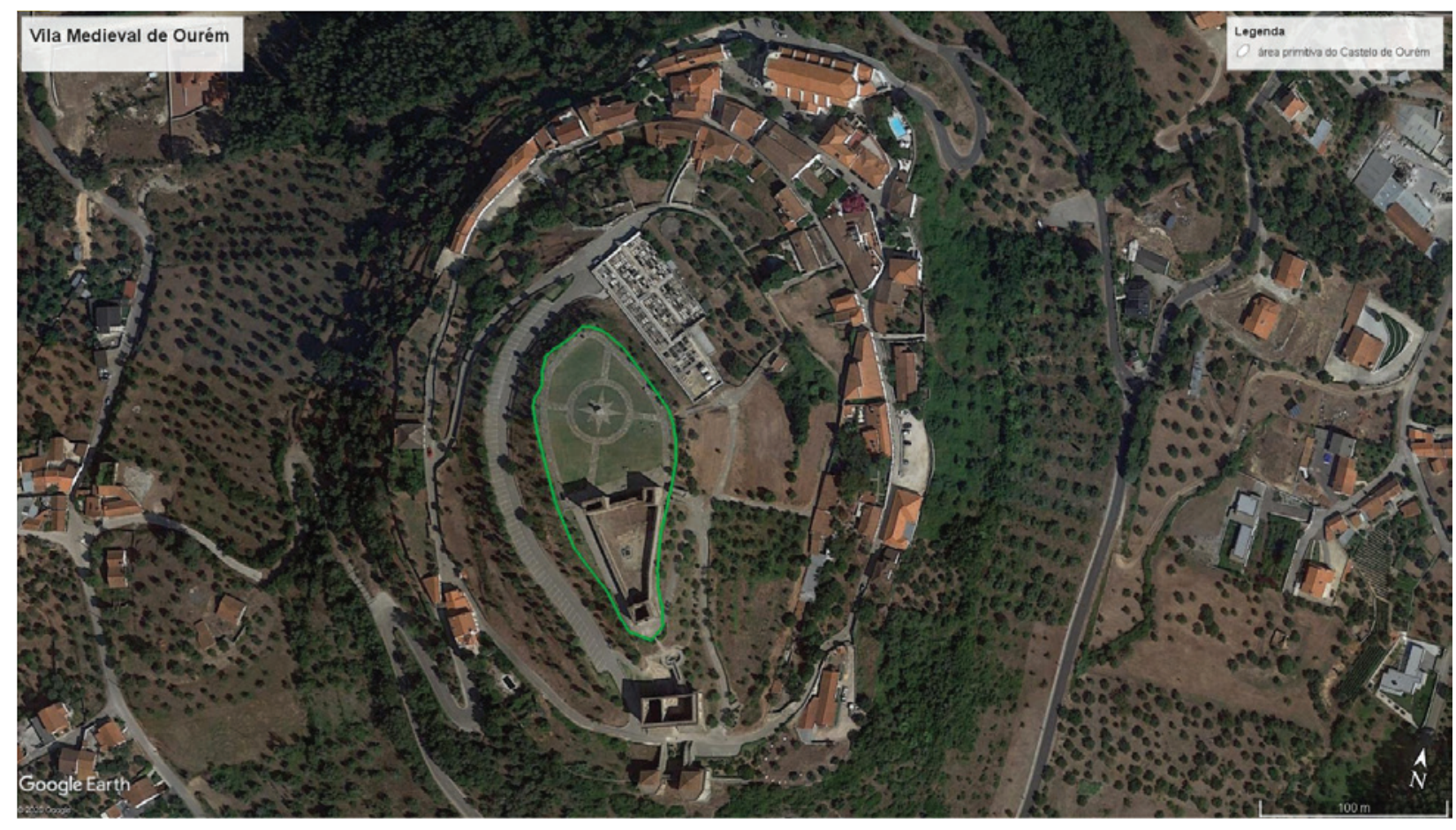

Figura 1 - Vista aérea do núcleo medieval de Ourém.-A verde está demarcada a área correspondente a área primitiva de ocupação que acabou por moldar todas a morfologia. Fonte: Google Earth.

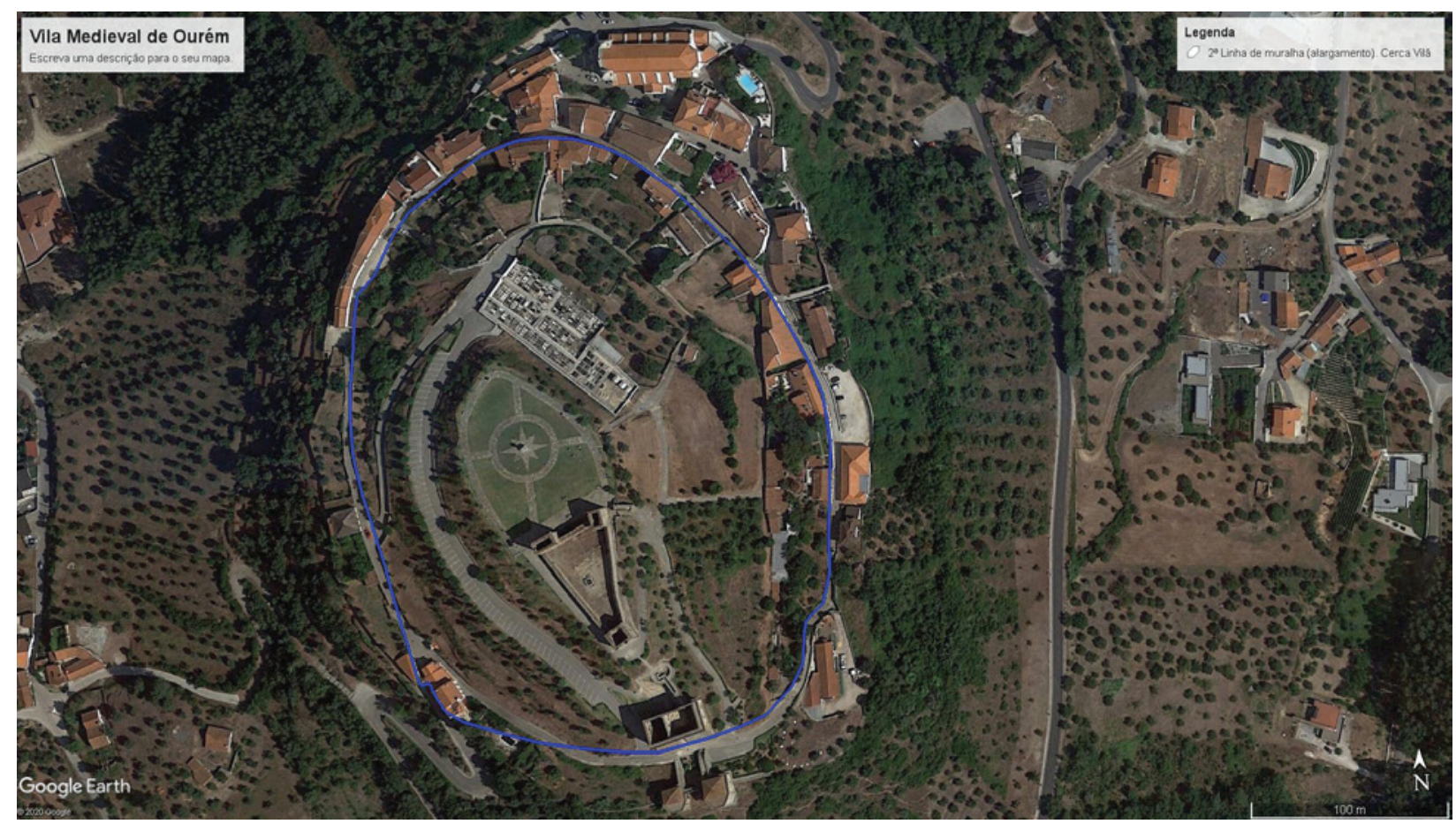

Figura 2 - Vista aérea do núcleo medieval de Ourém. -A azul está demarcada a área correspondente à cerca vilã e primeiro alargamento do burgo. Fonte: Google Earth. 


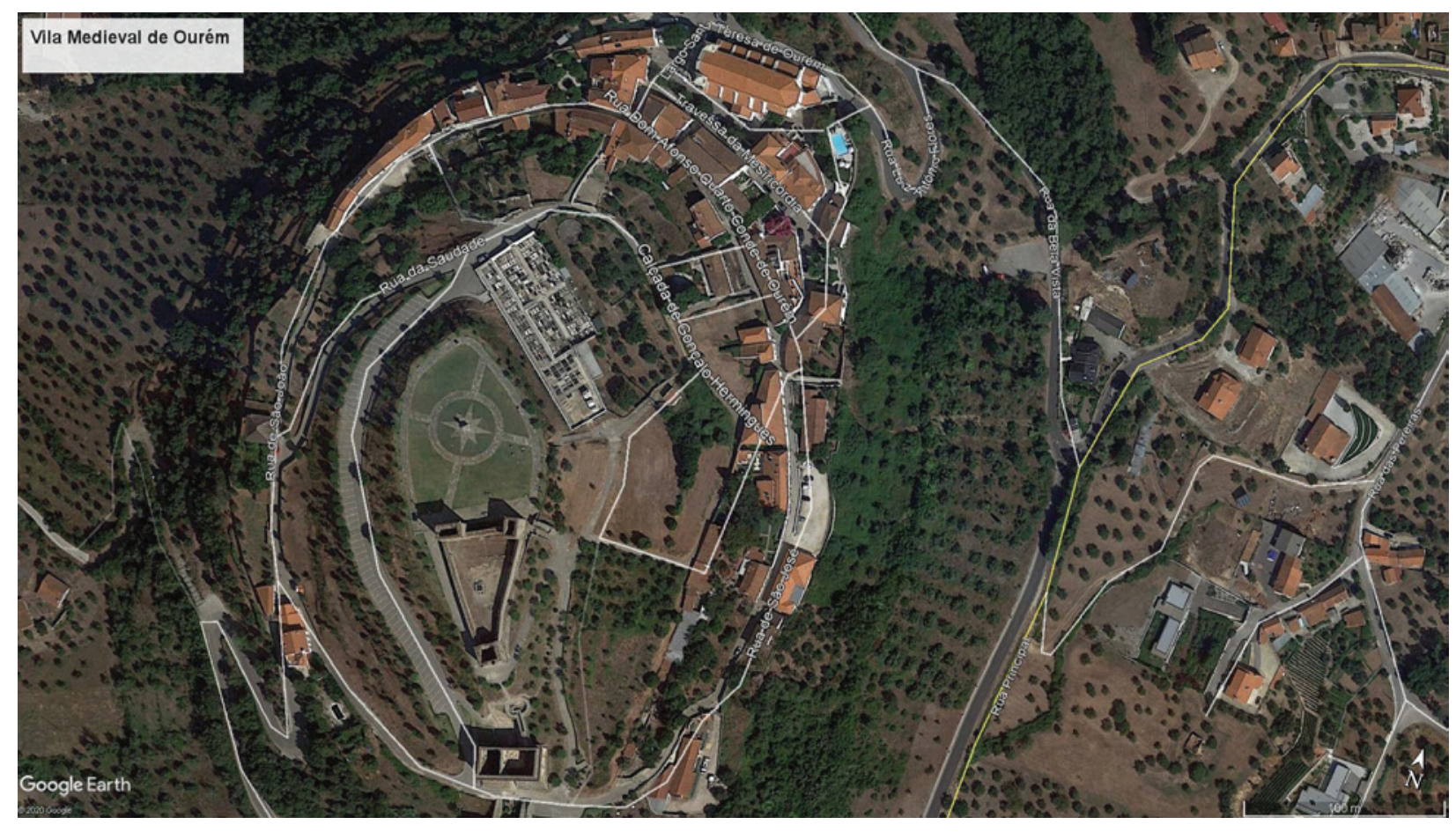

Figura 3 - Vista aérea do núcleo medieval de Ourém com os principais arruamentos assinalados. Fonte: Google Earth.

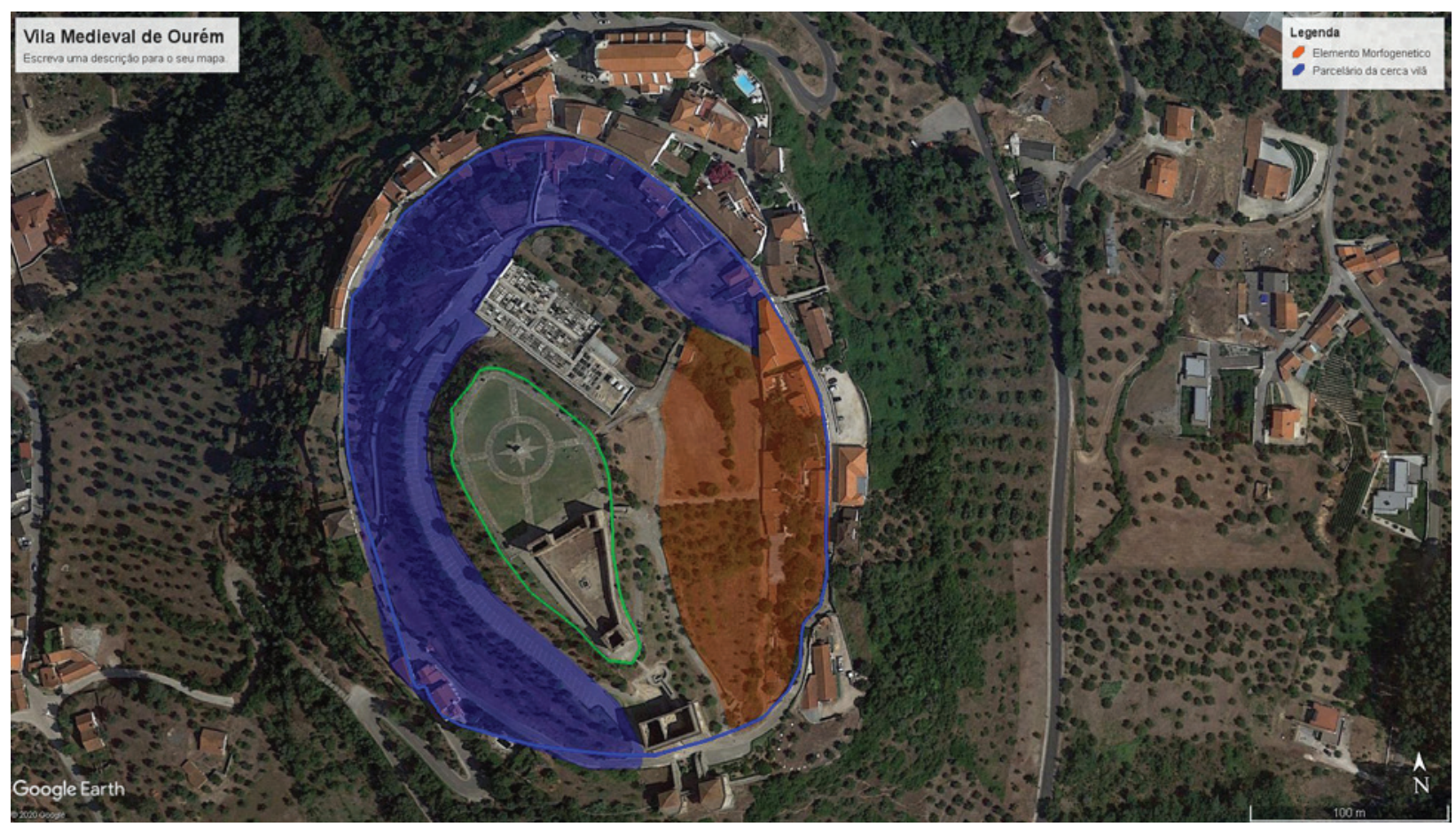

Figura 4 - Vista aérea do núcleo medieval de Ourém. Principais parcelários e transmissões isotópicas e isoclinas. Fonte: Google Earth. 


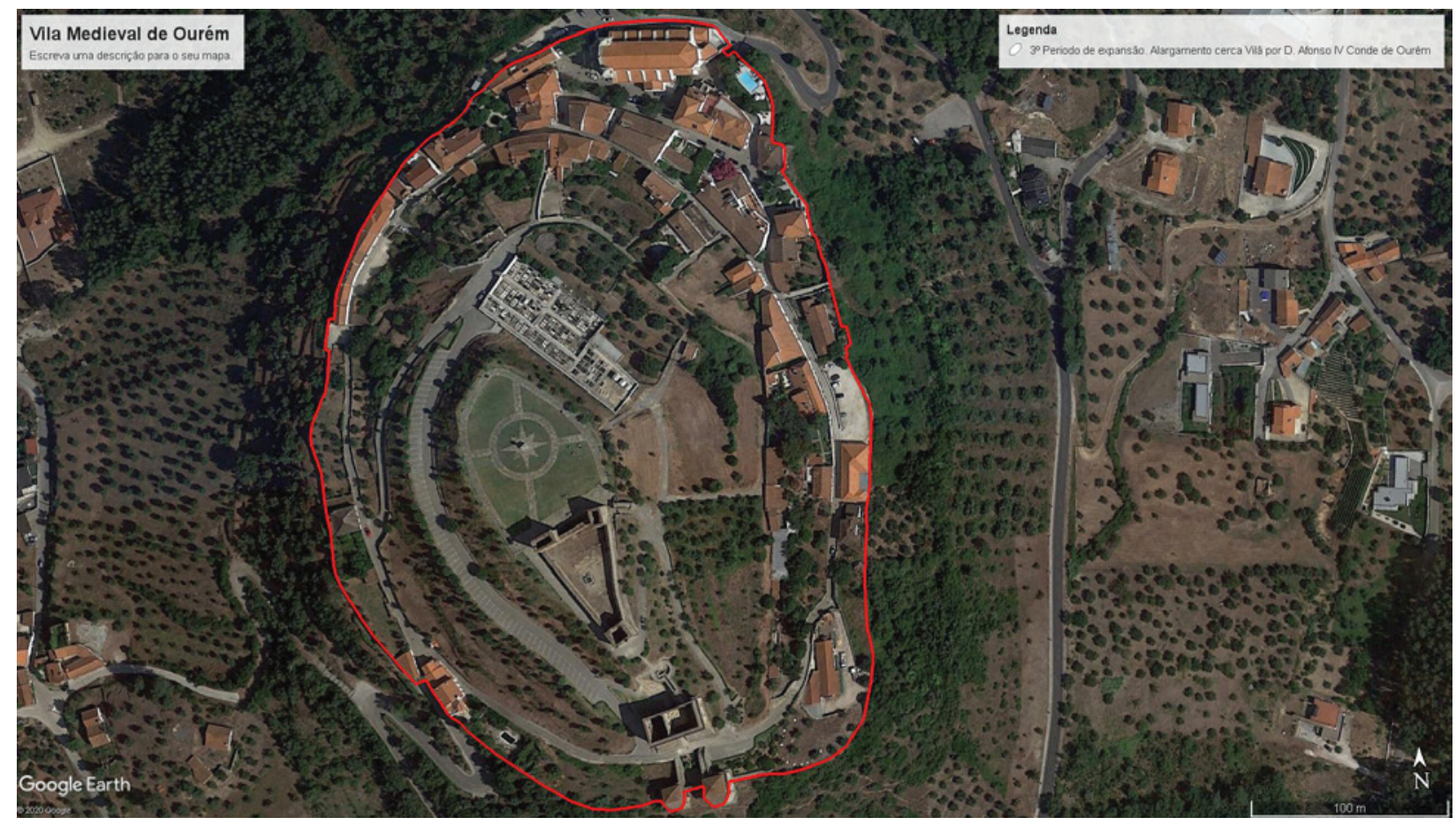

Figura 5-Vista aérea do núcleo medieval de Ourém. -A vermelho está assinalada a última linha de muralha correspondente à cerca vilã alargada. Fonte: Google Earth.

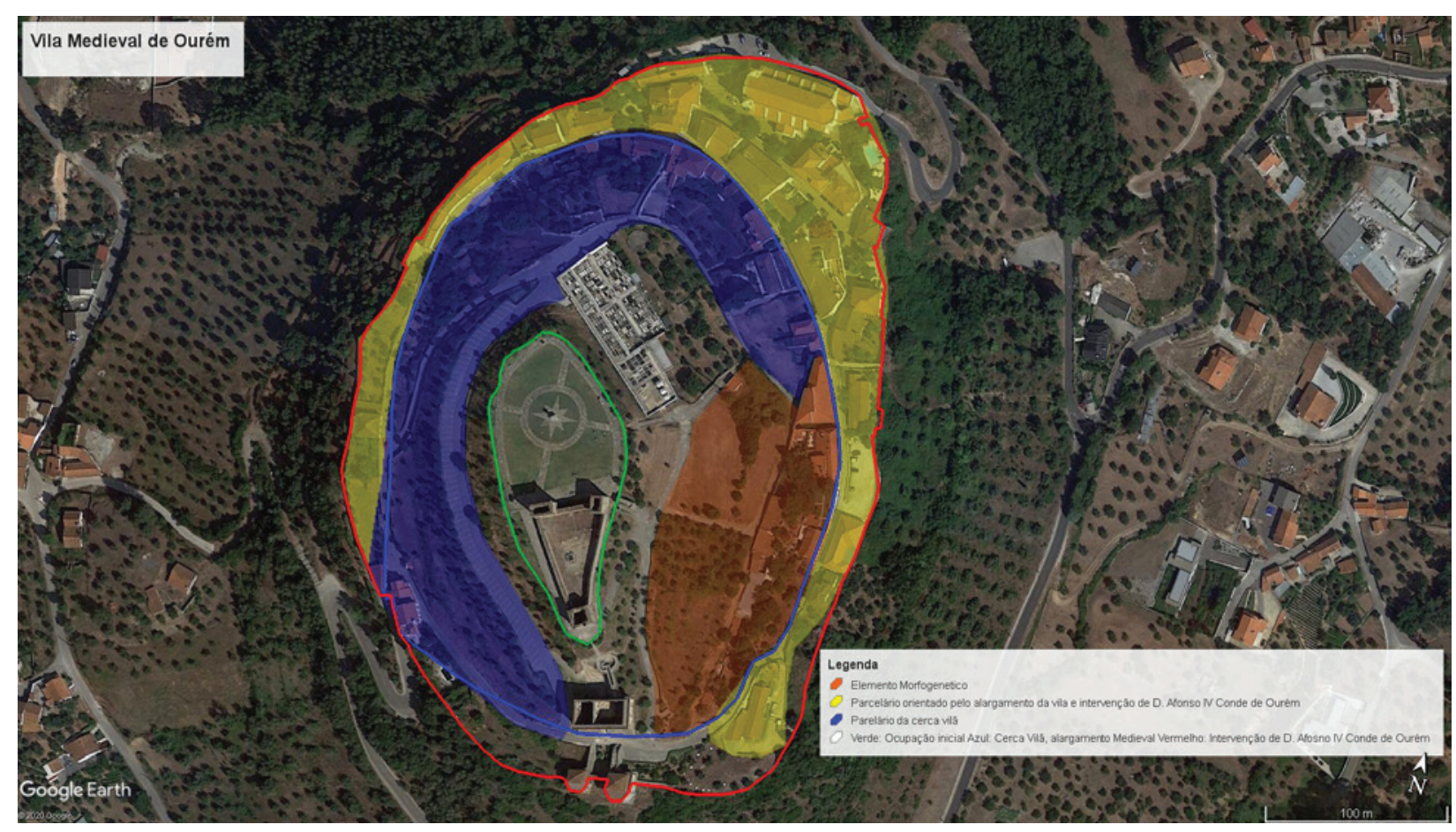

Figura 6 - Vista aérea do núcleo medieval de Ourém. Com os três parcelários assinalados. Fonte: Google Earth. 


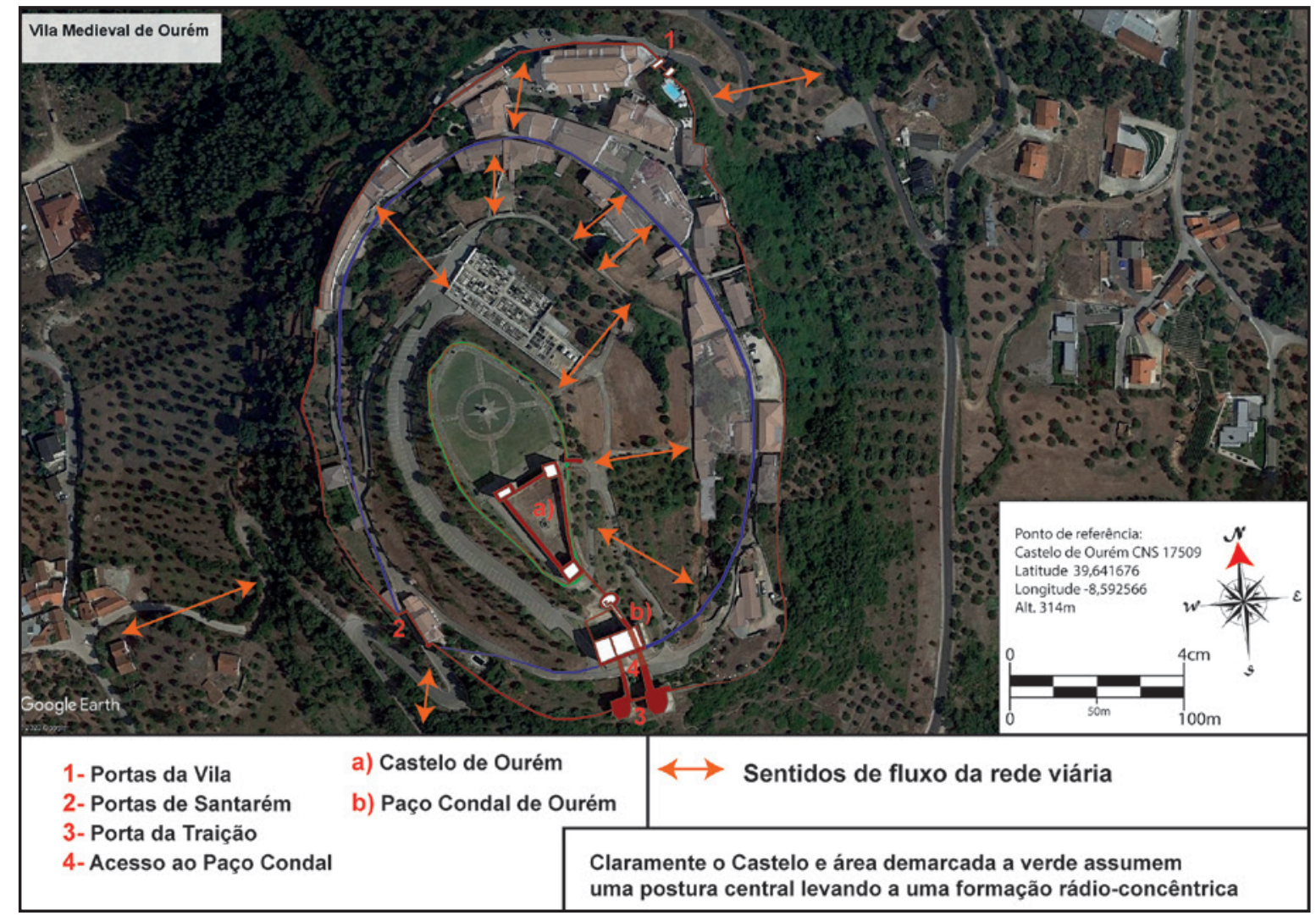

Figura 7 - Vista aérea do núcleo medieval de Ourém. Indicadores de sentidos de fluxo e formação rádio-concêntrica. Fonte: Google Earth.

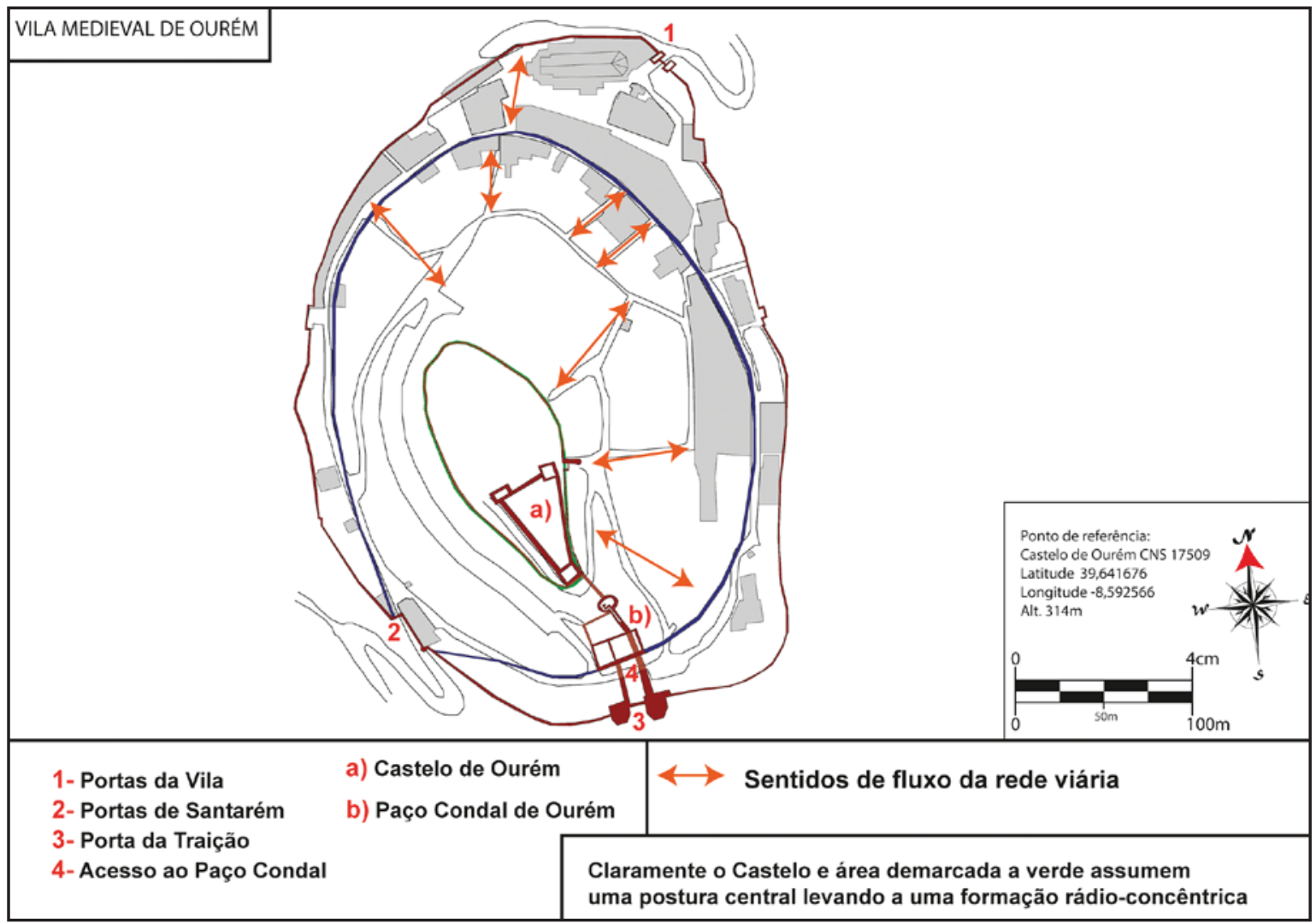

Figura 8 - Indicadores de sentidos de fluxo e formação rádio-concêntrica. 


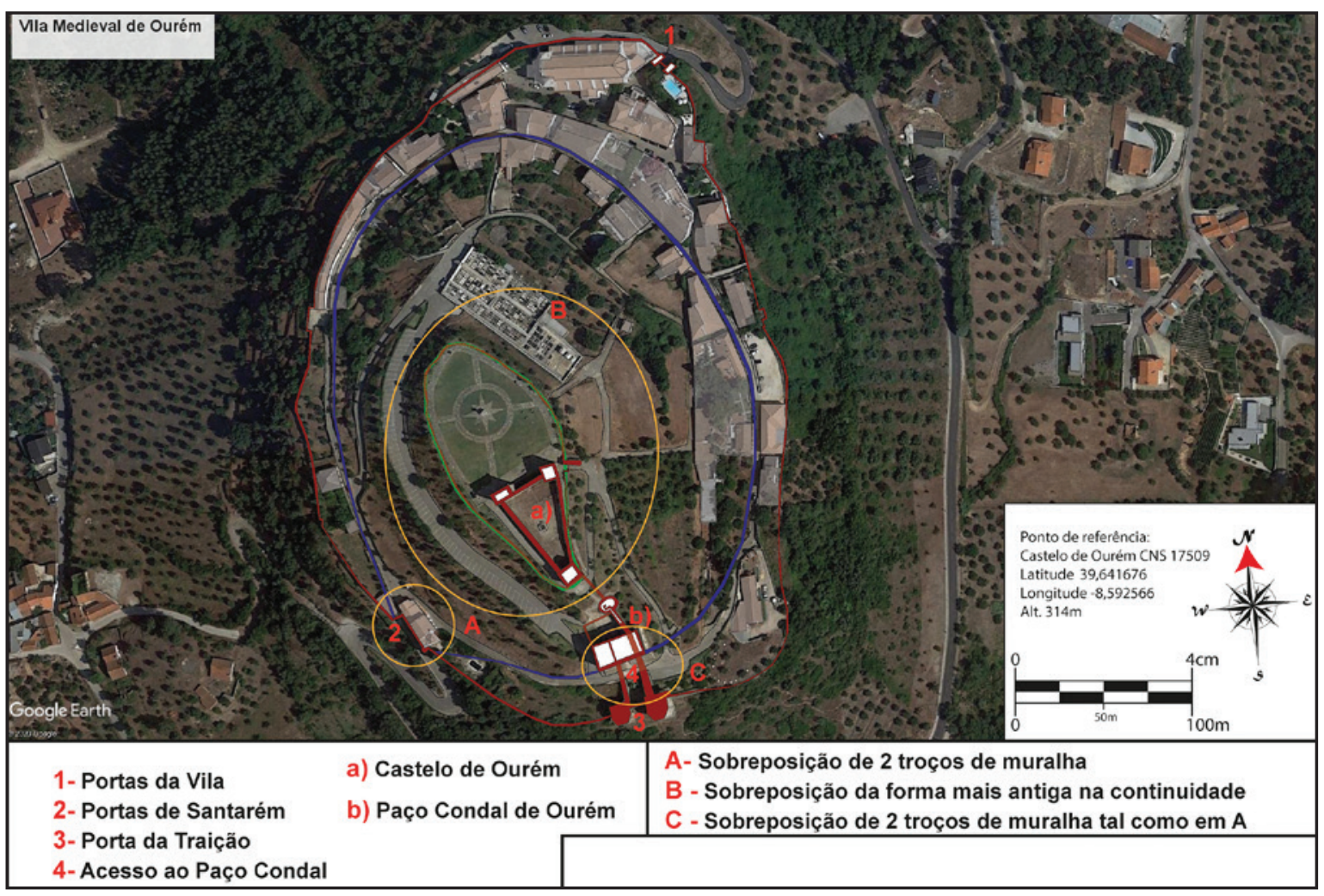

Figura 9 - Vista aérea do núcleo medieval de Ourém com as principais formas e transmissões assinaladas. Fonte: Google Earth.

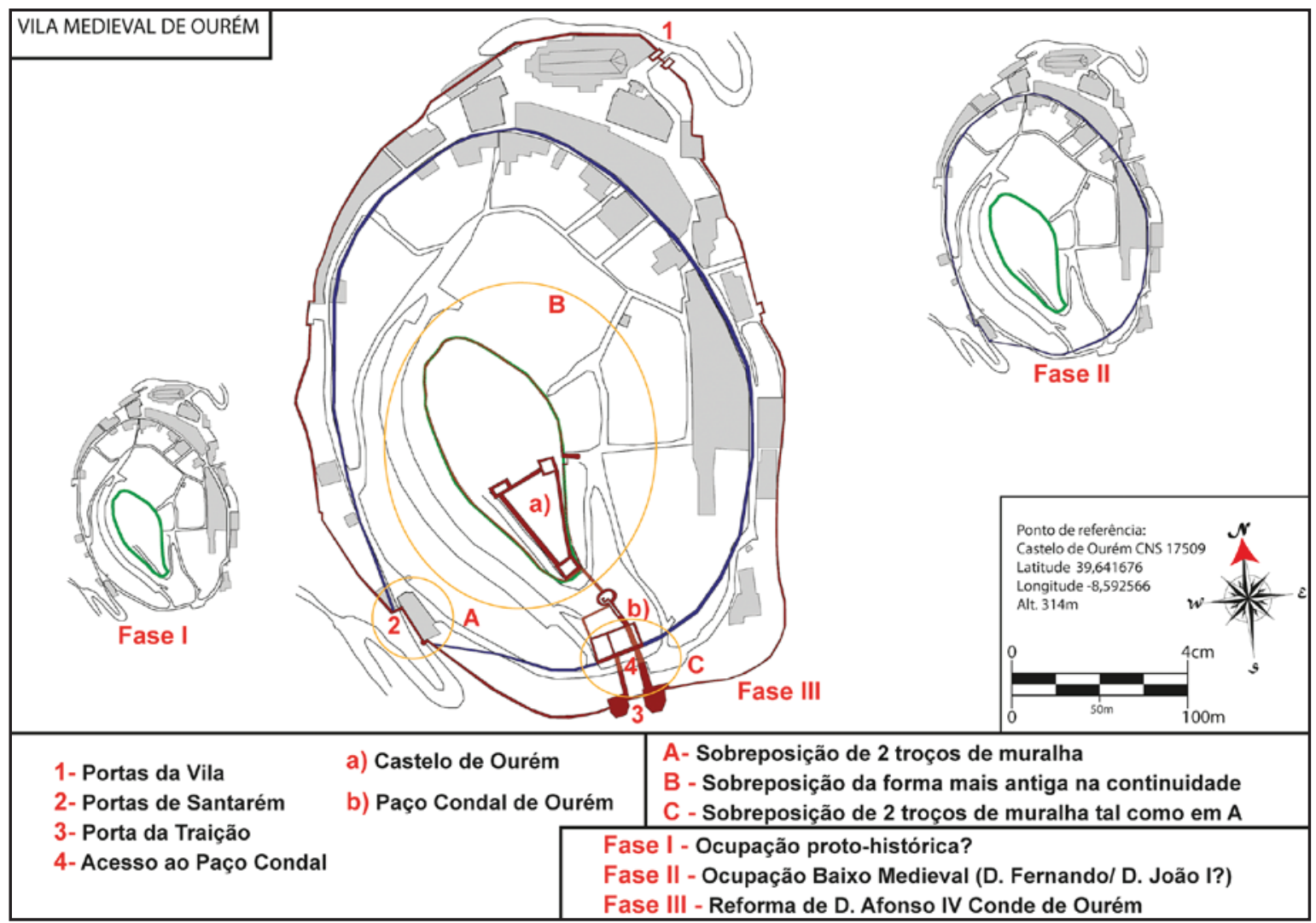

Figura 10 - Esquema interpretativo da evolução do núcleo medieval de Ourém com as principais formas e transmissões assinaladas. Fonte: Google Earth. 


\title{
INTERVENÇÃO ARQUEOLÓGICA NA RUA MARQUÊS DE POMBAL / LARGO DO ESPÍRITO SANTO (BUCELAS, LOURES)
}

Florbela Estêvão ${ }^{1}$, Nathalie Antunes-Ferreira², Dário Ramos Neves ${ }^{3}$, Inês Lisboa ${ }^{4}$

RESUMO

Em maio de 2018, a necessidade de repor um antigo muro de suporte de terras localizado na Rua Marquês de Pombal / Largo do Espírito Santo, em Bucelas, no concelho de Loures, expôs um contexto cemiterial que motivou uma intervenção arqueológica de emergência, a qual decorreu até dezembro de 2019, circunscrita à zona de afetação da obra.

Os trabalhos permitiram identificar uma necrópole que revelou 157 inumações primárias e secundárias, dois ossários (1 e 2) que continham, respetivamente, 101 e 262 indivíduos, além de reduções ósseas. Distribuiu-se por ampla cronologia (séculos XV a XIX). Sob ela, foram revelados vestígios de ocupação de época romana dos séculos I a II d. C., com estruturas murais simples, formando três compartimentos sub-quadrangulares. Palavras-Chave: Bucelas, Necrópole, Medieval/Moderno, Romano, Arqueologia Pública.

\begin{abstract}
In May 2018, the need to replace an old wall, located at Rua Marquês de Pombal / Largo do Espírito Santo, in Bucelas, in the municipality of Loures, exposed the remains of an ancient cemetery that motivated an archaeological intervention, that run until December 2019.

The archaeological excavations allowed the identification of a necropolis context, composed by 157 primary and secondary inhumations, two ossuaries ( 1 and 2) containing, respectively, 101 and 262 individuals, and bone reductions, distributed by a wide chronology ( $15^{\text {th }}$ to $19^{\text {th }}$ centuries). Under the necropolis layers, it was identified the remains of a Roman occupation dating back to the 1st and the 2nd centuries AD, consisting of simple mural structures, belonging to three sub-quadrangular compartments.
\end{abstract}

Keywords: Bucelas, Necropolis, Medieval/Modern era, Roman, Public Archaeology.

\footnotetext{
1. Câmara Municipal de Loures, Divisão de Cultura, Unidade de Património e Museologia; Instituto de História Contemporânea da Faculdade de Ciências Sociais e Humanas da Universidade Nova de Lisboa (IHC/ FCHS/ UNL), Lisboa, Portugal; florbela_estevao@ cm-loures.pt.

2. Centro de Investigação Interdisciplinar Egas Moniz (CiiEM), Instituto Universitário Egas Moniz, Monte da Caparica, Portugal; Laboratório de Ciências Forenses e Psicológicas Egas Moniz (LCFPEM), Egas Moniz Cooperativa de Ensino Superior, Monte da Caparica, Portugal; Laboratório de Antropologia Biológica e Osteologia Humana (LABOH), CRIA/FCSH, Universidade Nova de Lisboa, Lisboa, Portugal; naferreira@egasmoniz.edu.pt.

3. Empresa de arqueologia Cota. 8o. 86.; Instituto de Arqueologia e Paleociências da Faculdade de Ciências Sociais e Humanas da Universidade Nova de Lisboa (IAP/FCSH/UNL), Lisboa, Portugal; darioneves@cota8o86.pt.

4. Laboratório de Antropologia Egas Moniz, Instituto Universitário Egas Moniz, Monte da Caparica, Portugal; in_lisboa@hotmail.com.
} 


\section{INTRODUÇÃO}

A queda de um muro de suporte de terras, em abril de 2018, na rua Marquês de Pombal, em pleno núcleo antigo da vila de Bucelas, expôs uma antiga zona cemiterial, o que motivou uma intervenção arqueológica de emergência promovida pela Câmara Municipal de Loures. Os trabalhos arqueológicos decorreram entre 16 de maio de 2018 e 17 de dezembro de $2019^{5}$, e a zona intervencionada compreendeu toda a área de afetação da obra de construção do novo muro e da respetiva sapata fundacional, numa área de aproximadamente 28 metros de comprimento por 5 metros de largura. Nela foram implantadas quadrículas de $2 \mathrm{~m} \times 2 \mathrm{~m}$, sendo atribuída a cada unidade uma designação constituída pelos números 1 a 14, no sentido este-oeste, e pelas letras A a C, no sentido sul-norte.

De acordo com os resultados obtidos, a área arqueológica em questão corresponderá (pelo menos, maioritariamente) a uma parcela de um cemitério (necrópole cristã dos séculos XV a XIX) possivelmente associado à antiga capela do Espírito Santo que existiu na zona, e que foi demolida nos inícios do século XX. Abaixo deste nível arqueológico foram identificadas estruturas murais simples, formando três compartimentos sub-quadrangulares, datadas dos séculos I a II d. C., o que veio reforçar indícios anteriores da presença romana em Bucelas - como sejam uma pequena estatueta itifálica em bronze, inscrições funerárias no adro da igreja matriz local

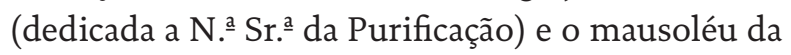
Romeira de Baixo, em Vila de Rei. Na verdade, tudo isso indicava uma potencial importância arqueológica do local, situado mesmo no centro da vila.

Ao longo dos vários meses de trabalhos arqueológicos, os poderes públicos, em estreita articulação com a equipa da escavação, procuraram assegurar um conjunto de ações variadas por forma a sensibi-

\footnotetext{
5. Agradecemos a todos aqueles que colaboraram na intervenção arqueológica enriquecendo a equipa, contribuindo para os resultados que aqui apresentamos: antropólogos e arqueólogos contratados; jovens estudantes universitários voluntários; estudantes universitários em contexto de formação resultante da colaboração entre o Município de Loures, a Cooperativa de Ensino Superior Egas Moniz e a Faculdade de Ciências Sociais e Humanas da Universidade Nova de Lisboa. Também o nosso reconhecimento vai para os especialistas que, no decurso do trabalho, nos visitaram e nos estimularam com as suas observações.
}

lizar a população local para a importância de uma intervenção tão demorada em espaço urbano, com as consequências inerentes. Além de sessões públicas, e de visitas comentadas ao local, dirigidas a vários tipos de públicos, múltiplas notícias na impressa local e nacional alertaram para o interesse do sítio arqueológico. Seguindo a mesma estratégia, está patente no Museu do Vinho e da Vinha, em Bucelas, uma exposição alusiva à intervenção no sítio - Largo do Espírito Santo. O Antigo Cemitério - a qual contém a informação passível de ser partilhada à data da sua inauguração (outubro de 2019), quando os trabalhos ainda estavam em curso. Esse conjunto de iniciativas teve comprovado êxito, visível na mudança da atitude das pessoas de Bucelas, para quem a arqueologia não era ainda familiar, e que passaram a admirá-la e a respeitá-la como beneficiadora da sua terra e suas raízes ancestrais.

Este trabalho apresenta, de modo sucinto, os resultados obtidos ainda numa fase de elaboração do relatório final. Para o estudo da extensa coleção osteológica está a decorrer o projeto "Antropologia Funerária e Paleobiologia de um Grupo Populacional Rural de Bucelas (Loures) nos séculos XVI a XIX”, cofinanciado pelo programa ProMuseus, sob a direção de Nathalie Antunes-Ferreira. Importa também referir que a colaboração com a empresa de arqueologia Cota. 80.86. - a qual levou a efeito uma parte dos trabalhos - inclui a atual fase de inventário dos materiais exumados, tarefa ainda em curso. Com o intuito de valorizar o sítio arqueológico, o Município de Loures demonstrou interesse em concretizar um projeto de musealização das estruturas romanas.

\section{ENQUADRAMENTO GEOGRÁFICO E HISTÓRICO}

O Município de Loures, como é sabido, está localizado a norte da cidade de Lisboa e incluído na região de Lisboa e Vale do Tejo, tendo sido criado por decreto de 26 de julho de 1886. Em 19 de novembro de 1997, a sua extensa área foi diminuída com a desanexação das freguesias de sudoeste, pela criação do Município de Odivelas. A freguesia de Bucelas inclui-se na zona norte do concelho, de feição predominantemente rural. O território da freguesia, atualmente com 33,99 km2, pertenceu durante muitos séculos ao Termo da cidade de Lisboa. Mundialmente conhecida pela sua produção vinícola, especialmente a de 
vinho branco arinto, Bucelas incorpora a maior parte da área demarcada desta qualidade de vinho, área essa criada em 1911. Os terrenos argiloso-calcários, e as serranias intercaladas por vales profundos, possibilitam um microclima específico, caraterizado por um inverno bastante frio com alto teor de humidade, e um verão temperado, condições que conferem aos vinhos aqui produzidos qualidades únicas.

A vila de Bucelas desenvolveu-se junto à margem do rio Trancão, sendo atravessada por dois importantes eixos viários, as atuais EN 115 e EN 116, constituindo o Largo do Espírito Santo a centralidade do aglomerado, no qual assume um papel de destaque a referida igreja matriz, edificação que ocupa uma posição altaneira relativamente ao restante casario (e, claro, à área arqueológica intervencionada). Até aos inícios do século XX este largo incluía outros dois edifícios, a mencionada capela do Espírito Santo e um pequeno hospital ou albergaria de origem medieval associado à mesma capela e com a mesma designação. Convém relembrar que o rio Trancão foi durante muito tempo em grande parte navegável, existindo mesmo carreiras diárias fluviais entre Lisboa e o porto de Santo Antão do Tojal nos finais do século XVIII. Este mesmo curso de água, juntamente com os seus afluentes, alimentava várias azenhas, muitas delas dispostas ao longo da ribeira do Boição (arredores de Bucelas), e mencionadas em vários documentos, entre eles emprazamentos do século XVI ou as Memórias Paroquiais do século XVIII.

Sabemos que no início do século XX o Largo do Espírito Santo era murado, com um portal de acesso, demarcando parcialmente uma área em torno da capela e da matriz. Esse espaço, de elevada carga simbólica, destinava-se não só à celebração de festividades religiosas, mas também à sepultação dos fiéis. Como é do conhecimento geral esta prática de enterramentos, dentro e fora das igrejas, foi abolida no século XIX com a criação dos cemitérios públicos. Já no século XX, obras de reformulação do espaço urbano levaram à demolição do muro, bem como da capela do Espírito Santo que já então se encontrava abandonada e em mau estado. O largo, como espaço cemiterial, transmutou-se em local público ajardinado. Assistiu-se, pois, a uma importante alteração dessa zona central da vila. Se durante as épocas medieval e moderna o cemitério estava inserido num núcleo da malha urbana onde vivos e mortos "conviviam", no século XIX a morte foi aqui, como em muitos outros lugares, afastada para a periferia.
Ora, a área arqueologicamente intervencionada encontrava-se num dos limites dessa zona conotada com os templos e seus adros, embora mais próxima do local da antiga capela do Espírito Santo (Figura 1). Mas, dadas as características do observado nas escavações, e o carácter relativamente limitado da área abarcada pelas mesmas, é difícil saber, com os nossos dados parcelares, quais os limites das áreas sepulcrais de ambos os templos, e se elas, em determinado momento, se terão parcial ou totalmente sobreposto. Imagens de fotografias antigas permitem descrever o edifício demolido: apresentava uma galilé rasgada nos três lados por arcos de volta perfeita, uma nave e um corpo mais pequeno correspondente à capela-mor. Deste antigo edifício subsiste um interessantíssimo retábulo quatrocentista da Santíssima Trindade, dedicado à chamada "descida do Espírito Santo” (Fernandes, 2018, pp. 37-65), magnificamente policromado.

Este templo, logicamente, era administrado pela confraria do Espírito Santo. Ora, sabemos que tanto as confrarias como as irmandades do Espírito Santo desenvolveram uma ação assistencial importante, nomeadamente assegurando o funcionamento de pequenos hospitais ou albergarias destinadas a peregrinos, religiosos ou pessoas pobres. Assim, junto à capela funcionou um hospital, também designado como albergaria. Nos livros de registo de óbitos da paróquia de Bucelas, datados da segunda metade do século XVI, existem referências a vários indivíduos que faleceram no aludido hospital. No entanto, no século XVIII as Memórias Paroquiais mencionam que o dito hospital apenas servia de pousada a peregrinos.

Relativamente à matriz de Bucelas, e não excluindo a possibilidade de ter existido no mesmo local um templo anterior ao atual edifício, sabe-se que o corpo da igreja estava concluído em 1566, conforme atesta a inscrição sobre o portal lateral do lado do Evangelho. A documentação assegura que em 1569 a capela-mor foi sagrada por D. Jorge de Ataíde, bispo de Viseu (Vilaverde, 2018, pp. 8-19). Outra inscrição numa lápide na sacristia, onde consta a data de 1573, poderá indicar o momento de finalização das obras no templo, todas elas, portanto, realizadas na segunda metade do século XVI. O livro mais antigo que se conhece da paróquia de Bucelas é um registo de batismo de 1564 . O corpo da igreja visto do exterior é relativamente sóbrio, mas imponente, destacando-se a cabeceira circular da capela-mor. 
Se atentarmos nos registos de óbito, verificamos que ao longo dos séculos muitos fiéis foram sepultados no interior da igreja, alguns deles junto dos altares das respetivas confrarias e irmandades. Muitos outros tiveram diferente destino; de facto, com frequência é mencionado nos documentos o enterramento no adro, ou seja, em "campo santo", mas que possivelmente também poderia incorporar o adro da capela do Espírito Santo, dada a proximidade dos dois templos.

Se a matriz, como referido e comprovado, já existia na segunda metade do século XVI, e a capela do Espírito Santo lhe seria anterior (século XV ou mesmo época mais antiga), o espaço atual do Largo do Espírito Santo teria sido ocupado durante um certo tempo por dois edifícios religiosos, implantados em níveis diferentes, a capela numa cota inferior, na base da colina, e junto a uma estrada (a atual Rua Marquês de Pombal), e a matriz no topo da elevação, assumindo a já referida posição dominante em consonância com o seu estatuto.

Mas em Bucelas existem outros indícios que apontam para uma ocupação muito anterior, durante $o$ período romano, em que todo este território estava integrado como zona essencialmente rural no Ager Olisiponensis, ou seja, na área administrativa da cidade romana de Lisboa, a Felicitas Iulia Olisipo. Não só as inscrições funerárias no adro da matriz nos indicam a presença romana nesta zona (Fernandes, 2003, pp. 27-55), como outros achados corroboram esta possibilidade; além de um tesouro monetário (Azevedo, 1897, pp. 249-252) hoje perdido, os indícios a que já atrás aludimos: uma pequena estatueta itifálica em bronze (Estêvão, 2019, pp. 138-143), e o mausoléu romano da Quinta de Romeira de Baixo (Estêvão, 2004, pp.45-51).

Outro aspeto importante a considerar para melhor compreender o povoamento romano da região de Loures éa existência de várias villae, em Frielas (Silva, 1998, pp. 43-48) e em Unhos (Silva, 2012, p. 92), e o sítio das Almoínhas (Oliveira, 2001, pp. 65-94), que poderá ter sido um vicus (Brazuna \& Coelho, 2012, pp. 103-116); estes locais, todos relacionados com a várzea do rio Trancão e integrados no Ager Olisiponensis, podem indiciar quão importante era já aquele curso de água e seus férteis terrenos anexos para o povoamento local da Antiguidade (Mantas, 2018, p.41). Também são relevantes para a zona em causa as conclusões dos estudos sobre a rede viária terreste (Mantas, 2012, pp. 76-85). Para alguns autores, a principal ligação por terra entre Olisipo e Scallabis atravessava Sacavém (Mantas, 1998, p. 20), cruzando o rio Trancão, e seguindo para Alverca. Outros, porém, creem que a estrada principal proveniente de Lisboa partia da atual Praça da Figueira, passava por Frielas e Almoínhas (Loures), e contornava a várzea em direção a Alverca (Guerra, 2018, pp. 52-63). Esta segunda hipótese é basicamente fundamentada nos marcos miliários identificados, nomeadamente em Frielas e nas Almoínhas, bem como nos sítios do atual concelho de Loures já mencionados. Esta última conjetura não exclui a possibilidade da existência de uma via secundária que entroncaria na estrada principal - que ligava Lisboa a Santarém - junto a São Julião do Tojal, passando por Bucelas, em direção a Santiago dos Velhos.

\section{O SÍTIO ARQUEOLÓGICO}

O atual Largo do Espírito Santo encontra-se a uma cota mais elevada em relação à Rua Marquês de Pombal, troço da EN 115, conforme já foi mencionado, existindo um muro de suporte no local - com a função de amparar a massa de terras que pende sobre a rua, nesse desnível - além de uma escadaria de acesso. As escavações arqueológicas, tendo incidido na área de construção do novo muro de suporte, que será mais potente que o anterior, foram implantadas na zona poente do largo e em área lateral, a norte da igreja matriz.

Após a remoção das duas primeiras camadas resultantes da transformação daquela zona do largo em pequeno jardim, no séc. XX, surgiram então os níveis mais antigos, compreendendo dois contextos arqueológicos distintos: o da necrópole cristã e o de época romana, tal como se pode observar na Figura 2. Sucintamente, a estratigrafia observada aponta para quatro camadas arqueológicas principais (camadas 3, 4, 10 e 14). A camada 3, sob os níveis contemporâneos, foi caracterizada como aterro, realizado com o fim de colmatar a pendente natural do local, em finais do séc. XVII ou inícios do séc. XVIII, dada a presença de faianças portuguesas de decoração a azul e vinoso (manganês) características dessa época (Casimiro \& Sequeira, 2016-17, pp. 266-267). Nesta camada foram integrados dois ossários de média a grande dimensão, além de algumas inumações primárias. A camada 4, revelando uma pendente sul-norte (isto é, descendo de nível da área voltada à matriz para a zona da atual rua), sob a camada 3, compreende o 
nível mais antigo da necrópole, nele tendo sido depositadas grande parte das inumações primárias e reduções ósseas, em covas simples ou em sepulturas estruturadas com elementos pétreos. A presença de cerâmica esmaltada a branco no enchimento de uma das sepulturas aponta para os inícios do século XVI (Casimiro \& Sequeira, 2016-17, pp. 262-263), pressupondo-se, pelas relações estratigráficas, que o nível mais antigo identificado se reporte ainda ao séc. XV. Ao contexto romano identificado imediatamente sob o nível sepulcral, correspondem a camada 10, onde se regista o abandono das estruturas murais, e a camada 14, correspondente à construção daquelas. Em termos cronológicos, situam-se os dois níveis respetivamente entre os séculos IV-V d.C. e os séculos I-II d.C., registando-se no primeiro ocorrências de terra sigillata africana e, no segundo, de cerâmicas de paredes finas.

\subsection{Necrópole cristã de Bucelas (Séculos XV-XIX)} O espaço da necrópole revelou vários níveis de inumações em deposição primária e secundária (como os dois ossários), distribuídos pela ampla cronologia mencionada (séculos XV a XIX). A sua proximidade com os dois templos atrás referidos pressupõe que este espaço poderia ter estado relacionado com os respetivos "campos santos", embora não consigamos cartografar a área de cada um deles, e saber se se terão, ou não, sobreposto num determinado momento do tempo. As inumações estavam orientadas no sentido este/oeste, com a cabeça a oeste (Figura 3), o que indicia o cânone cristão no ritual de enterramento.

Foram exumados 157 esqueletos que se encontravam em deposição primária, distribuídos pelas camadas 3 e 4, mas sobretudo abundantes na camada 4. Foram identificados (e levantados) várias reduções ósseas, associadas às inumações primárias, e dois ossários de grande (Ossário 2) e média (Ossário 1) dimensões, abertos na camada 3 , em que o número mínimo de indivíduos totaliza 262 e 101, respetivamente. Foram identificados dois tipos de sepulturas principais: cova simples, ovalada; e sepulturas estruturadas. Adentro destas últimas, distinguiu-se a cova simples ovalada e com pedra de cabeceira e/ou pedra aos pés; a sepultura estruturada com esteios laterais; a sepultura estruturada com lajes horizontais sobre cova simples ovalada; e a sepultura estruturada com esteios laterais e lajes horizontais sobrepostas. As diferenças formais registadas entre os tipos de enterramentos podem sugerir diversos níveis de deposição, correspondendo eventualmente a diferentes fases cronológicas, o que talvez o trabalho pós-escavação venha a esclarecer.

Os indivíduos foram colocados na sepultura em decúbito dorsal com as mãos sobre o peito ou região abdominal e pernas estendidas, estando a cabeça de frente (a olhar para o céu) ou para o lado. Os corpos estavam orientados a oeste-este com a cabeça no extremo oeste. A presença de alfinetes à volta de alguns esqueletos permitiu inferir que esses corpos foram amortalhados. Não foram encontrados vestígios de caixão. No espólio votivo identificaram-se contas de terços, e medalhas, assim com algumas moedas (Figura 4) nas mãos dos indivíduos (reminiscência do óbolo a Caronte?).

A breve análise bioantropológica de campo permitiu concluir, relativamente às 157 inumações primárias, que se trata de indivíduos de ambos os sexos e de todas as classes etárias (desde fetos em finais de gestação a idosos), estatura compreendida entre $142 \mathrm{~cm}$ e $178 \mathrm{~cm}$, sendo que as alterações esqueléticas mais comuns são as cáries, as lesões de etiologia infeciosa e os traumatismos. De destacar a presença de pelo menos três indivíduos com a dentição anterior intencionalmente modificada (Figura 5) e que apresentam características que sugerem uma ancestralidade africana.

\subsection{Estruturas do período romano (Séculos I-II a Séculos IV-V)}

A identificação de estruturas murais imediatamente sob o nível cemiterial permitiu (Figura 6), desde logo, conjeturar a possibilidade de as atribuir cronologicamente à época romana. Não só por todos os elementos que relacionavam a localidade de Bucelas com a presença romana, já indicados anteriormente, mas principalmente pelo surgimento indiciante, no contexto da necrópole cristã, de várias moedas em bronze, datadas de diferentes reinados imperiais, como foram, a título de exemplo, as moedas de Antonino Pio (séc. II), a de Adriano (séc. II) (na Figura 10) ou a de Constantino I (séc. IV).

Apesar de a abertura das covas de sepultamento em época medieval/moderna ter afetado o contexto romano, as estruturas murais mantiveram-se em relativo bom estado de conservação. Ainda assim, a construção de um muro, de orientação este-oeste, efetuada possivelmente nos séculos XVI-XVII, muro esse que atualmente se encontra junto ao pas- 
seio da rua Marquês de Pombal, truncou parte daquele contexto. Tal muro poderia ter correspondido ao limite norte do espaço sepulcral da capela do Espírito Santo, mas a escavação de emergência realizada, quer por motivos financeiros e temporais, quer logísticos - na verdade, trata-se de uma rua que é também estrada nacional de grande circulação - dificilmente poderia ter sido estendida para essa zona. Foram identificados no nível romano seis muros que formavam três compartimentos sub-quadrangulares, a que se atribuiu as letras A, B e C (Figura 7). Nenhum dos compartimentos foi escavado na totalidade da sua área, devido aos condicionalismos invocados no parágrafo anterior, o que não impediu a perceção, relativamente aos compartimentos $\mathrm{A}, \mathrm{a}$ este, e B, a oeste, dos respetivos limites; todavia, tal não foi possível no que toca ao compartimento $\mathrm{C}$, a norte, onde a intervenção teve de ser exígua.

Estas estruturas caracterizavam-se pela construção em alvenaria seca, com várias fiadas de pedra calcária local de pequena/média e grande dimensão sobrepostas umas às outras, sem recurso a ligante de tipo argamassa ou opus, e em que as pedras da base seriam de maiores dimensões. Não obstante, entre as fiadas de pedras foi colocado um sedimento de coloração castanho-avermelhado, de matriz argilosa, que pode ter servido como ligante, dada a grande compactação que o caracterizava quando seco; de notar, ainda, que os muros não ofereciam qualquer tipo de reboco. Tinham cerca de o,5o $\mathrm{m}$ de largura e, em algumas secções, atingiam, no seu estado atual, cerca de o,6o $\mathrm{m}$ de altura.

As estruturas murais assentavam no substrato geológico de composição arenítica ou em conglomerados areníticos. Como o local apresentava um nível de encosta, com uma pendente sul-norte, os muros com essa orientação foram construídos em "escada" por forma a anular o desnível natural do terreno. Quanto ao muros perpendiculares àqueles, isto é, com orientação este-oeste, o que se encontrava mais bem conservado, dos dois que se preservaram, detinha uma fiada de pedras fincadas na base da fundação, igualmente com a função de anular o efeito da pendente, funcionando como sapata.

No compartimento A, a frequência dos sepultamentos desfigurou muito do que potencialmente poderia ter sido recolhido em termos de informação arqueológica sobre o piso ou a cobertura daquele compartimento. A presença de alguns elementos em tijoleira e cerâmica de construção, além das lajes pétreas no canto sudeste do compartimento sugeria a existência inicial de um chão em pedra, colmatado, aqui e ali, por tijoleira em cerâmica. À presença de uma estrutura de piso neste compartimento pode associar-se uma função mais nobre, para a distinguir de tarefas eventualmente mais correntes (relacionados com atividades laborais, por exemplo) praticadas nos restantes. Assim, o compartimento A poderia corresponder a zona de alcova ou quarto, existindo uma porta a norte que o ligaria ao compartimento C. Quanto à cobertura, o escasso registo de telhas parece não apontar para uma cobertura de telhado, embora essa escassez possa estar relacionada com alterações provocadas pela intrusão do nível da necrópole que se lhe sobrepunha.

No compartimento B, por seu turno, o surgimento de um derrube de telhas (Figura 8), composto por telhas de meia cana de pasta de cor avermelhada e ou de pasta amarelada, sugeriu uma cobertura em telheiro ou telhado, sendo de referir igualmente, como paralelo, a escavação de um nível de derrube na villa de Frielas, associado ao abandono da mesma (Silva, 2020, pp.76 a 79).

Sob o derrube de telhas, e imediatamente sobre o afloramento rochoso, registou-se um depósito composto por sedimento de matriz argilo-arenosa, de cor castanha e cinzenta, contendo também abundantes nódulos de carvões e cinzas, o qual foi identificado como unidade de abandono ou destruição, talvez relacionada com um nível de incêndio ou de combustão (incêndio do travejamento em madeira que susteria o telheiro ou telhado?). A presença de um buraco de poste central, visível na Figura 8, e escavado no substrato geológico, parece apontar também para essa hipótese de cobertura.

No compartimento B, não foi detetado qualquer piso estruturado, pelo que o chão assentaria diretamente no substrato, o qual, para o efeito, parece ter sido nivelado. Em contrapartida, foi registada a existência de um caneiro, no canto noroeste do compartimento, construído com telhas, em que a parte côncava ficava voltada para baixo, cobrindo uma vala de pequena potência escavada no substrato (Figura 8). A escavação do interior do caneiro, infelizmente, não revelou qualquer espólio.

Ainda neste compartimento, foram registadas duas valas escavadas no substrato, de sentido sul-norte, sendo que uma surge do canto oeste e outra do canto este do compartimento, desembocando esta última na primeira. Funcionariam, muito provavelmente, 
como caleiras de água, uma vez que aproveitam a pendente natural do terreno, captando essa água de um ponto mais alto para um situado a cota inferior, a norte do compartimento $B$.

Ainda é de referir que, já fora da área deste conjunto de estruturas murais atribuídas à época romana, foi escavada uma estrutura negativa, de orientação este-oeste (Figura 9), sob o contexto de necrópole, que poderia ter funcionado também como caleira, mas neste caso talvez relacionada com um momento de atividade agrícola, contemporâneo ou posterior ao contexto romano; na verdade, foram detetadas fossas de pequena potência, subcirculares, correspondendo possivelmente ao negativo de plantações. Relativamente ao espólio e dada a intrusão no contexto romano dos níveis sepulcrais cristãos, muita da cerâmica romana exumada não pôde ser associada à estratigrafia diretamente relacionada com as estruturas (o mesmo se verificou com outros achados interessantes como uma fíbula, asa de lucerna e algumas moedas). A maior parte do espólio cerâmico que, assim, pôde ser associado à estratigrafia romana foram as cerâmicas comuns de pasta castanha ou de pasta alaranjada, medianamente grosseiras, com alguns elementos não plásticos, com grande predominância de quartzitos, onde se conseguiu identificar o predomínio de duas formas: panelas e dollia. Foi exumado também um conjunto de pesos de tear, maioritariamente de formato sub-rectangular e contendo um único orifício de suspensão, bem como cerâmica de paredes finas de pasta alaranjada, das quais se identificou um jarro de maiores dimensões e um outro de menor tamanho, podendo tratar-se de produções locais (Figura 10).

Será interessante, aquando de uma futura análise aprofundada do espólio romano, estabelecer uma relação também com artefactos encontrados fora de contexto, nomeadamente nos níveis sepulcrais cristãos. Preliminarmente, para a cronologia da construção daquelas estruturas romanas, aponta-se, pela análise geral do espólio encontrado junto às fundações dos muros, para os séculos I a II d.C. Porém, a observação e datação de numismas romanos encontrados em níveis posteriores pode futuramente dar mais algumas pistas sobre a fase romana do local ou de áreas adjacentes, de onde eles podem eventualmente ter provindo.

Tendo-se exumado fragmentos de cerâmica de tipo terra sigillata clara africana nos níveis de abandono ou pós abandono e nos depósitos associados ao ní- vel da necrópole cristã, além de uma moeda de Constantino I, propõe-se os séculos IV a V como baliza temporal para o abandono daquelas estruturas.

Para uma interpretação mais desenvolvida deste contexto romano, teria obviamente sido interessante estender a escavação tanto para norte como para sul das estruturas. Certamente, estamos perante um contexto rural, relacionado talvez com a atividade agrícola. Como já referido, parte das estruturas identificadas, nomeadamente o compartimento A, pode ter funcionado como habitação, enquadrado em atividades domésticas e/ou ofícios relacionados com a tecelagem, dada a presença de um conjunto de pesos de tear. No compartimento B, as valas de drenagem de água aí detetadas poderiam estar relacionadas com a presença de um moinho, interpretação sugerida para o contexto romano do sítio da Raposa, com características muito semelhantes ao de Bucelas (Robalo et al., 2011-12, pp. 34, 35).

O aprofundamento do estudo dos vários dados recolhidos na escavação permitirá, no futuro, compreender melhor o que pode ter sido a presença romana em Bucelas. Situada numa encruzilhada de estradas e caminhos, a localidade seria apropriada para a instalação de um aglomerado populacional romano (um vicus?), de vocação agrícola, o que faz sentido se tivermos em conta toda a informação já disponível sobre o concelho de Loures, integrado num mais amplo panorama daquela época relativo à área metropolitana da cidade romana de Lisboa. É nesse âmbito maior que os novos achados de Bucelas inserem a localidade, dando-lhe um estatuto mais significativo do que até agora detinha, e convidando à prossecução das investigações sobre o que foi a época clássica na região metropolitana como um todo.

\section{CONSIDERAÇÕES FINAIS}

Gostaríamos de salientar a contingência dos resultados já obtidos aqui descritos na generalidade, uma vez que a intervenção arqueológica de emergência ficou condicionada à área de afetação da obra. Para melhor compreender quer a necrópole, quer as estruturas romanas, seria necessário alargar a zona de trabalhos arqueológicos. Todavia, os vários meses de trabalho contribuíram para um conhecimento mais profundo sobre as diferentes ocupações do atual Largo Espírito Santo, como também, como sempre acontece quando se pesquisa, para a formulação de novas questões. 
Sabemos que durante o século XV e os inícios do século XIX tanto a igreja matriz como a capela do Espírito Santo ocupavam a área do atual largo, e que a área arqueologicamente intervencionada correspondeu a um dos seus limites. Podemos até pressupor que a constituição, nos séculos XVII a XVIII, de dois ossários de média e grande dimensão, procedendo da remodelação de algum espaço ocupado com sepultamentos, se tenha implantado, porventura, no limite do "campo santo" da igreja matriz, sobrepondo-se ao "campo santo" da capela do Espírito Santo. No entanto, é difícil saber, com os nossos dados parcelares, quais os limites das áreas sepulcrais de ambos os templos, e se elas, efetivamente, em determinado momento, se terão parcial ou totalmente sobreposto.

A escavação de parte da necrópole do Largo do Espírito Santo possibilitou reunir uma vasta e interessante coleção osteológica, não só por ser extensa, mas também por significar uma amostragem populacional de ampla diacronia. Sendo o enterramento nos adros destinado aos indivíduos de menor estatuto social e económico, os estudos sobre esta coleção proporcionarão um "olhar" sobre aqueles que muitas vezes estão ausentes dos documentos escritos. O cruzamento de dados de várias proveniências enriquecerá as interpretações sobre o modo de vida das pessoas que viveram na região. Merece destaque a presença, no registo arqueológico, de pelo menos três indivíduos com a dentição anterior intencionalmente modificada, prática cultural que sugere uma ascendência africana. Na época, uma das formas de integração de uma população heterogénea passava pela incorporação em confrarias e irmandades, o que também lhes assegurava alguma proteção social, e a garantia de enterramento em solo sagrado. A confirmação de estruturas romanas no centro da vila de Bucelas veio confirmar a sua antiguidade. A análise preliminar do espólio encontrando associado às fundações das aludidas estruturas permite apontar para uma cronologia entre os séculos I a II d.C. Recorde-se que os dois monumentos epigráficos funerários existentes no Largo Espírito Santo foram datados do mesmo período: o cipo incorporado no muro do adro da igreja matriz junto à cabeceira está datado de finais do século I d. C. ou mesmo dos inícios do século II d.C.; a outra inscrição adossada a um muro junto a uma escadaria próxima da entrada do templo foi, por sua vez, datada do século I d. C. A terminar, gostaríamos de acentuar que esta longa intervenção arqueológica veio dar nova vida a um setor da atividade cultural no concelho que já conta com longa tradição, esperando-se que outras circunstâncias, sejam quais forem as suas motivações (emergência, acompanhamento de obra, ou investigação), prossigam o nosso trabalho realizado, não deixando enfraquecer aquela que é uma das mais importantes contribuições para a qualificação de um território, seus habitantes e seus visitantes. Entretanto, os estudos de gabinete e de laboratório em curso sobre os dados de Bucelas aqui apresentados virão ainda, certamente, trazer-nos maior número de elementos valorativos do nosso trabalho, que prossegue.

\section{BIBLIOGRAFIA}

AZEVEDO, Pedro A. (1897) - Achados de moedas romanas e portuguesas no Tojal e Bucelas no século XVIII. O Archeologo Português. Lisboa. Série 1, III, pp. 249-252.

BRAZUNA, Sandra; COELHO, Manuela (2012) - A Villa das Almoínhas (Loures): trabalhos arqueológicos de diagnóstico e minimização. Cira-Arqueologia, 1. Vila Franca de Xira: Câmara Municipal de Vila Franca de Xira, pp. 103-116.

CASIMIRO, Tânia Manuel; SEQUEIRA, João (2016-17) Faiança Portuguesa dos Séculos XVI-XVIII recuperada no Tejo. Cira-Arqueologia, 5. Vila Franca de Xira: Câmara Municipal de Vila Franca de Xira, pp. 260-274.

ESTÊVÂO, Florbela (2004) - Notícia sobre a Estrutura Arquitetónica da Quinta da Romeira de Baixo (Bucelas): mausoléu familiar associado ao ritual de incineração. In Arqueologia como Documento. Loures: Câmara Municipal de Loures, pp. 45-51.

ESTÊVÂO, Florbela (2019) - Estatueta Itifálica de Bucelas: pequeno bronze figurativo do Ager Olisiponensis. In CAESSA, Ana; CAMPOS, Ricardo, coord. - Lisboa Romana Felicitas Iulia Olisipo. Os monumentos epigráficos. Lisboa: Câmara Municipal de Lisboa, Caleidoscópio - Edição e Artes Gráficas S.A, pp. 138-143.

FERNANDES, Luís da Silva (2003) - Inscrições Romanas do Termo de Loures. MÁTHESIS, 12. Braga: Universidade Católica Portuguesa, Departamento de Letras, pp. 27-55.

FERNANDES, Carla Varela (2018) - Património deslocado: o antigo retábulo da capela do Espírito Santo de Bucelas. In FERNANDES, Carla Varela, coord. - Igreja Matriz de Bucelas. Lisboa: Imprimatur, Secretariado Nacional para os Bens Culturais da Igreja, pp. 37-65.

GUERRA, Amílcar (2018) - O Contributo da Epigrafia de Olisipo e do seu Território para o Estudo da Mobilidade do Período Romano. In Meios Vias e Trajetos. Entrar e Sair de Lisboa. Lisboa: Centro de Arqueologia de Lisboa e Sociedade de Geografia de Lisboa, pp. 52-63. 
MANTAS, Vasco Gil (1998) - Vias romanas do concelho de Loures. In Da vida e da morte: os romanos em Loures. Loures: Câmara Municipal. pp. 17-28.

MANTAS, Vasco Gil (2012) - A estrada romana de Olisipo a Scallabis: traçado e vestígios. Cira-Arqueologia, 1. Vila Franca de Xira: Câmara Municipal de Vila Franca de Xira, pp. $76-85$.

MANTAS, Vasco Gil (2018) - O município de Felicitas Iulia Olisipo e as viagens por terra e por mar. In Meios Vias e Trajetos. Entrar e Sair de Lisboa. Lisboa: Centro de Arqueologia de Lisboa e Sociedade de Geografia de Lisboa, pp. 52-63.

OLIVEIRA, Ana Cristina (1998) - A villa romana das Almoínhas (Loures) no contexto da presença romana no concelho de Loures. In Da Vida e da Morte. Os romanos em Loures. Loures: Câmara Municipal de Loures, pp. 29-41.

OLIVEIRA, Ana Cristina (2001) - A villa das Almoínhas (Loures, Portugal). O Arqueólogo Português. Lisboa. Série IV. 19, pp. 65-94.
ROBALO, Elisabete; OSÓRIO, Marcos; SANTOS, Bruno (2011-12) - Resultado da Escavação do Habitat Romano da Raposa (Fundão). Eburobriga, 7. Revista do Museu Arqueológico Municipal José Monteiro do Fundão. Fundão, pp. 22-37.

SILVA, Ana Raquel. (1998) - A presença romana em Frielas. In Da Vida e da Morte. Os Romanos em Loures. Loures: Câmara Municipal de Loures, pp. 43-48.

SILVA, Ana Raquel (2000) - A villa Romana de Frielas. O Arqueólogo Português, Lisboa. Série IV. 18, pp. 71-84.

SILVA, Ana Raquel (2012) - Villa romana de Frielas. In Cira-Arqueologia, 1. Vila Franca de Xira: Câmara Municipal de Vila Franca de Xira, pp. 88-102.

VILLAVERDE, Manuel (2018) - Breves notas sobre a igreja de Bucelas e o seu contexto local. In FERNANDES, Carla Varela, coord. - Igreja Matriz de Bucelas. Lisboa: Imprimatur, Secretariado Nacional para os Bens Culturais da Igreja, pp. 8-19.

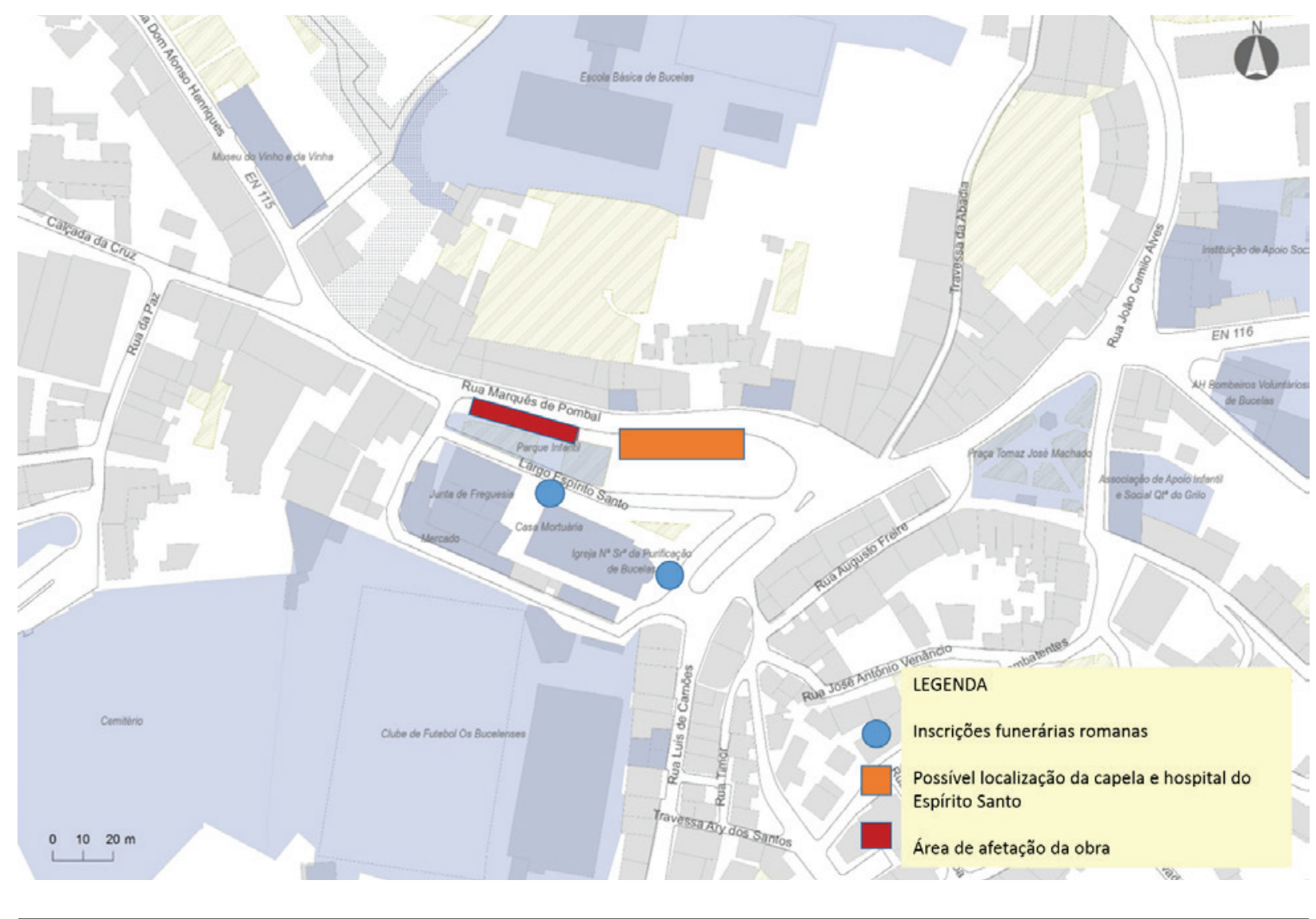

Figura 1 - Planta do núcleo antigo de Bucelas, com sinalização da zona de intervenção arqueológica, inscrições funerárias romanas, possível localização da capela do Espírito Santo e respetivo hospital ou albergaria de origem medieval. 


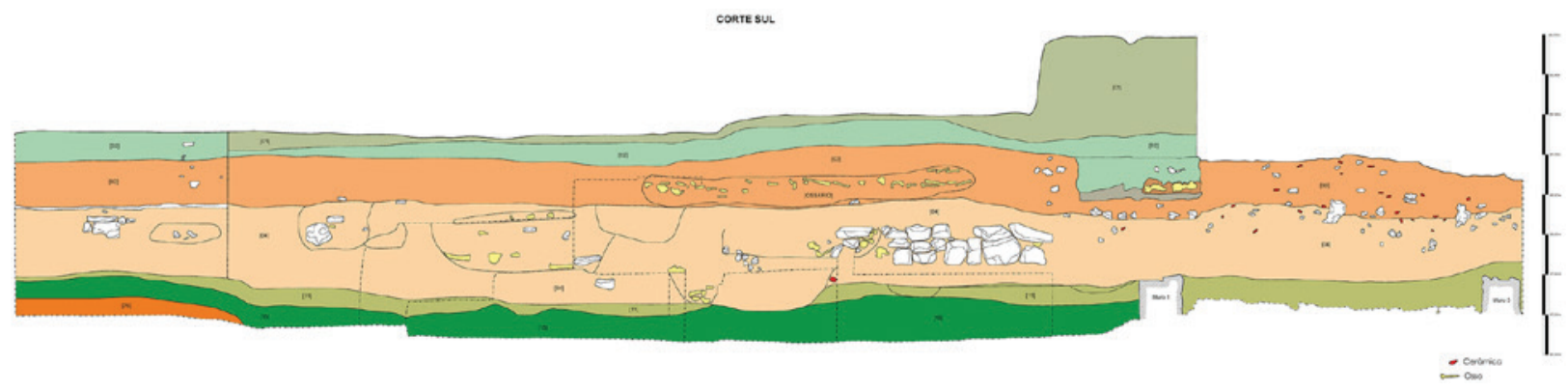

Figura 2 - Sítio arqueológico da Rua Marquês de Pombal/Largo do Espírito Santo (Bucelas, Loures), corte sul. Desenho de Vasco Vieira.

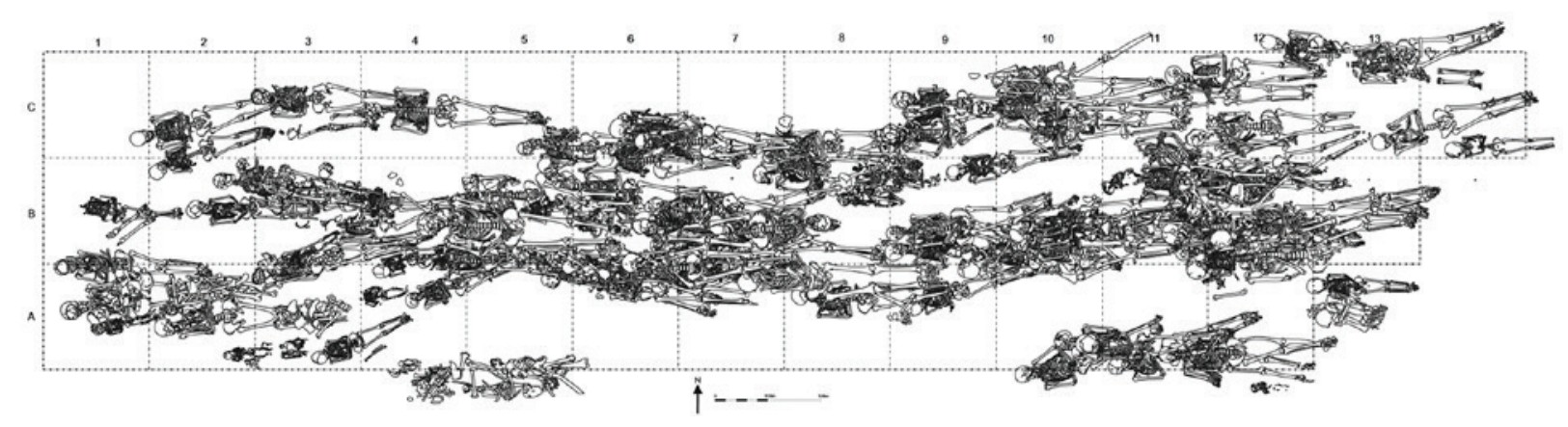

Figura 3 - Planta geral das inumações primárias distribuídas pelas quadrículas. Desenho de Vasco Vieira.
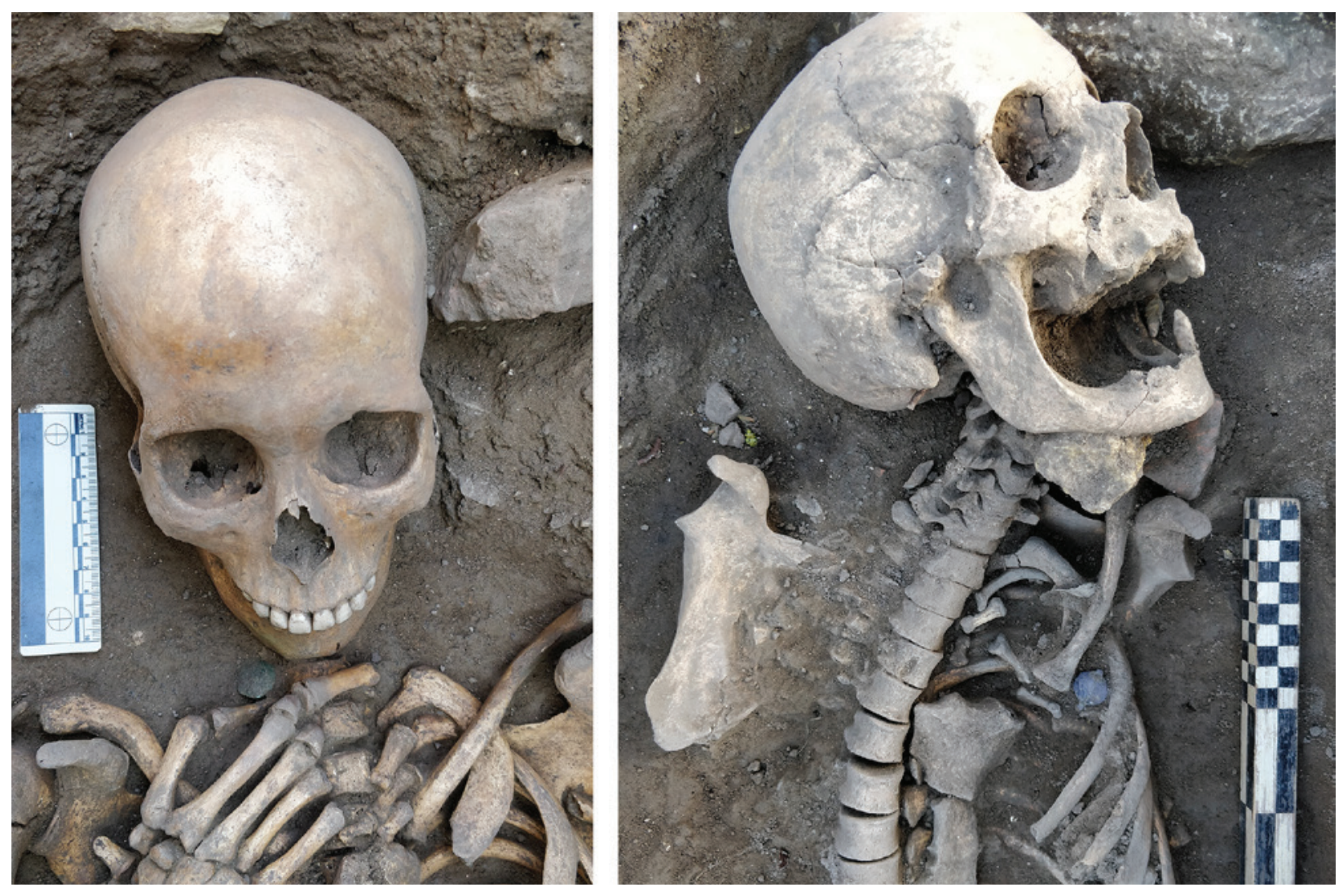

Figura 4 - À esquerda: moeda na mão de um indivíduo (Esqueleto 143). À direita: pendente ou relicário (Esqueleto 64). 


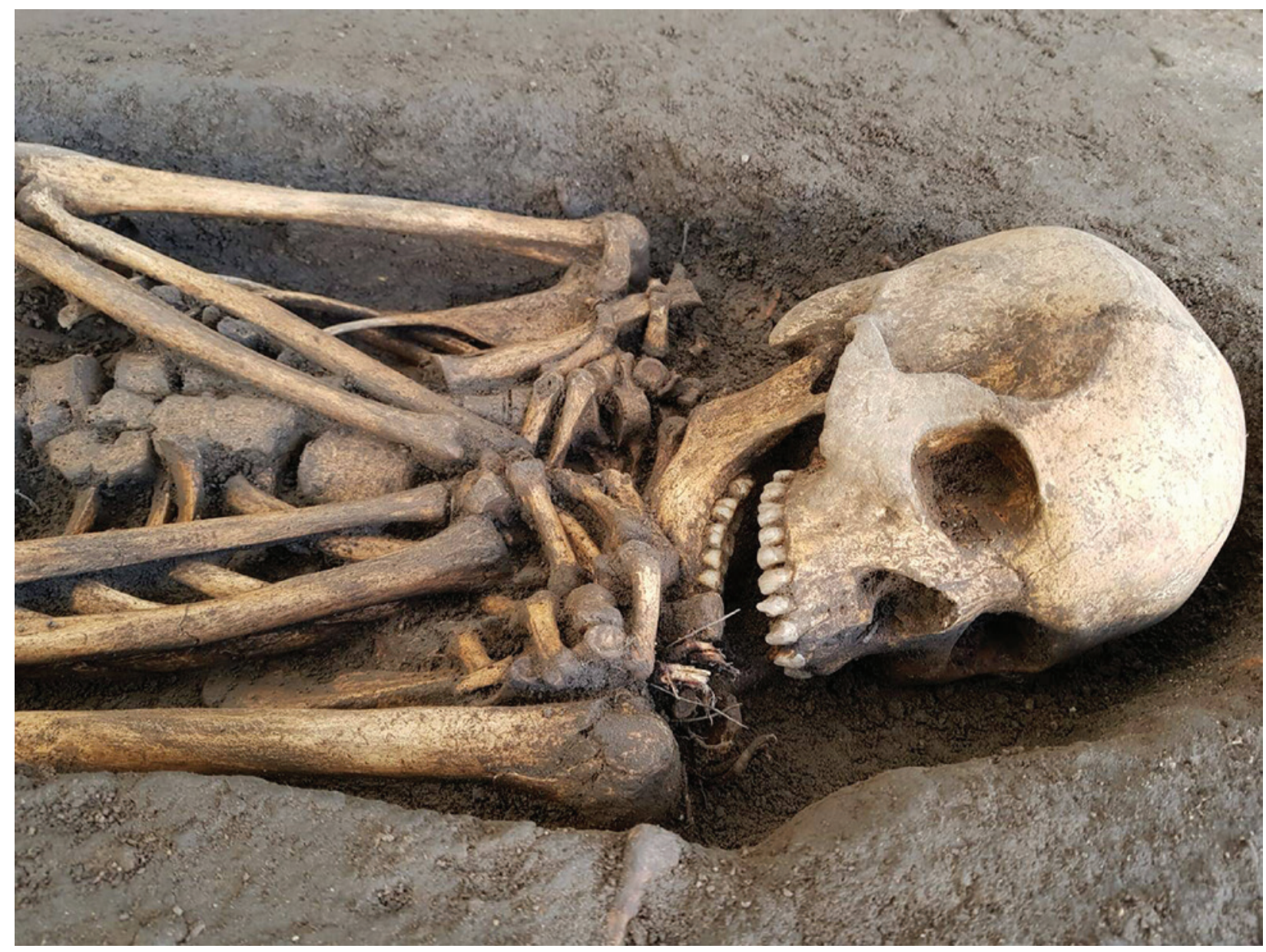

Figura 5 - Jovem adulta com dentição anterior modificada (Esqueleto 47).

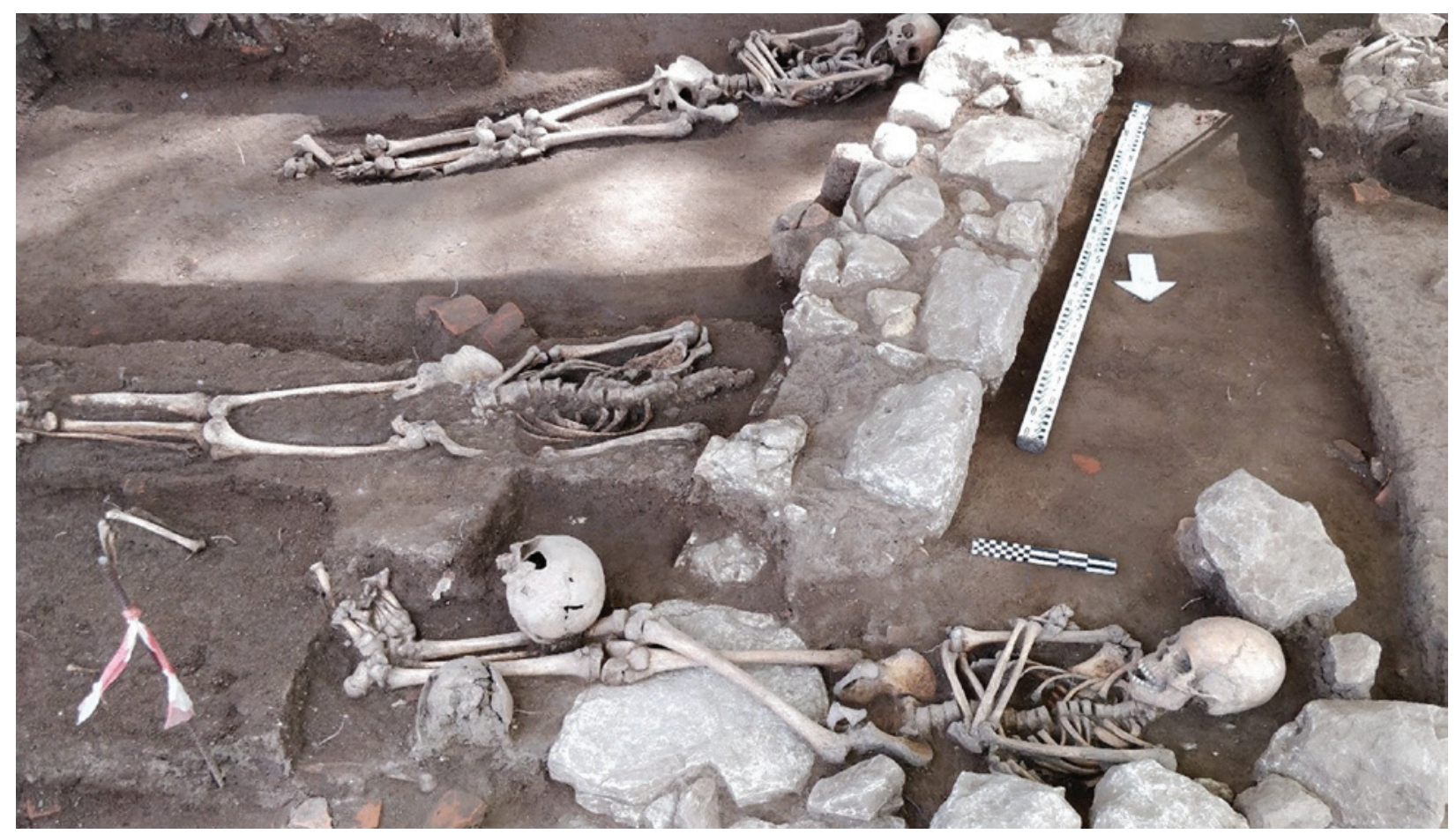

Figura 6 - Relação estratigráfica: contexto cemiterial cristão sobre estruturas murais do período romano. 


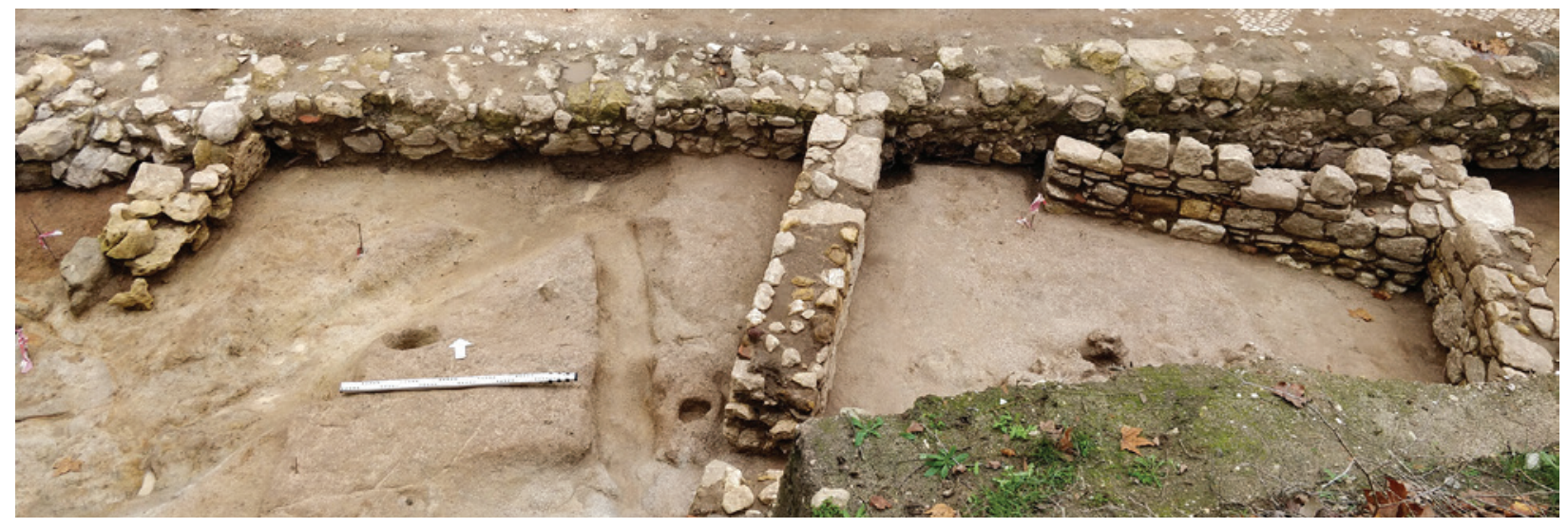

Figura 7 - Foto do plano final dos compartimentos A e B.

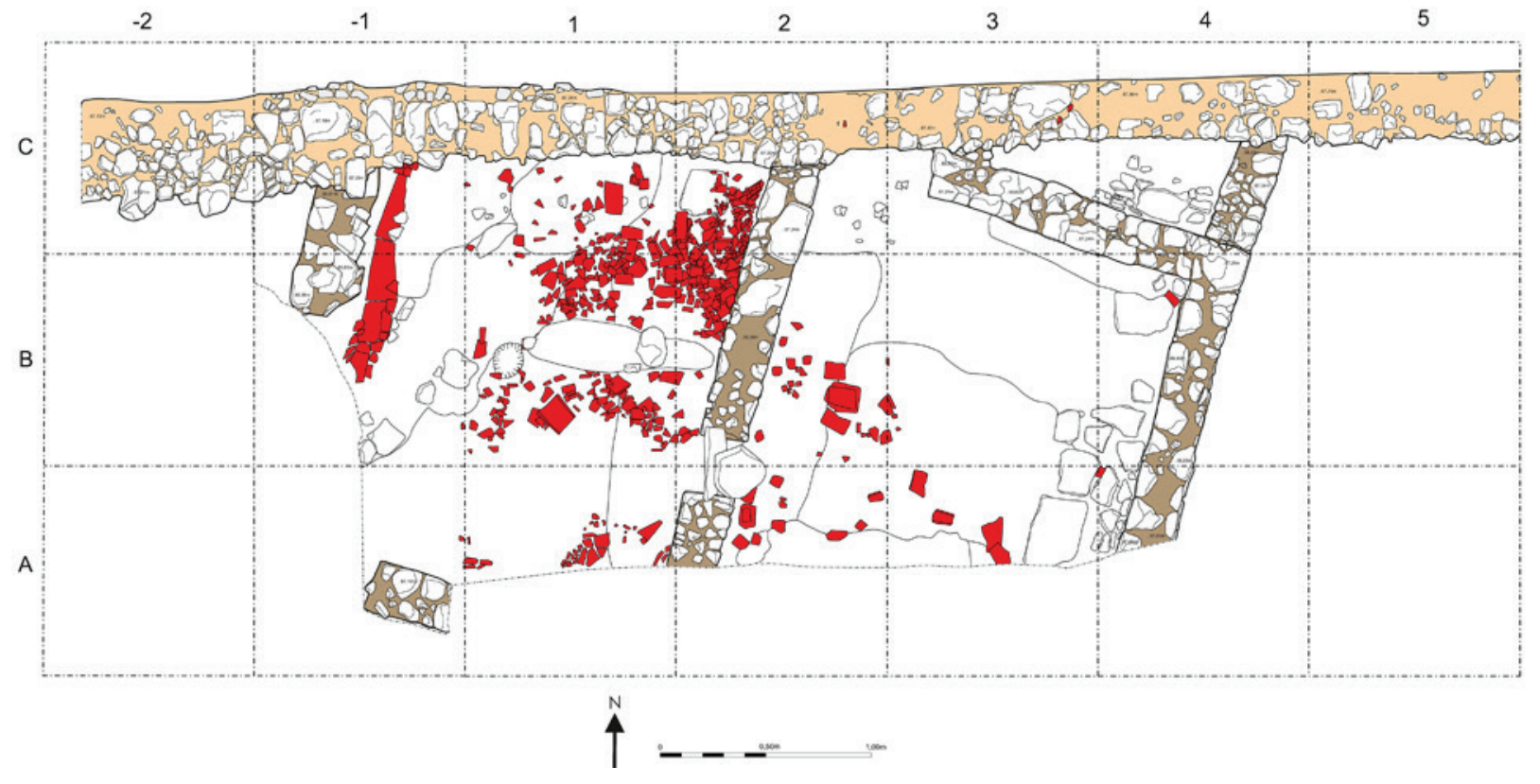

Figura 8 - Plano geral das estruturas romanas e do derrube de telhas no interior do compartimento B. Desenho de Vasco Vieira. 


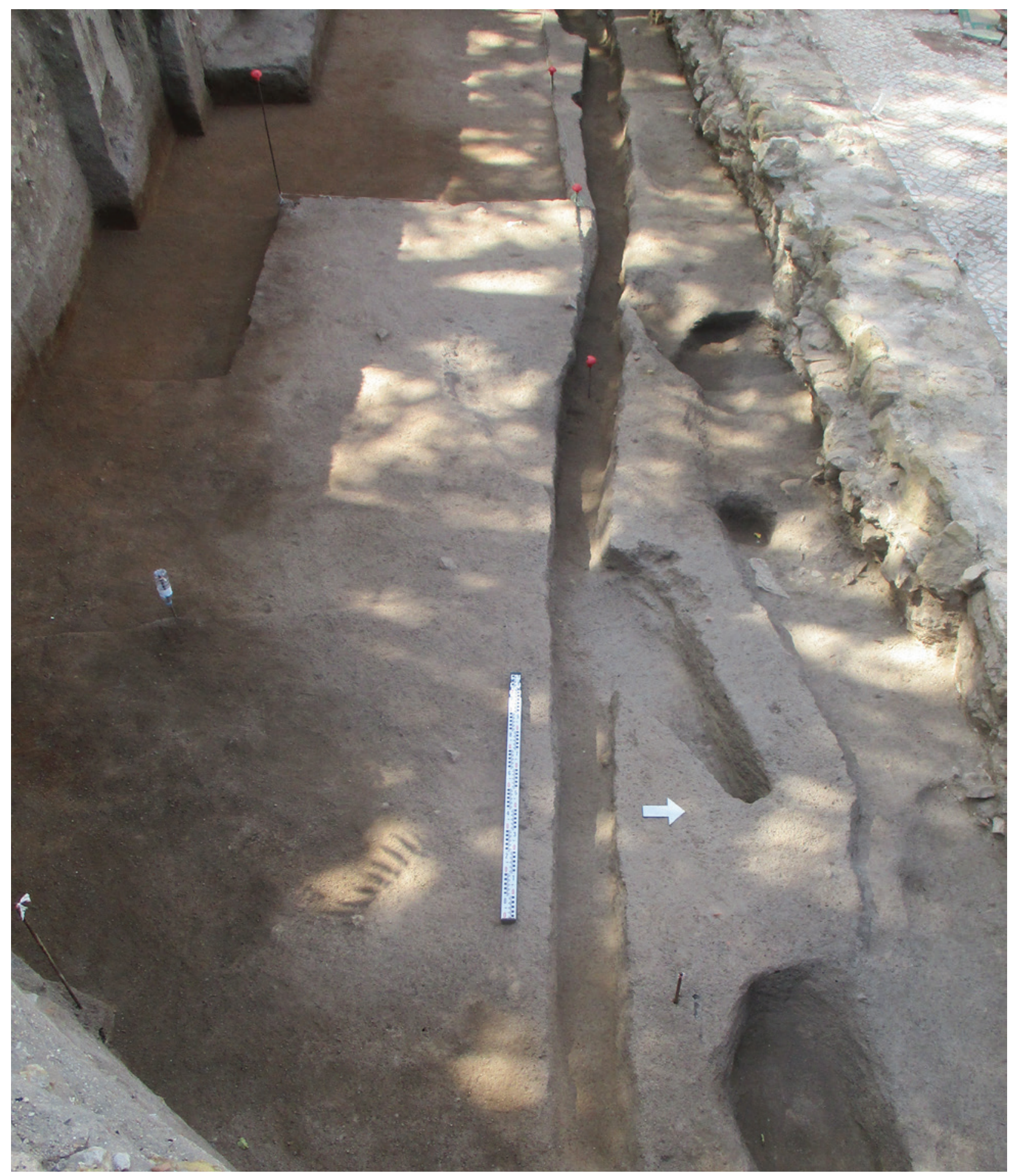

Figura 9-Estrutura negativa associada a contexto agrícola. 

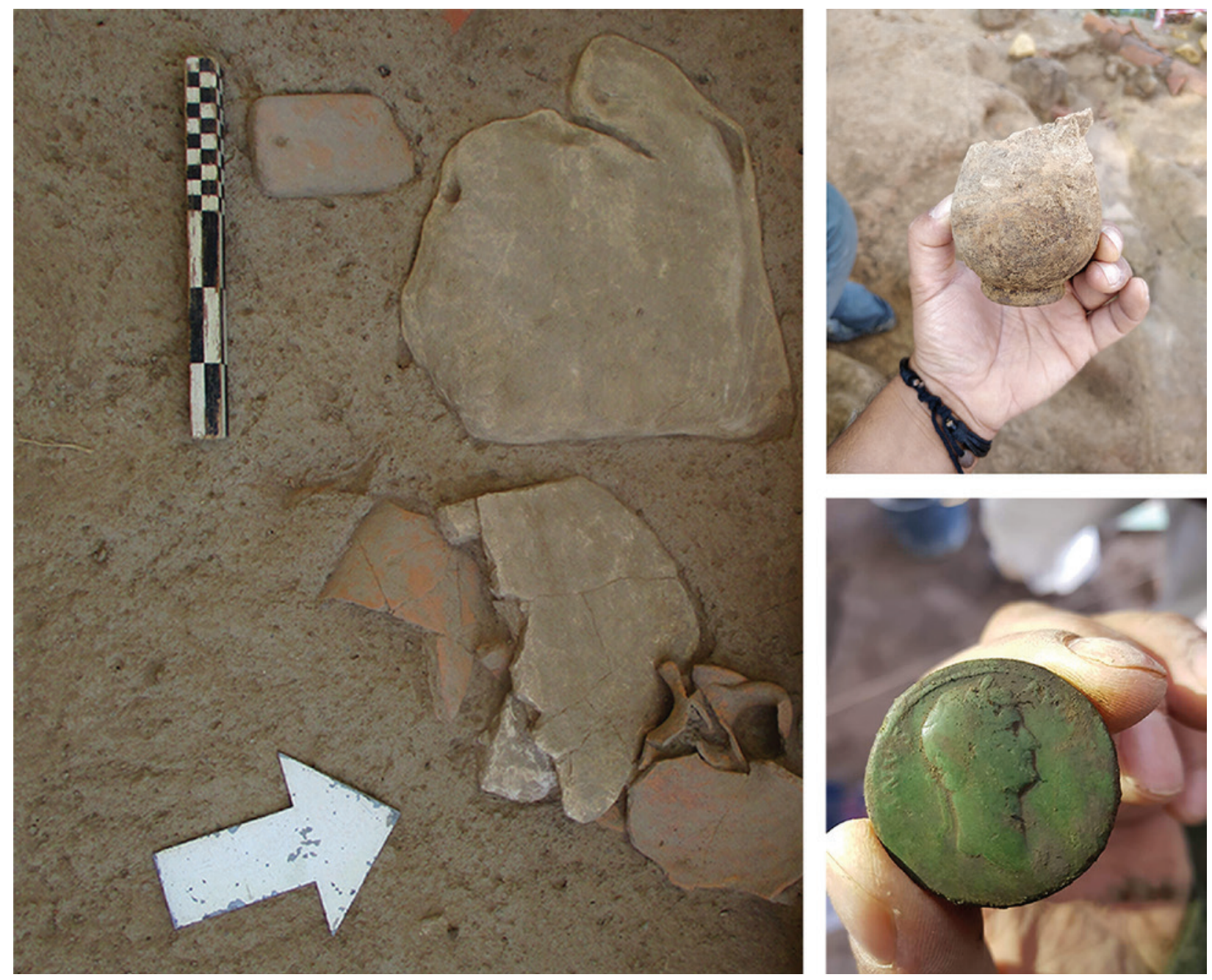

Figura 10 - À esquerda: fragmento de peso de tear e fragmentos de jarro. À direita: em cima, pequeno jarro em paredes finas; em baixo, moeda do Imperador Adriano (séc. II). 


\title{
O CEMITÉRIO MEDIEVAL DO POÇO DO BORRATÉM E A ESPACIALIDADE FUNERÁRIA NA CIDADE DE LISBOA
}

\author{
Inês Belém ${ }^{1}$, Vanessa Filipe ${ }^{2}$, Vasco Noronha Vieira ${ }^{3}$, Sónia Ferro ${ }^{4}$, Rodrigo Banha da Silva ${ }^{5}$
}

\begin{abstract}
RESUMO
A intervenção arqueológica levada a cabo em 2018 na Rua do Poço do Borratém em Lisboa, permitiu identificar um segmento de espaço funerário com cronologias dos séculos XIII a XV, pelo registo de cerâmicas de importação. Este estudo pretende apresentar o contexto identificado e, posteriormente integrá-lo na espacialidade da cidade de Lisboa, compilando outros contextos funerários de cronologia medieval intervencionados na mesma. Procura-se, portanto, apresentar um estado da questão relativo a estes contextos, dada a importância da colaboração de vários elementos.

Palavras-Chave: Arqueologia Urbana, Arqueologia Funerária, Necrópole, Séculos XIII-XV.
\end{abstract}

\begin{abstract}
The archaeological intervention that took place in 2018 at Rua do Poço do Borratém in Lisbon allowed the identification of a funerary context with chronologies of the $13^{\text {th }}$ and $15^{\text {th }}$ centuries since imported ceramics were registered. This study intends to present the identified context and, later integrate it into the spatiality of the city of Lisbon compiling other funerary contexts of medieval chronology intervened. Therefore, it is intended to present a state of the question regarding these contexts given the importance of the collaboration of various elements.
\end{abstract}

Keywords: Urban Archaeology, Funerary Archaeology, Medieval Burial Grounds, $13^{\text {th }}-15^{\text {th }}$ centuries.

\section{INTRODUÇÃO}

O presente estudo diz respeito a uma etapa ainda inicial da investigação desenvolvida na sequência da intervenção arqueológica realizada em 2018 no Largo do Poço do Borratém, Santa Maria Maior, Lisboa, (Figura 1), localizada na via pública. Os trabalhos sucederam-se no âmbito de um projeto municipal de colocação de ecopontos subterrâneos no local, numa área da via publica, sendo da responsabilidade da empresa de arqueologia Cota 8o.86. Lda.

Procura-se, num primeiro momento, dar a conhecer o contexto identificado no Largo do Poço do Borratém no que diz respeito à sua realidade histórica e arqueológica envolvente, assim como os "elemen- tos datantes" exumados. Por fim, propõe-se enquadrar o contexto funerário na espacialidade da cidade medieval de Lisboa, através da compilação de dados de semelhante natureza e cronologia que foram intervencionados arqueologicamente na cidade. No presente artigo pretende-se, portanto, integrar os elementos exumados na sua conjuntura cronológica tendo em conta os dados arqueológicos identificados assim como, cartografá-los tendo como foco de interesse a espacialidade funerária da época. Todavia, a análise extensiva do conjunto exumado encontra-se ainda em curso aquando da redação do presente texto, pelo que aqui se avançam apenas alguns dados preliminares.

\footnotetext{
1. NOVA FCSH; inesbelemmota@gmail.com.

2. IAP - NOVA FCSH / Cota 80.86 Lda.; vanessagfilipe@gmail.com.

3. Cota8o.86 Lda.; vav@sapo.pt.

4. Universidade de Évora; barishi@hotmail.com.

5. CHAM - NOVA FCSH; UAç; CAL - DPC - CML; rodrigo.banha@cm-lisboa.pt.
} 
2. ALGUNS ELEMENTOS PRÉVIOS

À INTERVENÇÃO ARQUEOLÓGICA: SÍNTESE HISTÓRICA SOBRE A ERMIDA DE SÃO MATEUS

De acordo com a investigação histórica, o espaço funerário revelado pela intervenção arqueológica realizada na via pública do Largo do Poço do Borratém está conectado com a desaparecida Ermida de São Mateus (Figura 2), cuja edificação os historiadores de Lisboa situam entre a segunda metade do século XII e o século XIII, embora não exista consenso quanto à data concreta da sua fundação (Castilho, 1935; Correia, 1941; Sequeira, 1960; Silva, 2017). Erguida junto a uma das principais saídas setentrionais da cidade, que se dirigia à Mouraria, esta adotou uma importância estratégica como eixo de comunicação junto à Porta de São Vicente da Mouraria da Muralha Fernandina, cerca urbana edificada em 1373-75 (Silva \& Lourenço, 2019, p. 106).

A instituição da Ermida estará diretamente relacionada com a instalação de uma albergaria por Paio Delgado, que fora alegadamente participante em 1147 na conquista cristã de Lisboa. A albergaria associada à Ermida São Mateus tornar-se-ia numa das principais instituições assistenciais da cidade nos primeiros séculos de domínio português. Tendo como cabeça da instituição o templo dedicado a São Mateus (Castilho, 1935; Correia, 1941; Sequeira, 1960), a Albergaria manteve-se por herança no interior familiar, que se veio a constituir num dos principais núcleos da nobreza portuguesa e que lhe deve o seu nome, os Soares de Albergaria (Sequeira, 1960, p.7).

Em 1371, D. Fernando ordenou a extinção da albergaria, podendo nesta altura ter sido constituído o morgado de São Mateus. De Dona Catarina Dias, descendente do Bispo de Silves D. João Alão e filha de Lopo Soares de Albergaria, partidária de Dona Beatriz na crise de $1383-85$, passaram a D. Martim Vasques da Cunha, a quem D. João I a confisca pelas mesmas razões e acaba por doar o morgado ao seu genro, o famoso jurisconsulto João das Regras (Sequeira, 1960, p. 7), através de carta régia datada de 1392 (Castilho, 1935). Em consequência desta iniciativa régia, nos finais do século XIV, após receber o recém-constituído morgado de São Mateus, o Doutor João das Regras concedeu mercês a 20 merceeiras e constituiu no local da antiga albergaria a Mercearia de João das Regras (Correia, 1941;
Sequeira, 196o, p. 7), mais tarde alargada pelos Castro, Condes de Monsanto, a 30 beneficiárias (Sequeira, 1960, p. 10).

A fundação do Convento de São Domingos, em 1242, junto a uma outra via de saída da cidade de primeira ordem, iria a partir de D. Afonso III integrar nas suas hortas os terrenos que se estendiam entre o Rossio e os limites dos domínios do morgadio de São Mateus, que com ele estabeleceu uma relação de estreita vizinhança.

Em finais do século XV o morgado estava na posse do Conde de Monsanto, conforme o testemunho produzido em 1545 por Garcia de Resende relativo ao Hospital Real de Todos-Os-Santos: “(...) no anno de mil e quatrocentos e noventa e dous a quyinze dias do mes de Mayo mandou el-rey [D. João II] perante si fundar e começar os primeiros aliceces do esprital grande de Lixboa da invocaçam de Todolos Sanctos (...). E esse dia andou todo ahi vendo como se começava e comeo em casa do Conde de Monsanto que he pegada com a horta do dito esprital (Resende, 1596: cap. CXL). A Ermida permaneceria incorporada nos bens condais, embora sofrendo diversos usos temporários, incluindo no século XVII o conventual pelas Comendadeiras de S. Bento de Avis (Silva, 2017, p. 23), até à sua paulatina desaparição a partir da segunda metade do século XVIII, na sequência da reconstrução pombalina de Lisboa (Silva, 2017, p. 31).

\section{INTERVENÇÃO ARQUEOLÓGICA}

A realização de trabalhos de diagnóstico do potencial arqueológico na Rua do Poço do Borratém em 2018 dirigida por dois dos autores (VF, VNV) e desencadeada no âmbito de um projeto de instalação de ilha ecológica com seis ecopontos, resultou na abertura de uma sondagem de aproximadamente 30 $\mathrm{m}^{2}$. Desta ação resultou a identificação de um segmento de espaço funerário onde se registaram quatro níveis de enterramento e a respetiva sequência estratigráfica, demonstrando a importância científica deste contexto.

O espaço funerário da Baixa Idade Média viu a sua cronologia relativa aferida através do material cerâmico recolhido nos depósitos de enchimento das sepulturas e nos diversos níveis de pavimentos identificados, em particular os fragmentos de importação que integram os conjuntos. Ainda que insuficientemente divulgados, o seu registo noutros contextos 
lisboetas têm resultado em publicações deste tipo de produções oleiras forâneas, permitindo atribuir-se-lhes cronologias dos finais do século XIII a meados do século XV (Gaspar \& Amaro, 1997; Fernandes \& alii, 2008; Marques, 2015; Oliveira \& alii, 2017, 2017a; Silva, 2019; Silva \& alii, no prelo).

\subsection{Estratigrafia}

Numa fase inicial os trabalhos consistiram no acompanhamento da remoção com recurso a meios mecânicos das U.E.s [OO1],[OO2] e [oO2-A]. O primeiro horizonte de enterramentos foi identificado na U.E [019], equivalendo a 17 inumações em coval aberto num nível de pavimento em terra batida, cuja cronologia aponta para a primeira metade do século XV (Figura 3). Um segundo horizonte foi registado na U.E [086], revelando 12 sepulturas cobertas por um piso identificado como U.E [035], sendo-lhes atribuída preliminarmente uma baliza cronológica entre a segunda metade do século XIV e os inícios do século XV. Um terceiro horizonte, em que se reconheceram 14 sepulturas, foi registado como tendo sido abertas no piso identificado como U.E [135], apresentando uma datação inserida no século XIV. O último momento intervencionado diz respeito aos pisos U.Es [191] e [202], horizonte onde se procedeu ao registo de 18 sepulturas com cronologia do século XIV, sendo que se atingiu a cota máxima de afetação da obra. Esta circunstância implicou que nem todas as sepulturas tenham sido totalmente escavadas. Em síntese, foi identificado um total de 61 sepulturas distribuídas por 4 níveis estratigraficamente distintos de enterramento, das quais se levantaram 47 enterramentos e ossários, tendo ficado 22 sepulturas preservadas e por escavar, das quais 13 no plano final, e 9 nos perfis estratigráficos (Figura 4).

\subsection{Gestos funerários}

No contexto funerário registaram-se diversas formas de enterramento que se associam diretamente com a conjuntura social e cultural da cronologia de atribuição, em todo o caso homogeneamente enraizadas em matrizes cristãs. Deste modo, no perfil oeste, detetou-se uma estela discóide (Figura 5) elemento arquitetónico que estaria originalmente in situ e usado como pedra de cabeceira de uma sepultura com orientação O-E não intervencionada.

Os enterramentos e sepulturas identificadas correspondem maioritariamente a inumações primárias e enterramentos individuais (Duday \& alii, 2014, p. 237), sendo que os indivíduos se encontram em decúbito dorsal com os membros inferiores distendidos e os membros superiores fletidos sobre a zona do abdómen (Figura 4). Através da identificação de alguns fragmentos de alfinete aferiu-se que os enterramentos foram realizados com recurso a mortalha. Todavia, destacam-se exemplos de reduções associadas a inumações primárias, demonstrando a reutilização da sepultura. A forma de deposição e a orientação O-E refletem, portanto, a ideologia religiosa cristã, mostrando-se, pois, como deposições "canónicas". Não foi identificado espólio com associação direta ao gesto funerário, salvo raros vestígios de um fragmento de anel e pendente lítico.

\subsection{Espólio identificado e cronologia relativa da necrópole}

Os dados preliminares exumados na intervenção arqueológica que dizem respeito ao conjunto cerâmico provêm dos enchimentos das sepulturas e dos níveis de pavimento registados. O conjunto identificado em três dos quatros horizontes exumados apresenta uma diversidade de fabricos, demonstrando a existência de produções oriundas de centros hispânicos (Valencia e Sevilha), flamengos (de Bruges), do Norte de França (de Rouen e "Francês muito decorado") e da região de La Rochele, de Saintonge ("Saintonge Mottled" e "Saintonge Plain") (Figura 6).

A virtualidade destes fragmentos cerâmicos destaca-se uma vez que permitem atribuir propostas de datação para o contexto respectivo. Todavia só o estudo global do registo cerâmico, "fosco", pintado e vidrado, será passível de permitir atribuir balizas cronológicas mais finas.

As produções valencianas destacam-se pelas pastas granulosas, de fratura de tendência irregular com elementos de pequena e média dimensão. O vidrado é branco de estanho com pintura a azul, de cobalto, e a "dourado", de cobre. As produções sevilhanas apresentam pastas de cor amarelada, medianamente granulosas e de fratura irregular e com elementos muito bem distribuídos, recobertos por vidrado amarelado. Estes fabricos apresentam cronologias passíveis de se integrar nos séculos XIII a XV (Oliveira \& alii, 2017, pp. 1525-1526). Nos fabricos flamengos atribuídos a Bruges, produzidos entre os finais do século XIII e a primeira metade do século $\mathrm{XIV}$, destacam-se as características pastas avermelhadas homogéneas e compactas, por vezes bícromas vermelho-acinzentadas, sendo granulosas e de 
fratura irregular, com elementos bem distribuídos. O vidrado é espesso, de coloração verde, quase sempre manchado, em parte dos exemplares aplicado sobre um engobe branco espesso, sendo o interior dos recipientes desprovido de vidrado. As decorações típicas do fabrico de Bruges compreendem no caso faixas de motivos geométricos estampilhados ou produzidas mediante roletilha/carreto (Oliveira \& alii, 2017, p. 1528).

As produções do Norte de França e de Rouen tiveram uma ampla difusão em momentos bem avançados do século XIII e primeira metade do século XIV, sendo que apresentam pastas compactas de coloração branca e bege-acinzentada muito clara, com fratura nítida e textura granulosa com pequenos elementos bem distribuídos e de pequena dimensão, destacando-se escassos e esparsos elementos ferro-magnesianos de média dimensão. O vidrado apresenta uma primeira camada branca brilhante, sobre o qual se aplicou um outro laranja de tonalidade acastanhada, com motivo estampilhado em relevo recoberto a vidrado amarelo. O tipo "Francês do Norte muito decorado" apresenta pastas brancas, vidrados predominantemente verdes, de chumbo, ou verde mais claro, quando cobre foi adicionado (Oliveira \& alii, 2017, pp. 15271528). As produções de Saintonge representadas no Poço do Borratém materializam-se em pastas calcárias e cauliníticas, muito homogéneas e muito depuradas, de paredes delgadas, apresentando os vidrados verdes uma "transparência" vítrea, o mesmo verde "mosqueado de castanho" ("Saintonge mottled") ou liso ("Saintonge plain"). O vidrado permite formar uma superfície texturada, com tonalidades desde o verde esbranquiçado ao verde escuro (Oliveira \& alii, 2017, p. 1527).

A distribuição do limitado conjunto presente, numa primeira abordagem que é preliminar, demonstra maior expressão das produções do Norte de França no primeiro horizonte de enterramentos identificado, enquanto que as produções flamengas de Bruges e de Rouen apresentam uma expressão mais significativa no segundo e quarto horizontes exumados. As produções de Saintonge encontram-se igualmente representadas no primeiro e quarto horizontes. Já as produções hispânicas apresentam igual expressão no primeiro e segundo horizontes (Tabela 1).

\section{A ARQUEOLOGIA DE CONTEXTOS FUNERÁRIOS MEDIEVAIS EM LISBOA}

Arqueologicamente, o estudo da evolução da cidade de Lisboa envolve distintos métodos de pesquisa, onde convergem diferentes fontes (Fabião, 1994, p. 147). Assim, a cidade enquanto objeto de estudo justifica a abordagem arqueológica das relações entre as materialidades e os espaços urbanos, permitindo deste modo construir leituras do passado (Silva, 1999, p. 239). Convém recordar aqui que a cidade é um local heterotópico e, portanto, polissémica na sua diversidade, só se compondo a sua leitura global mediante o conhecimento das partes.

No que diz respeito especificamente aos contextos funerários, destaca-se o facto de abrangerem aspetos físicos, o meio ambiente e também a construção social, cultural e económica dentro do modus operandi de cada sociedade, pressupondo uma colaboração interdisciplinar (Pereira, 2018, p. 21). Ora, na inexistência para Lisboa de uma ideia ou conceito global programático de arqueologia da cidade como um todo, o conhecimento tem sido construído com base em dados fragmentários e dispersos, resultantes da aplicação de metodologias díspares e com qualidades de registo muito variáveis (Gaspar \& alii, 1997), sobretudo obtidos através de trabalhos de arqueologia preventiva, que dominam largamente o tipo de práticas da disciplina na cidade (Gaspar \& alii, 1997; Bugalhão, 2008). Neste mesmo sentido, e apesar de trabalhos académicos de folego já realizados sobre a arqueologia da morte em Lisboa (Nunes, 2010), falta ainda uma leitura integrada e multidisciplinar, que integre e agregue os conteúdos dos domínios mais tradicionalmente tratados por várias disciplinas, designadamente a epigrafia, a história da arte, a arqueologia e a bioantropologia.

Em referência a estas, a tumulária medieval portuguesa de Lisboa é rica, e nela se fazem representar, sobretudo, um conjunto de monumentos onde os programas iconográficos identificam o indivíduo, o grupo familiar e o ordenamento social a que pertencem, oferecendo representações heráldicas e/ou de cenas relacionadas com o caminho para o Além (Goulão, 1995; Barroca, 1997, p. 656), sendo de referenciar aqui os conjuntos da Sé (Fernandes, 2002), do Convento de São Domingos (Vale, 2003), Igreja de São Cristóvão (Matoso, 2001), Convento do Carmo e da desaparecida Igreja de Santo André, estes últimos conservados na Igreja da Graça. 
As estelas funerárias discóides são indissociáveis dos rituais funerários e das sepulturas, sendo que a orientação da sepultura com estela e com a deposição do individuo é muito comum a partir do séc. $\mathrm{XI}$, representando a orientação da igreja de Cristo voltada para nascente (Gomes \& Gomes, 2006, pp. 323-324). Incorporam, por isso, um domínio de especialidade que vem merecendo especial atenção nos domínios da história da arte e da arqueologia. Fazendo a denominação da estela discóide referência à sua forma circular ou em disco, que apresenta variantes morfológicas, com motivos gravados maioritariamente cruciformes, mas também geométricos, fitomórficos, epigráficos, heráldicos, de ofícios, zoomórficos e antropomórficos.

Os motivos cruciformes são os mais comuns nesta iconografia (incluindo variantes formais como a cruz templária, cruz grega, cruz pátea, ornamento cruciforme, cruz latina e cruz de tau) (Malveiro, 2017, p. 980), representando o símbolo cristão de identificação do defunto e não meramente um motivo decorativo (Viana, 1949, p. 85). Assim demonstra a conceção cristã da morte e o desejo simbólico do crente tendo em vista a ressurreição conforme o exemplo de Cristo (Malveiro, 2017, p. 982). Para o caso lisboeta, a quase totalidade dos exemplares estudados foi encontrado desprovido de contexto arqueológico, deste modo impedindo a articulação da informação associada.

A epigrafia fúnebre, que serviu como os elementos anteriores, para a permuta simbólica entre o visível e o invisível (a sepultura e o sepultado), assinalando a memória do falecido, bem como os seus atos, serviu como sinal/aviso para o não esquecimento do mesmo, eternizando o finito (Delgado, 2006, p. 515). Para o caso lisboeta a epigrafia foi objeto de estudo de Cordeiro de Sousa (1940), retomada e atualizada depois por Mário Barroca (1987), mas estando ainda em falta um estudo compreensivo de uma parte significante de textos funerários medievais mantidos inéditos.

No que se refere à bioantropologia, esta tem centrado o seu interesse em aspetos fundamentalmente biológicos. Ora, a necessidade de um contributo multidisciplinar no registo de campo e no processo de recolha de dados traduz-se numa abordagem que, para além de ser aplicada no momento da identificação dos vestígios osteológicos em campo, salvaguarda os fatores inerentes ao processo de decomposição do cadáver assim como a sua relação com a envol- vência (Cruz, 2011, pp. 13-14). Neste contexto desenvolvem-se os princípios metodológicos que recorrem ao registo rigoroso das deposições, ao estudo paleoantropológico dos restos humanos exumados e à análise das alterações dos vestígios osteológicos após a morte e deposição do cadáver (Marado \& alii, 2017, p. 1926). Deste modo, a compilação destes dados permite caracterizar o gesto funerário (Marado \& alii, 2017, p. 1926) reconstituindo práticas do passado (Stjerna, 2017, p. 447), fatores socioculturais, ideológicos, económicos, paleobiológicos, entre outros (Soares, 2019, p. 23).

Por fim, e em síntese, a arqueologia da morte em Lisboa, para além de outros interesses sectoriais já antes enunciados, ou dos óbvios aspetos de índole cronológica e/ou cultural, tem-se preocupado no essencial com as dinâmicas, arquiteturas e espaços tumulares.

Na realidade, quando se conduz um "inquérito" rápido produzido com base bibliográfica completada com o recurso ao Portal do Arqueólogo, consegue-se identificar/assinalar na cidade múltiplos contextos funerários medievais reconhecidos arqueologicamente (Figura 7), em contrapartida muito sumariamente publicados na sua quase totalidade e em nenhum caso integrando os dados das várias disciplinas. Assim, há a registar a exumação de sepultamentos medievais em quadros topológicos, sociais e culturais bastante diversificados, sintetizados em tabela (Tabela 2), que reflectem as distintas cronologias mas também, e sobretudo, as três dimensões religiosas da Lisboa Medieval, que encerram bem distintas formas de sepultamento, dado que o islamismo e o judaísmo "segregam" o morto de um ponto de vista urbanístico, ao passo que o cristianismo o integra na paisagem quotidiana da cidade dos vivos.

\section{CONSIDERAÇÕES FINAIS}

A temática da relação espacial dos cemitérios com o restante da malha urbana é uma relevante condição de leitura da própria cidade, dado o potente significado emocional da necrópole para as vivências da cidade viva (Mumford, 1961, p. 7). Em consequência, a influência das crenças religiosas no desenho urbano das cidades da Baixa Idade Média faz com que os preceitos espirituais guiem a forma como se tratam os mortos.

Pretendeu-se, portanto, facultar informação arqueológica recente, apresentando alguns dados prelimi- 
nares exumados no contexto funerário identificado no Poço do Borratém. Destes, os elementos cerâmicos atribuíveis a produções europeias com difusões relativamente bem balizadas cronologicamente, permitiram avançar com uma primeira proposta de datação para o conjunto do contexto respetivo. Deste modo, a presença de cerâmicas europeias de importação no horizonte 4 do Poço do Borratém (o mais antigo escavado) implica que se não possa atribuir-lhe uma cronologia mais recuada que os finais do século XIII, considerando aqui a baliza cronológica inferior daquelas cerâmicas; em contrapartida, convém aqui destacar a presença no horizonte 1 (o mais recente) de uma elaboração valenciana de "azul e dourado" (muito fragmentária para que se consiga discernir a gramática decorativa), tornando plausíveis, segundo o mesmo principio, estar-se perante cronologias que se não podem recuar dos finais do século XIV - século XV.

Para o caso do Poço do Borratém/Ermida de São Mateus, zona notoriamente envolvida em matéria de proximidade com um eixo de intensa circulação, assoma como significante a definição dos consecutivos quatro níveis funerários e as pavimentações associadas, sugerindo ações deliberadas e sucessivas que procuraram maximizar a capacidade do cemitério, mas no respeito dos anteriores inumados, um interessante contributo para o conhecimento do gesto funerário medieval de Lisboa.

\section{BIBLIOGRAFIA}

BARROCA, Mário (1987) - Necrópoles e sepulturas medievais de entre Douro e Minho. (Provas Públicas de Aptidão Pedagógica e Capacidade Científica). Porto: Faculdade de Letras da Universidade do Porto.

BARROCA, Mário (1997) - Cenas de passamento e de lamentação na escultura funerária medieval portuguesa: séc. XIII a XV. Revista da Faculdade de Letras. Porto: Universidade do Porto, pp. 655-684.

BATALHA, Luísa; NETO, Nuno; PEÇA, Pedro; BRITO, Sara; CARDOSO, Guilherme (2017) - Os silos do Palácio de Santa Helena (lisboa). In ARNAUD, José Morais; MARTINS, Andrea, eds. - Arqueologia em Portugal / 2017 - Estado da Questão. Lisboa: Associação dos Arqueólogos Portugueses, pp. 1751-1766.

BOAVENTURA, Inês (2016) - Que histórias têm para contar os 70 cadáveres encontrados junto à Sé de Lisboa?. Público. Disponível em [https://www.publico.pt/2016/10/31/ local/noticia/que-historias-tem-para-contar-os-7o-cadaveres-encontrados-junto-a-se-de-lisboa-1749229. Data da consulta: 07/2020].
BUGALHÃO, Jacinta (2008) - Lisboa e a sua Arqueologia: uma realidade em mudança. ERA Arqueologia. 8. Lisboa, pp. 218-230.

BUSOM, Júlia (2017) - Late Medieval Lisbon. Seven individuals from Praça da Figueira. (Dissertação de Mestrado). Cranfield: University of Cranfield (policopiado).

CASTILHO, Júlio (1935) - Lisboa Antiga: Bairros Orientais. III. Lisboa: S. Industriais da Câmara Municipal de Lisboa.

CORDEIRO DE SOUSA, J. (1940) - Inscrições Portuguesas de Lisboa (Séculos XII a XIX). Publicações Comemorativas do duplo centenário da fundação e restauração de Portugal. Lisboa: Academia Portuguesa da História.

CORREIA, Fernando (1941) - Os Velhos Hospitais da Lisboa Antiga. Revista Municipal. 11. Lisboa: Câmara Municipal de Lisboa, pp. 3-13.

CRUZ, Cristina (2011) - Viver a morte em Portugal: o potencial informativo dos relatórios antropológicos de campo (1994-2007). (Dissertação de Doutoramento) Coimbra: Universidade de Coimbra (policopiado).

CUNHA, Armando; FERREIRA, F. Rodrigues (1998) Vida e Morte na época de D. Afonso Henriques. Lisboa: Hugin Editores.

DELGADO, António (2006) - Estela, escultura e memória. Actas do VIII Congresso Internacional de Estelas Funerárias: Suplemento $n^{\circ} 3$ a O Arqueólogo Português, pp. 515-522.

DIOGO, A. M. Dias; TRINDADE, Laura (1999a) - Estudos Arqueológicos efetuados pelo G.T.T.R.L no Martim Moniz e a sua envolvente. Boletim do grupo "Amigos de Lisboa". II Série. 8, pp. 44-54.

DIOGO, A. M. Dias; TRINDADE, Laura (1999) - Inscrição funerária paleocristã da Rua de São Mamede ao Caldas, em Lisboa. Ficheiro epigráfico. 62, pp. 14-16.

DUDAY,Henri;LEMORT, Françoise; TILLIER, Anne-Marie (2014) - Archaeothanatology and funeral archaeology. Application to the study of primary single burial. Anthropologie. 3, pp. $235-246$.

FABIÃO, Carlos (1994) - Ler as Cidades Antigas: Arqueologia Urbana em Lisboa. Fazer e desfazer a História. 13, pp. 147-161.

FERNANDES, Carla Varela (2002) - Memórias de Pedra. Escultura Tumular Medieval da Sé de Lisboa. Lisboa: Ippar / Soc. Agric. Valle-Flôr/Tribunal Administrativo C

FERNANDES, L.; MARQUES, A.; TORRES, A. (2008) "Ocupação baixo medieval do teatro romano de Lisboa: a propósito de uma estrutura hidráulica, as cerâmicas vidradas e esmaltadas». In MACIAS, S., Coord. - Arqueologia Medieval. 10. Porto/Mértola: Afrontamento, pp. 159-184.

FILIPE, Vanessa; NETO, Nuno; HENRIQUES, José Pedro; BRITO, Sara; TOSO, Alice; CASIMIRO, Sílvia; GRANJA, Raquel; INOCÊNCIO, Joana; FERRO, Sónia (no prelo) - 
Espaços de uma cidade: novos dados sobre a necrópole islâmica de Lisboa Oriental. JORNADAS INTERNACIONAIS TERRA, PEDRAS E CACOS DO GARB AL-ANDALUS (Janeiro de 2020). Palmela.

FILIPE, Vanessa; TOSO, Alice; INOCÊNCIO, Joana (2017) - Perspectivas arqueo-biológicas sobre a necrópole islâmica de Alfama. I Encontro de Arqueologia de Lisboa: Uma Cidade em Escavação. Lisboa: Centro de Arqueologia de Lisboa, pp. 338-347.

GASPAR, Sara (2016) - Estudo dos indicadores de stresse e a sua relação com o contexto nutricional da coleção osteológica não-identificada do Castelo de São Jorge (século XI). (Dissertação de mestrado). Lisboa: Instituto Superior de Ciências Sociais e Políticas da Universidade de Lisboa (policopiado).

GOMES, M. V.; GOMES, R. V. (2006) - Estelas discóides da necrópole da Sé de Silves (Algarve, Portugal). Contexto e cronologia. Actas do VIII Congresso Internacional de Estelas Funerárias: Suplemento $n^{\circ} 3$ de O Arqueólogo Português, pp. 309-330.

GOULÃO, Maria José (1995) - Figuras do além: a escultura e a tumulária. In PEREIRA, Paulo, dir. - História da Arte Portuguesa: Temas e Debates. 2. Lisboa, pp. 157-179.

MALVEIRO, José (2017) - Estelas Funerárias Medievais do Distrito de Beja - Formas, suportes e iconografia. In ARNAUD, José Morais; MARTINS, Andrea, eds. - Arqueologia em Portugal / 2017-Estado da Questão. Lisboa: Associação dos Arqueólogos Portugueses, pp. 979- 986.

MARADO, Luís; FONTES, Luís; ANDRADE, Francisco; PEREIRA, Belisa (2017) - Arqueotanatologia moderna/ contemporânea: práticas funerárias e cronologia relativa no adro da Igreja de Santa Maria dos Anjos, Valença. In ARNAUD, José Morais; MARTINS, Andrea, eds. - Arqueologia em Portugal / 2017 - Estado da Questão. Lisboa: Associação dos Arqueólogos Portugueses, pp. 1925-1932.

MARQUES, António Augusto (2015) - Jarro decorado: Pichel decorado com vieiras e cachos. In TEIXEIRA, A.; VILLADA PAREDES, F.; SILVA, R.B., eds. - Lisboa 1415 Ceuta: História de dos Ciudades. Ceuta: Ciudad Autónoma de Ceuta e Câmara Municipal de Lisboa, pp. 178-18o.

MARQUES, António; BASTOS, Margarida (2017) - Subsídios arqueológicos para a História da Igreja do Convento do Carmo (Lisboa). In ARNAUD, José Morais; MARTINS, Andrea, eds. - Arqueologia em Portugal/2017 - Estado da Questão. Lisboa: Associação dos Arqueólogos Portugueses, pp. 1091-1101.

MATOSO, Inês (2001) - Um apontamento de Tumulária Medieval: O Conjunto da Igreja de São Cristóvão em Lisboa. Arqueologia e História. 53. Lisboa: Associação dos Arqueólogos Portugueses, pp. 75-9o.

MUMFORD, Lewis (1961) - The City in History: Its Origins, Its Transformations, and Its Prospects. Nova Iorque: Harcourt, Brace \& World.
NUNES, Maria Margarida Athaíde (2010) - A morte em Lisboa na Idade Média. Contributo arqueológico (séculos XII a $X V)$. (Dissertação de Doutoramento) Lisboa: Faculdade de Ciências Sociais e Humanas da Universidade Nova de Lisboa (Policopiado).

OLIVEIRA, Filipe; MIGUEZ, João; FURTADO, Catarina; COSTA, Cláudia (2017a) - Caracterização da Ocupação Tardomedieval na Rua da Prata 221-231 e Rua dos Correeiros 158-168, Lisboa. In ARNAUD, José Morais; MARTINS, Andrea, eds. - Arqueologia em Portugal/2017 - Estado da Questão. Lisboa: Associação dos Arqueólogos Portugueses, pp. 1567-1580.

OLIVEIRA, Filipe; SILVA, Rodrigo Banha da; BARGÃO, André; FERREIRA, Sara (2017) - O comércio medieval de cerâmicas importadas em Lisboa: o caso da Rua das Pedras Negras n‥ 21-28. In ARNAUD, José Morais; MARTINS, Andrea, eds. - Arqueologia em Portugal / 2017 - Estado da Questão. Lisboa: Associação dos Arqueólogos Portugueses, pp. 1523-1538.

PEDROSO, Sérgio (2020) - Restos Humanos em Coleções e Museus: questões éticas e Legais: o caso de uma possível comunidade judaica em Alfama. (Trabalho académico realizado no âmbito do Seminário de Mestrado de Arqueologia da Morte). Lisboa: Faculdade de Ciências Sociais e Humanas da Universidade Nova de Lisboa.

PEREIRA, Verónica (2018) - A Espacialidade da Morte na Lisboa Moderna: Contributos para uma Arqueologia Funerária na Igreja de São Lourenço, Mouraria. (Dissertação de Mestrado). Lisboa: Faculdade de Ciências Sociais e Humanas da Universidade Nova de Lisboa (policopiado).

PONCE, Mónica; OLIVEIRA, Filipe; NUNES, Tiago; PINTO, Marina; LOURENÇO, Marina (2017) - O sítio dos Lagares (Lisboa): um espaço pluricultu(r)al. In ARNAUD, José Morais; MARTINS, Andrea, eds. - Arqueologia em Portugal/2017 - Estado da Questão. Lisboa: Associação dos Arqueólogos Portugueses, pp. 1703-1714.

RESENDE, Garcia de (1596) - Chronica que tracta da vida e grandíssimas virtudes [...] de Dom João o Segundo. Lisboa: Casa de Simão Lopez.

RODRIGUES, Jorge (2016) - A Sé de Lisboa, de panteão régio de $\mathrm{D}$. Afonso IV a necrópole de enterramentos privilegiados no final da Idade Média. In MELO, Joana; AFONSO, Luís, eds. - O Fascínio do Gótico. Um tributo a José Custódio Vieira da Silva. Lisboa: Instituto de História da Arte da Faculdade de Letras da Universidade de Lisboa, pp. 33-52.

SEQUEIRA, Matos (1960) - Uma viagem à roda da Praça da Figueira. Revista Municipal. 86. Lisboa: Câmara Municipal de Lisboa.

SERAFIM, Inês (2017) - Análise biocultural de indivíduos exumados do Mosteiro de São Vicente de Fora (Lisboa). (Dissertação de Mestrado). Coimbra: Faculdade de Ciências e Tecnologias da Universidade de Coimbra (policopiado). 
SILVA, André (2019) - As cerâmicas medievais dos antigos Armazéns Sommer, em Lisboa (Sécs. XIII-XIV). (Dissertação de Mestrado). Lisboa: Faculdade de Ciências Sociais e Humanas da Universidade Nova de Lisboa (policopiado).

SILVA, André Martins (2017) - O Convento da Encarnação das Comendadeiras de São Bento de Avis. Cadernos Culturais - Telheiras - Lumiar - Olivais. 2 $2^{\underline{a}}$ Série. 10 (Novembro 2017). Lisboa: Centro Cultural Eça de Queiroz, pp. 17-33.

SILVA, Hélia; LOURENÇO, Tiago (2019) - A Ilha. História e urbanismo do grande quarteirão onde se implantou o Hospital Real de Todos-os-Santos, ao Rossio (1750-1779). Cadernos do arquivo municipal. 2ª̂ série. 11. Lisboa, pp.103-126.

SILVA, Rodrigo Banha da (1999) - Conceções de Arqueologia Urbana em Lisboa. III Colóquio Temático Lisboa - Utopia na viragem do milénio. Lisboa: Fórum Lisboa - Edifício Roma, pp. 229-240.

SILVA, Rodrigo Banha da (2018) - O Convento de São Domingos, em Lisboa, e a leitura arqueológica das suas hortas, entre os séculos XIII e XV. In ANDRADE, Amélia Aguiar; TENTE, Catarina; SILVA, Gonçalo Melo da; PRATA, Sara, eds. - Espaços e poderes na Europa urbana medieval. Castelo de Vide: IEM/FCSH/NOVA, Câmara Municipal de Castelo de Vide (col. Estudos, 18), 2018, pp. 553-569.
SILVA, Rodrigo Banha da; BARGÃO, André; FERREIRA, Sara; TORRES, Joana Bento; TEIXEIRA, André (no prelo) - Um contexto cerâmico da Baixa Idade Média da Rua dos Correeiros (Baixa de Lisboa): revisão crítica dos dados da sondagem 24-1991. Actas do II Encontro de Arqueologia de Lisboa. Lisboa: Centro de Arqueologia de Lisboa, pp. 258-278.

SOARES (2019) - Análise de indivíduos da necrópole medieval-moderna da Igreja Matriz de São Salvador (Sines): raízes africanas entre o povo português. (Dissertação de Mestrado). Coimbra: Universidade de Coimbra (policopiado).

STJERNA, Rita (2017) - Arqueotanatologia e coleções museológicas: estratégias e desafios para o estudo das práticas funerárias do passado. In ARNAUD, José Morais; MARTINS, Andrea, eds. - Arqueologia em Portugal / 2017 - Estado da Questão. Lisboa: Associação dos Arqueólogos Portugueses, pp. 447-459.

VALE, Teresa Leonor M. (2003) - Breve percurso pela tumulária do antigo Convento de S. Domingos de Benfica, Lisboa: abordagem de alguns exemplares relevantes. Olisipo: Boletim do Grupo Amigos de Lisboa. Série 2. 18. Lisboa, pp. 18-30.

VIANA, Abel (1949) - Estelas discóides do Museu de Beja. Arquivo de Beja. VI, pp. 37-85.

\begin{tabular}{|c|c|c|c|c|c|c|c|c|c|}
\hline & & \multicolumn{8}{|c|}{ Produção } \\
\hline Horizonte & U.E. & Bruges & Paris - Rouen & Norte de França muito decorado & Saintonge "mottled" & Saintonge "Plain" & Norte de França? & Valencia & Sevilha \\
\hline I & [019] & 2 & & & & & & & \\
\hline I & [029] & 2 & & & & & & & \\
\hline $\mathrm{I}$ & [035] & 2 & & & & & & & \\
\hline I & [051] & 1 & & 1 & & & & & \\
\hline $\mathrm{I}$ & [053] & 1 & 1 & & & 1 & 2 & 1 & \\
\hline I & [059] & 1 & & & & & & & \\
\hline II & [086] & 8 & 1 & & & & & & 1 \\
\hline IV & [191] & 7 & 2 & & 1 & & 1 & & \\
\hline \multicolumn{2}{|c|}{ Total } & 24 & 4 & 1 & 1 & 1 & 1 & 1 & 1 \\
\hline
\end{tabular}

Tabela 1 - Distribuição dos fragmentos cerâmicos de importação nos horizontes identificados. 


\begin{tabular}{|c|c|c|c|c|c|c|c|c|c|c|}
\hline N. & Designaçào & $\begin{array}{l}\text { Espaço } \\
\text { Urbano }\end{array}$ & CNS & L.A.C. & $\begin{array}{c}N^{*} \text { de } \\
\text { sepulturas }\end{array}$ & Ritual & Zona & $\begin{array}{c}\text { Datacào } \\
\text { Atribuida }\end{array}$ & Observaç̄es & Bibliografia \\
\hline 1 & Igrcja do Santissimo Sacramento & Paroquial & 3503 & 1990 & 2 & Cristato & Nave & năo def. & $\begin{array}{l}\text { Enterramentos praticados sobre fragmentos } \\
\text { de tellha e tijoleira }\end{array}$ & Nuncs, 2010, p.219 \\
\hline 2 & $\begin{array}{l}\text { Igreja de Săo Mamede (Rua de S. Mamede ao } \\
\text { Caldas- VP) }\end{array}$ & Paroquial & 16063 & 1993 & 1 & Cristäo & Adro & XII-XIII & $\begin{array}{l}\text { Enterramento em coval, cobertura pétra, de } \\
\text { elementos arquitetónicos e epigrafico do séc. } \\
\text { VI reaproveitados }\end{array}$ & $\begin{array}{l}\text { Diogo \& Trindade, } \\
\text { 1999; Nunes, 2010, p. } \\
119 \text {. }\end{array}$ \\
\hline 3 & Convento do Salvador & Conventual & 35359 & $1960 ; 2008$ & $>10$ & Cristäo & Nave e Adro & $\begin{array}{l}>\text { XIIII e> } \\
1391\end{array}$ & $\begin{array}{l}\text { Caixa com lípide sepulcral (nave); } \\
\text { enterramentos e ossarios; estelas discoides e } \\
\text { tampa de sarcófago (adro a sul) }\end{array}$ & $\begin{array}{l}\text { Nunes, 2010, p. 262- } \\
263 ; \text { PA }\end{array}$ \\
\hline $4 ; 5$ & $\begin{array}{l}\text { Igreja e Convento de S. Domingos (Largo de S. } \\
\text { Domingos e Praça da Figueira) }\end{array}$ & Conventual & $\begin{array}{l}6187 / 19 \\
25\end{array}$ & $\begin{array}{l}1991 ; 1999- \\
2001\end{array}$ & $>12$ & Cristao & Adro e Cerca & $\begin{array}{l}>1242 \mathrm{e} \\
\mathrm{XV}\end{array}$ & $\begin{array}{l}12 \text { sepulturas em coval, mas com } \\
\text { enterramentos mútliplos (adro); } 10 \text { sepulturas } \\
\text { individuais em coval (cerca) }\end{array}$ & $\begin{array}{l}\text { Diogo e Trindade, } \\
\text { 1999, p.50: Busom, } \\
\text { 2017; Silva, 2018 }\end{array}$ \\
\hline 6 & Largo da Gracáa & Conventual & 36818 & Sem inf. & nào def. & Cristáo & Cerca & XIV? & Fnterramentos em coval & Nunes, 2010, p. 132 \\
\hline 7 & $\begin{array}{l}\text { Praca Nova do Castelo de S. Jorge } \\
\end{array}$ & Almocivar & 1101 & 1997-2007 & 14 & Islâmico & Junto a Mesquita & XII & $\begin{array}{l}\text { Enterramentos em coval, um infantil coberno } \\
\text { por telhas curvas; läpide funcriria inssrita }\end{array}$ & Gaspar, 2016, p. 29 \\
\hline 8 & Castelo de S. Jorge - Palácio das Cozinhas & $\begin{array}{l}\text { Almocávar; } \\
\text { Capela }\end{array}$ & 13306 & 1997-2007 & $20 ; 1$ & $\begin{array}{l}\text { Islâmico } \\
\text { Criståo }\end{array}$ & $\begin{array}{l}\text { Proximidade da Capela de } \\
\text { S. Miguel do Paço Real da } \\
\text { Alcácova }\end{array}$ & $\mathrm{XII} ; \mathrm{XV}$ ? & Enterramentos em coval; estela discóide & Gaspar, 2016, p. 29 \\
\hline 9 & $\begin{array}{l}\text { Castelo de Săo Jorge - Igreja de Santa Cruz } \\
\text { (Largo de Santa Crue) }\end{array}$ & Paroquial & 36195 & 2001 & nào def. & Cristlao & Adro & XII-XVI & Enterramentos em coval; estela discóide & P.A. \\
\hline 10 & Igreja de Såo Martinlıo & Paroquial & 22646 & 2005 & $\begin{array}{l}25 \mathrm{sep} \\
5 \text { oss }\end{array}$ & Cristio & Adro & XII-XVI & Enterramentos intensivos $\mathrm{em}$ coval; ossários & Nunes, 2010, p. 169 \\
\hline 11 & $\begin{array}{l}\text { Igreja de Santa Maria de Alcamim; Salo } \\
\text { Cristovio }\end{array}$ & Paroquial & 22557 & 2004 & 1 & Cristlo & Adro & $>\mathrm{XII}$ & $\begin{array}{l}\text { Enterramento in situ com restos osteológicos } \\
\text { de dois individuos }\end{array}$ & Nunes, 2010, p. 136 \\
\hline 12 & Sé e Cruzes da Sé & Catedral & $\begin{array}{l}3229 ; \\
36271\end{array}$ & c. $1940: 2016$ & $>70$ & Cristao & Adro a sul & $>1 / 2$ XII & $\begin{array}{l}\text { Sarcofagos; estelas discoides; emterramentos } \\
\text { em coval }\end{array}$ & $\begin{array}{l}\text { Boaventura, 2016; } \\
\text { Sousa 1940 }\end{array}$ \\
\hline 13 & Igreja e Convento do Carmo & Conventual & 3996 & $\begin{array}{l}2008 ; 2010- \\
2011\end{array}$ & 41 & Cristlo & Adro a oeste e a sul & $>\mathrm{XV}$ & Enterramentos em coval & $\begin{array}{l}\text { Marquese e Bastos, } \\
\text { 2017,p. } 1091\end{array}$ \\
\hline 14 & Mosteiro de Sảo Vicente & Conventual & 1453 & $\begin{array}{l}\text { 1982: 1987/89; } \\
\text { 1992; 1993/94; } \\
1997\end{array}$ & $\begin{array}{l}\text { 14: } \\
2 ; 9 ; 9 ; 2 ; 1\end{array}$ & Cristäo & $\begin{array}{l}\text { Ossário; Cerca } \\
\text { Conventual, Sacrário }\end{array}$ & $>\mathrm{XII}$ & Ossário, enterramentos $\mathrm{em}$ coval & $\begin{array}{l}\text { Cunha \& Ferreira, } \\
\text { 1998; Serafim, 2017; } \\
\text { Nunes, 2010, pp. } 148 \text {. } \\
159\end{array}$ \\
\hline 15 & Judiaria Pequena - Rua de S. Miguel, Alfama & ? & nào def. & $2005-2006$ & $>5$ & Judaico? & Proximidade da Sinagoga & XIII-XV & $\begin{array}{l}\text { Coval, com nivel de carneiro e uma sepultura } \\
\text { de inumaçâ }\end{array}$ & Pedroso, 2020 \\
\hline 16 & "Almocávar Grande" (Rua dos Lagares n $\left.n^{\circ} 74\right)$ & Almocávar & 36216 & $2015 / 2015$ & 335 & \begin{tabular}{|l|} 
Islâmico \\
Judaico
\end{tabular} & $\begin{array}{l}\text { Meia encosta do Monte de } \\
\text { S. Gens }\end{array}$ & $\begin{array}{l}\mathrm{XVI} \mathrm{e}^{<} \\
\mathrm{XVI}\end{array}$ & $\begin{array}{l}\text { fases distintas - islâmica do século XVI e } \\
\text { judaica }\end{array}$ & $\begin{array}{l}\text { Ponce \& alti, 2017, } \\
\text { p. } 1703-1703\end{array}$ \\
\hline 17 & $\begin{array}{l}\text { Rua dos Lagares } n^{\circ} 24 \text { - Necróppole do } \\
\text { Ouarteirấo dos Lagares }\end{array}$ & Almocívar & 35576 & 2013 & 7 & Islâmico & $\begin{array}{l}\text { Meia encosta do Monte de } \\
\text { S. Gens }\end{array}$ & nảo def. & Enterramentos em coval & PA \\
\hline 18 & Almocávar (Palácio de Santa Helena) & Almocávar & 36335 & 2016 & 19 & Islâmico & Morro a oriente de Alfarna & $\begin{array}{l}<\text { fim do } \\
\text { XIII }\end{array}$ & Enterramentos em coval & $\begin{array}{l}\text { Batalha \& alii, } 2017 . \\
\text { p.1752 }\end{array}$ \\
\hline 19 & Almocávar (Largo de Santa Marinha) & Almocivar & 35347 & $2018-2019$ & $>10$ & Islâmico & $\begin{array}{l}\text { Encosta do morro a oriente } \\
\text { de Alfama }\end{array}$ & $<\mathrm{XII}$ & Enterramentos em coval; ossário & Filipe \& alii, no prelo \\
\hline 20 & Igreja de São Lourenço & Paroquial & 13789 & 199293: & $>39$ & Cristao & $\begin{array}{l}\text { Nave; Capela gótica; } \\
\text { Antiga casa do guarda }\end{array}$ & $>$ XIII & Enterramentos em coval: ossários: & $\begin{array}{l}\text { Nuncs, } 2010 \text {, pp. } 172 \text { - } \\
174\end{array}$ \\
\hline 21 & Calçadinha do Tijolo in $37-43$ & Almocivar & 35347 & 2014 & 5 & Islâmico & Merro a oriente de Alfarma & $<\mathrm{XIII}$ & Enterramentos em coval & $\begin{array}{l}\text { Filipe \& a alii, 2017, } \\
\text { pp.338 - 347? }\end{array}$ \\
\hline
\end{tabular}

Tabela 2 - Compilação de contextos funerários medievais identificados e intervencionados arqueologicamente em Lisboa.

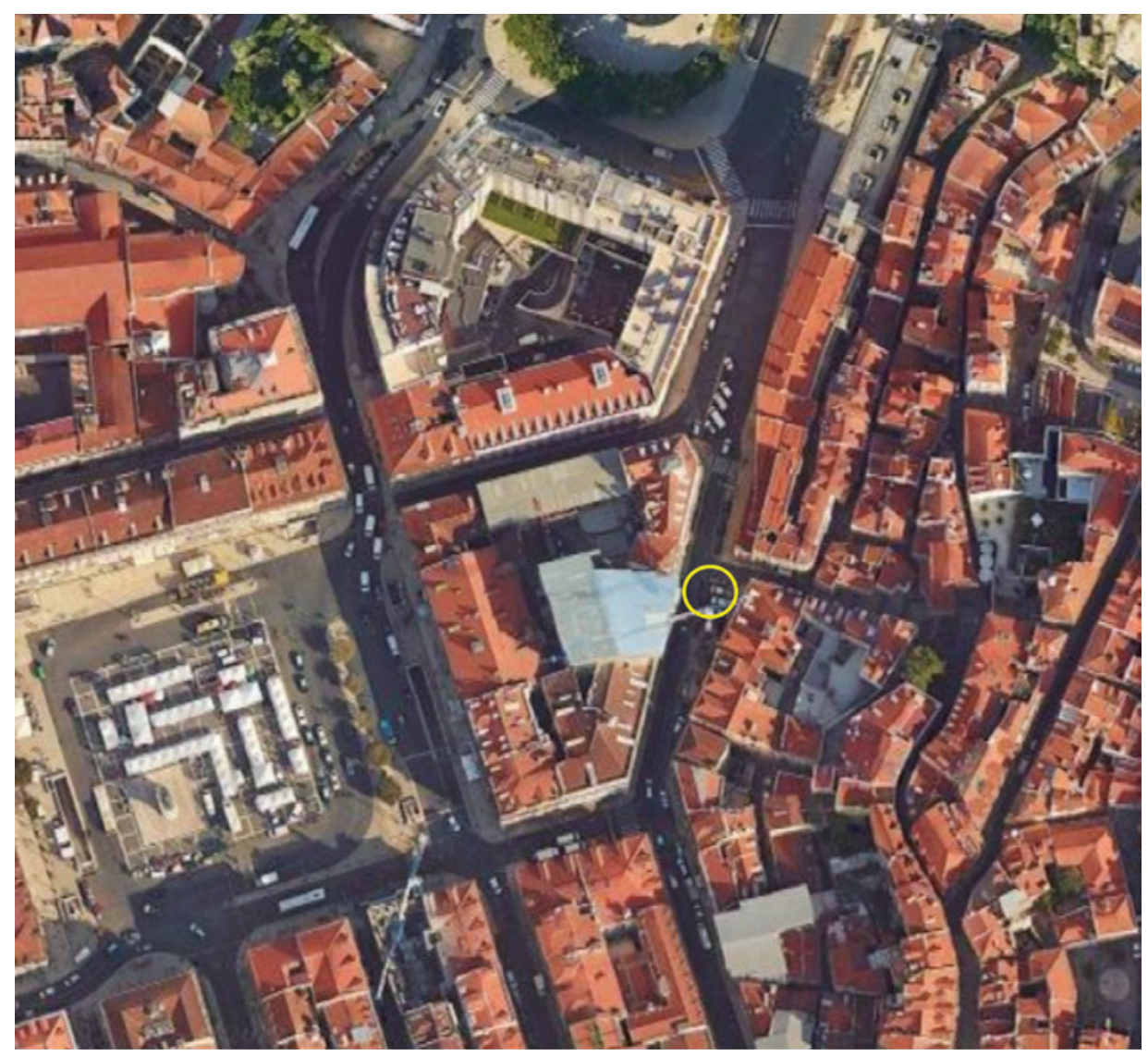

Figura 1 - Localização da intervenção arqueológica no Poço do Borratém. Fonte: Google Maps. 


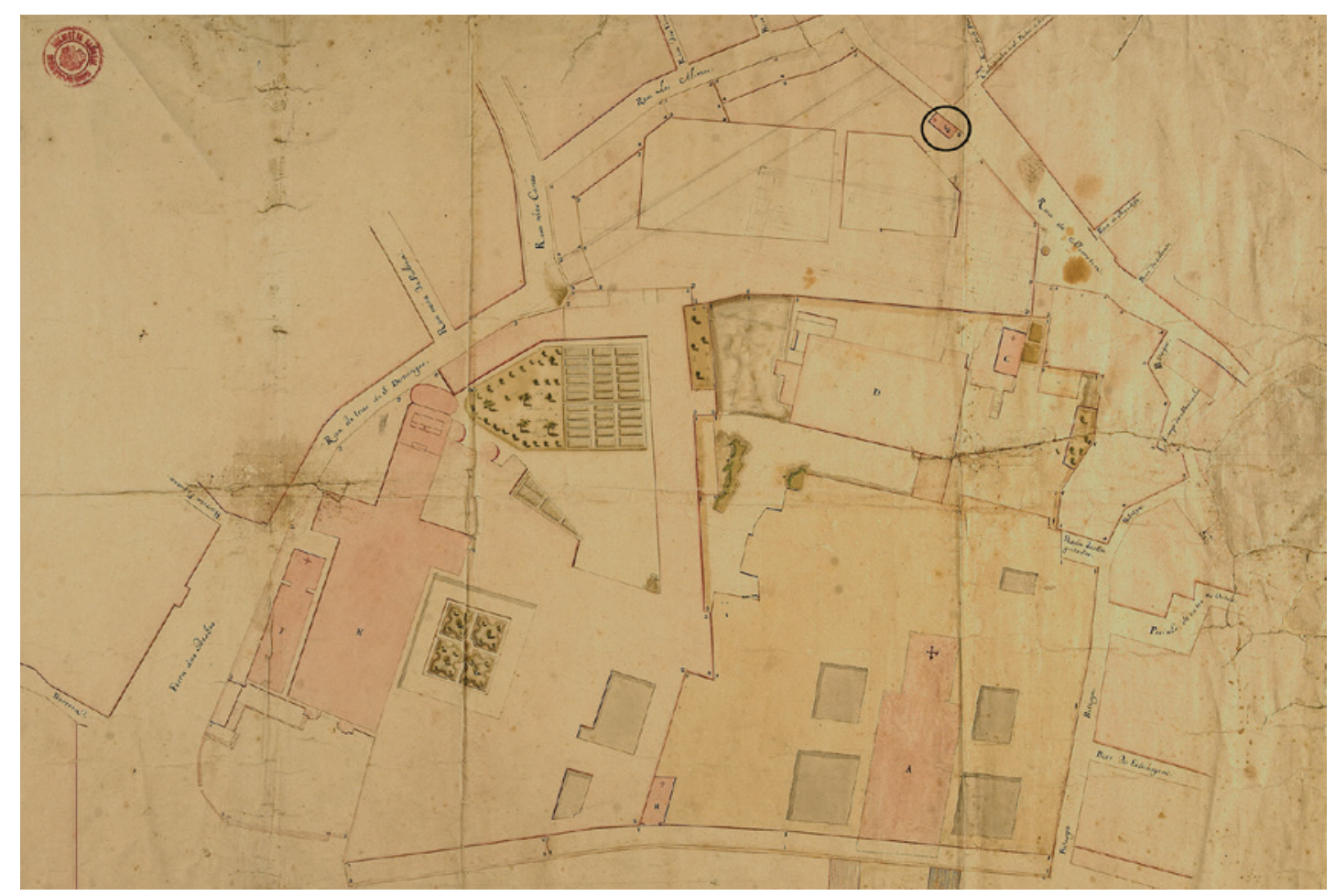

Figura 2 - Localização da Ermida de São Mateus na Planta Topográfica que compreende a Ilha em que estava edificado o Hospital Real de Todos os Santos do Ill.Mo e Exm.o Marquês de Cascaes, Guilherme J. Paes de Menezes e Tomás Roiz da Costa, 175o. Disponível em Biblioteca Nacional Digital [http://purl. pt/22488. Data da consulta: 07/2020].

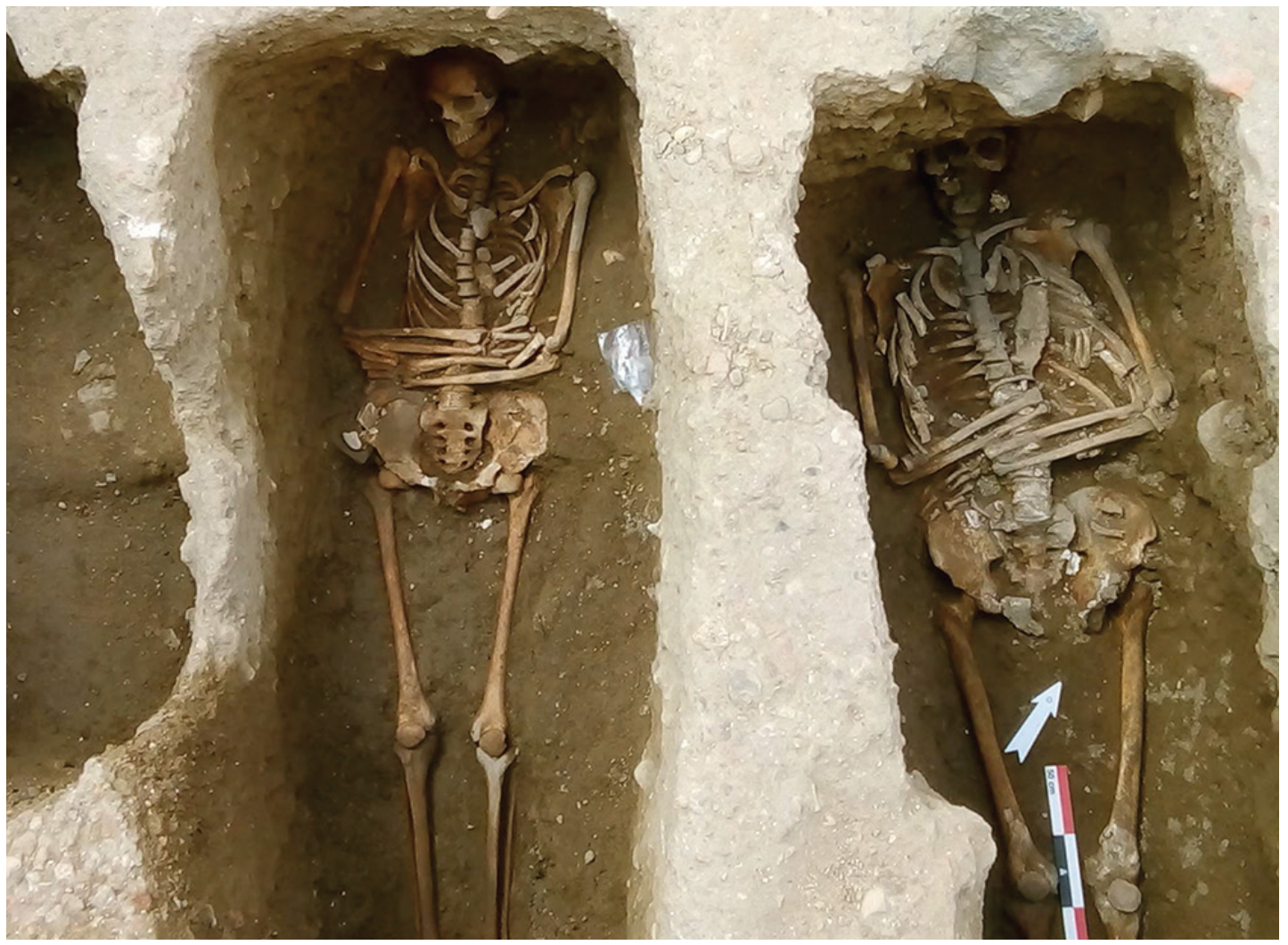

Figura 3 - Vista de um segmento do primeiro horizonte de enterramentos identificado. 


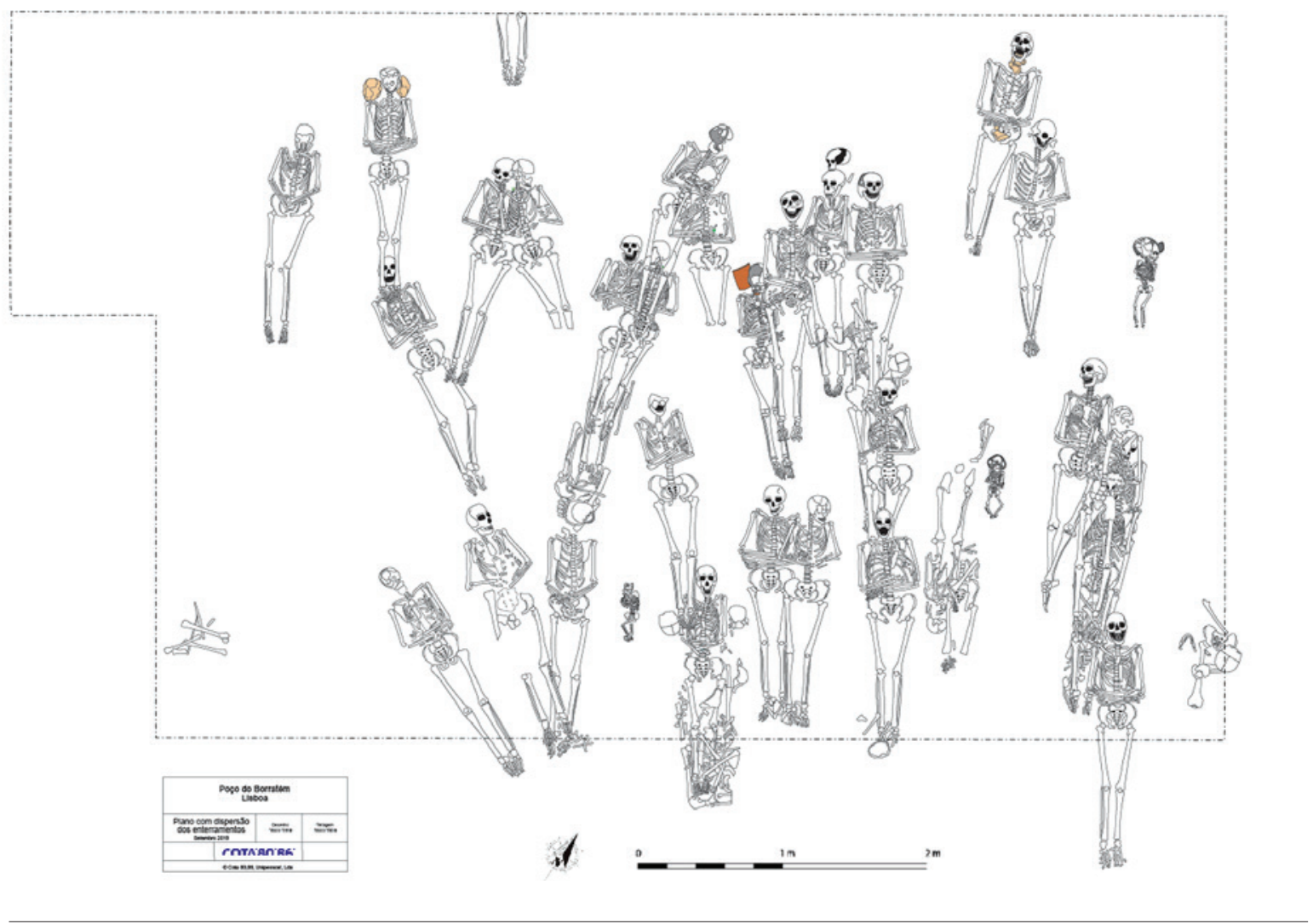

Figura 4 - Planta da distribuição dos enterramentos identificados no Poço do Borratém.

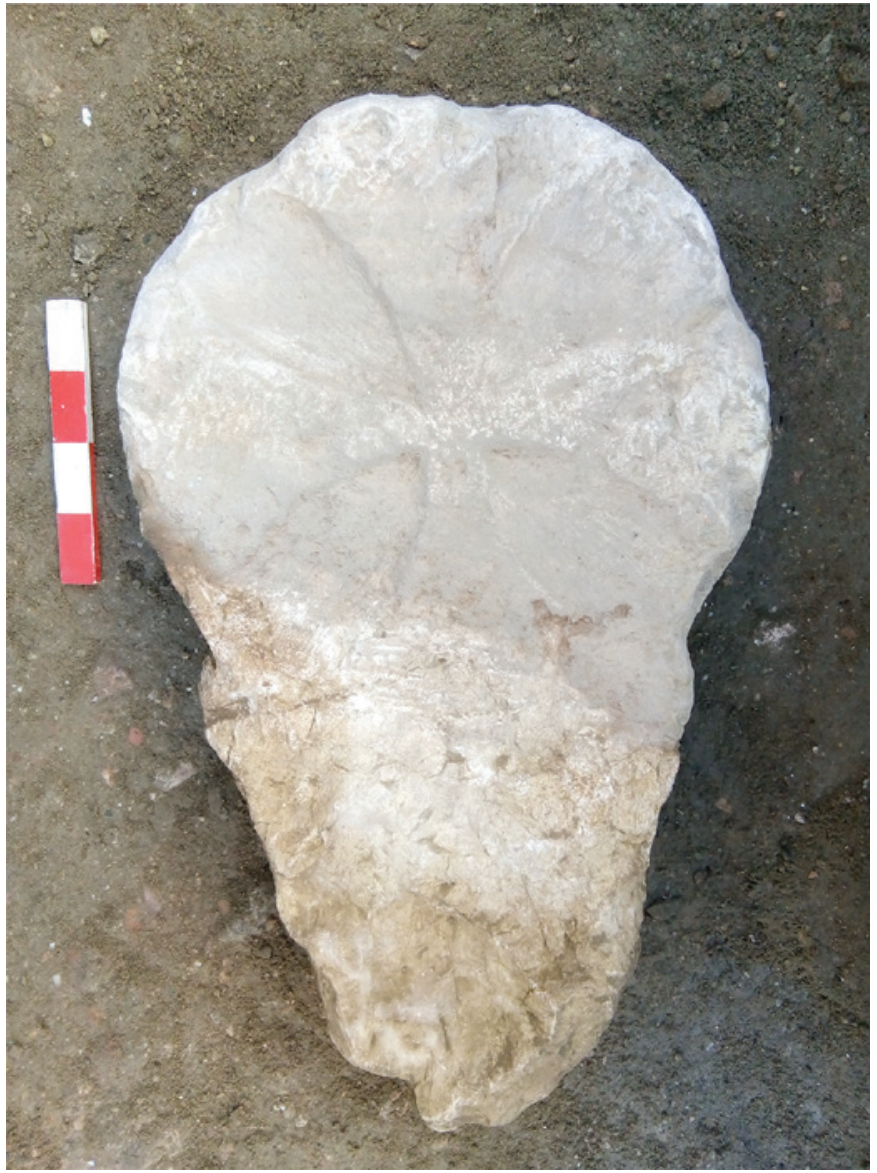

Figura 5 - Estela discoide identificada na intervenção arqueológica do Poço do Borratém. 


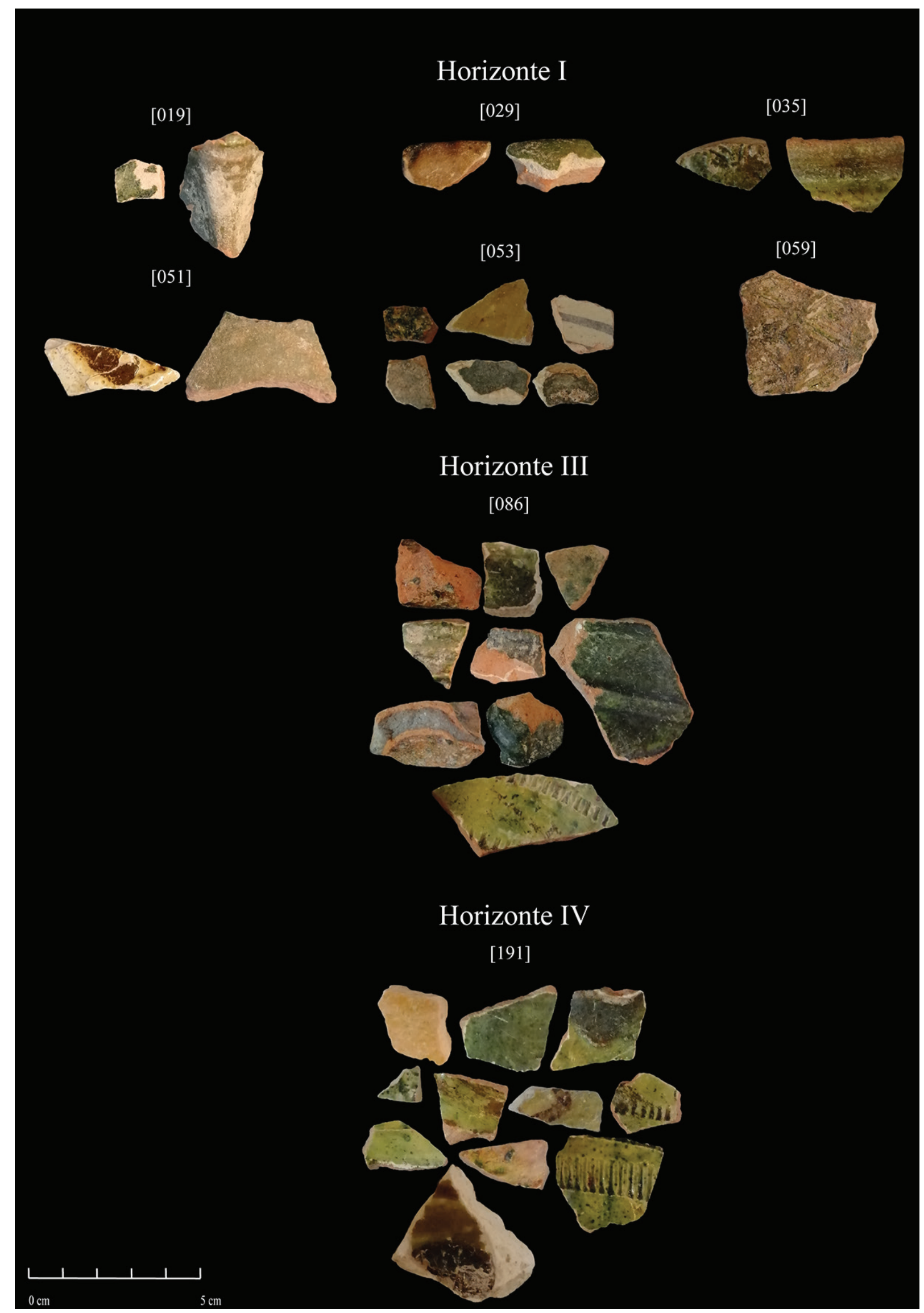

Figura 6 - Estampa dos fragmentos cerâmicos de importação exumados de três dos quatro horizontes de enterramentos identificados no Poço do Borratém. 


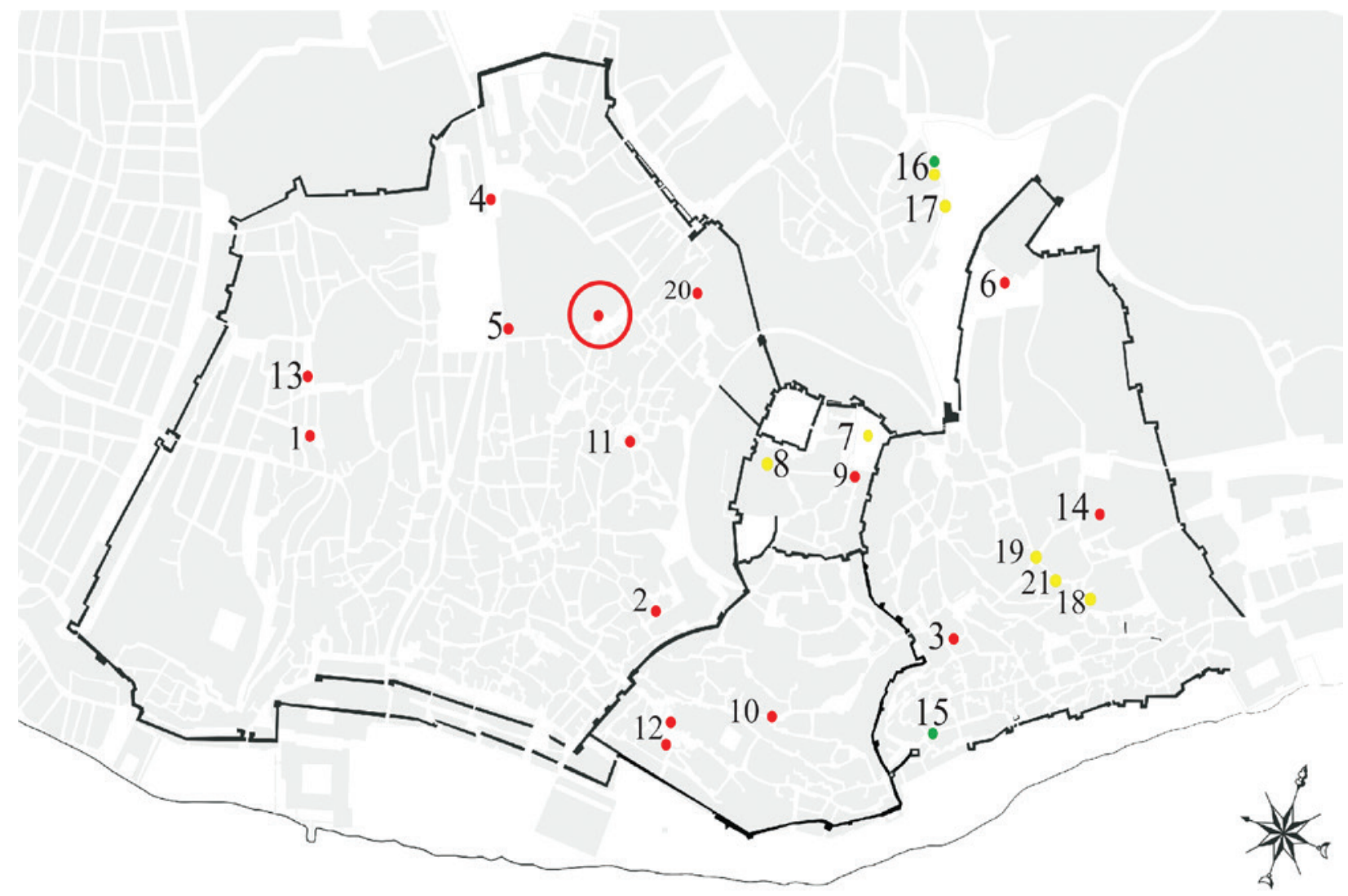

Legenda:

- Ritual Cristão

Ritual Islâmico

- Ritual Judaico ?

- Espaço funerário do Poço do Borratém

1- Igreja do Santíssimo Sacramento

2- Igreja de São Mamede (Rua de S.Mamede ao Caldas- VP)

3- Convento do Salvador

4- Igreja e Convento de S.Domingos (Largo de S.Domingos)

5- Praça da Figueira

6- Largo da Graça

7- Castelo de São Jorge - Praça Nova

8- Castelo de São Jorge - Palácio das Cozinhas

9- Castelo de São Jorge - Igreja de Santa Cruz (Largo de Santa Cruz)

10- Igreja de São Martinho
11- Igreja de Santa Maria de Alcamim (Igreja de São Cristóvão)

12- Sé e Cruzes da Sé

13- Igreja e Convento do Carmo

14- Mosteiro de São Vicente de Fora

15- Judiaria Pequena - Rua de S. Miguel, Alfama

16- "Almocávar Grande" (Rua dos Lagares n ${ }^{\circ} 74$ )

17- Rua dos Lagares n ${ }^{\circ} 24$

(Necrópole do Quarteirão dos Lagares)

18- Almocávar (Palácio de Santa Helena)

19- Almocávar (Largo de Santa Marinha)

20- Igreja de São Lourenço

21- Calçadinha do Tijolo n 37 - 43

Figura 7 - Dispersão dos contextos funerários intervencionados arqueologicamente na planta de Lisboa Medieval. 


\title{
UM ESPAÇO FUNERÁRIO CONVENTUAL DO SÉC. XV EM LISBOA: O CASO DO CON- VENTO DE SÃO DOMINGOS DA CIDADE
}

\author{
Sérgio Pedroso ${ }^{1}$, Sílvia Casimiro ${ }^{2}$, Rodrigo Banha da Silva ${ }^{3}$, Francisca Alves Cardoso 4
}

\begin{abstract}
RESUMO
A intervenção arqueológica da Praça da Figueira, em Lisboa, foi executada entre 1999 e 2001, tendo correspondido a uma acção reativa a um plano municipal de reabilitação e revitalização do espaço público. O conhecimento sobre a fisionomia da área na Baixa Idade Média encontrava-se mal-esclarecido, embora diversa documentação coeva garantisse que correspondia, na maior parte da área escavada, às antigas Hortas do Convento de São Domingos da Cidade, fundado em 1242, e sobre as quais se ergueria a partir de 1492 o Hospital Real de Todos-Os-Santos.

Neste contexto, no ângulo SO da intervenção arqueológica, reconheceu-se uma area murada à qual foi dada uso funerário, e onde foram identificadas oito sepulturas praticadas em covacho sugerindo uma regular gestão do espaço.

Palavras-Chave: Lisboa Medieval, Arqueologia da Morte, Espaços funerários, Arqueologia Conventual, Ordem dos Pregadores.

ABSTRACT

In 1999-2001, an archaeological excavation took place at Praça da Figueira (Lisbon), in response to a municipal plan for the rehabilitation and revitalization of public space. The knowledge about the physiognomy of the area in Late Middle Ages was poorly understood, although several coeval documents ensured it corresponded in most of the area excavated to the vegetable gardens area of the Dominican Convent, founded in the 1242, and on which it would rise, from 1492, the Royal Hospital of All Saints.

It is in this context that a medieval enclosed area was recognized, which in the $15^{\text {th }}$ century, was used for funerary practice. Eight shallow graves were identified, in a framework that suggests a regular spatial management. Keywords: Medieval Lisbon, Archaeology of Death, Burial Ground, Conventual Archaeology, Dominican Order.
\end{abstract}

\section{INTRODUÇÃO}

A Praça da Figueira é um ponto arqueológico de extrema importância para o conhecimento das antigas ocupações de Lisboa, devido à grande quantidade de informação histórico-arqueológica que gera desde a segunda metade do século XX. São em Lisboa mar- cantes os trabalhos da Conservadora de Museus Irisalva Moita, desenvolvidos entre 1960 e 1962, onde hoje se situa a estação do metropolitano do Rossio. Foi aqui que, devido ao seu "acompanhamento" e ulterior escavação, conduzida entre Agosto e Setembro de 1960, se encontraram estruturas pertencentes ao Hospital Real de Todos-os-Santos, anexos do

1. NOVA FCSH, Faculdade de Ciências Sociais e Humanas, Mestrando em Arqueologia; sergiopedroso1998@gmail.com.

2. LABOH, Laboratório de Antropologia Biológica e Osteologia Humana, CRIA, Centro em Rede de Investigação em Antropologia / IEM, Instituto de Estudos Medievais, NOVA FCSH, Faculdade de Ciências Sociais e Humanas, Universidade Nova de Lisboa; scasimiro@fcsh.unl.pt.

3. CAL, Centro de Arqueologia de Lisboa - Câmara Municipal de Lisboa; CHAM, Centro de Humanidades, NOVA FCSH; Departamento de História da NOVA FSCH; rodrigo.banha@cm-lisboa.pt.

4. LABOH, Laboratório de Antropologia Biológica e Osteologia Humana, CRIA, Centro em Rede de Investigação em Antropologia, NOVA FCSH, Faculdade de Ciências Sociais e Humanas, Universidade Nova de Lisboa; Cranfield Defense \& Security, Cranfield University, Reino Unido; francicard@fcsh.unl.pt. 
Convento de São Domingos da Cidade, o Cano Real de São Domingos (Silva, 2005) e se detetou parte de uma necrópole Romana, cuja existência já era antes sugerida por outros pontos arqueológicos próximos (Silva, 2005, p. 3).

Antes das ações de Moita, todavia, já em 1953 o olisipógrafo Gustavo de Matos Sequeira havia posto a descoberto restos da escadaria frontal da Igreja do Hospital Real de Todos-os-Santos no subsolo do estabelecimento comercial "Irmãos Unidos", ainda em considerável bom estado de conservação. Esta descoberta foi notoriamente noticiada na imprensa e alvo de visitas, incluindo a da própria investigadora do Museu da Cidade (Bargão, Ferreira \& Silva, no prelo). Não espanta, deste modo, que em 1960 o andamento das obras do metropolitano na Praça da Figueira tenha sido acompanhado por Moita, que é quem ali despoleta e conduz a primeira grande escavação arqueológica de contextos de Época Moderna em Portugal (Bargão, Ferreira \& Silva, no prelo). Porém, entre a exumação dos restos com aquela cronologia e a deteção dos achados romanos no subsolo, encontrados a muito maior profundidade já em meados de 1961, nada foi registado para as ocupações da Idade Média, que deste modo compuseram um completo vazio de conhecimento arqueológico (Silva, 2011, 2012, 2018).

Em sentido diverso, as únicas referências textuais minimamente discriminatórias relativas às Hortas de São Domingos reportam-se ao instrumento do escambo efetuado já por D. Manuel em 1502 (recorde-se que as obras se iniciaram em 1492 pela mão de D. João II), que explicitamente refere que "(...) fazemos saber que ouvemos do moesteyro de Sam Domingos desta cidade toda a orta e huum celeyro com sua manga que ho dito moesteiro tinha hy jumto pera se no chãao da dicta orta celeyro e manga aver de fazer o espital de Todollos Sanctos (...)"5, ou a descrição e condições de salubridade do terreno prévias e do próprio edifício conventual no século XIII, mencionando a ereção posterior de um muro de cerca, produzida muito mais tardiamente por Fr. Luís de Sousa, na segunda metade do séc. XVI (Sousa \& Cacegas, 1767, pp. 315-318). Como se conclui, o laconismo da documentação medieval e moderna

5. Transcrito de "Carta de D. Manuel sobre a doação por escambo da cerca do Convento de S. Domingos”, 22 Agosto 1502. ANTT, Registo de Escrituras do reinado de D. Manuel I, Liv. 1134, fl.1-2v. [Arquivo Nacional Torre do Tombo]. citada, de forma alguma permitia entrever a densidade de dois séculos e meio de uso do espaço pelos frades dominicanos.

Perante este panorama, a intervenção arqueológica desenvolvida na Praça da Figueira entre 1999 e 2001 representou a primeira ocasião em que se conheceram os vestígios materiais das ocupações medievais no seu todo e em toda a sua riqueza informativa, o que incluiu uma estrada muçulmana, mais de uma dezena de habitações e os quatro arruamentos respetivos de uma secção de um bairro arrabaldino da cidade islâmica (Silva, Gomes \& Gomes, 2011, pp. 19-22; Silva, 2012), vestígios das ocupações da segunda metade do séc. XII e primeira metade do século XIII e, por fim, as dinâmicas correspondentes à Corredoura medieval (que sucedeu no mesmo local à anterior estrada muçulmana (Silva, 2012, p. 141), às parcelas suburbanas setentrionais da antiga Rua da Betesga e, claro está, dos cerca de dois séculos e meio de utilização do terreno das Hortas de São Domingos (Lourinho, 1972, p. 32; Moita, 1994, p. 119; Silva, 2012, p. 10, 2018).

\section{MATERIAIS E MÉTODOS}

Com base nos registos de campo (descritivos, gráficos e estratigráficos), realizou-se uma análise do espaço funerário, considerando-se aspetos como a sua organização, o tipo de inumação, o modo de deposição, a orientação, a tipologia das sepulturas. A amostra osteológica associada a este contexto foi já alvo de estudo, pelo que consequentemente os dados relativos ao perfil biológico aqui apresentados estão de acordo com os da autora (Busom, 2017). No presente trabalho somente os dados referentes ao perfil biológico (e.g. idade à morte e diagnose sexual) são utilizados. A metodologia de análise utilizada pela autora na inferência destes parâmetros biológicos, obedeceu a métodos amplamente utilizados, com foco na análise morfológica dos vários elementos ósseos do esqueleto e níveis de desenvolvimento e maturação óssea (Busom, 2017). Aos indivíduos considerados como "não-adultos" não foi realizada a diagnose sexual, uma vez que dimorfismo sexual é ainda incipiente, e os métodos existentes têm associado um erro significativo ao nível do diagnóstico. $\mathrm{Na}$ apresentação da estimativa da idade à morte será introduzida uma ligeira alteração, relativamente à abordagem apresentada por Busom (2017), na apresentação dos resultados: as classifica- 
ções etárias serão qualitativas, ao invés de quantitativas, procurando assim minimizar-se o erro interpretativo de atribuição de uma cronologia etária com base em alterações ósseas, e fases de maturação e desenvolvimento.

Consequentemente, os indivíduos serão classificados de "não adultos", "adolescentes" e "adultos" contrariamente à classificação cronológica apresentada por Busom (2017). Os esqueletos classificados como sendo de indivíduos "adolescentes" compreendem intervalos etários entre os 11 anos e 18 anos. As questões associadas aos limites interpretativos da inferência do perfil biológico em material ósseo, assim como a reavaliação dos elementos ósseos desta amostra, serão exploradas no âmbito de dissertação de mestrado atualmente em desenvolvimento por um dos autores (S.P.).

\section{O ESPAÇO FUNERÁRIO DA PRAÇA DA FIGUEIRA}

O espaço funerário medieval identificado na intervenção da Praça da Figueira em 1999-2001 situava-se na área inserida nas quadrículas Cio e Ci1, localizadas no exterior do futuro parqueamento automóvel subterrâneo, no ângulo SO da escavação (Silva, 2018 e Figura 1).

Porque situado a uma cota inferior à da fachada do Hospital Real de Todos-os-Santos, esta localização fixa-lhe desde logo um intervalo cronológico superior, considerando aqui que os trabalhos de edificação se desenvolveram a partir de finais do séc. XV, segundo o testemunho produzido em 1545 por Garcia de Resende: "(...) no anno de mil e quatrocentose noventa e dous a quyinze dias do mes de Mayo mandou el-rey [D. João II] perante si fundar e começar os primeiros aliceces do esprital grande de Lixboa da invocaçam de Todolos Sanctos na maneira en que ora está feito, o qual lugar era horta do Moesteiro de Sam Domingos. E nos primeyros aliceces el-rey por sua mão por honrra de tam sancto, tam grande, e tam piadoso edeficio, lançou muytas moedas d'ouro. E esse dia andou todo ahi vendo como se começava e comeo em casa do Conde de Monsanto que he pegada com a horta do dito esprital" (Resende, 1597, cap. CXL).

A documentação histórica é omissa a respeito de edifícios sacros na área precisa onde se revelou o núcleo funerário. A norte da Igreja de São Domingos, fundada em 1242, mas concluída mais tarde, somente no reinado de D. Afonso III, encontrava-se a Ermida de Nossa Senhora da Escada ou de Nossa Senhora da Purificação (Lourinho, 1971, pp. 121-123; 1972, p. 33). Apesar de não existir documentação que date a implementação e construção desta Ermi$\mathrm{da}$, pensa-se que a sua fundação se deva ao primeiro bispo de Lisboa, D. Gilberto de Hastings (Lourinho, 1972, p. 36), pelo que já estaria em funcionamento antes da criação do edifício conventual dominicano (Marado, 2018, p. 65). As referências são, todavia, difusas e discordantes, aventando-se em contrapartida a hipótese da sua trasladação de um local próximo (possivelmente, do Alto da Corredoura) cerca do ano de 1300, altura em que é transportado para a vizinhança do templo dedicado a São Domingos (Lourinho, 1972, pp. 38-39). Ora, não só a cronologia do contexto arqueológico que aqui tratamos é discordante de qualquer destas realidades, por bem mais tardia, como a sua correspondência com a hipotética primeira localização da Ermida é desadequada em face da menção geográfica específica ao "Alto", o que está em desacordo com o que se pode intuir da paleotopografia da Praça da Figueira entre os séculos XII e XV.

A explicação para a presença dos sepultamentos exumados em 2001 terá, por conseguinte, de ser diretamente relacionada com as dinâmicas do complexo conventual dominicano, e terá que se considerar estar omissa das fontes escritas conhecidas até ao momento, o que, se por um lado lhe aumenta o interesse, não deixa, em contrapartida, de por isso colocar compreensíveis limitações.

\section{DADOS CONTEXTUAIS}

A área escavada em C1o/11 equivaleu a um polígono irregular destinado ao acesso pedonal do futuro parqueamento subterrâneo, estando localizado no exterior deste. Previamente à escavação arqueológica foram implantadas as paredes perimetrais de contenção em betão que seccionaram o espaço, naturalmente perturbando os contextos arqueológicos.

Merece especial menção a presença do espesso muro [7016] a Oeste, edificado em forte alvenaria de argamassa rica em cal e ao qual se encontrava adossado, na extremidade NO da zona escavada, uma cantaria oitavada, gótica, muito provavelmente equivalente à ombreira de um vão. $\mathrm{O}$ topo conservado do muro situava-se à cota $7,83 \mathrm{~m}$, tendo o restante da superestrutura sido desmantelado pelos trabalhos de aterro e preparação para a construção do Hospital 
Real de Todos-os-Santos, como antes vimos ocorridos a partir de 1492, bem como sido colmatado pela sua face interna por sucessivos depósitos e uma estrutura negativa (lixeira? [7113]) com destaque para um primeiro depósito [7107], mais espesso, que compõe a sequência (Figuras 2-3).

O lado interior (oriental, orientado para o interior das Hortas de São Domingos), estava apenas rebocado e, ao nível da sua base, próxima dos 6,90 $\mathrm{m}$ de cota absoluta, um aglomerado de pedra de pequena dimensão é relacionável com a ação da sua instalação. Um depósito [7115] foi violado pela abertura dos covachos destinados ao uso funerário e sobrepõe-se ao nível de instalação do muro [7016], pelo que necessariamente as sepulturas lhes serão posteriores. As características construtivas do muro, a despeito da sua maior espessura, são similares às apresentadas pelos restantes muros da cerca conventual identificados, incluindo aqui os muros da manga e os de dois poços hidráulicos ovais, qualquer deles exumados no interior do espaço das hortas (Silva, 2012, p. 5 ; 2018). As estruturas mencionadas, já antes divulgadas, encerram uma cronologia do século XV, que o tipo e exiguidade de "materiais datantes" não permite melhor precisar (Silva, 2018).

Fora do sector que vimos descrevendo, em B6/7, sob as potentes infraestruturas de assentamento da monumental escadaria de acesso à Igreja de Todos-os-Santos, já manuelina e dos últimos anos do século $\mathrm{XV} /$ primeiros do séc. XVI, haviam sido também detetados em 2000 pela intervenção arqueológica da Praça da Figueira. Aqui se somam vestígios de mais duas sepulturas, destruídas quase por completo no decorrer das obras de parqueamento de $1999 \mathrm{e}$ 2001, e na obra de D. Manuel. A cota aproximada era similar à que vimos tratando e permite integrá-las numa mesma realidade, muito embora o espólio osteológico seja claramente insuficiente para a caracterização dos dois indivíduos inumados.

A importância destes vestígios tornados discretos é, todavia, fundamental, por permitir entrever a existência de um uso funerário do espaço ao longo de, pelo menos, $27 \mathrm{~m}$ de extensão, encostados aos limites ocidentais da propriedade conventual. Deverá assinalar-se que de acordo com as observações arqueológicas da escavação, o uso funerário está completamente ausente dos restantes mais de $25 \mathrm{~m}$ que se reconheceram próximo da zona da cerca conventual mais a norte (Silva, 2018, fig. 2).

Retornando à área de C1o/11, e abaixo do nível das sepulturas, foi detetado um piso empedrado com fiada de limitação bem definida pelo lado oeste [7045], já recoberto por depósitos, situado à cota $6,85-6,88 \mathrm{~m}$. O piso estava ligeiramente sobrelevado em relação ao terreno imediatamente confinante para Oeste (já o nível do solo do Rossio medieval), situado cerca de $10 \mathrm{~cm}$ abaixo. Esta estrutura equivale, sem grandes reservas, a uma parcela da estrada nomeada na documentação medieva como "Corredoura": trata-se de um dos principais itinerários de entrada-saída da cidade de Lisboa, cuja origem mais remota se encontra nos inícios do Alto Império Romano, mas que com a feição medieval se fixou somente nos finais do século XI, durante o período de domínio islâmico de Lisboa (Silva, 2012) (Figura 4). A edificação do Hospital Real absorveria urbanisticamente o troço de passagem da Corredoura no Rossio, incorporando-o sob as 35 arcadas do pórtico manuelino da fachada do complexo do Hospital-Convento de São Domingos, numa intenção de aformoseamento do Rossio que, apesar da sua linhagem estética gótica, encerra claro sabor renascentista, desenhando uma fachada para a cidade naquela que foi, afinal, a sua primeira praça propriamente dita.

\section{A ORGANIZAÇÃO DO ESPAÇO FUNERÁRIO}

Os contextos funerários em análise equivalem a oito unidades estratigráficas negativas -U.E.s [7019], [7020], [7021], [7022], [7023], [7024], [7036], [7039] e [7128]. Nelas se assinalou material biológico humano (i.e., esqueletos em articulação e ossos dispersos) à exceção de [7021], onde estes estavam ausentes. Em todas as sepulturas a orientação é, grosso modo, oeste-este (na realidade em torno dos $19^{\circ} \mathrm{NO}$ ), o que não se distancia muito de uma orientação "canónica" (Figura 5).

As sepulturas caracterizavam-se como sendo covachos ovalados, com dimensões bastante variáveis, medindo entre $1 \mathrm{~m}$ e 1,90 $\mathrm{m}$ de comprimento máximo, não considerando aqui as sepulturas [7029] e [7041], cortadas pela construção das paredes de contenção em betão, preservando c, $90 \mathrm{~cm}$ e de $\mathrm{c} .70 \mathrm{~cm}$ de comprimento preservado, respetivamente. As dimensões dos eixos maiores dos covachos detêm uma relação direta com as dimensões dos inumados correspondentes, o que sugere a sua abertura num momento que pouco antecedeu a deposição do defunto. A profundidade total dos covachos situar-se- 
-ia em torno dos $60 \mathrm{~cm}$, embora com uma ligeira variação entre elas, com a mais profunda ([7021]) à cota $6,88 \mathrm{~m}$, e a mais superficial ([7026]) situada nos 7,02 $\mathrm{cm}$. Apesar do especto relativamente regular do espaço fúnebre, o distanciamento lateral entre sepulturas era também variável, entre os $10 \mathrm{~cm}$ e os $65 \mathrm{~cm}$. A despeito da exiguidade da área intervencionada, é fácil perceber-se a articulação da disposição dos covachos em respeito ao muro [7016], que supomos representar um limite da propriedade dominicana no séc. XV. Deste modo, parece existir um primeiro alinhamento a oeste, a que correspondem oito sepulturas, não se podendo afirmar categoricamente a existência de um segundo alinhamento para leste, dado estar somente representado por uma única sepultura; convém ter presente, em sentido inverso, que a instalação em 1999 dos muros de contenção da obra do parqueamento, poderão ter obliterado por completo as hipotéticas outras sepulturas de uma segunda fiada, caso estas se encontrassem um pouco mais para leste. Certo é, que mais para o interior do espaço medievo das Hortas de São Domingos (para leste) não se documentou qualquer uso funerário, pelo que se define assim in absentia a extensão deste. Em todo o caso, a disposição relativamente regular dos sepultamentos, como a inexistência de cerceamentos pela abertura de covachos mais recentes sugere uma efetiva e cuidadosa gestão do espaço funerário que, sublinhe-se, foi destinado a inumações individuais primárias. Este último aspeto assume alguma relevância se se comparar o caso em estudo com o identificado próximo, no adro da Igreja de São Domingos, em escavações dirigidas por Dias Diogo em 1991, onde foram identificadas sepulturas múltiplas, com dois a quatro indivíduos (Trindade \& Diogo, 2000, p. 6o; Trindade et alii, 2001, p. 109). Deverá assinalar-se, também, que ao nível da visibilidade externa das sepulturas, i.e., ao nível do solo coevo, nenhuma evidência arqueológica foi reconhecida, quer direta, quer relacionável. Os tipos de sinalização à superfície, de sepulturas individuais em covachos datados da Baixa Idade Média mais conhecidos arqueologicamente para na região equivalem à utilização de estelas (Oliveira, 2006, p. 217), de elementos pétreos nas suas muito variadas configurações, ou de um e outro combinados. A despeito dos tipos regionais identificados, de que se poderiam citar os exemplos coevos de Arruda dos Vinhos (Antunes-Ferreira, Cardoso \& Santos, 2013, p. 1113) ou São Miguel de Odrinhas (Coelho,
2006-2007, pp. 128-130), poder-se-á considerar alternativamente, a utilização de materiais perecíveis, mas é matéria que coloca especiais dificuldades de rastreamento em processo de escavação e que, por outro lado, raramente é considerada na Arqueologia Medieval de Lisboa. Deverá sublinhar-se que a ausência das evidências arqueológicas da sinalização à superfície das sepulturas na necrópole objeto deste trabalho corresponde tão somente a um vazio de informação, porque forçosamente se praticou neste cemitério uma cuidada gestão do espaço fúnebre, que o respeito colocado no distanciamento entre as sepulturas identificadas comprova.

Noutro sentido, nenhum elemento artefactual foi encontrado em associação com os inumados, o que na aparência poderia estar a sugerir um baixo nível socioeconómico dos sepultados. Este tipo de inferências, porém, deve ser bastante relativizado, para mais no caso presente considerando estarmos num quadro conventual de uma ordem mendicante. Ora, e não se tratando os sepultados de religiosos dominicanos, por haver elementos não adultos e femininos assinalados, a associação de elementos artefactuais como base para inferências de status perde qualquer sentido neste caso (como noutros) em função dos potenciais contornos mentais e devocionais dos indivíduos e da sua necessária relação com a regra mendicante que prega a pobreza e o despojo de bens como virtude, como é o caso dos dominicanos.

\section{PERFIL BIOLÓGICO DOS INDIVÍDUOS}

De acordo com Busom (2017), neste espaço funerário, os indivíduos encontram-se orientados de oeste para leste, em decúbito dorsal com os membros superiores fletido sobre o tórax, e os inferiores estendidos paralelamente (Figuras 6-9). Relativamente ao perfil biológico, foram identificados quatro adultos (um masculino e três femininos), dois adolescentes e um não adulto (Figura 10) (Busom, 2017, p. 30).

\section{DISCUSSÃO}

O uso funerário do espaço objeto do presente trabalho acarreta algumas implicações interpretativas, dado que na Idade Média o sepultamento cristão era praticado em espaço considerado como sagrado, ou seja, no interior ou imediações de edifícios religiosos (Barroca, 1987, p. 24; Cunha, 2017, p. 72; Antunes-Ferreira, Cardoso \& Santos, 2013, p. 1113). 
Ora, neste sentido, a despeito de nenhuma evidência documental nos documentar nesta zona das hortas conventuais de São Domingos a existência de qualquer espaço sacralizado, ou de a intervenção arqueológica não ter revelado qualquer tipo de outras evidências categóricas neste sentido, terá que se admitir a existência de tal sacralização. Convém, a este propósito, relembrar que a dimensão arquitetónica de um espaço desta natureza poderia ser tipologicamente muito variável, incluindo capelas ou pequenos oratórios (Bencatel, 2009, p. 210), geralmente situados em zonas periféricas ou até limítrofes da cerca conventual. Tal parece ser o caso detetado arqueologicamente em São Domingos da Cidade, e talvez assim se explicando a relativa robustez do muro de limite conventual e a existência de um vão/fenestração nele, composto por elementos arquitetónicos do gótico tardio de que se reconheceu apenas a base de uma ombreira.

Uma outra dimensão interpretativa do núcleo funerário do Convento de São Domingos assoma num outro sentido, histórico.

O estudo monográfico de Luís Ribeiro Gonçalves (2011) sobre a zona lisboeta dos Restauradores Rossio - Praça da Figueira - Martim Moniz na Idade Média veio mostrar, com base documental bastante consistente, que nesta área periurbana da cidade onde se implantaria na década de 1240 o Convento de São Domingos, se concentravam em matéria de propriedade os principais elementos do poder urbano, pois, “(...) entre cónegos regrantes, cavaleiros de Santiago, monges cistercienses e mendicantes, passando pelo clero secular e pelo próprio monarca, aqui estão presentes quase todas as principais instituições da cidade, se não mesmo do Reino" (Gonçalves, 2011, p. 102, p.142). Zona a um tempo marginal e polarizadora, o seu peculiar interesse prendeu-se com as muito boas acessibilidades, a elevada disponibilidade hídrica e a boa aptidão agrícola para o regadio, estando cumulativamente numa posição estratégica em relação à principal estrada de acesso e em relação ao Rossio como entidade urbana.

É o interesse desta zona que motivará, decerto, as tensões entre os vários poderes urbanos terratenentes ali representados, e que de alguma forma poderá ajudar a justificar o tipo de registo arqueológico revelado pela intervenção de 1999-2001. Assim, o achado do piso da corredoura medieval (que poderá datar dos finais do séc. XIII aos inícios do séc. XV) documenta, de forma cabal, que o espaço em causa era espaço público da cidade no período da sua construção, em última instância tutelado pelo monarca. Assim sendo, a edificação de um novo muro de limite da propriedade dos pregadores significará uma ação de apropriação marginal do terreno pela Ordem de São Domingos, episódio ocorrido algures durante o séc. XV. Será neste quadro, por conseguinte, que se terá que perspetivar a utilização da área apropriada com finalidade funerária. Porque os preceitos religiosos exigem que o sepultamento cristão seja praticado em solo sagrado, a utilização da área como funerária consubstanciaria o carácter religioso do solo e inviabilizaria a sua reclamação como terreno público, correspondendo deste modo a uma estratégia de materialização da apropriação por parte dos Dominicanos, afinal depois desfeita em 1492-1502 aquando a construção do Hospital Real de Todos-Os-Santos, que retoma o traçado anterior e implicitamente devolve a parcela de terreno ao domínio público.

\section{FONTES}

\section{Fontes Manuscritas}

Arquivo Nacional Torre do Tombo.

Registo de Escrituras do Reinado de D. Manuel I. Liv. 1134, fl. 1-2v.

\section{BIBLIOGRAFIA}

ANTUNES-FERREIRA, Nathalie; CARDOSO, Guilherme; SANTOS, Filipa (2013) - A Necrópole Medieval/ Moderna de Arruda dos Vinhos. In ARNAUD, José; MARTINS, Andrea; NEVES, César, Coords. - Actas do I Congresso da Associação de Arqueólogos Portugueses "Arqueologia em Portugal-15o anos", Lisboa: Associação dos Arqueólogos Portugueses, pp. 1111-1117.

BARGÃO, André; FERREIRA, Sara; SILVA, Rodrigo Banha da (no prelo) - Memórias de duas intervenções: o remanescente do Hospital Real de Todos-Os-Santos em 1960-1961 e 1999-2001. In Musa, 2, Atas do Colóquio de Homenagem a Irisalva Moita. Lisboa: Egeac, Museu de Lisboa.

BARROCA, Mário Jorge (1987) - Necrópoles e Sepulturas Medievais de Entre-Douro-e-Minho (Séc. V a XV). Porto: Faculdade de Letras da Universidade do Porto (Dissertação para Provas Públicas de Capacidade Científica).

BENCATEL, Diana (2009) - Sarcófagos e Sepulturas medievais (Maia e Matosinhos): análise tipológica e cronológica. In Revista Portuguesa de Arqueologia, Lisboa: Direção Geral do Património Cultural, 12:2, pp. 209-238.

BUSOM, Julia (2017) - Late Medieval Lisboa. Seven Individuals from Praça da Figueira. Cranfield: Universidade 
de Cranfield (Dissertação de Mestrado em Antropologia e Arqueologia Forense).

COELHO, Catarina (2006-2007) - Ruínas Arqueológicas de São Miguel de Odrinhas: a propósito da Campanha de 1997. In Arqueologia e História, Lisboa: Associação dos Arqueólogos Portugueses, Série 12, 58/59, pp. 119-142.

CUNHA, Mário (2017) - O Espaço Eclesial como local de sepultura: As visitações quinhentistas às Igrejas da Ordem de Santiago. In ROSAS, Lúcia; SOUSA, Ana Cristina; BARREIRA, Hugo, Coords. - Actas do Congresso "Genius Loci: Lugares e Significados / Places and Meanings", Porto: CITEM, Vol. 1, pp. 71-84.

DIOGO, António Dias; TRINDADE, Laura (1999) - Estudos Arqueológicos Efectuados pelo G.T.T.R.L. no Martim Moniz e sua Envolvente. In Olisipo, Série II, 8, Lisboa: Associação dos Amigos de Lisboa, pp. 44-54.

FR. LUÍS DE SOUSA; FR. LUÍS CACEGAS (1767) - Primeira Parte da História de S. Domingos particular do Reino e Conquistas de Portugal. Lisboa: Officina de Antonio Rodrigues Galhardo.

GONÇALVES, Luís Ribeiro (2011) - Sistemas de povoamento e organização territorial: dois vales na periferia de Lisboa (séculos IX-XIV). Lisboa: Faculdade de Letras da Universidade de Lisboa (Dissertação de Mestrado em História Medieval). (policopiado).

LOURINHO, Manuel (1971) - A Igreja e o Convento de S.

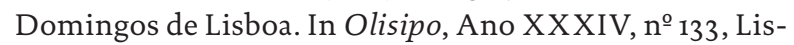
boa: Associação dos Amigos de Lisboa, pp.115-123.

LOURINHO, Manuel (1972) - A Ermida de Nossa Senhora da Escada nas suas relações com a Igreja e o Convento de S. Domingos. In Olisipo, Ano XXXV, no 134, Lisboa: Associação dos Amigos de Lisboa, pp. 32-45.

MARADO, Catarina (2018) - Arquitetura Conventual e Cidade Medieval: a Formação e os Impactos dos sistemas urbanísticos mendicantes em Portugal (Séc. XIII-XV). Coimbra: Imprensa da Universidade de Coimbra.

MOITA, Irisalva (1994) - O Hospital Real de Todos-os-Santos. In Exposição: Lisboa Subterrânea, Lisboa: Museu Nacional de Arqueologia, pp. 118-125.

OLIVEIRA, Ana (2006) - Cabeceiras de Sepultura do Concelho de Loures. In Actas do VIII Congresso Internacional de Estelas Funerárias, Suplemento n⿳ㅜㅜㅇ de O Arqueólogo Português, Lisboa: Museu Nacional de Arqueologia, pp. 215-238.

RESENDE, Garcia de (1596) - Chronica que tracta da vida e grandíssimas virtudes [...] de Dom João o Segundo. Lisboa: Casa de Simão Lopez.

SILVA, Rodrigo Banha da (2005) - "Marcas de Oleiro" em terra sigillata da Praça da Figueira (Lisboa): Contribuição para o conhecimento da economia de Olisipo (Séc. I a.C. - Séc. II d.C.). Minho: Instituto de Ciências Sociais da Universidade do Minho (Dissertação de Mestrado em Arqueologia).

SILVA, Rodrigo Banha da (2012) - A Ocupação do Período da Dominação Islâmica na Praça da Figueira (Lisboa). In SALVADO, Sallete, Coord. - Actas do Colóquio "Afonso I de Portugal nos 9 oo anos do seu nascimento", Lisboa: Associação dos Amigos de Lisboa, pp. 137-147.

SILVA, Rodrigo Banha da (2018) - O Convento de São Domingos, em Lisboa, e a leitura arqueológica das suas hortas, entre os séculos XIII e XV. In ANDRADE, Amélia Aguiar; TENTE, Catarina; SILVA, Gonçalo Melo da; PRATA, Sara, Coords. - Espaços e poderes na Europa urbana medieval. Castelo de Vide: IEM/FCSH/NOVA, Câmara Municipal de Castelo de Vide (col. Estudos, 18), 2018, pp. 553-569.

SILVA, Rodrigo Banha da, GOMES, Mário Varela; GOMES, Rosa Varela (2011) - O Bairro Islâmico da Praça da Figueira (Lisboa). In GOMES, Mário Varela, GOMES, Rosa Varela; TENTE, Catarina, Coords. - Actas do Colóquio "Cristãos e Muçulmanos na Idade Média Peninsular: Encontros e Desencontros”, Aljezur/ Lisboa: IAP, pp. 17-26.

TRINDADE, Laura; DIOGO, António Dias (200o) - Elementos sobre o cemitério do Adro da Igreja de S. Domingos. In Arqueologia e História: Estudo de Lisboa-Séculos XV a XIX: I Colóquio Temático, Lisboa: Associação dos Arqueólogos Portugueses, Série 11, 52, pp. 59-71.

TRINDADE, Laura; LOPES, Luís; NETO, José; DIOGO, António Dias (2001) - Elementos para o estudo dos restos humanos da intervenção arqueológica de 1991 no cemitério do adro da Igreja de São Domingos em Lisboa. In Arqueologia e História, Lisboa: Associação dos Arqueólogos Portugueses, Série 11, 53, pp.109-124. 


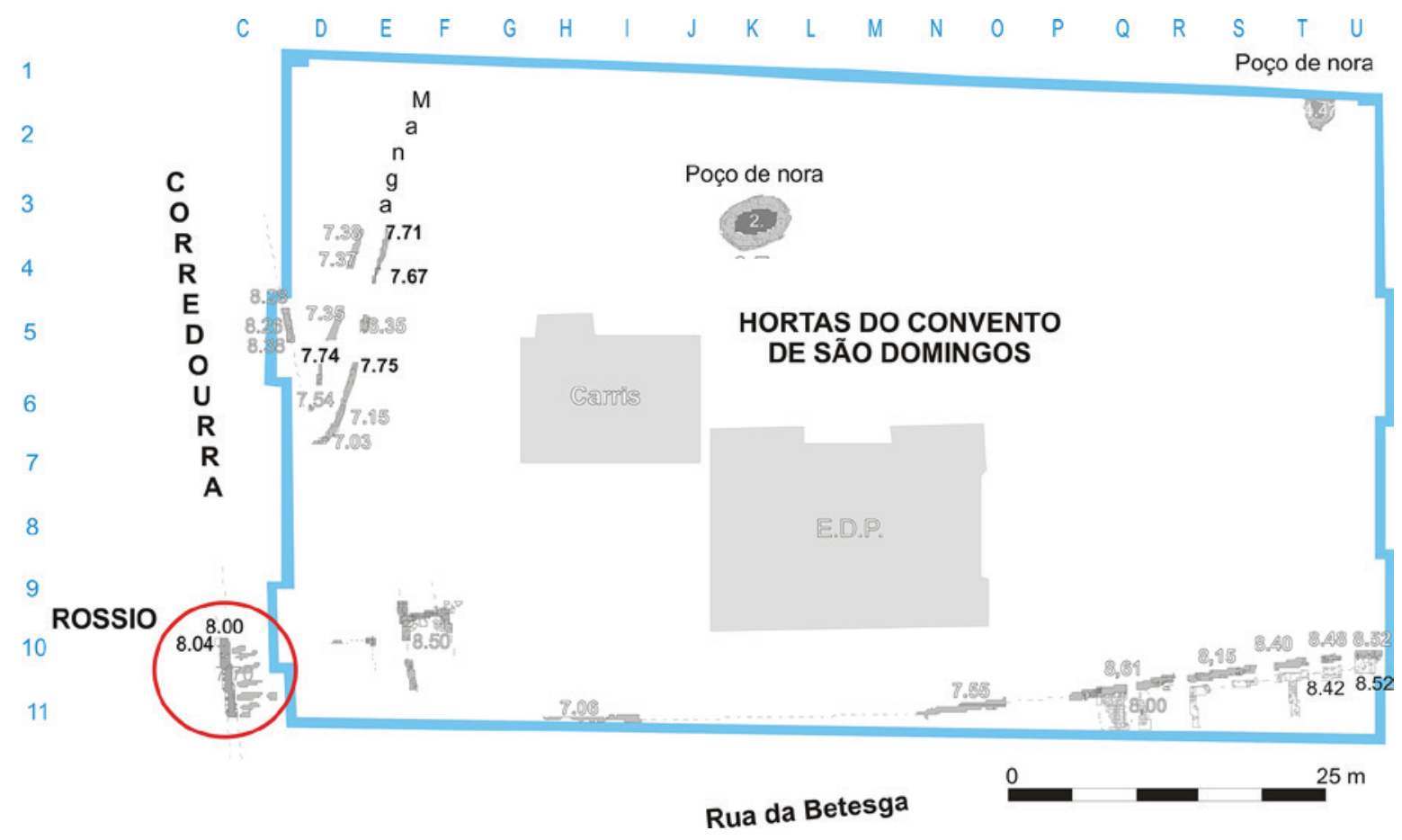

Figura 1 - Área intervencionada na Praça da Figueira (1999-2001) - localização do espaço funerário.

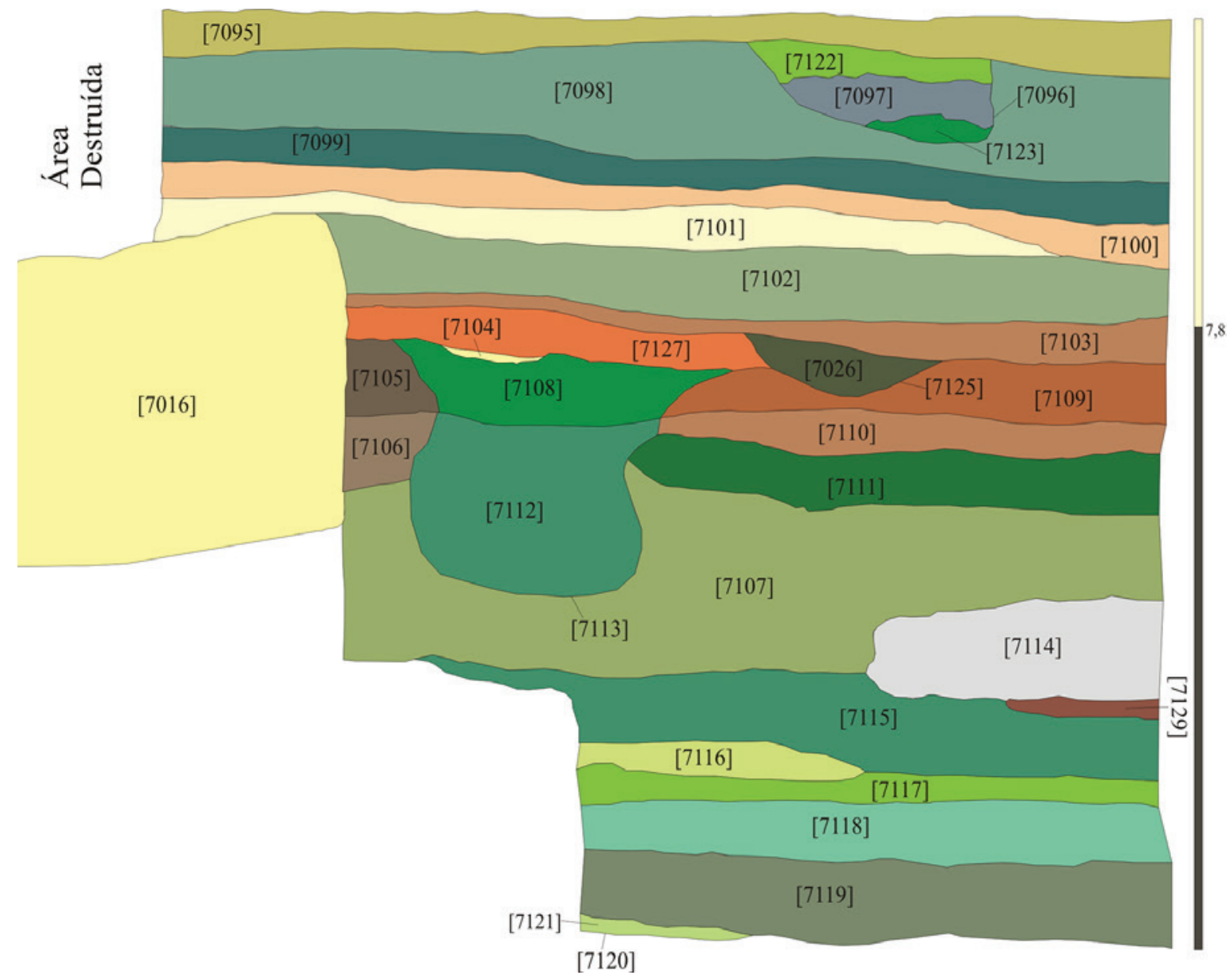

Figura 2 - Perfil Norte de C11. 


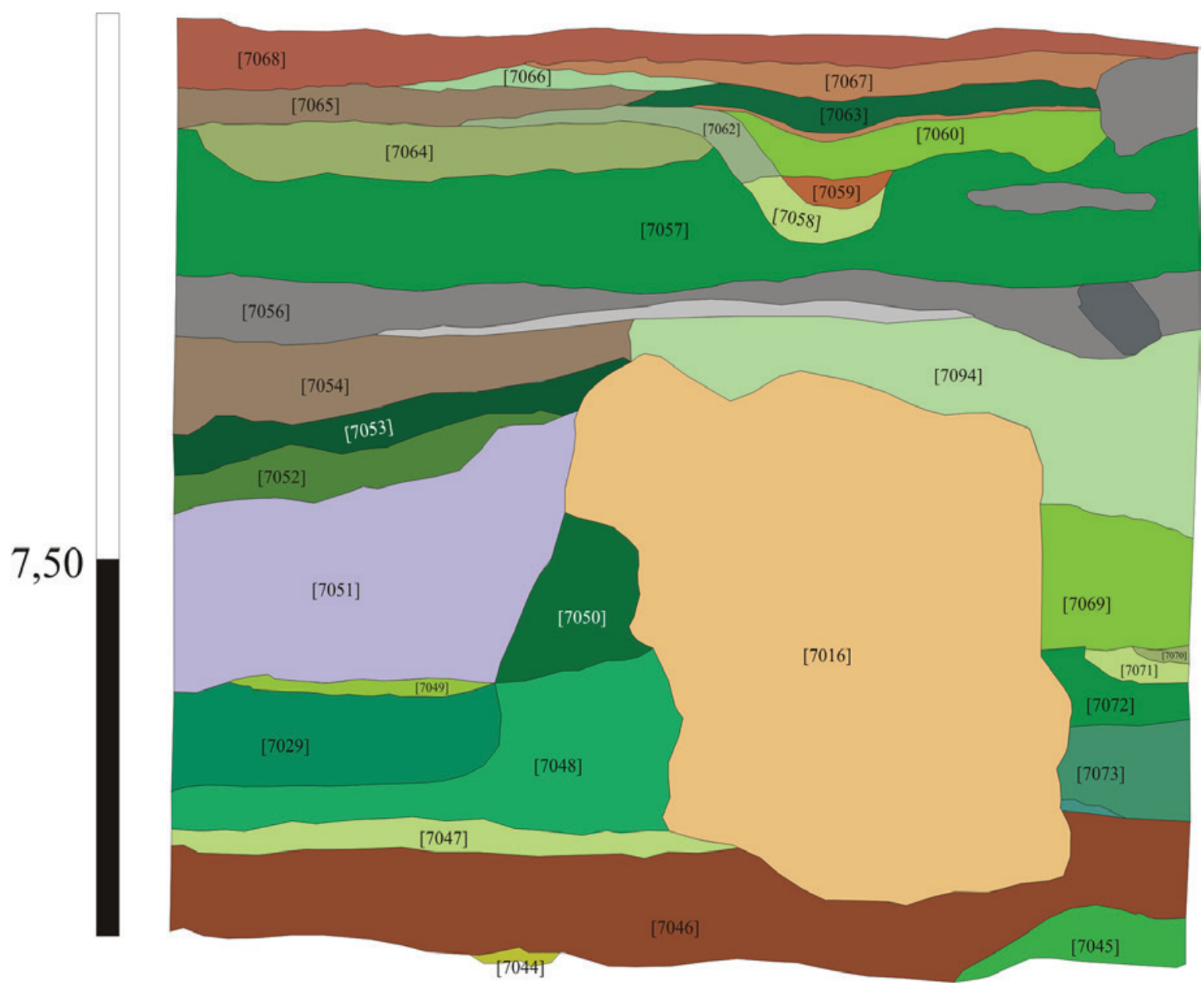

Figura 3 - Perfil Sul de C11

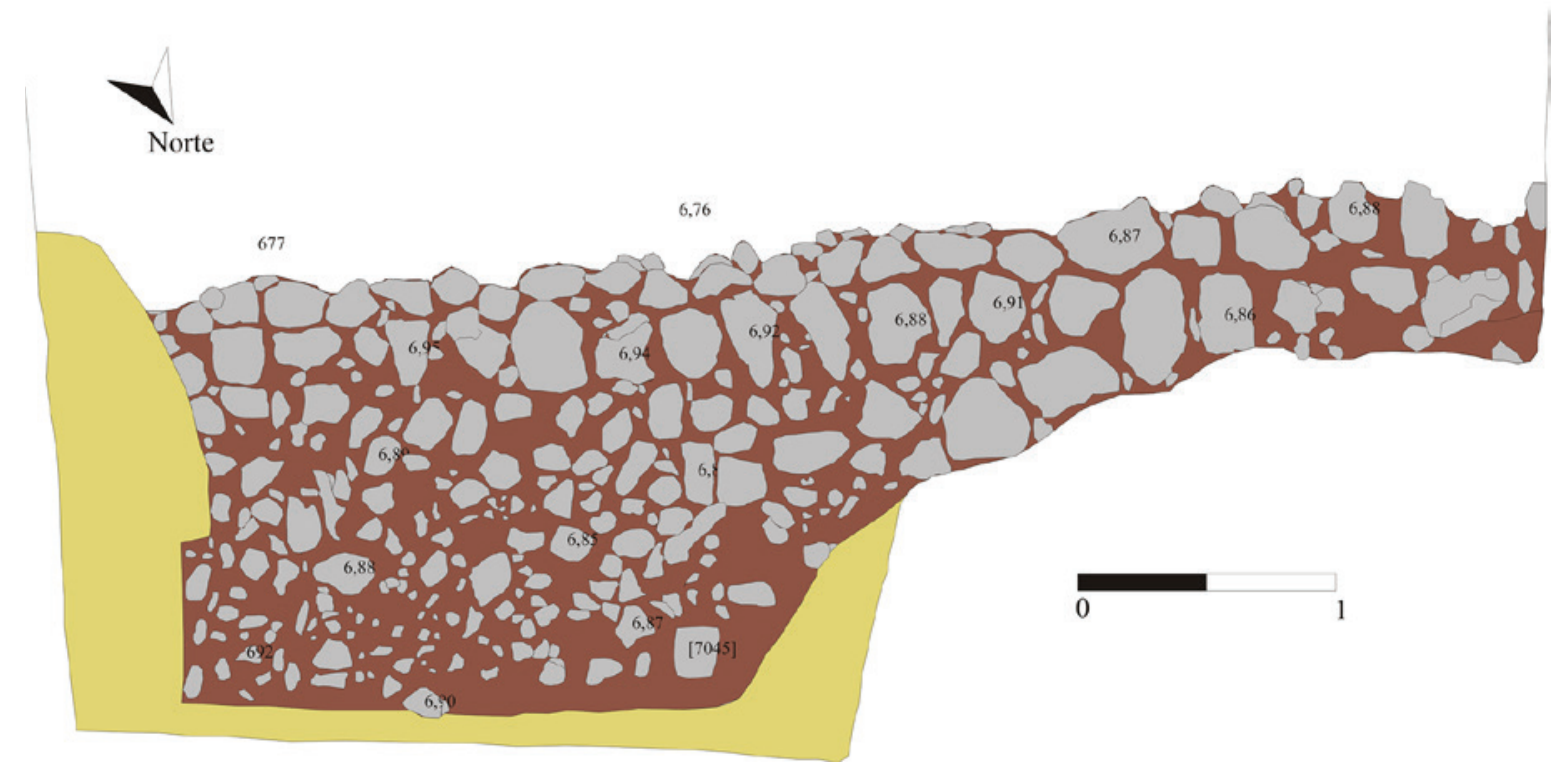

Figura 4 - Plano Geral do troço da Corredoura Medieva - Quad. Ci1, escala 1:20. 


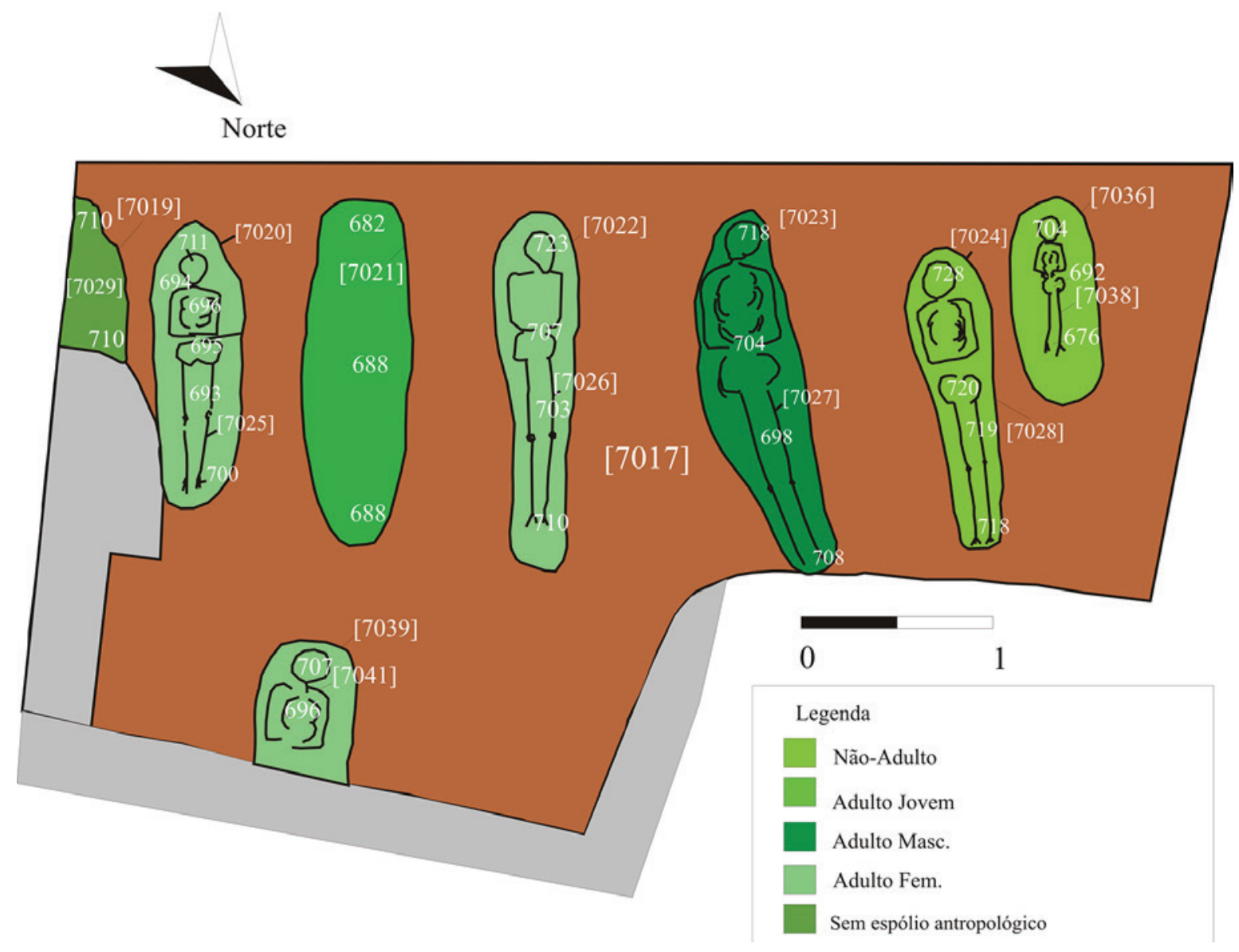

Figura 5 - Plano Geral de C11, Distribuição das sepulturas e perfil biológico dos Indivíduos, escala 1:20. 


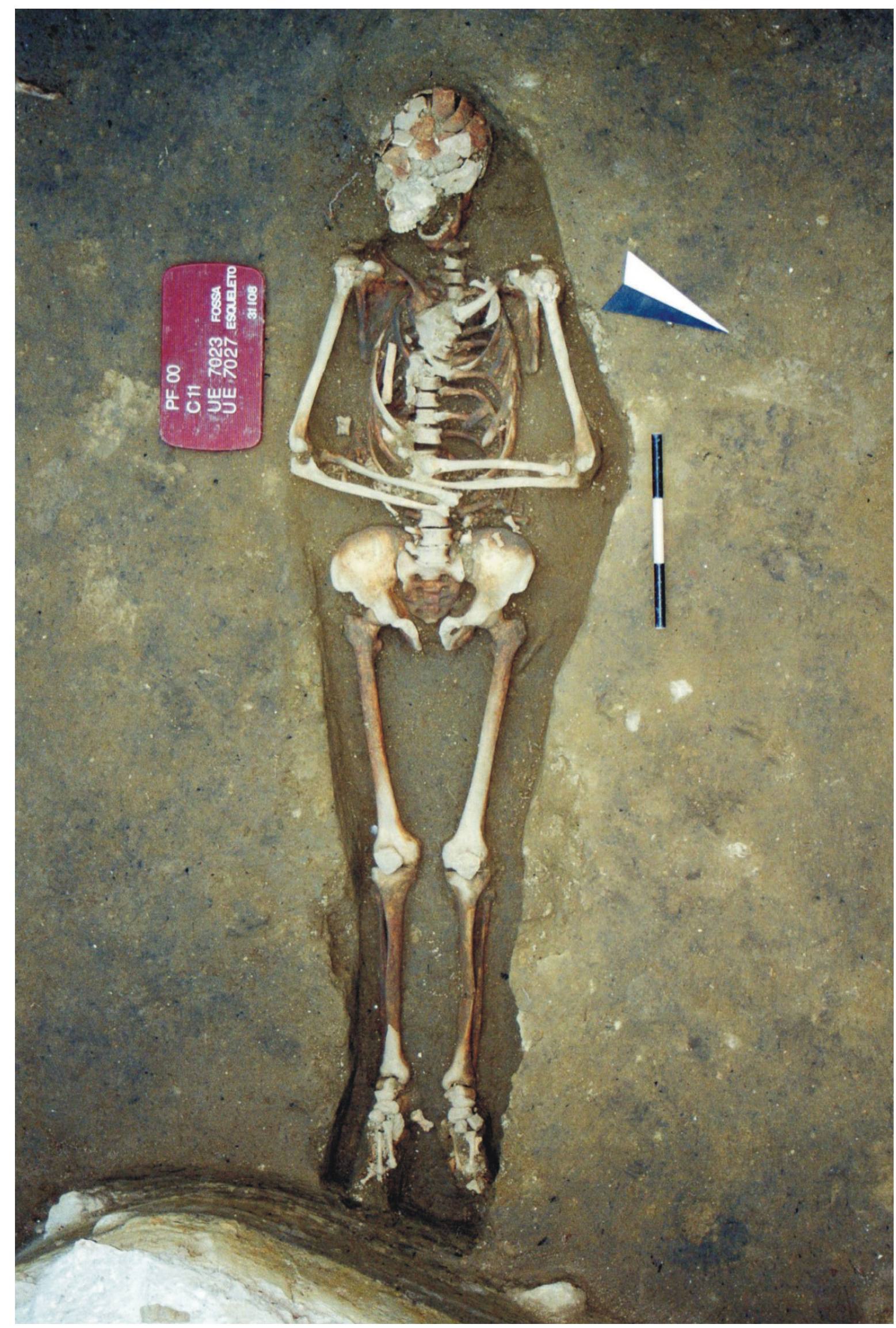

Figura 6 - Sepultura [7023], indivíduo [7027]. 


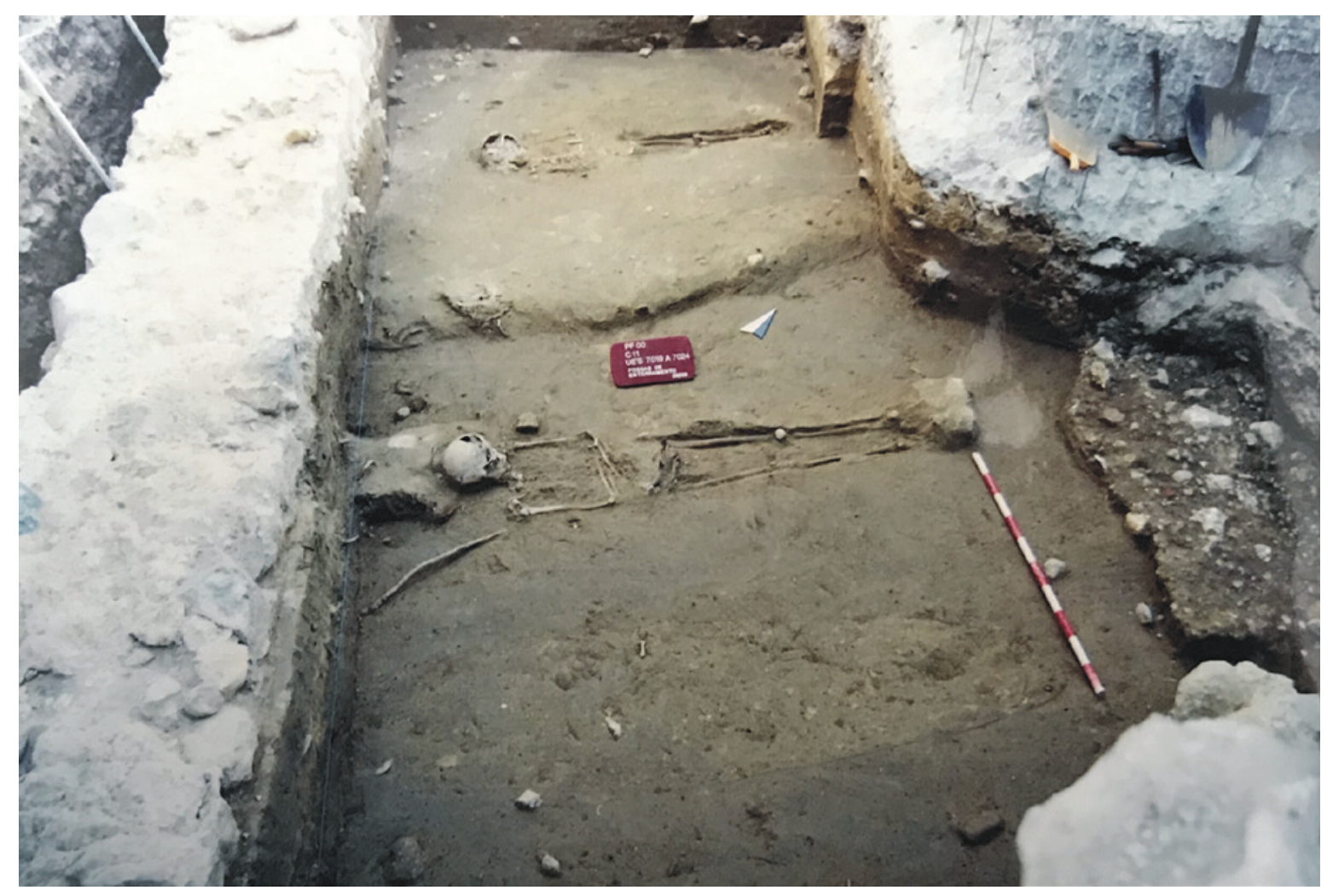

Figura 7 - Vista do espaço funerário, U.E.s [7019] a [7024].

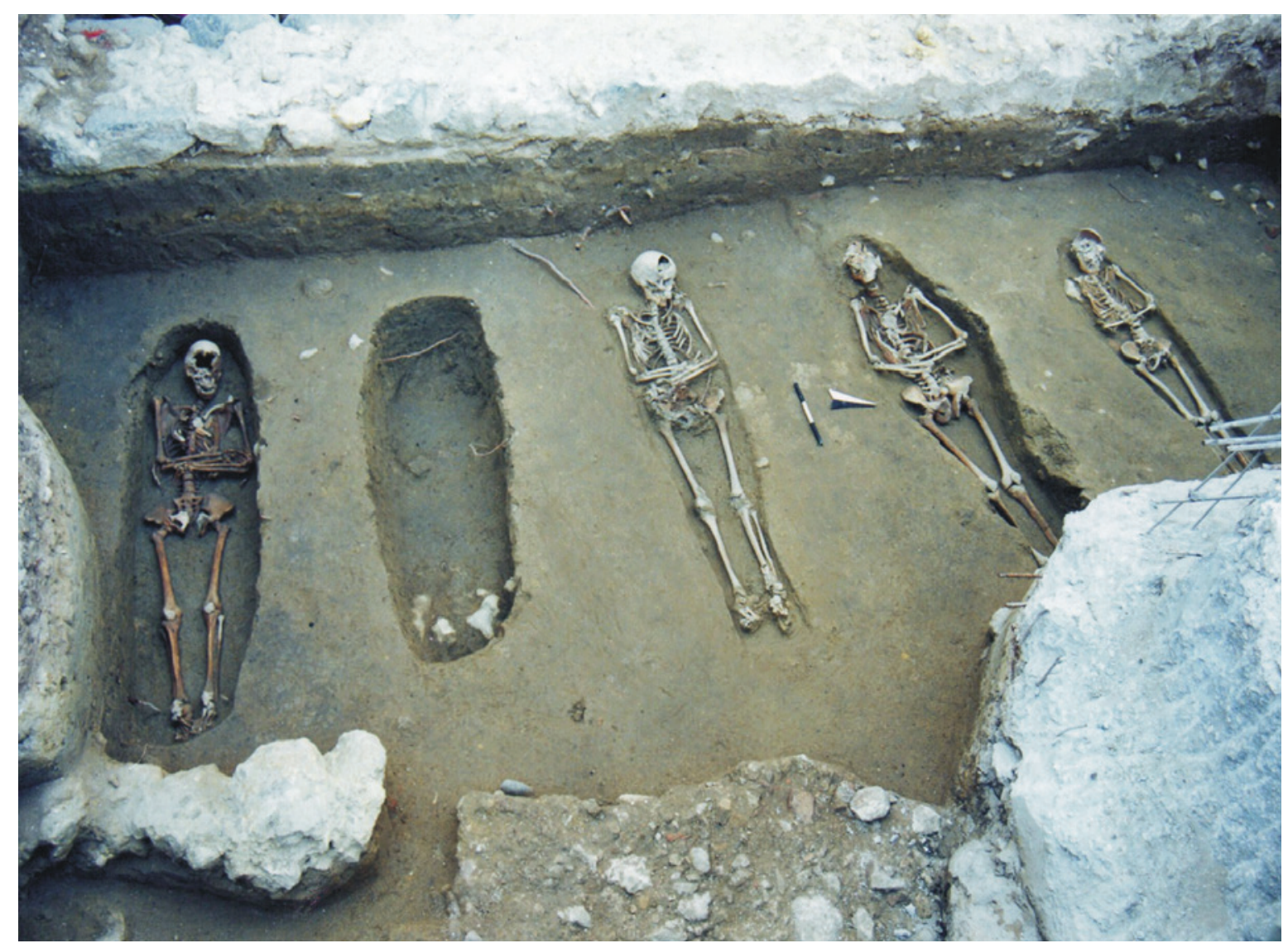

Figura 8 - Vista geral do espaço funerário. 


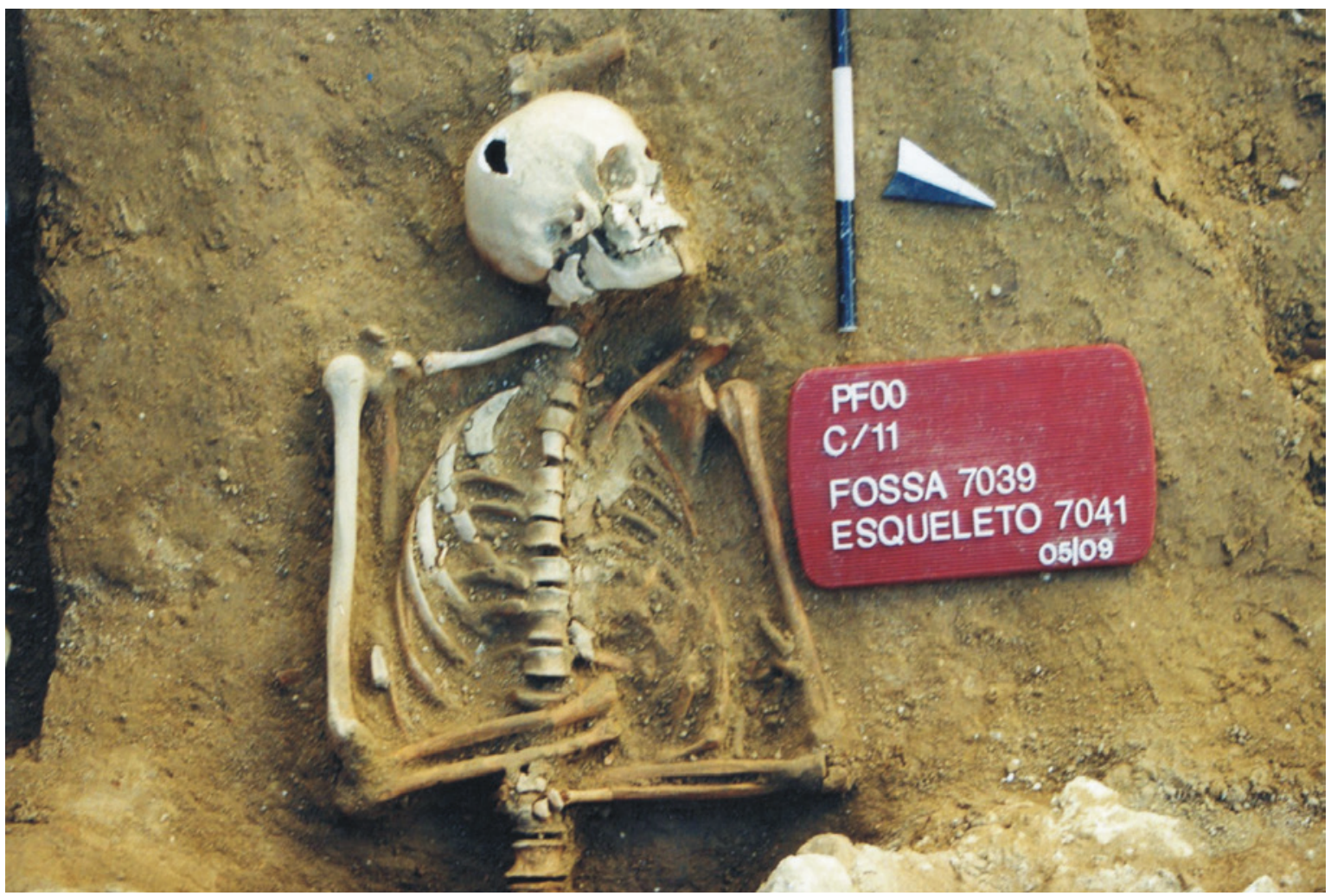

Figura 9-Sepultura [7039], indivíduo [7041] .

\begin{tabular}{|l|l|l|}
\hline Indivíduo & Diagnose Sexual & Categoria Etária \\
\hline$[7025]$ & Feminino & Adulto \\
\hline$[7026]$ & Feminino & Adulto \\
\hline$[7027]$ & Masculino & Adulto \\
\hline$[7028]$ & Indeterminado & Adolescente \\
\hline$[7038]$ & Indeterminado & Não Adulto \\
\hline$[7041]$ & Feminino & Adulto \\
\hline$[7128]$ & Indeterminado & Adolescente \\
\hline
\end{tabular}

Figura 10 - Perfil Biológico (adaptado de Busom, 2017). 
Época Moderna

9

$$
\text { a }
$$

.

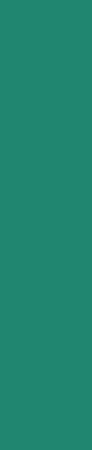

.
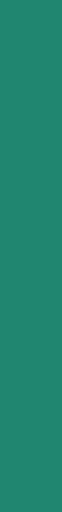

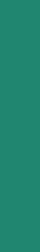$$
\text { (1) }
$$ 


\title{
ARQUEOLOGIA MODERNA EM PORTUGAL: ALGUMAS REFLEXÕES CRÍTICAS EM TORNO DA QUANTIFICAÇÃO DE CONJUNTOS CERÂMICOS E SUAS INFERÊNCIAS HISTÓRICAS E ANTROPOLÓGICAS
}

\author{
Rodrigo Banha da Silva ${ }^{1}$, André Bargão ${ }^{2}$, Sara da Cruz Ferreira ${ }^{3}$
}

\begin{abstract}
RESUMO
A Arqueologia Moderna vem notoriamente ganhando espaço na Arqueologia Portuguesa, não só no que se refere ao número de intervenções arqueológicas, como no que respeita ao número de publicações de sítios, contextos e cultura material. Ressalta, todavia, que este crescendo de conhecimento não aparece acompanhado de uma maior sofisticação metodológica, debruçando-se os autores sobre um dos aspectos deste panorama: a quantificação de conjuntos artefactuais, em particular cerâmicas, e a relação desta com o esclarecimento dos perfis funcionais dos contextos arqueológicos respectivos; deverá notar-se que um e outro elemento são condições de base essenciais para a produção das inferências de carácter histórico e antropológico. Palavras-chave: Arqueologia Moderna, Metodologia Arqueológica, Teoria em Arqueologia.
\end{abstract}

\begin{abstract}
Early Modern Archaeology is becoming a nodal área of study in Portuguese Archaeology, due to the increasing numbers of excavations, as in terms of publication of sites, contexts and material culture. Nevertheless, this progress doesn't display a refined preoccupation on methodology and theoretical frameworks. The authors address this issue focusing its interest on artefact assemblages and categories quantification and its narrow relation to context functional profile, noteworthy two of the fundamental basis allowing historical and anthropological inferences.

Keywords: Historical Archaeology, Post-Medieval Archaeology, Archaeological Quantification, Theoretical Archaeology.
\end{abstract}

\section{INTRODUÇÃO}

A Arqueologia Moderna em Portugal estabeleceu desde cedo benéficas pontes epistemológicas com outras disciplinas, em cujos domínios se enraíza o seu nascimento. A História desde cedo assomou como espaço de contacto privilegiado, proporcionando fontes escritas, cartográficas e iconográficas para a interpretação dos sítios, contextos, artefactos e suas cronologias. Todavia, e não poucas vezes ao longo da curta evolução da Arqueologia da Época Moderna em Portugal, o conhecimento obtido por esta área disciplinar assumiu o papel secundário de mera ilustração das leituras de outro modo produzidas previamente pela História (Gomes, 2012). Por seu turno, a História da Arte e, em paralelo com esta, quer o Coleccionismo, quer o Antiquarismo (com A grande), constituem outro ponto de forte contacto disciplinar, proporcionando à área valiosos capitais de conhecimento acumulados num tempo longo

\footnotetext{
1. Departamento de História NOVA FCSH. CHAM - Centro de Humanidades NOVA FCSH.rbds@fcsh.unl.pt

2. Bolseiro de Doutoramento FCT SFRH/BD/133757/2017. CHAM - NOVA FCSH, andrebargao@gmail.com

3. Bolseira de Doutoramento FCT SFRH/BD/137142/2018. CHAM - NOVA FCSH, sara.isabel91@hotmail.com
} 
(Gomes, 2012, pp. 53-59; Barker \& Majewski, 2014). Deverá notar-se, todavia, que nem a História nem a História da Arte, como as restantes disciplinas mencionadas, se fundam nos mesmos pressupostos da Arqueologia, encerram os mesmos objectivos ou fazem uso das mesmas metodologias de construção de conhecimento, pelo que os vários discursos disciplinares deveriam ser obviamente distintos. Por esta razão, também, a transferência simples dos conhecimentos obtidos pelas outras disciplinas para o domínio da Arqueologia encerra problemáticas sobre as quais importaria reflectir e discutir.

Ora, e no âmbito assim definido como pano de fundo, faz-se uso no presente texto das cerâmicas de Época Moderna e da sua quantificação como tema de abordagem privilegiado, considerando-se que a presença das elaborações oleiras nos contextos arqueológicos com aquelas cronologias encerram valor significante para a construção das leituras sociais e comportamentais do passado. As escolhas metodológicas de quantificação, portanto, são determinantes para a qualidade das inferências que compõem o discurso arqueológico, e constituem uma parte relevante do quadro teórico disciplinar: "The critical scrutiny of patterns of archaeological reasoning immediately exposes the basic importance of archaeological logic within archaeological philosophy and theory. Archaeological logic should outline for us the theory of correct reasoning within our discipline, without making any unwarranted assumptions that the principles of logic and explanation are simple universals which may be transferred from one discipline and level to another... It raises the problems of the nature of the logical conclusions between archaeological conclusions and the grounds for these conclusions" (Clarke, 1973, p. 15).

\section{QUANTIFICAÇÃO E PENSAMENTO ARQUEOLÓGICO: UMA CURTA REFERÊNCIA TEMPORAL}

O movimento anglo-saxónico da New Archaeology (mais tarde designado por Processualismo) pugnou, desde as suas etapas iniciais, por um refinamento metodológico, com a quantificação a encerrar um papel de primeiro plano, sendo aquele considerado fundamento indispensável para a produção de um discurso mais racionalizado, bem patente e expresso em textos "fundacionais", com especial no- toriedade para os de David Clarke (1986) e Lewis Binford (1968 - este último precedido na Antropologia norte-americana por Albert Spaulding, 1953). Defendia-se, então, uma ruptura com os paradigmas de pensamento precedentes, histórico-culturalistas, onde a relação dos artefactos com os modos de vida do passado se perdia assim que estes elementos eram incluídos no registo arqueológico e onde, portanto, a tarefa do arqueólogo se centrava na catalogação, descrição e criação de padrões classificatórios, sobretudo cronológicos (Trigger, 1989, p. 148). A reacção atingiu a mais vincada notoriedade décadas de 1980 e inícios da de 1990, com saliência para o "contextualista/simbolista" Ian Hodder (1982), mas também com a necessária referência aos seus ex-alunos cambrigianos como Michael Shanks e Christopher Tilley (1992). A inflamada controvérsia teórica anglo-saxónica ocorrida dos dois lados do Atlântico, envolveu as mais diversas "facções" (Hodder \& Hutton, 2003), e resultaria depois no pós-processualismo. Independentemente da tendência ou sensibilidade teórico-filosófica em que depois se posicionaram neste quadro, qualquer das tendências deixou incólume a validade da quantificação como uma das bases metodológicas disciplinares, transversal às várias "arqueologias" e ferramenta mental da disciplina (Shennan, 1997).

Pela via que acabámos de expor, de uma forma exageradamente sintética para a riqueza de problemáticas que o tema encerra, as arqueologias norte-americana e britânica rapidamente incorporaram na sua praxis a quantificação e a estatística ao nível mais básico do trabalho, o que incluiu o tratamento da cerâmica nos relatórios de escavação.

Rapidamente, a Europa Continental acompanhou a tendência, embora não de uma forma tão homogénea como a britânica. Um mapeamento, se executado, revelaria a expressão da generalização progressiva das metodologias ao nível básico da praxis por manchas geográficas, mas em contrapartida assinalaria numerosos vazios (entre um leque amplo de títulos que abordam o tema destacaríamos Madsen, 1988; Desbat, 1990; Arcelin \& Tuffreau-Libre, 1998; Husi, 2001).

De outro modo, a universalidade ontológica e a transversalidade das metodologias (Orton, 1980; Fletcher, 1991, mas sobretudo, Orton, Tyers \& Vince, 1993; Arcelin \& Tuffreau-Libre, 1998, Husi, 2001) não foi de igual modo acolhida nas várias "arqueolo- 
gias históricas" continentais (aqui entendidas de um ponto de vista cronológico alargado). A uma generalizada e forte aceitação e valorização no âmbito dos estudos em Arqueologia Clássica, contrapôs-se um incompreensível menor sucesso no âmbito das arqueologias Medieval e Moderna europeias. Será por estas estarem, por tradição, muito mais conectadas à História da Arte e à valorização do artefacto como "objecto individual” significante? E assim sendo, será esta via válida para as construções das leituras das sociedades pretéritas como alternativa à abordagem contextualizada do conjunto? A resposta, que é necessariamente negativa à segunda pergunta, implica uma outra forçosamente negativa à questão que a precede, pelo menos se não nos revemos de um ponto de vista conceptual nos paradigmas histórico-culturalistas da arqueologia, e se reconhecemos à disciplina a capacidade de proporcionar com base na cultura material leituras bem mais ricas e diversificadas sobre o passado (sociais, culturais, antropológicas...).

A respeito do que se vem expondo, é deveras evocativo que à chamada à primeira reunião francesa em torno da quantificação das cerâmicas, realizada em Glux-en-Glenne no ano de 1997, só num caso a resposta veio de fora da Arqueologia Romana (conf. Arcelin \& Tuffreau-Libre, 1998). Este panorama, que é também o português, vem sendo assinalado em diversa produção científica europeia de reflexão a propósito dos estudos sobre cerâmica abrangendo a do período moderno, cabendo citarem-se aqui exemplos como os de Philippe Husi (2001) para Tours, ou Maxime Poulain (2013), este último em referência circunstanciada à arqueologia post-medieval Belga e dos Países Baixos, qualquer dos dois indicando exemplos de múltiplas outras geografias elencados na bibliografia respectiva.

As problemáticas que envolvem o uso da quantificação da cerâmica arqueológica no âmbito dos estudos de Arqueologia Moderna são de natureza teórica porque esta lhes serve de pano de fundo: não correspondem, portanto, a uma qualquer manifestação de militância engagée, muito menos a uma moda ou estilo. Melhor seria, passado quase meio século das primeiras publicações que definiram metodologicamente a questão e os contornos do seu significado! (com destaque para o trabalho perseverante e fundamental de Clive Orton, 1975, 1979, 1980, 1982, 1989, 1993; Orton, Tyers \& Vince, 1993; Orton \& Hughes, 2013).
Não se pretende tomar aqui como objecto de discussão quais das distintas abordagens assumem maior ou menor fidedignidade, assunto amplamente discutido a nível internacional (ver por ex.: Husi, 2001). $\mathrm{Ou}$, sequer, se todos fizeram uso das ferramentas colocadas ao nosso dispor pela quantificação: claro que nem todos delas fizeram uso, não encerrando esta opção de per si um problema de maior. Todavia, não se pode deixar de fazer notar que permanecer ignorante acerca das ferramentas e pressupostos da quantificação é, não só infeliz, como desnecessário, porque, pelo menos, deter este tipo básico de conhecimento é condição necessária para entender e avaliar o trabalho dos outros investigadores que delas fazem uso...

\section{UMA MUITO CURTA, GENÉRICA E INCOMPLETA, MAS SIGNIFICANTE, REFERÊNCIA AO CASO PORTUGUÊS...}

De forma feliz se dá a coincidência de a reunião científica de arqueólogos que deu origem ao texto presente se realizar na cidade do Porto. Na realidade, terá que se encarar ao nível nacional como dotada de carácter inovador, e quiçá arrojado, a abordagem produzida para a Época Moderna pela equipa que trabalhou a intervenção urbana na Casa do Infante (Porto), que escavou, tratou e compulsou o vasto conjunto de meio milhão de fragmentos cerâmicos oriundos dos contextos datados de entre os séculos XVI e XVIII, aplicando em 1991 as mais actualizadas metodologias à época (Real et al., 1995), e logo incorporando as de quantificação (recorde-se que a obra de Orton, Tyers \& Vince fora pela primeira vez publicada em 1993). Mais importante, e depois de uma primeira publicação preliminar da longa sequência do ponto arqueológico da cidade do Porto (Real et al., 1995), de forma assaz rápida foram exaustivamente disponibilizados os resultados em 1995, por ocasião do II "colóquio de Tondela" (Castro, Dórdio \& Teixeira, 1998), prosseguindo pelos anos seguintes (conf. bibliografia cotejada em Real et al., 2015). Paulo Dórdio Gomes, inclusive, publicaria logo após um valioso artigo, circunstanciado, explicitando e clarificando com detalhe as opções metodológicas adoptadas pela equipa em relação à contabilização da cerâmica (Dórdio, 1997/1998).

Seria expectável, portanto, que o trabalho dos vários elementos da equipa da Casa do Infante representasse o bem-sucedido advento de uma praxis envol- 
vendo metodologias de quantificação de cerâmica na Arqueologia Moderna portuguesa, e que estas se tivessem rapidamente expandido à escala nacional. Infelizmente assim não aconteceu, e até data recente os protocolos quantitativos ficaram somente confinados a um grupo de investigadores nortenhos que se foi muito paulatinamente alargando, ao mesmo tempo que aquelas "ferramentas" se disseminavam e vulgarizavam em Portugal no âmbito das "outras arqueologias” (sobretudo pré, proto-histórica e romana). O que terá falhado então? Na perspectiva dos signatários, por um lado a forma de transmissão do saber e das instituições a quem este comete primordialmente. Por outro, a maneira dominante de fazer arqueologia em Portugal, por contrato, e à forma como o Estado desde cedo (década de 199o) desvalorizou todo o trabalho arqueológico pós-escavação. O panorama actual português actual é, todavia, o de transformação e viragem, mesmo que notoriamente insuficiente por força da massa ciclópica de dados acumulados nos últimos 30 anos. Tendo por força que se correr o risco de ser injusto ao nomear de maneira particularizada investigadores, para além de um conjunto alargado de arqueólogos nortenhos (Paulo Dórdio Gomes, Ricardo Teixeira, António Manuel Silva, Rosário Melo, Maria Isabel Pinto Osório, Miguel Rodrigues,...), cabe aqui destacarem-se em datas mais recentes Ricardo Costeira da Silva (ex.: 2013, 2016a, 2016b), para o caso coimbrão, ou o grupo de investigadores de Lisboa com conexões à Faculdade de Ciências Sociais e Humanas da Universidade Nova de Lisboa, independentemente do seu enquadramento actual, e no qual se inscrevem os autores. Trata-se, por conseguinte, de um tempo novo, que prenuncia abordagens bastante mais ricas e complexas do que as clássicas inferências que directamente se retiram do imprescindível trabalho classificatório inicial, que mais não permite do que a aferição dos elementos de origem e cronológico (do objecto e/ou do contexto respectivo), deste modo autorizando inferências genéricas e não poucas vezes vagas de cariz económico (seja a conexão entre distintos pontos geográficos, seja a noções imprecisas e difusas -quando não tantas vezes abusivas- sobre as dinâmicas) e de índole socio-cultural (evoluções do uso, definição de status social ou poder aquisitivo).

\section{ALGUMAS (POUCAS) PROBLEMÁTICAS SELECCIONADAS EM QUANTIFICAÇÃO DE CERÂMICAS DA ÉPOCA MODERNA EM PORTUGAL}

É um conceito basilar da disciplina que um objecto arqueológico encerra em si próprio diferentes tempos, compreendidos entre o momento da sua manufactura (que pressupõe a ideia prévia do objecto) até ao momento da sua recolha, envolvendo no entretanto um conjunto mais ou menos complexo de processos (Lamotta \& Schiffer, 2005, pp. 123-125). Como consequência, o primeiro passo da análise cerâmica relaciona-se com a tentativa de compreensão e leitura desses mesmos processos, condição para a construção do conhecimento subsequente sobre o conjunto cerâmico em estudo, o que é o mesmo que dizer que o pressuposto de partida é o esclarecimento da definição dos contornos funcionais dos contextos, expressão feliz avançada, noutro âmbito totalmente diferente, por Josep Antón Remolá Vallverdú (200o, p. 15 e segs.).

\subsection{O contexto como pressuposto: uma nota}

Ao contrário de outras "arqueologias", a Arqueologia Moderna (como a Medieval, sobretudo na Baixa Idade Média) encerra uma enorme virtualidade, que é a de dispor de uma vasta massa de informação histórica (textual, iconográfica, cartográfica, ...) que esclarece muitas vezes não só acerca da cronologia, como sobre a natureza socio-económica e cultural dos prováveis agentes da formação dos contextos, proporcionando ainda elementos sobre uma parte relevante das acções praticadas à época nos momentos de uso e nos de pós-desfuncionalização dos objectos (reciclagem, transporte, refuncionalização, ...).

A análise quantitativa dos conjuntos cerâmicos modernos beneficia, por consequência, desses dados externos altamente qualificados. O facto constitui uma enorme virtualidade disciplinar, a qual deveria fazer-lhe valer um local de destaque metodológico no âmbito geral da arqueologia, considerando o potencial informativo dos modelos empíricos que deveria produzir para a interpretação de contextos e "cultura material" também "histórica", mas de outras épocas.

Em sentido reverso, a análise de determinados parâmetros da contabilização cerâmica (com por exemplo o grau de fragmentação, entre outros) deveria verter também para a leitura dos contextos e do res- 
pectivo perfil funcional. Entre muitíssimos exemplos que se poderiam cotejar, veja-se o contraste extremo entre um contexto de uma lareira de uma cozinha doméstica, capsulado no tempo pelo terramoto de Lisboa de 1755, composto por quatro panelas e respectivos testos (Diogo \& Trindade, 1995; que é o mesmo que dizer $8 \mathrm{NMI}$ ), com os 12975 fragmentos $=7726$ NMI cerâmicos estudados dos contextos de um aterro formado após o cataclismo e antes de 1780 no quadro das intervenções ribeirinhas de ampliação do Forte de São Paulo (Ferreira, 2015); ou, na mesma cidade, e a propósito do perfil socio-económico, os ratios de fragmentos de cachimbo por $\mathrm{m} 2$ de vários locais que, a despeito de obtidos de forma assumidamente grosseira e impressionista, espelham o peso do contexto militar ou de ambientes britânicos neste tipo de ocorrências (vide Simão et al., no prelo, no presente volume).

\subsection{Para uma biografia dos objectos}

Retomando a ideia inicial do apartado, a dimensão biográfica dos artefactos e dos processos que medeiam entre a sua concepção e o descarte e desfuncionalização foi já abordada por numerosa e diversa literatura que aflorou circunstancialmente o tempo de vida a uso dos objectos com base na coerência contextual, na discrepância cronológica, envolvendo os traços de manuseamento ou, inclusive, a própria "esperança de vida" de diferentes categorias cerâmicas. Neste sentido, e viajando uma vez mais para fora do âmbito cronológico do presente trabalho, talvez mereça destaque o enfrentamento circunstanciado e claro da matéria desenvolvido por J. Theodor Peña, precedido muito tempo antes de forma menos sofisticada por Clive Orton $(1975,1979)$, que ensaiou a definição da "chaine operatoire" e os tempos de esperança de vida médios para várias categorias cerâmicas romanas com base em informação itálica (Peña, 2007, p. 58 e segs.).

Neste sentido, os dados obtidos mais recentemente para contextos modernos lisboetas são reveladores: nos contextos a que já aludimos do Mercado da Ribeira, quando as outras produções oleiras exógenas datadas com anterioridade aos meados do séc. XVII são escassas ( $36 \mathrm{NMI}=0,47 \%$ do total NMI), na porcelana as elaborações orientais (191 NMI $=1,32 \%$ do total NMI), do séc. XVI são 23,53 \% do total de porcelana, do último quartel do séc. XVI-primeira metade do séc. XVII são 17,64 \%, i.e., 41,17\% da porcelana do local tem 100 anos ou mais antes do seu descarte (Ferreira, 2015), implicando especiais cuidados no seu manuseamento que lhes prolongaram longamente a vida; no contexto de um poço do Hospital Real de Todos-Os-Santos, em curso de estudo por um dos autores (AB), apesar de desactivado após o grande incêndio de 1750, nele pontuava um exemplar único de faiança de Savona (Itália) anterior a 1640, e a faiança portuguesa, de uso corrente na cidade que era um dos seus principais centros produtores (senão o principal), revelou que $86,05 \%$ dos 155 NMI mostravam gramáticas decorativas que, de acordo com a mais recente investigação sobre o tema (Casimiro, 2010, 2013), deixaram de ser produzidas em 1700 ou antes; noutro contexto, amplo de 939 NMI cerâmicos, formado provavelmente no âmbito de uma obra no interior de um prédio nos primeiros anos do séc. XVIII (antes interpretado como o descarte de uma cozinha de 1755 - Trindade \& Diogo, 2003, p. 288), para além dos 640 indivíduos de "cerâmica fosca de barro vermelho" (panelas, sertãs, jarros, bilhas,...), e deixando de parte nova ocorrência solitária de faiança lígure da $1^{\underline{a}}$ metade do séc. XVII, na faiança portuguesa somente $13,19 \%$ (dos $144 \mathrm{NMI}$ ) equivalem a gramáticas decorativas a que se atribuem um início de produção ulterior a 1680 (Ferreira et al., no prelo, figs. 8 e 11).

\subsection{Curta referência em torno das escolhas meto- dológicas de contagem...}

As propostas compostas de forma mais estruturada e com intenção de difusão por Clive Orton, Paul Tyers e Alan Vince (1993), depois replicadas em Mont Beuvray (Arcelin \& Tuffreau-Livre, 1998) com porventura mais expressivo acolhimento continental, consideraram diferentes possibilidades estatísticas de enfrentamento da contabilização da cerâmica: o número máximo de indivíduos (MNI), equivalente à contagem de fragmentos (descartando a duplicação da contagem dos fragmentos com colagem entre si); o cálculo do peso, depois refinado em função de várias operações requeridas pelas diferenças entre as várias categorias e tipos cerâmicos; a estimativa do número mínimo de indivíduos (NMI), obtida pelo cruzamento da contabilização de todas as diferentes porções de peças (bordos, fundos, asas, pegas, carenas, paredes- conf. por exemplo Husi, 2001, p. 5), e que requer a execução prévia dos "puzzlings"; por fim o "EVE" (equivalent vessel estimate), obtido a partir de uma tabela de diâmetros onde conste a representação das percentagens da porção do ele- 
mento de bordo ou fundo presente, depois somada e transformada ou em número de indivíduos EVE, ou em percentagem.

Desde a década de 1990 que se encetou a discussão em torno de qual a escolha metodológica que melhor servia os propósitos da investigação, servindo a discussão para comprovar as virtualidades dos cálculos do peso em determinadas circunstâncias, nomeadamente na comparação entre distintas produções (Husi, 2001, p. 7); de aceitação mais generalizada aceite foi o cômputo dos NMI (Arcelin \& Tuffreau-Libre, 1998, Husi, 2001; Poulain, 2013); a adequação da aplicabilidade do EVE foi identificada para certos casos específicos, casuisticamente importantes para as inferências de natureza cronológica, visto que os EVE recorrentemente apresentam resultados em harmonia com os obtidos para o NMI por força dos procedimentos classificatórios antes adoptados para o estimar, parecendo jogar aqui um papel decisivo o maior grau de fragmentação das cerâmicas (Husi, 2001, p. 6).

No caso presente, efectuámos um ensaio-teste aos resultados obtidos para as cerâmicas contidas na colmatação de um poço medieval localizado junto às traseiras do Hospital Real de Todos-Os-Santos (Lisboa), desactivando-o nas primeiras décadas do séc. XVII, sendo evidente a harmonia dos gráficos obtidos em termos de EVE e NMI (Figura 1).

A conclusão a retirar é a de que, de facto, as discrepâncias na comparação entre NMI e EVE aumentam na mesma medida da subida do grau de fragmentação, como já tinha sido observado por Philippe Husi (2001, p. 6), mas necessariamente esta verificação só adquirirá validade mediante a sua aplicação noutros quadros geográficos portugueses, e, considerando o caso específico dos contextos urbanos, multiplicando a análise em diferentes molduras (sociais, económicas, culturais, ...), considerando a natureza necessariamente heterotópica das cidades.

\subsection{A quantificação como datação diacrónica}

Embora a Arqueologia Moderna beneficie fortemente dos contributos externos da documentação histórica para a definição das cronologias dos seus contextos, para uma parte importante dos casos das unidades estratigráficas exumadas, como para sequências estratigráficas complexas, o estudo global da cerâmica abre possibilidades de definição de frequências expressas em tendências de "associações", que compõem um útil instrumento na definição dos contornos cronológicos para outros contextos. Para tomar um caso português, impõe-se o "retorno" à Casa do Infante (Porto), dado que essa foi, justamente, a mais evidente virtualidade do trabalho desenvolvido para a Arqueologia Moderna Portuguesa ali executado na primeira metade da década de 1990 (Castro, Dórdio \& Teixeira, 1998 e todos os trabalhos ulteriores elencados em Real et al. 2015). Aqui, a contabilização usando as metodologias actualizadas de contagem descartou os mais ponderosos factores aleatórios, casos das assimetrias de representatividade induzidas pelos diferentes padrões de fragmentação, ou a selectividade classificatória que, um e outro, caracterizam as contagens tradicionais por número de fragmentos (MNI), definindo para o lugar os indicadores de tendências evolutivas do consumo cerâmico.

Obtêm-se também, e deste modo, as ferramentas de produção de dados que possibilitam tratamentos estatísticos ulteriores. Destes, elegemos somente um, por manifestamente acessível de um ponto de vista matemático: as curvas de tendência diacrónica. Estas podem ser globais, temáticas, tópicas ou contextuais, de qualquer das formas destinadas ao enfrentamento de conjuntos com uma boa qualidade de informação, quer ao nível da sua mínima representatividade quantitativa, quer da natureza dos conhecimentos crono-tipológicos das categorias cerâmicas prévios. As curvas de tendência diacrónica partem de um princípio quase elementar: com base no NMI, se uma cerâmica encerra balizas cronológicas situadas ao longo de 5 décadas, e se a análise for, por exemplo, quinquenal, isso significa no abstracto a probabilidade daquele indivíduo se distribuir equitativamente $\mathrm{o}$ individuo pelos 10 intervalos quinquenais que compõem as 5 décadas, i.e., procedendo-se à distribuição do valor 1 por todos os intervalos de forma equitativa, ou seja, representando o valor de o,1 distribuído por cada um dos intervalos. Repetindo-se o procedimento de forma cumulativa com os restantes indivíduos, obtém-se então uma curva probabilística de indicadores cronológicos.

O método, desenvolvido a outro propósito (Silva, 2005), mas afinal já antes ensaiado por Elisabeth Fentress e Philip Perkins (1988), fornece tão somente valores indiciadores, experimentados também com sucesso no âmbito da Arqueologia Moderna (exs.: Almeida, 2013; Ferreira, 2015; Ferreira \& Bargão, 2016; Ferreira et al., 2017; Ferreira et al., no prelo). 
4.5. "Size matters": metrologia...

Não cabe aqui entrar em profundidade com a relevância que teve a "arquitectura mental matemática" dos indivíduos do passado, em particular na Época Moderna, que para mais assiste ao desenvolvimento do empirismo e do racionalismo, e que tem vincada expressão científica (matemática, geometria, engenharias, arquitectura, náutica,...) mas também na arte, mobiliário, vestuário, ou nos esforços de regulação e formatação metrológica que a Coroa Portuguesa desenvolveu a partir do reinado de D. Manuel. Seria de esperar, portanto, que os objectos cerâmicos, na sua maioria intimamente vinculados às vivências do quotidiano, compreendendo aqui a modelação na olaria pelos artesãos, não encerrassem pressupostos genericamente análogos.

A vertente de trabalho arqueológico quantitativo sobre as dimensões, proporção e volume dos objectos cerâmicos modernos de contextos arqueológicos portugueses encontra-se, todavia, ainda num estádio incipiente. De facto, no interior de uma mesma morfologia encontram-se modelos de diversa envergadura, mostrando não só que no interior das olarias está em acção uma modelação, como essa modelação encerrará muitas vezes potencial significado a nível utilitário. Retomando o trabalho sobre o contexto formado nos inícios do séc. XVIII da Rua dos Correeiros (Lisboa), já citado acima (Ferreira et al., no prelo), a observação dos registos cumulativos dos EVE apresentados de acordo com a sua distribuição pelos diversos em raios de formas muito correntes de "cerâmica fosca de barro vermelho", de fabrico lisboeta, permite ler a existência de uma atracção por 3 e 4 módulos de raio definidos em função das variantes formais de panela, 5 para os testos, 4 nas caçoilas de bordo espessado, ao passo que nas de bordo em bisel se não constatou igual distinção, por fim, nos tachos se discernem 4 módulos distintos. Por conseguinte, a dimensão assume-se como essencial logo ao nível da primeira tarefa na abordagem da cerâmica, o trabalho classificatório, com as consequências implícitas ao nível da própria definição tipológica (Figura 2).

\section{CONSIDERAÇÕES FINAIS}

Os focos de interesse mais tradicional no âmbito disciplinar, casos das conexões entre geografias distantes, ou da aferição de status social e económico mediante a presença contextual das cerâmicas, nomeadamente as exógenas facultadas pelo incremento das relações à distância que se desenvolvem durante a expansão e o colonialismo europeus, poderão beneficiar largamente dos métodos quantitativos, ultrapassando o nível elementar de presença/ausência, ou situando na devida proporção as várias categorias cerâmicas mediante uma avaliação global sólida.

É certo que no âmbito da Arqueologia Moderna pesa o inevitável fascínio das aludidas ligações proporcionadas pela "primeira globalização", como as ocorrências asiáticas da porcelana, céladon, "thai jars" e potes martabã, ou o volume das importações de requintadas elaborações oleiras europeias, designadamente as italianas, holandesas e germânicas. Mas, e porque essa constitui uma das principais virtualidades da Arqueologia Moderna, que tem ao seu dispor a documentação, é imperioso que no discurso arqueológico disciplinar a narrativa seja, não só mais sólida de um ponto de vista metodológico, como mais informada. A esse propósito é quase irresistível invocar os preços dos bens em Vila Viçosa constantes do inventário produzido após o falecimento em 1563 do $5^{\circ}$ Duque de Bragança, D. Teodósio I, trabalhado para as matérias que mais interessam aqui por Joana Torres e André Teixeira (2018, p.326 e gráfico 25.1): nele, um “prato de Veneza” é avaliado em 20 reais, um "de Pisa" 65, um em porcelana 50 , em estanho 40 , em prata 3222; um pote vidrado 20, uma panela vidrada 50, um pote Martabã 400, um copo de vidro 50; ou contrastar os preços de um vaso empedradro de Badajoz, avaliado em 3 reais, com os 150 de um de Estremoz! Esta é apenas uma bem evocativa referência às potencialidades proporcionadas pelo cruzamento da informação altamente qualificada constante na documentação com o dado arqueológico, permitindo situar com precisão à época todo o contorno económico dos objectos mencionados e que ocorrem nos contextos modernos.

Como procurámos mostrar ao longo do presente texto, o refinamento metodológico na abordagem das cerâmicas que implica a quantificação, comporta vantagens evidentes ao nível da produção do discurso sobre as cerâmicas. Convém destacar aqui que, como afirmámos antes, o objectivo não é tanto o do apuramento da atribuição cronológica, ou do aprofundamento discriminatório na elaboração tipológica, como também não visa apenas a verificação de padrões, tendências, assimetrias ou distribuições: em última análise o que se persegue são as 
inferências que a partir daquelas observações e da produção de indicadores se podem elaborar, transportando a disciplina para outro nível da sua praxis, e facultando as ferramentas que permitem analisar comparativamente distintos contextos, quadros e geografias, e as inferências que, por seu turno, a partir daí se poderão de igual modo produzir.

\section{BIBLIOGRAFIA}

ALMEIDA, Mariana (2013) - As cerâmicas de importação do convento de Setúbal: Majólicas italianas e porcelana chinesa. In José Morais Arnaud, Andrea Martins e César Neves (coord.) - Arqueologia em Portugal: 150 anos. Lisboa: Associação dos Arqueólogos Portugueses (AAP), pp.1155-1162.

ARCELIN, Patrick; TUFFREAU-LIBRE, Marie (dir.) (1998) - La quantificacion des céramiques. Conditions et protocole. Ates de la table ronde du Centre Archéologique Européen du Mont Beuvray (Glux-en-Glenne, 7-9 avril 1998). Glux-enGlenne: Centre Archéologique Européen du Mont Beuvray (Colletion Bibrate, n.ำ 2).

BARCLAY, Keneth; BIDDLE, Martin; ORTON, Clive (1990) - The chronological and spatial distribution of the objects. In Martin Biddle (dir.) Object and economy in medieval Winchester. Artefacts from Medieval Winchester. Oxford: Clarendon Press (col. Winchester Studies, 1), pp. 42-73.

BARGÃO, André (2015) - Vivências do quotidiano do Hospital Real de Todos-Os-Santos (Lisboa). Os contextos do poço SE do claustro NE. Lisboa: Faculdade de Ciências Sociais e Humanas (Dissertação de Mestrado).

BARKER, David; MAJEWKI, Teresita (2014) - Chapter 12. Ceramic studies in historical archaeology. In Dan Hicks e Mary Beaudry (eds.), The Cambridge companion to Historical Archaeology ( $4^{\underline{a}}$ Ed.). Cambridge: Cambridge University Press, pp. 205-231.

BINFORD, Lewis (1968) - New Perspectives in Archaeology. Chicago: Aldine Press.

CASIMIRO, Tânia (2010) - Faiança Portuguesa nas Ilhas Britânicas (dos finais do século XVI aos inícios do século XVIII). Lisboa: Faculdade de Ciências Sociais e Humanas da Universidade Nova de Lisboa (Dissertação de doutoramento).

CASIMIRO, Tânia (2013) - Faiança portuguesa: datação e evolução crono-estilística. In Revista portuguesa de Arqueologia, n.. 16. Lisboa: Igespar, pp. 351-367.

CASTRO, Fernando; DÓRDIO, Paulo; TEIXEIRA, Ricardo (1998) - 200 anos de cerâmica na Casa do Infante: do séc. XVI a meados do séc. XVIII. In João Diogo e Hélder Chilra Abraços (Eds.) Actas das II Jornadas Cerâmica Medieval e Pós-Medieval. Métodos e resultados para o seu estudo (Tondela, 22-25 de Março de 1995). Tondela: Câmara Municipal de Tondela, pp. 223-230.
CLARKE, David (1968) - Analytical Archaeology. London: Methuen.

CLARKE, David (1973) - Archaeology: the loss of innocence. Antiquity. Cambridge: 47. pp. 6-18.

DESBAT, Alain (1990) - Les bons comptes font les bons amis ou la quantification des céramiques. In SFECAG Actes $d u$ Congès de Mandeure-Mathay. Mandeure-Mathay: Société Française d'Études de Céramique Antique en Gaule, pp. 131-135.

DIOGO, António Manuel Dias; TRINDADE, Laura (1995) - Cerâmicas de Lisboa provenientes de contextos datados : materiais de uma lareira de cozinha destruída pelo Terramoto de 1755. In João Manuel Diogo e Hélder Chilra Abraços (eds.), Actas das ias. Jornadas de Cerâmica Medieval e Pós- Medieval. Métodos e Resultados para o seu Estudo (Tondela, 1991). Tondela: Câmara Municipal de Tondela, pp. 163-170.

DÓRDIO, Paulo (1997/1998) - Como pôr ordem em 500 ooo fragmentos de cerâmica? Ou discussão da metodologia de estudo da cerâmica na intervenção arqueológica da Casa do Infante (Porto). In Olaria: Estudos Arqueológicos, Históricos e Etnológicos, $2^{\underline{a}}$ Série, $\mathrm{n}^{\circ} 2$ (duplo). Barcelos: Museu da Olaria, pp. 115-125.

FENTRESS, Elisabeth; PERKINS, Philip (1988) - Counting African Red Slip Ware. In A. Mastino (Ed.), L'Africa romana: Atti del V convegno di studi (Sassari 11-13 dicembre 1987). Sassari: Ed. Gallizi, pp. 205-214.

FERREIRA, Sara (2015) - O sítio do forte de São Paulo: estudo arqueológico da Ribeira Ocidental de Lisboa na época moderna. Lisboa, Faculdade de Ciências Sociais e Humanas (Dissertação de Mestrado).

FERREIRA, Sara da Cruz; BARGÃO, André; SILVA, Rodrigo Banha da; TORRES, Joana Bento; TEIXEIRA, André (no prelo) - Um contexto dos inícios do século XVIII da Rua dos Correeiros (Baixa de Lisboa): revisão crítica dos dados da Sondagem 14 (1991). In Actas dos II Encontros de Arqueologia de Lisboa. Lisboa: Departamento de Património Cultural, Centro de Arqueologia de Lisboa.

FERREIRA, Sara; BARGÃO, André (2016)-O Sítio do Forte de São Paulo: Estudo Arqueológico da Ribeira Ocidental de Lisboa na Época Moderna". In Inês Pinto Coelho, Luís Serrão Gil, (eds.), Entre ciência e cultura: da interdisciplinaridade à transversalidade da arqueologia. Actas das VIII Jornadas de Jovens em Investigação Arqueológica. Lisboa: CHAM-Centro de História d'Aquém e d'Além Mar (col. ArqueoArte, n. .4 ), pp. 243-250.

FERREIRA, Sara; NEVES, César; MARTINS, Andrea; TEIXEIRA, André (2017) - Fragmentos da Mesa Nobre e de uma cidade em transformação: porcelana chinesa em contexto de terramoto da Praça do Comércio (Lisboa, Portugal). In Ana Caessa, Cristina Nozes, Isabel Cameira e Rodrigo Banha da Silva (coord.), I Encontro de Arqueologia de Lisboa. Uma cidade em escavação (Teatro Aberto, 26, 27 e 28 de Nov. de 2015). 
Lisboa: Departamento de Património Cultural, Centro de Arqueologia de Lisboa, pp. 459-477.

FLETCHER, Lock (1991) - Digging numbers. Elementary satistics for archaeologists. Oxford: Oxford University (col. Oxford University Comitee for Archaeology monograph, 33).

GOMES, Paulo Dórdio; SILVA, António Manuel S. P.; TEIXEIRA, Ricardo; COUTO, Marcos; RODRIGUES, Miguel (2018) - Louça vermelha de Aveiro e de Ovar: ensaio de uma síntese atualizada. In FRANÇA, A.; PEREIRA, G.; ELVAS, R. (coord.), 3.7. Olaria de Ovar - Catálogo da Exposição. Ovar: Câmara Municipal de Ovar, pp. 4-43.

GOMES, Rosa Varela (2012) - A Arqueologia da Idade Moderna em Portugal - contributos e problemáticas. In O Arqueólogo Português, Série V, n.ํㅜ 2. Lisboa: Museu Nacional de Arqueologia, pp. 13-75.

HODDER, Ian (Ed.) (1982) - Symbolic and Structural Archaeology. Cambridge: Cambridge University Press.

HODDER, Ian; HUTTON, Scott (2003) - Reading the Past: Current Approaches to Interpretation in Archaeology ( $3^{\underline{a}}$ ed.). Cambridge: Cambridge University Press.

HUSI, Philippe (2001) - Quantification et datation en céramologie (Le nombre minimum d'indivius: la technique de quantification la mieux adaptée à la datation des contextes archéologiques à partir de l'ensemble de Tours. Tours: Université de Tours, Laboratoire Archéologie et Territoirs (col. Les Petits Cahiers d'Anatole, n.․ 6).

LAMOTTA, Vincent M; SCHIFFER, Michael B. (2005) Archaeological formation processes. In Colin Renfrew e Paul Bahn, Archaeology. The key concepts. Londres e Nova Iorque: Routledge, pp. 121-126.

MADSEN, Torsten (dir.) 1988 - Numerical approaches in Scandinavian Archaeology. Jutland: Aarhus University (Jutland Archaeoloical Society publications, 21).

OLIVEIRA, Filipe (2012) - Espólio de Idade Moderna, proveniente do Beco das Barrelas, Alfama, Lisboa. Lisboa: Faculdade de Ciências Sociais e Humanas (Dissertação de Mestrado).

ORTON, Clive (1975) - Quantitative pottery studies: some progress, problems and prospects. In Science and Archaeology, n. ${ }^{\circ} 16$. Stoke-on-Trent: Research Centre for computer Archaeology, pp. 30-35.

ORTON, Clive (1979) - Dealing with the pottery from a 6 oo acre urban site. In Martin Millet (Ed.) Pottery and the Archaeologist. Londres: Institute of Archaeology (col. Institute of Archaeology Occasional Publications, 4), pp. 61-71.

ORTON, Clive (1980) - Mathematics in Archaeology. Cambridge: Collins Publications (col. Cambridge Manuals in Archaeology).

ORTON, Clive (1982)- Computer simulation experiments to assess the perfomance of measures of quantity of pottery. In World Archaeology, 14, n. ${ }^{\circ}$, pp. 1-20.
ORTON, Clive (1989) - An introduction to the quantification of assemblages of pottery. In Journal of Roman Pottery Studies, n. ํㅜㄹ. Oxford: Oxbow Books, pp. 94-97.

ORTON, Clive (1993) - How many pots make five? - an historical review of pottery quantification. In Archaeometry, vol. 35-2. Oxford: Oxford University, pp. 169-184.

ORTON, Clive; HUGHES, Michael (2013) - 5. Quantification In Pottery in Archaeology (2 $2^{\underline{a}}$ Ed.). Cambridge: Cambridge University Press (col. Cambridge Manuals in Archaeology), pp. 203-218.

ORTON, Clive; TYERS, Paul; VINCE, Alan (1993) - Pottery in Archaeology. Cambridge: Cambridge University Press (col. Cambridge Manuals in Archaeology).

PEARCE, Jacqueline (1992) - Border Wares. In Post-Medieval Pottery in London 1500-170o, vol. I. London: Museum of London.

PEÑA, J. Theodor (2007) - Roman Pottery in the Archaeological Record. Cambridge: Cambridge University Press.

REAL, Manuel L.; DÓRDIO, Paulo; TEIXEIRA, Ricardo; MELO, Rosário (1995) - Conjuntos cerâmicos da intervenção arqueológica da Casa do Infante, Porto: elementos para uma sequência longa (Sécs. IV-XIX). In João Manuel Diogo e Hélder Chilra Abraços (Eds.), Actas das 1as. Jornadas de Cerâmica Medieval e Pós-Medieval. Métodos e Resultados para o seu Estudo (Tondela, 1991). Tondela: Câmara Municipal de Tondela, pp. 171-186.

REAL, Manuel Luís; GOMES, Paulo Dórdio; TEIXEIRA, Ricardo; SILVA, António Manuel (2015) - A investigação científica na Casa do Infante. In Amândio de Barros (coord.), Os Descobrimentos e as origens da convergência global. Porto: Câmara Municipal do Porto, Associação para a Divulgação da Cultura de Língua Portuguesa, pp. 325-333.

REMOLÁ VALLVERDÚ, Josep Antón (200o) - Las ánforas tardo-antiguas en Tarraco (Hispania Tarraconensis) Siglos IV-VII d.C. Barcelona: Universitat de Barcelona (Col.lecció Instrumenta, $\mathrm{n} .{ }^{\circ} 7$ ).

SEBASTIAN, Luís (2010) - A Produção Oleira de Faiança em Portugal (Séculos XVI-XVIII). Lisboa: Faculdade de Ciências Sociais e Humanas da Universidade Nova de Lisboa. (Dissertação de Doutoramento).

SHANKS, Michael; TILLEY, Christopher Y. (1992) - ReConstructing Archaeology. Theory and Practice. New Studies in Archaeology ( $2^{\underline{\underline{a}}}$ ed.). London e New York: Routledge.

SHENNAN, Stephen (1997) - Quantifying Archaeology. Edinburgh: Edinburgh University Press.

SILVA, Ricardo Costeira da (2013) - Primeira abordagem a um depósito moderno no Antigo Paço Episcopal de Coimbra (Museu Nacional de Machado de Castro): a cerâmica desde meados do século XV à consolidação da Renascença. In André Teixeira e José Bettencourt (coords.), Velhos e Novos Mundos, vol. II. Lisboa: Centro de História de Além-Mar (col. Estudos de Arqueologia Moderna, 1), pp. 877-89o. 
SILVA, Ricardo Costeira da (2016b) - The faience of the $2^{\text {nd }}$ half of the 16t century at the Episcopal Palace of Coimbra (Portugal). In Rosa Varela Gomes, Tânia Casimiro e Mário Varela Gomes (eds.), Proceedings of the $\mathrm{I}^{\mathrm{st}}$ International Conference of Portuguesa Faience (1 $6^{\text {th }}$ to $19^{\text {th }}$ centuries). S.l: Instituto de Arqueologia e Paleociências, pp. 181-188.

SILVA, Ricardo Jorge Costeira da (2016a) - O Museu Nacional de Machado de Castro: um ensaio de arqueologia urbana em Coimbra: do fórum augustano ao paço episcopal de Afonso de Castelo Branco. Coimbra: Faculdade de Letras da Universidade de Coimbra (dissertação de doutoramento).

SILVA, Rodrigo Banha da (2005) - As «marcas de oleiro» da terra sigillata da Praça da Figueira (Lisboa): uma contribuição para o conhecimento da economia de Olisipo (séc. I a.C. - séc. II d.C.). Braga: Universidade do Minho, Instituto de Ciências Sociais (Dissertação de mestrado).

SIMÃO, Inês; PINTO, Marina; PIMENTA, João; FERREIRA, Sara da Cruz; BARGÃO, André; SILVA, Rodrigo Banha da (no prelo) - Os cachimbos dos séculos XVII e XVIII do Palácio Mesquitela e Convento dos Inglesinhos (Lisboa). In José Morais Arnaud e Andreia Martins (eds.), Actas do III Congresso da Associação dos Arqueólogos Portugueses. Libsoa: Associação dos Arqueólogos Portugueses.

T1 NMI (477)

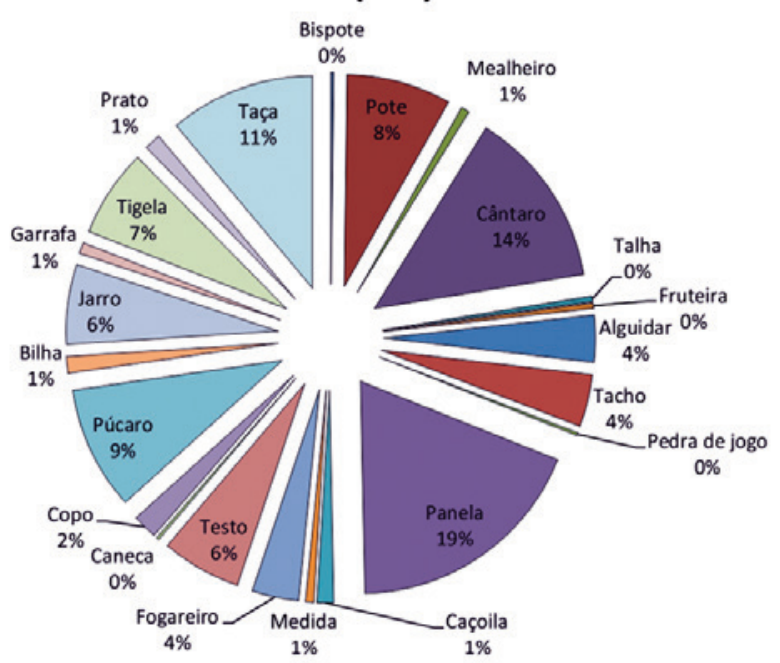

SPAULDING, Albert C. (1953) - "Statistical techniques for the discovery of artifact types". In American Antiquity. Vol. 18-4: pp. 305-313.

TORRES, Joana Bento; TEIXEIRA, André; (2018) - Capítulo 25. Com o lume aceso. As cozinhas do Paço Ducal no século XVI. In Jessica Hallet e Nuno Senos (coord.), De Todas as partes do mundo. O património do $5^{\circ}$ Duque de Bragança, D. Teodósio I, vol.I, Estudos. Lisboa: CHAM-Centro de Humanidades, Tinta da China, pp. 317-329.

TRIGGER, Bruce (1989)- A History of Archaeological Thought. New York: Cambridge University Press.

TRINDADE, Laura; DIOGO, A.M. Dias (2003) - Cerâmicas de Barro Vermelho de Entulhos do Terramoto de 1755 Provenientes da Sondagem 14 da Rua dos Coreeiros, em Lisboa.

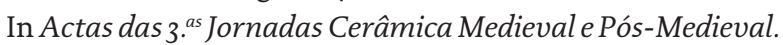
Métodos e resultados para o seu estudo. Tondela: Câmara Municipal de Tondela, pp. 285-293.

T1 EVE (191)

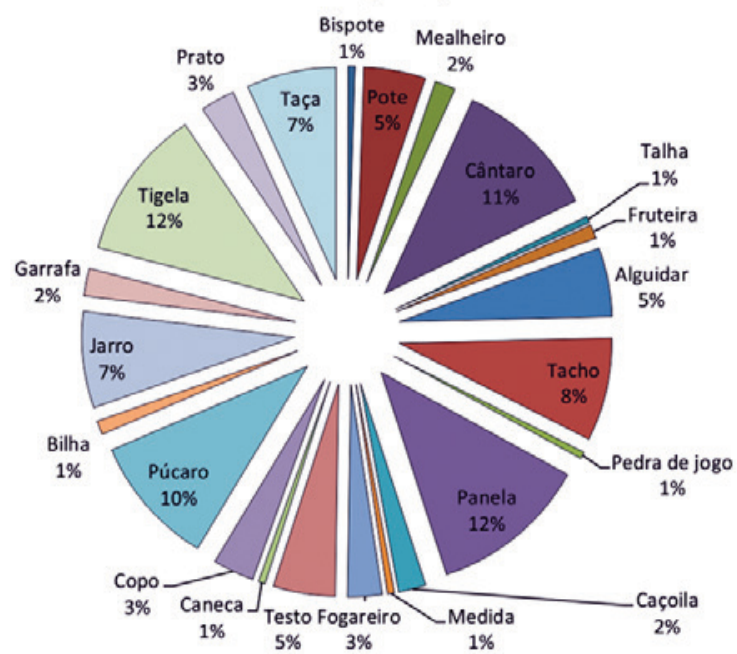

Figura 1 - Quantificação do conjunto cerâmico de um poço medieval nas traseiras do Hospital Real de Todos-os-Santos (Lisboa), segundo NMI e EVE. 


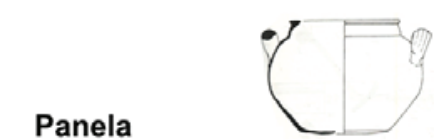

\begin{tabular}{|r|r|r|r|r|}
\hline \multirow{2}{*}{ Raio } & Exvertido & \multicolumn{3}{|c|}{ Invertido } \\
\cline { 2 - 5 } & Quadrangular & Quadrang & Semi-circular & Triangular \\
\hline 4 & & & & $10 \%$ \\
\hline 5 & & & $10 \%$ & $5 \%$ \\
\hline 5,5 & $12 \%$ & $22 \%$ & & \\
\hline 6 & $10 \%$ & $176 \%$ & $72,50 \%$ & $175,50 \%$ \\
\hline 6,5 & & $87 \%$ & $43 \%$ & \\
\hline 7 & $23 \%$ & $365 \%$ & $129,50 \%$ & $210,50 \%$ \\
\hline 7,5 & & $40 \%$ & $27 \%$ & $52,50 \%$ \\
\hline 8 & $8 \%$ & $223,50 \%$ & $240,50 \%$ & $286,50 \%$ \\
\hline 8,5 & & $90,50 \%$ & $47,50 \%$ & $115 \%$ \\
\hline 9 & $6 \%$ & $248 \%$ & $118,50 \%$ & $202 \%$ \\
\hline 9,5 & & & & $105 \%$ \\
\hline 10 & & $79 \%$ & $120,50 \%$ & $153,00 \%$ \\
\hline 10,5 & & & & $12,50 \%$ \\
\hline 11 & & & $60,50 \%$ & $28 \%$ \\
\hline 13 & & & & $19 \%$ \\
\hline
\end{tabular}

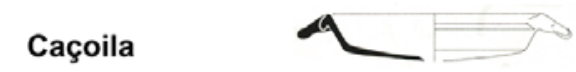

\begin{tabular}{|c|c|c|c|c|}
\hline \multirow[b]{2}{*}{ Raio } & \multicolumn{2}{|c|}{ Bisel } & \multicolumn{2}{|c|}{ Espessado } \\
\hline & Semi-circu & Triangular & Semi-circ & Triangular \\
\hline 6 & $12 \%$ & & & \\
\hline 7 & & & $10 \%$ & \\
\hline 9 & $32 \%$ & & $67,50 \%$ & \\
\hline 9,5 & $16 \%$ & & & \\
\hline 10 & $24 \%$ & & $131 \%$ & \\
\hline 11 & $13 \%$ & $2,50 \%$ & $183,50 \%$ & \\
\hline 12 & $21 \%$ & & $147,50 \%$ & \\
\hline 12,5 & $32,50 \%$ & & & \\
\hline 13 & & & $182 \%$ & \\
\hline 14 & $9 \%$ & & $75 \%$ & $7 \%$ \\
\hline 15 & $12 \%$ & & $30,50 \%$ & \\
\hline 16 & & & $39,50 \%$ & \\
\hline 17 & & & $20 \%$ & \\
\hline 19 & & $7 \%$ & & \\
\hline 8 & & & $17,50 \%$ & \\
\hline
\end{tabular}

\section{Tacho}

Testo

\begin{tabular}{|r|r|}
\hline Raio & \\
\hline 3,5 & $35,00 \%$ \\
\hline 4,5 & $10 \%$ \\
\hline 5 & $62,50 \%$ \\
\hline 5,5 & $20 \%$ \\
\hline 6 & $92 \%$ \\
\hline 6,5 & $174,50 \%$ \\
\hline 7 & $239 \%$ \\
\hline 7,5 & $34,50 \%$ \\
\hline 8 & $337,50 \%$ \\
\hline 8,5 & 36,5 \\
\hline 9 & $162,50 \%$ \\
\hline 10 & $120,50 \%$ \\
\hline 11 & $20 \%$ \\
\hline 12 & $7,50 \%$ \\
\hline
\end{tabular}

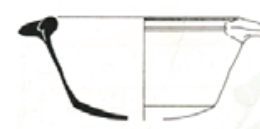

\begin{tabular}{|r|r|l|}
\hline \multirow{2}{*}{ Raio } & Espessado & Bisel \\
\cline { 2 - 3 } & Semi-cir & Semi-cir \\
\hline 5 & $10 \%$ & \\
\hline 7 & $46 \%$ & \\
\hline 8 & $105 \%$ & \\
\hline 8,5 & $10 \%$ & \\
\hline 9 & $239,50 \%$ & \\
\hline 9,5 & $208 \%$ & \\
\hline 10 & $375 \%$ & $18,50 \%$ \\
\hline 10,5 & $42,50 \%$ & \\
\hline 11 & $146 \%$ & $5 \%$ \\
\hline 11,7 & $100 \%$ & \\
\hline 12 & $219,50 \%$ & \\
\hline 12,5 & $75 \%$ & \\
\hline 13 & $139,50 \%$ & \\
\hline 13,5 & $19 \%$ & \\
\hline 14 & 172,5 & \\
\hline 16 & $57 \%$ & \\
\hline 17 & $7,50 \%$ & \\
\hline 18 & $15 \%$ & \\
\hline 19 & $7,50 \%$ & \\
\hline 22 & $18 \%$ & \\
\hline
\end{tabular}

Figura 2 - Contabilização comulativa dos EVE de quatro formas de "cerâmica fosca de barro vermelho" de um contexto de inícios do século XVIII da Rua dos Coreeiros (Lisboa). 


\title{
FAIANÇAS DE DOIS CONTEXTOS ENTRE OS FINAIS DO SÉCULO XVI E XVIII DO PALÁCIO DOS CONDES DE PENAFIEL, LISBOA
}

\author{
Martim Lopes ${ }^{1}$, Tomás Mesquita ${ }^{2}$
}

\begin{abstract}
RESUMO
O Palácio dos Condes de Penafiel, em Lisboa, foi alvo de intervenções arqueológicas entre 1992 e 1993, nas quais foram exumados três contextos de Época Moderna, entre os séculos XVI e XVIII (1755), quando está documentada a destruição do edifício prévio ao actual palácio dos Condes de Penafiel.

Os autores propõem-se analisar o espólio de faiança europeia proveniente dos dois contextos mais antigos, associados à desativação de uma conduta baixo-medieval (final do século XVI-XVII) e a edificação da primitiva unidade habitacional ( $1^{\circ}$ quartel do século XVI) que colapsa em 1755, onde foram recolhidas cerâmicas utilizadas na construção do edifício.

Palavras-chave: Faiança Portuguesa, Séculos XVI-XVIII, Majólica, Belarminos.
\end{abstract}

\begin{abstract}
The Palace of Condes de Penafiel, in Lisbon, was archaeological interventioned between 1992-1993, in which were recovered three contexts of historical archaeology, datable between the XVI century and the XVIII century, when is documented the collapse of the previous to the actual palace, during the 1755 earthquake.

The authors analyse the European faience recovered from the two oldest contexts (XVI-XVII century), associated to the deactivation of a medieval drain and the primitive edification of the building ( $1^{\text {st }}$ quarter of XVI century), which is destroyed in 1755 , where were collected ceramics reused within the walls.
\end{abstract}

Keywords: Portuguese Faience, XVI-XVIII Centuries, Maiolica, Belarmine.

\section{INTRODUÇÃO}

Os jardins do Palácio dos Condes de Penafiel estão situados numa das encostas do Castelo de São Jorge, no cruzamento da Rua de Martim Alho, o Largo do Correio Velho, a Rua de S. Mamede ao Caldas e a Calçada do Correio velho, tendo sido efectuada uma intervenção entre o ano de 1992 e 1993 pela equipa municipal, sob a direção de António Dias Diogo (Bargão, Ferreira e Silva, 2017, p.1781), estando o espaço actualmente ocupado com a sede da CPLP em Lisboa.

Esta área corresponde a uma edificação que remonta à reconstrução da cidade de Lisboa após os danos causados pelo terramoto de 1 de Novembro de 1755, sendo a datação da construção desta estrutura apontada para o período entre 1770 e 1773.

De acordo com o tombo pombalino, as unidades habitacionais prévias a 1770, exumadas no decorrer dos trabalhos, pertenceriam a D. Luís de Portugal (habitação Sul) e ao Padre João de Sequeira (habitação Norte) (Bargão, Ferreira e Silva, 2017, p. 1784). Já em 1650 é visível na planta de João Nunes Tinoco os contornos correspondentes às duas habitações, podendo ser recuadas as referências até à segunda metade do século XVI, através da iconografia de Bráunio, onde já está representado o quarteirão em causa (Bargão, Ferreira e Silva, 2017, p. 1784).

\footnotetext{
1. NOVA-FCSH; martimafonsorl@sapo.pt

2. ISCTE-IUL; tomasmmesquita@gmail.com
} 
No respeitante às condutas, estas estariam ainda em uso no século XVIII, ainda que a sua altura máxima de 1,30 m estivesse colmatado em mais de o,70 m por várias unidades, com profuso material cerâmico datável às primeiras décadas do século XVI, que sugerem o seu deficiente planeamento e falha de manutenção no curto prazo. Esta conduta, está referenciada no Livro dos Pregos, com uma datação de 1524 a 1545, onde se referencia a posse do espaço por Dona Catarina, denominado como as casas de Dona Catarina (Bargão, Ferreira e Silva, 2017, p. 1784-1785). Esta proprietária poderá tratar-se da Rainha D. Catarina de Áustria, ou de Habsburgo, casada com D. João III em 1524, situação que é coeva com a arquitectura (localização, área, saneamento e qualidade do edificado) exumada pela intervenção arqueológica. (Bargão, Ferreira e Silva, 2017, p. 1786).

Quanto aos materiais de Época Moderna, são conhecidos até ao momento informações parciais, com a publicação de algumas peças isoladas, do conjunto de porcelana (Henriques, 2012, p. 919-932), um jarro de cerâmica comum brunida, enquadrado entre os séculos XV-XVI (Silva e Ferreira, 2015, p. 134), e um conjunto de 866 azulejos hispano-mouriscos (Bargão, Ferreira e Silva, 2017, p. 1781-1782).

\section{CONTEXTO DA INTERVENÇÃO ARQUEOLÓGICA}

Em 1991, a transferência do Ministério das Obras Públicas, do Terreiro do Paço para a zona da Colina do Castelo, implicou a adaptação de um conjunto de imóveis situados entre as ruas de São Mamede, das Pedras Negras, a Travessa do Almada e a Calçada do Correio Velho. Os trabalhos arqueológicos, iniciaram-se em consequência da deteção de afetação do subsolo, provocada pela abertura de sondagens geotécnicas nos três edifícios contíguos com a Travessa do Almada (Guimarães, Silva, 2017, p. 1280).

Posto isto, aquando do inicio dos trabalhos no Palácio dos Condes de Penafiel, para a sua adaptação a sede do Ministério das Obras Públicas, a necessidade da construção de um piso de parqueamento subterrâneo no espaço do jardim, convergiu na execução de trabalhos arqueológicos com o consentimento do extinto Departamento de Arqueologia do Instituto Português do Património Cultural (Guimarães, Silva, 2017, p. 1280), sendo que a instalação dos organismos no novo espaço resultou num maior impacte no local onde se encontrava o jardim (Bargão, Ferreira e Silva, 2017, p. 1782).

A intervenção ficou a cargo do já extinto GTTRL (Gabinete de trabalho do Teatro Romano de Lisboa), extinto em 1998, e onde permaneceram todos os registos da escavação (Bargão, Ferreira e Silva, 2017, p.1782), razão pela qual a única análise que é possível elaborar quanto à estratigrafia é somente a que se consiga deduzir dos registos que existem de inventário, onde se identifica as quadrículas e camadas de origem dos materiais, apenas sendo possível a tentativa de uma reconstrução horizontal da estratigrafia do sítio arqueológico.

A área em intervenção foi divida utilizando o método de Mortimer Wheeler, com a adaptação através da não criação de banquetas, com um total 16 quadrículas de $5 \times 5 \mathrm{~m}$, contabilizadas no sentido de este para oeste, e de sul para norte a partir do vértice SE da superfície interna, delimitada pelos muros da fachada do jardim (Guimarães, Silva, 2017, p. 128o; Bargão, Ferreira e Silva, 2017, p.1782).

$\mathrm{Na}$ sequência desta intervenção, foram detetadas duas habitações distintas, uma escavada na sua quase totalidade, correspondendo esta às quadrículas 1 a 12; e a segunda, ás quadriculas 13 a 16.

Estas habitações terão sucumbido no terramoto de 1 de Novembro de 1755, conhecendo-se pelos trabalhos de Ferreira de Andrade na década de 40 do século XX, referentes à freguesia de $\mathrm{S}$. Cristóvão, que a primeira habitação estaria associada a D. Luís de Portugal (Andrade, 1946).

$O$ contexto em estudo é respeitante às condutas que se encontram na casa de D. Luís de Portugal, correspondendo estas às quadrículas 3,4 e 8 , que se inserem nas salas 3 e 6 da habitação 1 e ao muro Norte da sala 2, que separa o pátio da habitação e a sala 5 , tendo os materiais em estudo sido recolhidos integrando a argamassa que constitui o muro, que será datado, no mínimo, do $1^{\circ}$ quartel do século XVI, dados os materiais que compõem o contexto.

As condutas intervencionadas foram divididas em 3 partes, com a ligação através de caixas, correspondendo os materiais presentes no seu interior ao progressivo enchimento das mesmas, tendo sido recolhido um conjunto de espólio composto por, nomeadamente, cerâmica comum de barro vermelho; porcelana da dinastia Ming, do reinado Wanli; e faiança portuguesa. 


\section{O CONTEXTO DAS CONDUTAS}

O conjunto estudado, não correspondendo à totalidade dos materiais exumados nas condutas, é constituído por um total de 272 fragmentos de faiança portuguesa, sendo de realçar a ausência de qualquer espólio importado, com excepção de porcelana.

São possíveis de distinguir dois momentos do entulhamento da conduta, sendo a $1^{\underline{a}}$ fase da quadrícula 3 e 8 , e a $2^{\underline{a}}$ fase apenas na quadrícula 3 , sendo que a parte da conduta que se encontra na quadrícula 4 não apresenta qualquer espólio de faiança, o qual aparenta concentrar-se junto às caixas de junção da canalização.

As formas presentes correspondem maioritariamente à forma do prato, sendo que dentro desse grupo a forma do prato de bordo em aba, corresponde, aquando da análise do número mínimo de indivíduos geral do conjunto, a $24 \%$ dos NMI, num total de $58 \%$ de pratos. Encontram-se presentes também as formas de Covilhete (12\%), Taça (10\%) e Taça troncocónica (19\%) (Ver tabela 1).

Não foi possível determinar a que tipo de forma pertencem 149 fragmentos dos 272 em estudo, devido a estes se encontrarem em mau estado de conservação, não apresentando qualquer esmalte, ou estando muito fragmentados, não possibilitando mais nenhuma classificação para além de se determinar se se trata de bordo, fundo ou bojo.

As faianças recolhidas no contexto das condutas caracterizam-se por serem de fabrico regional, isto é, de Lisboa, com predomínio (91,18\%) das pastas de coloração amarela/creme (2.5Y 8/6), surgindo em minoria $(8,82 \%)$ pastas de coloração avermelhada (1oR 6/8), com apenas 24 fragmentos. As pastas amarelas possuem, na sua maioria um acabamento com esmalte de cor branca ( 5 YR 8/1), enquanto as pastas de coloração avermelhada são na sua maioria detentoras de um acabamento em esmalte verde (5YR 7/8) ou com uma tonalidade de transição entre verde e branco (5Y 8/2).

As pastas amarelas caracterizam-se por serem relativamente compactas, com textura moderadamente regular e reduzida resistência, com elementos não plásticos (ENP) que se caracterizam pela presença em grande quantidade de quartzo ferruginoso de média dimensão, pouca moscovite e alguns, raros, elementos ferruginosos.

As pastas avermelhadas caracterizam-se por serem pastas compactas, de textura e fractura irregulares.
Em termos de composição dos seus elementos não plásticos (ENP) partilha uma matriz comum com as pastas amarelas, notando-se apenas a adição de algum quartzo hialino de pequena/média dimensão. É de apontar que no interior do esmalte verde de acabamento, este apresenta também alguns quartzos ferruginosos embutidos em si, não sendo claro se fazem parte da superfície da pasta ou de constituintes do esmalte.

Quanto aos esmaltes, estes apresentam uma espessura muito fina, nunca excedendo os $0,5 \mathrm{~mm}$ de espessura.

Nas formas cujo esmalte é verde (pratos), ou de tonalidade verde (taças), estas nunca apresentam decoração, quer externamente, quer internamente. Estas faianças apresentam-se como as de cronologia mais recuada no contexto, enquadrando-se cronologicamente nos finais do século XVI e princípios do século XVII (Sebastian, 2010, p. 137).

Quanto às formas cerâmicas representadas no conjunto, destaca-se a por nós designada como prato de aba, para o qual possuímos somente um fragmento de perfil completo. Esta forma caracteriza-se por possuir um fundo em ônfalo, parede extrovertida em ângulo de cerca de $45^{\circ}$, com uma carena pronunciada na superfície externa, onde a orientação da parede verticaliza, terminando num bordo em aba, de forma côncava e tendência horizontal. Característica desta forma é ainda o esmalte esverdeado e as pastas avermelhadas, existindo, no entanto, alguns exemplares que possuem pasta amarela e um esmalte branco de muito boa qualidade, por vezes ainda com alguma tonalidade verde, denotando a transição para as produções canónicas Lisboetas.

Dentro da forma do prato, distinguiu-se ainda a forma do prato médio, que consideramos caracterizar-se por um bordo extrovertido, com uma secção côncava na transição entre o seu fundo e o bordo, apresentando internamente uma carena ligeiramente pronunciada na transição com o bordo. Esta forma apresenta ainda um pé em anel, que pode ser mais ou menos pronunciado. Apenas se optou por esta classificação aquando da presença de um perfil completo, situação que se verificou com o surgimento de dois pratos em muito bom estado de conservação, incluindo iconografia, a qual se distingue pela sua individualidade no conjunto.

A iconografia presente nestes dois exemplares de prato, remete, num dos casos para os temas barrocos, com a representação de um putti como tema 
central, havendo junto ao bordo uma inscrição em vináceo, ainda que, devido à fragmentação, não seja possível de interpretar. O outro prato, que se apresenta praticamente completo, e cuja forma não é completamente redonda, assemelhando-se a uma forma oval, é decorado com azul cobalto e amarelo, com motivos decorativos que não foram possíveis de precisar, ainda que a hipótese mais plausível seja a de motivos vegetalistas, à semelhança do ocorre na face externa, tendo este estilo decorativo uma cronologia de cerca de meados do século XVII.

No respeitante aos pratos fundos, considerou-se aqueles que possuindo o perfil completo, apresentam uma verticalidade entre $90^{\circ}$ e $70^{\circ}$ da parede, desde o fundo até ao bordo, sendo de difícil distinção uma área de transição clara entre o fundo e o bordo, contrariamente ao que ocorre no prato de aba e no prato médio. A decoração destas formas caracteriza-se por uma ou duas linhas a azul cobalto no interior junto à extremidade do bordo, e uma ou duas circunferências concêntricas no fundo, também em azul cobalto, podendo, na maioria dos casos, possuir uma decoração fitomórfica ou de inspiração oriental no interior do centro do fundo.

O prato covo carateriza-se pelo bordo côncavo e extrovertido, não existindo distinção entre a caleira do prato e o fundo, sendo somente uma só parte de forma hemisférica.

A forma de covilhete caracteriza-se por possuir um fundo plano, pé em anel, e uma parede muito verticalizada, com diâmetros de bordo enquadráveis entre os 13 e os 16 centímetros. Estas não possuem qualquer decoração, ou tendo será somente na superfície externa, com motivos barrocos, em arranhões e pêssegos, podendo possuir uma linha no interior, junto ao bordo, em manganês ou em azul cobalto.

A forma da taça caracteriza-se por ser hemisférica e por ter um diâmetro de bordo enquadrável entre 1o e 16 centímetros, com um bordo extrovertido, ligeiramente espessado externamente, e fundo em pé de anel. Estas formas apresentam-se como uma das mais representadas nas produções de esmalte verde e pasta avermelhada, nunca possuindo qualquer decoração nesse acabamento. Em esmalte branco, apresentam somente decoração em azul sobre branco, sem motivos compósitos.

A última forma identificada é a taça troncocónica, na qual considerámos as formas de grande dimensão, de fundo plano ou com tendência a descair para o plano do pé junto ao centro, parede de tendên- cia extrovertida, com um bordo espessado externamente, passível de ser considerado como lábio. Estas formas apresentam uma elaborada decoração em azul cobalto no seu interior, e apenas algumas linhas, que nos sugerem motivos vegetalistas, no exterior. Quanto ao seu pé, este não é marcadamente um pé de anel, no entanto, sem deixar de se destacar do fundo.

Dos materiais abordados, os únicos que não forneceram nenhuma forma relativamente bem preservada, apresentando o conjunto um elevado estado de fragmentação, foram as faianças de azul sobre azul, razão pela qual existe a possibilidade de um dos fragmentos poder ter possuído decoração a amarelo, mas sem certezas devido à sua fragmentação.

Quanto ao enquadramento cronológico do conjunto, este situa-se entre os finais do século XVI/princípios do século XVII ( $\mathrm{I}^{\mathrm{a}}$ fase), com as primeiras produções de faiança portuguesa, e os meados do século XVIII ( $2^{\underline{a}}$ fase), com as decorações em arranhões e pêssegos e os motivos fitomórficos simples (Gomes, Casimiro e Gonçalves, 2012, p.107).

Quanto à interpretação cronológica passível de ser efectuada a partir dos materiais, podemos afirmar, com certezas que estes correspondem a um progressivo processo de entulhamento e desativação das estruturas.

Assim, a primeira fase de entulhamento, enquadra-se entre o final do século XVI e a primeira metade do século XVII, de onde se destacam algumas camadas. Posto isto, observamos na quadricula $3 \mathrm{AB}$ - camada 42 , a presença de carena de prato de aba, sem decoração, com pasta amarela e cor branca com tom verde no exterior. Observa-se igualmente outro fragmento, agora um bordo, que se insere nas mesmas especificações que o fragmento suprarreferido. Propõe-se a cronologia centrada em torno a finais do século $\mathrm{XVI} /$ inicio do século XVII.

Já na camada 42 A foi exumado um fragmento correspondente a um prato de aba de tonalidade verde, com pasta avermelhada. Tendo em conta as informações expostas sobre o fragmento exumado é possível datar esta camada a finais do século XVI (Sebastian, 2010).

Na quadricula 8 - camada 7 , surge o fragmento de perfil completo de prato com decoração a azul e amarelo. Foi exumado também o fragmento de bordo de um prato de aba com esmalte a branco. E salientamos ainda um fragmento de um fundo em ônfalo também de prato de aba. Com base nas evidências, e 
em particular na decoração a amarelo e azul, apontamos a um momento próximo de meados do século XVII (Casimiro e Sequeira, 216 p. 263).

A segunda fase do processo de entulhamento e abandono das condutas, que apenas está documentada na quadrícula 3, na parte respeitante às condutas 2 e 3 , está datada entre a $2^{2}$ - metade do século XVII e o início do século XVIII.

Esta datação é corroborada pela recolha, na conduta 2 - camada 41, de três fragmentos de prato com decoração simples em azul; um do bojo de tigela sem decoração e um fragmento de prato com decoração a azul sobre azul e amarelo (berretino). Exposto isto, é possível datar a camada a meados do século XVII/XVIII.

Já para a conduta 3, na camada 23 c), foi exumado um fragmento de bordo de prato, que apresenta decoração em vináceo e azul de tema barroco com pêssegos. Surge também um fragmento de fundo de prato, cuja decoração apresenta motivos vegetalista a azul e vináceo da faixa barroca. Referimos por último um fragmento de bordo pertencente a uma taça decorado a azul e branco. Face ao exposto é possível sugerir a datação da camada entre o final do século XVII e o início do século XVIII. (Gomes, Casimiro, Gonçalves, 2012. p. 107).

Assim, e tendo em consideração que a adição de letras à numeração das camadas corresponde a extensões das camadas, podemos afirmar que o entulhamento da conduta 3 corresponde na sua fase mais antiga à camada 42 (entulhando então também parte da conduta 2), datada de finais do século XVI, seguida de novo entulhamento (camada 41) enquadrável já no século XVII, provavelmente durante o $1^{\circ}$ quartel do século XVII.

A conduta 2 terá tido também o seu primeiro entulhamento nos finais do século XVI, seguida de novo entulhamento já em pleno século XVII e no inicio do século XVIII.

$\mathrm{Na}$ sala 3, as condutas são colmatadas pela camada 23 e suas extensões, datadas do século XVIII.

Quanto à caixa N, ou seja, a transição entre a conduta 2 e a conduta 1, esta é datável, na sua colmatação, ao inicio do século XVII, já que as formas presentes assim o comprovam.

Apenas a conduta 1 não apresenta qualquer espólio de faiança, pelo que não é possível atestar o momento do seu abandono, no entanto, este deverá ser contemporâneo à caixa N, ou seja, inicio do século XVII. Assim, levantam-se algumas questões quanto à cro- nologia avançada por Luís Sebastian (2010) para as produções de esmalte verde, podendo, a nosso ver, ser remetido para meados do século XVI, ao invés do final da centúria. Quanto ao final das produções de pasta vermelha e esmalte verde, o espólio aparenta apontar o seu desaparecimento nos meados do século XVII, quando se encontra ausente e as suas formas são substituídas por iguais em esmalte branco, mantendo, ainda as mesmas pastas vermelhas inalteradas e em convivência com pratos com as pastas amarelas e formas do século XVII/XVIII.

\section{CONTEXTO DO MURO NORTE DA SALA 2}

A construção do edifício, integrado inicialmente nas casas de D. Catarina, e posteriormente propriedade de D. Luís de Portugal (Bargão, Ferreira e Silva, 2017, p. 1788; Andrade, 1946), terá resultado de uma remodelação profunda do espaço previamente existente, com a já analisada desactivação do cano baixo-medieval e a edificação de uma residência destinada a ocupantes da alta burguesia ou nobreza, podendo ser mencionada a riqueza do edifício através da sua decoração profusa com azulejos, dos quais se destacam as importações, que permitem situar a edificação ou remodelação do espaço em torno à década de 1520 (Bargão, Ferreira e Silva, 2017, p. 1787-1788).

Foi, no entanto, identificado no muro Norte da sala 2 um contexto referente à construção da habitação, onde se integraram materiais arqueológicos nas argamassas, podendo por tal ser atribuída uma cronologia entre os meados do século XVI e o inicio do século XVII que, ainda que correspondendo a um pequeno conjunto, encontram representadas produções italianas, alemãs (Westerwald) e de Manizes/Paterna. É de realçar que, sem contexto claro, surgem mais alguns fragmentos desta cronologia entre os materiais do contexto de 1755 , sendo que pelo estado de conservação dos fragmentos, é sugerido que se tratem de fragmentos provenientes de perturbações posteriores nos contextos mais antigos, com produções Valencianas e Sevilhanas, bem como, de Majólica.

O conjunto resultou, após analise estatística (tabela 1), na determinação de um número mínimo de indivíduos (NMI) de 14, sendo que, apenas 42,86\% do total tem proveniência nacional, com os fabricos enquadrando-se nas produções características de Lisboa, com esmalte de coloração branca. 
A nível decorativo, a faiança portuguesa caracteriza-se pela ausência de motivos decorativos, sendo de realçar a predominância das formas dos pratos e das taças, e a representação por apenas um individuo da forma de covilhete, a qual apresenta profundo desgaste do esmalte no bordo.

No respeitante às produções europeias realça-se sobretudo as produções italianas, com $35,71 \%$ do total de indivíduos.

Aqui poderá ser destacada supremacia das produções de majólica, com dois indivíduos de origem indeterminada, e um das fábricas de Montelupo, este com decoração policroma com azul, verde e amarelo sobre fundo branco.

De realçar que as produções de Montelupo destacam-se entre os finais do séc. XV e a primeira metade do séc. XVI, beneficiando de um grande porto, permitindo a difusão da cerâmica dentro e fora da península itálica (Barradas e Silva, 2017, p.1678), daí que esteja atestado com alguma abundância nos contextos portugueses e Lisboetas, realçando-se aqui as exumadas em Carnide, no largo do Coreto e no largo do Jogo da Bola, onde se recolheram fragmentos de Montelupo que apresentavam decoração a fogila bleu, que se manifesta pelos motivos vegetalistas a azul de grandes dimensões, a decoração nastri e decoração beretino a azul sobre azul. (Casimiro, Boavida e Moço, 2015, p. 61; Felício, Sousa, Guimarães e Gadanho, 2017, p. 1809-1820).

Estas produções combinam dois fragmentos de decoração policromática (a nastri spezzati,) um com decoração de estilo berretino, e um com decoração geométrica no fundo, inserindo-se proximamente do estilo orientale evoluto. $\mathrm{O}$ estilo a nastri spezzati (1550-16oo), é um motivo exclusivo de formas abertas que consiste em bandas entrelaçadas e cortadas, realizadas a azul e outras cores muito vivas, as quais rodeiam um tema central, que poderia ser uma espécie de flor ou de estrela; enquanto o estilo orientale evoluto (1550-159o), é constituído por uma rede de losangos e linhas curvas a azul, preenchidos por elementos estilizados realizados em cores vivas (Cavaco e Covaneiro, 2017, p. 208).

O estilo berretino poderá ser associado às oficinas de Faenza e Veneza que, no séc. XVI, desenvolveram o Stile Bello, composto por elementos monocromáticos azuis com pinceladas brancas sobre um fundo azul ou azul-acinzentado para o que se designa de berretino, o qual é inspirado na porcelana chinesa, sendo caracterizado pela gradação de cores dentro do espetro azul e manifesta-se pelo carater simplicista e vegetalista da decoração. (Farris e Ferrarese, 1969, p. 206).

Nas produções italianas foi ainda recolhido um bordo possível de identificar como uma produção Lígure, o qual se insere igualmente no estilo berretino, ainda que o esmalte se encontre mal preservado e não permita uma leitura profunda do motivo decorativo.

Menos representadas, com apenas 7,14\% do total de indivíduos, encontramos as produções de Manizes ou Paterna, as quais se encontram muito fragmentadas, apenas podendo ser consideradas como um individuo, apresentando a habitual ausência de decoração, com um esmalte brilhante e resistente de cor madrepérola.

Quanto às produções alemãs, no território nacional detectam-se as produções provenientes da região do Reno, destacando-se as peças do tipo Bellarmine. Estas, são jarras que se apresentam com a foram de um homem, sendo uma alusão ao cardeal jesuíta Roberto Bellarmino (Cavaco, Covaneiro, 2017, p. 210). No contexto dos jardins do Palácio dos Condes de Penafiel surge somente um fragmento de bojo desta produção em grés, com parte de decoração com uma bolota. Estas formas de grés, foram produzidas entre o séc. XVI e o séc. XVIII, sendo que estas representam uma inovação tecnológica, uma vez que a adição de sal durante a cozedura gera superfícies vitrificadas com aspeto acetinado, mais brilhantes e resistentes (Cavaco, Covaneiro, 2017, p. 210).

A representatividade das produções de Majólica no contexto (43\%), que em conjunto com a faiança portuguesa perfazem a quase totalidade do espólio, permitem apontar para a cronologia já sugerida entre meados do século XVI e o inicio do século XVII, sendo que, a nosso entender, este contexto deverá ter uma conexão com o contexto das condutas e os azulejos exumados nesta intervenção (Bargão, Ferreira e Silva, 2017), aproximando-se a cronologia de meados do século XVI, podendo inclusive ser anterior à data de 1550 apontada para as decorações de Majólica (Cavaco e Covaneiro, 2017, p.208; Farris e Ferrarese, 1969, p. 206).

\section{CONCLUSÕES}

Da escavação efetuada em 1992-1993, nos jardins do PPJ, nos contextos em análise, foram assim recolhidos um total de 294 fragmentos, dos quais se determinou um número mínimo de indivíduos total de 
97, que remetem para uma cronologia entre o século XVI e XVII.

Esta realidade observada é coeva com os dados já anteriormente fornecidos pelos 866 azulejos hispano-mouriscos, de onde se destacam dois exemplares utilizando a técnica de corda-seca, um alicatado, e os restantes, com a técnica "de aresta" ou "cuenca", os quais foram associados à decoração que revestiria os andares superiores das "casas de dona Catarina", com posteridade a 1524, e cuja produção poderia ser oriunda das oficinas de Triana de Juan ou Diego Polido, na década de 1520 (Bargão, Ferreira e Silva, 2017, p. 1786-1788).

Assim, de acordo com os resultados obtidos, confirmar-se a edificação das "casas de Dona Catarina" nas primeiras décadas do século XVI, bem como a anterioridade da conduta, a qual já se encontraria naquele espaço no século XV, parecendo ocorrer um aproveitamento da sua existência aquando do planeamento do edifício, com o cuidado da não obstrução com muro das caixas de junção, as quais foram, em função das evidências materiais, tidas pelos habitantes como áreas de descarte para os lixos do quotidiano.

O numeroso espólio aqui analisado, com destaque para as condutas, espelha o quotidiano do lugar, atestando desde cedo o que se poderá considerar como um relativamente elevado poder de compra por parte dos residentes, com o consumo de faiança portuguesa a seguir todas as suas transformações formais e estilísticas na diacronia, denotando-se uma tendência para a aquisição dos materiais mais recentes, situação que poderá espelhar um fenómeno do seguimento de modas, e por tal permite inferir quanto ao status dos que habitavam nas "casas de Dona Catarina”.

Por fim, ainda que o contexto do muro não permita compreender em maior profundidade o que seria aquele espaço antes da edificação da habitação, em torno à década de 1620, o espólio permite já inferir que naquela área existiriam habitantes com elevado poder económico que consumiam os bens importados de Espanha, Itália e Alemanha, ainda que pareça que nesta área o consumo destes bens, sobretudo da majólica, pareça ser mais tardio e menos expressivo que em outras zonas de Lisboa.

\section{BIBLIOGRAFIA}

ANDRADE, Ferreira de (1946) - A freguesia de S. Cristóvão. Volume I e II. Lisboa: Câmara Municipal de Lisboa.

ARCELIN, P.; TUFFREAU-LIBRE M., ed. (1998) - Protocole de quantification des céramiques. In La quantification des céramiques. Conditions et protocole, Actas da mesa redonda de Bibracte. Glux-en-Glenne: Centre archéologique européen, pp.141-157.

BARGÃO, André; FERREIRA, Sara; SILVA, Rodrigo Banha da (2017) - Policromias e padrões: azulejos "de aresta" e "de corda-seca" do Palácio dos Condes de Penafiel, Lisboa (séculos XV-XVI). In Arqueologia em Portugal - Estado da Questão, Lisboa: Associação dos Arqueólogos Portugueses, pp. 1781-1794.

BARRADAS, Ana Isabel; SILVA, Rodrigo Banha da (2017) - Cerâmicas Quinhentistas vidradas de um poço Medieval da Praça da Figueira (Lisboa). In Arqueologia em Portugal - Estado da Questão. Lisboa: Associação dos Arqueólogos Portugueses, pp. 1691-1702.

CASIMIRO, Tânia Manuel; BOAVIDA, Carlos; MOÇO, Ana (2015) - Louça "de fora" em Carnide (1550-1562) Estudo do consumo de cerâmica importada. In I Encontro de Arqueologia de Lisboa: Uma Cidade em Escavação. Lisboa: Centro de Arqueologia de Lisboa/Departamento de Património Cultural/Direção Municipal de Cultura/Câmara Municipal de Lisboa/ (CAL/DPC/DMC/CML), pp. 57-67.

CASIMIRO, Tânia; SEQUEIRA, João (2016) - Faiança Portuguesa dos séculos XVI-XVIII recuperada no Tejo. Cira Arqueologia. Vila Franca de Xira. Volume 5, pp. 260-273.

CAVACO, Sandra; COVANEIRO, Jaquelina (2017) - Evidências das relações comerciais do porto de Tavira através da cerâmica. Scientia Antiquitatis. Évora. Volume 1, no 2, pp. 195-218.

FARRIS, G; FERRARESE, V. A. (1969) - Contributo alla conoscenza della tipologia e della stilistica della maiolica ligure del XVI secolo. Atti della Società Ligure de Storia Patria. Génova, pp. 187-221.

FELÍCIO, Catarina; SOUSA, Filipe; GUIMARÃES, Raquel; GADANHO, André (2017) - A cerâmica Italiana dos séculos XV e XVI do Largo do Jogo da Bola em Carnide, Lisboa. In Arqueologia em Portugal - Estado da Questão. Lisboa: Associação dos Arqueólogos Portugueses, pp. 18o9-1820.

GOMES, Mário Varela; CASIMIRO, Tânia Manuel; GONÇALVES, Joana (2012) - Espólio do Naufrágio da Ponta do Leme Velho (Ilha do Sal, Cabo Verde): Contributo para a Arqueologia da Expansão. Lisboa: Instituto de Arqueologia e Paleociências.

GUIMARÃES, Raquel; SILVA, Rodrigo Banha da (2017) Um contexto cerâmico e vítreo da primeira metade do séc. III d.C. do Palácio dos Condes de Penafiel (Lisboa). In Arqueologia em Portugal - Estado da Questão. Lisboa: Associação dos Arqueólogos Portugueses, pp. 1279-1292. 
HENRIQUES, José Pedro Vintém (2012) - Do Oriente para Ocidente: contributo para o conhecimento da porcelana chinesa nos quotidianos de época moderna. Estudo de três contextos arqueológicos de Lisboa. Velhos e Novos Mundos. Estudos de Arqueologia Moderna. Lisboa: Centro de História de Além-Mar. Volume 2, pp. 919-932.

MUNSELL, Richard (1994) - Soil Color Charts. New widson: Kollmorgen Instruments, Macbeth Division.

SEBASTIAN, Luís Carlos Pereira (2010) - A produção oleira de faiança em Portugal (séculos XVI-XVIII). Tese de Doutoramento em História variante Arqueologia. Lisboa: Faculdade de Ciências Sociais e Humanas da Universidade Nova de Lisboa, pp. 91-516.

SILVA, Rodrigo Banha da; FERREIRA, Sara (2015) - Jarro. In Lisboa 1415 Ceuta. Uma história de duas cidades. Ceuta/ Lisboa: Ciudad Autónoma de Ceuta/Câmara Municipal de Lisboa e Faculdade de Ciências Sociais e Humanas da Universidade Nova de Lisboa, p. 134.

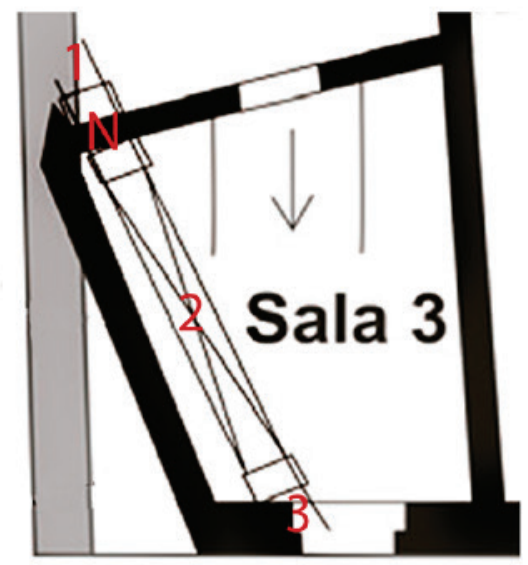

\section{1 - Conduta 1}

2 - Conduta 2

3 - Conduta 3

$\mathrm{N}$ - Caixa de junção $\mathrm{N}$ entre a conduta 1 e 2

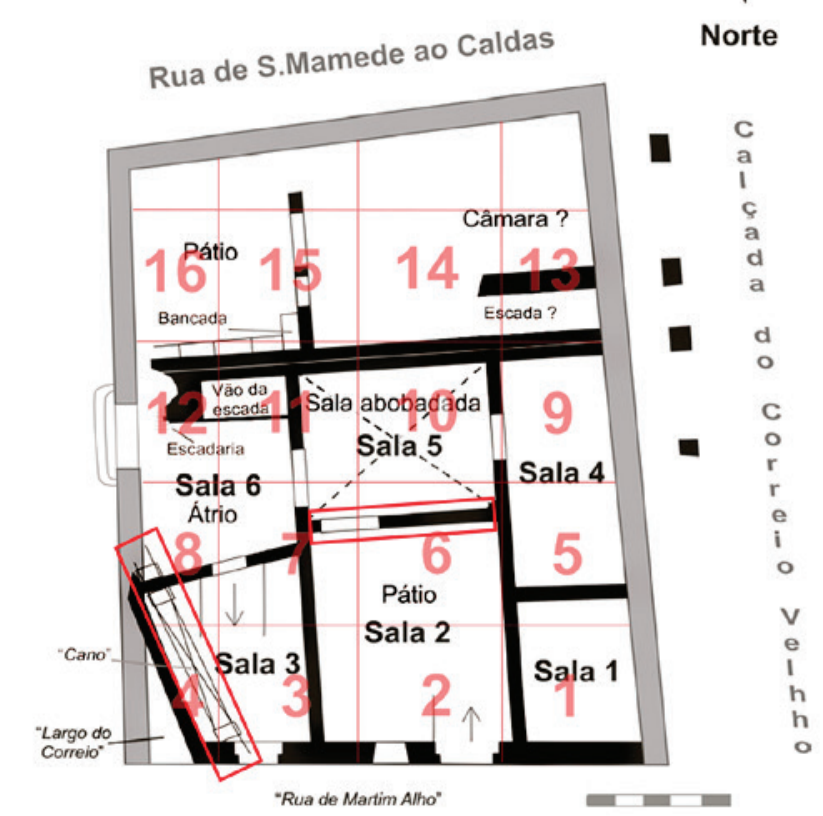

Figura 1 - Planta geral da intervenção de 1992-1993, estando assinalado com rectângulos vermelhos os contextos em análise. Adaptado de Bargão, Ferreira e Silva, 2017, p. 1791. 


\begin{tabular}{|c|c|c|c|c|c|}
\hline \multicolumn{6}{|c|}{ NMI Condutas 1-3 } \\
\hline Forma & № de fragmentos & Fragmento & № de fragmentos & NMI & \% NMI Prod. \\
\hline \multirow{2}{*}{ Covilhete } & \multirow{2}{*}{10} & Perfil Completo & 3 & \multirow{2}{*}{10} & \multirow{2}{*}{$12 \%$} \\
\hline & & Bordo & 7 & & \\
\hline \multirow{5}{*}{ Prato } & \multirow{5}{*}{45} & Perfil Completo & 2 & \multirow{5}{*}{20} & \multirow{5}{*}{$24 \%$} \\
\hline & & Bordo & 18 & & \\
\hline & & Fundo & 17 & & \\
\hline & & Bojo & 6 & & \\
\hline & & Carena & 2 & & \\
\hline \multirow{5}{*}{ Prato de aba } & \multirow{5}{*}{31} & Perfil Completo & 1 & \multirow{5}{*}{20} & \multirow{5}{*}{$24 \%$} \\
\hline & & Bordo & 19 & & \\
\hline & & Fundo & 5 & & \\
\hline & & Bojo & 3 & & \\
\hline & & Carena & 3 & & \\
\hline Prato médio & 4 & Perfil Completo & 4 & 4 & $5 \%$ \\
\hline Prato fundo & 3 & Perfil Completo & 3 & 3 & $4 \%$ \\
\hline Prato covo & 1 & Bordo & 1 & 1 & $1 \%$ \\
\hline \multirow{3}{*}{ Taça } & \multirow{3}{*}{10} & Perfil Completo & 1 & \multirow{3}{*}{8} & \multirow{3}{*}{$10 \%$} \\
\hline & & Bordo & 7 & & \\
\hline & & Fundo & 2 & & \\
\hline \multirow{4}{*}{ Tigela } & \multirow{4}{*}{19} & Perfil Completo & 4 & \multirow{4}{*}{16} & \multirow{4}{*}{$19 \%$} \\
\hline & & Bordo & 12 & & \\
\hline & & Fundo & 2 & & \\
\hline & & Bojo & 1 & & \\
\hline \multirow{3}{*}{ Indeterminada } & \multirow{3}{*}{149} & Bordo & 19 & \multirow{3}{*}{1} & \multirow{3}{*}{$1 \%$} \\
\hline & & Fundo & 26 & & \\
\hline & & Bojo & 104 & & \\
\hline Total & 272 & & 272 & 83 & $100 \%$ \\
\hline
\end{tabular}

Tabela 1 - Contabilização do número mínimo de indivíduos total do conjunto exumado nas condutas.

\begin{tabular}{|c|c|c|c|c|c|}
\hline \multicolumn{6}{|c|}{$\begin{array}{c}\text { Quadrícula 6/7 } \\
\text { Muro Norte da Sala } 2\end{array}$} \\
\hline Fabrico & Forma & Fragmento & $\begin{array}{c}\text { № de } \\
\text { Fragmentos }\end{array}$ & NMI & $\% \mathrm{NMI} /$ Total \\
\hline \multirow{4}{*}{$\begin{array}{c}\text { Faiança } \\
\text { Portuguesa }\end{array}$} & Prato & $\begin{array}{c}\text { Bordo } \\
\text { Bojo }\end{array}$ & $\begin{array}{l}2 \\
1 \\
\end{array}$ & 2 & $14,29 \%$ \\
\hline & Covilhete & Bordo & 1 & 1 & $7,14 \%$ \\
\hline & Taça & $\begin{array}{l}\text { Bordo } \\
\text { Fundo }\end{array}$ & $\begin{array}{l}2 \\
1\end{array}$ & 2 & $14,29 \%$ \\
\hline & Indeterminada & Bordo & 1 & 1 & $7,14 \%$ \\
\hline Alemão & Belarmino & Bojo & 1 & 1 & $7,14 \%$ \\
\hline Manizes/Paterna & Taça & Carena & 2 & 1 & $7,14 \%$ \\
\hline \multirow{3}{*}{$\begin{array}{l}\text { Majólica (origem } \\
\text { indeterminada) }\end{array}$} & \multirow{3}{*}{ Indeterminada } & Bordo & 1 & \multirow{3}{*}{2} & \multirow{3}{*}{$14,29 \%$} \\
\hline & & Fundo & 2 & & \\
\hline & & Bojo & 1 & & \\
\hline \multirow{2}{*}{ Montelupo } & Prato & Fundo & 1 & 1 & $7,14 \%$ \\
\hline & Indeterminada & Fundo & 1 & 1 & $7,14 \%$ \\
\hline Ligúria & Prato & Bordo & 1 & 1 & $7,14 \%$ \\
\hline Indeterminado & Indeterminada & Bojo & 4 & 1 & $7,14 \%$ \\
\hline Total & & & 22 & 14 & $100,00 \%$ \\
\hline
\end{tabular}

Tabela 2 - Contabilização do número mínimo de indivíduos total do conjunto exumado no muro Norte da sala 2. 
Condutas
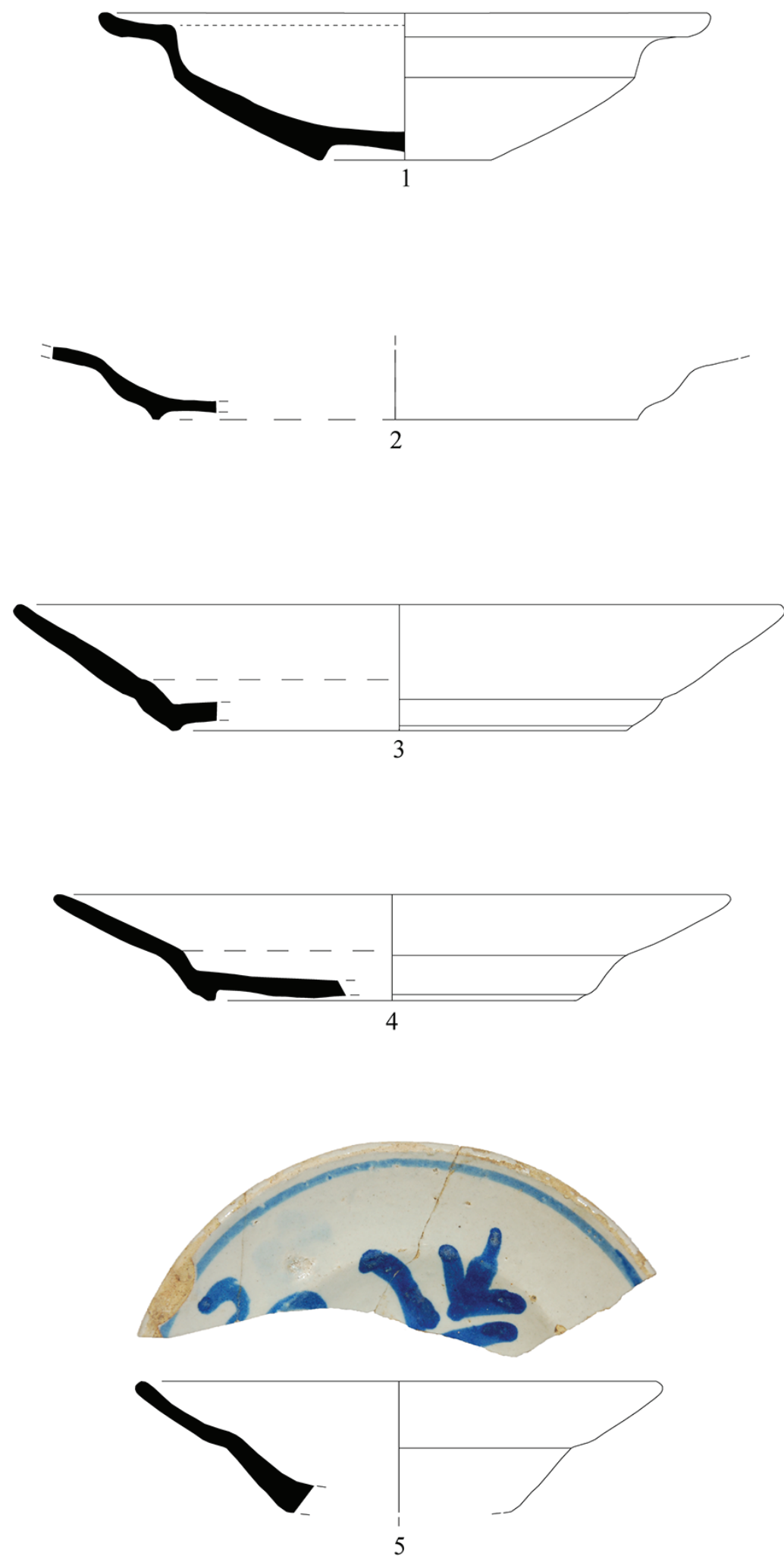

Escala 1:2

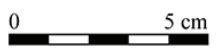

Figura 2 - Espólio de faiança portuguesa exumado nas condutas. 1 - prato de aba; 2-4 - pratos médios; 5 - prato covo. 

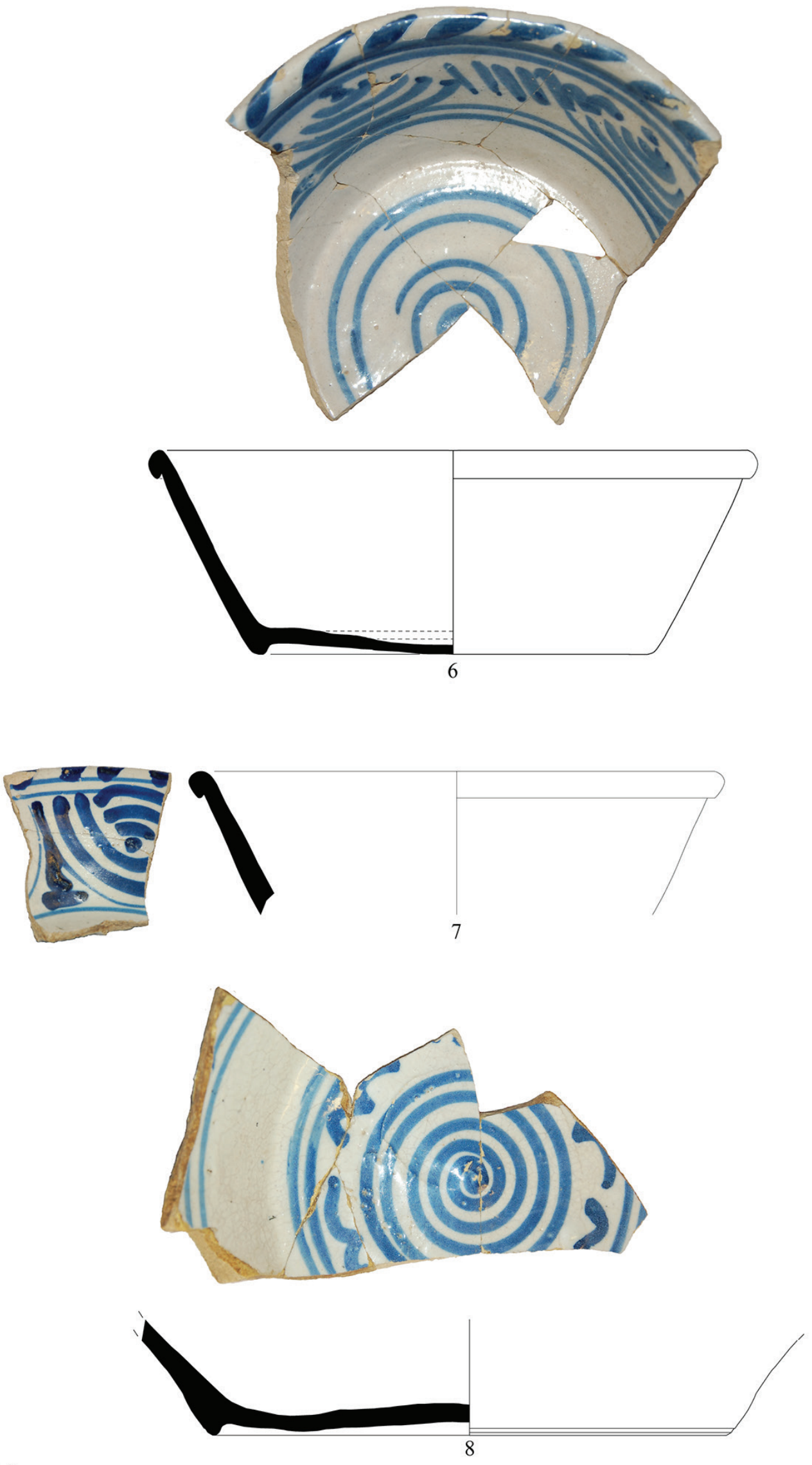

Escala 1:2

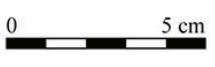

Figura 3 - Espólio de faiança portuguesa exumado nas condutas. 6-8 - Taça troncocónica com decoração em azul cobalto. 

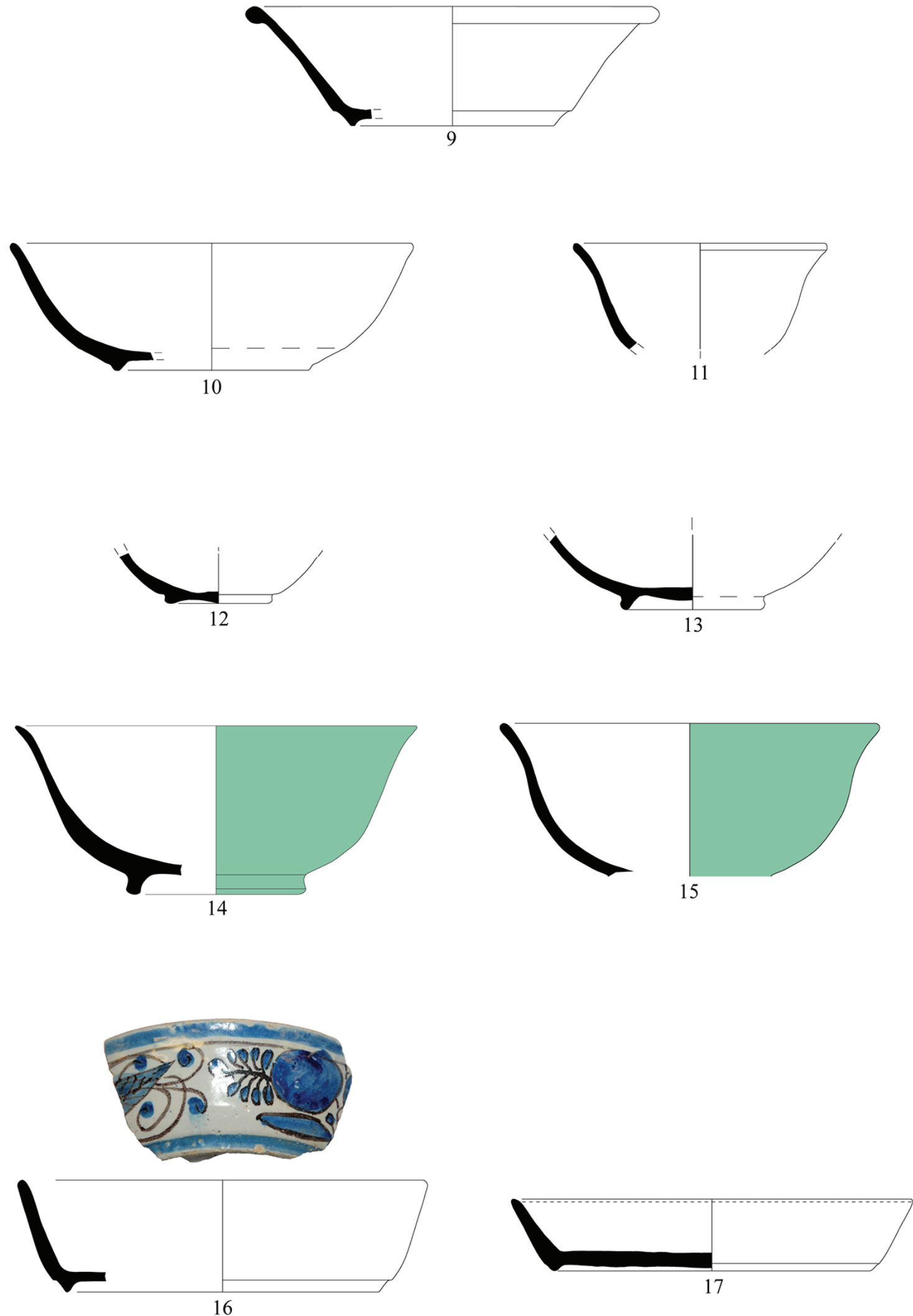

Escala 1:2

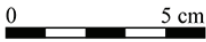

Figura 4-Espólio de faiança portuguesa exumado nas condutas. 9 - taça troncocónica; 10-13 - tigelas de esmalte branco; 14-15 - tigelas de esmalte verde; 16-17- covilhetes. 

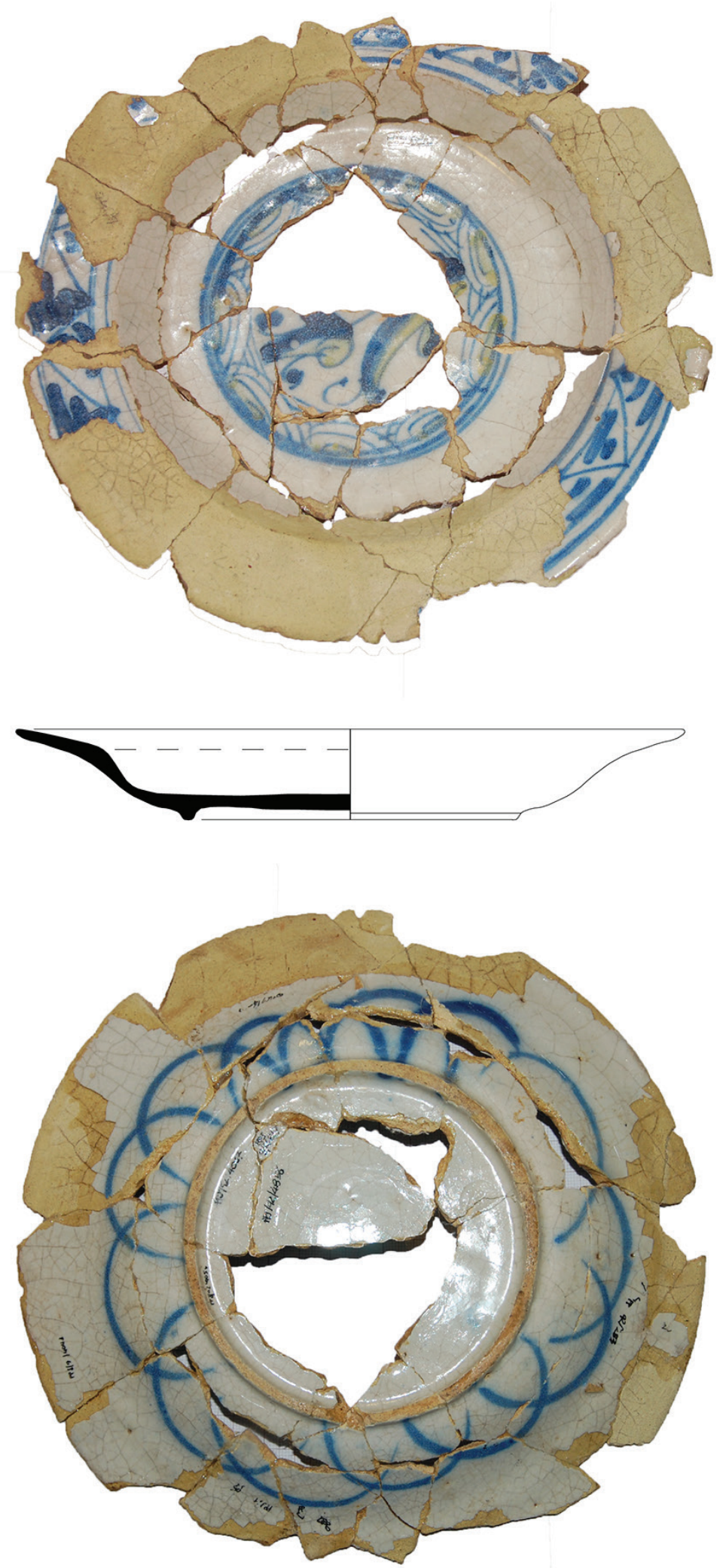

Figura 5-Espólio de faiança portuguesa exumado nas condutas. 18 - prato de motivos vegetalistas em azul cobalto e amarelo. 

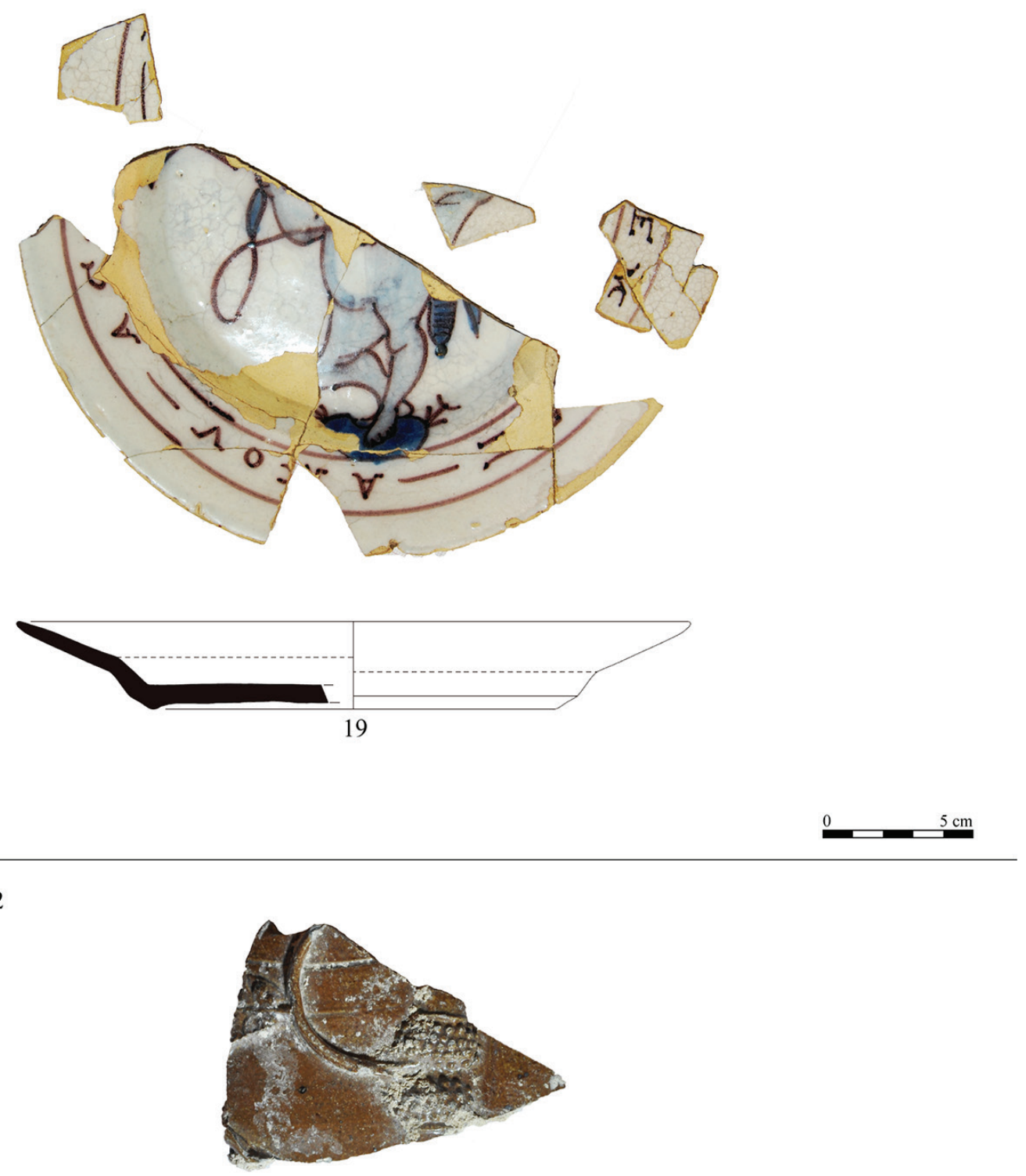

20

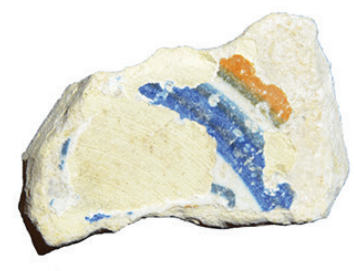

21

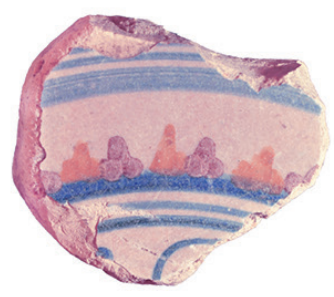

22

Escala $1: 1$

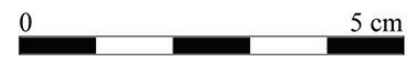

Figura 6 - Espólio de faiança portuguesa e europeia exumado nas condutas e muro Norte da Sala 2. 19 - prato com decoração barroca (putti); 20 - fragmento de Belarmino; 21-22 - fragmentos de majólica. 


\title{
UM PERFIL DE CONSUMO DO SÉCULO XVIII NA FOZ DO TEJO: O CASO DO MERCADO DA RIBEIRA, LISBOA
}

\author{
Sara da Cruz Ferreira ${ }^{1}$, Rodrigo Banha da Silva ${ }^{2}$, André Bargão ${ }^{3}$
}

\begin{abstract}
RESUMO
Nos finais de 2003 e em 2004, no âmbito da remodelação interna da ala este do Mercado da Ribeira, em Lisboa, foram colocados a descoberto os remanescentes do Forte e Cais de São Paulo. Estas estruturas encontravam-se erguidas sobre uma campanha de aterros, que visou reerguer a destruída freguesia de São Paulo após o terramoto de 1755 .

Nos estratos de nivelamento foi identificado um amplo conjunto cerâmico com cronologias homogéneas, compreendidas na primeira metade do século XVIII, exemplificativo do perfil de consumo da Ribeira Ocidental de Lisboa, sendo este conjunto o elemento de análise no presente estudo. Acresce, também, o objectivo de trazer à comunidade arqueológica diversas categorias cerâmicas que pautam estes quotidianos e que tão escassamente integram estudos de arqueologia de época moderna.
\end{abstract}

Palavras-chave: Arqueologia Urbana, Arqueologia Moderna, Cerâmicas Modernas, Ribeira de Lisboa.

\begin{abstract}
In late 2003 and in 2004, urban remodelation of the east wing of Mercado da Ribeira revealed the remains of São Paulo's Fort and Quay. Both structures were built on top of a land filing originated by post-1755 Lisbon Earthquake city reconstruction of S. Paulo's parish.

In the layers a large set of pottery was collected, enclosing chronologies within the first half of the $18^{\text {th }}$ century, a fine example of consumption pattern of Lisbon's Western Riverfront here displayed, including some pottery categories present in $18^{\text {th }}$ century daily life, often neglected by Early Modern Archaeology studies.

Keywords: Urban Archaeology, Early Modern Archaeology, Early Modern Pottery, Archaeological riverfront contexts.
\end{abstract}

\section{O SÍTIO ARQUEOLÓGICO DO MERCADO DA RIBEIRA, EM LISBOA}

O edifício do Mercado da Ribeira encontra-se edificado na actual freguesia da Misericórdia, antiga freguesia de São Paulo. A estrutura é delimitada a norte pela Rua da Ribeira Nova e a sul pela Avenida 24 de Julho (Figura 1).

$\mathrm{Na}$ transição de 2003 para 2004, o projecto de remodelação interna da ala este da infra-estrutura comercial exigiu a realização de trabalhos de peritagem arqueológica e consequente escavação em área, com- portando $765 \mathrm{~m}^{2}$. Esta empreitada, adjudicada à empresa ERA Arqueologia, S.A., subdividiu o espaço em dois sectores, nos quais foram identificados dois momentos de ordenamento urbano distintos (Charneca, Miguel \& Pinto, 2004).

O primeiro corresponde a uma sucessão de depósitos de aterro assentes sobre a praia fluvial, sobre o qual é construída uma calçada em sentido NO-SE no fim do século XVII (Ferreira, 2015, p. 43). Após uma acção de aterro de todo este espaço, foram erguidas, após o terramoto de 1755, duas estruturas: uma fracção do forte de São Paulo, a norte do denominado

\footnotetext{
1. Bolseira de Doutoramento FCT SFRH/BD/137142/2018. CHAM - NOVA FCSH; sara.isabel91@hotmail.com

2. CAL/DPC/CML. Departamento de História NOVA FCSH. CHAM FCSH e UAç.; rbds@fcsh.unl.pt

3. Bolseiro de Doutoramento FCT SFRH/BD/133757/2017. CHAM - NOVA FCSH; andrebargao@gmail.com
} 
Sector 1, e o Cais de São Paulo, a sul, no Sector 2, que permaneceram no registo cartográfico até à segunda metade do século XIX para depois serem anuladas por uma extensa campanha de aterro (Figura 2). Em 1882, o edifício em arquitectura do ferro, o Mercado da 24 de Julho, marca definitivamente o novo perfil urbano e comercial desta zona ribeirinha (Ferreira, 2015, p. 107).

\section{OS MATERIAIS ARQUEOLÓGICOS}

$\mathrm{Na}$ extremidade NO do Sector $\mathrm{I}$ foi identificada uma porção murária do Forte de São Paulo, servindo actualmente de alicerce do espaço de restauração/comercial contemporâneo. Apesar da análise estrutural ter sido altamente limitada por distintas condicionantes logísticas da empreitada, optou-se, simultaneamente, pela análise de todas as U.E'S que adossavam ao paramento externo do Forte, com o objectivo de aferir cronologias construtivas para o mesmo.

Alicerçada nos pressupostos metodológicos do Número Mínimo de Indivíduos (NMI - Orton, 1980; Orton \& Tyers, 1993), a organização do acervo passou pela seriação em grandes categorias de produção, tipologias, decorações, fabricos e consequentes atribuições de proveniência. Do total de 12975 fragmentos contabilizaram-se $7726 \mathrm{NMI}$, na maioria referentes a produções nacionais (faiança, cerâmica comum de barro vermelho fosco, cerâmica vidrada - Gráfico 1). Não obstante a diversidade tipológica e a vasta gama da geografia das produções presentes, o conjunto permite desenhar uma proposta de perfil de consumo na Ribeira Ocidental de Lisboa na primeira metade de setecentos.

\subsection{As Faianças Portuguesas}

O acervo exumado e aqui em estudo é maioritariamente formado por faiança portuguesa, representada por vasta panóplia formal referente a louça de uso à mesa: predominam no conjunto os pratos (2459 NMI), as tigelas (580 NMI) e as covilhetes (551 $\mathrm{NMI}$ ), atingindo menor expressividade os jarros (91 NMI), escudelas (16 NMI), salseiros/especieiros (12 $\mathrm{NMI}$ ) e as terrinas (3 NMI). A par desta categoria funcional de mesa foi igualmente possível registar outras formas: 48 bispotes, 286 bacias, 46 tampas, 27 pequenos potes, 8 castiçais e 2 boiões (NMI). De referir ainda 88 indivíduos indeterminados.

Esta análise foi cruzada com o levantamento decorativo, sendo este um elemento determinante para aferir as cronologias de produção, recorrendo-se, embora não somente, à proposta de categorização crono-estilística mais recente (Casimiro, 2013). Em função desta opção metodológica, registou-se uma maior presença de decoração minimalista em azul-cobalto circunscrita aos fundos e bordos, mas igualmente, no centro das peças, aplicada a partir do fim do século XVII. Deste modo se classificaram dentro do grupo "motivos geométricos e fitomórficos simples" 308 indivíduos (MRLX-05o; 068; 087 e o88), 253 no grupo de "semicírculos concêntricos" (MRLXo3/o4-070 e 079) e, com menor expressão, 33 indivíduos decorados por "pétalas e folhagem" (MRLXo3/o4-073) e dois pequenos fragmentos com "pequenas espirais".

No fim do século XVII, a produção de faiança portuguesa introduziu o óxido de manganês/castanho vinhoso, largamente aceite e empregue na centúria seguinte. Com esta particularidade, foram contabilizados 1104 indivíduos com superfícies decoradas com pequenos apontamentos de manganês (MRLXo3/o4-059; 062 e 078).

Simultaneamente à aplicação deste óxido nas produções nacionais, permaneceram em produção e circuito peças com decorações em azul cobalto amplamente difundidas a partir do fim de seiscentos e século seguinte. Exemplo desta simbiose decorativa, identificaram-se 448 indivíduos com o elemento de "contas" (MRLXo3/04-063; 064 e 08o), 232 com "faixas barrocas" (MRLXo3/O4-O53 e MRLXo3/O4-084)e, por fim, 57 indivíduos com a temática de "rendas".

Num mundo em constante contacto e interações, a louça portuguesa inspirou-se em determinados elementos decorativos já presentes na porcelana chinesa de então, nomeadamente as gramáticas de "pêssegos" e "aranhões", aqui representadas por 49 indivíduos (MRLXo3/o4-083 e o86.), bem como o "desenho miúdo", obtido através de finos traços a manganês, patente em 59 indivíduos (MRLXo3/ 04-056).

A vasta colecção de faiança portuguesa permite reconhecer outros grupos decorativos que podem ser interpretados como peças de encomenda, aspecto reforçado por representações heráldicas em 17 indivíduos (MRLXo3/o4-o61).

Apesar da elevada fragmentação das peças, enumeram-se 12 salseiros/especieiros (MRLXo3/O4-054) sem aparente decoração. Esta ausência corrobora a datação atribuída, inserindo-se nos horizontes de seiscentos e setecentos. 


\subsection{As cerâmicas de barro vermelho fosco}

As produções de barro vermelho sem revestimento produzidas nas olarias lisboetas estão representadas por 1756 indivíduos, sendo o grupo composto maioritariamente por morfologias ligadas à confecção alimentar, como os 288 fogareiros (MRLXo3/o4102), 267 tachos (MRLXo3/o4-09o; o91 e 10), 264 panelas (MRLXo3/o4-099; 108 e 112) e 59 caçoilas (MRLXo3/04-100).

No âmbito da restante cerâmica de barro vermelho não vidrada (da água, de armazenamento, de apoio e multiusos) identificaram-se 73 cântaros (MRLXo3/O4-118), 57 alguidares (MRLXo3/o4120), 35 potes (MRLXo3/O4-104; 113 e 122), 34 testos, 6 bilhas MRLXo3/o4-116), 5 garrafas (MRLXo3/o4124), 2 bispotes, 2 bacias e 4 alcatruzes (MRLXo3/O4110) e um copo de medida (MRLXo3/o4-111).

Os quotidianos à mesa do início de setecentos incluíam também, embora minoritariamente, morfologias como os prato-tampa, púcaros para o consumo de líquidos, covilhetes em chacota e especieiros/salseiros, cada uma destas formas, com valores de representatividade reduzidos, entre $15 \mathrm{e}$ 4 NMI (MRLXo3/O4-097).

\subsection{As cerâmicas comuns vidradas}

A par da produção regional de cerâmica comum de barro vermelho sem revestimento, o conjunto exumado no Mercado da Ribeira compreende, igualmente, exemplares diversos revestidos a vidrado plumbífero verde e/ou melado em 290 indivíduos oriundos das olarias lisboetas. Se no grupo da cerâmica de barro vermelho sem revestimento o predomínio formal recai em objectos ligados à confecção alimentar, no caso dos elementos vasculares vidrados observa-se a aplicabilidade desta técnica, que proporciona impermeabilização e maior facilidade na lavagem, de que se contabilizaram em 63 alguidares (63 - MRLXo3/04-095 e 105) e 43 bispotes (MRLXo3/04-098 e 114). Com menor expressão observam-se ainda panelas, tachos e caçoilas, com 10, 15 e 24 indivíduos, respectivamente, a que acrescem 19 potes (MRLXo3/o4-127) e apenas um indivíduo de garrafa (MRLXo3/O4-O92)

Não obstante as produções lisboetas, o conjunto integra, ainda que com menor expressão, produções flamengas de pasta alaranjada, depurada e com elementos não plásticos de pequeno e médio calibre. Estas características encontram-se presentes numa porção de bordo vertical de tigela de tendência tron- cocónica, revestida a vidrado espesso, brilhante e de coloração castanho-melado, com produção balizada entre a segunda metade do século XV e o decurso do século XVI (MRLXo3/o4-123) (Gomes \& Gomes, 1995, pp. 324-347).

De geografias mais próximas foi individualizado um fragmento (MRLXo3/o4-107) mostrando pasta rosada e compacta, coberto por esmalte espesso, brilhante e cinzento/esverdeado, com craquelet. O exemplar enquadra-se nas produções "Sevilha White" produzidas na cidade homónima entre 1530 e 1650 , e inspiradas nas peças esmaltadas a branco de Faenza, Itália (Ernst, 2011, pp. 85-86).

\subsection{Os cachimbos em barro caulínico}

A introdução de novos hábitos nos quotidianos europeus de Época Moderna justifica a presença de cachimbos nas estratigrafias aqui em estudo. Esta colecção, das mais expressivas em território português, é composta por 909 fragmentos de cachimbos em caulino produzidos na primeira metade de setecentos nas oficinas britânicas e holandesas (Pinto, et. al., 2011, pp. 41-47).

À primeira publicação deste conjunto ceramológico (idem) acrescentaram-se mais seis fragmentos de hastes proximais e cinco hastes decoradas com impressões de denticulados incisos. Aos fornilhos acresce um fragmento britânico (MRLXo3/o4[1230]223) com decoração denticulada incisa a delimitar o bordo e uma marca impressa de produção “RT”” no pedúnculo, remetendo para as elaborações de "Robert Tippet and Family", datadas de entre 1680-176o, idêntico aos exemplares recolhidos em Port Royal, na Jamaica (Fox, 1998, pp. 284-287).

\subsection{Os azulejos}

Nas unidades em estudo foram contabilizados 200 fragmentos de azulejo, cujas temáticas decorativas delineadas sobre as superfícies integra a maioria no grupo de “Azulejos de Padrão", portanto encerrando uma datação dos finais do século XVII e séc. XVIII. Assim se contabilizaram 103 fragmentos com decorações a azul de cobalto, com contornos delineados a manganês (MRLXo3/04-224 e 225); um outro subgrupo engloba 49 fragmentos e distingue-se do grupo anterior pela inclusão na cromática do amarelo (MRLXo3/o4-226 e 227).

Os restantes exemplares correspondem a espécimes com cronologias de produção mais recuadas, dos finais do século XV e da centúria seguinte. Inserem- 
-se nestes os 21 fragmentos de tipo "enxaquetado" e o único exemplar do tipo "Aresta" ou "Cuenca" (MRLXo3/o4-228).

\subsection{Os vidros}

No que concerne aos materiais vítreos, contabilizaram-se 172 indivíduos, dos quais 122 correspondentes a garradas cilíndricas e alongadas, com bordo composto por marisas de perfil triangular (MRLXo3/o4205 e 208), elemento datável do século XVIII e, ainda, um exemplar com gargalo em anel aplicado (MRLXo3/o4-209) (Medici, 2011, p. 337).

As garrafas com perfil mais compacto, do tipo apelidado do "cebolas" ou "cabaça", está representado por 13 indivíduos (MRLXo3/o4-210). Estas peças apresentam fundo em ônfalo com marca de pontel, elementos associados às produções pós-1650.

Com valores diminutos, registaram-se duas garrafas de perfil quadrangular datadas da primeira metade do século XVIII (Medici, 2011, p. 336).

A par das garrafas, registaram-se 11 frascos de vidro (MRLXo3/o4-211 e 216), um copo de pé alto (MRLXo3/o4-206) e um copo raso (MRLXo3/o4214), datados dos séculos XVII e XVIII (Medici, 2011, p. 331), 6 elementos de vidraça translúcida verde-água que, devido à elevada taxa de fragmentação e ausência de características conservadas, não permite determinar datação de produção. Este dado inviabiliza, desafortunadamente, a atribuição morfológica e tipológica, e consequente datação, de 32 indivíduos.

\subsection{As porcelanas chinesas}

O conjunto de porcelana chinesa compõe-se por 102 indivíduos. Para o consumo de alimentos à mesa foram contadas 38 tigelas e 39 pratos. Estes valores contrastam com os recipientes destinados à ingestão de líquidos espelhados apenas por oito pequenas tigelas/copos sem asa lateral (MRLXo3/O4-152 e 154) e duas chávenas com este elemento (MRLXo3/o4168): se os primeiros, sem elemento de pega, integram reportórios orientais, as chávenas onde se verifica a pega dizem respeito a formas de influência europeia ainda que de produção asiática setecentista. Todavia, identificaram-se ainda, formas associadas ao aparato nos quotidianos, como a presença de 4 grandes potes (MRLXo3/o4-159) e o fundo de uma pequena caixa.

No decorrer de setecentos, banaliza-se o consumo de bebidas quentes no quotidiano europeu, prática que fez surgir novas tipologias nas produções orientais, nas quais se integram as duas chávenas identificadas, assim como 3 pequenas tampas (MRLXo3/o4-178), que vedavam os copos altos nos quais se degustava chocolate quente (Antunes, 2000, p. 27).

Nos finais do século XVII e no decorrer do século XVIII, os espécimes eram pintados a azul a delinear temáticas florais, ao agrado do mercado Europeu, de que são exemplo os fundos de prato MRLXo3/o4155; 172 e 181. Contudo, às gramáticas a azul de cobalto descritas, o recuso a esmaltes polícromos é vulgarizado a partir do final da centúria de seiscentos. Neste grupo inserem-se os exemplares, cujo destaque são o recurso a decorações pintadas a verde: "Família Verde" (MRLXo3/o4-164) e "Família Chocolate" (MRLXo3/o4-163), como os exemplares de inspiração Japonesa que ostentam decorações a azul, vermelho e dourado, características das produções de Imari Chinês (MRLXo3/o4-177).

Em contraponto à policromia da Dinastia Qing, no mesmo período surgiram peças que apresentam a totalidade do corpo branca, sem recurso a qualquer esmalte colorido, designadas por "casca de ovo" ou "Blanc de Chine" (MRLXo3/O4-161), onde prevalece um certo gosto simplicista oriental. Nestas elaborações se insere também a tigela de perfil completo MRLXo3/o4-152, que difere do restante conjunto por apresentar uma decoração floral em relevo, sendo enquadrável nas peças fabricadas nos finais da dinastia Ming, designadas por Dehua Wares (Valenstein, 1989, p. 203).

Nos inícios do século XVII, a afirmação mercantil da Companhia Holandesa das Índias Orientais (V.O.C.) e a consequente massificação da produção, fizeram surgir uma gramática decorativa na porcelana chinesa muito própria deste período, numa clara tentativa de simplificar e esquematizar o processo decorativo. As peças apresentam decorações repartidas em cartelas, que irradiam para um medalhão central, reproduzido no fundo dos recipientes (MRLXo3/o4173), com gramáticas vegetalistas e zoomórficas.

O conjunto de porcelanas chinesas exumado no Mercado da Ribeira destaca-se do restante espólio exumado, pela presença de exemplares com datações mais recuadas. A identificação de um número considerável de exemplares da Dinastia Ming incita-nos, desde logo, a explicar a presença destas peças por encerrarem um mais longo "período de vida", resultante de um manuseamento mais cuidado, de uma posição de maior destaque nos quotidianos e, sobretudo, através de uma transmissão pluri-geracional. 
Neste âmbito identificaram-se peças, de bordos delimitados em cartelas prismáticas (MRLXo3/O4-183), enquadráveis das produções executadas nos últimos anos da Dinastia Ming e primeiros da Qing, designados por Período de Transição (Valenstein, 1989, p. 200). Relativamente às produções Ming mais recuadas, características do século XVI e dos reinados de Jiajing (MRLXo3/o4-171) e Wanli, inserem-se 9 peças que apresentam o bordo com delimitações fitomórficas, assim como 10 indivíduos que apresentam temáticas zoomórficas, naturalistas e paisagísticas, inscritas por um medalhão central, delimitado ao centro do fundo das peças (MRLXo3/o4-153; 162; 166 e 169) e, por fim, um fragmento de bojo de um grande pote com banda fitomórfica, na qual se definiram rectângulos entrecruzados, preenchidos a azul de cobalto, característico do final do reinado do imperador Jiajing (Matos, 1996).

\subsection{As produções lígures}

Identificou-se um curioso conjunto composto por 73 peças, claramente individualizáveis do restante conjunto por apresentarem as superfícies cobertas por um espesso esmalte azul-esverdado, a revestir uma pasta depurada de tonalidade amarelada. As características descritas permitem-nos integrá-las nas produções das olarias de Albisola, Savona e Génova, na Ligúria (Bercero \& Alaix, 2010, pp. 26-27), no caso do Mercado da Ribeira repartido pelas tipologias que compõem as formas "de mesa", ou seja, 34 pratos; 17 tigelas; 2 taças; 2 tampas, 1 fruteira e 11 indivíduos indeterminados (NMI).

Com base nas propostas crono-estilísticas de Barcero e Alaix (2010), no conjunto assinala-se a presença de peças com: Scenografia Barroca, com delimitações de enquadramentos paisagísticos/aquáticos a par de elementos arquitectónicos, com cronologias de produção do fim do século XVII e início da centúria seguinte (MRLXo3/o4-185; 192; 194); Calligrafico a Tapezaria, que se pauta pela inspiração oriental, com representação de elementos naturalistas e vegetalistas, cenas bíblicas ou mitológicas (MRLXo3/o4184; 186; 187; 193; 196; 197; 202 e 204), elaboradas em meados do século XVII e até 1717 (Bercero e Alaix, 2010, pp. 44-46); de tendência Calligrafico Naturalístico, isto é, imitações/inspiração de paisagens chinesas naturalísticas e zoomórficas (MRLXo3/o4199 e 201), partilhando, genericamente, a datação do grupo decorativo anterior (Bercero \& Alaix, 2010, pp.40-42); no domínio da decoração heráldica regis- tou-se um fragmento (MRLXo3/o4-200) que exibe o brasão de armas da cidade de Savona (Bercero \& Alaix, 2010, pp. 72-74); por fim, particularizam-se dois fragmentos que apresentam marca pintada de olaria do tipo Lanterna, símbolo das oficinas de Albisola (MRLXo3/O4-199 e 201), a par do grafismo de “asterisco" (MRLXo3/O4-[1349]-192).

\subsection{As produções europeias em grés}

No "universo objectual" que compõe o acervo do Mercado da Ribeira, foram analisados 23 indivíduos em grés com particularismos que permitem reconhecer quatro centros produtores ingleses e um germânico.

No que concerne às Ilhas Britânicas, mencione-se a produção White Salt-Glazed composta por pasta e vidrado de coloração branca, presente em servições de chá produzidos entre 1690-1770 (Skerry \& Hood, 2009, pp. 97-99) (MRLXo3/o4-133 e 229).

Seis indivíduos de garrafa (MRLXo3/o4-129 a 131 e 341) encontram paralelos nas produções Fulham Wares ou Brown Salt Glazed, distinguíveis dos anteriores pela pasta clara e granulosa sobre a qual foi aplicado revestimento em grés "salpicado", variando entre o castanho, amarelo e verde (MRLXo3/o4340), executados entre 1675/169o e 1775 (Hume, 1970, p. 114).

Sete peças de pasta laranja, com vidrado brilhante, de aspecto metálico e de tom castanho que exibe decoração modelada, encontram paralelos formais e estilísticos nas olarias que integram as Nottingham Wares, particularmente activas na centúria de setecentos (Hume, 1970, p. 180). Qualquer deles respeita a canecas (MRLXo3/O4-138 e 139) profusamente decoradas por motivos incisos (MRLXo3/o4-337 e 338).

As produções germânicas, nomeadamente da região renana de Westerwald, surgem com alguma expressão no contexto de aterro ribeirinho aqui em análise. Neste sentido, contabilizaram-se quatro garrafas (MRLXo3/O4-132 e 134), um bispote (MRLXo3/o4-37) e oito fragmentos morfologicamente indeterminados. As produções destas oficinas situam-se entre o século XVII e a primeira metade de oitocentos (Hinton, 2012, pp.6-11), mostrando pastas cinzentas claras e vidrado brilhante, variável entre o azul de cobalto e roxo de manganês, sendo possível sugerir uma intenção e/ou inspiração de peças vítreas (MRLXo3/o4-320-325). 


\subsection{As anforetas sevilhanas}

A intenção de identificar centros produtores e respetivas cronologias permitiu determinar a presença de 12 contentores cerâmicos de pasta porosa e acabamento branco de superfície, sendo estes elementos integrantes das produções da bacia do Guadalquivir (MRLXo3/o4-140; 144; 145; 147; 148; 149 e 151). Apesar das variadas designações (anforeta, botija ou olive jar, entre outras), estes vasos de tendência globular correspondem a um recipiente fundamental na conservação, armazenamento e transporte de inúmeros bens alimentares. $\mathrm{O}$ reduzido custo de produção e facilidade de transporte, quer por via terrestre quer marítima/fluvial, determinaram a sua presença nas viagens e no comércio desde o século XV até ao século XVIII (Avery, 1997, pp. 131-132).

A versatilidade destas peças é reflectida na presença de vidrado de chumbo esverdeado no interior que sugere o transporte de produtos vinícolas (MRLXo3/o4-146 e 150). Ainda assim, as peças não vidradas destinar-se-iam, possivelmente, ao transporte de líquidos mais espessos e gordurosos, como o azeite (Goggin, 196o, p. 6).

\subsection{As cerâmicas comuns manuais}

Com particularismos que permitem a sua classificação como cerâmicas manuais, foram identificados 19 fragmentos, equivalentes a cinco indivíduos. Elaboradas em ambiente redutor, apresentam pasta escurecida e com abundantes inclusões não plásticas de pequeno e médio calibre, macroscopicamente identificadas como quartzos. Apresentam, igualmente, acabamento em técnica de brunido, sobre o qual foi aplicado engobe castanho/vermelho.

Trata-se de quatro de panelas (MRLXo3/o4-043 ao 046), com a presença de asas de rolo horizontais (MRLXo3/o4-048) e uma forma aberta (MRLXo3/o4-047). Estas peças encontram paralelos formais e tecnológicos em variadas intervenções arqueológicas de Lisboa, amplamente integrantes de contextos de entulho resultantes de 1755, sendo geralmente associadas pela investigação a ambientes esclavagistas e a uma origem no Brasil ou na Costa Atlântica Africana, todavia sem qualquer suporte de estudos arqueométricos (Oliveira \& Brochado, 2017, pp. 251-26o).

\subsection{As alcarrazas sevilhanas}

Destacamos, ainda, 10 fragmentos (dois indivíduos: MRLXo3/o4-233 e 235 e os fragmentos de bojo
MRLXo3/o4-235 e 234), de paredes finas compostas por pastas porosas de matriz calcária com tonalidade esbranquiçada-amarelada, não apresentando qualquer tipo de revestimento. Este tipo de peças, delicadas e bem torneadas, exibe diversos esquemas decorativos à base de molduras, incisões e depressões executadas através de diversos tipos de instrumentos de preensão sobre a pasta ainda fresca. Correspondem maioritariamente a formas globulares, com panças e colos destacados, bordos sub-triangulares, bases destacadas em disco e com asas adossadas à peça com decoração plástica aplicada. As características descritas permitem enquadrar os exemplares lisboetas em apreço nas produções de recipientes destinados a líquidos sevilhanas, designadas por $\mathrm{Al}$ carrazas. Peças deste tipo têm vindo a ser documentadas em contextos do século XV ao XVIII em Espanha, encontrando-se frequentemente representadas nas obras barrocas dos pintores Diego Velázquez (1599-166o), Francisco de Zurbarán (1598-1664) e Luis Meléndez (1716-178o) (Pleguezelo, 20oo, pp. 134-136).

\subsection{Os Thai Jars}

Foram identificadas duas peças (MRLXo3/04-041 e 042; e os fragmentos MRLXo3/O4: 298 ao 303), distinguíveis pela pasta compacta, em grés, de tonalidade bege, recobertas por um vidrado de tonalidade castanha escura a negra. Estes elementos são enquadráveis nas produções dos fornos de Sawakhalok (província do norte da actual Tailândia), onde foram produzidos grandes contentores em grés de formato globular, colo curto, grandes potes designados por Thai Jars, produzidos desde os fins do século XIV até 1584. Com a ascensão do império Khmer na cidade de Angkor, as produções dos fornos de Sawakhalok afluíam à cidade costeira de Ayutthaya, servindo este importante entreposto comercial de ponto redistribuidor, por inserido nas rotas comerciais do Índico (Craig, 2013, p. 12).

\section{O PERFIL DE CONSUMO DA RIBEIRA OCIDENTAL DE LISBOA, NA PRIMEIRA METADE DO SÉCULO XVIII}

A intensiva análise do espólio associado às U.E.'s conectadas com o vestígio do Forte de São Paulo permitiu datar a construção deste troço de muralha de meados da segunda metade do século XVIII (Ferreira, 2015). O cálculo da dispersão dos dados reuni- 
dos permitiu observar a incidência das datações de todos os grupos de fabrico na primeira metade do século XVIII. (Tabela 1 e Gráfico 2). Deste modo, o acervo colectado sugere representar um hipotético perfil de consumo da cidade dos momentos anteriores ao terramoto de 1755 da Ribeira Ocidental.

A primeira reflexão ao conjunto prende-se na incidência das produções em faiança portuguesa, reduzidas maioritariamente ao reportório tipológico de formas de uso individual à mesa para a degustação de alimentos, como os pratos, tigelas e covilhetes. Paralelamente, para a confecção alimentar, o acervo circunscreve-se às produções em barro vermelho, através das variantes formais de tachos, panelas, caçoilas e fogareiros.

Relativamente aos exemplares revestidos por vidrados plumbíferos, executados de igual forma sobre pastas vermelhas regionais, assomam, percentualmente, os alguidares como tipologia de apoio à cozinha, as bacias referentes à higiene pessoal e os bispotes de funcionalidade sanitária.

Com menor incidência contabilizam-se as produções exógenas circunscritas às cerâmicas lígures, às porcelanas chinesas e às produções em grés europeias e asiáticas, sobretudo integrantes do reportório formal dos espécimes individuais de uso à mesa, que, por comparação com a quantificação global do espólio recolhido, denuncia o carácter excepcional e minoritário da sua presença nos quotidianos setecentistas.

Noutro sentido, a elevada frequência percentual de porcelanas chinesas com datações da Dinastia Ming num nível de aterro da primeira metade do século XVIII equivale a uma realidade cada vez mais documentada na cidade. Os dados arqueológicos apontam-nos, portanto, para uma insuspeitada longevidade da vasculária chinesa podendo atingir os dois séculos, significando deste modo que percorreram os quotidianos lisboetas pretéritos mediante um manuseamento mais cuidado e/ou pelos mecanismos do sistema de transmissão multi-geracional.

As elaborações oleiras chinesas, aliás, traduzem também, através da sua relativa expressividade quantitativa o crescendo de mercado ganho em Portugal, por contraponto com os minoritários grupos cerâmicos e vítreos de origem europeia, sendo o panorama assaz contrastante com o verificado nos contextos lisboetas do séc. XVI, quando as elaborações espanholas, e em particular sevilhanas, dominavam um mesmo nicho.
Do acervo material sobressai o quadro conjuntural lisboeta anterior ao terramoto de 1755, onde assoma a vulgarização dos hábitos disseminados em resultado das ligações transatlânticas mantidas pela capital do Reino, de onde se salienta o consumo de tabaco por inalação mediante cachimbo, como a incorporação nos hábitos lisboetas, como em geral europeus, da degustação das novas bebidas quentes, como o chá, o café e o chocolate.

\section{BIBLIOGRAFIA}

ANTUNES, Mary Espírito Santo, coord. (200o) - Porcelanas da China: Colecção Ricardo do Espírito Santo Silva. Lisboa: Fundação Ricardo Espírito Santo Silva.

AVERY, George (1997) - Pots as packaging: The Spanish Olive Jar and Andalusian Transatlantic Commercial Activity, 16th-18th Centuries. A dissertation presented to the Graduate School of the University of Florida. Gainesville: University of Florida.

BERCERO, Julia Beltrán de Heredia; ALAIX, Núria Miró I (2010) - "El comerç de cerâmica a Barcelona als segles XVI-XVII: Itàlia, França, Portugal, els tallers del rin i xina”. In QUARHIS, Época II, Num. 6. Barcelona, pp. 14-91.

CASIMIRO, Tânia (2013) - "Faiança portuguesa: datação e evolução crono-estilística”. In Revista Portuguesa de Arqueologia, Vol. 16. Lisboa: Direcção-Geral do Património Cultural, pp. 351-367.

CHARNOCA, Cristina; MIGUEL, Lúcia; PINTO, Marina (2005) - Mercado da Ribeira: Relatório Final dos Trabalhos Arqueológicos. Lisboa: ERA - Arqueologia, S.A.

CRAIG, Jennifer (2013)- "Southeast Asian and Chinese Ceramics in the Shipwreck Galleries: the Abbott Collection Catalogue". In Report - Department of Maritime Archaeology, No. 302. WA: Museum, pp. 1-31.

ERNST, Marlieke (2011) - Talking sherds: Spanish ceramics in Caribbean context. Bachelor thesis: Faculty of Archeology. Leiden: Leiden University.

FERREIRA, Sara (2015) - O sítio do forte de São Paulo: estudo arqueológico da Ribeira Ocidental de Lisboa na época moderna. Dissertação de Mestrado em Arqueologia. Lisboa: Faculdade de Ciências Sociais e Humanas (U.N.L.).

FOX, Georgia Lynne (1998) - The study and analysis of the Kaolin clay tobacco pipe collection from seventeenth-century archeological site of Port Royal, Jamaica. Major Subject Anthropology. Texas: A\&M University.

GOGGIN, John M (1960). - The Spanish Olive Jar: an Introductory Study. New Have: Yale University Publications in Anthropology.

GOMES, Rosa Varela; GOMES, Mário Varela (1993) - “Cerâmicas vidradas e esmaltadas dos seculos XIV, XV e XVI, 
do Poço-cisterna de Silves". In Xelb:Revista de Arqueologia, Arte, Etnologia e Historia, № 3. Silves: Câmara Municipal de Silves, pp. 143-205.

HINTON, Jack (2012) - The Art of German Stoneware 1300 -1900: from the Charles W. Nichols collection and Philadelphia Museum of Art. Philadelphia Museum of Art: Yale University Press.

HUME, Ivor Noël (1970) - A guide to artifacts of colonial America. New York: Alfred A. Knopf.

MATOS, Maria Antónia Pinto de (1996) - A casa das porcelanas: cerâmica chinesa da casa-museu Dr. Anastácio Gonçalves. Lisboa: Instituto Português de Museus; London: Philip Wilson.

MEDICI, Teresa (2011) - “O espólio vítreo do Núcleo Arqueológico da Rua dos Correeiros, Lisboa”. In Revista Portuguesa de Arqueologia, Vol. 14. Lisboa: Direcção-Geral do Património Cultural, pp. 313-353.

OLIVEIRA, F. S., BROCHADO, S. V. (2017) - "Produções cerâmicas manuais do período Moderno, um contributo para o seu estudo". In Coelho, I., Torres, J., Gil, L., and Ramos, T. (eds.), Entre Ciência e Cultura: Da Interdisciplinaridade à Transversalidade da Arqueologia. Actas das VIII Jornadas de Jovens em Investigação Arqueológica. Lisboa: CHAM, pp. 251-26o.
ORTON, C. (1980) - Mathematics in Archeology. Cambridge: Cambridge University Press.

ORTON, C., TYERS, P., VINCE, A., (1993) - Pottery in Archaeology. Cambridge: University Press.

PINTO, Marina; FILIPE, Iola; MIGUEL, Lúcia (2011) - “Cachimbos de caulinos provenientes do Mercado da Ribeira: contributo para a História sócio-económica da Lisboa Moderna”. In Apontamentos de Arqueologia e Património, № 7. Lisboa: Núcleo de Investigação Arqueológica, ERA-Arqueologia, S.A., pp. 41-47.

PLEGUEZUELO, Alfonso (200o) - “Cerámicas para agua en el Barroco Español: una primera aproximación desde la literatura y la pintura. In Ars Longa: cuadernos de arte, nㅜ 9-10. Madrid, pp. 123-138.

SKERRY, E. Janine; HOOD, Suzunne Finle (2009) - SaltGlazed Stoneware in Early America. Williamsburg: Colonial Williamsburg.

VALENSTEIN, Suzanne G. (1989) - A Hand Book ofChinese Ceramics. New York: The Metropolitan Museum of Art.

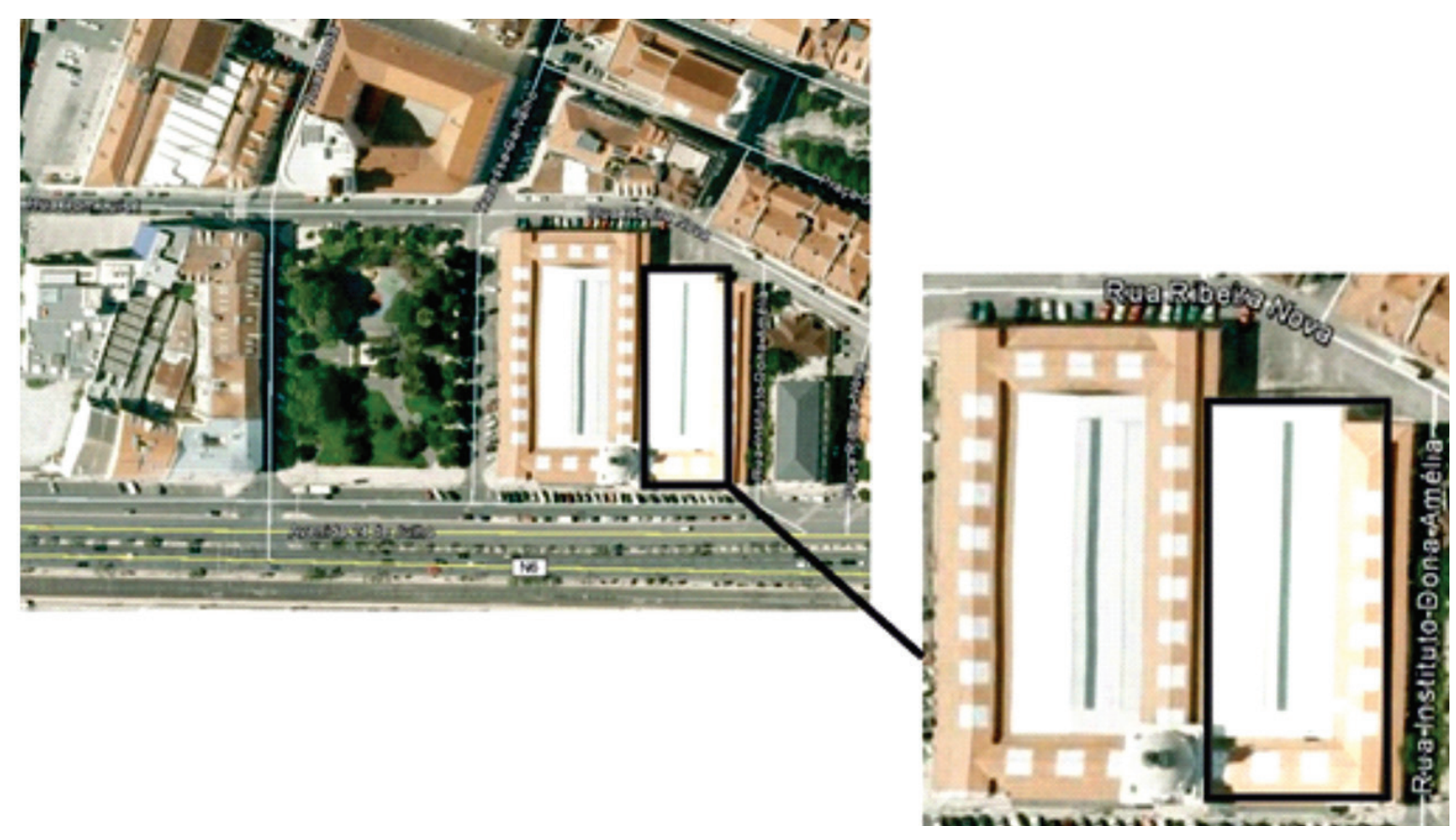

Figura 1 - Localização e pormenor da intervenção arqueológica. (Fonte: Google Earth,Dezembro de 2014, adaptado). 


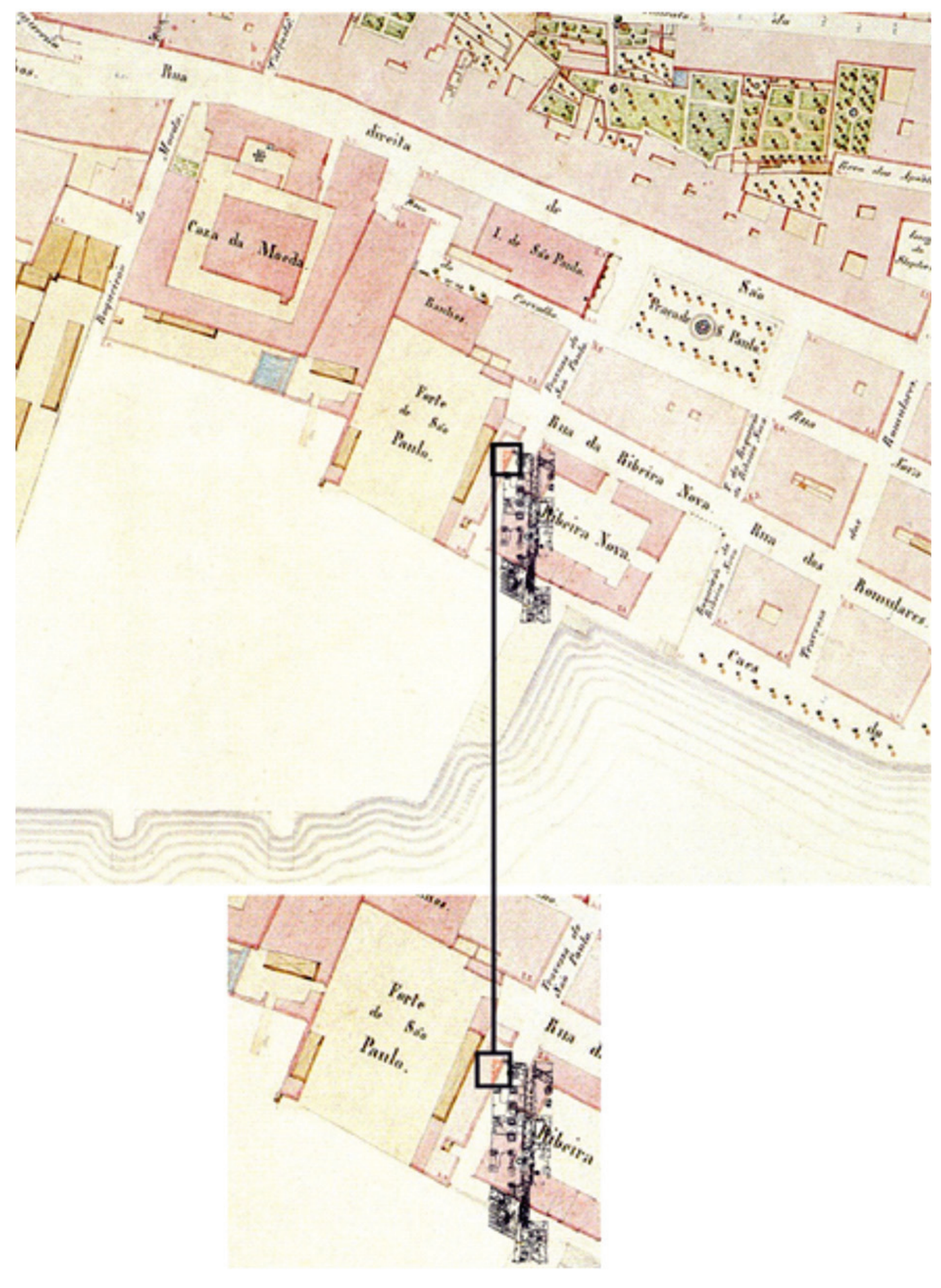

Figura 2 - Sobreposição do registo gráfico da intervenção ao levantamento topográfico de Filipe Folque de 1856. Em pormenor destaca-se o vestígio do lance Este do forte de São Paulo (Fontes: ERA-Arqueologia S.A. e Museu da Cidade de Lisboa, MC.GRA.48o, adaptado). 


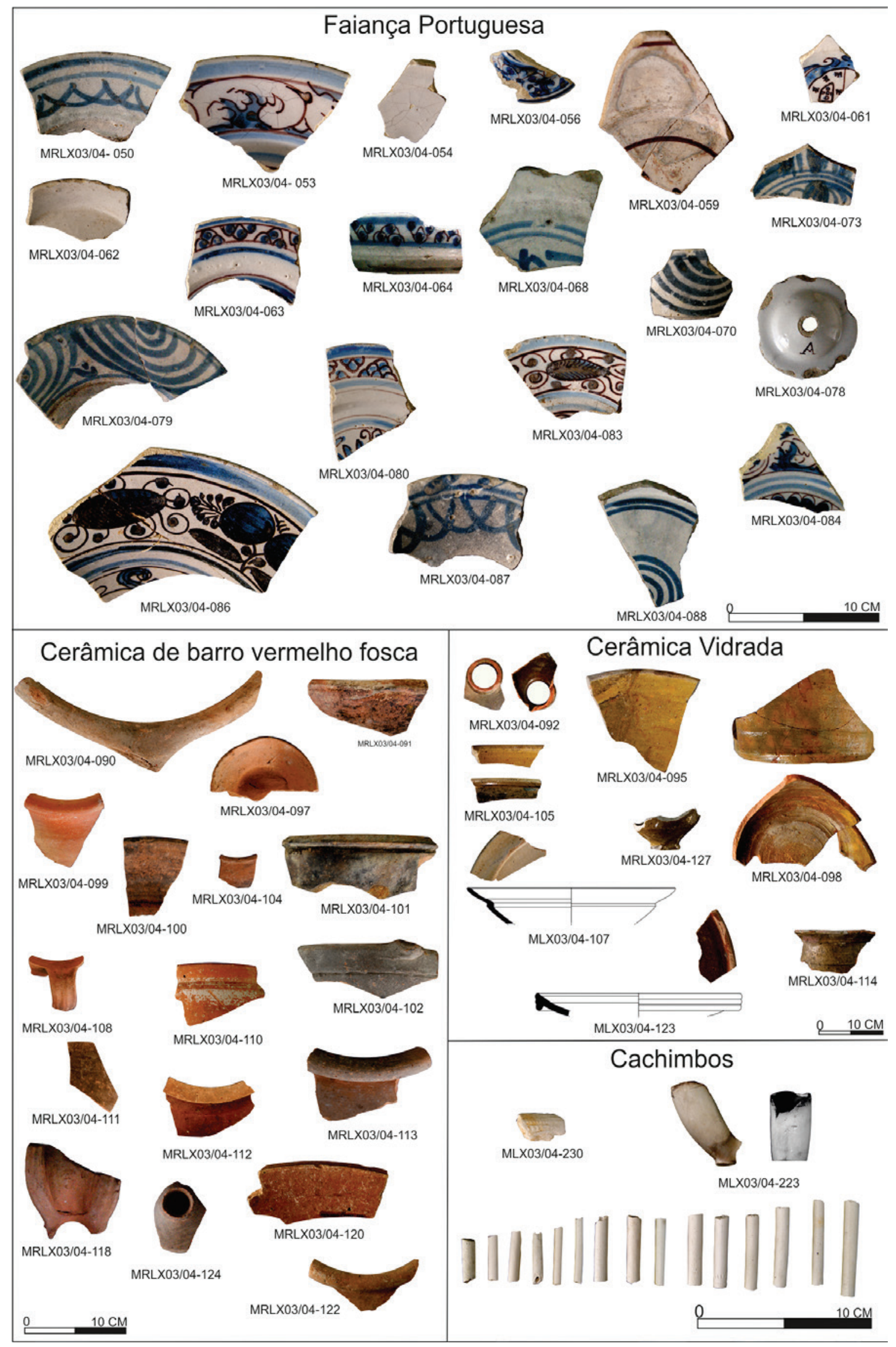

Figura 3 - Registo gráfico de alguns dos exemplares recolhidos em faiança portuguesa; cerâmica de barro vermelho fosca; cerâmica vidrada e cachimbos cerâmicos. 


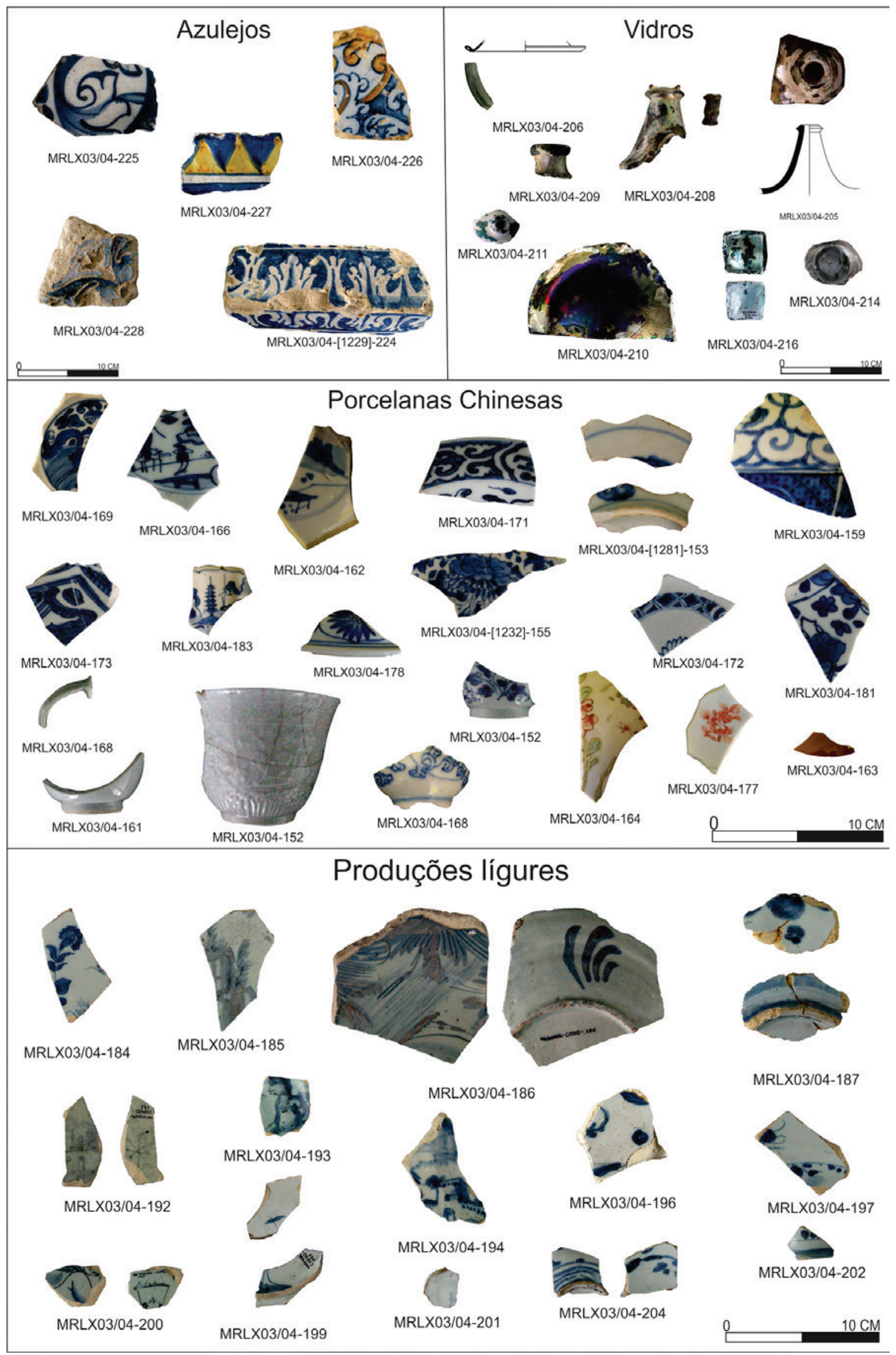

Figura 4 - Registo gráfico de alguns dos exemplares recolhidos de azulejos; em vidro; porcelanas chinesas e produções lígures. 


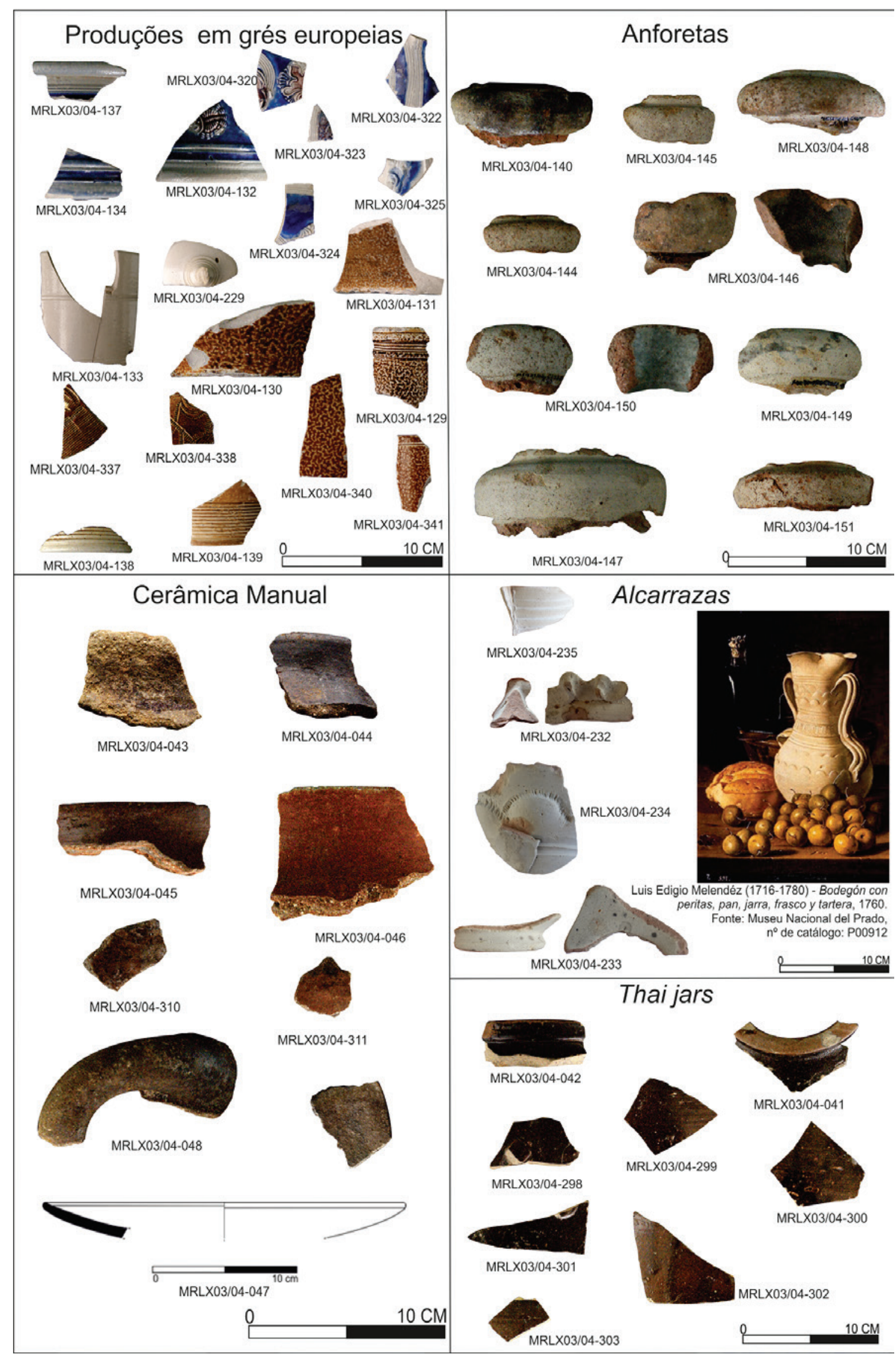

Figura 5-Registo gráfico de alguns dos exemplares recolhidos de produções em grés europeias; anforetas; cerâmica manual; alcarrazas e thai jars. 


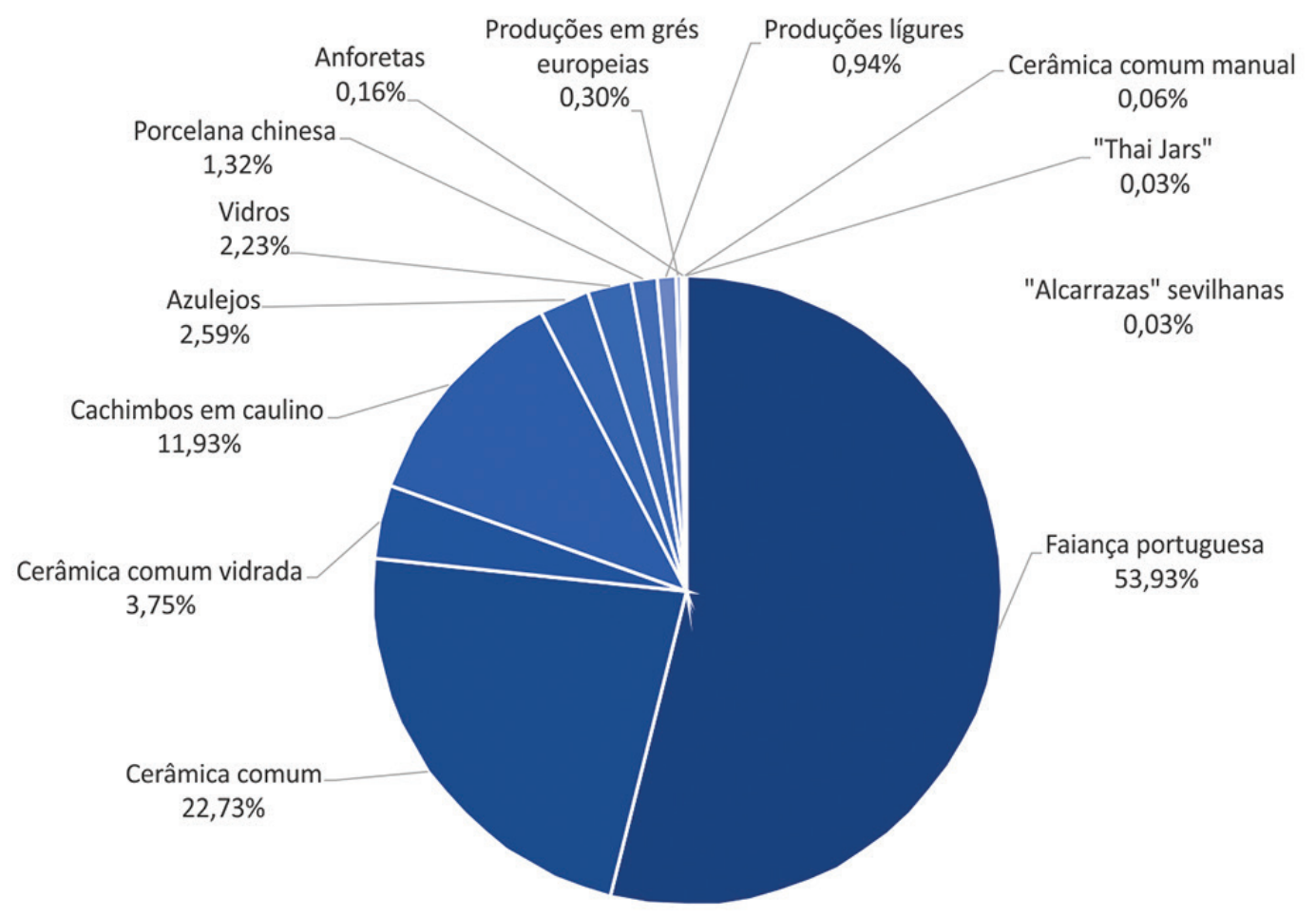

Gráfico 1 - Frequência percentual, por NMI, dos diferentes grupos de frabrico analisados, recolhidos nos depósitos de aterro do Sector 1 .

\begin{tabular}{|c|l|l|l|l|l|l|l|l|l|}
\hline Classe/Quartel & 1550 & 1575 & 1600 & 1625 & 1650 & 1675 & 1700 & 1725 & 1750 \\
\hline Faianças Portuguesas & & & & & & & & & \\
\hline C. barro vermelho fosco & & & & & & & & & \\
\hline C. Vidrada & & & & & & & & & \\
\hline Cachimbos em caulino & & & & & & & & & \\
\hline Azulejos & & & & & & & & & \\
\hline Vidros & & & & & & & & & \\
\hline Porcelanas Chinesas & & & & & & & & & \\
\hline Produções Lígures & & & & & & & & & \\
\hline Grés Europeus & & & & & & & & & \\
\hline Anforetas & & & & & & & & & \\
\hline Cerâmicas Manuais & & & & & & & & & \\
\hline Alcarrazas Sevilhanas & & & & & & & & & \\
\hline Thai Jars & & & & & & & & & \\
\hline
\end{tabular}

Tabela 1 - Confrontação da frequência cronológica no registo dos diferentes grupos de fabrico analisados, destaca-se a negro, a incidência cronológica das produções no primeiro quartel do século XVIII. 


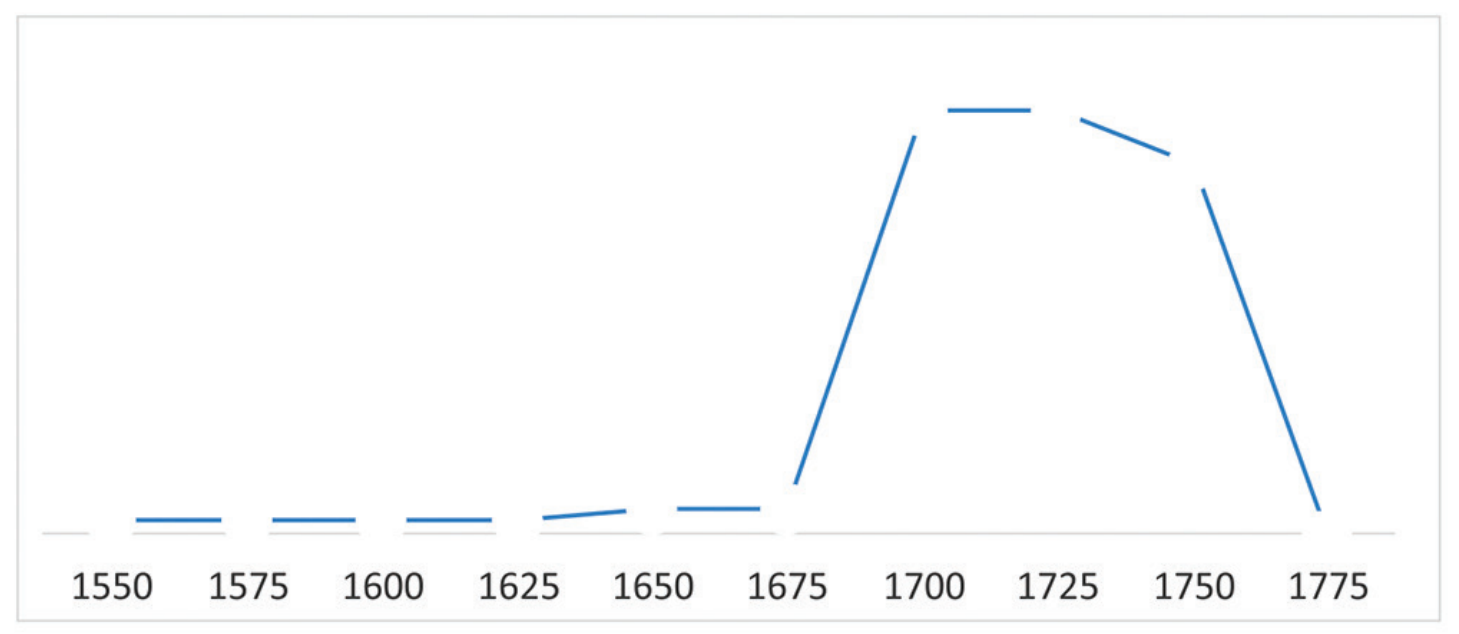

Gráfico 2 - Dispersão e frequência cronológica dos diferentes grupos de frabrico analisados, em NMI, recolhidos nos depósitos de aterro do Sector 1 (quartel). 


\title{
OS CACHIMBOS DOS SÉCULOS XVII E XVIII DO PALÁCIO MESQUITELA E CONVENTO DOS INGLESINHOS (LISBOA)
}

Inês Simão ${ }^{1}$, Marina Pinto ${ }^{1}$, João Pimenta ${ }^{2}$, Sara da Cruz Ferreira ${ }^{3}$, André Bargão ${ }^{4}$, Rodrigo Banha da Silva ${ }^{5}$

\begin{abstract}
RESUMO
Em 2004 e 2009 foram realizadas pela empresa Era-Arqueologia duas intervenções arqueológicas de carácter preventivo, decorrentes de projectos de reabilitação e reconversão de espaços na zona do Bairro Alto, em Lisboa. Sendo ambos os lugares de cronologia seiscentista, equivalem a bem distintos perfis socio-económicos de ocupação: o primeiro, o Venerável Colégio Pontifício de São Pedro e de São Paulo (vulgo Convento dos Inglesinhos), dedicado ao ensino católico da comunidade Inglesa; o segundo, o espaço residencial dos Condes de Mesquitela.

A despeito de todas as limitações contextuais arqueológicas, o estudo assinala as diferentes proporções com que os dois conjuntos se apresentam, deste modo se comprovando o uso dos cachimbos como indicador arqueológico significante para a análise dos espaços urbanos.

Palavras-chave: Cachimbos cerâmicos, Arqueologia Moderna, Arqueologia Conventual, Importações Cerâmicas, "Cultura do tabagismo".
\end{abstract}

\begin{abstract}
Era-Arqueologia excavated in 2004 and 2009 two significant buildings in Bairro Alto quarter in Lisbon, due to urban rehabilitation projects. With approximate $17^{\text {th }}$ century chronologies, they display very distinctive socioeconomic profiles: one, St. Peter's and St. Paul's Honourable Pontifical College (commonly known as the "Little English Convent"), and was devoted to catholic teaching to the British community living in Lisbon during Early Modern Age; the other, a noble mansion belonging to Mesquitela Earls.

Despite archaeological limitations of contextual data, they display some contrast between the religious context and the noble one, allowing some archaeological inference on social significance of pipe presence in Early Modern Age contexts from Lisbon.

Keywords: Clay Tobacco Pipes, Early Modern Archaeology, Conventual Archaeology, Pottery Consumption, "Tobacco Culture".
\end{abstract}

\section{INTRODUÇÃO}

Os cachimbos em cerâmica constituem, hoje, um domínio específico de estudo no âmbito das arqueologias moderna e colonial. Artefacto singular, de uso personalizado, detentor de uma funcionalidade úni- ca ao não poder ser reutilizado com outras finalidades, não só equivale a um útil "elemento-datante" como é de igual modo significante para outros níveis de inferência, ao documentar aspectos múltiplos da "cultura material": permite o estudo do hábito de consumo por inalação do tabaco, mas eventual-

\footnotetext{
1.Era-Arqueologia.inessimao@era-arqueologia.pt.marinapinto@era-arqueologia.pt

2. Uniarq-Centro de Arqueologia da Universidade de Lisboa. CEAX - Centro de Estudos Arqueológicos de Vila Franca de Xira; Joao-marques@cm-vxira.pt

3. Bolseira de Doutoramento FCT SFRH/BD/137142/2018. CHAM - NOVA FCSH; sara.isabel91@hotmail.com

4. Bolseiro de Doutoramento FCT SFRH/BD/133757/2017. CHAM - NOVA FCSH; andrebargao@gmail.com

5. CAL/DPC/CML. Departamento de História da FCSH. CHAM - NOVA FCSH; rodrigo.banha@cm-lisboa.pt
} 
mente também de outras substâncias psico-activas (Sousa, 2020), mas também disponibiliza evidências de conexões comerciais e, se bem manuseado, contribui para a definição de perfis sociais e culturais documentados pelos contextos arqueológicos.

\section{BREVE SINOPSE DOS ESTUDOS SOBRE CACHIMBOS EM LISBOA}

Para o caso da cidade de Lisboa, os primeiros elementos de cachimbo publicados equivalem aos colectados em 196o no remanescente do Hospital Real de Todos-Os-Santos, dependências do Convento de São Domingos e Colector Real de São Domingos por Irisalva Moita (1965, p. 75, Est. XV n.․ 212; três dos quatro que compunham o conjunto seriam mais tarde revisitados por Miguel Pombinho - Martins, 1988 - e expostos e de novo publicados no catálogo da exposição dedicada ao maior edifício da Lisboa Manuelina que teve lugar em 1993, de permeio com um bico de chaleira confundido com um cachimboPereira, 1993).

Fernando Rodrigues Ferreira daria a conhecer depois, em 1983, um outro fragmento de cachimbo procedente das suas escavações decorridas no Mosteiro de São Vicente de Fora, em Lisboa, ostentando marca britânica de John Stephens (Ferreira, 1983, p. 28).

Após um hiato, que se relaciona também com o historial do desenvolvimento das escavações na cidade (Caessa, Marques \& Silva, 2016), o estudo do conjunto amplo do Caminho da Ronda 1, no Castelo de São Jorge, apresentado em 2000 nas $4^{\text {a }}$ s Jornadas de Cerâmica Medieval e Pós-Medieval (Pimenta, Calado \& Silva, 2003; 2008), marcaria o ponto de viragem a partir do qual se encetou com um ritmo digno de nota a compulsão de conjuntos recolhidos em contextos variados na cidade de Lisboa. O século XXI marca, portanto, o início da compulsão deste tipo de elemento artefactual para Lisboa, reconhecendo-se-lhe a alta valia informativa de há muito assinalada para a leitura da cidade (Silva \& Guinote, 1998).

De entre os estudos entretanto publicados no século actual, são vários os que merecem nota de destaque. Em primeiro lugar, e em função dos seus números elevados, os expressivos conjuntos recolhidos no Mercado da Ribeira (Pinto, Filipe \& Miguel, 2011) e Palácio dos Marqueses de Marialva (Calado et al., 2013). Em segundo lugar, e por um critério de alta valia metodológica, dado o tratamento quantitativo da representatividade dos cachimbos no universo da amostragem geral e em função da sequência estratigráfica, os estudos de Sara Ferreira (2015), a propósito do Forte de São Paulo, e de Filipe Santos Oliveira (2012), a propósito de um contexto doméstico urbano no Beco das Barrelas, em Alfama.

Pelo seu exotismo, já antes sugerido através do achado de um exemplar oriental colectado no Caminho da Ronda 1 (Pimenta, Guinote \& Silva, 2008), merece de igual modo saliência, pelo seu potencial significado, o conjunto coerente e bastante dissonante de todo o restante quadro até então conhecido para a cidade dado a conhecer pelo trabalho académico de Miguel Martins de Sousa, que tratou os cachimbos colectados na escavação do Terreiro do Trigo (Sousa, 2020).

Por fim, o esclarecimento, produzido de forma categórica, da existência de uma produção de cachimbos cerâmicos em pasta vermelha na capital, antes defendida com base num sítio de consumo (Pimenta, Calado \& Silva, 2008), viu-se confirmada pela publicação de Filipe Santos Oliveira dos restos de produção em contexto estratigráfico das antigas olarias do Monte de São Gens exumados, na actual Rua Damasceno Monteiro (Oliveira, 2019).

\section{ENQUADRAMENTO HISTÓRICO}

Os dois espaços aqui em análise enquadram-se no "Bairro Alto», segmento do tecido urbano lisboeta de características singulares em termos históricos e de morfologia urbana. De facto, a origem deste sector da cidade correlaciona-se directamente com o aumento da pressão resultante do acelerado crescimento demográfico verificado ao longo da segunda metade do séc. $\mathrm{XV}$, resultando da expansão para poente dos antigos limites medievos da cidade corporizados pela muralha fernandina (1373-1375), dada a progressiva exaustão dos espaços agrários intra-muros, ocupados por mais densa edificação ao longo de quatrocentos (Figura 1).

Deste modo, os terrenos irão ser parcelados em talhões e sub-aforados por Bartolomeu de Andrade e Francisca Cordovil para a construção de novas casas e hortas a partir de 1513, de onde deriva o primitivo nome do "Bairro Alto", "Vila Nova de Andrade» (Carita, 1994, pp. 19-21; Pinto, 2004, p. 10), estendendo-se desde as portas de Santa Catarina até à Igreja das Chagas (Carita, 1994, p. 25), com um desenho regular e evocador de uma nova concepção do espaço urbano de cariz renascentista. 
Seria em pleno «Bairro Alto» que se instalaria o Convento dos Inglesinhos. A sua construção enquadra-se no clima de intolerância religiosa que tem lugar na Europa quinhentista e seiscentista, no caso particular inglês das fortes perseguições aos católicos movidas pelo anglicanismo durante os reinados de Isabel I e Jaime I, que aliás dão origem à fixação de comunidades oriundas das Ilhas Britânicas em Lisboa (Figura 2).

Seria o convento flamengo de Douai, fundação outorgada por Filipe I de Portugal com a finalidade de acolher jovens dissidentes ingleses que pretendessem receber uma formação católica, a servir de exemplo para a fundação ulterior de outras casas e conventos na Europa, casos de Roma (1579), Valladolid (1589), Sevilha (1592) e Lisboa (AA.VV., 2007, p. 25; Lima, 1950, p. 105; Pinto, 2004, p. 11). No caso da capital portuguesa, seria a capacidade de iniciativa do reitor da Residência Inglesa ali sediada, o Padre Newman, que perseguiria a intenção do seu antecessor em fundar um seminário inglês em Lisboa, para o que conseguiu o apoio e suporte financeiro do nobre português D. Pedro Coutinho e obteve a autorização das autoridades eclesiásticas em Inglaterra e a permissão do monarca português Filipe III em Madrid, em 1621 (AA.VV., 2007, p. 26; Lopes, 1950, p. 106).

Com o parecer favorável do Reino e de Roma, é emitida em 20 de Novembro de 1621 a carta régia relativa à fundação do seminário e, em 1622, a bula papal de Gregório XV concedia ao Colégio todos os privilégios de que usufruíam outras instituições do mesmo género (Carita, 1994: 96; AAVV, 2007: 31). O Colégio recebe o nome de São Pedro, ao qual foi dedicada a construção da igreja nele existente, e de São Paulo, ficando a ser conhecido popularmente por "Convento dos Inglesinhos", nome dado pelos habitantes do "Bairro Alto", ou por "Lisbon College», para os que o frequentavam. O nome popular, dado pelos habitantes locais, pode dever-se à clausura que a formação impunha aos alunos (Lopes, 1950, p. 105; AA.VV., 2007, p. 31).

Os trabalhos de edificação iniciaram-se a 1632, tendo ficado concluído em 1644, e o seu espaço era considerado limitado, uma vez que a construção reaproveitou a existência de anteriores e antigas habitações (Carita, 1994, p. 96).

A mole construída sofreria danos assinaláveis com o cataclismo de 1755, devendo aqui referir-se o falecimento do capelão Dr. Manley sob os escombros do colapso da torre do templo, o que aliás consta do epitáfio funerário da sua lápide sepulcral patente no templo. Tendo os ocupantes abandonado o espaço temporariamente, seria ocupado como refúgio de famílias desalojadas, e certas áreas, como o corredor, usadas com funções hospitalares. Após o retorno ao espaço, a instituição sofreria de novo com a ocupação pelas tropas francesas, não tendo porém cessado o ensino, que teria continuidade até 1882, muito para além do estabelecimento da liberdade religiosa no Reino Unido, ocorrida em 1829 (Pinto, 1993, p. 4). Entre 2004 e 2009, o complexo edificado seria adquirido para a instalação de um condomínio de luxo (Figura 3).

O Palácio Mesquitela resulta da reconversão urbana do espaço que por via do seu primeiro casamento o Doutor António de Sousa de Macedo promove. Figura destacada dos reinados de D.João IV e D.Afonso VI, jurista, escritor, diplomata e político, seria agraciado por ambos os monarcas com diversas mercês e correspondentes proventos para si e para seu filho único, Luis Gonçalo de Sousa de Macedo. O seu trajecto conduzi-lo-ia às funções de Secretário de Estado de D. Afonso VI. O mais significativo de todos foi certamente o título de Barão da Ilha Grande de Joanes para este, que lhe permitiu entrar no primeiro grau da nobreza titulada, embora sem grandeza.

Merece também referência, pela singularidade peculiar, mas muito significativa, a outorga do título de Barão de Mulingar com que o Rei Carlos II de Inglaterra reconheceu os serviços prestados em condições especialmente adversas a seu pai o Rei Carlos I, que à semelhança do título português de Barão recaiu directamente em D. Luis Gonçalo (Pinto \& Simão, 2009, p. 14). Desenvolveria este último uma política de casamentos com elementos da mais alta nobreza, o primeiro com os Menezes, de muito curta duração, e o segundo com D. Mariana de Távora, promissor não apenas pelos oito filhos que lhe deu, mas também por ter sido esta senhora a herdeira da Casa de sua mãe, permitindo acrescentar dois morgados com inúmeras propriedades no Alto Alentejo (Portalegre, Castelo de Vide, Marvão, Arronches, Veiros, Monforte), e por ter estabelecido uma aliança com os Furtado de Mendonça, família com inúmeras influências na Corte e na hierarquia religiosa, além de ter beneficiado com as mercês dos serviços que, como militar valoroso na Guerra da Restauração, recebeu o irmão D. João Furtado de Mendonça, que veio a morrer solteiro (Pinto \& Simão, 2009, p. 14). A documentação manuscrita, rica e diversificada, 
atesta os trabalhos sucessivos de configuração do espaço envolvendo profundas reformulações urbanas promovidas por D. António e D. Luís Gustavo ao longo da segunda metade do séc. XVII, prosseguidas na sequência das afectações provocadas por 1755 até à segunda metade do séc. XVIII pelo $1^{\circ}$ Visconde de Mesquitela, D. Luís de Sousa de Macedo, e que emprestaram ao complexo a feição modular que facilmente se lhe reconheceu (Pinto \& Simão, 2009, pp. 22-26, 79-102).

Como o conjunto urbano anterior dos Inglesinhos, também o Palácio Mesquitela foi alvo de um processo de renovação promovido por um investidor imobiliário, despoletando as intervenções arqueológicas, concluídas em 2009.

\section{OS CONJUNTOS DE CACHIMBOS CERÂMICOS}

\subsection{O conjunto do "Convento dos Inglesinhos"}

O conjunto colectado nas intervenções arqueológicas realizadas no local é composto por um total de 35 framentos (MNI), dos quais 5 equivalem a porções preservando o fornilho ou vestígios deste, e os restantes a hastes.

O conjunto revelou uma distribuição regular e homogénea dos exemplares, não se verificando a sua concentração em qualquer das zonas específicas sondadas. Nota-se, aliás, uma dispersão pelas estratigrafias representativas das várias acções construtivas dos séculos XVII ao XIX, ilustrando algumas destas ocorrências,pelas cronologias relativas dos exemplares, fenómenos de remobilização dos materiais, "empacotados" em formações deposicionais de cronologias ulteriores, à semelhança de outras categorias cerâmicas coevas dos mesmos com eles reveladas.

São assaz interessantes no interior do conjunto alguns exemplares de fornilhos como os C.Ing. 13, C.Ing. 14 e C.Ing. 22, equivalentes tipologicamente a produções quase de certeza britânicas enquadradas em cronologias centradas no segmento temporal de 1640-1670, de acordo com as propostas de evolução morfológica de Akinson e Oswald (1969), com o primeiro dos citados a poder equivaler a um exemplar de mais recuada datação.

Em contraponto com estes, C.Ing. 15 e C.Ing. 16, parecem equivaler a produções holandesas de Gouda. A sua forma, segundo Duco, aponta já para o século XVIII pleno e enquadrado no lapso entre 1725 e 1750
(Duco, 2003), que a ausência de marcas infelizmente não permite precisar quanto ao produtor. $\mathrm{A}$ excepção é a marca lateral, parcial, do exemplar C.Ing. 16, por nós interpretada como "Rosa Tudor". Trata-se de uma versão impressa de forma deficiente e, sobretudo, muito simplificada em relação ao motivo original, que os produtores holandeses tomaram dos fabricos britânicos no séc. XVII, período durante o qual conhece franca vitalidade, muitas vezes com letras identificativas ou coroado, e que acabará por sobreviver de forma limitada já dentro do séc. XVIII (Bradley \& DeAngelo, 1981) (Figura 4).

\subsection{O conjunto do Palácio Mesquitela.}

No Palácio dos Condes de Mesquitela se recolheram 17 fragmentos de cachimbo em cerâmica, dos quais 3 preservando o fornilho, equivalendo os restantes a porções de haste.

O exemplar P.Mes.13 é um interessante fornilho de produção inglesa do século XVII. Segundo proposta tipológica da evolução dos fornilhos já antes citada de Atkinson e Oswald (1969), deverá datado de 1600-1640, data anterior à vida do Palácio e deveras interessante para Lisboa, ao documentar o consumo de tabaco por inalação num momento na zona do Bairro Alto, constituindo um dos cachimbos de potencial mais recuada data na cidade no estado actual dos nossos conhecimentos. Ostenta a marca $\mathrm{RB}$, encontrando-se o $\mathrm{B}$ mal gravado, como é normal nesta "assinatura", correspondente ao produtor Richard Berryman, activo na cidade de Bristol no período 1619-1652, (Jackson \& Price, 1974; Walker, 1971), detendo a impressão um excelente paralelo no País Basco, em Gipuzkoa (López Colom, 1999, p. 120).

Os outros dois fragmentos preservando o fornilho, P.Mes.15 e P.Mes.17, são como elaborações lisboetas seiscentistas facilmente rastreáveis pela sua pasta vermelha e pela morfologia. Como referimos em apartado anterior, este fabrico encontra-se para já documentado categoricamente nos despejos de olaria da encosta da Graça por Filipe Oliveira (2019), sendo que a esta produção se pode também assimilar o exemplar de haste P.Mes.16.

P.Mes.02, 03 e 11 mostram decoração impressa incisa na parte mesial da haste, sendo que qualquer um deles equivale produções holandesas de Gouda com cronologias situadas entre os finais do séc. XVII e os meados do séc. XVIII (Duco, 2003) (Figura 5). 


\section{DISCUSSÃO}

Os dois conjuntos objecto de análise revelam números globalmente baixos e na aparência não muito díspares, ilustrando o consumo de tabaco por inalação em contextos distintos da sociedade moderna da zona do Bairro Alto, em Lisboa, ao longo de uma cronologia longa, que cobre desde os finais do primeiro quartel do séc. XVII aos meados do séc. XVIII. As evidências lisboetas já conhecidas vêm comprovando que os cachimbos detêm um valor instrumental na definição dos perfis de composição dos contextos da cidade, onde as elevadas quantidades registadas, casos dos c.90o exemplares do Caminho da Ronda 1 (Castelo de São Jorge - Pimenta et al. 2008) e dos c.8oo do Mercado da Ribeira (espaço confinante com o antigo Forte de São Paulo (Pinto, Filipe \& Miguel, 2011), espaços bem diversificados mas que partilham em comum a sua associação a ambientes militares setecentistas, são fortemente constrastantes com outros pontos arqueológicos da cidade para os quais o conhecimento histórico por via documental demonstra outro tipo de perfil socio-económico, que a escassez de cachimbos parece comprovar: cite-se, a esse propósito, o exaustivo estudo contextual e estratigráfico desenvolvido sobre o ambiente doméstico do Beco das Barrelas, em Alfama, nomeadamente a ausência de cachimbos no "momento I" ( $2^{\underline{a}}$ met. séc. XVI - $1^{\circ}$ terço do séc. XVII), o surgimento de 6 exemplares no "momento II" (meados séc. XVII) e de 9 no "momento III" (finais do séc. XVII - inícios do séc. XVIII), quando em todos os momentos os artefactos de outras naturezas são ali relativamente abundantes (Oliveira, 2012, pp. 71-72).

Como é compreensível, os dados terão de ser colocados em comparação com outros similares da cidade, cuja publicação todavia escasseia apesar do elevado número de intervenções arqueológicas em Lisboa. Podem-se esgrimir desde já dados quantitativos, ainda que forçosamente conseguidos mediante uma elaboração grosseira nossa em termos metodológicos, porque não leva em conta factores importantes como o perfil funcional de formação desses mesmos contextos, por realizar na totalidade dos casos: deste modo, no Palácio dos Marqueses de Marialva (aproveitando-se aqui para relembrar os habitantes do espaço até à data do grande terramoto de Lisboa, o $2^{\circ}$ e $04 . .^{\circ}$ Marquês de Marialva, ligados a importantes funções militares na proximidade da coroa), se estudaram 703 fragmentos (Calado et al., 2013), numa área palaciana aproximada de $1500 \mathrm{~m}^{2}$, a que corresponderia um ratio de $0,47 / \mathrm{m}^{2}$; em Mercado da Ribeira, nos c. $760 \mathrm{~m}^{2}$ se estudaram 935, construindo um ratio de $1,23 / \mathrm{m}^{2}$ (Pinto, Filipe \& Miguel, 2011); em Beco das Barrelas (antes citados), em c. de $240 \mathrm{~m}^{2}$ equivalentes a duas habitações do bairro de Alfama, se identificaram somente 15, resultando num ratio de $0,04 / \mathrm{m}^{2}$ (Oliveira, 2012); por fim, em Caminho da Ronda 1 se consideraram 817 fragmentos, oriundos de um espaço de $150 \mathrm{~m}^{2}$, resultando num ratio de $5,45 / \mathrm{m}^{2}$ (Pimenta, Calado \& Silva, 2008).

Mesmo que declaradamente imprecisos (e impressionistas!), os valores deste modo obtidos ajudam metodologicamente a colocar em perspectiva os resultados obtidos para os dois locais objecto do presente estudo. Deste modo, é assinalável que para a área intervencionada do Palácio Mesquitela, onde se obtém um ratio de $0,05 / \mathrm{m}^{2}$, os indicadores são consentâneos com o outro disponível em Lisboa e associável a ambientes de carácter doméstico, mas declaradamente distante do ambiente palaciano dos Marqueses de Marialva, onde potencialmente o factor militar de uma parte dos seus frequentadores poderá ter jogado um papel de relevo. Em contraste com aqueles, os $0,45 / \mathrm{m}^{2}$ do antigo "Venerável Colégio Pontifício de São Pedro e de São Paulo", valores próximos dos obtidos no ambiente Marialva, geograficamente não muito distantes um do outro, terão que encerrar explicações de outro cariz, podendo desde já aventar-se que os números estarão eventualmente a espelhar um outro tipo de perfil social e, sobretudo, cultural, considerando aqui a enraizada tradição britânica de consumo do tabaco mediante cachimbo, hábito que terá tido neste espaço de ensino um ambiente deveras propício.

\section{BIBLIOGRAFIA}

AA. VV. (2007) - Convento dos Inglesinhos / The English College. Lisboa: Highgrove - Clubes residenciais, S.A.

ATKINSON, David R.; OSWALD, Adrian (1969) - London clay tobacco pipes. In Journal of the British Archaeological Association (3d Series), n. ${ }^{3}$ 2, fasc.1. Londres: British Archaeological Association, pp. 171-227.

BRADLEY, James; DEANGELO, Gordon (1981) - European clay pipe marks from $17^{\text {th }}$ century Onondaga Iroquois sites. In Archaeology of Eastern North America, 9. S.1.: Eastern States Archaeological Federation, pp. 109-133. 
CALADO, Marco; PIMENTA, João, SILVA, Rodrigo Banha da (2003) - Cachimbos de cerâmica provenientes da escavação do Caminho de Ronda no Castelo de São Jorge em Lisboa. In Património Estudos, 5. Lisboa: IPPAR, pp. 83-95.

CALADO, Marco, PIMENTA, João, FERNANDES, Lídia; MARQUES, António (2013) - Os cachimbos cerâmicos do Palácio Marialva, in Revista Portuguesa de Arqueologia, vol. 16. Lisboa: IPPAR, pp. 383-392.

CARITA, Hélder (1994) - Bairro Alto - Tipologias e modos arquitectónicos. Lisboa: Câmara Municipal de Lisboa.

DAVEY, Peter (Ed.) (1978) - The Archaeology of the clay tobacco pipe III Britain: the north and west. Oxford: British Council for Arqchaeology (col. BAR, British Series: 78), pp. 40-272.

DUCO, Don H. (1982) - Merken van Goudse Pijpenmakers 1660-1940. Amsterdam: Pijpenkabinet.

DUCO, Don H. (2003) - Merken in merkenrecht van de pijpenmakers in Gouda. Amsterdam: Pijpenkabinet.

FERREIRA, Fernando E. Rodrigues (1983) - Escavações do ossário de S. Vicente de Fora, in Revista Municipal, Ano

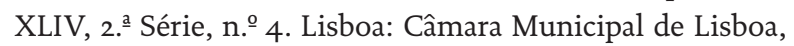
pp. 5-36.

FERREIRA, Sara (2015) - O sítio do Forte de São Paulo: estudo arqueológico da Ribeira Ocidental de Lisboa na Época Moderna. Lisboa: Faculdade de Ciências Sociais e Humanas da Universidade Nova de Lisboa (Dissertação de Mestrado).

JACKSON, Reginald Graham; PRICE, Roger Harvey (1974) - Bristol Clay Pipes a study of makers and their marks. In Research Monograph N.ำ 1. Bristol: City Museum, pp. 32-89.

LÓPEZ COLOM, Maria del M. (1999) - Pipas de Arcilla Halladas en Gipuzkoa. aproximación a su catalogación arqueológica y tipológica. Coleccion Hurbil. 1. Serie de monografias de arqueologia postmedieval. Gipuzkoa: Diputación Foral de Gipuzkoa.

MARTINS, Miguel (1988) - Três cachimbos do Hospital Real de Todos-Os-Santos, in Revista Municipal, Ano XLIX, 2..$^{\text {a }}$ Série, n. ํㅜㄹ. Lisboa: Câmara Municipal de Lisboa, pp. 16-18.

OLIVEIRA, Filipe (2012) - Espólio de Idade Moderna, proveniente do Beco das Barrelas, Alfama, Lisboa. Lisboa: Faculdade de Ciências Sociais e Humanas da Universidade Nova de Lisboa (Dissertação de Mestrado).

OLIVEIRA, Filipe Santos (2019) - Produção de cachimbos de barro na Rua Damasceno Monteiro (Olarias de São Gens), Lisboa - um contributo para o seu estudo, in Apontamentos de Arqueologia e Património, nº 13. Linda-a-Velha: Era-Arqueologia, pp. 67-73.
PIMENTA, João; CALADO, Marco; SILVA, Rodrigo Banha da (2008) - Cachimbos de cerâmica provenientes da escavação do Caminho da Ronda no Castelo de São Jorge, Lisboa , in ABRAÇOS, Hélder e DIOGO, João (Eds.) Actas das $4^{\underline{a}} s$ Jornadas de Cerâmica Medieval e Pós-Medieval (Tondela, 2000). Tondela: Câmara Municipal de Tondela, pp. 335-353.

PINTO, Marina Paiva (2004) - Relatório de Trabalhos Arqueológicos - Convento dos Inglesinhos, 2004. Lisboa: ERA, Arqueologia S.A.

PINTO, Marina; SIMÃO, Inês (2009) - Trabalhos Arqueológicos no Palácio da Mesquitela, Lisboa. Lisboa: Era-Arqueologia S.A.

PINTO, Marina; FILIPE, Iola; MIGUEL, Lúcia (2011) - Cachimbos de caulino provenientes do Mercado da Ribeira: contributo para a história socio-económica da Lisboa Moderna, in Apontamentos de Arqueologia e Património, $\mathrm{n}^{\circ} 7$. Linda-a-Velha: Era-Arqueologia, pp. 41-47.

SOUSA, Miguel Martins de (2020) - As evidências dos Estados Alterados de Consciência no registo arqueológico da Idade Moderna em Portugal. Lisboa: Faculdade de Ciências Sociais e Humanas da Universidade Nova de Lisboa (Dissertação de Mestrado).

WALKER, Ian C. (1971) - The Bristol Clay Tobacco-Pipe Industry. Bristol. City Museum. 


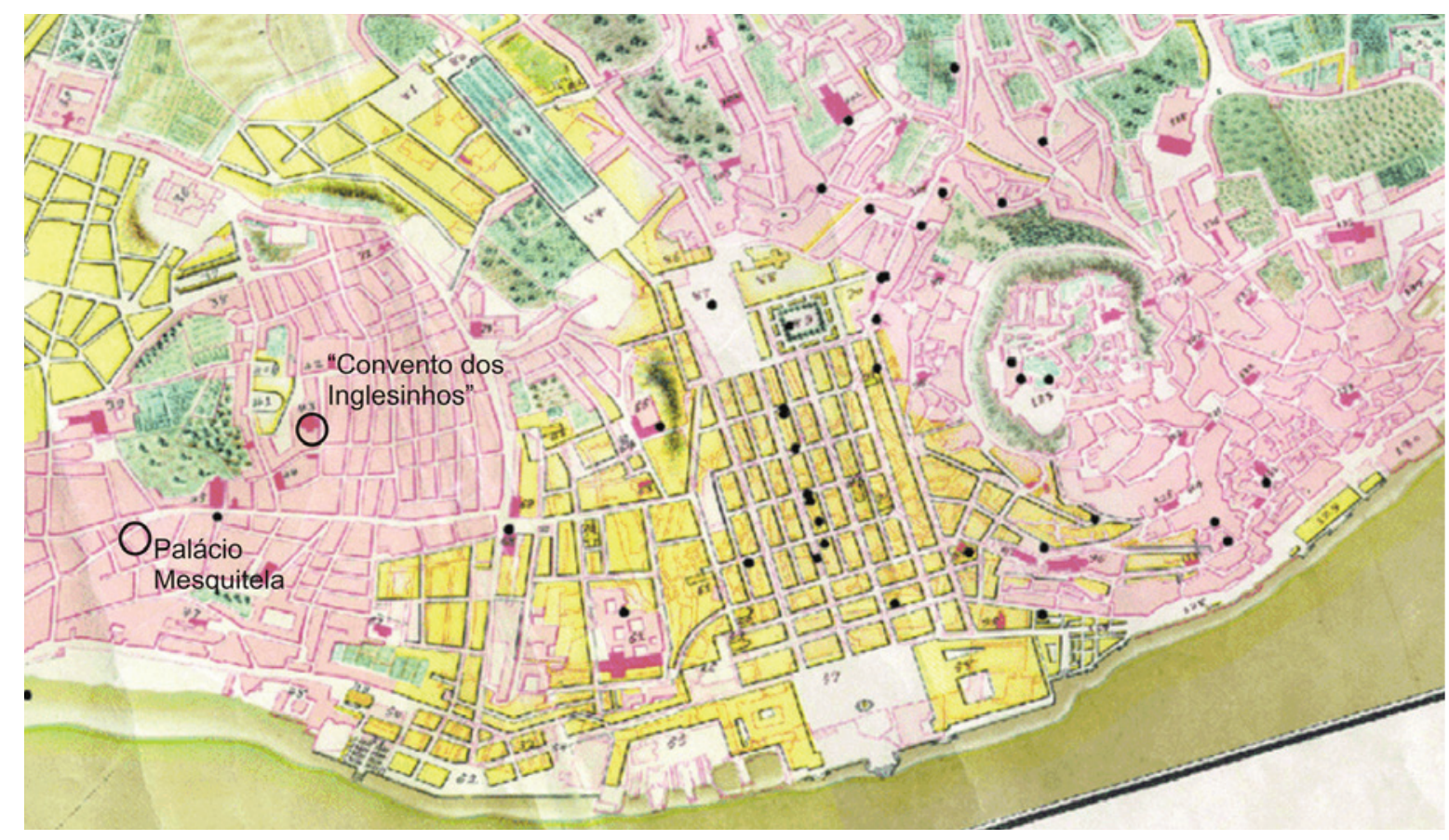

Figura 1 - Excerto da planta de Lisboa (anterior a 1780, Gabinete de Estudos Olisiponenses, CML), com localização do “Convento dos Inglesinhos” e do Palácio Mesquitela.

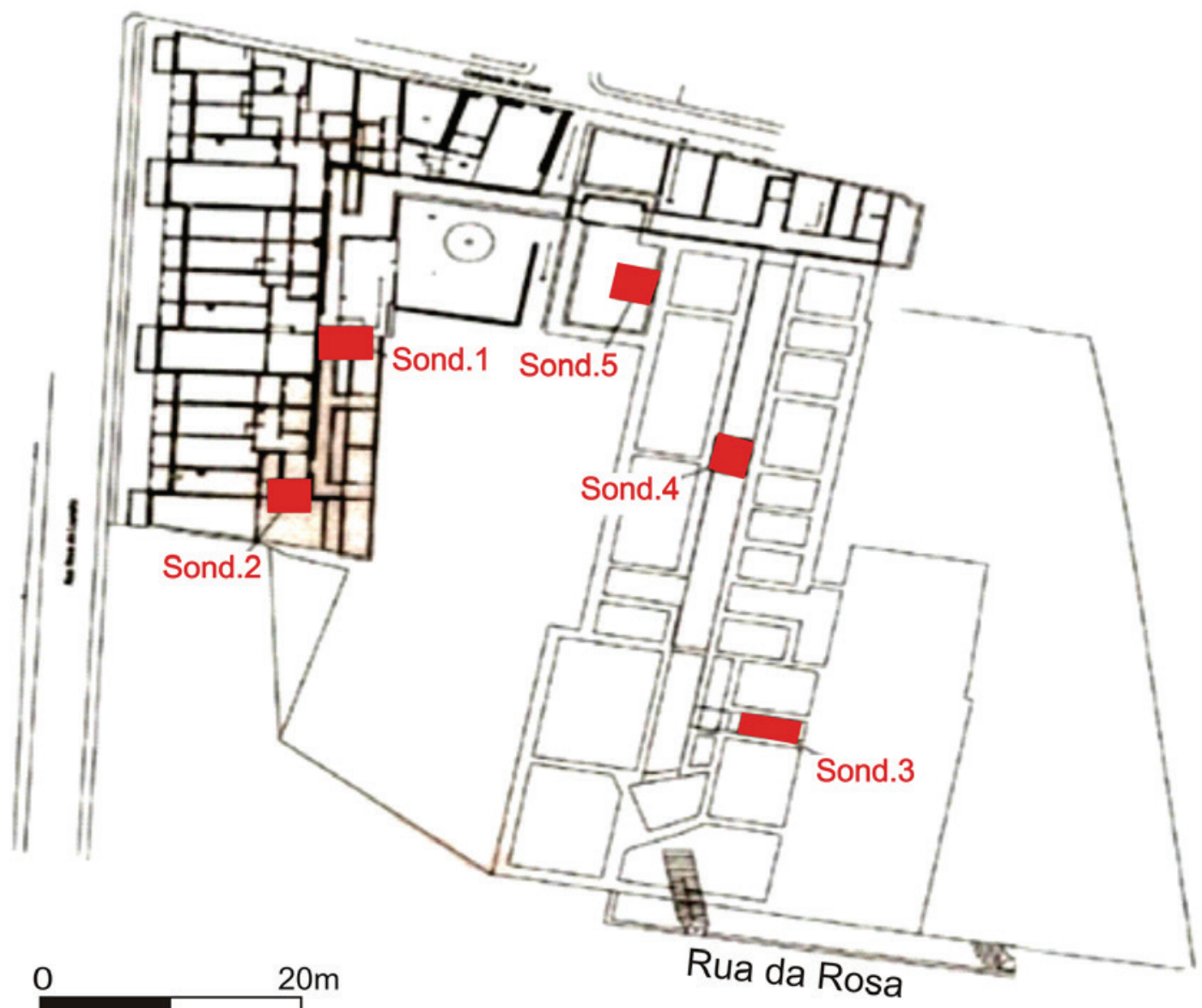

Figura 2 - Áreas intervencionadas pela I.A.U. do “Conventos dos Inglesinhos” (seg. Pinto, 2004). 


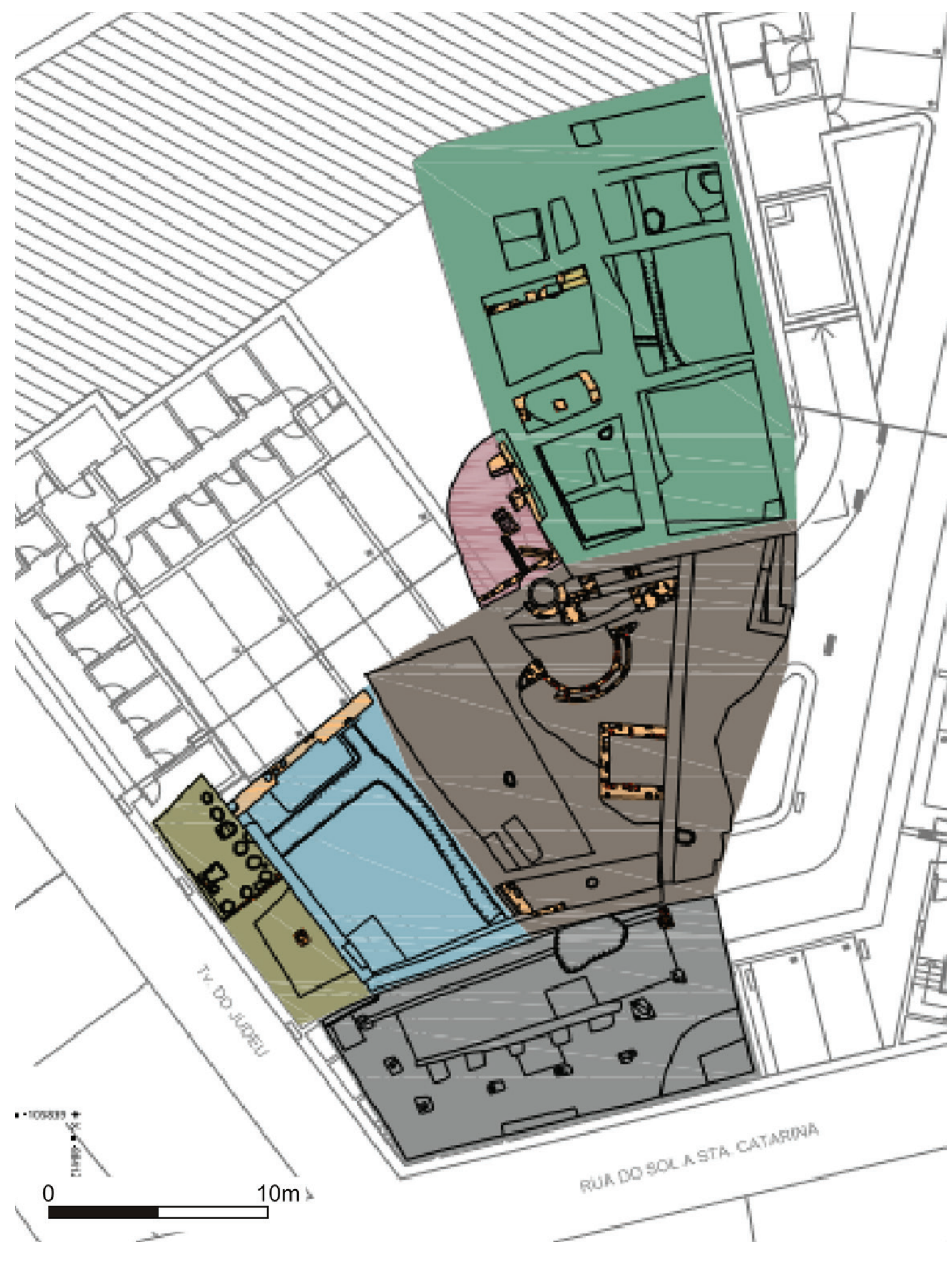

Figura 3 - Área intervencionada e estruturas reveladas pela I.A.U. do Palácio Mesquitela (seg. Pinto e Simão, 2009). 


\begin{tabular}{|c|c|c|c|c|c|c|c|c|c|c|c|c|c|c|c|c|c|c|c|c|c|c|c|}
\hline \multirow{4}{*}{ Inv. 2} & \multirow{2}{*}{\multicolumn{2}{|c|}{$\begin{array}{c}\text { Ind. } \\
\text { Contextuais }\end{array}$}} & \multirow{2}{*}{\multicolumn{6}{|c|}{ Porção }} & \multicolumn{8}{|c|}{ Caract. Fornilho } & \multicolumn{7}{|c|}{ Caract. Haste } \\
\hline & & & & & & & & & & & & & \multicolumn{4}{|c|}{ Decoração } & \multicolumn{5}{|c|}{ Dimensões } & \multicolumn{2}{|c|}{ Decoração } \\
\hline & \multirow[b]{2}{*}{ U.E. } & \multirow[b]{2}{*}{ Sond. } & \multirow[b]{2}{*}{ Forn. } & \multirow[b]{2}{*}{ Ped. } & \multicolumn{3}{|c|}{ Haste } & \multirow[b]{2}{*}{ Boq. } & \multicolumn{4}{|c|}{ Dimensões } & \multirow[b]{2}{*}{$\mathrm{sim}$} & \multirow[b]{2}{*}{ Não } & \multicolumn{2}{|c|}{ Marca de Produtor } & & Distal. & $\begin{array}{l}\text { Diâm. } \\
\text { Distal. }\end{array}$ & $\begin{array}{l}\text { Diâm. } \\
\text { Prox. }\end{array}$ & $\begin{array}{l}\text { Diâm. } \\
\text { Prox. }\end{array}$ & & \\
\hline & & & & & \begin{tabular}{|l|} 
Distal \\
\end{tabular} & Mesial & roxims & & iâm. $\mathrm{Fo}_{\mathrm{O}}$ & ầm. $\mathrm{Ha}$ & m. Orif. & Penú & & & \begin{tabular}{|l|} 
Sim \\
\end{tabular} & Não & Comp. & Ext. & & & & $\operatorname{sim}$ & Não \\
\hline C.Ing. 1 & {$[1020]$} & 1 & & & & & & $x$ & & & & & & & & & & & & & & & \\
\hline C.Ing. 2 & [1033] & 1 & & & & & $x$ & & & & & & & & & & 3,2 & 0,6 & 0,4 & 0,5 & 0,3 & & $x$ \\
\hline C. Ing. 3 & [1037] & 1 & & & & $x$ & & & & & & & & & & & 6,6 & 0,7 & 0,3 & 0,6 & 0,2 & & $x$ \\
\hline C.Ing. 4 & [2001] & 2 & & & & & $x$ & & & & & & & & & & 2,3 & 0,7 & 0,3 & 0,7 & 0,3 & & $x$ \\
\hline C.Ing. 5 & [2001] & 2 & & & $\mathrm{x}$ & & & & & & & & & & & & 4,3 & 1 & 0,3 & 0,9 & 0,3 & & $x$ \\
\hline C.Ing. 6 & [2014] & 2 & & & $\mathrm{x}$ & & & & & & & & & & & & 3,4 & 0,8 & 0,2 & 0,8 & 0,2 & & $x$ \\
\hline C.Ing. 7 & [2020] & 2 & & & & & $x$ & & & & & & & & & & 2,6 & 0,6 & 0,2 & 0,6 & 0,2 & & $x$ \\
\hline C.Ing. 8 & [2020] & 2 & & & & & $x$ & & & & & & & & & & 3,9 & 0,7 & 0,3 & 0,7 & 0,3 & & $x$ \\
\hline C.Ing. 9 & {$[2029]$} & 2 & & & & & $x$ & & & & & & & & & & 4,4 & 0,7 & 0,3 & 0,6 & 0,3 & & $x$ \\
\hline C.Ing. 10 & {$[2029]$} & 2 & & $x$ & $x$ & & & & & & & 0,3 & & & & $x$ & 2,1 & 0,7 & 0,2 & 0,7 & 0,2 & & $x$ \\
\hline C.Ing. 11 & [3003] & 3 & & & $\mathrm{x}$ & & & & & & & & & & & & 4,5 & 0,8 & 0,3 & 0,7 & 0,3 & & $x$ \\
\hline C.Ing. 12 & [3003] & 3 & & & $x$ & & & & & & & & & & & & 2,6 & 0,7 & 0,3 & 0,7 & 0,3 & & $x$ \\
\hline C.Ing. 13 & [3003] & 3 & $x$ & $x$ & $x$ & & & & 1,2 & 1,1 & 0,3 & 1,1 & B1 & & & $x$ & & & & & & & \\
\hline C.Ing. 14 & [3003] & 3 & $x$ & $x$ & $x$ & & & & 1,2 & 0,9 & 0,3 & 1,4 & B1 & & & $x$ & & & & & & & \\
\hline C. Ing. 15 & [4018] & 4 & & & & & $x$ & & & & & & & & & & 2,2 & 0,7 & 0,2 & 0,7 & 0,2 & & $x$ \\
\hline C. Ing. 16 & [4018] & 4 & $x$ & & & & & & 1,7 & 0,8 & 0,2 & 0,4 & B1 & & Rosa Tudor & & & & & & & & \\
\hline C. Ing. 17 & [4022] & 4 & & & & & $x$ & & & & & & & & & & 8,7 & 0,6 & 0,2 & 0,6 & 0,2 & $\mathrm{H} 1$ & \\
\hline C.Ing. 18 & {$[5004]$} & 5 & & & $x$ & & & & & & & & & & & & 3,6 & 0,8 & 0,3 & 0,8 & 0,3 & & $x$ \\
\hline C.Ing. 19 & {$[5004]$} & 5 & & & $x$ & & & & & & & & & & & & 3,2 & 0,8 & 0,3 & 0,8 & 0,3 & & $x$ \\
\hline C. Ing. 20 & [5004] & 5 & & & $x$ & & & & & & & & & & & & 5,6 & 0,9 & 0,3 & 0,8 & 0,3 & & $x$ \\
\hline C. Ing. 21 & $5003 / 5004$ & 5 & & & & & $x$ & & & & & & & & & & 4,7 & 0,7 & 0,3 & 0,7 & 0,3 & & $x$ \\
\hline C. Ing. 22 & $5003 / 5004$ & 5 & $x$ & $x$ & $x$ & & & & & 1 & 0,3 & 1,3 & & $x$ & & $x$ & 3 & 1 & 0,3 & 1 & 0,3 & & $x$ \\
\hline C. Ing. 23 & $5005 / 500$ & 5 & & & $x$ & & & & & & & & & & & & 5,4 & 0,9 & 0,2 & 0,8 & 0,2 & & $x$ \\
\hline C. Ing. 24 & $5005 / 500$ & 5 & & & $x$ & & & & & & & & & & & & 8,7 & 1,1 & 0,3 & 0,9 & 0,3 & & $x$ \\
\hline C. Ing. 25 & {$[5021]$} & 5 & & & & $x$ & & & & & & & & & & & 7,1 & 0,9 & 0,3 & 0,7 & 0,3 & & $x$ \\
\hline C. Ing. 26 & {$[5006]$} & 5 & & & & $x$ & & & & & & & & & & & 3,5 & 0,9 & 0,3 & 0,8 & 0,3 & & $x$ \\
\hline C. Ing. 27 & {$[5006]$} & 5 & & & & & $x$ & & & & & & & & & & 3 & 0,8 & 0,3 & 0,7 & 0,3 & & $x$ \\
\hline C. Ing. 28 & {$[5009]$} & 5 & & & $x$ & & & & & & & & & & & & 4,5 & 0,9 & 0,3 & 0,8 & 0,3 & & $x$ \\
\hline C. Ing. 29 & {$[5009]$} & 5 & & & & & $x$ & & & & & & & & & & 6,5 & 0,8 & 0,4 & 0,7 & 0,3 & & $x$ \\
\hline C. Ing. 30 & [5016] & 5 & & & & & $x$ & & & & & & & & & & 4,7 & 0,7 & 0,3 & 0,6 & 0,3 & & $x$ \\
\hline C. Ing. 31 & {$[5042]$} & 5 & & & & & $x$ & & & & & & & & & & 3,3 & 0,8 & 0,3 & 0,7 & 0,3 & & $x$ \\
\hline C. Ing. 32 & {$[3020]$} & & & & $x$ & & & & & & & & & & & & 2,7 & 0,9 & 0,3 & 0,8 & 0,3 & & $x$ \\
\hline C. Ing. 33 & & & & & $x$ & & & & & & & & & & & & 5,3 & 0,9 & 0,3 & 0,8 & 0,3 & & $x$ \\
\hline C. Ing. 34 & & & & & $x$ & & & & & & & & & & & & 5,6 & 0,8 & 0,2 & 0,7 & 0,2 & & $x$ \\
\hline C. Ing. 35 & & & & & $x$ & & & & & & & & & & & & 6,7 & 0,9 & 0,3 & 0,7 & 0,2 & & $x$ \\
\hline
\end{tabular}

Figura 4 - Tabela dos cachimbos cerâmicos da I.A.U. do Convento dos Inglesinhos.

\begin{tabular}{|c|c|c|c|c|c|c|c|c|c|c|c|c|c|c|c|c|c|c|c|c|c|c|c|}
\hline \multirow{4}{*}{ Inv.? } & \multirow{2}{*}{\multicolumn{2}{|c|}{$\begin{array}{c}\text { Ind. } \\
\text { Contextuais }\end{array}$}} & \multirow{2}{*}{\multicolumn{6}{|c|}{ Porção }} & \multicolumn{8}{|c|}{ Caract. Fornilho } & \multicolumn{7}{|c|}{ Caract. Haste } \\
\hline & & & & & & & & & \multirow{2}{*}{\multicolumn{4}{|c|}{ Dimensões }} & \multicolumn{4}{|c|}{ Decoração } & \multicolumn{5}{|c|}{ Dimensões } & \multicolumn{2}{|c|}{ Decoração } \\
\hline & \multirow[b]{2}{*}{ U.E. } & \multirow[b]{2}{*}{ Sond. } & \multirow[b]{2}{*}{ Forn. } & \multirow[b]{2}{*}{ Ped. } & \multicolumn{3}{|c|}{ Haste } & \multirow[b]{2}{*}{ Boq. } & & & & & \multirow[b]{2}{*}{ Sim } & \multirow[b]{2}{*}{ Não } & \multicolumn{2}{|c|}{ Marca de Produtor } & \multirow[b]{2}{*}{ Comp. } & \multirow[b]{2}{*}{$\begin{array}{l}\text { Distal. } \\
\text { Ext. }\end{array}$} & \multirow[b]{2}{*}{$\begin{array}{c}\text { Diâm. } \\
\text { Distal. } \\
\text { Int. }\end{array}$} & \multirow[b]{2}{*}{$\begin{array}{c}\text { Diâm. } \\
\text { Prox. } \\
\text { Ext. }\end{array}$} & \multirow[b]{2}{*}{$\begin{array}{l}\text { Diâm. } \\
\text { Prox. } \\
\text { Int. }\end{array}$} & \multirow[b]{2}{*}{$\operatorname{Sim}$} & \multirow[b]{2}{*}{ Não } \\
\hline & & & & & Distal & Mesial & Proxi. & & $\begin{array}{c}\text { Diàm. } \\
\text { For. }\end{array}$ & $\begin{array}{l}\text { Diâm. } \\
\text { Hast. }\end{array}$ & $\begin{array}{c}\text { Diâm. } \\
\text { Orifíi } \\
0\end{array}$ & $\begin{array}{c}\text { Diâm. } \\
\text { Penún } \\
\text { culo }\end{array}$ & & & Sim & Não & & & & & & & \\
\hline P. Mes. 1 & {$[1000]$} & & 1 & & $x$ & & & & & & & & & & & & 3,7 & 0,7 & 0,2 & 0,6 & 0,2 & & $x$ \\
\hline P. Mes. 2 & [1062] & $\begin{array}{c}\text { Área } \\
1\end{array}$ & & & $\mathrm{x}$ & & & & & & & & & & & & 5 & 0,9 & 0,3 & 0,9 & 0,2 & $\mathrm{H} 2$ & \\
\hline P. Mes. 3 & [2002] & $\begin{array}{l}\text { Área } \\
\text { S/so }\end{array}$ & & & $\mathrm{x}$ & & & & & & & & & & & & 6,9 & 1,1 & 0,3 & 0,9 & 0,3 & H3 & \\
\hline P. Mes. 4 & [2033] & & & & & & $\mathrm{x}$ & & & & & & & & & & 4,2 & 0,5 & 0,2 & 0,5 & 0,2 & & $x$ \\
\hline P. Mes. 5 & [2033] & & & & & $\mathrm{x}$ & & & & & & & & & & & 2,1 & 0,7 & 0,2 & 0,7 & 0,2 & & $x$ \\
\hline P. Mes. 6 & [2033] & & & & $x$ & & & & & & & & & & & & 2,3 & 1,1 & 0,2 & 1,1 & 0,2 & & \\
\hline P. Mes. 7 & [2033] & & & & $x$ & & & & & & & & & & & & 5,5 & 0,8 & 0,2 & 0,8 & 0,2 & & $x$ \\
\hline P. Mes. 8 & [2036] & & & & $\mathrm{x}$ & & & & & & & & & & & & 5,2 & 0,9 & 0,2 & 0,7 & 0,2 & & $x$ \\
\hline P. Mes. 9 & [2038] & & & & & & $x$ & & & & & & & & & & 3,3 & 0,7 & 0,2 & 0,6 & 0,2 & & $x$ \\
\hline P. Mes. 10 & [2045] & & & & & & $\mathrm{x}$ & & & & & & & & & & 5 & 0,8 & 0,3 & 0,6 & 0,2 & & $x$ \\
\hline P. Mes. 11 & [2045] & & & & $x$ & & & & & & & & & & & & 4,6 & 1 & 0,3 & 1 & 0,3 & $\mathrm{H}_{4}$ & \\
\hline P. Mes. 12 & [2058] & & & & $\mathrm{x}$ & & & & & & & & & & & & 5,2 & 1,2 & 0,4 & 0,9 & 0,3 & & $x$ \\
\hline P. Mes. 13 & [2065] & & & $\mathrm{x}$ & & & & & 1,4 & 0,9 & 0,3 & 1,1 & B1 & & "RB" & & & & & & & & \\
\hline P. Mes. 14 & [2102] & & & & $\mathrm{x}$ & & & & & & & & & & & & 4,4 & 1,1 & 0,4 & 0,9 & 0,3 & & $x$ \\
\hline P. Mes. 15 & {$[4000]$} & $\begin{array}{c}\text { Área } \\
4\end{array}$ & & $\mathrm{x}$ & & & $\mathrm{x}$ & & & 0,7 & 1,2 & & & $\mathrm{x}$ & & $x$ & 2,5 & & & & & & $x$ \\
\hline P. Mes. 16 & [4010] & $\begin{array}{c}\text { Área } \\
4\end{array}$ & & & $x$ & & & & & & & & & & & & 3,3 & 1 & 0,4 & 0,9 & 0,3 & & $x$ \\
\hline P. Mes. 17 & {$[4027]$} & & & $x$ & & & $x$ & & 1,9 & 1,2 & 0,2 & & & $x$ & & $x$ & & 3,9 & & & & & \\
\hline
\end{tabular}

Figura 5-Tabela dos cachimbos cerâmicos da I.A.U. do Palácio Mesquitela. 


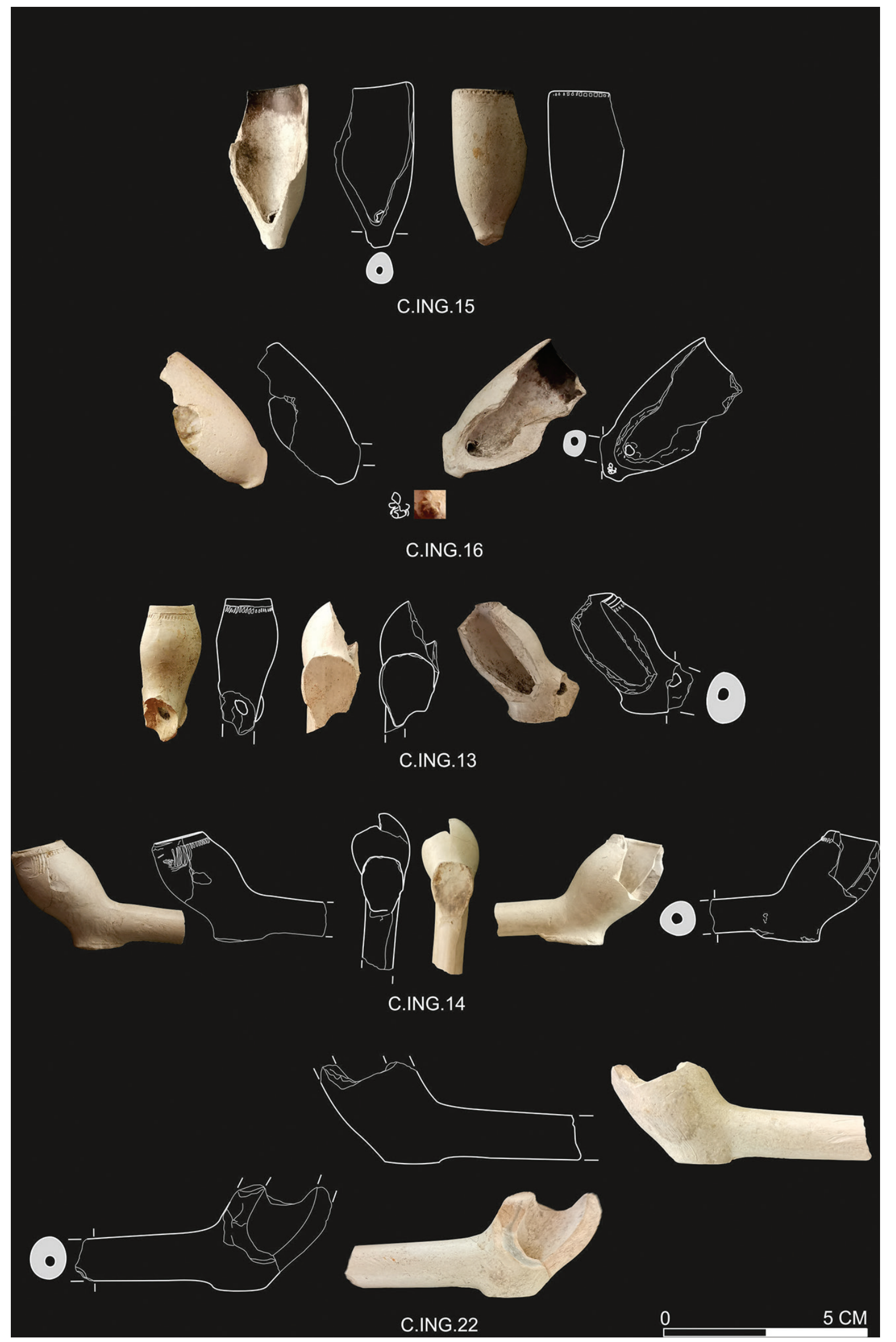

Figura 6 - "Convento dos Inglesinhos": fragmentos preservando o fornilho. 


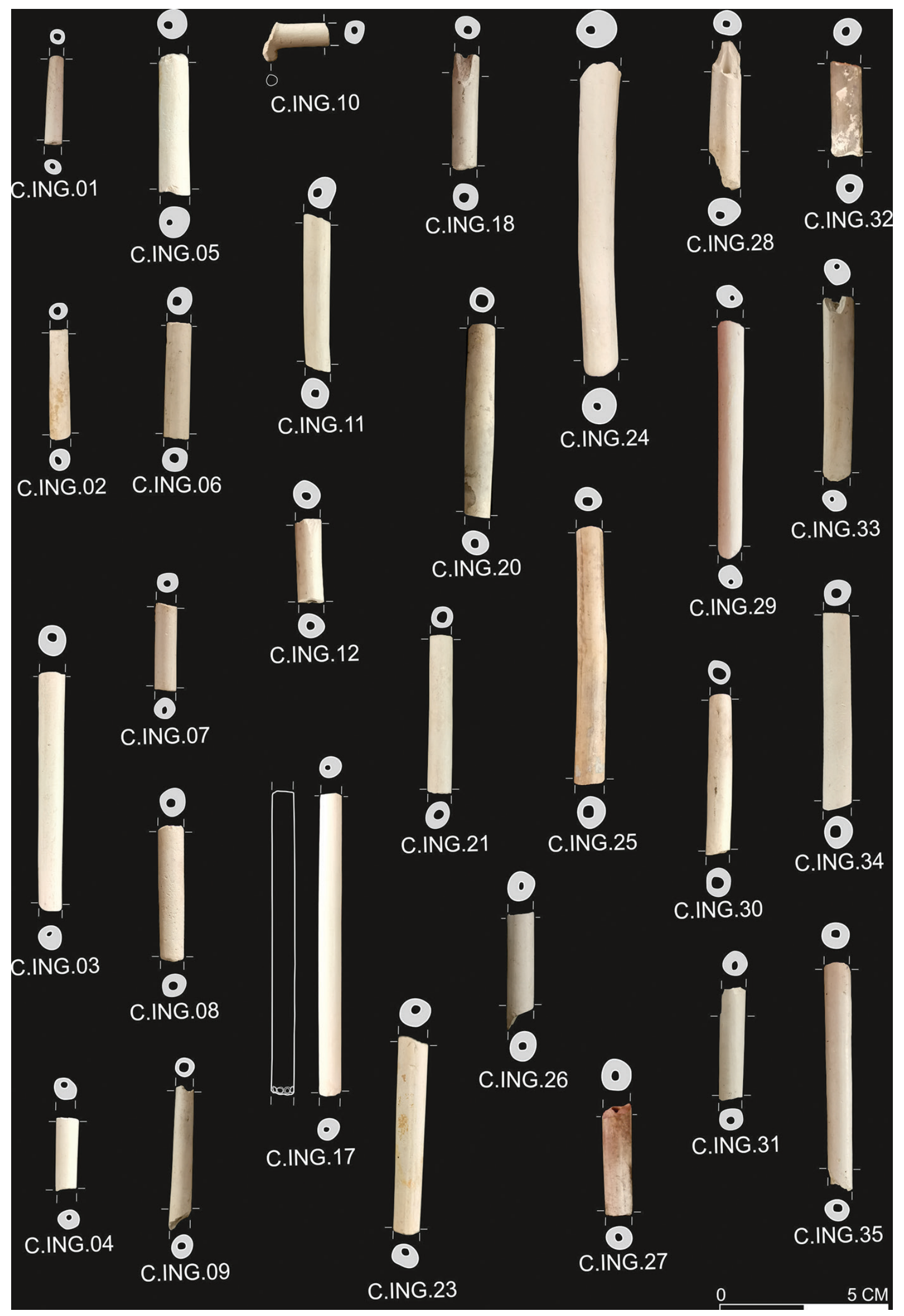

Figura 7 - "Convento dos Inglesinhos”: fragmentos de haste. 


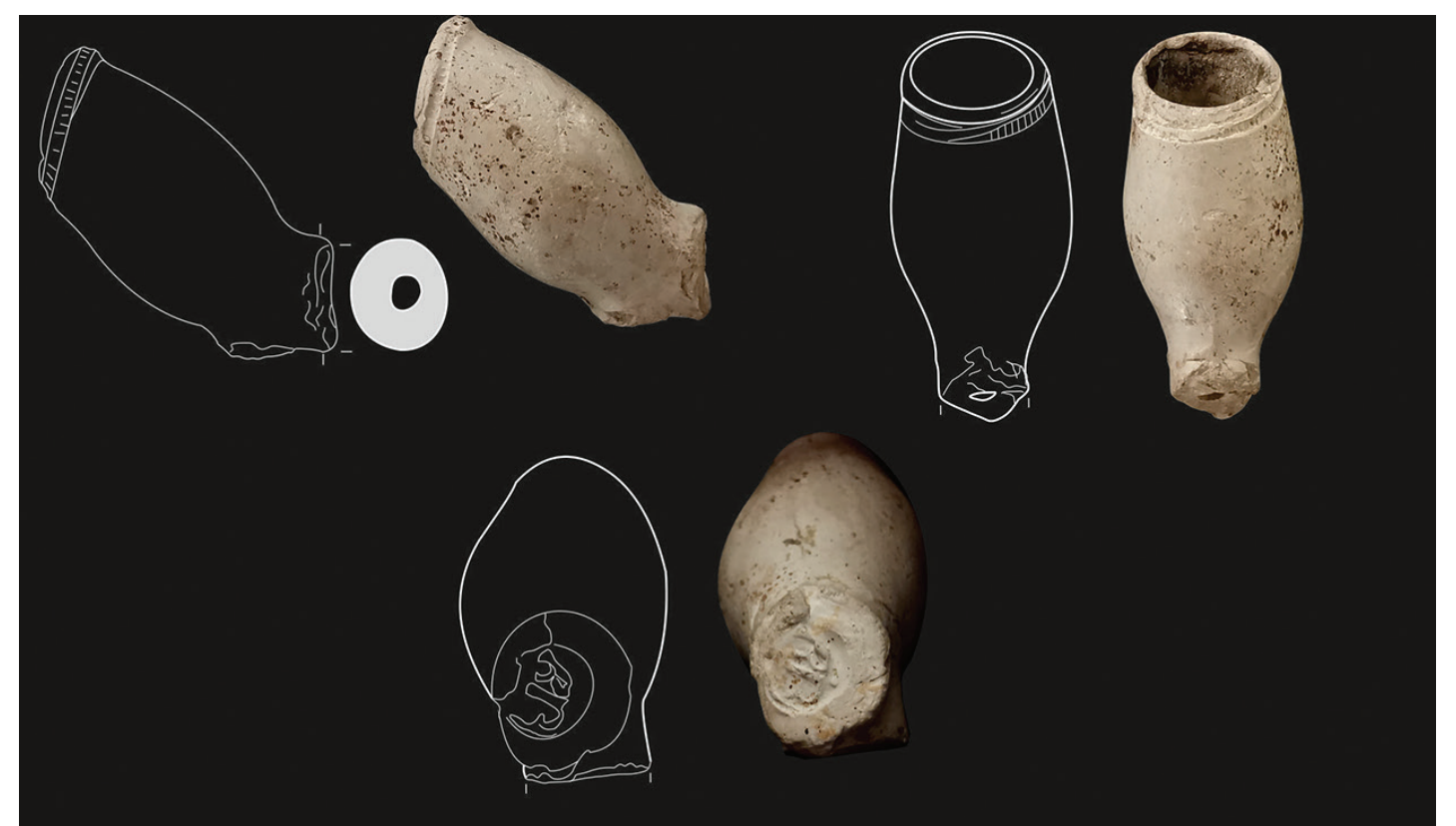

P.MES.13

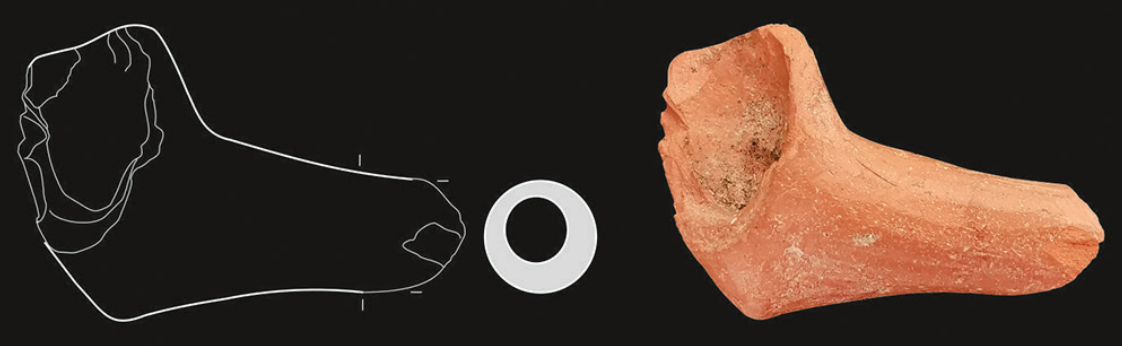

P.MES. 15
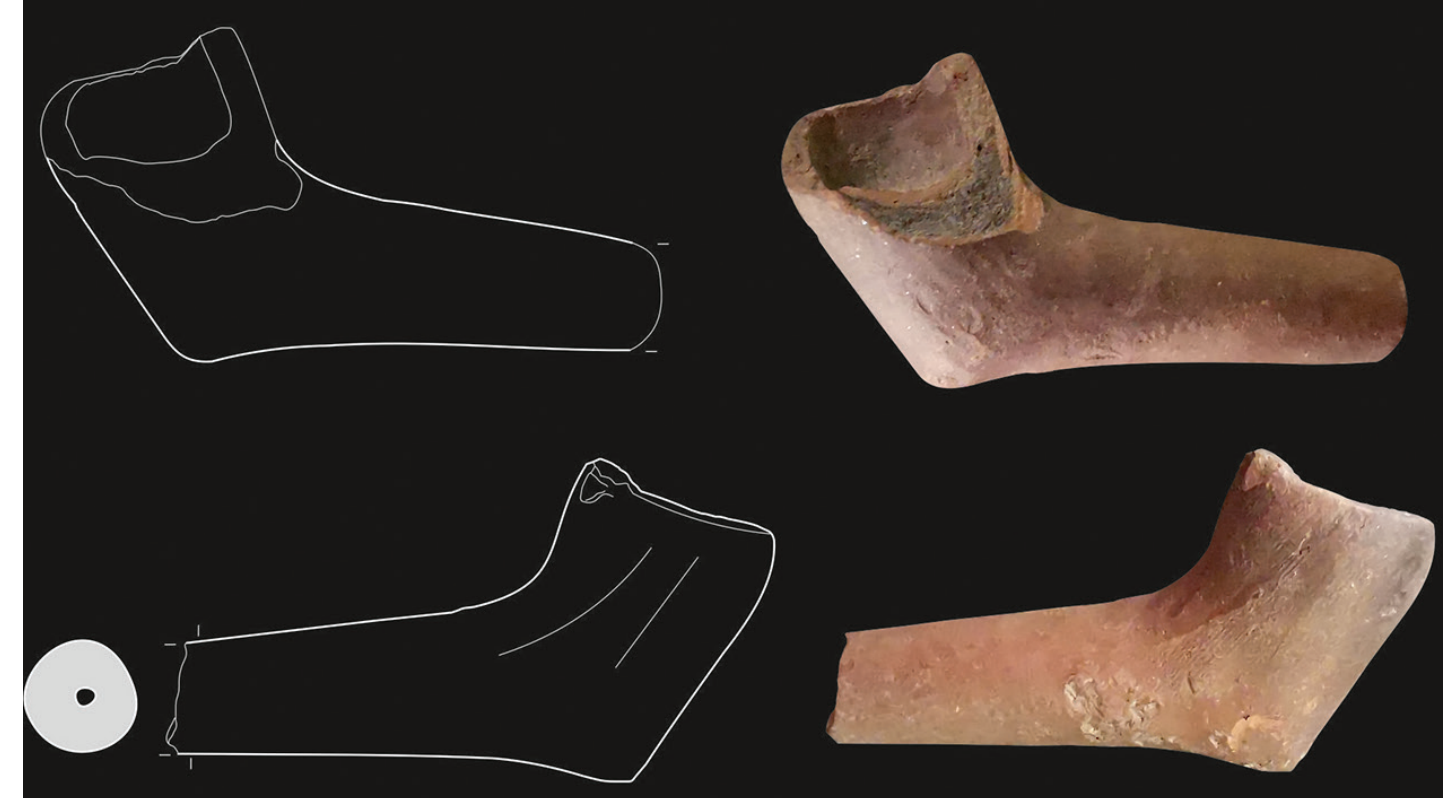

P.MES.17

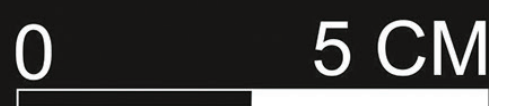

Figura 8 - Palácio Mesquitela: fragmentos preservando o fornilho. 


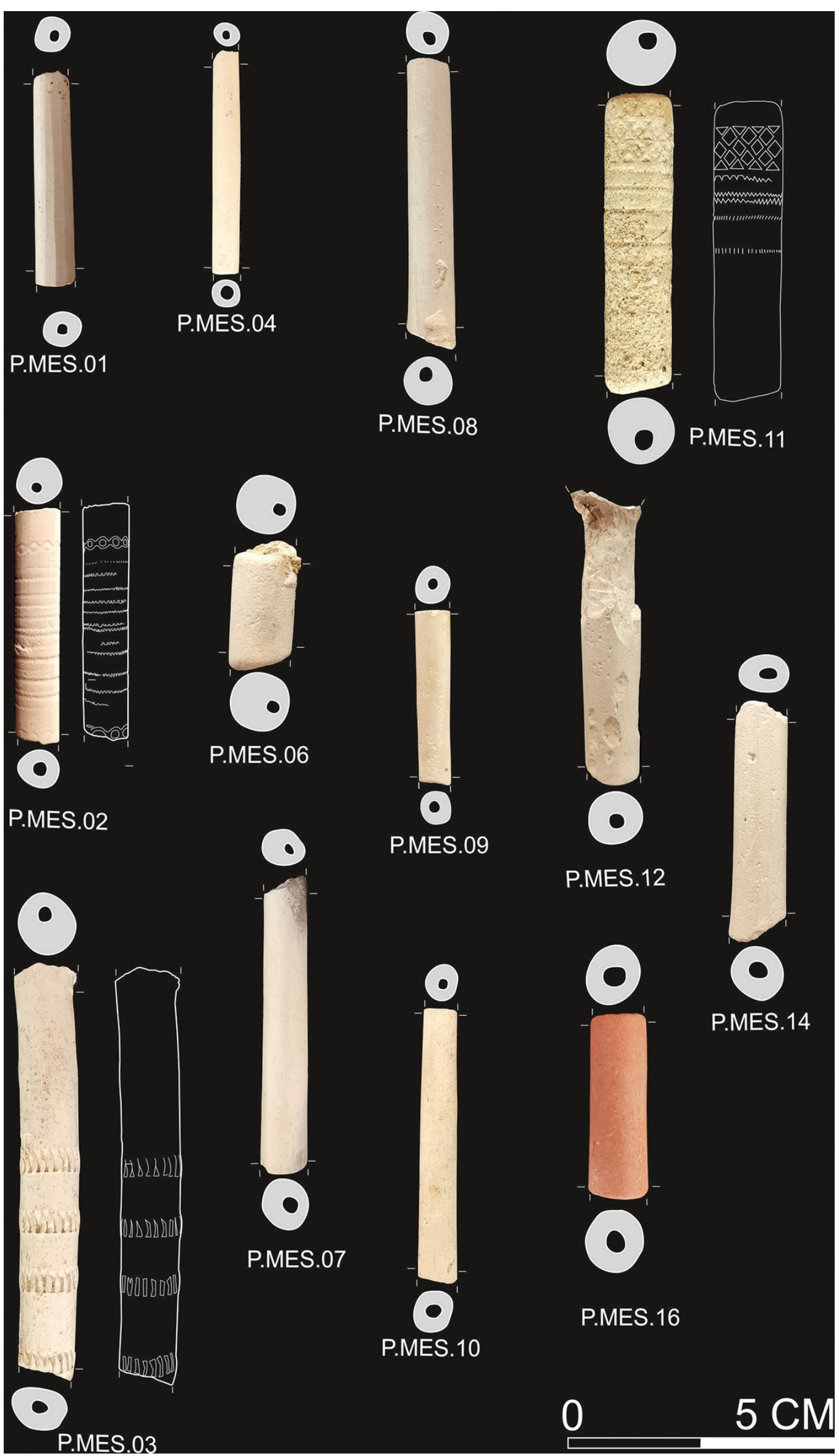

Figura 9-Palácio Mesquitela: fragmentos de haste. 


\title{
"TOMAR OS FUMOS DA ERUA QUE CHAMÃO EM PORTUGAL ERUA SANCTA». ESTUDO DE CACHIMBOS PROVENIENTES DA RUA DO TERREIRO DO TRIGO, LISBOA
}

\author{
Miguel Martins de Sousa ${ }^{1}$, José Pedro Henriques ${ }^{2}$, Vanessa Galiza Filipe ${ }^{3}$
}

\begin{abstract}
RESUMO
A intervenção arqueológica da Rua do Terreiro do Trigo reporta-se ao ano de 2018 e foi motivada pela intenção camarária de instalar ecopontos subterrâneos em determinadas áreas de Lisboa. Entre o conjunto de cachimbos exumados é possível identificar um numeroso grupo de cachimbos de caulino europeus, cronologicamente inseridos entre os séculos XVII e XVIII, bem como um conjunto peculiar de chibuques de pasta negra e cinzenta de origem desconhecida. Este estudo procura, em primeira instância, apresentar o conjunto de cachimbos da Rua do Terreiro do Trigo, mas também abordar o hábito do consumo de tabaco a partir de fontes interdisciplinares referentes à investigação da Idade Moderna.

Palavras-chave: Cachimbos, Chibuques, Idade Moderna, Lisboa, Hábitos de consumo.
\end{abstract}

\begin{abstract}
In 2018 an archaeological intervention in Rua do Terreiro do Trigo was undertaken by municipal determination for the installation of recycling containers in Lisbon. Amongst the sherds recovered it's possible to identify a great amount of European kaolin smoking pipes fragments dated from the 17th to the 18th centuries and also a set of unusual black and grey earthenware chibouks of unknown origin. Therefore, this approach seeks to report the smoking pipe assemblage recovered in Rua do Terreiro do Trigo and to discuss the study of smoking devices in the Portuguese early modern contexts.
\end{abstract}

Keywords: Smoking pipes, Chibouks, Early modern period, Lisbon, Consuming habits.

\section{INTRODUÇÃO}

O estudo de cachimbos corresponde a um dos campos de investigação mais gratificantes da Arqueologia Moderna, devido à fragilidade e consequente ocorrência frequente destes objetos, permitindo a realização, em condições estratigráficas favoráveis, de datações coerentes de sítios arqueológicos. Em acrescento, os cachimbos consistem em evidências de aspetos quotidianos, nomeadamente ao denunciar o ato de fumar e relacionando-se com trocas de gentes de hábitos e mercancias, particularmente o tabaco. "Tomar os fumos da erua que chamão em
Portugal erua sancta" (ANTT, TSO-IL, proc. 1335: fol. 11) surge pois, em concordância com este hábito, no processo inquisitorial quinhentista de Iria Álvares forra da, então, Capitania da Baía de Todos os Santos, filha de indígenas e acusada de crença gentílica e superstições, assinalando o século das primeiras experiências dos portugueses com o hábito de "tomar os fumos".

O presente estudo insere-se na consequente investigação do espólio decorrente da intervenção arqueológica realizada no âmbito de uma das empreitadas do projeto de instalação de ecopontos subterrâneos na cidade de Lisboa. Esta decorreu na

\footnotetext{
1. NOVA FCSH; miguelmsousa1996@gmail.com

2. IAP-NOVA FCSH / Cota 8o.86 Lda.; jpedro-henriques@gmail.com

3. IAP-NOVA FCSH / Cota 8o.86 Lda.; vanessagfilipe@gmail.com
} 
Rua do Terreiro do Trigo, no dinâmico bairro de Alfama, em área defronte à fachada noroeste do antigo edifício da Alfândega de Lisboa, apresentando as seguintes coordenadas geográficas: $38^{\circ} 42^{\prime} 38.64$ " N de latitude e $9^{\circ} 7^{\prime}$ 41.486" O de longitude.

Procura-se, assim, dar a conhecer o conjunto de cachimbos da Rua do Terreiro do Trigo, relevando previamente elementos históricos e arqueológicos da área intervencionada e envolvente. Em complemento, pretende-se abordar aspetos relacionados com o consumo de tabaco e a utilização de cachimbos em Portugal.

\section{ENQUADRAMENTO HISTÓRICO- -ARQUEOLÓGICO DO ESPAÇO}

A nível histórico, dados acerca deste sítio surgem desde o seu topónimo que pressupõe um local destinado ao abastecimento cerealífero, pelo menos até às profundas mudanças neste âmbito que se iniciam em grande medida no século XVIII, com o advento da industrialização em território nacional (Ferreira, 1995, pp. 143-161). Todavia, devemos alertar que o local da sondagem que apresentamos corresponde ao Terreiro do Trigo existente após o terramoto de 1755 , também denominado como Celeiro Público. Em oposição à antiga estrutura estudada por Francisco Duarte Mangas (2016), localizada a sul da Igreja de Nossa Senhora da Misericórdia, atual Igreja de Nossa Senhora da Conceição Velha, o "novo" Terreiro do Trigo situou-se numa área que corresponde a extenso aterro desenvolvido desde o século XVI (Figura 1) e tem vindo a ser re-descoberto graças a obras de requalificação urbana. Prova disso, para além do trabalho que se apresenta, são as intervenções de Cristina Gonzalez que, através de projetos ocorridos em 2010 para a requalificação do sistema de saneamento "entre a Rua do Cais de Santarém e sensivelmente metade da extensão da Rua do Terreiro do Trigo, incluindo o Largo do Terreiro do Trigo e o início da Travessa de São João da Praça” (2012a, p. 847), a sudoeste do presente sítio, desvendou informações inéditas da Ribeira, "um espaço da cidade de Lisboa que ganha destaque com a chegada da Idade Moderna” (2012b, p. 92). Na mesma perspetiva, a nordeste da área intervencionada no Largo do Chafariz de Dentro, a campanha arqueológica promovida pela renovação do sistema de tratamento de águas revelou a ocorrência de aterros desde o século XVI com o intuito de ganhar espaço ao rio, oferecendo expressiva diacronia de materialidades e estruturas (Silva \& alii, 2012, p. 71).

Surge então, neste meio, o espaço que se pode vislumbrar atualmente, perpendicular à fachada de edifício erguido em parte através de material de construção de troço da muralha fernandina da área do Largo do Chafariz de Dentro (Ibid., p. 73). Da Alfândega interina pode referir-se que através de decreto de 12 de junho de 1756 encontra-se atestado o impulso da sua construção, concluída em 1766, desenvolvendo-se a estrutura em três pisos, onde é ainda possível notar a grande solidez da fachada sul, outrora, para suportar as cargas que eram armazenadas, particularmente "açúcar, tabaco e outras mercadorias volumosas” (Santos, 2014, p. 112).

\subsection{Intervenção Arqueológica}

Entre 17 de setembro e 20 de novembro de 2018 decorreu a intervenção arqueológica da Rua do Terreiro do Trigo, no bairro de Alfama, dirigida por um dos signatários (JPH). Este trabalho foi procedente da determinação camarária de realizar diversas empreitadas de escavação para a instalação de contentores de reciclagem. Nestas circunstâncias, a ação arqueológica aludiu a acompanhamento geral da empreitada e a sondagem com área de $28 \mathrm{~m}^{2}$ e profundidade entre 2,2 e 3,3 m. O processo de escavação adotou o método preconizado por Philip Barker (1989), procurando a remoção dos depósitos num processo inverso ao da sua formação e com aplicação da leitura estratigráfica definida por Edward C. Harris (1991).

Estes trabalhos caraterizam-se por consideráveis movimentações no subsolo e evidentes constrangimentos inerentes aos prazos de execução, levando a limitação ou mesmo interdição de circulação na via pública, para além da consequente destruição efetiva da realidade arqueológica. Todavia, não deixam simultaneamente de nos proporcionar a oportunidade de recolher informações em relação à evolução urbanística do núcleo citadino e das pessoas que o ocuparam.

\subsection{Estratigrafia}

A área da sondagem apresentou uma sucessão estratigráfica relativamente simples e em concordância com intervenções na área envolvente. Nesta em particular, as primeiras unidades estratigráficas reportaram-se a realidades contemporâneas de pavimentação e colocação de infra-estruturas de dre- 
nagens de águas domésticas e pluviais, bem como uma vala de grés que cortou parte da realidade estratigráfica, pelo que nela se observou um mistifório de espólio, cronologicamente balizado entre os séculos XVI e XXI.

Em posição subsequente, surgiram níveis relacionados com a construção do Celeiro Público (1756-1766), notando-se a ocorrência frequente de buracos de poste e níveis de circulação. Seguiram-se depósitos, de onde surgiu a maioria dos fragmentos de cachimbos, relacionados com o abandono e destruição do local em consequência do terramoto de 1755 (Figura 2).

Estratigraficamente a baixo, verificou-se um nível de construção ou remodelação de estrutura indeterminada, mas que pode corresponder a uma das que se verificam no Grande Panorama de Lisboa (à guarda no Museu Nacional do Azulejo) entre o Campo das Cebolas e o Chafariz da Praia, surgindo novamente buracos de poste numerosos e dois pavimentos parcamente preservados. Por fim, o último nível detetado, cronologicamente da primeira metade do século XVII ou anterior, corresponde a unidades heterogéneas aplicadas como regularização da frente ribeirinha tendo em vista a colocação de um pavimento em cerâmica moída bastante compacto. É ainda de mencionar, no mesmo nível estratigráfico, uma estrutura não identificada na iconografia e cartografia coeva (Figura 1), que atravessa a sondagem no sentido norte-sul.

\section{OS CACHIMBOS}

Com vista em analisar o conjunto, efetuou-se a lavagem e individualizaram-se todos os fragmentos dos cachimbos, procedendo às possíveis colagens. Os fragmentos foram depois inventariados e marcados com o devido acrónimo, efetuaram-se desenhos, vetorizações e examinaram-se elementos significativos como as pastas e respetivos ENPs, as marcas de produtor e evidências da produção, utilização e/ ou descarte.

Entre os 472 fragmentos exumados de 34 unidades estratigráficas, correspondentes a um número máximo de 447 indivíduos, é possível verificar uma maioria de cachimbos de caulino, com origem europeia e que, através das marcas de produtor identificadas, se podem reportar desde a segunda metade do século XVII até ao século XVIII (Tabela 1). Porém, registam-se também cachimbos pouco recorrentes na investigação arqueológica nacional, de pasta brunida com coloração negra e cinzenta, que se assemelham aos designados como cachimbos turcos/otomanos (Simpson, 1990) ou, não inferindo qualquer noção geográfica, chibuques (Robinson, 1985) e que sugerem corresponder a produções exógenas.

Ainda que numa primeira abordagem os 12 fragmentos de chibuques parecessem bastante diminutos em relação aos 435 fragmentos de cachimbos de caulino, a contagem do número mínimo de indivíduos (NMI), segundo os preceitos de Clive Orton (1982), identificando-se nos pedúnculos dos cachimbos de caulino e no orifício do fornilho dos chibuques elementos singulares, evidenciou-se que, na diminuta área intervencionada, os $15 \mathrm{NMI}$ de cachimbos de caulino e os 8 NMI de chibuques não eram, afinal, tão dispares (Gráfico 1).

\subsection{Cachimbos de caulino}

Registaram-se cerca de 32 fragmentos de fornilhos de cachimbos de caulino, dos quais seis podemos classificar seguramente como ovóides. Todavia, destes, 17 correspondem a fragmentos de parede e 12 apresentam, para além da parede do fornilho, pedúnculo, observando-se três exemplares completos dos quais um não ostenta qualquer tipo de evidência de exposição ao fogo.

Contabilizaram-se 12 fragmentos de fornilhos com decoração sendo que o motivo denticulado inciso, também designado como anel serrilhado ou somente serrilhado (Pereira, 2003, p. 257; Hissa, 2018, p. 116), na superfície exterior do bordo - técnica utilizada na produção inglesa e holandesa de cachimbos, observou-se em 10 fragmentos. Os restantes dois apresentam decoração moldada na superfície exterior, um baseia-se numa moldura circular onde se insere um busto em relevo orientado para elemento fitomórfico (Figura 3-9), semelhante ao identificado em Évora atribuído a produção bávara do último quartel do século XVII (Lopes; Roque, 2012, p. 207) e a conjunto de sete cachimbos provenientes dos antigos Armazéns Sommer que atualmente correspondem a unidade hoteleira designada como Eurostars Museum onde se encontra o conjunto exposto, sendo indicado como de proveniência inglesa e com cronologia da primeira metade do século XVIII. O outro fragmento com decoração moldada, de menor dimensão, apresenta pequenos bolbos e pode corresponder ao mesmo cachimbo do fragmento anterior. 
No que concerne às marcas de produtor, analisaram-se 10 fragmentos que as apresentam no pedúnculo registando-se ainda três fragmentos com marcas ilegíveis e dois com pedúnculo em spur. Com gravação na parte lateral surgiram dois fragmentos de produção londrina (Figura 3-7, 8), os quais se relacionaram com outros dois sem marcas de produtor que também consideramos ingleses, pois apresentam a base do pedúnculo pontiaguda (spur), como em várias produções britânicas (Atkinson; Oswald, 1969, pp. 56-57). Não obstante, a maior parte das marcas que surgiram reportam-se a produções da primeira metade do século XVIII provenientes de Gouda (Tabela 1), o maior centro produtor de cachimbos holandeses (Meulen, 2003), como se comprova pelo brasão da referida cidade presente em três dos exemplares exumados (Figura 3-3, 5, 6) e que pode funcionar como terminus post quem tendo sido utilizado a partir de 1739-1740, várias vezes encimado por um "S", do holandês Slegt (inferior), que denuncia a baixa qualidade das produções em caulino por oposição a produções mais delicadas (Calado; Pimenta; Silva, 2003, pp. 87-88).

De acordo com o que geralmente se sucede em diversos estudos de cachimbos (Higgins, 2017, p. 6), os 403 fragmentos de hastes superaram largamente o número de fornilhos, correspondendo a $93 \%$ dos fragmentos neste suporte. Contaram-se 15 hastes referentes à secção proximal que podem corresponder a fragmentos de boquilhas, muito embora não seja esta uma afirmação segura, pois a execução destas resultava num corte sem acabamento dificultando a sua distinção face aos 385 fragmentos da secção mesial. Contudo, alguns aspetos como a evidência de afeiçoamento, certas marcas de perfuração dentária e o valor do diâmetro do furo visivelmente mais largo, causado pela saída de matéria-prima, permitiram uma classificação como proximal.

Em relação às secções distais das hastes, facilmente identificadas pelo seu maior diâmetro, optámos por acrescentar aos três fragmentos contabilizados, 11 de fornilhos anteriormente referidos com arranque de haste, obtendo um total de 414 fragmentos com vista a medir o comprimento total do conjunto das hastes. Seguiu-se assim a soma de valores, entre 1,2 e $10,7 \mathrm{~cm}$, pelo que se obteve o comprimento total de $1181,15 \mathrm{~cm}$. Esta metodologia, meramente experimental, deveu-se à tomada de consciência de que a partir do século XVIII as hastes apresentariam de 33,02 a 34,29 cm (segundo Hume, 1991, p. 296) sendo que o valor obtido poderia corresponder a 36 cachimbos. No entanto, as hastes de determinados cachimbos poderiam chegar aos $45,72 \mathrm{~cm}$ (Ibid.) cobrindo, neste caso, 26 destes, apesar de ser necessário aprimorar esta metodologia com mais exemplares completos, em particular recolhidos em intervenções arqueológicas.

De qualquer modo, o facto é que o número de hastes é maior do que o dos fornilhos, até no que concerne ao NMI ( 26 hastes por 15 fornilhos). Torna-se assim evidente a reutilização dos fornilhos mesmo com a haste quebrada, denunciando a utilização por parte de indivíduos com poder de compra inferior e que se relaciona simultaneamente com a fragilidade destes objetos, verificando-se ainda casos onde ocorrem quebras intencionais da haste com vista a permitir um melhor encaixe noutro suporte menos compacto (Caldo; Pimenta; Silva, 2003, pp. 92-93). Em termos cromáticos, é de indicar um fragmento de haste com tonalidade avermelhada ( $10 \mathrm{R} 5 / 8$ ) que mede $3,1 \mathrm{~cm}$ de comprimento, o, $6 \mathrm{~cm}$ de diâmetro e, para além de poder corresponder a contaminações de óxido de ferro, pode também aludir a elemento de produção local ou regional, muito embora mais se assemelhe com os restantes fragmentos de pastas homogéneas, fabricadas a molde, constituídos por argilas de caulino bastante depuradas e com acabamento cuidado do qual resultam superfícies lisas. Ainda assim, cachimbos designados como "de barro vermelho", com pastas de matriz calcária, compostas por concentração acentuada de ENPs quartzosos e micáceos, ocorrem em vários sítios do território nacional (Sousa, 2020, pp. 80-81), caraterizando-se por uma estética artesanal, pois talvez "tencionavam satisfazer uma procura de quem não teria acesso às produções ditas de maior qualidade" (Pimenta; Silva, 2019, p. 256) e recorria a produções com grande probabilidade oriundas de Lisboa (Oliveira, 2019). Por sua vez, analisaram-se 45 hastes com decorações no sentido transversal, registando-se $39 \mathrm{com}$ decorações geométricas, nomeadamente um fragmento com uma linha ondulada (Figura 4-1), dois fragmentos que apresentavam somente linhas denticuladas (Figura 4-3), nove que apresentavam linhas de círculos e 27 que conjugavam estes dois últimos motivos (Figura 4-5, 8), ficando as linhas denticuladas inscritas num espaço delimitado por linhas de círculos. Este motivo decorativo, recorrentemente registado em estudos arqueológicos de cachimbos de caulino, teve o seu maior êxito desde 
o final do século XVII e no decorrer do século XVIII nas oficinas holandesas, muito embora fosse utilizado em produções inglesas e francesas (Pinto; Filipe; Miguel, 2011, p. 44).

Com decoração epigráfica em cartelas são de referir seis hastes, três apresentaram a impressão IN GOUDA (Figura 4-4), largamente utilizada pelos produtores dessa cidade. Um diferente fragmento apresenta parte desta impressão, [...] OUDAS, no entanto é antecedido por VIE[...] (Figura 4-7) que, na falta de marcas existentemente com essa disposição, pode corresponder a B:V:EVEN da oficina de Barend Evers ou van Even que laborou entre 1744 e 1768 (Meulen, 2003, p. 101). Surgiu ainda uma cartela com [...]W[I?] EWE[...] (Figura 4-6), contudo esta encontra-se bastante fragmentada levando à hipotética associação com a oficina de Jan van der Wies que funcionou de 1746 a 1776 (Ibid., p. 102). Já a última haste legível apresentou [...]DE VINKo (Figura 4-2), podendo relacionar-se com a oficina de Jacob of Jan de Vinck e Jan of Jacob de Vinck que fabricaram cachimbos de 1730 a 1764 ou com a oficina de Teunis de Vink que laborou entre 1745 e 1782 (Ibid., pp. 102-103).

\subsection{Chibuques}

Sem paralelo apurado em território nacional ${ }^{4}$ exumaram-se, em bom estado de conservação, 21 fragmentos de fornilhos de chibuques, designados em estudo prévio como "cachimbos de barro negro" (Sousa, 202O, p. 82) devido à tonalidade da sua pasta, com caraterísticas mais artesanais e superfícies brunidas que variam entre a tonalidade cinzenta (5YR 5/1) e negra (5YR 2.5/1), com presença de ENPs quartzosos e micáceos. Da colagem destes cachimbos resultaram 12 fragmentos, respetivamente $8 \mathrm{NMI}$, a que correspondem dois elementos completos (Figura 5-1, 2), cinco canas com arranque de corpo (Figura 5-3, 4, 5, 6,7), três bordos, uma secção proximal ou de encaixe da cana e um fragmento de corpo com arranque da base (Figura 5-8). Os exemplares completos permitiram aferir as seguintes medições: cerca de $1 \mathrm{~cm}$ de diâmetro no furo da cana, até $1,7 \mathrm{~cm}$ de diâmetro no bordo, entre 3,7 e 4,5 cm

\footnotetext{
4. Pelo menos para a cronologia enquadrável, dado que se localizaram objetos semelhantes no Museu de Tavira, provenientes do Convento de Nossa Senhora da Graça de Tavira, interpretados como "cachimbos de haxixe" dos séculos XIV ou XV, provenientes do Reino de Granada (Cavaco; Covaneiro, 2017, pp. 203-204).
}

de comprimento e altura média no fornilho, com a base assente em fundo plano, de $3,5 \mathrm{~cm}$.

No que concerne à decoração, estas peças caraterizam-se pela sua pobre expressividade, em particular comparando com conjuntos tipologicamente semelhantes, mas mais substanciais (Robinson, 1985; Simpson, 1990). Não obstante, verificou-se que seis fragmentos (50\% deste conjunto) apresentavam duas linhas incisas transversalmente na secção proximal da cana do fornilho e eram, assim, idênticos morfologicamente a cachimbos encontrados em Barcelona e aos quais se atribuiu estilo balcânico e cronologia seiscentista/setecentista (Beltrán de Heredia; Miró i Alaix; Soberón Rodríguez, 2012, p. 178). Observou-se ainda um fragmento que ostenta denotado espessamento aplicado na cana (Figura 5-7) e uma parede de fornilho com porção da base que apresenta cinco caneluras verticais na superfície exterior (Figura 5-8), ambos com paralelos em espólio oriundo da ilha de Malta (Wood, 2014, pp. 56-59).

Não é possível para já, atendendo às parcas caraterísticas dos chibuques estudados, omitir uma hipotética importação africana, constatando-se a utilização de tabaco por escravos e forros e principalmente atendendo a produções africanas utilizadas em Cabo Verde (Cardoso; Soares, 2010, p. 200) e ao cachimbo, idêntico aos exemplares estudados, com o acrónimo AZ6-072, "em forma de saco", exumado em Azamor e com cronologia setecentista (Teixeira; Karra; Carvalho, 2016, pp. 182, 189). É pois de realçar que fumar tabaco afigurou-se uma ação prestigiante para a comunidade africana, estando associada a membros da elite no século XVII, como a rainha Nzinga Mbande ou Dona Ana de Sousa, verificada em iconografia coeva (Bassani, 1987), propagandose a prática por comunidades africanas em contacto com o continente americano, onde independentemente de se conhecer previamente o tabaco, várias são as relações culturais que se desenvolvem e propagam (Figueirôa-Rêgo, 2015, pp. 87-88).

\section{ABORDAGEM AO HÁBITO DO CONSUMO DE TABACO EM PORTUGAL}

Lisboa e outros pontos nacionais, em particular no litoral, correspondem a aglomerados populacionais de diversa riqueza multi-cultural, realidade não divergente durante a Idade Moderna. É pois neste período histórico que o consumo de tabaco se consolida gradualmente, muito embora a nicotina não seja a única 
substância psicoativa em cachimbos provenientes de análises arqueológicas (Cardomy \& alii, 2018).

Ian Gately, na sua obra relativamente à história do tabaco, refere que em meados do século XVII o consumo desta espécie torna-se num hábito de grande parte da humanidade, tendo atravessado fronteiras onde nenhum americano ou europeu tinha estado até então, através da sua assimilação por parte das comunidades mercadoras da Rota da Seda que a transmitiram por pontos desérticos e quase inabitados (2001, pp. 91-92). Não obstante, deve-se à ação portuguesa a introdução do tabaco no Império Persa, bem como a sua plantação no continente africano e nas cidades de Goa, Macau, Java e Nagasáqui, pontos estratégicos para a expansão deste produto pelo resto do continente asiático (Goodman, 1993, p. 51), embora existam espécies nativas de Nicotiana na Ásia e na Oceânia (Santos; Bracht; Conceição, 2013, p. 121).

Em relação aos cachimbos, é possível avançar que o consumo de tabaco na metrópole, protagonizado por cachimbos de caulino e doutros suportes, apresentou maior destaque durante o século XVIII, em consideração pelos contextos e marcas de produtor aferidas em cerca de 87 arqueossítios nacionais (Sousa, 2020, p. 64). Ainda assim o tabaco, conhecido pelos europeus possivelmente desde 1492 (Rodríguez Gordillo, 2015, p. 29), que se instalou como panaceia em Portugal no século XVI e que se consolidou como bem económico a partir do século XVII, apresenta um consumo mais recorrente segundo modos que escapam aos aferidos arqueologicamente e inclusive antropologicamente (Carvalho; Wasterlain, 2017), em concreto e entre outros (Figura 6), pela inalação em pó, designadamente através de rapé, método preferível aparentemente até ao final do século XVIII (Ruders, 2002, p. 157) e denunciado no século passado como "um grave problema social”, em referência a consumidoras discretas provenientes do mundo rural dos lugares, então quase despovoados, de Marrocos e Roncão na freguesia de Espírito Santo, concelho de Mértola (Ribeiro, 1969, pp. 235-236).

\section{BIBLIOGRAFIA}

ANTT - Arquivo Nacional da Torre do Tombo, Tribunal do Santo Ofício - Inquisição de Lisboa, Processo de Iria Álvares, proc. 1335 .

ATKINSON, David; OSWALD, Adiran (1969) - London Clay Tobacco Pipes. Londres: The Museum of London.

BARKER, Philip (1989) - Techniques of Archaeological Excavation. Londres: B. T. Batsford.

BASSANI, Ezio (1987) - Un Cappuccino nell'Africa nera del seicento: I disegni dei Manoscritti Araldi del Padre Giovanni Antonio Cavazzi da Montecuccolo. Milão: Associazione Poro (Quaderni Poro; 4).

BELTRÁN DE HEREDIA, Julia; MIRÓ I ALAIX, Núria; SOBERÓN RODRÍGUEZ, Mikel (2012) - Les Pipes de Ceràmica no Caolinítica Trobades a Barcelona: Producció i Comerç als Segles XVII-XIX. Quarhis: Quaderns d'Arqueologia i Historia de la Ciutat de Barcelona. Vol. 7. Barcelona: Museu d'Història de Barcelona, pp. 166-191.

CALADO, Marco; PIMENTA, João; SILVA, Rodrigo Banha da (2003) - Cachimbos de cerâmica provenientes da escavação do Caminho de Ronda no Castelo de São Jorge em Lisboa. Estudos/Património. N. 5. Lisboa: IPPAR, pp. 83-95.

CALDEIRA, Arlindo Manuel (2008) - O Tabaco: percurso de uma "planta medicinal" entre a América e a Europa. In Workshop Plantas Medicinais e Fitoterapêuticas nos Trópicos. Lisboa: Instituto de Investigação Científica Tropical, pp. 1-25.

CARDOSO, João Luís; SOARES, António Manuel Monge (2010) - A estação arqueológica de Salamansa (ilha de São Vicente, República de Cabo Verde). Revista Portuguesa de Arqueologia. Vol. 13. Lisboa: IGESPAR, pp. 167-214.

CARDOMY, Stephen B.; KASSABAUM, Megan C.; HUNT, Ryan K.; PRODANOVICH, Natalie; ELLIOTT, Hope; RUSS, Jon (2018) - Residue analysis of smoking pipe fragments from the Feltus archaeological site, Shoutheastern North America. Journal of Archaeological Science: Reports. Vol. 17, pp. 640-649.

CARVALHO, Liliana M. de; WASTERLAIN, Sofia N. (2017) - A Minha Boca Conta uma História: Abrasão Dentária e a sua Relação com Actividade e Hábitos Pessoais numa Amostra Portuguesa de Época Medieval/Moderna. In Arnaud, J. M.; Martins, A. (eds.), Arqueologia em Portugal/2017-Estado da Questão. Lisboa: Associação dos Arqueólogos Portugueses, pp. 1469-1480.

CAVACO, Sandra; COVANEIRO, Jaquelina (2017) - Evidências das Relações Comerciais do Porto de Tavira através da Cerâmica. In Scientia Antiquitatis. Vol. 1. N.ㄹ 2, pp. 195-218.

FERREIRA, J. A. do C. (1995) - A Dessacralização do Pão: Políticas de Abastecimento no Antigo Regime: do Concelho ao Estado Iluminista. Porto: Campo das Letras. 
FIGUEIRÔA-RÊGO, João de (2015) - «Escravos do fumo». Notas sobre a escravatura no contexto tabaqueiro: Bahia, Costa da Mina e Angola. In Lúxan, S. de; Figueirôa-Rêgo, J. de; Sanz Rozalén, V. (eds.), Tabaco e Escravos nos Impérios Ibéricos. Lisboa: CHAM (Estudos e Documentos; 24), pp. 87-108.

GATELY, Iain (2001) - Tobacco. A Cultural History of How an Exotic Plant Seduced Civilization. Nova Iorque: Grove Press.

GONZALEZ, Cristina (2012a) - "Majólicas Italianas do Terreiro do Trigo (Lisboa)”. In Teixeira, A.; Bettencourt, J. (eds.), Velhos e Novos Mundos. Estudos de Arqueologia Moderna. Vol. 2. Lisboa: CHAM (ArqueoArte; 1), pp. 847-854.

GONZALEZ, Cristina (2012b) - Os Novos Espaços da Cidade Moderna. Uma Aproximação à Ribeira de Lisboa através de uma intervenção no Largo do Terreiro do Trigo. In Teixeira, A.; Bettencourt, J. (eds.), Velhos e Novos Mundos. Estudos de Arqueologia Moderna. Vol. 1. Lisboa: CHAM (ArqueoArte; 1), pp. 85-94.

GOODMAN, Jordan (1993) - Tobacco in History. The cultures of dependence. Londres e Nova Iorque: Routledge.

HARRIS, Edward C. (1991) - Principios de Estratigrafia Arqueológica. Barcelona: Editorial Crítica.

HIGGINS, David (2017) - Guidelines for the Recovery and Processing of Clay Tobacco Pipes from Archaeological Projects. Liverpool: Historic England.

HISSA, Sarah de Barros Viana (2018) - O Petyn no cachimbo branco: arqueologia e fumo nos séculos XVII ao XIX. Rio de Janeiro: Tese do Programa de Pós-Graduação em Arqueologia do Museu Nacional, UFRJ.

HUME, Ivor Noël (1991) - A Guide to Artifacts of Colonial America. Nova Iorque: Vintage Books/A Division of Random House, Inc.

LOPES, Gonçalo; ROQUE, Conceição (2012) - A intimidade palaciana no século XVII: objectos provenientes de um esgoto do Paço dos Lobos da Gama (Évora). In Teixeira, A; Bettencourt, J. (eds.), Velhos e Novos Mundos. Estudos de Arqueologia Moderna. Vol. 1. Lisboa: CHAM (ArqueoArte; 1), pp. 201-208.

MANGAS, Francisco Duarte Ferreira (2016) - Segurar a Fome: O Terreiro do Trigo de Lisboa no século XVI. Lisboa: Dissertação de Mestrado em História, especialização História da Época Moderna e dos Descobrimentos apresentada à FCSH-UNL.

MEULEN, J. van der (2003) - Goudse pijpenmakers en hun merken. Leiden: Pijpelogische Kring Nederland.

MUNSELL (1994) - Munsell Soil Color Charts. New Widson, NI: Kollmorgen Instruments - Macbeth Division.
OLIVEIRA, Filipe Santos (2019) - Produção de Cachimbos de Barro na Rua Damasceno Monteiro (Olarias de São Gens), Lisboa - Um Contributo para o seu Estudo. Apontamentos de Arqueologia e Património. Vol. 13. Lisboa: ERA Arqueologia / Núcleo de Investigação Arqueológica - NIA, pp. 67-74.

ORTON, Clive (1982) - Mathematics in Archaeology. Cambridge: Cambridge University Press.

PEREIRA, António Luis (2003) - Cachimbos cerâmicos do século XVII da Casa do Infante (Porto). In Actas das 3..$^{-}$ Jornadas de Cerâmica Medieval e Pós-Medieval. Métodos e Resultados para o seu Estudo. Tondela: CMT, pp. 253-269.

PIMENTA, João; SILVA, Rodrigo Banha da (2019) - Cachimbos de cerâmica provenientes da escavação do Centro de Saúde de Alhandra. Cira-Arqueologia. N.7 7. Vila Franca de Xira: CMVFX-CEAX, pp. 252-258.

PINTO, Marina; FILIPE, Iola; MIGUEL, Lúcia (2011) - Os Cachimbos de Caulino Provenientes do Mercado da Ribeira: Contributo para a História Sócio-Económica da Lisboa Moderna. Apontamentos de Arqueologia e Património. Vol. 7. Lisboa: ERA - Arqueologia / Núcleo de Investigação Arqueológica - NIA, pp. 41-48.

RIBEIRO, Margarida (1969) - Mulheres Fumadoras. In Trabalhos de Antropologia e Etnologia. Vol. XXI. Porto: Instituto de Antropologia «Dr. Mendes Corrêa» - Faculdade de Ciências, pp. 231-242.

ROBINSON, Rebecca C. W. (1985) - Tobacco Pipes of Corinth and of the Athenian Agora. In Hesperia: the Journal of the American School of Classical Studies at Athens. Vol. 54. N.. 2, pp. 149-203.

RODRÍGUEZ GORDILLO, José Manuel (2015) - El descubrimiento y abrigo del tabaco (1492-170o). In Lúxan, S. de; Figueirôa-Rêgo, J. de; Sanz Rozalén, V. (eds.), Tabaco e Escravos nos Impérios Ibéricos. Lisboa: CHAM (Estudos e Documentos; 24), pp. 29-40.

RUDERS, Carl Israel (2002) - Viagem em Portugal 1798-1802. Vols. 1-2. Lisboa: Biblioteca Nacional.

SANTOS, Maria Helena Ribeiro dos (2016) - A Praça do Comércio e os planos para a Renovação da Lisboa baixa. In FARIA, M. F. de (coord.), Do Terreiro do Paço à Praça do Comércio - História de um Espaço Urbano. Lisboa: INCM, pp. 111-134.

SANTOS, Christian Fausto Moraes dos; BRACHT, Fabiano; CONCEIÇÃO, Gisele Cristina da (2013) - Esta que "é uma das delícias, e mimos desta terra...”: o uso indígena do tabaco (N.rustica e N.tabacum) nos relatos de cronistas, viajantes e filósofos naturais dos séculos XVI e XVII. Topoli. Vol. 14. N. ${ }^{2}$, , pp. 119-131. 
SILVA, Rodrigo Banha da; MIRANDA, Pedro; VIEIRA, Vasco Noronha; VICENTE, António Moreira; LOPES, Gonçalo C.; NOZES, Cristina (2012) - Largo do Chafariz de Dentro: Alfama em Época Moderna. In Teixeira, A.; Bettencourt, J. (eds.), Velhos e Novos Mundos. Estudos de Arqueologia Moderna. Vol. 1. Lisboa: CHAM (ArqueoArte; 1), pp. 71-84.

SIMPSON, St John (1990) - A brief introduction to Ottoman clay pipes. Society for Clay Pipe Research Newsletter. N. ${ }^{27}$, pp. 6-10.

SOUSA, Miguel Martins de (2020) - As Evidências dos Estados Alterados de Consciência no Registo Arqueológico da Idade Moderna em Portugal. Lisboa: Dissertação de Mestrado em Arqueologia apresentada à FCSH-UNL.
TEIXEIRA, André; KARRA, Azzeddine; CARVALHO, Patrícia (2016) - Le quotidien de la ville d'Azemmourà l'époque moderne: étude des contextes archéologiques. Arqueologia Medieval. N.ำ 13. Porto: Edições Afrontamento, pp. 171-192.

WOOD, John (2014) - Tobacco Pipes from Dockyard Creek, Birgu Malta. In Higgins, D. (ed.), Journal of Clay Pipe Research. Vol. 3. Wallasey: SCPR, pp: 53-64.
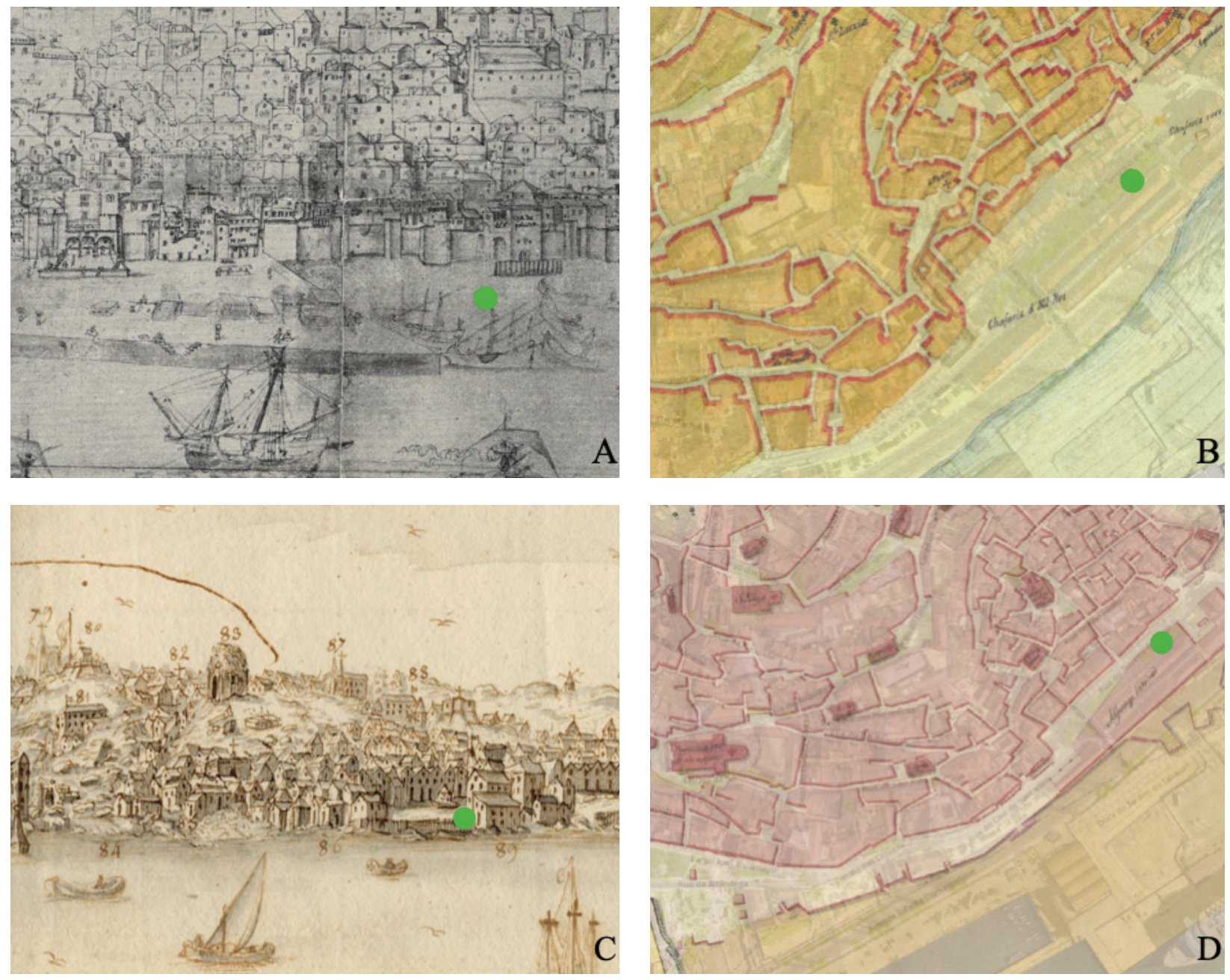

Figura 1 - Localização do sítio escavado em iconografia e sobreposições cartográficas (Fonte: Lisboa Interactiva). A: Vista de Lisboa de anónimo, c. 1570-1580 (Leiden University Library: 29-15-7831-110/30aq). B: Planta de Lisboa de João Nunes Tinoco, 1650 (BNP: cc-1081-a). C: Vista de Lisboa de Bernardo Caula, 1763 (BNP: d-177-r). D: Planta de projeto de Lisboa de Eugénio Santos e Carvalho e Carlos Mardel, 1758 [cópia datada de 1947] (CML: MC.GRA.35). 

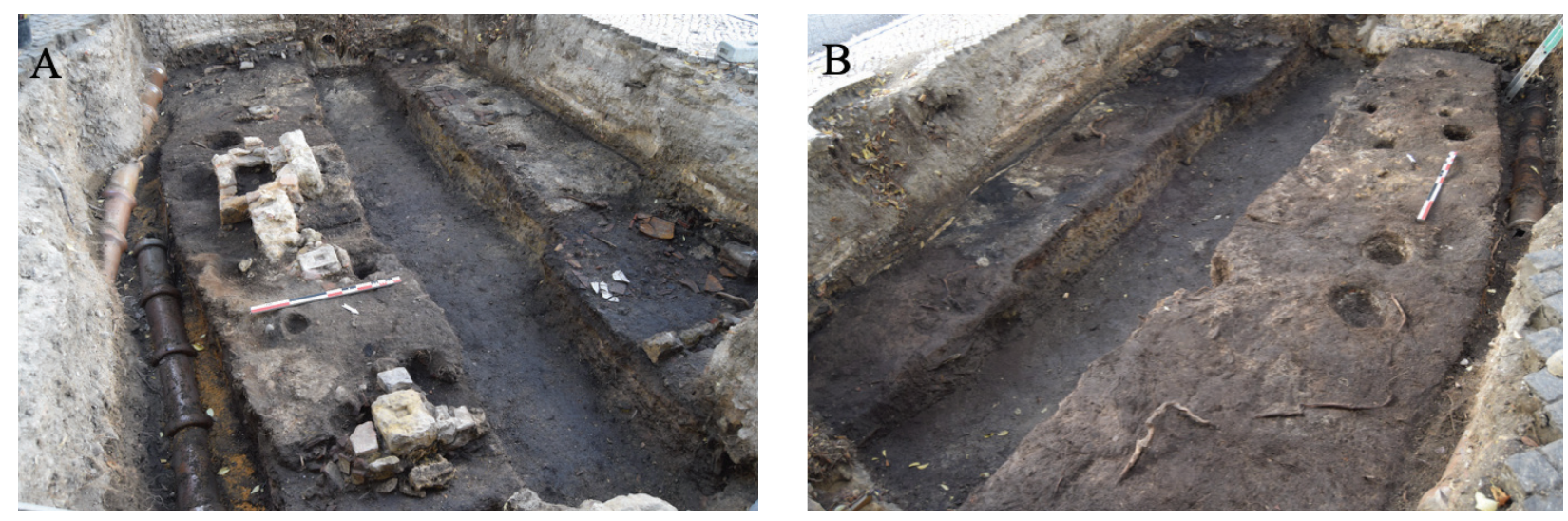

Figura 2 - Registos fotográficos do sítio escavado. A: Vista geral dos níveis de destruição de 1755. B: Vista geral dos níveis de (re-/)construção antes de 1755. Autor: J. P. Henriques.

\begin{tabular}{|c|c|c|c|c|c|c|}
\hline $\begin{array}{c}\text { N. }{ }^{\circ} \text { de } \\
\text { Inventário }\end{array}$ & U.E. & $\begin{array}{l}\text { N. }{ }^{\circ} \text { de } \\
\text { Fragmentos }\end{array}$ & $\begin{array}{l}\text { Marca de } \\
\text { Produtor }\end{array}$ & $\begin{array}{l}\text { Produtor } \\
\text { Atribuído }\end{array}$ & Cronologia & $\begin{array}{l}\text { Local de } \\
\text { Produção }\end{array}$ \\
\hline RTT'18.76 & $\begin{array}{c}{[041-} \\
054]\end{array}$ & 1 & $\begin{array}{c}64 \text { coroado }+ \\
\text { Brasão de Gouda }\end{array}$ & Andries de Vries & $\begin{array}{c}\text { c. } \\
1739 / 40-1755\end{array}$ & Gouda \\
\hline RTT'18.82 & {$[042]$} & 1 & HK coroado & Hendrick Kwast & c. $1719-1749$ & Gouda \\
\hline RTT'18.163 & [049] & 1 & $\begin{array}{l}\text { Homem a fumar } \\
\text { um cachimbo } \\
\text { numa carroça } \\
\text { (Man in Sjees, } \\
\text { Kar) }\end{array}$ & $\begin{array}{l}\text { Dominicus van } \\
\text { Klaveren/Willem } \\
\text { Hendricksz van } \\
\text { Boksel/Jan van } \\
\text { der Werf }\end{array}$ & $\begin{array}{l}\text { c. } 1733-1740 / \\
\text { c. } 1740-1749 / \\
\text { c. } 1749-1767\end{array}$ & Gouda \\
\hline $\begin{array}{c}\text { RTT'18.191 } \\
/ \\
\text { RTT'18.252 }\end{array}$ & $\begin{array}{c}{[050] /} \\
{[054]}\end{array}$ & 2 & B coroado & $\begin{array}{c}\text { Jan Overwesel/ } \\
\text { Bastiaan } \\
\text { Overwesel }\end{array}$ & $\begin{array}{l}\text { c. } 1730-1746 / \\
\text { c. } 1737-1770\end{array}$ & Gouda \\
\hline RTT'18.216 & {$[050]$} & 1 & $\begin{array}{c}\text { Cesto de fruta } \\
\text { (Fruitben) }+ \\
\text { Brasão de Gouda }\end{array}$ & Jan Nieuwveld & $\begin{array}{c}\text { c. } \\
1739 / 40-1789\end{array}$ & Gouda \\
\hline RTT'18.256 & {$[040]$} & 1 & $\begin{array}{c}\text { L coroado + } \\
\text { Brasão de Gouda }\end{array}$ & $\begin{array}{l}\text { Cornelis de } \\
\text { Licht/Jacob de } \\
\text { Licht }\end{array}$ & $\begin{array}{c}\text { c. } \\
1739 / 40-1745 / \\
c .1745-1753\end{array}$ & Gouda \\
\hline RTT'18.361 & {$[075]$} & 1 & $\begin{array}{c}\text { Mão a escrever } \\
\text { (Schrijvende hand) }\end{array}$ & $\begin{array}{l}\text { Hage Jaspersz } \\
\text { van Kint }\end{array}$ & c. $1714-1759$ & Gouda \\
\hline RTT'18.411 & - & 1 & F S & $\begin{array}{c}\text { Ferdinando } \\
\text { Smith/Francis } \\
\text { Saywell/Francis } \\
\text { Stray }\end{array}$ & c. $1642-1732$ & Londres \\
\hline RTT'18.423 & {$[052]$} & 1 & I R & $\begin{array}{c}\text { Joseph Rande/ } \\
\text { John Roome/ } \\
\text { John Reynolds/ } \\
\text { James Roome }\end{array}$ & c. $1667-1730$ & Londres \\
\hline
\end{tabular}

Tabela 1 - Estudo das marcas de produtor dos fornilhos de cachimbos de caulino. 


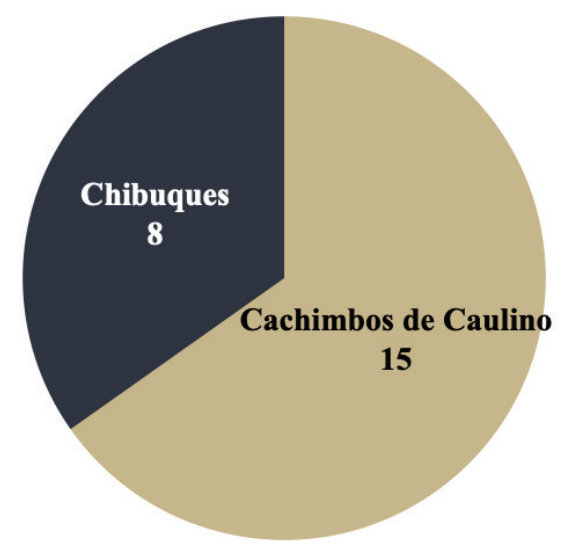

Gráfico 1 - Variação de NMI de cachimbos da Rua do Terreiro do Trigo, Lisboa por tipologia de cachimbo.
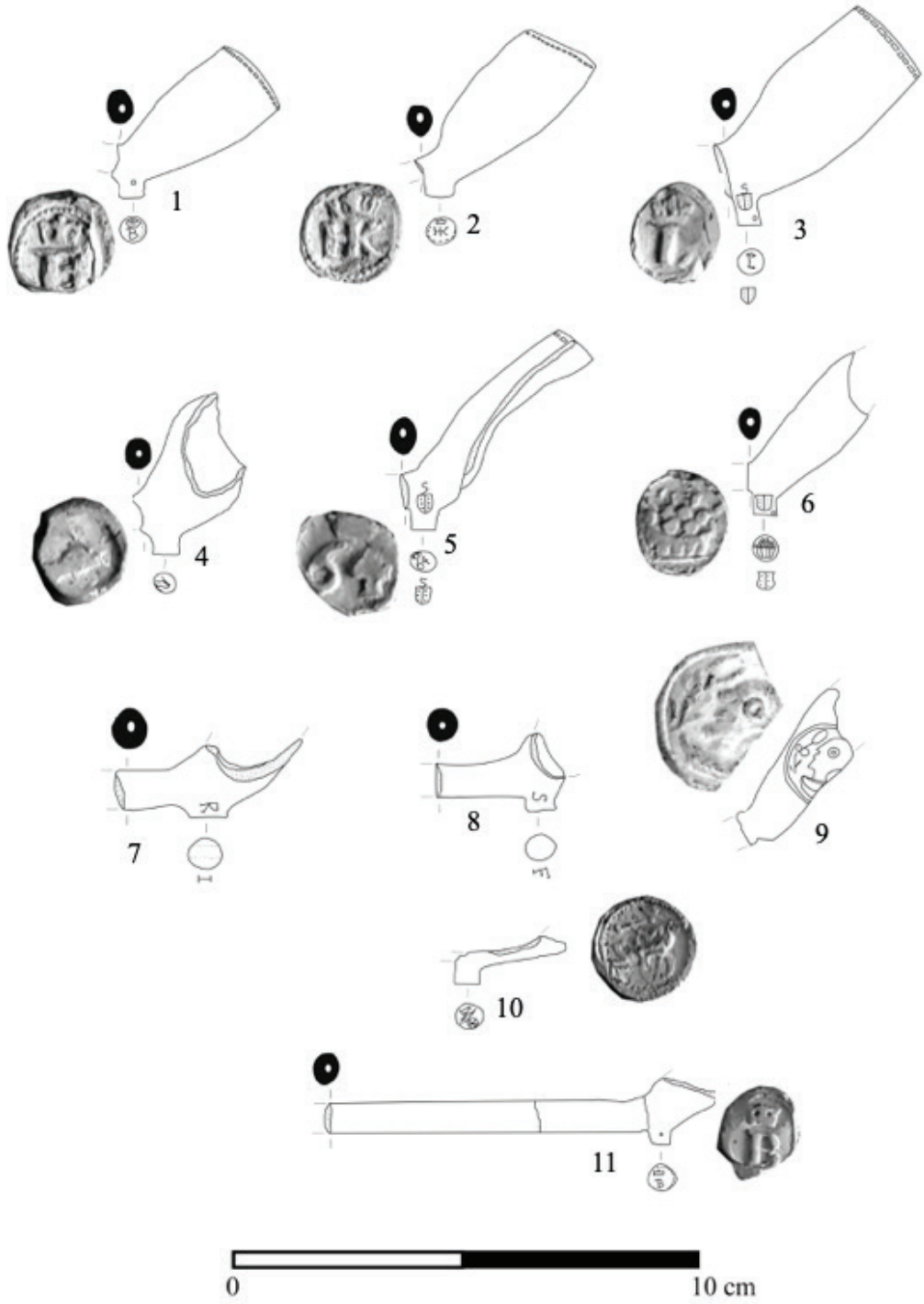

Figura 3-Fornilhos de cachimbos de caulino decorados e com marcas de produtor. 1: RTT'18.252. 2: RTT'18.82. 3: RTT'18.256. 4: RTT'18.361. 5: RTT'18.76. 6: RTT'18.216. 7: RTT'18.423. 8: RTT'18.411. 9: RTT'18.435. 10: RTT'18.163.11: RTT'18.191. Autor: M. M. de Sousa. 
1

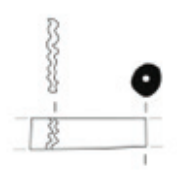

3<smiles>C#CC1CC1</smiles>

5

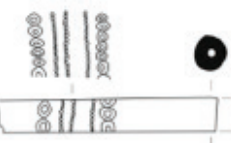

2

(1)
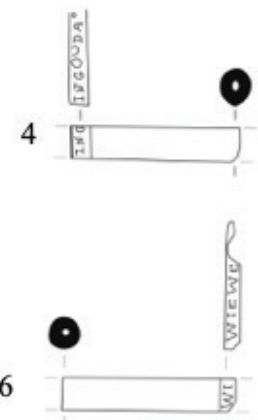

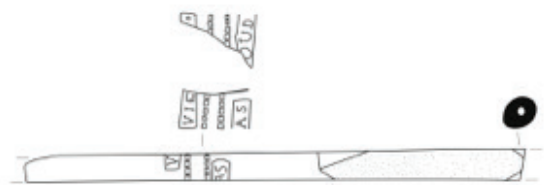

8

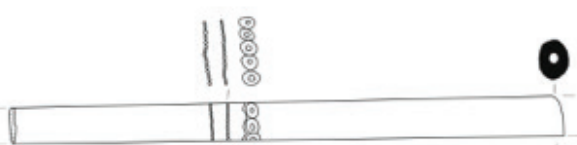

0

Figura 4 - Hastes decoradas de cachimbos de caulino. 1: RTT'18.4. 2: RTT'18.291. 3: RTT'18.5. 4: RTT'18.332. 5 RTT'18.6. 6: RTT'18.165. 7: RTT'18.255. 8: RTT'18.140. Autor: M. M. de Sousa.
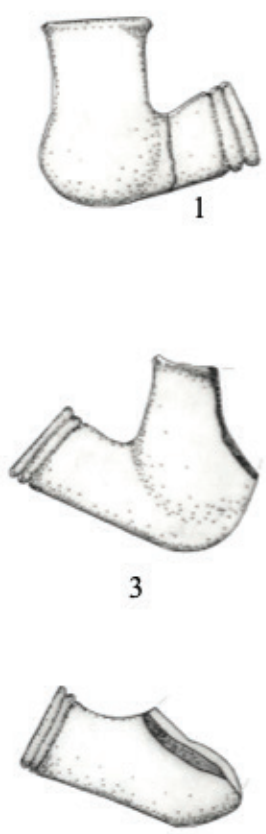

5
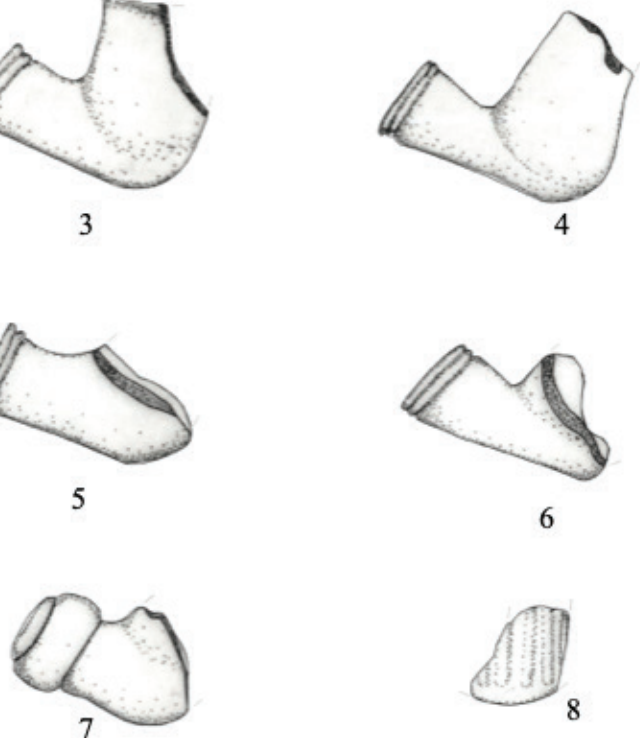

6

8
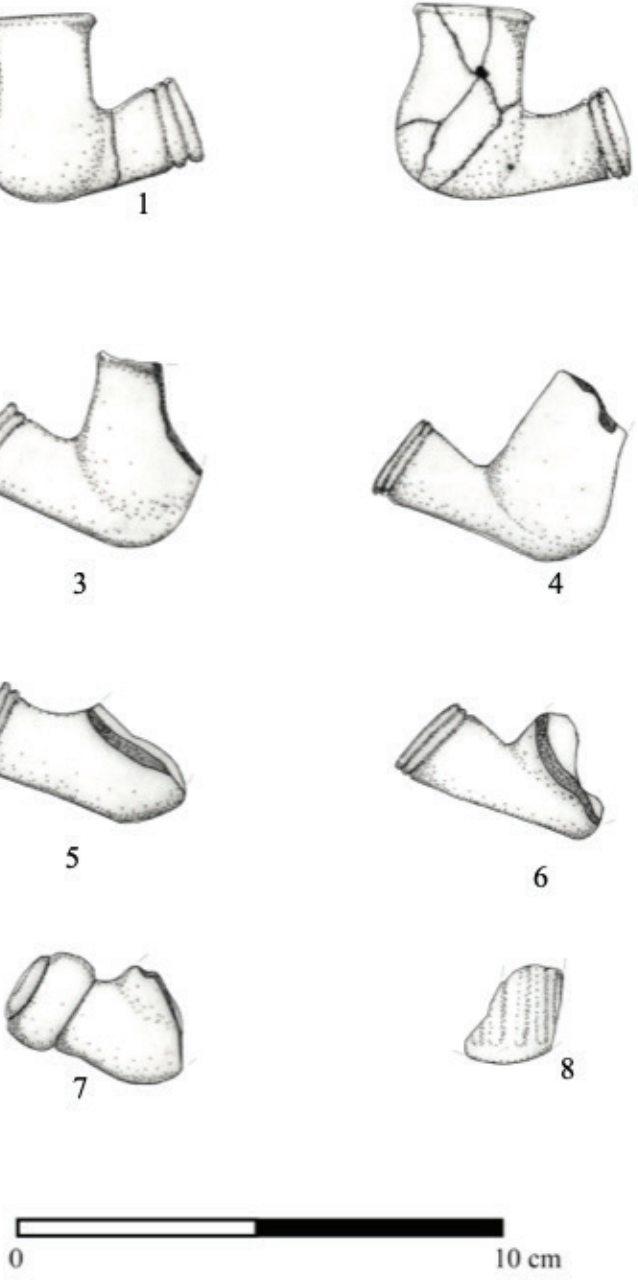

Figura 5-Fornilhos de chibuques.1: RTT'18.441. 2: RTT'18.437. 3: RTT'18.440.4: RTT'18.442. 5: RTT'18.443. 6: RTT'18.447. 7: RTT'18.436. 8: RTT'18.444. Autor: M. M. de Sousa. 

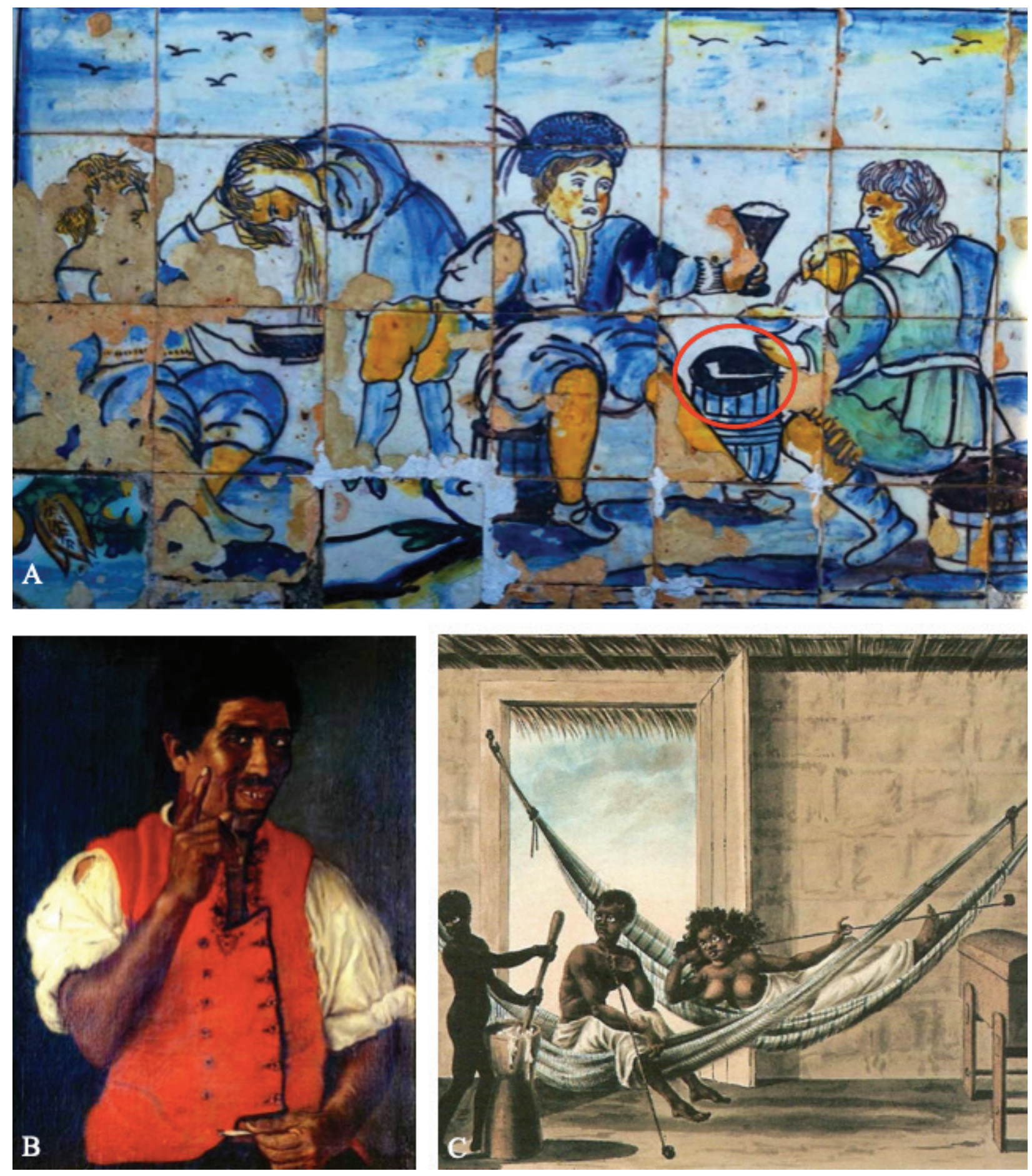

Figura 6 - Iconografia relacionada com o hábito de fumar. A: Pormenor de painel de azulejos, século XVII (Palácio dos Marqueses de Fronteira). B: “Retrato de Negro” por Morgado de Setúbal, século XVIII (MNAA: 33987 TC). C: Pormenor de “Interior de uma casa do baixo povo" por anónimo, c. 1820 (Fonte: Hissa, 2018, p. 39). 


\title{
CACHIMBOS DE BARRO CAULÍNITICO DA SÉ DA CIDADE VELHA (REPÚBLICA DE CABO VERDE)
}

\author{
Rodrigo Banha da Silva ${ }^{1}$, João Pimenta ${ }^{2}$, Clementino Amaro ${ }^{3}$
}

\begin{abstract}
RESUMO
Numa cooperação entre as autoridades da República de Cabo Verde e o extinto Instituto Português do Património Cultural, uma escavação arqueológica extensa foi dirigida entre 1989 e 1993 por um dos autores (C.A. - Amaro, 2013) nas ruínas da catedral da antiga cidade da Ribeira Brava.

Os trabalhos revelaram diversos contextos dos séculos XVII e XVIII realcionados com reformas do edifício religioso, providenciando uma valiosa visão sobre a cultura material do período colonial em Cabo Verde. Àparte outras evidências de produtos oleiros europeus, foram recolhidos fragmentos de 21 cachimbos, evocativos das realações comerciais entre o Império Português e outros espaços políticos, igualmente sugestivos da frequência do consumo de tabaco na época.
\end{abstract}

Palavras-chave: Cachimbos cerâmicos, “Cultura Tabágica”, Arqueologia Moderna, Arqueologia Colonial.

\begin{abstract}
The authorities of the Republic of Cape Verde and the former Portuguese institute of heritage (IPPC) cooperate to do an archaeological excavation between 1989 and 1993 in the ruins of the Cathedral of "Cidade Velha", the former main religious spot of the archipelago, under the direction of one of the authors (C.A. - Amaro, 2013). The work revealed several contexts connected with reformations of the religious temple dating from late $17^{\text {th }}$ and $18^{\text {th }}$ century, providing an insight on material culture of the colonial period in Cape Verde Archipelago. Clay tobacco pipe sherds were identified, displaying some data related to commercial links between the Portuguese Empire and other European spaces, as well as suggestive of the frequency of tobacco consumption in Cape Verde at the time.
\end{abstract}

Keywords: Clay Tobacco Pipes, “Tobacco Culture”, Early Modern Archaeology, Colonial Archaeology.

\section{INTRODUÇÃO}

Ao abrigo de um protocolo estabelecido entre as autoridades da cultura da República de Cabo Verde e o então Instituto Português do Património Cultural (IPPC), realizaram-se três campanhas arqueológicas dirigidas por um de nós (C.A.), entre 1989 e 1993, nas ruínas da Sé da Cidade Velha, antiga Ribeira Grande, a primeira capital do arquipélago.

De entre o conjunto de construções da antiga capital colonial de Cabo Verde ao longo da Época Moderna, a Sé resultou de um vector da política de D. João
III de criação de sete novas dioceses, para o que o monarca foi obtendo a necessária autorização papal (Ribeira Grande e Goa - 1533; Angra do Heroísmo - 1534; Miranda do Douro e Leiria - 1545; Portalegre - 1549; São Salvador da Baía-1551 - MIMOSO, 1996: p.10). Os projectos de algumas destas novas catedrais do tipo igreja-salão de três naves mostram as afinidades fortes e evidentes entre as sés da $\mathrm{Ri}$ beira Grande, Portalegre, Leiria e Miranda do Douro (Mimoso, 1996). A construção da Sé da Cidade Velha só seria mais tarde projectada e iniciada somente em 1556-8. Contudo, a despeito de fortemente fi-

\footnotetext{
1. CHAM-FCSH/UNL e Uaç; rbds@fcsh.unl.pt

2.UNIARCH-FLUL; joao.marques@cm-vfxira.pt

3. Associação Olisipo Forum
} 
nanciada, não seria todavia concluída, detendo-se a edificação cerca de 1571 (Mimoso, 1996, p. 16). Deste modo se aproveitaram nos finais do século XVII as paredes externas entretanto esgalgadas para acondicionar um outro modelo arquitectónico de nave única, sendo que a construção por fim se terminaria antes de 1705 (Mimoso, 1996, p. 38)

Em progressivo estado de ruína, a Sé da Cidade Velha seria portanto alvo da intervenção articulada entre as autoridades da cultura da República de Cabo Verde e o extinto IPPC, e iria permitir a reabilitação e consolidação deste espaço emblemático, marcando o início de um conjunto de diversificadas iniciativas e estabelecimento de protocolos de colaboração que se alargaram a vários pontos da antiga cidade (Tavares, 2017), culminando este processo com a classificação da Cidade Velha pela UNESCO como Património Mundial da Humanidade, em 2009, e a reposição do município, com a designação de Ribeira Grande de Santiago.

A intervenção arqueológica na Sé foi centrada, numa primeira fase, no desentulhamento do espaço interior da sé, antecedido pela remoção de cerca de duas centenas e meia de cantarias e elementos arquitetónicos e escultóricos que, nesta fase, são deslocados para o antigo adro da Sé, onde se procedeu ao seu inventário e registo fotográfico.

Com a segunda campanha deu-se início a um conjunto de sondagens, preferencialmente destinadas ao reconhecimento da estabilidade e assentamento das fundações das paredes estruturais e pilares, acção que decorreu em articulação com a equipa de engenharia. Procedeu-se, em simultâneo, à realização sondagens pontuais, como na capela-mor, e uma limpeza e decapagem geral, mais fina, de todo o espaço interior.

Esta acção permitiu a identificação do alinhamento dos pilares de sustentação das três naves do templo, dos alicerces das capelas laterais, lado norte, bem como a definição integral do transepto e do embasamento das torres sineiras, dados disponibilizados à equipa de arquitetura, para retificação do levantamento inicial.

O Gabinete Técnico de apoio à obra, vai ser igualmente utilizado como um depósito visitável de cantarias e elementos escultóricos, entretanto aqui recolhidos, como de doações por parte da população, para além de aqui se proceder ao inventário, tratamento e conservação do espólio cerâmico, dos elementos pétreos, madeiras, ferros, argamassas e espólio osteológico.
Na fase final da intervenção, procedeu-se ao desaterro da envolvente exterior à capela-mor e à recuperação do soco primitivo do edifício, após significativa remoção de aterros. Nesta acção, são recuperados os alicerces e soleiras de porta de duas salas laterais à capela-mor, lado sul, correspondendo à sacristia e sala anexa.

Foi tomada a iniciativa de se proceder ao preenchimento de espaços vazios nas paredes mais altas a fim colmatar uma visível degradação, para o que foi contratado um pedreiro local, familiarizado com a construção de alvenaria em pedra e a utilização de argamassa de base tradicional.

Sendo o território cabo-verdiano sujeito a ventos fortes em determinados meses do ano, e como resultado da ausência dos pisos, que teriam sido em tijoleira, optou-se por cobrir integralmente o espaço interior com areia do rio de origem vulcânica, num diálogo de contrastes entre o tom negro da areia e o tom claro do edificado em calcário.

\section{OS RESULTADOS DA INTERVENÇÃO NA SÉ DA CIDADE VELHA}

Do conjunto dos túmulos identificados nas sondagens abertas junto à face interna das paredes e dos pilares das naves, da maioria já só subsistia o covacho, muitas vezes com a presença ainda de nódulos de cal, e onde o espólio associado se limita a alfinetes do sudário, escassos fragmentos de tecido e várias dezenas contas de rosário. Registámos igualmente dois ossários. Um significativo número de tampas sepulcrais e outros elementos pétreos foram reutilizados na construção de casas, nomeadamente a partir das primeiras décadas do século XX, como constatámos em duas habitações contíguas à Sé.

Foram, no entanto, identificadas três sepulturas com a respetiva tampa lavrada e com dedicatória. Refere-se uma delas ao capitão-mor António José Xavier, falecido em 1755, e uma segunda ao coronel Manuel Dias de Moura, falecido em 1818 e de sua mulher. O grande destaque, no entanto, e com impacto local, foi a identificação da caixa tumular e respetiva tampa sepulcral do primeiro bispo residente de Cabo Verde, D. João Parvi, que foi sepultado na Igreja de Nossa Senhora do Rosário em 1546 e depois trasladado para a sepultura de D. Fr. Vitoriano Portuense, bispo que concluiu as obras da Sé e falecido em 1705. O túmulo encontra-se em posição central na capela-mor e estava ladeado pelo cadeiral. 
No decurso da terceira campanha, na nave lateral norte, foi identificada uma estrutura com planta em U, desalinhada com a orientação da sé e que se interpretou como sendo os alicerces de um pequeno templo que existiu neste local no início do século XVI, fora da cidade, e de invocação a São Sebastião, ficando a sua memória ligada ao nome do bairro onde veio a construir-se a Sé.

O espólio exumado caracteriza-se maioritariamente pela sua modéstia, encontrando-se associado aos enterramentos, nomeadamente das sondagens junto aos pilares, como alfinetes, medalha, contas de rosário em osso e escassas em vidro, e alguns numismas. Na torre sul foi recuperada uma pulseira em prata e coral, e na torre norte uma tampa em bronze de vaso litúrgico.

O único local identificado com uma diversidade de espólio algo significativo, correspondeu ao aterro que nivelou, em certo momento, o espaço compreendido entre o embasamento dos degraus de acesso ao altar e a parede de fundo da capela-mor.

A sondagem revelou uma vasta profusão de materiais em deposição secundária, oriundos duma presumível lixeira. Do conjunto, destacamos a presença de porcelana da China, faiança portuguesa e espanhola e, presumivelmente, italiana, loiça vidrada, cerâmica modelada e pedrada, alguma cerâmica comum de ir à mesa, base de fogareiro, anforetas de produção andaluza, algumas marcas de jogo e um pequeno conjunto de cachimbos, objeto do presente estudo.

Proveniente ainda do aterro de nivelamento, destaca-se um significativo conjunto de cerâmica de tradição africana, fabricada ao torno lento ou de modelagem manual, a partir da técnica do rolo, e de cozedura redutora (Amaro, 2013).

Em termos globais, o espólio exumado é enquadrável num período entre a segunda metade do século XVI até finais do século XVII.

Da modesta coleção de numismas exumados no decurso da intervenção, e que apresenta uma cronologia de meados do século XVI à $1^{\mathrm{a}}$ República, merecem destaque III reis de D. Pedro II (1699) exumados na sondagem de acesso ao túmulo do bispo, sendo passível de associar este achado com o momento de trasladação do primeiro bispo de Cabo Verde (Amaro, 2013).

\section{O CONJUNTO DE CACHIMBOS RECO- LHIDO NAS ESCAVAÇÕES DE 1989-1993 DA SÉ DA CIDADE VELHA}

O conjunto é formado por 28 fragmentos atribuíveis a um mínimo de 21 exemplares de cachimbo produzidos com argilas caulínicas. Entre estes contam-se duas porções decoradas da haste e 8 fragmentos conservando parte ou a totalidade do fornilho, elementos mais qualificados para uma atribuição cronológica e de origem. Entre os indivíduos encontram-se quatro ostentando marcas no pedúnculo que permitem situar com total segurança os respectivos oleiros e/ou centros produtores, ilustrando no momento a exclusividade no local de produções holandesas e britânicas, igualmente discerníveis através da tipologia das decorações das hastes e das morfologias dos fornilhos.

Dos diversos contextos onde foram exumados fragmentos de cachimbo, apenas para os achados relacionados com a capela-mor se poderá propor uma cronologia, já que os materiais que se encontram associados, apontam para datações entre a segunda metade do século XVI até finais do século XVII. As obras de conclusão da Sé também reforçam esta data limite, já que as mesmas terão terminado em finais do século XVII. Em sentido contrário, os elementos cronológicos proporcionados pelos cachimbos não contradizem esta leitura produzida com base estratigráfica.

\subsection{Catálogo}

1. Fragmento de haste de cachimbo em cerâmica. Fragmento da parte mesial da haste, de secção ovalada e mostrando vestígios do alisamento externo, preservando $45 \mathrm{~mm}$ de comprimento. O perfil mostra muito ligeira tendência convergente e arqueada. A pasta é caulínica, um pouco granulosa, de coloração branca e tonalidade amarfinada.

Dimensões: espessura mín. $=6,7 \mathrm{~mm}$; espessura máx. $=7,8 \mathrm{~mm}$; diâmetro do orifício int. $=3 \mathrm{~mm}$. Indicações contextuais: Altar-Mór / Corredor Sul / Altar (n.․ Inv: CV/90/15).

2. Fragmentos de haste de cachimbo em cerâmica. Dois fragmentos com colagem da parte mesial da haste, de secção quase circular e mostrando vestígios do alisamento externo, com algumas estrias, preservando $65 \mathrm{~mm}$ de comprimento. Como o an- 
terior, o perfil mostra ligeira tendência convergente e arqueada.

Pasta similar ao número anterior.

Dimensões: espessura mín. $=7 \mathrm{~mm}$; espessura máx. $=7,7 \mathrm{~mm}$; diâmetro do orifício int. $=3,1 \mathrm{~mm}$.

Indicações contextuais: Altar-Mór / Corredor Sul / Altar (n..$^{\circ}$ Inv: CV/9o/11462).

3. Fragmento de haste de cachimbo em cerâmica. Fragmento da parte mesial da haste, de secção circular, com vestígios do alisamento externo, preservando $43 \mathrm{~mm}$ de comprimento. O perfil mostra-se ligeiramente convergente.

Pasta similar à dos números anteriores.

Dimensões: espessura mín $=7 \mathrm{~mm}$; espessura máx. $=7,8 \mathrm{~mm}$; diâmetro do orifício int. $=2,7 \mathrm{~mm}$.

Indicações contextuais: Altar-Mór / Decapagem do A.M. (n. ${ }^{\circ}$ Inv: CV/89/7478).

4. Fragmento de haste de cachimbo em cerâmica. Fragmento da parte mesial da haste, de secção circular, com vestígios do alisamento externo, preservando $22 \mathrm{~mm}$ de comprimento. O perfil mostra-se ligeiramente convergente.

Pasta similar à dos números anteriores, um pouco alterada na superfície.

Dimensões: espessura $=9,2 \mathrm{~mm}$; diâmetro do orifício int. $=2,9 \mathrm{~mm}$.

Indicações contextuais: Capela-Mór/ Enchimento da caixa central (n.. Inv: CV/89/7071).

5. Fragmento de haste de cachimbo em cerâmica. Fragmento da parte mesial da haste, de secção circular, com vestígios do alisamento externo, preservando $56 \mathrm{~mm}$ de comprimento. O perfil mostra-se ligeiramente paralelo.

Pasta similar à dos números anteriores. A superfície apresenta-se esbocelada.

Pode fazer parte do mesmo cachimbo apresentado de seguida.

Dimensões: espessura $=5,7 \mathrm{~mm}$; diâmetro do orifício int. $=2,0 \mathrm{~mm}$.

Indicações contextuais: Torre Sul / G15 / plano o / Camada 1 (s/n.․․ Inv.).

6. Fragmento de haste de cachimbo em cerâmica. Fragmento da parte mesial da haste, de secção circular, com vestígios do alisamento externo, preservando $28 \mathrm{~mm}$ de comprimento. O perfil mostra-se ligeiramente convergente.
Pasta similar à dos números anteriores, um pouco alterada na superfície.

Pode fazer parte do mesmo cachimbo apresentado antes.

Dimensões: espessura $=5,8 \mathrm{~mm}$; diâmetro do orifício int. $=2,4 \mathrm{~mm}$.

Indicações contextuais: Torre Sul / G15 / plano o / camada 1 (s/n. ${ }^{\circ}$ Inv.).

7. Fragmento de haste de cachimbo em cerâmica. Fragmento da parte mesial da haste, de secção circular, com vestígios do alisamento externo, com estrias, preservando $29 \mathrm{~mm}$ de comprimento. O perfil mostra-se paralelo.

Pasta similar à dos números anteriores.

Dimensões: espessura $=6,2 \mathrm{~mm}$; diâmetro do orifício int. $=2,0 \mathrm{~mm}$.

Indicações contextuais: Sepultura 1 / F18 E (n. ํำ Inv: CV.SÉ 1-198).

8. Fragmento de haste de cachimbo em cerâmica. Fragmento da parte distal da haste, de secção circular, com vestígios do alisamento externo, preservando $22 \mathrm{~mm}$ de comprimento. O perfil mostra-se paralelo, com marcada divergência na parte mais distal da junção com o formilho.

Pasta depurada, de coloração acinzentada clara, mostrando textura granulosa e fractura nítida.

Dimensões: espessura $=9,2 \mathrm{~mm}$; diâmetro do orifício int. $=2,0 \mathrm{~mm}$.

Indicações contextuais: Quadrícula P13 / Camada 1 (n.. Inv: CV.SÉ/ PB 1-2).

9. Fragmento de haste de cachimbo em cerâmica. Fragmento da parte distal da haste, de secção circular, com vestígios do alisamento externo, preservando $40 \mathrm{~mm}$ de comprimento. O perfil mostra-se convergente.

Pasta depurada, granulosa, de coloração branco-marfim.

Dimensões: espessura $=8$, o mm; diâmetro do orifício int. $=3,1 \mathrm{~mm}$.

Indicações contextuais: Pilar F / Camada 2 (n.ํ Inv: CV.SÉ/3-206).

10. Fragmento de haste de cachimbo em cerâmica. Fragmento da parte mesial da haste, de secção quase circular, com vestígios do alisamento externo, preservando $40 \mathrm{~mm}$ de comprimento. O perfil mostra-se paralelo. 
Pasta como a do número anterior.

Dimensões: espessura $=9,4 \mathrm{~mm}$; diâmetro do orifício int. $=2,9 \mathrm{~mm}$.

Indicações contextuais: Descontextualizado (n..$^{\circ}$ Inv: CV.SÉ/3-195).

11. Fragmento de haste de cachimbo em cerâmica.

Fragmento da parte distal da haste, de secção circular, com vestígios do alisamento externo, preservando $44 \mathrm{~mm}$ de comprimento. O perfil mostra-se paralelo, com marcada divergência na parte mais distal da junção com o formilho.

Pasta como a dos números anteriores, mas com as superfícies um pouco alteradas.

Dimensões: espessura = 9,9 mm; diâmetro do orifício int. $=3,0 \mathrm{~mm}$.

Indicações contextuais: Pilar F / Camada 2 (n. ํㅡㄴ CV.SÉ/3-50).

12. Fragmento de haste de cachimbo em cerâmica. Fragmento da parte mesial da haste, de secção circular, com vestígios do alisamento externo, preservando $53,5 \mathrm{~mm}$ de comprimento. O perfil mostra-se paralelo. A superfície externa mostra uma decoração alternando circulos e denticulados, impressa com roletilha. Este tipo de ornamentação da haste foi usada intensivamente pelos fabricantes de Gouda (Países Baixos) entre os séculos XVII e XIX. Todavia, as características da haste denunciam uma elaboração que poderá datar de 169o, pelo menos, sendo admissível datas de até c.1780, pelo mais (DUCO, 2003: pp. 204-207).

Pasta como a dos números anteriores.

Dimensões: espessura $=7,5 \mathrm{~mm}$; diâmetro do orifício int. $=2,4 \mathrm{~mm}$.

Indicações contextuais: Sacristia/ Camada 2 (desentulhamento) (S/n.o Inv).

13. Fragmento de haste de cachimbo em cerâmica. Fragmento da parte distal da haste, de secção circular, com vestígios do alisamento externo, preservando 53,5 mm de comprimento. O perfil mostra-se ligeiramente divergente, mais acentuado na zona de junção com o fornilho. A superfície externa mostra uma decoração impressa com punção, com flor-de-lis inscrita em losângo delimitado por cercadura, repetida por quatro vezes e com disposição em cruz, denotando vestígios da repetição deste tipo de decoração de que restou somente a parte superior de um outro losângo com a parte superior da flor-de-lis.
A morfologia da haste, em particular as suas dimensões, como a temática ornamental, apontam para tratar-se de uma elaboração oriunda da cidade holandesa de Gouda, com maior probabilidade datada de cerca de 1640/1650 (DUCO, 2003: pp. 202-203). Pasta como a dos números anteriores.

Dimensões: espessura $=9,4 \mathrm{~mm}$; diâmetro do orifício int. $=3,0 \mathrm{~mm}$.

Indicações contextuais: Altar-Mór / Camada 2 (desmontagem) (n.ํo Inv: CV.SÉ/3-23).

14.Fragmento de fornilho e haste de cachimbo em cerâmica.

Fragmento conservando parte do fornilho, dotade de pedúnculo cilíndrico, também truncado, e da parte distal terminal da haste, de secção de tendência ovalada, com vestígios do alisamento externo, preservando aquela $36,5 \mathrm{~mm}$ de comprimento. $O$ perfil da haste é quase paralelo, mas ligeiramente divergente da zona terminal distal para a mesial.

Pasta como a dos números anteriores.

Dimensões: espessura da haste $=9,5 \mathrm{~mm}$; diâmetro do orifício int. $=2,9 \mathrm{~mm}$.

Indicações contextuais: Altar-Mór / Camada 2 (desmontagem) (n.ํo Inv: CV.SÉ/3-22).

15. Fragmento de fornilho de cachimbo em cerâmica. Fragmento conservando parte do fornilho.

Pasta como a dos números anteriores.

Indicações contextuais: Nave lateral Sul / G17 / plano o / Camada i (S/n.o Inv.).

16. Fragmento de fornilho de cachimbo em cerâmica. Fragmento conservando o fornilho, em "forma de túlipa”, e vestígios do arranque da haste. Na face externa da boca ostenta decoração de filete executado com roletilha fina. O pedúnculo é baixo e quase circular, ostentando a marca executada a punção RT. Pasta similar à dos números anteriores.

Dimensões: altura máxima $=31,7 \mathrm{~mm}$; diâmetro interno da boca: 13,1 mm.

Indicações contextuais: Quadrícula P13 / Camada 1 (n. ${ }^{\circ}$ Inv: CV.PB 1-3).

17. Fragmento de fornilho de cachimbo em cerâmica. Fragmento conservando a parte inferior do fornilho, em "forma de túlipa", o arranque da haste. Esta é de secção ovalada, preservando somente $4,4 \mathrm{~mm}$ de comprimento. O pedúnculo é baixo e quase circular, ostentando a marca executada a punção AL/+. 
Pasta similar à dos números anteriores.

Dimensões: altura máxima preservada $=29,1 \mathrm{~mm}$; espessura máxima da haste $=11,4 \mathrm{~mm}$; diâmetro do orifício int. $=2,6 \mathrm{~mm}$.

Indicações contextuais: sem indicação.

18. Fragmento de fornilho de cachimbo em cerâmica. Fragmento conservando parte do fornilho, em "forma de túlipa" alta, e vestígios do arranque da haste. $\mathrm{Na}$ face externa da boca ostenta decoração de filete executado com roletilha fina. O pedúnculo é baixo e oval, isento de marca. A morfologia do fornilho, caracteristicamente holandesa, aponta para uma cronologia em torno de 1640/1650 (Duco, 2003: p. 203). Pasta similar à dos números anteriores.

Dimensões: altura máxima =34,3 mm; diâmetro interno da boca: 12,8 $\mathrm{mm}$.

Indicações contextuais: Sem indicação (n. ํ. Inv: CV.SÉ 3-24).

19. Fragmento de fornilho de cachimbo em cerâmica. Fragmento conservando o fornilho, alto e em forma de campânula, com vestígios do arranque da haste. Na face externa da boca mostra desbaste resultante de afeiçoamento no momento do fabrico. O pedúnculo éalto e cilíndrico. Na face esquerda do pedúnculo mostra marca em relêvo composta por três pontos circulares alinhados. A haste era de secção circular. Pasta similar à dos números anteriores.

Dimensões: altura máxima $=38,4 \mathrm{~mm}$; espessura máxima da haste $=8,3 \mathrm{~mm}$; diâmetro do orifício int. $=2,2 \mathrm{~mm}$.

Indicações contextuais: Pilar F / Camada 2 (n.ำ Inv: CV.SÉ 3-51).

20. Fragmento de fornilho de cachimbo em cerâmica. Fragmento da boca e parede de fornilho, alto e em forma de campânula. A boca ostenta decoração de filete fino executado a roletilha.

Pasta similar à dos números anteriores.

Dimensões: altura máxima conservada =c. $43 \mathrm{~mm}$. Indicações contextuais: Quadrícula P13 / Camada 1 (n. ${ }^{\circ}$ Inv: CV.PB 1-4).

21. Fragmentos de fornilho de cachimbo em cerâmica. Fragmentos conservando a totalidade do fornilho, alto e em forma de campânula, com vestígios do arranque da haste. Na face externa da boca mostra decoração de filete fino executado a roletilha. O pedúnculo é alto e cilíndrico. Em ambas as faces do pe- dúnculo estão patentes as armas da cidade de Gouda encimadas pela letra S. A base do pedúnculo mostra a marca impressa a punção com o numeral 54, coroado. A haste era de secção circular.

Pasta similar à dos números anteriores.

Dimensões: altura máxima $=54,0 \mathrm{~mm}$; espessura máxima da haste $=$ c. $8,0 \mathrm{~mm}$; diâmetro do orifício int. $=1,7 \mathrm{~mm}$.

Indicações contextuais: Quadrícula F16 Sul / plano o / camada 1 (s/n..$^{\circ}$ Inv.).

\subsection{Marcas e fabricantes}

O n. ${ }^{\circ} 16$ (Figura 7, n. ${ }^{1}$ 16), equivale a uma produção marcada "RT não coroado" de Gouda, nos Países Baixos, correspondendo ao punção do fabricante de cachimbos Rogier Tonstal, activo entre 1637/1640 e 1654/166o (Duco, 1982; 2003, p. 167).

O n. ${ }^{\circ} 17$ (Figura.7, n.․ำ 17 ostenta a marca AL/+. Trata-se de impressão usada em fabricos sediados em Chester (Inglaterra), estratigraficamente situados no lapso 1630-1680 (Rutter \& Davey, 1980). No caso presente, a morfologia do fornilho e a impressão enquadram-se no lapso de 1640-1680 (Rutter \& Davey, 1980, p. 217).

19, por seu turno, equivale a um tipo de marca presente em várias produções europeias, sem que se lhe possa atribuir categoricamente uma origem a partir do punção. A morfologia do fornilho, todavia, sugere um fabrico inglês datado dos finais do século XVII. Já o n.ำ 21 ostenta em ambas as laterais do pedúnculo as armas da cidade de Gouda (Países Baixos), encimada pela letra $S$, que lhe atestava a qualidade inferior. Na base foi aplicado o punção com o numeral "54 coroado", utilizado durante um período longo pelos fabricantes da cidade holandesa, entre 1685 e 1940 (Duco, 2003, p. 193). Dentro deste lapso de tempo, 7 fabricantes usaram o punção, sendo de excluir todos os que não são compatíveis com a cronologia denunciada pela morfologia do fornilho, setecentista. Deste modo se apura dever corresponder a um produto fabricado por Dirck de Jong, que laborou entre 1685 e 1728 (Duco, 2003, p. 193).

\section{CONSIDERAÇÕES FINAIS}

O pequeno conjunto de 21 indivíduos recolhidos nas escavações arqueológicas da Sé da cidade antiga da Ribeira Grande (Cidade Velha), capital colonial do arquipélago de Cabo Verde durante a Época Moderna, permite um conjunto de inferências rele- 
vantes quer quanto às conexões comerciais mantidas pelo arquipélago, quer em relação aos contornos sociais do consumo do tabaco nos séculos XVII e XVIII em Cabo Verde.

O consumo do tabaco mediante o uso de cachimbo é um fenómeno onde a Inglaterra e a Holanda jogam um papel fundamental, aí se iniciando a partir dos inícios do último quartel do século XVI o fabrico em escala do objecto, não se estranhando por isso a ausência de execplares com estas cronologias nos contextos arqueológicos cabo-verdianos. Os dados da Sé, aliás, parecem corroborar o panorama reinol, em particular lisboeta, onde os dados de maior antiguidade parecem não remontar com anterioridade a cerca de 1630/1640 ((Pimenta, Calado \& Silva, 2008; Calado et al., 2013).

É a partir do segundo terço do século XVII que o registo arqueológico da Sé assinala e atesta a disseminação do consumo tabágico mediante cachimbo cerâmico, que além disso regista uma predominância seiscentista em resultado da própria estratigrafia exumada, fortemente condicionada pela história da Sé que, recorde-se, somente se inaugura algures entre 1699 e antes de 1705.

Ora, é do maior interesse arqueológico situar esta atestação de cachimbos em relação ao conhecimento histórico existente da população da cidade da Ribeira Grande, de maneira a se aferir o perfil social do consumo atestado pela arqueologia...

Assim, na transição do século XVI para o século XVII, após a deslocação do centro nevrálgico do comércio escravo de Cabo Verde para a costa continental africana, inicia-se um processo de decadência urbana com o abandono dos armadores e grandes comerciantes, formando-se na cidade da Ribeira Grande uma outra camada social composta por intermediários comerciais, tais como feitores e procuradores de grandes mercadores reinóis, pequenos parceiros de mercadores estrangeiros (Cabral, 1995). Neste quadro se verifica, in absentia, a ascensão de uma elite mestiça, de tal forma que à chegada dos Jesuítas, em 1617 se declara que na composição do concelho camarário "chegou a terra a tais termos que quantos ha hoje na Câmara são crioulos" (Arsi, Lus., Cód. 74, fls. 141-143 v, 27 de Junho de 1617 in Brásio, 1968: p. 613. apud Cabral et al. 2012: p. 8), uma nova elite urbana de um aglomerado que passara dos 500 vizinhos nos meados do séc. XVI a 15/16 brancos de Portugal e 35 da terra, crioulos, em 1630 (excluindo-se escravos, decerto pouco numerosos -
Cabral et al. 2012). É portanto a esta composição social, incluindo aqui os escravos africanos da Ribeira Grande, que se deverá cometer o uso dos cachimbos exumados na Sé da Cidade Velha.

Afortunadamente, as evidências arqueológicas cabo-verdianas apontam categoricamente para o cachimbo e o consumo tabágico se terem disseminado no século XVII aos mais variados níveis sociais, devendo-se a este propósito invocarem-se os dados valiosos colectados no "concheiro" da Baía de Salamansa, na Ilha de São Vicente pelas escavações de João Luís Cardoso, onde se identificou um fundo de cabana com o mesmo tipo de associação material presente na Sé da Cidade Velha, e que incluía três cachimbos cerâmicos cauliníticos, dois dos quais equivalentes a porções com fornilho do séc. XVII, de provável fabrico britânico (Cardoso \& Soares, 2010:, p. 198, fig. 27 e p. 199).

$\mathrm{O}$ acesso pela comunidade da Cidade Velha às importações britânicas e holandesas, no caso da Sé comprovadas por uma impressão de Chester (Inglaterra) e três de Gouda (Países Baixos), não surpreende, dado o carácter de importante escala desempenhado por Cabo Verde em Época Moderna no âmbito da navegação triangular atlântica. A atestação cabo-verdiana pode, contudo, reflectir no todo ou em parte um fenómeno muito mais amplo. Não se tendo conseguido aceder a mais dados de natureza arqueológica, o exemplo estudado do entreposto dinamarquês de Christiansborg Castle (Gana) revelou uma presença muito numerosa de cachimbos desde os finais do século XVII, que só se pode justificar pelo seu uso instrumental no comércio esclavagista praticado pelos escandinavos do Golfo da Guiné (Engmann, 2018). Sintomaticamente, o registo manuscrito de um navio negreiro danês de 1770, assinala que o vaso transportava 360 "cachimbos longos" e 228 "cachimbos de escravos", destinados a serem distribuídos pelo capitão um a cada escravo, a que se acrescentava uma dose diária de tabaco-excepto aos sábados- ao longo de todo o trajecto da viagem até ao continente americano (Handler, 2009, p. 9 apud Engmann, 2018, p. 48). É admissível que o tipo de prática fosse bem mais generalizado pelos negreiros dos séculos XVII e XVIII e que seja por essa via o cachimbo tenha sido incorporado nos hábitos das populações cabo-verdianos.

O uso de cachimbo entre a comunidade da Ribeira Grande, portanto, terá constituído um traço da "bricolage cultural" operacionalizada no aglomerado 
urbano da Ilha de Santiago, um elemento da composição do "patchwork cultural" (para usar aqui felizes expressões a um outro muito distinto propósito inauguradas por Nicola Terranato - 1998) que caracteriza a identidade cabo-verdiana seiscentista.

\section{BIBLIOGRAFIA}

AMARO, Clementino (2013) - "Sé da Cidade Velha, República de Cabo Verde”, in A.Teixeira e J Bettencourt (coord.), Velhos e Novos Mundos, Estudos de Arqueologia Moderna, vol. 1. Lisboa, Centro de História de Além Mar, pp.452-464.

BRÁSIO, António (1968) - Monumenta Missionária Africana, 2ª̣ . série, vol. IV. Lisboa, Agência Geral do Ultramar.

CABRAL, Iva (1995) - "Ribeira Grande: vida urbana, gente, mercancia, estagnação”, in Maria Emília Madeira Santos (coord.) História Geral de Cabo Verde. Lisboa, Instituto de Investigação Nacional, vol. II, pp. 225-274.

CABRAL, Iva; SANTOS, Maria Emília Madeira; SOARES, Maria João; TORRÃO, Maria Manuel Ferraz (2012) - Cabo Verde, uma experiência colonial acelerada (séculos XVI-XVII). http://www.portaldoconhecimento.gov. cv/bitstream/10961/358/1/Cabo\%2oVerde\%2oUma\%20 Experi\%C3\%A Ancia\%2oColonial\%2oAcelerada\%2o \%28Sec.XVI-VII\%29.pdf [Consultado a 09-03-2020]

CALADO, Marco; PIMENTA, João; FERNANDES, Lidia; MARQUES, António (2013) - Os cachimbos cerâmicos do Palácio Marialva", in Revista Portuguesa de Arqueologia. Lisboa: 16, pp. 383-392.

CARDOSO, João Luís; SOARES, António Manuel Monge (2010) - "A estação arqueológica de Salamansa (ilha de São Vicente, República de Cabo Verde)". Revista Portuguesa de Arqueologia: 13. Lisboa, pp. 167-214.

DUCO, Don H. (1982) - Merken van Goudse Pijpenmakers 166o-1940. Amsterdam: Pijpenkabinet.

DUCO, Don H. (2003) - Merken in merkenrecht van de pijpenmakers in Gouda. Amsterdam: Pijpenkabinet.

ENGMANN, Rachel Ama Asaa (2018) - "Dutch Clay Smoking Pipes from Christiansborg Castle, Ghana, West Africa”. Society for Clay Pipe Research Newsletter: 93 - 40-52.

MIMOSO, Alexandre Brás (2016) - “Interpretação e consolidação da Sé da Cidade Velha em Cabo Verde", Sumara. Cidade da Praia: Fundação João Lopes, ano II, n.. 2 (https://www. academia.edu/39530791/Interpreta\%C3\%A7\%C3\%A30_e_ consolida\%C3\%A7\%C3\%A3O_da_S\%C3\%A9_da_Cidade_ Velha_em_Cabo_Verde) [Consultado a 09/03/202O].

PIMENTA, João; CALADO, Marco; SILVA, Rodrigo Banha da (2008) - "Cachimbos de cerâmica provenientes da escavação do Caminho da Ronda no Castelo de São Jorge, Lisboa" , in Hélder Abraços e João Diogo (Eds.) Actas das $4^{\underline{a}} \mathrm{~s}$ Jornadas de Cerâmica Medieval e Pós-Medieval (Tondela, 2000). Tondela: Câmara Municipal de Tondela, pp. 335-353.
RUTTER, Janet; DAVEY, Peter (1980) - 'Clay pipes from Chester', in P. Davey (ed.) The Archaeology of the clay tobacco pipe III Britain: the north and west. Oxford, BAR British Series: 78, pp. 40-272.

TAVARES, Nireide Pereira(2017) - Inventário Arqueológico de Cabo Verde: contributo para uma ferramenta de gestão e valorização do Património Cultural. Lisboa: Universidade de Lisboa, Faculdade de Letras (dissertação de mestrado - https://repositorio.ul.pt/bitstream/10451/28730/1/ ulfl234009_tm_Vol-\%20I.pdf) [Consultado a 10/o6/2020].

TEIXEIRA, André; BETTENCOURT, José(coord.) (2013) VelhoseNovosMundos,EstudosdeArqueologiaModerna,vol.1. Lisboa, Centro de História de Além Mar.

TERRANATO, Nicola (1998) - “The Romanization of Italy: Global Acculturation or Cultural Bricolage?”, in TRAC 97: Proceedings of the Seventh Annual Theoretical Roman Archaeology Conference, Nottingham 1997. Oxford: Oxbow Books, pp. 20-27. 


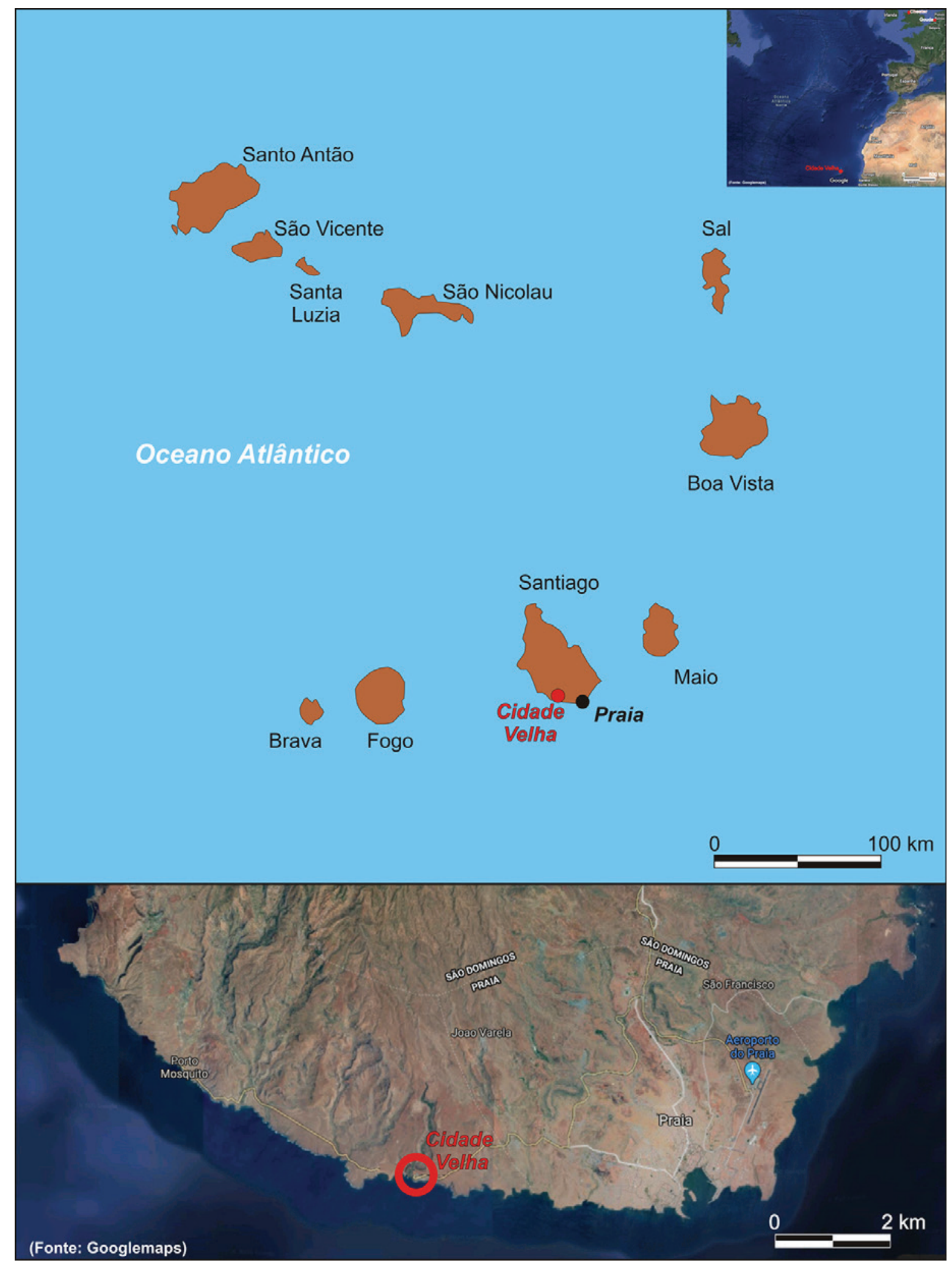

Figura 1 - República de Cabo Verde e sul da Ilha de Santiago com localização da Cidade Velha. 


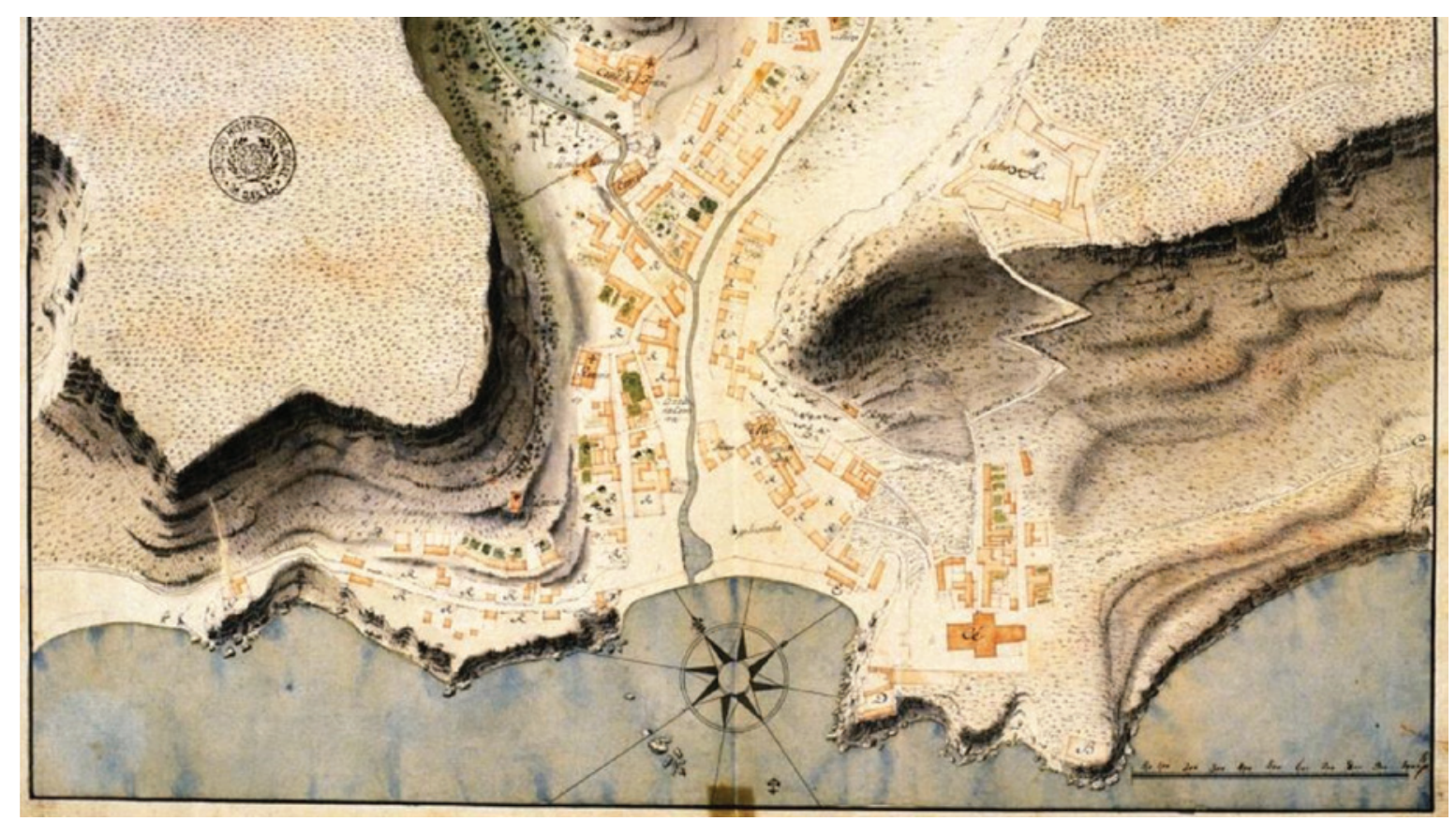

Figura 2 - Planta da Cidade de Ribeira Grande ("Cidade Velha) de José Carlos Andreias, 1769 (Arquivo Histórico Ultramarino, s/n.o). (Segundo Mimoso, 2016, p. 39, fig.27).

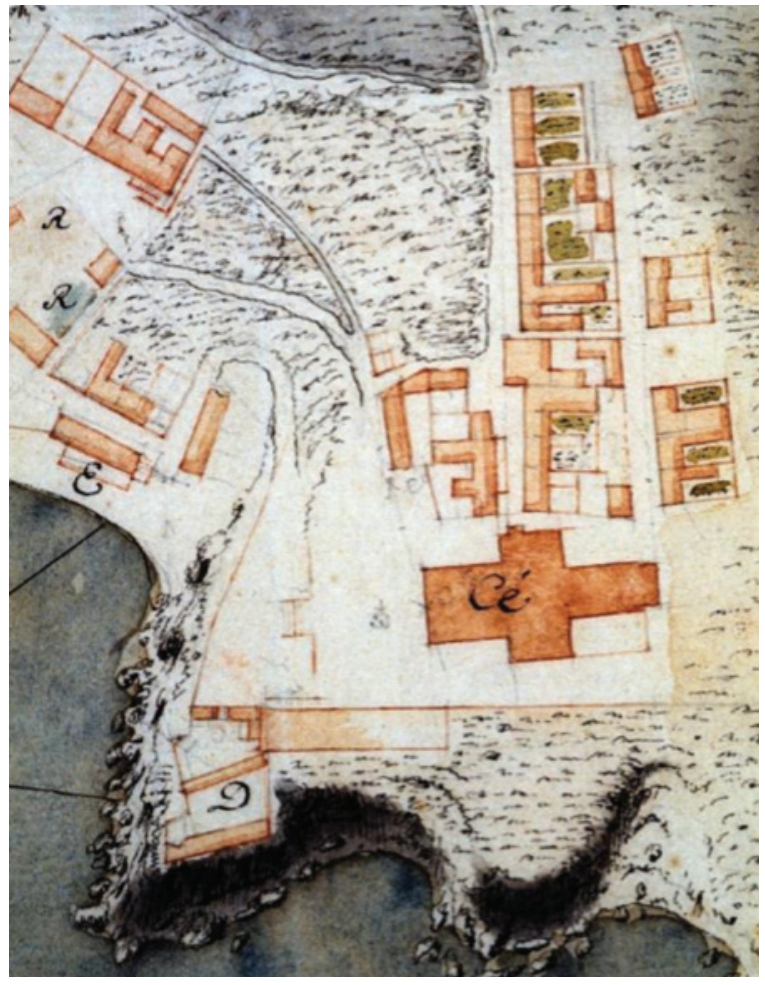

Figura 3 - Detalhe da planta anterior com a localização da Sé (Idem: p. 39, fig. 28).

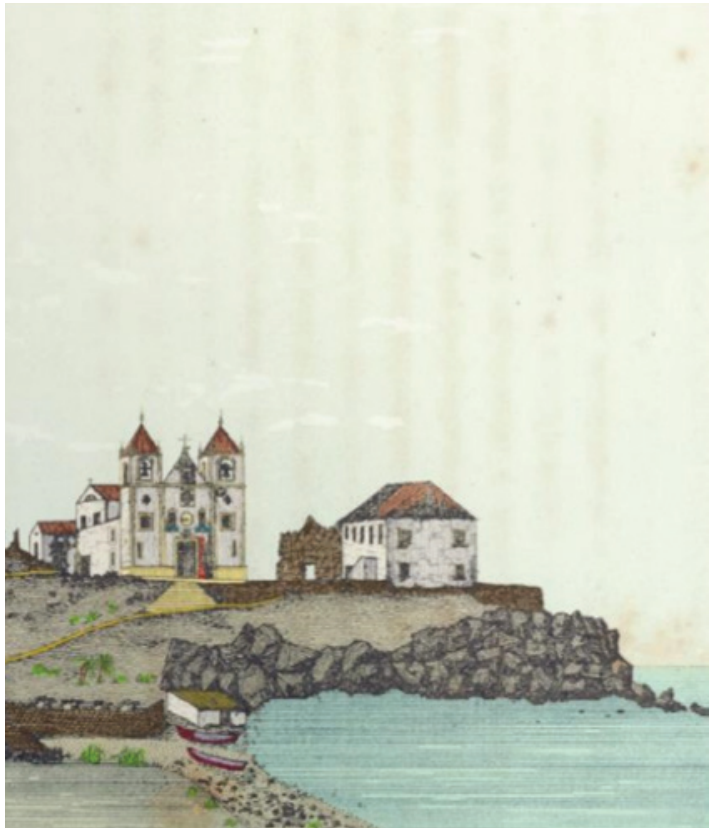

Figura 4 - Detalhe com a fachada da Sé de gravura de Francico Travassos Valdez, 1869 (Idem: p. 43, fig. 29). 


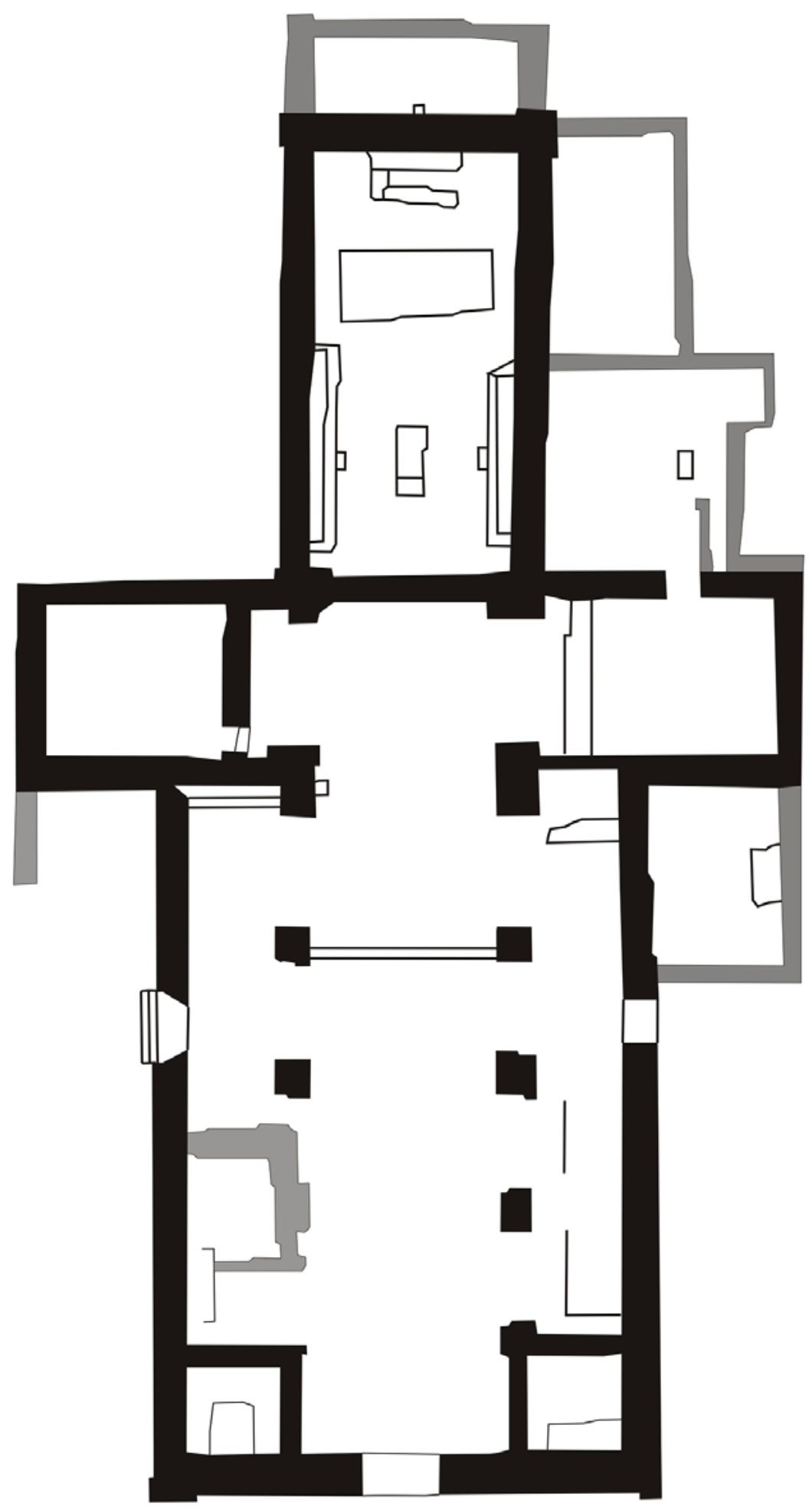

Figura 5 - Planta simplificada da Sé da Cidade Velha (Segundo levantamento da Univ. Beira Interior, adaptada). 

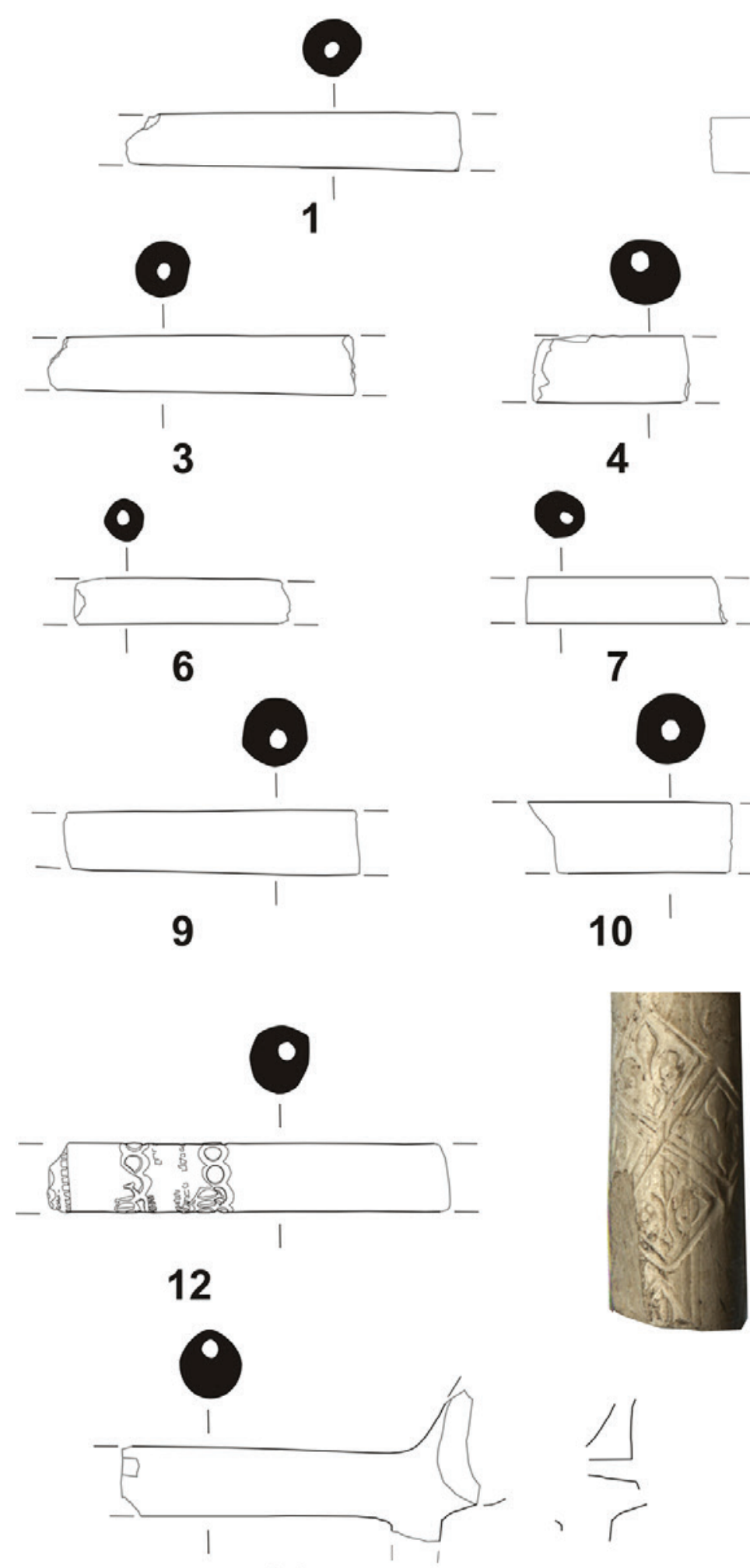

14
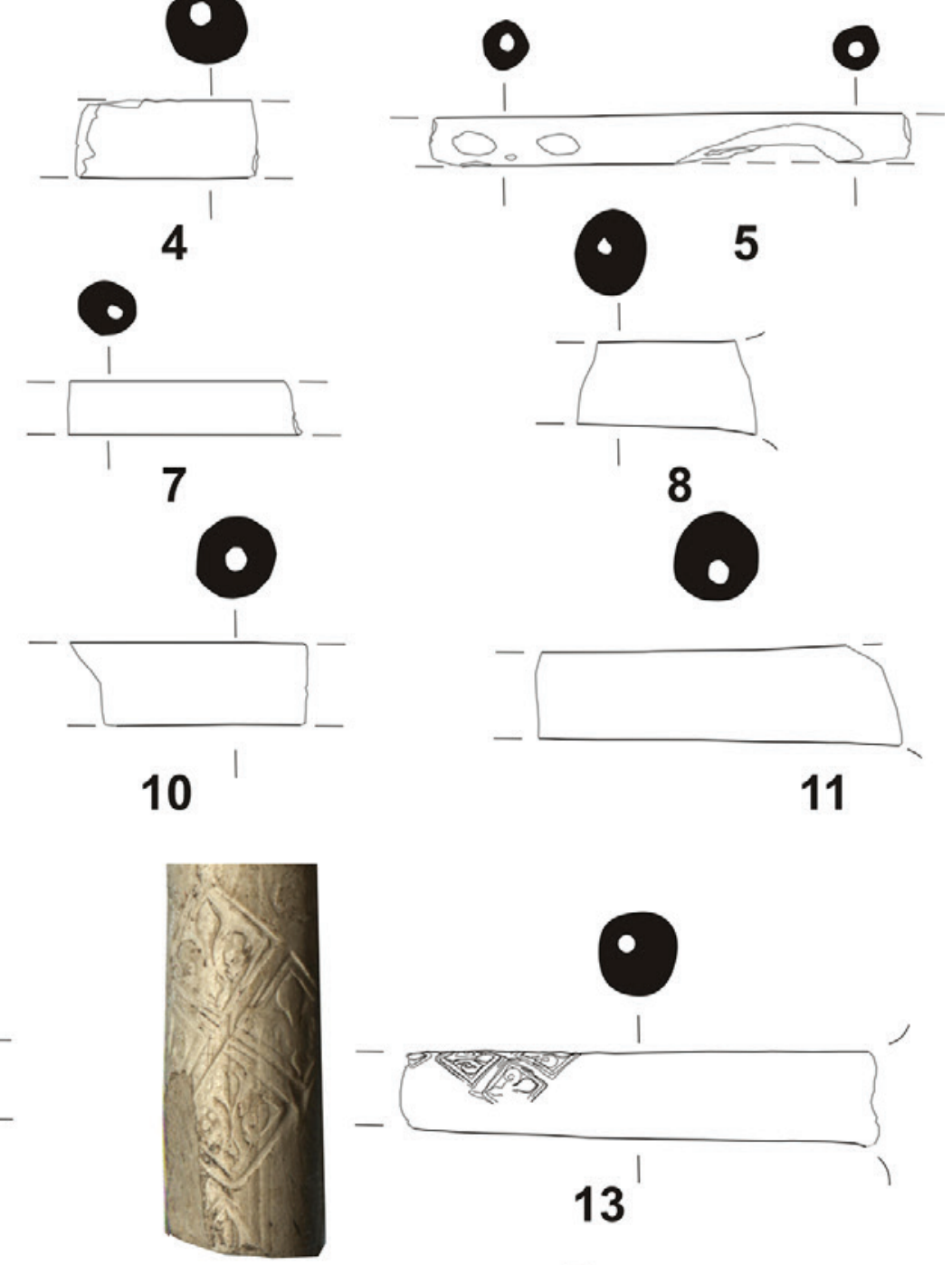

Esc.1/1 (foto 2/1)

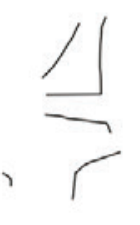

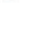



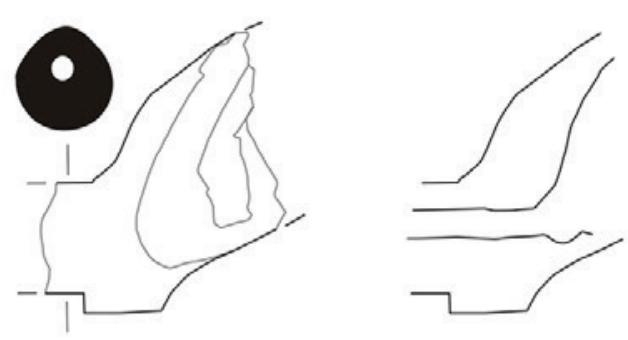

16
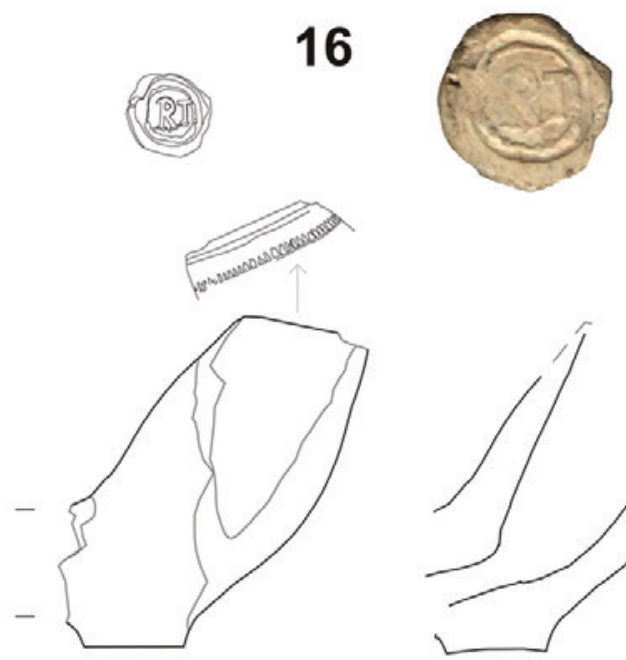

18

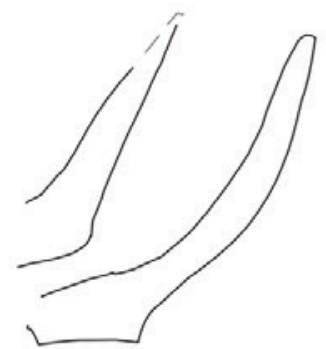

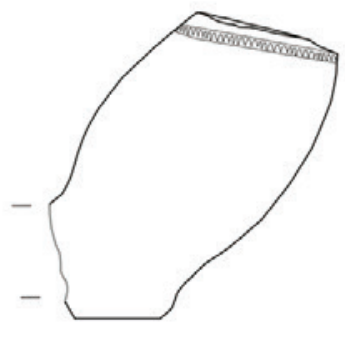
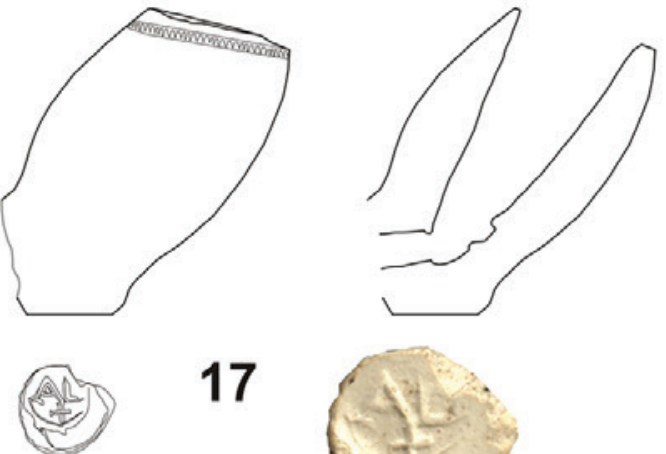

17
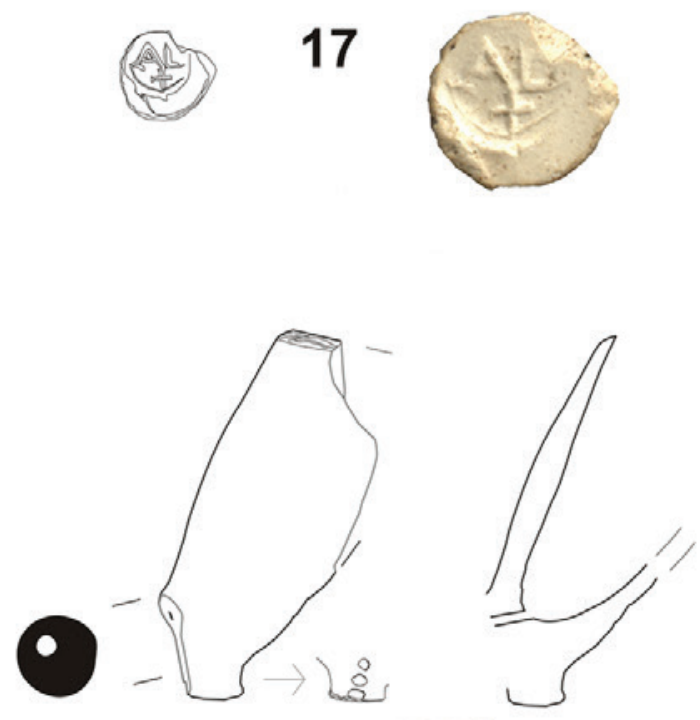

19

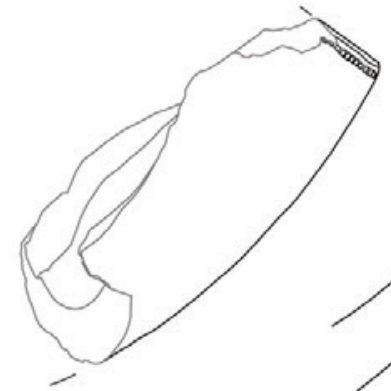

20

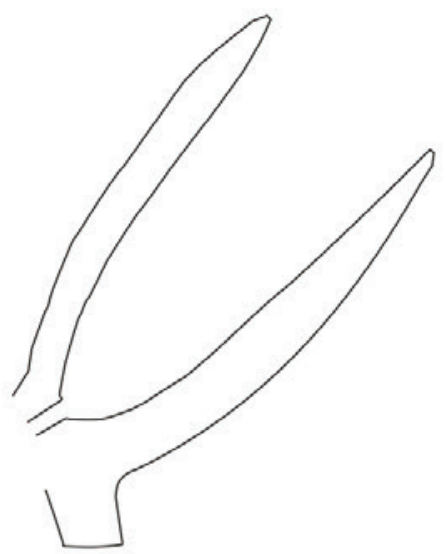

Esc.1/1 (fotos 2/1)
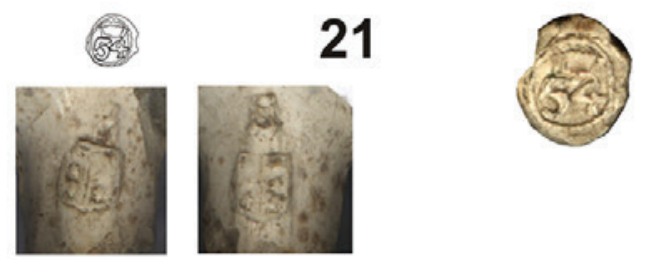

$5 \mathrm{~cm}$

Figura 7 - Fragmentos de fornilho de cachimbos em cerâmica caulínica das escavações de 1989-1993 da Sé da "Cidade Velha" (República de Cabo Verde). 


\title{
ALGUMAS CONSIDERAÇÕES SOBRE ESPÓLIO NÃO CERÂMICO RECUPERADO NO LARGO DE JESUS (LISBOA)
}

\author{
Carlos Boavida ${ }^{1}$
}

\begin{abstract}
RESUMO
Em 2005, a construção de um parque de estacionamento subterrâneo no Largo de Jesus, em Lisboa, levou à realização de uma intervenção arqueológica, num espaço que corresponde ao antigo adro da Igreja de Jesus, actual igreja paroquial das Mercês. Além de outros vestígios, ali foram identificadas as fundações de uma escadaria de acesso à igreja, assim como diversas estruturas murárias, ao que tudo indica, anteriores ao Terramoto de 1755 e relacionadas com uma zona de armazéns que poderiam ter pertencido ao palácio Mendia, a Oeste do largo e totalmente remodelado após o sismo. A intervenção permitiu também verificar que distintas obras de remodelação daquele espaço foram progressivamente eliminando as realidades espaciais anteriores, comprometendo e dificultando a sua leitura, pois afectaram daquele modo todos os contextos estratigráficos detectados.

São numerosos os vestígios das materialidades quotidianas que se encontravam naquelas realidades, com especial destaque para os recipientes cerâmicos; no entanto, é objectivo deste trabalho dar a conhecer alguns dos artefactos não cerâmicos ali recuperados.
\end{abstract}

Palavras-chave: Lisboa, Época Moderna, Artefactos não cerâmicos.

\begin{abstract}
The construction of an underground car park at Largo de Jesus, in Lisbon, led to an archaeological intervention in 2005. That space corresponds to the old churchyard of the Jesus' Church, the Mercês' current parish seat. In addition to other remains, the foundations of the staircase leading to the church were identified, as well as several wall structures. Some of those seem to be prior to the 1755 earthquake and related to an area of warehouses that could have belonged to the Mendia palace, on the west side of the square, completely remodeled after the earthquake. The intervention also made it possible to verify that different rebuilding works on that place eliminated, progressively, the previous spatial realities, affected it in all the stratigraphic contexts detected, compromising and hindering their reading.

There are numerous remains of everyday material that were found in those realities, with special emphasis on ceramic containers; however, the objective of this work is to present some of the non-ceramic artifacts recovered there.
\end{abstract}

Keywords: Lisboa, Modern Age, Non-ceramic artifacts.

\section{EVOLUÇÃO URBANA E A INTERVENÇÃO ARQUEOLÓGICA NO LARGO DE JESUS (2005)}

O Largo de Jesus, antigo adro da igreja daquela invocação, foi alvo de uma intervenção arqueológica no âmbito da construção de um parque de estacionamento subterrâneo em 2005. Aqueles trabalhos foram coordenados por Maria João Santos, então colaboradora da empresa GeoArque (Santos, 2005). A igreja e respectivo convento foram erguidos no final do século XVI, por iniciativa da Ordem Terceira de São Francisco, estando a obra concluída na centúria seguinte (Cardoso, 2004: 15-16). Junto da igreja foi também instituído um hospício que actualmente permanece em funcionamento como hospital (Figura 1A).

Através de uma imagem oitocentista anónima, pu-

1. IAP-FCSH/UNL; AAP. 
blicada por Ferreira de Andrade (1945: 95), é possível verificar que no adro da igreja, fronteiro à sua fachada principal, existia um pequeno escadório ladeado por volutas (Figura 1B). Embora aquela estrutura tenha sido demolida no século XIX devido a alterações à circulação no local, os trabalhos arqueológicos ocorridos em 2005 permitiram a identificação das suas fundações (Santos, 2007: 382; 2017: 192) (Figura 1C).

Estes vestígios encontravam-se sobre vários depósitos, muito revolvidos, que nivelaram a área do largo, onde existe uma pendente natural do terreno, principalmente do lado Este. Nestes níveis foi recuperado diverso espólio dos séculos XVII e XVIII, em muitos casos com evidências de exposição ao fogo, eventualmente relacionadas com os incêndios provocados na sequência do Terramoto de 1755 . Foram igualmente encontrados alguns restos osteológicos humanos desconexos (Santos, 2017: 192).

Após a remoção daqueles depósitos foram colocados à vista vários compartimentos constituídos por muros paralelos entre si, em alvenaria, muito provavelmente anteriores ao Terramoto de 1755 , associados aos quais foi recolhida grande quantidade de fragmentos de cerâmica de construção. Foram igualmente encontrados escassos restos de pavimento, assim como algumas talhas, evidência de uma possível área de armazéns que terá pertencido ao palácio $\mathrm{Mendia}^{2}$, a Oeste do largo, e que terá sido remodelado após o sismo (Santos, 2007: 389-392) (Figura 1D). Este palácio, cuja entrada seria feita pela então Rua Larga de Jesus (actual Rua dos Poiais de São Bento), foi residência de várias individualidades, entre os quais se destacam, no final do século XVII, o Desembargador Diogo Carvalho de Sequeira e, ao longo de quase toda a primeira metade do século XVIII, a família de Manuel Vasconcelos e Sousa. Este último, além de trinchante-mor do rei D. Pedro II, era filho do 2.. Conde de Castelo Melhor, irmão do $3 .^{\circ}$ titular dessa casa e também de D. António Vasconcelos e Sousa, que foi Bispo de Lamego e. mais tarde. de Coimbra (Flor, 2017).

A par das estruturas murárias referidas foi ainda identificado um depósito onde abundavam restos de revestimento e grelha de forno cerâmico, juntamente com loiça chacotada e várias trempes (Santos, 2007: 387-389; 2017:192-193). Estes achados deverão

2. Esta designação surge, a partir de 1861, quando José Matheo de Mendia y Elorza adquiriu o edifício. corresponder a olaria aqui existente, ou nas proximidades, em data anterior à construção do Palácio Mendia, pois o espólio que surge associado a estes vestígios remonta ao final do século XVI e meados do século XVII (Cardoso \& Batalha, 2017: 147-148; Santos, 2017: 193-194). A reorganização urbana que se verificou nesta zona com a fundação do Convento de Jesus terá levado à desactivação das olarias próximas (Cardoso \& Batalha, 2017: 161).

\section{ESPÓLIO ARQUEOLÓGICO RECUPERADO - PEQUENA SÍNTESE}

Apesar de várias intervenções ocorridas no Largo de Jesus terem progressivamente comprometido a leitura dos contextos ali existentes, as escavações arqueológicas de 2005 possibilitaram a identificação de vestígios de diversas estruturas. Além destas, embora os depósitos estratigráficos se encontrassem muito revolvidos, foi recuperado um importante conjunto de materiais, nomeadamente cerâmicos, nos contextos associados aos restos do forno. Foram igualmente recolhidos alguns numismas, na maioria, do reinado de D. Sebastião (Cardoso \& Batalha, 2017).

Nos outros contextos referidos foram encontrados também variados tipos cerâmicos (Sousa, 2007: 393399), assim como objectos em vidro, sendo estes últimos atribuídos aos finais do século XVI e primeira metade da centúria seguinte (Boavida, 2017a).

Além destes, embora em quantidades muito reduzidas (quando não apenas raros exemplares) foram recuperados também artefactos produzidos com ligas metálicas, distintas matérias de origem animal e azeviche.

\section{ARTEFACTOS METÁLICOS}

Os alfinetes e as agulhetas são os mais numerosos deste conjunto.

No caso dos primeiros (Figura 2A), trata-se de pequenas hastes de cobre às quais foi enrolado fio do mesmo material constituindo a cabeça. Além de poderem ter sido usados como elementos de vestuário, a sua presença é também comum em contextos funerários, pois eram frequentemente usados nos sudários (Boavida, 2016).

Em relação às agulhetas (Figura $2 \mathrm{~B}$ ), elas eram produzidas a partir de finas folhas de cobre, enroladas em formato afunilado, sendo depois aplicadas na 
ponta de atilhos. Alguns exemplares mostram marca de punção junto da extremidade mais larga, que permitia a fixação do fio no seu interior. Estes dois tipos de elementos de vestuário são normalmente encontrados em contextos arqueológicos portugueses atribuídos a cronologias entre os séculos XV e XVII (Fernandes \& Carvalho, 1997; Mourão, 2004; Nolen, 2004; Cardoso, 2007; Cardoso, 2008; Boavida, 2016; 2017b). Sendo peças de pequena dimensão, facilmente se dispersam surgindo muitas vezes fora de contexto. A sua presença é recorrente na iconografia da época, principalmente as agulhetas, que aparecem em quase todas as obras da Escola Portuguesa de Pintura dos séculos XV e XVI (Boavida, 2016). Tal facto é raro em relação aos alfinetes, em obras de autores portugueses, mas usual nas realizadas pela mão de pintores flamengos, onde podem ser vistos a auxiliar a fixação de véus e toucados (Boavida, 2016). Além desta função, este tipo de alfinetes pode estar igualmente relacionados com actividades como a costura, em particular quando são encontrados em associação com dedais (Nolen, 2004), que também foram recolhidos no Largo de Jesus, mas não nos mesmos contextos estratigráficos. Estes objectos (Figura ${ }_{2} \mathrm{C}$ ), de cobre, têm formato cónico com a extremidade distal plana. Normalmente são usados como auxiliar para empurrar agulhas ou alfinetes na perfuração dos tecidos a coser, tendo a superfície externa, quase sempre, preenchida na totalidade por pequenas concavidades que evitam que a cabeça daqueles deslize sobre a superfície do dedal. Servem igualmente para proteger a cabeça do dedo de eventuais picadas.

Os seis dedais encontrados no Largo de Jesus estão muito danificados, apresentando todos evidências de esmagamento, estando três totalmente esmagados e desfeitos. São idênticos a um outro presente no painel da "Anunciação" que integra o retábulo da Sé de Viseu, atribuído a Francisco Henriques (?-1518) e Vasco Fernandes (1475-1542) (Henriques, 2010) (Figura 4A).

Foi recolhido também parte de um pequeno colchete de cobre (Figura 2D). Estes elementos de vestuário, normalmente em pares, sendo a fêmea em forma de argola e o macho em formato de gancho, articulam-se entre si para prender diferentes partes do vestuário. No caso do Largo de Jesus trata-se um colchete fêmea.

Entre os artefactos metálicos colectados no âmbito da intervenção arqueológica estão igualmente dois que se podem classificar como objectos sonoros. São eles um fragmento de guizo e um címbalo, ambos de cobre.

O guizo (Figura 2E), do qual só se preserva um quarto da peça, correspondendo aquela a metade de uma das meias esferas que o constitui. Apresenta a superfície externa dividida em quartos, por pequena nervura, tendo aqueles uma perfuração na zona central. Este tipo de objecto poderia ter distintas funções. Embora o seu uso possa estar relacionado com a falcoaria, os guizos também surgem associados às vestimentas de alguns clérigos, pois existia a convicção de que o som provocado por estes afastava os maus espíritos (Deagan, 2002: 140). Veja-se a esse propósito alguns retábulos portugueses do século XVI que se encontram nas colecções do Museu Nacional de Arte Antiga, nomeadamente os provenientes do Convento de Santa Joana (Lisboa) e da Ermida de Nossa Senhora do Paraíso (Lisboa), respectivamente da autoria de Garcia Fernandes (1514-1565) e de Gregório Lopes (1490-1550) (Figuras 4B/4C).

Tal como os colchetes, os címbalos (Figura $2 \mathrm{~F}$ ) também funcionam mediante a presença de um par, ou associados a pandeiretas, que eram usados tanto em cerimónias religiosas como profanas (Boavida, 2017b).

No âmbito de um outro trabalho sobre objectos metálicos usados na cozinha e à mesa, foi publicado preliminarmente um fragmento de eventual escumadeira de cobre recolhido no Largo de Jesus (Boavi$\mathrm{da}, 2017 \mathrm{c}$ ) (Figura 2H). Devido à sua fragilidade, pois trata-se de fina folha metálica, redonda e algo côncava, com várias perfurações, são raros os achados desta forma em contexto arqueológico. A sua presença é frequente em diversas pinturas flamengas, dos séculos XVI e XVII, tanto em naturezas-mortas como em cenas que mostram espaços de cozinha, como por exemplo "Natureza morta com peixe e gato" de Wallerant Vaillant (1623-1677) (Boavida, 2017c: 128) (Figura 4D).

No que diz respeito aos utensílios de cozinha, a colecção de objectos metálicos do Largo de Jesus inclui também um elemento de cabo de faca (Figura $2 \mathrm{G}$ ). Trata-se peça de cobre, de formato sub-hemisférico, que era colocada entre o cabo, provavelmente de madeira, e a lâmina da faca. Ao centro, mostra incisão triangular onde encaixava o espigão de fixação daquela ao cabo. É quase sempre esta a forma básica de uma faca, com uma lâmina de secção sub-triangular e formato idêntico alongado, por vezes com a ponta 
arredondada. Este utensílio extramente versátil, com poucas variações desde a Antiguidade, também surge por vezes com cabo metálico na continuidade da lâmina, no qual, por meio de rebites, são fixados peças de madeira ou outros materiais mais nobres como marfim, madrepérola ou diferentes pedras duras.

São conhecidos vários exemplares de facas desta cronologia na região de Lisboa, alguns com peças de madeira aplicada no cabo, onde se destaca a colecção de objectos metálicos de Carnide (Boavida, 2017b: 1824 e 1832, figs. 5A-5B). As facas são um objecto recorrente, normalmente sobre mesas, na iconografia de várias escolas de pintura europeias. Veja-se a esse propósito o já citado retábulo de № . $\mathrm{Sr}^{\mathrm{a}}$. do Paraíso (Figura 4 F). No painel da "Última Ceia", do retábulo do Convento de São Francisco (Évora), há uma personagem que usa uma faca para palitar os dentes (Figura 4E). Peças idênticas surgem também em obras de Josefa d'Ayala Figueira ${ }^{3}$ (1630-1684), de Diego Velásquez (1599-1660), de António de Pereda (1611-1678), de Georg Flegel (1566-1638) e de Jan Steen (1626-1679), só para citar alguns exemplos de várias escolas de pintura europeias (Figuras 4G-4K). Entre as peças de vidro encontradas neste arqueossítio foi identificado o gargalo de garrafa quadrangular cuja tampa seria em chumbo, como atestam os restos de rosca naquela matéria (Boavida, 2017a). Estas tampas de chumbo normalmente apresentavam na parte superior uma pequena argola, fixa por meio de um espigão, que se articula com outra argola de maior dimensão. Entre os artefactos metálicos recolhidos está precisamente um espigão deste tipo com as respectivas argolas (Figura 2I). Provavelmente estas argolas estavam associadas a uma corrente pendente da rosca, impossibilitando assim a perda da tampa. Exemplares deste tipo podem ser vistos em pinturas de origem flamenga, como "Natureza morta com instrumentos musicais" de Pieter Claesz (1597-1661) (Figura 4N).

Foram ainda recuperados outros elementos, de cobre, que terão pertencido a peças de mobiliário, a saber, três pregos de forro de cadeira (Figuras 2J-2L), um provável puxador (Figura $2 \mathrm{M}$ ) e fragmento de uma dobradiça (Figura $2 \mathrm{~N}$ ).

A dobradiça é exactamente igual a outras duas encontradas em Carnide, estando uma daquelas completa ao contrário de o exemplar agora apresentado (Boavida, 2017b: 1823). Trata-se de um elemento que

3. Dita Josefa d'Óbidos. seria provavelmente de um armário copeiro ou de outra peça de mobiliário de algum aparato. Os eixos de fixação, tal como nas dobradiças de Carnide, encontram-se dobrados, permitindo perceber qual a espessura das tábuas de madeira que constituíam o móvel.

Entre os objectos metálicos foram ainda recolhidas algumas aparas de cobre, assim como duas peças em chumbo cuja função não foi possível determinar.

\section{ARTEFACTOS EM OSSO, MARFIM, MADREPÉROLA E AZEVICHE}

Neste grupo está incluída uma série de objectos frequentemente raros em contextos arqueológicos, uma vez que as matérias em que são produzidos são muito perecíveis. Subsistem no entanto, em colecções museológicas, exemplares bem conservados, na maioria dos casos completos, que dizem respeito a objectos vistos como coleccionáveis por quem os adquiriu e não para uso quotidiano.

Em osso foram recuperados quatro conjuntos de pequenos elementos cilíndricos, algo facetados, com um acabamento pouco regular, como se o seu talhe não tivesse sido concluído (Figura 3A). Uma das pontas é totalmente plana, como que truncada, enquanto a outra é algo desbastada, em cunha, talvez para permitir a sua fixação em embutido em peças de mobiliário, como por exemplo as designadas cadeiras de braços de Mombaça (Henriques, 2003: 144; Dias, 2004: 18). Estas peças de embutir surgem muitas vezes também em marfim, matéria em que existem também dois elementos com idênticas características aos produzidos em osso, mas ambas as extremidades são truncadas e o acabamento é de muito melhor qualidade. Um deles é substancialmente maior que todos os outros.

Um destes elementos mostra numa das extremidades uma pequena protuberância, muito provavelmente realizada ao torno. É pouco provável que este tenha tido a função que aqui se atribuí aos demais, embora também não se possa excluir a hipótese de que todos estes elementos tenham tido função distinta, que não foi possível aferir. $\mathrm{O}$ seu aspecto irregular, como referido anteriormente, pode indicar que se trata de peças inacabadas, possível evidência da existência de pequena oficina artesanal de talhe de objectos/elementos em osso que funcionaria no Largo de Jesus, ou nas suas proximidades. Da segunda metade do século XVI, é conhecida a presen- 
ça de oficina de talhe de objectos em osso na antiga prisão do Aljube (Ferreira, 2005/2006). Uma outra oficina, oitocentista, foi localizada no Largo da Atafona, onde se produziam maioritariamente botões (Vieira et al., 2019).

Também em osso foi recolhido uma empunhadura (Figura 3 B). A sua pequena dimensão prossupõe que seria de um talher, talvez o cabo de uma faca ou garfo. De secção sub-quadrangular, apresenta decoração incisa na face externa em padrão de losangos, no centro dos quais está um pequeno círculo com ponto central, ambos provavelmente obtidos com recurso a punção. Só se preserva, muito danificada, metade desta peça.

Um outro fragmento de talher, neste caso em marfim, que poderá ter sido uma colher ou garfo, mostra cabeça e parte do pescoço de uma ave de pico longo e ligeiramente entreaberto (Figura ${ }_{3} \mathrm{C}$ ). O corpo e a cabeça, onde sobressaem dois olhos circulares, são preenchidos por recticulado inciso reproduzindo as penas. Objectos deste tipo, produzidos nesta matéria, são referidos em diversa documentação alfandegária, em crónicas e inventários, ao longo de grande parte do século XVI e da centúria seguinte, provindos de regiões que hoje fazem parte da Serra Leoa e do Benim (Bassani \& Fagg, 1988: 59-6o). A primeira referência inequívoca a colheres vindas daquele último território remonta a 1588, sendo então descritas como peculiares colheres feitas a partir de dente de elefante, de diversos tamanhos, decoradas comvariados animais e aves; no entanto, colheres com estas características já se encontravam presentes, pelo menos desde 1560, em algumas colecções europeias (Bassani \& Fagg, 1988: 150).

Trabalhos de reclassificação dos marfins afro-portugueses nas colecções etnográficas do Museu Britânico, nos anos 50/6o do século XX, levaram a que algumas peças que apresentavam semelhanças com outros objectos artesanais provindos do Benim, fossem então designados como Bini-Portuguesas (Bassani \& Fagg, 1988: 150).

Tratando-se de uma produção artesanal, não há peças iguais entre si, embora alguns dos elementos escultóricos se repitam. É o caso de colheres de marfim presentes nas colecções do Museu Etnológico de Dresden ou dos Museus Estatais de Braunschweig, ambos na Saxónia, em cujo cabo surge ave de bico longo, algo entreaberto, como no exemplar encontrado no Largo de Jesus (Bassani \& Fagg, 1988: 242245 , figs. 137, 142, 148 e 166). As três primeiras aqui referidas pertenciam à colecção do Príncipe Christian da Saxónia, tendo sido registadas em 1590 e a última surge pela primeira vez em 1805, no inventário da Câmara de Maravilhas do Duque que então governava aquele estado germânico.

Talvez com idêntica origem, subsiste um pequeno fragmento de marfim, com algumas linhas incisas, que parece ter constituído parte de figura de vulto, talvez integrada em saleiro, mas a sua forma pouco clara não permite outras considerações (Figura 4D). Igualmente em marfim, mas com origem distinta, foi colectado um pequeno bordão de peregrino de Santiago de Compostela (Figura 3E). Trata-se de pequena haste, trabalhada ao torno, o que criou vários conjuntos de caneluras. Tal como as conchas de vieira (Pecten maximus) também estes pequenos objectos eram colocados nos chapéus e na roupa dos romeiros. Vários exemplares podem ser vistos na indumentária de Stephan Praun III, peregrino alemão que viveu na segunda metade do século XVI, que integra a colecção do Museu Nacional Germânico de Nuremberga (Franco Mata, 1986: 133 e 145, figs. 1 e 6). Um outro chapéu, actualmente no Museu de Poznań, e que terá pertencido a peregrino polaco do século XVII, mostra vários pequenos bordões em marfim, juntamente com outros símbolos compostelanos (Franco Mata, 2005: 180 e 201, fig. 24).

Também a iconografia alusiva a esta temática mostra por vezes a utilização deste elemento associado aos peregrinos. É o caso da tela seiscentista intitulada "Menino Jesus vestido de romeiro de Santiago", de eventual discípulo de Josefa de Óbidos ${ }^{4}$, que se encontra no Museu de Aveiro, onde podem ver-se no manto alguns exemplares (Figura $4 \mathrm{O}$ ). $\mathrm{O}$ mesmo sucede no chapéu do próprio Santiago, que surge a abençoar uma freira dominicana, numa obra da oficina de Mestre Hilário ${ }^{5}$ (Coimbra), na colecção do mesmo museu, atribuída ao início do século XVI (Figura $4 \mathrm{P}$ ). Numa das pinturas de um retábulo, da primeira metade daquela centúria, da autoria dos Mestres de Ferreirim, que se guarda no Museu Nacional Machado de Castro, surgem São Simão e São Tiago Maior. No chapéu deste último, junto da concha de vieira, estão dois pequenos bordões cruzados (Figura 4Q).

\footnotetext{
4. Informação conforme Matriznet (consultado em Junho 2020).

5. Informação conforme Matriznet (consultado em Junho 2020).
} 
A Arqueologia também já permitiu identificar peça deste tipo. Foi encontrada, a par com duas conchas de vieira e uma miniatura de cabaça, junto da cabeça de um peregrino, do século XVI, sepultado no cemitério da igreja de Saint-Martin de Vevey, na Suiça (Picod, 2018: 42, fig. 2).

Recuperaram-se no Largo de Jesus mais três peças em marfim. Uma delas é uma pequena ficha de jogo (Figura $3 \mathrm{G}$ ), de formato circular, semelhante a outras encontradas no Convento de Sant'Ana, em Lisboa (Gomes, Gomes \& Gonçalves, 2017: 96).

Outra, tendo em conta o seu diâmetro e espessura, parece corresponder a fragmento de seringa de lavagens (Figura $3 \mathrm{H}$ ), também com paralelos naquele último arqueossítio (Gomes, Gomes \& Gonçalves, 2017: 92), assim como em peça de idêntica função da qual foram recolhidos vestígios num contexto associado ao Hospital Real de Todos-os-Santos (Boavida, 2017d: 447). Este instrumento é normalmente constituído por várias partes que encaixam entre si por meio de roscas, como as que se podem observar na face interna do exemplar do Largo de Jesus.

Existe também uma pequena colher, plana e muito fina (Figura $3 \mathrm{~F}$ ). A extremidade distal mostra pequena concha côncava, enquanto na extremidade proximal existe uma perfuração que certamente permitia a sua fixação, por meio de corrente, a uma caixa de rapé.

Produzido em madrepérola, a colecção incluí também um fragmento de uma travessa de cabelo, nomeadamente um dente de um destes adornos (Figura $\left.{ }_{3} \mathrm{I}\right)$.

No Largo de Jesus foi ainda recolhido um pequeno fragmento em azeviche (Figura 3J). Aquele apresenta formato espiralado, afilado na ponta, enquanto a outra extremidade está fracturada. Visto que não existe qualquer tipo de perfuração, não parece tratar-se uma conta.

Usado contra o mau-olhado, o azeviche surge frequentemente utilizado em figas, como as que foram encontradas em Santarém (Arruda, Viegas \& Almeida, 2002: 202), Coimbra (Mourão, 2004: 144) e Montemor-o-Novo ${ }^{6}$. Também na iconografia a sua presença é constante em retratos de crianças, juntamente com outros amuletos, tendo como objectivo

6. Cf. "Um objecto, uma história, mês a mês” (Março 2012), Programa do Castelo - Oficina de Arqueologia do Centro Interpretativo do Castelo de Montemor-o-Novo, flyer 9. proteger aquelas. Vejam-se a este propósito os retratos das infantes Ana Maria Maurícia e Margarida Francisca, filhas de Filipe III de Espanha, ambos da primeira década do século XVII, pintados, respectivamente por Juan Pantoja de la Cruz (1553-16o8) e Santiago Morán (1571-1626).

Embora o exemplar agora analisado não tenha o formato de uma figa, tal não invalida que possa ter integrado um pingente, engastado em metal precioso, como sucede amiúde com pontas de coral, exactamente com o mesmo objectivo, como mostram os retratos mencionados.

\section{CONSIDERAÇÕES FINAIS}

A área onde se localiza actualmente o Largo de Jesus encontrava-se na periferia da cidade de Lisboa até a meados do século XVI. A construção a Igreja de Jesus nas últimas décadas daquela centúria despoletou a integração daquele espaço na urbe, que há muito tinha ultrapassado os limites das suas muralhas, como evidencia a urbanização do vizinho Bairro Alto de São Roque (a leste) a partir de 1513.

No âmbito dos trabalhos arqueológicos realizados em 2005 no Largo de Jesus foram identificadas evidências dessas alterações, assim como também da evolução espacial daquele local. Verificou-se assim a desactivação de estruturas que deram lugar a outras, por iniciativa humana ou em resultado de catástrofes naturais, como o Terramoto de 1755 e os incêndios que lhe sucederam.

No que diz respeito ao espólio recolhido, aquele foi atribuído a um período cronológico que se estende de finais do século XVI até meados do século XVIII, data em que a ocupação do espaço se altera completamente, com a nivelação daquele para a criação do largo propriamente dito. Entre aquelas materialidades, além das habituais cerâmicas, estão alguns, raros, artefactos não cerâmicos, onde se destacam os produzidos em ligas metálicas e matérias de origem animal, nomeadamente em osso e marfim.

$\mathrm{Na}$ maioria dos casos trata-se de objectos quotidianos comuns a outros contextos arqueológicos conhecidos para estas cronologias, no entanto, outros há que são pouco frequentes. É o caso dos fragmentos de talheres em osso e marfim, que denunciam a presença de comunidades algo abastadas, provavelmente os ocupantes do Palácio Mendia. Seriam também esses os eventuais proprietários de mobiliário decorado com elementos na mesma matéria, 
caso estes não sejam provindos de possível oficina artesanal localizada nas proximidades.

Digno de nota é igualmente o pequeno bordão de peregrino, pois reflecte um aspecto das mentalidades da época. A questão que fica em aberto em relação a este objecto é se ele pertencia a algum dos residentes na zona ou se foi perdido por algum romeiro que tenha passado por aqui.

\section{AGRADECIMENTOS}

Guilherme Cardoso, António Marques, Nathalie Antunes-Ferreira, Joana Gonçalves, Edgar Fernandes e João Pedro Boavida pelos esclarecimentos sobre diversos aspectos, assim como a indicação e cedência de alguma bibliografia.

Centro de Arqueologia de Lisboa - CML pela cedência do espólio para o seu estudo e publicação.

\section{BIBLIOGRAFIA}

“Um objecto, uma história, mês a mês" (Março 2012). Programa do Castelo - Oficina de Arqueologia do Centro Interpretativo do Castelo de Monte-o-Novo. Montemor-o-Novo: Câmara Municipal (flyer 9).

ANDRADE, Ferreira de (1945) - A Igreja de Nossa Senhora de Jesus. Olisipo - Boletim do Grupo Amigos de Lisboa, 30. Lisboa: Grupo Amigos de Lisboa, pp. 85-99.

ARRUDA, Ana Margarida; VIEGAS, Catarina; ALMEIDA, Ma․ José (coord.) (2002) - Scallabis a Santarém (catálogo da exposição no Museu Nacional de Arqueologia). Lisboa: Museu Nacional de Arqueologia / Instituto Português dos Museus.

BASSANI, Ezio; FAGG, William Buller (1988) - Africa and the Renaissance: Art in Ivory. New York: The Center for African Art / Prestel-Verlag.

BOAVIDA, Carlos (2016) - "Objectos de uso pessoal medievais e modernos no castelo de Castelo Branco" in VILAÇA, R. (coord.) Actas do II Congresso Internacional de Arqueologia da Região de Castelo Branco. Castelo Branco: Sociedade dos Amigos do Museu de Francisco Tavares Proença Júnior, pp. 391-405.

BOAVIDA, Carlos (2017a) - "Entre copos e garrafas. Os vidros do Largo de Jesus" in SENNA-MARTINEZ, J. C.; MARTINS, A. C.; MELO, A. A.; CAESSA, A.; MARQUES, A.; CAMEIRA, I. (edit.) Diz-me o que comes. . Alimentação antes e depois da cidade (Fragmentos de Arqueologia de Lisboa 1). Lisboa: Centro de Arqueologia de Lisboa / Câmara Municipal de Lisboa, Secção de Arqueologia / Sociedade de Geografia de Lisboa, pp. 131-137.

BOAVIDA, Carlos (2017b) - "Dos objectos inúteis, esquecidos ou perdidos. Os artefactos metálicos do Largo do Coreto
(Carnide, Lisboa)" in ARNAUD, J. M.; MARTINS, A. (edit.) Arqueologia em Portugal. 2017 - Estado da Questão. Lisboa: Associação dos arqueólogos Portugueses, pp. 1821-1834.

BOAVIDA, Carlos (2017c) - "Preparar, servir e comer. Vestígios arqueológicos metálicos do que se usava na cozinha e à mesa na Lisboa Moderna. Uma primeira abordagem" in SENNA-MARTINEZ, J. C.; MARTINS, A. C.; MELO, A. A.; CAESSA, A.; MARQUES, A.; CAMEIRA, I. (edit.) Diz-meo que comes. . Alimentação antes e depois da cidade (Fragmentos de Arqueologia de Lisboa 1). Lisboa: Centro de Arqueologia de Lisboa / Câmara Municipal de Lisboa, Secção de Arqueologia / Sociedade de Geografia de Lisboa, pp. 122-130.

BOAVIDA, Carlos (2017d) - “Objectos do quotidiano num poço do Hospital Real de Todos-os-Santos” in CAESSA, A.; NOZES, C.; CAMEIRA, I.; SILVA, R. B. (coord.) Uma cidade em escavação. Actas do I Encontro de Arqueologia de Lisboa. Lisboa: Centro de Arqueologia de Lisboa - Câmara Municipal de Lisboa, pp. 440-457.

CARDOSO, Guilherme (2007) - A Igreja de Nossa Senhora da Conceição do Cadaval. Arqueologia do Cadaval, 3. Cadaval: Câmara Municipal.

CARDOSO, Guilherme; BATALHA, Luísa (2017) - "Evidências de produção oleira dos finais do século XVI a meados do século XVII no Largo de Jesus (Lisboa)" in CAESSA, A.; NOZES, C.; CAMEIRA, I.; SILVA, R. B. (coord.) Uma cidade em escavação. Actas do I Encontro de Arqueologia de Lisboa. Lisboa: Centro de Arqueologia de Lisboa - Câmara Municipal de Lisboa, pp. 146-181.

CARDOSO, João Luís (2008) - Resultados das escavações arqueológicas no claustro do antigo Convento de Jesus (Academia das Ciências de Lisboa) entre Julho e Dezembro de 2004. Revista Portuguesa de Arqueologia 11:1. Lisboa: Instituto Português de Arqueologia, pp. 259-284.

CARDOSO, M. F. V. (2004) - De templo conventual de Nossa Senhora de Jesus a Paróquia de Nossa Senhora das Mercês. Lisboa: Paróquia de Nossa Senhora das Mercês.

DEAGAN, Kathleen (2002) - Artifacts of the Spanish Colonies of Florida and the Caribbean, 150o-18oo - vol. II: Portable personal possessions. [S.1.]: Smithsonian Institution Press.

DIAS, Pedro (2004) - A Arte do Marfim. O mundo onde os portugueses chegaram. Porto: V. O. C. Antiguidades, Lda.

FERNANDES, Isabel Cristina; CARVALHO, Ant.ำ Rafael (1997) - Intervenção arqueológica na Rua de Nenhures (área urbana de Palmela). Setúbal Arqueológica 11/12. Setúbal: Museu de Arqueologia e Etnografia, Assembleia Distrital de Setúbal, pp. 279-295.

FERREIRA, A. Rita M. (2005/2006): Arqueozoologia num contexto prisional: Métodos e técnicas de trabalho do osso utilizados na prisão do Aljube-Lisboa na segunda metade do Século XVI. Dissertação de Mestrado em Quaternário e Pré-História, apresentada à Universidade de Trás-os-Montes e Alto Douro (policopiado, não publicado). 
FLOR, Pedro (2017) - "Palácio de Manuel Vasconcelos e Sousa" in FLOR, P. (coord.) Lisboa em Azulejo antes do Terramoto de 1755. Lisboa: Instituto de História da Arte da Faculdade de Ciências Sociais e Humanas da Universidade NOVA de Lisboa (http://lisboaemazulejo.fcsh.unl.pt, consultado em Maio 2020).

FRANCO MATA, Ángela (2005) - “Iconografía jacobea en azabache" in Lacarra Ducay, M. C. (coord.) Los caminos de Santiago. Arte, Historia y Literatura. [S.1.]: Instituto Fernando el Católico, pp.169-212.

FRANCO MATA, María Ángela (1986) - Azabaches del M.A.N.. Boletín del Museo Arqueológico Nacional, Tomo IV -2. Madrid: Museo Arqueológico Nacional, pp. 131-167.

GOMES, Mário Varela; GOMES, Rosa Varela; GONÇALVES, Joana (2017) - "Objectos produzidos em matérias duras de origem animal, do Convento de Santana, de Lisboa" in CAESSA, A.; NOZES, C.; CAMEIRA, I.; SILVA, R. B. (coord.) Uma cidade em escavação. Actas do I Encontro de Arqueologia de Lisboa. Lisboa: Centro de Arqueologia de Lisboa - Câmara Municipal de Lisboa, pp. 84-105.

HENRIQUES, Ana de Castro (2003) - Museu Nacional de Arte Antiga. Roteiro. Lisboa: Instituto Português dos $\mathrm{Mu}-$ seus / Edições Asa.

HENRIQUES, Ana de Castro (coord.) (2010) - Os Primitivos Portugueses 1450-1550. O Século de Nuno Gonçalves (catálogo da exposição no Museu Nacional de Arte Antiga). Lisboa: Museu Nacional de Arte Antiga / Athena.

MOURÃO, Teresa P. S. M. (2004) - Entre murmúrios e orações: Aspectos da vida quotidiana do Convento de Santa-Clara-a-Velha captados através do espólio funerário (séc. XVI e XVII). Vol. II - Anexos. Dissertação de Mestrado em Museologia e Património Cultural apresentada à Faculdade de Letras da Universidade de Coimbra (policopiado, não publicado).

NOLEN, Jeanette U. S. (2004) - Museu de Arqueologia do Castelo de Vila Viçosa (roteiro). Vila Viçosa: Fundação da Casa de Bragança.

PICOD, C. (2018) - Le tournage 'l'archet d'un bourdon de pèlerinage miniature en os: experimentation par un Tourneur marocain. Instrumentum, 47. Chauvigny: Musées de Chauvigny, pp. 43-47.

SANTOS, Ma․ João (2005) - Sondagens arqueológicas no Largo de Jesus (freguesia das Mercês, Lisboa). Relatório Final. [S.1.]: GeoArquE - Consultores na Área do Património Cultural, Lda. (98 p. + 130 est.) (policopiado, não publicado).

SANTOS, Mํa João (2007) - Largo de Jesus: contributo para a história incógnita de Lisboa antiga. Revista Portuguesa de Arqueologia, 10.1. Lisboa: Instituto Português de Arqueologia, pp. 381-399.

SANTOS, Ma․ João Correia (2017) - "Pavimentos antigos no Largo de Jesus (Mercês, Lisboa)" in BUGALHÃO, J.;
FERNANDES, L.; FERNANDES, P. A. (coord.) Debaixo dos Nossos Pés (catálogo da exposição no Museu de Lisboa/ Torreão Poente). Lisboa: EGEAC/Museu de Lisboa - CML, pp. 192-196.

VIEIRA, Vasco; CASIMIRO, Tânia Manuel; FILIPE, Vanessa; DETRY, Cleia (2019) - "Vamos falar com os nossos botões. Uma oficina do século XIX na Mouraria” in SENNA-MARTINEZ, J. C.; MARTINS, A. C.; CAESSA, A.; MARQUES, A.; CAMEIRA, I. (edit.) Extrair e produzir... Dos primeiros artefactos à industrialização (Fragmentos de Arqueologia de Lisboa 3). Lisboa: Centro de Arqueologia de Lisboa/Câmara Municipal de Lisboa, Secção de Arqueologia/Sociedade de Geografia de Lisboa, pp. 133-140.

\section{DOCUMENTAÇÃO ICONOGRÁFICA}

Autor desconhecido (séc. XVII) - "Menino Jesus vestido de romeiro de Santiago" (Museu de Aveiro, Aveiro). Disponível em http://www.matriznet.dgpc.pt/MatrizNet/Objectos/ ObjectosConsultar.aspx?IdReg=97234 (consultado em Junho 2020).

BARCO, Gabriel del (c. 1750) - "Grande panorama de Lisboa" (Museu Nacional do Azulejo, Lisboa). Disponível em http:// www.matriznet.dgpc.pt/MatrizNet/Objectos/ObjectosConsultar.aspx?IdReg=228321 (consultado em Junho 2020).

CLAESZ, Pieter (1623) - "Still life with musical instruments" (Musée du Louvre, Paris). Disponível em http://www.the-athenaeum.org/art/display_image.php?id=449698 (consultado em Dezembro 2016).

FERNANDES, Garcia (1538) - "Retábulo do Convento de $S t^{\underline{a}}$. Joana” (Museu Nacional de Arte Antiga, Lisboa). Disponível em http://www.matriznet.dgpc.pt/MatrizNet/Objectos/ObjectosConsultar.aspx?IdReg=250093 (consultado em Junho de 2020).

FERREIRIM, Mestres de (1525/1550) - "São Simão e São Tiago Maior / Apostolado de Ferrerim” (Museu Nacional Machado de Castro, Coimbra). Disponível em http://www. matriznet.dgpc.pt/MatrizNet/Objectos/ObjectosConsultar. aspx?IdReg=1582988 (consultado em Junho 2020).

FIGUEIRA, Josefa Ayala (166o/1670) - “Natureza morta: caixas, barros eflores" (Museu Nacional de Arte Antiga, Lisboa). Disponível em http://www.matriznet.dgpc.pt/MatrizNet/Objectos/ObjectosConsultar.aspx?IdReg=250995 (consultado em Novembro 2016).

FLEGEL, Georg (1635) - "Still life with stag bettle" (WallrafRichartz-Museum \& Fondation Corboud, Koln). Disponível em http://www.the-athenaeum.org/art/display_image. php?id=384787 (consultado em Novembro 2016).

HENRIQUES, Francisco (1508/1511) - “Retábulo da Igreja de São Francisco de Évora" (Museu Nacional de Arte Antiga, Lisboa). Disponível em http://www.matriznet.dgpc.pt/ MatrizNet/Objectos/ObjectosConsultar.aspx?IdReg= 248469 (consultado em Novembro 2016). 
HENRIQUES, Francisco; FERNANDES, Vasco (1501/o6) "Políptico da Capela-Mor da Sé de Viseu" (Museu Grão Vasco, Viseu). Disponível em http://www.matriznet.dgpc.pt/ MatrizNet/Objectos/ObjectosConsultar.aspx?IdReg=207599 (consultado em Outubro 2017).

HILÁRIO, Oficina de Mestre (1505) - "Santiago abençoando uma freira dominicana" (Museu de Aveiro, Aveiro). Disponível em http://www.matriznet.dgpc.pt/MatrizNet/Objectos/ObjectosConsultar.aspx?IdReg=97205 (consultado em Junho 2020).

LOPES, Gregório (1523?) - “Retábulo da Ermida de NNa . Sr ․ do Paraíso” (Museu Nacional de Arte Antiga, Lisboa). Disponível em http://www.matriznet.dgpc.pt/MatrizNet/Objectos/ ObjectosConsultar.aspx?IdReg=247959 (consultado em Novembro 2016).

MORÁN, Santiago (1610) - "Retrato de la infanta Margarita Francisca (1610-1616), hija de Felipe III” (Museo del Prado, Madrid). Disponível em https://commons.wikimedia.org/ wiki/File:Retrato_de_la_infanta_Margarita_Francisca_ (1610-1616),_hija_de_Felipe_III.jpg (consultado em Junho 2020).

PANTOJA DE LA CRUZ, Juan (1602) - "La infanta Ana Mauricia de Austria" (Convento de Las Descalzas Reales, Madrid). Disponível em https://commons.wikimedia.org/ wiki/File:Juan_Pantoja_de_la_Cruz_o2o.jpg (consultado em Junho 2020).

PEREDA Y SALGADO, Antonio de (1650/55) - “Two figures at a table with kitchen utensils" (Penrhyn Castle, Gwynedd). Disponível em http://www.nationaltrustcollections. org.uk/object/1421752 (consultado em Outubro 2017).

STEEN, Jan (1661) - "The Satyr and the Peasant Family" (J. Paul Getty Museum, Los Angeles). Disponível em https:// commons.wikimedia.org/wiki/File:Jan_Steen_(Dutch_-_The _and_the_Peasant_Family_-_Google_Art_Project.jpg (consultado em Outubro 2017).

VAILLANT, Wallerant (1640/166o) - "Still life with fish and cat" (Boijmans van Beuningen Museum, Roterdam). Disponível em http://www.the-athenaeum.org/art/full. php?ID=102054 (consultado em Dezembro 2016).

VELÁZQUEZ, Diego (1618) - "Vieja friendo huevos" (National Galleries of Scotland, Edimburg). Disponível em https://www.wikiart.org/pt/diego-velazquez/an-old-woman-cooking-eggs-1618 (consultado em Outubro 2017). 

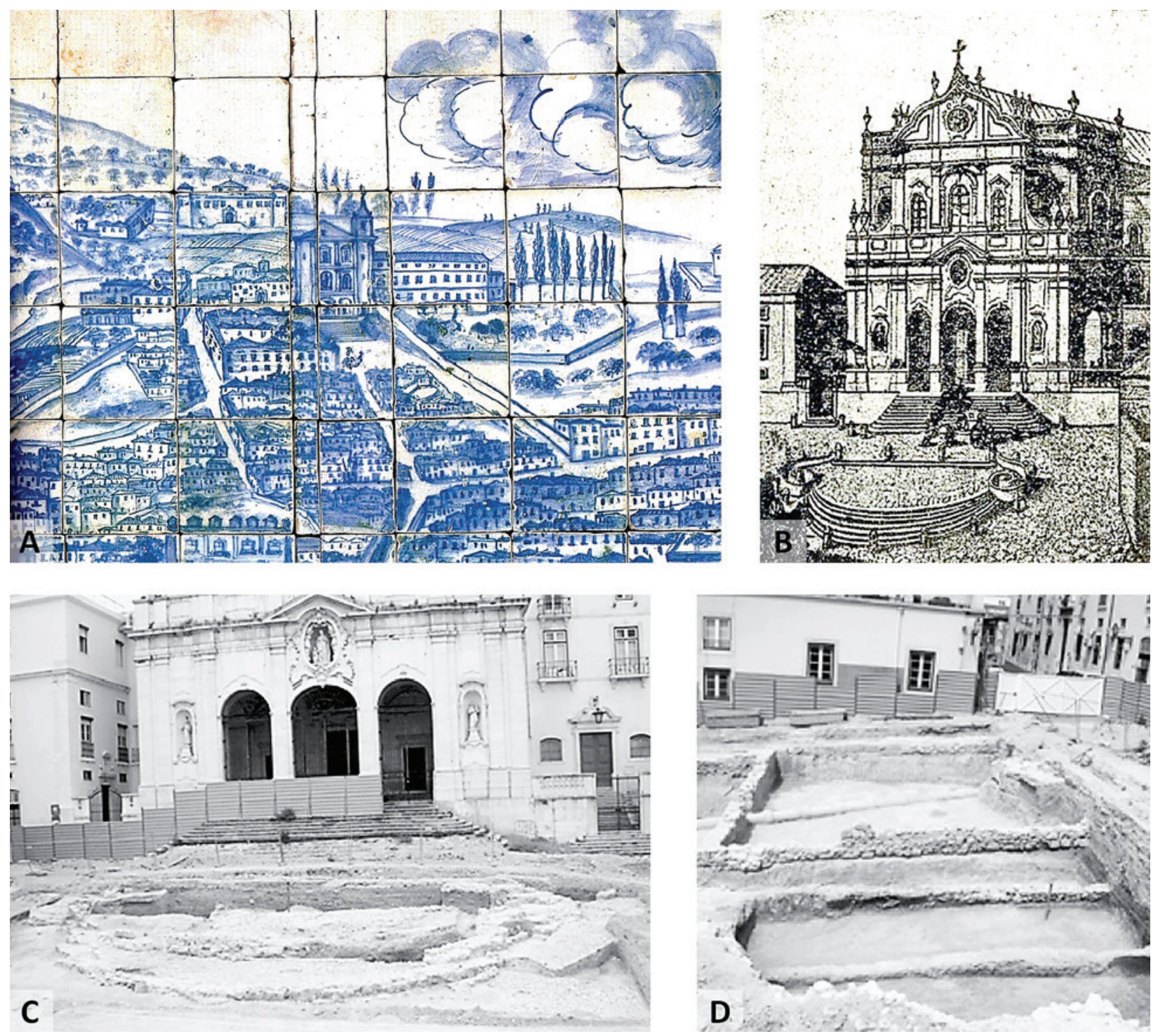

Figura 1 - Aspectos do Largo de Jesus e da intervenção arqueológicas de 2005. A - Pormenor do Grande panorama de Lisboa (Gabriel del Barco, 1750 - Museu Nacional do Azulejo. Foto: Carlos Boavida); B - Vista da fachada da Igreja de Jesus (autor desconhecido, séc. XIX - seg. Ferreira de Andrade, 1945); C/D - Vistas gerais dos trabalhos arqueológicos ocorridos no Largo de Jesus (seg. Santos, 2007). 
$1 / 1$

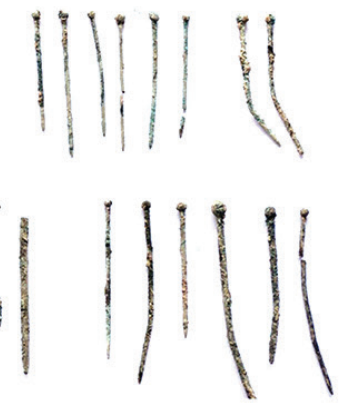

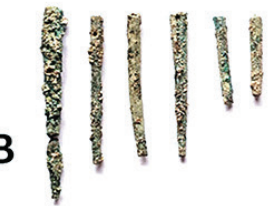

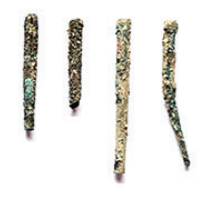

D 6
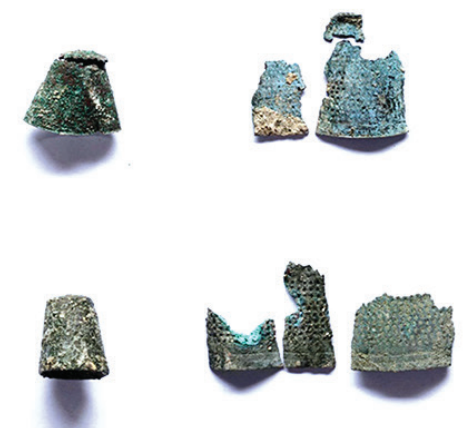

C

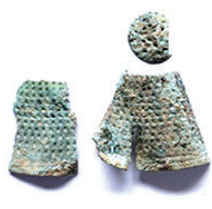

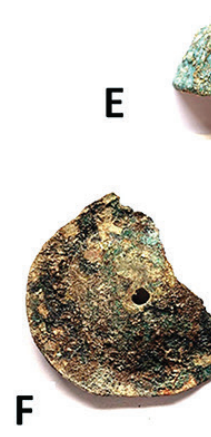
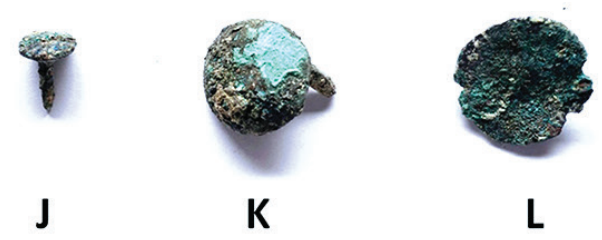

J

L
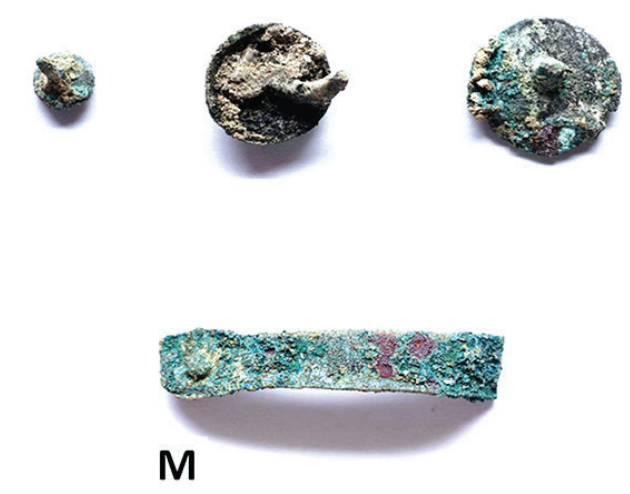

G
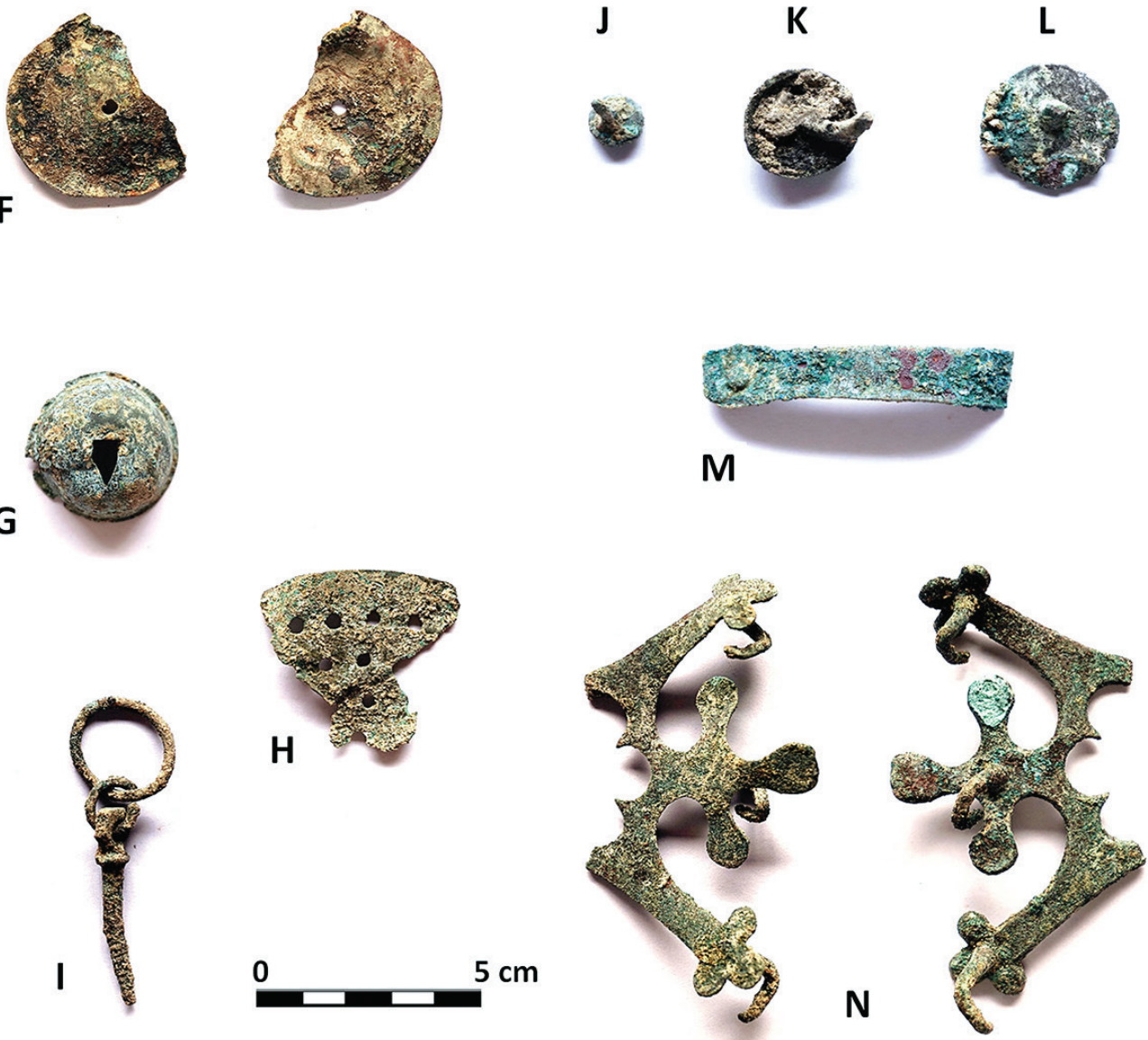

Figura 2 - Objectos metálicos recuperados no Largo de Jesus. A - Alfinetes; B - Agulhetas; C- Dedais; D - Colchete; EGuizo (fragmento); F-Címbalo; G - Peça de cabo de faca; H - Escumadeira (fragmento); I - Espigão e argolas de tampa de garrafa; J/K/L - Pregos de cadeiras; M - Puxador; N - Dobradiça (fragmento). Fotos: Carlos Boavida. 


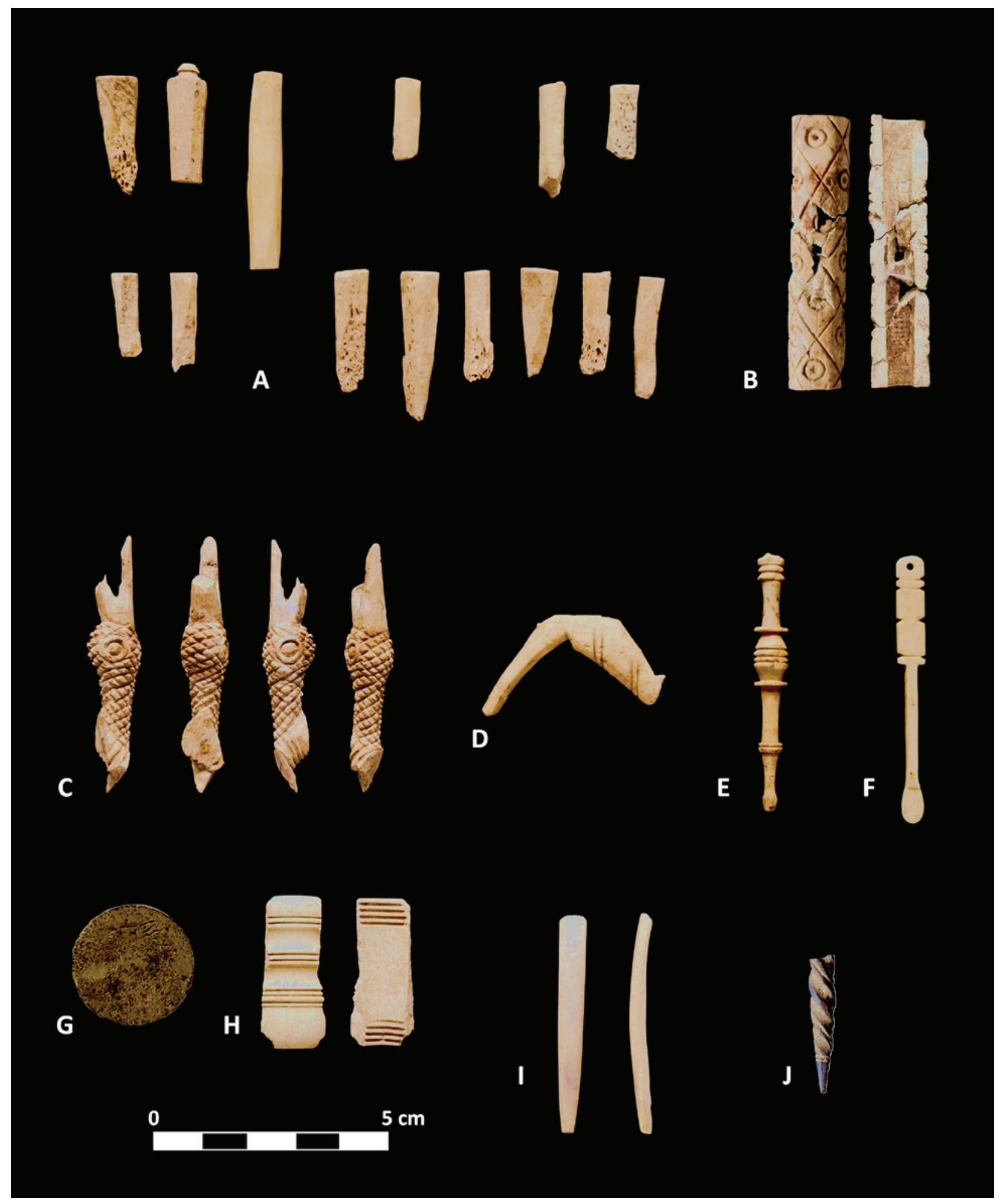

Figura 3 - Objectos em osso, marfim, madrepérola e azeviche recuperados no Largo de Jesus. A - Elementos em osso e marfim (?); B - Empunhadura de talher em osso; C - Fragmento de talher em marfim; D - Elemento decorativo em marfim; E - Pequeno bordão de peregrino em marfim; F-Colher de rapé em marfim; G-Marca de jogo em marfim; $\mathrm{H}$ - Fragmento de seringa de lavagens (?) em marfim; I - Fragmento de travessa de cabelo em madrepérola; J - Fragmento de pendente/amuleto (?) em azeviche. Fotos: Carlos Boavida. 

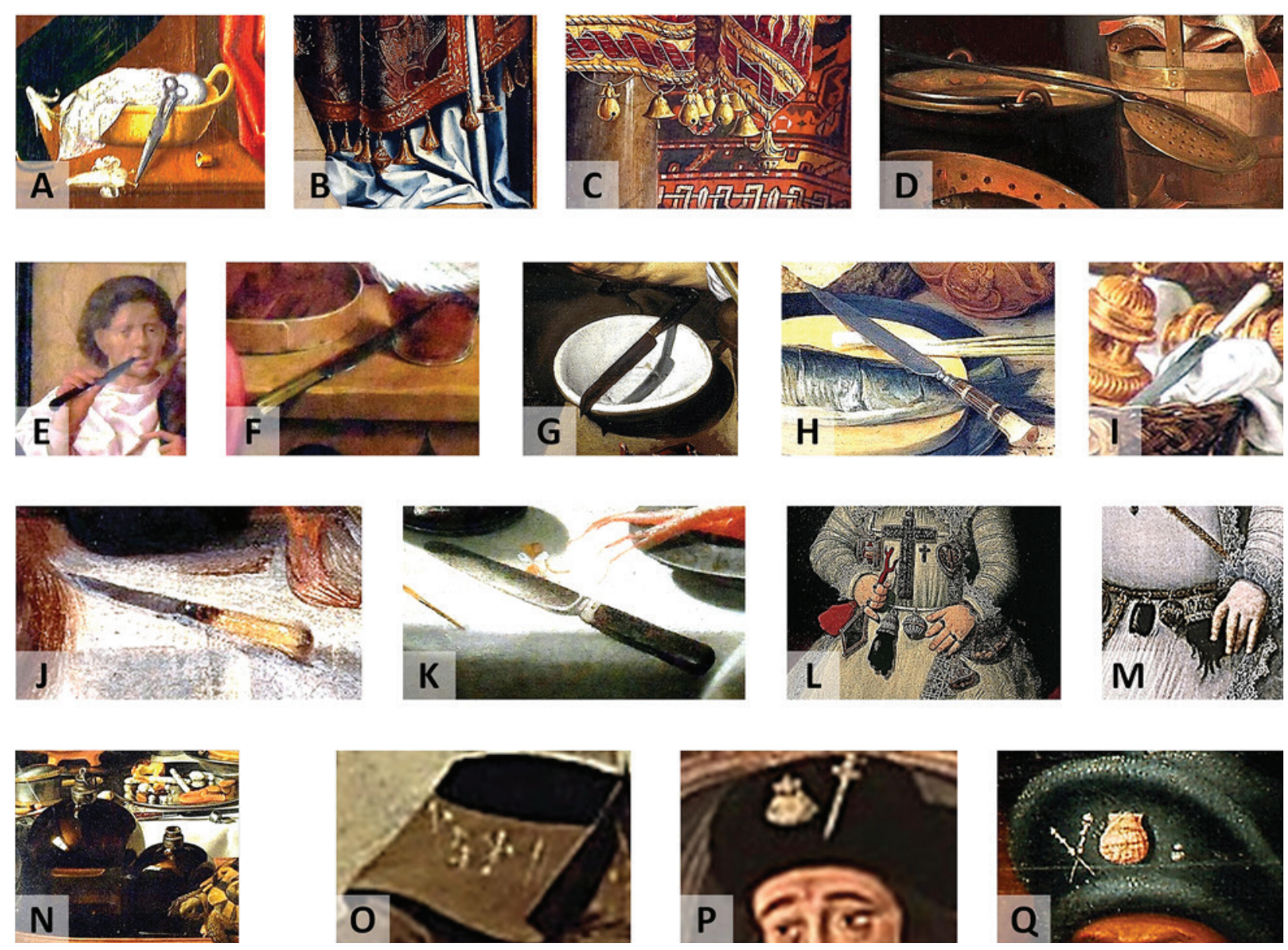

Figura 4 - Alguns pormenores iconográficos. A - Henriques e Fernandes (?), 1501/1506; B - Lopes, 1523 (?); C - Fernandes, 1538; D - Vaillant, 1650; E - Henriques, 1508/1511; F - Lopes, 1523 (?); G - Velázquez, 1618; H - Flegel, 1635; I - Pereda y Salgado, 1650/1655; J - Steen, 1661; K - Figueira, 1674; L - Pantoja de la Cruz, 16o2; M - Moran, 1610; N - Claesz, 1623; O - Autor desconhecido, séc. XVII; P- Oficina de Mestre Hilário, início do século XVI; Q-Mestres de Ferreirim, 1. ${ }^{\text {a }}$ metade do século XVI. 


\title{
ADEREÇOS DE VIDRO, DOS SÉCULOS XVI-XVIII, PROCEDENTES DO ANTIGO CONVENTO DE SANTANA DE LISBOA (ANÉIS, BRACELETES E CONTAS)
}

\author{
Joana Gonçalves ${ }^{1}$, Rosa Varela Gomes ${ }^{2}$, Mário Varela Gomes ${ }^{3}$
}

\begin{abstract}
RESUMO
A escavação de parte do espaço onde se erguia o Convento de Santana de Lisboa (sécs XVI-XIX), proporcionou não só o conhecimento de algumas das suas estruturas, como milhares de artefactos ou os seus fragmentos, entre os quais se contam adereços de vidro. Nestes incluímos anéis, braceletes e significativa colecção de contas, procedentes de lixeiras ou de sepulturas. As contas apresentam acentuado poliformismo e cromatismo, podendo ser classificadas nos finais do século XVI e principalmente na centúria seguinte. São originárias de Itália, Holanda e, talvez, Inglaterra denunciando, tal como o restante espólio, sociedade abastada, de gosto requintado, capaz de recorrer aos circuitos comerciais internacionais, tendo em vista responder à moda de então, mas também à manutenção dos seus estatutos sociais.
\end{abstract}

Palavras-chave: Lisboa, Convento de Santana, Vidros, Anéis, Braceletes, Contas.

\begin{abstract}
The archaeological excavation of a portion of the area were the Santana Convent once stood (Lisbon, $17^{\text {th }}-19^{\text {th }}$ centuries), brought to light some of its structures, has well as thousands of artefacts or their fragments. Amongst them, numerous glass adornments, which include rings, bracelets and a significant collection of beads, collected in cesspits and graves. The beads present an accentuated polymorphism and chromatism, being attributed to the late $16^{\text {th }}$ century and, mainly, to the following one. Their origins can be traced to Italy, Netherlands and, perhaps, England, which denounces, as happens with the remaining testimonies collected, a wealthy society, with exquisite taste, able to access international trading routes to provide not only for the high demands of fashion but also the maintenance of their social status.
\end{abstract}

Keywords: Lisbon, Santana Convent, Glass, Rings, Bracelets, Beads.

\section{INTRODUÇÃO}

O espaço onde se erguia parte do Convento de Santana, na cidade de Lisboa, foi escavado sob direcção de dois dos presentes autores (R.V.G. e M.V.G.) em 2002/2003 e em 2009/2010, dado que ali se viria a construir edifício da Faculdade de Ciências Médicas da Universidade NOVA de Lisboa.
Aquela casa religiosa foi fundada em 1557, com o patrocínio régio de $\mathrm{D}$. João III e da sua esposa $\mathrm{D}$. Catarina, ocupando o local onde antes existia a Ermida de Santana. Em 1561 o projecto do novo convento foi entregue a Miguel de Arruda, falecido circa 1563, pelo que aquele terá sido seguido por outro arquitecto, talvez o seu sobrinho Dionísio de Arruda, beneficiando de ulteriores campanhas de ampliação

\footnotetext{
1. Instituto de Arqueologia e Paleociências da Universidade Nova de Lisboa / Associação dos Arqueólogos Portugueses; joanafrgoncalves@gmail.com

2. Faculdade de Ciências Sociais e Humanas, Instituto de Arqueologia e Paleociências da Universidade Nova de Lisboa / Associação dos Arqueólogos Portugueses; rv.gomes@fcsh.unl.pt

3. Instituto de Arqueologia e Paleociências da Universidade Nova de Lisboa, Academia Portuguesa de Belas Artes, Academia Portuguesa da História, Associação dos Arqueólogos Portugueses; mv.gomes@fcsh.unl.pt
} 
e de obras diversas, chegando a ser um dos maiores conventos da capital. Apesar da Extinção das Ordens Religiosas ter ocorrido em 1834, a última freira de Santana faleceu já quase no final daquele século (1884), com as instalações conventuais já muito degradadas, tendo sido demolidas em 1897 , não sem que tivesse havido alguma polémica, pois ali se guardavam os ossos de Luís Vaz de Camões. Tal ficou a dever-se sobretudo a se querer edificar o Real Instituto Bacteriológico, inaugurado em 19oo, depois designado Instituto Bacteriológico de Câmara Pestana.

Tivemos já oportunidade de dar a conhecer diversos estudos sobre aspectos decorrentes das estruturas e do imenso espólio exumado, nomeadamente no que concerne aos testemunhos arquitectónicos, da igreja e do claustro (Gomes e Gomes, 2007), e à necrópole, aos azulejos (hispano-árabes, de enxaquetado, de padrão, monocromos ou policromos, esponjados) (Almeida, Gomes e Gomes, 2018), cerâmicas finas e comuns (Gomes et alii, 2013), faianças (Gomes, Gomes e Casimiro, 2016), porcelanas chinesas (Gomes, Gomes e Casimiro, 2015; Gomes e Gomes, 2018), vidros millefiori (Valente et alii, 2019), artefactos em matérias duras de origem animal (marfim, osso, tartaruga, madrepérola, coral) (Gomes, Gomes e Gonçalves, 2017) ou em azeviche (Gomes, Gomes e Gonçalves, 2020), brinquedos e miniaturas de cerâmicas (Gomes, Gomes e Casimiro, 2019), etc.

Foi chegada a hora de estudarmos os adereços de vidro, compreendendo anéis, braceletes e contas. Estas constituem o acervo mais numeroso da classe artefactual referida, apresentando tanto acentuado polimorfismo como cromatismo. A colecção de contas é sobretudo procedente de lixeiras, reutilizando poços ou em fossas, e mais raramente de sepulturas. Ela integra exemplares com formas esféricas, subesféricas ou achatadas, as mais comuns, outras ovóides, cilíndricas, prismáticas, lisas, facetadas e torsas, onde se incluem exemplares elaborados com vidro cristalino, translúcido e opaco, de cores diversas, nomeadamente, os muito vistosos de cor azul-turquesa. Talvez menos espectável, no contexto de casa religiosa, foi o termos encontrado restos de produção de contas vítreas, os fragmentos de canudos, ou canas, e de varetas, de vidro incolor ou colorido, com diversas dimensões, que serviam àquela manufactura, assim como contas coladas, aquando da regularização, a quente, das arestas, depois do corte. No conjunto de contas prismáticas existe raro frag- mento de exemplar do tipo chevron, de produção italiana (vetri del malochio). Contas de muito pequenas dimensões comummente designadas missangas serviram, por certo, aplicadas em peças de vestuário profano. Outras, maiores, terão feito parte de colares, mas também de rosários ou de terços. As longas contas prismáticas de cor turquesa, lisas e torsas, de origem veneziana seiscentista, denunciam verdadeira ostentação. Outras, porém, serão originárias dos Países Baixos ou de França, produção que constitui novidade, desconhecendo-se, por ora, manufactura industrial portuguesa de tais artefactos.

\section{ANÉIS}

As escavações nas ruínas do antigo Convento de Santana proporcionaram alguns fragmentos de anéis de vidro, lisos ou decorados com motivo floral e, um deles, com protuberâncias em ambas laterais do aro, do tipo conhecido como anel de martírio, pelo incómodo e dor que provocava o seu uso.

Exumámos alguns fragmentos de anéis similares durante a escavação da Igreja de Santa Maria do Castelo, de Torres Novas, atribuíveis aos séculos XVI e, sobretudo, XVII.

K. Deagan (2002: 124, fig. 6.7) publicou anel, possuindo motivo floral, de vidro moldado, de San Luís de Talimali, na Florida, datado em 1650-170o. Anéis muito pequenos eram usados por crianças ou dependurados em fios, trazidos ao pescoço ou, no caso de serem lisos, terão pertencido a cadeias (Cabart, 1996: 440, 444, fig. 3). Podem ter sido produzidos em Itália ou em alguma pequena oficina de outro país europeu. (Tabela 1)

\section{BRACELETES}

Nas ruínas do Convento de Santana de Lisboa, exumámos apenas quatro fragmentos correspondentes a braceletes. Três produzidas com vidro incolor transparente, apresentando contorno e secção circulares, sendo ocas. Uma delas provém de zona de jardim, alterada e com os sedimentos remexidos pelas obras de edificação do Instituto Bacteriológico, tratando-se de deposição secundária, enquanto outras duas foram descartadas para lixeira, quando se terão partido. O quarto fragmento, de vidro com cor azul-turquesa, maciço, provém do Poço 1.

Com longa tradição no subcontinente indiano e no Mundo Islâmico, tal como na Europa, onde remon- 
tam à Idade do Ferro (La Tène, sécs III-I A.C.), as braceletes de vidro foram também produzidas na Anatólia (Tyana, Kermeshisar), do século III ao XI, Síria (Qsar el-Hayr), Palestina (Hebron), Sinai (al-Tür), Iémen (Kawd am-Saila, Shabwr, Shihr, Adém) (sécs IV-XVI), Qatar, Egipto (al-Fustat, nos séculos IX-XIV e Quseir al-Qasim), Etiópia e na Índia (Sankalia, séc. XIV, Brahmapuri e Arikamedu, na Costa do Coromandel) (Whitcomb, 1983: 106; Patitucci e Uggeri, 1984: 374, 375; Spaer, 1994: 46, 57; Shindo, 2001: 74; Boulogne e Henderson, 2009; Zanon, 2013). Elas surgem na Península Ibérica desde o Período Califal (séc. X), embora fossem mais difundidas durante o Período Nazarí (sécs XIII e XIV) e depois, entre as comunidades judaicas e cristãs, até ao século XVI, como meio apotropaico e profiláctico, acreditando-se no seu poder para prevenir ou curar doenças, como para proteger contra o mau-olhado e a morte, dada a sua forma circular e a cor, sobretudo quando negras, como o azeviche.

As braceletes de vidro, lisas, possuindo secção circular, oval ou plano-convexa, torcidas em espiral, simples ou com aplicações e cabos, foram usadas no Próximo e Médio Oriente, tal como na Europa, por adolescentes, mulheres jovens e até, por crianças, nos braços e pernas, por vezes em pares ou em conjuntos maiores. As de menores dimensões podiam ser penduradas em colares (Malalana Ureña, 1997: 306, 309-311). Dez braceletes de vidro, nas cores azul de cobalto, azul-turquesa e negra, algumas com enrolamentos de cor branca e medindo o, $055 \mathrm{~m}$ a o,o6o m de diâmetro, distribuíam-se pelos dois antebraços de mulher jovem inumada, no século XIII, em Málaga (Malalana Ureña e Hernández, 2014). Também enterramentos, dos finais do século XV ou dos inícios do século XVI, de Madrid (San Andrés), Córdova (Santa Maria) e de muitos outros sítios da Península Ibérica, eram acompanhados por braceletes de vidro, encontradas geralmente nos pulsos, mas também, no caso das crianças, nos tornozelos (Malalana Ureña e Hernandez, 2014: 253).

Fragmentos de braceletes de vidro foram descobertos em contexto do século XVII, com presença portuguesa, no Forte de Jesus (Mombaça, Quénia) (sécs XVII-XIX), cuja origem foi atribuída a produção da Índia Oriental (Kirkman, 1974: 158, 317). Em outros sítios coloniais, portugueses e espanhóis, também se identificaram braceletes, tal como em Qsar es-Seguir, em Marrocos (sécs XV e XVI) (duas delas, com o,053 $\mathrm{m}$ de diâmetro, encontravam-se nos pulsos de uma adolescente, inumada no cemitério da igreja principal), em La Isabella (1493-98), na República Dominicana, ou em Puerto Real, no Haiti (1503-78) (Deagan, 2002: 134, 135).

Conhecem-se fragmentos de braceletes de vidro exumados nas ruínas da Igreja de Santa Maria do Castelo, de Torres Novas (escav. de M. V. G.), embora descontextualizados, assim como procedentes do Poço-Cisterna islâmico de Silves, desactivado e entulhado em finais do século XVI (escav. de R. V. G.e M. V. G.) (Gomes e Gomes, 2017).

A origem de tais artefactos de vidro, exumados na Península Ibérica e Norte de África, pode ter sido a região de Barcelona (Espanha) ou a de Veneza-Murano (Itália), esta última activa desde o século XIII (Redman, 1986: 204). Todavia, muitos destes adereços foram manufacturados em Hebron, o principal centro produtor de vidro do Próximo Oriente, desde o século XIV ao século XIX (Spaer, 1994: 46, 48). Braceletes de vidro de idade pós-medieval da Palestina e regiões vizinhas oferecem diâmetros que variam desde menos de $0,050 \mathrm{~m}$ a $0,075 \mathrm{~m}$, onde exemplares com secção quase triangular parecem ser mais tardios.

A enorme difusão das braceletes de vidro, pode, por certo, dever-se a distintos factores: constituírem adereços não muito dispendiosos, embora vistosos; produzirem som quando entrechocam, usadas nos pulsos ou tornozelos; também por mostrarem, na maioria dos casos, cor negra, como a do azeviche e, acreditar-se conterem as propriedades profilácticas e talismânicas daquele mineral, ou cor azul, como a cor da abóbada celeste; mas ainda, por serem de forma circular. (Tabela 2)

\section{MISSANGAS (CONTAS DE MUITO PEQUENAS DIMENSÕES, SEED BEADS)}

Vários textos que referem pequenas contas de vidro ou pasta vítrea, possuindo $0,002 \mathrm{~m}$ a 0,004 $\mathrm{m}$ de diâmetro, levadas para as colónias europeias na África, Ásia e América, nomeadamente para as portuguesas, fazem a distinção entre a missanga grossa e a missanga miúda, também chamada olho de rola (Sousa, 1967: 46).

Entre os testemunhos do naufrágio da Ponta do Leme Velho (Ilha do Sal, Cabo Verde), navio português do tráfico colonial datado no século XVII, contam-se pequenos blocos de sedimentos concrecionados que conservam grande quantidade de 
missangas, de muito pequenas dimensões. Aquelas ocorrências correspondem, por certo, a carga, transportada a granel, em recipientes que desconhecemos, talvez de madeira, mas que se terão mantido durante algum tempo, após o naufrágio, dado o seu estado aglomerado e o concrecionamento que apresentam. Também aqui se identificaram dois tamanhos distintos de missangas, as que denominámos pequenas, dado terem forma esférica achatada e cerca de $0,005 \mathrm{~m}$ de diâmetro, e as médias, quando ofereciam forma cilíndrica e cerca de 0,006 $\mathrm{m}$ de diâmetro. As missangas pequenas surgiram em três cores, branca, azul de cobalto e azul-turquesa, enquanto as médias eram todas de cor branca.

Usadas na Europa em rosários e adereços, durante o século XVII, as missangas constituíram bens muito apreciadas pelos autóctones de África, da América e da Ásia. O seu valor como objecto de troca foi sempre elevado entre as populações mencionadas, pelo que se incluíram nos sistemas paleomonetários.

Em 1526 é elaborado documento intitulado o Livro de Armação do Navio Santiago (navio de trato real) que parte de Lisboa em direcção à Ilha de Santiago (Cabo Verde), ali deixando alguns produtos não descriminados. No entanto, o mesmo, após escala na Ribeira Grande, dirige-se aos rios da Guiné com diversas mercadorias a bordo, destinadas a serem trocadas por escravos. De entre aqueles bens destacamos as alaquecas, cristalino, matamungo e olho de peixe, variedades que se podem incluir na contaria. As alaquecas (do árabe al-akika) e cristalino designavam pedraria variada, alguma de origem veneziana, com que se faziam jóias de pouca valia, enquanto a designação olho de peixe pode corresponder a pequenas contas de cor azul.

Foram muito apreciadas em toda a África Austral pequenas contas, designadas Maria II, de cor vermelha e com o interior branco, medindo cerca de $3 \mathrm{~mm}$ de diâmetro. Uma peça de fazenda, valia em Angola, na segunda metade do século XIX, 1200 contas Maria II (Sousa, 1967: 46).

As missangas de várias cores e muito pequenas, as missangas miúdas, ou "olho de rola", eram, no século XIX, transaccionadas em fios com uma dezena de elementos, agrupados em conjuntos de dez.

Nas descrições seiscentistas da Guiné, de Francisco Lemos Coelho, em 1669 e 1684, publicadas por Damião Peres, refere-se "contaria miúda preta e branca" que se trocava, com outros produtos, por "couros, cera e marfim" no porto da barra do rio Gâmbia
(Coelho, 1990: 111). Cera, escravos e marfim eram transaccionados com os Felupes de Casamansa e no reino de Jasé, por "ferro e conta avelorio miúda, de cor preta, branca e cor de telha" (Coelho, 1990: 141, 143). As chamadas "contas avelório" (do castelhano abeloiro), correspondem a missangas.

Em Cacheu (Guiné), Mandigas e Soninqués também negociavam vários produtos, no século XVII, a troco de "ferro e contaria", embora preferissem "prata em patacas para fazerem manilhas", algumas vindas da Índia (Coelho, 1990: 159). Ainda no mesmo século se refere que na zona do porto da Borrancheira o "coral miúdo e conta avelorio" serviam para comprar arroz (Coelho, 1990: 228).

O explorador e comerciante Henrique de Carvalho reconheceu, na sua obra sobre os Lunda, o elevado valor simbólico e venal das missangas, usadas em especial pelo sexo feminino: "As missangas e contaria grossa constituem a maior riqueza das mulheres que transformam o corpo em verdadeiras mostras, em que se vêem contas de todas as côres, formas $e$ grandezas, que o commercio portuguez para lá tem levado. Algumas vi que de certo eram de facturas muito antigas, pois o nosso commercio já ahi as não leva" (Carvalho, 189o: 335, 336). O seu papel no sistema de trocas e vendas ficou bem atestado pelo mesmo autor, ao escrever: "As mulheres que possuem estas riquezas e mesmo os homens recorrem a ellas muitas vezes, quando não teem outro recurso, tirando algumas missangas ou contas de que precisam para comprarem o seu pedaço de carne, peixe ou mesmo malufo ou marra (garapa). || Tiram apenas as que são estrictamente precisas na occasião. Sei que Mucanza (o Muatiânvua interino), querendo comprar no Calânhi um pouco de sal para me mandar, tirára do cabello quatro contas grandes apipadas. II As mulheres teem a sua riqueza contada, e a falta de uma missanga ou conta é para a possuidora motivo de grande tristeza" (Carvalho, 1890: 336).

As contas, cujo uso tem longa tradição em África, produzidas em diversos materiais naturais ou de pasta vítrea, possuem significados múltiplos para as populações daquele continente e etnográficas em geral, motivando a sua aquisição usos muito diversificados, devido à excepcional criatividade de tais sociedades. Elas podem ser utilizadas de modos diversos, como ornamento e/ou com valor simbólico e ritual, evidenciando estatutos sociais e bem-estar económico (Handler, 1997: 115).

Foram diversos, na Europa, os centros de produ- 
ção de contas e missangas que Portugal exportava para África, sendo os principais Veneza-Murano, Nuremberga, Boémia (República Checa) e Holanda (Harlem e Roterdão) (Karklins, 1985; Jargstorf, 1995: 72-74). Recentes escavações arqueológicas no bairro judeu de Waterlooplein, em Amesterdão, cujas relações com Portugal se encontram bem comprovadas (Baart, 1988), trouxeram à luz do dia mais de cinquenta mil exemplares de contas de vidro. Esta indústria terá sido iniciada cerca de 1580 e funcionou até 1750 , fornecendo o comércio holandês, inglês, francês e, muito possivelmente, também o espanhol e o português (Dubin, 1987: 112, 113).

Tanto em África, como em outros Continentes, os indígenas sempre preferiram contaria de cores claras, aspecto não só decorrente de simbolismos diversos, como tendo em vista melhor sobressaírem na pele escura. Todavia, no Bailundo (Angola) houve preferência por missangas pretas e na Lunda, por brancas e grossas, a missanga leite (Sousa, 1967: 46). (Tabela 3)

\section{CONTAS DE VIDRO INCOLOR, TRANSPA- RENTE, COM LINHAS BRANCAS}

A escavação das ruínas do Convento de Santana proporcionou apenas quatro exemplares deste tipo de contas. Um com forma cilíndrica e doze linhas verticais, encontrando-se algo queimado (CS/Q219-1), outro com onze linhas verticais, igualmente algo queimado (CS/Q219-2) e duas, fundidas, de forma esférica achatada, com onze linhas brancas (CS/ Q219-27).

Produção veneziana antiga, alcançou os inícios do século XX, sendo muito apreciada e com alto valor na Costa do Ouro, nomeadamente nos Camarões, onde, por vezes, acompanha contas do tipo chevron (Harter, 1981: 12, 13, fig. 5). (Tabela 4)

\section{CONTAS DE VIDRO OPACO DE COR NEGRA}

Exemplares esféricos e esféricos achatados, de cor negra intensa, opacos mas de superfícies brilhantes, parecem querer imitar o azeviche, cujas propriedades profilácticas e apotropaicas tiveram elevada aceitação entre todas as classes das sociedades europeias, tendo sido produzidas na Boémia e em Amsterdão, entre 1550-1750 (Francis, 1994: 38; Dubin, 1987: 112). (Tabela 5)

\section{CONTAS TUBULARES DE COR AZUL-TURQUESA (NUEVA CÁDIZ)}

Conhecem-se exemplares desta categoria de contas, possuindo seç̧ão cilíndrica ou quadrangular, apresentando as superfícies lisas, torsas ou apenas ligeiramente torsas. Os seus comprimentos variam, embora os maiores atinjam 0,0552 m (CS/P2-1).

Estácio da Veiga (1891, est. XXX), deu a conhecer algumas destas contas, como procedentes de Silves e Estômbar, não sendo muito comuns nos contextos europeus.

Em 1905, C. H. Read publicou colar, que incluía contas tubulares de vidro de cor azul-turquesa, a par de vidro cristalino e de cor âmbar, com possível origem veneziana, encontrado em sepultura de chefe tribal em Mansu, próximo de São Jorge da Mina (Elmina), feitoria que os portugueses edificaram e detiveram até à sua tomada pelos Holandeses, em 1637. Esta encontra-se associada à presença do activo comércio, nomeadamente esclavagista, nos séculos XVI e XVII. No ano seguinte, H. H. Johnston (1906: 22-24 figs 17, 18), volta a relatar o achado mencionado e publica contas tubulares azuis, com secção quadrangular, da Libéria, a que atribui procedência mediterrânica, mas anterior à presença europeia naquela região. Estas contas, chamadas pelos arqueólogos americanos Nueva Cádiz, denominação dada por C. H. Fairbanks (1968), conhecidas na América Central ainda no século XVI, chegaram à América do Norte no século XVII (Deagan, 1987: 162-164; Hume, 1991: 54).

M. da C. Rodrigues (1993) publicou conjunto de 29 contas tubulares, prismáticas, direitas ou ligeiramente torsas, encontradas em Luanda e então conservadas no CPHA. Esta investigadora colocou como hipótese terem sido achadas no cemitério da Samba, sendo semelhantes a outras procedentes da Praia do Bispo (Faria, 1974), concluindo pela sua origem no Mediterrâneo Oriental, ali chegadas através do comércio árabe, em data anterior à presença portuguesa. Na mesma linha de raciocínio, também liga as contas do Algarve, publicadas por Estácio da Veiga, à presença islâmica, teses já à data completamente anacrónicas, tanto quanto à origem como à difusão e contexto de tais adornos. A mesma investigadora haveria de dar a conhecer dezasseis contas tubulares, de cor azul-turquesa, descobertas em escavações ocorridas, em Lisboa, na última década do século XX. Dez destas são procedentes da Praça D. Pedro 
IV (Rossio), nove de secção quadrangular, onde se incluem dois exemplares torsos, e um com secção circular. Seis contas tubulares de secção quadrangular, uma das quais torsa, provêm da zona de São Mamede ao Caldas, admitindo-se serem ulteriores aos finais do século XV e anteriores a 1755, dadas as condições de jazida. Cinco das contas da Praça D. Pedro IV encontraram-se em camada arqueológica pré Terramoto de 1755, contendo moedas de D. João V (1706-1750), e uma de D. José (1750-1777). As restantes procedem de estratos mais antigos, mas conturbados (Rodrigues, 1997: 258, 262; 2003: 213, 217). M. da C. Rodrigues (1997: 271-274; 2003: 230-232) insistiu na existência, em Angola, de tais contas em data anterior à presença portuguesa, como na sua vinda para Portugal, trazidas por escravos, que as usariam como identificação étnica, hipóteses destituídas de quaisquer provas. Duas contas tubulares azuis, torsas, foram encontradas em sepultura de Caotinha, a sul de Benguela (Angola) (Gutierrez, 2001: 50).

Quatro contas tubulares, com secção quadrangular, de cor azul-turquesa, inteiras ou fragmentadas, foram encontradas, em 1999-2000, nas ruínas do Palácio dos Marqueses de Marialva, na Praça Luís de Camões, em Lisboa, podendo genericamente serem datadas entre cerca de 1640 e 1755 , cronologia daquela edificação, embora uma delas se associasse a numisma de três réis de 1703 (D. Pedro II) (Torres, 2007: 216, 217, 219, 220, 225). Mais tarde, M. da C. Rodrigues (2014: 12, 13, 36, 37, 85, figs 8 e 9) mencionou a existência de seis de tais contas procedentes daquele local, retornando as suas teses, nomeadamente da existência na África Ocidental, daquelas, em data anterior à presença portuguesa, pondo em causa a sua produção veneziana e argumentando em relação ao seu uso pela população escrava africana em Lisboa, dos séculos XV e XVI, tudo aspectos que nem a informação literária ou a arqueológica sustentam ou, até pelo contrário, infirmam. Conta tubular de cor azul, com secção quadrangular foi encontrada nas escavações arqueológicas, efectuadas, em 1997, na Praça do Município em Lisboa (Rodrigues, 2014: 15). Constitui variante das contas tubulares lisas, com secção circular, o exemplar de vidro com cor azul escura e listas brancas, do Convento de Santana, podendo proceder de oficina italiana, holandesa ou inglesa, da primeira metade do século XVII, dada a conhecida deslocação dos artífices vidreiros italianos para aqueles dois últimos países (Karklins, 1985: 38; Karlins, Dussubieux e Hancock, 2015: 19).
Estas contas, embora não muito comuns, chegaram ao Continente Americano (Texas, Florida, México, Venezuela, Peru) e Filipinas, através do comércio colonial espanhol (Smith e Good, 1982: 41, 42, figs 5, 6; Feinzig, 2017).

Outra variante, de que dispomos apenas de um exemplar, apresenta vidro de cor azul e listas longitudinais de cor vermelha escura. Trata-se de adereço raro, cuja produção pode ser atribuída às oficinas italianas de Veneza ou Murano, ainda do século XVI. E uma outra, embora comum em alguns contextos, tanto medievais como modernos, mostra forma tubular e reduzido diâmetro.

As contas tubulares, produzidas com vidro "puxado", são conhecidas somente a partir da última década do século XV. (Tabela 6)

\section{CONTA TUBULAR, TORSA, DE COR VERDE ESMERALDA}

Pode integrar as contas chamadas Nueva Cádiz, produzidas em Murano, onde eram denominadas, em 1496, parternostri voltati. Contas similares foram encontradas durante escavações arqueológicas em Antuérpia e datadas de 1575 (Jargstorf, 1995: 47, 109). (Tabela 7)

\section{CONTA CHEVRON}

A escavação do Convento de Santana proporcionou apenas um fragmento deste tipo de contas, permitindo reflectirmos sobre ainda tão controversos artefactos.

Também conhecidas por "grandes contas multicolores", "policrómicas", agri/aggry/aigris, ou de rosetta, constituem as ocorrências da denominada conterie que mais atenção suscitaram, desde o século XIX, aos investigadores nacionais, e não só. Produzidas em pasta vítrea, translúcida e opaca, nas cores branca, negra, azul escura e vermelha, cor de tijolo, em seis camadas alternadas, mas a última das quais azul, oferecem forma cilíndrica ou prismática, possuindo as extremidades facetadas, com o aspecto de tronco de pirâmide de base poligonal, com a policromia formando estrela de doze pontas. As maiores chegam a medir o,o7o m de comprimento. Sabe-se, através de informação literária, que foram produzidas nas vidrarias de Veneza e Murano, a partir de 1482 (paternostri a rosette), se não antes, e depois de 1590, na Holanda. O aspecto estrelado, com 
doze raios, chegou a ser conotado com o número de apóstolos de Cristo (Dubin, 1987: 117; Quiggin, 1992: 36-44; Francis, 1994: 64, 65; Jargstorf, 1995: 15, 47). Talvez a mais antiga menção a este tipo de contas corresponda às que, segundo Duarte Pacheco Pereira (1892: 69), eram transaccionadas na feitoria de São Jorge da Mina, em ca 1507, nos seguintes termos: "humas contas azues a que elles chaman coris". Mais tarde, John Barbot $(1732: 348,349)$ mencionou que holandeses e ingleses vendiam, na Costa Ocidental de África, "blue stones called Agry or Accory, very valuable at the Gold Coast" e "Venice beads". Nas primeiras décadas do século XIX, T. E. Bowdich (1819: 218) enviou para o British Museum colar daquelas contas. Em 1851 J. Y. Akerman (pl. 5, nos 9 , 10) deu a conhecer bonita representação aguarelada de contas antigas, entre as quais duas do tipo chevron, uma delas verde, encontrada perto da London Bridge, em 1847.

Julgamos que a primeira notícia, com carácter científico, dedicada especificamente às contas chevron, deve-se a John Brent (1880) e remonta a comunicação académica de sua autoria, de 1872, oito anos depois publicada na revista Archaeologia. Ali se inventariaram as significativas ocorrências de tais contas em Inglaterra, registando-se os locais e condições de origem, quando conhecidos, e as colecções, públicas e privadas a que pertencem as três dezenas de exemplares mencionados, mas também as conservadas em museus europeus ou as procedentes da América do Norte, do Sul e de África (Egipto e Núbia). Estudaram-se novas contas chevron do Museu de Colchester, a par das encontradas no País Axante (Costa do Ouro, Gana), onde o seu valor era igual, em peso, ao do ouro, ou até superior, e se acreditava crescerem no solo (Price, 1883: 65). O. Tischler $(1886: 5,7)$ também dedicou trabalho às contas chevron (aggry-perlen), encontradas na Europa, mencionando o achado daquelas no Rio Grande do Sul (Brasil) e em sepultura peruana, como em África.

Os primeiros exemplares de contas chevron encontrados em Portugal foram publicados pelo arqueólogo pioneiro Estácio da Veiga (1891: 257, 259, 262264, ests XXX, XXXII). Este deu a conhecer doze exemplares provenientes de Silves e Estômbar, que pertenceram à colecção de Júdice dos Santos, mas então depositadas no Gabinete de Numismática e Antiguidades da Biblioteca Nacional. Três daqueles apresentam os topos de forma tronco-piramidal e nove são cilíndricas. Também publicou, com mag- nífico desenho, montagem em colar, de nove contas com as extremidades tronco-piramidais e sete outras lisas, que o Museu Geológico conservava, graças a oferta de Alfredo Bem-Saúde sem que, contudo, se conheça a sua origem. Estácio da Veiga (1891: $262,263)$ refere ainda as contas dos nichos dos Conventos de Chelas (das Albertas, nicho da Madalena, no Claustro, já desaparecido em 1910) e de Marvila, este concluído em 168o, encontrava-se então grandemente vandalizado. O mesmo autor disse guardar, pelo menos, três de tais contas na sua colecção particular, duas com as extremidades facetadas e uma tubular, assim como possuir notícia da existência de dois exemplares no Museu do Rio de Janeiro, encontradas em Linha Grande (Rio Grande do Sul), publicadas mais tarde por A. Childe (1919: 57) que as compara com achados diversos da América do Norte. Estes seriam depois classificados entre a primeira metade do século XVII a meados da centúria seguinte (Smith e Good, 1982; Hume, 1991: 53). Estudo, da autoria de R. C. Temple (1899: 119-121), sobre o valor e circulação monetária em sociedades etnográficas, refere, em tal contexto, as contas de vidro em África e, nomeadamente, as agri, tidas como produzidas em Veneza e para ali levadas pelos portugueses. No entanto, H. H. Johnston (1906: 22-24, fig. 18) defendeu origem mediterrânica, com cronologia "anterior à Renascença", para contas chevron e tubulares azuis, na Libéria, que deu a conhecer.

A. I. Marques da Costa (1910: 69, nota 1, est. VII, fig. 511) publicou conjunto de sete contas chevron, associadas a outras procedentes da Quinta das Mesas, nos arredores de Setúbal, que pertenciam, com fragmentos de porcelana da China e muitas outras contas, ao revestimento de fonte, junto de capela. Também refere fonte e cascata, na Quinta de Brancanes, situada nas proximidades daquela primeira, em cujas paredes se encontravam contas tubulares e de extremidades facetadas do tipo chevron, colocando a hipótese de terem procedência ultramarina ulterior ao século XV. No mesmo ano, G. Pereira (1910: $287,288)$ mencionou embrechado com contas chevron e outras, da Quinta das Lapas (Torres Vedras). Em 1925, A. W. Cardinall assinou artigo no Journal of the Royal African Society, onde trata a origem do nome aggrey/agri dado às contas chevron, na costa ocidental de África, designando "coral azul", da espécie Allopora subviolacea, das contas dos Camarões, como relata a crença de que entre muitas populações, daquela região, tais contas nasceriam 
da terra (Quiggin, 1992: 38), aspecto comparável ao coral, cuja origem é o fundo do mar, chegando aquelas a terem o mesmo valor do ouro, argumentando claramente a sua produção veneziana, e até, ulteriormente, em Birmingham (Reino Unido), embora aquela primeira chegasse através do comércio árabe terrestre a tais paragens, nos início do século XV e, portanto, antes da presença comercial portuguesa. $\mathrm{Na}$ Alemanha, P. Reinecke (1929), argumentou contra as cronologias recuadas atribuídas às contas agri (chevron), que datou como sendo não anteriores ao século XV.

Algo mais tarde, R. de Serpa Pinto (1932) menciona duas contas existentes no Museu de Antropologia da Faculdade de Ciências do Porto, uma vinda do Sul do país, oferecida pelo P. J. Brenha e a outra provinda de Carregal (Sernancelhe), onde era usada ao pescoço contra os "áres ou quebranto", referindo ainda o achado de outros exemplares, no Ribeiro de Valongo (Barroso) e São Julião de Freixo (Ponte de Lima).

Félix Alves Pereira (1927,-29: 49-51, fig. 41; 1933: 29$31,78,120$; 1934) haveria de dar a conhecer as ocorrências procedentes da encosta do Castro de São Julião de Freixo (Ponte de Lima), uma das quais entregou ao Museu Etnológico em 1909, apresentando relação de tais artefactos existentes naquela instituição, onde inclui exemplar de Ganfei (Valença), dezanove fragmentos do nicho da Madalena (Chelas), um comprado em Setúbal e outro em Roma por J. L. de Vasconcellos. Também menciona a existência do mesmo tipo de contas nos embrechados da Quinta das Lapas (Torres Vedras), dos Conventos de Chelas e de Marvila ou de convento, usado como quartel, na Estrela, em Lisboa, colocando como hipótese serem algumas das que se encontram no Museu do Carmo. $\mathrm{O}$ mesmo autor repete antigas teorias que tentaram explicar a origem daqueles adornos, como as velhas teses egípcia ou normanda (séculos IX e X), embora também proponha Murano, a partir do século XV. Quase na mesma data, Armando de Matos (1934) inventariou os poucos exemplares então conhecidos, o encontrado na Quinta de São Salvador em Ganfei (Valença do Minho), outro comprado em 1909 por J. Leite de Vasconcellos no Cairo, mas tido como procedente da Síria, e oito que conservava o Museu da Sociedade de Geografia de Lisboa, vindos da Índia, onde foram encontrados em sepultura, ou sepulturas, tal como estuda três exemplares que se conservavam no Museu Municipal de Azuaga, em Gaia, procedentes da cidade de Luanda, as maiores até agora identificados.

Ainda naquele ano foi publicada notícia do achado, ocorrido no ano anterior, de conta chevron no interior de casa do Castro de Sabroso, que permitiria recordar a tese oriental e antiga da origem de tais adornos (Silva, 1934).

Mário Cardozo (1943) deu a conhecer duas contas chevron, surgidas durante trabalhos agrícolas em São Caetano (Chaves), ao que parece com outras idênticas, talvez constituindo colar. Também refere o achado de contas do mesmo tipo em Vila da Ponte (Trás-os-Montes), uma delas oferecida a Mendes Corrêa para o Museu de Antropologia.

Curiosamente, em volume da Revista de Guimarães, datado de 1955, surgiram três curtos trabalhos sobre as contas, então chamadas policromas. M. Cardozo (1955) escreveu sobre a distribuição de tais artefactos em território nacional, desde o Minho (Valença, Ponte de Lima, Guimarães) e Trás-os-Montes (Barroso, Chaves), passando pelas Beiras (Sernancelhe) e Estremadura (Lisboa, Sintra, Torres Vedras, Setúbal), atingindo o Algarve (Silves, Estombar). Também refere a existência de exemplares no $\mathrm{Mu}$ seu Britânico (15), no de Cantuária (1), nos museus do Louvre e de Copenhaga (2), referindo ainda a sua presença em túmulos índios do Missouri e em outros pontos da América do Norte (10), como em Madagáscar e na Índia, lançando a ideia da sua difusão universal, uma, mais antiga, a partir da Fenícia e Egipto e outra, durante o século XV e seguintes, com origem em Murano (Veneza).

Th. Monod (1952) comparou as duas contas chevron do Museu de Antropologia da Faculdade de Ciências do Porto, com exemplares encontrados na África Ocidental (Camarões, Daomé, Senegal), nada concluindo sobre a sua origem.

Texto de L. Chaves (1955) refere-se principalmente aos exemplares do Museu Etnológico, hoje Museu Nacional de Arqueologia, fazendo revisão das restantes ocorrências. Assim, menciona a mais de meia centena de exemplares, quase todos fragmentados, provindos dos Conventos de Chelas e Marvila, em Lisboa, as duas dezenas do Convento de Brancanes de Setúbal, dois exemplares da Quinta das Mesas, também em Setúbal, a que acima referimos, e outros dois do Convento de Brancanes que pertenceram a Marques da Costa.

J. M. Cordeiro de Sousa $(1954 ; 1955)$ tratou as anteriormente referidas oito contas chevron do Museu da Sociedade de Geografia, de Lisboa, atribuindo- 
-lhes produção fenícia, referindo os embrechados portugueses com contas no mesmo tipo e discorre sobre a sua difusão, juntando às regiões já mencionadas a Escandinávia, o Norte de África, e o México. $\mathrm{O}$ mesmo conjunto de contas seria mais tarde publicado, como de origem italiana, dos séculos XV ou XVI, embora sem alusão às condições do achado (Cantinho, 2008).

Em 1961 e 1964, T. E. Haevernick publicou artigos onde faz a história da investigação das contas chevron e inventaria os exemplares conhecidos, atribuindo a sua produção a Veneza e Amsterdão, durante o século XVII.

F. de Almeida e J. L. de Matos (1970), revelaram conta chevron encontrada no centro da cidade de Luan$\mathrm{da}$, oferecida àquele primeiro arqueólogo. Ao darem a conhecer mais esta ocorrência, referem achados similares nas praias daquela cidade (Cacuaco e Praia do Bispo), indicando como possíveis centros manufactores de tais artefactos, Veneza (1500-180o) e Amesterdão (até 1680). Este tipo de contas tem surgido na Mauritânia, Senegal, Camarões, Nigéria, Congo e Angola (Delarozière, 1994: 78-81, fig. 79), mas também na América do Norte e do Sul (Venezuela, Peru), onde acompanham com as contas tubulares azuis (Deagan, 1987: 164-167, fig. 7.4; Feinzig, 2017: 21, 51).

Escavações em Lisboa têm proporcionado contas chevron, nomeadamente as efectuadas em 1999200o, onde se erguia o Palácio dos Marqueses de Marialva, na actual Praça Luís de Camões. Dali provêm quatro exemplares, com cronologia situada entre cerca de 1640, data da edificação daquele imóvel, e 1755, quando ele caiu devido ao Terramoto (Torres, 2007: 215, 216, 220-223, 229, 230). Todavia, é também referido que ali se encontraram onze exemplares, desconhecendo-se o seu paradeiro (Torres, 2007: 192). M. da C. Rodrigues (2014: 36, 39, fig. 11) indica a existência de uma conta chevron completa e de dois fragmentos de outras.

A. M. Torres $(2007:$ 193, 202) fez referência a embrechados da Capela de Nossa Senhora da Conceição e jardim de palácio em Alcáçovas, do século XVII, contendo contas chevron e tubulares de cor azul (Nueva Cádiz). A mesma autora regista que conta chevron, na Colecção de Antiguidades, da Biblioteca Nacional de Lisboa provém da Amadora (Torres, 2007: 192).

As contas chevron, de diferentes dimensões, obtiveram larga difusão, alcançando zonas diversas de todos os continentes. (Tabela 8)

\section{CONTA DE COR VERMELHA COM O INTERIOR DE COR NEGRA}

Foram produzidas em Veneza, durante a segunda metade do século XVII (Dubin, 1987: 110). (Tabela 9)

\section{CONTAS DE VIDRO DE COR VERMELHA (BORDEAUX), COM LISTAS BRANCAS}

Este tipo de contas, normalmente de forma esférica achatada, produzidas em vidro opaco e com listas verticais de cor branca, foi produzido em Veneza e Murano, desde finais do século XVI a meados do século XVII, mas também na Holanda e em Hammersmith Embankment (Londres), durante o século XVII (Dubin, 1987: 113; Karklins, Dussubieux e Hancock, 2015: 19, 20). (Tabela 10)

\section{CONTAS DE VIDRO DE COR ÂMBAR}

Trata-se de produção veneziana ou francesa, dos finais do século XVI e dos inícios da centúria seguinte (Dubin, 1987: 113). Ruão foi centro produtor de contas, onde trabalharam artífices venezianos, existindo documentos que comprovam a venda de grandes quantidades daquelas para Portugal, "Expédition en Portugal de 676 milliers de patenôtres jaunes et de 58 milliers de patenôtres façon et manufacture de Rouen, 10 janvier 1607 " e de " 5 lives de patenôtres d'ambre, manufacture de Rouen, 19 mars 1607" (Tougard, 1897: 429). V. Magalhães Godinho (1962: 206) mencionou "contas amarelas e verdes de Nuremberg", no comércio português com África, durante o reinado de D. João II. (Tabela 11)

\section{CONTAS OCAS COM APLICAÇÕES DE VIDRO AMARELO}

Identificaram-se apenas dois raros exemplares, unidos por elo metálico, sugerindo pertencerem a terço. Encontrámos paralelo, para este tipo de produção, entre os testemunhos arqueológicos de pequena oficina vidreira de Ruão (Normandia), do século XVII. Esta produziu pequenos objectos de vidro em quantidades limitadas, com decorações variadas, entre os quais contas ocas com aplicações em forma de flor (Cabart, 1996: 440, fig. 3.47). (Tabela 12) 


\section{CONTAS COM DECORAÇÃO DOURADA}

Dois fragmentos de contas tubulares, de vidro branco, opaco, com secção circular, exibem linhas incisas espiraladas preenchidas por dourado. Trata-se de produção rara, sugerindo que a decoração dourada foi efectuada após a conta se encontrar terminada. Sabemos que algumas oficinas, dos chamados "esmaltadores" introduziam motivos decorativos em peças de vidro existentes e até as transformavam. Testemunhos de oficina de "esmaltadores" de Ruão mostrou trabalho de aplicação de ouro em pequenas peças de vidro (Cabart, 1996: 442). (Tabela 13)

\section{OUTRAS CONTAS}

Incluímos nesta categoria as contas com formas ou decorações para os quais não encontrámos paralelos. Conta de vidro azul de cobalto, oferece forma bi-tronco-piramidal hexagonal (paternostro a $f a$ cette), através de lapidação, podendo ter origem em Veneza. Encontra paralelo em exemplar da Liberia (Johnston, 1906: fig. 18). Rara conta periforme apresenta cor verde água. (Tabela 14)

\section{CANAS E VARAS}

A produção de contas de vidro, e de outros artefactos, recorre ao uso de varetas naquele material, chamadas canas (rods), quando perfuradas longitudinalmente, e varas se maciças. No Convento de Santana, conjunto significativo de fragmentos de canas denuncia a produção de pequenos objectos de vidro, nomeadamente de contas. Todavia, as canas podiam também ser segmentadas, ficando com diferentes comprimentos e usadas como contas, uma vez perfuradas em um ou nos dois topos, ou usando a perfuração central.

Colar que integra contas chevron e canas, perfuradas em um dos topos, provém de San Pedro Quitatoni, em Oaxaca (México), de produção hispânica e possivelmente do século XVIII. Também foram encontradas canas em Saint Augustine na Florida, em contexto do século XVIII, remetendo para a produção local de contas e outros adereços de vidro (Deagan, 2002: 131, fig. 6.21). Em Ruão (França), foi escavada área onde existiu, no século XVII, pequena oficina vidreira de "esmaltadores", certamente das muitas que naquela cidade produziam contas e outros adereços exportados para Portugal (Cabart,
1996). Eram espaços pequenos, com poucos artesãos, cujo trabalho dependia de lamparina metálica, com chama insuflada por fole, aumentando a temperatura de modo a fundir o vidro, conforme ilustra a Encyclopédia de Diderot e d'Alembert (1755: 545). (Tabela 15)

\section{ALGUMAS CONCLUSÕES}

Os adereços vítreos cumpriam, e ainda hoje o mesmo ocorre entre muitas comunidades humanas de todos os continentes, funções ornamentais ou de adorno, de pessoas, usados directamente sobre diferentes partes do corpo, nomeadamente visíveis, como em peças de vestuário, mas também em diferentes artefactos, entre os quais alguns de carácter religioso, como os conjuntos organizados em rosários e terços, da cristandade ou as contas de rezar (prayer beads) de outras religiões. Para além daquela função primária houve, por certo, desde sempre, outra, ligada aos anéis e braceletes e principalmente às contas, a apotropaica, dado a simbologia das formas daquelas últimas, principalmente a esférica ou globular, a sua resistência, como as características e origens das matérias-primas em que foram produzidas (cor, textura, brilho, raridade), funcionamento como amuletos (valor mágico das matérias-primas) e talismãs (formas), tornando-as, isoladas e sobretudo constituindo conjuntos, em "objectos de virtude". Estes foram usados por todas as classes sociais e etárias, alguns tornaram-se em bens herdados, sendo capazes de proteger contra a inveja e o mau-olhado (fastinatio), mas ainda de muitos outros males.

No que concerne às contas, elas tiveram valor monetário, chegando em algumas regiões de África a ser igual ao do ouro. Não obstante, as contas foram ainda usadas em jogos e para contar, em ábacos, e, portanto, com funções lúdicas ou ligadas ao cálculo matemático. A presença de contas em sepulturas nem sempre reflecte a existência de adereços ou de rosários e terços que acompanhavam os falecidos, pois antigas tradições, como a que registou, ainda na primeira metade do século XX, Albano Vieira Braga (1943: 88), no concelho de Marco de Canaveses, onde colocavam no caixão "uma moeda de cinco réis, umas contas e uma agulha enfiada. A moeda é para passar no campo de Jusafaz e meter na bôca do Diabo, que lá está de guarda; as contas são para o morto se ir encomendando a Deus, e a agulha para se remendar no outro mundo". A função protectora 
das contas ultrapassa as suas relações com os humanos, em vida ou depois de mortos, pois em Inglaterra lançavam-se contas aos poços para proteger as suas águas (Brent, 1880: 298).

Os adereços vítreos reflectem não só questões de gosto ou estéticos e aspectos idiossincráticos das sociedades humanas, como ideológicos, mas também nos informam sobre redes comerciais, influências e interacções económicas e culturais, constituindo testemunhos com enorme potencial histórico.

A existência de contas de vidro, ou de pasta vítrea, ascende, no território hoje português, à Idade do Bronze Médio (1500-1200 A.C.), de que são testemunhos raros exemplares procedentes do Mediterrâneo Oriental. Todavia, o seu uso desenvolveu-se durante o surto civilizacional ocorrido durante a I Idade do Ferro (séculos VIII-V A.C.), no Sul de Portugal, quando se importaram grandes quantidades de tais adereços, e depois na II Idade do Ferro, momento em que se terá iniciado a sua produção naquele território e em outras regiões ibéricas, a par da de braceletes, também de vidro (Alarcão e Gomes, 1989; 15-19).

Os adereços vítreos exumados nas ruínas do Convento de Santana, de Lisboa, sugerem, na maior parte dos casos, proceder das oficinas italianas de Veneza-Murano, embora seja difícil, não dispondo de análises físicas e químicas, termos certezas. Produções da Boémia e Morávia, muito activas desde 1548 , como as holandesas, podem ter sido responsáveis por alguns exemplares. Todavia, pudemos atribuir algumas contas às manufacturas inglesa $\mathrm{e}$ francesa, cuja importância só agora foi reconhecida através de documentos escritos.

Tal como o restante espólio exumado neste arqueossítio, os adereços de vidro ilustram sociedade abastada, de gosto requintado, capaz de recorrer aos circuitos comerciais internacionais, tendo em vista responder a gosto pessoal e à moda de então, mas também à manutenção dos estatutos sociais, através da posse e exibição de bens materiais de luxo. Jóias e adornos de vidro, eram usados com permissão em algumas instituições religiosas, num quadro longe da austeridade que a fé religiosa e a devoção deveriam impor, aspecto que não deixou de então ser criticado por alguns moralistas.

\section{BIBLIOGRAFIA}

AKERMAN, John Yonge (1851) - Remarks on a coloured drawing of some ancient beads, executed by Benjamin Nightingale, Esq. from specimens in his possession, Archeologia, vol.34(1), pp.46-50.

ALARCÂO, Adília; GOMES, Mário Varela (1989) - Da Proto-História aos Alvores da Idade Média, O Vidro em Portugal, pp. 15-25. Lisboa: Associação Portuguesa de Arqueologia Industrial.

ALMEIDA, Fernando de; MATOS; José Luís Martins de (1970) - Notícias arqueológicas, Actas das I Jornadas Arqueológicas, vol. II, pp. 413-424. Lisboa: Associação dos Arqueólogos Portugueses.

ALMEIDA, Mariana; GOMES, Rosa Varela; GOMES, Mário Varela (2018) - A first approach to the tile collection from the Convento de Santana (Lisbon, Portugal), International Conference Glazed Ceramics in Cultural Heritage, GlazeArt 2018, Sílvia Pereira, Marluci Menezes e José Delgado Rodrigues (eds): 42-44, 251-267. Lisboa: Laboratório Nacional de Engenharia Civil.

ALMEIDA, Mariana; GOMES, Rosa Varela; GOMES, Mário Varela (2020) - Os azulejos do Convento de Santana de Lisboa: primeira abordagem. Arqueologia \& História, vol. 70, pp. 293-309.

BARBOT, John (1732) - A Description of the Coasts of North and South-Guinéa; And of Ethiopia Inferior, Vulgary Angola: Being a New and Accurate Account of the Western Maritime Countries of Africa. London: A \& J Churchill.

BOWDICH, Thomas Edward (1819) - Mission from Cape Coast Castle to Ashantee. London: John Murray.

BRAGA, Alberto Vieira (1943) - Curiosidades de Guimarães, VIII - Mortórios, Revista de Guimarães, vol. LIII (1, 2), pp. 14-97.

BRENT, John (1880) - On glass beads with chevron pattern, Archaeologia, vol. XLV (2), pp. 297-308, 1 pl.

CABART, Hubert (1996) - Un atelier d'émailleur au $17^{\circ}$ siècle à Rouen (France), Annales du $13^{e}$ Congrès de l'Association International pour l'Histoire du Verre, pp. 437-446. Lochem: Association Internationale pour l'Histoire du Verre.

CANTINHO, Manuela (2008) - As contas chevron da Sociedade de Geografia de Lisboa; rosetas tricolores (séc. XV e XVI), Boletim da Sociedade de Geografia de Lisboa, série $126^{\mathrm{a}}, \mathrm{n}^{\mathrm{os}} 1-12$, pp. 247-251.

CARDINALL, Allan Wolsey (1925) - Aggrey beads of the Gold Coast, Journal of the Royal African Society, vol. 24(96), pp. 287-298.

CARDOZO, Mário (1943) - Antiguidades transmontanas. II - contas polícromas de pasta vítrea, Revista de Guimarães, vol. LIII(1, 2), pp. 112-116. 
CARDOZO, Mário (1955) - Breves notas acerca de um tipo conhecido de antigas contas de vidro polícromas, Revista de Guimarães, vol. LXV, pp. 133-136.

CARVALHO, Henrique Augusto Dias de (189o) - Ethnographia e Historia Tradicional dos Povos da Lunda. Lisboa: Imprensa Nacional.

CHAVES, Luís (1955) - Contas de pasta vítrea polícrómicas do Museu Etnológico, Revista de Guimarães, vol. LXV, pp. 137-141, 1 est.

CHILDE, Alberto (1919) - Guia das Colecções de Archeologia Clássica, Museu Nacional do Rio de Janeiro. Rio de Janeiro: Imprensa Nacional.

COSTA, António Inácio Marques da (1910) - Estações prehistoricas dos arredores de Setúbal, Appendice, O Archeologo Português, vol. XV, pp. 55-83, IX ests.

DEAGAN, Kathleen (1987) - Artifacts of the Spanish Colonies of Florida and the Caribbean, 150o-18oo. vol. I, Ceramics, Glassware and Beads, Washington D.C.: Smithsonian Institution Press.

DEAGAN, Kathleen (2002) - Artifacts of the Spanish Colonies of Florida and the Caribbean, 1500-180o. vol. II, Portable Personal Possessions, Washington D.C.: Smithsonian Institution Press.

DELAROZIÈRE, Marie-Françoise (1994) - Perles d’Afrique. Aix-en-Provence: Édisud.

DIDEROT, Denis; D’ALEMBERT, Jean le Rond (1755) - Encyclopédie ou Dictionnaire Raisonné des Sciences, des Arts et des Métiers, vol. V. Paris: André Le Breton Éditeur.

DUBIN, Lois Sherr (1987) - The History of Beads. From 30, oo B.C. to the Present. New York: Harry N. Abrams, Inc.

FAIRBANKS, Charles H. (1968) - Early Spanish Colonial beads, Conference on Historic Sites Archaeology Papers, vol. (1), pp. 3-21.

FARIA, Bettencourt (1974) - Subsídios para um melhor conhecimento das contas de vidro encontradas na Praia do Bispo em Luanda - Angola, Boletim do Grupo dos Amigos de Luanda, $\mathrm{n}^{\circ} 28$.

FEINZIG, Kristi May (2017) - Tracing Sixteenth Century Beads in South America to Understand their Impact on Indigenous Ritual Practices and Material Culture at the Time of the Spanish Conquest. Master's Thesis. Harvard: Harvard Extension School.

FRANCIS, Peter (1994) - Beads of the World, A Collector's Guide with Price Reference. Atglen: Shiffer Publishing Ltd.

GODINHO, Vitorino Magalhães (1962) - A Economia dos Descobrimentos Henriquinos. Lisboa: Livraria Sá da Costa.

GOMES, Mário Varela (2019) - Braceletes de vidro, Identidade e Cultura. Património Arqueológico de Sharjah (EAU), pp. 126-132. Lisboa: Museu Nacional de Arqueologia, Shar- jah Archaeology Authority, Instituto de Arqueologia e Paleociências da Universidade Nova de Lisboa.

GOMES, Mário Varela; CASIMIRO, Tânia Manuel; GONÇALVES, Joana (2012) - Espólio do Naufrágio da Ponta do Leme Velho (Ilha do Sal, Cabo Verde). Contributo para a Arqueologia da Expansão. Lisboa: Instituto de Arqueologia e Paleociências da Universidade Nova de Lisboa.

GOMES, Mário Varela; GOMES, Rosa Varela (2017) - Vidros do século XVI, do Poço-Cisterna de Silves, Proceedings of the $5^{\text {th }}$ GLASSAC International Conference (Glass Science in Art and Conservation), p. 128. Lisboa: NOVA-FCT Editorial.

GOMES, Mário Varela; GOMES, Rosa Varela (2018) - Garrafa, Três Embaixadas Europeias à China, p. 106 Lisboa: Fundação Oriente.

GOMES, Mário Varela; GOMES, Rosa Varela; CASIMIRO, Tânia Manuel (2019) - Ceramic toys and miniatures from the 16th-18th century found in Lisbon, Europa Postmediavalis 1, pp. 261-268, Archaeopress Publications LTD, Oxford.

GOMES, Mário Varela; GOMES, Rosa Varela; CASIMIRO, Tânia Manuel (2016) - Portuguese faience in Santana Convent, Lisbon. In Rosa Varela GOMES, Tânia Manuel CASIMIRO, Mário Varela GOMES, edit. - Proceedings of the First International Conference of Portuguese Faience ( $16^{\text {th }}$ $19^{\text {th }}$ Centuries), pp. 79-9o. Lisboa: Instituto de Arqueologia e Paleociências da Universidade Nova de Lisboa

GOMES, Mário Varela; GOMES, Rosa Varela; GONÇALVES, Joana (2017) - Objectos produzidos em matérias duras de origem animal, do Convento de Santana, de Lisboa, I Encontro de Arqueologia de Lisboa: Uma Cidade em Escavação, Ana Caessa, Cristina Nozes, Isabel Cameira, Rodrigo Banha da Silva (coord.): 84-105. Lisboa: Centro de Arqueologia de Lisboa / Departamento de Património Cultural / Direção Municipal de Cultura / Câmara Municipal de Lisboa.

GOMES, Mário Varela; GOMES, Rosa Varela; GONÇALVES, Joana (2020) - Artefactos de azeviche no Convento de Santana de Lisboa, Arqueologia \& História, vol. 70, pp. 311-327.

GOMES, Mário; GOMES, Rosa Varela (2007) - Escavações arqueológicas no Convento de Santana, em Lisboa. Resultados Preliminares. Olisipo. Lisboa. II série. 27, pp. 75-92.

GOMES, Mário; GOMES, Rosa Varela; CASIMIRO, Tânia Manuel (2015) - Convents, monasteries and porcelain: a case study of Santana Convent, Lisbon. In Jaume BUXEDA I GARRIGÓS, Marisol MADRID I FERNÁNDEZ, Javier G. IÑANEZ, edit., Global Pottery1. Historical Archaeology and Archaeometry for Societies in Contact, pp. 93-101. British Archaeological Reports, I.S. 2761. Oxford: Archaeopress.

GOMES, Rosa Varela; GOMES, Mário Varela; ALMEIDA, Mariana; BOAVIDA, Carlos; NEVES, Dário; HAMILTON, Kierstin; SANTOS, Carolina (2013) - Convento de Santana (Lisboa). Estudo preliminar do espólio da Fossa 7. In 
José Morais ARNAUD, Andrea MARTINS, César NEVES, coord. - Arqueologia em Portugal. 150 Anos, pp. 1057-1065. Lisboa: Associação dos Arqueólogos Portugueses.

GUTIERREZ, Manuel (2001) - Découverte d'un site funéraire inconnu. La sépulture de Caotinha, Archéologia, $\mathrm{n}^{\circ}$ 377, pp. 46-50.

HAEVERNICK, Thea Elisabeth (1961) - Beiträge zur geschichte des antiken glases. IV - Die aggryperlen = chevron pattern beads = rosettaperlen = star-beads, Jahrbuch des Romisch-Germanischen Zentralmuseums Mainz, vol. 8, pp. 121-138.

HAEVERNICK, Thea Elisabeth (1964) - Contribuição para a história dos vidros antigos, Revista de Guimarães, vol. $\operatorname{LXXIV(3,4),~pp.~290-316,~III~ests.~}$

HARTER, Pierre (1981) - Les perles de verre au Cameron, Arts d'Afrique Noire, vol. 40, pp. 6-22.

HUME, Ivor Noël (1991) - A Guide to Artifacts of Colonial America. New York: First Vintage Books Edition.

JARGSTORF, Sibylle (1995) - Glass Beads from Europe: With Value Guide. Atglen: Shiffer Publishing Ltd.

JOHNSTON, Harry Hamilton (1906) - Liberia, vol. I. London: Hutchinson \& Co.

KARKLINS, Karlis (1985) - Early Amsterdam trade beads, Ornament, vol. 9(2), pp. 36-41.

KARKLINS, Karlis; DUSSUBIEUX, Laure, HANCOCK, Ronald George Vincent (2015) - A $17^{\text {th }}$ century glass bead factory at Hammersmith Embankment, London, England. BEADS: Journal of the Society of Bead Researchers, $\mathrm{n}^{\circ} \mathbf{2 7}$, pp. 16-24.

MATOS, Armando de (1934) - Contas de massa vítrea encontradas em Angola, Trabalhos do $1^{\circ}$ Congresso Nacional de Antropologia Colonial, vol. II, pp. 455-462, Edições da $1^{\underline{a}}$ Exposição Colonial Portuguesa, Porto.

MONOD, Theodore (1952) - Perles anciennes au Portugal et en Afrique Noire Occidentale, Conferencia Internacional dos Africanistas Ocidentais, vol. IV, pp. 387-391, I est. Lisboa: Ministério das Colónias.

PEREIRA, Duarte Pacheco (1892) - Esmeraldo de Situ Orbis. Lisboa: Imprensa Nacional.

PEREIRA, Félix Alves (1927-29) - Jornadas de um curioso pelas margens do Lima, O Archeologo Português, vol. XXVIII, pp. 1-51, 1 est.

PEREIRA, Félix Alves (1933) - Contas policrómicas de pasta vítrea, Portvcale, vol. VI, pp. 24-31, 72-8o, 118-121.

PEREIRA, Félix Alves (1934) - A propósito das contas vítreas policrómicas, Portvcale, vol. VIII, pp. 16-18.

PEREIRA, Gabriel (1910) - Pelos Suburbios e Visinhanças de Lisboa. Lisboa: Livraria Clássica Editora.
PINTO, Rui de Serpa (1932) - Etnografia arqueológica, I. Antigas contas empregues como amuletos, Trabalhos da Sociedade Portuguesa de Antropologia e Etnologia, vol. V(III), pp. 245-250.

PRICE, John Edward (1883) - On aggri beads, The Journal of the Anthropological Institute of Great Britain and Ireland, vol. 12, pp. 64-68.

QUIGGIN, Alison Hingston (1992) - A Survey of Primitive Money. The Beginnings of Currency. Ocala: First Impressions Printing, Inc.

READ, Charles H. (1905) - A necklace of glass beads from West Africa, Man, $\mathrm{n}^{\circ}$ 5(1), pp. 1, 2, pl. A.

REINECKE, Paul Heinrich Adalbert (1929) - Das alter des aggryperlen, Praehistorische Zeitschrift, vol. 2O, pp. 278, 279.

RODRIGUES, Maria da Conceição (1993) - Contribuição para o estudo de contas de origem mediterrânea recolhidas em Angola, Mediterrâneo, nº 3, pp. 349-364.

RODRIGUES, Maria da Conceição (1997) - Contribuição para o estudo de contas de vidro de origem mediterrânica recolhidas na baixa pombalina de Lisboa, II Colóquio Temático Lisboa Ribeirinha. Lisboa, Câmara Municipal de Lisboa.

RODRIGUES, Maria da Conceição (2003) - The importance of the long glass beads of Mediterranean origin collected in the "Baixa Pombalina", Lisbon. Contribution to the study of the "Nueva Cadiz" type beads, Zephyrus, vol. 56 , pp. 207-233.

RODRIGUES, Maria da Conceição (2014) - As "Contas Longas" de Vidro como Elemento de Identidade dos Africanos no Passado Histórico e Cultural de Lisboa. De Meados do Século XV ao Terramoto de 1755. Porto: Universidade do Porto Editorial.

SILVA, Rosas da (1934) - Conta de vidro policromo encontrada no Castro de Sabroso, Revista de Guimarães, vol. XLIV(1), pp. 35-38.

SMITH, Marvin, T.; GOOD, Mary Elizabeth (1982) - Early Sixteenth Century Glass Beads in the Spanish Colonial Trade. Greenwood, Mississipi: Cottonlandia Museum Publications.

SOUSA, José Maria Cordeiro de (1954) - Grandes contas vítreas multicolores do Museu da Sociedade de Geografia de Lisboa, Boletim da Sociedade de Geografia de Lisboa, $72^{\underline{\underline{a}}}$ série, $\mathrm{n}^{\mathrm{os}} 1-3$, pp. 115-117, I est.

SOUSA, José Maria Cordeiro de (1955) - As grandes contas vítreas multicolores do Museu da Sociedade de Geografia de Lisboa, Revista de Guimarães, vol. LXV, pp. 142-144, 1 est.

SOUSA, Luís Rebelo de (1967) - Moedas de Angola. Luanda: Banco de Angola.

TEMPLE, Richard Carnac (1899) - Beginnings of currency, The Journal of the Anthropological Institute of Great Britain and Ireland, vol. 29 (1, 2), pp. 99-122. 
TISCHLER, Otto (1886) - Ueber aggry-perlen und über die Herstellung farbiger gläser im alterthume, Bericht über die in den Sitzungen der Physikalisch-Ökonomischen Gesellschaft zu Königsberg in Preussen, vol. 27, pp. 5-15.

TORRES, Andreia Martins (2007) - Contas exumadas na intervenção arqueológica do Palácio dos Marqueses de Marialva - Uma tipologia usada no trato colonial, Anais de História de Além-Mar, vol. VIII, pp. 181-237.

TOUGARD, A. (1897)-Vénitien receu à faire des patenôtres en France, en verre esmaillé, Bulletin de la Commission des Antiquités de la Seine-Inférieure, vol. 10, pp. 427-430.
VALENTE, Francisca Pulido; GOMES, Rosa Varela; GOMES, Mário Varela; COUTINHO, Inês; MEDICI, Teresa; VILARIQUES, Márcia (2019) - Renaissance Millefiori glass: the Portuguese case study, Recent Advances in Glass and Ceramics Conservation, pp. 217-221. London: British Museum.

VEIGA, Sebastião Philippes Martins Estácio da (1891) - Antiguidades Monumentaes do Algarve. Tempos Prehistóricos, vol. IV. Lisboa: Imprensa Nacional.

\begin{tabular}{|l|l|l|l|l|}
\hline Referência & Unid. & Descrição (anéis) & $\varnothing(\mathrm{m})$ & Esp. (m) \\
\hline CS/F6-1658 & 1 & $\begin{array}{l}\text { frag., de vidro negro, opaco, com protuberâncias em ambas laterais do aro, } \\
\text { possível anel de martírio }\end{array}$ & 0,0180 & 0,0022 \\
\hline CS/F6-1657 & 1 & vidro negro, opaco, com pequeno elemento esférico & 0,0120 & 0,0019 \\
\hline CS/F6-1649 & 1 & vidro negro, opaco, com enrolamento oblíquo e pequeno elemento esférico & 0,0135 & 0,0019 \\
\hline CS/F6-1650 & 1 & $\begin{array}{l}\text { frag., de vidro negro, opaco, de secção conc./conv., com flor de oito pétalas } \\
(\varnothing=0,0080 \text { m })\end{array}$ & 0,0150 & 0,0047 \\
\hline CS/P2-4 & 1 & $\begin{array}{l}\text { vidro azul índigo, translúcido, secção oval, e motivo floral de oito pétalas } \\
(\varnothing=0,0083 \text { m) }\end{array}$ & 0,0190 & 0,0033 \\
\hline CS/Zona F-1 & 1 & frag., de vidro negro, opaco, com secção circular & 0,0200 & 0,0024 \\
\hline
\end{tabular}

Tabela 1 - Convento de Santana, Lisboa. Anéis de vidro.

\begin{tabular}{|l|l|l|l|l|}
\hline Referência & Unid. & Descrição (braceletes) & $\varnothing(\mathrm{m})$ & esp. (m) \\
\hline CS/Q219-21 & I & frag., oca, de vidro incolor, transparente e secção circular & 0,0800 & - \\
\hline CS/F6-1864 & 1 & frag., oca, de vidro azul translúcido, de secção circular & 0,080o & 0,0084 \\
\hline CS/F1o-1 & I & frag., oca, de vidro incolor, transparente, com secção circular & 0,0600 & 0,0088 \\
\hline CS/P-240 & 1 & frag., maciça, de vidro azul-turquesa, translúcido e secção oval & 0,0158 & 0,0075 \\
\hline
\end{tabular}

Tabela 2 - Convento de Santana, Lisboa. Braceletes de vidro. 


\begin{tabular}{|c|c|c|c|c|c|c|}
\hline Referência & Unid. & Descrição (missangas) & Forma & $\varnothing(\mathrm{m})$ & Altura (m) & $\varnothing$ do orif. (m) \\
\hline $\begin{array}{l}\text { CS/Sep.7-2 } \\
\text { CS/Sep.7-3 }\end{array}$ & 2 & vidro branco, translúcido & esférica achat. & $\begin{array}{l}0,0041 \\
0,0032\end{array}$ & $\begin{array}{l}0,0025 \\
0,0020\end{array}$ & \\
\hline $\begin{array}{l}\text { CS/Sep.7-4 } \\
\text { a } 156\end{array}$ & 153 & vidro azul, translúcido & esférica achat. & $\begin{array}{l}0,0032 \\
0,0031 \\
0,0028 \\
0,0030\end{array}$ & $\begin{array}{l}0,0024 \\
0,0028 \\
0,0017 \\
0,0014\end{array}$ & $\begin{array}{l}0,0012 \\
0,0013 \\
0,0013 \\
0,0009\end{array}$ \\
\hline CS/Sep.3B-3 & 15 & $\begin{array}{l}\text { vidro branco, opaco, unidas por } \\
\text { elos metálicos (prata?) formando } \\
\text { corrente }\end{array}$ & esférica achat. & $\begin{array}{l}\text { c. o, } 0035 \\
-0,0040 \\
\text { elo } 0,0008\end{array}$ & $\begin{array}{l}\text { o,o030 } \\
-0,0036 \\
\text { o,oogo } \\
\text { c. total o,110o }\end{array}$ & \\
\hline $\begin{array}{l}\text { CS/Sep.18-1 } \\
\text { a } 142\end{array}$ & $\begin{array}{l}71 \\
69 \\
2\end{array}$ & vidro branco, opaco & $\begin{array}{l}\text { esférica achat. } \\
\text { cilíndrica } \\
\text { pequena }\end{array}$ & $\begin{array}{l}0,0041 \\
0,0037 \\
0,0027\end{array}$ & $\begin{array}{l}\mathrm{O}, \mathrm{OO} 25 \\
\mathrm{O}, \mathrm{OO} 34 \\
\mathrm{O}, \mathrm{OO} 23\end{array}$ & $\begin{array}{l}0,0015 \\
0,0014 \\
0,0012\end{array}$ \\
\hline $\begin{array}{l}\text { CS/Sep.4-1 } \\
\text { a } 16 \\
\text { CS/Sep.4-17 } \\
\text { a } 54\end{array}$ & $\begin{array}{l}16 \\
38\end{array}$ & vidro branco, opaco & $\begin{array}{l}\text { cilíndrica } \\
\text { esférica achat. }\end{array}$ & $\begin{array}{l}0,0036 \\
0,0041\end{array}$ & $\begin{array}{l}0,0044 \\
0,0032\end{array}$ & $\begin{array}{l}0,0013 \\
0,0012\end{array}$ \\
\hline $\begin{array}{l}\text { CS/Sep.5B-1 } \\
\text { e } 2\end{array}$ & 2 & vidro azul translúcido & cilíndrica & $\begin{array}{l}0,0062 \\
0,0059\end{array}$ & $\begin{array}{l}0,0040 \\
0,0048\end{array}$ & $\begin{array}{l}0,0020 \\
0,0019\end{array}$ \\
\hline $\begin{array}{l}\text { CS/Sep.5B-3 } \\
\text { a } 12\end{array}$ & 10 & vidro branco opaco & cilíndrica & 0,0036 & 0,0038 & 0,0012 \\
\hline $\begin{array}{l}\text { CS/Oss.4-11 } \\
\text { a } 105\end{array}$ & $\begin{array}{l}87 \\
8\end{array}$ & vidro branco translúcido (rosário ?) & $\begin{array}{l}\text { esférica achat. } \\
\text { cilíndrica }\end{array}$ & $\begin{array}{l}0,0030 \\
0,0032\end{array}$ & $\begin{array}{l}0,0028 \\
0,0035\end{array}$ & $\begin{array}{l}0,0010 \\
0,0014\end{array}$ \\
\hline $\mathrm{CS} / \mathrm{P}-228$ & 1 & vidro azul, translúcido & esférica achat. & 0,0044 & 0,0029 & 0,0012 \\
\hline $\mathrm{CS} / \mathrm{P}-229$ & 1 & vidro azul, translúcido & esférica achat. & 0,0048 & 0,0042 & 0,0020 \\
\hline $\mathrm{CS} / \mathrm{P}-230$ & 1 & vidro branco, opaco & cilíndrica & 0,0044 & 0,0034 & 0,0018 \\
\hline $\mathrm{CS} / \mathrm{P}-232$ & 1 & vidro verde água, translúcido & esférica achat. & 0,0046 & 0,0029 & o,0011 \\
\hline $\begin{array}{l}\mathrm{CS} / \mathrm{Q}_{3} \mathrm{O} 6 / \\
\mathrm{C}_{2}-5\end{array}$ & 1 & vidro verde azeitona, translúcido & cilíndrica & 0,0031 & 0,0028 & 0,0009 \\
\hline CS/Oss.4-7 & 1 & vidro branco, opaco & cilíndrica & 0,0058 & 0,0049 & 0,0012 \\
\hline CS/Oss.4-8 & 1 & vidro branco, opaco & cilíndrica & 0,0056 & 0,0047 & 0,0014 \\
\hline $\mathrm{CS} / \mathrm{F} 6-1653$ & 1 & vidro branco, opaco & esférica & 0,0047 & 0,0045 & 0,0011 \\
\hline CS/Oss.4-10 & 1 & vidro branco, opaco & esférica & 0,0030 & 0,0025 & 0,0009 \\
\hline CS/Q219-4 & 1 & vidro branco, opaco & esférica & 0,0023 & 0,0025 & 0,0008 \\
\hline
\end{tabular}

Tabela 3 - Convento de Santana, Lisboa. Missangas (contas de muito pequenas dimensões, seed beads), de vidro.

\begin{tabular}{|l|l|l|l|l|l|l|}
\hline Referência & Unid. & Descrição & Forma & $\varnothing(\mathrm{m})$ & Altura (m) & $\varnothing$ do orif. (m) \\
\hline CS/Q219-27 & 2 & $\begin{array}{l}\text { duas contas fundidas, de vidro } \\
\text { incolor, transparente, com onze linhas } \\
\text { brancas cada (o,ooo9 m) }\end{array}$ & esférica achat. & $\begin{array}{l}\text { 0,0049 } \\
\text { 0,0060 }\end{array}$ & $\begin{array}{l}\text { 0,0044 } \\
\text { 0,0051 }\end{array}$ & $\begin{array}{l}\text { 0,0012 } \\
\text { 0,0012 }\end{array}$ \\
\hline CS/Q219-2 & 1 & $\begin{array}{l}\text { conta, de vidro incolor, transparente, } \\
\text { com 11 linhas de cor branca, opaca } \\
\text { (o, ooo4 m). apresenta-se deformada, } \\
\text { talvez por acção do calor }\end{array}$ & cilíndrica & 0,0070 & 0,0109 & 0,0009 \\
\hline CS/Q219-1 & 1 & $\begin{array}{l}\text { conta, de vidro incolor, transparente, } \\
\text { com 12 linhas transversais de cor } \\
\text { branca, opaca (o,ooo4 m) }\end{array}$ & cilíndrica & 0,0059 & 0,0089 & 0,0018 \\
\hline
\end{tabular}

Tabela 4 - Convento de Santana, Lisboa. Contas de vidro incolor, transparente, com linhas brancas. 


\begin{tabular}{|c|c|c|c|c|c|c|}
\hline Referência & Unid. & Descrição & Forma & $\varnothing(\mathrm{m})$ & Altura $(\mathrm{m})$ & $\varnothing$ do orif. $(\mathrm{m})$ \\
\hline $\mathrm{CS} / \mathrm{P}_{2}-10$ & 1 & conta, de vidro preto, opaco, brilhante & esférica & 0,0109 & 0,0092 & 0,0029 \\
\hline $\mathrm{CS} / \mathrm{P}_{2}-16$ & 1 & conta, de vidro preto, opaco, brilhante & esférica achat. & 0,0103 & 0,0083 & 0,0024 \\
\hline $\mathrm{CS} / \mathrm{P}-94$ & 1 & conta, de vidro preto, opaco, brilhante & esférica achat. & 0,0084 & 0,0051 & 0,0029 \\
\hline $\mathrm{CS} / \mathrm{P}_{2}-6$ & 1 & conta, de vidro preto, opaco, brilhante & esférica achat. & 0,0124 & 0,0095 & 0,0035 \\
\hline $\mathrm{CS} / \mathrm{P}_{2-9}$ & 1 & conta, frag., de vidro preto, opaco, brilhante & esférica & 0,0114 & 0,0112 & 0,0027 \\
\hline $\mathrm{CS} / \mathrm{P}_{2-7}$ & 1 & conta, de vidro negro, opaco, brilhante & esférica achat. & :0,009o & 0,0079 & 0,0019 \\
\hline
\end{tabular}

Tabela 5-Convento de Santana, Lisboa. Contas de viro opaco de cor negra.

\begin{tabular}{|c|c|c|c|c|c|c|}
\hline Referência & Unid. & Descrição (contas tubulares) & Forma & $\begin{array}{l}\varnothing \\
(\mathrm{m})\end{array}$ & $\begin{array}{l}\text { Altura } \\
(\mathrm{m})\end{array}$ & $\begin{array}{l}\varnothing \text { do } \\
\text { orif. (m) }\end{array}$ \\
\hline $\mathrm{CS} / \mathrm{P}-231$ & 1 & vidro azul-turquesa, translúcido, de secção circular & tubular lisa & 0,0075 & 0,0095 & 0,0023 \\
\hline CS/Q224-1 & 1 & vidro azul-turquesa, translúcido, de secção circular & tubular lisa & 0,0064 & 0,0179 & 0,0025 \\
\hline $\begin{array}{l}\text { CS/ } \\
\text { Oss.4-106 }\end{array}$ & 1 & $\begin{array}{l}\text { frag., de vidro azul-turquesa, translúcido, } \\
\text { de secção circular }\end{array}$ & tubular lisa & 0,0064 & 0,0144 & 0,0028 \\
\hline $\mathrm{CS} / \mathrm{P}_{2}-45$ & 1 & $\begin{array}{l}\text { vidro azul água, translúcido, de secção circular, } \\
\text { biselada em ambas extremidades }\end{array}$ & tubular lisa & 0,0067 & 0,0209 & 0,0029 \\
\hline $\mathrm{CS} / \mathrm{P}_{2-2}$ & 1 & vidro azul-turquesa translúcido, de secção circular & tubular lisa & 0,0073 & 0,0314 & 0,0030 \\
\hline CS/P-93 & 1 & vidro azul-turquesa, opaca, de secção circular & tubular lisa & 0,0059 & 0,0126 & 0,0026 \\
\hline $\begin{array}{l}\text { CS/Q155/ } \\
C_{3-2}\end{array}$ & 1 & $\begin{array}{l}\text { frag., de vidro azul-turquesa / branco / } \\
\text { azul-turquesa, translúcido, de secção quadrangular }\end{array}$ & tubular lisa & 0,0073 & 0,0202 & 0,0022 \\
\hline $\mathrm{CS} / \mathrm{P}_{2}-1$ & 1 & $\begin{array}{l}\text { vidro azul-turquesa / branco / azul-turquesa, } \\
\text { translúcido, de secção quadrangular, com os cantos } \\
\text { ligeiramente facetados numa das extremidades }\end{array}$ & tubular lisa & 0,0084 & $0,055^{2}$ & 0,0041 \\
\hline $\begin{array}{l}\text { CS/Q173/ } \\
\text { C2-1 }\end{array}$ & 1 & $\begin{array}{l}\text { frag., de vidro azul-turquesa / branco / azul- } \\
\text { turquesa, translúcido, de secção trapezoidal, com } \\
\text { os cantos da extremidade existente facetados }\end{array}$ & tubular lisa & 0,0153 & 0,0289 & 0,0046 \\
\hline $\begin{array}{l}\mathrm{CS} / \mathrm{Q}_{231} / \\
\mathrm{C} 1-1\end{array}$ & 1 & $\begin{array}{l}\text { frag., de vidro azul-turquesa / branco / azul- } \\
\text { turquesa, translúcido, com secção quadrangular }\end{array}$ & tubular lisa & 0,0085 & 0,0239 & 0,0028 \\
\hline $\begin{array}{l}\mathrm{CS} / \mathrm{Q}_{180} / \\
\mathrm{C} 2-2\end{array}$ & 1 & $\begin{array}{l}\text { frag., de vidro azul-turquesa / branco / azul-turquesa, } \\
\text { translúcido, de secção quadrangular e cantos } \\
\text { facetados numa das extremidades }\end{array}$ & tubular lisa & 0,0109 & 0,0185 & 0,0046 \\
\hline $\begin{array}{l}\mathrm{CS} / \mathrm{Q} 18 \mathrm{o} / \\
\mathrm{C} 2-3\end{array}$ & 1 & $\begin{array}{l}\text { frag., de vidro azul-turquesa / branco / azul-turquesa, } \\
\text { translúcido, de secção quadrangular }\end{array}$ & tubular lisa & 0,0135 & & 0,0069 \\
\hline CS/FI1-2 & 1 & $\begin{array}{l}\text { vidro azul-turquesa / branco / azul-turquesa, } \\
\text { translúcido, de secção quadrangular, com os cantos } \\
\text { de uma das extremidades facetados }\end{array}$ & tubular torsa & 0,0092 & 0,0302 & 0,0034 \\
\hline $\mathrm{CS} / \mathrm{P}_{2}-44$ & 1 & $\begin{array}{l}\text { vidro azul-turquesa / branco / azul-turquesa, } \\
\text { translúcido, de secção quadrangular, com os cantos } \\
\text { de uma das extremidades facetados }\end{array}$ & tubular torsa & 0,0092 & 0,0241 & 0,0030 \\
\hline $\mathrm{CS} / \mathrm{Q}_{3} \mathrm{O}^{-1}$ & 1 & $\begin{array}{l}\text { vidro azul-turquesa / branco / azul-turquesa, } \\
\text { translúcido, de secção quadrangular, com os cantos } \\
\text { de uma das extremidades facetados }\end{array}$ & tubular torsa & 0,0092 & 0,0309 & 0,0033 \\
\hline $\begin{array}{l}\text { CS/Q113/ } \\
\text { C1-1 }\end{array}$ & 1 & $\begin{array}{l}\text { frag., de vidro azul-turquesa / branco / azul-turquesa, } \\
\text { translúcido, de secção quadrangular, com os cantos } \\
\text { de uma das extremidades facetados }\end{array}$ & tubular torsa & 0,0107 & 0,0251 & 0,0036 \\
\hline CS/Q219-16 & 1 & $\begin{array}{l}\text { dois frags, de secção circular, perfurada, de vidro azul } \\
\text { índigo, translúcido, com } 3 \text { linhas brancas }\end{array}$ & cilindrica & 0,0059 & - & 0,0027 \\
\hline $\mathrm{CS} / \mathrm{P}_{2}-47$ & 1 & $\begin{array}{l}\text { frag., de vidro azul-turquesa translúcido, com três } \\
\text { listas transversais de cor bordeaux/castanha, opaca, } \\
\text { de secção circular }\end{array}$ & tubular lisa & 0,0064 & 0,0307 & 0,0029 \\
\hline CS/Q219-19 & 1 & conta, de vidro azul translúcido & tubular lisa & 0,0026 & 0,0158 & 0,0012 \\
\hline
\end{tabular}

Tabela 6 - Convento de Santana, Lisboa. Contas tubulares de cor azul-turquesa (Nueva Cádiz). 


\begin{tabular}{|l|l|l|l|l|l|l|}
\hline Referência & Unid. & Descrição & Forma & $\varnothing(\mathrm{m})$ & Altura (m) & $\varnothing$ do orif. (m) \\
\hline CS/P2-46 & 1 & $\begin{array}{l}\text { conta, de vidro verde esmeralda, } \\
\text { translúcido, de secção quadrangular }\end{array}$ & tubular torsa & 0,0066 & 0,0392 & 0,0021 \\
\hline
\end{tabular}

Tabela 7 - Convento de Santana, Lisboa. Conta tubular, torsa, de vidro de cor verde esmeralda.

\begin{tabular}{|l|l|l|l|l|l|l|}
\hline Referência & Unid. & Descrição & Forma & $\varnothing(\mathrm{m})$ & Altura (m) & $\varnothing$ do orif. (m) \\
\hline CS/Q219-6 & 1 & $\begin{array}{l}\text { frag., de tipo chevron, de vidro } \\
\text { azul-turquesa transl. / branco opaco / } \\
\text { azul-turquesa transl. / branco opaco / } \\
\text { bordeaux opaco / azul índigo } \\
\text { translúcido }\end{array}$ & $\begin{array}{l}\text { cilíndrica, } \\
\text { facetada nos } \\
\text { topos }\end{array}$ & 0,0220 & 0,0192 & 0,0036 \\
\hline
\end{tabular}

Tabela 8 - Convento de Santana, Lisboa. Conta chevron.

\begin{tabular}{|l|l|l|l|l|l|l|}
\hline Referência & Unid. & Descrição & Forma & $\varnothing(\mathrm{m})$ & Altura (m) & $\varnothing$ do orif. (m) \\
\hline $\begin{array}{l}\text { CS/Q305/ } \\
\text { C2-5 }\end{array}$ & 1 & $\begin{array}{l}\text { conta, de vidro vermelho e negro, } \\
\text { opaco }\end{array}$ & esférica achat. & 0,0058 & 0,0046 & 0,0010 \\
\hline
\end{tabular}

Tabela 9 - Convento de Santana, Lisboa. Conta de vidro de cor vermelha com o interior de cor negra.

\begin{tabular}{|c|c|c|c|c|c|c|}
\hline Referência & Unid. & Descrição & Forma & $\varnothing(\mathrm{m})$ & Altura (m) & $\varnothing$ do orif. (m) \\
\hline $\begin{array}{l}C S / Q 219-22 \\
\text { e } 23 \\
C S / Q 219-24\end{array}$ & 3 & $\begin{array}{l}\text { contas, de vidro de cor bordeaux, } \\
\text { opaco, com quatro linhas brancas }\end{array}$ & $\begin{array}{l}\text { esférica achat. } \\
\text { esférica }\end{array}$ & $\begin{array}{l}0,0068 \\
0,0051\end{array}$ & $\begin{array}{l}0,0055 \\
0,0054\end{array}$ & $\begin{array}{l}0,0012 \\
0,0008\end{array}$ \\
\hline $\begin{array}{l}C S / Q_{219-25} \\
C S / Q_{219-26}\end{array}$ & 2 & $\begin{array}{l}\text { conta, de vidro de cor bordeaux, } \\
\text { opaco, com quatro linhas brancas }\end{array}$ & $\begin{array}{l}\text { esférica } \\
\text { cilíndrica }\end{array}$ & $\begin{array}{l}0,0049 \\
0,0033\end{array}$ & $\begin{array}{l}0,0042 \\
0,0038\end{array}$ & $\begin{array}{l}0,0014 \\
0,0013\end{array}$ \\
\hline $\mathrm{CS} / \mathrm{Q} 219-28$ & 3 & $\begin{array}{l}\text { três contas fundidas, de vidro de cor } \\
\text { bordeaux, opaco, com quatro linhas } \\
\text { brancas cada (o,0017 m) }\end{array}$ & esférica achat. & 0,0067 & 0,0048 & 0,0017 \\
\hline $\begin{array}{l}C S / Q 219-29 \\
\text { e } 30 \\
C S / Q 219-31 \\
\text { e } 32\end{array}$ & 10 & $\begin{array}{l}\text { dois pares e dois conjuntos de três } \\
\text { contas fundidas, de vidro de cor } \\
\text { bordeaux, opaco, com quatro linhas } \\
\text { brancas cada }\end{array}$ & $\begin{array}{l}\text { esférica achat. } \\
\text { esféricas }\end{array}$ & $\begin{array}{l}0,0051 \\
0,0045\end{array}$ & $\begin{array}{l}0,0032 \\
0,0044\end{array}$ & $\begin{array}{l}0,0014 \\
0,0010\end{array}$ \\
\hline
\end{tabular}

Tabela 1o - Convento de Santana, Lisboa. Contas de vidro de cor vermelha (bordeaux), com listas brancas.

\begin{tabular}{|l|l|l|l|l|l|l|}
\hline Referência & Unid. & Descrição & Forma & $\varnothing(\mathrm{m})$ & Altura (m) & $\varnothing$ do orif. (m) \\
\hline CS/Oss.4-6 & 1 & $\begin{array}{l}\text { missanga, de vidro de cor âmbar, } \\
\text { translúcido }\end{array}$ & cilíndrica & 0,0062 & 0,0047 & 0,0028 \\
\hline CS/F6-1655 & 1 & $\begin{array}{l}\text { missanga, de vidro de cor âmbar } \\
\text { vermelho, translúcido }\end{array}$ & cilíndrica & 0,0066 & 0,0040 & 0,0019 \\
\hline $\begin{array}{l}\text { CS/Jardim } \\
\text { N-1 }\end{array}$ & 1 & $\begin{array}{l}\text { conta, de vidro de cor âmbar, } \\
\text { translúcido }\end{array}$ & esférica & 0,0128 & 0,0124 & 0,0031 \\
\hline CS/P-89 & 1 & $\begin{array}{l}\text { conta, de vidro de cor âmbar, } \\
\text { translúcido }\end{array}$ & esférica achat. & 0,1000 & 0,0074 & 0,0039 \\
\hline
\end{tabular}

Tabela 11 - Convento de Santana, Lisboa. Contas de vidro de cor âmbar. 


\begin{tabular}{|l|l|l|l|l|l|l|}
\hline Referência & Unid. & Descrição & Forma & $\varnothing(\mathrm{m})$ & Altura (m) & $\varnothing$ do orif. (m) \\
\hline CS/Q219-4 & 2 & $\begin{array}{l}\text { vidro bordeaux, opaco, com pequenas } \\
\text { aplicações de vidro amarelo, em relevo }\end{array}$ & esférica & $\begin{array}{l}\text { 0,0107 } \\
\text { 0,006o }\end{array}$ & $\begin{array}{l}\text { 0,0100 } \\
\text { o, 0050 }\end{array}$ & \\
\hline
\end{tabular}

Tabela 12 - Convento de Santana, Lisboa. Contas ocas com aplicações de vidro amarelo.

\begin{tabular}{|l|l|l|l|l|l|l|}
\hline Referência & Unid. & Descrição & Forma & $\varnothing(\mathrm{m})$ & Altura (m) & $\varnothing$ do orif. (m) \\
\hline CS/Q219-35 & 1 & $\begin{array}{l}\text { vidro branco, opaco, com secção circular } \\
\text { e três conjuntos de três incisões douradas }\end{array}$ & tubular lisa & 0,0053 & 0,0139 & 0,0016 \\
\hline CS/Q219-3 & 1 & $\begin{array}{l}\text { vidro branco, opaco, com secção circular } \\
\text { e três conjuntos de três incisões douradas }\end{array}$ & tubular lisa & 0,0054 & 0,0337 & 0,0020 \\
\hline
\end{tabular}

Tabela 13 - Convento de Santana, Lisboa. Contas com decoração dourada.

\begin{tabular}{|c|c|c|c|c|c|c|}
\hline Referência & Unid. & Descrição & Forma & $\varnothing(\mathrm{m})$ & Altura (m) & $\varnothing$ do orif. (m) \\
\hline $\begin{array}{l}\text { CS/Sep.7- } \\
-157 \text { a } 174\end{array}$ & 18 & vidro incolor, translúcido & prismática & $\begin{array}{l}0,0029 \\
0,0041\end{array}$ & 0,0049 & 0,0013 \\
\hline $\begin{array}{l}\text { CS/ } \\
\text { Q219-20 }\end{array}$ & 1 & $\begin{array}{l}\text { vidro incolor, transparente, em forma } \\
\text { de gota, com orifício descentrado }\end{array}$ & oval & $\begin{array}{l}0,0077 x \\
0,0101\end{array}$ & $\begin{array}{l}\text { esp. máx. } \\
\text { o,oo70 }\end{array}$ & $\begin{array}{l}0,0016 x \\
0,0021\end{array}$ \\
\hline $\mathrm{CS} / \mathrm{Q}_{307-3}$ & 1 & vidro azul cobalto, transparente & $\begin{array}{l}\text { bi-tronco- } \\
\text {-piramidal }\end{array}$ & 0,0073 & 0,0084 & o,0019 \\
\hline CS/P-91 & 1 & $\begin{array}{l}\text { frag., de vidro negro, opaco, oval, plana } \\
\text { numa face e facetada na outra, com três } \\
\text { perfurações transversais }\end{array}$ & facetada & $\begin{array}{l}0,0254 x \\
0,0128\end{array}$ & 0,0068 & 0,0012 \\
\hline CS/F6-1659 & 1 & $\begin{array}{l}\text { vidro incolor, transparente, secção } \\
\text { quadrangular }\end{array}$ & tubular & 0,0053 & 0,0495 & 0,0021 \\
\hline $\begin{array}{l}\mathrm{CS} / \\
\text { Q219-34 }\end{array}$ & 1 & frag., de vidro verde água, translúcido & periforme & 0,0062 & 0,0116 & \\
\hline
\end{tabular}

Tabela 14 - Convento de Santana, Lisboa. Outras contas de vidro.

\begin{tabular}{|c|c|c|c|c|c|c|}
\hline Referência & Unid. & Descrição & Forma & $\varnothing(\mathrm{m})$ & Altura (m) & $\varnothing$ do orif. (m) \\
\hline $\mathrm{CS} / \mathrm{Q} 219-33$ & 65 & $\begin{array}{l}\text { canas, frag., três deles fundidos e } \\
\text { deformados, perfuradas, de vidro } \\
\text { vermelho, opaco, com } 4 \text { linhas } \\
\text { brancas cada }\end{array}$ & cana & $\begin{array}{l}0,0025 \\
0,0035 \\
0,0040 \\
0,0046 \\
0,0057\end{array}$ & & $\begin{array}{l}0,0012 \\
0,0015 \\
0,0020 \\
0,0030 \\
0,0022\end{array}$ \\
\hline $\mathrm{CS} / \mathrm{Q}_{219-18}$ & 1 & $\begin{array}{l}\text { cana, frag., de secção circular, de vidro } \\
\text { bordeaux, opaco, com três linhas brancas }\end{array}$ & vara & 0,0020 & 0,0217 & \\
\hline $\mathrm{CS} / \mathrm{Q} 219-17$ & 1 & vara, frag., de vidro azul / branco / azul & vara & 0,0042 & 0,0151 & \\
\hline $\begin{array}{l}\mathrm{CS} / \mathrm{Q}_{1} 82 / \\
\mathrm{C} 2-3\end{array}$ & 1 & vara, de vidro incolor, transparente & vara & 0,0047 & 0,0596 & \\
\hline $\begin{array}{l}\text { CS/ } \\
\text { Q219-36 }\end{array}$ & 1 & $\begin{array}{l}\text { vara, frag., de vidro incolor, transparente, } \\
\text { decorada com listas de cor branca, em } \\
\text { espiral, alternando uma lista isolada com } \\
\text { conjunto de quatro listas }\end{array}$ & vara & 0,0037 & 0,0277 & \\
\hline
\end{tabular}

Tabela 15 - Convento de Santana, Lisboa. Canas e varas de vidro. 


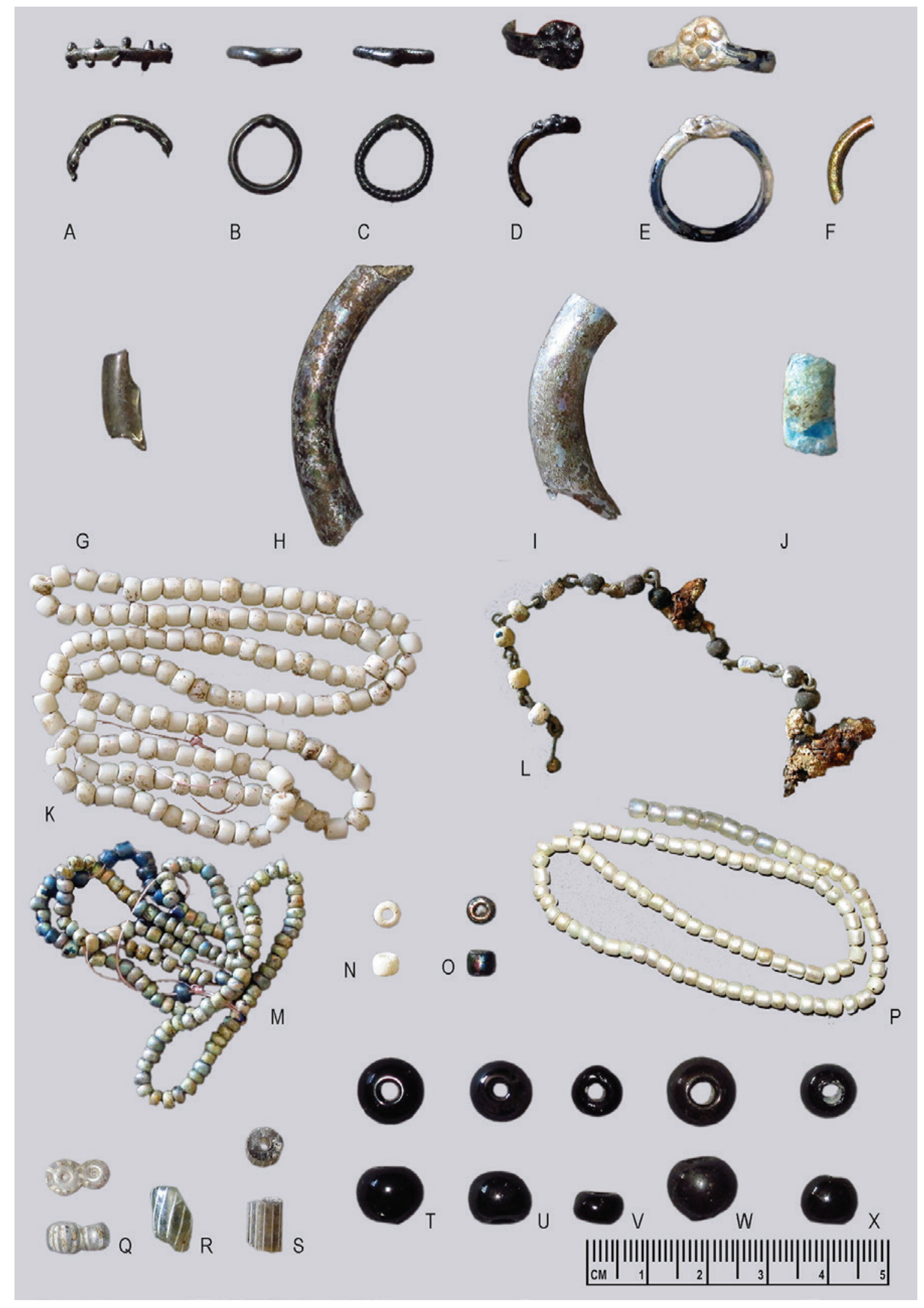

Figura 1 - Convento de Santana, Lisboa. Anéis (A. CS/F6-1658; B. CS/F6-1657; C. CS/F6-1649; D. CS/F6-1650; E. CS/P2-4; F. CS/Zona F-1), braceletes (G. CS/Q219-21; H. CS/F6-1864; I. CS/F1O-1; J. CS/P-24O), missangas (K. CS/Sep.18-1 a 142; L. CS/Sep.3B-3; M. CS/Sep.7-4 a 156; N. CS/P-229; O. CS/P-23O; P. CS/Oss.4-11 a 105), contas de vidro incolor, transparente, com linhas brancas (Q. CS/Q219-27; R. CS/Q219-2; S. CS/Q219-1), contas de vidro opaco de cor negra (T. CS/P2-10; U. CS/P2-16; V. CS/P-94; W. CS/P2-6; X. CS/P2-7) (fotos J. Gonçalves). 


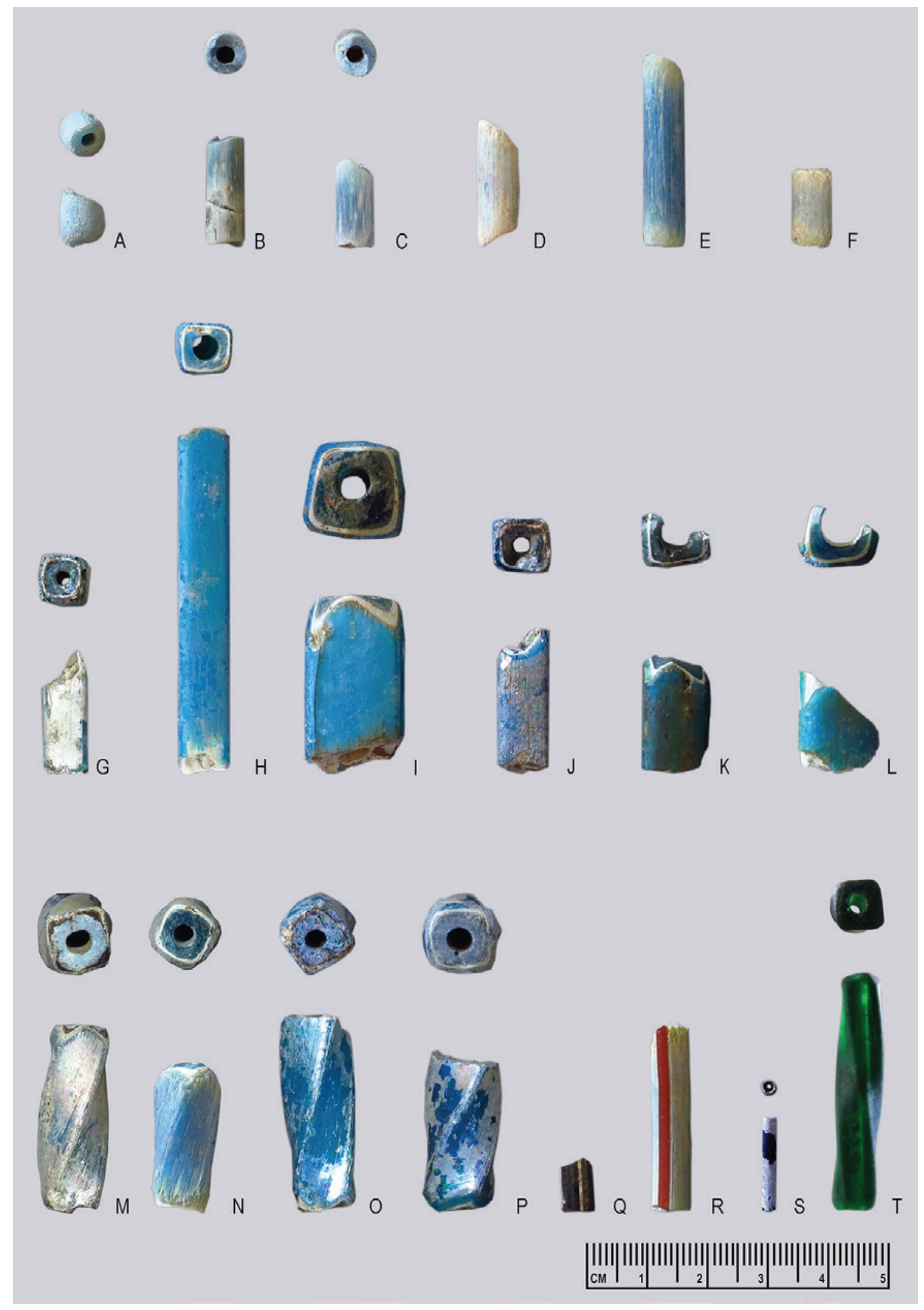

Figura 2 - Convento de Santana, Lisboa. Contas tubulares, de cor azul-turquesa (Nueva Cádiz) (A. CS/P-231; B. CS/Q224-1; C. CS/Oss.4-106; D. CS/P2-45; E. CS/P2-2; F. CS/P-93; G. CS/Q155/C2-2; H. CS/P2-1; I. CS/Q173/ C2-1; J. CS/Q231/C1-1; K. CS/Q180/C2-2; L. CS/Q180/C2-1; M. CS/F11-2; N. CS/P2-44; O. CS/Q304-1; P. CS/ Q113/C1-1; Q. CS/Q219-16; R. CS/P2-47; S. CS/Q219-19) e verde esmeralda (T. CS/P2-46) (fotos J. Gonçalves). 


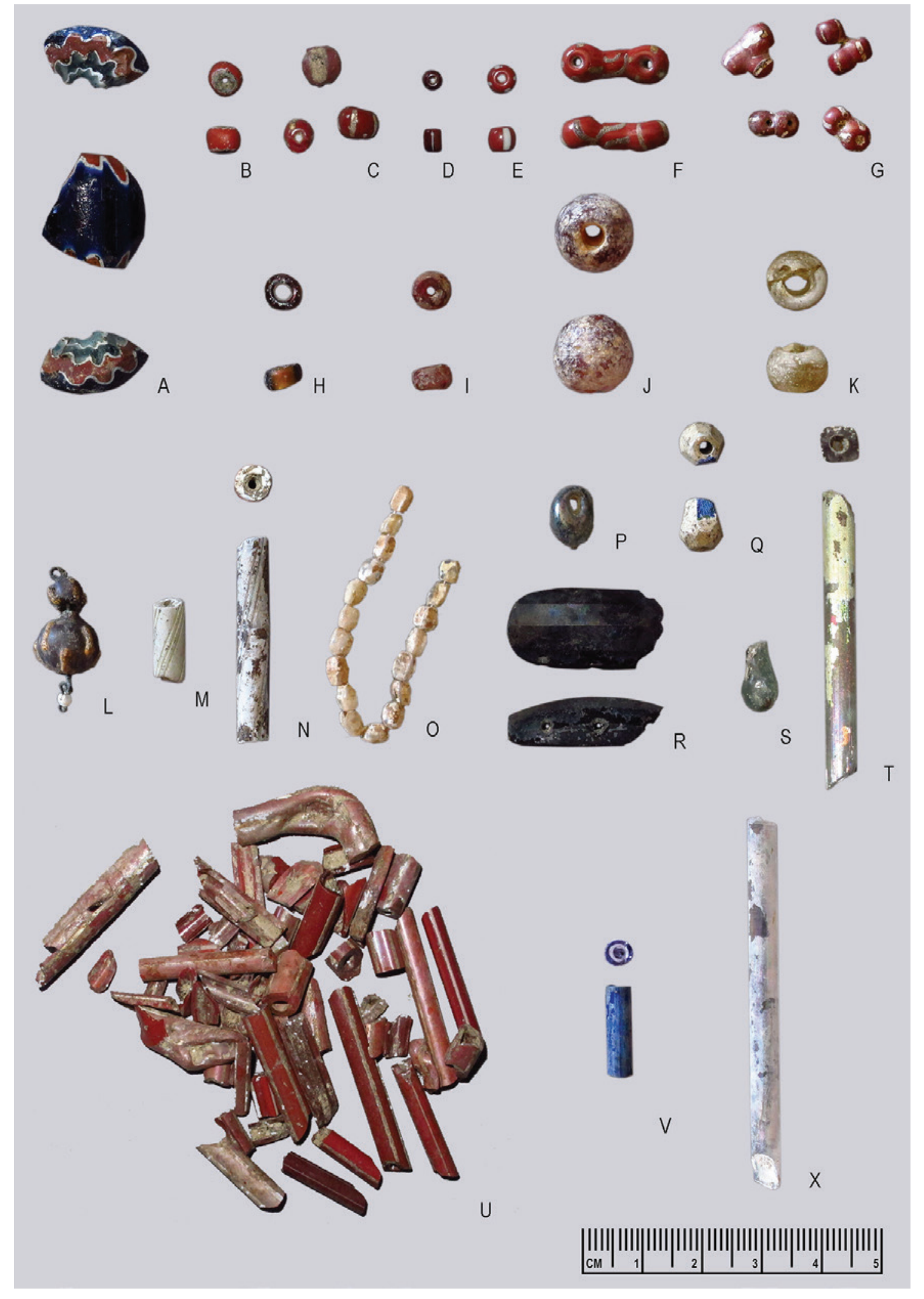

Figura 3 - Convento de Santana, Lisboa. Contas de vidro. Chevron (A. CS/Q219-6), vermelho e negro (B. CS/ Q305/C2-5), vermelho com listas brancas (C. CS/Q219-22 a 24; D. CS/Q219-25; E. CS/Q219-26; F. CS/Q21928; G. CS/Q219-29 a 32), de cor âmbar (H. CS/Oss.4-6; I. CS/F6-1655; J. CS/JardimN-1; K. CS/P-89), ocas com aplicações de vidro amarelo (L. CS/Q219-4), com decoração dourada (M. CS/Q219-35; N. CS/Q219-3), várias (O. CS/Sep.7-157 a 174; P. CS/Q219-20; Q. CS/Q307-3; R. CS/P-91; S. CS/Q219-34; T. CS/F6-1659), canas (U. CS/ Q219-33) e varas (V. CS/Q219-17; X. CS/Q182/C2-3) (fotos J. Gonçalves). 


\title{
DA OSTENTAÇÃO, LUXO E PODER À SIMPLICIDADE DO USO QUOTIDIANO: ARQUEOLOGIA E SIMBOLOGIA DE JOIAS E ADORNOS DA IDADE MODERNA PORTUGUESA
}

\author{
Jéssica Alexandra Martins Teixeira Iglésias ${ }^{1}$
}

\begin{abstract}
RESUMO
Ao longo dos séculos e pelo mundo, as joias e os objetos de adorno pessoais, desde sempre fascinaram o ser humano. Estes objetos passaram a ser usados como uma demonstração pública de riqueza cultural, pessoal, e do gosto próprio do seu utilizador tanto em vida como na morte.

Neste sentido o uso destes objetos durante os séculos XIV-XVIII, elaborados em diversas matérias primas, proporcionaram o surgimento e criação de elementos híbridos, que em grande medida foram consequentes de influências provocadas pela experiência ultramarina portuguesa, e pelas transformações sofridas nos gostos e modas europeias que contribuíram para a criação de uma nova sociedade, que continuou a acreditar nos valores apotropaicos e profiláticos de matérias-primas absorvendo novas crenças resultantes dos contactos com novas culturas.

Palavras-chave: Joias, Adornos, Idade Moderna; Cultura Material, Simbologia.
\end{abstract}

\begin{abstract}
Over the centuries and around the world, jewelry and personal adornments have always fascinated the human being. These objects came to be used as a public demonstration of cultural, personal wealth, and the user's own taste both in life and in death.

In this sense, the use of these objects during the $14^{\text {th }}-18^{\text {th }}$ centuries, made of different raw materials, provided the appearance and creation of hybrid elements, which were largely the result of influences caused by the Portuguese overseas experience, and by the changes undergone in tastes and fashions. Europeans who contributed to the creation of a new society, who continued to believe in the apotropaic and prophylactic values of raw materials absorbing new beliefs resulting from contacts with new cultures.
\end{abstract}

Keywords: Jewels, Adornments, Modern Age, Material Culture, Symbolism.

\section{INTRODUÇÃO}

A cultura material produzida por uma sociedade é fundamental para a compreensão da sua evolução e sucessivas transformações, e tal como outos elementos profusamente analisados, a joalharia e adornos também possibilitam a compreensão dos nossos ancestrais e da sua sociedade, entrar nas suas casas e compreender o seu modo de vida, entender os seus sentimentos, pensamentos e crenças. Contudo estes materiais, tratam-se de um registo arqueológico muito particular e frequentemente mal interpretado, o que regularmente conduz erroneamente à sua associação a uma cultura material pouco expressiva. Para além desta problemática, podemos adicionar o facto destes objetos apresentarem dois valores 
distintos, por um lado o económico, pois foram elaborados com metais e matérias de grande valor comercial, e consequentemente um grande alvo de colecionismo e venda. Por outro lado, a possibilidade de fundição dos seus metais e extração de pedrarias para a formação de novas peças, conferindo-lhes um design que fosse de encontro à moda do período em questão, permitindo assim a sua reciclagem e menores gastos face à aquisição de novas peças.

Neste sentido, "fausto" e "exotismo" são os termos que melhor descrevem a sociedade portuguesa no auge das conquistas e descobertas ultramarinas, com eles uma onda de mercadorias exóticas e objetos "curiosos" inundam e transformam o quotidiano. Consequentemente este intercâmbio cultural e lucrativo comércio acabou por invadir e influenciar todos as esferas da sociedade portuguesa desde o mais humilde dos cidadãos, aos membros religiosos até às elites.

Estas novas matérias primas surgem identificadas na documentação como sendo portadoras de propriedades medicinais e mágicas, contudo estas caraterísticas sobrenaturais são em grande parte herdadas da Idade Média, resgatadas durante a Idade Moderna e aliadas às tradições dos seus locais de origem. Apesar da forte religiosidade cristã, a necessidade de proteção e consequentemente a utilização de amuletos não se alterou, o que permitiu a integração e readaptação destas crenças e simbologias a esta religião ${ }^{2}$ (TAIT, 1996, p. 207).

Assim o significado e utilização de elementos de adorno é muito mais complexo do que esta simples equação de joias versus poder pode sugerir, as joias tornam-se um reflexo de gosto pessoal, arte, riqueza, investimento de capital e em alguns casos mnemónica para acontecimentos, individualidades ou grupos coletivos.

\section{ADORNOS DE CABELO}

Os adornos de cabelo e aplicação destes objetos como elementos decorativos ou rituais no tratamento e higiene do cabelo, foi de grande importância desde tempos mais remotos, em vida, na morte, identida-

2. Exemplo deste fator é a crença de que algumas pedras teriam virtudes religiosas como por exemplo "the contemplation of the deep blue of the sapphire could raise men's souls to the contemplation of heavenly kingdom". (TAIT, 1996, p. 207). de, inclusão ou exclusão social, ambientes estes que tendem a ser realizados em privado e consequentemente mais difícil de ser vistos no registo arqueológico e históricos. Estes elementos encontram-se simbolicamente associados ao sexo e sexualidade, à existência de espíritos e propriedades mágicas, à ideia de personalidade e representação de vitalidade do seu proprietário (ASHBY, 2014, p. 159).

Neste sentido, o cabelo e o seu enfeite, seriam uma mais valia na transmissão de poder social, político, económico, militar, demonstração de estatuto social, idade, género, religião, diferenciação étnica e em última instância cultivo da beleza, pois é um elemento facilmente visível, acessível e manipulável pelo seu usuário (ASHBY, 2014, p. 170).

No caso dos pentes e travessas, os adornos de cabelo que comummente surgem em contexto arqueológico, teriam como função primária a higiene e confeção de penteados, contudo não deve ser desmerecida a sua utilização como elemento de adorno e elemento apotropaico, ligado à força vital do cabelo e transformação da aparência, devendo-se em parte, às pontas aguçadas dos seus dentes capaz de repelir o mau olhado e até mesmo doenças, o que promoveu a sua utilização não só como ornamento, mas também pendurado ao pescoço (GOMES, 2010, p. 356). Contudo, não é fiável assumir que teriam sido usados exclusivamente com a função de pentear o cabelo humano, também poderiam ser utilizados como elemento de higiene contra a redução de pragas de piolhos, ou para a preparação de barbas e bigodes. Para além destas utilizações é de ressaltar a possibilidade de aplicação destes objetos em diversas outras áreas, sendo de destacar o alinho do pelo de animais domésticos, na preparação de fibras animais e vegetais para a produção têxtil, em ambientes rituais, como decoração ou como suporte a complexos arranjos de cabelo (GOMES, 2010, p. 356).

É ainda de ressaltar que o aparecimento destes materiais em contexto funerário poderá estar conotado com um simbolismo religioso de limpeza e purificação do corpo, como metáfora para a final transformação do corpo humano ou com a sua utilização na vida post-mortem, com o interesse em demonstrar que em vida o indivíduo teve acesso e apreço por este tipo de materiais e tecnologias.

Nas escavações realizadas na Igreja de Nossa Senhora da Esperança do Convento de São Francisco de Castelo de Vide, foram coletados treze pentes ou travessas (Figura 1. a, b, c, d, e, f) provenientes 
de oito sepulturas junto ao altar, algumas das quais ainda apresentavam, nas suas tampas, epigrafe com o nome de família e seus herdeiros. Apesar de não ter sido possível realizar a diagnose sexual nestes casos, os elementos em questão foram recolhidos em indivíduos adultos e associados com fragmentos de cerâmica de cozinha, faianças, alfinetes de mortalha, objetos de vestuário (botões, fivelas) e anéis (SANTOS S. , 2010, p. 8), o que demonstra um elevado poder social e económico dos inumados, não só devido ao posicionamento das suas sepulturas, mas também pelo facto de todos os elementos serem produzidos em carapaça de tartaruga, matéria-prima de importação. Dos treze elementos, apenas três possuem decoração incisa com linhas horizontais. Para além deste fator, apenas um elemento (Figura 1.c) apresentava um dente polido, o que poderá indicar uma contínua utilização, talvez até por várias gerações, o que implicaria o seu uso mesmo danificado, tanto pelo seu simbolismo sentimental como pelo do próprio objeto.

Elementos semelhantes poderão ser visualizados em utilização em pinturas dos séculos XVIII e XIX, tais como Margaret Sarah Carpenter, de autor desconhecido ou Head of a Woman, de Alfred Wadsworth.

Outra classe de adornos capilares utilizados no início da modernidade foram os toucados, elementos estes com algumas reminiscências medievais. Um exemplar destes objetos surge em escavações realizadas na Igreja de Santa Maria de Sabonha (Alcochete) (Figura 1. g) proveniente de um enterramento feminino datado do século XVI. Para além do toucado in situ preso por cinco alfinetes, no esqueleto ainda foram recuperados um fino anel de vidro preto na mão direita e entre as mãos um rosário em osso e fibras vegetais (CORREIA, 2005, pp. 10-12). O local de enterramento e os adornos recolhidos permitem determinar que a inumada, teria um elevado estatuto social e algum poder económico, pois os materiais recolhidos, apesar de não serem confecionados em matérias preciosas, claramente marcam a necessidade de demonstrar um certo estatuto social e capital monetário acumulado em vida.

O estilo de adorno de cabeça é um claro exemplar documentado na iconografia dos séculos XV e XVI, o que confirma claramente a datação do século XVI apresentada, tais como Portrait of a Lady de Giovanni Predis ou Eleonora di Toledo, de Agnolo Bronzino. Para além dos pentes, travessas e toucados, podemos acrescentar aos elementos de adornos de Idade
Moderna as bandoletes. Um exemplar metálico surge in situ na Igreja do Convento de Nossa Senhora da Conceição de Almodôvar, na zona frontal do crânio, juntamente com fragmentos de um tecido fino, provavelmente pertencente a um véu. Este estilo de adorno capilar poderá ser semelhante ao elemento apresentado num retrato de Maria Madalena, de Ambrosius Benson. Esta figura feminina ostenta um véu translúcido preso, pelo que poderemos supor ser uma bandolete metálica.

Elemento semelhante porem em carapaça de tartaruga, emerge nas escavações do Convento de Santana de Lisboa, em contexto de descarte juntamente com alguns pentes ou travessas. Estes elementos pertenceram a uma comunidade religiosa feminina, que ocupou o espaço durante os séculos XVII e XVIII, cronologia a que pertence a maioria do espólio ali exumado (GOMES , GOMES , \& GONÇALVES, 2017, pp. 102-103).

Como vimos anteriormente, a utilização de casco de tartaruga em adornos de cabelo é particularmente frequente, devido às suas origens exógenas, propriedades apotropaicos, associação simbológica à fecundidade, imortalidade, longevidade, conhecimento e sabedoria e facilidade de trabalho, foi considerada um material semiprecioso na Europa medieval e Moderna sendo que as mais apreciadas nestes períodos provinham das Maldivas e Filipinas. As propriedades curativas destes animais foram tão afamadas que o rei francês Luís XI promoveu uma expedição a Cabo Verde, tendo em vista averiguar estas curas milagrosas, pois suspeitava que padecia de lepra (LOUREIRO \& TORRÃO, 2008, p. 50).

\section{ANÉIS}

Desde os tempos pré-históricos que o homem utiliza estes elementos como símbolos de adorno, poder, autoridade, riqueza, de identidade individual e coletiva, nas suas mais variadas formas e infinidade de materiais, alguns deles considerados como tendo propriedades mágicas e protetoras, para além de realçarem a beleza, elegância e personalidade dos seus utilizadores, estes poderiam ser usados em qualquer dedo das mãos de acordo com gostos, modas e evitando a penetração de más energias.

Devido à sua forma circular, os anéis podem ser associados a um movimento de continuidade, eternidade, sendo capazes de reter indeterminadamente os maus espíritos e assim proteger e trazer boa sorte 
aos seus usuários. Para além destes elementos, os anéis também poderão ser associados à perfeição, união e compromisso, daí a tradição de troca de anéis durante a cerimónia matrimonial como associação à eternidade, cumplicidade e amor eterno (ROOP, 2011, pp. 2-11).

Para além desta simbologia, também poderão ser relacionados aos genitais femininos, numa clara alusão ao ato sexual.

As escavações realizadas no Edifício das cavalariças do Castelo de Castelo de Vide, possibilitaram a recolha de um anel que apresenta um "V" grosseiramente gravado (Figura 2.a), provavelmente realizado após a sua produção. Este tipo de ação não é rara em objetos de joalharia, pois reforçam a ideia de posse e pertença do elemento a um determinado individuo. Um inventário realizado após a morte de Lourenço de Medici em 1492, lista a posse de setenta e seis gemas preciosas das quais quarenta e duas apresentam o seu nome ou iniciais gravadas expondo claramente a ideia de posse e importância de demonstração da sua riqueza através da associação do seu nome (SESSIN, 2014, p. 14).

O modelo deste anel é muito semelhante a elementos exumados em liga de cobre nas escavações de uma antiga colónia espanhola, La Isabela, localizada na atual República Dominicana, estes anéis foram considerados como estando em utilização durante o século $\mathrm{XV}$, pois a ocupação do assentamento foi muito breve (1493-1496) (DEAGAN, 2002, p. 83). Neste sentido podemos pressupor que o elemento em estudo, provavelmente esteve em utilização durante os séculos XIV e XV, tal como outros elementos de adorno, os seus modelos permaneceram em voga durante um largo período de tempo.

Seguindo esta ideia de joias enquanto elementos de demostração e posse, poderemos integrar os anéis sinete, simbolicamente estes elementos pretendiam autentificar qualquer documento, representar, substituir, identificar ou completar a imagem e personalidade do seu possuidor. Exemplo destes elementos é um anel metálico banhado a dourado recolhido nos trabalhos do Castelo de Torres Vedras (Figura 2.b) este exumado num contexto de lixeira do século XVI-XVII, apresenta na zona central um monograma com a letra "N".

Estes elementos de adorno também poderiam representar o poder político, militar ou religioso do seu usuário como é exemplo de dois achados na Sinagoga de Castelo de Vide, um dos anéis em vidro negro apresentava como decoração uma cartela circular com cinco círculos em relevo (Figura 2.c), este elemento é semelhante a um recolhido no assentamento espanhol San Luis de Talimali na Flórida (1650-1700), (DEAGAN, 2002, p. 124). A representação de cinco elementos poderá estar relacionada com a simbologia cristã das cinco chagas de Cristo ou à estrela de cinco pontas de do rei David. Em ambos os casos estes elementos têm claramente conotação apotropaica e de identidade religiosa.

Para além deste elemento vítreo do mesmo sítio arqueológico português surge um anel que parece exibir uma cruz florenciada (Figura 2.d) provavelmente uma insígnia da ordem militar de Avis. Esta ordem parece não ser rara em Castelo de Vide, pois nas escavações realizadas na Igreja de Nossa Senhora da Esperança do Convento de São Francisco de Castelo de Vide foi recolhida uma insígnia militar (Figura 2.e) com a mesma decoração, como suspensão ostentava um laço ou laça, esta tipologia de elementos decorativos popularizou-se durante os século XVII-XVIII. As cruzes e insígnia apresentadas são muito semelhantes a uma divisa militar patente no Palácio Nacional da Ajuda, na qual são ostentadas em pedrarias a ordem de Cristo, Santiago e Avis.

Também nestes séculos visualizamos o surgimento do costume de utilização de anéis em crianças e nas falanges, estes dois elementos poderão ser vistos em representações femininas e de crianças desde o século XV ao XVII. Infelizmente a sua diferenciação é quase impossível, como acontece com os dois elementos coletados nas escavações realizadas na Sinagoga de Castelo de Vide (Figura 2.f, g).

Paralelamente o surgimento de anéis de forma quadrangular com uma pedra na zona central parecem integrar uma tendência joalheira com grande divulgação durante os séculos XVI e XVII, elementos semelhantes surgem em escavações do Edifício das Cavalariças, contudo a pedra que ostentam é em vidro (Figura 2.h). Em várias culturas a produção de adornos através desta matéria siliciosa, foi frequentemente associada à tentativa de imitação de pedras preciosas, paulatinamente vão adquirindo o mesmo valor mágico e simbólico que os elementos que pretendem substituir, o que permitiu o crescente prestígio e importância sociocultural deste material (RODRIGUES, 2001, p. 165).

Esta tentativa de imitação ou substituição através da utilização do vidro poderá ser visualizada num anel proveniente da Igreja de Nossa Senhora da Espe- 
rança do Convento de São Francisco de Castelo de Vide e produzido em liga metálica com vestígios de banho dourado, em ambas as laterais exibe encastrado três elementos redondos em vidro verde claro e ao centro um em vidro transparente (Figura 2.i). Alguns autores apresentam este modelo de adorno como sendo uma produção francesa do século XVII-XVIII. Elementos semelhantes foram descobertos em cobre ou prata, com pedraria semipreciosa e pasta de vidro em Santa Rosa Pensacola (1723-1752), local com forte relação com o comércio francês (DEAGAN, 2002, p. 125). A cronologia apresentada por Kathleen Deagan, para estes anéis poderá ser aplicada no objeto aqui apresentado, pois o sítio arqueológico português só teve um abandono efetivo entre os séculos XVIII-XIX.

Apesar de não ter sido possível encontrar referencias pictóricas ou documentais, foram identificadas três categorias de anéis que devido à sua facilidade de confeção e reprodução vemo-los surgir em contextos com balizas cronológicas muito díspares. Um destes modelos são os anéis com forma de espiral (Figura 2.j), como é o caso dos elementos recolhidos no Castelo de Castelo de Vide, elementos semelhantes surgem noutros sítios arqueológicos balizados entre os séculos XV e XVI. Porém a forma espiralada deste elemento parece ser um modelo com uma intensa divulgação geográfica e cronológica, pois elementos semelhantes apareceram em contextos de escavações romanos no Reino Unido, atribuídas ao século V-VI d.C. (CRUMMY, 1983, p. 48). O The Metropolitan Museum of Art apresenta um anel em ouro com decoração em espiral, porém datado da segunda metade do século VIII-X d.C. e originário de Java (www.metmuseum.org/art), para além destes foi possível identificar um exemplar mais tardio recuperado numa antiga colónia espanhola com ocupação setecentista (DEAGAN, 2002, p. 126). A forma de espiral é um motivo decorativo conhecido desde o Paleolítico Superior, tanto em cerâmicas, pinturas parietais como em objetos de arte móvel. A nível simbólico "(...) a espiral expressa o esforço perpétuo da periferia para alcançar o centro e vice-versa" (GOMES, 2010, p. 394), esta é frequentemente associada a energia, continuidade, eternidade, tempo cíclico e renovação, elementos estes oferecidos pela sua forma fluída e dinâmica. Os elementos aqui apresentados permitem-nos constatar uma difusão e perpetuação deste modelo de anel e amuleto desde pelo menos do século $\mathrm{V}$ ao XVIII.
O segundo modelo anteriormente referido, é uma categoria de anel em que a sua decoração consiste em envolver um fio em torno de um aro (Figura 2. k) e a sua facilidade de confeção reflete a mesma amplitude cronológica, vários exemplares foram recolhidos num ossário do Convento de São Vicente de Fora e nas escavações do Edifício das Cavalariças do Castelo de Castelo de Vide. Por fim o terceiro padrão consiste na composição de três fios metálicos entrelaçados entre si (Figura 2. 1), em território português foi possível identificar nas escavações do Convento de São Vicente de Fora e nos trabalhos da Praça de Armas do Castelo de Castelo de Vide, ambos os locais com ocupação findada por volta do século XVIII. Para estes elementos foi possível localizar um paralelo londrino proveniente de um contexto de século XIV (EGAN \& PRITCHARD, 1991, p. 331). Podemos então pressupor que os dois elementos nacionais estiveram pelo menos em utilização desde o século XIV ao XVIII, esta cronologia tão dilatada só é possível devido à sua fácil produção, pois apenas seria necessário torcer os fios metálicos entre si.

\section{BRINCOS}

A perfuração de orelhas, uma das práticas mais antigas de modificação corporal, permitiu a utilização de brincos como adornos, estes foram utilizados por homens, mulheres e crianças de todas as idades e estratos sociais, podendo ser utilizados um ou mais em cada orelha, produzidos com uma grande diversidade de materiais, formas e tamanhos. Como elemento decorativo estes têm a função de atrair a atenção para o rosto e consequentemente para a pessoa que os utiliza, marcando a sua personalidade, simbolicamente têm a função de abrir os orifícios auditivos para receber os sons exteriores, nutrir e purificar o espírito do seu utilizador. Estes também protegem contra a entrada de energias negativas garantindo um contínuo bem-estar físico, mental e evitam o ataque de espíritos.

No que se refere a brincos, os registos arqueológicos apresentam uma ampla diversidade de modelos, um destes exemplares é um brinco com uma pérola em forma de lágrima, com um pequeno laço ou laça fragmentado numa das pontas e preso a uma argola (Figura 3.a), este é proveniente de um enterramento junto de uma das paredes da Igreja Matriz de Loures. A análise osteológica identificou o inumado como sendo do sexo feminino de idade avançada, os 
materiais recolhidos na mesma camada de enterramento identificaram a sepultura como sendo do século XVII (OLIVEIRA, 2003, pp. 3-7). A morfologia deste objeto evolui dos laços de seda e veludo que suspendiam elementos decorativos nas vestes ou no seu utilizador, posteriormente irão ser produzidos em outros materiais, tais como demonstram os brincos em azeviche e com um laço na parte central recolhidos nas escavações da Fragata Santo António de Taná, naufragada ao largo de Mombaça em 1697 (GIL, TEIXEIRA, 2012, p.48o).

Um brinco de modelo semelhante poderá ser visualizado na pintura Female portrait de Alessandro Bonvicino contemporâneo do brinco aqui apresentado, porém o retrato apresenta o laço em tecido. A utilização de pérolas nos lóbulos não é uma ação casual, estes elementos são uma das matérias preciosas mais antigas conhecidas pelo homem que o fascinaram pela sua diversidade de cores, formas e pela ausência de esforço ou ferramenta para revelar o seu esplendor. Tal como outras matérias primas, também às pérolas estiveram associadas propriedades míticas, curativas e supersticiosas?3.

3. Na mitologia Greco-Romana acreditava-se que a sua formação derivava de lagrimas de deuses e consequentemente é-lhe atribuída uma origem divina, neste sentido não é surpreendente a sua associação com a deusa grega Afrodite e romana Vénus e aos seus mitos de criação, estas associadas à beleza, amor e sedução, o seu nascimento do mar, tal como originalmente descrito pelo poeta grego Hesíodo, fortaleceu a sua associação com as pérolas. Para além desta associação a erudição romana considerava a formação de pérolas como uma transformação de gotas de orvalho, que teriam sido recebidas por conchas marinhas durante as noites de lua cheia, momento este em que estes moluscos emergiam à superfície.

As civilizações orientais não se mantiveram indiferentes à atribuição de propriedades sobrenaturais e curativas às pérolas, sendo frequentemente associadas à perpetuação de juventude, cura de doenças oculares e mentais, antídoto para envenenamento, potencializa força e saúde (ELIADE, 1991, pp. 144-145) Mais tardiamente esta matéria preciosa é integrada na cultura cristã como representativa do amor de Deus, sinónimo de pureza, castidade, inocência, humildade e consequentemente tornam-se um símbolo da Virgem Maria.

Esta associação cristã, mantem-se e perlongou-se por toda a medievalidade e modernidade. Com o crescente culto à Virgem Maria, a adoção de pérolas como sinónimo de pureza, maternidade, consequentemente verificou-se um crescente aumento da sua veneração por gestantes que procuravam obter proteção. Alguns lapidários medievais e renascentistas descrevem as propriedades mágicas e medicinais das
Outro elemento desta categoria de adornos foi recolhido na Igreja de Santa Maria de Sabonha de Alcochete (Figura 3.b), exumado num enterramento datado do século XV, juntamente com uma moeda ilegível e um anel em forma de nó, parece ter sido inspirado num modelo romano em ouro eáguas marinhas patente no Museum of Cycladic Art (www. cycladic.gr), neste elemento podemos visualizar o processo de reavivamento da glória greco-romana, sentido durante a Idade Moderna, estas reminiscências Clássicas irão marcar a joalharia desta cronologia e posterior, o mesmo modelo de brinco poderá ser observado numa representação de século XVIII intitulada Poetry de Marie-Victoire Lemoine.

\section{PULSEIRAS}

Tal como outros objetos de adorno, também as pulseiras e os materiais em que são realizadas integram a categoria de objetos profiláticos que combatem o que não pode ser controlado, o desconhecido, enfermidades e superam o medo da morte, protegendo a pessoa que os ostenta, podendo aparecer isolados ou em combinação com outros elementos com a mesma forma, tais como anéis ou colares.

Devido á sua forma circular relacionada com o sentido de movimento contínuo, sem fim, que aprisiona indefinidamente o mal, daí a sua associação aos mais

pérolas, um destes exemplares é o Lapidario de Afonso X rei de Castela, que apresenta esta matéria como sendo benéfica para "... arte de fisica es muy buena, ca presta mucho a la tremor del corazón y a los que son tristes o medrosos, y a toda enfermedad que venga por melancolía, ca ella limpia la sangre del corazón. ..” "... que ponen en los ojos porque esclarece mucho el viso, esforzando los nervios, y tollendo los vahos, y enjugando la humedad que desciende a ellos." (www.xtal. iqfr.csic.es).

A crença nas propriedades medicinais das pérolas persistiu por toda a Idade Média e Moderna, o cientista Francis Bacon em c.16oo relata a pulverização de pérolas numa mistura de sumo de limão como um elixir de prolongação da vida. A esposa do arquiduque Fernando II da Áustria, c. 1570 elabora um livro onde descreve uma série de curas medicinais, recomendava esmagar pérolas e combiná-las com todo o tipo de produtos de origem animal para a cura de debilidades e doenças femininas (HOLZACH, SCHMIDT-MAPPES, \& GOODMAN, 2013, p. 13).

Nestes séculos as pérolas são utilizadas principalmente pelo seu significado religioso, propriedades mágicas e medicinais, passando a ser um indiciador do nível de riqueza e status social não só nas cortes ibéricas, mas as suas ramificações estendem-se por toda a Europa. 
desprotegidos e à proteção dos pontos mais sensíveis do corpo, pulsos e tornozelos maioritariamente de mulheres e crianças (CRESSIER, 1993, p. 79; SOUSA \& alii, 2018, p. 448; UREÑA, 1997, p. 306). Estes elementos de adorno podem apresentar uma ampla gama cromática, tal como sucede com as suas decorações desde as mais simples, sem decoração, às mais elaboradas.

Outra característica a ter em consideração é o número de pulseiras que cada indivíduo transportava, normalmente mais do que uma no mesmo membro, estas quando chocam com outros objetos ou entre si produzem um ruido característico, que também poderia ter o propósito de afastar o mau olhado.

Neste sentido não é de estranhar que a colocação de cada pulseira formaria parte de um ritual, talvez com a leitura de uma espécie de oração ou formula mágica que protegeria o seu proprietário. Exemplo desta atividade, é uma pulseira em bronze do século XII-XIII, descoberta no Castelo de Allende, localizado em Córdova, esta ainda conserva em cada uma das extremidades, elementos relacionados com o sistema de fecho, apresenta também decoração geométrica, fitomórfica e uma inscrição "La bendición completa y el [¿̇beneficio universal?] [. . . y la prosperidad, la bendición (?) y la generosidad". Apesar desta inscrição estar incompleta, é compreensível o caracter profilático e protetor que a sua epígrafe apresenta (ENAMORADO \& CARMONA, 1999, p. 162).

A simbologia das pulseiras, permanece ressoante até à atualidade, na tradição indiana considera-se que o período de lua de mel de uma mulher termina quando a última bracelete de vidro, que foi posta no dia do casamento se parte, em caso de viuvez, as mesmas seriam despedaçadas em sinal de luto e fim de compromisso. Em função destes fatores a quebra acidental destes adornos é encarado como sinal de mau presságio e de azar.

Exemplo destes elementos é uma pulseira metálica (Figura 4.a) recolhida nos trabalhos realizados no Edifício das cavalariças do Castelo de Castelo de Vide, esta apresenta decoração semelhante a pulseiras representadas por Nicolaes Eliasz Pickenoy ou a pulseiras de vidro recolhidas na Arrochela de Silves (GOMES, 2005, p. 24) e Igreja Matriz de Loures (OLIVEIRA, 2003, pp. 3-7).

Para além destes elementos é de referir os objetos recolhidos no ossário do Convento de São Vicente de Fora (Figura 4.b,c), devido às suas reduzidas dimensões, provavelmente seriam pertencentes a crianças, este tipo de prática ancestral permaneceu em voga até ao século XX. Para além da simbologia destes elementos a quantidade de pulseiras também poderá apresentar um carácter apotropaico.

Esta tipologia de braceletes de vidro são bem conhecidas desde a Antiguidade, sobretudo durante a Idade do Ferro e Período Romano (MEDICI, 2014, p. 505), em contexto moderno português a sua utilização foi comprovada em Alcácer Ceguer numa sepultura datada do século XV, com esqueleto feminino jovem que apresentava uma bracete de vidro em cada braço, e no convento de Santa Clara-a-Velha de Coimbra utilizados durante o século XVII mesmo num contexto em que elementos de adorno e joias seriam expressamente proibidos pelas constituiçõens Gerais da Ordem de Santa Clara (MEDICI, 2014, p. 505).

\section{ELEMENTOS DECORATIVOS}

Nesta categoria de materiais arqueológicos foram apresentados elementos que pela sua morfologia poderiam integrar uma panóplia de funções.

O elemento decorativo (Figura 5.a), à primeira vista poderá aparentar ser um pendente, contudo a decoração semelhante a um camafeu não deveria ser representada na transversal. Um objeto igual foi exumado nas escavações de Alcácer-Ceguer, em contexto de ocupação portuguesa (séculos XV a $\mathrm{XVI}$ ), este objeto ainda conserva um elemento em forma de "s" e decorado com uma cobra (REDMAN, ANZALONE, \& RUBERTONE, 1979, p. 14). Face à visualização deste paralelo, a utilização deste objeto como pendente poderá ser descartada e lava-nos a cogitar a possibilidade de ter sido utilizada como fivela de cinto.

No caso do amuleto em forma de figa (Figura 5.b), claramente foram utilizadas como elemento apotropaico, tanto pela sua forma como pelo seu material. A utilização de figas em azeviche ${ }^{4}$ como elementos de joalharia é muito comum principalmente como amuleto contra o mão olhado, principalmente nos

\footnotetext{
4. A esta matéria foram sendo atribuídas propriedades mágicas e protetoras, bem como medicinais e quiromânticas, sendo de destacar a sua capacidade de afugentar demónios, serpentes e tratar as suas mordeduras, curar dores de dentes, bem como histeria e epilepsia, doenças cardiovasculares, obstruir a inveja, a má sorte, o mau-olhado, etc. Tal como o coral, também esta pedra era considerada potente contra todas as formas de males.
} 
elementos sociais mais vulneráveis, crianças e mulheres. $\mathrm{O}$ aparecimento deste elemento em contexto conventual, figuras estas que remontam à antiguidade pagã, confirmam o estranho casamento da superstição com a religião. A utilização de figas não se cingiu apenas à proteção contra o mau olhado (DEAGAN, 2002, p. 95). O azeviche foi a principal matéria prima para a produção de figas, contudo estas também foram produzidas em coral, vidro, cristal de rocha, metal, concha, âmbar e outros materiais, também poderiam ser empregues para a sua produção. O elemento decorativo com uma águia bicéfala ( $\mathrm{Fi}$ gura 5.c), tal como outros elementos provenientes do local, também não apresenta indicação da estratigrafia onde este foi exumado, contudo foi possível encontrar um objeto semelhante num museu madrileno datado do século XVII. Estes elementos poderão ter sido utilizados como pendente, insígnia militar ou decoração de vestuário pertencente a um membro da família Habsburgo. Elemento semelhante surge representado num retrato de Ana da Áustria, família a que a nova rainha pertencia por parte de pai Maximiliano II e por parte de mãe, Maria da Áustria.

O corno metálico (Figura 5.c) recolhido em Castelo de Vide apresenta um pequeno orifício para aplicar um elemento de suspensão. Desde a antiguidade o corno foi associado a força, poder, fertilidade e vitalidade (AMATO, 2018, p. 53) e tal como outros elementos apotropaicos estes também são utilizados pelos grupos sociais mais frágeis, razão pela qual aparecem frequentemente em representações de mulheres e crianças.

\section{CONSIDERAÇÕES FINAIS}

Os objetos em estudo demonstram a sua mais íntima ligação com a vida humana evocando datas, acontecimentos, tristezas ou alegrias independentemente dos materiais empregues na sua produção serem dispendiosos ou vulgares, face a estes fatores, as joias e elementos de adorno são sempre um reflexo do gosto e vivências de um indivíduo, inserido num grupo e sociedade integrada no seu tempo e espaço. Como foi possível percecionar os adornos foram utilizados como elementos de beleza, de enfeite, de proteção, medicinal na forma de amuletos, pertença social, enquanto elemento identificativo, estado civil, demonstração e procura de status social, uso funcional enquanto elemento participativo em ves- timentas e por fim exibição e armazenamento de riqueza. Assim este conjunto evidencia a diversidade de modelos e singularidades constituindo um interessante e eloquente testemunho de um passado que muitas vezes só eles podem decifrar.

A chegada da armada de Vasco da Gama à Índia permitiu a ligação entre a Europa e os principais centros de produção e extração de matérias preciosas e semipreciosas. Este internacionalismo comercial adjunto à invenção da imprensa, a requisição de artesãos para trabalhar em capitais estrangeiras, movimentação de princesas, dotes e respetivos séquitos que continuaram a usar e a produzir os seus estilos de adornos, mas abrindo horizontes face às novas realidades e influências do seu envolvente, geraram uma maior profusão e circulação de modelos, formas, através de gravuras e desenhos por toda a Europa.

Esta nova realidade promoveu a diversificação e aumentou a panóplia de materiais e tipologias ao longo do avanço dos séculos, os elementos de adorno devido à sua perecibilidade e fragilidade surgem em contexto arqueológico de forma reduzida, em comparação com outros materiais. Para além deste fator os elementos em estudo, frequentemente encontram-se em estado de conservação deficitário o que dificulta em muito a sua análise e estudo. A maioria destes não sendo alvo de estudos sistemáticos acaba em depósitos ou reservas, apenas inventariados de forma sumária e na maioria das vezes sem informação acerca do seu local de exumação, acabando por nunca serem apresentados, publicados, isoladamente ou em bibliografia especifica sobre os mesmos.

A investigação acerca de elementos de adornos arqueológicos em contextos modernos encontra-se muito incipiente em Portugal, razão pela qual dificultou a compreensão e procura de paralelos arqueológicos portugueses para os elementos estudados. Contudo a análise de materiais realizada, possibilitou demonstrar a grande profusão de elementos considerados como "joias populares" ou de caracter quotidiano, elementos estes que dificilmente se vem representados, ao contrário dos seus semelhantes em matérias preciosas.

Assim é possível compreender que a joia difunde-se, espalha-se e torna-se objeto de desejo e de adorno, vaidade, enfeite e embeleza de quem as coloca, "democratizando-se" o seu uso. Contudo é de ter em atenção que as peças de maior valor dificilmente aparecem no registo arqueológico. pois face ao seu elevado valor monetário facilmente poderiam ser 
readaptadas e reutilizadas continuamente por várias gerações.

Por fim concluímos que os materiais estudados permitiram compreender a profusão de joias cada vez mais diversificadas a nível estilístico e de material, o que permitiu a utilização destes por boa parte da sociedade, assim como compreender as redes de interações comerciais e simbologias.

\section{BIBLIOGRAFIA}

AMATO, M. (2018) - Os simbolismos dos animais com chifres em bestiários ingleses. Lisboa: Dissertação de Mestrado em História Medieval apresentada à Faculdade de Ciências Sociais e Humanas da Universidade Nova de Lisboa (Texto Policopiado).

ASHBY, S. (2005) - Bone and antler combs: towards a methodology for the understanding of trade and identity in Viking Age England and Scotland. In H. LUIK, A. M. CHOYKE, C. E. BATEY, \& L. LOUGAS (ed.), From Hooves to Horns, from Mollusc to Mammoth: Manufacture and Use of Bone Artefacts from Prehistoric Times to the Present. Muinasaja Teadus (pp. 255-262.). Tallinn: University of Tartu.

CORREIA, M. (2005) - Santa Maria de Sabonha - São Francisco (Alcochete) Relatório arqueológico. Alcochete: (Texto Policopiado).

CRESSIER, P. (1993) - Humildes joyas: pulseras de vidrio en una casa andalusí de Senés (Almería). Revista del Celtro de Estudios Históricos de Granada y su Reino nº 7, pp. 67-84.

CRUMMY, N. (1983) - Colchester Archaeological Report 2: The Roman small finds from excavations in Colchester 1971-9. Essex: Colchester Archaeological Trust.

DEAGAN, K. (2002) - Artifacts of the Spanish Colonies of Florida and the Caribbean, 1500-1800: Portable Personal Possessions v. 2. Washington \& London: Smithsonian Institution Press, pp. 63-77.

EGAN, G., \& PRITCHARD, F. (1991). Dress Accessories, c. 1150 - c. 1450 (Medieval Finds from Excavations in London). London: Boydell Press.

ELIADE, M. (1991) - Images and Symbols: Studies in Religious Symbolism. Princeton: Princeton University Press.

ENAMORADO, V., \& CARMONA, R. (1999) - Una pulsera epigráfica de época almohade hallada en el castillo de Allende (Zuheros, Córdoba). Antiquitas nº 10, pp. 161-166.

GIL, L., \& TEIXEIRA, A. (2012) - Cada botão sua casaca. Indumentária recuperada nas escavações arqueológicas da fragata Santo António de Taná, naufragada em Mombaça em 1697. in Velhos e Novos Mundos, Estudos de Arqueologia Moderna, pp. 671-682.

GOMES, M. V (2010) - Arte rupestre do Vale do tejo: um ciclo artístico-cultural Pré e Proto-Histórico. Lisboa: Dissertação de Doutoramento em História, especialização em Arqueologia, apresentada à Faculdade de Ciências Sociais e Humanas de Lisboa.

GOMES, M.; GOMES, R.; \& GONÇALVES, J. (2017) - Objetos produzidos em matérias duras de origem animal, do convento de Santana de Lisboa. I Encontro de Arqueologia de Lisboa: Uma Cidade em Escavação, pp. 84-105.

GOMES, R. V. (2006) - Silves (Xelb), uma cidade do Gharb Al-Andalus: a zona da Arrochela, espaços e quotidianos. Lisboa: Instituto de Gestão do Património Arquitetónico e Arqueológico.

HOLZACH, C.; SCHMIDT-MAPPES, I.; \& GOODMAN, S. (2013) - Schaumgeboren und sagenumwoben - Schmuck aus Perlen/Angels Tears or Gems oft he Ocean-Pearls in the History of Jewellery. Pforzheim: Schmuckmuseum.

LIORET, R., \& SANCHIS, S. (1999) - Joyas y sociedad. Estudis: Revista de História Moderna, pp. 7-24.

LOUREIRO, N.; \& TORRÃO, M. (2008) - Homens e tartarugas marinhas. Seis séculos de história e histórias nas ilhas de Cabo Verde. Anais de História de Além-Mar vol 9, pp. 37-78.

MEDICI, T. (2014) - O vidro tardomedieval e moderno em Portugal (séculos XIV-XVII). O contributo da arqueologia. Coimbra: Dissertação de Doutoramento apresentada à Faculdade de Letras da Universidade de Coimbra (Texto Policopiado).

REDMAN, C.; ANZALONE, R.; \& RUBERTONE, P. (1979) - Medieval Archaeology at Qsar es-Seghir, Morocco. Journal of Field Archaeology, vol. 6, $n^{\circ}$ 1, pp. 1-16.

RODRIGUES, M. (2001) - Actas das Sessões IV Colóquio Temático: As Escalas de Lisboa Morfologias População Identidades. A Presença das contas de vidro como elemento de identidade do Africano no passado histórico e cultural de Lisboa Dos meados do século XV ao terramoto de 1755, pp. 161-208.

ROOP, E. (2011) - History and Meaning of symbolic rings - a creative project. Indiana: Dissertação de Mestrado em Artes apresentada à Universidade de Ball State Universitu Muncie (Texto Policopiado).

SANTOS, S. (2010) - Reabilitação e Reconversão do Convento de S. Francisco em Castelo de Vide Acompanhamento arqueológico - Relatório Final. Archeo'Estudos, Investigação Arqueológica: Castelo de Vide.

SESSIN, S. (2014) - Gems in Renaissance Material Culture. London: Dissertação de Mestrado apresentada à University of London (texto policopiado).

SOUSA, J.; LACAMBRA, M.; JIMÉNEZ, A.; PERNÍA, M.; \& GÓMEZ, J. (2018) - Elementos de adorno y amuletos de pasta vítre recuperados en el yacimento arqueológico de "La Mezquita”, Cadalso de los vidrios (Madrid). III Jornadas Jóvens Investigadores en Arqueologia, 445-453. 
TAIT, H. (1996) - Seven thousand years of jewellery. London: British Museum Press.

UREÑA, A. (1997) - Un conjunto de pulseras de vidrio hallado en la excavación del Hospital de San Andrés (Escalona, Toledo). Boletín de Arqueología Medieval nº 11, pp. 293-312.

www.metmuseum.org (consultado a 24/05/2019)

www.xtal.iqfr.csic.es (consultado a 24/05/2019)

a)

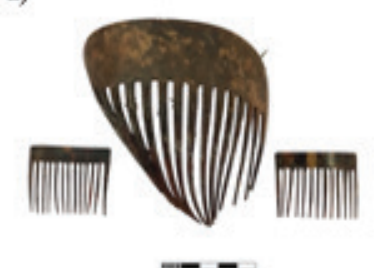

d)

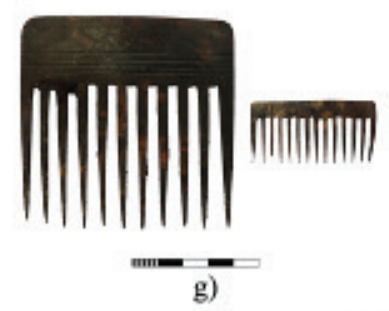

b)

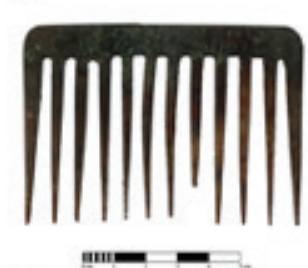

e)

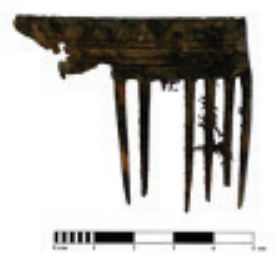

h) c)

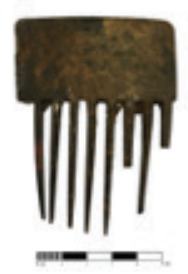

f)

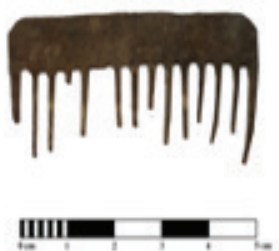

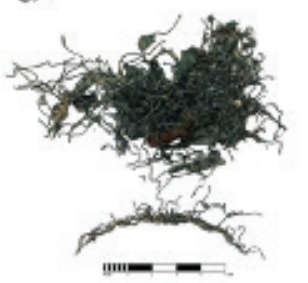

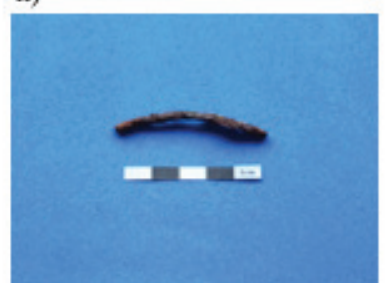

Figura 1-a)b) c) d) e) f) Pentes ou travessas, casca de tartaruga, Igreja de Nossa Senhora da Esperança do Convento de São Francisco de Castelo de Vide (Autor: Jéssica Iglésias). g) Toucado de cabelo, liga metálica, Igreja de Santa Maria de Sabonha (Alcochete) (Autor: Jéssica Iglésias). h) Bandolete, liga metálica Igreja do Convento de Nossa Senhora da Conceição de Almodôvar (Autor: Sara Luz). 
a)

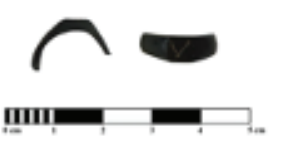

e)

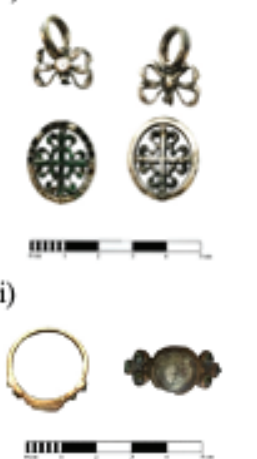

b)

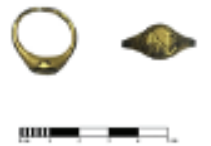

f)

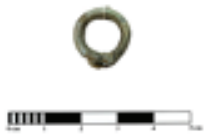

j)

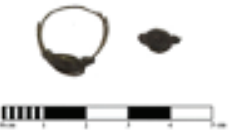

c)

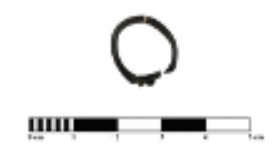

g)

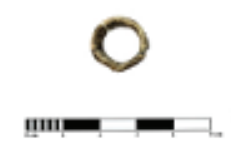

k)

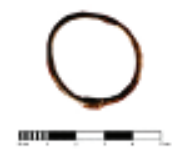

d)

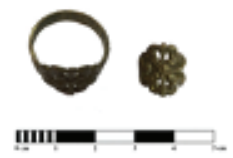

h)

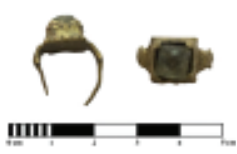

1)

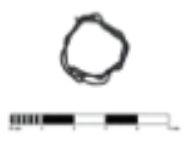

Figura 2 - a) Anel, azeviche, Edifício das Cavalariças do Castelo de Castelo de Vide (Autor: Jéssica Iglésias). b) Anel, liga metálica, Castelo de Torres Vedras (Autor: Jéssica Iglésias). c) Anel, pasta de vidro de cor negra, Edifício das Cavalariças do Castelo de Castelo de Vide (Autor: Jéssica Iglésias). d) Anel, liga metálica, Sinagoga de Castelo de Vide (Autor: Jéssica Iglésias). e) Pendente, liga metálica, Igreja de Nossa Senhora da Esperança do Convento de São Francisco de Castelo de Vide (Autor: Jéssica Iglésias). f) g) Anéis, vidro negro, Sinagoga de Castelo de Vide (Autor: Jéssica Iglésias). h) Anel, liga metálica, Edifício das Cavalariças do Castelo de Castelo de Vide (Autor: Jéssica Iglésias). i) Anel, liga metálica, Igreja de Nossa Senhora da Esperança do Convento de São Francisco de Castelo de Vide (Autor: Jéssica Iglésias). j) Anel, liga metálica, Sinagoga de Castelo de Vide (Autor: Jéssica Iglésias). k) Anel, liga metálica, Convento de São Vicente de Fora (Autor: Jéssica Iglésias). 1) Anel, liga metálica, Convento de São Vicente de Fora (Autor: Jéssica Iglésias).

a)
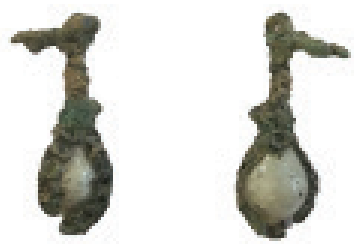

IIII

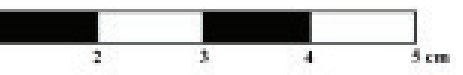

b)

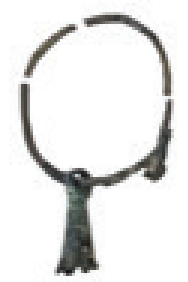

\section{IIIII}

Figura 3-a) Brinco, liga metálica e pérola, Igreja Matriz de Loures (Autor: Jéssica Iglésias). b) Brinco, liga metálica, Igreja de Santa Maria de Sabonha (Alcochete) (Autor: Jéssica Iglésias). 

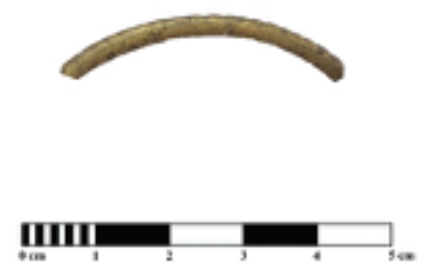

b)

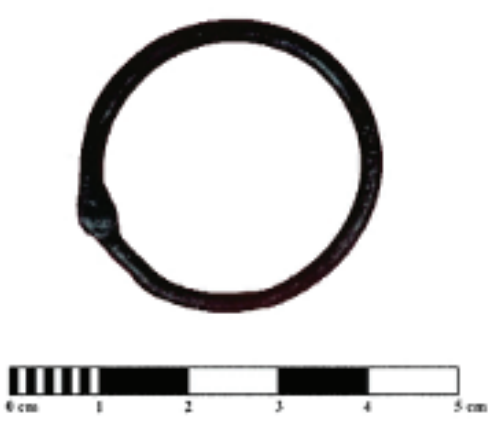

c)

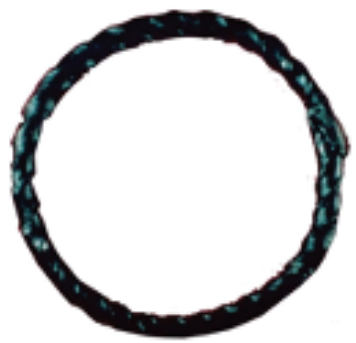

IIIII

Figura 4 - a) Pulseira, liga metálica, Edifício das cavalariças do Castelo de Castelo de Vide (Autor: Jéssica Iglésias). b) c) Pulseiras, vidro negro, Convento de São Vicente de Fora (Autor: Jéssica Iglésias).

a)

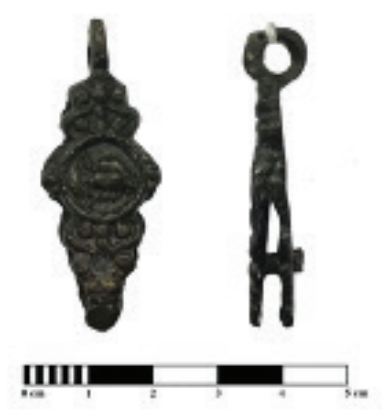

c)

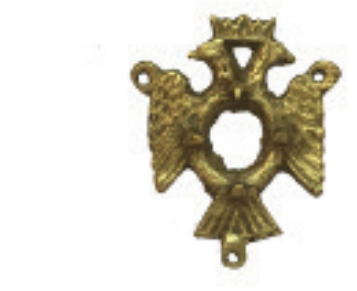

ШII b)

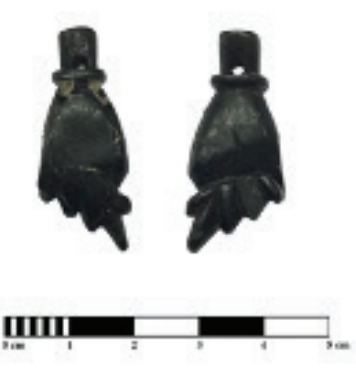

d)

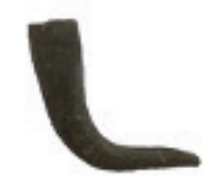

IIIIII

Figura 5-a) Elemento decorativo, liga metálica, Castelo de Torres Vedras (Autor: Jéssica Iglésias). b) Figa, azeviche, Castelo de Torres Vedras (Autor: Jéssica Iglésias). c) Decoração de vestuário, liga metálica, Edifício das cavalariças do Castelo de Castelo de Vide (Autor: Jéssica Iglésias). d) Corno, liga metálica, Praça de Armas do Castelo de Castelo de Vide (Autor: Jéssica Iglésias). 


\title{
OS AMULETOS EM PORTUGAL - DOS OBJETOS ÀS SUPERSTIÇÕES: O CORAL VERMELHO
}

\author{
Alexandra Vieira ${ }^{\mathrm{T}}$
}

\begin{abstract}
RESUMO
O estudo dos amuletos - objetos com um carácter apotropaico, ou seja, de proteção física e espiritual -, que possuem, por exemplo, o poder de evitar doenças, malefícios ou desgraças, e das superstições a eles associadas, contempla uma parte importante da vida das comunidades: as suas crenças e tradições, que refletem a forma como as pessoas se relacionam com o universo que as rodeia, com a sua interpretação do mundo em que vivem, com as suas práticas do quotidiano. O objetivo deste trabalho passa por tentar conhecer os amuletos elaborados a partir de corais (vermelhos) que se encontram associados às tradições e aos costumes das comunidades portuguesas, durante as épocas moderna e contemporânea.

Palavras-chave: Amuletos, Superstição, Coral Vermelho, Portugal.
\end{abstract}

\begin{abstract}
The transmission of knowledge about amulets - objects with an apotrophic character - physical and spiritual protection, which have, for example, the power to avoid disease, harm or misfortune - and theirs superticions, contemplates an important part of the life of communities: their beliefs and traditions, which reflect how people relate to the universe around them, their interpretation of the world in which they live, their everyday practices. The main purpose of this work is to try to understand the amulets made from (red) corals that are associated with the traditions and customs of the portuguese communities, during the modern and contemporary times.
\end{abstract}

Keywords: Amulets, Superstition, Red Coral, Portugal.

\section{INTRODUÇÃO}

O mundo das crenças populares e superstições sempre nos afigurou como algo fascinante. Estudar essa forma de ver o mundo transportávamo-nos para o imaginário popular, para a explicação do mundo, para a relação com fenómenos cuja explicação científica era praticamente inexistente antes dos séculos XIX/XX. Após a leitura dos dois volumes da coleção Etnografia Portuguesa relativos às superstições, o ingressar no universo das superstições passou a ser um exercício difícil, pois implica entrar num mundo que está intrinsecamente associado ao sofrimento. As difíceis e duras condições de vida, a fome, a elevada taxa de mortalidade, nomeadamente das parturientes e das crianças, o frágil papel social da mulher, remete-nos para uma sociedade moldada pela fome, morte e medo, daí a importância dada aos amuletos pelas diferentes comunidades portugueses e por todos os grupos sociais. $\mathrm{O}$ uso de amuletos "deve-se ao facto de o homem, no seu imaginário sobrenatural, ao ver-se rodeado de seres maldosos, procurar sempre opor-lhes resistência (...). Os amuletos são dotados, segundo o povo, de virtudes maravilhosas contra o mal" (Coelho, 2017, p. 26).

\footnotetext{
“Amuletos ou talismãs são objetos aos quais são atribuídas virtudes sobrenaturais, carregam atrações mágicas de caráter apotropaico e normalmente, o ritual de sua confecção é o que confere a força de seu poder. (...)” (Rodrigues, 2016, p. 73).
}

1. Instituto Politécnico de Bragança; CITCEM - Centro de Investigação Transdisciplinar Cultura, Espaço e Memória; alexandra. vieira@ipb.pt; alexxandra.vieira@gmail.com 
José Leite de Vasconcelos divide os talismãs em amuletos e mascotes ou porte-bonheur: "assim como há objetos que preservam do Mal, também os há que, pela mesma força natural, atraem o Bem. À primeira categoria pertencem os amuletos; à segunda os que os Franceses chamam porte-bonheur (...) e os Portugueses começam a chamar mascotes." Face às suas capacidades "mágicas" os amuletos poderiam ser divididos em duas grandes categorias: pagãos e religiosos, ambos utilizados contra o sobrenatural; fenómenos naturais, doenças; acidentes, perigos e desastres em geral (Vasconcelos, [1985] 2007, p. 279). Há autores que fazem uma distinção entre amuletos e talismãs. Os primeiros protegem do mal, os segundos atraem o bem (a fortuna, a sorte, a saúde e etc.). Há uma certa discrepância nos termos utlizados em relação a José Leite de Vasconcelos, mas no fundo temos duas grandes categorias: 1) objetos, símbolos ou materiais que protegem e afastam o Mal, cuja palavra amuleto parece ser consensual; e 2) objetos, símbolos ou materiais que atraem o Bem, a fortuna e a saúde e para os quais adotaremos a palavra talismã. Existem situações em que o mesmo objeto/símbolo ou material pode exercer esta dupla função. E, por vezes, estes objetos ou símbolos podem ser usados para invocar o Bem, protegendo pessoas, propriedades, negócios ou animais ou podem ser usados para Mal, tal como é o caso do pentagrama, que apontado para cima atrai o bem, mas apontando para baixo, está associada ao mal.

\footnotetext{
"Há amuletos cuja virtude depende ou apenas da sua fôrma , ou ao mesmo tempo da sua fôrma e substancia: figa, sino-saimão, moedas, meia-lua, noz de três esquinas, cornicho; e ha-os cuja virtude depende apenas da sua substancia , ainda que possam ter fôrma definida: contas (de azeviche, de coral), anéis metálicos, ferraduras, mãos de toupeira, dentes, pedras de raio, e outros. Um cornicho actua fundamentalmente pela sua substância; mas pôde ser imitado de osso, e então actua pela sua fôrma. As moedas actuam ou sô por serem de metal, ou porque nelas se representam figuras" (Vasconcelos, 1915, p. 234).
}

Os amuletos servem para proteger pessoas em geral, os animais, a casa e seus pertences, e os campos; e existem em todo o país, com pequenas variações de uma região para a outra (Vasconcelos, 1915, p. 235). O Portugal da Época Moderna e Contemporânea é um mundo de grandes contrastes; se por um lado se encontra profundamente marcado pela religião católica (a devoção a Nossa Senhora é um bom exemplo disso), por outro lado é "como bem notou Francisco Bethencourt, "um universo saturado de magia». Ela era praticada por um sem-número de indivíduos com múltiplas designações (feiticeiros, bruxas, curadores, mezinheiros, benzedores, casa-aberta, adivinhos, magos)" que podiam ser encontrados em qualquer parte do país. Estes indivíduos (homens e mulheres) tinham clientes aos milhares, que eram membros dos mais distintos grupos sociais, dos mais humildes aos mais abastados (Paiva, 2000, pp. 369-370). As curas, as adivinhações, a inclinação de vontades e a elaboração de amuletos faziam parte das funções desses indivíduos (Oliveira, 2013, p. 123). Aqui podemos fazer uma distinção entre amuletos pagãos, feitos por estes indivíduos, dos amuletos cristãos que seriam produzidos pelos ourives e consagrados/benzidos pelos padres.

Por fim, é interessante a crença de que alguns minerais, animais e vegetais possuíam "virtudes naturais" estando associados ao conceito de "magia natural", ou seja, trata-se da manipulação de algo que "com causas naturais produz efeitos extraordinários» (Paiva, 200o, p. 374). Estamos em crer, face às diferentes leituras que fizemos, que o coral é um desses animais e iremos retratar essas diferentes virtudes ao longo deste artigo.

\section{O CORALLIUM RUBRUM}

\begin{abstract}
“Isto é coral vermelho!” A segurar uma pequena amostra do que foi recolhido no fundo do mar, é assim que Joana nos apresenta aquele bem precioso, a rama que os pescadores algarvios costumam trazer agarrada às redes, sem saberem que há quem pague milhares para ter uma joia daquela cor. Aqui só soubemos da sua existência depois de anunciarem a detenção de uma rede ilegal” (...). Joana afirma que o Corallium rubrum, de seu nome científico, vive, sobretudo, em águas profundas do Mediterrâneo e do Atlântico, numa área mais próxima do Estreito de Gibraltar” (Visão, 2014).
\end{abstract}

Corallium rubrum (Lamarck, 1816), Gorgonia nobilis (Linnaeus, 1789), Isis nobilis (Pallas, 1766), Madrepora rubra (Linnaeus, 1758) são alguns dos nomes científicos atribuídos ao coral vermelho (FOA, 2020), pertencente à classe Anthozoa, subclasse Octocorallia, ordem Alcyonacea, subordem Escleraxo- 
nia e família Coralliidae. Existem cerca de 30 espécies de Coralliidae (Jiménez \& Orejas, 2017).

É uma espécie mediterrânea, embora tenha sido detetada em algumas áreas do Atlântico, perto do Estreito de Gibraltar. Costuma formar populações densas, com mais de 40 colónias por metro quadrado, em locais pouco iluminados (Gili \& Diaz, 2001, p. 42). Vive entre os $15 \mathrm{~m}$ e os $300 \mathrm{~m}$ de profundidade. Tem grande longevidade e cresce, em média, apenas um milímetro por ano. É conhecido como o Ouro Vermelho do Mediterrâneo (Visão, 2014). Distribui-se pelo Mediterrâneo Ocidental e Oriental: da Grécia e Tunísia ao Estreito de Gibraltar, incluindo Córsega, Sardenha e Sicília e pelo Atlântico Leste: Sul de Portugal, Marrocos, Canárias e Ilhas de Cabo Verde (FOA, 2020).

O coral vermelho foi explorado de forma irregular, em Portugal, no Algarve, entre 1200 e 1700, até ao colapso da pesca. Nos últimos 300 anos não são conhecidos relatos da sua ocorrência (Boavida $\&$ alii, 2016). Encontra-se documentada a pesca de coral por portugueses no Norte de Marrocos (Cabo Espartel), assim como nas ilhas de Cabo Verde, na segunda metade do século XIX (Zibrowius $\mathbb{\&}$ alii, 1984, p. 165). A referência mais antiga à pesca em Portugal que encontramos no decorrer da nossa pesquisa é a seguinte:

"A apanha de coral, na costa portuguesa, encontra-se documentada, em termos literários, para a Idade Média, designadamente a partir de, pelo menos, meados do século IX. De facto, Ibn Jurdadbih, em 844, mas baseado em informações anteriores, refere, entre outros produtos peninsulares exportados para o Norte de África e o Oriente, o coral obtido nas costas hoje portuguesas" (Gozalbes Cravioto, 1991, p. 31 apud Gomes \& alii, 2015, p. 101).

Durante os reinados de D. Afonso III e D. Dinis, ter-se-iam estabelecido, em Lagos, milaneses para se dedicarem à pesca do coral. Estes dados são referidos por José Bonifácio de Andrade e Silva, mas sem que tenha apresentado documentos que comprovem esta informação. Segundo Gama Barros, o documento mais antigo relativo a esta indústria é um Alvará de 16 de abril de 1462, onde se estabelece o contrato para a pesca do coral "certamente na costa do Algarve” entre D. Afonso V e Filipe Peroço (Torres, 1971). Em 1450 há o registo de uma carta de privilégio ao Infante D. Henrique concedendo-lhe a exclusividade da pesca do coral por D. Afonso V (Viterbo, 1903, p. 316). Lopo de Almeida obtém do rei D. Afonso V, a 22 de abril de 1473, uma carta de concessão da pesca do coral desde o Cabo de Espartel até ao rio Tagadarte (Marrrocos), durante 9 anos, com a exclusividade da apanha do coral na referida área (Rau, 1986, p. 153).

Sabemos que no séc. XVI Lisboa se torna um importante centro comercial onde se estabelecem ourives e lapidários estrangeiros e para onde convergiam metais nobres e pedras preciosas, nomeadamente o coral, vindos dos entrepostos comerciais que Portugal detinha em todo o mundo (MNMC, Joalharia, online).

No Dicionário Geográfico do Padre Luis Cardoso (1747, p. 285) sobre o Algarve diz-se que "Houve antigamente pescaria de coral, que iam buscar a três léguas do mar; era de grande proveito, mas hoje já não se pesca". Efetivamente, cessam os registos documentais relacionados com a pesca do coral. O interesse por esta prática ressurge quando o rei $\mathrm{D}$. João $\mathrm{V}$ concede ao negociante lisboeta Vicente Francisco o privilégio exclusivo, durante cinco anos, da pescaria do coral no Algarve através do Alvará de 2 de novembro de 1711 (Torres, 1971). A pesca do coral vermelho no Algarve volta a ser notícia com a captura de corais através da pesca ilegal, em 2014, o que origina um processo de proteção desta espécie ameaçada.

\footnotetext{
“Os jardins de corais - lugares de refúgio para outras espécies do mundo subaquático - estão ameaçados pela pesca ilegal. Uma lacuna legislativa tem permitido que um dos tesouros marinhos do Algarve, o coral vermelho (Corallium rubrum), esteja a ser capturado e vendido para fabrico de peças de joalharia. O Governo prepara um diploma que interdita a apanha desta espécie rara (...). Os corais vermelhos encontram-se por toda a zona do barlavento, podendo estender-se à Costa Vicentina. "Temos registos de pescadores que dão conta da sua existência ao largo da Carrapateira”, adiantou Jorge Gonçalves (...)" (Revez, 13 de julho de 2020).
}

E, deste modo, ficamos a conhecer alguns apontamentos sobre as características do coral enquanto animal marinho e sobre a pesca do coral em Portugal. 


\section{CORAIS - MEDICINA, AMULETOS E SUPERSTIÇÕES}

"Entre as criaturas aquáticas reais ungidas pelo paganismo greco-romano e acolhidas pelo cristianismo contam-se o peixe, o golfinho, os bivalves e o coral, todos eles considerados, outrora e agora, como animais divinos e benéficos" (Miranda \& Chambel, 2014, p. 81). "Os materiais orgânicos, como coral e pérolas, eram considerados produtos de um longo processo influenciado pelos astros, que lhes conferiam poderes sobrenaturais (Penalva \& Franco, 2016, p. 29).

No Diccionario Histórico de los Artes de la Pesca Nacional, de D. Antonio Sáñez Reguart, Tomo V. 1795, diz-se que o coral tinha ficado conhecido com (...) «el antiquíssimo nombre de "Arbol de Piedra"" (Arbez, 1990, p. 149).

É o universo relativo a estas "árvores de pedra", animais divinos e benéficos, influenciados pelos astros, detentores de poderes sobrenaturais, que vamos abordar nas próximas páginas.

De acordo do José Leite de Vasconcelos, o coral pode ser usado como amuleto, em ramo ou pedaço, ou sob forma de conta ou de figa. É mais comum encontrá-lo trabalhado sob a forma de conta, muitas das vezes formando colares de contas (Vasconcelos, 1929: 50). Para este autor também se usam objetos de coral, simplesmente como joia/adorno, tendo-se perdido a sua propriedade enquanto amuleto e refere ter visto em 1893, "em Lisboa uma senhora com uns brincos feitos de ramos de coral encastoado em ouro: cada brinco seu ramo" (Vasconcelos [1985] 2007, p. 216). Vieira Natividade, sobre Alcobaça, a propósito das superstições associadas ao "culto da pedra", diz que o povo da terra ainda conserva os seguintes amuletos: a pedra do raio; a conta leiteira; a conta de azeviche; as contas do âmbar "para que os dentes nasçam ás creancinhas, e as figas de coral e azeviche, substancias que téem um poder particular contra o mau olhado e outros feitiços" (Natividade, 1917, pp. 123-124). Neste caso o coral é interpretado como sendo uma pedra.

"Tido como possuindo propriedades apotropaicas, capazes de protegerem dos trovões, relâmpagos e tempestades, do mau-olhado, do demónio, dos feitiços, da loucura e demais doenças, mas igualmente de restaurar forças e o sangue, usando-se contra hemorragias, os males das gengivas e dos dentes, a gota, problemas do fígado e intestinos, designadamente lombrigas, a epilepsia, em feridas diversas ou, ainda, para o sucesso dos partos, o coral era tomado moído e sobretudo a sua variedade branca” (Gomes \& alii, 2015, p. 85).

Em relação às propriedades medicinais do coral, vermelho ou branco, o Abade de Baçal cita a obra de Francisco da Fonseca Henriques (Mirandela, 6 de Outubro de 1665 - Lisboa, 17 de Abril de 1731), médico do rei $\mathrm{D}$. João $\mathrm{V}$, que tendo escrito a obra: Medicina Lusitana - Socorro Délfico aos clamores da natureza humana para total profligação de seus males (1710, 1731, 1750) declara que a "agua de sal ammoniaco, destillada por alambique de vidro faz cahir os dentes sem nenhuma dôr; a mesma virtude tem o coral vermelho feito em pó e mettido na cavidade do dente; (...)" (Alves, [1934] 200o, pp. 239-240). Por seu turno, José Leite de Vasconcelos (1929, p. 52), no que concerne esta mesma obra (1731) refere outra das virtudes do coral, como por exemplo, "os pós, tomando-os os meninos antes de outra cousa, quando nascem, os preservam da gota coral" (= epilepsia). Ainda em relação a questões de saúde, JLV recolheu a seguinte informação: em Vila Pouca [de Aguiar] "as mulheres que amamentam usam colar de corais, para se livrarem de dadas nos seios"; um colar de contas de coral, colocado ao pescoço, tira a icterícia; e, por último, quando usado por alguém, se a pessoa estiver triste ou melancólica, o coral torna-se baço, anunciando o estado de ânimo dessa pessoa (Vasconcelos [1985] 2007, p. 216). Para além da analogia da cor vermelha do coral com o sangue, o formato dos ramos de coral remete igualmente para os vasos sanguíneos. Deste modo, utilizado enquanto medicamento, era recomendado para quem tivesse distúrbios relacionados com o sangue: "Tanto em Plínio quanto no Lapidário de Afonso X, o Sábio, há a informação de que a ingestão do coral triturado é benéfica para aqueles que porventura vomitassem ou cuspissem sangue” (Ragazzi, 2016, p. 38).

Enquanto elemento de proteção contra o Mal "diz-se em Vila do Conde que o coral vale o mesmo que o azeviche contra o bruxedo ou mau-olhado. Também se quebra se alguém lança mau-olhado a quem o usa" (Vasconcelos [1985] 2007, p. 216) e livra de quebranto quem o traz no braço ou no pescoço (Vasconcelos, 1929, p. 52). A rainha D. Catarina, mulher de D. João III, possuía nas suas coleções alguns objetos e materiais usados para o parto, como duas línguas de escorpião (dentes de tubarão fossilizados), "uma cabeça de cobra coberta de ouro, ambos 
usados como antídoto para veneno, talvez também como amuleto e com finalidades medicinais, duas pedras de jaspe em forma de coração para estancar o sangue; um ramo de coral para afastar o mau-olhado; (...)" (Buescu, 2019, p. 32).

Éloise Mozzani (1995 - Le Livre des Superstitions. Mythes, Croyances et Légendes - Paris: Robert Laffont, pp. 497-498) menciona existir uma forte tradição desde os cananeus onde o coral tinha a função de "porte-bonheur", passando pela época clássica até à contemporaneidade, no seu uso enquanto amuleto. Em França, Bélgica e Itália o coral é usado principalmente para a proteção das crianças. Outra das crenças sugeridas é que o coral presente numa obra de ourivesaria se perder a cor é sinal de doença. O sentido mais comum em várias tradições é a proteção da doença e de tudo o que está associado ao mal. Nesta obra faz-se referência à sua semelhança com a árvore da vida (como "arbe des eaux") e por isso possui um grande valor simbólico (Informação pessoal de Álvaro Campelo).

A peça portuguesa que melhor parece representar a árvore da vida é o relicário de Santo Lenho, feito de prata e coral, decorado de esmaltes coloridos, uma peça ímpar da joalharia portuguesa. O coral mantém a sua forma natural, de "árvore marinha", a que se atribui o dom da longevidade (MNMC, Joalharia, online). Integra o Tesouro da Rainha Santa, um conjunto de cinco peças constituído pelo relicário, um bordão de peregrina, uma cruz processional, uma imagem-relicário da Virgem com o Menino e um colar (Penalva e Franco, 2016: 28). O ramo de coral, com os seus múltiplos braços destaca-se como peça central deste relicário (Idem: 31). Este grande pólipo de corallium rubrum poderá ser originário da área do mar Mediterrâneo (Carvalho, 2010-2011 apud Penalva \& Franco, 2016, p. 53).

"Os corais foram admirados na Antiguidade, mas sem que que a sua espécie a que pertenciam fosse verdadeiramente conhecida. A sua peculiar morfologia e a diferente reação físico-química quando expostos aos elementos água e ar, tornando-se flexíveis como seres vivos ou rígidos como pedras, colocavam-nos numa mística fronteira entre os reinos vegetal, mineral e animal, sendo a este último que efetivamente pertencem. A mitologia greco-romana forjou-lhes uma origem lendária, fazendo-os resultar da metamorfose das algas pelo contacto com o petrificante sangue da Medusa” (Miranda \& Chambel, 2014, pp. 84-85).
Através de um processo de sincretismo, o sangue da Medusa teria sido posteriormente "transformado" pelo cristianismo para simbolizar o sangue sagrado de Cristo, ambos considerados protetores. O uso de contas de coral em rosários e em colares retratados em volta do pescoço do Santo Menino em pinturas devocionais, é evidência dessa crença (Balzan \& Deidun, 2010, p. 436).

\begin{abstract}
"Os corais tiveram uma dupla utilização medicinal e mágica, (...) como amuletos apotropaicos destinados a afastar o mau-olhado e a proteger os lares e as crianças. Esta última utilização, originalmente pagã, foi conservada pelos cristãos que atribuíram o coral a Jesus Menino (...) Correlativamente, o coral foi considerado profilático e redentor, como o Sangue de Cristo, e, pela sua cristalização e perpétua integridade, foi ainda tomado como metáfora da eternidade da alma do cristão (...)” (Miranda \& Chambel, 2014, pp. 84-85).
\end{abstract}

A este propósito Luísa Penalva e Anísio Franco referem que o uso do coral [vermelho]:

“sublinha este sentido cristológico, pois sabe-se que
este material, ao conjugar, segundo se acreditava na
época, os três reinos da Natureza - animal, vegetal
e mineral —, simbolizava a própria Árvore da Vida,
portanto, a árvore do Novo Testamento e a Vera
Cruz. Também a cor e a estrutura ramificada do coral
reforçavam o sentido do sacrifício do Filho de Deus”
(Penalva \& Franco, 2016, p. 31).

Efetivamente, na iconografia cristã europeia são vários os exemplos de pinturas onde o Menino Jesus se encontra representado com um raminho de coral ao pescoço. Este raminho funcionaria como amuleto, sendo considerado como um elemento de proteção. Também se encontram pinturas em que o Menino Jesus usa ao pescoço um rosário de contas de coral' ${ }^{2}$. Na obra a "Madonna della Vittoria" de An-

\footnotetext{
2. Podemos referir, a título de exemplo, as seguintes pinturas: "La Virgen con Niño", de Francesco Traini (c. 1345); o "o "Retablo de la vida de la Virgen y de San Francisco", Nicolás Francés (1445-146o); a "Virgen de los "Consellers»" de Lluís Dalmau (1428-1461); a "Virgen de la Porciúncula", de Albocácer (Castellón), (c. 1450); "Madonna col bambino", Piero della Francesca (1432-39); "The Trivulzio Madonna" de Andrea Mantegna, (1497). "La Virgen con Niño", Gérard David, (c. 1520). Na obra Sacra Conversazione de Piero della Francesca, 1472, o Menino Jesus usa um colar de contas de coral com um pendente (raminho de coral).
} 
drea Mantegna (1496) podemos ver uma pérgula de folhas, flores e frutos da qual pendem fios de contas de coral e cristal de rocha e um grande ramo inteiro de coral, que não sendo trabalhado/transformado e tendo sido extraído recentemente do mar conservava intacto o seu poder de proteção. Tanto as contas como o ramo de coral proporcionavam uma maior proteção à Virgem e ao Menino Jesus (Bruce-Mitford, 1997).

\footnotetext{
"No Mediterrâneo, achava-se que o coral, como o âmbar, contivesse a "essência da vida" da Deusa-Mãe, que habitava numa "árvore" de coral no oceano. Os povos antigos utilizavam o coral que não tinha sido trabalhado por mãos humanas para se tornarem poderosos em magia. O coral não era polido, cortado, esculpido ou furado. Acreditava-se que qualquer interferência com o coral poderia "matar" as suas energias mágicas, pois achava-se que estava vivo (como de fato estivera)" (Cunningham, 1988, p. 98).
}

Este texto parece ser particularmente significativo se olharmos para o Relicário de Santo Lenho, assim como para os diferentes pendentes sob a forma de ramo de coral utilizados por Cristo, nas pinturas referidas anteriormente, e pelas crianças no seu quotidiano. Ainda hoje se acredita que as pedras em bruto, ou seja, que não foram polidas, perfuradas nem trabalhadas possuem propriedades mágicas mais poderosas.

Em relação a Portugal, afiguram-se menos numerosas as pinturas que representam ramos de coral ou rosários deste mesmo material, mas existem alguns exemplares. Nossa Senhora das Neves, da autoria de Francisco Henriques, é uma pintura a óleo datada de 1509-1511, na qual a Virgem segura o Menino ao colo, que tem à volta do pescoço um colar de contas de coral (Matriznet).

No Museu Nacional de Arte Antiga encontra-se depositado um Rosário com Avé-Marias em contas de coral polido e Padre-Nossos em contas de filigrana de ouro, num total de treze dezenas incompletas, datado de 1601-1650 com $71 \mathrm{~cm}$ de altura (Matriznet) e uma pintura intitulada "Retrato de Senhora com rosário [supostamente em coral], de autor desconhecido (Jooris van der Straeten?), datado de meados do século XVI (Serrão, 2009, p. 28). Será que podemos estabelecer uma relação entre o crescimento da im- portância do Rosário ${ }^{3}$ e a sua produção na ourivesaria, assim como a sua representação nas pinturas? Muitos defuntos eram enterrados com terços ou rosários, alguns em coral. Será que, tal com advoga, Alexandre Ragazzi (2016, p. 39) o raminho de coral em bruto provindo de uma tradição pagã, começou a causar algum desconforto na Igreja, tornando-se as representações do Menino com os pendentes de coral na pintura "cada vez mais raros a partir de meados do Quinhentos. A tendência (...) era para o passado pagão ficar escondido sob a forma de um rosário. De facto, a Contrarreforma se encarregaria de substituir o raminho de coral por esse objeto".

No Museu da Terra de Miranda encontra-se depositado uma pintura a óleo sobre madeira de Santa Catarina de Alexandria, representada com um colar de coral vermelho (1664-1666). No Museu Nacional Machado de Castro existe uma pintura a óleo de Santa Catarina de Siena, que é representada com uma cruz de coral sobre o regaço (1650-170o) (Matriznet). No inventário de 1761 do Tesouro da Catedral de Braga é feita referência a uma casula, datada, provavelmente, de finais do séc. XVI, início do séc. XVII, embora a sua datação não seja consensual. Esta peça realizada com fios de ouro e prata possui duas fiadas de contas de coral e pérolas (Museu da Sé de Braga, em linha). Poderão estas contas de coral e as pérolas terem sido aqui colocadas não só para dar valor a uma peça essencial da liturgia cristã, mas teriam igualmente uma função protetora?

Já em finais do século XIX, José Leite de Vasconcelos (1897, p. 88) refere que é difícil distinguir um amuleto moderno de um objeto de adorno, como por exemplo as contas de colar, neste caso em particular, dos cordões de coral e explica: "No nosso país não só o coral é ainda hoje trazido em collares, ao mesmo tempo como amuleto e como enfeite, mas usão-se supersticiosamente, para certos fins, (...). Posso aqui mencionar igualmente os rosários de contas" (Idem: 154). No fundo, podemos dizer que alguns

\footnotetext{
3. Durante parte da Idade Média a devoção à Virgem Maria invadiu a "piedade cristã desde a Liturgia às Artes e Literatura.” Surgiu, entre outros, a devoção do Rosário. Na Idade Moderna, já num contexto de questionamento da Igreja, a Igreja Católica reage criando a Festa do Rosário, propagando a reza do Rosário e do Terço, entre outros fenómenos. Durante a Época Contemporânea atingiu-se o auge de devoção mariana; foram criados os meses do Rosário e houve uma renovação das Confrarias do Rosário. Outubro é o mês da devoção do Rosário e do Terço (Dias, 1987, pp. 228-229).
} 
materiais nobres, pedras preciosas e semipreciosas, foram "usadas primeiramente como amuletos talismânicos" (Penalva \& Franco, 2016, p. 50), mas vão sendo desprovidos lenta e progressivamente da sua carga mágica/protetora limitando-se a ser observados como um mero enfeite ou adorno, prevalecendo a sua carga estética em detrimento da carga mágico-religiosa.

\section{CORAIS - OBJETOS E CONTEXTOS ARQUEOLÓGICOS}

Um dos maiores desafios deste trabalho consistiu em encontrar amuletos elaborados a partir de coral vermelho e/ou, se possível, contextos arqueológicos associados à sua descoberta. Por possuirmos tão poucos dados sobre o assunto, optámos por registar todas as referências a corais que nos foi possível detetar na pesquisa bibliográfica que realizamos. Não foi possível proceder a uma recolha exaustiva e sistemática, quer em museus, quer nas diversas publicações de arqueologia, quer ainda em relatórios de escavação. Desta forma, possuímos apenas meia dúzia de referências bibliográficas à existência de tais amuletos, assim como algumas indicações de peças e fragmentos de coral em bruto, contas, colares, pulseiras e rosários em coral, que nos foram referidos por alguns colegas, a quem agradecemos, desde já, as suas valiosas indicações.

No povoado fortificado calcolítico do Outeiro Redondo (Sesimbra) foi recolhido na camada 2 um fragmento de coral de cor violeta. Segundo Cardoso e Martins (2017, p. 342):

\footnotetext{
“Quanto ao fragmento de coral, a sua ocorrência vem provar que esta matéria-prima seria já procurada para a confecção de adornos, apesar da colheira ser efectuada em profundidade, eventualmente através de ancinhos que se arrastavam pelo fundo. É provável que a proveniência desta peça se possa situar no litoral algarvio, ou mais além”.
}

Este é o vestígio de um raminho de coral mais antigo em Portugal que conseguimos detetar, até ao momento, através da nossa pesquisa. É possível que uma investigação mais aprofundada venha demonstrar a presença de outros corais em sítios arqueológicos portugueses com cronologias antigas.

Nas intervenções arqueológicas levadas a cabo em Silves [islâmica] tanto na alcáçova como na medina foram detetados materiais provenientes de outras regiões do "al-Andalus, do Norte de África e o do Mediterrâneo Oriental, desde o século VIII ao século XIII" (Portugal Islâmico, 1998, p. 139). Para além dos materiais cerâmicos destacam-se objetos e joias produzidos com recurso a metais preciosos (ouro e prata), marfim, azeviche, osso, e neste caso em particular salienta-se a existência de "amuletos, um deles com a representação da "mão de Fátima" e outro com elemento de coral, (...)" (Idem: 141). Ou seja, no Sul de Portugal, durante a Idade Média já se encontram amuletos produzidos em coral. Esta foi a referência mais antiga a amuletos elaborados a partir de coral, em Portugal, que conseguimos determinar até ao momento.

No Archivo nacional, Visita às Igrejas de Setúbal feita por D. Jorge, filho de D. João II. Anno de 151O. N. 148 da Ordem de Santiago, $f_{2} 2$ e sqq a propósito da "Visitaçam da Jrmida de Nosa Senhora da Troya" aparecem referências a duas peças de coral cuja caracterização passamos a descrever: «it. vymte e sete peças de prata meudjnhas s. olhos e coraçõees e outras muytas cousas em huua argola de prata que pesarã Juutamenre com este coral debaixo três omças cimquo reaes e meio-iij onças b reaes e meio. (...) it. Huu corall encastoado e prata, posto na dita argola que pesou cõ a prata de çima cõ que foy pesado Juutamente o peso que dito he" (Azevedo, 1897, p. 262).

José Leite de Vasconcelos refere que o Prof. Belluci lhe ofereceu um ramo natural de coral, com argola, contra o mau-olhado e que o Sr. Manuel Vieira Natividade lhe ofereceu um amuleto de coral encastoado (Vasconcelos, [1985] 2007, p. 241). Num artigo sobre os amuletos de coral (Vasconcelos, 1929, p. 52) explica que obteve um amuleto "feito de um pedaço de coral, encastoado em prata, e provido de duas argolas, uma fixa, outra móvel, para andar pendurada" no concelho de Arcos, em 1928 e que faz parte da coleção por ele organizada no Museu Etnológico. Não sabemos se estes dois amuletos de coral encastoados serão a mesma peça, descrita em dois textos diferentes ou se correspondem a duas peças distintas.

No Museu Nacional de Arqueologia, encontra-se um "amuleto de coral e casquinha?, composto por três elementos: uma mão fechada com dois dedos abertos a simular chifres, um coração opado tendo de ambos os lados, em relevo, um crucifixo cruzado com uma âncora, e uma haste de coral, que se supõe ter sido fabricado em Lisboa, algures durante a Época Contemporânea (Matriznet). Estará relacionado 
com alguma das peças anteriormente descrita por José Leite de Vasconcelos?

Foram realizadas escavações arqueológicas no Convento de Santana de Lisboa, que permitiram a identificação de estruturas e de um abundante e variado espólio, cuja cronologia se situa entre os finais do século XVI (data de construção do Convento) e o século XVIII. Estamos na presença, entre outros, de objetos produzidos em matérias duras de origem animal que podem ser interpretados com utilitários, de adorno ou devoção. Os mais frequentes utilizam o osso como matéria-prima e os mais raros são produzidos em marfim, madrepérola, carapaça de tartaruga ou coral (Gomes $\&$ alii, 2015, p. 85). O nosso interesse foca-se nos objetos em coral, que neste caso em particular se cingem a duas pequenas contas de cor vermelho rosado, de formas diferentes e contextos distintos: uma conta esférica com $4 \mathrm{~mm}$ de diâmetro que foi exumada de uma fossa (fossa 3 ) e uma conta cilíndrica com $8 \mathrm{~mm}$ de comprimento, proveniente de um nível arqueológico com inúmeros restos orgânicos. A dimensão destas contas, de dimensão muito reduzida, "parece afastar a hipótese de se tratar de elementos de rosários ou de terços e terem feito parte de brincos ou de outros adereços, podendo, nomeadamente, terem sido fixados a vestidos" (Idem: 100).

Mário Varela Gomes crê "ser possível que pequenas contas de coral, de cor rosada, exumadas nas ruínas da Igreja de Santa Maria do Castelo (Torres Novas) pertencessem a um rosário" (Gomes $\&$ alii, 2015, p. 101).

De acordo com a informação pessoal de António Marques, da Câmara Municipal de Lisboa: "Existe um pendente de prata com coral que foi encontrado nas escavações dos Terraços do Carmo. Trata-se de espólio funerário que estava associado a um enterramento, possivelmente dos séculos XVI ou XVII". Nas escavações arqueológicas da Igreja do Convento do Carmo foram exumadas, a par de muitos outros objetos, duas peças elaboradas a partir de coral: a) uma pulseira do século XVII formada por 42 contas de coral branco e 10 contas de metal com 3,5 mm de diâmetro; b) um colar de coral vermelho dos séculos XVI-XVII, composto por 121 contas com 3 mm de diâmetro e 3 contas cilíndricas com o comprimento de $26,5 \mathrm{~mm}$ e $5 \mathrm{~mm}$ de diâmetro médio (Ferreira \& Neves, 2005, pp. 607-608). O contexto funerário destes objetos relaciona-se com a escavação das Capelas da Cabeceira da Igreja (onde foram detetadas 43 sepulturas), bem como da nave principal e transepto (onde se registaram cerca de mil e quinhentas inumações). O espólio proveniente das sepulturas foi divido em diferentes grupos/categorias, nomeadamente: sumptuária (objetos de adorno); mágico-religiosos; indumentária, armas e diversos. Estamos em crer que neste caso em particular, tanto o colar como a pulseira terão sido catalogados como objetos de adorno, mas efetivamente um objeto pode ter várias funções. Neste caso, poderiam ser objetos de adorno com um carácter mágico-religioso (Figura 1 e 2).

A Igreja da Misericórdia de Almada foi intervencionada nos inícios dos anos 80 do passado século, e, novamente, em 2013. Foram escavadas diversas sepulturas onde foram detetados restos osteológicos e diverso espólio arqueológico. Tanto os enterramentos como a utilização do espaço sepulcral podem ser balizados entre os séculos XVI e XVIII (Dias \& alii, 2017, p. 1675). Na sepultura 9, uma fossa simples, sub-rectangular, escavada no solo, detetaram-se diversos indivíduos. Aqui foram exumadas 110 contas esféricas e ovais e 12 contas torneadas, em osso e identificou-se ainda uma conta em coral, de coloração rosa e tom claro (Idem: 1679). Nas escavações realizadas no interior da Capela de Nossa Senhora dos Passos foram aí encontrados, para além de muitos outros objetos, uma conta em coral e um fragmento que pode ter pertencido a um qualquer tipo de adorno (Dias \& alii, 2017, p. 1681).

A exposição "Os Expostos da Roda da Santa Casa da Misericórdia de Lisboa”, é acompanhada de um catálogo onde se regista o aparecimento de uma conta de coral: Manuscrito e conta - Papel e coral. Portugal 179. Documento ${ }^{\circ} 16$.

“Este menino nasceu no dia 28 do mes de Outubro deste
presente ano de 1792. Foi baptizado em cas[a] a nascen-
ça por vir de perigo e faltam-lhe OS santos oleos. Ha-de-
-se chamar Jose. Leva por sin[a]l um coral. E leva vestido
um manteu' preto, uma envolta de chita, [e] uns man-
guitos de baeta alvadia”" (Os expostos..., 2001, p. 56).

Os "sinais de expostos" são na sua maioria manuscritos acompanhados por um ou mais objetos que teriam tido algum tipo de significado para as famílias que se viam obrigadas deixar os seus filhos ao cuidado da Misericórdia de Lisboa. Estamos na presença de: 
"artefactos de significado particularmente afectivo, em diversos casos de sentido simbólico, mágico e religioso. De facto, o valor real destas peças reside, fundamentalmente, na sua importância como forma de identificação da criança, podendo os familiares, na posse de fragmentos dos sinais deixados na Roda, comprovarem as suas afinidades de parentesco no ato de recuperação dos seus entes queridos” (Morna \& alii, 2001, p. 12).

A maior parte dos sinais escritos têm como suporte o papel, mas também podemos encontrar outros tipos de suportes (têxtil, metal, coral, etc.) que os acompanham (Reis, 2016, p. 90). Os materiais nobres, semi-nobres ou exóticos têm uma menor expressão. A diversidade de sinais, de formas e materiais demonstram-nos a preocupação de colocar a criança sob proteção: "Assim as figas e os trevos de quatro folhas funcionam como talismãs que reforçam a protecção pedida para aquela criança, (...)” (Reis, 2016, p. 128). Tartaruga, marfim, madrepérola, corais e osso eram utilizados em amuletos e talismãs, apelando a uma protecção mágica para a criança. Podem aparecer sozinhos ou acompanhados por outros "elementos de simbologia cristã, reforçando um desejo de protecção de ambas as esferas" (Idem: 267).

Em Lagos, nas escavações da lixeira medieval-moderna, onde apareceram esqueletos de escravos africanos, foi encontrado um coral vermelho (Figura 3). Está exposto no Núcleo Museológico da Rota da Escravatura (informação pessoal de Elena Morán). O Valle da Gafaria situa-se em Lagos (Santa Maria, Lagos) junto à Porta dos Quartos, a poucos metros da Cerca Nova que foi mandada construir por D. João III (Neves \& alii, 2011, pp.29;31).Éneste local que se nota um crescimento urbano durante a época medieval e moderna, tornando-se Lagos num centro comercial com bastante dinamismo durante a Idade Média. $O$ fragmento de coral que destacamos no nosso trabalho foi descoberto durante a escavação dos depósitos que constituem o contexto da "lixeira" moderna de Lagos (Almeida $\&$ alii, 2012, p. 95):

"um conjunto estratigráfico composto por centenas de unidades de terreno, correspondentes a sucessivos despejos antrópicos intencionais de diversos desperdícios domésticos e urbanos que constituíram montículos de dimensões variáveis que se recobriam/justapunham, formando níveis lenticulares, que incluiriam sobretudo muita matéria orgânica" (Neves \& alii, 2011, p. 33).
Esta lixeira urbana, acumulada em Época moderna no interior e em torno de um "boqueirão". revelou a presença de 155 de esqueletos humanos (Neves $\mathbb{8}$ alii, 2011, p. 29). Nestes depósitos, e à medida que se acumulavam os lixos, foram sendo depositados os corpos dos escravos (Idem: 36 ) que chegavam a Lagos vindos de África. Este sítio ficou conhecido como o "Poço de Negros" e está datado por carbono 14, desde meados do séc. XV (Almeida \& alii, 2012, p. 96). Em Lagos, por volta de 1555, será criada a "Confraria dos Homens Pretos da Senhora do Rosário”, na igreja de S. Sebastião (Neves \& alii, 2011, p. 43) (Figura 4). O sítio do Cabo Raso é o local do naufrágio do navio florentino Grande Princesa da Toscânia ("Gran Principessa di Toscana”), que ocorreu em 1696. Alguns documentos reportam a situação que levou ao afundamento do navio, dos quais apenas vamos retirar um pequeno excerto:

“(.) Paul Methuen (1689) refere que o correio inglês
voltou a falhar nessa semana, devido ao mau tempo,
que havia estado tempestuoso vinte e cinco dias sem
interrupção. Refere ainda que um grande navio legor-
nês chamado a Grande Princesa da Toscânia, comanda-
do pelo capitão Benoict Prasca de Livorno, naufragou
no Cabo da Roca a uma légua de distancia de Cascais,
tendo-se afogado a maior parte da tripulação, no dia de
Santo André, à meia noite, depois de três dias de tem-
pestade que lhes fez gritar Misericórdia, que lhes dei-
tou abaixo todos os mastros e que os fez lançar à costa
com três ancoras ao mar que não impediram o navio de
naufragar porque o fundo era muito mau (...)” (Car-
doso, 2012, p. 11).

A primeira indicação que nos foi dada sobre este sítio foi de Guilherme Cardoso que viu ser retirado coral vermelho de um naufrágio do século XVII, junto ao Cabo Raso, em Cascais. No seguimento desta informação contactámos Mário Jorge Almeida, do Museu Nacional de Arqueologia, que afirmou ter encontrado pequenos fragmentos de coral entre os 5 e os $10 \mathrm{~mm}$ no Cabo Raso (informação pessoal de Mário Jorge Almeida). Mas já antes em 1967, uma equipa de mergulhadores tinha recuperado neste mesmo local, a par de outros objetos, cinco fragmentos de coral vermelho (Cardoso, 2012, p. 9). Os vinte e dois elementos de coral, recuperados em 1968, por Soares Branco (coleção particular) consiste num conjunto de contas furadas e "trabalhadas", embora se note alguma erosão associada à dinâmica 
dos sedimentos arenosos dos fundos sobre os materiais (informação pessoal de Mário Jorge Almeida). Em 1996, Mário Jorge Almeida e alguns amigos recuperaram um vasto conjunto de artefactos - pratos de estanho, compasso, arma, moedas de prata, balas de mosquete, peças de chumbo, - a par de 35 fragmentos de coral vermelho (Cardoso, 2012, p. 10).

Como vimos, as recolhas efetuadas em diferentes momentos no local do naufrágio deste navio, vindo da Toscânia, uma região de Itália cuja capital é Florença, trouxeram à superfície vários fragmentos de coral, na sua forma natural, ou seja, em bruto, com ramos de pequenas dimensões ou ainda contas furadas. Ambos poderiam vir a integrar diferentes tipos de joias ou amuletos, num trabalho de manufatura dos ourives e joalheiros portugueses, que adquiriam esta matéria-prima fora de Portugal, atendendo ao declínio da pesca do coral em Portugal durante este período (Figura 5).

Apesar do nosso estudo se focar essencialmente no coral vermelho, registam-se corais brancos no âmbito de escavações subaquáticas no leito do rio Ave, realizadas por Ivone Magalhães em 2005, onde foram exumados alguns fragmentos de corais brancos (dendrophyllia sp.), no local onde teriam existido os estaleiros navais de Vila do Conde, nos séculos XV e XVI, junto a um paredão. Estes achados surgem aquando da construção do cais para a réplica da nau quinhentista, na área da ensecadeira e foram encontrados no Cais das Lavandeiras, em Vila do Conde. Este importante porto comercial dos séculos XV e $\mathrm{XVI}$, onde se procedeu igualmente à construção naval, detinha um volumoso trânsito comercial interno, com o Norte da Europa (Antuérpia) e com o Mediterrâneo (informação pessoal de Pedro Brochado de Almeida) (Figura 6).

Segundo Amélia Polónia “(...) cremos estar na posse de dados que apontam para uma notória posição de relevo assumida pela frota vilacondense no conjunto do poder naval do reino, no que se refere à capacidade de transporte marítimo, na segunda metade do século XVI (Polónia, 1999, p. 367). Não sabemos a proveniência do coral branco, nem a que fins se destinava, mas é plausível, com base na informação exposta anteriormente, que fosse utilizado para fins medicinais, reduzido a pó, ou na produção de joias - contas utilizadas em brincos, colares ou pulseiras.

O Museu do Mar Rei D. Carlos, em Cascais, também possui nas suas Reservas Museológicas alguns exemplares de corais brancos (informação pessoal de Maria Fernanda Costa, Museu do Mar de Cascais).

\section{CONSIDERAÇÕES FINAIS}

Quando demos início ao nosso estudo sobre os amuletos, estávamos longe de imaginar a riqueza e diversidade que este tema encerra em si mesmo. O nosso primeiro trabalho foi sobre as pedras de raio (Vieira, 2019) no qual pudemos perceber como as comunidades portuguesas interpretavam estes vestígios pré-históricos e a forma como os "integravam" no seu quotidiano.

Este segundo trabalho, sobre os corais, levou-nos para um mundo completamente distinto do anterior. É um mundo relacionado com a medicina, com o mar, com a pesca, com a ourivesaria/joalharia, com a arte, permitindo aceder a algumas fases deste saber-fazer que contempla determinadas materialidades; um conhecimento específico sobre a transformação desses materiais em objetos; a adoção de um conjunto determinado de formas; a sua consagração enquanto objeto de proteção (amuleto) e, por fim, a sua utilização no dia-a-dia por crianças e adultos.

Estamos assim na presença de objetos com uma carga mágica-religiosa-simbólica muito expressiva, mas igualmente marcada pela qualidade estética dos objetos produzidos a partir do coral vermelho (e branco). É um tema que se ramifica, permitindo a análise de diversos subtemas, o que se torna muito aliciante.

Em suma, sabemos que existiu a pesca de coral vermelho em Portugal e que foram confecionadas peças a partir desse material (pescado cá ou importado do Mediterrâneo) por ourives/joalheiros/artesãos ao longo da Época Moderna e Contemporânea. Existem evidências da existência de raminhos de coral utilizados como pendentes pelas crianças, como forma de proteção, contas de colar em coral vermelho utilizadas para a confeção de rosários ou terços, pulseiras, colares, brincos, peças de tecido, entre outros. Vimos que muitas destas peças foram representadas na arte, nomeadamente na pintura e que possuem um carácter profano, como as figas de coral, por exemplo; religioso, como os rosários e terços; e, simultaneamente profano e religioso, como os raminhos de coral. Estamos em crer que as contas utilizadas em colares, pulseiras e brincos, poderiam ter tido, pelo menos no início da época moderna, um duplo carácter de proteção/adorno. Estes objetos não só acompanham crianças e adultos em vida, 
como surgem em contextos de enterramento, acompanhando-os também na morte.

Daremos continuidade à investigação dos corais em Portugal, investindo numa pesquisa bibliográfica mais exaustiva; procurando mais exemplares da representação destes objetos em pinturas, esculturas e peças de ourivesaria; sistematizando a inventariação das peças que se encontram em museus ou que surgem em contextos arqueológicos; procurando perceber com maior profundidade a pesca do coral vermelho nas costas algarvias. São estes alguns dos caminhos de pesquisa que o corallium rubrum nos aponta.

\section{AGRADECIMENTOS}

Alexandre Gonçalves, Álvaro Campelo, António Marques (Câmara Municipal de Lisboa), Carla Azevedo (BPMP), César Neves (AAP - MAC), Cónego Carlos César Chantre (Paróquia de S. Pedro de Faro), Elena Morán (Câmara Municipal de Lagos), Guilherme Cardoso, Lois Ladra, Luísa Penalva (MNAA), Maria Fernanda Costa (Museu do Mar de Cascais), Mário Jorge Almeida (MNA), Miguel Almeida (Dryas Octopetala), Miguel Rodrigues (DRCN), Pedro Brochado de Almeida (Câmara Municipal de Vila do Conde), Sandra Santos e Tânia Manuel Casimiro.

\section{BIBLIOGRAFIA}

ALMEIDA, Miguel; NEVES, Maria João; FERREIRA, M. Teresa, (2012) - Intervenção de arqueologia preventiva-Parque de Estacionamento do Anel Verde (Santa Maria, Lagos, Faro). Março de 2012 Relatório final: parte 1.

ALVES, Francisco, (200o [1934]) - Memórias Arqueológico-Históricas do Distrito de Bragança. Tomo VII -Arqueologia, Etnografia e Arte. Porto.

ARBEX, Juan Carlos, (1990) - Pescadores Españoles, Secretaria General de Pesca Maritima. Madrid: Ministerio de Agricultura, Pesca y Alimentacion, volume 2.

AZEVEDO, P. A., (1897) - Estudos sobre Tróia de Setúbal. 4. Nossa Senhora de Tróia nos sécs. XV e XVI. In O Archeologo Português, 3. Lisboa, pp. 257-265.

BALZAN, Francesca; DEIDUN, Alan, (2010) - Notes for a history of coral fishing and coral artefacts in Malta. The Malta Historical Society.

BOAVIDA, Joana; \& alii. (2016) - A Well-Kept Treasure at Depth: Precious Red Coral Rediscovered in Atlantic Deep Coral Gardens (SWPortugal) after 300 Years. PLOS ONE. 11 (2) https://doi.org/10.1371/journal.pone.0150654
BRUCE-MITFORD, Miranda, (1997) - El Libro Ilustrado de Signos Y Simbolos. Editorial Diana.

BUESCU, Ana Isabel, (2019) - D. Beatriz de Portugal, a Infanta Esquecida (1504-1538). Lisboa: Letras \& Diálogos.

CARDOSO, João Luís; MARTINS, Filipe, (2017) - O Povoado Pré-histórico do Outeiro Redondo (Sesimbra): resultados das campanhas de escavação de 2013 e 2014. Estudos Arqueológicos de Oeiras. Oeiras: Câmara Municipal de Oeiras. 23. pp.233-392.

CARDOSO, João Pedro, (2012) - Sobre os destroços da Gran Principessa di Toscana, naufragada em 1696 nas imediações do Cabo Raso, Cascais. Cascais: Junta de Freguesia.

CARDOSO, Luis, (1747) - Dicionário Geográfico ou Notícia Historica de todas as Cidades, Villas, Lugares e Aldeas, Rios, Ribeiras, e Serras dos Reynos de Portugal, e Algarve, com todas as cousas raras, que nelles se encontraõ, assim antigas, como modernas. Lisboa: Na Regia Officina Sylviana e da Academia Real. Tomo I.

Portugal Islâmico. (1998) - Catálogo da Exposição: Os Últimos Sinais do Mediterrâneo, Lisboa: Min.Cult.; IPM; MNA.

COELHO, Miguel Alexandre Batista, (2017) - Religiosidade popular: tradições, práticas e mitos. Tese de doutoramento. Lisboa: Universidade Católica Portuguesa.

CUNNINGHAM, Scott, (1988) - Enciclopédia de Cristais, Pedras Preciosas e Metais. Coleção Gaia. Alemdalenda.

DIAS, Geraldo Coelho, (1987) - A devoção do povo português a Nossa Senhora nos tempos modernos. In Revista da Faculdade de Letras. História, №. 4, pp. 227-256.

DIAS, Vanessa; CASIMIRO, Tânia Manuel; GONÇALVES, Joana (2017) - Os bens terrenos da Igreja da Misericórdia (Almada): séculos (XVI-XVIII). In Arqueologia em Portugal. 2017-Estado da Questão, coord. ed. ARNAUD, J. M.; MARTINS, A. Lisboa: Associação dos Arqueólogos Portugueses. pp. 1675-169o.

FERREIRA, F. E. R.; NEVES, M. C. M., (2005) - Intervenção Arqueológica na Igreja do Convento do Carmo. In ARNAUD, J. M.; FERNANDES, C. V. (coord.), Construindo a Memória. As Colecções do Museu Arqueológico do Carmo. Lisboa: Associação dos Arqueólogos Portugueses, pp. 58o-6o9.

FOA - Food and Agriculture Organization of the United Nations. Fisheries and Aquaculture Department. Species Fact Sheets: Corallium Rubrum (Linnaeus, 1758) 2020. Disponível em: http://www.fao.org/fishery/species/3611/en

GILI, J. M. \& DIAZ, D., (2001) - El coral rojo. Investigación y Ciencia, 299: 42-43.

GOMES, Mário Varela; GOMES, Rosa Varela; GONÇALVES, Joana, (2015) - Objectos produzidos em matéria animal, do Convento de Santana, de Lisboa. In Actas do I Encontro de Arqueologia de Lisboa, Uma Cidade em Escavação. Lisboa: Centro de Arqueologia de Lisboa. 
JIMÉNEZ, C., \& OREJAS, C., (2017) - The Builders of the Oceans. Part II: Corals from the Past to the Present (The Stone from the Sea). Springer International Publishing.

MIRANDA, Adelaide; CHAMBEL, Pedro, (2014) - Bestiário Medieval. Perspectivas de Abordagens. Lisboa: Instituto de Estudos Medievais.

MORNA, Teresa Freitas; BRITO, Maria Filomena; MANOEL, Francisco d'Orey; COLEN, Maria Luísa Barbosa, (2001) - O acolhimento de crianças enjeitadas da Misericórdia de Lisboa. In Os expostos da Roda da Santa Casa da Misericórdia de Lisboa. Lisboa: Museu de São Roque e Arquivo Histórico/Biblioteca.

Museu da Sé de Braga [em linha] (1999)-Tesouro do Museu da Sé Catedral de Braga. Disponível em: http://www.geira. pt/Msebraga/Coleccoes/casula_frontal.html

Museu Nacional Machado de Castro - Joalharia [em linha]. Disponível em http://www.museumachadocastro.gov.pt/ pt-PT/coleccoes/PrintVersionContentDetail.aspx?id=616

Museu Nacional Machado de Castro-Ourivesaria [em linha]. Disponível em: http://www.museumachadocastro.gov.pt/ pt-PT/coleccoes/Ourivesaria/ContentDetail.aspx?id=180

NATIVIDADE, M. Vieira, (1917) - O Povo da Minha Terra - Notas e registos de etnografia alcobacense - Crenças e superstições - A Pedra. Sep. de: Terra portuguesa: revista ilustrada de arqueologia artistica e etnografia. Lisboa: Annuario Commercial.

NEVES, Maria João, ALMEIDA, Miguel M, FERREIRA, M. Teresa. (2011) - História de um arrabalde durante os séculos XV e XVI: "o Poço dos Negros" em Lagos (Algarve, Portugal) e o seu contributo para o estudo dos escravos africanos em Portugal. In A Herança do Infante. Lisboa: Centro de Estudos dos Povos e Culturas de Expressão Portuguesa pp. 29-46.

OLIVEIRA, Ricardo Pessa de (2013) - Pobres e perseguidos: os mágicos em Pombal (séculos XVII e XVIII). In I Congresso Histórico Internacional. As Cidades na História: População. III - Cidade Moderna I. Câmara Municipal de Guimarães.

PAIVA, José Pedro, (200o) - A magia e a bruxaria. In AZEVEDO, Carlos Moreira (Dir.) - História Religiosa de Portugal. Lisboa: Círculo de Leitores. vol. II, pp. 369-375.

PENALVA, Luísa; FRANCO, Anísio, (2016) - Matéria e Devoção. O Tesouro da Rainha Santa. In O Tesouro da Rainha Santa. Imagem e poder (coord. Luísa PENALVA). Lisboa: Museu Nacional de Arte Antiga, Lisboa.

POLÓNIA, Amélia, (1999) - Vila do Conde. Um porto nortenho na expansão ultramarina quinhentista. Tese de doutoramento. Faculdade de Letras da Universidade do Porto.

RAGAZZI, Alexandre, (2016) - Entrecruzamentos Culturais: Superstição, Mito e Fé nos Amuletos de Coral. In Anais do XXXVI Colóquio do Comitê Brasileiro de História da Arte: Arte em Ação, Campinas-SP. 4-6 de outubro. Rio de Janeiro: Comitê Brasileiro de História da Arte - CBHA, 2016.
RAU, Virgínia, (1986) - Aspectos do 'trato' da 'Adiça' e da 'pescaria' do 'coral' nos finais do século XV. In Estudos de História Medieval. Lisboa: Editorial Presença. pp. 142-151.

REIS, Maria José, (2016) - Ler sinais: os sinais dos expostos da Santa Casa da Misericórdia de Lisboa (1790-1870). Tese de doutoramento, História (Sociedades e Poderes), U. L., ISCTE- Instituto Universitário de Lisboa, UCP, UE.

REVEZ, Idálio. Corais vermelhos do Algarve: um "tesouro" a saque e sem protecção legal (em linha). Publico. 13 de Julho de 2020. Disponível em: https://www.publico. $\mathrm{pt} / 2020 / 07 / 13 /$ local/noticia/corais-vermelhos-algarve-tesouro-saque-proteccao-legal-1924281

RODRIGUES, Andreia, (2016) - O poder dos amuletos antigos: afastando a melancolia. Anais do XXXVI Colóquio do Comitê Brasileiro de História da Arte: Arte em Ação, Campinas-SP. 4-6 de outubro. Rio de Janeiro: Comitê Brasileiro de História da Arte - CBHA.

TORRES, Ruy d'Abreu, (1971) - Coral. In Joel SERRÃO (dir.) Dicionário de História de Portugal. Lisboa: Iniciativas Editoriais.

SERRÃO, Vítor, (2009) - A Pintura Maneirista e Proto-Barroca. In Arte Portuguesa, da Pré-história ao Século XX (coord. Dalila RODRIGUES) vol. 11. Vila Nova de Gaia: Fubu Editores.

VASCONCELOS. José Leite de, (1897) - Religiões da Lusitânia: na parte que principalmente se refere a Portugal. Lisboa: Imprensa Nacional. Vol. 1.

VASCONCELOS. José Leite de, (1915) - História do Museu Etnológico Português (1893-1914). Lisboa. Imprensa Nacional.

VASCONCELOS. José Leite de (1929) - Amuletos de coral. In Boletim de Etnografia, Museu Etnológico Português, IV, Lisboa. pp. 50-53.

VASCONCELOS. José Leite de (1985] 2007) - Etnografia Portuguesa. Volume IX. Lisboa: Imprensa Nacional-Casa da Moeda.

VIEIRA, Alexandra (2019) - Raios e Coriscos. In Revista Memória Rural, nº 2, Museu da Memória Rural Carrazeda de Ansiães: Câmara Municipal de Carrazeda de Ansiães.

Visão - Em busca do coral vermelho (em linha). 29.07.2014. Disponível em: https://visao.sapo.pt/atualidade/ambiente /2014-07-29-em-busca-do-coral-vermelhof791208/\#\&gid $=0 \&$ pid $=1$

VITERBO, Francisco Sousa, (1903) - A pesca do coral no século XV. In Archivo Historico Portuguez, vol. I. Lisboa. pp. 315-320.

ZIBROWIUS H, MONTEIRO MARQUES V, GRASSHOFF M., (1984) - La Repartition du Corallium rubrumdans l'Atlantique (Cnidaria: Anthozoa: Gorgonaria). In Téthys. 11. pp.163-170. 

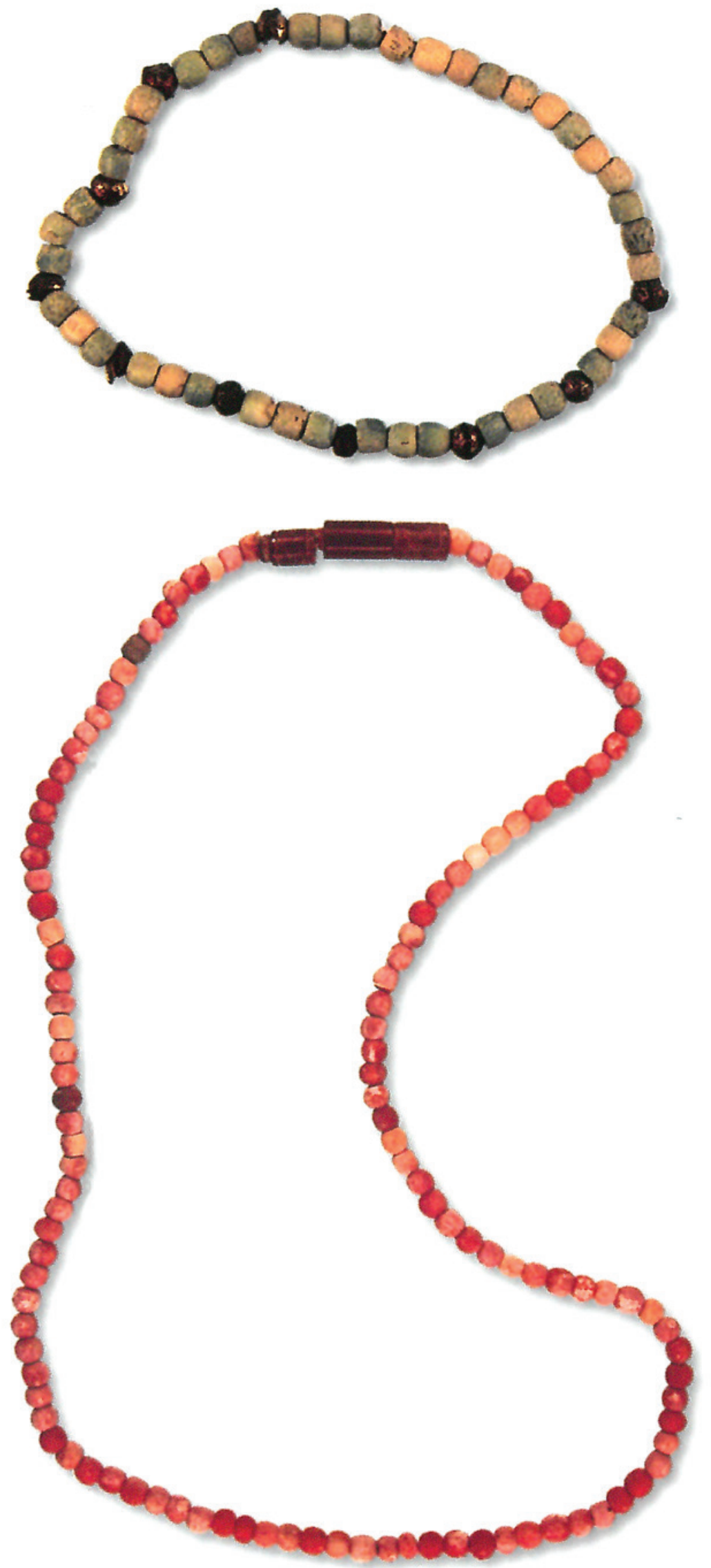

Figuras 1 e 2 - Pulseira de coral branco (em cima) e colar de coral vermelho (em baixo). Fotografias cedidas pelo Museu Arqueológico do Carmo. 


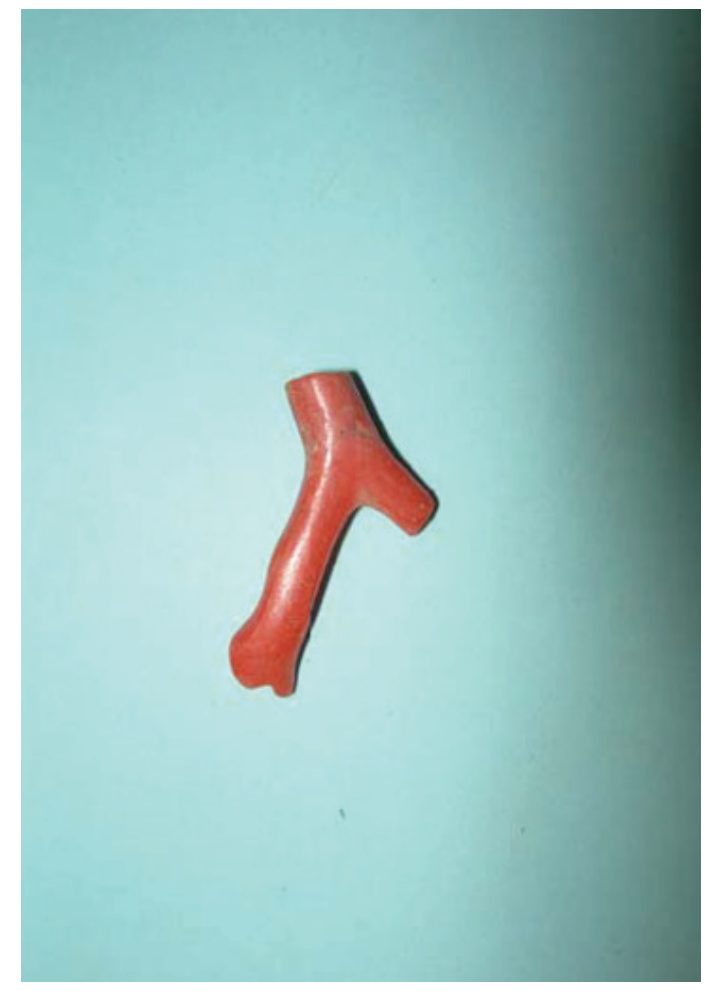

Figura 3 - Fragmento de coral vermelho. Fotografia cedida pela Dryas, Arqueologia.

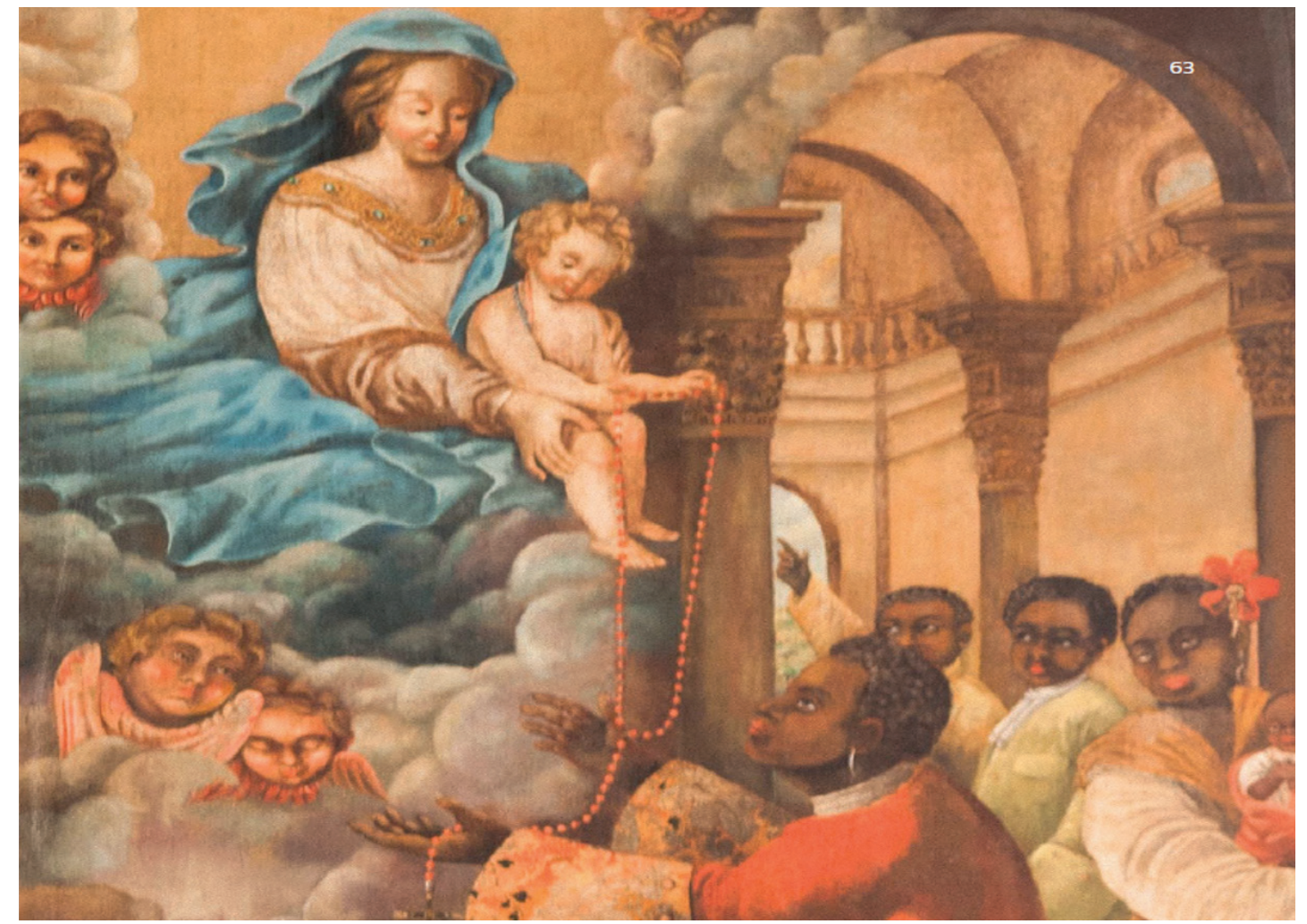

Figura 4 - Nossa Senhora do Rosário, Igreja de S. Pedro. Fotografia cedida pela Paróquia de S. Pedro de Faro. 

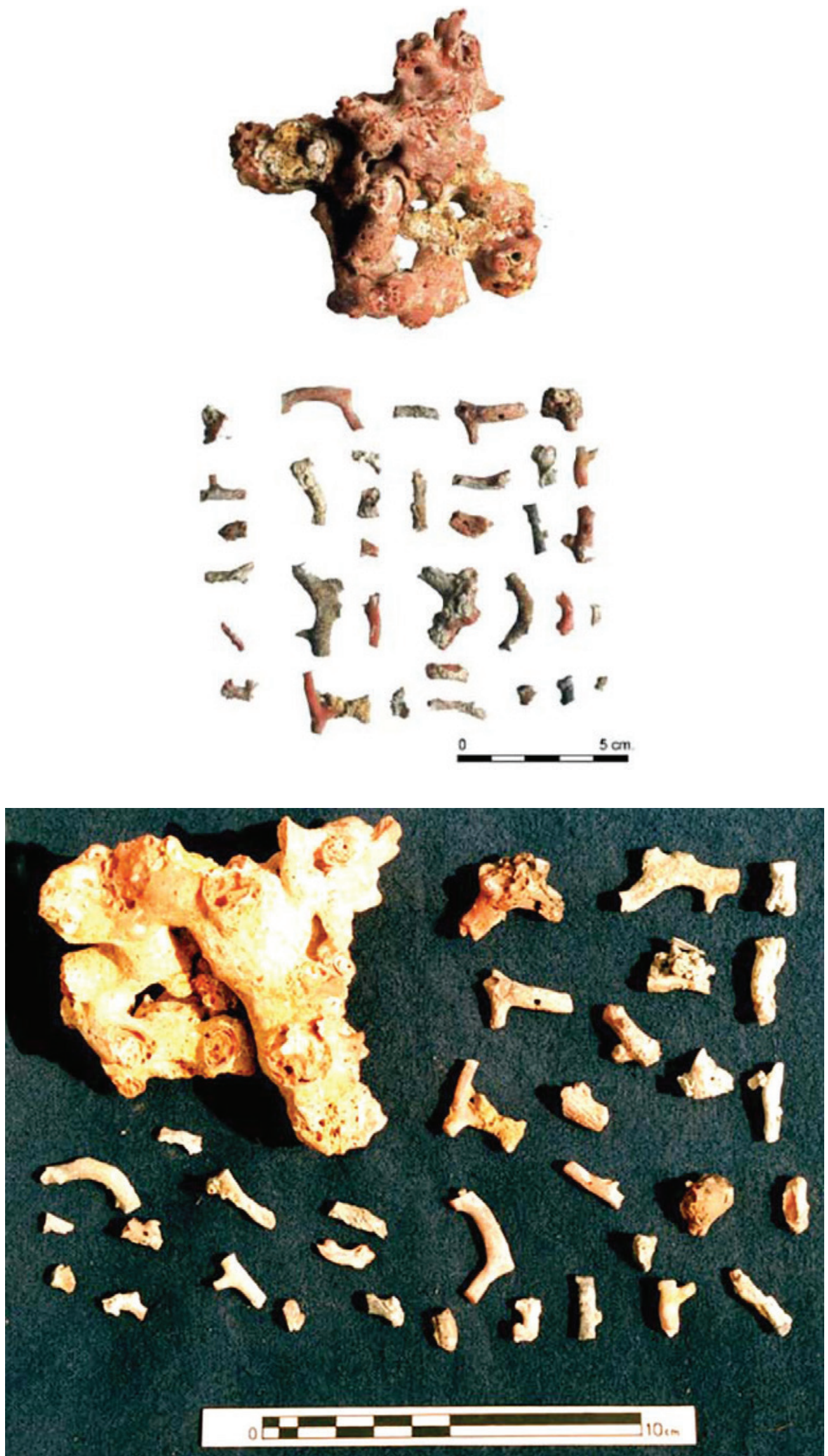

Figura 5a e 5b - Trinta e cinco fragmentos de coral vermelho recuperados em 1996 por Mário Jorge Almeida. Fotografias cedidas por Mário Jorge Almeida. 


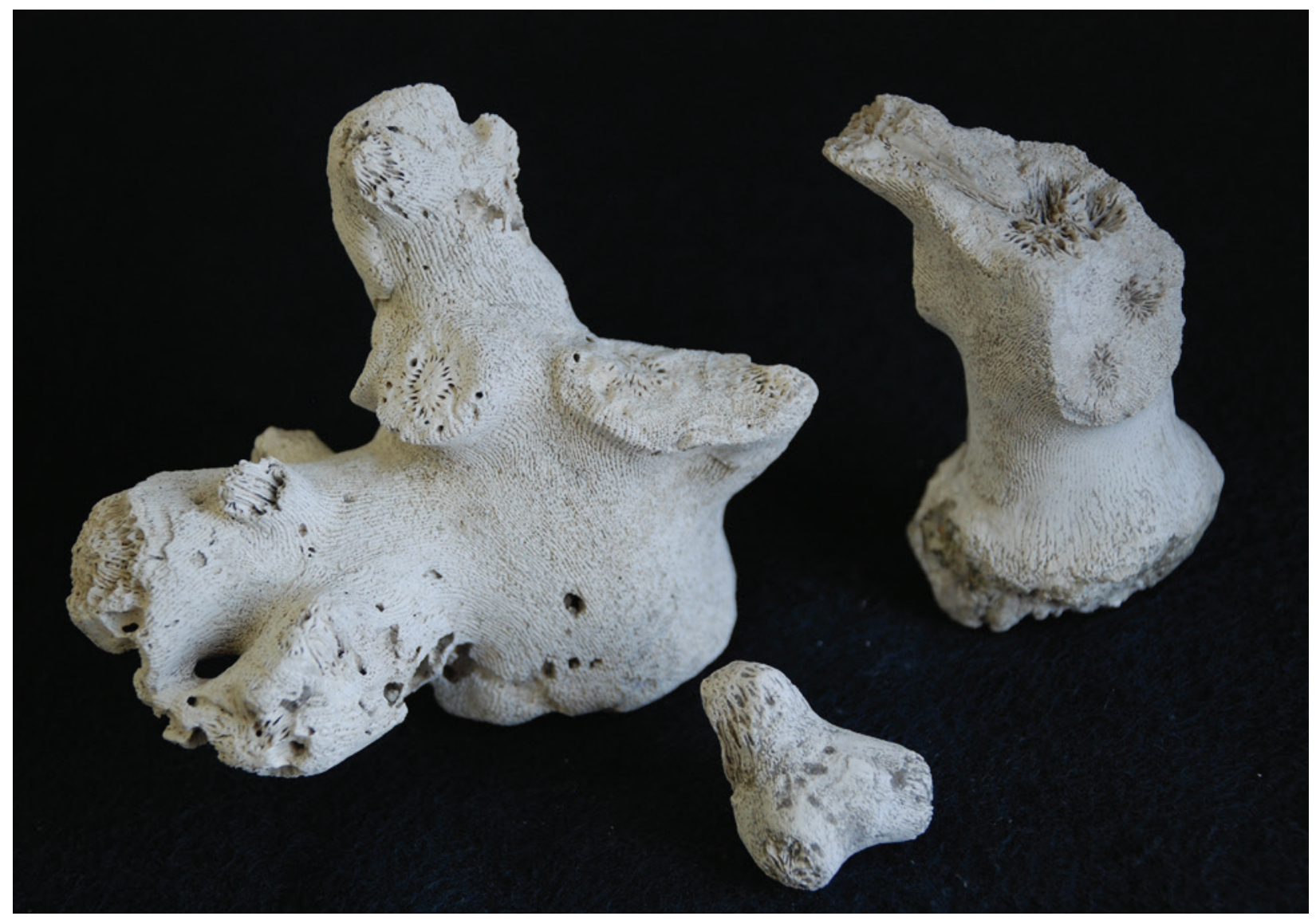

Figura 6 - Fragmentos de coral branco, Vila do Conde. Fotografia cedida pelo Gabinete de Arqueologia Municipal de Vila do Conde. 


\title{
CERÂMICAS DE VILA FRANCA DE XIRA NOS SÉCULOS XV E XVI
}

Eva Pires ${ }^{1}$

\begin{abstract}
RESUMO
A intervenção arqueológica efectuada no sítio do Ateneu Artístico Vilafranquense em 2007, no âmbito da arqueologia preventiva, revelou dados acerca do aglomerado urbano de Vila Franca de Xira durante a Baixa Idade Média e início da Idade Moderna.

O estudo realizado sobre a totalidade do espólio proveniente desta intervenção, constituído por um conjunto de cerâmicas, faunas, vidros, metais e líticos, permitiu inferir o cariz doméstico deste contexto composto por restos de consumo da população urbana. Apresentam-se os resultados finais da análise dos materiais cerâmicos que correspondem a um total de 492 peças identificáveis (NMI), associadas maioritariamente aos séculos XV e XVI. Palavras-chave: Arqueologia Urbana, Cerâmica, Idade Moderna, Séculos XV-XVI, Vila Franca de Xira.
\end{abstract}

\begin{abstract}
The archaeological intervention in the Ateneu Artístico Vilafranquense site in 2007, in the context of preventive archaeology, revealed data about the urban center of Vila Franca de Xira during the Late Middle Ages and Early Modern Age.

The study of the entire set of materials from this intervention, made up of ceramics, faunal remains, glass, metals and lithic materials, allowed us to infer the domestic nature of this context comprised of the town population's consumption remains. We present the final results of the ceramic materials analysis, which correspond to a total of 492 identifiable objects (NMI), mainly related to the $15^{\text {th }}$ and $16^{\text {th }}$ centuries.
\end{abstract}

Keywords: Urban Archaeology, Ceramics, Modern Age, $15^{\text {th }}-16^{\text {th }}$ Centuries, Vila Franca de Xira.

\section{INTRODUÇÃO}

O sítio do Ateneu Artístico Vilafranquense, situado no centro histórico de Vila Franca de Xira, era composto por diversas estruturas negativas preenchidas com materiais cuja análise permitiu definir diversas fases de ocupação do espaço situadas entre a formação da vila no século XIII e os nossos dias. Para além de três fossas de pequenas dimensões, destaca-se a presença de um silo, um poço e um tanque, bem como um troço de pavimento lajeado (Figura 1). Determinou-se que antes do final do século XV este local terá sido um espaço aberto utilizado como área de armazenamento, tratando-se provavelmente de uma zona de quintal anexo a um ou mais edifícios de habitação. Não podemos, porém, afastar a hipótese desta área ter então constituído uma zona periurbana dedicada ao armazenamento de víveres e à labo- ração agro-pastoril, sem qualquer espaço de habitação permanente. Entre final do século XV e inícios do século XVI observa-se o preenchimento de diversas estruturas, nomeadamente o silo e o tanque. Dado o importante volume de detritos domésticos descartados para o seu interior, parece evidente a existência no entorno de habitações de carácter permanente, pelo que esta área já estaria relativamente consolidada em termos urbanos. Nesta fase o poço encontrar-se-ia em funcionamento, embora não tenha sido possível averiguar a sua data de construção (Pires, 2019, pp. 110-115).

Posteriormente, entre a segunda metade do século XVI e a centúria seguinte, dá-se o preenchimento de uma das pequenas estruturas negativas. Baseado na datação de um azulejo encontrado no seu interior, o poço terá sido desactivado entre o final do século XVII e o terceiro quartel do século XVIII, antes da

1. Intituição: Faculdade de Ciências Sociais e Humanas. Universidade Nova de Lisboa; evaantunespires@gmail.com 
construção de um edificado visível numa planta de 1786 (Pimenta \& Mendes, 2016, pp. 190-191). Algures nesta data toda a zona terá sido aterrada para dar lugar a esta construção. Mais tarde, durante o século XIX, o edifício setecentista terá sido demolido para dar lugar ao antigo edifício do Ateneu Artístico Vilafranquense, que deu o nome a este local.

\section{A CERÂMICA}

Este sítio revelou uma grande diversidade de cerâmica destacando-se produções regionais, bem como importações. Neste conjunto, composto por 3361 fragmentos que correspondem a 492 peças identificáveis (NMI = Número Mínimo de Indivíduos), a observação das pastas permitiu identificar diversos grupos de fabrico repartidos por cerâmica fosca, brunida, vidrada e esmaltada. A cerâmica fosca é o grupo mais abundante, seguida pela cerâmica brunida, enquanto a presença da cerâmica vidrada e esmaltada é residual neste contexto (Gráfico 1).

A maioria das peças corresponde a produções do Vale do Tejo que terão origem local ou regional, colocando-se a hipótese de resultarem de uma produção vilafranquense (Gráfico 2). Outras peças, igualmente presentes em abundância, terão sido produzidas em Lisboa e, em menor número, no Barreiro e em Alenquer. As importações, embora se encontrem em quantidades residuais, têm origens diversas sendo oriundas principalmente de Sevilha, mas também de Montelupo, Brugges e possivelmente de Saintonge (Figura 2).

Em termos formais a cerâmica registada insere-se em diversas categorias relacionadas com o contexto doméstico, principalmente com o consumo, confecção e armazenamento de alimentos e líquidos. Observam-se ainda alguns objectos de higiene e iluminação, assim como materiais relacionados com actividades lúdicas e cerâmica de construção. A maioria das formas enquadra-se na cerâmica de cozinha que corresponde a $46 \%$ do NMI total, bem como na cerâmica de mesa, que representa $34 \%$.

\subsection{Cerâmica de produção local e/ou regional} A cerâmica que poderá ter sido produzida localmente constitui $45 \%$ da cerâmica registada no Ateneu Artístico Vilafranquense. Neste grupo inserem-se nomeadamente os fabricos $\mathrm{F}_{1} / \mathrm{B}_{1}$ e $\mathrm{F}_{2} / \mathrm{B}_{2}$ (Figuras 3 e 4), nos quais se enquadra a grande maioria das peças identificadas, bem como os fabricos F9 a F11, correspondentes a cerâmica de construção e afins que terá sido fabricada na vila. Assinala-se também a presença expressiva destas pastas noutros contextos vilafranquenses tais como o Museu do Neo-realismo (Pimenta \& Mendes, 2006; Mendes \& Pimenta, 2007). Estes fabricos apresentam pastas com abundantes inclusões de pequena a grande dimensão, sendo estas maioritariamente quartzo, assim como elementos de cor branca, preta e vermelha, com muito rara presença de micas. Em termos de coloração observam-se principalmente tons laranja e avermelhados resultantes de uma cozedura oxidante, por vezes de núcleo cinzento devido a uma cozedura redutora-oxidante. As superfícies, mais ou menos rugosas, são frequentemente recobertas por aguadas de tons semelhantes aos da pasta ou, mais raramente, com um engobe vermelho ou negro. Alguns exemplares apresentam superfícies brunidas, geralmente apenas na face interna.

A fraca presença de micas nestas pastas afasta a hipótese de uma origem nas olarias de Lisboa, embora os exemplares aqui registados apresentem numerosas semelhanças morfológicas com a cerâmica moderna exumada na capital, sendo por vezes idênticos (Pires, 2019, pp. 15-28). A confirmar-se como produções locais, estas copiariam de forma próxima os modelos da capital, como se atesta pelos paralelos com zonas de produção oleira localizadas na área da Mouraria, com cronologias situadas entre os séculos XV e XVII, nomeadamente na Rua do Benformoso (Marques, Leitão \& Botelho 2012, pp. 126-128), no Quarteirão dos Lagares (Nunes \& Filipe, 2012, pp. 143-145) e na Rua das Portas de Santo Antão (Cardoso \& alii, 2017, pp. 1718-1728). Embora menos frequentes, observam-se ainda alguns paralelos formais com peças produzidas entre finais do século XV e a primeira metade do século XVI no Barreiro, nomeadamente em Santo António da Charneca (Barros \& alii, 2012, pp. 702-703). O comércio de louça de barro entre Vila Franca de Xira e o exterior é comprovado pelo foral de 1510. Até à data, não se conhecem vestígios de nenhuma olaria desta época no interior da antiga vila, porém, o foral medieval concedido em 1212, refere a presença de fornos de louça, sugerindo a existência de produção oleira durante o século XIII (Camacho, 1985, pp. 147-175). Por outro lado, o foral quinhentista apenas refere a produção de telhas e tijolos, sendo incerto se nessa época ainda existia produção de louça de barro. Se essa produção tiver subsistido, a sua ausência neste foral pode indicar que não seria 
relevante na economia local face a outros produtos referidos no documento. A louça de barro seria possivelmente um complemento da produção de cerâmica de construção, à semelhança do que acontecia, por exemplo, na olaria do Alto do Castelo em Alcochete, em funcionamento durante os séculos $\mathrm{XV}$ -XVI (Correia, 2005/o7, pp. 67-73).

\subsection{Cerâmica de Lisboa}

As produções que terão origem nas olarias de Lisboa representam $44 \%$ da cerâmica identificada neste local. Neste conjunto enquadram-se os fabricos de pasta micácea, incluindo cerâmica fosca e brunida (fabricos $\mathrm{F}_{3} / \mathrm{B}_{3}$ a $\mathrm{F}_{5} / \mathrm{B}_{5}, \mathrm{~F}_{7}$ ), cerâmica vidrada (fabricos $\mathrm{V}_{1}$ e $\mathrm{V}_{2}$ ) e a faiança portuguesa (fabrico $\mathrm{E}_{4}$ ).

No caso da cerâmica fosca e brunida, as pastas apresentam abundantes inclusões de muito pequena dimensão onde se destaca uma grande quantidade de micas, quartzo e raros elementos ferruginosos e brancos. Na coloração das pastas observam-se maioritariamente tons bege rosado e avermelhados, com cozeduras em ambiente oxidante ou redutor-oxidante. As superfícies são lisas ou mediamente rugosas, possuindo geralmente aguadas de tons semelhantes às pastas e sendo por vezes brunidas. Conhecem-se diversas olarias na capital onde se encontram pastas semelhantes, nomeadamente na área da Mouraria (Castro \& alii, 2017, pp. 1737-1742; Marques Leitão \& Botelho, 2012, pp. 126-128, Nunes \& Filipe, 2012, pp. 143-146; Paula, 2019, pp. 98-117), em contextos situados cronologicamente entre os séculos XV e XVII, assim como na Rua das Portas de Santo Antão (Cardoso \& alii, 2017, pp. 1718-1728), contexto dos séculos XV-XVI.

Na cerâmica vidrada observam-se pastas de coloração vermelha ou alaranjada, num caso muito bem depurada com raras inclusões de cor branca (fabrico Vi), noutro caso com abundantes micas de pequena dimensão, raros quartzos e elementos de cor negra (fabrico V2). Em ambos observam-se superfícies recobertas de vidrado verde ou melado aplicado em ambas as faces da peça ou apenas no exterior. Embora as características das pastas apontem para uma produção lisboeta, assemelhando-se a desperdícios oleiros do século XVI e início do XVII do Largo das Olarias (Castro \& alii, 2017: 1737-1742) e da Praça da Figueira (Barradas \& Silva, 2017, pp. 1694-1700), não foi possível associar estes fabricos a nenhum contexto de produção específico.

A cerâmica esmaltada de origem lisboeta corres- ponde a faiança portuguesa, cuja produção se inicia na segunda metade do século XVI (Casimiro, 2013, pp. 355; Sebastian, 2012, pp. 937-943). Estas peças possuem uma pasta bege amarelada bem depurada e superfícies recobertas de esmalte branco com motivos pintados a azul-cobalto e, por vezes, a manganês. Conhecem-se vestígios de produção de faiança na capital, nomeadamente no Largo das Olarias entre a segunda metade do século XVI e início do XVII (Castro \& alii, 2017, pp. 1737-1742), na zona do Largo de Jesus, entre finais do século XVI e meados do XVII (Cardoso \& Batalha, 2015, pp.148-170), ou na Rua de Buenos Aires com uma cronologia situada nos séculos XVII-XVIII (Batalha $\&$ alii, 2012, pp. 952-962). É na Rua de Buenos Aires que se observam os exemplares mais semelhantes às formas vilafranquenses (Pires, 2019, pp. 59-6o). Porém, essas peças encontraram-se apenas no interior de uma das estruturas negativas de pequenas dimensões e no conjunto de materiais de superfície descontextualizados.

\subsection{Cerâmica do Barreiro e Alenquer}

No conjunto de cerâmica vidrada observam-se peças de pasta bege (fabrico $\mathrm{V}_{4}$ ), com muito raras inclusões de pequena dimensão, maioritariamente elementos ferruginosos e de cor negra, assim como alguns brancos. As suas superfícies encontram-se recobertas de vidrado melado ou verde. Este fabrico deverá corresponder a uma produção do Barreiro, com origem na Mata da Machada (Carmona \& Santos, 2005, pp. 14-16) ou em Santo António da Charneca (Barros \& alii, 2012, pp. 701-705), área oleira que funcionou entre finais do século XV e a primeira metade do século XVI. Embora seja complexo distinguir esta produção das importações sevilhanas, algumas características das pastas, nomeadamente as diferenças de textura, permitem considerar uma origem portuguesa para estes materiais (Coelho \& Teixeira, 2018, pp. 261-264).

Paralelamente, este fabrico poderá corresponder a uma produção de Alenquer, onde foi identificada uma olaria que se encontrou em funcionamento entre o final do século XV e início do XVII (Cardoso \& alii, 2016, pp. 56-62). Porém, embora as formas de Alenquer apresentem semelhanças com os exemplares aqui registados, a textura das pastas é distinta (Pires, 2019, pp. 50-52). De facto, as peças registadas no Ateneu Artístico Vilafranquense e associadas a Alenquer (fabrico $V_{5}$ ) possuem uma pasta bege rosada e menos rígida, com algumas inclusões de 
muito pequena dimensão, nomeadamente quartzo, micas e elementos de cor negra e branca. As superfícies encontram-se recobertas de vidrado amarelo esverdeado ou verde.

\subsection{Cerâmica de importação}

Apesar do claro predomínio das produções locais e regionais, existem igualmente elementos exógenos que, embora em quantidades residuais, apresentam origens diversas. Estas importações provêm nomeadamente de Espanha, Itália, Bélgica e França, representando no seu conjunto $6 \%$ do total da cerâmica do Ateneu Artísitco Vilafranquense. Destacam-se as produções sevilhanas que representam $5 \%$, correspondendo à quase totalidade das importações identificadas. As restantes produções têm origem em Montelupo, Brugges e Saintonge.

A localização de Vila Franca de Xira numa importante linha de comunicação fluvial, assim como a sua proximidade ao porto de Lisboa, facilitaria o acesso aos mercados regionais e europeus. De facto, Lisboa contava, desde os séculos XII-XIII, com a presença de importações do Sul peninsular e do Norte europeu, às quais se juntam as cerâmicas italianas nos séculos XV-XVI (Bettencourt \& alii, 2018, pp. 142). Porém, observa-se neste contexto a ausência de alguma cerâmica de importação que frequentemente se encontra em contextos arqueológicos portugueses de cronologia moderna, tais como objectos em grés oriundos do Norte da Europa ou porcelanas da China, assim como certas produções peninsulares tais como cerâmicas de corda-seca ou de reflexo metálico. Enquanto questões cronológicas poderiam explicar a inexistência das primeiras, sendo as porcelanas importadas maioritariamente a partir de finais do século XVI, não justificam a ausência de cerâmica de corda seca e reflexo metálico que se encontram nos contextos lisboetas entre a segunda metade do século XV e inícios do XVI (Silva \& Guinote, 1998, pp. 74-87). Além disso, os números relativos à presença de cerâmica importada são aqui reduzidos. Eventualmente a singularidade deste sítio pode residir no tipo de contexto arqueológico, um espaço possivelmente periurbano ou nas franjas do antigo aglomerado populacional, podendo ainda estar relacionada com o poder económico dos habitantes.

Nas importações sevilhanas encontramos maioritariamente cerâmica vidrada e esmaltada, assim como uma reduzida quantidade de cerâmica fosca, nomeadamente fragmentos de anforetas Spanish Olive Jars (fabrico F8), produzidas entre o final do século XV e durante século XVI (Amores Carredano \& Chisvert Jiménez, 1993, pp. 283-297; Pleguezuelo \& alii, 1999, p. 269). Estes recipientes eram objectos comuns utilizados no transporte marítimo ou fluvial de mercadorias, tendo-se recuperado diversos exemplares no rio Tejo na zona de Vila Franca de Xira (Calado, Pimenta \& Regala, 2000, pp. 106-107), assim como um exemplar no Museu do Neo-realismo (Pimenta \& Mendes, 2006, p. 23).

A cerâmica vidrada identificada como produção andaluza (fabrico $V_{3}$ ) possui uma pasta de cor bege ou bege rosada, com raras inclusões de muito pequena dimensão, nomeadamente quartzos e elementos brancos. Este fabrico, com origem nas olarias de Sevilha entre o século XV e durante o século XVI, distingue-se pela sua pasta de textura porosa e macia, bem como as suas superfícies recobertas de vidrado melado, amarelo ou verde que podem ser decoradas com riscos a manganês (Pleguezuelo \& Lafuente, 1995, pp. 226-236).

No conjunto de cerâmica esmaltada de origem sevilhana registam-se dois grupos de fabrico, ambos de pasta bege com superfícies recobertas de esmalte branco (fabricos E1 e E2). O primeiro enquadra-se na série blanca lisa ou Columbia Plain produzida em Sevilha durante os séculos XV-XVI (Pleguezuelo \& Lafuente, 1995, pp. 226-236). Alguns investigadores afirmam que este tipo de cerâmica terá sido produzido em Portugal durante o século XVI na olaria da Mata da Machada (Casimiro, 2013, pp. 354). Porém, a ausência nesse local de peças esmaltadas a branco com defeitos de fabrico, mas antes com marcas de uso, indica que estas correspondem provavelmente a objectos de consumo importados do Sul peninsular e não restos de produção local (Coelho \& Teixeira, 2018, pp. 264). Em Coimbra identificaram-se cerâmicas esmaltadas a branco que poderão ter sido produzidas localmente a partir de meados do século XVI, embora essas pastas possuam maior abundância de inclusões, distinguindo-se dos exemplares do Ateneu Artístico Vilafranquense que atribuímos a Sevilha (Sebastian, 2012, pp. 941-945). Estas peças andaluzas encontram-se frequentemente em contextos portugueses dos séculos XV-XVI, nomeadamente em Vila Franca De Xira (Mendes \& Pimenta, 2007, pp. 69-75) e em Lisboa (Sabrosa, 2008, pp. 111-117; Martingil, 2015, pp. 431-433). Estas estão ainda presentes em contextos lisboetas dos séculos XVI-XVII como, por exemplo, no Hospital 
Real de Todos-os-Santos (Silva $\mathbb{Z}$ alii, 2012, pp. 71-8o). Neste conjunto identificou-se ainda uma tigela com um escorrimento de vidrado verde aplicado sobre o esmalte branco, enquadrando-se na série blanco $y$ verde de mitades ou Columbia Plain white and green, produzida entre o século XV e início do XVI (Pleguezuelo \& Lafuente, 1995, pp. 228). Exemplares semelhantes encontram-se igualmente em contextos dos séculos XV-XVI, nomeadamente em Lisboa (Gonzalez, 2012a, pp. 87-88) ou em Palmela (Fernandes \& Carvalho, 1998, pp. 222-246).

O segundo fabrico de cerâmica esmaltada andaluza distingue-se por uma pasta mais porosa e pela presença de decoração geométrica a azul-cobalto e manganês sobre a superfície interna. Este grupo de fabrico enquadra-se na série azul y morada ou Isabella Polychrome produzida entre o final do século XV e início do XVI nas olarias sevilhanas (Pleguezuelo \& Lafuente, 1995, pp. 228-236). Também estas peças são frequentes em contextos situados entre os séculos XV-XVI (Mendes \& Pimenta, 2007, pp. 76 -77; Teixeira, Villada Paredes \& Silva, 2015, pp. 202; Sabrosa, 2008, pp. 113).

A cerâmica com origem nas olarias italianas de Montelupo corresponde a pratos esmaltados a branco e decorados com motivos geométricos pintados a azul-cobalto, laranja e vermelho. As peças registadas neste sítio apresentam pastas brancas e porosas e encontram-se decoradas com o motivo ad ovali e rombi. Esta majólica, produzida durante os séculos XV e XVI, é comum nos contextos arqueológicos lisboetas dessa época (Felício \& alii, 2017, pp. 1812-1819; Gonzalez, 2012b, pp. 850-853; Martingil, 2015, pp. 431-433; Sabrosa, 2008, pp. 138), encontrando-se igualmente em níveis do século XVI e início do XVII (Barradas, Silva, 2017, pp. 1697-1702; Silva \& alii, 2012, pp. 71-77). Infelizmente, no Ateneu Artístico Vilafranquense, estas peças encontraram-se apenas no conjunto de materiais de superfície descontextualizados.

A cerâmica importada de Brugges caracteriza-se por uma pasta de cor vermelha alaranjada, com inclusões de quartzo de pequena dimensão. A superfície externa é recoberta de vidrado verde que se sobrepõe a um engobe branco visível entre o vidrado e a pasta. Esta cerâmica flamenga, produzida entre o final do século XIII e a primeira metade do XIV, encontra-se em alguns contextos lisboetas dessa época (Oliveira \& alii, 2017, pp. 1528-1536; Teixeira, Villada Paredes \& Silva, 2015, pp. 179).
O grupo de fabrico que poderá corresponder às produções de Saintonge apresenta uma pasta de cor cinza ou esbranquiçada, com muitas inclusões de pequena e média dimensão, nomeadamente quartzos, micas e raros elementos ferruginosos. As superfícies possuem vidrado verde aplicado em ambas as superfícies ou apenas na face externa. Observa-se maioritariamente o grupo de vidrado liso denominado Saintonge Bright Green, existindo também um fragmento de vidrado manchado correspondente ao grupo Saintonge Motled Green (Haggarty, 2006, pp. 22-57). Todavia, não descartamos a possibilidade de alguns fragmentos enquadrados neste fabrico corresponderem a uma produção do Norte de França e não de Saintonge, dada a dificuldade em distinguir os fabricos dessas regiões a partir de fragmentos de pequena dimensão. Estas produções francesas eram importadas durante os séculos XIII-XIV, encontrando-se em contextos lisboetas dessa época (Oliveira \& alii, 2017, pp. 1527-1534) ou do início do século XV (Pinheiro, 2015, pp. 41).

\section{CASO DE ESTUDO: O SILO}

No que toca às estruturas reveladas nesta intervenção, o caso do silo é o mais claro. Trata-se de uma estrutura muito comum nos aglomerados urbanos portugueses medievais. Inicialmente utilizado para o armazenamento de alimentos, particularmente cereais, os silos eram entulhados quando a sua função de armazenamento se tornava obsoleta, podendo ser substituídos por talhas ou pela utilização de celeiros (Silva, 2003, pp. 57). A datação dos materiais cerâmicos e, mais precisamente, a identificação de um ceitil de D. João II, sendo este o objecto de cronologia segura mais recente registado no seu interior, coloca o preenchimento do silo no final do século XV. Todavia, tendo em consideração o período de circulação dos numismas, podemos eventualmente avançar a cronologia de formação deste depósito para os inícios do século XVI (Teixeira, Villada Paredes, Silva, 2015, pp. 217).

Este silo é o contexto conservado com mais abundância de espólio, contendo $45 \%$ da cerâmica recuperada neste local. Este conjunto, constituído por cerâmica fosca (65\%), brunida (24\%), vidrada ( $8 \%$ ) e esmalta (2\%), é composto maioritariamente por produções do Vale do Tejo que possuem uma vasta continuidade, não permitindo o estabelecimento de cronologias seguras. Dentro destas regista-se 
cerâmica possivelmente de origem local (fabricos F1/B1, F2/B2 e F9), bem como produções de Lisboa (fabricos $\mathrm{F}_{3} / \mathrm{B}_{3}$ a F5/B5, F7, V1 e V2) e do Barreiro (fabrico $\mathrm{V}_{4}$ ). Em termos formais, na cerâmica fosca observa-se a abundância de peças de cozinha, principalmente panelas, bem como um número significativo de cerâmica de mesa e de armazenamento, compostas maioritariamente por púcaros e potes, respectivamente. Na cerâmica brunida as formas mais abundantes correspondem à cerâmica de mesa representada por pratos, púcaros e tigelas, encontrando-se em menores quantidades as peças de cozinha e de higiene.

Neste conjunto identificaram-se igualmente fragmentos de cerâmica importada, alguns correspondendo a uma produção sevilhana enquanto outros serão oriundos do Norte da Europa. No conjunto de cerâmica sevilhana destaca-se a presença de fragmentos de anforetas Spanish Olive Jar (fabrico F8), bem como peças vidradas (fabrico $\mathrm{V}_{3}$ ) e esmaltadas (fabricos $E_{1}$ e E2). As peças vidradas correspondem a um prato vidrado a melado com riscos a manganês e um alguidar vidrado a verde, enquanto na cerâmica esmaltada observam-se pratos e tigelas. Estas peças esmaltadas correspondem maioritariamente à série blanca lisa, encontrando-se ainda um fragmento de prato enquadrado na série azul y morada. Na cerâmica proveniente do Norte europeu destaca-se a produção flamenga de Brugges (fabrico V9) e as produções francesas de Saintonge (fabrico V6). Ambas contabilizam apenas alguns fragmentos vidrados a verde, não tendo sido possível reconstituir nenhuma forma.

Em suma, neste silo encontra-se cerâmica de cozinha, mesa e armazenamento, bem como objectos relacionados com a higiene, iluminação e a prática de uma actividade lúdica (Gráfico 3). A cerâmica de mesa é a categoria mais abundante e diversificada, observando-se ainda percentagens significativas de cerâmica de cozinha e de armazenamento. Embora individualmente as panelas sejam a forma mais representada, a estas seguem-se os púcaros, tigelas e pratos. A abundância de cerâmica de mesa dever-se-á à transformação dos hábitos alimentares durante o final da Idade Média, época na qual o consumo se individualiza, multiplicando-se os recipientes tais como pratos e tigelas. $\mathrm{O}$ aumento de pratos aponta também para a presença de refeições mais sólidas, que ao invés dos ensopados não necessitavam de ser consumidas em recipientes fundos (Silva, 2003, pp.
56-75). Porém, o predomínio das panelas em relação aos tachos e frigideiras, sugere que os alimentos seriam consumidos maioritariamente sob a forma de cozidos ou ensopados (Casimiro, Boavida \& Detry, 2017, pp. 112-114).

A distribuição das formas pelos diferentes tipos de cerâmica poderá assinalar preferências da população. Neste conjunto denota-se a preferência pela cerâmica fosca no que toca ao armazenamento de alimentos e líquidos. Também na confecção de alimentos utilizava-se maioritariamente cerâmica fosca, particularmente no caso das panelas, as quais são fabricadas exclusivamente nesse tipo. Porém, nos tachos e frigideiras observam-se igualmente peças brunidas, o que poderá estar relacionado com o tipo de cozinhados para os quais seriam utilizados, podendo estes beneficiar de superfícies alisadas e menos aderentes (Casimiro, Boavida \& Detry, 2017, pp. 112-114). Na cerâmica de mesa a diversidade de tipos sugere uma maior exigência com a qualidade dos recipientes utilizados no consumo de alimentos face às peças utilizadas na sua confecção e armazenamento. Enquanto no consumo de líquidos registamos uma preferência pela cerâmica fosca e brunida, nos pratos e tigelas destaca-se a maior abundância de cerâmica brunida e vidrada, bem como algumas peças esmaltadas. Dessa forma, podemos depreender que estas seriam preteridas pelas suas superfícies lisas e impermeabilizadas, não se excluindo possíveis questões estéticas e de estatuto social, particularmente no caso das peças importadas.

\section{CONCLUSÕES}

A análise do espólio do Ateneu Artístico Vilafranquense revelou uma grande diversidade de cerâmica, com a presença de várias produções regionais, assim como escassas peças importadas. Observou-se que a cerâmica regional compõe a maioria deste conjunto, sendo constituída por produções do Vale do Tejo provenientes nomeadamente de Lisboa, do Barreiro e de Alenquer, colocando-se a hipótese também de uma produção local, que carece de confirmação arqueológica. Mesmo a cerâmica de pasta não micácea, que não terá sido produzida em Lisboa, apresenta formas semelhantes ou idênticas às que aí encontramos, evidenciando uma certa padronização desta cerâmica a nível regional. Dessa forma, podemos concluir que a proximidade de Lisboa teria um impacto significativo no consumo das 
populações das vilas próximas que tinham acesso ao seu mercado. Esta poderá ter sido tanto uma questão de gosto, devido à eventual popularidade e qualidade destes produtos face a outros, assim como de acesso aos mesmos.

Em relação às importações, registou-se a presença maioritária de produções sevilhanas, bem como algumas peças com origem em Montelupo, Saintonge e Brugges, cerâmicas que se encontram frequentemente nos contextos portugueses de época tardomedieval e moderna. Ressalta, porém, a sua escassez, bem como a ausência de alguns materiais geralmente presentes em contextos desta época.

Em termos formais, constatou-se que a cerâmica identificada se relaciona principalmente com o consumo, confecção e armazenamento de alimentos, observando-se ainda alguns objectos relacionados com a higiene e iluminação. Em quantidades residuais encontram-se peças relacionadas com uma actividade lúdica, assim como cerâmica de construção. Estes dados permitem inferir o cariz doméstico deste contexto, composto por restos de consumo da população urbana. Embora a cerâmica de cozinha seja a categoria predominante neste conjunto, denota-se a abundância da cerâmica de mesa, sugerindo uma prática de consumo mais individualizada.

\section{BIBLIOGRAFIA}

AMORES CARREDANO, Fernando; CHISVERT JIMÉNEZ, Nieves (1993) - Tipología de la Cerámica Común Bajomedieval y Moderna Sevillana (s. XV-XVIII): I, la Loza Quebrada de Relleno de Bóvedas. SPAL: Revista de prehistoria y arqueología de la Universidad de Sevilla. Sevilla. 2, pp. 269-235.

BARRADAS, Ana Isabel; SILVA, Rodrigo Banha da (2017)Cerâmicas quinhentistas vidradas de um poço medieval da Praça da Figueira (Lisboa). In ARNAUD, José Morais; MARTINS, Andreia, coords. - Arqueologia em Portugal - 2017. Estado da questão. Actas do IIo Congresso da Associação dos Arqueólogos Portugueses Lisboa: Associação dos Arqueólogos Portugueses, pp. 1691-1702.

BARROS, Luís; BATALHA, Luísa; CARDOSO, Guilherme; GONZALES, António (2012) - A Olaria Renascentista de Santo António da Charneca - Barreiro. A Louça Doméstica. In TEIXEIRA, André; BETTENCOURT, José António, coords. - Velhos e Novos Mundos: Estudos de Arqueologia Moderna (ArqueoArte 1). 2. Lisboa: Centro de História de Além-Mar, pp. 699-710.

BATALHA, Luísa; CAMPÕA, Andreia; CARDOSO, Guilherme; NETO, Nuno; REBELO, Paulo, SANTOS, Raquel (2012) - Vestígios de um Centro Produtor de Faiança dos
Séculos XVII e XVIII. Dados de uma Intervenção Arqueológica Na Rua de Buenos Aires, n.ํำ 10, Lisboa. In TEIXEIRA, André; BETTENCOURT, José António, coords. - Velhos e Novos Mundos: Estudos de Arqueologia Moderna (ArqueoArte 1). 2. Lisboa: Centro de História de Além Mar, pp. 951-962.

BETTENCOURT, José; COELHO, Inês Pinto; FONSECA, Cristóvão; LOPES, Gonçalo; CARVALHO, Patrícia; SILVA, Tiago (2018) - Entrar e sair de Lisboa na época moderna: uma perspectiva a partir da arqueologia marítima. In SENNAMARTINEZ, João Carlos; MARTINS, Ana Cristina; CAESSA, Ana; MARQUES, António; CAMEIRA, Isabel, coords. - Meios, vias e trajetos... entrar e sair de Lisboa: Fragmentos de Arqueologia de Lisboa 2. Lisboa: Câmara Municipal de Lisboa/ Sociedade de Geografia de Lisboa, pp. 146-161.

CALADO, Marco; PIMENTA, João; REGALA, Frederico (200o) - Olive Jars Encontradas no Tejo. In Al-Madan. Almada. Série II. 9, pp. 206-207.

CAMACHO, Clara Frayão, coord. (1985) - Fontes Documentais - Forais do concelho de Vila Franca de Xira. In Boletim Cultural. Vila Franca de Xira. 1, pp. 147-175.

CARDOSO, Guilherme; GOMES, João José Fernandes; RODRIGUES, Severino; BATALHA, Luísa (2016) - Produção Oleira Renascentista na Bacia Hidrográfica do Baixo Tejo: a produção de cerâmicas vidradas em Alenquer, durante o século XVI. In Al-madan Online. Almada. Série II, 20: 2, pp. 54-63.

CARDOSO, Guilherme; BATALHA, Luísa; REBRLO, Paulo; ROCHA, Miguel; NETO, Nuno; BRITO, Sara (2017) - Uma olaria na Rua das Portas de Santo Antão (Lisboa) séculos XV e XVI. In ARNAUD, José Morais; MARTINS, Andreia, coords. - Arqueologia em Portugal - 2017. Estado da questão. Actas do II ${ }^{\circ}$ Congresso da Associação dos Arqueólogos Portugueses. Lisboa: Associação dos Arqueólogos Portugueses, pp. 1715-1719.

CARDOSO, Guilherme; BATALHA, Luísa (2015) -Evidências de produção oleira dos finais do século XVI a meados do século XVII no Largo de Jesus (Lisboa). In SENNA MARTINEZ, João Carlos; MARTINS, Ana Cristina; MELO, Ana Ávila de; MARQUES, António; CAMEIRA, Isabel, CAESSA, Ana, eds. - I Encontro de Arqueologia de Lisboa: Uma Cidade em Escavação. Lisboa: Câmara Municipal de Lisboa/ Sociedade de geografia de Lisboa, pp. 147-181.

CARMONA, Rosalina; SANTOS, Cátia (2005) - Olaria da Mata da Machada. Cerâmicas dos séculos XV-XVI. Barreiro: Camara Municipal do Barreiro.

CASIMIRO, Tânia Manuel (2013) - Faiança portuguesa: datação e evolução crono-estilística. Revista Portuguesa de Arqueologia. Lisboa. 16, pp. 351-367.

CASIMIRO, Tânia Manuel; BOAVIDA, Carlos; DETRY, Cleia (2017) - Cozinhar e comer: cerâmicas e alimentação em Carnide (1550-1650). In SENNA MARTINEZ, João Carlos; MARTINS, Ana Cristina; MELO, Ana Ávila de; MARQUES, António; CAMEIRA, Isabel, CAESSA, Ana, eds. - I 
Encontro de Arqueologia de Lisboa: Uma Cidade em Escavação. Lisboa: Câmara Municipal de Lisboa / Sociedade de geografia de Lisboa, pp. 110-121.

CASTRO, Anabela; PAULA, Nuno Amaral de; TORRES, Joana, CURADO, Tiago; TEIXEIRA, André (2017) - Evidências de produção oleira nos séculos XVI e XVII no Largo das Olarias, Mouraria (Lisboa). In ARNAUD, José Morais; MARTINS, Andreia, coords. - Arqueologia em Portugal 2017. Estado da questão. Actas do II ${ }^{\circ}$ Congresso da Associação dos Arqueólogos Portugueses. Lisboa: Associação dos Arqueólogos Portugueses, pp. 1731-1749.

COELHO, Inês Pinto; TEIXEIRA, André (2018) - Glazed pottery production from Mata da Machada, Barreiro (Portugal). In KARAKAYA, Defne; LITTLE, Timothy Glenn, eds. - Medieval and Modern Period Mediterranean Ceramics. Ankara: Koç Universitesi VEKAM, pp. 261-265.

CORREIA, Miguel (2005/2007) - Um forno de produção cerâmica dos séculos XV-XVI, em Alcochete. In Musa. Setúbal. 2, pp. 67-73.

FELÍCIO, Catarina; SOUSA, Filipe; GUIMARÃES, Raquel; GADANHO, André (2017) - A cerâmica italiana dos séculos XV e XVI do Largo do Jogo da Bola em Carnide, Lisboa. In ARNAUD, José Morais; MARTINS, Andreia, coords. Arqueologia em Portugal - 2017. Estado da questão. Actas do II ${ }^{o}$ Congresso da Associação dos Arqueólogos Portugueses. Lisboa: Associação dos Arqueólogos Portugueses, pp. 1809-1820.

FERNANDES, Isabel Cristina.; CARVALHO, A. Rafael (1998) - Conjuntos Cerâmicos Pós-Medievais de Palmela. In DIOGO, João Manuel; ABRAÇOS, Hélder Chilra, eds. Actas das 2 $2^{\underline{a}}$ Jornadas de Cerâmica Medieval e Pós-Medieval. Métodos e resultados para o seu estudo. Tondela: Câmara Municipal de Tondela, pp. 211-255.

GONZALEZ, Cristina (2012a) - Os novos espaços da cidade moderna. Uma aproximação à Ribeira de Lisboa através de uma intervenção no Largo do Terreiro do Trigo. In TEIXEIRA, André; BETTENCOURT, José António, coords. Velhos e Novos Mundos: Estudos de Arqueologia Moderna. (ArqueoArte 1). 1. Lisboa: Centro de História de Além Mar, pp. 85-94.

GONZALEZ, Cristina (2012b) - Majólicas italianas do Terreiro do Trigo (Lisboa). In TEIXEIRA, André; BETTENCOURT, José António, coords. - Velhos e Novos Mundos: Estudos de Arqueologia Moderna. (ArqueoArte 1). 2. Lisboa: Centro de História de Além Mar, pp. 847-854.

HAGGARTY, George (2006) - A gazetteer and summary of French pottery imported into Scotland c. 1150 to c. 1650 a ceramic contribution to Scotland's economic history Ceramic Resource. In Tayside and Fife Archaeological Journal. 12: 3, pp. 117-118.

LUCAS, Maria Miguel (2003) - Vila Franca de Xira: História, Urbanismo e Identidade. In Vila Franca de Xira: Tempos do Rio, Ecos da Terra. Vila Franca de Xira: Câmara Municipal de Vila Franca de Xira, pp. 99-106.

MARQUES, António; LEITÃO, Eva; BOTELHO, Paulo (2012) - Rua do Benformoso 168/186 (Lisboa-Mouraria/Intendente). Entre a nova e a velha cidade, aspectos da sua evolução urbanística. In TEIXEIRA, André; BETTENCOURT, José António, coords. - Velhos e Novos Mundos: Estudos de Arqueologia Moderna. (ArqueoArte 1). 1. Lisboa: Centro de História de Além Mar, pp. 123-134.

MARTINGIL, Márcio (2015) - Testemunhos Arqueológicos na Rua do Jardim do Regedor nํำ a 32, Lisboa. In CAESSA, Ana; NOZES, Cristina; CAMEIRA, Isabel, SILVA, Rodrigo Banha da, eds. - I Encontro de Arqueologia de Lisboa: Uma Cidade em Escavação. Lisboa: Câmara Municipal de Lisboa, pp. 426-439.

MENDES, Henrique; PIMENTA, João (2007) - Contexto quinhentista das escavações do Museu do Neo-Realismo. Vila Franca de Xira: Câmara Municipal de Vila Franca de Xira.

NUNES, Tiago; FILIPE, Iola (2012) - Quarteirão dos Lagares. Contributo para a História económica da Mouraria. In TEIXEIRA, André; BETTENCOURT, José António, coords. - Velhos e Novos Mundos: Estudos de Arqueologia Moderna. (ArqueoArte 1). 1. Lisboa: Centro de História de Além-Mar, pp. 141-150.

OLIVEIRA, Filipe; SILVA, Rodrigo Banha da; BARGÃO, André; FERREIRA, Sara (2017) - O comércio medieval de cerâmicas importadas em Lisboa: O caso da Rua das Pedras Negras n.ํㅗ 22-28. In ARNAUD, José Morais; MARTINS, Andreia, coords. - Arqueologia em Portugal-2017. Estado da questão. Actas do II ${ }^{\circ}$ Congresso da Associação dos Arqueólogos Portugueses. Lisboa: AAP - Associação dos Arqueólogos Portugueses, pp. 1523-1538.

PAULA, Nuno (2019) - A produção oleira na Lisboa dos séculos XVI e XVII: Um forno cerâmico no Largo das Olarias (Mouraria). Dissertação de Mestrado em Arqueologia / Faculdade de Ciências Sociais e Humanas / Universidade Nova de Lisboa.

PIMENTA, João; MENDES, Henrique (2006) - Relatório escavações do Museu do Neo-realismo (Vila Franca de Xira). Vila Franca de Xira: Município de Vila Franca de Xira/Divisão de Património e Museus.

PIMENTA, João; MENDES, Henrique (2016) - Carta Arqueológica de Vila Franca de Xira. Vila Franca de Xira: Câmara Municipal de Vila Franca de Xira.

PINHEIRO, Helena (2015) - Arqueologia Urbana em Lisboa: o Convento do Carmo entre os séculos XIV e XIX. Relatório de Estágio de Mestrado em Arqueologia/Faculdade de Ciências Sociais e Humanas/Universidade Nova de Lisboa.

PINTO, Maria Adelaide (2007) - Relatório Final da Intervenção Arqueológica no Ateneu Artístico Vilafranquense, Torres Novas: Crivarque, Lda. 
PIRES, Eva (2019) - O sítio Ateneu Artístico Vilafranquense (Vila Franca de Xira): contributo para o conhecimento do quotidiano nos séculos XVe XVI. Dissertação de Mestrado em Arqueologia / Faculdade de Ciências Sociais e Humanas / Universidade Nova de Lisboa.

PLEGUEZUELO, Alfonso; LAFUENTE, M. Pilar (1995) Cerámicas de Andalucia Ocidental (1200-16oo). In GERRARD, Christopher M.; GUTIERREZ, Alejandra; VINCE, Alan G., eds. - Spanish medieval ceramics in Spain and the British Isles. Cerámica medieval española en España y en las Islas Británicas. (BAR International Series.610), pp. 217-244.

PLEGUEZUELO, Alfonso; LIBRERO, Antonio; ESPINOSA, María; MORA, Pedro (1999) - Loza Quebrada” Procedente de la Capilla del Colegio-Universidad de Santa María de Jesús (Sevilla). In SPAL: Revista de prehistoria y arqueología de la Universidad de Sevilla. 8, pp. 263-294.

FERNANDES, Isabel Cristina F.; CARVALHO, A. Rafael (1998) - Conjuntos Cerâmicos Pós-Medievais de Palmela. In DIOGO, João Manuel; ABRAÇOS, Hélder Chilra, eds. Actas das $2^{\underline{a}}$ Jornadas de Cerâmica Medieval e Pós-Medieval. Métodos e resultados para o seu estudo. Tondela: Câmara Municipal de Tondela, pp. 211-255.

SABROSA, Armando (2008) - As faianças da Casa Côrte-Real, Largo do Corpo Santo, Lisboa. In DIOGO, João Manuel, coord. - Actas das $4^{\underline{a}}$ Jornadas de Cerâmica Medieval e Pós-Medieval. Métodos e resultados para o seu estudo. Tondela: Câmara Municipal de Tondela, pp. 109-142.

SEBASTIAN, Luís (2012) - Faiança Portuguesa. Centros produtores, matérias, técnicas de fabrico e critérios de distinção", In TEIXEIRA, André; BETTENCOURT, José António, coords. - Velhos e Novos Mundos: Estudos de Arqueologia Moderna. (ArqueoArte 1). 2. Lisboa: Centro de História de Além Mar, pp. 937-950.

SILVA, Rodrigo Banha da (2003) - Olaria medieval e dos Descobrimentos do Vale do Tejo: um Enquadramento. In Olaria portuguesa: do fazer ao usar. Lisboa: Assírio \& Alvim, pp. 35-61.

SILVA, Rodrigo Banha da; GUINOTE, Paulo (1998) - O Quotidiano na Lisboa dos Descobrimentos. Roteiro dos lugares e objectos. Lisboa: Ministério da Educação.

SILVA, Rodrigo Banha da; MIRANDA, Pedro; VIEIRA, Vasco Noronha; VICENTE, António Moreira; LOPES, Gonçalo C.; NOZES, Cristina (2012) - Largo do Chafariz de Dentro: Alfama em Época Moderna, In TEIXEIRA, André; BETTENCOURT, José António, coords. - Velhos e Novos Mundos: Estudos de Arqueologia Moderna. (ArqueoArte 1). 2. Lisboa, Centro de História de Além-Mar, pp.71-84.

TEIXEIRA, André; VILLADA PAREDES, Fernando; SILVA, Rodrigo Banha da, coords. (2015) - Lisboa 1415 Ceuta: historia de dos ciudades - história de duas cidades. Ciudad Autonoma de Ceuta / Câmara Municipal de Lisboa. 


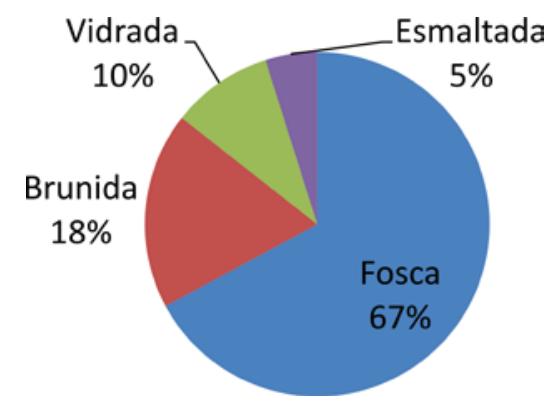

Gráfico 1 - Distribuição do conjunto de cerâmica do Ateneu Artístico Vilafranquense por tipo.

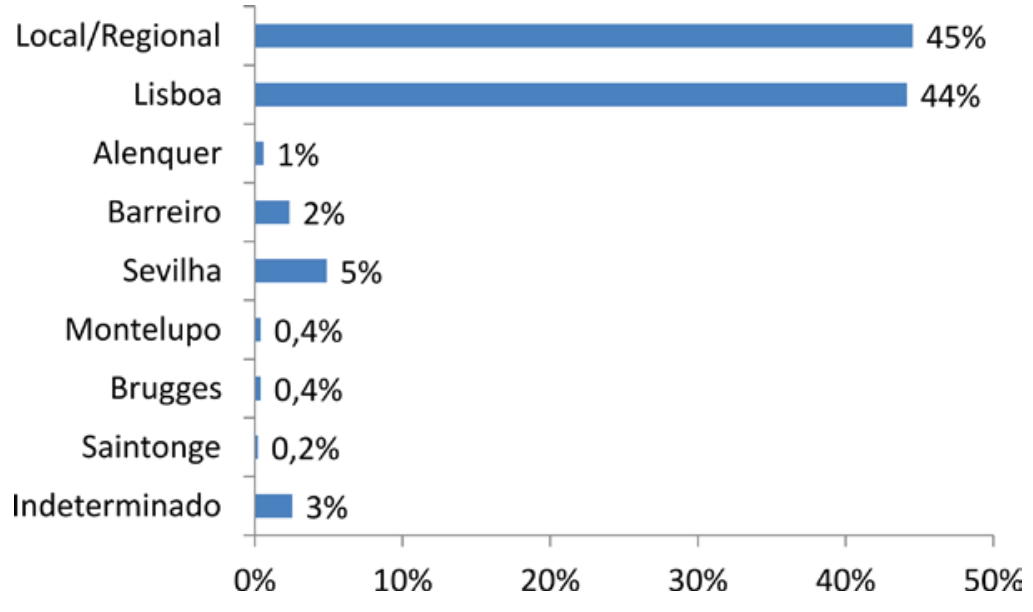

Gráfico 2-Distribuição dos fabricos identificados no conjunto de cerâmica do Ateneu Artístico Vilafranquense.

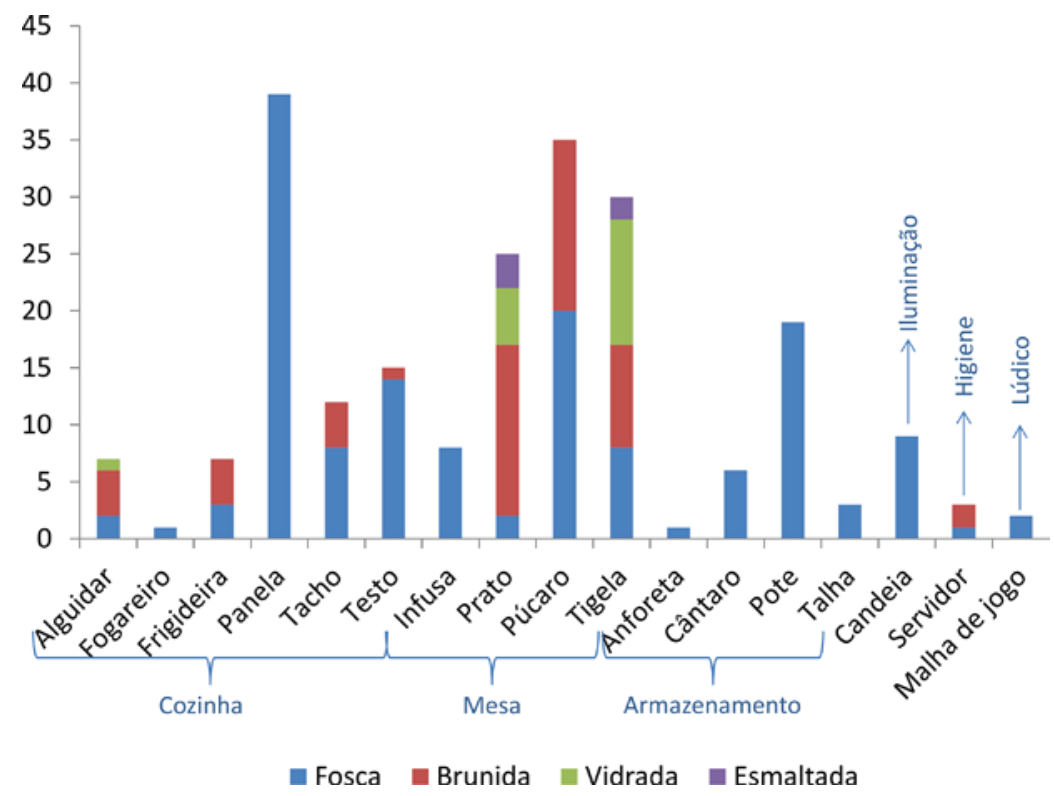

Gráfico 3 - Distribuição do NMI das peças identificadas no silo, por forma e tipo de cerâmica. 


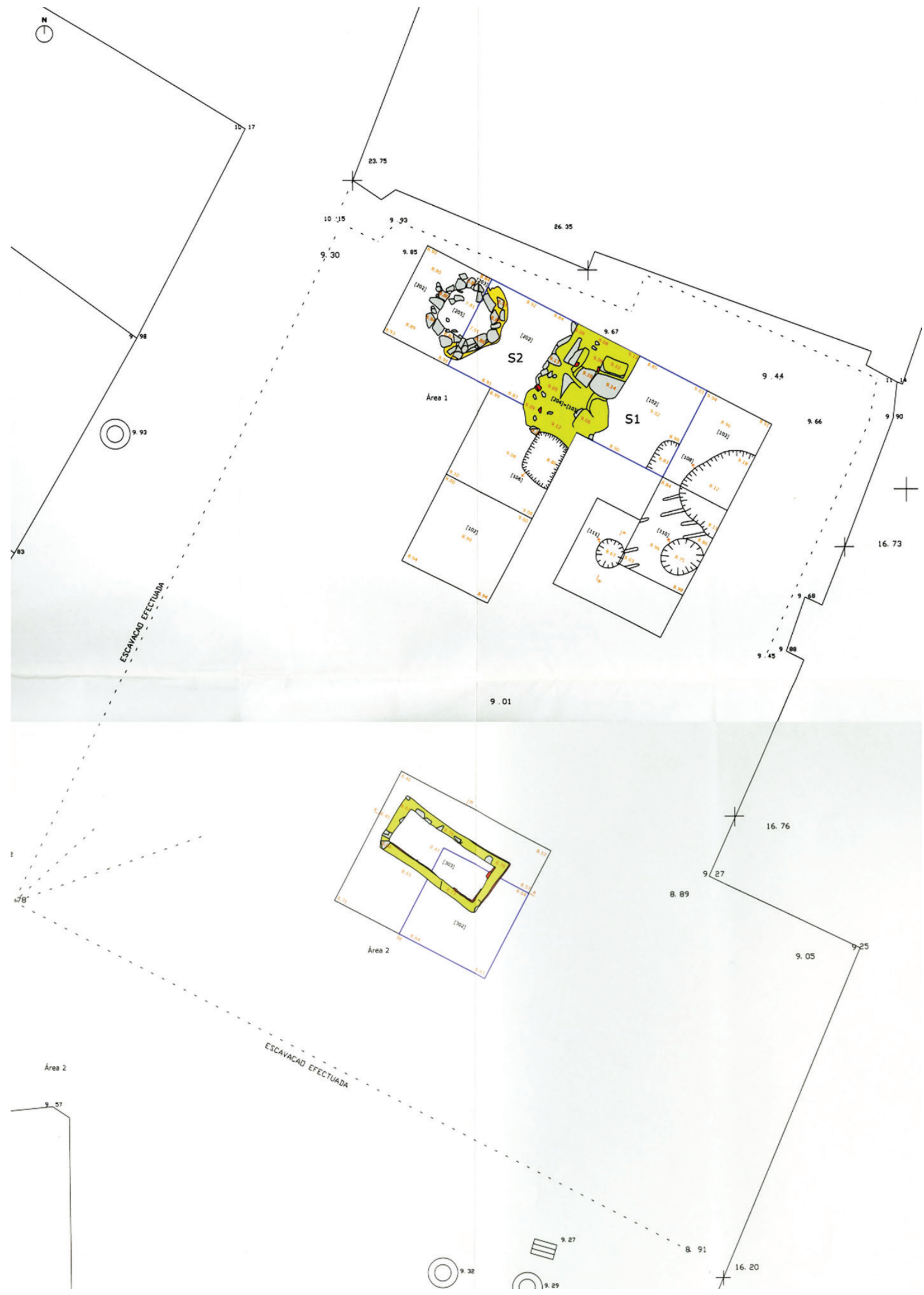

Figura 1 - Plano final da intervenção arqueológica no sítio do Ateneu Artístico Vilafranquense (In Pinto, 2007, Anexo III). 203 = poço; $204 / 203=$ pavimento lajeado; 106,110 e $111=$ estruturas negativas de pequenas dimensões; $108=$ silo; $304=$ tanque . 
Local/regional

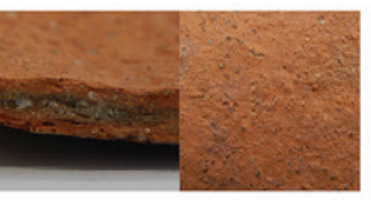

F1/B1

Lisboa

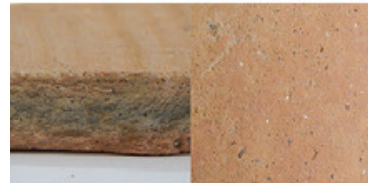

F3/B3

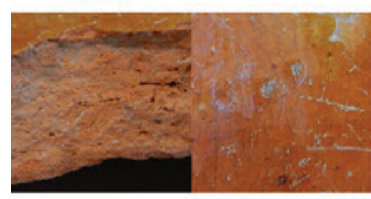

v1

Barreiro

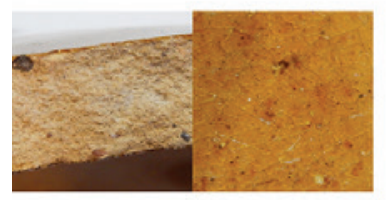

v4

Sevilha

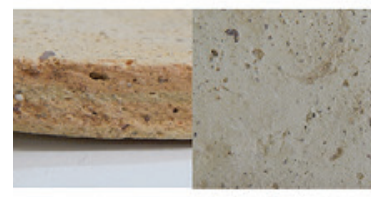

F8

Saintonge

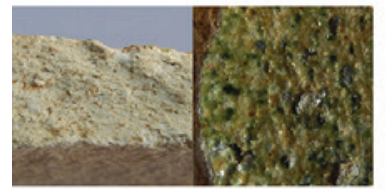

v6

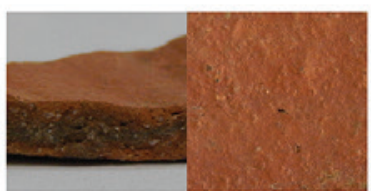

F2/B2

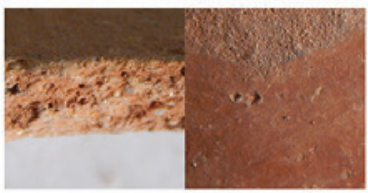

F4/B4

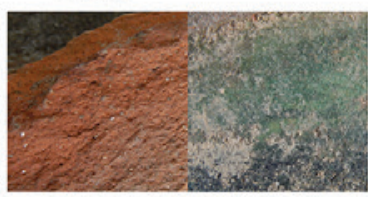

v2

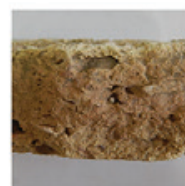

F9

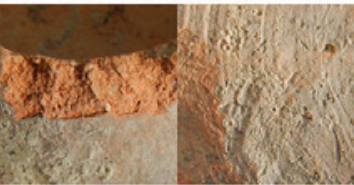

F5/B5

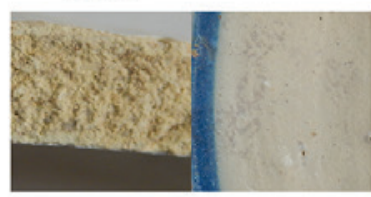

E4

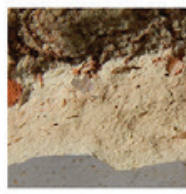

F10

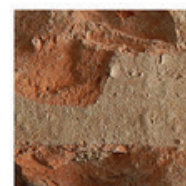

F11

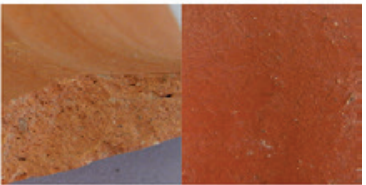

F7

\section{Alenquer}

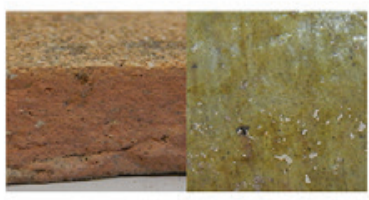

v5

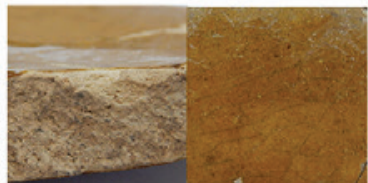

v3

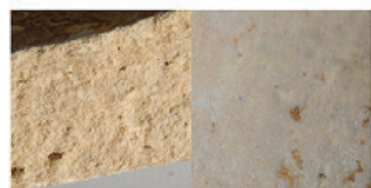

E1

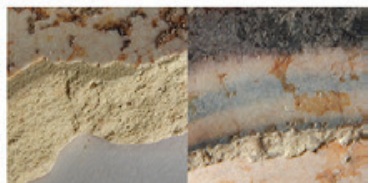

E2
Brugges

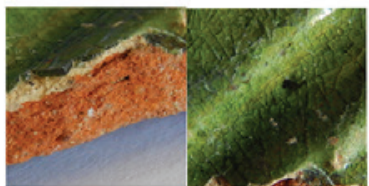

v9
Montelupo

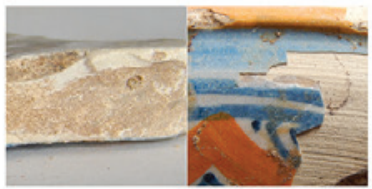

E3

Figura 2 - Pormenores dos fabricos identificados no Ateneu Artístico Vilafranquense. 

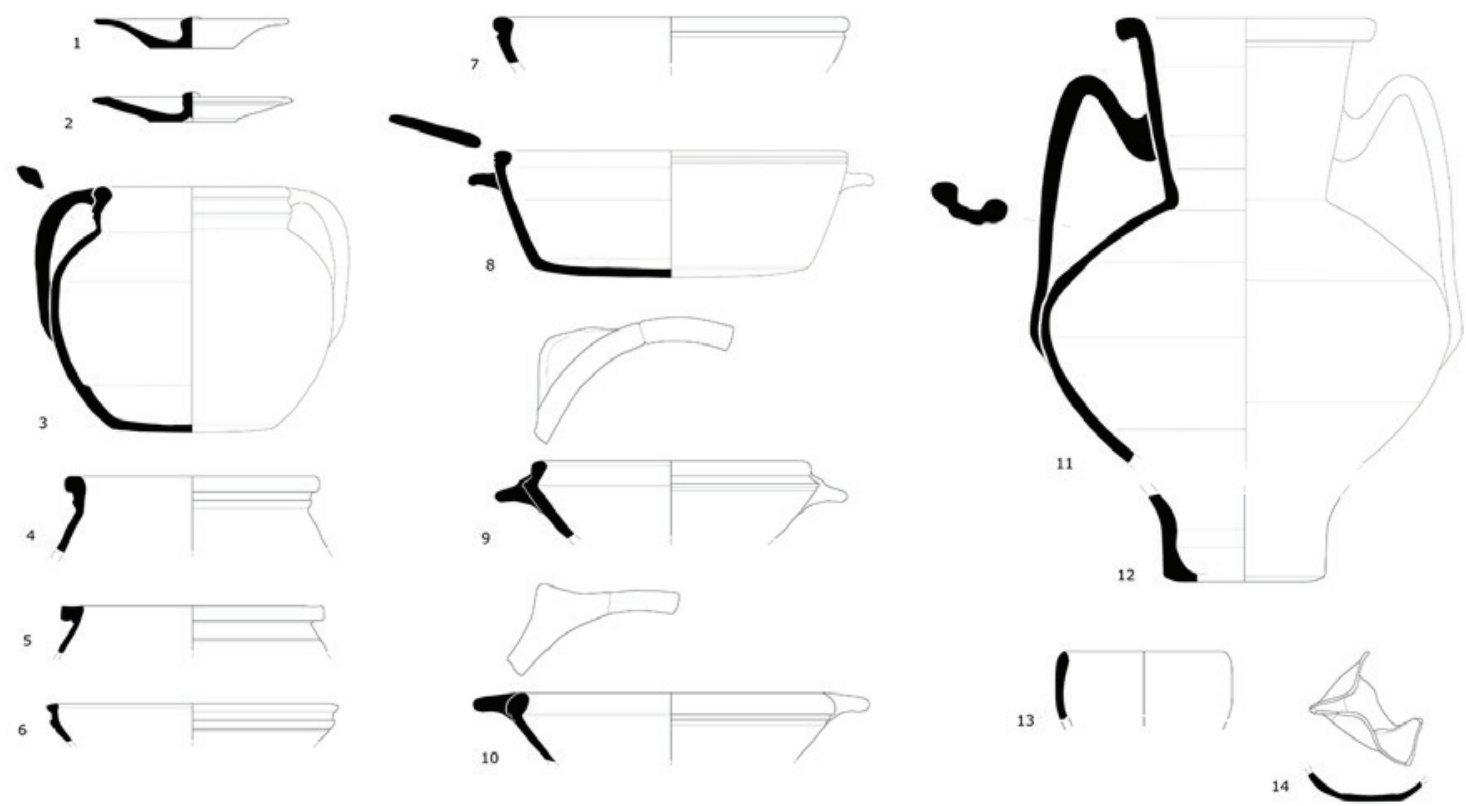

Fabrico F2
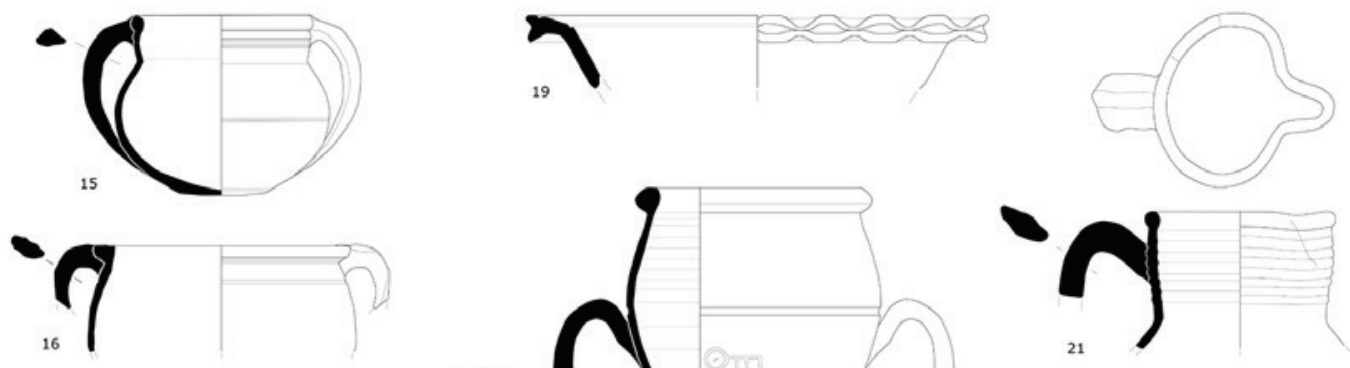

17 -
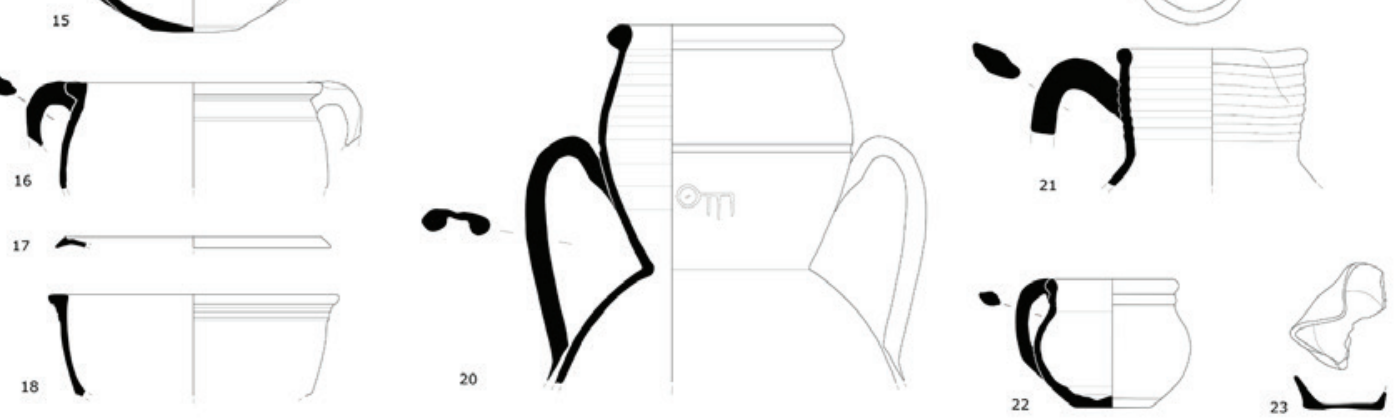

Figura 3 - Cerâmica fosca, possivelmente de produção local, registada no Ateneu Artístico Vilafranquense: testos nํㅗ 1-2 e 17; panelas $n^{\circ}$ 3-5 e 15-16; tigela $n^{\circ}$ 6; frigideira $n^{\circ}$ 7; tachos $n^{\circ}$ 8-10 e 18; cântaro $n^{\circ}$ 11-12 e 20-21; infusa $n^{\circ}$ 13; candeias $n^{\circ}{ }^{\circ} 14$ e 23; alguidar $n^{\circ}$ 19; púcaro $n^{\circ} 22$. 
=abrico B1

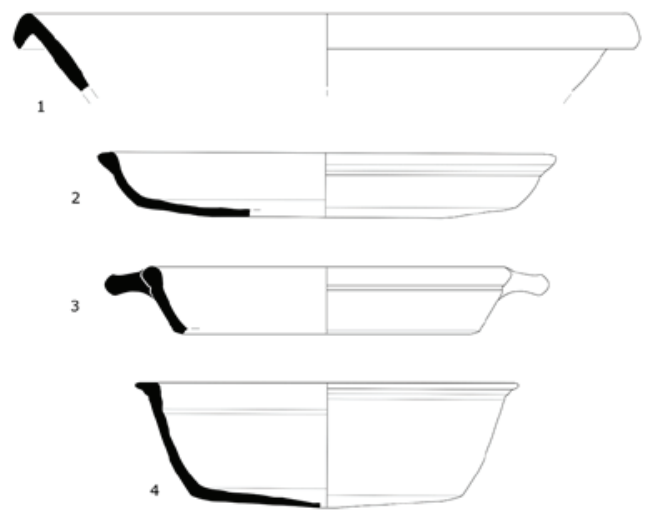

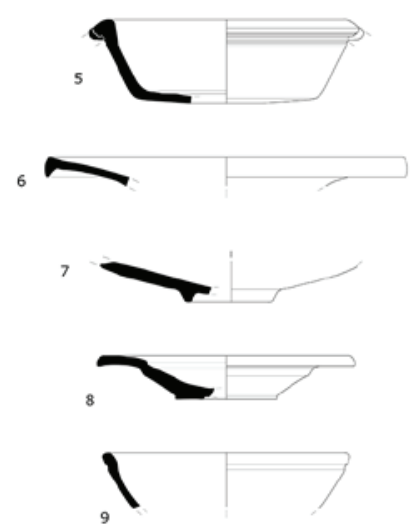

Fabrico B2

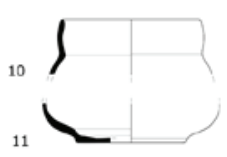

11

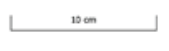

Figura 4 - Cerâmica brunida, possivelmente de produção local, registada no Ateneu Artístico Vilafranquense: alguidar nํㅜㄹ;

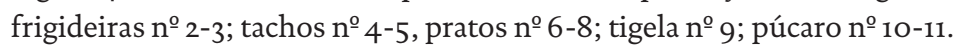




\title{
«NÃO PASSA POR TEU O QUE ME PERTENCE॥. MARCAS DE INDIVIDUALIZA- ÇÃO ASSOCIADAS A FAIANÇAS DO CONVENTO DE NOSSA SENHORA DE ARACOELI, ALCÁCER DO SAL
}

\author{
Catarina Parreira ${ }^{1}$, Íris Fragoso ${ }^{2}$, Miguel Martins de Sousa ${ }^{3}$
}

\begin{abstract}
RESUMO
Fundado em 1573 por Rui Salema e Catarina Sotto Mayor Salema, o Convento de Nossa Senhora de Aracoeli, instalou-se nos antigos paços mestrais da Ordem de Santiago. Extinto em 1874, foi-se degradando até à requalificação em Pousada D. Afonso II. Na sequência das campanhas arqueológicas realizadas entre 1993 e 1997, identificou-se expressivo espólio do qual se destaca uma ampla coleção de faiança portuguesa de diversas tipologias e cronologias.

A problemática que se apresenta relaciona-se com motivos incisos que o estudo das faianças, recolhidas em duas áreas da cerca conventual, proporcionou. Assim, a análise aferida utiliza o espólio como indicador socioeconómico, levando à inserção do conjunto de faianças no quotidiano conventual, quiçá profilático, de Alcácer do Sal. Palavras-chave: Cultura Material, Idade Moderna, Marcas incisas, Alcácer do Sal, Faiança Portuguesa.
\end{abstract}

\begin{abstract}
Founded in 1573 by Rui Salema and Catarina Sotto Mayor Salema, the Convento de Nossa Senhora de Aracoeli was located in the old house of the Order of Santiago. Extinct in 1874 it was in ruins by the renovation undertaken for the building of Pousada D. Afonso II. Following the excavation, carried out between 1993 and 1997, expressive archaeological remains were identified, including a diverse collection of Portuguese faience.

The issue that is presented relates to incised motifs which the study of the faience, collected in two sites from the conventual fence, reveled. Therefore, this study uses a selected assemblage as a socioeconomic indicator, leading it to be associated with the conventual, perhaps prophylactic, daily routine of Alcácer do Sal.

Keywords: Material culture, Early modern age, Incised marks, Alcácer do Sal, Portuguese faience.
\end{abstract}

\section{INTRODUÇÃO}

Com o objetivo de reverter o estado de degradação do Castelo de Alcácer do Sal, nos anos 90 avançou-se com um projeto de remodelação no espaço do antigo convento tendo em vista torná-lo numa pou- sada. A ação arqueológica, com início em 1993, assumiu o carácter de uma intervenção de emergência. Incidindo na área do edifício religioso, as campanhas foram programadas proporcionando a identificação de estruturas que permitissem, simultaneamente, fornecer maior informação histórico-arqueológica

\footnotetext{
1. Mestre em Arqueologia pela Faculdade de Ciências Sociais e Humanas da Universidade Nova de Lisboa, Avenida de Berna, 26-C, 1069-061 Lisboa; catarinaparreira@live.com.pt

2. Mestre em Arqueologia pela Faculdade de Ciências Sociais e Humanas da Universidade Nova de Lisboa, Avenida de Berna, 26-C, 1069-061 Lisboa; irisfragoso@live.com.pt

3. Mestre em Arqueologia pela Faculdade de Ciências Sociais e Humanas da Universidade Nova de Lisboa, Avenida de Berna, 26-C, 1069-061 Lisboa; miguelmsousa1996@gmail.com
} 
e delegando aos técnicos responsáveis pelas obras de adaptação do monumento a pousada, elementos úteis que pudessem contribuir para a valorização do edifício (Paixão; Faria, 1996, p. s. n..o).

$\mathrm{Na}$ aferição de estudos relativos a marcas incisas, em particular em faiança, este revelou-se parcamente desenvolvido no panorama científico nacional. A sua apresentação é meramente descritiva (Amaro \& alii, 2016, p. 71, 75; Almeida; Fernandes; Cândido, 2016, p. 154), estando em falta um esclarecimento para a necessidade da execução das mesmas. O mote que desencadeia este artigo, nomeadamente "Não passa por teu o que me pertence", sugere assim a consideração levada a cabo por quem pretendia demarcar uma ou um conjunto de peças indicando uma finalidade específica. Num difuso grupo de finalidades, as marcas exibem-se nos dias de hoje como testemunhos essenciais para que se possa, mesmo de forma subjetiva, alcançar uma interpretação possível.

Procuramos, deste modo, através da análise de parte de um diversificado conjunto de faiança portuguesa, apresentar um dos elementos mais insólitos das mesmas. As marcas incisas podem, assim, revelar detalhes da caracterização socioeconómica dos fácies cerâmicos portugueses provenientes do Convento de Nossa Senhora de Aracoeli.

\section{ELEMENTOS DE CONTEXTUALIZAÇÃO HISTÓRICA DO CONVENTO DE NOSSA SENHORA DE ARACOELI}

Aquando da degradação do edifício que albergava a sede mestral da Ordem de Santiago de Espada, do qual fez parte o convento espatário e os paços santiaguistas, após a sua transferência para Palmela no ano de 1482 , este é retratado na visitação de $1534^{4}$, onde se anuncia que "as casas do castelo desta villa estam muito danificadas desta maneira que não tem nenhuas portas nem genellas e homde nos portaes avia umbrejras de pedrarja leuadas que não ficam se não as traves tee as chumjnees derrybadas o de dentro e leuados os tijolos dellas" (Pereira, 2015, p. 223). Rui Salema ${ }^{5}$ e Dona Catarina Sotto Mayor Salema

\footnotetext{
4. Visitações a Alcácer do Sal efetuadas pelo Mestre D. Jorge, Álvaro Mendes, Cavaleiro da Ordem de Santiago, e Afonso Henriques, Prior da Igreja de São Pedro de Palmela, visitadores da Comarca de Campo de Ourique.

5. Criado do Infante Luís e comendador de Cristo em 1530 (Correia, 1972, p. 146; Leal, 1873, p. 58).
}

requerem a doação dos "Paços Velhos" da Ordem de Santiago com a sua cerca, torres e quinta, existentes dentro do castelo, com a pretensão de fundar um convento franciscano feminino (Fig.1), da Ordem de Santa Clara, na segunda metade do século XVI, que dotariam com bens para a respetiva manutenção e sustento. Através do Arquivo Gama Lobo Salema é possível aferir que o casal não teve descendência, talvez por isso tivesse o desejo de fundar o convento. Neste sentido, estariam a partilhar parte dos seus bens para uma causa que seria espiritualmente tranquilizadora na qual buscavam a intercessão do divino (Pereira, 2015, p. 223; Andrade, 2011, p. 172), numa lógica de devoção que se prende com as distâncias não apenas de âmbito cronológico, mas também culturais e sociais, que nos separam das mentalidades do século XVI.

Em 1561 é outorgado um breve do legado apostólico que concede a licença para a edificação do convento, numa comissão enviada por D. Sebastião, onde se revelam as condições necessárias para que este convento fosse edificado. Deste modo, a sua (re)construção traria nova vida àquele espaço que se encontrava em ruínas, para o qual era doada a Quinta de Arapouco que incluía outras propriedades e três moinhos, pomares, olivais e vinhas, o que "era boa renda e dote conveniente" para o dito convento (AHMALCS, oo5, f.3). Caso este deixasse de existir ou mudasse para outro local, todos os bens seriam transferidos para a Santa Casa da Misericórdia de Alcácer do Sal, de quem eram também mecenas, nunca se podendo vender ou doar a Quinta e os seus bens pertencentes (Pereira, 2015, p. 224; AHMALCS, oo5, f.3).

Da residência espatária que por ordem do segundo mestre D. Lourenço Anes se começou a edificar em fins do século XIII pouco restou, segundo Virgílio Correia (1972, p. 138), "as concessões de pedra para a construção e desenvolvimento do convento fizeram obliterar a sua memória”. No entanto, os princípios aplicados para a implantação do convento pouco diferem dos que foram essenciais para a do castelo islâmico aprofundado noutros trabalhos (Leitão, 2015). A proximidade de vias de comunicação, quer terrestres, quer fluviais, a proximidade de um cenóbio masculino, nomeadamente o Convento de Santo António, em que os frades se encarregam de zelar pelo cumprimento e observância da vida religiosa interna e também pela organização social e económica, bem como a sua localização nas imediações 
da urbe são elementos que justificam a sua escolha, como ao longo dos tempos foi ocorrendo (Andrade, 2011, p. 132, 413).

Podemos verificar ainda que existem diferentes tipos de soluções construtivas, mostrando que o convento não foi edificado de raiz, mas que aproveitou uma série de estruturas pré-existentes no local pertencentes a outros edifícios, como é o exemplo da alcáçova muçulmana e do Paço Real da Ordem de Santiago (Leitão, 2015, p. 47). Assim, o convento era delimitado a norte, poente e sul pelas muralhas do castelo e a nascente com o caminho que ia para o postigo e com outro que seguia para a Porta Nova sendo inaugurado, nesta configuração, a 3 de junho de 1573 (Pereira, 2015, p. 225).

Mais tarde, numa petição datada de 1792, a Abadessa Maria da Conceição revelava a D. Maria I o reduzido número de 13 religiosas que se encontravam no convento, muito longe do número designado de 33 na sua fundação. A abadessa descreve-as ainda como doentes e decrépitas, não podendo estas satisfazer ao ofício divino no coro e às necessárias obrigações da comunidade. Referia que desde 1755 que não entravam ali noviças, ao contrário e a "favor" do que acontecia noutras casas religiosas, imputando sua majestade pela possibilidade de extinção desta comunidade. A suplicante pleiteia a que se conceda licença para aceitar 12 noviças passando o seu número para 25 (ANTT, N. 54). Sabe-se também que após um período de paz o convento é notícia por albergar os oficiais de guarnições militares, tanto liberais como miguelistas, em tempos de guerra civil (1828-1834), que pernoitaram no hospício dos Padres. Houve também encargos para o Convento, em comida e bebida, destinadas aos soldados e oficiais (Pereira, 2015, p. 226).

A degradação do Castelo vem a agravar-se devido a sucessivos abalos de terra, à extinção das Ordens Religiosas em 1834 e à morte da última religiosa, Soror Maria da Conceição de São José, em 1874. Deste momento em diante este espaço ficou, para além de desabitado, completamente abandonado tendo-se perdido algumas das estruturas fortificadas do castelo e muitos dos vestígios das estruturas que se erguiam no interior do seu recinto (Pereira, 2015, p. 227).

\section{ASPETOS GENÉRICOS SOBRE A ESCAVA- ÇÃO DO CONVENTO DE NOSSA SENHORA DE ARACOELI 1993-1995}

Caracterizada como uma intervenção de emergência, a escavação foi individualizada em três fases. A primeira incidiu sobre o espaço delimitado como convento, nomeadamente nas zonas do Coro Baixo - área H (torre 4), Corredor Norte-Sul/Deambulatório - área C, E, G, I, J, Refeitório - área B, Sala do Capítulo - área D, Claustro - área L e Igreja - área M. Já a segunda fase estendeu-se pela cerca conventual e a terceira reporta-se ao acompanhamento das obras de construção (Paixão; Faria, 1996, p. s. n.o.). Da referida primeira fase, destacam-se várias sondagens pelas zonas em questão de $2 \mathrm{~m}$ por $2 \mathrm{~m}$ e de $4 \mathrm{~m}$ por $4 \mathrm{~m}$, e que proporcionaram descobertas numerosas em termos de níveis de enterramento, através dos restos osteológicos e artefactos arqueológicos, como medalhas, contas de terço, entre outros e cerâmica, sobretudo dos séculos XVI ao XVIII. Não esquecendo todos os elementos construtivos como o esgoto, destinado ao escoamento das águas provenientes da cozinha, identificado na zona do refeitório e os vários troços de canalizações que transportavam a água pluvial recolhida no telhado do convento para a cisterna (localizada na parede sul), bem como para o pequeno tanque com repuxo, localizado no centro do Claustro (Paixão; Faria, 1996, p. s. n.o).

Na segunda fase, na zona da cerca, onde estavam implantados os acréscimos estruturais, que se estendiam para este e para norte das estruturas visíveis do edifício religioso, foram designados 14 quadrados de $9 \mathrm{~m}$ por $9 \mathrm{~m}$, os quais teriam a si atribuídas letras de $\mathrm{A} \mathrm{a} \mathrm{O}^{6}$ (Fig. 2). É desta zona, nomeadamente das áreas $\mathrm{B}$ e $\mathrm{H}$, que surgem as peças em estudo, uma vez que a partir destas se pretendia alargar o espetro formal examinado.

O sítio intervencionado apresentava uma reduzida potência estratigráfica, bem como um impressionante revolvimento de terras e sobreposição de construções (Gomes, 2008, p. 18; Barata, 2007, p. 12). Apesar de nos terem sido disponibilizados desenhos de cortes estratigráficos e registos fotográficos de planos e cortes das áreas em estudo 7 , foi-nos praticamente impossível conseguir acrescentar a este trabalho alguma interpretação dos níveis estratigráficos em que foram recolhidas as faianças portuguesas que aqui apresentamos. Neste aspeto, a ausência de cadernos de campos que nos pudessem propor-

\footnotetext{
6. Sendo que a área $\mathrm{L}$ corresponde excecionalmente à zona descoberta do Claustro.

7. Informação disponibilizada pela Dr. ․ㅡ Esmeralda Gomes.
} 
cionar esclarecimentos relativamente à ligação entre camadas, estruturas e material recolhido afetou substancialmente a concretização da interpretação arqueológica do sítio.

A Planta Geral das estruturas arqueológicas individualizadas por períodos (Fig. 2), divulgada pelo Gabinete de Arqueologia da CMAS, exibe nestas duas áreas um compartimento com estruturas identificadas atribuídas às Idades Média e Moderna, o qual se encontrava encostado à muralha do convento e que por falta de sustentação arqueológica não se confirma que tipo de utilização teria e se este poderia estar associado à deposição das faianças estudadas. No entanto, a observação de alguns dos desenhos de cortes estratigráficos destas áreas em associação com as fichas de sítio salientam as diferentes camadas, apesar de não se encontrarem atribuídas na totalidade das peças. $\mathrm{Na}$ área $\mathrm{H}$ surgem as camadas 1 e 2, sendo que a camada 1 surge maioritariamente relacionada a material disperso ou de superfície e a camada 2 surge associada a uma possível lixeira. Esta também é mencionada em certas fichas de sítio da área B, bem como, parcamente caracterizadas, as camadas 1,2 e 3.

A última fase apesar de ser indicada apenas como de acompanhamento focou-se no espaço do claustro, nas zonas a céu aberto e arcaria periférica, onde se evidenciaram paredes construídas nos séculos XIII e XIV, tal como mais níveis de enterramentos, estes datados na sua maioria dos séculos XVII a XVIII (Gomes; Ferreira, 2008, p. 10-11).

\section{O CONJUNTO DE FAIANÇAS DAS ÁREAS B E H DA CERCA CONVENTUAL}

Identificámos neste conjunto, correspondendo respetivamente à área $\mathrm{H} 338 \mathrm{NMI}$ num total de 1201 fragmentos, na área B 261 de 785 e no testemunho H/B 56 de 168 , perfazendo um total de 655 NMI e 2154 fragmentos de faiança portuguesa (Parreira, 2020, p. 48).

A análise formal e decorativa a partir de paralelos foi essencial neste trabalho, uma vez que as evidências arqueológicas apresentam-se pouco explícitas em relação ao contexto em que foram recolhidas. Numa primeira abordagem a este conjunto do acervo de material arqueológico recolhido no Convento de Nossa Senhora de Aracoeli, avançámos com conclusões que não podem deixar de ser parciais.

A maioria das formas de faiança recuperada corres- pondem aos denominados recipientes abertos, dos quais se reconheceram pratos de várias dimensões, rasos e fundos, covilhetes, taças, fruteira/travessa, bacia de degolada para sangria, escudelas e especieiro. Foram igualmente identificadas formas fechadas como púcaro, pote e garrafas ou frascos, variando em cada uma delas as dimensões. Outras formas como as pegas, asas, tampas e pequeno elemento de estatueta encontram-se identificadas neste conjunto. Tal como seria expectável, nesta coleção (Graf. 1) encontram-se melhor representados os pratos $(56,44 \%)$, seguindo-lhes as taças $(18,91 \%)$ e em menor número de exemplares identificados o púcaro, a degolada para sangria, o especieiro e o elemento de estatueta (o,23\%). Já os covilhetes, fruteira/travessa, escudelas, potes e tampas representam 2,13\% do conjunto, enquanto os fragmentos não identificáveis configuram um total de 21,44\% (Parreira, 202O, p. 50).

As decorações surgem sobretudo na superfície interior do fundo dos pratos e, por vezes nas superfícies interiores das abas, tal como nas paredes exteriores de covilhetes e taças. Apenas três fragmentos exibem decoração de amarelo e azul (o,17\%), 18 apresentam somente decoração de cor violeta (1,03\%), 219 não possuem pintura (12,59\%), enquanto $1018(58,51 \%)$ têm-na na cor de azul de cobalto e $482(27,70 \%)$ ostentam ornamentação que associa aquelas duas cores (Parreira, 202O, p. 65).

As ornamentações observadas podem subdividir-se, conforme os principais motivos que ostentam como antropomórficos, zoomórficos, heráldicos, inscrições, fitomórficos, geométricos e compósitos. Compondo esta última e a pretexto ilustrativo, contabilizamos os motivos das escamas, das três contas, das rendas, das volutas e dos aranhões (Tab.1) (Parreira, 2020, p. 65).

Deste modo, o conjunto arqueológico recuperado nas áreas B e H no Convento de Nossa Senhora de Aracoeli pode ser atribuível a um longo período, entre os finais do século XVI e os meados do século XVIII, mais precisamente produzida entre $1570 \mathrm{e}$ 1700/1766, de acordo com o acervo de faiança portuguesa ali recolhida (Parreira, 2020, p. 89).

\subsection{As marcas}

Apreciando o conjunto de faianças das áreas B e H do Convento de Nossa Senhora de Aracoeli, foram identificadas marcas que designamos como marcas incisas ou grafitos e dividimos em marcas alfabéticas e geométricas. Apresentamos também o número de 
marcas indeterminadas (3) pela sua relevância na totalidade do diminuto conjunto de faianças. Identificamos assim um total de 49 marcas, das quais 30 surgem em pratos, $15 \mathrm{em}$ taças e uma num covilhete, incidindo grande parte no tardoz das peças. No entanto, também se evidenciam estas marcas na base e no pé dos testemunhos cerâmicos (Tab. 2).

As marcas apresentam uma tendência alfabética (Graf. 2) mais demarcada, em relação às marcas geométricas (Graf.3). Neste âmbito, os grafitos alfabéticos exibem uma grande variedade de letras, as quais se encontram bastante percetíveis enquanto os motivos geométricos estão em número residual. Registaram-se as letras: $\mathrm{O}, \mathrm{P}$ (com elementos esféricos de distinção em torno), MI, F, S, U, G, N, H e h, E, I (com os mesmos elementos mencionados anteriormente), J, C e A (Fig. 4). Os motivos geométricos apresentam-se com os grafitos que se assemelham a: III, * e JL (Fig. 5).

Na sua grande maioria, estas peças apresentam marcas de desgaste, o que pode evidenciar que seriam usadas frequentemente. De notar que $48,79 \%$ das peças revelam marcas de desgaste tanto no bordo como no fundo. Evidenciam-se também em maior número nos fragmentos decorados, num total de 39 fragmentos, e em menor número, apenas 8 , nos que estão apenas revestidos a esmalte branco, nas áreas $\mathrm{B}, \mathrm{H}$ e testemunho $\mathrm{H} / \mathrm{B}$.

Por fim, estes são motivos incisos que se executavam com algum tipo de material afiado, como uma faca ou tesoura, e que seriam realizados depois da peça ser cozida, uma vez que o esmalte não cobre esta zona. Em alguns destes conseguimos ainda observar as zonas de incisão, onde este objeto afiado teria o seu primeiro contacto com a peça.

\section{DISCUSSÃO}

Identificaram-se paralelos no fundo ou tardoz de pratos e taças carenadas de faiança portuguesa provenientes do Convento de Jesus de Setúbal (Almeida; Fernandes; Cândido, 2016, p. 154) e da antiga prisão do Aljube em Lisboa (Amaro \& alii, 2016, p. 71, 75). Em Setúbal, particularmente, estes surgem em número residual no tardoz de duas taças hemisféricas e no fundo de um prato em ônfalo. Os grafitos de Lisboa possuem natureza alfabética, de cariz geométrico sendo identificados 24 exemplares, entre estes os de natureza alfabética mostram a forma da letra $\mathrm{V}$, $\mathrm{M}$ e X. Neste caso, a diferenciação feita entre as mar- cas aproxima-se de um significado muito próximo aos indivíduos que as produzem, como a inicial do nome próprio ou do apelido, tal como se regista para as marcas de canteiro de elementos arquitetónicos (Silvério, 2017, p. 1513).

Num âmbito ibérico, o estudo, de José Luiz Menéndez Fueyo, revela-se pertinente. Para este autor, o paradigma que se impõe é que estas marcas são por si sinais de História, testemunhos que representam um indivíduo ou mesmo um grupo a quem queremos minuciosamente compreender cada detalhe da sua vida. O elemento central no estudo de Menéndez Fueyo, proveniente da Basílica de Santa Maria de Alicante e correspondente a mais de 50 marcas incisas, o que supõe uma percentagem superior a $30 \%$ do total de peças com marcas e, que as converte num dos tipos de marcas principais localizados nos conjuntos recolhidos na igreja. Localizadas mais frequentemente na parte superior do corpo, de forma a estarem visíveis, em oposição ao conjunto presentemente estudado, estas surgem com uma enorme variedade de motivos, das quais se destacam as chamadas letras góticas, sobretudo o "b" e a estrela de cinco pontas (Menéndez Fueyo, 2012, p. 112).

Para o investigador valenciano a marca representa a propriedade, como um selo que garante a qualidade do produto (Menéndez Fueyo, 2012, p. 113). Considera também as marcas numerárias, que são as que mostram duas linhas verticais cruzadas por uma linha perpendicular e que podem corresponder a marcas de contabilidade (Menéndez Fueyo, 2012, p. 117). No conjunto do Convento de Nossa Senhora de Aracoeli, a semelhança que surge entre alguns dos grafitos de natureza alfabética (Graf. 2), tal como a sua repetição, sugere a utilização dessas peças pela mesma pessoa ou grupo socioeconómico dentro do ambiente clausural, nomeadamente freiras, noviças, padres, criadas, etc. (Almeida; Fernandes; Cândido, 2016, p. 154). Pelo menos a sua localização como é o caso da marca "S", no tardoz da caldeira de pratos, ou mesmo do "h", na mesma orientação, variando o tamanho, permite com alguma subjetividade afirmá-lo. Pressupõe-se ainda a associação de uma letra ou símbolo geométrico a uma pessoa sabendo mesmo que essa pode ter criado mais do que um símbolo para identificar o que lhe pertencia.

Neste âmbito, estes dados podem remeter-nos para as iniciais de algumas das freiras do convento, pois as letras incisas apresentam grande variabilidade entre si, como exemplo a letra $\mathrm{H}$ que surge em le- 
tra maiúscula e minúscula. Bem como o I, letra que tem dois pontos sobre si e outro que se encontra representado com quatro pontos à sua volta. Pode isto talvez significar que cada uma estaria associada a um indivíduo diferente com iniciais semelhantes, e que justificasse a necessidade desta distinção.

Qualquer hipótese que se exponha pode ser apresentada como viável, mas sempre subjetiva. Assim a necessidade de identificação individual dos conjuntos pode estar associada à consciencialização da individualização do consumo de alimentos que surge para controlo e proteção contra doenças contagiosas e epidemias (Almeida; Fernandes; Cândido, 2016, p. 154; Amaro \& alii, 2016, p. 70-71). No entanto, usando como exemplo uma taça do Convento de Jesus de Setúbal com a palavra Emferm ${ }^{a}$ (CJ o6 AVE Lix. XVII 11179 - Almeida, 2012, p. 444) a cursivo, esta pode indicar, para além de se relacionar com a Enfermaria, ainda, tal como Mendénez Fuyo refere, a importância de registar estas marcas em zonas visíveis da peça, uma vez que para alguém nesta condição ou numa peça de armazenamento talvez fosse efetivamente necessário algo que indicasse a sua exclusividade de utilização, para que se impedisse a propagação de doenças, ou mesmo para a indicação do tipo e capacidade de armazenamento dos contentores.

Neste sentido, as peças do conjunto que se analisou apresentam marcas em zonas ocultas. Pode isto significar que poderiam ser peças utilizadas à mesa e que identificariam um indivíduo ou uma utilização especial da peça para algum alimento? Estariam elas associadas ao uso exclusivo na preparação de alimentos ou seriam peças com qualquer outra utilização no quotidiano conventual?

Neste contexto, Joana Torres refere que apesar do carácter individual destes recipientes, nos séculos XVII e XVIII, não há uma preocupação, pelo menos em ambientes conventuais, em fazer marcas de posse, como muitas vezes sucedia em contextos medievais, sendo que estas marcas podiam surgir esporadicamente, para distinguir um objeto que fosse particular, tendo como propósito a sua identificação e não individualização (Torres, 2011, p. 87).

No conjunto que analisamos, a percentagem de fragmentos com grafitos inserida no total das áreas $\mathrm{B} \mathrm{e} \mathrm{H}$ é bastante diminuta $(2,27 \%)$. Mas a manifestação diversificada de letras que pudessem estar associadas a iniciais de indivíduos em contacto com o ambiente conventual, não poderá significar mais que uma simples identificação e assumir um carácter indivi- dualista? Os gráficos 2 e 3 podem ser justificativos disso mesmo, pois mostram a maior necessidade da utilização de letras e não símbolos, estas que podiam mais facilmente estar associadas ao nome próprio e individualizar a utilização de uma peça específica. No entanto, a corroboração deste estudo só pode ser justificada com a análise mais alargada de todo o conjunto cerâmico recolhido no contexto no Convento de Nossa Senhora de Aracoeli. Pretendemos somente, deste modo, dar a conhecer algumas destas marcas para que seja possível mais tarde, com o surgimento de novos elementos recolhidos em trabalhos arqueológicos, chegar cada vez mais próximo do verdadeiro significado destas.

\section{BIBLIOGRAFIA}

AHMALCS, CMALCS/CNSA/O2/o05, Pública Forma Transcrição da Escritura de doação da Herdade de Arapouco [3 Jun. 1573-7 Fev. 1857].

ALMEIDA, Mariana Brito (2012) - Convento de Jesus (Setúbal) Arqueologia e História: Faiança decorada. Lisboa: Dissertação de Mestrado apresentada à FCSH-UNL.

ALMEIDA, Mariana Brito; FERNANDES, Edgar; CÂNDIDO, Maria João (2016) - Portuguese Faience inspired by spanish forms in the Convento of Jesus of Setúbal ( $16^{\text {th }}$ and $\left.17^{\text {th }}\right)$. In GOMES, R. V.; CASIMIRO, Tânia; GOMES, M. V., eds. - Proceedings of the First Internacional Conference of Portuguese Faience ( $16^{\text {th }}-19^{\text {th }}$ Centuries). Lisboa: Instituto de Arqueologia e Paleociências, pp. 151-16o.

AMARO, Clementino; FILIPE, Vanessa; HENRIQUES, José Pedro; MANSO, Cláudia (2016) - Faiança quinhentista recuperada num compartimento da antiga prisão do Aljube, Lisboa. In GOMES, R. V.; CASIMIRO, Tânia; GOMES, M. V., eds. - Proceedings of the First Internacional Conference of Portuguese Faience ( $16^{\text {th }}-19^{\text {th }}$ Centuries). Lisboa: Instituto de Arqueologia e Paleociências, pp. 67-78.

ANDRADE, Maria (2011) - IN OBOEDIENTIA, SINE PROPRIO, ET IN CASTITATE, SUB CLAUSURA: A Ordem de Santa Clara em Portugal (Sécs. XIII - XIV). Lisboa: Dissertação de Doutoramento em História apresentada à FCSH-UNL.

ANTT, Província dos Algarves, Ordem dos Frades Menores, Alcácer do Sal/Aracoeli, Maço 1, № 54, Petição apresentada ao Príncipe Nosso Senhor para conceder licença para aceitar doze noviças [9 Set. 1792].

BARATA, Maria Filomena, coord. (2007) - Roteiro. Castelo de Alcácer do Sal: Cripta Arqueológica. Lisboa: Instituto de Gestão do Património Arquitetónico e Arqueológico.

CORREIA, Virgílio (1972) - Alcácer do Sal, esboço de uma monografia”. In Obras: Estudos Arqueológicos, Vol. 4. Coimbra: Acta Universitatis Coninbrigensis, pp. 127-155. 
GOMES, Esmeralda (2008) - Os ex-votos proto-históricos do Castelo de Alcácer do Sal. Lisboa: Tese de mestrado em Arqueologia apresentada à FL-UL.

GOMES, Esmeralda; FERREIRA, Marisol Aires (2008) Detalhes da vida privada no Convento de Aracaeli. In Alcácer do Sal: Terra de Deusas. Alcácer do Sal: CMAS, pp.7-14.

LEAL, Augusto Pinho (1873) - Alcácer do Sal. In Portugal Antigo e Moderno, Vol. I. Lisboa: Mattos Moreira \& Companhia, pp. 56-61.

LEITÃO, Marta Isabel Caetano (2015) - A Presença Islâmica em al-Qasr: Uma análise sobre o urbanismo e o sistema defensivo. Lisboa: Dissertação de Mestrado em Arqueologia apresentada à FCSH-UNL.

MENÉZES Fueyo, José Luís (2012) - Marcar la tinaja, firmar la historia. In La cerâmica medieval de la Basílica de Santa Maria de Alicante. Arqueología, arquitetura y cerâmica de una excavación arqueológica insólita en España. Oxford: Archaeopress (BAR Internacional Series; 2378), pp. 109-132.

NÓVOA, Rita Luís Sampaio da (2016) - O Arquivo Gama Lobo Salema e a produção, gestão e usos dos arquivos de família nobre nos séculos XV-XVI. Lisboa: Dissertação de Doutoramento apresentada à FCSH-UNL.

PAIXÃO, António Cavaleiro; FARIA, João Carlos (1996) Escavações arqueológicas no Convento de Nossa Senhora de Aracaeli (Alcácer do Sal): Relatório (Novembro de 1996). Alcácer do Sal: Câmara Municipal de Alcácer do Sal.

PARREIRA, Catarina Sofia Delgado (2020) - A Faiança Portuguesa do Convento de Nossa Senhora de Aracoeli (Alcácer do Sal). Lisboa: Dissertação de Mestrado em Arqueologia apresentada à FCSH-UNL.

PEREIRA, Maria Teresa Lopes (2015) - Os Cavaleiros D’Santiago em Alcácer do Sal (século XII a fins do século XV). Lisboa: Edições Colibri.

TORRES, Joana (2011) - Quotidianos no Convento de São Francisco de Lisboa: uma análise da cerâmica vidrada, faiança portuguesa e porcelana chinesa. Lisboa: Dissertação de Mestrado em Arqueologia apresentada à FCSH-UN.

SILVÉRIO, Sara (2017) - As Marcas de Canteiro da Sé de Lisboa. In Arnaud, J. M.; Martins, A. (eds.), Arqueologia em Portugal / 2017 - Estado da Questão. Lisboa: Associação dos Arqueólogos Portugueses, pp. 1513-1521. 

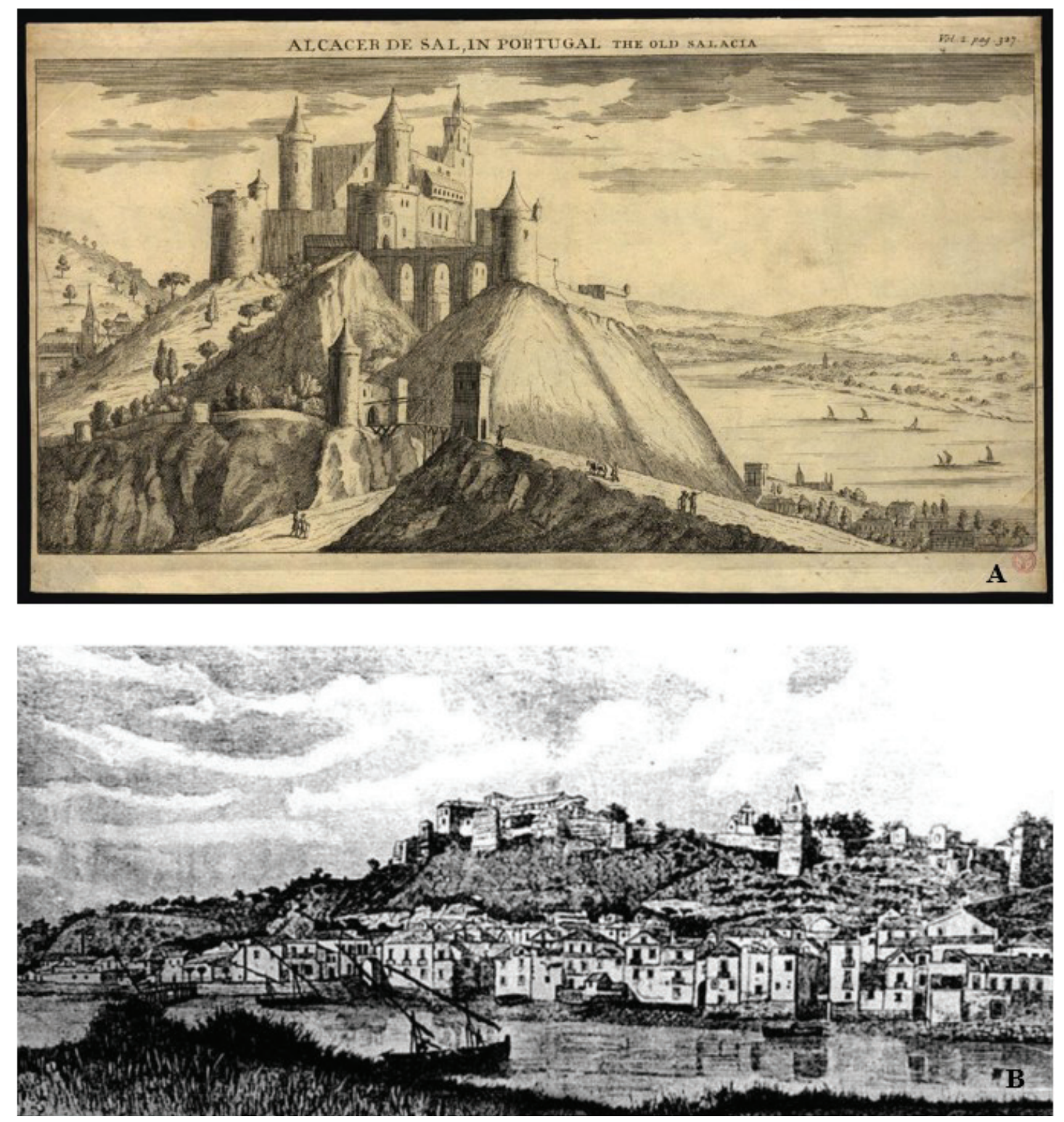

Figura 1 - A: Gravura fantasiosa da fortificação de Alcácer do Sal no século XVIII (Fonte: Biblioteca Nacional de Portugal - Autor desconhecido); B: Gravura de Alcácer do Sal, de 1889, onde se observa no topo do outeiro o Convento de Nossa Senhora de Aracoeli (Fonte: Arquivo do Museu Municipal de Alcácer do Sal - Autor Desconhecido). 

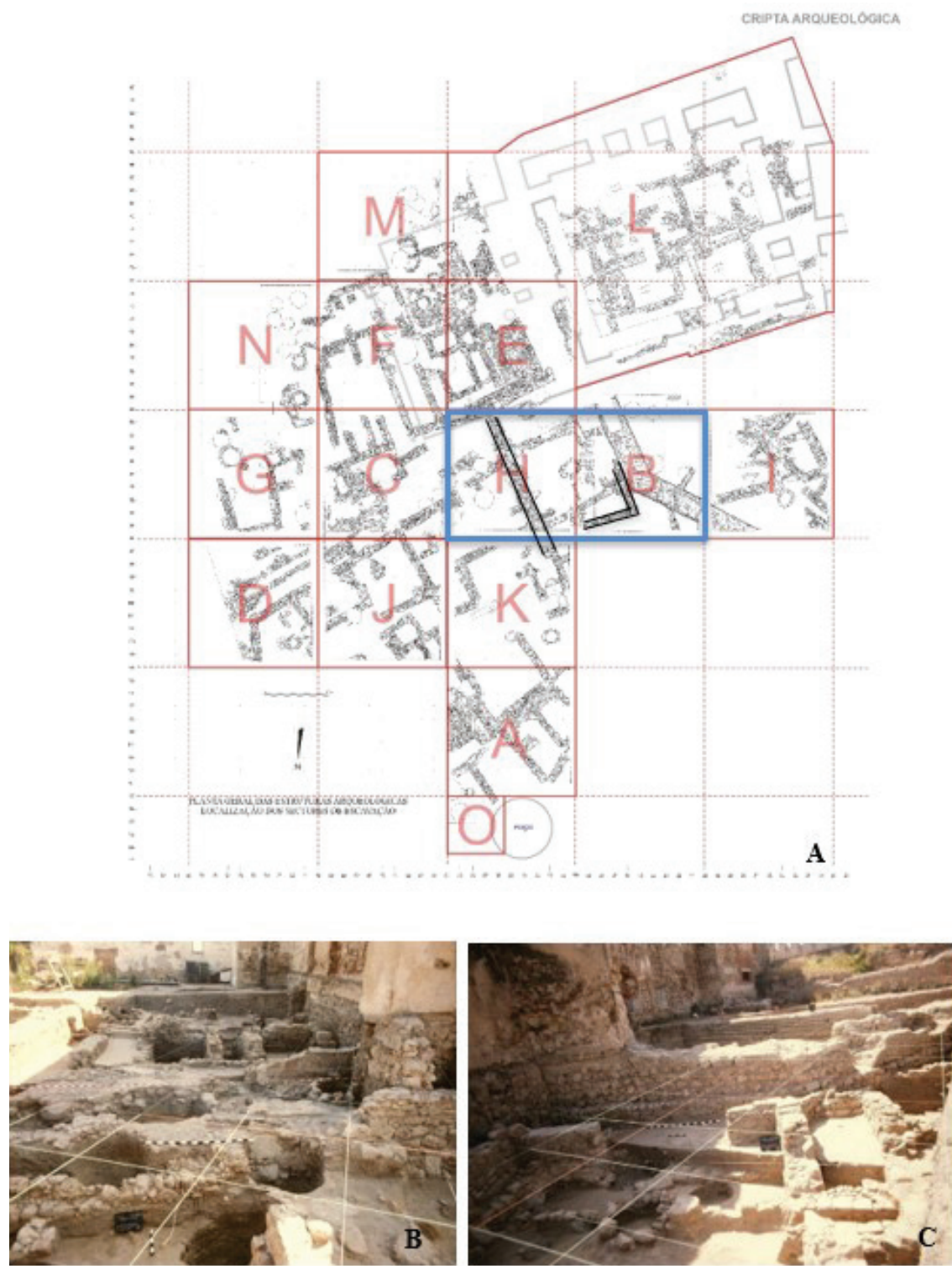

Figura 2 - A: Planta geral das estruturas arqueológicas e localização dos setores. Destaque a azul para os setores $\mathrm{H}$ e B e individualizadas a preto as estruturas da Idade Medieval/Moderna (cedida pelo Gabinete de Arqueologia de Alcácer do Sal); B: Vista geral das áreas H, B e E (fotografia de Manuel Perna cedida pela Câmara Municipal de Alcácer do Sal / Direção Regional de Cultura do Alentejo); C: Pano de muralha que fazia a divisão entre o convento e a cerca. Visíveis as estruturas da área B e H (fotografia de Manuel Perna cedida pela Câmara Municipal de Alcácer do Sal / Direção Regional de Cultura do Alentejo). 


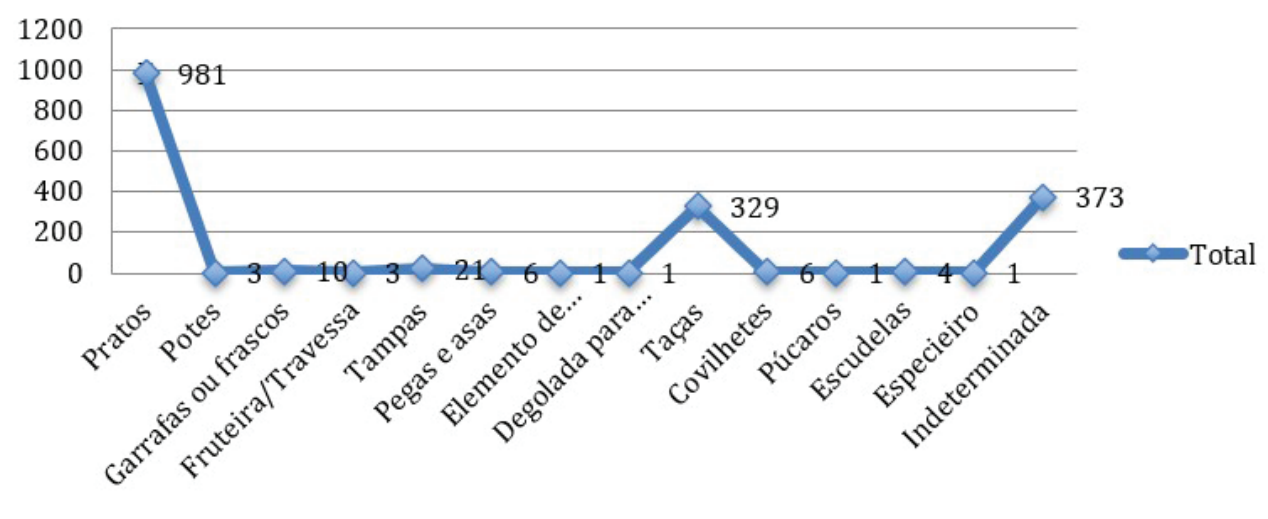

Gráfico 1 - Formas presentes na coleção das áreas B e H da cerca do Convento de Nossa Senhora de Aracoeli, por número fragmentos.

\begin{tabular}{|c|c|c|c|c|c|c|c|c|c|c|c|c|c|c|c|c|c|c|c|c|c|c|c|c|c|c|}
\hline \multirow[t]{3}{*}{ Formas } & \multicolumn{25}{|c|}{ Motivos decorativos } & \multirow{3}{*}{ Total } \\
\hline & \multicolumn{4}{|c|}{ Antrop. } & \multicolumn{3}{|c|}{ Zoom. } & \multicolumn{4}{|c|}{ Heráldicos } & \multicolumn{3}{|c|}{ Inscrições } & \multicolumn{4}{|c|}{ Fitomórfico } & \multicolumn{3}{|c|}{ Geométricos } & \multicolumn{4}{|c|}{ Compósitos } & \\
\hline & $\mathrm{v}$ & \begin{tabular}{l|l}
$\mathrm{A}$ & $\mathrm{I}$ \\
\end{tabular} & VA & AA & \begin{tabular}{l|l}
$\mathrm{V}$ & $\mathrm{A}$ \\
$\mathrm{n}$
\end{tabular} & $\begin{array}{l}\mathrm{A} \text { VA } \\
\end{array}$ & AA & $\mathrm{v}$ & \begin{tabular}{l|l}
$\mathrm{A}$ & $\mathrm{V}$ \\
\end{tabular} & \begin{tabular}{l|l}
$\mathrm{A}$ & $\mathrm{A}$ \\
\end{tabular} & $\begin{array}{lll}\mathrm{AA} & \mathrm{V} \\
\end{array}$ & \begin{tabular}{l|l|}
$\mathrm{V}$ & $\mathrm{A}$ \\
\end{tabular} & VA & AA & $\mathrm{v}$ & A & VA & AA 1 & \begin{tabular}{l|l}
$\mathrm{V}$ & $\mathrm{A}$ \\
$\mathrm{C}$
\end{tabular} & \begin{tabular}{l|l}
$\mathrm{A}$ & $\mathrm{V}$ \\
\end{tabular} & \begin{tabular}{l|l}
$\mathrm{A}$ & $\mathrm{AA}$ \\
\end{tabular} & \begin{tabular}{l|l}
$A$ & $V$ \\
\end{tabular} & \begin{tabular}{|l|l|}
$V$ & $\mathrm{~A}$ \\
\end{tabular} & VA & AA & \\
\hline Pratos & & 2 & 1 & & 3 & \begin{tabular}{l|l|}
3 & 1 \\
\end{tabular} & & & \begin{tabular}{l|l}
26 & 1 \\
1
\end{tabular} & \begin{tabular}{l|l}
16 & \\
\end{tabular} & & \begin{tabular}{|l|l|}
2 & 8 \\
\end{tabular} & 5 & & 2 & 118 & 25 & & & \begin{tabular}{l|l}
53 & 2 \\
\end{tabular} & \begin{tabular}{l|l}
2 & \\
\end{tabular} & & 131 & 230 & & 725 \\
\hline Potes & & & & & & & & & & & & & & & & 2 & & & & & & & & 1 & & 3 \\
\hline $\begin{array}{c}\begin{array}{c}\text { Garrafas ou } \\
\text { frascos }\end{array} \\
\end{array}$ & & & & & & & & & & & & & & & & 2 & 1 & & & 3 & & & & & & 6 \\
\hline Fruteiras/travessas & & & & & & & & & & & & & & & & & & & & 2 & & & & & & 2 \\
\hline Tampas & & & & & & & & & & & & & 2 & & & 2 & 2 & & 2 & 1 & 1 & 1 & 1 & 5 & & 16 \\
\hline Pegas e asas & & & & & & & & & & & & & & & & & & & & & & & 1 & & & 1 \\
\hline $\begin{array}{l}\text { Degolada para } \\
\text { sangria }\end{array}$ & & & & & & & & & & & & & & & & 1 & & & & & & & & & & 1 \\
\hline Taças & & & & & & & & & & & & 1 & 2 & & 5 & 21 & 1 & & & 53 & 1 & & 37 & 77 & & 198 \\
\hline Covilhetes & & & & & & & & & & & & & & & 1 & & & & & 1 & & & 1 & 2 & & 5 \\
\hline Púcaros & & & & & & & & & & & & & & & & 1 & & & & & & & & & & 1 \\
\hline Escudelas & & & & & & & & & & & & & & & & & & 1 & & & & & & 1 & & 2 \\
\hline Indeterminadas & & & & & 1 & & & 1 & 4 & & & \begin{tabular}{l|l|}
1 & 1 \\
\end{tabular} & 1 & & & 18 & 7 & & \begin{tabular}{l|l}
1 & 19 \\
\end{tabular} & 19 & & & 22 & 51 & & 127 \\
\hline Total & & 2 & 1 & & 4 & \begin{tabular}{l|l|}
44 & 1 \\
\end{tabular} & & \begin{tabular}{l|l}
1 & 3 \\
\end{tabular} & \begin{tabular}{l|l}
30 & 1 \\
\end{tabular} & 16 & & \begin{tabular}{|l|l|}
3 & 10 \\
\end{tabular} & 10 & & 8 & 165 & 36 & 1 & \begin{tabular}{l|l}
3 & 23 \\
\end{tabular} & 32 & 1 & 1 & 193 & 367 & & 1087 \\
\hline
\end{tabular}

Tabela 1 - Formas e cores das decorações da faiança das áreas B e H da cerca do Convento de Nossa Senhora de Aracoeli (V = Violeta; A = Azul; VA = Violeta e Azul; AA = Azul e amarelo), por número de fragmentos. Não se incluem as peças sem pintura.

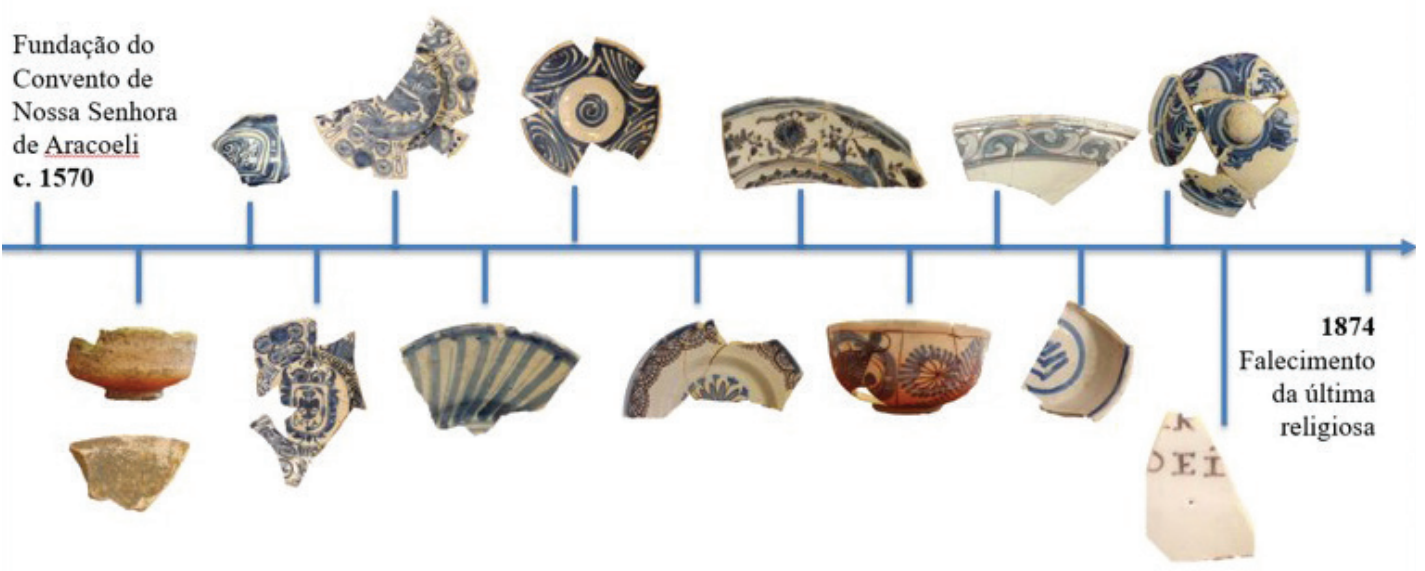

Figura 3 - Conjunto arqueológico, que pode ser atribuível a um longo período, entre os finais do século XVI e os meados do século XVIII (1570-1700/1766). Autor: Catarina Parreira. 


\begin{tabular}{|c|c|c|c|c|c|c|c|c|c|}
\hline \multirow{2}{*}{ Marcas } & \multicolumn{3}{|c|}{ Formas } & \multicolumn{2}{c|}{$\begin{array}{c}\text { Marcas de } \\
\text { desgaste }\end{array}$} & \multicolumn{2}{c|}{ Zona de incisão } \\
\hline & Pratos & Taças & Covilhetes & Ind. & C/m & S/m & Base & Tardoz & Pé \\
\hline Geométricas & 5 & - & - & - & 5 & 1 & 1 & 4 & 1 \\
\hline Alfabéticas & 15 & 8 & 1 & - & 18 & 6 & 8 & 16 & - \\
\hline Indeterminadas & 10 & 7 & - & 3 & 11 & 9 & 3 & 14 & - \\
\hline Total & 30 & 15 & 1 & 3 & 34 & 16 & 12 & 34 & 1 \\
\hline
\end{tabular}

Tabela 2 -Incidência de marcas geométricas e alfabéticas na faiança do Convento de Nossa Senhora de Aracoeli (Ind. = Indeterminado; $\mathrm{C} / \mathrm{m}=\mathrm{Com}$ marca; $\mathrm{S} / \mathrm{m}=$ Sem marca), por número de fragmentos.

Marcas Alfabéticas

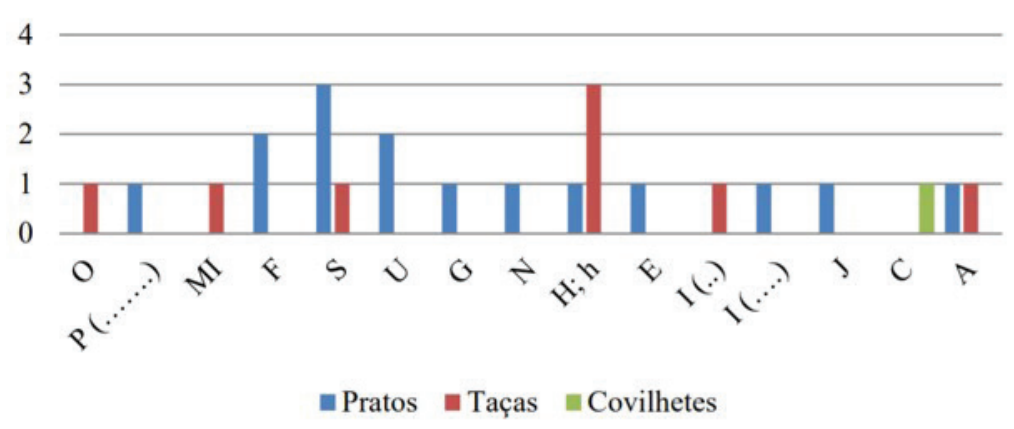

Gráfico 2 - Total de marcas alfabéticas distribuídas por formas (pratos; taças e covilhetes), por número de fragmentos.

\section{Marcas Geométricas}

4

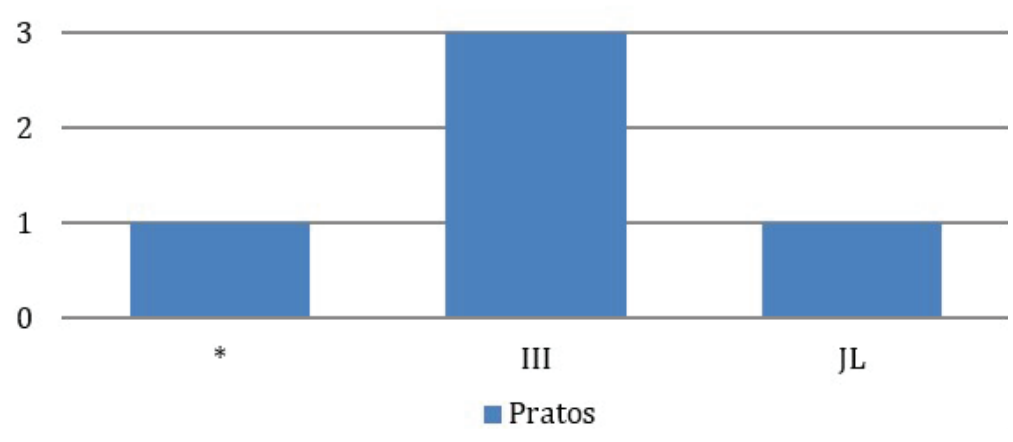

Gráfico 3 - Total de marcas geométricas identificadas exclusivamente em pratos, por número de fragmentos. 

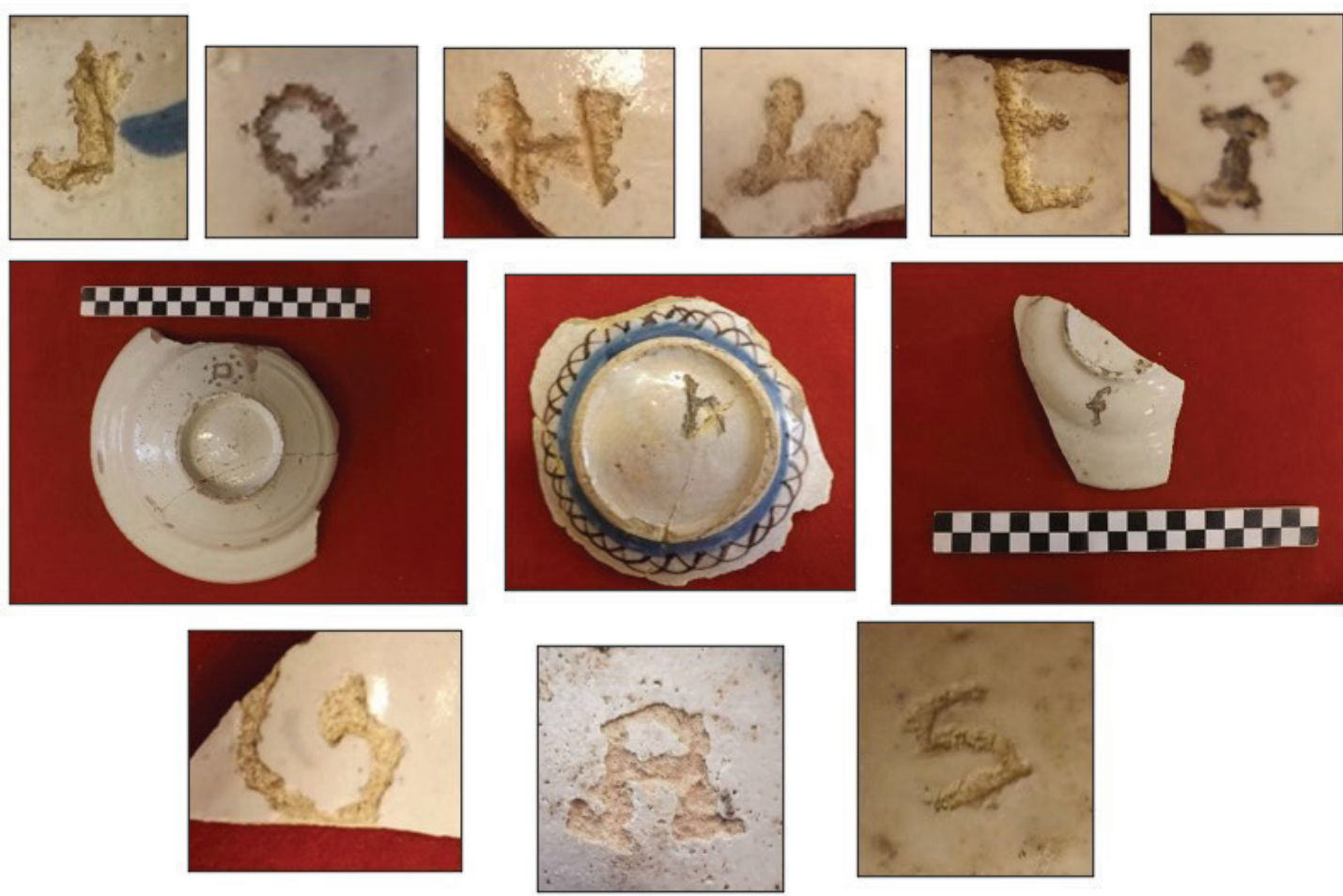

Figura 4 - Exemplares de marcas alfabéticas. Autor: Catarina Parreira.
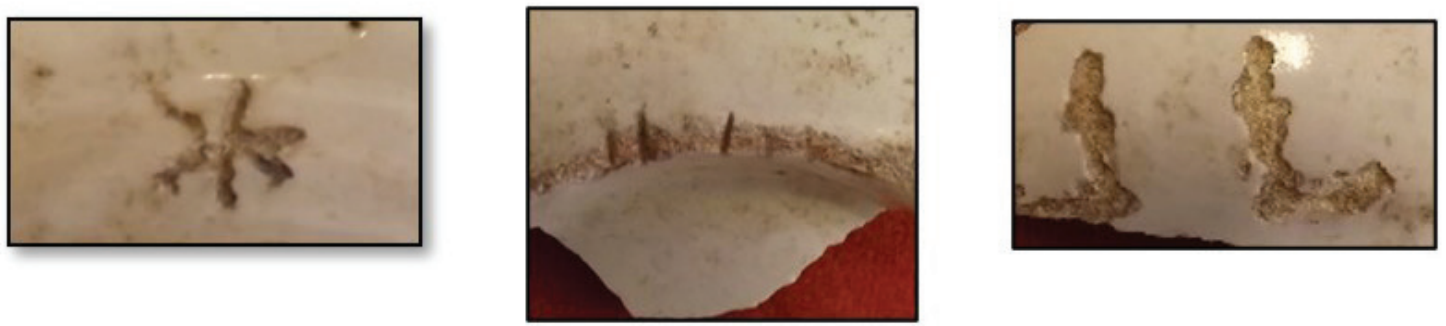

Figura 5 - Exemplares de marcas geométricas. Autor: Catarina Parreira. 


\title{
CERÂMICA DE LEIRIA: ALGUNS FOCOS DE PRODUÇÃO
}

\author{
Jaqueline Pereira $^{1}$, André Donas-Botto ${ }^{2}$
}

\begin{abstract}
RESUMO
A dinâmica urbanística de Leiria, de matriz medieval, é estruturada no século XIII e XIV. Consolida-se e expande-se nas centúrias seguintes. A emergência de cerâmica em Leiria, centro onde abunda a matéria prima, parece acontecer paralelamente à produção noutros centros. As recentes descobertas arqueológicas na zona urbana, mostram estruturas e produtos resultantes desta actividade e revelam a deposição dos refugos em diferentes áreas, sempre que fosse necessário atulhar alguns pontos, dentro ou fora de edifícios.
\end{abstract}

Palavras-chave: Época Moderna, Cerâmica, Centros produtores.

\begin{abstract}
The urban dynamics of Leiria is strutured in the 13th asnd 14th century. It consolidates and expands in the following centuries. The emergence of ceramics in Leiria seems to happen in parallel with prodution in olthers centres. Recente archaeological discoveries in the urban área, show structures and products resulting from this activity and reveal the depositions of wast in diferent areas, whenever it was necessary to pile up some points inside or outside buildings.
\end{abstract}

Keywords: Modern Period, Ceramics, Production Centers.

Em redor do monte do castelo ${ }^{3}$, o povoamento da área de Leiria, foi essencialmente orientado pela exploração agrícola das terras férteis de aluvião. Fora de muralhas, o principal aglomerado urbano de Leiria cresceu ao longo da rua Direita, à volta da Igreja de S. Martinho e do Terreiro. A partir do século XIII, nomeadamente até ao século XVI, a expansão estava balizada por dois elementos: o morro do castelo, onde foi implantado o primeiro núcleo, e o rio, fator de crescimento. Nos séculos posteriores, a ampliação do espaço urbano continuaria a acontecer. Mais tarde, a abertura da praça Rodrigues Lobo, antes Praça de São Martinho, aliada à existência da Sé Catedral e à regularização do leito do rio, que sempre teimava em se espraiar para oeste, fazendo estragos repetidos, conduzem a uma melhor expansão urbana. O rio Lis, ao mesmo tempo que se revelava um factor de desenvolvimento económico por via da fertilização dos campos, funcionava, no interior da malha urbana, como um obstáculo à sua natural expansão (MARGARIDO, 1988: 45-46). ${ }^{4}$ Antes da alteração do seu percurso, passaria em frente do antigo Convento de Santana, tomava a direcção do Edifício do Antigo Paço Episcopal e trespassava a área onde se implantou o edifício da antiga padaria (edifício construído no género arte moderna), conhecido por Garage, continuando em direcção ao Convento de São Francisco. Paralela ao leito antigo seguiria a

\footnotetext{
1. Arqueóloga, Divisão de arqueologia da Ediestreido, Lda.; agape@sapo.pt

2. Arqueólogo, Divisão de arqueologia da Ediestreido, Lda.; adonasbotto@gmail.com

3. A área em causa situa-se na ZEP do Castelo de Leiria, Monumento Nacional, Decreto de 16-o6-1910, DG, 1.. série, n. ․ำ 136 de 23 junho 1910 / ZEP / Zona “non aedificandi”, Portaria, DG, 2.. série, n.. 134 de 08 junho 1967, alterada pela Portaria n.․․ 201/2018, DR, 2. ${ }^{\underline{a}}$ série, $\mathrm{n} .{ }^{\circ} 58 / 2018$ de 22 março 2018 .

4. A avaliar pelo relatório realizado pelos Estudos Geológicos - Geotécnicos, elaborado com a finalidade "de obter elementos para a escolha da solução de fundações” do edifício na Av. Heróis de Angola (CÊGÊ, 1987: 1) e considerando os trabalhos arqueológicos já efectuados na cidade, confirma-se que o traçado actual do rio é resultado de alterações provocadas no século XVII e início do século XVIII.
} 
rua Direita antes de ser decepada e credivelmente o Beco de São Francisco.

Até finais do século XVII, conforme clarificam diferentes autores, a baixa de Leiria era uma zona muito alagadiça. Grandes inundações ocorriam frequentemente e quase todas com consequências catastróficas e avultados danos materiais, conforme a interpretação dos diferentes contextos e vestígios detectados ao longo da cidade.

O processo demográfico esteve sempre ligado à riqueza da terra e, até ao século XIII, dominava uma população activa ligada à agricultura as terras férteis de aluvião ou sedimento clástico, depositado por um sistema fluvial no leito e nas margens de drenagem (MATTOSO, 1987: 95-111). Na paróquia de São Martinho habitavam os estratos sociais mais altos da vila e era onde se tomavam as decisões de âmbito judicial e administrativo do município (GOMES, 2004: 16).

A rua Direita teria começado por ser um atalho que, vindo da Portela, seguia para norte contornando, numa cota baixa, o morro onde se situava a Leiria intramuralhas. Se não havia nada de relevante onde hoje está a Sé, é provável que a rua em causa viesse de sul e trespassasse a área onde hoje figura a Sé, em direcção ao Convento de S. Francisco. O aglomerado urbano de Leiria funcionava como centro económico redistribuidor dos excedentes produzidos na área agrária circundante. E a rua Direita é, portanto, uma via de origem orgânica, fortemente percorrida, de vocação comercial e que corresponde à espinha dorsal do urbanismo leiriense, já desde a primeira metade de XV. No limite a norte, a Sé seria construída, no século XVI, sobre o traçado desta rua (onde não haviam casas em banda) e onde os frades franciscanos eram donos de terrenos, no Sítio da Ordem (PORTELA \& QUEIROZ, 2004: 336).

No território da cidade de Leiria cultivaram-se os núcleos distintos, com funções sociais ou funcionais específicas. Esta realidade marcou profundamente a morfologia e a dinâmica urbanística de Leiria que, tendo uma matriz medieval estruturada no século XIII e XIV, consolidou-se nas centúrias seguintes, passando por uma expansão que definiu os limites atuais do centro histórico, apenas em finais do século XIX e durante o século XX (GOMES, 1993; VALE, 2005; GOMES, 2004).

E, no que diz respeito diretamente à produção de cerâmica em Leiria, as recentes descobertas arqueológicas, clarificam que esta área do país, procurada também pela matéria prima excelente, foi um centro produtor de cerâmica, nomeadamente na época Moderna. No espaço urbano, do que se percebe até hoje, tratar-se-ia de uma área de produção situada entre a Rua das Olarias, Rua Fonte do Pocinho, um ponto mais elevado, e a Rua José Estevão, ao lado do Terreiro, a sul da antiga Rua Direita, abarcando, portanto, a Rua Dom Nuno Alvares Pereira, a Rua Pinheiro Chagas até ao Largo Cândido dos Reis e, talvez mesmo, alargando-se à rua dos Poços. As águas circulariam por toda esta área. A leste do Terreiro, a antiga rua do Pocinho desapareceu e foi substituída pela Rua Machado de Castro e, logo ao lado, um arruamento de elevada importância, a Rua da Água (agora Comandante João Belo), dava continuidade ao trânsito que seguia de sul para norte.

Credivelmente esta área estaria interligada com a zona de Santo Estevão, um dos núcleos populacionais importantes da Leiria medieval. Relativamente periférico, era um bairro cujos residentes pertenciam a um estrato social não elevado. Instalaram-se também ali os Mouros forros e mesteirais, de atividades relativamente poluentes, como são o exemplo das forjas, olarias, lagares de vinho e de azeite (GOMES, 2004). A consolidar o núcleo populacional estaria ali também um Hospital, administrado por ferreiros, serralheiros, caldeireiros, picheleiros, ferradores, ourives, cutileiros e carvoeiros (Anónimo, 1868, 6o), bem como uma albergaria e a Igreja de Santo Estevão, já edificada no ano de 1211.

A rede viária dessa freguesia seria reduzida, sendo constituída pela rua da Mouraria (muito provavelmente antecessora da atual rua das Olarias), a rua da Ferraria e, provavelmente, a rua Corredoira.

O principal ponto de abastecimento público de água da antiga freguesia de Santo Estêvão, desde antes de 1300, seria, segundo o investigador Saul António Gomes, a Fonte do Freire, na confluência da Travessa da Fonte Freire e da R. José Estevão (GOMES, 1993). Esta fonte, embora não se saiba a data da sua construção, tem-se conhecimento que no ano de 1702 foi submetida a "obra nuderna”. Já o tanque que existe ao seu lado terá sido reconstruído emi879 (GONÇALVES, 2010: 30-31). É provável que essa nascente de água tenha sido aproveitada para a produção de cerâmica, agora claro, neste ponto da cidade.

E é ao lado da referida Fonte, no cruzamento da Rua José Estevão com a Rua Pinheiro Chagas, que se detectou um dos fornos de cerâmica já encontrados na zona urbana. A estrutura apresentava uma forma 
quadrangular, com cerca de $150 \mathrm{~cm}^{2}$. Associada a esta estrutura existiria uma estrutura pétrea e a estrutura em negativo.

Os trabalhos de decapagem permitiram apurar a interconexão neste complexo de produção: a estrutura de combustão, propriamente dita; a estrutura pétrea de apoio [05]; o alinhamento composto por blocos e outro barro, orientado SO-NO [06], sob a Unidade 07; e a fossa para deposição de desperdício, resultante da actividade produtiva, aqui localizado com o número [20].

Estrutura quadrangular era constituída por paredes executadas com dois tijolos, sobrepostos. A face interior desse alinhamento/, parede exterior estava coberto por escórias e vidrado pelo material usado para vidrar as peças cerâmicas - vidrado verde e amarelo-, tornando-se assim a superfície da parede rija. Estrutura quadrangular era constituída por paredes executadas com dois tijolos, sobrepostos. A face interior desse alinhamento/, parede exterior estava coberto por escórias e vidrado pelo material usado para vidrar as peças cerâmicas - vidrado verde e amarelo-, tornando-se assim a superfície da parede rija. A estrutura foi abandonada. Onserida num prédio urbano com cerca de $20 \mathrm{~m}^{2}$, vem referir a ideia de que no interior do tecido urbano existiam barreiros e oficinas de oleiros onde o ofício passaria de pais para filhos.

Ali recolhemos cerca de 100 trempes e grande quantidade de cerâmicas, ao todo cerca de 311 peças, em particular vidradas, quer no interior da estrutura de combustão, quer na fossa onde figuravam peças abandonadas.

Sob a unidade 05 vamos encontrar uma camada ténue [21], de cariz plástico, cor branca - cinza e pequenos carvões -, contendo um fragmento de cerâmica brioso (vinoso e azul - XVIII).

A estrutura de combustão encontrada teria já deixado de ser funcional ou de ter actividade; havia sido abandonada e entulhada com recurso a peças da produção de cerâmica: fragmentos de chacota, peças defeituosas e com marcas de vidrado, trempes, telhas... A abóboda do forno teria caído a posteriori sobre as camadas de deposições de materiais. O interior dessa estrutura apresentava as paredes vidradas, resultante de um segundo momento da cozedura, após colocação de vidrado nas peças.

Em 2005, no edifício imediatamente a leste, haviam-se verificado fortes indícios de combustão (carvão e cinza), num nível de cota inferior, durante a abertura para sapatas para remodelação do edifício. Fica assim claro, parece-nos, que a área de produção se expandia para leste.

E logo a norte da Rua Pinheiro Chagas, no conhecido edifício do Barão Salgueiro, no Terreiro, verificaram-se diferentes restos de estruturas de combustão em similar situação. Contexto quase destruído aquando da construção dos edifícios ali existentes. Restaram ténues marcas de estruturas, tendo-se percebido, no entanto, um exemplar com forma ligeiramente oval.

Quiçá que algumas dessas estruturas, francamente decepadas, fossem também usadas por um nível referente a abatimento de cobertura ferreiros ou mestre de arte afim, já que aí se detectou alguma quantidade de escórias, no interior de algumas das estruturas negativas, tipo fossa.

As estruturas detectadas estarão, no entanto, associadas à produção de cerâmica, dado que os exemplares cerâmicos ali recolhidos se integram num mesmo conjunto, onde figura a chacota, trempes, cerâmica fosca e cerâmica vidrada, grandemente com marcas de pingos de vidrado. Já mais para sul fica clara uma estrutura de maiores dimensões, construída por muros de pedra, também com vestígios de batimento de cobertura. No interior recolheram-se inúmeros exemplares de cerâmica.

Também numa área urbana de cota superior, na Rua D. Nuno Alvares Pereira, haviam já sido detectados vestígios de materiais similares e uma estrutura de combustão com planta da câmara de um forno, de forma ligeiramente oval, com abundantes nódulos de argila cozida, alguns dos quais com pingos de vidrado (BASÍlIO, 2011). Exemplares de trempes, fragmentos de cerâmica vidrada, cerâmica fosca, e duas candeias, também peças enquadradas no período Moderno.

Entretanto ao conjunto cerâmico recolhido juntaram-se outros conjuntos noutros sítios já da rua Direita e até mesmo no edifício em frente da Sé Catedral de Leiria, onde se recolheram exemplares de cerâmica fosca, do período Moderno, portanto. Dois testemunhos marcantes da produção cerâmica de período Moderno e até mesmo Contemporâneo de Leiria são os níveis de aterro identificados em dois edifícios do centro histórico de Leiria. Um deles, conhecido como Edificio Narciso Costa situado na Rua D. Afonso Henriques apresentou diversos níveis de aterro com entulhos compostos praticamente por restos de produção cerâmica, peças des- 
cartadas e mesmo algumas praticamente intactas, como acontece noutros locais da cidade.

Para além destes entulhos que marcaram a estratigrafia do local em todos os níveis térreos do edificado foi possível observar em corte uma sucessão de níveis estratigráficos que se assemelham aos cortes das áreas de fornos cerâmicos do edifício do Barão Salgueiro. As margas escavadas em meia lua e a sucessão de terras com carvões, cinzas, argilas com cerâmicas e camadas de carvões deixam adivinhar o que seria uma área de limpeza de uma estrutura ligada à produção cerâmica.

O núcleo de produção teria antecedentes no período medieval e também se expandiu no espaço, para outros pontos de Leiria, com menos população. Em meados do século XIX um arrematante faz um pedido à autarquia, no sentido de lhe ser cedida a cozinha do Convento de São Francisco para aí instalar "um forno para cozer louça"s.

E durante a intervenção no edifício da Moagem, antigo Convento de S. Francisco, recolheram-se, inúmeros elementos associáveis à produção de cerâmica.

Alguns dos elementos recolhidos estão directamente ligados a actividades domésticas do dia a dia, mas importa referir a presença de inúmeros exemplares que nos remetem para a produção, como sejam as dezenas de trempes, a chacota, os fragmentos de cerâmica fosca e cerâmica vidrada com marcas de pingos de vidrado que nos remetem para à produção de cerâmica. O conjunto cerâmico corresponde a elementos utilizados no espaço, mas na sua maior parte, são elementos usados para atulhar a área, credivelmente após as inundações: lixos resultantes de produção aproveitados para encher vazios criados pela água ou abandonados devido a estragos provocados pela água.

Outros dados recolhidos, após o inventário dos elementos e numa primeira abordagem, são trazidos por peças cuja importância e singularidade trazem a capacidade de caracterizar o grupo que as produzia e a comunidade que delas faria uso. Recolheu-se um grande conjunto cerâmico do complexo do Convento de S. Francisco de Leiria, destacando-se elementos como a panela, o prato, a tijela como louça para ir à mesa e/ou para líquidos e outros elementos para serviço; outras peças figuram associadas à iluminação, à pratica da higiene corporal ou enquadradas em actividades de lazer.

5. CABRAL, 1975: 29.
Assim, no conjunto da chamada cerâmica de uso doméstico, contamos com diferentes tipos de indivíduos, nomeadamente, a panela (cerca de 44 elementos surgiram com marcas de fogo, maioritariamente na UE 68) e o prato, a tijela como louça para ir à mesa e/ou para líquidos, o pote, o copo, o púcaro, o jarro; outros elementos para serviço e higiene, como são o alguidar, e o bispote; peças enquadradas em actividades de lazer, como são a peça de jogo, o cachimbo; e ainda a candeia e o castiçal, para iluminação.

Não fazemos aqui um estudo aprofundado do conjunto e muito menos de cada peça, promovemos uma abordagem geral, sempre sujeita posteriores revisões. Contabilizadas peças inteiras e fragmentos, a cerâmica fosca apresenta a maior percentagem, com cerca de 8602 exemplares; a cerâmica vidrada está representada por 8031 elementos; o conjunto da faiança está presente em 4078 exemplares; e, por último, a porcelana está representada por menos de meia centena de exemplares.

Em termos de localização no espaço, verifica-se que cerâmica fosca surge em maior número na unidade 409, com cerca de 1706 elementos, sendo seguida pela unidade 68 , com cerca de 1592 elementos e a UE 212, com 1349.

Já o conjunto de cerâmica vidrada fica constituído por cerca de 2163 indivíduos na unidade 212; cerca de 1905 exemplares na unidade 409; e 916 exemplares na unidade 217, enquanto na unidade 68 tínhamos 787 peças.

A faiança surge aqui ilustrada por cerca de 956 elementos, inseridos na unidade 68; cerca de 572 exemplares na UE 135; e aproximadamente 245 elementos na unidade 117.

A maior presença de matérias cerâmicos está sempre em unidades com caraterísticas de aluvião, lama de cor preta, depósitos de sedimentos. O espólio osteológico associado a estas unidades interpreta-se como estando relacionado com a vivência da comunidade, mas na maior parte com a deposição dos restos de produção e consiste em desperdícios que são depositados na cerca do convento, em unidades que integram também materiais mamalógicos, ictiológicos e malacológicos, provenientes de lixeiras e/ou até trazidos pelas águas do rio.

Do conjunto total exumado, recolheram-se cerca de 3737 peças, na a unidade 68 . Trata-se de uma unidade de cariz aluvionar, presente sobre as primeiras estruturas exumadas, abaixo dos contextos fabris e desde o limite oeste da área intervencionada; na UE 
409 recolheu-se um conjunto significativo de peças, num total de 4720 e apresenta uma larga quantidade de peças inteiras e/ou com ligeiras fissuras; na UE 212 recolheram-se 4176 exemplares; e na UE 217 cerca de 1916 unidades. Todas estas unidades caracterizam-se como aquelas de aluvião e mesmo com vestígios da desconstrução de estruturas. São aquelas que se sobrepõem à grande maioria de estruturas existentes na área em estudo, abaixo das areias e grande parte delas existiam no mesmo alinhamento eixo $\mathrm{X}$, na faixa mais a leste da área edificada onde que se verifica maior quantidade de materiais, nomeadamente inúmeras peças inteiras.

Não estando o leito do rio acalmado, a cheia de Dezembro de 1600 afectou a cidade e em 1612 existiram mais duas cheias. Em 1646 as perdas foram notáveis. Estas inundações contribuíram para o consecutivo abandono do local. Grande parte das unidades decapadas no Convento de S. Francisco, com relação dierecta com comportamento do rio, como sejam a UE 268, a UE 212 e a UE 68, apresentam materiais com datação centrada no século XVII.

\section{CONCLUSÃO}

Seguindo uma anterior tradição de produção de cerâmica, do período medieval, claramente que existiu na malha urbana de Leiria uma área onde se executava a produção de cerâmica em séculos da Época Moderna.

Figuram estruturas de combustão e realidades afins, níveis associados à prática de cozedura de cerâmica e contextos de deposição secundária.

De entre o espólio arqueológico de período Moderno, encontrado na cidade, e credivelmente originado aqui, são de realçar a os vestígios de cerâmica fosca, cerâmica vidrada e faiança. As peças recolhidas apresentam, credivelmente, o ponto cronológico central no século XVII, alargando as margens cronológicas para o século XVI, XVIII, nomeadamente. Considerando os dados por nós conhecidos, por onde estão disseminados os vestígios que referimos, gera-se uma mancha de dispersão entre a Rua das Olarias e a Rua José Estevão, abarcando a Rua Dom Nuno Alvares Pereira, a Rua Pinheiro Chagas até ao Largo Cândido dos Reis e, talvez, alargando-se à rua dos Poços. Eà zona do Convento de São Francisco.

Esta é uma zona onde a água e a matéria prima existiam abundantemente. E onde a actividade de produção de cerâmica se manteve até hoje.

\section{BIBLIOGRAFIA}

AZEVEDO (Ricardo Charters d') (2009) - Destruições Provocadas pelas Invasões Francesas em Leiria [CEPAE].

ANÓNIMO (1868) - O couseiro ou memórias do bispado de Leiria. Leiria: [O Mensageiro], [198-?]. (Reprodução facsimilada da $1^{\underline{a}}$ ed. que no frontispício averba o seguinte: Braga - Tipografia Lusitana - Rua Nova, $\mathrm{n}^{\circ} 3$-1868)

CABALLERO ZOREDA, L. (2006) - Arqueología de la Arquitectura: conocimiento e intervención. Estudos/Património. Lisboa. 9, p. 33-43.

CABRAL, João (1975) - Anais do Município de Leiria, Leiria, Câmara Municipal de Leiria.

COSTA, Lucília Verdelho da (1989) - Leiria. Cidades e Vilas de Portugal, n. ${ }^{\text {4 }}$, Lisboa, Editorial Presença.

GOMES, S. A. (1993) - A Organização do Espaço Urbano numa Cidade Estremenha: Leiria Medieval, in A Cidade. Jornadas Inter e Pluridisciplinares, Actas, Vol. II, Lisboa, Universidade Aberta, pp. 81-112.

GOMES, S. A. (1995) - Sobre a Fundação Undecentista de Leiria, in II Colóquio Sobre História de Leiria e da sua Região, Actas, I Volume, Leiria, Câmara Municipal de Leiria, pp. 205-251.

GOMES, S. A. (1997) - Leiria e a Tipografia Judaica dos Ortas..., in Estudos Orientais. VI. Homenagem ao Professor António Augusto Tavares, Lisboa, Instituto Oriental - Universidade Nova de Lisboa, pp. 221-235.

GOMES, S. A. (1999 - Higiene e saúde na Leiria Medieval. In Actas do III Colóquio sobre História de Leiria e da sua Região (1996). Leiria. Câmara Municipal de Leiria.

GOMES, S. A. (2004) - Introdução à História do Castelo de Leiria, ( $2^{\underline{a}}$ edição revista e ampliada), Leiria, Câmara Municipal de Leiria, $448 \mathrm{pp}$.

GOMES, S. A. (2005) - Notícias e Memórias Paroquiais Setecentistas. 2. Marinha Grande, Viseu, Palimage e Centro de História da Sociedade e da Cultura da Universidade de Coimbra.

GOMES, Tiago M. (2016) - Caracterização do Parque Edificado do Centro Histórico de Leiria, Dissertação Mestrado em Engenharia Civil - Construções Civis, IPL, Leiria.

GONÇALVES, Alda S, M. (2010) - LEIRIA As Fontes o rio Lis e as suas pontes, Junta de Freguesia de Leiria, folheto ed. e design, Leiria.

MARGARIDO, Ana Paula, (1988) - Leiria. História e morfologia urbana, Leiria, Câmara Municipal de Leiria.

MATTOSO, José, (1987) - Fragmentos de uma composição Medieval, ed. Estampa, Lisboa, pp. 95-111.

PEREIRA, Jaqueline. (2017) - Relatório Final, I, II e III, Requalificação do Edifício da Companhia Leiriense de Moagem 
S. A., Leiria. Empreitada Geral de Remodelação e Construção. Projecto de Intervenção Arqueológica - CFML, Leiria.

PORTELA, A. M. E QUEIROZ, F. (2004) - Dinâmicas Urbanas em Portugal na primeira metade do século XV. IN D. Afonso, 4.․ㅡ. Conde de Ourém, e sua Época, Congresso Histórico, Ourém, 6 a 8 Novembro 2003, Actas, Câmara Municipal de Ourém. Actas. CMO, 329-346.

TRINDADE, Ana Rita Rodrigues Baptista de Palma (2012) - Convento de Santana de Leiria: história, vivências e cultura material. (Cerâmicas dos Séculos XV a XVIII). Dissertação de Mestrado em Arqueologia, apresentada à Faculdade de Ciências Sociais e Humanas da Universidade Nova de Lisboa.
Vários, (2012) - Carta Arqueológica do Concelho de LeiriaCARLEI, C. M. L. https://www.cm-leiria.pt/uploads/document/file/1442/4430o.pdf

VALE, Nuno. (2005)-CentrohistóricoLeiria.IPA-DGEMN. www.monumentos.pt

ZUQUETE, Afonso, (1943) - Leiria. Subsídios para a história da sua diocese, Leiria. S/a, 1-2-19o6, Convento de S. Francisco, in Leiria Ilustrada.

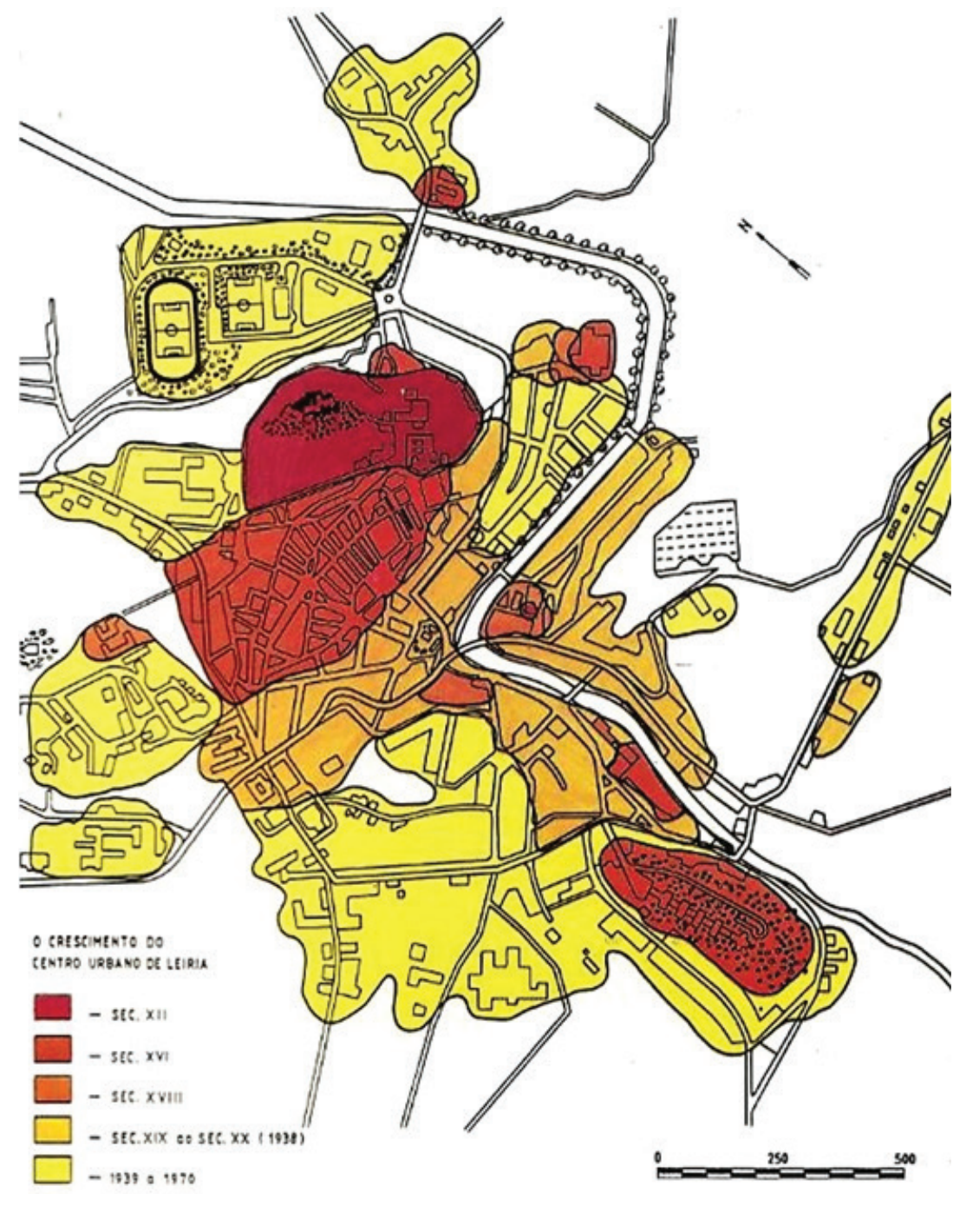

Figura 1 - Fases de crescimento do Centro Urbano. 


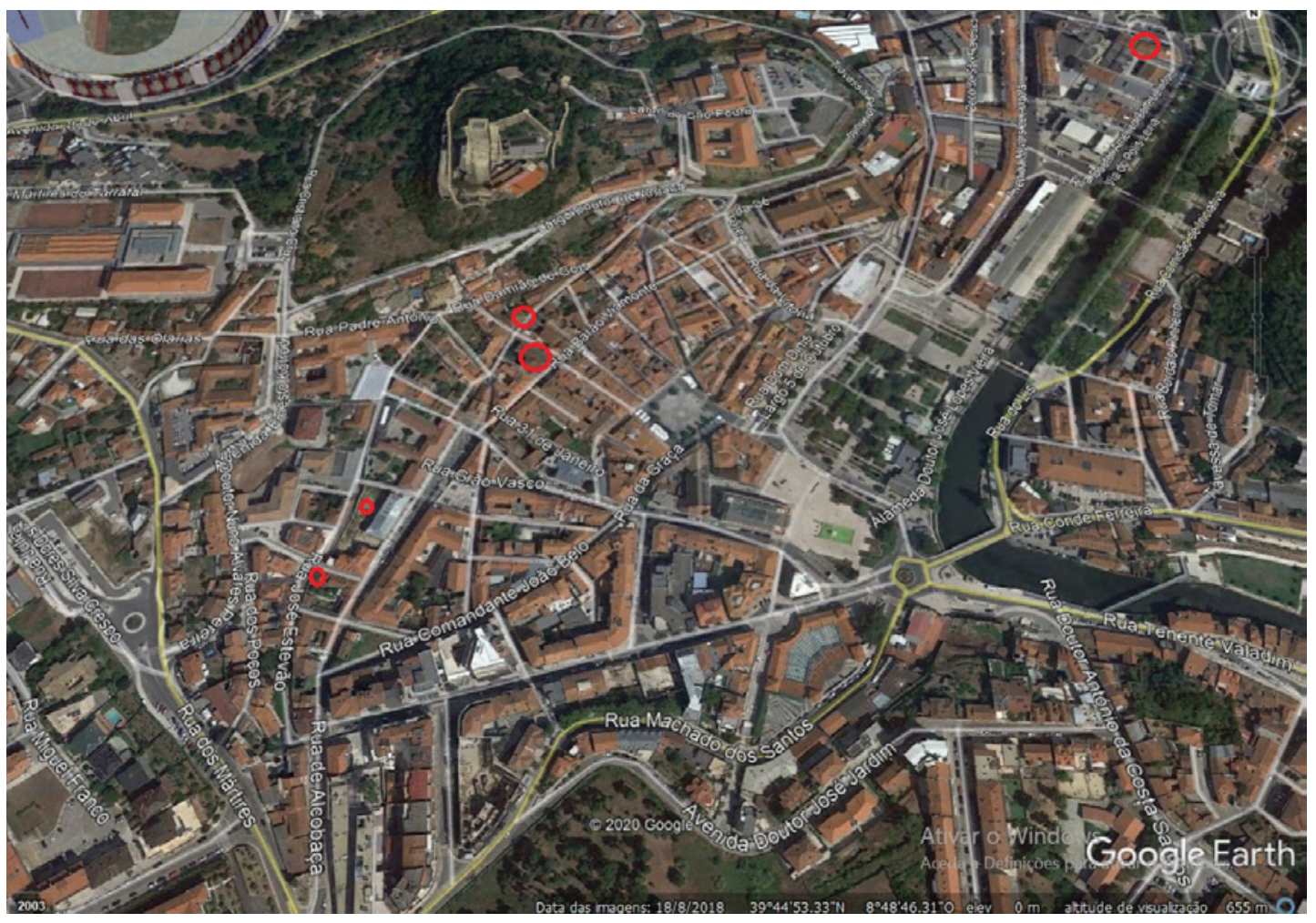

Figura 2 - Localização dos locais intervencionados.
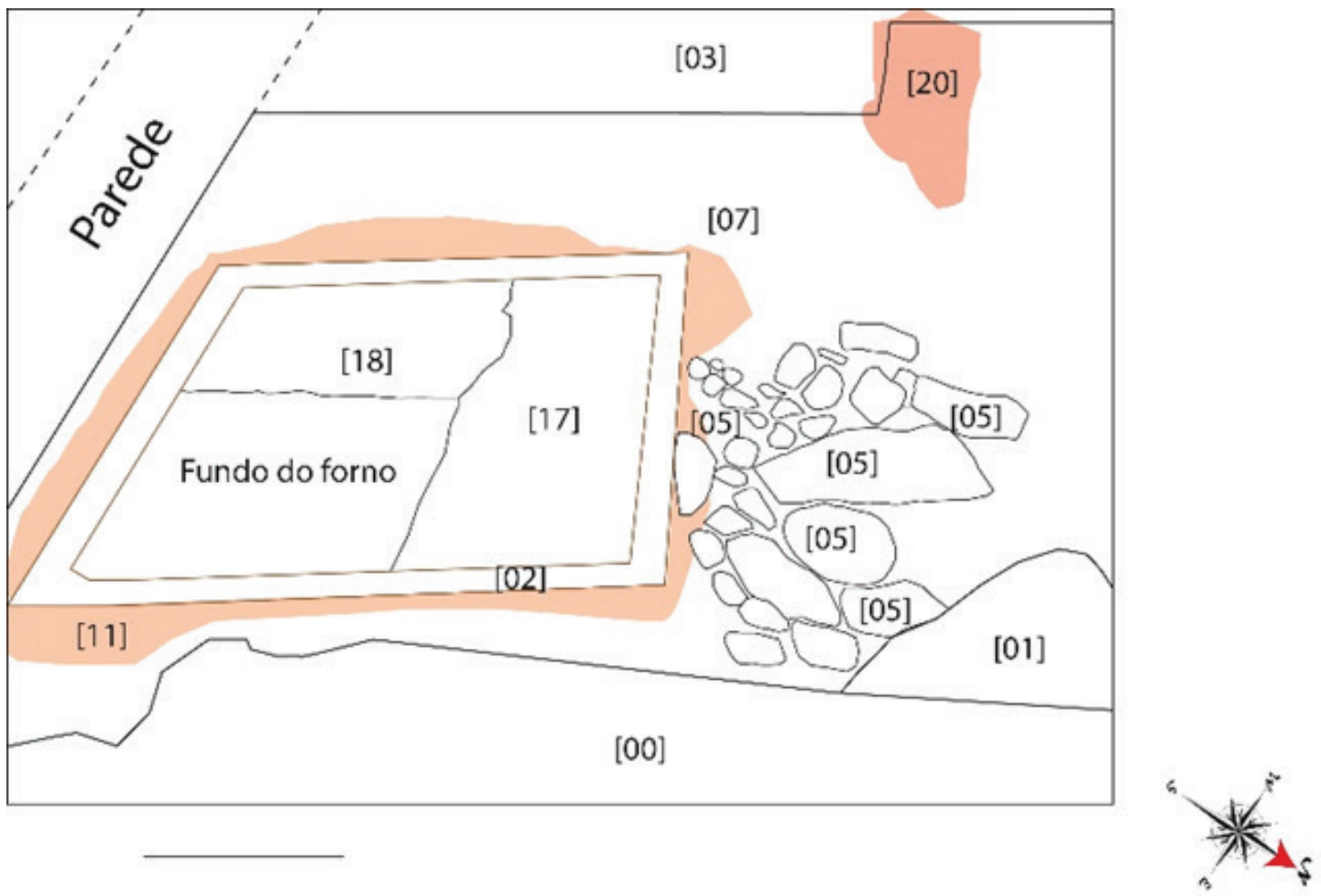

Figura 3 - Desenho da estrutura detectada na Rua Pinheiro Chagas. 


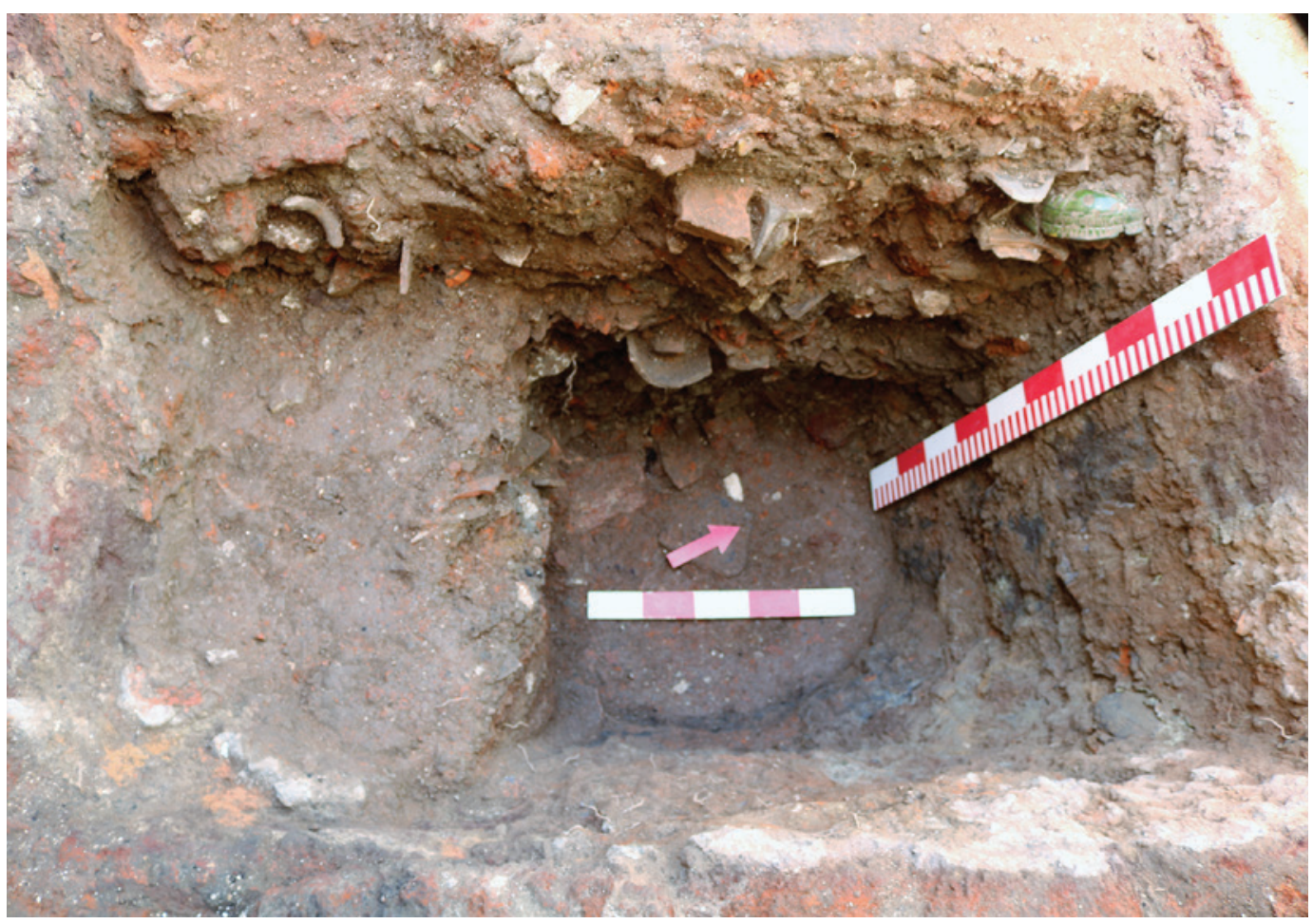

Figura 4 - Interior da estrutura depois de decapar parte do interior.

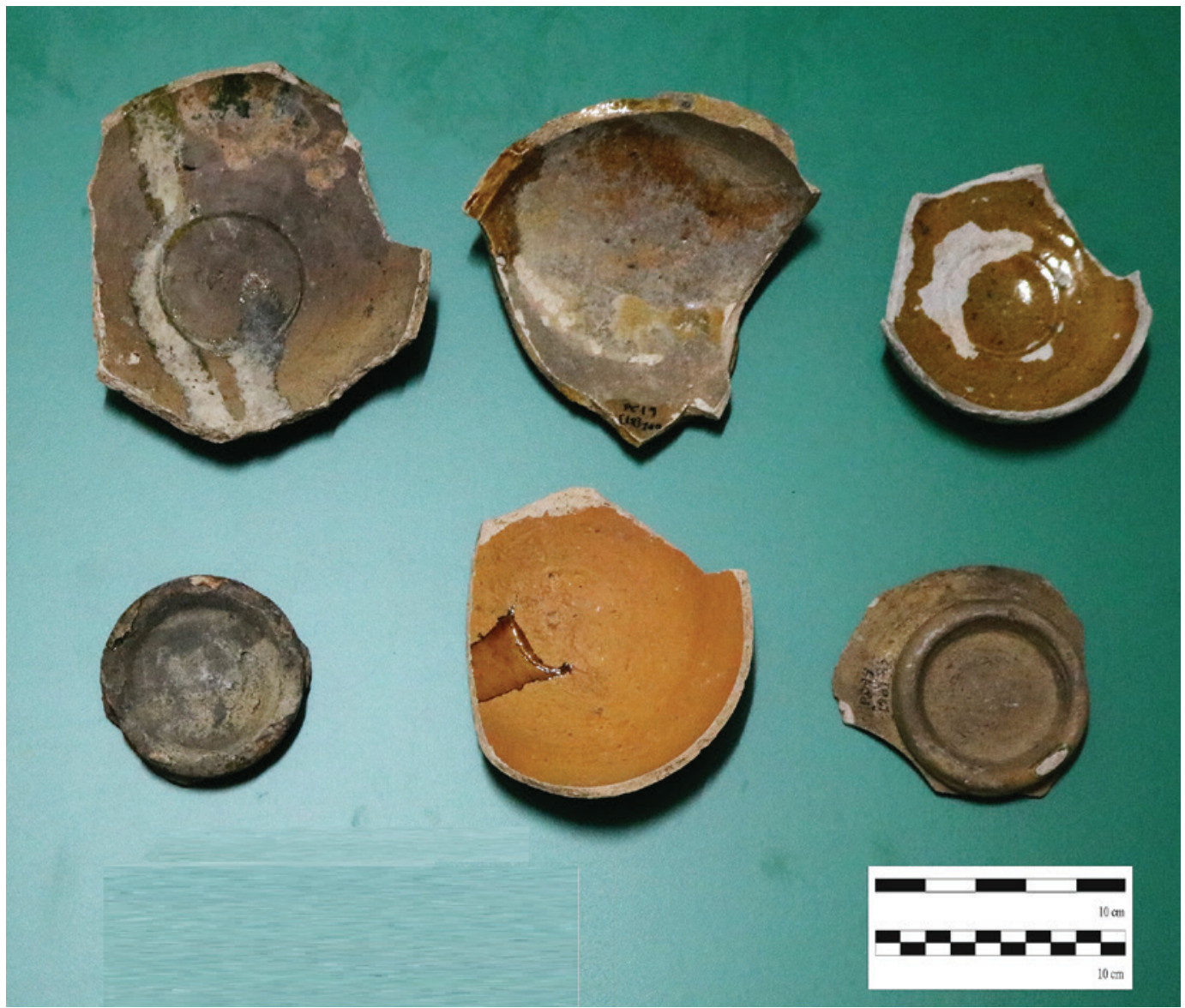

Figura 5-Fragmentos recuperados - séc. XVIII. 


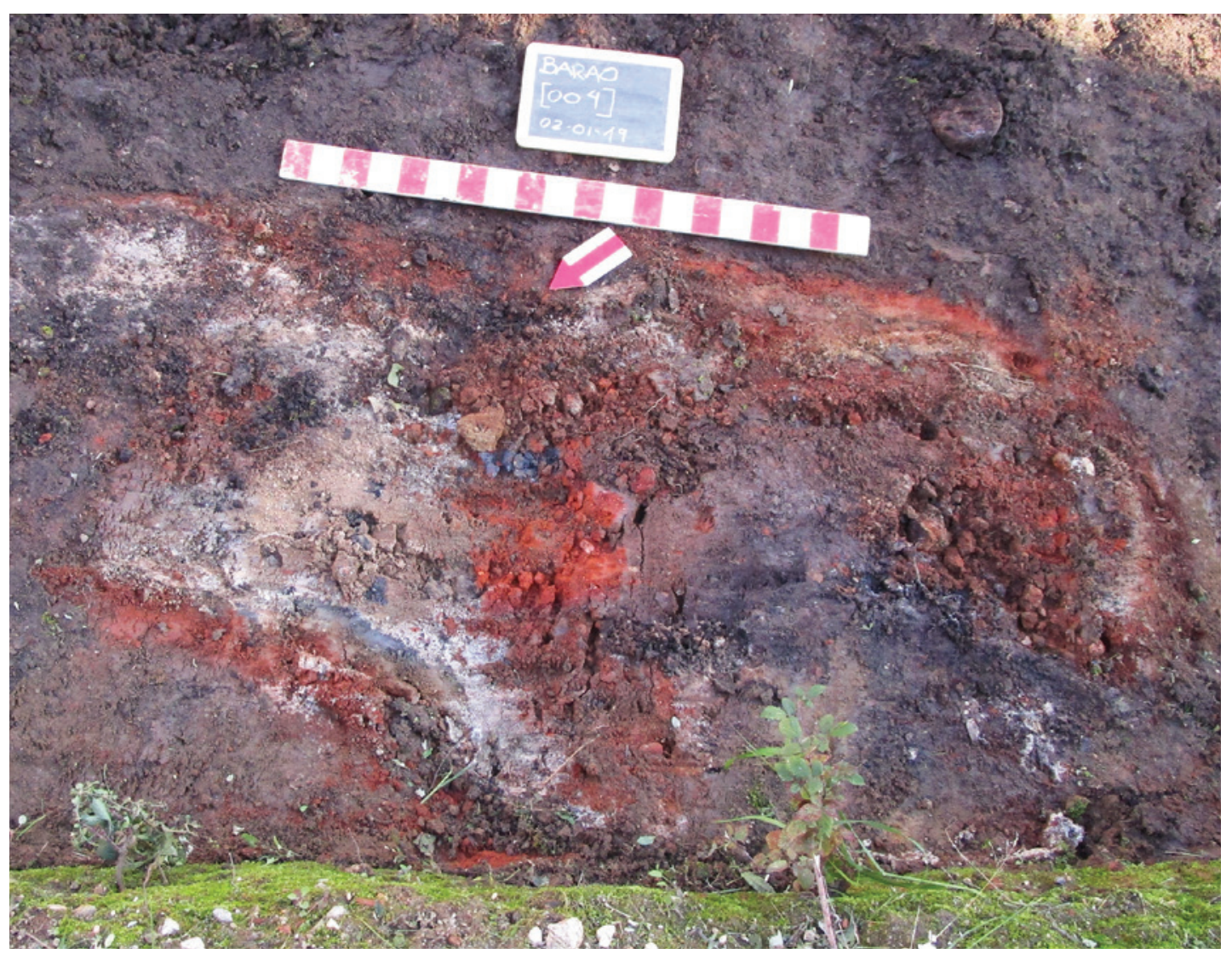

Figura 6 - Estrutura de pequena dimensão -aquela menos destruída.

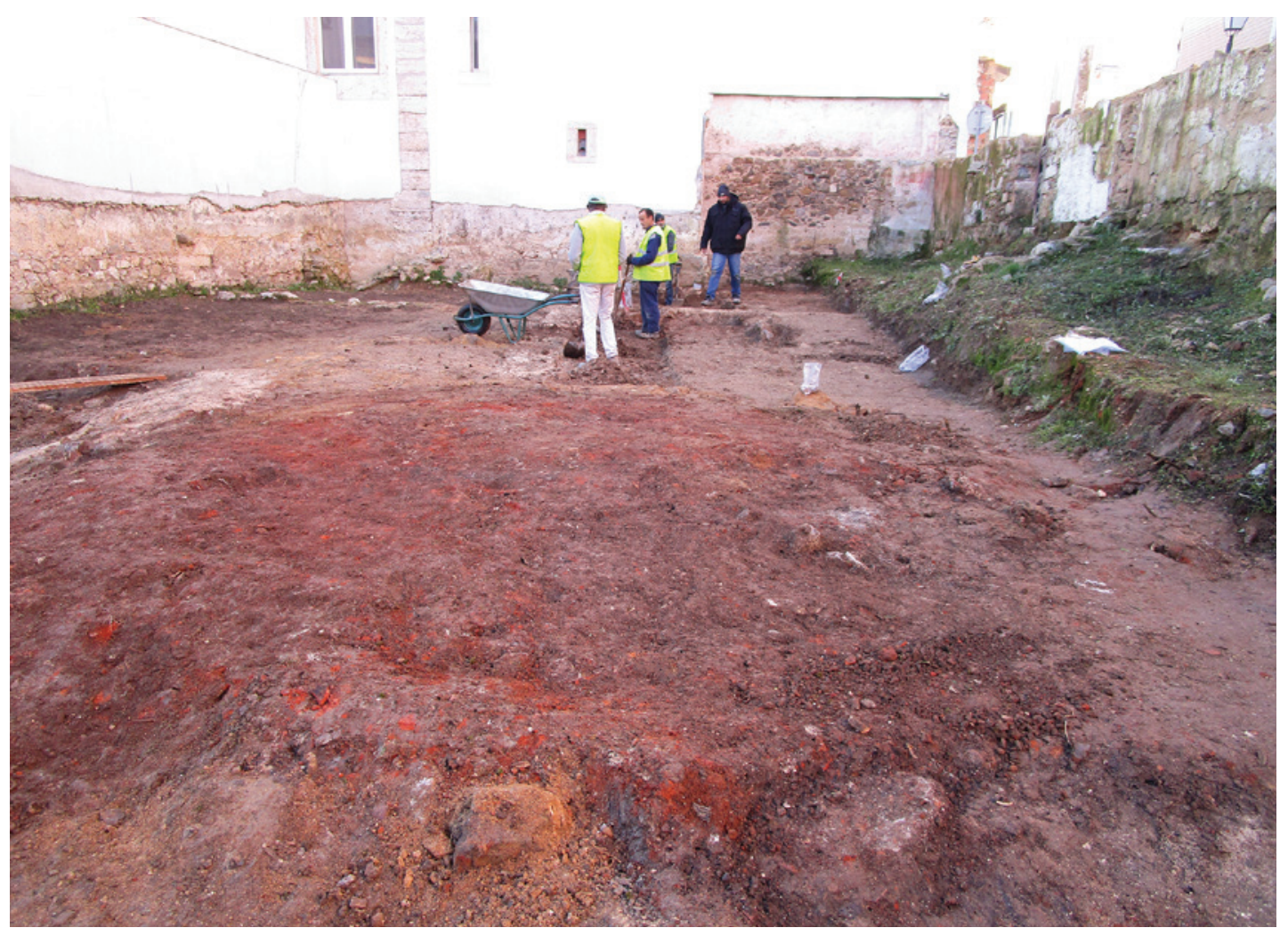

Figura 7 - Imagem a partir de norte para sul, antes da escavação de cobertura. 


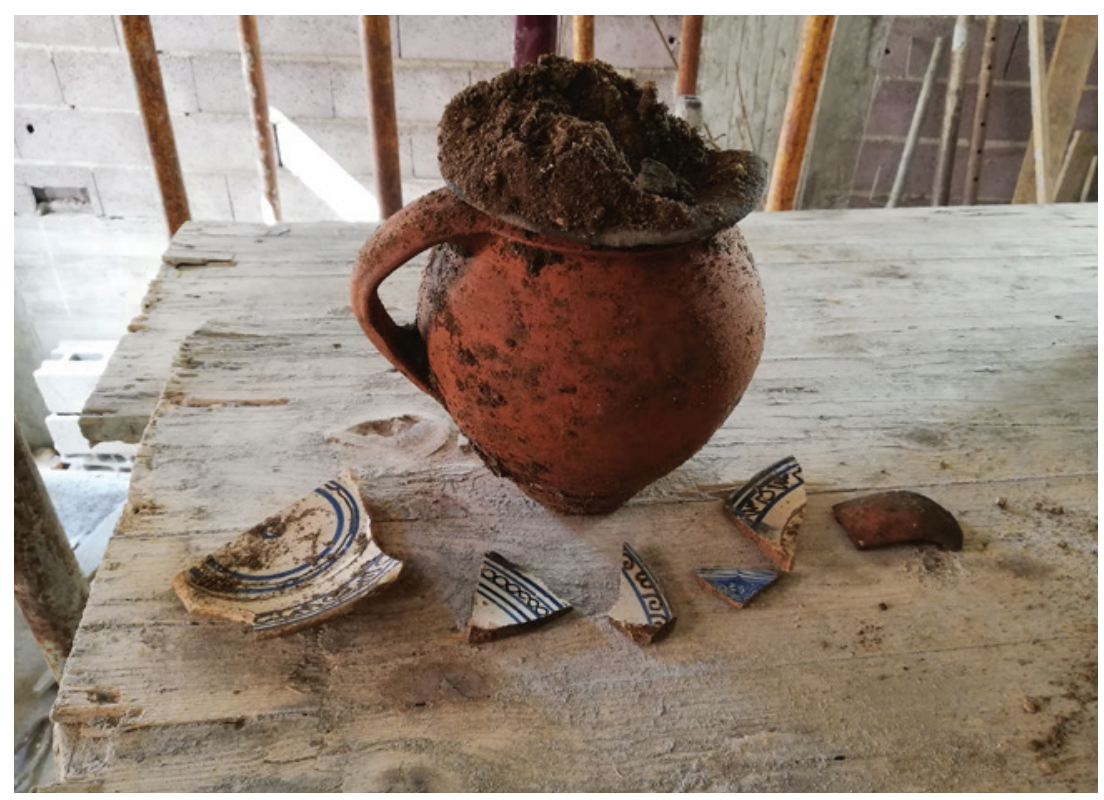

Figura 8 - Fragmentos em faiança e perfil completo, em cerâmica fosca.

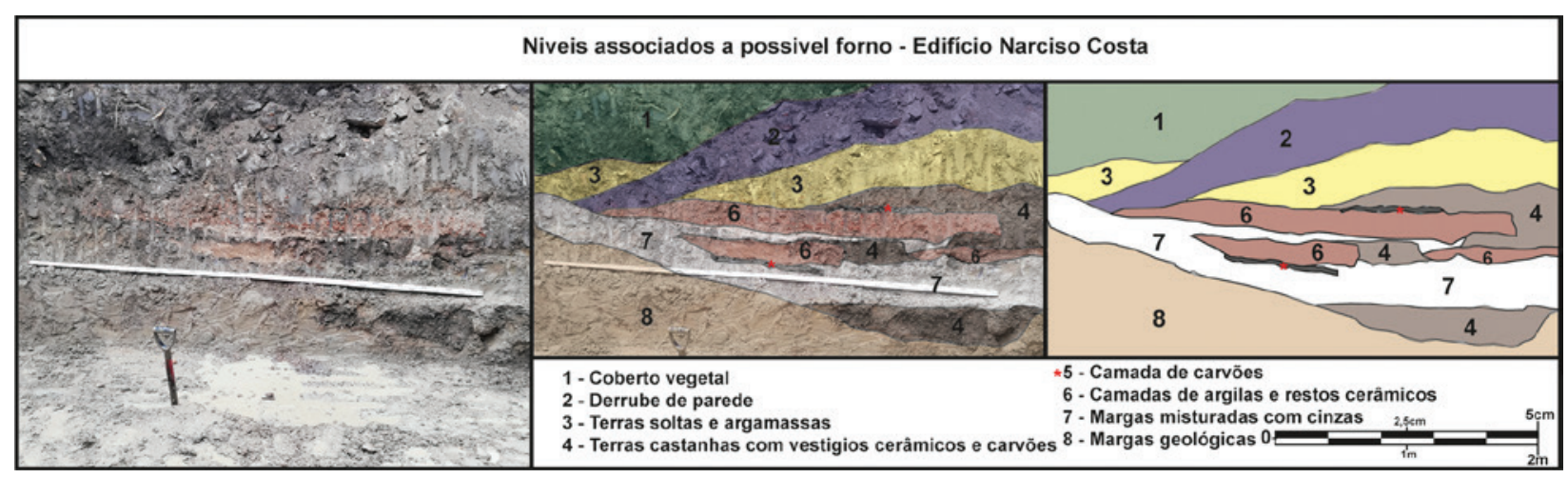

Figura 9 - Níveis associados a estrutura de combustão.

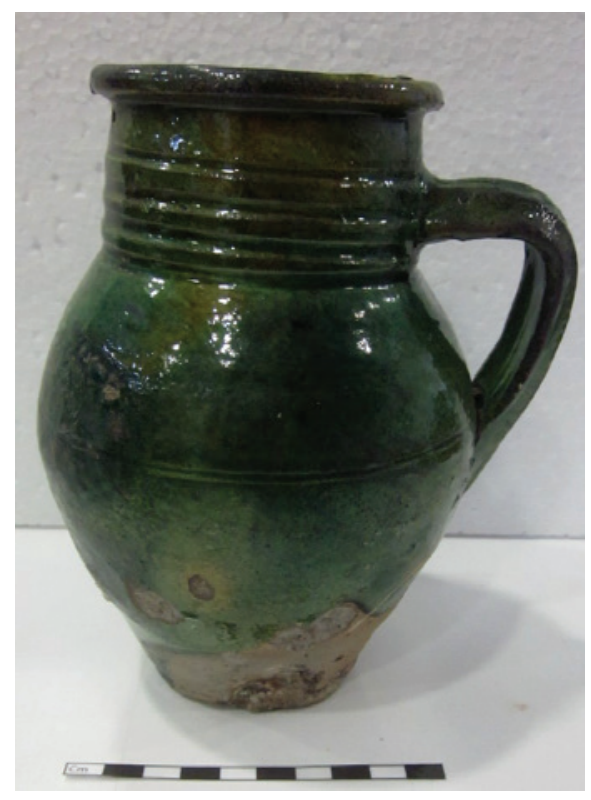

Figura 10 - Canjirão, vidrado plumbífero verde, XVI-XVII, UE 409. 


\title{
OS FORNOS NA RUA DA BIQUINHA, EM ÓBIDOS
}

\author{
Hugo Silva ${ }^{\mathrm{T}}$, Filipe Oliveira ${ }^{\mathrm{T}}$
}

\begin{abstract}
RESUMO
Na sequência dos trabalhos arqueológicos (sondagens e acompanhamento), que decorreram no âmbito da requalificação do edifício n64, na Rua da Biquinha, situada no perímetro extra muralhas do Castelo de Óbidos, foram identificados e intervencionados contextos arqueológicos preservados que retratam a ocupação do local entre finais do séc. XV / princípio do séc. XVI até ao séc. XX.

Estes trabalhos permitiram a identificação de um conjunto de quatro fornos localizados no interior do edifício. Estas estruturas de combustão, de plano sub-circular e possível produção cerâmica, encontravam-se escavada no geológico e tinham associado um escasso acervo material, de cronologia Medieval/Moderna.

Palavras-chave: Óbidos, Fornos, Medieval/Moderno.
\end{abstract}

\begin{abstract}
Following archaeological works (surveys and monitoring), executed during the requalification of a building outside the walls of Óbidos Castle, in Rua da Biquinha, 64, preserved archaeological contexts were identified that depict the occupation of the site between the late $15^{\text {th }} /$ beginning of the $16^{\text {th }}$ century until the $20^{\text {th }}$ century. The works allowed for the identification of a set of four ovens located inside the building. These combustion structures, of sub-circular plan were probably used for pottery production. They were excavated into the bedrock and a small collection of materials of Medieval/Modern chronology were found associated with them.
\end{abstract}

Keywords: Óbidos, Kiln, Medieval/Modern age.

\section{O SÍTIO}

O local intervencionado, situa-se no n־64 da Rua da Biquinha, freguesia de Santa Maria, São Pedro e Sobral da Lagoa, concelho de Óbidos. Localizado fora do espaço amuralhado de Óbidos, na encosta a Este do castelo, o terreno encontra-se hoje ocupado por um edifício de dois pisos, com o nível superior e térreo funcionando como espaço habitacional, e o inferior e o lote a Sul a acolherem áreas de apoio como cocheiras/curral, celeiro ou arrumos.

A natureza modular da planta do edificado e o predomínio de paredes estruturais em adobe e pedra, parece indicar que corresponde a uma construção oitocentista, que sofreu mudanças e ampliações ao longo das centúrias seguintes, observando-se várias divisórias internas em tijolo cerâmico e reboco de cimento, até atingir as características atuais.

Os trabalhos de arqueologia desenvolvidos no âmbito de um projeto de reabilitação urbana possibili- taram a observação de toda a sequência estratigráfica do local, assim como a deteção de vestígios relacionados com a evolução deste núcleo populacional e as mutações da malha urbana desde finais da Idade Média até à atualidade.

Destacamos em particular a identificação de quatro estruturas de combustão, associadas a acervos materiais enquadráveis entre os séculos XV-XVI, que corresponderão à primeira fase de ocupação deste espaço, e nos oferecem um vislumbre de algumas das atividades quotidianas dos obidenses nas centúrias de quatrocentos e quinhentos (Figura 1).

\section{A OLARIA}

A remoção dos pisos pertencentes ao edificado intervencionado, assim como de um conjunto de aterros (séc. XVII/XVIII), permitiu a identificação de um conjunto de quatro estruturas de combustão, muito afetadas pela construção do edifício e suas

1.ERA-Arqueologia, S.A.; geral@era-arqueologia.pt 
diversas remodelações até à atual requalificação, apresentando ainda danos mais próximos, cronologicamente, do términus do seu funcionamento (construção de um tanque no piso oo, abertura de interfaces de funcionalidade desconhecida e construção de um caneiro no piso -O1).

Embora muito afetadas, oferecendo-nos assim informações limitadas, tanto no que diz respeito à sua tipologia como ao seu funcionamento, foi possível concluir que correspondiam a quatro estruturas de combustão, encontrando-se estruturadas de modo similar, formadas por uma câmara de combustão de tendência sub-circular, algo ovalada, escavada diretamente no geológico, onde não foram identificados vestígios de grelha. Apresentam paredes estruturadas em barro, com cerca de $10 \mathrm{~cm}$ de espessura, com uma tonalidade avermelhada devido à combustão. É de referir que, ao contrário dos restantes, o forno no 2 apresenta um orifício circular situado na base da sua parede Sul, o qual fazia ligação ao exterior através de uma pequena valeta com paredes revestidas por telhas colocadas em cutelo, encontrando-se o interior preenchido por uma concentração abundante de cinzas. Este canal poderia tratar-se de um meio para abastecer a câmara de combustão com oxigénio, ou meramente uma saída para fumos. É igualmente de mencionar que o forno $\mathrm{n}^{\circ} 2$ mostra sinais de reconstrução, tendo-se verificado que as suas paredes internas foram restauradas com recurso à colocação de elementos pétreos em calcário, revestidos com cerâmica de construção, ladrilhos e argila, presentes nomeadamente na parede Norte, preenchendo uma fissura vertical.

No interior as estruturas de combustão encontravam-se entulhadas por uma sucessão de depósitos sedimentares intercalados entre argilas e camadas compactadas de carvões/cinzas, com presença escassa de elementos cerâmicos, possuindo o acervo recolhido uma cronologia tardo-medieval/ moderna (XV-XVI). Posteriormente, estes níveis foram cobertos por uma sucessão de aterros associados a um acervo que aponta para uma cronologia compreendida entre o século XVI e o século XX (Figura 2 e 3).

\section{CULTURA MATERIAL}

Do acervo material recuperado da Rua da Biquinha $\mathrm{n}$ ‥64, Óbidos, é possível discernir dois grandes conjuntos: os materiais correlacionáveis com os for-

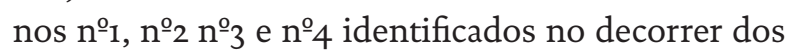

trabalhos de arqueologia e que, como tal, são vitais para a definição de cronologias de funcionamento destas estruturas e no aferir das produções e tipologias que seriam produzidas neste sítio; e as cerâmicas recolhidas de entre os níveis de aterro utilizados na desativação do espaço e remodelação do terreno para novos usos.

No primeiro conjunto encontramos uma forte presença de fabricos locais, e em particular produções de cerâmica comum ou de superfícies vidradas em tons de melado ou verde (óxidos de cobre ou ferro). No geral, as pastas apresentam cores castanha-avermelhadas (5YR 4/4 ou 7.5YR 8/4), sendo algo granulosas mas bem depuradas, o que denota um cuidado razoável na preparação e depuração dos barros. Nos depósitos relacionados com a desativação do forno 2, nomeadamente o nível [230] foram recolhidos vários fragmentos de panelas de bordo reto com lábio semicircular encimando um gargalo alto e corpo ovóide decorado com caneluras, acompanhadas de testos discoidais de lábio biselado simples e com pega central cilíndrica algo estrangulada.

Para além de peças de cozinha encontram-se também fragmentos contentores de fogo como candeias de forma troncocónica, algo achatada, paredes exvertidas e deformadas por modo a produzir um bico triangular. Nenhum dos exemplares observados apresentava asa ou pega vertical.

Todas são produções enquadráveis nos finais do século XV e inícios do XVI, podendo ser observados noutros contextos de produção oleira como aqueles observados no Largo das Olarias em Lisboa (PONCE, 2017, p. 4-5) .

Há igualmente a destacar os fragmentos de alguidar presentes no depósito [221], caracterizando-se estes por um bordo exvertido de lábio em aba semicircular ou espessado com lábio semicircular, e vestígios de engobe vermelho no anverso. Estas tipologias são tendencialmente atestadas nos finais do XV e inícios do XVI. A presença destes materiais no interior dos fornos poderá estar relacionada com a sua desativação e entulhar com lixo de produção oleira, sendo que estas tipologias estariam no repertório ali produzido. No entanto, é igualmente possível que alguns fragmentos estejam associados a tentativas de remodelar ou reparar a câmaras de combustão com fragmentos cerâmicos mais espessos e resistentes, sendo conhecidos outros casos similares, como o forno identificado no quarteirão dos Lagares e datado do século XVI (CASTRO et all, 2017: 1733). 
Os depósitos [316], [317] e [313] relacionados com o forno $\mathrm{n}^{\mathrm{o}} 3$ ofereceram cultura material similar composta, sobretudo, por fragmentos de bojos cerâmica comum pertencente a panelas e tachos. As primeiras mostram bordo reto com lábio semicircular encimando um gargalo alto e corpo ovóide decorado com caneluras. Os tachos mostram forma troncocónica com bordo invertido de lábio biselado. Ambas as tipologias são tendencialmente atestadas nos finais do XV e inícios do XVI e encontram paralelos nas produções do Largo das Olarias e Beco dos Lagares, e das peças identificadas na Rua em Óbidos. Por último os depósitos [705] e [712] no interior do forno $\mathrm{n}^{\circ} 4$ continham um número reduzido de fragmentos cerâmicos, pertencentes a bojos de panelas e exemplares de testos discoidais, similares aos recolhidos no forno $\mathrm{n}^{\circ} 2$ e, como tal, cronologicamente consentâneo com o mesmo.

No geral as cerâmicas recolhidas do interior dos fornos e dos depósitos relacionados com a sua desativação e abandono correspondem a peças de cozinha ou armazenamento, com alguns exemplares multifuncionais como os alguidares, ou para iluminação, como as candeias.

Perante este panorama, podemos assumir que esta produção oleira abasteceria o mercado local, focando-se nas necessidades dos habitantes de Óbidos e terras envolventes, sendo que algumas das peças de cerâmica comum e vidrada observadas em vários contextos modernos da cidade, como os das Rua Direita de Óbidos 54-58 (LIBERATO e RAMOS, 2017) poderão provir destas mesmas olarias.

O segundo conjunto engloba as produções provenientes dos depósitos utilizados no aterrar dos fornos ou das áreas envolventes mas que não correspondem a produtos locais, provindo de outros pontos do país ou sendo importadas de outros pontos da Europa. Este conjunto apresenta ainda um espectro cronológico mais amplo.

Associado ao abandono dos fornos, particularmente nos depósitos [612] e [616] encontramos vários fragmentos de peças de mesa de superfícies esmaltada. As pastas de tom amarelo pálido, granulosas e compactas, revestidas com um esmalte de estanho branco pouco espesso e baço, apontam para a sua natureza como produções sevilhanas do século XV e inícios do XVI (GUTIÉRREZ, 200o). Entre os exemplares identificados encontramos peças apenas esmaltadas, denominadas como louça malegueira ou "Plain White" acompanhadas de outras que apresentavam nas superfícies decoração pintada a tons de azul e manganês, de padrões decorativos geométricos, como linhas concêntricas intercaladas com bandas (Isabella Polichrome), ou temáticas vegetalistas ou fitomórficas a azul claro (Ibidem: 306). A presença de tais produções estará ligada com os hábitos aquisitivos da comunidade local, aqui representados nos descartes de lixos domésticos. Destaca-se a presença de importações de serviços de mesa do mercado hispano, nomeadamente peças esmaltadas a branco de Sevilha, presentes noutros contextos arqueológicos escavados em Óbidos (LIBERATO, 2017, p. 1595), e que permitiam aos locais complementar os seus serviços, formados por peças produzidas em locais similares ao sítio da Rua da Biquinha 54, com produções forâneas mais elaboradas.

Relacionadas com a contínua ocupação do espaço encontramos exemplares de faiança portuguesa, nomeadamente um fragmento recolhido no depósito [10o] da sala 1, correspondendo a fundo de prato, apresentando ao centro espiral em tom manganês, uma produção atribuível às olarias de Coimbra e datável de meados do século XVIII. Noutros pontos, nomeadamente, [203], [502], [508], [612], [617], foram recolhidos fragmentos de outras peças de faiança portuguesa, datadas de finais do século XVII e inícios do XVIII, apresentando decoração de semicírculos concêntricos ou motivo de contas a azul e vinhoso na aba (CASIMIRO, 2013 p.363).

As produções mais recentes identificadas são exemplares de faiança portuguesa coimbrã de tipo "ratinho", apresentando as superfícies decoradas com motivos vegetalistas em tom de verde e manganês. A estas juntam-se vários fragmentos de peças da fábrica de Sacavém, exibindo a sua marca no reverso, e a típica decoração monocromática de uma paisagem com uma estátua equestre. Ambos os conjuntos, integram-se cronologicamente no século $\mathrm{XX}$, marcando a adopção pela comunidade local das produções já claramente industriais que dominaram o mercado desde então.

A evolução e o contínuo uso deste espaço está bem demonstrado na presença destas produções do período moderno tardio e inícios da contemporaneidade. A aquisição de produções de faiança industrial sobretudo em áreas mais distantes dos grandes centros urbanos demonstra a expansão e impacto que estas novas produções tiveram no quotidiano destas populações.

A evolução e o contínuo uso deste espaço estão bem 
demonstrados na presença destas produções do período moderno tardio e inícios da contemporaneidade. A aquisição de produções de faiança industrial, sobretudo em áreas mais distantes dos grandes centros urbanos, demonstra a expansão e impacto que estas novas produções tiveram no quotidiano destas populações (Figura 4).

\section{CONCLUSÃO}

O sítio da Rua da Biquinha no. 64 aporta interessantes dados para o conhecimento da história da cidade de Óbidos.

Apresentando-se como um centro urbano de relevância regional, a confirmação da presença de produção oleira no local durante o século XV-XVI é, embora expectável, importante, confirmando-se assim a sua natureza como centro abastecedor não só das suas necessidades no que concerne ao vasilhame cerâmico, mas certamente dos acentamentos rurais envolventes. De facto, no que concerne à cultura cerâmica recuperada neste local, apenas as produções finas, nomeadamente as peças de mesa esmaltadas a estanho correspondem a produções importadas, e mesmo estas de mercados próximos como o hispano (Sevilha).

A restante cultura cerâmica recolhida do interior dos fornos e dos depósitos relacionados com a sua desativação e abandono correspondem a peças de cozinha ou armazenamento, com alguns exemplares multifuncionais como os alguidares, ou para iluminação como as candeias, as quais seriam comuns em todos os contextos habitacionais, podendo-se assumir, embora não confirmar sem os devidos estudos petrográficos, que algumas das peças de cerâmica comum e vidrada observadas em vários contextos modernos da cidade, como os das Rua Direita de Óbidos 54-58 (LIBERATO e RAMOS, 2017) poderão provir destas mesmas olarias.

De igual modo, a presença destes fornos oleiros numa área exterior ao perímetro amuralhado, insere-se claramente nas práticas medievais de colocar atividades perigosas ou insalubres fora das áreas habitacionais, normalmente em arrabaldes ou zonas periféricas. De facto, outros casos conhecidos no território nacional, são o forno identificado na Travessa de Nenhures em Palmela (possuindo igualmente uma câmara de combustão de plano sub-circular, e possuindo uma cronologia do século XVII); os dois fornos na Mata da Machada (onde foi inter- vencionado o denominado "forno grande" com uma planta retangular, provida de câmara de combustão, grelha e câmara de enfornamento formada por pequeno átrio (Torres, 1990). O outro forno de dimensões mais reduzidas, mostrava planta circular, sendo atribuída uma cronologia relativa ao século XVI (Santos, 2003, p.38)); o forno tardo-medieval (UE 215) da olaria da Porta da Lagoa (Évora, Portugal), escavado por baixo do Palácio de Sepúlvedas Além de responderem a questões de salubridade a colocação destas estruturas fora das muralhas poderá ter facilitado o acesso aos barreiros usados no abastecimento das olarias, o acesso a combustível vegetal ou facilitar o escoamento da produção para a vila ou territórios próximos. A eventual desativação destes fornos oleiros, por motivos que nos são de momento, alheios, parece ter levado a uma fase de abandono do lote, apenas quebrada com a construção do presente edificado e a sua reintegração na malha urbana de Óbidos. Assim é aceitável supor que nas imediações deste lote poderão encontrar-se outros vestígios similares ou outros elementos relacionados com a produção oleira.

\section{BIBLIOGRAFIA}

CASIMIRO, Tânia. (2013) - Faiança portuguesa: datação e evolução crono-estilística, Revista Portuguesa de Arqueologia, vol.16, Lisboa, pp. 351-367.

CASTRO, Anabela; PAULA, Nuno Amaral; de; TORRES, Joana.; CURADO, Tiago; TEIXEIRA, André, (2017) - Evidências de produção oleira nos séculos XVI e XVII no Largo das Olarias, Mouraria (Lisboa), ARNAUD, J. M. e MARTINS, A. (coords.) Arqueologia em Portugal: 2017-Estado da Questão, AAP, FLUL e NOVA/FCSH, Lisboa, pp. 1731-175o.

DORDIO, Paulo, TEIXEIRA, Ricárdo, SÁ, Anesrle. (2002) - Faianças do Porto e Gaia: o recente contributo da arqueologia: Itinerário da Faiança do Porto e Gaia, Lisboa, IPM.

GUTIÉRREZ, Alejandra. (200o) - Mediterranean Pottery: Wessex Households ( $13^{\text {th }}$ to $17^{\text {th }}$ Centuries), BAR British Series 306 .

LIBERATO, MARCO; SANTOS, HELENA; GOUFA, ELIANA (2017) - Quatro Intervenções de Arqueologia Preventiva em Óbidos, Almadan Online, II Série (21), Tomo 3, Centro de Arqueologia de Almada (https://issuu.com/almadan/ docs/al-madanonline21_3)

PONCE, Monica; NUNES, Tiago; PINTO, Marina; LOURENÇO, Marina; OLIVEIRA, Filipe (2017) - O sítio dos Lagares (Lisboa): um espaço pluri cultu(r)al. ARNAUD, J. M. e MARTINS, A. (coords.) Arqueologia em Portugal: 2017 - Estado da Questão, AAP, FLUL e NOVA/FCSH, Lisboa, pp. 1703-1714. 
SANTOS, Helena; LIBERATO, Marco; RAMOS, Romão (2017) - Resultados da Intervenção Arqueológica realizada nos №s 54 a 58 da Rua Direita, em Óbidos. ARNAUD, J. M. e MARTINS, A. (coords.) Arqueologia em Portugal: 2017 - Estado da Questão, AAP, FLUL e NOVA/FCSH, Lisboa, pp. 1593-1605.

SILVA, Manuela Silva (1994) - A Região de Óbidos na Época Medieval: estudos. Caldas da Rainha.
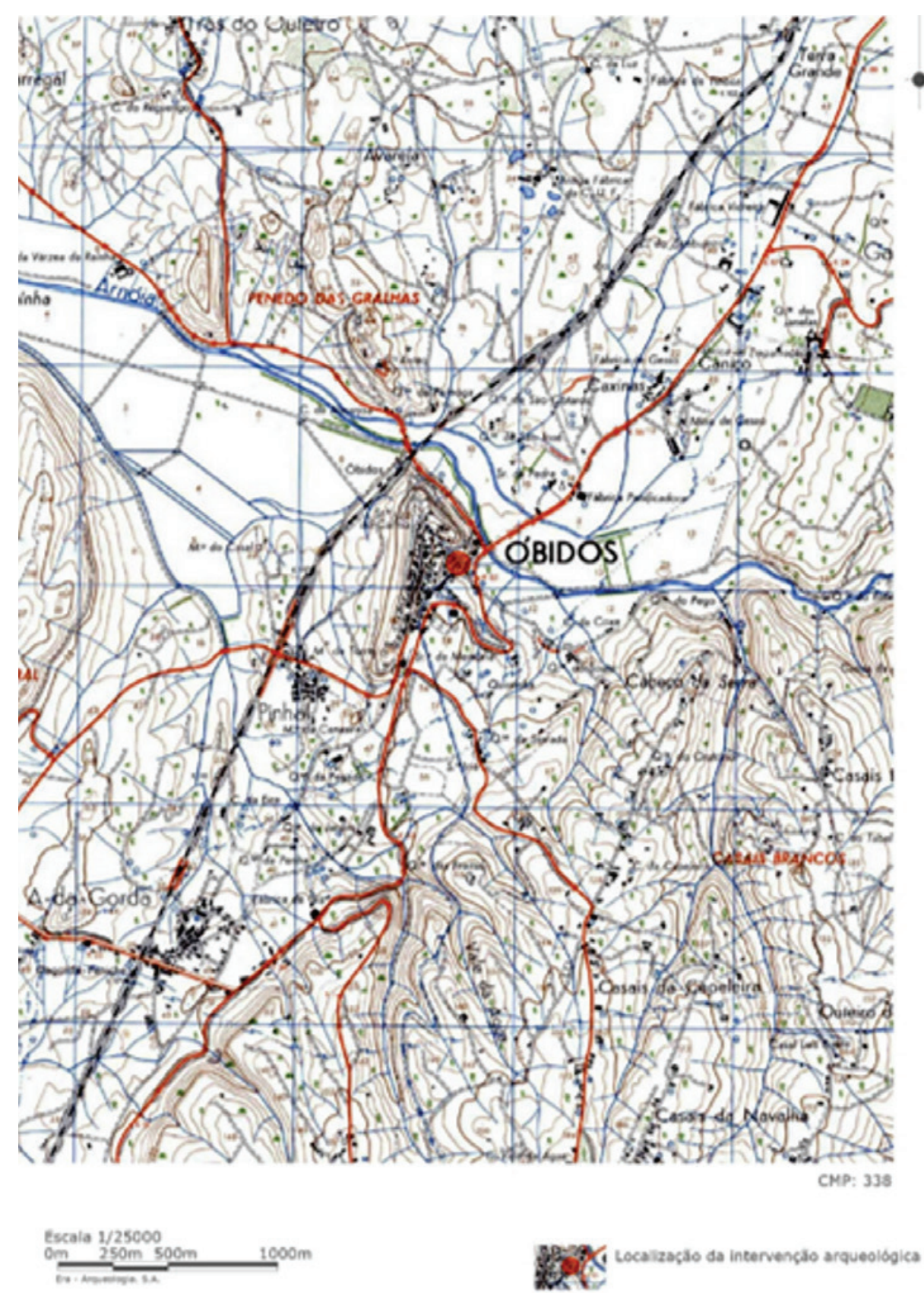

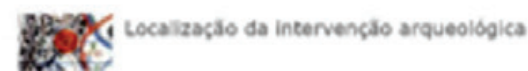

Figura 1 - Localização do local intervencionado em excerto da CMP, folha 338, à escala 1/2500o; Hugo Silva. 

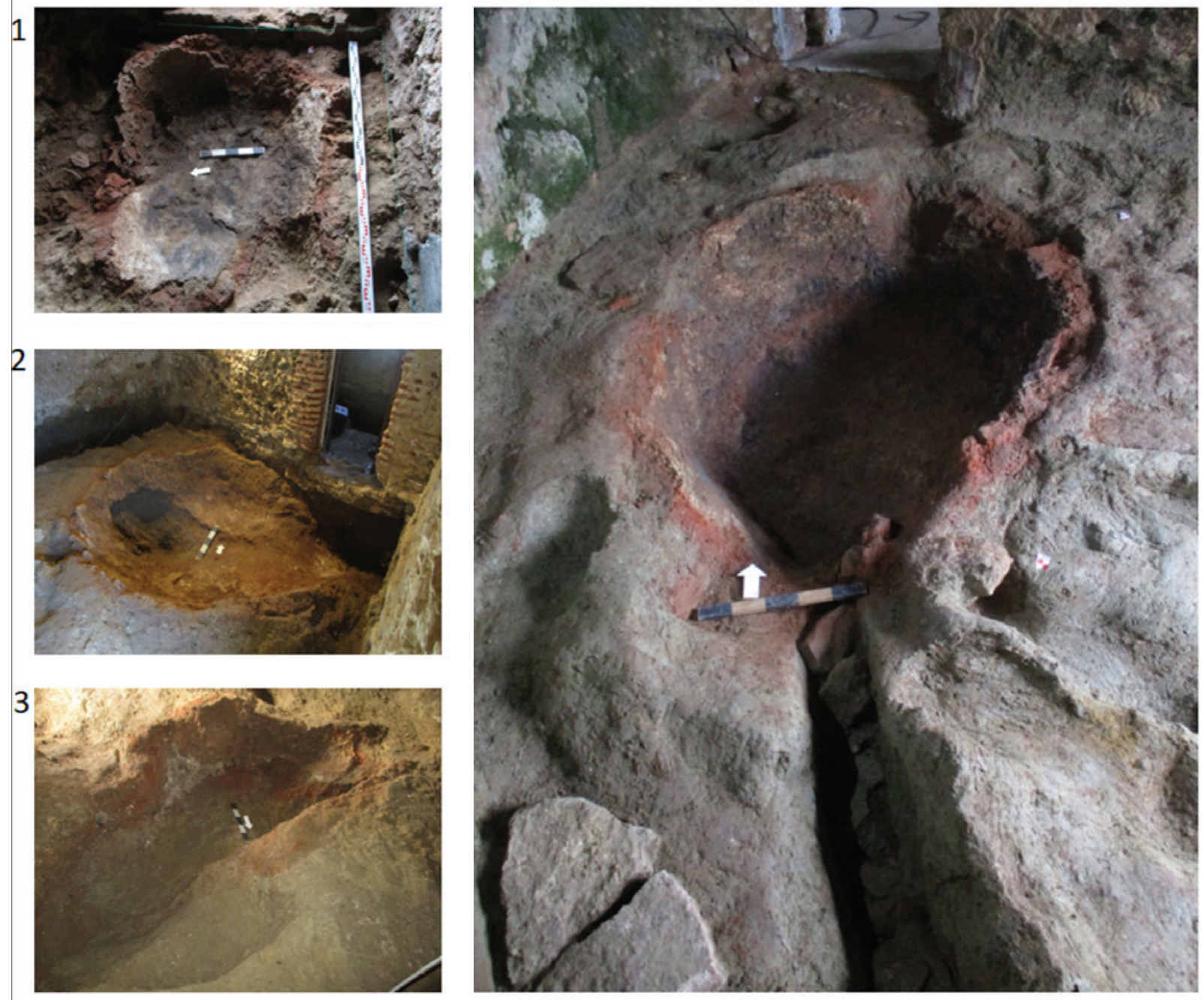

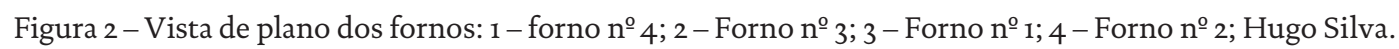


1

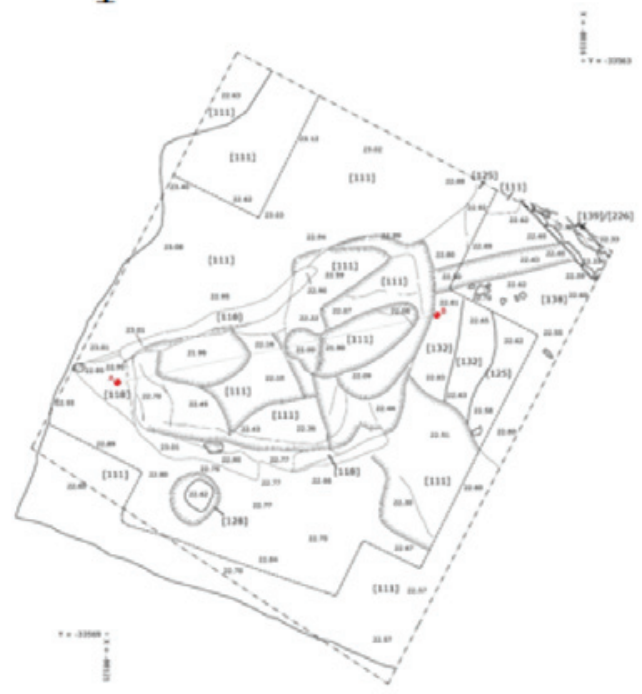

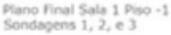
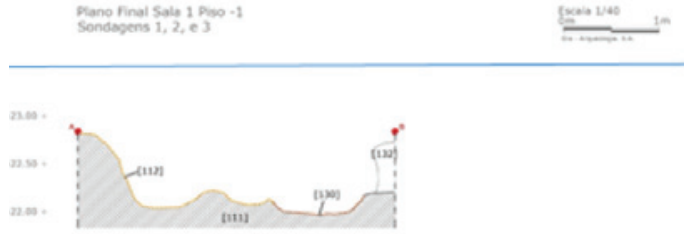

Secello Longtudinat do Formo
UE118 (Sudeste-Noroeste)

3

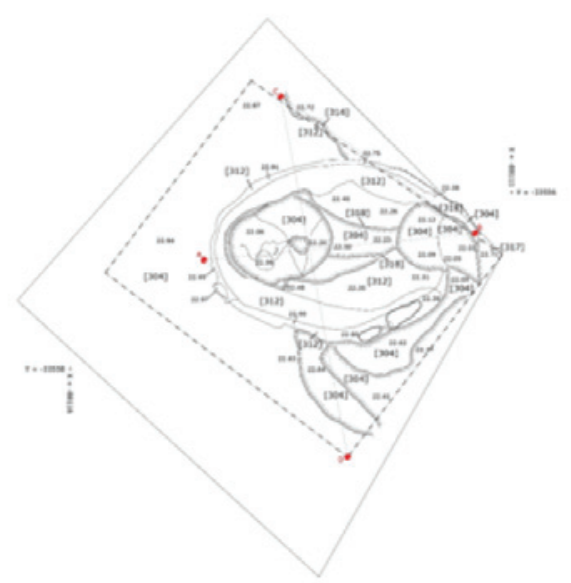

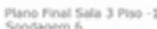
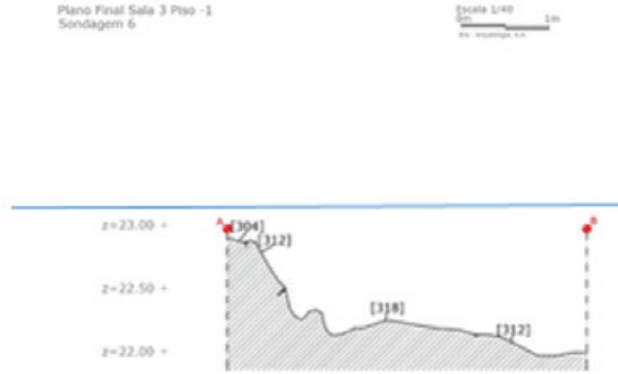
Seç30 Longitudinal do Forno
UE312 (Sudoeste-Nordeste)

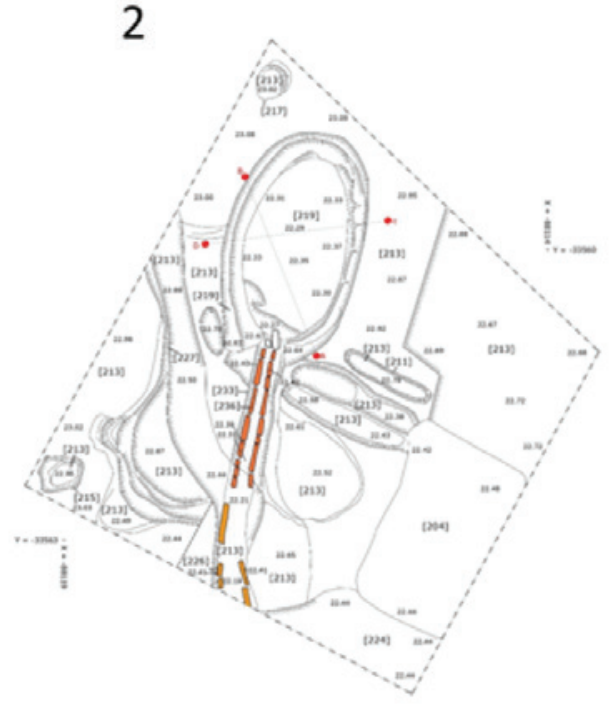

Plano Final Salo 2 Piso -1
Sondagens 4 es

Syatio yeo

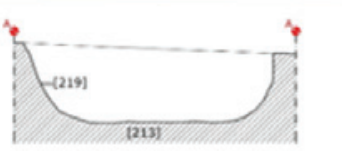

Secç̄o Longitudinal do Forno UE219 (Sul-Norte)

4
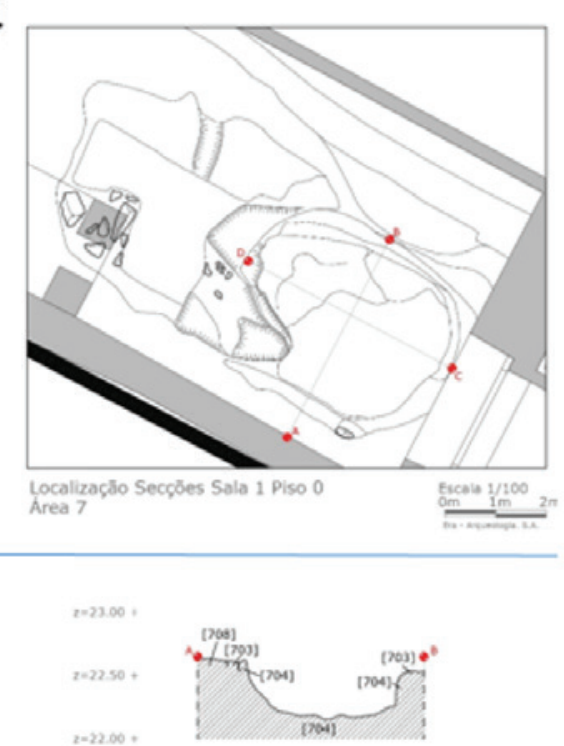

Secçăo Transversal do forno $n^{\circ} 4$ UE708, 703, 704

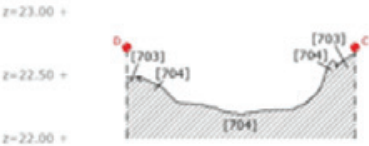

Seçăo Longitudinal do Forno $n^{\circ} 4$

Escalo $1 / 40$

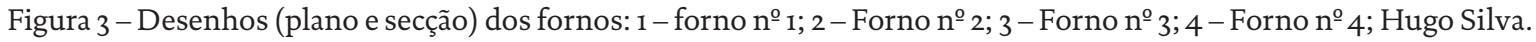



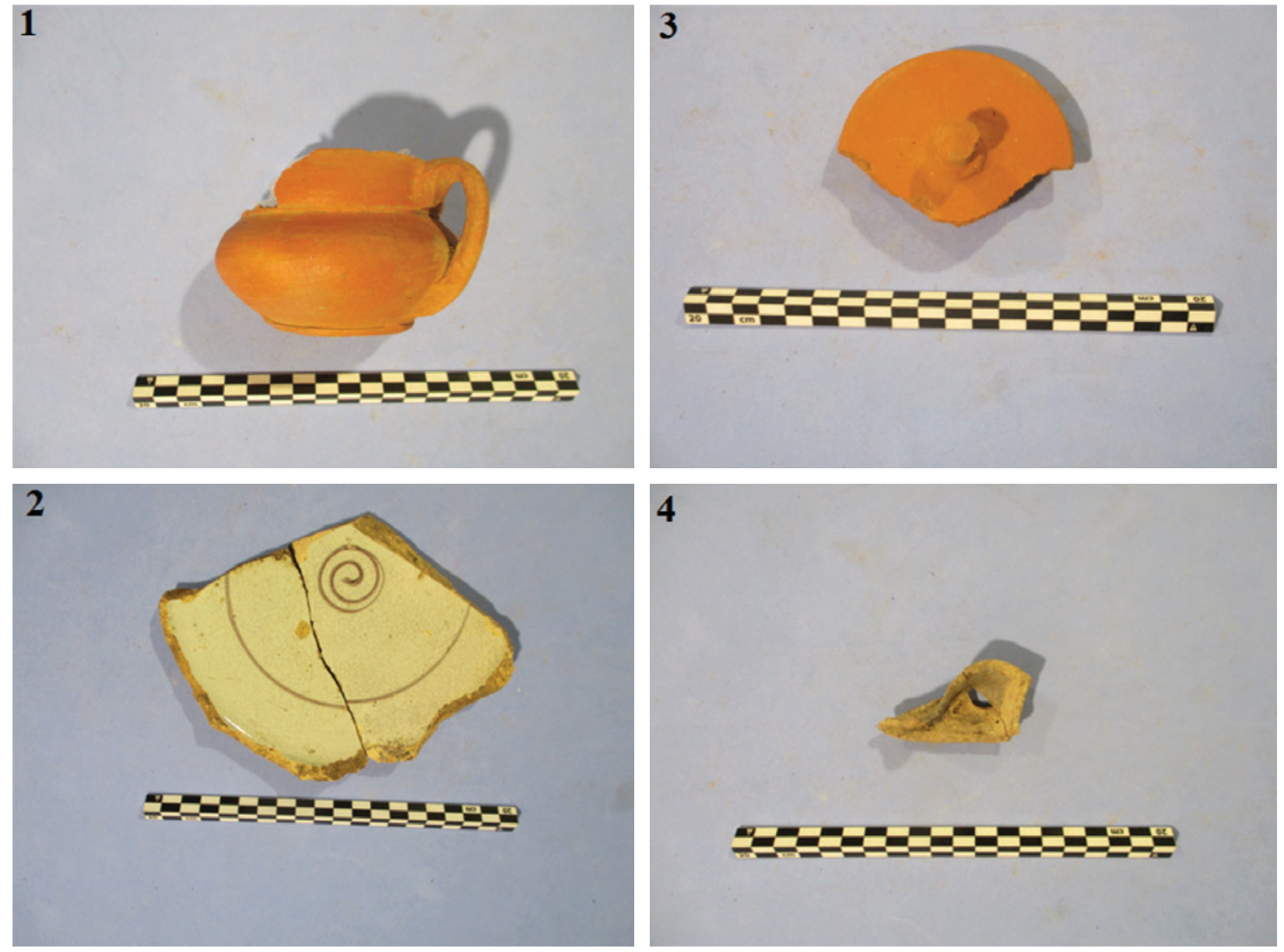

Figura 4 - Fragmentos cerâmicos: 1 - Púcaro (níveis de abandono do forno noำ $) ; 2$ - Fragmento de faiança (fundo de prato, em níveis de aterro da sala 1, piso -o1); 3 - Testo (recolhido em níveis de abandono do forno $\mathrm{n}^{\circ}$ 4); 4 - Fragmento de candeia (recolhida no forno nํㅜㄹ); Hugo Silva. 


\title{
A CASA DE PÊRO FERNANDES, CONTADOR DOS CONTOS DE D. MANUEL I: O SÍTIO ARQUEOLÓGICO DA SILHA DO ALFERES, SEIXAL (SÉCULO XVI)
}

\author{
Mariana Nunes Ferreira ${ }^{1}$
}

\begin{abstract}
RESUMO
O sítio arqueológico da Silha do Alferes foi descoberto em 1984. Escavações não autorizadas foram desenvolvidas por detectoristas e o local pilhado. Nesse mesmo ano, o Ecomuseu do Seixal procedeu à recolha, lavagem e armazenamentos dos materiais.

O espólio sobrevivente, do qual não contam metais, encontra-se bem preservado. É composto por várias peças completas tais como taças, pratos, púcaros, testos, fogareiros entre outros, característicos de um contexto doméstico. A tipologia dos artefactos corresponde a um deposição da primeira metade do século XVI. Este trabalho pretende dar a conhecer este sítio arqueológico debatendo a sua importância para o conhecimento da zona do Seixal nesta época.

Palavras-chave: Idade Moderna, Cultura Material, Contexto Doméstico, Seixal.
\end{abstract}

\begin{abstract}
The archaeological site of Silha do Alferes was discovered in 1984. Illegal excavations were made by metal detector owners and in that same year the Museum of Seixal recorded the site and recovered the material culture left behind.

The collection is well preserved with several complete objects such as bowls, plates, cups, lids, and braziers among others. This is the typical collection of a domestic context. The typology of the artefacts corresponds to a first half of the $16^{\text {th }}$ century context formation. This paper aims to acknowledge this site debating its importance in the study of Seixal are.
\end{abstract}

Keywords: Early Modern Age, Material Culture, Domestic Context, Seixal.

\section{INTRODUÇÃO}

O sítio arqueológico da Silha do Alferes (CNS 37628 ) situa-se na margem esquerda do Rio Tejo, no município do Seixal pertencente à Península de Setúbal e à Área Metropolitana de Lisboa, a cerca de 10 quilómetros do núcleo urbano (Figura 1). Em 1984 foram realizadas escavações não autorizadas auxiliadas por detectores de metais tendo o sítio sido parcialmente destruído. O sítio foi assim ilegalmente escavado não havendo resultados dessa ação, nem qualquer registo de campo. Nesse mesmo ano, arqueólogos do Museu do Seixal dirigiram-se ao local. Foi reali- zada uma limpeza superficial do terreno e recolhidos os materiais arqueológicos ali deixados. Foram lavados, separados por tipologias e armazenados por mais de 30 anos.

O sítio encontra-se na área do Parque Industrial do Seixal mais propriamente no perímetro da empresa Extruplás, Reciclagem, Recuperação e Fabrico de Produtos Plásticos, Lda e devido ao aumento da zona de armazenamento de plásticos o sítio encontra-se em risco de ser tapado.

A Silha do Alferes não é o único contexto da Idade Moderna conhecido neste município. Em 2016 desenvolveram-se trabalhos arqueológicos na frente

1. FSCH; mariananunesferreira@hotmail.com 
ribeirinha do Seixal, no âmbito da remodelação da zona, tendo sido encontrados mais contextos desta época. Ainda que apenas sejam conhecidos os resultados preliminares foram identificados diversos contextos de aterro (McClelland et all, 2016) nomeadamente na Rua da República e no Largo da Igreja. No entanto, a Silha do Alferes é um sítio de elevada importância. Em primeiro lugar porque é possível atribuir um proprietário aos terrenos onde este sítio arqueológico foi formado no século XVI. Existe na Chancelaria de D. Manuel datado de 14 de Março de 1517 (TT/CHR/K/10/17-62V), a atribuição a a atribuição a pedro fernamdez comtador dos comtos $\mathrm{d}$ el Rey doaçom de hua quinta que se chama a torre queimada de sesmaria que esta no termo da villa d almada.

Pedro Fernandes ocupava um cargo na administração central que tinha como função fiscalizar e controlar as finanças públicas. Como funcionário do estado e detentor de uma teria uma posição de destaque nesta zona da margem sul do Tejo. É impossível dizer qual o tempo que Pedro Fernandes passou nesta quinta e o espólio aqui identificado poderá nunca ter tido uma relação direta com o seu proprietário, sendo apenas o resultado das muitas casas que ali se encontravam. É, no entanto, fundamental, compreender que este sítio, apesar de não ter sido alvo de uma escavação rigorosa, representa uma ocupação rural de Idade Moderna que, até então, não se conhecia para a zona do Seixal. Por tal, não pode ser ignorado.

Dada a ausência de uma escavação arqueológica efectuada por arqueólogos creditados leva a que a estratigrafia não seja segura. Em visita ao local surgem à superfície vestígios de muros que não conseguimos interpretar. No entanto com a análise dos materiais foi possível concluir que estamos perante uma coleção cronologicamente enquadrada na primeira metade do século XVI, sem qualquer objeto que seja datável quer de momentos anteriores quer de momentos posteriores.

O estudo foi assim efectuado única e exclusivamente em torno dos materiais ali identificados. Foi efectuada uma contabilização total dos fragmentos onde se considerou a sua forma, tipo de bordo e fundo, caracterização e coloração das pastas, o código de cores Munsell Soil Color Chart, tal como a dimensão, o tratamento de superfície e a caracterização dos elementos decorativos.

A contabilização dos objetos foi efectuada relativamente ao número total de fragmentos. Para o seu estudo foi realizada a contabilização através do número mínimo de indivíduos - NMI. Executou-se o desenho das peças mais completas ou que mostrassem detalhes importantes.

\section{A COLEÇÃO}

A ausência de estruturas arqueológicas que pudessem auxiliar na interpretação dos objetos identificados levou a que os mesmos tivessem de ser organizados de acordo com a sua funcionalidade.

Nos contextos arqueológicos do século XVI a maioria da cerâmica recuperada insere-se no grupo das loiças utilizadas na cozinha que tem como função a confecção de alimentos e o apoio a esta atividade.

Nos contextos da Idade Moderna as formas mais frequentes são as panelas (Casimiro, Boavida e Detry; 2017 p. 112) tal como acontece na Silha do Alferes (Figura 2). Estas peças são caracterizadas pela forma globular, um fundo plano, colo alto e duas asas verticais. No que diz respeito ao bordo este pode indicar cronologias diferentes sendo que um bordo subvertical, marcado por duas caneluras pode representar o século XVI, um bordo espessado e extrovertido o século XVII e um bordo de lábio de secção biselada o século XVIII (Gomes et al., 2013, p. 1059). As panelas, devido à função primordial que encontram dentro dos contextos habitacionais, são peças que são encontradas em contextos arqueológicos por todo o país, em todos os locais onde foram identificadas casas e ocupação doméstica. (Casimiro, Boavida e Detry, 2017, p. 113 ; Gomes et al., 2013, p. 1059.; Barbosa, Casimiro e Manaia, 2009, p. 123; Rodrigues et al., 2013, p. 866).

Sabemos pelos livros de receitas da época que as panelas estão associadas à cozedura de alimentos $\mathrm{e}$ produção de ensopados sejam eles carne, peixe ou até legumes (Casimiro, Boavida e Detry, 2017, p. 112). A segunda forma mais frequente neste contextos doméstico são os tachos, estes apresentam uma forma hemisférica com paredes altas, assentes em plano fundo com asas horizontais ou pegas triangulares (Casimiro, Boavida e Detry, 2017, p. 113) (Figura 2). É associado à confecção de refugados ou estufados nos livros de receitas. Tal como as panelas, os tachos são frequentemente encontrados em contextos domésticos (Fernandes e Carvalho, 2003, p. 233).

Outras das formas usada na cozinha é a frigideira, sendo esta usada para fritar, mas também são mencionadas como peças que podem ir ao forno. Estas 
são caracterizadas por ter uma forma hemisférica, paredes mais baixas e pegas triangulares ou um cabo tubular.

Os testos e tampas serviam para tapar as formas acima mencionadas. Os testos aqui estudados apresentam forma tronco cónica, um fundo plano, bordo semicircular ou bordo extrovertido com uma pega na parte superior (Figura 2). Tal como os tachos, panelas e frigideiras são peças frequentes nos contextos arqueológicos, sobretudo associados a contextos domésticos (Casimiro, Boavida e Detry, 2017, p. 114; Fernandes e Carvalho, 2003, p. 233; Gomes et al., 2013, p. 1059).

Os alguidares (Figura 3) tem como função ajudar na preparação da comida como por exemplo na preparação de enchidos como é referido no livro Arte da Cozinha de Domingos Rodrigues (Casimiro, Boavida e Detry, 2017, p. 115).

Uma peça fundamental para a vida dentro da cozinha é o fogareiro pois é este que permite ter um lume brando para a confecção dos alimentos (Figura 3). Esta é uma peça que aparece nos contextos domésticos desde a Idade Média (Casimiro, Boavida e Detry, 2017, p. 116) e por isso é uma peça com alguma expressão nos contextos modernos.

O cuscuzeiro (Figura 3) é uma peça menos frequente em contexto arqueológico mas são mencionados nos livros de receitas como no livro Arte da Cozinha. O consumo de cuscuz é introduzido na alimentação dos portugueses a partir dos finais do século XV (Casimiro, Boavida e Detry, 2017, p. 115; Gomes, Casimiro e Neto, 2017, p. 9) tendo sido encontrado dois fragmentos na Silha do Alferes.

O segundo grande grupo de estudo são as cerâmicas de servir à mesa, neste grupo é importante destacar a faiança que supera em número a cerâmica vidrada de chumbo. Os objetos encontrados fazem parte do serviço de mesa e são utlizados para servir e consumir os alimentos (Figura 4).

Os pratos em faiança possuem todos as mesmas características morfológicas tendo uma forma tronco cónica com fundo em ônfalo. Os pratos revestidos com vidrado de chumbo, podem também representar fundos anelares ou planos. O bordo é também na maioria das vezes semicircular, podendo existir bordos extrovertidos. O prato era a forma mais comum de servir à mesa (Casimiro, Boavida e Detry, 2017, p. 116).

As taças são peças com alguma expressão neste contexto, existindo taças em vidrado de chumbo e vi- drado estanífero. As suas formas correspondem a peças hemisféricas ou carenadas, assentes em fundo com pé anelar. Os objetos de servir à mesa são parcamente decorados. As peças em faiança apresentam a ocasional linha azul concêntrica junto ao bordo e as peças revestidas a vidrado de chumbo, verde ou amarelo, apresentam pequenas caneluras abaixo do bordo (Casimiro et al., 2018, p. 275) Destacam-se alguns fragmentos decorados a azul e manganês num estilo por norma reconhecido como Isabella Polychrome, muito possivelmente produzido na Andaluzia.

Neste grupo de louça de mesa podemos ainda incluir os púcaros (Figura 5) que apresentam um corpo bojudo, bordo semicircular, fundo plano e superfícies brunidas. Estes eram essencialmente utilizados para beber água. No entanto, surgem nos livros de receitas como unidades de medida (Casimiro e Newstead, 2019, p. 146).

Destaca-se um pequeno recipiente, cujo tamanho não permite atribuir funcionalidades, em cerâmica vermelha decorada com pequenas pedrinhas, nas quais surgem duas iniciais.

Sabe-se que a louça esmaltada era produzida $n$ e o forno da Mata da Machada a partir da década 20 do século XVI mas esta só se torna abundante nos contextos arqueológicos a partir de 1560 (Casimiro, 2013, p. 354). No conjunto de faiança da Silha do Alferes encontramos duas tipologias, taças carenadas e pratos.

Não nos é possível concluir se estas peças forma produzidas no vale do Tejo ou importadas do sul de Espanha. Contudo, a produção em Lisboa de louça revestida a branco encontra-se documentada arqueologicamente pelo menos desde os finais do século XV (Henriques et al., 2019, p. 920).

A acreditar que a louça esmaltada é maioritariamente produzida na zona do vale do Tejo, os objetos de importação são raros e oriundos de Sevilha, Veneza e China.

De Itália o centro produtor que mais abasteceu Portugal foi Montelupo. Na Silha do Alferes encontraram-se quatro fragmentos de pratos oriundos de Montelupo. Este tipo de cerâmica, sobretudo pratos e taças, caracteriza-se por ser bastante decorada recorrendo à policromia. Nos pratos encontramos decoração que podemos classificar de fiori centrale, spirali arancio e a blu grafito (Amaro et al., 2013, p. 1021) apresentando as cores laranja, azul, verde e amarelo. Este tipo de decoração é característica do século XVI (Amaro et al., 2013, p. 1021). 
As produções em Isabella Polychrome (Figura 6) têm sido identificados em diversas partes do país. O mesmo se pode dizer das peças vidradas a melado e decoradas com traços de manganês. Em 1996, no Largo Corpo Santo ao serem realizados trabalhos arqueológicos, foram encontrados fragmentos de pratos semelhantes aos da Silha do Alferes (Caroscio, 2015, p. 105).

A porcelana chinesa, como expectável, também aqui aparece, ainda que em quantidades mais reduzidas. A importação da porcelana encontra-se documentada a partir da primeira viagem de Vasco da Gama (Henriques, 2012, p. 920). A porcelana faz parte do grupo que se denomina de azul e branca que se desenvolveu na dinastia Ming e Qing (Gomes et al., 2013, p. 1059). Na Silha do Alferes encontraram-se quatro fragmentos de porcelana, um bordo com decoração geométrica e três fragmentos de bojo sendo que um apresenta decoração fitomórfica. Foram classificados como produções do período Zhendde e Jiajing. O número é na verdade reduzido para a quantidade que costuma aparecer nos contextos urbanos. Um único fragmento de vidros de Veneza, ou ao estilo de Veneza foi recuperado.

A cerâmica de armazenamento também tende em aparecer muitos nos contextos arqueológicos modernos (Figura 7). Deste grupo fazem parte os cântaros, as jarras, garrafas, bilhas e potes. Muitos destes objetos são designados ao armazenamento de água mas podiam também conter outros líquidos (Casimiro, 2020, p. 236).

Os cântaros caracterizam-se por ter um bordo semicircular ou extrovertido, um fundo plano, um corpo bojudo e duas asas equidistantes. A bilha caracteriza-se por ter só uma asa (Casimiro e Valongo, 2017, p. 1837). Os potes são recipientes bojudos, desprovidos de asas. As garrafas, jarras, jarros e bilhas são formas bojudas distinguindo-se pelo tipo de bordo e asa.

Surgiram ainda algumas malhas de jogo. Estes objetos em forma de disco, muitas vezes aproveitando fragmentos de outros recipientes são constantes nos contextos arqueológicos e poderiam ser utilizados em tabuleiros de madeira móveis ou desenhados diretamente sobre as mesas ou no chão ou bancadas e degraus de pedra (Fernandes, 2013).

\section{CONCLUSÃO}

Mesmo sem um método arqueológico e sem estratigrafia segura, o sítio arqueológico da Silha do Alferes não pode ser ignorado. Este é um sítio importante pois não só temos uma cronologia segura que nos é dada pelo material estudado e que está em excelente estado de conservação, mas é possível perceber a quem pertenciam aqueles terrenos. $\mathrm{O}$ conjunto de materiais permite concluir que apesar de a propriedade ser de um funcionário régio quem ali vivia possuía uma capacidade económica moderada. Os objetos maioritários correspondem a produções locais/ regionais da zona do Vale do Tejo. As importações são mínimas correspondem a achados isolados de cerâmica italiana, espanhola e chinesa que, à época, estavam a ser abundantemente utilizadas ou já mesmo descartadas noutros contextos arqueológicos. Esta não seria a zona principal de habitação daquela quinta, mas apenas a casa de um dos seus ocupantes, mostrando como viveriam as comunidades rurais nas quintas da margem sul no século XVI.

Mas a Silha do Alferes é também um sítio que foi pilhado e destruído antes de ser possível uma escavação com método científico. A importância deste local não pode ser recusada porque não há estratigrafia. A implementação do espaço na zona rural do Seixal, o conhecimento do seu proprietário e a coleção aqui encontrada não pode ser ignorada no estudo desta zona. Os contextos destruídos, por norma secundarizados nos estudos arqueológicos, devem ser considerados pelas informações que transmitem.

Este é assim um contexto doméstico importante para a arqueologia moderna, sobretudo por se encontrar na margem sul do Tejo, e a sul de Lisboa onde a arqueologia moderna se encontra mais desenvolvida.

Ao estudar o material encontrado sabemos que estamos perante uma ocupação doméstica e é possível compreender que tipo de objetos eram utilizados em ambientes domésticos no século XVI no Seixal. As peças de importação que foram encontradas são essenciais na compreensão das trocas comerciais que existiam com outros países e também são fundamentais para o enquadramento sócio-económico e com isso perceber qual a base social dos indivíduos que vivam na Quinta da Torre Queimada.

\section{AGRADECIMENTOS}

O meu mais sincero obrigada aos arqueólogos da Câmara Municipal do Seixal, nomeadamente o Jorge Raposo, o Cézer Neves e o José Henrique, bem como à Tânia Casimiro, minha orientadora de mestrado, por ter instigado esta publicação. 


\section{BIBLIOGRAFIA}

AMARO, Clementino; FILIPE, Vanessa; HENRIQUES, José; MANSO, Cláudia (2013) - Prisão do Aljube no século XVI vidros, majólica italiana e cerâmica esmaltada espanhola in: ARNAUT, José Morais; MARTINS, Andrea; NEVES, César. (eds.) Arqueologia em Portugal - 150 anos. Lisboa: Associação dos Arqueólogos Portugueses, pp. 1019-1024.

BARBOSA, Teresa; CASIMIRO, Tânia; MANAIA, Rodolfo (2009) - A late $15^{\text {th }}$ century household pottery group from Aveiro (Portugal). Medieval Ceramics, 30, pp. 119-136.

CAROSCIO, Marta (2015) - Jaúdenes 5: um contexto arqueológico de época portuguesa em Ceuta in TEIXEIRA, André; PAREDES, Fernando Villada; SILVA, Rodrigo Banha da (coord) Ciudad Autonoma de Ceuta. Câmara Municipal de Lisboa, pp. 169-211.

CASIMIRO, Tânia Manuel (2013) - Faiança portuguesa: datação e evolução crono-estilística, Revista Portuguesa de Arqueologia, 16. Lisboa: Direção- Geral do Património Cultural, pp. 351-367.

CASIMIRO, Tânia Manuel (2020) - Materialidades Quotidianas de Idade Moderna em Alhandra. Os contextos arqueológicos da escavação do Centro de Saúde, in Cira Arqueologia, número 7, Vila Franca de Xira: Museu Muncicipal Vila Franca de Xira, pp. 233-245.

CASIMIRO, Tânia Manuel; BOAVIDA, Carlos; DETRY Cleia (2017) - Cozinhar e comer: cerâmicas e alimentação em Carnide (1550-1650)", in Actas do Encontro Diz-me o que comes... Alimentação antes e depois da cidade, Lisboa, Centro Arqueologia de Lisboa, pp. 105-116.

CASIMIRO, Tânia Manuel; VALONGO António (2017) Uma lixeira nas casas nobres do infantado. In Arqueologia em Portugal, Lisboa, Associação dos Arqueólogos Portugueses, pp. 1835-1848.

CASIMIRO, Tânia Manuel; HENRIQUES, José Pedro; FILIPE, Vanessa; BOAVIDA, Carlos. (2018) - Lead glazed ceramics in Lisbon $\left(16^{\text {th }}-18^{\text {th }}\right.$ centuries), Lisboa: LNEC, pp. 268-282.

CASIMIRO, Tânia Manuel; NEWSTEAD, Sarah (2019) 400 Years of water consumption: early modern pottery cups from Portugal, Ophiussa, 3, pp. 125-133.

FELÍCIO, Catarina; SOUSA, Filipe; GUIMARÃES Raquel; GADANHO, André (2017) - A ceramic Italiana dos séculos XV e XVI do Largo do Jogo da Bola em Carnide, in Arqueologia em Portugal - 150 anos. Lisboa: Associação dos Arqueólogos Portugueses, pp. 1791-1802.

FERNANDES, Isabel; CARVALHO, Rafael. (2003) - A loiça seiscentista do Convento de São Francisco de Alferrara (Palmela), in Actas das 3 . $^{\text {as }}$ Jornadas de Cerâmica Medieval e Pós Medieval, Métodos e Resultados para o seu Estudo. Tondela: Câmara Municipal de Tondela, pp. 231-252.

FERNANDES, Lídia (2013) - Tabuleiros de Jogos inscritos na pedra 2013, Lisboa: Apenas Livros.
GOMES, Rosa Varela; GOMES, Mário Varela; ALMEIDA, Mariana; Boavida, Carlos; NEVES, Dário; HAMILTON, Kierstin; SANTOS, Carolina (2013) - Convento de Santana (Lisboa). Estudo preliminar do espólio da fossa 7", in: ARNAUD, José Morais; MARTINS, Andrea; NEVES, César (eds.), Arqueologia em Portugal - 150 anos, Lisboa, Associação dos Arqueólogos Portugueses, pp. 1057-1065.

HENRIQUES, José Pedro Vitém (2012) - Do Oriente para Ocidente: contributo para o conhecimento da porcelana chinesa nos quotidianos da época moderna. Estudo de três contextos arqueológicos de Lisboa. In TEIXEIRA, André; BETTENCOURT, José (coord.), Velhos e Novos Mundos: Estudo de Arqueologia Moderna. Lisboa: CHAM - FCSH/ NOVA-UAç, vol. 2, pp. 919-932.

HENRIQUES, José Pedro; FILIPE, Vanessa; CASIMIRO, Tânia Manuel; KRUS, Alexandra (2019) - Vestígios de produção oleira dos finais do século XV (Escadinhas da Barroca, Lisboa), in: Fragmentos de Arqueologia, Extrair e Produzir... Dos primeiros artefactos à Industrialização, Lisboa: Centro Arqueologia de Lisboa, pp. 108-120.

MCCLELLAND, Susana; JESUS, Luciana de; BAÇO, Joana; AVELINO, Andreia (2016) - Projeto integrado de requalificação do espaço público do Seixal - Relatório Preliminar.

RODRIGUES, D. (1821) - Arte de Cozinha dividida em quatro partes..., Lisboa: Na oficina da Viúva de Lino da Silva.

RODRIGUES, J. A. Severino; BOLILA, Catarina; FILIPE, Vanessa; HENRIQUES, José Pedro; RIBEIRO, Inês Alves; SIMÕES, Sara Teixeira (2013) - As cerâmicas da Idade Moderna da Fortaleza de Nossa Senhora da Luz, Cascais, in: TEIXERA, André e BETTENCOURT, José, (eds), Velhos e Novos Mundos. Estudos de Arqueologia Moderna, Lisboa, Centro de História de Além-Mar, pp. 865-876.

GOMES, Rosa Varela; CASIMIRO, Tânia Manuel; Neto, J. L. (2017) - Acerca do consumo do cuscuz na alimentação açoriana, Atlântida. Revista de Cultura, vol. LXII, pp. 2-12. 


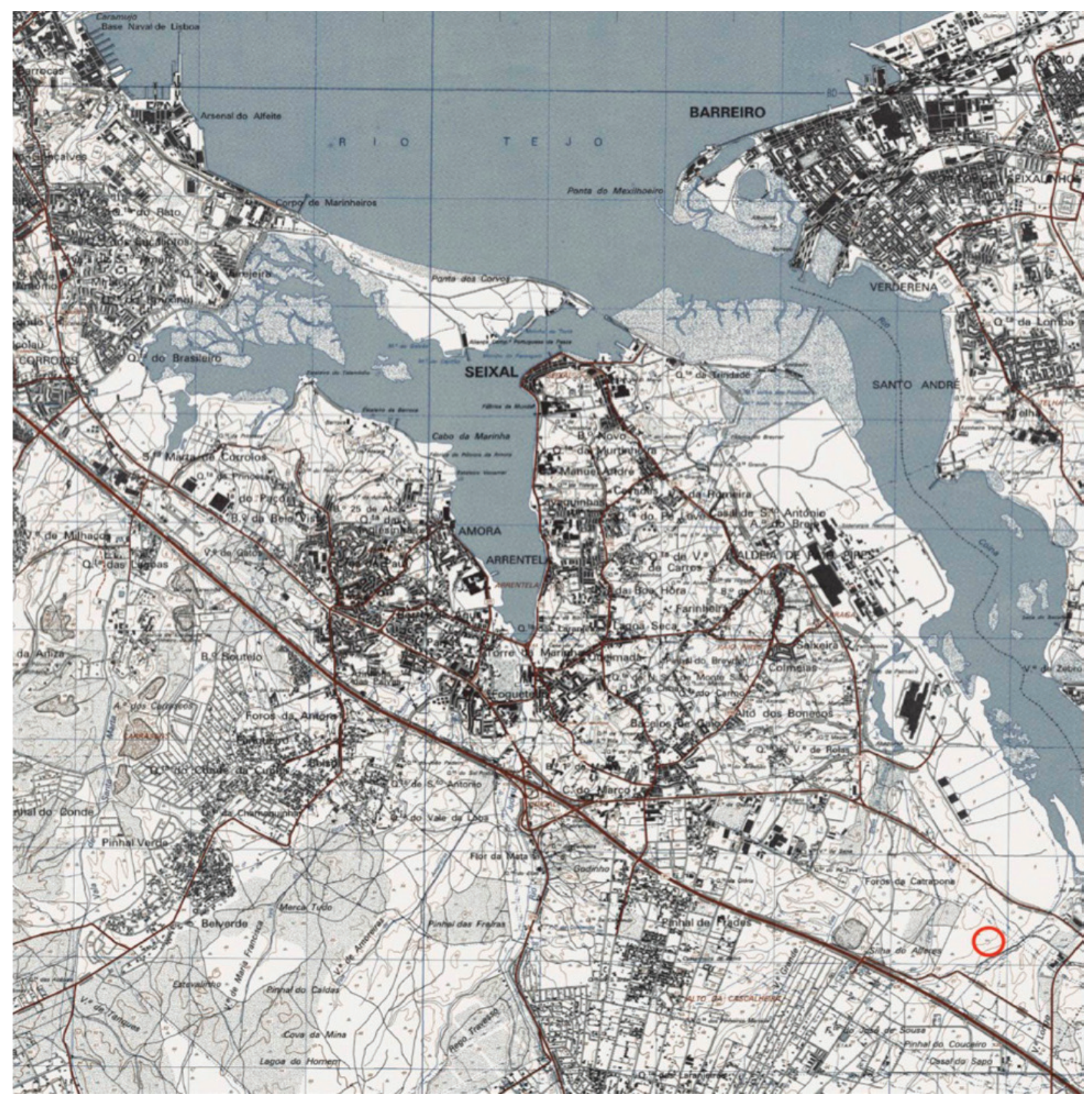

Figura 1 - Localização da Silha do Alferes. Carta Militar Seixal. 

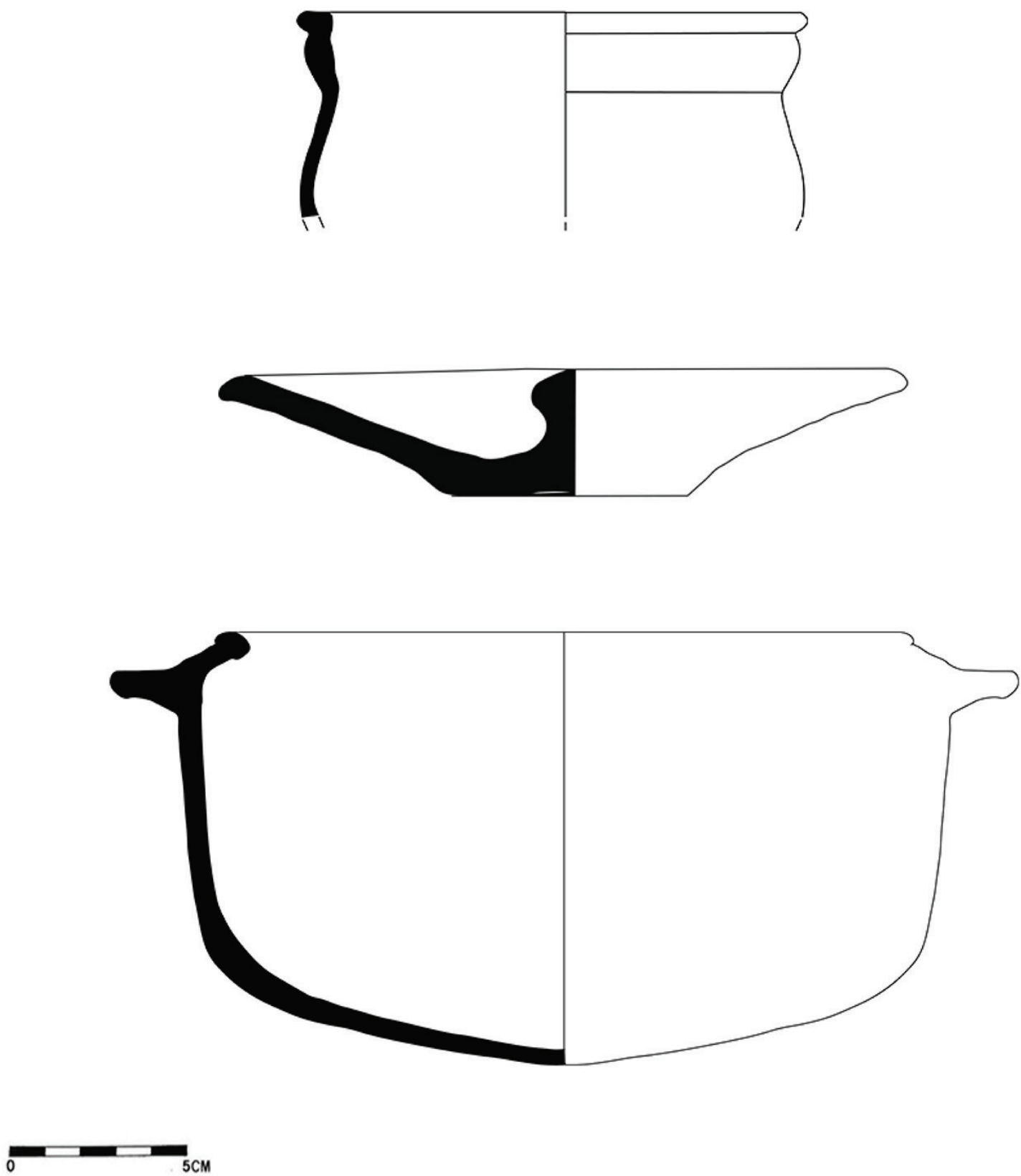

Figura 2 - Panela, Testo, Tacho. 


$$
\dot{I}
$$



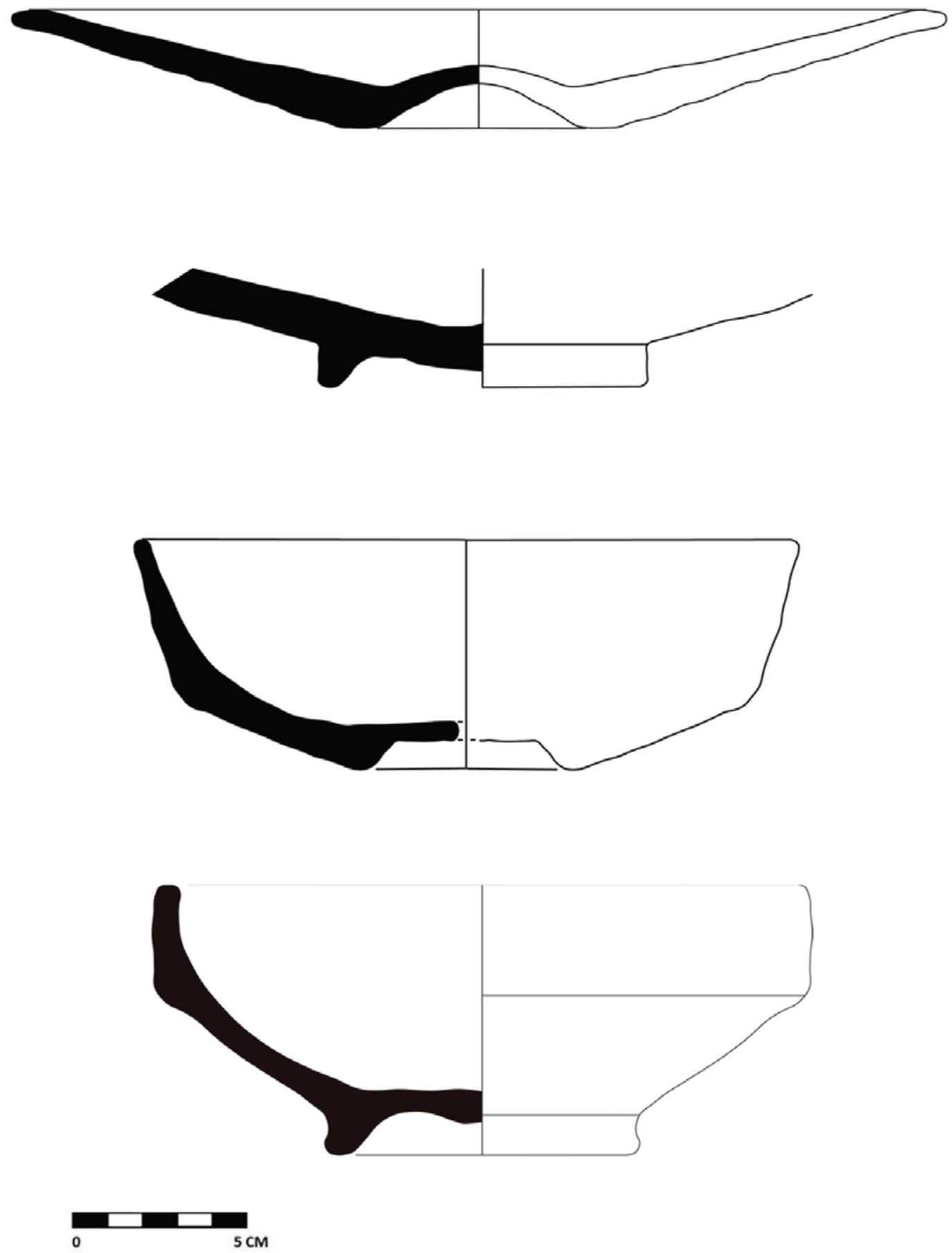

Figura 4-Pratos e Taças. 

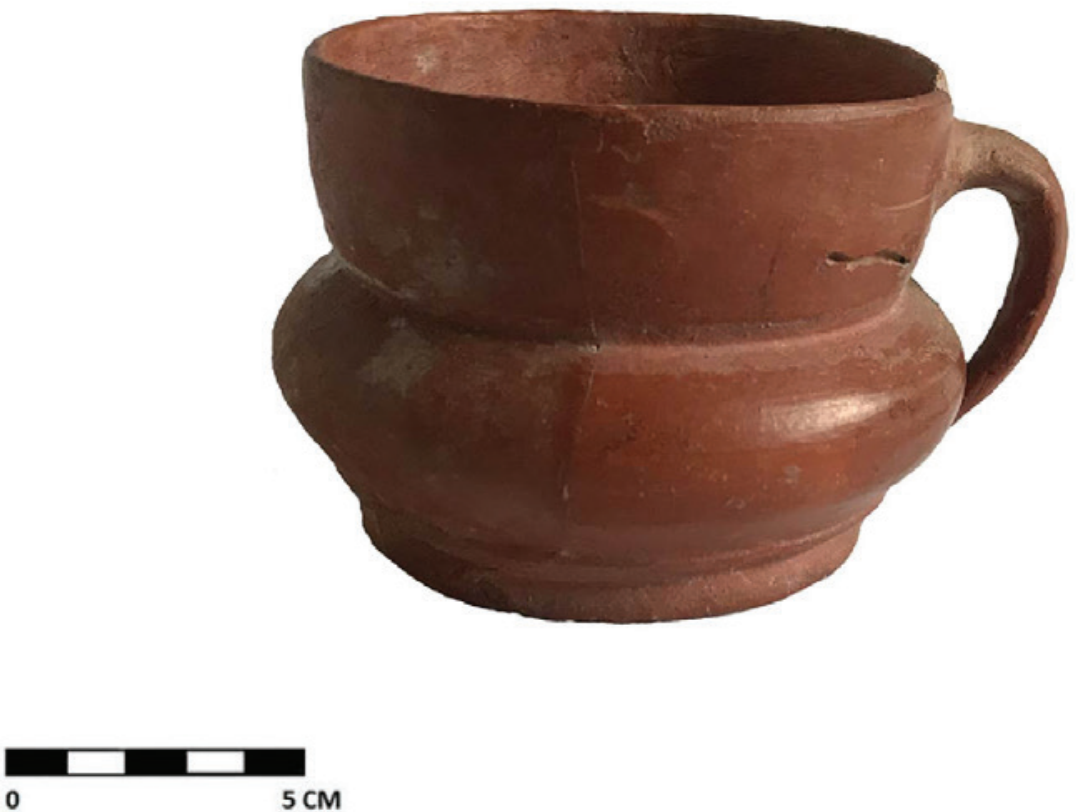

Figura 5-Púcaro.

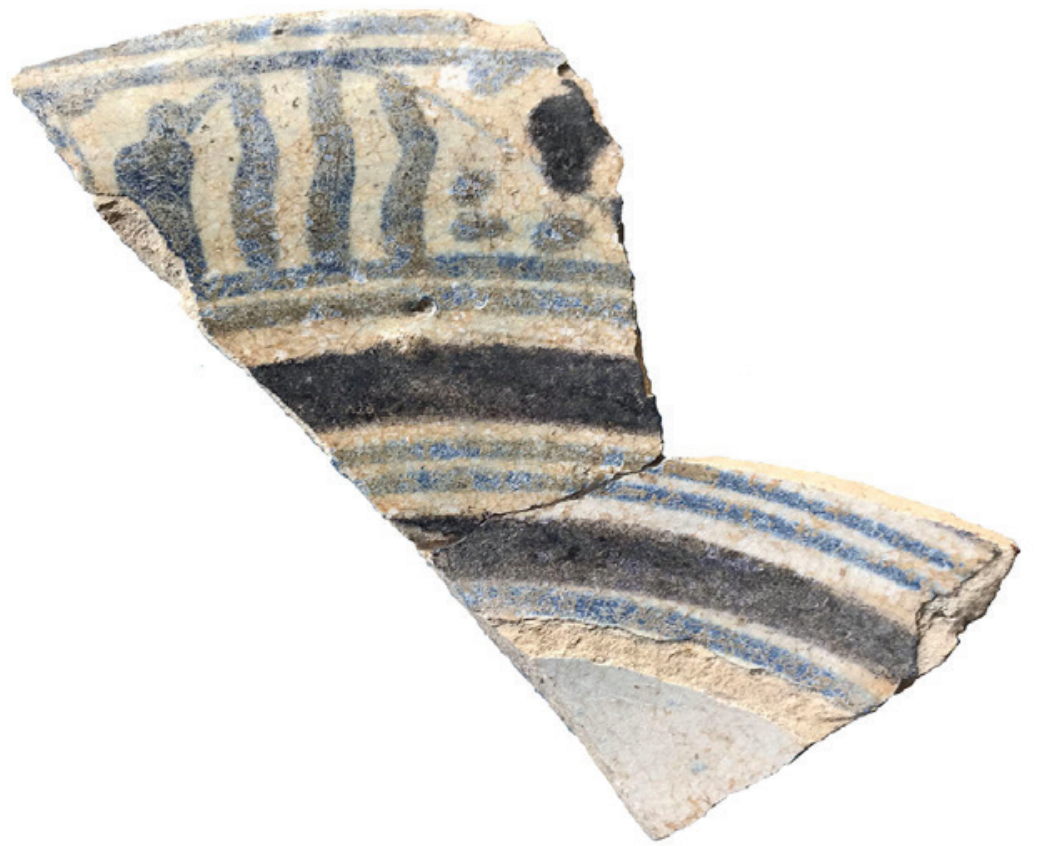

Figura 6 - Prato com decoração tipo Isabella Polychrome. 

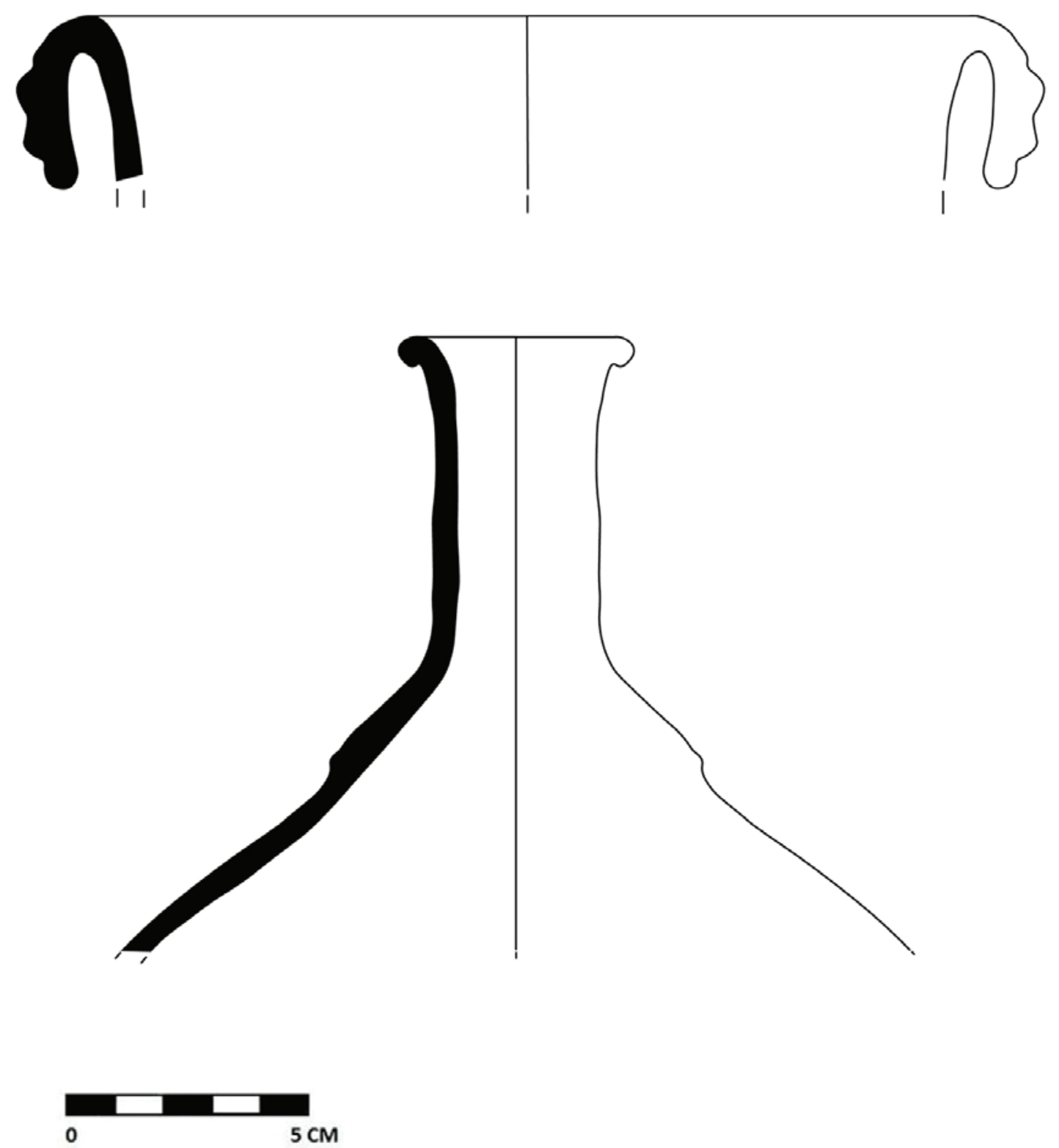

Figura 7-Cântaro, Garrafa. 


\title{
O ALTO DA VIGIA (SINTRA) E A VIGILÂNCIA E DEFESA DA COSTA
}

\author{
Alexandre Gonçalves ${ }^{1}$, Sandra Santos ${ }^{2}$
}

\begin{abstract}
RESUMO
O Alto da Vigia localiza-se numa arriba sobranceira ao mar junto à foz do rio de Colares, em Sintra, tendo sido identificados no local vestígios de um santuário romano, de um ribat islâmico e de uma vigia da costa de época moderna. Apresentam-se aqui algumas materialidades relativas a esta última ocupação, datável do início do século XVI até à primeira metade do XIX, um período de vários séculos durante o qual o sítio integrou um sistema de vigilância do litoral.

Para além da escavação arqueológica, a realização de prospeções e a consulta de fontes históricas, permitiu adicionar novos elementos relacionados com a vigilância do litoral da região a Norte do estuário do Tejo entre os séculos XVI e XIX.

Palavras-chave: Vigia moderna, Defesa costeira, Sintra, Colares.
\end{abstract}

\begin{abstract}
The archaeological site of Alto da Vigia is located in the mouth of the river of Colares, in the municipality of Sintra, and traces of a Roman sanctuary, an Islamic ribat and a coastal surveillance shelter have been identified. We now present some materialities from the latter occupation, dating back from the beginning of the $16^{\text {th }}$ to the $19^{\text {th }}$ century, a long period during which the site had an important role in the defence and surveillance of the coast.

The research of old cartography and archive documentation, complemented with archaeological survey, allowed the identification of new data related to coastal surveillance in the northern region of the Tagus River between the $16^{\text {th }}$ and $19^{\text {th }}$ centuries.
\end{abstract}

Keywords: Lookout point, Coastal defence, Sintra, Colares.

O presente trabalho encontra-se dividido em duas partes. Na primeira é feito o enquadramento geográfico e histórico do sítio, seguido da apresentação dos contextos e materiais arqueológicos relativos à vigia de época moderna. Na segunda parte relacionam-se aquelas evidências com informações recolhidas em documentação antiga, contextualizando o Alto da Vigia no âmbito da vigilância e defesa da costa na área a Norte do rio Tejo entre os séculos XVI e XIX.

\section{O SÍTIO ARQUEOLÓGICO DO ALTO DA VIGIA}

O Alto da Vigia localiza-se numa plataforma sobranceira ao mar na margem esquerda da foz do

1. Município de Sintra / UNIARQ - Universidade de Lisboa.

2. Município de Cascais. rio de Colares, junto à Praia das Maçãs, em Sintra. Corresponde a um local com uma posição geográfica estratégica, já que uma reentrância na linha de costa deu origem a que no passado ali se formasse um esteiro de mar (Daveau, 1994, p. 25) que possibilitava o acesso de embarcações ao interior do território, o que terá sucedido pelo menos até ao final da Idade Média (Cardim Ribeiro, 2019, p. 9o; Caetano, 200o, p. 13 e seguintes). O progressivo assoreamento da foz impediu aquele tipo de navegação a partir da época moderna, altura em que passou a ser possível apenas o desembarque no areal entretanto formado, continuando o local a ser utilizado como zona de desembarque e de entrada e escoamento de produtos (Figura 1). 
A importância da foz do rio de Colares encontra-se refletida na sua representação em alguma cartografia antiga, geralmente de escala muito grande e na qual se incluem apenas os locais mais significativos. Com efeito, aquele curso de água figura no Portugalliae quae olim Lusitania, de 156o (Secco, 1560), mas também em mapas dos séculos seguintes.

Será precisamente a sua implantação a determinar as distintas ocupações identificadas no Alto da Vigia em diferentes épocas, nomeadamente do santuário romano dedicado ao Sol, à Lua e ao Oceano (Cardim Ribeiro, 2019), do ribat $^{3}$ em época islâmica e de um edifício de vigia usado nas épocas moderna e contemporânea.

As referências mais antigas que temos acerca da existência de vestígios naquele local remontam a 1505 e são da autoria de Valentim Fernandes, também conhecido por Valentinus Moravus, que terá integrado o séquito que acompanhou D. Manuel quando o monarca se deslocou àquele local ermo do litoral sintrense no dia 9 de agosto de 1505, a propósito do aparecimento de inscrições do referido santuário romano (Cardim Ribeiro, 2016, p. 140).

Reconhecida na época a importância da descoberta, as ditas inscrições passam a integrar os itinerários epigráficos do século XVI, sendo registadas, nomeadamente, por André de Resende e Francisco d'Ollanda, tendo este último, décadas depois, feito um desenho dos vestígios que terá observado ( $D a$ Fabrica que falece ha Cidade de Lysboa, 1571).

Com o passar do tempo, a localização exata do santuário no litoral sintrense acaba por se perder, até que os trabalhos arqueológicos iniciados em 2008 permitiram não só confirmar a sua localização, como identificar ocupações posteriores do local e que eram desconhecidas até então.

No início da intervenção arqueológica afloravam à superfície do terreno o topo de estruturas, associadas a fragmentos de telha e cerâmica de época moderna. Estas evidências e o registo do topónimo vigia num sítio com aquela implantação, deixavam já antever a possibilidade da existência de uma estrutura relacionada com a vigilância da costa.

3. Da ocupação de época islâmica foram escavados dois edifícios, um deles uma mesquita com $12,50 \mathrm{~m}$ por $4,5 \mathrm{~m}$, com um mihrab centrado e orientado $130^{\circ}$ a Sudeste, $\operatorname{com} 1,80 \mathrm{~m}$ de largura e 1,5 $\mathrm{m}$ de profundidade; um enterramento de rito islâmico que faz parte de uma necrópole que se prolonga para lá dos limites da escavação e da qual se identificaram já 6 sepulturas; 3 silos de armazenamento.
A escavação dos vestígios assinalados revelou que correspondiam aos alicerces de uma vigia construída no início do século XVI que teve pelo menos duas remodelações, a primeira entre o início e meados do século XVIII, a outra já no final daquela centúria ou mais provavelmente no início da seguinte.

A vigia foi implantada junto à arriba e não no sítio de maior altitude da plataforma onde a mesma está localizada, que se situa numa área mais afastada da linha de costa, num sítio onde se regista o topónimo "Vigia Velha de Colares" e de onde se tem visibilidade quer para a foz do rio, quer para o interior do território em direção à vila de Colares. Apesar de no local o denso coberto vegetal não permitir aferir a eventual presença de vestígios, as estruturas visíveis parecem corresponder a simples muros de limite de propriedade.

\subsection{A construção da vigia no início do século XVI} Quando se abriram as valas para os alicerces da vigia, na areia que cobria os níveis de derrube dos edifícios islâmicos, terão sido identificados materiais lapidares romanos - inscrições e elementos arquitetónicos - que foram reutilizados como simples material de construção nas paredes de uma mesquita, sobre cujas ruínas a nova estrutura quinhentista foi em parte edificada.

Para além das fundações, registaram-se outras valas cuja configuração acompanha o alinhamento das paredes da mesquita, estando a sua abertura relacionada com a extração das pedras daquelas estruturas, possivelmente para as reutilizar na vigia que ali se estava a edificar. Esta ação resultou no desmonte quase integral do edifício islâmico, tendo sido identificados na escavação arqueológica ainda alguns negativos nos locais de onde foram extraídos os blocos. Com efeito, nos depósitos de preenchimento daquelas valas recuperaram-se grandes quantidades de elementos lapidares romanos muito fragmentados, alguns conservando ainda vestígios de inscrição, que resultam da sua segmentação in loco para criar peças mais pequenas.

A sequência estratigráfica acima descrita parece corresponder ao relato de Valentim Fernandes nas cartas que enviou a Hieronymus Münzer e a Konrad Peutingernas - sendo a remetida a este último datada de 16 de agosto de 1505 - nas quais descreve que «No ano 1505 (...) na base do promontório da Lua, que o vulgo chama Roca de Sintra, junto à costa do Mar Oceano, descobriram-se debaixo da terra (...) três 
colunas de pedra de forma quadrada, com caracteres romanos de grande antiguidade» que dali foram retiradas "utilizando um ferro e com cuidado, de entre as pedras com que estavam misturadas no terreno" (Cardim Ribeiro, 2016, p. 140). O já referido desenho de Francisco d'Ollanda situa as descobertas na «foz do ryo de Colares (...) sobre hu piqueno outeiro junto do Mar Oçeano" (Ibidem. p. 141), o que as escavações em curso permitiram confirmar.

A recolha, no depósito de enchimento da vala de fundação da vigia, de um ceitil datável de $1499 \mathrm{em}$ diante $^{4}$, (Figura 8, n. 3 ), permite enquadrar a sua construção no início do século XVI, próxima, assim, ao relato de Valentim Fernandes. O restante conjunto artefactual associado a este momento de construção é constituído por escassos fragmentos de cerâmica, essencialmente louça vermelha, dois dos quais permitem a sua reconstituição formal. A reduzida dimensão preservada de um bordo com pequeno espessamento interno dificulta a sua atribuição tipológica (Figura 8, n.ำ 1), reconhecendo-se, no entanto, algumas semelhanças com panelas datáveis do século XVI recuperadas em Cascais (Cardoso \& Rodrigues, 1999, p. 201) e Palmela (Fernandes \& Carvalho, 1995, pp. 235-236). A segunda peça corresponde a uma panela de bordo com pequena aba de secção retangular e colo direito (Figura 8, n.․ 2), com paralelos próximos em formas conhecidas para o século XVI, por exemplo, em Cascais (Cardoso \& Rodrigues, 1999, p. 201; Idem, 1991, pp. 581 e 583; Cardoso \& Encarnação, 199o, Est. VI-VII) e Palmela (Fernandes \& Carvalho, 1995, pp. 235-236).

O edifício da vigia apresentava uma planta aproximadamente retangular, com cerca de $6 \mathrm{~m}$ por $4,5 \mathrm{~m}$, sendo os seus alicerces construídos usando blocos de calcário com formas muito irregulares ligados por argila. Alguns foram assentes sobre materiais dos níveis de derrube da mesquita, enquanto outros se encontravam diretamente dispostos sobre os já referidos depósitos de areia usados para preencher as valas relacionadas com o desmonte das paredes da mesquita, acima descritas.

No exterior da parede Sul da vigia foi adossada uma estrutura maciça de pedra com aproximadamente

4. Ceitil de Dom Manuel compatível quanto a tipologia no "Grupo 5" definido por Magro (1986, pp. 45-46 e 208, exemplar-tipo no 5.1.6), que reúne os ceitis manuelinos cunhados a partir de inícios de 1499 (Cardim Ribeiro, 2016, p. 140, nota 5).
$3 \mathrm{~m}$ de comprimento e $1 \mathrm{~m}$ de largura, que poderá corresponder às fundações de uma escada pétrea que conduziria a um ponto de observação mais elevado, o que não implica necessariamente a existência de um terraço. Com efeito, durante os trabalhos arqueológicos foram identificados vestígios de derrubes de cobertura em telha associados às distintas fases de abandono. Por outro lado, a existência de uma tal plataforma na cobertura obrigaria a que o edifício fosse provavelmente mais alto, por forma a acomodar a necessária abóbada de suporte, colocando-se ainda a questão de saber até que ponto os seus alicerces - pouco profundos, construídos sem argamassa e parcialmente assentes em areia solta suportariam a carga introduzida por uma estrutura daquele tipo.

Exemplos de estruturas de vigia com terraço acessível através de escada exterior encontram-se, por exemplo, na vigia da Parede (Figura 4), que terá sido demolida no final da década de 1930 (AHMCSC/ CMC/C-A/O29/94/14) e naquela que ainda subsiste junto à Boca do Inferno, ambas em Cascais, porém de cronologia mais tardia. A primeira surge assinalada num mapa publicado em Inglaterra em 1810 (BND/PURL21797), encontrando-se também representada no levantamento geológico da costa efetuado por Carlos Ribeiro no início da segunda metade do século XIX ${ }^{5}$ (Ribeiro, 1949, Pl. VII), enquanto para a segunda, a referência documental mais antiga data de 1805 , apesar de a sua construção poder remontar ao final do XVIII (Boiça, Barros \& Ramalho, 2001, p. 162).

Durante a primeira fase de ocupação da vigia da foz de Colares não foram identificados vestígios da existência de um piso estruturado, por exemplo, com argila, madeira ou pedra, sendo a circulação efetuada diretamente sobre a areia, a qual seria possivelmente coberta com material de origem vegetal para facilitar a passagem, que naturalmente não se preservou no registo arqueológico.

Os vestígios desta fase de utilização materializaram-se no registo arqueológico através da formação de um nível com quantidades significativas de conchas e alguma cerâmica, materiais que se encontravam misturados com a areia que constituía a superfície de circulação.

5. Na edição daquela obra, George Zbyszewski indica como datas prováveis para a realização daqueles levantamentos os anos entre 1857 e 1868 . 
O conjunto artefactual recuperado naquele contexto é constituído essencialmente por louça vermelha, destacando-se a presença de panelas, que correspondem à forma mais frequente na cerâmica de época moderna em Lisboa (Casimiro \& Valongo, 2017, p. 1836). As peças deste depósito do Alto da Vigia têm bordos com pequena aba horizontal de secção retangular (Figura 8, n..ㅇ 5,7 e 9) e trapezoidal (Figura 8, n.o.s 6 e 8), tendo sido também recolhido um fragmento de parede com uma característica asa torça. Correspondem a formas com grande longevidade, que se enquadram nas tipologias conhecidas para os séculos XVII e XVIII (Ibidem, p. 1844; Casimiro, 2019, p. 238; Fernandes \& Carvalho, 1995, pp. 235-236). Recolheu-se ainda um bordo de pasta vermelha com vestígios de fogo nas duas superfícies, correspondendo a uma grande panela ou mesmo a um fogareiro (Figura 8, no .4 ).

Entre os referidos materiais encontram-se também vários fundos planos de panelas e de contentores para líquidos, nomeadamente de cântaros (Figura 8, n.․ำ 10 14).

Sobre aquele nível de utilização formou-se um depósito com grandes quantidades de carvão, que dificilmente se justificará com a simples realização de fogueiras no local. Tais vestígios distribuem-se de forma relativamente homogénea por todo o interior do edifício, prolongando-se para o seu exterior, onde encostam nas paredes Norte e Este (Figuras 3 e 5).

As suas características são compatíveis com um episódio de incêndio, sobre o qual se formou depois o derrube do telhado que assinala o fim da primeira fase de utilização da vigia. A presença de alguma cerâmica queimada reforça a possibilidade de um abandono rápido, sem que, no entanto, se registem quaisquer outros elementos concretos que permitam a sua associação a um eventual episódio bélico relacionado com a natureza e funcionalidade do edifício.

\subsection{Reformulação da vigia no século XVIII}

A reconstrução do edifício terá ocorrido pouco tempo depois do seu colapso parcial, sendo as telhas do derrube da cobertura, acima descrita, utilizadas como base para criação de uma superfície regular sobre a qual se dispôs uma camada de argila, criando assim um piso de circulação estruturado sobre os níveis de abandono da primeira ocupação do edifício. Este pavimento encontra-se associado à introdução de uma nova estrutura apoiada ao longo de toda a extensão da parede Sul do edifício (Figura 2, UE
349), com aproximadamente $1 \mathrm{~m}$ de largura, construída com blocos de calcário de formas irregulares, não sendo clara a sua funcionalidade. Na argila usada para ligar os blocos que a constituíam, foi recuperada uma moeda de D. João V cunhada em 1734 (Figura 8, n.ํำ 15).

Entre os fragmentos de cerâmica misturados no sedimento utilizado para construir o novo piso, encontrava-se um bordo de faiança decorado com faixa barroca contendo motivos de folha de acanto (Figura 8, n.․ 18 ), datável da segunda metade do século XVII a início do seguinte (Casimiro, 2013, p. 362). Esta peça, mas sobretudo o numisma atrás referido, permitem enquadrar a primeira reformulação da vigia no segundo quartel do século XVIII em diante, cronologia que se pode prolongar por meados desta centúria se atendermos ao tempo de circulação da moeda e ao facto de a peça de faiança se encontrar já descartada quando é misturada na argila do piso.

Sabemos que para a época em causa se encontram documentados estragos noutros edifícios da região de Sintra, associados ao grande sismo de 1755, podendo ser colocada como possibilidade ser essa a causa do colapso e consequente reestruturação da vigia em meados do século XVIII.

\subsection{Reformulação do interior da vigia - fim do sé- culo XVIII/início do XIX}

Foi ainda possível documentar uma segunda intervenção de remodelação parcial da vigia que incluiu a introdução de duas novas estruturas no seu interior, feitas com recurso a pedras de calcário aparelhadas de forma muito rudimentar e sem qualquer vestígio de argamassa de ligação (Figura 2, UE 42). Os blocos vão sobrepor-se parcialmente à construção adicionada em meados do século XVIII (a UE 349, atrás descrita), mantendo-se em uso nesta fase o piso de circulação anteriormente construído.

A introdução das duas estruturas não parece corresponder à criação de um novo compartimento, já que os exíguos cerca de $50 \mathrm{~cm}$ de largura entre as duas paredes tornariam muito pouco funcional a sua utilização. Atendendo ainda à sua pouca solidez e à ausência de alicerces, podemos deduzir que as mesmas provavelmente não foram projetadas para ter grande altura, podendo, em alternativa, ser complementadas com outros materiais, como a madeira. Esta solução permitiria, por exemplo, criar uma plataforma assente na base de pedra e a escassa altura do chão, com uma área de cerca de $1 \mathrm{~m}$ de largura por 2,50 $\mathrm{m}$ 
de comprimento, que podia ser usada para armazenamento de equipamento ou mesmo o espaço para o necessário descanso dos vigias ${ }^{6}$.

Uma das pedras empregue naquelas estruturas assenta em fragmentos de uma tigela decorada com linhas concêntricas no fundo e no interior do bordo, com decoração estilizada no centro (Figura 8, n.ํㅜㄹ), datável da primeira metade do século XVIII, mas podendo alcançar os meados do século XIX (Casimiro, 2013, pp. 363-364). Considerando ainda os materiais apresentados para enquadrar cronologicamente a anterior fase de remodelação - que situamos genericamente em meados do século XVIII -, as alterações agora verificadas na vigia deverão, pois, situar-se entre o fim daquele século e o início do XIX.

Os vestígios de uso desta última fase de ocupação correspondem a um depósito com algumas conchas associadas a sedimentos com carvão, sem que tenha sido registada qualquer lareira estruturada. $\mathrm{O}$ conjunto artefactual ali recuperado é constituído por louça de cozinha não vidrada, reconhecendo-se uma panela de fabrico e perfil semelhante às peças da fase anterior, com bordo de seção retangular formando uma pequena aba (Figura 8, n. ${ }^{\circ}$ 17). Uma segunda panela tem o bordo de secção triangular e a sua pasta encontra-se bem depurada, distinguindo-se nesse aspeto do fabrico das demais peças com análogas funcões recolhidas no sítio. A superfície interna é de cor creme e a exterior apresenta tons de vermelho (Figura 8, n.ำ16).

A cobertura do edifício vai colapsar sobre os contextos acima descritos, formando um depósito com fragmentos de telha misturados com alguma argamassa do reboco das paredes, para além de vários pregos de ferro, possivelmente relacionados com o colapso das estruturas de madeira do telhado.

Posteriormente, sobre o derrube acima descrito irão acumular-se ainda ténues vestígios da frequentação do espaço - essencialmente conchas associadas a pequenas fogueiras - numa altura em que o edifício se encontraria já em estado parcial de ruína e sem telhado, mas possivelmente com algumas paredes erguidas, proporcionando ainda algum abrigo a uti-

6. Note-se que de acordo com o estipulado no «Regimento dos capitães-mores», de 1570, (Systema ou Collecção de Regimentos Reais, 1789, pp. 183-194) deverão estar de serviço nas vigias duas pessoas durante o dia e três durante a noite "os quaes velarão aos quartos» (Ibidem, p. 193), pressupondo-se a alternância entre períodos de vigia e de descanso. lizações mais esporádicas, provavelmente já não relacionadas com a função de vigilância.

Finalmente, é bem provável que a partir da segunda metade do século XIX em diante as paredes caiam sobre os últimos vestígios de utilização do espaço, dando origem a um contexto que se encontra muito perturbado por se encontrar muito próximo da superfície, no qual se misturam materiais de distintas cronologias.

\section{O ALTO DA VIGIA E A VIGILÂNCIA E DEFESA DA COSTA}

A vigilância da atual costa portuguesa foi uma necessidade sentida ao longo de diferentes épocas, remontando pelo menos ao período islâmico, por altura das primeiras incursões normandas de que há registo, no século IX (Pires, 2012, p. 243; Fernandes, 2005; Catarino, 2004, p. 267). O problema mantém-se nos séculos seguintes com os constantes ataques de piratas e corsários, responsáveis por inúmeros assaltos às povoações costeiras e embarcações visando a captura de bens e cativos, pelos quais se exigia resgaste (Alberto, 2010, p. 6).

$\mathrm{O}$ controlo da navegação junto à costa era feito a partir de pontos de observação estratégicos que podiam dispor de estruturas de apoio muito diversas, desde torres com vários metros de altura, como se verificou, por exemplo, no Algarve (Silva, 1998), até simples abrigos (Alarcão \& Barroca, 2012, pp. 4849). Tais locais constituíam «auxiliares de primeira importância (...) servindo de guardas avançadas no controlo e aviso dos movimentos de barcos inimigos, em operações de saque ou desembarque» (Boiça, Barros \& Ramalho, 2001, p. 162).

Importa salientar que, não obstante se registarem investimentos distintos na construção de estruturas de apoio à vigilância costeira, os locais de observação deverão manter-se os mesmos ao longo do tempo, por força da sua localização estratégica, uma vez que é precisamente essa característica geográfica que permite que os mesmos sítios integrem um sistema de transmissão de mensagens.

Da leitura do já referido "Regimento dos capitães-mores", de 1570, depreende-se que vigia designa, antes de mais, o local e as pessoas encarregues da vigilância, não estando a palavra associada a um tipo específico de construção. Por conseguinte, os vestígios materiais que subsistem daquela atividade são também necessariamente diversos, por vezes apenas 
detetáveis através da análise de documentação antiga, não sendo raros os casos em que apenas topónimos como Vigia, Atalaia, Vela, Facho, Azóia ${ }^{7}$, entre outros, testemunham a existência de sítios com esta função no passado (Alarcão \& Barroca, 2012, pp. 4849; figura 1).

Os vestígios identificados na foz do rio de Colares estavam integrados numa rede alargada de comunicações - através da qual se procurava acautelar a defesa do território e que funcionou pelo menos desde época islâmica - da qual faziam parte um conjunto diversificado de estruturas, desde simples locais de vigia a construções militares. As unidades deste sistema mais amplo não se encontravam sempre com o mesmo nível de alerta, que era acionado em épocas de maior perigo, verificando-se frequentemente que durante os períodos mais calmos a manutenção de alguns equipamentos era descurada (Boiça, Barros \& Ramalho, 2001, p. 16).

Na região a Norte da foz do Tejo podemos antever a existência deste sistema de comunicação, que certamente alcançaria Lisboa, através de um alvará régio de 1589, no qual se refere a necessidade do responsável por controlar as vigias entre Colares e Torres Vedras de manter "comonicasão e boa correspondencia no que toqa as ditas vigias» com a pessoa que exerce funções análogas na área imediatamente a Sul, em Cascais (AHMCSC/SCMC/A-A/oo2/o14/fl.1).

Apesar de a partir de alguns pontos de Sintra - como do seu castelo implantado na crista da serra - se alcançarem visualmente áreas tão amplas como a margem esquerda do Tejo, pelo facto de esta região estar "permanentemente mergulhada numa bruma que se não dissipa» (Coelho, 1989, p. 63) os sistemas de comunicação visual a longas distâncias podiam ser comprometidos, sendo então necessário um sistema de maior proximidade entre os distintos pontos de observação, constituídos essencialmente por vigias, que garantissem a eficaz passagem dos necessários sinais (Borges, 2017a, p. 36).

A comunicação entre os diferentes sítios integrados no mesmo sistema de vigilância seria feita através de

7. Na área da Azóia, a par do topónimo Atalaia, registam-se ainda junto ao farol do Cabo da Roca os microtopónimos Cruzeiro do Facho e Vigia da Roca. A Sul daquela zona, no Espigão das Ruivas, já no litoral de Cascais, os vestígios da Idade do Ferro, das épocas romana e islâmica estarão provavelmente relacionados com esta atividade naquele local (Encarnação \& Cardoso, 2017). "fumos», "fachos" (conforme Regimento de 1570) e rebate de sino, como se depreende de um decreto de 1646 que determina que os vigias em serviço na "Cabeça de Oitavos" (próximo do forte de São Jorge de Oitavos, em Cascais) deviam tocar a "rebate na hora de que se descobrirem de dez velas para cima", sendo nessas situações competência da Vila de Cascais e seu termo organizar e garantir a defesa. $\mathrm{Na}$ eventualidade de o número de velas ser superior a 20 deverão responder a um sinal diferente as companhias de Sintra e Colares. O referido sítio funcionou ainda em 1796 como local de retransmissão de mensagens vindas do Cabo da Roca por meio de bandeiras, destinadas a avisar quando fossem avistados "navios de mais de três mastros e esquadras de guerra» (Calixto, 1980, p. 151).

O conjunto de balas de chumbo para arcabuz recolhidas no Alto da Vigia (Figura 8, n.․19), atesta a presença daquelas armas de fogo para dissuadir eventuais desembarques, mas também possivelmente para dar o sinal de alerta perante alguma ameaça, conforme o disposto no referido Regimento de 1570. A análise de documentação antiga, complementada com prospeções arqueológicas, permitiu identificar vários locais de vigia na costa a Norte da foz do rio de Colares (Figura 1). No já citado trabalho de Carlos Ribeiro encontram-se registados os sugestivos topónimos de Alto da Vela e Ponta da Vigia, a Sul da foz da ribeira de Maceira, na Lourinhã (1949, Pl. I), certamente testemunhos de um passado ligado à vigilância costeira.

Já no atual concelho de Mafra, na descrição da povoação da Carvoeira numa obra do século XVIII, é referido que aquele local «tem tambem o privilegio para se não fazer nella Soldados, pela sentinela, que fazem os moradores em hum facho, que tem esta na foz do rio, pelo perigo de poderem alli desembarcar Mouros. Passa por esta Freguesia hum rio, chamado Rio grande do Porto" (Cardoso, 1751, p. 498).

Saliente-se que na foz do "Rio grande do Porto" (nome pelo qual o rio Lizandro era por vezes referido), à semelhança do verificado no rio de Colares, se formaria um pequeno braço de mar (Daveau, 1994, p. 25) que permitiria que a parte final daquele curso de água fosse navegável no passado (Cardim Ribeiro, 1983, p. 165) e onde foi também necessário instalar um ponto de vigia. A sua localização, porém, permanece incerta, correspondendo talvez ao outeiro onde se ergueu no início do século XIX um dos fortes das linhas de Torres. 
Seguindo para Sul, uma elevação na margem esquerda da foz da ribeira do Falcão regista atualmente o topónimo Vigia da Assafora, ainda que no local não sejam atualmente visíveis qualquer tipo de vestígios materiais.

Num mapa editado em Viena [1791] (UC/BGD/ NC-321) encontra-se referenciada a Atalaia do Magoito, que corresponderá provavelmente àquela que surge mais tarde identificada como "Vigia da Matta" numa colina junto à praia do Magoito. No local são visíveis as ruínas de um edifício de planta retangular, com cerca de $3 \mathrm{~m}$ de largura por $4 \mathrm{~m}$ de comprimento e paredes de o,65 $\mathrm{m}$ de espessura rebocadas no paramento exterior, que correspondem provavelmente aos vestígios daquela vigia. Conservam-se ainda aproximadamente $2 \mathrm{~m}$ de altura de parede no canto Sudoeste da estrutura, no topo da qual foi instalado um marco geodésico em 1945 (Figura 6).

\subsection{A foz do rio de Colares durante a época me-} dieval - Entre mouros e cristãos

O Alto da Vigia, pela sua localização estratégica, parece ter adquirido, desde cedo, relevância particular em contextos históricos pautados por uma franca instabilidade política e militar, como sucederia durante a época islâmica, quando no local são erigidas estruturas compatíveis com um ribat - sítios onde se conjuga a função religiosa com o controlo de pontos estratégicos para a defesa do território.

As evidências materiais ali recuperadas até ao momento atestam uma ocupação islâmica enquadrável nos séculos XI e XII, não dissociável da pressão cristã exercida a partir de Coimbra e da conquista da região de Sintra e Lisboa, em 1147. Embora não seja possível, com os dados atuais, determinar a cronologia do início da ocupação, é provável que seja anterior aos vestígios remanescentes se tivermos em conta as referências às investidas normandas na costa atlântica pelo menos desde o século IX (Fernandes, 2005; Pires, 2012, p. 243).

A espessa duna acumulada sobre os níveis de derrube dos dois edifícios islâmicos já escavados neste sítio arqueológico, sugere que os mesmos são abandonados e assim permaneceram até ao início do século XVI, quando a vigia é ali construída. Tal não significa, no entanto, que outras construções ainda não escavadas - mas cujos vestígios afloram à superfície e que a prospeção geofísica realizada deixa também antever - possam ter sido parcialmente adaptadas e usadas da segunda metade do século XII em diante como local de abrigo para os vigias que cumpriam a sua função neste lugar.

Note-se que no ribat da Arrifana, junto a Aljezur, igualmente implantado num sítio estratégico do litoral, se regista já em época cristã a utilização de uma mesquita como local de habitação. Aquela ocupação estará relacionada com a utilização do minarete como torre de vigia (Gomes \& Gomes, 2006, p. 336), que se mantém em uso até ao século XVIII (Idem, 2019, p.334).

A propósito das antigas ocupações da foz do rio de Colares, há ainda a destacar que na margem direita daquele curso de água, no subsolo da atual povoação da Praia das Maçãs, foram identificados vestígios de uma necrópole (Azevedo, 1907, pp. 100-101) possivelmente relacionada com um templo cristão, bem como evidências de habitações associadas a materiais datáveis dos séculos XIII e XIV, contextos compatíveis com a povoação de Mazanaria, referida num documento de 1220 (Costa, 1980, p. 62). $\mathrm{O}$ posterior abandono deste local junto à costa não será certamente alheio à insegurança verificada no litoral durante a Idade Média, problema que terá certamente contribuído, apesar das iniciativas régias tomadas no sentido de o minimizar, para o afastamento do povoamento das áreas costeiras (Andrade, 2005, p. 65), devendo ser ainda consideradas as dificuldades naturais decorrentes de viver na proximidade do mar (Marques, 1989, p. 10).

\subsection{A vigia de Colares - Da expansão marítima à guerra Liberal}

Com a expansão marítima portuguesa do século $\mathrm{XV}$ em diante verificou-se o incremento das ações de corso e pirataria, sendo tomadas iniciativas para debelar essa ameaça constante, entre as quais destacamos neste trabalho o "Regimento dos capitães-mores» de 1570, no qual se procura regulamentar e uniformizar a atividade das vigias, que já era praticada nas zonas costeiras (Feio, 2013, p. 59).

No citado documento é definido o funcionamento das vigias, determinando-se que as áreas costeiras "para que naõ recebaõ damno algum das continuas armadas dos cossarios (...) em todos os ditos lugares, portos de mar, haja vigias todo o veraõ, e em qualquer outro tempo de bonança, com que imigos possaõ desembarcar, ou fazer outros damnos (...). Os moradores de cada hum dos ditos lugares, portos de mar, seraõ obrigados a vigiar de dia nas pontas que mais descobrirem ao mar, e de noite nos por- 
tos, calhetas, praias, ou pedras em que parecer que os ditos inimigos poderaõ desembarcar» (Systema ou Collecção de Regimentos Reais, 1789, p. 192).

Atendendo às especificidades geográficas de cada região e reconhecendo que "he necessario saber-se os lugares mais convenientes, e em que melhor, e mais seguramente se poderaõ pôr as ditas vigias" ordena-se que as pessoas designadas para o efeito «vaõ (...) á Camara da Cidade, Villa, ou Lugar de que for Capitaõ, e faça juntar nella os Juizes, Officiaes, e Pessoas do Regimento, e as mais pessoas moradores na dita Villa, que lhe parecer necessario, e com elles repartirá onde se devem pôr as ditas vigias, assim de dia como de noite», devendo as localizações definidas ter "assento no livro da Camera» (Ibidem).

A necessidade de vigilância da costa acentua-se durante as décadas de domínio castelhano dos territórios portugueses (1580-1640), uma vez o reino se vê envolvido nos conflitos da coroa espanhola com outros países europeus, estando documentados inúmeros relatos de ataques de navios ingleses, franceses e holandeses ao nosso litoral (Silva, 1985: 311 ). É neste contexto, através de um alvará régio de 1589 , que António de Mello de Castro ${ }^{8}$ é encarregue da «superintendencia da gente que a na villa de Collares e seu termo e no termo da villa de Cintra e nas villas e termos de mafara iriçeira (...) athe o termo da villa de Torres Vedras (...) para fazer vigiar de dia e de noite com fachos (...) tendo Com a pesoa a cujo cargo esta a jente de Casqaes e com dom martinho soares toda a comonicasão e boa correspondencia no que toqa as ditas vigias» (AHMCSC/SCMC/A-A/002/014/fl.1).

Através de uma adenda feita a este documento por "manoell dias de payva sprivão da camara» da "vyla de collares e seu termo", ficamos a saber que "amtonio alluarez caualleyro fidallgo" "foj emlleyto pera capitam della e das vegias da costa desta vylla» (Ibidem, fl. 1v.).

Como se viu atrás, o registo arqueológico atesta que a vigia da foz de Colares se encontrava ocupada nos séculos XVII e XVIII, período durante o qual o edifício sofre uma destruição e é de novo rapidamente reconstruído. Apesar de recolhidos fora do seu contexto arqueológico original, a presença de um prato decorado com faixa barroca contendo motivos de

8. Possivelmente da importante família que no início do século XVII adquiriu o edifício do antigo castelo de Colares para ali construir um palácio. folha de acanto (Figura 8, n.․․ 21) e alguns fragmentos de faiança com decorações vegetalistas, materiais datáveis dos XVII e XVIII, reforçam a ideia da ocupação do sítio durante estas centúrias.

Mais tarde, já no contexto dos acontecimentos em curso no centro da Europa, decorrentes da revolução francesa, é realizado em 1796 um levantamento das fortificações costeiras, a fim de averiguar a sua operacionalidade e o perigo de desembarque, concluindo-se que a Praia das Maçãs «está sem defença e não admite dezembarque por causa do mar arrebentar de longe sobre bancos de arêa móvilı. No entanto, cerca de $1 \mathrm{~km}$ a Sul, a Praia Grande de Colares «está sem defença, e em toda ella se pode dezembarcar pois atualmente se fazem nella pescarias de batéis e redes de arrastar». Saliente-se, ainda, que no desenho que acompanha o documento, com a configuração da Praia das Maçãs, encontra-se representado um edifício no local correspondente à localização da vigia (BDR/DIE/8129-3-43).

Apesar do que é enunciado no documento acima referido sobre a dificuldade de desembarque na Praia das Maçãs, através de um requerimento apresentado em 1822 por um candidato ao emprego de vigia na dita praia, ficamos a saber que esse perigo era real, dada a "facelidade do desembarque que os Francezes no tempo em que occuparão o Reyno tanto Reconhecerão que sempre tiverão naquelle citio huma força Armada consideravel» (ANTT, Min. Reino, Mç. 759, Proc. 32, fl. 6).

Cerca de uma década volvida sobre o sobressalto provocado pelas invasões francesas, sabemos que em 1819 João Anastácio fora nomeado para o «Emprego de vigia da Praia das Maçans, para denunpciar qualquer desembarque que possa ali acontecer». Tal decisão decorre do facto de ali ter "havido e podem haver faceis dezembarques (...) precizando haver naquelle Lugar ou a elle muito proximo uma Pessoa capaz (...) para vigia da ditta Praia a fim de cuidar que a ela não se approxime vazo algum que se suspeite vir ou ter pasado por Pais infecionado de Peste ou da mesma suspeito" (Ibidem, fls. 1 e 11).

No verão de 1831, no contexto que antecede a guerra civil, o governo absolutista de D. Miguel determinou a realização de um levantamento das condições de defesa da costa, no qual se reconhece o perigo de desembarque de tropas na área compreendida entre a Praia das Maçãs e numa extensão de cerca de 2,5 km para Sul, até à Pedra de Alvidrar, propondo-se, em 
conformidade, a construção de várias baterias naquela zona, uma delas na foz de Colares.

No projeto que resulta do levantamento então feito, indica-se que a bateria da Praia das Maçãs não deverá ser construída com alvenaria permanente, propondo-se que o seu "parapeito fique formado de terras virgens revestido de lajes», por ser mais económica a sua reconstrução em caso de eventual derrocada provocada pela erosão costeira, decorrente das especificidades da geologia do local. Porém, no parecer posteriormente elaborado sobre este projeto, refere-se que tal estrutura «ainda que seja própria para bater os navios e lanchas do inimigo, não o parece para o bater na praia ou no desembarque (...) pelo que não julga satisfeito o quesito de defender o desembarquel, concluindo-se que a eficaz defesa da Praia das Maçãs teria de ser feita noutro local que não o indicado pelo referido projeto (AHM/Div.3/9/D1/36). Desconhece-se se tal bateria terá sido edificada. Atendendo a que nem no local proposto, nem em toda a área a Sul até à Pedra de Alvidrar se identificaram até ao momento quaisquer tipos de estruturas militares, devemos admitir que o projeto ficou por executar. Note-se que poucos meses depois da apreciação final daqueles planos de defesa da costa, datados do outono de 1831, as forças liberais desembarcaram no Mindelo.

$\mathrm{Na}$ já referida representação da costa traçada por Carlos Ribeiro no início da segunda metade do século XIX, verificamos que no pequeno outeiro da margem esquerda do rio de Colares se encontra figurado um edifício de telhado de duas águas designado de "Vigia de Collares» (Ribeiro, 1949, Pl. V; figura 7), atestando que a mesma se encontraria ainda erguida naquela época, cerca de três décadas passadas sobre os últimos acontecimentos para os quais encontrámos referências documentais sobre o sítio. A vigia da Praia das Maçãs terá entrado progressivamente em declínio a partir de meados do século XIX, à semelhança de outras estruturas relacionadas com a vigilância e a defesa da costa (Boiça, Barros \& Ramalho, 2001, p. 23).

Materiais recolhidos à superfície junto à vigia, como garrafas de grés ou um bordo de prato com decoração vegetalista estampada, provavelmente com o motivo "estátua", atestam, contudo, que o local foi frequentado durante a segunda metade do século XIX e início do século XX.

Num postal que se encontrava em circulação em 1912, é visível a vigia já arruinada com as paredes re- duzidas a cerca de um metro de altura (Gaspar, 2010, p.125), tendo estas sido posteriormente desmanteladas e as suas pedras reaproveitadas, à semelhança do que sucedera no passado, para novas construções, possivelmente, desta vez, para erguer muros de delimitação de terrenos.

De acordo com o que foi exposto ao longo deste texto, constata-se que no Alto da Vigia, na foz do rio de Colares, foi construído no início do século XVI um edifício de vigia ${ }^{9}$ sobre as ruínas de uma mesquita que integra o ribat existente neste local. A esta vigia primitiva que se arruinaria, sucederia uma outra, erguida ainda no decurso do século XVII ou já na centúria seguinte, situação que documenta a sua importância na rede de vigilância da linha de costa próxima a Lisboa, que se prolongaria até Oitocentos.

\section{AGRADECIMENTOS}

Ao Vítor Serrão e a Rita Sampaio da Nóvoa pela ajuda na transcrição do alvará régio; a Tânia Casimiro pela colaboração na classificação do espólio; ao Joaquim Boiça pelas sugestões a este trabalho; a Ana Neves pelo desenho dos materiais; ao Joel Marteleira pelo mapa e planta e à equipa de escavação do Alto da Vigia, na qual os estudantes e os voluntários têm tido um papel importante.

\section{FONTES HISTÓRICAS}

Arquivo Histórico Militar/Divisão 3/9/D1/36.

Arquivo Histórico Municipal de Cascais/Câmara Municipal de Cascais/C-A/O29/94/14.

Arquivo Histórico Municipal de Cascais/Coleção Antiga do Município/B/oo4/179.

Arquivo Histórico Municipal de Cascais/Santa Casa da Misericórdia de Cascais/A-A/oo2/14/2 fls.

Arquivo Nacional Torre do Tombo, Ministério do Reino, Maço 759, Proc. 32, 16 fls..

Biblioteca Nacional Digital, PURL21797.

Biblioteca Digital do Exército, Direção de Infraestruturas do Exército, 8129-3-43.

Universidade de Coimbra, Biblioteca Geral Digital, Nabais Conde-321.

9. Apesar de ter sido proposta uma cronologia mais antiga para a vigia da Foz de Colares (Borges, 2017b, pp. 252-253), os dados arqueológicos indicam que tal terá ocorrido apenas no início do século XVI. 


\section{BIBLIOGRAFIA}

ALARCÃO, Jorge; BARROCA, Mário, coord. (2012) - Dicionário de Arqueologia Portuguesa. Porto: Figueirinhas.

ALBERTO, Edite Maria da Conceição Martins (2010) - Um Negócio Piedoso: o Resgate de Cativos em Portugal na Época Moderna. Dissertação de doutoramento apresentada à Universidade do Minho. Braga.

ANDRADE, Amélia Aguiar (2005) - A estratégia régia em relação aos portos marítimos do Portugal medieval: o caso da fachada atlântica. In ARÍZAGA BOLUMBURU, Beatriz e SOLÓRZANO TELECHEA, Jesus A. eds. - Ciudades y villas portuarias del Atlântico en La Edad Media, Nájera. Encuentros Internacionales del Medievo - atas. Logroño: Gobierno de La Rioja, Instituto de Estudios Riojanos, pp. 57-89.

AZEVEDO, Pedro (1907) - Miscellanea: I - Notícias várias. Archeologo Português, Série I. XII, pp. 92-103.

BOIÇA, Joaquim Manuel F.; BARROS, Maria de Fátima R.; RAMALHO, Margarida de Magalhães (2001) - As Fortificações Marítimas da Costa de Cascais. Lisboa: Quetzal Editores.

BORGES, Marco (2017a) - A importância estratégica do conhecimento do território na formação de um sistema defensivo: o caso de Sintra (Portugal) durante o Período Islâmico. Anuario de Historia Regional y de las Fronteras. Bucamaranga, Vol. 22, no. 2 pp. 17-48.

BORGES, Marco (2017b) - Paisagem cultural marítima de Sintra: uma abordagem histórico-arqueológica. In FIDALGO, Pedro, coord., Estudos de paisagem. Lisboa: Instituto de História Contemporânea da FCSH-UNL, Vol. III, pp. 230-27.

CAETANO, Maria Teresa (200o) - Colares. Mem Martins: Câmara Municipal de Sintra.

CALliXTO, Carlos Pereira (1980) - Fortificações da Praça de Cascais a Ocidente da Vila. Separata da Revista Militar. Lisboa: Gráfica da Liga dos Combatentes.

CARDIM RIBEIRO, JOSÉ (1982-83) - Estudos historico-epigraficos em torno da figura de L. Iulius Maelo Caudicus. Sintria, 1-2, pp. 151-476.

CARDIM RIBEIRO, José (2016) - Ad antiquitates vestigandas. Destinos e itinerários antiquaristas nos campos olisiponenses ocidentais desde inícios a meados do século XVI. In González Germain, G., ed. - Peregrinationes ad inscriptiones colligendas. Estudios sobre epigrafía de tradición manuscrita. Actas do Seminário - Colóquio Saxosas vias terere. Hollando los Caminos de la Geografia Antigua (150o-170o). Barcelona, 2015. Barcelona: Universidat Autònoma, pp. 135-249.

CARDIM RIBEIRO, José (2019) - Escrever sobre a margem do Oceanus: epigrafia e religio no santuário do Sol poente (provincia Lusitania). Barcelona: (Sylloge Epigraphica Barcinonensis, Annexos 3).

CARDOSO, Guilherme; ENCARNAÇÃo, José (1990) Uma sondagem de emergência no casal do Geraldo (Estoril-Cascais). Arquivo de Cascais: Boletim cultural do município. Câmara Municipal de Cascais, 9, pp. 45-62.
CARDOSO, Guilherme; RODRIGUES, Severino (1991) Alguns tipos de cerâmica dos séculos XI a XVI encontrados em Cascais. In SILVA, Luís Alves da; MATEUS, Rui, eds. - A Cerâmica Medieval no Mediterrâneo Ocidental: atas do IV Congresso Internacional. Mértola: Campo Arqueológico de Mértola, pp. 575-585.

CARDOSO, Guilherme; RODRIGUES, Severino (1999) Tipologia e cronologia das cerâmicas dos séculos XVI, XVII e XIX encontradas em Cascais. Arqueologia Medieval. Porto: Afrontamento, 6, pp. 193-212.

CARDOSO, Padre Luís (1747-1751) - Diccionario geografico, ou noticia historica de todas as cidades, villas, lugares, e aldeas, rios, ribeiras, e serras dos Reynos de Portugal, e Algarve, com todas as cousas raras, que nelles se encontraõ, assim antigas, como modernas. Lisboa: na Regia Officina Sylviana e da Academia Real, 2 Vols.

CASIMIRO, Tânia Manuel (2013) - Faiança portuguesa: datação e evolução crono-estilística. Revista Portuguesa de Arqueologia. Lisboa. Vol.16, pp. 351-367.

CASIMIRO, Tânia (2019) - Materialidades quotidianas de Idade Moderna em Alhandra. Os contextos arqueológicos da escavação do Centro de Saúde. Cira-Arqueologia. Câmara Municipal de Vila Franca de Xira, 7.

CASIMIRO, Tânia; VALONGO, António (2017) - Uma lixeira nas Casas Nobres do Infantado. In Arqueologia em Portugal: 2017 Estado da Questão. Lisboa: Associação dos Arqueólogos Portugueses, pp. 1835-1848.

CATARINO, Helena (2004) - Breve sinopse sobre topónimos Arrábida na costa portuguesa. In FRANCO SÁNCHEZ, Francisco; EPLALZA, Míkel, eds., - La Rábita en el Islam. Estudios Interdisciplinares. Congressos Internacionals de Sant Carles de la Ràpita (1989, 1997). Sant Carles de la Ràpita/ Alacant: Ajuntament de Sant Carles de la Ràpita/Universitat d'Alacant, pp. 263-274.

COELHO, António Borges (1989) - Portugal na Espanha Árabe. Lisboa: Caminho, 2. ․ㅡ ed., vol. I.

COSTA, Francisco (1980) - O Paço Real de Sintra: Novos Subsídios para a sua História. Sintra: Câmara Municipal.

DAVEAU, Suzanne (1994) - A foz do Tejo, palco da história de Lisboa. In Lisboa Subterrânea. Lisboa: Museu Nacional de Arqueologia.

ENCARNAÇÃO, José d'e CARDOSO, Guilherme (2017) - O sítio arqueológico do Espigão das Ruivas (Cascais). Arqueologia em Portugal. 2017 - Actas do II Congresso de Arqueologia da Associação dos Arqueólogos Portugueses, realizado, em Lisboa, de 22 a 25 de Novembro de 2017. ARNAUD, José Morais e MARTINS, Andrea (Coord.).

FEIO, Gonçalo Couceiro (2013) - O ensino e a aprendizagem militares em Portugal e no Império, de D. João III a D. Sebastião: a arte portuguesa da guerra. Dissertação de doutoramento apresentada à Faculdade de Letras de Lisboa. Lisboa. Edição policopiada. 
FERNANDES, Isabel Cristina (2005) - Aspectos da litoralidade do Gharb al-Andalus. Os portos do baixo Tejo e do baixo Sado. Arqueologia Medieval. Porto: Afrontamento, 9, pp. 47-6o.

FERNANDES, Isabel Cristina; CARVALHO, Rafael António (1995) - Conjuntos Cerâmicos Pós-Medievais de Pal-

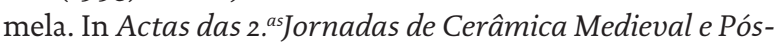
-medieval. Tondela, pp. 211-255.

GASPAR, Miguel; GASPAR, Nuno (2010) - Um Passeio de Cintra até ao Mar. Postais e Fotografias do Passado. [Lisboa]: Artlandia.

GOMES, Rosa V. \& Gomes, Mário V. (2006) - O Ribat da Arrifana (Aljezur, Algarve): Resultados das escavações arqueológicas no Sector 3 (2003/2004). Revista Portuguesa de Arqueologia. 9.2. Lisboa, pp. 329-352.

Idem (2019) - A necrópole do ribat da arrifana (Aljezur, Portugal). In Al-kitab. Juan Zozaya Stabel-Hansen. Madrid: Carmelo Fernández Ibáñez (ed.), pp. 343-352.

MARQUES, António Henrique de Oliveira (1989) - Carta da Vila de Cascais 1334: estudo e transcrição. Cascais: Câmara Municipal.

PIRES, Hélio (2012) - Incursões nórdicas no Ocidente Ibérico (844-1147): fontes, história e vestígios. Dissertação de doutoramento apresentada à Universidade Nova de Lisboa.

OLLANDA, Francisco d' (1571) - Da Fabrica que falece ha Cidade de Lysboa. [Lisboa, Biblioteca Nacional da Ajuda, códice 51/III/9.]

RIBEIRO, Carlos (1949) - Vues de la côte portugaise entre l'estuaire de la rivière de Maceira et Pedra do Frade a l'ouest de Cezimbra. Compil. e texto Georges Zbyszewski. Lisboa: Serviços Geológicos de Portugal.

SECCO, Fernando Alvares (156o) - Portugalliae quae olim Lusitania novissima \& exactissima descriptio. Roma. [s.n.].

SILVA, Celeste Nogueira (1998) - As torres de vigia do antigo Concelho de Faro. Anais do Município de Faro. Câmara Municipal de Faro, Vols. 27-28, pp. 117-140.

SILVA, Francisco Ribeiro da (1985) - O corso inglês e as populações do litoral lusitano (1580-1640). In Colóquio «Santos Graça» de etnografia marítima. Actas III. Povoamento. Administração. Aspectos sociais. Câmara Municipal da Póvoa de Varzim, pp. 311-339.

Systema ou Colleção de Regimentos Reais. Contèm os Regimentos Pertencentes a`Fazenda Real, Justiças e Militares (1789). Lisboa: Na Officina Patriacal de Francisco Luiz Ameno, Tomo V. 


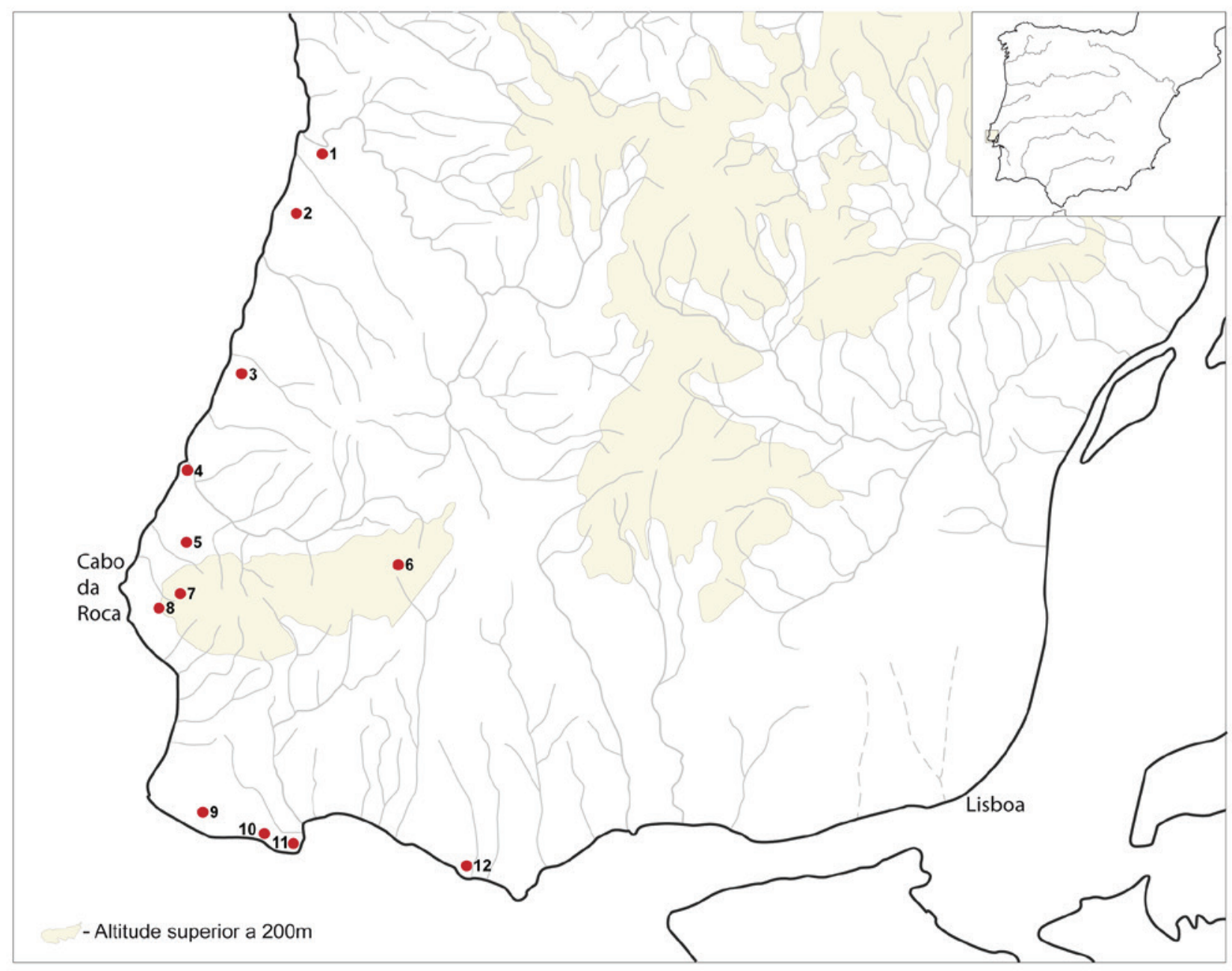

Figura 1 - Localização dos principais sítios referidos no texto: 1: Foz do Lizandro; 2: Vigia da Assafora; 3: Vigia da Mata/ Magoito; 4: Alto da Vigia; 5: Colares; 6: Sintra; 7: Atalaia; 8 Azóia; 9: Cabeça de Oitavos; 8: Vigia da Boca do Inferno; 10: Cascais; 11: Parede. Autor: Joel Marteleira. 


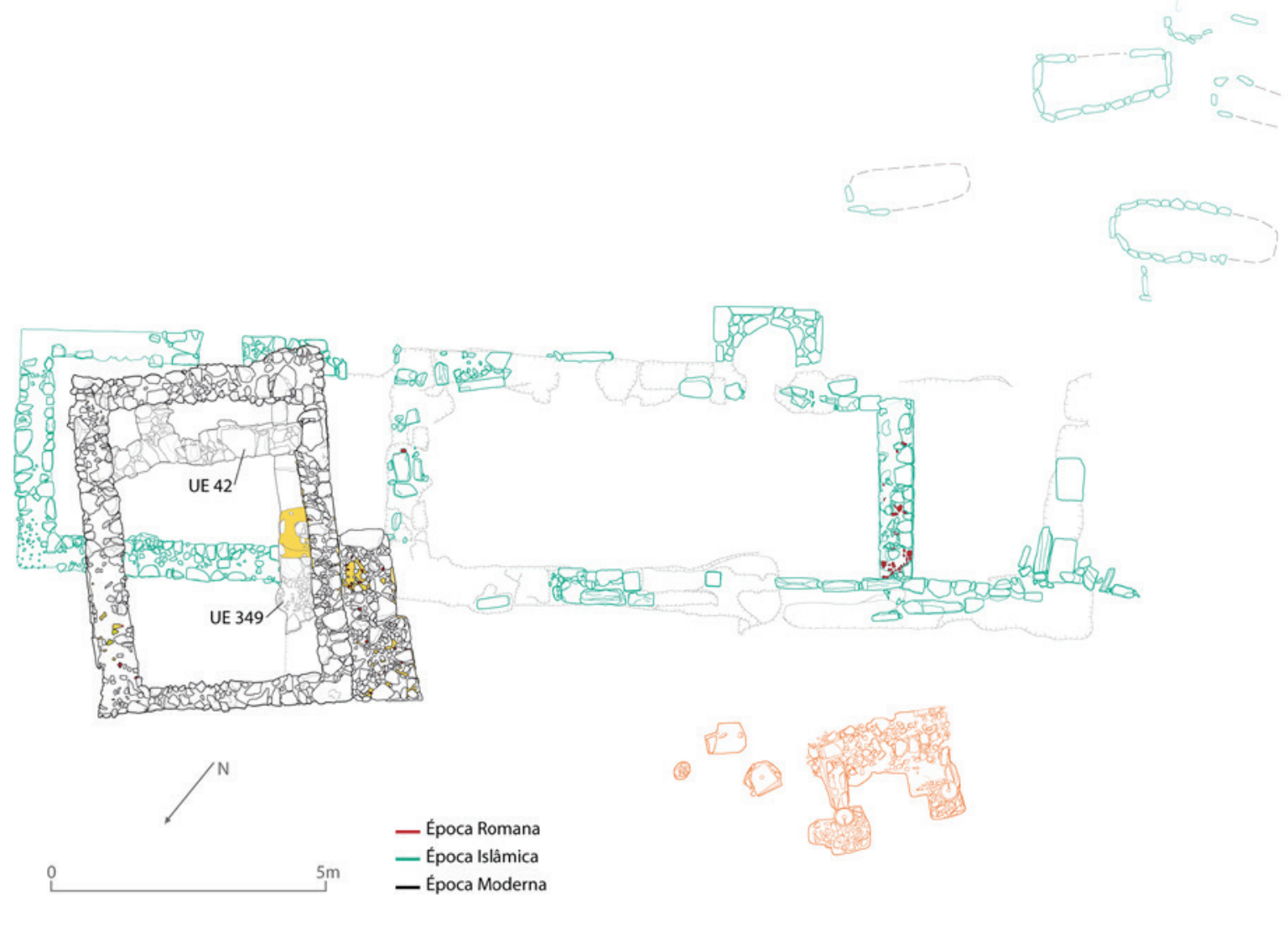

Figura 2- Planta com os principais vestígios identificados no sítio arqueológico do Alto da Vigia. Autor: Joel Marteleira.

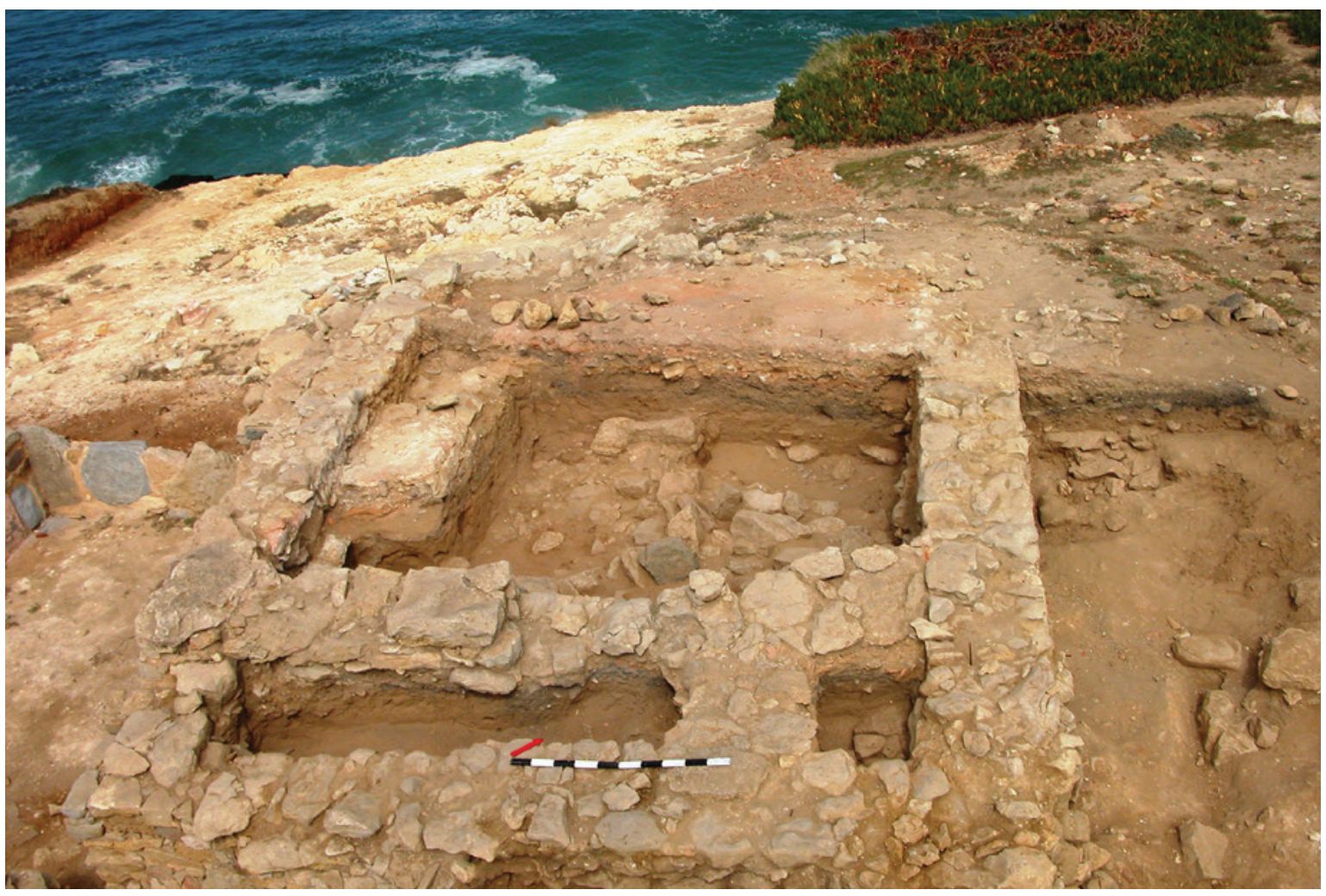

Figura 3 - Aspeto da vigia da Foz de Colares durante os trabalhos. O corte na área de escavação ilustra a sequência estratigráfica daquele edifício. 


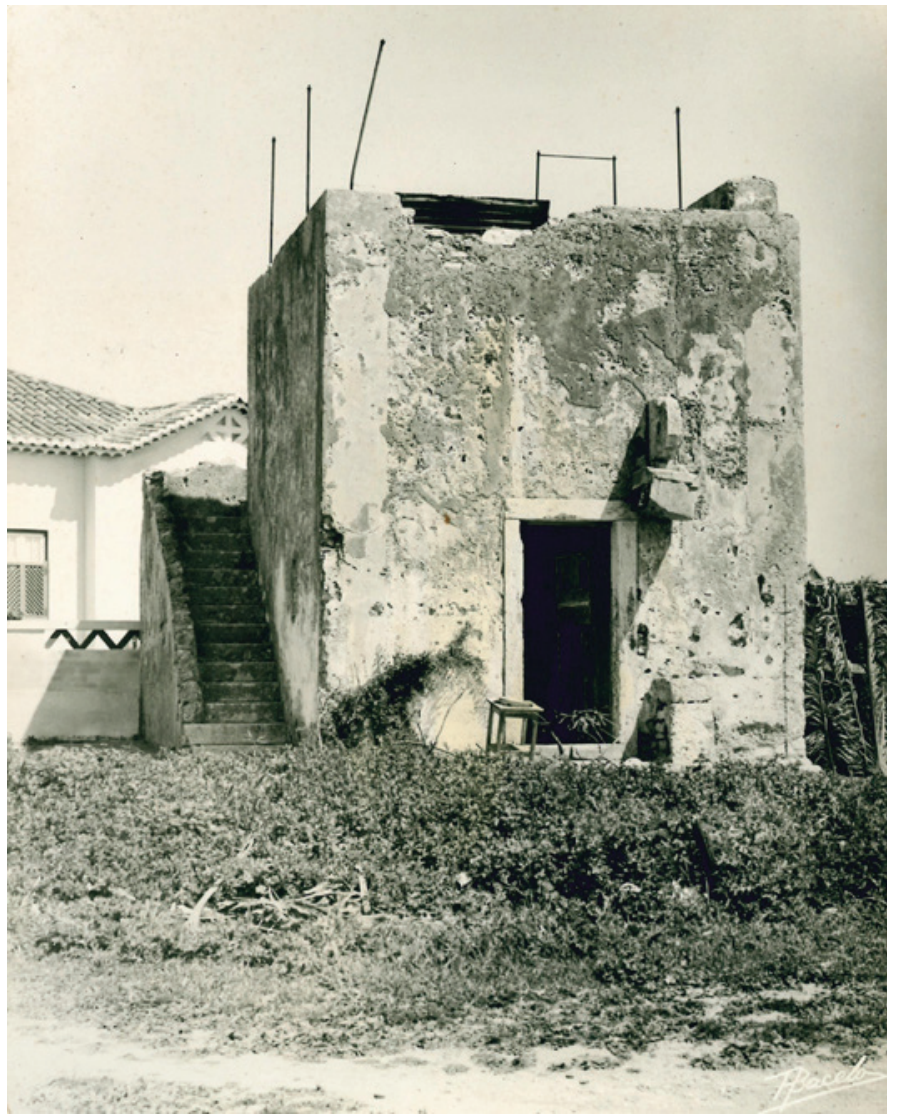

Figura 4 - Fachada Sul da vigia da Parede, em Cascais.

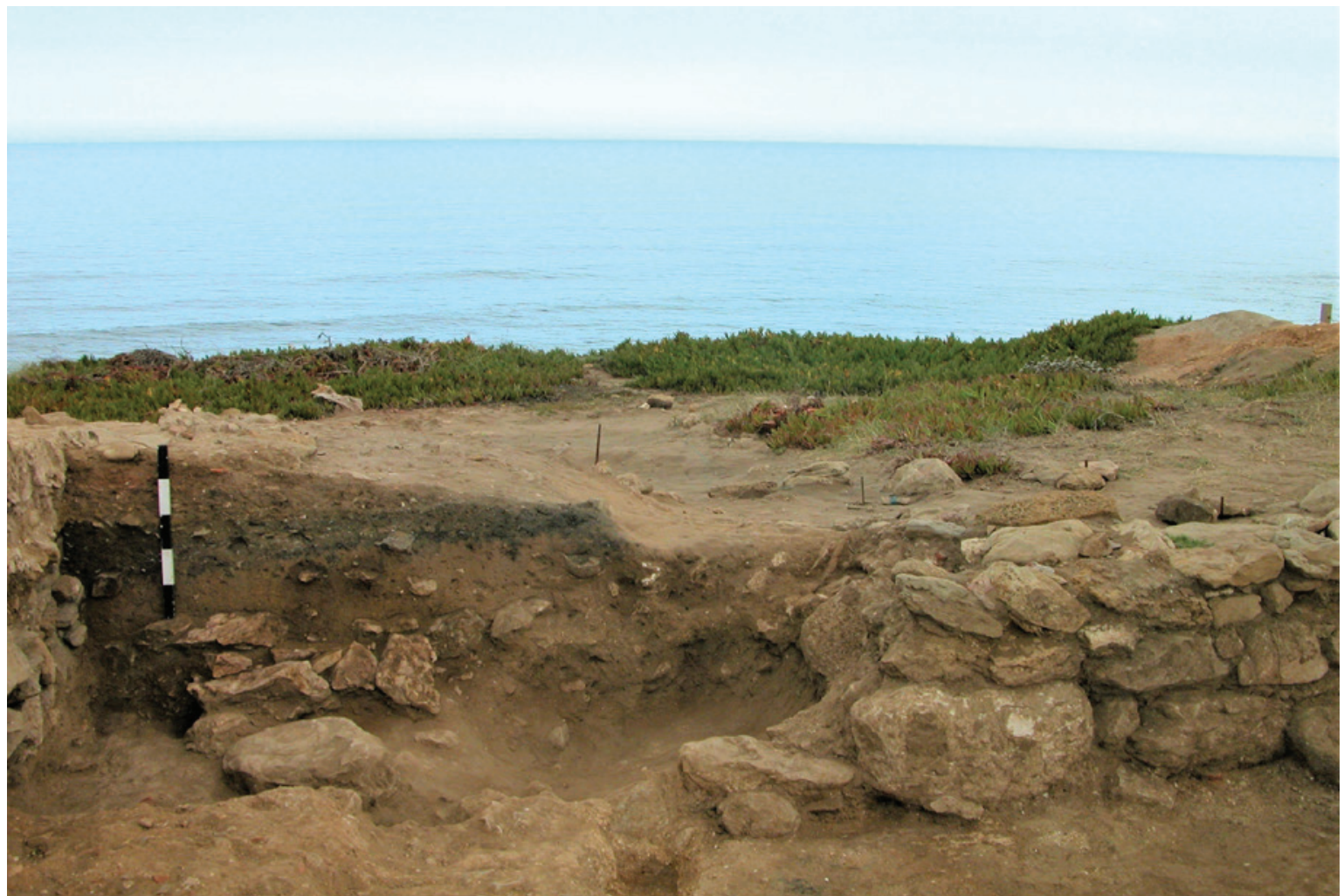

Figura 5 - Pormenor de corte da vala dos alicerces da vigia, com fragmentos de peças lapidares romanas misturados com areia. À direita é visível uma parede islâmica parcialmente desmontada. 


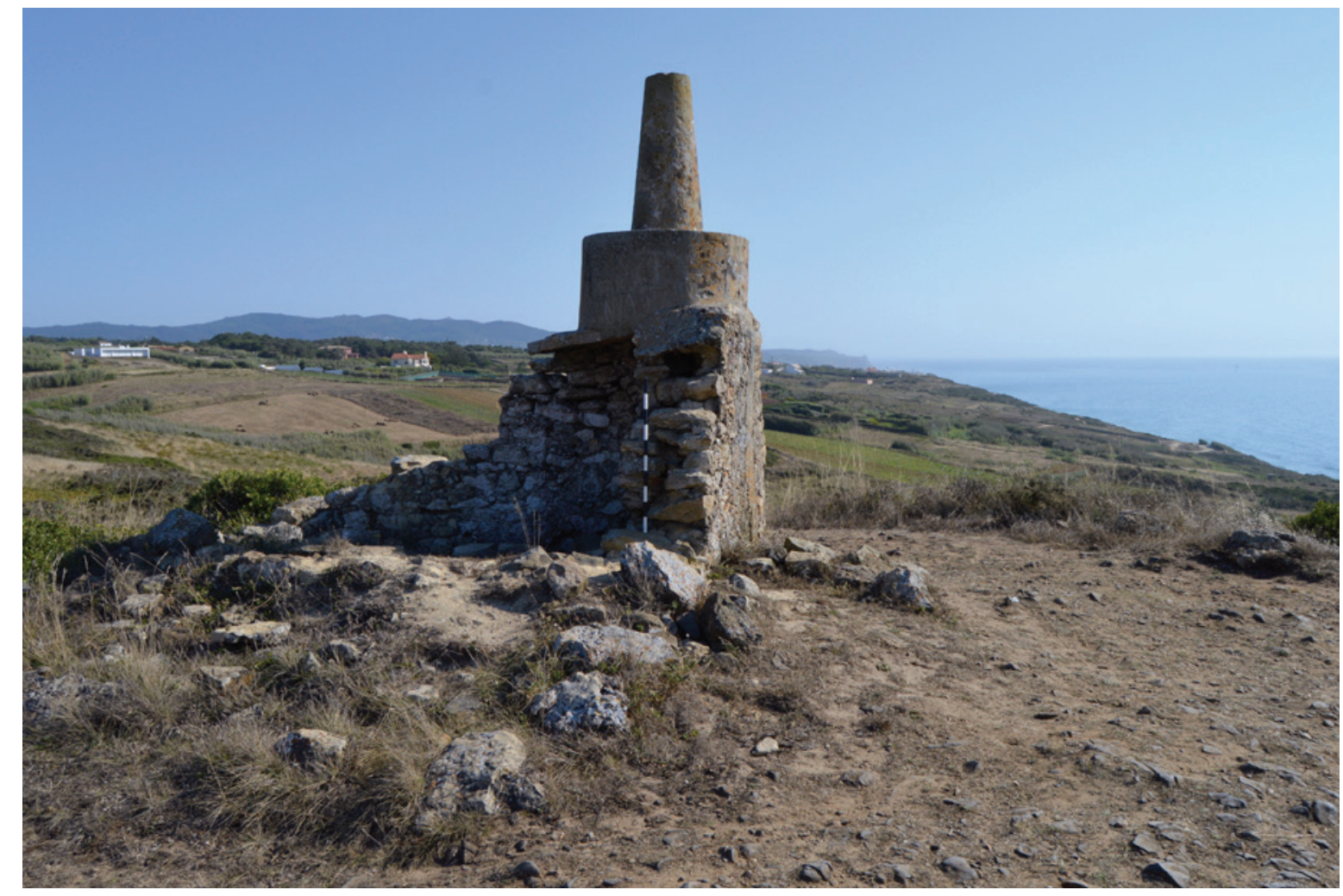

Figura 6 - Prováveis ruínas da vigia da Mata ou do Magoito.

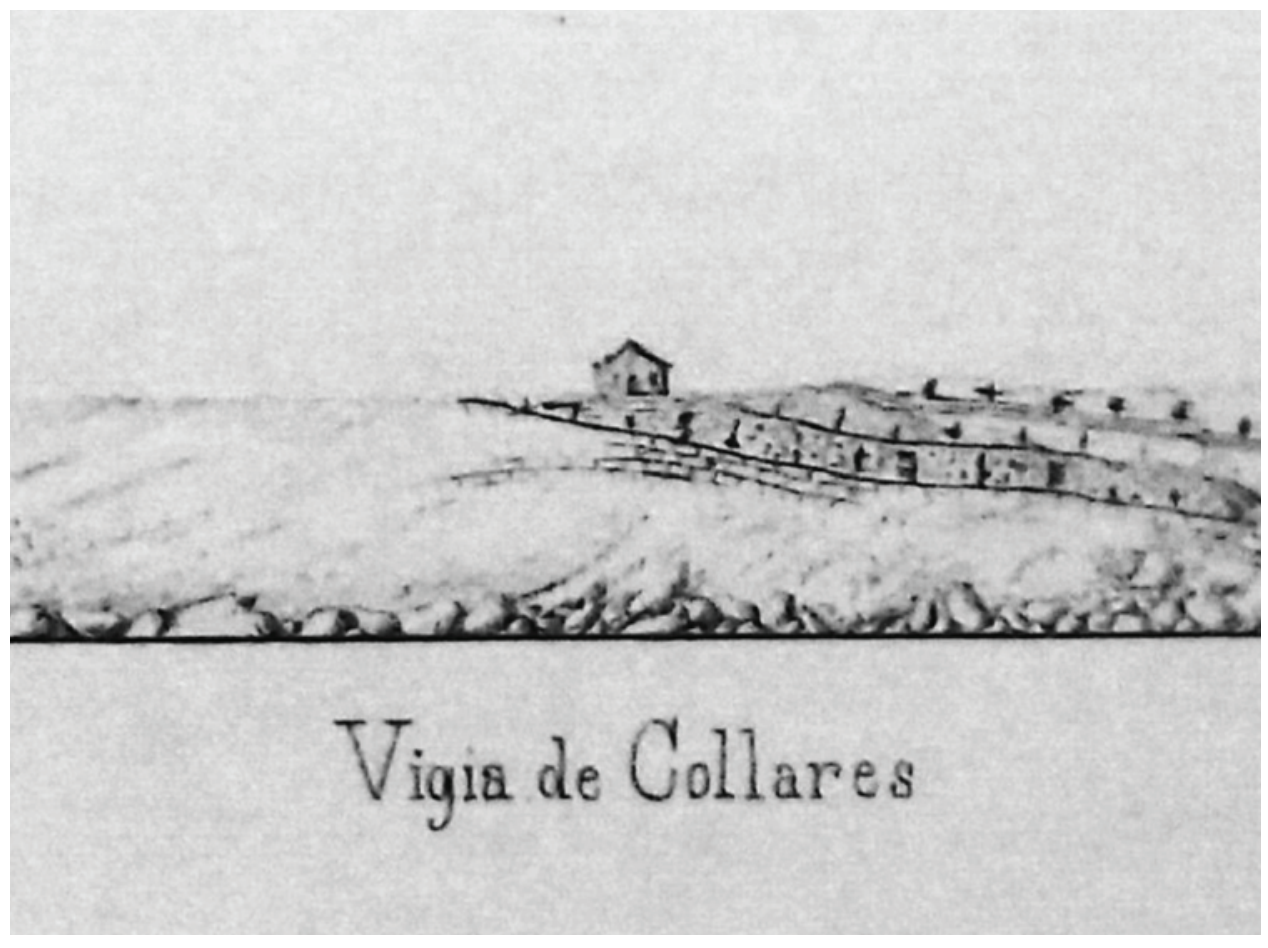

Figura 7 - Representação da "Vigia de Collares" feita por Carlos Ribeiro no início da segunda metade do século XIX. 

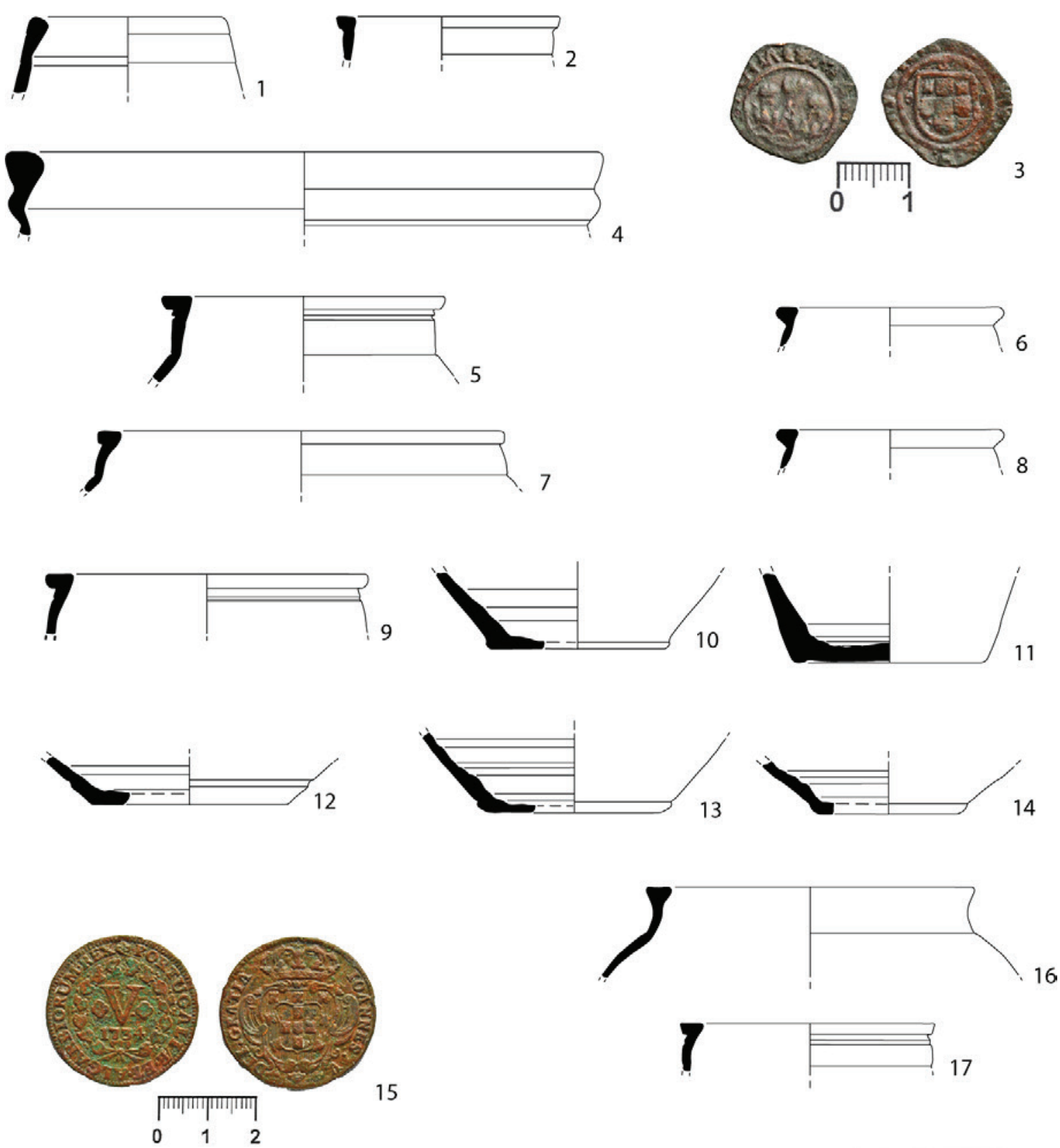

15
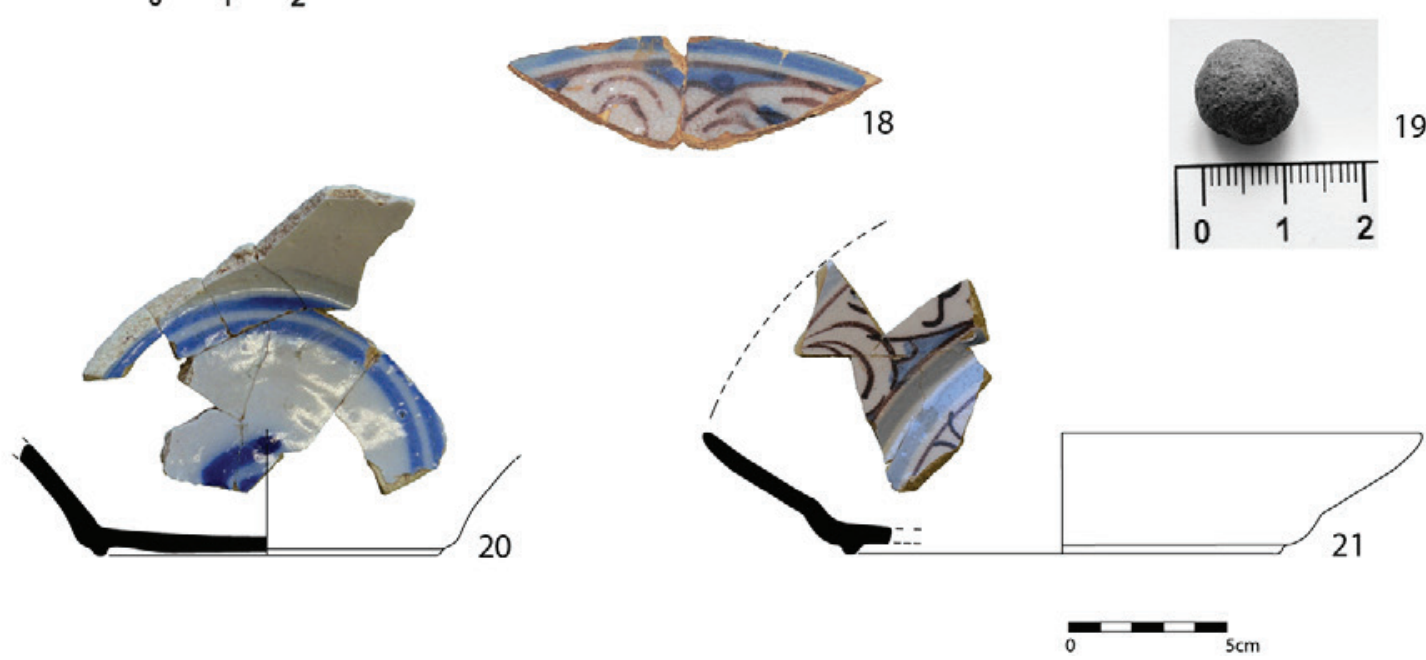

Figura 8 - Materiais associados às ocupações da Vigia: século XVI a XIX. Autor: Ana Isabel. 


\title{
O CONTEXTO DA TORRE SINEIRA DA IGREJA DE SANTA MARIA DE LOURES
}

\author{
Paulo Calaveira ${ }^{1}$, Martim Lopes ${ }^{2}$
}

\begin{abstract}
RESUMO
Teve lugar em 2003 uma intervenção arqueológica de emergência, por parte do município de Loures na área exterior da Igreja de Santa Maria de Loures.

Os autores procuram efetuar uma contextualização histórica deste edificado, bem como uma análise das evidências materiais exumadas e a sua relação com o contexto em que se inserem. Assim, apresentam-se os dados obtidos pelo estudo do espólio cerâmico e metálico, e a sua relação com as sepulturas e ossários que foram escavados, tendo também em consideração as relações estratigráficas existentes.

Este é um contexto de relevância para a história de Loures Medieval/Moderna, dado que a igreja desempenhará um papel crucial no desenvolvimento do traçado urbano da povoação.

Palavras-chave: Loures, Arqueologia Moderna, Cultura Material, Séculos XVI-XVIII, Câmbios espaciais.
\end{abstract}

\begin{abstract}
In 2003, an archaeological intervention, of emergence, was coordinated by the city council of Loures on the external area of the church of Santa Maria de Loures.

The authors try to make a historical contextualization of the building, forwarded by an analysis of the material evidences collected and their relation with the stratigraphy of which they are part.

Whereby are presented the results of the study of the ceramic and metallic evidences and the analysis of the stratigraphy and structures detected.

This is a context with relevance for the history of the evolution of the Medieval/Modern Loures because of the decisive paper of the church in the layout of the oldest part of the contemporary city.

Keywords: Loures, Historical Archaeology, Material Culture, XVI-XVIII centuries, Spatial changes.
\end{abstract}

\section{INTRODUÇÃO}

A Igreja de Santa Maria, Matriz de Loures, localiza-se em Loures, distrito de Lisboa. Circundada a Norte, Este e Oeste pelo rio de Loures, local caracterizado por minifúndios e habitações de caráter rural (Oliveira, 2018, p. 1).

Construída antes da segunda metade do século XIII pelos Templários sobre as ruinas de uma igreja mais antiga (Oliveira, Silva e Estêvão, 1999, p. 55), teve um vigário nomeado em 1250 por D. Ayres Vasques. Mendes Leal autor do livro Admiravel Egreja Matriz de Loures, de 1909, conseguiu consultar a documentação referente á Igreja, sendo alguma dela, à época, inédita e anterior a 1600. Essa documentação relati- vamente ao adro e envolvente da Igreja transmitiu informação importante, desde logo por assinalar o início da construção da Torre Sineira em 1620. Esta iria substituir o antigo campanário, demolido em 1625, um ano após o término da construção (Oliveira,2018, p. 2-3). Pelo facto de esta se encontrar isolada houve a construção de 6 moradias em 1626, cujo objetivo seria por um lado evitar o isolamento desta e por outro garantir o seu cuidado (Leal, 1909). Entre as décadas de 70 e 80 do século XVII existem diversas construções no local, as quais, na sua maioria não terão impacto sobre a temática deste artigo, tratando-se de 2 arrecadações e uma plantação de oliveiras no adro da Igreja. Contudo a construção da torre do relógio terá impacto, uma vez que será

1. NOVA-FCSH; paulocalaveiras@gmail.com

2. NOVA-FCSH; martimafonsorl@sapo.pt 
construída junto ao lado Este da Torre Sineira, entretanto demolida (Oliveira, 2018, p. 3).

\section{A ESCAVAÇÃO DA TORRE SINEIRA}

A escavação ocorreu em 2003 como resultado da implementação de um projeto camarário que visava a reformulação do espaço exterior da Igreja. Os trabalhos arqueológicos, inicialmente planeados enquanto intervenção de acompanhamento, ficaram a cargo do Gabinete de Arqueologia da Divisão do Património Cultural da Câmara Municipal de Loures, sob a responsabilidade da arqueóloga Ana Cristina Oliveira (Oliveira, 2018, p.5).

Durante o acompanhamento foi detetada uma estrutura quadrangular, denominada de estrutura $\mathrm{T}$, interpretada como o único testemunho preservado da torre sineira. Nessa zona foi intervencionado, quer o interior, quer o exterior da estrutura, até à cota máxima de afetação da obra, com uma profundidade total de um metro. Foram então definidas três áreas de intervenção, que seguiram a orientação proporcionada pela própria estrutura da Igreja. área A - correspondente ao interior da estrutura; área B - situada no exterior, a Norte, limitada pelo prolongamento do alinhamento exterior da torre e por área de sondagem; área $\mathrm{C}$ - faixa adjacente exterior, a Este, com um metro de largura, sendo o comprimento definido pela área B a Norte e a Sul pela parede Norte da Igreja (Oliveira, 2018, p.5).

No decorrer dos trabalhos foi detetada também uma necrópole, a qual terá pelo menos três ossários e dezassete esqueletos, nas três áreas intervencionadas. Devido a limitações relacionadas com a cota e área de afetação da obra a real dimensão da necrópole é desconhecida, tendo por essa razão a parte escavada sido considerada apenas como uma amostra da realidade arqueológica aí existente.

\section{ESTRUTURA “T”}

Estrutura formada por duas paredes uma a nascente e outra a Norte, que forma um ângulo reto. Estas tocam os silhares da parede da igreja fazendo, assim, uma estrutura quadrangular (Oliveira, 2018, p. 9). O aparelho é constituído por blocos de calcário de grande dimensão no exterior. O interior, constituído por calcários e basaltos, apresenta também alguns seixos rolados e alguns fragmentos cerâmicos, unidos por uma argamassa elaborada à base de cal
(Oliveira, 2018, p. 9). O método construtivo aqui aplicado é composto por pedras abundantes regionalmente, nomeadamente os calcários, os basaltos e os seixos rolados, dado que esta região se encontra na junção entre um maciço calcário e basáltico, tendo os seixos, muito provavelmente, ter sido recolhidos no rio de Loures.

\section{ESPÓLIO CERÂMICO}

O espólio analisado no presente estudo apresenta-se bastante fragmentado, condicionando a informação passível de ser retirada. A cerâmica comum é a melhor representada, com $69 \%$ do total recolhido. Segue-se a faiança com $14 \%$ do total exumado e os azulejos com $13 \%$. Apenas $3 \%$ dos materiais são porcelanas e $1 \%$ corresponde a cerâmica de construção, a qual não foi estudada.

Uma grande percentagem de materiais saiu da área A, com $42 \%$ do total. Isso pode dever-se a diversos fatores, um dois quais poderá estar relaçionado com os enterramentos que existem nessa área, os quais também são, numericamente, superiores em relação às outras áreas de escavação. Salientar que, do universo em análise, não se sabe a área de $42 \%$ do espólio. Da área B vem ${ }_{12} \%$ e da área C vem $4 \%$, situação que pode dever-se ao facto de ser nesta área onde foram detetadas menos sepulturas. Com menos de $1 \%$ registam-se materiais em que não é precisa a origem na área B ou C.

\subsection{Cerâmica Comum}

A cerâmica comum é a melhor representada dos materiais analisados, correspondendo a $69 \%$ do conjunto estudado. $\mathrm{O}$ que se traduz quantitativamente em 210 fragmentos e, pelo menos, 72 indivíduos, de acordo com o protocolo de Breauvray (Arcelin e Tuffreau-Libre, 1998).

Seguindo a proposta, no que respeita à função, de Jacinta Bugalhão e Inês Coelho, as cerâmicas comuns foram agrupadas em cozinha, mesa, armazenamento e transporte (Bugalhão e Coelho, 2017, p. 109).

A nível de cerâmica de cozinha foram exumados 1 alguidar, 1 bacia, 3 possíveis frigideiras, 8 panelas, e 3 que poderão ser panelas, 3 tachos, a possibilidade de haver um quarto, existindo 4 em que morfologicamente não se distingue bem entre tacho ou panela. Funcionalmente o alguidar está associado à preparação de alimentos, mas também à higiene pessoal. A frigideira era utilizada para fritar alimentos, ou 
em azeite, ou em banha animal. O tacho e a panela teriam utilizações semelhantes, contudo o tacho podia-se servir à mesa, passando a ter uma dimensão comunitária (Bugalhão e Coelho, 2017, p. 111, 120 e 130).

Nas cerâmicas de mesa destaca-se a presença de 1 possível bilha, de 4 jarrinhas, de 1 possível jarro, de 2 púcaros e um possível terceiro de 11 potinhos, havendo um décimo segundo potinho interrogado, de 6 pratos, de 2 tigelas, de uma peça que poderá ser uma tacinha e de 2 possíveis taças.

As bilhas seriam usadas para armazenar alimentos líquidos. Os pratos eram usados para servir à mesa ou para comer e, no caso de exemplares de maiores dimensões, podiam ser de uso comunitário. Os jarrinhos, os púcaros e os potinhos teriam utilizações semelhantes, podendo servir para se beber, em uso individual, ou para servir líquidos, com uso, possivelmente, coletivo (Bugalhão e Coelho, 2017, p. 118-126).

No que respeita a cerâmicas de armazenamento e transporte há 1 talha e um pote. As talhas eram usadas para o armazenamento de alimentos líquidos, ou de cereais. O pote funcionava de forma semelhante à talha (Bugalhão e Coelho, 2017, p. 124-131). Há quem coloque a hipótese de os potes serem cobertos por testos (Fernandes, 2012, p. 331).

Observa-se que a maior concentração de cerâmica comum vem da área A, num total de 57 fragmentos cerâmicos. Verifica-se que esta é a zona de onde mais material arqueológico saiu, como já constatado. Da área B saíram 26 fragmentos. Da área C foram exumados 5 , zona de onde saíram menos materiais, facto também já constatado. E da área C/B saiu 1 fragmento cerâmico.

No que respeita à origem das cerâmicas comuns destaca-se o que é designado como Local/Regional, querendo isso dizer, que contendo uma matriz quartzo-micácea, não muito depurada, com grãos de uma pequena média dimensão, com matriz geológica atribuível a produções com origem no vale do Rio Tejo, sendo impossível restringir mais geograficamente, ou procurar mesmo centros produtores, com um total de 211 fragmentos cerâmicos. Existe apenas um bojo atribuído a produções de barro vermelho, tratando-se de cerâmicas não vidradas de uso doméstico, com uma diversidade formal bastante ampla, o qual deverá tratar-se de uma produção Lisboeta (Castro et all, 2017, p. 1742).

No que toca às cozeduras a maioria delas, mais con- cretamente 147 fragmentos, apresentam uma cozedura oxidante. Apenas 2 fragmentos possuem uma cozedura oxidante-redutora. Com cozedura redutora existem 16 fragmentos. Com cozedura redutora-oxidante existem 45 fragmentos. Ou seja, ocorre um predomínio de pastas com tons vermelhos, ou alaranjados, em detrimento das que possuem cores como cinzento ou castanho-escuro. Isso sugere um elevado grau de qualidade nos fornos onde as peças foram cozidas, com um profundo controlo da entrada de oxigénio no interior da câmara de cozedura.

\subsection{Faiança}

A faiança, que corresponde a $14 \%$ do conjunto, trata-se do segundo grupo com maior dimensão. É assim um grupo constituído por 43 fragmentos e, pelo menos, 11 indivíduos.

Existe uma maior concentração de faianças na área A, num total de 29 fragmentos. A área B contém 4 fragmentos e a área $C$ um total de 6 fragmentos. Contabilizam-se 4 fragmentos dos quais se desconhece a área. Destaca-se a área C que, quanto à faiança, contraria a tendência que registava como local com menor número de espólio.

A forma mais representada é a do prato, num total de 5 indivíduos. Destaca-se a existência de 3 escudelas, assim como de 35 fragmentos classificados como indeterminados.

Em relação ao acabamento das faianças, ou seja, ao esmalte, registam-se as seguintes cores: azul sobre branco; azul sobre azul e azul e vináceo, sendo que estas colorações correspondem às habituais em contextos modernos. Destaca-se o azul sobre branco com um total de 33 fragmentos. Sem decoração estão apenas presentes um total de 8 fragmentos, bem como apenas um fragmento de cor azul sobre azul, de estilo berretino (Bercero e Alaix, 2010), e um decorado a azul e vináceo, com temas barroquizantes,. A decoração de muitos dos fragmentos, num total de 26 , foi difícil de precisar, dado o estado de conservação em que se encontravam, sendo dados como motivos indeterminados. Destacam-se os motivos vegetalistas, num total de 7 fragmentos, sobretudo no tema de pétalas de malmequeres (Casimiro, 2013).

Segue-se a decoração com apenas uma banda azul no exterior e motivos vegetalistas no interior, $\mathrm{da}$ qual foram exumados 3 fragmentos.

Regista-se ainda, nas decorações com azul, a existência de um fragmento com decoração em motivo Berettino (Bercero e Alaix, 2010), dois fragmentos 
com círculos concêntricos no fundo, dois fragmentos com motivos compósitos e dois apenas com uma linha simples no interior.

Por fim, surge um fragmento com decoração de motivos barrocos, com a representação de aranhões e pêssegos, com o emprego das cores azul e vináceo sobre fundo branco.

A análise crono-estilística teve por base os trabalhos de Tânia Casimiro (2013) e de Anabela de Sá (2012). Assim sendo, as faianças em estudo inserem-se, no que respeita à decoração em dois tipos o A e o D1, tipos esses que não são fáceis de discernir um do outro neste caso dado que o espólio se encontra bastante fragmentado.

O tipo A caracteriza-se pelas bandas junto ao bordo e por conter círculos concêntricos e motivos vegetalistas como decoração (Sá, 2012, p. 966). O tipo Di contém como principal motivo de decoração bandas geométricas de cor azul (Sá, 2012, p. 968). Esses tipos decorativos encontram-se datados do primeiro quartel do século XVII (Sá, 2012, p. 973). Em termos cronológicos peças com decorações com motivos geométricos e vegetalistas enquadram-se na denominada Fase IV, balizada entre 1635-166o, (Casimiro,2013, p.350). A fase V, datada de 1660-1700, caracteriza-se pelas decorações compósitas, mas também pela difusão por camadas mais modestas, neste caso destaca-se uma peça que contém uma decoração barroca (aranhões e pêssegos), datada, tendo em conta o autor já citado, da última década do século XVII (Casimiro, 2013, p. 362-363). A fase VI, de 1700 a 1766, caracteriza-se por decorações em linhas concêntricas e por peças brancas (Casimiro, 2013, p. 364).

Assim, é possível balizar o conjunto de faianças, a nível decorativo, entre o primeiro quartel do século XVII e meados do século XVIII.

A maioria das faianças, mais concretamente 41 fragmentos, têm origem em Lisboa. Os outros 2 não foi possível determinar com certeza a sua origem dado o seu mau estado de conservação.

\subsection{Porcelanas}

Oriundas da China, as porcelanas são o material mais escasso de todo o espólio estudado constituindo $3 \%$ do total. Efetivamente, neste sítio arqueológico, regista-se a presença de 9 fragmentos resultando em, pelo menos, 5 indivíduos. Estas concentram-se sobretudo na área $\mathrm{A}$, num total de 7 fragmentos. $\mathrm{A}$ área B relevou 2 fragmentos. Não foi encontrada qualquer porcelana na área $\mathrm{C}$.
As formas parecem concentrar-se em pratos com pé anelar, contudo a maioria das formas não são passiveis de classificar pelo estado muito fragmentado do contexto, sendo possível balizar o conjunto das porcelanas sobretudo do século XVII.

As porcelanas em conjunto com as faianças indicam, entre muitas outras coisas, a presença, não propriamente de elites com grande poder económico, mas de populações que possuíam condições financeiras para adquirirem pequenas peças, algo comprovado com o baixo número de indivíduos de porcelana. Como defendido por alguns autores quando afirmam que a compra de porcelanas não era exclusiva de elites (Henriques, 2012, p.930).

\subsection{Azulejos}

Foram exumados um total de 40 fragmentos de azulejos na escavação da Torre Sineira da Igreja Matriz. Destaca-se o facto de a maioria vir da área $\mathrm{A}$, num total de 32. Da área B saíram 6 e 2 da área C.

A policromia da coleção de azulejos é variada, aparecendo as seguintes cores: azul; branco; verde e azul e branco e castanho. A cor com maior número de exemplares é a branca, 15 fragmentos. Destaca-se cor a verde com 10 fragmentos. Com a cor azul existem 7 fragmentos. Com a policromia azul e branco existem 2 fragmentos. Contendo a policromia azul, branco e castanho existem dois fragmentos de azulejo. Esses últimos destaca-se por ser o único importado, tratando-se de um azulejo hispano-mourisco executado segundo a técnica de aresta, produzido, possivelmente, em oficinais sevilhanas. Os exemplares feitos nessa técnica situam-se cronologicamente no segundo quartel do século XVI (Bargão, Ferreira e Silva,2017, p.1786).

Seria inverosímil presumir que estes fossem parte da decoração do exterior da torre. Isso deve-se ao facto de estratigraficamente estes se encontrarem em camadas anteriores à construção da Torre Sineira. Os que foram recolhidos nas áreas exteriores à estrutura $\mathrm{T}$, nas áreas $\mathrm{B}$ e $\mathrm{C}$, não indicam que esta estivesse forrada por eles, por diversos motivos. Em primeiro lugar um dos azulejos da área C data, na sua produção, da primeira metade do século XVI; em segundo lugar o número em que aparecem é quantitativamente bastante baixo; em terceiro lugar encontram-se associados a ossários e a esqueletos. Contudo tem de se colocar a hipótese de grande parte dos azulejos fossem parte de um rodapé que a igreja poderia ter, destruído aquando da construção 
da torre sineira. Tal facto parece ser verosímil pelo facto de na sua maioria, os fragmentos com origem na área $\mathrm{A}$ se encontrarem em camadas anteriores à edificação da torre.

\subsection{Espólio não cerâmico}

Destaca-se uma grande quantidade de pregos encontrados, com um total de 42 na área $\mathrm{A}, 16$ na área $B, 3$ na área C. Destacar que os encontrados nas áreas $\mathrm{B}$ e C estavam dispersos, enquanto os da área A estavam associados a esqueletos, situação que aparenta ser coeva com uso de caixões.

A nível de numismas destacam-se duas moedas em bronze, uma associada ao Esqueleto XII, área A; e outra retirada de terras remexidas, tratando-se ambas de dois ceitis do reinado de D. João II (1455-1495). $\mathrm{Na}$ área $\mathrm{B}$ foram exumadas duas moedas, ambas correspondendo a um real e meio, uma encontrava-se associada ao Esqueleto I, datada de 1712, ou seja, do reinado de $\mathrm{D}$. João $\mathrm{V}$, enquanto a outra estava associada ao Esqueleto II, estando datada do reinado de D. Afonso VI (Oliveira, 2018, p. 10-13)

$\mathrm{Na}$ área A foi encontrada uma conta em osso com perfuração central, assim como mais duas na área B, também em osso, sendo uma delas alongadas, esta com decoração anelar. Estes materiais poderão tratar-se de evidências de colares ou terços dado o seu contexto (Oliveira, 2018, p. 10-11), situação reforçada pela forma circular e lisa da outra conta recolhida na área B.

Destacam-se os alfinetes exumados, possivelmente em bronze, um sem cabeça localizado perto do Esqueleto II, e um completo na camada 2, ambos na área $\mathrm{B}$. Na área $\mathrm{C}$ foi encontrado também um alfinete em bronze sem cabeça.

$\mathrm{Na}$ área $\mathrm{A}$ foi exumado um brinco, associado ao Esqueleto VIII, cujo sexo desconhecemos, em metal, em forma de lágrima, com uma pérola branca. Esta estava ladeada pelos negativos de possíveis pedrinhas. Este não continha o sistema de fechar (Oliveira, 2018, p. 10). Esta evidência sugere que se poderá tratar de um individuo do sexo feminino.

Também foram exumados vidros da escavação, contudo pelo facto da informação que se obteria com o seu estudo ser praticamente nula, optou-se por não se proceder ao seu estudo.

\section{CONCLUSÕES}

A escavação revelou uma zona de descarte cerâmico, assim como um cemitério. Destaque para a cerâmica comum enquanto material dominante em termos estatísticos. Contudo, são as faianças e as porcelanas que permitem tirar conclusões mais prementes sobre os habitantes de Loures. As faianças foram produzidas quase todas em Lisboa, algo compreensível pela proximidade à dita cidade. As porcelanas, não sendo indicador de elites, atestam que seriam consumidas um pouco por todas as classes sociais.

Dos materiais os azulejos poderiam ser os que possuíam uma associação direta com a igreja. Algo que não sendo totalmente verdade, também não deixa de ser uma impossibilidade, pelo facto de existir uma concentração na área onde foi implantada a Torre. Essa situação pode ser explicável com a destruição parcial de um possível rodapé que o exterior da Igreja poderia possuir. Contudo um grupo de azulejos não pertenceriam à igreja, nomeadamente um hispano-mourisco, de aresta, que foi lá descartado, azulejos estes que surgem habitualmente associados a contextos habitacionais.

Apesar dos resultados, estes permitem levantar algumas questões. Poderá parte do espólio estar relacionado com as seis casas mandadas construir na primeira metade do século XVII? Qual a será a verdadeira dimensão e efetiva diacronia do cemitério? No que respeita a dados obtidos em relação ao cemitério, ressalvando que o objetivo principal não era um estudo aprofundado deste, destaca-se a sua aparente cronologia lata, pelo menos entre o século $\mathrm{XV}$ e o XVIII. A grande quantidade de pregos associados a esqueletos leva-nos a crer que estes foram inumados dentro de caixões, já a presença de alfinetes em bronze, associados a certos esqueletos, pode significar o envolvimento do corpo do defunto numa mortalha ou sudário.

\section{BIBLIOGRAFIA}

ARCELIN, P.; TUFFREAU-LIBRE M., ed. (1998) - Protocole de quantification des céramiques. In La quantification des céramiques. Conditions et protocole, Actes de la table ronde du Centre archéologique européen du Mont Beauvray. Glux-en-Glenne: centre archéologique européen du Mont Beauvray, pp. 141-157.

BARGÃO, André; FERREIRA, Sara; SILVA, Rodrigo Banha da (2017) - Policromias e padrões: azulejos "de aresta" e "de corda-seca” do Palácio dos Condes de Penafiel, Lisboa (Sé- 
culos XV-XVI). In Arqueologia em Portugal 2017-Estado da Questão. Lisboa: Associação dos Arqueólogos Portugueses, pp. 1781-1794.

BERCERO, Julia Beltrán; ALAIX, Núria Miró I (2010) - El comerç de cerâmica a Barcelona als segles XVI-XVII: Itàlia, França, Portugal; els tallers del rin i Xina. Quarhis. Barcelona. Época II, no 6, pp. 14-91.

BUGALHÃO, Jacinta; COELHO, Inês (2017) - Cerâmica Moderna de Lisboa: Proposta Tipológica. In I Encontro de Arqueologia de Lisboa: Uma Cidade em Escavação. Lisboa: Centro de Arqueologia de Lisboa / Departamento de Património Cultural / Direção Municipal de Cultura / Câmara Municipal de Lisboa, pp. 106-146.

CASIMIRO, Tânia (2013) - Faiança portuguesa: datação e evolução crono-estilística. Revista Portuguesa de Arqueologia. Lisboa. Volume 16, pp. 351-367.

CASTRO, Anabela; PAULA, Nuno; TORRES, Joana; CURADO, Tiago; TEIXEIRA, André (2017) - Evidências de produção oleira nos séculos XVI e XVII no largo das Olarias, Mouraria (Lisboa). In ARNAUD, J. M. e MARTINS, A. (coords.) Arqueologia em Portugal 2017 - Estado da Questão. Lisboa: Associação dos Arqueólogos Portugueses, pp. 1731-1749.

FERNANDES, I. (2012) - A louça preta em Portugal: estudo histórico, modos de fazer e de usar. Tese de Doutoramento em História, Especialidade em Idade Contemporânea, Braga, Instituto de Ciências Sociais / Universidade do Minho.

HENRIQUES, José. (2012) - Do Oriente para o Ocidente: contributo para o conhecimento da porcelana chinesa nos quotidianos da época moderna. Estudo de três contextos arqueológicos de Lisboa. In TEIXEIRA, André; BETTENCOURT, José, eds. - Velhos e Novos Mundos: Estudos de Arqueologia Moderna. Lisboa: CHAM/Faculdade de Ciências Sociais e Humanas da Universidade Nova de Lisboa e Universidade dos Açores. Volume 2, pp. 919-932.

LEAL, Joaquim José (1909) - Admiravel Egreja Matriz de Loures. Lisboa: Typographia do Commercio.

OLIVEIRA, Ana Cristina (2018) - Notas sobre a intervenção arqueológica na zona envolvente da Igreja Matriz de Loures: Confirmações e Novidades. In Colóquio Igreja de Santa Maria de Loures: Descodificar o Passado, Projetar o Futuro. Loures, pp. 1-26.

OLIVEIRA, Ana Cristina; SILVA, Ana Raquel e ESTÊVÃO, Florbela (1999) - Património edificado do Conselho de Loures. In Catálogo da Exposição "O Medieval e o Moderno em Loures - Viagens pelo Património”. Loures: Câmara Municipal de Loures e Museu Municipal de Loures, pp. 47-67.

SÁ, Anabela (2012) - Elementos para a caracterização da faiança portuguesa do século XVII: a tipologia de Pendery aplicada à realidade da Casa do Infante (Porto). In TEIXEIRA, André; BETTENCOURT, José, eds. - Velhos e Novos Mundos: Estudos de Arqueologia Moderna. Lisboa: CHAM / Faculdade de Ciências Sociais e Humanas da Universidade Nova de Lisboa e Universidade dos Açores. Volume 2, pp. 963-974. 


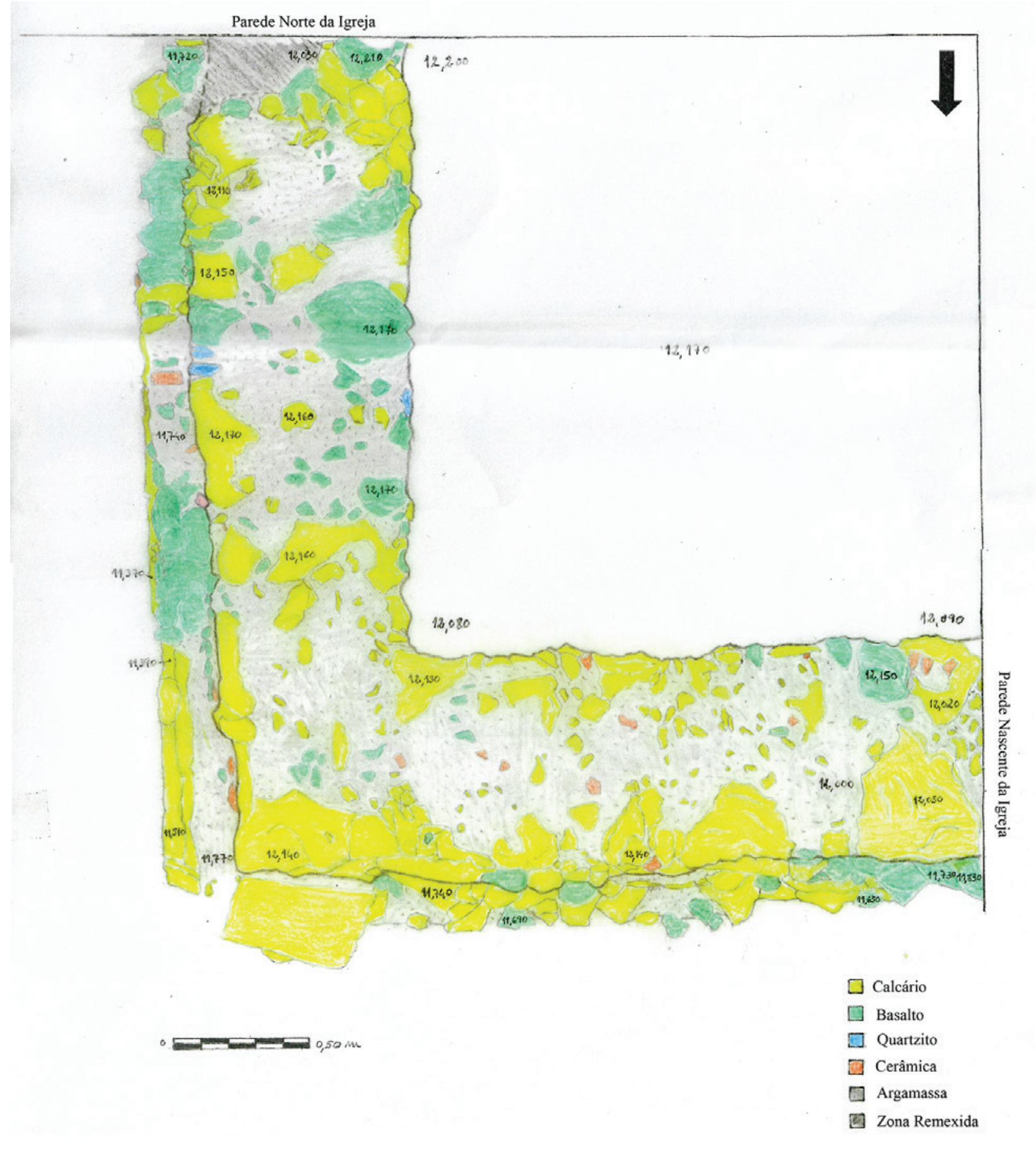

Figura 1 - Planta geral da estrutura T, correspondente aos restos da torre sineira. Museu Municipal de Loures. 


\begin{tabular}{|c|c|c|c|c|c|c|c|c|c|c|}
\hline \multicolumn{11}{|c|}{ NMI total por forma e área } \\
\hline & & \multicolumn{2}{|c|}{ Área A } & \multicolumn{2}{|c|}{ Área B } & \multicolumn{2}{|c|}{ Área C } & \multicolumn{2}{|c|}{ Sem Área } & \multirow{2}{*}{$\begin{array}{l}\text { NMI } \\
\text { Tota }\end{array}$} \\
\hline & Forma & NMI & Total & NMI & Total & $\mathrm{NMI}$ & Total & NMI & Total & \\
\hline \multirow{18}{*}{$\begin{array}{c}\text { Cerâmica } \\
\text { Comum }\end{array}$} & Alguidar & 1 & \multirow{18}{*}{16} & & \multirow{18}{*}{6} & & \multirow{18}{*}{2} & & \multirow{18}{*}{48} & \multirow{23}{*}{88} \\
\hline & Pote & 1 & & & & & & & & \\
\hline & Tacho & 1 & & & & & & 2 & & \\
\hline & Jarrinha & 1 & & & & & & 2 & & \\
\hline & Prato & 1 & & & & & & 5 & & \\
\hline & Indeterminado & 7 & & 3 & & 2 & & 13 & & \\
\hline & Potinho & 4 & & 1 & & & & 6 & & \\
\hline & Panela & & & 1 & & & & 6 & & \\
\hline & Taça? & & & 1 & & & & & & \\
\hline & Bacia & & & & & & & 1 & & \\
\hline & Panela? & & & & & & & 2 & & \\
\hline & Potinho? & & & & & & & 1 & & \\
\hline & Púcaro & & & & & & & 2 & & \\
\hline & Talha & & & & & & & 1 & & \\
\hline & Tigela & & & & & & & & & \\
\hline & Tacinha? & & & & & & & 1 & & \\
\hline & Tacho/Panela? & & & & & & & 3 & & \\
\hline & Tacho? & & & & & & & 1 & & \\
\hline \multirow{3}{*}{ Faiança } & Escudela & 1 & \multirow{3}{*}{7} & 1 & \multirow{3}{*}{2} & & & & \multirow{3}{*}{2} & \\
\hline & Prato & 4 & & & & & & 1 & & \\
\hline & Indeterminada & 2 & & 1 & & & & 1 & & \\
\hline \multirow{2}{*}{ Porcelana } & Prato & 2 & \multirow{2}{*}{5} & & & & & & & \\
\hline & Indeterminada & 3 & & & & & & & & \\
\hline
\end{tabular}

Tabela 1 - Contabilização geral do número mínimo de indivíduos por fabrico, forma eárea de intervenção.

\begin{tabular}{|c|c|c|c|c|}
\hline & \multicolumn{4}{|c|}{ Quadro síntese dos azulejos } \\
\hline & Cores & Quantificação & $\begin{array}{c}\text { Total por } \\
\text { área }\end{array}$ & TOTAL \\
\hline \multirow{4}{*}{ Área A } & Azul & 7 & \multirow{4}{*}{32} & \multirow{9}{*}{40} \\
\hline & Azul e branco & 1 & & \\
\hline & Branco & 15 & & \\
\hline & Verde & 9 & & \\
\hline \multirow{3}{*}{ Área B } & Verde & 4 & \multirow{3}{*}{6} & \\
\hline & $\begin{array}{c}\text { Azul, branco e } \\
\text { castanho(Azulejo de } \\
\text { aresta) }\end{array}$ & 2 & & \\
\hline & Indeterminado & 2 & & \\
\hline \multirow{2}{*}{ Área C } & Azul e branco & 1 & \multirow{2}{*}{2} & \\
\hline & Indeterminado & 1 & & \\
\hline
\end{tabular}

Tabela 2 - Contabilização total do número de fragmentos de azulejo recolhidos na intervenção arqueológica da igreja matriz de Loures. 


\section{Porcelana}
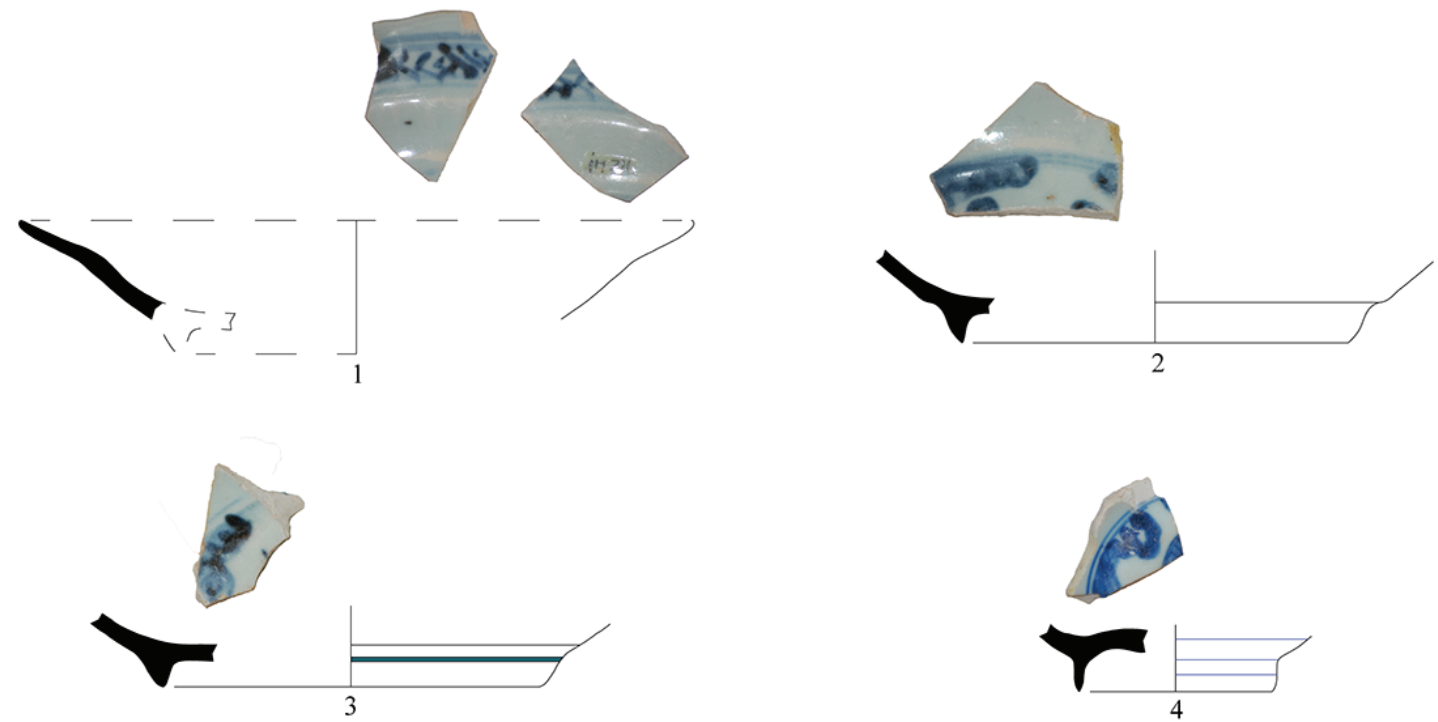

Faiança Portuguesa
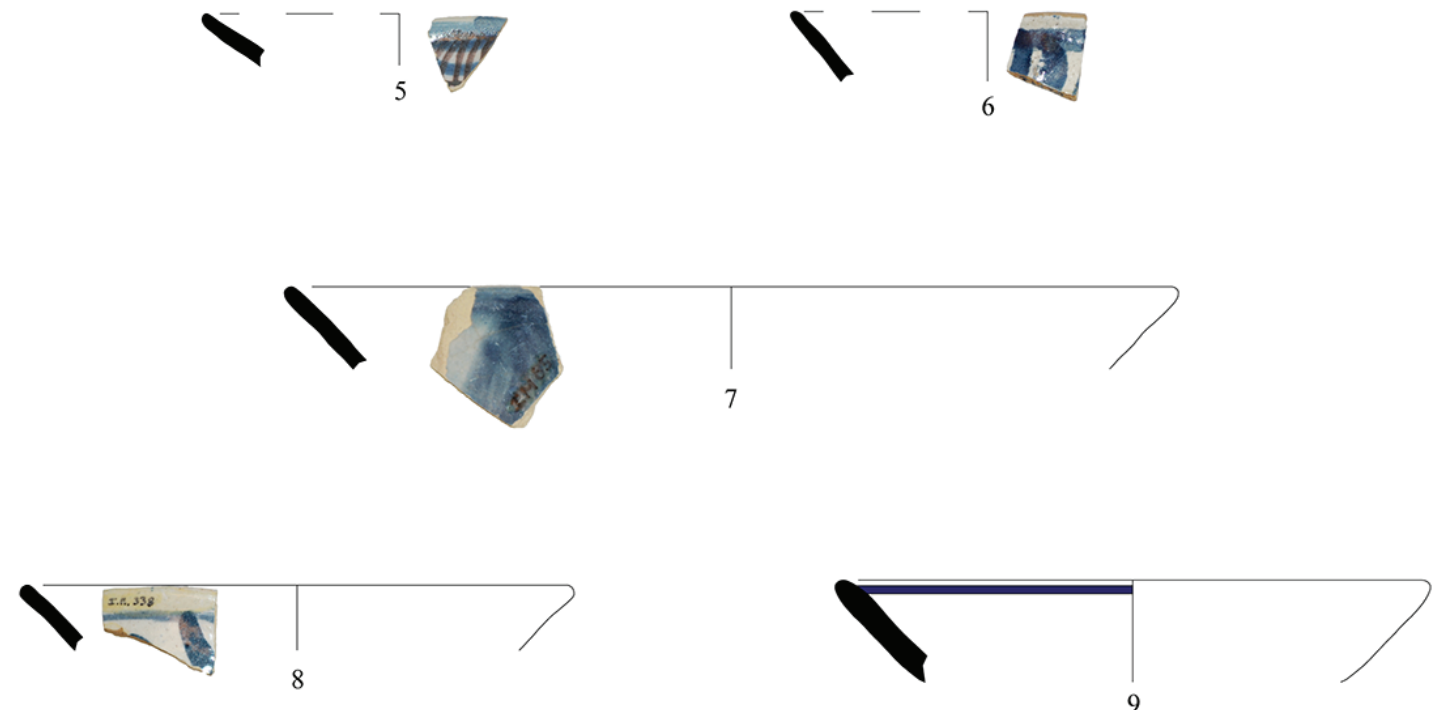

Cerâmica Comum
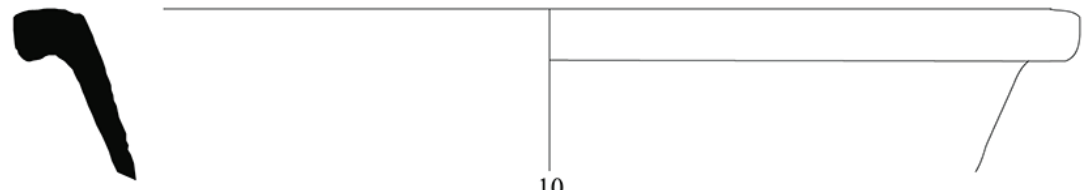

Escala 1:2

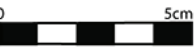

Figura 2-1-3-pratos; 4 - fundo indeterminado; 5- prato com decoração em azul cobalto e manganês; 6-9 - pratos com decoração em azul cobalto; 10 - Bacia. 
Cerâmica Comum
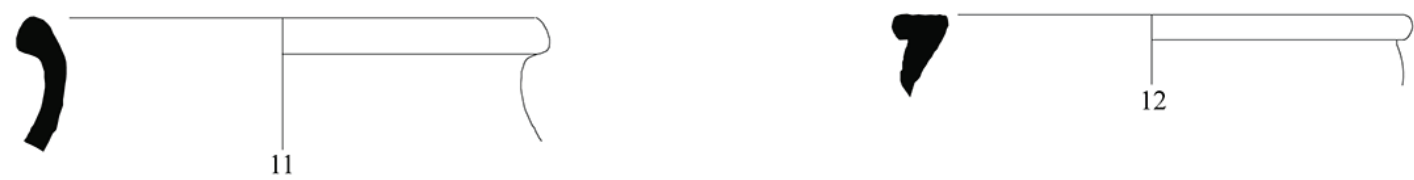

$\int$
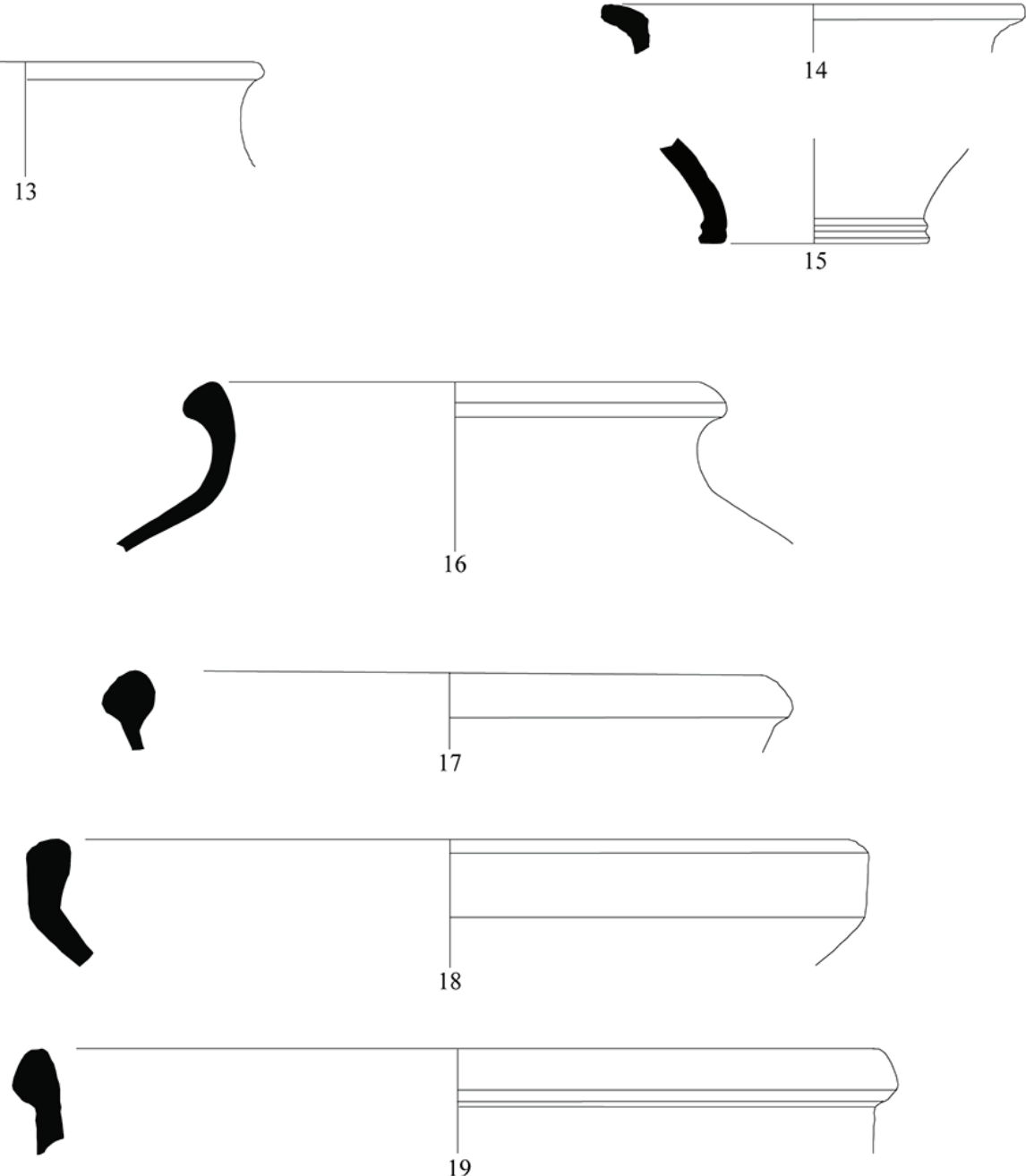

19
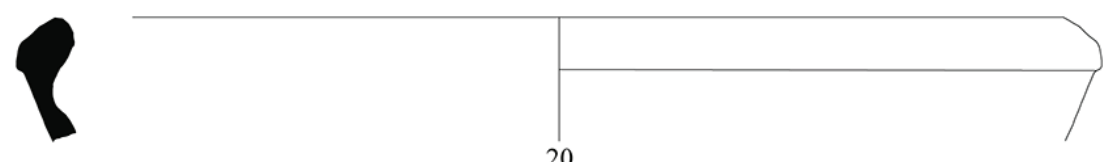

20
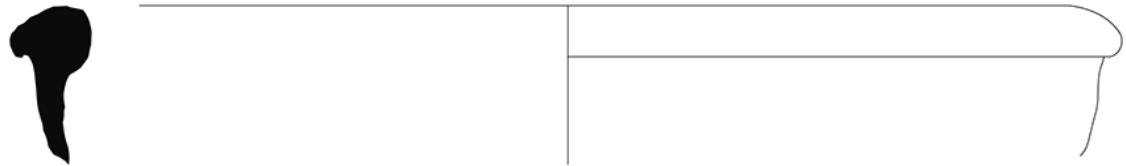

21

Escala 1:2

Figura 3-11-12 - Panelas; 13-15 - Potinhos; 16 - Tacho; 17 - Panela; 18-20 - Tacho; 21 - Panela. 
Cerâmica Comum

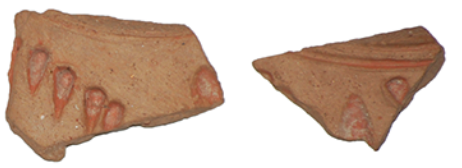

22

Faiança Portuguesa

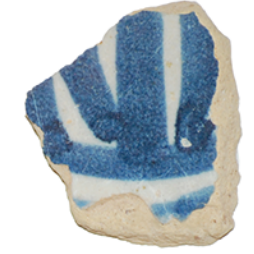

23

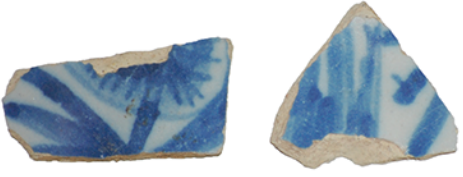

24

Azulejo
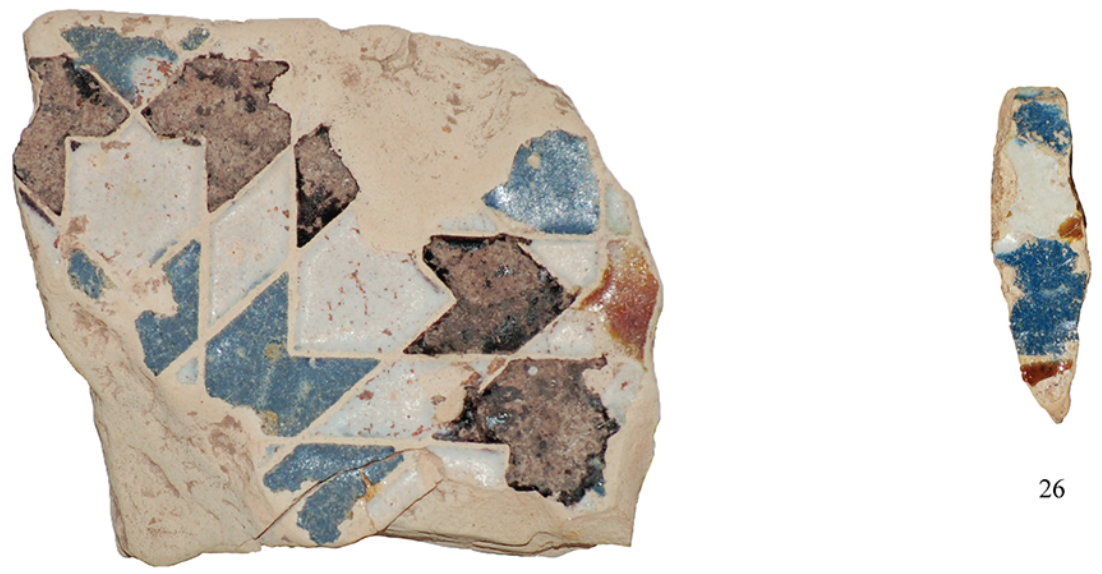

26

25

Numismas

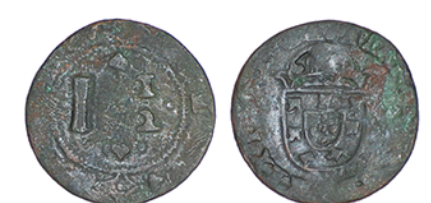

27
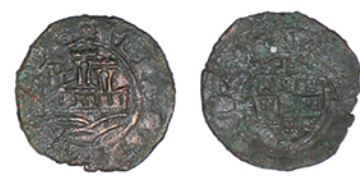

29

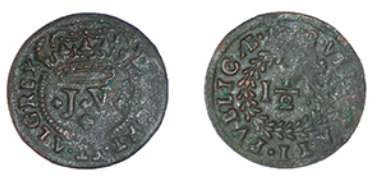

28

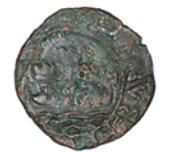

30
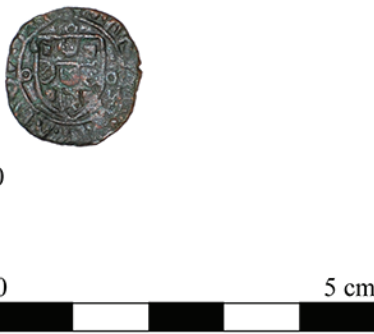

Escala 1:1

Figura 4-22 - Cerâmica comum fina com incisões; 23 - Faiança decorada com motivos de pétalas de malmequer em azul cobalto; 24 - Faiança de motivos vegetalistas em azul cobalto; 25-26 - Fragmentos de azulejo hispano-mourisco; 27 - Real e meio de D. Afonso VI, 1643-1683, associado ao Esq. II; 28 - Real e meio de D. João V, 1712, associado ao Esq. I; 29 - Ceitil de D. João II; 30 - Ceitil de D. João II, associado ao esq. XII. 


\title{
A NECRÓPOLE DO HOSPITAL MILITAR DO CASTELO DE SÃO JORGE E AS PRÁTICAS FUNERÁRIAS NA LISBOA DE ÉPOCA MODERNA
}

\author{
Susana Henriques ${ }^{1}$, Liliana Matias de Carvalho ${ }^{2}$, Ana Amarante ${ }^{3}$, Sofia N. Wasterlain ${ }^{2,3}$
}

RESUMO

A necrópole identificada na Rua do Recolhimento 7/9, Castelo de São Jorge (Lisboa, Portugal) corresponderá ao cemitério do Hospital Militar, localizado nas proximidades, activo entre os Séculos XVI e XVIII. Durante a escavação arqueológica foram identificadas sepulturas individuais, múltiplas, valas comuns e ossários. A organização espacial torna-se evidente em vários enterramentos, com a sobreposição de enterramentos que cortam os mais antigos, tendo sido observados esqueletos em decúbito dorsal, ventral e lateral (alguns contra paredes/ muros), nem sempre em conformidade com a regra canónica cristã.

Nesta necrópole da Idade Moderna existe uma grande variedade de práticas funerárias que refletem o tratamento da morte na moderna sociedade de Lisboa, transmitindo as suas preocupações sociais, culturais e religiosas. Simultaneamente, as práticas funerárias neste local tornaram-se uma ameaça à saúde pública, consequência da quantidade de corpos depositados num limitado espaço, físico e cronológico.

Palavras-chave: Época Moderna, Hospital Militar, Necrópole.

\section{ABSTRACT}

The necropolis found in Rua do Recolhimento 7/9, Castle of São Jorge, Lisbon, Portugal, corresponds to the military hospital cemetery, located nearby, in activity from the $16^{\text {th }}$ to the $18^{\text {th }}$ centuries. During the archaeological excavation both individual, multiple, and mass graves as well as ossuaries were identified. Space management becomes evident on several burials, mainly with overlap of other burials that end cutting the oldest ones, skeletons in supine, ventral and lateral position (and against walls), not always in conformity with the canonical Christian rules.

This post-medieval necropolis presents an array of funerary practices as a reflection of the Lisbon modern society, transmitting social, cultural and religious worries, becoming a public health issue due to the amount of bodies deposit in such a small space and in a short time.

Keywords: Post Medieval, Military Hospital, Necropolis.

"The cemetery can be seen as a long-lived parchment, in which the digging of new graves is a text laid on after only partial erasure of the older texts (earlier graves) creating an ever-changing palimpsest in which the new cannot entirely wipe away the old, and indeed may preserve the only evidence of the old."

Sian Anthony, 2015

\footnotetext{
1. EON-Indústrias Criativas; susana79henriques@gmail.com

2. University of Coimbra, Research Centre for Anthropology and Health, Department of Life Sciences, Calçada Martim de Freitas, 300o-456 Coimbra, Portugal

3. University of Coimbra, Centre for Functional Ecology, Department of Life Sciences, Calçada Martim de Freitas, 30oo-456 Coimbra, Portugal
} 


\section{INTRODUÇÃO}

Os rituais funerários afetam os mortos, mas acima de tudo refletem as necessidades dos vivos, na forma de lidar com o corpo e de salvar a alma do defunto, na gestão das limitações físicas do espaço funerário e os desafios do coveiro nas suas tarefas diárias (Anthony, 2015; Boyle, 2015; Johnson, 2008; Rugg, 200o; Souquet-Leroy et al., 2015; Worpole, 2003). Esta realidade é evidente na necrópole identificada na Rua do Recolhimento nำ 7/9 em Lisboa, Portugal. Os registos de óbito da Freguesia de Santa Cruz do Castelo fazem referência a duas necrópoles no Castelo de São Jorge, uma pertencente à Igreja Matriz de Santa Cruz, que se localizaria no adro do referido templo e, outra ao Hospital Militar (também referido como Hospital dos Soldados, Hospital do Castelo ou Hospital de São João de Deus), em atividade entre os séculos XVI e XVIII (Borges, 2007, p. 57). Os dados recolhidos durante a escavação arqueológica na Rua do Recolhimento, aqui descritos, referem-se à segunda necrópole (Figura 1).

O espaço funerário da Rua do Recolhimento apresenta uma área de cerca de $107 \mathrm{~m}^{2}$ escavados, de onde foram exumados 954 indivíduos, e está associado ao hospital/prisão (do castelo ou da "cadea nova desta freguesia" como aparece referenciado no livro de óbitos). Através da ocupação deste sítio, tanto em área como em profundidade, foi possível identificar várias práticas funerárias relacionadas com aspetos culturais, religiosos e de carácter prático. É, até ao momento e, em número de enterramentos a maior necrópole de soldados de época moderna associada a um Hospital Militar em Portugal.

\section{HOSPITAL MILITAR}

A primeira referência ao Hospital Militar no Castelo de São Jorge é de finais do século XVI, num documento que enuncia a entrada da Ordem de João de Deus no Hospital de S. Filipe e Santiago, sito no castelo de Lisboa a 4 de maio de 1592. Sendo assim, a presença de um hospital seria anterior a esta data (provavelmente 1580) e advém da necessidade de auxílio a marinheiros e soldados espanhóis ativos na conquista de Portugal (Borges, 2007, p. 57). Devido à sua relevância e à crescente importância dada aos cuidados médicos, foram feitas obras de expansão e melhoramento do edificado por decreto régio de 22 de maio de 166o (Borges, 2007, p. 94; Carreira, 2012), presididas pelos Irmãos Hospitaleiros de João de Deus.

Dentro da organização da instituição, que é um Hospital Militar gerido por uma ordem religiosa, o cemitério surge mais tarde (os defuntos dos hospitais seriam enterrados nos cemitérios paroquiais), sendo sempre referenciado que tinha de estar localizado perto do Hospital, paredes meias com o edificado ou num terreno escolhido só para essa função (Borges, 2007 , p. 48 e 227). No entanto, infelizmente, não foram identificadas até à data referências concretas sobre a data inicial de uso do espaço escavado, enquanto necrópole, associada ao Hospital dos Soldados. Uma escavação arqueológica de diagnóstico, dirigida pelas arqueólogas Ana Gomes e Alexandra Gaspar (Gaspar e Gomes, 2001), circunstanciada pela construção de um novo edifício, identificou as instalações do Hospital Militar no lado Sul da Rua do Recolhimento (em frente aos terrenos por nós intervencionados), com elementos arquitetónicos do século XVII, nomeadamente pisos, uma escadaria com degraus de madeira e uma parede revestida a azulejos, que levaria a um primeiro andar. Também foram registados elementos arquitetónicos do século XVI (por exemplo, uma cisterna) (Mestre, Gaspar e Gomes, 2002). Um dos compartimentos escavados foi interpretado como uma prisão, devido ao número elevado de cachimbos identificados, pelos elementos construtivos e grafítos das paredes (Gaspar e Gomes, 2005, p. 867). Estes achados apresentam-nos uma estrutura bem estabelecida no seio da comunidade, com um grande nível de organização e investimento arquitetónico, mostrando a importância do Hospital Militar instalado na área do castelo.

Entre 1640 e 1668, Portugal estava envolvido na Guerra da Restauração contra a Coroa de Reino de Castela, o que originou uma situação em que eram necessários hospitais militares (Borges 2007, p. 29). Contudo, este não esteve funcional durante um longo tempo, já que aquando do terramoto, o hospital ruiu, não sendo novamente erigido. Esta opção pode dever-se à mudança operada pela planificação pombalina da cidade de Lisboa, em que o Castelo perde influência face a uma cada vez mais marcante viragem para as margens ribeirinhas e Terreiro do Paço (Tavares, 2015). As escavações arqueológicas levadas a cabo por Gaspar e Gomes puseram em evidência sinais desta ocorrência, como pavimentos queimados e paredes estaladas que colapsaram. Os dados 
cronológicos (materiais e arquitetónicos) identificam um edificado que esteve em uso desde meados do século XVI até 1 de novembro de 1755 (Gaspar e Gomes, 2005, p. 868). Existe a possibilidade, evidenciada pelos trabalhos por nós conduzidos, de a necrópole em análise ter continuado a ser utilizada algum tempo após o terramoto, mesmo sem a presença física de um hospital militar, talvez como um espaço sepulcral de recurso uma vez que o cemitério da Igreja de Santa Cruz estaria sobrelotado com as vítimas do terramoto. Relembra-se que esta necrópole seria um espaço consagrado e por isso apto a receber enterramentos cristãos. Sabe-se que os militares que se encontravam internados no Hospital do Castelo de São Jorge e sobreviveram à catástrofe foram transferidos para o Hospital do Convento de São João de Deus na Pampulha (Carreira, 2012, p. 317).

A primeira referência ao Hospital dos Soldados no livro de óbitos da freguesia de Santa Cruz do Castelo é do ano de 1626, sendo curioso verificar que é denominado, em tal documentação, Hospital dos Castelhanos, referência ao facto de o Hospital ter sido criado durante a ocupação espanhola. Uma análise do livro de óbitos revela que o tratamento de pacientes não se limitava à população militar ativa, mas que se estendia também a uma parte da população prisional, como se pode constatar por este registo: "Aos quatro dias do mes de Abril de mil e setecentos e quarenta e outo annos faleceo no Hospital deste Castello com todos os sacramentos Manuel Ribeiro ou Antunes solteiro filho de Domingos Antunes já defunto, natural da freguesia de Sam Julião de Sarafoens termo de Guimaraens e faleceo no dito hospital por se achar prezo na cadea nova deste castello; não fez testamento está sepultado no somiterio do dito hospital de que fiz este assento dia era ut supra. O cura António Mauricio do Coutto." (www.tombo. pt: PT-ADLSB-PRQ-PLSB12-OO3-O3_mo358). A população de presidiários poderia assim ser também inumada na necrópole deste hospital, embora não se saiba se seria uma situação excecional ou recorrente. Os presos, na época, podiam ser criminosos que aguardavam uma sentença (inocência, degredo ou execução), os considerados loucos ou os vagabundos e mendigos (Sá, 2010). Verifica-se, contudo, através dos registos de óbitos, que nem todos os indivíduos que morriam no Hospital dos Soldados eram alvo de enterramento na necrópole adjacente.

O edifício do Hospital, no lado Sul da rua, parece relacionar-se com as extensões e melhoramentos orde- nados por $\mathrm{D}$. Afonso VI no já referido decreto régio de 166o (Borges, 2007, p. 94). As arqueológas responsáveis pelos trabalhos de escavação interpretam estas estruturas como um segundo hospital (Gaspar e Gomes, 2005, p. 866), considerando que o primeiro, datado de 1580 (Borges, 2007, p. 33 e 9o), estaria localizado noutra zona ainda por identificar, uma vez que não foram encontrados vestígios de uma estrutura anterior. Nesta mesma rua, mas no lado oposto ao Hospital escavado por Gaspar e Gomes, foi por nós identificada a necrópole que lhe corresponderia.

\section{NECRÓPOLE}

A necrópole está localizada no lado Norte da Rua do Recolhimento, defronte das estruturas principais identificadas como sendo do hospital. Este espaço sepulcral estaria delimitado por quatro paredes/muros e desenvolver-se-ia, à época, sobre elevadamente em relação à cota da rua.

A criação de uma área sepulcral instituiu-se através de novas realidades construtivas. Verificou-se durante os trabalhos arqueológicos que as escadas de acesso ao atual logradouro eram as mesmas escadas de acesso à necrópole. Estas escadas eram delimitadas pela parede fronteiriça com a rua e uma nova construção murária. Ao entrar neste espaço, com piso de baldosas dispostas em espinha, encontramo-nos imediatamente perante uma pintura mural, delimitada por um arco de tijoleira, inserido no novo muro. O corpo central deste painel exibe duas pinturas sobrepostas, executadas em momentos distintos. No estrato mais recente, evidenciam-se duas figuras de hábito negro apostadas no regaste de indivíduos, representados ladeados por labaredas. Esta representação remete para um imaginário associado ao Purgatório. Da campanha mais antiga, é visível nas zonas de descontinuidade da segunda, um resplendor que complementaria uma cruz de madeira, sendo ainda possível ver in situ os 4 encaixes metálicos que susteriam a cruz.

Atendendo à tipologia dos elementos pictóricos podemos balizar cronologicamente a estrutura entre os finais do século XVII e a primeira metade do século do XVIII, uma vez que os resplendores, elemento pertencente à campanha mais antiga, surgem, em termos de motivo artístico, na arte religiosa a partir do século XVII, banalizando-se, sobretudo ao nível da ourivesaria, a partir do século XVIII. As representações do Purgatório surgem a partir a $2^{\underline{a}}$ metade 
do século XVI (após Concílio de Trento) (Mendes, 2013, p. 35), sendo amplamente utilizadas na arte religiosa até aos séculos XIX e XX. Referimos, porém, que nesta representação as figuras de hábito negro podem ser interpretadas como sendo os monges da Ordem Hospitaleira de S. João de Deus, cujo hábito era caracterizado por uma túnica negra com capuz, determinado por Santo Agostinho nas "Regras. Constituições de la Ordem de Hospit.d de S. Juan de Dios”, em 1640, mas só aprovadas em 1741 (Borges, 2007, p. 293).

O painel, que pertenceria a um tipo de oratório, estava inserido no arco de tijolo e seria protegido por gradeamento, tendo-se verificado a existência de encaixes nas laterais e base do arco. Foram inclusivamente identificados elementos metálicos in situ, do possível gradeamento ou do seu encaixe no arco.

A escadaria da entrada terminava num degrau que denotava concavidades de encaixes de ferrolhos, onde também se denota a utilização pela abertura e fecho de um portão/porta. Esta porta ou portão dariam acesso a uma calçada de seixos delimitada por lajes de calcário dispostas na vertical.

A identificação de um oratório à entrada do cemitério do Hospital do Soldados fortalece, pela sua qualidade e imponência (seria visto da rua), a importância desta instituição no Castelo, e enunciava igualmente que este espaço era consagrado pela presença de uma pintura mural e de uma cruz (que relembramos não seria apenas uma representação mas também uma presença física, evidência corroborada pela presença de pregos): "The erection of a monument near the burial grounds of the event, as well as the presence of a cross, became the memory of the catastrophic episodes but not of the individuals affected by the epidemic" (Souquet-Leroy et al., 2015, p. 82), referem os autores para definir o que deveria ser o mínimo para a identificação de um local funerário consagrado, a cruz e, eventualmente, um pequeno monumento.

Podemos supor que a fase mais recente do mural, com a presença das figuras com o hábito hospitaleiro negro, ou seja, monges da ordem de São João de Deus, poderá estar relacionada com a canonização do mesmo a santo, no ano de 1691 (Borges, 2007, p. 99), afirmando e reivindicando desta forma aquele espaço.

A pintura enunciava a sacralização da área, já que um indivíduo, ao entrar no espaço, deparar-se-ia imediatamente, ao nível dos seus olhos, com a imagem do purgatório em que as figuras de túnica ne- gra estendem as mãos demonstrando visualmente a salvação das almas dos doentes que tinham morrido no hospital. A população teria assim conhecimento de que aquele espaço murado era um local sepulcral, uma comunicação por meio arquitetónico e imagético. Estamos perante a dicotomia do longe, mas próximo, de uma barreira física que protegia os mortos de serem perturbados pelos vivos e que igualmente isolava os vivos dos mortos (Rugg, 2000, p. 262).

A data de abandono do espaço funerário é incerta, mas, como referido, terá sido certamente após o terramoto de 1755. Nos anos que o precederam deu-se uma reorganização da cidade, sendo possível vislumbrar o mesmo na zona do Castelo de São Jorge. Note-se que a grande alteração nas práticas funerárias ocorreu, por força de lei estatal, apenas em 1835 , sendo uma consequência das ideias iluministas e de uma maior preocupação com a saúde pública (Carreira, 2012; Carvalho, 2012; França, 2008). A construção, posterior ao abandono, de uma nova estrutura habitacional civil, possivelmente datada de 1773 (como enuncia a placa que se encontra por cima da porta de entrada), sobre a área da necrópole afetou vários enterramentos. Esta afetação dos enterramentos reflete duas possibilidades: uma falta de conhecimento de que este espaço funcionou como necrópole, o que nos parece pouco plausível, ou a desconsideração desse fator (Figura 2).

Apesar da possibilidade do uso do espaço após 1755, a data de 1773, associada à construção do primeiro andar do edifício que aí se encontra hoje em dia, sela a utilização deste espaço enquanto necrópole. Será que a memória coletiva deste lugar como cemitério foi esquecida em tão curto espaço de tempo? Ou foi a tragédia do terramoto, um enorme marco mental, que forçou um novo paradigma urbanístico, com um design mais regular e as preocupações de salubridade como resultado da aplicação das teorias iluministas (Anthony, 2015; Boyle, 2015; Cabaço, 2009; Carreira, 2012; Carvalho, 2012; Johnson, 2008; Rugg, 2000; Tarlow, 2007, 2013; Worpole, 2003)? Parece que a decisão de não reconstruir o hospital do outro lado da rua levou ao abandono da necrópole militar nos anos seguintes.

A maior parte dos enterramentos da necrópole pertencem a indivíduos do sexo masculino com idades compreendidas entre os $12 \mathrm{e}$ os 50 anos. O mesmo padrão é observado nos ossários. Não foram identificadas lesões traumáticas ocorridas no momento de morte dos indivíduos (peri mortem) numa frequên- 
cia fora do comum, excluindo uma ligação direta com um teatro de guerra ou conflitos interpessoais. Por outro lado, foi registado um grande número de patologias infeciosas, desde sempre associadas a populações militares, o que vai de encontro a um hospital que servia toda a comunidade militar, para além das épocas de maior intensidade combativa (Ortner, 2003). Os indivíduos eram mais frequentemente enterrados em decúbito dorsal, mas também se identificaram deposições em decúbito ventral e lateral (geralmente contra paredes/muros de forma a maximizar o espaço) (Boyle, 2015; Souquet-Leroy et al., 2015). Durante a escavação arqueológica foram identificadas seis fases de utilização deste espaço, que correspondem a seis diferentes métodos de abordagem à gestão do espaço sepulcral.

Fase 1: A primeira fase foi identificada através de uma única sepultura estruturada, com orientação Oeste-Este, associada a uma pequena estrutura murária construída em duas fases e a um piso de terra batida. A sepultura foi construída com fragmentos de tijolo, tijoleira e calcário unidos por argamassa de cal. A sepultura exibe uma forma ovalada com $25 \mathrm{~cm}$ de profundidade sendo igualmente selada por argamassa da mesma tipologia. Infelizmente apenas o lado sul da sepultura se encontrava visível. Até agora não foi possível associar este enterramento ao Hospital Militar (Figura 3 e 4).

Fase 2: Foi efetuado um aterro de toda a área com sedimento de coloração amarela de forma a nivelar e sobrelevar a quota útil. É nesta área que se desenvolve a necrópole. Nesta fase identificaram-se vários enterramentos, seguindo a deposição canónica Oeste-Este, parecendo, no entanto, confinados à zona mais Oeste da área escavada.

Fase 3: Após o primeiro depósito foi efetuado um segundo aterro com um sedimento arenoso de coloração castanha-acinzentada. Os enterramentos desta fase caracterizam-se pela inumação em sepulturas múltiplas com 3 a 5 indivíduos, depositados com a cabeça e pés intercalados em orientações que poderiam ser Este-Oeste ou Oeste-Este. Identificou-se parco espólio em associação com os enterramentos desta fase, demonstrando a ausência de adornos/peças de vestuário, sugerindo que os corpos eram provavelmente enterrados despidos ou só com sudário (Muiznieks, 2015). As valas estavam alinhadas em fileiras que não se cortavam, sugerindo planeamento (Boyle, 2015; Souquet-Leroy et al., 2015) (Figura 5). Fase 4: Esta fase reflete a necessidade de conciliar um grande número de mortos com a saúde da comunidade (Carreira, 2012; Souquet-Leroy, 2015). É caracterizada por sepulturas duplas (cabeça-pés, lateral, um por cima do outro), em aparentes filas, maximizando o espaço. Devido a restrições impostas às partes anatómicas dos esqueletos e à identificação de alfinetes de bronze é de assumir que os corpos estavam envoltos num sudário (Souquet-Leroy, 2015). Mais uma vez, o planeamento está presente já que nenhuma das valas das sepulturas é cortada por outra, não afetando também as sepulturas da fase 3. Esta organização mostra um conhecimento da localização das sepulturas e uma preocupação de forma a não perturbar os mortos já inumados. As Fases 3 e 4 podem refletir duas crises mortuárias de curta duração. Estas crises de mortalidade eram comuns em Lisboa de época Moderna, já que a cidade ao mesmo tempo que dispunha de poucas condições sanitárias tinha uma abrangência global e recebia muitos mercadores e viajantes (e os seus vírus e bactérias) (Boyle, 2015; Carreira, 2012; Mitchell, 2015; Rodrigues, 1990; Souquet-Leroy et al., 2015; Tarlow, 2015) (Figura 6 e 7 ).

Fase 5: Esta fase reflete as normas, práticas culturais e religiosas da época, seguindo a deposição canónica Este-Oste/Oeste-Este, mas não o estrito Oeste-Este que surge noutras necrópoles cristãs (Souquet-Leroy, 2015). O pragmatismo encontra-se refletido na afetação parcial presente em quase todos os enterramentos (mas não o seu total levantamento), devido à necessidade de uso contínuo da área, onde novas valas cortavam as anteriores (Anthony, 2015). Uma vez que a área estava delimitada por muros e não permitia a expansão, outras soluções foram postas em prática pelos coveiros e pela administração do espaço sepulcral. Uma vala - carneiro - foi aberta (afetando vários enterramentos das Fase 3 e 4) com o propósito de reposicionar os ossos resultantes da abertura de novas sepulturas. Este ossário de grande dimensão tinha um número mínimo de indivíduos de 116 e terá sido utilizado durante toda a fase 5 . Esta é provavelmente a fase de utilização cronologicamente mais longa e a mais semelhante com as realidades dos cemitérios cristãos urbanos de época moderna (Anthony, 2015; Boyle, 2015; Souquet-Leroy et al., 2015) (Figura 8).

Fase 6: Na sua última fase, a memória da localização das sepulturas já era ténue (provavelmente já em fase de abandono deste cemitério pelas entidades militares/Irmãos Hospitaleiros de São João de Deus). Os enterramentos são menos numerosos, dispersos, 
com adultos junto a paredes (orientação Norte-Sul), e, pela primeira vez, três enterramentos infantis de idade muito jovem (dos 6 meses intrauterinos até aos 2 anos de idade). Esta utilização quase clandestina sugere a necessidade de enterramentos repentinos, podendo-se inferir a falta de espaço do cemitério da Igreja de Santa Cruz do Castelo ou a necessidade de esconder ou discriminar certos enterramentos (nados mortos/recém-nascidos). O ignorar da deposição canónica devido à urgência de enterrar é evidência de que o pragmatismo se sobrepôs ao aspeto religioso, uma característica das comunidades da era moderna, que iria terminar com os novos cemitérios ajardinados municipais de finais do século XVIII e século XIX (Anthony, 2015; Boyle, 2015; Jonhson, 2008; Rugg, 2000; Souquet-Leroy et al., 2015; Tarlow, 2007, 2013, 2015; Worpole, 2003) (Figura 9).

\section{PEQUENA NOTA SOBRE OS OSSÁRIOS}

Foram levantados vinte e três ossários, registando-se três tipos diferentes. O carneiro (NMI 116), com 4 metros de comprimento e provavelmente uma tampa removível (tábuas de madeira seriam suficientes). Devido ao seu uso constante seria essencial à gestão do espaço para a deposição dos ossos em espaço consagrado. No fundo do mesmo foi identificado uma camada de cal, provavelmente como acelerante para a decomposição. O uso da cal também foi identificado nas inumações (Figura 10).

O ossário 2 é de tamanho médio, com 2,10 m de comprimento e 1,20 m de largura, e um número mínimo de indivíduos de 32. Está relacionado com a construção do novo edifício civil que assentou em parte da necrópole (Este). A abertura de vala para construção de uma parede externa cortou vários enterramentos, sendo que posteriormente os ossos foram depostos ao lado da mesma vala, na zona exterior do novo edifício.

O ossário número 23 (NMI 10 a 14) também está relacionado com a construção do primeiro piso do edificado. Neste caso foi a construção das escadas interiores em cima da necrópole que cortou algumas sepulturas. Os trabalhadores terão decidido construir um nicho por baixo de um dos degraus, escondendo aí os ossos que tiveram mais significado para eles: crânios e os ossos longos das pernas.

Finalmente, os outros vinte ossários eram de pequena dimensão, a maior parte deles reduções, com um número mínimo de indivíduos variando entre 1 e 5 .

\section{DISCUSSÃO}

A não conformidade presente nas práticas de enterramento aponta para as realidades socioeconómicas vividas durante a era moderna. É razoável afirmar que o estudo dos rituais funerários é vital no conhecimento das práticas culturais de uma sociedade representando mais do que o simples "onde e como" são os mortos descartados (Fahlander e Oestigaard, 2008). A necrópole do Hospital Militar do castelo de São Jorge apresenta uma panóplia de soluções que refletem claramente as preocupações dos vivos.

A diversidade de sepulturas (múltiplas e duplas) pode estar associada a crises de mortalidade, comuns em Lisboa, devido a episódios epidémicos (Carreira, 2012, p. 37 e ss.; Rodrigues, 1990). As fontes históricas relatam vários períodos de crise desde finais do século XVI até ao XVIII, causadas por peste, febre tifoide, varíola ou tifo, muitas vezes aliadas a anos com más colheitas, resultando em escassez alimentar e inflação dos preços (Barbosa, 2001, p. 13; Carreira, 2012, p. 37 e ss.).

O uso intensivo do espaço sepulcral, com os enterramentos individuais, correspondente à quinta fase, mostra um hospital em pleno funcionamento, importante no cuidado aos militares, provavelmente associado com o crescimento da instituição no final do século XVII, e durante o século seguinte. Apesar de haver evidências do uso de caixões (pregos de ferro), a maior parte dos enterramentos terá sido feita diretamente no solo ou, eventualmente, com sudário. Num documento de 4 de Maio de 1645, o Alvará da entrega da administração dos Reais Hospitais Militares de Elvas, Campo Maior e Olivença aos Irmãos Hospitaleiros de S. João de Deus, é referido no capitulo 22: "As mortalhas dos defuntos e covas se tirará a despesa dos vestidos que levam os soldados para os Hospitais (...)” (Borges, 2017, p. 379 e 382).

Apesar do documento ser referente a hospitais da região alentejana, a sua gerência pertence aos Irmãos Hospitaleiros de São João de Deus, levando-nos a inferir que a realidade para o Hospital no Castelo de São Jorge não seria diferente, como ficou evidenciado pela posição das inumações e pela presença de alfinetes de bronze.

Podemos supor que a evidência dos alfinetes de sudário representa uma ritualização da forma de tratamento do morto, uma normalização. Este ato íntimo seria perpetuado pelos hospitaleiros de São João 
de Deus, podendo conter rituais como a lavagem do corpo e rezas (Inall e Lillie, 2020: 12).

Ainda pertencente à mesma cronologia (século XVII/XVIII) o Hospital de Ponte de Lima gerido pela Santa Casa indica que a responsabilidade do tratamento dos mortos recai sobre o casal de hospitaleiros, em que à hospitaleira cabia a função de amortalhar o defunto e ao hospitaleiro a de abrir a cova (Araújo, 214, 50 e 51). Esta menção aos trabalhadores civis de um hospital gerido por uma ordem religiosa é interessante e acaba por explicar a presença, diminuta é certa, de elementos do sexo feminino entre os indivíduos inumados.

Para uma cronologia pós-terramoto, com base em documentação de 1765 , sobre as Ordens que se devem observar num Hospital Militar, encontramos referência ao facto de que o lençol de um infetado passasse a servir de mortalha, de forma a não queimar o mesmo e assim o desperdiçar, não usando "nova grossaria em que se costumam amortalhar" (Borges, 2017, p. 386). É também sabido que quando ingressavam no hospital as pessoas eram despojadas de todos os seus objetos pessoais e vestuário (alvo de inventário à entrada) trocando-os por uma camisa do estabelecimento (Sá, 2010). Esta destituição de individualidade à entrada no hospital perpetua-se assim, segundo o que podemos observar, no tratamento funerário após a morte, já que se identificaram raros sinais de individualidade tanto no vestuário como no adorno (quase sempre de cariz religioso).

Verifica-se, pois, que seria prática normal o enterro em sudário para os defuntos dos hospitais militares e não só, sendo talvez a razão pela qual não foi possível até à data diferenciar os enterramentos dos soldados dos dos prisioneiros que tiveram assistência no hospital.

A organização espacial parece ter estado presente no planeamento desta necrópole de Época Moderna. Contudo, mostrando preocupações sociais, culturais e religiosas tornou-se um problema de saúde pública devido ao número de corpos depositados num espaço tão pequeno em tão curto espaço de tempo, o que comprometia a normal decomposição cadavérica (Anthony, 2015; Carreira, 2012, p. 38 e ss; Rodrigues, 1990). Um relatório de maio de 1694, no pico de uma crise epidémica, da autoria do Comendador-Mor da Saúde, Domingos Nogueira de Araújo, descreve que as doenças no Castelo estavam provavelmente relacionadas com os corpos, já à superfície, no cemitério do hospital militar, sendo uma situação grave de saúde pública (Andrade, 1954; Carreira, 2012, p. 38; Rodrigues, 1990).

\section{CONCLUSÃO}

Embora a disposição do corpo seja determinada por um ritual, neste caso a inumação, mostrando uma experiência cultural e religiosa feita pelos vivos, o corpo pode também constituir uma ameaça para os vivos (Anthony, 2015; Chapman, 2003; Fahlander e Oestigaard, 2008, p. 6). O funeral está imerso num ritual simbólico, mas também prático, que devido à falta de espaço levou à adoção de diferentes dinâmicas sociais, ignorando a ritualização convencional do enterro. A morte e os mortos são parte de um processo embebido num ambiente religioso, mas os aspetos sociais, culturais e económicos (aos quais se podem juntar os higiénicos/saúde pública) são tão ou mais importantes para a interpretação dos dados recolhidos.

Olhar o estudo de necrópoles com uma grelha analítica que privilegie a leitura integrada dos vários registos, fontes históricas, dados antropológicos e arqueológicos, permite o acesso a uma visão mais abrangente dos gestos e processos que levaram às práticas registadas.

Na Rua do Recolhimento, notou-se que, embora a necrópole se tenha iniciado seguindo uma ordem e gestão - muito militar até - esta foi abandonada, tal como a regra canónica, assim que foi necessário mais espaço para responder ao elevado grau de mortalidade registado no Hospital dos Soldados. Do mesmo modo, o sentido prático do iluminismo, o afastamento gradual da razão e da religião e a premência das regras de saúde pública devem ter levado ao abandono total desta necrópole considerada insalubre e o seu olvidamento sob uma construção civil (ainda assim de carácter popular como o atestam imagens da mesma datadas do século XIX).

\section{AGRADECIMENTOS}

As autoras gostariam de agradecer ao Centro de Investigação em Antropologia e Saúde, ao Centro de Ecologia Funcional è̀ EON - Industrias Criativas. A co-autora Liliana M. Carvalho foi financiada pela FCT - Fundação para a Ciência e Tecnologia, sob o projecto com a referência SFRH/BD//BIA/04004/2020. A co-autora Sofia N. Wasterlain foi financiada por fundos nacionais via FCT - Fundação para a Ciência 
e Tecnologia, sob o projecto com a referência FCT-PEst-OE/SADG/UIo283/2019.

\section{BIBLIOGRAFIA}

ANDRADE, F. de (1954) - A freguesia de Santa Cruz da Alcáçova de Lisboa.

ANTHONY, Sian (2015) - Hiding the body: ordering space and allowing manipulation of body parts within Modern cemeteries. The archeology of death in post-medieval Europe (Tarlow, S., ed.), pp. 170-188.

ARAÚJO, Ma . Marta Lobo de (2005) - Hospitais Reais. As freguesias do Distrito de Viana do Castelo na Memórias Paroquiais de 1758. Alto Minho: Memórias, História e Património, (Capela, José Viriato, coord.) Braga, Casa Museu de Monção/Universidade do Minho, pp. 651-652.

BARBOSA, Hermínia, e GODINHO Anabela (2001) - Crises de mortalidade em Portugal desde meados do século XVI até ao início do século XX. Universidade do Minho. Núcleo de Estudos de População e Sociedade (NEPS).

BORGES, Augusto José Moutinho (2007) - Os reais hospitais militares em Portugal administrados e fundados pelos Irmãos Hospitaleiros de S. João de Deus 1640-1834, Dissertação de doutoramento em História Das Ciências da Saúde. Faculdade de Ciências Médicas da Universidade Nova.

BOYLE, Angela (2015) - Approaches to post-medieval burial in England: past and present. The archeology of death in post-medieval Europe (Tarlow, S., ed.), pp. 39-6o.

CABAÇO, Patrícia Gonçalves (2009) - Cemitérios municipais de Lisboa: estratégias de articulação entre Thanatos $e$ Pólis. Dissertação de mestrado em arquitectura, Instituto Superior Técnico de Lisboa.

CARREIRA, Adélia Maria Caldas (2012) - Lisboa de 1731 a 1833: da desordem à ordem no espaço urbano. Dissertação de doutoramento em História de Arte. Faculdade de Humanidades e Ciências Sociais da Universidade Nova.

CARVAlHO, Hugo Pereira de (2012) - A inclusão do cemitério no espaço da cidade. Dissertação de mestrado para obtenção do grau em Arquitectura, Faculdade de Arquitectura, Universidade Técnica de Lisboa.

CHAPMAN, Robert (2003) - Death, society and archaeology: the social dimensions of mortuary practices. Mortality 8:3, pp. 305-312.

FAHLANDER, Fredrik, OESTIGAARD, Terje, eds. (2008) - The materiality of death: bodies, burials, beliefs. Oxford: Archaeopress.

FRANÇA, José Augusto (2008) - Lisboa: história fisica e moral. Horizonte.

GASPAR, A; GOMES, A. (2001) - Castelo de São Jorge Relatório das Escavações Arqueológicas.
MESTRE, V.; GASPAR, M.A.; GOMES, A.M. (2002) - Reabilitação do troço sul/nascente do caminho de ronda do castelo de São Jorge, Lisboa; in: Monumento - Revista Semestral de Edificios e Monumentos, nํ17, p. 132-139.

GASPAR, Alexandra e GOMES, Ana (2005) - O Hospital de São João de Deus no Castelo de São Jorge - Vestígios Arqueológicos. Actas do XVI Colóquio de História Militar - O Serviço de Saúde Militar nas comemoraçôes do IV centenário dos Irmão Hospitaleiros de São João de Deus em Portugal. pp. 863-889.

INALL, Y., e LILLIE, M. (2020) - Meaning and mnemonic in archaeological studies of death. Mortality, 25(1), pp.7-24.

MENDES, R. D. M. (2013) - A Devoção às Almas do Purgatório na Arte Azulejar de Coimbra Fé, Piedade e Emoção Estéti$c a$, dissertação de mestrado em história de Arte, Património e Turismo Cultural pela Universidade de Coimbra.

MESTRE, V.; GASPAR, M.A.; GOMES, A.M. (2002) - Reabilitação do troço sul/nascente do caminho de ronda do castelo de São Jorge, Lisboa; in: Monumento - Revista Semestral de Edificios e Monumentos, $\mathrm{n}^{\circ}$ 17, pp. 132-139.

MITCHELL, Piers D. ed. (2015) - Sanitation, Latrines and Intestinal Parasites in Past Populations. Ashgate.

MUIZNIEKS, Vitolds (2015) - The co-existence of two traditions in the territory of present-day Latvie in the $13^{\text {th }}-18^{\text {th }}$ centuries: burial in Dress and in a Shroud. The archeology of death in post-medieval Europe (Tarlow, S., ed.), pp. 88-110.

RODRIGUES, Teresa Ferreira (1990) - As Crises de Mortalidade em Lisboa (séculos XVI e XVII), Livros Horizonte.

RUGG, Julie (2000) - Defining the place of burial: what makes a cemetery a cemetery? Mortality 5:3, pp. 259-275.

SÁ, Isabel dos Guimarães (2010) - Os espaços de reclusão e a vida nas margens. História da Vida Privada em Portugal: a Idade Moderna (Monteiro, N.G., ed.).

SILVA, Augusto Vieira (1937) - O Castelo de S. Jorge em Lisboa: estudo histórico-descritivo. Emprêsa Nacional de Publicidade.

SOUQUET-LEROY, Isabelle, RÉVEILLAS, Hélène, e CASTEX, Dominique (2015) - The impact of epidemics on funerary practices in Modern France $\left(16^{\text {th }}-18^{\text {th }}\right.$ centuries). The archeology of death in post-medieval Europe (Tarlow, S., ed.), pp. 61-87.

TAVARES, Rui (2005) - O pequeno livro do grande terramoto. Tinta-da-China.

THARLOW, Sarah (2000) - Landscapes of memory: the nineteenth-century garden cemetery. European Journal of Archaeology, 3:2, pp. 217-239.

THARLOW, Sarah. (2007) - The archaeology of improvement in Britain, 1750-1850. Cambridge University Press.

WORPOLE, Ken (2003) - Last Landscapes: the architecture of the cemetery in the West. Reaktion Books. 


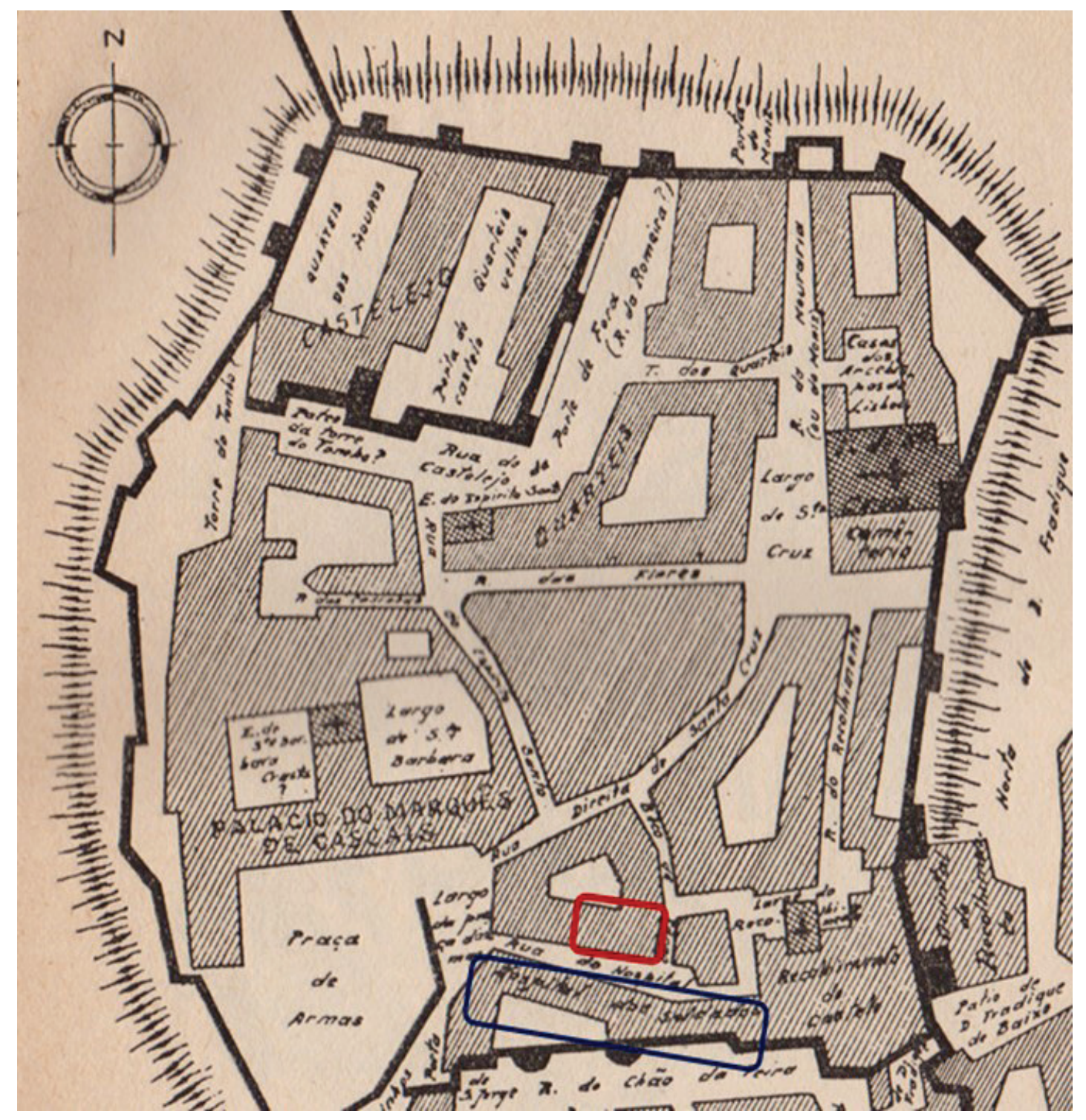

Figura 1 - Localização da necrópole (vermelho) e do Hospital Militar (Azul). In: Vieira da Silva (1937). O castelo de São Jorge em Lisboa, Lisboa, 2 edição. Página 2. 


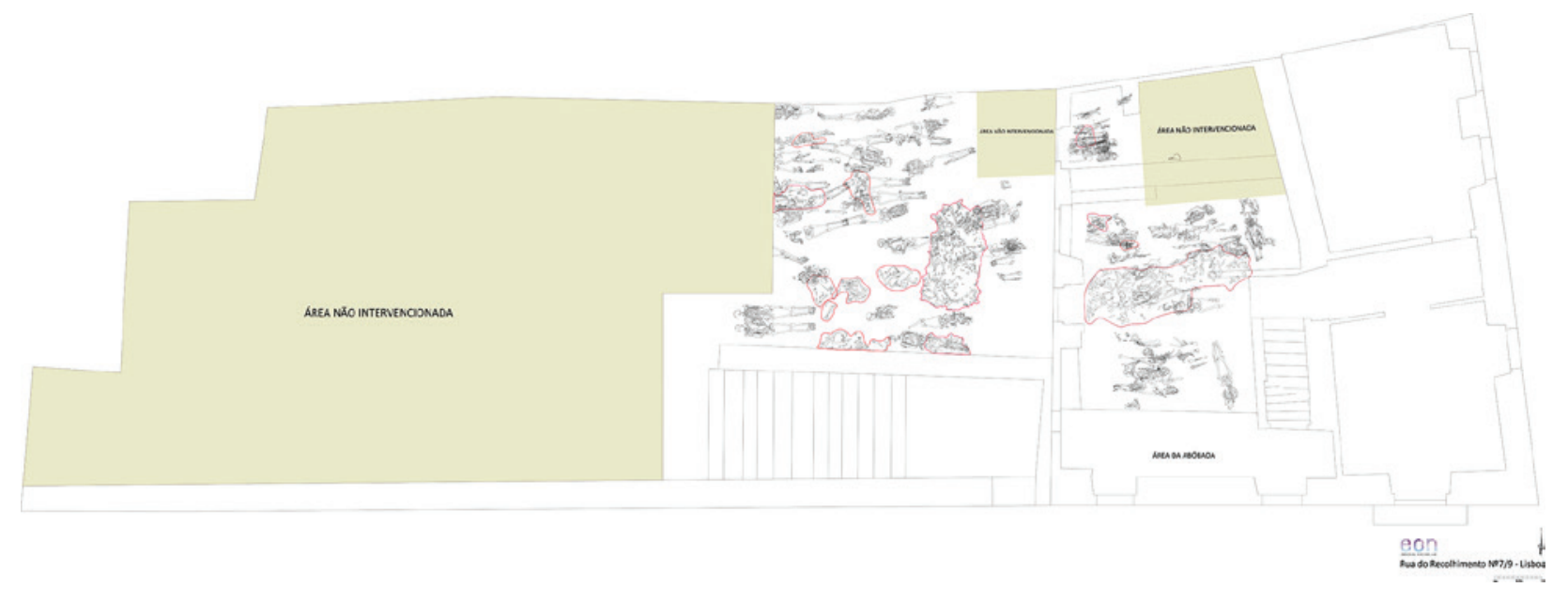

Figura 2-Plano compósito (primeira camada) mostrando a densidade e a afetação dos enterramentos. Desenho de Filipe Rebelo.

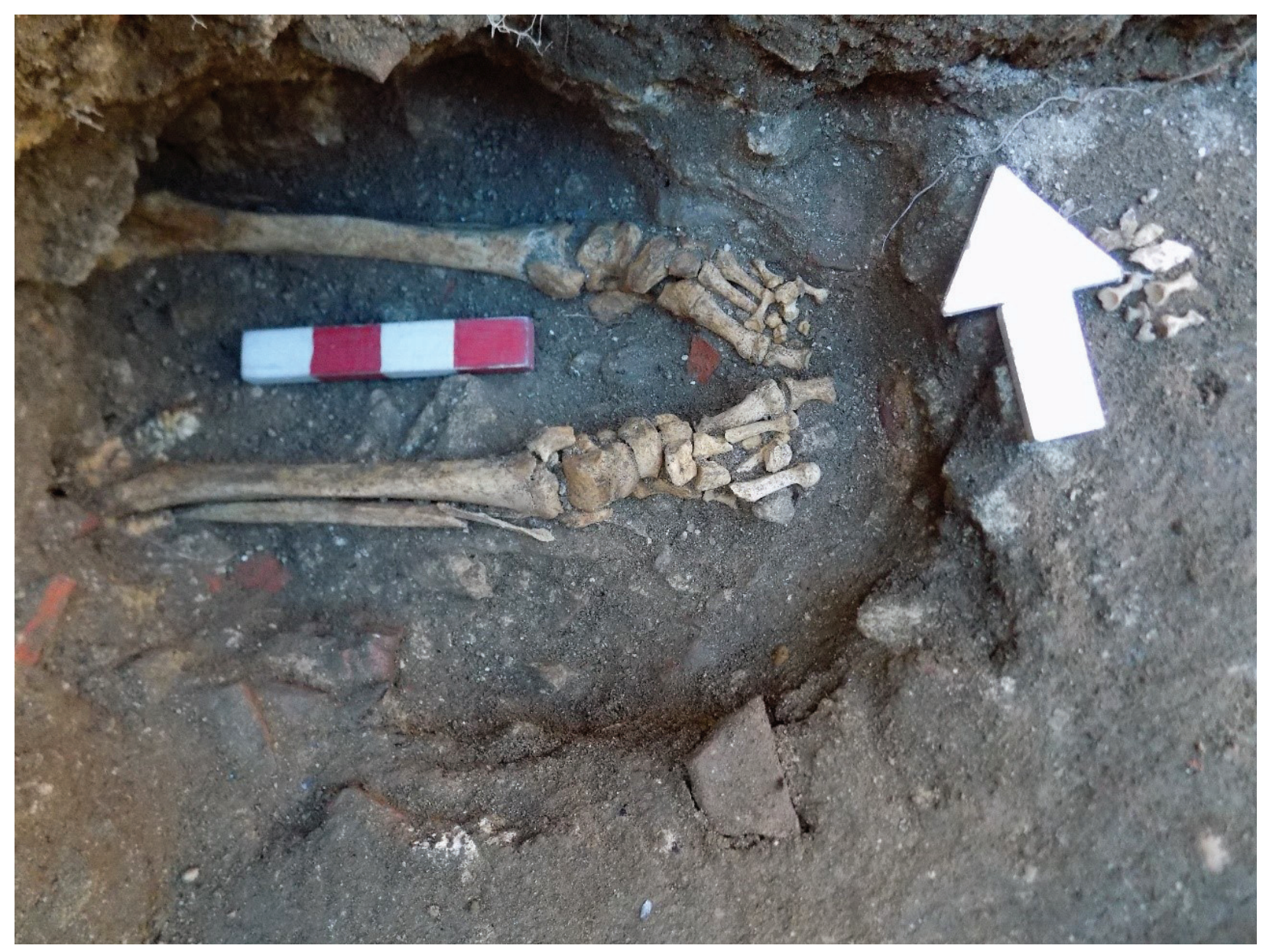

Figura 3 - Sepultura estruturada [Individuo 841]. Fase 1. 


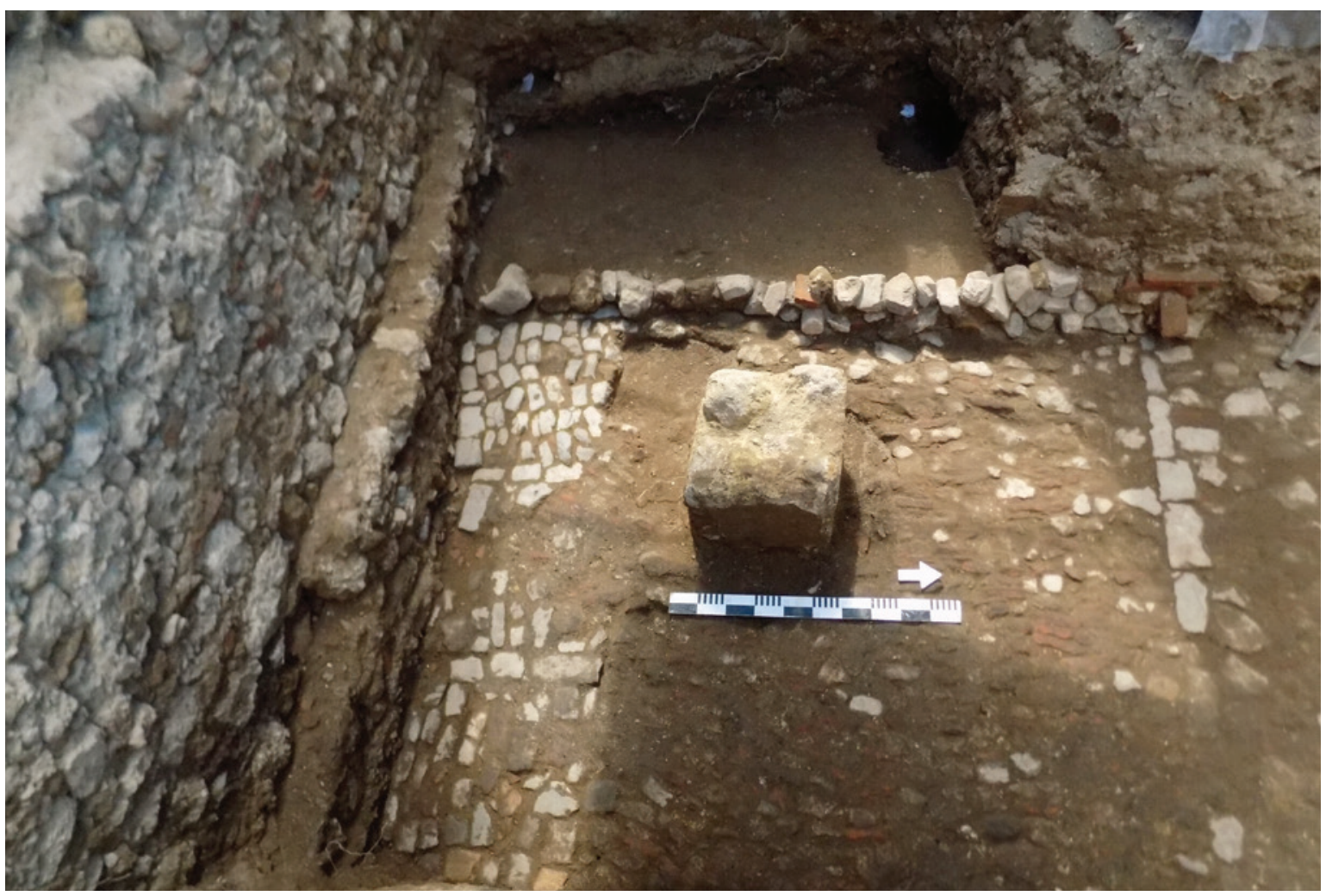

Figura 4 - Plano geral com a localização da sepultura, do piso de terra batida e dos muros que delimitam aquele espaço.

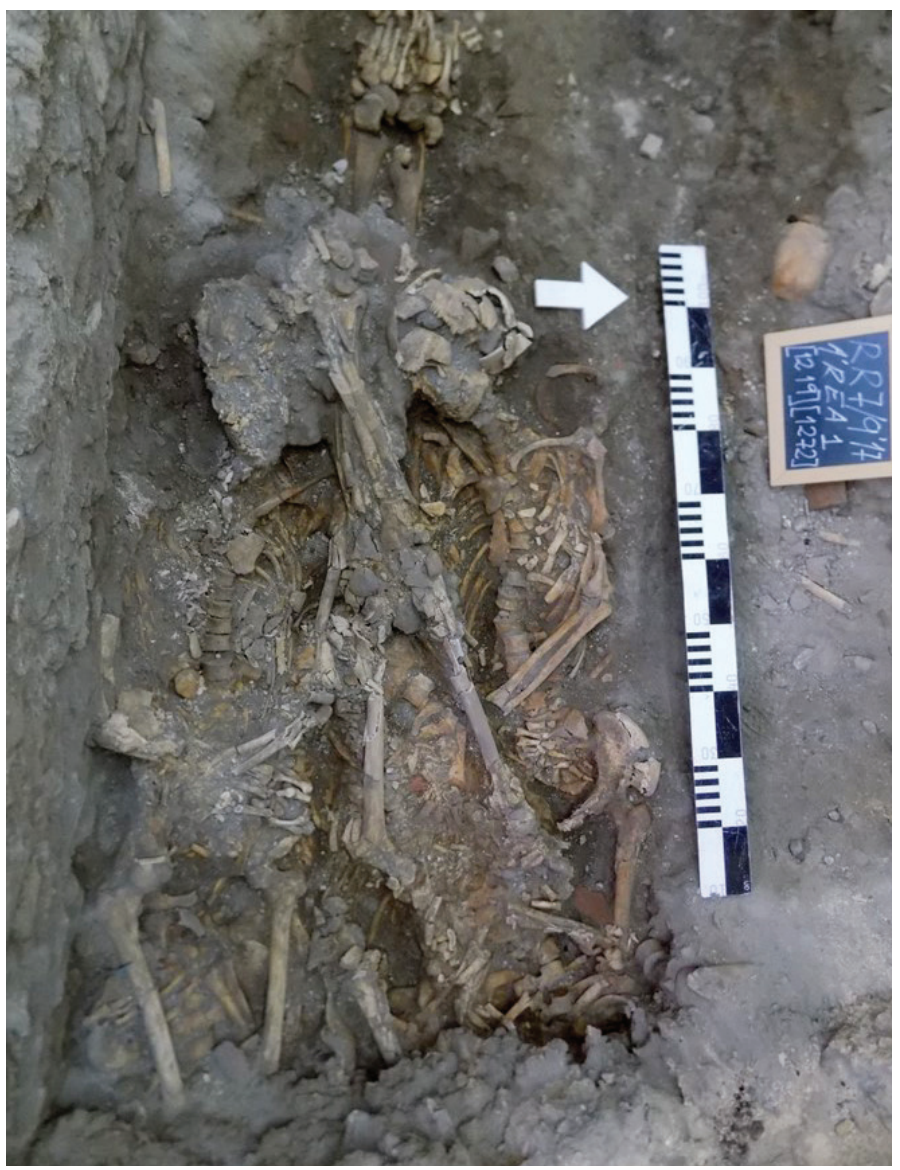

Figura 5-Sepultura múltipla, vala comum 1 (cinco indivíduos) Fase 3. 


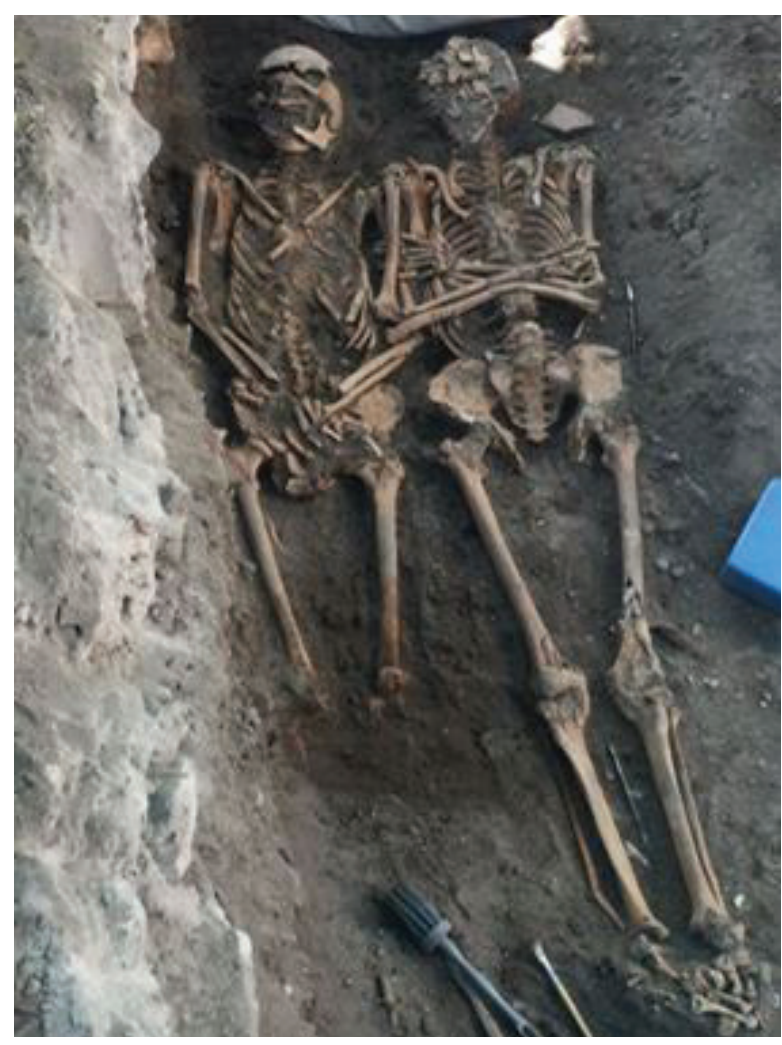

Figura 6 - Enterramento duplo [Indivíduos 18 e 19]. Fase 4.

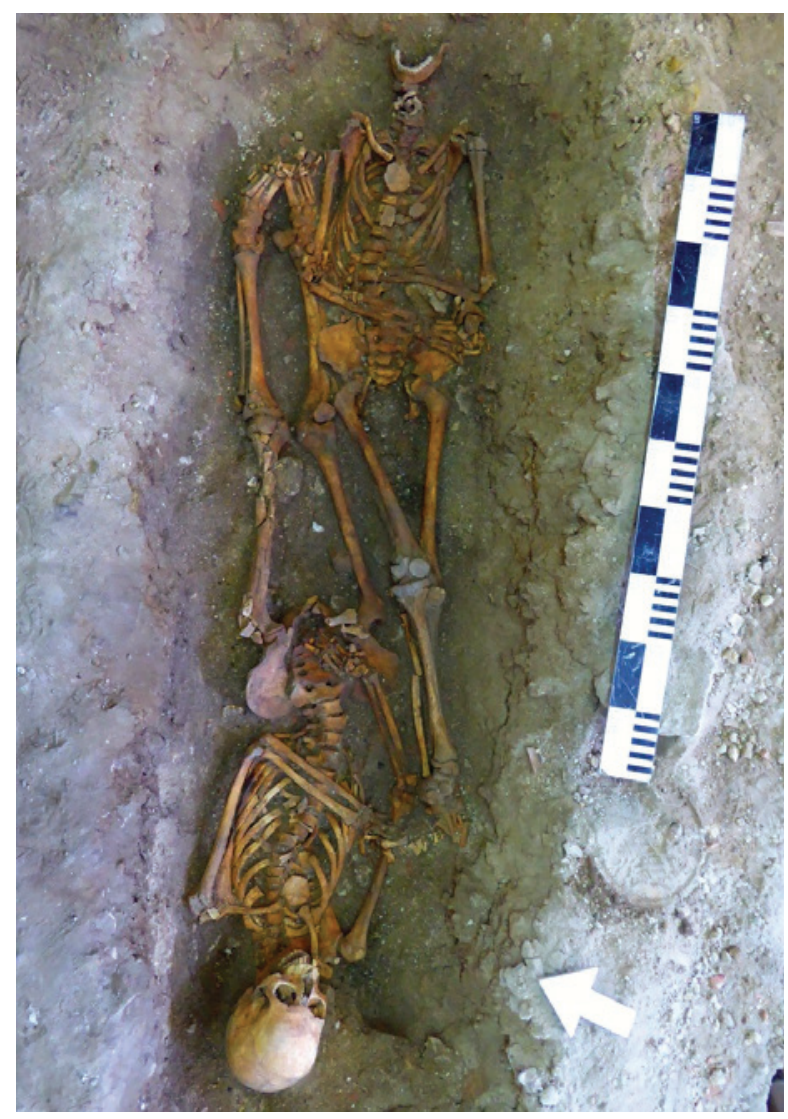

Figura 7-Sepultura dupla [Indivíduos 335 e 336]. Fase 4.

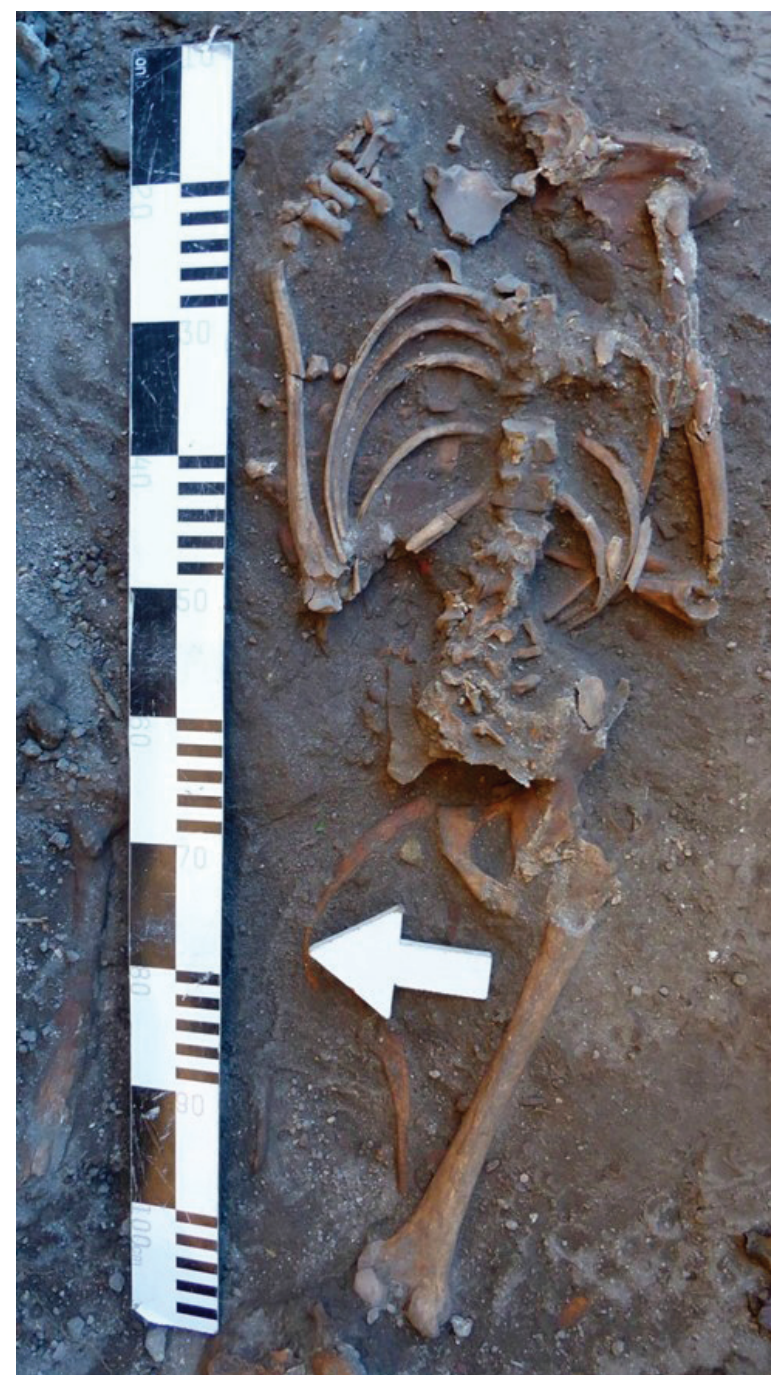

Figura 8 - Enterramento em decúbito ventral [Individuo 644]. Fase 5 . 


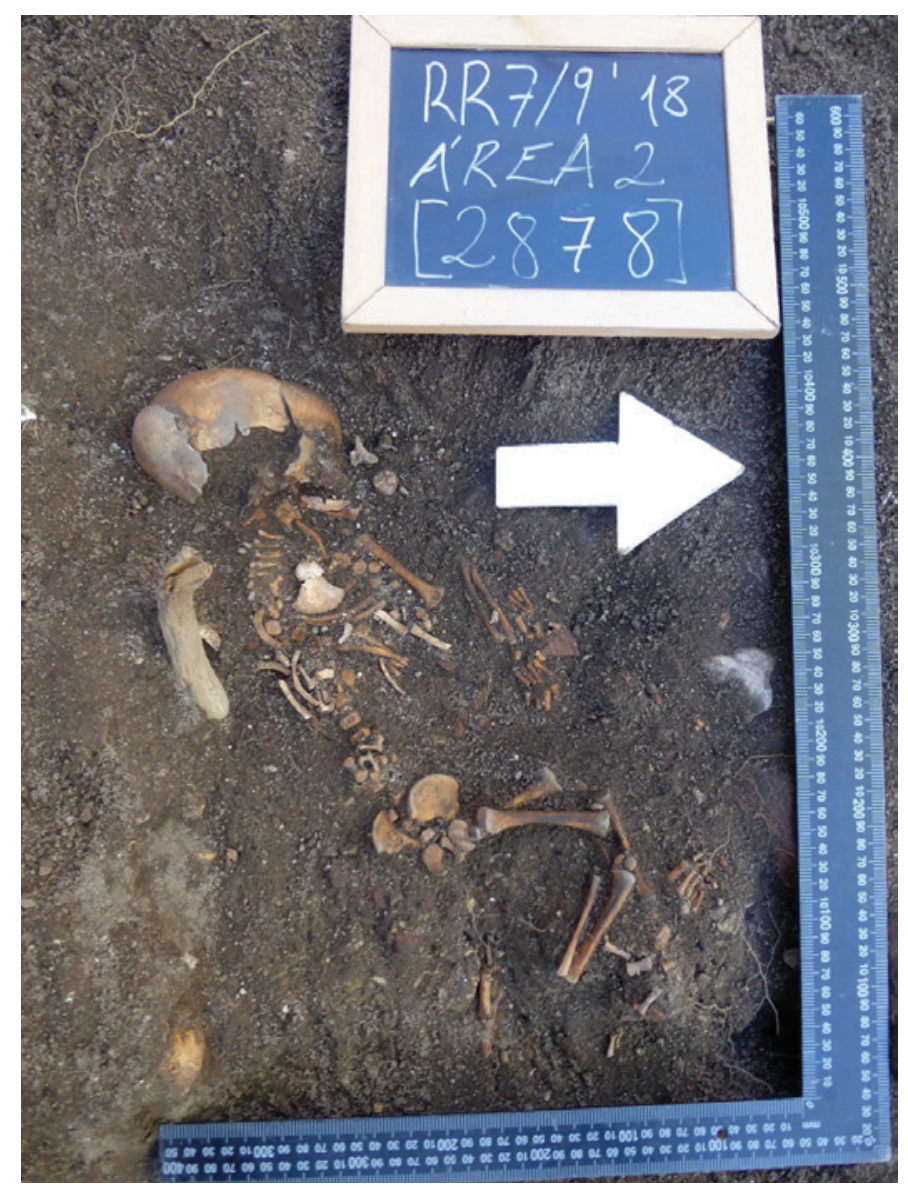

Figura 9 - [Individuo 620]. Fase 6.

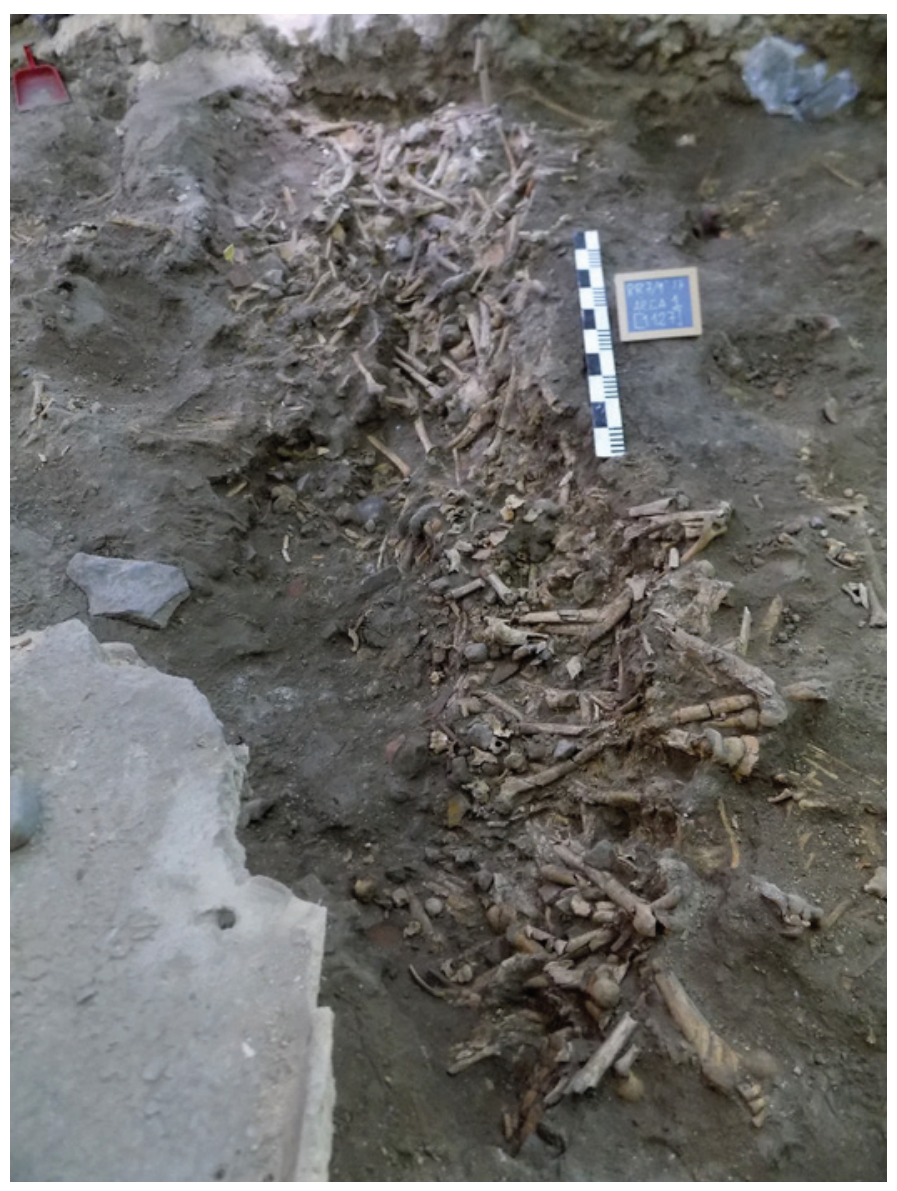

Figura 10 - Ossário 11/Carneiro. 


\title{
SAND - SARILHOS GRANDES ENTRE DOIS MUNDOS: O ADRO DA IGREJA E A PALEOBIOLOGIA DOS OSSOS HUMANOS RECUPERADOS
}

\author{
Paula Alves Pereira ${ }^{1}$, Roger Lee Jesus ${ }^{2}$, Bruno M. Magalhães ${ }^{3}$
}

\begin{abstract}
RESUMO
A escavação arqueológica de salvaguarda realizada em 2008 no Largo da Igreja de Sarilhos Grandes originou um projeto de investigação interdisciplinar que visa o estudo da sua população desde época Medieval. Este trabalho pretende discutir a análise paleobiológica da coleção osteológica humana escavada em 2008. Foi estimado um número mínimo de 24 indivíduos entre o total de 21 enterramentos mal preservados, 5 ossários e restantes ossos desarticulados. De entre as lesões identificadas (e.g., cáries, tártaro, osteomas, nódulo de Schmorl, osteoartrose), várias parecem indiciar deficiências nutricionais, principalmente nos indivíduos mais jovens. Uma nova intervenção arqueológica está já programada para o local de forma a serem aprofundadas várias questões e abertas novas perspetivas sobre a população de Sarilhos Grandes.
\end{abstract}

Palavras-chave: Arqueologia, Necrópole, Paleodemografia, Paleopatologia, Stresse nutricional.

\begin{abstract}
The archaeological excavation carried out in 2008 at the Largo da Igreja of Sarilhos Grandes triggered an interdisciplinary research project aiming to study its population since the medieval period. This work aims to discuss the paleobiological analysis of the human osteological remains excavated in 2008. A minimum number of 24 individuals were estimated out of 21 poorly preserved skeletons, five ossuaries and other disarticulated bones. Several pathologies were identified (e.g., caries, calculus, osteomas, Schmorl nodules, osteoarthrosis) with special focus on lesions possibly associated with nutritional stress in younger individuals. A new archaeological excavation is programmed aiming to better understand several issues and open new perspectives about the population of Sarilhos Grandes.
\end{abstract}

Keywords: Archaeology, Churchyard, Palaeodemography, Palaeopathology, Nutritional stress.

\section{O PROJETO “SAND - SARILHOS GRANDES ENTRE DOIS MUNDOS"}

O projeto SAND incide na zona especial de proteção da Ermida de Nossa Senhora da Piedade e Igreja de S. Jorge, classificados como imóveis de Interesse Público pelo Decreto $n^{\circ} 45 / 93$, DR, r. ${ }^{\circ}$ série-B, n. ${ }^{\circ} 280$ de 30 novembro 1993. O monumento localiza-se no Largo da Igreja da freguesia de Sarilhos Grandes, concelho do Montijo, distrito de Setúbal (Figura 1). A génese do projeto recua à intervenção arqueológica de 2008 onde foram recolhidas amostras de solo dos enterramentos escavados com vista à sua pesquisa paleoparasitológica, isto é, o estudo de parasitas associados ao material osteológico humano recuperado. As amostras foram analisadas no laboratório

\footnotetext{
1. Coordenadora do projeto; paulalvespereira@gmail.com

2. Historiador. Bolseiro do projeto de investigação "SAND”. CHAM - Centro de Humanidades (FCSH, Universidade NOVA de Lisboa); CHSC (UC); rogerlee.pj@gmail.com

3. Bioantropólogo. Bolseiro do projeto de investigação "SAND”. CIAS - Centro de Investigação em Antropologia e Saúde; Departamento de Ciências da Vida, Universidade de Coimbra; bruno.miguel.silva.magalhaes@gmail.com
} 
da Fundação FioCruz, no Rio de Janeiro. As análises, concluídas em 2015, revelaram, para além de ovos de Ascaris lumbricoides, vulgarmente conhecida como lombriga, cuja ocorrência é relativamente comum em populações humanas pelo contacto com fezes ou pela ingestão de água ou alimentos contaminados, ovos de Oxyuroidea, provavelmente adquiridos pelo consumo de carne de caça, e do género Trichostrongylus, relacionado com animais domésticos como coelhos, porcos, ovinos e bovinos, parasitas pela primeira vez reportados em populações históricas europeias (Pereira $\&$ alii, 2017; Sianto $\&$ alii, 2018). As pesquisas aos conteúdos intestinais mostraram, igualmente, vestígios diversos dos quais se salientam alimentos como o arroz, moluscos e amido de batata. Estes dados, associados a algumas das cronologias, obtidas por radiocarbono, conferem grande importância a este pequeno grupo de indivíduos e a Sarilhos Grandes. O conhecimento atual indica que a batata (Solanum tuberosum) terá sido trazida da América para as Ilhas Canárias em 1567 (Lobo-Cabrera, 1988), desconhecendo-se a data de chegada a Portugal. As questões alimentares levantadas continuaram a ser exploradas por análise de isótopos que evidenciaram uma alimentação variada, com consumo de proteínas de origem animal, vegetal e marinha (peixe de rio e de mar e moluscos), como seria expectável pela localização geográfica de Sarilhos Grandes. Mais recentemente, iniciou-se o estudo do tártaro dentário cujas primeiras análises levaram à identificação de conídios do fungo Candida albicans, cuja presença na cavidade oral potencia o surgimento de cáries (Pereira \& alii, 2017).

\subsection{Enquadramento Histórico}

A freguesia de Sarilhos Grandes situa-se no actual concelho do Montijo e encontra-se ligada administrativamente a esse centro urbano desde tempos medievais. A referência documental mais antiga ao lugar data de 1251, numa sentença relativa aos dízimos arrecadados pela Sé de Lisboa nos territórios na banda d'além do Tejo. Já desde esse século que todas as terras da Península de Setúbal e das suas proximidades estavam sob jurisdição da Ordem de Santiago, uma das mais importantes ordens militares em território português. Com um desenvolvimento modesto ao longo dos séculos, Sarilhos obteve autorização do bispo de Lisboa, D. João Anes, em 1390, para a construção de uma nova igreja, dependente da igreja de S. Maria de Sabonha, então sede de um concelho que abrangia os actuais territórios do Montijo (então Aldeia Galega do Ribatejo) e Alcochete (Dias, 2005).

Já nos inícios do século XVI a igreja de S. Jorge ganhou uma capela adjacente, colada ao corpo do templo, mas com acesso pelo exterior, dedicada ao culto de Nossa Senhora da Piedade. Era uma capela privativa, da responsabilidade do Dr. João Cotrim, um dos mais importantes desembargadores do reinado de D. Manuel I, envolvido na própria reorganização administrativa dos forais. O seu cunhado, Rui de Castanheda, fora um dos capitães da segunda armada de Vasco da Gama à Ásia, em 1502, e tinha também vastas propriedades em Sarilhos Grandes. Estas acabariam por ser herdadas pelo seu sobrinho, Rui Cotrim de Castanheda (filho do mencionado Dr. João Cotrim), fidalgo da Casa Real cujo túmulo se encontra devidamente assinalado na ermida da Virgem da Piedade.

Paralelamente a esta pequena fidalguia radicada em Sarilhos, a terra foi crescendo nesse século, à sombra das suas salinas, dos moinhos de maré e dos seus frondosos pinhais. De uma população de c. 130 habitantes em 1532 passa para quase 200 em 1620, iniciando então um paulatino decréscimo populacional assinalado em múltiplas fontes do século XVIII e que se prolongaria até finais do XIX, quando o lugar voltaria a ganhar destaque no contexto da crescente industrialização de Lisboa e da sua área metropolitana. O objetivo do presente trabalho é apresentar e discutir a análise paleobiológica da coleção osteológica humana proveniente da escavação de 2008.

\section{MATERIAL E MÉTODOS}

Neste trabalho são estudados os 21 esqueletos, 5 ossários e restantes ossos desarticulados escavados em 2008 durante a intervenção arqueológica no adro da igreja matriz de S. Jorge de Sarilhos Grandes (concelho do Montijo).

O primeiro passo consistiu na limpeza a seco de todos os ossos e dentes, seguido da sua marcação. Posteriormente, foi avaliada a preservação dos esqueletos através do método proposto por Bello \& alii (2006), tendo sido calculado o Índice de Preservação Anatómica (IPA), o Índice de Representatividade Óssea (IRO) e o Índice de Qualidade Óssea (IQO). Para a análise paleodemográfica foram analisados o número mínimo de indivíduos (NMI), a diagnose sexual e a estimativa da idade à morte. Para a análi- 
se do NMI foi utilizado o método desenvolvido por Herrmann (1990 in Silva, 1993) para os ossos longos do esqueleto pós-craniano e o método sugerido por Ubelaker (1974), para os restantes tipos de peças ósseas completas e fragmentadas. A observação do tipo de dentição (decidual, mista ou definitiva), do tamanho dos ossos e da presença e/ou fusão das epífises permitiu a separação dos vestígios osteológicos humanos em não adultos ou adultos. A categoria etária determinou a escolha dos métodos para avaliação do perfil biológico dos indivíduos. Assim, para a diagnose sexual foram aplicados os métodos sugeridos por Ferembach $\&$ alii (1980) e por Buikstra e Ubelaker (1994) para o esqueleto axial e de Cardoso (2000), Wasterlain (2000) e Silva (1995) para o esqueleto apendicular. No que diz respeito à idade à morte, para os não adultos foram usadas as estimativas osteométricas referidas por Carneiro (2016) e Scheurer e Black (200o), para além das de AlQahtani, Hector e Liversidge (2010) para os dentes; para os adultos foram usadas as metodologias referidas por MacLaughlin (1990) para a clavícula e por Iscan e Loth (1993) e de DiGangi \& alii (2009), para as costelas.

Todos os ossos foram analisados macroscopicamente e para o dignóstico diferencial foram seguidas as recomendações gerais dos manuais de Ortner (2003) e Aufderheide e Rodríguez-Martín (2011) e, especificamente para não adultos, de Lewis (2018). As cáries foram registadas segundo o método desenvolvido por Hillson (2001) e o tártaro através do método de Buikstra e Ubelaker (1994). A osteoartrose foi registada segundo as indicações de Rogers e Waldron (1995) através de classificação binária, como presente ou ausente, quando a superfície articular é afetada por eburnação ou por porosidade e labiação.

Todos os dados foram inventariados no software microsoft Excel 2010 e analisados estatisticamente com o Statistical Package for the Social Sciences (SPSS), versão 21.0.

\subsection{A preservação dos esqueletos e as dificulda- des na análise osteológica}

Os 21 esqueletos encontram-se em muito mau estado de preservação. Mostram um índice de representatividade óssea (IRO) geral de $44,7 \%$, o que significa que a maioria dos ossos ou partes anatómicas se encontra ausente (Figura 2). Para além disso, enquadram-se também nas piores classes de preservação (classes 1, 2 e 3), quer no Índice de Preserva- ção Anatómica (IPA), quer no Índice de Qualidade Óssea (IQO).

$\mathrm{Na}$ realidade, a preservação dos esqueletos limitou sobremaneira a restante análise paleobiológica e vários terão sido os agentes tafonómicos, principalmente extrínsecos ao próprio osso, que contribuíram para a degradação. Se nos detivermos nos fatores especificamente observados aquando da escavação (a que, de resto, nos iremos limitar neste trabalho), a ausência de 55,3\% de ossos ou partes anatómicas dos esqueletos parece estar associada à pouca profundidade dos enterramentos, uma vez que apenas um não tinha sido perturbado pela construção de infra-estruturas mais recentes (Pereira $\mathbb{\&}$ alii, 2008). A reutilização contínua do espaço funerário terá também tido importância (Pereira \& alii, 2008), tal como é compreensível e descrito em outros cemitérios no país com utilização intensiva ao longo de centenas de anos.

O ambiente extremamente húmido das areias onde os indivíduos foram inumados (a Formação Pliocénica de Santa Marta) e a que estiveram sujeitos durante séculos parece ter sido outro fator relevante para a deficiente preservação. Isto terá contribuido para que muitos dos ossos, apesar de mais ou menos 'completos' e in situ, fragmentassem ou, em último caso, se desfizessem depois de recolhidos, mesmo com o maior dos cuidados. Foi o que aconteceu, por exemplo, com quase todos os ossos dos indivíduos 1, 2, 3, 4 ou 5, aspecto que é, no entanto, comum a outros esqueletos. A literatura mostra-nos que a inumação em solos arenosos húmidos pode acelerar a perda de estabilidade óssea (e.g., Carter e Tibbett, 2008), sendo que o processo de degradação principal de material orgânico no solo aeróbico e húmido está associado à oxidação biológica através do ecossistema presente e que geralmente resulta na sua destruição (Kibblewhite, Tóth e Hermann, 2015).

\subsection{Avaliação do perfil biológico e paleodemogra- fia: a população de Sarilhos Grandes proveniente do adro da igreja de $\mathrm{S}$. Jorge}

Foi estimado um número mínimo de 24 indivíduos entre o total de 21 enterramentos, 5 ossários e restantes ossos desarticulados escavados no adro da igreja matriz de Sarilhos Grandes. O número mínimo foi conseguido através do fémur direito, o osso mais representado entre todos os restos osteológicos humanos recuperados. Foi seguida uma abordagem conservadora em que os fémures direitos 
desarticulados poderiam pertencer aos indivíduos inumados, desde que dentro da mesma faixa etária. Foram identificados 7 indivíduos não adultos $(3$ fetos/recém-nascidos e 4 enquadráveis na $1^{\underline{a}}$ infância [até 6 anos]), 12 adultos (10 >2O anos, 1 adulto jovem [20-29 anos] e 1 adulto maduro [ $>29$ anos]) e 2 de idade indeterminada.

Dada a presença de bastantes indivíduos não adultos (para os quais a aplicação de métodos para o sexo biológico é bastante mais difícil que nos adultos) e a má preservação dos ossos recuperados, a avaliação no terreno (Pereira \& alii, 2008) e em laboratório apenas permitiu identificar 3 indivíduos de sexo feminino e 3 de sexo masculino, sendo os restantes $15(71,4 \%)$ indivíduos de sexo indeterminado. Relativamente aos ossos desarticulados, foram identificados 2 crânios de indivíduos do sexo feminino (ossário_1[UE7A-2] e ossário_5[UE50-9]) e um úmero de um indíviduo masculino (UE144-1).

2.3. Paleopatologia: que lesões foram identificadas nos indivíduos inumados no adro da igreja de Sarilhos Grandes?

\section{- Patologia oral}

Do total de 21 indivíduos inumados, 8 (38,1\%) preservaram dentição erupcionada. Se tivermos em conta toda a amostra, foram estudados 219 dentes erupcionados, 95 maxilares $(43,4 \%)$ e 124 mandibulares $(56,6 \%)$, dos quais 212 se encontravam soltos e apenas 7 nos respetivos alvéolos. Desta forma, apenas foi possível estudar a presença de lesões cariogénicas, tártaro e hipoplasias do esmalte.

Dos 8 indivíduos que apresentavam dentes erupcionados, 7 evidenciavam pelo menos uma cárie dentária e o não adulto $\mathrm{n}^{\circ}{ }^{\circ}, \operatorname{com} 4,5$ a 6 anos de idade à morte, era o único que não apresentava qualquer lesão cariogénica (Tabela 1). Do total da amostra analisada, 123 dos 219 dentes (56,2\%) apresentavam pelo menos uma cárie, sendo que a dentição inferior apresenta mais cáries que a superior $(58.1 \%$ vs 53.3\%), mas sem diferença estatística significativa (Pearson $\chi^{2}=0,419 ; d . f=1 ; p=0,517$ ). Se tivermos em conta apenas as lesões cavitadas, 49 dos 219 dentes $(22,4 \%)$ apresentam pelo menos uma cárie, pelo que a maior parte das lesões se encontrava numa fase inicial. Infelizmente, estas frequências não podem ser comparadas com outras populações coevas, uma vez que o número de dentes estudado é pequeno. No entanto, as cáries são das patologias mais fre- quentes nas diferentes épocas históricas e podem ter causas multifatoriais, estando associadas a fatores de risco como a placa dentária, o ambiente ou a genética (Lucas $\mathbb{Z}$ alii, 2010). Um dos factores que pode ter contribuído para o desenvolvimento de cáries, particularmente nos indivíduos em análise, é o fungo da espécie Candida albicans, identificado com microscópio eletrónico de varrimento no tártaro do $\mathrm{I}^{\circ}$ molar superior direito do indivíduo adulto $\mathrm{n}^{\circ}{ }^{17}$, um indivíduo adulto do sexo feminino (Pereira $\mathbb{\&}$ alii, 2017). Este microorganismo pode estar presente na cavidade oral humana como agente patogénico e potenciar a origem de doença periodontal e de cáries (e.g., Falsetta $\mathbb{E}$ alii, 2014).

Quanto ao tártaro, foi identificado em 5 dos 8 (62,5\%) indivíduos com dentes erupcionados, todos adultos (1 masculino, 1 feminino, 3 indeterminados). No total, foi registado tártaro em 25,6\% (56/219) dos dentes, sendo que não há diferenças significativas entre a presença de tártaro na dentição maxilar e mandibular (Pearson $\chi^{2}=1,174 ; d . f=1 ; p=0,279$ ). O tártaro dentário resulta da mineralização dos depósitos de placa, mas a sua quantidade parece estar associada à interação entre fatores genéticos, alimentares (proteínas), fraca higiene dentária, entre outros ainda não completamente compreendidos (Hillson, 2005). No entanto, os valores aqui obtidos devem ser interpretados com precaução devido às alterações tafonómicas bastante evidentes nos dentes e que terão também condicionado as observações em laboratório, muito possivelmente subestimando as frequências em vida.

No que diz respeito às hipoplasias do esmalte, foram registadas na dentição dos indivíduos adultos no 13 e 17 e, se tivermos em conta o conjunto estudado, em 13 do total de 217 (9\%) dentes. As hipoplasias foram identificadas em dentes definitivos e são de tipo linear, as mais comummente encontradas em populações do passado (Towle e Irish, 2020). Apesar de uma maior frequência na dentição maxilar em relação à mandibular, não foram observadas diferenças estatísticas (Pearson $\chi^{2}=3,640 ; d . f=1 ; p=0,056$ ). As hipoplasias do esmalte são interpretadas por bastantes estudos como marcadores de stresse não específico durante o desenvolvimento dentário e podem dar pistas sobre doenças e stresses nutricionais das crianças na comunidade em que se inserem (Towle e Irish, 2020). No entanto, atualmente é reconhecido que algumas destas lesões podem ter outras causas, como trauma ou doenças infeciosas 
coexistentes ou ainda fatores genéticos ou ambientais específicos (Towle e Irish, 2020).

\section{- Os não adultos de Sarilhos Grandes e o stresse nutricional}

Para além da patologia oral, várias foram as lesões ósseas observadas e algumas podem também dar-nos luzes sobre possíveis stresses nutricionais. Neste particular, são os indivíduos não adultos que ganham maior protagonismo. Foi identificada porosidade e formação de osso novo em três ossos temporais desarticulados de lateralidade indefinida (UEo1-9, UE84-7 e UE101-2), todos de indivíduos não adultos, assim como nos ossos temporais (ambos de lado indeterminado) dos indivíduos 12 (35 a 39 semanas de vida) e 18 ( $>40$ semanas e $<1,5$ meses) (Figura 3). As alterações nos temporais UEı12 e no esqueleto 12 enquadram-se nos casos mais típicos das alterações 'hair-on-end' observadas na hipertrofia medular descrita para a hiperostose porótica (Ortner, 2003). Para além disso, no indivíduo 12 foi também identificada formação de osso novo porótico no zigomático direito, maxilar (de lado indeterminado), pars lateralis esquerdo do occipital e (embora menos evidentes) na mandíbula, na escápula (face dorsal e fossa supraespinhosa) e ilium (principalmente na face gluteal) direitos, para além de uma costela bífida ou bifurcada, isto é, com a metade esternal dividida em duas (Figuras 3 e 4). Esta última condição é raramente descrita em paleopatologia e não parece associada às restantes lesões do indivíduo. Estudos clínicos referem que ocorre em cerca de 0,15\%-0,31\% da população, com predileção pelo lado direito da caixa torácica (Kurihara $\&$ alii, 1999), tal como acontece no indivíduo aqui estudado. Numa coleção de 101 tomografias axiais do Centro Hospitalar Universitário de Coimbra e 74 indivíduos da Coleção de Esqueletos Identificados do Século XXI, curada pela Universidade de Coimbra, a costela bífida foi identificada em 1,7\% (3/175) dos indivíduos, todos de sexo masculino (Nogueira, 2013/2014). São normalmente assintomáticas ou com poucas implicações clínicas (Kurihara $\&$ alii, 1999). No feto/recém-nascido no 10 foi ainda registada formação de osso novo na face anterior do osso zigomático direito e, na base dessa órbita, juntamente com porosidade (Figura 3 ).

Particularmente no que diz respeito às lesões do indivíduo 12, diversas doenças (assim como a sua coexistência) podem provocar formação de osso novo e porosidade similar em não-adultos, como é o caso do escorbuto, do raquitismo, da talassemia ou da anemia falciforme (Tabela 2). No entanto, o padrão de distribuição das lesões enquadra-se no descrito na literatura para o escorbuto (e.g., Lewis, 2018). A deficiência de vitamina $C$ será mais evidente em não adultos não amamentados, uma vez que os seus níveis são muito mais baixos no leite de vaca (Lewis, 2018). Neste contexto, a hipovitaminose precisaria de um período de alguns meses de forma a manifestar-se no esqueleto, até porque os seus sintomas são reconhecidos clinicamente apenas entre os $4 \mathrm{e}$ os 10 meses de vida (Lewis, 2018) e o indivíduo em análise terá entre 35 a 39 semanas de gestação, o que parece excluir este diagnóstico. Infelizmente, essas alterações ósseas em recém-nascidos estão ainda pouco estudadas para qualquer das doenças incluídas no diagnóstico diferencial, pelo que, na falta de evidências patognomónicas e, uma vez que o indivíduo é um feto/recém-nascido, o diagnóstico não poderá ser afirmativo. O mesmo acontece para as lesões inespecíficas dos indivíduos 1o e 18 (Figura 3) e restantes ossos desarticulados.

Já a identificação isolada de hiperostose porótica requer um diagnóstico diferencial ainda com maiores reservas. É uma das lesões mais comummente identificadas em restos arqueológicos humanos e que leva ao aumento da porosidade do osso esponjoso no crânio, principalmente em prejuízo da tabula exter$n a$, sendo que, até há pouco tempo, a sua patogénese era quase exclusivamente associada à anemia por deficiência de ferro (e.g., Ortner, 2003). No entanto, o âmbito das condições que podem causar hiperostose porótica é atualmente tido como mais alargado (Brickley, 2018). Walker \& alii (2009) referem que vários estudos hematológicos mostraram que a anemia megaloblástica resultante da deficiência das vitaminas B9 e B12, quer com origem nutricional, quer associada a infeções parasíticas gastrointestinais, estão na base da hiperostose porótica. No primeiro caso, essas deficiências nutricionais estão associadas a dietas com escassez de alimentos de origem animal, praticamente a única fonte de vitamina B12; no segundo caso, correlacionam-se com infeções parasitárias, como as associadas ao Giardia lamblia, Enterobius vermicularis ou Ascaris lumbricoides, que interfere e diminui significativamente a absorção de vitamina B12 (Walker \& alii, 2009). Os mesmo investigadores sugerem que os recém-nascidos adquirem essa deficiência em vitamina B12 das suas mães, nascem com 
reservas que diminuem pelos efeitos sinergéticos que o leite materno, também carente da vitamina, lhes proporciona, acrescido das condições de vida insalubres que muitas vezes resultam em infeções gastrointestinais. Não sabemos se haveria escassez de alimentos de origem animal, particularmente para as progenitoras destes indivíduos, mas as análises paleoparasitológicas realizadas nas amostras de solo recolhidas na zona pélvica de 5 indivíduos adultos $\left(n^{\circ} 8,9,13,17\right.$ e 22) revelaram a presença de parasitas em 4, em dois deles ( $\mathrm{n}-8$ e 22) de Ascaris lumbricoides, o mais comum na Europa e frequentemente associado à falta de condições de higiene e salubridade (Pereira \& alii, 2017; Sianto \& alii, 2018). O indivíduo 22 revelou também a presença de ovos de Oxyoroidea de origem não humana, possivelmente adquirido atráves do consumo de carne de caça, enquanto os indivíduos 9 e 13 manifestaram a presença de ovos do género Trichostrongylus, um parasita de animais de criação como coelhos, porcos, bovinos e ovinos (Pereira \& alii, 2017; Sianto $\&$ alii, 2018). No entanto, é importante referir que são vários os processos patológicos que podem contribuir para este tipo de alterações morfológicas específicas, tais como certos processos inflamatórios do escalpe, alterações decorrentes de lesões no periósteo do exocrânio, hematomas subperiostais com origem traumática ou mesmo a malária (Ortner, 2003; Smith-Guzmán, 2015). A taxa de mortalidade nos períodos Medieval e Moderno, quer entre adultos quer entre não adultos, era alta. Era frequente cada núcleo familiar ter perdido vários filhos na sua infância e calcula-se que um terço das crianças falecesse antes de completar um ano de vida (Marques, 2010; Rodrigues, 2008) Apesar da preocupação existente nos tratados médicos destes períodos, o sistema imunitário infantil via-se frequentemente associado à má alimentação generalizada. No caso de não adultos, o consumo alimentar similar ao dos adultos afectava consideravelmente o desenvolvimento fisiológico. Por sua vez, estes problemas interligavam-se invariavelmente a febres de várias origens e a problemas do foro intestinal, aumentando, desta forma, a taxa de mortalidade (Oliveira, 2015). Mas eram as doenças infecciosas a principal causa de mortalidade. Como já foi defendido, nos séculos XVI e XVII a esperança média de vida à nascença não ultrapassava a barreira dos 25 para os homens e 38 anos para as mulheres (Rodrigues, 2008). O desenvolvimento dos grandes centros urbanos portugueses a partir do séc. XVI, com especial destaque para Lisboa, levou a que a cidade e as suas áreas periféricas - como é o caso de Sarilhos Grandes - se vissem afectadas por surtos endémicos de peste e de outras doenças.

\section{- Outras lesões identificadas}

Cinco fragmentos de ossos do crânio (um frontal e parietais e quatro indeterminados) do mesmo indivíduo apresentam múltiplos osteomas disseminados sem um padrão observável, alguns com o típico aspeto de formação óssea pedunculada, com o pescoço mais estreito que a sua extremidade e que Eshed $\&$ alii (2002) definem como hamartomas (Figura 5). Estas lesões são descritas como tumores benignos de crescimento lento e são mais frequentes a partir da quarta ou quinta década de vida (Eshed \& alii, 2002). Duas mulheres adultas (no 9 e 19) exibem nódulos de Schmorl, na primeira na superfície inferior de uma vértebra torácica e, na segunda, numa torácica e numa lombar. Estes nódulos são depressões encontradas nos corpos vertebrais, normalmente nas vértebras torácicas mais inferiores e nas lombares, possivelmente resultado da tensão biomecânica associada às atividades do quotidiano, mas também do peso corporal, deficiências metabólicas ou da predisposição genética (Plomp, Roberts e Vidarsdóttir, 2012; Burt \& alii, 2013). A dor nas costas é frequentemente referida como um dos sintomas; há, no entanto, estudos que mostram que podem ser assintomáticos (Plomp, Roberts e Vidarsdóttir, 2012).

Foram ainda registados vários exemplos de patologia articular, apesar do pequeno número de epífises preservadas. O indivíduo masculino $\mathrm{n}^{\circ} 22$ possuia osteoartrose no cotovelo e anca. Nos ossos desarticulados, a mandíbula [UE47-10], a vértebra cervical [UE47-11], o fragmento de tíbia [UE50-8], o cuneiforme lateral [UE59-12] e a primeira falange proximal do pé direito [UE7A-23] evidenciam também esse tipo de lesões. A osteoartrose, caraterizada pela deterioração da cartilagem e do osso de uma ou mais articulações, é uma das doença mais frequentes em populações do passado (Burt \& $\mathbb{\&}$ alii,, 2013). Este desgaste progressivo resulta numa distorção da posição articular que causa dor, inchaço e rigidez na articulação do indivíduo vivo (Burt $\&$ alii,, 2013). Tem uma etiopatogénese multifatorial mais associada ao sexo feminino, à idade mais avançada, a ocupações com maior exigência física ou à repetição de movimentos, à genética ou à obesidade (e.g., Weiss e Jurmain, 2007). 
A superfície articular da $\mathrm{I}^{\mathrm{a}}$ falange proximal [UE7A23] do pé direito, para além da osteortrose evidenciada pela eburnação, apresenta perda do contorno ósseo normal na área medial e destruição óssea na zona mais profunda da articulação, assim como entre esta e a zona de perda de contorno normal do osso (Figura 6). Também a $1^{\mathrm{a}}$ falange proximal [UEo1-2] do pé direito possui destruição óssea no centro da superfície articular, com forma bastante irregular e com o osso em torno da lesão aparentemente em diferentes fases de remodelação (Figura 6). Ambos os casos devem incluir a osteocondrite dissecante no diagnóstico diferencial, embora não se enquadrem na descrição típica daquela condição (Aufderheide e Rodríguez-Martin, 2011). A osteonecrose, uma condição circulatória que se carateriza pela morte das células ósseas (Ortner, 2003), deve ser também equacionada. A cabeça de fémur esquerdo [UE131-12] evidencia remodelação óssea bem demarcada e regular (Figura 6), alterações que podem ser também associadas à osteocondrite dissecante ou a uma muito fase inicial de artrite séptica; no entanto, o diagnóstico diferencial é, mais uma vez, bastante difícil, por um lado porque se tratam de ossos desarticulados (não é possível perceber se há simetria nas lesões ou se existiriam noutras articulações) e, por outro, especificamente porque neste último caso são interpretadas alterações ósseas num pequeno fragmento. O trauma é descrito como o fator etiológico mais provável para a osteocondrite dissecante, seja num único episódio ou em sucessivos de microtraumatismo resultante de atividade vigorosa (Ortner, 2003). É mais frequente em indivíduos do sexo masculino e no joelho, embora a anca também seja uma articulação relativamente afetada (Ortner, 2003). A osteoartrose é tida como uma complicação a longo prazo (Ortner, 2003), o que pode estar na base da eburnação observada na falange [UE7A-23].

Finalmente, no indivíduo no 21 foi identificada fusão simétrica e bilateral de duas falanges intermédias e distais do $4^{\circ}$ ou $5^{\circ}$ dedo do pé, podendo ter origem congénita. Um possível diagnóstico será o de sinfalangismo, uma malformação mais comum nas falanges distais do $2^{\circ}$ ao $5^{\circ}$ dedo (Aufderheide e Rodríguez-Martin, 2011).

\section{PERPETIVAS FUTURAS}

O atual programa de investigação plurianual do projeto SAND propõe o estudo sistemático dos ves- tígios osteológicos (humanos e fauna), cerâmicos e demais materiais recuperados nas escavações realizadas em 2008 e a realizar em 2020. Para concretizar estes objetivos, o projeto envolve uma equipa multidisciplinar de História, Arqueologia, Antropologia, Biologia, Química e Paleoparasitologia. A realização de uma nova intervenção bio-arqueológica na necrópole da Igreja de São Jorge e na Ermida de Nossa Senhora da Piedade permitirá aprofundar questões por esclarecer e abrir novas perspetivas de estudo sobre a população de Sarilhos Grandes desde época Medieval.

\section{AGRADECIMENTOS}

Os autores gostariam de agradecer ao Vítor Matos e à Ana Rita Sampaio a ajuda prestada.

\section{REFERÊNCIAS BIBLIOGRÁFICAS}

ALQAHTANI, S. J.; HECTOR, M. P.; LIVERSIDGE, H. M. (2009) - Brief communication: the London Atlas of $\mathrm{Hu}-$ man Tooth Development and Eruption. American Journal of Physical Anthropology, 142, pp. 481-49o.

AUFDERHEIDE, A. C; RODRÍGUEZ-MARTÍN, C. (2011) - The Cambridge encyclopedia of human paleopathology. Cambridge: Cambridge University Press.

BELLO, S. M.; THOMANN, A.; SIGNOLI, M.; DUTOUR, O.; ANDREWS, P. (2006) - Age and sex bias in the reconstruction of past population structures. American Journal of Physical Anthropology, 129, pp. 24-38.

BUIKSTRA, Jane E.; UBELAKER, H. Douglas (1994) Standards for data collection from human skeletal remains. Fayetteville: Arkansas Archaeological Survey Research Series, No. 44 .

BURT, Nicole M.; SEMPLE, Dyan; WATERHOUSE, Kathryn; LOVELL, Nancy C. (2013) - Identification and interpretation of joint disease in Paleopathology and Forensic Anthropology. Springfield: Charles C. Thomas Publisher, Ltd.

CARDOSO, Hugo Filipe Violante (200o) - Dimorfismo sexual na estatura, dimensões e proporções dos ossos longos dos membros: o caso de uma amostra Portuguesa dos séculos XIX-XX. Dissertação de Mestrado em Evolução Humana. Coimbra: Departamento de Antropologia da Univerisdade de Coimbra.

CARNEIRO, Cristiana; CURATE, Francisco; CUNHA, Eugénia (2016) - A method for estimating gestational age of fetal remains based on long bone lengths. International Journal of Legal Medicine, 130, pp. 1333-1341.

CARTER,DavidO.;TIBBETT,Mark(2008)-Cadaverdecomposition and soil: processes. In TIBBETT, Mark e CARTER, 
David O., eds. - Soil analysis in forensic taphonomy. Boca Raton, CRC Press - Taylor and Francis, pp. 29-51.

DIAS, Mário Balseiro Dias (2005) - Visitações e provimentos da Ordem de Sant'Iago em Aldeia Galega de Ribatejo. Volume 1 (1486-1537). Montijo: ed. autor.

DIGANGI, E. A.; BETHARD, J. D.; KIMMERLE, E. H.; KONIGSBERG, L. W. (2009) - A new method for estimating age-at-death from the first rib. American Journal of Physical Anthropology, 138, pp. 164-176.

ESHED, V.; Latimer, B.; GREENWALD, C. M.; JELLEMA, L. M.; ROTHSCHILD, B. M.; Wish-Baratz, S.; HERSHKOVITZ, I. (2002) - Button osteoma: its etiology and pathophysiology. American Journal of Physical Anthropology, 118, pp. 217-230.

FALSETTA, Megan L.; KLEIN, Marlise I.; COLONNE, Punsiri M.; SCOTT-ANNE, Kathleen; GREGOIRE, Stacy; PAI, Chia-Hua, GONZALEZ-BEGNE, Mireya;WATSON, Gene; KRYSAN, Damian J.; BOWEN, William H.; KOOM, Hyun (2014) - Symbiotic relationship between Streptococcus mutans and Candida albicans synergies virulence of plaque biofilms in vivo. Infection and Immunity, 82:5, pp. 1968-1981.

FEREMBACH, D.; SCHWIDETZKY, I.; STLLOUKAL, M. (1980) - Recommendations for age and sex diagnoses of skeletons. Journal of Human Evolution, 9:7, pp. 517-549.

HILLSON, S. (2001) - Recording dental caries in archaeological human remains. International Journal of Osteoarchaeology, 11, pp. 249-289.

HILLSON, S. (2005) - Teeth. Cambridge Manuals in Archaeology. Cambridge: Cambridge University Press.

ISCAN, M. Y.; LOTH, S. R. (1993) - Casts of age phases from the sternal end of the rib for white males and females. Bellevue (CO): France Casting.

KIBBLEWHITE, Mark; TÓTH, Gergely; HERMANN, Tamás (2015) - Predicting the preservation of cultural artefacts and buried materials in soil. Science of the Total Environment, 529, pp. 249-263.

KURIHARA, Yasuyuki; YAKUSHIJI, Yoshiko; MATSUMOTO, Junichi; ISHIKAWA, Tohru; HIRATA, Kazuaki (1999) - The ribs: anatomic and radiologic considerations. Radiographics, 19(1): 105-119.

LEWIS, M. (2012) - Thalassaemia: its diagnosis and interpretation in past skeletal populations. International Journal of Osteoarchaeology, 22, pp. 685-693.

LEWIS, M. (2018) - Paleopathology of children: identification of pathological conditions in the human skeletal remains of non-adults. San Diego: Academic Press.

LUCAS, S.; SEVIN, A.; PASSARIUS, O.; ESCLASSAN, R.; CRUBEZY, E.; GRIMOUD, A. M. (2010) - Study of dental caries and periapical lesions in a Mediaeval population of the southwest France: differences in visual and radiograph- ic inspections. HOMO - Journal of Comparative Human Biology, 61:5, pp. 359-72.

MACLAUGHLIN, S. M. (1990) - Epiphyseal fusion at the sternal end of the clavicle in a Modern Portuguese skeletal sample. Antropologia Portuguesa, 8, pp. 59-68.

MARQUES, A.H. de Oliveira (2010) - A Sociedade Medieval Portuguesa. Aspectos de vida quotidiana. Lisboa: Esfera dos Livros. 6 $6^{\underline{a}}$ ed.

OLIVEIRA, Ana Rodrigues (2015) - O dia-a-dia em Portugal na Idade Média. Lisboa: Esfera dos Livros.

ORTNER, D. J. (2003) - Identification of pathological conditions in human skeletal remains. San Diego: Academic Press.

PEREIRA, Paula Alves; SANTOS, José Costa; GODINHO, Ricardo; GONÇALVES, David (2008) - Relatório final da escavação de emergência da Necrópole do Largo da Igreja (Sarilhos Grandes). Pengest/TFP Planege.

PEREIRA, Paula Alves; SIANTO, Luciana; CHAVES, Sérgio Augusto de Miranda; TEIXEIRA-SANTOS, Isabel; GONÇALVES, D.; SANTOS, Ana Luísa; TOSO, Alice; CALLEJA, Álvaro M. Monge; COUTINHO, António Pereira; ARAÚJO, Ana Cristina; GODINHO, Ricardo Miguel (2017) A necrópole do largo da igreja (Sarilhos Grandes): evidências bioarqueológicas de contato entre Portugal e o Novo Mundo. Sines, História e Património, o Porto e o Mar Actas, pp. 123-141.

PLOMP, K. A.; ROBERTS, C. A.; VIDARSDÓTTIR, U. N. (2012) - Vertebral morphology influences the development of Schmorl's nodes in the lower thoracic vertebrae. American Journal of Physical Anthropology, 149, pp. 572-582.

RODRIGUES, T. F. (coord) (2008) - História da População Portuguesa. Porto: CEPESE \& Edições Afrontamento.

ROGERS, J.; WALDRON, T. (1995) - A field guide to joint disease in Archaeology. Chichester: John Wiley \& Sons.

SCHEUER, L.; BLACK, S. (200o) - Developmental juvenile osteology. San Diego: Academic Press.

SIANTO, Luciana, CHAVES, Sérgio Augusto de Miranda; TEIXEIRA-SANTOS, Isabel; PEREIRA, Paula Alves; GODINHO, Ricardo Miguel; GONÇALVES, David; SANTOS, Ana Luísa (2018) - Evidence of contact between New and Old World: paleoparasitological and food remains study in the Tagus river population of Sarilhos Grandes (Montijo, Portugal). Archaeological and Anthropological Sciences, 10: 75-81.

SILVA, A. M. G. da (1993) - Os restos humanos da gruta artificial de São Pedro do Estoril II: estudo antropológico. Volume I. Relatório de Investigação em Ciências Humanas. Coimbra, Departamento de Antropologia da Universidade de Coimbra.

SILVA, A. M. (1995) - Sex assessments using the calcaneus and talus. Antropologia Portuguesa, 13, pp. 107-119. 
SMITH-GUZMÁN, Nicole E. (2015) - The skeletal manifestations of malaria: an epidemiological approach using documented skeletal collections. American Journal of Physical Anthropology, 158, pp. 624-635.

TOWLE, Ian; IRISH, Joel, D. (2020) - Recording and interpreting enamel hypoplasia in samples from archaeological and palaeoanthropological contexts. Journal of Archaeological Science, 114, pp. 105077.

UBELAKER, D. H. (1974) - Reconstruction of demographic profiles from ossuary skeletal samples: a case study from the tidewater Potomac. Smithsonian Contributions to Anthropology, 18. Washington; Smithsonian Institution Press.

WALKER, Phillip L.; BATHURST, Rhonda R.; RICHMAN, Rebecca; GJERDRUM, Thor; ANDRUSHKO, Valerie A. (2009) - The causes of porotic hyperostosis and cribra orbitalia: a reappraisal of the iron-deficiency-anemia hypothesis. American Journal of Physical Anthropology, 139, pp. 109-125.
WASTERLAIN, R. S. C. N. (200o) - Morphé: análise das proporções entre os membros, dimorfismo sexual e estatura de uma amostra da colecção de esqueletos identificados do Museu Antropológico da Universidade de Coimbra. Dissertação de Mestrado em Evolução Humana. Coimbra, Departamento de Antropologia da Universidade de Coimbra.

WEISS, E.; JURMAIN, R. (2007) - Osteoarthritis revisited: a contemporary review of aetiology. International Journal of Osteoarchaeology, 17, pp. 437-450.

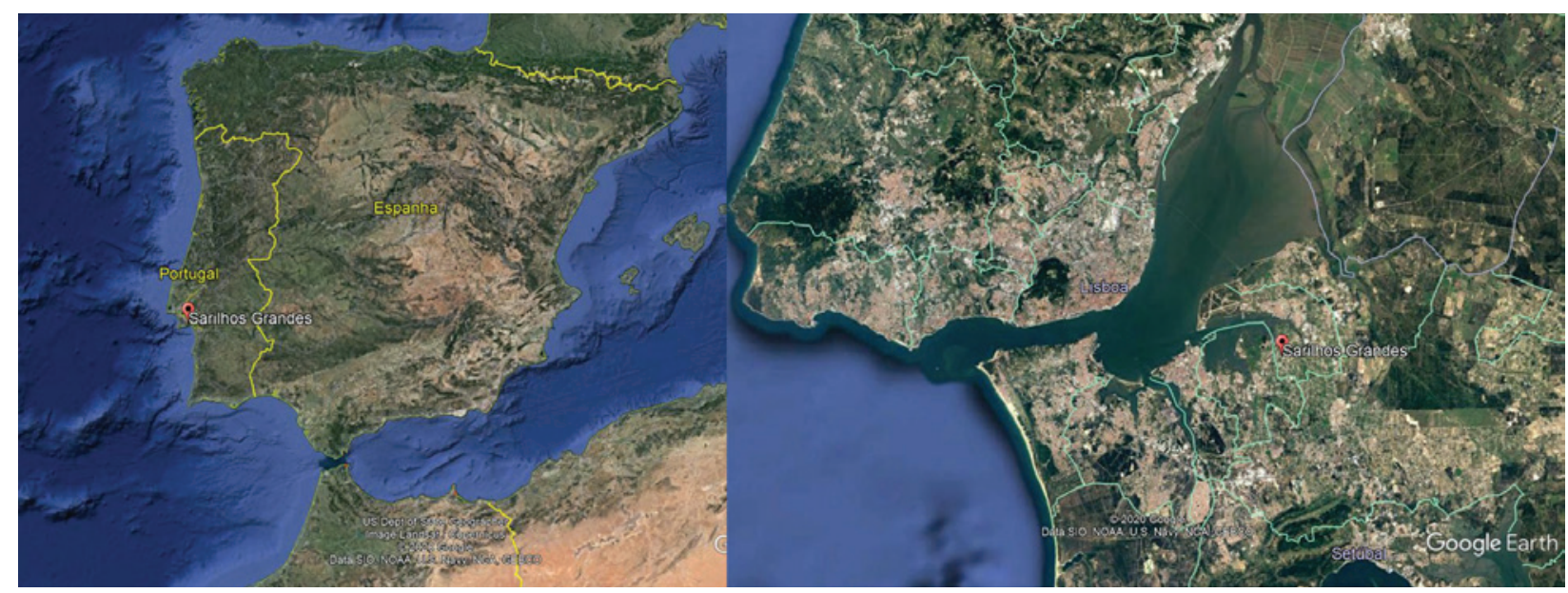

Figura 1 - Localização de Sarilhos Grandes. Mapa adaptado Google Earth. Consulta 22 de junho de 2020.

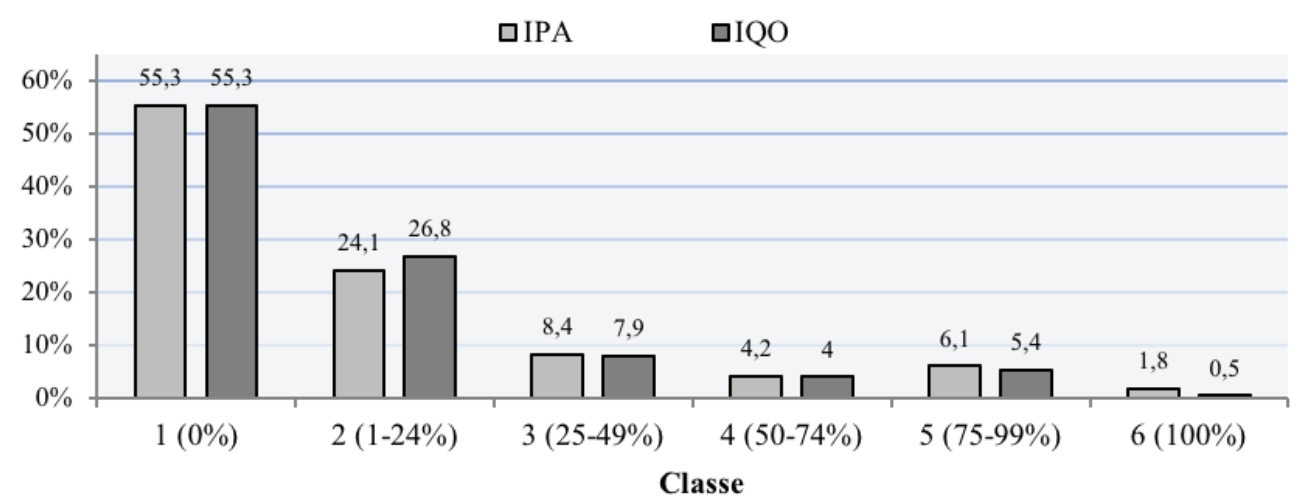

Figura 2 - Índice de Preservação Anatómica (IPA) e Índice de Qualidade Óssea (IQO) por classe de preservação entre os 21 esqueletos. 

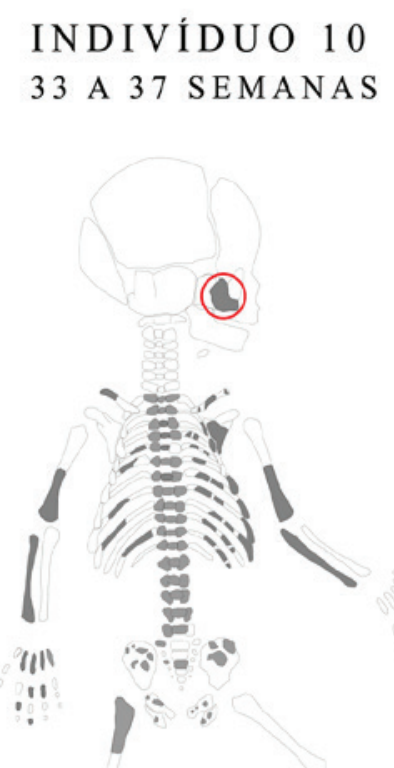

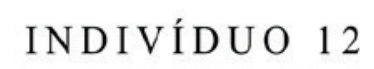

35 A 39 SEMANAS

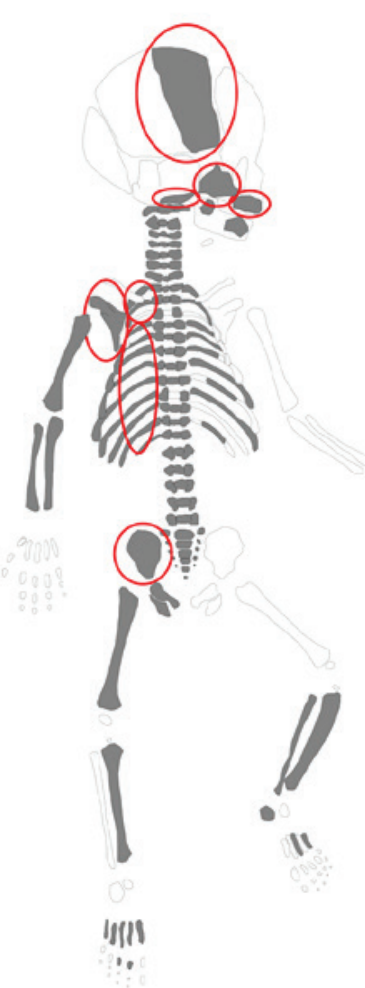

\author{
INDIVÍDUO 18 \\ $>40$ SEMANAS \\ $<1,5$ MESES
}

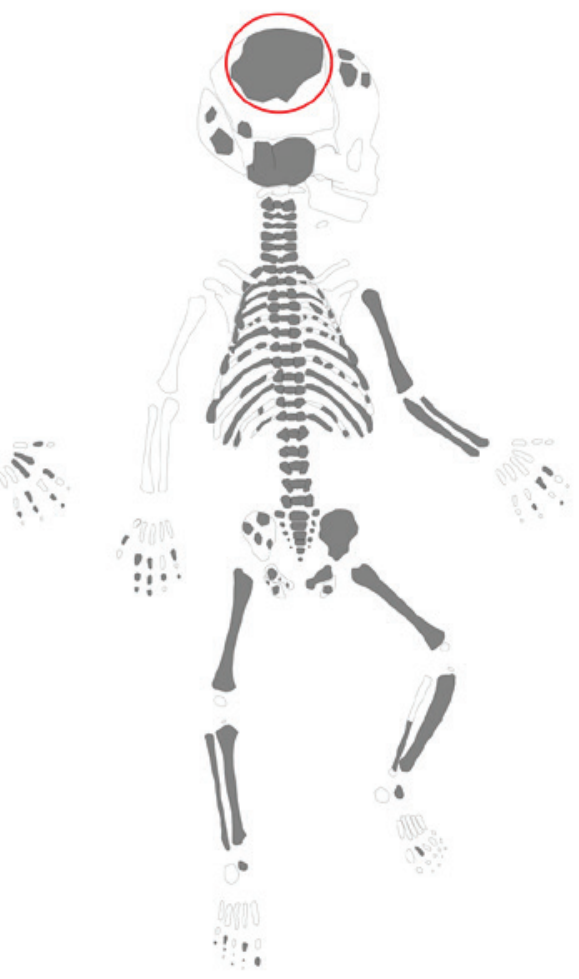

ossos PRESEntes Olesóns

Figura 3 - Ossos e lesões presentes nos indivíduos 10, 12 e 18, os três indivíduos mais novos.

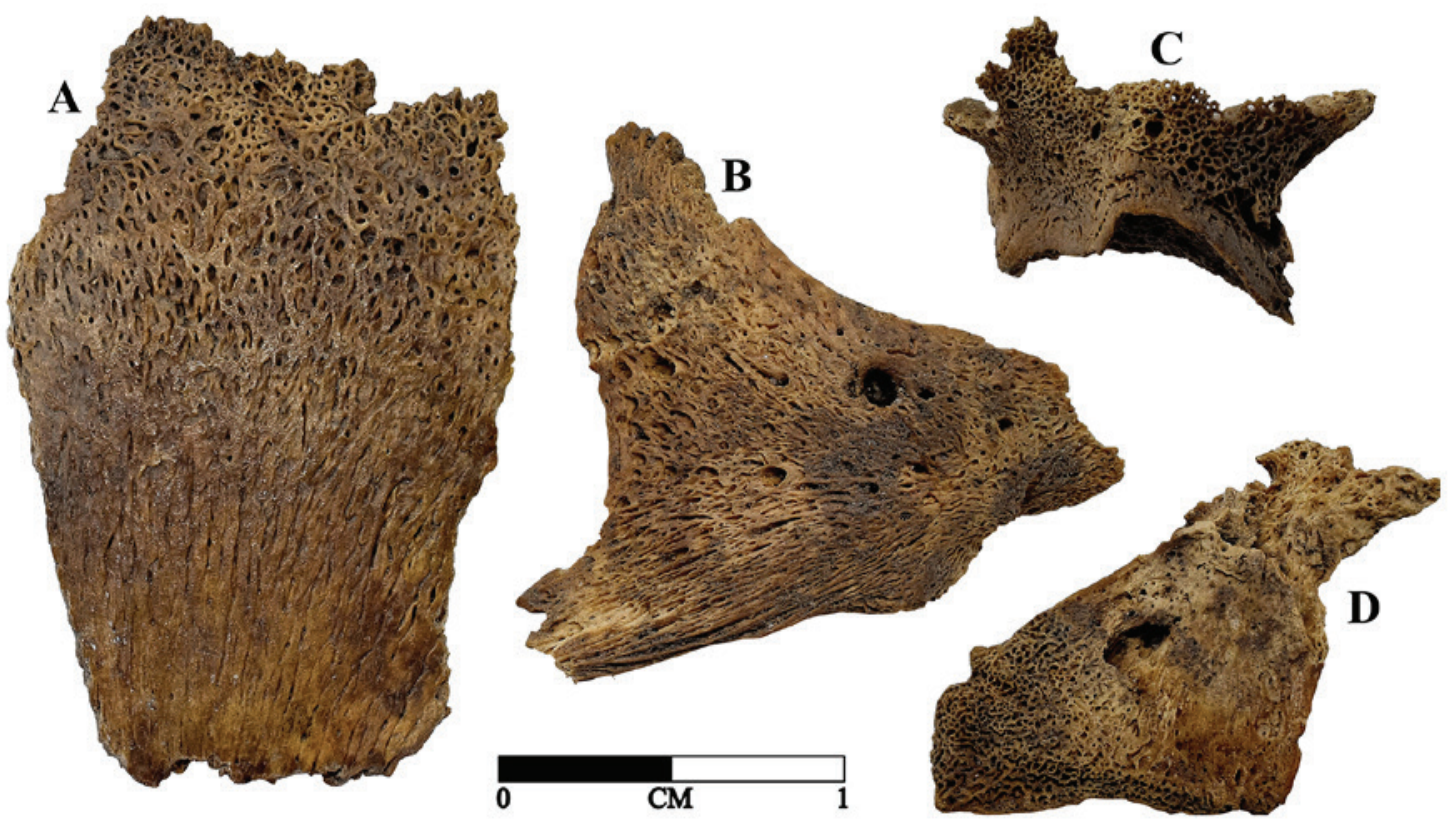

Figura 4 - Ossos do crânio do esqueleto 12 (35 a 39 semanas) com evidências de lesões patológicas: parietal (A) com hiperostose porótica e zigomático direito (B), maxilar (C) e pars lateralis esquerda (D) com formação de osso poroso. 


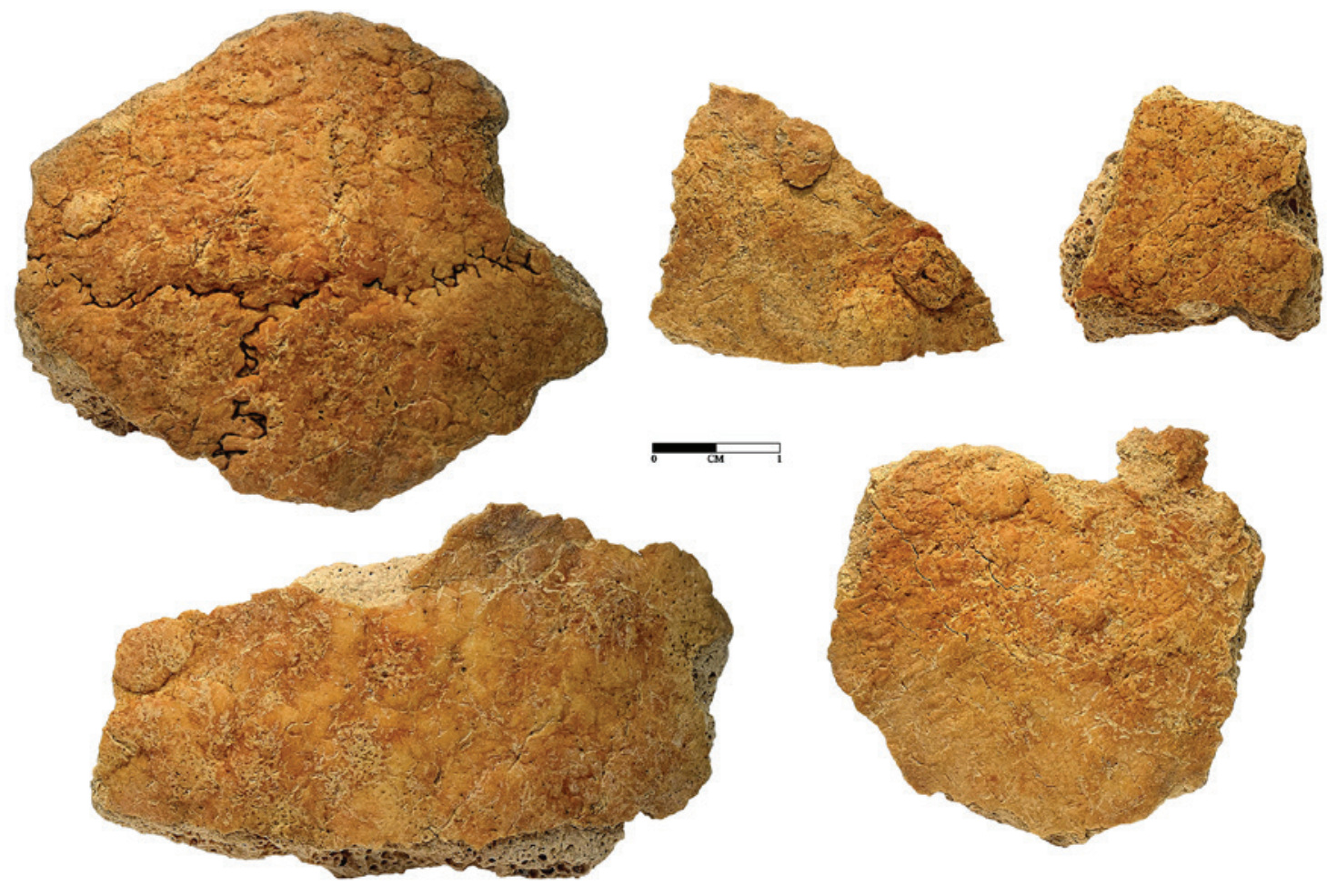

Figura 5 - Fragmentos desarticulados de um crânio de adulto provenientes da [UE18] com osteomas múltiplos disseminados.

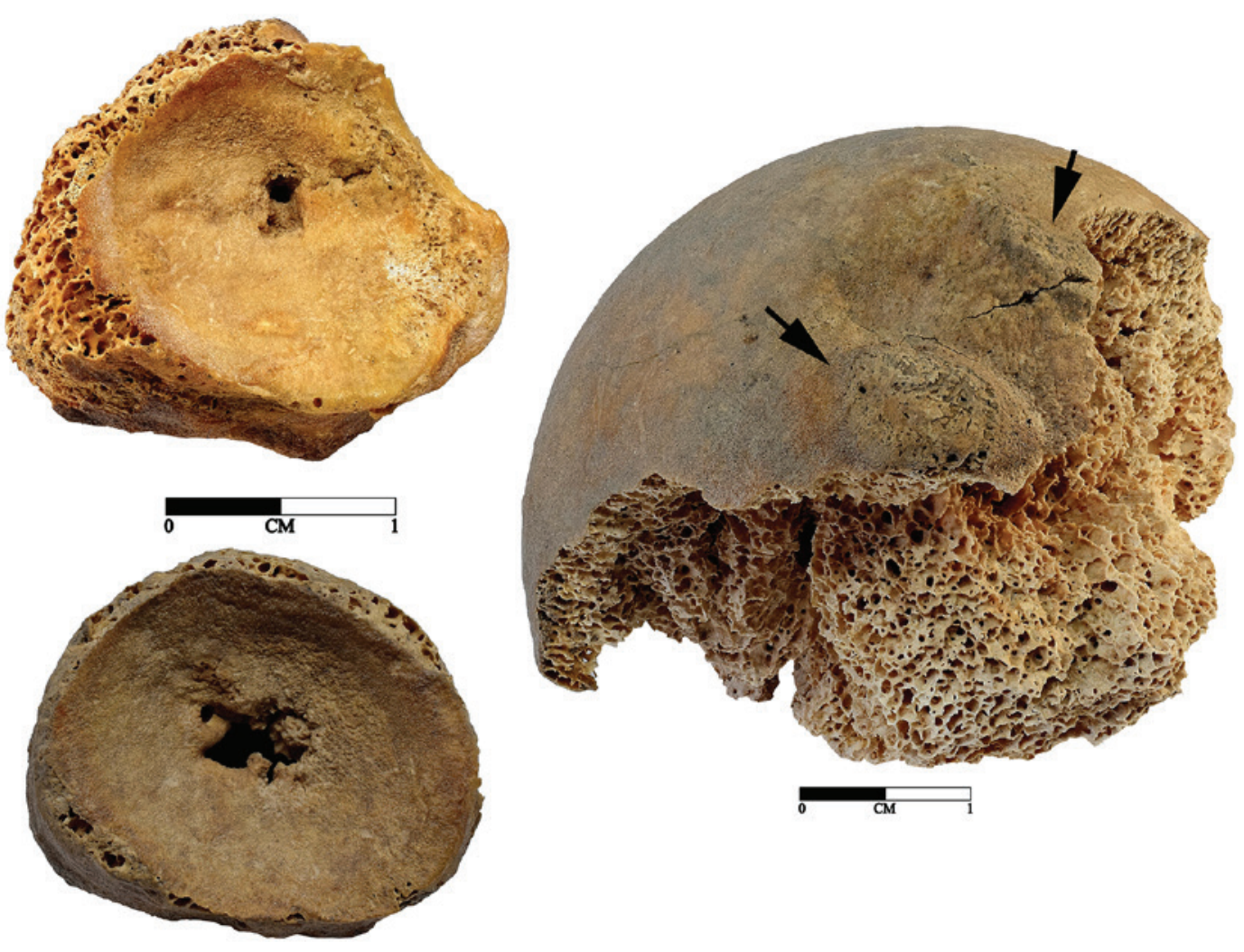

Figura 6 - Ossos desarticulados com lesões provavelmente associadas a osteocondrite dissecante: falanges proximais do pé [UE7A-23] (à esquerda em cima) e UEo1-2 (à esquerda em baixo) e cabeça do fémur [UE131-12] (à direita). A falange [UE7A-23] apresenta ainda eburnação que evidencia a presença de osteoartrose. 


\begin{tabular}{|c|c|c|c|c|c|c|c|c|c|c|c|}
\hline \multirow{2}{*}{ Indivíduo [UE] } & \multirow{2}{*}{$\begin{array}{l}\text { Idade à morte e } \\
\text { sexo biológico }\end{array}$} & \multirow{2}{*}{ Dentição } & \multicolumn{3}{|c|}{ Cáries } & \multicolumn{3}{|c|}{ Tártaro } & \multicolumn{3}{|c|}{$\begin{array}{l}\text { Hipoplasias } \\
\text { do esmalte }\end{array}$} \\
\hline & & & $\mathrm{n}$ & $\mathrm{O}$ & $\%$ & $\mathrm{n}$ & $\mathrm{O}$ & $\%$ & $\mathrm{n}$ & $\mathrm{O}$ & $\%$ \\
\hline \multirow{2}{*}{ № 1 [09] } & \multirow{2}{*}{4,5 a 6 anos } & Superior & 4 & 5 & 80 & $\mathrm{O}$ & 5 & $\mathrm{o}$ & $\mathrm{O}$ & 5 & $\mathrm{o}$ \\
\hline & & Inferior & 1 & 1 & 100 & $\mathrm{o}$ & 1 & $\mathrm{o}$ & $\mathrm{o}$ & 1 & $\mathrm{o}$ \\
\hline \multirow{2}{*}{ № 3 [15] } & \multirow{2}{*}{4,5 a 6 anos } & Superior & $\mathrm{o}$ & 1 & o & $\mathrm{o}$ & 1 & $\mathrm{o}$ & $\mathrm{o}$ & 1 & $\mathrm{o}$ \\
\hline & & Inferior & $\mathrm{o}$ & 1 & $\mathrm{o}$ & $\mathrm{o}$ & 1 & $\mathrm{o}$ & $\mathrm{o}$ & 1 & $\mathrm{o}$ \\
\hline \multirow{2}{*}{ № $6[40]$} & \multirow{2}{*}{ Adulto } & Superior & 4 & 10 & 40 & 1 & 10 & 10 & $\mathrm{o}$ & 10 & $\mathrm{o}$ \\
\hline & & Inferior & 9 & 13 & 69,2 & $\mathrm{o}$ & 13 & $\mathrm{o}$ & $\mathrm{o}$ & 13 & $\mathrm{o}$ \\
\hline \multirow{2}{*}{ № $8[51]$} & \multirow{2}{*}{ Adulto masculino } & Superior & 1 & 6 & 16,7 & 5 & 6 & 83,3 & $\mathrm{O}$ & 6 & $\mathrm{O}$ \\
\hline & & Inferior & 8 & 11 & 72,7 & 4 & 11 & 36,4 & $\mathrm{o}$ & 11 & $\mathrm{o}$ \\
\hline \multirow{2}{*}{ № 13 [77] } & \multirow{2}{*}{ Adulto } & Superior & 10 & 10 & 100 & 4 & 10 & 40 & 4 & 10 & 40 \\
\hline & & Inferior & 7 & 8 & 87,5 & $\mathrm{o}$ & 8 & $\mathrm{o}$ & 2 & 7 & 28,6 \\
\hline \multirow{2}{*}{ № 14 [82] } & \multirow{2}{*}{ Adulto jovem } & Superior & 8 & 16 & 50 & $\mathrm{o}$ & 16 & $\mathrm{o}$ & $\mathrm{o}$ & 16 & $\mathrm{o}$ \\
\hline & & Inferior & 13 & 16 & 81,3 & $\mathrm{o}$ & 16 & $\mathrm{o}$ & $\mathrm{o}$ & 16 & $\mathrm{o}$ \\
\hline \multirow{2}{*}{ № 15 [9o] } & \multirow{2}{*}{ Adulto } & Superior & 9 & 12 & 75 & 5 & 12 & 41,7 & $\mathrm{o}$ & 12 & $\mathrm{o}$ \\
\hline & & Inferior & 5 & 9 & 55,6 & 5 & 9 & 55.6 & $\mathrm{o}$ & 9 & $\mathrm{o}$ \\
\hline \multirow{2}{*}{ № 17 [100] } & \multirow{2}{*}{ Adulto feminino } & Superior & 5 & 6 & 83,3 & 3 & 6 & 50 & 4 & 6 & 66,7 \\
\hline & & Inferior & 2 & 5 & 40 & 3 & 5 & 60 & $\mathrm{O}$ & 5 & $\mathrm{o}$ \\
\hline \multirow{2}{*}{ Dentes desarticulados } & \multirow{2}{*}{-} & Superior & 10 & 29 & 34,5 & 2 & 29 & 6,9 & 1 & 29 & 3,4 \\
\hline & & Inferior & 27 & 60 & 45 & 22 & 60 & 36,7 & 2 & 60 & 3,3 \\
\hline \multicolumn{3}{|c|}{ Total dentição superior } & 51 & 95 & 53,3 & 20 & 95 & 21,1 & 9 & 95 & 9,5 \\
\hline \multicolumn{3}{|c|}{ Total dentição inferior } & 72 & 124 & 58,1 & 34 & 124 & 27,4 & 4 & 122 & 3,3 \\
\hline \multicolumn{3}{|c|}{ Total } & 123 & 219 & 56,2 & 54 & 219 & 24,7 & 13 & 217 & 6 \\
\hline
\end{tabular}

$\mathrm{n}=$ Cáries presentes; $\mathrm{O}=$ Dentes observáveis

Tabela 1 - Resultados referentes às lesões cariogénicas, tártaro e hipoplasias do esmalte do indvíduos com dentição preservada e dos dentes desarticulados.

\begin{tabular}{|c|c|c|c|}
\hline \multicolumn{2}{|c|}{ Doença } & Causa & Alterações ósseas normalmente associadas \\
\hline \multirow[t]{2}{*}{ Metabólica } & Escorbuto & $\begin{array}{l}\text { Deficiência } \\
\text { de vitamina C }\end{array}$ & $\begin{array}{l}\text { Hiperostose porótica craniana, porosidade nas grandes asas do esfenóide, } \\
\text { impressões vasculares ectocranianas, cribra orbitalia e formação de osso } \\
\text { nas órbitas, inflamação das gengivas, formação de osso na fossa supra e } \\
\text { infra espinhosa da escápula, fraturas ou alargamento adjacente à junção } \\
\text { costocondral das costelas, formação de osso e porosidade nas metáfises } \\
\text { dos ossos longos, porosidade nas superfícies interna e externa do ilium } \\
\text { (e possível espessamento). }\end{array}$ \\
\hline & Raquitismo & $\begin{array}{c}\text { Deficiência } \\
\text { de vitamina D }\end{array}$ & $\begin{array}{l}\text { Ramo mandibular deformado, erupção dentária atrasada, fratura, } \\
\text { curvatura anormal e achatamento das costelas, desgaste na extremidade } \\
\text { esternal e porosidade anormal nas costelas, deformação dos ossos longos } \\
\text { inferiores, osteopenia. }\end{array}$ \\
\hline \multirow[b]{2}{*}{$\begin{array}{l}\text { Anemia } \\
\text { genética }\end{array}$} & Talassemia & $\begin{array}{l}\text { Desequilíbrio } \\
\text { na síntese da } \\
\text { hemoglobina }\end{array}$ & $\begin{array}{l}\text { Hiperostose porótica craniana; alterações nos ossos faciais ('fácies de } \\
\text { roedor'); aspeto radiográfico de 'costela dentro de costela' representada } \\
\text { por uma banda de osso radiopaco; osteomas costais; osteopenia e } \\
\text { porosidade generalizadas. }\end{array}$ \\
\hline & $\begin{array}{l}\text { Anemia } \\
\text { falciforme }\end{array}$ & $\begin{array}{l}\text { Produção } \\
\text { anormal de } \\
\text { hemoglobina }\end{array}$ & $\begin{array}{l}\text { Osso cortical da tabula externa mais fino nos parietais devido a progressão } \\
\text { do diploe, que pode acontecer também nos zigomáticos e teto das órbitas, } \\
\text { formação de osso novo, osteomielite e alargamento do osso cortical na tíbia } \\
\text { e fíbula em contraste com o adelgaçamento nas talessemias, epífises podem } \\
\text { tornar-se necróticas (necrose da cabeça do fémur é frequente), dactilite } \\
\text { (aspeto de 'dedo em salsicha'). }\end{array}$ \\
\hline
\end{tabular}

Tabela 2 - Doenças que podem causar alterações similares às verificadas no indivíduo 12 (a partir de Ortner, 2003; Lewis 2012, 2018). 


\title{
EXPANSÃO URBANA DA VILA DE CASCAIS NO SÉCULO XVII E XVIII: A INTERVENÇÃO ARQUEOLÓGICA NA RUA DA VITÓRIA $\mathrm{N}^{\circ} 15$ A 17
}

Tiago Pereira ${ }^{1}$, Vanessa Filipe ${ }^{2}$

\begin{abstract}
RESUMO
Os trabalhos arqueológicos realizados na Rua da Vitória nํ15 a 17 em Cascais, no âmbito de um projeto de reabilitação urbana, tiveram como objectivo a escavação integral do subsolo no interior do edifício. A intervenção permitiu caracterizar o edifício original implantado neste local entre os finais do século XVII início do século XVIII. Os dados aqui apresentados apontam para um espaço urbano que é precedido por uma pequena área de exploração agrícola, abandonado com o aparecimento de aterros e fossas para despejo de lixo doméstico.

Estamos perante a evolução urbana da vila de Cascais com a expansão para áreas limítrofes pouco urbanizadas e anteriormente utilizadas como lixeiras da vila.

Palavras-chave: Arqueologia Urbana, Idade Moderna, Cultura material, Vila de Cascais.
\end{abstract}

\begin{abstract}
The archaeological intervention at Rua da Vitória 15-17, Cascais, was motivated by an urban rehabilitation project for a buldind located nearby the center of the village.

The original bulding foundation date from late $17^{\text {th }}$ century and $18^{\text {th }}$ century, above a series of deposits containing ceramics, fauna, glass and metals as a result of landfill of domestic waste. Between these deposits we registered several small pits used as household waste disposal. The previous occupation in this area corresponds to a minor agricultural production from $15^{\text {th }}$ or $16^{\text {th }}$ century probably a small vineyard field.

We report were evidence of the urban expansion of ancient village of Cascais occurred since $16^{\text {th }}$ century, and the development of urban area to open areas of landfill.
\end{abstract}

Keywords: Urban archaeology, Modern Age, Material Culture, Village of Cascais.

\section{INTRODUÇÃO}

O núcleo histórico da vila de Cascais tem sido alvo de estudo de forma sistemática desde os anos 80 do século XX. Nas últimas décadas as intervenções no subsolo do espaço urbano da vila, motivadas pelos diversos empreendimentos de reabilitação urbana e de infraestruturas, têm revelado potencial arqueológico para o delinear da evolução urbanística de Cascais.

A reabilitação do edifício nํㅗ 15 a 17 da Rua da Vitória em Cascais (Figura 1), localizado em diversas zonas de proteção patrimonial, conduziu à prossecução da intervenção arqueológica entre Março e Maio de 2018. Foi realizada a escavação integral do subsolo no interior do edifício condicionada pela cota de afetação de obra, permitindo aferir algumas ocorrências patrimoniais, identificando-se diversas estruturas e espólio arqueológico nos diversos compartimentos do edifício.

Este trabalho é o resultado da análise preliminar dos dados da intervenção realizada em 2018, a importân-

1. Arqueólogo COTA 8o 86 / Instituto de Estudos Medievais; tiagopereira@cota8o86.pt

2. Arqueóloga COTA 8086 / Instituto de Arqueologia e Paleociências; vanessafilipe@cota8o86.pt 
cia dos contextos analisados e cronologias estabelecidas da urbanização desta área no enquadramento do contexto urbanístico da antiga vila de Cascais.

\section{A INTERVENÇÃO ARQUEOLÓGICA}

Os trabalhos arqueológicos levados a cabo no edifício ocorreram após as demolições efectuadas do interior do edifício, com o levantamento dos diferentes pavimentos contemporâneos do edifício. Após a remoção destes pisos a área intervencionada foi condicionada a seis compartimentos definidos pelos muros da estrutura interna do edifício (Figura 2). Essa estrutura interna é composta por elementos estruturais relacionada com a construção primitiva do edifício.

A espinha dorsal do edifício corresponde a uma estrutura de alvenaria em pedra e argamassa com cerca de o,8 $\mathrm{m}$ de largura, no sentido este-oeste, subsidiado por dois muros perpendiculares e duas estruturas muradas de diferentes características, apresentando ainda vestígios de uma antiga soleira afetada pelas sucessivas alterações estruturais no edifício.

Este conjunto estrutural forma uma série de compartimentos na área intervencionada, com diferentes dimensões, compreendendo três a norte e três a sul. Em quatro dos compartimentos (Compartimento 1, 2, 3 e 5) foram identificados diferentes ramais de saneamento do edifício, assim como as estruturas a eles associados - trata-se de muros elaborados com pedra de pequena e média dimensão em fiadas relativamente regulares com ligante de argamassa amarelada e pouco compacta, sustentam tubos de manilha em grês encontrando-se praticamente em toda a área intervencionada. No interior de um destes compartimentos, a sul do edifício, identificou-se um tanque ou fossa desactivado recentemente encontrando-se preenchido no seu interior com entulho de obra. Estas estruturas assentam praticamente em terreno estéril no lado norte do edifício, e em determinadas zonas directamente na rocha.

$\mathrm{Na}$ área do compartimento 6, após a escavação de um nível de entulho sob os pavimentos, identificou-se uma estruturação composta pelo reaproveitamento de lajes de calcário com sulco para encaixe de barrotes ou postes de madeira, assentes em argamassa pouco compacta, com inclusão de soleira de grande dimensão junto à parede sul do edifício. Esta estrutura parece corresponder aos vestígios de uma antiga parede em tabique no interior do edifício, formando um corredor e provavelmente adossado ao muro interior do edifício (Figura 3). O tabique assentava ainda num depósito de aterro para nivelamento do local. No compartimento junto à fachada do edifício, com acesso pela porta $\mathrm{n}^{\circ}{ }^{17}$, foi ainda possível observar vestígios de uma calçada interior de acesso à casa.

A implantação do edifício afectou alguns níveis de aterro, registando-se estratigraficamente níveis de fossas detríticas, de pequena dimensão, entre os aterros identificados na área intervencionada sobretudo nos compartimentos 4, 5 e 6 (Figura 4). No compartimento 4 uma das fossas destaca-se pelo material arqueológico exumado (Figura 5), com a recolha de quatro peças de cerâmica praticamente completas, incluindo um recipiente de importação do norte da Europa.

Entre as estruturas negativas registadas estão ainda associadas um conjunto de buracos de poste de pequena e média dimensão nos diferentes níveis de aterro, alguns deles corresponderão ao momento de construção do edifício.

O nível de ocupação mais antigo identificado durante a intervenção caracteriza-se por um conjunto de buracos sub-rectangulares e alongados, com cerca de $10 \mathrm{~cm}$ de profundidade, associado a pés de vinha, alguns sub-circulares e um sub-ovalado com profundidades entre os $15 \mathrm{e}$ os $30 \mathrm{~cm}$ e pequenos buracos de poste, escavados num depósito quase estéril e bastante argiloso, circunscritos ao compartimento 4 e 6 (Figura 6 e 7 ).

Durante a escavação do depósito onde se inserem foi identificada ainda uma panela depositada in situ praticamente completa (Figura 8). Este depósito sobrepõe o coluvião composto por sedimento siltoso de coloração avermelhada muito compacto que corresponde ao substrato geológico observado em quase toda a área de escavação, excepto nos compartimentos junto à fachada do edifício (compartimentos 5 e 6) onde se atingiu a cota de obra antes do substrato geológico, e no local onde está implantada o tanque/fossa cuja profundidade atinge cotas superiores ao nível dos depósitos estéreis.

Alguns destes depósitos corresponderão a níveis de colovião compostos por sedimento siltoso compacto avermelhado, consolidadas por cimento calcário, ausentes de materiais arqueológicos sobrepondo e/ ou encostando aos lapiás existentes no local. 


\section{EVOLUÇÃO DO ESPAÇO}

Os contextos arqueológicos registados durante a intervenção arqueológica na Rua da Vitória ํㅡำ 15 a 17, permitiram definir diferentes fases de ocupação do espaço em estudo. Porém, a compartimentação $\mathrm{da}$ área intervencionada limitou o enquadramento geral de todas as estruturas identificadas, e uma visão global dos diferentes momentos de utilização do espaço. Estes evidenciam uma progressiva transição de um ambiente rural, ligado a uma produção agrícola possivelmente de carácter familiar, fixando-se posteriormente na malha urbana da vila de Cascais. Os diferentes momentos de ocupação ocorreram entre o século XV/XVI e a atualidade e evidenciam quatro fases distintas.

\subsection{Fase 1 - Século XV/XVI}

Este é o nível de ocupação mais antigo registado durante a intervenção e encontra-se representado sobretudo no compartimento 4 .

Inserem-se neste contexto diversas estruturas negativas relacionadas com uma pequena exploração agrícola em pequena escala: um conjunto de "covachos" alongados, geralmente com orientação NE-SO, que corresponderão aos negativos da implantação de pés de vinha nesta área. São relativamente semelhantes a diversas estruturas negativas desde género, encontrando-se exemplos desde época romana (Pereira, 2017, pp. 99-102).

Os pés de vinha estão associados a pequenos buracos de poste de estruturas de apoio à produção vinícola e a covas ou buracos com maior profundidade, relacionados com a produção de outras culturas como a oliveira - representada por uma cova sub-ovalada com sulco central e cerca de $40 \mathrm{~cm}$ de profundidade identificada no compartimento 4 .

Estas estruturas revelaram escassos materiais arqueológicos assinalando-se apenas o aparecimento de uma bilha parcialmente completa inserida num dos pequenos buracos.

O depósito correspondente ao nível de utilização agrícola revelou igualmente escassos materiais, destacando-se uma panela praticamente completa utilizada possivelmente como vaso de canteiro. Pelas características morfológicas trata-se de um recipiente que se enquadra no século XV.

A exploração agrícola é abandonada durante o século XVI com o aterro de lixo doméstico em toda a área.

\subsection{Fase 2 - Século XVI/XVII}

Durante o século XVI e XVII o local foi aproveitado como lixeira, sucessivos aterros de lixo doméstico com grande quantidade de material cerâmico, de restos alimentares compostos sobretudo por fauna ictiológica, mamalógica e malacológica, e provavelmente de terras sobrantes.

Em pleno século XVII são realizadas diversas fossas nos aterros pré-existentes para descarte de lixo doméstico. Neste contexto, no compartimento 4 , uma fossa detrítica com grande quantidade de material cerâmico revelou algumas peças praticamente completas após colagem, assinalando-se um pequeno pote de farmácia (Albarello) proveniente do norte da Europa.

Entre o século XVII e XVIII o espaço de lixeira cessa com a implantação do edifício original, consequência da expansão urbana da vila de Cascais.

\subsection{Fase 3-Século XVII/XVIII}

A edificação de uma habitação ocorrida entre os finais do século XVII ou já no século XVIII encerra a existência de lixeiras nesta área. A sua configuração primitiva corresponde a um muro em alvenaria de pedra e argamassa, no sentido este-oeste, com vestígios de soleira de acesso à casa do $\mathrm{n}^{0} 15$, posteriormente anulada, e dois muros solidários transversais definindo alguns compartimentos e dividindo possivelmente a área em duas habitações distintas, que corresponderão aos atuais no 15 e 17. A base destas estruturas corta os depósitos de aterro precedentes assentando em determinadas zonas na rocha ou no nível agrícola.

A fase de implantação do edifício caracteriza-se ainda pela presença de distintos buracos de poste, nos diversos compartimentos junto às estruturas, que serviram de apoio para estruturas perecíveis de apoio à sua construção, e vestígios de uma calçada que corresponderá a um pequeno pátio interior de acesso à casa $\mathrm{n}^{\circ} 17$ e obliterada pelas alterações posteriores.

\subsection{Fase 4-Século XIX/XX}

Este período caracteriza-se pelas constantes alterações estruturais no edifício entre os séculos XIX e XX. Durante o século XIX regista-se o assentamento de uma estrutura de tabique junto à entrada $\mathrm{n}^{\circ}{ }^{15}$, com reaproveitamento de soleira, e que reconfigura o compartimento definido pelos muros originais do edifício, muito provavelmente contemporâneo da 
construção de um tanque abobadado recentemente entulhado e de função indeterminada junto a um possível saguão existente na zona oeste do edifício. A implantação de diferentes estruturas de saneamento descritas anteriormente afetam algumas das estruturas mais antigas e os níveis de aterro, com sucessivas alterações e fusões de ramais de esgotos presentes no edifício desde o século XIX.

\section{ESPÓLIO ARQUEOLÓGICO}

O espólio exumado durante a intervenção arqueológica enquadra-se na sua grande maioria no século XVII.

Os depósitos de aterro e fossas detríticas forneceram sobretudo cerâmica comum, vidrada, faiança e alguma cerâmica esmaltada, destacando-se a cerâmica utilitária de cozinha e armazenamento. Algumas destas fossas forneceram abundante cerâmica comum e vidrada, mas também cerâmica esmaltada, faiança, metais e vidros (inclusive um anel).

No contexto dos aterros foram recolhidos recipientes quase completos provenientes de uma das fossas detríticas: uma taça e tacho em cerâmica comum inteiros (Figura 9), um cântaro com perfil completo de uma asa, destacando-se um albarello praticamente completo.

Esta peça apresenta uma pasta entre o rosa e o salmão, decorada com linhas horizontais na parte superior e inferior e linhas onduladas entrelaçadas a meio da peça, pintadas a azul cobalto sobre esmalte branco (Figura 10). A característica da pasta e a decoração utilizada indica que se trata provavelmente de uma produção inglesa da segunda metade do século XVII (Orser, 2018, pp. 48-108) em concordância com a cronologia dos aterros.

A escavação do nível agrícola revelou uma panela colocada in situ (Figura 8), com perfuração circular na base da peça, feita intencionalmente após a cozedura, possivelmente utilizada como vaso de canteiro já que não se verificam marcas uso como superfícies queimadas por acção directa do fogo, associada ao depósito de implantação dos pés de vinha e dos buracos de árvore. Apresenta um bordo em aba de secção rectangular com canelura abaixo do bordo, corpo ovóide com duas asas e fundo convexo. Este tipo de cerâmica apresenta cronologias entre os séculos XIV e XVI à semelhança de outras peças recolhidas no núcleo urbano de cascais (Cardoso e Rodrigues, 1991, pp. 573-584).
As faunas predominantes nestes contextos correspondem à fauna ictiológica e malacológica com menor percentagem da fauna mamalógica, em relação ao número mínimo de indivíduos. Estão associadas às lixeiras do século XVI e XVII, através dos sucessivos despejos, e representam alguma das dietas da população residente na vila durante os séculos XVI e XVII que não será abordada em específico nes te trabalho.

Os materiais de cronologias entre o século XIX e XX estão associados às várias construções do edifício ocorridas neste período. Estes depósitos além da cerâmica, continham metais e vidros com cronologias entre os séculos XVII e XIX, e alguns materiais mais antigos (século XVI), resultante dos sucessivos remeximentos de terras efetuados no local.

Em relação aos metais correspondem sobretudo a pregos e cavilhas em ferro com excepção de alguns alfinetes, numismas e um anel bastante deteriorado, identificado nos níveis de aterro de lixo doméstico.

\section{CONCLUSÃO}

A área correspondente à empreitada permitiu um conhecimento mais aprofundado das suas valências arqueológicas e patrimoniais. Esta análise reflete a necessidade de caracterizar o espaço envolvente à empreitada, respeitando a sua antropização ao longo dos tempos bem como a sua valorização patrimonial. A integração do espaço num contexto mais abrangente, atendendo à delimitação urbana em que se insere a obra, apresenta um carácter imperativo no que concerne ao âmbito da salvaguarda e valorização do património.

A informação recolhida durante a intervenção permite-nos afirmar que as origens do edifício remontam aos finais do século XVII e/ou inícios do século XVIII.

A expansão urbana da Vila de Cascais nesta área parece ter ocorrido neste período, corroborada pelos diversos contextos arqueológicos identificados em zonas próximas da Rua da Vitória. A necessidade de construir novos edifícios habitacionais, estimulada por um aumento demográfico da vila de Cascais a partir do século XVI, conduziu à ocupação de anteriores espaços de lixeira integrando novas áreas na malha urbana da vila (Cardoso \& Rodrigues, 1999, p.194).

No caso específico da Rua da Vitória nํ15 a 17, a urbanização é precedida por uma área rural de exploração 
agrícola, com indícios de produção vinícola de cariz familiar. A limitação da área intervencionada não permitiu relacionar qualquer edifício habitacional associado a um espaço de horta para auto consumo. A utilização agrícola deste espaço perdeu a sua importância ou mesmo abandonado surgindo uma zona livre, para a partir do século XVI, se acumularem diversos aterros e fossas resultantes do descarte de lixo doméstico.

Foram ainda detectadas arqueologicamente algumas alterações e anulações ao edificado, ocorridas ao longo de todo o período de ocupação e uso do mesmo. A expansão urbana ocorrida a partir do século XVI da antiga vila de Cascais encontra-se bem caracterizada neste local, com a ocupação de áreas limítrofes e anteriormente livres para a implantação de novos edifícios habitacionais.

\section{BIBLIOGRAFIA}

ANDRADE, Ferreira de, (1964) - Vila de Corte. Oito Séculos de História. Cascais.

CARDOSO, Guilherme (1993) - Carta arqueológica do concelho de Cascais, Cascais: Câmara Municipal de Cascais.

CARDOSO, Guilherme; Rodrigues, Severino (1991) - Alguns tipos de cerâmica dos sécs. XI a XVI encontrados em Cascais. In A cerâmica medieval no mediterrâneo ocidental: actas do IV Congresso Internacional. Mértola: Campo Arqueológico de Mértola; pp. 573-585.

CARDOSO, Guilherme; RODRIGUES, Severino (1999) Tipologia e cronologia de cerâmicas dos séculos XVI, XVII e XIX encontradas em Cascais. In Arqueologia Medieval (6), pp. 193-212.

CARDOSO, Guilherme; RODRIGUES, Severino (2002) Conjunto de peças de cerâmica do século XVII do Convento da Piedade de Cascais. In Actas do $3^{\circ}$ Encontro Nacional de Arqueologia Urbana. Almada: Museu Municipal, pp. 269-288.

CARDOSO, Guilherme; CABRAL, João Pedro (2004) Povoamento e arquitectura popular na freguesia de Cascais. Cascais: Junta de Freguesia de Cascais.

ENCARNAÇÃO, José de, (1973) - Obras na igreja matriz de Cascais. In Jornal da Costa do Sol, Cascais.

HENRIQUES, João Miguel, (2004) - História da freguesia de Cascais (1870-1908): Uma Proposta de estudo. Edições Colibri, Cascais: Câmara Municipal de Cascais.

ORSER, Charles E. (2018) - An archaeology of the English Atlantic world, 160o-170o. Cambridge: Cambridge University Press.

PEREIRA, Pedro Abrunhosa (2017) - O vinho na Lusitânia. CITCEM, Centro de investigação transdisciplinar "Cultura,
Espaço e memória”. Coleção: Teses Universitárias, 8. Porto: Edições Afrontamento.

RODRIGUES, Severino; BOLILA, Catarina; FILIPE, Vanessa; HENRIQUES, José Pedro Henriques; RIBEIRO, Inês Alves; SIMÕES, Sara Teixeira (2012) - As cerâmicas da Idade Moderna da Fortaleza de Nossa Senhora da Luz, Cascais. Velhos e Novos Mundos: Estudos de Arqueologia Moderna. Lisboa. Volume 2, Colecção Arqueoarte nº 1, Centro de História de Além-Mar, Faculdade de Ciências Sociais e Humana, Universidade Nova de Lisboa, pp. 865-876.

SHLASKO, Ellen (1989) - Delftware chronology: A new approach to dating English tin-glazed ceramics. Dissertations, Theses, and Masters Projects. Paper 1539625501. https://dx. doi.org/doi:10.21220/s2-tmdb-do88 


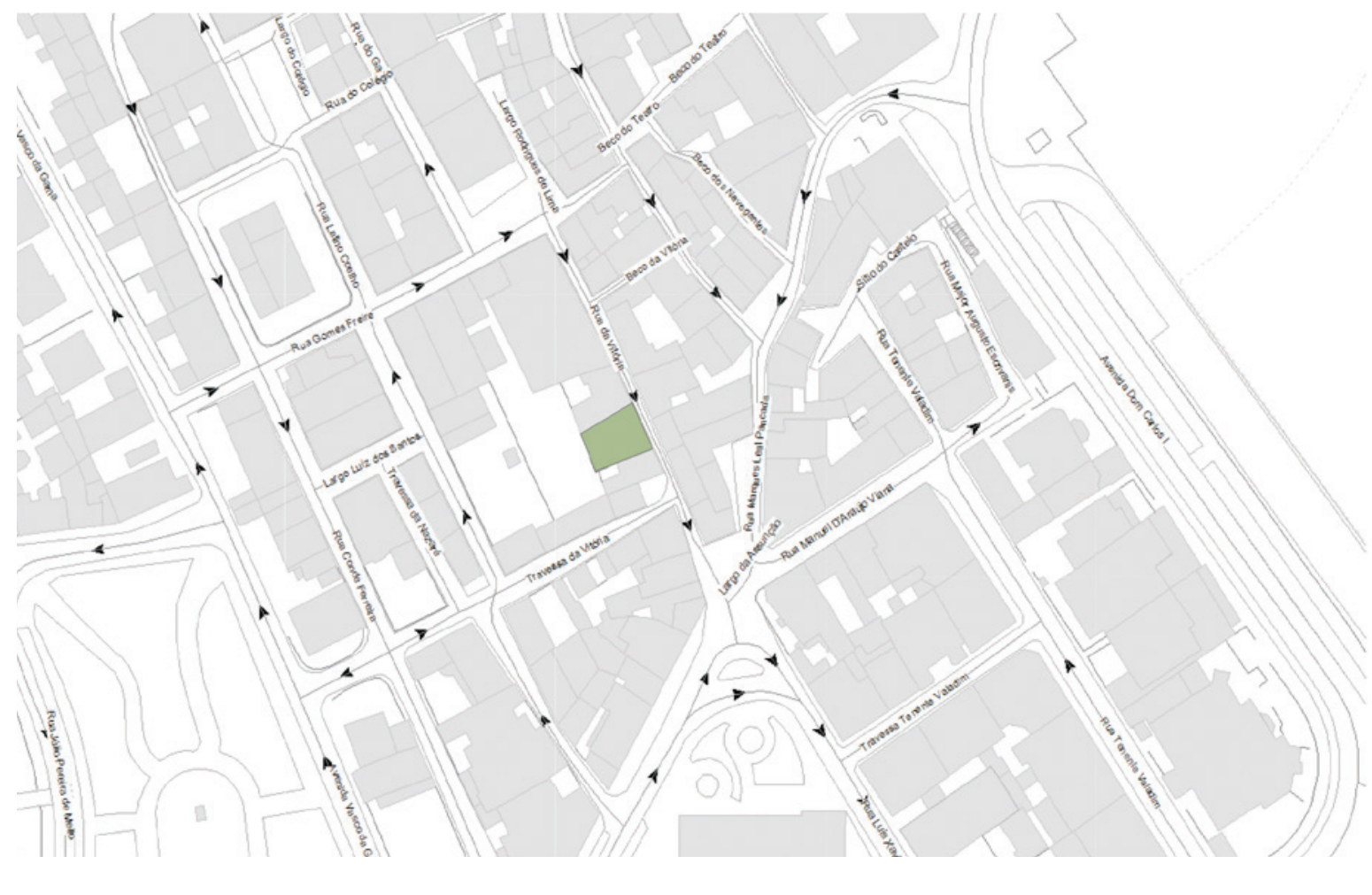

Figura 1 - Planta com localização do edifício (a verde) (Fonte: geocascais.cascais.pt).

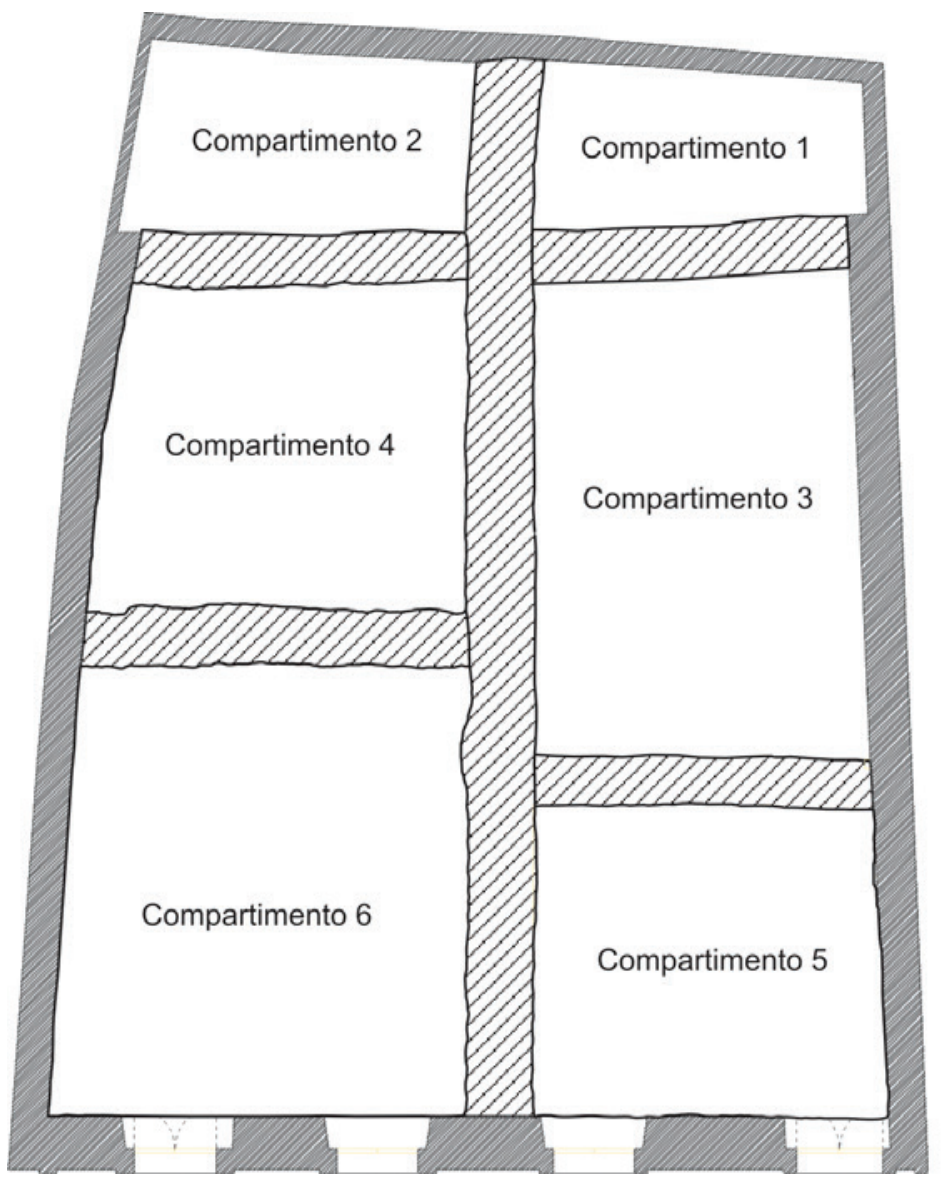

Figura 2 - Esquema dos compartimentos intervencionados. 


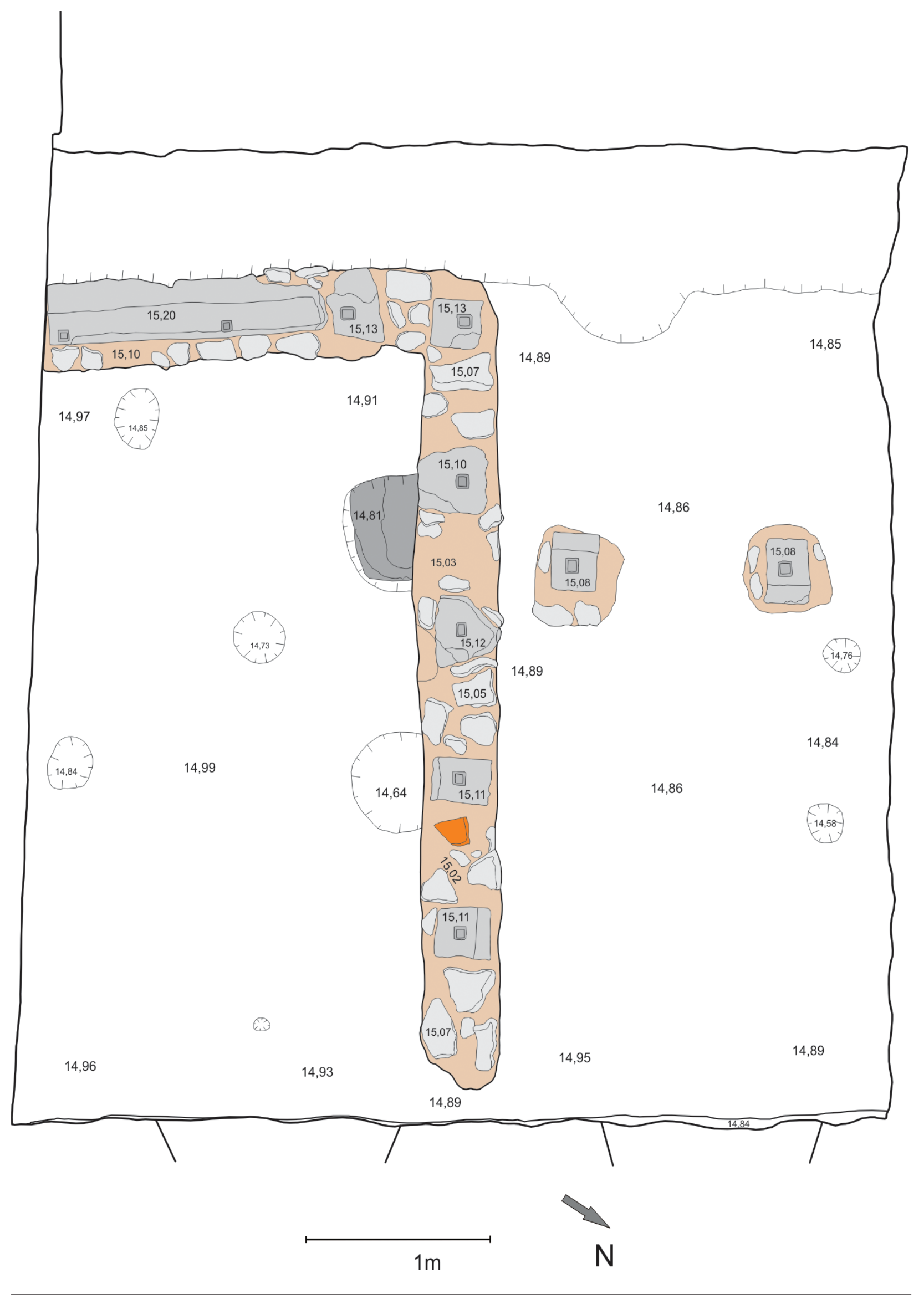

Figura 3-Estrutura de tabique identificado no compartimento 6. 


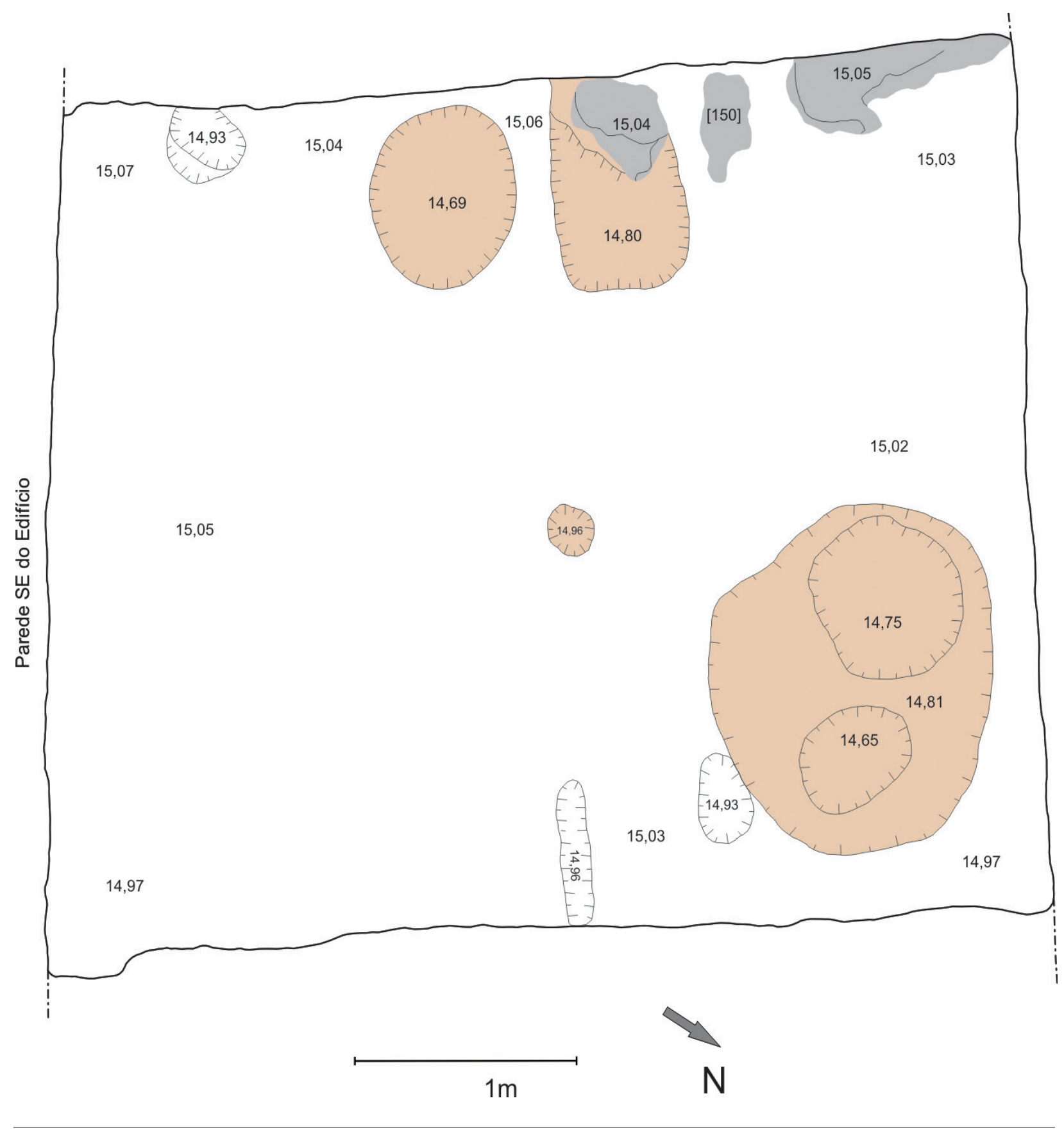

Figura 4 - Nível de fossas detríticas do compartimento 4 (a castanho claro). 


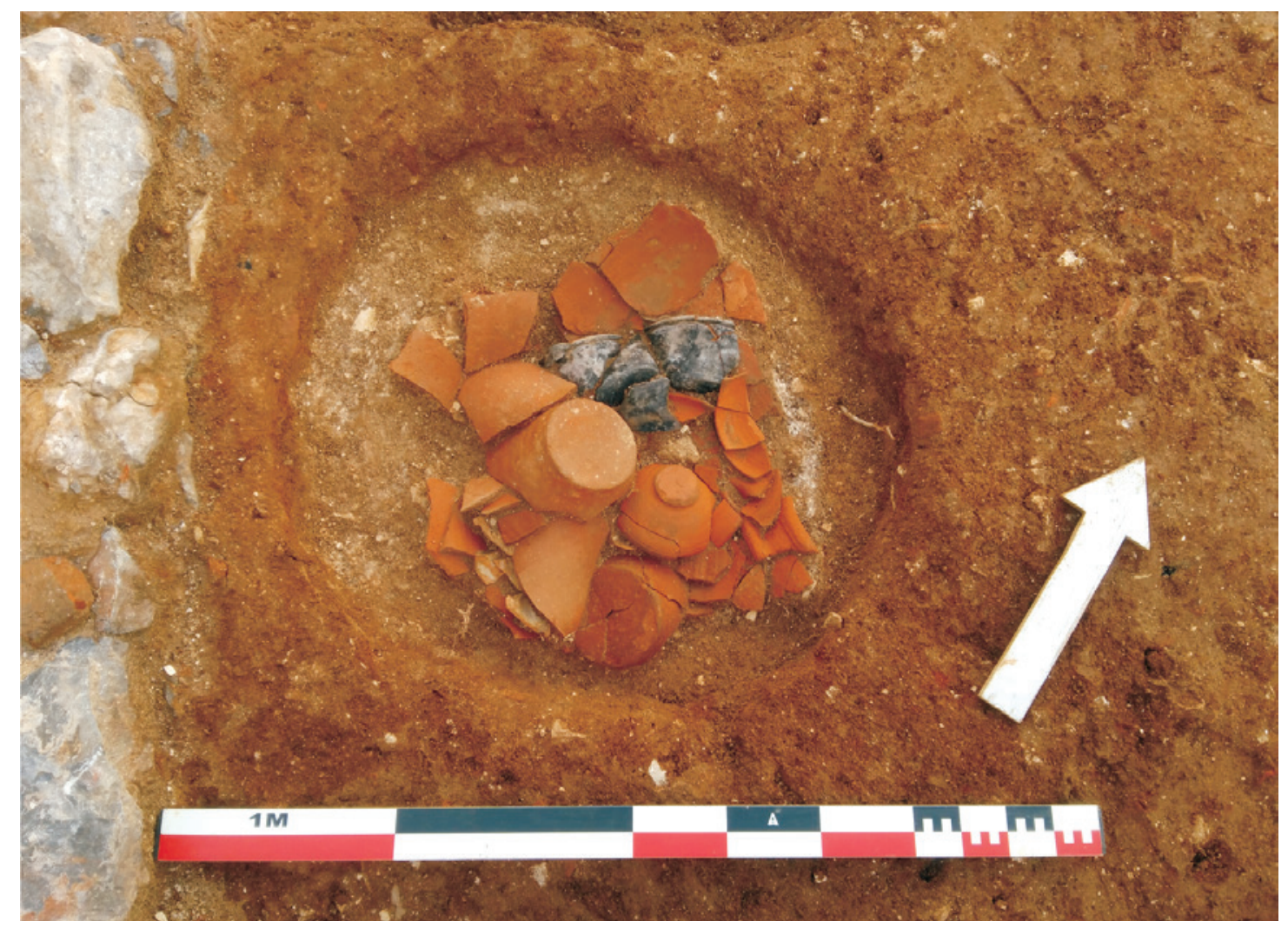

Figura 5- Pormenor da fossa detrítica identificada no compartimento 4.

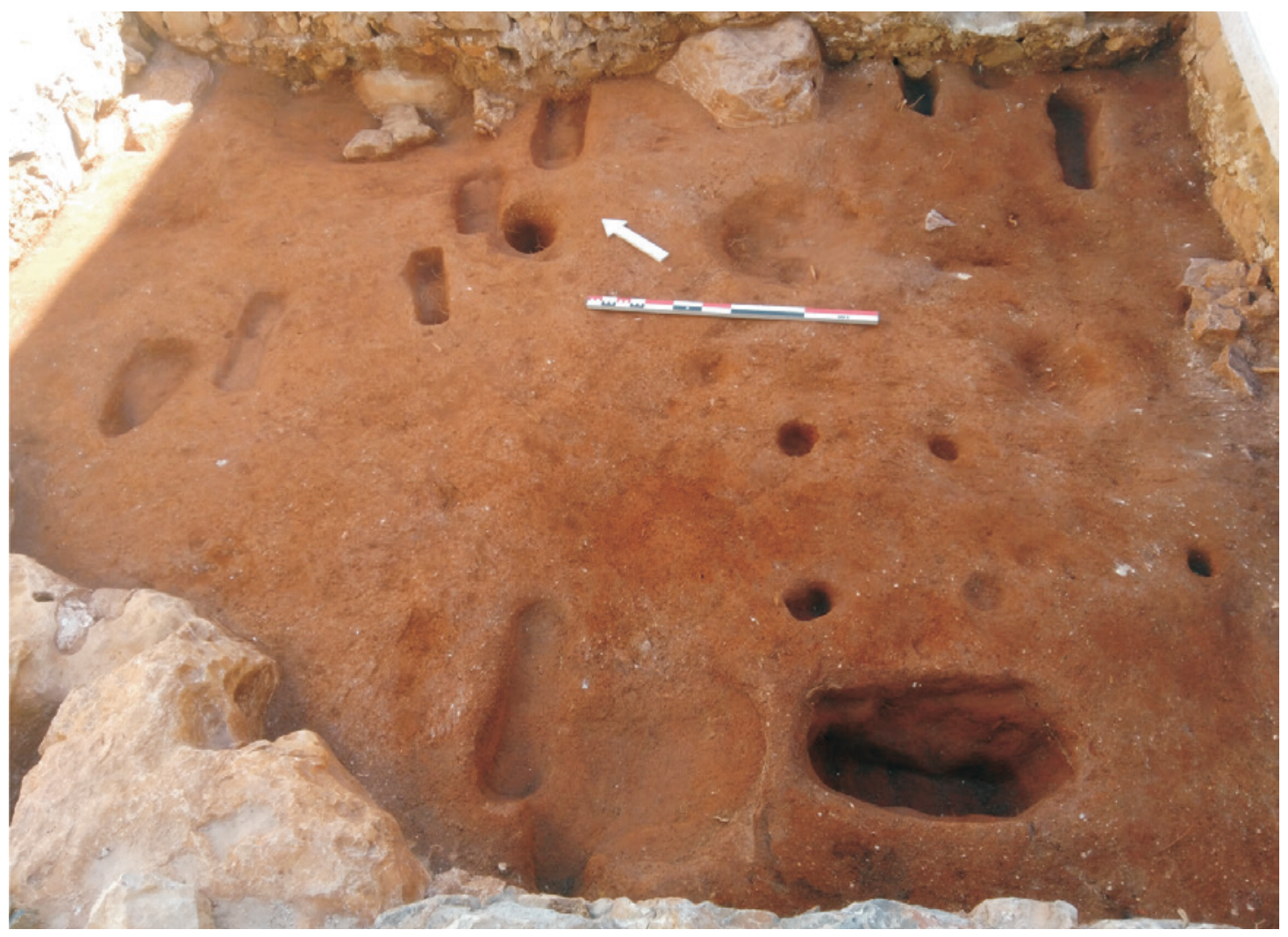

Figura 6 - Vista geral das estruturas negativas para pés de vinha do compartimento 4. 


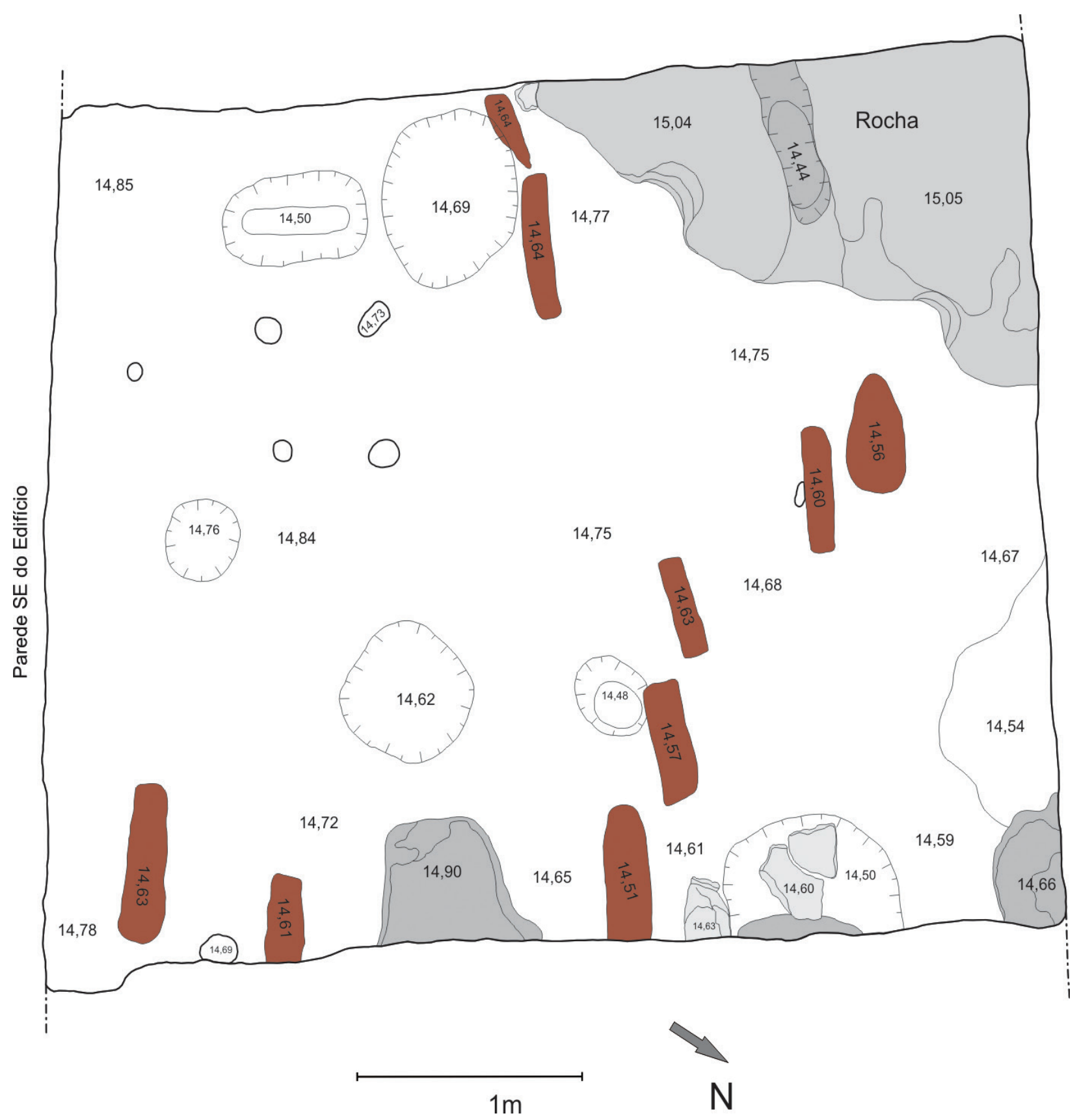

Figura 7 - Nível de ocupação agrícola com a implantação dos pés de vinha (a castanho). 


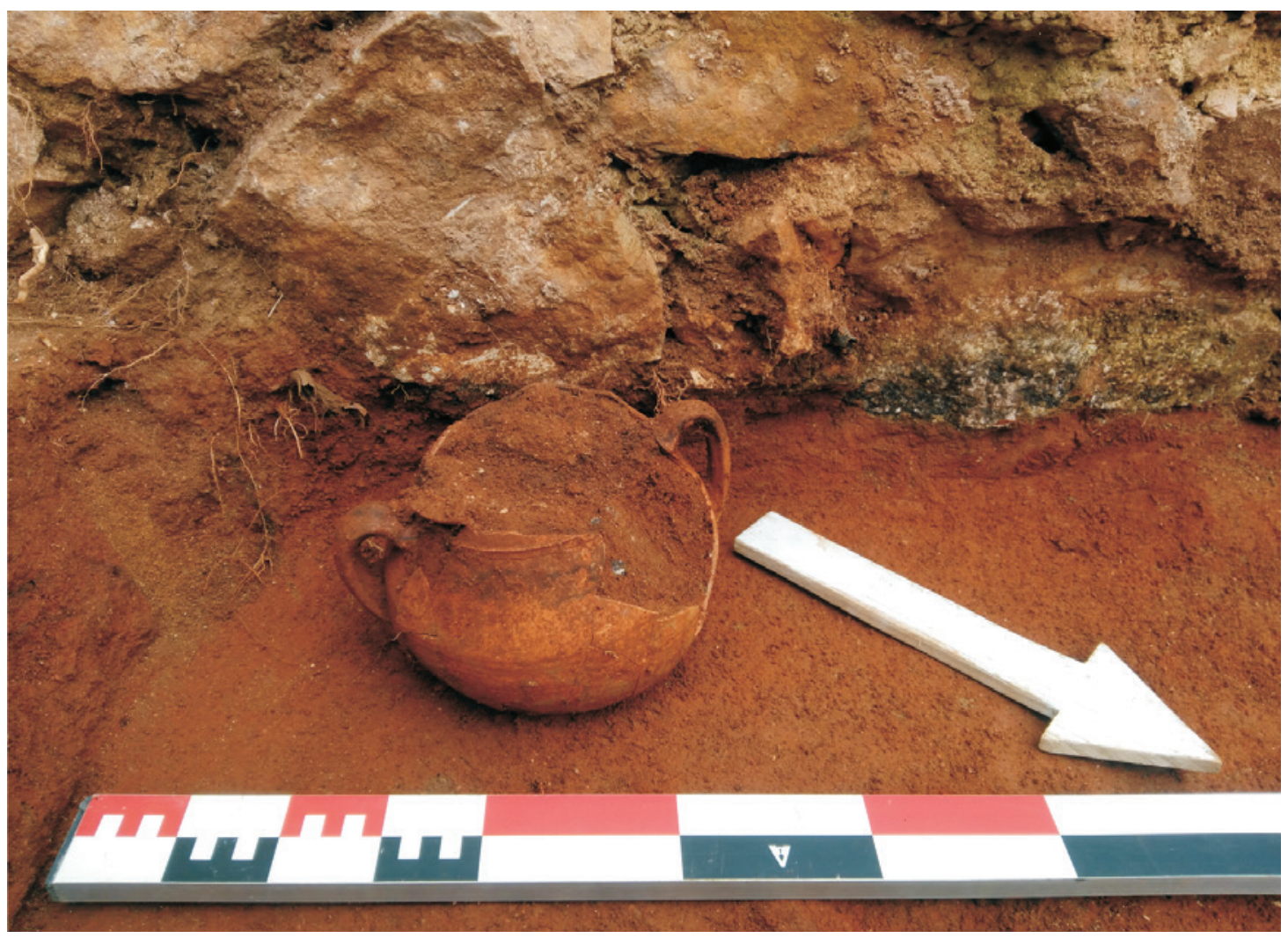

Figura 8 - Pormenor da panela in situ exumada no compartimento 4.

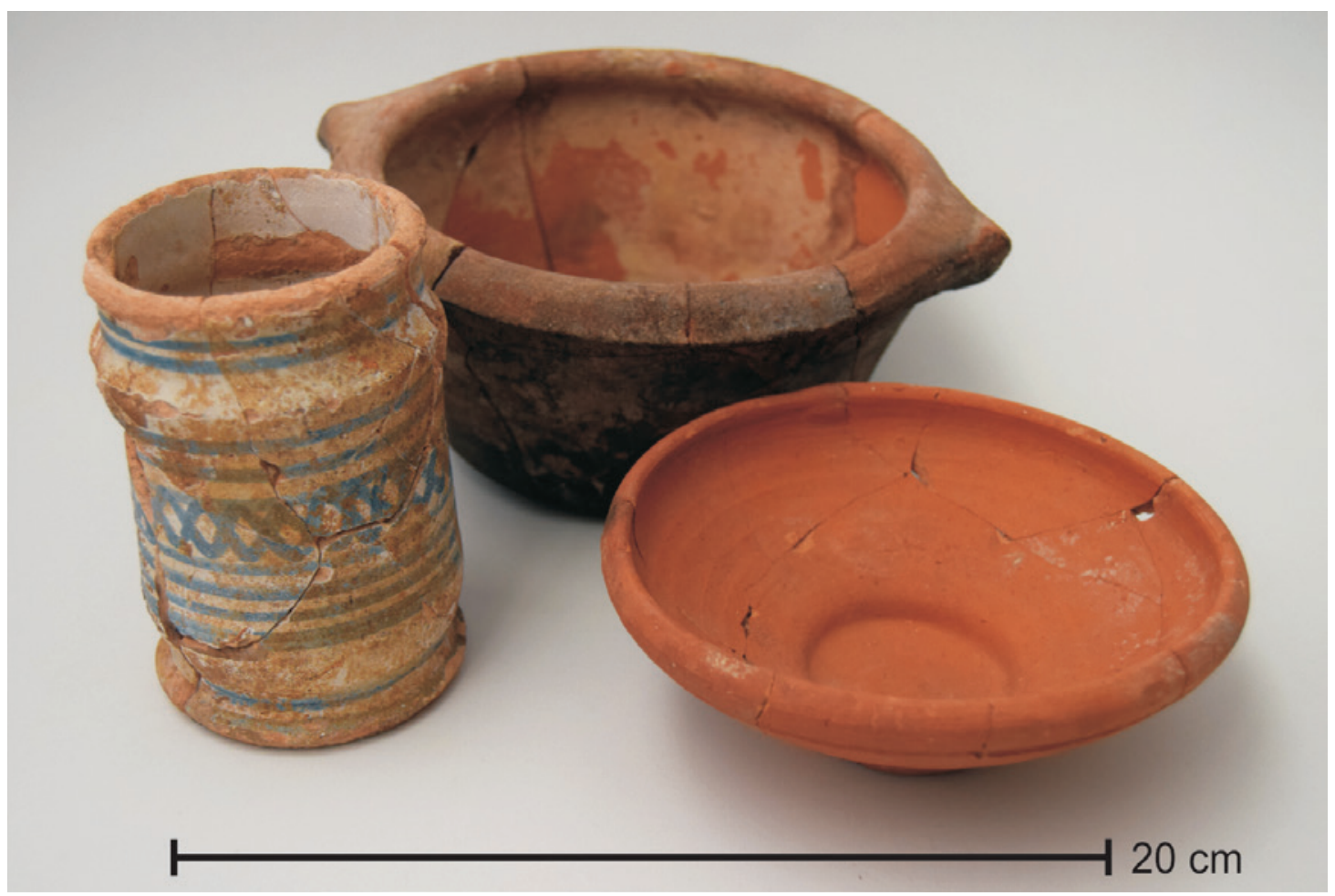

Figura 9-Materiais exumados na fossa do compartimento 4 (Autor: José Pedro Henriques). 


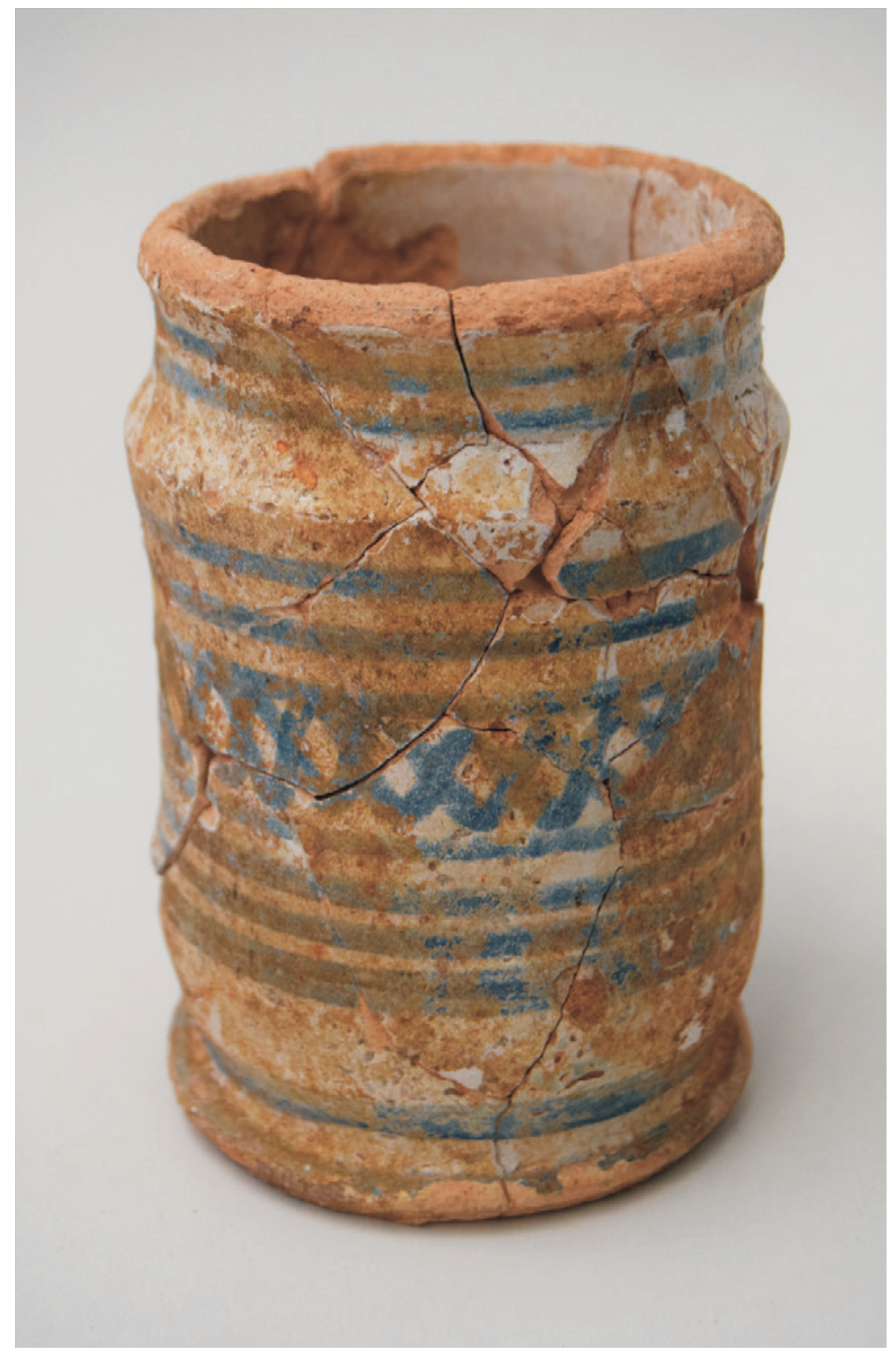

Figura 10 - Albarello de produção inglesa da segunda metade do século XVII (Autor: José Pedro Henriques). 


\title{
NOVOS DADOS PARA O CONHECIMENTO DO URBANISMO DE FARO EM ÉPOCA MODERNA
}

\author{
Ana Rosa ${ }^{1}$
}

\begin{abstract}
RESUMO
Em 2018, no âmbito de um Projecto Hoteleiro a construir na área delimitada pela Rua Vasco da Gama e a Rua Santo António (Faro), foram realizadas nove sondagens de diagnóstico e acompanhamento arqueológico de todas as movimentações de terras, na área a intervencionar, até à cota de afectação da obra.

Os trabalhos arqueológicos permitiram desvendar parte do traçado pré-urbano da Baixa de Faro e contextos associados ao quotidiano da população em época Moderna. Decorrente da expansão da cidade fora do núcleo primitivo (Vila-Adentro), esta área foi integrada, no século XVI, por um novo recinto amuralhado, indicando-nos uma ocupação contínua do espaço até ao presente.

Palavras-chave: Arqueologia preventiva, Urbanismo, Faro, Época Moderna.
\end{abstract}

\begin{abstract}
In 2018, as part of an Hotel Project to be built in the area bounded by Rua Vasco da Gama and Rua Santo António (Faro), nine diagnostic surveys and archaeological monitoring of all earth movements were carried out in the area to be intervened, until the allocation level of the work.

The archaeological work allowed to unveil part of the old urban layout of Baixa de Faro and contexts associated with the daily life of the population in Modern times. Due to the expansion of the city outside the primitive nucleus (Vila-Adentro), this area was integrated, in the 16th century, by a new walled enclosure, indicating a continuous occupation of the area at present day.
\end{abstract}

Keywords: Preventive archeology, Urban, Faro, Modern Times.

\section{ENQUADRAMENTO}

Os trabalhos, realizados na área delimitada pela Rua Vasco da Gama e a Rua Santo António, iniciaram-se com uma fase de diagnóstico para avaliar o potencial arqueológico do sítio. Nas primeiras oito sondagens implantadas, foram identificados contextos arqueológicos preservados, enquadrados, cronologicamente, entre os séculos XVI e XVIII. Dada a informação obtida, avançámos para o alargamento de sondagens e para a realização de uma sondagem adicional, de forma a compreender o conjunto recuperado de uma forma mais alargada.

$\mathrm{O}$ acompanhamento arqueológico que se seguiu, nas áreas não afectadas pelo diagnóstico, permitiu registar estruturas que se apresentavam na continuidade dos contextos observados.
Administrativamente, o sítio intervencionado situa-se na freguesia da Sé, concelho e distrito de Faro (Carta Militar de Portugal, folhas 610-611, à escala 1/25000) (Figura 1).

\section{CONTEXTOS ARQUEOLÓGICOS PRESERVADOS}

O terreno intervencionado era ocupado por um edifício devoluto e em avançado estado de degradação, o qual, apresentava características da arquitectura vigente dos séculos XVIII e XIX, com adaptações nas dependências internas durante o século XX. Após a sua demolição, foram realizadas, no total, 9 sondagens de diagnóstico, nas quais se detectaram diversas estruturas colmatadas por níveis de aterros. Exceptuam-se nesta sucessão de camadas, pontuais

1. ERA Arqueologia, S.A; anarosa@era-arqueologia.pt 
despejos de lixos presentes in situ. Tratam-se de algumas bolsas com pouca espessura mas com uma imensa concentração de materiais, carvões e faunas. Os vestígios identificados integram-se no urbanismo de Faro, anterior à formação da cidade actual, sob a qual, foi possível definir uma relação entre os espaços público e privado, compreendidos por compartimentos habitacionais, áreas de circulação, pisos, poços e estruturas de combustão.

Consideramos relevante tecer um comentário relativamente à tipologia construtiva dos contextos habitacionais identificados, uma vez, termos verificado que as paredes da actual moradia coincidiam com os alicerces pré-existentes. Sempre que oportuno, as paredes, compostas por alvenaria de taipa, tão típicas da construção algarvia, sobrepunham-se directamente aos muros de pedra e alvenaria. Nesse sentido, poderíamos até supor, não uma ruptura, mas uma adaptação da habitação à nova realidade urbana, imposta a partir do século XIX (Figura 2).

Os contextos habitacionais, registados na sondagem 4, revestiam-se de alguma complexidade comparativamente aos das restantes sondagens. Efectivamente, estava presente uma maior articulação entre os muros principais e as linhas divisórias das áreas internas, cuja construção, composta por pedra e argamassa de coloração alaranjada, apresentava ainda reaproveitamento de tijolos ou outros elementos como alicerces.

Nesta sondagem, foi também observado um desmonte parcial entre muros. Este intervalo (Figura 3), correspondeu a uma intenção propositada de criar um acesso, tendo sido posteriormente encerrado como se compreendeu pela remontagem, executada com recurso a pedra calcária com material de ligação em argila.

A separação, entre os espaços interior e exterior, estava igualmente bem demarcada na sondagem 4 . No decorrer dos trabalhos, verificámos que um murete intercalava um pavimento em calçada e um piso em tijoleira (Figura 4), o qual, assente sobre um nível constituído por argila, vermelha e compacta.

As estruturas de combustão, identificadas nas sondagens 1, 4, 6 e 9, apresentavam distintas tipologias construtivas. As estruturas presentes nas sondagens 1 e 4, caracterizavam-se pela planta semi-circular, de paredes tendencialmente rectas e fundo plano, cuja construção partiu do recurso a blocos pétreos de pequenas dimensões, com ligante em argila (Figura 5). As suas dimensões variavam entre $1 \mathrm{~m}$ x o,8om e 1,20m x 1,40m. Por outro lado, nas sondagens 4, 6 e 9, identificámos estruturas em negativo, estruturadas em argila, de plantas e dimensões muito variáveis. A melhor conservada foi detectada na sondagem 4 e caracterizava-se pela planta semi-oval, de paredes côncavas e fundo irregular, tendo aproveitado uma parede a Este para limitar a sua posição (Figura 6). Esta estrutura apresentava as dimensões de $2 \mathrm{~m} \times 1,10 \mathrm{~m}$.

Da mesma forma, foram identificados dois poços na sondagem $7 \mathrm{e}$, um outro, durante o acompanhamento arqueológico (Figura 7). Caracterizavam-se pela planta de contorno circular e o diâmetro de boca variava entre $1 \mathrm{~m}$ e $1,6 \mathrm{om}$. Tipologicamente, $\mathrm{o}$ aparelho construtivo utilizado partiu do recurso a blocos pétreos de pequena e média dimensão, não afeiçoados, unidos por cal e areia, tendo sido forrados internamente a estuque. Estas estruturas, uma vez desactivadas da sua função original, foram reaproveitadas para a deposição de lixos (cronologia contemporânea).

Um conjunto de infra-estruturas de saneamento, essenciais ao funcionamento da urbe, foram registadas nas sondagens 3, 4, 6 e 7, diferenciando-se em termos de cronologia e tipologia. A construção e desactivação das condutas é clara dos sucessivos melhoramentos efectuados nesta parte da cidade.

Dentro do conjunto identificado, as caleiras [453] e [309] correspondiam às estruturas mais antigas. Estas, não se encontravam em bom estado de conservação e apresentavam-se como construções pouco cuidadas, atendendo à sua composição mista de blocos pétreos (calcário e basalto), ao passo que, nos restantes casos observados - [406], [407], [715], [606] verificou-se a presença de caleiras bem estruturadas em pedra ou tijolo de alvenaria (Figura 8).

De forma a se obter uma amostra integral da sequência estratigráfica do local, optou-se pela escavação da sondagem 4 (área que se apresentou como a mais representativa da ocupação do sítio), até ao substrato geológico. Os trabalhos resultaram apenas na contínua remoção de depósitos de aterro. Na base, identificámos o substrato geológico, afectado pela abertura de um alinhamento de buracos de poste (Figura 9), os quais, associamos às fundações das casas.

O espólio recuperado enquadra-se na realidade apresentada, tendo sido identificado uma elevada concentração de material derivado, na sua maioria, dos níveis de aterro. A partir de uma análise preliminar, constata-se a presença de uma enorme variedade 
de peças relacionadas com o serviço à mesa, confecção e armazenamento, produzidas, sobretudo, em âmbito local. O conjunto, compreendido entre os séculos XVI e XVIII, inclui também fragmentos de faiança e porcelana que, fora deste contexto, nos remete para cronologias mais recentes de ocupação do sítio (Figura 10).

\section{CONSIDERAÇÕES FINAIS}

A intervenção arqueológica na Baixa de Faro resultou na identificação de contextos que nos remete para uma ocupação contínua deste espaço a partir do século XVI, decorrente da expansão da cidade fora do núcleo primitivo (Vila-Adentro).

As construções de novas artérias urbanas dependeram das vias de comunicação, herdadas do período medieval. A Rua Santo António, constituindo-se como uma das entradas da cerca, passou a funcionar em conjunto com as alterações da planta urbana, reforçando a sua veia comercial.

Na Rua Vasco da Gama ou Rua Forno do Bousela, assim conhecida à época, foi reconhecida uma área residencial compartimentada por vários sectores, alguns dos quais, ocupados por fornos. As várias esruturas de combustão presentes enquadram-se em actividades de utilização doméstica, embora, as distintas tipologias identificadas nos possa remeter para usos diferentes. Nas habitações algarvias, é usual "a individualização do forno da estrutura da casa e a construção junto à entrada de pequenas fornalhas (borralheiras), onde se cozinham nos dias de Verão para entrar ganhos de calor dentro da casa" (Fernandes, 2012, p. 102).

Desta forma, contrariamente ao que avançámos inicialmente, estes fornos seriam de utilização culinária e não de produção oleira (Rosa, 2018), visto que, de facto, as actividades de carácter industrial estão situadas normalmente "na área peri-urbana para evitar os incómodos que produziam (fumo, maus cheiros, dificuldade no acarretamento de matérias primas - água, barro e combustível)" (Palma, 2009, p. 42).

Até aos finais do século XVIII, é prática recorrente a construção de quintal com poço, o que, efectivamente, coincide com o momento de colmatação dos poços identificados no terreno pelo planeamento do novo traçado urbano.

O urbanismo de Faro ainda é uma realidade mal conhecida, tornando o crescente número de trabalhos realizados no âmbito das medidas de salvaguarda arqueológica, uma ferramenta imprescindível para decifrar a estrutura de antigamente. Através do presente texto, pretendeu-se uma apresentação preliminar dos dados recolhidos no quarteirão delimitado pela Rua Vasco da Gama e a Rua Santo António, bastante reveladores da dinâmica e transformadora cidade, em época moderna.

\section{BIBLIOGRAFIA}

CORREIA, José Horta (1998) - A arquitectura do Algarve como expressão privilegiada da sua especificidade cultural. In O Algarve na perspectiva da Antropologia Ecológica. Lisboa: Instituto Nacional da Investigação Científica, pp. 135-146.

FERNANDES, Jorge Emanuel Pereira (2012) - O contributo da Arquitectura vernacular portuguesa para a sustentabilidade dos edifícios. Dissertação para a obtenção do Grau de Mestre em Construção e Reabilitação Sustentáveis. Escola de Engenharia. Minho: Universidade.

GAMITO, Teresa Júdice (1991) - Contribuição da arqueologia para o estudo da evolução urbana de Faro. In Actas das IV Jornadas Arqueológicas (Lisboa 1990). Lisboa: Associação dos Arqueólogos Portugueses, pp. 19-26.

GOMES, Rosa Varela (2012) - A Arqueologia da Idade Moderna em Portugal - contributos e problemáticas. O Arqueólogo Português. Lisboa. Série V. 2, pp. 13-75.

LAMEIRA, Francisco (1999) - Faro, a arte na história da cidade. Faro: C.M.F.

PALMA, Maria de Fátima Gomes da Costa Rodrigues (2009) - Arqueologia Urbana na Biblioteca Municipal de Mértola (Portugal) - contributos para a História Local. Dissertação para a obtenção do Grau de Mestre em Arqueologia e Património. Huelva: Universidade.

PAULA, Rui.; PAULA, Frederico (1993) - Faro, Evolução Urbana e Património. Faro: C.M.F.

RODRIGUES, Tânia Alexandra Cabecinha (2010) - Faro na época Moderna: do Urbanismo à Arquitectura. Dissertação para a obtenção do Grau de Mestre em História da Arte, Faculdade de Ciências Sociais e Humanas. Faro: Universidade.

ROSA, Ana (2018) - Relatório Final dos Trabalhos Arqueológicos na Rua Vasco da Gama (Faro). ERA-Arqueologia. Lisboa. 


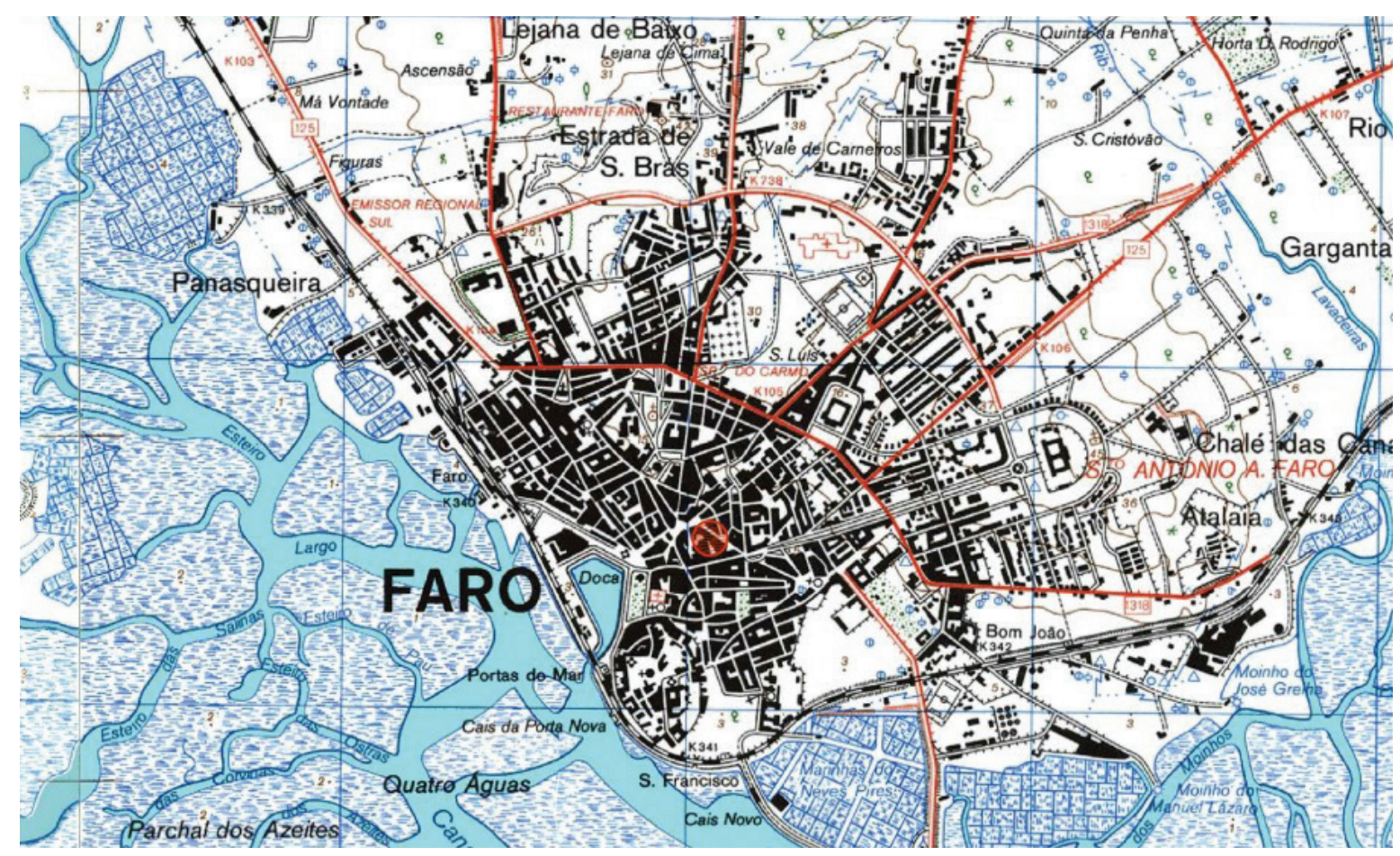

Figura 1 - Localização do sítio intervencionado em excerto da CMP, folhas 610-611, à escala 1/250oo (modificado).

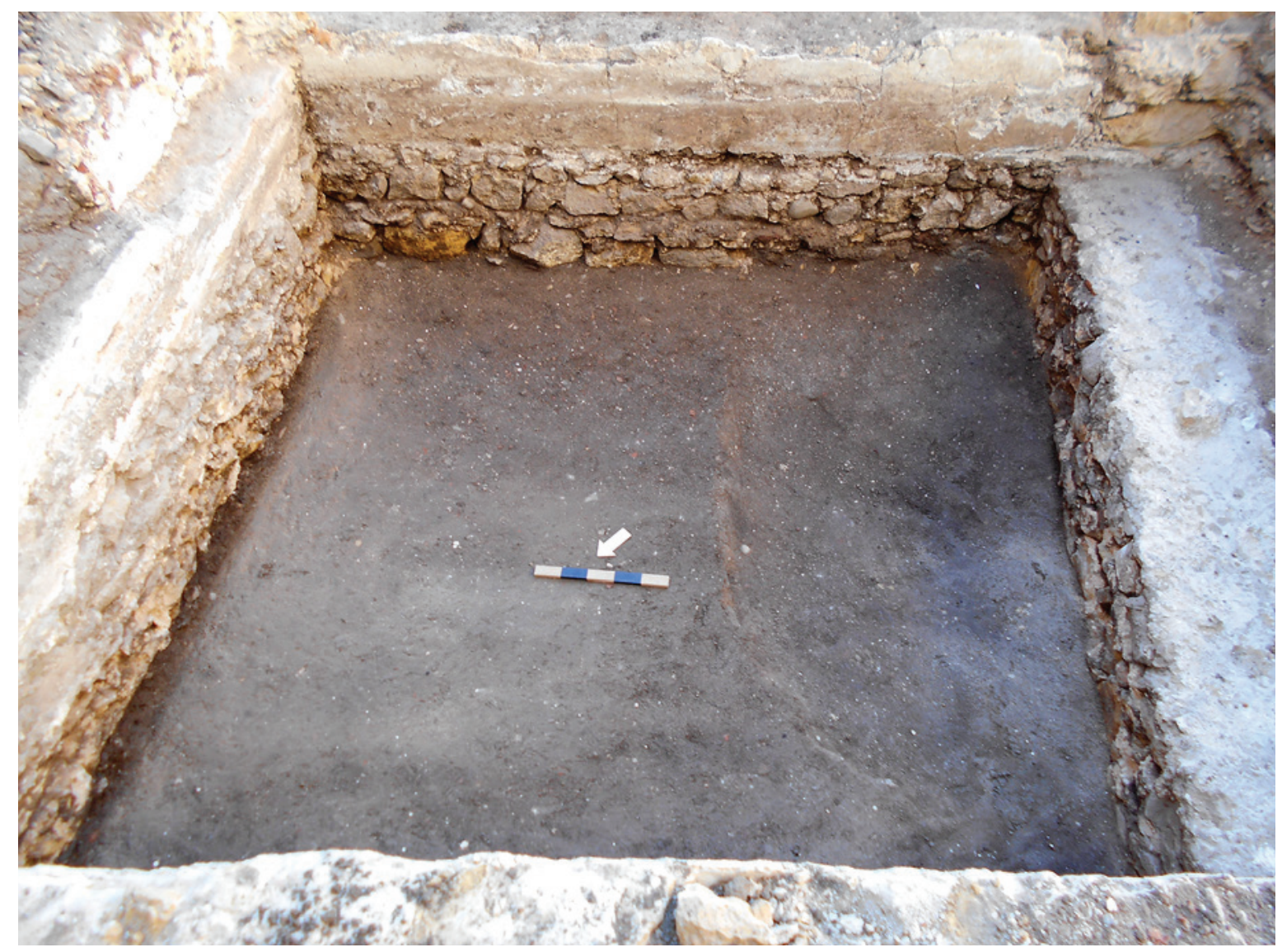

Figura 2-Compartimento identificado na sondagem 2. 


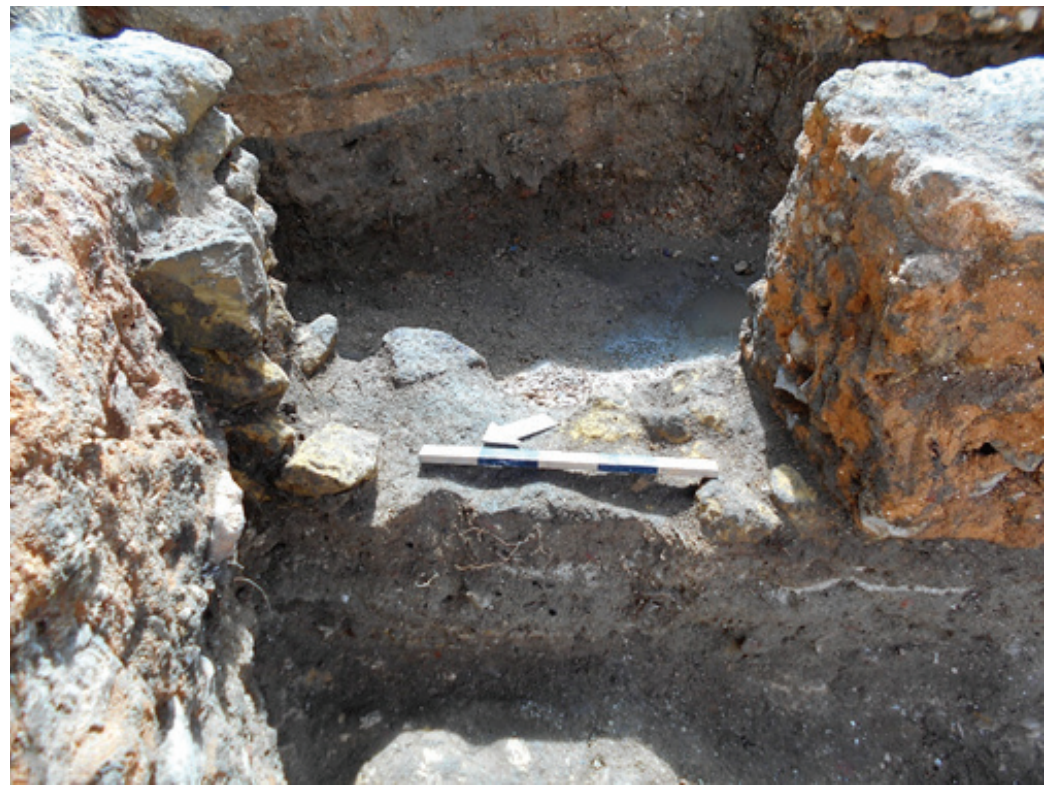

Figura 3 - Acesso criado entre as estruturas [904] e [425], onde aparentemente foi desmontada e remontada a estrutura [435].

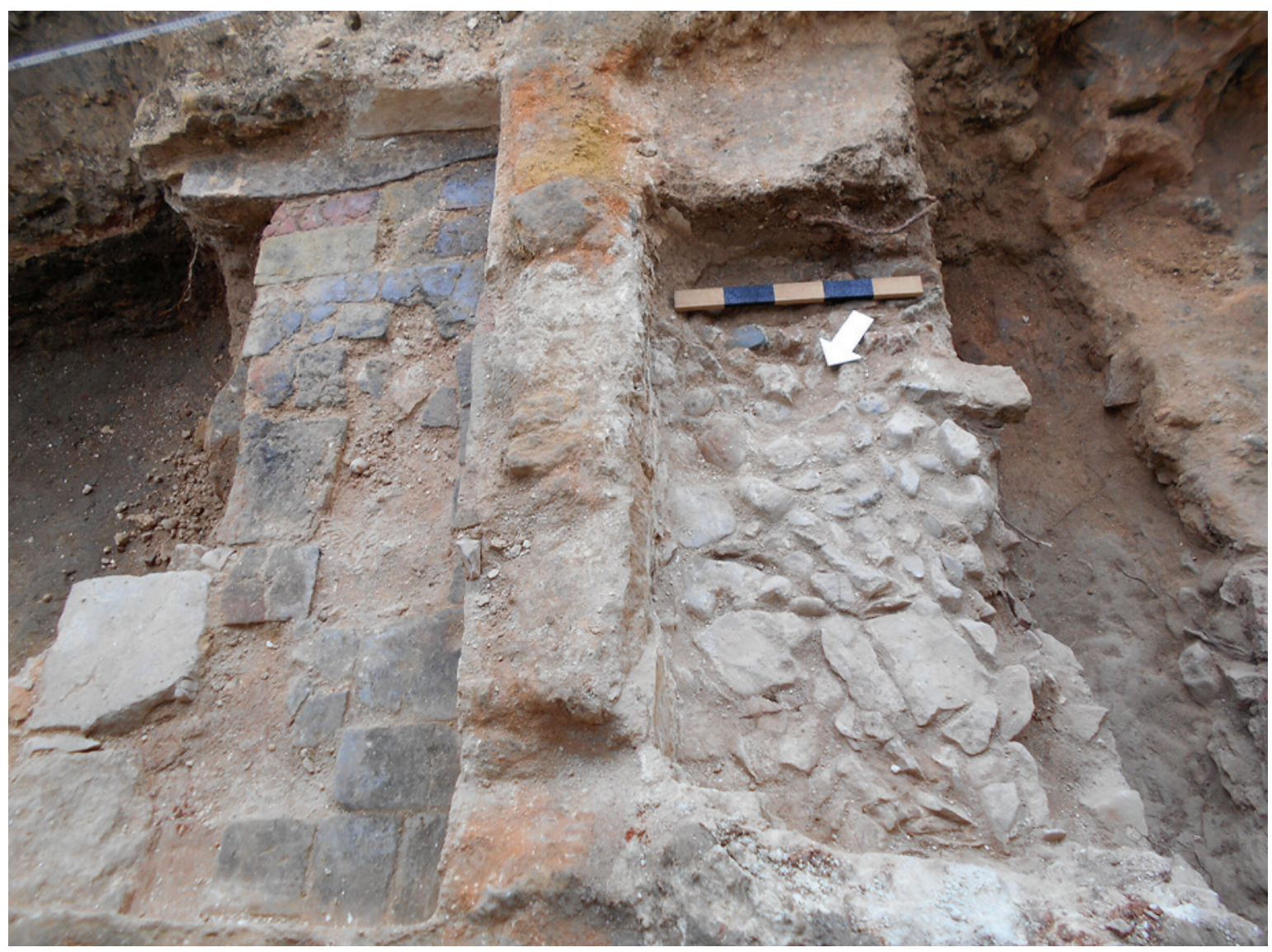

Figura 4 - Pormenor de separação de espaços. 


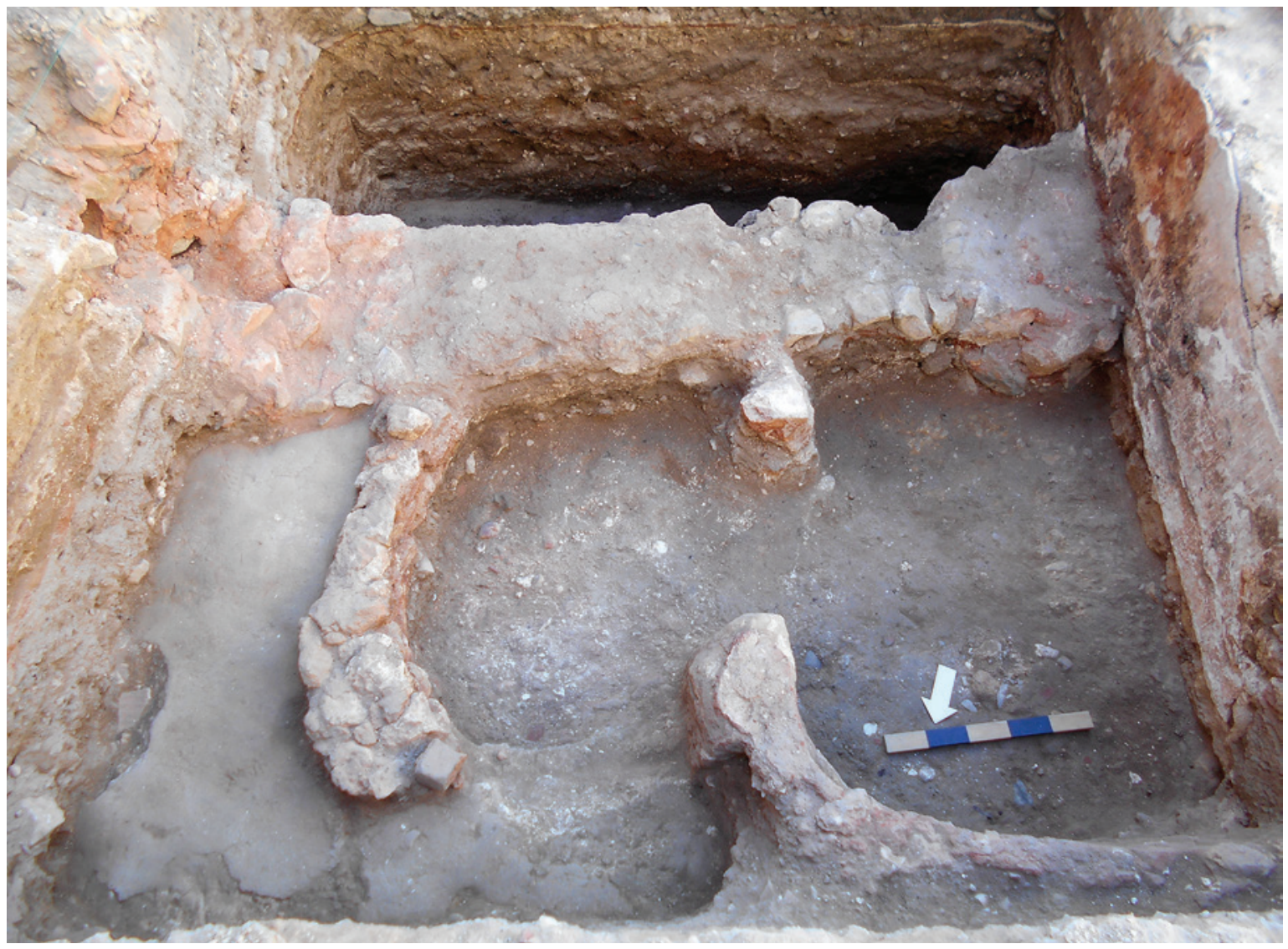

Figura 5-Estruturas de combustão identificadas na sondagem 1.

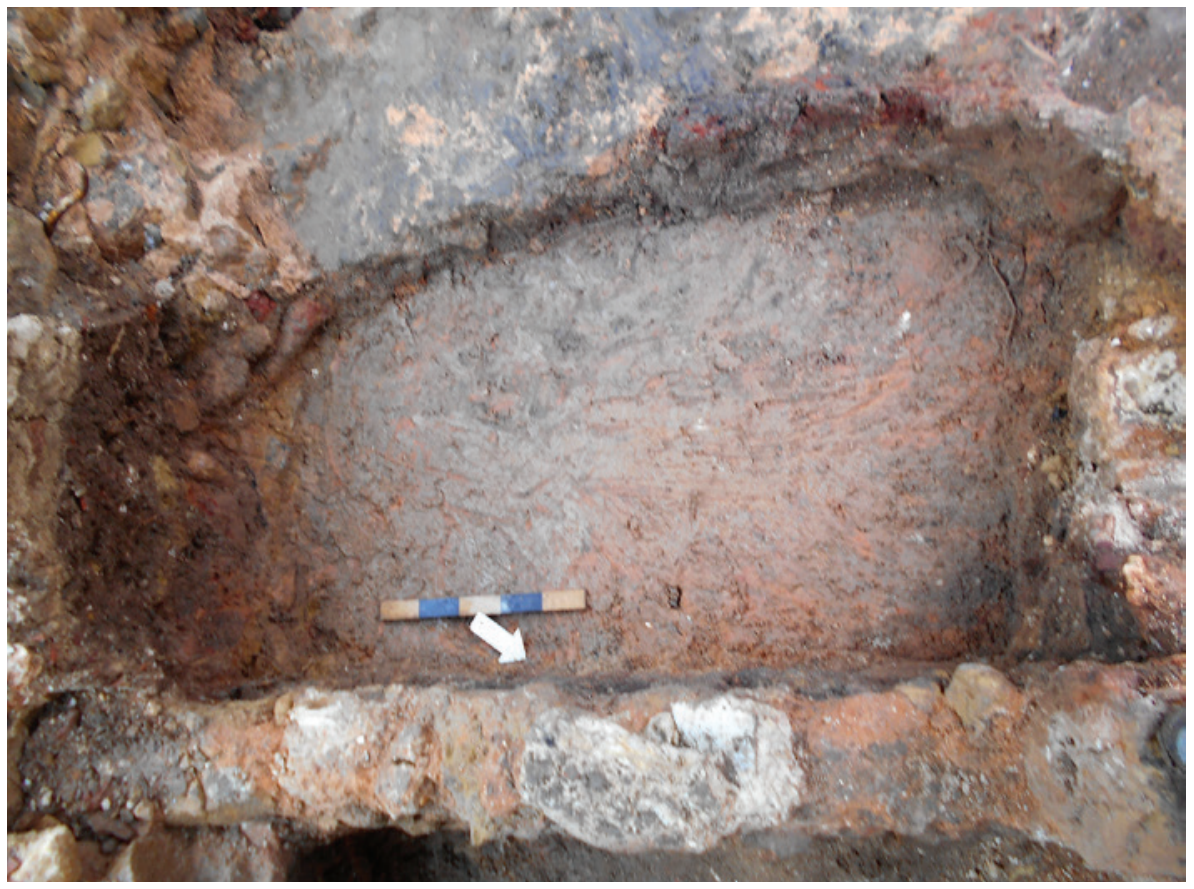

Figura 6 - Estrutura de combustão identificada na sondagem 4 . 


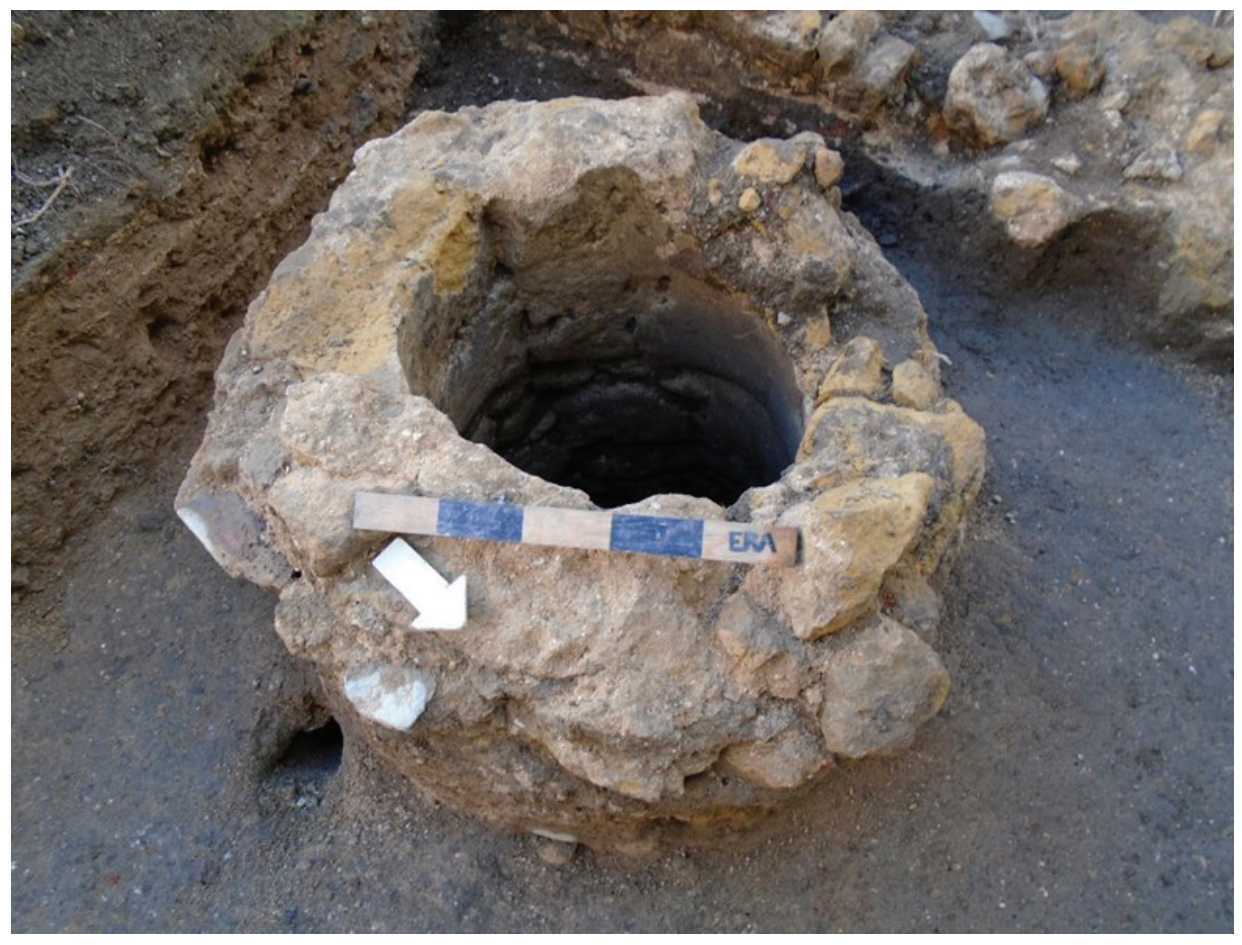

Figura 7 - Poço identificado na fase do acompanhamento arqueológico.

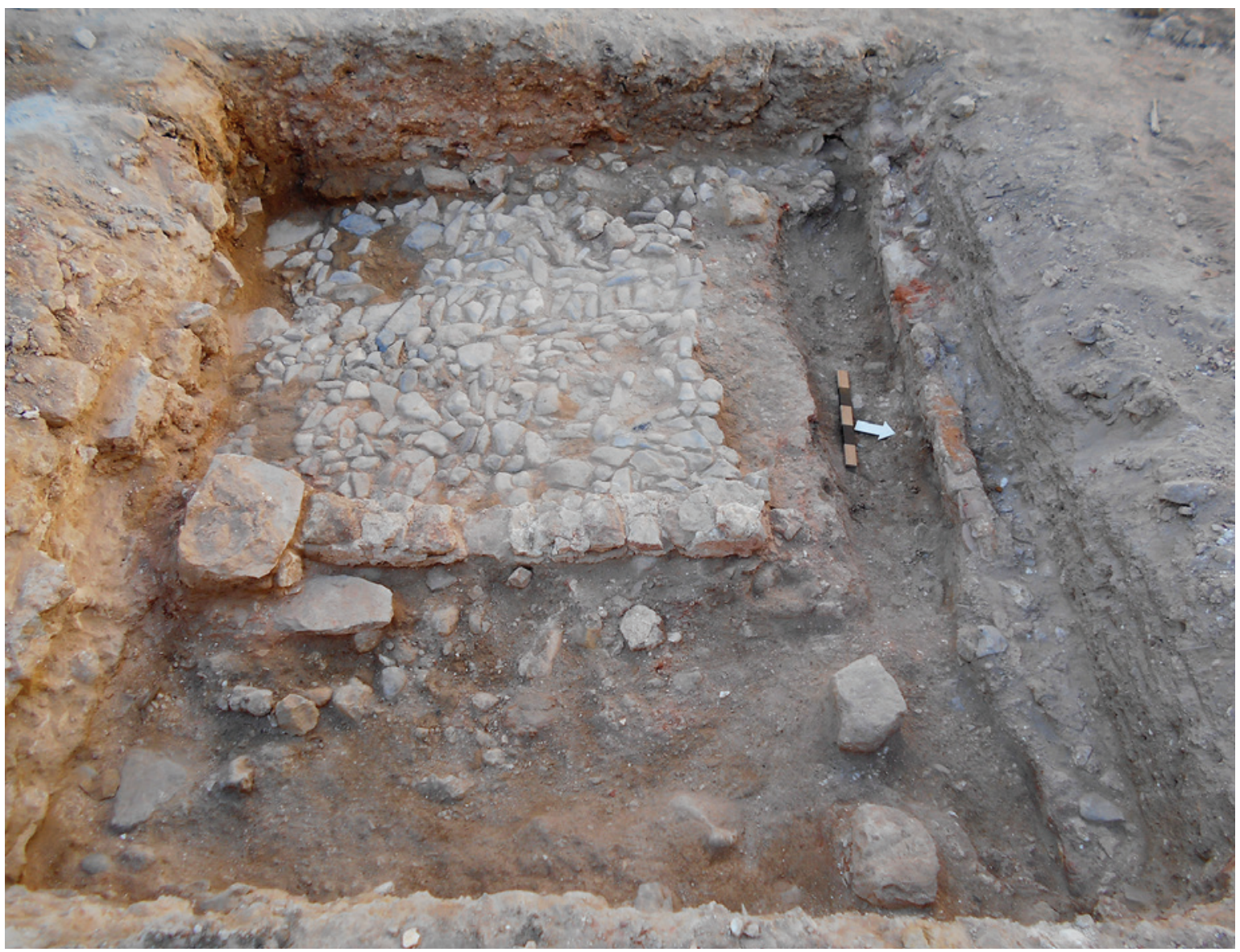

Figura 8 - Plano do traçado pré-urbano (Sondagem 6). 


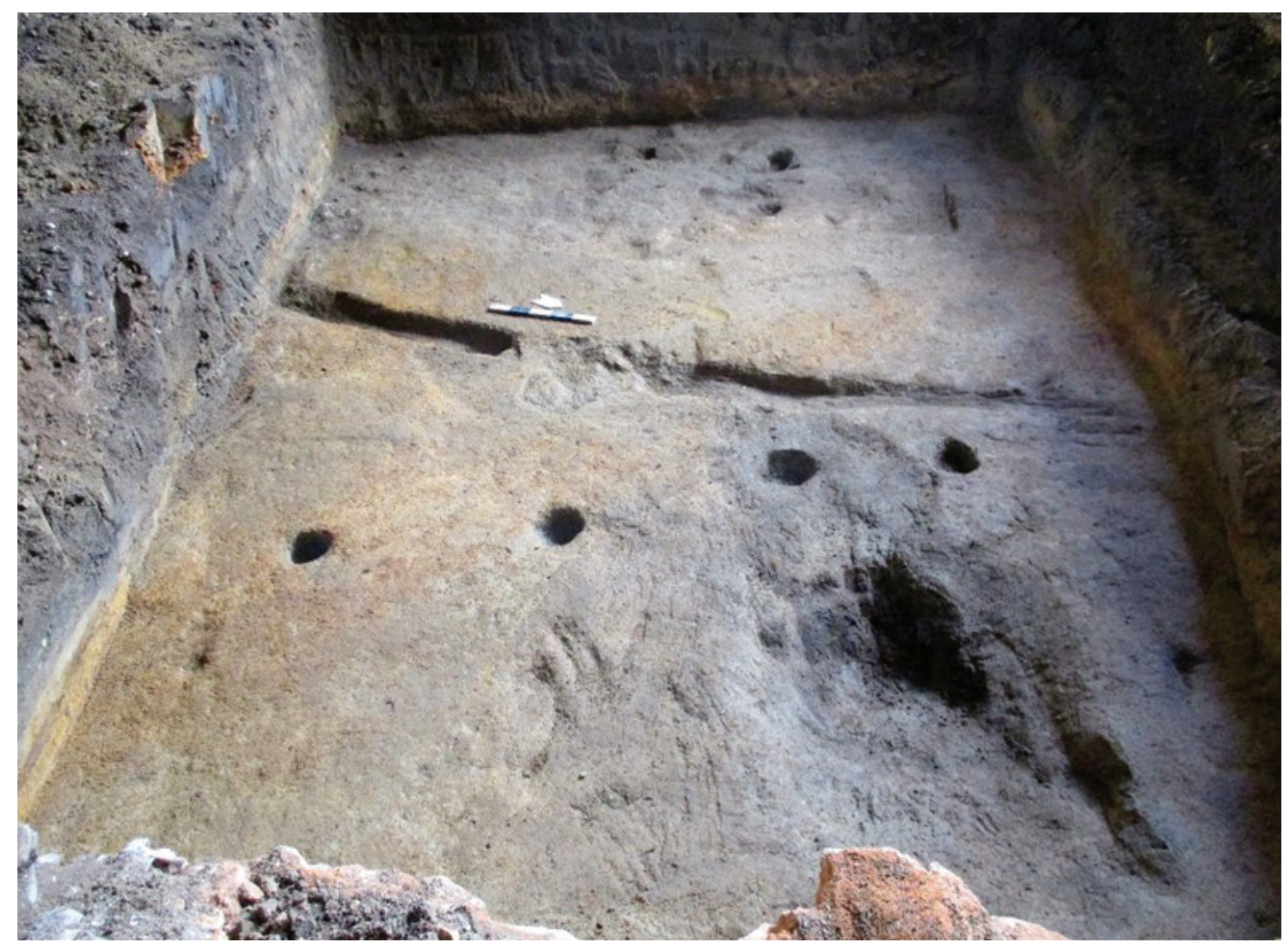

Figura 9-Alinhamento de buracos de poste.

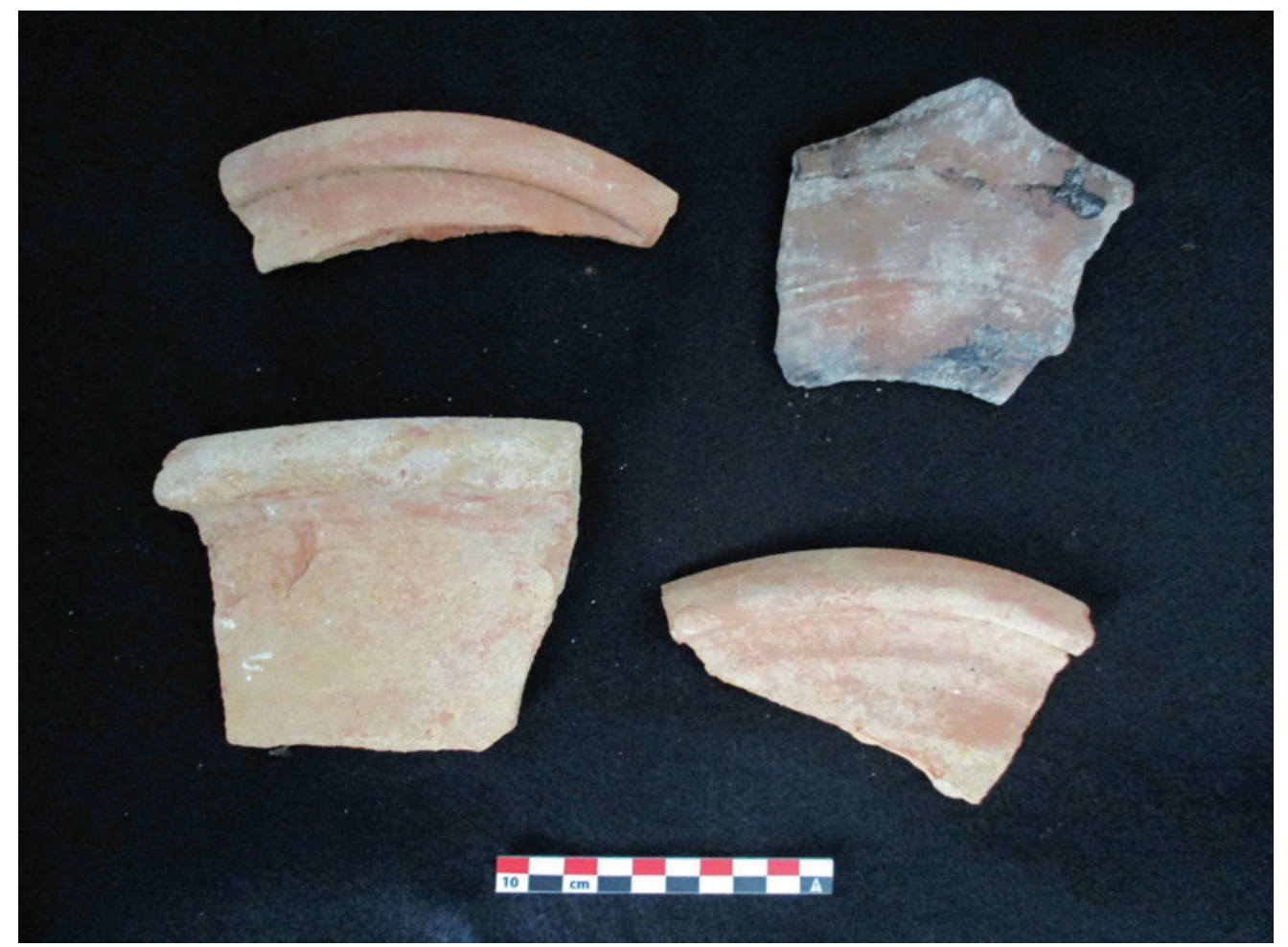

Figura 10 - Fragmentos de cerâmica comum. 


\title{
UM EXEMPLO DE ARQUEOLOGIA URBANA EM ALCOUTIM: O ANTIGO EDIFÍ́CIO DOS CTT
}

\author{
Marco Fernandes ${ }^{1}$, Marta Dias ${ }^{2}$, Alexandra Gradim ${ }^{3}$, Virgílio Lopes ${ }^{4}$, Susana Gómez Martínez ${ }^{5}$
}

\begin{abstract}
RESUMO
Este artigo pretende divulgar os principais resultados dos trabalhos arqueológicos desenvolvidos, entre Agosto de 2019 e Fevereiro de 2020, pela equipa do Campo Arqueológico de Mértola, num edifício conhecido como os Antigos CTT. Este imóvel localizava-se a Oeste do castelo de Alcoutim e dentro do seu perímetro amuralhado de período moderno, sendo, desde logo, uma área de carácter arqueológico importante para a compreensão da dinâmica ocupacional deste aglomerado.

Esta intervenção decorreu em duas fases distintas: sondagens de diagnóstico eacompanhamento arqueológico / escavação. Tais acções permitiram a identificação de um conjunto de estruturas e de níveis associados que apontam para uma diacronia que se inicia no século XV.
\end{abstract}

Palavras-chave: Alcoutim, Arqueologia Urbana, Idade Moderna e Contemporânea.

\section{ABSTRACT}

The aim of the present article is to divulge the main results of the archaeological works developed by the Campo Arqueológico de Mértola team in a building known as the Antigos CTT, between August 2019 and February 2020. This property is located to the west of Alcoutim Castle and inside its $17^{\text {th }}$ century walls, being an important archaeological site to understand the occupational dynamic of this urban area.

This intervention was performed in two distinct phases: diagnostic survey and archaeological monitoring / excavation. These interventions led to the identification of an associated group of structures and layers that point to a diachrony beginning in the $15^{\text {th }}$ century.

Keywords: Alcoutim, Urban Archaeology, Modern and Contemporary Age.

\section{INTRODUÇÃO ${ }^{6}$}

Os trabalhos arqueológicos realizados no Antigo Edifício dos CTT de Alcoutim, no âmbito do projecto de construção, neste local, de um novo edifício de habitação colectiva, numa área total de $305 \mathrm{~m}^{2}$, promovido pela Câmara Municipal de Alcoutim, foram realizados pelo Campo Arqueológico de Mértola e decorreram entre Agosto de 2019 e Fevereiro de 2020 (Figura 1).

\footnotetext{
1. CEAACP - Centro de Estudos de Arqueologia, Artes e Ciências do Património / CAM - Campo Arqueológico de Mértola; marcodiasf@gmail.com

2. CAM - Campo Arqueológico de Mértola; mrtdiax@gmail.com

3. Câmara Municipal de Alcoutim; arqueologia@cm-alcoutim.pt

4. CEAACP - Centro de Estudos de Arqueologia, Artes e Ciências do Património / CAM - Campo Arqueológico de Mértola / Bolseiro Pós-doutoramento da FCT - Fundação para a Ciência e Tecnologia; virgilioamlopes@sapo.pt
}

5. Departamento de História da Universidade de Évora / CEAACP - Centro de Estudos de Arqueologia, Artes e Ciências do Património / CAM - Campo Arqueológico de Mértola; susanagomez@sapo.pt

6. Este artigo segue o antigo acordo ortográfico. 


\section{ENQUADRAMENTO GEOGRÁFICO E HISTÓRICO}

O imóvel localizava-se na Rua D. Sancho II, nº 3, em Alcoutim, sede de Concelho, na União de freguesias de Alcoutim e do Pereiro, na zona Nordeste da Região do Algarve, pertencente ao Distrito de Faro.

Esta localidade implanta-se na margem direita do Rio Guadiana, defronte da povoação espanhola de Sanlúcar de Guadiana, numa pequena península orientada a Norte, fechada no lado Noroeste pela Ribeira dos Cadavais ou de S. Marcos (Nunes, 1985, pp. 21 e 46), afluente do Guadiana, onde, em termos geológicos, predominam os xistos e grauvaques.

O território de Alcoutim tem uma ocupação humana atestada desde o Paleolítico Médio, notando-se um incremento a partir do Calcolítico, com a fixação de vários núcleos habitacionais ao longo deste espaço territorial (Gradim, 2006, p. 20), ligados à exploração dos recursos metalíferos, relacionados com a Faixa Piritosa Ibérica que se estende por toda esta região.

No local da actual vila foram identificados, de forma residual, durante os trabalhos arqueológicos no castelo, dos anos 9o do século XX, estruturas e materiais enquadrados na Idade do Ferro e época romano-republicana (Catarino, 2003, p. 163; 1994, p. 666). Durante o período romano deverá ter existido uma ocupação humana, na zona do Rossio, uma vez que, durante a construção de um tanque de tratamento de esgotos se identificaram materiais de construção deste período, dos quais "se destacam alguns tijolos de quadrante» (Catarino, 1994, p. 666). Durante a Antiguidade Tardia e o período islâmico não existem elementos identificados que permitam supor a existência de uma comunidade residente neste local, exceptuando o sítio do Castelo Velho de Alcoutim, a cerca de $1 \mathrm{~km}$ a Norte, cujas escavações dirigidas por Helena Catarino permitiram auferir que a sua fundação se dá em finais do século VIII, ou já no século IX, durante o período omíada, recebendo uma restruturação durante o século $\mathrm{X}$, em período califal (Catarino, 1997/1998, pp. 586-587), e, finalmente, sendo abandonado no final do período das taifas (Catarino, 1997/1998, p. 598).

No final da década de trinta do século XIII o território de Alcoutim entra, de modo definitivo, na esfera do controlo cristão, e em 1302 D. Dinis atribui o padroado das igrejas e do termo de Alcoutim à Ordem de Santiago (Magalhães, 2008, p. 52). A 9 de janeiro de 1304, o mesmo monarca concede carta de foral, instituindo "que esta zona fosse povoada por homiziados, criminosos civis", dando-se a construção do castelo de Alcoutim, que funcionará como praça militar fronteiriça (Catarino, 1994, p. 659).

No governo de D. Fernando são assinadas as Pazes de Alcoutim (1371), entre este monarca e D. Henrique II de Castela (Catarino, 1994, p. 659). É provável que, neste momento, tenha sido construída a barbacã do castelo (Gradim, 2006, p. 36), identificável no desenho do Livro das Fortalezas de Duarte d'Armas, de 1509-1510, em avançado estado de ruína (Almeida, 1943, pp. 25 e 27) (Figura 2).

Nos finais do século XV, por iniciativa de D. Manuel, é criado o Condado de Alcoutim (Gradim, 2008, pp. 40-41), que, mais tarde, será integrado na Casa do Infantado, na segunda metade do século XVII, até à sua extinção em 1834 (Nunes, 1985, pp. 165-166). Durante as Guerras da Restauração (1640-1668), "face à necessidade de reforçar o sistema defensivo desta vila fronteiriça, assiste-se à construção das muralhas e das suas três portas. Pensamos que a cerca moderna poderá ter sido edificada na década de sessenta, [do século XVII,] durante o reinado de D. Afonso VI (...). Facto surpreendente na muralha seiscentista é a sua longa extensão em taipa. Esta debilidade construtiva da frente terrestre pressupõe uma urgência na edificação que se sobrepõe à resistência e eficácia do aparelho, só verificada do lado da via fluvial onde o aparelho era de alvenaria de pedra" (Gradim, 2006, pp. 40-41).

Em 1855 dá-se a instalação do telégrafo em Portugal e pouco tempo depois este serviço chega a Alcoutim. O edifício, no qual se realizaram estes trabalhos arqueológicos, terá sido, pelo menos, a partir de 1880, a sede da estação de telégrafo - postal, conforme era designada, sendo que o serviço postal já existia desde 1853 , aquando da primeira reforma postal (Borralho, 2015, pp. 3-17), assim como a residência dos guarda-fios, profissão que tinha como função a manutenção da linha telegráfica na área da sua circunscrição. No século XX o edifício foi adaptado a posto dos CTT, perdendo o seu carácter residencial só nos anos 9o, mantendo-se esta utilização até 2002.

\section{TRABALHOS REALIZADOS}

Os trabalhos arqueológicos realizaram-se entre 20 de Agosto de 2019 a 7 de Fevereiro de 2020 e desenvolveram-se em dois momentos distintos. Na pri- 
meira fase, pré-empreitada, realizaram-se quatro sondagens de diagnóstico, duas no logradouro do imóvel, uma no compartimento 7 (cozinha) e outra na sala de atendimento / recepção (compartimento 1), num total de $26 \mathrm{~m}^{2}$ (Figura 3). No segundo momento, com o arranque dos trabalhos da empreita$\mathrm{da}$, realizou-se o acompanhamento arqueológico da demolição do edifício pré-existente, assim como da escavação mecânica dos depósitos até ao final do período moderno. A partir dos níveis deste período fez-se uma escavação arqueológica manual, até ao substrato rochoso. As únicas zonas que não foram contempladas com escavação integral dos níveis de formação antrópicos tratam-se da área $\mathrm{A}$, pela cota de afectação estar estabelecida nos $26,85 \mathrm{~m}$, e a área $\mathrm{B}$, por não estar prevista qualquer construção ali, dentro deste empreendimento.

\section{SÍNTESE EVOLUTIVA DO ESPAÇO}

Dado que o edifício dos Antigos CTT de Alcoutim está localizado em meio urbano, muito próximo do castelo, projectou-se que este trabalho poderia responder quando e de que forma se teria dado a evolução do aglomerado nesta zona da vila.

De facto, este revelou ser um espaço vivo e dinâmico durante seis séculos, onde, de forma gradual, se foi construindo, usando e umas vezes abandonando, outras refuncionalizando.

Devido a este emaranhado de elementos recuperados, foi necessário destrinçar que estruturas e contextos pertenciam a cada momento, de modo a se recuperar uma leitura fundamentada da dinâmica de ocupação humana daquele espaço. Através da informação estratigráfica recolhida, foram identificados seis momentos diferentes (Figura 4).

\subsection{Fase I (século XV)}

O momento mais antigo identificado e atribuído, de forma genérica, ao século $\mathrm{XV}$, está associado à edificação de um ambiente, do qual apenas restou pouco mais do que $0,5 \mathrm{~m}$ de altura do seu aparelho construtivo, e vestígios associados do antigo arruamento da Rua das Portas de Tavira (Gradim, 2006, p. 47), actual Rua D. Sancho II, na metade Norte do compartimento I (Figura 3). Deste modo, é possível fazer recuar a existência de construções, neste lado do antigo arruamento, ainda nesta fase (Gradim, 2006, p. 66).

\subsection{Fase II (século XVI)}

Na segunda fase ocupacional dá-se a construção de um muro de contenção de talude (área C - Figuras. 3 e 4) e de duas novas vivendas. A primeira destas unidades habitacionais era constituída, pelo menos, por três compartimentos. Dela apenas se identificou, dentro da área de intervenção, uma das suas divisões (Área E - Figuras. 3, 4, 5 e 6), mas depreendeu-se a existência dos outros dois ambientes pela ocorrência de vãos de acesso, na direção das parcelas vizinhas a Noroeste e a Nordeste. Este conjunto integrava um sistema de drenagem de águas pluviais. A segunda moradia, localizada entre a metade Norte do compartimento 1 e os compartimentos 2 e 3 (Figuras. 3, 4 e 6), era composta por duas divisões, tendo a casa de entrada um nível de circulação em calçada de seixos rolados.

\subsection{Fase III (século XVII)}

Ao terceiro momento estão associadas quatro fossas de despejo de resíduos, identificadas entre a metade Sul do compartimento 1 e compartimento 6 (Figura 3 e 6), resultantes da actividade de uma forja situada nas proximidades, mas não identificada dentro da área deste empreendimento.

$\mathrm{Na}$ área $\mathrm{B}$ construiu-se um primeiro ambiente, possivelmente, de carácter habitacional, enquanto que na área A surgem dois alinhamentos, que também indicam tratarem-se de uma construção com as mesmas características (Figuras 3 e 4).

Em relação à segunda habitação (Figura 4 e 6), acima referida para a fase II, dá-se a desactivação do nível de circulação original da casa de entrada, em calçada de seixos rolados, que será cortado por um novo sistema de drenagem de águas pluviais, e em cima do qual será colocado um novo pavimento de tijoleira. $\mathrm{Na}$ casa de dentro desta unidade habitacional é construído um pavimento de calçada de pedra de xisto durante esta fase.

\subsection{Fase IV (século XVIII)}

No quarto momento sucede-se o abandono do ambiente da área E (Figuras 3, 4, 5 e 6), referido na fase II, dando-se o entaipamento dos vãos de acesso que com ele comunicavam, assim como o preenchimento deste espaço com um nível de aterro.

$\mathrm{Na}$ área $\mathrm{D}$ constrói-se um novo muro de contenção de talude, identificado, inicialmente, durante os trabalhos da sondagem 2 (Figuras 3 e 4).

$\mathrm{Na}$ área $\mathrm{B}$ ocorre a construção de um novo comparti- 
mento, cujos embasamentos eram constituídos por alvenaria de xisto ligada com terra, desenvolvendo-se a construção em altura dos mesmos em taipa (Figuras 3 e 4).

$\mathrm{Na}$ área A erguem-se dois alinhamentos, um deles limítrofe com o Largo do Castelo, que atestam a existência de uma nova unidade habitacional confinante com este arruamento (Figuras 3 e 4 ).

$\mathrm{Na}$ segunda habitação referida para a fase II, localizada entre a metade Norte do compartimento 1 e os compartimentos 2 e 3 (Figuras 3, 4 e 6), procede-se ao entaipamento do vão de acesso que ligava os dois ambientes desta unidade. Para tal é construído um novo pequeno compartimento no seu canto Norte, possível despensa, desactivando-se, para tal, o conjunto de degraus que estabeleciam a ligação com o vão de acesso atrás referido.

Na metade Sul do compartimento 1 é construído um novo caneiro de drenagem de águas pluviais, que se articularia com um outro, identificado no compartimento 7 (Figuras 3, 4 e 6). Ainda neste último espaço, dá-se a construção de duas estruturas positivas que indiciam a existência de um novo ambiente, de carácter habitacional.

É também, neste momento, que são construídos os primeiros alinhamentos em alvenaria de pedra do compartimento 9 (Figuras 3 e 4 ), formando um conjunto de dois espaços desnivelados entre si. No ambiente do patamar inferior, dá-se a construção de um poial e de um sistema de drenagem de águas pluviais.

4.5. Fase V (finais do século XVIII - inícios do século XIX)

No quinto momento, o ambiente interior do conjunto habitacional, referido na zona da metade Norte do compartimento 1 e compartimentos 2 e 3 , é desfuncionalizado durante a fase IV e começa a servir como vazadouro de lixo doméstico. Já a casa de entrada desta unidade habitacional é abandonada e o seu espaço preenchido com entulhos produzidos pela sua demolição, após a construção de uma nova parede exterior, na Rua D. Sancho II. Com a regularização do topo deste nível de entulho, dá-se a construção de uma nova divisão, cujo nível de pavimento era composto por argamassa, que articulava com um ambiente que terá existido, e do qual não se identificaram vestígios, no lado da metade Sul do compartimento 1 e compartimento 6 (Figuras 3,4 e 6).
4.6. Fase VI (Segunda metade do século XIX inícios do século XXI)

Será no sexto momento que surge o edifício que servirá de casa de residência dos guarda-fios e estação de correios da vila de Alcoutim.

A partir de meados do século XX acrescenta-se ao corpo arquitectónico existente o compartimento das instalações sanitárias e a ligação de esgotos à rede de saneamento básico público, assim como a criação do nível de circulação em grés hidráulico nos compartimentos 2, 4, 5 e 7. Neste último compartimento, espaço de cozinha, construíram-se bancadas de apoio e uma zona de fogo com chaminé (Figura 3 ). Já no final do século XX e inícios do século XXI ocorre a reconstrução dos prédios vizinhos com serventia pelo Largo do Castelo.

\section{ESPÓLIO ARQUEOLÓGICO}

A caracterização do espólio foi organizada em dois momentos principais.

Ao primeiro momento, correspondente aos contextos mais antigos de construção, uso e desactivação, dos séculos XV-XVI, contam-se alguns numismas, nomeadamente seis moedas portuguesas, onde se identificaram três ceitis de $\mathrm{D}$. Afonso $\mathrm{V}$, um ceitil de D. João II, um ceitil de D. Manuel I e um dinheiro de D. Afonso III.

Relativamente ao espólio cerâmico deste primeiro momento, este conjunto é composto, maioritariamente, por cerâmica comum vermelha, de pastas porosas, com abundantes materiais não plásticos e cozeduras oxidantes. Neste grupo destacam-se as caçoilas e as frigideiras, em alguns casos vidradas em melado no seu interior.

No segundo momento, cronologicamente atribuído aos finais do século XIX e ao início do XX, foram identificados materiais datados entre os séculos XVII a XX.

De forma geral, estão associadas a este segundo momento produções de cerâmica de cozinha, comum e vidrada no seu interior, nomeadamente caçoilas, de cerâmica vidrada polícroma, onde se salientam pratos, palanganas e malgas, da chamada faiança popular de Coimbra (Figura 7) ou louça de "Ratinhos" (Pereira, 1998). Existe também neste grupo cerâmica vidrada decorada com temas impressos, onde nalguns fragmentos se consegue distinguir uma produção de Sacavém.

Destaca-se, também, a recolha de duas safras em 
osso (Figura 8), de faces aplanadas, onde se observam uma série de incisões, que resultam do processo de "picar foicinhas" de gume serrilhado (Moreno-García, Pimenta \& Ruas, 2005, pp. 571-574).

De referir, em relação aos materiais metálicos, que os mais significativos se tratam de nove projécteis de pirobalística em ferro, quatro moedas espanholas (dois maravedis de D. Filipe IV e dois maravedis de D. Carlos IV), e, por fim, objectos de adorno do quotidiano, como, por exemplo, dois botões de punho com decoração fitomórfica (Figura 9).

Também foram recolhidos testemunhos do uso deste espaço como residência dos guarda-fios e estação dos CTT, como foi o caso de diferentes isoladores telegráficos, em porcelana, e um selo de chumbo, do tipo "bula" (Sousa, 2016, pp. 8), que apresenta pequenos orifícios para a passagem de um cordel nas suas extremidades e onde se percebe, numa das faces, o escudo monárquico português e, na outra face, se lê: "Correios de Lisboa" (Figura 10).

\section{CONSIDERAÇÕES FINAIS}

Estes trabalhos permitiram compreender que, pelo menos, a partir do século XV se registam construções nesta zona do perímetro urbano da vila de Alcoutim, assim como a existência do antigo arruamento das Portas de Tavira, actual R. D. Sancho II (Gradim, 2006, pp. 47 e 66).

O edificado detectado, por se situar em zona de encosta, organizou-se sobre plataformas / patamares de natureza antrópica e as técnicas construtivas adoptadas sugerem uma economia de recursos. Dentro das opções identificadas encontrámos alvenarias de pedra local, cujo ligante podia ser em terra ou argamassa, taipas, tijolos de adobe e cerâmicas de construção, tais como ladrilhos, telhas de canudo ou tijolos maciços.

Esta economia de recursos também foi verificada no caso concreto do canto Norte do edifício dos Antigos CTT (Fig. 3). Aqui existiram dois espaços construídos sobre os entulhos nivelados de ocupações anteriores, entretanto abandonadas / desactivadas. Relativamente ao espólio arqueológico recolhido, este abrange um arco temporal, de forma genérica, balizado entre os séculos XIV ao XX, onde se exceptua um numisma recolhido na sondagem $I$ (Fig. 3), classificado como um dinheiro de Afonso III (Vaz, 1969, pp. 101-105). Como tal, suspeita-se que, imediatamente antes da fundação do castelo por
D. Dinis, existisse aqui um pequeno aglomerado populacional.

Outro dado relevante observado foi a recolha de vários projécteis pirobalísticos em ferro, de diferentes nódulos de escórias de ferro e de vidro, assim como a identificação de quatro fossas de despejo de resíduos associados à actividade de uma forja nas cercanias. Estes dados, associados à recolha de duas safras de osso, parecem indicar a existência de ferreiros, ligados à produção de alfaias agrícolas (Moreno-García, Pimenta \& Ruas, 2005, p. 574) e / ou de utensílios pirobalísticos.

\section{BIBLIOGRAFIA}

ALMEIDA, João de (1943) - Reprodução anotada do Livro das Fortalezas de Duarte d'Armas. Lisboa: Editorial Império.

BORRALHO, António Gonçalves (2015) - O Transporte de Correio por Caminho de Ferro. O Mensageiro do Algarve. Faro. Ano III, 9, pp. 3-17.

CATARINO, Helena (1994) - Arqueologia Medieval no Algarve Oriental. Os Castelos de Alcoutim. In Arqueología en el entorno del Bajo Guadiana, Encuentro Internacional de Arqueología del sudoeste. Huelva: Grupo de Investigación Arqueológica del Patrimonio del Suroeste, Universidad de Huelva, pp. 657-671.

CATARINO, Helena (1997/1998) - O Algarve Oriental Durante a Ocupação Islâmica. Povoamento rural e recintos fortificados. al-ưlyã. Loulé. 6, 3 vols.

CATARINO, Helena (2003) - Cerâmicas da Baixa Idade Média e de inícios do período moderno registadas no caste-

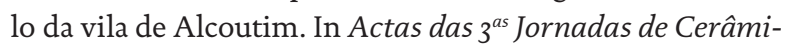
ca Medieval e Pós-Medieval. Tondela: Câmara Municipal de Tondela. pp. 161-177.

GRADIM, Alexandra (2006) - Alcoutim Urbano e Rural. Dos finais da Idade Média ao fim do antigo regime. Lisboa: Edições Colibri / Câmara Municipal de Alcoutim.

GRADIM, Alexandra (2008) - Os condes Meneses e a vila moderna de Alcoutim. In al Gharb, Revista Cultural do Algarve. Olhão: Gente Singular, pp. 38-44.

MAGALHÃES, Natércia (2008) - Algarve: Castelos, Cercas e Fortalezas. Faro: Letras Várias, Edições e Arte.

MORENO-GARCÍA, Marta; PIMENTA, Carlos M.; RUAS, José Paulo (2005) - Safras em osso para picar foicinhas de gume serrilhado... a sua longa história. Revista Portuguesa de Arqueologia. Lisboa. 8-2, pp. 571-627.

NUNES, António Miguel Ascensão (1985) - Alcoutim: Capital do Nordeste Algarvio (Subsídios para uma Monografia). Alcoutim: Câmara Municipal de Alcoutim. 
PEREIRA, João Castel-Branco, coord. (1998) - Os Ratinhos, Faiança Popular de Coimbra. Lisboa: IPM / Museu Nacional do Azulejo.

SOUSA, José de (2016) - Selos de Chumbo. Os testemunhos dos intercâmbios comerciais e de controlo fiscal no Algarve, do século XV ao século XIX. Portimão: Associação Projecto IPSIIS.

VAZ, Joaquim Ferraro (1969) - Livro das Moedas Portuguesas. I. Braga: Livraria Cruz.

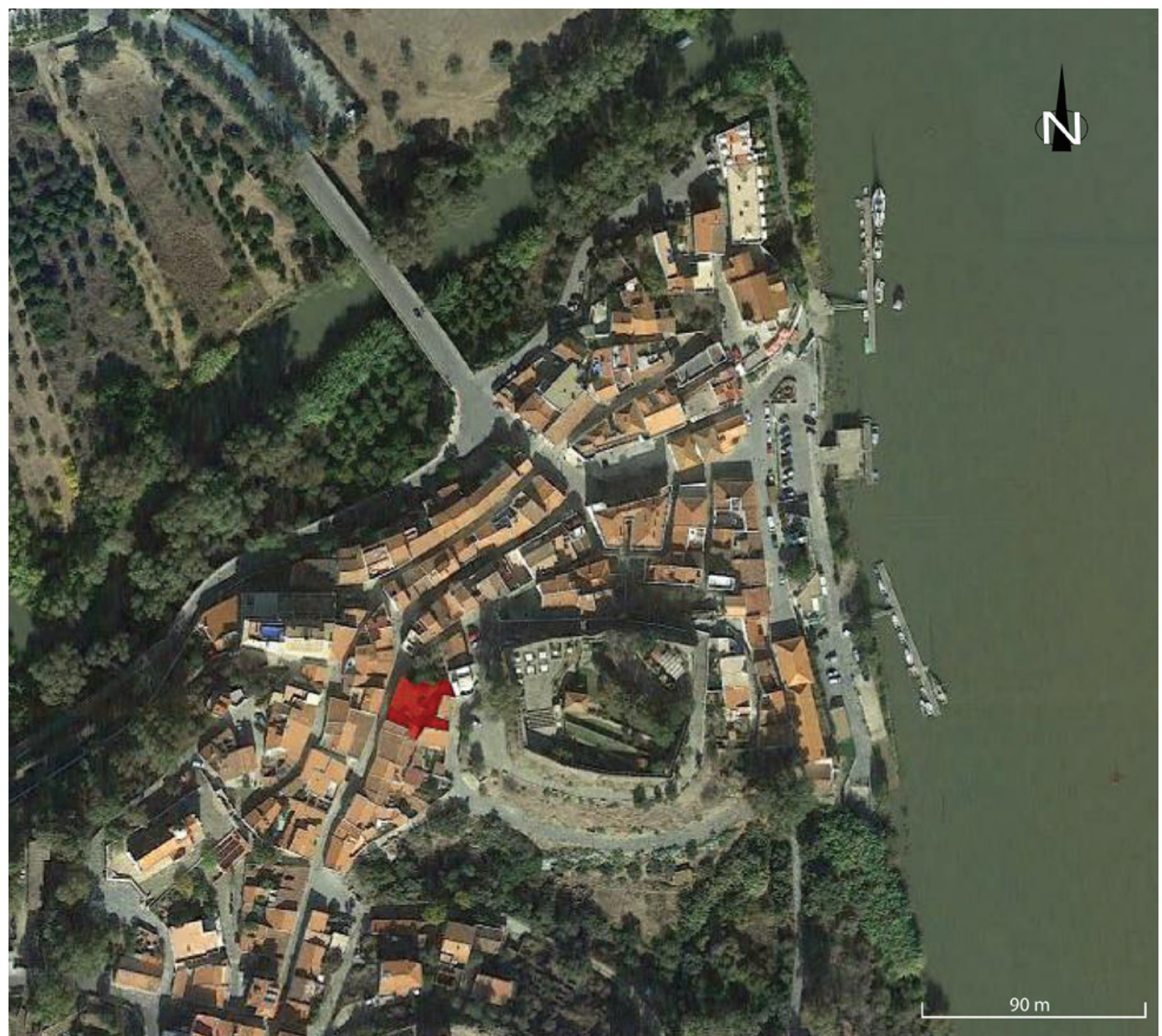

Figura 1 - Localização do imóvel dentro do perímetro urbano da vila de Alcoutim, assinalado a vermelho. 


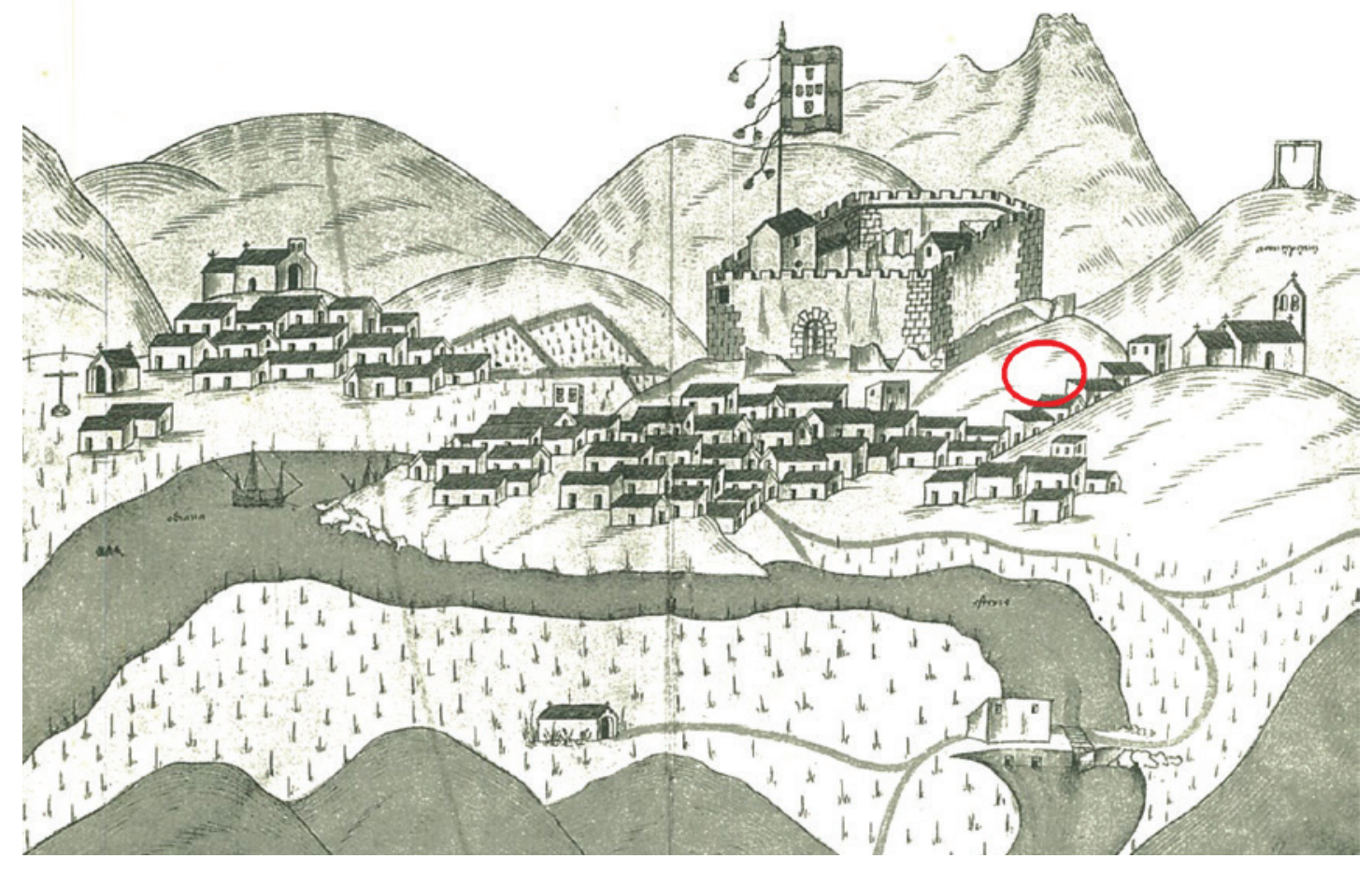

Figura 2 - Vista desde o lado Norte de Alcoutim, por volta de 1509 (Livro das Fortalezas, Duarte d'Armas), com localização da área do edifício dos Antigos CTT assinalada a vermelho.

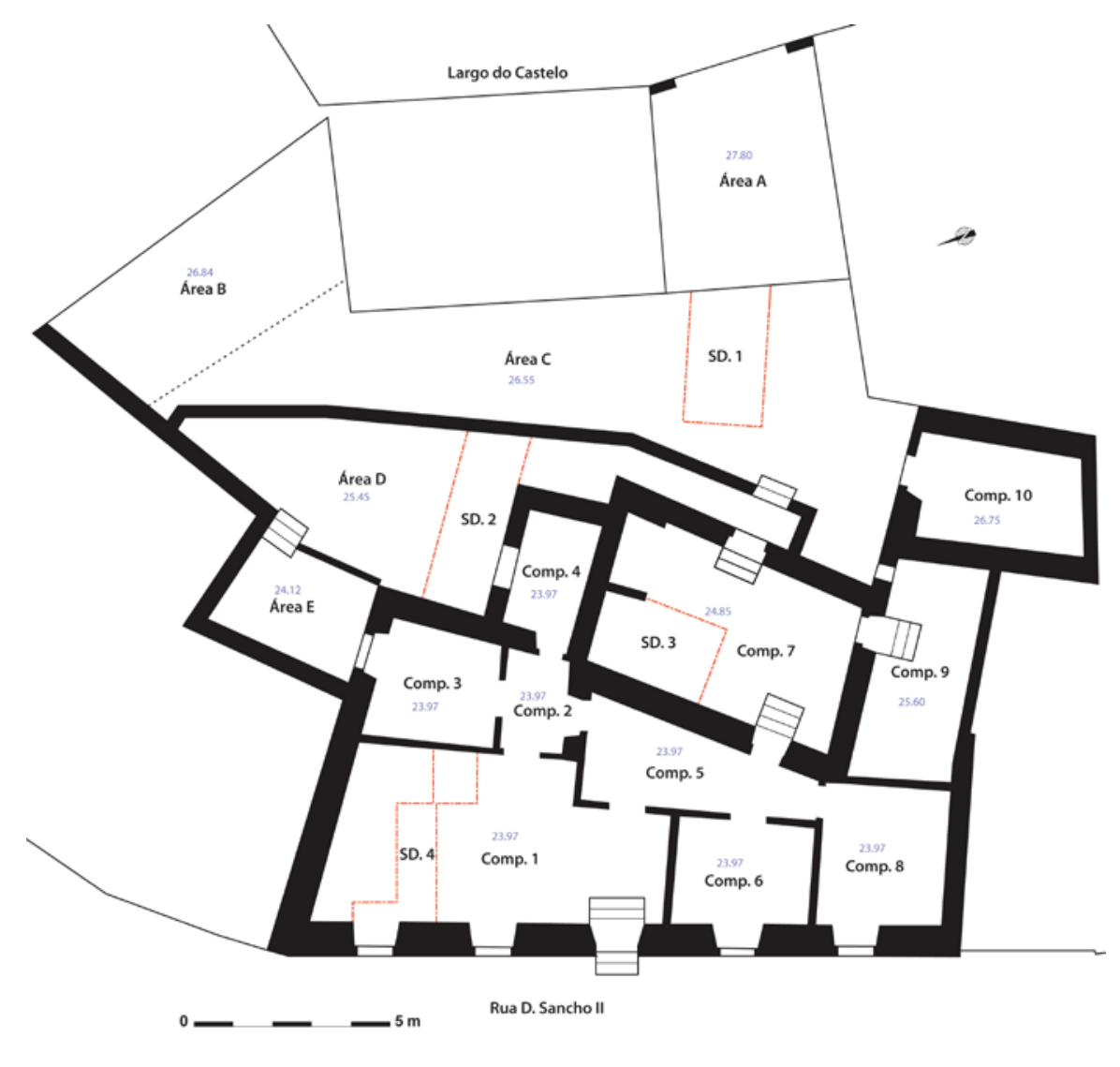

Figura 3 - Localização das sondagens, áreas e compartimentos no levantamento do edifício dos Antigos CTT de Alcoutim. 


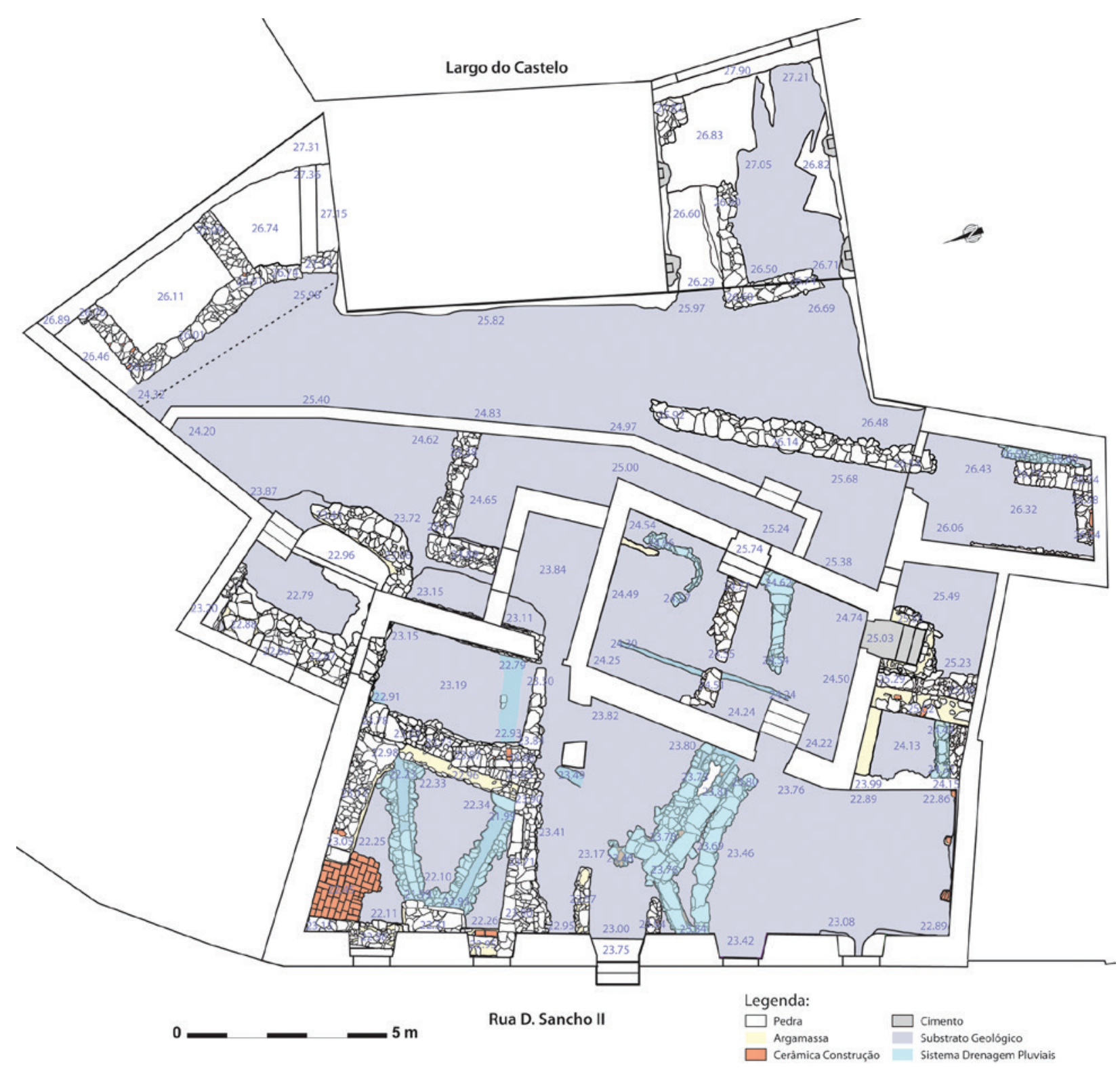

Figura 4 - Planta geral com o edifício pré-existente e as principais estruturas arqueológicas identificadas durante os trabalhos. 


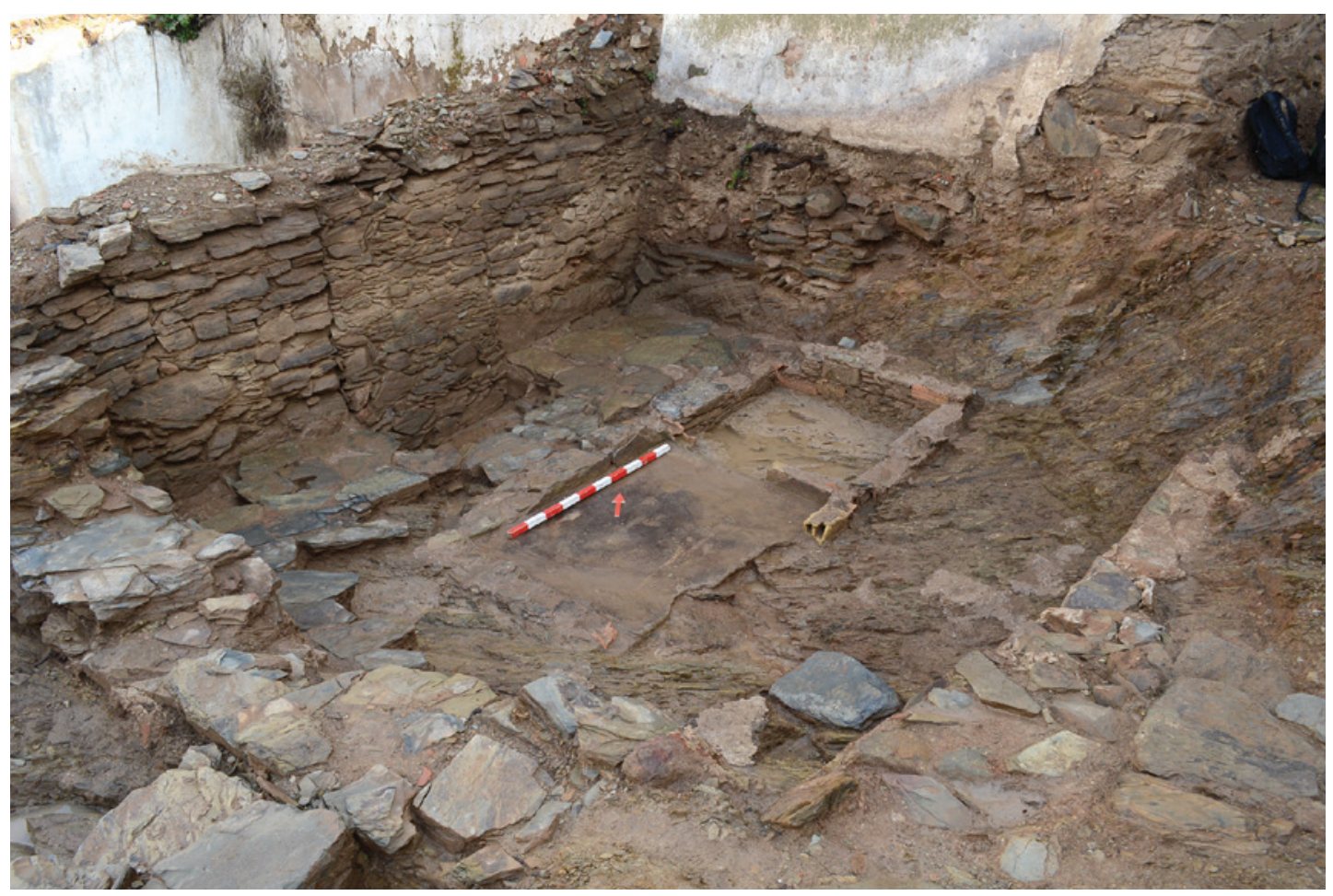

Figura 5 - Aspecto geral do ambiente mais antigo identificado na área E. No lado esquerdo o vão de acesso à casa de entrada, entaipado durante a fase IV, e outro vão de porta, à direita, na direção do terreno vizinho Norte.

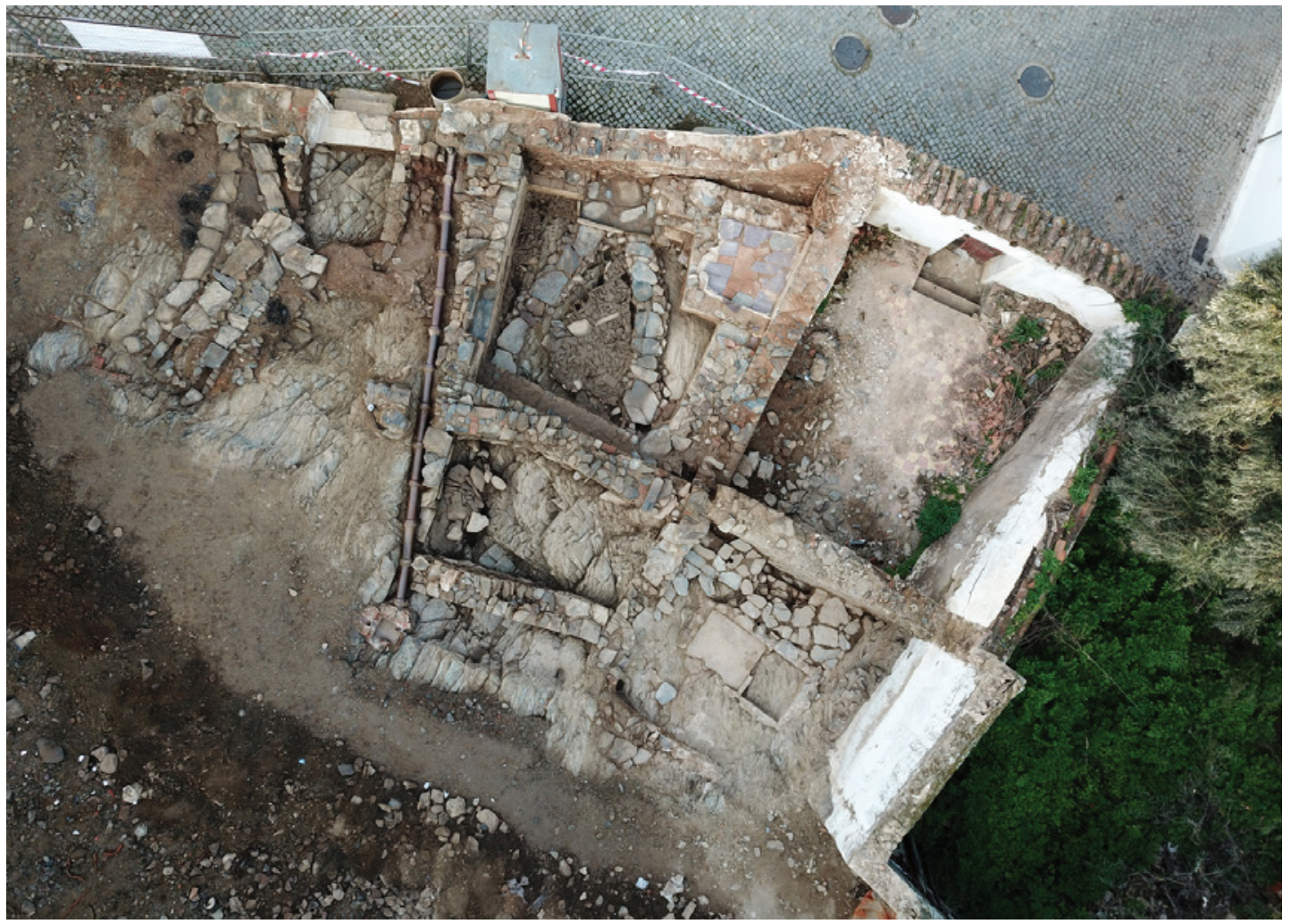

Figura 6 - Vista aérea sobre os contextos arqueológicos identificados na zona Noroeste do empreendimento (Fotografia de Alexandra Gradim / João Carlos Simões). 


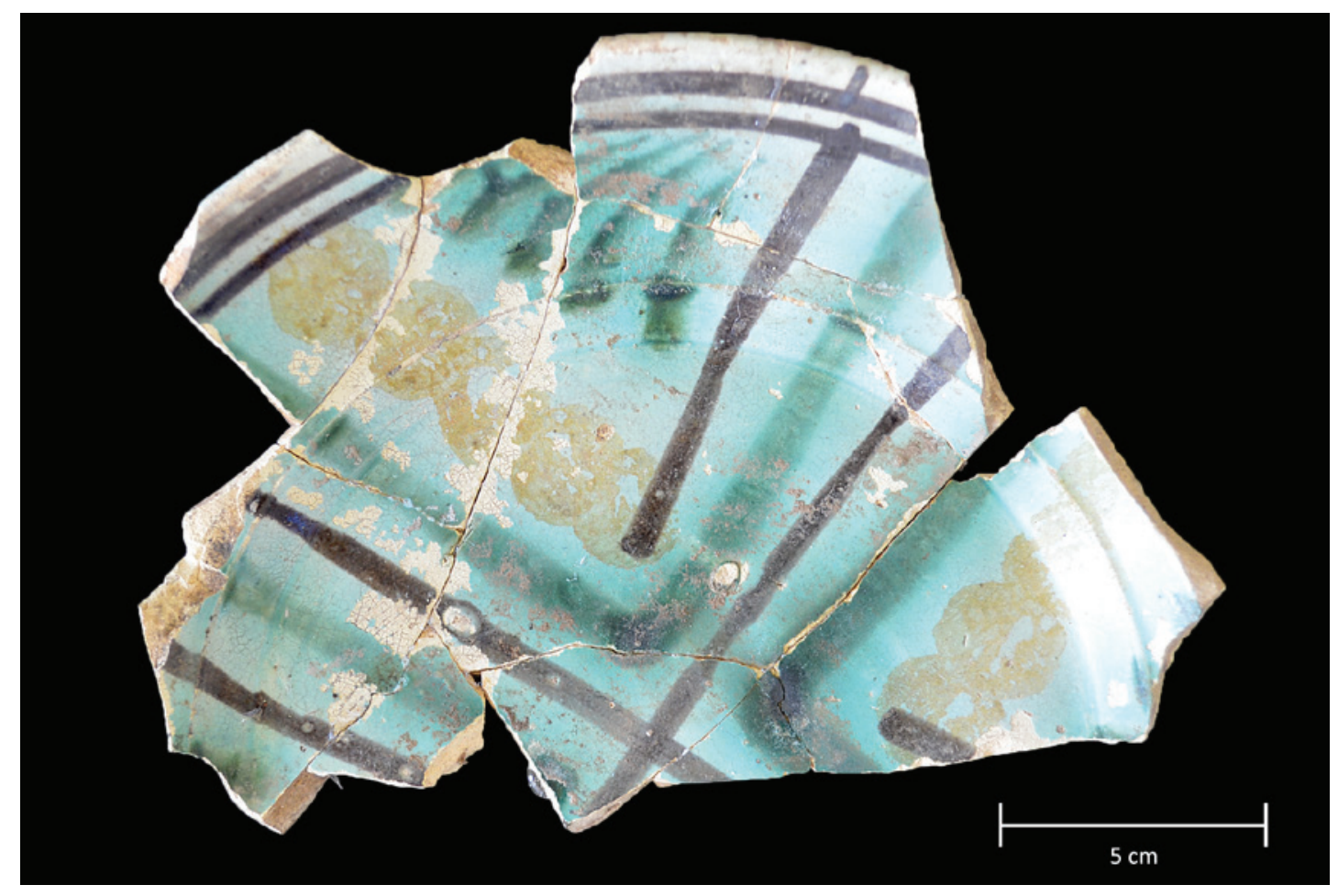

Figura 7 - Prato de faiança popular de Coimbra ou louça de "Ratinhos".

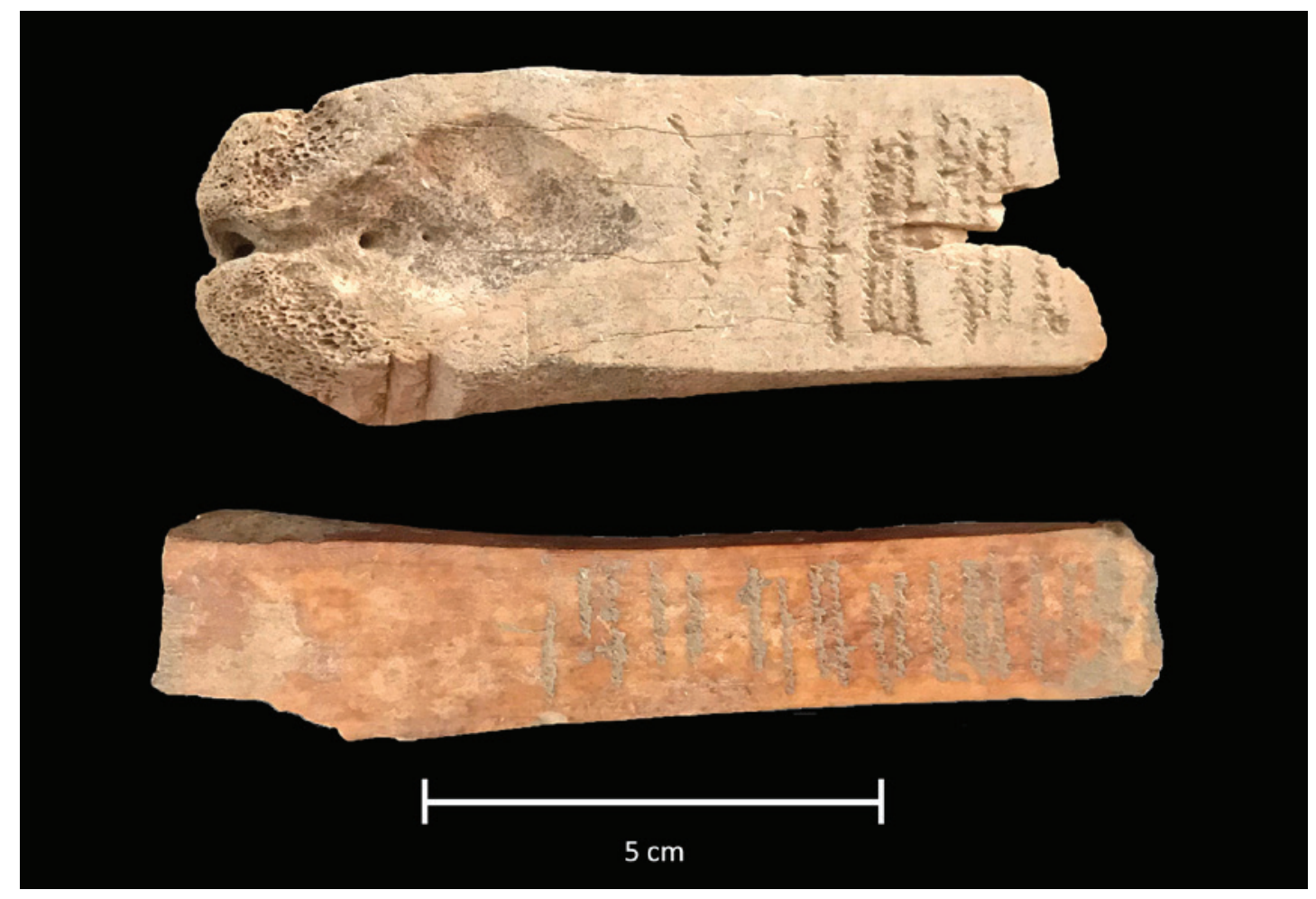

Figura 8 - Safras em osso. 


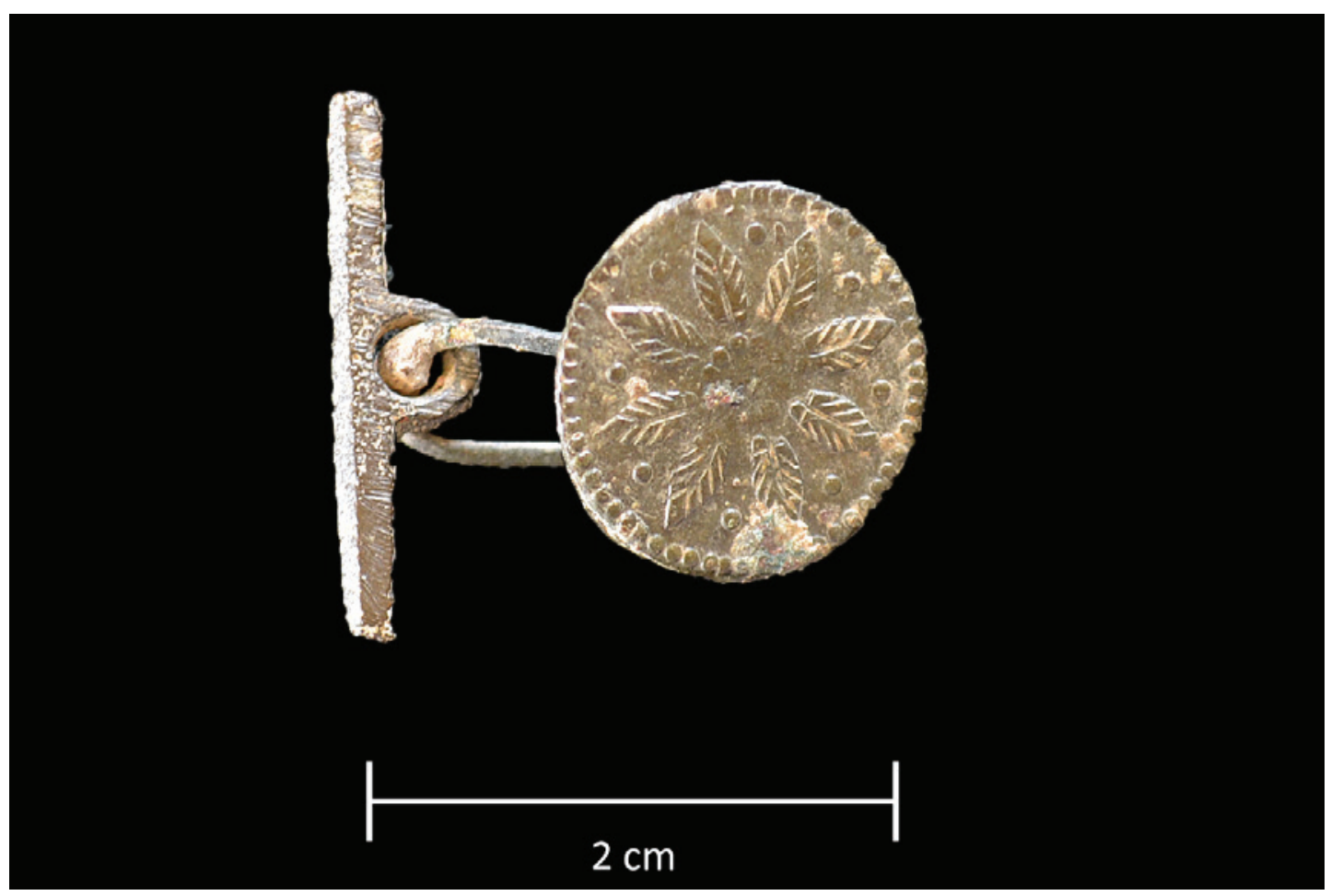

Figura 9 - Botão de punho com decoração fitomórfica.

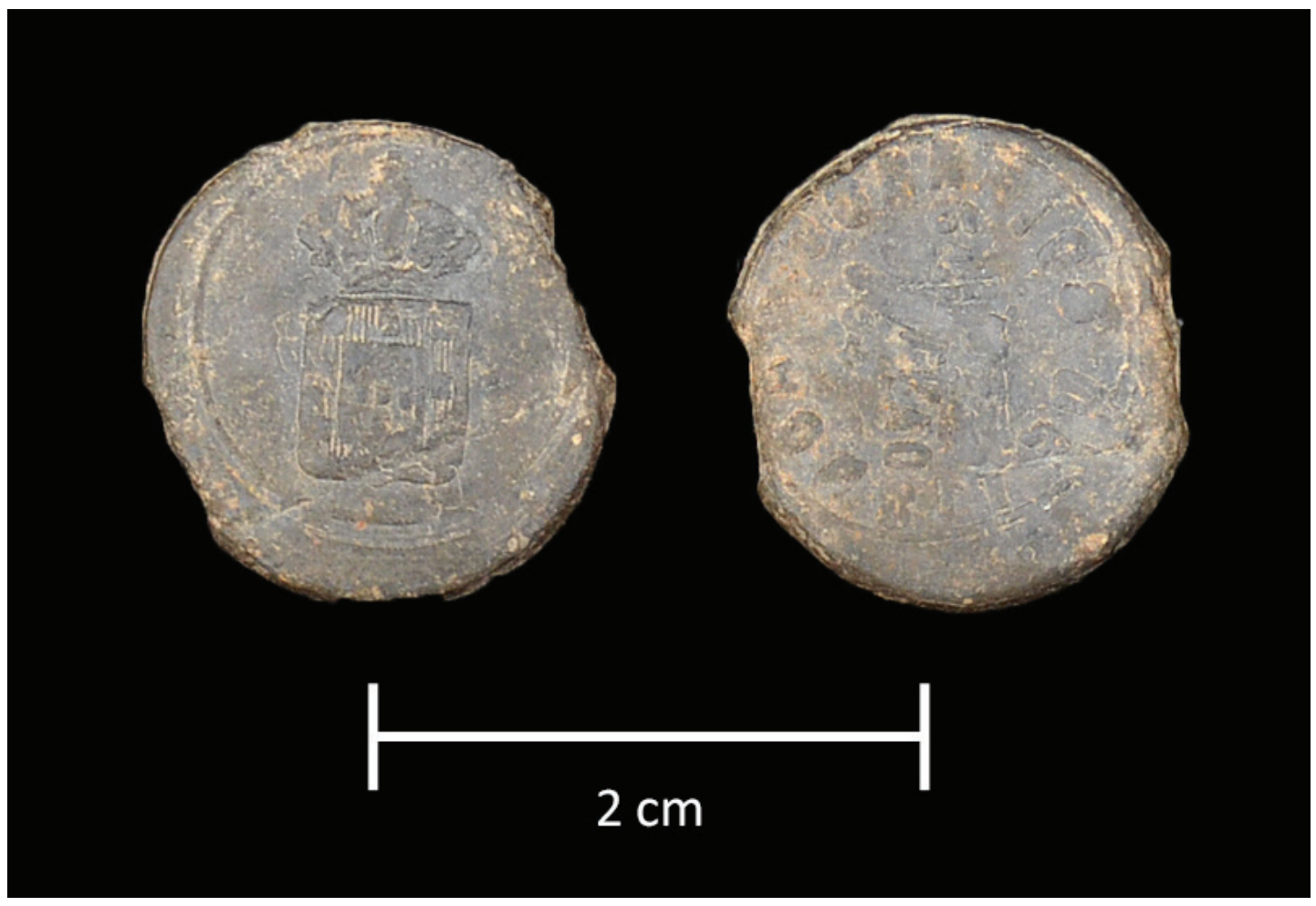

Figura 1o - Selo em chumbo, do tipo “bula” (século XIX a inícios do século XX). 


\title{
PALÁCIO DOS FERRAZES (RUA DAS FLORES/RUA DA VITÓRIA, PORTO): A COCHEIRA DE DOMINGOS OLIVEIRA MAIA
}

\section{Francisco Raimundo ${ }^{1}$}

\begin{abstract}
RESUMO
No âmbito da empreitada de reabilitação e reconversão do Palácio dos Ferrazes numa unidade hoteleira, cuja implantação englobava dois edifícios, um voltado para a Rua das Flores (Palácio) e outro para a Rua da Vitória (duas unidades fabris) incluindo o logradouro existente entre eles, apresenta-se uma breve caracterização da ocupação do espaço na área correspondente ao segundo edifício. Esta caracterização é elaborada com base no acompanhamento arqueológico do desmonte/demolição do edificado existente, aliada aos dados recolhidos na escavação arqueológica e suplementada por algumas fontes documentais, o que nos permitiu reconstituir a cocheira datada do século XIX, mandada construir por Domingos Oliveira Maia, assim como ocupações anteriores datáveis dos séculos XVII/XVIII.
\end{abstract}

Palavras-chave: Domingos Oliveira Maia, Palácio do Ferrazes, Rua da Vitória, Século XVII/XVIII, Século XIX.

\begin{abstract}
Within the scope of the rehabilitation of the Ferrazes Palace into a hotel unit, whose implementation encompassed two buildings, one facing Rua das Flores (Palácio) and the other facing Rua da Vitória, as well as the existing space between them, we present a short description about the occupation of the second building. This characterization is elaborated based on the archaeological monitoring of the dismantling / demolition of the existing building, combined with the data collected during the archaeological excavation and complemented with some documentary sources that made it possible to reconstruct the old stable dated from the XIX century, ordered to be built by Domingos Oliveira Maia, as well as previous occupations dating from the $17^{\text {th }} / 18^{\text {th }}$ centuries.

Keywords: Domingos Oliveira Maia, Ferrazes Palace, Rua da Vitória, $17^{\text {th }}, 18^{\text {th }}$ and $19^{\text {th }}$ centuries.
\end{abstract}

\section{INTRODUÇÃO}

O conjunto arquitectónico do Palácio dos Ferrazes, comummente conhecido por Casa dos Ferrazes Bravo ou Casa dos Maias, encontra-se numa zona de elevada sensibilidade histórica e arqueológica, estando abrangida pelas servidões administrativas do Centro Histórico do Porto, Ponte Luiz I e Mosteiro da Serra do Pilar (inscrito na Lista do Património Mundial da UNESCO em 1996), da Zona Histórica do Porto e classificado como Imóvel de Interesse Público - Casa dos Ferrazes Bravos (IIP, Decreto n. $\frac{0}{45} / 93$, DR/28o de 30-11-1993).
A área de implantação da empreitada englobava dois edifícios, um voltado para a Rua das Flores e outro para a Rua da Vitória, assim como a zona de logradouro existente entre eles composta por dois socalcos. Os dados históricos disponíveis (Afonso, 2008) situam a primeira construção no local aproximadamente nos inícios do século XVI, cuja evolução dará mais tarde origem à casa de uma das famílias mais notáveis do Porto de seiscentos, os Ferraz Bravo. O segundo edifício, situado na Rua da Vitória, albergava em tempos recentes (segunda metade do século $\mathrm{XX}$ ) duas unidades fabris de pequena dimensão construídas sobre os alicerces de uma co-

1. OMNIKNOS, LDA; franciscoraimundo@omniknos.pt. 
cheira mandada erguer por Domingos de Oliveira Maia em meados do século XIX.

A empreitada em questão, previa a reabilitação do palacete, a construção de um novo edifício de 8 pisos voltado para a Rua da Vitória, a requalificação do logradouro e o restauro da capela oitocentista. Desta forma, a afectação da obra no edifício voltado para a Rua da Vitória foi total, implicando a demolição do edificado existente e o desaterro mecânico do lote até à cota da Rua das Flores. Também os socalcos intermédios foram alvo de afectação total pelas acções de demolição e desaterro mecânico. O edificado correspondente ao Palácio do Ferrazes foi totalmente reabilitado e remodelado, tendo sido demolidas a maioria das suas paredes interiores, substituídas as coberturas e os elementos estruturais em madeira, rebaixada a cota de soleira do edifício e acrescentado um piso ao corpo da ala poente. Este último, foi ampliado de forma a garantir a ligação ao novo edificado.

A abordagem arqueológica realizada teve por base o estudo histórico e espacial elaborado por José Ferrão Afonso, em 2008, sob o título "A casa Ferraz-Bravo na Rua das Flores do Porto", bem como o relatório preliminar dos trabalhos Arqueológicos aí desenvolvidos no ano de 2008, pela empresa Era-Arqueologia, S.A. Os trabalhos de acompanhamento arqueológico deram cumprimento às medidas de minimização propostas neste último, assim como ao parecer prévio emitido pela DRCN, em Novembro 2016, e tiveram a duração de 24 meses $^{2}$. Todos os trabalhos de demolição, desmonte de estruturas, levantamento de pisos e movimentação de terras foram alvo de acompanhamento arqueológico, tendo-se elaborado o registo fotográfico da evolução da empreitada, procedendo-se ao registo fotográfico e gráfico (à escala 1/20) dos elementos patrimoniais e de todos os vestígios/pormenores considerados úteis para a compreensão de evolução do edificado. De salientar que durante o acompanhamento da demolição do edifício da Rua da Vitória, foram identificadas várias estruturas relacionadas com anteriores

\footnotetext{
2. No decurso dos trabalhos integraram a equipa técnica de campo os arqueólogos Ana Cristina Hermínio, Carlos Jorge, Cristiana Valpaços, Fátima Costa, Marco Araújo Pereira, João Hipólito, José Nuno Gomes, Óscar Teixeira, Tiago Gil e Vítor Gomes, dirigidos pelo arqueólogo responsável Francisco Raimundo, sendo a coordenação dos trabalhos arqueológicos e gestão de projeto realizada pelo departamento técnico da ERA-Arqueologia.
}

ocupações do espaço, o que conduziu à adopção de medidas de minimização que implicaram a escavação arqueológica, em área, de todo o patamar ao nível da Rua da Vitória.

\section{ENQUADRAMENTO GEOGRÁFICO E HISTÓRICO}

Os imóveis onde se localizaram os trabalhos de acompanhamento arqueológico situam-se entre a Rua das Flores (números 21 a 39) e a Rua da Vitória (149 a 157), ambos pertencentes às antigas freguesias da Sé e da Vitória, que desde 2012, por força da reorganização administrativa do território, introduzida pela Lei n.ำ 22/2012 de 30 de maio, integram a União das Freguesias de Cedofeita, Santo Ildefonso, Sé, Miragaia, São Nicolau e Vitória, criada por agregação das extintas freguesias de Cedofeita, Miragaia, Santo Ildefonso, São Nicolau e das anteriormente citadas.

A Rua das Flores terá sido mandada rasgar no ano de 1521 por ordem do rei D. Manuel I, visando estabelecer ligação entre o mosteiro feminino de S. Bento da Ave-Maria, construído, em 1518, e o Largo onde se situava o convento de S. Domingos. O traçado da Rua das Flores é coincidente com o da antiga estrada de Guimarães, que estará na origem dos antigos caminhos das Barreiras, do rio da Vila e das ruas de serviço das habitações que aí se viriam a construir (Afonso, 2008, p.5). O carácter inovador desta rua, deve-se sobretudo, à regularidade do loteamento, especialmente na zona próxima ao Largo de São Domingos, com frentes de seis varas (6,6o metros), e à considerável extensão dos lotes, onde existiriam grandes e flóreos jardins, que terão estado na origem do nome do novo arruamento, a Rua de Santa Catarina das Flores (Afonso, 2001).

A zona onde se erigiram as construções, que mais tarde vieram a enformar o 'Palácio dos Ferrazes' integrava terrenos propriedade da Mitra da Sé do Porto, então conhecidos como as "Hortas do Bispo". Estes confrontavam com os do Cabido e com os terrenos da recém-fundada Santa Casa da Misericórdia do Porto. Logo após a sua construção, a Rua das Flores adquire uma importância vital como eixo estruturante da dinâmica social e comercial da cidade intramuros e, é nela, que se instalam as residências das principais famílias aristocráticas e burguesas e as mais ricas lojas da cidade (Barbosa, 2015, 160).

Os Ferraz Bravo serão dos primeiros proprietários da rua. Em 1542, o Tombo das propriedades da Mi- 
tra refere Manuel Bravo como proprietário de três chãos, sendo que, em dois destes chãos, já se achavam erguidas casas e no terceiro apenas os portais. Uma das casas terá pertencido a Manuel Carneiro e Ana Bravo (filha de Catarina Bravo, por sua vez sobrinha de Manuel Bravo) e outra a Martim Ferraz por casamento com Catarina Rebelo (filha de Manuel Bravo e Maria Carneiro), uniões que terão consolidado os laços entre as duas famílias, Bravo e Ferraz. Entre 1639 e 1697 a propriedade agregava já os quatro chãos, sendo dela proprietários Miguel Ferraz Bravo e seus irmãos (Afonso, 2008, p.6-7).

Em 1746, ano em que se procedeu ao reconhecimento das propriedades da Mitra, da qual os quatro chãos eram foreiros, a habitação aparecia designada como 'morada de casas nobres'. Esta vedoria apresenta uma detalhada descrição do espaço construído. Segundo este documento, na fachada abrir-se-iam apenas dois portões, quatro janelas de peitoril e duas portas pequenas, estas no corpo poente. A existência de janelas de peitoril poderá estar relacionada com uma ocupação comercial dos chãos do edifício, já que o aluguer das lojas para comércio era prática comum, também nas casas nobres (Afonso, 2008, p. 8).

O século que se seguiu à vedoria é o período menos conhecido e sobre o qual dispomos de parca ou nenhuma informação acerca dos proprietários do edifício. O Tombo da Mitra refere que a propriedade foi legada à casa professa de São Roque da Companhia de Jesus, que era a administradora do legado perpétuo de Bartolomeu Ferraz de Almeida, talvez o último elemento da família em posse do edifício (Afonso, 2008, p.12). Assim, nas primeiras décadas do século XVIII este não estaria já na posse da família fundadora. Sabemos, todavia, que as principais alterações ao edificado, sobretudo ao nível da fachada, terão ocorrido durante a segunda metade da centúria de setecentos.

Nos alvores do século XIX o proprietário do palácio era António de Oliveira Maia, como atesta o pedido de licenciamento de alterações na fachada aprovado a 27 de Maio de 1810 (Afonso, 2008, p.13). Estas modificações contemplaram a transformação de duas janelas de peitoril em dois portões centrais, conferindo a monumentalidade e simetria que ainda se podem apreciar na fachada actual. A aquisição do edifício terá sido por compra, embora não disponhamos de nenhum documento que o confirme (Figura 1).

Com a morte de António Maia, sucedeu-lhe na casa o seu filho Domingos de Oliveira Maia, que será porventura o proprietário mais conhecido da 'Casa dos Ferrazes Bravo', ou 'Casa dos Maias', como terá passado a ser designada no século XIX. Este promoveu alterações importantes no Palácio e no jardim do mesmo, saindo da sua pena o projecto de construção da cocheira voltada à Rua da Vitória datado de 1851 . Grande capitalista da cidade do Porto de oitocentos, Fidalgo-Cavaleiro da Casa Real - foi também Diretor do Banco Comercial do Porto, Jurado da Inspeção-geral dos Teatros e Espetáculos Públicos Nacionais, Irmão da Real Irmandade da Ordem de Nossa Senhora da Lapa e Membro da Comissão da Câmara Municipal do Porto para levantar o monumento a Dom Pedro V - é reconhecido pelos seus projectos e realizações arquitectónicas, das quais se destaca a Casa do Passeio Alegre (Graça, 2004, p.213, apud Afonso, 2008, p.13). Domingos de Oliveira Maia, quer pelos vínculos familiares, quer pelos cargos que exerceu, assumiu uma posição privilegiada na sociedade portuense da primeira metade do século XIX. Muito mais do que aristocrata ou negociante - ou 'comerciante', como jocosamente o tratavam alguns - Oliveira Maia era um ilustrado viajante (Resende, 2017, p.345) que conhecia as principais cidades da Europa (Graça, 2007, p.323-325; Encarnação, 2012-2013, p.126) e dispunha de uma vasta e diversa rede de contactos dentro e fora do país. Estas particularidades ajudarão a compreender, em parte, as transformações levadas a cabo no edificado do palácio.

Após a morte deste, a casa foi herdada pela sua irmã Maria Ludovina de Oliveira Maia. A partir daí sabemos muito pouco sobre o destino do Palácio, apenas que terá ficado na posse dos herdeiros desta até finais do século XX. Nesse século, o edifício foi ocupado por algumas lojas das quais se destacam o alfarrabista Chaminé da Mota e a Barbearia Brasão (Afonso, 2008, p.19). Também o edifício voltado para a Rua da Vitória sofreu alterações importantes durante este período, tendo sido dividido em duas unidades autónomas, onde terão laborado duas indústrias, encontrando-se, muito provavelmente, já desanexado do lote correspondente ao palácio.

Nos últimos anos do século $\mathrm{XX}$, tanto o palácio como o edificado voltado para a Rua da Vitória entraram num processo acelerado de degradação que apenas viria a ser revertido com o início da empreitada de reabilitação no ano de 2016, com vista à construção do "Hotel Palácio dos Ferrazes”, inaugurado em Setembro de 2019 sob o nome de "Hotel Portobay Flores". 


\section{TRABALHOS ARQUEOLÓGICOS}

Os trabalhos arqueológicos decorreram entre os meses de Novembro de 2016 e 2018 na totalidade da área a ser intervencionada pela empreitada de reconstrução e ampliação do Palácio dos Ferrazes, com especial enfoque no edifício correspondente ao Palácio e no edificado voltado para a Rua da Vitória. Todas as acções que implicaram demolições, desaterros, abertura de valas e escavação (manual e mecânica), no subsolo e no edificado do palácio, pátio exterior, socalcos e unidades fabris, e que permitiram aportar novas informações acerca da evolução do edificado, foram objecto de registo fotográfico e, sempre que possível, de registo gráfico e descritivo, o que originou um portefólio de 171 desenhos de campo, na sua grande maioria à escala 1/20.

No decorrer dos trabalhos de acompanhamento arqueológico na área correspondente ao edificado voltado para a Rua da Vitória, e quando se acompanhava a remoção dos pisos térreos, foram identificadas várias estruturas que aparentavam não corresponder ao edificado datado do século XX. A possibilidade destas estruturas poderem estar relacionadas com a cocheira projetada por Domingos de Oliveira Maia no século XIX ou com alguma construção de cronologia anterior, conduziu à suspensão dos trabalhos e à comunicação com as entidades tutelares, sendo que as medidas de minimização a implementar, à semelhança do que fora proposto no relatório das sondagens de diagnóstico realizadas em 2008, passariam pela escavação de toda a área por forma a registar e caracterizar os vestígios identificados.

\subsection{Acompanhamento Arqueológico}

Durante o acompanhamento arqueológico dos trabalhos de desmonte/demolição dos edifícios com os números 149 a 157, sitos na Rua da Vitória, onde terão laborado duas indústrias durante a segunda metade do século XX, foram identificados alguns pormenores construtivos que estarão relacionados com a cocheira do século XIX e que terão servido de base à construção das duas unidades fabris (Figura 2). Nas paredes laterais que fazem divisão de propriedade com os lotes contíguos, é perceptível o aumento feito às paredes da cocheira de modo a subir a cota da fachada voltada para a Rua da Vitória que terá ocorrido em meados do século XX.

A parede do edifício situado a nascente apresenta ainda o negativo do edificado que terá pertencido à cocheira, o que indica que quando esta parede foi rebocada o edifício localizado neste lote apresentava ainda as suas características originais. Também na parede poente, que faz divisão com a Santa Casa da Misericórdia, é visível o acrescento feito no canto superior esquerdo, bem como, na outra extremidade, os três encaixes que serviriam de suporte ao segundo piso da cocheira.

Na fachada tardoz, no edificado da unidade fabril encostada ao lote da Santa Casa da Misericórdia, foram ainda identificadas quatro janelas, duas no piso ao nível da Rua da Vitória e as restantes no piso superior, construídas com moldura em granito. As duas janelas do piso inferior terão sido transformadas em portas durante a ocupação do espaço pela fábrica.

A remoção dos entulhos permitiu colocar a descoberto parte de um lajeado de grandes dimensões formado por lajes de granito. Na área nascente deste lajeado foram registados uma série de sulcos que formavam um reticulado, provavelmente associados à cocheira do século XIX. O facto de este lajeado se encontrar coberto por uma espessa camada de cimento, que remontará à ocupação do espaço durante o século XX, não permitiu o seu registo integral. De qualquer das formas, foi possível comprovar que este cobria toda a área do patamar ao nível da Rua da Vitória (Figura 3).

Abaixo do piso do edifício da fábrica, localizado ao nível da Rua da Vitória, foram registados vários elementos que pertenceriam à cocheira do século XIX e que foram aproveitadas na instalação da unidade fabril. Foi identificada uma escadaria interior de acesso à cocheira passando no topo desta para o exterior através de um vão aberto na parede traseira da cocheira. Daqui, seguiam duas andainas de escadas, uma para cada lado, que eram formadas por lajes de granito inseridas na parede e que derivavam nas extremidades para dentro do edifício. Na parede traseira, para além da porta de lintel arredondado, foi também registada uma janela de lintel semi-circular, localizada sensivelmente a meio da escadaria, e acima desta um peitoril de uma outra janela que não chegou a ser terminada.

Ainda embutida na parede traseira, e também relacionada com a cocheira do século XIX, foi registada uma fonte de morfologia semelhante à existente no terceiro socalco do logradouro. Esta estrutura, de planta rectangular e abóbada em arco abatido construída em tijolo de burro e rematada na face exterior por uma moldura em silhares graníticos, inte- 
grava um tanque formado por quatro grandes blocos graníticos. O abastecimento desta fonte era feito por uma mina, composta por um corredor em forma de 'L' por onde corriam várias canalizações que conduziam a água para o tanque da fonte (Figura 4). Com base nos resultados obtidos com o acompanhamento arqueológico do desmonte do edificado existente foi possível proceder à reconstituição parcial do alçado tardoz da cocheira do século XIX, à excepção da zona central por onde era feito o acesso ao interior do edifício através das duas andainas de escadas, bem como do acesso entre o Palácio e a cocheira através do logradouro (Figura 5).

\subsection{Escavação Arqueológica}

No decorrer dos trabalhos de acompanhamento arqueológico e coincidindo com a entrada da maquinaria pesada em obra, a fim de iniciar a escavação mecânica da área correspondente ao edificado voltado para a Rua da Vitória (números 149 a 157), foram identificadas várias estruturas que aparentavam não corresponder ao edificado datado do século XX. O facto destas estruturas poderem estar relacionadas com a cocheira projectada por Domingos de Oliveira Maia, em 1851, ou até mesmo com um edifício anterior a esta, conduziu à suspensão dos trabalhos e à comunicação com as entidades tutelares. Em reunião, realizada no local, ficou determinado que as medidas de minimização a implementar, à semelhança do que fora proposto no relatório das sondagens de diagnóstico realizadas em 2008, passariam pela escavação em área de modo a colocar todas as estruturas a descoberto, permitindo assim, o seu correcto registo e caracterização.

Constrangimentos relacionados com o decorrer da empreitada e a necessidade de manter parte do patamar a intervencionar para apoio aos trabalhos de desaterro a desenvolver nos patamares inferiores designadamente para a montagem de uma autogrua - não permitiram a escavação simultânea de toda a área, pelo que os trabalhos de escavação arqueológica foram divididos em quatro fases (Figura 6).

A primeira fase (Janeiro 2017) incidiu sobre a parte central mais recuada do patamar, onde foram identificados os muros correspondentes ao alicerce da cocheira da segunda metade do século XIX, que se encontravam preenchidos por vários depósitos associados a uma regularização da cota do socalco para a construção da cocheira. Foi também colocada a descoberto parte da parede tardoz da cocheira cons- truída em alvenaria de pedra de grandes dimensões e argamassa, que se encontrava suportada por dois contrafortes interiores em alvenaria preenchida com pedra miúda e argamassa. Adossados a estes, existiam dois muros de construção semelhante, mas de menor profundidade, que parecem corresponder a alicerces para suporte das paredes representadas na planta de 1851 . Sob estas estruturas situava-se uma fonte e respectiva mina de água que será coetânea da construção da cocheira. A mina, composta por um corredor em forma de 'L' por onde corriam duas canalizações: a primeira, construída em telha de meia cana sobre um pequeno murete argamassado, abastecia de água uma pia/depósito rectangular de granito coberto por 3 lajes de xisto e que depois seguia através de um canalização de chumbo até à cozinha situada no segundo piso da ala poente do palácio; a segunda, situada ao nível do chão, era composta por uma fiada de telha de meia cana adossada a uma tubagem cerâmica, que conduzia a água para o tanque da fonte. A fonte, de planta rectangular e abóbada em arco abatido construída em tijolo de burro e rematada na face exterior por uma moldura em silhares graníticos, integrava um tanque formado por quatro grandes blocos graníticos.

Aparentemente todos os muros identificados pertenceriam à cocheira do século XIX, à excepção de uma estrutura de planta rectangular, que parece tratar-se de um tanque, e que estará relacionado com a indústria que aí laborou durante o século XX. A construção desta estrutura implicou o corte de um dos muros que compõem as fundações da cocheira. A segunda fase (Junho 2017) consistiu na abertura de duas sondagens de planta rectangular, com cerca de 5,6o metros de comprimento por 2,10 metros de largura e 1 metro de profundidade ( $\mathrm{S}_{1}$ e S2), na zona central do lote - decorrente da necessidade de construir duas sapatas de apoio à auto-grua, imprescindível para içar a maquinaria da obra. A escavação desta área colocou a descoberto a continuação dos muros identificados na primeira fase, parte do muro correspondente à fachada da cocheira do século XIX e duas caixas de saneamento com as respectivas tubagens. Uma das caixas construída em betão estaria associada a uma casa de banho existente no edifício fabril poente (SI), a segunda construída em alvenaria de pedra de granito de feição sub-circular estaria relacionada com o aqueduto também em pedra, ambos coetâneos da construção da cocheira no século XIX (S2). Posteriormente, aquando da construção do 
edificado fabril foi colmatada com cimento e ligada a uma conduta de grés que rasgou parte do muro da fachada da cocheira e do aqueduto em pedra.

A terceira fase (Outubro 2017) incidiu sobre toda a parte nascente do patamar e aquela por escavar entre as duas sondagens acima descritas e revelou a continuação das estruturas correspondentes ao edificado da cocheira: a fachada e respectivo alicerce, os dois contrafortes interiores e os alicerces a estes adossados, já descritos na primeira fase.

Abaixo destas identificou-se uma construção de planta aparentemente rectangular, em alvenaria de pedra miúda e argamassa, rebocada e pintada de cinzento na face exterior voltada ao Palácio. Esta estrutura corresponderá a um edifício mais antigo e terá sido cortada pela construção da mina de água que abastecia a fonte embutida na parede tardoz da cocheira. No topo desta estrutura eram ainda visíveis os negativos correspondentes a entalhes onde assentariam estruturas perecíveis (tabique?). No canto Sul foi registado parte de um empedrado composto por blocos irregulares de pequena e média dimensão, preenchido por um sedimento argiloso e com marcas de desgaste pelo uso e uma soleira com sulcos quadrangulares nas extremidades.

Este muro antigo desenvolvia-se desde a parede que faz divisão com o terreno da Santa Casa da Misericórdia até cerca de um metro da parede do edifício do Instituto Português de Fotografia (IPF) onde flectia para Noroeste. Assim, neste pequeno espaço entre os dois edifícios terá existido uma pequena passagem entre a Rua da Vitória e um socalco localizado nas traseiras do edifício.

Os materiais aí exumados apontam para uma cronologia entre finais do século XVII e inícios do século XVIII.

A quarta fase (Dezembro 2017) incidiu na parte poente da plataforma, junto à parede meeira com a Santa Casa da Misericórdia, e permitiu confirmar a continuação das estruturas relacionadas com as duas ocupações já conhecidas, que se estendiam até ao limite do lote. Sob estes vestígios, registou-se ainda parte de um muro em alvenaria de pedra seca que pertenceria a uma construção anterior, cuja cronologia não foi possível aferir dada a ausência de espólio associado (Figura 7).

\section{SÍNTESE INTERPRETATIVA}

Os trabalhos de escavação arqueológica realizados na área onde se situava o edifício voltado para a Rua da Vitória, permitiram colocar a descoberto uma série de estruturas relacionadas com a Cocheira projectada por Domingos de Oliveira Maia, em meados do século XIX, e com os edifícios que se lhe sobrepuseram no século $X X$, relacionados com duas indústrias que aí laboraram. Abaixo destas, foram detectadas estruturas que aparentam reportar a cronologias anteriores, das quais não se conhecia referência e que, com base nos materiais exumados, podem remontar aos séculos XVII/XVIII.

Segundo a vedoria de 1746, a casa nobre a que mais tarde se chamou Palácio dos Ferraz/Bravo possuía um "quintal [com] muitas arvores de fruto, e laranjeyras, e esta feito em quatro taboleyros, e nos tres primeiros da parte do sul tem em cada hum sua fonte de agoa com seo tanque de pedra, cuja agoa vem do tanque do chatariz da Porta do Olival e tem para a parte do norte sua porta e serventia" (Arquivo Distrital do Porto, Cabido, 5399, fls $214 \mathrm{v}^{\mathrm{o}}-216 \mathrm{v}^{\mathrm{o}}$ Apud Afonso, 2001, pp. 265-266). Todavia, os trabalhos de escavação arqueológica colocaram a descoberto vestígios de edifícios que poderão ser anteriores a esta cronologia, embora a ausência de material arqueológico associado não permita confirmar esta suposição. Acima desta estrutura, foi exumada a parede tardoz e lateral de um edifício posterior, que de acordo com os materiais que lhe estão associados, terá sido construído em finais do século XVII ou inícios do século XVIII. Este edifício apresenta uma planta rectangular, com plataforma construída em alvenaria de pedra miúda e de média dimensão argamassada, rebocada no exterior e pintada de cinzento. As paredes acima do piso de circulação seriam constituídas por materiais perecíveis (tabique?), facto sugerido pelos inúmeros entalhes identificados nos silhares de topo das sapatas. Esta construção não encostaria ao edifício localizado a norte (actual IPF) dado que foram encontrados vestígios da existência de um acesso à rua da Vitória, provavelmente através de uma escadaria composta por silhares de granito, da qual foi possível identificar um degrau durante os trabalhos de acompanhamento. Tal parece ser confirmado pela planta do arquitectos Joaquim da Costa Lima Júnior, datada de 23 de Janeiro de 1851, onde se propõe um "novo alinho que a Exma. Câmara Muni- 
cipal projeta dar à Viela dos Calhaus" e se encontra já representada a planta da cocheira projectada por Domingos da Maia. Nessa mesma planta, é representado um vão de acesso à rua da Vitória que terá sido encerrado com a construção da dita cocheira e que corresponderá aquele identificado no decorrer dos trabalhos arqueológicos (Figura 8).

Esse edifício prolongar-se-ia para noroeste (actual Rua da Vitória), mas terá sido cortado pela construção da fachada da cocheira que parece respeitar o novo alinhamento ditado pela Câmara Municipal. As estruturas identificadas no decurso da escavação arqueológica, nomeadamente aquelas voltadas à actual Rua da Vitória, e que podem ser atribuídas à cocheira parecem decalcar a planta constante no projecto de Domingos Oliveira Maia, aprovada em 1851 (Figura 9).

A cocheira terá sido construída aproveitando as paredes de um edifício já existente, sobre o qual se ergueram dois contrafortes que serviram de suporte a uma parede traseira levantada de raiz e na qual se construiu uma fonte com tanque de água e mina de acesso. As paredes eram robustas e construídas em alvenaria de pedra de média e grande dimensão com argamassa de saibro e cal. Por forma a aumentar o tamanho do patamar voltado à rua da Vitória, procedeu-se ao aterro do socalco superior, o que possibilitou aumentar a área de construção. Conforme projectado na planta de 1851, a cocheira era composta por dois pisos, o primeiro recuado em relação à rua e um piso térreo com um lajeado granítico de grandes dimensões, que apresentava uma trama quadriculada de caneluras das quais desconhecemos a função. Desconhece-se quando é que a cocheira terá deixado de o ser, mas sabe-se que pelo menos até à década de 40 do século $\mathrm{XX}$, o edifício terá mantido a sua traça original, como se comprova pelas fotografias aéreas dos anos 30-40, nas quais se observa uma panorâmica de todo o lote correspondente ao Palácio dos Ferrazes e se assinala a ausência do corpo tardoz poente, que terá sido acrescentado a esta construção em fase posterior (Figura 10).

Na segunda metade do século XX, o edifício onde existia a cocheira terá sido dividido em duas partes iguais, sendo que à metade poente foi acrescentado um outro edifício, e a metade nascente terá sofrido grandes alterações ao nível das paredes estruturais. Aí, segundo o estudo histórico e espacial de J. Afonso, terão funcionado duas unidades indus- triais, das quais não foi possível até à data apurar a que se dedicavam.

\section{CONSIDERAÇÕES FINAIS}

Os contextos identificados no decorrer dos trabalhos arqueológicos correspondem a um quadro cronológico compreendido entre o século XVI e o XX e fornecem dados importantes no que respeita à evolução do espaço construído e às sucessivas transformações de que foi alvo.

Foram identificados e recolhidos uma série de materiais arqueológicos que ajudam a compreender a vivência quotidiana no espaço ao longo dos últimos séculos. Destacam-se também, os elementos arquitectónicos de características particulares ou únicas, como é o caso da fonte renascentista existente no piso térreo do palácio, ou a lareira e chaminé da cozinha do primeiro piso do Palácio, cuja preservação foi possível conciliar com as alterações previstas no projecto de arquitectura.

Se os trabalhos arqueológicos permitiram reunir um corpus de informações relevantes para a caracterização da ocupação humana do espaço entre os séculos XVII e XIX, os mesmos, revelaram-se inconclusivos em relação às ocupações mais recentes do palácio e do edifício voltado para a Rua da Vitória, nomeadamente no que alude às indústrias que aí terão laborado e que são por nós desconhecidas. Tal informação só poderá ser recuperada através de um estudo aprofundado das fontes documentais disponíveis relativas ao último século.

Conquanto, através do acompanhamento arqueológico dos trabalhos de desmonte/demolição do edificado existente junto à Rua da Vitória, em conjunto com os dados recolhidos através da escavação arqueológica manual de toda esta área e complementado pelas fontes documentais, foi possível executar uma boa caracterização da cocheira datada de meados do século XIX, mandada construir por Domingos de Oliveira Maia.

Tendo em conta a complexidade da intervenção e o vasto conjunto de informação reunida, as considerações que por ora se apresentam são ainda incipientes, carecendo de aturado exame e confrontação com um leque mais alargado das fontes documentais disponíveis. 


\section{BIBLIOGRAFIA}

AFONSO, J. F. (2001) - A rua das Flores no século XVI. Elementos para a história urbana do Porto quinhentista. Porto: F.A.U.P.

AFONSO, J. F. (2008) - A casa Ferraz - Bravo na rua das Flores do Porto, Estudo histórico e espacial.

BARBOSA, J. F. (2017) - "Reabilitação do património, cidade do Porto: estratégias e factos - Rua (Sta. Catarina) das Flores". Revista Arquitetura Lusíada, 7 (1.․osemestre 2015): 153-206.

BARREIRA, Paula; GOMES, Paulo Dórdio; TEIXEIRA, Ricardo (1995) - “200 anos de cerâmica na Casa do Infante: do século XVI a meados do século XVIII". In Actas das 2.as Jornadas de Cerâmica Medieval e Pós-Medieval, métodos e resultados para o seu estudo. Tondela: Câmara Municipal, pp. $145^{-184}$.

CASIMIRO, T.M. (2013) - "Faiança Portuguesa: datação e evolução crono-estilística”. Revista Portuguesa de Arqueologia, 14: 355-373.

ENCARNAÇÃO, J. (2012-2013) - “Uma pátera envolta em mistério?", Anas, 25-26:117-132.

FLÓRIDO, M. (2010) - “Tipificação de Soluções de Reabilitação de Paredes de Madeira em Edifícios Antigos”, FEUP, Dissertação submetida para satisfação parcial dos requisitos do grau de Mestre em Engenharia Civil - Especialização em Construções Civis, pp. 12-20.

GOMES, Paulo Dórdio; TEIXEIRA, Ricardo Jorge; SÁ, Anabela (2001) - "Faianças do Porto e Gaia: o recente contributo da arqueologia". In Itinerário da Faiança do Porto e Gaia. Porto: Museu Nacional de Soares dos Reis, pp. 117-166.

GRAÇA, M. S. A. (2007) - "Domingos de Oliveira Maya percurso de um riscador amador ou da responsabilidade técnica no Porto de meados de Oitocentos", In Natália Marinho Ferreira-Alves (Coord.) Artistas e Artífices e sua Mobilidade no Mundo de Expressão Portuguesa, ACTAS VII Colóquio Luso-Brasileiro de História da Arte, DCTP-FLUP, pp. 321-330.

OSÓRIO, M. (2014) - "Sobre as marcas cruciformes do Concelho do Sabugal”. In SARAIVA, António e CAMEIJO, Alcina (Org.) Judeus, Judiarias e Cristãos-Novos na Beira Interior. Guarda: Agência para a Promoção da Guarda, pp. 157-166. [versão digital disponível em https://www. academia.edu/10168733/Sobre_as_marcas_cruci-formes_ do_Concelho_do_Sabugal]

REBUGE, J. e PINTO, M. (2008) - Relatório Preliminar dos trabalhos Arqueológicos, Sondagem de Diagnóstico Arqueológico na Rua das Flores, n.. 25-33 ("Casa Ferraz-Bravo, Casa dos Maias”); Rua da Vitória, n.․149-157, Era-Arqueologia, SA.

RESENDE, N. (2017) - “"Para aprender, viajar e escrever»: uma carta para Domingos de Oliveira Maia (1821)”, CEM Cultura, Espaço \& Memória, 8: 339-356.
SOUSA, F. \& CIRNE, T. (2007) - "Portugueses do norte de Portugal com destino ao Brasil (1805-1832)", In Fernando de Sousa et all (Coord.) A Imigração Portuguesa para o Brasil, CEPESE - Centro de Estudos da População, Economia e Sociedade / Edições Afrontamento, pp. 489-556.

\section{FONTES CARTOGRÁFICAS E OUTRAS}

Cidade do Porto / T. S. Maldonado delin., Porto; Godinho sculp. - [Porto: na Officina de António Alvares Ribeiro, 1789] [cópia digital disponível em http://purl.pt/4036]

Vista da cidade do Porto, desde a Torre de Marca até as Fontainhas / [M. M.] Aguilar delin. e exculp. no anno de 1791. [cópia digital disponível em http://purl.pt/13546]

Planta da cidade do Porto contendo o palácio de Christal, nova alfândega, e diversos melhoramentos posteriores a 1844 / por F. Perry Vidal; Emygdio, gr. - Escala [ca 1:66oo], 4000 Palmos $=[13,30 \mathrm{~cm}] .-$ Lisboa: Off. de Vasques \& c ca ., 1865 [cópia digital disponível em http://purl.pt/3556]

Alinhamento da Rua da Vitória (...) - 1851, por Joaquim da Costa Lima Júnior (Arquivo Histórico Municipal do Porto) [cópia digital disponível em http://gisaweb.cm-porto.pt/ units-of-description/documents/335656/]

Alinhamento na Rua da Vitória e Viela de São Roque até às Taipas (...) - 1851, por Joaquim da Costa Lima Júnior (Arquivo Histórico Municipal do Porto) [cópia digital disponível em http://gisaweb.cm-porto.pt/units-of-description/ documents/335635/]

Arquivo Distrital do Porto, Cabido, 5399, fls. $214 \mathrm{v}^{\mathbf{0}}-216 \mathrm{v}^{\mathrm{o}}$. Apud AFONSO, José Ferrão - A rua das Flores no século XVI. Elementos para a história urbana do Porto quinhentista. Porto: F.A.U.P, 2001, pp. 265-266.

Planta topográfica da cidade do Porto: quadrícula 258 / 1880 - [1892], escala 1:500, levantada sob direção de Augusto Gerardo Teles Ferreira [cópia digital disponível em http://gisaweb.cm-porto.pt/units-of-description/documents/519579/]

Vista aérea da baixa do Porto, 1930 [consultada em http:// portoarc.blogspot.com/2015/o7/governo-politico-v. htmlFICHA]

Fotografia aérea da cidade do Porto: 1939-1940: fiada 18, n. 347 (Arquivo Histórico Municipal do Porto) [cópia digital disponível em http://gisaweb.cm-porto.pt/units-ofdescription/documents/587801/]

Carta Militar de Portugal, folha 365 Escala 1/25 ooo, Serviço Cartográfico do Exército. 


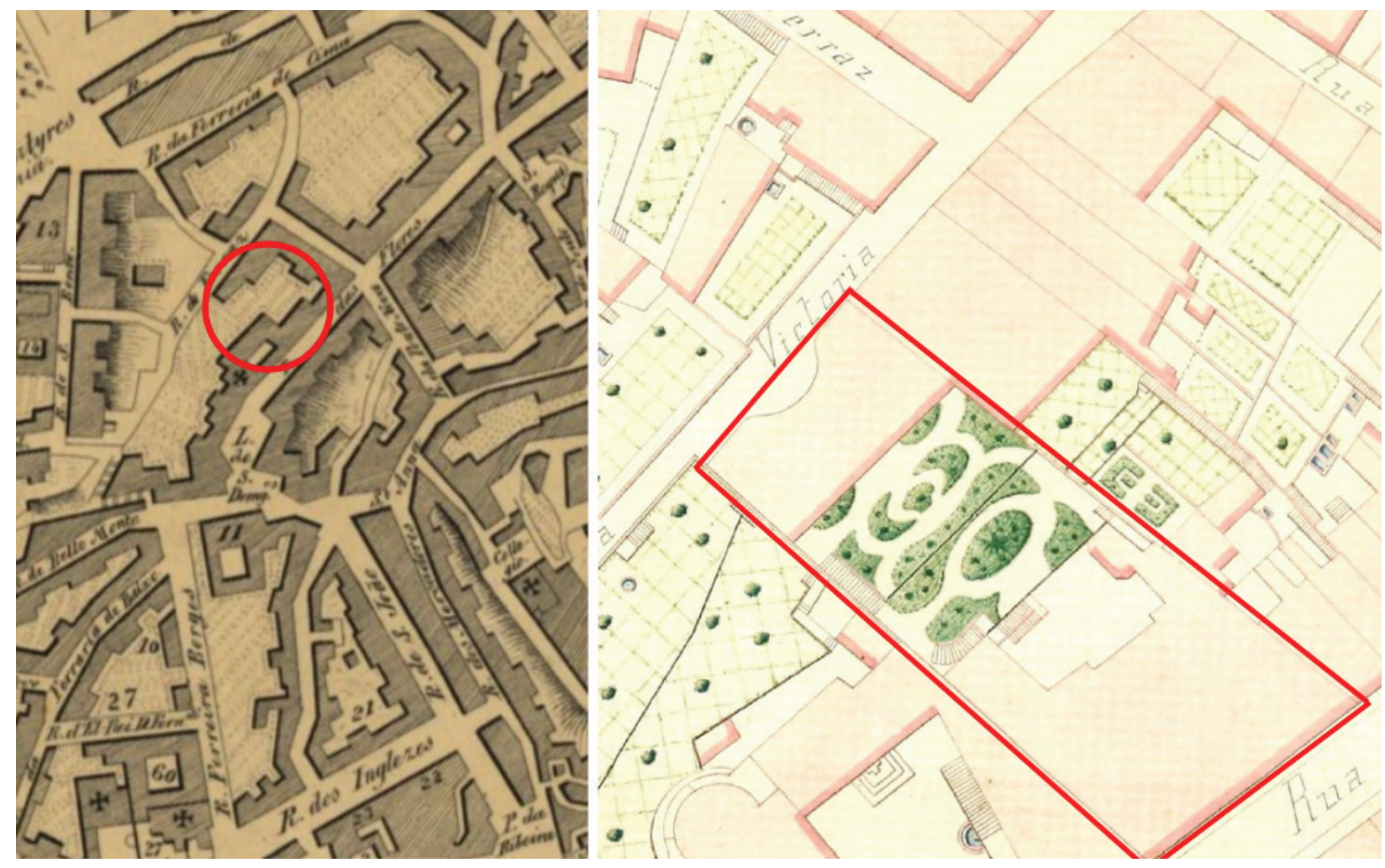

Figura 1 - Localização do palácio em extracto da Planta de Perry Vidal (1844) e do Levantamento de Teles Ferreira de (1880/92).
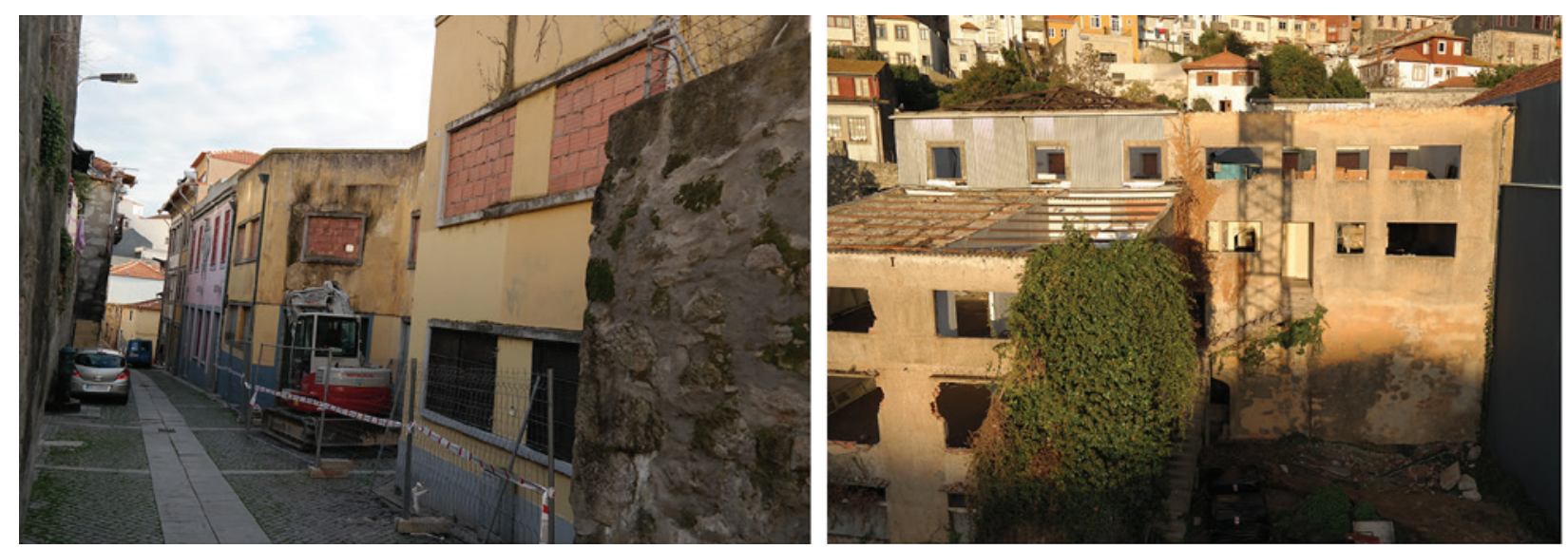

Figura 2 - Vistas da fachada e do alçado tardoz do edifício sito na Rua da Vitória. 

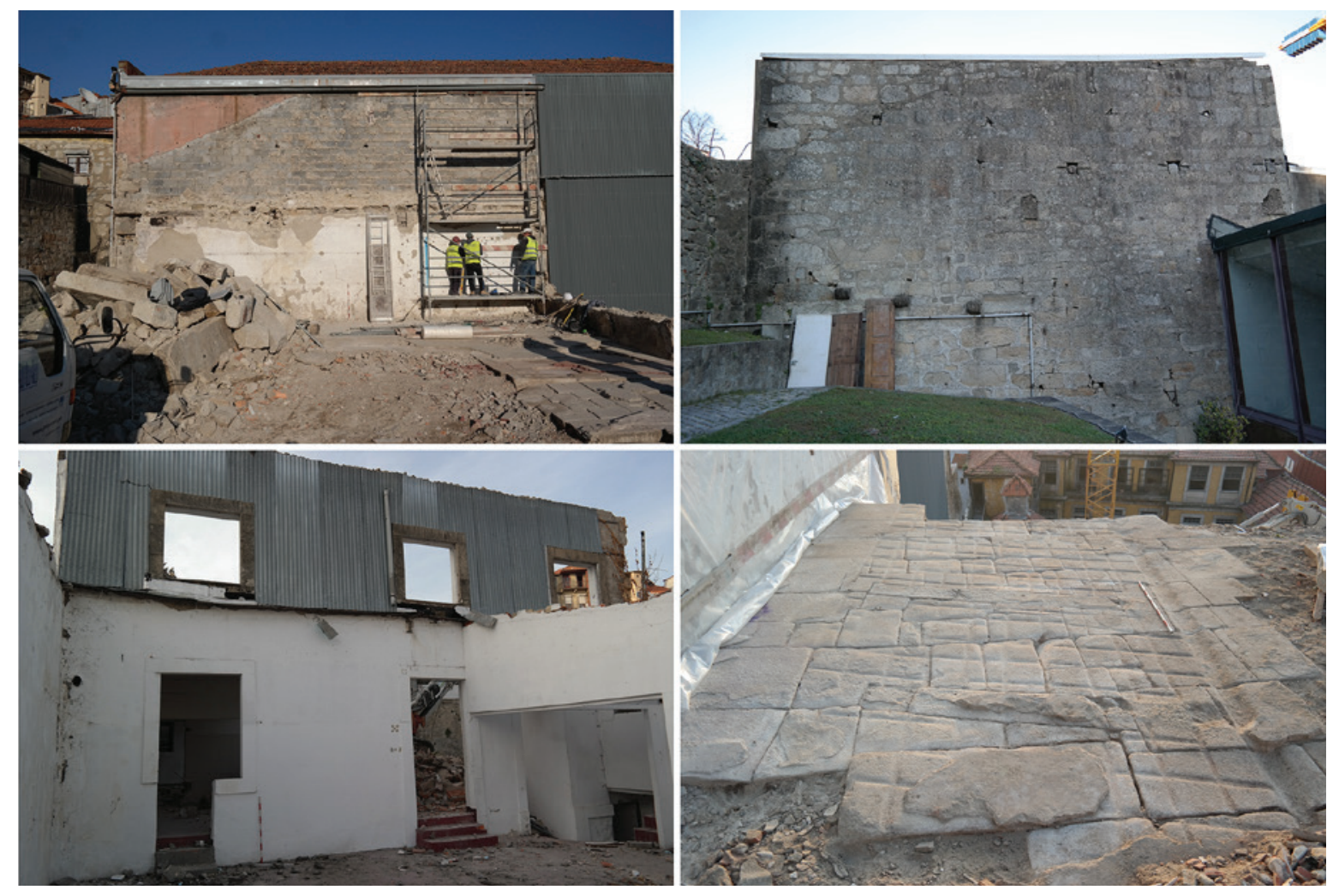

Figura 3 - Vistas dos negativos nas paredes nascente e poente do edifício, das janelas reaproveitadas e do piso lajeado da cocheira.
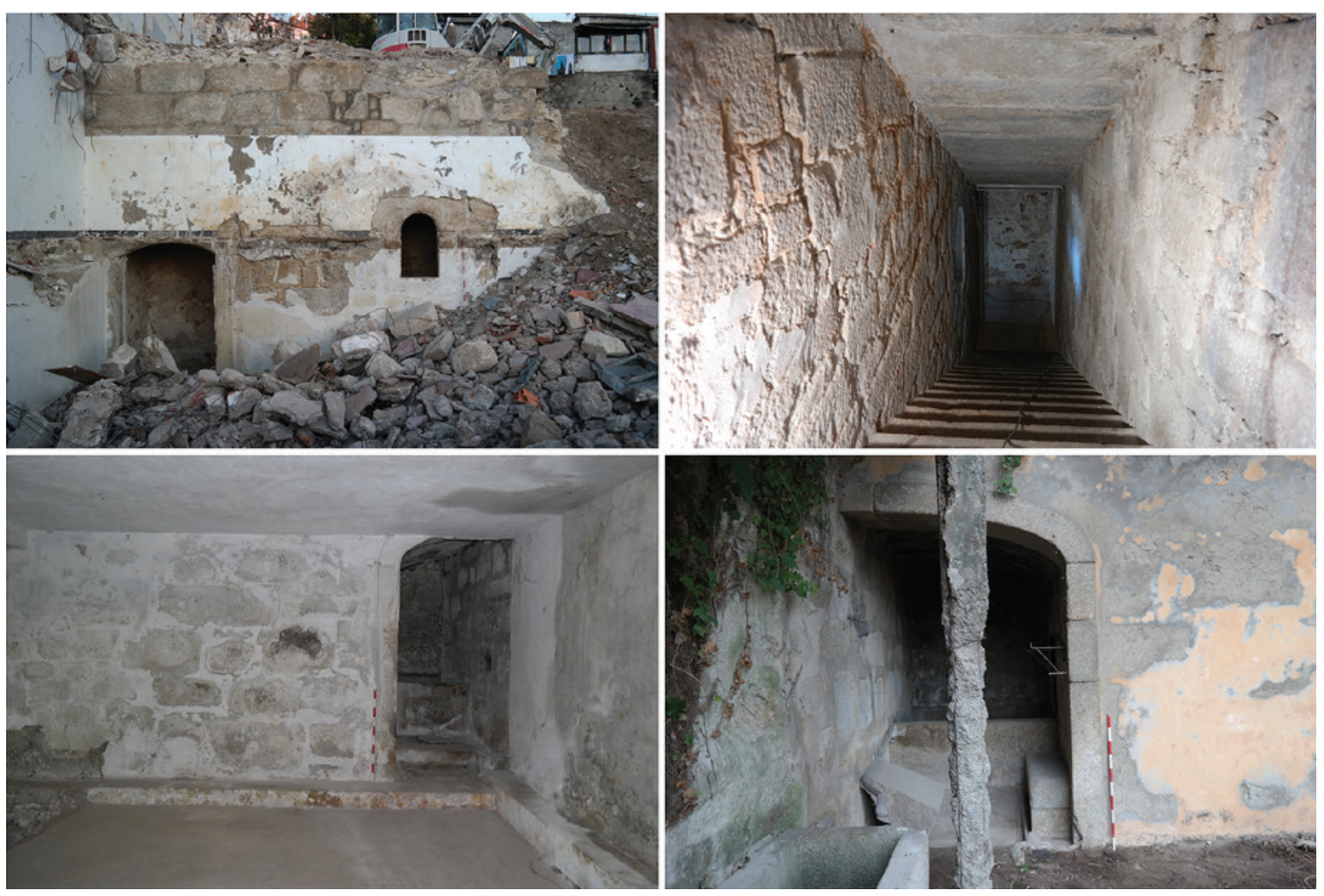

Figura 4 - Vistas do alçado tardoz da cocheira com a porta e janela, da escadaria interior e das duas partes que constituem a fonte. 


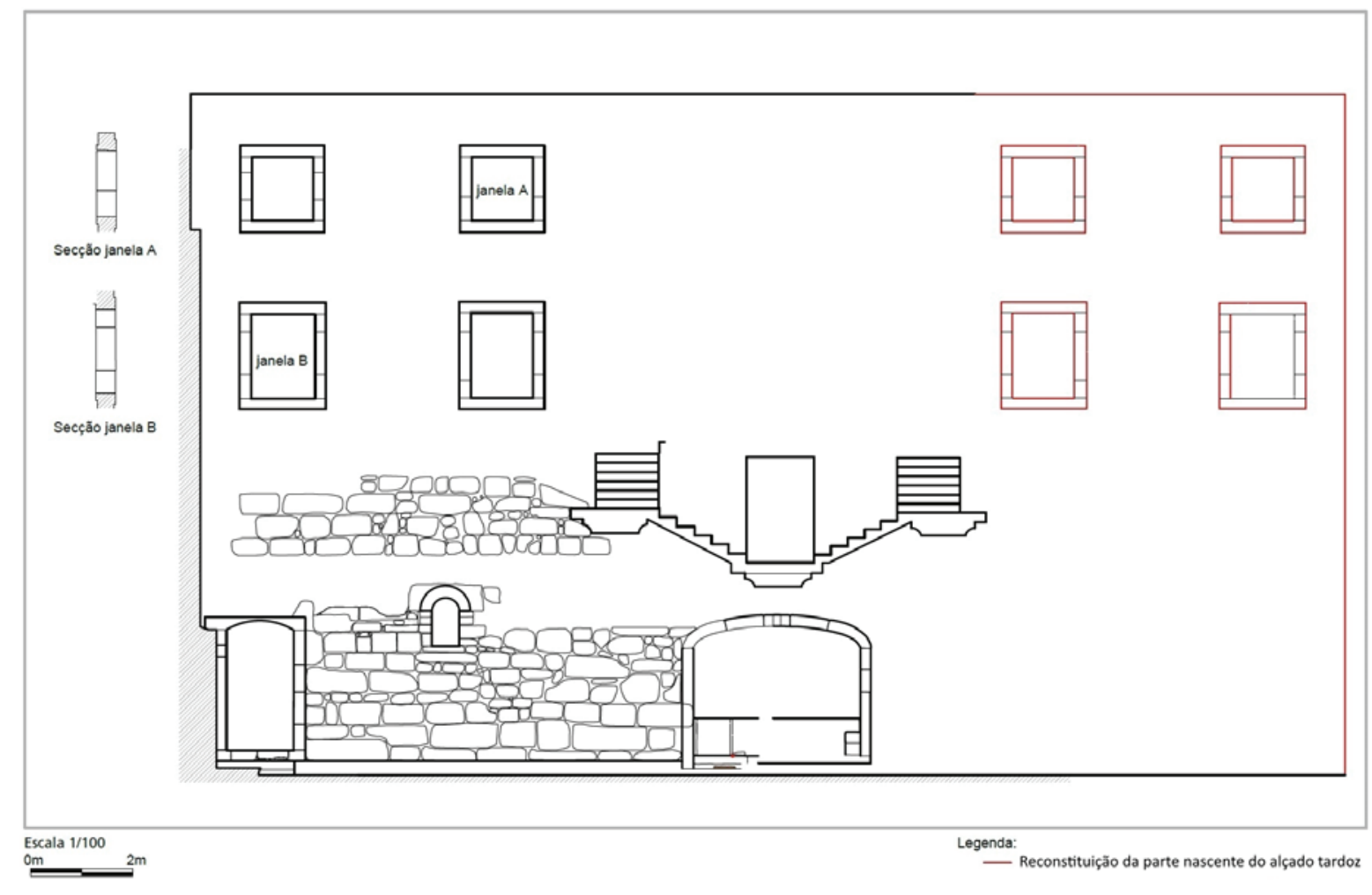

Figura 5- Reconstituição do alçado tardoz da cocheira.

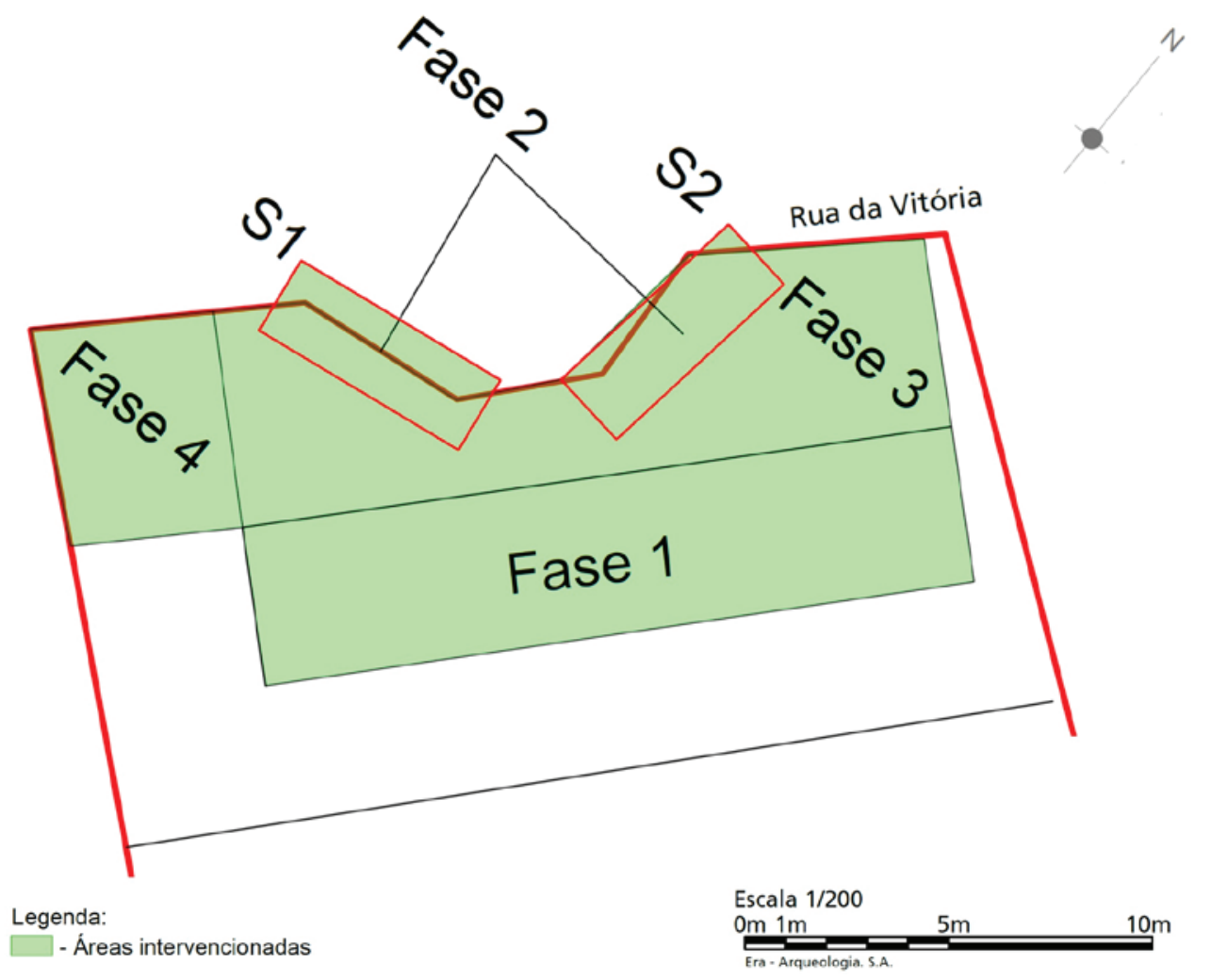

Figura 6 - Esquema das várias fases intervencionadas durante as várias fases de escavação. 


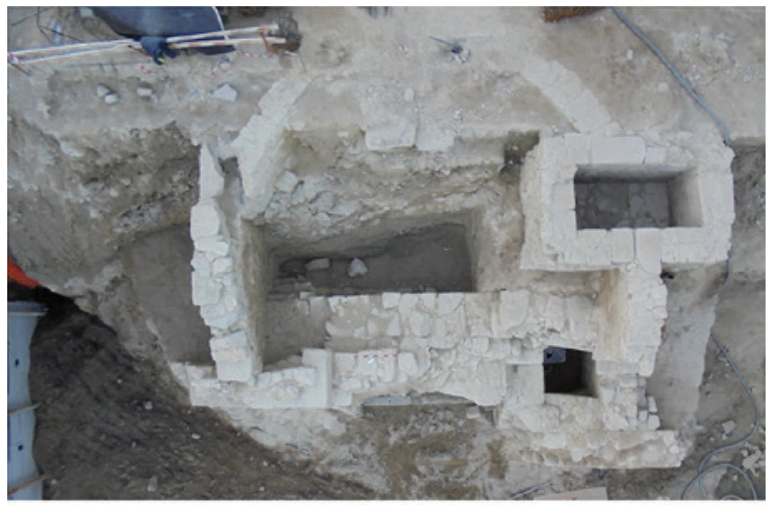

Fase 1

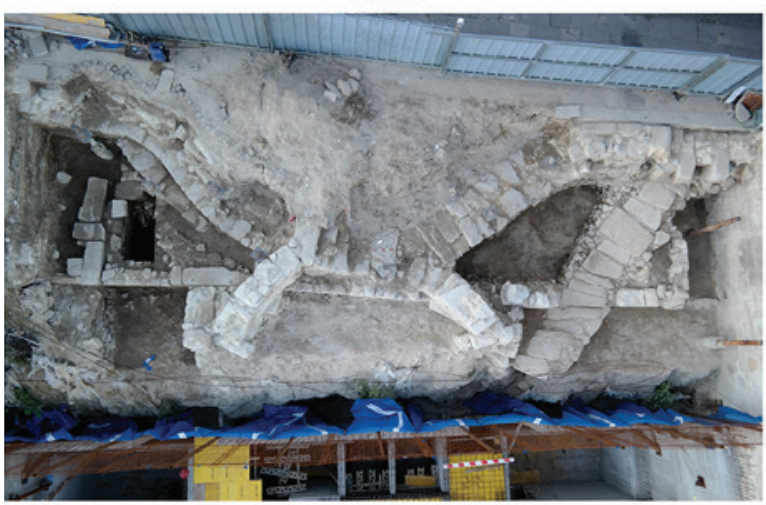

Fase 3

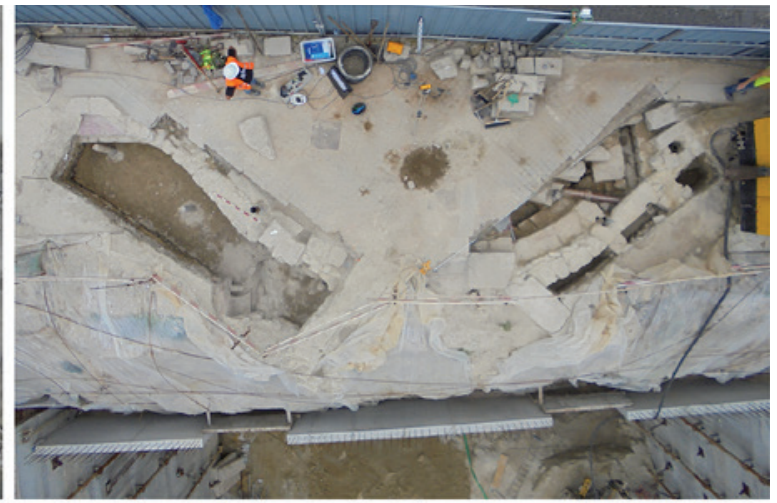

Fase 2

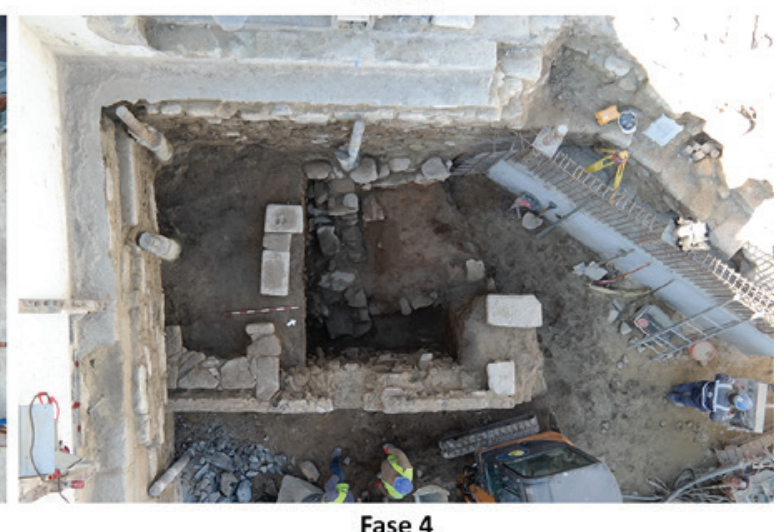

Figura 7 - Vistas dos planos finais das quatro fases de escavação arqueológica.

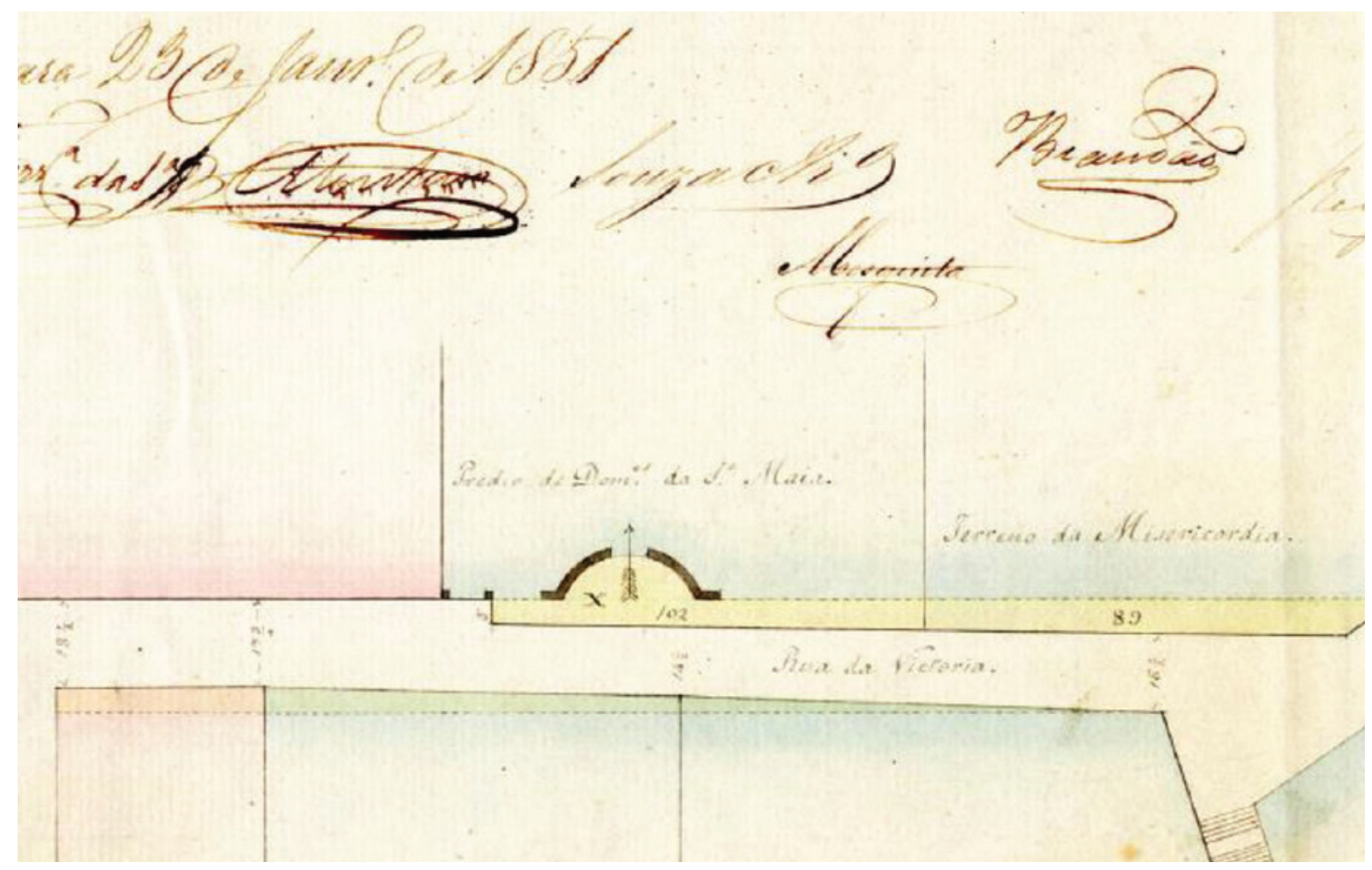

Figura 8 - Extrato do alinhamento da Rua da Vitória pelo Arquitecto Joaquim da Costa Lima Júnior, datada de 23 de Janeiro de 1951. 


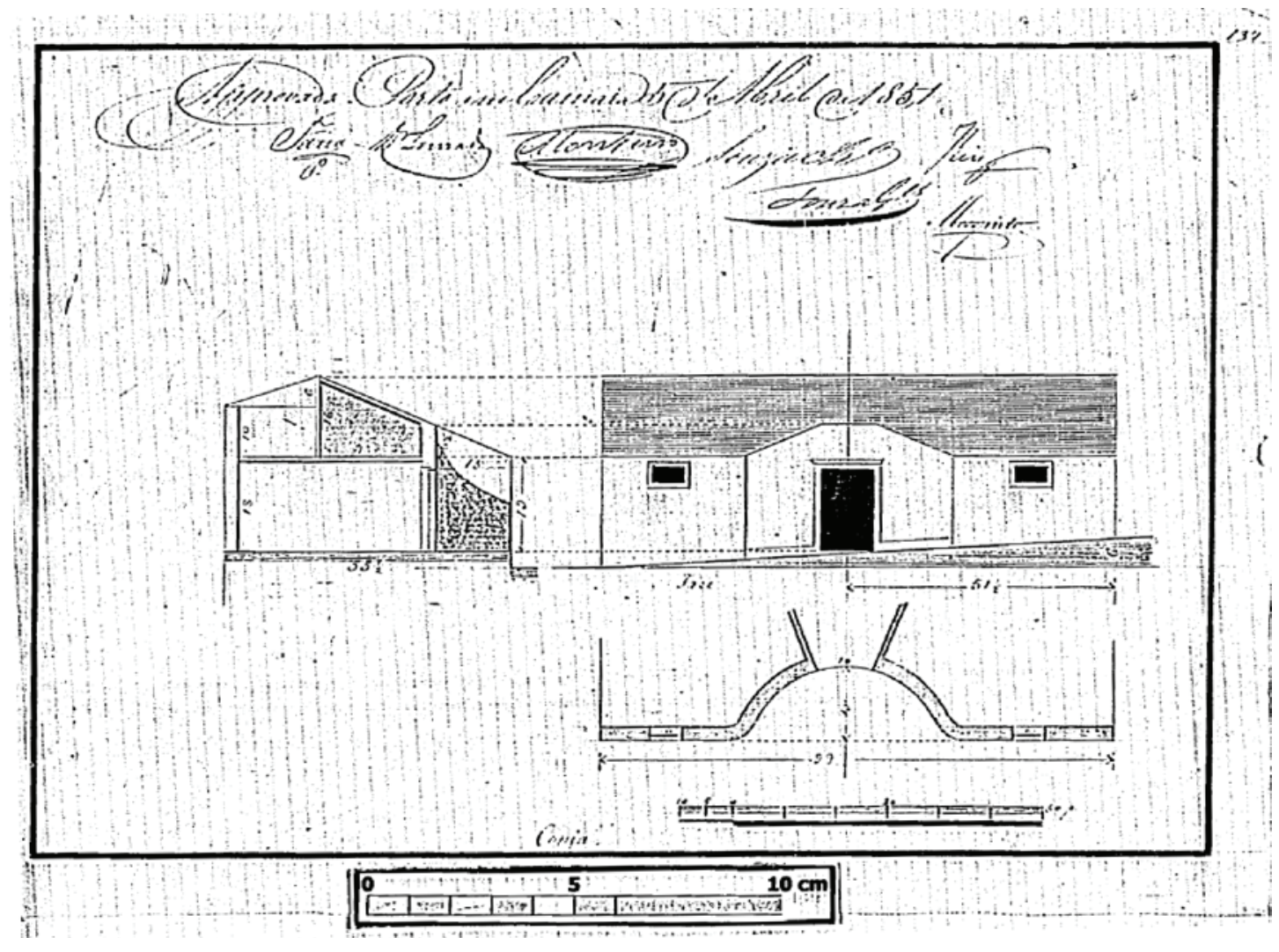

Figura 9 - Planta da cocheira projectada por Domingos de Oliveira Maia (AFONSO, 2008).

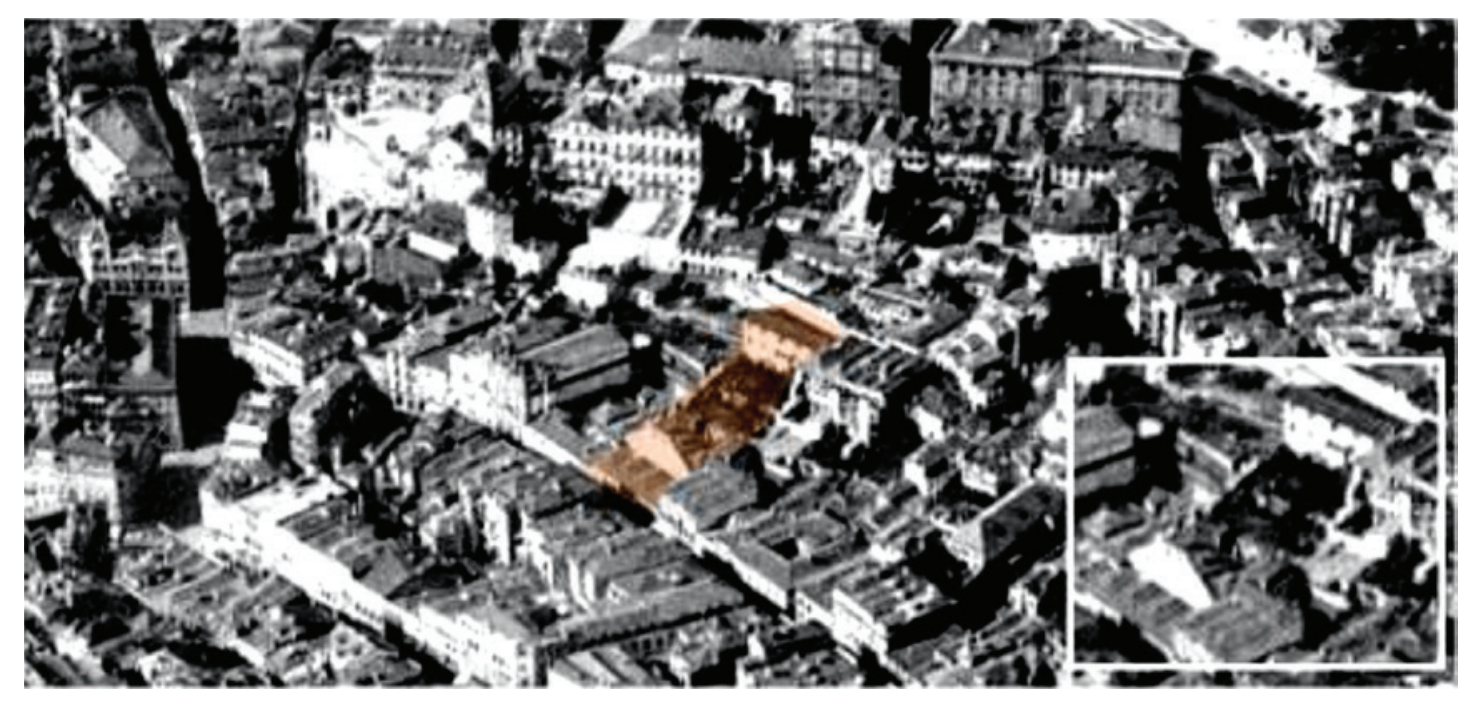

Figura 10 - Palácio e Cocheira - Adaptado da foto aérea da baixa do Porto, 1930 (Foto Beleza). 


\title{
AS MUITAS VIDAS DE UM EDIFÍCIO URBANO: HISTÓRIA, ARQUEOLOGIA E ANTROPOLOGIA NO ANTIGO RECREATÓRIO PAROQUIAL DE PENAFIEL
}

\author{
Helena Bernardo ${ }^{1}$, Jorge Sampaio ${ }^{2}$, Marta Borges ${ }^{3}$
}

\begin{abstract}
RESUMO
O trabalho que ora se apresenta sintetiza os resultados da intervenção arqueológica levada a cabo entre Outubro de 2018 e Abril de 2019, no âmbito do Projecto de Recuperação e Restauro do Recreatório Paroquial Penafidelense (freguesia e concelho de Penafiel, distrito do Porto), localizado no núcleo primitivo do lugar de Arrifana de Sousa, da antiga freguesia de S. Martinho de Moazares, hoje em pleno Centro Histórico da cidade de Penafiel. O edifício reveste-se de particular interesse patrimonial pelo conjunto variado de funções que lhe foram destinadas entre o século XIV (?) e a actualidade: albergaria/hospital, capela, sede da Irmandade da Misericórdia e teatro.
\end{abstract}

Palavras-chave: Recreatório Paroquial, Albergaria, Hospital, Capela, Necrópole.

\begin{abstract}
The work presented here summarizes the results of the archaeological intervention carried out between October 2018 and April 2019, within the Recovery and Restoration Project of the Recreatório Paroquial Penafidelense (parish and municipality of Penafiel, district of Porto), located in the primitive nucleus of the place Arrifana de Sousa, in the old parish of S. Martinho de Moazares, today in the heart of the Historic of the city of Penafiel. The building is a particular patrimonial interest due to the varied set of functions that were assigned to it between the $14^{\text {th }}$ century (?) and today: hostel/hospital, chapel, headquarters of the Irmandade $d a$ Misericórdia and theater.
\end{abstract}

Keywords: Recreatório Paroquial, Hostel, Hospital, Chapel, Necropolis.

\section{INTRODUÇÃO}

Este artigo tem por base os resultados dos trabalhos de acompanhamento e subsequente escavação arqueológica levados a cabo no âmbito do Projecto de Recuperação e Restauro do "Recreatório Penafidelense", da autoria dos arquitectos Salomé Campos e Rui Santos da empresa Arché, requerido pela Fábrica da Igreja Paroquial da freguesia de Penafiel e implementado em parceria com a Câmara Municipal/ Museu Municipal (Figura 1).

O edifício, em vias de classificação (DR, 2.. ${ }^{a}$ serie,
Anúncio n. ${ }^{\circ}$ 126/2018, de 26 de Julho), encontra-se abrangido pela Área de Protecção e Enquadramento ao Património relativa ao Centro Histórico da Cidade de Penafiel (Resolução do Conselho de Ministros n. $.163 / 2007$, de 12 de Outubro), beneficiando ainda da Zona de Protecção da Igreja paroquial de S. Martinho (MN desde 1910), que lhe é fronteira.

A intervenção arqueológica foi da responsabilidade dos signatários, coadjuvados pela antropóloga Marta Borges, na sequência da detecção de vestígios osteológicos humanos. A área a intervencionar foi dividida em três zonas $\left(\mathrm{Z}_{1}, \mathrm{Z}_{2}\right.$ e $\left.\mathrm{Z}_{3}\right)$, tendo os traba-

\footnotetext{
1. Museu Municipal de Penafiel; helena.bernardo@cm-penafiel.pt

2. Museu Municipal de Penafiel; jorge.sampaio@cm-penafiel.pt

3.mspborges@gmail.com
} 
lhos de escavação incidido apenas nas duas primeiras, dada a reduzida potência estratigráfica na $Z_{3}$, que apenas foi alvo de acompanhamento.

Optámos por não aprofundar a análise da arqueologia da arquitectura, tal como os aspectos relacionados com a adaptação a teatro e os usos que se seguiram, por os considerarmos demasiado extensos para o presente artigo, privilegiando os dados relativos às ocupações mais antigas deste espaço construído. Também não foi possível concluir em tempo útil a análise antropológica dos vestígios osteológicos que serão apresentados posteriormente.

\section{APONTAMENTO HISTÓRICO}

O desenvolvimento do lugar de Arrifana de Sousa (hoje cidade de Penafiel), documentado pela primeira vez em 1258 (PMH, Inq., p. 593), elevado a vila em 1741, e a cidade e sede de bispado em $1770^{4}$, beneficiou da sua localização na margem de um caminho medieval, com princípio na Porta de Cimo de Vila, no Porto, que seguia para as Beiras e Trás-os-Montes, sendo também preferencialmente utilizado nas peregrinações a Roma (Almeida, 1968, pp. 173-174). Ao longo desta stratam (PMH, Inq., p. 592), são referenciados albergarias, hospitais e gafarias para assistência a viandantes, doentes e peregrinos. Na povoação de S. Martinho de Moazares (Penafiel), dá-se nota da existência de uma albergaria que estava dedicada ao Espírito Santo (Almeida, 1968, pp. 173-174). Na verdade, encontrámos referências a uma Albergaria do Espírito Santo nas Memórias do Mosteiro de Bustelo, no Testamento de Martim Rodrigues Leitão, Cavaleiro de Lodares, Vezinho de Santarem, datado de 27 de Maio de 1329, que deixa à Albergaria do Espirito santo, á de Santa Maria de Palhains, de S. João eá da Trindade sinco sinco soldos (Dias, 2007, pp. 55-56). Embora o testamento não identifique a povoação, dois autores penafidelenses (Miranda, 1937, pp. 24-25; Mendes, 1992, p. 10) localizam-na no burgo de Arrifana de Sousa e identificam-na com parte do edifício objecto deste estudo. Assim, a albergaria já estaria em funcionamento antes de 1329. A sua implantação nas traseiras de uma capela voltada para a Estrada Real/rua Direita e face à do Espírito Santo, já edificada em 1399 (Dias, 2007, pp. 78-79), sobre a

4. Para aprofundar a história e evolução do lugar de Arrifana de Sousa no município de Penafiel consultar SOEIRO, 1993; SANTOS 2005; BERNARDO, 2012. qual foi construída a igreja matriz, em 1569/1570, parece reforçar essa possibilidade.

Tal como a maioria das suas congéneres, desta albergaria descenderá o primeiro hospital do lugar, na zona apelidada de of fraguedo (Ferreira, 1991-1992, pp. 231), com existência confirmada em 1466 (PT/ADPRT/MON/CVSMBPNF/ooor, fl. 172v, n.p. $258 \mathrm{v}$ a 259v) (Figura 2).

Em 1509 (Compromisso... 1788, pp. 22-23; Sousa, 1983, pp. 22-27; Fernandes, 2016, pp. 56-57), a capela agora intervencionada, que tinha como orago Nossa Senhora das Dores (Ferreira, 1991/1992, p. 231), com o hospital anexo, foi escolhida para sede da recém-criada Irmandade da Misericórdia, tendo esta permanecido aí até à construção da nova igreja no lugar das Chans (praça Municipal), obra que decorreu entre 1621 e 1631 (Miranda, 1927, p. 40; Miranda, 1928, pp. 85-89; Soeiro, 1993, vol. 1, pp. 256-26o). Em 1896, Simão Rodrigues Ferreira refere que Este estabelecimento [Santa Casa da Misericórdia] começou na casa aonde é hoje o teatro, defronte da egreja Matriz; tinha na frente a capella de N. Senhora das Dores, e para o lado de traz, casa aonde haviam quartos para os transeuntes no andar de baixo, e em cima alguns para poucos doentes, e para os enfermeiros, tudo porem pequeno, emuito acanhado (Ferreira, 1991/1992, p. 231). Por contrato de 1 de Outubro de 1619, a Irmandade deu a Capela do Hospital a Amaro Moreira, licenciado na Universidade de Coimbra, pároco em Ermelo (Mondim de Basto) e provedor da Santa Casa da Misericórdia de Penafiel, em 1627 (Miranda, 1928, pp. 88-89; Sousa, 1985, pp. 46), por não se haver dado ainda a alguem, passando a ser privativa, e que este pretendia modificar e usar como panteão para si e para a sua família (Almeida, 1815, p. 53). O contrato refere ser capela pequena e antiga, e talvez por essa razão não tenha sido cumprido (Fernandes, 2009, pp. 42-46), optando Amaro Moreira por construir o novo templo.

Se nesta ocasião não houve lugar a obras de monta, exceptuando talvez no hospital, alvo de trabalhos de pedraria em 1632 (Garcia, 2001, vol. 2, Doc. n. ${ }^{\circ}$ 19), o mesmo não se poderá dizer dos anos seguintes. Em 1641, o tecto da Capela do Hospital ameaçava ruína pelo que, a 24 de Agosto de 1642, os Irmãos da Misericórdia deliberam proceder à sua reconstrução e que se fisese a capella de novo, trabalhos que terão alterado profundamente o edifício (Garcia, 2001, vol. 2, Doc. n.ำ 101 e 102; Garcia, 2009, pp. 95-96; Fernandes, 2009, p. 85). Este empenho em reformar 
a capela terá recebido impulso com uma apreciável doação, feita em 1637, por António Vaz Ferreira, provedor em 1623 (Sousa, 1985, p. 46), e da mulher, Ana de Meireles (Garcia, 2001, vol. 2, Doc. n.ํ9ㅇ). A reformulação inspirar-se-ia na fachada da nova igreja da Misericórdia, iniciada em 1621; também se mudaria o orago para Senhor do Hospital (Garcia, 2009, p. 100) (Figura 3). Isabel Bessa Garcia refere que a capela original apresentaria uma feição gótico-manuelina, coetânea da antiga e fronteira igreja do Espírito Santo e a fachada posterior, do hospital, vestígios estilísticos manuelinos, desconhecemos, no entanto, com que fundamento (Garcia, 2001, vol. 1, p. 81). Hoje, no alçado de alvenaria de granito pobre, despido de rebocos, vários "agrafos" de ferro denunciam as dificuldades em se suster. Observam-se também vãos encerrados, outros abertos de novo e, na linha do beiral, parte de uma goteira em pedra de secção circular.

Falecido António Vaz Ferreira, a 4 de Agosto de 1644 (PT/ADPRT/PRQ/PPNF24/oo3/ooora/mo224, fl. 156), a sua viúva e o filho, Frei José de Meireles, estabelecem um novo contrato, a 27 de Setembro de 1648 (Garcia, 2001: vol. 2, Doc. n.o 96). Nele se estipula a doação de uma quantia para ajuda do retábulo e de uma cruz de prata com a relíquia do Santo Lenho, e várias propriedades, incluindo a herdade da Folha (Arcozelo/ Novelas, Penafiel). Como contrapartidas recebiam missas quotidianas pelos familiares e por si, quando falecessem, celebradas na Capela do Senhor do Hospital, e também metade deste templo (da grade pera dentro somente se comprehende esta doação [...] com o Christo que nella está), passando a panteão de família, para Ana de Meireles e herdeiros, os descendentes dos seus irmãos, Jerónimo e Ângela de Meireles, e os do seu marido (Garcia, 2001, vol. 2, Doc. n. 96 e 97 ).

Nos anos seguintes, a Misericórdia encetaria novas obras de beneficiação da casa do hospital e enfermaria (Garcia, 2001, vol. 2, Doc. n.ำ 103). Realçamos a decisão (23 de Abril de 1656) de abrir sepulturas à entrada da capela para os pobres falecidos no hospital (Garcia, 2001, vol. 2, Doc. n.․ 104). Contudo, os registos de óbitos da paróquia de S. Martinho nunca referem enterramentos no adro desta capela. Os pobres, estrangeiros, peregrinos e doentes que faleciam em Arrifana, alguns com cartas de guia de outras Misericórdias, eram enterrados no adro da matriz, apelidado cemitério paroquial ou semiterio adro dos peregrinos por cima do Cruzeiro de fora da igreja paroquial (PT/ADPRT/PRQ/PPNF24/Oo3/Ooo2, fl. 401v e 428). Entre 1691 e 1772, foram aí sepultadas 27 pessoas $^{5}$, das quais apenas oito tinham falecido no hospital de passageiros de Arrifana ${ }^{6}$. Entre $22 \mathrm{de} \mathrm{Ou}$ tubro de 1642 e 14 de Novembro de 1833 , registámos 173 falecidos no Hospital e nenhum foi sepultado na sua Capela.

De acordo com a documentação disponível, entre os séculos XVII e XIX, foram inumados 24 defuntos no interior da capela ${ }^{7}: 20$ com registo de óbito na paróquia de S. Martinho; três (Ana de Meireles, o Capitão Baltasar Barbosa de Meireles e a mulher, Maria Vieira) apenas mencionados na vedoria de 1749, que descreve os epitáfios das suas sepulturas na capela-mor. Em relação ao ex-provedor António Vaz Ferreira, o registo de óbito da paróquia arrifanense não refere o local de sepultura, pelo que também considerámos as informações do mencionado tombo.

Ao longo da segunda metade do século XVII e primeira do XVIII, realizam-se pequenas obras de manutenção. Em 1706, António Carvalho da Costa faz uma simples menção a Hum Hospital, em que se recolhem os passageiros, \& nelle huma Imagem de Christo crucificado, que faz muitos milagres (Costa, 1706, p. 384). Já a vedoria realizada a 22 de Maio de 1749, um tombo para efeyto de medir e comfrontar a capella e hospital realizado pelo Juiz de Fora e do Tombo da Misericórdia, por requerimento do Procurador do mesmo (PT/AMPNF/SCMP/D/Oo2/ Lvo1 a 04, fl. 57-65, transcrito em Garcia, 2001, vol. 2, Doc. n.․ำ 109) descreve com pormenor toda a estrutura construída bem como o seu interior. Considerando que, até à transformação do edifício em teatro, em 1844, não se efectuaram outras obras

5. PT/ADPRT/PRQ/PPNF24/oO3/ooo2, fl. 311v, 320v, 322, 323v, 325v, 326, 327, 358, 361, 369, 309v-310, 321v, 398v, 401v, 428, 431v; PT/ADPRT/PRQ/PPNF24/o03/ooo4, fl. 215v,300,30ov; PT/ADPRT/PRQ/PPNF24/Oo3/oo18, fl. 79v-8o, 103v, 104-104v, 113v, 122.

6. PT/ADPRT/PRQ/PPNF24/oo3/ooo2, fl. 322, 323v, 326, 361, 401v, 428; PT/ADPRT/PRQ/PPNF24/oo3/ooo6, fl. 300; PT/ADPRT/PRQ/PPNF24/O03/oo18, 104-104v, 122.

7.PT/ADPRT/PRQ/PPNF24/oo3/ooo2,fl.323v,347v,378v, 440, 454, 498v; PT/ADPRT/PRQ/PPNF24/oo3/ooo3, fl. 15V, 16, 33V; 45-45V, 52-52v, 54v, 61, 131v; PT/ADPRT/PRQ/ PPNF24/Oo3/ooo5, fl. 266v; PT/ADPRT/PRQ/PPNF24/ 003/oo18, fl. 12v, 559; PT/ADPRT/PRQ/PPNF24/Oo3/ oo19, fl. 107v, 144; PT/ADPRT/PRQ/PPNF24/oo3/oo2o, fl. 129 . 
de fundo, a vedoria deverá espelhar o resultado das obras de meados do século XVII. Assim, a capela apresentaria uma fachada de feição dórica, com portal de padieira, com pilastras e cornija encimada por um pequeno frontão. Acima deste conjunto, tinha um nicho com a Nossa Senhora da Caridade, ladeado por duas frestas com grades e sobrepujado pelo óculo com rollwerk, de gosto maneirista nórdico, com uma enjunta em ressalto de cada lado (Figura 4). O telhado de duas águas era rematado por uma cruz na empena e ladeado por pirâmides dóricas, com uma torreleta sineira com abertura dupla no lado esquerdo (Garcia, 2001, vol. 1, p. 85). De acordo com uma nota de despesa, a capela teria apenas um sino, cuja corrente necessitou de concerto em 1699; a vedoria de 1749 refere seu campanario com sua garrida aparelhada (PT/AMPNF/SCMP/D/oo2/ Lvo1 a 04, fl. 57-65). Garrida era um sino pequeno que se tangia para ultimo sinal do principio dos officios divinos (Bluteau, 1713, tomo IV, p. 35).

Também António de Almeida conheceu o edifício em funcionamento, tendo considerado a capela pequena e a sua constituição interna algum tanto rustica e antiga e informa que, no hospital, há commodo somente para seis doentes, [...] e ser esta caza mais albergaria do que Hospital, para recolher pobres, que passão com carta de guia de humas Mizericordias para as outras, dando lhes sustento enquanto se demorão, e ate cavalgadura sendo indispensável (Almeida, 1815, p. 50-53).

Em 1836, as funções do velho Hospital, bem como as imagens da Capela, foram transferidas para as dependências do Convento de Santo António dos Capuchos (Beça, 1896, pp. 115, 133-134), deixando o templo sem uso (Soeiro, 1993, vol. 1, pp. 267 e 423). Logo após a mudança, terá surgido a ideia de se fazer aí um teatro e o edifício foi então aforado à Sociedade Phylo-dramática Penafidelense (Beça, 1896, pp. 135-136), que adaptou o espaço, tendo sido apagados todos os traços da sua antiga função, restando apenas alguns elementos da fachada, como a moldura rollwerk do óculo do frontão (Soeiro, 1993, vol. 1, p. 267). Inicialmente, o palco localizava-se junto à rua Direita e o público entrava pelo quelho, nas traseiras, disposição alterada em 1857/1858, passando $\mathrm{o}$ acesso à sala de espectáculos a fazer-se pela rua principal (Beça, 1896, pp. 135-138; Soeiro, 1993, vol. 1, pp. 423-426; Melo, 1927, p. 26; Melo, 1933, pp. 9o, 93-94), aspecto que se manteve e é hoje alvo do restauro. No interior, o edifício apresenta duas linhas de balcões em U suportados por estrutura e pilares em ferro, com gradeamentos do mesmo material, o primeiro com a data 1858 no centro e o segundo com as armas da cidade (Figura 5).

\section{RESULTADOS}

\subsection{Estratigrafia (Figura 6)}

Após a remoção dos pavimentos actuais, na $\mathrm{Z}$ foram detectados estratos relacionados com alterações recentes da soleira da porta principal (UE2O1 a 204, 208) e com remodelações do pavimento e adaptações do edifício, que afectaram grande parte desta zona, em particular as sepulturas 12/13 (UE211), bem como os fossos (UE227 e 228). Unidades constituídas por uma amálgama de espólio de diferentes cronologias e fragmentos de um pavimento de betão. Registou-se também a vala de fundação da parede Norte das bilheteiras (que separa a $Z_{1}$ da $Z_{2}$ ), em alvenaria de granito (a restante estrutura, que se desenvolvia para a Z2, era em madeira) (UEo11 e 205). A esta parede estavam adossadas as escadarias de madeira de acesso aos andares superiores e aos balcões e, sob estes degraus, as camadas de preparação constituídas por lajes de granito, algumas com entalhes e restos de reboco, reaproveitadas de outras construções ou da demolição da estrutura interior da antiga capela (UE248, 249, 256, 257). Após a remoção de todas estas camadas de cronologia contemporânea, estavam as várias sepulturas abertas no substrato geológico, matéria ainda a desenvolver.

Em vários locais da Z1, sobre o afloramento, foram ainda detectados vestígios de um sedimento preto muito compacto (UE225 e 226), um provável nível de circulação, com nódulos de argamassa amarela (e, no caso da primeira UE, ossos de fauna e granito de pequeno módulo rubefactos), cortada pelas sepulturas 15 e 16 (UE242 e 245) e pela UE223. Esta última corresponde à vala de fundação do alicerce da parede da fachada, constituído por uma fiada de pedras com bom acabamento, em particular no ângulo SO desta zona, e que não se encontra alinhado com o alçado actual. Por sua vez, esta vala foi aberta na já referida camada preta (UE226), onde se recolheu um ceitil atribuível aos reinados de D. Manuel I/ D. João III (?) (1495-1521/ 1521-1557) ${ }^{8}$.

Neste mesmo espaço $(\mathrm{ZI})$, próximo da entrada prin-

8. Agradecemos a disponibilidade do Professor Doutor Mário Barroca para a classificação das moedas. 
cipal, foram ainda registados um fosso e negativos de outro, este muito destruído, de contorno subcircular e origem antrópica, escavados no saibro (UE227 e 228). O que se encontra mais bem preservado, apresenta uma profundidade máxima aproximada de $0,72 \mathrm{~m}$, cerca de 1,10 $\mathrm{m}$ de diâmetro, na zona mais larga das paredes convexas, e $0,75 \mathrm{~m}$ de fundo, com uma provável rampa de acesso (ou canal de alimentação e ventilação?) voltada para a única entrada de ar. Na estrutura identificada como UE227, as paredes apresentam-se avermelhadas, coloração possivelmente resultante da exposição a altas temperaturas, facto também atestado pela presença de pequenos carvões na sua base, embalados numa camada de cerca de $2 \mathrm{~cm}$, compacta e de cor castanha escura (UE265). Estas estruturas, que foram muito afectadas pela abertura das sepulturas 12/13 e 15 e pelas obras de adaptação do imóvel, poderão ser contemporâneas dos vestígios do piso mais antigo (UE225 e 226), situado directamente sobre o substrato geológico, onde foram recolhidos fragmentos de louça preta e um ceitil ilegível (c. 1438-1578). A tonalidade escura deste sedimento talvez seja resultante da acção do forno de fundição do metal que era posteriormente vertido no molde, no interior do fosso.

Embora sem qualquer outro indício, consideramos a possibilidade de se estar perante negativos de fossos de fundição de sinos. Servem-nos de referência os exemplares destas estruturas identificados em várias escavações arqueológicas, até 2006, num total de 15 fossos (Sebastian, 2006, p. 19-20), nomeadamente no Mosteiro de Pombeiro (Felgueiras), onde, até ao século XVI, os sinos eram fundidos in loco por mestres sineiros itinerantes (Erasun Cortés, 2008, p. 145) e segundo processos tradicionais quase inalterados até aos séculos XIX-XX, prática que se manteve desde, pelo menos, o século VIII até meados do século XIX, paralelamente às oficinas fixas (Sebastian, 2006, p. 11; Pinto, 2019, pp. 77-95; Erasun Cortés, 2007, p. 104). Esta possibilidade é reforçada pela localização das estruturas no interior da capela, que convinha ao sigilo da arte, nas proximidades da porta principal, única entrada do ar necessário à combustão, e junto da torre sineira, facilitando o transporte e colocação dos sinos no lugar definitivo, como era usual (Erasun Cortés, 2007, p. 99).

$\mathrm{Na} Z$ 2, sob a tijoleira, registou-se um depósito de terra de coloração amarela, muito saibrosa (UEoo2), resultante de obras mais recentes, que acumula detritos da antiga capela (azulejos) e do teatro (rebo- cos pigmentados) e "encosta" às lajes que suportam os prumos do primeiro balcão. Segue-se a UEoo4, um sedimento castanho claro, muito solto, que ainda inclui materiais recentes, como tijolo, mas também vestígios osteológicos, pregos, e onde foi aberta uma vala para a colocação de um tubo de esgoto (UEoo5 a 007), que atravessou toda a $\mathrm{Z}_{2}$ e afectou várias sepulturas.

A adaptação a teatro, levada a cabo em 1857/1858, obrigou à remoção do pavimento até ao afloramento, considerando que as valas para colocação das lajes que suportam os prumos do primeiro balcão foram abertas directamente no substrato geológico. Algumas afectaram mesmo os negativos dos barrotes de um soalho que relacionamos com a primeira fase desta sala de espectáculos (1844). Este chão de madeira, também visível na Z1, foi colocado directamente sobre sepulturas destruídas, provavelmente na mesma altura, até porque, em vários dos enchimentos revolvidos, encontramos partes dos azulejos da capela do século XVII (Sep. 1, 8, 10 e 18).

$\mathrm{Na} Z_{2}$, há também a registar dois alinhamentos de pedras talhadas e de grande porte, provavelmente para suporte da estrutura em madeira da boca de cena (UEoo3 e 029). Sob a camada de enchimento da vala associada à estrutura UEo29, foi identificada uma pequena vala circular (UE127, 128), que continha um crânio. Este vestígio osteológico encontra-se a cerca de 6 metros das sepulturas mais próximas, registo para o qual não encontrámos explicação. A construção destes "muros" também afectou um estrato de terra preta com alguma compactação e nivelamento, circunscrito à parte mais a Norte da Zona 2 (UEo32 e 024?), também interpretado como de circulação. Nesta camada foi recolhido o maior número de fragmentos de cerâmica.

A estratigrafia da $Z_{3}$ é constituída apenas por uma camada de entulhos que serviu para nivelar o piso de circulação em betão, a que se segue um estrato muito fino, sobre o nível geológico, que poderá corresponder a um pavimento em terra batida, onde registámos alguns negativos de estruturas, possivelmente em madeira (para instalação de soalho?). Os negativos no solo parecem relacionar-se com as “juntas vivas" existentes na parede Nascente e aparentemente com ligação à parede Poente. Do mesmo local, o espólio é essencialmente vítreo, correspondente a fragmentos de pequenos frascos de paredes pouco espessas. 


\subsection{Espólio}

A intervenção arqueológica forneceu um variado conjunto de espólio. Entre este, destaca-se o cerâmico, constituído por um total de 1520 fragmentos, dos quais 685 são de materiais de construção e 835 de cerâmica comum utilitária, entre pastas de cozedura oxidante ou vermelhas (359) e as que resultam de cozedura redutora (316) e, embora com menor incidência, a faiança (84), os vidrados de chumbo (71) e a porcelana $(7)$.

Embora a diferença quantitativa seja pouco significativa em relação à louça preta, a vermelha surge em maior número (cântaro, tigelas, panelas e púcaros) que, no seu conjunto, apresenta uma grande diversidade de proveniências, reflectida nas pastas, colorações, acabamentos das superfícies (por vezes brunidas), mas sempre com boa cozedura. No conjunto da louça preta, as pastas variam entre finas, homogéneas e de boa cozedura, e outras mais porosas e grosseiras, em tons acinzentados. Alguns fragmentos são de reduzida dimensão, o que dificulta a análise morfológica, contudo verifica-se o predomínio da forma mais comum, a panela, com muita fuligem, mas de dimensões e perfis variados (algumas com bordo em V, para colocação de testo). Há, também, um assador de castanhas, com pelo menos uma asa, e outros recipientes destinados à preparação de alimentos na lareira. Quer de cerâmica vermelha, quer de louça preta, regista-se um número significativo de fragmentos na UEO32 (102 e 58, respectivamente), que corresponde à camada antrópica mais antiga da Z2. Embora estas produções sejam características dos séculos XVI ao XVIII (Barreira; Dordio; Teixeira 1998, pp. 170-172; Alves \& alii 1998, pp. 189-192), pela análise estratigráfica e do conjunto artefactual, apontamos para um arco temporal mais próximo das centúrias de quinhentos e seiscentos, ou até talvez um pouco anterior, no caso da cerâmica vidrada (Real \& alii, 1995, pp. 177-178).

A faiança é pouco significativa, 66 fragmentos foram recolhidos na camada de entulhos $\left(Z_{3}\right)$, sendo na sua maioria dos séculos XIX e XX. Durante a escavação, apenas foram encontrados 18 , de pequenas dimensões, embora, pelo tipo de decoração, alguns possam remontar ao século XVII (Gomes; Botelho, 2001, pp. 148-149).

A maioria dos fragmentos de azulejo, do total de 93, integra-se cronologicamente no século XVII. Revela tons de azul, amarelo e branco, consentâneos com os que foram localizados in situ no alçado interior
Poente, após picagem dos rebocos, com a data de $1658^{9}$ (Figura 7). Registaram-se partes de cercadura, friso e padrão considerados os mais frequentemente aplicados nesta época (Simões; Oliveira 1997, tomo I, pp. 136-138 (C1), 127 e 131 (F-10); 41-42 (P-101) e 136). $\mathrm{O}$ tombo de 1749 descreve dois painéis situados nas paredes laterais da capela-mor, com as imagens de Nossa Senhora da Apresentação e de Cristo Senhor Ressuscitado, no entanto, não encontrámos qualquer indício figurativo nos fragmentos recolhidos. Restam quatro fragmentos que traduzem dois padrões distintos dos anteriores, três ainda por classificar e um que, embora de pequena dimensão (UEo11), parece apresentar uma decoração mudéjar (?), em corda seca, revestimentos cerâmicos também designados hispanos-mouriscos, muito difundidos entre o último quartel do século XV e a primeira metade do século XVI (Simões; Oliveira 1990: EST. XXIX). No contexto dos enterramentos, para além do espólio osteológico, que trataremos no capítulo relativo à necrópole, foram resgatadas partes de objectos em ligas de cobre, tais como alfinetes e fivelas de calçado, botões, tachas e dobradiças dos caixões (?). Mas também uma verónica, com duas faces gravadas (Mater Dolorosa e Nossa Senhora das Dores) e uma cruz que parece representar o Cristo Bom Pastor, cuja cronologia ainda não foi possível apurar. Entre o espólio numismático encontramos dez ceitis, dois do reinado de D. Afonso V, quatro de D. João III, um atribuível a D. Manuel I/ D. João III (?), outro ao de D. João II (?) e dois de difícil leitura mas que remontarão ao período entre 1438 e 1578 , sensivelmente. Durante o acompanhamento foram ainda recolhidos $\mathrm{XX}$ réis (1884), outro ilegível, e seis escudos (de entre 1957 e 1970). Pregos em ferro, madeira dos caixões, ossos de fauna e vidro estão também representados.

Entre os fragmentos de vidro foram contabilizados 297, tendo sido recolhidos 233 exemplares durante o acompanhamento, na $Z_{3}$. Na maioria destaca-se a pouca espessura das paredes translúcidas, mas alguns permitem identificar várias formas de boiões ou pequenos potes, e mesmo uma tampa, associadas a antigas boticas (Medici, 2014, pp. 370, 372-373). De notar que o espaço deixou de ser utilizado como hospital por volta de 1836 , pelo que estes materiais serão

9. No que resta do padrão, verificámos que este foi recortado para que um fragmento de azulejo com a data gravada com algum objecto perfurante fosse inserido, não sendo esta referência produzida na fábrica. 
anteriores a esta data e a sua localização, no rés-do-chão do espaço identificado como hospital, poderá indicar a área destinada a botica. Nas sepulturas há a registar dois anéis, um verde e outro azul escuro, e ainda um fragmento de outro de cor preta. O uso de anéis de vidro era comum no século XVI entre a população mais remediada, material que substituía os metais mais nobres, sendo frequentes em sepulturas (Medici, 2014, pp. 393-394).

Nos contextos de enterramento destacam-se as contas de terços, rosários ou colares (616 unidades) em madeira, vidro, osso, marfim (?) e azeviche.

\section{NECRÓPOLE}

No total, foram contabilizadas 18 sepulturas abertas no saibro, em diferentes graus de conservação, consequência da maior ou menor afectação a que estiveram sujeitas nas obras de adaptação a teatro. Embora sem evidências de enterramentos estruturados, até porque o pavimento foi rebaixado, sabemos que, no chão da capela-mor, as sepulturas tinham frizoz (vedoria de 1749), que entendemos por algum relevo que as destacava no solo, e que a nave teria lajeado no centro e soalho nas laterais.

A Zı não foi tão afectada pelas intervenções oitocentistas, apenas remexida a sua zona central, como referimos, tendo estes trabalhos afectado, em particular, a vala das sepulturas 12 e 13 que conteria dois enterramentos, um dos quais com o único caixão aqui registado. Nesta área, foram detectadas sete inumações (S12 a S18), que atingem uma profundidade em torno dos $50 \mathrm{~cm}$, quase sempre com o esqueleto total ou parcialmente completo, em conexão anatómica e bom estado de conservação (Figura 8 e 9).

$\mathrm{Na} \mathrm{Z}_{2}$ foram registadas 11 sepulturas ( $\mathrm{S}_{1}$ a Si1) embora, em relação a duas (Sio e Si1), mantenhamos algumas dúvidas, considerando que a sua identificação se baseia em indícios muito ténues. Assim, restam-nos nove com conteúdo osteológico e, entre estas, apenas duas com vestígios de madeira e pregos do caixão ( $\mathrm{S}_{1}$ e $\mathrm{S}_{5}$ ), concluindo-se assim que as restantes sete não dispunham deste invólucro. A profundidade actual das valas varia entre $5 \mathrm{e} 20 \mathrm{~cm}$ e todo o conteúdo apresentava um avançado estado de degradação, numa amálgama indistinta de ossos e tecido, não tendo sido possível a recolha destes vestígios de forma íntegra. Esta situação dever-se-á não só às remodelações do imóvel, mas também à possibilidade de terem sido compactados por um segundo nível de sepulturas entretanto destruídas. O documento de 1749 explica o facto de as sepulturas não se estenderem até à parede Nascente, junto da qual descreve a escadaria do púlpito e, sob esta, a entrada em arco para o corredor de acesso à sacristia e ao hospital.

Todos os enterramentos têm orientação Norte-Sul, tal como a implantação da antiga capela, que também não obedece à orientação canónica, sendo que catorze voltam a cabeça para o altar-mor e três para a porta principal. Três dos sepultados possuíam caixão e os restantes treze terão sido inumados envoltos em sudário, pela ausência de evidências materiais, excepto alguns alfinetes, ou vestidos e calçados. Desta indumentária encontramos fivelas, couro e solas de sapatos, botões e restos de tecidos. (Figura 10).

\section{CONCLUSÕES}

A capela já estaria em funções pelo menos no segundo quartel do século XV (?), considerando a cronologia do espólio numismático recolhido. Contudo, o espaço de implantação, enquanto área edificada, poderá ser de cronologia mais recuada (século XIV?) se considerarmos os fragmentos de vidrado de chumbo de tom verde. A restante cerâmica recolhida nas unidades apoiadas no substrato geológico está muito fragmentada para se retirarem conclusões mais aturadas.

A Irmandade da Misericórdia, sabemos, ter-se-á instalado num templo pré-existente dedicado a Nossa Senhora das Dores, em 1509. O registo do alicerce de uma antiga fachada, com um ligeiro desvio em relação à actual, apenas visível no interior, cuja vala foi aberta na UE226 (e na qual se recolheu um ceitil atribuível aos reinados de D. Manuel I / D. João III), poderá confirmar a realização de obras na fachada ou a construção do edifício original?

Permanece a dúvida relativamente à eventual estrutura de fundição de sinos. A confirmar-se, esta estará relacionada com o templo mais antigo ou com as alterações levadas a cabo pela Misericórdia no início do século XVI? A partir do século XVII, a Irmandade da Misericórdia de Arrifana mantinha organizada a documentação relativa às receitas e despesas (Fernandes, 2016, pp. 55-57) pelo que, certamente, não deixaria de mencionar os gastos com o fabrico de um novo sino para a Capela do Hospital.

Considerando que, em 1648, Ana de Meireles e o filho, José de Meireles, no contrato que estabelecem com a Irmandade da Misericórdia, recebem apenas 
metade da capela, que correspondia ao espaço da capela-mor, da grade pera dentro somente, onde esta viria a ser sepultada, bem como os seus familiares, e que, na vedoria de 1749 se refere que, na nave, com licença do provedor e meza e dando sua esmola se enterra quem tem devossam disso junto do arco da capella, confirma-se que algumas das sepulturas encontradas não pertencem à família dos dotadores. Tendo em conta que na $Z_{1}$, na primeira fase de adaptação a teatro, não houve necessidade de rebaixamento, dado que inicialmente o palco estava localizado nesta área, junto à rua Direita, a maioria das sepulturas ficaram mais bem preservadas, relativamente à Z2. Cremos que, em particular na Z2, um provável segundo nível de enterramentos, sobre os vestígios antes mencionados, terá sido totalmente destruído, possibilidade que poderá explicar o facto de alguns esqueletos estarem completamente esmagados. Por outro lado, a profundidade actual destas sepulturas é insuficiente para albergar um corpo. Alguns enterramentos são anteriores aos registos paroquiais, iniciados a 21 de Julho de 1631, embora apenas o possamos confirmar para as S2, 3 e 18, que forneceram ceitis dos reinados de D. Afonso V e D. João III.

Relativamente à albergaria/hospital, as materialidades não parecem confirmar a sua existência em cronologia tão recuada como o início do século XIV, apontada por alguns autores locais que a identificaram com a Albergaria do Espírito Santo referida nas Memórias do Mosteiro de Bustelo. Contudo, a área envolvente onde estava implantada, bastante alterada ao longo das centúrias, ainda não foi objecto de intervenção arqueológica sistemática.

\section{FONTES}

\section{Fontes documentais}

Arquivo Distrital do Porto (ADPRT) - Convento de S. Miguel de Bustelo.

PT/ADPRT/MON/CVSMBPNF/ooo1 - Prazos, fl. 172v a $173 \mathrm{~V}$ [nova paginação $258 \mathrm{v}$ a 259v].

ADPRT - Registos paroquiais de S. Martinho de Arrifana de Sousa.

PT/ADPRT/PRQ/PPNF24/oo3/ooo1a a /oo6, /oo18 a /OO21.

Arquivo Municipal de Penafiel (AMPNF) - Santa Casa da Misericórdia de Penafiel.

PT/AMPNF/SCMP/D/oo2/Lvo1 a 04, Tombos, 1750, fl. $57-65$.
Fontes impressas

ALMEIDA, António d' (1815) - "Descrição Historica e Topografica da Cidade de Penafiel”, Parte III, In SOEIRO, Teresa (1993) - O Progresso também chegou a Penafiel. Resistência e mudança na cultura material, 1741-1910. Tese de doutoramento, vol. III. Porto: FLUP.

BEÇA, Coriolano de Freitas (1896) - Penafiel Hontem e Hoje: Recordações e impressões. Penafiel: Typ. de «O Penafidelense».

BLUTEAU, Raphael (1713) - Garrida. In Vocabulario Portuguez \& Latino, Tomo IV (1713). Lisboa: Officina de Pascoal da Silva, p. 35 .

Compromisso da Misericórdia de Arrifana de Sousa. Impresso no Anno de 1697. Porto: Offic. de António Alvarez Ribeiro, 1788.

COSTA, António Carvalho da (1706) - Corografia portugueza [...]. Lisboa: Off. de Valentim da Costa Deslandes, 1706-1712.

DIAS, Fr. Geraldo J. A. Coelho (2007) - Memórias do Mosteiro de S. Miguel de Bustelo (180o-1801) de MEIRELES, Fr. António d’Assunção. Penafiel: Museu Municipal.

FERREIRA, Simão Rodrigues (1991/1992) - “Apontamentos para a historia topografica de Penafiel”, In Penafiel, Boletim Municipal de Cultura, 3.․ㅗ série, n.ㅇ6/7. Penafiel: Câmara Municipal, pp. 223-245.

PMH, Inq. = PORTUGALIAE Monumenta Historica. Inquisitiones, volume I, fascículo IV-V (1897). Lisboa: Academia das Ciências de Lisboa.

\section{BIBLIOGRAFIA}

ALMEIDA, Carlos Alberto Ferreira de (1968) - Vias medievais. Entre Douro e Minho. Dissertação para licenciatura. Porto: FLUP.

ALVES, Francisco J. S.; RODRIGUES, Paulo J. P.; GARCIA, Catarina; ALELUIA, Miguel (1998) - "A cerâmica dos destroços do navio dos meados do século XV. Ria de Aveiro A e zona Ria de Aveiro B. Aproximação tipológica preliminar”, In Actas das 2. ${ }^{a s}$ Jornadas de Cerâmica Medieval e Pós-Medieval. Tondela: Câmara Municipal, pp. 185-210.

BERNARDO, Helena (2012) - Do lugar de Arrifana de Sousa à cidade de Penafiel: Urbanismo e arquitetura (séculos XVI-XVIII). Dissertação de Mestrado. Porto: FLUP, edição policopiada.

BARREIRA, Paula; DORDIO, Paulo; TEIXEIRA, Ricardo (1998) - "200 anos de cerâmica na Casa do Infante: do século XVI a meados do século XVIII”, In Actas das 2. ${ }^{\text {as }}$ Jornadas de Cerâmica Medieval e Pós-Medieval. Tondela: Câmara Municipal, pp. 145-184.

ERASUN CORTÉS, Ricardo (2007) - "Um fosso de fundição de sinos no Mosteiro de Santa Maria de Pombeiro - Felgueiras”, Revista OPPIDUM, n.ํㅜ 2. Lousada: Câmara Municipal de Lousada, pp. 95-114. 
ERASUN CORTÉS, Ricardo (2008) - “A fundição de sinos no Mosteiro de Santa Maria de Pombeiro”, Revista OPPIDUM, número especial. Lousada: Câmara Municipal de Lousada, pp. 131-149.

FERNANDES, Paula Sofia (2009) - "Fundação e consolidação da Misericórdia”, In Misericórdia de Penafiel: 500 anos. Penafiel: Santa Casa da Misericórdia de Penafiel, p. 15-62.

FERNANDES, Paula Sofia Costa (2016) - O Hospital e a Botica da Misericórdia de Penafiel. Penafiel: Santa Casa da Misericórdia.

GOMES, Luís Filipe; BOTELHO, Iva Teles (2001) - "Faianças do séc. XVII num Arrabalde do Porto”, In Itinerário da Faiança do Porto e Gaia, Museu Nacional de Soares dos Reis (Coord). Lisboa: IPM.

GRACIA, Isabel Bessa (2001) - A Arquitectura de raiz clássica no Vale do Sousa. Dissertação de Mestrado. Coimbra: FLUC, edição policopiada.

GRACIA, Isabel Bessa (2009) - “As igrejas da Misericórdia de Penafiel. Um percurso arquitectónico”, In Misericórdia de Penafiel: 500 anos. Um baluarte histórico-cultural. Penafiel: Santa Casa da Misericórdia de Penafiel, pp. 63-124.

MEDICI, Teresa (2014) - Vidros da Terra. O vidro tardomedieval e moderno em Portugal (séculos XIV-XVII). O contributo da arqueologia. Tese de doutoramento. Coimbra: FLUC, edição policopiada.

MENDES, J. J. (1992) - “Da origem, formação e desenvolvimento de Arrifana de Sousa e Penafiel”, 2. ․ Edição. Penafiel: MAIA \& MENEZES.

MELO, Ernesto de (1927) - "Do nosso teatro", In Penha-fidelis, 1.ำ Ano, n.ำ 1. Penafiel: Biblioteca Municipal, composto e impresso na Tipografia Minerva.

MELO, Ernesto de (1933) - Dos Tempos passados. Penafiel: Tipografia de «O Povo de Penafiel».

MIRANDA, Abílio (1928) - "História da Misericórdia de Penafiel”, In Penha-fidelis, 1.․ Ano, n..$^{\circ}$ 5, pp. 83-89; n.ำ 7, pp. 129-131. Penafiel: Biblioteca Municipal.

MIRANDA, Abílio (1937) - “A Freguesia de S. Martinho de Moazares”, Separata dos folhetins de O Penafidelense, Terras de Penafiel, vol. 1, pp. 1-30.

PINTO, Diana Felícia (2019) - De Campanis Fundentis. A fábrica de Fundição de Sinos de Rio Tinto, Relatório de Estágio no âmbito do Mestrado em História da Arte, Património e Cultura Visual apresentado à FLUP. Porto: FLUP, edição policopiada.

REAL, Manuel Luís; DORDIO, Paulo; TEIXEIRA, Ricardo; MELO, Rosário Figueiredo (1995) - “Conjuntos cerâmicos da intervenção arqueológica na Casa do Infante - Porto: elementos para uma sequência longa - séculos IV-XIX", In Actas das 2. ${ }^{\text {as }}$ Jornadas de Cerâmica Medieval e Pós-Medieval. Tondela: Câmara Municipal, pp. 171-186.
SANTOS, Maria José Ferreira dos (2005) - A Terra de Penafiel na Idade Média. Estratégias de ocupação do território (875-1308), Cadernos do Museu, n.ํ1o. Penafiel: Câmara Municipal / Museu Municipal de Penafiel, pp. 5-10o.

SEBASTIAN, Luís (2006) - "A fundição sineira em Portugal, da História à Investigação”, In Actas do 3. Simpósio sobre Mineração e Metalurgia históricas no Sudoeste europeu. Porto.

SIMÕES, J. M. dos Santos; OLIVEIRA, Emílio Guerra de (1997) - Azulejaria Portuguesa em Portugal no século XVII, Tomo I-Tipologia. Lisboa: Fundação Calouste Gulbenkian.

SOEIRO, Teresa (1993) - O Progresso também chegou a Penafiel. Resistência e mudança na cultura material. Tese de Doutoramento. Porto: FLUP, edição policopiada.

SOEIRO, Teresa (1994) - Penafiel. Lisboa: Editorial Presença.

SOUSA, António Gomes de (1983) - “Um livro de Índices da Misericórdia de Penafiel”, Anais da Santa Casa da Misericórdia de Penafiel, Ano 3.․ Penafiel: Santa Casa da Misericórdia.

SOUSA, António Gomes de (1985) - "Galeria dos Provedores da Santa Casa de 1570 a 1669", Anais da Santa Casa da Misericórdia de Penafiel, Ano 5. ‥ Penafiel: Santa Casa da Misericórdia. 


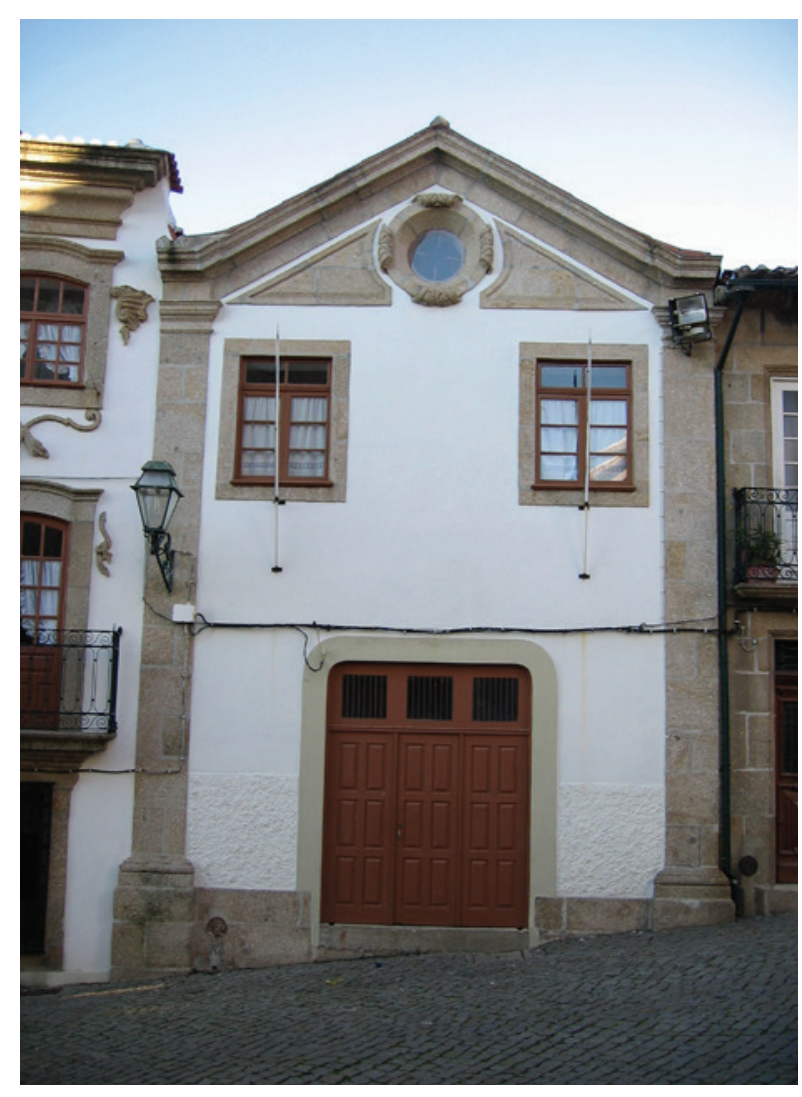

Figura 1 - Recreatório Paroquial (Oficina de Reabilitação GTL, 2006).

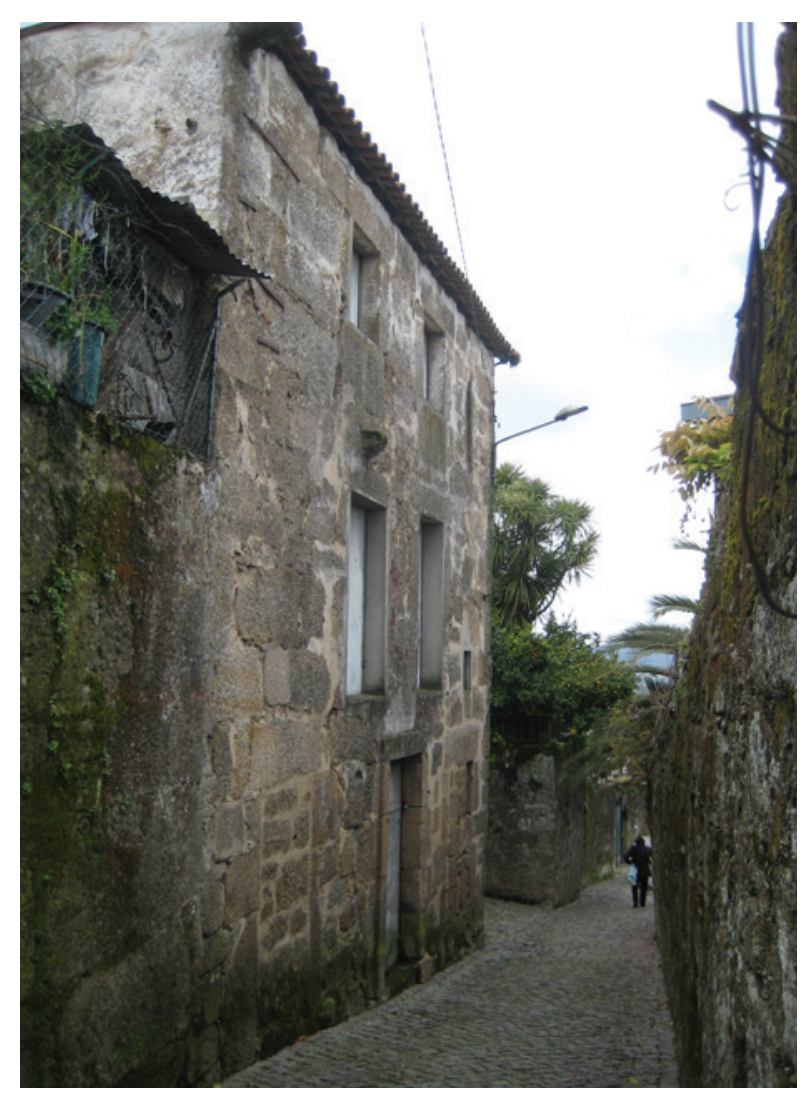

Figura 2 - Fachada do antigo hospital de Arrifana de Sousa.

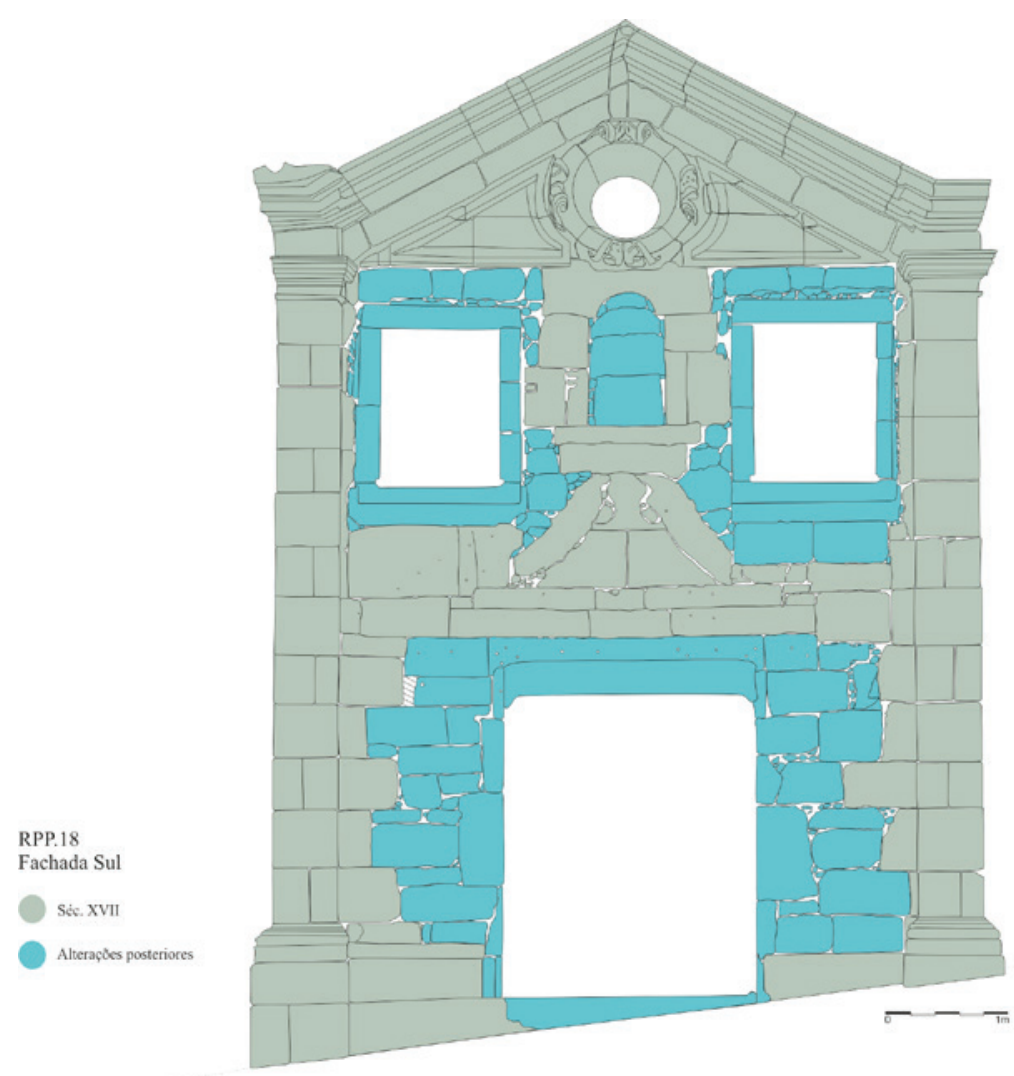

Figura 3 - Alçado principal da antiga Capela do Hospital após remoção do revestimento. 


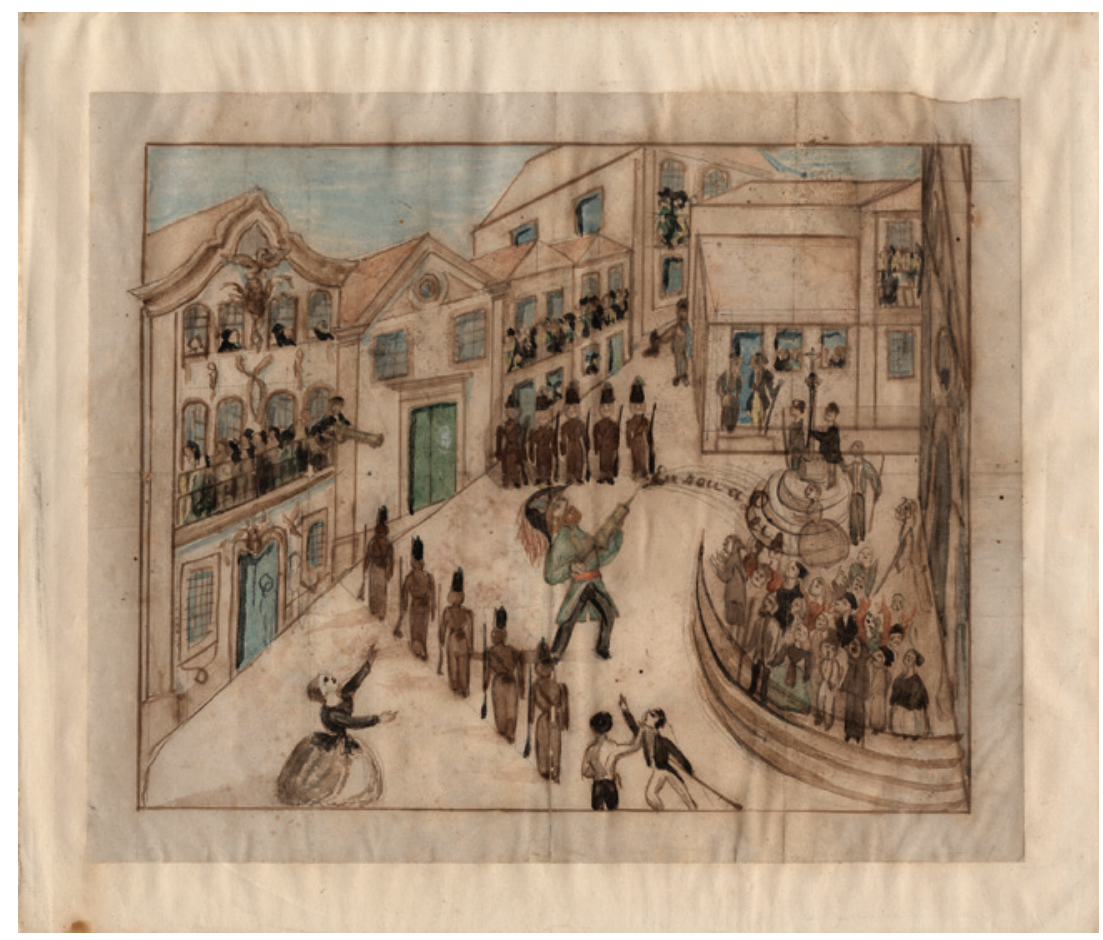

Figura 4 - Registo caricatural de um diferendo ocorrido em 1861 entre o Administrador do Concelho, D. Miguel Vaz Guedes de Ataíde Malafaia Júnior, e o público que se dirigia ao teatro, por aquele ter proibido o espectáculo do dia 1 de Dezembro por ainda não terem sido realizadas as exéquias pelo falecimento do rei D. Pedro V. Junto à igreja matriz vê-se o cruzeiro, atualmente localizado na Quinta da Aveleda, e em frente, a fachada do Recreatório, com o portal da antiga capela (n.. inv.. MMPNF/2009/7908, publicado em Soeiro, 1994, p. 56).

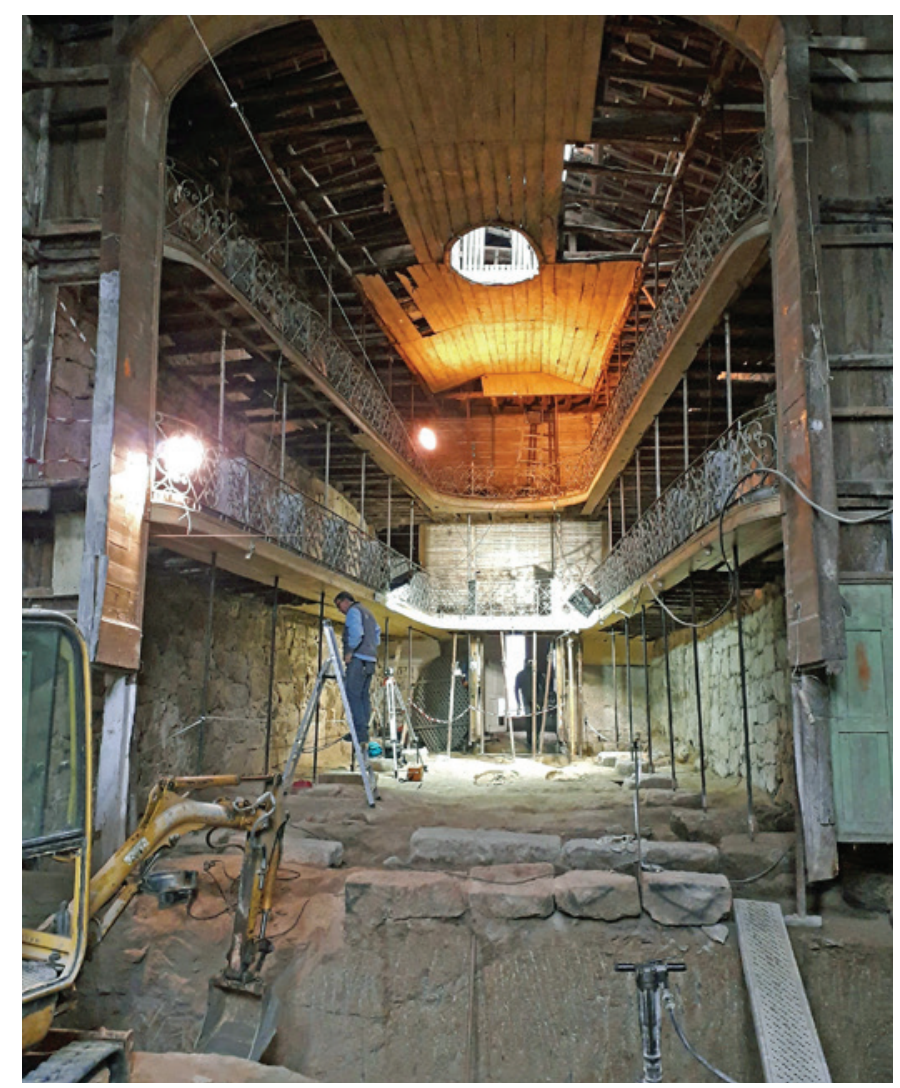

Figura 5 - Interior do Recreatório em obras, com os dois níveis de balcões e lanternim de iluminação. 


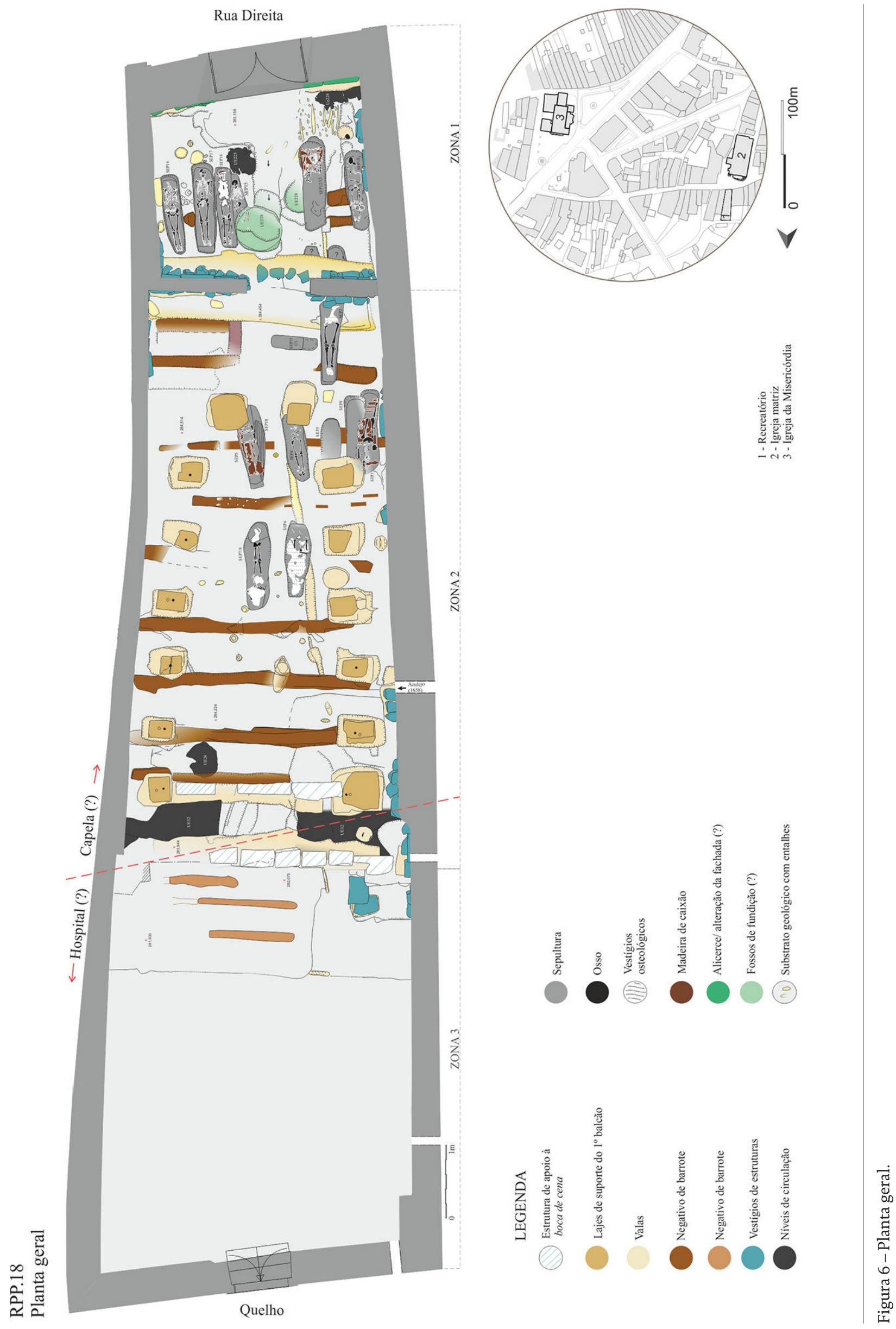




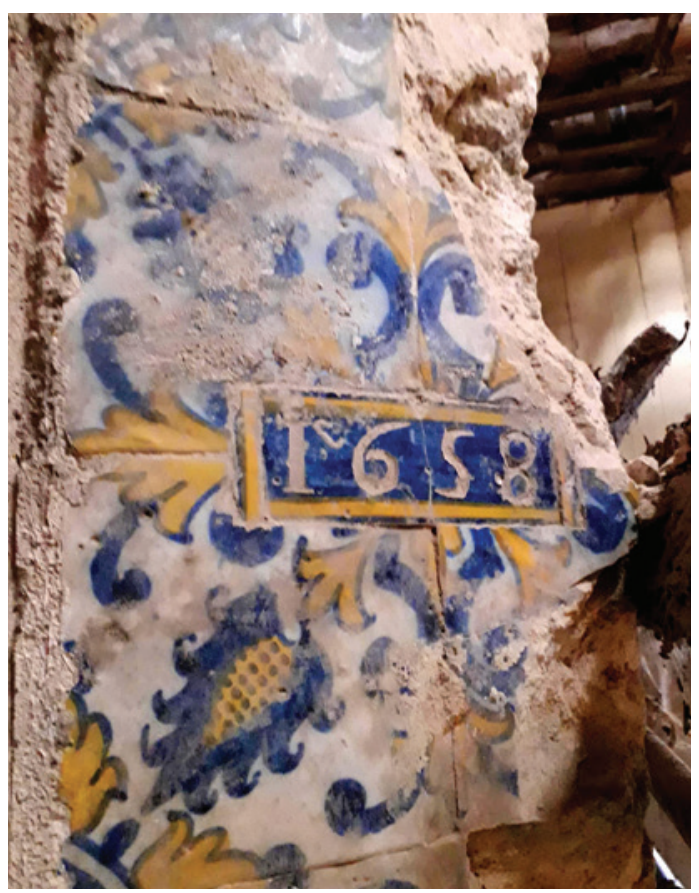

Figura 7 - Parte do padrão azulejar que revestia a antiga capela-mor localizado in situ com a data de 1658 .

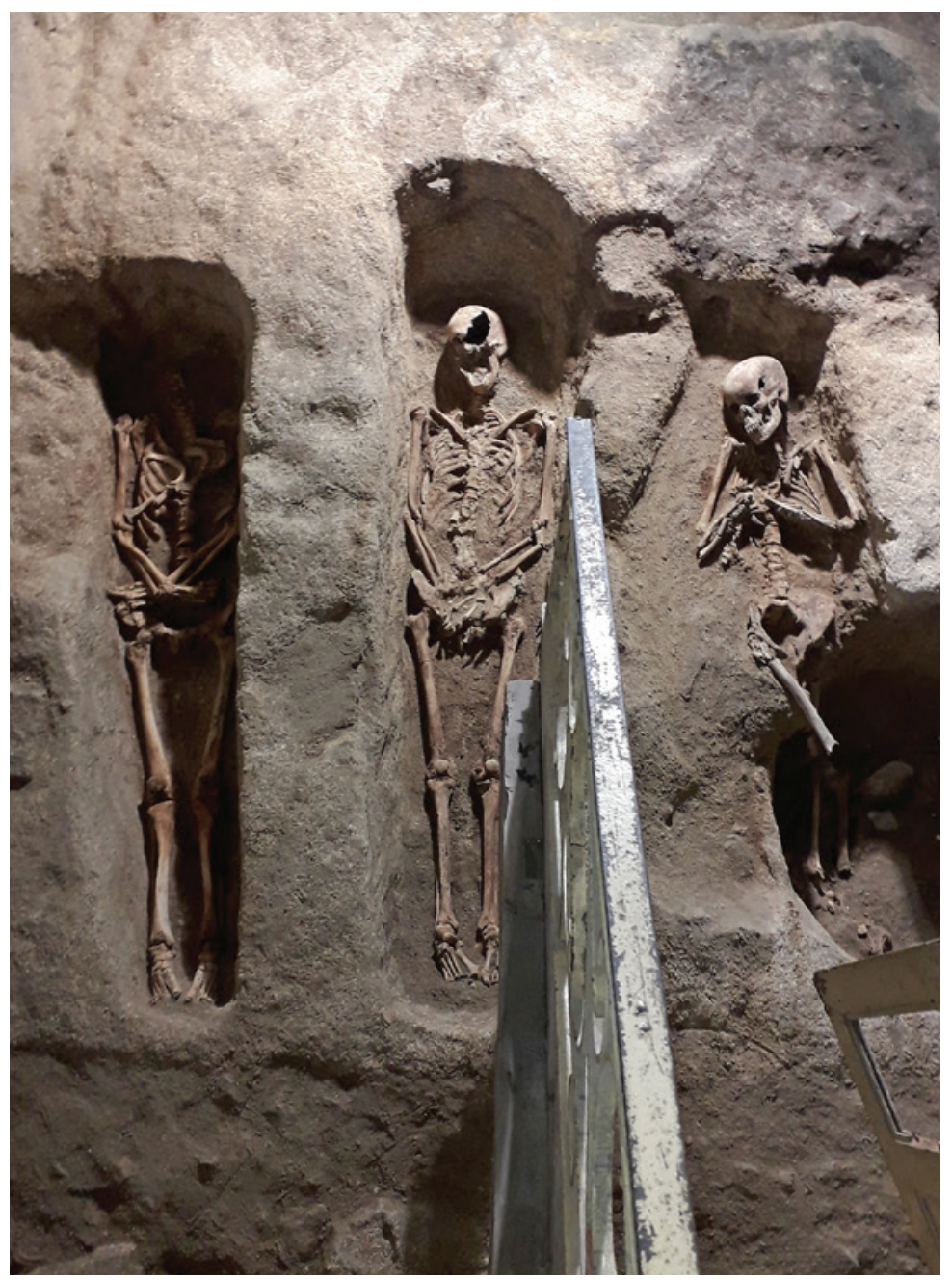

Figura 8 - Sepulturas 14, 17, 15 e, entre as duas últimas, a 16, ainda por escavar. 


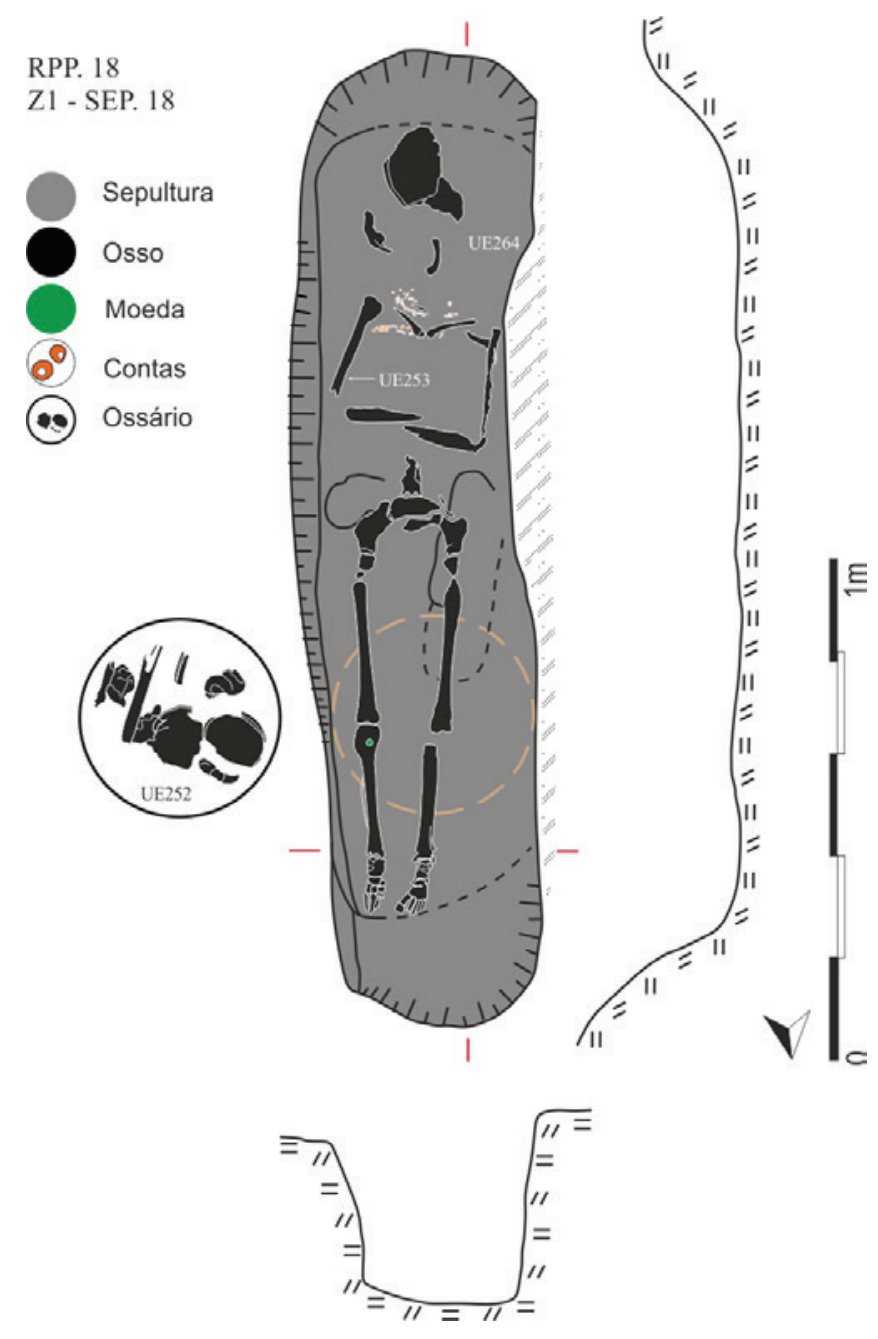

Figura 9 - Sepultura 18, com ossário posterior, ceitil de D. João III e contas em osso e pasta de vidro azul escuro.

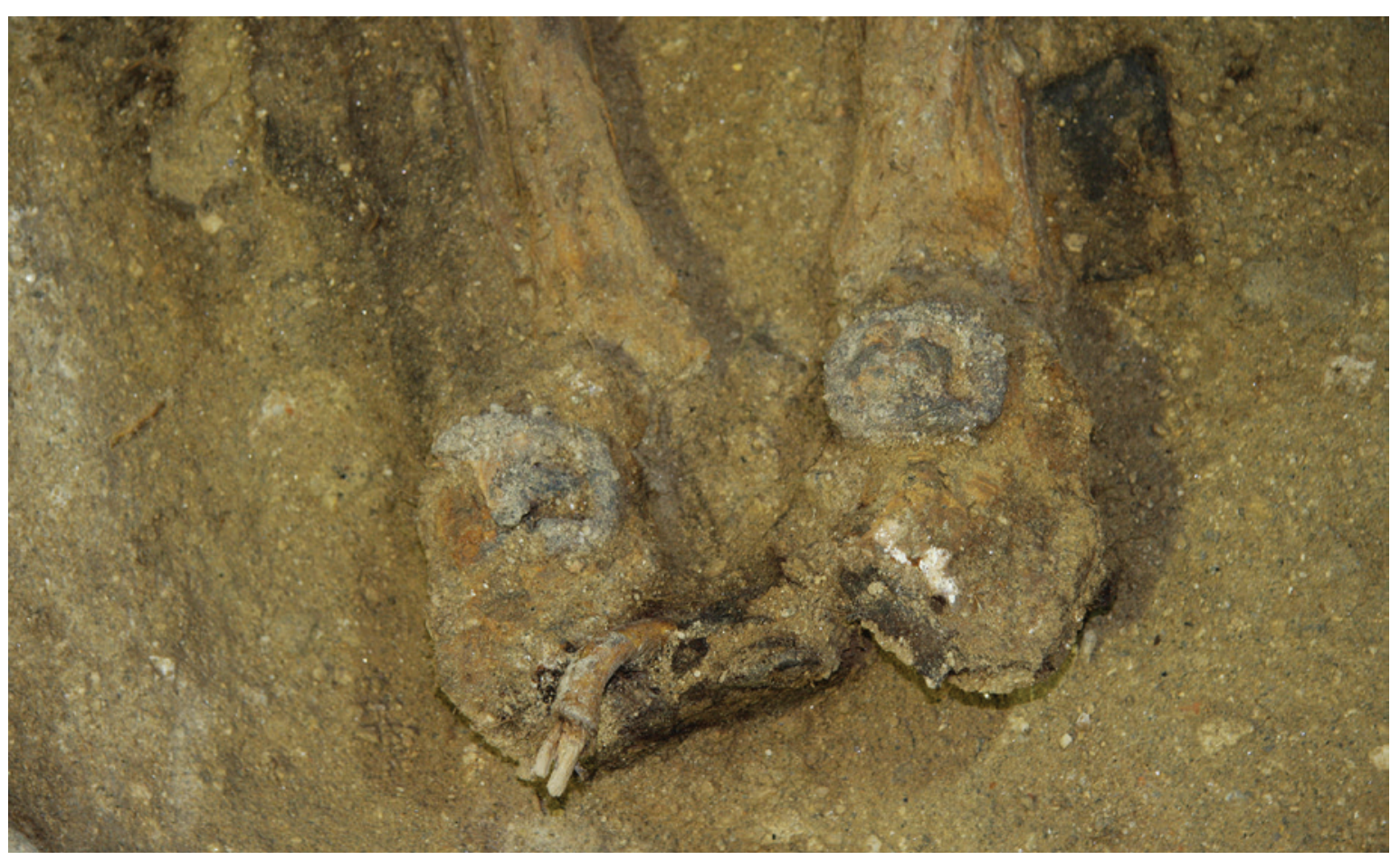

Figura 10 - Sapatos com fivelas, parte da indumentária do indivíduo inumado na sepultura 7. 


\title{
O CONVENTO DE NOSSA SENHORA DA ESPERANÇA DE PONTA DELGADA: O CONTRIBUTO DA ARQUEOLOGIA PARA O CONHECIMENTO DE UM MONUMENTO IDENTITÁRIO
}

\author{
João Gonçalves Araújo ${ }^{1}$, N’Zinga Oliveira²
}

\begin{abstract}
RESUMO
O convento Nossa Senhora da Esperança localiza-se na cidade de Ponta Delgada e assume-se como um dos principais conjuntos patrimoniais do arquipélago dos Açores. O espaço foi alvo de uma intervenção arqueológica entre 2015 e 2016 no âmbito de um projeto de restauro e reabilitação. Os resultados alcançados permitiram detetar diversas fases de ocupação entre os séculos XVI e XIX, particularmente intensas a partir da segunda metade do século XVII e inícios do século XVIII, época em que surge o culto do Senhor Santo Cristo dos Milagres. O convento de Nossa Senhora da Esperança foi um dos poucos que sobreviveu na ilha ao decreto de extinção das ordens religiosas, mantendo, em parte, a sua função original até à atualidade.

Palavras-chave: Arqueologia Moderna e da Expansão Portuguesa, Arqueologia Contemporânea, Convento de Nossa Senhora da Esperança, Ponta Delgada, Açores.
\end{abstract}

\begin{abstract}
The Nossa Senhora da Esperança convent located in Ponta Delgada city is one of the main cultural heritage sites of the Azores islands. An archaeological evaluation was carried between 2015 and 2016 as part of a project of restoration and rehabilitation. The results achieved allowed to disclose an occupation range between the $16^{\text {th }}$ and $19^{\text {th }}$ centuries, particularly intense from the second half of the $17^{\text {th }}$ and the beginning of the $18^{\text {th }}$ centuries, when the cult of Senhor Santo Cristo dos Milagres began. The convent of Nossa Senhora da Esperança was one of the few that survived on the island, after the decree of extinction of the religious orders, maintaining its original function until today.

Keywords: Modern Era Archaeology, Contemporary Archaeology, Convent of Nossa Senhora da Esperança, Ponta Delgada, Azores.
\end{abstract}

\section{INTRODUÇÃO}

O convento de Nossa Senhora da Esperança, monumento nacional desde 1953 (Decreto n.. 39 175, de 17 de abril de 1953), localiza-se na cidade de Ponta Delgada, ilha de São Miguel, arquipélago dos Açores (Figura 1). A intervenção arqueológica realizada neste convento foi requerida como medida de proteção e salvaguarda do património arqueológico pela Di- reção Regional da Cultura da Região Autónoma dos Açores, de acordo com a legislação em vigor, no seguimento do projeto: Convento de Nossa Senhora da Esperança - Conservação, Restauro e Reabilitação. A intervenção arqueológica decorreu entre 2015 e 2016, abrangendo as áreas em torno da capela do Senhor Santo Cristo dos Milagres e do coro-baixo, o claustro, a antiga cozinha conventual e o armazém, futuro centro de apoio aos peregrinos.

\footnotetext{
1. CHAM - Centro de Humanidades, FCSH/NOVA - UAc; araujo.jng@gmail.com

2. CHAM - Centro de Humanidades, FCSH/NOVA - UAc; nzinga.oliveira@gmail.com
} 


\section{ENQUADRAMENTO HISTÓRICO}

Os primeiros conventos de clarissas nos Açores datam do início do século XVI, multiplicando-se ao longo desse século e do seguinte, acompanhando a tendência geral do reino. A proliferação de casas religiosas reflete a estratégia familiar de concentração de bens em alguns descendentes, recorrendo ao enclausuramento de membros da família, sobretudo do sexo feminino (Costa, 2008, p. 188). No caso do convento de Nossa Senhora da Esperança de Ponta Delgada, essa estratégia é clara, acolhendo elementos femininos das elites da cidade e da ilha.

Para nos inteirarmos das circunstâncias que envolvem a sua fundação devemos recuar à fundação do convento de Nossa Senhora da Conceição de Vale de Cabaços, no início do século XVI. Devido à ameaça constante da pirataria, pelo facto de se localizar muito próximo do mar, o edifício acaba por ser abandonado, tendo uma parte das religiosas ido fundar o convento de Santo André, em 1533, em Vila Franca do Campo, e a outra o convento de Nossa Senhora da Esperança, em 1541, em Ponta Delgada. O antigo convento ficou desocupado desde então até 1663 , aquando da sua conversão em cenóbio masculino (Campos, 2017, p. 263).

Rui Gonçalves da Câmara, capitão do donatário da ilha de São Miguel, e sua mulher, D. Filipa Coutinho, patrocinaram a construção do convento de Nossa Senhora da Esperança, a primeira casa de clausura feminina de Ponta Delgada, em terrenos doados por Fernão de Quental e sua mulher na zona ocidental da cidade. A construção do convento inicia-se em 1535, ano em que faleceu o próprio capitão do donatário (Sousa, 1986, p.209), tendo ficado responsável pela continuação dos trabalhos sua mulher. A mudança das religiosas terá sido feita a 23 de abril de 1541, ou 1540 segundo Gaspar Frutuoso (201133 , p. 306).

Numa primeira fase, o convento terá sido relativamente modesto, constituído por pouco mais do que a igreja, um dormitório e o claustro. À época albergava apenas oito religiosas e quatro noviças (Monte Alverne, $1961^{2}$, p. 72) ascendendo a 25 religiosas e cinco noviças no final do século XVI (Frutuoso, 201133, p. 175). Para o início do século XVIII as fontes refletem o grande crescimento que o convento terá sofrido, contando já com 102 feiras professas em 1723 (Cordeiro, $\mathbf{2 0 0 7}^{2}$, p. 138). Tal impulso estará em parte relacionado com a crescente importância do culto do Senhor Santo Cristo dos Milagres, iniciado na viragem do século XVII para o XVIII (Ataíde, 2011, p. 10). Atualmente o convento constitui-se como um complexo arquitetónico de dimensões significativas, tendo-lhe sido acrescentado vários espaços e elementos arquitetónicos de relevo ao longo dos séculos, em linha com outros conventos femininos micaelenses (França, 2019).

\section{A INTERVENÇÃO ARQUEOLÓGICA}

A metodologia utilizada na intervenção arqueológica que abaixo descrevemos segue, no geral, as metodologias propostas por Edward Harris $\left(1989^{2}\right)$ e Philip A. Barker (19933), adaptadas ao sítio em questão e com a particularidade de se tratar não de uma escavação em área aberta (open area), mas sim da realização de várias sondagens arqueológicas em distintas áreas do espaço conventual, seguindo as diretivas da Direção Regional da Cultura dos Açores e do próprio projeto de restauro e reabilitação (Araújo e Oliveira, 2020). Iremo-nos debruçar neste artigo sobre os três setores intervencionados que nos forneceram dados arqueológicos de maior relevo. São eles: a capela do Senhor Santo Cristo e coro-baixo; o claustro; e a cozinha conventual.

\section{A CAPELA DO SENHOR SANTO CRISTO E CORO-BAIXO}

O coro-baixo constitui um dos mais importantes espaços do convento de Nossa Senhora da Esperança. Foi alvo de várias intervenções ao longo dos séculos, resultando num significativo enobrecimento artístico, recorrendo sobretudo à azulejaria portuguesa, destacando-se, para o efeito, os interessantes painéis setecentistas da autoria de Oliveira Bernardes (Simões, 1963, p. 104-108). O coro-baixo é indissociável da imagem do Senhor Santo Cristo dos Milagres e do incremento do seu culto, numa primeira fase no seio da comunidade religiosa, alastrando-se rapidamente à população em geral. A tradição refere que a imagem do Ecce Homo, conhecida por Senhor Santo Cristo dos Milagres, foi oferecida pelo Papa Paulo III aquando da atribuição da Bula concedida para a fundação do convento de Nossa Senhora da Conceição de Vale de Cabaços (Ataíde, 2011, p. 182). Esse relato é, contudo, pouco credível. Na verdade, salientamos, entre outras questões, o facto de alguns especialistas em arte sacra do período em questão datarem a imagem do início do século XVII, ou seja, 
cerca de 100 anos posterior à data de fundação do referido convento (apud Sá, 2017, p. 35).

A imagem terá estado na ermida de Nossa Senhora da Paz, no interior da cerca do convento, tendo passado depois, algures durante o século XVII, para um pequeno altar existente no coro-baixo (Moreira, 2000, p. 89). Teresa da Anunciada, uma religiosa que ingressou no convento na segunda metade do século XVII, tendo realizado os votos religiosos em 1682 (Ataíde, 2011, p. 194), é a grande responsável pelo início do culto, tendo sido ela a promotora de alguns melhoramentos no altar da imagem. É a partir de 169o, sob o patrocínio e proteção dos condes da Ribeira Grande, que a dedicação à imagem e enobrecimento da mesma se intensificam (Ataíde, 2011, p. 195-196).

Consequentemente, é construída a primeira capela do Senhor Santo Cristo, ao fundo do coro-baixo, entre 1697 e 1698 (Moreira, 200o, p. 89-93). Contudo, pouco tempo depois inicia-se a construção de uma nova capela, maior, concluída entre 1702 e 1703. Terá sido no período entre a construção da primeira e da segunda capela que se começou a realizar a procissão do Senhor Santo Cristo dos Milagres, algures entre 1698 e 1701 (Soares, 2018, p. 89). A atual capela do Senhor Santo Cristo dos Milagres data já do terceiro quartel do século XVIII, tendo sido concluída em 1771. A par da capela, foi criado um jardim a ela diretamente associado, a sul, como forma de garantir um fornecimento constante de flores.

\subsection{Sondagens arqueológicas}

Neste setor foram realizadas nove sondagens arqueológicas. As sondagens permitiram-nos conhecer as dinâmicas de ocupação de toda a área intervencionada, revelando distintas fases de ocupação, grosso modo entre a segunda metade do século XVI e a atualidade. Destacaram-se duas sondagens pelos contextos arqueológicos nelas identificados, as sondagens O2 e 07. As restantes revelaram-se pouco esclarecedoras para as fases de ocupação mais antigas (séculos XVI-XVIII), embora nos tenham fornecido interessantes dados para a ocupação dos espaços exteriores contíguos ao coro-baixo e à capela para cronologias posteriores à segunda metade do século XVIII.

As sondagens em questão demonstram realidades muito semelhantes, quer do ponto de vista estratigráfico, quer do ponto de vista cronológico. Ambas foram implantadas na área central da capela, uma no lado norte (sondagem o2) e a outra no lado sul (sondagem 07), com o objetivo de se obter informação relativa às fundações da estrutura. Desse modo, expuseram-se as fundações da capela e da sacristia a ela anexa, a poente, revelando alicerces constituídos por pedras irregulares de média e grande dimensão, sem argamassa ligante, atingindo profundidades de cerca de $1,20 \mathrm{~m}$.

Os níveis superficiais adjacentes apresentaram, em ambos os casos, características típicas de contextos de jardim, no que concerne aos sedimentos e tipo de artefactos neles existentes. São níveis constituídos por sedimento de grão médio, pouco compactos e com tonalidades que variam entre o castanho-médio e o castanho-escuro, apresentando-se ricos em raízes de plantas. O espólio arqueológico recolhido resume-se a elementos osteológicos de origem animal e algum espólio cerâmico, em ambos os casos com elevados graus de fragmentação. Nesses níveis superficiais, os materiais dos séculos XIX e XX, mais abundantes, encontravam-se lado a lado com materiais dos séculos XVI, XVII e XVIII.

Sob esses níveis de jardim foram identificadas duas grandes estruturas negativas preenchidas por níveis sedimentares de origem antrópica, dos quais foi recolhido abundante espólio arqueológico. Esses níveis caracterizam-se por apresentarem sedimentos de grão médio a grosseiro, pouco compactos, com tonalidades dentro da gama dos castanhos-escuros. Apresentavam alguns vestígios de materiais de construção, nomeadamente fragmentos de telhas, argamassas, rebocos e alguns nódulos de cal. Ambas as bolsas foram escavadas nos níveis geológicos e serviram como lixeiras do convento numa área que, até então, aparenta ter sido utilizada como área de deposição de resíduos. É nessa lógica que se justifica a existência de um extenso espólio cerâmico, assim como abundantes vestígios osteológicos de origem animal, resultantes do consumo alimentar. A utilização desta área do convento como lixeira terá sido interrompida pela construção da capela, resultando numa expectável dignificação do espaço exterior circundante.

Dos materiais exumados desses níveis destacamos algumas peças completas e outras que, estando fragmentadas, permitiram uma reconstituição quase integral. Os materiais arqueológicos, especialmente os cerâmicos, apontam para uma cronologia entre a segunda metade do século XVII e inícios do século XVIII. Destaca-se a cerâmica comum de origem lo$\mathrm{cal} /$ regional, nomeadamente as formas de cozinha como as panelas (Figura 2, n.ำ1 a 6) e os alguidares. É 
também de destacar alguma loiça de mesa, sobretudo púcaros (Figura 3, n.․․ a 7), tacinhas e pratinhos/ especieiros (Araújo \& Oliveira, 2017, p. 91-92), e formas de armazenamento e transporte, nomeadamente uma botija decorada com linhas onduladas incisas. A presença de cerâmica comum importada do reino e de cerâmica vidrada é pouco significativa, atingindo valores em torno dos $4,5 \%$ e $7,5 \%$.

A faiança portuguesa recolhida nesses contextos revelou-se particularmente importante para a atribuição cronológica, constituindo percentagens mais significativas, entre os $9,5 \%$ e os $17,5 \%$. Destacamos algumas peças com decoração a azul-cobalto sobre esmalte branco, como é o caso de um prato com aranhões, uma tigela decorada com o motivo da Espada-Cruz da Ordem de Santiago e outras duas tigelas decoradas com o tema semicírculos concêntricos. Mais frequentes são as peças com pintura a azul-cobalto e vinoso (óxido de manganês), nomeadamente um prato com contas e motivos fitomórficos (Figura 4), um prato com o tema pêssegos e fitomórficos, um prato decorado com um brasão associável à família Silva ou Bettencourt na superfície interna do fundo e um prato com decoração epigráfica a manganês na superfície interna da peça. Recolheu-se também uma tigela de faiança totalmente branca que se inclui nas produções mais tardias de faiança portuguesa, devendo corresponder a um exemplar do final do século XVII ou inícios do XVIII (Casimiro, 2013, p. 362-366) (Fig. 343). Todos esses elementos apontam para um horizonte cronológico comum, situado na segunda metade do século XVII, podendo, em alguns casos, alargar-se até ao final desse século e início do XVIII.

Foram também recolhidos alguns exemplares de produções de azul sobre azul. Um dos exemplares aparenta corresponder às produções sevilhanas, com paralelos registados nos açores datados do século XVII (Bettencourt et alii, 2013, p. 35). Contudo, não colocamos de parte a possibilidade de se tratar de uma produção italiana, veneziana ou lígure, ou mesmo lisboeta (Cardoso \& Batalha, 2017, p. 150-155). Destacamos ainda dois fragmentos de faiança azul sobre azul de provável origem norte europeia, inglesa ou holandesa, datável da segunda metade do XVII e primeira metade do XVIII (Ferreira, Machado \& Casimiro, 2017). Foi também recolhido um fragmento de porcelana chinesa decorado na superfície externa com motivos vegetalistas e pêssegos a azul-cobalto sobre esmalte branco brilhante. $\mathrm{O}$ frag- mento é pequeno e por isso de difícil atribuição cronológica, mas deverá corresponder a produções da segunda metade do século XVI ou da primeira metade do século XVII (Pinto Coelho, 2008, p. 102-110).

Além da cerâmica utilitária foi recolhido um fragmento de azulejo com pintura a azul e amarelo sobre esmalte branco, correspondente a um azulejo de friso do tipo $\mathrm{F}_{2}$ da tipologia de azulejos portugueses registados nos Açores e na Madeira por João Miguel dos Santos Simões (1963, p. 74). Destacamos, por fim, alguns elementos metálicos de interesse, nomeadamente uma chave de ferro e um anel em liga de cobre que, a nosso ver, poderia ter sido originalmente de bronze dourado, apresentando vestígios de ter possuído uma pedra no topo (Figura 5).

\section{CLAUSTRO CONVENTUAL}

O claustro assume-se como um dos mais característicos elementos do convento, organizando topograficamente os seus outros espaços. O atual claustro, pela sua tipologia e elementos arquitetónicos, deverá datar do século XVIII, embora a sua origem remonte à fase inicial do convento (século XVI). Trata-se de um claustro com fachadas de três pisos separados por cornija. O piso térreo apresenta arcadas de arcos abatidos em cada ala, com pavimento de lajes e cobertura em falsa abóbada de arestas. Os vãos são retilíneos ou abatidos e as molduras terminadas em cornija contracurvada. O segundo e terceiro andares apresentam janelas de sacada, com moldura em cantaria encimada por friso e cornija contracurvada. Nas alas nascente e poente o terceiro andar encontra-se recuado, criando uma varanda protegida por guarda de balaustrada em cantaria. O pavimento da área central do claustro apresenta-se revestido por lajes em rocha vulcânica (ignimbrito), quadrangulares e retangulares. Ao centro existe um chafariz com tanque de planta circular. Em anteriores obras, realizadas em data incerta, foi recuperada uma pia esculpida em pedra vulcânica, com a seguinte inscrição: "MANDOV F / AZER ES / TA OBRA / A SORA / DONA / FELIP / COUT /... A...". Esta pia é, portanto, associável à fundadora da casa religiosa, encontrando-se exposta atualmente no pequeno núcleo museológico existente na antiga cozinha conventual.

\subsection{Sondagens arqueológicas}

Neste setor foram realizadas três sondagens arqueo- 
lógicas, todas elas na metade poente do claustro. As sondagens permitiram-nos conhecer as dinâmicas de ocupação da área intervencionada, confirmando-se distintas fases de ocupação deste espaço, grosso modo entre meados do século XVI e a atualidade. Dos elementos estratigráficos identificados destacamos os que se relacionavam com a própria estrutura do claustro, nomeadamente as fundações e respetivos reforços estruturais. Outros elementos dignos de realce são as condutas de água e canalizações, em pedra ou cerâmica, desativadas ou ainda em utilização. Os níveis arqueológicos podem ser agrupados pela sua natureza e cronologia. Os superficiais relacionam-se, naturalmente, com o atual pavimento do claustro, sendo muito provável que anteriormente tenham existido outros pisos. Sob esses níveis identificaram-se outros correspondentes a aterros realizados ao longo dos séculos XVII e XVIII. Foram ainda identificados vestígios dos níveis arqueológicos mais antigos que remontaram ao século XVI e inícios do XVII, assumindo-se como os níveis mais antigos identificados durante toda a intervenção arqueológica.

Na sondagem or do claustro destacamos a existência de duas condutas de água. Uma delas datará do século XVIII, ou mesmo já do XIX, construída em argamassa de terra e pedra miúda e coberta por lajes retangulares. Esta conduta sobrepõe-se a uma canalização em cerâmica, anterior, envolta em argamassa de cal e areia grosseira, que se desenvolve no sentido sudoeste/nordeste, encontrando-se interrompida na zona central da sondagem. Esta conduta deverá ser uma das mais antigas na medida em que a ela encontrava-se associado um nível arqueológico com materiais que apontam para uma cronologia em torno do século XVI ou inícios do XVII.

Destacamos também a identificação de uma estrutura negativa escavada no nível geológico, preenchida por um nível de sedimento de grão fino, pouco compacto e escuro. Os materiais arqueológicos apontam para uma cronologia que andará em torno de meados do século XVII.

Do espólio arqueológico recolhido, salientamos um fragmento de bordo de botija correspondente a uma produção andaluza cronologicamente atribuível aos séculos XVI a XVIII (Gutiérrez, 200o, p. 58-60) e dois fragmentos de loiça importada do reino, nomeadamente um fragmento de alguidar e outro de púcaro com origem provável na região de Aveiro (Carvalho \& Bettencourt, 2012, p. 736-739). Salien- tamos ainda um fragmento de faiança portuguesa a azul e branco com decoração geométrica, datável da primeira metade do século XVII, e um fragmento de porcelana chinesa, com decoração vegetalista a azul-cobalto sobre esmalte branco brilhante.

Contudo, ao analisarmos o espólio proveniente deste contexto, o tipo de material que mais se destaca é o vidro. Foram recolhidos vários gargalos e bordos de garrafas, frascos e taças, bem como de várias outras formas não identificadas. $O$ facto da maioria do vidro ser fino resultou num elevado grau de fragmentação dos materiais, facto esse que dificultou a identificação de várias formas. O vidro identificado apresenta várias colorações, variando entre o negro, o verde-garrafa, o verde-água, o azul-claro, o azul-escuro, o cinzento e o melado. Do mesmo modo, a decoração identificada é diversa, variando entre a pintura, a branco ou policroma e a modelagem.

$\mathrm{Na}$ sondagem $\mathrm{o} 2$ do claustro destacamos a identificação de outra conduta de água que liga a caleira perimetral do claustro à sua área central. Esta conduta é constituída por uma estrutura de pedra irregular coberta por lajes retangulares ligadas por argamassa de terra e cal. Cronologicamente deverá datar do século XVIII, possivelmente contemporânea da grande campanha de obras que conferiram ao claustro o seu aspeto atual. Além dessa conduta foi identificada uma outra mais antiga, desativada aquando da construção daquela, constituída por telhas de meia cana sobrepostas. Os materiais a ela associados apontam para uma cronologia anterior, em torno do século XVII.

Em relação aos níveis sedimentares identificados, destacamos um que deverá remontar ao século XVII, e um conjunto de estratos que preenchem uma grande estrutura negativa escavada nos níveis geológicos e que deverá datar da segunda metade do século XVII e inícios do XVIII.

Quanto ao espólio arqueológico recolhido, embora não tenhamos identificado um contexto estratigráfico preservado do século XVI, recolhemos alguns materiais que remontam à fase inicial de ocupação do convento, destacando, a título de exemplo, um fragmento de cerâmica vidrada correspondente às séries meladas de Sevilha datadas de finais do século XV e primeira metade do século XVI (Gutiérrez, 200o, p.51). Com efeito, o contexto mais antigo preservado nessa sondagem data já de meados do século XVII. Desse contexto, destacamos alguns exemplares de cerâmica comum de produção local/regional, 
concretamente um alguidar e alguns fragmentos de formas de mesa como bilhas e púcaros (Figura 3, n.․ 1). Destacamos também alguns fragmentos de alguidares vidrados a verde de provável origem sevilhana, muito característicos dos séculos XVI e XVII. Ainda dentro das produções espanholas, recolheu-se um fragmento de tigela/escudela que se insere no grupo de reflexos metálicos valencianos. A pequena dimensão do fragmento não permite uma atribuição tipológica e cronológica mais precisa, contudo parece corresponder a uma produção valenciana tardia datada dos séculos XVI ou XVII (Gutiérrez, 200o, p. 28-34).

Destacamos ainda um pequeno fragmento correspondente a uma produção marmoreada de Pisa (Itália) e dois fragmentos de porcelana chinesa com decoração vegetalista a azul-cobalto intenso sobre esmalte branco brilhante, possivelmente correspondentes a produções da segunda metade do século XVI e primeira metade do século XVII.

A sondagem 03 do claustro foi implantada na área central, próxima do chafariz. Nesta sondagem foi possível reconhecer-se a continuação da conduta de água setecentista identificada na sondagem o2, constatando-se que a mesma muda de direção, para sul, voltando a mudar de direção, para este. Julgamos que a estrutura estará ligada a um sumidouro que sabemos existir a sul do chafariz do claustro. O trajeto da conduta evidencia a intenção de contornar o chafariz, pelo que se conclui que este elemento remonta pelo menos à data de construção da conduta. Identificaram-se também vestígios da canalização de cerâmica assente em argamassa de cal e areia correspondente à continuação da canalização identificada na sondagem or do claustro.

Além dessas estruturas identificaram-se vários níveis estratigráficos reveladores de um assinalável dinamismo no que respeita às intervenções operadas neste setor. Os níveis a cotas inferiores correspondem a depósitos de sedimentos no interior da grande vala aberta na zona central do claustro. Estes níveis são estratigraficamente estanques, apontando para cronologias em torno do século XVII e inícios do XVIII.

A sondagem 03 do claustro destaca-se por ser a que forneceu a maior quantidade de material arqueológico. Para contextos do século XVIII, destacamos a base de um castiçal produzido em cerâmica comum local/regional, almagrada e com decoração incisa. Identificou-se também uma porção de uma forma fechada, possivelmente um pote, com a superfície esmaltada a branco e pintada a azul-cobalto. Aparenta tratar-se de uma produção holandesa, na qual consta a representação de um indivíduo do sexo masculino com indumentária típica da época a fumar cachimbo (Figura 7). Foi ainda identificado o bordo de um prato de faiança industrial inglesa que se inclui no tipo creamware. Outra peça que se destaca no conjunto é um prato em porcelana chinesa oriundo da província de Fuijan, no sul da China. Estas produções eram concebidas para o mercado interno chinês e caracterizam-se por serem decoradas na superfície interna da peça com traços vigorosos. O exemplar em questão apresenta a cena de um dragão a perseguir uma pérola em chamas, com um paralelo em território português datado de meados do século XVIII (Henriques, 2012, p. 930).

Os níveis arqueológicos existentes na base da grande vala correspondem a depósitos sucessivos de sedimentos e materiais arqueológicos, existindo a possibilidade de estarmos perante um fenómeno de estratigrafia invertida. Com efeito, os níveis superiores apresentam materiais arqueológicos cuja cronologia aponta, grosso modo, para o século XVII, enquanto os níveis inferiores aparentam datar da segunda metade do século XVII, ou até mesmo inícios do século XVIII. Consideramos esses intervalos temporais pouco expressivos na sua diferença, contudo não deixa de ser curioso constatar tal facto. Julgamos ser possível que tais níveis resultem de deposições de sedimento e materiais provavelmente oriundas de outras áreas do convento, com o objetivo de preencher a vala de modo a que sobre ela fosse possível construir-se a conduta de água central do claustro.

No que concerne aos tipos de cerâmica identificados nestes contextos mais antigos, a maioria corresponde, novamente, a cerâmica comum de produção local/regional, sendo as percentagens de cerâmica comum importada e cerâmica vidrada francamente minoritárias. Por sua vez, as faianças correspondem a cerca de $12,5 \%$ do total da cerâmica, destacando-se, sem surpresas, as produções portuguesas.

A título de exemplo destacamos um pote modelado de produção local/regional, um fragmento de tigela correspondente às produções de Montemor-o-Novo (Casimiro \& Newstead, 2019, p. 148), uma tigela em cerâmica comum importada correspondente ao tipo 1A das produções de Aveiro (Carvalho \& Bettencourt, 2012, p. 737), uma forma fechada vidrada a laranja na superfície interna da peça e verde 
na superfície externa, com paralelos em Lisboa (Torres, 2011, p. 235) e um fragmento de um recipiente de cerâmica fina modelada, com pequena asa, correspondente a uma produção de Lisboa (Bugalhão \& Pinto Coelho, 2017, p. 110).

Destacamos também três peças de origem europeia, concretamente uma taça de faiança azul sobre azul de provável origem sevilhana (Gutiérrez, 200o, p. 53-58), uma tigela/escudela correspondente às séries sevilhanas de azul linear, datadas dos séculos XVI e XVII (Gutiérrez, 2000, p. 53-58), e um fragmento de aba de um prato que deverá corresponder a uma produção italiana de sgraffito. Foi também recolhido o fundo de um prato de porcelana chinesa com representação de motivos geométricos e uma camélia, a azul e branco, devendo corresponder a uma produção de kraak-porcelain, datável do período Ming final ou Wanli (Pinto Coelho, 2008, p.117). Foram ainda recolhidos alguns alfinetes de cabeça em bronze/liga de cobre. Esse tipo de alfinetes era utilizado como elemento funcional na fixação dos tecidos utilizados como vestimentas. Contudo, énecessário referir que esse tipo de alfinetes surge igualmente, e em abundância, em contextos funerários, geralmente associados à fixação das mortalhas.

\subsection{A cozinha conventual}

A cozinha contemporânea da fase fundacional do convento, a julgar pela estrutura arquitetónica existente, localizar-se-ia na ala poente do claustro e o refeitório, quase sempre a ela associado, situar-se-ia provavelmente na ala norte do claustro, permitindo, dessa forma, a comunicação com o mesmo (Soares, 2018, p. 64). A atual cozinha conventual, mais recente, foi construída entre 1826 e 1828 . Trata-se de uma divisão ampla e excêntrica em relação ao resto do corpo edificado do convento, com um forno central, relativamente exíguo, e uma chaminé de grandes dimensões, com dois contrafortes a norte, apresentando uma epígrafe com a data de 1828 , referindo-se ao ano da sua conclusão.

\subsection{Sondagens arqueológicas}

As três sondagens arqueológicas realizadas neste setor foram implantadas ao longo dos lados sul e poente da cozinha. As sondagens or e o2 abrangeram a área exterior a poente e revelaram realidades arqueológicos relativamente simples. Foram identificados níveis que, na melhor das hipóteses, remontam à data de construção desse equipamento conventual, não tendo fornecido espólio arqueológico digno de destaque. Vale a pena apenas ressalvar a identificação de várias estruturas subterrâneas de condução de águas, pluviais e residuais, que se relacionam diretamente com a cozinha e que conduziriam as águas para estruturas subterrâneas existentes na área exterior do convento. Uma ocupação prévia dessa área da cerca conventual é provável, certamente numa lógica agrícola, embora os vestígios materiais anteriores ao século XIX sejam residuais.

Destaca-se, porém, a sondagem 03, implantada no exterior do lado sul da cozinha. Tal como nas outras sondagens deste setor, identificou-se uma conduta de água subterrânea bem como elementos diretamente a ela associados, concretamente um sumidouro. Esse sumidouro apresenta claras semelhanças com as estruturas do género identificadas noutras áreas do convento, remontando, muito provavelmente, ao final do século XVIII ou inícios do século XIX. Identificaram-se também vestígios de antigos pisos relacionados já com a conversão desse espaço exterior em jardim, concretamente um pavimento de seixos rolados e vestígios de um outro piso anterior, constituído por bagacina vermelha. Os restantes níveis arqueológicos, por sua vez, caracterizam-se por terem sido alvo de revolvimento e contaminação por intervenções posteriores, embora com distintos graus de afetação. Destacamos alguns contextos estratigráficos cuja cronologia aponta já para a segunda metade do século XVIII e primeira metade do século XIX e um outro, testemunho da ocupação mais antiga registada nesta sondagem, cronologicamente enquadrável entre a segunda metade do século XVII e inícios do século XVIII.

Dos contextos da segunda metade do século XVIII e primeira metade do século XIX destacamos algumas peças de produção local/ regional, concretamente um alguidar de grandes dimensões, uma bilha e uma garrafa. Foi também identificado nestes contextos um fragmento de haste de cachimbo de caulino. Em relação ao nível mais antigo, registamos a identificação de um fragmento de uma produção exógena, que julgamos poder ser de origem italiana, com pintura a óxido de manganês (castanho) sobre esmalte azul-turquesa, datável do século XVII.

\section{CONCLUSÕES}

O convento de Nossa Senhora da Esperança, pelo seu elevado valor artístico e patrimonial, material 
e imaterial, assume-se como um conjunto cultural único no panorama regional Açoriano. A intervenção arqueológica em questão veio confirmar a excecionalidade desse monumento, habitado ininterruptamente desde o século XVI.

O sector da capela do Senhor Santo Cristo e coro-baixo permitiu-nos conhecer as diferentes fases de ocupação desta área, tendo sido possível conhecer-se em grande medida a sua interessante dinâmica de utilização, particularmente intensa durante a segunda metade do século XVII e início do século XVIII como área de depósito de resíduos conventuais. Igualmente interessante foi também percecionar a dignificação de toda essa área após a construção das primeiras capelas do Senhor Santo Cristo dos milagres. O setor do claustro conventual revelou-nos, igualmente, realidades particularmente ricas e elucidativas dos quotidianos conventuais, tendo sido nele identificados os contextos arqueológicos mais antigos. Também neste setor ficou claro que a partir de meados do século XVII se assiste a um intenso incremento no registo arqueológico, sendo um interessante indicador do crescimento significativo da população do convento durante esse período. Os materiais arqueológicos recolhidos nesses estratos são suficientemente representativos da riqueza das elites sociais micaelenses em época moderna, tendo sido recolhidos neles fragmentos com as mais diversas origens geográficas. O sector da cozinha conventual, por sua vez, não revelando realidades tão impactantes como os dois sectores anteriormente descritos, acabou por nos fornecer dados pertinente sobre os quotidianos de finais de setecentos e inícios de oitocentos.

O convento de Nossa Senhora da Esperança terá sido um convento importante desde a sua origem. Contudo, é na transição do século XVII para o XVIII que se verifica um crescimento exponencial da sua importância e influência na vida espiritual e secular da ilha. A evolução do espaço construído, bem como o progressivo enobrecimento artístico que se verifica ao longo do século XVIII são sinais dessa crescente importância, com reflexos claros no registo arqueológico.

\section{BIBLIOGRAFIA}

ARAÚJO, João Gonçalves; OLIVEIRA, N’Zinga (2020) Convento de Nossa Senhora da Esperança - Ponta Delgada: sondagens arqueológicos de diagnóstico da campanha de 2015-2016. Ponta Delgada: Texto policopiado.

ARAÚJO, João Gonçalves; OLIVEIRA, N'Zinga (2017) Fragmentos do quotidiano conventual: o contributo do espólio arqueológico do convento de Nossa Senhora da Esperança (séculos XVI-XIX). In CHAVES, Duarte Nuno, ed. - Açores e Madeira: percursos de memória e identidade. Velas: CHAM - Centro de Humanidades, Santa Casa da Misericórdia das Velas, pp. 85-103.

ATAÍDE, Luís Bernardo leite de (2011) - Etnografia, Arte e Vida Antiga nos Açores. Volume I. Edição Facsimile. Presidência do Governo e Direção Regional da Cultura.

BARKER, Philip (1993) - Thecniques of Archaeological Excavation. $3^{\mathrm{a}}$ Edição. Taylor and Francis Routledge.

BETTENCOURT, José António; DÂMASO, Carla; PORTEIRO, Filipe; BRUNO, Jorge Paulus (2013) - Histórias que vêm do Mar. Angra do Heroísmo: Secretaria Regional da Educação, Ciência e Cultura, Direção Regional da Cultura, Museu de Angra do Heroísmo, Observatório do Mar dos Açores; Centro de História de Além Mar.

BUGALHÃO, Jacinta; PINTO COELHO, Inês (2017) - Cerâmica moderna de Lisboa: proposta tipológica. In CAESSA, Ana, et alii - I Encontro de Arqueologia de Lisboa: Uma Cidade em Escavação. Lisboa: Centro de Arqueologia de Lisboa, Departamento de Património Cultural, Direção Municipal de Cultura, Câmara Municipal de Lisboa, pp. 107-145.

CAMPOS, Fátima. (2017) - A Ordem das Ordens Religiosas: Roteiro Identitário de Portugal (séculos XII-XVIII). Caleidoscópio.

CARDOSO, Guilherme; BATALHA, Luísa (2017) - Evidências de produção oleira dos finais do século XVI a meados do século XVII no largo de Jesus (Lisboa). In CAESSA, Ana et alii eds. - I Encontro de Arqueologia de Lisboa: Uma Cidade em Escavação. Lisboa: Centro de Arqueologia de Lisboa, Departamento de Património Cultural, Direção Municipal de Cultura, Câmara Municipal de Lisboa, pp. 147-181.

CARVALHO, Patrícia; BETTENCOURT, José António (2012) - De Aveiro para as margens do Atlântico: a carga do navio Ria de Aveiro e a circulação de cerâmica na Época Moderna. In TEIXEIRA, André; BETTENCOURT, José António, eds. - Velhos e Novos Mundos. Estudos de Arqueologia Moderna. Volume 2. Lisboa: CHAM - Centro de História de Além Mar, pp. 733-746.

CASIMIRO, Tânia Manuel; NEWSTEAD, Sarah (2019) 400 years of water consumption: Early Modern pottery cups in Portugal. In Ophiussa. Volume 3. Lisboa: UNIARQ-Centro de Arqueologia da Universidade de Lisboa, pp. 145-153. 
CASIMIRO, T. (2013) - Faiança portuguesa: datação e evolução crono-estilística. Revista Portuguesa de Arqueologia. Vol. 16. Lisboa, pp. 351-367.

CORDEIRO, António. (2007) - História Insulana das Ihas a Portugal Sugeytas no Oceano Occidental. $2^{2}$ edição facsimilada. Presidência do Governo Regional dos Açores; Direção Regional da Cultura.

COSTA, Susana Goulart. (2008) - A Igreja: implantação, práticas e resultados. In TEODORO DE MATOS, Artur; MENESES, Avelino de Freitas de; REIS LEITE, José Guilherme, eds. - História dos Açores. Do Descobrimento ao século XX. Volume I. Angra do Heroísmo: Instituto Açoriano de Cultura. pp. 173-198.

Decreto n.ำ 39 175, de 17 de Abril de 1953. Diário do Governo - 1 Série-Número 77. Presidência do Conselho de Ministros. Lisboa.

FERREIRA, Luís Filipe Vieira; MACHADO, Isabel Ferreira; CASIMORO, Tânia Manuel (2017) - Cerâmica portuguesa azul sobre azul - séculos XVI e XVII. In ARNAUD, José Morais; MARTINS, Andrea eds. - Arqueologia em Portugal: 2017 - O Estado da Questão. Lisboa: Associação dos Arqueólogos Portugueses, pp. 1863-1872.

FRANÇA, Igor (2019) - Os mosteiros femininos micaelenses e a tipologia arquitetónica do torreão mirante. In CHAVES, Duarte Nuno, eds. - Memória e Identidade Insular. Religiosidade, Festividades e Turismo nos Arquipélagos da Madeira e Açores. Velas: CHAM - Centro de Humanidades; Santa Casa da Misericórdia das Velas. pp. 397-410.

FRUTUOSO, Gaspar (2011) - Saudades da Terra - Livro IV. Terceira tiragem. Ponta Delgada: Instituto Cultural de Ponta Delgada.

GUTIÉRREZ, Alejandra (200o) - Mediterranean Pottery in Wessex Households (13 $3^{\text {th }}$ to $17^{\text {th }}$ centuries). BAR British Series 306. Oxford: Hadrian Books

HARRIS, Edward (1989) - Principles of archaeological stratigraphy. 2를 Edição. Londres: Academic Press.

HENRIQUES, José Pedro (2012) - Do oriente para ocidente: contributo para o conhecimento da porcelana chinesa nos quotidianos de época moderna. Estudo de três contextos arqueológicos de Lisboa. In TEIXEIRA, André; BETTENCOURT, José António, eds. - Velhos e Novos Mundos. Estudos de Arqueologia Moderna. Volume 2. Lisboa: CHAM, pp. 919-932.

MONTE ALVERNE, Agostinho. (1961) - Crónicas da Província de S. João Evangelista das ilhas do Açores. $2^{2}$ Edição. Volume II. Ponta Delgada: Instituto Cultural de Ponta Delgada.

MOREIRA, Hugo (200o) - o Convento de Nossa Senhora da Esperança. Imagem e culto do Senhor Santo Cristo dos Milagres. Ponta Delgada: Irmandade do Senhor Santo Cristo dos Milagres.
PINTO COELHO, Inês (2008) - A Cerâmica Oriental da Carreira da Índia no contexto da carga de uma nau - a presumível Nossa Senhora dos Mártires. Tese de Mestrado em Arqueologia apresentada à Faculdade de Ciências Sociais e Humanas da Universidade Nova de Lisboa. Lisboa: Texto policopiado.

SÁ, Daniel de (2017) - O Senhor Santo Cristo dos Milagres e o seu Culto. In MELO, Pedro Pascoal de, ed. - O Património Perto de Si: Entre o passado e o presente. Ponta Delgada: CRESAÇOR, pp. 34-35.

SIMÕES, João Miguel dos Santos (1963) - Azulejaria portuguesa nos Açores e na Madeira. Lisboa: Fundação Calouste Gulbenkian.

SOARES, Hélio (2018) - O Mosteiro de Nossa Senhora da Esperança de Ponta Delgada: uma proposta de valorização patrimonial em diálogo com a comunidade. Tese de Mestrado em Património, Museologia e Desenvolvimento apresentada ao Departamento de História, Filosofia e Artes da Faculdade de Ciências Sociais e Humanas da Universidade dos Açores. Ponta Delgada: Texto policopiado.

SOUSA, Nestor (1986) - A Arquitetura Religiosa de Ponta Delgada nos séculos XVI a XVIII. Ponta Delgada: Universidade dos Açores.

TORRES, Joana Bento (2011) - Quotidianos do convento de São Francisco: uma análise à cerâmica vidrada, faiança portuguesa e porcelana chinesa. Tese de Mestrado em Arqueologia apresentada à Faculdade de Ciências Sociais e Humanas da Universidade Nova de Lisboa. Lisboa: Texto policopiado. 


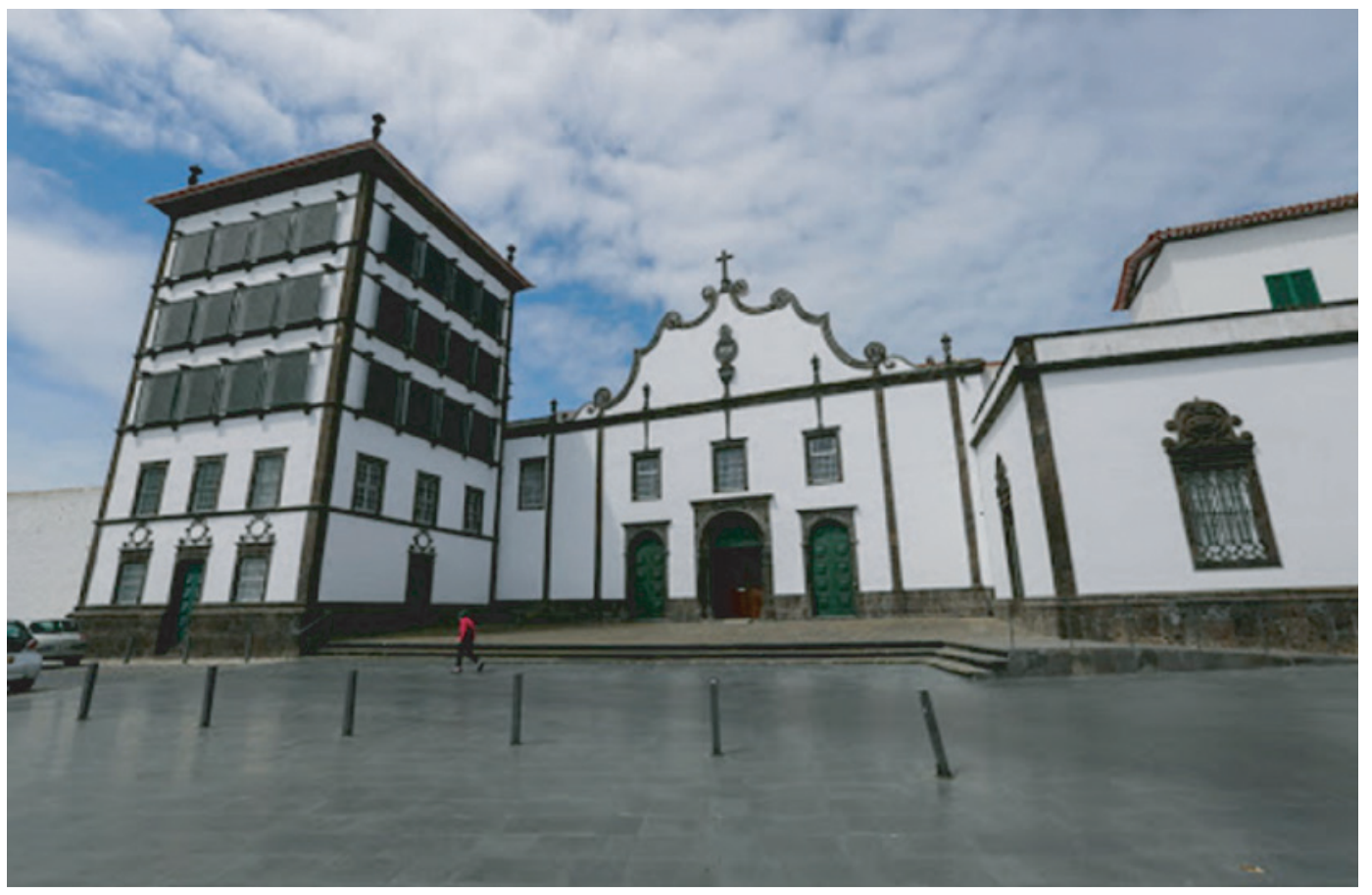

Figura 1 - Convento de Nossa Senhora da Esperança, em Ponta Delgada.

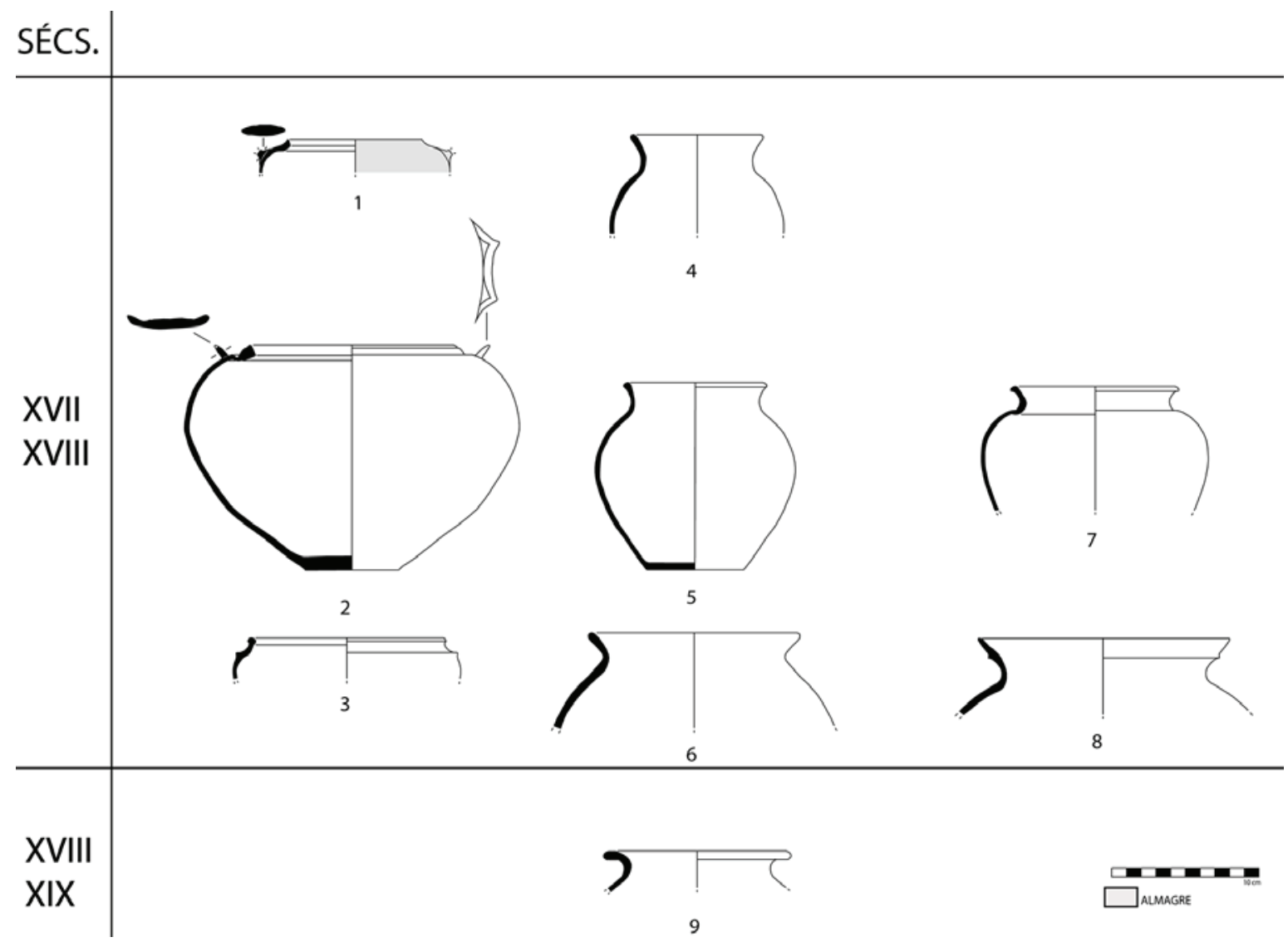

Figura 2-Panelas de fabrico local/regional identificadas no convento de Nossa Senhora da Esperança (sécs. XVII-XIX). 
SÉCS.

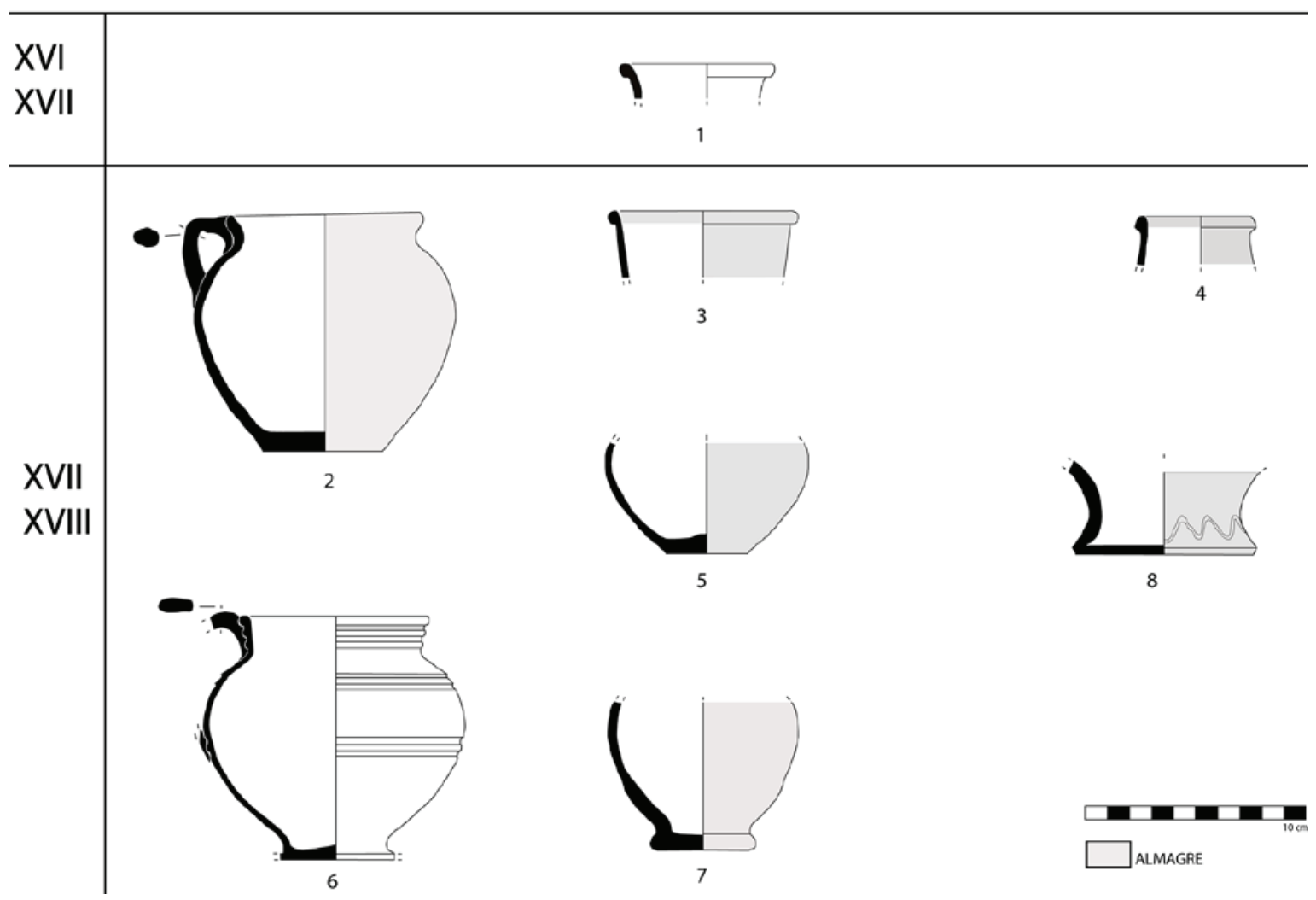

Figura 3-Púcaros de fabrico local/regional identificados no convento de Nossa Senhora da Esperança (sécs. XVI-XVIII).

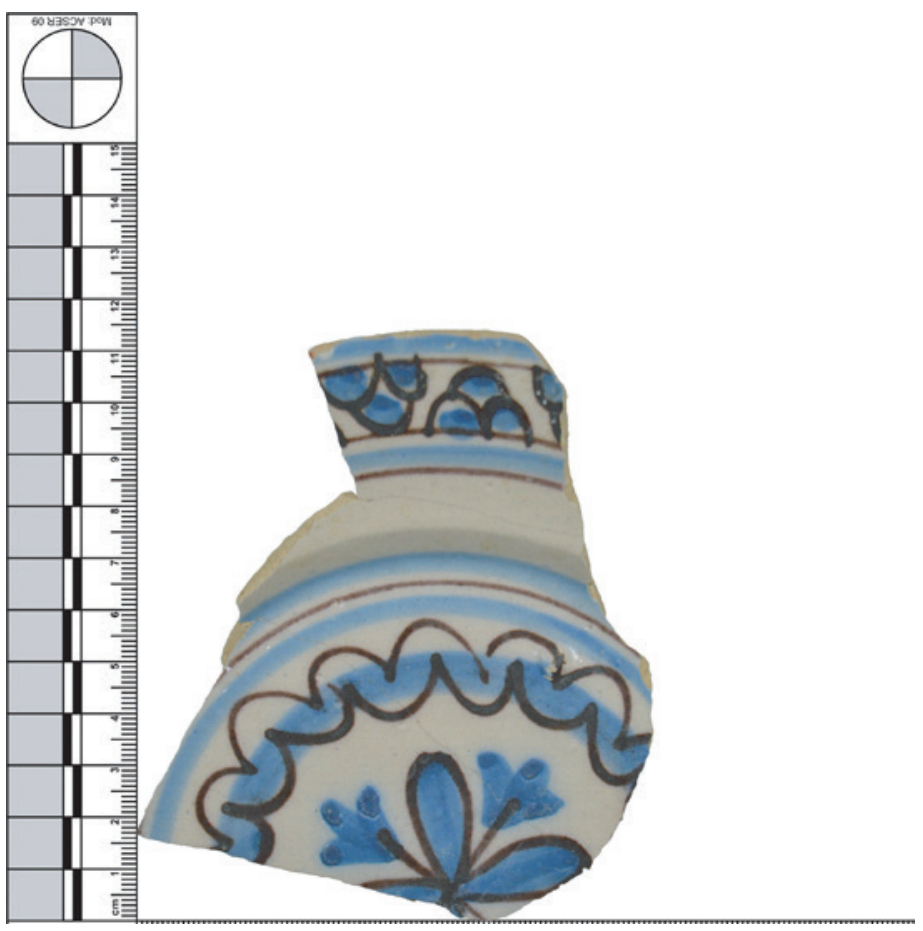

Figura 4 - Prato de faiança portuguesa com decoração a azul e vinoso recolhido na sondagem o2 do setor capela do Senhor Santo Cristo e coro-baixo. 


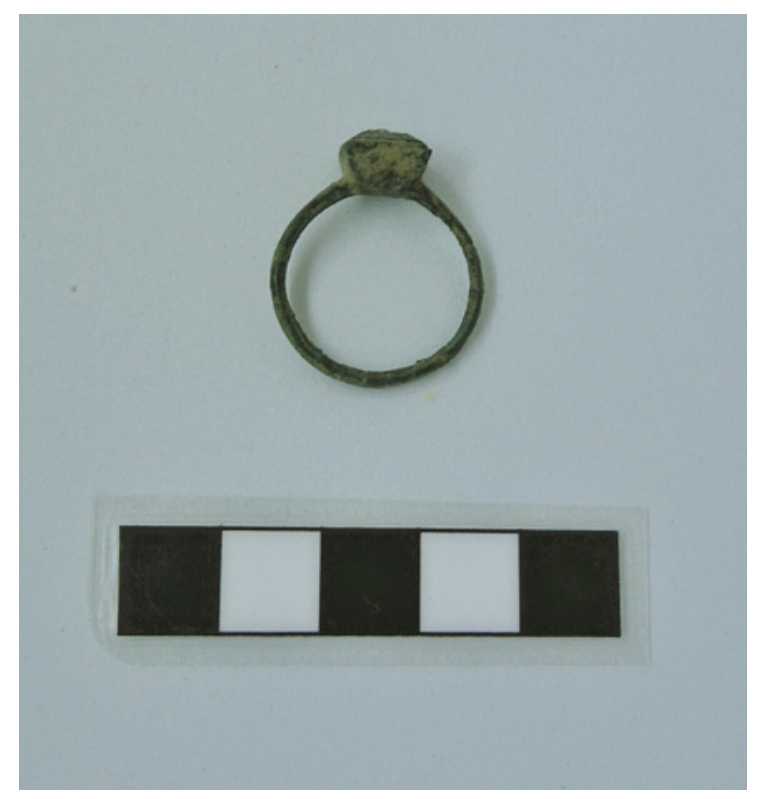

Figura 5-Anel em liga de cobre recuperado na sondagem o7 do setor capela do Senhor Santo Cristo e coro-baixo.

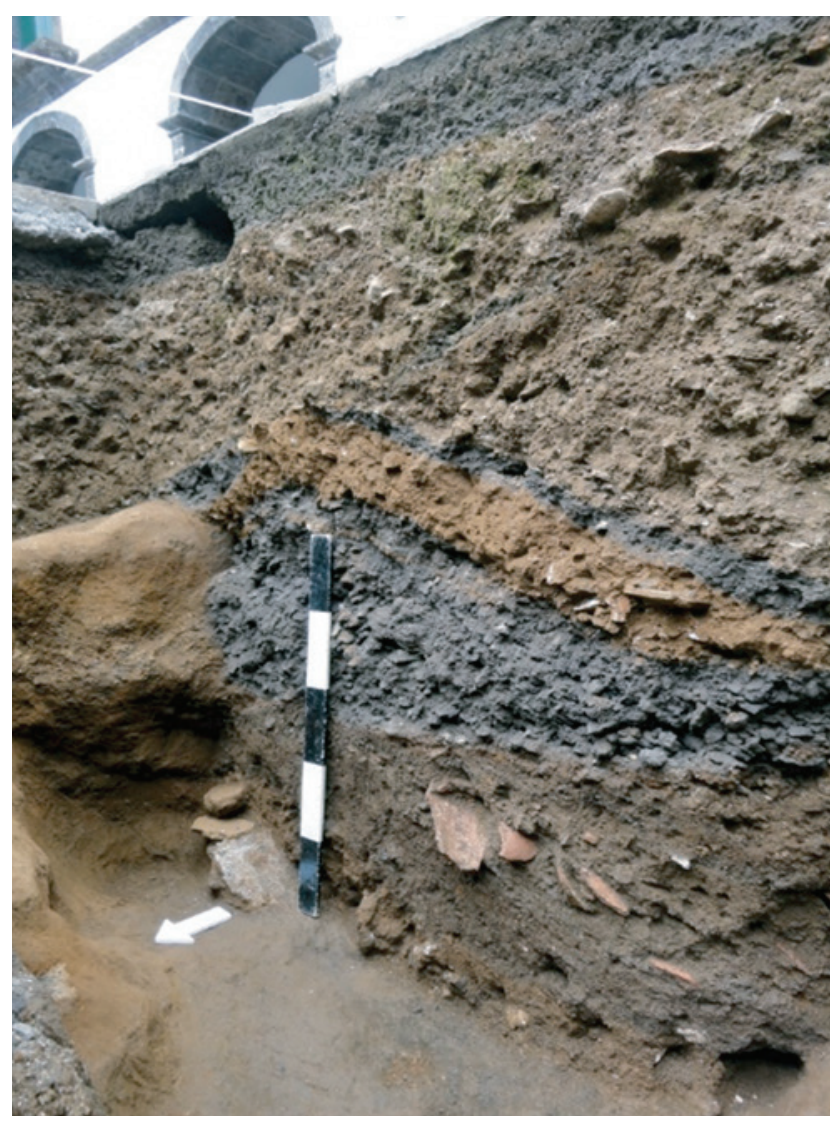

Figura 6 - Corte estratigráfico (este-oeste) da sondagem o3 do claustro.

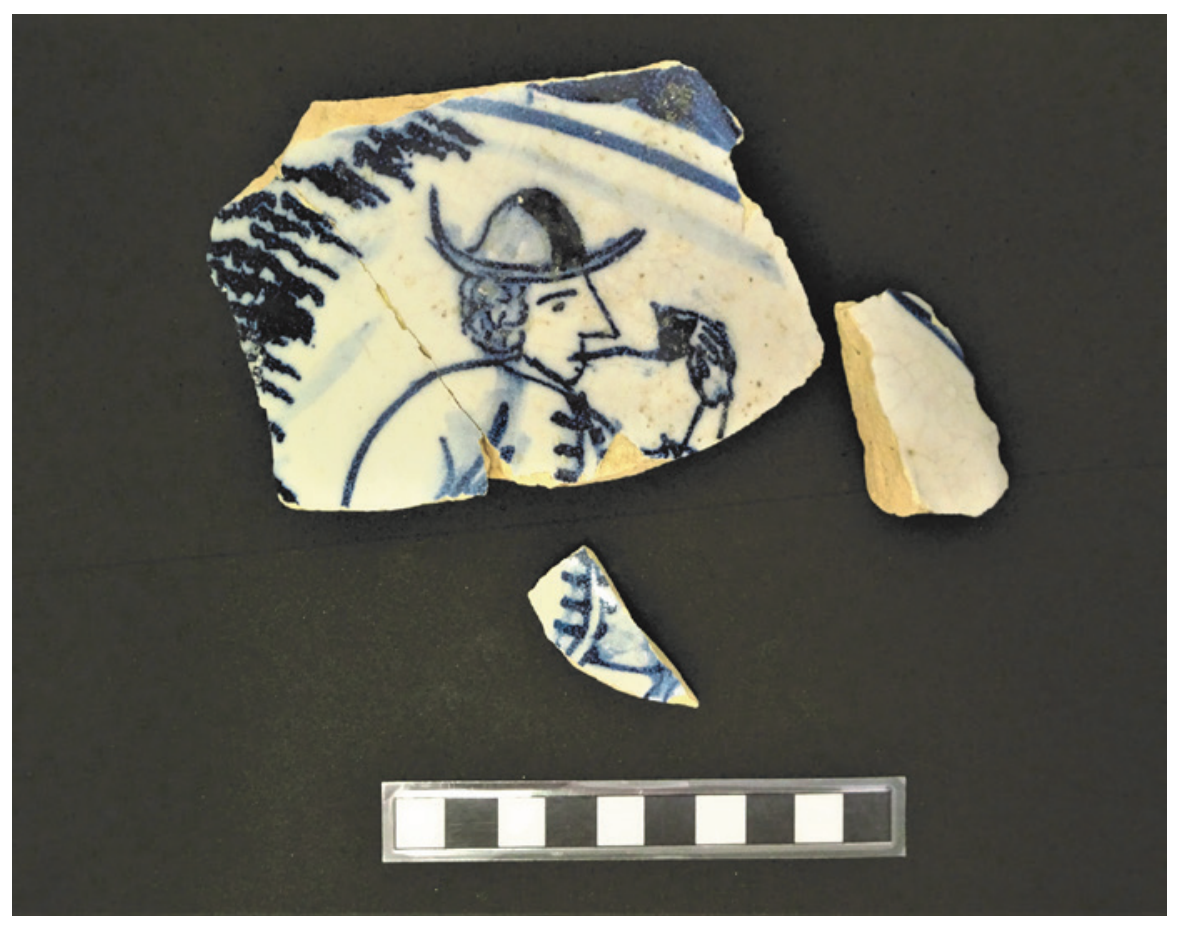

Figura 7 - Fragmento de forma fechada de provável origem holandesa recolhido na sondagem 03 do claustro. 


\title{
ARQUEOLOGIA NA ILHA DO CORVO... EM BUSCA DA CAPELA DE NOSSA SENHORA DO ROSÁRIO
}

Tânia Manuel Casimiro ${ }^{1}$, José Luís Neto² ${ }^{2}$ Luís Borges $^{3}$, Pedro Parreira ${ }^{4}$

\begin{abstract}
RESUMO
Entre 2014 e 2018 efectuaram-se quatro missões de arqueologia na ilha do Corvo, no arquipélago dos Açores, procurando promover a ligação entre a história, a arqueologia e a comunidade local. O objectivo principal era a descoberta de vestígios da primitiva capela de Nossa Senhora do Rosário, primeiro templo da ilha, fundado nos finais do século XVI, entretanto desaparecido. Ainda que a existência da dita capela não tenha sido confirmada foram produzidos novos contributos para o estudo da realidade insular de uma ilha periférica, mas intrinsecamente ligada às grandes rotas transatlânticas da Época Moderna. A cultura material identificada permitiu gerar conclusões sobre a ocupação daquele território entre o século XVI e o século XX sobretudo a nível do consumo doméstico, tipo de alimentação e economia.
\end{abstract}

Palavras-chave: Arqueologia Moderna, Arqueologia nos Açores, Ilha do Corvo

\begin{abstract}
From 2014 to 2018, four archaeological expeditions took place in Corvo island, on the Azorean archipelago, seeking to encourage stronger relationships between its local historical and archaeological heritage, and the local community. The main goal of these campaigns was to locate the remains of the Nossa Senhora do Rosário chapel, the first religious temple of the island built on the late sixteenth century. The excavations did not permit the identification of the chapel, however provided new contributions towards the study of the everyday life of that small island, located on the periphery of the European world, though connected to the great transatlantic routes of the Modern Age. The material culture provided new evidence regarding the human occupation of that territory, between the $16^{\text {th }}$ and the $20^{\text {th }}$ century, concerning domestic activities, food consumption and economic realities.
\end{abstract}

Keywords: Early Modern Archaeology, Archaeology in Azores, Corvo island.

\section{INTRODUÇÃO}

Apesar da ilha do Corvo deter as referências a investigações de cariz arqueológico mais antigas nos Açores (Podolijn, 1778); (Agostinho, 1946), só em 1964 estudiosos alemães aí procuraram indícios arqueológicos que se relacionassem com a origem do povoamento, todavia não foram identificadas evidências que conseguissem suportar qualquer conclusão (Medeiros, 1987: 48). Alguns anos depois, em
1982, arqueólogos americanos desenvolveram nova prospecção seguidos, em 1983, por Benedikt Isserlin (1984). Em 1986, Isserlin voltou à ilha, para a realização de uma campanha de quatro sondagens na vila, com o objectivo de procurar provas arqueológicas que documentassem uma ocupação pré-portuguesa, sem sucesso. Em Agosto de 2010, Nuno Ribeiro e Anabela Joaquinito fizeram uma visita ao Corvo tendo alegadamente descoberto estruturas-abrigo que poderiam, segundo os mesmos (Ribeiro et al.,

\footnotetext{
1. IHC/IAP - FCSH, Universidade Nova de Lisboa; tmcasimiro@fcsh.unl.pt

2. Direção Regional da Cultura do Governo Regional dos Açores; jose.lp.neto@azores.gov.pt

3. Direção Regional da Cultura do Governo Regional dos Açores; luis.cs.borges@azores.gov.pt

4. Direção Regional da Cultura do Governo Regional dos Açores; pedro.tc.parreira@azores.gov.pt
} 
2011), ser eventualmente pré-portuguesas, mas evidências científicas que conseguissem comprovar tal teoria nunca foram apresentadas (Figura 1).

A presente equipa signatária foi responsável por quatro campanhas arqueológicas, terrestres e subaquáticas, entre 2014 e 2018. Um dos objectivos principais passava pela localização da capela de Nossa Senhora do Rosário, primeiro templo da ilha do Corvo documentalmente registado, abandonado em 1690. A tradição local aponta a sua localização para uma casa que ali se encontra, conhecida como a casa de João Dias, local onde foram efectuadas duas sondagens em 2014. A comprovação que aquele não era o local da ermida levou a equipa a abrir uma sondagem numa das ruas da vila em 2015, bem como diversas sondagens em locais diversos em 2018. O local certo da ermida contínua, à data deste trabalho, por identificar (Figura 2).

\section{CAPELA DE NOSSA SENHORA DO ROSÁRIO}

A primeira referência à capela de Nossa Senhora do Rosário remonta ao século XVI, e mais concretamente a Gaspar Frutuoso, que se lamenta do facto de muitas crianças, filhas de escravos negros e de mulatos, que então constituíam a maioria da população no Corvo, poderem morrer sem baptismo: "Dizem que é anexa a igreja [Capela de Nossa Senhora do Rosário] à freguesia da Ponta Delgada da ilha das Flores, que será de trinta vizinhos, cujo vigairo, por causa os vai confessar cada Quaresma, algumas das quais, e muito tempo adiante, ficarão por confessar não podendo ir lá o vigairo, por causa da tromenta, e pelo mesmo caso estão as criaturas pagãs sete, oito meses até à vinda do sacerdote que as baptiza; o qual também às vezes não pode tornar tão cedo, por causa dos tempos rijos e dos ruins portos, assi do ilhéu, como da ilha das Flores, em que não se pode entrar e sair senão com mar manso." (Frutuoso, 1985: 136). A capela havia sido construída por volta de 1570 a 1580 por Gonçalo da Fonseca, descendente do donatário João da Fonseca ${ }^{5}$.

A situação eclesiástica mudou em finais de Quinhentos, sendo destacado um sacerdote permanente para a ilha do Corvo. Um desses sacerdotes, posterior-

5. Natural de Évora, recebeu as duas ilhas em 1504, tendo iniciado o seu povoamento pela ilha das Flores entre $1508 \mathrm{e}$ 1510 (Bragaglia: 2009, 22-23). mente pároco de Santa Cruz das Flores por trinta anos, o Padre Inácio Coelho, foi o padroeiro da construção do convento franciscano de São Boaventura, nas Flores, tendo igualmente patrocinado, do seu pecúlio, a reedificação "da igreja de Santa Cruz, e as ermidas de Santa Catarina, São Pedro e de São Sebastião, na ilha das Flores, as quais haviam sido queimadas pelos ingleses e estiveram cobertas de palha durante cerca de 40 anos, e ainda a de Nossa Senhora do Rosário, na ilha do Corvo" (Amaral: 1992, 123), em cerca de 1642. É natural que durante essa campanha de obras, a capela de Nossa Senhora do Rosário tenha adquirido uma traça arquitectónica da época e tenha sido, igualmente, telhada.

Seja como fôr, pouco mais de quarenta anos volvidos, a capela acabaria por ser fechada e o culto transitou para a actual igreja matriz de Nossa Senhora dos Milagres, inaugurada em 169o, tendo sido iniciada a sua construção cinco anos antes. As razões que a isso levaram são narradas pelo antigo sacerdote corvino, o Padre Lourenço Jorge: "Pelos livros $d a$ "Arca", e principalmente pelos das Visitas se pode saber o que era a primeira igreja do Corvo. Foi erigida a ermida por Gonçalo da Fonseca "para paróquia de seus escravos e vassalos" sobre a "rocha frágil e quebradiça" do Porto do Rosário, actual Porto da Casa, à direita da ladeira que dá acesso às casas. Não comportava mais que a terça parte do povo, assistindo a maior parte no adro aos oficios divinos. A sua porta não tinha chave e permanecia aberta dia e de noite. O primeiro visitador manda ao Vigário que, no mais breve tempo que lhe seja possível, mande, à custa da Fábrica Pequena, pôr uma fechadura com sua boa chave na porta travessa com que a mandará fechar e estar fechada, sendo a outra trancada por dentro; e recolherá a dita chave à sua mão, onde a poderão procurar os devotos que quiserem fazer oração. Avisa o Vigário que "por nenhuma maneira consinta que pessoa alguma da freguesia ou fora dela, coma, beba, cante, baile ou durma na igreja, por mais que lho peçam"! "A Tumba sempre esteve no adro, posta no chão, maltratada de chuvas e calmas, por ser pequena a igreja". Para obviar a esta inconveniência, mas não querendo sobrecarregar com gastos a Fábrica da igreja, manda que o mordomo da Fábrica Pequena, faça meter na parede da igreja, pela banda de dentro, defronte da pia baptismal, do meio para o alto, dois barrotes a par, sobre os quais se porá a dita tumba, para melhor resguardo seu, sem que impeça estar por baixo bancos em que se assentem. $O$ adro 
franqueado sempre aos "animais que vagueavam pelos caminhos" por cuja causa foi encarregada a Fábrica Pequena de mandar fechá-lo com uma cancela dentro do prazo de dois meses a contar da terceira publicação da "Visita", sob pena de 500 réis para a bula e meirinho.

Não era um edificio robusto. O pavimento de terra, coberto de junco. Ao lado da porta, uma tosca pia de pedra para baptismos. Um pouco mais acima uma "imagem do Santo Cristo à coluna, posta em um caixão pouco decente", colocado no chão. Uma escada dava acesso ao púlpito. O retábulo era constituído por "um pano cuja cor primitiva se ignora e que se não sabe se é de linho ou lã", cobrindo a parede do fundo. Em um pequeno nicho, colocado a meio, estava a "veneranda imagem, e tão milagrosa da Senhora do Rosário, em tal estado que não há nela mais que uma cabilla (sic) e algumas roupas, sem braços, $e$ o Menino que neles havia de sustentar, com a mesma deformidade". "A pedra do altar quebrada", o frontal "no mesmo estado" do pano-retábulo; "quatro castiçais de pau, muito indecentes"; "um cálice com o pé quebrado" e "um missal mui antigo, mui roto e mui pequeno, em muitas partes escrito e remendado, de modo que é preciso adivinhar para se dizer a missa"! Durante a segunda Visita manda-se "ao Feitor do Senhor Conde que mande fazer um armário à parte direita do altar, com duas portas, bem feito e capaz para se recolherem os ditos ornamentos, o que assim cumprirá sob pena de $2 \$$ ooo réis que pagará de sua fazenda", nunca se fazendo menção à sacristia, que certamente não existia. Os paramentos eram "de sarja e lã e muito usados e não os há de todas as cores litúrgicas". Uma "custódia de pau, limitada a não ter sequer um círculo de prata" nem pintura alguma; "umas galhetas de estanho"; "um Batistério podre e em muitas partes falto de folhas". Foi esta a descrição da igreja do Corvo em 1684. [...]

O terceiro visitador João Garcia Dutra foi o primeiro que tratou da construção de outra igreja em lugar mais amplo e seguro, pois que a rocha onde assentava a igreja se ia arruinando a respeito dos "baques do mar" "e "o sítio era incapaz de se alargar". (Jorge, 2001: 205-207).

\section{AS CAMPANHAS ARQUEOLÓGICAS}

As campanhas arqueológicas foram efectuadas por uma equipa da Direcção Regional da Cultura dos Açores e Museu de Angra do Heroísmo. O trabalho assentou em ações de prospeção, pesquisa documental e realização de sondagens arqueológicas conforme determinado pela Direção Regional da Cultura, no âmbito das atribuições e incumbências definidas no Decreto Legislativo Regional n.. $27 / 2004 / A$, de 24 de agosto e no Decreto Regulamentar Regional n.. $8 / 2013 / A$, de 17 de junho.

$\mathrm{Na}$ campanha de 2014 foram efectuadas duas sondagens na Casa de João Dias, que corresponde a um lote de terreno de habitação sobranceiro à escarpa Sudeste da Rua do Porto da Casa, sem número de polícia, tal como acontece com todas as casas da vila. A casa está desocupada, devido à mudança da proprietária para a ilha do Pico. O lote apresenta uma forma retangular, orientado Nascente-Poente, com as portas e janelas viradas a Sul, obtendo assim maior exposição solar. O edifício apresenta uma forma paralelepipédica, com dois pisos de pequena altura (1,90 metros de pé-direito), telhado de duas águas, sustentado numa estrutura simples de madeira. O piso térreo apresenta, de Poente para Nascente, uma cozinha com forno (divisão A), uma sala retangular comprida (divisão B), uma casa-de-banho com banheira, lavatório e retrete (divisão C), um pequeno alpendre no vão da escadaria exterior de acesso ao primeiro piso (divisão D) e uma sala de arrumos (divisão E) (Figura 3).

Faz-se notar que, apesar da casa se integrar claramente na tipologia tradicional da habitação corvina (Caldas, 2001, 23-26), a habitação foi sofrendo alterações claras à estrutura primitiva. A inclusão do forno na estrutura habitacional, realizada com blocos de cimento, à vista, é demonstrativa da sua contemporaneidade; a supressão da finalidade original da divisão $B$, que era a de albergar animais domésticos (loja), a inclusão da casa-de-banho (divisão C) na mesma divisão $B$, que a corta de toda a sua extensão primeva, são disso mesmo testemunhos exemplares. Toda a área não coberta foi pavimentada com uma calçada de seixos rolados, que, entretanto, em muitas áreas, foi substituída por cimento. Aliás, os currais e outros edifícios de apoio foram desactivados e substituídos por um único, de tijolo de cimento, também ele actualmente desactivado.

O material de construção das paredes é a pedra vulcânica local, ligada por terra, rebocado com terra e cal e caiado. $\mathrm{O}$ acesso aos quartos é feito pelo exterior, por escadaria de pedra.

A sondagem 1 tinha 2 × 3 metros, tendo sido implantada no extremo Nordeste da sala B. Após a limpe- 
za dos detritos ali acumulados, apresentou um piso de cimento (piso 1) que, após ser levantado, revelou uma camada de terra castanha avermelhada, argilosa, compacta (camada 1), camada essa que se prolongou até aos $60 \mathrm{~cm}$ de profundidade, onde se revelou totalmente estéril. Sensivelmente a meio do lado Sul, a partir dos $30 \mathrm{~cm}$ de profundidade, apresentou algumas pedras aglomeradas, que depois de limpas, revelaram tratar-se de um simples amontoado criado para deixar outras áreas mais transitáveis. Acresce o baixíssimo grau de exumação de materiais, bem como a sua natureza, aliada à do próprio solo, que nos levaram a concluir tratar-se simplesmente de solo agrícola. De referir que, no canto Noroeste, detetámos uma bolsa semicircular, de terra castanha escura, correspondente a uma fossa de detritos da Casa de João Dias (camada 2). A sondagem 2 correspondeu a toda a divisão D. Após a limpeza dos detritos ali acumulados, detetou-se um piso de seixos rolados (piso 1) que ocupou a metade Este da sondagem. Prosseguindo a escavação na metade Poente, detetámos uma camada uniforme de bagacina (camada 1) até $30 \mathrm{~cm}$ de profundidade, onde constatámos estar perante uma outra fossa, ainda activa, pelo que se suspendeu a escavação (Figura 4).

Entre os dias 18 a 31 de Agosto de 2015 foi realizada a segunda campanha arqueológica terrestre e a primeira marítima. O objectivo da segunda campanha terrestre foi igualmente a identificação da ermida de Nossa Senhora do Rosário. Nesse sentido e atendendo que os resultados do ano anterior tinham demonstrado que a ermida não se localizava na Casa de João Dias, foi aberta uma sondagem na Rua do Porto da Casa, no exterior da Casa de Maria João. A escolha do local recaiu nas proximidades de um edifício com uma arquitectura particular e destacável, que pode ter correspondido à de uma igreja (Figura 5).

A sondagem tinha $2,5 \mathrm{X}_{3}$ metros, orientada Norte-Sul, sendo executada na via pública, com vista a detectar o eventual adro do antigo templo. A camada 1 tratava-se de um piso que era constituído por cimento, sendo removido com o auxílio de um martelo pneumático. Sob este, apareceu um outro piso, constituído por seixos de dimensões variáveis, somente preservado na metade Poente da sondagem, uma vez que, na metade Este, a terra encontrava-se revolvida para instalação de tubagens muito recentes. A partir de então recorreu-se unicamente a escavação manual. Removido este piso, defrontámo-nos com uma camada de terra castanha escura, muito argilosa, que, ao ser metodicamente removida, mostrou, de perfil, uma estrutura de canalização arcaica feita de seixos rolados. Os materiais exumados pertencem, inequivocamente, ao século XX (Figura 6). Mais abaixo surgiu uma outra camada, possível de datar entre os séculos XVI e XVIII. Esse contexto, que se anuncia pela materialidade cerâmica, é coevo com a ocupação que se pretendia localizar, a capela de Nossa Senhora do Rosário. A escavação teve de ser interrompida a cerca de, sensivelmente, 120 $\mathrm{cm}$ de profundidade, porquanto foi inundada pelo conteúdo de uma fossa séptica localizada a Norte da sondagem, impedindo que se chegasse aos níveis estratigráficos pretendidos. Com celeridade, depois de se constatar que não se tratava de uma fuga da rede pública, ponderadas as razões de saúde pública, procedeu-se, em conformidade com o parecer da autarquia, fazendo-se o recobrimento imediato da sondagem (Figura 7 ).

A terceira campanha, exclusivamente subaquática, teve lugar em 2016.

Entre os dias 7 e 18 de Maio de 2018, decorreu a quarta campanha, motivada pela intenção de se avançar com obras de reabilitação no espaço privado, interior, que não fora escavado em 2015, no imóvel na Rua do Porto da Casa, conhecido como a Casa de Maria João. Atendendo aos resultados aí obtidos, alargou-se as sondagens à Casa de Luís Pacheco e ao quintal da Casa de Paula Dias.

Na primeira casa foi aberta uma sondagem, de $2 \mathrm{x} 2$ metros, na zona da loja, com vista a detectar o eventual corpo do templo. Devido à exiguidade do espaço, em sondagem correspondeu a cerca de $40 \%$ da loja. O piso 1 era composto por um pavimento de seixos rolados e que, à data dos trabalhos arqueológicos, se encontrava coberto por uma camada de palha. Imediatamente abaixo, a camada 1 era composta por terra homogénea, castanho avermelhada, compacta, com presença de numerosas pedras vulcânicas de diversos calibres. Da camada I foram recolhidos 11 fragmentos de cerâmica de cronologias atribuíveis aos séculos XIX e XX. Rapidamente se alcançou o substrato geológico, estando este, em média, a cerca de $90 \mathrm{~cm}$ de profundidade, não se encontrando evidências de quaisquer estruturas arqueológicas. Foi decidido alargar a sondagem junto à parede Sul da divisão, de modo a procurar fósseis diretores na vala de fundação das paredes, que pudessem indicar uma datação para a construção do imóvel, algo que se revelou infrutífero (Figura 8). 
Num pequeno espaço de horta de cultivo, no quintal da Casa de Maria João, foi aberta a sondagem 2 com 2 x 1 metros, com vista a, com a sondagem no tardoz, excluir definitivamente a hipótese de ali ter sido a capela. A camada 1 apresentava uma coloração castanha escura, pouco compacta, correspondendo à terra arada da horta em uso. A camada 2, apresentava sedimento homogéneo, castanho escuro, com muita incidência de pedras de grande e médio calibre. Apenas alguns vestígios de fauna foram encontrados nesta sondagem. Há que salientar a presença de uma pia, em pedra, encastrada no muro do quintal, que terá servido para alimentação de suínos e/ ou aves de capoeira.

Após, e com a autorização e incentivo dos moradores da vila, e especificamente dos do Porto da Casa, prosseguiu a iniciativa de se efectuarem mais sondagens de verificação do espaço, naquela área.

A sondagem 3 foi aberta na Casa de Luís Pacheco. Devido à exiguidade do espaço, esta foi aberta do lado interior da parede Sul da casa, com uma dimensão de 2 x 1 metros. O piso 1 , de cor esbranquiçada, era muito compacto e composto por detritos quotidianos do uso doméstico. Sob o piso 1, e cortando longitudinalmente a sondagem a meio, foi detetado o muro 1, de pedra seca, de médio a grande calibre. A Nascente do muro 1 foram identificadas duas camadas. A camada 1 apresentava coloração cinza escuro, pouco compacta e com pedras soltas de médio e pequeno calibre, de onde foram retirados materiais arqueológicos; a camada 2, homogénea, de cor castanho avermelhada, extremamente compacta a cerca de 1,20 metros de profundidade. A Poente do muro 1, a sondagem apresentava outra estratigrafia, sob o piso 1, camada 3, de terra castanho avermelhada pouco compacta e camada 4 , de cerca de $5 \mathrm{~cm}$ de espessura, de carvões; continuidade da camada 2, homogénea, de terra castanho avermelhada extremamente compacta.

As sondagens 4 e 5 foram abertas no quintal da Casa de Paula Dias. Do lado Norte da pequena baía do Porto da Casa, a Nascente do Canto do Porto da Casa, e separado deste por um barranco, destacavam-se os vestígios de uma construção com cunhais em cantaria. O interior dessa estrutura encontra-se entulhado e suporta uma pequena piscina. Optou-se por abrir duas sondagens no exterior, a Sul, da estrutura. A sondagem 1, de 2 x 1 e a sondagem 2, de 1 x 1 metros. $\mathrm{Na}$ sondagem 1, destacavam-se duas camadas. A camada 1 de terra castanha, pouco compacta, e a cama- da 2, de terra castanha, compacta, com incidência de seixos de pequeno calibre. Nesta sondagem não foram encontrados quaisquer artefactos. A sondagem 2 apresentava as mesmas camadas da sondagem 1, excepção feita ao facto de terem sido recolhidos fragmentos de cerâmicas dos séculos XIX e XX.

\section{CULTURA MATERIAL}

Na intervenção de 2014, na Casa de João Dias, as recolhas materiais efectuadas na camada 2, da sondagem 1 , bem como da camada 1, da sondagem 2 levam-nos a concluir que a construção da Casa de João Dias ocorreu em finais do século XVIII, não se tratando do edifício do primeiro templo da ilha. Anteriormente a esta casa, este espaço, mercê de se encontrar alcandorado sobre a falésia, terá sido somente um campo agrícola. E esse campo agrícola, como é comum nos campos agrícolas, foi sendo adubado com os sobejos da casa de quem o cultivava. Assim se explicam os poucos materiais encontrados, de cronologias demasiado longas, referentes aos anteriores séculos de ocupação. Algumas delas, independentemente do seu estado muito fragmentário, oferecem uma datação precisa. Estes fragmentos, se bem que pouco numerosos, são evidentes indicadores que o local apenas foi urbanizado, pela primeira vez, com a construção da Casa de João Dias e asseguram que não foi este o local da construção da capela de Nossa Senhora do Rosário, abandonada em 1690.

Os materiais exumados da sondagem 1, camada 1 , apresentam-se muitíssimo fragmentados e quebradiços, podendo ser divididos em dois grupos distintos, com o primeiro a compreender materiais orgânicos, que correspondem a fragmentos ósseos. Há diversos fragmentos de ossos, e dentes de ruminante, nomeadamente um chifre de pequeno ruminante carbonizado. Existe um fragmento de costela de coelho, diversos fragmentos de espinhas de um mesmo peixe, um fragmento de crânio de roedor, bem como duas costelas, um fémur e uma tíbia de morcego. $\mathrm{O}$ segundo grupo corresponde a inorgânicos, no caso materiais cerâmicos e um pétreo. Os cerâmicos são de construção e de uso comum. Do primeiro tipo existem trinta fragmentos de telha mourisca, muito provavelmente das Flores, que é o centro produtor mais próximo (Fernandes, 1993; 2001), tendo lá sido registado um forno de telha (Neto et al., 2014). De uso comum foram exumados dois fragmentos, de pastas claras, compactas, com a inclusão de alguns 
elementos não plásticos. Um é esmaltado a branco e recebeu engobe transparente e o outro é vidrado a melado. Pelas características da pasta, do engobe e do vidrado, correspondem a exemplares das produções da região de Sevilha, enquadráveis no século XVI (Sousa, 2012) (Figura 9).

Existem dois fragmentos de faianças portuguesas, a azul e branco, feitas a partir de pastas claras, sugerindo produções de Lisboa. Correspondem a um fragmento de bordo de um prato, decorado com círculos concêntricos na aba, datável entre 1660 e 1720, apresentando um furo, indicando uma possível reparação (Casimiro, 2013). Surgiu também um fragmento de cerâmica de pastas vermelhas. O acabamento interno demonstra vestígios de aplicação de vidrado melado. Pelas características da pasta e do vidrado, corresponde a um exemplar das produções da região de Lisboa enquadrável nos séculos XVII a XVIII (Casimiro, et al., 2018).

Há igualmente louças comuns de pastas vermelhas não vidradas. Deste tipo de cerâmicas existe um fragmento de bordo de alguidar, extrovertido, em aba pendente, um fragmento de taça, apresentando um bordo extrovertido, brunido na face interna e outros dois fragmentos. Pelas características das pastas e da aguada correspondem a produções regionais, muito provavelmente das Flores, centro produtor mais próximo (Andrade, 2014; Fernandes, 2001). As formas são genericamente enquadráveis entre os séculos XVI a XVIII.

Uma âncora de pedra foi identificada. Trata-se de um monólito quartzítico com um furo, que mede $42 \mathrm{~cm}$ de comprimento, tendo $26 \mathrm{~cm}$ de altura. O buraco, onde passava uma corda, apresentou $6 \mathrm{~cm}$ de diâmetro. Este tipo de âncora improvisada, para pequenas embarcações, ainda hoje está em uso.

Os materiais exumados na sondagem 2, camada 1, são exclusivamente materiais cerâmicos. Existem dois fragmentos de faianças portuguesas, a azul e branco, produção de Lisboa. Um fragmento de bordo de uma taça, esmaltado a branco e pintado a azul, com um círculo concêntrico, e um fragmento de prato. Pelas caraterísticas da pasta, do vidrado e da decoração, correspondem a exemplares enquadráveis no século XVIII.

De produção industrial, e já enquadráveis na segunda metade do século XIX, temos dois fragmentos de louça estampada. Um deles apresenta decoração com motivo de estátua, a verde, ostentando a marca da fábrica de louça de Sacavém, tendo sido produzi- do entre as décadas de sessenta a inícios de noventa do século XIX (Assunção, 1997). Dois fragmentos são integráveis nas produções da Fábrica de Loiça Terceirense, correspondendo a faianças com motivos decorativos florais, a azul, datando da década de 20 do século XX. Dois outros fragmentos, de faiança industrial, com decoração de "chinoiserie", a azul sobre branco, podem corresponder a uma produção exógena, mas a reduzida dimensão não permite mais assertiva classificação. Por fim, um outro fragmento de faiança, a azul sobre branco, de tipo geométrico e com a decoração em relevo, é genericamente enquadrável entre as décadas de 30 e 50 do século XX.

Na intervenção da Rua do Porto da Casa, em frente à Casa de Maria João, em 2015, foram identificados objectos que podem ser datados entre os séculos XVI e XX. Correspondem a cerâmica de construção, semelhante à identificada na Casa João Dias e a louça de uso doméstico. As produções possíveis de atribuir aos finais do século XIX e XX correspondem a louça branca ou estampada com paisagens. As cerâmicas regionais, nomeadamente os alguidares, podem ter sido utilizados durante mais de três séculos, sem permitirem uma cronologia mais detalhada. Ainda possíveis de datar do século XIX e XX, dois fragmentos de garrafas em grés, produzidas no Norte da Europa, que transportariam água ou genebra (Sequeira e Casimiro, 2015), e alguns fragmentos de garrafas de vidro verde. Os fragmentos possíveis de datar dos séculos XVI e XVII correspondem a faianças com decoração a azul, sobretudo pratos e taças, ou cerâmicas vidradas de produção lisboeta, com possibilidade de algumas produções andaluzas. Destacam-se alguns fragmentos a azul e branco, de possível produção holandesa.

Nas sondagens abertas em 2018 a maioria dos objectos corresponde a peças produzidas nos séculos XIX e XX, tais como cerâmicas regionais e produções industriais (Figura 10).

\section{CONCLUSÃO}

No ano de 2014, os indicadores estratigráficos das sondagens conjugados com os materiais exumados na Casa de João Dias foram suficientes para invalidarem a localização tradicional da Capela de Nossa Senhora do Rosário. A ausência de estruturas arquitectónicas na sondagem 1 , a escassez de cultura material e sua excessiva fragmentação, bem como os vestígios 
faunísticos de roedores e morcegos apontam coerentemente para a aludida interpretação do espaço, enquanto campo agrícola. $\mathrm{O}$ facto de existirem escassos elementos ósseos e cerâmicos que se relacionem com o quotidiano alimentar, não a coloca em causa, porquanto é comum que os restos alimentares fossem usados como fertilizante. Em meados do século XVIII, o terreno recebeu a sua primeira edificação que, apesar das remodelações, acrescentos e adaptações, continua a ser a mesma desde então até aos dias de hoje, pelo que é seguro afirmar que a Casa de João Dias foi construída por meados de Setecentos.

A procura da capela nos anos seguintes também não se revelou conclusiva. Na Rua do Porto da Casa, na Casa de Maria João, a interrupção da escavação antes de chegarmos às camadas mais antigas não deu acesso às camadas coevas à ocupação da ermida (no caso, do seu primitivo adro) pelo que não conseguimos chegar a nenhuma conclusão, em 2015, mas na intervenção de 2018, foram identificados locais ocupados durante os séculos XIX e XX, sem possibilidade de identificação da ermida em nenhum deles. A impossibilidade, até agora, de identificação positiva da capela não retira o interesse aos contextos arqueológicos identificados, mesmo que mais tardios do que aqueles que inicialmente procurámos. Através dessas realidades é possível concluir que os habitantes da ilha do Corvo, ainda que em quantidades mais moderadas, tinham acesso ao mesmo tipo de materialidades que os restantes habitantes dos Açores. A cerâmica de produção regional parece ser sobretudo utilizada na confecção de alimentos, enquanto o consumo de alimentos à mesa era, sobretudo, efectuado com louça importada de Portugal continental, maioritariamente de Lisboa. Um fragmento de prato holandês, passível de datar dos finais do século XVII, ou inícios do século XVIII, demonstra que poderiam existir habitantes com capacidade económica para a aquisição de peças importadas. Essa realidade parece ter-se mantido, desde o século XVII até ao XIX.

Não obstante a sua periférica localização, face à Europa, mas também no contexto do arquipélago dos Açores, a ilha do Corvo parece ter sido frequentemente abastecida pelos produtos em uso corrente, na época, ainda que certamente condicionada à sua realidade, reduzido tamanho da sua comunidade e constante presença de intempéries climatéricas, partilhando a sua gente identidade insular característica das ilhas.

\section{BIBLIOGRAFIA}

AGOSTINHO, José (1946) - Achados arqueológicos nos Açores. In Açoreana, Angra do Heroísmo: Boletim da Sociedade Afonso Chaves (separata, 11 páginas).

AMARAL, Maria Regina Amorim de Carvalho (1992) - O convento de São Boaventura em Santa Cruz das Flores. In Insulana. Vol. 48. Ponta Delgada: Instituto Cultural de Ponta Delgada. pp. 121-137.

ANDRADE, Alexandra (2014) - Cerâmica dos Açores. Ponta Delgada: Vice-Presidência do Governo, Emprego e Competitividade Empresarial - Centro Regional de Apoio ao Artesanato.

ASSUNÇÃO, Ana Paula (1997) - Fábrica de louça de Sacavém. Sintra: Inapa.

BRAGAGLIA, Pierluigi (2009) - Ilha das Flores. Açores. Roteiro histórico e pedestre. Fajã Grande, Flores: Edição de autor.

CALDAS, João Vieira (2001) - A casa do Corvo. In Inventário do Património Imóvel dos Açores - Vila Nova do Corvo. Angra do Heroísmo: Direção Regional da Cultura e Instituto Açoriano de Cultura. pp. 23-26.

CASIMIRO, Tânia Manuel (2013) - Faiança portuguesa: datação e evolução crono-estilística. In Revista Portuguesa de Arqueologia, volume 16. Lisboa: DGPC. pp. 351-367.

CASIMIRO, Tânia Manuel, HENRIQUES, José Pedro, FILIPE, Vanessa e BOAVIDA, Carlos (2018) - Lead glazed ceramics in Lisbon (16th-18th centuries). In GlazeArt 2018. Lisboa: LNEC. pp. 268-282.

FERNANDES, Isabel Maria (1993) - Cerâmica Açoriana. Catálogo. Barcelos: Museu de Olaria.

FERNANDES, Isabel Maria (2001) -“Cerâmica. In Enciclopédia Açoriana. Angra do Heroísmo: Direção Regional da Cultura, Centro de Conhecimento dos Açores. http:// www.culturacores.azores.gov.pt/ea/pesquisa/default. aspx?id=1615

FRUTUOSO, Gaspar (1985) - Saudades da Terra. Livro VI. Ponta Delgada: Instituto Cultural de Ponta Delgada.

ISSERLIN, B. S. J. (1984) - Did Carthaginian mariners reach the Island of Corvo (Azores)? Report on the results of the joint field investigations undertaken on Corvo in June 1983. in Rivista di Studi Fenici. Sommari del volume XII, 1. Roma: Fabrizio Serra Editore. pp. 31-46.

JORGE, Lourenço (2001) - Notas do Corvo. (Organização de João Saramago). Vila do Corvo: Câmara Municipal do Corvo.

MEDEIROS, Carlos Alberto (1987) - A ilha do Corvo. Lisboa: Livros Horizonte.

NETO, José Luís, BORGES, Luís e PERES, Magda (2014) Forno de cerâmica da Rua Padre Luís Pimentel Gomes. In Carta Arqueológica dos Açores. Portal Cultura Açores do Governo Regional dos Açores. Disponível em http://www. culturacores.azores.gov.pt/paa/ca/default.aspx 
PODOLIJN, Johan (1778) - Nagra anmarkningar om de Gamles sjofart, i anledning af nagra carthaginensiska och cyrenaiska mynt, fundne ar 1749, pa ena f de acoriska oarne. In Det Gotheborgska Wetenskaps och Witterhets Samhallets Handlingar. Goteborg. pp. 106-108.

RIBEIRO, Nuno, JOAQUINITO, Anabela, PEREIRA, Sérgio (2011) - Phoenicians in the Azores, myth or reality? In 15th Symposium on Mediterranean archaeology, Catania, Sicilia: Universitá di Catania.

SEQUEIRA, João e CASIMIRO, Tânia Manuel (2015) Fragmentos do mundo contemporâneo: objectos em grés recuperados no Tejo. In CIRA - Arqueologia, n. IV. Vila Franca de Xira: Museu Municipal da Câmara Municipal de Vila Franca de Xira. pp. 209-215.

SOUSA, Élvio (2012) - A importação de cerâmica europeia para os arquipélagos da Madeira e dos Açores no século XVI. In Velhos e Novos Mundos: Estudos de arqueologia moderna. Volume II. Lisboa: Centro de História Além-Mar, FCSH, Universidade Nova Lisboa. pp. 797-81o.

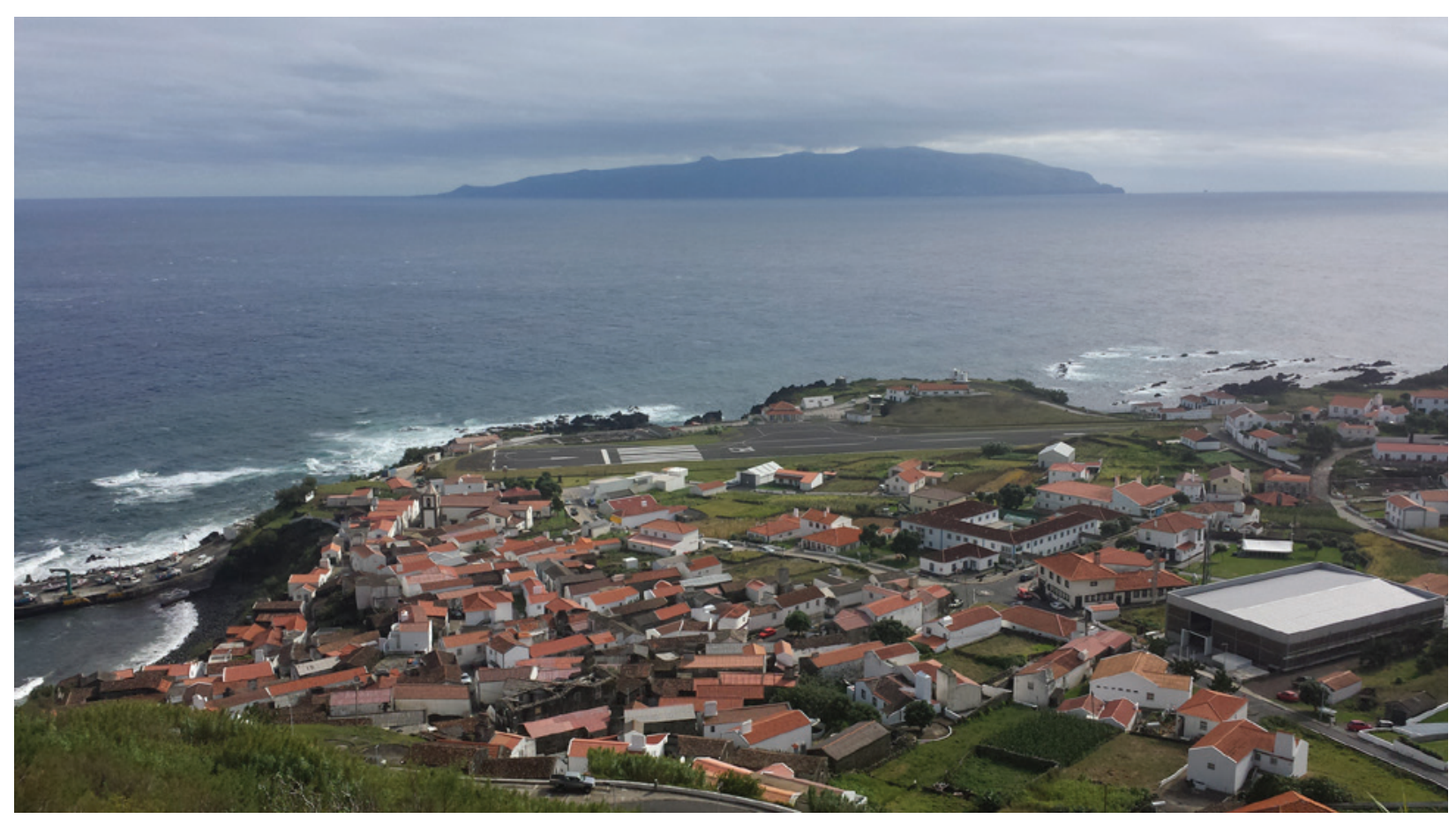

Figura 1 - Vista elevada da Vila do Corvo; Autor: Direção Regional da Cultura dos Açores. 


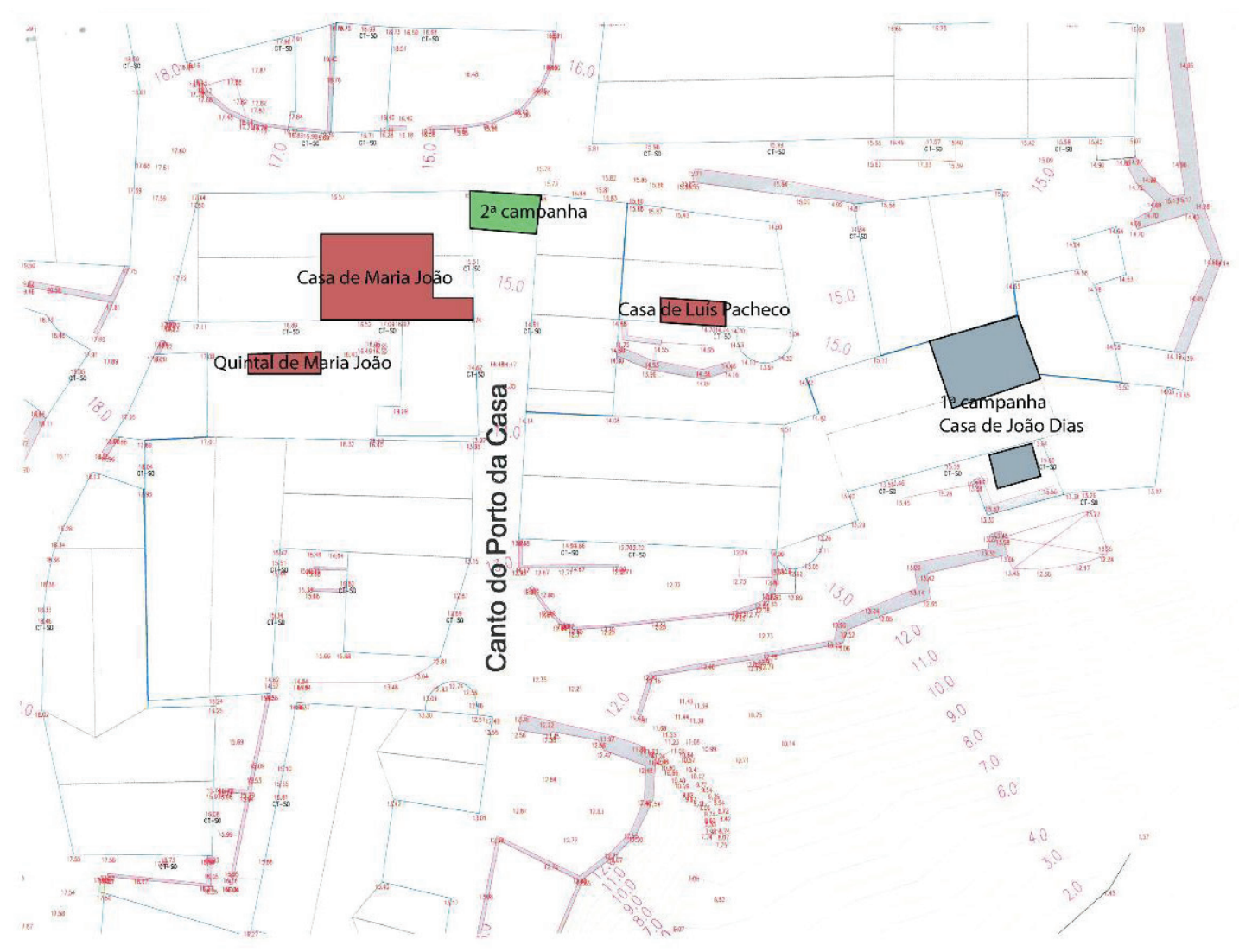

Figura 2 - Mapa da Vila do Corvo, com implantação das áreas intervencionadas; Autor: Luís Borges.

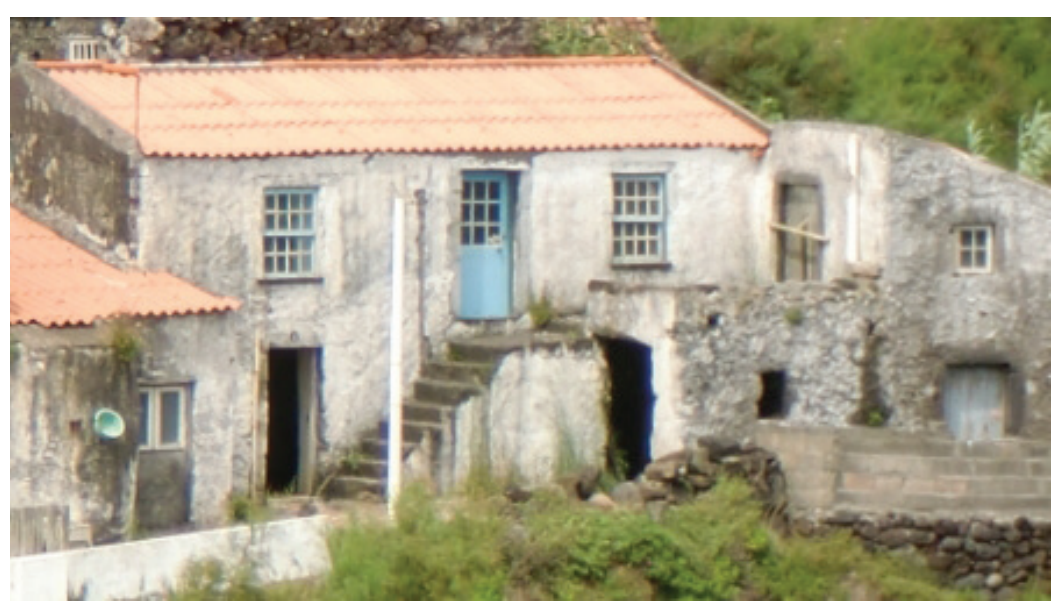

Figura 3 - A Casa de João Dias; Autor: Direção Regional da Cultura dos Açores. 
Alcado Nascinte

Comaden 1

Akado Norte

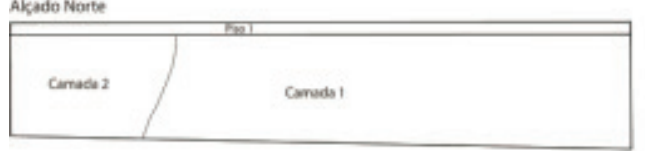

Alcado Poente

\begin{tabular}{|l|l|}
\hline Camata 1 & comade 2 \\
\hline
\end{tabular}

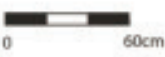

Cura de loba Dlas

Lils Borges / Magda Pere

11 de Agorto de 2014

Figura 4 - Cortes estratigráficos da intervenção na Casa de João Dias; Autor: Luís Borges e Magda Peres.

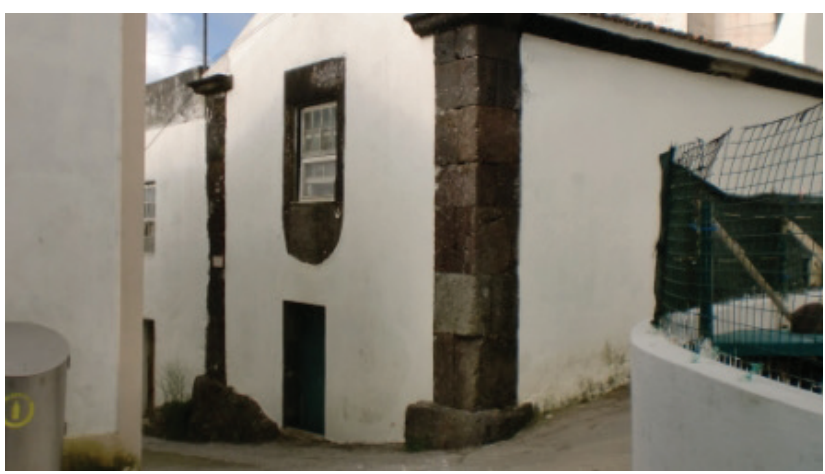

Figura 5 - A Casa de Maria João, na Rua do Porto da Casa; Autor: Direção Regional da Cultura dos Açores.

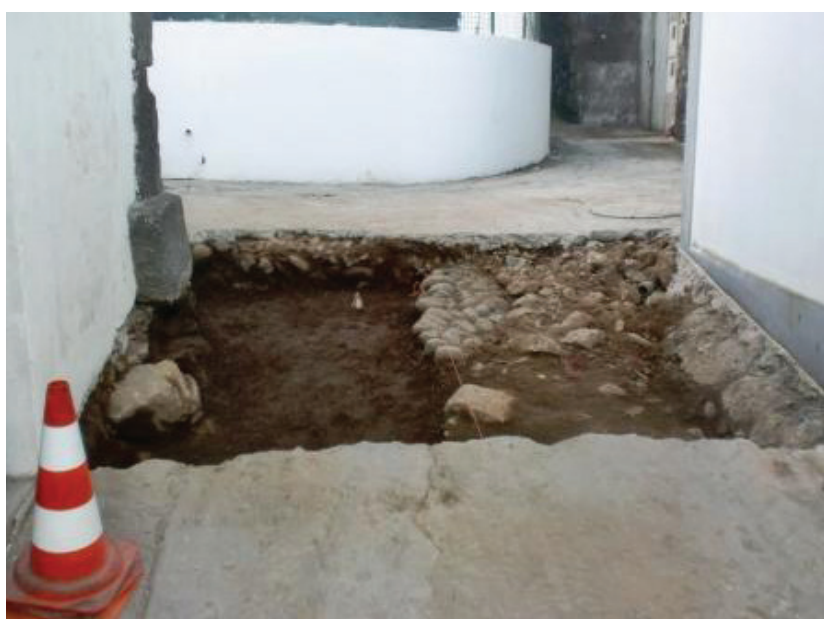

Figura 6 - Sondagem no exterior na Casa de Maria João; Direção Regional da Cultura dos Açores. 

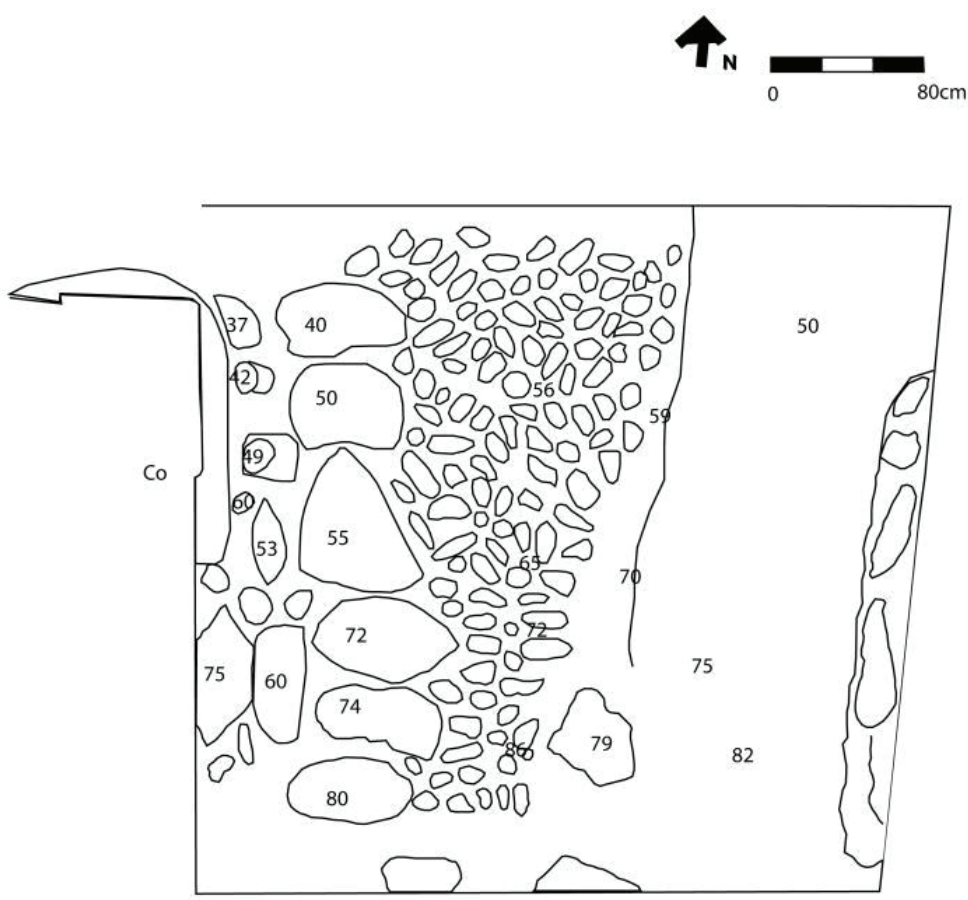

Sondagem 1

Porto da Casa - Vila do Crovo

22/08/2015

Desenho:J.L. Neto / P. Parreira / R. Borges

Tintagem:L. Borges

Figura 7 - Registo técnico de plano da sondagem no exterior da Casa de Maria João; Autor: José Luís Neto, Pedro Parreira e Luís Borges.

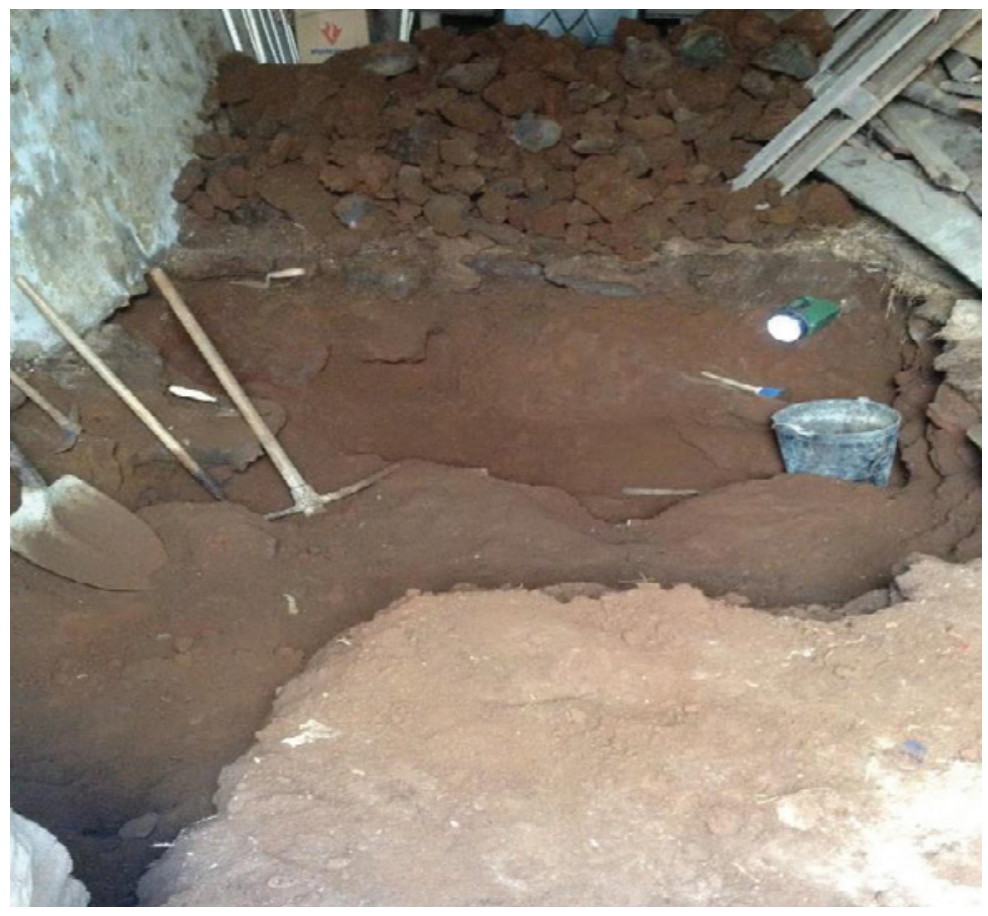

Figura 8 - Sondagem no interior da Casa de Maria João; Autor: Direção Regional da Cultura dos Açores. 

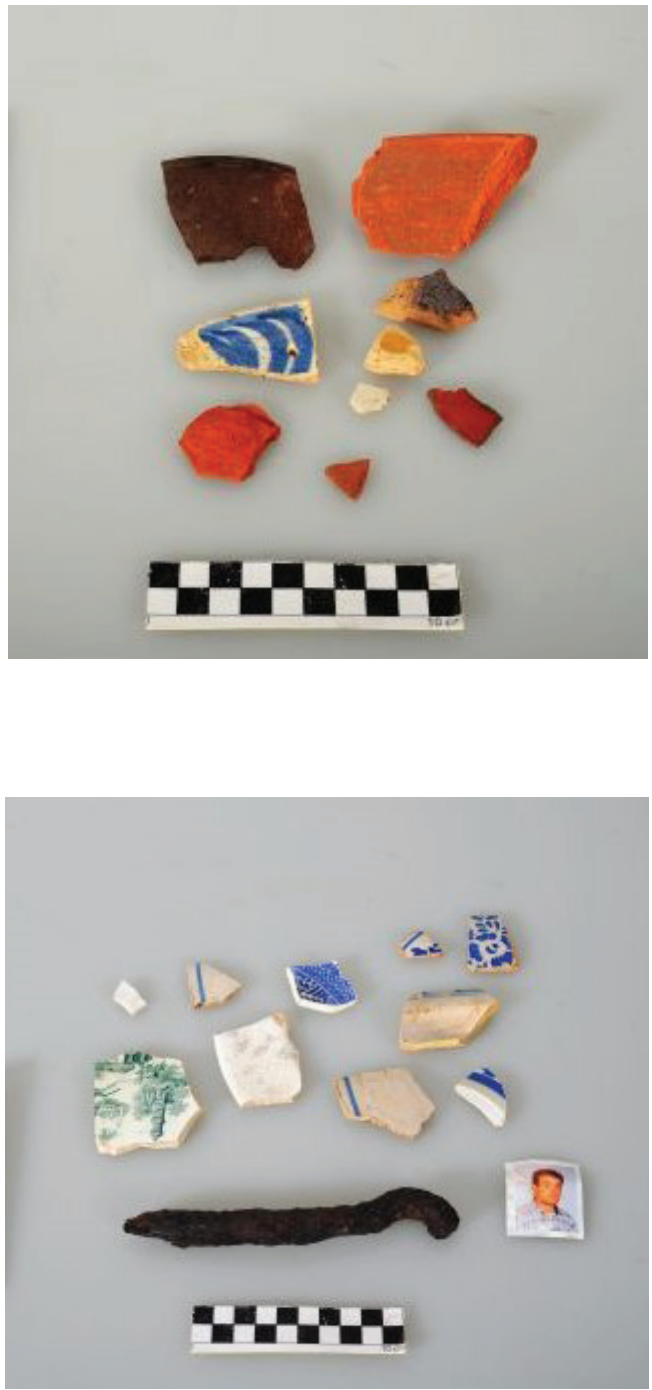

Figura 9-Material arqueológico exumado na Casa de João Dias, passível de datação entre o século XVI e o XVII; Autor: Direção Regional da Cultura dos Açores.

Figura 10 - Material arqueológico exumado na Casa de João Dias, passível de datação entre o século XIX e o XX; Autor: Direção Regional da Cultura dos Açores. 


\title{
PERDIDOS À VISTA DA COSTA. TRABALHOS ARQUEOLÓGICOS SUBAQUÁTICOS NA BARRA DO TEJO
}

\author{
Jorge Freire ${ }^{\mathrm{T}}$, José Bettencourt ${ }^{2}$, Augusto Salgado ${ }^{3}$
}

\begin{abstract}
RESUMO
Desde tempos imemoriais que todos os navios que entram ou saem de Lisboa, capital de um vasto Império Marítimo desde o século XV, têm que passar por um dos dois canais estreitos na entrada do Tejo. Esses canais encontram-se limitados não apenas pelas margens, como também por duas línguas de areia, denominadas “Cachopos”. Pela sua geografia, esta área está bem protegida dos ventos do norte ou leste, mas completamente aberta a tempestades do sul. Principalmente durante essas tempestades, foram vários os navios que naufragaram na costa norte, ou contra ambos os cachopos. Desde a década de 1960 que vários naufrágios modernos e contemporâneos foram ali descobertos. Esta comunicação pretende apresentar os trabalhos que têm estado a decorrer na zona desde 2015, no âmbito da Carta Arqueológica Subaquática de Cascais.
\end{abstract}

Palavras-chave: Arqueologia Marítima, Arqueologia Subaquática, Atlântico, Tejo.

\begin{abstract}
All ships entering or leaving Lisbon, the capital of a vast Maritime Empire since the $15^{\text {th }}$ century, have to pass through one of the two narrow canals at the entrance to the Tagus. These channels are limited by the coast but also by two sand banks, called "Cachopos". By its geography, this area is well protected from the north or east winds, but entirely open to southern storms. Especially during these storms, several ships sank on the north coast, or against both sand banks. Since the 196os, several early modern and contemporary shipwrecks have been discovered in this area. This communication intends to present the work taking place since 2015, within the framework of the Cascais Underwater Archaeological Chart.
\end{abstract}

Keywords: Maritime Archaeology, Underwater Archaeology, Atlantic, Tagus river.

\section{INTRODUÇÃO}

No entender de Cascais, os valores culturais do município são testemunhos com valor de civilização ou de cultura, portadores de interesse relevante, devendo como tal ser objeto de especial proteção e valorização. O modelo consignado no Plano Diretor Municipal define como património arqueológico todos os vestígios, bens e outros indícios da evolução do Homem, designadamente sítios, depósitos estratificados, estruturas, construções, agrupamentos arquitetónicos, sítios valorizados, bens móveis e monumentos de outra natureza, bem como o respe- tivo contexto, quer estejam localizados em meio rural ou urbano, no solo, subsolo ou em meio submerso, no mar territorial ou na plataforma continental. Este modelo de gestão e protecção explica a aposta municipal na carta arqueológica subaquática de Cascais (PROCASC). Em curso desde 2009, este projecto adoptou uma abordagem holística ao património cultural subaquático, visto enquanto elemento de uma Paisagem Cultural Marítima em constante construção (Freire, 2014). Aqui, a arqueologia subaquática não se limita ao estudo da história através dos artefactos que o tempo nos legou. Reflete também a ligação do Homem ao meio ambiente. A concepção

\footnotetext{
1. Câmara Municipal de Cascais; jorge.freire@cm-cascais.pt

2. CHAM - Centro de Humanidades e FCSH, Universidade Nova de Lisboa; jbettencourt.cham@gmail.com

3. Centro de História da Faculdade de Letras da Univ. Lisboa e CINAV; alves.salgado@marinha.pt
} 
de Paisagem Cultural Marítima - "the whole network of sailing routes, with ports, havens and harbours along the coast, and its related constructions and other remains of human activity, underwater as well terrestrial" (Westerdahl 2011: 212), aproxima-nos do conceito metafísica de Bruno Latour (Actor Network Theory), que procura compreender a paisagem através de uma rede de relações sociais e económicas que se estabelece entre o humano e o não humano (Latour, 2005). Os bens arqueológicos deixam de ser apenas artefactos, cuja significação é atribuída pelo homem, e passam a ser agência, ou seja, participam das ações nas situações quotidianas e provocam transformações. Esta participação remete-nos para um último aspeto concetual, que foi sinteticamente resumido por Lofgren (1981) - a nossa perceção enquanto atores da paisagem atual e histórica: "the mapping and imprinting of the functional aspects of the surroundings in the human mind. Man in landscape, landscape in man" (apud Westerdahl, 1992).

Os despojos perdidos nas águas de Cascais são assim um reflexo das dificuldades que os navios encontraram neste mar, que se traduziu em várias tragédias humanas. Mas são também novos focos de vida, ao transformarem-se em habitats únicos para o desenvolvimento e fixação da biodiversidade marinha, que se revestem de interesse económico e cultural para os vários utentes do mar e para a comunidade em geral. Estes sítios constituem, também, uma simbiose única de História, estruturas sociais e sistemas ecológicos. Eles ilustram a utilização milenar do meio aquático, considerando as características e as vantagens oferecidas pelo ambiente natural, do mesmo modo que relacionam o estabelecimento humano na costa ao longo dos tempos, através da existência de zonas de naufrágio e áreas de navegação. O seu conhecimento contribui para a gestão sustentada do mar e da costa, preservando ou aumentando a sua diversidade biológica, sendo por isso de estudo necessariamente interdisciplinar.

O PROCASC procurou consequentemente responder aos maiores desafios da moderna arqueologia subaquática, em transformação devido à crescente aposta na multidisciplinaridade, com novas necessidades logísticas e dos meios técnicos. O projeto da Câmara Municipal de Cascais tem sido realizado em rede, em colaboração com a Direção Geral do Património Cultural (DGPC), o Centro de Investigação Naval da Escola Naval (CINAV), o CHAM - Centro de Humanidades, da Faculdade de Ciências Sociais e Humanas da Universidade Nova de Lisboa, e a empresa de arqueologia Archaeofactory. O PROCASC tem igualmente desenvolvido novas parcerias, potenciando sinergias que resultaram na aplicação de métodos de trabalho inovadores, por equipas verdadeiramente transdisciplinares. Os trabalhos têm ultrapassado as ciências sociais e humanas, através da aceitação do contributo de outras áreas, menos suspeitas, como a biologia e a robótica oceanográfica. Neste âmbito, o apoio do Laboratório de Robótica e Sistemas de Engenharia do Instituto Superior Técnico (LaRSYS), da Estrutura de Missão para a Extensão da Plataforma Continental (EMEPC) e da Agência Portuguesa do Ambiente (APA) foram essenciais.

O projeto desenvolve igualmente um programa educacional de património arqueológico de uma forma viva, transformando momentos multidisciplinares de laboratório em ações de sensibilização e de educação, promovendo a fruição direta aos elementos de várias proveniências académicas e sociais, procurando uma transmissão recíproca do valor identitário e sentimental do património. A formação, o treino dos arqueólogos e a prática do mergulho têm, deste modo, vindo a adaptar-se às novas tecnologias, cabendo na experiência deste projecto através da realização de estágios académicos de alunos de várias universidades portuguesas. Mais ainda, as actividades desenvolvidas têm permitido a aproximação entre aquilo que é público - entendido como atribuições e deveres dos organismos municipais e de Estado - e difuso - baseado no conhecimento popular e na pertença de uma comunidade costeira ou ribeirinha. Esta abordagem tem incluído, além das formas usuais de divulgação científica e das apresentações anuais à comunidade local, a difusão mais lata, alcançada através de disseminações de maior escala, como são o caso da revista National Geographic Society Portugal ou as actividades com a Rede de Escolas Associadas da Comissão Nacional da UNESCO Portugal. Por tudo isto, o Projeto Municipal de Arqueologia Subaquática de Cascais foi considerado um projeto "Boas Práticas" pela UNESCO, em maio de 2017, no âmbito da Convenção 2001 para a Proteção do Património Cultural Subaquático.

Com um âmbito de acção que abarca a costa do concelho de Cascais, entre o Cabo da Roca e São Julião da Barra, este artigo apresenta dos principais resultados obtidos entre 2015 e 2019, com especial incidência sobre o Bugio, espaço com um lugar especial na paisagem marítima do litoral português. 


\section{DESTROÇOS CONTEMPORÂNEOS NO BUGIO}

A quasi maritimidade do espaço geograficamente delimitada por dois promontórios, Cabo da Roca e Cabo Espichel, é interrompida a meio pela existência da embocadura do estuário do rio Tejo. Nesta, as trocas culturais são de longa duração e foram capturadas por uma história polvilhada de dinâmicas, continuidades e ruturas (Freire, 2014). Esta área é um paradoxo natural em si mesmo. Não é rio, mas também não é oceano. É uma zona de transporte marítimo em que o estuário condiciona, transforma e modifica o presente numa história de longa duração, marcada pela frequente perda de navios, contra a costa e nos areais dos Cachopos.

No Cachopo Sul, areal do Bugio, a uma profundidade que oscila entre os 7 e os 15 metros, a vida marinha refugia-se por entre os restos metálicos de dois naufrágios esquecidos. A memória do local, essa, perdura pelas visitas frequentes e atrevidas dos pescadores e dos praticantes de caça submarina (Figura 1).

Foi essa ligação à vida marinha que levou à redescoberta destes destroços em 2015, no âmbito da última campanha da M@RBIS, da Estrutura de Missão para a Extensão da Plataforma Continental (EMEPC), naquela que foi a primeira incursão da arqueologia na área do Bugio. Felizmente, nesta campanha, os biólogos eram acompanhados por dois arqueólogos da Câmara Municipal de Cascais, que imediatamente divulgam à comunidade a história desse "pequeno herói” (Rosa, 2015).

Esses vestígios iam ficando mais ou menos à vista, conforme as dinâmicas sedimentares da barra do estuário do Tejo (Figura 2). O Navio de Salvamento Patrão Lopes, totalmente desconhecido da maioria da comunidade científica, ou de localização incerta para os que conheciam a sua história, haveria de ressurgir num encontro feliz, mas inopinado, entre uns e outros.

A história do Patrão Lopes termina abruptamente, após 20 anos de um percurso exemplar ao serviço da Armada portuguesa. No dia 29 de Fevereiro de 1936, durante um violento temporal, tentava entrar a barra de Lisboa dando reboque, de braço dado, a um grande batelão de nome Franz que, à deriva, se tornara um perigo para a navegação. Subitamente, o Patrão Lopes é arrastado pelo batelão e sai do canal de navegação. Os dois encalham no areal do Bugio. O Franz afunda-se primeiro. Os seus mastros acabam por perfurar o casco do velho navio de salvamento, que acaba também por se perder (Figura 2).

Apesar de ter navegado sob bandeira portuguesa desde Abril de 1916, o navio foi construído em 188o, em Rostock, no Nordeste da Alemanha, pela Rostocker Act. Ges. Tinha 49 metros de comprimento, deslocava 467 toneladas brutas e tinha uma tripulação de 63 elementos. Era, a 23 de Fevereiro de 1916, o mais pequeno dos 72 navios das potências centrais (Alemanha e Império Austro-húngaro) que se encontravam refugiados em portos nacionais desde o início do confronto e que, nesse dia, foram requisitados e ocupados por elementos da Marinha portuguesa.

O Newa, à semelhança do conhecido Gil Eannes, também foi integrado na Armada, inicialmente com o nome Patrão Joaquim Lopes e, logo depois, apenas com o nome Patrão Lopes, em singela homenagem a um herói de muitos salvamentos na barra de Lisboa. De imediato, dá início a uma intensa actividade de salvamento que vai caracterizar o seu percurso, nos próximos 20 anos, de navegação sob bandeira portuguesa (Oliveira, 1936).

A descoberta do Patrão Lopes, no âmbito da campanha M@rbis 2015, deu origem a um programa específico de estudo colaborativo. Podendo tratar-se de um navio que pertenceu à Marinha Portuguesa, rapidamente o Centro de Investigação Naval (CINAV) da Marinha efetuou um conjunto de ações para confirmar a correlação entre destroço-navio, para avaliar as ações necessárias no futuro próximo, juntamente com elementos da Câmara Municipal de Cascais.

Encontrando-se os despojos em excelente estado de conservação, possivelmente devido aos longos anos que esteve quase todo tapado pela areia, são várias as possibilidades futuras para a preservação e dinamização deste último e único sobrevivente da " $c a$ sus belli" que levou Portugal a entrar, formalmente, na Grande Guerra.

Ainda antes do final desse Verão, e durante um levantamento geofísico com multifeixe do navio de salvamento Patrão Lopes, o mestre da embarcação da Administração do Porto de Lisboa (APL) que prestava assistência aos trabalhos indicou a localização de um novo destroço, que teria permanecido esquecido nas páginas da Ilustração Portuguesa e nos arquivos de Marinha e das Minas de São Domingos, não fosse esta importantíssima ligação entre a "academia" e os utilizadores do mar.

De acordo com as fontes, terá sido o temporal que se abateu na costa Ocidental de Portugal continen- 
tal nos dias 8 e 9 de Fevereiro de 1923 a provocar o afundamento do rebocador Rhona junto ao Bugio. O navio vinha a Lisboa para proceder a reparações, trazendo 9 pessoas a bordo.

Este pequeno rebocador, de 141 toneladas de Deslocamento Bruto e cerca de 30 metros de comprimento, pertencia à Mason \& Barry, empresa proprietária das Minas de S. Domingos (Mértola). Era habitualmente utilizado para rebocar as barcaças com minério entre o Pomarão e Vila Real de Santo António através do Guadiana, onde aquele era embarcado em navios maiores com destino a Inglaterra. O navio tinha sido construído em Inglaterra em 1897, precisamente para a Mason \& Barry. A viagem que tinha começado no Algarve às 17:0o do dia 6 , começou a complicar-se cerca de 24 horas depois, com o vento de sudoeste a aumentar até ao navio passar o Espichel. Foi já com o enfiamento da barra de Lisboa à vista que um conjunto de grandes ondas apanhou o rebocador, rebentado nas superestruturas do navio, provocando diversas avarias e entrada de água. Uma das ondas chegou mesmo a levar parte da ponte do pequeno rebocador, que assim ficou completamente desgovernado. Nesta altura, já perto do farol do Bugio, a tripulação conseguiu largar o ferro e começou a emitir sinais de socorro. Cerca das 22:0o horas, quando parecia aos tripulantes que tudo já estava perdido, estes juntaram-se na câmara, "dispostos a morrer ali". Os sobreviventes acabaram por subir ao que restava da ponte e ao mastro do navio, e ao nascer do dia, apenas já só lá estavam dois.

Foi nessa altura que chegou o salva-vidas de Paço d'Arcos, que a remos e, apesar do estado do mar, conseguiu aproximar-se do que restava do rebocador. $\mathrm{O}$ mestre do salva-vidas atirou-se ao mar, conseguindo colocar um cabo no mastro e, assim, salvar os dois únicos sobreviventes da tripulação do Rhon ${ }^{4}$.

Naturalmente, que em 2016 e 2017 foram realizados os mergulhos com o objectivo de tentar confirmar a identidade dos destroços (Figura 3), nomeadamente com recurso a metodologias arqueológicas forenses (resultados ainda preliminares), embora uma breve pesquisa na Ilustração Portuguesa nos tivesse dado pistas sobre a identidade do naufrágio de imediato (Figura 3).

4. Ilustração Portuguesa, №887, de 17 Fevereiro 1923, p.205, e Ilustração Portuguesa, №889, de 3 Março 1923, p.274.

\section{UM “CEMITÉRIO” DE NAVIOS DE ÉPOCA MODERNA}

Com variações que não conseguimos precisar, os sedimentos que são regularmente trazidos pelo rio Tejo e transportados por processos costeiros vão sendo depositados na sua foz, nomeadamente em duas zonas laterais da "Barra Sul" do porto de Lisboa. Estes dois locais de depósito da areia formam o Cachopo Norte (junto a São Julião da Barra) e o Cachopo Sul (envolvendo o forte de S. Lourenço da Cabeça Seca, tradicionalmente conhecido por Bugio). Estas duas zonas de areia, cujas características se têm alterado ao longo dos anos, estão directamente associadas às fortes correntes provocadas pelo caudal do Tejo e às condições de mar e vento, o que as tornam particularmente perigosas para a navegação à vela.

O Cachopo Sul, em particular, chegou a prolongar-se por quase duas milhas lateralmente à Barra Sul e, na baixa-mar, era possível caminhar desde a Trafaria até ao Bugio. Nos anos 80 do século passado, ainda havia uma parte que nunca se encontrava submersa, pois tinha inclusivamente alguma vegetação.

Não é, portanto, de estranhar, que um levantamento da bibliografia aponte para, pelo menos, 23 naufrágios ocorridos especificamente no Cachopo Sul, entre os anos de 1451 e 1936 (Silva e Cardoso, 2005) e certamente que muitos outros terão ali ocorrido anteriormente.

É nesta realidade que em Outubro de 2017 mariscadores profissionais declaram a descoberta de dois destroços, um localizado entre o Bugio e a Trafaria (designado inicialmente por Tejo B, atribuído aos restos de uma embarcação com uma carga de barricas em madeira com o envase de uma substância ainda por identificar) ${ }^{5}$. O outro, então designado por Tejo A, localizava-se sensivelmente a Sudoeste do Bugio, na zona de intervenção do PROCASC. Deste local os achadores terão retirado pelo menos dois pratos de estanho, que foram depositados no Instituto de Arqueologia e Paleociências, da Faculdade de Ciências Sociais e Humanas.

No mergulho de avaliação realizado neste contexto (Bugio 1) pela equipa do PROCASC em 28 de Outubro confirmou-se a existência de dois canhões em ferro semi-enterrados e três âncoras. Para além

5. Este local não foi caracterizado pelo ProCASC, nem será tratado neste artigo, pois encontra-se fora do âmbito espacial deste projecto. 
destes vestígios, visíveis no filme disponibilizado pelos achadores e referidos no auto de achado, dois elementos do CINAV registaram ainda nas proximidades o que aparentava ser os restos de uma estrutura em madeira, apenas visível nalgumas extremidades, mas com alguma coesão. Todos os vestígios sugeriam ser pertencentes aos restos de um navio dos inícios do século XVIII, de origem e função indeterminadas (Monteiro et al., 2018).

O PROCASC retomou os trabalhos nas áreas do projeto em julho de 2018, incluindo o espaço circundante ao Bugio, tendo realizado um novo mergulho de verificação no local do Tejo A. Apesar da visibilidade reduzida, verificou-se que o local se encontrava muito menos assoreado. Era possível visualizar um maior número de peças de artilharia em ferro e de âncoras, sobre areia e lastro em pedra (Figura 4). Em redor destas peças de maiores dimensões surgiam algumas concreções ferrosas, onde era possível identificar fragmentos de faiança portuguesa do século XVIII (Figura 5), para além de dois cadernais. Adicionalmente, aos dois conjuntos de âncoras, era agora possível vislumbrar cabos de grande bitola, habitualmente utilizados nas amarras dos navios. O interessante destas descobertas prende-se com a possível natureza do material com que eram feitos esses cabos. Apesar de não se ter efectuado nenhuma análise, estes aparentam ser, pela sua dureza, de piaçaba, fibra vegetal de origem brasileira utilizada a partir dos finais do século XVII (Hutter, 2005: 345), até ser substituído pelas amarras em corrente de ferro (Figura 4 e 5 ).

Os trabalhos no Bugio viriam a ser retomados em Setembro desse ano, tendo como objetivos determinar as potencialidades do sítio para a realização de um campus escola e para o seu levantamento com recurso a sonar de varrimento lateral pela EMEPC. Durante esta fase viriam a ser localizados vários depósitos inéditos, manifestamente distintos dos anteriores, visíveis sobretudo em quatro zonas, então designadas como Bugio 2.

Numa zona (Área C), situada $65 \mathrm{~m}$ a leste dos achados declarados em 2017, era visível um fragmento de secção central do navio, com a quilha e as balizas, constituindo por isso um indicador do eixo longitudinal do naufrágio. O bordo sul desta estrutura surgia a mais de $1 \mathrm{~m}$ de altura do nível da areia (sem estar apoiado) e as madeiras a menor profundidade mostravam evidências claras de exposições anteriores a maior escala do que a daquele momento, surgindo por exemplo parte de uma tábua de resbordo invertida e enterrada junto à quilha ou outra tábua do forro deslocada, encostada às balizas (Figura 6).

A observação preliminar desta estrutura indica tratar-se de um navio de grande porte, com paralelos próximos na nau Nossa Senhora dos Mártires, que naufragou em São Julião da Barra em 1605 quando voltava do Estado da Índia (Castro, 2005). A quilha é compósita, com alefriz, medindo $30 \mathrm{~cm}$ de altura e $23,5 \mathrm{~cm}$ de largura, na zona das escarvas, lisas verticais, que ligam diferentes troços. As balizas centrais teriam uma secção quadrangular, com cerca de 23 $\mathrm{cm}$, tendo sido observada pelo menos uma escarva na ligação caverna/ braço. As tábuas do forro exterior, com 11 a $12 \mathrm{~cm}$ de espessura, estavam fixas às balizas com pregos em ferro de secção quadrangular. $\mathrm{Na}$ calafetagem das costuras das tábuas recorreu-se à utilização de cordões de chumbo (Figura 6).

Uma segunda zona (Área B), situada a $20 \mathrm{~m}$ a norte da Área C, corresponde a uma acumulação com pelo menos cinco bocas-de-fogo em bronze, madeiras da estrutura do navio e numerosos materiais na areia pimenta, fragmentos de porcelana e cauris (Figura 7). Neste conjunto destacam-se dois pedreiros com as armas da coroa portuguesa (Figura 8) e uma acumulação de pimenta localizada sob uma provável tampa em madeira.

Uma terceira zona (Área D), situada $20 \mathrm{~m}$ a leste da Área B e a $25 \mathrm{~m}$ a nordeste da Área C, corresponde também a um depósito com três bocas-de-fogo (possivelmente do tipo colubrina ou colubrina bastarda) em bronze, elementos de madeiras e numerosas concreções, algumas com outros artefactos, nomeadamente um almofariz em pedra. Sobre os sedimentos surgem igualmente materiais, sobretudo porcelana e cauris $^{6}$ (Figura 7 e 8).

Foram mapeadas mais duas estruturas em madeira, mais afastadas. A Área F, a leste, corresponde a outro fragmento de navio, onde podem ser observadas porcelanas e outros materiais entre as balizas. $\mathrm{O}$ ângulo entre o forro exterior e as balizas sugere tratar-se uma secção extrema da embarcação. A última estrutura, de grandes dimensões, está situada cerca de

6. Após a divulgação do projecto de estudo deste contexto, fomos informados pelas "Redes Sociais" e pela própria DGPC que teriam sido recuperadas algumas peças do local, incluindo um possível almofariz de pedra, registado durante os nossos trabalhos. A retirada deste material foi considerada ilícita pelo Procurador da Comarca de Lisboa, DIAP - 4- ${ }^{-2}$ Secção de Lisboa, de 14-10-2019. 
$40 \mathrm{~m}$ a norte da Área B e $50 \mathrm{~m}$ a nordeste do Tejo A, agora designado por Bugio 1, e parece corresponder ao bordo de um navio, onde ainda não foi possível identificar características que permitam relacionar com nenhum dos contextos determinados.

Em todo o caso, os dados disponíveis à data sugerem a existência de dois naufrágios distintos numa zona com uma área de pelo menos $120 \mathrm{~m}$ no sentido oeste-leste e 50 no sul-norte. A proximidade entre as duas realidades não é surpreendente, pois há registo de pelo menos 23 naufrágios na zona dos Cachopos, entre 1451 e 1936, conforme já mencionado. Os vestígios identificados no Bugio 1 apontam para um naufrágio posterior a meados do século XVII ou inícios do século XVIII, marcado pela utilização exclusiva de artilharia em ferro, uso de lastro em pedra, presença de faiança portuguesa da época e cabos em piaçaba. Os depósitos identificados em Bugio 2 sugerem tratar-se de uma nau da Carreira da Índia, com paralelos na $N^{\underline{a}}$. Sr $r^{\underline{a}}$. dos Mártires (1606), em especial em termos de construção naval. Nos diversos núcleos, predomina a artilharia em bronze e são abundantes materiais arqueológicos relacionados com origem no Índico e Ásia, como a porcelana ou a pimenta. Uma análise das fontes, e tendo em conta as evidências materiais que este destroço apresenta, sugere podermos estar na presença dos vestígios da nau portuguesa São Francisco Xavier, perdida a 23 de Outubro de 1625 quando regressava da Índia nos baixios da Cabeça Seca (Silva e Cardoso, 2005: 63).

\section{OS AVANÇOS DE 2019}

Os trabalhos no Bugio efetuados durante a campanha de 2019 decorreram em dois períodos distintos, entre 27 de Maio e 1 de Julho e 2 de Agosto e 16 de Setembro, tendo o trabalho sido dividido em quatro fases - monitorização, mapeamento, delimitação, caracterização e avaliação dos contextos -, conhecidos e a confirmar.

Foi de imediato possível constatar uma reposição do nível sedimentar. Esta situação fez com que grande parte do espólio do Bugio 2, observado em 2018, em particular as peças de artilharia em bronze, se encontrassem completamente enterrados. Adicionalmente, foi possível constatar que ambos os destroços contemporâneos, o Patrão Lopes e o Rhona, voltaram a estar cobertos de uma extensa camada de bivalves (mexilhão), fenómeno que se encontrava em regressão nos anos anteriores.
Para além dos mergulhos de monitorização realizados nos locais anteriormente identificados, foram ainda realizados mergulhos de verificação de anomalias que surgiram num levantamento com multifeixe realizado em Setembro de 2018, pela Agência Portuguesa do Ambiente (APA), no âmbito Projeto COSMO - Programa de Monitorização da Faixa Costeira de Portugal Continental. Neste levantamento, além dos contextos já mencionados, de Bugio $1 \mathrm{e}$ Bugio 2, é possível observar mais de uma dúzia de anomalias batimétricas. Em três dessas anomalias, das cinco avaliadas, foram detetados contextos arqueológicos, dois provavelmente naufrágios - Bugio 3 e Bugio 4 .

Bugio 3 é caracterizado por uma grande concreção, com cerca de 20 metros de comprimento, coberta na sua maior parte de bivalves (mexilhão). Os vestígios estendem-se com uma orientação nordeste, e embora tudo indique que se trata de um naufrágio, não foi possível detetar nenhum objeto que possibilite a sua identificação. No entanto, encontravam-se visíveis três aspetos que importa realçar. Na zona mais a sul, encontram-se espalhadas, isoladamente ou em pequenos aglomerados, várias dezenas de pelouros de ferro. Na face leste da concreção, e avançando de sul para norte, encontra-se um objeto que aparenta ser uma peça em ferro, mas que se encontra meio tapada pela areia, com o que poderá ser a parte da culatra encastrada na concreção. Avançando sempre em direção a norte, na mesma face leste, surgem vários vestígios de madeira, muito degradada.

O sítio Bugio 4 corresponde a um depósito com mais de meia centena de barricas de madeira, com aros de vime, que transportariam uma substância cinzenta sólida, da qual foram recolhidas amostras para análise, por elementos da DGPC (Figura 9). As características do contexto são marcadamente semelhantes às identificadas no naufrágio Tejo B.

Para além dos alvos detetados na zona do Cachopo Sul, foi realizada a verificação de um outro naufrágio, da época contemporânea, muito bem preservado, que também surgiu no levantamento da APA. Este destroço, no Cachopo Norte, corresponde possivelmente um vapor inglês de meados do século XIX, encontrando-se fora dos canais de navegação da Barra de Lisboa, cerca de 500 metros a sul da fortaleza de São Julião da Barra (Figura 9). 


\section{CONSIDERAÇÕES FINAIS}

Os naufrágios da Barra do Tejo têm um potencial muito significativo, que ultrapassa o contexto regional, apontando para um questionário científico que diz respeito ao estudo da navegação global, que se desenvolveu a partir de inícios do século XV.

Os vestígios em Bugio 2, provavelmente os restos da nau São Francisco Xavier, que ali naufragou em 1625 quando voltava da Índia, permitem antever um contributo importante para a investigação de variadas temáticas, como a construção naval, o equipamento, nomeadamente militar, e as cargas que circulavam entre vários oceanos. A Rota do Cabo foi uma das mais importantes dos séculos XVI e XVII, tendo permitido prolongar e desviar a Rota da Seda por mar até à Europa, aumentando o fluxo de produtos asiáticos, como a especiarias, os têxteis indianos e chineses ou a porcelana chinesa, a uma escala sem precedentes. Esta teve por isso um impacto na cultura e na sociedade a uma escala global. Ter acesso ao Bugio 2 constitui uma oportunidade para estudar os veículos, as mercadorias, as pessoas e a geografia desta rota. Constitui também uma oportunidade para revisitar a historiografia e repensar conceitos sobre esta fase da globalização, que colocou em contacto direto o Atlântico, o Indico e o Pacífico pela primeira vez, oceanos ocupados por povos com experiências muito diversas.

O potencial do Bugio 1 é mais difícil de determinar por agora. No entanto, é óbvia a complementaridade que este sítio pode ter no estudo das dinâmicas de navegação na época moderna. Marcadamente mais recente, este contexto é dominado pela presença de artilharia e várias âncoras em ferro, surgindo igualmente alguns fragmentos de faiança portuguesa e botijas de fabrico peninsular, a par de cabos de piaçaba, utilizada sobretudo a partir do século XVIII e explorada no Brasil. Este sítio poderá por isso anunciar uma ligação ao Atlântico, numa fase para a qual não dispomos de estudos sistemáticos de navios ou naufrágios em Portugal, além dos dois navios da Boa Vista (Bettencourt et al., 2017).

Menor é ainda o conhecimento que temos de Bugio 3 e Bugio 4, sobre os quais não há ainda pistas sobre a cronologia, embora estes materializem de uma forma clara a importância da zona do Bugio enquanto ponto de transição entre a navegação oceânica e fluvial.

Os naufrágios em ferro, Patrão Lopes e Rhona, transportam a região de Lisboa para a navegação no século
XX, enquanto cenário da Primeira Guerra Mundial ou porto estratégico na exploração de recursos minerais em Portugal.

Esta importância científica e patrimonial constitui um desafio para a arqueologia portuguesa, tendo resultado num protocolo de colaboração entre o Município de Cascais, a Marinha e a Faculdade de Ciências Sociais e Humanas da Universidade Nova de Lisboa. Este prevê articular um plano plurianual para o estudo, salvaguarda de valorização dos sítios de época moderna, incluindo ainda uma componente de formação superior.

\section{BIBLIOGRAFIA}

BETTENCOURT,J., FONSECA, C., SILVA, T., CARVALHO, P., COELHO, I. e LOPES, G. (2017) - Os Navios de época Modernos de Lisboa: balanço e perspectivas de investigação. In CAESSA, A., NOZES, C., CAMEIRA, I. e SILVA, R.B. (coord.), I Encontro de Arqueologia de Lisboa: Uma cidade em escavação. Lisboa: CML, CAL, pp. 478-495.

FREIRE, Jorge (2014) - Maritime Cultural Landscape. A New Approach to the Cascais coastline. Journal of Maritime Archaeology, 9 (1), pp. 143-157.

HUTTER, Lucy Maffei (2005) - Navegação nos séculos XVII e XVIII. Rumo: Brasil, São Paulo. São Paulo: Editora da Universidade de São Paulo.

LATOUR, Bruno (2005) - Reassembling the social: an introduction to actor-network theory. Oxford University Press.

MONTEIRO, Alexandre, FREIRE, Jorge, BISCAIA, Flávio, COSTA, Paulo, GAUTHIER-BÉRUBÉ, Marijo, PATACAS, Pedro e PINTO, Sandro (2018) - Notícia preliminar da descoberta de dois naufrágios na entrada do estuário do Tejo. Al-Madan Online, II ${ }^{a}$ Série, n. ${ }^{\circ}$ 22, Tomo 1, pp. 166-17o.

OLIVEIRA, Maurício de (1939) - Allô! Allô! Patrão Lopes. Lisboa, Parceria António Maria Pereira, 2 vols.

ROSA, Gonçalo (2015) - Patrão Lopes. National Geographic, n‥ 177, Dezembro de 2015.

SILVA, Manuel Eugénio da e CARDOSO, Gilherme (2005) - Naufrágios e Acidentes Marítimos no litoral Cascalense, Cascais: Junta de Freguesia, $2^{2}$ edição.

WESTERDAHL, Christer (1992) - The Maritime Cultural Landscape. The International Journal of nautical Archaeology, 21(1), pp. 5-14.

WESTERDAHL, Christer (2011) - The Maritime Cultural Landscapes. In Catsambis, A., Ford, B. Hamilton, D. L. (Eds), The Oxford Handbook of Maritime Archaeology. Oxford University Press, pp. 733-762. 


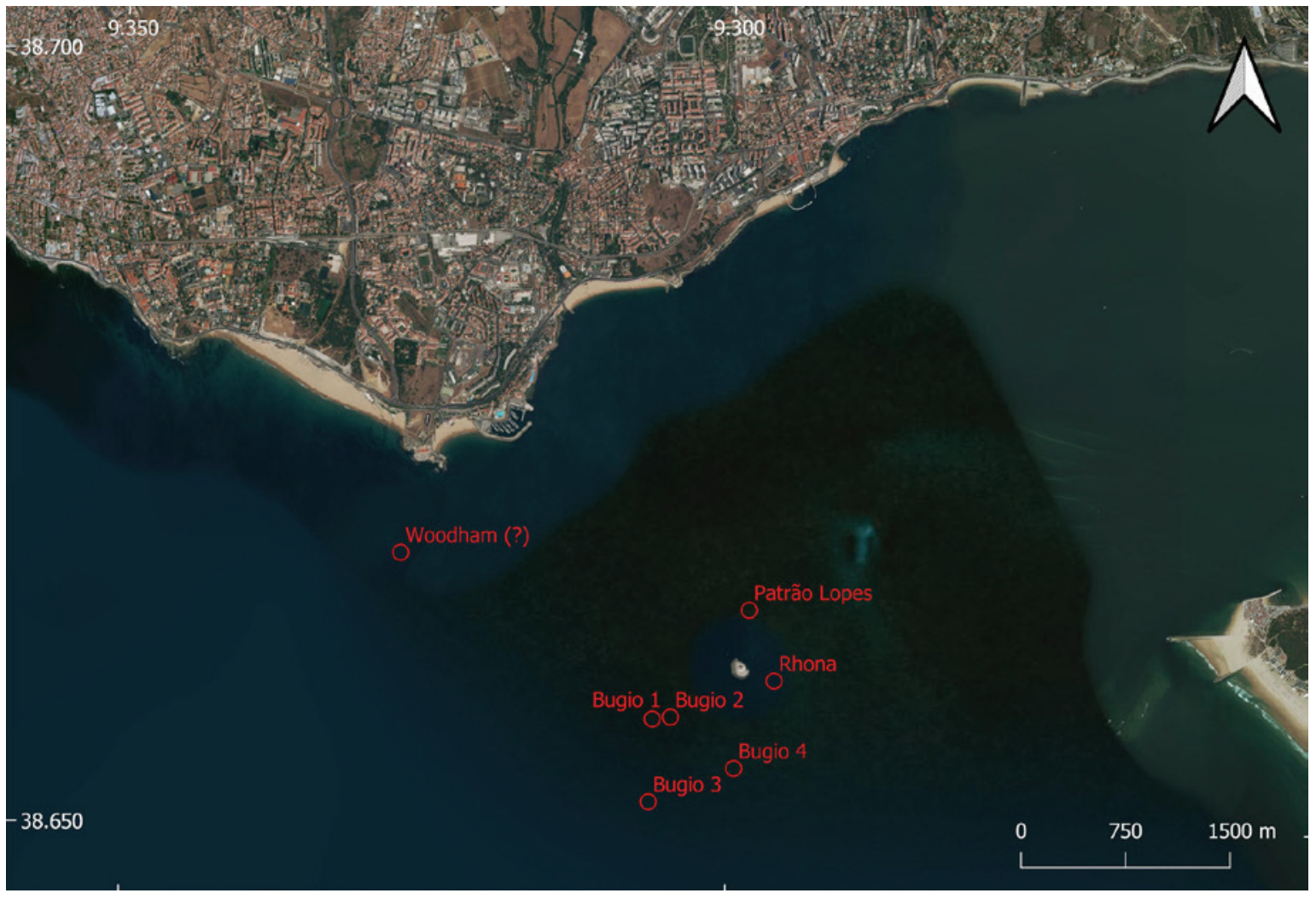

Figura 1 - Localização dos sítios intervencionados na Barra do Tejo em 2018 e 2019 (imagem base: ESRI Satellite).

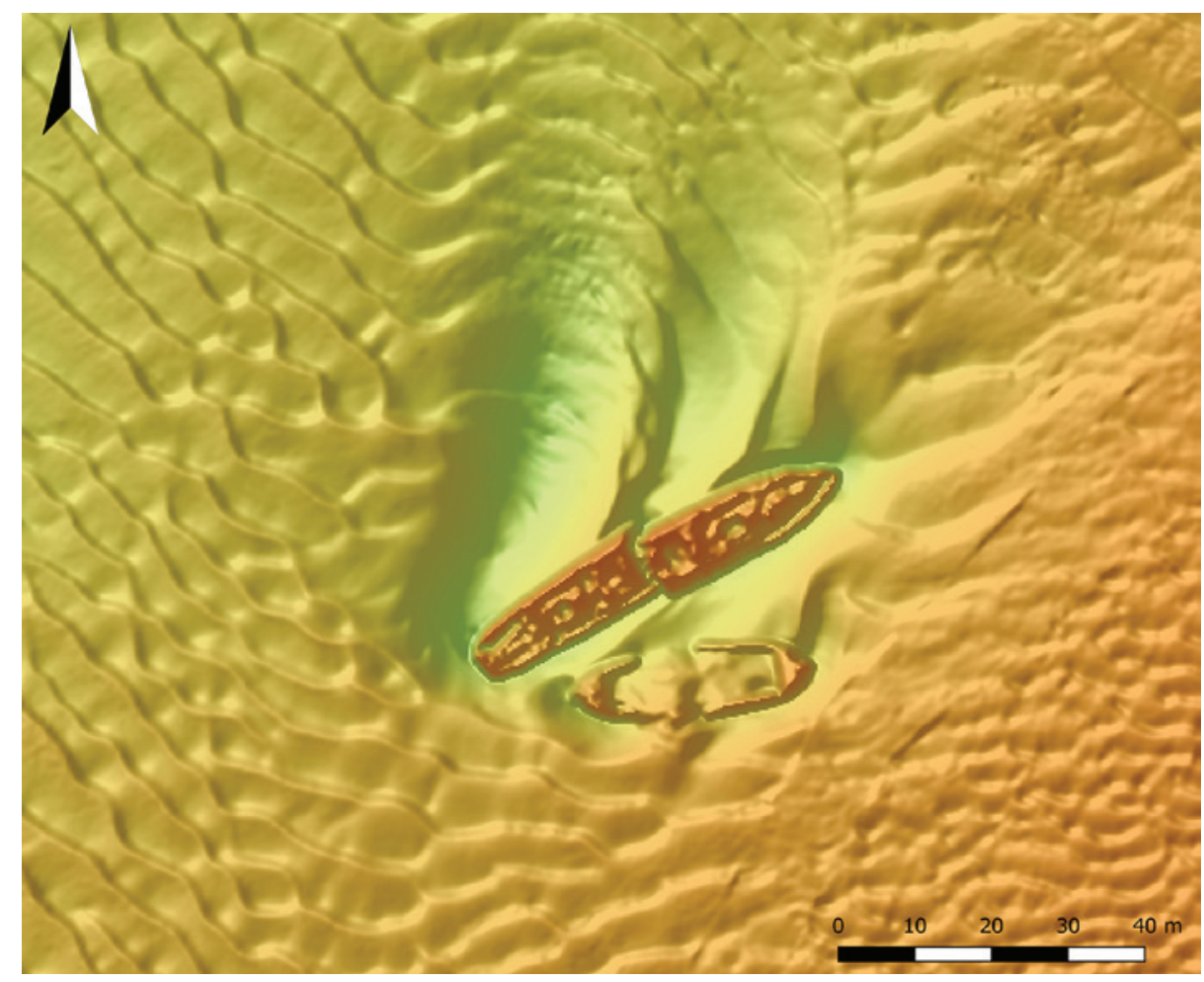

Figura 2 - Modelo batimétrico do Patrão Lopes, efectuado em 2018 (dados: Projeto COSMO - Programa de Monitorização da Faixa Costeira de Portugal Continental, Agência Portuguesa do Ambiente). 


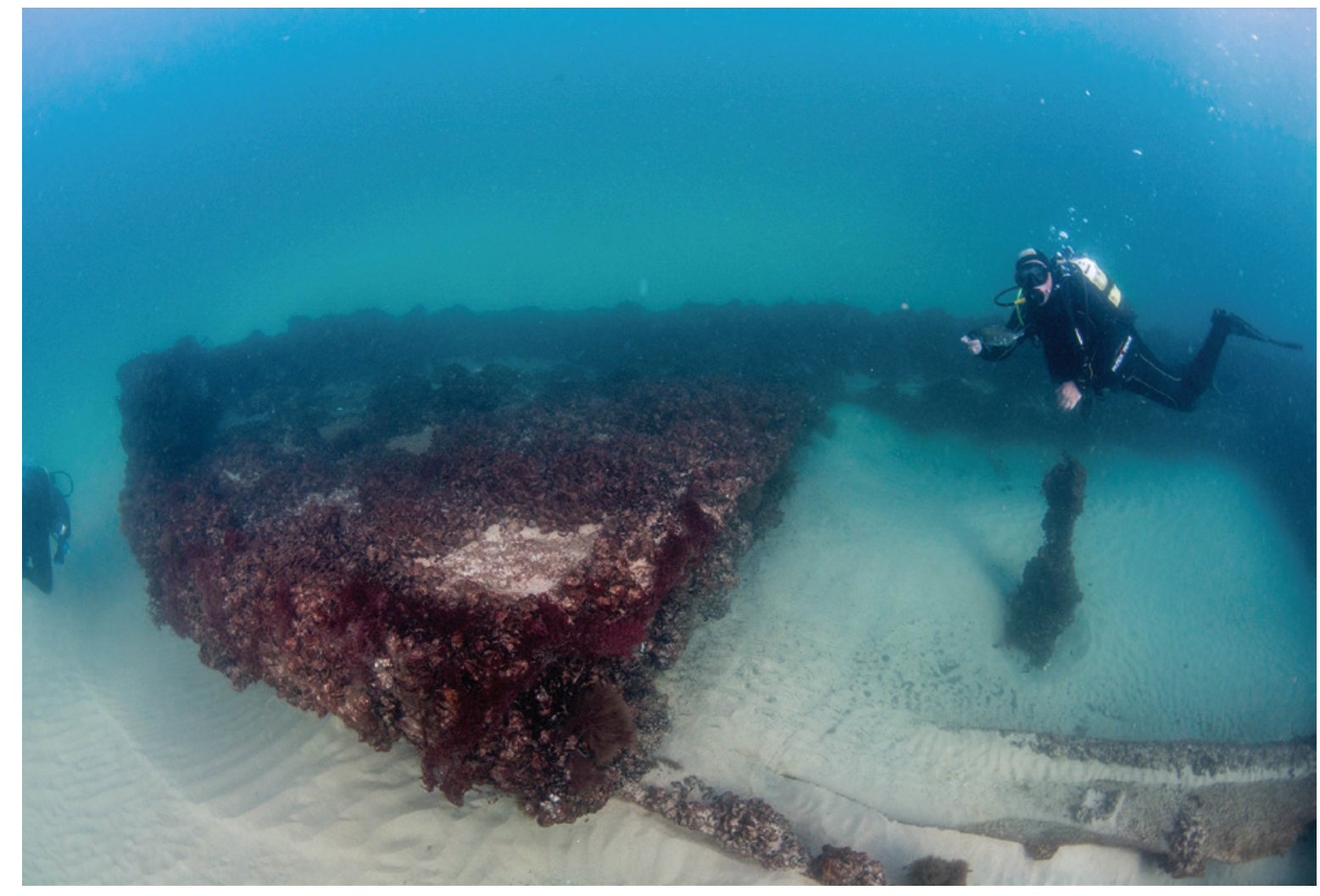

Figura 3 - Vestígios do Rhona, em Agosto de 2018 (foto: Augusto Salgado).

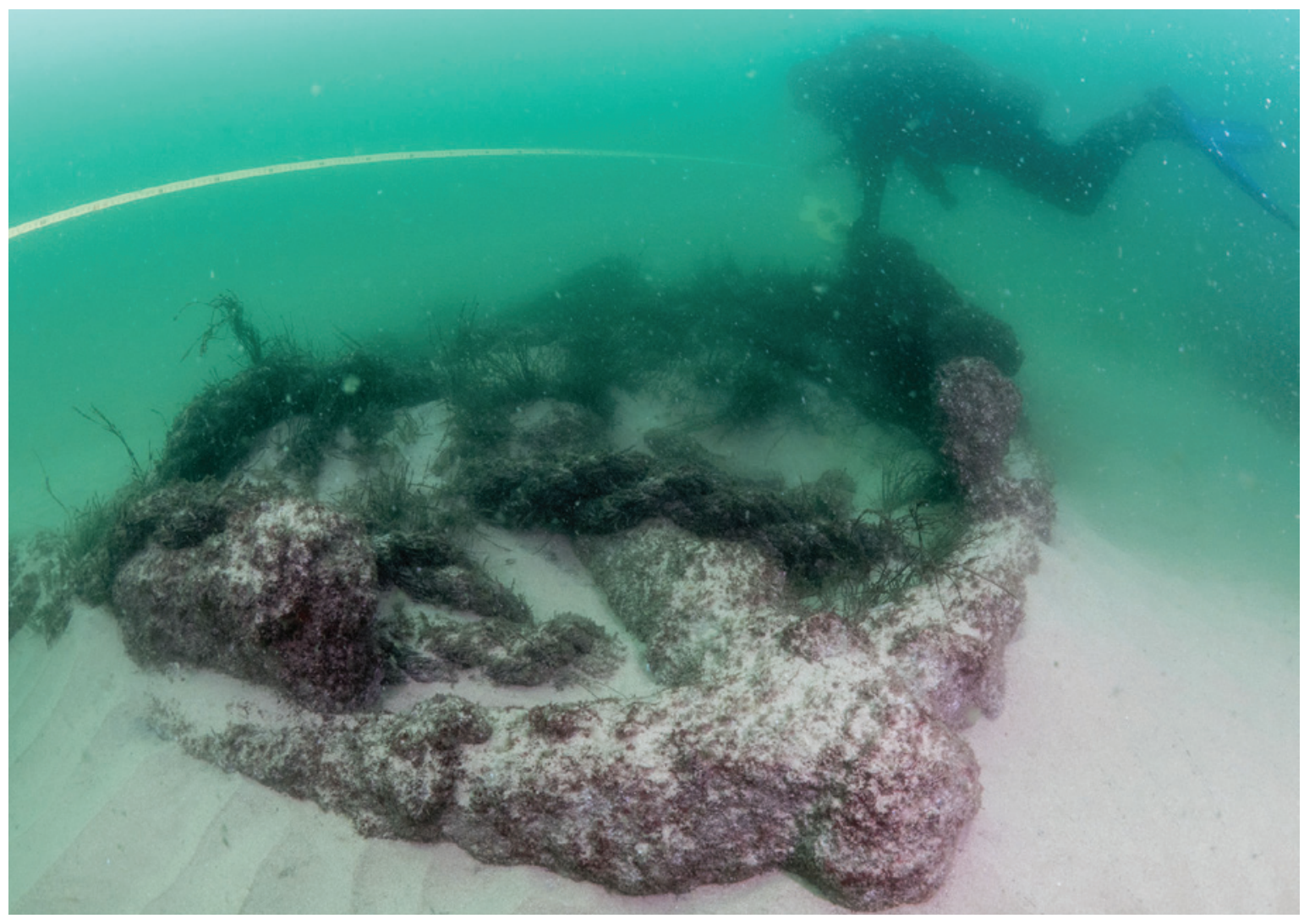

Figura 4-Bugio 1 (foto: Augusto Salgado). 


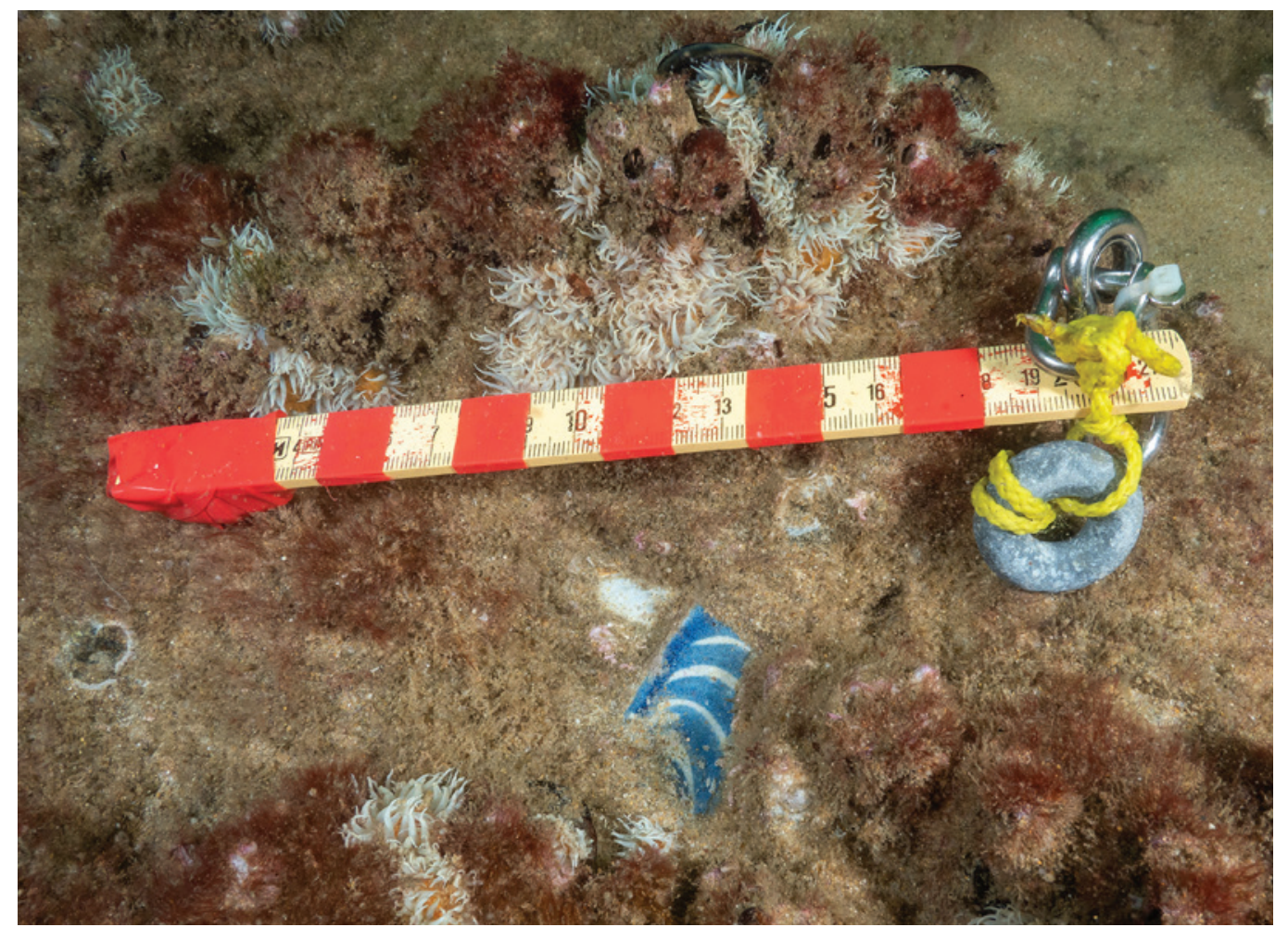

Figura 5 - Fragmento de faiança documentado nas concreções de Bugio 1 (foto: Augusto Salgado).

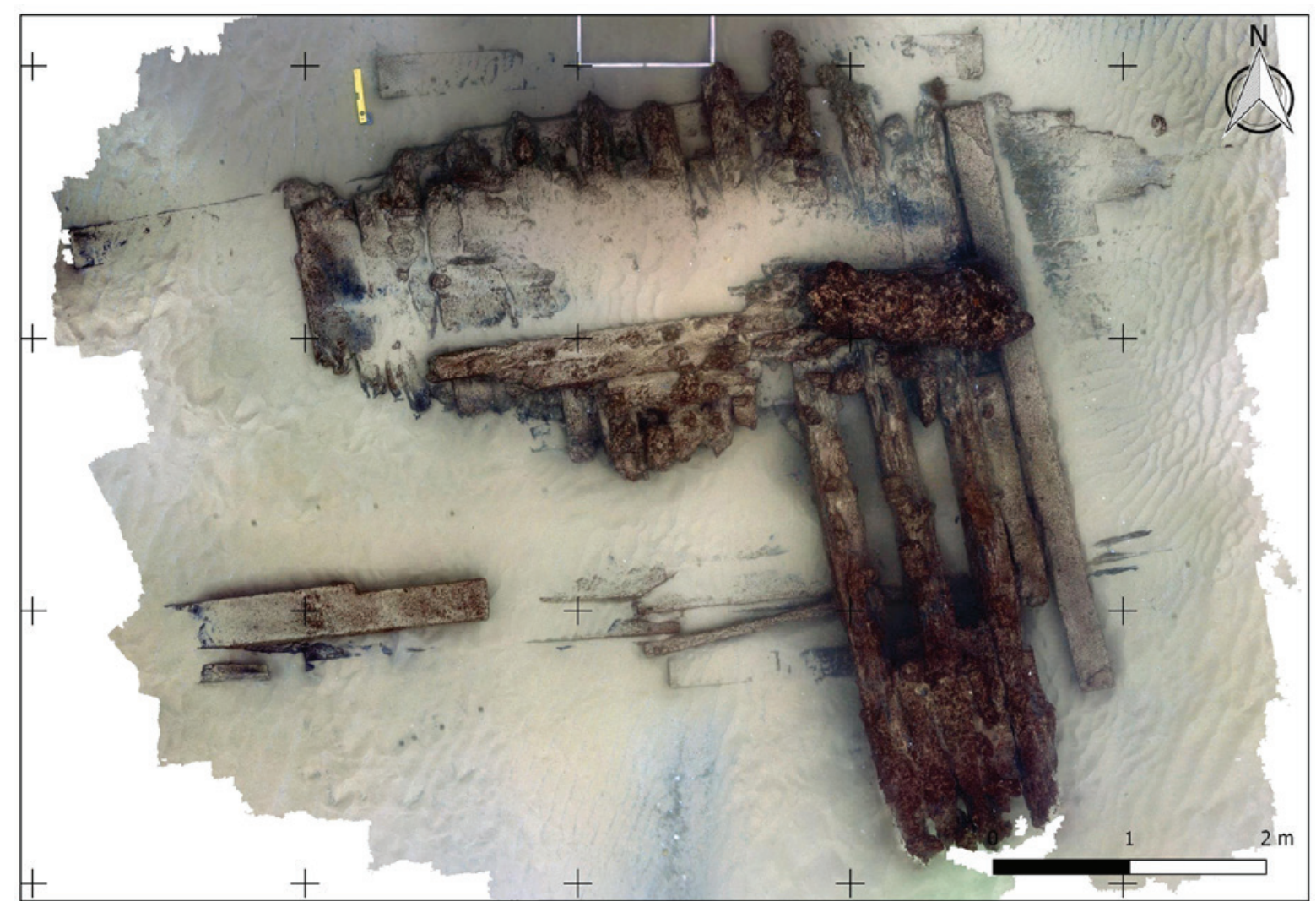

Figura 6 - Área C (ortofotografia: José Bettencourt; norte magnético). 


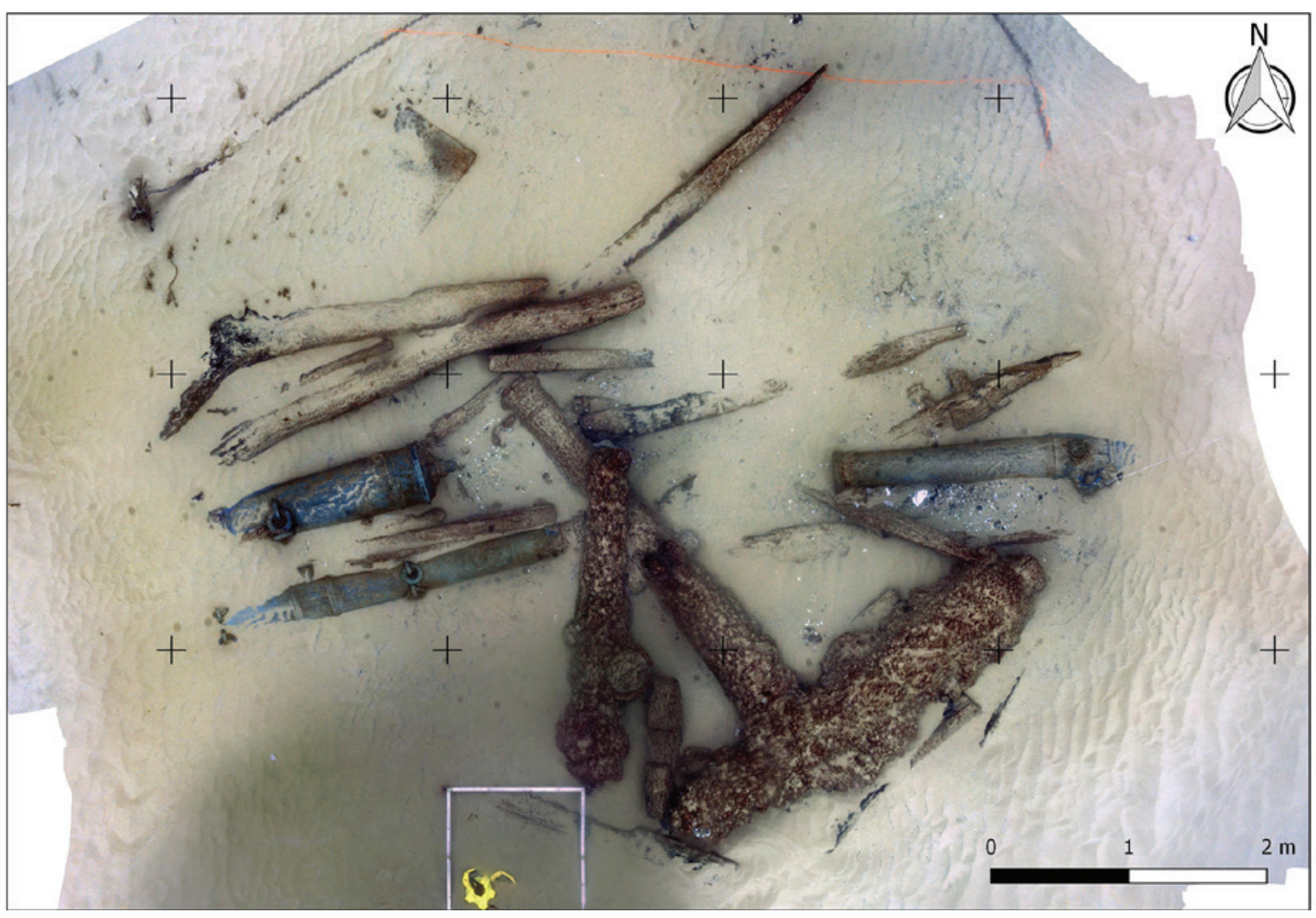

Figura 7- Área B (ortofotografia: José Bettencourt; norte magnético).

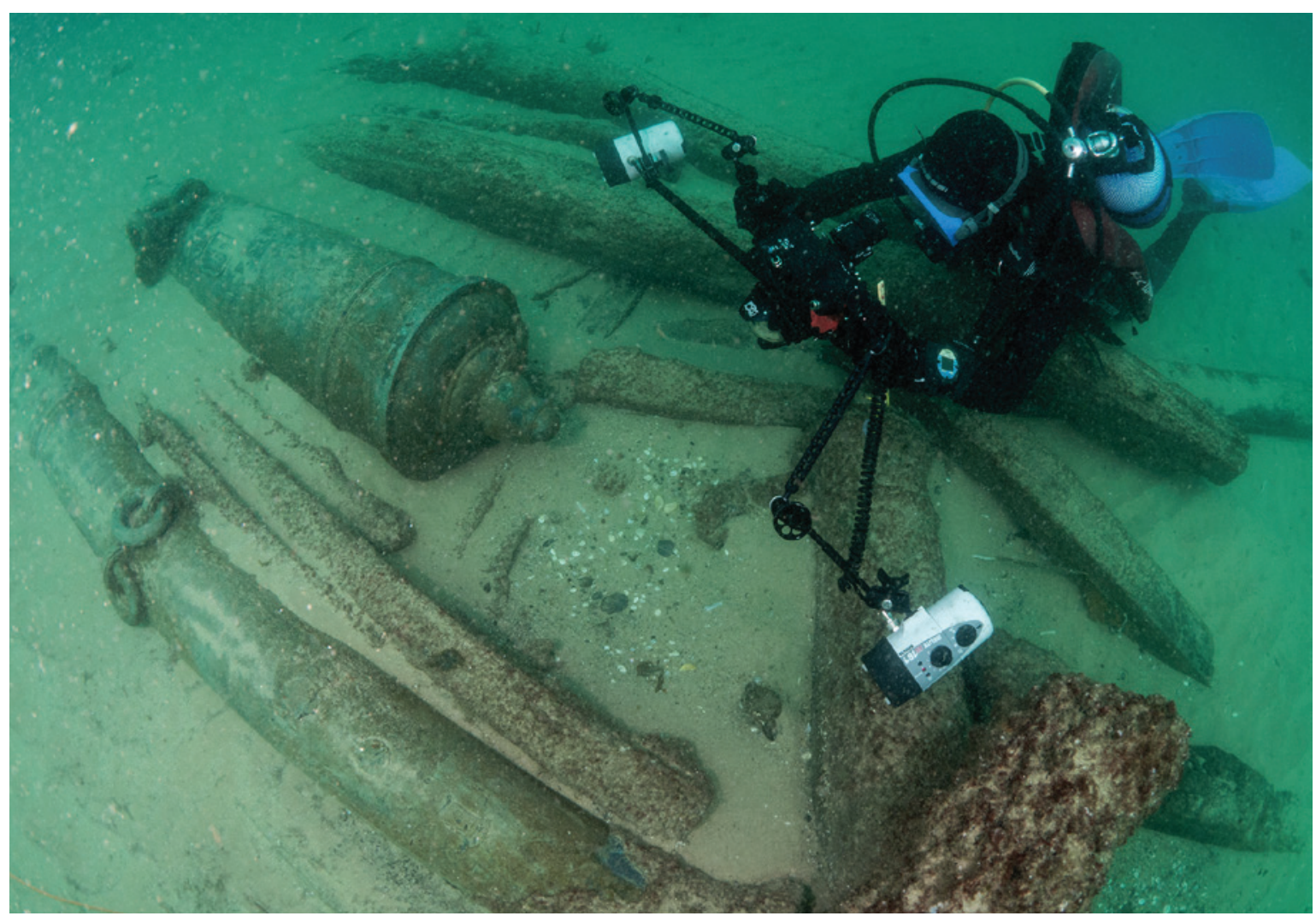

Figura 8 - Conjunto de bocas-de-fogo documentado na Área B (foto: Augusto Salgado). 


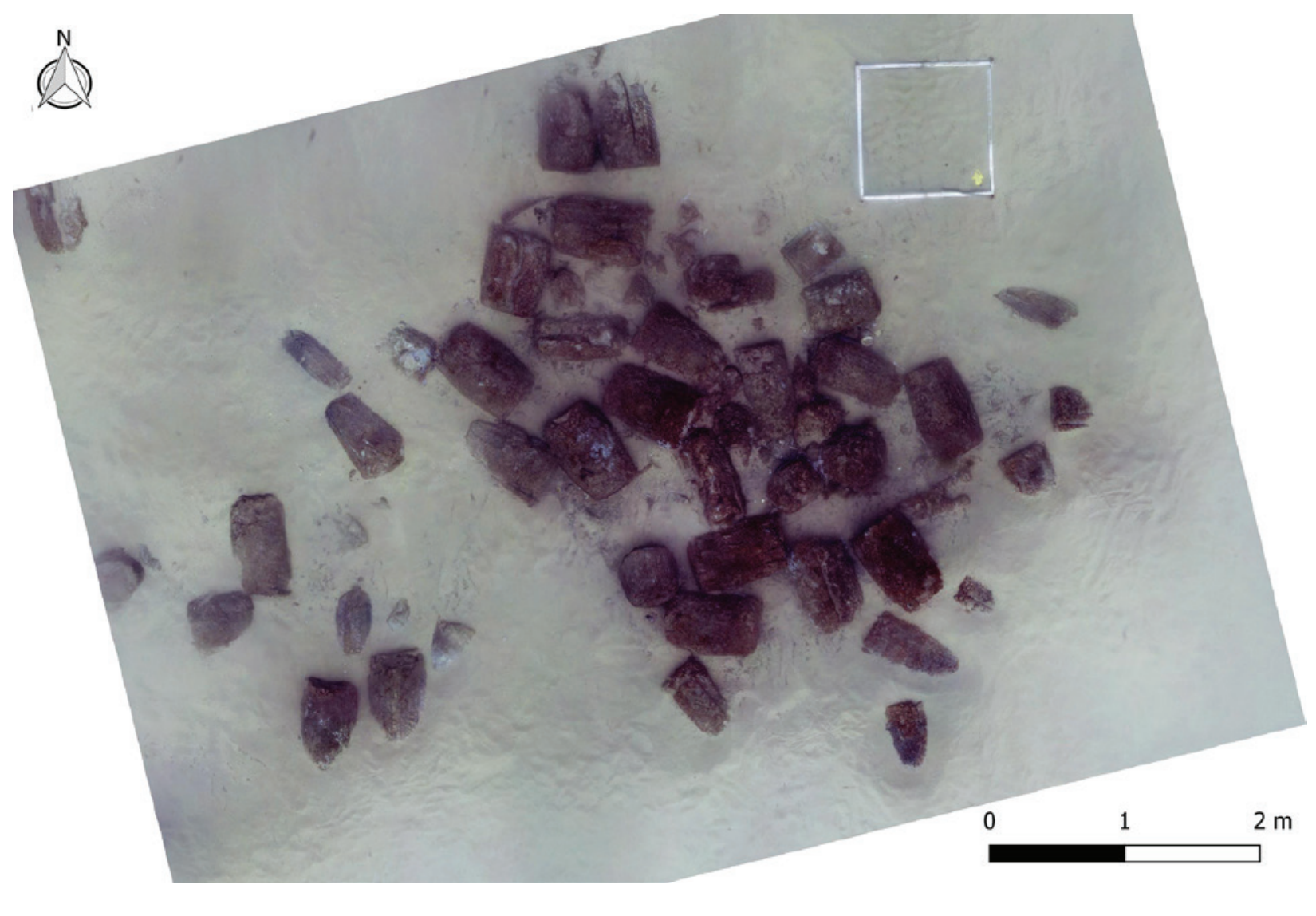

Figura 9-Bugio 4, em 2019 (ortofotografia: José Bettencourt; norte magnético). 


\title{
ARQUEOLOGIA MARÍTIMA EM CABO VERDE: ENQUADRAMENTO E PRIMEIROS RESULTADOS DO PROJECTO CONCHA
}

José Bettencourt ${ }^{1}$, Adilson Dias ${ }^{2}$, Carlos Lima ${ }^{3}$, Christelle Chouzenoux ${ }^{4}$, Cristóvão Fonseca ${ }^{5}$, Dúnia Pereira ${ }^{6}$, Gonçalo Lopes $^{7}$, Inês Coelho ${ }^{8}$, Jaylson Monteiro ${ }^{9}$, José Lima ${ }^{10}$, Maria Eugénia Alves ${ }^{11}$, Patrícia Carvalho ${ }^{12}$, Tiago Silva ${ }^{13}$

\section{RESUMO}

Entre os parceiros da Cátedra UNESCO O Património Cultural dos Oceanos contam-se o CHAM e o Instituto do Património Cultural de Cabo Verde, que definiram como tarefa essencial a carta arqueológica subaquática daquele arquipélago. Esta acção iniciou-se em 2018 no âmbito do projecto Europeu CONCHA, que tem como objectivo analisar o desenvolvimento das cidades portuárias no Atlântico durante a época moderna.

As missões do CONCHA realizaram-se na ilha de Santiago, no fundeadouro da Ribeira Grande, no naufrágio de São Francisco (século XVII) e no Urânia (1809). Incluíram o mapeamento e a revisão de documentação e dos materiais arqueológicos destes sítios, em depósito no Museu de Arqueologia. Foram igualmente desenvolvidas actividades de divulgação e acções de formação. Esta comunicação sistematiza os resultados destes trabalhos. Palavras-chave: Arqueologia Marítima, Arqueologia Moderna, Atlântico, Cabo Verde.

\begin{abstract}
Among the partners of the UNESCO Chair The Ocean's Cultural Heritage are CHAM and IPC (Cape Verde) which defined as essential action the underwater archaeological site inventory of that archipelago. This action started in 2018 as part of the European project CONCHA, that aims to address the different ways that port cities developed around the Atlantic during the early modern era.

CONCHA's surveys were conducted on the island of Santiago, in Ribeira Grande anchorage, in São Francisco ( $17^{\text {th }}$ century) and in Urânia shipwrecks (1809). The project included the underwater survey, a review of the documentation and of the archaeological materials, recovered from the sites, at the Museum of Archaeology in Praia. Dissemination and training activities were also carried out. This paper systematizes the results of these works. Keywords: Maritime Archeology, Early Modern Archeology, Atlantic, Cape Verde.
\end{abstract}

\footnotetext{
1. CHAM - Centro de Humanidades e FCSH, Universidade Nova de Lisboa; jbettencourt.cham@gmail.com 2. Instituto do Património Cultural de Cabo Verde (IPC); didias386@gmail.com

3. Instituto do Património Cultural de Cabo Verde (IPC); conser-rest.lima@ootlook.com

4. EVEHA; krist_aile@yahoo.fr

5. CHAM - Centro de Humanidades; cristovaofonseca@gmail.com

6. Instituto do Património Cultural de Cabo Verde (IPC); duniapereira79@gmail.com

7. CHAM - Centro de Humanidades; goncaloncsl@gmail.com

8. CHAM - Centro de Humanidades; inesalexandrapinto@gmail.com

9. Instituto do Património Cultural de Cabo Verde (IPC); Jaylson.Monteiro@iipc.gov.cv

10. Instituto do Património Cultural de Cabo Verde (IPC); joselima1995@hotmail.com

11. Instituto do Património Cultural de Cabo Verde (IPC); eugenialves9@hotmail.com

12. CHAM - Centro de Humanidades; patriciasanchescarvalho@gmail.com

13. CHAM - Centro de Humanidades; toiago@gmail.com
} 


\section{INTRODUÇÃO}

Cidades Globais; Redes; Oceano Atlântico; Património Cultural são as palavras chave por detrás do projecto CONCHA: The construction of early modern global Cities and oceanic networks in the Atlantic: An approach via Ocean's Cultural Heritage. O projecto resulta de uma rede de contactos e parcerias estabelecidas no âmbito da Cátedra UNESCO O Património Cultural dos Oceanos e pretende abordar as diferentes formas pelas quais se desenvolveram as cidades portuárias nas margens do Atlântico, entre o final do século XV e início do XVIII. Liderado pela Universidade NOVA de Lisboa, e sedeado no CHAM, o projecto reúne 11 parceiros internacionais de entidades académicas e não-académicas: Associação para as Ciências do Mar (APCM), Observatório do Mar dos Açores (OMA), Universidad Pablo de Olavide (UPO), Trinity College Dublin (TCD), EVEHA, Instituto de Património Cultural (IPC), Universidad del Norte (UniNorte), MARAPA, Mar Ambiente e Pesca Artesanal, Universidade Federal de Sergipe (UFS) e Old Dominiom University (ODU). É financiado ao abrigo do Programa H2O2O, no âmbito das acções Marie Slodowska Curie Actions: Research and Inovation Staff Exchange (RISE).

Com relações já estabelecidas pelo envolvimento na Cátedra UNESCO O Património Cultural dos Oceanos, os parceiros CHAM e IPC definiram como área prioritária de intervenção o estudo e a valorização do Património Cultural Subaquático (PCS) de Cabo Verde, nomeadamente através do desenvolvimento da carta arqueológica subaquática do arquipélago. As primeiras missões arqueológicas deste programa realizaram-se na ilha de Santiago ao abrigo do projecto CONCHA. Focaram-se no fundeadouro da Ribeira Grande (Cidade Velha), uma das primeiras ocupações europeias na África subsariana, porto fundamental no comércio de escravos no Atlântico e Património Mundial da UNESCO desde 2009. Além da Cidade Velha, foram selecionados mais dois sítios arqueológicos relevantes para o conhecimento da importância do arquipélago nas redes de circulação atlântica: o naufrágio de São Francisco, o mais antigo conhecido até à data no arquipélago, e o naufrágio da fragata portuguesa Urânia, perdida em frente à Cidade da Praia (Smith 2002; D’Oliveira 2005, pp. 9o91; Fig. 1) (Figura 1).

O trabalho foi desenvolvido faseadamente, em três campanhas de terreno, entre Abril de 2018 e Feve- reiro de 2019, que contaram com a participação dos técnicos do IPC, dos investigadores do CHAM, dos parceiros franceses da empresa EVEHA, e também com a colaboração de Emanuel Charles de Oliveira e de Alexandre Semedo.

Estas missões centraram-se na avaliação do potencial científico dos sítios arqueológicos e consistiram na georreferenciação e no registo dos contextos em mergulho. Foi também efectuada uma revisão da documentação e dos materiais arqueológicos provenientes destes sítios, actividades de divulgação para o público escolar e acções de formação. Neste artigo apresentam-se os principais resultados obtidos.

\section{ENQUADRAMENTO}

A história de Cabo Verde, do seu povoamento e desenvolvimento, está intimamente ligada ao mar. A sua posição geográfica privilegiada tornou as ilhas em plataformas de apoio logístico às rotas transoceânicas, ponto de passagem quase obrigatório, tanto para os navios da Coroa Portuguesa, como das restantes monarquias europeias que demandavam os mares do Sul. Numa primeira fase, o seu principal porto, Ribeira Grande de Santiago, era apenas ponto de passagem e abastecimento, mas no final da primeira década após o seu descobrimento este ganhou uma nova ordem, passando a residência dos principais comerciantes e local de produção de bens para trocas comerciais nos Rios da Guiné. A Ribeira Grande, um dos primeiros burgos edificados por portugueses na África subsariana, transformou-se num importante entreposto comercial ligado ao tráfego negreiro, obtendo foro de Cidade e estatuto de Bispado em 1533, o primeiro de África, com jurisdição evangélica nos chamados 'Rios de Guiné", no Continente fronteiro (Torrão e Teixeira, 2009).

A importância económica e estratégica de Cabo Verde, que marcou a história do arquipélago, legou também um património subaquático de valor inestimável, que pela sua variedade e proveniência diversa representa a primeira globalização. O número de navios afundados na orla marítima cabo-verdiana está ainda por apurar, mas estudos preliminares referenciam já mais de uma centena de naufrágios, a maioria localizados ao largo da Boa Vista, Maio e Santiago, perdidos quando passavam entre as ilhas ou faziam escalas de apoio, com origens muito diversas (D’Oliveira, 2005, pp.138-156).

O interesse por estes vestígios revelou-se cedo, ainda 
antes da independência, contando-se mais de uma dezena de iniciativas. Deste período resultou pouca informação sobre os contextos intervencionados, as recuperações efectuadas e o respectivo destino dos materiais exumados, mas as notícias na imprensa eram comuns (D'Oliveira, 2005, pp. 137-139).

O interesse por este património subaquático regressou após a independência. O Estado Cabo-verdiano passou a ser frequentemente assediado, com propostas de pesquisa em várias ilhas, algumas de exploradores célebres em salvados em vários países. Em 1980, Robert Marx fez um pedido para localizar uma embarcação fenícia. No mesmo ano, Robert Sténuit propõe recuperar objectos de dois naufrágios específicos, um do reinado de Luís XIV e outro da Companhia Holandesa das Índias Orientais (VOC), missões que não se chegaram a realizar ( $\mathrm{D}^{\prime}$ 'Oliveira, 2005, p. 139). Nos anos seguintes continuaram a surgir propostas, entre as quais a World Wide First, em 1984, representada por Franck Goddio e Edmound Balm, que se comprometia a formar um conservador e dois mergulhadores locais, o que também não chegou a acontecer. Na mesma altura, foi negociado um possível contrato com Erick Surcouf, onde estavam definidos parâmetros como a repartição do material recuperado, as despesas de execução dos trabalhos e as contrapartidas para o governo de Cabo Verde, que incluíam mais uma vez a formação de um conservador ou dois mergulhadores.

A exploração há muito adiada acabaria por ser efetivada na década de 1990, altura em que o Estado empreendeu um conjunto de missões de "salvamento de espólio subaquático" e de escavações arqueológicas terrestres. Para a vertente subaquática, o Estado de Cabo Verde assinou, inicialmente, em 1992, um contrato com a empresa sul-africana Afrimar, que concentrou as suas ações na ilha da Boa Vista, nos naufrágios do Hartwell, Santo André e Leimuiden. Em 1995, o Estado assinou outro contrato de exploração com a Empresa Arqueonautas South Atlantic, posteriormente Arqueonautas World Wide, S.A. Entre 1995 e 2001, esta empresa portuguesa, sediada na ilha da Madeira, deu continuidade ao trabalho da Afrimar, alargado a outras ilhas. De acordo com os dados disponíveis na documentação em depósito no IPC, foram identificados 71 sítios subaquáticos e terão sido escavados 11 naufrágios e duas zonas na Cidade Velha.

Apesar da quase ausência de publicações, o legado desta exploração teve impacto na arqueologia cabo- -verdiana, dando origem ao Museu de Arqueologia, à formação de técnicos de conservação e a uma maior exigência no tratamento do PCS do arquipélago. Esse caminho viria a ser iniciado ainda durante o trabalho de campo. O acordo entre a Arqueonautas e Cabo Verde previa a cedência de um edifício na zona portuária da Praia, ocupado em Dezembro de 1998, com o início da instalação da equipa técnica e administrativa que viria a garantir o apoio às intervenções de terreno. Depois de algumas obras de adaptação realizadas no edifício, este recebeu a denominação de Centro de Conservação e Restauro, sendo aí instalada uma equipa de técnicos estrangeiros e nacionais contratados pela empresa para apoio aos trabalhos de campo. Posteriormente, este espaço passou a ser denominado Centro de Restauro e Museologia (CRM). A introdução de estantes e prateleiras numa das salas para acondicionamento dos objetos conservados levou à sua exibição, por forma a serem usufruídos pelos visitantes que afluíam a esse espaço em número crescente, quer em delegações oficiais (inclusive a Delegação da Presidência da República de Cabo Verde, chefiada pelo então Presidente Pedro Verona Pires; Membros do Conselho de Ministros e Delegações Estrangeiras), quer em visitas casuais de curiosos.

Por conseguinte, nota-se a introdução da vertente museológica numa instalação cuja vocação inicial era acolher os objetos, conservá-los, documentá-los e armazená-los, para no final se fazer a partilha, conforme estipulado no contrato de concessão firmado entre a empresa e o Estado de Cabo Verde.

O Museu de Arqueologia nasce neste contexto, materializando assim a recomendação do Grupo de Trabalho sobre Pesquisas Arqueológicas que nos anos 8 o já tinha acautelado o princípio de dar a conhecer o acervo arqueológico resultante dos trabalhos de pesquisa e escavações subaquáticas, a serem realizadas, quando afirma que "As operações podem conduzir à recolha de um $\mathrm{n}^{\circ}$. apreciável de objectos com valor histórico que justifique um local para sua guarda e exposição." (Cardoso, 1984, p. 5).

A partir de 2002, altura em que se efetuou a partilha dos objetos, o então IIPC decidiu trabalhar no sentido de divulgar o acervo arqueológico que Cabo Verde conseguiu obter com a intervenção das empresas. Depois dos trabalhos de adequação do edifício, o Núcleo Museológico da Praia foi inaugurado em Dezembro de 2005, com a exposição denominada de "Nos Patrimoniu". Foi o materializar da vontade 
do IIPC em divulgar e promover o património arqueológico do país, com o objetivo de sensibilizar as pessoas para a questão da preservação e valorização dos bens culturais.

Esta exposição tinha duas vertentes: uma arqueológica e outra etnográfica. $\mathrm{O}$ facto de se reunir numa mesma exposição testemunhos de proveniências disciplinares diferentes justificava-se porque, nessa altura, o Museu Etnográfico da Praia estava a ser encerrado, para receber obras de beneficiação do edifício, algo que aconteceu nos finais de 2005 e princípios de 2006. Terminadas as obras no Museu Etnográfico da Praia, todo o espólio em exposição foi devolvido à origem, ficando no Núcleo Museológico da Praia apenas objetos relativos ao património arqueológico. Em 2007, com o apoio financeiro da Embaixada dos Estados Unidos da América, o então IIPC fez obras no edifício, melhorando a qualidade das instalações, transformando-o naquilo que é hoje o Museu de Arqueologia, inaugurado no dia 24 de Outubro de 2008. O Museu de Arqueologia é de tutela e gestão estatal (IIPC), de âmbito nacional e temática disciplinar, com um acervo testemunho da importância histórica de Cabo Verde entre os séculos XV e XIX. Tem como principal missão a preservação e divulgação do património arqueológico do país, nas suas várias vertentes subaquática e terrestre, visando alcançar o público em geral, e em particular os investigadores, professores e alunos dos vários níveis de ensino.

O espólio à sua guarda inclui o resultado dos trabalhos subaquáticos da década de 1990. Proveniente de várias paragens e, chegado a Cabo Verde em embarcações com bandeira das principais potências marítimas europeias (Espanha, Portugal, Inglaterra, Holanda e França) e dos Estado Unidos da América, enquanto principal patrulheiro do atlântico na luta contra o tráfico ilegal de escravos, o espólio mostra a diversidade e riqueza do conteúdo imaterial associado a cada artefacto. As coleções são diversas, incluindo instrumentos de navegação, elementos da estrutura e equipamento de navios, armamento, vestígios de cargas - que incluem presas em marfim, moedas, correntes e algemas, faunas, cerâmicas -, para além de artefactos que representam a vida a bordo das embarcações, incluindo, por exemplo, utensílios de cozinha e objectos de uso pessoal. Inclui-se também extensa documentação sobre os trabalhos efectuados.

O Museu guarda igualmente um importante legado patrimonial fruto das escavações terrestres, constituído por objetos provenientes da Cidade Velha (Ribeira Grande de Santiago), Trindade (Praia), Alcatraz (São Domingos), Igreja de Santiago Maior (Santa Cruz), Concheiro de Salamansa (São Vicente) e Forte da Preguiça (S. Nicolau). São particularmente relevantes os vestígios dos primeiros assentamentos humanos na Cidade Velha, na Trindade e na Baía de Alcatraz - Nossa Senhora da Luz, que documentam o modo de vida, social, cultural e religioso, dos primeiros colonizadores.

Além do material em reserva, o Museu de Arqueologia apresentou o espólio proveniente da exploração de sítios subaquáticos em duas exposições na última década, mantendo também uma parte exposta no Museu do Mar, no Mindelo, e no Museu do Sal, em Santa Maria.

A actual exposição, na Praia, intitulada de "Hi(é)stórias que o nosso Mar Preservou", foi inaugurada em 2018 e assume uma estrutura temática, que parte da apresentação de materiais de acordo com a sua utilidade nos navios. A visita é iniciada com objetos e equipamentos associados à navegação e aos navios, seguindo-se uma amostra de marfim da carga do naufrágio Princess Louise e por vitrines onde se encontram jóias, relógios e objetos associados à beleza moedas de vários países e outros objetos utilizados em trocas comerciais, e ainda materiais que documentam a vida a bordo. A exposição termina com a colecção de equipamentos bélicos e com uma apresentação multimédia com conteúdos sobre a coleção do Museu de Arqueologia. O Museu dispõe ainda de uma vitrine temporária intitulada "Uma Questão de Escala", montada em parceria entre o IPC e o projecto CONCHA, que conjuga a Arqueologia e a História Ambiental Marinha.

\section{AS MISSÕES DO CONCHA}

3.1. O inventário dos materiais e da documentação Além de trabalho de campo, a avaliação dos sítios intervencionados durante o projecto foi realizada através da consulta de processos e do estudo de uma amostra dos materiais depositados no Museu de Arqueologia da Praia.

$\mathrm{O}$ arquivo da arqueologia de Cabo Verde corresponde a várias pastas com documentação administrativa e fotocópias de fichas de conservação dos materiais recuperados nos vários sítios intervencionados pela empresa Arqueonautas. Esta documentação inclui o 
historial das intervenções, bem como alguns processos relativos às vendas em leilão dos artefactos mais valiosos; documentos sobre a organização das várias missões, equipas de trabalho ou contratos firmados entre o Governo de Cabo Verde e vários intervenientes. Foi igualmente consultada documentação em papel recentemente entregue pela Arqueonautas ao IPC, em trânsito em Lisboa, onde se encontram fichas de mergulho, plantas ou inventários dos materiais recuperados nos vários contextos, além de dados históricos sobre naufrágios.

Esta informação, em grande parte duplicada, foi tratada em dois momentos distintos, de modo a reunir um arquivo digital o mais completo possível: num primeiro, foram fotografadas a totalidade das páginas de cada dossier no Museu da Praia; num segundo, em Lisboa, a documentação em trânsito foi digitalizada.

A análise dos materiais em depósito no Museu de Arqueologia foi restringida ao espólio proveniente dos sítios intervencionados no âmbito do CONCHA. A selecção procurou ser o mais representativa possível das colecções, correspondendo a uma amostra dos diferentes materiais recuperados (cerâmica comum e vidrada, faiança, vidro, materiais em liga de estanho e de cobre), que foram inventariados, fotografados e desenhados. Algumas peças de maior dimensão, nomeadamente as botijas que se encontravam completas, foram registadas através de fotogrametria, base para o posterior desenho.

\subsection{Os trabalhos subaquáticos}

Foram avaliados em mergulho o fundeadouro da Cidade Velha e os sítios subaquáticos de naufrágio de São Francisco e do Urânia, todos na ilha de Santiago (Figura 1). Além da observação e documentação em vídeo e fotografia, o registo incluiu o levantamento fotogramétrico dos contextos e das áreas com maior potencial arqueológico.

Os trabalhos de prospecção efectuados no fundeadouro da Cidade Velha, em frente ao centro histórico, permitiram confirmar o seu potencial científico e patrimonial. A zona corresponde a um fundo de areia e cascalho, encaixada entre duas plataformas rochosas, onde a profundidade evolui rapidamente, atingindo os $25 \mathrm{~m}$ apenas a $400 \mathrm{~m}$ da praia. A área arenosa, com boas condições de ancoragem, atinge aproximadamente $80 \mathrm{~m}$ de largura, terminando abruptamente a leste e oeste em plataformas rochosas constituídas por escoadas vulcânicas, limitando e dificultando, por isso, as condições de operação dos navios (Figura 2).

O registo material da utilização portuária da baía em frente à Ribeira Grande surge sobretudo a partir dos $17 \mathrm{~m}$ de profundidade. Os vestígios arqueológicos incluem numerosas âncoras em ferro, de dimensões, tipologias e cronologias distintas, depositadas na zona de areia, mas também nas plataformas rochosas que a limitam, além de cerâmicas, também de várias tipologias, distribuídas por todo o espaço prospetado, mas com maior densidade algumas áreas.

As cerâmicas incluem diversas produções, mas abundam sobretudo os bordos e paredes de botijas e outros fabricos claramente peninsulares: formas quotidianas em cerâmica comum vermelha, formas de açúcar, louça esmaltada a branco sem decoração e cerâmica vidrada.

Estes materiais são idênticos a outros depositados no Museu de Arqueologia da Praia recuperados pela empresa Arqueonautas. Esta colecção é na verdade vasta e heterógena, com origens distintas, mas com uma cronologia que abarca principalmente os séculos XVI e XVII, com presença maior de produções peninsulares. Destacam-se as mesmas tipologias documentadas durante os nossos trabalhos - botijas, formas de açúcar, cerâmica esmaltada a branco sem decoração ou cerâmica vermelha. As botijas, por exemplo, de diversas tipologias, são sobretudo de fabrico andaluz, origem que pode ser também atribuída a, pelo menos, uma forma de açúcar em exposição no Museu (Amores Carredano e Chisvert Jiménez, 1993, p. 278; Fig. 3). A mesma proveniência poderá ser conferida a pratos e escudelas esmaltadas a branco, também frequentes. Em menor quantidade, surgem produções andaluzas com decoração, cerâmicas vidradas a verde ou melado, várias tipologias de cerâmica vermelha sem decoração, faiança portuguesa, cachimbos do noroeste europeu, algumas porcelanas chinesas, majólicas italianas e cerâmicas de origem africana (Figura 4). A colecção proveniente do fundeadouro da Cidade Velha inclui também algumas peças metálicas, nomeadamente bocas-de-fogo e manilhas (Figura 3).

Os trabalhos permitiram igualmente localizar três possíveis contextos de naufrágio na Cidade Velha. $\mathrm{Na}$ zona de areia foram documentados os restos de um navio em madeira ( $\mathrm{CV}_{1}$; Figura 5). Os outros prováveis contextos de naufrágio correspondem a conjuntos de canhões. No primeiro, localizado junto aos ilhéus, estão documentados três canhões em 
ferro, cuja origem é difícil de determinar, embora o arquivo da empresa Arqueonautas refira a recuperação ali de materiais durante sondagens, nomeadamente balas em chumbo (AGO-050). O segundo $\left(\mathrm{CV}_{2}\right)$ corresponde a um claro contexto de naufrágio, situado a sudoeste da Ponta Grande da Cidade, com 13 canhões em ferro, depositados numa depressão ao longo de $29 \mathrm{~m}$. A cronologia é em ambos difícil de determinar nesta fase.

A segunda área de intervenção corresponde ao naufrágio de São Francisco, localizado em Passa Pau, numa costa rochosa, exposta e de difícil acesso. Apesar das dificuldades, a intervenção em Passa Pau justificava-se pela importância histórica e simbólica que este naufrágio encerra. Intensamente explorado pela empresa Arqueonautas, é o mais antigo até à data identificado em Cabo Verde. Dali foi recuperado um raro astrolábio, na origem de uma das poucas publicações sobre a intervenção daquela empresa no arquipélago (Smith, 2002). Actualmente no The Mariners' Museum and Park, nos Estados Unidos, é uma peça banhada a prata que terá sido fabricada por Nicolao Rvffo em 1645, terminus post quem para a constituição do contexto, que inclui também uma diversificada colecção de materiais, metálicos e cerâmicos, globalmente atribuíveis à segunda metade do século XVII.

Os trabalhos ali efectuados permitiram verificar que os contextos deste naufrágio se encontram num fundo muito irregular, que varia entre afloramentos rochosos, que emergem à superfície nalgumas áreas, formando caneiros perpendiculares à costa. Os restos encontram-se concentrados ao longo de aproximadamente $30 \mathrm{~m}$, sobretudo num desses caneiros, mas a dispersão dos materiais estende-se a depressões periféricas. Actualmente os vestígios dominantes correspondem a 17 canhões em ferro e três âncoras no mesmo material.

Além destas peças em ferro, observaram-se vários materiais de superfície, nomeadamente numerosos fragmentos de cerâmica, tendo sido recuperados um bordo de botija (SFig-oor) e um bordo de talha (SF19-O02). Estes materiais são semelhantes aos recuperados em Passa Pau pela empresa Arqueonautas (Figura 6). Nesta colecção contam-se, pelo menos, meia centena de bordos com a mesma morfologia do SFi9-oor, com possível fabrico andaluz. A talha SFig-oo2 também encontra paralelo nos materiais no Museu, sendo provavelmente da mesma área de produção que as botijas (Amores Carredano e Chisvert Jiménez, 1993, p. 276 e 301). A origem Andaluza também pode ser atribuída às cerâmicas esmaltadas a branco sem decoração proveniente do mesmo contexto, embora também tenham surgido vários fragmentos de cachimbos em grés de fabrico do noroeste europeu e pelo menos dois fornilhos de tradição africana.

Além das cerâmicas, o Museu de Arqueologia guarda um vasto espólio do naufrágio de São Francisco, incluindo um número elevado de moedas em prata, pratos em estanho, sondas, balas e placas em chumbo, um compasso de navegação, um crucifixo e um candelabro em liga de cobre. Neste último metal destaca-se um conjunto de escudelas encontradas empilhadas. Em estanho é particularmente relevante a extensa colecção de tampas de garrafas quadradas em vidro, com diversas tipologias. Destaque também para uma manilha recta e um eixo, provavelmente de uma ou mais grilhetas, com claras semelhanças, na forma e nas dimensões, às encontradas no sítio de perda do navio negreiro inglês Henrietta Marie, que naufragou em Marquesas Keys, Golfo do México, em 1700 (Moore e Malcom, 2008, p. 28).

A grilheta, a par da presença de elementos africanos no contexto, atribui particular relevância ao naufrágio de São Francisco. Além de ser o mais antigo conhecido em Cabo Verde, esta assinatura material coloca-nos na pista das rotas negreiras. A predominância de moedas espanholas e de cerâmicas andaluzas sugere corresponder a um navio espanhol em rota para Cabo Verde, algures na segunda metade do século XVII (com grande probabilidade no terceiro quartel), possivelmente para adquirir escravos.

O último sítio intervencionado corresponde ao único do qual se conhece com segurança a identidade. A fragata Urânia naufragou na cidade da Praia a 5 de Fevereiro de 1809, quando voltava ao Brasil depois de uma escolta a Inglaterra. Lançada à água a 15 de Dezembro de 1792 com o nome Ulisses, que manteve até 1807 , esta fragata da Marinha Portuguesa tinha 132 pés de comprimento $(43,56 \mathrm{~m}), 34$ de boca (11,22 m) e 25 de pontal $(8,25 \mathrm{~m})$ e armava entre $32 \mathrm{e}$ 36 peças. A tripulação rondava os 300 homens, entre oficiais, cozinheiros, marinhagem e guarnições. Ao longo da sua carreira efectuou diversas missões no Canal da Mancha, Argel, Açores, Inglaterra, Tânger, ou Brasil, tendo, por exemplo, integrado a esquadra que retirou a família Real para o Brasil em Novembro de 1807 (Esparteiro, 1979, p. 87-99). Os vestígios atribuídos ao Urânia encontram-se 
aproximadamente a sul do Ilhéu da Praia, ocupando um fundo essencialmente rochoso, de afloramentos e grandes blocos. O contexto é dominado por canhões em ferro dispersos e por uma extensa concreção constituída por canhões e barras no mesmo metal, ao longo de $41 \mathrm{~m}$ (Figura 7). A distribuição dos materiais sugere que o tumulus corresponde sensivelmente à posição do fundo do casco, ao lastro depositado no porão do navio, constituído por canhões e barras em ferro, e a um paiol de pelouros, onde estavam armazenadas balas no mesmo metal. Os canhões alinhados a oeste deverão corresponder ao local de deposição final de parte das peças de uma das baterias do navio. As outras terão sido recuperadas após o naufrágio, o mesmo acontecendo com as âncoras e outros equipamentos.

Os vestígios móveis de pequenas dimensões ainda existentes no sítio são escassos, tendo apenas sido observados alguns fragmentos de pregaduras e chapas em liga de cobre. O Museu de Arqueologia da Praia guarda, no entanto, uma pequena colecção constituída sobretudo por objectos metálicos. Entre estes, encontram-se uma das fêmeas do leme, vários fragmentos de pregos e chumaceiras em ligas de cobre. Destaque igualmente para um botão com as armas da Marinha Portuguesa, de um almofariz, ambos em liga de cobre, ou de um prato e um jarro, em estanho. Foram também recuperados alguns fragmentos de cerâmicas e vidros.

\subsection{Divulgação e actividades educativas}

Os Museus, espaços culturais por excelência de preservação da nossa história coletiva, onde a educação e o lazer são primordiais para a disseminação e democratização do conhecimento, devem privilegiar a relação de proximidade com o público e a sua comunicação deter a capacidade de formar/ informar, desenvolver competências e promover mudanças de atitude para quem visita a Instituição (Assiz, 2017, p. 19).

Nesta perspetiva, o Museu de Arqueologia da cidade da Praia, uma instituição de âmbito nacional e de tutela estatal, tem responsabilidades acrescidas no que toca a divulgação do património. Tendo isso em consideração, disponibiliza, através das suas exposições permanentes e temporárias, visitas orientadas, publicações, acções educativas e de disseminação, atividades socioeducativas, colónias de férias ou oficinas, entre outras atividades, como forma de comunicar o seu acervo e atingir vários públicos. Por se caracterizar como um espaço de memória e de salvaguarda do património nacional cabo-verdiano, é um lugar ideal para se realizar actividades tendentes à dinamização e divulgação da riqueza do espólio cultural subaquático e terrestre, figurando-se também como um espaço de lazer e consolidação do conhecimento científico.

Por conseguinte, no seguimento das acções de divulgação, sensibilização e educativas já programadas, em 2018 o Museu definiu redinamizar a actividade "Arqueólogo por um dia", em parceria com o CONCHA, introduzindo a vertente subaquática (Figura 8). Esta iniciativa teve como público-alvo os estudantes de vários níveis de ensino e consistiu numa introdução à Ciência Arqueologia, iniciando os participantes no processo de investigação arqueológica, com enfoque nas simulações de escavações subaquáticas e terrestres. Tendo em conta a aceitação positiva por parte do público/visitantes, a acção, inicialmente com a participação dos investigadores do CONCHA, continua actualmente, materializada pelos técnicos nacionais do Museu de Arqueologia. Foi igualmente efectuado um workshop de introdução à arqueologia subaquática, onde participaram técnicos de várias entidades cabo-verdianas, incluindo a Polícia Marítima e a Guarda Costeira, e representantes de centros de mergulho da ilha de Santiago. A divulgação dos trabalhos foi assegurada através das redes sociais, partindo da publicação de notícias na página do Facebook do IPC, e teve cobertura pela imprensa escrita e televisiva.

\subsection{A conservação do material recuperado}

O projeto CONCHA tem proporcionado ao Museu de Arqueologia a realização de algumas ações de conservação curativa de materiais recuperados durante as missões de terreno de 2018 e 2019, tanto em contextos subaquáticos, como terrestres. $\mathrm{O}$ tratamento dos artefactos teve como objetivo principal estabilizar o seu estado de conservação, garantindo a sua preservação para as gerações atuais e vindouras, em condições que permitam a sua apresentação e utilização em acções de educação patrimonial, nas comunidades, escolas, universidades, e em estudos científicos. Os materiais deram entrada no Museu submergidos em água salgada, para evitar a secagem brusca, evitando a sua deterioração. Esta medida é o primeiro passo na conservação dos artefactos de contextos submarinos, sendo recomendada para todos os materiais. Estes passaram depois por uma processo 
de dessalinização, sendo mantidos em tanques com água doce com $\mathrm{pH}$ ajustado, substituída e controlada progressivamente até que os componentes químicos ( $\mathrm{NaCl}$ - cloreto de sódio) do material estejam estabilizados.

Este procedimento foi realizado em todos os artefactos recuperados. Estes foram depois documentados, começando com a guia de entrada de objetos no Museu, seguido de um registo fotográfico com detalhes do objeto em diferentes perspetivas, fases anteriores a outras acções específicas necessárias.

Entre estas acções encontra-se uma análise óptica, com lupa, a fim de avaliar o estado físico, as incrustações calcárias marinhas e outros resíduos associados. Verificou-se que as peças apresentavam alterações resultantes da colonização e do crescimento de bactérias e algas sobre as superfícies enquanto submersas. Entre os itens encontrados, refiram-se as clorofíceas, também chamadas algas verdes, a Fissurella, que é um género de pequenos e médios caracóis (lapas) marinhos da família Fissurellidae com entre $8 \mathrm{~mm}$ a $1 \mathrm{~cm}$. Refira-se também os cerca de 21 gramas de areia multicolor, devida à contaminação de metais ferrosos, minerais e algas, e uma ligeira fissura numa das extremidades do alguidar CV18-oo1, recuperado no fundeadouro da Ribeira Grande de Santiago.

A remoção desta alteração foi efectuada por limpeza mecânica, que consistiu em golpes sobre as camadas de incrustação com auxílio de bisturi e trincha de cedro fina, até remover os depósitos, seguida de lavagem geral em água corrente com escova. Para remoção das incrustações marinhas mais resistentes foi efectuado um tratamento químico, com uma solução de $50 \%$ de $\mathrm{C}_{2} \mathrm{H}_{5} \mathrm{OH}$ (etanol 96\%) e $50 \%$ de $\mathrm{H}_{2} \mathrm{O}$ (água desmineralizada), com ajuda de bisturi, estilete de madeira e cotonete feita com algodão hidrófilo e escova macia. Depois deste procedimento, foi realizada outra lavagem geral e a secagem natural completa por um período de 72 horas. Para consolidar a fissura da extremidade do alguidar foram aplicadas duas camadas de paraloid B-72 em 10\% de etanol. A proteção geral da superfície foi assegurada com paraloid B-72 em $5 \%$ de etanol. Para concluir, foi efectuada uma fotografia do estado final, o preenchimento da ficha de conservação e o armazenamento da peça na reserva técnica do Museu de Arqueologia.
3.5. Um projecto de gestão - a articulação com as outras entidades

O património arqueológico subaquático de Cabo Verde representa um enorme potencial, ainda pouco desenvolvido. Esse legado é de grande importância para a investigação científica, educação patrimonial, mas também para o desenvolvimento sustentável, com especial enfoque no turismo cultural.

A vulnerabilidade de Cabo Verde, país insular com recursos limitados, tem contribuído para que as suas águas territoriais sejam muitas vezes frequentadas por caçadores de tesouros, que aproveitam as fragilidades da vigilância marítima para pilhar um património de grande importância para o arquipélago, empobrecendo assim, o seu legado patrimonial subaquático.

Atendendo a estas limitações, a participação do IPC no projecto CONCHA foi encarada como uma oportunidade de melhorar a capacidade nacional na gestão do PCS. O IPC entendeu por isso envolver outros parceiros nacionais ligados à gestão do espaço marítimo, através de protocolos de colaboração. Entre estes parceiros, destacam-se a Polícia Marítima e o Comando da Guarda Costeira de Cabo Verde. A sua participação foi fundamental na execução das missões do projeto. Uma vez que o IPC não dispõe de meios logísticos para a realização de mergulhos, estes dois parceiros nacionais disponibilizaram toda a logística necessária, nomeadamente as embarcações e tripulações, que acompanharam as missões de campo, garantindo igualmente a segurança dos investigadores.

Partindo da experiência do CONCHA, de envolvimento de várias entidades na salvaguarda do património subaquático, o Governo de Cabo Verde deliberou a institucionalização desta parceria, através da criação da Comissão para a Proteção e Valorização do Património Subaquático de Cabo Verde (Resolução no 66/2018). Esta comissão multidisciplinar é constituída por entidades académicas e estatais ligadas a atividades marítimas, nomeadamente: Instituto do Património Cultural (IPC); Direção Nacional de Ambiente; Direção Geral do Património e Contratação Publica; Guarda Costeira; Polícia Marítima; Polícia Judiciária; Direção Geral do Turismo e Transportes; Universidade de Cabo Verde; Centros de Investigação ligados ao Mar; Comissão Nacional para UNESCO; Fundo de Sustentabilidade Social do Turismo e Instituto Marítimo e Portuária. 


\section{BALANÇO}

O trabalho desenvolvido até à data confirma o elevado potencial, científico e patrimonial, do PCS de Cabo Verde e demonstra a sua integração nas dinâmicas Atlânticas entre os séculos XV e XIX. A prospecção na Cidade Velha revelou a existência de extensos depósitos de superfície relacionados com a utilização portuária daquele espaço, incluindo ainda, pelo menos, os restos de um navio em madeira e concentrações de cerâmica que podem constituir contextos coerentes de naufrágio. O mapeamento dos naufrágios de São Francisco e Urânia permitiu novas interpretações sobre os sítios arqueológicos e a sua formação. No seu conjunto, estes contextos documentam várias fases da navegação no Atlântico na época moderna, sendo particularmente significativos o fundeadouro da Ribeira Grande de Santiago e os restos do naufrágio de São Francisco, relacionados com o comércio de escravos.

Os dados disponíveis permitem também dar corpo a um inventário georreferenciado do PCS de Cabo Verde, servindo como situação de referência à adopção de medidas de protecção, monitorização e valorização.

A documentação gráfica (fotografia, vídeo, modelos e desenho) tem também potencial que vai além da investigação, permitindo a sua apresentação e divulgação em vários suportes - publicações, painéis, vídeos e documentários. O mapeamento do Urânia, por exemplo, permite a criação de um roteiro de visitação, e poderá dar lugar à criação de um parque arqueológico subaquático, um valor turístico acrescentado. As acções socioeducativas desenvolvidas a partir do Museu de Arqueologia permitiram melhorar a sua comunicação com o público, atingindo várias faixas etárias.

O trabalho foi também particularmente positivo na articulação entre todos os parceiros e participantes, incluindo a Polícia Marítima e a Guarda Costeira, constituindo uma experiência única em países lusófonos, que culminou na criação da Comissão para a Proteção e Valorização do Património Subaquático de Cabo Verde.

Deste modo, considera-se importante dar continuidade a este projecto, através do aprofundamento da investigação na ilha de Santiago; do alargamento do trabalho a outras ilhas, adoptando a mesma estratégia de avaliação não intrusiva dos sítios já conhecidos; do fomento do acesso a sítios de baixa sensibilidade; do desenvolvimento de actividades de formação especializada em ambiente de investigação, garantindo a transferência de conhecimento e a colaboração, nomeadamente com outros projectos; e de acções de divulgação e sensibilização das comunidades para a importância do património cultural subaquático.

\section{AGRADECIMENTOS}

Este trabalho só foi possível com o apoio e a cumplicidade de várias pessoas e instituições. Gostaríamos de agradecer ao Presidente do IPC, Hamilton Lopes Fernandes, o empenho neste projecto desde o primeiro momento. O apoio logístico da Polícia Marítima e da Guarda Costeira foi essencial e uma experiência de partilha dificilmente repetível.É impossível enumerar todos os participantes, mas não podemos deixar de destacar o Comandante Faustino Moreno Sanches e os Agentes Paulo Furtado e Adélio Silva, da Polícia Marítima, e o Director de Operações Capitão de Patrulha Silvino Chantre e o Comandante do navio Djeu, $1^{\circ}$ Tenente Adérito Cardoso, da Guarda Costeira, enquanto representantes de ambas as Instituições. Agradecimento também particular a Emanuel Charles de Oliveira e a Alexandre Semedo, com quem demos os primeiros mergulhos em águas cabo-verdianas.

Este projecto foi financiado pela UE-H2O2O-MSCA-RISE-2017 ao abrigo do programa de investigação e inovação sob o acordo de projecto $\mathrm{n}^{\circ}$ 777998; This project has received funding from the EU H2O2O-MSCA-RISE-2O17 research and innovation programme under grant agreement № 777998 .

\section{BIBLIOGRAFIA}

AMORES CARREDANO, Fernando e CHISVERT JIMÉNEZ, Nieves (1993) - Tipologia de la cerâmica común bajomedieval y moderna Sevillana (ss. XV-XVIII): La loza quebrada de relleno de bóvedas. SPAL, 2, pp. 269-325.

ASSIZ, Janette Jean Corrêa de (2017) - A Disseminação da Informação por meio dos Museus: O caso do Museu do Tribunal de Justiça do Estado do Pará, Trabalho de Conclusão de Curso- Grau Bacharel, Pará: Universidade Federal do Pará.

CARDOSO, Renato (1984) - Relatório do Grupo de Trabalho Sobre Pesquisas Arqueológicas, de 26 de Novembro de 1984. Praia, Arquivo do Museu de Arqueologia - IIPC.

D'OLIVEIRA, Emanuel Charles (2005) - Cabo Verde na rota dos naufrágios. Praia, s/ ed. 
ESPARTEIRO, António Marques (1979) - Três Séculos no Mar 1640/1910 - III Parte/Fragatas/3ํ. Volume, Lisboa: Ministério da Marinha (Colecção Estudos).

MOORE, D. D. e MALCOM, C. (2008) - SeventeenthCentury Vehicle of the Middle Passage: Archaeological and Historical Investigations on the Henrietta Marie Shipwreck Site. International Journal of Historical Archaeology, 12(1), pp. 20-38.

SMITH, B. S. (2002) - An astrolabe from Passa Pau, Cape Verde Islands. The International Journal of Nautical Archaeology, 31.1, pp. 99-107.

TORRÃO, M. M. e TEIXEIRA, A. (2009) - Negócios de escravos de um florentino em Cabo Verde: descrições e reflexões sobre a sociedade e o tráfico em finais do século XVI, em linha, disponível em URL: http://cvc.instituto-camoes. pt/eaar/coloquio/comunicacoes/mmtorrao_ateixeira.pdf, consultado a 1 de Julho de 2019.

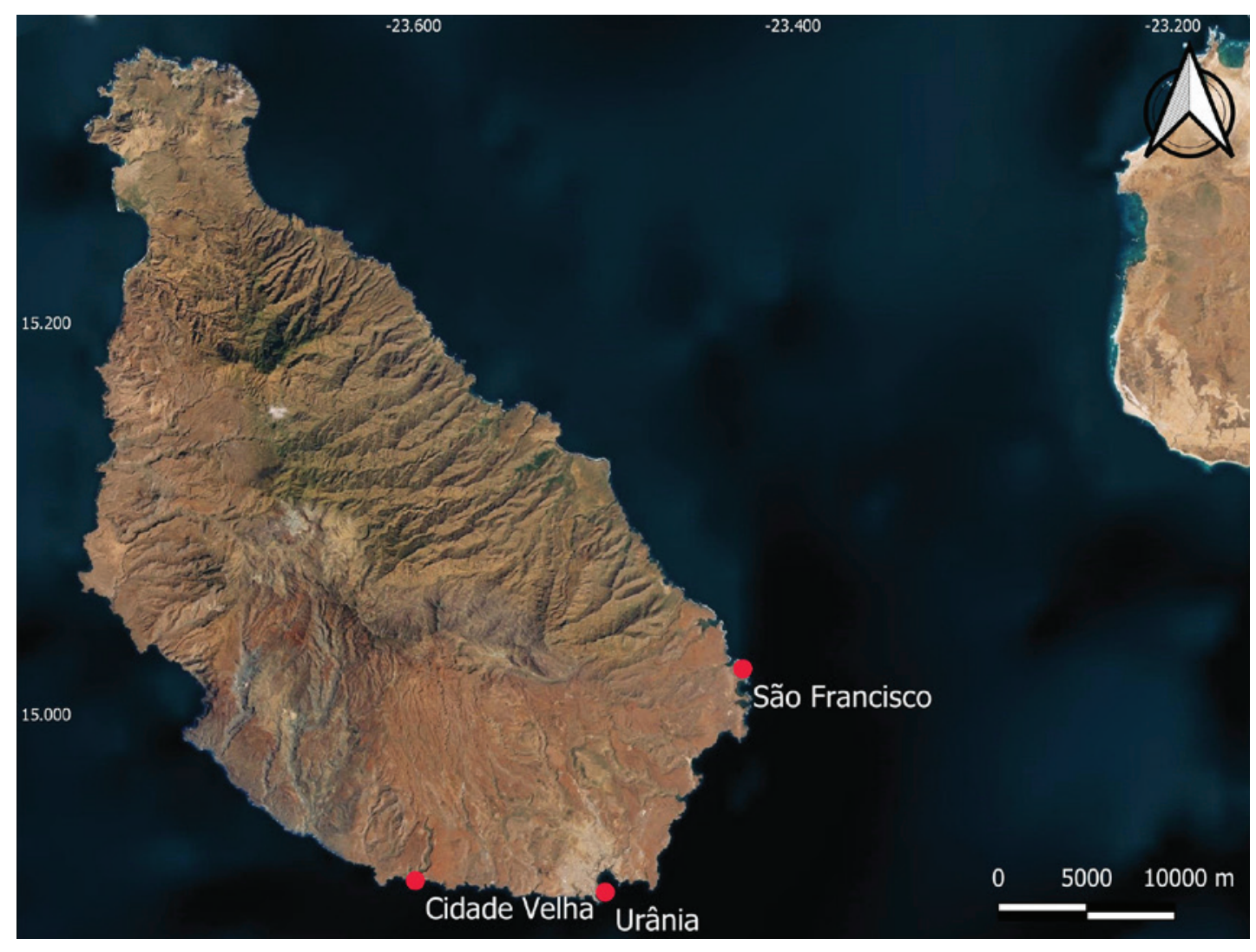

Figura 1 - Localização dos sítios intervencionados na ilha de Santigo (imagem base: Bing Sattelite). 


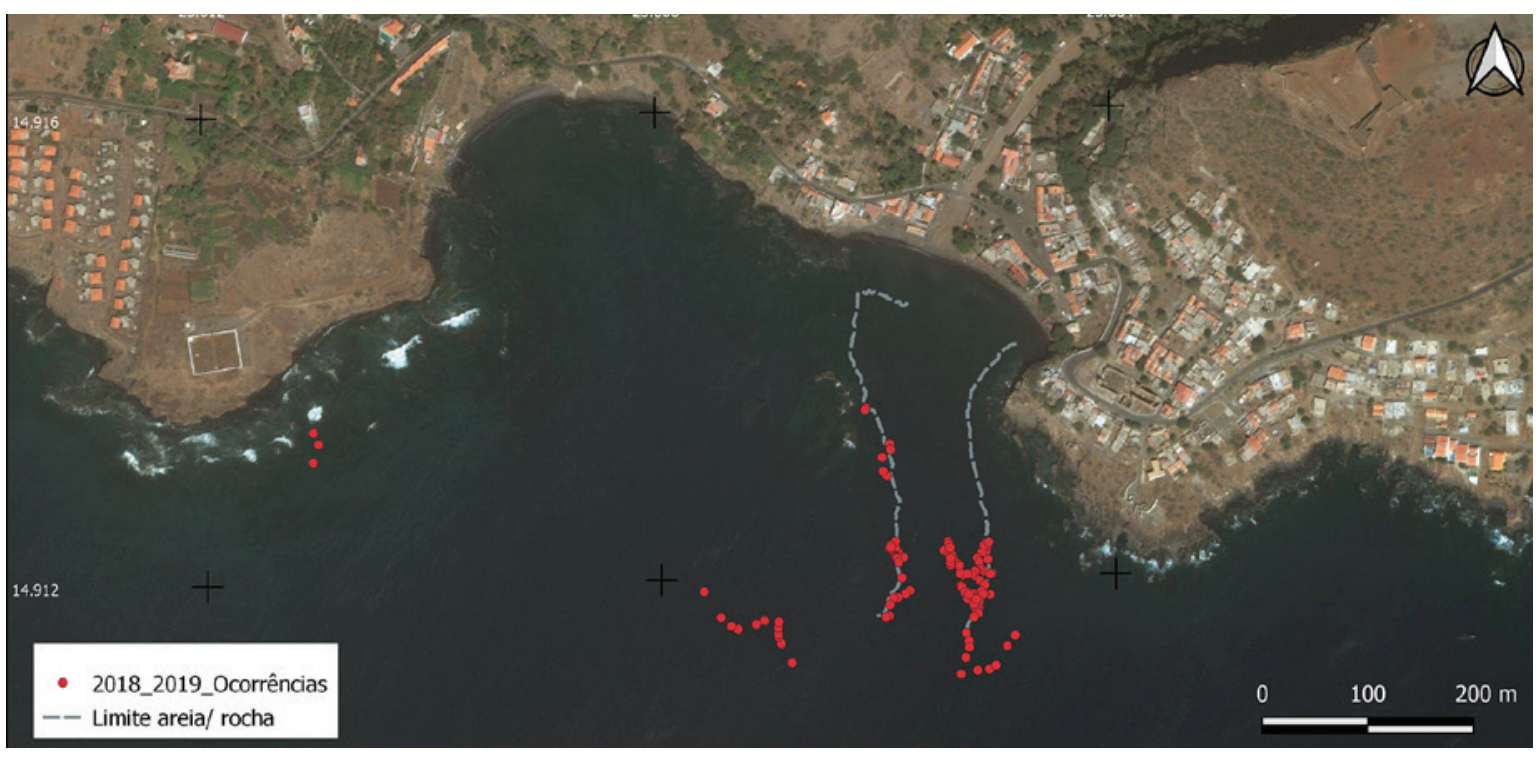

Figura 2 - Distribuição geral das ocorrências identificadas no fundeadouro da Cidade Velha.
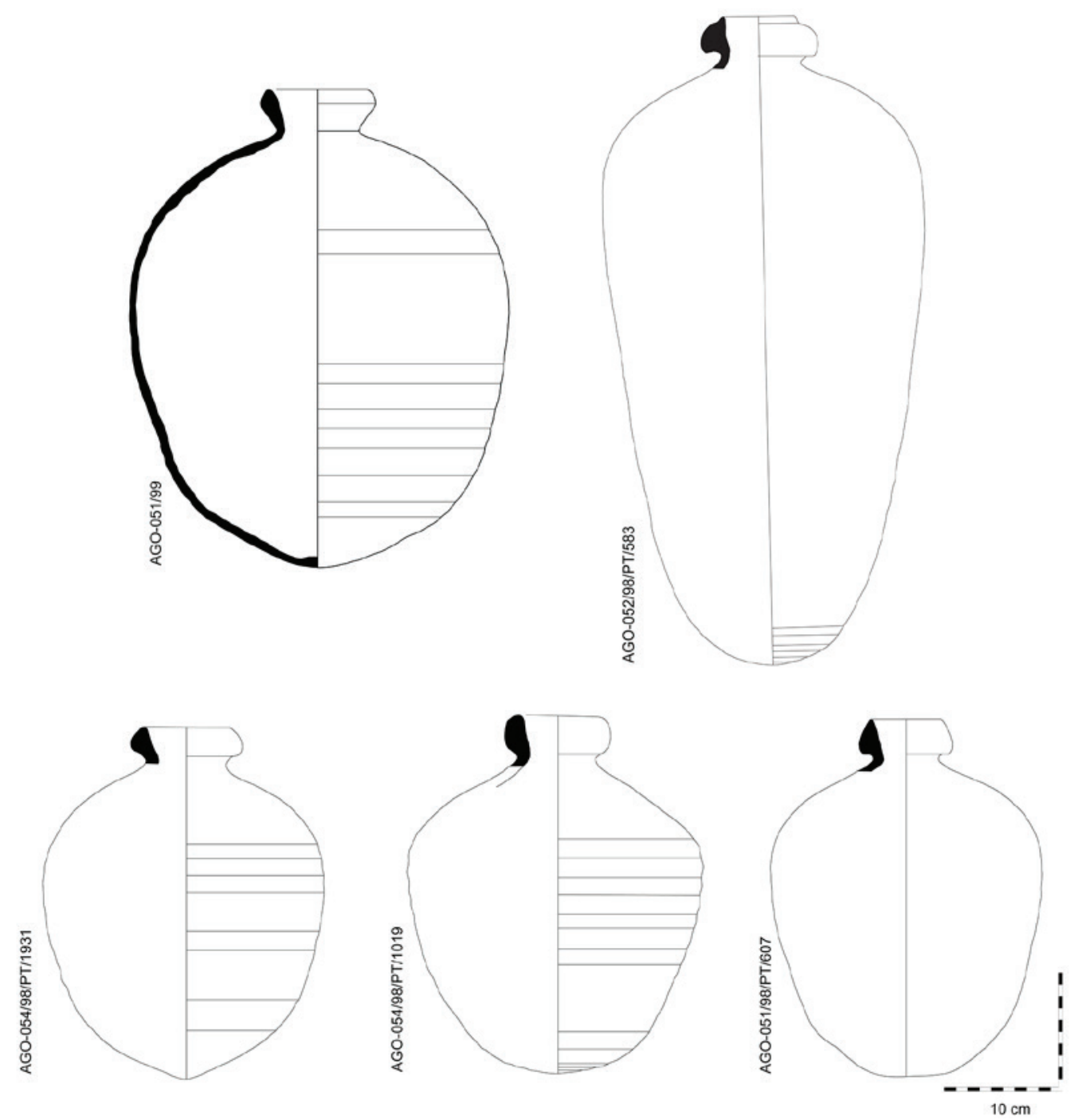

Figura 3 - Botijas, com fabricos andaluzes, recuperadas na Ribeira Grande de Santiago pela empresa Arqueonautas S.A.. 

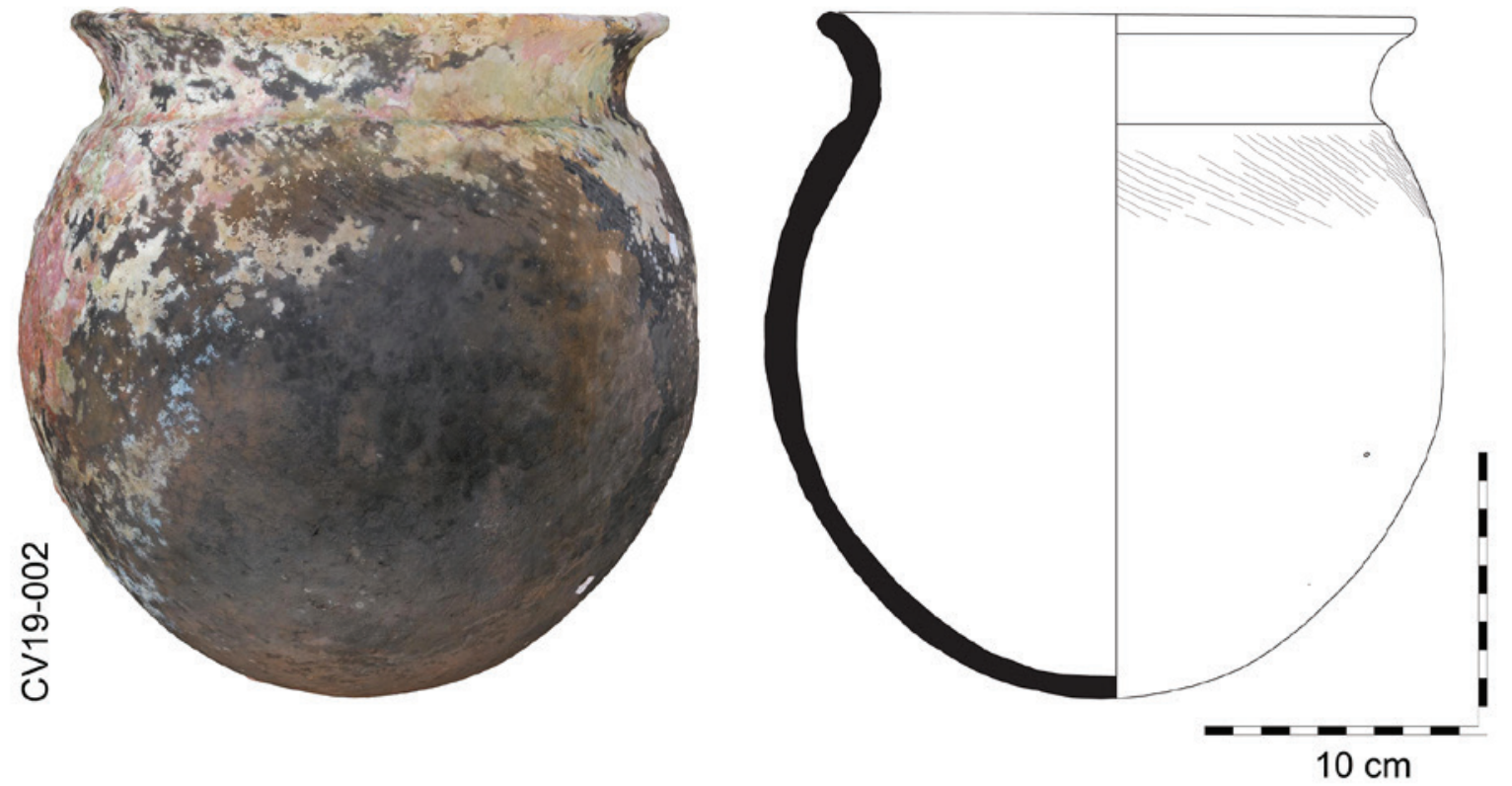

Figura 4 - Cerâmica de tradição africana, recuperada pelo CONCHA no fundeadouro da Cidade Velha.

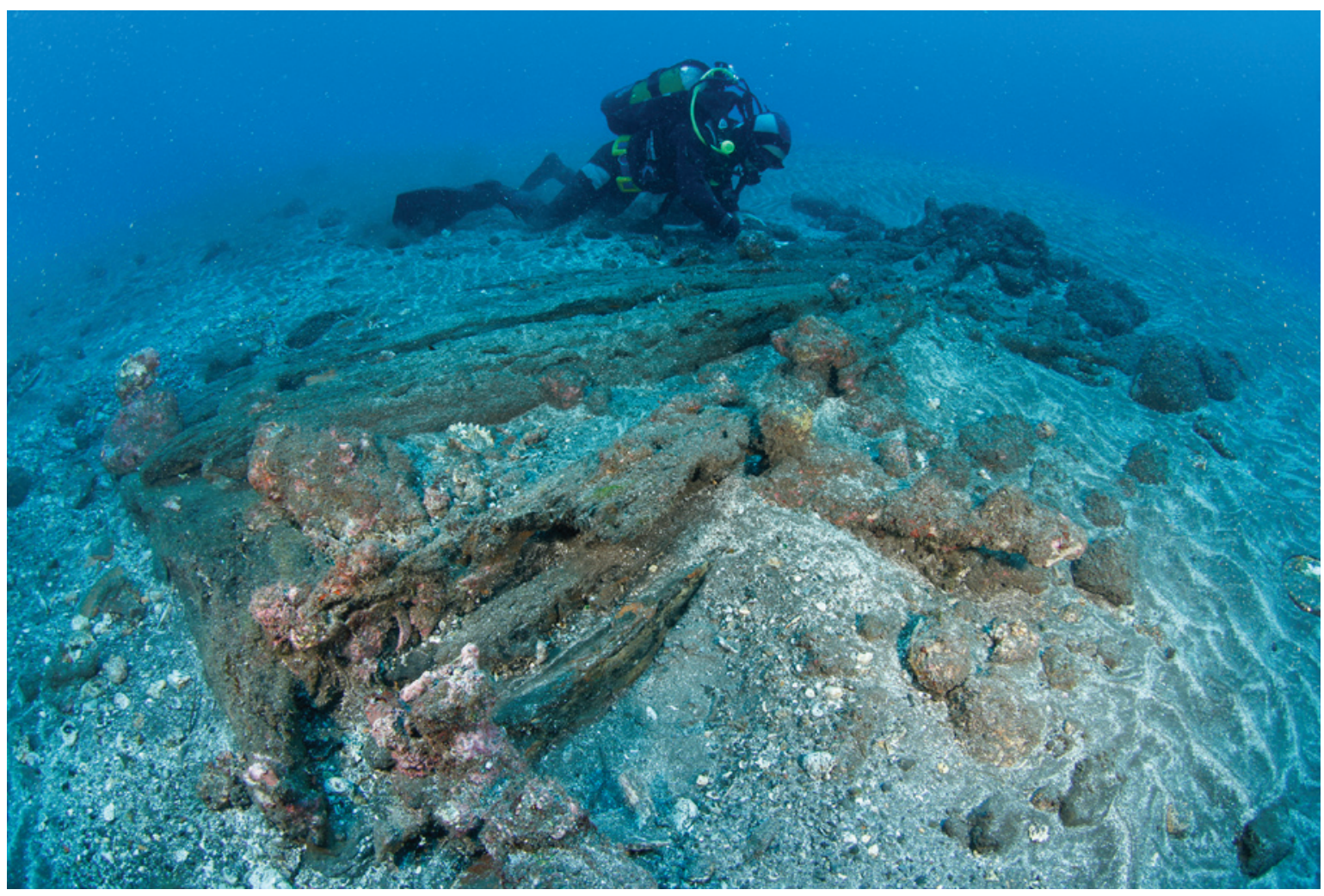

Figura 5 - Vista geral do navio Cidade Velha 1, a partir de sul (foto: José Bettencourt). 

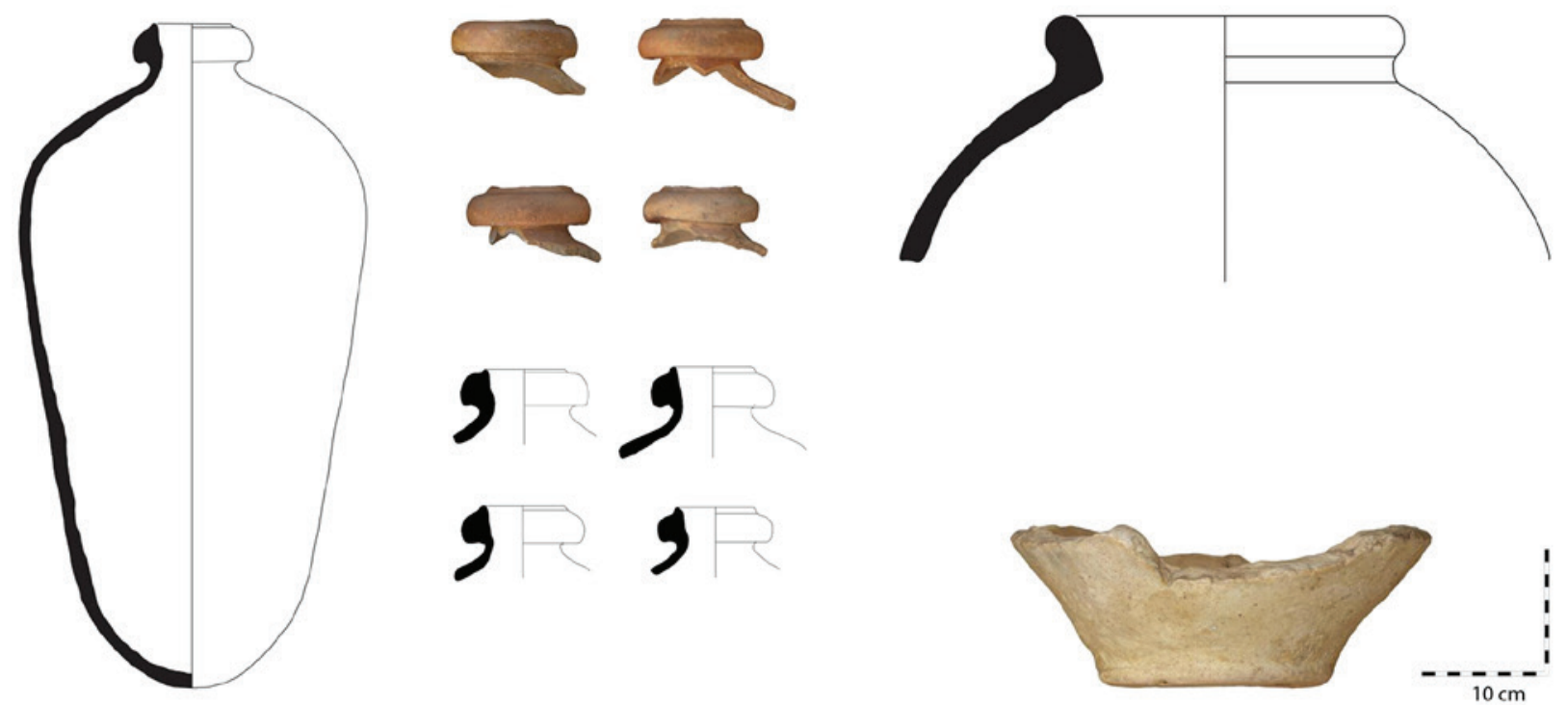

Figura 6 - Botijas e talhas recuperadas no naufrágio de São Francisco pela empresa Arqueonautas S.A..

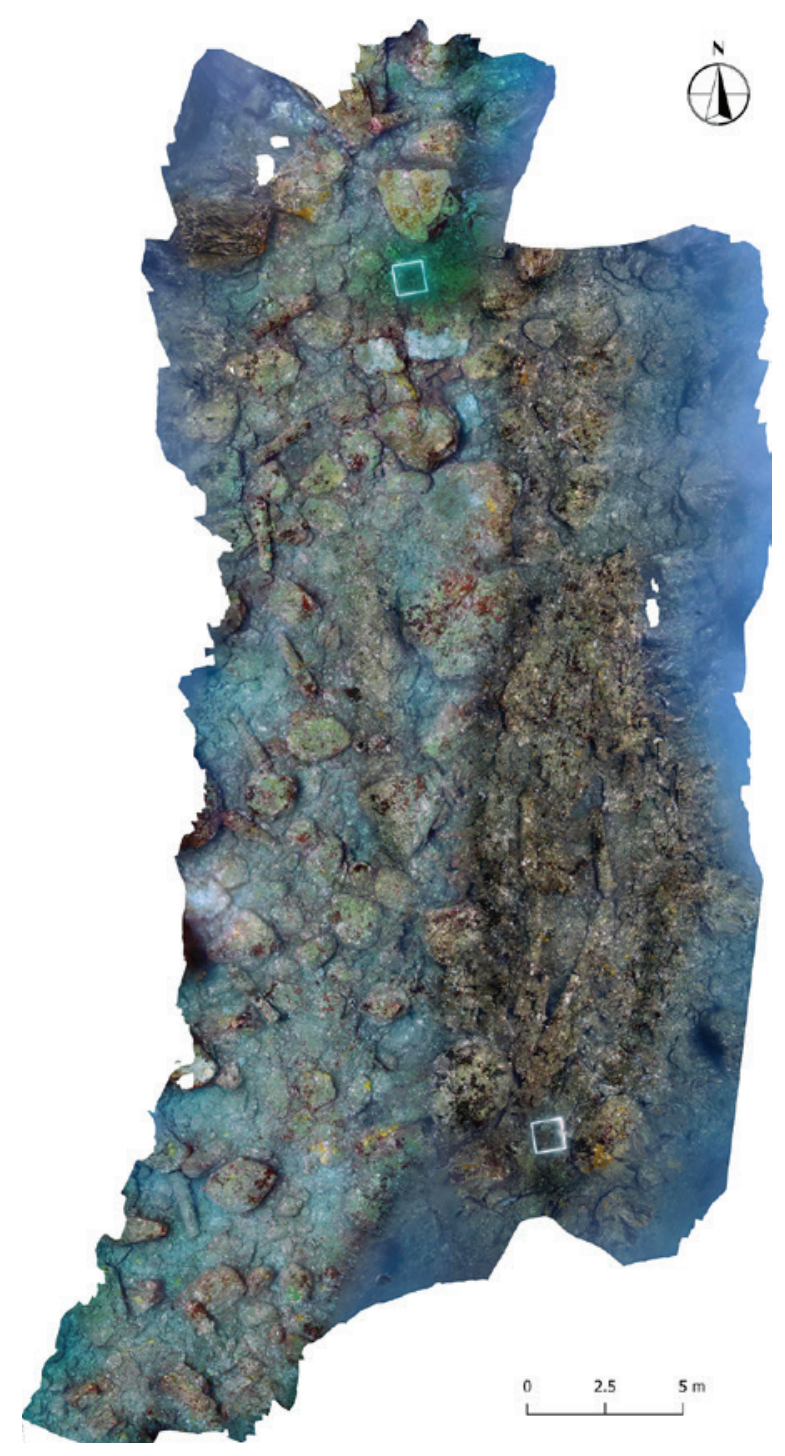

Figura 7 - Ortofotomapa do naufrágio do Urânia (versão 1, de Agosto de 2018). 


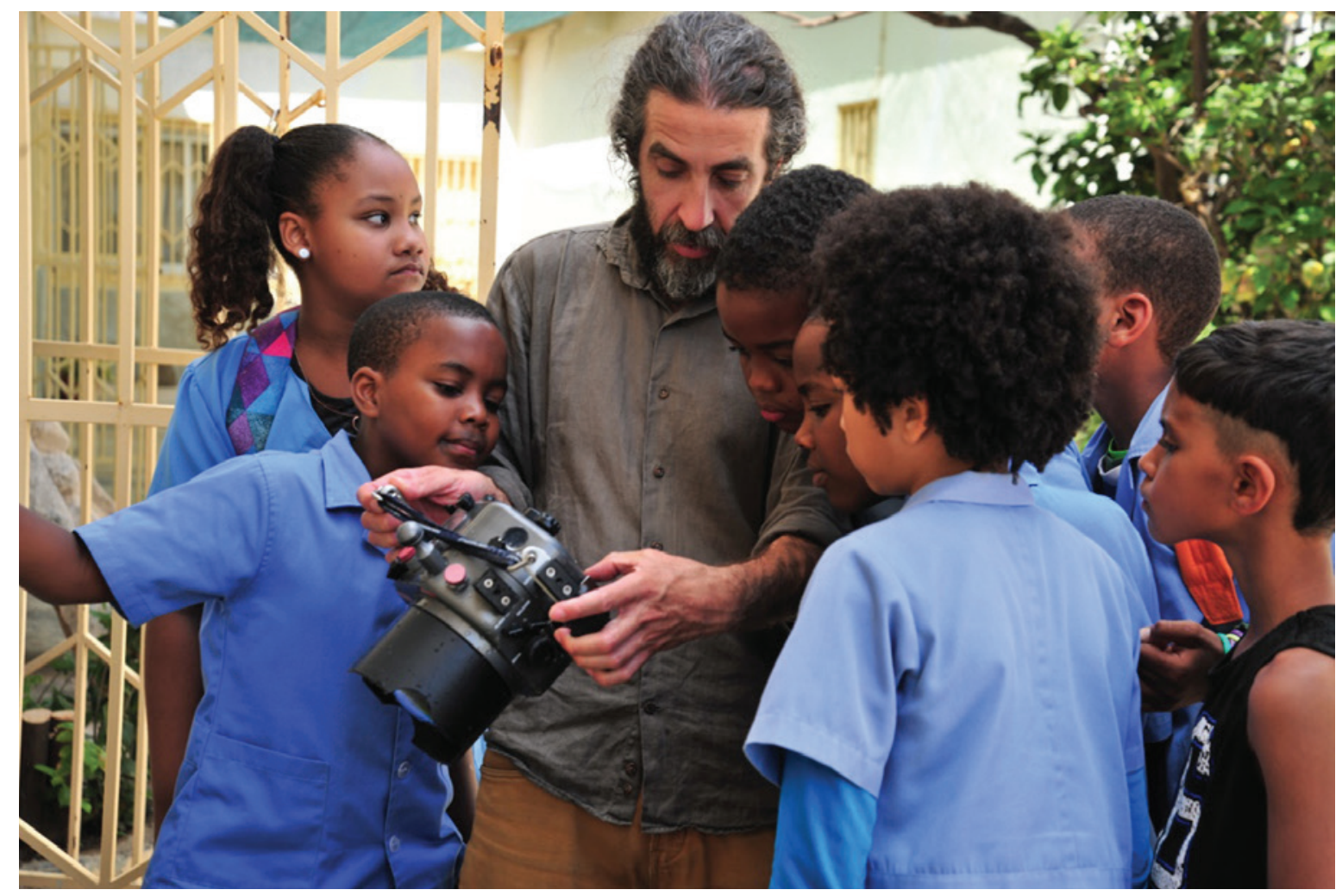

Figura 8 - Aspecto das acções de divulgação e sensibilização para o público escolar, desenvolvidas no Museu de Arqueologia da cidade da Praia (foto: IPC). 


\section{TRABALHOS ARQUEOLÓGICOS NA CIDADE VELHA (RIBEIRA GRANDE DE SANTIAGO, CABO VERDE): REFLEXÕES SOBRE UM PROJECTO DE INVESTIGAÇÃO E DIVULGAÇÃO PATRIMONIAL}

André Teixeira ${ }^{1}$, Jaylson Monteiro ${ }^{2}$, Mariana Mateus ${ }^{3}$, Nireide Tavares ${ }^{4}$, Cristovão Fonseca ${ }^{5}$, Gonçalo C. Lopes ${ }^{6}$, Joana Bento Torres ${ }^{7}$, Dúnia Pereira ${ }^{8}$, André Bargão ${ }^{9}$, Aurélie Mayer ${ }^{10}$, Bruno Zélie ${ }^{11}$, Carlos Lima ${ }^{12}$, Christelle Chouzenoux $^{13}$, Inês Henriques ${ }^{14}$, Inês Pinto Coelho ${ }^{15}$, José Lima ${ }^{16}$, Patrícia Carvalho ${ }^{17}$, Tiago Silva ${ }^{18}$

RESUMO

Entre 2018 e 2020 decorreram trabalhos arqueológicos na Cidade Velha, a antiga capital de Cabo Verde, que prosperou entre os séculos XVI e XVII como entreposto atlântico do comércio de escravos e base de apoio à navegação oceânica. As escavações incidiram sobre dois locais: um contexto habitacional numa das suas principais artérias, a rua da Banana, e num dos mais antigos espaços de culto do arquipélago, a igreja de Nossa Senhora do Rosário. Estas intervenções permitiram recolher novos dados sobre o urbanismo e espaços de habitat da antiga cidade aquando do seu abandono no século XVIII, bem como sobre a configuração daquela estrutura religiosa. A investigação articulou-se com o programa educativo do Museu de Arqueologia, de Cabo Verde.

Palavras-chave: Urbanismo, Arquitectura religiosa, Casas, Idade Moderna, Educação patrimonial.

1. Departamento de História e CHAM, FCSH, Universidade NOVA de Lisboa; texa@fcsh.unl.pt

2. Instituto do Património Cultural, mjaylson95@gmail.com

3. CHAM, FCSH, Universidade NOVA de Lisboa; marianacpsmateus@gmail.com

4. Instituto do Património Cultural; Uniarq - Centro de Arqueologia da Universidade de Lisboa; nireidapereira.cv@hotmail.com

5. CHAM, FCSH, Universidade NOVA de Lisboa; cristovaofonseca@gmail.com

6. CHAM, FCSH, Universidade NOVA de Lisboa; goncaloncsl@gmail.com

7. CHAM, FCSH, Universidade NOVA de Lisboa; joanabtorres@gmail.com

8. Instituto do Património Cultural; duniapereira79@gmail.com

9. CHAM, FCSH, Universidade NOVA de Lisboa; andrebargao@gmail.com

10. Éveha -Études et valorisations archéologiques; aurelie.mayer@eveha.fr

11. Éveha - Études et valorisations archéologiques; bruno.zelie@eveha.fr

12. Instituto do Património Cultural, conser-rest.lima@outlook.com

13. Éveha - Études et valorisations archéologiques; CHAM, FCSH, Universidade NOVA de Lisboa; krist_aile@yahoo.fr

14.CHAM, FCSH, Universidade NOVA de Lisboa; ineshenriques95@gmail.com

15. CHAM, FCSH, Universidade NOVA de Lisboa; inesalexandrapinto@gmail.com

16. Instituto do Património Cultural; joselima1995@hotmail.com

17. CHAM, FCSH, Universidade NOVA de Lisboa; patriciasanchescarvalho@gmail.com

18. CHAM, FCSH, Universidade NOVA de Lisboa; toiago@gmail.com 


\begin{abstract}
Between 2018 and 2020, archaeological work took place in Cidade Velha, the former capital of Cape Verde, which flourished amid the $16^{\text {th }}$ and $17^{\text {th }}$ centuries as an Atlantic trading post for the slave trade and a support base for the ocean navigation. The excavations focused on two sites: a housing context in one of its main arteries, Rua da Banana, and the other on one of the oldest religious spaces in the archipelago, the church of Nossa Senhora do Rosário. These archaeological interventions made it possible to collect new data on the urbanism and habitat areas of the old city, when it was abandoned in the $18^{\text {th }}$ century, as well as on the configuration of that religious structure. The investigation was linked to the educational program of the Museum of Archaeology, of Cape Verde.
\end{abstract}

Keywords: Urbanism, Religious architecture, Houses, Early Modern Age, Heritage education.

\section{INTRODUÇÃO}

O presente texto sintetiza os resultados dos trabalhos arqueológicos realizados na Cidade Velha, a antiga Ribeira Grande, principal núcleo urbano de Cabo Verde durante os primeiros dois séculos de ocupação do arquipélago sob domínio português. Fundada em 1462, perdeu o estatuto de capital sede de bispado em 1769, mais de um século depois do início da sua decadência, resultante da perda de importância como centro redistribuidor de escravos entre a África e a América e base de apoio à navegação atlântica, em favor dos estabelecimentos nos rios da Guiné e da própria cidade da Praia, com melhores condições portuárias e de salubridade (ver Cabral, 1995).

As escavações decorreram em três campanhas, de 13 a 31 de Agosto de 2018, de 13 a 31 de Janeiro de 2019 e de 6 a 17 de Janeiro e 3 a 14 de Fevereiro de 2020. Realizaram-se no âmbito do no projecto CONCHA: The construction of early modern global cities and oceanic networks in the Atlantic: an approach via ocean's cultural heritage, financiado ao abrigo do Programa H2O2O, no âmbito das acções Marie Slodowska Curie Actions: Research and Inovation Staff Exchange (RISE) sob o GA ํㅜㄱ77998, envolvendo investigadores portugueses, cabo-verdianos e franceses e, institucionalmente, o Instituto do Património Cultural, de Cabo Verde, e o CHAM - Centro de Humanidades, de Portugal, através de protocolo entretanto firmado.

Os trabalhos tiveram quatro objectivos fundamentais (Figura 1). Em primeiro lugar, realizar uma acção de investigação, através de escavação arqueológica, num contexto habitacional, neste caso localizado na intersecção entre a rua Direita e a rua da Banana da Cidade Velha. Efectivamente, existiam já intervenções neste espaço em igrejas (Amaro, 2012; Evans, Sørensen \& Richter, 2012), complexos de ordens religiosas (Cáceres \& De Juan, 2002) e fortificações (De Juan \& Cáceres, 2002), pelo que nos pareceu importante obter outro tipo de registo arqueológico. Destaque ainda para os importantes acompanhamentos realizados anteriormente em várias ruas do burgo, que forneceram importantes pistas para a compreensão do espaço urbano (Sørensen, Evans \& Richter, 2011), entre outras iniciativas (síntese da arqueologia na cidade em Tavares, 2017). Em segundo lugar, foi nosso objectivo acompanhar arqueologicamente a empreitada de reabilitação e conservação da igreja da Nossa Senhora do Rosário, aproveitando para recolher dados e simultaneamente fornecer informações nesta acção levada a efeito pelo Instituto do Património Cultural. Em terceiro lugar, gizaram-se uma série de acções de educação e sensibilização patrimonial junto dos alunos das escolas da ilha de Santiago, através da divulgação dos trabalhos arqueológicos e da própria disciplina, em articulação com Museu de Arqueologia, da Praia. Por fim, no quadro da pesquisa de colegas historiadores sobre a sociedade insular, procedeu-se ao registo individual e leitura epigráfica de lápides funerárias da Cidade Velha, tema que aqui não abordaremos.

De notar que, parte destas campanhas ocorreu em simultâneo com missões de arqueologia subaquática no âmbito do mesmo projecto, incluindo o levantamento de sítios arqueológicos, o registo de materiais no Museu de Arqueologia, bem como as mencionadas acções de educação patrimonial, pressupondo trabalho conjunto.

\section{ESCAVAÇÃO ARQUEOLÓGICA NA RUA DA BANANA - RUA DIREITA}

O primeiro núcleo urbano da Ribeira Grande constitui-se junto ao porto, a partir de um largo central onde pontuava o pelourinho (que ainda se preser- 
va), limitado a Nordeste por um edifício da Câmara (sensivelmente onde hoje se encontra a autarquia), a Sudoeste pelo ancoradouro e a baía e a Noroeste pelo lago existente no termo da ribeira de Maria Par$\mathrm{da}$, que dava ao vale uma paisagem inusitadamente verdejante no quadro da ilha de Santiago, um dos motivos para a sua selecção como principal burgo do arquipélago. Apesar da escassez de investimentos da Coroa na Ribeira Grande até meados de Quinhentos, esta desenvolveu-se em função da sua actividade mercantil, alargando-se para a margem esquerda da ribeira, constituindo-se o bairro de São Pedro, onde pontuavam três ruas lineares tendencialmente paralelas - Direita, Carreira e Banana -, local de residência das individualidades mais abastadas, funcionários régios e principais vizinhos (Pires, 2007: 41, 45). A intervenção arqueológica deu-se no extremo setentrional da rua da Banana, numa pequena travessa que partia da rua Direita - que ladeava a margem direita da Ribeira - para Norte, em direcção à "casa da janela gótica", um edifício que a tradição indica ter pertencido aos jesuítas, que possuíam efectivamente um "hospício" nas proximidades, junto da igreja de Nossa Senhora da Conceição. Os contornos desta artéria são ainda visíveis no tecido urbano, não obstante a área estar coberta de entulhos no espaço que medeia a área de escavação e a dita "casa da janela gótica”. O quarteirão, com um comprimento calculado em 315 palmos $(69,3 \mathrm{~m})$ e uma largura de 90 palmos (19,8m) (Pires, 2007: 148), seguia o curso do beco da Majaja, que lhe ficava traseiro e que, na verdade, era um curso de água subsidiário da ribeira de Maria Parda, proveniente do lugar onde se veio a erguer o convento dos franciscanos.

Antes das escavações observavam-se, em terreno plano - ladeado por vegetação frondosa a Norte, pela ribeira a Sul, por habitações a Oeste e pelo referido beco da Majaja a Este -, três muros bem aparelhados [901, 902, 903] formando uma possível habitação, disposta ao longo da mencionada travessa (Figura 2). A estrutura preservava $6 \mathrm{~m}$ de comprimento no muro que confinava com a via pública [901], sendo que, se o canto Noroeste se pode reconstituir, pela provável articulação com o muro que lhe é perpendicular [902], já para Sul é impossível determinar os seus limites e, assim, conhecer a extensão da habitação; assinale-se, porém, que os vestígios de derrube da estrutura se prolongavam para sudeste por 12,6m. Já quanto à largura, a distância entre o muro confinante com a travessa [901] e o de fundo da habitação
[903] é de 5,5m, o que constitui 5 varas na métrica da vara craveira, em uso durante o período baixo-medieval e moderno. Assim, a casa parece aproximar-se do padrão maior de áreas construídas da cidade, com 13,2x6,6m (Pires, 2007: 131-132). De referir que no interior desta provável casa e na cota actual existia um curral de porcos, erguido certamente há escassos anos com pedras irregulares sem argamassa, aproveitando o canto Nordeste das ruínas da habitação. A intervenção arqueológica consistiu nas seguintes tarefas: abertura de uma sondagem a toda a largura das ruínas da referida casa, com 5,5mxım, alargada em $2 \mathrm{~m}$ nos $2 \mathrm{~m}$ finais da extremidade Este; escavação da área a Este da presumível habitação, na direcção do beco da Majaja e em espaço que se julgava constituir as traseiras desta moradia, com $6 \times 2,3 \mathrm{~m}$; verificando-se neste flanco a existência de novo muro paralelo à fachada [906], fez-se a escavação de uma sondagem com $2 \times 2 m$ no extremo Nordeste da área de intervenção (Figura 2).

Assim, os referidos muros paralelos, o confinante com a travessa [901] e o de fundo [903], tinham características idênticas (Figura 3): com o,7m de largura, eram compostos por fiadas alternadas de pedras de média e grande dimensão, afeiçoadas apenas na face externa, ligadas por uma argamassa de cal, com muitas pequenas inclusões de seixos; em altimetria idêntica, observaram-se nos dois muros orifícios, seguramente para suporte de barrotes de madeira que suportavam um piso superior. Estamos, pois, face a uma casa de sobrado, como já se adivinhava pela mencionada espessura dos muros, um sinal da relevância social dos seus habitantes no momento de construção. De referir que a extremidade Noroeste de [901] tinha muito menor estruturação, sendo resultante por certo de reutilização recente da ruína (fig. 2). Além disso, [903] preservava reboco de cal no alçado Este, consolidado com argamassa. Quanto ao muro perpendicular a estes dois, a Norte, o [902], tinha apenas $0,57 \mathrm{~m}$ de espessura, mas apresentava uma constituição idêntica; se a relação com [901] não se encontrava preservada, embora seja muito provável, a articulação com [903] era evidente.

A escavação da sondagem realizada entre estes muros revelou uma sucessão de estratos (Figuras 3 e 4) de sedimento humoso castanho pouco compacto, com linhas horizontais de pequenas pedras e seixos e espólio de época contemporânea: [101], [104], [105], [106] e [107]; interpretamo-los como torrentes fluviais ocorridas no último século e meio, após 
o abandono desta habitação, que ao encontrarem nos seus destroços um obstáculo acabaram por se acumular aqui de forma sucessiva. Paralelamente, registaram-se estratos mais finos arenosos, soltos, homogéneos e mais claros, sem materiais arqueológicos [102, 103], que poderão corresponder a acumulação eólica. De facto, a ribeira de Maria Parda, embora seca na maior parte do ano e sendo fonte de vida nesta ilha inóspita, constituiu-se como condicionante do desenvolvimento urbano, obrigando a que a construção se afastasse do seu leito, para evitar as enxurradas (Pires, 2007: 100). Se tais fenómenos aconteceram seguramente na época de esplendor da cidade, obrigando os habitantes à limpeza de ruas e casas atingidas, é claro que prosseguiram após o seu abandono, desta feita sem que se tenha procedido à remoção de lamas e pedras, que assim se acumularam sobre as ruínas das antigas habitações. Este fenómeno só foi ultrapassado no final do século XX, com a regularização das margens da ribeira.

Sob estes estratos de escassa ocupação antrópica basicamente materiais de escorrência conduzidos para este espaço em ruína - foi detectado um nível de derrube de sedimento homogéneo castanho-claro compacto, de grão fino, com presença de cal e de muitas pedras [109], onde se recolheu uma grande quantidade de azulejos seiscentistas (idênticos a outros já detectados em vários locais da cidade, conforme Almeida, 2018: 285), materiais em ferro, dois fragmentos de haste de cachimbo em caulino e bastante material de construção, como telhas, tijolos e ladrilhos, tudo espólio de época moderna. Sob esta camada identificou-se sedimento homogéneo castanho-escuro de grão médio, relativamente compacto [111], contendo artefactos domésticos classificáveis por espólio numismático como da segunda metade do século XVIII (5 reis de 1732 e 3 reis de 1764), além de abundante fauna, especialmente ictiológica, azulejos, cavilhas e pregos em ferro, interpretado como os vestígios da derradeira ocupação desta habitação, materiais perdidos antes do abandono. Por fim, foi detectada uma calçada em seixos de pequena e média dimensão [112], articulada com os muros em torno, que constituiu o derradeiro piso do andar térreo desta casa de sobrado. De referir que a altimetria deste nível de solo, face aos buracos de barrote verificados nos muros [901] e [903], é de 1,85m, altura do nível térreo da habitação. Estes espaços eram geralmente usados como zonas de armazenamento, trabalhos domésticos ou residência de serviçais, reservando-se os pisos superiores para morada dos senhores da casa.

Quanto à intervenção realizada na zona Este desta habitação (Figuras 2 e 5), que se presumia constituir as suas traseiras, detectaram-se mais estruturas. Por um lado, a [904] que continuava para nascente o muro que limitava a casa a Norte [902], mas tendo a espessura dos muros da fachada [901] e de tardoz [903], cerca de o,7m, encontrando-se perfeitamente articulado com este último e tendo também idêntico aparelhamento. Verificou-se, porém, que [904] se prolongava apenas por $0,45 \mathrm{~m}$, inflectindo para Norte, no que poderá corresponder à continuidade desta área habitacional para este flanco, hipótese que não trabalhámos. Ainda assim, este muro [904] tinha um outro adossado, [905], que lhe dava continuidade para nascente (Figura 5), mas que corresponde seguramente a um acrescento face à primitiva estrutura; tinha um aparelho idêntico, a mesma composição com fiadas alternadas de pedras de menores e maiores dimensões, embora de forma mais irregular que os predecessores, além de menor espessura, apenas 0,59m. Encontrava-se também preservado a cota inferior, parecendo ter sido afeiçoado para dar lugar a um largo acesso. Por outro lado, foi descoberto o muro [906], já citado, paralelo aos de fachada [901] e tardoz [903] da habitação, com $0,55 \mathrm{~m}$ de espessura, encostando e sucedendo no tempo ao dito [905].

Assim, coloca-se a hipótese de uma primitiva estrutura ter sido composta pelos muros [901], [902], [903] e [904], basicamente uma casa de sobrado de formato rectangular, disposta ao longo da via pública e não perpendicular a ela, como era norma, embora seja possível que o lado mais curto confinasse com a rua Direita, podendo elevar-se aí a sua fachada. Esta estrutura podia ter continuidade noutra grande habitação para Norte (não sondada), pertencente ou não ao mesmo proprietário, mas erguida num mesmo momento e confinando também com aquela travessa. Para nascente estaria uma zona de quintal, nas traseiras da habitação, seguindo o padrão dos lotes da cidade e, aliás, do urbanismo português coevo. Recorde-se que a única cobertura de bom reboco de cal se preservou no alçado Este do muro de tardoz da habitação, o [903], já que este confinaria com área a descoberto. Posteriormente, a conjugação dos muros [905] e [906] terá permitido o prolongamento da habitação para as traseiras, cerceando espaço de quintal. A escavação realizada entre estes dois últimos mu- 
ros, não atingindo infelizmente os seus alicerces, permitiu detectar duas sucessões estratigráficas distintas (Figura 6). Entre os muros [903] e [906], o espaço conquistado à zona de numa segunda etapa desta área habitacional, verificou-se, após os estratos superficiais [201] e [202], um enorme derrube de pedras [250], não se logrando atingir a base deste estrato, alcançando-se apenas $1,2 \mathrm{~m}$ de profundidade. É evidente que, ao contrário do que sucedeu no interior da parte mais antiga da casa, onde o grosso das pedras de colapso da estrutura foi removido, aqui tal não sucedeu, permanecendo este derrube como barreira para as enxurradas registadas após o abandono de todo o conjunto. Já para Este do muro [906], em zona que terá permanecido como quintal, verificou-se uma sucessão estratigráfica mais próxima da referida no interior da parte mais antiga da habitação: aos referidos estratos superficiais muito recentes, sucederam camadas de sedimento castanho humoso, pouco compacto, de grão médio, com escasso espólio contemporâneo [204] e [207], resultantes de torrente fluvial, e estratos com sedimentos arenosos soltos de grão muito fino, estéreis arqueologicamente [203], [205] e [206], possivelmente acumulações eólicas; o grande volume de pedras detectado nestes últimos pode corresponder a parcelas do derrube das estruturas da habitação. Segue-se um estrato com grande quantidade de argamassa, tijolos e pedras [208], um eventual piso toscamente concebido ou, mais provavelmente, fino nível de derrube. Por fim, observa-se um espesso estrato de sedimento castanho humoso, pouco compacto, de grão médio [209], novamente interpretado como torrente fluvial, contendo materiais arqueológicos Setecentistas. Este termina em nível com muitas pedras de pequena dimensão aparelhadas, provável piso coevo ao da habitação, entre as quais se vislumbrou um alinhamento conformando possível muro, que poderá corresponder a fase mais antiga de ocupação deste espaço (que não indagámos). Não estamos em crer que esta área fosse telhada, constituindo antes um quintal, mesmo após o alargamento da casa até ao muro [906], mas a escassez de dados arqueológicos não permite ir além da suposição.

Em suma, com estas escavações atingimos o derradeiro nível de ocupação desta casa da Ribeira Grande, abandonada provavelmente no último terço do século XVIII, distinguindo duas etapas de construção - uma primeira composta apenas por uma estrutura rectangular ao longo da travessa, outra aumen- tando o espaço coberto em detrimento do quintal nas traseiras - cuja cronologia contudo não conseguimos apurar, já que não atingimos os respectivos alicerces. De assinalar que a cartografia do capitão-engenheiro António Carlos Andreis regista na versão de 1778 apenas o contorno do quarteirão, mas na de 1769 figura uma estrutura rectangular ao longo da travessa que une a rua Direita e a rua da Banana, assinalando que estava já em ruína; esta deverá corresponder à habitação cuja investigação arqueológica aqui iniciamos. Nestes mapas figuram-se a Este, depois do beco da Majaja, o edifício da Companhia Geral do Grão-Pará e Maranhão, e a Oeste, depois da dita travessa, as casas de Domingos Espíndola e o edifício da Casa da Câmara, todos eles confinando com a rua Direita. A casa de sobrado em estudo devia, pois, pelas suas características e vizinhança, pertencer a um dos principais moradores da cidade, que a deixou logo após a transferência da capital para a Praia, acto simbólico que terá sido, porém, o golpe fatal na Ribeira Grande, a breve trecho apelidada de Cidade Velha.

\section{O ACOMPANHAMENTO ARQUEOLÓGICO NA IGREJA DE NOSSA SENHORA DO ROSÁRIO}

A igreja de Nossa Senhora do Rosário foi um dos primeiros e mais destacados edifícios públicos da cidade, apontando-se 1495 como possível ano da sua conclusão. Seria inicialmente uma pequena capela, que após várias ampliações veio dar origem à igreja que hoje é a principal do burgo (Pereira, 2009: 67). Refere-se que terá sido erguida com o concurso de africanos forros, sendo mais tarde instituída aqui uma confraria de "homens pretos" (Santos \& Soares, 1995: 473). A erecção deste edifício de culto é coeva de outras realizações importantes: a igreja do Espírito Santo (que mais tarde terá sido renomeada com a evocação de Nossa Senhora da Conceição), que terá sido lançada entre 1466 e 1470 e seguramente concluída antes de 1502 (Santos \& Soares, 1995: 376; Santos, 2015: 66-67), situada junto do referido hospício dos jesuítas e resgatada do esquecimento pela arqueologia (Evans, Sørensen \& Richter, 2012); o hospital, já em construção em 1497, ano em que também já existia uma Câmara no burgo (Baleno, 1991: 136), ambos provavelmente situados no largo principal fronteiro ao mar, o primeiro onde mais tarde se veio a construir a Misericórdia com o respectivo 
hospital, a segunda onde se ergueu depois a cadeia. Assim, não são conhecidos dados documentais relativos aos primeiros decénios da igreja de Nossa Senhora do Rosário, restando a análise dos vestígios construídos. Em termos gerais, são ainda válidos os apontamentos de Luís de Benavente, arquitecto que aqui se deslocou para proceder a projectos de restauro e que dirigiu obra neste edifício em 1969, num contexto propagandístico do regime colonial, então acossado pelas lutas de libertação (Mariz, 2013). Distinguiu claramente três grandes etapas de construção. A primeira, da segunda metade do século XV, seguindo o "gótico tardio", incluiu a torre sineira e os dois arcos rasgados na parede Noroeste da igreja, bem como a abóboda da capela a que se acede a partir do primeiro destes arcos, junto da porta da fachada. Anota-se que desta cobertura não consta a esfera armilar, sendo a cruz de Cristo colocada em posição secundária, dando-se antes primazia à cruz de Avis; sentencia-se que "nada da abóbada daquela capela é ainda manuelino". A segunda etapa, da segunda metade do século XVI, coeva portanto do lançamento de outras grandes obras na cidade (Misericórdia, Sé), inspirada já em contexto "clássico”, incluiria a porta principal e as duas portas laterais da parede Sudeste, além das peças de cantaria que ladeiam a escada de acesso ao altar-mor - ou seja, o essencial da volumetria da igreja actual. Por fim, de época posterior, seria a escadaria de acesso ao altar, que reaproveitou lápides sepulcrais, entre outros elementos (ANTT, Luís Benavente, cx. 76, pasa 0535, doc. 3).

Relativamente àquela primitiva fase, outros defendem que a "capela lateral, sobre o qual se ergue a torre quadrangular (...), não deixa qualquer tipo de dúvidas que se trata de uma capela ao estilo tardo-gótico, mais especificamente de estilo manuelino, construída nos finais de Quatrocentos (Santos, 2015: 72). Também seria possível que esta tenha constituído a capela-mor do primitivo edifício de culto, que assim teria uma orientação perpendicular à actual, podendo também incluir o volume anexo de corpo cilíndrico, onde se inseriam as escadas de acesso à torre (Pires \& Fernandes, 2010: 311). Menos sustentada é a hipótese de que a possante torre sineira tenha sido uma antiga torre defensiva da cidade, como parece revelar a volumetria de iconografia de 1655 e 1699, sendo inverosímil que o edifício servisse simultaneamente de espaço religioso e residência do capitão (Santos, 2015: 69). Também parece claro que, quando se estruturou o bairro de São
Pedro, já existia esta igreja, em cota superior à rua da Carreira, pelo que se intui que terá sido durante a primeira metade do século XVI que se estruturou o respectivo largo, “adaptando-o ao eixo da rua” (Pires, 2007: 120).

As nossas observações realizadas aquando da referida obra na igreja permitem-nos aventar algumas hipóteses, não obstante os limites da nossa intervenção e sem grandes considerações no campo da história da arte. Assim, o segundo arco ogival da igreja encontrava-se efectivamente emparedado antes desta intervenção, especulando-se se seria uma entrada, ou antiga sacristia (Santos, 2015: 73), embora no final anos de 196o, durante a missão de Benavente, o compartimento tenha sido registado em planta. A desobstrução deste espaço permitiu reconhecer tratar-se de uma segunda capela (fig. 7). Esta estrutura estava limitada por quatro paredes que a conformavam um rectângulo de 4,3m de comprimento (do arco ao tardoz) e $4 \mathrm{~m}$ de largura: a da entrada a Sudeste, onde se notava um claro acrescento em altura correspondente à nave principal da igreja; a do altar a Noroeste, mais exposta aos desprendimentos rochosos que afectaram a capela; a parede que a fechava a Nordeste e que permaneceu como limite da actual sacristia; e a parede a Sudoeste, relativamente bem preservada, mas com a altura afectada pela falta de estruturas de sustentação a ladeá-la. Tanto a parede Sudeste, como a Nordeste e Noroeste parecem estar construtivamente articuladas. A excepção parece ser a parede Sudoeste que se encosta ao aparelho das paredes Sudeste e Nordeste. Provavelmente, no momento de construção da nave central da igreja apenas as paredes Sudeste e Nordeste foram alteadas.

Os trabalhos de escavação começaram pela remoção dos escombros das respetivas paredes e telhado, mas sobretudo deslizamentos de sedimentos e pedras da arriba setentrional da cidade [7oo], idênticos aos encontrados naqueles restauros do século XX (Mariz, 2013: 4); foram recolhidos materiais de construção pertencentes a esta campanha de obras. Atingido e escavado um nível de deposição mais fina [702], detectou-se a base do altar [731], adossado e a meio da parede Noroeste da capela, que confina com o exterior, circundado por um pavimento em tijolo cobrindo sensivelmente metade do recinto da capela [730] (Figura 8). De assinalar que, no canto Norte da capela, existia um grande bloco pétreo, que foi estruturado com pedras e argamassa (de que res- 
tam escassos vestígios) formando um volume quadrangular, hipotética base de armário para guardar objetos religiosos.

Relativamente ao altar identificam-se, na realidade, duas fases nesta estrutura: o primitivo corresponde a um muro com $2,2 \mathrm{~m}$ de comprimento e $0,42 \mathrm{~m}$ de largura (duas varas por sensivelmente dois palmos, segundo a métrica da época), adossado à referida parede Noroeste da capela, constituído por pedra basáltica de pequena a média dimensão unida por argamassa de cal homogénea [731a]; o mais recente, resultante do espessamento do anterior, atingindo 2,2X1,1m (duas varas por uma vara), composto por pedras basálticas de média a grande dimensão, ligadas por sedimento fino solto e castanho, contendo telhas posicionadas em cutelo e fragmentos de azulejos hispano-mouriscos, observando-se num dos vértices a reutilização de uma pedra calcária chanfrada [731b]. Se o primeiro poderá corresponder à primitiva capela, o segundo reutiliza elementos suprimidos que lhe terão pertencido e com uma datação de finais do século XV ou início da centúria seguinte. Quanto ao piso [73o], era na verdade uma plataforma sobrelevada da capela, visando dar maior nobreza ao altar, na sua última fase (Figura 8). Tinha 4,3x1,9m, sendo formado por tijolo burro rectangular (o,14xo, 27xo, 04m) disposto no sentido SE-NO, constituído por seis filas de seis tijolos em cada lado do altar e 15 filas de apenas três linhas de tijolos na sua frente; estes assentam em pedras de pequena a média dimensão unidas por argamassa de cal contendo grande quantidade de pequeníssimos seixos, idêntica à que foi utilizada na parede Sudoeste.

Na outra metade da capela, junto ao arco de entrada, prosseguiu-se com a escavação. Sob o referido depósito [7oo], reconheceu-se um pavimento em terra batida e cal, pouco homogéneo [703], que deverá corresponder à mais recente fase de ocupação da capela na primeira metade do século XX. Seguiu-se a escavação de um sedimento [705], com muitos seixos de pequena dimensão e nódulos de argamassa, que datará da mesma época, incluindo material contemporâneo, mas também fragmentos de azulejos hispano-mouriscos baixo-medievais e outros do século XVII, fragmentos de vidro e ossos humanos dispersos. Foi identificada uma estrutura negativa aberta de forma aleatória [704], preenchida com sedimento idêntico, que deverá resultar de "caça ao tesouro" numa época em que este espaço estaria em ruína. Seguem-se os níveis de épocas mais recuadas (Fi- gura 8). Ao centro, [706] e [707], parecem estratos equivalentes de um lado e outro da referida fossa [704], compondo-se de sedimento castanho de grão médio muito compacto, com pedras de pequena e média dimensão, além de um azulejo hispano-mourisco, cerâmica esmaltada branca, cavilhas em ferro, dentes e ossos humanos desarticulados e restos de fauna. O perfil rectangular bastante regular da área que preenchem corresponde, por certo, a um antigo enterramento coberto por lápide de sepultura, que entretanto desapareceu, sedimento que não foi escavado. É bastante sugestiva a referência documental ao enterramento do bispo de Cabo Verde D. Frei Sebastião da Ascensão em 1614, "na igreja do Rosário junto ao altar de São Sebastião”, provável referência ao orago da capela agora revelada (Carreira, 1985: 44-45).

Já nas laterais desta área da capela reconheceram-se três níveis de piso feitos com argamassa de cal, separados por estrato com sedimento castanho-escuro, cuja correlação nos parece evidente (Figura 9). Assim, [709], no canto Este, e [714], junto ao canto Sul, pertencerão ao piso mais recente de utilização desta capela como espaço de culto, sendo o mais destruído. Após o fino sedimento [710], apenas visível no canto Este da capela, segue-se novo piso de características idênticas, representado por [711] a nascente e [717] a poente, sendo que neste último articula-se com uma fiada de negativos de tijolos [715], que existia junto à parede Sudoeste. Já abaixo do sedimento [712], preservado sobretudo junto à entrada da capela, onde é mais espesso, do que próximo ao altar, onde é mais fino, detectámos o piso mais antigo descoberto nesta intervenção, sensivelmente ao mesmo nível da parte inferior do chanfro do arco de entrada na capela, pelo que poderá ser o primitivo, de que subsiste [713], visível junto ao altar e na entrada a nascente, e [719], do lado poente. De destacar que estes pavimentos mais antigos foram rasgados de um e outro lado da capela, em duas valas a poente e uma a nascente, de pequena dimensão e ovaladas, possivelmente para enterramento de crianças, pertencendo às primeiras o sedimento [720], que não foi escavado.

Em suma, esta capela funcionou com o primitivo espaço de culto aqui erguido, articulando-se muito provavelmente com a capela abobadada e sobreposta pela torre sineira a que já fizemos referência, de finais do século XV. É provável que esta seja coeva da estruturação do primitivo núcleo do bairro de São Pedro, com as referidas ruas Direita, Banana e Carreira. 
É, contudo, impossível reconhecer a planta deste edifício com os dados de que dispomos, mas é forçoso incluir as duas capelas laterais da actual igreja como fazendo parte do primitivo edifício, que assim não deveria ser simplesmente uma pequena nave perpendicular à actual. Mais certo é que, entre este último momento e o enterramento do bispo D. Frei Sebastião da Ascensão, em 1614, foi seguramente realizada a reformulação da capela - provavelmente dedicada a São Sebastião -, com o engrandecimento do altar e sua nobilitação através do piso sobrelevado que o rodeia, anulando-se e reutilizando-se elementos pertencentes à estética anterior baixo-medieval; novo piso será coevo do enterramento do prelado dominicano. É impossível esclarecer até que época se utilizou este espaço, momento em que se terá operado a trasladação da sepultura e lápide do bispo para a nave principal, onde se encontrava antes desta intervenção. O seu fim estará relacionado com deslizamentos de sedimentos da encosta a Norte da igreja, problema detectado aquando do restauro dos anos de 1960 e novamente verificado agora.

Outra intervenção arqueológica realizada no âmbito da obra de restauro desta igreja foi o acompanhamento arqueológico da remoção dos degraus de acesso ao adro a partir da rua da Carreira, que se constituíam de lápides de sepulturas reaproveitadas, com más condições de acesso. Foi possível recuperar três deste tipo de elementos, destacando-se um exemplar fracturado em várias partes, transferido para o Museu de Arqueologia (na Praia), que constava de gravação nas duas faces pertencente ao mesmo indivíduo, João Alemão, falecido em 1524, morador e armador em Santiago, proprietário de terras em São Martinho, único oficial que acumulou as funções de capitão da Ribeira Grande e corregedor das ilhas (Santos e Cabral, 1991: 402). Paralelamente, foi possível recolher um conjunto de materiais depositados abaixo dos degraus: se na parte inferior e superior da escadaria se detectaram estratos com materiais contemporâneos, [750] e [751], foi possível reconhecer também níveis com espólio que não superava o século XVIII, [752] e [753], incluindo muitos ossos humanos, num dos casos em articulação. O espaço poderá ter sido usado como necrópole até esta data, sendo depois sobreposto pela referida escada, que aproveitou lápides de sepultura que estariam dispersas no interior da igreja, então seguramente em franca ruína. Superou-se, assim, um problema encontrado nas intervenções realizadas aqui a partir de 1969 e de 2000, a primeira pelo governo colonial português, visando a constituição de um futuro $\mathrm{Mu}$ seu Lapidar e Arqueológico, a segunda pela Cooperação Espanhola em Cabo Verde, que ao invés terá levantado, acrescentado e remobilizado sem critério as lápides existentes no interior do espaço de culto (Mariz, 2013: 7 e 9).

\section{EDUCAÇÃO PATRIMONIAL}

No domínio da educação patrimonial destacam-se dois tipos de acções: por um lado, uma actividade no Museu de Arqueologia, na Praia, no âmbito do seu programa de serviço educativo; por outro, visitas às áreas de escavação, na Cidade Velha, no quadro dos trabalhos arqueológicos em desenvolvimento.

A primeira iniciativa dirigiu-se aos alunos da Escola Técnica Grão Duque Henri da Assomada, frequentando o $10^{\circ}$ ano, totalizando uma centena de alunos. Visava essencialmente o conceito de património arqueológico como instrumento para o conhecimento da história de Cabo Verde e das suas relações com o mundo, fornecendo informações sobre os principais sítios do arquipélago e o seu significado para a investigação sobre o passado. Ao mesmo tempo, a iniciativa pretendia explorar as práticas arqueológicas, desde o processo de escavação, ao registo, construção de conhecimento e musealização, tanto em ambiente terrestre, como subaquático. Foram assim criados quatro ateliers, visando dar corpo a estes objectivos. O primeiro procurava recriar uma escavação arqueológica em meio terrestre numa caixa de areia, onde se reproduziam diferentes momentos de ocupação, plasmados numa estratigrafia claramente apreensível, bem como a sua relação com estruturas (uma lareira) e materiais (cerâmicas, restos faunísticos); os alunos foram convidados a fazer essa escavação estratigráfica e registar as suas diferentes fases (Figura 10). O segundo pretendia demonstrar a utilização de equipamentos de mergulho, projectando-se o seu emprego em meio subaquático. Em terceiro lugar, os alunos foram estimulados a proceder à colagem, marcação e registo (desenho e fotografia) de materiais arqueológicos, bem como ao seu inventário, tanto em meio terrestre como subaquático, como forma de integrar o património arqueológico nos museus, seja em reserva ou em exposições abertas ao público. Por fim, a última acção consistia numa visita à sala principal do museu de arqueologia, procurando-se articular objectos e a história cabo-verdiana, 
integrada no mundo global, sobretudo através dos diferentes naufrágios identificados no país, incluindo objetos utilizados no quotidiano a bordo, instrumentos de navegação, equipamentos bélicos (armas de fogo), contentores de transporte e fauna ictiológica e mamalógica. Seguiu-se o guião da exposição permanente do museu. Estas acções socioeducativas auxiliam o museu na melhoria da sua comunicação com o público, promovendo actividades complementares à educação formal, permitindo que os seus visitantes/estudantes, de diferentes faixas etárias, alarguem o seu conhecimento, ao mesmo tempo que se dinamiza o Museu de Arqueologia.

Quanto à segunda iniciativa, procurou-se levar alunos de diferentes idades a conhecer a primeira cidade cabo-verdiana, Ribeira Grande de Santiago, o sítio arqueológico de maior relevância nacional, também património cultural da humanidade. Além de assinalar os principais monumentos, fizeram-se visitas aos três locais de intervenção arqueológica recente, o sítio arqueológico da igreja de Nossa Senhora da Conceição, a habitação da Rua da Banana e a capela da igreja de Nossa Senhora do Rosário (Figura 11). Contaram-se com uma centena de alunos do $3^{\circ}$ ano do Ensino Básico Integrado do Centro Educativo Miraflores, da cidade da Praia, adaptando-se naturalmente o discurso para os diferentes públicos. Além de transmitir a história dos principais edifícios e monumentos e do seu papel na história da cidade, procurou-se difundir a importância do património invisível, arqueológico, que se esconde debaixo de terra e do mar. O papel da arqueologia e dos arqueólogos também foi explicado, como um veículo para recuperar e estudar a história e o património de Cabo Verde.

\section{CONCLUSÕES}

Os trabalhos arqueológicos que aqui se transmitiram, num balanço naturalmente preliminar, acrescentam elementos pontuais para o conhecimento da antiga Ribeira Grande, principal aglomerado urbano de Cabo Verde nos primeiros dois séculos de ocupação e grande sítio arqueológico património da humanidade, que há décadas vem sendo intervencionado pontualmente sem um enquadramento global efectivo dessas diversas actividades. De sublinhar que, no decurso deste projecto, alguns de nós se envolveram num outro projecto, o de carta arqueológica da Cidade Velha, coordenado por Jaylson Monteiro e Nireide Tavares, financiado pelo Gabinete do Ensino Superior, Ciência e Tecnologia do Ministério da Educação de Cabo Verde no âmbito de um concurso competitivo, que constitui um passo decisivo na construção de uma estratégia nacional para a gestão e salvaguarda deste importante legado.

As escavações levadas a efeito no contexto do projecto CONCHA permitiram recuperar uma pequena parcela do urbanismo da antiga Ribeira Grande, na verdade uma casa de sobrado que se intui de grandes proporções no contexto local, de fundação ainda impossível de determinar, mas que terá sido abandonada no ocaso desta cidade, quando a capital foi transferida para a Praia e boa parte dos seus mais importantes proprietários, que possuíam ainda aí habitações mau grado a decadência que se vinha verificando há um século, a deixaram por completo, votando-a à ruína. Naquele domínio, é interessante assinalar que o nível de piso setecentista da casa, detectado nesta extremidade setentrional da rua da Banana, se encontra a mais de um metro de profundidade face ao solo actual, o que é bem revelador de como, pelo menos nesta área baixa da cidade, os vestígios da antiga capital do arquipélago se encontram ainda guardados no seu subsolo.

No que toca à igreja de Nossa Senhora do Rosário, uma das mais antigas do arquipélago e que se encontra ainda em uso, foi importante a participação numa verdadeira acção de minimização de impactes sobre o património arqueológico durante a obra pública de conservação e restauro do edifício. Destaque para a proveitosa articulação com o director da intervenção, arquitecto Adalberto Tavares, tanto nas várias etapas do trabalho, como nas soluções de musealização; com Artur Jaime Duarte, que aqui se encontrava em iniciativa da Universidade de Aveiro, fez-se a conservação da capela objecto de escavação, depois musealizada. Do ponto de vista arqueológico, foi, pois, possível descobrir e caracterizar mais um elemento importante da primitiva estrutura do edifício religioso, a capela de São Sebastião, nas suas duas mais importantes fases de ocupação: uma primitiva, que será coeva da fundação de finais do século XV, outra de finais de Quinhentos ou inícios da centúria seguinte, conectada com a integração da sepultura de D. Frei Sebastião da Ascensão no seu tempo em Cabo Verde. É também relevante sublinhar o resgate de informação sobre a história do edifício e da cidade através dos testemunhos epigráficos, que não foram objecto deste texto. 
Por fim, decisiva foi a participação de vários agentes locais durante a escavação, bem como as acções de sensibilização e divulgação do património arqueológico cabo-verdiano, tanto no sítio arqueológico, como no Museu de Arqueologia, na Praia, que aguarda ainda uma acção que potencie o seu importante acervo como testemunho material da história nacional nos seus vários domínios e cronologias. Pela participação e empenho das centenas de estudantes envolvidos nestas iniciativas dir-se-ia que, estando ou não na moda, a arqueologia tem futuro e se pode esperar um destino risonho para nos patrimóniu.

\section{BIBLIOGRAFIA}

ALMEIDA, Mariana (2018) - The $17^{\text {th }}$-century tile panorama in the island of Santiago, Cabo Verde: a first approach to a work in progress. In Pereira, Sílvia, Menezes, Marluci \& Rodrigues, José Delgado - Glaze Art 2018 International Conference: Glazed Ceramics in Cultural Heritage. Lisboa: Laboratório Nacional de Engenharia Civil, pp. 283-297.

AMARO, Clementino (2012) - Sé da Cidade Velha, República de Cabo Verde, Resultados da $1^{2}$ fase de campanhas arqueológicas. In TEIXEIRA, André; BETTENCOURT, José eds. - Velhos e Novos Mundos: Estudos da Arqueologia Moderna. Lisboa: CHAM, vol. I. pp. 451-464.

BALENO, Ilídio Cabral (1991) - Povoamento e Formação da Sociedade. In ALBUQUERQUE, Luís de \& SANTOS, Maria Emília Madeira, coord. - História Geral de Cabo Verde, vol. I. Lisboa \& Praia: Instituto de Investigação Científica Tropical \& Direcção-Geral do Património Cultural de Cabo Verde, pp. 125-177.

CABRAL, Iva (1995) - Ribeira Grande: Vida Urbana, Gente, Mercancia e Estagnação. In SANTOS, Maria Emília Madeira, coord. - História Geral de Cabo Verde, vol. II. Lisboa \& Praia: Instituto de Investigação Científica Tropical \& Instituto Nacional de Cultura de Cabo Verde, pp. 225-273.

CÁCERES GUTIÉRREZ, Yasmina; DE JUAN ARES, Jorge (2002) - La Historia de Cabo Verde a través uno de sus edificios emblemáticos: la excavación del convento de San Francisco (Cidade Velha, Cabo Verde). In Actas del IV Coloquio Internacional de Estudios sobre África y Asia. Málaga: Diputación Provincial de Alicante / Editorial Algazara, pp. 209-229.

CARREIRA, António, ed. (1985) - Notícia corográfica e cronológica do bispado de Cabo Verde desde o seu principio até o estado presente. Lisboa: Instituto Caboverdeano do Livro.

DE JUAN ARES, Jorge; CÁCERES GUTIÉRREZ, Yasmina (200o) - Restabelecendo o passado: investigaç̃es arqueológicas na Fortaleza Real de São Filipe. In Cabo Verde:fortalezas, gente e paisagem. Madrid: Agencia Española de Cooperación Internacional, pp. 133-162.
EVANS, C.; SØRENSEN, M. L. S.; RICHTER, K. (2012) Excavation of one of the earliest Christian churches in the tropics: N. . S.. da Conceição, Cidade Velha, Cape Verde. In GREEN, T.; NAFAFÉ, J. Lingna, eds. - Brokers of change: Atlantic commerce and cultures. London: British Academy, pp. 173-192.

MARIZ, Vera Félix (2013) - Cabo Verde no programa de salvaguarda do património português ultramarino - o caso da igreja de Nossa Senhora do Rosário (1962-1974). In Atas do Colóquio Internacional Cabo Verde e Guiné-Bissau: percursos do saber e da ciência. Lisboa: Instituto de Investigação Científica Tropical.

PEREIRA, Daniel (2009) - Marcos Cronológicos da Cidade Velha. $2^{\underline{a}}$ edição, Praia: Instituto da Biblioteca Nacional e do Livro.

PIRES, Fernando de Jesus Monteiro dos Reis (2007) - Da cidade da Ribeira Grande à Cidade Velha em Cabo Verde: análise histórico-formal do espaço urbano (séc. XV-séc. XVIII). Praia: Universidade de Cabo Verde.

PIRES, Fernando \& FERNANDES, José Manuel (2010) Igreja de Nossa Senhora do Rosário. In MATTOSO, José, dir. - Património de Origem Portuguesa no Mundo: arquitectura e urbanismo, vol. África, Mar Vermelho, Golfo Pérsico. Lisboa: Fundação Calouste Gulbenkian, p. 311.

SANTOS, Carlos Emanuel Sousa da Cruz dos (2015) - A Cidade da Ribeira Grande, Cabo Verde: Urbanismo e Arquitetura (Séculos XV a XVIII). Lisboa: Faculdade de Ciências Sociais e Humanas da Universidade Nova de Lisboa (tese de doutoramento).

SANTOS, Maria Emília Madeira \& CABRAL, Iva (1991) O Nascer de uma Sociedade Através do Morador - Armador. In ALBUQUERQUE, Luís de \& SANTOS, Maria Emília Madeira, coord. - História Geral de Cabo Verde, vol. I. Lisboa \& Praia: Instituto de Investigação Científica Tropical \& Direcção-Geral do Património Cultural de Cabo Verde, pp. 371-430.

SANTOS, Maria Emília Madeira \& SOARES, Maria João (1995) - Igreja, Missionação e Sociedade. In SANTOS, Maria Emília Madeira, coord. - História Geral de Cabo Verde, vol. II. Lisboa \& Praia: Instituto de Investigação Científica Tropical \& Instituto Nacional de Cultura de Cabo Verde, pp. 359-508.

SØRENSEN, M. L. S.; EVANS, C.; RICHTER, K. (2011) - A place of history: Archaeology and heritage at Cidade Velha, Cape Verde. In LANE, P. J.; MacDONALD, K.C., eds. - Slavery in Africa: Archaeology and Memory. Oxford: Oxford University Press, pp. 421-442.

TAVARES, Nireide Pereira (2017) - Inventário Arqueológico de Cabo Verde: contributo para uma ferramenta de gestão e valorização do Património Cultural. Lisboa: Faculdade de Letras da Universidade de Lisboa (dissertação de mestrado em Arqueologia). 


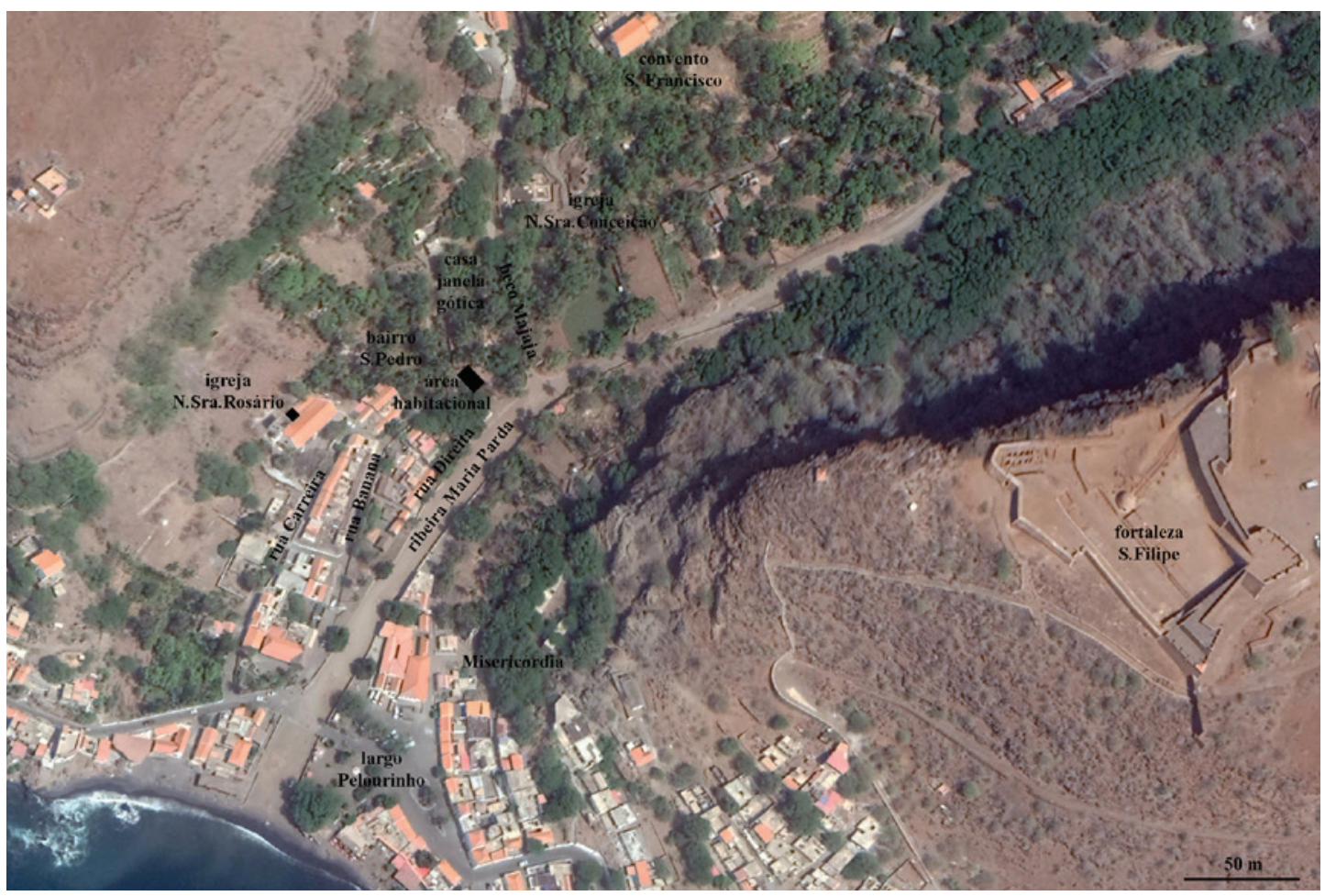

Figura 1 - A cidade da Ribeira Grande de Santiago, com indicação das áreas de intervenção arqueológica em 2018-2020 e demais sítios mencionados no texto.

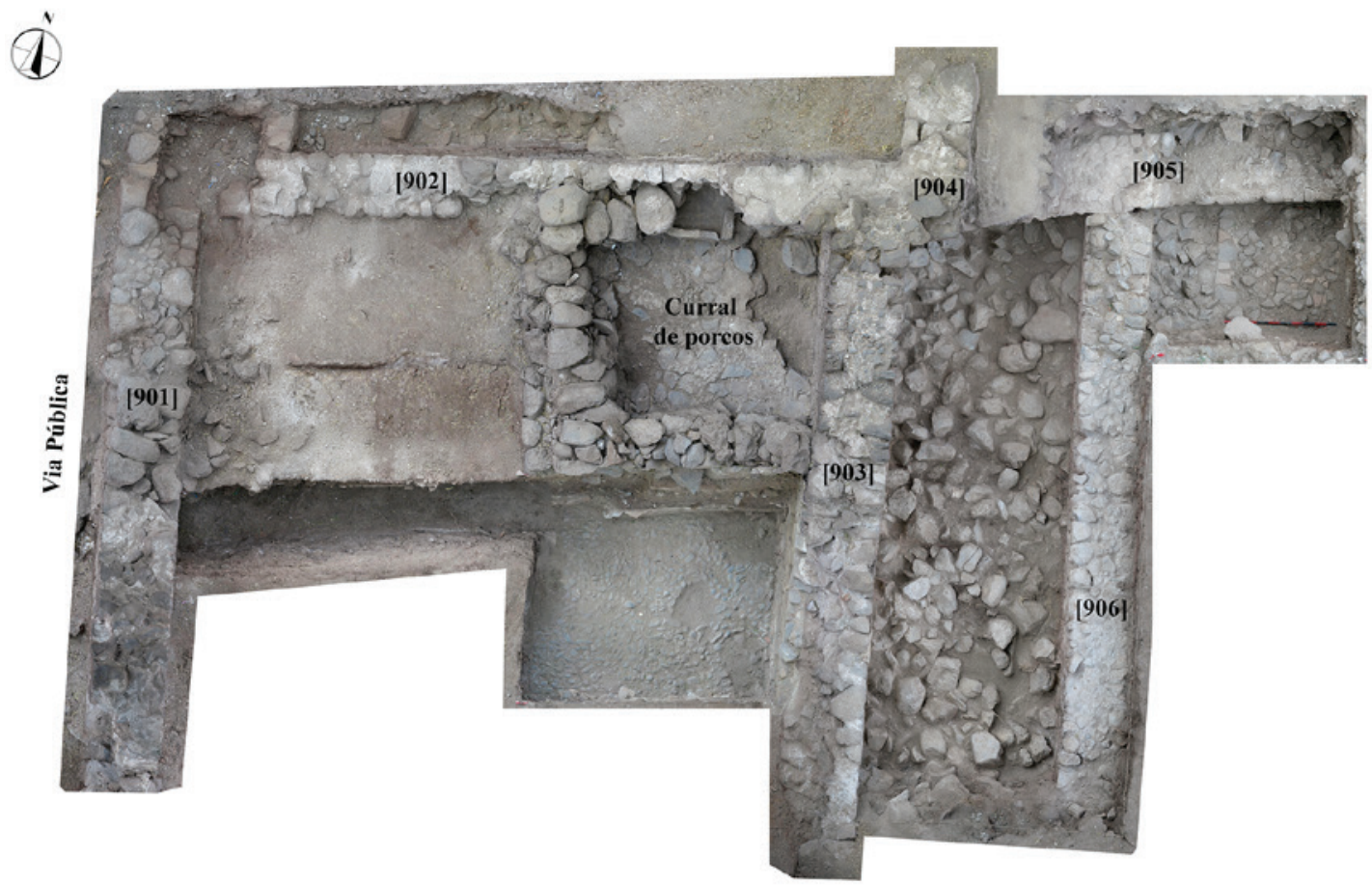

Figura 2 - Plano final da escavação da habitação na intersecção das ruas Direita e da Banana. 


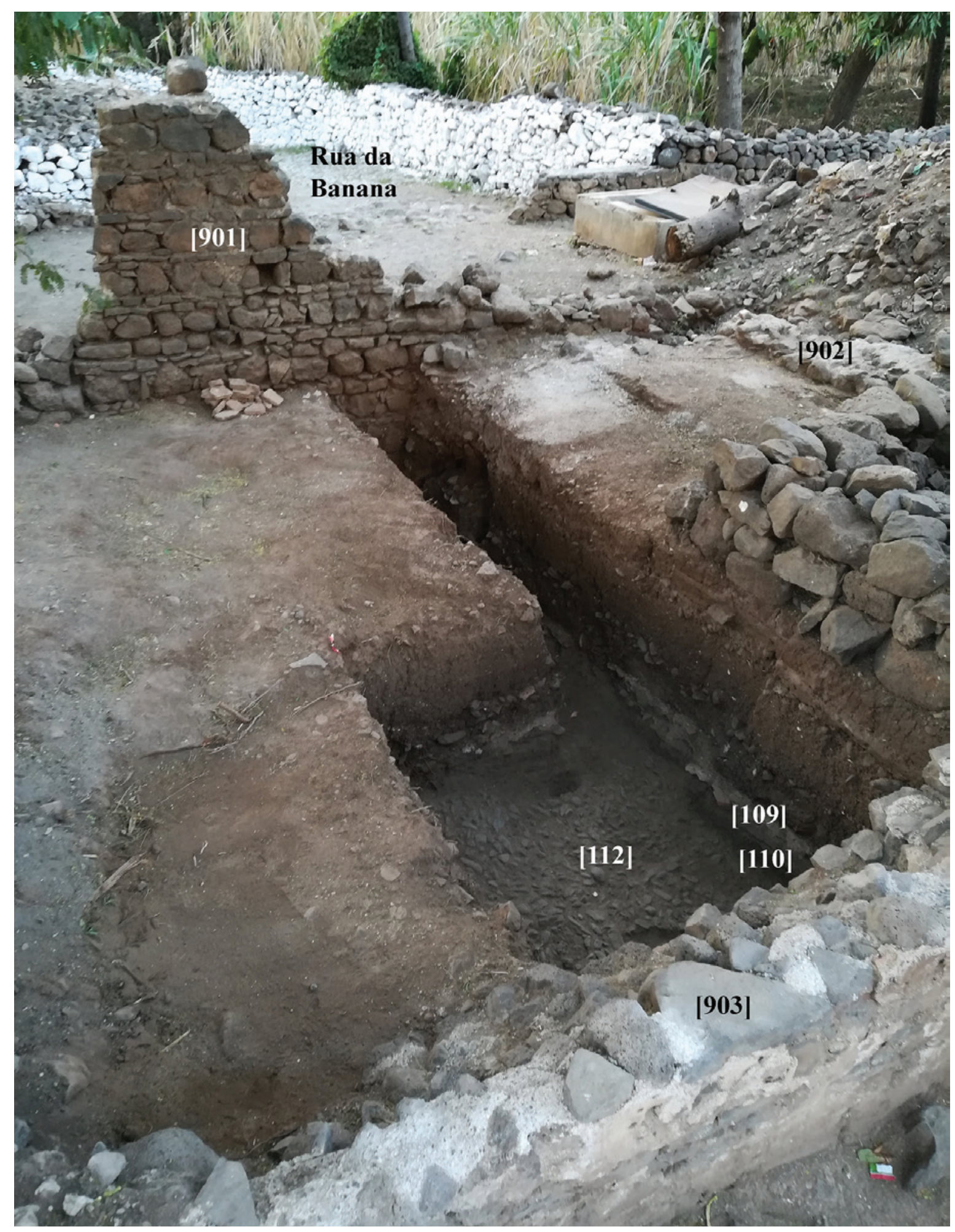

Figura 3 - Espaço residencial da habitação na intersecção das ruas Direita e da Banana, vendo-se a área entre os muros [901], [902] e [903]. 
901
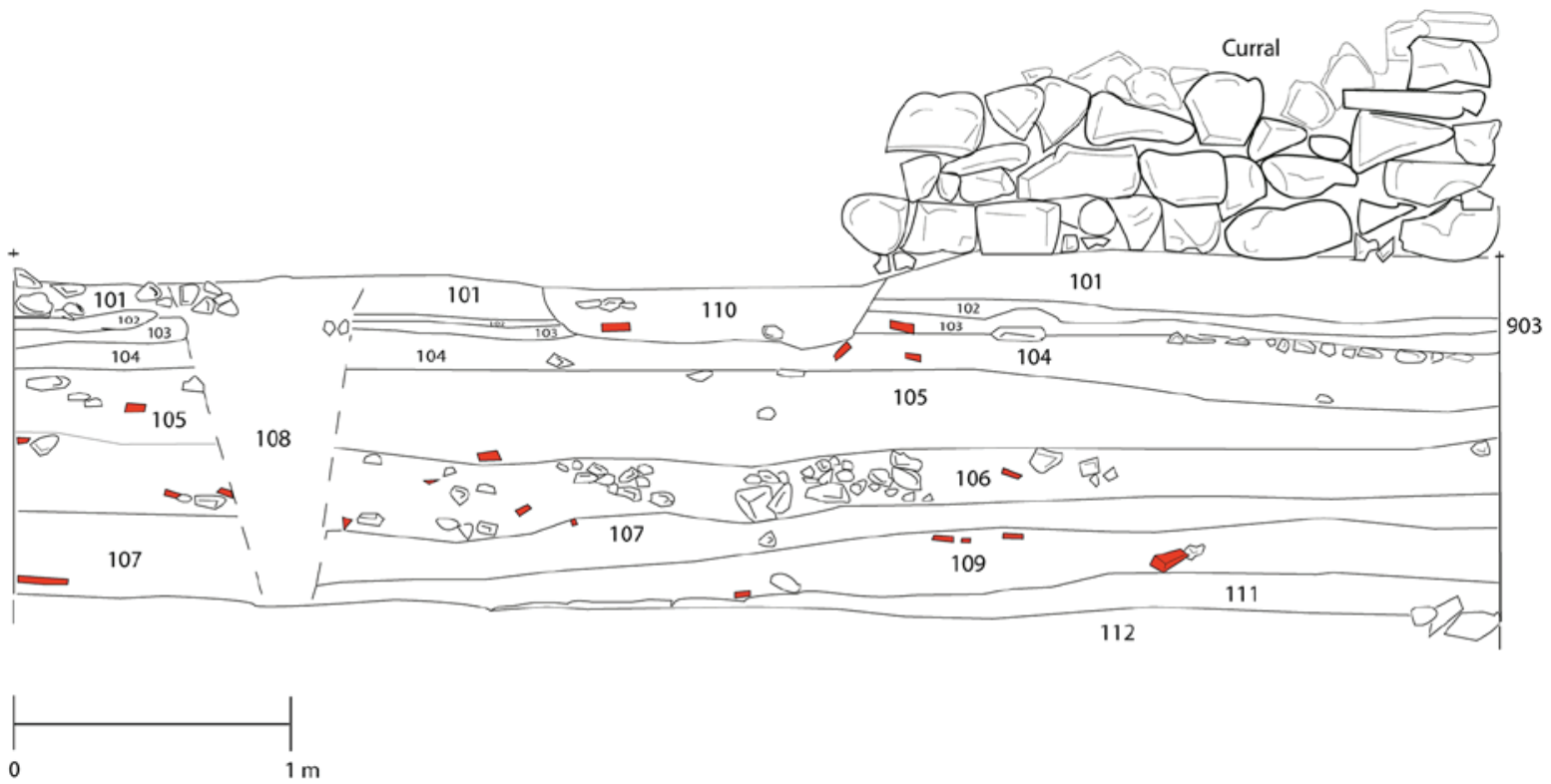

Figura 4 - Perfil Noroeste do espaço residencial da habitação na intersecção das ruas Direita e da Banana, entre os muros [901], [902] e [903].

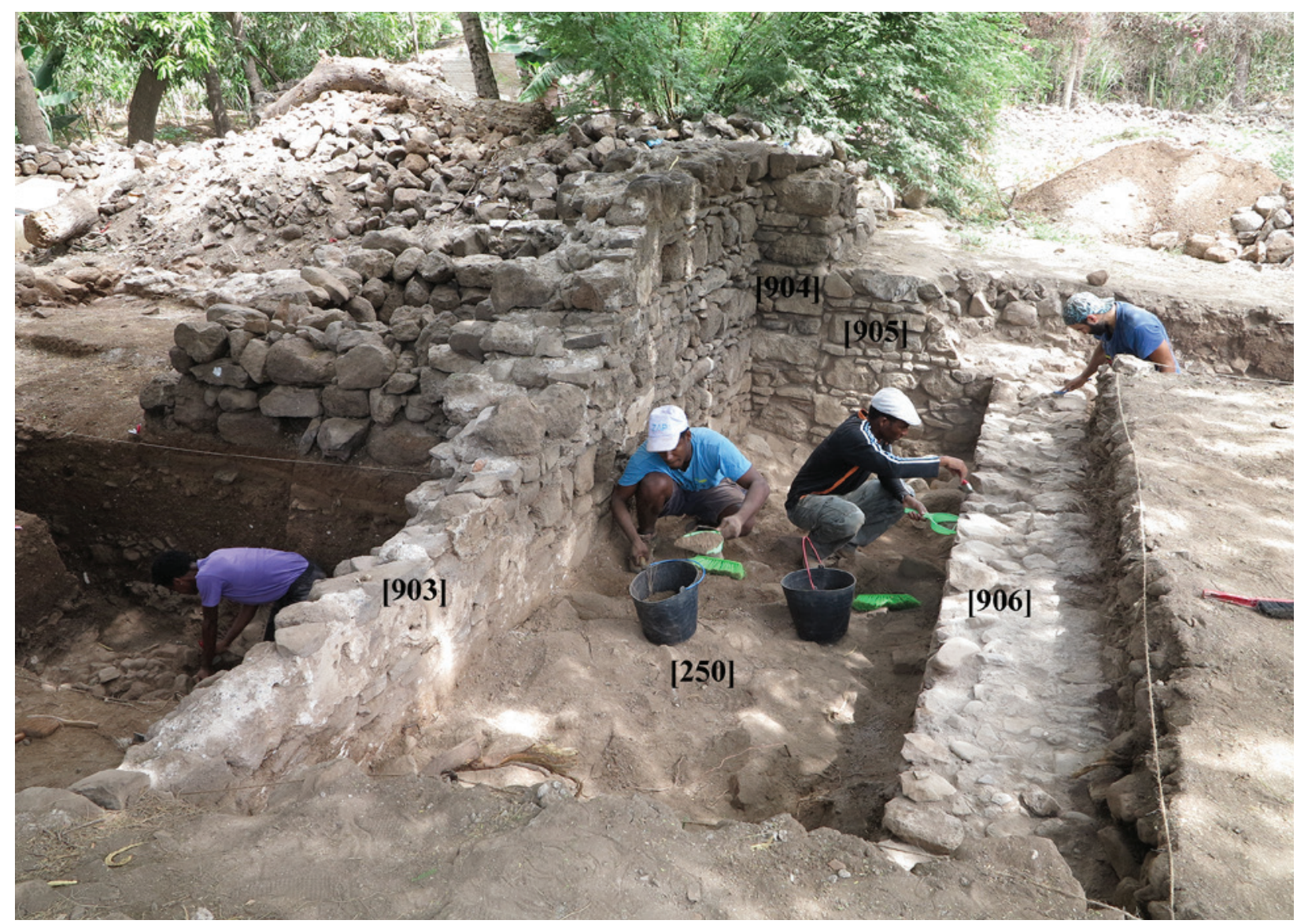

Figura 5 - Espaço de traseiras da habitação na intersecção das ruas Direita e da Banana, vendo-se a área entre os muros [903], [904], [905] e [906]. 


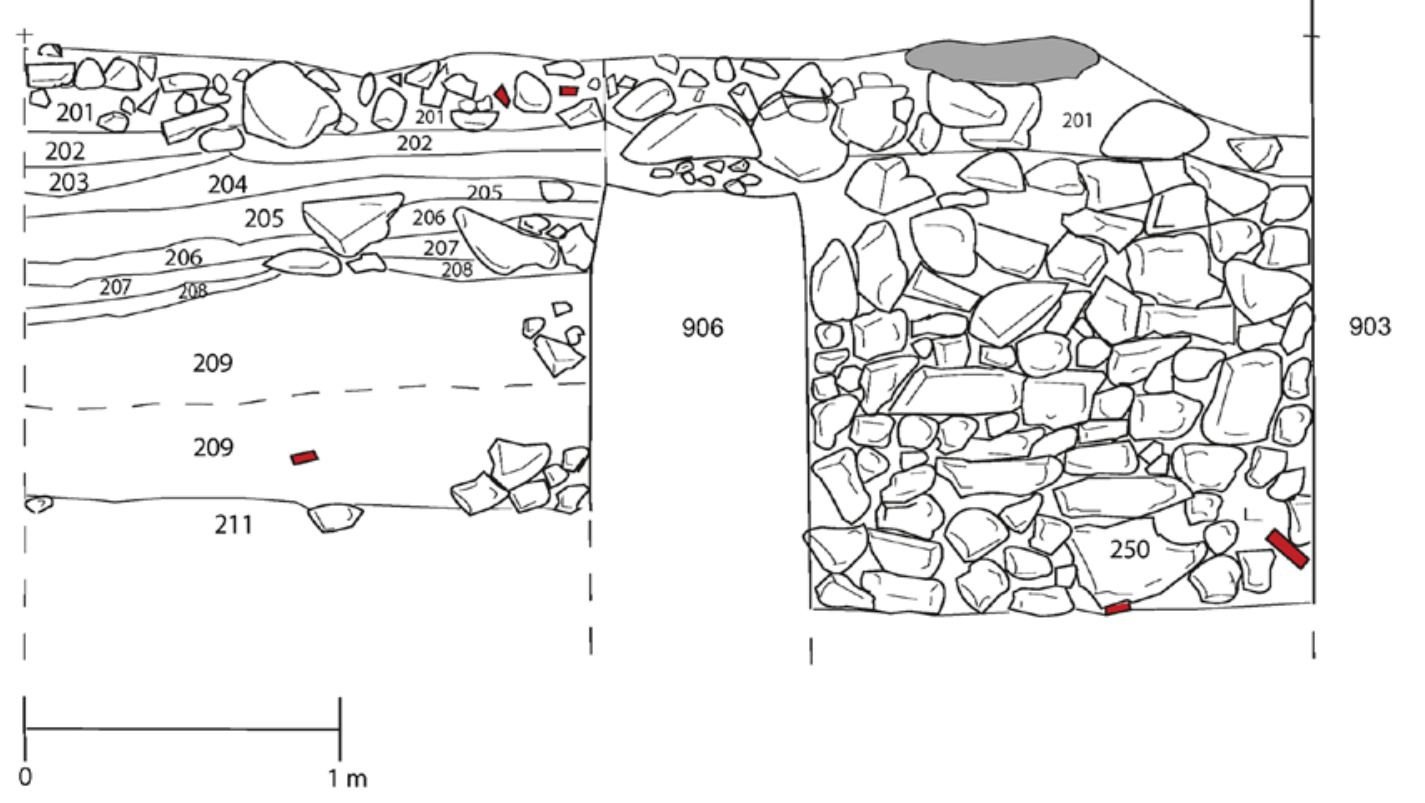

Figura 6 - Perfil Sudeste do espaço de traseiras da habitação na intersecção das ruas Direita e da Banana, entre os muros [903], [904], [904] e [906].

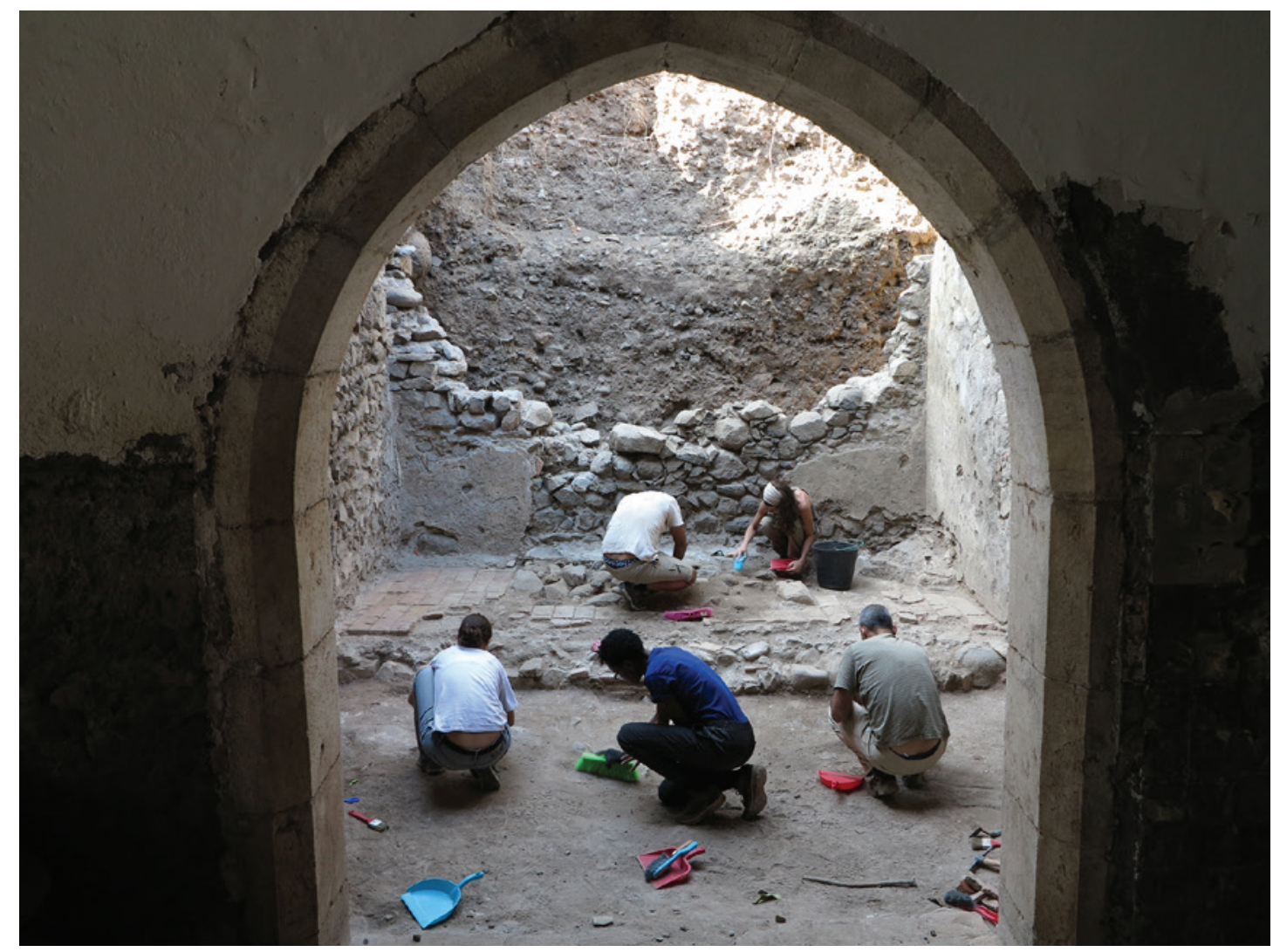

Figura 7 - Capela escavada na igreja de Nossa Senhora do Rosário, a partir da nave. 


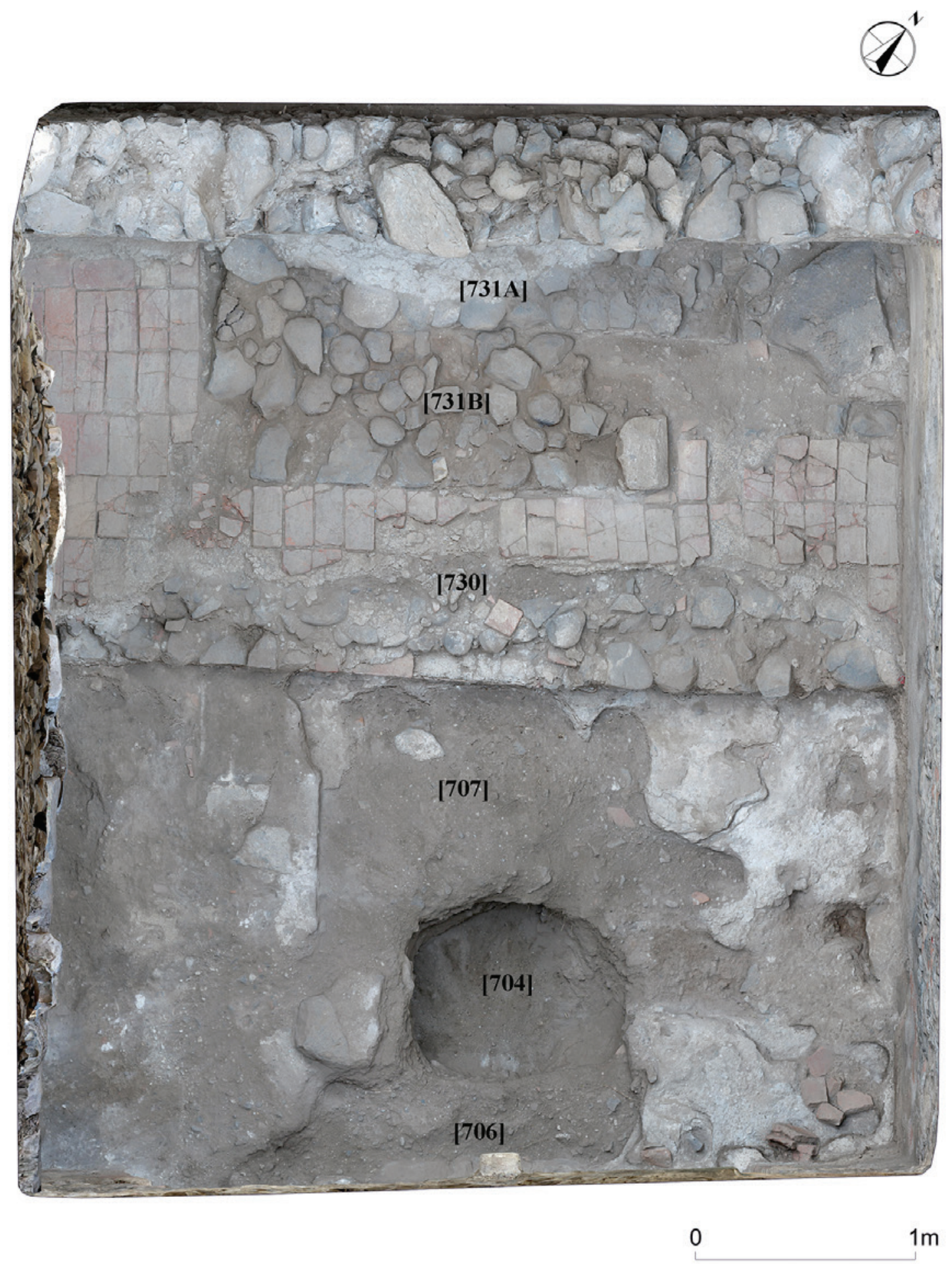

Figura 8 - Plano intermédio da escavação da capela da igreja de Nossa Senhora do Rosário. 


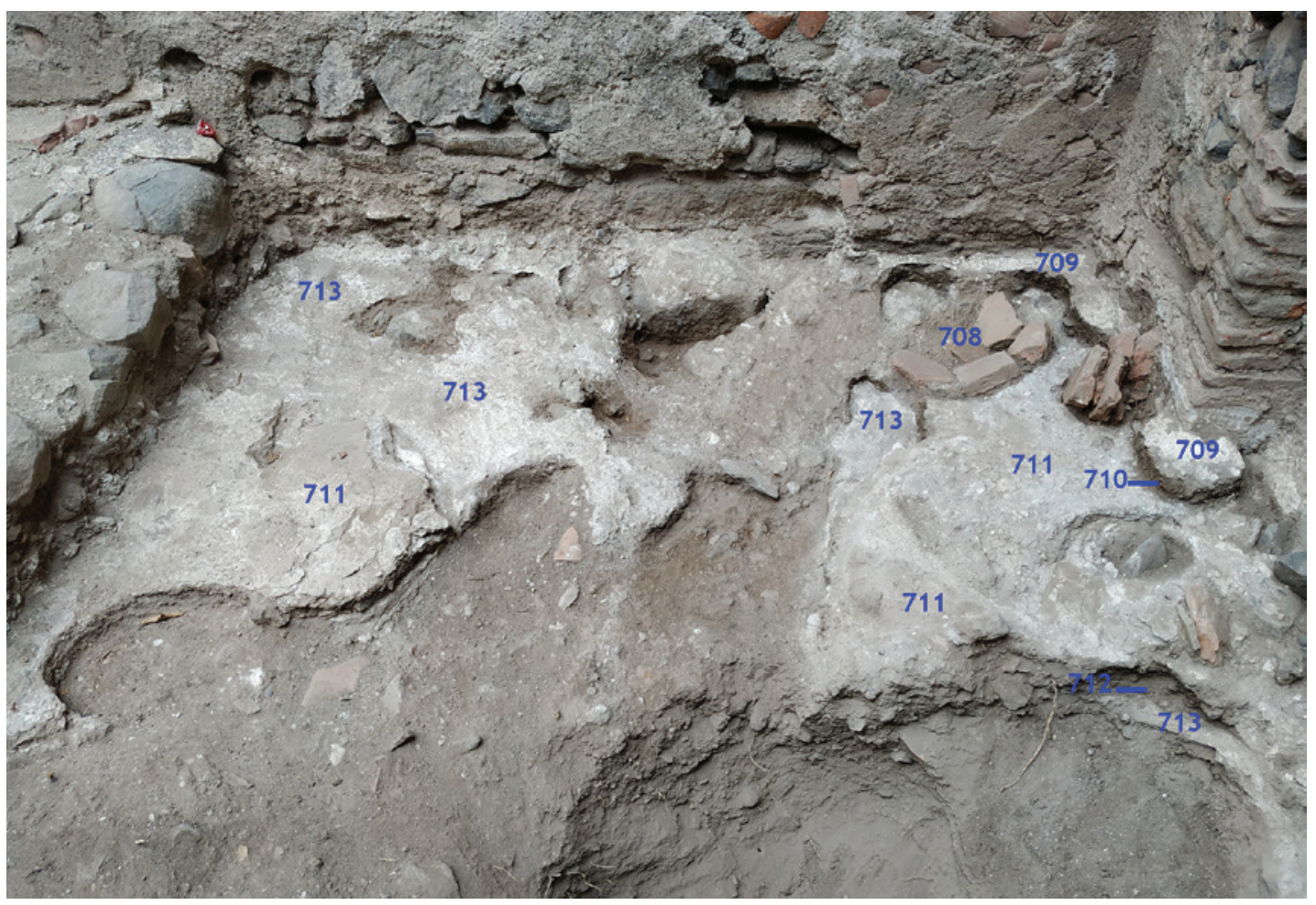

Figura 9 - Plano final da área de pisos de argamassa junto às paredes Nordeste e Sudeste da capela da igreja de Nossa Senhora do Rosário.

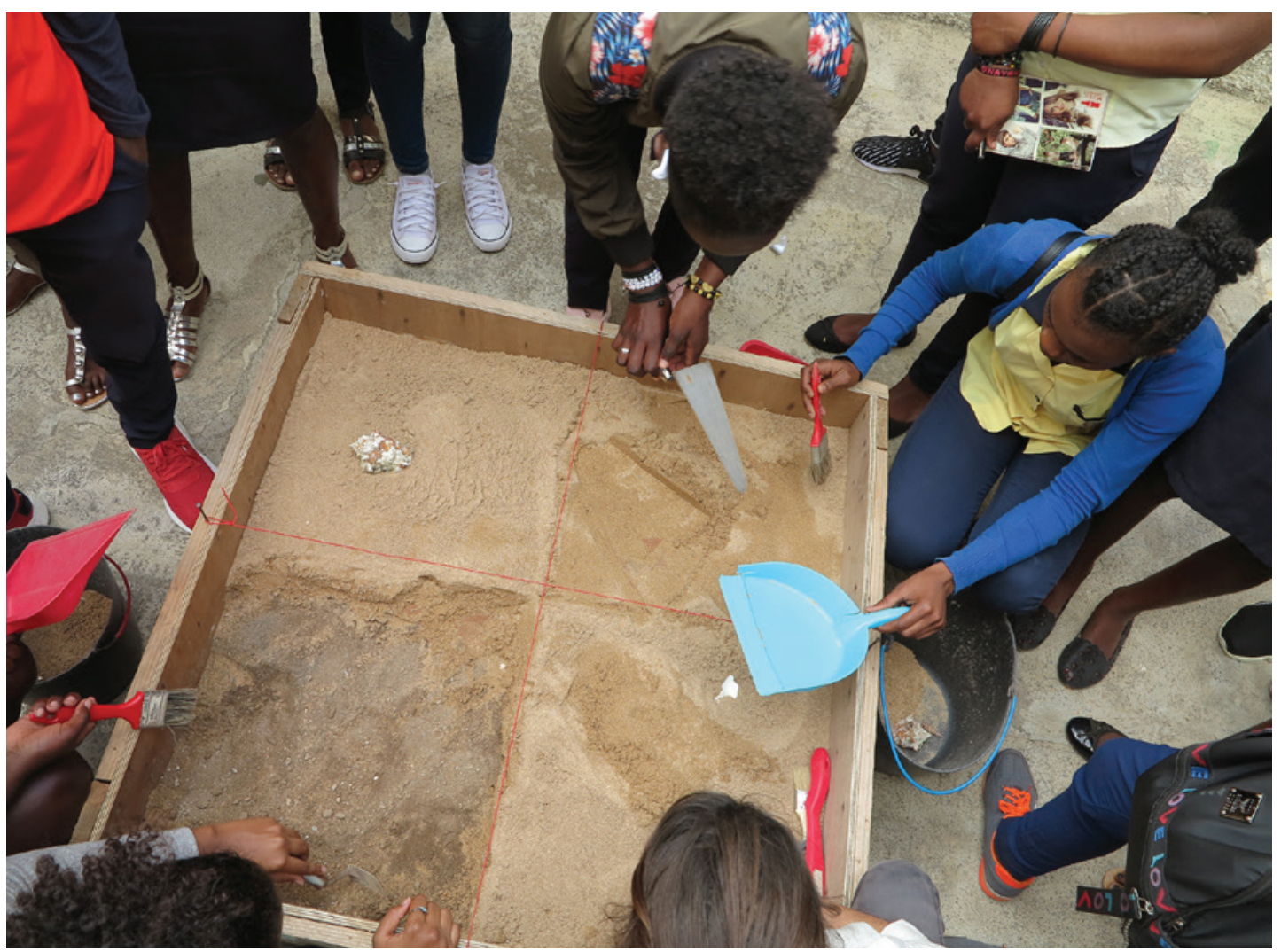

Figura 10 - Recriação de escavação arqueológica em meio terrestre no Museu de Arqueologia, Praia, em visita da Escola Técnica Grão Duque Henri, Assomada. 


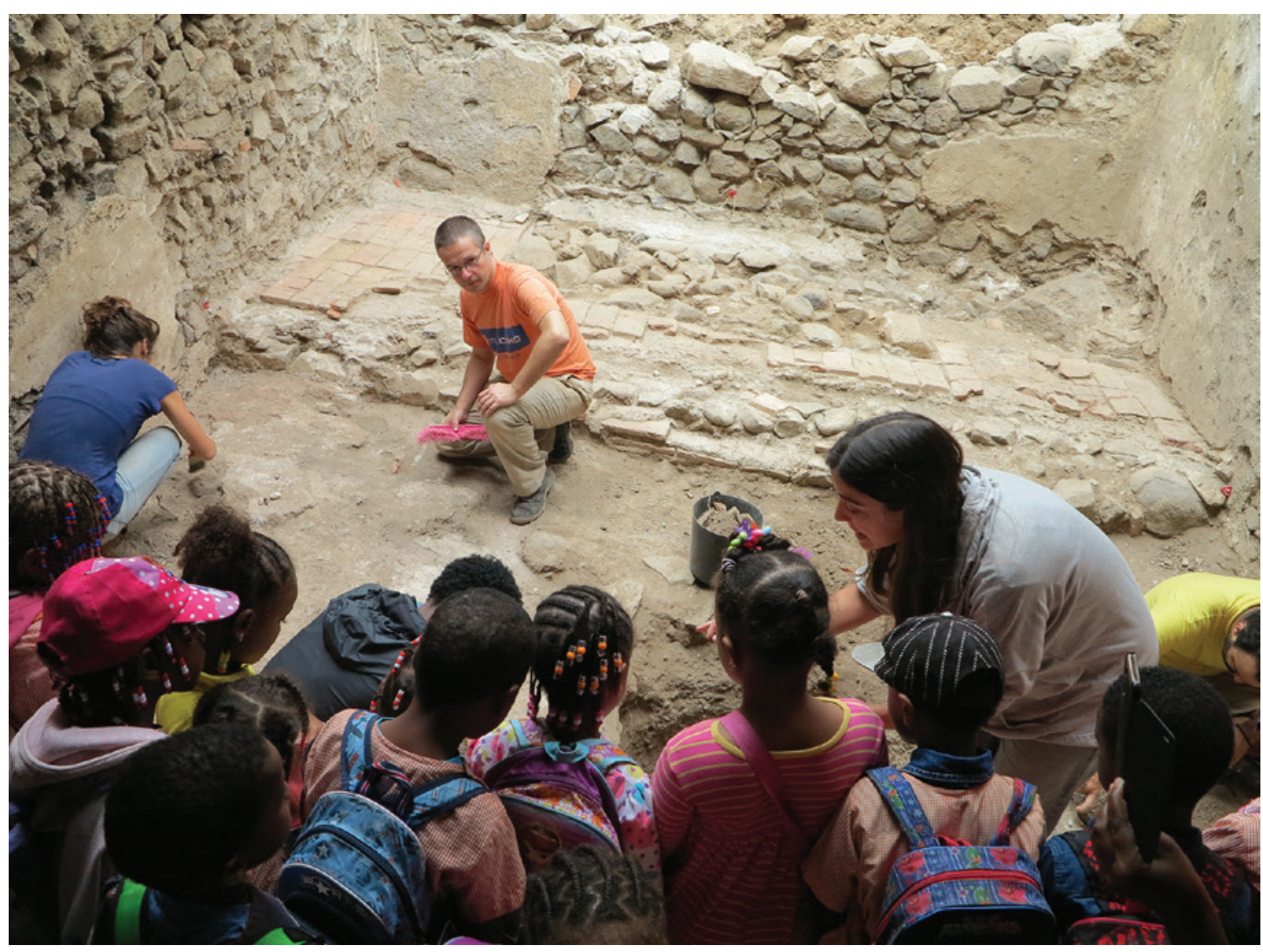

Figura 11 - Visita dos alunos do jardim de infância Arco-Íris, Praia, à capela da igreja de Nossa Senhora do Rosário da Cidade Velha. 


\title{
A ANTIGA FORTIFICAÇÃO DE QUELBA / KHOR KALBA (E.A.U.). RESULTADOS DE QUATRO CAMPANHAS DE ESCAVAÇÕES, PROBLEMÁTICAS E PERSPECTIVAS FUTURAS
}

\author{
Rui Carita ${ }^{1}$, Rosa Varela Gomes ${ }^{2}$, Mário Varela Gomes ${ }^{3}$, Kamyar Kamyad ${ }^{4}$
}

\begin{abstract}
RESUMO
Quatro curtas campanhas de escavações arqueológicas, efectuadas de 2017 a 2020, conduziram à identificação de ruínas da antiga fortaleza de Quelba/Khor Kalba (Emirado de Sharjah), na costa do Golfo de Omã, que os portugueses, sob o comando de Gaspar Leite, tomaram em 1624 e onde terão permanecido cerca de duas décadas. A fortificação foi construída em taipa, apenas parcialmente assente em alicerces de pedra, possuía planta de forma quadrangular, medindo $50 \mathrm{~m}$ de lado e era protegida, pelo menos nos dois cantos voltados para o mar, por torres de planta circular.

No seu interior identificámos solos de ocupação, de gesso e areia, buracos de poste de casas, fornos culinários, estruturas de combustão, lixeiras e um poço, assim como diversificado espólio, nomeadamente cerâmicas, datável entre os finais do século XVI e o século XVIII.

Palavras-chave: Emirados Árabes Unidos, Quelba/Khor Kalba, Fortificação portuguesa, Século XVII, Poço.
\end{abstract}

\begin{abstract}
Four brief archaeological digging campaigns, taking place from 2017 to 2020, lead to the identification of the old Quelba/Khor Kalba (Sharjah Emirate) fortress remains, on the Oman Gulf coast, where the Portuguese, under the Gaspar Leite command, took in 1624 and they stayed about two decades.

The fortress was built with mud walls, only partially laying on stone foundations, with quadrangular shape plan, measuring $50 \mathrm{~m}$ each side, and was protected, at least, on the two corners turned to the see, by circular plan towers.

Inside the fortification walls we have found living floors made with gypsum and sand, house postholes, ovens, fire places, dirt pits and a well, as diversified artefacts remains, namely ceramics, that we can date between the late $16^{\text {th }}$ and $18^{\text {th }}$ centuries.
\end{abstract}

Keywords: United Arab Emirates, Quelba/Khor Kalba, Portuguese fort, $17^{\text {th }}$ century, Well.

\section{INTRODUÇÃO}

Convite do Emir de Sharjah (E.A.U.), Sua Alteza Xeque Doutor Sultão bin Muhammad Al-Qasimi, endereçado a um de nós (RC) e o apoio da Autoridade para a Arqueologia de Sharjah (AAS), permitiu que efectuássemos visita de prospecção àquele emirado e ali dirigíssemos, depois, quatro curtas campanhas de escavações arqueológicas, de 2017 a 2020, ao abrigo de protocolo efectuado entre a AAS e a NOVA

\footnotetext{
1. IAP/NOVA FCSH, Univ. Madeira, Acad. Portuguesa da História, AAP; ruicarita@gmail.com

2. IAP/NOVA FCSH, AAP; rv.gomes@fcsh.unl.pt

3. IAP/NOVA FCSH, Acad. Portuguesa da História, Acad. Nacional de Belas-Artes, AAP; mv.gomes@fcsh.unl.pt

4. Sharjah Archaeology Authority; kmr.kmb@gmail.com
} 
FCSH, através do Instituto de Arqueologia e Paleociências (IAP). Fomos coadjuvados em tal tarefa por uma dezena de alunos, dos três níveis de ensino e ex-alunos, do Curso de Arqueologia da NOVA FCSH, no sítio de Khor Kalba, onde os portugueses ocuparam fortificação, durante duas décadas, que denominaram Quelba. Colaboraram naqueles trabalhos, em datas distintas, os Profs Doutores Fernando Almeida (Univ. de Aveiro) e Pedro Callapez (Univ. de Coimbra), neles participando trabalhadores não especializados da AAS, paquistaneses, indianos e tanzanianos. Os trabalhos de gabinete contaram com a prestimosa colaboração dos Profs Doutores Pedro A. Dinis (Univ. de Coimbra), Miguel Telles Antunes (NOVA FCT e Academia das Ciências de Lisboa), Luís Filipe Vieira Ferreira e Inês Ferreira Machado (Instituto Superior Técnico), Carmen Barceló Torres (Univ. de Valência) e Dr. José Pedro Henriques (IAP / NOVA FCSH).

A antiga fortificação de Quelba/Khor Kalba encontra-se mencionada no álbum das fortalezas da Índia, elaborado por Manuel Godinho de Erédia ( $c a$ 1563-1623) e outros, datado de pouco depois de 1622, mas com desenhos anteriores e ulteriores, hoje na Biblioteca da Fortaleza de São Julião da Barra. Pouco mais de uma década depois surgirá o Livro das Plantas de Todas as Fortalezas, Cidades e Povoações do Estado da Índia Oriental, de 1635, da autoria de António Bocarro, o cronista oficial do Estado da Índia e guarda-mor do Arquivo de Goa (ca 1594-1642), no que foi auxiliado nas suas representações gráficas pelo secretário do vice-rei, Pedro Barreto de Resende e, por certo, iluminadores luso-orientais. Desta obra manuscrita existem várias versões (Carita, 1999).

Em 1639, António de Mariz Carneiro fez uma breve descrição das fortalezas da costa do Golfo de Omã, onde de igual modo consta referência a Quelba.

Os parcos testemunhos chegados até nós da antiga fortificação de Quelba/Khor Kalba situam-se em planície litoral costeira do Golfo de Omã, imediatamente a norte do estuário do rio Kalba e a cerca de $500 \mathrm{~m}$ do Oceano Índico.

Antigo ponto de chegada das caravanas vindas do interior e do sul da Península Arábica, com conexão com as rotas litorais, tanto terrestres como marítimas, desde cedo que Khor Kalba obteve importância nas redes comerciais e estratégicas daquela costa, situada entre dois grandes emporia, a norte Ormuz e, a sul, Mascate.

Depois da passagem de Afonso de Albuquerque pela zona, a presença portuguesa em Quelba/Khor Kalba efectiva-se sob o comando de Gaspar Leite, em 1624, incluída no ambicioso plano de domínio do Golfo Arábico, das costas do Índico e Mar Vermelho, de Rui Freire de Andrade. Todavia, em 1648, quando é assinado tratado de paz na praia de Reame, entre o capitão-general de Mascate, D. Gil Eanes de Noronha e os xeques locais, já Quelba/Khor Kalba não surge entre as possessões portuguesas, embora o antigo xeque da mesma, Yusuf ben Ali ben Salih Al-Qasi$\mathrm{mi}$, se encontrasse presente. Deduz-se, assim, que aquela fortificação já havia sido entregue (Al-Salimi e Jansen, 2015: 385-388).

Foram publicados alguns trabalhos que dão a conhecer os resultados das primeiras campanhas arqueológicas de Quelba/Khor Kalba (Gomes et alii, 2017; Carita et alii 2019; 2019a). Algum espólio, dali procedente, integra a exposição Identidade e Cultura. Património Arqueológico de Sharjah (EAU), inaugurada em Novembro de 2019, no Museu Nacional de Arqueologia e de que se editou o catálogo respectivo (Gomes, 2019).

\section{PRINCIPAIS PROBLEMÁTICAS}

Os restos da fortificação de Quelba/Khor Kalba, desmontada segundo a tradição oral e a informação arqueológica, no século XVIII, por o mar chegar às suas muralhas, encontravam-se, à data do início dos nossos trabalhos, completamente submersos no terreno arenoso característico daquela área costeira. Todavia, eles haviam estado integrados em área fortemente ocupada por bairro de pescadores, depois arrasado tendo em vista efectivar moderna urbanização da zona. Esta integra extensas praias, bonita avenida marginal e área de reserva natural correspondente a mangal, que se desenvolve nas margens do Khor Kalba.

Constituiu importante desafio que enformou o nosso projecto de investigação em Quelba/Khor Kalba encontrarmos vestígios da sua antiga fortificação e materiais arqueológicos que, de algum modo, denunciassem a presença portuguesa; aspecto difícil, dada a fugaz ocupação portuguesa da edificação, ao que parece não alterada pelos portugueses e deixada sob a guarda e administração de comandante e tropas lascarins, ou seja de mercenários, com possível origem no Irão. Se estes objectivos não puderam ser plenamente concretizados, exumámos artefactos, ou os seus fragmentos, cuja origem é clara, mesmo 
quando exógenos, continuando relações há muito anteriores à presença portuguesa, embora outros tanto foram usados por portugueses como por populações estrangeiras e autóctones. Talvez algumas marcas de jogo, elaboradas sobre fragmentos de cerâmica, indiquem a presença portuguesa, dado que entre certas populações islâmicas a prática do jogo não é permitida.

Importa referir que a colecção artefactual exumada é constituída por conjunto de utensílios e restos de talhe, de pedra lascada e picotada/polida, correspondendo a pré-existências, anteriores à edificação do dispositivo defensivo que temos vindo a mencionar, sendo contemporâneos deste, numismas safávidas e outros artefactos de bronze, fragmentos de objectos de vidro e de concha, assim como copiosa colecção de cerâmicas, que incluem produções locais ou regionais, peças importadas do Irão e, em menor número, da China, assim como restos osteológicos de mamíferos, aves e peixes, a par de abundantes exemplares malacológicos (Antunes, 2019; 2019a; Callapez e Dinis, 2019; 2019a).

\section{A FORTALEZA}

Os testemunhos da antiga fortaleza, com planta aproximadamente quadrangular, medindo em cada lado cerca de $50 \mathrm{~m}$ (= 15 qala), encontrava-se orientada segundo a direcção dos pontos cardeais e era provida de torre circular, no canto sudeste, $\operatorname{com} 7,5$ $\mathrm{m}$ de diâmetro (= 4 qasaba). $\mathrm{O}$ canto sudoeste apresentaria torre com forma e dimensões semelhantes à referida. As paredes possuíam 2,35 $\mathrm{m}$ de espessura e eram construídas em taipa, pedra e gesso, ou seja, "à maneira dos mouros" conforme mencionaram Bocarro e Erédia.

Fortalezas com planta quadrangular, com torres circulares a cada canto, ou apenas com duas torres, erguidas em pedra, taipa ou adobe, têm longa tradição, ocorrendo no Norte de África, Mediterrâneo Oriental e Próximo Oriente, durante a Antiguidade Tardia, devido à difusão da presença romana e bizantina, persistindo nos inícios da Idade Moderna e, até, depois desta.

No Limes Arabicus, estabelecido depois da conquista e anexação da Península Arábica, sob a administração de Trajano em 106 A.D., foram construídas fortalezas durante o reino de Septímio Severo (196-211 A.D.), possuindo torres redondas projectadas, nas paredes e nos ângulos, como acontece na forta- leza quadrangular de Ain Sinu no norte do Iraque (Lander, 1984: 132, 133). Qseir es-Sele, na Síria, teve também um forte com planta quadrangular ( $37 \mathrm{~m} \mathrm{x}$ $37 \mathrm{~m}$ ), protegido por quatro torres de traçado circular, dispostas a cada canto, medindo $12 \mathrm{~m}$ de diâmetro. Esta construção é datada no Período da Tetrarquia (século III), quando as províncias romanas do Oriente eram administradas por Diocleciano (293-313) (Lander, 1984: 190, 192, 240). Existem também outros exemplos na Síria e, em Ed Dour (Emirado d'Umm al Quwain), foi escavada fortificação, edificada em pedra, com planta quadrangular, medindo $30 \mathrm{~m}$ de lado, protegida por torres circulares nos cantos, mostrando ocupação datada nos séculos II e III (Lecomte, 2018: 90-92). No Emirado de Sharjah, o forte de Dayd oferece planta de forma quadrada, com duas torres circulares nos cantos (Cardi e Doe, 1971: 240, 250, 255). Teria constituição semelhante o forte de Libidia/Bidiyya, cuja edificação é atribuída aos portugueses (1623), medindo cerca de $60 \mathrm{~m}$ de lado, com torres redondas (?) nos cantos (Ziolkowski, 1999; 2002, vol. II: 81). Também o forte de Al-Qurainiyah, a $450 \mathrm{~m}$ para sudeste da aldeia com o mesmo nome, na ilha de Failakah (Kuwait), próximo do mar, mostra planta de forma quadrangular. Mede $32 \mathrm{~m}$ em cada lado e era protegido por quatro torres de canto, com planta circular, possuindo 2,40 m de diâmetro. Esta fortaleza foi edificada pelos portugueses, em pedra local e, possivelmente, adobes (Laino, 2015).

A tradição refere que a antiga "fortaleza portuguesa” de Quelba/Khor Kalba foi arrasada, informação reiterada recentemente, dada a frequente inundação da área pelo mar. Uma outra fortificação, ainda hoje existente, foi erguida nas proximidades, junto da qual se situava aldeia de pescadores.

A fortaleza que os portugueses registaram através de desenhos, aparece com planta quadrangular, possuindo bastiões em cada canto, um dos quais mais alto e mais complexo, com plataforma, protegendo a entrada voltada a norte.

\section{SOLOS DE OCUPAÇÃO}

Foram reconhecidos e cuidadosamente postos à vista, dada a sua fragilidade, restos de pavimentos de massa de gesso, tanto no interior como nas áreas exteriores da fortificação, mas nas proximidades daquela, tanto no seu lado nascente como sul.

São superfícies horizontais, alisadas, assentes nas 
areias que correspondem ao solo da zona, e que conservam buracos de poste, com diâmetros que variam entre $0,120 \mathrm{~m} \mathrm{e} 0,260 \mathrm{~m}$. Alguns constituem alinhamentos, por vezes dispostos paralelamente, indicando terem sido usados para suportarem postes de casas, constituídos com toros e ramos de palmeira-tamareira, espécie muito comum na zona e de grande importância económica.

Tais casas (barasti) teriam plantas de forma rectangular, com $5 \mathrm{~m}$ a $6 \mathrm{~m}$ de comprimento, surgindo sobretudo orientadas no sentido nascente-poente, sendo idênticas a estruturas habitacionais, edificadas do mesmo modo e utilizadas até meados da passada centúria, nomeadamente pelas populações piscatórias da costa de Kalba.

\section{ESTRUTURAS DE COMBUSTÃO E FORNOS DOMÉSTICOS}

Nas áreas em torno do dispositivo defensivo, a norte, nascente e a sul, escavaram-se algumas estruturas de combustão, constituídas quase sempre por pequenas fossas abertas no solo, com contorno circular ou oval, reconhecíveis por conterem sedimentos de cor negra, carvões e algum espólio arqueológico. Este corresponde a fragmentos de cerâmica e mais raramente de vidro, restos de fauna, mamíferos, aves, peixes, decapodos e de moluscos marinhos, de diversas espécies.

Identificámos quatro fornos domésticos, usados sobretudo para cozer pão, três localizados no interior do recinto fortificado e um no exterior, junto à sua fachada voltada a sul. Três daquelas estruturas são muito semelhantes entre si e, também, às por nós descobertas no Ribāt da Arrifana e na aldeia piscatória da Ponta do Castelo, ambos arqueossítios islâmicos no concelho de Aljezur. Elas apresentam planta de forma subcircular, com a base constituída por massa compacta, cozida devido ao uso, e paredes erguidas com pequenas pedras e massa de gesso, ligeiramente inclinadas para o interior, denunciando forma troncocónica. Por vezes encontram-se associadas a manchas de cinzas, correspondentes ao seu uso. Todavia, um dos tānnur de Quelba/Khor Kalba (T3) reutilizou grande talha de cerâmica, colocada em posição invertida no solo e com o fundo amputado.

\section{FOSSA-LIXEIRA}

Durante a campanha de 2019 surgiu no lado sul da fortificação, pequena fossa, com planta de forma subcircular, $(\varnothing=0,60 \mathrm{~m})$ não muito profunda, contendo fragmentos de cerâmicas, nomeadamente de taças, uma delas vidrada nas cores castanha e verde, e de jarro, artefactos metálicos, em liga de cobre (numisma safávida, alfinete de cabelo e fragmento de espeto), um peso de rede de pedra, ossos de pequenos mamíferos e peixes, assim como conchas de moluscos marinhos.

$\mathrm{O}$ alfinete de cabelo, com $0,082 \mathrm{~m}$ de comprimento, possui secção circular e cabeça encurvada. Estes artefactos eram usados para unir elementos de vestuário, véu ao cabelo, ou como adornos. No Próximo Oriente, os alfinetes de cabelo metálicos são conhecidos desde o I milénio A.C., apresentando tal utilização grande continuidade devido à sua simplicidade e funcionalidade.

\section{ARTEFACTOS DE CERÂMICA}

Os trabalhos, tanto de prospecção sistemática da zona da fortificação e espaço imediatamente anexo, como a escavação, proporcionaram a descoberta de milhares de fragmentos de cerâmica. A maioria destes correspondem a recipientes, com formas e funções diversas, mas também se registaram marcas de jogo, fusaiolas e, até, contas, que reutilizam fragmentos daqueles primeiros.

Entre tal acervo, distingue-se pelas suas características peculiares, a porcelana chinesa, datável entre o século XVII e o XX, embora a maioria, procedente do nível de ocupação $\left(\mathrm{C}_{2}\right)$, possa ser atribuída ao século XVIII. Todavia, identificámos, macroscopicamente, mais sete classes de cerâmica, de que a seguir damos conta, e iniciámos a sua caracterização química (Ferreira et alii, 2019).

Faiança de Kerman. Durante o século XVII os fornos de Kerman, no Irão, produziram faiança com decoração fitomórfica, de cor azul cobalto sobre esmalte de cor branca mate, na tentativa de copiar a muito apreciada e dispendiosa porcelana chinesa do fim da dinastia Ming. Apesar de não ser muito comum nos arqueossítios da Península Arábica, aquela classe de cerâmica ocorre, como seria expectável, em alguns assentamentos costeiros do Golfo Arábico e do Golfo de Omã, como Julfār (Ras al-Khaimah), Kashm 
Nadir ou no forte de Wadi Haqil (Cardi e Doe, 1971: $249,250,268)$. Apesar de ser rara na antiga fortaleza de Quelba/Khor Kalba, ela ajuda a compreender a sua difusão, as rotas comerciais de então e as influências culturais, directas e indirectas.

Cerâmica vidrada de cor castanha clara. Produção atribuída ao Irão, talvez a Kung/Khunj, distingue-se muito bem das cerâmicas vidradas omanitas, de cor castanha ou verde, pois além da sua pasta muito fina e homogénea, não muito compacta, de cor amarela, apresenta vidrado espesso e brilhante, de cor castanha clara ou amarela, com aspecto melado. Esta produção pode ser datada dos séculos XVI e XVII, fazendo parte do pouco conhecido grupo das "Cerâmicas vidradas do Golfo", de T. Powel (2015: 11, 12). Todavia, alguns fragmentos de recipientes, parecendo pertencer ao mesmo tipo de produção, foram exumados nos dois fortes de Fili (al-Madam, Sharjah), onde se consideraram como não sendo anteriores ao século XVIII (Sasaki, Sasaki e Yousif, 2017: 5, Figura 1).

Cerâmicas vidradas de cor castanha ou verde, do tipo Bahlā. Trata-se de produções com pastas não muito homogéneas, mas compactas, cor-de-laranja ou vermelha, cozidas a altas temperaturas e cujas superfícies, uma, as duas ou apenas parte daquelas, receberam espesso vidrado de cor castanha clara, escura ou verde e, não raro, com pequenas manchas de cor castanha escura (mosqueado). Estas cerâmicas podem ter tido diversas origens, nomeadamente em Kung/Khunj (Irão), onde os portugueses tiveram feitoria, fundada por Rui Freire de Andrade, a partir de 1628 e até 1725 , mas foram também produzidas em Bahlā (Omã), onde a sua manufactura parece ter ocorrido desde o século XIII, tendo depois evoluído (sécs XVI e XVII) e chegando ao século XIX. Em Silhat (Sohar, Omã) esta classe de cerâmicas foi datada nos séculos XVI e XVII (Ziolkowski, 2002: 233-236, 373; Al-Salimi e Korn, 2008: 227, 228; Power, 2015: 10, 11). Nos dois fortes de Fili (al-Madam, Sharjah), esta cerâmica está representada e foi datada no século XVIII, ou até mais tarde (Sasaki, Sasaki e Yousif, 2017: 5, fig. 2). Alguns fragmentos procedentes da fortaleza de Khor Fakkan serão, por certo, do século XVII (Sasaki e Sasaki, 2017: 14).

Cerâmica com pintura sob vidrado. Esta classe de cerâmicas distingue-se, muito bem, através da sua técnica decorativa, acreditando-se que teve origem no Irão, em finais do século XII, de onde foi transmitida para o Iraque e Egipto. As produções iranianas individualizam-se das restantes, dado o uso de decoração geométrica, de cor negra ou violácea escura, de manganês, sob vidrado de cor azul-turquesa ou verde, muito claro. Apresenta pastas homogéneas, não muito compactas, de cor amarela clara. Pratos e taças, alguns de grande tamanho, constituem as principais formas identificadas, providas de fundo destacado, plano ou em anel. Em Sirāf, algumas cerâmicas desta classe, dataram-se do século XV, mas em Silhat (Sohar, Omã), exemplares do mesmo tipo foram classificados nos séculos XVI e XVII, admitindo-se, até, que possam ter sido usadas em datas mais recentes (Cardi e Doe, 1971: 267, 268; Ziolkowski, 2002: 231; Power, 2015: 12). De facto, em dois dos fortes de Fili (al-Madam, Sharjah), com ocupação não anterior ao século XVIII, encontraram-se fragmentos daquelas produções (Sasaki, Sasaki e Yousif. 2017: 5, fig. 1). Cardi e Doe (1971: 267, 268) identificaram dois grupos distintos de cerâmicas desta classe: uma pintada de azul ou preto, com vidrado de cor azul-turquesa clara e o outro com pinturas nas cores violeta, castanho escuro ou verde escuro, cobertas por vidrados de cor verde clara.

Cerâmica fina incisa ou impressa. Alguns fragmentos de cerâmicas, produzidas com pastas muito homogéneas e compactas, bem cozidas, em tons claros, de cor amarela ou rosada, com paredes finas, apresentando, nas superfícies exteriores, muito lisas, decoração incisa, impressa ou plásticas, de carácter geométrico, por vezes inserida em cartelas. Foram encontradas, tanto à superfície do terreno como no estrato de ocupação da antiga fortificação de Quel$\mathrm{ba} /$ Khor Kalba ( $\left.\mathrm{C}_{2}\right)$. Aqueles testemunhos arqueológicos provêm principalmente de recipientes fechados, jarros e cântaros, de pequenas ou médias dimensões, que serviam, para conter, servir, transportar ou armazenar, água ou outros líquidos. Acreditamos tratar-se de tipo de cerâmicas a que T. Power (2015: 6) chamou "branca incisa", muito comum nos Emirados e no Golfo do Omã, entre o século XVII e o XIX, talvez alcançando o século XX. Até agora a origem precisa de tal produção é desconhecida, embora se julgue provir de diferentes centros no Irão, ou talvez da Península Arábica. Fragmentos de recipientes desta classe de cerâmicas exumaram-se nos dois fortes de Fili (al-Madam, Sharjah), onde não 
serão anteriores, conforme atribuição do restante acervo da cultura material ali exumado, ao século XVIII (Sasaki, Sasaki e Yousif, 2017: 5, fig. 3). O mesmo tipo de cerâmica foi descoberto em Julfār (Ras al-Khaimah), Dibba e Kashm Nadir (Cardi e Doe, 1971: 249, 250, 270). Entre os jarros, a forma mais comum (tipo Julfār) é aquela que possui corpo bitroncocónico, gargalo alto e cilíndrico, longo bico e asa no lado oposto a ele, com secção semicircular, unindo o gargalo a ponto do volume mesial do corpo. Os fundos podem ser planos ou algo convexos (Ziolkowski, 2002: 227).

Cerâmicas de pastas escuras. Recipientes de pequenas, médias e grandes dimensões, foram produzidos com pastas pouco homogéneas e pouco compactas, contendo elementos não plásticos, de grão médio a grosseiro, sendo cozidas em ambiente redutor e apresentando o núcleo, assim como as superfícies, de cor castanha muito escura, cinzenta escura ou negra. Tais exemplares sugerem corresponder a manufactura local ou regional, que utilizou argilas e inclusões de origem metamórfica, de cores escuras, da família dos basaltos, gabros e grauvaques. Por vezes as superfícies daqueles recipientes receberam aguadas de cores escuras, castanha ou cinzenta, talvez para melhor isolarem as suas paredes ou por questão de gosto. É possível que as cerâmicas de pastas escuras procedam dos mesmos centros que produziram as de pastas vermelhas, dada a similaridade de formas e de cronologias existentes entre ambas. T. Power (2015: 7-9), inclui ambas classes de cerâmicas na categoria de "cerâmicas de Julfär".

Cerâmicas de pastas vermelhas. Correspondem a manufacturas locais e regionais, com tradição ancestral, montadas com pastas não muito homogéneas nem compactas, contendo elementos não plásticos, de grão fino a grosseiro, calibre que varia consoante a dimensão dos recipientes, mostrando pastas e superfícies de cor vermelha ou cor-de-laranja. Os centros produtores antigos são, por ora, desconhecidos, embora se saiba que al-Fara, perto de Wadi Miduk (Emirado de Fujeira) produziu, até à segunda metade do passado século, cerâmicas deste tipo, com formas muito diversificadas (Ziolkowski, 2002: 228). Também em Lima, no norte do Omã, ainda se fazem cerâmicas seguindo os processos tradicionais (Al-Salimi e Korn, 2008: 279). Outros fornos podem ter cozido esta classe de cerâmicas, as mais comuns entre os séculos XII e XX, como as encontradas em Ras al-Khaimah e antiga Julfār (Cardi e Doe, 1971: 249, 250, 259; Power, 2015: 7). T. Power (2015: 8, 9, fig. 5) distinguiu três tipos de panelas de cerâmica vermelha. $\mathrm{O}$ mais antigo, com bordo introvertido e pequenas pegas triangulares, aplicadas nos ombros, que datou nos séculos XVII e XVIII (Late Islamic I), como diversos exemplares recolhidos em Quelba/ Khor Kalba, um deles no alicerce da sua muralha. Alguns fragmentos apresentam aguada ou decoração pintada, como aqueles possuindo linhas de cor vermelha que encontrámos ou os precedentes dos dois fortes de Fili (Sasaki, Sasaki e Yousif, 2017: 7, fig. 11). Também se conhecem exemplares em Kashm Nadir, a sul de Ras al-Kaimah (Julfār) e em Sirāf, onde foram atribuídos ao século XV (Cardi e Doe, 1971: 250-271). Sectores de grandes jarras, para armazenamento, com decoração elaborada através de impressões digitadas, de Quelba/Khor Kalba, encontram paralelos em cerâmicas de cor vermelha escura, algumas delas apresentando engobe de cor cinzenta nas paredes exteriores e ornamentação digitada, dos dois fortes de Fili (al-Madam, Sharjah), espólio tido como não anterior ao século XVIII. Procede deste mesmo arqueossítio tampa de panela de cerâmica, embora algo diferente dos exemplares exumados em Quelba/Khor Kalba (Sasaki, Sasaki e Yousif, 2017: 6, 7, figs 4, 6, 12). (Quadro 1)

\section{FUSAIOLAS E MARCAS DE JOGO}

Uma fusaiola reutiliza fundo de taça de cerâmica, com pé anelar, aspecto que oferece paralelos em exemplares do Forte Ocidental de Corfacão (Sasaki e Sasaki, 2017: 15) e em outros sítios arqueológicos da Península Arábica. Fusaiola de cerâmica foi encontrada na aldeia de Luliyah, do século XIII. Também de Bydiyya provêm exemplares que utilizam fragmentos de recipientes de cerâmica (Ziolkowski, 2002: 371).

A prática de fiar foi corrente na Europa, desde a Pré-História até aos tempos actuais, onde fragmentos de cerâmica foram reutilizados em fusaiolas ou balanços de fusos. As fusaiolas são conhecidas nas margens do Mediterrâneo desde o IV milénio A.C. A morfologia daqueles artefactos foi mudando desde então, podendo ser esférica, esférica achatada, hemisférica, cónica, bitroncocónica ou cilíndrica, com diversas dimensões e matérias-primas, como pedra, cerâmica, osso e até metal. 
As fusaiolas, usadas nos fusos, são indicadores da fiação de fibras vegetais (linho, algodão) ou animais (lã) formando fios, usados na manufactura de têxteis, tarefa executada no contexto familiar, geralmente atribuída à esfera feminina, a única produção artesanal até agora identificada em Quelba/Khor Kalba.

Marca de jogo obtida a partir do fundo de taça vidrada, de cor verde azeitona, e as produzidas com fragmentos de panelas ou recipientes de armazenamento, indicam prática, detectada nas margens do Mediterrâneo e na Península Ibérica, desde o Neolítico Final e Calcolítico (IV milénio A.C.) até à Idade Contemporânea (Gomes, Ninitas e Borralho, 2012-13: 17, 53; Gomes, 2015: 51, 107).

Tais artefactos, normalmente produzido em pedra, cerâmica ou osso, e com diferentes dimensões, são conhecidos em contextos islâmicos, tanto urbanos como rurais, desde o oriente da Península Arábica (Rasal-Khaimah, Khor Fakkan, Quelba/Khor Kalba), até à Península Ibérica, entre o século X e o XV, assim como mais tarde, em contextos cristãos. Eles denunciam actividades lúdicas e meio de socialização, próprio de todas as idades e, talvez, de ambos os géneros, embora os jogos de azar (quinar) sejam proibidos pelas leis islâmicas (Gomes e Gomes, 2007: 107-109).

Peças de madeira ou cerâmica, e lajes de pedra, foram usadas como tabuleiros para aqueles entretenimentos, com espaços definidos por linhas incisas ou série de covinhas, e eles podiam também ser improvisados no solo ou em diferentes tipos de pavimentos.

\section{ARTEFACTOS DE VIDRO}

Numerosos fragmentos de braceletes de vidro, mostram corpo maciço, com secção plano-convexa ou semicircular, embora ligeiramente apontada. Somente um deles possui secção elíptica e é oco. As braceletes foram produzidas em vidro opaco, preto ou azul escuro, mas também translúcido de cor castanha, medindo entre 0,05 m e o,10 m de diâmetro.

Porções de braceletes de vidro negro ou azul escuro opaco, sem decoração, datadas do século VII ao século XII, foram encontrados na área de habitat de A’Ali (Ilha do Barém) (Sasaki e Sasaki, 2011: 24). Ainda no Barém, em Barbar-Sud, identificaram-se exemplares lisos e torsos, atribuídos ao século XVIII (Ziolkowski, 2002: 369). Outros fragmentos de artefactos similares, foram escavados em Ras al-Khaimah, Kashm Nadir, ao sul de Ras al-Khaimah e em
Husaiyy (Cardi e Doe, 1971: 250-257; Shindo, 2001: 77). Exemplares de Bídia, um deles torcido, possuem cronologias situadas entre os séculos XIV e XVIII (Ziolkowski, 2002: 368, 376).

Descobriram-se doze fragmentos de braceletes de vidro negro em Sa'îdi (al-Qurainīyah) e um fragmento, com cor verde escura, provém de al-Qusūr (Ilha de Failakah), sendo ambos lugares com presença portuguesa, podendo ser datados nos séculos XVI e XVII. As suas medidas variam entre $0,05 \mathrm{~m}$ e 0,08 $\mathrm{m}$ de diâmetro. Outros exemplares, detectados em Ormuz apresentam diacronia mais ampla, do século XIV ao século XVII. Em al-Huwailah (Qatar), peças semelhantes foram datadas no século XVIII (Patitucci e Uggeri, 1984: 75, 78, 82, 88, 113-115, 200, 374, 375). Também foram exumados fragmentos de braceletes em Julfar, Wadi Masilah (Iémen), Jazirat al-Hulayla e al-Hasa (Arábia Saudita), com cronologias entre os séculos XI e o XIII (Whitcomb, 1983: 106; Vogt, 1994: 142, 143, 158). Outros foram exumados em Tell Abu Sarbut e em Khirbat Faris, na Jordânia, talvez procedentes de Hebron (Palestina) (Boulogne e Henderson, 2009). Exemplares de Quseir al-Qadim, no Egipto, medindo entre o,o4 m e o,o6 m de diâmetro, nas cores azul escura e negra, ou mais raramente azul clara e verde, planos e com secção triangular ou torcidos e de secção circular, podem ter origem nas manufacturas do Iémen (Adém) dos séculos XIII e XIV. Em cerca de 1258, Sa'di escreveu àcerca de comerciante que carregava vidro de Alepo para o lémen (Whitcomb, 1983: 106, 107).

Fragmentos de braceletes de vidro foram encontrados em Qasr-i Abu Nass no Irão (sécs XIII-XIV), outros em Samarra, Ana e Tell Gubba, no Iraque, e em contexto do século XVII, com presença portuguesa, no Forte de Jesus (Mombaça, Quénia) (sécs XVII-XIX), cuja origem foi atribuída a produção da Índia Oriental (Kirkman, 1974: 158, 317). Em outros sítios coloniais, portugueses e espanhóis, foram igualmente identificadas braceletes de vidro (Qsar es-Seguir, em Marrocos, sécs XV e XVI; La Isabella (1493-98), na República Dominicana ou em Puerto Real, no Haiti (1503-78) (Deagan, 2002: 134, 135). Com longa tradição no subcontinente indiano e no Mundo Islâmico, tal como na Europa onde remontam à Idade do Ferro (La Tène, sécs III - I A.C.), as braceletes de vidro foram produzidas na Anatólia (Tyana, Kermeshisar), do século III ao XI, Síria (Qsar el-Hayr), Palestina (Hebron, sécs XIV-XIX), Sinai (al-Tūr), Iémen (Kawd am-Saila, 
Shabwr, Shihr, Adém) (sécs IV-XVI), Qatar, Egipto (al-Fustat, nos séculos IX-XIV e Quseir al-Qasim), Etiópia e na Índia (Sankalia, séc. XIV, Brahmapuri e Arikamedu, na Costa do Coromandel) (Whitcomb, 1983: 106; Patitucci e Uggeri, 1984: 374, 375; Spaer, 1994: 46, 48, 57; Shindo, 2001: 74; Boulogne e Henderson, 2009; Zanon, 2013). As braceletes de vidro, lisas, com secção circular, oval e plano-convexa, torcidas em espiral, simples ou com aplicações e cabos, foram usadas no Próximo e Médio Oriente, tal como na Europa, por adolescentes, mulheres jovens e até por crianças, nos braços e pernas, por vezes em pares ou em conjuntos maiores, medindo entre $0,05 \mathrm{~m} \mathrm{e}$ o,o8 m de diâmetro. As de menores dimensões podiam também ser penduradas em colares (Malalana Ureña, 1997: 306, 309-311).

A enorme difusão das braceletes de vidro, pode, por certo, dever-se a distintos factores: por constituírem adereços não muito dispendiosos, mas vistosos, por produzirem som quando entrechocam, usadas nos pulsos ou tornozelos, mas também por mostrarem, na maioria dos casos, cor negra, como a do azeviche e, acreditar-se conterem as propriedades profilácticas e talismânicas daquele mineral, ou cor azul, como a cor da abóbada celeste, mas ainda por serem de forma circular. Para M. Spaer (1994:56), os séculos XIV e XV "podem ser vistos como a Idade dourada das braceletes de vidro islâmico".

Também se encontraram aplicadores de kohl e fragmentos de garrafas, de vidro, talvez holandesas, do século XVII.

Duas contas apresentam forma esférica e cor azul celeste, uma tem forma esférica achatada e é de vidro translúcido e uma outra, mais recente, apresenta forma cilíndrica e cor laranja. Esta deve ser originária do subcontinente indiano e datar dos inícios do século XX. As contas esféricas de cor azul podem ter origem chinesa, de $c a 1800$ e foram muito difundidas, chegando ao continente americano, através dos missionários católicos, pelo que ali são conhecidas por "padre beads" (Francis, 1994: 86). Conta mais antiga foi produzida em vidro translúcido.

As contas de vidro constituem adornos atraentes à vista, devido às formas e cores que apresentam, sendo duráveis, usados desde os tempos proto-históricos e depois em todo o mundo. Segundo antigas crenças, as contas de cor azul, como as de vidro ou na rocha semipreciosa que é o lápis-lazúli, simbolizam a noite estrelada e o céu, protegendo contra o mau-olhado. O valor apotropaico dos colares de contas assenta na ideia de que aquelas, sendo esféricas, traduzem a imagem e o conceito de perfeição e ordem, quando em colares, simbolizam a unidade cósmica do múltiplo. Contas de vidro, produzidas no subcontinente indiano, certamente chegaram à Península Arábica, talvez importadas de Chaúl, porto de comércio e centro de produção de tais adereços (Dussubieux et alii, 2008).

\section{PEDRAS DE FUNDA}

Na área da antiga fortificação de Quelba/Khor Kalba encontraram-se pedras de funda, de rochas com cor branca, cinzenta escura ou negra, mas com dimensões e pesos semelhantes. Pequenas pedras de funda foram identificadas nas ruínas do sítio de A'Ali (Ilha de Barém), datadas entre os séculos VIII e XII (Sasaki e Sasaki, 2011: 24).

Não é raro surgirem, em contextos pré-históricos de diferentes cronologias, artefactos esféricos, talhados em diferentes rochas e com distintas dimensões. Eles são, por vezes, denominados "esferas de pedra" e as possíveis funções que lhes são atribuídas geralmente compreendem duas vastas categorias: a dos percutores e a das armas de arremesso. Artefactos similares são conhecidos em períodos históricos subsequentes, até à Idade Moderna, onde foram usados como pedras de funda, os mais pequenos, e os maiores como balas de canhão ou catapulta, medindo até mais de o,40 $\mathrm{m}$ de diâmetro.

Não podemos afastar a hipótese de que alguns daqueles artefactos, com diâmetros medindo entre 0,06 $\mathrm{m}$ e 0,10 $\mathrm{m}$, tenham pertencido a bolas, armas de arremesso conhecidas desde a Pré-História e até aos nossos dias.

A funda (funda em latim) é arma rudimentar, mas eficaz, feita de tiras de couro ou tecida com fibras de origem vegetal ou animal, que usa a força centrifuga, transferida pelo braço humano, como meio de propulsão. Trata-se de elemento cultural primitivo, usado desde o Paleolítico Superior, ou talvez desde o Paleolítico Médio, resultando de invenção policentrada ou tendo difusão quase universal, embora mostre maior concentração nas margens do Mediterrâneo, utilizado tanto pelas últimas sociedades de caçadores-recolectores como por muitas ulteriores, como armas de guerra ou de caça, no abate de animais de pequeno e médio porte, mas também na direcção, defesa e controlo dos rebanhos, particularmente de cabras e ovelhas, para afastar aves e outros 
predadores das terras agrícolas ou, como brinquedo ou entretenimento para crianças e jovens.

Empregue na região do Mar Egeu, frequentemente desde o Neolítico e sobretudo durante a Idade do Bronze (Rex González, 1953: 275-277; Vutiropoulos, 1991), este tipo de arma foi comum na Península Ibérica, desde o Neolítico (V milénio A.C.), pois têm sido encontradas pedras de funda em dólmenes portugueses, espanhóis, tal como em franceses e irlandeses, produzidas em diferentes rochas locais, com diâmetros medindo entre $0,02 \mathrm{~m} \mathrm{e} 0,07 \mathrm{~m}$, confirmando o valor votivo destes artefactos, sucedendo às funções primárias já indicadas (Eogan, 1990: 126).

Plínio-o-Antigo (23-75 A.D.) (Naturalis Historiae, VII, 57) atribuiu a invenção de tal arma de arremesso aos fenícios, apesar de ter sido largamente usada em tempos mais remotos e na Antiguidade, como alguma iconografia documenta, não só por aquele povo mas também por hititas, persas, assírios, mesopotâmios, egípcios, cretenses, gregos, etruscos e romanos.

Em Hassuna (Iraque) foram encontradas balas de cerâmica para funda, num contexto de 5000 A.C. (Korfmanm, 1973: 39). Howard Carter descobriu, em câmara anexa à do sarcófago de Toutankamon, cesto contendo brinquedos e algumas fundas, possivelmente usadas pelo faraó na sua infância. No chão, mas fazendo parte do mesmo conjunto, jaziam pequenos seixos, que aquele arqueólogo ligou às fundas (Lindblom, 1940: 13).

Conhecida passagem do Antigo Testamento (Primeiro Livro de Samuel), descreve o sucesso do jovem David, oitavo filho de Jessé, na luta contra o gigante filisteu e campeão Golias de Gath, abatendo-o com tiro certeiro de funda na testa.

Homero refere, na Ilíada, que os lócrios usaram fundas durante o cerco de Tróia, na costa da Anatólia. Políbio (IV, 61, 2) mencionou os atiradores de funda aqueus, que fizeram parte do exército de Filipe da Macedónia. Lívio (XX, 21, 12) escreveu acerca dos famosos funditores (atiradores com funda) da Mauritânia e das Ilhas Baleares (topónimo que parece derivar de ballai, significando em grego atirar) que, durante a Segunda Guerra Púnica (século II A.C.), combateram nas tropas do cartaginês Haníbal (Lindblom, 1940: 40). Todavia, para este autor os atiradores de funda aqueus foram, na Antiguidade, exímios (Korfmann, 1973: 39). Diodoro da Sicília reporta a presença dos atiradores de funda das Baleares, no sé- culo I A.C., durante a batalha de Eknomos, na qual os cartagineses derrotaram Agatodes de Siracusa.

As balas de funda são fáceis de obter, podendo servir a tal propósito, seixos naturalmente esféricos, ovóides ou poliédricos, de diferentes rochas, blocos com muito ou pouco trabalho de afeiçoamento, por lacagem e, em seguida, regularizados por picotagem e alguns até polidos. Podem também ser usadas esferas de cerâmica, tal como as que se descobriram em contextos calcolíticos no Sul de Portugal, e projécteis de materiais metálicos.

A forma esférica, aquela que permite maior balanço no lançamento, menores desvios da trajectória e, igualmente, melhor pontaria e eficiência, é a mais comum.

Dimensões e peso, que contribuem para os projécteis alcançarem maior distância, tal como a sua velocidade e força de impacto, pouco variam nos exemplares portugueses neolíticos e calcolíticos. Estes apresentam diâmetros que medem desde 0,030 m a o,054 m, com o,040 m de média e peso médio de $90 \mathrm{gr}$, algo menor que os exemplares do contexto histórico de Quelba/Khor Kalba (125 gr, 118 gr e 108 gr) (Gomes, Ninitas e Borralho, 2012-13: 38-42). Usadas em campo aberto, as fundas podem lançar pequenos projécteis, pesando entre 20 gr e 50 gr até $200 \mathrm{~m}$ de distância e a alta velocidade. Por exemplo, um projéctil com 30 gr pode alcançar a velocidade de $100 \mathrm{~km} /$ hora e assinalável impacto (Vutiroupolos, 1991: 279). Fundas mais robustas e atiradores treinados podem lançar balas até cerca de meio quilograma de peso e mais de o,1o m de diâmetro, capazes de causar danos sérios e, acima de tudo, a morte àqueles que sejam atingidos por elas (Gomes, 2002: 132-136).

\section{CONCHAS DINHEIRO}

A presença de conchas de Monetaria moneta (Linnaeus, 1758) e de Monetaria annulus (Linnaeus, 1758) na área da antiga fortificação de Quelba/ Khor Kalba pode derivar do seu uso como paleo-moeda, denominadas "conchas dinheiro ou moeda", "dinheiro de porcelana" ou cauris.

O nome cauri, difundido universalmente devido à designação hindi e urdu kauri, deriva da palavra em sânscrito kaparda. Aquelas conchas eram também conhecidas como porcelanas, da língua francesa e esta derivada do latim (pequeno porco), sendo ainda usada, pelos Portugueses e outros, a denominação búzios, em francês bouges, de onde derivam os 
termos boejies e boesies. Em árabe a sua designação é ouda (Quiggin, 1992: 26, 30).

O uso de cauris, como objecto de troca e representação, ascende no Mediterrâneo aos tempos pré-históricos, dado o facto de se terem recolhido exemplares de Monetaria moneta (Cypraea moneta) em contextos calcolíticos (III milénio A.C.) do Ocidente da Península Ibérica e, mais tarde, no mundo etrusco (Península Itálica), devido aos contactos ocorridos com o Mediterrâneo Oriental, onde aqueles já eram apreciados. De facto, parece que eles surgiram no Egipto pré-dinástico, na Síria e Mesopotâmia, ocorrendo durante o I milénio na África subsariana, onde o seu valor monetário era reconhecido e que, com algumas variantes, havia de permanecer até ao século XX.

Alguns túmulos, subterrâneos ou em abrigos, da enorme necrópole de Jebel al-Buhais (Sharjah), continham conchas de Monetaria moneta ou de Monetaria annulus, a maioria datada na Idade do Bronze (Período Wadi Suq, III milénio A.C.) (Jasim, 2018: $48,133,220,279$ ).

$\mathrm{Na}$ região de al-Madam (Sharjah), a $50 \mathrm{~km}$ da costa do Golfo de Omã, foram encontradas conchas de Monetaria annulus, em contextos arqueológicos dos séculos VI e V B.C. (Morales e Llorente-Rodríguez, 2016: 141).

Sulayman, um comerciante árabe, refere as conchas-moedas durante o século IX nas Ilhas Maldivas, o que é confirmado, na centúria seguinte, pelo historiador árabe Masudi de Bagdade (Quiggin, 1992: 28). El Bekri regista a presença, em 1068, de conchas-dinheiro no Sudão (Kangha), também mencionadas no Mali e Gao, durante o século XIV, por autores como Al-Omari e Ibn Battuta. O seu valor era então alto, dado que um dinar (moeda de ouro) valia 1150 cauris. Marco Polo escreveu, em 1297-98 acerca da importância monetária dos cauris, dizendo que eles eram aceites da Índia à China (Província de Yunnan). Em meados do século XV, Cadamosto, um italiano a trabalhar para a Coroa Portuguesa, observou o seu uso na Mauritânia e Leão Africano, no início do século XVI, atesta o seu apreço e valor, dado que quatrocentos cauris valiam um ducado (Saul, 1974: 79; Rivallain, 1986: 32, 33; Quiggin, 1992: 29, 31). No Daomé os cauris tiveram valor relativamente estável durante um século e meio, onde 32000 cauris valiam uma onça de ouro (Coquery-Vidrovitch, 1969: 75). Monetaria moneta (Linnaeus, 1758) e Monetaria annulus (Linnaeus, 1758), são moluscos gastrópodes pertencentes à família Cypraeidae (Rafinesque,
1815), que possui mais de cento e sessenta variedades (Lorenz e Hubert, 2002). O seu habitat são as águas profundas de "mares quentes", o Índico e o Pacífico. Todavia, aquela primeira espécie é mais comum na região de Lakshadweep (Ilhas Laquedivas) e Ilhas Maldivas, no sudoeste do subcontinente indiano, enquanto a segunda espécie é sobretudo encontrada nas águas da Ilha de Pemba, Zanzibar até Moçambique, na África Oriental, mas também no mar das Filipinas. As Maldivas eram conhecidas como Divah Kanzah ou Ilhas Cauri, e o maior centro de comercialização das conchas-dinheiro foi Bengal, conforme mencionado por Pyrard de Laval (Castro e Bouchon, 1998), nos inícios o século XVII (1601-1611), onde os Portugueses se abasteciam de cauris, tal como de pimenta e têxteis de algodão, bens depois transaccionados na China, trocados por arroz, ou na Costa do Malabar, Golfo Arábico e Mar Vermelho. Este comércio também ocorria em Goa e Cochim, de onde os produtos destinados à costa oriental de África, integravam o tráfico de escravos negros. Além de Bengal, Bombaim foi, durante o século XVI e de acordo com Gaspar Correa (séc. XVI) em "Lendas da Índia", um dos maiores portos de comércio de cauris (Sousa, 1967:41). Outros negociantes europeus interessaram-se pelo tráfico de cauris, como os holandeses (Saul, 1974: 80, 81; Quiggin, 1992: 27, 28, 30; Boyajian, 1993: 225).

Uma terceira espécie de cauri, a Cyprea errones, com concha similar às acima mencionadas e também com valor monetário reconhecido, é comum na área do Oceano Pacífico (Samoa, Tonga, Fiji, Ilhas Marshall e Filipinas) (Rivallain, 1985: 28, 29).

A partir do Oceano Pacífico e principalmente desde o Oceano Índico, o valor das conchas-moeda, ou dinheiro cauri, difundiu-se ao Afeganistão e à Pérsia e, através do Mar Vermelho, ao Mediterrâneo (Egipto e Maghreb). Dali passou para o Sudão e África subsariana, através de rotas caravaneiras, alcançando o Reino do Congo, como relataram Filippo Digafetta (1881), em 1591, e Olfert Dapper, em 1668, propagação que se ficou a dever a factores, como a sua origem oceânica e remota, forma, cor, brilho, dificuldade em partir-se e alterar-se, com valor igual, fácil de contar, manusear e transportar, impossível de contrafazer, mas também capaz de criar mitos e biografia simbólica, ligada à fecundidade e bem-estar (talismãs e amuletos). A sua grande dispersão, dado o uso do seu valor monetário, tal como ornamental e a conotação com conceitos mágicos (nomeada- 
mente apotropaicos), levou a que também estivesse presente em muitas zonas do Golfo Arábico, do Iémen, de África, da Ásia, América e Europa, através do comércio a longa distância proporcionado pela interacção colonial europeia.

Em meados do século XX, as autoridades coloniais de diversos países, asiáticos e africanos, procederam à desmonetização das moedas tradicionais, como os cauris, tendo em vista o melhor controlo das economias locais (Sousa, 1967: 15-20, 43; Rivallain, 1985: 265; Quiggin, 1992: 46, 47; Fuller, 2009: 60). Todavia, os cauris foram classificados como "o dinheiro mais longamente usado que o mundo alguma vez conheceu" (Saul, 1974: 77).

\section{CONCLUSÕES}

A presença portuguesa nas costas da Arábia recua aos inícios do século XVI e, um pouco depois, existiram entrepostos comerciais fortificados, tal como parece ter acontecido em Mascate e Soar, no actual Sultanato de Omã, ou em Khor Fakkan, no Emirado de Sharjah, de acordo com alguns registos antigos e escavações arqueológicas recentes naqueles sítios (Al-Qasimi, 2013; 2013a). No que concerne a Quelba/ Khor Kalba, os portugueses ali chegaram, em Março de 1624, e de acordo com o texto de Manuel Godinho de Erédia, a zona encontrava-se então sob a administração de um famoso líder da região, Al-Qasimi, certamente antepassado do actual Emir de Sharjah.

A guarnição portuguesa era constituída por um capitão lascarim com treze soldados com a mesma origem, recrutada na área de influência de Ormuz, actualmente Irão. Em princípio, a fortaleza não sofreu sérias reconstruções ou trabalhos de adaptação com a ocupação portuguesa. Ela foi abandonada pelos portugueses alguns anos depois, dado que a 30 de Outubro de 1648, foi assinado, o já mencionado tratado de paz entre Portugal e os xeques árabes, com a presença de Al-Qasimi, mas onde a fortificação de Quelba/Khor Kalba não é mencionada. O relacionamento comercial entre os portugueses e os líderes das tribos arábicas manteve-se por certo na região, porque beneficiava ambas partes, facto mencionado no tratado acima referido.

Confrontados com a tradição de que existiu uma fortaleza portuguesa em Quelba/Khor Kalba, quando a evidência arqueológica sugere indicar uma estrutura islâmica, somos conduzidos a reflectir se a presença portuguesa na área não ficaria aquém do mencionado nos documentos oficiais portugueses. $\mathrm{O}$ achado de numerosas moedas iranianas de baixo valor (safávidas), de fragmentos de artefactos de vidro e metálicos, a par de faiança iraniana e de fragmentos de porcelana chinesa, permite corroborar a ideia de que Quelba/Khor Kalba gozou de posição estratégica, continuada, como importante centro de comércio, com ocupação intensa, suportado por antigas rotas caravaneiras que atravessavam a Península Arábica ou por rotas marítimas, que tanto cruzaram o Golfo Arábico como o Oceano Índico, entre os séculos XVI e XVIII.

A colecção artefactual encontrada, durante os trabalhos arqueológicos de 2017-2020, traduz espécie de palimpsesto, onde se reconhece presença humana muito antiga (utensílios de pedra lascada ou picotada/polida) e testemunhos arqueológicos que evidenciam importantes relações económicas e culturais, mas igualmente a estratégia comercial e política então ocorrida na área da antiga fortaleza de Quelba/ Khor Kalba.

\section{BIBLIOGRAFIA}

ALMEIDA, Fernando (2019) - Khor Kalba UAE Mission Geophysical report, Annual Sharjah Archaeology, vol. 17: 137-160.

AL-QASIMI, Sultan bin Muhammad (2013) - Research of Fortress of Muscat and Other Forts in the Coast of Oman. Sharjah: Al Qasimi Publications.

AL-QASIMI, Sultan bin Muhammad (2013a) - Power Struggles and Trade in the Gulf 1620-1820. Sharjah: Al Qasimi Publications.

AL-SALIMI, Abdulrahman; JANSEN, Michael (2015) - Portugal in the Sea of Oman. Religion and Politics. Research on Documents, Corpus 1, Part 2, vol. 9 (Documents from 16421649). Hildesheim: Georg Olms Verlag.

AL-SALIMI, Abdulrahman; KORN, Heinz Gaube Lorenz (2008) - Islamic Art in Oman. Muscat: Sultanate of Oman.

ANTUNES, Miguel Telles (2019) - Preliminary report on the Palaeozoology, Annual Sharjah Archaeology, vol. 17: 165-174.

ANTUNES, Miguel Telles (2019a) - Preliminary palaeozoological report - mammals, birds and fishes, Annual Sharjah Archaeology, vol. 17: 305-313.

BOCARRO, António (1635) - Livro das Plantas de Todas as Fortalezas, Cidades e Povoações do Estado da Índia Oriental, com 52 desenhos de fortalezas de Pedro Barreto de Resende. Évora: Biblioteca Pública e Arquivo Distrital de Évora (Inv. CXV-2-1). 
BOULOGNE, Stéphanie; HENDERSON, Julian (2009) Indian glass in the Middle East? Medieval and Ottoman glass bangles from Central Jordan, Journal of Glass Studies, vol. 51, pp. 53-75.

BOYAJIAN, James C. (1993) - Portuguese Trade in Asia under the Habsburgs, 1580-1640. Baltimore/London: The Johns Hopkins University Press.

CALLAPEZ, Pedro Manuel; DINIS, Pedro Alexandre (2019) - Mollusc remains from the Quelba/Khor Kalba fortification (late $16^{\text {th }}$ to $18^{\text {th }}$ centuries, Sharjah, UAE): taxonomic, taphonomic, environmental and cultural implications, Annual Sharjah Archaeology, vol. 17: 175-216.

CALlAPEZ, Pedro Manuel; DINIS, Pedro Alexandre (2019a) - Edible crabs from Quelba/Khor Kalba fortification, Annual Sharjah Archaeology, vol. 17: 315-320.

CARDI, Beatrice de; DOE, Donald Brian (1971) - Archaeological survey in the Northern Trucial States, East $\mathbb{B}$ West, vol. $21(3,4)$, pp. 225-289.

CARITA, Rui (ed.) (1999) - O Lyvro de Plantaformas das Fortalezas da Índia (fac-simile do códice n- ${ }^{\circ} 1805$ da Biblioteca da Fortaleza de São Julião da Barra em Oeiras, Ministério da Defesa, atrib. a Manuel Godinho de Herédia, ca 1620/ ca. 1640). Lisboa: Edições Inapa.

CARITA, Rui; GOMES, Mário Varela; GOMES, Rosa Varela; KAMYAB, Kamyar Daryoush (2019) - The Portuguese Archaeological Mission at Sharjah (U.A.E.). Quelba/Khor Kalba - Report of the First Excavation Season (January 2017), Annual Sharjah Archaeology, vol. 17: 9-128.

CARITA, Rui; GOMES, Mário Varela; GOMES, Rosa Varela; KAMYAB, Kamyar Daryoush (2019) - The Portuguese Archaeological Mission at Sharjah (U.A.E.). Quelba/Khor Kalba - Report of the Second Excavation Season (January 2018), Annual Sharjah Archaeology, vol. 17: 219-303.

CARNEIRO, António de Mariz (1990) - Descrição da Fortaleza de Sofala e das mais da India com Huma Rellaçam das Religiões Todas q Há no Mesmo Estado (1639), Reprodução do códice iluminado 149 da Biblioteca Nacional de Lisboa. Lisboa: Fundação Oriente.

CASTRO, Xavier de; Bouchon, Geneviève (1998) - Voyage de Pyrard de Laval aux Indes Orientales (1601-1611), 2 vols. Paris: Éditions Chandeigne.

COQUERY-VODROVITCH, Catherine (1969) - Recherches sur un mode de production africain, La Pensée. Revue du Rationalisme Moderne, $\mathrm{n}^{\mathrm{o}}$ 144, pp. 61-78.

CORREA, Gaspar (1858) - Lendas da Índia, Tomo I. Lisboa: Typographia da Academia das Sciencias.

DEAGAN, Kathleen (2002) - Artifacts of the Spanish Colonies of Florida and the Caribbean 1500-180o, vol. 2 - Portable Personal Possessions. Washington: Smithsonian Institution Press.
DUSSUBIEUX, Laure; KUSIMBA, Chapurukha M.; GOGTE, Vaibhav; KUSIMBA, Sibel B.; GRATUZE Bernard; OKA, Rahul (2008) - The trading of ancient glass beads: new analytical data from South Asian and East African soda-alumina glass beads, Archaeometry, vol.5o(5), pp.797-821.

EOGAN, George (1990) - Irish megalithic tombs and Iberia: Comparisons and contrasts, Probleme der Megalithgräberforschung. Vorträge zum 100 Geburtstag von Vera Leisner, pp. 113-137. Berlin: Walter de Gruyter.

ERÉDIA, Manuel Godinho de (1610) - Plantas de Praças das Conquistas de Portugal Feytas por Ordem de Ruy Lourenço de Tavora Vizo rey da Índia (códice CAM - 3,5), Biblioteca Nacional do Rio de Janeiro.

ERÉDIA, Manuel Godinho de (atr.) (1999) - Lyvro das Plataformas das Fortalezas da Índia, fac-simile com estudo de Rui Carita de exemplar da Biblioteca da Fortaleza de São Julião da Barra. Lisboa: Ministério da Defesa e Inapa.

FERREIRA, Luís Filipe Vieira; MACHADO, Inês Ferreira; CARITA, Rui; GOMES, Rosa Varela; GOMES, Mário Varela; KAMYAB, Kamyar Daryoush (2019) - A preliminary characterization of four ceramic sherds found in a $17^{\text {th }}$ century deposite from the site of the primitive fort Quelba in the Sharjah Emirate, Annual Sharjah Archaeology, vol. 17: 161-164.

FRANCIS, Peter (1994) - Beads of the World. Atglen: Schiffer Publishing Ltd.

FULLER, Harcourt (2009) - From cowries to coins: Money and colonialism in the Gold Coast and British West Africa in the early $2 \mathrm{O}^{\text {th }}$ century, Money in Africa, pp. 54-61. London: The British Museum.

GOMES, Mário Varela (2002) - Cromeleque dos Almendres. Um Monumento Sócio-Religioso Neolítico. Lisboa: Faculdade de Ciências Sociais e Humanas da Universidade Nova de Lisboa.

GOMES, Mário Varela (2015) - The Vale da Telha Necropolis (Aljezur) in the context of the Southwest Iberian Bronze Age. Lisboa: Instituto de Arqueologia e Paleociências da Universidade Nova de Lisboa.

GOMES, Mário Varela (coord. edit.) (2019) - Identidade e Cultura. Património Arqueológico de Sharjah (EAU). Lisboa: Museu Nacional de Arqueologia, Sharja Archaeology Authority e Instituto de Arqueologia e Paleociências da Universidade Nova de Lisboa.

GOMES, Mário Varela; GOMES, Rosa Varela (2007) - Ribāt da Arrifana. Cultura Material e Espiritualidade. Aljezur: Município de Aljezur.

GOMES, Mário Varela; GOMES, Rosa Varela; CARITA, Rui; KAMYAB, Kamyar Daryoush (2017) - Resultados preliminares da primeira campanha da missão arqueológica portuguesa em Sharjah (EAU). Escavação Arqueológica em Quelba/Khor Kalba, Arqueologia em Portugal-2017. Estado 
da Questão: 1641-1657. Lisboa: Associação dos Arqueólogos Portugueses.

GOMES, Mário Varela; NINITAS, João; BORRALHO, Rita (2012-13) - Artefactos líticos do povoado calcolítico do Escoural (Montemor-o-Novo), Almansor, $2^{\underline{a}}$ série, $\mathrm{n}^{\circ}$ 10, pp. 5-6o.

JASIM, Sabah Abboud (2018) - The Necropolis of Jebel alBuhais, Prehistoric Discoveries in the Emirate of Sharjah, $2^{\text {nd }}$ edition. Sharjah: Sharjah Archaeology Authority.

KIRKMAN, James (1974) - Fort Jesus: a Portuguese Fortress on the East African Coast. Oxford: Clarendon Press.

KORFMANN, Manfred (1973) - The sling as a weapon, Scientific American, vol. 229, pp. 34-42.

LAINO, Raffaele (2015) - Otheractivities. Al Qurainiyah Fort, Kuwaiti - Italian Archaeological Mission at Failaka 20102014, pp. 70-72. Perugia: Università degli Studi di Perugia.

LANDER, James (1984) - Roman Stone Fortifications. Variation and Change from the First Century A.D. to the Fourth, British Archaeological Reports, International Series 206. Oxford: British Archaeological Reports.

LECOMTE, Olivier (2018) - Le site d'Ed Dour (Emirat d'Humm al Quwain, 40 Ans de Coopération Archéologique entre les Emirats Arabes Unis et la France, pp. 90-92. Sharjah: Sharjah Archaeology Authority.

LINDBLOM, Karl Gerhard (1940) - The Sling, Especially in Africa, Additional Notes to a Previous Paper. Stockholm: The Ethnographical Museum of Sweden.

LORENZ, Felix; HUBERT, Alex (2002) - A Guide to Worldwide Cowries, $2^{\text {nd }}$ revised edition. Hackenheim: Conchbooks.

MALALANA UREÑA, Antonio (1997) - Un conjunto de pulseras de vidrio hallado en la excavación del Hospital de San Andrés (Escalona, Toledo), Boletín de Arqueologia Medieval, vol. 11, pp. 293-312.

MORALES, Arturo; LLORENT-RODRÍGUEZ, Laura (2016) - Cíencias Físicas y Naturales e Historia, En los Confines de Oriente Próximo. El Hallazgo Moderno del País de Magán, pp. 141, 142. Madrid: Museo Arqueologico Nacional.

PATITUCCI, Stella; UGGERI, Giovanni (1984) - Failakah. Insediamenti Medievali Islamici. Ricerche e Scavinel Kuwait, Col. La Fenice. Roma: L’Erma di Bretschneider.

PIGAFETTA, Filippo (1881) - A Report of the Kingdom of Congo and the Surrounding Countries. London: John Murray.

POWER, Timothy (2015) - A first ceramic chronology for the Late Islamic Arabian Gulf, Journal of Islamic Archaeology, vol. 2(1), pp. 1-33.

QUIGGIN, Alison Hingston (1992) - A Survey of Primitive Money. The Beginnings of Currency, $2^{\text {nd }}$ ed. Ocala, Florida: First Impressions Printing Inc.
REX GONZÁLEZ, Alberto (1953) - La boleadora. Sus áreas de dispersión y tipos, Revista del Museo de la Universidad Eva Perón, vol. 4, pp. 133-292, XIV ests.

RIVALLAIN, Josette (1985) - Paléomonnaies africaines: formes et fonctions, Bulletin de la Société Préhistorique Française, vol. 82(9), pp. 265-269.

RIVALLAIN, Josette (1986) - Les Collections Monétaires VIII. Paléo-Monnaies Africaines. Paris: Administration des Monnaies et Médailles.

SASAKI, Tatsuo; SASAKI, Hanae (2011) - Excavations at A'Ali Islamic site, Bulletin of Archaeology, The University of Kanazawa, vol. 32, pp. 13-46.

SASAKI, Tatsuo; SASAKI, Hanae (2017) - Ceramics from Khor Fakkan West Fort, Emirate of Sharjah, United Arab Emirates (unpublished report), $32 \mathrm{pp}$.

SASAKI, Tatsuo; SASAKI, Hanae; YOUSIF, Eisa Abbas Hussein (2017) - Fili forts in al-Madam plain, Emirate of Sharjah, The United Arab Emirates, Japan Society for Hellenistic-Islam Archaeology Studies, vol. 24, pp. 83-116.

SAUL, Mary (1974) - Shells an Illustrated Guide to a Timeless and Fascinating World, Country Life. London: The Hamlyn Publishing Groups Limited.

SHINDO, Yoko (2001) - The classification and chronology of the Islamic glass bracelets from al-Tūr, Sinai, Senri Ethnological Studies, vol. 55, pp. 73-100.

SOUSA, Luís Rebelo de (1967) - Moedas de Angola. Luanda: Banco de Angola.

SPAER, Maud (1994) - The Islamic glass bracelets of Palestine: Preliminary findings, Journal of Glass Studies, vol. 34, pp. $44-62$.

VOGT, Burkhard (1994) - A lost late Islamic port on the South Arabian Coast, Bulletin of Archaeology. The University of Kanazawa, vol. 21, pp. 137-168.

VUTIROPOULOS, Nikos (1991) - The sling in the Aegean Bronze Age, Antiquity, vol. 65, pp. 278-286.

WHITCOMB, Donald S. (1983) - Quseir Islamic glass from Al-Qadim, Egypt, Journal of Glass Studies, vol. 25, pp. 101-108.

ZANON, Michela (2013) - Tyana/Kemerhisar (Nigde): glass bracelets of the Byzantine and Islamic period, Anatolia Antiqua, tomo 21, pp. 181-197.

ZIOLKOWSKI, Michele Christina (1999) - Excavations at Al-Bidiyya: new light on the Portuguese presence in the Emirates, Tribulus - Bulletin of the Emirates Natural History Groups, vol. 9 (2), pp. 19-21.

ZIOLKOWSKI, Michele Christina (2002) - The Historical Archaeology of the Coast of Fujairah, United Arab Emirates: From the Eve of Islam to the Early Twentieth Century, Vol. I: Text; Vol. II: Appendices. Sydney: University of Sydney. 


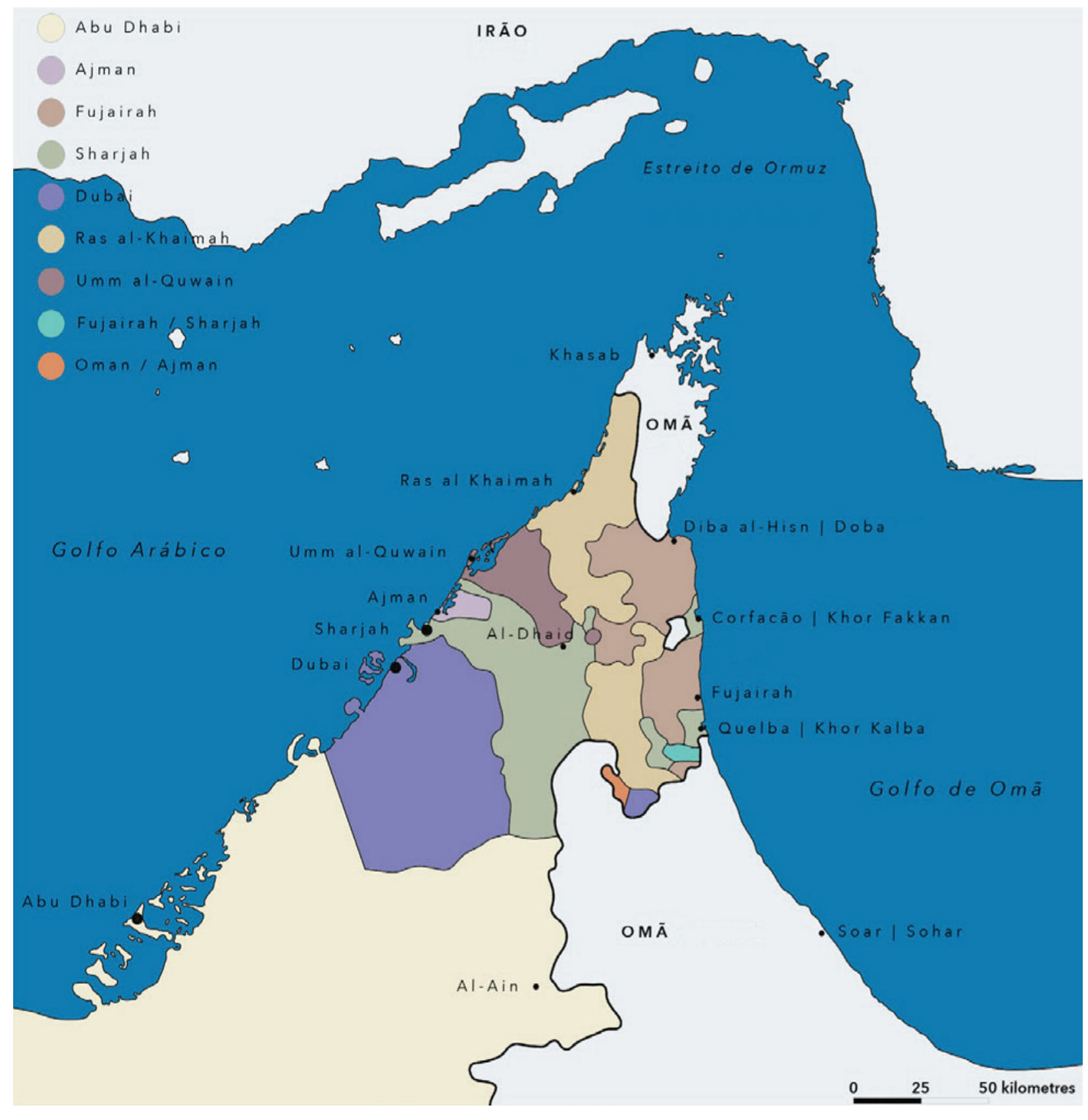

Figura 1 - Os Emirados Árabes Unidos e localização da antiga fortificação Quelba/Khor Kalba (Emirado de Sharjah). 

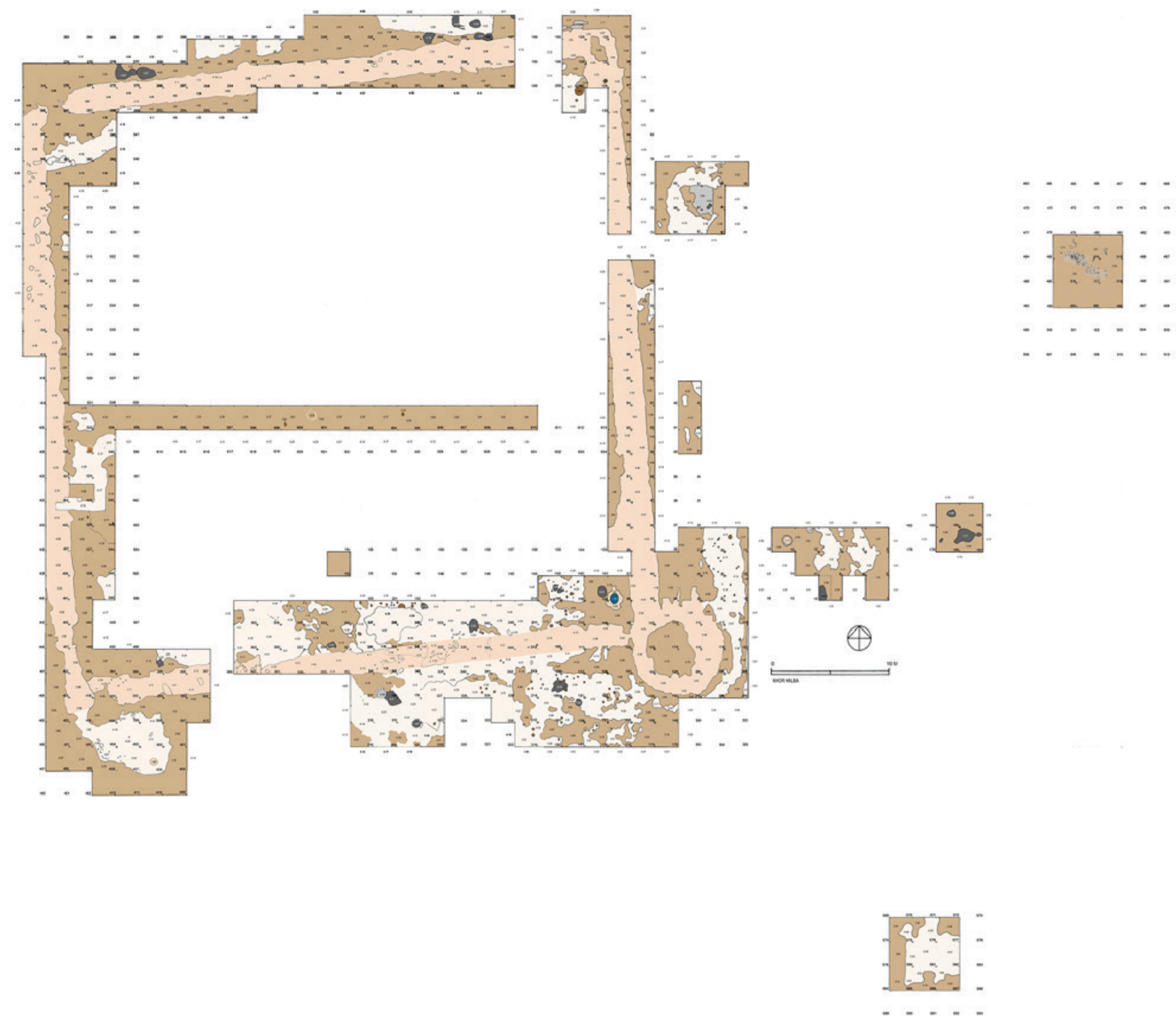

Figura 2 - Planta dos testemunhos arquitectónicos da antiga fortificação de Quelba/Khor Kalba (lev. J. Gonçalves, J. Iglésias e M.V. Gomes). 


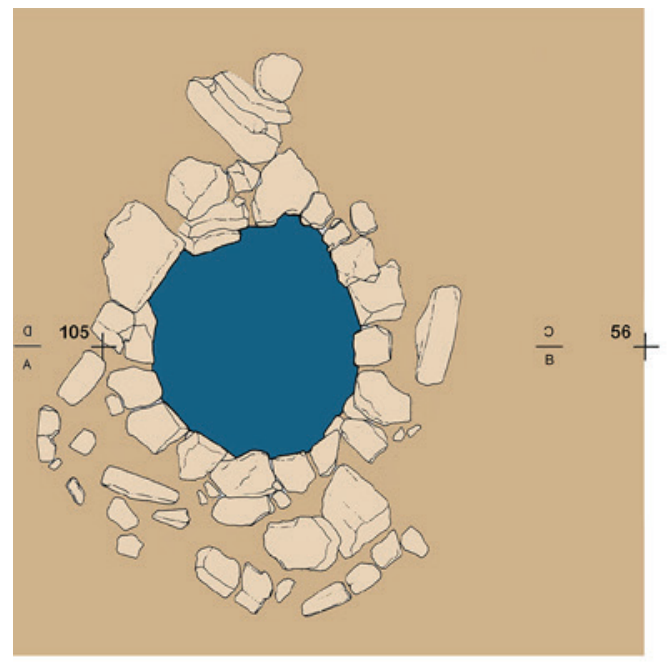

$\oplus$ $3^{m}$
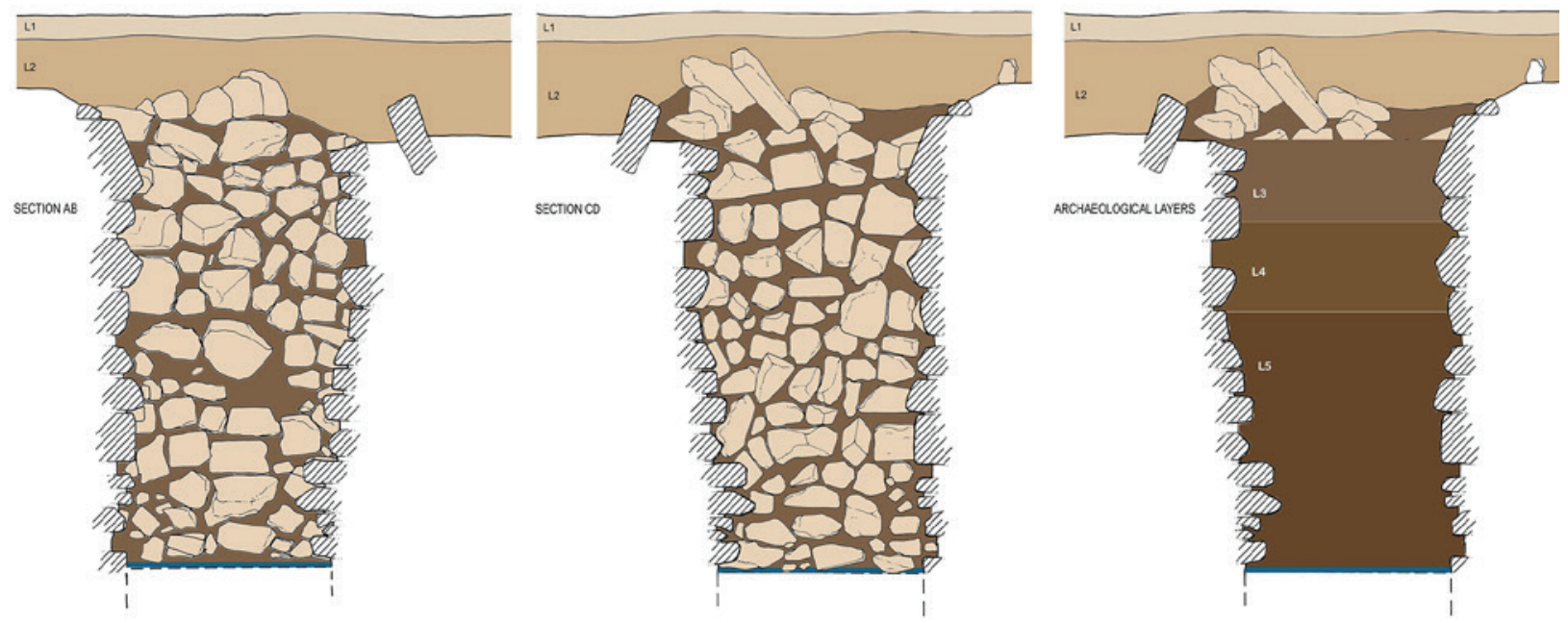

Figura 3 - Poço. Planta, alçados e corte estratigráfico (lev. J. Gonçalves). 

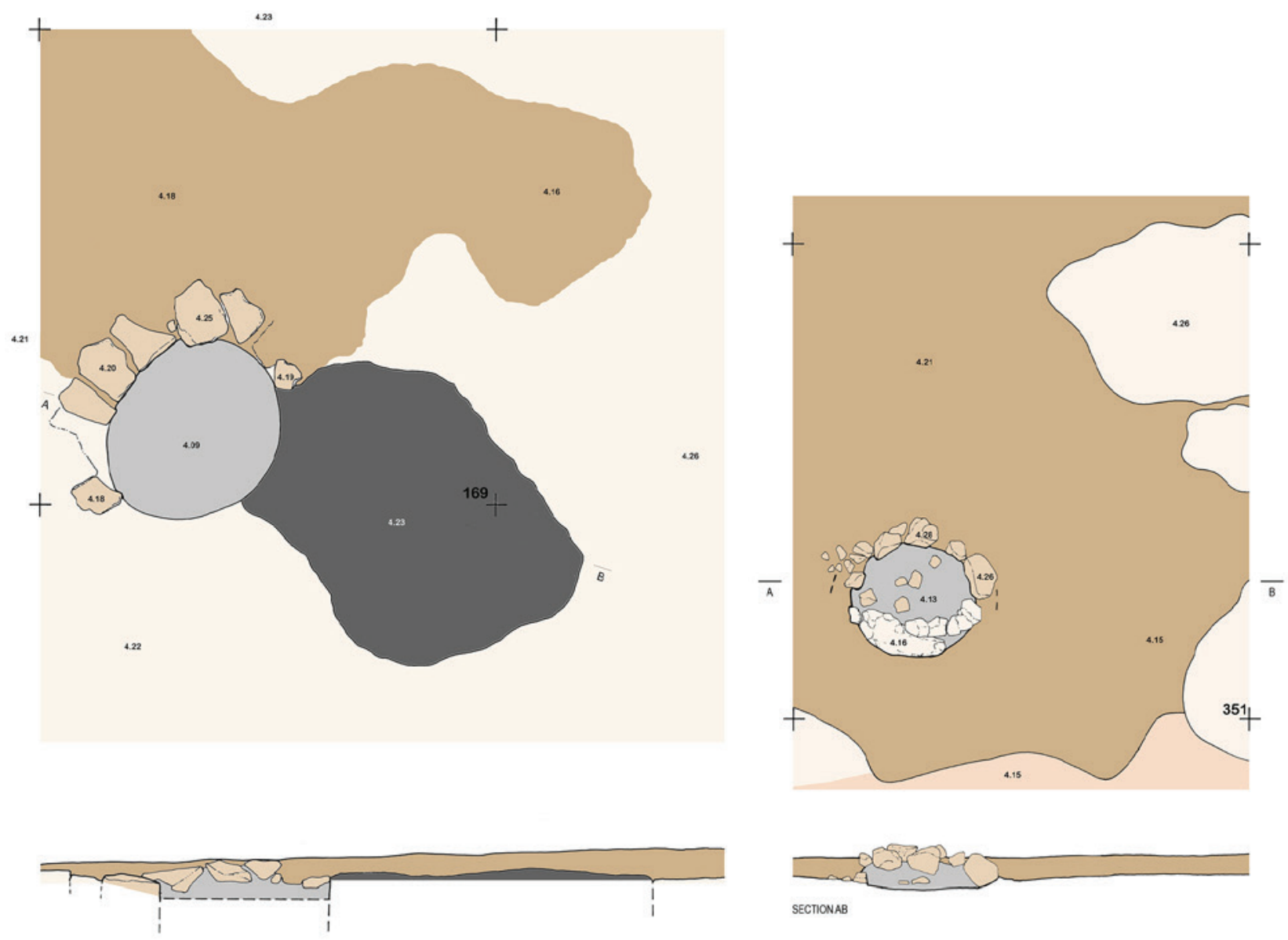

SECTION AB
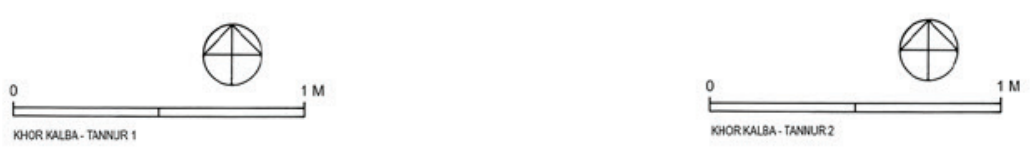

Figura 4 - Dois fornos domésticos de Quelba/Khol Kalba. Plantas e cortes (lev. J. Gonçalves). 


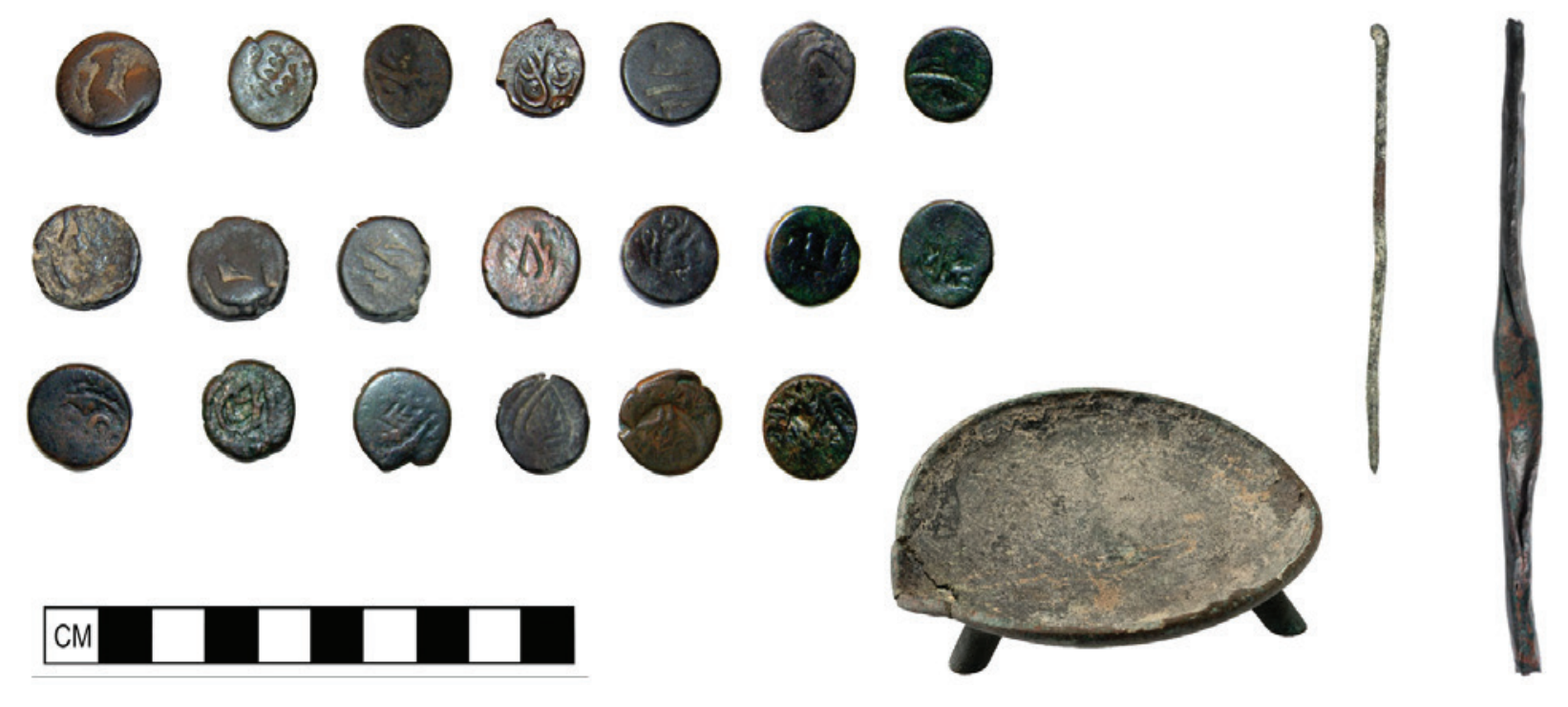

Figura 5 - Numismas safávidas e outros artefactos metálicos (queimador, alfinete e frag. de espeto) (fotos J. P. Ruas).
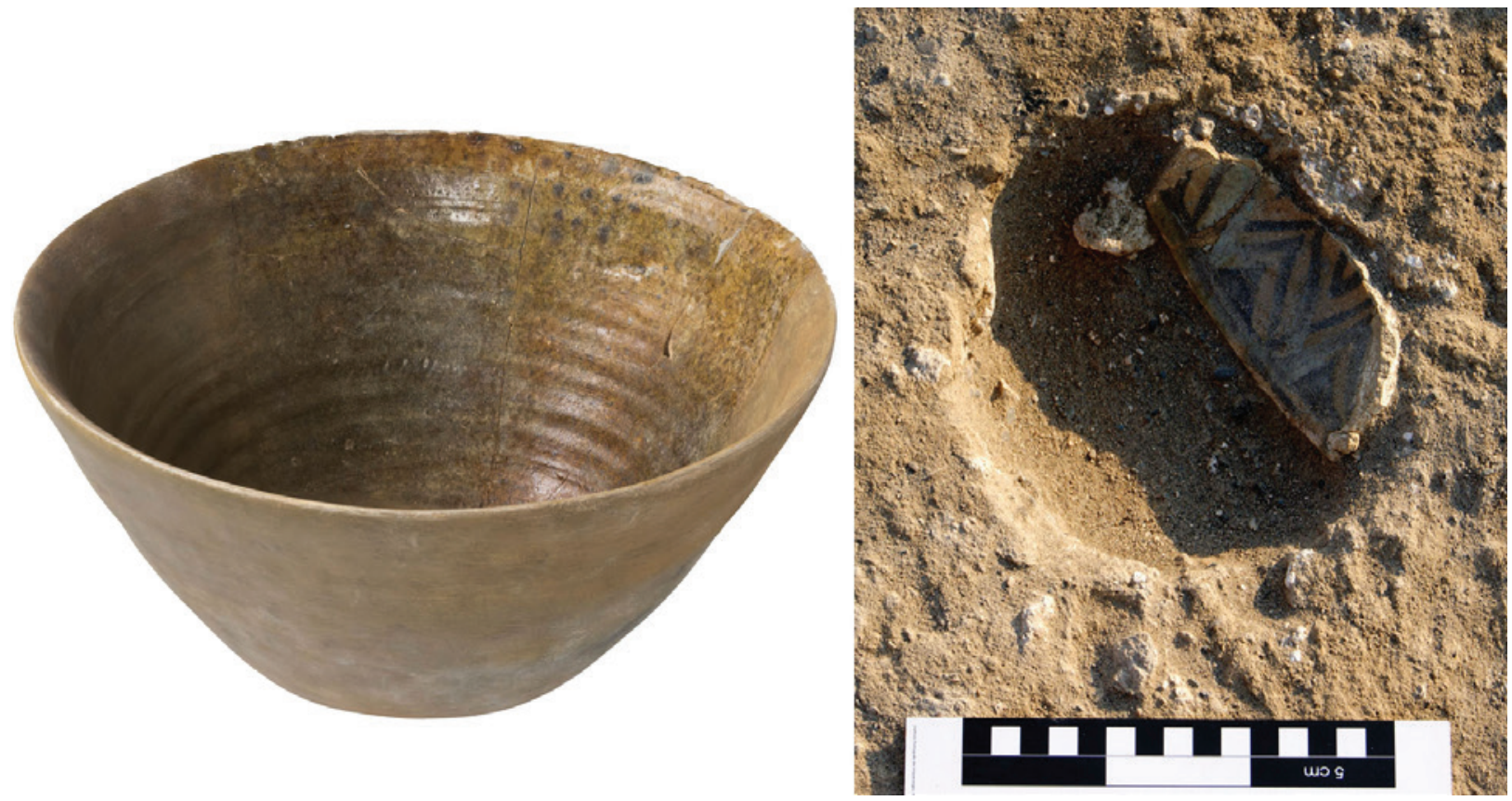

Figura 6 - Grande taça do tipo cerâmica de Bahlā e fragmento de taça de cerâmica com pintura sob vidrado, em buraco de poste (fotos: J. P. Ruas 2019 e M. V. Gomes 2018). 

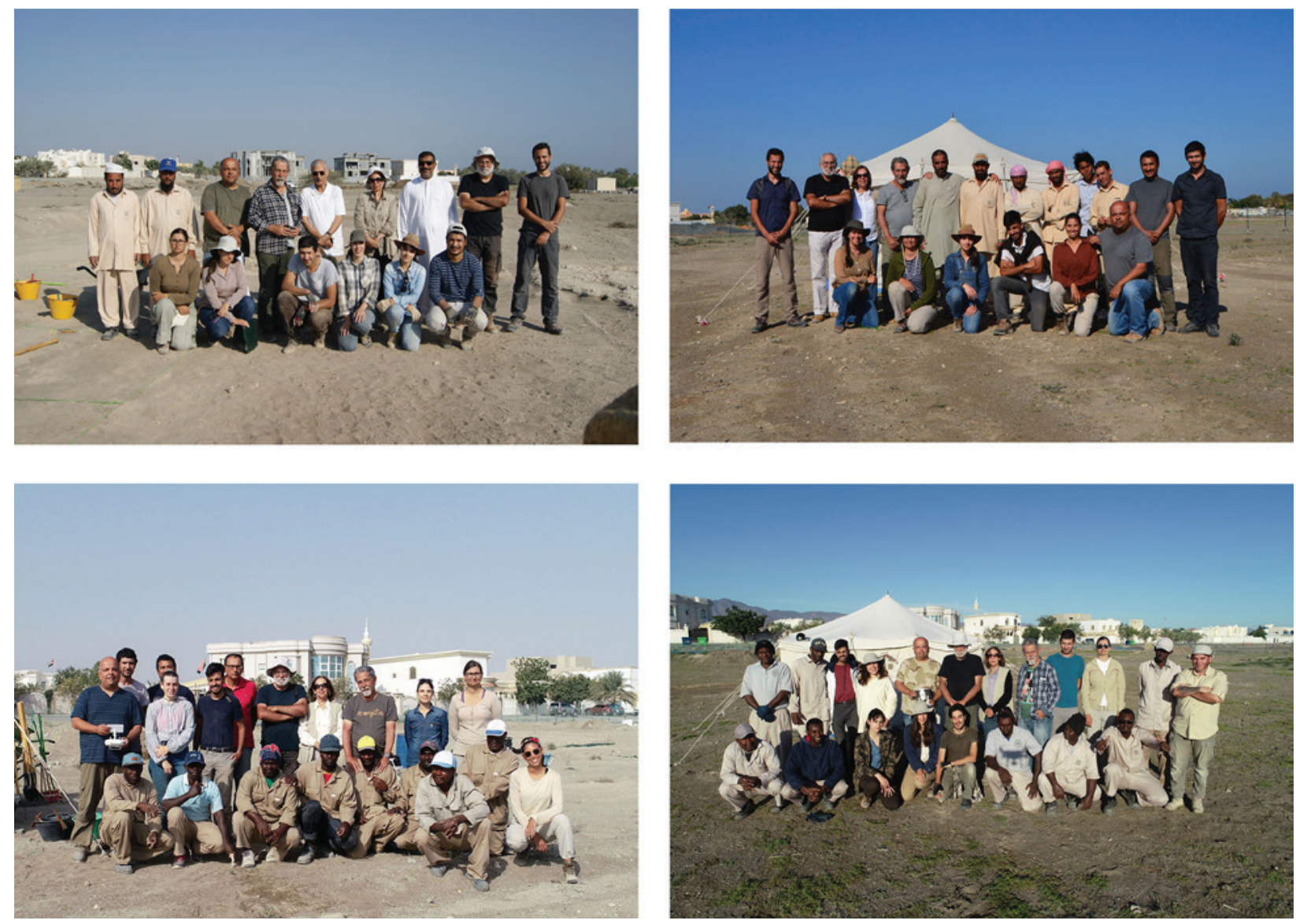

Figura 7 - Fotos das equipas de 2017 a 2020 (fotos M. N. Villanueva e K. Kamyab).

\begin{tabular}{lcccccc}
\hline Cerâmicas vidradas de cor castanha clara & 2017 & 2018 & 2019 & 2020 & Total & $\%$ \\
\hline Cerâmicas vidradas de cor castanha escura ou verde & 75 & 66 & 55 & 7 & 203 & 3,26 \\
\hline Cerâmicas com pintura sob vidrado & 1 & 57 & 10 & 9 & 77 & 1,24 \\
\hline Cerâmica fina incisa ou impressa & 283 & 179 & 168 & 51 & 681 & 10,93 \\
\hline Cerâmicas de pastas escuras & 777 & 964 & 939 & 196 & 2876 & 46,14 \\
\hline Cerâmicas de pastas vermelhas & 277 & 202 & 218 & 35 & 732 & 11,75 \\
\hline Total & 430 & 729 & 382 & 122 & 1663 & 26,68 \\
\hline
\end{tabular}

Quadro I - Fragmentos das principais classes de cerâmicas, pertencentes a recipientes, exumados na Camada 2 (sécs XVIXVII) de Quelba/Khor Kalba. 


\title{
COLÓNIAS PARA HOMENS NOVOS: ARQUEOLOGIA DA COLONIZAÇÃO AGRÁRIA FASCISTA NO NOROESTE IBÉRICO
}

\author{
Xurxo Ayán Vila ${ }^{1}$, José Ma ${ }^{a}$. Señorán Martín ${ }^{2}$
}

\begin{abstract}
RESUMO
A partir de uma abordagem comparativa, propomos nesta nossa comunicação uma Arqueologia de algumas das colônias agrárias implantadas no noroeste da península bérica: Lamas (Paredes de Coura), o projeto de colonização dos terrenos baldios de Montalegre e Boticas (Barroso) e o Plan de Colonización de la Tierra Llana (Lugo, Galiza). Apesar de ser uma área que compartilha características comuns (mesmo clima, pequenos proprietários, marginalidade), as soluções adotadas geraram diferentes materialidades. A partir da Arqueologia do Passado Recente, recém desenvolvida em Portugal, levantamos questões teóricas e metodológicas para o estudo desse tipo de espaço doméstico contemporâneo. Esta pesquisa é realizada no âmbito do projeto de Archaeology of Contemporary Past and Heritage Socialization, financiado pela FCT (CEECIND / 04218/2017).

Palavras-chave: Colonização agraria, Fascismo, Espaço doméstico, Arqueologia rural, Arqueologia da paisagem.
\end{abstract}

\begin{abstract}
From a comparative approach, we propose in this communication an Archaeology of some of the agrarian colonies implanted in the northwest of the Iberian peninsula: Lamas (Paredes de Coura), the colonization project of the wastelands of Montalegre and Boticas (Barroso) and the Plan de Colónización de la Tierra Llana (Lugo, Galicia). Despite being an area that shares common characteristics (same climate, small landowners, marginality), the solutions adopted have generated different materialities. From the Archaeology of the Recent Past, recently developed in Portugal, we raised theoretical and methodological questions for the study of this type of contemporary domestic space. This research is carried out within the scope of the Archaeology of Contemporary Past and Heritage Socialization project, funded by FCT (CEECIND / 04218/2017).
\end{abstract}

Keywords: Agrarian colonization, Fascism, Domestic space, Rural archaeology, Landscape archaeology.

\section{INTRODUÇÃO}

Desde o início que as ditaduras ibéricas de Salazar e Franco propuseram a criação de um novo Estado baseado na autarquia, no intervencionismo estatal no mercado, no controlo da mão-de-obra rural e na defesa da propriedade. Tudo isto para favorecer e recompensar os grandes proprietários de terras que tinham apoiado o bando rebelde no caso espanhol e que lutavam contra a mobilização política dos trabalhadores rurais nas grandes propriedades do centro-sul de Portugal (Barrones, 2012; Baptista, 1993). A colonização seria o elemento-chave desta política agrícola, apresentada em Espanha como uma reforma inteligente em contraste com a reforma agrária realizada durante a Segunda República e o processo de coletivização. Para além da transformação de milhares de hectares em terras irrigadas e da redistribuição de parcelas entre os novos colonos, o objetivo final era redimir o campesinato, uma vez que a ruralidade era apresentada pelos ideólogos fascistas como a reserva moral das nações espanholas e portuguesas (Alares, 2010; Rosas, 2018). As novas aldeias de colonização, cuja tarefa inicial era dar apoio material às pessoas que estavam a transformar os terrenos baldios em terrenos agrícolas, estavam vestidos com o

1. IHC, FCSH, Universidade Nova de Lisboa; xurxoayan@fcsh.unl.pt

2. Universidade Complutense; jose.m.senoran@gmail.com 
manto ideológico do Estado Novo e a Nueva España (Silva, 2011; Guerreiro, 2016; Flores, 2013).

A Junta de Colonização Interna (1936) promoveu a criação de novos assentamentos em Portugal seguindo as orientações de Rafael Duque (Ministro da Agricultura entre 1934 e 1940 e da Economia entre 1940 e 1944) e os ensaios prévios realizados durante a monarquia e a República (Carvalho 2018). Em 1937 a reabilitação das colónias em Leiria e Sabugal serviu de base para a definição dos modelos de povoamento que mais tarde se materializariam. Entre 1936 e 1967, foram construídas sete colónias agrícolas: Milagres (Leiria), Martim Rei (Sabugal), Pegões (Setúbal), Barroso (Montalegre e Boticas), Gafanha (Ílhavo), Boalhosa (Paredes de Coura) e Alvão (Vila Pouca de Aguiar). Por outro lado, a colonização promovida pelo regime franquista através do Instituto Nacional de Colonização (1939) foi levada a cabo em muito maior escala. De facto, afetou $2 \%$ da população ativa rural em Espanha, ou seja, cerca de 60.000 colonos com a aquisição de meio milhão de hectares. Embora tenha produzido pouca redistribuição social - cerca de 50.000 famílias até 1971 - levou a cabo uma intensa política de construção, representada por 11.000 quilómetros de valas e canais, 113.0oo hectares nivelados e 300 novas aldeias (Pérez Escolano, 2005). Em ambos os casos, estamos perante autênticos projetos de engenharia social que modificaram decisivamente o meio ambiente e a paisagem cultural de regiões rurais inteiras em prol de uma certa ideia de Progresso e Modernidade. Um projeto colonizador que apresenta enormes semelhanças com iniciativas similares realizadas por outros estados totalitários, como a Itália fascista (Stampacchia, 20oo; Samuels, 2010) ou o estado comunista etíope (González Ruibal, 2006), para citar dois exemplos que conhecemos em primeira mão.

Nas últimas décadas, foram publicados trabalhos sobre este fenómeno (sejam abordagens gerais ou particulares, limitadas no tempo ou restritas a áreas territoriais específicas) por economistas, antropólogos, historiadores, geógrafos, engenheiros agrícolas, sociólogos e políticos. No entanto, a materialidade gerada por estas políticas colonizadoras só tem despertado interesse no campo da arquitetura e do planeamento urbano. Assim, temos estudos que se centraram no trabalho dos arquitetos das povoações e na análise dos projetos de ação (Centellas, 2010; Tordesillas e Meiss, 2013; Flores, 2013; Guerreiro, 2016; Oliveira, 2018). Estas abordagens têm dado uma valiosa contribuição, já que conseguiram recuperar para as Ciências Sociais uma experiência que, como dissemos, foi praticamente esquecida. No entanto, é de notar que estes estudos mal abordam o contexto sociopolítico e económico que explica o surgimento destas arquiteturas. Até agora, os aspetos estéticos e mesmo artísticos desses ambientes arquitetónicos têm sido mais tratados, deixando de lado a sua relação com a ideologia dominante e o projeto social imposto pela ditadura.

Acreditamos que a arqueologia do passado contemporâneo pode preencher esta lacuna e proporcionar uma nova abordagem às materialidades e memórias do processo de colonização. Neste sentido, em 2014 os autores deste texto iniciaram um projeto ( $\mathrm{Ar}$ queología postcolonial na Espanha) da Universidade do País Basco onde começámos a estudar arqueologicamente as colónias agrícolas e industriais promovidas pelo regime franquista em zonas como o vale do rio Alagón (Cáceres, Estremadura) (Señorán e Ayán, 2015) ou o vale do rio Sil (León, Ourense, Lugo) (Ayán e Señorán, 2015). Agora, no âmbito de um novo projeto ${ }^{3}$, pretendemos realizar um estudo comparativo das aldeias de colonização criadas pelas duas ditaduras ibéricas.

O primeiro estudo de caso centra-se na zona de pequenos proprietários da Galiza e do norte de Portugal, onde a dispersão do habitat e do regime de propriedade condicionou significativamente o projeto de colonização. Como já mencionámos, os planos de colonização na Nueva España foram criados com a intenção clara de intervir nas áreas de latifúndio do Estado onde o conflito sobre a propriedade da terra tinha gerado um profundo conflito social. Isto explica porque os grandes projetos colonizadores foram desenvolvidos na metade sul da península (Plano Jaén, Plano Badajoz), enquanto no Atlântico e no norte, não foram estabelecidos colonos, exceto no caso excepcional do noroeste. A Galiza serviu de enquadramento para quatro experiências colonizadoras: a rede de irrigação de Terra de Lemos (Lugo), a dissecação da Lagoa de Antela (A Limia, Ourense), o repovoamento da ilha de Ons (Pontevedra) e a colonização de A Terra Chá (Lugo). Vamos centrar-nos neste último caso, comparando-o com os assentamentos portugueses de A Boulhosa (Paredes de Coura) e Barroso (Montalegre e Boticas).

3. Archaeology of Contemporary Past and Heritage Socialization, financiado pela FCT (CEECIND / 04218/2017). 
Infelizmente, as circunstâncias impostas pela pandemia da COVID-19 nos últimos meses impediram-nos de completar o trabalho de campo necessário para podermos apresentar aqui um avanço mais elaborado da investigação. Em qualquer caso, aproveitamos a oportunidade para apresentar algumas reflexões e avaliar o potencial de uma linha de trabalho em arqueologia do passado recente que ainda está a descolar em Portugal (Coelho e Ayán, 202O; Casimiro e Sequeira, 2020).

\section{DO AGRO PONTINO ÀS «AGRAS» DA «TIERRA LLANA»: UM MODELO DE COLONIZAÇÃO FASCISTA NA GALIZA}

Em 2009, o ciclone Klaus derrubou uma antena de 112 metros de altura no lugar de Arneiro (Cospeito, Lugo). Este era o último vestígio material do complexo Elektra Sonne, construído pela Alemanha nazista com equipamento da casa Telefunken para guiar os submarinos da Kriegsmarine e aos caças da Luftwaffe. A torre de Arneiro, como as ruínas das explorações de volfrâmio na Galiza (Tejerizo e Rodríguez, 2020), são materiais que testemunham a ajuda dada por Franco a Hitler, em troca dos serviços prestados pelo Terceiro Reich durante a guerra civil espanhola. Tanto a antena como o aeródromo anexo de As Rozas, permaneceram ativos após a $2^{\underline{a}}$ Guerra Mundial, desta vez já em mãos espanholas.

Em 1953, um avião militar sobrevoou o Arneiro com uma nova missão. É preciso lembrar que, no período imediato do pós-guerra, o exército de Franco colaborou estreitamente no desenvolvimento da fotografia aérea como uma ferramenta útil para os cientistas e técnicos fascistas comprometidos com a Nova Espanha. Assim, os falangistas Julio Martínez Santa-Olalla (1905-1972) e Martín Almagro Basch (1911-1984) foram os primeiros a utilizar a aviação militar para a deteção de sítios arqueológicos (Almagro, 1953). O mesmo fizeram, mas na área da agricultura, Rafael Cabestany de Anduaga (19021958) e Odón Fernández Lavandera (1915-2001), os dois engenheiros agrícolas que naquela manhã de 1953 observaram do ar a manta arborizada que cobria esta área de planície conhecida como Terra Chá. Cabestany trabalhou na Guiné Equatorial entre 1925 e 1931 e nessa colónia fundou a Companhia Agrícola e Florestal. Filiado ao Falange, quando a guerra eclodiu mudou-se para a zona franquista e lutou como alferes na 150 ${ }^{\underline{a}}$ Divisão marroquina nas batalhas de
Guadalajara, Teruel e Ebro. Em 1951 foi nomeado Ministro da Agricultura por Franco, cargo que ocupou até 1957. Por sua vez, Fernández Lavandera foi diretor-geral de Agricultura e um dos responsáveis técnicos pelos projetos propostos pelo Instituto $\mathrm{Na}$ cional de Colonização na Galiza. Tanto os arqueólogos Julio e Martín, como os engenheiros agrícolas Rafel e Odón, todos os quatro fascistas, são bons exemplos daqueles ingenieros de Franco (Camprubí, 2017), especialistas que conceberam e implementaram as políticas de modernização de um regime baseado nas sinergias entre fascismo, nacional-catolicismo, ciência e tecnologia. Portanto, a colonização agrícola na Galiza foi obra de homens (somente homens) com nome e apelidos, de técnicos que desenharam todo um projeto de engenharia social como foi, neste caso, a criação da Zona de Colonização da Tierra Llana.

Do avião, o ministro e o diretor viram um imenso terreno baldio, não cultivado e sem uso, que tinha de ser colocado em produção. Do mesmo modo que drenavam sapais e lagoas insalubres (Antela na região ourensana de A Limia), aqui foi proposta a expropriação por utilidade pública da terra, o desmatamento maciço e a concentração parcelária. O que estes engenheiros agrícolas não viam era a paisagem rural tradicional das comunidades locais. Como ficou demonstrado pela história agrária, os camponeses destas paróquias mantinham um sistema de exploração sustentável em que a floresta e a montanha desempenharam um papel fundamental, como complemento da agricultura intensiva desenvolvida nas chamadas agras (Cabana, 2008). O uso comunal destes espaços tem sido regido pelo direito consuetudinário desde os tempos medievais. Esta paisagem dizia respeito a uma lógica camponesa diametralmente oposta à racionalidade manejada pelo INC. Não eram terrenos baldios e as pessoas viviam lá.

Desde a elaboração do Plano Geral, em 1956, a história tecnocrática foi baseada numa visão colonial que contribuiu para subordinar ainda mais os habitantes da área. Os técnicos queriam criar uma nova realidade en donde no hay nada, apontavam uma e outra vez hábitos rutinarios destes camponeses primitivos (Fernández e Pizarro, 1980) e propunha-se a colonização como uma missão, como aquelas que realizavam as ordens religiosas nas zonas rurais para recristianizar os habitantes do pagus. Para Cavestany, a colonização foi uma tarefa fundamental tanto nas colónias africanas como na Espanha rural, uma 
missão necessária para conduzir os Bubis, os Fang e os camponeses galegos pelos caminhos do progresso e da modernidade.

A expropriação por utilidade pública das florestas comunitárias foi um golpe para a oposição e resistência da população local. O Estado, como noutras regiões do país, recrutou a nova população de colonos entre os expulsos pela construção de barragens e pelo reflorestamento maciço. Neste caso, mais de $20 \%$ dos colonos vieram de zonas montanhosas afetadas por estes processos, como Quiroga ou Negueira de Muñiz. Foi necessário recrutar famílias de outras regiões espanholas (León, Cantábria) e mesmo do norte de Marrocos, que recentemente se tinha tornado independente de Espanha (Cardesín, 1987). Na sua vida anterior, os colonos faziam parte do grupo mais baixo da sociedade camponesa galega, conhecidos como caseiros, as famílias sem casa ou terra própria, que trabalhavam e viviam na terra de casas grandes em troca de uma parte da colheita. Estes caseiros passaram de dependentes dos fidalgos e dos camponeses ricos, a ficar dever tudo agora ao regime franquista. A construção desta nova identidade foi um instrumento de controlo social concebido pela ditadura para acabar com os caprichos da reforma agrária republicana e a luta de classes no campo. Esperava-se que os colonos fossem leais ao regime, razão pela qual muitos deles foram selecionados de entre antigos combatentes da guerra civil e da Divisão Azul (no caso português exigia-se ser, entre outras coisas, robusto, ter amor ao trabalho e à família, não ser alcoólico, nem desordeiro, nem comunista, acatar a Constituição em Fonseca 2004: 79)

Como já mencionámos, a colonização da Terra Chá foi o único caso na Galiza que levou à instalação efetiva de populações. Após a anterior expropriação de 2800 Ha de floresta comunal pertencente a freguesias dos municípios de Cospeito e Castro de Rei, 189 famílias de colonos foram reassentadas em Matodoso (Setor III, 1959-1962), em Arneiro e Veiga do Pumar (Setor II) e A Espiñeira (Setor I), estas duas últimas habitadas desde 1966 (Cardesín, 1987). Engenheiros agrícolas como Odón Fernández tiveram um papel essencial na definição deste modelo de ocupação colonial, e não tanto os arquitetos que colocaram no mapa as ideias prévias, com Alejandro de la Sota (1913-1996) como figura principal (Zas Gómez, 2002).

O projeto não pode ser compreendido sem reconhecer a influência decisiva do fascismo italiano. Tanto as instituições criadas pelo Estado Novo na década de 1930 como pelo Nuevo Estado são uma imitação das entidades promovidas pelo regime de Mussolini (Rosas, 2019). O INC nasce em 1939, no auge da fase mais filofascista da ditadura. Os ideólogos e técnicos falangistas olham com admiração para o trabalho do Duce. É a partir destas coordenadas que o Plano de Colonização da Planície reproduz, em menor escala, obviamente, o modelo do Agro Pontino, ao sul de Roma. Mussolini pretendia resolver o problema do desemprego no mundo rural enviando habitantes de áreas densamente ocupadas para repovoar áreas marginais que estavam a ser colonizadas. É a mesma lógica demográfica (e também o mesmo imaginário de dominação) que utilizou para justificar a aventura colonial na Cyrenaica Líbia e no Corno de África: o Imperio del Lavoro. Como aponta L. Veracini (2018, p. 19), o Agro Pontino é o paradigma da Bonifica integrale, de uma região definida pelos seguintes epítetos: desabitada, bárbara, primitiva, selvagem e improdutiva. A sua drenagem e ruralização contribuiria para a autonomia nacional e para a criação de uma classe de colonizadores-proprietários-cooperativos que acabaria com os conflitos gerados pelo latifúndio e o perigo de uma revolução socialista (Stampacchia, 200o). Este projeto megalomaníaco e propagandístico começou em 1927 com a drenagem e loteamento do território; em poucos anos 30.000 colonos chegaram à região e 3.000 fazendas, 88 aldeias e cinco novas cidades foram construídas (Littoria, Sabaudia, Pontinia, Aprilia e Pomezia). Como o Imperador Augusto, o ditador modificou a paisagem numa escala nunca antes vista, para reinstalar os seus legionários, os cidadãos fascistas, nas colónias rurais: un esercito di fieri rural fascisti. A Opera Nazionale per i Combattenti (ONC) selecionava os colonos e atribuía-lhes uma casa e uma parcela de terra para cultivo. Aos 30 anos, a propriedade passava para as famílias. Este modelo de habitat disperso baseava-se em núcleos centrais, centros cívicos administrativos suburbanosem que se encenava o poder (a Câmara Municipal, a Casa do Partido Fascista), e se ofereciam serviços civis (mercado, espaços de lazer) e religiosos (igreja) (Capresi, 2019). A piazza era o forum do fascismo do século XX. As missas dominicais ou eventos do partido fascista eram praticamente as únicas redes de sociabilidade fora da vida familiar nas fazendas. As colónias eram ilhas de italianidade, formavam uma feliz Arcádia rural e os colonos eram o epítome do uomo novo, o homem 
novo. A Nueva España e o Estado Novo assumiram mimeticamente esta proposta ideológica tanto nas colónias internas como nas colónias em África (Rosas, 2001; Gonçalves, 2018).

O INC conhecia perfeitamente a experiência fascista italiana desde a sua fundação. Mesmo em 1951, ex-chefes do projeto do Agro Pontino visitaram Espanha e deram palestras para engenheiros e arquitetos ligados aos projetos de colonização (Bazán e Lozano, 2015, pp. 207-9). É sobre esta base que assentou a colonização da Tierra Llana, resultando numa paisagem que desde então será familiar e será associada à modernização das zonas rurais na Galiza. Os marcos materiais são, por um lado, os canais de irrigação e, por outro, os caminhos retos que atravessam e delimitam o terreno concentrado e ao pé do qual as novas quintas familiares se estabelecem equidistantes. O módulo carro (substituído pelo módulo trator na década de 1960) estabelece uma distância mínima $(2,5$ e $3 \mathrm{~km})$ entre a casa-parcela e a casa-centro cívico (Zas, 2002, p. 199). O horizonte está pontilhado com os novos símbolos da Modernidade: os tanques de água, os silos cilíndricos e as torres dos campanários das igrejas localizadas nos centros cívicos. Num período de tempo muito curto, passamos das paróquias aos setores, das agras às parcelas, dos carros aos tratores, dos tradicionais espigueiros aos silos, da lareira, dos quinqués e das velas à luz elétrica, das cortes das vacas debaixo da casa aos estábulos de cimento, dos agricultores e caseiros aos colonos, desde os mortos no átrio da igreja paroquial até aos mortos segmentados da comunidade e enterrados em cemitérios isolados.

As fazendas consistem numa casa típica com alpendre, uma planta retangular e dois andares, e uma série de anexos (celeiro, chiqueiro, estábulo, galinheiro, monturo) ao redor de um grande pátio. $\mathrm{Na}$ casa são utilizadas técnicas tradicionais de construção, com ardósia no telhado e paredes de alvenaria. Como novidade, e seguindo o modelo do colonizador do sul, o exterior da casa é coberto com cal. A conceção (1957) foi obra não só de arquitetos, mas também de engenheiros agrícolas, o que explica a abordagem produtivista que rege este modelo de espaço doméstico. Ao mesmo tempo, o centro cívico, como já assinalámos, é uma clara adaptação do modelo fascista italiano, uma nova realidade (fracassada) que rompe com a organização paroquial galega de mil anos e com as câmaras municipais criadas no século XIX pelo Estado liberal. Em torno de uma praça ajardinada e geralmente com secções porticadas estão dispostas a Igreja, a sede da Ação Católi$\mathrm{ca}$, as escolas, as casas dos professores, instalações comerciais e um centro corporativo. Na periferia do complexo está o novo cemitério, sempre localizado em localizações conspícuas de grande visibilidade. O caso do Arneiro é paradigmático a este respeito. O centro cívico simbolizava a proteção do Estado franquista, o mesmo que tinha provocado o desenraizamento destes caseiros e camponeses, deslocados pelas obras públicas do regime. Não importava, eles deviam tudo à Nueva España. Como os montanheses de Leão que foram enviados para a terra de Campos em Castela (protagonistas do romance de Julio Llamazares Diferentes formas de mirar al agua), ou os camponeses neolíticos pré-históricos, estes novos colonos começaram realmente a ocupar o espaço quando começaram a enterrar os seus mortos nestes cemitérios tão modernos. Na sociedade camponesa galega, os nichos são agrupados sob o nome ou apelido de uma casa. Aqui não, são propriedade de pessoas com nomes e apelidos. $\mathrm{O}$ indivíduo, tal como o trator, o cimento e a luz elétrica, é uma criação da Modernidade.

\section{PLANIFICAÇÃO RURAL SALAZARISTA: O NÚCLEO DE COLÓNIAS DO BARROSO (MONTALEGRE E BOTICAS)}

$\mathrm{O}$ arquiteto nazi Albert Speer desenhou toda uma estratégia de propaganda para promover a cultura do Terceiro Reich em países neutros durante a Segunda Guerra Mundial. Foi neste contexto que se enquadrou a exposição itinerante A Moderna Arquitetura Alemã inaugurada em Lisboa em novembro de 1941, com o apoio do Sindicato Nacional dos Arquitetos e da Sociedade Nacional de Belas-Artes (Vilanova, 2014; Ninhos, 2017, pp. 222-226). O que ali se viu teve uma influência notável, não tanto na adoção da arquitetura moderna, mas no desenvolvimento da arquitetura oficial monumentalista e classicista do Estado Novo, como se pode ver no projeto da Cidade Universitária de Coimbra (1943). O arquiteto Raul Lino, presente no jantar de gala oferecido a Speer após a abertura da exposição, também não se deixou levar pela arquitetura moderna. A sua visão do que deveria ser a casa portuguesa, seja num bairro económico ou numa colónia agrária, materializava duas ideias-chave da ideologia do Estado Novo: o culto à família e a reivindicação do mundo rural. A arquite- 
tura colossal estava reservada para as grandes cidades. A arquitetura vernacular era suficiente para os camponeses e colonos. Foi neste contexto, e sob esta influência, que os arquitetos do regime (Vasco Lobo, Alfredo da Mata Antunes, António Trigo, José Luiz Pinto Machado, entre outros) começaram a planear as habitações e povoações promovidas pela JCI.

O plano de colonização de Barroso foi concebido em 1943 no âmbito da típica política fascista de promoção da autossuficiência alimentar. Era a altura das campanhas a favor da produtividade agrária e da cultura da batata (1939-1943). Para os engenheiros agrónomos que trabalham no Estado Novo, os baldios montanhosos concentrados no norte foram um obstáculo para a modernização do mundo rural. Os usos comunais e sazonais destes recursos decorriam de práticas medievais que colidiam com uma utilização racional do meio (Freire, 2004). Os técnicos definem um cliché para a identidade barrosã, criadores de gado primitivos e promíscuos ancorados no passado, selvagens que convivem com os animais, cabaneiros e cabaneiras que ocupavam o último lugar da sociedade rural e estavam nos antípodas da imagem da família cristã defendida pelo Estado Novo (Freire et al., 1998). Uma agricultura eficiente exigia o estabelecimento de camponeses mais avançados, daí que muitos colonos tivessem vindo do Alto Minho e de Viseu. Também na Terra Chá os colonos provenientes de Cantábria ensinaram boas práticas agrícolas aos primitivos nativos.

Como no caso espanhol, o projeto colonizador assentava em três pilares: a concentração parcelária, o repovoamento florestal e as infraestruturas hidráulicas. A colonização do Barroso teve lugar na década de 1950, afetando 36.477 hectares e levando à construção de sete núcleos habitacionais: Chã, Sepeda, Criande, Vidoeiro, Fontão, Pinhal Novo e Veiga de Montalegre (Oliveira, 2018). O modelo do tipo de casa concebido pelos arquitetos baseava-se numa peça principal com planta retangular, seguindo padrões já experimentados na Itália e Espanha. O espaço doméstico contava com edifícios especializados: dois silos, uma nitreira, estábulo, compartimento para pocilgas e um alpendre para carros e ferramentas. Ao contrário do habitat disperso da Terra Chá, no Barroso apostou-se na concentração das casas em assentamentos, seguindo o conceito de Unidade de Vizinhança e sob a influência anglo-saxónica da Aldeia-Jardim (Rapazote, 2012). No entanto, como no caso da Galiza, existiam aldeias centrais como a
Aldeia Nova do Barroso, com uma distância máxima de $2 \mathrm{~km}$ a pé das aldeias satélites (módulo carro em Espanha e mochav em Israel). Como aponta Silva (2011), é muito interessante ver as mudanças na evolução do projeto original. Em 1953 foi concebido um espaço segmentado do resto, com personalidade própria: o Centro Social, uma imitação do Centro Cívico do Fascismo Italiano, que, como vimos, estava também a ser aplicado na altura no noroeste de Espanha. Este núcleo acolhe materialmente os representantes do Estado Novo: professores, engenheiros e GNR. Funcionários públicos separados espacialmente dos subordinados administrados (os colonos), tal como acontecia no Ultramar e já tinha sido praticado pelos ocupantes italianos no Corno de África.

Este peculiar urbanismo rural combinava tradição e modernidade. As casas seguem modelos locais adaptados ao clima, com grandes chaminés, chão de terra batida e um telhado de duas águas (originalmente, foi ponderada a possibilidade de utilizar colmo nas coberturas), bem como práticas domésticas que enfatizam a cozinha e a vida familiar em espaços comuns. No espaço público, como nas antigas aldeias da zona, construem-se lavadouros e fornos comunais como espaços indispensáveis à socialização. No entanto, os núcleos também são desenhados com critérios modernos longe do folclore local, com rotundas, plantas circulares, jardins, áreas arborizadas e até escadas e miradouros monumentais (Rapazote, 2012). Todo esse cenário suburbano sanciona o projeto ideológico do Estado Novo, com a igreja e a escola em lugares de destaque. Este interesse estético também pode ser visto nas obras de engenharia hidráulica e nos povoados de empresa construídos nos dois países desde finais dos anos 50 (Ayán e Señorán, 2015).

Enquanto o projeto inicial nos anos 40 falava de fazendas familiares autossuficientes, já nos anos 50 o objetivo era a criação de empresas agrícolas familiares. Como no caso galego, a colonização finalmente procurou capitalizar as zonas rurais e incluí-las na lógica do mercado capitalista, mas foi totalmente confrontada com o processo de desintegração das comunidades rurais da zona a partir dos anos 60 (abandono do campo, emigração, envelhecimento). O símbolo desta política fracassada é a construção da barragem de Pisões pela Hidroelétrica do Cávado, que em 1963 inundou $24 \%$ da Aldeia Nova, $58 \%$ da Aldeia de Criande, cortou a estrada de acesso e isolou muitas parcelas. 
Numa reportagem recente, ${ }^{4}$ em março de 2019, o vice-presidente da câmara municipal de Montalegre mostrou o seu desconforto com a situação de abandono por que tinha estado a passar a zona perante a inação estatal e reclamou a cessão e utilização pública das casas dos engenheiros da JCI, abandonadas à sua sorte num pinhal próximo à barragem. $\mathrm{O}$ que antes tinha sido uma Aldeia Nova é agora uma ruína (Figura 1).

\section{A COLÓNIA NEOLÍTICA DE A BOULHOSA (LAMAS, VASCÕES, PAREDES DE COURA)}

O pré-historiador marxista Vere Gordon Childe foi convidado a visitar Portugal em dezembro de 1949. Tal como na Espanha de Franco, o reconhecido arqueólogo australiano foi homenageado por representantes académicos, neste caso, do Estado Novo (Gonçalves, 2011). Childe aproximou-se do Norte para visitar as citânias de Sanfins, Briteiros e o castro de Sabroso. Se tivesse visitado Paredes de Coura poderia ter conhecido a paisagem megalítica pré-histórica de Chã de Lamas. Childe foi o grande teórico da revolução neolítica e da sua expansão por toda a Europa. Os primeiros camponeses colonizaram novos espaços e semantizaram-nos com a construção de monumentos funerários. O núcleo megalítico de Chã de Lamas, perto da Lagoa da Salgueirinha, é a evidência material da primeira colonização humana deste território selvagem na bacia superior do rio Coura. Em 1881 Narcizo A. Cunha e Pestana de Vasconcelos escavaram a mamoa 3, expondo uma câmara funerária poligonal, constituída por cinco lajes (Silva, 2006). Neste sentido, a colónia agrária da Boalhosa significou um regresso do Estado Novo à pré-história, mas na década de 1950. Esta ideia de continuidade histórica entre os primeiros colonos e os camponeses de hoje esteve sempre presente na mente dos técnicos que realizaram a pesquisa antes do desenho da colónia agrária salazarista. Os pastores e agricultores da região eram vistos como aqueles moradores mesolíticos primitivos que não conseguiam avançar em termos evolutivos. A nova colónia, como o Neolítico, deveria trazer progresso e inovação, o desenvolvimento de uma agricultura racional e moderna, mas ancorada nos valores conservadores da tradição e da propriedade da terra.

4.https://sicnoticias.pt/programas/reportagemespecial/ 2019-03-31-Os-ultimos-colonos
O Estado Novo chegou à paisagem rural tradicional de Paredes de Coura sob a forma de uma nave alienígena. Os arquitectos que conceberam colónias agrárias sob os regimes fascistas eram capazes de gerar realidades geométricas nunca antes vistas. A modernidade aterrou sob a forma de círculos, semicírculos e casas geminadas. A colónia agrícola de A Boalhosa, ao longe, parece um OVNI encalhado numa planície neolítica. O projeto começou em 1952 e os primeiros colonos foram instalados em 1957. Os engenheiros agrónomos do Estado Novo viam o sopé da serra de Corno de Bico um espaço virgem para o desenvolvimento da agricultura. A sua particular visão dos baldios não se importava com os processos históricos. A área já tinha sido colonizada pelos primeiros camponeses na Europa, pelas comunidades neolíticas que marcaram a sua presença no território através dos seus antepassados há milhares de anos. Assim, a necrópole megalítica de Chã de Lamas, ao pé da colónia agrícola de 1954 ainda está preservada.

$\mathrm{Na}$ Boalhosa, o arquiteto António Trigo aplicou o modelo de aldeia-jardim já experimentado no Barroso e escolheu 15 habitações geminadas com cobertura de duas águas e capacidade para 30 famílias. O design da casa modelo deve-se a José Luiz Pinto Machado (Guerreiro, 2016, p. 175). No topo, em torno da "Praceta do Centro Social”, foram construídas a escola e a casa do professor, dois edifícios que devido ao seu design moderno rompem com o padrão formal folclórico das casas dos colonos. A igreja e o posto médico nunca se materializaram devido à falta de financiamento. O modelo arquitetónico ruralizante é evidenciado pela notável presença em cada unidade doméstica de um espigueiro tradicional, normalmente localizado na esquina do terreno, com visibilidade direta da rua. À entrada da colónia, o primeiro edifício a ser visto é o forno comunitário, atualmente local social da associação de moradores. Em 1958, os primeiros colonos chegaram e ocuparam 14 casas, elevando o número total de habitantes para 70. Em 1973, das 30 casas planeadas, apenas tinham sido ocupadas 10.

Hoje, visitar a colónia é uma verdadeira viagem sideral. A estrada de acesso é marcada por monólitos com o nome de diferentes planetas: aqui Saturno, ali Marte. Cientistas conceberam um percurso pedestre completo, um trilho do sistema solar de $8,6 \mathrm{~km}$ de distância. Um projeto espetacular e do qual participam diferentes entidades de olhos postos na valorização do mundo rural. Esta viagem interplanetária 
pode ser completada sem se obter qualquer informação histórica sobre esta aldeia criada ex novo. Assumimos que o Centro de Educação e Interpretação Ambiental da Paisagem Protegida de Corno de Bico (fechado) irá albergar algo daquilo que foi a história da colónia, embora já tenha suficiente com o facto de ser o centro do sistema solar. Uma antiga placa na Rua do Cimo é a única fonte que cita a origem e a função deste assentamento humano. O breve texto fala sobre os benefícios da colonização agrária dos baldios no Estado Novo.

\section{BALANÇO E PERSPETIVAS}

Está um dia quente no final de junho, a meio da manhã. Acabámos de sair do estado de emergência. A praça e e a área ajardinada do Centro Cívico de Matodoso (Castro de Rei, Terra Chá) está cheia de vegetação. O dono do bar El Centro orgulha-se da história da colónia, quando esta era uma ilhota de modernidade na Terra Chá: tínhamos escola, maquinaria, tecnologia, vida... e está tudo acabado. As pessoas foram embora e todos os serviços estão concentrados na capital do concelho de Castro de Rei. O passado colonial é um empecilho para a classe política local. A aventura da colonização interna teve, com o fim do regime de Franco, também um mau fim. Entre a relva que cobre o local do centro cívico, há um monumento ilegal bem cuidado, localizado numa posição central, na entrada do povoado e na beira da estrada: uma placa de bronze, com a efígie do ditador, diz o seguinte: SIENDO FRANCISCO FRANCO CAUDILLO DE ESPAÑA - TERRA CHA AÑO 1968.

Gerar um grupo social fiel aos regimes ditatoriais ibéricos foi um dos objetivos da colonização agrária. Materialidade, arquitetura e tecnologia contribuíram para construir esta nova identidade. Os colonos eram entes subalternos, crianças por reeducar (missões religiosas, Obra de Mães pela Educação Nacional, Educación y Descanso) aos quais era preciso "racionalizar» através da instrução correta na agricultura moderna. Os colonos eram diretamente governados por técnicos, que supervisionavam a produtividade e o seu trabalho diário. Os engenheiros, símbolos do Estado, foram os verdadeiros tutores destas comunidades criadas ex novo. Fernando Rosas, para o caso português, salientou também o elitismo cientificista do salazarismo; segundo ele, o Estado Novo promoveu todo um projeto neo- -fisiocrático de promoção rural e de reforma agrária, baseado num neo-iluminismo tecnocrático e autoritário comandado por uma elite de engenheiros (Rosas, 2019, p. 144)... e arquitetos, acrescentamos nós. E estes engenheiros de Salazar e Franco ainda hoje são reverenciados, literalmente. No bar de Matodoso, numa parede com iluminação própria, encontramos pendurado o retrato de Odón Fernández Lavandeira (Don Adón para os vizinhos, com a), o criador desta nova realidade. Os seus restos mortais encontram-se no cemitério vizinho do Centro Cívico do Arneiro. O túmulo, num lugar preferencial, recebe o visitante assim que atravessa a porta. Foi pago por assinatura popular entre os colonos, que o nomearam Filho Adotivo. Como os párocos enterrados nos átrios das igrejas galegas, este engenheiro tornou-se uma espécie de santo ou Bom Pastor. A própria propaganda de Franco explorou esta imagem do Caudilho como o Bom Pastor, após a celebração do Congresso Eucarístico Nacional em Barcelona em 1952 (Figura 2).

Esta visão apologética, triunfalista e aparentemente apolítica tornou-se muito difundida entre os descendentes daqueles colonos, como pudemos ver pelos autores deste texto durante o trabalho de campo. Nos últimos anos, tem havido uma proliferação de placas comemorativas, pequenos monumentos em praças de aldeia e centros de interpretação que honram a memória dos pioneiros (Señorán e Ayán, 2015). A aventura colonial é vista com condescendência, assumindo uma abordagem narcotizante do passado. Na colónia da Boalhosa, prevalece o discurso naturalista: é sempre mais confortável e menos controverso abrigar um Centro de Educação e Interpretação Ambiental de uma Paisagem Protegida ou uma rota interplanetária. Outra coisa seria divulgar o passado recente da área e recuperar o seu sentido de lugar. No caso da Terra Chá, não só este passado não é óbvio, como ainda se reivindica com orgulho este passado franquista.

As ruínas e restos materiais destas colónias do noroeste desafiam-nos diretamente e lembram-nos que estamos diante de um cenário político, um laboratório social projetado e executado de acordo com uma ideologia específica por especialistas com nomes e apelidos (Saraiba, 2010; Camprubí, 2017). São a expressão material da propaganda e da cosmovisão fascista (Capresi, 2019). Embora os projetos de colonização fossem herdeiros de uma tradição liberal anterior e os técnicos portugueses e espanhóis se 
inspirassem em iniciativas desenvolvidas em vários países (da Colômbia à Bélgica, passando pela Tunísia e Argélia), a JCI e o INC bebiam diretamente das fontes do fascismo italiano. Os falangistas optaram por uma arquitetura radicalmente moderna e por um habitat disperso na Terra Chá, enquanto os arquitetos do Estado Novo assumiram um habitat concentrado e um estilo regionalista que gradualmente se abriu a critérios modernos no nível do assentamento. Em ambos os casos, os regimes levaram a cabo uma política de depredação do território (expropriações, barragens, consolidação de terras, reflorestamento) que levou à mobilização forçada das populações rurais e a uma notável resistência das comunidades locais (Fonseca, 2004; Cabana, 2008). Tanto em Lugo como em Paredes de Coura ou Barroso, os habitantes das aldeias desenvolveram diferentes estratégias de resistência. A oposição e a apatia levaram ao recrutamento de colonos em lugares como Marrocos, no caso da Galiza, e em outras regiões, no caso de Portugal. O próprio dirigismo implícito nesta arquitetura planeada falhou diante da realidade de alguns colonos que reinterpretaram, readaptaram e ressignificaran espaços domésticos e agrícolas (o mesmo fizeram os arquitetos e engenheiros ao longo das décadas de 1940, 1950 e 1960).

A arqueologia é uma ferramenta útil aqui. A nossa intenção no próximo ano é realizar escavações arqueológicas em casas abandonadas nestas colónias com o objetivo de analisar qual foi a utilização real de toda esta arquitetura doméstica e se o projeto de engenharia social da colonização atingiu algum dos seus objetivos. Embora talvez as próprias ruínas sejam a evidência mais objetiva do fracasso de uma colonização que se estava a tornar cada vez mais anacrónica e extemporânea. O eletrofascismo impôs um novo campo de jogo com a chegada da barragem, no caso de Barroso. Aqui o Estado Novo pretendia deslocar os habitantes para outras zonas do país ou mesmo enviá-los para as colónias agrárias de Angola e Moçambique, outras ilhas de portugalidade nos confins do Império (Gonçalves, 2018). No entanto, após receber a indemnização, a grande maioria dos colonos tornou-se emigrante, indo para França, Alemanha, Espanha e EUA. Como Alfredo González-Ruibal (2006) assinalou sobre os reassentamentos na Etiópia comunista, o sonho da razão produz ruínas. As casas dos engenheiros, abandonadas no Centro Administrativo, são o reflexo material do fracasso da colonização fascista interna. Assim como os centros cívicos da Terra Chá, mal sinalizados na estrada, em decadência e cheios de vegetação.

Uma arqueologia pós-colonial permitir-nos-á descolonizar estas materialidades, explicitar o carácter fascista dos regimes salazarista e franquista e propor narrativas e novos usos de um património crítico, por vezes traumático, outras vezes rejeitado, mas também naturalizado e branqueado através de histórias tecnocráticas que nos falam de produtividade, saneamento, higiene, progresso e luta do homem contra a natureza. Foi a partir do ponto de vista dos engenheiros fascistas que o comunal passou a ser concebido como um baldio subutilizado, improdutivo e insalubre. A Arqueologia é um know-how, uma técnica útil para o desenvolvimento sustentável destes espaços rurais. As colónias de que aqui falamos são autênticas paisagens arqueológicas fossilizadas (Cabana, 2008, p. 51) e têm enorme potencial para o que é conhecido como turismo de memória. Através das ruínas e da arquitetura podemos percorrer todo o século XX, elaborar sugestivas histórias sobre o Estado Novo, a $2^{\underline{a}}$ Guerra Mundial, a exploração do volfrâmio, o eletrofascismo e o fim do salazarismo e do franquismo. E tudo isto com a intenção de gerar recursos visitáveis, mas também para estimular o espírito crítico dos cidadãos quando se trata de lidar com os vestígios materiais das ditaduras ibéricas.

São doze e meia, num dia ensolarado de outono. Estamos na praça do centro social da colónia de A Boalhosa-Lamas-Vascões. Em frente a Mercúrio, e o indicador de Vénus, é uma das casas geminadas concebidas no início da década de 1950. Na entrada, uma idosa utiliza um chapéu largo de palha e está vestida com um luto rigoroso. Talvez seja uma das últimas sobreviventes da primeira geração de colonos. Está a rezar o terço e vira o olhar para a minúscula Nossa Senhora que encontra logo após Mercúrio, ao pé da moderna casa da professora (1958), hoje abandonada. A colónia agrícola parece um enorme henge do século XX, construído sobre as cinzas dos primeiros colonos neolíticos. Não há mais crianças. Apenas os fantasmas do passado, um centro de interpretação ambiental fechado e uma rota interplanetária. O Estado Novo foi capaz de gerar fenómenos reais poltergeist. 


\section{BIBLIOGRAFIA}

ALARES LÓPEZ, Gustavo (2010) - El vivero eterno de la esencia española. Colonización y discurso agrarista en la España de Franco. In ALCUTÉN SABIO, Alberto, ed.-Colonos, territorio y Estado. Los pueblos del agua de Bardenas. Zaragoza: Institución Fernando el Católico, pp. 57-8o.

ALMAGRO BASCH, Martín (1943) - La colaboración de la aviación española en el campo de la Arqueología. Ampurias. Barcelona. 5, pp. 247-249.

AYÁN VILA, Xurxo e SEÑORÁN MARTÍN, José Mํㅗ. (2015) - La vivienda como necesidad y deber de la justicia social. Por una Arqueología de los poblados obreros del noroeste. In ÁLVAREZ ARECES, Miguel Ángel, ed. - Vivienda obrera en la ciudad industrial del siglo XX. Madrid: TICCIH España, pp. 193-199.

BAPTISTA, F. Oliveira. (1993) - A política agrária do Estado Novo. Porto: Afrontamento.

BARRONES BUZÓN, Miguel A. (2012) - Colonización franquista: la cruzada interior. In Colonización y Memoria [http://www.magrama.gob.es/es/ministerio/archivos-bibliotecas-mediateca/mediateca/expo-memoria-colonizacion_tcm7-346691.pdf [Data de Consulta: 25/03/2015].

BAZÁN DE HUERTA, Moisés e LOZANO BARTOLOZZI, María del Mar (2015) - El Agro Pontino italiano y los pueblos de colonización en la provincia de Cáceres. Boletín del Seminario de Estudios de Arte y Arqueología. Valladolid. 31, pp. 203-229.

CABANA IGLESIAS, Ana (2008) - Lo que queda de las agras. La evolución del paisaje agrario en Galicia: A Terra Chá (1954-1968). Ager. Madrid. 7, pp. 33-56.

CAMPRUBÍ, Lino (2017) - Los ingenieros de Franco. Ciencia, catolicismo y Guerra Fría en el Estado franquista. Barcelona: Crítica.

CAPRESI, Vittoria (2019) - The Afterlife of Fascist Architecture and Town Planning. The Case of Itlaly's Pontine Plain and Colonial Lybia. In MELENHORST, Michel; POTTGIESSER, Uta; KELLNER, Theresa e JASCHKE, Franz, eds. - 100 Years Bauhaus. What interest do we take in Modern Movement Today? Berlín: Hochschule OWL. DOCOMOMO Deutschland, pp. 33-47.

CARVALHO, Rita Almeida de. (2018) - The Junta of Colonização Interna and the shaping of the Estado Novo's peasantry. In Regionalism, Nationalism and Architecture. Conference Proceedings (Porto, October 25-27, 2018): 54-62. Lisboa: Universidade de Lisboa, pp. 54-62.

CARDESÍN DÍAZ, José María (1987) - Política agraria y transformaciones en la agricultura gallega: la zona de colonización de Terra Chá (1954-1973). Agricultura y Sociedad. Madrid. 44, pp. 243-28o.

CASIMIRO, Tánia e SEQUEIRA, João, coords. (2020) - Arqueologia contemporânea em Portugal. Lisboa: Mazu press.
CENTELLAS SOLER, Miguel (2010) - Los pueblos de colonización de la administración franquista en la España Rural. $P+C$ : proyecto y ciudad, revista de temas de arquitectura, 1 , pp. 109-126.

COELHO, Rui G. e AYÁN VILA, Xurxo (2020) - Cambedo, 1946: "Carta do achamento de Portugal". Vestígios: Revista Latino-Americana de Arqueologia Histórica, 13(2), pp. $63-87$.

COSTA, Ana Mafalda Almeida Guimaraes. (2017) - Arquitectura agrícola. As Colónias do Estado Novo para o Barroso. Dissertação de Mestrado. Porto: Universidade Lusíada do Porto.

FERNÁNDEZ LAVANDERA, Odón e PIZARRO CHECA, Antonio (1980) - La transformación del brezal a la pradera en Galicia. Revista de Estudios Agrosociales, 110. pp. 61-82.

FLORES SOTO, José Antonio (2013) - La construcción del lugar. La plaza en los pueblos del Instituto Nacional de Colonización. Historia Agraria. Madrid. 6o, pp. 119-154.

FONSECA, Inês (2004) - A bem da nação! Modernização e resistência em meio rural durante o Estado Novo. In FREIRE, Dulce; FONSECA, Inês e GODINHO, Paula, coords. - Mundo Rural. Transformação e Resistência na Península Ibérica (Século XX). Lisboa: Colibri, pp. 71-85.

FREIRE, Dulce (2004) - Os baldios da discórdia: as comunidades locais e o Estado. In FREIRE, Dulce; FONSECA, Inês e GODINHO, Paula, coords. - Mundo Rural. Transformação e Resistência na Península Ibérica (Século XX). Lisboa: Colibri, pp. 191-224.

FREIRE, Dulce; FONSECA, Inês e GODINHO, Paula. (1998) - Soluções do Estado Novo. Educar o Barrosão no cultivo racional das suas terras. História. Lisboa. 6, pp. 34-41.

GONÇALVES, Vítor S. (2011) - Vere Gordon Childe em Portugal. Uma pequena história (moral?) sobre um joven lobo ainda inexperente e uma raposa matreira. O Arqueólogo Português. Lisboa. Série V, 1, pp.313-329.

GONÇALVES, Márcia (2018) - Of peasants and settlers: ideals of Portugueseness, imperial colonialism and European settlement in Africa, c. 1930-c. 1945. European Review of History: Revue Européenne d'Histoire, 25(1), pp. 166-186.

GONZÁLEZ RUIBAL, Alfredo (2006) - The Dream of Reason: An archaeology of the failures of modernity in Ethiopia. Journal of Social Archaeology, 6(2): 175-201.

GUERREIRO, Filipa de Castro. (2016) - Colónias Agrícolas Portuguesas Construídas pela Junta de Colonização Interna entre 1936 e 1960. A casa, o asentamento, o territorio. Tese de Doutoramento. Porto: Universidade do Porto.

NINHOS, Cláudia (2017) - Portugal e os nazis. Histórias e segredos de uma aliança. Lisboa: A Esfera dos Livros.

OLIVEIRA, Ana das Mercês (2018) - Colónias Agrárias da Junta de Colonização Interna no concelho de Montalegre - 
Modos de habitar a ruralidade. Dissertação de Mestrado. Porto: Facultade de Arquitectura da Universidade do Porto.

PÉREZ ESCOLANO, Víctor (2005) - Pueblos de colonización franquista: objetivo patrimonial. $\mathrm{PH}$ Boletín del Instituto Andaluz del Patrimonio Histórico. Sevilla. 52: 38-42.

RAPAZOTE, João (2012) - “Aldeias-Jardim” no concelho de Montalegre. O projeto da Junta de Colonização Interna para os baldios do Barroso. Revista de Geografia e Ordenamento do Território, 1, pp. 207-36.

ROSAS, Fernando (2001) - O salazarismo e o homem novo: Ensaio sobre o Estado Novo e a questão do totalitarismo. Análise Social, XXXV, 157, pp. 1031-1054.

ROSAS, Fernando. (2018) - Salazar e o Poder. A Arte de Saber Durar. Lisboa: Tinta-da-China.

ROSAS, Fernando. (2019) - Salazar e os Fascismos. Lisboa: Tinta-da-China.

SAMUELS, Joshua (2010) - Of Other Scapes: Archaeology , Landscape and Heterotopia in Fascist Italy. Archaeologies, 6(1), pp. 62-81.

SARAIBA, Tiago (2010) - Fascist Landscapes: Geneticists, Wheat, and the Landscapes of Fascism in Italy and Portugal. Historical Studies in the Natural Sciences, 40 (4), pp. 457-498.

SEÑORÁN MARTÍN, José Mª e AYÁN VILA, X. (2015) Los pueblos del agua. Colonización agraria y control social en la provincia de Cáceres durante la dictadura franquista. Arkeogazte. Vitoria-Gasteiz. 5, pp. 189-205.

SILVA, María Fátima Matos da (2006) - O povoamento pre-histórico e a romanização da bacia superior do rio Coura: estudo, musealização e divulgação. Tese de Doutoramento. Universidade de Granada.

SILVA, Maria Elisa Oliveira Silva da Lopes (2011) - A propriedade e os sujeitos: colonização interna e colónias agrícolas durante o Estado Novo. Dissertação de Mestrado, Universidade Nova de Lisboa.

STAMPACCHIA, Mauro (2000) - Ruralizzare l'Italia! Agricolture e bonifiche tra Mussolini e Serpieri (1928-1943). Milán: Franco Angeli.

TEJERIZO GARCÍA, Carlos e RODRÍGUEZ GUTIÉRREZ, Alejandro (2020) - Arqueología de la guerra después de la guerra. Vestígios. Revista Latino-Americana de Arqueología Histórica, 13 (2), pp. 9-35.

TORDESILLAS, Antonio A. e MEISS, Alberto (2013) - “El corazón de los pueblos de colonización”. Boletín académico. Revista de investigación y arquitectura contemporánea, 3, pp. 37-48.

VERACINI, Lorenzo (2018) - Italian Colonialism through a Settler Colonial Studies Lens. Journal of Colonialism and Colonial History, 19(3).
VILANOVA I VILA-ABADAL, Francesc (2014) - Bajo el signo de la esvástica. La Exposición de Arquitectura Moderna alemana en España (1942). Diacronie. Studi di Storia Contemporanea, 18(2).

ZAS GÓMEZ, Evaristo (2002) - A Terra Chá de Lugo, un caso atípico de poblado INC. In Actas del Congreso Arquitectura, ciudad e ideología antiurbana. Pamplona: Universidad de Navarra, pp. 197-203. 


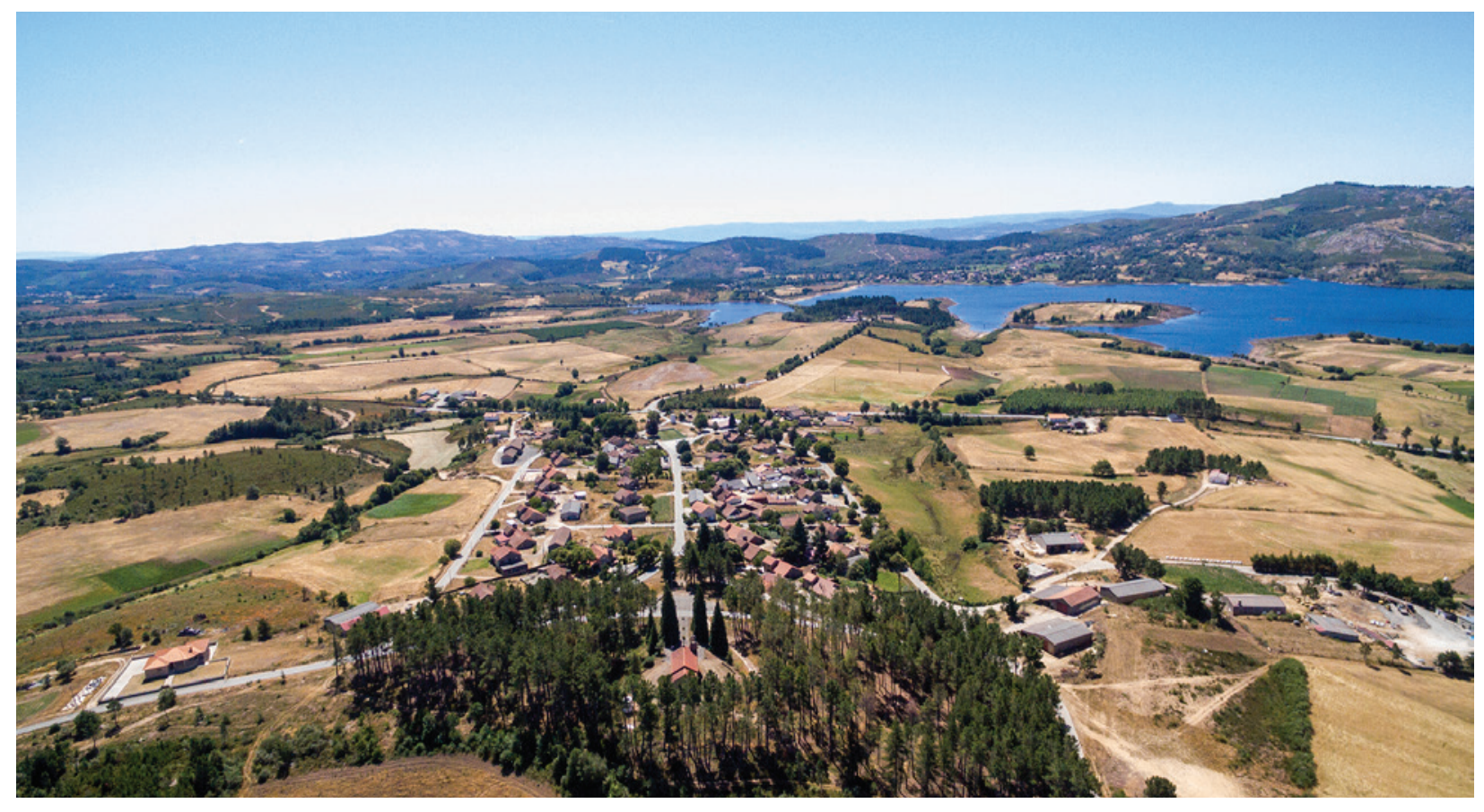

Figura 1-A colonia agrária de Aldeia Nova de Barroso (Montalegre) em julho de 2020 (ortofoto de Manoel A. Franco Fernández).

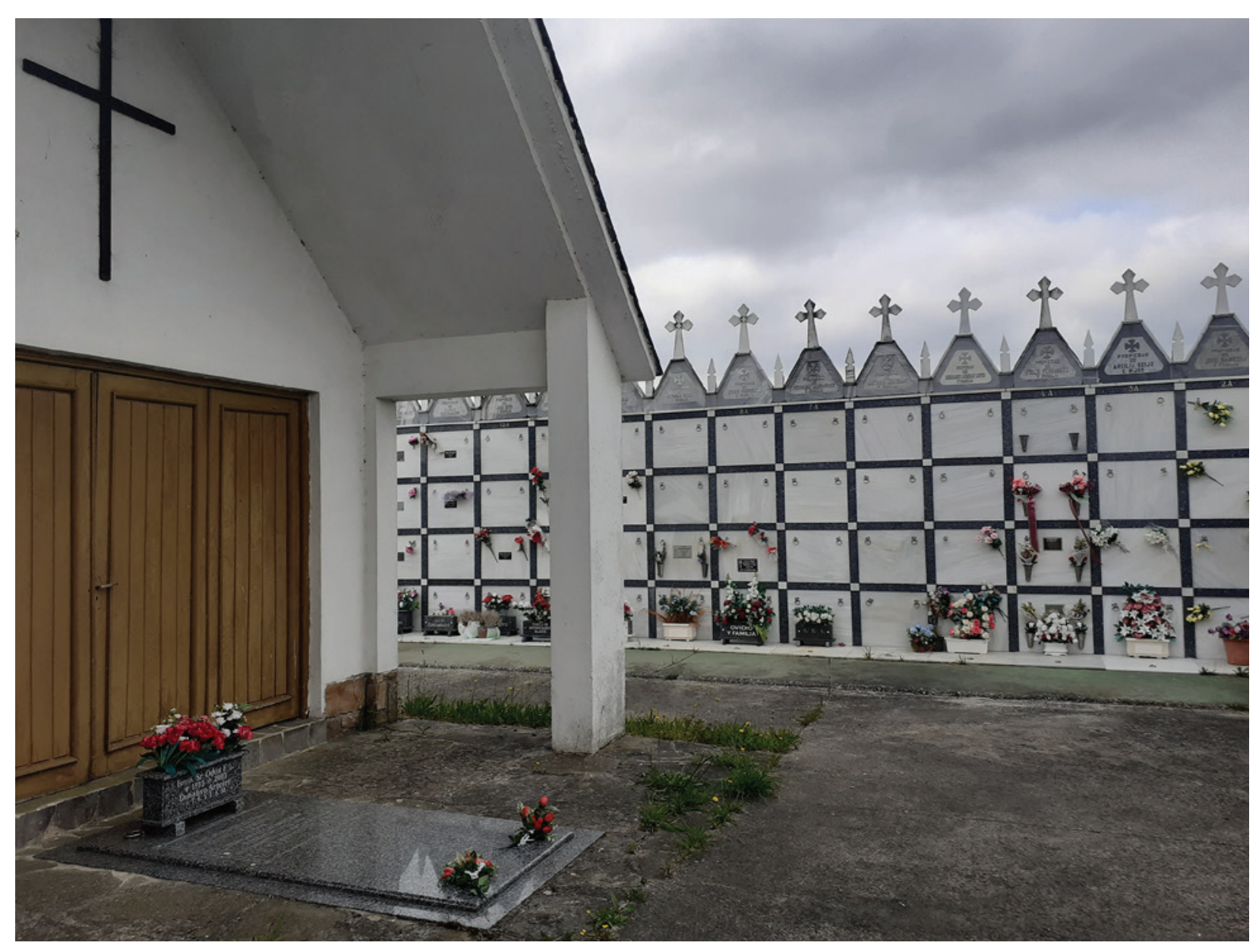

Figura 2 - Túmulo funerario do engenheiro Odón Fernández Lavandeira no cemitério vizinho do Centro Cívico do Arneiro. Junho de 2020 (foto de Xurxo Ayán). 



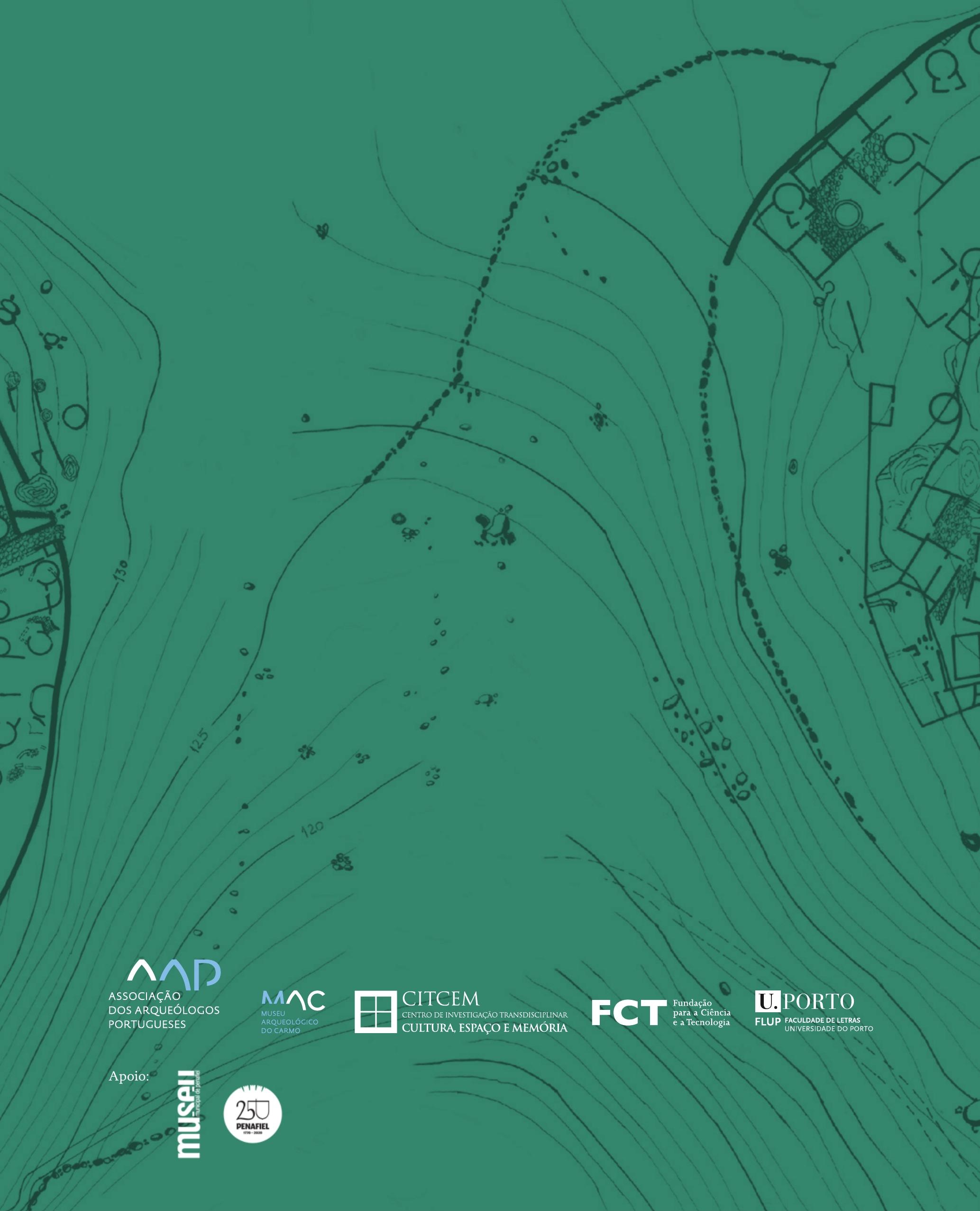

